ENCICLOPEDIA DE SALUD Y SEGURIDAD EN EL TRABAJO 



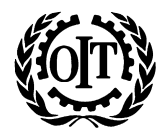

\title{
ENCICLOPEDIA DE SALUD Y SEGURIDAD EN EL TRABAJO
}

\author{
Directora de edición \\ Jeanne Mager Stellman, PhD \\ Subdirector general de edición \\ Michael McCann, PhD, $\mathrm{ClH}$ \\ Subdirectores de edición \\ Leon Warshaw, MD \\ Carole Brabant, PhD

\section{Editores} \\ John Finklea, MD, Dr PH Jacqueline Messite, MD \\ Georges H. Coppée, MD Steven L. Sauter, PhD \\ Vilma R. H unt, BDS, AM Jerry Spiegel, MA, MSC \\ Richard S. Kraus, PE, CSP Colin L. Soskolne, PhD \\ Wolfgang Laurig, Dr-Ing Benedetto Terracini, MD \\ Melvin L. Myers, BS, MPA \\ Gestión editorial \\ Chantal Dufresne, BA
}

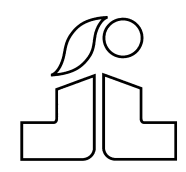




\section{SUMARIO COMPIETO}

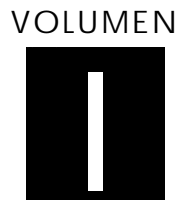

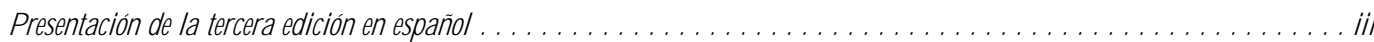

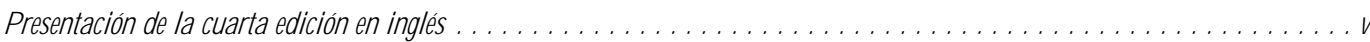

Extractos de presentaciones de ediciones anteriores $\ldots \ldots \ldots \ldots \ldots \ldots \ldots \ldots \ldots \ldots \ldots \ldots \ldots \ldots \ldots \ldots \ldots \ldots$

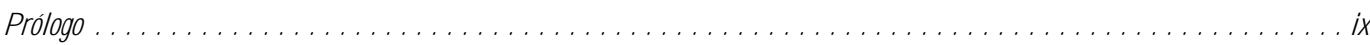

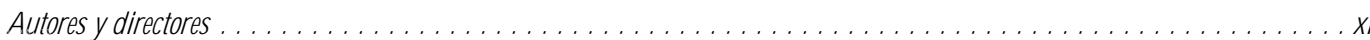

PARTE I. EL CUERPO HUMANO

\section{Sangre}

Sistema hematopoyético y linfático

Leucemia, linfomas malignos

y mieloma múltiple.

Agentes o condiciones de trabajo que afectan a la sangre.
Bernard D. G oldstein, Director del capítulo . B ernard D. Goldstein 1.2

T imo Partanen, Paolo B offetta, E lisabete W eiderpass 1.3 . B ernard D. Goldstein 1.6

\section{Cáncer}

Paolo Boffetta, Director del capítulo

Introducción. Neil Pearce, Paolo B offetta y M anolis Kogevinas 2.2

Cancerígenos profesionales

. Paolo B offetta, R odolfo Saracci, M anolis Kogevinas, J ulian W ilbourn y H arri Vainio 2.4

Cáncer de origen ambiental $\ldots \ldots \ldots \ldots \ldots \ldots \ldots \ldots \ldots$ B ruce K. A rmstrong y Paolo B offetta 2.8

Prevención.

Per Gustavsson

\section{Sistema cardiovascular}

\section{L othar H einemann} y G erd H euchert, Directores del capítulo

Introducción . L othar $\mathrm{H}$ einemann y $\mathrm{G}$ erd $\mathrm{H}$ euchert 3.2

M orbilidad y mortalidad cardiovascular en la población activa. Gottfried $E$ nderlein y L othar $H$ einemann

El concepto de factor de riesgo en la enfermedad

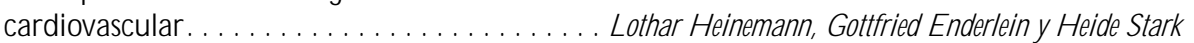

\section{PELIGROS FISICOS, QUIMICOSY BIOLOGICOS}

Factores físicos $\mathrm{H}$ edde Stark y $\mathrm{G}$ erd $\mathrm{H}$ euchert 3.11

M ateriales químicos peligrosos. . U lrike T ittelbach y W olfram D ietmar Schneider 3.16

Peligros biológicos R egina J äckel, U Irike T ittelbach y W olfram D ietmar Schneider 3.18

4. Aparato digestivo

H eikki Savolainen, Director del capítulo

A parato digestivo G. Frada 4.2

Boca y dientes. F. Gobbato 4.3

Hígado. G eorge Kazantzis 4.5

U Icera péptica. K.S. Cho 4.8

Cáncer hepático T imo Partanen, T imo Kauppinen, Paolo B offetta y E lisabete W eiderpass

Cáncer pancreático T imo Partanen, T imo Kauppinen, Paolo B offetta y E lisabete W eiderpass 
5. Salud Mental

Joseph J. H urrell, Lawrence R. Murphy, Steven L. Sauter y Lennart Levi, D irectores del capítulo

Trabajo y salud mental . . I rene L.D. H outman y M ichied A.J. Kompier 5.2

Psicosis relacionadas con el trabajo . Craig Stenberg, J udith $\mathrm{H}$ older y K rishna Tallu

ESTADO DE ANIMO Y AFECTO

Depresión ay L asser y J effrey P. Kahn

Ansiedad relacionada con el trabajo . Randal D. B eaton

Trastorno por estrés postraumático y su relación con la salud laboral y la prevención de lesiones. . . M ark B raverman

El estrés y el agotamiento, y sus implicaciones en el medio ambiente de trabajo . H erbert I. F reudenberger 5.17

Trastornos cognitivos . Catherine A. H eaney 5.19

$\mathrm{K}$ aroshi: muerte por exceso de trabajo.

Takashi $\mathrm{H}$ aratani

6. Sistema musculosquelético

Hilkka Riihimäki y Eira Viikari-J untura, D irectores del capítulo

Visión general . . H ilkka Riihimäki 6.2

M úsculos. Gisela Sjøgaard 6.2

Tendones. T homas J. Armstrong 6.4

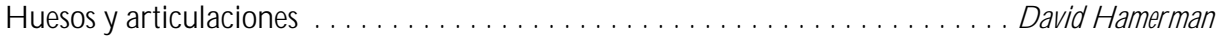
6.6

Discos intervertebrales Sally R oberts y J ill P.G. U rban

Región lumbar .. . H ilkka Riihimäki 6.11

Región de la columna dorsal

J arl-E rik M ichelsson

Cuello . Asa Kilbom 6.16

Hombro $\mathrm{M}$ ats $\mathrm{H}$ agberg 6.19

Codo. E ira Viikari-J untura 6.23

Antebrazo, muñeca y mano E ira Viikari-J untura

Cadera y rodilla E va Vingård

Pierna, tobillo y pie. J arl-E rik M ichelsson

0 tras enfermedades.

$M$ arjatta L érisalo-R epo

7. Sistema nervioso

Donna Mergler, Directora del capítulo

Sistema nervioso: visión general . . . . . . . . . . . . . . D onna M ergler y J osé A. Valciukas Anatomía y fisiología oséA. Valciukas 7.3

Agentes químicos neurotóxicos Peter Arlien-Søborg y Leif Simonsen 7.9

M anifestaciones de intoxicación aguda y crónica precoz . . . . . . . . . . . . . . . . D onna M ergler 7.15

Síndromes clínicos asociados a neurotoxicidad . . . . . . . . . . . . . . . . . Robert G. Feldman 7.18

D eterminación de los déficit neurotóxicos ...................... D onna M ergler 7.22

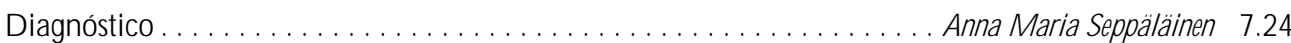

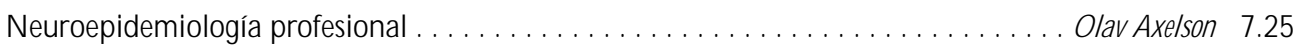

8. Sistemas renal y urinario G eorge P. Hemstreet, Director del capítulo Los sistemas renal y urinario. . . . . . . . . . . . . . . . . . . . G eorge P. H emstreet Cánceres renales y urinarios ....... . T imo Partanen, $\mathrm{H}$ arri Vainio, Paolo B offetta y E lisabete W eiderpass

\section{Sistema reproductor}

G race Kawas Lemasters, Directora del capítulo

Introducción Lowell E. Sever 9.2 
El sistema reproductor masculino y la toxicología . . . . . . . . Steven Schrader y G race Kawas L emasters 9.4

La estructura del sistema reproductor femenino y la vulnerabilidad

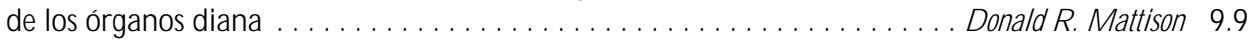

Exposiciones profesionales maternas y resultados adversos en

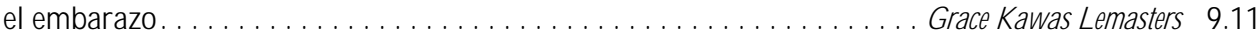

El parto pretérmino o prematuro y el trabajo ................... Nicole M amelle 9.16

Exposiciones del recién nacido a sustancias tóxicas de origen industrial y ambiental ......................... W ary S. W olff y Patrisha M. Woolard 9.19

La protección de la maternidad en la legislación ................. M arieClaire Séguret 9.25

Recomendaciones de Estados U nidos en relación con el embarazo y el trabajo ................................. Leon $\mathrm{J}$. W arshaw

\section{Aparato respiratorio Alois David y G regory R. Wagner, Directores del capítulo}

Estructura y función . . . . . . . . . . . . . . . . . . . . . . . . . . . orton Lippmann

Examen de la función pulmonar . . . . . . . . . . . . . . . . . . U If U Ifvarson y M onica D ahlqvist

Enfermedades causadas por irritantes respiratorios y

productos químicos tóxicos ..................... D avid L.S. R yon y W illiam N. R om

Asma ocupacional George F riedman-J iménez y $E$ dward L. Petsonk

Enfermedades causadas por polvos orgánicos. . . . . . . . . R agnar R ylander y R ichard $S$. F. Schilling

Enfermedad por berilio H omayoun Kazemi

Neumoconiosis: definición Alois D avid

Clasificación internacional de radiografías de neumoconiosis de la O IT ... M ichel Lesage 10.37

Etiopatogenia de la neumoconiosis. . Patrick Sébastien y R aymond B égin

Silicosis J ohn $E$. Parker y G regory $R$. W agner 10.48

Enfermedades pulmonares de los mineros del carbón

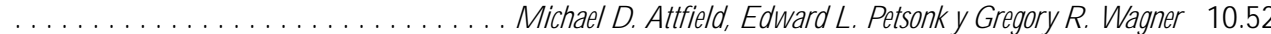

Enfermedades relacionadas con el amianto ................... argaret $R$. B ecklake 10.57

Enfermedades por metales pesados. ..................... Gerolamo C hiappino

A parato respiratorio: la variedad de las neumoconiosis.

Steven R. Short y E dward L. Petsonk

Enfermedad pulmonar obstructiva crónica. . . Kazimierz M arek y J an E. Z ejda

Efectos de las fibras artificiales sobre la salud . . James E. L ockey y Clara S. R oss

Cáncer respiratorio Paolo B offetta y E lisabete W éderpass

Infecciones pulmonares de origen ocupacional

$$
\text { . Anthony A. M arfin, Ann F. H ubbs, Karl J. M usgrave y J ohn E. Parker }
$$

\section{O rganos sensoriales}

H eikki Savolainen, D irector del capítulo

El oído M arce-André B oillat

Trastornos auditivos inducidos por productos químicos . . . . . . . . . . . . Peter J acobsen

Trastornos auditivos provocados por agentes físicos . Peter L. Pelmear

Equilibrio .. Lucy Yardley

Visión y trabajo. Paule R ey y J ean-J acques $M$ eyer

Gusto April E. M ott y N orman M ann

Olfato A pril E. M ott

Receptores cutáneos. R obert $D$ ykes y $D$ aniel $M C B$ ain

\section{Enfermedades de la piel}

\section{Louis-Philippe Durocher, Director del capítulo}

Visión general: enfermedades profesionales de la piel. D onald I. B irmingham Cáncer de piel no melanocítico. . . . . . . . . . . . . E lisabete W eiderpass, T imo Partanen, Paolo B offetta 
Dermatitis de contacto profesionales. ..................... D enis Sasseville

Prevención de las dermatosis profesionales. . . . . . . . . . . . . . . L ouis-P hillipe D urocher

Distrofia ungüeal profesional .................................. . Calnan

13. Condiciones del entorno

H oward M. Kipen, Director del capítulo

Condiciones del entorno: introducción ....................... oward M . Kipen

Síndrome del edificio enfermo .............................. ichael $\mathrm{f} . \mathrm{H}$ odgson

Multisensibilidad química

M ark R. Cullen

PARTE II. ASISTENCIA SANITARIA

\section{Primeros auxilios y servicios médicos de urgencia} Antonio J. Dajer,
Director del capítulo

Primeros auxilios . Antonio J. Dajer 14.2

L esiones craneoencefálicas . . Fengsheng $\mathrm{He}$

\section{Protección y promoción de la salud}

\section{y Leon J. Warshaw, Directores del capítulo}

Protección y promoción de la salud: visión general . . . . . . . . L L eon J. W arshaw y J acqueline M essite Promoción de la salud en el lugar de trabajo . ................... onathan E. Fielding 15.2

Promoción de la salud en el lugar de trabajo: Inglaterra Leon K reitzman

Promoción de la salud en las pequeñas organizaciones: experiencia de Estados $U$ nidos . . . . . . . . . . . . . . . Sonia $M$ uchnick-B aku y L eon J. W arshaw

Función del servicio de salud de los empleados en los programas de prevención

Programas de mejora de la salud en M aclaren Industries, Inc.: estudio de caso . . . . . . . . . . . . . . . . . . . . . . . . . Ian M .F. A rnold y L ouis D amphousse 15.22

Función del servicio de salud en el trabajo en los programas de prevención:

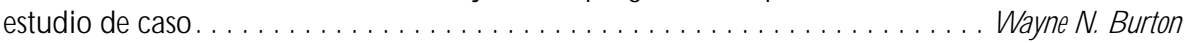

Promoción de la salud en el lugar de trabajo en Japón . . . . . . . . . . . . . . Toshiteru 0 kubo

Evaluación del riesgo para la salud . . . . . . . . . . . . . . . . . . . L eon J. W arshaw

Programas de ejercicio físico y de mantenimiento de la capacidad física para el trabajo: un activo de la organización . . . . . . . . . . . . . . . . . . ames Corry

Programas de nutrición en el lugar de trabajo ......... Penny M . K ris-E therton y J ohn W. Farquhar Control del tabaco en el lugar de trabajo ....................... on R udnick

Los programas de control del tabaco en M errill Lynch and Company, Inc.:

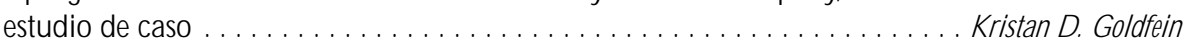
Prevención y control del cáncer. . . . . . . . . . . . . . . . . Peter $G$ reenwald y $L$ eon J. W arshaw La salud de la mujer . . . . . . . . . . . . . . . . . . . . . . . Patricia A. Last Estudio de caso: el programa de mamografías de M arks and Spencer . . . . . . . . J illian H aslehurst 15.60

Estrategias en el lugar de trabajo para la mejora de la salud maternal e infantil: experiencias de los trabajadores en Estados U nidos . . . . . M auren P. Corry y E llen C utler 15.62 Educación sobre el VIH / SIDA . . . . . . . . . . . . . . . . . . . . . . . B.J. Stiles 15.66 Protección y promoción de la salud: enfermedades infecciosas . . . . . . . . . . W illiam J. Schneider 15.69

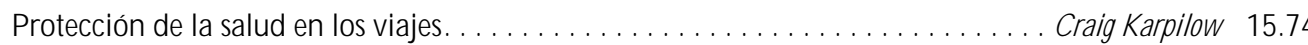

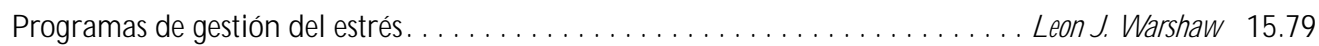
A buso de alcohol y de drogas . . . . . . . . . . . . . . . . . . . . . . Sheila B. Blume 15.82

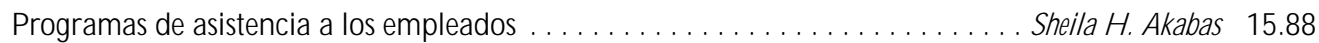


La salud en la tercera edad: programas de prejubilación . . .

H. B eric W right

Recolocación. .

Saul G. Gruner y L eon I. W arshaw

16. Servicios de salud en el trabajo

Igor A. Fedotov, Marianne Saux y Jorma Rantanen, Directores del capítulo

$\mathrm{N}$ ormas, principios y enfoques de los servicios de salud

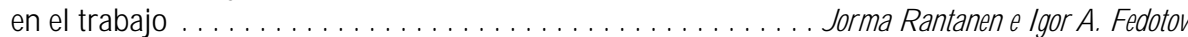

L os servicios de la salud en el trabajo y la práctica ................... G eorges H . Coppée 16.2

Inspección médica del trabajo en Francia . . . . . . . . . . . . . . . . . . M arianne Saux

L os servicios de salud en el trabajo en la pequeña empresa .... . . J orma $R$ antanen y $L$ eon J. W arshaw 16.25

EI seguro de accidentes y los servicios de salud en el trabajo

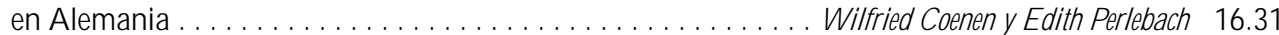

Los servicios de salud en el trabajo en Estados U nidos: introducción Sharon L. M orris y Peter O rris

O rganismos públicos de salud en el trabajo en Estados U nidos. Sharon L. M orris y L inda R osenstock 16.35

Servicios de salud en el trabajo en las empresas de Estados U nidos: servicios prestados internamente. . W illiam B. B unn y R obert I. M cC unney 16.38

Servicios de salud en el trabajo mediante contrato en

Estados U nidos . . . . . . . . . . . . . . . . . . . . . . . . . . Penny H iggins 16.41

Actividades sindicales en Estados U nidos . . . . . . . . . . . . . . . . . . . . . L Lamont Byrd 16.43

Servicios académicos de salud en el trabajo en Estados U nidos. . . . . . . . . . . . . . . D ean B. Baker 16.45

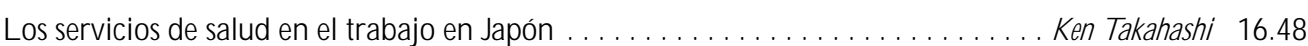

La protección de los trabajadores en la Federacion Rusa:

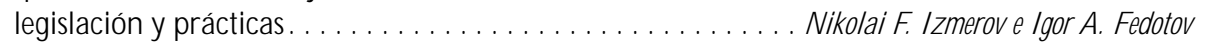
16.49

La práctica de los servicios de salud en el trabajo en la República Popular China................................ Zhi Su 16.53

Salud y seguridad en el trabajo en la R epublica Checa . . . . . . . . . Vladimír B encko y D aniela Pelclová 16.61 La práctica de la salud en el trabajo en la India ..................... T. K. J oshi

\section{PARTE III. GESTION Y POUTICA}

\section{Discapacidad y trabajo Willi Momm y Robert Ransom, Directores del capítulo}

D iscapacidad: conceptos y definiciones. ..................W illi M omm y 0 tto G eiecker

Estudio de caso: clasificación legal de las personas discapacitadas en Francia . . . . . . . . . . . . . . . . . . . . . . M arie $L$ ouise $C$ ros-C ourtial y $M$ arc Vericel

Política social y derechos humanos: conceptos de la discapacidad. Carl Raskin

$\mathrm{N}$ ormas laborales internacionales y legislación nacional de empleo en favor de las personas discapacitadas . . . . . . . . . . . . . . . W illi M omm y M asaaki I uchi

Servicios de rehabilitación profesional y de apoyo a los trabajadores. . . . . . . . . . E rwin Seyfried

Gestión de la discapacidad en el lugar de trabajo: visión de conjunto y tendencias futuras.

Rehabilitación y pérdida auditiva inducida por el ruido R aymond $\mathrm{H}$ étu

Derechos y obligaciones: el punto de vista de la empresa

usan Scott-Parker

D erechos y obligaciones: el punto de vista de los trabajadores . . . . Angela Traiforos y D ebra A. Perry

\section{Educación y formación}

Steven H ecker, Director del capítulo

Introducción y visión general . . . Steven H ecker Principios de formación Gordon A therley y D ilys R obertson

Educación y formación de los trabajadores. Robin B aker y $\mathrm{N}$ ina W allerstein 


\section{ESTUDIOSDE CASO}

Evaluación de la formación sobre salud y seguridad: estudio de caso de la educación de los trabajadores de residuos peligrosos del Sindicato Internacional de Trabajadores Q uímicos. . . . . . . . . . . . . T homas H . M cQ uiston, Paula Coleman, N ina W allerstein, .................................... M arcus, J.S. M orawetz, D avid W. O rtlieb y Steven H ecker

Educación y formación ambiental: situación de la educación de los trabajadores que manejan materiales peligrosos en Estados U nidos . . . . . . . . . . . . . . . G lenn Paul son, M ichelle M adelien, Susan Sink y Steven H ecker

L a educación de los trabajadores y la mejora ambiental . . . . . . . . . . . . E dward C ohen-R osenthal

Formación sobre salud y seguridad de los directivos. . . . . . . . . . . . . . . ohn R udge

Formación de los profesionales en materia de salud y seguridad Wai-On Phoon

Un nuevo enfoque del aprendizaje y la formación: estudio de caso del Proyecto Africano de Salud y Seguridad de la OIT-FIN NIDA Antero Vahapassi y M erri W einger

\section{Cuestiones relacionadas con la ética G eorges H. Coppée, Director del capítulo}

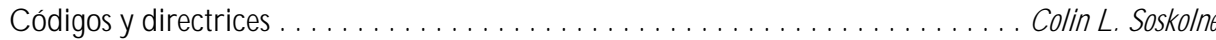

Ciencia y responsabilidad: normas éticas y conducta moral en la medicina del trabajo. .......................... Richard A. Lemen y Phillip W. Strine

Aspectos éticos de la investigación sobre la salud y la seguridad en el trabajo . . . . . . . . . . . . . . . . . Paul W. B randt-R auf y Sherry I. B randt-R auf

L a ética en el lugar de trabajo: marco para el juicio moral. . .............. Sheldon W. Samuels

Vigilancia del medio ambiente de trabajo . . Law rence $D$. Kornreich

Aspectos éticos de la información y la confidencialidad ............... Peter J. M . W esterholm

Etica en la protección y promoción de la salud

Estudio de caso: consideraciones éticas sobre el consumo de drogas y alcohol en el lugar de trabajo . ................... Behrouz Shahandeh y R obert H usbands

Código deontológico internacional para los profesionales de la salud en el trabajo. . Comisión I nternacional de M edicina del Trabajo

20. Desarrollo, tecnología y comercio Jerry Jeyaratnam, Director del capítulo Tendencias de la salud en el trabajo en el ámbito de los países en desarrollo . . . . . J erry J eyaratnam Países industrializados y salud y seguridad en el trabajo . . . . . . . . . . . . . . . . Toshiteru 0 kubo Estudios de caso sobre cambio tecnológico ..................... M ichael $\mathrm{J}$. W right

Pequeñas empresas y salud y seguridad en el trabajo . . . . . . . . . . . . . . . B ill Glass

Transferencia de tecnología y elección tecnológica.................. J oseph L aD ou 20.7

A cuerdos de libre comercio . . . . . . . . . . . . . . . . . . . . . . . . ow ard $F$ rumkin 20.8

R esponsabilidad respecto a los productos y traslado de riesgos industriales . . . . . . B arry C astleman

Aspectos económicos de la salud y la seguridad en el trabajo . . . . . . . . . . . . . . Alan M aynard 20.16

Estudio de caso: industrialización y problemas de salud en el trabajo en C hina. . . . . . . . . Su Z hi

\section{Relaciones laborales y gestión de recursos humanos}

Anne Trebilcock, Directora del capítulo

Relaciones laborales y gestión de recursos humanos: visión general . . . . . . . . . . Anne T rebilcock 21.2

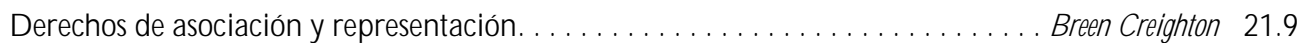

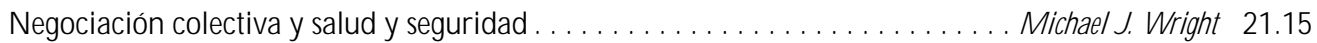

Cooperación tripartita y bipartita a escala nacional en materia de salud y seguridad en el trabajo . . . . . . . . . . . . . . . . . . . . . obert $\mathrm{H}$ usbands 21.19

Formas de participación de los trabajadores ................ uneto Ozaki y Anne Trebilcock 21.23 
Consulta e información sobre salud y seguridad M arco B iagi

Aspectos de la formación vinculados a las relaciones laborales . . . . M A Doyle 21.31

Aspectos de la inspección de trabajo vinculados a las relaciones laborales . . . M aría Luz Vega Ruiz 21.32

Conflictos colectivos por cuestiones de salud y seguridad .............. Shauna L. O Iney 21.34

C onflictos individuales por cuestiones de salud y seguridad . . . . . . . . . . . Anne T rebilcock 21.38

22. Recursos: información y salud y seguridad en el trabajo

Jukka T akala, Director del capítulo

La información: una condición previa para la acción J ukka Takala 22.2

Acceso a la información P.K. A beytunga, E mmert Clevenstine, Vivian M organ y Sheila Pantry

Gestión de la información Gordon A therley

Estudio de caso: servicio de información de M alaisia

sobre toxicidad de pesticidas. ............. D.A. Razak, A.A. Latiff, M .I. A. M ajid y R. Awang

Estudio de caso: una experiencia de gestión de información eficaz en Tailandia.

23. Recursos institucionales, estructurales y jurídicos

Rachael F. Taylor

y Simon Pickvance, Directores del capítulo

O rígenes, medios institucionales, estructurales y

jurídicos: introducción Simon Pickvance

Inspección de trabajo. W olfgang von R ichthofen

Responsabilidad civil y penal en el campo de la salud y seguridad en el trabajo Felice M orgenstern (adaptación)

L a salud en el trabajo como derecho humano . I lise L evy Feitshans

\section{AM BITO COMUNITARIO}

O rganizaciones de ámbito comunitario $\ldots \ldots \ldots \ldots \ldots \ldots \ldots \ldots \ldots$ Simon Pickvance

Derecho de saber: función de las organizaciones de ámbito comunitario . . . . . . C arolyn N eedleman

EI movimiento $\mathrm{COSH}$ y el derecho a conocer. J oel Shufro

EJEM PLOS DE AMBITO REGIONAL Y NACIONAL

Salud y seguridad en el trabajo: la U nión Europea

Frank B. W right 23.37

L egislación tutelar de los derechos de los trabajadores en China . . . Su Zhi

ORGANIZACIONES INTERNACIO NALES GUBERNAMENTALES Y NO GUBERNAMENTALES

Cooperación internacional en la salud laboral: función de las organizaciones internacionales Georges H. Coppée 23.42

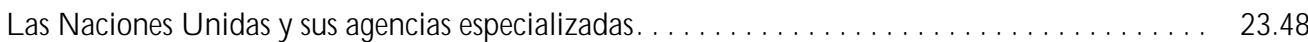

O rganización Internacional del Trabajo . . . . . . . . . . . . . . . . . . . . . Georg R. Kliesch 23.53

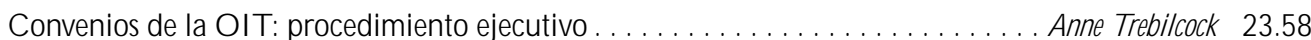

O rganización Internacional de N ormalización (ISO ) . . . . . . . . . . . . . . . . Lawrence D. E icher 23.60

A sociación Internacional de la Seguridad Social (AISS) . . . . . . . . . . . . . . D Dick J. M eertens 23.63

Comisión Internacional de M edicina del Trabajo (CIM T) . . . . . . . . . . . . . erry J eyaratnam 23.67

A sociación Internacional de Inspectores de Trabajo $(\mid A L I) \ldots \ldots \ldots \ldots \ldots$. . . . . D avid Snowball 23.69

\section{Trabajo y trabajadores}

Jeanne Mager Stellman y Leon J. Warshaw, Directores del capítulo

Trabajo y trabajadores Freda L. Paltie

Cambio de paradigmas y políticas. Freda L. Paltie 


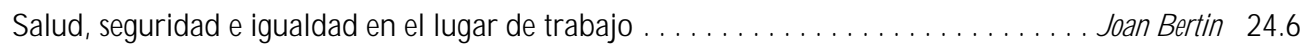

Empleo precario y trabajo infantil .......................... E eon J. W arshaw 24.10

Transformación de los mercados y la mano de obra. . . . . . . . . . . . . . . . . . . Pat Armstrong 24.17

Tecnologías mundializadoras y reducción/ transformación del trabajo. . . . . . . . . . . eather M enzies 24.20

25. Indemnización a los trabajadores, visión general

Terence G. Ison,

Director del capítulo

Sistemas de indemnización a los trabajadores por accidentes de trabajo,

visión general ............................................. Terence $G$. I son 25.2

PARTE PRIMERA: INDEMNIZACION A LOSTRABAJADORES

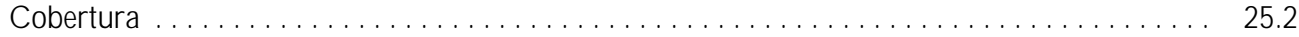

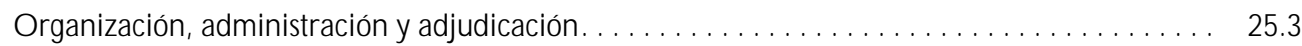

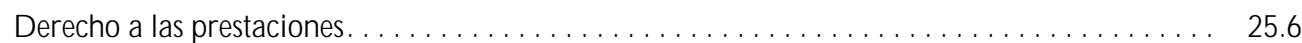

Causas múltiples de incapacidad $\ldots \ldots \ldots \ldots \ldots \ldots \ldots \ldots \ldots \ldots \ldots \ldots \ldots \ldots \ldots \ldots \ldots$

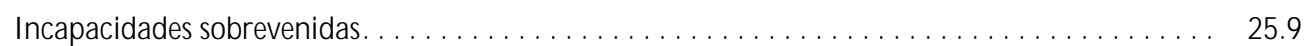

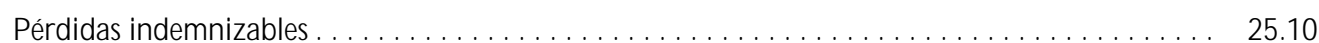

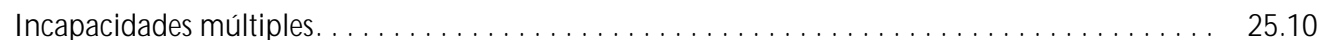

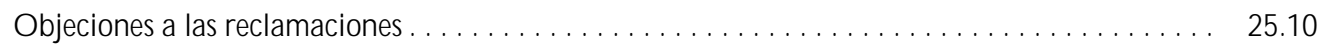

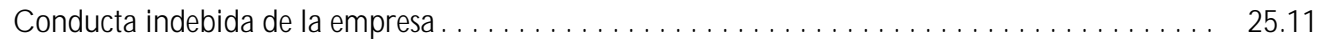

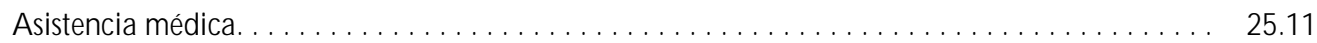

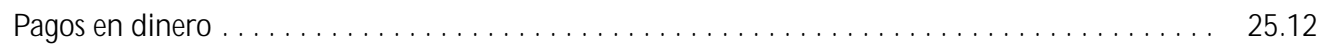

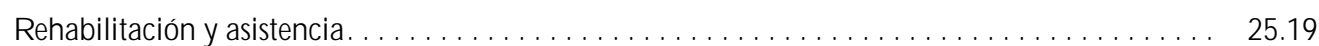

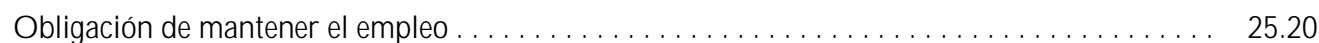

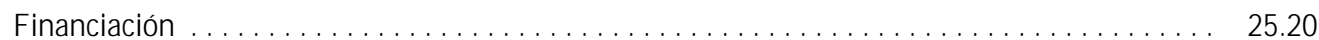

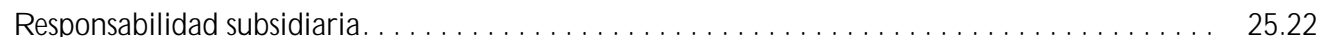

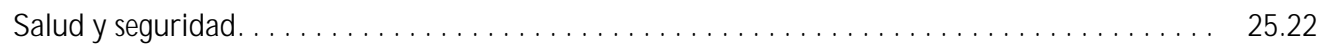

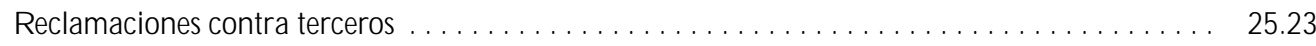

PARTE SEGUNDA: OTROSREGIMENES

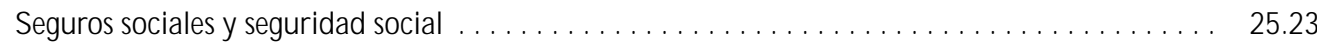

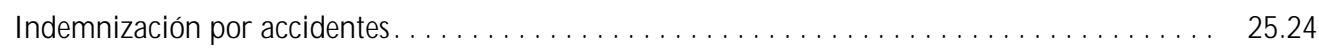

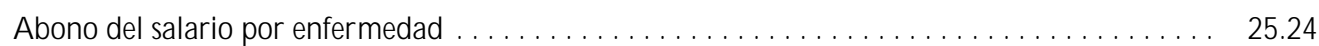

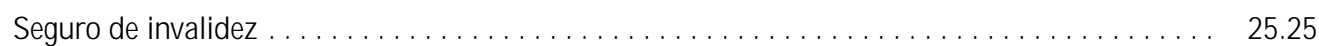

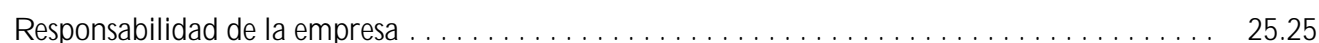

26. Indemnización a los trabajadores: temas relacionados Paule Rey y

Michel Lesage, Directores del capítulo

Enfermedades relacionadas con el trabajo y enfermedades profesionales:

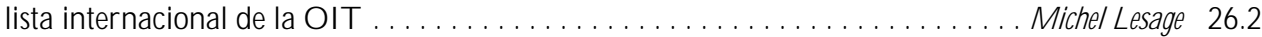

Indemnización por accidentes de trabajo: tendencias y perspectivas . . . . . . . . . Paule Rey 26.6

Prevención, rehabilitación e indemnización en el sistema alemán de seguro de accidentes. . . . . . . . . . . . . . . . . . . . . D ieter G reiner y A ndreas Kranig 26.17

Seguro e indemnización de las lesiones profesionales en Israel . . . . . . . . . . . . H aim Chayon 26.22

La indemnización por accidentes de trabajo en Japón. . . . . . . . . . Kazutaka Kogi y H aruko Suzuki 26.26

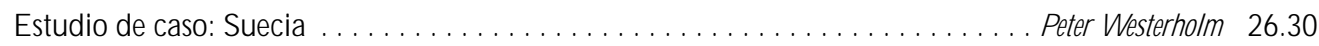


27. Control biológico

Principios generales.

Garantía de calidad.

M etales y compuestos organometálicos.

D isolventes orgánicos

Sustancias químicas genotóxicas

Pesticidas. . .
R obert L auwerys, Director del capítulo 27.2 27.6 27.8 27.13 27.15 27.20

\section{Epidemiología y estadística}

M étodo epidemiológico aplicado a la salud y seguridad en el trabajo. . . . . . . . . . . . . . . . F ranco M erletti, Colin L. Soskolne y Paolo V ineis 28.2

Evaluación de la exposición ................................ Gerald 0 tt 28.7

M edidas que resumen la exposición durante toda una vida laboral . . . . . . . . . C Colin L. Soskolne 28.10

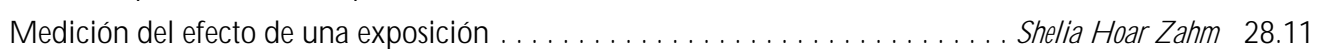

Tipos de diseño de los estudios . . . . . . . . . . . . . . . . . . . . . . Sven H ernberg 28.16

A spectos relacionados con la validez del diseño del estudio . . . . . . . . . . . . . . . Annie J. Sasco 28.22

Consecuencias del error de medida aleatorio . . . . . . . . . . . . . Paolo V inés y C olin L. Soskolne 28.25

M étodos estadísticos .......................... Annibale B iggeri y M ario B raga 28.26

Evaluación de la causalidad y ética en la investigación epidemiológica. . . . . . . . . . Paolo Vineis 28.31

Estudio de caso que ilustra los problemas metodológicos en la vigilancia de

las enfermedades profesionales .......................... ung-D er W ang 28.33

Cuestionarios en la investigación epidemiológica ......... . Steven D. Stellman y C olin L. Soskolne 28.34

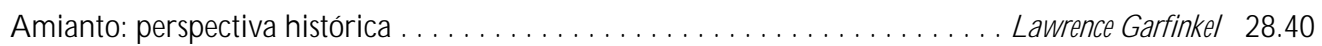

29. Ergonomía

Wolfgang Lauring y
Joachim Vedder, Directores del capítulo

Introducción Wolfgang L aurig y Joachim Vedder

OBJETIVOS, PRINCIPIOSY METODOS

Naturaleza y objetivos de la ergonomía . . . . . . . . . . . . . . . W illiam T. Singleton 29.2

A nálisis de actividades, tareas y sistemas de trabajo . . . . . . . . . . . . . . . Véronique D e Keyser 29.6

Ergonomía y normalización . . . . . . . . . . . . . . . . . . . . . . . . . . . . F riedhelm $N$ achreiner 29.12

Listas de comprobación . . . . . . . . . . . . . . . . . . . . . . . . . . . . . Pranab Kumar N ag 29.16

ASPECTOS FISICOSY PSICOLOGICOS

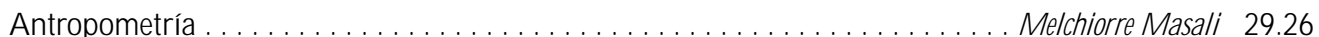

Trabajo muscular. . . . . . . . . . . . . . . . . . . . J uhani Smolander y Vékko L ouhevaara 29.29

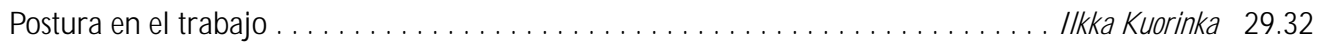

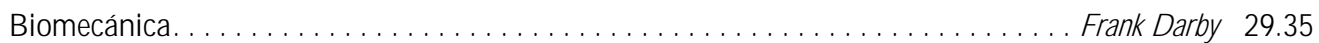

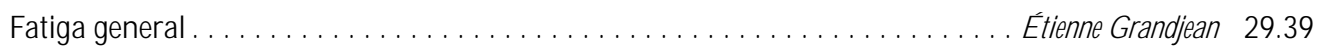

Fatiga y recuperación $\ldots \ldots \ldots \ldots \ldots \ldots \ldots \ldots \ldots \ldots$ R olf $\mathrm{H}$ elbig y W alter $\mathrm{R}$ ohmert 29.40

ASPECTOS PSICOLOGICOS

Carga mental de trabajo. . . . . . . . . . . . . . . . . . . . . . . . . W infried H acker 29.44

Vigilancia ......................................... erbert H euer 29.46

Fatiga mental $\ldots \ldots \ldots \ldots \ldots \ldots \ldots \ldots \ldots \ldots \ldots \ldots \ldots \ldots \ldots \ldots \ldots \ldots$. $\ldots \ldots \ldots$ Richter 29.50 
ASPECTOS ORGANIZATIVOS DEL TRABAJO

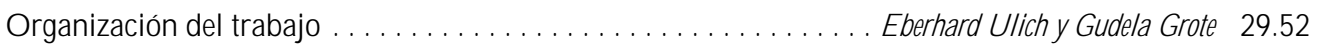

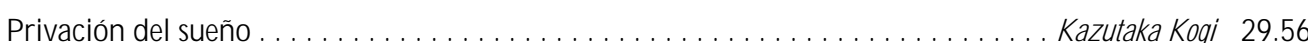

DISEÑO DE LOS SISTEMAS DE TRABAJO

Puestos de trabajo . . . . . . . . . . . . . . . . . . . . . . . . . . . . . . Roland Kadefors 29.61

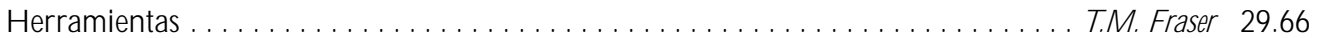

Controles, indicadores y paneles ........................... Karl H. E. Kroemer 29.69

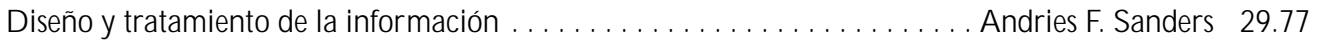

DISEÑO PARA TODOS

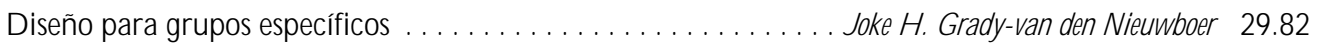

Diferencias culturales. . . . . . . . . . . . . . . . . . . . . . . . . . . . . oushang Shahnavaz 29.86

Trabajadores de edad avanzada. . . . . . . . . . . . . . . . . . . . . Antoine L aville y Serge Volkoff 29.91

Trabajadores con necesidades especiales. . . . . . . . . . . . . . . . . . . oke H . G rady-van den N ieuwboer 29.94

DIVERSIDAD E IMPORTANCIA DE LA ERGONOMIA: DOS EJEMPLOS

Diseño de sistemas en la fabricación de diamantes. . . . . . . . . . . . . . . . . . . . I ssachar Gilad 29.99

Violación de los principios del diseño ergonómico:

Chernobil . . . . . . . . . . . . . . . . . . . . . . . . . . . . . . . . . . . . . . Vladimir M. M unipov 29.102

30. H igiene industrial

Robert F. Herrick, Director del capítulo

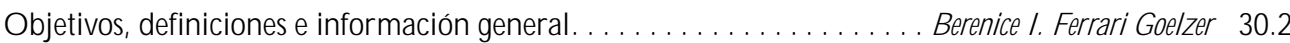

I dentificación de riesgos . . . . . . . . . . . . . . . . . . . . . . . . . . . Linnéa Lillienberg 30.11

Evaluación del medio ambiente de trabajo . . . . . . . . . . . . . . . . L ori A. Todd 30.15

H igiene industrial: control de las exposiciones mediante la intervención . . . . . . . . . l ames Stew art 30.25

Fundamentos biológicos para evaluar la exposición .................. Dick H eederik 30.27

Límites de exposición profesional . . . . . . . . . . . . . . . . . . . . . . . . . D ennis J. Paustenbach 30.31

31. Protección personal Robert F. Herrick, Director del capítulo

A spectos generales y principios de la protección personal $\ldots \ldots \ldots \ldots \ldots \ldots$ R obert $F$. H errick 31.2

Protectores de ojos y cara . . . . . . . . . . . . . . . . . . . . . . . . . . Kikuzi Kimura 31.3

Protección de pies y piernas . . . . . . . . . . . . . . . . . . . . . . . . . . . Toyohiko M iura 31.7

Protección de la cabeza . . . . . . . . . . . . . . . . . . . . . . . . . . . I sabelle B alty y Alain M ayer 31.9

Protección de los oídos ......................... ohn R. Franks y E lliott H . B erger 31.11

Ropa protectora ................................ Z ack M ansdorf 31.17

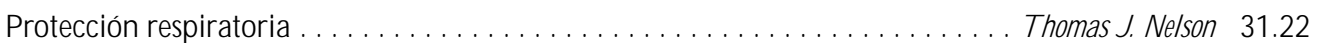

32. Sistemas de notificación y vigilancia Steven D. Stellman, Director del capítulo

Sistemas de vigilancia y notificación de enfermedades profesionales . . . . . . . Steven B. M arkowitz 32.2

V igilancia de los riesgos profesionales . . . . . . . . . . . . . . D avid H. W egman y Steven D. Stellman 32.8

V igilancia en los países en vías de desarrollo.................. D avid K oh y Kee Seng Chia 32.11

Desarrollo y aplicación de un sistema de clasificación de lesiones y

enfermedades profesionales $\ldots \ldots \ldots \ldots \ldots \ldots \ldots \ldots \ldots \ldots \ldots \ldots \ldots \ldots \ldots \ldots \ldots \ldots$ y $\ldots \ldots \ldots$ iddle 32.13

A nálisis del riesgo de lesiones y enfermedades no mortales en el

lugar de trabajo . . . . . . . . . . . . . . . . . . . . . . . . . . . . . ohn W. R user 32.20

Estudio de caso: protección del trabajador y estadísticas sobre

accidentes y enfermedades profesionales - HV BG, Alemania. . M artin B utz y B urkhard H offmann 32.22 
Estudio de caso: Wismut-las consecuencias de la exposición al uranio

Estrategias y técnicas de medición para la evaluación de la exposición en epidemiología. F rank B ochmann y $\mathrm{H}$ elmut B lome 32.31

Estudio de caso: encuestas de higiene industrial en China . Zhi Su 32.34

\section{Toxicología}

\section{Ellen K. Silbergeld, Directora del capítulo}

Introducción. E llen K. Silbergeld

PRINCIPIOS GENERALES DE LA TOXICOLOGIA

D efiniciones y conceptos. . . . . . . . . . . . . . B o H ol mberg, J ohan H ögberg y Gunnar J ohanson

Toxicocinética. . . Dušan D juric' 33.8

O rgano diana y efectos críticos. M arek J akubow sk

Efectos de la edad, el sexo y otros factores. Spomenka Telišman 33.18

D eterminantes genéticos de la respuesta tóxica. . D anie W. N ebert y R oss A. M cKinnon

MECANISMOSDE LA TOXICIDAD

Introducción y conceptos. Philip G. W atanabe 33.29

Lesión celular y muerte celular. B enjamin F. T rump el rene K. B erezesky 33.33

Toxicología genética . R. R ita M isra y M ichael $P$. W aalkes

Inmunotoxicología J oseph $G$. Vos y H enk van L overen

Toxicología de órganos diana E llen K. Silbergeld

\section{METODOSDE ENSAYO EN TOXICOLOGIA}

Biomarcadores.

Philippe G randjean 33.44

Evaluación de la toxicidad genética David M . D elM arini y J ames H uff 33.49

Ensayos de toxicidad in vitro. . J oanne Zurlo 33.51

Relaciones estructura-actividad . . . E llen K. Silbergeld

TOXICOLOGIA REGULADORA

L a toxicología en la regulación de la salud y la seguridad. Ellen K. Silbergeld 33.57

Principios de la identificación de los peligros: el enfoque japonés M asayuki I keda

El enfoque estadounidense de la evaluación del riesgo de los tóxicos para la reproducción y agentes neurotóxicos.

Enfoques en la identificación de los peligros: Ia IARC . H arri Vainio y J ulian W ilbourn 33.65

A péndice: evaluaciones globales de carcinogenicidad para los humanos: monografías de la IARC, volúmenes 1-69 (836)

Evaluación del riesgo de carcinogenicidad: otros enfoques Cees A. van der Heijden 


\section{voumes \\ II}

Autores y directores

PARTE V. FACTORES PSICOSOCIALES Y DE ORGANIZACION

34. Factores psicosociales y de organización

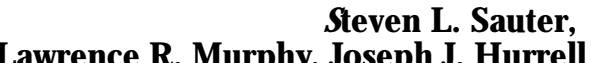
y Lennart Levi, Directores del capítulo

TEORIAS DEL ESTRES DEL TRABAJO

Factores psicosociales, estrés y salud Lennart Levi 34.3

El modelo de demandas/ control: enfoque social, emocional y fisiológico del riesgo de estrés y desarrollo de comportamientos activos............. R obert Karasek

El apoyo social: un modelo interactivo del estrés Kristina Orth-Gomér 34.16

FACT ORES INHERENTES AL TRABAJO

El ajuste persona-entorno R obert D. Caplan 34.18

La carga de trabajo M arianne $F$ rankenhaeuser 34.20

La jornada de trabajo T imothy H. M onk 34.21

El diseño del entorno. . D aniel Stokols 34.22

Factores ergonómicos. M ichae J. Smith 34.25

Autonomía y control . Daniel Ganster 34.26

El ritmo del trabajo. Gavrie Salvendy 34.28

La supervisión electrónica del trabajo Lawrence M. Schleifer 34.29

Claridad y sobrecarga de los roles asignados. . Steve M. J ex 34.31

FACTORES INTER PER SONALES

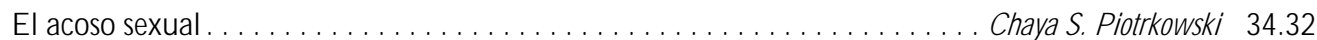

$L$ a violencia en el lugar de trabajo $\ldots \ldots \ldots \ldots \ldots \ldots \ldots \ldots \ldots \ldots \ldots \ldots \ldots \ldots$ ulian Barling 34.33

LA SEGURIDAD EN EL EM PLEO

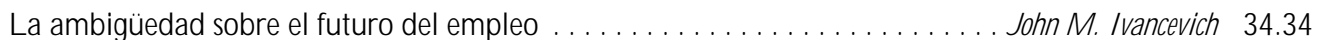

El desempleo . . . . . . . . . . . . . . . . . . . . . . . . . . . . . . . . . . . . Amiram D. Vinokur 34.35

FACTORES MACROORGANIZATIVOS

Gestión de la calidad total. . . . . . . . . . . . . . . . . . . . . . . . . . . . . . . . . . Dennis Tolsma 34.37

Estilo de dirección $\ldots \ldots \ldots \ldots \ldots \ldots \ldots \ldots \ldots \ldots \ldots \ldots \ldots \ldots \ldots \ldots \ldots \ldots \ldots \ldots \ldots \ldots \ldots$ ary L. Cooper y M ike Smith 34.39

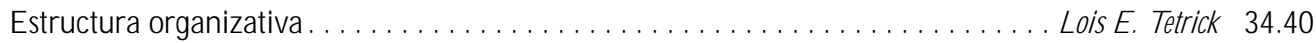

Clima y cultura organizativos . . . . . . . . . . . . . . . . . . D enise M. R ousseau 34.41

M edición y remuneración del rendimiento .....................Richard L. Shell 34.43

Cuestiones de personal. . . . . . . . . . . . . . . . . . . . . . . . . M arilyn K. Gowing 34.44

DESARROLLO DE LA CARRERA PROFESIONAL

Socialización ........................ D ebra L. N elson y J ames Campbell Quick 34.46

Etapas de la carrera profesional . . . . . . . . . . . . . . . . . . . . . . . . . Kari L indström 34.47 
FACTORES INDIVIDUALES

Patrones de comportamiento de los tipos A y B C. D avid J enkins 34.49

Resistencia. Suzanne C. O uellette 34.50

Autoestima . J ohn M. Schaubroeck 34.52

Locus de control L aw rence $R$. M urphy y J oseph J. H urrell, J r. 34.52

Estilos de afrontamiento . Ronald J. Burke 34.54

A poyo social D. W ayne Cornél 34.55

Género, estrés en el trabajo y enfermedad R osalind C. B arnett 34.57

Aspectos étnicos G wendolyn Puryear Keita

\section{REACCIONES DE ESTRES}

Algunos resultados fisiológicos agudos .................. Andrew Steptoe y Tessa M. Pollard 34.60

Resultados de comportamiento . . . . . . . . . . . . . . . . . . . . . . . . . . A rieshirom 34.62

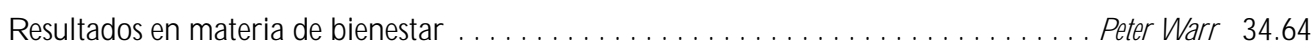

Reacciones inmunitarias . . . . . . . . . . . . . . . . . . . . . . . . . . . . . . . . . . olger U rsin 34.66

EFECTOSCRONICOSEN LA SALUD

Enfermedades cardiovasculares. . . . . . . . . . . . . . . . . T öres T heorell y J effrey V. J ohnson 34.67

Problemas gastrointestinales $\ldots \ldots \ldots \ldots \ldots \ldots \ldots \ldots \ldots \ldots \ldots \ldots \ldots \ldots \ldots \ldots$ erry Suls 34.68

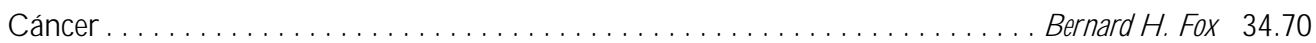

Trastornos musculosqueléticos. ................ Soo-Yee L im, Steven L. Sauter y Naomi G. Swanson 34.72

Trastornos mentales ....................... Carles M untaner y W illiam W. E aton 34.73

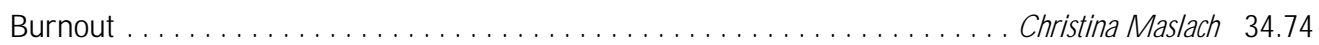

PREVENCION

Resumen de las estrategias generales de prevención y control. . . . . C Cary L. Cooper y Sue C artwright 34.75

35. O rganizaciones y salud y seguridad G unnela Westllander, D irectora del capítulo Factores psicosociales y gestión organizativa . . . . . . . . . . . . . . G unnela W estlander

\section{PARTE VI. RIESGOS GENERALES}

36. Presión barométrica, aumento

T. J. R. Francis, Director del capítulo

Trabajo en situaciones de aumento de la presión barométrica . . . . . . . . . . . . . . E ric Kindwall

Trastornos por descompresión Dees F. Gorman 36.10

37. Presión barométrica, reducción

Walter Dümmer, Director del capítulo

Aclimatación ventilatoria a grandes altitudes J ohn T. R eves y J ohn V. W èl 37.2

E fectos fisiológicos de la reducción de la presión barométrica... Kenneth I. B erger y W illiam N. R om Aspectos sanitarios asociados al trabajo a grandes altitudes............... ohn B. W est Prevención de los peligros profesionales a grandes altitudes. . . . . . . . . . .W alter D ümmer M edida cautelar: muestreo del aire Kenneth I. B erger y W illiam N. R om

38. Riesgos biológicos

Zuheir I brahim Fakhri, Director del capítulo

R iesgos biológicos en el lugar de trabajo $\ldots \ldots \ldots \ldots \ldots \ldots \ldots \ldots \ldots$. $\ldots$ uheir I. F akhri A nimales acuáticos. 
39. Desastres naturales y tecnológicos Pier Alberto Bertazzi, Director del capítulo

Catástrofes y accidentes mayores Pier Alberto B ertazzi 39.2

Preparación para las catástrofes Peter I. Baxte

Actividades posteriores a las catástrofes. . B enedetto Terracini y U rsula Ackermann-L iebrich 39.15

Problemas relacionados con el clima. . J ean F rench 39.20 39.23

Avalanchas: riesgos y medidas de protección Gustav Poinstingl

Transporte de materiales peligrosos: sustancias químicas y radiactivas. . . . . . D onald M . Campbell

Salud en el trabajo y medidas de seguridad en áreas agrarias contaminadas por radionuclidos: la experiencia de Chernóbil . . . . . . . . . . . . . . . . . . . Yuri Kundiev, L eonard D obrovolsky y V. I. Chernyuk

Estudio de caso: el incendio de la fábrica de juguetes $K$ ader . . . . . . . . . C asey C avanaugh $G$ rant

Consecuencias de las catástrofes: lecciones desde una perspectiva médica . . . . . . J osé L uis Z eballos

40. Electricidad

Dominique Folliot, Directora del capítulo

Efectos fisiológicos de la electricidad $\ldots \ldots \ldots \ldots \ldots \ldots \ldots \ldots \ldots \ldots$. ominique Folliot

Electricidad estática . . . . . . . . . . . . . . . . . . . . . . . Claude M enguy

Prevención y normas

. Renzo Comini

41. Incendios

Casey C. G rant, Director del capítulo

Conceptos básicos. D ougal D rysdale

Fuentes de peligro de incendio. . Tamás B ánky

M edidas de prevención contra incendios ...................... Peter F. J ohnson

M edidas de protección pasiva contra incendios.

Yngve Anderberg

M edidas activas de protección contra incendios.

Gary Taylor

O rganización de la lucha contra incendios

42. Calor y frío

Jean-Jacques Vogt, Director del capítulo

Respuestas fisiológicas a la temperatura ambiente . . . . . . . . . . . . . W. L arry K enney

Efectos del estrés por calor y trabajo en ambientes calurosos. . . . . . . . . . . . . . B odil N ielsen

Trastornos producidos por el calor. Tokuo 0 gawa

Prevención del estrés por calor ......................... Sarah A. Nunneley

Fundamentos físicos del trabajo en condiciones de calor

J acques $M$ alchaire

Evaluación del estrés por calor e índices de estrés por calor.

Kenneth C. Parsons

Intercambio de calor a través de la ropa.

W outer A. L otens

Ambientes fríos y trabajo con frío . I Ingvar H ol mér, Per-O la G ranberg y G oran D ahl strom

Prevención del estrés por frío en condiciones extremas al aire libre . . . . . . . . . . . . . . . . . . . . . . . . acques B ittel y G ustave Savourey

43. H oras de trabajo

Peter Knauth, Director del capítulo

H oras de trabajo Peter Knauth

44. Calidad del aire interior

Xavier G uardino Solá, Director del capítulo

Calidad del aire interior: introducción

X avier Guardino Sol

$N$ aturaleza y fuentes de los contaminantes químicos en el interior D errick Crump

Radón . M aría J osé B erenguer 
Regulación del consumo de tabaco

X avier Guardino Solá

44.16

Determinación y valoración de los contaminantes químicos

M. Gracia R osell Farrás 44.17

Contaminación biológica

B Bian Flannigan 44.22

Reglamentos, recomendaciones, normas y patrones

M aría J osé B erenguer 44.28

45. Control ambiental en interiores Juan Guasch Farrás, Director del capítulo

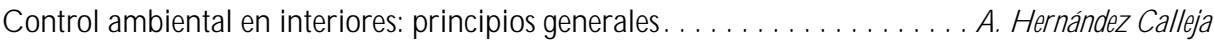

El aire en interiores: métodos de control y depuración .... . . E. A dán L iébana y A. H ernández Calleja 45.2

O bjetivos y principios de la ventilación general y de la ventilación de dilución . . . . E milio Castejón 45.11

Criterios de ventilación para edificios no industriales. . . . . . . . . . . . . . . H ernández Calleja 45.14

Sistemas de cal efacción y aire acondicionado . . . . . . . . . . . . F. R amos Pérez y J. Guasch F arrás 45.18

El aire en interiores: ionización . . . . . . . . . . . . . . . . . . . E. A dán Liébana y J. Guasch F arrás 45.24

46. Iluminación

Juan G uasch Farrás, Director del capítulo

Tipos de lamparas e iluminación.

Condiciones necesarias para el confort visual ....... F Fernando R amos Pérez y A na $\mathrm{H}$ ernández Calleja

Condiciones de la iluminación general

N. Alan Smith

47. Ruido

Alice H . Suter, Directora del capítulo

Naturaleza y efectos del ruido Alice H. Suter 47.2

M edición del ruido y evaluación de la exposición. . . E duard I. D enisov y German A. Suvorov 47.6

T écnicas de control del ruido D ennis P. D riscoll

Programas de conservación de la audición Larry H. R oyster y J ulia D oswell R oyster

Normas y reglamentaciones.

Alice H. Suter

48. Radiaciones ionizantes

Robert N. Cherry, Jr., Director del capítulo

Introducción R obert N. Cherry, J r. 48.2

Biología radiológica y efectos biológicos. . Arthur C. U pton 48.4

Fuentes de radiación ionizante. Robert N. Cherry, I r. 48.11

Diseño de puestos de trabajo para seguridad radiológica. . Gordon M. Lodde 48.18

Seguridad radiológica. Robert N. Cherry, J r. 48.26

Planificación de medidas y gestión de accidentes radiológicos. Sydney W. Porter, J r. 48.34

49. Radiaciones no ionizantes

Bengt Knave, Director del capítulo

Campos eléctricos y magnéticos y consecuencias para la salud . Bengt Knave 49.2

El espectro electromagnético: características físicas básicas. Kjell $\mathrm{H}$ ansson M ild 49.4

R adiación ultravioleta. David $H$. Sliney 49.6

R adiación infrarroja. . R. M atthes 49.10

Luz y radiación infrarroja. David $H$. Sliney 49.14

Láseres. David $H$. Sliney

Campos de radiofrecuencia y microondas.

. Kjell $\mathrm{H}$ ansson $\mathrm{M}$ ild

Campos eléctricos y magnéticos de V LF y ELF

M ichae H. R epacholi

Campos eléctricos y magnéticos estáticos

$\mathrm{M}$ artino $\mathrm{G}$ randolfo

50. Vibraciones

Michael J. G riffin, Director del capítulo

Vibraciones. M ichael J. Griffin 50.2

Vibraciones de cuerpo completo H elmut Seide y M ichad I. Griffin 50.3 
Vibraciones transmitidas a las manos . . . . . . . . . . . . . . . . . M assimo B ovenzi 50.8

M areo inducido por el movimiento

Alan J. B enson 50.14

51. Violencia

Leon J. Warshaw, Director del capítulo

L a violencia en el lugar de trabajo L eon J. W arshaw

52. Pantallas de visualización de datos

Diane Berthelette, Directora del capítulo

Visión general D iane B erthelette 52.2

Características de los puestos de trabajo con pantallas de visualización de datos. . . . A Ahmet Çakir 52.4 Problemas oculares y visuales. . . . . . . . . . . . . . . . . . . Paule R ey y J ean-J acques $M$ eyer 52.11 R iesgos para la reproducción: datos experimentales . . . . . . . . . . . . . . . . . U If B ergqvist 52.15

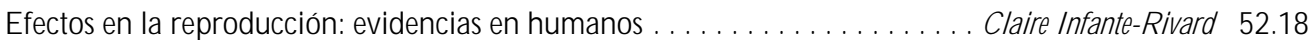

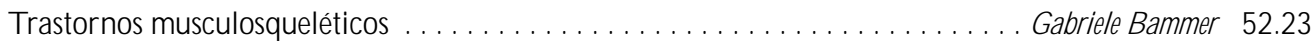

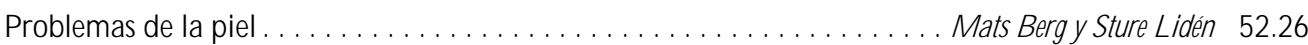

A spectos psicosociales del trabajo con PVD . . . . . . . . . . . M ichad J. Smith y Pascale C arayon 52.26

A spectos ergonómicos de la interacción ordenador/ hombre . . . . . . . . . . . ean-M arc R obert 52.31

Normas ergonómicas . . . . . . . . . . . . . . . . . . . . . . . . . . . . Tom F. M . Stewart 52.35

\section{PARTE VII. EL MEDIO AMBIENTE}

\section{Riesgos ambientales para la salud}

\section{Annalee Yassi y Tord Kjellström,} Directores del capítulo

Conexiones entre la salud ambiental y la salud en el trabajo. Annale Yassi y Tord Kjellström 53.2 La alimentación y la agricultura. . . . . . . . . . . . . . . . . . . . . . . F riedrich $K$. Käferstén

La contaminación industrial en los países en desarrollo . Niu Shiru 53.9

Los países en desarrollo y la contaminación. TeL. Guidotti

La contaminación del aire. I sabelle R omieu 53.11

La contaminación del suelo . Te L. Guidotti y Chen W eiping 53.14

La contaminación del agua . . I vanildo $\mathrm{H}$ espanhol y Richard $\mathrm{H}$ elmer 53.18

L a energía y la salud . L. D. H amilton

La urbanización E dmundo W erna

El cambio climático mundial y el agotamiento del ozono . . . . . . . . . . . . . . onathan A. Patz 53.27 La extinción de especies, la pérdida de diversidad biológica y la salud humana. . . . . . E ric C hivian 53.32

54. Política en materia de medio ambiente Larry R. Kohler, Director del capítulo

Panorama: la salud y la seguridad en el trabajo y el medio ambiente: dos caras de la misma moneda . . . . . . . . . . . . . . . . . . . . Larry R. Kohler 54.2

El medio ambiente y el mundo del trabajo: un concepto integral del desarrollo sostenible, el medio ambiente y el medio ambiente de trabajo . . . . . L L arry R. Kohler 54.2

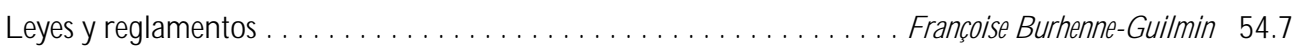

Convenios internacionales sobre el medio ambiente. . . . . . . . . . . . . . . D avid F reestone 54.10

Evaluaciones de impacto ambiental . . . . . . . . . . . . . . . . . . . . . . . . . R on Bisset 54.15

Evaluación del ciclo vital (de la cuna a la tumba). . . . . . . . . . . . . . . . . Sven-0 lof Ryding 54.18

Evaluación y comunicación de riesgos. . . . . . . . . . . . . . . . . Adrian V. G heorghe y H ansjörg Seiler 54.24

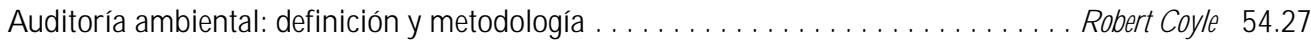

Estrategias de gestión del medio ambiente y protección de los trabajadores. . . . . . . C ecilia B righi 54.30

Control de la contaminación ambiental: la prevención de la contaminación como objetivo prioritario de la empresa. . . . . . . . . . . . . . . . . . . . . Robert P. B ringer y Tom Z osel 54.34 


\section{Control de la contaminación ambiental}

\section{Jerry Spiegel y Lucien Y. Maystre,} Directores del capítulo

Control y prevención de la contaminación ambiental J erry Spiegel y L ucien Y. M aystre 55.2

G estión de la contaminación atmosférica. Dietrich Schw ela y B erenice G odzer 55.3

Contaminación atmosférica: modelos de dispersión de contaminantes atmosféricos M arion W ichmann-Fiebig 55.8

V igilancia de la calidad atmosférica ................. ans-U Irich P feffer y Peter B ruckmann

Control de la contaminación atmosférica......................... ohn E lias

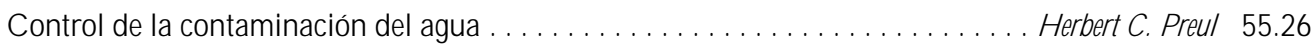

Proyecto de regeneración de aguas residuales en la R egión de Dan:

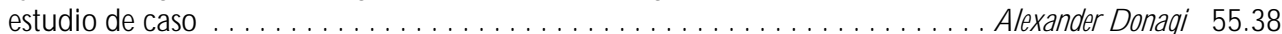

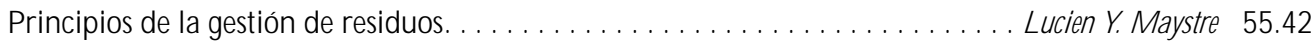

G estión y reciclado de residuos sólidos. ................ Niels J orn H ahn y Poul S. Lauridsen 55.44

Estudio de caso: control y prevención de la contaminación de

los G randes Lagos de Canadá ............... T homas T seng, Victor Shantora el an R. Smith 55.46

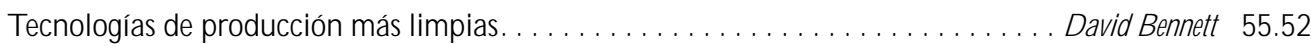

\section{PARTE VIII. ACCIDENTES Y GESTION DE LA SEGURIDAD}

\section{Prevención de accidentes}

Jorma Saari, D irector del capítulo

Introducción J orma Saari 56.2

Conceptos del análisis de accidentes . Kirsten J ørgensen 56.3

Teoría de las causas de los accidentes Abdul Raouf 56.6

Factores humanos en los modelos de accidentes. . Anne M arie Feyer y Ann M. W illiamson

M odelos de accidentes: homeostasis del riesgo Gerald J. S. W ilde 56.11

M odelos de accidentes Andrew R. H ale 56.14

M odelos de secuencia de accidentes . Ragnar Andersson 56.18

M odelos de desviación de accidentes . U rban Kjellén 56.22

EI M AIM : modelo de información de accidentes de M erseyside ... H arry S. Shannon y J ohn Davies 56.24

Principios de la prevención: el planteamiento de la sanidad pública respecto a la reducción de las lesiones en el lugar de trabajo ... Gordon S. Smith y M ark A. Veazie 56.28 Principios teóricos de la seguridad en el trabajo . . . . . . . . . . . . . . . . . . . R énald Skiba 56.34 Principios de prevención: información sobre seguridad . . . . . . . . M ark R. L ehto y J ames M . M iller 56.37 Costes de los accidentes relacionados con el trabajo . . . . . . . . . . . . . . . . . . D iego Andreoni 56.42

57. Auditorías, inspecciones e investigaciones Jorma Saari, D irector del capítulo Auditorías de seguridad y de gestión J ohan Van de Kerckhove 57.2

A nálisis de riesgos: el modelo de causalidad de accidentes. .J op G roeneweg 57.7

$\mathrm{R}$ iesgos de los equipos Carsten D. G roenberg 57.13

A nálisis de riesgos: factores organizativos-M O RT U U rban Kjellén 57.19

Inspección en el lugar de trabajo y aplicación normativa. . Anthony Linehan

A nálisis y presentación de informes: investigación de accidentes ................. M onteau 57.24

Comunicación y recopilación de estadísticas sobre accidentes Kirsten J orgensen

\section{Aplicaciones de la seguridad}

\section{Kenneth G erecke y Charles T. Pope, Directores del capítulo}

A nálisis de sistemas. M anh Trung H $\mathrm{O} \quad 58.2$

Seguridad de las herramientas portátiles y de mano ......... D epartamento de Trabajo de E E .U U. 0 ccupational Safety and $\mathrm{H}$ ealth Administration; dirigido por K enneth Gerecke 58.5 
Partes móviles de máquinas .

. Tomas B ackström y M arianne D öos

58.8

D efensas de máquinas

D epartamento de T rabajo de la 0 ccupational Safety and $\mathrm{H}$ ealth Administration; dirigido por Kenneth Gerecke 58.12

D etectores de presencia Paul Schreiber 58.24

D ispositivos para controlar, aislar y conmutar energía René T roxler 58.29

A plicaciones relacionadas con la seguridad. . D ietmar R einert y Karlheinz M effert 58.32

Software y ordenadores: sistemas híbridos automatizados. . . . . W aldemar Karw ow ski y J ozef Zurada 58.37

Principios del diseño de sistemas de control seguros. G eorg Vondracek

Principios de seguridad para máquinas herramienta C NC Toni R esch, Guido Schmitter y Albert M arty 58.51

Principios de seguridad para robots industriales Toni R esch, Guido Schmitter y Albert M arty 58.59 Sistemas de control de seguridad eléctricos, electrónicos y programables . . . . . . . . . R on Bell 58.62

R equisitos técnicos para sistemas relacionados con la seguridad basados en dispositivos eléctricos, electrónicos y programables. . . . . . . . . . . . ohn B razendaley $R$ on $B$ ell 58.67

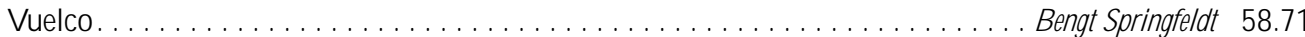

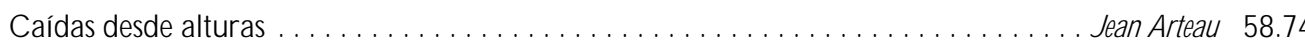

Espacios confinados . . . . . . . . . . . . . . . . . . . . . . . . . . eil M cM anus 58.77

Principios de la prevención: manipulación de materiales y tráfico interno . . . . . . Kari H äkkinen 58.82

59. Política de seguridad y liderazgo Jorma Saari, D irector del capítulo

Política de seguridad, liderazgo y cultura $\ldots \ldots \ldots \ldots \ldots \ldots \ldots$. . . . . . . . . . . D an Petersen 59.2

C ultura y gestión de la seguridad . . . . . . . . . . . . . . . . . . . . . . . . . . . . . . . arce Simard 59.4

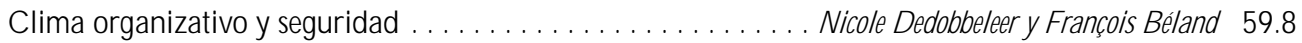

Proceso participativo de mejora del lugar de trabajo . . . . . . . . . . . . . . . . orma Saari 59.12

M étodos de toma de decisiones en el campo de la seguridad . . . . . . . . . . . . . . . . Terje Sten 59.19

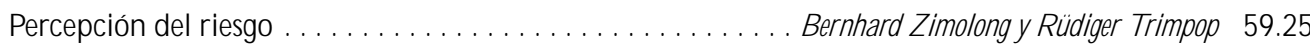

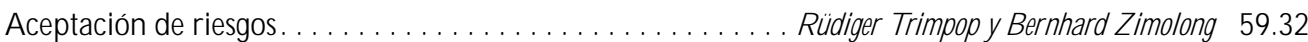

60. Programas de seguridad

Jorma Saari, D irector del capítulo

Investigación de la seguridad en el trabajo: panorama general . . . . . . . . . . . . . . . . . . . . . . . . . . . erbert I. L inn y Alfred A. A mendola 60.2

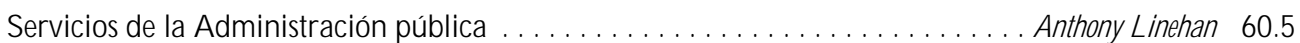

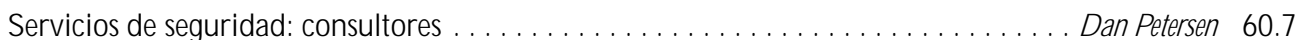

Ejecución de un programa de seguridad . . . . . . . . . . . . . . . . . . . . . . . . Tom B. L eamon 60.11

El éxito en los programas de seguridad. . . . . . . . . . . . . . . . . . . . . Tom B. L eamon 60.13

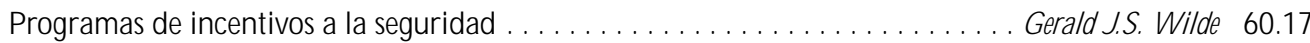

Promoción de la seguridad . . . . . . . . . . . . . . . . . . . . . . T homas W. Planek 60.20

Estudio de caso: campañas nacionales de salud y seguridad

en el trabajo en la India ....................................... C. G upta 60.28

PARTE IX. PRODUCTOS QUIMICOS

61. Utilización, almacenamiento y transporte de productos químicos

Jeanne Mager Stellman y Debra 0 sinsky, Directoras del capítulo

Seguridad en la manipulación y la utilización de productos químicos

Sistemas de clasificación y etiquetado para

productos químicos

Konstantin K. Sidorov e I gor V. Sanotskiy

Seguridad en la manipulación y el almacenamiento de productos químicos

A. E. Quinn

61.11 
Gases comprimidos: manipulación, almacenamiento y transporte .. A. T ürkdogan y K. R. M athisen 61.14

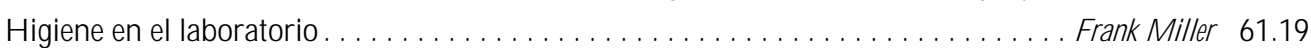

M étodos para el control localizado de contaminantes atmosféricos. . . . . . . . . L ouis D iB ernardinis 61.23

EI sistema de información química GEST IS: estudio de caso . . . . . Karlheinz M effert y R oger Stamm 61.27

62. Minerales y productos químicos para la agricultura Debra 0 sindky y Jeanne Mager Stellman, D irectoras del capítulo

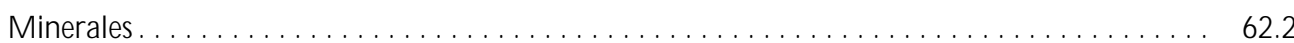

Productos químicos para la agricultura $\ldots \ldots \ldots \ldots \ldots \ldots \ldots \ldots \ldots \ldots \ldots \ldots \ldots$ ary A. Page 62.7

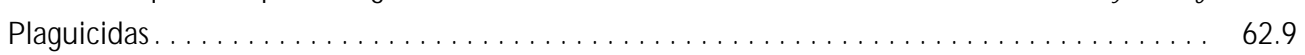

Directrices de la O M S para la clasificación de los plaguicidas según el riesgo . . . . . . . . . 62.18

63. Metales: propiedades químicas y toxicidad G unnar Nordberg,

Director del capítulo

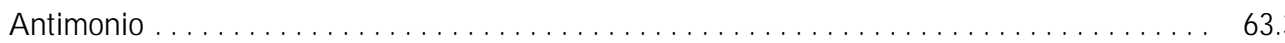

A rsénico ................................... Gunnar N ordberg 63.5

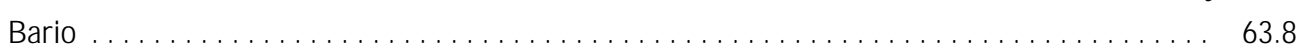

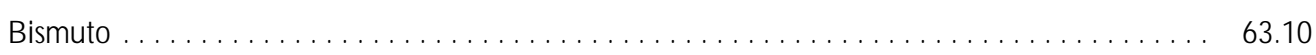

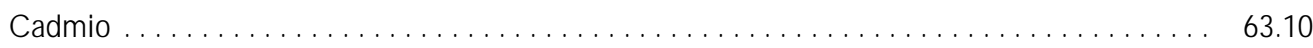

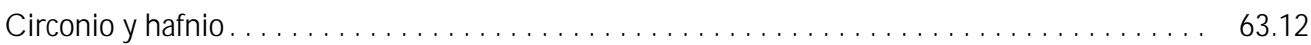

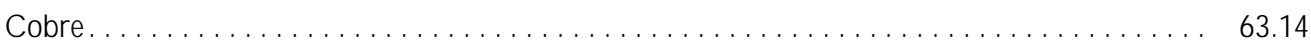

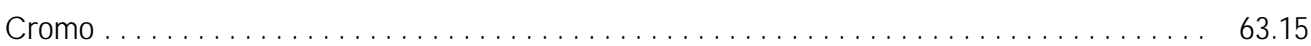

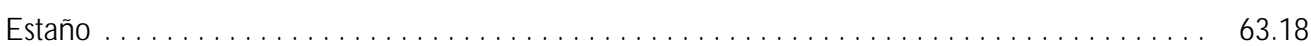

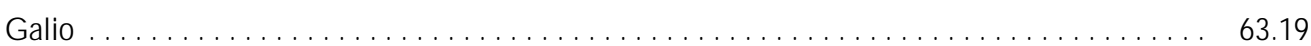

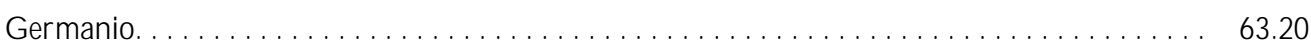

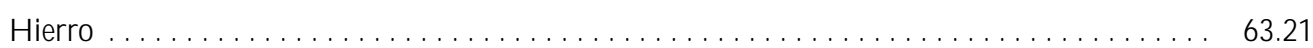

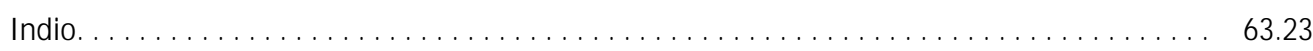

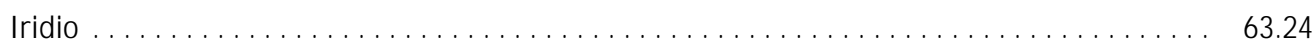

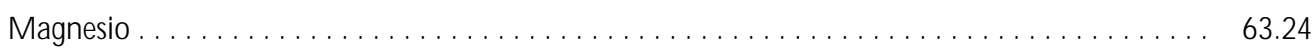

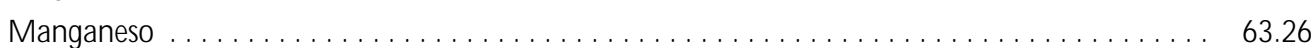

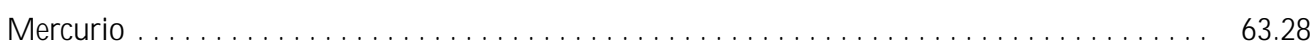

M etalcarbonilos (en especial, níquel carbonilo) . . . . . . . . . . . . . . F. W illiam Sunderman, J r. 63.31

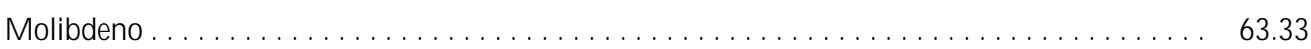

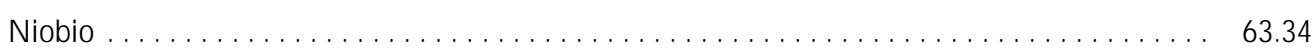

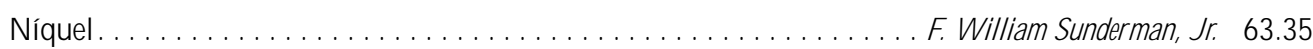

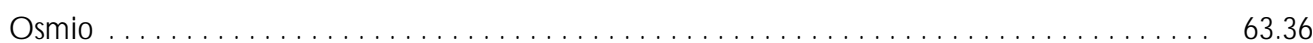

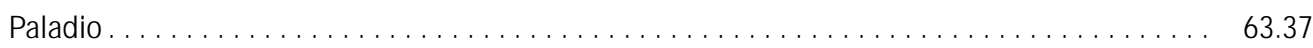

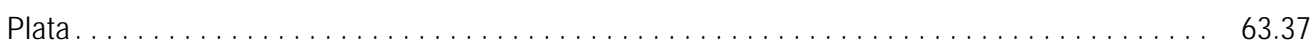

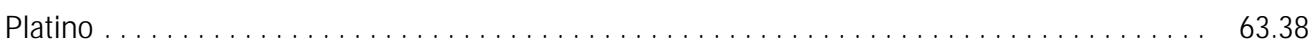

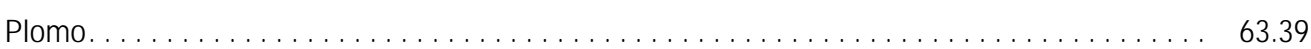

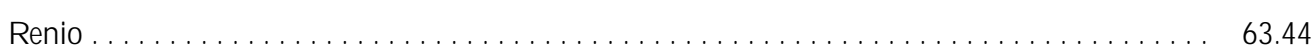

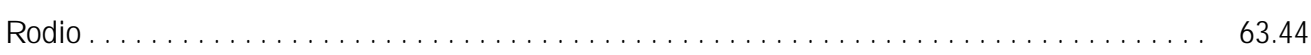

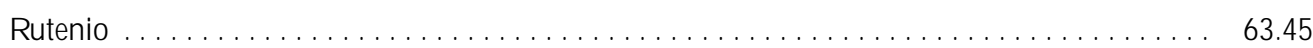

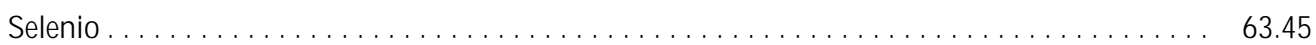

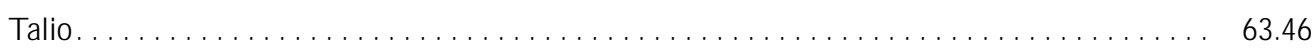

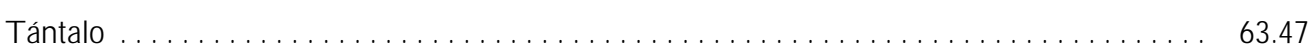

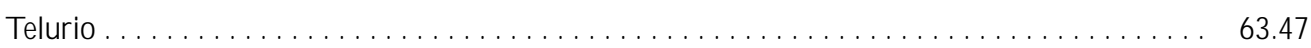

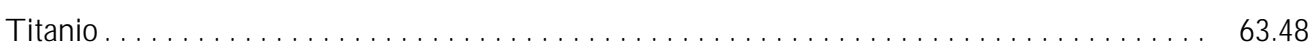




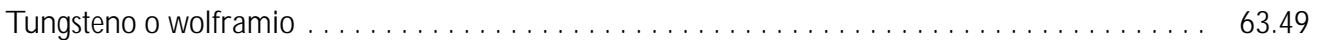

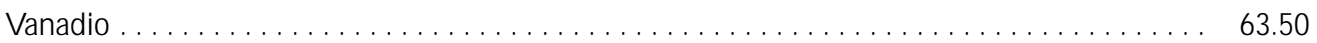

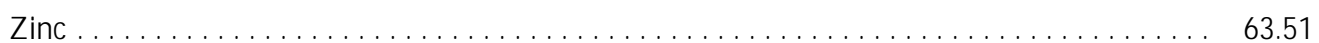




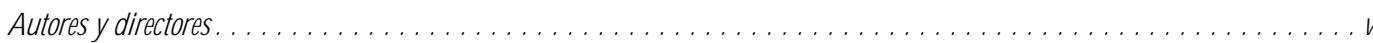

\section{Agricultura y sectores basados en recursos naturales}

Melvin L. Myers Director del capítulo

Perfil general M elvin L. M yers 64.2

Explotaciones familiares. Ted Scharf, D avid E. Baker y J oyce Salg 64.4

SISTEM AS AGRICOLAS

Plantaciones . . . M elvin L. M yers el.T. Cabrera 64.5

Trabajadores agrícolas migrantes y temporeros ................... M arc B. Schenker 64.8

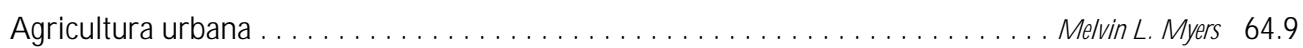

O peraciones en viveros e invernaderos . . . . . . . . . . . . . M ark M. M ethner y J ohn A. M iles 64.11

Floricultura . . . . . . . . . . . . . . . . . 64.14

E ducación de los trabajadores agrícolas sobre los plaguicidas: estudio de un caso . . . M erri W einger 64.16

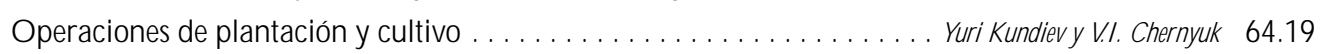

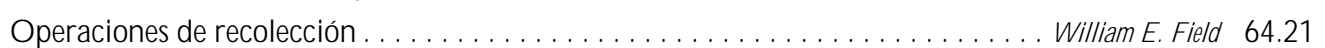

O peraciones de almacenamiento y transporte . . . . . . . . . . . . . . . . Thomas L. B ean 64.23

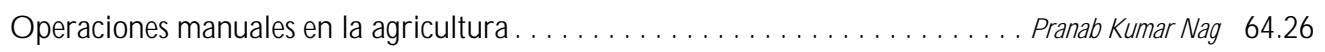

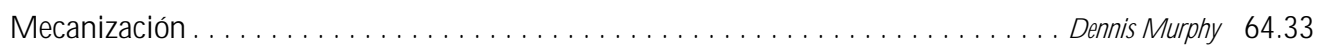

M aquinaria agrícola ................................ Knapp, J r. 64.35

CULTIVO DE ALIMENTOSY FIBRAS

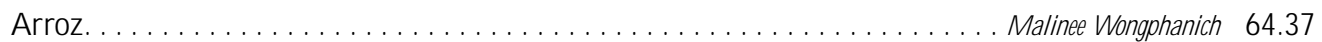

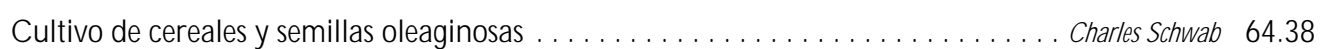

Cultivo y transformación de la caña de azucar . . . . . . . . . . . . . . . . R.A. M uñoz, E.A. Suchman,

J.M. Baztarrica y Carol J. Lehtola 64.40

Recolección de la patata . . . . . . . . . . . . . . . . . . . . . . . . . . Steven B. J ohnson 64.41

H ortalizas y melones. . . . . . . . . . . . . . . . . . . . . . . . . . . . . . . X u y Toshio M atsushita 64.42

CULTIVO DE ARBOLES, ZARZASY VIDES

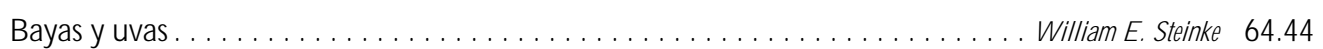

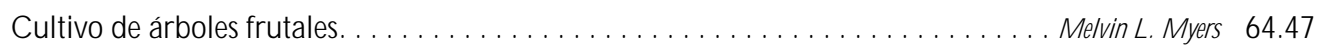

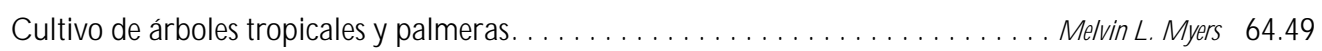

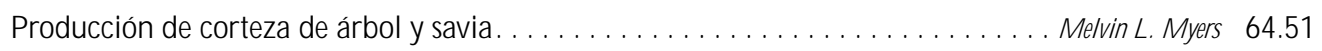

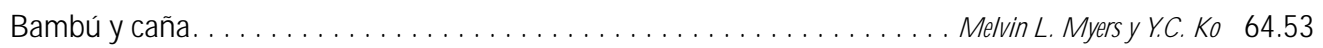

CULTIVOS ESPECIALES

Cultivo de tabaco . . . . . . . . . . . . . . . . . . . . . . . . . Gerald F. Peedin 64.54

Ginseng, menta y otras hierbas culinarias y medicinales . . . . . . . . . . . L arry J. Chapman 64.58

Setas .............................................D. Van Griensven 64.60

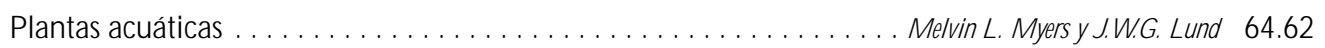


CULTIVO DE PLANTAS PARA LA PRODUCCION DE BEBIDAS

Cultivo de café. . . . . . . . . . . . . . . . . . . . . . orge da R ocha $G$ omes y B ernardo B edrikow 64.63

Cultivo de té $\ldots \ldots \ldots \ldots \ldots \ldots \ldots \ldots \ldots \ldots \ldots \ldots \ldots \ldots \ldots \ldots \ldots \ldots \ldots \ldots \ldots$. . . Fernando 64.66

Lúpulo. . T homas Karsky y W illiam B. Symons

CUESTIONES DE SALUD Y AMBIENTALES

Problemas de salud y pautas patológicas en la agricultura . . . . . . . . . . . . . . . . . M elvin L. M yers 64.68 Agromedicina . . . . . . . . . . . . . . . . . . . . . . . . . . . . . . . . Stanley H. Schuman y J ere A. B rittain 64.69

C uestiones ambientales y de salud pública en la agricultura . . . . . . . . . . . . . M elvin L. M yers 64.73

65. Industria de las bebidas Lance A. Ward, Director del capítulo

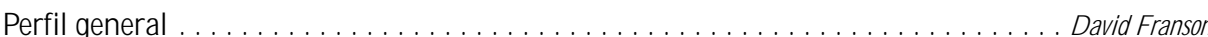

Fabricación de concentrados de bebidas refrescantes . . . . . . . . . . . . . . . . . Z aida Colon

E mbotellado y envasado de bebidas refrescantes. . . . . . . . . . . . . . . . . . . . M atthew H irsheimer

Industria del café $\ldots \ldots \ldots \ldots \ldots \ldots \ldots \ldots$. . . . . . . . . . . . . . $R$ ocha $G$ omes y B ernardo $B$ edrikow Lou Piombino

Industria del té

R.G. Aldi y Rita Seguin

Industria de licores destilados

. Alvaro Durao

Industria del vino

. J.F. E ustace

Industria de la cerveza

Lance A. W ard

C uestiones ambientales y de salud pública

66. Pesca

H ulda Ó lafsdóttir y Vilhjálmur Rafnsson, D irectores del capítulo

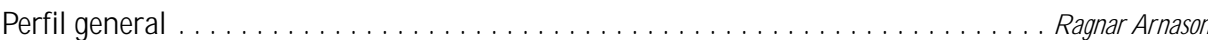

Principales sectores y procesos. . . . . . . . . . . . . . . . . . . . . . . H jálmar R. B árdarson 66.2

Características psicosociales de los trabajadores en el mar E va $M$ unk-M adsen 66.6

C aracterísticas psicosociales de los trabajadores del mar dedicados al procesamiento del pescado en tierra . . . . . . . . . . . . . . . . . . . arit H usmo

E fectos sociales de la dependencia de una sola industria pesquera . . . . . . . . . . . . . B arbara $N$ eis

E fectos sobre la salud y pautas patológicas. . . . . . . . . . . . . . . . . . Vilhjálmur R afnsson

A fecciones musculosqueléticas: pesca y procesamiento de pescado . . . . . . . . . . . H ulda Ólafsdóttir

Pesquerías comerciales: medio ambiente y sanidad pública. . . . . . . . . . B ruce M cKay y Kieran M ulvaney

\section{Industria alimentaria}

\section{Deborah E. Berkowitz, Directora del capítulo}

VISION GENERAL Y EFECTOS SOBRE LA SALUD

Procesos de la industria alimentaria . . . . . . . . . . . M. M alagié, G. J ensen, J.C. Grahamy D onald L. Smith

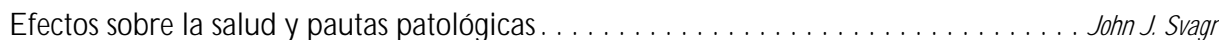

Protección ambiental y cuestiones de salud pública.

. J erry Spiegel

\section{SECTORES DE LA PRODUCCION ALIMENTARIA}

Industria cárnica. . . . . . . . . . . . . . . . . . . . . . . . . . D eborah E. B erkowitz y M ichael J. Fagel 67.16

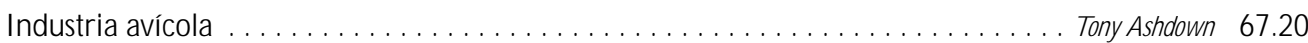

Industria láctea . . . . . . . . . . . . . . . . . . . . . . . . . . . . M arianne Smukowski y N orman B rusk 67.26

Producción de cacao e industria del chocolate . . . . . . . . . . . . . . . A Anaide Vilasboas de Andrade 67.27

Cereales, elaboración de cereales y productos de consumo basados

en cereales. . . . . . . . . . . . . . . . . . . . . . . Tomas E. H awkinson, J ames J. Collins y Gary W. O Imstead 67.28

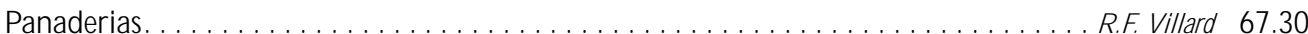


Industria de la remolacha azucarera . . . . . . . . . . . . . . . . . . . . . . . . . Carol J. Lentola 67.32

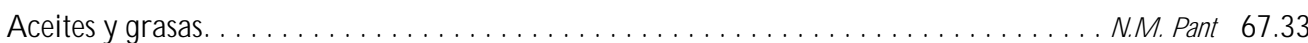

68. Industria forestal

Peter Poschen, Director del capítulo

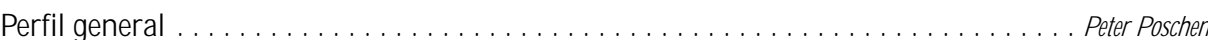

A provechamiento maderero $\ldots \ldots \ldots \ldots \ldots \ldots \ldots \ldots \ldots$. . ennis D ykstra y Peter Poschen

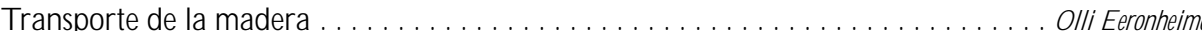

A provechamiento de productos forestales no madereros . . . . . . . . . . . . . . . . . . R Rudolf H einrich 68.14

Plantación de árboles . . . . . . . . . . . . . . . . . . . . . . . . . . . . . . . D enis Giguère 68.15

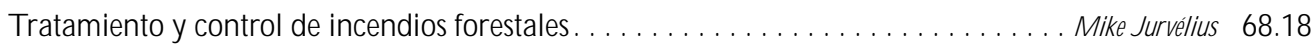

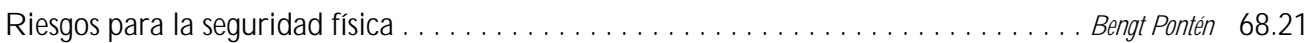

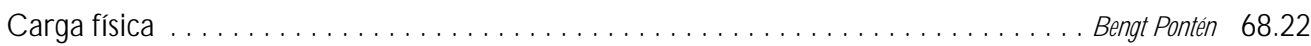

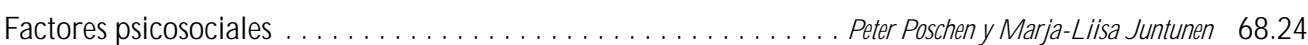

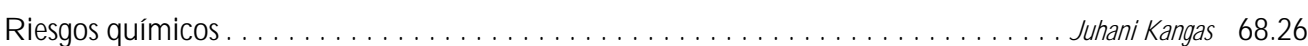

R iesgos biológicos entre los trabajadores forestales . . . . . . . . . . . . . . . . . . . . A ugusta 68.28

N ormas, legislación, disposiciones y recomendaciones . . . . . . . . . . . . . . . . 0 thmar W ettmann 68.28

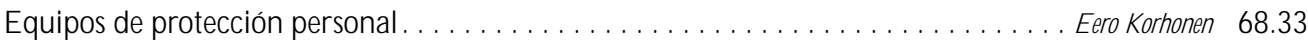

Condiciones de trabajo y seguridad en el trabajo forestal . . . . . . . . . L L ucie L aflamme y E sther Cloutier 68.36

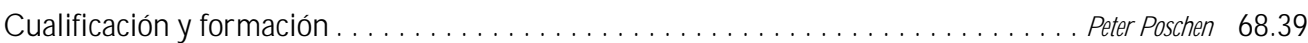

Condiciones de vida. . . . . . . . . . . . . . . . . . . . . . . . . . . . . . . . . . Elias Apud 68.40

Problemas para la salud del medio ambiente. . . . . . . . . . . . . . . . . . . . . Shane M cM ahon 68.42

69. Caza

George A. Conway, Director del capítulo

Un perfil de la caza y de la caza con cepo en el decenio de $1990 \ldots \ldots \ldots \ldots \ldots$. . . . . . . ohn N. Trent 69.2

Enfermedades asociadas con la caza y la caza con cepo. . . . . . . . . . . . . . . . . M ary E. B rown 69.4

\section{G anadería y cría de animales}

Melvin L. Myers, Director del capítulo

Ganadería: ámbito y efectos sobre la salud. . . . . . . . . . . . . . . . . . . . . . . M dvin L. M yers

Problemas de salud y pautas patológicas . ............. Kendall T hu, Craig Z werling y K elley D onham

Problemas de salud en el trabajo relacionados con los artrópodos. . . . . . . . . . . . . D onald B arnard

Cultivos forrajeros . . . . . . . . . . . . . . . . . . . . . . . . . . . . . L orann Stallones

Confinamiento del ganado

. Kelley D onham

Cría de animales domésticos . . . . . . . . . . . . . . . . . . . . D ean T. Stueland y Paul D. G underson

Comportamiento de los animales. . . . . . . . . . . . . . . . . . . . . . . . . D avid L. H ard

Gestión del estiercol y de los excrementos . . . . . . . . . . . . . . . . . . . . W illiam Popendorf

L ista de comprobación de las prácticas de seguridad de la ganadería . .......... M evin L. M yers

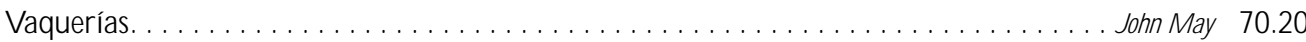

Vacuno, ovino y caprino . . . . . . . . . . . . . . . . . . . . . . . . . . . M dvin L. M yers 70.22

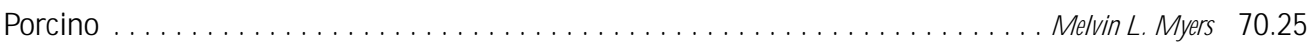

Producción de aves de corral y de huevos. . . . . . . . . . . . . . . . . . . . Steven W. Lenhart 70.26

Captura, enjaulado y sacrificio de las aves de corral . . . . . . . . . . . . . . Tony Ashdown 70.28

Caballosy otros équidos. . . . . . . . . . . . . . . . . . . . . . . . . . . . L ynn B arroby 70.30

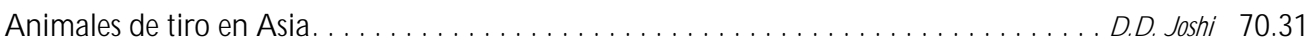

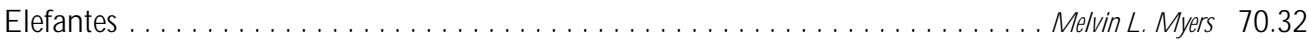

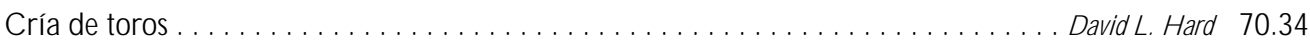

Producción de animales de compañía, de peleteria y de laboratorio . . . . . . . Christian E. Newcomer 70.36 
Piscifactorias y acuicultura . George A. Conway y R ay RaL onde

A picultura, cría de insectos y producción de seda. . M elvin L. M yers y D onald B arnard

71. Industria de la madera Paul Demers y Kay Teschke, Directores del capítulo

Perfil general

. Paul D emers

Principales sectores y procesos: riesgos profesionales y controles. H ugh D avies, Paul D emers, T imo Kauppinen y Kay Teschke 71.4

Lesiones y enfermedades ... Paul D emers 71.10

Cuestiones ambientales y de salud pública.

Kay Teschke y Anya Keefe

72. Industria del papel y de la pasta de papel

\section{Kay Teschke y Paul Demers, Directores del capítulo}

Perfil general

Kay Teschke

PRINCIPALES SECTORES Y PROCESOS

Fuentes de fibra para la fabricación de pasta y de papel . . . . . . . . . . . . . Anya Kefe y Kay Teschke

M anipulación de la madera . Anya Keefey Kay Teschke

Elaboración de la pasta . . Anya K efe, G eorge A strakianakis y J udith Anderson

Blanqueo . G eorge A strakianakis y J udith Anderson 72.8

Fábricas de papel reciclado . Dick H eederik

Producción de papel y transformados: pasta papelera, papel, y cartón G eorge A strakianakis yJ udith Anderson 72.9

Generación de energía y tratamiento de las aguas . G eorge A strakianakis y ] udith Anderson 72.11

Producción de productos químicos y de subproductos. . G eorge A strakianakis y J udith Anderson 72.11

R iesgos profesionales y controles Kay Teschke, G eorge Astrakianakis, J udith Anderson, Anya Keefe y Dick H eederik

PAUTAS DE ENFERMEDADES Y LESIONES

L esiones y enfer medades no malignas . . . . . . . . . . . . . . . . . . . . . . Susan Kennedy y Kjell Torén

Cáncer Kjell Torén y Kay Teschke

Cuestiones de salud pública y ambiental Anya Kefey Kay Teschke

\section{PARTE XI. INDUSTRIAS BASADAS EN RECURSOS NATURALES}

73. Hierro y acero

La industria del hierro y el acero

Trenes de laminación.

Problemas y pautas de seguridad y salud.

Cuestiones ambientales y de salud pública
Augustine Moffit, Directora del capítulo . ohn M asaitis 73.2

74. Minas y canteras James Armstrong y Raji Menon, Directores del capítulo

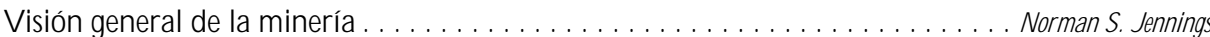
Prospección. . . . . . . . . . . . . . . . . . . . . . . . . . . . . . . . . . W illiam S. M itchel y Courtney S. M itchell

T ipos de minería de carbón $\ldots \ldots \ldots \ldots \ldots \ldots \ldots \ldots \ldots \ldots \ldots \ldots \ldots \ldots \ldots \ldots \ldots \ldots \ldots \ldots \ldots$ red $\ldots \ldots$ H ermann

T écnicas de minería subterránea . . . . . . . . . . . . . . . . . . . . . . . . H ans $\mathrm{H}$ amrin

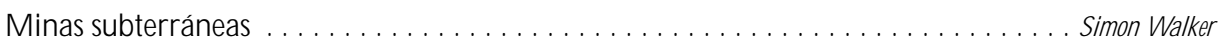

M inas a cielo abierto . . . . . . . . . . . . . . . . . . T homas A. H ethmon y Kyle B. D otson 74.2 
Procesamiento del mineral. . . . . . . . . . . . . . . . . . . . . . . Sydney Allison

Preparación del carbón . . . . . . . . . . . . . . . . . . . . . . Anthony D. W alters

Control del terreno en las minas subterráneas. . . . . . . . . . . . . . . . L L u B eauchamp

Ventilación y refrigeración en las minas subterráneas. . ................................ H owes 74.35

Iluminación en las minas subterráneas . . . . . . . . . . . . . . . . . . . . . . . . . . . . . . . . . D on Trotter 74.41

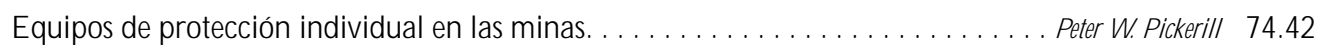

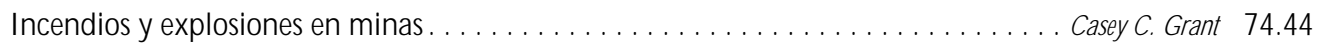

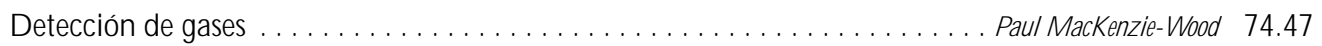

Preparación de emergencias . . . . . . . . . . . . . . . . . . . . . . . Gary A. Gibson 74.52

Peligros para la salud en la minería y las canteras. . . . . . . . . . . . . . . . . . . . ames L. W ekks 74.58

75. Petróleo: prospección y perforación Richard S. Kraus, Director del capítulo

Prospección, perforación y producción de petróleo y gas natural . ........... Richard $\mathrm{S}$. Kraus

76. Producción y distribución de energía eléctrica

\section{Michael Crane, Director del capítulo}

Perfil general M ichad Crane 76.2

Generación de energía hidroeléctrica.

. N eil M cM anus

Generación de energía a partir de combustibles fósiles

. Anthony W. J ackson

Generación de energía nuclear

W.G. M orison

Seguridad en la generación, transmisión y distribución de energía eléctrica:

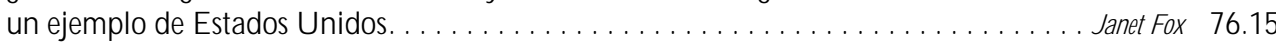

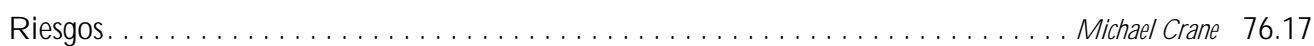

Problemas para la salud pública y el medio ambiente. . . . . . . . . . . . . . . . Alexander C. Pittman, 」 r. 76.17

PARTE XII. INDUSTRIAS QUIMICAS

77. Procesado químico

Jeanne Mager Stellman y Michael McC ann, Directores del capítulo

Industria química.

Elaboración de un programa de gestión de seguridad de procesos . ............ Richard $\mathrm{S}$. Kraus

O peraciones y actividades principales de las unidades de proceso: visión general . . . . Sydney Lipton

EJEM PLOS DE OPERACIONES DE TRATAMIENTO DE PRODUCTOS QUIMICOS

Producción de cloro y cáusticos . . . . . . . . . . . . . . . . . . . . . . . . . T he Chlorine Institute, Inc. 77.20

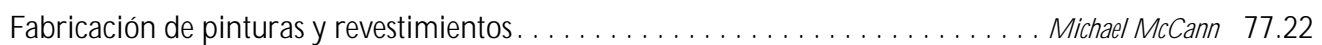

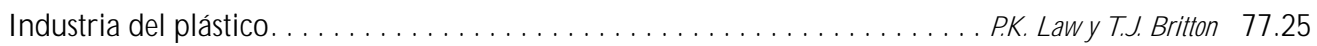

Industria de la biotecnología . . . . . . . . . . . . . . . . . . . . . . Susan B. Ley L inda B. W olfe 77.32

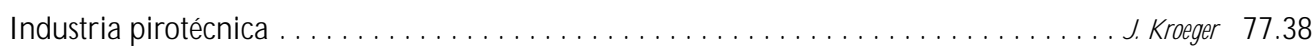

78. Petróleo y gas natural

Richard S. Kraus, Director de capítulo

Proceso de refino del petróleo Richard S. Kraus

79. Industria farmacéutica

Keith Tait, Director del capítulo

Industria farmacéutica Keith Tait 79.2

Efectos de los estrógenos sintéticos sobre los trabajadores de la industria

farmacéutica: un ejemplo de Estados U nidos 
80. Industria del caucho Louis S. Beliczky y John Fajen, Directores del capítulo

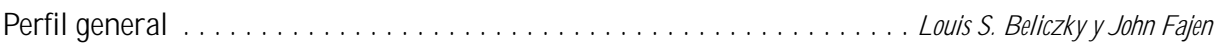

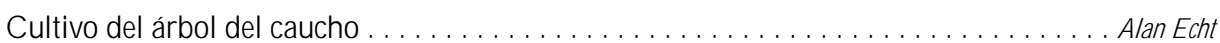

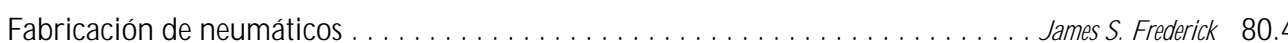

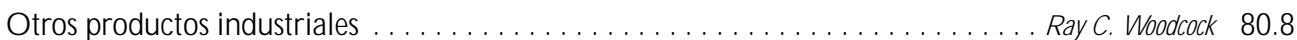

1,3-butadieno . . . . . . . . . . . . . . . . . . . . . . . . . . . . . . . . . . R . onald L. M elnick 80.9

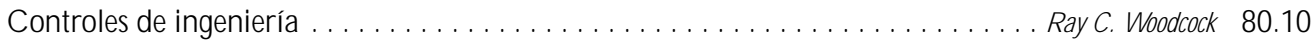

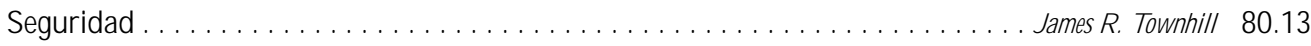

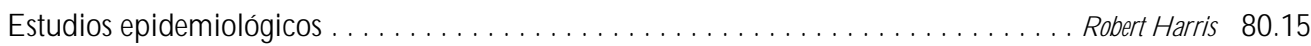

Dermatitis por contacto con caucho y alergia al látex. . . . . . . . . . . J ames $\mathrm{S}$. Taylor y Yung $H$ ian $L$ eow 80.16

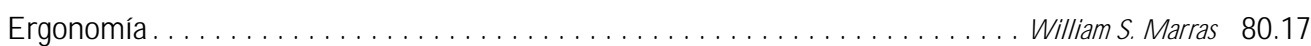

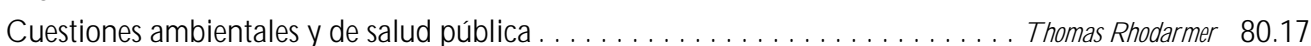

PARTE XIII. INDUSTRIAS MANUFACTURERAS

81. Aparatos y equipos eléctricos

N.A. Smith, Director del capítulo

Perfil general N. A. Smith 81.2

Fabricación de acumuladores de plomo $\ldots \ldots \ldots \ldots \ldots \ldots \ldots \ldots \ldots \ldots$ Barry P. Kelley 81.2

Pilas y baterías. N. A. Smith 81.4

Fabricación de cables eléctricos. . . . . . . . . . . . . . . . . . . . D avid A. 0 'M alley 81.8

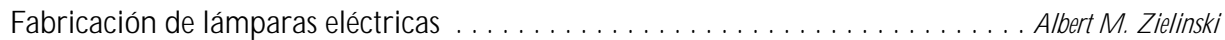
81.11

Fabricación de aparatos electrodomésticos..................... A. Smith y W. Klost 81.14

Cuestiones ambientales y de salud pública.

. N. A. Smith

\section{Metalurgia y metalistería}

Michael McCann, Director del capítulo

OPERACIONES DE FUNDICION Y AFINO

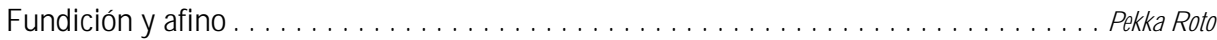

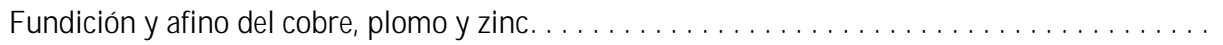

Fundición y afino del aluminio . . . . . . . . . . . . . . . . . . B ertram D. Dinman

Fundición y afino del oro

I.D. Gadaskina y L.A. Ryzik

METALURGIA Y METALISTERIA

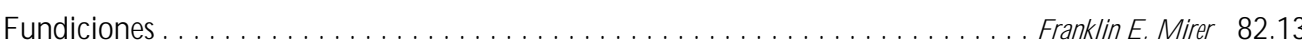

Forja y estampación . . . . . . . . . . . . . . . . . . . . . . . . . . . R obert M. Park 82.22

Soldadura y corte térmico . . . . . . . . . . . . . . . . . . . . . . . . . . Philip A. Platcow y G.S. Lyndon 82.25

Tornos . . . . . . . . . . . . . . . . . . . . . . . . . . . . . . . . . . . . . . . Toni Retsch 82.31

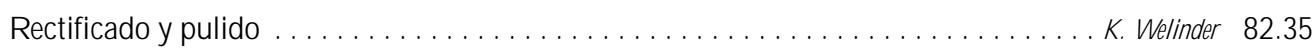

L ubricantes industriales, fluidos de mecanizado y aceites para automóviles. . . . . . Richard S. Kraus 82.37

M etales, tratamiento de superficie ........ J.G. J ones, J.R. B evan, J.A. Catton, A. Z ober, N. Fish, K.M . M orse, G. T homas, M .A. El Kadeem y Philip A. Platcow 82.42

Recuperación de metales .................. elvin E. Cassady y Richard D. Ringenwald, J r. 82.48

Cuestiones ambientales en el acabado de superficies metálicas y los

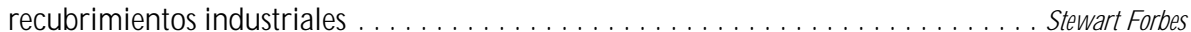


83. Microelectrónica y semiconductores Michael E. Williams, Director del capítulo Perfil general . ........................................... M ichad E. W illiams Fabricación de semiconductores de silicio .... . . . . . D avid G. B aldwin, J ames R. R ubin y Afsaneh $G$ erami Indicadores de cristal líquido . . . . . . . . . . . . . . D avid $G$. B aldwin, J ames $R$. R ubin y Afsaneh $G$ erami Fabricación de semiconductores III-V . . . . . . . . . . D avid G. B aldwin, Afsaneh $G$ erami y J ames R. Rubin Instalación de placas de circuito impreso y ordenadores . . . . . . . . . . . . M ichael E. W illiams Efectos sobre la salud y pautas patológicas .............................. D onald V. Lassiter Cuestiones ambientales y de salud pública. . . . . . . . . . . . . . . . . . Corky Chew

84. Vidrio, cerámica y materiales afines Joel Bender y Jonathan P. H ellerstein, Directores del capítulo

Vidrio, cerámica y materiales afines . I onathan P. H ellerstein, J oel B ender J ohn $G$. H adley y Charles M. H ohman

Fibras ópticas George R. O sborne

Piedras preciosas sintéticas. Basil Dolphin

\section{Industria de las artes gráficas, fotografía y reproducción}

Artes gráficas y publicación

David Richardson, Director del capítulo Características generales . . . . . . . . . . . . . . . . . . . . . . . . . D avid Richardson Servicios de reproducción y duplicación $\ldots \ldots \ldots \ldots \ldots \ldots \ldots \ldots \ldots \ldots$ obert W. Kilpper Efectos sobre la salud y pautas patológicas ........................... Barry $R$. F riedlander Descripción general de riesgos para el medio ambiente . . . . . . . . . . . . . . D aniel R. E nglish Laboratorios fotográficos comerciales. David Richardson

86. Carpintería Jon Parish, D irector del capítulo

Perfil general D ebra 0 sinsky 86.2

Procesos de carpintería .. J on K. Parish 86.2

M áquinas copiadoras-fresadoras . . B eat W egmüller

M áquinas de cepillado de madera. . . B eat W egmüller

Efectos sobre la salud y pautas patológicas

Leon J. W arshaw

PARTE XIV. INDUSTRIAS TEXTILES Y DE LA CONFECCION

87. Confección y productos textiles acabados

Robin H erbert y R ebecca Plattus, Directores del capítulo Principales sectores y procesos. . . . . . . . . . . . . . . . . . R ebecca Plattus y $R$ obin $H$ erbert Accidentes en el sector de la confección . . . . . . . . . . . . . . . . . . . . . . . . . A.S. Bettenson Efectos sobre la salud y aspectos ambientales. R obin H erbert y R ebecca Plattus

88. Cueros, pieles y calzado

Michael McCann, Director del capítulo

Perfil general D ebra 0 sinsky

Curtido, acabado de pieles .................................. D ean B. Baker

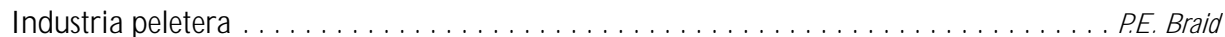

Calzado, industria. ................................ Conradi y Paulo Portich

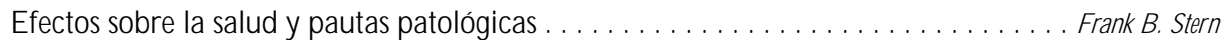

Cuestiones ambientales y de salud pública 


\section{Industria de productos textiles}

La industria textil: historia y salud y seguridad

Tendencias mundiales en la industria textil . . .

A. Lee Ivester y John D. N eefus, Directores del capítulo

Producción y desmotado del algodón . . . . . . . . . . . . . . . . . . . . . . W. Stanley Anthony

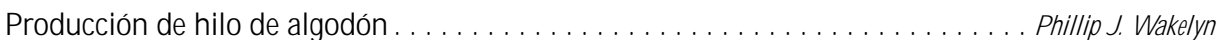

Industria de la lana

D.A. H argrave

Industria de la seda

.. J. Kubota

Viscosa (rayón)

M.M. El Atta

Fibras sintéticas

A.E. Q uinn and R. M attiusi

Productos de fieltro natural $\ldots \ldots \ldots \ldots \ldots \ldots \ldots \ldots \ldots \ldots \ldots \ldots \ldots \ldots$. $\ldots \ldots \ldots$ erzy A. Sokal

T inción, estampado y acabado . . . . . . . . . . . . . . . . . . . . . . M. Strother y A.K. N iyogi

Generos textiles no tejidos. . . . . . . . . . . . . . . . . . . . . W illiam A. B lackburn y Subhash K. Batra

Tejido y tricotado

Charles Crocke

Alfombras y moquetas.

T he Carpet and R ug I nstitute

Alfombras tejidas o anudadas a mano

. M .E. Radjabi

Afecciones respiratorias y de otro tipo observadas en la industria textil

. E. N eil Schachter

\section{PARTE XV. INDUSTRIAS DEL TRANSPORTE}

90. Construcción y mantenimiento aerospacial Buck Cameron,D irector del capítulo La industria aeroespacial ....................................... Buck Cameron

Seguridad y ergonomía en la construcción aeronáutica .................. D ouglas F. Briggs 90.2

Protección contra las caídas en la construcción y el mantenimiento de los aviones comerciales . . . . . . . . . . . . . . . . . . . . . . . . . R obert W. H ites

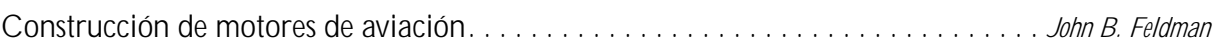

Controles y efectos sobre la salud $\ldots \ldots \ldots \ldots \ldots \ldots \ldots \ldots \ldots \ldots \ldots \ldots \ldots \ldots$. . . . enis B ourcier

Cuestiones ambientales y de salud pública . . . . . . . . . . . . . . . . . . . . . . Steve $M$ ason

91. Vehículos de motor y maquinaria pesada

Franklin E. Mirer,

Director del capítulo

Industria del automóvil y el material de transporte

Franklin E. M irer

92. Construcción y reparación de buques y embarcaciones de recreo

James R. Thornton, Director del capítulo

Perfil general

Chester $M$ atthews

Construcción y reparación de buques y embarcaciones . . . . . . . . . . . . J ames $R$. T hornton

Cuestiones ambientales y de salud pública. F rank H. T horn, Page Ayres y L ogan C. Shelman

PARTE XVI. CONSTRUCCION

93. Construcción

\section{SALUD, PREVENCION Y GESTION}

$R$ iesgos de salud y seguridad en el sector de la construcción. .............. ames $L$. W eks

R iesgos para la salud en obras subterráneas . . . . . . . . . . . . . . . . B ohuslav M álek

Servicios preventivos sanitarios en la construcción ...................... Pekka R oto

Normas de seguridad y salud: la experiencia de los Países Bajos
Knut Ringen, Jane L. Seegal y J ames L. Weeks, Directores del capítulo 
Factores de organización que afectan a la salud y la seguridad . . . . . . . . . . . . D oug J. M cVittie 93.14

Gestión de calidad y prevención integradas. . . . . . . . . . . . . . . . Rudolf Scholbeck 93.17

PRINCIPALES SECTORES Y SUS RIESGOS

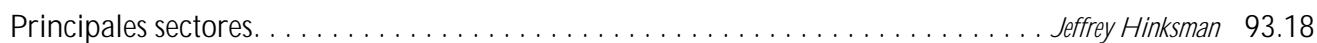

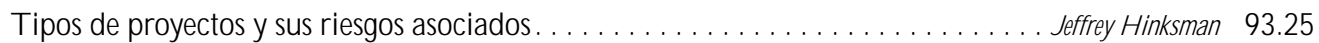

Zanjas ...................................................... . . . . . M ickle 93.34

HERRAMIENTAS, MAQUINAS Y MATERIALES

H erramientas . . . . . . . . . . . . . . . . . . . . . . . . . . . . . . . . . . Scott P. Schneider 93.37

Equipos, máquinas y materiales $\ldots \ldots \ldots \ldots \ldots \ldots \ldots \ldots \ldots \ldots \ldots \ldots \ldots \ldots \ldots \ldots$ ans $\mathrm{G}$ oran $\mathrm{L}$ inder 93.39

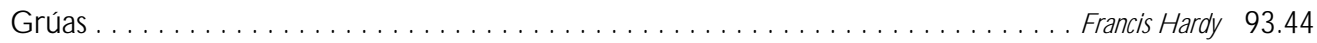

Ascensores, escaleras mecánicas y elevadores . . . . . . . . . . . . . . . . J. Staal y J ohn Q uackenbush 93.45

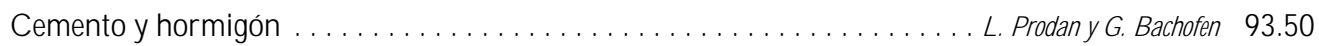

Estudios de casos: Prevención de las dermatosis profesionales entre los trabajadores expuestos al polvo de cemento . . . . . . . . . . . . . . . . . . . . . . Pekka R oto 93.54

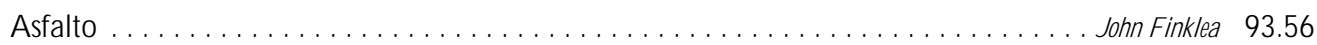

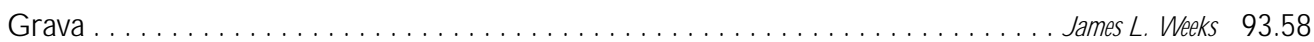

PARTE XVII. SERVICIOS

94. Servicios de educación y formación Michael McC ann, Director del capítulo

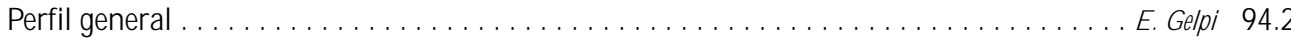

Centros de enseñanza elemental y secundaria. . . . . . . . . . . . . . . . . . M ichael M cC ann 94.3

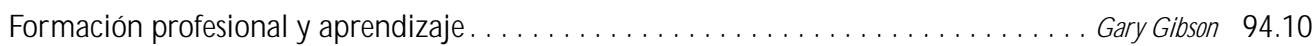

Escuelas universitarias y universidades . . . . . . . . . . . . . . . . . . . . . . Susan M agor 94.11

Enseñanza artística . . . . . . . . . . . . . . . . . . . . . . . . . . . . . . . . . Ted Rickard 94.12

Problemas de salud y pautas patológicas. ....................... Steven D. Stellman y J oshua E. M uscat 94.13

Cuestiones ambientales y de salud pública ....................... Susan M agor 94.14

95. Servicios de seguridad y de emergencia Tee L. G uidotti, D irector del capítulo

Servicios de seguridad y de emergencia $\ldots \ldots \ldots \ldots \ldots \ldots \ldots \ldots \ldots \ldots$. $\ldots \ldots \ldots$ L. Guidotti

M étodos de extinción de incendios . . . . . . . . . . . . . . . . . . . . . . . . . Alan D. J ones

Riesgos de la lucha contra incendios. . . . . . . . . . . . . . . . . . . . . . . . Te L. G uidotti

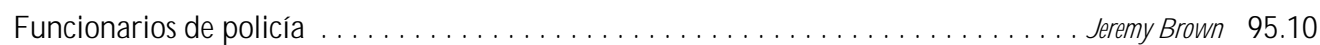

Guardias de seguridad: desarrollo y situación de la seguridad en el trabajo

en Alemania. . . . . . . . . . . . . . . . . . . . . . . . . . . . . . . . . anfred $F$ ischer 95.14

Fuerzas armadas . . . . . . . . . . . . . . J oel C. Gaydos, Richard $J$. T homas, D avid M. Sack y R elford Patterson 95.16

Riesgos para la seguridad y la salud de los rescates marítimos. . . . . . . . . . . . . T imothy J. U ngs 95.19

Personal auxiliar y de ambulancias. . . . . . . . . . . . . . . . . . . . . . . . . ohn D. M eyer 95.21

Personal de control de riesgos por sustancias peligrosas . . . . . . . . . . . . . . . . . . J oseph Fedoruk 95.22

96. Actividades artísticas, culturales y recreativas

Michael McC ann, Director del capítulo

ACTIVIDADES ARTISTICAS Y ARTESANALES

Actividades artísticas, culturales y recreativas ..................... M ichael M cC ann 96.2

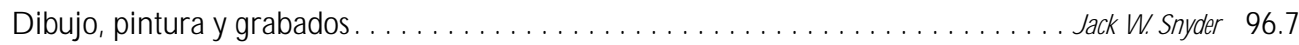

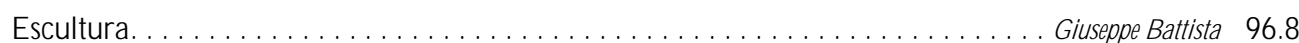


Fotografía D avid Richardson 96.11

M etalistería . . Angela Babin 96.12

Nuevas tecnologías en el arte. W illiam E. Irwin 96.14

Artesanía textil . Gail Coningsby B arazani 96.15

Cerámica M onona R ossol

Artesanía de la madera M ichael M cCann 96.17

Joyería T sun-J en Cheng y J ung-D er W ang 96.19

Artes gráficas. 96.21 96.23

\section{ARTES ESCENICASY AUDIOVISUALES}

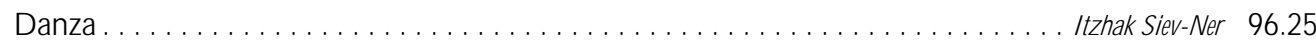

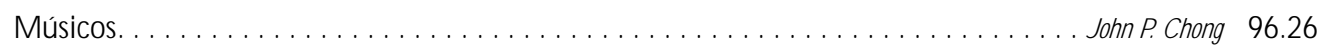

Cantantes ........................................... Anat Keidar 96.28

Actores. . . . . . . . . . . . . . . . . . . . . . . . . . . . . . . . . . . . . . Sandra Karen Richman 96.30

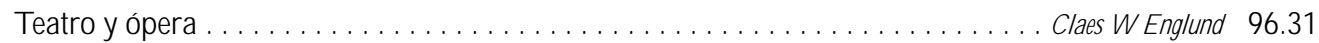

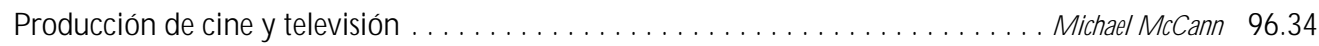

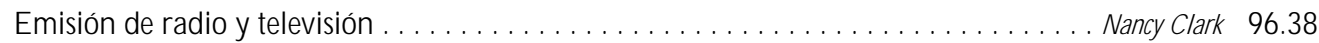

Periodismo ........................................ Aidan W hite 96.39

\section{ACTIVIDADES CULTURALES Y RECREATIVAS}

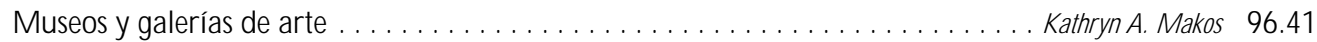

Parques zoológicos y acuarios . . . . . . . . . . . . . . . . . . . . . . . . . . . . . . . Ken sims 96.44

Parques y jardines botánicos. . . . . . . . . . . . . . . . . . . . . . . . . . . . . . . . . . . Paul V. L ynch 96.46

Circos, parques de atracciones y temáticos . . . . . . . . . . . . . . . . . . . . W illiam Avery 96.48

Corridas de toros y rodeos. . . . . . . . . . . . . . . . . . . . . . . . . . . . . . . . . . . . . ichael M CC ann 96.50

D eportes profesionales . . . . . . . . . . . . . . . . . . . . Gordon H uie, Peter J. B runo y W. N orman Scott 96.52

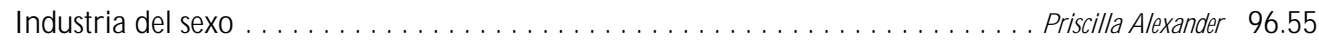

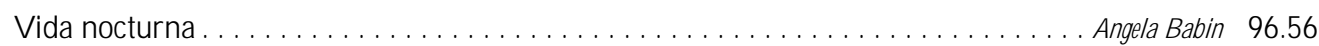

La protección del medio ambiente y la salud pública . . . . . . . . . . . . . . . . M ichael M cC ann 96.57

\section{Centros y servicios de asistencia sanitaria Annalee Yassi, Directora del capítulo}

A sistencia sanitaria: naturaleza y problemas de salud en el trabajo. . . . Annale Yassi y L eon J. W arshaw ¿Son también trabajadores sanitarios? . . . . . . . . . . . . . . . . . . . . L eon J. W arshaw

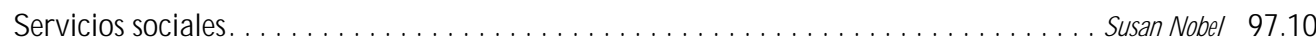
97.2

Trabajadores de la atención domiciliaria: la experiencia de N ueva York . . . . . . . . . . L enora Colbert 97.11 Estudio de un caso: Violencia en el trabajo sanitario . . . . . . . . . . . . . . . D anie M urphy 97.12 La práctica de la salud y seguridad en el trabajo: la experiencia rusa . . . . . . . . Valery P. Kaptsov y L yudmila P. Korotich 97.13

ERGONOMIA Y ASISTENCIA SANITARIA

Perspectiva de la ergonomia hospitalaria. . . . . . . . . . . . . . . . . . . M adeleine R. Estryn-Béhar 97.15

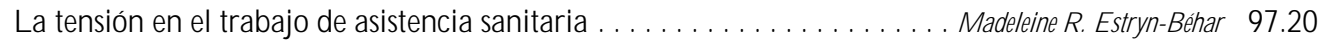

H orarios de trabajo y trabajo nocturno en la asistencia sanitaria . . . . . . . . M adeleine R. Estryn-Béhar 97.25

MEDIO AMBIENTE FISICO Y ASISTENCIA SANITARIA

Exposición a agentes físicos. ............................ Robert M. L ewy 97.30 Ergonomía del medio ambiente físico de trabajo . . . . . . . . . . . . M adelene E stryn-Béhar 97.33 
Prevención y manejo de los dolores de espalda en el personal de enfermeria . . . . . . . . U Irich Stössel

Tratamiento del dolor de espalda
97.38

97.41

\section{LOS TRABAJADORES SANITARIOS Y LAS ENFERMEDADES INFECCIOSAS}

Perspectiva de las enfermedades infecciosas $\ldots \ldots \ldots \ldots \ldots \ldots \ldots \ldots \ldots$ riedrich $\mathrm{H}$ ofmann

Prevención de la transmisión profesional de los agentes patógenos en sangre . . . . . Linda S. M artin, Robert J. M ullan y D avid M. Bell

Prevención, control y vigilancia de la tuberculosis. Robert J. M ullan

\section{SUST ANCIAS QUIMICAS PRESENTES EN EL MEDIO AM BIENTE SANITARIO}

Perspectiva de los riesgos de origen químico en la asistencia sanitaria . . . . . . . J eanne M ager Stellman 97.55

A bordaje de los riesgos de origen químico en los hospitales. . . . . . . . . . . . . . . . . . . . Annale Yassi 97.57

Gases anestésicos residuales . . . . . . . . . . . . . . . . . . . . . . . X Xavier Guardino Solá

EL MEDIO AMBIENTE HOSPITALARIO

E dificios destinados a la asistencia sanitaria ..... . Cesare Catananti, Gianfranco D amiani y Giovanni Capelli 97.65

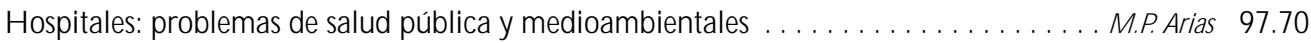

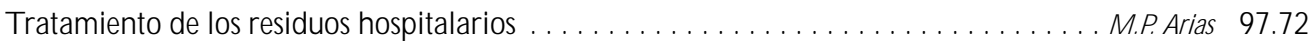
M anejo de la eliminación de los residuos sanitarios peligrosos

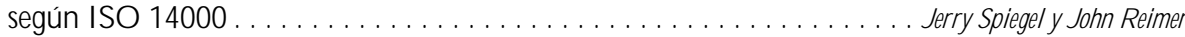

98. H oteles y restaurantes

Pam T au Lee, Director del capítulo

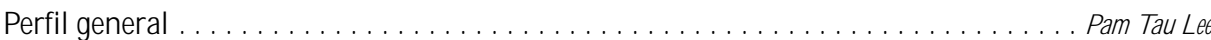

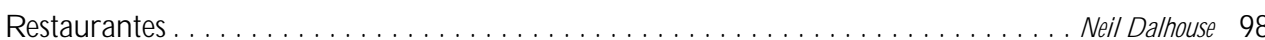

H oteles. . . . . . . . . . . . . . . . . . . . . . . . . . . . . . . . . . . . . Pam Tau Le 98.6

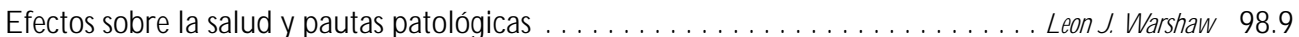

99. O ficinas y comercio minorista

Jonathan Rosen, Director del capítulo

$\mathrm{N}$ aturaleza del trabajo en oficinas y comercios . . . . . . . Charles $L$ evenstein, B eth R osenberg y $\mathrm{N}$ inica $\mathrm{H}$ oward Profesionales y directivos. . . . . . . . . . . . . . . . . . . . . . . . . . . Nona M cQ uay

O ficinas: resumen de riesgos W endy $\mathrm{H}$ ord

La seguridad del cajero: situación en Alemania . . . . . . . . . . . . . . M anfred $F$ ischer

Teletrabajo. . J amie Tessler

El comercio minorista Adrienne M arkowitz

100. Servicios personales y comunitarios

Angela Babin, Directora del capítulo

Servicios de limpieza en interiores . Karen M essing 100.2

Peluquería y cosmética . Laura Stock y J ames Cone Lavanderías y limpieza en seco . . Gary S. E arnest, L ynda E wers y Avima M . R uder 100.6

Servicios funerarios . M ary 0 . B rophy y J onathan $\mathrm{T}$. $\mathrm{H}$ aney

Empleados del hogar. . Angela B abin

\section{Servicios públicos y estatales}

David LeG rande, Director del capítulo

$\mathrm{R}$ iesgos para la seguridad y la salud en el trabajo en los servicios públicos y

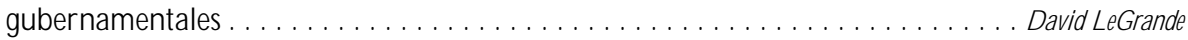

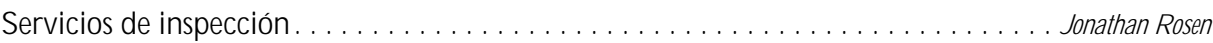
Servicios postales 
Telecomunicaciones. D avid L EG rande 101.9

$\mathrm{R}$ iesgos en las plantas de tratamiento de aguas residuales (residuos) M ary 0. B rophy

Recogida de basuras domésticas $M$ adelene $B$ ourdouxhe

Limpieza viaria J.C. Gunther, I r.

Tratamiento de las aguas residuales. . . . . . . . . . . . . . . . . . . . . . . . . . Agamennone

Industria de reciclado municipal. . . . . . . . . . . . . . . . . . . . . . . . . D avid E. M alter

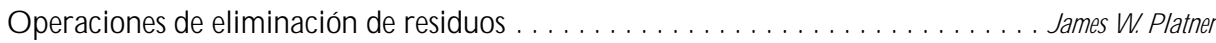

Generación y transporte de residuos peligrosos: problemas sociales y éticos. . . . . . . Colin L. Soskolne

\section{Industria del transporte y el almacenamiento}

LaMont Byrd, Director del capítulo

Perfil general LaM ont Byrd

R etos para la salud y la seguridad de los trabajadores en la industria del transporte y del almacenamiento . . . . . . . . . . . . . . . . . . . . . . . . . . L eon J. W arshaw

\section{TRANSPORTE AEREO}

O peraciones aeroportuarias y de control del tráfico aéreo Christine Proctor

Estudios de caso de controladores del tráfico aéreo en Estados U nidos eltalia ............................................ Paul A. Landsbergis

O peraciones de mantenimiento de aeronaves . . . . . . . . . . . . . . . . . Buck Cameron

0 peraciones de vuelo de aeronaves . . . . . . . . . . . . . . . . N ancy Garcia y H. Gartmann

M edicina aeroespacial: efectos de la gravedad, la aceleración y la microgravedad en el entorno aeroespacial . . . . . . . . . . . . . . . . . R elford Patterson y $R$ ussell $B$. Rayman

H elicópteros. D avid L. H untzinger

\section{TRANSPORTE POR CARRETERA}

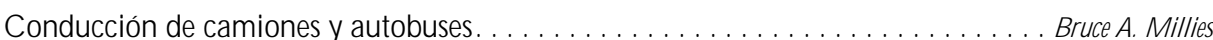

Ergonomía de la conducción de autobuses Alfons G rösbrink y Andreas M ahr

O peraciones de suministro de combustible y mantenimiento de vehículos

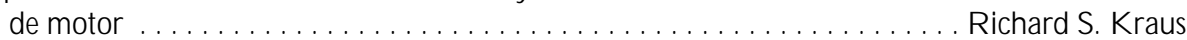

Violencia en las gasolineras. Leon I. W arshaw

\section{TRANSPORTE FERROVIARIO}

Explotaciones ferroviarias. . . . . . . . . . . . . . . . . . . . . . . . . . . . . . . . . . . . . N eil M cM anus 102.37

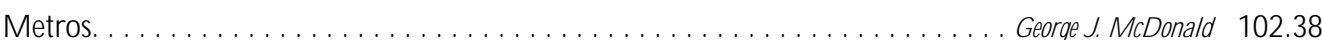

\section{TRANSPORTE FLUVIAL Y MARITIMO}

Transporte fluvial y marítimo e industrias marítimas . . T imothy I. U nos y M ichael Adess

\section{ALM ACENAMIENTO}

A Imacenamiento y transporte de petróleo crudo, gas natural, productos de petróleo licuados y otras sustancias químicas. . . . . . . . . . . . . . . . . . . Richard $\mathrm{S}$. K raus

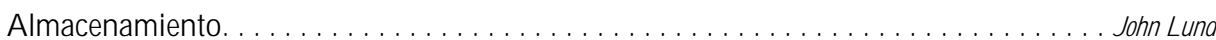




\section{vouner \\ IV}

A utores y directores.

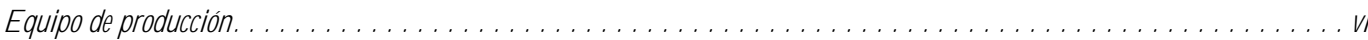

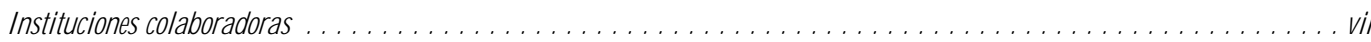

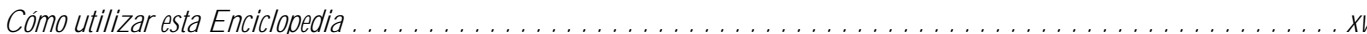

PARTE XVIII. GUIAS

\section{G uía de profesiones}

Alexander Donagi, Avraham Aladjem y Menachem Schwartz, Directores del capítulo

Sistematización de los riesgos profesionales

por ocupación . . . . . . . . . . . . . . . . . . . . . . . . Alexander D onagi y Avraham Aladjem 103.2

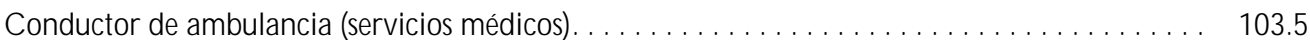

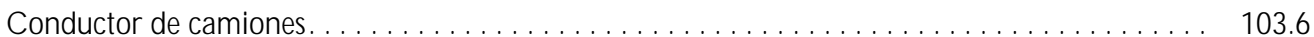

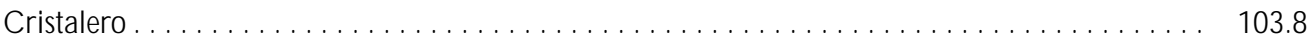

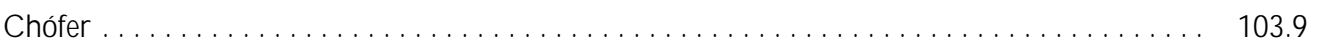

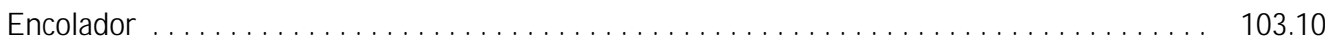

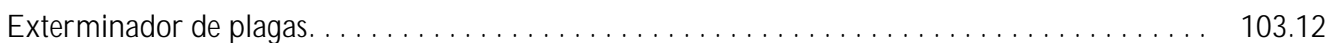

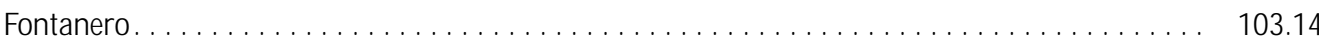

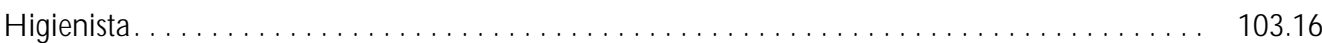

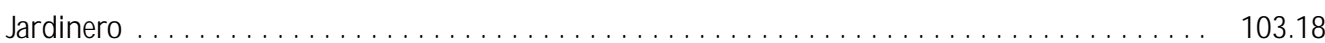

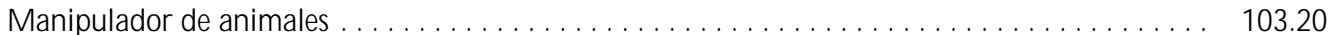

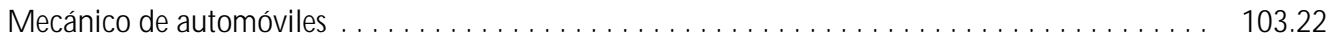

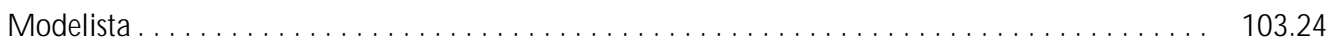

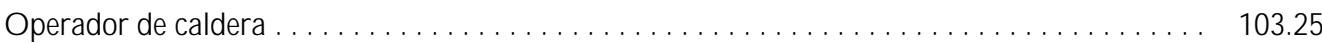

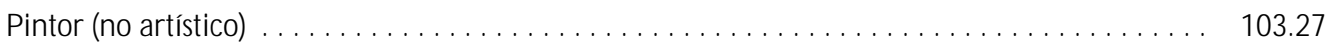

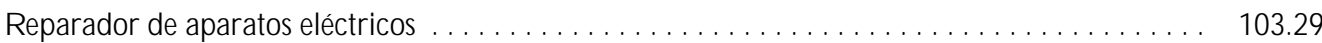

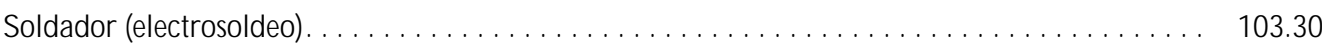

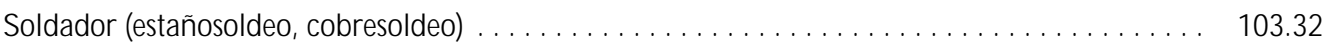

Técnico de laboratorio . . . . . . . . . . . . . . . . . . . . . . . . . . . . . . . . . . . . . 103.34

104. G uía de productos químicos Jeanne Mager Stellman, Debra 0 sinsky y Pia Markkanen, Directoras del capítulo

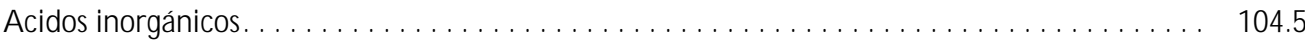

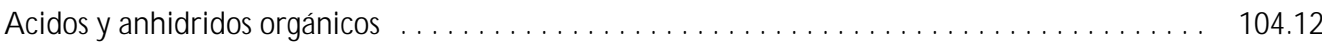

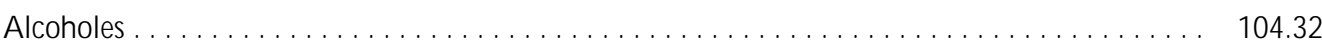

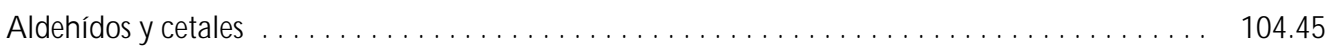

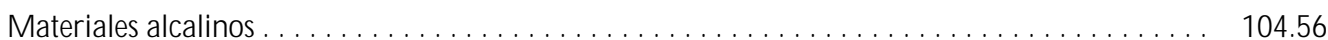

Amidas. . . . . . . . . . . . . . . . . . . . . . . . . . . . . . . . . . . . . . . . . . . . . 104.73

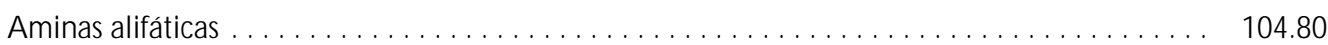

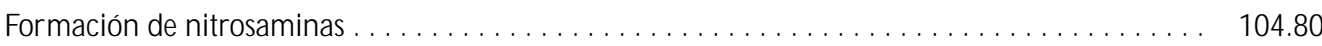


A minas aromáticas . . . . . . . . . . . . . . . . . . . . . . . . . . . . . . . . . . . . . . . 104.95

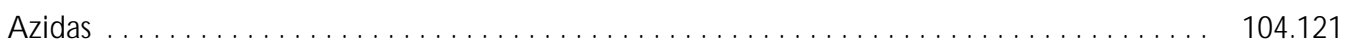

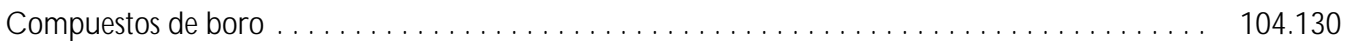

Compuestos de ciano . . . . . . . . . . . . . . . . . . . . . . . . . . . . . . . . . . . . . . . . . . . . . 104.137

Compuestos epoxidicos. . . . . . . . . . . . . . . . . . . . . . . . . . . . . . . . . . . . 104.152

Esteres, acetatos. . . . . . . . . . . . . . . . . . . . . . . . . . . . . . . . . . . . . . . . . . . . . . 104.162

Esteres acrílicos . . . . . . . . . . . . . . . . . . . . . . . . . . . . . . . . . . . 104.172

Esteres, alcanoatos (excepto acetatos) . . . . . . . . . . . . . . . . . . . . . . . . . . . . . . . . 104.176

Eteres. . . . . . . . . . . . . . . . . . . . . . . . . . . . . . . . . . . . . . . . . . . . 104.183

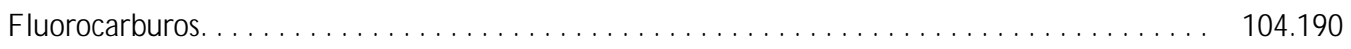

Eteres glicólicos . . . . . . . . . . . . . . . . . . . . . . . . . . . . . . . . . . . 104.201

G liceroles y glicoles . . . . . . . . . . . . . . . . . . . . . . . . . . . . . . . . . . . 104.209

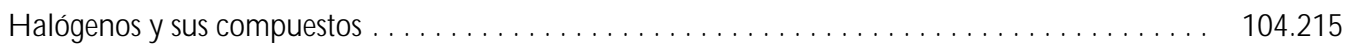

Compuestos heterocíclicos. . . . . . . . . . . . . . . . . . . . . . . . . . . . . . . . . . . . . . . . . 104.227

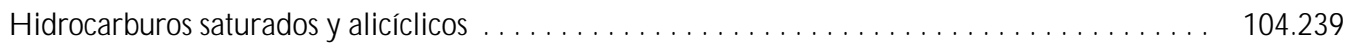

H idrocarburos, alifáticos y halogenados . . . . . . . . . . . . . . . . . . . . . . . . . . . . . 104.249

H idrocarburos alifáticos insaturados . . . . . . . . . . . . . . . . . . . . . . . . . . . . . . . . . . . . 104.275

H idrocarburos aromáticos. . . . . . . . . . . . . . . . . . . . . . . . . . . . 104.282

H idrocarburos aromáticos halogenados . . . . . . . . . . . . . . . . . . . . . . . . . 104.296

H idrocarburos poliaromáticos. . . . . . . . . . . . . . . . . . . . . . . . . . . . . . . . 104.310

I socianatos. . . . . . . . . . . . . . . . . . . . . . . . . . . . . . . . . . . . . . . . 104.320

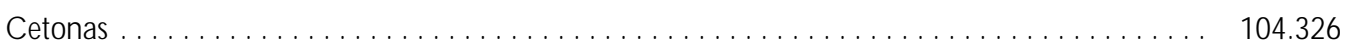

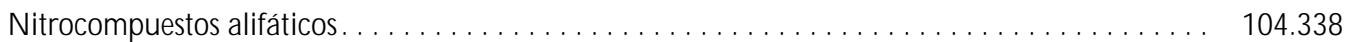

Nitrocompuestos aromáticos . . . . . . . . . . . . . . . . . . . . . . . . . . . . . . . . . . . 104.346

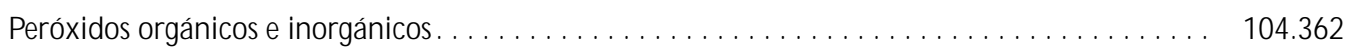

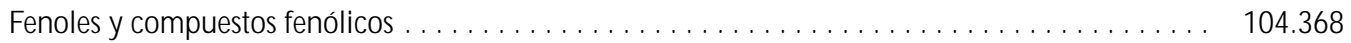

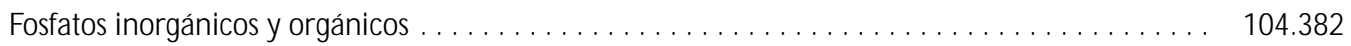

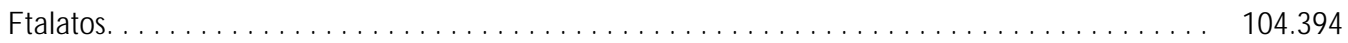

Sílice y compuestos organosilíceos. . . . . . . . . . . . . . . . . . . . . . . . . . . . . . 104.399

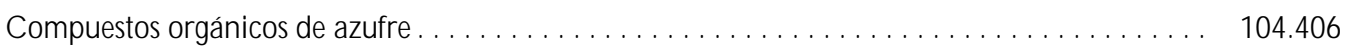

Compuestos inorgánicos de azufre . . . . . . . . . . . . . . . . . . . . . . . . . . . . . . . . . . 104.417

M onóxido de carbono . . . . . . . . . . . . . . . . . . . . . . . . . . . . . . . . . . . . . . . . . 104.429

\section{5. $\mathrm{G}$ uía de unidades y abreviaturas}

Sistema internacional de unidades . . . . . . . . . . . . . . . . . . . . . . . . . . . . . . . . . 105.2

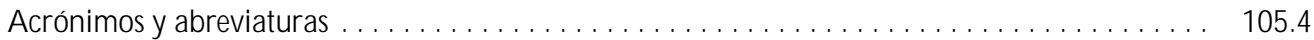

PARTE XIX. INDICES

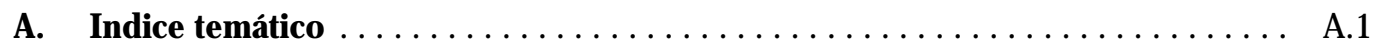

B. Indice de productos químicos $\ldots \ldots \ldots \ldots \ldots \ldots \ldots \ldots \ldots \ldots \ldots \ldots \ldots \ldots \ldots$

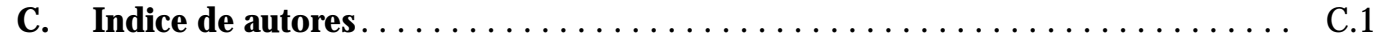




\section{PARTE XX. DIRECTORIO DE EXPERTOS}

\section{Directorio de expertos}

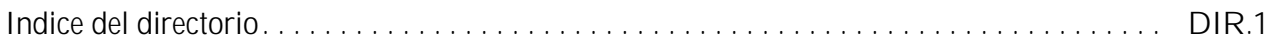

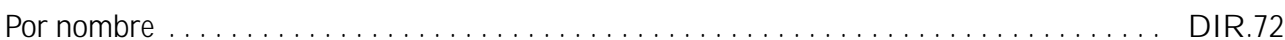

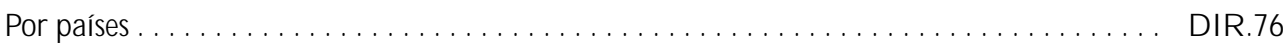

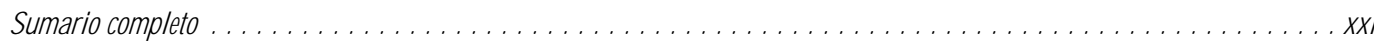

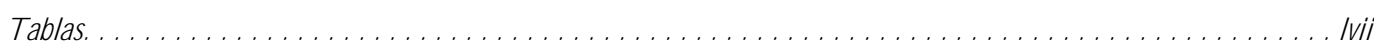

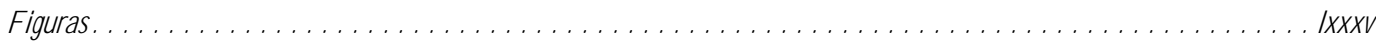





\section{TABLAS}

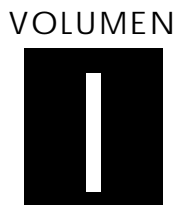

PARTE I. EL CUERPO HUMANO

\section{Capítulo $1 . \quad$ Sangre}

Tabla 1.1 Agentes seleccionados relacionados con la metahemoglobinemia de etiología ambiental y profesional. . . . . . . . . . . . . . . . . . . . . 1.2

\section{Capítulo 2.}

Tabla 2.1

Tabla 2.2

Tabla 2.3

Tabla 2.4

Tabla 2.5

Tabla 2.6

Tabla 2.7

Tabla 2.8

Tabla 2.9

Tabla 2.10

Tabla 2.11

Tabla 2.12

Tabla 2.13

\section{Capítulo 3.}

Tabla 3.1

Tabla 3.2

Tabla 3.3

\section{Cáncer}

Cáncer profesional: factores clave.

Porcentajes calculados de cáncer (PAR ) atribuible a la profesión en estudios seleccionados. . . . . . . . . . . . . . . . . . . . . . . 2.3

Evaluación de las pruebas de carcinogenicidad en el programa de monografías de la IARC . . . . . . . . . . . . . . . . . . . . . . . . . . . . . 2.4

Grupos de clasificación del programa de monografía de la IARC . . . . . . . 2.5

Sustancias químicas, grupos de sustancias químicas o mezclas a las que la exposición es fundamentalmente profesional (excluidos los pesticidas y los fármacos): G rupo 1: cancerígenos para los seres humanos. . . . . . . . . . . 2.5

Sustancias químicas, grupos de sustancias químicas o mezclas a las que la exposición es fundamentalmente profesional (excluidos pesticidas y fármacos): G rupo 2A: probablemente cancerígenos para los seres humanos. 2.6

Sustancias químicas, grupos de sustancias químicas o mezclas a las que la exposición es fundamentalmente profesional (excluidos pesticidas y fármacos): G rupo 2B: Posiblemente cancerígenos para los seres humanos. . 2.6 Pesticidas evaluados en las monografías de la IARC, volúmenes 1-63 (1972-1995). . . . . . . . . . . . . . . . . . . . . . . . . 2.8

Fármacos evaluados en las monografías de la IARC, volúmenes 1-63 (1972-1995). . . . . . . . . . . . . . . . . . . . . . . . . . . 2.9

Agentes y exposiciones ambientales que se sabe o se sospecha que causan cáncer en los seres humanos. . . . . . . . . . . . . . . . . . . . . 2.10

Industrias, profesiones y exposiciones reconocidas como causantes de un riesgo cancerígeno. . . . . . . . . . . . . . . . . . . . . . . . 2.11 Industrias, profesiones y exposiciones en las que se ha informado de una incidencia excesiva de cáncer, pero en las que la valoración del riesgo cancerígeno no es definitiva. . . . . . . . . . . . . . . . . . . . . 2.13

Variación de la incidencia de cánceres comunes en distintas poblaciones en las que existen registros de cáncer. . . . . . . . . . . . . . . . . . . . . . 2.15

\section{Sistema cardiovascular}

M ortalidad por enfermedades cardiovasculares en 1991 y 1990 en los grupos de edades comprendidas entre 45-54 años y 55-64 años en países seleccionados . . . . . . . . . . . . . . . . . . . . 3.2

Tasas de mortalidad de grupos diagnósticos cardiovasculares especiales en los años 1991 y 1990 en el grupo de edades comprendidas entre 55-64 años en países seleccionados. . . . . . . . . . . . . . . . . . . . . . . 3.3

Tasa de enfermedad cardiovascular en jubilados precoces debido a la reducción de la capacidad para trabajar $(\mathrm{N}=576,079)$ y discapacidad laboral en relación con el diagnóstico en Alemania occidental, 1990-92. . . . 3.4 
Tabla 3.4

Tabla 3.5

\section{Capítulo 5.}

Tabla 5.1

\section{Capítulo 6.}

Tabla 6.1

Tabla 6.2

Tabla 6.3

Tabla 6.4

Tabla 6.5

Tabla 6.6

Tabla 6.7

Tabla 6.8

Tabla 6.9

Tabla 6.10

\section{Capítulo 7.}

Tabla 7.1

Tabla 7.2

Tabla 7.3

Tabla 7.4

Tabla 7.5

Tabla 7.6

Tabla 7.7

Tabla 7.8

Tabla 7.9

Tabla 7.10

Tabla 7.11

Tabla 7.12

Tabla 7.13

\section{Capítulo 8.}

Tabla 8.1

Tabla 8.2

Tabla 8.3
Selección de actividades y de ramas industriales que pueden asociarse a riesgos cardiovasculares. . . . . . . . . . . . . . . . . . . . . . 3.16

Visión global de enfermedades infecciosas posiblemente relacionadas con el trabajo y que afectan al sistema cardiovascular. . . . . . . . . . . . . . . 3.18

\section{Salud mental}

Resumen esquemático de las estrategias de gestión de los problemas de salud mental, con algunos ejemplos. . . . . . . . . . . . . . . . . . . 5.5

\section{Sistema musculosquelético}

R elaciones estructura-función e interdependencia de los componentes articulares. . . . . . . . . . . . . . . . . . . . . . . . . 6.6

Prevalencia de los trastornos de espalda en la población finlandesa de más de 30 años de edad en porcentajes. . . . . . . . . . . . . . . . . . . 6.12

Parámetros que deben considerarse para reducir los riesgos de dolor lumbar en el trabajo.. . . . . . . . . . . . . . . . . . . . . . . . . . . . 6.14

Clasificación de los trastornos lumbares según el grupo de trabajo sobre trastornos espinales de Q uebec (Q uebec Task Force on Spinal Disorders). . . 6.15

A mplitud de movimiento normal y permisible para conducción prolongada, en grados, de la cabeza. . . . . . . . . . . . . . . . . 6.16 Incidencia de epicondilitis en diversas poblaciones. . . . . . . . . . . . . . 6.23 Incidencia de tenosinovitis/ peritendinitis en diversas poblaciones. . . . . . . . 6.24 Prevalencia de osteoartrosis primaria de cadera en agricultores y poblaciones de varones de diferentes grupos de edad de la ciudad de M almoe. . . . . . . . 6.29 Directrices para el tratamiento de la artritis reumatoide. . . . . . . . . . . . . 6.34 Infecciones conocidas como desencadenantes de la artritis reactiva. . . . . . . 6.34

\section{Sistema nervioso}

N ombres y principales funciones de los pares craneales. . . . . . . . . . . 7.8

A grupación de los efectos neurotóxicos para reflejar su potencia relativa en el establecimiento de la neurotoxicidad. . . . . . . . . . . . . . . . . . 7.9

G ases asociados a efectos neurotóxicos. . . . . . . . . . . . . . . . . . . 7.10

M etales y sus compuestos inorgánicos asociados a neurotoxicidad. . . . . . 7.10

M onómeros neurotóxicos. . . . . . . . . . . . . . . . . . . . . 7.11

Disolventes orgánicos asociados a neurotoxicidad. . . . . . . . . . . . . . 7.12

Clasificación de pesticidas neurotóxicos comunes, exposición, efectos y

síntomas asociados. . . . . . . . . . . . . . . . . . . . . . . . 7.13

O tros productos químicos asociados a neurotoxicidad. . . . . . . . . . . . 7.14

Lista de control de los síntomas crónicos. . . . . . . . . . . . . . . . . 7.17

E fectos neurofuncionales característicos de exposiciones a algunas sustancias neurotóxicas importantes en el lugar de trabajo. . . . . . . . . . . . . . . 7.17

Exposiciones a productos químicos y síndromes neurotóxicos asociados . . . 7.19

Ejemplos de baterías "nucleares" para la evaluación de los efectos

neurotóxicos precoces. . . . . . . . . . . . . . . . . . . . . . . 7.23

A rbol de decisión para las enfermedades neurotóxicas. . . . . . . . . . . . 7.25

\section{Sistema renal y urinario}

Enzimas renales metabilizadoras de fármacos. . . . . . . . . . . . . . . . . 8.4

Causas más frecuentes de hematuria, según el sexo y la edad. . . . . . . . . 8.6

Criterios de selección de los marcadores biológicos. . . . . . . . . . . . . . 8.7 
Tabla 8.4

Tabla 8.5

Tabla 8.6

Tabla 8.7

\section{Capítulo 9.}

Tabla 9.1

Tabla 9.2

Tabla 9.3

Tabla 9.4

Tabla 9.5

Tabla 9.6

Tabla 9.7

Tabla 9.8

Tabla 9.9

Tabla 9.10

\section{Capítulo 10.}

Tabla 10.1

Tabla 10.2

Tabla 10.3

Tabla 10.4

Tabla 10.5

Tabla 10.6

Tabla 10.7

Tabla 10.8

Tabla 10.9

Tabla 10.10

Tabla 10.11

Tabla 10.12

Tabla 10.13

Tabla 10.14

Tabla 10.15

Tabla 10.16

Tabla 10.17

Tabla 10.18

Tabla 10.19

Tabla 10.20
M arcadores biológicos potenciales asociados a daños celulares. . . . . . . . . 8.8

C ausas principales de insuficiencia renal aguda de origen profesional.. . . . 8.10 Segmentos de la nefrona afectados por sustancias tóxicas seleccionadas. . . . 8.11 A plicaciones de la citología urinaria. . . . . . . . . . . . . . . . . . 8.13

\section{Sistema reproductor}

Ejemplos de exposiciones asociadas a múltiples problemas reproductivos. . 9.4 Estudios epidemiológicos de efectos paternos sobre el embarazo. . . . . . . . 9.7 Sustancias potencialmente tóxicas para la reproducción femenina. . . . . . . 9.10 Definición de pérdida fetal y muerte perinatal. . . . . . . . . . . . . . . . 9.12 Factores asociados al resultado de neonato pequeño para la edad gestacional y pérdida fetal. . . . . . . . . . . . . . . . . . . . . . . . . . . 9.13 Fuentes conocidas de fatiga profesional. . . . . . . . . . . . . . . . . 9.17 R iesgos relativos ( $R$ R ) e índices de fatiga para el parto pretérmino. . . . . . 9.17 $R$ iesgo relativo de nacimiento prematuro en función de los índices de fatiga profesional. . . . . . . . . . . . . . . . . . . . . . . . 9.17 R iesgo relativo de nacimiento prematuro asociado con la modificación de las condiciones de trabajo. . . . . . . . . . . . . . . . . . . . . . . . 9.19 Fuentes potenciales y niveles de exposición para el recién nacido. . . . . . . . 9.23

\section{Aparato respiratorio}

R egiones del tracto respiratorio definidas según el mecanismo de deposición particulada. . . . . . . . . . . . . . . . . . . . . . . . . . . . . 10.4 Criterios para el polvo inhalable, torácico y respirable de la ACGIH, la ISO y el CEN, y de la MP10 de la US EPA. . . . . . . . . . . . . . . . . 10.5 Resumen de los irritantes respiratorios. . . . . . . . . . . . . . . . . . . . 10.15 M ecanismos de lesión pulmonar por sustancias inhaladas. . . . . . . . . . . . 10.17 Compuestos con capacidad de toxicidad pulmonar despúes de una exposición leve o moderada. . . . . . . . . . . . . . . . . . . . . 10.18 Definición de caso médico de asma ocupacional del ACCP. . . . . . . . . . . 10.22 Pasos en la evaluación diagnóstica del asma en el lugar de trabajo. . . . . . . 10.22 A gentes sensibilizantes que pueden causar asma ocupacional. . . . . . . . . . 10.23 Ejemplos de fuentes de riesgo de exposición a polvo orgánico. . . . . . . . . . . 10.27 A gentes principales en los polvos orgánicos con actividad biológica potencial. 10.28 Enfermedades inducidas por polvos orgánicos y sus códigos de la ICD. . . . . 10.28 Criterios diagnósticos de bisinosis. . . . . . . . . . . . . . . . . . . . . . 10.30 Propiedades del berilio y sus compuestos. . . . . . . . . . . . . . . . . . 10.31 D escripción de radiografías estándar. . . . . . . . . . . . . . . . . . . . . 10.38 Clasificación Internacional de 1980 de la O IT de R adiografías de Neumoconiosis: resumen de los detalles de la clasificación. . . . . . . . . . 10.41 Enfermedades y procesos relacionados con el amianto. . . . . . . . . . . . 10.59 Principales fuentes, productos y usos comerciales. . . . . . . . . . . . . . . 10.60 Prevalencia de la EPOC en varíos países: resultados de estudios a gran escala. . . . . . . . . . . . . . . . . . . . . . . 10.80 Factores de riesgo implicados en la EPO C . . . . . . . . . . . . . . . . 10.81 Pérdida de función ventilatoria en relación a exposiciones ocupacionales: resultados de varios estudios longitudinales basados en grupos de trabajadores.. . . . . . . . . . . . . . . . . . . . . . . . . 10.81 
Tabla 10.21

Tabla 10.22

Tabla 10.23

Tabla 10.24

Tabla 10.25

Tabla 10.26

\section{Capítulo 11.}

Tabla 11.1

Tabla 11.2

Tabla 11.3

Tabla 11.4

Tabla 11.5

Tabla 11.6

\section{Capítulo 12.}

Tabla 12.1

Tabla 12.2

Tabla 12.3

Tabla 12.4

Tabla 12.5

Tabla 12.6

Tabla 12.7

Tabla 12.8

Tabla 12.9
Clasificación diagnóstica de los dos tipos clínicos de EPO C, la bronquitis crónica y el enfisema. . . . . . . . . . . . . . . . . . . . . . . . . . 10.82

Pruebas de función pulmonar en el diagnóstico diferencial de los dos tipos clínicos de EPOC , la bronquitis crónica y el enfisema. . . . . . . . . . . . . . 10.83 Fibras sintéticas. . . . . . . . . . . . . . . . . . . . . . . . . . . . . . . . . . . 10.84

Cancerígenos respiratorios humanos demostrados según el IARC . . . . . . 10.90 Carcinógenos respiratorios humanos probables de acuerdo con el IARC . . . . 10.90 Enfermedades infecciosas de origen ocupacional contraídas por microaspiración o inhalación de partículas infecciosas. .

\section{0 rganos sensoriales}

Cálculo típico de la pérdida funcional a partir de un audiograma. . . . . . . . 11.7

R equisitos visuales para diferentes actividades con un $\mathrm{T}$ itmus $\mathrm{O}$ ptimal $\mathrm{C}$ Tester, con corrección. . . . . . . . . . . . . . . . . . . . . . . . . . . . . 11.13 Valores de iluminación recomendados para el diseño de la iluminación de algunos puestos de trabajo. . . . . . . . . . . . . . . . . . . . . . 11.17 R equisitos visuales para obtener el permiso de conducción en Francia. . . . . 11.19 A gentes/ procesos descritos que alteran el sistema del gusto. . . . . . . . . . . 11.24 A gentes/ procesos asociados a trastornos olfatorios en el ser humano. . . . . . 11.30

\section{Enfermedades de la piel}

O cupaciones de riesgo. . . . . . . . . . . . . . . . . . . . . . . . . . . . . . . . . . . 12.8

Tipos de dermatitis de contacto. . . . . . . . . . . . . . . . . . 12.10

I rritantes comunes . . . . . . . . . . . . . . . . . . . . . . . . . . 12.11

Alergenos cutáneos comunes . . . . . . . . . . . . . . . . . . . . . . . . . . 12.11

Factores predisponentes de dermatitis profesionales. . . . . . . . . . . . . . 12.12

Ejemplos de irritantes y sensibilizantes cutáneos en las profesiones en que puede producirse el contacto con la piel. . . . . . . . . . . . . . . . . . . . 12.14

D ermatosis profesionales en Q uebec en 1989: distribución por período de baja laboral. . . . . . . . . . . . . . . . . . . . . . . . . . . . . 12.15

Factores de riesgo y sus efectos sobre la piel. . . . . . . . . . . . . . . . . . 12.15

M edidas colectivas (participación en grupos) de prevención. . . . . . . . . . . 12.16

PARTE II. ASISTENCIA SANITARIA

\section{Capítulo 14.}

Tabla 14.1

Tabla 14.2

\section{Capítulo 15.}

Tabla 15.1

Tabla 15.2

Tabla 15.3

Tabla 15.4

Tabla 15.5

Tabla 15.6

Tabla 15.7

\section{Primeros auxilios, servicios médicos de urgencia}

Clasificación de las lesiones craneoencefálicas (Gennarelli y K otapa 1992). . . 14.9

Escala del coma de Glasgow. . . . . . . . . . . . . . . . . . . . . . . 14.9

\section{Protección y promoción de la salud}

A ctividades relacionadas con la salud en función del tamaño de la plantilla.

Tasas de participación (espontánea y fomentada) en las actividades de cribado de cáncer de mama y cuello del útero en función del porcentaje de mujeres en la plantilla. . . . . . . . . . . . . . . . . . . . 15.15 Temas del "D ía mundial sin tabaco" . . . . . . . . . . . . . . . . . . . . . 15.47 Cribado de enfermedades neoplásicas. . . . . . . . . . . . . . . . . . 15.53 Prestaciones del seguro de enfermedad. . . . . . . . . . . . . . . . . 15.63 O tras prestaciones ofrecidas por la empresa. . . . . . . . . . . . . . . . . 15.64 Sustancias que pueden producir dependencia. . . . . . . . . . . . . . . . . 15.84 


\section{C apítulo 16. Servicios de salud en el trabajo}

Tabla 16.1 Seis principios y tres niveles para una buena práctica de la salud en

Tabla 16.2 M édicos con conocimientos especializados en medicina del trabajo.. . . . . . 16.33

Tabla 16.3 Distribución por sectores de la afiliación sindical. . . . . . . . . . . . . 16.33

Tabla 16.4 Distribución por sectores de la afiliación sindical de la población activa en IOSEE.UU. en 1994.. . . . . . . . . . . . . . . . . . . . . . . . . . 16.44

Tabla 16.5 Requisitos mínimos de las instalaciones sanitarias internas. . . . . . . . . . . 16.54

Tabla 16.6 Exploraciones periódicas obligatorias para los trabajadores expuestos al polvo. . . . . . . . . . . . . . . . . . . . . . . 16.57

Tabla 16.7 Exploraciones físicas para los trabajadores expuestos a peligros profesionales. 16.58

Tabla 16.8 Resultados del control medioambiental de los peligros del lugar de trabajo. . . 16.59

Tabla 16.9 Exposición al polvo y prevalencia de la silicosis en la mina de tungsteno

Yiao Gang Xian. . . . . . . . . . . . . . . . . . . . . . . . . 16.59

Tabla $16.10 \quad$ Tasa de detección de silicosis en la acería Anshan. . . . . . . . . . . . . . 16.60

PARTE III. GESTION Y POUTICA

Capítulo 18.

Tabla 18.1

Capítulo 20.

Tabla 20.1

Tabla 20.2

Tabla 20.3

Tabla 20.4

Tabla 20.5

Tabla 20.6

Tabla 20.7

Tabla 20.8

Tabla 20.29

Tabla 20.10

Tabla 20.11

Capítulo 21.

Tabla 21.1

Capítulo 22.

Tabla 22.1

Tabla 22.2

Tabla 22.3

\section{Educación y formación}

Gráfico de métodos de enseñanza.

\section{Desarrollo, tecnología y comercio}

Características de las pequeñas empresas y sus consecuencias. . . . . . . . . 20.9

Información solicitada a los inversores extranjeros para la realización de análisis medioambientales. . . . . . . . . . . . . . . . . . . . . . 20.22

Costes para la economía del Reino U nido de los accidentes de trabajo y la

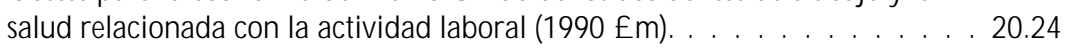

Tipos de evaluación económica. . . . . . . . . . . . . . . . . . . . . 20.25

Desarrollo de las empresas locales en China. . . . . . . . . . . . . . . . . 20.26

La cobertura de los SST prestados a las empresas por las ESPE de distrito. . . 20.26

Tasas de conformidad relativas a seis riesgos planteados en los lugares de trabajo. . . . . . . . . . . . . . . . . . . . . . . 20.26

Tasas detectables de enfermedades profesionales. . . . . . . . . . . . . . 20.27 Distribución de actividades laborales peligrosas y educación de los directivos. . 20.27 D atos generales sobre la salud en el trabajo en las empresas de financiación extranjera. . . . . . . . . . . . . . . . . . . . . . . . 20.28 Instrumentos ordinarios en materia de salud en el trabajo en las ESPE de 28 distritos chinos en 1990. . . . . . . . . . . . . . . . . . . . . . . . . . 20.29

\section{Relaciones laborales y gestión de recursos humanos}

Actividades prácticas - formación en materia de salud y seguridad. . . . . . . 21.33

\section{Recursos: informacion y salud y seguridad en el trabajo}

Ejemplos de publicaciones destacadas en el campo de la salud y seguridad en el trabajo.. . . . . . . . . . . . . . . . . . . . . . 22.8

Formato de búsqueda normalizado. . . . . . . . . . . . . . . . . . 22.12 Información necesaria en el ámbito de la salud y la seguridad en el trabajo. . 22.14 


\section{Capítulo 23. Recursos institucionales, estructurales y jurídicos}

Tabla 23.1 Comparación de algunos de los fundamentos conceptuales de las normas rusas y norteamericanas. . . . . . . . . . . . . . . . . . . . . . . 23.41

Tabla 23.2 Comités técnicos de la ISO más estrechamente relacionados con la prevención de los accidentes de trabajo y enfermedades profesionales. . . . . 23.62

Tabla $23.3 \quad$ Sedes de los congresos trienales desde 1906. . . . . . . . . . . . . . 23.68

Tabla 23.4 Relación de comités científicos y grupos de trabajo de la CIM T (1966). . . . . 23.68

\section{Capítulo 24. T Trabajo y trabajadores}

Tabla $24.1 \quad$ Algunas actividades y sectores en los que trabajan niños, y los riesgos asociados. . . . . . . . . . . . . . . . . . 24.16

\section{Capítulo 26. Indemnización a los trabajadores: temas relacionados}

Tabla $26.1 \quad$ Lista de enfermedades profesionales propuesta por la O IT. . . . . . . . . . 26.4

Tabla 26.2 Perceptores de las prestaciones por accidente de trabajo y enfermedad profesional en Israel. . . . . . . . . . . . . . . . . . . . . . . . . . . . . . . 26.24

Tabla 26.3 Primas del seguro de indemnización por accidentes de trabajo en Japón (abril de 1992). . . . . . . . . . . . . . . . . . . . . . . . . . . . 26.28

Tabla 26.4 Empresas y trabajadores afiliados al seguro de indemnización por accidente de trabajo e importe de las prestaciones en Japón. . . . . . . . . . . . . . . . . 26.28

Tabla $26.5 \quad$ Pago de prestaciones del seguro por sectores, en Japón. . . . . . . . . . . . . . 26.29

\section{PARTE IV. HERRAMIENTAS Y ENFOQUES}

\section{Capítulo 27. Control biológico}

Tabla 27.1 M etales: Valores de referencia y límites biológicos propuestos por la A merican C onference of G overnmental Industrial H ygienists (ACGIH), D eutsche

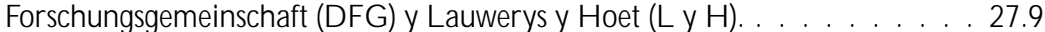

Tabla 27.2 Algunos ejemplos de sustancias químicas diana para el control biológico y momentos de muestreo. . . . . . . . . . . . . . . . . . . . . . . . . 27.14

Tabla 27.3 Algunos ejemplos de métodos analíticos para el control biológico de la exposición a disolventes orgánicos. . . . . . . . . . . . . . . . . . . . . 27.15

Tabla 27.4 G enotoxicidad de los compuestos químicos evaluados en los Suplementos 6 y 7 de las monografías IARC (1986). . . . . . . . . . . . . . . . . . . . . . 27.17

Tabla 27.5 Biomarcadores utilizados en el control genético de exposiciones genotóxicas y muestras de células y tejidos más utilizadas. . . . . . . . . . . . . 27.17

Tabla 27.6 Cancerígenos humanos demostrados, probables y posibles para los cuales hay exposición profesional y para los cuales se han medido criterios citogenéticos en el hombre y en animales de experimentación. . . . . . . . . 27.19

Tabla 27.7 Algunos principios éticos relacionados con la necesidad de saber en estudios de biocontrol genético profesional. . . . . . . . . . . . . . . . . . 27.20

Tabla 27.8 Comparación de peculiaridades de la exposición durante la fabricación y el uso de pesticidas. . . . . . . . . . . . . . . . . . . . . . . . . 27.20

Tabla $27.9 \quad G$ ravedad y pronóstico de la toxicidad aguda por compuestos $\mathrm{O} \mathrm{P}$ a distintos grados de inhibición de la ACHE.. . . . . . . . . . . . . . . . . . . 27.21

Tabla 27.10 Variaciones de las actividades de ACH E y PCHE en sujetos sanos y en determinados estados fisiopatológicos. . . . . . . . . . . . . . . . . 27.21

Tabla 27.11 Actividades de la colinesterasa en sujetos sanos sin exposición a O P medidas por métodos seleccionados. . . . . . . . . . . . . . . . . . . . . . . . 27.21

Tabla 27.12 Alquilfosfatos detectables en orina como metabolitos de pesticidas O P. . . . . 27.22 
Tabla 27.13 Ejemplos de concentraciones urinarias de alquilfosfatos medidas en distintas condiciones de exposición a O P. . . . . . . . . . . . . . . . . . 27.22

Tabla 27.14 Concentraciones urinarias de metabolitos del carbamato medidas en estudios de campo. . . . . . . . . . . . . . . . . . . 27.23

Tabla 27.15 Concentraciones urinarias de metabolitos del ditiocarbamato medidas en estudios de campo. . . . . . . . . . . . . . . . . . . . . . . . . . . . . . . 27.23

Tabla 27.16

O tros índices propuestos en la bibliografía para el control biológico de exposición a pesticidas. . . . . . . . . . . . . . . . . . . . . 27.25

Tabla $27.17 \quad$ Valores biológicos límite recomendados (en 1996). . . . . . . . . . . . 27.26

\section{Capítulo 28.}

Tabla 28.1

Tabla 28.2

Tabla 28.3

Tabla 28.4

Tabla 28.5

Tabla 28.6

Tabla 28.7

Tabla 28.8

Tabla 28.9

Tabla 28.10

Tabla 28.11

Tabla 28.12

Tabla 28.13

Tabla 28.14

Tabla 28.15

Tabla 28.16

Tabla 28.17

\section{Capítulo 29.}

Tabla 29.1

Tabla 29.2

Tabla 29.3

Tabla 29.4

Tabla 29.5

Tabla 29.6

Tabla 29.7

\section{E pidemiología y estadística}

Fórmulas y dimensiones o unidades de las cinco medidas que resumen la exposición durante toda una vida laboral. . . . . . . . . . . . . . . . . 28.10

M edidas de la aparición de enfermedades: población hipotética observada durante un período de cinco años. . . . . . . . . . . . . . . . . . . . 28.11

M edidas de asociación en un estudio de cohortes. . . . . . . . . . . . . . . 28.12

M edidas de asociación en estudios de casos y controles: exposición al polvo de madera y adenocarcinoma de la cavidad nasal y de los senos paranasales. . 28.13

Formato habitual de las tablas de frecuencias para presentar los datos de una cohorte. . . . . . . . . . . . . . . . . . . . . . . . . 28.17

Ejemplo de presentación de los datos de casos y controles. . . . . . . . . . . . 28.20

Presentación de los datos de casos y controles si se empareja un control con cada caso. . . . . . . . . . . . . . . . . . . . . . . . . . 2820

Cohorte hipotética de 1.959 personas (expuestas y no expuestas), reclutadas en el momento $T_{0}$ y cuyo estado de salud se determina en $T_{2} \ldots$. . . . . . . 28.26 Indices de la tendencia central y la dispersión según la escala de medición. . . 28.27 Posibles resultados de un experimento binomial (sí $=1$, no $=0$ ) y sus

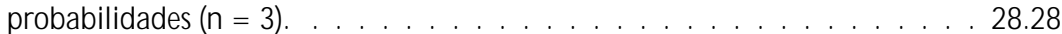

Posibles resultados de un experimento binomial (sí $=1$, no $=0$ ) y sus probabilidades $(n=3) \ldots \ldots \ldots \ldots$

Distribución binomial. Probabilidades para diferentes valores de para

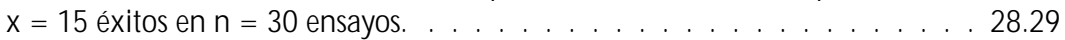

Distribución binomial. Probabilidades de éxito para $\pi=0,25$ en $n=30$ ensayos. . . . . . . . . . . . . . . . . . . . . . . . . . . . . . . . . . . . . 28.29

Error tipo II y potencia para $x=12, n=30, \alpha=0,05 \ldots 28.30$ Error tipo II y potencia para $x=12, n=40, \alpha=0,05 \ldots . . . .28 .30$ $\mathrm{H}$ ombre-años de experiencia de 632 trabajadores del amianto expuestos a polvo de amianto durante 200 más años. . . . . . . . . . . . . . . . . . 28.41 $N$ úmero observado y esperado de fallecimientos en 632 trabajadores del amianto expuestos a polvo de amianto durante 20 o más años. . . . . . . . . 28.41

\section{Ergonomía}

Lista fundamental antropométrica básica. . . . . . . . . . . . . . . . . . 29.28

Fatiga y recuperación en función de los niveles de actividad. . . . . . . . . . . 29.42

R eglas del efecto de combinación de dos factores de estrés sobre la tensión.. . 29.43

C riterios de diferenciación entre las distintas consecuencias negativas de la tensión mental. . . . . . . . . . . . . . . . . . . . . . . . . 29.51 Principios orientados al trabajo para la estructuración de la producción. . . . 29.53 Participación en un contexto organizativo. . . . . . . . . . . . . . . . . . 29.54 Participación de los usuarios en el proceso tecnológico. . . . . . . . . . . . 29.56 
Tabla 29.8

Tabla 29.9

Tabla 29.10

Tabla 29.11

Tabla 29.12

Tabla 29.13

Capítulo 30.

Tabla 30.1

Tabla 30.2

\section{Capítulo 31.}

Tabla 31.1

Tabla 31.2

Tabla 31.3

Tabla 31.4

Tabla 31.5

Tabla 31.6

Tabla 31.7

Tabla 31.8

Tabla 31.9

Tabla 31.10

Tabla 31.11

Tabla 31.12

Tabla 31.13

\section{Capítulo 32.}

Tabla 32.1

Tabla 32.2

Tabla 32.3

Tabla 32.4

Tabla 32.5

Tabla 32.6

Tabla 32.7
Principales condiciones de un horario de trabajo irregular que contribuyen en distintos grados a la privación de sueño. . . . . . . . . . . . . . . . . . . . 29.56 Aspectos del sueño "por adelantado", "de mantenimiento" o "retrasado" como sustituto de un sueño nocturno normal. . . . . . . . . . . . . . . . . . 29.59 M ovimientos de control y efectos esperados. . . . . . . . . . . . . . . . . . 29.72 Relaciones control-efecto de los controles manuales comunes. . . . . . . . . . 29.73 Normas para la disposición de los controles. . . . . . . . . . . . . . . . . 29.74 Directrices para los rótulos. . . . . . . . . . . . . . . . . . . . . . . . . . 29.76

\section{H igiene industrial}

Peligro de agentes químicos, biológicos y físicos. . . . . . . . . . . . . . . . 30.12 Límites de exposición profesional (O ELs) en distintos países (1986). . . . . . . . 30.32

\section{Protección personal}

Requisitos de transmitancia (ISO 4850-1979). . . . . . . . . . . . . . . . . 31.5

G rados de protección que deben utilizarse en operaciones de soldadura con gas y con latón. . . . . . . . . . . . . . . . . . . . . . . . 31.5

Grados de protección que deben utilizarse en operaciones de corte con oxígeno. . . . . . . . . . . . . . . . . . . . . . . . . . 31.5

Grados de protección que deben utilizarse en operaciones de corte con arco de plasma. . . . . . . . . . . . . . . . . . . . . . . . . 31.6

G rados de protección que deben utilizarse en operaciones de soldadura 0 vaciado con arco eléctrico. . . . . . . . . . . . . . . . . . . . . . . 31.6

G rados de protección que deben utilizarse en operaciones de soldadura directa con arco de plasma. . . . . . . . . . . . . . . . . . . . . . . 31.6

Cascos de seguridad: requisitos de ensayo de la norma ISO 3873-1997.. . . . 31.9

Ejemplo de cálculo de la puntuación de reducción de ruido (NRR) de un protector auditivo. . . . . . . . . . . . . . . . . . . . . . . . . . . 31.13

Ejemplo de método de cálculo de banda de octava de la reducción de ruido ponderada A correspondiente a un protector auditivo en un medio ruidoso conocido. . . . . . . . . . . . . . . . . . . . . . . . . 31.14 Ejemplos de categorías de riesgos dérmicos. . . . . . . . . . . . . . . . . 31.18 Requisitos comunes de comportamiento físico, químico y biológico. . . . . . . 31.19 Riesgos materiales asociados con actividades determinadas. . . . . . . . . . 31.23 Factores de protección asignados según AN SI.Z88.2 (1992). . . . . . . . . . . 31.27

\section{Sistemas de notificación y vigilancia}

Número de casos de angiosarcoma de hígado registrados en todo el mundo, por países y años en que se inició la producción de cloruro de vinilo. . . . . . . 32.3 N úmero de nuevos casos de enfermedades profesionales por categorías de enfermedad-Encuesta A nual de la O ficina de Estadísticas $L$ aborales de Estados U nidos, 1986 frente a 1992. . . . . . . . . . . . . . . . . . . . . 32.4

M ortalidad causada por neumoconiosis y mesotelioma maligno de la pleura. Causa subyacente y causas múltiples, E stados U nidos, 1990 y 1991.. . . . . . . 32.7

Ejemplo de lista de enfermedades profesionales notificables. . . . . . . . . . . 32.12 Ejemplos del sistema de códigos de clasificación de enfermedades y lesiones, O ficina de Estadísticas L aborales de Estados U nidos. . . . . . . . . . . . . . 32.17

Número y porcentaje de lesiones y enfermedades profesionales relacionadas con caídas, que no tienen consecuencias fatales pero que causan baja laboral, por tipos de trabajadores y características del caso, Estados U nidos 1993 . . . 32.18 Riesgo de lesiones y enfermedades profesionales . . . . . . . . . . . . . . . 32.20 
Tabla 32.8

Tabla 32.9

Tabla 32.10

Tabla 32.11

Tabla 32.12

Tabla 32.13

Tabla 32.14

\section{Capítulo 33.}

Tabla 33.1

Tabla 33.2

Tabla 33.3

Tabla 33.4

Tabla 33.5

Tabla 33.6

Tabla 33.7

Tabla 33.8

Tabla 33.9

Tabla 33.10

Tabla 33.11

Tabla 33.12

Tabla 33.13

Tabla 33.14

Tabla 33.15

Tabla 33.16

Tabla 33.17

Tabla 33.18
Indice de riesgo relativo de enfermedades por movimientos repetitivos que causan baja laboral durante varios días, por profesiones y sexo, trabajadores no agrícolas del sector privado de 15 o más años de edad, Estados U nidos,

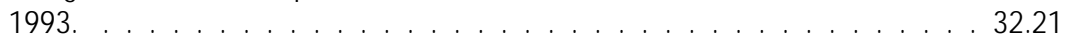
Número de accidentes en el lugar de trabajo. Alemania, 1981-93. . . . . . . . . 32.25 Accidentes en el lugar de trabajo con máquinas portátiles de rectificado en el trabajo de metalurgia, A lemania, 1984-93. . . . . . . . . . . . . . . . 32.26 Número de casos de enfermedades profesionales, Alemania, 1980-93. . . . . . 32.26 Enfermedades infecciosas de origen profesional reconocido, Alemania,

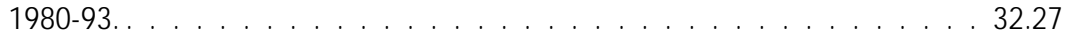
Estimación de la exposición a radiación ( $N$ ivel de Trabajo M eses/ Año) en las minas de Wismut. . . . . . . . . . . . . . . . . . . . . . . . . . . . . . . . . 32.29

Resumen completo de las enfermedades profesionales conocidas en las minas de uranio de Wismut 1952-90 . . . . . . . . . . . . . . . . . . . . 32.29

\section{T oxicología}

Ejemplos de órganos críticos y efectos críticos. . . . . . . . . . . . . . . . . 33.17

E fectos básicos de posibles interacciones múltiples de los principales metales y metaloides tóxicos y/ o esenciales en los mamíferos. . . . . . . . . . . . . 33.20

Aductos de hemoglobina en trabajadores expuestos a anilina y acetanilida. . . 33.28 Trastornos hereditarios con propensión al cáncer en los que parece intervenir una reparación defectuosa del ADN . . . . . . . . . . . . . . . . . . . . 33.38 Ejemplos de sustancias químicas que muestran genotoxicidad en células humanas. . . . . . . . . . . . . . . . . . . . . . . . . 33.38 Clasificación de los ensayos con arreglo a los marcadores inmunitarios. . . . . 33.43 Ejemplos de biomarcadores de la exposición o del efecto que se emplean en los estudios toxicológicos relacionados con la salud en el trabajo. . . . . . . . 33.45 Ventajas e inconvenientes de los actuales métodos de identificación del riesgo de cáncer humano. . . . . . . . . . . . . . . . . . . . . . . . . . . 33.48 Comparación de sistemas in vitro empleados en estudios de hepatotoxicidad. . 33.54 Comparación entre predicciones SAR y datos de ensayos: análisis de la OCDE y el NTP. . . . . . . . . . . . . . . . . . . . . . . 33.56 Regulación legal de las sustancias químicas, Japón.. . . . . . . . . . . . . 33.58 Parámetros de ensayo según la Ley de control de las sustancias químicas, Japón. . . . . . . . . . . . . . . . . . . . . . . 33.58

Características y regulación de las sustancias químicas clasificadas conforme a la L ey de control de las sustancias químicas, Japón. . . . . . . . . . . . . 33.59 Casos importantes de neurotoxicidad. . . . . . . . . . . . . . . . . . 33.61 Ejemplos de ensayos especializados para medir la neurotoxicidad. . . . . . 33.62 Parámetros de toxicología en la reproducción. . . . . . . . . . . . . . . . 33.64 Comparación de diversos procedimientos de extrapolación a dosis bajas. . . . 33.77 M odelos más citados de caracterización del riesgo de carcinogenicidad. . . . 33.79 


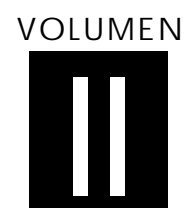

PARTE V. FACTORES PSICOSOCIALES Y DE ORGANIZACION

\section{Capítulo $34 . \quad$ Factores psicosociales y de organización}

Tabla 34.1 Recursos de diseño del lugar de trabajo y posibles beneficios para la salud. . . 34.25

Tabla 34.2 Perfiles psicológicos de los operarios que prefieren el trabajo de ritmo autorregulado y los que prefieren el trabajo con el ritmo marcado por una máquina. . . . . . . . . . . . . . . . . . . . . 34.29

PARTE VI. RIESGOS GENERALES

Capítulo 36.

Tabla 36.1

Tabla 36.2

\section{Capítulo 38.}

Tabla 38.1

T abla 38.2

T abla 38.3

Capítulo 39.

Tabla 39.1

Tabla 39.2

Tabla 39.3

Tabla 39.4

Tabla 39.5

T abla 39.6

Tabla 39.7

T abla 39.8

Tabla 39.9

Tabla 39.10

Tabla 39.11

Tabla 39.12

Tabla 39.13

Tabla 39.14

Tabla 39.15

\section{Presión barométrica, aumento}

Instrucciones para los trabajadores en entornos de aire comprimido. . . . . . 36.7

Sistema revisado de clasificación de las enfermedades por descompresión. . . 36.13

\section{Riesgos biológicos}

Entornos laborales con posible exposición de los trabajadores a agentes biológicos. . . . . . . . . . . . . . . . . . . . 38.2

Virus, bacterias, hongos y plantas: riesgos biológicos conocidos en el lugar de trabajo. . . . . . . . . . . . . . . . . . . . . . . . . . . . . 38.3

Los animales como fuente de riesgos profesionales.. . . . . . . . . . . . . . . 38.4

\section{Desastres naturales y tenológicos}

D efinición de los tipos de catástrofes. . . . . . . . . . . . . . . . . . . 39.3

Número de víctimas de catástrofes debidas a fenómenos naturales de 1969 a 1993: media correspondiente a 25 años por zona. . . . . . . . . . . . . . . . 39.4

Número de víctimas de catástrofes no debidas a fenómenos naturales de 1969 a 1993: media correspondiente a 25 años por zona. . . . . . . . . . . . 39.5

Número de víctimas de catástrofes debidas a fenómenos naturales de 1969 a 1993: media correspondiente a 25 años por tipo. . . . . . . . . . . . . 39.5

$\mathrm{N}$ úmero de víctimas de catástrofes no debidas a fenómenos naturales de 1969 a 1993: media correspondiente a 25 años por tipo. . . . . . . . . . . . 39.6

Catástrofes debidas a fenómenos naturales de 1969 a 1993: número de acontecimientos en 25 años. . . . . . . . . . . . . . . . . . . . . . . . 39.6

C atástrofes no debidas a fenómenos naturales de 1969 a 1993: número de

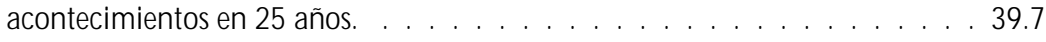

C atástrofes debidas a fenómenos naturales: número por región del mundo y por tipo en 1994. . . . . . . . . . . . . . . . . . . . . . . . . . . . . 39.7

C atástrofes no debidas a fenómenos naturales: número por región del mundo y por tipo en 1994. . . . . . . . . . . . . . . . . . . . . 39.7

Ejemplos de explosiones industriales. . . . . . . . . . . . . . . . . . . 39.7

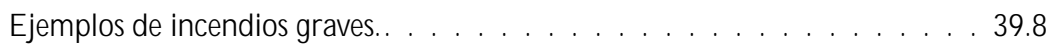

Ejemplos de escapes tóxicos graves. . . . . . . . . . . . . . . . . . . . . . . 39.8

Función de los responsables de la gestión de instalaciones con riesgos de accidentes mayores en sistemas de control de riesgos. . . . . . . . . . . . . 39.8

M étodos de trabajo para la evaluación de riesgos. . . . . . . . . . . . . . . . 39.11

Directiva de la CE relativa a los riesgos de accidentes graves en instalaciones industriales . . . . . . . . . . . . . . . . . . . . . . . . . . 39.14 
Tabla 39.16 Principales sustancias químicas utilizadas en la identificación de instalaciones con riesgos de accidentes mayores. . . . . . . . . . . . . . . . . . . 39.15

Tabla 39.17

Tabla 39.18

Tabla 39.19

Tabla 39.20

Tabla 39.21

Tabla 39.22

Tabla 39.23

Tabla 39.24

Tabla 39.25

Tabla 39.26

Tabla 39.27

Tabla 39.28

Tabla 39.29

Tabla 39.30

Tabla 39.31

Tabla 39.32

Tabla 39.33

Tabla 39.34

Tabla 39.35

Tabla 39.36

Tabla 39.37

Tabla 39.38

\section{C apítulo 40.}

Tabla 40.1

Tabla 40.2

Tabla 40.3

Tabla 40.4

Tabla 40.5

Tabla 40.6

\section{C apítulo 41.}

Tabla 41.1

Tabla 41.2
R iesgos profesionales asociados con fenómenos atmosféricos. . . . . . . . . 39.23

R adionúclidos típicos y sus correspondientes semividas radiactivas. . . . . . . 39.32

Comparación de distintos accidentes nucleares. . . . . . . . . . . . . . 39.33

Superficie de las zonas contaminadas, tipos de poblaciones expuestas y modalidades de exposición en U crania, Bielorrusia y Rusia tras el accidente de Chernóbil. . . . . . . . . . . . . . . . . . . . . . . . . . . . . . . . . . . 39.34

Superficie de las zonas contaminadas y dimensión de las poblaciones expuestas a contaminación por estroncio-90 tras el accidente de $\mathrm{K}$ hyshtym (Urales, 1957). . . . . . . . . . . . . . . . . . . . . . . . . . . . . . . . . 39.34 Accidentes por pérdida de fuentes de radiación, que provocaron la exposición de la población general. . . . . . . . . . . . . . . . . . . . . . . . . . 39.35

Principales accidentes con fuentes industriales de radiación. . . . . . . . . . 39.36 Accidentes de radiación incluidos en el registro (mundial, 1944-1988) de accidentes de $\mathrm{O}$ ak R idge (Estados U nidos). . . . . . . . . . . . . . . . . . . 39.37 Evolución temporal de la exposición profesional a radiación ionizante artificial en todo el mundo (en miles). . . . . . . . . . . . . . . . . . . . . . 39.37 Efectos deterministas: cantidades máximas en determinados órganos. . . . . . 39.38 Distribución de pacientes con síndrome de radiación agudo (SAG) tras el accidente de Chernóbil, por gravedad de la patología. . . . . . . . . . . . 39.38 Resultados de los estudios epidemiológicos del efecto de una alta cuantía de dosis de radiación externa sobre el cáncer. . . . . . . . . . . . . . . . . . . 39.39

Evolución temporal de la incidencia y número total de cánceres de tiroides en niños en Bielorrusia, U crania y Rusia, 1981-94.. . . . . . . . . . . . . . . 39.40 Escala internacional de incidentes nucleares. . . . . . . . . . . . . . . . . 39.41 Ejemplos de niveles generales de intervención en las medidas de protección de la población general. . . . . . . . . . . . . . . . . . . . . . . . . . . . . . 39.41 Criterios para las zonas de contaminación. . . . . . . . . . . . . . . . . . 39.43 Principales catástrofes en América L atina y el C aribe, 1970-1993.. . . . . . . . 39.49 Pérdidas ocasionadas en seis catástrofes naturales. . . . . . . . . . . . . . . . 39.49 Número de hospitales y de camas de hospital dañadas o destruidas en tres catástrofes naturales graves. . . . . . . . . . . . . . . . . . . . . . . 39.50 V íctimas del derrumbamientos de dos hospitales en el terremoto de M éxico de 1985. . . . . . . . . . . . . . . . . . . . . . . 39.50 Camas de hospital perdidas a consecuencia del terremoto de $\mathrm{C}$ hile de marzo

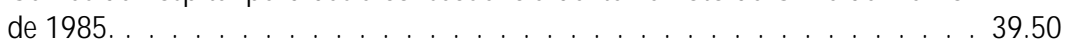
Factores de riesgo asociados con los daños sísmicos a la infraestructura hospitalaria. . . . . . . . . . . . . . . . . . . . . . 39.50

\section{Electricidad}

Estimaciones de la tasa de electrocución, 1988. . . . . . . . . . . . . . . . 40.2

Relaciones básicas en electrostática: conjunto de ecuaciones. . . . . . . . . . 40.7

Afinidades electrónicas de determinados polímeros . . . . . . . . . . . . 40.8

Límites inferiores típicos de inflamabilidad. . . . . . . . . . . . . . . . . 40.9

Carga específica asociada a determinadas operaciones industriales. . . . . . . 40.10

Ejemplos de equipos sensibles a descargas electrostáticas. . . . . . . . . . . . 40.11

\section{Incendios}

Límites inferior y superior de inflamabilidad en el aire. . . . . . . . . . . . 41.2 Puntos de inflamación y de ignición de combustibles líquidos y sólidos. . . . . 41.4 
Tabla 41.3

Tabla 41.4

\section{Capítulo 42.}

Tabla 42.1

Tabla 42.2

Tabla 42.3

Tabla 42.4

Tabla 42.5

Tabla 42.6

Tabla 42.7

Tabla 42.8

Tabla 42.9

Tabla 42.10

Tabla 42.11

Tabla 42.12

Tabla 42.13

Tabla 42.14

Tabla 42.15

Tabla 42.16

Tabla 42.17

Tabla 42.18

Tabla 42.19

Tabla 42.20

Tabla 42.21

Tabla 42.22

Tabla 42.23

Tabla 42.24

Tabla 42.25

Tabla 42.26

Tabla 42.27

Tabla 42.28

Tabla 42.29

Tabla 42.30
Fuentes de ignición. . . . . . . . . . . . . . . . . . . . . . 41.5

Comparación de las concentraciones de inertización de diferentes gases. . 41.6

\section{Calor y frío}

Concentración de electrolitos en el plasma sanguíneo y en el sudor. . . . . . . 42.6

E cuaciones utilizadas para calcular el índice de estrés por calor (H SI ) y los tiempos de exposición permisibles (AET) . . . . . . . . . . . . . . . . . . . . 42.19

Interpretación de los valores del índice de estrés por calor (H SI). . . . . . . . 42.19

Valores de referencia para los criterios de estrés y carga térmica

(ISO 7933, 1989b). . . . . . . . . . . . . . . . . . . . . . . . 42.20

M odelo de evaluación del estrés por calor basado en la frecuencia cardíaca. . 42.21

Valores de referencia del WBGT obtenidos de ISO 7243 (1989a). . . . . . . . 42.21

Prácticas de trabajo en ambientes calurosos. . . . . . . . . . . . . . . . . . 42.23

Ecuaciones utilizadas para el cálculo del índice $S W_{\text {req }}$ y en el método de

evaluación de ISO 7933 (1989b). . . . . . . . . . . . . . . . . . . . . . . 42.24

Descripción de los términos utilizados en ISO 7933 (1989b). . . . . . . . . . 42.24

Valores de WBGT $\left({ }^{\circ} \mathrm{C}\right)$ para cuatro fases de trabajo. . . . . . . . . . . . . . . 42.25

Datos básicos para la evaluación analítica utilizando ISO 7933. . . . . . . . 42.25

Evaluación analítica utilizando ISO 7933. . . . . . . . . . . . . . . . . . 42.26

Duración del estrés por frío descompensado y reacciones asociadas. . . . . . . 42.33

E fectos esperados de la exposición a frío leve e intenso. . . . . . . . . . . . . 42.34

I mportancia de la temperatura de los tejidos corporales para el rendimiento

físico del ser humano. . . . . . . . . . . . . . . . . . . . . . . . . . . . 42.35

Respuestas del ser humano al enfriamiento: reacciones indicativas a

diferentes niveles de hipotermia. . . . . . . . . . . . . . . . . . . . . . . . . 42.37

Componentes recomendados de los programas de control de la salud para los trabajadores expuestos a estrés por frío y factores relacionados con el frío. . . . 42.42

Componentes de los programas de acondicionamiento para los trabajadores expuestos al frío. . . . . . . . . . . . . . . . . . . . 42.43

Estrategias y medidas durante distintas fases del trabajo para prevenir y reducir el estrés por frío. . . . . . . . . . . . . . . . . . . . . . . 42.45

Estrategias y medidas relacionadas con factores y equipos específicos. . . . . . 42.46

M ecanismos generales de adaptación al frío estudiados durante una prueba normal de exposición al frío realizada antes y después de un período de aclimatación. . . . . . . . . . . . . . . . . . . . . . . . 42.50

$\mathrm{N}$ úmero medio de días al mes y al año con una temperatura inferior a $15 \stackrel{\circ}{\circ}$. . . . . . . . . . . . . . . . . . . . . . . . . . . . . . 42.53

Temperaturas del aire en distintos ambientes de trabajo expuestos al frío. . . . 42.54

Clasificación esquemática del trabajo en ambientes fríos. . . . . . . . . . . . 42.54

Clasificación de los niveles de tasa metabólica. . . . . . . . . . . . . . . . . 42.55

Ejemplos de valores del aislamiento básico $\left(l_{c}\right)$ proporcionado por la ropa. . . 42.56

Clasificación de los guantes en función de su resistencia térmica (I) al

enfriamiento convectivo. . . . . . . . . . . . . . . . . . . 42.58

Clasificación de los guantes en función de su resistencia térmica al enfriamiento por contacto (I). . . . . . . . . . . . . . . . . . . . . . . . . 42.58

Indice de enfriamiento por el viento (Wind Chill Index, WCI), temperatura equivalente de enfriamiento $\left(\mathrm{T}_{\text {eq }}\right)$ y tiempo de congelación de la carne al desnudo . . . . . . . . . . . . . . . . . . . . . . 42.58

C apacidad de enfriamiento del viento en la carne al desnudo expresada como temperatura equivalente de enfriamiento en condiciones de calma casi total (velocidad del viento $1,8 \mathrm{~m} / \mathrm{s}$ ) . . . . . . . . . . . . . . . . . . . 42.59 


\section{Capítulo 43.}

Tabla 43.1

Tabla 43.2

\section{Capítulo 44.}

Tabla 44.1

Tabla 44.2

Tabla 44.3

Tabla 44.4

Tabla 44.5

Tabla 44.6

Tabla 44.7

Tabla 44.8

Tabla 44.9

Tabla 44.10

Tabla 44.11

Tabla 44.12

Tabla 44.13

Tabla 44.14

Tabla 44.15

Tabla 44.16

Tabla 44.17

Tabla 44.18

Tabla 44.19

Tabla 44.20

\section{Capítulo 45.}

Tabla 45.1

Tabla 45.2

\section{H oras de trabajo}

Intervalos de tiempo entre el comienzo del trabajo por turnos y el momento en que se diagnosticaron las tres enfermedades (desviación media y típica en años). . . . . . . . . . . . . . . . . . . . . . . . . . . . . . . . . . . 43.4

R elación entre el trabajo por turnos y la frecuencia de trastornos cardiovasculares. ...........................

\section{Calidad del aire interior}

Clasificación de los contaminantes orgánicos en interiores.

Tasas de emisión de formaldehído de diversos materiales de decoración y productos de consumo. . . . . . . . . . . . . . . . . . . .

Concentraciones de compuestos orgánicos volátiles totales (C OVT) y tasas de emisión asociadas a los diversos recubrimientos y revestimientos de suelos y paredes. . . . . . . . . . . . . . . . . . . . . . . . . 44.8

Componentes y emisiones de productos de consumo y otras fuentes de compuestos orgánicos volátiles (COV). . . . . . . . . . . . . . . . . . . 44.9

Principales contaminantes químicos del aire interior y sus concentraciones en el medio urbano del Reino U nido. . . . . . . . . . . . . . . . . . . . . . . . 44.9

R esumen de las determinaciones de campo de óxidos de nitrógeno $\left(\mathrm{No}_{\mathrm{x}}\right)$ y monóxido de carbono (CO). . . . . . . . . . . . . . . . . . . . . . . . . 44.10

Algunos agentes tóxicos y tumorígenos en el humo de flujo lateral de los cigarrillos no diluido. . . . . . . . . . . . . . . . . . . . . . . . . 44.13

Algunos agentes tóxicos y tumorígenos en ambientes de interior contaminados con humo de tabaco. . . . . . . . . . . . . . . . . . . 44.14

Cotinina urinaria en no fumadores en función del número de horas notificadas de exposición al humo de tabaco de otras personas en los siete días previos. . . . . . . . . . . . . . . . . . . . . . . . . . . . . . . . . 44.14 M etodología para la toma de muestras. . . . . . . . . . . . . . . . . . . 44.20

M étodos de detección de gases en el aire interior. . . . . . . . . . . . . . . .44.20 M étodos utilizados para el análisis de contaminantes químicos. . . . . . . . . 44.21 Límites inferiores de detección para algunos gases por monitores utilizados para valorar la calidad del aire interior. . . . . . . . . . . . . . . . . . . . . . 44.21

Ejemplos de tipos de hongos en el aire interior que pueden causar rinitis o asma. . . . . . . . . . . . . . . . . . . . . . . . . . . 44.25

M icroorganismos presentes en el aire interior descritos como causas de alveolitis alérgica extrínseca relacionada con los edificios. . . . . . . . . . . 44.25 $\mathrm{N}$ iveles observados de microorganismos en el aire y el polvo de ambientes de interior no industriales. . . . . . . . . . . . . . . . . . . . . 44.27

$\mathrm{N}$ ormas en materia de calidad del aire de la Environmental Protection Agency de Estados Unidos. . . . . . . . . . . . . . . . . . . . . . 44.30

Valores de referencia de la 0 M S para algunas sustancias presentes en el aire, basados en los efectos conocidos sobre la salud humana aparte del cáncer o los olores molestos. . . . . . . . . . . . . . . . . . . . 44.31 Valores de referencia de la 0 M S para algunas sustancias no cancerígenas presentes en el aire, basados en los efectos sensoriales o reacciones de molestia durante un promedio de 30 minutos. . . . . . . . . . . . . . . . 44.31 Valores de referencia para el radón de tres organizaciones. . . . . . . . . . . 44.32

\section{Control ambiental en interiores}

Los contaminantes de interiores más comunes y sus fuentes. . . . . . . . . . 45.2

Requisitos básicos de un sistema de ventilación por dilución. . . . . . . . . . . 45.6 
Tabla 45.3 M edidas de control de la calidad del aire en interiores y sus efectos en los ambientes interiores. . . . . . . . . . . . . . . . . . . . . . . . 45.7

Tabla $45.4 \quad$ Ajustes del medio ambiente de trabajo y sus efectos sobre la calidad del aire en interiores. . . . . . . . . . . . . . . . . . . . . . . . . 45.7

Tabla 45.5 Eficacia de los filtros (conforme a la norma ASH R AE 52-76) para partículas de $3 \mu$ m de diámetro. . . . . . . . . . . . . . . . . . . . . . 45.9

Tabla 45.6

R eactivos utilizados como absorbentes para varios contaminantes. . . . . . . 45.10

Tabla 45.7

Niveles de calidad del aire en interiores. . . . . . . . . . . . . . . . . . . . 45.15

Tabla 45.8

Contaminación originada por los ocupantes de un edificio. . . . . . . . . . . 45.16

Tabla 45.9

Ejemplos del grado de ocupación de diferentes edificios. . . . . . . . . . . . . 45.16

Tabla 45.10

Tabla 45.11

Tabla 45.12

Tabla 45.13

Tabla 45.14

Contaminación debida al edificio. . . . . . . . . . . . . . . . . . . . . 45.16

Niveles de calidad del aire exterior. . . . . . . . . . . . . . . . . . . . . . 45.17

Normas propuestas para factores ambientales. . . . . . . . . . . . . . . . . 45.19

Temperaturas de confort térmico $\left({ }^{\circ} \mathrm{C}\right)$ con una humedad relativa del $50 \%$

(a partir de la fórmula de P. O. Fanger).. . . . . . . . . . . . . . . . . . 45.21

Características de los iones en función de la movilidad y el diámetro. . . . . . 45.24

\section{Capítulo $46 . \quad$ Iluminación}

Tabla 46.1 M ejora de los requisitos de rendimiento lumínico y vataje de algunas lámparas de tubo fluorescente de $1.500 \mathrm{~mm}$. . . . . . . . . . . . . . . 46.2

Tabla 46.3 Sistema Internacional de Codificación de Lámparas (SICL), sistema de codificación en formato abreviado para algunos tipos de lámparas. . . . . . . 46.3

Tabla 46.4

Colores y formas comunes a las lámparas incandescentes, con sus códigos del SICL . . . . . . . . . . . . . . . . . . . . . . . . . . . . . . . . . . . . 46.4

Tabla 46.5

T ipos de lámparas de sodio de alta presión. . . . . . . . . . . . . . . . 46.7

Tabla 46.6

Contrastes de color.

Tabla 46.7

Factores de reflexión de diferentes colores y materiales iluminados con luz blanca. . . . . . . . . . . . . . . . . . . . . . 46.13

Tabla 46.8

$\mathrm{N}$ iveles típicos recomendados de iluminancia mantenida para diferentes ubicaciones o tareas visuales . . . . . . . . . . . . . . . . . . . . . . . 46.14

\section{Capítulo 47.}

\section{Ruido}

Tabla 47.1 Límites de exposición permisibles (PEL), factores de acumulación y otros requisitos de la exposición al ruido según el país. . . . . . . . . . . . . . . . 47.17

\section{Capítulo $48 . \quad$ Radiaciones ionizantes}

Tabla 48.1

Tabla 48.2

Factores de ponderación de la radiación $\mathrm{w}_{\mathrm{R}}{ }^{1} \ldots \ldots \ldots$. . . . . . . . . 48.4

Tabla 48.3

Tabla 48.4

Factores de ponderación de tejidos $\mathrm{w}_{T}{ }^{1}$

D osis umbral aproximadas de radiación $X$ terapéutica en fracciones convencionales que originan efectos clínicos no estocásticos perjudiciales en diversos tejidos. . . . . . . . . . . . . . . . . . . . . . . . 48.6

Tabla 48.5

Tabla 48.6 Formas y características principales del síndrome de radiación agudo.. ... . 48.7 $R$ iesgos estimados de contraer cáncer durante la vida atribuibles a una irradiación rápida de 0,1 Sv. . . . . . . . . . . . . . . . . . . . . 48.9 Frecuencias estimadas de trastornos heredables que pueden atribuirse a la irradiación ionizante natural de fondo. . . . . . . . . . . . . . . . . . . . . . 48.10

Tabla 48.7 Principales anomalías del desarrollo producidas por irradiación prenatal.. . . 48.11

Tabla 48.8 C lasificación de los neutrones por su energía cinética. . . . . . . . . . . . . 48.15 
Tabla 48.11

Tabla 48.12

Tabla 48.13

Tabla 48.14

Tabla 48.15

Tabla 48.16

Capítulo 49.

Tabla 49.1

Tabla 49.2

Tabla 49.3

Tabla 49.4

Tabla 49.5

Tabla 49.6

Tabla 49.7

Tabla 49.8

Tabla 49.9

Tabla 49.10

Tabla 49.11

\section{Capítulo 50.}

Tabla 50.1

Tabla 50.2

Tabla 50.3

Tabla 50.4

Tabla 50.5

Tabla 50.6

Tabla 50.7

Tabla 50.8

Capítulo 51.

Tabla 51.1

Tabla 51.2
Clasificación de los radionucleidos por la radiotoxicidad relativa de una unidad de actividad. . . . . . . . . . . . . . . . . . . . . . . 48.18 Clasificación de zonas de trabajo. . . . . . . . . . . . . . . . . . . . . . . 48.19 Clasificación de los laboratorios de manipulación de materiales radiactivos. . 48.19 Instrumentos detectores de contaminación. . . . . . . . . . . . . . . . . 48.25

Límites de dosis recomendados por la Comisión Internacional de Protección Radiológica. . . . . . . . . . . . . . . . . . . . . . . . . . . . . . . . . . 48.27 Estimaciones de la exposición de K a la radiación. . . . . . . . . . . . . . . . 48.34

\section{Radiaciones no ionizantes}

Diferentes fuentes de IR, población expuesta y niveles de exposición aproximados . . . . . . . . . . . . . . . . . . . . . . . . 49.11

Función de riesgo térmico para la retina. . . . . . . . . . . . . . . . . . . . 49.13

Límites de exposición para láseres usuales. . . . . . . . . . . . . . . . . 49.19

A plicaciones de los equipos que trabajan dentro de la gama de 0 a $30 \mathrm{kH} \mathrm{z..} \mathrm{.} 49.24$

Fuentes de exposición laboral a campos magnéticos. . . . . . . . . . . . . 49.25

Efectos del paso de corrientes por el cuerpo humano. . . . . . . . . . . . . . 49.26

Intervalos aproximados de densidad de corriente correspondientes a diversos efectos biológicos. . . . . . . . . . . . . . . . . . . . . . . . . . . 449.27

Límites de exposición laboral a campos eléctricos y magnéticos en el intervalo de frecuencias $>0$ a $30 \mathrm{kHz}$ (f se indica en $\mathrm{Hz}$ ). . . . . . . . . . . . 49.27

E studios en animales expuestos a campos electrostáticos . . . . . . . . . . 49.29

Principales tecnologías en las que se utilizan grandes campos magnéticos estáticos y niveles de exposición correspondientes. . . . . . . . . . . . . . . 49.30

Límites de exposición a campos magnéticos estáticos recomendados por la Comisión Internacional de Protección contra la Radiación no Ionizante (ICNIR P). . . . . . . . . . . . . . . . . . . . . . . . . . . 449.32

\section{Vibraciones}

A ctividades para las que puede ser conveniente alertar sobre los efectos desfavorables de la vibración de cuerpo completo. . . . . . . . . . . . . . . 50.3

Resumen de medidas preventivas que han de considerarse cuando las personas están expuestas a vibración global de todo el cuerpo. . . . . . . . 50.8

Algunos factores potencialmente relacionados con efectos lesivos durante las exposiciones a las vibraciones transmitidas a las manos. . . . . . . . . . . 50.9

Fases neurosensoriales de la escala del Taller de Estocolmo para el síndrome de vibraciones mano-brazo. . . . . . . . . . . . . . . . . . . . . . . 50.10

E scala del Taller de Estocolmo para las fases del fenómeno de R aynaud inducido por el frío en el síndrome de vibraciones mano-brazo. . . . . . . . . 50.11 Valores límite umbral para vibraciones transmitidas a las manos. . . . . . . . 50.12 Propuesta del Consejo de la U nión E uropea para una Directiva del Consejo sobre agentes físicos: A nexo II A. V ibraciones transmitidas a la mano (1994). . 50.12

$M$ agnitudes de aceleración de vibración ponderada en frecuencia $\left(\mathrm{m} / \mathrm{s}^{2} \mathrm{r}\right.$.m.s.) que es de prever que produzcan dedo blanco por vibración en el $10 \%$ de las personas expuestas. . . . . . . . . . . . . . . . . . . . . . . 50.13

\section{Violencia}

Lugares de trabajo con las mayores tasas de homicidios laborales en Estados Unidos, 1980-1989. . . . . . . . . . . . . . . . . . . . . . . . . . . . 51.3

Profesiones con las mayores tasas de homicidios laborales en Estados Unidos, 1980-1989. . . . . . . . . . . . . . . . . . . . . . . 51.4 
Tabla $51.3 \quad$ Factores de riesgo de los homicidios en el lugar de trabajo. . . . . . . . . 51.4

Tabla $51.4 \quad$ Guías para la implantación de programas de prevención de la violencia en el lugar de trabajo. . . . . . . . . . . . . . . . . . . . . 51.7

Capítulo 52. Pantallas de visualización de datos

Tabla $52.1 \quad$ Distribución de los ordenadores en distintas regiones del mundo. . . . . . . . 52.3

Tabla 52.2 Frecuencia e importancia de los elementos del equipo para una tarea determinada. . . . . . . . . . . . . . . . . . . 52.6

Tabla 52.3 Prevalencia de los síntomas oculares en 196 operadores de PVD, clasificados en cuatro categorías. . . . . . . . . . . . . . . . . . . . . . . . . . . . . . 52.12

Tabla 52.4 Estudios teratológicos con ratas o ratones expuestos a campos magnéticos en dientes de sierra de 18-20 kHz . . . . . . . . . . . . . . . . . . . 52.16

Tabla 52.5 Estudios teratológicos con ratas o ratones expuestos a campos magnéticos de 15-60 kH z sinusoidales o de impulsos cuadrados. . . . . . . . . . . . . . 52.17

Tabla 52.6 U tilización de PV D como un factor de las consecuencias adversas en el embarazo. . . . . . . . . . . . . . . . . . . . . . . . . . . . 52.21

Tabla 52.7 Resumen de los estudios de campo empíricos que han utilizado un análisis multivariante para estudiar las causas de los problemas musculosqueléticos entre los trabajadores de oficina. . . . . . . . . . . . . . . . . . . . . . . . 52.24

Tabla 52.8 Resumen de estudios que muestran la implicación de ciertos factores considerados causa de problemas musculosqueléticos en los trabajadores de oficina. . . . . . . . . . . . . . . . . . . . . . . . . . 52.25

PARTE VII. EL MEDIO AMBIENTE

Capítulo 53.

Tabla 53.1

Tabla 53.2

Tabla 53.3

Tabla 53.4

Tabla 53.5

Tabla 53.6

Tabla 53.7

Tabla 53.8

Tabla 53.9

Tabla 53.10

Tabla 53.11

Tabla 53.12

\section{Capítulo 54.}

Tabla 54.1

Tabla 54.2

\section{R iesgos ambientales para la salud}

Algunos episodios importantes de "enfermedad de origen ambiental". . . . . . 53.2

Agentes de importantes enfermedades transmitidas por los alimentos y principales características epidemiológicas. . . . . . . . . . . . . . . . . . . 53.6

Principales fuentes de contaminantes del aire exterior. . . . . . . . . . . . . 53.12

Resumen de la relación entre exposición de corta duración y respuesta a las PM ${ }_{10}$, con diversos indicadores de efectos sobre la salud. . . . . . . . . . . 53.12

C onsecuencias para la salud asociadas a cambios en la concentración máxima diaria del ozono ambiental en estudios epidemiológicos. . . . . . . . 53.12

Tasas mundiales de morbilidad y mortalidad de las principales enfermedades relacionadas con el agua. . . . . . . . . . . . . . . . . . . . . . . . . . . 53.21

Principales efectos de las tecnologías de generación de electricidad sobre la salud (grupo de combustibles). . . . . . . . . . . . . . . . . . . . . 53.23

Principales efectos de las tecnologías de generación de electricidad sobre la salud (grupo de energías renovables). . . . . . . . . . . . . . . . . . . 53.23

Principales efectos de las tecnologías de generación de electricidad sobre la salud (grupo nuclear). . . . . . . . . . . . . . . . . . . . . . . . . . . . . . 53.24 Vivienda y salud. . . . . . . . . . . . . . . . . . . . . . . . . . . . . . . . 53.25 Infraestructuras urbanas y salud. . . . . . . . . . . . . . . . . . . 53.26 Situación mundial de las principales enfermedades transmitidas por vectores.

\section{Política en materia de medio ambiente}

A mbito de una auditoría ambiental.

Etapas fundamentales de una auditoría ambiental. 
Tabla 54.3

Tabla 54.4

Tabla 54.5

\section{Capítulo 55.}

Tabla 55.1

Tabla 55.2

Tabla 55.3

Tabla 55.4

Tabla 55.5

Tabla 55.6

Tabla 55.7

Tabla 55.8

Tabla 55.9

Tabla 55.10

Tabla 55.11

Tabla 55.12

Tabla 55.13

Tabla 55.14

Tabla 55.15

Tabla 55.16

Tabla 55.17

Tabla 55.18

Tabla 55.19

Tabla 55.20
Agentes sociales intervinientes en los acuerdos voluntarios relativos al medio ambiente. . . . . . . . . . . . . . . . . . . . . . 54.33

Ambito de aplicación de los acuerdos voluntarios sobre medidas de protección del medio ambiente concertados entre las partes otorgantes de los convenios colectivos. . . . . . . . . . . . . . . . . . . . . . 54.33 Naturaleza de los acuerdos sobre medidas de protección del medio ambiente concertados entre las partes otorgantes de los convenios colectivos.

\section{Control de la contaminación ambiental}

Contaminantes atmosféricos más comunes y sus fuentes.

Parámetros para la planificación de la medición de concentraciones de contaminantes atmosféricos y ejemplos de su aplicación.. . . . . . . . . . . 55.12

Procedimientos manuales para la medición de gases inorgánicos. . . . . . . . 55.14

Procedimientos automáticos para la medición de gases inorgánicos. . . . . . . 55.15

Procedimientos para la medición de partículas en suspensión. . . . . . . . . . 55.15

Procedimientos para mediciones a grandes distancias. . . . . . . . . . . . . 55.17

M étodos cromatográficos más habituales para la determinación de compuestos orgánicos contaminantes de la atmósfera y ejemplos de su aplicación. . . . . . . . . . . . . . . . . . . . . . . . . 55.18

V igilancia sistemática de la atmósfera en la región de Renania del Norte/ Westfalia (Alemania). . . . . . . . . . . . . . . . . . . . . . 55.20

Etapas en la selección de los controles de contaminación. . . . . . . . . . . 55.20

Normas sobre la calidad atmosférica para un contaminante controlado habitualmente (dióxido de azufre). . . . . . . . . . . . . . . . . 55.21

N ormas sobre la calidad atmosférica para un contaminante controlado menos habitualmente (benceno). . . . . . . . . . . . . . . . . . . . . 55.21

Ejemplos de tecnología BACT (mejor tecnología de control disponible), indicando los métodos de control utilizados y la eficiencia estimada. . . . . . 55.21

M étodos de depuración de gases para eliminar de las emisiones industriales partículas, gases, vapores nocivos. . . . . . . . . . . . . . . . . . . . 55.22

Velocidad de emisiones no controladas de algunos procesos industriales. . . . 55.23

Clasificación general de las operaciones y los procesos de tratamiento de aguas residuales. . . . . . . . . . . . . . . . . . . . 55.32

Lista de parámetros investigados. . . . . . . . . . . . . . . . . . . . . . 55.40

Parámetros investigados en los pozos de recuperación. . . . . . . . . . . . . . 55.41

Fuentes de residuos. . . . . . . . . . . . . . . . . . . . . . . . . 55.45

Criterios de selección de sustancias para la Política de Control de Sustancias

Tóxicas en la alternativa 1. . . . . . . . . . . . . . . . . . . . . . . . . . 55.50

Resumen de las reducciones conseguidas en las emisiones de dioxina y furano en Canadá. . . . . . . . . . . . . . . . . . . . . . . . . . . 55.52

\section{PARTE VIII. ACCIDENTTES Y GESTION DE LA SEGURIDAD}

Capítulo 56.

Tabla 56.1

Tabla 56.2

Tabla 56.3

Tabla 56.4

\section{Prevención de accidentes}

Ejemplos de taxonomías para la clasificación de desviaciones. . . . . . . . . . 56.24 La matriz de $\mathrm{H}$ addon aplicada a las lesiones por accidente con vehículo de motor. . . . . . . . . . . . . . . . . . . . . . . . . 56.32 L as diez estrategias de prevención de $\mathrm{H}$ addon aplicadas a las lesiones debidas a caídas en el sector de la construcción.

O bjetivos y ejemplos de fuentes de información sobre seguridad adaptadas a la secuencia de accidente. . . . . . . . . . . . . . . . . . . . . . . . . . . 56.37 
Tabla 56.5 Resumen de las recomendaciones incluidas en una selección de sistemas de advertencia. . . . . . . . . . . . . . . . . . . . . . . . . . . . . 56.40

\section{Capítulo 57.}

Tabla 57.1

Tabla 57.2

Tabla 57.3

Tabla 57.4

Tabla 57.5

Tabla 57.6

\section{Capítulo 58.}

Tabla 58.1

Tabla 58.2

Tabla 58.3

Tabla 58.4

Tabla 58.5

Tabla 58.6

Tabla 58.7

Tabla 58.8

Tabla 58.9

Tabla 58.10

Tabla 58.11

Tabla 58.12

Tabla 58.13

Tabla 58.14

\section{Capítulo 59.}

Tabla 59.1

Tabla 59.2

Tabla 59.3

Tabla 59.4

\section{Capítulo 60.}

Tabla 60.1

Tabla 60.2

\section{Auditorías, inspecciones e investigaciones}

Niveles en la política de calidad y seguridad. . . . . . . . . . . . . . . . 57.5

Elementos de la auditoría de seguridad del SAP. . . . . . . . . . . . . . . . 57.6

Seis modos de inducir un comportamiento seguro y evaluación de su eficacia en función del coste. . . . . . . . . . . . . . . . . . . . . . 57.8

Tipos de fallo general y sus definiciones. . . . . . . . . . . . . . . . . . 57.10

Conceptos principales del fenómeno del accidente, sus características y las repercusiones para la prevención . . . . . . . . . . . . . . . . . . . . 57.25

Variables informativas que caracterizan un accidente. . . . . . . . . . . . 57.30

\section{Aplicaciones de la seguridad}

Posibles disfunciones de un circuito de control de dos botones y sus consecuencias . . . . . . . . . . . . . . . . . . . . 58.3

D efensas de máquinas. . . . . . . . . . . . . . . . . . . . . . 58.16

Dispositivos. . . . . . . . . . . . . . . . . . . . . . . . . . . . . . . . . . . . 58.19

M étodos de alimentación y expulsión. . . . . . . . . . . . . . . . . . . 58.22

A lgunas posibles combinaciones de estructuras de circuitos en controles de máquinas para funciones relacionadas con la seguridad. . . . . . . . . . 58.47

$\mathrm{N}$ iveles de integridad de la seguridad para sistemas de protección: medidas de fallos considerados como objetivos. . . . . . . . . . . . . . . . . . 58.68 Diseño y desarrollo de software. . . . . . . . . . . . . . . . . . . . . . . 58.69 $\mathrm{N}$ ivel de integridad de la seguridad - Requisitos de los fallos para componentes del tipo B. . . . . . . . . . . . . . . . . . . . . . . 58.70

R equisitos para el nivel 2 de integridad de la seguridad - A rquitecturas de sistemas electrónicos programables para sistemas de protección. . . . . . . 58.70

Caídas desde alturas: Q uebec 1982-1987. . . . . . . . . . . . . . . . . . . 58.75

Sistemas típicos de prevención y detención de caídas. . . . . . . . . . . . . 58.77

Diferencias entre la prevención de caídas y la detención de caídas. . . . . . . 58.77

Ejemplo de formulario para evaluar situaciones peligrosas. . . . . . . . . . 58.78

Un ejemplo de permiso de acceso. . . . . . . . . . . . . . . . . . . . . . 58.79

\section{Política de seguridad y liderazgo}

M ediciones del clima de seguridad. . . . . . . . . . . . . . . . . . . . . . 59.10

Diferencias entre el programa Tuttava y otros programas y técnicas. . . . . . 59.15

Ejemplo de prácticas de trabajo correctas. . . . . . . . . . . . . . . . . . 59.17

O bjetivos de actuación en una fábrica de tintas para impresión. . . . . . . . . 59.17

\section{Programas de seguridad}

Comparación de los modelos O BM y TQM de motivación de los trabajadores. . . . . . . . . . . . . . . . . . . . . 60.21

$\mathrm{N}$ úmero de fábricas en funcionamiento en la India, media estimada de las jornadas de trabajo diarias, lesiones de declaración obligatoria y su frecuencia.. . . . . . . . . . . . . . . . . . 60.31 
PARTE IX. PRODUCTOS QUIMICOS

Capítulo 61. U tilización, almacenamiento y transporte de productos químicos

Tabla 61.1

Gases que suelen presentarse en forma comprimida . . . . . . . . . . . . . . 61.14

Capítulo 62. Minerales y productos químicos para la agricultura

Tabla 62.1 Lista de productos de grado técnico clasificados en la Clase IA:

"Extremadamente peligrosos" . . . . . . . . . . . . . . . . . . . . 62.20

Tabla 62.2 Lista de productos de grado técnico clasificados en la C lase IB:

"Altamente peligrosos" . . . . . . . . . . . . . . . . . . . . . . . . . 62.22

Tabla 62.3 Lista de productos de grado técnico clasificados en la C lase II:

"M oderadamente peligrosos". . . . . . . . . . . . . . . . . . . . . . . 62.24

Tabla 62.4 Lista de productos de grado técnico clasificados en la Clase III:

"Ligeramente peligrosos".. . . . . . . . . . . . . . . . . . . . . . . . . . . . 62.29

Tabla 62.5 Lista de productos de grado técnico que es improbable que presenten riesgo agudo en condiciones de uso normales. . . . . . . . . . . . . . . . .62.33

Tabla 62.6 Productos de grado técnico no incluidos en la Clasificación de la 0 M S y considerados obsoletos o no utilizados ya como plaguicidas. . . . . . . . . . 62.42

Tabla 62.7 Lista de fumigantes gaseosos o volátiles no incluidos en la Clasificación Recomendada de Plaguicidas según el R iesgo de la O M S. . . . . . . . . . . . 62.42

\section{C apítulo 63. Metales:propiedades químicas y toxicidad}

Tabla $63.1 \quad$ Propiedades físicas de algunos metalcarbonilos . . . . . . . . . . . 63.32

Tabla 63.2 Riesgos físicos y químicos. . . . . . . . . . . . . . . . . . . 63.52

Tabla 63.3 Riesgos para la salud. . . . . . . . . . . . . . . . . . . 63.62 


\section{IIII}

\section{PARTE X. SECTORES BASADOS EN RECURSOS BIOLOGICOS}

\section{Capítulo 64.}

Tabla 64.1

Tabla 64.2

Tabla 64.3

Tabla 64.4

Tabla 64.5

Tabla 64.6

Tabla 64.7

Tabla 64.8

Tabla 64.9

Tabla 64.10

Tabla 64.11

Tabla 64.12

Tabla 64.13

Tabla 64.14

Tabla 64.15

Tabla 64.16

Tabla 64.17

Tabla 64.18

Tabla 64.19

Tabla 64.20

Tabla 64.21

\section{Capítulo 65.}

Tabla 65.1

\section{Capítulo 66.}

Tabla 66.1

Tabla 66.2

\section{Capítulo 67.}

Tabla 67.1

Tabla 67.2

Tabla 67.3

Tabla 67.4

\section{Agricultura y sectores basados en recursos naturales}

Fuentes de nutrientes. . . . . . . . . . . . . . . . . . . . . . . . . . 64.2

Diez etapas en un estudio de los riesgos del trabajo en una plantación. . . . . 64.6

Sistemas agrarios en las zonas urbanas. . . . . . . . . . . . . . . . . . 64.10

M edidas de seguridad en el empleo de equipos mecánicos de jardinería y

cuidado del césped. . . . . . . . . . . . . . . . . . . . . . . . . . . . . . . 64.10

Clasificación de las actividades agrícolas. . . . . . . . . . . . . . . . . . . . 64.27

R iesgos comunes de los tractores y cómo se producen. . . . . . . . . . . . . 64.33

R iesgos comunes de la maquinaria y cómo se producen. . . . . . . . . . . . . 64.34

M edidas de seguridad en el empleo de segadoras giratorias, barrenadoras de postes e hincapostes. . . . . . . . . . . . . . . . . . . . . . . . . 64.48

Arboles, frutas y palmeras tropicales y subtropicales cultivados con fines comerciales. . . . . . . . . . . . . . . . . . . . . . . . . . . . . . 64.49

Productos de las palmeras. . . . . . . . . . . . . . . . . . . . . . 64.50

Productos y usos de la corteza y la savia de los árboles.. . . . . . . . . . . . 64.52

Comparación de dos tipos de programas de agromedicina. . . . . . . . . . . 64.68

Riesgos respiratorios. . . . . . . . . . . . . . . . . . . . . . . . . . 64.70

Riesgos dermatológicos. . . . . . . . . . . . . . . . . . . . . . . . . . . . 64.70

Riesgos tóxicos y neoplásicos. . . . . . . . . . . . . . . . . . . . . . . . . 64.71

Riesgos de accidentes. . . . . . . . . . . . . . . . . . . . . . . . . . 64.71

Porcentaje de accidentes con pérdida de horas de trabajo, clasificado por los orígenes de los accidentes, por naturaleza de éstos y por la actividad, en cuatro tipos de operaciones agrícolas, Estados U nidos,1993.. . . . . . . . . . 64.72

Riesgos de estrés mecánico y térmico. . . . . . . . . . . . . . . . . . . . 64.72

Riesgos derivados del comportamiento. . . . . . . . . . . . . . . . . . . . 64.73

Cultivos obtenidos mediante ingeniería genética. . . . . . . . . . . . . . . . 64.74

Cultivo de drogas ilegales, 1987, 1991 y $1995 \ldots$. . . . . . . . . . . . . . . . . 64.74

\section{Industria de las bebidas}

Principales importadores de café (en toneladas).

\section{Pesca}

Cifras de mortalidad por lesiones mortales entre pescadores procedentes de estudios de varios países. . . . . . . . . . . . . . . . . . . . . 66.16

Trabajos o puestos más expuestos a riesgos de lesiones. . . . . . . . . . . . . 66.17

\section{Industria alimentaria}

Las industrias alimentarias, sus materias primas y procesos. . . . . . . . . . 67.3

Enfermedades profesionales más habituales en las industrias alimentarias de varios países. . . . . . . . . . . . . . . . . . . . . . . . 67.9

Tipos de infecciones registrados en las industrias alimentarias. . . . . . . . 67.11

Ejemplos de utilización de subproductos de las industrias alimentarias. . . . . 67.15 
Tabla 67.5 Coeficientes de reutilización del agua habituales en diferentes subsectores de

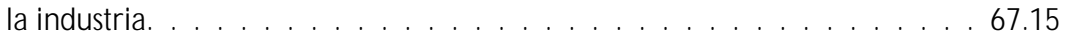

\section{Capítulo 68. \\ Industria forestal}

Tabla 68.1

Superficie forestal por región (1990). . . . . . . . . . . . . . . . . . . . 68.2

Tabla 68.2

C ategorías de productos forestales no madereros y ejemplos.

Tabla 68.3

R iesgos del aprovechamiento de productos no madereros y ejemplos. . . . . . 68.15

Tabla 68.4

Carga típica transportada durante el trabajo de plantación. . . . . . . . . . . . 68.16

Tabla 68.5

Tabla 68.6

Clasificación de los accidentes más frecuentes de los plantadores según la parte corporal afectada (porcentaje de 122 informes relativos a 48 individuos en Q uebec). . . . . . . . . . . . . . . . . . . . . . . . . . . . . . . . 68.17

Tabla 68.7

Consumo energético en el trabajo forestal.

Tabla 68.8

Ejemplos de productos químicos utilizados en la industria forestal en Europa y Norteamérica en el decenio de 1980. . . . . . . . . . . . . . . . . . . . 68.27

Tabla 68.9 Infecciones más comunes en la industria forestal..

Tabla 68.10 Equipos de protección individual apropiados para operaciones forestales. . Posibles beneficios para la salud del medio ambiente . . . . . . . . . . . . 68.42

\section{Capítulo 69.}

Tabla 69.1

\section{Capítulo 70.}

Tabla 70.1

Tabla 70.2

Tabla 70.3

Tabla 70.4

Tabla 70.5

Tabla 70.6

Tabla 70.7

Tabla 70.8

Tabla 70.9

Tabla 70.10

Tabla 70.11

Tabla 70.12

Tabla 70.13

Tabla 70.14

Tabla 70.15

Tabla 70.16

Tabla 70.17

Tabla 70.18

Tabla 70.19

Tabla 70.20

\section{Caza}

Ejemplos de enfermedades de posible importancia para cazadores y tramperos.

\section{G anadería y cría de animales}

U sos del ganado. . . . . . . . . . . . . . . . . . . . . 70.2

Producción ganadera internacional (en miles de toneladas). . . . . . . . . . . 70.3

Producción anual de heces y orina del ganado en EE.UU. . . . . . . . . . . 70.5

T ipos de problemas de salud para el hombre relacionados con la producción ganadera. . . . . . . . . . . . . . . . . . . 70.7

Principales zoonosis, por regiones del mundo. . . . . . . . . . . . . . . 70.9

Diferentes ocupaciones y su potencial de contacto con artrópodos que pueden afectar de modo adverso a la salud y la seguridad. . . . . . . . . . 70.10 Peligros potenciales derivados de los artrópodos en el lugar de trabajo y sus agentes causales. . . . . . . . . . . . . . . . . . . . . . . . . . . . . . . . . 70.10 R eacciones normales y alérgicas a las picaduras de insectos. . . . . . . . . . . 70.10 Compuestos identificados en la atmósfera de los recintos confinados de explotaciones porcinas. . . . . . . . . . . . . . . . . . . . . . . . . . . . 70.13

Concentraciones atmosféricas de diversos gases en los recintos confinados de explotaciones porcinas. . . . . . . . . . . . . . . . . . . . . . 70.14 Enfermedades respiratorias asociadas a la producción porcina. . . . . . . . 70.15 Zoonosis de los manipuladores de ganado. . . . . . . . . . . . . . . . . . 70.17 Propiedades físicas del estiércol excretado al día por cada $500 \mathrm{~kg}$ de peso animal, en seco. . . . . . . . . . . . . . . . . . . . . . . . . . . . . 70.19 Algunas características toxicológicas importantes del ácido sulfhídrico $\left(\mathrm{H}_{2} \mathrm{~S}\right)$. . 70.19 Procedimientos de seguridad relacionados con los distribuidores de estiércol. . 70.20 Tipos de rumiantes domesticados . . . . . . . . . . . . . . . . . 70.22 Procesos de la ganadería y peligros potenciales. . . . . . . . . . . . . . . 70.23 Enfermedades respiratorias, por tipos de exposición en las explotaciones ganaderas. . . . . . . . . . . . . . . . . . . . . . . . . . . . . . 70.24

Zoonosis asociadas a los caballos. . . . . . . . . . . . . . . . . . . 70.31 Potencia de tiro normal de diversos animales. . . . . . . . . . . . . . . 70.32 
Capítulo 71.

Tabla 71.1

Tabla 71.2

Tabla 71.3

\section{Capítulo 72.}

Tabla 72.1

Tabla 72.2

Tabla 72.3

Tabla 72.4

Tabla 72.5

Tabla 72.6

Tabla 72.7

\section{Industria de la madera}

Estimación de la producción de madera en 1990 (miles de m³). . . . . . . . 71.2

Estimación de la producción de madera por sectores en los 10 mayores productores del mundo (miles de $\mathrm{m}^{3}$ ). . . . . . . . . . . . . . . . . . 71.4

R iesgos para la seguridad y la salud en el trabajo, por procesos industriales. . 71.7

\section{Industria del papel y de la pasta de papel}

Empleo y producción en operaciones de fabricación de pasta y de papel, en 1994, paises seleccionados. . . . . . . . . . . . . . . . . . . . . . 72.4 Componentes químicos de las fuentes de pasta y de papel (\%) . . . . . . . . 72.5 Agentes blanqueantes y condiciones para su empleo.. . . . . . . . . . . . 72.9 A ditivos en la fabricación de papel. . . . . . . . . . . . . . . . . . . . . 72.10 $\mathrm{R}$ iesgos potenciales de salud y seguridad en la producción de pasta y de papel, por áreas de proceso. . . . . . . . . . . . . . . . . . . . . . . . . 72.13 Resumen de los estudios sobre cáncer de pulmón, cáncer de estómago, linfoma y leucemia en trabajadores de la pasta y el papel. . . . . . . . . . . 72.17 Total de sólidos en suspensión y DBO asociados con los efluentes no tratados, en varios procesos de la formación de pasta. . . . . . . . . . . . . . . . . . 72.20

\section{PARTE XI. INDUSTRIAS BASADAS EN RECURSOS NATURALES}

\section{Capítulo 73.}

Tabla 73.1

Tabla 73.2

\section{Capítulo 74.}

Tabla 74.1

Tabla 74.2

Tabla 74.3

Tabla 74.4

Tabla 74.5

Tabla 74.6

Tabla 74.7

Tabla 74.8

Tabla 74.9

\section{Capítulo 75.}

Tabla 75.1

Tabla 75.2

Tabla 75.3

Tabla 75.4

\section{Capítulo 76.}

Tabla 76.1

Tabla 76.2

\section{H ierro y acero}

Subproductos recuperables de los hornos de coque. . . . . . . . . . . . 73.9

Residuos generados y reciclados por la industria acerera de Japón. . . . . . . 73.18

\section{Minas y canteras}

Factores nominales de cantidad de aire. . . . . . . . . . . . . . . . . . . . 74.36

Potencias de refrigeración de aire con corrección de ropa (W/ m2) . . . . . . . 74.37

Comparación de fuentes de iluminación en minería. . . . . . . . . . . . . 74.41

Calentamiento del carbón - jerarquía de temperaturas. . . . . . . . . . . 74.51

Elementos y subelementos críticos de preparación de emergencias. . . . . . . 74.53

Instalaciones, equipos y materiales de emergencia. . . . . . . . . . . . . . 74.55

M atriz de formación para preparación de emergencias. . . . . . . . . . . . 74.56

Ejemplos de auditoría horizontal de planes de emergencia. . . . . . . . . . 74.57

D enominación común de los gases nocivos existentes en las minas de carbón y sus efectos sobre la salud. . . . . . . . . . . . . . . . . . . . . . 74.60

\section{Petróleo: prospección y perforación}

Características y propiedades usuales aproximadas y potencial de gasolina de varios crudos de petróleo comunes. . . . . . . . . . . . . . . . . . 75.3

Composición del petróleo y el gas natural. . . . . . . . . . . . . . . . . . 75.4

Composición normal aproximada de los gases naturales y gases de procesado del petróleo (porcentaje en volumen). . . . . . . . . . . . . . . . . . . 75.5

Tipos de plataformas de perforación submarina. . . . . . . . . . . . . . . 75.7

\section{Producción y distribución de energía eléctrica}

Control de las exposiciones a determinados riesgos químicos y biológicos en la generación de energía hidroeléctrica. . . . . . . . . . . . . . . . 76.4

Control de las exposiciones a determinados riesgos físicos y en materia de seguridad en la generación de energía hidroeléctrica. . . . . . . . . . . . 76.6 
Tabla $76.3 \quad$ Características de las centrales nucleares (1997). . . . . . . . . . . . . . . 76.10

Tabla $76.4 \quad$ Principales riesgos ambientales por la generación de energía. . . . . . . . . 76.18

PARTE XII. INDUSTRIAS QUIMICAS

C apítulo 77.

Tabla 77.1

Tabla 77.2

Tabla 77.3

Tabla 77.4

Tabla 77.5

Tabla 77.6

Tabla 77.7

Tabla 77.8

Tabla 77.9

Tabla 77.10

Tabla 77.11

Tabla 77.12

Capítulo 78.

Tabla 78.1

Tabla 78.2

Tabla 78.3

Capítulo 79.

Tabla 79.1

Tabla 79.2

C apítulo 80.

Tabla 80.1

Tabla 80.2

\section{Procesado químico}

Número de trabajadores de la industria química en algunos países (1995). . . 77.3

Algunos factores para la selección de los emplazamientos de las fábricas. . . . 77.9

Aspectos en la seguridad del emplazamiento de la planta. . . . . . . . . . . 77.9

Instalaciones que suelen situarse separadas en la disposición general de las

plantas . . . . . . . . . . . . . . . . . . . . . . . 77.10

Consideraciones generales en la disposición de una unidad de proceso. . . . . 77.10

M edidas para limitar las existencias. . . . . . . . . . . . . . . . . . . . 77.11

Separación de tanques y consideraciones sobre la localización. . . . . . . . . 77.12

Bombas en la industria de proceso de productos químicos. . . . . . . . . . . . 77.17

Posibles fuentes de explosión en los equipos. . . . . . . . . . . . . . . . 77.18

Productos volátiles en la descomposición de los plásticos (componentes de referencia).. . . . . . . . . . . . . . . . . . . . . . . 77.31

M icroorganismos de importancia industrial. . . . . . . . . . . . . . . . . 77.34

M aterias primas utilizadas en la fabricación de productos pirotécnicos. . . . . 77.38

\section{Petróleo y gas natural}

Cronología resumida del proceso de refino. . . . . . . . . . . . . . . . 78.2

Principales productos del refino de petróleo crudo.. . . . . . . . . . . . . 78.4

Resumen de los procesos de refino del petróleo.

78.11

\section{Industria farmacéutica}

Principales categorías farmacológicas، . . . . . . . . . . . . . . . . . . . 79.4

D isolventes utilizados en la industria farmacéutica. . . . . . . . . . . . . . 79.7

\section{Industria del caucho}

Principales polímeros del caucho. . . . . . . . . . . . . . . . . . . . . 80.2

Consumo mundial de caucho en 1993.

\section{PARTE XIII. INDUSTRIAS MANUFACTURERAS}

\section{Capítulo 81.}

Tabla 81.1

Tabla 81.2

C apítulo 82.

Tabla 82.1

Tabla 82.2

\section{Aparatos y equipos eléctricos}

Composición de las pilas y baterías más comunes. . . . . . . . . . . . . 81.5

Ejemplos de materiales utilizados en la fabricación de aparatos electrodomésticos. . . . . . . . . . . . . . . . . . . . . . . . . . . 81.14

\section{Metalurgía y metalisteria}

$M$ ateriales de proceso de partida y residuos contaminantes generados en la fundición y afino del cobre . . . . . . . . . . . . . . . . . . . . . . . 82.6

$M$ ateriales de proceso de partida y residuos contaminantes generados en la fundición y afino del plomo. . . . . . . . . . . . . . . . . . . . . . 82.6 
Tabla 82.3

Tabla 82.4

Tabla 82.5

Tabla 82.6

Tabla 82.7

Tabla 82.8

Tabla 82.9

Tabla 82.10

Tabla 82.11

Tabla 82.12

Tabla 82.13

Tabla 82.14

Tabla 82.15

Tabla 82.16

Tabla 82.17

Tabla 82.18

Tabla 82.19

Tabla 82.20

\section{Capítulo 83.}

Tabla 83.1

Tabla 83.2

Tabla 83.3

Tabla 83.4

Tabla 83.5

Tabla 83.6

Tabla 83.7

Tabla 83.8

Tabla 83.9

Tabla 83.10

Tabla 83.11

Tabla 83.12

Tabla 83.13

\section{Capítulo 84.}

Tabla 84.1

Tabla 84.2

Tabla 84.3

Tabla 84.4

Tabla 84.5
$M$ ateriales de proceso de partida y residuos contaminantes generados en la fundición y afino del zinc. . . . . . . . . . . . . . . . . . . . . . . . . 82.7

$\mathrm{M}$ ateriales de proceso de partida y residuos contaminantes generados en la fundición y afino del aluminio. . . . . . . . . . . . . . . . . . . . . . 82.9

Tipos de hornos de fundición. . . . . . . . . . . . . . . . . . . . . .82.14

D escripción y riesgos de los procesos de soldadura. . . . . . . . . . . . . 882.26

Resumen de los riesgos inherentes a los distintos métodos de tratamiento de metales. . . . . . . . . . . . . . . . . . . . . . 82.43

Controles técnicos y administrativos para el aluminio, por operaciones. . . . . 82.51

Controles técnicos y administrativos para el cobre, por operaciones. . . . . . 82.53

Controles técnicos y administrativos para el plomo, por operaciones. . . . . . 82.54

Controles técnicos y administrativos para el zinc, por operaciones. . . . . . . 82.55

Controles técnicos y administrativos para el magnesio, por operaciones. . . . 82.56

Controles técnicos y administrativos para el mercurio, por operaciones. . . . . 82.56

Controles técnicos y administrativos para el níquel, por operaciones. . . . . . 82.57

Controles técnicos y administrativos para los metales preciosos, por

operaciones. . . . . . . . . . . . . . . . . . . . . . . 82.57

Controles técnicos y administrativos para el cadmio, por operaciones. . . . . . 82.58

Controles técnicos y administrativos para el selenio, por operaciones. . . . . . 82.58

Controles técnicos y administrativos para el cobalto, por operaciones. . . . . . 82.59

Controles técnicos y administrativos para el estaño, por operaciones. . . . . . 82.60

Controles técnicos y administrativos para el titanio, por operaciones. . . . . . 82.61

\section{Microelectrónica y semiconductores}

Sistemas de fotoprotección. . . . . . . . . . . . . . . . . . . . . . . . 83.5

Disolventes de fotoprotección. . . . . . . . . . . . . . . . . . . . . . . . . 83.7

Reactivos para grabado químico húmedo. . . . . . . . . . . . . . . . . 83.7

Gases mordientes en plasma y materiales grabados. . . . . . . . . . . . . 83.8

Impurificadores de formación de uniones para difusión e implantación

iónica. . . . . . . . . . . . . . . . . . . . . 83.10

C ategorías principales de epitaxia del silicio en fase de vapor. . . . . . . . . . 83.12

Categorías principales de la deposición química del silicio en forma de

vapor (CVD). . . . . . . . . . . . . . . . . . . . . . . . . 83.13

Limpieza de paneles indicadores planos. . . . . . . . . . . . . . . . . . . 83.21

Proceso de PW B: aspectos ambientales, de higiene y de seguridad. . . . . . . 83.28

PWB, generación y controles de residuos. . . . . . . . . . . . . . . . . . . 83.38

PCB, generación y controles de residuos. . . . . . . . . . . . . . . . . . . . . 83.39

Generación y controles de residuos en la fabricación de semiconductores. . 83.39

M atriz de necesidades prioritarias. . . . . . . . . . . . . . . . . . . . . 83.40

\section{Vidrio, cerámica y materiales afines}

Componentes típicos del cuerpo (\%). . . . . . . . . . . . . . . . . . 84.13

Procesos de fabricación. . . . . . . . . . . . . . . . . . . . . . . . . 84.13

Selección de aditivos químicos empleados para optimizar el tratamiento del polvo y el moldeado en crudo de los productos cerámicos. . . . . . . . . . . . . 84.16

U tilización de refractarios por industria en Estados U nidos. . . . . . . . . . 84.19

R iesgos para la salud y la seguridad que pueden presentarse durante la

fabricación de materiales de vidrio, cerámica y afines. . . . . . . . . . . . . 84.23 
Tabla 84.6 Tasas de incidencia de las lesiones y enfermedades ocupacionales no mortales por 100 trabajadores a jornada completa para empresas de Estados U nidos

en Código SIC 32, industria privada y fabricación, 1994. . . . . . . . . . . . 84.29

\section{Capítulo 85. Industria de las artes gráficas, fotografía y reproducción}

Tabla $85.1 \quad$ Exposiciones potenciales en las industrias gráficas. . . . . . . . . . . . 85.10

Tabla $85.2 \quad$ Estudios con cohortes sobre el riesgo de mortalidad en el sector de la imprenta . . . . . . . . . . . . . . . . . . . . . . . . . 85.10

Tabla 85.3 Operaciones de los laboratorios fotográficos con potencial de exposición química. . . . . . . . . . . . . . . . . . 85.11

\section{Capítulo 86. Carpintería}

Tabla $86.1 \quad$ Variedades de madera tóxicas, alérgicas y biológicamente activas. . . . . . 86.14

\section{PARTE XIV. INDUSTRIAS TEXTIES Y DE LA CONFECCION}

\section{C apítulo 87. Confección y productos textiles acabados}

Tabla 87.1 Ejemplos de enfermedades laborales que se observan entre los trabajadores de la confección.. . . . . . . . . . . . . . . . . . . 87.6

\section{Capítulo 88. Cuero, pieles y calzado}

Tabla 88.1

\section{C apítulo 89. Industria de productos textiles}

Tabla $89.1 \quad$ Número de empresas y empleados de la industria textil y de prendas de vestir en determinados países y territorios de la zona de Asia-Pacífico en 1985 y

Tabla 89.2

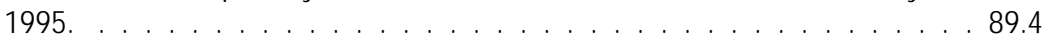

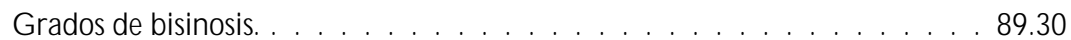

\section{PARTE XV. INDUSTRIAS DEL TRANSPORTE}

\section{C apítulo 90. Construcción y mantenimiento aeroespacial}

Tabla $90.1 \quad$ R iesgos para la seguridad en las industrias aeronáutica y aeroespacial. . . . . 90.5

Tabla 90.2 Requisitos de desarrollo tecnológico en materia de sanidad, seguridad y control ambiental para nuevos procesos y materiales. . . . . . . . . . . . . 90.12

Tabla 90.3 Consideraciones toxicológicas de los principales componentes de las resinas utilizadas en los materiales compuestos para aplicaciones aeroespaciales. . . . 90.12

Tabla 90.4 R iesgos derivados de la utilización de productos químicos en la industria aeroespacial. . . . . . . . . . . . . . . . . . . . . . . . . . . . . . 90.13

Tabla 90.5 Resumen de las Emisiones para C ontaminantes A tmosféricos Peligrosos (NESH AP) de Estados U nidos en las instalaciones de construcción y reprocesado. . . . . . . . . . . . . . . . . . . . . . . . 90.14

Tabla 90.6 R iesgos químicos característicos de los procesos de fabricación. . . . . . . . . 90.14

Tabla $90.7 \quad$ Prácticas características relativas al control de emisiones. . . . . . . . . . 90.15

\section{Capítulo 91. Vehículos de motor y maquinaria pesada}

Tabla $91.1 \quad$ Procesos de producción para la fabricación de automóviles. . . . . . . . . . 91.2 
Capítulo 93.

Tabla 93.1

Tabla 93.2

Tabla 93.3

Tabla 93.4

Tabla 93.5

Tabla 93.6

\section{Construcción}

Diversas profesiones de la construcción. . . . . . . . . . . . . . . . . 93.2

R iesgos primarios en oficios especializados de construcción. . . . . . . . . . . 93.4

Profesiones de la construcción con índices de mortalidad (SM R ) e índices de incidencia (SIR) significativamente superiores a los normales por causas diversas. . . . . . . . . . . . . . . . . . . . . . . . 93.8

Importe de los proyectos de construcción en Canadá, en 1993 (basado en el importe de las licencias de construcción expedidas en el mismo año). . . . . . . 93.14

Contratistas/ subcontratistas en proyectos industriales/ comerciales/ institucionales típicos. . . . . . . . . . . . . . . . . . . . . . . . . . 93.15

Distancia preceptiva para voltajes normales en trabajos próximosa tendidos eléctricos de alta tensión. . . . . . . . . . . . . . . . . . . . . . 93.45

PARTE XVII. SERVICIOS

\section{Capítulo 94.}

Tabla 94.1

Tabla 94.2

Tabla 94.3

\section{Capítulo 95.}

Tabla 95.1

\section{Capítulo 96.}

Tabla 96.1

Tabla 96.2

Tabla 96.3

Tabla 96.4

Tabla 96.5

Tabla 96.6

Tabla 96.7

Tabla 96.8

Tabla 96.9

\section{Capítulo 97.}

Tabla 97.1

Tabla 97.2

Tabla 97.3

Tabla 97.4

Tabla 97.5

Tabla 97.6

\section{Servicios de educación y formación}

Enfermedades infecciosas que afectan al personal docente y a los trabajadores de las guarderías. . . . . . . . . . . . . . . . . . . 94.5

R iesgos y precauciones de determinadas disciplinas. . . . . . . . . . . . . 94.6

Resumen de los y riesgos existentes en escuelas universitarias y universidades.

\section{Servicios de seguridad y de emergencia}

Resumen de recomendaciones, incluidos los criterios de rechazo y consideraciones especiales, para las decisiones sobre indemnización por accidentes de trabajo. . . . . . . . . . . . . . . . . . . . . . 95.9

\section{Actividades artísticas, culturales y recreativas}

Precauciones relacionadas con los riesgos en las artes y entretenimientos. . . . 3.96

Riesgos de las técnicas artísticas. . . . . . . . . . . . . . . . . . . . . 4.96

Riesgos de las piedras comunes. . . . . . . . . . . . . . . . . . . 9.96

Principales riesgos derivados de la utilización de materiales empleados en el modelado de esculturas. . . . . . . . . . . . . . . . . . . . . . 10.96

Descripción de las distintas modalidades de artesanía textil. . . . . . . . . . . 16.96

D escripción de los procesos de manufacturas textiles. . . . . . . . . . . . 16.96

Compuestos de los cuerpos de cerámica y barnices. . . . . . . . . . . . . 18.96

R iesgos y precauciones de las actividades de coleccionismo. . . . . . . . . . . 42.96

R iesgos del coleccionismo de objetos. . . . . . . . . . . . . . . . . . . 43.96

\section{Centros y servicios de asistencia sanitaria}

Ejemplos de funciones de la asistencia sanitaria y profesionales que las desempeñan . . . . . . . . . . . . . . . . . . . . . . . . . 97.2

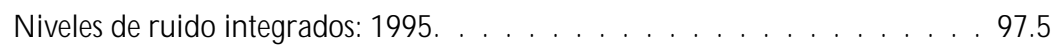

O pciones ergonómicas para la reducción del ruido. . . . . . . . . . . . . 97.6

$\mathrm{N}$ úmero total de lesiones, mecanismo y naturaleza de las mismas (un hospital, todos los departamentos), 1 de abril de 1994 a 31 de marzo de 1995. . . . . . 97.9

Distribución del tiempo de las enfermeras según tres estudios. . . . . . . . . . 97.17

$\mathrm{N}$ úmero de tareas independientes realizadas por las enfermeras, e

interrupciones durante cada turno. . . . . . . . . . . . . . . . . . . . . . . 97.20 
Tabla 97.7

Tabla 97.8

Tabla 97.9

Tabla 97.10

Tabla 97.11

Tabla 97.12

Tabla 97.13

Tabla 97.14

Tabla 97.15

Tabla 97.16

Tabla 97.17

Tabla 97.18

Tabla 97.19

Tabla 97.20

Tabla 97.21

Tabla 97.22

\section{Capítulo 99.}

Tabla 99.1

Tabla 99.2

Tabla 99.3

Tabla 99.4

\section{Capítulo 100.}

Tabla 100.1

Tabla 100.2

\section{Capítulo 101.}

Tabla 101.1

Tabla 101.2

Tabla 101.3

Tabla 101.4

\section{Capítulo 102.}

Tabla 102.1

Tabla 102.2

Tabla 102.3

Tabla 102.4

Tabla 102.5

Tabla 102.6
Tensión cognitiva y afectiva, y sensación de burn-out entre los trabajadores sanitarios. . . . . . . . . . . . . . . . . . . . . . . 97.23

Frecuencia de quejas sobre el trabajo, por turnos. . . . . . . . . . . . . . . 97.26

A nomalías congénitas tras la infección por la rubéola. . . . . . . . . . . . . 97.44 Indicaciones para la vacunación de los trabajadores sanitarios. . . . . . . . 97.45 Recomendación de profilaxis postexposición en los casos de exposición percutánea o permucosa al virus de la hepatitis B en Estados U nidos. . . . . . 97.47

Recomendaciones provisionales del Servicio de Salud Pública de Estados U nidos para la quimioprofilaxis tras exposición profesional al VIH, por tipos de exposición y fuentes de materiales, 1996. . . . . . . . . . . . . . . . . 97.49

Categorías de sustancias químicas utilizadas en la asistencia sanitaria. . . . . . 97.56 Productos químicos mencionados en la Base de datos de sustancias peligrosas (H SD B) . . . . . . . . . . . . . . . . . . . . . . . . . . . . . . 97.57 Propiedades de los anestésicos inhalados. . . . . . . . . . . . . . . . . 97.60 Criterios y variables que se deben considerar en la elección de los materiales. 97.68 Necesidades de ventilación en distintas áreas de los centros sanitarios. . . . . . 97.69 Enfermedades infecciosas y residuos del grupo III.. . . . . . . . . . . . . 97.73 Estructura jerárquica del Sistema de G estión del M edio Ambiente (SG M ) del HSC . . . . . . . . . . . . . . . . . . . . . . . . . . . . 97.76 Función y responsabilidades. . . . . . . . . . . . . . . . . . . 97.77 Aportaciones al proceso . . . . . . . . . . . . . . . . . . . . . . 97.77 Lista de actividades. . . . . . . . . . . . . . . . . . . . . . . . . . . 97.77

\section{O ficinas y comercio minorista}

Profesionales. . . . . . . . . . . . . . . . . . . . . . . . . . . . . . . . . 99.4

Empleados de oficinas y comercio. . . . . . . . . . . . . . . . . . . . 99.6

Contaminantes del aire de interiores que pueden encontrarse en oficinas. . . . 99.8

Estadísticas laborales en el comercio minorista (selección de países).. . . . . . 99.14

\section{Servicios personales y comunitarios}

Posturas observadas durante la limpieza del polvo de un hospital. . . . . . . . 100.2

Productos químicos peligrosos utilizados para la limpieza. . . . . . . . . . . . 100.4

\section{Servicios públicos y estatales}

R iesgos de los servicios de inspección. . . . . . . . . . . . . . . . . 101.5

O bjetos peligrosos encontrados en la recogida de basuras domésticas. . . . . . 101.14

Accidentes de trabajo más comunes en la recogida de basuras domésticas,

Quebec, Canadá. . . . . . . . . . . . . . . . . . . . . . . . . . . . . . 101.16

Lesiones más comunes en la industria del reciclado. . . . . . . . . . . . . . 101.22

\section{Industria del transporte y el almacenamiento}

M edidas y escalas de ajuste del asiento de un conductor de autobús. . . . . . 102.27 Niveles de iluminación en las distintas áreas de las estaciones de servicio. . . . . 102.31

Factores de riesgo asociados a la administración y a las operaciones ferroviarias. . . . . . . . . . . . . . . . . . . . . . . . . . . 102.39

Factores de riesgo asociados al mantenimiento y los accidentes de transporte. . . . . . . . . . . . . . . . . . . . . . . . . 102.40

Factores de riesgo asociados al mantenimiento de las vías y los pasos a nivel. . 102.42 Planteamientos de la industria ferroviaria respecto al control de los factores de riesgo. . . . . . . . . . . . . . . . . . . . . . . . . . . . . . 102.43 
Tabla $102.7 \quad$ Tipos de buques mercantes. . . . . . . . . . . . . . . . . . . 102.46

Tabla $102.8 \quad$ R iesgos para la salud comunes en todos los tipos de buques. . . . . . . . . 102.48

Tabla 102.9 Principales riesgos físicos y químicos en determinados tipos de

embarcaciones. . . . . . . . . . . . . . . . . . . . . . . . 102.49

Tabla 102.10 Control y actividades de reducción de riesgos en embarcaciones $\ldots . . .102 .49$

Tabla 102.11 Propiedades de combustión aproximadas habituales en gases de hidrocarburos licuados. . . . . . . . . . . . . . . . . . . . . . 102.69

Tabla 102.12 Comparación de las características de los gases comprimidos y licuados. . . . 102.70

Tabla 102.13 Lesiones de espalda y generales y enfermedades en el lugar de trabajo de los selectores de pedidos de dos almacenes de alimentos analizados por el NIOSH, 1987-1992. . . . . . . . . . . . . . . . . . . . . . 102.72

Tabla 102.14 A nálisis de la seguridad en el trabajo: operarios de carretillas elevadoras. . . . 102.74

Tabla 102.15 A nálisis de la seguridad en el trabajo: selectores de pedidos. . . . . . . . . 102.75 


\section{voumsen \\ IV}

PARTE XVIII. GUIAS

\section{Capítulo 103.}

Tabla 103.1

\section{Capítulo 104.}

Tabla 104.1

Tabla 104.2

Tabla 104.3

Tabla 104.4

Tabla 104.5

Tabla 104.6

Tabla 104.7

Tabla 104.8

Tabla 104.9

Tabla 104.10

Tabla 104.11

Tabla 104.12

Tabla 104.13

Tabla 104.14

Tabla 104.15

Tabla 104.16

Tabla 104.17

Tabla 104.18

Tabla 104.19

Tabla 104.20

Tabla 104.21

Tabla 104.22

Tabla 104.23

Tabla 104.24

Tabla 104.25

Tabla 104.26

Tabla 104.27

Tabla 104.28

Tabla 104.29

T abla 104.30

Tabla 104.31

Tabla 104.32

Tabla 104.33

Tabla 104.34

Tabla 104.35

Tabla 104.36

\section{G uía de profesiones}

Lista de comprobación (plantilla)

103.3

\section{Guía de productos químicos}

A cidos inorgánicos: Identificación química. . . . . . . . . . . . . . . . . . . 104.8

A cidos inorgánicos: R iesgos para la salud. . . . . . . . . . . . . . . . . . 104.8

A cidos inorgánicos: R iesgos químicos y físicos. . . . . . . . . . . . . . . . . . 104.9

A cidos inorgánicos: Propiedades físicas y químicas. . . . . . . . . . . . . . . 104.10

A cidos y anhidridos orgánicos: Identificación química. . . . . . . . . . . . . 104.54

A cidos y anhidridos orgánicos: R iesgos para la salud. . . . . . . . . . . . . 104.59

A cidos y anhidridos orgánicos: R iesgos físicos y químicos. . . . . . . . . . . . 104.62

A cidos y anhidridos orgánicos: Propiedades físicas y químicas. . . . . . . . . 104.65

Alcoholes: Identificación química. . . . . . . . . . . . . . . . . . . . . . . 104.74

Alcoholes: R iesgos para la salud. . . . . . . . . . . . . . . . . . . . . . 104.77

Alcoholes: R iesgos físicos y químicos. . . . . . . . . . . . . . . . . . . . . 104.80

Alcoholes: Propiedades físicas y químicas. . . . . . . . . . . . . . . . . . . 104.82

Aldehídos y cetales: Identificación química. . . . . . . . . . . . . . . . . . . 104.88

Aldehídos y cetales: Riesgos para la salud. . . . . . . . . . . . . . . . . . . 104.90

Aldehídos y cetales: R iesgos físicos y químicos. . . . . . . . . . . . . . . . 104.92

A ldehídos y cetales: Propiedades físicas y químicas. . . . . . . . . . . . . . . 104.93

M ateriales alcalinos: Identificación química. . . . . . . . . . . . . . . . . . 104.100

M ateriales alcalinos: R iesgos para la salud. . . . . . . . . . . . . . . . . 104.102

M ateriales alcalinos: R iesgos físicos y químicos. . . . . . . . . . . . . . . . . 104.105

M ateriales alcalinos: Propiedades físicas y químicas. . . . . . . . . . . . . . . 104.107

A midas: Identificación química. . . . . . . . . . . . . . . . . . . . . . . . . 104.115

A midas: R iesgos para la salud. . . . . . . . . . . . . . . . . . . . . . . . . . 104.117

A midas: R iesgos físicos y químicos. . . . . . . . . . . . . . . . . . . . . . . . 104.118

A midas: Propiedades físicas y químicas. . . . . . . . . . . . . . . . . . . . . 104.118

A minas alifáticas: Identificación química. . . . . . . . . . . . . . . . . . . . 104.122

Aminas alifáticas: R iesgos para la salud. . . . . . . . . . . . . . . . . . . . 104.127

Aminas alifáticas: R iesgos físicos y químicos. . . . . . . . . . . . . . . . . . . 104.130

Aminas alifáticas: Propiedades físicas y químicas. . . . . . . . . . . . . . . 104.132

Aminas aromáticas: Identificación química. . . . . . . . . . . . . . . . . . . 104.142

Aminas aromáticas: Riesgos para la salud. . . . . . . . . . . . . . . . . . . . 104.149

Aminas aromáticas: Riesgos físicos y químicos. . . . . . . . . . . . . . . . . . 104.153

A minas aromáticas: Propiedades físicas y químicas . . . . . . . . . . . . . . 104.156

Azidas: Identificación química. . . . . . . . . . . . . . . . . . . . . . . . 104.165

Azidas: Riesgos para la salud. . . . . . . . . . . . . . . . . . . . . . . . . 104.167

Azidas: Riesgos físicos y químicos. . . . . . . . . . . . . . . . . . . . . . . 104.168

Azidas: Propiedades físicas y químicas. . . . . . . . . . . . . . . . . . . . . . 104.170 
Tabla 104.37

Tabla 104.38

Tabla 104.39

Tabla 104.40

Tabla 104.41

Tabla 104.42

Tabla 104.43

Tabla 104.44

Tabla 104.45

Tabla 104.46

Tabla 104.47

Tabla 104.48

Tabla 104.49

Tabla 104.50

Tabla 104.51

Tabla 104.52

Tabla 104.53

Tabla 104.54

Tabla 104.55

Tabla 104.56

Tabla 104.57

Tabla 104.58

Tabla 104.59

Tabla 104.60

Tabla 104.61

Tabla 104.62

Tabla 104.63

Tabla 104.64

Tabla 104.65

Tabla 104.66

Tabla 104.67

Tabla 104.68

Tabla 104.69

Tabla 104.70

Tabla 104.71

Tabla 104.72

Tabla 104.73

Tabla 104.74

Tabla 104.75

Tabla 104.76

Tabla 104.77

Tabla 104.78

Tabla 104.79

Tabla 104.80

Tabla 104.81

Tabla 104.82
Boranos: Identificación química. . . . . . . . . . . . . . . . . . . . . . . . 104.174

Boranos: R iesgos para la salud. . . . . . . . . . . . . . . . . . . . . . . . . 104.175

Boranos: R iesgos físicos y químicos. . . . . . . . . . . . . . . . . . . 104.176

Boranos: Propiedades físicas y químicas. . . . . . . . . . . . . . . . . . . . . 104.177

Compuestos de ciano: I dentificación química. . . . . . . . . . . . . . . . . 104.183

Compuestos de ciano: R iesgos para la salud. . . . . . . . . . . . . . . . . . 104.186

Compuestos de ciano: R iesgos físicos y químicos . . . . . . . . . . . . . 104.188

Compuestos de ciano: Propiedades físicas y químicas. . . . . . . . . . . . . 104.190

Compuestos epoxídicos: Identificación química. . . . . . . . . . . . . . . . . 104.198

Compuestos epoxídicos: R iesgos para la salud. . . . . . . . . . . . . . . . . 104.200

Compuestos epoxídicos: R iesgos físicos y químicos. . . . . . . . . . . . . . . 104.201

Compuestos epoxídicos: Propiedades físicas y químicas. . . . . . . . . . . . . 104.202

Esteres, acetatos: Identificación química. . . . . . . . . . . . . . . . . . . . 104.206

Esteres, acetatos: R iesgos para la salud. . . . . . . . . . . . . . . . . . . . . 104.208

Esteres, acetatos: R iesgos físicos y químicos. . . . . . . . . . . . . . . . . . 104.210

Esteres, acetatos: Propiedades físicas y químicas. . . . . . . . . . . . . . . . . 104.211

Esteres acrílicos: I dentificación química. . . . . . . . . . . . . . . . . . . 104.215

Esteres acrílicos: R iesgos para la salud. . . . . . . . . . . . . . . . . . . . . 104.216

Esteres acrílicos: R iesgos físicos y químicos. . . . . . . . . . . . . . . . . . 104.216

Esteres acrílicos: Propiedades físicas y químicas. . . . . . . . . . . . . . . . . 104.217

Esteres, alcanoatos (excepto acetatos): I dentificación química. . . . . . . . . . 104.170

Esteres, alcanoatos (excepto acetatos): R iesgos para la salud.. . . . . . . . . . 104.173

Esteres, alcanoatos (excepto acetatos): R iesgos físicos y químicos. . . . . . . . 104.174

Esteres, alcanoatos (excepto acetatos): Propiedades físicas y químicas. . . . . . 104.176

Eteres: Identificación química. . . . . . . . . . . . . . . . . . . . . . . . . . 104.177

Eteres: R iesgos para la salud. . . . . . . . . . . . . . . . . . . . . . . . . 104.178

Eteres: R iesgos físicos y químicos. . . . . . . . . . . . . . . . . . . . . 104.179

Eteres: Propiedades físicas y químicas. . . . . . . . . . . . . . . . . . . 104.180

Eteres halogenados: Identificación química. . . . . . . . . . . . . . . . 104.181

Eteres halogenados: R iesgos para la salud. . . . . . . . . . . . . . . . . . 104.182

Eteres halogenados: R iesgos físicos y químicos. . . . . . . . . . . . . . . . . 104.182

Eteres halogenados: Propiedades físicas y químicas. . . . . . . . . . . . . . 104.183

Fluorocarburos: Identificación química. . . . . . . . . . . . . . . . . . . . 104.187

Fluorocarburos: R iesgos para la salud. . . . . . . . . . . . . . . . . . . . . 104.189

Fluorocarburos: R iesgos físicos y químicos. . . . . . . . . . . . . . . . . . . 104.190

Fluorocarburos: Propiedades físicas y químicas. . . . . . . . . . . . . . . . . 104.192

Eteres glicólicos: Identificación química. . . . . . . . . . . . . . . . . . 104.196

Eteres glicólicos: R iesgos para la salud. . . . . . . . . . . . . . . . . . . . 104.198

Eteres glicólicos: R iesgos físicos y químicos. . . . . . . . . . . . . . . . . . 104.200

Eteres glicólicos: Propiedades físicas y químicas. . . . . . . . . . . . . . . . . 104.201

Gliceroles y glicoles: Identificación química. . . . . . . . . . . . . . . . . . 104.205

Gliceroles y glicoles: R iesgos para la salud. . . . . . . . . . . . . . . . . . . . 104.206

G liceroles y glicoles: R iesgos físicos y químicos. . . . . . . . . . . . . . . . . 104.207

Gliceroles y glicoles: Propiedades físicas y químicas. . . . . . . . . . . . . . . 104.207

H alógenos y sus compuestos: I dentificación química de algunos halógenos y

sus compuestos. . . . . . . . . . . . . . . . . . . . . . . . . . . . . . 104.214

H alógenos y sus compuestos: R iesgos para la salud. . . . . . . . . . . . . . . 104.216 
Tabla 104.83

Tabla 104.84

Tabla 104.85

Tabla 104.86

Tabla 104.87

Tabla 104.88

Tabla 104.89

Tabla 104.90

Tabla 104.91

Tabla 104.92

Tabla 104.93

Tabla 104.94

Tabla 104.95

Tabla 104.96

Tabla 104.97

Tabla 104.98

Tabla 104.99

Tabla 104.100

Tabla 104.101

Tabla 104.102

Tabla 104.103

Tabla 104.104

Tabla 104.105

Tabla 104.106

Tabla 104.107

Tabla 104.108

Tabla 104.109

Tabla 104.110

Tabla 104.111

Tabla 104.112

Tabla 104.113

Tabla 104.114

Tabla 104.115

Tabla 104.116

Tabla 104.117

Tabla 104.118

Tabla 104.119

Tabla 104.120

Tabla 104.121

Tabla 104.122

Tabla 104.123

Tabla 104.124

Tabla 104.125

Tabla 104.126

Tabla 104.127

Tabla 104.128

Tabla 104.129
H alógenos y sus compuestos: R iesgos físicos y químicos. . . . . . . . . . . . . 104.217

H alógenos y sus compuestos: Propiedades físicas y químicas. . . . . . . . . . . 104.219

Compuestos heterocíclicos: I dentificación química. . . . . . . . . . . . . . 104.223

Compuestos heterocíclicos: R iesgos para la salud. . . . . . . . . . . . . . . . 104.226

Compuestos heterocíclicos: R iesgos físicos y químicos. . . . . . . . . . . . . 104.228

Compuestos heterocíclicos: Propiedades físicas y químicas. . . . . . . . . . . 104.229

H idrocarburos saturados y alicíclicos: I dentificación química. . . . . . . . . . 104.236

H idrocarburos saturados y alicíclicos: R iesgos para la salud. . . . . . . . . . 104.237

H idrocarburos saturados y alicíclicos: R iesgos físicos y químicos. . . . . . . . 104.239

H idrocarburos saturados y alicíclicos: Propiedades físicas y químicas. . . . . . 104.240

H idrocarburos halogenados saturados: Identificación química. . . . . . . . . 104.250

H idrocarburos halogenados saturados: R iesgos para la salud. . . . . . . . . . 104.253

H idrocarburos halogenados saturados: R iesgos físicos y químicos. . . . . . . . 104.257

H idrocarburos halogenados saturados: Propiedades físicas y químicas. . . . . 104.259

H idrocarburos halogenados insaturados: Identificación química. . . . . . . . 104.262

H idrocarburos halogenados insaturados: R iesgos para la salud. . . . . . . . . 104.264

H idrocarburos halogenados insaturados: R iesgos físicos y químicos. . . . . . . 104.265

H idrocarburos halogenados insaturados: Propiedades físicas y químicas. . . . 104.267

H idrocarburos alifáticos insaturados: I dentificación química. . . . . . . . . . 104.271

H idrocarburos alifáticos insaturados: R iesgos para la salud. . . . . . . . . . . . 104.272

H idrocarburos alifáticos insaturados: R iesgos físicos y químicos. . . . . . . . . . 104.273

H idrocarburos alifáticos insaturados: Propiedades físicas y químicas. . . . . . 104.274

H idrocarburos aromáticos: Identificación química. . . . . . . . . . . . . . . 104.280

H idrocarburos aromáticos: R iesgos para la salud. . . . . . . . . . . . . . . . 104.282

H idrocarburos aromáticos: R iesgos físicos y químicos. . . . . . . . . . . . . . . 104.284

H idrocarburos aromáticos: Propiedades físicas y químicas. . . . . . . . . . . 104.286

H idrocarburos aromáticos halogenados: Identificación química. . . . . . . . 104.295

H idrocarburos aromáticos halogenados: Riesgos para la salud. . . . . . . . . 104.297

H idrocarburos aromáticos halogenados: Riesgos físicos y químicos. . . . . . . 104.299

H idrocarburos aromáticos halogenados: Propiedades físicas y químicas. . . . 104.300

H idrocarburos poliaromáticos: Identificación química. . . . . . . . . . . . . 104.307

H idrocarburos poliaromáticos: R iesgos para la salud. . . . . . . . . . . . . . 104.308

H idrocarburos poliaromáticos: R iesgos físicos y químicos. . . . . . . . . . . . 104.309

H idrocarburos poliaromáticos: Propiedades físicas y químicas. . . . . . . . . 104.310

Isocianatos: Identificación química. . . . . . . . . . . . . . . . . . . . . 104.315

Isocianatos: R iesgos para la salud. . . . . . . . . . . . . . . . . . . . . . . 104.316

I socianatos: R iesgos físicos y químicos. . . . . . . . . . . . . . . . . . . . . 104.317

Isocianatos: Propiedades físicas y químicas. . . . . . . . . . . . . . . . . . 104.318

Cetonas: Identificación química. . . . . . . . . . . . . . . . . . . . . . . . . 104.321

Cetonas: R iesgos para la salud. . . . . . . . . . . . . . . . . . . . . . . . . . 104.324

Cetonas: Peligros físicos y químicos . . . . . . . . . . . . . . . . . . . . . 104.326

Cetonas: Propiedades físicas y químicas. . . . . . . . . . . . . . . . . . . . . 104.328

N itrocompuestos alifáticos: Identificación química. . . . . . . . . . . . . . . 104.335

Nitrocompuestos alifáticos: R iesgos para la salud. . . . . . . . . . . . . . . . 104.337

N itrocompuestos alifáticos: R iesgos físicos y químicos. . . . . . . . . . . . . . 104.337

N itrocompuestos alifáticos: Propiedades físicas y químicas. . . . . . . . . . . 104.338

N itrocompuestos aromáticos: I dentificación química. . . . . . . . . . . . . . 104.343 
Tabla 104.130

Tabla 104.131

Tabla 104.132

Tabla 104.133

Tabla 104.134

Tabla 104.135

Tabla 104.136

Tabla 104.137

Tabla 104.138

Tabla 104.139

Tabla 104.140

Tabla 104.141

Tabla 104.142

Tabla 104.143

Tabla 104.144

Tabla 104.145

Tabla 104.146

Tabla 104.147

Tabla 104.148

Tabla 104.149

Tabla 104.150

Tabla 104.151

Tabla 104.152

Tabla 104.153

Tabla 104.154

Tabla 104.155

Tabla 104.156

Tabla 104.157

Tabla 104.158

Tabla 104.159

Tabla 104.160

Tabla 104.161

\section{Capítulo 105.}

Tabla 105.1

Table 105.2

Tabla 105.3

Tabla 105.4

Table 105.5

Table 105.6

Table 105.7

Table 105.8

Tabla 105.9
N itrocompuestos aromáticos: R iesgos para la salud. . . . . . . . . . . . . . . 104.347

Nitrocompuestos aromáticos: R iesgos físicos y químicos. . . . . . . . . . . . . 104.350

Nitrocompuestos aromáticos: Propiedades físicas y químicas. . . . . . . . . . 104.353

Peróxidos orgánicos e inorgánicos: Identificación química. . . . . . . . . . . 104.360

Peróxidos orgánicos e inorgánicos: R iesgos para la salud. . . . . . . . . . . . 104.361

Peróxidos orgánicos e inorgánicos: R iesgos físicos y químicos. . . . . . . . . . 104.362

Peróxidos orgánicos e inorgánicos: Propiedades físicas y químicas. . . . . . . . 104.362

Fenoles y compuestos fenólicos: Identificación química. . . . . . . . . . . . . 104.367

Fenoles y compuestos fenólicos: R iesgos para la salud. . . . . . . . . . . . . . 104.370

Fenoles y compuestos fenólicos: R iesgos físicos y químicos. . . . . . . . . . . 104.373

Fenoles y compuestos fenólicos: Propiedades físicas y químicas. . . . . . . . . 104.375

Fosfatos inorgánicos y organicos: Identificación química. . . . . . . . . . . . 104.382

Fosfatos inorgánicos y organicos: R iesgos para la salud. . . . . . . . . . . . . 104.384

Fosfatos inorgánicos y organicos: Riesgos físicos y químicos. . . . . . . . . . . 104.386

Fosfatos inorgánicos y organicos: Propiedades físicas y químicas. . . . . . . . 104.388

Ftalatos: Identificación química. . . . . . . . . . . . . . . . . . . . . . . 104.392

Ftalatos: R iesgos para la salud. . . . . . . . . . . . . . . . . . . . . . 104.393

Ftalatos: R iesgos físicos y químicos. . . . . . . . . . . . . . . . . . . 104.393

Ftalatos: Propiedades físicas y químicas. . . . . . . . . . . . . . . . . . . 104.394

Sílice y compuestos organosilíceos: I dentificación química. . . . . . . . . . 104.397

Sílice y compuestos organosilíceos: R iesgos para la salud. . . . . . . . . . . . 104.398

Sílice y compuestos organosilíceos: R iesgos físicos y químicos. . . . . . . . . . 104.399

Sílice y compuestos organosilíceos: Propiedades físicas y químicas. . . . . . . 104.400

Compuestos orgánicos de azufre: Identificación química. . . . . . . . . . . . 104.405

Compuestos orgánicos de azufre: R iesgos para la salud. . . . . . . . . . . . . 104.407

Compuestos orgánicos de azufre: R iesgos físicos y químicos. . . . . . . . . . . 104.409

Compuestos orgánicos de azufre: Propiedades físicas y químicas. . . . . . . . 104.411

Compuestos inorgánicos de azufre: I dentificación química. . . . . . . . . . . 104.418

Compuestos inorgánicos de azufre: R iesgos para la salud. . . . . . . . . . . . 104.420

Compuestos inorgánicos de azufre: R iesgos físicos y químicos.. . . . . . . . . . 104.421

Compuestos inorgánicos de azufre: Propiedades físicas y químicas. . . . . . . . 104.422

Principales signos y síntomas correspondientes a distintas concentraciones

de carboxihemoglobina.. . . . . . . . . . . . . . . . . . . . . . . 104.426

\section{Guía de unidades y abreviaturas}

Unidades de base del SI . . . . . . . . . . . . . . . . . . . . . . 105.2

U nidades suplementarias del SI . . . . . . . . . . . . . . . . . . . . . . . 105.2

U nidades derivadas seleccionadas del SI expresadas en términos de

unidades de base . . . . . . . . . . . . . . . . . . . . . 105.2

U nidades derivadas del SI con nombres especiales. . . . . . . . . . . . . . . 105.2

Ejemplos de unidades derivadas del SI expresadas con nombres especiales . . 105.3

Ejemplos de unidades derivadas del SI formadas con unidades

suplementarias . . . . . . . . . . . . . . . . . . . . . . . 105.3

Prefijos del SI . . . . . . . . . . . . . . . . . . . . . . . . . . . . 105.3

Unidades usadas junto con el SI . . . . . . . . . . . . . . . . . . . 105.3

Conversión a unidades SI de unidades que no forman parte del SI . . . . . . 105.4 


\section{FIGURAS}

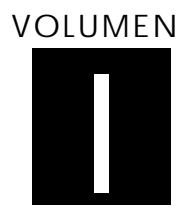

PARTE I. EL CUERPO HUMANO

\section{Capítulo 1.}

Figura 1.1

Capítulo 3.

Figura 3.1

Figura 3.2

Figura 3.3

\section{Capítulo 4.}

Figura 4.1

\section{Capítulo 5.}

Figura 5.1

Figura 5.2

Figura 5.3

\section{Capítulo 6.}

Figura 6.1

Figura 6.2

Figura 6.3

Figura 6.4

Figura 6.5

Figura 6.6

Figura 6.7

\section{Sangre}

Enzimas eritrocíticas de la defensa oxidativa y reacciones relacionadas. . . . . 1.7

\section{Sistema cardiovascular}

R iesgo de mortalidad relativa por enfermedades cardiovasculares en los fumadores (incluidos los ex fumadores), según la clase social, en comparación con trabajadores cualificados (varones) de peso normal y no fumadores, basado en los exámenes médicos realizados en el trabajo en A lemania oriental, mortalidad 1985-89, $\mathrm{N}=2,7$ millones de años-persona. . . . . . . . 3.6

Prevalencia de la hipertensión por edad, sexo y seis niveles de peso corporal relativo según el índice de masa corporal (IM C) en los exámenes médicos realizados en el trabajo en Alemania oriental (los valores normales del IM C están subrayados). . . . . . . . . . . . . . . . . . . . . . . 3.7

R iesgo relativo del sobrepeso según la duración del período de educación (años de escolaridad) espacio en Alemania (población entre 25 a 64 años). . . 3.8

\section{Aparato digestivo}

Excreción de la bilirrubina por el hígado, mostrando la circulación enterohepática. . . . . . . . . . . . . . . . . . . . 4.6

\section{Salud mental}

Un modelo para la salud mental. . . . . . . . . . . . . . . . . . . 5.2

Los tres ejes principales para determinar el bienestar afectivo. . . . . . . . . . 5.3

R iesgo de estrés y mala salud mental en diferentes grupos profesionales, determinados por los efectos combinados del ritmo de trabajo y la discreción respecto al uso de las destrezas. . . . . . . . . . . . . . . . . . . . . 5.4

\section{Sistema musculosquelético}

Representación esquemática de los principales componentes de una célula muscular que participan en el acoplamiento excitación-contracción, así como del lugar de producción de AT P, la mitocondria. . . . . . . . . . . 6.3

Ampliación de la membrana muscular y de las estructuras del interior del músculo de la Figura 6.1. Se ilustra la cadena de acontecimientos en la patogenia de la lesión de las células musculares inducida por el calcio $\left(\mathrm{C}^{2+}\right)$. 6.3 Clasificación de las enfermedades musculares. . . . . . . . . . . . . . . 6.4 Diagrama esquemático de un tendón estirado alrededor de una superficie anatómica o polea, con las correspondientes fuerzas de tracción $\left(F_{t}\right)$, de compresión $\left(F_{c}\right)$ y de fricción $\left(F_{f}\right)$ y la presión hidrostática o del líquido $\left(P_{f}\right)$. . . 6.5 Proporciones relativas de los tres componentes principales del disco intervertebral y de la placa basal de cartílago en un adulto normal humano. . 6.7

Representación esquemática de la estructura del disco, donde se muestran las fibras de colágeno en bandas intercaladas con numerosas moléculas de proteoglicano en forma de botella y cepillo y algunas células. . . . . . . . 6.8 Diagrama de parte de un disco agregado de proteoglicano. G 1, G2 y G 3 son regiones globulosas insertadas en una proteína nuclear central. . . . . . . 6.8 
Figura 6.8

Figura 6.9

Figura 6.10

Figura 6.11

Figura 6.12

Figura 6.13

Figura 6.14

Figura 6.15

Figura 6.16

Figura 6.17

Figura 6.18

Figura 6.19

Figura 6.20

Figura 6.21

Figura 6.22

Figura 6.23

Figura 6.24

\section{Capítulo 7.}

Figura 7.1

Figura 7.2

Figura 7.3

Figura 7.4

Figura 7.5

Figura 7.6

Figura 7.7

Figura 7.8

Figura 7.9

\section{Capítulo 8.}

Figura 8.1

Figura 8.2

Figura 8.3
Presiones intradiscales relativas en diferentes posturas, en comparación con la presión en bipedestación erecta $(100 \%)$. . . . . . . . . . . . . . 6.9

Las principales vías de nutrición del disco intervertebral son la difusión a partir de la vascularización del interior del cuerpo vertebral $(V)$, a través de la placa basal $(E)$ hasta el núcleo $(\mathrm{N})$ o a partir del riego sanguíneo del exterior del anillo (A). . . . . . . . . . . . . . . . . . . . . . . . . . . 6.10

La columna, sus vértebras y curvaturas. . . . . . . . . . . . . . . . 6.11

La unidad funcional básica de la columna. . . . . . . . . . . . . . . . . 6.12

Herniación del disco intervertebral. . . . . . . . . . . . . . . . . . . 6.12

Dibujo esquemático de un corte transversal de tres de los cuerpos vertebrales cervicales inferiores (1) con discos intervertebrales (2), agujeros intervertebrales (3) y raíces nerviosas; (4) vista lateral. . . . . . . . . . . . . 6.17

Prevalencia en doce meses de síntomas de problemas del cuello en una muestra aleatoria de la población islandesa $(n=1000) \ldots \ldots . \ldots .17$

Porcentaje de la fuerza de extensión máxima del cuello necesario al aumentar la inclinación (flexión) del cuello. . . . . . . . . . . . . . . . . . . . . . . 6.17

Visión esquemática de las partes esqueléticas de la cintura escapular (hombro). . . . . . . . . . . . . . . . . . . . . . . . . 6.20

Fuerza en la mujer y el varón; se muestran los resultados de sostener una herramienta de 1 kilogramo en la mano manteniendo el brazo recto a diferentes ángulos de flexión del hombro.. . . . . . . . . . . . . . . . . 6.20 Impactación. . . . . . . . . . . . . . . . . . . . . . 6.22 La elevación del brazo a diferentes alturas y en distintos ángulos ejerce diferentes presiones intramusculares sobre el músculo supraespinoso . . . . . . 6.22 La unidad musculotendinosa. . . . . . . . . . . . . . . . . . . . . 6.24 La rodilla. . . . . . . . . . . . . . . . . . . . . . . . . . . . . 6.27

Puntos hiperestésicos en la fibromialgia. . . . . . . . . . . . . . . . . 6.33 C riterios de 1990 del American College of R heumatology para el diagnóstico de fibromialgia. . . . . . . . . . . . . . . . . . . . . 6.33 Criterios para el diagnóstico de artritis reumatoide. . . . . . . . . . . . . . 6.33

\section{Sistema nervioso}

Anatomía de la neurona. . . . . . . . . . . . . . . . . . . . . . . . . . 7.3 Las organelas. . . . . . . . . . . . . . . . . . . . . . . . . . . . . . . . . . . . 7.4 Las divisiones centrales y periféricas del sistema nervioso. . . . . . . . . . 7.5 Visión lateral del cerebro. . . . . . . . . . . . . . . . . . . . . . . 7.5 Distribución segmentaria de los nervios espinales (metameras). . . . . . . . 7.6 V isión inferior del cerebro, con la entrada y salida de los nervios craneales. . . 7.7 E fectos neurológicos y comportamentales de la exposición a agentes químicos neurotóxicos. . . . . . . . . . . . . . . . . . . . . . . . . 7.9 E spectro del deterioro de salud con el aumento de la dosis. . . . . . . . . . 7.15 Prevención de la neurotoxicidad laboral. . . . . . . . . . . . . . . . . . 7.16

\section{Sistema renal y urinario}

Relaciones entre el aporte vascular, el glomérulo y los túbulos de la nefrona, y orientación de estos componentes dentro de la corteza y la médula renales. . 8.2 Categorías de marcadores biológicos. . . . . . . . . . . . . . . . . 8.7 Cuatro marcadores biológicos, G-actina, P-300, DD 23 y AD N, en relación con la progresión tumoral y la respuesta al tratamiento quirúrgico y la quimioprevención. . . . . . . . . . . . . . . . 8.9 
Capítulo 9.

Figura 9.1

Figura 9.2

Figura 9.3

Figura 9.4

Figura 9.5

\section{Capítulo 10.}

Figura 10.1

Figura 10.2

Figura 10.3

Figura 10.4

Figura 10.5

Figura 10.6

Figura 10.7

Figura 10.8

Figura 10.9

Figura 10.10

Figura 10.11

Figura 10.12

Figura 10.13

Figura 10.14

Figura 10.15

Figura 10.16

Figura 10.17

Figura 10.18

Figura 10.19

Figura 10.20

Figura 10.21

Figura 10.22

Figura 10.23

Figura 10.24

\section{Sistema reproductor}

Anomalías del desarrollo y resultados de la reproducción potencialmente asociados con exposiciones profesionales. . . . . . . . . . . . . . . . . 9.3

A parato reproductor masculino. . . . . . . . . . . . . . . . . . . . 9.4

Exposiciones sobradamente asociadas con efectos adversos para la calidad del semen. . . . . . . . . . . . . . . . . . . . . . . . . 9.6

A parato reproductor femenino. . . . . . . . . . . . . . . . . . . 9.9

Consecuencias para la descendencia de la exposición materna a sustancias tóxicas. . . . . . . . . . . . . . . . . . . . . . 9.12

\section{Aparato respiratorio}

M orfometría, citología, histología, función y estructura del aparato respiratorio y regiones utilizadas en el modelo de dosimetría de la ICR P de 1994. . . . . . . . . . . . . . . . . . . . . . . 10.2

M ecanismos de depósito de partículas en las vías aéreas pulmonares. . . . . . 10.3

M odelo compartimental para representar el transporte de partículas en el tiempo para cada región del modelo de la ICR P de 1994. . . . . . . . . . . . 10.3

Depósito fraccional en cada región del tracto respiratorio para personas de referencia que realizan un trabajo físico leve (respiración nasal normal) en el modelo de la ICR P de 1994. . . . . . . . . . . . . . . . . . . . 10.4

Espirometría forzada mostrando la derivación del $F E V_{1}$ y de la FVC de acuerdo al principio de extrapolación. . . . . . . . . . . . . . . . . 10.9

Curva de flujo-volumen que muestra la derivación del flujo espiratorio máximo (PEF), los flujos máximos al $50 \%$ y el $75 \%$ de la capacidad vital forzada $\left(\mathrm{M} \mathrm{EF}_{50} \mathrm{y} \mathrm{M} \mathrm{EF}_{25}\right.$, respectivamente). . . . . . . . . . . . . . . 10.9

Esquema principal del equipo para la determinación de la capacidad pulmonar total (TLC) de acuerdo con la técnica de dilución de helio. . . . . . 10.10 Espirograma etiquetado para mostrar las subdivisiones de la capacidad total.. 10.10 E squema principal del registro del cierre de la vía aérea y pendiente de la meseta alveolar $\left(\% \mathrm{~N}^{2}\right)$. . . . . . . . . . . . . . . . . . . . . . 10.10 Esquema principal del registro del factor de transferencia. . . . . . . . . . . . 10.11 Producción de óxido de berilio por el proceso de fluoruro. . . . . . . . . . . . 10.32 Tejido pulmonar en un paciente con enfermedad crónica por berilio. . . . . . 10.33 $R$ adiografía de tórax de un paciente con enfermedad crónica por berilio, en la que se observan infiltrados fibronodulares difusos e hilios prominentes. . . . 10.34 Nódulo silicótico típico, corte microscópico . . . . . . . . . . . . . . . 10.50 R adiografía de tórax, silicoproteinosis aguda en un perforador de una mina de carbón de superficie. . . . . . . . . . . . . . . . . . . . . . . . . . 10.51 R adiografía de tórax, silicosis complicada que muestra fibrosis masiva progresiva.. . . . . . . . . . . . . . . . . . . . . . . 10.51 Tipos de fibras de amianto. . . . . . . . . . . . . . . . . . . . . . . 10.58 Producción mundial de amianto en miles de toneladas 1900-92. . . . . . . 10.58 Cuerpo de amianto. . . . . . . . . . . . . . . . . . . . . . . . . . . 10.61 Enfermedad de las pequeñas vías aéreas relacionadas con el amianto.. . . . . . 10.63 Imágenes del tórax en la enfermedad pulmonar relacionada con el amianto. . 10.64 Enfermedad pleural relacionada con el amianto.. . . . . . . . . . . . . 10.66 M esotelioma maligno. . . . . . . . . . . . . . . . . . . . . 10.68 (A) Ejemplos de algunos insertos móviles de moldeado de metales pesados, chapados con nitruro de tungsteno dorado; (B) Inserto soldado a la herramienta trabajando en moldeado de acero. . . . . . . . . . . . . . . . 10.72 
Figura 10.25

Figura 10.26

Figura 10.27

Figura 10.28

Figura 10.29

Figura 10.30

Figura 10.31

Figura 10.32

Figura 10.33

Figura 10.34

Figura 10.35

\section{Capítulo 11.}

Figura 11.1

Figura 11.2

Figura 11.3

Figura 11.4

Figura 11.5

Figura 11.6

Figura 11.7

Figura 11.8

Figura 11.9

Figura 11.10

Figura 11.11

Figura 11.12

Figura 11.13

Figura 11.14

Figura 11.15

Figura 11.16
Insertos fijos soldados a (A) una perforadora de rocas y (B) a un disco de sierra. . . . . . . . . . . . . . . . . . . . . . . . . . . . . . . 10.72

M icroestructura de un aglomerado de WC / C o; las partículas de WC están incorporadas a la matriz clara de Co (x 1.500). . . . . . . . . . . . . 10.73

$\mathrm{M}$ icroestructura de un aglomerado de $\mathrm{WC}+\mathrm{TiC}+\mathrm{TaC}+\mathrm{Co}$. Junto a las partículas globulosas formadas por una solución sólida de T iC + TaC. La matriz está formada por Co (x1.500). . . . . . . . . . . . . . . . . . . . . . 10.73 M icroestructura de aglomerado chapada con múltiples capas muy pesadas (x2.000) . . . . . . . . . . . . . . . . . . . . . . . . . . . 10.73

BAL citológico en un caso de alveolitis macrofágica mononuclear de células gigantes causada por metales pesados. Entre los macrófagos mononucleares y el linfocito, se observa una célula gigante de tipo cuerpo extraño (x 400). . . . . 10.74

R adiografía de tórax de un sujeto afectado por fibrosis intersticial causada por metales pesados. Se observan una opacidad lineal y difusa y un patrón en panal de abejas. . . . . . . . . . . . . . . . . . . . . . . . 10.75

M icrofotografía electrónica de barrido (M EB) de fibras de óxido de aluminio. . . . . . . . . . . . . . . . . . . . . . . 10.85

MEB de fibras de carbono. . . . . . . . . . . . . . . . . . . . . 10.85

M EB de fibras para-arámidas de Kevlar.. . . . . . . . . . . . . . . . . . . 10.85

MEB de fibras (A) y pelos (B) de carburo de silicio. . . . . . . . . . . . . . 10.86

MEB de lana de escoria. . . . . . . . . . . . . . . . . . . . . . . . 10.87

\section{O rganos sensoriales}

Diagrama del oído. . . . . . . . . . . . . . . . . . . . . . . . . . . 11.2

Corte horizontal de la cóclea. Diámetro aproximado: 1,5 mm. . . . . . . . . 11.2

Audiograma de una pérdida auditiva bilateral inducida por el ruido. . . . . . 11.5

Ejemplos de audiogramas del oído derecho. Los círculos representan una pérdida auditiva de conducción aérea, y los "<" , la conducción ósea. . . . . 11.6

Diagrama de los principales elementos del sistema del equilibrio. . . . . . . . 11.9

Diagrama esquemático del laberinto vestibular. . . . . . . . . . . . . . . 11.9

Representación esquemática de los efectos biomecánicos de una inclinación de la cabeza de noventa grados (hacia adelante). . . . . . . . . . . . . . . . . 11.10

Representación esquemática del ojo. . . . . . . . . . . . . . . . . . . . . . . 11.11

Ejemplo de un gráfico de Snellen: anillos de L andlot (agudeza en valores decimales (no se especifica la distancia de lectura)). . . . . . . . . . . . . . . . 11.13

Ejemplo de un gráfico de Snellen: letras de Sloan para medir la visión de cerca $(40 \mathrm{~cm}$ ) (agudeza en valores decimales y en equivalentes de distancia). . 11.14

D ensidad de conos y bastones en la retina en comparación con la agudeza visual relativa en el campo visual correspondiente. . . . . . . . . . . . . . . . 11.15 Porcentaje de distribución de la agudeza visual estudiada en trabajadores de oficina. . . . . . . . . . . . . . . . . . . . . . . . . . 11.15

T iempo de respuesta antes y después de la exposición a reflejos para percibir el hueco en un anillo de L andlot: adaptación a la luz tenue. . . . . . . . . . . . 11.16

Relación entre la agudeza visual de un objeto oscuro percibido sobre un fondo iluminado de forma creciente con cuatro valores de contraste. . . . . . 11.17

Curvas de fusión-parpadeo conectando la frecuencia de la estimulación luminosa intermitente y su amplitud de modulación en el umbral (curvas de De L ange), media y desviación estándar, en 43 pacientes con traumatismo craneal y 57 controles (línea discontinua). . . . . . . . . . . . . . . . . . 11.19

C urva de De L ange en un hombre joven en tratamiento con etambutol; el efecto del medicamento puede deducirse comparando la sensibilidad de parpadeo del sujeto antes y después del tratamiento. . . . . . . . . . . . . . . 11.20 
Figura 11.17

Figura 11.18

Figura 11.19

Figura 11.20

Figura 11.21

Figura 11.22

Figura 11.23

\section{Capítulo 12.}

Figura 12.1

Figura 12.2

Figura 12.3

Figura 12.4

Figura 12.5

\section{Capítulo 13.}

Figura 13.1

Figura 13.2

Figura 13.3
Representación esquemática de los errores de refracción y su corrección. . . . 11.21

Punto próximo determinado con la regla de Clement y Clark, porcentaje de distribución de 367 trabajadores de oficina de 18 a 35 años (abajo) y 414 trabajadores de oficina de 36 a 65 años (arriba). . . . . . . . . . . . . . . . . 11.22 Ilustración esquemática de un corte de la piel. . . . . . . . . . . . . . . . . 11.34 La cúpula táctil de cada región elevada de la piel contiene de 30 a 70 células de M erkel. . . . . . . . . . . . . . . . . . . . . . . . . . . . . . . . . . . 11.34 A mayor aumento, con el microscopio electrónico, la célula de M erkel, una célula epitelial especializada, se observa unida a la membrana basal que separa la epidermis de la dermis. . . . . . . . . . . . . . . . . . . . . 11.34 Los tallos pilosos son una plataforma para las terminales nerviosas que detectan el movimiento. . . . . . . . . . . . . . . . . . . . . . . . . 11.35 EI corpúsculo de M eissner es un receptor sensorial con una cápsula laxa que se localiza en las papilas dérmicas de la piel lampiña. . . . . . . . . . . . 11.36

\section{Enfermedades de la piel}

Representación esquemática de la piel. . . . . . . . . . . . . . . . . . . . . 12.2

La estructura de la uña. . . . . . . . . . . . . . . . . . . . . . . 12.18

O nicodistrofia secundaria a una dermatitis de contacto por irritación

crónica. . . . . . . . . . . . . . . . . . . . . . . . . . . . . . 12.18

Estigmas profesionales en las manos. . . . . . . . . . . . . . . . . 12.20

Callos en puntos de presión sobre la palma de la mano. . . . . . . . . . . . . 12.20

\section{Condiciones del entorno}

Síndrome del edificio enfermo. . . . . . . . . . . . . . . . . . . . . 13.3

Factores de riesgo y causas del síndrome del edificio enfermo. . . . . . . . . . 13.4

Principales categorías de contaminantes. . . . . . . . . . . . . . . . . . . 13.5

PARTE II. ASISTENCIA SANITARIA

Capítulo 15.

Figura 15.1

Figura 15.2

Figura 15.3

Figura 15.4

Figura 15.5

Figura 15.6

Figura 15.7

Figura 15.8

Figura 15.9

Figura 15.10

Figura 15.11

Figura 15.12

Figura 15.13

\section{Protección y promoción de la salud}

Categorías de resultados de la promoción de la salud. . . . . . . . . . . . . 15.6

Elementos de un programa de promoción de la salud. . . . . . . . . . . . 15.10

Información 0 actividades de promoción de la salud clasificadas por temas (1985 y 1992). . . . . . . . . . . . . . . . . . . . . . . . . . . 15.10

¿Se han llevado a cabo actividades relacionadas con la salud en los últimos 12 meses? . . . . . . . . . . . . . . . . . . . . . . . . . . . . . 15.14

Probabilidad de que se aplique un número determinado de programas de promoción de la salud, en función del tamaño de la plantilla. . . . . . . . . . 15.15 Ejemplos de programas "hágalo usted mismo" de promoción de la salud en el lugar de trabajo que se ofrecen en Estados U nidos. . . . . . . . . . . . . 15.17 Programa de vigilancia de la salud a lo largo de toda la vida. . . . . . . . . . 15.21 Lista de control de la evaluación del riesgo para la salud (ERS). . . . . . . . . 15.31 O bjetivos para un programa de ejercicio físico y mantenimiento de la capacidad física para el trabajo . . . . . . . . . . . . . . . . . . 15.35 Clasificación según el índice de masa corporal.. . . . . . . . . . . . . . . . 15.38 Ejemplo de una buena guía diaria de alimentación. . . . . . . . . . . . . . 15.39 Directrices para un programa razonable de reducción de peso. . . . . . . . 15.40 Principales factores de riesgo de cardiopatía coronaria. . . . . . . . . . . . 15.40 
Figura 15.14

Figura 15.15

Figura 15.16

Figura 15.17

Figura 15.18

Figura 15.19

Figura 15.20

Figura 15.21

Figura 15.22

Figura 15.23

Figura 15.24

Figura 15.25

Figura 15.26

Figura 15.27

Capítulo 16.

Figura 16.1

Figura 16.2

Figura 16.3

Figura 16.4

Figura 16.5

Figura 16.6

Figura 16.7

Figura 16.8

Figura 16.9

Figura 16.10
Ejemplos de interacción entre trabajo y consumo de cigarrillos que provocan enfermedades. . . . . . . . . . . . . . . . . . . . . 15.42

Resumen de las restricciones al tabaco vigentes en la ciudad y el estado de Nueva York. . . . . . . . . . . . . . . . . . . . . . . . . . . . . . . . . . . . 15.49

$\mathrm{R}$ azones a favor y en contra de la restricción del tabaco en los lugares de trabajo. . . . . . . . . . . . . . . . . . . . . . . . . . 15.49

Criterios de calidad de la mamografía en los Estados U nidos. . . . . . . . . 15.58

Cribado del cáncer de mama. Contribución de la exploración clínica y de la mamografía a la detección del cáncer, por grupos de edad. . . . . . . . . . 15.61 Distribución por edades de los cánceres detectados mediante cribado. . . . . 15.61 Número de cánceres detectados en la exploración inicial, en el intervalo y de los no detectados, por grupos de edad. . . . . . . . . . . . . . . . . . 15.61 Tamaño de los cánceres detectados en las pruebas de cribado.. . . . . . . . . 15.62 Ejercicios que pueden realizarse en viajes aéreos prolongados. . . . . . . . . 15.77 Ejemplo de un prospecto informativo de la Organización M undial de la Salud sobre la diarrea del viajero. . . . . . . . . . . . . . . . . . . . . 15.79 Algunas orientaciones para reducir la vulnerabilidad individual. . . . . . . . 15.81 Factores de estrés que afectan a los trabajadores y programas en el lugar de trabajo que ayudan a neutralizarlos. . . . . . . . . . . . . . . . . . . 15.81 Problemas que el consumo de alcohol o drogas puede causar en el trabajo. . . 15.83 Cuestionario CAGE. . . . . . . . . . . . . . . . . . . . . . . . . . 15.86

\section{Servicios de salud en el trabajo}

Enfoque multidisciplinar para un desarrollo sostenible y equitativo. . . . . . . 16.23 O bligaciones de los médicos del trabajo en las empresas de Alemania. . . . . 16.32 Sumario de servicios externos de las B erufgenossenschaften del sector. . . . . . . . 16.33 Red nacional de servicios de salud en el trabajo. . . . . . . . . . . . . . . . 16.55 G estión de la elaboración de estándares sanitarios. . . . . . . . . . . . . . . . 16.55 G estión del diagnóstico de enfermedades profesionales en China. . . . . . . . 16.58 Estrategia del estudio piloto de servicios de salud en el trabajo en empresas de pequeñas ciudades. . . . . . . . . . . . . . . . . . . . . . . 16.60 Número de trabajadores expuestos a los riesgos profesionales más graves en la República Checa. . . . . . . . . . . . . . . . . . . . . . . . . . . . . 16.62 Enfermedades profesionales en la República $C$ heca en el período 1981-1992. . . . . . . . . . . . . . . . . . . . . . 16.62 Enfermedades profesionales en la República Checa en 1992. . . . . . . . . 16.63

\section{PARTE III. GESTION Y POUTICA}

\section{Capítulo 17.}

Figura 17.1

Figura 17.2

Figura 17.3

Figura 17.4

Figura 17.5

Figura 17.6

Figura 17.7

\section{Discapacidad y trabajo}

Cuatro tipos de legislación sobre derechos de los discapacitados. . . . . . . . 17.19

M arco conceptual de los efectos de la discapacidad. . . . . . . . . . . . . . . 17.31

M odelo de limitaciones producidas por la pérdida auditiva. . . . . . . . . . . 17.32

D erechos y obligaciones: prácticas de selección, contratación y empleo.. . . . . 17.41

Derechos y obligaciones: salud y seguridad. . . . . . . . . . . . . . . . . . 17.44

D erechos y obligaciones: apoyo, rehabilitación e indemnización. . . . . . . . 17.45

D erechos y obligaciones: inserción e integración en la sociedad y en el lugar de trabajo. . . . . . . . . . . . . . . . . . . . . . . . . . 17.47 
Capítulo 18.

Figura 18.1

Figura 18.2

Figura 18.3

Figura 18.4

Figura 18.5

Figura 18.6

Figura 18.7

Figura 18.8

Figura 18.9

Figura 18.10

Figura 18.11

Figura 18.12

Capítulo 20.

Figura 20.1

Figura 20.2

Figura 20.3

Capítulo 21.

Figura 21.1

Figura 21.2

Figura 21.3

Capítulo 22.

Figura 22.1

Figura 22.2

Figura 22.3

Figura 22.4

Figura 22.5

\section{Capítulo 23.}

Figura 23.1

Figura 23.2

Figura 23.3

Figura 23.4

\section{Capítulo 24.}

Figura 24.1

\section{Educación y formación}

Jerarquía de los objetivos de formación. . . . . . . . . . . . . . . . 18.10

El aprendizaje es un proceso de tres direcciones. . . . . . . . . . . . . . 18.13

Contenidos curriculares de los módulos. Guía de recursos del proyecto

Minerva.. . . . . . . . . . . . . . . . . . . . . . . 18.21

Un sistema de gestión de salud y seguridad. . . . . . . . . . . . . . 18.22

El proceso error-lesión. . . . . . . . . . . . . . . . . . . . . 18.23

Representación de los elementos del lugar de trabajo relevantes para las causas y el control de lesiones. . . . . . . . . . . . . . . . . . . 18.23

Programa de estudios de salud y seguridad en el trabajo. . . . . . . . . 18.24

Programas cortos de estudios de salud y seguridad en el trabajo. . . . . . . 18.24

Programa de formación de postgrado para médicos y enfermeros. . . . . . . 18.27

Programa de especialización técnica en seguridad en el trabajo. . . . . . . . 18.28

Base orientativa para la actividad laboral del inspector de fábricas. . . . . . 18.32

A reas temáticas clave del curso de FDF. . . . . . . . . . . . . . 18.32

\section{Desarrollo, tecnología y comercio}

Categorías de enfermedades que afectan a los trabajadores. . . . . . . . . 20.2

Relación biunívoca entre trabajo y salud. . . . . . . . . . . . . . . 20.2

M odelos de asistencia sanitaria para los trabajadores en fábricas pequeñas. . . 20.11

\section{Relaciones laborales y gestión de recursos humanos}

El papel de la gestión de recursos humanos en la dotación de valor añadido a las personas y las organizaciones. . . . . . . . . . . . . . . . . 21.4

Tasas de afiliación a sindicatos, 1980-1990.. . . . . . . . . . . . . . . . . 21.8

Salud y seguridad en el Reino U nido: instituciones principales. . . . . . . . . 21.21

\section{Recursos: información y salud y seguridad en el trabajo}

El ciclo de la información. . . . . . . . . . . . . . . . . . . . . . 22.4

Posibles aplicaciones de la información informatizada.. . . . . . . . . . . . 22.4

Vías sencillas hacia la información. . . . . . . . . . . . . . . . . . . . . 22.13

Flujo de información y acceso relacional en el sistema de información sobre pesticidas. . . . . . . . . . . . . . . . . . . . . . . . . . . . . 22.18

Red del Sistema de Información Integrado sobre M edicamentosy

Sustancias Tóxicas (IDPIS). . . . . . . . . . . . . . . . . . . . . . . . . . . . . . 22.19

\section{Recursos institucionales, estructurales y jurídicos}

Etiqueta de advertencia sobre sustancias químicas inspirada en el derecho a conocer. . . . . . . . . . . . . . . . . . . . . . . . . . 23.35

O rganización estatal y división de funciones en la salud y seguridad en el trabajo. . . . . . . . . . . . . . . . . . . . . . 23.40

En la C arta de las N aciones U nidas se crean seis órganos principales. . . . . . 23.50

Estructura de la A sociación Internacional de la Seguridad Social (AISS). . . . 23.64

\section{Trabajo y trabajadores}

Variación neta de los puestos de trabajo equivalentes a tiempo completo entre 1981 y 1986, por actividad y nivel salarial (en miles de dólares). . . . . . 24.22 
PARTE IV. HERRAMIENTAS Y ENFOQUES

Capítulo 27.

Figura 27.1

Figura 27.2

Figura 27.3

Figura 27.4

Figura 27.5

Figura 27.6

Figura 27.7

Figura 27.8

Figura 27.9

Figura 27.10

Capítulo 28.

Figura 28.1

Figura 28.2

Capítulo 29.

Figura 29.1

Figura 29.2

Figura 29.3

Figura 29.4

Figura 29.5

Figura 29.6

Figura 29.7

Figura 29.8

Figura 29.9

Figura 29.10

Figura 29.11

Figura 29.12

Figura 29.13

Figura 29.14

Figura 29.15

Figura 29.16

Figura 29.17

Figura 29.18

\section{Control biológico}

R elación entre control medioambiental, biológico y de la exposición y vigilancia de la salud. . . . . . . . . . . . . . . . . . . . . . 27.2

Diagrama de control de Shewhart para muestras de control de calidad.. . . . 27.7

Representación esquemática del paradigma científico de la toxicología genética y el efecto sobre la salud humana. . . . . . . . . . . . . . . . . . 27.16 Interrelaciones entre genotoxicidad y carcinogenicidad. . . . . . . . . . . . 27.16 La predictividad de los biomarcadores permite adoptar medidas preventivas para reducir el riesgo para la salud de las poblaciones humanas. . . . . . . . . 27.17

Cromosomas linfocíticos humanos en metafase; se observa una mutación cromosómica inducida (fragmento acéntrico indicado por la flecha). . . . . . 27.18 A plicabilidad de distintos tipos de biocontrol genético a la evaluación del riesgo de cáncer. . . . . . . . . . . . . . . . . . . . . . . . . . . . . . . . . 27.19 Hidrólisis de insecticidas O P. . . . . . . . . . . . . . . . . . . . . 27.22 Perfiles de excreción urinaria de los metabolitos de la atrazina. . . . . . . . . 27.24 Ciclo de la vitamina $\mathrm{K} \ldots \ldots$. . . . . . . . . . . . . . . . . . . . . . . 27.25

\section{Epidemiología y estadística}

Etapas de una encuesta . . . . . . . . . . . . . . . . . . . . . . . . . . . . 28.35

Relación entre validez y fiabilidad. . . . . . . . . . . . . . . . . . . . 28.36

\section{Ergonomía}

Criterios y subcriterios de la taxonomía de micromundos propuesta por Brehmer (1990). . . . . . . . . . . . . . . . . . . . . . . . . . . 29.7

A nálisis cognitivo de la tarea: anestesia general. . . . . . . . . . . . . . . . 29.8

D escripción simplificada de los determinantes de una secuencia de comportamientos en una tarea de control de energía: caso de consumo inaceptable de energía. . . . . . . . . . . . . . . . . . . . . . . 29.9

D iscrepancias entre la cantidad de personal presente y necesaria de acuerdo con PR N 80. . . . . . . . . . . . . . . . . . . . . . . . . . . . . . . . . . 29.10

A nálisis de la actividad mental. Estrategias del control de procesos con tiempos de respuesta prolongados: necesidad de soporte informático para

el diagnóstico. . . . . . . . . . . . . . . . . . . . . . . . . . . . . . . . . . . 29.10

Diseño integrado del ciclo de vida. . . . . . . . . . . . . . . . . . . . . . 29.11

Antropómetro.. . . . . . . . . . . . . . . . . . . . . . . . . . . 29.26

Pie de rey y compás de espesores. . . . . . . . . . . . . . . . . . . . 29.26

Conjunto básico de variables antropométricas. . . . . . . . . . . . . . . . . 29.27

Trabajo estático frente a trabajo dinámico. . . . . . . . . . . . . . . . . 29.30

M odelo de estrés tensión expandida modificado por R ohmert (1984). . . . . . 29.30

A nálisis de las cargas de trabajo aceptables. . . . . . . . . . . . . . . . . . 29.31

L as posturas con las manos demasiado elevadas o con la cintura doblada se cuentan entre las formas más comunes de crear una carga "estática" . . . . . . 29.33 Aspectos ergonómicos de la postura de pie. . . . . . . . . . . . . . . . 29.35 Los músculos esqueléticos trabajan por pares para iniciar o revertir un movimiento. . . . . . . . . . . . . . . . . . . . . . . . . . . 29.36

La tensión muscular varía dependiendo de la longitud del músculo. . . . . . . 29.36 Posiciones idóneas para el movimiento de las articulaciones. . . . . . . . . . . 29.36 Fuerza de la mordaza de unos alicates ejercida por hombres y mujeres, en función de la distancia de separación del mango. . . . . . . . . . . . . . . . . . . 29.37 
Figura 29.19 Representación esquemática del efecto acumulativo de las causas cotidianas de fatiga.. . . . . . . . . . . . . . . . . . . . . . . . . . 29.39

Figura $29.20 \quad$ Representación esquemática del control de la disposición al trabajo a través de los sistemas inhibidor y activador. . . . . . . . . . . . . . . . . . . 29.40

Figura 29.21 Estrés, tensión y fatiga. . . . . . . . . . . . . . . . . . . . . . . . . . . . . . 29.41

Figura 29.22

Figura 29.23

Tendencia principal de la fatiga y la recuperación. . . . . . . . . . . . . . . . 29.42

Estrés en función del tiempo. . . . . . . . . . . . . . . . . . . . . . . 29.42

Figura 29.24

Figura 29.25

Porcentaje de periodos de descanso para diversas combinaciones de fuerzas mantenidas y tiempo. . . . . . . . . . . . . . . . . . . . . . . . 29.42

Combinación de dos factores de estrés. . . . . . . . . . . . . . . . . . . 29.43

Figura 29.26

Figura 29.27

Tipos y consecuencias de las relaciones exigencias-recursos. . . . . . . . . . 29.45

U mbrales y capacidad de discriminación. . . . . . . . . . . . . . . . . 29.47

Figura 29.28

Componentes del proceso de tensión y sus consecuencias. . . . . . . . . . . . 29.50

Figura 29.29

Características de las tareas completas. . . . . . . . . . . . . . . . . . . 29.53

Figura 29.30

Figura 29.31

Figura 29.32

Proposición para reestructurar una empresa de producción. . . . . . . . . . . 29.54

R endimiento, valoración del sueño y variables fisiológicas en un grupo de personas sometidas durante dos noches a la privación del sueño. . . . . . . . 29.57

Figura 29.33 Duración media del sueño en función de la hora de inicio del sueño. Comparación entre los datos de trabajadores por turnos alemanes y japoneses. . . . . . . . . . . . . . . . . . . . . . . 29.59

Figura 29.34 Valoración media de la sensación subjetiva de fatiga durante dos turnos nocturnos consecutivos y durante el período de recuperación sin trabajo para grupos con o sin siesta.. . . . . . . . . . . . . . . . . . . . . 29.60

Figura 29.35 "M odelo del cubo" para la evaluación ergonómica. Cada cubo representa una combinación de exigencias relacionadas con la fuerza, la postura y el tiempo. Color claro: combinación aceptable; gris: condicionalmente aceptable; negro: inaceptable. . . . . . . . . . . . . . . . . . . . . . . . . . 29.63

Figura 29.36

Versión CAD de un puesto de trabajo de soldadura manual, conseguida durante el proceso de diseño. . . . . . . . . . . . . . . . . . . . . . . . . . 29.64

Figura 29.37

Ejecución del puesto de trabajo de soldadura. . . . . . . . . . . . . . . . 29.65

Figura 29.38

E spacio normal y preferente para los pies (en cm). . . . . . . . . . . . . . . 29.70

Figura 29.39

Espacio normal y preferente para las manos (en cm). . . . . . . . . . . . . 29.71

Figura 29.40

Figura 29.41

Figura 29.42

Figura 29.43

Figura 29.44

Figura 29.45

Figura 29.46

Figura 29.47

Figura 29.48

Línea oreja-ojo. . . . . . . . . . . . . . . . . . . . . . . . . . . . . . . 29.71

Algunos ejemplos de controles de "detención" y "continuos". . . . . . . . . . 29.73

Código de colores de las luces de indicación. . . . . . . . . . . . . . . . . . 29.74

Características de los indicadores visuales. . . . . . . . . . . . . . . . 29.75

Directrices para el uso de colores en los indicadores visuales. . . . . . . . . 29.75

En una situación normal, todos los valores de los parámetros son iguales y forman un hexágono. En una situación anormal, algunos valores varían y crean una distorsión específica. . . . . . . . . . . . . . . . . . . . . . . 29.78

Diseño creativo. . . . . . . . . . . . . . . . . . . . . . . . . . . . . . . . . . . . 29.84

Diseño de sistemas. . . . . . . . . . . . . . . . . . . . . . . . . . . . . . 29.84

Diseño ergonómico de sistemas. . . . . . . . . . . . . . . . . . . . 29.85

Figura 29.49 M odelo de utilidad de la tecnología de rehabilitación (M UT R) en combinación con el enfoque de diseño ergonómico de sistemas. . . . . . . . . 29.85 
Figura 29.50

Figura 29.51

Figura 29.52

\section{Capítulo 30.}

Figura 30.1

Figura 30.2

Figura 30.3

Figura 30.4

Figura 30.5

Figura 30.6

Figura 30.7

Figura 30.8

Figura 30.9

Figura 30.10

\section{Capítulo 31.}

Figura 31.1

Figura 31.2

Figura 31.3

Figura 31.4

Figura 31.5

Figura 31.6

Figura 31.7

Figura 31.8

Figura 31.9

Figura 31.10

Figura 31.11

Figura 31.12

Figura 31.13

Figura 31.14

Figura 31.15

Figura 31.16

Figura 31.17

Figura 31.18

Figura 31.19

Figura 31.20

Figura 31.21
U so de las tijeras para chapa por hojalateros profesionales (agarre inverso

de la herramienta). . . . . . . . . . . . . . . . . . . . . . . . 29.88

M odelo de utilidad de la tecnología de rehabilitación (M UTR). . . . . . . . . 29.95

Presentación esquemática de una celda de pulido. . . . . . . . . . . . . . . . 29.101

\section{H igiene industrial}

Interacciones entre las personas y el medio ambiente. . . . . . . . . . . . 30.2

Ambitos de actuación de los médicos del trabajo y los higienistas

industriales . . . . . . . . . . . . . . . . . . . 30.3

Elementos de la evaluación de riesgos. . . . . . . . . . . . . . . . . . . 30.8

Contaminantes laborales. . . . . . . . . . . . . . . . . . . . . 30.16

O bservaciones y preguntas que deben hacerse en un estudio sobre el

terreno. . . . . . . . . . . . . . . . . . . . 30.16

O bservaciones y preguntas para un estudio sobre el terreno de la calidad

del aire del interior. . . . . . . . . . . . . . . . . . . . . 30.17

O bjetivos del control biológico. . . . . . . . . . . . . . . . . . . . . . . . 30.19

Factores que se tienen en cuenta para crear GEH basados en la zonificación.. 30.20

Cronología de los límites de exposición profesional $(O E L)$. . . . . . . . . 30.30

D atos que suelen utilizarse para establecer un límite de exposición

profesional. . . . . . . . . . . . . . . . . . . . . . . . 30.34

\section{Protección personal}

Tipos comunes de gafas de protección ocular, con y sin protectores laterales. . 31.4 Ejemplos de gafas de montura integral de protección ocular. . . . . . . . . 31.4

Pantallas faciales para trabajar a temperaturas elevadas. . . . . . . . . . . . 31.4

Protectores para soldadura. . . . . . . . . . . . . . . . . . . . . . . . . . . 31.4

Zapatos de seguridad. . . . . . . . . . . . . . . . . . . . . . . . . . . . . . . . . 31.7

Botas de protección térmica. . . . . . . . . . . . . . . . . . . . . . . . . 31.7

Zapatillas de seguridad. . . . . . . . . . . . . . . . . . . . . . . . . . . . 31.8

Ejemplo de elementos esenciales de la estructura de un casco de seguridad.. . 31.8

Ejemplos de cascos de seguridad con barboquejo (a), filtro óptico (b) y

faldilla de lana para proteger el cuello del viento y el frío (c). . . . . . . . . . . 31.11

Ejemplos de distintos tipos de protectores auditivos. . . . . . . . . . . . . 31.12

Disminución de la protección eficaz a medida que aumenta el tiempo sin

usarla en una jornada de 8 horas (basado en una tasa de cambio de $3 \mathrm{~dB}$ ). . . 31.12

O rejeras bien y mal ajustadas y consecuencias para la atenuación. . . . . . . 31.14

Tapón de espuma para los oídos, bien y mal ajustado, y consecuencias para la atenuación. . . . . . . . . . . . . . . . . . . . . . . . . 31.15

Tapón premoldeado para los oídos, bien y mal ajustado, y consecuencias para la atenuación. . . . . . . . . . . . . . . . . . . . . . . . . . 31.16

Ropa y guantes de protección para trasvasar productos químicos. . . . . . . . 31.19

D os trabajadores con trajes de protección química de distinta configuración. . 31.19

D istintos tipos de guantes resistentes a los compuestos químicos. . . . . . . . 31.20

Guantes de fibra natural de longitud suficiente para proteger la muñeca. . . . 31.20

Guía de selección de equipos de protección respiratoria. . . . . . . . . . . . . 31.26

M étodo cuantitativo del acetato de isoamilo para comprobar el ajuste. . . . . 31.29

M étodo cuantitativo del aerosol de sacarina para comprobar el ajuste. . . . . 31.30 


\section{Capítulo 32. Sistemas de notificación y vigilancia}

Figura 32.1

Ejemplo de un impreso de notificación de accidente.. . . . . . . . . . . . 32.23

Figura 32.2

Frecuencia de accidentes en el lugar de trabajo. . . . . . . . . . . . . . 32.26

Figura 32.3

Zonas mineras de SDAG Wismut en Alemania O riental. . . . . . . . . . . 32.28

Figura 32.4

Empleados de Wismut 1946-90. . . . . . . . . . . . . . . . . . . . 32.28

Figura 32.5

Registros de la exposición de la antigua SDAG Wismut. .

32.28

\section{Capítulo 33.}

Figura 33.1

Figura 33.2

Figura 33.3

Figura 33.4

Figura 33.5

Figura 33.6

Figura 33.7

Figura 33.8

Figura 33.9

Figura 33.10

Figura 33.11

Figura 33.12

Figura 33.13

Figura 33.14

Figura 33.15

\section{Toxicología}

Curvas hipotéticas de dosis-respuesta para diversos efectos.

Interrelaciones entre evaluación de la exposición, diferencias étnicas, edad, dieta, nutrición y evaluación de la susceptibilidad genética - factores todos que afectan al riesgo individual de toxicidad y cáncer. . . . . . . . . . . . 33.22

Relación genérica entre cualquier respuesta tóxica y la dosis de cualquier agente químico o físico ambiental. . . . . . . . . . . . . . . . . . 33.23

Expresión clásica de las Fases I y II de las enzimas metabolizantes de xenobióticos o de fármacos . . . . . . . . . . . . . . . . 33.23

Ejemplos de enzimas metabolizantes de fármacos. . . . . . . . . . . . 33.24

Procesos generales de la toxicidad. . . . . . . . . . . . . . . . . . . . . . 33.28

Modelo farmacocinético simplificado. . . . . . . . . . . . . . . . . . . . 33.30

Representación de los mecanismos de la toxicidad. . . . . . . . . . . . . . 33.31

Lesión celular. . . . . . . . . . . . . . . . . . . . . . . . . . . . . . . . . 33.34

O rganización de la información hereditaria en los seres humanos:

a) primaria, b) secundaria y c) terciaria.. . . . . . . . . . . . . . . . . . 33.36

Bioactivación de a) benzo(a)pireno y b) N-nitrosodimetilamina. . . . . . . . 33.36

Principales localizaciones del daño al ADN inducido por sustancias

químicas. . . . . . . . . . . . . . . . . . . . . . . . . . . . . 33.37

Diversos tipos de daño al complejo AD N-proteína. . . . . . . . . . . . 33.37

O rganos y tejidos primarios y secundarios del sistema linfático. . . . . . . . 33.40

Diagrama del examen. . . . . . . . . . . . . . . . . . . . . . . . . . . . 33.59

Figura 33.16

Sustancias químicas especificadas y designadas conforme a la Ley de control de las sustancias químicas, Japón. . . . . . . . . . . . . . . . . . . 33.59 


\section{III}

PARTE V. FACTORES PSICOSOCIALES Y DE ORGANIZACION

\section{Capítulo 34.}

Figura 34.1

Figura 34.2

Figura 34.3

Figura 34.4

Figura 34.5

Figura 34.6

Figura 34.7

Figura 34.8

Figura 34.9

Capítulo 35.

Figura 35.1

Figura 35.2

Figura 35.3

Figura 35.4

Figura 35.5

\section{Factores psicosociales y de organización}

M odelo de estrés del trabajo del $\mathrm{N}$ ational Institute for $\mathrm{O}$ ccupational Safety

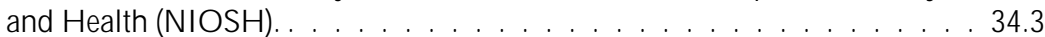

Modelo de exigencia psicológica/ margen de toma de decisiones. . . . . . . . 34.7

A sociaciones dinámicas entre la tensión del entorno y el aprendizaje y la evolución de la personalidad. . . . . . . . . . . . . . . . . . . . . . . 34.12

Componentes del estrés en el modelo de estrés-enfermedad de $\mathrm{K}$ agan y Levi (1971). . . . . . . . . . . . . . . . . . . . . . . . . . . . . . . 34.16

Esquema de la teoría del ajuste persona-entorno (PE) de French, R ogers y Cobb (1974).. . . . . . . . . . . . . . . . . . . . . . . . . . 34.18

$\mathrm{H}$ ipotética relación en forma de $\mathrm{U}$ entre el ajuste persona-entorno y la tensión psicológica. . . . . . . . . . . . . . . . . . . . . . . . . . . . . . . . 34.19 Clasificación del ritmo de trabajo. . . . . . . . . . . . . . . . . . . . 34.28 Efectos de la retroalimentación sobre el rendimiento en la reducción del estrés . . . . . . . . . . . . . . . . . . . . . . . . . . . . . . . . . . . 34.29 Los tres ejes principales para la medición del bienestar afectivo . . . . . . . . 34.65

\section{O rganizaciones y salud y seguridad}

El modelo de vínculos de Likert. . . . . . . . . . . . . . . . . . . . . 35.2

La forma organizativa clásica original. . . . . . . . . . . . . . . . . . 35.3

La forma clásica ampliada. . . . . . . . . . . . . . . . . . . . . . . 35.3

La organización horizontal. . . . . . . . . . . . . . . . . . . . 35.4

La organización de la seguridad en el trabajo: una estructura paralela. . . . . 35.5

PARTE VI. RIESGOS GENERALES

\section{Capítulo 37.}

Figura 37.1

Figura 37.2

Figura 37.3

Figura 37.4

Figura 37.5

Figura 37.6

Figura 37.7

\section{Capítulo 39.}

Figura 39.1

Figura 39.2

\section{Presión barométrica, reducción}

Aclimatación ventilatoria. . . . . . . . . . . . . . . . . . 37.2

Sucesión de acontecimientos durante la aclimatación. . . . . . . . . . . . 37.3

Evolución temporal de la aclimatación ventilatoria de personas situadas al nivel del mar que ascienden a una altitud de 4.300 m. . . . . . . . . . . . 37.4

En las personas que residen al nivel del mar, el tiempo necesario para lograr la aclimatación ventilatoria completa aumenta con la ascensión a altitudes gradualmente mayores. . . . . . . . . . . . . . . . . . . . . . . . . 37.4

Efectos de la altitud en la presión barométrica y en la inspirada $\mathrm{PO}_{2} \ldots \ldots$

Curva de disociación de la oxihemoglobina. . . . . . . . . . . . . . . . . . 37.6

Evolución temporal de la tensión de oxígeno en el capilar alveolar. . . . . . . 37.8

\section{Desastres naturales y tecnológicos}

Número de personas afectadas anualmente por catástrofes en todo el mundo en el período de 1967 a 1991.. . . . . . . . . . . . . . . . . . . . . . . . 39.2

Número de personas muertas a consecuencia de catástrofes en 1991: los 20 países con más víctimas mortales. . . . . . . . . . . . . . . . . . . . 39.2 
Figura 39.3

Figura 39.4

Figura 39.5

Figura 39.6

Figura 39.7

Figura 39.8

Figura 39.9

Figura 39.10

Figura 39.11

Figura 39.12

Figura 39.13

Figura 39.14

\section{Capítulo 40.}

Figura 40.1

Figura 40.2

Figura 40.3

\section{Capítulo 41.}

Figura 41.1

Figura 41.2

Figura 41.3

Figura 41.4

Figura 41.5

Figura 41.6

Figura 41.7

Figura 41.8

Figura 41.9

Figura 41.10

Figura 41.11

\section{Capítulo 42.}

Figura 42.1

Figura 42.2

Figura 42.3

Figura 42.4
Número total de acontecimientos por cada tipo de catástrofe. . . . . . . . . . 39.4

EI riesgo es el producto de peligro por vulnerabilidad: curvas características. . 39.17

Trayectoria de la exposición a radiaciones ionizantes tras un escape accidental de radiactividad al medio ambiente. . . . . . . . . . . . . . . 39.32

Trayectoria de las emisiones del accidente de C hernóbil, 26 de abril - 6 de mayo de 1986. . . . . . . . . . . . . . . . . . . . . . . . . . 39.33

Deposición de cesio-137 en Bielorrusia, Rusia y U crania, tras el accidente de Chernóbil. . . . . . . . . . . . . . . . . . . . . . . . . . . . . . . . 39.34

Precipitación de cesio-137 (kBq/ km²) sobre Europa tras el accidente de Chernóbil. . . . . . . . . . . . . . . . . . . . . . . 39.36

Ciclo de tratamiento del combustible nuclear. . . . . . . . . . . . . . . . . 39.36

Distribución mundial de reactores de generación de energía y de centrales de reprocesamiento de combustible, 1989-1990. . . . . . . . . . . . . . . . 39.38

Incidencia del cáncer de tiroides en niños menores de 15 años en Bielorrusia. . . . . . . . . . . . . . . . . . . . . . . . . . . 39.40

Límites temporales del trabajo agrícola en función de la intensidad de la radiación gamma en los lugares de trabajo. . . . . . . . . . . . . . . . . 39.44 Plano de la instalación de la fábrica de juguetes K ader . . . . . . . . . . . 39.46 Disposición interna de los edificios U no, Dosy Tres. . . . . . . . . . . . . . 39.46

\section{Electricidad}

M ecanismo de carga de un conductor por inducción. . . . . . . . . . . . . 40.8

Dibujo esquemático del problema de la descarga electrostática. . . . . . . . . 40.11

Estructura de las normas y reglamentos internacionales. . . . . . . . . . . . . 40.14

\section{Incendios}

Representación esquemática de una superficie en ignición y de los procesos de transferencia de calor y masa en la misma. . . . . . . . . . . . . . . 41.3 Representación de una ignición dirigida. . . . . . . . . . . . . . . . . . . 41.4 Tipos más comunes de tanques para el almacenamiento de líquidos inflamables y combustibles. . . . . . . . . . . . . . . . . . . . . . . . 41.12 Producción de humo en un incendio. . . . . . . . . . . . . . . . . . . . . 41.21 Principios básicos de seguridad de escape. . . . . . . . . . . . . . . . . . . 41.21 Ejemplo de señal pictográfica para ascensores. . . . . . . . . . . . . . . . . 41.23 Extintores portátiles. . . . . . . . . . . . . . . . . . . . . . . . . . . . . 41.24 Instalación tipo de rociadores con entradas de agua, tomas de agua exteriores y canalizaciones subterráneas. . . . . . . . . . . . . . . . . . . . . 41.24 Esquema de un sistema de dióxido de carbono a alta presión para inundación total. . . . . . . . . . . . . . . . . . . . . . . . . . 41.25 Sistema de inundación total instalado en una habitación con doble suelo.. . . 41.25 El diamante NFPA 704. . . . . . . . . . . . . . . . . . . . . . . . . . . . . . 41.29

\section{Calor y frío}

M odelo de regulación térmica del cuerpo humano. . . . . . . . . . . . . . 42.3 Distribuciones calculadas de agua en el compartimiento extracelular (CEC) y el compartimiento intracelular ( $\mathrm{CIC}$ ) antes y 2 horas después de deshidratación por esfuerzo a una temperatura ambiente de $30^{\circ} \mathrm{C} \ldots$. . . . . 42.5 Diagrama psicrométrico. . . . . . . . . . . . . . . . . . . . . . . . 42.16 Variación de tres medidas de la carga térmica con niveles crecientes de estrés térmico ambiental. . . . . . . . . . . . . . . . . . . . . . 42.18 
Figura 42.5

Figura 42.6

Figura 42.7

Figura 42.8

Figura 42.9

Figura 42.10

Figura 42.11

Figura 42.12

Figura 42.13

Figura 42.14

Figura 42.15

Figura 42.16

Figura 42.17

Figura 42.18

Figura 42.19

Figura 42.20

Figura 42.21

Figura 42.22

Figura 42.23

Figura 42.24

Figura 42.25

Figura 42.26

\section{C apítulo 43.}

Figura 43.1

Figura 43.2

Figura 43.3

Figura 43.4

Figura 43.5

Figura 43.6

Figura 43.7
Diagrama de flujos de decisión para SW (tasa de sudoración requerida). . . . 42.20 N omograma para la predicción de la "tasa de sudoración prevista durante 4 horas" (TSP4). . . . . . . . . . . . . . . . . . . . . . . . . . . . . . 42.21 Efecto de la velocidad del aire en la capacidad aislante de una capa de aire. . 42.28 Relación entre el grosor y la resistencia al vapor $\left(d_{e q}\right)$ de tejidos sin revestimiento. . . . . . . . . . . . . . . . . . . . . . 42.28 Aislamiento intrínseco e influencia de la curvatura del cuerpo, la piel desnuda y la velocidad del viento. . . . . . . . . . . . . . . . . . . . . . . . 42.29

Aislamiento total resultante del grosor de la ropa y su distribución sobre el cuerpo. . . . . . . . . . . . . . . . . . . . . . . . . . . . . . 42.30 Articulación del cuerpo humano en cilindros. . . . . . . . . . . . . . . . 42.30 D isminución de la resistencia al vapor de distintas prendas para la lluvia con el viento y la acción de caminar. . . . . . . . . . . . . . . . . . . . . . . 42.31 Descripción general de un modelo térmico dinámico. . . . . . . . . . . . . . 42.31 Ejemplos de los efectos del frío. . . . . . . . . . . . . . . . . . . . . . . . 42.33 Temperatura óptima para el "bienestar" térmico dependiendo de la ropa y

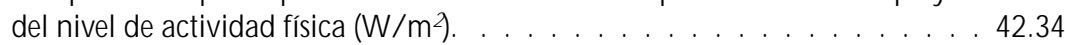
Relación entre destreza manual y temperatura cutánea de los dedos. . . . . . 42.35 Efectos brutos estimados en la destreza manual con diferentes niveles de temperatura de manosy dedos. . . . . . . . . . . . . . . . . . . . 42.36

La vasodilatación inducida por el frío de los vasos sanguíneos de los dedos produce un aumento cíclico de la temperatura tisular. . . . . . . . . . . . . . 42.37

Temperaturas estimadas a las que pueden producirse ciertos desequilibrios térmicos del organismo. . . . . . . . . . . . . . . . . . . . . . 42.44 T iempos previstos de supervivencia para situaciones típicas de alta mar en el $\mathrm{M}$ ar del Norte . . . . . . . . . . . . . . . . . . . . . . . . . . . . . . . . . 42.49 Evaluación del estrés por frío en relación con los factores climáticos y los efectos del enfriamiento. . . . . . . . . . . . . . . . . . . . . 42.56 Valores IREQ necesarios para mantener un bajo nivel de estrés fisiológico (sensación de neutralidad térmica) a distintas temperaturas. . . . . . . . . . . 42.57 Límites de tiempo para el trabajo ligero y moderado con dos niveles de aislamiento de la ropa. . . . . . . . . . . . . . . . . . . . . . . . . 42.57 Valores IREQ ponderados en el tiempo para la exposición intermitente y continua al frío. . . . . . . . . . . . . . . . . . . . . . . . . 42.57 Protección de los dedos. . . . . . . . . . . . . . . . . . . . . . . . 42.57 Relación entre el riesgo esperado de estrés por frío y los procedimientos de medición necesarios . . . . . . . . . . . . . . . . . . . . . 42.58

\section{Horas de trabajo}

M odelo de estrés y tensión de los trabajadores por turnos. . . . . . . . . . . . 43.2

Recomendaciones para el diseño de sistemas de turnos. . . . . . . . . . . . . 43.6

Sistema de turnos continuos rotativos. . . . . . . . . . . . . . . . . 43.9

Sistema de turnos discontinuos rotativos. . . . . . . . . . . . . . . . . . . 43.9

Sistema de turnos discontinuos rotativos con siete equipos. . . . . . . . . . . 43.9

Sistema de turnos discontinuos con una reducción del personal del turno de noche del $50 \% \ldots \ldots$. . . . . . . . . . . . . . . . . . . 43.10

Frecuencia cardíaca durante y después de un trabajo físico pesado con diferentes duraciones de los períodos de trabajo y de descanso y una relación

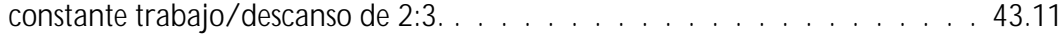


Figura 43.8

Figura 43.9

Capítulo 44.

Figura 44.1

Figura 44.2

Figura 44.3

Figura 44.4

Figura 44.5

C apítulo 45.

Figura 45.1

Figura 45.2

Figura 45.3

Figura 45.4

Figura 45.5

Figura 45.6

Figura 45.7

Figura 45.8

Figura 45.9

Figura 45.10

Figura 45.11

Figura 45.12

Figura 45.13

C apítulo 46.

Figura 46.1

Figura 46.2

Figura 46.3

Figura 46.4

Figura 46.5

Figura 46.6

Figura 46.7

Figura 46.8

Figura 46.9

Figura 46.10

Figura 46.11

Figura 46.12

Figura 46.13

Figura 46.14
Efecto de los períodos de descanso sobre el aprendizaje del rendimiento

sensoriomotor. . . . . . . . . . . . . . . . . . . . . . . . . . . . . 43.12

Efecto de los períodos breves de descanso sobre el rendimiento mental. . . . . . 43.12

\section{Calidad del aire interior}

Síntomas y enfermedades relacionadas con la calidad del aire interior. . . . . 44.2

Diagrama de un edificio que muestra diversas fuentes de contaminantes de interior y de exterior. . . . . . . . . . . . . . . . . . . . . . . . . . . . . 44.4

Concentraciones diarias de diversos compuestos en ambientes de interior. . . 44.10

Fuentes de radón en el medio ambiente de interior. . . . . . . . . . . . . . . 44.11

Planificación de las determinaciones para una evaluación de exploración. . . 44.18

\section{Control ambiental en interiores}

L os habitantes de las ciudades pasan entre un 80 y un $90 \%$ de su tiempo en interiores. . . . . . . . . . . . . . . . . . . . . 45.2

Penetración de la contaminación del exterior. . . . . . . . . . . . . . . . . 45.4

Ejemplo de cómo puede cortocircuitarse la distribución del aire en espacios

interiores . . . . . . . . . . . . . . . . . . 45.6

Esquema de circulación del aire en una habitación con dos aberturas de suministro. . . . . . . . . . . . . . . . . . . . . . . . . . 45.12

Factores $\mathrm{K}$ recomendados para ubicar entradas y salidas de aire . . . . . . 45.13

Curva de definición de la unidad olf. . . . . . . . . . . . . . . . . . . . 45.15

Relación entre la calidad percibida del aire expresada en porcentaje de personas insatisfechas y en decipoles. . . . . . . . . . . . . . . . . . . . . . . 45.15

Eficacia de la ventilación en la zona de respiración de acuerdo con

diferentes principios de ventilación. . . . . . . . . . . . . . . . . . . . . 454.17

Ecuaciones para el cálculo de las necesidades de ventilación. . . . . . . . . . 45.18

M ecanismos termorreguladores en los seres humanos. . . . . . . . . . . . . 45.19

Zonas de confort basadas en mediciones limitadas a la temperatura global y a la velocidad de las corrientes de aire. . . . . . . . . . . . . . . . . . . . .45.20

Características de los sistemas de cal efacción más utilizados en los lugares de trabajo. . . . . . . . . . . . . . . . . . . . . . . . . . . . . 45.22

Esquema simplificado de un sistema de aire acondicionado. . . . . . . . . . . 45.23

\section{Iluminación}

Construcción de una lámpara GLS. . . . . . . . . . . . . . . . . . . . . 46.4

El ciclo halógeno. . . . . . . . . . . . . . . . . . . . . . . . . . . . . 46.4

Lámpara reflectora dicroica de baja tensión. . . . . . . . . . . . . . . . 46.4

Lámparas de filamento G LS y tensión de alimentación. . . . . . . . . . . 46.5

Principio de la lámpara fluorescente. . . . . . . . . . . . . . . . . . . . 46.5

Fluorescente de tamaño reducido de cuatro patas. . . . . . . . . . . . . . . 46.6

Componentes de una lámpara de mercurio. . . . . . . . . . . . . . . . . 46.6

Componentes de una lámpara de sodio de alta presión. . . . . . . . . . . . . 46.7

Niveles de iluminación en función de las tareas realizadas. . . . . . . . . . . . 46.8

Distribución de las zonas visuales en el puesto de trabajo. . . . . . . . . . . . 46.9

Valores aproximados de luminancia. . . . . . . . . . . . . . . . . . . . . . 46.10

Factores que afectan al deslumbramiento. . . . . . . . . . . . . . . . . . . 46.10

Sistemas de iluminación. . . . . . . . . . . . . . . . . . . . . . . . . . . . . 46.11

Pérdida de la agudeza visual con la edad. . . . . . . . . . . . . . . . . . . . 46.11 
Figura 46.15

Figura 46.16

Figura 46.17

Figura 46.18

Figura 46.19

Figura 46.20

Figura 46.21

Figura 46.22

Figura 46.23

Figura 46.24

Figura 46.25

Figura 46.26

Figura 46.27

Figura 46.28

Figura 46.29

\section{Capítulo 47.}

Figura 47.1

Figura 47.2

Figura 47.3

Figura 47.4

Figura 47.5

Figura 47.6

Figura 47.7

Figura 47.8

Figura 47.9

Capítulo 48.

Figura 48.1

Figura 48.2

Figura 48.3

Figura 48.4

Figura 48.5

Figura 48.6

Figura 48.7

Figura 48.8

Figura 48.9
Tonalidades de colores "cálidos" y "fríos".

46.12

Diagrama de confort en función de la iluminación y las temperaturas

colorimétricas. . . . . . . . . . . . . . . . . . . . . . . . . . . . . . . 46.12

Sistemas de iluminación. . . . . . . . . . . . . . . . . . . . . . . . . . . . .46.14

Relación típica entre la agudeza visual y la iluminancia. . . . . . . . . . . . . 46.15

Relación típica entre el rendimiento visual y la iluminancia. . . . . . . . . . . 46.15

Variación de la luminancia a lo largo de una tarea. . . . . . . . . . . . . . . 46.15

Valores típicos de iluminancia relativa junto con valores recomendados de

reflectancia. . . . . . . . . . . . . . . . . . . . . . . . . . 46.15

Control del flujo luminoso por obstrucción. . . . . . . . . . . . . . . . . 46.16

Control del flujo luminoso por reflexión. . . . . . . . . . . . . . . . . . 46.16

Control del flujo luminoso por difusión. . . . . . . . . . . . . . . . . . 46.16

Control del flujo luminoso por refracción. . . . . . . . . . . . . . . . . 46.16

Reflejos cegadores. . . . . . . . . . . . . . . . . . . . . . . . . . . . 466.17

Representación esquemática del ángulo prohibido. . . . . . . . . . . . . . . 46.17

Alzado y planta de un interior típico (utilizado como ejemplo). . . . . . . . . 46.18

Posibles combinaciones de orientación de las luminarias y la dirección de

la visión dentro del interior analizado como ejemplo. . . . . . . . . . . . . . . 46.18

\section{Ruido}

Exposición al ruido en el trabajo: la experiencia de Estados U nidos. . . . . . 47.2

Sonómetro: control de calibración. Cortesía de Larson Davis. . . . . . . . . 47.6

Sonómetro con guardaviento. Cortesía de Larson Davis. . . . . . . . . . . 47.6

Comparación entre datos de octavas y tercios de octava.. . . . . . . . . . . 47.9

Comparación entre la tubería de unión y el nivel de fondo. . . . . . . . . . . 47.9

Puesto de trabajo del operario de embalajes. . . . . . . . . . . . . . . . 47.10

O peración de perforación final para líneas de proceso idénticas. . . . . . . . 47.10

Estimación del peligro derivado de la exposición al ruido en diferentes

poblaciones. . . . . . . . . . . . . . . . . . . . . . . . . . 47.13

Lista de control de prácticas adecuadas del PCA . . . . . . . . . . . . . . . 47.14

\section{Radiaciones ionizantes}

Importancia relativa de las tres interacciones principales de los fotones con la materia. . . . . . . . . . . . . . . . . . . . 48.2

Factores de ponderación de la radiación para neutrones (la curva suave debe considerarse una aproximación). . . . . . . . . . . . . . . . 48.4

Diferencias entre el poder penetrante en los tejidos de distintos tipos de radiación ionizante. . . . . . . . . . . . . . . . . . . . . 48.5

Frecuencia de aberraciones cromosómicas dicéntricas en linfocitos humanos en relación con la dosis, la tasa de dosis y la calidad de la irradiación in vitro.. 48.5 Inhibición mitótica inducida por rayos $X$ en células del epitelio corneal de ratas. . . . . . . . . . . . . . . . . . . . . 48.5

Curvas típicas dosis-supervivencia de células de mamíferos expuestas a rayos X y neutrones rápidos. . . . . . . . . . . . . . . . . . . . 48.6

Secuencia característica de acontecimientos en la patogenia de efectos no estocásticos de la radiación ionizante. . . . . . . . . . . . . . . . . . . . . 48.6

Frecuencia del retraso mental grave en relación con la dosis de radiación en supervivientes de la bomba atómica que recibieron irradiación prenatal. . . . . 48.10 Relación entre alcance y energía de partículas alfa lentas en el aire a 15 y

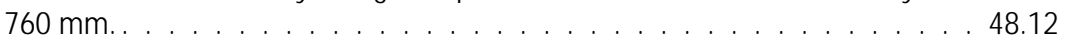


Figura 48.10

Figura 48.11

Figura 48.12

Figura 48.13

Figura 48.14

Figura 48.15

Figura 48.16

Figura 48.17

Figura 48.18

Figura 48.19

Figura 48.20

Figura 48.21

Figura 48.22

Figura 48.23

Figura 48.24

Figura 48.25

Figura 48.26

Figura 48.27

Figura 48.28

\section{C apítulo 49.}

Figura 49.1

Figura 49.2

Figura 49.3

Figura 49.4

Figura 49.5

Figura 49.6

Figura 49.7

Figura 49.8

\section{C apítulo 50.}

Figura 50.1

Figura 50.2

Figura 50.3

Figura 50.4

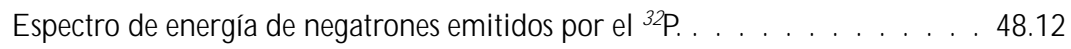

E squema de desintegración radiactiva del ${ }^{60} \mathrm{C} 0 \ldots \ldots . .13$

E squema de desintegración radiactiva del ${ }^{99} \mathrm{M}$ o . . . . . . . . . . . . . . . . . 48.13

Esquema de desintegración radiactiva del ${ }^{74} \mathrm{As}$, que ilustra los procesos competidores de emisión de negatrones, emisión de positrones y captura de electrones ( $m_{0}$ es la masa residual del electrón).. . . . . . . . . . . . . . . 48.13

Atenuación de rayos gamma de $667 \mathrm{keV}$ en $\mathrm{Al}$ y $\mathrm{Pb}$ en condiciones de buena geometría (la línea discontinua representa la atenuación de un haz polienergético de fotones).. . . . . . . . . . . . . . . . . . . . . . . . . . 48.14

Espectro de rayos $X$ que ilustra la contribución de los rayos $X$ característicos producidos a medida que los electrones llenan los huecos de la capa $\mathrm{K}$ de W (la longitud de onda de los rayos $\mathrm{X}$ es inversamente proporcional a su energía). . . . . . . . . . . . . . . . . . . . . . . . . . . . . . . . 48.14

Dibujo simplificado de un tubo de rayos $X$ con un ánodo estacionario y un filamento calentado. . . . . . . . . . . . . . . . . . . . . . . . . . . . 48.14

Series de desintegración ( $\mathrm{Z}=$ número atómico; $\mathrm{N}$ = número másico). . . . . . 48.16

Distribución típica de alcances de partículas alfa. . . . . . . . . . . . . . . 48.23

Símbolo de radiación. . . . . . . . . . . . . . . . . . . . . . . . . . . . 48.30

Categoría I - etiqueta BLANCA . . . . . . . . . . . . . . . . . 48.31

Categoría II - etiqueta AM ARILLA . . . . . . . . . . . . . . . . . 48.31

Categoría III - etiqueta AM ARILLA . . . . . . . . . . . . . . . 48.32

Placa de vehículo. . . . . . . . . . . . . . . . . . . . . . . . . 48.32

Cámara de radiografías industriales. . . . . . . . . . . . . . . . . . 48.37

Ejemplo de plan de emergencia de central nuclear, índice de materias. . . . . 48.38

Procedimientos típicos de implantación de un reactor nuclear. . . . . . . . 48.38

D esignación de sectores y zonas para muestreo radiológico y puntos de

vigilancia dentro de las zonas de planificación de emergencias. . . . . . . . . 48.38

R adiólogo industrial con dosímetros termoluminiscentes (DT L ): uno en el

bolsillo superior y otro de anillo (opcional en EE.UU.). . . . . . . . . . . . . . 48.40

\section{Radiaciones no ionizantes}

Espectro electromagnético. . . . . . . . . . . . . . . . . . . . . . . . . 49.5

O nda plana propagándose a la velocidad de la luz en dirección a X . . . . . 49.6

Algunas de las sustancias fotosensibilizantes. . . . . . . . . . . . . . . . . . 49.8

$R$ adiancia espectral $L_{\lambda}$ de un cuerpo negro radiante a la temperatura

absoluta indicada en grados K elvin en cada curva.. . . . . . . . . . . . . . 49.11

Absorción espectral de los medios oculares. . . . . . . . . . . . . . . . . 49.12

Profundidad de penetración en la piel a diferentes longitudes de onda. . . . . 49.13

Límites de exposición según la IR PA (1988) para la intensidad de campo

eléctrico $\mathrm{E}$, la intensidad de campo magnético $\mathrm{H}$ y la densidad de potencia. . 49.22

Límites de exposición según el IEEE (1991) para la intensidad de campo eléctrico $\mathrm{E}$, la intensidad de campo magnético $\mathrm{H}$ y la densidad de potencia.

\section{Vibraciones}

Dependencias de la frecuencia en cuanto a la respuesta humana a la vibración de cuerpo completo. . . . . . . . . . . . . . . . . . 50.6

Dependencias del tiempo en cuanto a la respuesta humana a la vibración de cuerpo completo.. . . . . . . . . . . . . . . . . . . . . . 50.7

Ejes para medir exposiciones a la vibración en personas sentadas. . . . . . . . 50.7

Sistema de coordenadas basicéntrico para la medición de las vibraciones transmitidas a las manos. . . . . . . . . . . . . . . . . . . . . . . . . 50.12 
Figura 50.5 Valores medios y rango de distribución de la aceleración eficaz ponderada en frecuencia en el eje dominante medida en la(s) empuñadura(s) de algunas herramientas a motor utilizadas en trabajos forestales y en la industria. . . . . . 50.13

Figura 50.6 Incidencia de cinetosis en función de la frecuencia de onda y la aceleración para 2 horas de exposición a movimiento senoidal vertical. . . . . . . . . . . 50.15

Figura 50.7 Relación entre incidencia de vómito y dosis de estímulo ( M SDV $_{2}$ ), calculada por el procedimiento descrito en el texto. $D$ atos procedentes de experimentos de laboratorio con oscilación vertical $(x-)$ y pruebas en el mar $(+)$. . . . . . 50.16

\section{Capítulo 52. \\ Figura 52.1 \\ Figura 52.2 \\ Figura 52.3 \\ Figura 52.4 \\ Figura 52.5 \\ Figura 52.6 \\ Figura 52.7 \\ Figura 52.8 \\ Figura 52.9 \\ Figura 52.10 \\ Figura 52.11}

Figura 52.12

\section{Pantallas de visualización de datos}

D isposición de un puesto de trabajo flexible que pueda adaptarse a las necesidades de los usuarios para distintas tareas. . . . . . . . . . . . . . 52.5

Disposición de un puesto de trabajo flexible. . . . . . . . . . . . . . . 52.5

Campo visual en el espacio de trabajo. . . . . . . . . . . . . . . . . . . 52.6

C riterios para la evaluación de la imagen. . . . . . . . . . . . . . . 52.7

A specto de una letra con distintas resoluciones de pantalla, y a la derecha, tal como aparece en papel. . . . . . . . . . . . . . . . . . . . . . . . . . . 52.8

Estrategias para reducir los reflejos en las pantallas. . . . . . . . . . . . . . 52.11

Factores que aumentan el riesgo de fatiga del ojo en los trabajadores que utilizan PVD. . . . . . . . . . . . . . . . . . . . . . . . . 52.13

Porcentaje de ratones hembras con reabsorciones placentarias en relación con la exposición. . . . . . . . . . . . . . . . . . . . . . . . . 52.15

M odelo de las condiciones de trabajo y su impacto sobre el individuo. . . . . 52.27

Claves para reducir el aislamiento y el estrés. . . . . . . . . . . . . . . . . . 52.29

G rupos de trabajo del Comité T écnico sobre la ergonomía de la interacción persona/ sistema (ISO TC 159 SC 4). ISO 9241: cinco grupos de trabajo han desglosado las "partes" de la norma, que se indican a continuación. Se muestra la correspondencia entre las partes de la norma y los distintos aspectos del puesto de trabajo con los que se relacionan. . . . . . . . . . . . 52.36 Directrices y requisitos de la tarea. . . . . . . . . . . . . . . . . . . . . 52.37

\section{PARTE VII. EL MEDIO AMBIENTE}

\section{Capítulo 53. \\ Figura 53.1 \\ Figura 53.2 \\ Figura 53.3 \\ Figura 53.4 \\ Figura 53.5 \\ Figura 53.6 \\ Figura 53.7 \\ Figura 53.8 \\ Figura 53.9 \\ Figura 53.10 \\ Figura 53.11 \\ Figura 53.12}

\section{R iesgos ambientales para la salud}

Enfermedades transmitidas por los alimentos en Venezuela. . . . . . . . . . 53.5 Enteritis infecciosa y fiebres tifoideas y paratifoideas (A, B y C) en Alemania. . 53.8 Serotipos de Salmonella en Suiza. . . . . . . . . . . . . . . . . . . . . . 53.8 $\mathrm{N}$ iveles de ozono en dos zonas de Ciudad de M éxico. M áximo diario en una hora, por meses, 1994. . . . . . . . . . . . . . . . . . . . . . . 53.13 Partículas $\left(\mathrm{PM}_{10}\right)$ en dos zonas de Ciudad de M éxico, 1988-1993. . . . . . . . 53.13 $\mathrm{N}$ iveles de plomo en el aire en dos zonas de Ciudad de M éxico, 1988-1994 . . 53.14 Sección transversal de un hipotético vertedero de desechos peligrosos. . . . . 53.15 Tipos de problemas de contaminación del agua. . . . . . . . . . . . . . . . 53.18 Sistema energético de referencia, 1979. . . . . . . . . . . . . . . . . . . 53.22 E fectos sobre la salud por unidad de cantidad de energía. . . . . . . . . . . . 53.24 R iesgo de muerte para una persona, debido a la utilización de leña como combustible doméstico durante 40 años. . . . . . . . . . . . . . . . . . . . 53.24

Efectos sobre la salud pública de los principales componentes del cambio climático mundial.. . . . . . . . . . . . . . . . . . . . . . . . . 53.28 
Capítulo 54.

Figura 54.1

Figura 54.2

Figura 54.3

Figura 54.4

Figura 54.5

Figura 54.6

\section{Capítulo 55.}

Figura 55.1

Figura 55.2

Figura 55.3

Figura 55.4

Figura 55.5

Figura 55.6

Figura 55.7

Figura 55.8

Figura 55.9

Figura 55.10

Figura 55.11

Figura 55.12

Figura 55.13

Figura 55.14

Figura 55.15

Figura 55.16

Figura 55.17

Figura 55.18

Figura 55.19

Figura 55.20

Figura 55.21

Figura 55.22

Figura 55.23

Figura 55.24

Figura 55.25

Figura 55.26

\section{Política en materia de medio ambiente}

E sbozo de las sucesivas etapas de la fijación de prioridades en la toma de decisiones sobre la adopción de medidas de protección del medio ambiente en la industria.. . . . . . . . . . . . . . . . . . . . . . . . . . . . . . . . . . . 54.19

O bjetivos e integridad de la evaluación del ciclo vital. . . . . . . . . . . . . . 54.20

E lementos sucesivos de un análisis de inventario del ciclo vital. . . . . . . . . . 54.21

$M$ arco conceptual de los niveles sucesivos de agregación de datos en los componentes de la evaluación de impacto. . . . . . . . . . . . . . . 54.22

E specificaciones que debe satisfacer un método de valoración de la evaluación del ciclo vital. . . . . . . . . . . . . . . . . . . . . . . . 54.22

E sbozo de algunas experiencias generales sobre los momentos del ciclo vital de los productos en los que se producen las principales cargas ambientales. .

\section{Control de la contaminación ambiental}

Sistema mundial de vigilancia ambiental/ C ontrol de la contaminación atmosférica. . . . . . . . . . . . . . . . . . . . . . . 55.10

Estructura topográfica de una región modelo. . . . . . . . . . . . . . . . 55.11

D istribución de frecuencias superficiales determinada a partir de la distribución de frecuencias geostróficas. . . . . . . . . . . . . . . . . . 55.11

Concentraciones medias anuales de contaminantes en una región hipotética calculadas a partir de la distribución de frecuencias geostróficas para campos de viento heterogéneos. . . . . . . . . . . . . . . . . . . . . . . . . . . 55.11

Diagrama de un tren de muestreo isocinético para dióxido de azufre. . . . . . 55.25 Transmisómetro sencillo para medir partículas en una chimenea. . . . . . . . 55.26 El ciclo hidrológico. . . . . . . . . . . . . . . . . . . . . . . . . . . 55.27 Distribución de las precipitaciones. . . . . . . . . . . . . . . . . . . . . . . 55.27 Ciclo hidrológico regional. . . . . . . . . . . . . . . . . . . . . . . 55.27

Zonas de mezclado. . . . . . . . . . . . . . . . . . . . . . . . . . . . . . . 55.29

M étodos de valoración de riesgos para niveles sucesivos de análisis. N ivel 1: M ediciones preliminares. $\mathrm{N}$ ivel 2: C uantificación de riesgos potencialmente significativos. Nivel 3: C uantificación de riesgos específicos de un lugar. . . . . 55.30 Lista esquemática de fuentes y sumideros de nutrientes (nitrógeno y fósforo) en el Lago Sunapee, N ew H ampshire (Estados U nidos). . . . . . . . . . . . . 55.31 E squema de un tratamiento convencional de aguas residuales. . . . . . . . . 55.32 Sección transversal de un estanque de estabilización de doble celda. . . . . . 55.34 Esquema de los diferentes tipos de laguna aireada. . . . . . . . . . . . . . . 55.34 Diagrama de flujo de un sistema de reciclado de las aguas residuales vertidas por una tenería. . . . . . . . . . . . . . . . . . . . . . . . . . . . 55.34 Intercambio de calor en los límites de la sección transversal de una cuenca receptora de agua.. . . . . . . . . . . . . . . . . . . . . . . . . . . 55535 Capacidad de un río para asimilar adiciones térmicas. . . . . . . . . . . . . 55.35 Ciclo hidrológico y fuentes de contaminación de las aguas subterráneas. . . . 55.36 Plano del sistema de regeneración de aguas residuales en la R egión de D an. . 55.38 Diagrama de flujo del proyecto de la Región de Dan. . . . . . . . . . . . . . 55.39 M odelo global de los principios de la gestión de residuos. . . . . . . . . . . 55.42 Función de utilidad para representar la relación entre reciclado y producción. . . . . . . . . . . . . . . . . . . . . . . . 55.43 Cuenca de drenaje de los G randes Lagos: río St. Lawrence. . . . . . . . . . . 55.47 Progresos en el control de la contaminación de fuentes industriales. . . . . . . 55.47 Contenido de M irex en los huevos de la gaviota plateada. . . . . . . . . . . . 55.48 
Figura 55.27 Proceso de toma de decisiones para la total eliminación de sustancias

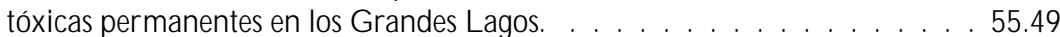

Figura $55.28 \quad$ Selección de objetivos de la política de gestión de sustancias tóxicas. . . . 55.50

Figura $55.29 \quad$ Prevención de la contaminación en los G randes Lagos. . . . . . . . . . . . 55.51

\section{PARTE VIII. ACCIDENTES Y GESTION DE LA SEGURIDAD}

\section{Capítulo 56.}

Figura 56.1

Figura 56.2

Figura 56.3

Figura 56.4

Figura 56.5

Figura 56.6

Figura 56.7

Figura 56.8

Figura 56.9

Figura 56.10

Figura 56.11

Figura 56.12

Figura 56.13

Figura 56.14

Figura 56.15

Figura 56.16

Figura 56.17

Figura 56.18

\section{Capítulo 57.}

Figura 57.1

Figura 57.2

Figura 57.3

Figura 57.4

Figura 57.5

Figura 57.6

Figura 57.7

Figura 57.8

Figura 57.9

Figura 57.10

Figura 57.11

\section{Prevención de accidentes}

Diferentes niveles de análisis de accidentes. . . . . . . . . . . . . . . . . . . 56.6

Estructura de los accidentes. . . . . . . . . . . . . . . . . . . . . . 56.7

M odelo de causalidad de los accidentes . . . . . . . . . . . . . . . . . 56.9

M odelo homeostático en el que se relacionan los cambios en las pérdidas por accidente con los cambios en el comportamiento de los operarios y viceversa; el nivel de riesgo asumido es la variable de control. . . . . . . . . . . . 56.13

Resolución de problemas específicos al enfrentarse al peligro. . . . . . . . . . 56.15

Ciclo de resolución de problemas. . . . . . . . . . . . . . . . . . . 56.16

Comportamiento ante el peligro. . . . . . . . . . . . . . . . . 56.17

El modelo de Surry. . . . . . . . . . . . . . . . . . . . . . . . . . . . . . . 56.19

El modelo WEF. . . . . . . . . . . . . . . . . . . . . . . . . . . . 565.20

EI modelo WEF ampliado mediante la introducción de otra primera secuencia. . . . . . . . . . . . . . . . . . . . . . . . . 56.21

M odelo general aproximado de la causalidad de los accidentes (basado en Surry 1969 y versiones posteriores).. . . . . . . . . . . . . . . . . . . . . 56.21

Análisis de un accidente en una obra de construcción conforme al modelo UIAT. . . . . . . . . . . . . . . . . . . . . . . . . . . . 56.23

Alcance de diferentes instrumentos utilizados en la práctica de la seguridad. . 56.24 El modelo de accidente M AIM . . . . . . . . . . . . . . . . . . . . 56.25

Resumen de un accidente registrado en una entrevista con el paciente. . . . . 56.27

Causas principales de muerte por lesión profesional, Estados U nidos 1980 -1989. . . . . . . . . . . . . . . . . . . . . . 56.30

L os efectos de las disposiciones sobre la minería del carbón en las tasas de mortalidad del sector, Estados U nidos 1950-1990. . . . . . . . . . . . . . . . 56.32

M odelo para el diseño y la evaluación de la información de un producto. . . . 56.41

\section{Auditorías, inspecciones e investigaciones}

L os valores, la misión y la cultura organizativa de una empresa de acuerdo con la estructura de los 7 factores de M cK insey. . . . . . . . . . . . . . . . 57.2

Teorías organizativas. . . . . . . . . . . . . . . . . . . . . 57.3

Un sistema de información sobre seguridad. . . . . . . . . . . . . . . . . . 57.9

Perfil de un tipo de accidente. . . . . . . . . . . . . . . . . . . . . 57.11

Ejemplo del perfil de seguridad de un sistema. . . . . . . . . . . . . . . . . 57.11

Conexión temporal entre depósitos en Flixborough. . . . . . . . . . . . . . 57.16

Conducto de transmisión para el transporte de gas licuado de un buque a un tanque de almacenamiento. . . . . . . . . . . . . . . . . . . . 57.17

Una versión del diagrama analítico M O RT (Supervisión de la gestión y diagrama de riesgos). . . . . . . . . . . . . . . . . . . . . . . . 57.19

Vínculos lógicos utilizados en el método del "diagrama de causas". . . . . . . . 57.26

árbol de causas de un accidente sufrido por un aprendiz de mecánico al volver a montar un motor en un coche. . . . . . . . . . . . . . . . . . 57.27

Ejemplo de representación posible mediante el método ST EP. . . . . . . . . 57.28 
Figura 57.12

Figura 57.13

\section{Capítulo 58.}

Figura 58.1

Figura 58.2

Figura 58.3

Figura 58.4

Figura 58.5

Figura 58.6

Figura 58.7

Figura 58.8

Figura 58.9

Figura 58.10

Figura 58.11

Figura 58.12

Figura 58.13

Figura 58.14

Figura 58.15

Figura 58.16

Figura 58.17

Figura 58.18

Figura 58.19

Figura 58.20

Figura 58.21

Figura 58.22

Figura 58.23

Figura 58.24

Figura 58.25

Figura 58.26

Figura 58.27

Figura 58.28

Figura 58.29

Figura 58.30

Figura 58.31

Figura 58.32

Figura 58.33

Figura 58.34

Figura 58.35

Figura 58.36

Figura 58.37
Lecciones extraídas de los accidentes y utilización de las mismas. . . . . . . . 57.28

Formulario tipo. . . . . . . . . . . . . . . . . . . . . . . . . . . . . 57.32

\section{Aplicaciones de la seguridad}

Circuito de control de dos botones. . . . . . . . . . . . . . . . . . . . . 58.2

Simulador para el estudio de circuitos de control de prensas. . . . . . . . . 58.3

Posible cadena de sucesos.. . . . . . . . . . . . . . . . . . . . . . . . . . 58.4

R epresentación de dos operaciones lógicas. . . . . . . . . . . . . . . . . . 58.4

Destornillador. . . . . . . . . . . . . . . . . . . . . . . . . . . 58.5

Sierra circular con defensa. . . . . . . . . . . . . . . . . . . . . . . . . 58.6

Taladro eléctrico. . . . . . . . . . . . . . . . . . . . . . . . . . . . . 58.7

Ejemplos de movimientos mecánicos que pueden lesionar a una persona. . . . 58.9

Ejemplo típico de lesión causada por el movimiento de una máquina

controlada por ordenador. . . . . . . . . . . . . . . . . . . . . . . . 58.10

Tipos de problemas técnicos relacionados con accidentes de automatización (número de accidentes $=127) \ldots \ldots$. . . . . . . . . . . . . . . . . 58.11

Tipos de correcciones de las perturbaciones en el momento del accidente (número de accidentes $=76$ ) . . . . . . . . . . . . . . . . . . . 58.11

Prensa mecánica de perforar. . . . . . . . . . . . . . . . . . . . . . . . . . 58.12

Ejemplos de salientes peligrosos en máquinas rotativas. . . . . . . . . . 58.13

Puntos de atrapamiento corrientes en partes en rotación. . . . . . . . . . . 58.13

Puntos de atrapamiento entre elementos rotativos y partes con movimientos longitudinales . . . . . . . . . . . . . . . . . . . . . . 58.13

Puntos de atrapamiento entre componentes rotativos de máquinas. . . . . . . 58.13

M ovimiento alternativo peligroso. . . . . . . . . . . . . . . . . . . . . 58.14

Ejemplo de movimiento transversal. . . . . . . . . . . . . . . . . . . . . . . 58.14

Ejemplos de peligros en el corte. . . . . . . . . . . . . . . . . . . . . . . 58.14

O peración típica de perforación. . . . . . . . . . . . . . . . . . . . . . 58.14

O peración de cizallamiento. . . . . . . . . . . . . . . . . . . . . . . . 58.15

O peración de doblado. . . . . . . . . . . . . . . . . . . . . . . . 58.15

D efensa fija en una prensa mecánica. . . . . . . . . . . . . . . . . 58.15

D efensa fija que encierra correas y poleas. . . . . . . . . . . . . . . . 58.15

Defensas fijas en una sierra de cinta. . . . . . . . . . . . . . . . . . 58.17

D efensa enclavada en una máquina plegadora. . . . . . . . . . . . . . . 58.17

D efensa ajustable en una sierra de cinta. . . . . . . . . . . . . . . . . . 58.17

D efensa autoajustable en una sierra de brazo radial. . . . . . . . . . . . . . 58.17

Dispositivo fotoeléctrico de detección de presencia en una plegadora. . . . . . 58.18

D ispositivo detector de presencia por radiofrecuencia en una prensa

mecánica de rotación parcial. . . . . . . . . . . . . . . . . . . . . 58.18

D ispositivo detector electromecánico en una máquina sacabocados.. . . . . . 58.18

Dispositivo de retirada en una prensa mecánica. . . . . . . . . . . . . . . 58.18

Barra para el cuerpo sensible a la presión en un molino de goma. . . . . . . . 58.20

Varilla de disparo de seguridad en un molino de goma. . . . . . . . . . . . 58.20

Cable de disparo de seguridad en una calandria. . . . . . . . . . . . . . . . 58.20

Botones de control para las dos manos en una prensa con embrague de rotación parcial. . . . . . . . . . . . . . . . . . . . . . . . . . . . . . 58.20

Botones de control para las dos manos en una prensa con embrague de rotación completa. . . . . . . . . . . . . . . . . . . . . . . . . . . 58.21 
Figura 58.38

Figura 58.39

Figura 58.40

Figura 58.41

Figura 58.42

Figura 58.43

Figura 58.44

Figura 58.45

Figura 58.46

Figura 58.47

Figura 58.48

Figura 58.49

Figura 58.50

Figura 58.51

Figura 58.52

Figura 58.53

Figura 58.54

Figura 58.55

Figura 58.56

Figura 58.57

Figura 58.58

Figura 58.59

Figura 58.60

Figura 58.61

Figura 58.62

Figura 58.63

Figura 58.64

Figura 58.65

Figura 58.66

Figura 58.67

Figura 58.68

Figura 58.69

Figura 58.70

Figura 58.71

Figura 58.72

Figura 58.73
Prensa mecánica con compuerta. . . . . . . . . . . . . . . . . . . . . . 58.21

Prensa mecánica con alimentación automática. . . . . . . . . . . . . . . . 58.21

Prensa mecánica con alimentación por rampa. . . . . . . . . . . . . . . . . 58.23

Sistema de expulsión por lanzadera. . . . . . . . . . . . . . . . . . . . 58.23

M ecanismo semiautomático de expulsión. . . . . . . . . . . . . . . . . . . 58.23

U so de barreras para proteger el recorrido del robot. . . . . . . . . . . . . . 58.23

Vista posterior de una cizalla. . . . . . . . . . . . . . . . . . . . . . . . 58.24

A plicaciones de los escudos. . . . . . . . . . . . . . . . . . . . . . . . 58.24

H erramientas de sujeción. . . . . . . . . . . . . . . . . . . . . . . . . . . . 58.24

U so de varilla o bloque de empuje. . . . . . . . . . . . . . . . . . . . . . . . 58.24

U na persona (a la derecha) y dos robots en cuerpos envolventes

informatizados . . . . . . . . . . . . . . . . . . . . 58.26

D etector pasivo por infrarrojos como detector de aproximación en una zona de peligro. . . . . . . . . . . . . . . . . . . . . . . . 58.27

Robot móvil con escáner de láser para uso en desplazamiento y detección de presencia.. . . . . . . . . . . . . . . . . . . . . . . . . . . 58.27

Disposición del cabezal de medida y zona vigilada en la parte lateral posterior de un camión. . . . . . . . . . . . . . . . . . . . . . . . . . 58.28

Camión de tamaño medio equipado con dispositivo de aviso en la parte trasera (foto M icrosonic). . . . . . . . . . . . . . . . . . . . . . . . . . . 58.28 Principios de los dispositivos de aislamiento eléctricos y neumáticos. . . . . . 58.29 Ejemplos de dispositivos de interruptores maestros eléctricos y neumáticos. . . 58.30 Ilustración de principios elementales de un dispositivo de desconexión de seguridad. . . . . . . . . . . . . . . . . . . . . . . 58.30

D ispositivos actuadores en los equipos de control para subsistemas operativos móviles y estacionarios. . . . . . . . . . . . . . . . . . 58.31 I lustración de los principios de paneles de control en interruptores de emergencia. . . . . . . . . . . . . . . . . . . . . . . . 58.31 Representación esquemática de un panel de control de operaciones. . . . . . 58.32 Esquema de un interruptor con funcionamiento mecánico positivo y desconexión positiva. . . . . . . . . . . . . . . . . . . . . 58.32

A irbus de L ufthansa después del accidente de Varsovia en 1993. . . . . . . . 58.34 Procedimiento cualitativo para determinación de riesgos. . . . . . . . . . . 58.36 E ficacia de las precauciones adoptadas contra errores, independientemente del riesgo. . . . . . . . . . . . . . . . . . . . . . . 58.36

Ejemplos de precauciones adoptadas para controlar y evitar errores en sistemas informáticos. . . . . . . . . . . . . . . . . . . . . . . . . . . . 58.37

Fuente principal de peligros en fabricación integrada por ordenador (CIM) (según ISO 1991). . . . . . . . . . . . . . . . . . . . . . . 58.41

Diseño general de sistemas de control. . . . . . . . . . . . . . . . . . 58.43

Fórmula de la fiabilidad. . . . . . . . . . . . . . . . . . . . . . . 58.44

C urvas de fiabilidad de componentes conectados en serie. . . . . . . . . . . 58.44

Curvas de fiabilidad de componentes conectados en paralelo. . . . . . . . . . 58.44

Ejemplo práctico de la figura 58.68. . . . . . . . . . . . . . . . . . 58.45

U n canal de control de seguridad ejecutando la función de seguridad requerida. . . . . . . . . . . . . . . . . . . . . 58.45 U n canal de control de seguridad con dos subcanales totalmente separados. . 58.45 U n canal de control de seguridad con dos subcanales totalmente separados que se supervisan recíprocamente . . . . . . . . . . . . . . . . . 58.45 Fiabilidad de sistemas redundantes con o sin detección de fallos. . . . . . . 58.45 
Figura 58.74

Figura 58.75

Figura 58.76

Figura 58.77

Figura 58.78

Figura 58.79

Figura 58.80

Figura 58.81

Figura 58.82

Figura 58.83

Figura 58.84

Figura 58.85

Figura 58.86

Figura 58.87

Figura 58.88

Figura 58.89

Figura 58.90

Figura 58.91

Figura 58.92

Figura 58.93

Figura 58.94

Figura 58.95

Figura 58.96

Figura 58.97

Figura 58.98

Figura 58.99

Figura 58.100

Figura 58.101

Figura 58.102

Figura 58.103

\section{C apítulo 59.}

Figura 59.1

Figura 59.2

Figura 59.3

Figura 59.4

Figura 59.5

Figura 59.6

Figura 59.7

Figura 59.8

Figura 59.9
Un interruptor de acción positiva. . . . . . . . . . . . . . . . . . . 58.48

Circuito que incluye un detector de fallos. . . . . . . . . . . . . . . . . 58.48

Un circuito de SEP. . . . . . . . . . . . . . . . . . . . . . . . . . . . 58.49

Un circuito de SEP con un sistema de detección de fallos . . . . . . . . . . 58.49

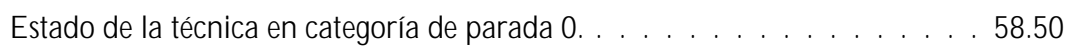

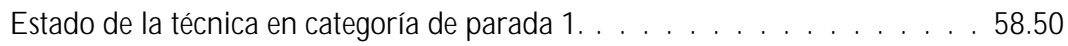

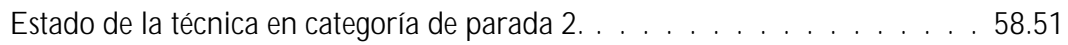

Sistema sofisticado con dos SE P. . . . . . . . . . . . . . . . . . . . . 58.51

Sistema especial de control del funcionamiento para la preparación de un robot de soldadura móvil. . . . . . . . . . . . . . . . . . . . . 58.60

Diagrama de bloques de un sistema de seguridad personal. . . . . . . . . . . 58.60

Robot industrial de seis ejes en una jaula de seguridad con puertas de

entrada de materiales. . . . . . . . . . . . . . . . . . . . . . . . . 58.61

Normas genéricas y de sectores de aplicación. . . . . . . . . . . . . . . 58.63

Sistemas eléctricos, electrónicos y programables. . . . . . . . . . . . . . . . 58.64

Características principales de los elementos relacionados con la seguridad. . . 58.64

Categorías de fallos . . . . . . . . . . . . . . . . . . . . . . . . 58.65

Términos de prestaciones de seguridad. . . . . . . . . . . . . . . . . . . 58.65

Causa primaria (por fases) de fallos del sistema de control. . . . . . . . . . . . 58.66

Influencia del ciclo de vida de la seguridad en la consecución de la seguridad funcional. . . . . . . . . . . . . . . . . . . . . 5866

Influencia de los niveles de integridad de la seguridad en el proceso de

diseño. . . . . . . . . . . . . . . . . . . . . . . . . 58.67

Influencia del ciclo de vida de la seguridad en el proceso de especificación

y diseño. . . . . . . . . . . . . . . . . . . . . . . . . . . . . . 58.67

Reducción de riesgos: conceptos generales. . . . . . . . . . . . . . . 58.68

M odelo global: niveles de protección. . . . . . . . . . . . . . . . . . . 58.68

Sistema típico de protección. . . . . . . . . . . . . . . . . . . . . . . 58.68

Especificación de diseño: solución de diseño . . . . . . . . . . . . . . . . 58.69

Tipos habituales de EPV en tractores. . . . . . . . . . . . . . . . . . . 58.71

Lesiones por vuelco por 100.000 tractores en Suecia entre 1957 y 1990 . . . . 58.72

M uertes por caídas y altura de caída en el sector de la construcción en

EE.UU., 1985 - 1993. . . . . . . . . . . . . . . . . . . . . . . . . . 58.74

Instalaciones de lectura de un manómetro. . . . . . . . . . . . . . . . 58.76

Estrategia de prevención de caídas. . . . . . . . . . . . . . . . . . 58.76

Un sistema de manipulación de materiales. . . . . . . . . . . . . . . 58.83

\section{Política de seguridad y liderazgo}

Ejemplo de resultados de las encuestas sobre percepciones. . . . . . . . . . 59.4

Tipología de las culturas de la seguridad. . . . . . . . . . . . . . . . . . 59.7

La modificación del comportamiento como sistema de gestión de la seguridad. . . . . . . . . . . . . . . . . . . . . . . . . 59.13

La modificación del comportamiento en la seguridad consta de los pasos

siguientes. . . . . . . . . . . . . . . . . . . . . . . . 59.14

Las cuatro fases del éxito de un programa de seguridad. . . . . . . . . . . . 59.16

El programa Tuttava se compone de cuatro etapas y ocho pasos. . . . . . . . 59.16

Resultados generados por un departamento de unos astilleros. . . . . . . . . 59.18

Ciclo de resolución de los problemas. . . . . . . . . . . . . . . . . . . . . 59.22

El proceso de toma de decisiones en las organizaciones. . . . . . . . . . . . 59.22 
Figura 59.10

Figura 59.11

Figura 59.12

Figura 59.13

Figura 59.14

Figura 59.15

Figura 59.16

Figura 59.17

Figura 59.18

Figura 59.19

Figura 59.20

\section{Capítulo 60.}

Figura 60.1

Figura 60.2

Figura 60.3

Figura 60.4

Figura 60.5

Figura 60.6

Figura 60.7

Figura 60.8

Figura 60.9

Figura 60.10
Siete clases de comportamientos negociadores. . . . . . . . . . . . . . . . . . 59.24

Tipología de la política de resolución de problemas. . . . . . . . . . . . . . . 59.24

D etección y percepción de los indicadores de riesgos en la industria. . . . . . . 59.26

Previsión y evaluación de los indicadores de peligro. . . . . . . . . . . . . . . 59.27

Ejemplos típicos de comportamientos preventivos individuales en la industria y frecuencia de las medidas preventivas. . . . . . . . . . . . . . . . . 59.31

Aspectos de la aceptación y el rechazo de riesgos. . . . . . . . . . . . . . . 59.32

Factores que influyen en la aceptación de riesgos. . . . . . . . . . . . . . . 59.34

Sesgos individuales que influyen en la evaluación y aceptación de riesgos. . . 59.35

Seis fases de la elección, decisión y aceptación de los riesgos óptimos. . . . . . 59.37

O bjetivos de la comunicación de riesgos. . . . . . . . . . . . . . . . . . 59.37

Factores que influyen en la eficacia de la comunicación de riesgos. . . . . . . 59.38

\section{Programas de seguridad}

Servicios complementarios prestados por los consultores. . . . . . . . . . 60.9

Funciones básicas del consultor de gestión. . . . . . . . . . . . . . . . . 60.9

Cinco estilos de consultoría. . . . . . . . . . . . . . . . . . . . . . . . . . 60.10

Elección de un consultor. . . . . . . . . . . . . . . . . . . . . . 60.10

Evaluación de la actuación del consultor. . . . . . . . . . . . . . . . . . . . . 60.11

El proceso de gestión y la seguridad en el trabajo. . . . . . . . . . . . . . . . 60.13

Teoría del dominó de Bird, modificada por Adams. . . . . . . . . . . . . . . 60.14

D esarrollo de la campaña de celebración del Día N acional de la Seguridad:

número de receptores de insignias. . . . . . . . . . . . . . . . . . 60.29

Aumento de los ingresos generados por la venta de materiales de promoción del Día N acional de la Seguridad (1972-1982). . . . . . . . . . . . . . . . 60.29

Aumento de los ingresos generados por la venta de materiales de promoción del Día N acional de la Seguridad (1983-1995). . . . . . . . . . . . . . . . 60.30

\section{PARTE IX. PRODUCTOS QUIMICOS}

\section{Capítulo 61. U tilización, alamacenamiento y transporte de productos químicos}

Figura $61.1 \quad$ Cerramiento completo: caja de manipulación con guantes. . . . . . . . . . 61.24

Figura 61.2 Cerramiento completo: cámara de almacenamiento de gas tóxico. . . . . . . 61.24

Figura $61.3 \quad$ Cerramiento completo: cámara de chorreo abrasivo. . . . . . . . . . . . 61.25

Figura $61.4 \quad$ Cerramiento parcial: cabina de pintura con pistola pulverizadora. . . . . . 61.25

Figura $61.5 \quad$ Campana de techo: aspiración en un horno. . . . . . . . . . . . . 61.25

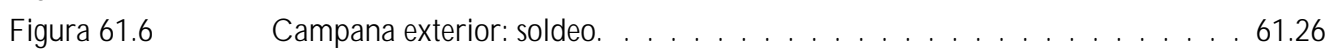

Figura $61.7 \quad$ Campana exterior: llenado de bidones. . . . . . . . . . . . . . . . 61.26

Figura $61.8 \quad$ Centro de recogida de datos e información para fichas de seguridad estructura básica. . . . . . . . . . . . . . . . . . . . . . 61.28

Figura 61.9 Sistema de medición de las BG para las sustancias peligrosas (BG M G) cooperación entre el BIA y las BG . . . . . . . . . . . . . . . . . . 61.28 
PARTE X. SECTORES BASADOS EN RECURSOS BIOLOGICOS

\section{Capítulo 64.}

Figura 64.1

Figura 64.2

Figura 64.3

Figura 64.4

Figura 64.5

Figura 64.6

Figura 64.7

Figura 64.8

Figura 64.9

Figura 64.10

Figura 64.11

Figura 64.12

Figura 64.13

Figura 64.14

Figura 64.15

Figura 64.16

Figura 64.17

Figura 64.18

Figura 64.19

Figura 64.20

Figura 64.21

Figura 64.22

Figura 64.23

Figura 64.24

Figura 64.25

Figura 64.26

Figura 64.27

Figura 64.28

Figura 64.29

Figura 64.30

Figura 64.31

Figura 64.32

\section{Agricultura y sectores basados en recursos naturales}

M illones de trabajadores agrícolas por regiones del mundo (1994). . . . . . . 64.3

$\mathrm{N}$ iño trabajando en la agricultura en la India. . . . . . . . . . . . . . . 64.3

Cortadores de plátanos trabajando en la plantación ecuatoriana “La Julia” . . 64.7

Prendas protectoras para la aplicación de plaguicidas. . . . . . . . . . . . 64.8

Plantación de café en un vivero de Costa de M arfil. . . . . . . . . . . . . . . 64.11

Corte de plantas trasplantadas de tabaco en un invernadero de $\mathrm{C}$ arolina del

Norte . . . . . . . . . . . . . . . . . . . . . . . . . 64.13

Un trabajador con equipo de protección completo aplicando un plaguicida en un invernadero. . . . . . . . . . . . . . . . . . . . . . . . . 64.13

Cuidado de las flores en un invernadero. . . . . . . . . . . . . . . . . . . 64.14

Plantación de esquejes en un invernadero. . . . . . . . . . . . . . . . . . 64.15

Las posturas encorvadas durante largos períodos son una causa frecuente de problemas ergonómicos. . . . . . . . . . . . . . . . . . . . . . . 64.16

Exposición de los tractoristas al polvo durante el trabajo. . . . . . . . . . . . 64.19

Parámetros angulares de la postura óptima de trabajo de un tractorista. . . . 64.20

Recolección manual de mijo. . . . . . . . . . . . . . . . . . . . . . . . . . 64.21

Arado chisel desi tirado por bueyes. . . . . . . . . . . . . . . . . . . 64.26

Escardado en el desherbado de un arrozal. . . . . . . . . . . . . . . . . 64.27

Trabajo con una sembradora germinadora mejorada. . . . . . . . . . . . . 64.28

A carreo de agua de un canal de riego utilizando un cesto oscilante. . . . . . . 64.29

Recolección de trigo con una hoz. . . . . . . . . . . . . . . . . . . . . 64.29

Recolección manual de patatas con una azada. . . . . . . . . . . . . . 64.30

Trillado de las cimas de arroz mediante batido. . . . . . . . . . . . . . . 64.30

Trilladora a pedales en funcionamiento. . . . . . . . . . . . . . . . . . . 64.31

Aventado manual. . . . . . . . . . . . . . . . . . . . . . . . . . . . 64.31

N omograma para optimizar la carga a transportar sobre la cabeza o yugo,

con respecto a la velocidad de marcha y a la demanda de oxígeno del

trabajo. . . . . . . . . . . . . . . . . . . . . . 64.32

Línea base de estabilidad de un tractor de tres ruedas y de un tractor con parte frontal ancha. . . . . . . . . . . . . . . . . . . . . . 64.33

Cosechadora combinada para la recolección de trigo, sin cabina cerrada.. . . 64.36

Recolección manual de arroz en China, 1992. . . . . . . . . . . . . . . . . 64.37

Trabajo manual en una explotación de hortalizas cerca de Assam, Jordania. . 64.43

Corte manual de semilleros de tabaco con tijeras de podar en Zimbabwe. . . 64.55

Trasplante mecánico del tabaco curado al humo en C arolina del Norte

(Estados U nidos). . . . . . . . . . . . . . . . . . . . . . . . . . . . 64.55

Preparación del tabaco oriental para el curado al aire poco después de su recolección manual. . . . . . . . . . . . . . . . . . . . . . . 64.56

Recolección manual del tabaco curado al humo por un pequeño agricultor en el sur de Brasil. . . . . . . . . . . . . . . . . . . . . . . . . . . . 64.56

Arranque manual de las hojas de los tallos del tabaco Burley curado. . . . . . 64.56 
Figura 64.33

Figura 64.34

Figura 64.35

Figura 64.36

Figura 64.37

Figura 64.38

Figura 64.39

Figura 64.40

\section{Capítulo 65.}

Figura 65.1

Figura 65.2

Figura 65.3

Figura 65.4

Figura 65.5

Figura 65.6

Figura 65.7

Figura 65.8

\section{Capítulo 66.}

Figura 66.1

Figura 66.2

Figura 66.3

Figura 66.4

Figura 66.5

Figura 66.6

Figura 66.7

Figura 66.8

Figura 66.9

\section{Capítulo 67.}

Figura 67.1

Figura 67.2

Figura 67.3

Figura 67.4
Separación manual del tabaco curado al humo en clases homogéneas en Zimbabwe. . . . . . . . . . . . . . . . . . . . . . . . . . . . . . 64.57

C arga de balas de tabaco para su transporte a un centro comercial en el sur de Brasil.. . . . . . . . . . . . . . . . . . . . . . . . . . . . . . . . . . . . . 64.57

D escarga de las balas de tabaco de un agricultor en el centro de subastas de Zimbabwe, que cuenta con el sistema de comercialización de tabaco curado al humo más mecanizado y eficiente del mundo. . . . . . . . . . . . . . 64.58 Plantas de café mostrando los granos. . . . . . . . . . . . . . . . . . . 64.64 Producción mundial de café en 1995-96. . . . . . . . . . . . . . . . . 64.64 R ecolectores de hojas de té trabajando en una plantación de U ganda. . . . . . 64.66 Recolección manual en una plantación de té cerca del $M$ ar N egro. . . . . . . 64.67 Tasas de mortalidad de los trabajadores agrícolas, Estados U nidos, 1980-89. . 64.71

\section{Industria de las bebidas}

Panel de control de una planta automática de bebidas refrescantes en N ovosibirsk, Rusia. . . . . . . . . . . . . . . . . . . . . . . . 65.4 Diagrama de flujo de las operaciones básicas de embotellado. . . . . . . . . 65.5 Línea de enlatado de bebidas refrescantes que muestra las operaciones de Ilenado. . . . . . . . . . . . . . . . . . . . . 65.5 Paquetes de 8 botellas de plástico de 2 litros de bebidas refrescantes de camino a un apilador automático. . . . . . . . . . . . . . . . . . . 65.5 Diagrama de flujo de la fabricación del café. . . . . . . . . . . . . . . . 65.7

Envasado de té en la fábrica de té y café Brooke Bond en D ar-es-Salaam, Tanzania. . . . . . . . . . . . . . . . . . . . . . . . . . . . . . . 65.10 Diagrama de flujo de la fabricación de licores destilados. . . . . . . . . . . 65.11 Diagrama de flujo del proceso de producción de cerveza. . . . . . . . . . . . 65.14

\section{Pesca}

Buzo indígena pescando. . . . . . . . . . . . . . . . . . . . . . . 66.4

Buzo en aguas de Phuket, Tailandia, preparándose para sumergirse desde una lancha abierta. . . . . . . . . . . . . . . . . . . . . . 66.4 Pesca con un arrastrero de fondo de popa. . . . . . . . . . . . . . . . 66.5 Arrastrero de popa. . . . . . . . . . . . . . . . . . . . . . . . . . . 66.6 Palangrero. . . . . . . . . . . . . . . . . . . . . 66.7 Pequeño palangrero de alta velocidad (parado). . . . . . . . . . . . 66.7 Pequeño palangrero de alta velocidad (en funcionamiento). . . . . . . . . . 66.7 Diagrama de pesca y procesamiento. . . . . . . . . . . . . . . . . . . 66.8 M anipulación manual de pescado en una planta embaladora en Tailandia. . . 66.19

\section{Industria alimentaria}

Trinchado de carne de ballena congelada con una sierra de banda y sin protección adecuada de la maquinaria ni precauciones de carácter eléctrico. Japón, 1989. . . . . . . . . . . . . . . . . . . . . . . 67.6

E squema de las fases del sacrificio de ganado bovino. . . . . . . . . . . . . . 67.16

Trinchado y clasificación de carne sin equipo protector en un centro de producción cárnica thailandés. . . . . . . . . . . . . . . . . . . . . 67.17

Con cintas transportadoras situadas al lado de las mesas de trabajo, los trabajadores pueden arrojar los productos terminados a través de una abertura practicada en la mesa, en lugar de tener que lanzar la carne sobre su cabeza. . . . . . . . . . . . . . . . . . . . . . . . . . . . . . . . . . . 67.18 
Figura 67.5 Extraer los huesos de las aletas mediante la fuerza de una cadena anexa, evitando la extracción manual, reduce los riesgos musculosqueléticos. .

Figura 67.6 La utilización de elevadores por vacío para levantar cajas permite a los trabajadores moverlas sin tener que cargarlas a mano. . . . . . . . . . . . . . 67.19

Figura 67.7 Las máquinas de corte múltiple reducen el trabajo manual repetitivo; los trabajadores deben acabar el tratamiento de las aves que las máquinas dejan pasar. . . . . . . . . . . . . . . . . . . . . . 67.22

Figura 67.8 Producción de pan para una cadena de supermercados en Suiza. . . . . . . . .

Capítulo 68.

Figura 68.1

Figura 68.2

Figura 68.3

Figura 68.4

Figura 68.5

Figura 68.6

Figura 68.7

Figura 68.8

Figura 68.9

Figura 68.10

Figura 68.11

Figura 68.12

Figura 68.13

Figura 68.14

Figura 68.15

Figura 68.16

Figura 68.17

Figura 68.18

Figura 68.19

\section{Capítulo 70.}

Figura 70.1

Figura 70.2

Figura 70.3

Figura 70.4

Figura 70.5

Figura 70.6

Figura 70.7

Figura 70.8

\section{Industria forestal}

Los nueve mayores productores de rollizos industriales, 1993 (antigua URSS 1991). . . . . . . . . . . . . . . . . . . . . . . . . 68.3

El empleo en la industria forestal (equivalentes a tiempo completo).

Países con mayor nivel de empleo asalariado en la industria forestal y producción de rollizos industriales (desde finales del decenio de 1980 hasta principios del decenio de 1990).. . . . . . . . . . . . . . . . . . . . . . . 68.4

Distribución de fallecimientos entre los distintos trabajos de saca forestal, M alaisia (Sarawak), 1989. . . . . . . . . . . . . . . . . . . . . . . . . . 68.5 M ujer transportando leña, Addis A beba (Etiopía). . . . . . . . . . . . . . . 68.6 A peo con sierra mecánica: secuencia de cortes. . . . . . . . . . . . . . . 68.8 Retroceso de una sierra mecánica. . . . . . . . . . . . . . . . . . 68.9

Señales manuales convenidas internacionalmente para trabajar con arrastradores provistos de cabrestantes mecánicos. . . . . . . . . . . . . . . 68.10

Carga manual (con y sin rampas).. . . . . . . . . . . . . . . . . 68.13

Carga mecanizada y semimecanizada. . . . . . . . . . . . . . . . . . . . 68.13

O peraciones de saca en N igeria realizada por trabajadores sin protección. . . 68.14

Plantadores trabajando en Canadá. . . . . . . . . . . . . . . . . . . . . 68.17

El triángulo del fuego. . . . . . . . . . . . . . . . . . . . . . . . 68.19

Equipo de seguridad del bombero forestal. . . . . . . . . . . . . . . . . . . 68.20

Representación en círculo de los problemas que pueden encontrarse en el trabajo forestal. . . . . . . . . . . . . . . . . . . . . . . . . . . . . . . 68.24

Esquema simplificado de relaciones causa-efecto en las operaciones subcontratadas. . . . . . . . . . . . . . . . . . . . . . 68.25

Localización corporal de las lesiones y equipos de protección individual recomendados para el trabajo forestal, Países Bajos, 1989. . . . . . . . . . . 68.36 Factores determinantes de los riesgos para la seguridad en el trabajo forestal. . 68.37 Los factores humanos repercuten en la seguridad del trabajo forestal. . . . . . . 68.38

\section{G anadería y cría de animales}

Producción mundial de carne y de pescado. . . . . . . . . . . . . . . . . 70.3 Población humana dedicada a la agricultura, por regiones del mundo, 1994. . 70.4 Visión panorámica del ganado vacuno. . . . . . . . . . . . . . . . 70.16 Herrado de un caballo en Suiza. . . . . . . . . . . . . . . . . . . . . 70.17 Frecuencia estimada de lesiones causantes de pérdida de jornadas de trabajo, por actividades agrarias en Estados U nidos, 1993. . . . . . . . . . . . . . . 70.24 Parte de un rebaño comercial de avestruces de 3 a 6 semanas de edad. . . . . . 70.27 Rebaño comercial de emús de 12 meses de edad. . . . . . . . . . . . . . . 70.27 O perarios capturando pollos y colocándolos en jaulas para trasladarlos a un matadero industrial. . . . . . . . . . . . . . . . . . . . . . 70.27 
Figura 70.9

Figura 70.10

Capítulo 71.

Figura 71.1

Figura 71.2

Figura 71.3

Figura 71.4

Figura 71.5

Figura 71.6

\section{Capítulo 72.}

Figura 72.1

Figura 72.2

Figura 72.3

Figura 72.4

Figura 72.5

Figura 72.6

Figura 72.7

Figura 72.8

Figura 72.9

Figura 72.10

Figura 72.11

Figura 72.12
O perarios capturando pavos para conducirlos al corral. . . . . . . . . . . . . 70.28

Sistema de estabulación libre. . . . . . . . . . . . . . . . . . . . . . . . 70.28

\section{Industria de la madera}

Clasificación de los tableros manufacturados por el tamaño de las partículas, la densidad y el tipo de proceso. . . . . . . . . . . . . . . . . . . . 71.3 Carga de astillas con almacenamiento acuático de troncos al fondo. . . . . . . . 71.4 Troncos entrando a una serrería; almacenes y secaderos al fondo. . . . . . . . 71.5 Interior de la fábrica; cintas y rodillos de transporte de madera. . . . . . . . 71.5 Carretilla elevadora cargada. . . . . . . . . . . . . . . . . . . . 71.5 Cintas de transporte de desechos a un quemador tipo colmena. . . . . . . . . 71.12

\section{Industria del papel y de la pasta de papel}

Ilustración de la secuencia de procesos en las operaciones de fabricación de pasta y de papel. . . . . . . . . . . . . . . . . . . . . . . . . 72.2

M oderno complejo fabril de pasta y papel situado en la ribera de un río navegable. . . . . . . . . . . . . . . . . . . 72.3 Producción mundial de pasta y de papel, 1980 a 1993. . . . . . . . . . . . . 72.3 Consumo de papel y cartón como indicador del desarrollo económico. . . . . . 72.3 Producción mundial de pasta, por tipos. . . . . . . . . . . . . . . . . . 72.6 Zona de almacenaje de astillas con alas cargadoras frontales. . . . . . . . . . 72.6 Depurador de pasta mecánica. . . . . . . . . . . . . . . . . . . . . . 72.7 Digestor continuo de kraft, con transportador de astillas en construcción.. . . 72.7 Extremo húmedo de una máquina de papel mostrando fieltro de fibra sobre la rejilla. . . . . . . . . . . . . . . . . . . . . . . . . . . . . . . . . 72.10

Extremo seco de una máquina de papel mostrando la bobina de papel y al trabajador utilizando la cizalla de aire para cortar el extremo. . . . . . . . . 72.11 Trabajador levantando la tapa del digestor discontinuo controlado manualmente. . . . . . . . . . . . . . . . . . . . . . . . . . . . . 72.12 Indicadores ambientales en fábricas canadienses de pasta y de papel, 1980 a 1994, mostrando el uso de residuos de madera y de papel reciclado en la producción, y la demanda biológica de oxígeno (DBO ) y compuestos organoclorados (AOX) en las aguas residuales efluentes. . . . . . . . . . . . 72.19

\section{PARTE XI. INDUSTRIAS BASADAS EN RECURSOS NATURALES}

\section{Capítulo 73.}

Figura 73.1

Figura 73.2

Figura 73.3

Figura 73.4

Figura 73.5

Figura 73.6

Figura 73.7

Figura 73.8

Figura 73.9

Figura 73.10

Figura 73.11

Figura 73.12

\section{$\mathrm{H}$ ierro y acero}

Producción mundial de arrabio en 1995, por regiones. . . . . . . . . . . . 73.2

Producción mundial de acero en bruto en 1995, por regiones. . . . . . . . . . 73.2

Cargas de chatarra para hornos eléctricos. . . . . . . . . . . . . . . . 73.2

Proceso de fabricación del acero. . . . . . . . . . . . . . . . . . . . 73.3

Control de temperatura del metal fundido en un alto horno. . . . . . . . . 73.3

C arga de metal caliente para un convertidor. . . . . . . . . . . . . . . . . . 73.4

Vista general de la fundición en horno eléctrico. . . . . . . . . . . . . . . . 73.4

Parte posterior de la carga de metal caliente. . . . . . . . . . . . . . . . . 73.4

Crisol de colada continua. . . . . . . . . . . . . . . . . . . . . . 73.4

Palanquilla de colada continua. . . . . . . . . . . . . . . . . . 73.5

Tocho de colada continua. . . . . . . . . . . . . . . . . . . . 73.5

Sala de control del proceso de colada continua. . . . . . . . . . . . . . . . 73.6 
Figura 73.13

Figura 73.14

\section{Capítulo 74.}

Figura 74.1

Figura 74.2

Figura 74.3

Figura 74.4

Figura 74.5

Figura 74.6

Figura 74.7

Figura 74.8

Figura 74.9

Figura 74.10

Figura 74.11

Figura 74.12

Figura 74.13

Figura 74.14

Figura 74.15

Figura 74.16

\section{Capítulo 75.}

Figura 75.1

Figura 75.2

Figura 75.3

Figura 75.4

Figura 75.5

Figura 75.6

Figura 75.7

\section{Capítulo 76.}

Figura 76.1

Figura 76.2
Proceso de laminación de chapa en frío y en caliente.

73.11

Diagrama de flujos de contaminantes y residuos generados por diferentes

procesos. . . . . . . . . . . . . . . . . . . . . . . . . . 73.16

\section{Minas y canteras}

Pequeña cantera en Bengala occidental. . . . . . . . . . . . . . . . 74.3

Pequeña mina de oro en Zimbabwe. . . . . . . . . . . . . . . . . . 74.4

Perforación en las montañas de la Columbia Británica (C anadá) con un equipo ligero Winkie. . . . . . . . . . . . . . . . . . . . 74.5

Campamento de verano en los Territorios del Noroeste (Canadá). . . . . . . 74.6

Perforadora montada sobre un camión en Australia. . . . . . . . . . . . . . . 74.6

Perforación de circulación inversa en un lago helado de Canadá. . . . . . . . 74.7

Transporte de campo en pleno invierno en Canadá. . . . . . . . . . . . . . 74.8

Descarga de suministros de campo desde un De H avilland DH C-6 Twin

Otter, Territorios del Noroeste (C anadá). . . . . . . . . . . . . . . . . . . . 74.8

Patrón de perforación de la mina G arpenberg (plomo y zinc) en el centro de Suecia. . . . . . . . . . . . . . . . . . . . . . . . . . 74.10

Cargador CLV. . . . . . . . . . . . . . . . . . . . . . . . . . . . . 74.10

M étodos de perforación de pozos. . . . . . . . . . . . . . . . . . . . . . 74.11

M áquina perforadora de pozos. . . . . . . . . . . . . . . . . . . . . 74.11

M ina de cámaras y pilares en un filón plano. . . . . . . . . . . . . . . . 74.12

Explotación por subniveles con perforadora circular y carga en galerías

cruzadas . . . . . . . . . . . . . . . . . . . . . . . . . . . . . . . . . . 74.14

Equipo de perforación de pozos profundos. . . . . . . . . . . . . . . . . 74.15

Equipo para frentes de pequeño tamaño. . . . . . . . . . . . . . . . . . . 74.17

\section{Petróleo: prospección y perforación}

Producción mundial de crudo para 1995. . . . . . . . . . . . . . . . . 75.2

Producción mundial de líquidos de plantas de gas natural para 1995. . . . . . 75.2

Plataforma marina de producción de gas natural instalada en aguas de

87,5 metros de profundidad en la zona de Pitas Point del Canal de Santa

Bárbara, en el sur de California. . . . . . . . . . . . . . . . . . . . . 75.4

La planta de GNL más grande del mundo, en Arzew, Argelia.. . . . . . . . 75.5

A rabia Saudí, operaciones sísmicas. . . . . . . . . . . . . . . . . . . 75.6

Embarcaciones de perforación; buque perforador Ben 0 cean L aneer. . . . . 75.7

Equipo de perforación en Ellef Ringnes I sland, en el Artico canadiense. . . . 75.8

\section{Producción y distribución de energía eléctrica}

Tipos de centrales nucleares. . . . . . . . . . . . . . . . . . . . . 76.9

Descenso del calor tras la parada del reactor. .

76.14

\section{PARTE XII. INDUSTRIAS QUIMICAS}

\section{Capítulo 77. Procesado químico}

Figura 77.1 Cambio en la producción química de algunos países, 1992-1995 . . . . . . 77.2

Figura 77.2 Tanques típicos de almacenamiento sobre el suelo.. . . . . . . . . . . . 77.11

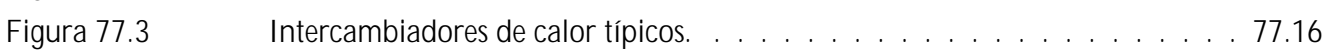

Figura $77.4 \quad$ Tipos de procesos en celdas de cloruros alcalinos. . . . . . . . . . . 77.21 
Figura 77.5 Diagrama de flujo para la fabricación de revestimientos de polvo por el método de fusión y extrusión-mezcla.. . . . . . . . . . . . . . . . . 77.23

Figura $77.6 \quad$ Sistema de control de polvo. . . . . . . . . . . . . . . . . . . 77.24

Figura $77.7 \quad$ Secuencia de producción en el proceso de plásticos. . . . . . . . . . . . . . . 77.24

Figura 77.8 Esquema que ilustra la versatilidad de la producción, a partir de fracciones del petróleo, de materias primas en la fabricación de diversos tipos de plástico. . . . . . . . . . . . . . . . . . . . . 77.26

Figura 77.9 Técnico sacando un recipiente de polipropileno de una máquina de moldeo por inyección. . . . . . . . . . . . . . . . . . . . . . . 77.27

Figura 77.10 Extrusión de plástico: la cinta se parte con el fin de hacer pastillas para las máquinas de moldeo por inyección. . . . . . . . . . . . . . . . . . . . 77.27

Figura 77.11 Extrusión de plástico con campana de extracción local y baño de agua en el cabezal del extrusor. . . . . . . . . . . . . . . . . . . . . . . . . 77.28

Figura 77.12 C ampanas para captar las emisiones calientes de molinos de calentamiento en un proceso de calandrado. . . . . . . . . . . . . . . . . . . . . . . . . . . 77.28

\section{Capítulo 78.}

Figura 78.1

Figura 78.2

Figura 78.3

Figura 78.4

Figura 78.5

Figura 78.6

Figura 78.7

Figura 78.8

Figura 78.9

Figura 78.10

Figura 78.11

Figura 78.12

Figura 78.13

Figura 78.14

Figura 78.15

Figura 78.16

Figura 78.17

Figura 78.18

Figura 78.19

Figura 78.20

Figura 78.21

Figura 78.22

Figura 78.23

Figura 78.24

Figura 78.25

\section{Capítulo 79.}

Figura 79.1

Figura 79.2

Figura 79.3

Figura 79.4

\section{Petróleo y gas natural}

O rganigrama del proceso de una refinería. . . . . . . . . . . . . . . . . 78.3

Proceso de desalinización (tratamiento previo). . . . . . . . . . . . . . . . . 78.8

Proceso de destilación atmosférica. . . . . . . . . . . . . . . . . . . . . 78.9

Esquema del proceso de destilación atmosférica. . . . . . . . . . . . . . . . 78.9

Proceso de destilación al vacío. . . . . . . . . . . . . . . . . . . . . . . . 78.10

Esquema del proceso de destilación al vacío. . . . . . . . . . . . . . . . . 78.10

Proceso de ruptura de la viscosidad. . . . . . . . . . . . . . . . . . . . . 78.12

Proceso de coquización. . . . . . . . . . . . . . . . . . . . . . . . . . . . . . 78.12

Proceso de craqueo catalítico. . . . . . . . . . . . . . . . . . . . . . 78.13

Esquema del proceso de craqueo catalítico. . . . . . . . . . . . . . . . . . 78.14

Proceso de hidrocraqueo. . . . . . . . . . . . . . . . . . . . . . . . . . 78.15

Proceso de polimerización. . . . . . . . . . . . . . . . . . . . . . . . . 78.15

Proceso de alquilación. . . . . . . . . . . . . . . . . . . . . . . . . . 78.16

Proceso de reforma catalítica. . . . . . . . . . . . . . . . . . . . . . . 78.18

Isomerización de C4 . . . . . . . . . . . . . . . . . . . . . . . . . 78.18

Proceso de isomerización. . . . . . . . . . . . . . . . . . . . . . . . . . . . . 78.19

Proceso de reforma al vapor. . . . . . . . . . . . . . . . . . . . . . . . . . . 78.19

Proceso de fabricación de aceite lubricante y cera. . . . . . . . . . . . . . . . 78.20

Proceso de extracción de disolvente. . . . . . . . . . . . . . . . . . . . . 78.21

Proceso de desparafinado de disolvente. . . . . . . . . . . . . . . . . . . . . 78.21

Proceso de desasfaltado de disolvente. . . . . . . . . . . . . . . . . . . . 78.22

Proceso de hidrodesulfuración. . . . . . . . . . . . . . . . . . . . . . 78.23

Esquema del proceso de hidrodesulfuración. . . . . . . . . . . . . . . . . . 78.23

Procesos de desmercaptanización y tratamiento. . . . . . . . . . . . . . . . . 78.24

Proceso de una planta de gas insaturado. . . . . . . . . . . . . . . . . . . 78.25

\section{Industria farmacéutica}

D esarrollo de fármacos en la industria farmacéutica. . . . . . . . . . . . 79.2

Proceso de fabricación en la industria farmacéutica. . . . . . . . . . . . . . . 79.5

Diagrama de un proceso de fermentación. . . . . . . . . . . . . . . . 79.6

Diagrama de un proceso de síntesis orgánica. . . . . . . . . . . . . . . 79.6 
Figura 79.5

Figura 79.6

Figura 79.7

Figura 79.8

Figura 79.9

Figura 79.10

Figura 79.11

Figura 79.12

Figura 79.13

Figura 79.14

Figura 79.15

\section{Capítulo 80.}

Figura 80.1

Figura 80.2

Figura 80.3

Figura 80.4

Figura 80.5

Figura 80.6

Figura 80.7

Figura 80.8

Figura 80.9

Figura 80.10

Figura 80.11

Figura 80.12

Figura 80.13

Figura 80.14
Diagrama de un reactor químico en síntesis orgánica. . . . . . . . . . . . 79.8

Ejemplos de estructuras de estrógenos esteroideos y no esteroideos. . . . . . . 79.8

Flujo del proceso de fabricación de una píldora anticonceptiva oral típica. . . 79.8

Fabricación farmacéutica de formas galénicas. . . . . . . . . . . . . . . . . 79.11

Filtro. . . . . . . . . . . . . . . . . . . . . . . . . . . . . . 79.14

Granulador de vapor. . . . . . . . . . . . . . . . . . . . . . . . . . . . . . . 79.14

Secador rotativo vacio. . . . . . . . . . . . . . . . . . . . . . . . . 79.15

Autosecador de vacío. . . . . . . . . . . . . . . . . . . . . . . . . 79.15

M áquina de comprimir con tolva de carga y recogida espiral de polvo para

la recuperación del producto. . . . . . . . . . . . . . . . . . . . . . 79.15

M áquina de recubrimiento de comprimidos. . . . . . . . . . . . . . . . . 79.16

Diagrama de una instalación de fabricación de líquidos estériles. . . . . . . . 79.16

\section{Industria del caucho}

Un trabajador del caucho coagula el látex recogido colocándolo sobre un palo y manteniéndolo sobre el humo que emana de un recipiente. . . . . . . 80.3

Procesamiento del caucho en una plantación de Camerún oriental. . . . . . . 80.4

Proceso de fabricación de neumáticos. . . . . . . . . . . . . . . . . . 80.5

Laminador antiguo con una barra de seguridad situada a una altura excesiva para que resulte efectiva. Sin embargo, el operario lleva guantes de gran tamaño que protegerían sus manos en caso de que quedaran atrapadas entre los cilindros. . . . . . . . . . . . . . . . . . . . . 80.5

L aminador de una línea de calandrias con una barra de seguridad a nivel del cuerpo que desconecta el equipo al ser accionada por el operario. . . . . . 80.6 Laminador y secador con campana de aspiración y cables de seguridad. . . . 80.6 O perario montando un neumático en una máquina monofase. . . . . . . . 80.6 Prensa de vulcanizado con ventilador de techo Bag-o-matic M cNeal para neumáticos de vehículos ligeros y camionetas A kron, O hio (EE.UU.). . . . . 80.6 Un colector de polvo de una muela abrasiva recoge el polvo de caucho.. . . . 80.7 U n elevador por vacío coloca las bolsas en el transportador de carga de un malaxador Banbury, evitando el dolor de espalda causado por la manipulación manual. . . . . . . . . . . . . . . . . . 80.8

U na campana de aspiración controla los humos producidos durante el acabado de un tubo en una fábrica industrial de caucho en Italia. . . . . . . . 80.11 Aspiración local en una estación de pesado de compuestos. . . . . . . . . . . 80.11 U na cortina colocada alrededor de una campana de aspiración sobre un laminador ayuda a controlar el polvo. . . . . . . . . . . . . . . . . . . 80.11 U na plancha de caucho procedente de un laminador Banbury pasa por un baño de agua donde se le aplica un compuesto antiadherente. . . . . . . . . . 80.12

PARTE XIII. INDUSTRIAS MANUFACTURERAS

\section{Capítulo 81.}

Figura 81.1

Figura 81.2

Figura 81.3

Figura 81.4

Figura 81.5

\section{Aparatos y equipos eléctricos}

Proceso de fabricación de acumuladores de plomo. . . . . . . . . . . . . . 81.3

Corte de una pila alcalina de botón. . . . . . . . . . . . . . . . . 81.5

Diagrama de flujo de la producción de pilas Leclanché. . . . . . . . . . . . 81.6

Diagrama de flujo de la producción de pilas de níquel-cadmio utilizando níquel sinterizado. . . . . . . . . . . . . . . . . . . . . . 81.7

O rden habitual de los procesos de fabricación y riesgos probables. . . . . . . 81.15 
Capítulo 82.

Figura 82.1

Figura 82.2

Figura 82.3

Figura 82.4

Figura 82.5

Figura 82.6

Figura 82.7

\section{Capítulo 83.}

Figura 83.1

Figura 83.2

Figura 83.3

Figura 83.4

Figura 83.5

Figura 83.6

Figura 83.7

Figura 83.8

Figura 83.9

Figura 83.10

Figura 83.11

Figura 83.12

Figura 83.13

Figura 83.14

\section{Capítulo 84.}

Figura 84.1

Figura 84.2

Figura 84.3

Figura 84.4

Figura 84.5

Figura 84.6

\section{Metalurgia y metalisteria}

Forja en prensa. . . . . . . . . . . . . . . . . . . . . . . . . . . . .82.23

Soldadura y corte con gas con soplete y varilla de metal de aportación. EI soldador está protegido por un mandil de cuero, manoplas y gafas de seguridad. . . . . . . . . . . . . . . . . . . . . . . . . . . 82.25

Soldadura en un espacio cerrado. . . . . . . . . . . . . . . . . . . . . 82.31

Tornos, máquinas de cortar y máquinas de roscar. . . . . . . . . . . . . . . 82.32

M uela abrasiva vitrificada, debidamente protegida, montada en una esmeriladora de superficie y con una velocidad periférica de $33 \mathrm{~m} / \mathrm{s} \ldots \ldots . . .82 .36$

Esquema del recubrimiento electrolítico. . . . . . . . . . . . . . . . . . . . 82.42

$M$ aterias de partida y residuos generados en una cadena típica de recubrimiento electrolítico.

\section{Microelectrónica y semiconductores}

Evolución temporal del número de transistores por pastilla de circuito integrado (1970 a 2000). . . . . . . . . . . . . . . . . . . . . . . 83.2

Previsión de ventas mundiales de semiconductores, 1993 a 1998.

Sala limpia en una zona de tecnología avanzada donde los operadores trabajan en la fabricación de semiconductores.

Equipo fotolitográfico de "sala amarilla" en una sala limpia de tecnología avanzada. . . . . . . . . . . . . . . . . . . . . . . . . . . 83.6

M oléculas básicas de los polímeros de cristal líquido.. . . . . . . . . . . . . 83.20

A cidos abiético y pimárico. . . . . . . . . . . . . . . . . . . . . . . . 83.30

E squema de una unidad de soldadura por ola. . . . . . . . . . . . . . . . 83.31

Carro de desechos con cubierta de vacío. . . . . . . . . . . . . . . . . . 83.32

Distribución de las tasas de incidencia de lesiones y enfermedades profesionales por áreas mundiales, 1993 y 1994. . . . . . . . . . . . . . . . 83.34

Distribución de las tasas de incidencia de lesiones y enfermedades profesionales con días de ausencia del trabajo por áreas mundiales, 1993

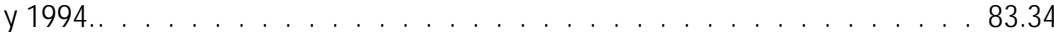

Incidencia comparada de los casos de días de trabajo perdidos por tipo de suceso o de exposición, 1993. . . . . . . . . . . . . . . . . . . . . . . . 83.35

Incidencia comparada de los casos de días de trabajo perdidos por causas de lesión o enfermedad, 1993. . . . . . . . . . . . . . . . . . . . . . 83.35

Incidencia comparada de los casos de días de trabajo perdidos por la naturaleza de la lesión o enfermedad, 1993. . . . . . . . . . . . . . . . . 83.35

Incidencia comparada de los casos de días de trabajo perdidos según la parte del cuerpo afectada, 1993. . . . . . . . . . . . . . . . . . . . 83.36

\section{Vidrio, cerámica y materiales afines}

T écnico de control de calidad tomando muestras de vidrio del horno y usando equipo de protección personal contra el calor y gafas antirrayos I.R . . 84.3

U tilización del elevador de vacío para la manipulación de paquetes de 20 a 35 kilos de vidrio textil. . . . . . . . . . . . . . . . . . . . . . . .84.3

Los robots utilizados en la manipulación de luna pulida reducen los riesgos de heridas y ergonómicos. . . . . . . . . . . . . . . . . . . . 84.3

Ingreso a espacios reducidos durante la reconstrucción del horno en una planta de fibra de vidrio. U na llovizna o vaho acuoso reduce las partículas en suspensión en el aire durante la demolición del horno. . . . . . . . . . . . 84.4 La caña de soplar vidrio. . . . . . . . . . . . . . . . . . . . . . . 84.4 Procesos y materiales que intervienen en la fabricación de vidrio. . . . . . . . 84.6 
Figura 84.7

Figura 84.8

Figura 84.9

Figura 84.10

Figura 84.11

Figura 84.12

Figura 84.13

Figura 84.14

Figura 84.15

Figura 84.16

Figura 84.17

Figura 84.18

Figura 84.19

Figura 84.20

Figura 84.21

Figura 84.22

Figura 84.23

Figura 84.24

Figura 84.25

Figura 84.26

Figura 84.27

\section{Capítulo 85.}

Figura 85.1

Figura 85.2

Figura 85.3

Figura 85.4

Figura 85.5

Figura 85.6

\section{Capítulo 86.}

Figura 86.1

Figura 86.2

Figura 86.3

Figura 86.4

Figura 86.5

Figura 86.6

Figura 86.7
Proceso continuo de flotación. . . . . . . . . . . . . . . . . . . . . . 84.7

Cinta de vidrio flotado saliendo del túnel de recocido. . . . . . . . . . . . . 84.7

Esquema de la boquilla de fusión directa. . . . . . . . . . . . . . . . . . . . 84.8

Esquema de una hilera de bolas. . . . . . . . . . . . . . . . . . . . . . . . 84.8

Filamentos de vidrio textil en el momento de ser extraídos de la hilera. Los filamentos se reúnen en manojos y se enrollan en fardos para el procesado. . . 84.8

Fabricación de filamento continuo de vidrio. . . . . . . . . . . . . . . . 84.9

Proceso de rotación para la fabricación de fibras de lana de vidrio. . . . . . .84.10

Producción de lana mineral (piedra y escoria). . . . . . . . . . . . . . . . 84.10

Fibras ópticas uni y multimodales. . . . . . . . . . . . . . . . . . . . . . . . . . . . . . . . . . . . . . . . . . . . . . .

Diagrama de flujo de la fabricación de fibra óptica. . . . . . . . . . . . . . . 84.12

Diagrama de flujo por tipo de producto cerámico. . . . . . . . . . . . . . . 84.14

La fabricación de ladrillos y baldosas. . . . . . . . . . . . . . . . . . . 84.18

Diagrama de flujo general de la fabricación de refractarios. . . . . . . . . . . 84.22

Los dispositivos de protección de la maquinaria evitan que los operarios

sufran accidentes por contacto con ejes giratorios, correas y cadenas de transmisión. . . . . . . . . . . . . . . . . . . . . . . . . . . . . . . . 84.26

Las superficies de paso y de trabajo deben estar libres de riesgos de tropiezos

y resbalones. . . . . . . . . . . . . . . . . . . . . . . . . . . . . . . . 84.28

Porcentaje de lesiones y enfermedades con pérdida de tiempo de trabajo,

por edades. Estados U nidos, Código SIC 32, 1994. . . . . . . . . . . . . . . 84.28

$\mathrm{N}$ aturaleza de los casos de días de trabajo perdidos por lesiones y enfermedades ocupacionales, Estados U nidos, Código SIC 32, 1994 . . . . . . 84.28

Circunstancia o exposición en los casos de días de trabajo perdidos por

lesiones o enfermedades ocupacionales, Estados U nidos, Código

SIC 32, 1995. . . . . . . . . . . . . . . . . . . . . . . . . . . . . . 84.28

Parte del cuerpo afectada en los casos de pérdida de días de trabajo por lesión o enfermedad, Estados U nidos, Código SIC 32, 1994. . . . . . . . . . 84.30

Fuentes de los casos de días de trabajo perdidos por lesiones y enfermedades ocupacionales, Estados U nidos, Código SIC 32, 1994 . . . . . 84.30

Los aerosoles de agua de condensación reutilizada que no es tratada

pueden provocar enfermedades por las materias en suspensión en el agua. . . 84.30

\section{Industria de la artes gráficas, fotografía y reproducción}

o peraciones finales del proceso de impresión; el material impreso que sale de la rotativa se corta y se le da la forma del producto definitivo. . . . . . . 85.2

Esquema de las operaciones de procesamiento de materiales fotográficos. . . . 85.11

Ventilación en tanque cerrado. . . . . . . . . . . . . . . . . . . . . . 85.16

Extracción en tanque mezclador de productos químicos con cierre parcial. . . 85.16

Campana de extracción de tiro ascendente (no recomendable). . . . . . . . . 85.16

Tanque de mezcla de productos químicos con cierre parcial. . . . . . . . . 85.17

\section{Carpintería}

Diagrama de flujos de la fabricación de muebles de madera. . . . . . . . 86.3

Sierra de cinta. . . . . . . . . . . . . . . . . . . . 86.3

Sierra circular. . . . . . . . . . . . . . . . . . . . . . . . 86.3

Utiles de empuje . . . . . . . . . . . . . . . . . . . . . . . . . . . . . . . 86.4

Protectores-presores vertical y horizontal tipo "peine".. . . . . . . . . . . . 86.4

Copiadora-fresadora. . . . . . . . . . . . . . . . . . . . . 86.4

Cepilladora. . . . . . . . . . . . . . . . . . . . . . . . . . 86.4 
Figura 86.8

Figura 86.9

Figura 86.10

Figura 86.11

Figura 86.12

Figura 86.13

Figura 86.14

Figura 86.15

Figura 86.16

Figura 86.17
Fresadora vertical (tupí). . . . . . . . . . . . . . . . . . . . . . . . 86.5

Torno. . . . . . . . . . . . . . . . . . . . . 86.5

Sierra para cortar al hilo. . . . . . . . . . . . . . . . . . . . . 86.5

Sierra radial. . . . . . . . . . . . . . . . . . . . . . . . . 86.5

Lijadora. . . . . . . . . . . . . . . . . . . . . . . . . . 86.6

D istancia entre la defensa y el punto de operación. . . . . . . . . . . . . 86.6

M ecanismo de seguridad de la SU VA con la herramienta copiadora-

fresadora en posición de trabajo. . . . . . . . . . . . . . . . . . . 86.9

M ecanismo de seguridad de acuerdo con la Figura 86.14, con la herramienta copiadora-fresadora en posición inicial (posición de reposo). . . . . . . . . . . 86.9

Escuadra o guía y defensa trasera del portacuchillas. . . . . . . . . . . . . . . 86.11

Cepilladora combinada de superficies y espesores (combinada cepilladoraregruesadora). . . . . . . . . . . . . . . . . . . . . . . 86.12

\section{PARTE XIV. INDUSTRIAS TEXTIES Y DE LA CONFECCION}

\section{Capítulo 87. Confección y productos textiles acabados}

Figura 87.1

Figura 87.2

Figura 87.3

Tabla 87.1

\section{Capítulo 88.}

Figura 88.1

Figura 88.2

Figura 88.3

Figura 88.4

Figura 88.5

Figura 88.6

Figura 88.7

Figura 88.8

Figura 88.9

\section{Capítulo 89.}

Figura 89.1

Figura 89.2

Figura 89.3

Figura 89.4

Figura 89.5

Figura 89.6

Figura 89.7

Figura 89.8

Figura 89.9

Figura 89.10

Figura 89.11

Figura 89.12
Taller de fabricación de lentejuelas. . . . . . . . . . . . . . . . . . . . 87.2

Fábrica de confección en Filipinas. . . . . . . . . . . . . . . . . . . 87.3

M ujer trabajando con una máquina de coser sin guardaguja. . . . . . . . . 87.3

Ejemplos de enfermedades laborales que se observan entre los trabajadores de la confección.. . . . . . . . . . . . . . . . . . . . . 87.6

\section{Cuero, pieles y calzado}

Trabajo manual en una curtiduría de A fganistán. . . . . . . . . . . . . . . 88.3

Procesos típicos de curtido y acabado del cuero. . . . . . . . . . . . . . . . 88.4

Diagrama de tratamiento de las pieles. . . . . . . . . . . . . . . . . . 88.5

Departamento de remojo en un taller de procesado de pieles. . . . . . . . . 88.5

D escarnado a máquina de pieles de cordero. . . . . . . . . . . . . . . . . 88.6

O peración de rasado en pieles de castor canadiense. . . . . . . . . . . . . . 88.6

O perarios cosiendo pieles a máquina . . . . . . . . . . . . . . . . . . 88.6

Esquema del impacto ambiental relacionado con las operaciones de curtido. . 88.11

Esquema de una planta municipal para la recuperación del cromo. . . . . . . 88.12

\section{Industrias textiles y de la confección}

Etiquetas ecológicas para productos textiles.

Variación de la oferta de fibras en la industria textil antes de 1994 y

extrapolación hasta 2004 . . . . . . . . . . . . . . . . . . . . . 89.4

Peinado. . . . . . . . . . . . . . . . . . . . . . 89.5

Cardado . . . . . . . . . . . . . . . . . . . . . 89.5

Batán moderno. . . . . . . . . . . . . . . . . . . . . . . 89.5

Urdido. . . . . . . . . . . . . . . . . . . . . . . . 89.5

Relación entre humedad y limpieza en el desmotado del algodón.. . . . . . . 89.8

Sistema de extracción del polvo en una máquina cardadora. . . . . . . . . 89.12

Tejedora de chorro de aire. . . . . . . . . . . . . . . . . . . . . . . . . . . 89.24

Tricotosa circular. . . . . . . . . . . . . . . . . . . . . . . . . . . . . . 89.25

M áquina de anudar alfombras. . . . . . . . . . . . . . . . . . . . . . . . 89.25

Sección de moqueta doméstica. . . . . . . . . . . . . . . . . . . . . . . 89.26 
Figura 89.13

Figura 89.14

Figura 89.15
Sección de moqueta utilizada en ambientes no residenciales. . . . . . . . . .89.26

Bucle uniforme; corte y bucle; felpa de terciopelo; sajonia. . . . . . . . . . . . . 89.26

Trabajo en cuclillas ante un telar. . . . . . . . . . . . . . . . . . . . . . . 89.28

\section{PARTE XV. INDUSTRIAS DEL TRANSPORTE}

\section{C apítulo 90. Construcción y mantenimiento aeroespacial}

Figura $90.1 \quad$ Sistema portátil de barandillas para los Boeing 747; el sistema de barandillas protectoras de dos lados se acopla al costado del fuselaje, como protección contra posibles caídas durante los trabajos efectuados en las puertas situadas sobre el ala y en la zona del extradós. . . . . . . . . . . . . . . . . . . 90.7

Figura 90.2 Andamio de motor, con protección frente a caídas, para trabajadores especialistas en motores de avión. . . . . . . . . . . . . . . . . . . . 90.7

Figura 90.3 Sistema de desconexión rápida sobre el ala de un Boeing 747. . . . . . . . . . 90.8

Figura 90.4 Zonas de protección contra caídas del sistema de desconexión rápida sobre el ala de un Boeing 747.. . . . . . . . . . . . . . . . . . . . . 90.8

\section{Capítulo 91. Vehículos de motor y maquinaria pesada}

Figura $91.1 \quad$ Diagrama de flujo de la producción de automóviles. . . . . . . . . . . . 91.3

\section{C apítulo 92. Construcción y reparación de buques y embarcaciones de recreo}

Figura $92.1 \quad$ Diagrama de flujos de construcción naval. . . . . . . . . . . . . . . 92.3

Figura $92.2 \quad$ Corte de planchas de acero con soplete automático en un taller de fabricación. . . . . . . . . . . . . . . . . . . 92.3

Figura $92.3 \quad$ Curvado de láminas de acero.. . . . . . . . . . . . . . . . . . 92.3

Figura $92.4 \quad$ Plancha de acero soldada que forma parte del casco de un buque. . . . . . 92.4

Figura $92.5 \quad$ Trabajos en un subconjunto del buque. . . . . . . . . . . . . . . . . . 92.4

Figura $92.6 \quad$ Combinación de subconjuntos del buque en bloques mayores. . . . . . . . 92.5

Figura $92.7 \quad$ Limpieza de barcos con chorro abrasivo antes de pintar. . . . . . . . . . . . 92.5

Figura $92.8 \quad$ M ontaje de la proa en el casco de un buque. . . . . . . . . . . . . . . 92.5

Figura $92.9 \quad$ Corte de planchas de acero con soplete de arco de plasma sumergido. . . . . 92.8

Figura $92.10 \quad$ Retoques de pintura en el casco de un buque. . . . . . . . . . . . . . . 92.10

Figura $92.11 \quad$ Corte por la mitad de un buque para añadir una nueva sección. . . . . . . . 92.12

Figura $92.12 \quad$ Sustitución de la proa de un barco accidentado. . . . . . . . . . . . . 92.13

\section{PARTE XVI. CONSTRUCCION}

\section{Capítulo 93.}

Figura 93.1

Figura 93.2

Figura 93.3

Figura 93.4

Figura 93.5

Figura 93.6

Figura 93.7

\section{Construcción}

Trabajador portando una carga sin ropa ni equipo de trabajo adecuados. . . . 93.5 Andamio inseguro en K atmandú, Nepal, 1974. . . . . . . . . . . . . . . 93.5 Trabajador de la construcción en Nairobi, K enya, sin casco ni calzado de protección.. . . . . . . . . . . . . . . . . . . . . . . . . 93.7

M ontaje de andamios en una obra en Ginebra, Suiza, sin las protecciones adecuadas. . . . . . . . . . . . . . . . . . . . . . . . . . . . 93.27 Las entibaciones consisten en montantes a ambos lados de la zanja, sujetos por codales. . . . . . . . . . . . . . . . . . . . . . . . . 93.35

L os largueros mantienen verticales los montantes, permitiendo un mayor espaciamiento de los codales . . . . . . . . . . . . . . . . . . . . . . . 93.36 Entibación con tablones y codales en terreno granuloso. . . . . . . . . . . . 93.36 
Figura 93.8

Figura 93.9

Figura 93.10

Figura 93.11

Figura 93.12

Figura 93.13

Figura 93.14

Figura 93.15

Figura 93.16
Las planchas protegen a los trabajadores del derrumbamiento de las paredes

de la zanja. . . . . . . . . . . . . . . . . . . . . . . . 93.36

Excavación mecánica en una obra en Francia. . . . . . . . . . . . . . . . 93.40

M odelo de retroexcavadora con pala cargadora y dirección articulada. . . . . 93.40

Vista esquemática de una instalación de ascensor con los principales

componentes. . . . . . . . . . . . . . . . . . . . . . . . . 93.46

Disposición de la protección inferior de la cabina para evitar atrapamientos. . 93.47

Ejemplo de práctica peligrosa en un montacargas. . . . . . . . . . . . . . . 93.47

E scalón de una escalera mecánica. . . . . . . . . . . . . . . . . . . . . . 93.48

Escalera mecánica. . . . . . . . . . . . . . . . . . . . . . . . . . . . . . . 93.49

Proceso de fabricación de cemento.. . . . . . . . . . . . . . . . . . . . 93.51

\section{PARTE XVII. SERVICIOS}

\section{Capítulo 94.}

Figura 94.1

Figura 94.2

\section{Capítulo 95.}

Figura 95.1

Figura 95.2

Figura 95.3

Figura 95.4

Figura 95.5

Figura 95.6

Figura 95.7

Figura 95.8

\section{Capítulo 96.}

Figura 96.1

Figura 96.2

Figura 96.3

Figura 96.4

Figura 96.5

Figura 96.6

Figura 96.7

Figura 96.8

Figura 96.9

Figura 96.10

Figura 96.11

\section{Servicios de educación y formación}

Taller metalúrgico industrial en un centro de enseñanza secundaria. . . . . . 94.4

Campanas de extracción de humos y ducha de emergencia en un laboratorio de ciencias de un centro de enseñanza secundaria. . . . . . . . . . . . . . . 94.10

\section{Servicios de seguridad y de emergencía}

Prioridades tácticas de las operaciones de lucha contra incendios estructurales. . . . . . . . . . . . . . . . . . . . 95.4 Un bombero dirige el chorro de agua hacia un edificio en llamas. . . . . . . . 95.4 Un bombero rescata a un compañero atrapado por los humos tóxicos producidos en el incendio de un almacén de neumáticos. . . . . . . . . . . 95.6

El personal de la cubierta de vuelo de un portaaviones trabaja en la proximidad inmediata de helicópteros y reactores de geometría fija, lo que les expone a riesgos de seguridad, a los productos resultantes de la combustión de los tubos de escape y al ruido. . . . . . . . . . . . . . 95.17

Este generador mecánico de humo produce una cortina de niebla artificial mediante la evaporación del calor. Este sistema convierte el suelo en resbaladizo. . . . . . . . . . . . . . . . . . . . . . . . . . . . . 95.18

Salvamento marítimo realizado por un barco. . . . . . . . . . . . . . . . 95.20

Salvamento marítimo efectuado por un helicóptero. . . . . . . . . . . . . . . 95.20

Pautas de prevención. . . . . . . . . . . . . . . . . . . . . . . . . . . . . . . 95.24

\section{Actividades artísticas, culturales y recreativas}

Serigrafía con campana extractora. . . . . . . . . . . . . . . . . . . . . 96.8

Vertido de metal fundido en la fundición artística. . . . . . . . . . . . . . 96.12

A plicación de una pátina sobre metal con campana extractora. . . . . . . . . 96.13

Elaboración de una escultura fluorescente con el artista detrás de una pantalla protectora. . . . . . . . . . . . . . . . . . . . . . . 96.15

Tejido con un telar manual. . . . . . . . . . . . . . . . . . . . . . . 96.17

D ecoración de jarrones con pinturas para cerámica. . . . . . . . . . . . . . 96.18

Exposición a polvo de arcilla y barniz en el lijado manual de una pieza de alfarería. . . . . . . . . . . . . . . . . . . . . . . . . . . . . . 96.19

Ventilación por extracción en la mezcla de arcillas . . . . . . . . . . . . . 96.19

Fabricación de muebles. . . . . . . . . . . . . . . . . . . . . . 96.20

Tallado de la madera con herramientas manuales. . . . . . . . . . . . . 96.20

M aquinaria para trabajar la madera con recolector de polvo. . . . . . . . . . 96.21 
Figura 96.12

Figura 96.13

Figura 96.14

Figura 96.15

Figura 96.16

Figura 96.17

Figura 96.18

Figura 96.19

Figura 96.20

Figura 96.21

Figura 96.22

Figura 96.23

Figura 96.24

Figura 96.25

Figura 96.26

Figura 96.27

Figura 96.28

Figura 96.29

Figura 96.30

Figura 96.31

Figura 96.32

\section{C apítulo 97.}

Figura 97.1

Figura 97.2

Figura 97.3

Figura 97.4

Figura 97.5

Figura 97.6

Figura 97.7

Figura 97.8

Figura 97.9

Figura 97.10

Figura 97.11

Figura 97.12
Rotulación manual en artes gráficas. . . . . . . . . . . . . . . . . . . . . 96.24

Orquesta. . . . . . . . . . . . . . . . . . . . . . . . . . . . . . . . . 96.26

M ontaje de luces y focos sobre el suelo para preparar la iluminación. . . . . . 96.32

Efectos especiales con fuego. . . . . . . . . . . . . . . . . . . . . . . 96.35

U tilización de maniquíes para rodar una escena en una montaña rusa. . . . . 96.37

Caída de un especialista desde gran altura. . . . . . . . . . . . . . . . . . 96.37

Argel, Argelia, 11 de febrero de 1996: Las oficinas destruidas de Le Soir, uno de los tres periódicos alcanzados por un coche bomba terrorista. . . . . . . . 96.40

U tilización de la voz y el lenguaje corporal con los animales. . . . . . . . . . 96.45

Un trabajador llevando un pesado disfraz. . . . . . . . . . . . . . . . . . . . 96.49

Carga de artefactos pirotécnicos para una exhibición de fuegos artificiales. . . 96.49

Pañol para almacenar fuegos artificiales. . . . . . . . . . . . . . . . . . . . 96.49

Grúa levantando una atracción. . . . . . . . . . . . . . . . . . . 96.50

Payaso de rodeo distrayendo al toro después de la caída de un jinete. . . . . . 96.51

Corrida de toros. . . . . . . . . . . . . . . . . . . . . . . . . . 96.51

H ombreras ajustadas de fútbol americano. . . . . . . . . . . . . . . . . 96.52

Casco de fútbol americano. . . . . . . . . . . . . . . . . . . . . . 96.52

Rodillera. . . . . . . . . . . . . . . . . . . . . . . . . . . 96.52

Tobillera rígida. . . . . . . . . . . . . . . . . . . . . . . . . . . . 96.53

Máscara de catcher. . . . . . . . . . . . . . . . . . . . . . . . . . . 96.53

Guantes acolchados para hockey sobre hielo. . . . . . . . . . . . . . . 96.53

Crioterapia compresiva.. . . . . . . . . . . . . . . . . . . . . . . . . . . . . 96.54

\section{Centros y servicios de asistencia sanitaria}

M anipulación de material biológico contaminado. . . . . . . . . . . . . . . . 97.3

Recipiente para evacuación de instrumentos y dispositivos cortantes 0 punzantes. . . . . . . . . . . . . . . . . . . . . . . . . . . . 97.4 Armario de sustancias químicas peligrosas. . . . . . . . . . . . . . . . 97.4

Equipo eléctrico en un hospital.. . . . . . . . . . . . . . . . . . . 97.5

La incorporación de los pacientes constituye un riesgo ergonómico en la mayoría de los hospitales. . . . . . . . . . . . . . . . . . . . . . 97.6

La pintura de zonas elevadas constituye uno de los riesgos ergonómicos característicos de los hospitales. . . . . . . . . . . . . . . . . . . . . . 97.6

La colocación de escayolas implica la exposición a numerosos factores de presión ergonómica.. . . . . . . . . . . . . . . . . . . . . 97.7

El trabajo de lavandería del tipo que se ilustra en la foto puede producir lesiones por estrés repetitivo en las extremidades superiores. . . . . . . . . . 97.7

Esta parte del trabajo de lavandería obliga a permanecer en una postura forzada. . . . . . . . . . . . . . . . . . . 97.7

U na instalación de lavandería mal diseñada puede producir tensión en la espalda. . . . . . . . . . . . . . . . . . . . . . . 97.8

Los dispositivos electrónicos para la elevación del tronco en las camas de los hospitales permiten reducir sensiblemente el número de accidentes en la incorporación de los pacientes. . . . . . . . . . . . . . . . . . . . . 97.18

El uso de dispositivos montados en el techo para la incorporación de los pacientes contribuye a reducir los accidentes. . . . . . . . . . . . . . . . . 97.19 


\section{Capítulo 99.}

Figura 99.1

Figura 99.2

Figura 99.3

\section{Capítulo 100.}

Figura 100.1

Figura 100.2

Figura 100.3

Figura 100.4

Capítulo 101.

Figura 101.1

Figura 101.2

Figura 101.3

Figura 101.4

Figura 101.5

Figura 101.6

Figura 101.7

\section{Capítulo 102.}

Figura 102.1

Figura 102.2

Figura 102.3

Figura 102.4

Figura 102.5

Figura 102.6

Figura 102.7

Figura 102.8

Figura 102.9

Figura 102.10

Figura 102.11

Figura 102.12

Figura 102.13

Figura 102.14

\section{O ficinas y comercio minorista}

M ercado de alimentos al aire libre de M alatia, Islas Salomón,1995 . . . . . . . 99.13

Cestos pesados de erizos de mar distribuidos por un pequeño comerciante, Japón, 1989. . . . . . . . . . . . . . . . . . . . . . . . . . . . . 999.13

Corte manual de cecina para su venta local, Japón, 1989. . . . . . . . . . . . 99.15

\section{Servicios personales y comunitarios}

Reducción de la exposición a los riesgos químicos. . . . . . . . . . . . . . . 100.7

M esa comercial de manicura de tiro invertido modificada para la colocación de uñas postizas. . . . . . . . . . . . . . . . . . . . . . . . . . . . . . . . . 100.8

Trabajo con los brazos por encima del nivel del hombro en una peluquería en Zimbabue. . . . . . . . . . . . . . . . . . . . . . . . . . . . . . . . . . 100.8

Representación gráfica del proceso de limpieza en seco. . . . . . . . . . . . 100.10

\section{Servicios públicos y estatales}

EI manejo manual de paquetes pesados es un riesgo ergonómico grave. Son necesarios límites de peso y de tamaño de los paquetes. . . . . . . . . . 101.6 O peradores de pupitre codificador clasificando cartas con ayuda de maquinaria informatizada. . . . . . . . . . . . . . . . . . . . . . . . . . . 101.7

Boca de registro con la tapa retirada. . . . . . . . . . . . . . . . . . . . 101.11 Tanque vacío en una planta de tratamiento de aguas residuales. . . . . . . . . . 101.11 U nidad de renovación de aire para entrar en un espacio cerrado. . . . . . . . 101.11 Camión de recogida automática de basuras de carga lateral. . . . . . . . . . . 101.14 Camión compactador cerrado de carga trasera. . . . . . . . . . . . . . . . . 101.15

\section{Industria del transporte y el almacenamiento}

Distribución de la red viaria mundial 1988-1989, en kilómetros. . . . . . . . 102.2

Distribución de la red ferroviaria mundial, 1988-1989, en kilómetros. . . . . 102.3

El levantamiento de paquetes por encima de la altura del hombro constituye un riesgo ergonómico.. . . . . . . . . . . . . . . . . . . . 102.5

Un controlador de tráfico aéreo frente a una pantalla de radar de un centro de control local manual.. . . . . . . . . . . . . . . . . . . . . . . . . . . . . 102.6

U n helicóptero H -46 aterriza en el desierto de A rizona, Estados U nidos. . . . 102.22 Un helicóptero 5-76A Cougar aterriza sobre el terreno en el lugar de un accidente. . . . . . . . . . . . . . . . . . . . . . . . . . . . . . . . . 102.24

Puesto de conducción unificado y optimizado ergonómicamente de un autobús en Alemania. . . . . . . . . . . . . . . . . . . . . . . . . . . . . . . 102.26 Imagen de un tablero de instrumentos. . . . . . . . . . . . . . . . . . . 102.28 Ilustración de un tablero de instrumentos y leyenda. . . . . . . . . . . . . . . 102.28 Lista de comprobación de salud y seguridad en estaciones de servicio. . . . . 102.34 Encapsulamiento portátil para la prevención de la exposición al polvo de amianto procedente de tambores de freno. Está equipado con una pistola de aire comprimido con una manga de algodón y conectado a un limpiador de vacío HEPA. . . . . . . . . . . . . . . . . . . . . . . . . . . . . . 102.36 Causas de los principales accidentes con resultado de muerte atribuidos a errores humanos (industrias marítimas de Estados U nidos, 1983-1993). . . . 102.47 Causas de los principales accidentes sin resultado de muerte atribuidos a errores humanos (industrias marítimas de E stados U nidos, 1983-1993). . . . 102.47

Un trabajador transfiere producto de la refinería Pasagoula a los depósitos de la terminal D eraville, cerca de Atlanta, Georgia, Estados U nidos. . . . . . 102.53 
Figura 102.15

Petrolero SS Paul L. Fahrney. .

102.55

Figura 102.16

Carga del buque tanque dedicado al transporte de GN L L eo en Arun,

Sumatra, Indonesia. . . . . . . . . . . . . . . . . . . . . . . . . 102.55

Figura 102.17 Propagación a favor del viento de una nube de vapor de GNL procedente

de diversos derrames (velocidad del viento, 8,05 km/ h) . . . . . . . . . . . 102.69

Figura 102.18

Carga de cajas de manzanas en una carretilla elevadora en un almacén del Reino Unido. . . . . . . . . . . . . . . . . . . . . . . . . . . . . 102.71

Figura 102.19 Un trabajador portuario en el Reino U nido utiliza máquinas elevadoras para trasladar cuartos traseros de ganado bovino. . . . . . . . . . . . . . 102.72

Figura 102.20 Un dispositivo de protección superior instalado en una carretilla elevadora. . 102.76 
PARTE XVIII. GUIAS

\section{Capítulo 104. G Gía de productos químicos}

Figura 104.1 Ruta metabólica del n-hexano y la metil-n-butil cetona. . . . . . . . . . . 104.234 
La edición original de esta obra ha sido publicada por la O ficina Internacional del Trabajo (G inebra) bajo el título "Encyclopaedia of 0 ccupational $\mathrm{H}$ ealth and Safety, fourth edition". Esta edición española se publica con la autorización de la O IT y bajo las condiciones del Acuerdo firmado entre la O ficina Internacional del Trabajo y el M inisterio de Trabajo y A suntos Sociales de España en materia de publicaciones.

Copyright (C) de la edición inglesa, O rganización Internacional del Trabajo, 1998

Copyright @ de la edición española, M inisterio de Trabajo y A suntos Sociales, 1998

Las denominaciones empleadas, en concordancia con la práctica seguida en $\mathrm{N}$ aciones $\mathrm{U}$ nidas, y la forma en que aparecen presentados los datos en las publicaciones de la O IT no implican juicio alguno por parte de la O ficina Internacional del Trabajo sobre la condición jurídica de ninguno de los países, zonas o territorios citados o de sus autoridades, ni respecto de la delimitación de sus fronteras.

La responsabilidad de las opiniones expresadas en los artículos, estudios y otras colaboraciones firmadas incumbe exclusivamente a sus autores y su publicación no significa que la O IT las sancione.

El lector asume que las partes facilitan la presente documentación sin garantía de ningún tipo. Las partes no se hacen responsables de la validez ni de la integridad de ninguno de los datos, incluidos errores, inexactitudes u omisiones, ni de las posibles consecuencias que implique la utilización de dichos datos. $\mathrm{Ni}$ los autores ni la OIT, ni las instituciones colaboradoras son responsables de los daños ni de cualquier otra reclamación o demanda que se deriven de la utilización de estos datos.

Las referencias a firmas, procesos o productos comerciales no implica aprobación alguna por la 0 ficina Internacional del Trabajo, y el hecho de que no se mencionen firmas, procesos o productos comerciales no implica desaprobación alguna.

La presente edición es la versión española de la cuarta edición inglesa, revisada y enriquecida con las aportaciones ofrecidas y destinadas a la misma por la OIT y con las peculiaridades y conceptos incorporados al cuerpo de la enciclopedia por especialistas, con objeto de hacer su utilización más asequible en los países de habla hispana. En la traducción, coordinación y financiación de la presente edición han colaborado:

- M inisterio deSanidad y Consumo

- Instituto Nacional de M edicina y Seguridad en el Trabajo

- Instituto Nacional de la Salud

- Instituto N acional de Seguridad e H igiene en el Trabajo

- Agencia E spañola de Cooperación Internacional

- M inisterio de Trabajo y A suntos Sociales

- Oficina Internacional del Trabajo

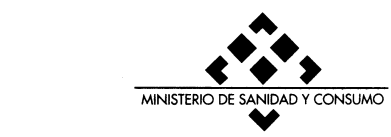

G MINISTERIO DE TRABAJO

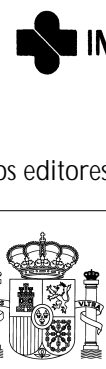

Edita y distribuye:

Ministerio de Trabajo y Asuntos Sociales

Subdirección General de Publicaciones

Agustín de Bethencourt, 1128003 M adrid

NIPO : 201-01-029-5

ISBN : 84-8417-047-0

Depósito legal: M . 13.001 - 2001

Traducción y maquetación: CELER PAWLOWSKY

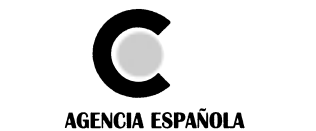

DE COOPERACION INIERNACIONAL

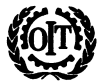

OFICINA INTERNACIONAL

DEL TRABAJO

Detraba 


\section{Presentacion de la tercera edicion en español}

a difusión de los conocimientos sobre los riesgos para la seguridad y la salud de los trabajadores y la forma de prevenirlos es, posiblemente, la herramienta más poderosa y eficaz en la lucha contra los accidentes y las enfermedades derivadas del trabajo. El conocimiento crea cultura la creación o incremento de la "cultura preventiva" entre los agentes sociales implicados, es uno de los deseos más frecuentemente expresados, como condición necesaria para el avance en este terreno.

La rápida evolución científica y técnica convierte este conocimiento en algo continuamente cambiante porque, al tiempo que se superan muchos riesgos, aparecen otros; y porque también evolucionan los enfoques preventivos que tienen que ver, ineludiblemente, con la evolución social y de las ideas. Esto produce un paulatino, pero continuo, incremento de la información en esta materia, que requiere ir revisando tanto los contenidos como los canales y las fuentes de información, a fin de mantener ésta actualizada y de hacerla cada vez más accesible.

Los procesos de liberalización del comercio y de integración regional y, en su conjunto, de globalización de la economía, hacen especialmente conveniente la existencia de mecanismos 0 instrumentos divulgativos que abarquen todos los aspectos y soluciones de una determinada problemática y que puedan estar al alcance de todos los interesados. Esta "globalización de la información" es particularmente necesaria en el campo de la prevención de los riesgos, en el que la armonización de las condiciones de seguridad de los productos comercializados y las condiciones de seguridad existentes en las empresas resulta esencial para garantizar una competencia libre, leal y compatible con el derecho de los trabajadores a su seguridad y salud.

En este contexto, la E nciclopedia de Salud y Seguridad en el Trabajo de la OIT puede ser considerada como el mejor ejemplo de instrumento divulgativo por la amplitud de los temas que recoge, por la rigurosidad con que los trata, por su tradición consolidada y por su enorme difusión, que la convierten en el libro de consulta por excelencia en esta materia, a lo largo y ancho del mundo entero.

Para el Gobierno español ya fue una satisfacción aceptar la tarea de editar las dos primeras versiones españolas de la E nciclo- pedia y vuelve a serlo ahora con esta tercera edición, que ha supuesto una revisión en profundidad de las anteriores, y que representa una excelente actualización de los conocimientos en la materia. $Y$ es una satisfacción por partida doble, teniendo en cuenta que en la elaboración de algunos de los nuevos temas incluidos en esta edición de la E nciclopedia y en la revisión de otros han tenido una destacada participación expertos españoles.

La presente edición española de la E nciclopedia se inscribe en la ya tradicional y siempre fructífera colaboración entre la O IT y el Gobierno español, que se viene materializando, esencialmente, por un lado, en el desarrollo conjunto de programas de cooperación técnica con los países hispanoamericanos y, por otra parte, en materia de publicaciones, a partir del Acuerdo suscrito en 1986, entre la O IT y el M inisterio de Trabajo y Asuntos Sociales, facilitando la edición en español de una serie de publicaciones de la OIT, de particular relevancia para asegurar su difusión en el conjunto de los países con los que compartimos nuestra lengua.

El esfuerzo realizado por universalizar el acceso al extraordinario conjunto de datos e informaciones recogidas en la Enciclopedia se inscribe también en el marco de la actual política española en la materia, que concede especial atención a la prevención de los riesgos laborales y que está propiciando un esfuerzo extraordinario de renovación normativa en este campo y un no menor esfuerzo divulgativo al respecto.

La nueva edición en español de la Enciclopedia es el resultado feliz de la colaboración de un amplio abanico de profesionales en actividades que van desde la traducción hasta la revisión por el personal especializado del Instituto Nacional de Seguridad e Higiene en el Trabajo y del Instituto Nacional de Medicina y Seguridad en el Trabajo, así como de la Subdirección General de Publicaciones de la Secretaría G eneral Técnica del M inisterio de Trabajo y A suntos Sociales.

Al congratularme de que sea nuestro Departamento el que haya impulsado y llevado a término este valioso empeño como servicio eficaz al mundo del trabajo, deseo manifestar públicamente nuestro reconocimiento a la O IT por la asistencia y las facilidades dadas en todo momento para que hoy sea una realidad la obra que ofrecemos como fruto de nuestra colaboración. 

M ichel $\mathrm{H}$ ansenne

Director $G$ eneral

Organización Internacional de Trabajo

Ginebra, 1998

\section{Presentacion de la Cuarta edicion en ingles}

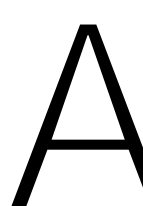

nadie ha de extrañar que las presentaciones de las anteriores ediciones de esta Enciclopedia no hayan quedado obsoletas, porque - desgraciadamente- las enfermedades profesionales y los accidentes de trabajo siguen siendo un azote del todo innecesario para la humanidad. De todos modos, desde que se publicó la primera edición de esta obra, se han realizado grandes progresos. Se ha erradicado por completo la exposición a sustancias tóxicas muy peligrosas, algunas de ellas mortales (como la pintura de radio que se aplicaba a las esferas de los relojes para que brillaran en la oscuridad) y otras que generaban parálisis o malformaciones (como el fósforo utilizado en las cerillas como material combustible). Los gobiernos han promulgado leyes y adoptado medidas de gran importancia para proteger a los trabajadores de tragedias que se pueden evitar perfectamente, como las muertes, enfermedades y discapacidades relacionadas con el trabajo. EI nivel general de conocimientos ha aumentado mucho, y la propia O IT ha contribuido a este progreso con sus convenios, recomendaciones y repertorios de recomendaciones prácticas, que reglamentan las condiciones en los lugares de trabajo, así como con sus numerosos programas de cooperación técnica y sus publicaciones especializadas. I gualmente importante ha sido la creciente contribución de la medicina, la ciencia y la ingeniería a la solución de problemas y a la dotación de mejores medios para identificar y prevenir los riesgos. Actualmente existen sistemas sociales para la protección de los trabajadores y para que participen en las decisiones que afectan a sus lugares de trabajo.

Sin embargo, a pesar de los constantes esfuerzos de la O IT por formentar mejores condiciones de trabajo, ésta y otras organizaciones siguen teniendo que combatir muchas formas de explotación de los trabajadores, como el empleo de mano de obra infantil, la servidumbre de ciertos contratos de aprendizaje y el trabajo clandestino, con sus inevitables riesgos y sus condiciones abusivas. Decenas de millones de trabajadores siguen expuestos a peligros químicos, físicos y sociales que perjudican su salud física y mental. La solución al problema de las enfermedades y las lesiones profesionales no se conseguirá sólo con publicaciones como ésta o con el asesoramiento de los expertos. La salud y el bienestar de los trabajadores es una cuestión de justicia social, y la OIT defiende por encima de todo el ideal de promover la justicia social en el mundo. En el fondo, las soluciones tienen una naturaleza social, y no sólo técnica. El pesado lastre de muertes, discapacidades y enfermedades que tiene que soportar la población activa se debe no sólo a la falta de conocimientos técnicos sino también a la falta de medios sociales y de voluntad social para hacer algo al respecto. La base social de la seguridad y la salud en el trabajo es quizá la razón más poderosa que ha llevado a la OIT a publicar la Enciclopedia de salud y seguridad en el trabajo. En ella presentamos un panorama de los problemas, sus soluciones técnicas y sociales y los campos en los que es necesario actuar.

La popularidad e influencia de la E nciclopedia han sido enormes. D ecenas de miles de ejemplares se han utilizado durante la mayor parte de este siglo. Las ediciones anteriores se han traducido al español, francés, ruso, chino, húngaro y serbocroata. La E nciclopedia es la publicación más difundida de la O IT. En la preparación de esta cuarta edición, se ha mantenido la tradición de pedir ayuda a expertos de todo el mundo, que la 0 ficina considera esencial para que pueda ampliarse y mantenerse actualizada. $\mathrm{H}$ emos creado una red de más de 2.000 expertos en más de 65 países que, dedicando a ello tiempo, esfuerzo y conocimientos especializados, han llevado a cabo una importante contribución a la redacción y revisión de los artículos, y a la corrección de muchos capítulos. Muchas de las principales instituciones del mundo que se relacionan con temas de salud y seguridad, tanto gubernamentales como académicas y privadas, han contribuido de una u otra manera a esta inmensa empresa, en un acto de generosidad y apoyo que agradecemos profundamente. N uestra esperanza y pretensión es que esta E nciclopedia establezca las bases técnicas, teóricas y éticas del trabajo que se está desarrollando para lograr el objetivo de la justicia social en una economía mundializada. 
Wilfred Jenks

D irector G eneral

Organización Internacional del Trabajo

Ginebra, 1971

\section{EXTRACTOS DE LA PRESENTACION DE LA SEGUNDA EDICION EN INGLES}

os accidentes de trabajo y las enfermedades profesionales constituyen la más aterradora tragedia de la industria moderna y una de las más importantes formas de quebranto económico. Las mejores estimaciones disponibles en la actualidad, a nivel mundial, estiman que el úmero de accidentes de trabajo mortales, cada año, se aproxima a los 100.000. En algunos países altamente industrializados, los accidentes son responsables de una pérdida de jornadas laborales cuatro o cinco veces superior a la derivada de los conflictos laborales. En ciertos casos, su costo es comparable al presupuesto de defensa nacional. La industrialización y mecanización de la agricultura se ha convertido en un problema agudo en un rango de actividades y países mucho más amplio.

La carga económica sobre la comunidad no puede expresarse únicamente en términos de costos de indemnización, sino que, también, implica una pérdida de producción, la alteración de los esquemas productivos, los daños en los equipos de fabricación y - en el caso de accidentes a gran escala - inmensos desajustes sociales. Sin embargo, la carga económica no representa la magnitud total del costo humano. (...)

O riginalmente, el principal objeto de la acción preventiva fue la mejora de las condiciones de trabajo insalubres y poner remedio a la tremenda carencia de protección física frente a los riesgos profesionales más peligrosos. Las primeras normas internacionales se concibieron bien para terminar con los más flagrantes abusos lesivos para la salud, como podrían ser los trabajos encomendados a niños de muy corta edad, las jornadas excesivas, la ausencia de cualquier forma de protección a la maternidad y los trabajos nocturnos para mujeres y niños; bien para combatir los riesgos más frecuentes a que estaban sometidos los trabajadores de la industria, como el carbunco e intoxicaciones crónicas por fósforo o plomo.

Cuando la O IT fue más allá en la formulación de estas normas básicas, para enfrentarse con el problema de la seguridad social, la primera cuestión que se consideró fue la indemnización de los accidentes de trabajo y las enfermedades profesionales. En muchos países existía ya legislación sobre indemnización de los trabajadores; dicha legislación se desarrolló sobre la base de las normas de la OIT y sus implicaciones económicas dieron un fuerte impulso a las medidas preventivas. La OIT hizo mucho en favor de la normalización de las estadísticas en materia de accidentes de trabajo y enfermedades profesionales y la captación sistemática de datos sobre la frecuencia de los accidentes (...)

Paulatinamente, esa concentración de la atención sobre los abusos más flagrantes y los índices de accidentes de trabajo y enfermedades profesionales más altos, se fue ampliando hacia un modelo más amplio, dirigido a promover mejores cotas de seguridad y salud en todas las industrias y profesiones. EI monumental Reglamento Tipo de Seguridad en los Establecimientos Industriales, para Guía de los Gobiernos y de la Industria, editado por vez primera en el año 1949, sobre la base de un trabajo iniciado durante la Segunda Guerra M undial y revisado periódicamente, significó un paso importante en este campo. Esto imprimió un ímpetu que en la actualidad se ha traducido en gran cantidad de códigos prácticos y de guías prácticas que lo complementan. En la década de 1950, esta mayor amplitud se reflejó en nuevas y extensas normas internacionales para la protección de la salud de los trabajadores, su bienestar y los servicios de salud laboral.

En la década de 1960 todo lo anterior se suplementó con nuevas series de disposiciones específicas dedicadas a determinados riesgos que fueron cobrando creciente importancia. En las fábricas, un accidente de cada seis lo provocan las máquinas; de ahí la importancia de las normas internacionales sobre los resguardos de piezas móviles que regulan, no solamente el uso, venta y alquiler de la maquinaria que tenga partes peligrosas sino, también, su fabricación. (...)

La medicina del trabajo moderna ha superado la etapa en que se ocupaba solamente de los primeros auxilios en caso de accidente y del diagnóstico de las enfermedades profesionales; en la actualidad está relacionada con todos los efectos del trabajo sobre la salud física y mental e, incluso, con el impacto de las limitaciones físicas y psicológicas del hombre sobre su trabajo. (...)

El progreso tecnológico, en el momento actual es mucho más dinámico que hace cuarenta años. Existen razones para creer que la velocidad será mayor. Esta nueva E nciclopedia constituirá exclusivamente la nueva etapa de nuestro trabajo, pero cada etapa constituye a su vez la base de partida de la siguiente. Durante los años venideros la E nciclopedia de Salud y Seguridad en el Trabajo será una herramienta esencial para humanizar los ambientes laborales y para beneficio de gran número de trabajadores en todo el mundo. En términos humanos y económicos, la consecución de normas de salud y seguridad uniformes constituye la principal responsabilidad en el campo de la política social y de la dirección eficaz. Tampoco puede ser efectiva sin la totalidad del conocimiento necesario para valorar la importancia de la presente información para la política y la acción. Esta E nciclopedia, que se preparó bajo la responsabilidad técnica del $\mathrm{Dr}$. Luigi Parmeggiani, Jefe de la Rama de Salud y Seguridad en el Trabajo, está concebida para el acceso rápido a estas materias tal como disponemos de ellas en la actualidad. En la edición de esta Enciclopedia, el Dr. Parmeggiani ha mantenido dignamente las tradiciones establecidas por el Dr. Luigi Carozzi, que estableció las bases de las acciones en M edicina del Trabajo de la O IT. 
Francis Blanchard

Directora General

O rganización Internacional del Trabajo

Ginebra, 1983

\section{EXTRACTOS DE LA PRESENTACION DE LA TERCERA EDICION EN INGLES}

a decisión de publicar la segunda edición de la Enciclopedia de Salud y Seguridad en el Trabajo se tomó hace aproximadamente quince años, y su preparación se efectuó entre los años 1966 y 1971. Desde entonces se han producido importantes progresos en el conocimiento y las actividades flejadas en esta publicación. Paralelamente al progreso tecnológico se han producido grandes avances en lo que respecta a los métodos de identificación, evaluación y control de los riesgos profesionales, así como a la protección de la salud en los puestos de trabajo. Las sustancias tóxicas, el polvo en la industria, las fibras minerales, las radiaciones no ionizantes, la alergia y el cáncer de etiología profesional son, todos ellos, problemas que han sido objeto de muchas investigaciones experimentales e importantes estudios epidemiológicos. No obstante, los cambios que han experimentado los ambientes laborales en la década de 1970 no son fruto, solamente, de un mayor conocimiento técnico; una nueva tendencia ha comenzado a tomar cuerpo: las exigencias de los trabajadores para obtener una mejor calidad de vida en el trabajo y la mayor implicación de los sindicatos en la protección de la salud y la seguridad en los puestos de trabajo; la mayor asunción, por parte de los patronos, de amplios programas de seguridad y salud laboral; y los crecientes esfuerzos de los gobiernos para que se apliquen, en este campo, medidas trascen- dentales. Esta tendencia se ve reflejada en la legislación nacional e internacional referente a los ambientes laborales y a las condiciones de trabajo, que han avanzado en una magnitud sin precedentes. Así, el panorama de la seguridad e higiene del trabajo, la seguridad industrial y la ergonomía ha experimentado profundos cambios en muchos países miembros de la OIT, no sólo en lo que respecta a la teoría sino, también, en lo que se refiere a la aplicación práctica de estas disciplinas en los propios puestos de trabajo. (...)

H ace ya sesenta y tres años que la O IT estableció, como uno de sus objetivos básicos: "la protección del trabajador frente a las indisposiciones, las enfermedades y los accidentes que pueden producirse como consecuencia de su trabajo". El objetivo actual sigue siendo el mismo, si bien la forma y los métodos de esta protección se han modificado paralelamente al progreso técnico y al desarrollo económico... La divulgación internacional de los más recientes conocimientos científicos y prácticos en este campo constituye una parte integral de la actividad de la OIT - junto con los modos de actuación tradicionales: normalización y cooperación técnica - para promover una mayor efectividad de la protección de la salud y la seguridad en el trabajo en todo el mundo. La nueva edición de la E nciclopedia contribuirá, en gran medida, a este gran empeño. 

Jeanne M ager Stellman

Directora de la publicación

Organización Internacional de Trabajo

Ginebra, 1998

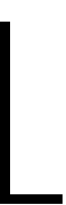

a finalidad de esta cuarta edición de la E nciclopedia de salud y seguridad en el trabajo de la O rganización Internacional del Trabajo es presentar un panorama general de la información básica disponible en este ámbito. Pero, ¿qué es lo que comprende dicho "ámbito"? Veamos un ejemplo.

¿Cómo enfocaría un grupo formado por distintos expertos los aspectos de salud y seguridad que se relacionan con el uso prolongado de las pantallas de ordenador con las que estamos tan familiarizados en nuestros días? EI médico responsable del servicio de medicina del trabajo para un grupo de trabajadores que utilizan pantallas de ordenador les sometería a un reconocimiento médico para determinar posibles síntomas de trastornos físicos. U na de las medidas sería sin duda el examen de la vista y una de las soluciones podría ser el uso de gafas especiales para trabajar delante de las pantallas. El epidemiólogo, por su parte, abordaría el problema desde el punto de vista estadístico. Recabaría los resultados de los reconocimientos efectuados en el grupo de trabajadores que utilizan pantallas de ordenador y los compararía con los de trabajadores que no las utilizan en sus puestos de trabajo, para determinar así los riesgos para la salud que están en relación con el puesto de trabajo. El higienista industrial se centraría en el medio ambiente de trabajo y mediría la iluminación o determinaría la presencia de contaminantes. El ergonomista se centraría en el diseño de los equipos y estudiaría las interacciones físicas entre la máquina y el trabajador. El psicólogo analizaría factores relacionados con la organización (la estructura social en el lugar de trabajo), centrándose en las exigencias del puesto de trabajo, el control del trabajo y la vigilancia electrónica del rendimiento, mientras que el investigador de base estaría inte-

resado en experimentar con los mecanismos biológicos que podrían explicar los efectos observados. El educador prepararía materiales didácticos para ayudar a los trabajadores a obtener un mejor rendimiento en sus puestos de trabajo. El sindicalista y el empresario tratarían de aplicar los principios de la medicina del trabajo a los contratos laborales y otros acuerdos contractuales. Finalmente, el abogado y el inspector considerarían otros aspectos pragmáticos, como la indemnización de los trabajadores, o intentarían "demostrar" consecuencias para la salud de la regulación del lugar de trabajo.

Todos estos enfoques son perfectamente válidos y constituyen importantes aspectos de la salud y seguridad en el trabajo que se complementan entre sí. Ningún profesional tiene la clave para comprender y resolver los problemas de los riesgos relacionados con el trabajo. El "ámbito" de la seguridad y la salud en el trabajo es verdaderamente interdisciplinario.

Este enfoque interdisciplinario ha sido un verdadero desafío para el director de la E nciclopedia. Los datos pueden ser neutrales, pero la manera de comprenderlos, interpretarlos y aplicarlos depende de factores culturales, entendiendo por cultura todo el conjunto de creencias, conductas y conocimientos de los seres humanos. En los campos técnicos, la cultura reflejará la formación académica básica y la filosofía personal. Lo que uno es - abogado, higienista, sindicalista o médico- influye en la manera de pensar, y quien uno es - por ejemplo, representante del gobierno, de los trabajadores o de la empresa- influye inevitablemente en la manera de percibir el universo, en sus demandas y en sus efectos. El lugar donde adquiere uno sus conocimientos de experto es otro factor decisivo, porque los fundamentos filosóficos y empíricos de la ciencia y la medicina están también vinculados a la cultura, y por consiguiente no son iguales en todo el mundo. Todos estamos limitados, como mínimo, por los recursos disponibles, que alteran inevitablemente nuestra perspectiva. El profesional maduro intentará reducir estas influencias, pero una simple mirada al mundo real basta para comprender su importancia.

Los problemas de enfoque interdisciplinario no se han resuelto en esta Enciclopedia y probablemente nunca llegarán a resolverse del todo. Aquí hemos adoptado un planteamiento pragmático. La Enciclopedia se ha estructurado en partes, secciones y capítulos que se corresponden con las distintas disciplinas que integran el campo de la salud y la seguridad en el trabajo. Ha sido concebida para proporcionar al usuario general una información básica sobre las distintas disciplinas de la salud y la seguridad en el trabajo, que sea fácil de comprender, pero que al mismo tiempo sea rigurosa para los profesionales de cada ámbito. Hemos intentado simplificar al máximo las descripciones de la identificación y el control de riesgos, reduciendo al mínimo la jerga científica al uso. La estructura general de esta Enciclopedia es la siguiente:

\section{Volumen I}

- En El cuerpo humano y Asistencia sanitaria se adopta un enfoque médico y se facilita información sobre las enfermedades, su detección y prevención, los servicios de medicina del trabajo y las actividades de promoción de la salud.

- En Gestión y política se abordan los aspectos jurídicos, éticos y sociales del campo, así como los recursos educativos, informativos e institucionales.

- En H erramientas y enfoques se describen las disciplinas relacionadas con el estudio y la aplicación de la salud y la seguridad en el trabajo: ingeniería, ergonomía, higiene industrial, epidemiología y estadística e investigación de laboratorio.

\section{Volumen II}

- En R iesgos se describen los distintos riesgos químicos, físicos y sociales, los accidentes y los métodos de gestión de la seguridad que pueden encontrarse en el mundo. Se describe también la naturaleza de los riesgos y se facilita información técnica sobre su identificación, evaluación y control. 


\section{Volumen III}

- En Sustancias químicas se presenta información básica sobre los usos industriales y las propiedades químicas, físicas y toxicológicas de más de 2.000 sustancias químicas clasificadas por familias químicas.

- En Sectores de la industria y profesiones se explica "cómo funcionan las cosas" y "cómo se controlan los riesgos" en los principales sectores de la industria. Los riesgos asociados a determinadas profesiones que abarcan distintos sectores de la industria, se presentan en forma de una ficha de riesgos.

\section{Volumen IV}

- En Indices y G uías se brinda una guía para utilizar la E nciclopedia. Esta sección incluye una lista de tablas y figuras, así como de las instituciones que han colaborado en esta publicación, e índices de sustancias químicas, referencias cruzadas, temas y autores citados.

Varios miles de expertos de prestigio internacional procedentes de las principales instituciones del mundo han contribuido en calidad de autores o revisores a esta E nciclopedia. H emos intentado asegurarnos de que estuvieran representadas las perspectivas internacionales, ya que las perspectivas no son las mismas en todas partes y la Organización Internacional del Trabajo es responsable de promover el libre intercambio de ideas diferentes. Por otra parte, los problemas y las soluciones son diferentes en cada país, y es conveniente conocer de primera mano la opinión de los que tratan los problemas de manera directa.

En esta Enciclopedia hemos plantado el jardín de la salud y la seguridad en el trabajo con datos, cifras e interpretaciones, para ayudar a que florezcan unas condiciones de trabajo saludables y seguras en todo el mundo. $\mathrm{H}$ emos plantado las semillas en grupos más o menos ordenados por disciplinas, de manera que el lector, una vez que se familiarice con los senderos del jardín, pueda formar cualquier ramo de datos que desee. Los índices del volumen IV proporcionan un mapa más detallado, incluido un valioso índice de referencias cruzadas básicas. El lector experimentado sabrá averiguar con rapidez qué se ha plantado y dónde, y podrá elegir el camino más rápido. La versión electrónica de este trabajo incluye otras ayudas a la navegación, incorporando hiperenlaces y funciones de búsqueda especializada. Con las claves de búsqueda adecuadas, el astuto usuario de CD-ROM podrá incluso plantar él solo un jardín totalmente nuevo y reorganizado.

Por supuesto, la E nciclopedia no está completa al cien por cien. Faltan datos aislados. Es posible que algunos conceptos se hayan quedado desfasados incluso antes de que se publique, señal de que se trata de un campo dinámico y creativo del esfuerzo humano. Esta Enciclopedia no podría haberse escrito sin las incontables horas de trabajo de numerosas personas en todo el mundo. El lector encontrará los nombres de nuestros colaboradores en la lista de autores y directores de edición, así como en el Directorio de Expertos que se incluye en la versión electrónica de la obra. La mayoría de las personas han contado con el pleno respaldo y ayuda de las instituciones a las que pertenecen. EI Volumen IV contiene también una lista (no exhaustiva) de las instituciones que han colaborado.

D eseamos expresar nuestro agradecimiento por el gran apoyo que hemos recibido para este proyecto mundial. Por último conviene aclarar que las opiniones que se expresan son responsabilidad exclusiva de los autores y no implican en modo alguno a las instituciones que los encuadran, ni a la 0 ficina Internacional del Trabajo. Esperamos que este compendio de ideas que les presentamos sirva para adelantar el día en que las muertes y las enfermedades relacionadas con el trabajo lleguen a ser acontecimientos excepcionales en el mundo. 


\section{AUTORES Y DIRECTORES}

P.K. Abeytunga, PhD, MSc

Vice President, D irector G eneral

Canadian $\mathrm{C}$ entre for $\mathrm{O}$ ccupational $\mathrm{H}$ ealth and Safety

$\mathrm{H}$ amilton, $\mathrm{O}$ ntario

Canadá

\section{Sheila H. Akabas, PhD, MBA}

Professor, Director

Workplace C enter

School of Social W ork

Columbia U niversity

Nueva Y ork, N ueva Y ork

Estados U nidos

Munehira Akita, PhD, MA

Profesor de psicología

Facultad de Ciencias Sociales y de la Información

U niversidad de Nihon Fukushi

K ioto

Japón

\section{Lorenzo Alessio, MD}

Profesor, Director

Instituto de M edicina del T rabajo

Universidad de Brescia

Brescia

Italia

\section{Peter Arlien-Soborg, MD}

Profesor adjunto, J efe

Departamento de N eurología

$\mathrm{H}$ ospital de $\mathrm{H}$ vidovre,

Universidad de Copenhague

Copenhague

Dinamarca

\section{Bruce K. Armstrong, MB, D Phil}

Director

Cancer Control Information Centre

New South Wales Cancer Council

Sidney

Australia

\section{Pat Armstrong, PhD, MA}

Professor, D irector

School of $C$ anadian Studies

Carleton U niversity

O ttawa, O ntario

Canadá

\section{Thomas J. Armstrong, PhD, MPH}

Professor

$\mathrm{O}$ ccupational $\mathrm{H}$ ealth and Industrial and

$O$ perations Engineering

$U$ niversity of $M$ ichigan

Ann Arbor, M ichigan

Estados U nidos
Ian M.F. Arnold, MD, MSc

Director

$\mathrm{O}$ ccupational $\mathrm{H}$ ealth and Safety

Alcan Aluminium Ltd.

M ontreal, Q uebec

Canadá

Gordon Atherley, MB, ChB, MD

President

O beron C omposer Software

0 akville, 0 ntario

Canadá

Michael D. Attfield, PhD

Division of R espiratory D isease Studies

$N$ ational Institute for $O$ ccupational Safety and $\mathrm{H}$ ealth

M organtown, W est $V$ irginia

Estados U nidos

\section{Rahmat Awang, Phar MD}

Profesor asociado, J efe

U nidad de I nformación sobre Fármacos y Sustancias Tóxicas

C entro Nacional de T oxicología

U niversidad Sains de M alaisia

Penang

M alaisia

\section{Olav Axelson, MD}

Profesor

División de M edicina del T rabajo y A mbiental

D epartamento de Salud y M edio A mbiente

U niversidad de Linköping

Linköping

Suecia

\section{Dean B. Baker, MD, MPH}

Professor, Director

Center for $O$ ccupational and

Environmental $\mathrm{H}$ ealth

U niversity of California-I rvine

Irvine, California

Estados U nidos

\section{Robin Baker, MPH}

Director

L abor $\mathrm{O}$ ccupational $\mathrm{H}$ ealth Program

U niversity of C alifornia-Berkeley

Berkeley, California

Estados Unidos

\section{Isabelle Balty, MS}

Consultora técnica

Dirección de A plicaciones para Prevención Instituto $\mathrm{N}$ acional de Investigación sobre Seguridad y Prevención de Riesgos Profesionales

París

Francia
Randal D. Beaton, PhD

Clinical Psychologist,

R esearch A ssociate P rofessor

School of N ursing

U niversity of Washington

Seattle, W ashington

Estados U nidos

\section{Margaret R. Becklake, MD}

Professor

Departments of M edicine, Epidemiology and Biostatistics and $\mathrm{O}$ ccupational

$\mathrm{H}$ ealth

M cG ill U niversity

M ontreal, Q uebec

Canadá

\section{Raymond Bégin, MD}

Professor of M edicine

U niversity H ospital

U niversity of Sherbrooke

Sherbrooke, Q uebec

Canadá

Vladimír Bencko, MD, PhD

Profesor, Director

Instituto de H igiene y Epidemiología

U niversidad de $C$ harles

Praga

República Checa

\section{Irene K. Berezesky, BA}

Instructor

Department of Pathology

School of M edicine

U niversity of $\mathrm{M}$ aryland

Baltimore, $M$ aryland

Estados U nidos

\section{Elliott H. Berger, MS}

Senior Scientist

Auditory R esearch Department

E-A-R / A earo Company

Indianapolis, Indiana

Estados U nidos

Joan Bertin, JD

School of Public Health

Columbia U niversity

Nueva Y ork, NuevaY ork

Estados Unidos

\section{Marco Biagi}

Profesor de derecho del trabajo

Departamento de Administración de Empresas

U niversidad de M ódena

Bolonia

Italia 


\section{Elyce Anne Biddle}

National Institute for O ccupational Safety and $\mathrm{H}$ ealth

M organtown, V irginia occidental

Estados U nidos

\section{Annibale Biggeri, MD \\ P rofesor de estadística médica \\ Facultad de M edicina \\ U niversidad de Florencia \\ Florencia \\ Italia}

\section{Donald Birmingham, MD}

Professor E meritus

D epartment of D ermatology

W ayne State U niversity

$D$ etroit, M ichigan

Estados U nidos

\section{Helmut Blome, Dr rer nat}

Subdirector

Berufsgenossenschaftliches I nstitute für Arbeitssicherheit

$\mathrm{H}$ auptverband der gewerblichen

Berufsgenossenschaften

Sankt A ugustin

Alemania

\section{Sheila B. Blume, MD, CAC}

M edical D irector

Alcoholism, Chemical D ependency and

C ompulsive $\mathrm{G}$ ambling Programs

South $\mathrm{O}$ aks $\mathrm{H}$ ospital

A mityville, Nueva Y ork

Estados U nidos

\section{Frank Bochmann, Dr}

fe de sección

Berufsgenossenschaftliches Institute für Arbeitssicherheit

$\mathrm{H}$ auptverband der gewerblichen

Berufsgenossenschaften

Sankt A ugustin

Alemania

\section{Paolo Boffetta, MD, MPH}

I fe

Unidad de E pidemiología de

Cáncer A mbiental

Agencia Internacional para

la Investigación sobre el Cáncer

Lyon

Francia

\section{Marcel-André Boillat, MD, MS}

Profesor asociado

Instituto de Ciencias de M edicina del Trabajo

U niversidad de L ausanne

L ausanne

Suiza

\section{Carole Brabant, PhD}

Subdirectora de edición

E nciclopedia de salud y seguridad en el trabajo

O ficina Internacional del T rabajo

Ginebra

Suiza

\section{Mario Braga, MD}

Subdirector

U nidad de Evaluación Epidemiológica

A gencia de Servicios R egionales de Salud

R oma

Italia

Paul Brandt-Rauf, MD, ScD, Dr PH

Professor, D irector

O ccupational and Environmental

M edicine

School of Public Health

Columbia U niversity

N uevaY ork, NuevaY ork

Estados U nidos

\section{Sherry I. Brandt-Rauf, JD, M Phil} Assistant Professor of Social M edicine

Columbia U niversity

N ueva Y ork, Nueva Y ork

Estados U nidos

\section{Mark Braverman, PhD, M Ed}

Principal

$C$ risis $M$ anagement $G$ roup Inc.

N ewton U pper Falls, M assachusetts

Estados U nidos

William B. Bunn, MD, JD, MPH

$D$ irector of $\mathrm{H}$ ealth

W orkers' Compensation and Safety

$\mathrm{N}$ avistar Corporation

Chicago, Illinois

Estados U nidos

\section{Wayne N. Burton, MD}

First Vice-P resident, Corporate M edical Director

First C hicago N BD

Chicago, Illinois

Estados U nidos

\section{Martin Butz, PhD}

lefe de sección

$\mathrm{H}$ auptverband der gewerblichen

Berufsgenossenschaften

Sankt Augustin

Alemania

\section{LaMont Byrd, MSc}

$D$ irector of Safety and $\mathrm{H}$ ealth

International Brotherhood of T eamsters

Washington, DC

Estados U nidos

\section{D. Calnan}

Institute of Dermatology

St. John's H ospital for D iseases of the Skin Londres

Reino U nido

Barry I. Castleman, ScD, MSE

E nvironmental $C$ onsultant

Baltimore, $\mathrm{M}$ aryland

Estados U nidos

\section{Chaiyuth Chavalitnitikul, PhD,} MPH

Director

Instituto Nacional para la M ejora de las $\mathrm{C}$ ondiciones y el M edio A mbiente de Trabajo

Bangkok

Tailandia

\section{Haim Chayon, MJ}

Antiguo director

Departamento de Incapacidad L aboral Instituto Nacional del Seguro Jerusalén

srae

Kee-Seng Chia, MD, MBBS, MSc

Profesor asociado

Departamento de M edicina Comunitaria, del Trabajo y de Familia

U niversidad Nacional de Singapur

Singapur

\section{Gerolamo Chiappino, MD}

Profesor, Director

Centro de M edicina del T rabajo

Instituto de M edicina del Trabajo

Milán

I talia

\section{K.S. Cho, MD*}

Director

Instituto de H igiene Industrial

Escuela Católica de M edicina

Seúl

República de Corea

Emmert Clevenstine, PhD, MS

Centro Internacional de Información sobre Seguridad y Salud en el T rabajo

O ficina Internacional del Trabajo

Ginebra

Suiza

\section{W. Coenen, Dipl Ing}

D irector de prevención

$\mathrm{H}$ auptverband der gewerblichen Berufsgenossenschaften

Sankt Augustin

Alemania

* Colaborador de la 3a edición de esta Enciclopedia. Esta información bibliográfica no se ha actualizado. 


\section{Edward Cohen-Rosenthal, Ed M}

Director

W ork and Environment I nitiative

School of Industrial and L abor R elations

C ornell U niversity

I thaca, N ueva Y ork

Estados U nidos

\section{Paula Coleman, BS}

Curriculum Specialist

$\mathrm{C}$ arpenters $\mathrm{H}$ ealth and Safety Fund

Washington, DC

E stados U nidos

\section{Georges H. Coppée, MD}

J efe de sección médica

$R$ ama de Seguridad y Salud en

$$
\text { el Trabajo }
$$

O ficina Internacional del T rabajo

Ginebra

Suiza

\section{Wayne Corneil, ScD}

Director

$O$ perations E astern R egion

$\mathrm{H}$ ealth Canada

O ttawa, O ntario

Canadá

James Corry, PhD, MS

Director

Corporate W ellness and Fitness Services $M$ etropolitan Life Insurance Company

N ueva Y ork, Nueva Y ork

Estados U nidos

\section{Maureen P. Corry, MPH}

General Director

$M$ aternity Center Association

N ueva Y ork, Nueva Y ork

Estados U nidos

John W.F. Cowell, MD, MSc

P resident, C hief E xecutive 0 fficer

W orkers' Compensation Board of Alberta

Edmonton, A lberta

Canadá

\section{Breen Creighton, LLB, PhD}

Special C ounse

Corrs $C$ hambers W estgarth

M elbourne

Australia

\author{
Marie L. Cros-Courtial, Dr d'Etat \\ en droit \\ Profesora de derecho \\ D epartamento A.E.S. \\ U niversidad de Paul V aléry \\ M ontpellier \\ Francia
}

Mark R. Cullen, MD

P rofessor of $M$ edicine and $P$ ublic $H$ ealth

$\mathrm{Y}$ ale $\mathrm{U}$ niversity $\mathrm{Sch}$ ool of $\mathrm{M}$ edicine

$\mathrm{N}$ ew $\mathrm{H}$ aven, Connecticut

Estados U nidos

\section{Ellen Cutler, MPA}

National Director

Program Services

$M$ arch of D imes Birth D efects Foundation

White Plains, N ueva Y ork

Estados U nidos

\section{Monica Dahlqvist, PhD}

P rofesora adjunta

Departamento de T ecnología

A mbiental y Ciencias del Trabajo

Real Instituto de T ecnología

Estocolmo

Suecia

\section{Antonio J. Dajer, MD}

Neuilly-sur-Seine

Francia

Louis Damphousse, MD, MSc

M edical C onsultant

$M$ aclaren Inc.

$M$ asson, Q uebec

Canadá

\section{Frank Darby, MSc}

Consultant in E rgonomics

Wellington

Nueva Zelanda

\section{Alois David, MD, PhD}

Profesor asociado

Departamento de M edicina del T rabajo

Escuela de Estudios M édicos

Postuniversitarios

Praga

República C heca

\section{Véronique De Keyser, PhD}

Profesora de psicología del trabajo, D ecana de F acultad

Universidad de Lieja

Lieja

Bélgica

\section{David M. DeMarini, PhD}

Environmental Carcinogenesis D ivision

US Environmental Protection Agency

R esearch T riangle Park, Carolina

del Norte

Estados U nidos
Dušan Djurić DSc, ChE

Instituto de M edicina del T rabajo y

R adiológica

Belgrado

Yugoslavia

\section{Mel Doyle, MPhil}

$D$ eputy General Secretary

W orkers' E ducational A ssociation

Londres

R eino Unido

\section{Louis-Philippe Durocher, MD,} FRCPC

Professor of $D$ ermatology

N otre D ame H ospital

$\mathrm{H}$ ead

Dermatology T raining Programme

U niversity of $\mathrm{M}$ ontreal

M ontreal, Q uebec

Canadá

\section{Robert W. Dykes, PhD}

Director

Center for R esearch

R ehabilitation Institute of $M$ ontreal

U niversity of $\mathrm{M}$ ontreal

M ontreal, Q uebec

Canadá

\section{Lawrence D. Eicher, PhD}

Secretario general

O rganización Internacional de N ormalización

Ginebra

Suiza

\section{G. Enderlein, Dr rer nat}

J efe de grupo

D epartamento de E valuación de R iesgos y Diseño de Estudios Epidemiológicos

Instituto Federal de Seguridad y Salud en el Trabajo

Berlín

Alemania

John W. Farquhar, MD

Professor of M edicine, D irector

Stanford Center for R esearch in Disease Prevention

Stanford U niversity School of M edicine Palo Alto, California

Estados U nidos

Igor A. Fedotov, MD, MSc

E specialista en medicina del trabajo

O ficina Internacional del T rabajo

Ginebra

Suiza 
Ilise Levy Feitshans, Esq JD, ScM Trustee

Society of M edical Jurisprudence

G lobal Alliance for W omen's $\mathrm{H}$ ealth

Riverdale, Nueva Y ork

Estados U nidos

\section{Robert G. Feldman, MD \\ Professor, Chair \\ Department of N eurology \\ School of M edicine \\ Professor \\ School of Public H ealth \\ Boston U niversity \\ Boston, M assachusetts \\ Estados U nidos}

\author{
Adalberto Ferioli, MD, PhD \\ Científico \\ D epartamento de T oxicología del T rabajo \\ Centro Internacional para la Seguridad \\ de los Plaguicidas \\ Busto $\mathrm{G}$ arolfo \\ Italia
}

Jonathan E. Fielding, MD, MBA, MPH

Professor of $H$ ealth Sciences and Pediatrics

U niversity of C alifornia- L os Angeles

Los Angeles, California

Estados U nidos

\section{John Finklea, MD, Dr PH}

M edical Officer

Center to Protect W orkers' R ights

F ormer D irector

National Institute for $\mathrm{O}$ ccupational

Safety and $\mathrm{H}$ ealth

W ashington, DC

Estados U nidos

\section{Vito Foà, MD}

Profesor de higiene industrial

Instituto de M edicina del T rabajo

U niversidad de M ilán

M ilán

Italia

\section{G. Frada, Dr Prof}

Director

Instituto de M edicina del T rabajo

U niversidad de Palermo

Palermo

Italia

\section{John R. Franks, PhD}

Chief

Bioacoustics and $O$ ccupational Vibration Section

$\mathrm{N}$ ational Institute for $\mathrm{O}$ ccupational Safety and $\mathrm{H}$ ealth

Cincinnati, $\mathrm{O}$ hio

Estados U nidos
T.M. Fraser, MD, Msc, P Eng

Professor E meritus

Systems D esign Engineering

University of Waterloo

W aterloo, 0 ntario

Canadá

Herbert J. Freudenberger, PhD

Psychologist, P sychoanalyst

N ueva Y ork, Nueva Y ork

Estados U nidos

\section{George Friedman-Jiménez, MD}

Director

Bellevue $O$ ccupational and Environmental

$M$ edicine $\mathrm{Clinic}$

Bellevue H ospital C enter

N ueva Y ork, Nueva Y ork

Estados U nidos

\section{Howard Frumkin, MD, Dr PH, MPH}

Associate Professor, Chair

D epartment of Environmental and

$O$ ccupational $\mathrm{H}$ ealth

$\mathrm{R}$ ollins School of Public H ealth

Emory U niversity

Atlanta, G eorgia

Estados U nidos

\section{Lawrence Garfinkel, MA}

F ormer V ice P resident for E pidemiology and Statistics

American Cancer Society

N ueva Y ork, Nueva Y ork

Estados U nidos

\section{Otto Geiecker, Dkfm}

Antiguo subdirector general

D epartamento de R ehabilitación Interna

Allgemeine U nfall V ersicherungsanstalt

Viena

Austria

\section{Issachar Gilad, PhD}

Profesor de ingeniería industrial y ergonomía Instituto de T ecnología de I srael $\mathrm{H}$ aifa

Israel

William. I. Glass, MB ChB, DIH, DPH

$O$ ccupational M edicine Specialist

Christchurch

N ueva Zelanda

\section{F. Gobbato*}

Instituto de M edicina del T rabajo

U niversidad de T rieste

Trieste

Italia
Berenice I. Ferrari Goelzer, CIH, MPH

$H$ igienista industrial

O ficina de M edicina del T rabajo

O rganización M undial de la Salud

Ginebra

Suiza

Kristan D. Goldfein, Ed D

$M$ anager of $C$ orporate $W$ ellness

$M$ errill Lynch Inc.

A djunct Assistant P rofessor

T eacher's College

Columbia U niversity

Nueva Y ork, N ueva Y ork

Estados U nidos

\section{Bernard D. Goldstein, MD}

D irector

Environmental and $\mathrm{O}$ ccupational $\mathrm{H}$ ealth Sciences Institute

Chair

Department of Environmental and Community $M$ edicine

U M DN J-R obert W ood Johnson M edical School

Piscataway, Nueva J ersey

Estados U nidos

\section{David Gompert, MD, PhD}

Senior L ecturer (H onorary)

Institute of $\mathrm{O}$ ccupational $\mathrm{H}$ ealth

U niversity of Birmingham

Birmingham

Reino U nido

Joke H. Grady-van den Nieuwboer, MSc

Centro R oessingh de R ehabilitación

$\mathrm{H}$ aáksbergen

Países Bajos

E. Grandjean, Dr med (fallecido)*

Antiguo director

Instituto de H igiene y Fisiología del Trabajo

Zurich

Suiza

Philippe Grandjean, MD, DMSc

Profesor

M edicina Ambiental

U niversidad de 0 dense

$O$ dense

Dinamarca

\footnotetext{
* Colaborador de la 3a edición de esta Enciclopedia. Esta información bibliográfica no se ha actualizado.
} 
Peter Greenwald, MD, Dr PH

Director

Division of $\mathrm{C}$ ancer Prevention and $\mathrm{C}$ ontrol

$\mathrm{N}$ ational $\mathrm{C}$ ancer Institute

Bethesda, M aryland

Estados U nidos

\section{Dieter Greiner, Dr jur}

Director general adjunto

$H$ auptverband der gewerblichen

Berufsgenossenschaften

Sankt Augustin

Alemania

\section{Gudela Grote, PhD}

Profesor

Psicología del Trabajo y las

O rganizaciones

Instituto Federal Suizo de T ecnología

Zurich

Suiza

\section{Saul G. Gruner, MS}

SG G runer A ssociates Inc.

W estport, Connecticut

Estados U nidos

\author{
Per Gustavsson, MD, PhD \\ Profesor asociado \\ D epartamento de M edicina del T rabajo \\ $\mathrm{H}$ ospital de $\mathrm{K}$ arolinska \\ Estocolmo \\ Suecia
}

Winfried Hacker, Dr rer nat habil

Profesor, Catedrático

Psicología G eneral

U niversidad T ecnológica de

D resde

Alemania

\section{Mats Hagberg, MD, PhD}

Profesor

División de Fisiología del T rabajo y

A mbiental

Instituto $\mathrm{N}$ acional del Trabajo

Solna

Suecia

\section{David Hamerman, MD}

U niversity P rofessor of $M$ edicine

Albert E instein College of $M$ edicine

N ueva Y ork, Nueva Y ork

Estados U nidos

\section{Takashi Haratani, PhD}

I nvestigador

Instituto $\mathrm{N}$ acional de $\mathrm{H}$ igiene Industrial K awasaki

Japón
Jillian Haslehurst, MB, ChB

M edical Advisor

$M$ arks and Spencer PLC

Londres

R eino U nido

\section{Fengsheng $\mathrm{He}$, MD}

Profesor de medicina del trabajo y

neurotoxicología, D irector honorario

Instituto de M edicina del Trabajo

A cademia China de M edicina Preventiva

Pekín

China

Catherine A. Heaney, PhD, MPH

Associate P rofessor

School of Public H ealth

O hio State U niversity

Columbus, $\mathrm{O}$ hio

Estados U nidos

\section{Steven Hecker, MSPH}

Associate P rofessor

Labor E ducation and R esearch Center

$U$ niversity of $O$ regon

Eugene, Oregon

Estados U nidos

Dick Heederik, PhD, MSc

Profesor asociado de epidemiología del trabajo

U niversidad de $W$ ageningen

Wageningen

Países Bajos

Lothar A.J. Heinemann, MD, DSc

Director

Centro de E pidemiología e Investigaciones M édicas

Zepernick

Alemania

Adjunct P rofessor for E pidemiology and Biostatistics

M CG ill U niversity

M ontreal, Q uebec

Canadá

\section{Rolf Helbig, Dr-Ing}

Ingeniero jefe

Institut für Arbeitswissenschaft

T echnische H ochschule D armstadt

Darmstadt

Alemania

George P. Hemstreet III, MD, PhD

Professor of U rology

College of M edicine

U niversity of $\mathrm{O}$ klahoma

O klahoma City, O klahoma

Estados U nidos

\section{Sven Hernberg, MD}

P rofesor emérito, Antiguo director

D epartamento de E pidemiología y

Bioestadística

Instituto Finés de M edicina del

Trabajo

H elsinki

Finlandia

\section{Robert F. Herrick, ScD}

L ecturer on I ndustrial $\mathrm{H}$ ygiene

D epartment of Environmental $\mathrm{H}$ ealth

$\mathrm{H}$ arvard School of Public $\mathrm{H}$ ealth

Boston, M assachusetts

Estados U nidos

Raymond Hétu, PhD (fallecido)

F ormer D irector

A coustic Group

M edical Faculty

U niversity of M ontreal

M ontreal, Q uebec

Canadá

\section{Gerd E. Heuchert, MD, Dr med sci}

Profesor, I efe

D epartamento de E pidemiología

Instituto Federal de Seguridad y Salud en el Trabajo

Berlín

Alemania

\section{Herbert Heuer, Dr rer nat}

Profesor, J efe

D epartamento de Psicología

del Trabajo y Experimental

Institut für Arbeitsphysiologie

D ortmund

Alemania

\section{Penny D. Higgins, RN, BS}

President

$\mathrm{OH}$ A ssociates, Ltd.

D es Plaines, Illinois

Estados U nidos

Michael J. Hodgson, MD, MPH

A ssociate P rofessor of $M$ edicine

U niversity of $\mathrm{C}$ onnecticut $\mathrm{H}$ ealth $\mathrm{C}$ enter

Farmington, Connecticut

Estados U nidos

Perrine Hoet, MD, MIH, MSc

Investigadora asociada

U nidad de T oxicología I ndustrial y M edicina del Trabajo

Facultad de M edicina

Universidad C atólica de L ovaina

Bruselas

Bélgica 


\author{
Burkhard Hoffmann, DPhil \\ lefe de sección \\ D ocumentación y Estadísticas \\ $\mathrm{H}$ auptverband der gewerblichen \\ Berufsgenossenschaften \\ Sankt Augustin \\ Alemania
}

\section{Johan Högberg, MD, PhD \\ Profesor de toxicología \\ Instituto Nacional del Trabajo \\ Solna \\ Suecia}

\section{Judith C. Holder, PhD}

Assistant $D$ irector of $O$ ccupational

$M$ ental $H$ ealth Programs

Duke U niversity M edical C enter

Durham, Carolina del Norte

Estados U nidos

\section{Bo Holmberg, PhD}

Profesor emérito

D epartamento de T oxicología

Instituto Nacional del T rabajo

Solna

Suecia

\section{Irene L.D. Houtman, PhD}

Investigadora

NIA TNO

Amsterdam

Países Bajos

Ann F. Hubbs, DVM, PhD, MS

$\mathrm{H}$ ealth $\mathrm{E}$ ffects $L$ aboratory Division

N ational Institute for $\mathrm{O}$ ccupational Safety and $\mathrm{H}$ ealth

$M$ organtown, $V$ irginia occidental

Estados U nidos

\section{James Huff, PhD, MS}

Environmental $\mathrm{C}$ arcinogenesis Program National Institute of Environmental $\mathrm{H}$ ealth Sciences

R esearch T riangle Park

Carolina del Norte

Estados U nidos

\section{Vilma Hunt, BDS, AM}

Adjunct Professor

D epartment of Work Environment

$U$ niversity of M assachusetts-L owell

L owell, M assachusetts

Estados U nidos
Joseph J. Hurrel, Jr., PhD

Senior R esearch E pidemiologist

$H$ azard Evaluation and T echnical A ssistance Branch

$\mathrm{N}$ ational Institute for $\mathrm{O}$ ccupational Safety and $\mathrm{H}$ ealth

Cincinnati, Ohio

Estados U nidos

\section{Robert Husbands}

$R$ ama de $R$ ehabilitación Profesional

O ficina Internacional del T rabajo

Ginebra

Suiza

Masayuki Ikeda, MD, PhD

Profesor enérito de salud pública

U niversidad de $\mathrm{K}$ ioto

$\mathrm{K}$ ioto

Japón

\section{Terence G. Ison, LLD}

Professor E meritus

$\mathrm{O}$ sgoode $\mathrm{H}$ all Law School

Y ork U niversity

$\mathrm{N}$ orth $\mathrm{Y}$ ork, $\mathrm{O}$ ntario

Canadá

\section{Masaaki Iuchi, BL}

Subdirector

División de Planificación de Políticas

D epartamento de M edidas para la

Promoción del Empleo entre las

Personas de E dad A vanzada y

D iscapacitadas

M inisterio de T rabajo

Tokio

Japón

\section{Nikolai Izmerov, PhD}

Profesor de medicina, D irector

Instituto R AM S de M edicina del Trabajo

M oscú

Federación R usa

\section{Regina Jäckel, MD}

D epartamento de E fectos en la Salud de Sustancias Peligrosas

Instituto Federal de Seguridad y Salud en el Trabajo

Berlín

Alemania

\section{Peter Jacobsen, MD}

Inspector médico

Centro de M edicina del T rabajo

Rigshospitalet

Copenhague

Dinamarca
Marek Jakubowski, PhD, MSc

Profesor, J efe

División de M edicina del T rabajo y

Sanidad A mbiental

Instituto $\mathrm{N}$ ofer de M edicina del T rabajo

Lodz

Polonia

Jerry Jeyaratnam, PhD, MSc

J efe

División de M edicina del T rabajo

U niversidad Nacional de Singapur

Singapur

\section{Gunnar Johanson, Dr med sci}

I nvestigador

D epartamento de T oxicología

Instituto $\mathrm{N}$ acional del Trabajo

Solna

Profesor asociado

U niversidad de U ppsala

U ppsala

Suecia

\section{Barry L. Johnson, PhD}

Assistant Surgeon General, A ssistant

Administrator

A gency for T oxic Substances and Disease Registry

A tlanta, G eorgia

Estados U nidos

T. K. Joshi, MS, MSc

O ficina Internacional del T rabajo (Bhután e India)

Nueva Delhi

India

\section{Roland Kadefors, PhD}

Profesor

Departamento de Prevención de Accidentes

U niversidad T ecnológica de Chalmers G öteborg

Suecia

\section{Jeffrey P. Kahn, MD}

President

Center for W ork Stress R eduction

Farmington, Connecticut

W orkPsych A ssociates Inc.

Scarsdale, Nueva Y ork

Estados Unidos

\section{Craig Karpilow, MD}

President

International Professional Associates, Ltd.

Seattle, Washington

Estados U nidos 
Timo Kauppinen, PhD

J efe de la U nidad de R egistros

Instituto Finlandés de M edicina

del Trabajo

$\mathrm{H}$ elsinki

Finlandia

\section{George Kazantzis, FRCP, FFCM, FFOM*}

L ondon School of $\mathrm{H}$ ygiene and T ropical $M$ edicine

T U C C entenary Institute of O ccupational $\mathrm{H}$ ealth

Londres

R eino U nido

\section{Homayoun Kazemi, MD}

Professor of M edicine

$\mathrm{H}$ arvard M edical School

Chief

Pulmonary and Critical $\mathrm{C}$ are U nit

$M$ assachusetts $G$ eneral H ospital

Boston, M assachusetts

Estados U nidos

\section{Ása Kilbom, MD}

Profesor, Director

Departamento de Ergonomía

Instituto $\mathrm{N}$ acional del T rabajo

Solna

Suecia

\section{Kikuzi Kimura, Dr med sci}

Instituto de Ciencias del T rabajo

K awasaki

Japón

\section{Howard M. Kipen, MD, MPH}

Associate $P$ rofessor, D irector

Division of $\mathrm{O}$ ccupational $\mathrm{H}$ ealth

Environmental and $\mathrm{O}$ ccupational $\mathrm{H}$ ealth

Science Institute

U M D NJ-R obert Woods J ohnson M edical School

Piscataway, N ueva Jersey

Estados U nidos

\section{George R. Kliesch}

Antiguo director

Condiciones de Trabajo y M edio Ambiente

O ficina Internacional del T rabajo

Ginebra

Suiza

Manolis Kogevinas, MD, PhD, MSc

Profesor asociado

U nidad de Investigación de la Salud

R espiratoria y Ambiental

Institut M unicipal d'Investigació M édica

Barcelona

España

\author{
Kazutaka Kogi, MD, Dr med sci \\ Director \\ Instituto de Ciencias del T rabajo \\ K awasaki \\ Japón
}

\section{David Koh, MBBS, PhD, MSc}

Profesor asociado

D epartamento de M edicina Comunitaria, del Trabajo y de Familia

U niversidad $\mathrm{N}$ acional de

Singapur

\section{Michie A. J. Kompier, PhD}

Profesor

D epartamento de Psicología del T rabajo y de las 0 rganizaciones

U niversidad de Nijmegen

$\mathrm{N}$ ijmegen

Países Bajos

\section{Lawrence D. Kornreich, PhD,} M SPH

President

EnviroH ealth and Safety $M$ anagement

$M$ t A rlington, N ueva Jersey

Estados U nidos

\section{Andreas Kranig, Dr jur}

J efe de sección

Legislación Alemana sobre el Seguro de Accidente

$H$ auptverband der gewerblichen Berufsgenossenschaften

Sankt Augustin

Alemania

\section{Richard S. Kraus, PE, CSP}

Principal

Petroleum Safety Consultants

Annandale, Virginia

Estados U nidos

\section{Leon Kreitzman, DSc, MSc}

Director

$M$ aturity $M$ arketing $L t d$.

Londres

R eino U nido

\section{Penny M. Kris-Etherton, PhD, RD}

Professor

D epartment of $\mathrm{N}$ utrition

Pennsylvania State U niversity

University Park, Pensilvania

Estados U nidos

\footnotetext{
${ }^{*}$ Colaborador de la 3a edición de esta Enciclopedia. Esta información bibliográfica no se ha actualizado.
}

Karl H.E. Kroemer, Dr-Ing

Professor, Director

Industrial Ergonomics L aboratory H uman Factors Engineering C enter

ISE D epartment

$\checkmark$ irginia T ech

Blacksburg, V irginia

Estados Unidos

\section{Ilkka Kuorinka, MD, PhD}

D irector

Safety and Ergonomics Division

Institute for $\mathrm{O}$ ccupational $\mathrm{H}$ ealth and Safety R esearch

$M$ ontreal, Q uebec

Canadá

\section{Joseph LaDou, MD, MS}

D irector

International C enter for O ccupational $M$ edicine

U niversity of California-San Francisco

San Francisco, California

Estados U nidos

\section{Jay Lasser, MD}

President

C enter for W ork Stress R eduction

Farmington, Connecticut

Estados U nidos

Patricia A. Last, FRCS, FRCOG

Consultant, W omen's $H$ ealth

$\mathrm{H}$ ertfordshire

R eino U nido

\section{Aishah A. Latiff, PhD}

D irector

Centro de Control del Doping

U niversidad Sains de M alaisia

Penang

M alaisia

\section{Wolfgang Laurig, Dr-Ing}

Profesor, D irector

D epartamento de Ergonomía Institut für Arbeitsphysiologie

U niversidad de D ortmund

D ortmund

Alemania

\footnotetext{
Robert R. Lauwerys, MD, DSC, MIH, MSc

Profesor

U nidad de T oxicología Industrial y

M edicina del T rabajo

Facultad de M edicina

U niversidad Católica de L ovaina

Bruselas

Bélgica
} 


\section{Antoine Laville}

Professor, Director

Laboratoire d'Ergonomie

Physiologique-Cognitive

É cole Pratique des H autes Études

París

Francia

\section{Marjatta Leirisalo-Repo, MD}

Consultora de reumatología

D epartamento de M edicina

H ospital Central de la U niversidad de $\mathrm{H}$ elsinki

$\mathrm{H}$ elsinki

Finlandia

\section{Grace Kawas Lemasters \\ Professor \\ D epartment of Epidemiology and Environmental $\mathrm{H}$ ealth \\ $U$ niversity of $\mathrm{C}$ incinnati \\ Cincinnati, $\mathrm{O}$ hio \\ Estados U nidos}

Richard A. Lemen, PhD, MS

F ormer Assistant Surgeon G eneral, D eputy

$D$ irector

$\mathrm{N}$ ational Institute for $\mathrm{O}$ ccupational Safety and $\mathrm{H}$ ealth

A tlanta, Georgia

Estados U nidos

\section{Michel Lesage, MD, CSPQ}

E specialista en medicina del trabajo O ficina Internacional del T rabajo

G inebra

Suiza

\section{Lennart Levi, MD, PhD}

Profesor emérito, Antiguo director

D epartamento de Investigación del Estrés Instituto $\mathrm{K}$ arolinska

Estocolmo

Suecia

\section{Linnéa Lillienberg, PhD \\ $H$ igienista industrial \\ D epartamento de M edicina del T rabajo \\ U niversidad de Sahlgrenske \\ G öteborg \\ Suecia}

\section{Morton Lippmann, PhD}

Professor of E nvironmental M edicine

$N$ elson Institute of Environmental

M edicine

N ew Y ork U niversity M edical C enter

T uxedo, Nueva Y ork

Estados U nidos
James E. Lockey, MD, MS

Professor, Director

D epartment of O ccupational and Environmental $M$ edicine

U niversity of $\mathrm{C}$ incinnati

Cincinnati, $\mathrm{O}$ hio

Estados U nidos

\section{Veikko Louhevaara, PhD}

P rofesor de ergonomía, I nvestigador

U nidad de Ergonomía

D epartamento de Fisiología

U niversidad de K uopio

Instituto Finlandés de M edicina del Trabajo

Kuoppio

Finlandia

\section{Michelle Madelien}

Paulson and Cooper Inc.

Chicago, Illinois

Estados U nidos

\section{Mohd Isa Abd Majid, PhD \\ I fe \\ U nidad del Laboratorio de T oxicología \\ Centro Nacional de T oxicología \\ U niversidad Sains de M alaisia \\ Penang \\ $M$ alaisia}

\section{Nicole Mamelle, PhD}

D irectora de investigación

Instituto $\mathrm{N}$ acional de Investigaciones

Sanitarias y M édicas

$$
\text { Lyon }
$$

Francia

\section{Norman M. Mann, MD}

Chemosensory Clinical R esearch C enter

D epartment of M edicine

U niversity of C onnecticut

Farmington, Connecticut

Estados U nidos

\section{S. Zack Mansdorf, PhD \\ $M$ anaging $D$ irector \\ Liberty International R isk Services \\ Boston, $M$ assachusetts \\ Estados U nidos}

\section{Alfred C. Marcus, PhD}

Director

Division of Behavioral Science R esearch

AM C C ancer R esearch Center

Denver, Colorado

Estados U nidos
Kazimier J. Marek, MD, PhD

Profesor, I efe

D epartamento Clínico

Instituto de M edicina del T rabajo y

Sanidad A mbiental

Sosnowiec

Polonia

\section{Anthony A. Marfin, MD, MPH}

Division of R espiratory Disease Studies

$\mathrm{N}$ ational Institute for O ccupational Safety and $\mathrm{H}$ ealth

M organtown, $V$ irginia occidental

Estados U nidos

\section{Steven B. Markowitz, MD}

Associate Professor, D eputy D irector

Division of Environmental and O ccupational M edicine

$M$ ount Sinai School of M edicine

N ueva Y ork, N ueva Y ork

Estados U nidos

\section{Marco Maroni, MD}

Director

C entro Internacional para la Seguridad de los Plaguicidas

Instituto de M edicina del T rabajo

Milán

Italia

\section{Masali*}

Instituto de Antropología y Etnología

U niversidad de T urín

Turín

Italia

\section{Donald R. Mattison, MD, MS}

Professor, D ean

Graduate School of Public H ealth

U niversity of Pittsburgh

Pittsburgh, Pensilvania

Estados U nidos

\section{A. Mayer, Eng}

J efe

Departamento de $M$ aquinaria y

Dispositivos de Protección

C entro de Investigación

Instituto $\mathrm{N}$ acional de Investigaciones sobre la Seguridad

$\checkmark$ andoeuvre

Francia

\section{Alan Maynard, BA, B Phil}

D epartment of E conomics

$U$ niversity of $Y$ ork

H eslington, Y ork

$R$ eino U nido

\footnotetext{
${ }^{*}$ Colaborador de la 3a edición de esta Enciclopedia. Esta información bibliográfica no se ha actualizado.
} 


\section{Daniel McBain, MA}

$\mathrm{H}$ amilton, $\mathrm{O}$ ntario

Canadá

\section{Michael McCann, PhD, CIH}

Senior Associate E ditor

E ncycl opaedia of $O$ ccupational $H$ ealth and Safety

International L abour $O$ ffice

N ueva Y ork, Nueva Y ork

Estados Unidos

\section{Robert J. McCunney, MD, MPH}

Director

Environmental M edical Service

$M$ assachusetts I nstitute of T echnology

C ambridge, M assachusetts

Estados U nidos

\section{Ross A. McKinnon, PhD}

Lecturer in Pharmaceutical Biotechnology

School of Pharmacy and M edical Sciences

U niversity of South Australia

Adelaide

Australia

Thomas H. McQuiston, MS

University of N orth Carolina

Chapel H ill, Carolina del Norte

Estados U nidos

\section{Dick J. Meertens, Engsaf}

Director de programa

$R$ ama de Estudios y A ctividades relacionadas con la Prevención y

el Seguro de Accidentes

A sociación Internacional de la

Seguridad Social

Ginebra

Suiza

Heather Menzies, BA

School of Canadian Studies

C arleton U niversity

O ttawa, O ntario

Canadá

\section{Donna Mergler, PhD}

Professor

Centre for the Study of Biological Interactions in $\mathrm{H}$ ealth and Environment U niversity of Q uebec-M ontreal M ontreal, Q uebec

Canadá

Franco Merletti, MD, MSc

Profesor de estadística médica

D epartamento de Ciencias M édicas

Universidad de T urín

T urín

Italia
Jacqueline Messite, MD

Clinical Professor

Department of Environmental M edicine

$\mathrm{N}$ ew Y ork U niversity C ollege of M edicine

Nueva Y ork, Nueva Y ork

Estados U nidos

Jean-Jacques Meyer, PhD

Profesor de ergonomía, J efe de laboratorio

Laboratorio de Ergonomía de la V isión

Instituto de Ciencias de la M edicina del Trabajo

Lausanne

Suiza

Jarl-Erik Michelsson, MD, PhD

Loviisa

Finlandia

\section{H. Mierzecki*}

Antiguo jefe

Instituto de D ermatología

Academia de M edicina

Wroclaw

Polonia

\section{R. Rita Misra, PhD}

Laboratory of Comparative

Carcinogenesis

National Cancer Institute

Frederick, $\mathrm{M}$ aryland

Estados U nidos

Toyohiko Miura, MD

Instituto de C iencias del T rabajo

K awasaki

Japón

\section{Willi Momm, MA}

lefe

Rama de R ehabilitación Profesiona

O ficina Internacional del Trabajo

Ginebra

Suiza

John S. Morawetz, ScM

Director

ICWU Center for Worker $\mathrm{H}$ ealth and Safety Education

Cincinnati, 0 hio

Estados U nidos

\section{Vivian K. Morgan, BS}

Acting Chief

Information R esources Branch

National Institute for $\mathrm{O}$ ccupational

Safety and $\mathrm{H}$ ealth

Cincinnati, O hio

Estados U nidos
Sharon L. Morris, BA

Assistant C hair for $\mathrm{C}$ ommunity $\mathrm{O}$ utreach

$D$ epartment of Environmental $\mathrm{H}$ ealth

U niversity of W ashington

Seattle, W ashington

Estados U nidos

April E. Mott, MD

$M$ edical Director

Chemosensory Clinical R esearch $\mathrm{C}$ enter

U niversity of $\mathrm{C}$ onnecticut $\mathrm{H}$ ealth $\mathrm{C}$ enter

Farmington, Connecticut

Estados U nidos

\section{Sonia Muchnick-Baku, MA, ScM}

Director

W ashington Business $\mathrm{G}$ roup on $\mathrm{H}$ ealth

W ashington, DC

Estados U nidos

Vladimir M. Munipov, MS

C atedrático, Profesor de ergonomía

Instituto de Ingeniería R adioeléctrica,

Electrónica y Automatización de M oscú

M oscú

Federación R usa

\section{Lawrence R. Murphy, PhD}

R esearch P sychologist

Applied Psychology and Ergonomics Branch

National Institute for $O$ ccupational Safety and $\mathrm{H}$ ealth

Cincinnati, 0 hio

Estados U nidos

Karl J. Musgrave, DVM, MPH

Wyoming State $\mathrm{H}$ ealth D epartment Cheyenne, W yoming

Estados U nidos

Melvin L. Myers, BS, MPA

D eputy Director

O ffice of Extramural Coordination and Special Projects

$\mathrm{N}$ ational Institute for $\mathrm{O}$ ccupational Safety and $\mathrm{H}$ ealth

Atlanta, G eorgia

Estados U nidos

Friedhelm Nachreiner, Dr rer nat

Profesor de psicología aplicada

U nidad de Psicología del T rabajo y las 0 rganizaciones

U niversidad de Carl von 0 ssietzky

O ldenburg

Alemania 
Pranab Kumar Nag, PhD, DSc, MSc

Subdirector

Consejo de Investigaciones M édicas de la India

Instituto Nacional de M edicina

del Trabajo

Ahmedabad

India

Danie W. Nebert, MD, MS

Professor, Director

Center for Environmental G enetics

U niversity of $\mathrm{C}$ incinnati $\mathrm{M}$ edical $\mathrm{C}$ enter

Cincinnati, O hio

Estados U nidos

\section{Carolyn Needleman, PhD}

Professor, Director

O ccupational/ E nvironmental $\mathrm{H}$ ealth Program

G raduate School of Social Work and Social R esearch

Bryn M awr College

Bryn M awr, Pensilvania

Estados U nidos

\section{Thomas J. Nelson, BS, CIH}

NIHS Inc.

Ardentown, D elaware

Estados U nidos

\section{Toshiteru Okubo, MD, Dr Med Sc}

Profesor, Director

D epartamento de E pidemiología Ambiental

U niversidad de M edicina del T rabajo y Sanidad Ambiental

K itakyushu

Japón

\section{Shauna Olney, LLB, BCL}

Director jurídico

R ama de Libertad de A sociación

$O$ ficina Internacional del T rabajo

Ginebra

Suiza

\section{Peter Orris, MD, MPH}

Associate P rofessor of $M$ edicine

Cook County H ospital

U niversity of Illinois

Chicago, Illinois

Estados U nidos

\section{Dave W. Ortlieb, BS}

Director

Safety and H ealth Department

U nited Paperworkers I nternational U nion

Nashville, T ennessee

Estados U nidos
M. Gerald Ott, PhD, MS

$D$ irector of E pidemiology

BASF Corporation

$M$ ount O live, N ueva J ersey

Estados U nidos

\section{Heinz Otten, Dr rer nat}

J efe de sección

$\mathrm{H}$ auptverband der gewerblichen Berufsgenossenschaften

Sankt Augustin

Alemania

\section{Muneto Ozaki}

R ama de $D$ erecho del T rabajo y R elaciones $L$ aborales

O ficina Internacional del T rabajo

Ginebra

Suiza

Freda L. Paltie, CSW, MPH, CM

F ormer Senior Advisor, Status of W omen

Consultant in $\mathrm{H}$ ealth and Social Policy

$\mathrm{H}$ ealth Canada

O ttawa, O ntario

Canadá

\section{Sheila Pantry, OBE, BA, FLA,} FIInf Sci

Sheila Pantry A ssociates-I nformation Services Consultancy

\section{Sheffield}

R eino U nido

\section{John E. Parker, MD}

Chief

Examination Processing Branch

Division of R espiratory Disease Studies

$\mathrm{N}$ ational Institute for O ccupational Safety and $\mathrm{H}$ ealth

M organtown, V irginia occidental

Estados U nidos

Timo Partanen, PhD, MSc, MPH

Departamento de E pidemiología y Bioestadística

Instituto Finlandés de M edicina del Trabajo

$\mathrm{H}$ elsinki

Finlandia

\section{Glenn Paulson, PhD}

President

Paulson and Cooper Inc.

Jackson H ole, W yoming

Estados U nidos

Dennis J. Paustenbach, PhD, MS

President, Chief E xecutive 0 fficer

$\mathrm{M} \mathrm{CL}$ aren $\mathrm{H}$ art/ Chem Risk ${ }^{\circledR}$

Alameda, California

Estados U nidos
Neil Pearce, PhD

Associate P rofessor

W ellington Asthma R esearch G roup

W ellington School of M edicine

Wellington South

N ueva Zelanda

Daniela Pelclová, MD, PhD

Profesora asociada, I efa

D epartamento de Enfermedades

Profesionales

U niversidad de $\mathrm{C}$ harles

Praga

R epública Checa

Peter L. Pelmear, MD, FFOM

A ctive Staff C onsultant

Department of $O$ ccupational and Environmental $\mathrm{H}$ ealth

St. M ichael's H ospital

T oronto, 0 ntario

Canadá

\section{Edith Perlebach, MD}

I efa de sección

M edicina del T rabajo

$H$ auptverband der gewerblichen

Berufsgenossenschaften

Sankt Augustin

Alemania

\section{Debra A. Perry, M Ed}

President

Perry, Winans and Company

Washington, DC

Estados U nidos

\section{Edward L. Petsonk, MD, CM}

Chief, Clinical Section

Division of R espiratory Disease Studies

$\mathrm{N}$ ational Institute for $\mathrm{O}$ ccupational Safety and $\mathrm{H}$ ealth

M organtown, V irginia occidental

Estados U nidos

\section{Wai-On Phoon, MB, DIH}

P rofessor, $\mathrm{H}$ ead

D epartment of O ccupational $\mathrm{H}$ ealth

U niversity of Sydney

Sidney

Australia

\section{Simon Pickvance, BA}

$O$ ccupational $\mathrm{H}$ ealth $\mathrm{Advisor}$

Sheffield $\mathrm{O}$ ccupational $\mathrm{H}$ ealth Project

Sheffield

R eino U nido 


\section{Robert Ransom, MA}

E specialista

R ama de R ehabilitación Profesional

$O$ ficina I nternacional del T rabajo

Ginebra

Suiza

\section{Jorma Rantanen, MD, PhD}

Director genera

Instituto Finlandés de M edicina del Trabajo

H elsinki

Finlandia

\section{Carl Raskin, BA, Dip Ed}

Coordinator

G lobal Applied Disability R esearch and Information N etwork on Employment and $T$ raining

Canadian L abour Force D evelopment Board

$\mathrm{N}$ epean, $\mathrm{O}$ ntario

Canadá

\section{Dzulkifli Abdul Razak, MSc}

Profesor, Director

Centro Nacional de T oxicología

U niversidad Sains de M alaisia

Penang

M alaisia

\section{Paule Rey, MD, MPH}

Profesora emérita

Facultad de M edicina

U niversidad de Ginebra

Ginebra

Suiza

\section{Annie Rice, BSc}

Directora

H ealth Safety Environment Consultants

Petit Bornand

Francia

Peter Richter, Dr rer nat

Profesor

Institut für Arbeits, 0 rganisations und Sozialpsychologie

U niversidad T ecnológica de Dresde

Dresde

Alemania

\section{Wolfgang von Richthofen}

E specialista en inspección del trabajo $R$ ama de $A$ dministración del T rabajo

O ficina I nternacional del T rabajo

Ginebra

Suiza
Hilkka Riihimäki, MD, Dr med sci

D irector

Departamento de Epidemiología y

Bioestadística

Instituto Finlandés de M edicina del Trabajo

$\mathrm{H}$ elsinki

Finlandia

\section{Sally Roberts, PhD}

Clinical Scientist

Centre for Spinal Studies

Robert J ones and Agnes H unt $\mathrm{O}$ rthopaedic and District H ospital

O swestry, Shropshire

Reino Unido

\section{Dilys Robertson, BA}

Consultant

$\mathrm{O}$ ccupational $\mathrm{H}$ ealth and Safety

Toronto, 0 ntario

Canadá

\section{Walter Rohmert, Prof Dr-Ing}

Profesor emérito

Institut für Arbeitswissenschaft

T echnische H ochschule Darmstadt

Darmstadt

Alemania

\section{William N. Rom, MD, MPH}

Professor of $M$ edicine

Division of Pulmonary and Critical Care $M$ edicine

N ew Y ork U niversity

Nueva Y ork, Nueva Y ork

Estados U nidos

\section{Linda Rosenstock, MD, MPH}

Director

National Institute for 0 ccupational Safety and $\mathrm{H}$ ealth

Washington, DC

Estados U nidos

\section{Clara Sue Ross, MD, JD}

President

Environmental and $\mathrm{O}$ ccupational $\mathrm{H}$ ealth Consultants Inc.

Cincinnati, O hio

Estados U nidos

\section{John Rudge, MBA}

Senior L ecturer and OH S P rogrammes Coordinator

School of $M$ anagement

University of South Australia

Adelaide

Australia
Jon Rudnick, MD, MPh, MSc

Corporate M edical Director

D ow Corning Corporation

$M$ idland, M ichigan

Estados U nidos

John W. Ruser, PhD, MA

Chief

Compensation R esearch Group

U nited States Bureau of $L$ abor Statistics

W ashington, DC

Estados U nidos

\section{Ragnar Rylander, MD, PhD}

Profesor

D epartamento de M edicina A mbiental

U niversidad de G öteborg

Göteborg

Suecia

\section{David L.S. Ryon, MD}

Division of Pulmonary and Critical Care M edicine

New Y ork U niversity

Nueva Y ork, N ueva Y ork

Estados U nidos

\section{Sheldon W. Samuels, AB}

$F$ ormer D irector of $\mathrm{H}$ ealth, Safety and $E$ nvironment

Industrial U nion D epartment

A merican Federation of $L$ abor and

C ongress of I ndustrial 0 rganizations

Washington, DC

Estados U nidos

\section{Andries F. Sanders, PhD}

P rofesor de psicología cognitiva

D epartamento de Psiconomía

U niversidad Pública

Amsterdam

Países Bajos

\section{Rodolfo Saracci, MD}

Director de investigación

Consejo $\mathrm{N}$ acional de Investigación

Pisa

Italia

Annie J. Sasco, MD, Dr PH

J efa

Programa de Epidemiología para la

Prevención del Cáncer

Agencia Internacional para la

Investigación sobre el Cáncer

Lyon

Francia 
Denis Sasseville, MD, FRCPC Associate $P$ rofessor of $M$ edicine ( $D$ ermatology) M cG ill U niversity

M ontreal, Q uebec

Canadá

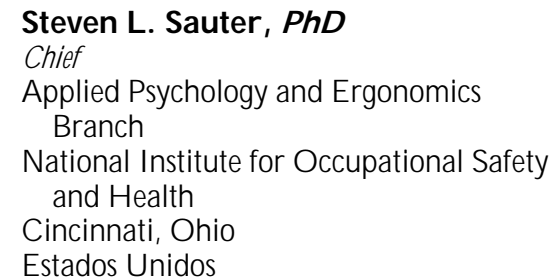

\section{Marianne Saux, MD}

J efa

D epartamento de M edicina del T rabajo

Directora del Servicio de Inspección $M$ édica

M inisterio de T rabajo

París

Francia

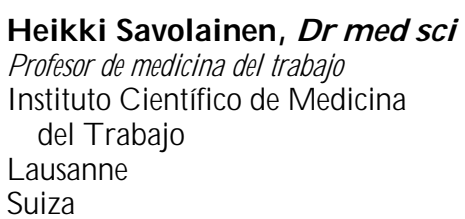

Richard Schilling, MD, DSc

0 ccupational $\mathrm{H}$ ealth Consultant

Londres

R eino U nido

William J. Schneider, MD, MPH

Director of $\mathrm{H}$ ealth Services

J.P. M organ and $\mathrm{Co}$. Inc.

Nueva Y ork, N ueva Y ork

Estados U nidos

Wolfram D. Schneider, Prof Dr med

I fe

D epartamento de E fectos en la Salud de Sustancias Peligrosas

Instituto Federal de Seguridad y Salud en el Trabajo

Berlín

Alemania

Steven M. Schrader, PhD
Chief
Functional T oxicology Section
National Institute for O ccupational Safety
and H ealth
Cincinnati, O hio
Estados U nidos

Horst Schulz, Dipl Volkswirt

I efe

Departamento de Informática y D ocumentación

$\mathrm{H}$ auptverband der gewerblichen Berufsgenossenschaften

Sankt Augustin

Alemania

\section{Susan Scott-Parker, BA}

Chief Executive

Employers' Forum on Disability

Londres

R eino U nido

\section{Patrick Sébastien, PhD}

Scientific D irector

Institute of $\mathrm{O}$ ccupational $\mathrm{H}$ ealth and Safety R esearch

M ontreal, Q uebec

Canadá

\section{Marie-Claire Séguret}

$\mathrm{R}$ ama de Condiciones de T rabajo y Servicios de Bienestar

O ficina Internacional del T rabajo

Ginebra

Suiza

Anna Maria Seppäläinen, MD, PhD Jefa

División de N eurofisiología Clínica

U niversidad de $\mathrm{H}$ elsinki

H elsinki

Finlandia

\section{Lowell E. Sever, PhD}

Program D irector for Public $\mathrm{H}$ ealth Sciences Battelle Seattle R esearch C enter

Seattle, Washington

Estados U nidos

\section{Erwin Seyfried, PhD}

Profesor de psicología social, D irector

U nidad de Investigación sobre

Formación Profesional,

M ercado de T rabajo y Evaluación

Berlín

Alemania

\section{Behrouz Shahandeh, MA}

A sesor de drogas y al cohol

$R$ ama de $R$ ehabilitación Profesional

O rganización Internacional del T rabajo

Ginebra

Suiza
Houshang Shahnavaz, PhD, MSc

Profesor de ergonomía industrial

Director

Centro de E rgonomía de los Países en Vías de D esarrollo

U niversidad T ecnológica de Luleå

Luleå

Suecia

\section{Steven Short, DO}

M edical 0 fficer

Division of R espiratory Disease Studies

National Institute for $O$ ccupational Safety and $\mathrm{H}$ ealth

M organtown, V irginia occidental

Estados U nidos

Donald E. Shrey, PhD

Associate Professor

Department of Physical M edicine and R ehabilitation

$U$ niversity of $\mathrm{C}$ incinnati $\mathrm{M}$ edical $\mathrm{C}$ enter

Cincinnati, O hio

Estados Unidos

Joel Shufro, PhD

Executive D irector

$\mathrm{NYCOSH}$

Nueva Y ork, Nueva Y ork

Estados U nidos

\section{Ellen Silbergeld, PhD}

Professor of E pidemiology and Pathology

$U$ niversity of $M$ aryland at Baltimore Baltimore, $\mathrm{M}$ aryland

Estados U nidos

\section{Leif Simonsen, PhD}

Departamento de T oxicología y Biología Instituto $\mathrm{N}$ acional de $\mathrm{M}$ edicina del

Trabajo

Copenhague

Dinamarca

William T. Singleton, DSc, MA

Professor E meritus of A pplied Psychology

Aston U niversity

Birmingham

Northumberland

Reino U nido

\section{Susan Sink, MFA}

Artist

Chicago, Illinois

Estados Unidos 


\section{Gisela Sjøgaard, PhD, Dr med sci}

Directora

Departamento de Fisiología

Instituto Nacional de M edicina del

Trabajo

Copenhague

Dinamarca

\section{Juhani Smolander, PhD \\ Investigador \\ Instituto Finlandés de M edicina del Trabajo \\ Vantaa \\ Finlandia}

\section{David Snowball, PhD}

Deputy D irector G eneral's O ffice

$\mathrm{H}$ ealth and Safety Executive

$L$ ondres

Reino U nido

\section{Marja Sorsa, PhD}

Directora

M inisterio de E ducación

$\mathrm{H}$ elsinki

Finlandia

Colin L. Soskolne, PhD

P rofessor, D irector of $G$ raduate $T$ raining Department of Public H ealth Services U niversity of Alberta

Edmonton, Alberta

Canadá

\section{Jerry Spiegel, MA, MSc}

Director

Pollution Prevention

$M$ anitoba Environment

Winnipeg, M anitoba

Canadá

Heide Stark, Dr med

Departamento de Epidemiología

Instituto Federal de Seguridad y Salud en el Trabajo

Berlín

Alemania

\section{Jeanne M. Stellman, PhD}

Directora de edición

Enciclopedia de salud y seguridad en el trabajo

O ficina Internacional del Trabajo

Ginebra

Suiza

School of Public H ealth

Columbia U niversity

Nueva Y ork, Nueva Y ork

Estados U nidos

\section{Steven D. Stellman, PhD, MPH}

Chief

Division of Epidemiology

American $\mathrm{H}$ ealth Foundation

Nueva Y ork, N ueva Y ork

Estados U nidos

\section{Craig R. Stenberg, PhD}

Director

O ccupational/ M ental $\mathrm{H}$ ealth Programs

D epartments of Psychiatry and

Community and Family $M$ edicine

Duke U niversity M edical School

Durham, C arolina del N orte

Estados U nidos

\section{James H. Stewart, PhD, CIH}

School of Public H ealth

$\mathrm{H}$ arvard U niversity

Boston, M assachusetts

Estados U nidos

B.J. Stiles, BD, BA

President, Chief Executive 0 fficer

National AIDS Fund

Washington, DC

Estados U nidos

\section{Phillip W. Strine, BA}

Special Assistant to the Assistant Surgeon General and $\mathrm{D}$ eputy Director, Public $\mathrm{H}$ ealth Advisor

$N$ ational Institute for $O$ ccupational Safety and $\mathrm{H}$ ealth

Atlanta, G eorgia

Estados U nidos

\section{Zhi Su, MD, MPH}

Director

D epartamento de Inspección y Supervisión Sanitaria

M inisterio de Sanidad

Pekín

China

\section{Haruko Suzuki}

División de Información Científica

Instituto de Ciencias del Trabajo

K awasaki

Japón

\section{Ken Takahashi, MD, D MSc, MPH}

Profesor asociado

Departamento de Epidemiología

Ambiental

U niversidad de M edicina del T rabajo y Ambiental

K itakyushu

Japón
Jukka Takala, Dr Tech, MSc

Je efe

R ama de Seguridad y Salud en el Trabajo

O ficina Internacional del T rabajo

Ginebra

Suiza

Krishna Talluri, MB

D epartment of Psychiatry

Duke U niversity M edical Center

Durham, Carolina del N orte

Estados U nidos

\section{Rachael F. Taylor, LLB}

Consultora

O ficina Internacional del T rabajo

Ginebra

Suiza

Spomenka Telišman, DSc, MSc

Consultor científico

Instituto de Investigaciones M édicas y

M edicina del T rabajo

Zagreb

Croacia

\section{Benedetto Terracini, MD}

Antiguo jefe

U nidad de Epidemiología del Cáncer

H ospital U niversitario y U niversidad de Turín

Turín

Italia

\section{Ulrike Tittel bach, Dr med}

D epartamento de Efectos en la Salud de Sustancias Peligrosas

Instituto Federal de Seguridad y

Salud en el T rabajo

Berlín

Alemania

\section{Lori Todd, PhD, MS}

Associate P rofessor

D epartment of Environmental Science and Engineering

U niversity of N orth Carolina Chapel H ill, Carolina del Norte Estados U nidos

\section{Angela K. Traiforos, M Ed}

E xecutive $D$ irector

Center for Administration, R ehabilitation and Employment Services

International Association of $M$ achinists

U pper M arlboro, M aryland

Estados U nidos 
Anne Trebilcock, JD

D irectora jurídica

O ficina de A sesoramiento Jurídico

O ficina Internacional del T rabajo

Ginebra

Suiza

\section{Benjamin F. Trump, MD}

Professor, Chair

D epartment of Pathology

School of M edicine

$U$ niversity of $\mathrm{M}$ aryland

Baltimore, $M$ aryland

Estados U nidos

\section{Ulf Ulfvarson, PhD}

P rofesor de ergonomía industrial

D epartamento de T ecnología

A mbiental y Ciencias del Trabajo

R eal Instituto de T ecnología

Estocolmo

Suecia

\section{Eberhard Ulich, Prof Dr, Dr hc \\ Profesor \\ D epartamento de Psicología del T rabajo y las 0 rganizaciones \\ Instituto Federal Suizo de Tecnología \\ Zurich \\ Suiza}

Jill P.G. Urban, PhD

Senior R esearch F ellow

Laboratory of Physiology

U niversity of 0 xford

Oxford

R eino U nido

\section{Antero Vähäpassi, MSc}

A sesor técnico

R ama de Administración del T rabajo

O ficina Internacional del T rabajo

Ginebra

Suiza

\section{Harri Vainio, MD, PhD \\ J efe \\ U nidad de Q uimioprevención \\ Agencia I nternacional para la Investigación sobre el Cáncer \\ Lyon \\ Francia}

\section{José A. Valciukas, PhD}

Associate P rofessor, D irector

Psychology Internship T raining Program

$L$ incoln $M$ edical and $M$ ental $H$ ealth

Center

N ueva Y ork, N ueva Y ork

Estados U nidos
Kees A. van der Heijden, Dr

Director

División de Bilthoven

Centro Europeo de M edio Ambiente

y Salud de la O rganización M undial de la Salud

Bilthoven

Países Bajos

\section{Henk van Loveren, PhD}

J efe

Sección de Inmunobiología y H ematología

Laboratorio de Patología e Inmunobiología

Instituto $\mathrm{N}$ acional de Salud Pública y M edio Ambiente

Bilthoven

Países Bajos

Joachim Vedder, Dipl-Ing, MS

Departamento de Ergonomía

Institut für A rbeitsphysiologie

U niversidad de D ortmund

Dortmund

Alemania

\section{María Luz Vega Ruiz, Lab Law}

E specialista en derecho del trabajo y relaciones laborales

O ficina Internacional del T rabajo

Ginebra

Suiza

\section{Marc Vericel, Dr d’État en droit}

Profesor

Facultad de D erecho

Universidad de Saint-Etienne

Saint-Etienne

Francia

\section{Eira Viikari-Juntura, MD,}

\section{Dr med sci}

U nidad de Investigación

M usculosquelética

D epartamento de Fisiología

Instituto Finlandés de M edicina del Trabajo

$\mathrm{H}$ elsinki

Finlandia

\section{Paolo Vineis, MD}

Subdirector

U nidad de E pidemiología del Cáncer

$\mathrm{H}$ ospital C entral y U niversidad

Turín

Italia

Eva Vingård, MD, PhD

M édica, I nvestigadora

Instituto $\mathrm{N}$ acional del T rabajo

Solna

Suecia

\section{Serge Volkoff}

D irector

Centro de Investigación y Estudios sobre

la Edad y la Población Activa

París

Francia

Joseph G. Vos, DVM, PhD

efe

Laboratorio de Patología e

Inmunobiología

Instituto N acional de Salud Pública y

M edio A mbiente

Bilthoven

Países Bajos

\section{Michael P. Waalkes, PhD}

Chief

Inorganic Carcinogenesis Section

$\mathrm{N}$ ational Cancer Institute

Frederick, $\mathrm{M}$ aryland

Estados U nidos

\section{Gregory R. Wagner, MD}

D irector

Division of R espiratory Disease Studies

N ational Institute for $\mathrm{O}$ ccupational Safety and $\mathrm{H}$ ealth

M organtown, V irginia occidental

Estados U nidos

Nina B. Wallerstein, Dr PH, MPH

Associate P rofessor

Department of Family and C ommunity

M edicine

U niversity of $\mathrm{New} \mathrm{M}$ exico

Albuquerque, N uevo M éxico

Estados U nidos

Jung-Der Wang, MD, ScD, MIH

Profesor, Director

Instituto de M edicina del T rabajo e

$\mathrm{H}$ igiene Industrial

Escuela de Salud Pública de la

U niversidad Nacional de T aiwán

Taipei

China

Leon J. Warshaw, MD

Clinical Professor

D epartment of Environmental M edicine

N ew Y ork U niversity

N ueva Y ork, Nueva Y ork

Estados U nidos

Philip G. Watanabe, PhD, DABT

T oxicology C onsultant

Blaine, Washington

Estados U nidos 
David Howe Wegman, MD, MS

Professor, Chair

D epartment of W ork Environment U niversity of M assachusetts-L owell

L owell, M assachusetts

Estados U nidos

Elisabete Weiderpass, MD, MSc

Departamento de Epidemiología del Cáncer

U niversidad de U ppsala

Uppsala

Suecia

\section{Merri Weinger, MPH}

O ficina de Sanidad A mbiental G lobal e Integrada

O rganización M undial de la Salud

Ginebra

Suiza

Peter J.M. Westerholm, MD

Profesor de epidemiología del trabajo

Instituto $\mathrm{N}$ acional del T rabajo

Solna

Suecia

\section{Julian Wilbourn, BSc}

Científico

Unidad de Identificación y Evaluación de $C$ arcinógenos

A gencia Internacional para la Investigación sobre el Cáncer

Lyon

Francia

\section{Mary S. Wolff, PhD}

Professor of Community M edicine

$M$ ount Sinai School of M edicine

Nueva Y ork, Nueva Y ork

Estados U nidos

\section{Patrisha Woolard, BA}

M ount Sinai School of M edicine

Nueva Y ork, Nueva Y ork

Estados U nidos

\section{Frank B. Wright}

Director

European $\mathrm{O}$ ccupational $\mathrm{H}$ ealth and Safety Law U nit

U niversity of Salford

$M$ anchester

Reino U nido

\section{H. Beric Wright, MB, BS}

F ormer M edical D irector

British U nited Provident Association

Bucks

R eino U nido

\section{Michael J. Wright, MS}

D irector

$H$ ealth, Safety and Environment Department

U nited Steelworkers of America

Pittsburgh, Pensilvania

Estados U nidos

\section{Lucy Yardley, PhD, MSc}

Senior L ecturer in P sychology

D epartment of Psychology

U niversity C ollege-L ondon

Londres

R eino U nido

\section{Annalee Yassi, MD, MSc}

Director

O ccupational and Environmental M edicine

$\mathrm{H}$ ealth Sciences $\mathrm{C}$ entre and $\mathrm{U}$ nit

$U$ niversity of $M$ anitoba

Winnipeg, M anitoba

Canadá

\section{Shelia Hoar Zahm, ScD}

D eputy Chief

O ccupational Epidemiology Branch

National $C$ ancer Institute

R ockville, M aryland

Estados U nidos

\section{Jan E. Zejda, MD, PhD}

J efe

D epartamento de E pidemiología Instituto de M edicina del Trabajo y

Sanidad A mbiental

Sosnowiec

Polonia

\section{Joanne Zurlo, PhD}

Associate Director

Johns $\mathrm{H}$ opkins Center for Alternatives to Animal T esting

Baltimore, M aryland

Estados U nidos 



\title{
Para la versión inglesa original
}

\author{
Sarah Alvarez \\ $M$ aria Arteta \\ $\mathrm{M}$ ay Ballerio-H ofman \\ Lillian Benjamin \\ M ichel Berka \\ Walter Benjamin \\ Christian Bolufer \\ Claude Chaperon \\ $\mathrm{K}$ yle $\mathrm{Creane}$ \\ D enis Cullinan \\ Johanna de V ries \\ $R$ obert $D$ ees \\ $M$ argaret Fennessy \\ $R$ aymond Figuières \\ Betty G oldman \\ Susan G uthridge \\ $\mathrm{K}$ athleen Susan H urst \\ Claudia H ommel \\ R achael H orner \\ Sanna Immonen \\ $\mathrm{L}$ isa $\mathrm{K}$ ellner \\ Diana Signe K line \\ Nana-Ekua L eigh \\ R obert L euze \\ Elizabeth $M$ ahiga \\ Christiane M elin \\ Jacky M erteau
}

\author{
John M cK enna \\ Julie N ayler \\ Catherine $\mathrm{H}$. Perring \\ Peter Perring \\ Bodhani Pieris \\ Giles R eed \\ $K$ irsten R eed \\ John G. Rodwan, Jr. \\ N ancy J. R odwan \\ David R osenweig \\ David Rowley \\ $O$ riele $\mathrm{R}$ ovaletti \\ $D$ aniel $R$ uffieux \\ Jacques $P$. T remblet \\ Steven Sacks \\ Barbara Sandi \\ Gabor Sandi \\ Anneliese Shulte \\ Jonathon Stampf \\ Fred Stanton \\ Prabha Sundaram \\ Juan T enorio \\ Jennifer $V$ aldes \\ Tracy W eber \\ Berit W iding-Pry \\ Sydney G. Williams \\ Su Zen
}

\section{Para la versión española}

$\mathrm{H}$ an colaborado de forma desinteresada en las diversas fases de correcciones técnicas los/ las siguientes expertos/ expertas.

Por el Instituto Nacional de Seguridad e Higiene en el Trabajo (E spaña), coordinados por D ña. M a Carmen Guardiola H uertas:

\author{
I gnacio Cáceres A rmendariz \\ Dolores Carreño M artín \\ Pilar Casla Benito \\ R osa Cuenca Alvarez \\ Antonio De la I glesia \\ $M \stackrel{a}{a}$ Angeles Del $\mathrm{H}$ oyo Delgado \\ $R$ afael $D$ enia $C$ andel \\ $M$ anuel $F$ idalgo $V$ ega \\ $X$ avier Guardino Solá \\ Andrés $\mathrm{H}$ arto Castaño \\ J esús L edesma de M iguel \\ Jerónimo M aqueda Blasco \\ Luis V icente M artín M artín \\ Esther M artín de Dios \\ L ourdes Pacheco R eyna \\ Pilar Pancorbo Aguilera \\ Joaquín Pérez Nicolás \\ Javier Pinilla García \\ Jesús Portillo G arcía-Pintos \\ T omás Sancho Figueroa \\ Alberto Sanz M erinero \\ M a D olores Solé G ómez \\ M a Félix Villar Fernández
}

Por el Instituto Nacional de M edicina y Seguridad en el Trabajo (España), coordinados por D. E duardo M ascías Saracho:
$M$ anuel Callejas Berdonés
Luis C onde Salazar
M anuel Domínguez Carmona
José $M$ anuel Fernández $O$ nieva
Carlos $\mathrm{G}$ onzalo G uisande
Javier $M$ ascías $C$ adavid
Javier Sanz G onzález
José M iguel Seoane R uiz 



\section{SUMARIO}

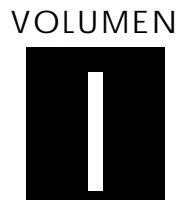

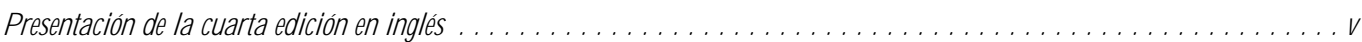

Extractos de presentaciones de ediciones anteriores $\ldots \ldots \ldots \ldots \ldots \ldots \ldots \ldots \ldots \ldots \ldots \ldots \ldots \ldots \ldots \ldots \ldots \ldots \ldots$

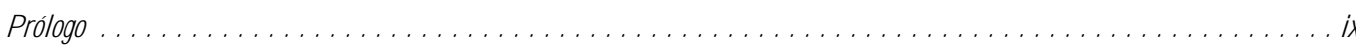

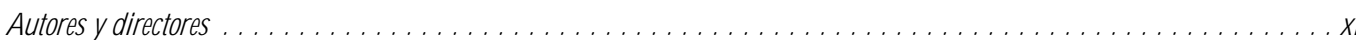

PARTE I. EL CUERPO HUMANO

\section{Sangre}

Bernard D. Goldstein, Director del capítulo

Sistema hematopoyético y linfático B ernard D. Goldstein 1.2

Leucemia, linfomas malignos y mieloma múltiple . ................ T imo Partanen, Paolo B offetta, E lisabete W eiderpass

\section{Cáncer}

Paolo Boffetta, Director del capítulo

Introducción.

N eil Pearce, Paolo B offetta y M anolis Kogevinas 2.2

Cancerígenos profesionales .............. . Paolo B offetta, R odolfo Saracci, M anolis Kogevinas, J ulian W ilbourn y H arri Vainio 2.4

Cáncer de origen ambiental . .................... B ruce K. Armstrong y Paolo B offetta

Prevención. . Per Gustavsson

\section{Sistema cardiovascular}

\section{y G erd H euchert, Directo}

Introducción

M orbilidad y mortalidad cardiovascular

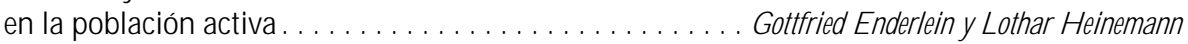

El concepto de factor de riesgo en la enfermedad cardiovascular. . . . . . . . . . . . . . . . . . . L othar $\mathrm{H}$ énemann, Gottfried E nderlein y $\mathrm{H}$ éde Stark 3.5

Programas de rehabilitación y prevención . . . . . . . . . . L L othar H énemann y Gottfried E nderlein 3.9

\section{PELIGROS FISICOS, QUIMICOSY BIOLOGICOS}

Factores físicos $\mathrm{H}$ eide Stark y $\mathrm{G}$ erd $\mathrm{H}$ euchert 3.11

M ateriales químicos peligrosos. . U Irike T ittelbach y W olfram D ietmar Schneider

Peligros biológicos R egina J äckel, U Irike T ittelbach y W olfram D ietmar Schneider

4. Aparato digestivo

H eikki Savolainen, Director del capítulo

A parato digestivo . G. Frada 4.2

Boca y dientes. F. Gobbato 4.3

Hígado. G eorge Kazantzis 4.5

U Icera péptica. K.S. Cho 4.8

Cáncer hepático T imo Partanen, T imo Kauppinen, Paolo B offetta y E lisabete W eiderpass

Cáncer pancreático T imo Partanen, T imo Kauppinen, Paolo B offetta y E lisabete W eiderpass 
5. Salud Mental

Joseph J. H urrell, Lawrence R. Murphy, Steven L. Sauter y Lennart Levi, D irectores del capítulo

Trabajo y salud mental . . I rene L.D. H outman y M ichie A.J. Kompier 5.2

Psicosis relacionadas con el trabajo . Craig Stenberg, J udith $\mathrm{H}$ older y K rishna Tallu

EST ADO DE ANIMO Y AFECTO

Depresión J ay L asser y J effrey P. Kahn

Ansiedad relacionada con el trabajo ... Randal D. B eaton

Trastorno por estrés postraumático y su relación con la salud laboral y la prevención de lesiones. $M$ ark B raverman

El estrés y el agotamiento, y sus implicaciones en el medio ambiente de trabajo H erbert I. F reudenberger 5.17

Trastornos cognitivos . Catherine A. H eaney 5.19

$\mathrm{K}$ aroshi: muerte por exceso de trabajo. Takashi $\mathrm{H}$ aratani

6. Sistema musculosquelético

Hilkka Riihimäki y Eira Viikari-juntura, Directores del capítulo

Visión general . H ilkka Riihimäki 6.2

M úsculos. Gisela Sjøgaard 6.2

Tendones. T homas J. Armstrong 6.4

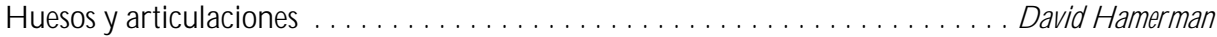
6.6

Discos intervertebrales Sally R oberts y J ill P.G. U rban

Región lumbar .. . H ilkka Riihimäki 6.11

Región de la columna dorsal

J arl-E rik M ichelsson

Cuello . Asa Kilbom 6.16

Hombro $M$ ats $\mathrm{H}$ agberg 6.19

Codo. E ira Viikari-J untura 6.23

Antebrazo, muñeca y mano E ira Viikari-J untura

Cadera y rodilla E va Vingård

Pierna, tobillo y pie. . J arl-E rik M ichelsson

0 tras enfermedades.

$M$ arjatta L érisalo-R epo

\section{Sistema nervioso}

Donna Mergler, Directora del capítulo

Sistema nervioso: visión general . . . . . . . . . . . . . . . . . D onna M ergler y $J$ osé A. Valciukas A natomía y fisiología

A gentes químicos neurotóxicos Peter A rlien-Søborg y Leif Simonsen 7.9

M anifestaciones de intoxicación aguda y crónica precoz. . . . . . . . . . . . . . D onna M ergler 7.15

Síndromes clínicos asociados a neurotoxicidad . . . . . . . . . . . . . . . . . . . . Robert G. Feldman 7.18

D eterminación de los déficit neurotóxicos ...................... D onna M ergler 7.22

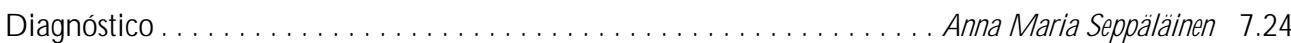

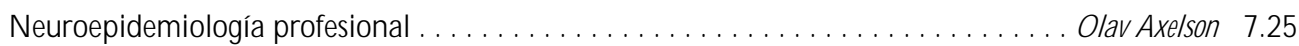

8. Sistemas renal y urinario G eorge $P$. H emstreet, Director del capítulo Los sistemas renal y urinario. . . . . . . . . . . . . . . . . . . . G eorge P. H emstreet 8.2 Cánceres renales y urinarios ....... . T imo Partanen, H arri Vainio, Paolo B offetta y E lisabete W eiderpass 8.11

\section{Sistema reproductor G Gace Kawas Lemasters, Directora del capítulo}

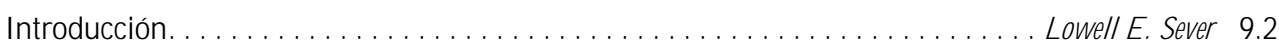
Introducción a la función reproductora masculina y femenina . . . . . . . . . . . D onald R. M attison 9.4 
El sistema reproductor masculino y la toxicología Steven Schrader y Grace Kaw as L emasters

L a estructura del sistema reproductor femenino y la vulnerabilidad de los órganos diana . . . . . . . . . . . . . . . . . . . . . . . . D onald R. M attison 9.9

Exposiciones profesionales maternas y resultados adversos en el embarazo Grace Kawas L emasters 9.11

El parto pretérmino o prematuro y el trabajo . . . . . . . . . . . . . . . Nicole M amelle 9.16

Exposiciones del recién nacido a sustancias tóxicas de origen industrial y ambiental . ........................ W ary S. W olff y Patrisha M. Woolard 9.19

La protección de la maternidad en la legislación . . . . . . . . . . . . . . M arie Claire Séguret 9.25

Recomendaciones de Estados U nidos en relación con el embarazo y el trabajo Leon J. W arshaw

10. Aparato respiratorio Alois David y G regory $R$. Wagner, D irectores del capítulo Estructura y función ..................................... orton Lippmann

Examen de la función pulmonar..................... U If U Ifvarson y M onica $D$ ahlquist

Enfermedades causadas por irritantes respiratorios y productos químicos tóxicos....................... D avid L.S. R yon y W illiam N. R om

Asma ocupacional . George F riedman-J iménez y E dward L. Petsonk 10.20

E nfermedades causadas por polvos orgánicos. .......... R agnar R ylander y R ichard $S$. F. Schilling

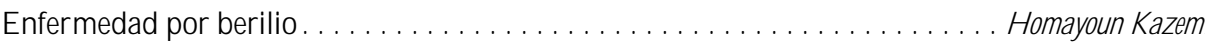
10.31

Neumoconiosis: definición Alois D avid

Clasificación internacional de radiografías de neumoconiosis de la O IT . ........ M ichel Lesage 10.37 E tiopatogenia de la neumoconiosis. . . . . . . . . . . . . . . . . . Patrick Sébastien y R aymond Bégin 10.40 Silicosis . . . . . . . . . . . . . . . . . . . . . . . . . . . . . . . . ohn E. Parker y G regory R. W agner 10.48

Enfermedades pulmonares de los mineros del carbón

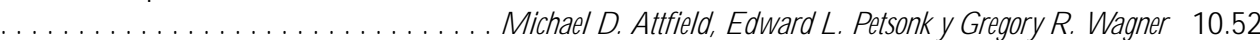
Enfermedades relacionadas con el amianto . . . . . . . . . . . . . . . . . . . . . M argaret $R$. B ecklake 10.57 Enfermedades por metales pesados. . . . . . . . . . . . . . . . . . . G erolamo Chiappino 10.71 A parato respiratorio: la variedad de las neumoconiosis. . . . . . . Steven R. Short y E dward L. Petsonk 10.75 Enfermedad pulmonar obstructiva crónica................ Kazimierz M arek y J an E. Z ejda E fectos de las fibras artificiales sobre la salud ............... ames $E$. L ockey y C lara S. R oss 10.79 Cáncer respiratorio . . . . . . . . . . . . . . . . . . . . . . . . . Paolo $B$ offetta y $E$ lisabete W eiderpass Infecciones pulmonares de origen ocupacional M arcel-André B oillat

Trastornos auditivos inducidos por productos químicos .. Peter J acobsen

Trastornos auditivos provocados por agentes físicos Peter L. Pelmear

Equilibrio... . Lucy Yardley

Visión y trabajo .............................. Paule R ey y $\mathrm{J}$ ean- $\mathrm{J}$ acques $M$ eyer

Gusto A pril E. M ott y N orman M ann

O Ifato A pril E. M ott

Receptores cutáneos. R obert $D$ ykes y $D$ anied $M C B$ ain

\section{Enfermedades de la piel Louis-Philippe Durocher, Director del capítulo} Visión general: enfermedades profesionales de la piel. . . . . . . . . . . . . D onald $]$. B irmingham Cáncer de piel no melanocítico . . . . . . . . . . . . E lisabete W eiderpass, T imo Partanen, Paolo B offetta M elanoma maligno . . . . . . . . . . . . . . . . T imo Partanen, Paolo B offetta, E lisabete W eiderpass 
Dermatitis de contacto profesionales.

D enis Sasseville

Prevención de las dermatosis profesionales.

L ouis-Phillipe D urocher

Distrofia ungüeal profesional .

C.D. Calnan

Estigmas

H. M ierzecki

13. Condiciones del entorno

H oward M. Kipen, Director del capítulo

Condiciones del entorno: introducción . ..................... oward M . Kipen

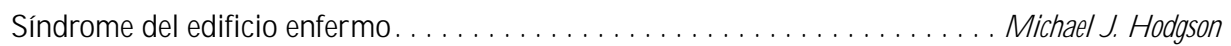

M ultisensibilidad química

. M ark R. Cullen

\section{PARTE II. ASISTENCIA SANITARIA}

\section{Primeros auxilios y servicios médicos de urgencia}

\section{Antonio J. Dajer,}

Primeros auxilios . Antonio J. Dajer

Lesiones craneoencefálicas .

\section{Protección y promoción de la salud}

Jacqueline Messite y Leon J. Warshaw, Directores del capítulo

Protección y promoción de la salud: visión general .......... L eon J. W arshaw y J acqueline M essite Promoción de la salud en el lugar de trabajo . . . . . . . . . . . . . . . onathan $E$. Fielding Promoción de la salud en el lugar de trabajo: Inglaterra Leon Kreitzman 15.13

Promoción de la salud en las pequeñas organizaciones: experiencia de Estados $U$ nidos................. Sonia M uchnick-Baku y L eon J. W arshaw

Función del servicio de salud de los empleados en los programas de prevención . J ohn W.F. Cowell

Programas de mejora de la salud en M aclaren Industries, Inc.: estudio de caso.

Función del servicio de salud en el trabajo en los programas de prevención:

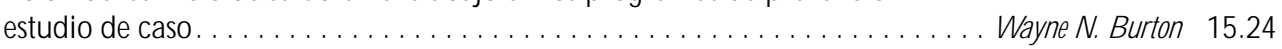

Promoción de la salud en el lugar de trabajo en Japón . . . . . . . . . . . . . Toshiteru 0 kubo 15.27

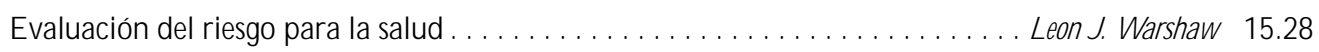

Programas de ejercicio físico y de mantenimiento de la capacidad física para el trabajo: un activo de la organización ...................... ames Corry 15.32

Programas de nutrición en el lugar de trabajo . . . . . . . . Penny M . Kris-E therton y J ohn W. Farquhar 15.37

Control del tabaco en el lugar de trabajo. . . . . . . . . . . . . . . . . . on R udnick 15.42

Los programas de control del tabaco en M errill Lynch and Company, Inc.: estudio de caso . . . . . . . . . . . . . . . . . . . . . . . . . . . . Kristan D. Goldfein 15.47

Prevención y control del cáncer.................... Peter $G$ reenwald y L eon J. W arshaw 15.48

La salud de la mujer . . . . . . . . . . . . . . . . . . . . . . . Patricia A. Last 15.54

Estudio de caso: el programa de mamografías de M arks and Spencer . . . . . . . . . illian H aslehurst 15.60

Estrategias en el lugar de trabajo para la mejora de la salud maternal e infantil: experiencias de los trabajadores en Estados U nidos . . . . . M aureen P. Corry y E llen C utler 15.62

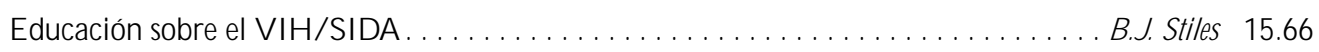
Protección y promoción de la salud: enfermedades infecciosas . . . . . . . . . W illiam J. Schneider 15.69

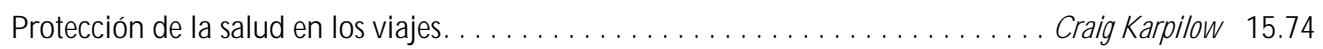

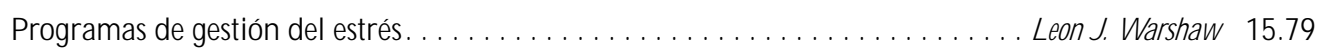

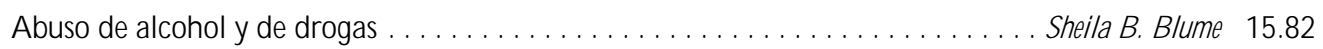


Programas de asistencia a los empleados . . . . . . . . . . . . . . . Sheila $H$. A kabas

L a salud en la tercera edad: programas de prejubilación. . . .

H. B eric W right

15.91

Recolocación.

Saul G. G runer y L eon J. W arshaw

16. Servicios de salud en el trabajo

Igor A. Fedotov, Marianne Saux y Jorma Rantanen, D irectores del capítulo

N ormas, principios y enfoques de los servicios de salud

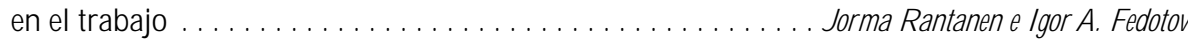

Los servicios de la salud en el trabajo y la práctica ................. Georges $H$. Coppée 16.2

Inspección médica del trabajo en Francia . . . . . . . . . . . . . . . . . . . . . M arianne Saux

Los servicios de salud en el trabajo en la pequeña empresa .... . . J orma $R$ antanen y $L$ eon J. W arshaw 16.25

El seguro de accidentes y los servicios de salud en el trabajo

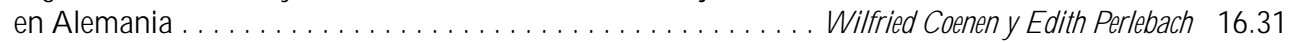

Los servicios de salud en el trabajo en Estados U nidos:

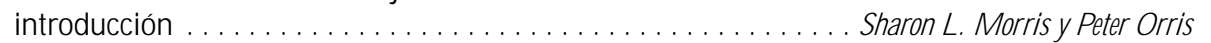

O rganismos públicos de salud en el trabajo en Estados U nidos. . . . . . . . . . . . . . . . . . . . . . . . Sharon $L$. M orris y $L$ inda R osenstock

Servicios de salud en el trabajo en las empresas de Estados U nidos: servicios prestados internamente. . . . . . . . . . . . . . . W illiam B. B unn y R obert J. M cC unney 16.38

Servicios de salud en el trabajo mediante contrato en Estados U nidos. . Penny H iggins 16.41

Actividades sindicales en Estados U nidos . Lamont B yrd 16.43

Servicios académicos de salud en el trabajo en Estados U nidos. . . . . . . . . . . . . D ean B. Baker

Los servicios de salud en el trabajo en Japón ..................... Ken Takahashi 16.45

La protección de los trabajadores en la Federacion Rusa: legislación y prácticas. . . . . . . . . . . . . . . . . . . N ikolai F. I zmerov el gor A. F edotov 16.49

La práctica de los servicios de salud en el trabajo en la República Popular China. .............................. Zhi Su

Salud y seguridad en el trabajo en la R epublica Checa. . . . . . . . . V Vladimír B encko y D aniela Peldová La práctica de la salud en el trabajo en la India

\section{PARTE III. GESTION Y POUTICA}

\section{Discapacidad y trabajo Willi Momm y Robert Ransom, D irectores del capítulo}

D iscapacidad: conceptos y definiciones. . . . . . . . . . . . . . W illi M omm y 0 tto $G$ eiecker

Estudio de caso: clasificación legal de las personas discapacitadas

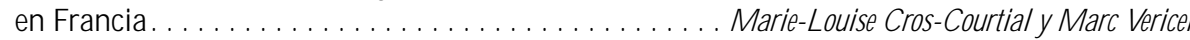

Política social y derechos humanos: conceptos de la discapacidad. . . . . . . . . . . C arl R askin

N ormas laborales internacionales y legislación nacional de empleo en

favor de las personas discapacitadas . . . . . . . . . . . . . . W illi M omm y M asaaki I uchi

Servicios de rehabilitación profesional y de apoyo a los trabajadores. . . . . . . . . . . E rwin Seyfried

Gestión de la discapacidad en el lugar de trabajo: visión de conjunto

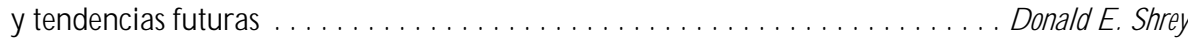

Rehabilitación y pérdida auditiva inducida por el ruido $\ldots \ldots \ldots \ldots \ldots \ldots \ldots$ R aymond $\mathrm{H}$ étu

D erechos y obligaciones: el punto de vista de la empresa . . . . . . . . . . . . . . Susan Scott-Parker

Derechos y obligaciones: el punto de vista de los trabajadores . . . . Angela Traiforos y D ebra A. Perry 


\section{ESTUDIOS DE CASO}

Evaluación de la formación sobre salud y seguridad: estudio de caso de la educación de los trabajadores de residuos peligrosos del Sindicato Internacional de Trabajadores Q uímicos . . . . . . . . . . . . . . T homas H . M cQ uiston, Paula Coleman, Nina W allerstein,

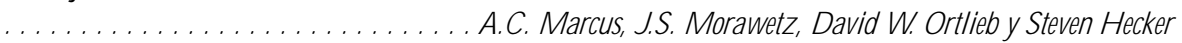

Educación y formación ambiental: situación de la educación de los trabajadores que manejan materiales peligrosos

en Estados U nidos . . . . . . . . . . . . . . G lenn Paul son, M ichelle M adelien, Susan Sink y Steven H ecker 18.15

La educación de los trabajadores y la mejora ambiental . . . . . . . . . . . Edward Cohen-R osenthal 18.17

Formación sobre salud y seguridad de los directivos ................. J ohn Rudge 18.20

Formación de los profesionales en materia de salud y seguridad ............ Wai-0 n Phoon 18.25

Un nuevo enfoque del aprendizaje y la formación: estudio de caso del Proyecto Africano de Salud y Seguridad de la OIT-FIN NIDA ................ Antero Vahapassi y $M$ erri W einger

\section{Cuestiones relacionadas con la ética G eorges H. Coppée, Director del capítulo}

Códigos y directrices .................................. Colin L. Soskolne

Ciencia y responsabilidad: normas éticas y conducta moral en la medicina del trabajo. ....................... Richard A. Lemen y Phillip W. Strine

Aspectos éticos de la investigación sobre la salud y la seguridad en el trabajo ..................... Paul W. B randt-R auf y Sherry I. B randt-R auf 19.8

La ética en el lugar de trabajo: marco para el juicio moral. . . . . . . . . . . . . Sheddon W. Samuels 19.10

Vigilancia del medio ambiente de trabajo . . . . . . . . . . . . . . . . . . . . . L aw rence D. Kornreich 19.13

Aspectos éticos de la información y la confidencialidad ............... Peter J. M. W esterholm 19.14

Etica en la protección y promoción de la salud ............. D. W ayne Corneil y Annalee Yassi 19.20

Estudio de caso: consideraciones éticas sobre el consumo de drogas y alcohol en el lugar de trabajo ................... B ehrouz Shahandeh y R obert $\mathrm{H}$ usbands 19.25

Código deontológico internacional para los profesionales de la salud en el trabajo. .................... . Comisión I nternacional de M edicina de Trabajo

\section{Desarrollo, tecnología y comercio}

Tendencias de la salud en el trabajo en el ámbito de los países en desarrollo..... . e ery J eyaratnam Países industrializados y salud y seguridad en el trabajo .................. Toshiteru 0 kubo

Estudios de caso sobre cambio tecnológico ........................ M ichael J. W right

Pequeñas empresas y salud y seguridad en el trabajo . . Bill Glass

Transferencia de tecnología y elección tecnológica . J oseph LaD ou 20 Acuerdos de libre comercio ............................... ow ard F rumkin

Responsabilidad respecto a los productos y traslado de riesgos industriales ...... Barry Castleman

Aspectos económicos de la salud y la seguridad en el trabajo................ Alan M aynard

\section{Relaciones laborales y gestión de recursos humanos}

Anne Trebilcock, Directora del capítulo

Relaciones laborales y gestión de recursos humanos: visión general . . . . . . . . . . Anne T rebilcock Derechos de asociación y representación. ........................ B reen C réghton 
Cooperación tripartita y bipartita a escala nacional en materia de salud

y seguridad en el trabajo . . . . . . . . . . . . . . . . . . . . R obert $H$ usbands

Formas de participación de los trabajadores ................. uneto 0 zaki y Anne T rebilcock

Consulta e información sobre salud y seguridad.

Aspectos de la formación vinculados a las relaciones laborales . . . M arco Biagi 21.28

Aspectos de la inspección de trabajo vinculados a las relaciones laborales ... M aría L uz Vega Ruiz 21.31

Conflictos colectivos por cuestiones de salud y seguridad . . . . . . . . . . . Shauna $L$. O Iney

C onflictos individuales por cuestiones de salud y seguridad . . Anne Trebilcock

\section{Recursos: información y salud y seguridad en el trabajo}

\section{Jukka T akala, Director del capítulo}

La información: una condición previa para la acción . J ukka Takala

Acceso a la información .......... P.K. A beytunga, E mmert Clevenstine, Vivian M organ y Sheila Pantry 22.2

Gestión de la información Gordon A therley 22.5

Estudio de caso: servicio de información de M alaisia sobre toxicidad de pesticidas. .............. D.A. Razak, A.A. L atiff, M .I. A. M ajid y R. Awang

Estudio de caso: una experiencia de gestión de información eficaz en Tailandia. .

\section{Recursos institucionales, estructurales y jurídicos Rachael F. T aylor} y Simon Pickvance, D irectores del capitulo

O rígenes, medios institucionales, estructurales y

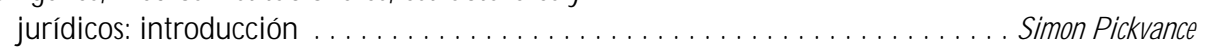

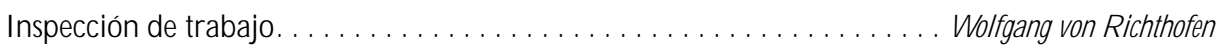
23.2

R esponsabilidad civil y penal en el campo de la salud y seguridad en el trabajo Felice M orgenstern (adaptación)

L a salud en el trabajo como derecho humano I lise L evy Feitshans

AM BITO COMUNITARIO

O rganizaciones de ámbito comunitario Simon Pickvance

Derecho de saber: función de las organizaciones de ámbito comunitario . . . . . . C arolyn N eedleman 23.34

EI movimiento COSH y el derecho a conocer. J oel Shufro 23.35

EJEM PLOS DE AMBITO REGIONAL Y NACIONAL

Salud y seguridad en el trabajo: la U nión Europea . . . . . . . . . . . . . . Frank B. W right 23.37 Legislación tutelar de los derechos de los trabajadores en China . . Su Z hi

Estudio de caso: normas de exposición rusas. Nikolai F. I zmerov

ORGANIZACIONES INTERNACIONALES GUBERNAM ENTALES Y NO GUBERNAMENTALES

Cooperación internacional en la salud laboral: función de las organizaciones internacionales ........................ Georges H. Coppée 23.42

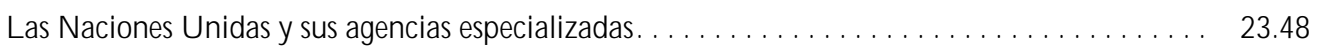

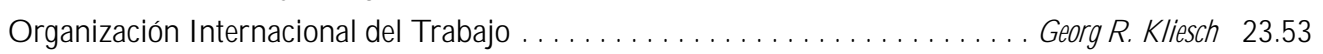

Convenios de la O IT : procedimiento ejecutivo ................... Anne T rebilcock 23.58

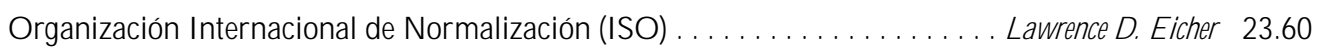

A sociación Internacional de la Seguridad Social (AISS) . . . . . . . . . . . . . D ick J. M eertens 23.63

Comisión Internacional de M edicina del Trabajo (CIM T) . . . . . . . . . . . erry J eyaratnam 23.67

A sociación Internacional de Inspectores de Trabajo (IALI) . . . . . . . . . . D avid Snowball 23.69 
24. Trabajo y trabajadores

Jeanne Mager Stellman y Leon J. Warshaw, Directores del capítulo

Trabajo y trabajadores. Freda L. Paltie 24.2

Cambio de paradigmas y políticas. Freda L. Paltiel 24.2

Salud, seguridad e igualdad en el lugar de trabajo .................. oan B ertin 24.6

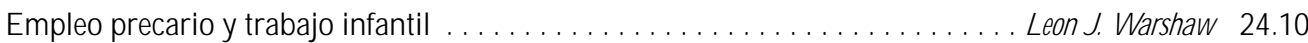

Transformación de los mercados y la mano de obra. . . . . . . . . . . . . . . . . Pat Armstrong 24.17

Tecnologías mundializadoras y reducción/ transformación del trabajo. . . . . . . . . H eather M enzies 24.20

25. Indemnización a los trabajadores, visión general Terence G. I son, Director del capítulo Sistemas de indemnización a los trabajadores por accidentes de trabajo, visión general

PARTE PRIMERA: INDEM NIZACION A LOSTRABAJADORES

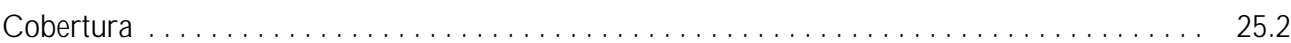

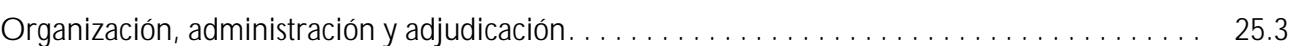

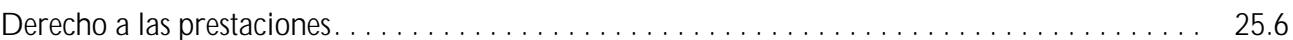

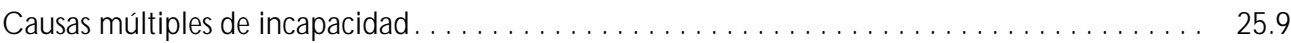

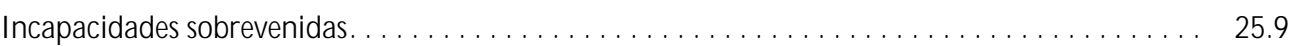

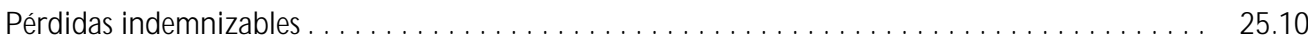

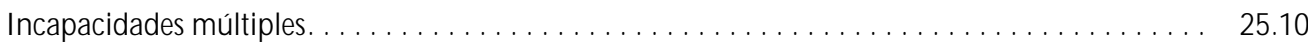

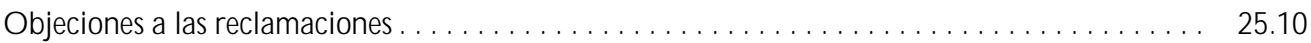

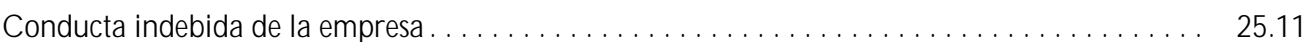

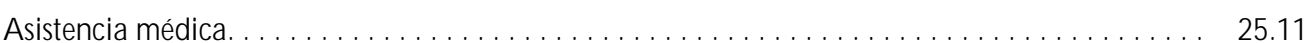

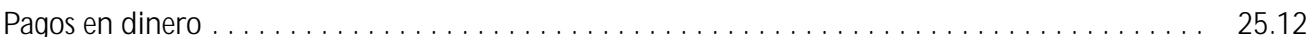

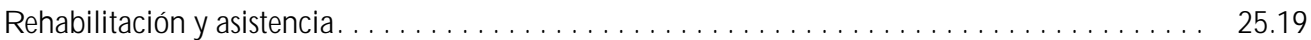

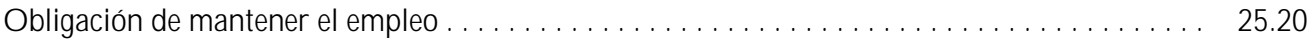

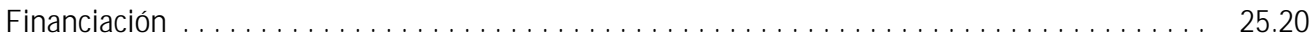

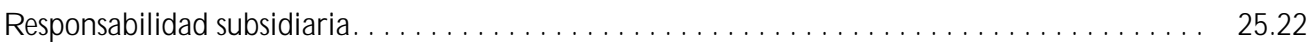

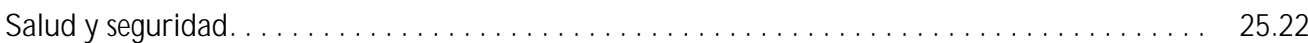

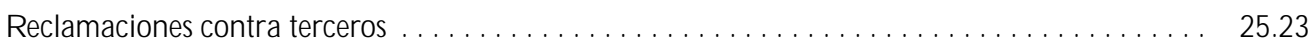

PARTE SEGUNDA: OTROSREGIMENES

Seguros sociales y seguridad social $\ldots \ldots \ldots \ldots \ldots \ldots \ldots \ldots \ldots \ldots \ldots \ldots \ldots \ldots \ldots \ldots \ldots \ldots \ldots$

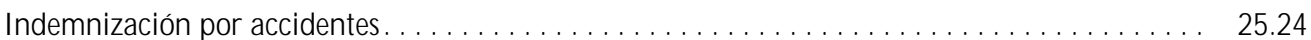

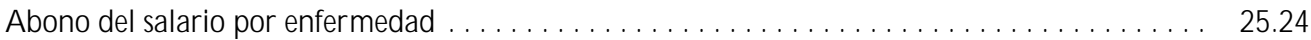

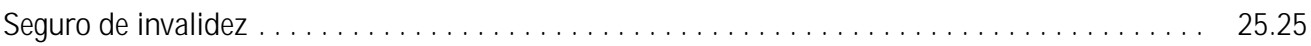

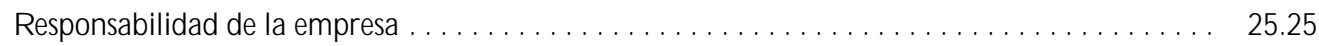

\section{Indemnización a los trabajadores: temas relacionados Paule Rey y}

Michel Lesage, Directores del capítulo

Enfermedades relacionadas con el trabajo y enfermedades profesionales:

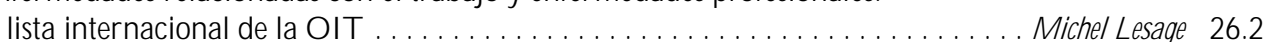

Indemnización por accidentes de trabajo: tendencias y perspectivas . . . . . . . . . . Paule R ey 26.6

Prevención, rehabilitación e indemnización en el sistema alemán de seguro de accidentes. . . . . . . . . . . . . . . . . . . . . . . D ieter G réner y A ndreas K ranig 26.17

Seguro e indemnización de las lesiones profesionales en I srael . . . . . . . . . . . . H aim Chayon 26.22

La indemnización por accidentes de trabajo en Japón. . . . . . . . . . Kazutaka Kogi y H aruko Suzuki 26.26 Estudio de caso: Suecia . . . . . . . . . . . . . . . . . . . . . . . . . . . . . . . Peter W esterholm 26.30 


\section{PARTE IV. HERRAMIENTAS Y ENFOQUES}

27. Control biológico

Principios generales.

G arantía de calidad.

M etales y compuestos organometálicos.

Disolventes orgánicos

Sustancias químicas genotóxicas

Pesticidas.
Robert Lauwerys, Director del capítulo

... V ito $F$ oà y L orenzo Alessio . D avid Gompertz

Perrine $H$ oet y $R$ obert $L$ auw erys ...M asayuki I keda

. M arja Sorsa

$\mathrm{M}$ arco $\mathrm{M}$ aroni y $\mathrm{A}$ dal berto Ferioli

\section{Epidemiología y estadística}

M étodo epidemiológico aplicado a la salud y seguridad en el trabajo.

Franco Merletti, Colin L. Soskolne y Paolo Vineis, Directores del capítulo M. Gerald 0 tt

Evaluación de la exposición M edidas que resumen la exposición durante toda una vida laboral Colin L. Soskolne M edición del efecto de una exposición . . . . . . . . . . . . . . . . . . . . . Shelia H oar Z ahm Tipos de diseño de los estudios . . . . . . . . . . . . . . . . . . . . . . . . . Sven $\mathrm{H}$ ernberg

A spectos relacionados con la validez del diseño del estudio . AnnieJ. Sasco C onsecuencias del error de medida aleatorio ................. Paolo V ineis y Col in L. Soskolne M étodos estadísticos Annibale B iggeri y $M$ ario Braga Paolo Vinés

Evaluación de la causalidad y ética en la investigación epidemiológica.

las enfer medades profesionales $\ldots \ldots \ldots \ldots \ldots \ldots \ldots \ldots \ldots \ldots \ldots \ldots \ldots \ldots \ldots \ldots \ldots$ ung $D$ er $W$ ang

Estudio de caso que ilustra los problemas metodológicos en la vigilancia de

C uestionarios en la investigación epidemiológica

Steven D. Stellman y Colin L. Soskolne

A mianto: perspectiva histórica

L aw rence G arfinkel

29. Ergonomía

\section{Wolfgang L auring y Joachim Vedder, Directores del capítulo}

Introducción . Wolfgang L aurig y Joachim Vedder

\section{OBJETIVOS, PRINCIPIOS Y METODOS}

$\mathrm{N}$ aturaleza y objetivos de la ergonomía . . . . . . . . . . . . . . . W illiam T. Singleton

A nálisis de actividades, tareas y sistemas de trabajo

Véronique D e Keyser

Ergonomía y normalización Friedhelm Nachreiner

\section{ASPECTOS FISICOSY PSICOLOGICOS}

A ntropometría .....................................

Trabajo muscular . J uhani Smolander y Veikko L ouhevaara

Postura en el trabajo Ilkka Kuorinka

Biomecánica. . . . Frank $D$ arby

Fatiga general . É tienne Grandjean

Fatiga y recuperación R olf $\mathrm{H}$ ebig y Walter R ohmert

\section{ASPECTOS PSICOLOGICOS}

C arga mental de trabajo. 
Vigilancia H erbert H euer 29.46

Fatiga mental Peter Richter

ASPECT OS ORGANIZATIVOS DEL TRABAJO

O rganización del trabajo . . . . . . . . . . . . . . . . . . . E berhard U lich y Gudela G rote 29.52

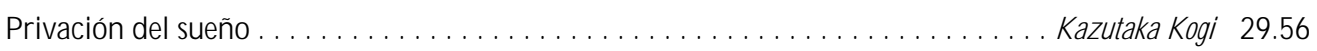

DISEÑO DE LOS SISTEMAS DE TRABAJO

Puestos de trabajo . . . . . . . . . . . . . . . . . . . . . . . . Roland Kadefors 29.61

Herramientas ................................... Fraser 29.66

Controles, indicadores y paneles . . . . . . . . . . . . . . . . . . . Karl H. E. Kroemer 29.69

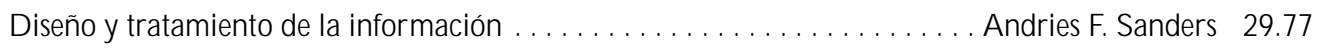

DISEÑO PARA TODOS

Diseño para grupos específicos . . . . . . . . . . . . . . . . . . oke H . G rady-van den N ieuwboer 29.82

Diferencias culturales. . . . . . . . . . . . . . . . . . . . . . . . . oushang Shahnavaz 29.86

Trabajadores de edad avanzada. . . . . . . . . . . . . . . . . . Antoine L aville y Serge Volkoff 29.91

Trabajadores con necesidades especiales................. oke H. G rady-van den N ieuwboer 29.94

DIVERSIDAD E IMPORTANCIA DE LA ERGONOMIA: DOS EJEMPLOS

Diseño de sistemas en la fabricación de diamantes. . . . . . . . . . . . . . . . I ssachar Gilad 29.99

Violación de los principios del diseño ergonómico:

Chernobil. .

Vladimir M . M unipov 29.102

\section{0. $\mathrm{H}$ igiene industrial}

Robert F. Herrick, Director del capítulo

O bjetivos, definiciones e información general. ............... B erenice I. Ferrari G oelzer

Identificación de riesgos. . Linnéa Lillienberg 30.11

Evaluación del medio ambiente de trabajo. Lori A. Todd 30.15

H igiene industrial: control de las exposiciones mediante la intervención . . . . . . . . . . ames Stew art Fundamentos biológicos para evaluar la exposición .................. Dick H eederik Límites de exposición profesional.

. D ennis J . Paustenbach 30.25 30.27 30.31

\section{Protección personal}

Robert F. H errick, Director del capítulo

Aspectos generales y principios de la protección personal $\ldots \ldots \ldots \ldots \ldots \ldots$. obert $F$. H errick

Protectores de ojos y cara . . . . . . . . . . . . . . . . . . . . . Kikuzi Kimura

Protección de pies y piernas Toyohiko M iura

Protección de la cabeza I sabelle Balty y Alain M ayer 31.9

Protección de los oídos J ohn R. Franks y E lliott H . B erger 31.11

Ropa protectora . S. Zack M ansdorf 31.17

Protección respiratoria T homas J. Neson 31.22

32. Sistemas de notificación y vigilancia Steven D. Stellman, Director del capítulo Sistemas de vigilancia y notificación de enfermedades profesionales ........ Steven B. M arkowitz 32.2 Vigilancia de los riesgos profesionales. D avid $H$. W egman y Steven D. Stellman V igilancia en los países en vías de desarrollo. D avid Koh y Kee Seng Chia 32.11

Desarrollo y aplicación de un sistema de clasificación de lesiones y enfermedades profesionales Elyce Biddle 32.13 
A nálisis del riesgo de lesiones y enfermedades no mortales en el lugar de trabajo. .J ohn W. R user 32.20

Estudio de caso: protección del trabajador y estadísticas sobre accidentes y enfermedades profesionales- HVBG, Alemania. . M artin B utz y B urkhard H offmann 32.22

Estudio de caso: Wismut- las consecuencias de la exposición

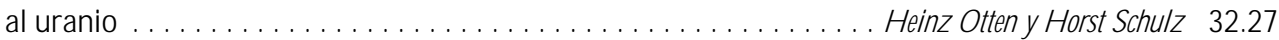

Estrategias y técnicas de medición para la evaluación de la exposición en epidemiología. Frank B ochmann y $\mathrm{H}$ elmut B lome 32.31

Estudio de caso: encuestas de higiene industrial en China . . . . . . . . . . . . . . Z hi Su 32.34

\section{Toxicología}

Introducción.
Ellen K. Silbergeld, Directora del capítulo E llen K. Silbergeld 33.2

PRINCIPIOS GENERALES DE LA TOXICOLOGIA

D efiniciones y conceptos. . . . . . . . . . . . . . . . . B B H ol mberg, J ohan $\mathrm{H}$ ögberg y $\mathrm{G}$ unnar J ohanson 33.3

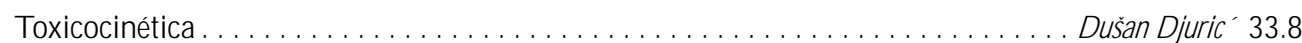

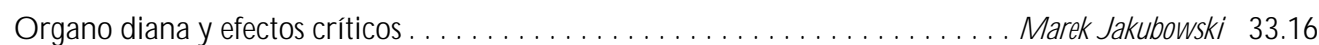

E fectos de la edad, el sexo y otros factores . . . . . . . . . . . . . . . . . . Spomenka Telišman 33.18

D eterminantes genéticos de la respuesta tóxica. . . . . . . . . . . . . D aniel W. N ebert y R oss A. M cK innon 33.21

MECANISM OS DE LA TOXICIDAD

Introducción y conceptos. . . . . . . . . . . . . . . . . . . . . . . . . Philip G. W atanabe 33.29

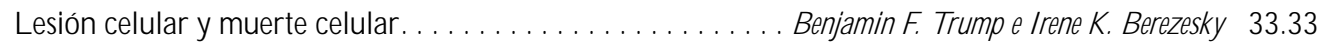

Toxicología genética ........................... R ita M isra y M ichael P. W aalkes 33.35

Inmunotoxicología ........................... oseph $G$. Vos y $H$ enk van $L$ overen 33.39

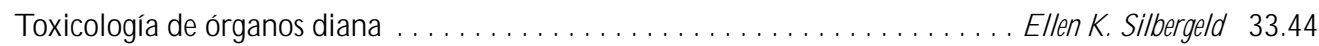

\section{METODOSDE ENSAYO EN TOXICOLOGIA}

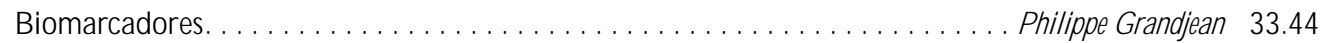

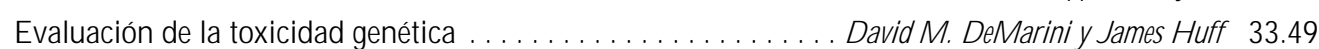

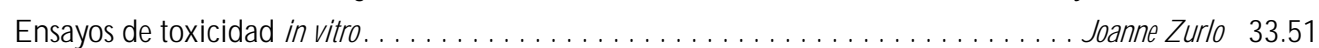

R elaciones estructura-actividad . . . . . . . . . . . . . . . . . . . . . E llen K. Silbergeld 33.55

TOXICOLOGIA REGULADORA

La toxicología en la regulación de la salud y la seguridad . . . . . . . . . . . . . . . E Ellen K. Silbergeld 33.57

Principios de la identificación de los peligros: el enfoque japonés . . . . . . . . . M asayuki l keda 33.57

El enfoque estadounidense de la evaluación del riesgo de los tóxicos para

la reproducción y agentes neurotóxicos. . . . . . . . . . . . . . . . . . E Ellen K. Silbergeld 33.60

Enfoques en la identificación de los peligros: la IARC . . . . . . . . . . H arri Vainio y J ulian W ilbourn 33.65

A péndice: evaluaciones globales de carcinogenicidad para los

humanos: monografías de la IARC, volúmenes $1-69(836) \ldots \ldots \ldots \ldots \ldots \ldots \ldots \ldots \ldots . \ldots \ldots$

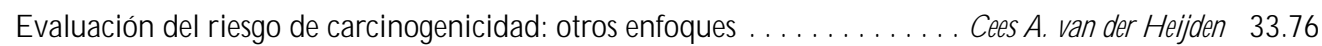


A nálisis del riesgo de lesiones y enfermedades no mortales en el lugar de trabajo. .J ohn W. R user 32.20

Estudio de caso: protección del trabajador y estadísticas sobre accidentes y enfermedades profesionales- HVBG, Alemania. . M artin B utz y B urkhard H offmann 32.22

Estudio de caso: Wismut- las consecuencias de la exposición

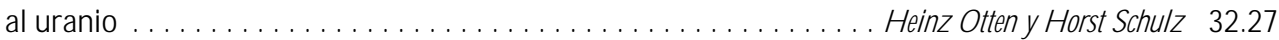

Estrategias y técnicas de medición para la evaluación de la exposición en epidemiología. Frank B ochmann y $\mathrm{H}$ elmut B lome 32.31

Estudio de caso: encuestas de higiene industrial en China . . . . . . . . . . . . . . Z hi Su 32.34

\section{Toxicología}

Introducción.
Ellen K. Silbergeld, Directora del capítulo E llen K. Silbergeld 33.2

PRINCIPIOS GENERALES DE LA TOXICOLOGIA

D efiniciones y conceptos. . . . . . . . . . . . . . . . . B B H ol mberg, J ohan $\mathrm{H}$ ögberg y $\mathrm{G}$ unnar J ohanson 33.3

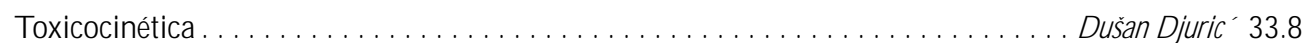

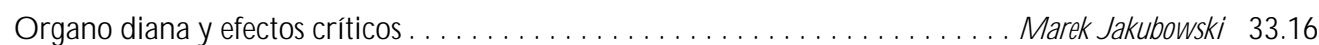

E fectos de la edad, el sexo y otros factores . . . . . . . . . . . . . . . . . . Spomenka Telišman 33.18

D eterminantes genéticos de la respuesta tóxica. . . . . . . . . . . . . D aniel W. N ebert y R oss A. M cK innon 33.21

MECANISM OS DE LA TOXICIDAD

Introducción y conceptos. . . . . . . . . . . . . . . . . . . . . . . . . Philip G. W atanabe 33.29

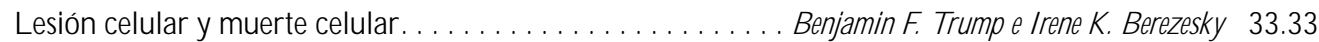

Toxicología genética ........................... R ita M isra y M ichael P. W aalkes 33.35

Inmunotoxicología ........................... oseph $G$. Vos y $H$ enk van $L$ overen 33.39

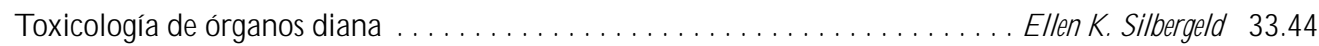

\section{METODOSDE ENSAYO EN TOXICOLOGIA}

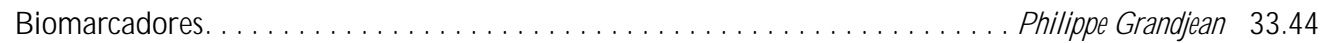

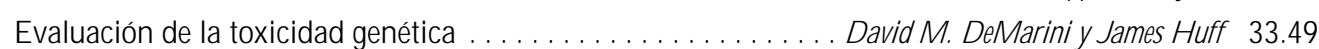

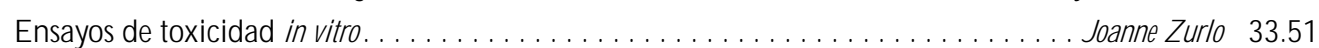

R elaciones estructura-actividad . . . . . . . . . . . . . . . . . . . . . E llen K. Silbergeld 33.55

TOXICOLOGIA REGULADORA

La toxicología en la regulación de la salud y la seguridad . . . . . . . . . . . . . . . E Ellen K. Silbergeld 33.57

Principios de la identificación de los peligros: el enfoque japonés . . . . . . . . . M asayuki l keda 33.57

El enfoque estadounidense de la evaluación del riesgo de los tóxicos para

la reproducción y agentes neurotóxicos. . . . . . . . . . . . . . . . . . E Ellen K. Silbergeld 33.60

Enfoques en la identificación de los peligros: la IARC . . . . . . . . . . H arri Vainio y J ulian W ilbourn 33.65

A péndice: evaluaciones globales de carcinogenicidad para los

humanos: monografías de la IARC, volúmenes $1-69(836) \ldots \ldots \ldots \ldots \ldots \ldots \ldots \ldots \ldots . \ldots \ldots$

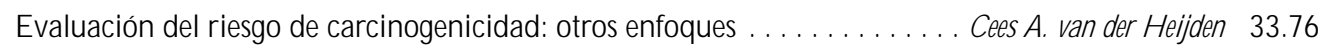


ENCICLOPEDIA DE SALUD Y SEGURIDAD EN EL TRABAJO 



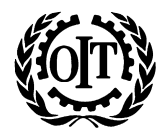

\title{
ENCICLOPEDIA DE SALUD Y SEGURIDAD EN EL TRABAJO
}

\author{
Directora de edición \\ Jeanne Mager Stellman, PhD \\ Subdirector general de edición \\ Michael McCann, PhD, $\mathrm{ClH}$ \\ Subdirectores de edición \\ Leon Warshaw, MD \\ Carole Brabant, PhD

\section{Editores} \\ John Finklea, MD, Dr PH Jacqueline Messite, MD \\ Georges H. Coppée, MD Steven L. Sauter, PhD \\ Vilma R. H unt, BDS, AM Jerry Spiegel, MA, MSC \\ Richard S. Kraus, PE, CSP Colin L. Soskolne, PhD \\ Wolfgang Laurig, Dr-Ing Benedetto Terracini, MD \\ Melvin L. Myers, BS, MPA \\ Gestión editorial \\ Chantal Dufresne, BA
}

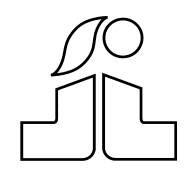


La edición original de esta obra ha sido publicada por la O ficina Internacional del Trabajo (G inebra) bajo el título "Encyclopaedia of 0 ccupational $\mathrm{H}$ ealth and Safety, fourth edition". Esta edición española se publica con la autorización de la O IT y bajo las condiciones del Acuerdo firmado entre la O ficina Internacional del Trabajo y el M inisterio de Trabajo y A suntos Sociales de España en materia de publicaciones.

Copyright (C) de la edición inglesa, O rganización Internacional del Trabajo, 1998

Copyright @ de la edición española, M inisterio de Trabajo y A suntos Sociales, 1998

Las denominaciones empleadas, en concordancia con la práctica seguida en $\mathrm{N}$ aciones $\mathrm{U}$ nidas, y la forma en que aparecen presentados los datos en las publicaciones de la O IT no implican juicio alguno por parte de la O ficina Internacional del Trabajo sobre la condición jurídica de ninguno de los países, zonas o territorios citados o de sus autoridades, ni respecto de la delimitación de sus fronteras.

La responsabilidad de las opiniones expresadas en los artículos, estudios y otras colaboraciones firmadas incumbe exclusivamente a sus autores y su publicación no significa que la O IT las sancione.

El lector asume que las partes facilitan la presente documentación sin garantía de ningún tipo. Las partes no se hacen responsables de la validez ni de la integridad de ninguno de los datos, incluidos errores, inexactitudes u omisiones, ni de las posibles consecuencias que implique la utilización de dichos datos. $\mathrm{Ni}$ los autores ni la OIT, ni las instituciones colaboradoras son responsables de los daños ni de cualquier otra reclamación o demanda que se deriven de la utilización de estos datos.

Las referencias a firmas, procesos o productos comerciales no implica aprobación alguna por la 0 ficina Internacional del Trabajo, y el hecho de que no se mencionen firmas, procesos o productos comerciales no implica desaprobación alguna.

La presente edición es la versión española de la cuarta edición inglesa, revisada y enriquecida con las aportaciones ofrecidas y destinadas a la misma por la OIT y con las peculiaridades y conceptos incorporados al cuerpo de la enciclopedia por especialistas, con objeto de hacer su utilización más asequible en los países de habla hispana. En la traducción, coordinación y financiación de la presente edición han colaborado:

- M inisterio deSanidad y Consumo

- Instituto Nacional de M edicina y Seguridad en el Trabajo

- Instituto Nacional de la Salud

- Instituto N acional de Seguridad e H igiene en el Trabajo

- Agencia E spañola de Cooperación Internacional

- M inisterio de Trabajo y A suntos Sociales

- Oficina Internacional del Trabajo

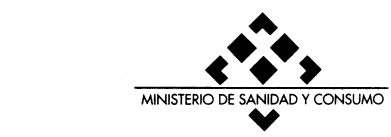

G MINISTERIO DE TRABAJO

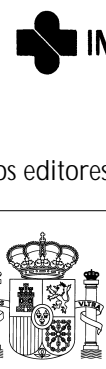

Edita y distribuye:

Ministerio de Trabajo y Asuntos Sociales

Subdirección General de Publicaciones

Agustín de Bethencourt, 1128003 M adrid

NIPO : 201-01-029-5

ISBN : 84-8417-047-0

Depósito legal: M . 13.001 - 2001

Traducción y maquetación: CELER PAWLOWSKY

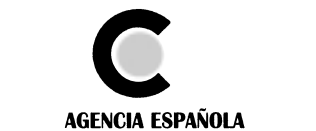

DE COOPERACION INIERNACIONAL

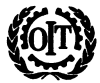

OFICINA INTERNACIONAL

DEL TRABAJO

Detraba 


\section{Presentacion de la tercera edicion en español}

a difusión de los conocimientos sobre los riesgos para la seguridad y la salud de los trabajadores y la forma de prevenirlos es, posiblemente, la herramienta más poderosa y eficaz en la lucha contra los accidentes y las enfermedades derivadas del trabajo. El conocimiento crea cultura la creación o incremento de la "cultura preventiva" entre los agentes sociales implicados, es uno de los deseos más frecuentemente expresados, como condición necesaria para el avance en este terreno.

La rápida evolución científica y técnica convierte este conocimiento en algo continuamente cambiante porque, al tiempo que se superan muchos riesgos, aparecen otros; y porque también evolucionan los enfoques preventivos que tienen que ver, ineludiblemente, con la evolución social y de las ideas. Esto produce un paulatino, pero continuo, incremento de la información en esta materia, que requiere ir revisando tanto los contenidos como los canales y las fuentes de información, a fin de mantener ésta actualizada y de hacerla cada vez más accesible.

Los procesos de liberalización del comercio y de integración regional y, en su conjunto, de globalización de la economía, hacen especialmente conveniente la existencia de mecanismos 0 instrumentos divulgativos que abarquen todos los aspectos y soluciones de una determinada problemática y que puedan estar al alcance de todos los interesados. Esta "globalización de la información" es particularmente necesaria en el campo de la prevención de los riesgos, en el que la armonización de las condiciones de seguridad de los productos comercializados y las condiciones de seguridad existentes en las empresas resulta esencial para garantizar una competencia libre, leal y compatible con el derecho de los trabajadores a su seguridad y salud.

En este contexto, la E nciclopedia de Salud y Seguridad en el Trabajo de la OIT puede ser considerada como el mejor ejemplo de instrumento divulgativo por la amplitud de los temas que recoge, por la rigurosidad con que los trata, por su tradición consolidada y por su enorme difusión, que la convierten en el libro de consulta por excelencia en esta materia, a lo largo y ancho del mundo entero.

Para el Gobierno español ya fue una satisfacción aceptar la tarea de editar las dos primeras versiones españolas de la E nciclo- pedia y vuelve a serlo ahora con esta tercera edición, que ha supuesto una revisión en profundidad de las anteriores, y que representa una excelente actualización de los conocimientos en la materia. $Y$ es una satisfacción por partida doble, teniendo en cuenta que en la elaboración de algunos de los nuevos temas incluidos en esta edición de la E nciclopedia y en la revisión de otros han tenido una destacada participación expertos españoles.

La presente edición española de la E nciclopedia se inscribe en la ya tradicional y siempre fructífera colaboración entre la O IT y el Gobierno español, que se viene materializando, esencialmente, por un lado, en el desarrollo conjunto de programas de cooperación técnica con los países hispanoamericanos y, por otra parte, en materia de publicaciones, a partir del Acuerdo suscrito en 1986, entre la O IT y el M inisterio de Trabajo y Asuntos Sociales, facilitando la edición en español de una serie de publicaciones de la OIT, de particular relevancia para asegurar su difusión en el conjunto de los países con los que compartimos nuestra lengua.

El esfuerzo realizado por universalizar el acceso al extraordinario conjunto de datos e informaciones recogidas en la Enciclopedia se inscribe también en el marco de la actual política española en la materia, que concede especial atención a la prevención de los riesgos laborales y que está propiciando un esfuerzo extraordinario de renovación normativa en este campo y un no menor esfuerzo divulgativo al respecto.

La nueva edición en español de la Enciclopedia es el resultado feliz de la colaboración de un amplio abanico de profesionales en actividades que van desde la traducción hasta la revisión por el personal especializado del Instituto Nacional de Seguridad e Higiene en el Trabajo y del Instituto Nacional de Medicina y Seguridad en el Trabajo, así como de la Subdirección General de Publicaciones de la Secretaría G eneral Técnica del M inisterio de Trabajo y A suntos Sociales.

Al congratularme de que sea nuestro Departamento el que haya impulsado y llevado a término este valioso empeño como servicio eficaz al mundo del trabajo, deseo manifestar públicamente nuestro reconocimiento a la O IT por la asistencia y las facilidades dadas en todo momento para que hoy sea una realidad la obra que ofrecemos como fruto de nuestra colaboración. 

M ichel $\mathrm{H}$ ansenne

Director $G$ eneral

Organización Internacional de Trabajo

Ginebra, 1998

\section{Presentacion de la Cuarta edicion en ingles}

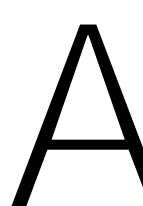

nadie ha de extrañar que las presentaciones de las anteriores ediciones de esta Enciclopedia no hayan quedado obsoletas, porque - desgraciadamente- las enfermedades profesionales y los accidentes de trabajo siguen siendo un azote del todo innecesario para la humanidad. De todos modos, desde que se publicó la primera edición de esta obra, se han realizado grandes progresos. Se ha erradicado por completo la exposición a sustancias tóxicas muy peligrosas, algunas de ellas mortales (como la pintura de radio que se aplicaba a las esferas de los relojes para que brillaran en la oscuridad) y otras que generaban parálisis o malformaciones (como el fósforo utilizado en las cerillas como material combustible). Los gobiernos han promulgado leyes y adoptado medidas de gran importancia para proteger a los trabajadores de tragedias que se pueden evitar perfectamente, como las muertes, enfermedades y discapacidades relacionadas con el trabajo. EI nivel general de conocimientos ha aumentado mucho, y la propia O IT ha contribuido a este progreso con sus convenios, recomendaciones y repertorios de recomendaciones prácticas, que reglamentan las condiciones en los lugares de trabajo, así como con sus numerosos programas de cooperación técnica y sus publicaciones especializadas. I gualmente importante ha sido la creciente contribución de la medicina, la ciencia y la ingeniería a la solución de problemas y a la dotación de mejores medios para identificar y prevenir los riesgos. Actualmente existen sistemas sociales para la protección de los trabajadores y para que participen en las decisiones que afectan a sus lugares de trabajo.

Sin embargo, a pesar de los constantes esfuerzos de la O IT por formentar mejores condiciones de trabajo, ésta y otras organizaciones siguen teniendo que combatir muchas formas de explotación de los trabajadores, como el empleo de mano de obra infantil, la servidumbre de ciertos contratos de aprendizaje y el trabajo clandestino, con sus inevitables riesgos y sus condiciones abusivas. Decenas de millones de trabajadores siguen expuestos a peligros químicos, físicos y sociales que perjudican su salud física y mental. La solución al problema de las enfermedades y las lesiones profesionales no se conseguirá sólo con publicaciones como ésta o con el asesoramiento de los expertos. La salud y el bienestar de los trabajadores es una cuestión de justicia social, y la OIT defiende por encima de todo el ideal de promover la justicia social en el mundo. En el fondo, las soluciones tienen una naturaleza social, y no sólo técnica. El pesado lastre de muertes, discapacidades y enfermedades que tiene que soportar la población activa se debe no sólo a la falta de conocimientos técnicos sino también a la falta de medios sociales y de voluntad social para hacer algo al respecto. La base social de la seguridad y la salud en el trabajo es quizá la razón más poderosa que ha llevado a la OIT a publicar la Enciclopedia de salud y seguridad en el trabajo. En ella presentamos un panorama de los problemas, sus soluciones técnicas y sociales y los campos en los que es necesario actuar.

La popularidad e influencia de la E nciclopedia han sido enormes. D ecenas de miles de ejemplares se han utilizado durante la mayor parte de este siglo. Las ediciones anteriores se han traducido al español, francés, ruso, chino, húngaro y serbocroata. La E nciclopedia es la publicación más difundida de la O IT. En la preparación de esta cuarta edición, se ha mantenido la tradición de pedir ayuda a expertos de todo el mundo, que la 0 ficina considera esencial para que pueda ampliarse y mantenerse actualizada. $\mathrm{H}$ emos creado una red de más de 2.000 expertos en más de 65 países que, dedicando a ello tiempo, esfuerzo y conocimientos especializados, han llevado a cabo una importante contribución a la redacción y revisión de los artículos, y a la corrección de muchos capítulos. Muchas de las principales instituciones del mundo que se relacionan con temas de salud y seguridad, tanto gubernamentales como académicas y privadas, han contribuido de una u otra manera a esta inmensa empresa, en un acto de generosidad y apoyo que agradecemos profundamente. N uestra esperanza y pretensión es que esta E nciclopedia establezca las bases técnicas, teóricas y éticas del trabajo que se está desarrollando para lograr el objetivo de la justicia social en una economía mundializada. 
Wilfred Jenks

D irector G eneral

Organización Internacional del Trabajo

Ginebra, 1971

\section{EXTRACTOS DE LA PRESENTACION DE LA SEGUNDA EDICION EN INGLES}

os accidentes de trabajo y las enfermedades profesionales constituyen la más aterradora tragedia de la industria moderna y una de las más importantes formas de quebranto económico. Las mejores estimaciones disponibles en la actualidad, a nivel mundial, estiman que el úmero de accidentes de trabajo mortales, cada año, se aproxima a los 100.000. En algunos países altamente industrializados, los accidentes son responsables de una pérdida de jornadas laborales cuatro o cinco veces superior a la derivada de los conflictos laborales. En ciertos casos, su costo es comparable al presupuesto de defensa nacional. La industrialización y mecanización de la agricultura se ha convertido en un problema agudo en un rango de actividades y países mucho más amplio.

La carga económica sobre la comunidad no puede expresarse únicamente en términos de costos de indemnización, sino que, también, implica una pérdida de producción, la alteración de los esquemas productivos, los daños en los equipos de fabricación y - en el caso de accidentes a gran escala - inmensos desajustes sociales. Sin embargo, la carga económica no representa la magnitud total del costo humano. (...)

O riginalmente, el principal objeto de la acción preventiva fue la mejora de las condiciones de trabajo insalubres y poner remedio a la tremenda carencia de protección física frente a los riesgos profesionales más peligrosos. Las primeras normas internacionales se concibieron bien para terminar con los más flagrantes abusos lesivos para la salud, como podrían ser los trabajos encomendados a niños de muy corta edad, las jornadas excesivas, la ausencia de cualquier forma de protección a la maternidad y los trabajos nocturnos para mujeres y niños; bien para combatir los riesgos más frecuentes a que estaban sometidos los trabajadores de la industria, como el carbunco e intoxicaciones crónicas por fósforo o plomo.

Cuando la O IT fue más allá en la formulación de estas normas básicas, para enfrentarse con el problema de la seguridad social, la primera cuestión que se consideró fue la indemnización de los accidentes de trabajo y las enfermedades profesionales. En muchos países existía ya legislación sobre indemnización de los trabajadores; dicha legislación se desarrolló sobre la base de las normas de la OIT y sus implicaciones económicas dieron un fuerte impulso a las medidas preventivas. La OIT hizo mucho en favor de la normalización de las estadísticas en materia de accidentes de trabajo y enfermedades profesionales y la captación sistemática de datos sobre la frecuencia de los accidentes (...)

Paulatinamente, esa concentración de la atención sobre los abusos más flagrantes y los índices de accidentes de trabajo y enfermedades profesionales más altos, se fue ampliando hacia un modelo más amplio, dirigido a promover mejores cotas de seguridad y salud en todas las industrias y profesiones. EI monumental Reglamento Tipo de Seguridad en los Establecimientos Industriales, para Guía de los Gobiernos y de la Industria, editado por vez primera en el año 1949, sobre la base de un trabajo iniciado durante la Segunda Guerra M undial y revisado periódicamente, significó un paso importante en este campo. Esto imprimió un ímpetu que en la actualidad se ha traducido en gran cantidad de códigos prácticos y de guías prácticas que lo complementan. En la década de 1950, esta mayor amplitud se reflejó en nuevas y extensas normas internacionales para la protección de la salud de los trabajadores, su bienestar y los servicios de salud laboral.

En la década de 1960 todo lo anterior se suplementó con nuevas series de disposiciones específicas dedicadas a determinados riesgos que fueron cobrando creciente importancia. En las fábricas, un accidente de cada seis lo provocan las máquinas; de ahí la importancia de las normas internacionales sobre los resguardos de piezas móviles que regulan, no solamente el uso, venta y alquiler de la maquinaria que tenga partes peligrosas sino, también, su fabricación. (...)

La medicina del trabajo moderna ha superado la etapa en que se ocupaba solamente de los primeros auxilios en caso de accidente y del diagnóstico de las enfermedades profesionales; en la actualidad está relacionada con todos los efectos del trabajo sobre la salud física y mental e, incluso, con el impacto de las limitaciones físicas y psicológicas del hombre sobre su trabajo. (...)

El progreso tecnológico, en el momento actual es mucho más dinámico que hace cuarenta años. Existen razones para creer que la velocidad será mayor. Esta nueva E nciclopedia constituirá exclusivamente la nueva etapa de nuestro trabajo, pero cada etapa constituye a su vez la base de partida de la siguiente. Durante los años venideros la E nciclopedia de Salud y Seguridad en el Trabajo será una herramienta esencial para humanizar los ambientes laborales y para beneficio de gran número de trabajadores en todo el mundo. En términos humanos y económicos, la consecución de normas de salud y seguridad uniformes constituye la principal responsabilidad en el campo de la política social y de la dirección eficaz. Tampoco puede ser efectiva sin la totalidad del conocimiento necesario para valorar la importancia de la presente información para la política y la acción. Esta E nciclopedia, que se preparó bajo la responsabilidad técnica del $\mathrm{Dr}$. Luigi Parmeggiani, Jefe de la Rama de Salud y Seguridad en el Trabajo, está concebida para el acceso rápido a estas materias tal como disponemos de ellas en la actualidad. En la edición de esta Enciclopedia, el Dr. Parmeggiani ha mantenido dignamente las tradiciones establecidas por el Dr. Luigi Carozzi, que estableció las bases de las acciones en M edicina del Trabajo de la O IT. 
Francis Blanchard

Directora General

O rganización Internacional del Trabajo

Ginebra, 1983

\section{EXTRACTOS DE LA PRESENTACION DE LA TERCERA EDICION EN INGLES}

a decisión de publicar la segunda edición de la Enciclopedia de Salud y Seguridad en el Trabajo se tomó hace aproximadamente quince años, y su preparación se efectuó entre los años 1966 y 1971. Desde entonces se han producido importantes progresos en el conocimiento y las actividades flejadas en esta publicación. Paralelamente al progreso tecnológico se han producido grandes avances en lo que respecta a los métodos de identificación, evaluación y control de los riesgos profesionales, así como a la protección de la salud en los puestos de trabajo. Las sustancias tóxicas, el polvo en la industria, las fibras minerales, las radiaciones no ionizantes, la alergia y el cáncer de etiología profesional son, todos ellos, problemas que han sido objeto de muchas investigaciones experimentales e importantes estudios epidemiológicos. No obstante, los cambios que han experimentado los ambientes laborales en la década de 1970 no son fruto, solamente, de un mayor conocimiento técnico; una nueva tendencia ha comenzado a tomar cuerpo: las exigencias de los trabajadores para obtener una mejor calidad de vida en el trabajo y la mayor implicación de los sindicatos en la protección de la salud y la seguridad en los puestos de trabajo; la mayor asunción, por parte de los patronos, de amplios programas de seguridad y salud laboral; y los crecientes esfuerzos de los gobiernos para que se apliquen, en este campo, medidas trascen- dentales. Esta tendencia se ve reflejada en la legislación nacional e internacional referente a los ambientes laborales y a las condiciones de trabajo, que han avanzado en una magnitud sin precedentes. Así, el panorama de la seguridad e higiene del trabajo, la seguridad industrial y la ergonomía ha experimentado profundos cambios en muchos países miembros de la OIT, no sólo en lo que respecta a la teoría sino, también, en lo que se refiere a la aplicación práctica de estas disciplinas en los propios puestos de trabajo. (...)

H ace ya sesenta y tres años que la O IT estableció, como uno de sus objetivos básicos: "la protección del trabajador frente a las indisposiciones, las enfermedades y los accidentes que pueden producirse como consecuencia de su trabajo". El objetivo actual sigue siendo el mismo, si bien la forma y los métodos de esta protección se han modificado paralelamente al progreso técnico y al desarrollo económico... La divulgación internacional de los más recientes conocimientos científicos y prácticos en este campo constituye una parte integral de la actividad de la OIT - junto con los modos de actuación tradicionales: normalización y cooperación técnica - para promover una mayor efectividad de la protección de la salud y la seguridad en el trabajo en todo el mundo. La nueva edición de la E nciclopedia contribuirá, en gran medida, a este gran empeño. 

Jeanne M ager Stellman

Directora de la publicación

Organización Internacional de Trabajo

Ginebra, 1998

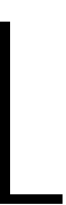

a finalidad de esta cuarta edición de la E nciclopedia de salud y seguridad en el trabajo de la O rganización Internacional del Trabajo es presentar un panorama general de la información básica disponible en este ámbito. Pero, ¿qué es lo que comprende dicho "ámbito"? Veamos un ejemplo.

¿Cómo enfocaría un grupo formado por distintos expertos los aspectos de salud y seguridad que se relacionan con el uso prolongado de las pantallas de ordenador con las que estamos tan familiarizados en nuestros días? EI médico responsable del servicio de medicina del trabajo para un grupo de trabajadores que utilizan pantallas de ordenador les sometería a un reconocimiento médico para determinar posibles síntomas de trastornos físicos. U na de las medidas sería sin duda el examen de la vista y una de las soluciones podría ser el uso de gafas especiales para trabajar delante de las pantallas. El epidemiólogo, por su parte, abordaría el problema desde el punto de vista estadístico. Recabaría los resultados de los reconocimientos efectuados en el grupo de trabajadores que utilizan pantallas de ordenador y los compararía con los de trabajadores que no las utilizan en sus puestos de trabajo, para determinar así los riesgos para la salud que están en relación con el puesto de trabajo. El higienista industrial se centraría en el medio ambiente de trabajo y mediría la iluminación o determinaría la presencia de contaminantes. El ergonomista se centraría en el diseño de los equipos y estudiaría las interacciones físicas entre la máquina y el trabajador. El psicólogo analizaría factores relacionados con la organización (la estructura social en el lugar de trabajo), centrándose en las exigencias del puesto de trabajo, el control del trabajo y la vigilancia electrónica del rendimiento, mientras que el investigador de base estaría inte-

resado en experimentar con los mecanismos biológicos que podrían explicar los efectos observados. El educador prepararía materiales didácticos para ayudar a los trabajadores a obtener un mejor rendimiento en sus puestos de trabajo. El sindicalista y el empresario tratarían de aplicar los principios de la medicina del trabajo a los contratos laborales y otros acuerdos contractuales. Finalmente, el abogado y el inspector considerarían otros aspectos pragmáticos, como la indemnización de los trabajadores, o intentarían "demostrar" consecuencias para la salud de la regulación del lugar de trabajo.

Todos estos enfoques son perfectamente válidos y constituyen importantes aspectos de la salud y seguridad en el trabajo que se complementan entre sí. Ningún profesional tiene la clave para comprender y resolver los problemas de los riesgos relacionados con el trabajo. El "ámbito" de la seguridad y la salud en el trabajo es verdaderamente interdisciplinario.

Este enfoque interdisciplinario ha sido un verdadero desafío para el director de la E nciclopedia. Los datos pueden ser neutrales, pero la manera de comprenderlos, interpretarlos y aplicarlos depende de factores culturales, entendiendo por cultura todo el conjunto de creencias, conductas y conocimientos de los seres humanos. En los campos técnicos, la cultura reflejará la formación académica básica y la filosofía personal. Lo que uno es - abogado, higienista, sindicalista o médico- influye en la manera de pensar, y quien uno es - por ejemplo, representante del gobierno, de los trabajadores o de la empresa- influye inevitablemente en la manera de percibir el universo, en sus demandas y en sus efectos. El lugar donde adquiere uno sus conocimientos de experto es otro factor decisivo, porque los fundamentos filosóficos y empíricos de la ciencia y la medicina están también vinculados a la cultura, y por consiguiente no son iguales en todo el mundo. Todos estamos limitados, como mínimo, por los recursos disponibles, que alteran inevitablemente nuestra perspectiva. El profesional maduro intentará reducir estas influencias, pero una simple mirada al mundo real basta para comprender su importancia.

Los problemas de enfoque interdisciplinario no se han resuelto en esta Enciclopedia y probablemente nunca llegarán a resolverse del todo. Aquí hemos adoptado un planteamiento pragmático. La Enciclopedia se ha estructurado en partes, secciones y capítulos que se corresponden con las distintas disciplinas que integran el campo de la salud y la seguridad en el trabajo. Ha sido concebida para proporcionar al usuario general una información básica sobre las distintas disciplinas de la salud y la seguridad en el trabajo, que sea fácil de comprender, pero que al mismo tiempo sea rigurosa para los profesionales de cada ámbito. Hemos intentado simplificar al máximo las descripciones de la identificación y el control de riesgos, reduciendo al mínimo la jerga científica al uso. La estructura general de esta Enciclopedia es la siguiente:

\section{Volumen I}

- En El cuerpo humano y Asistencia sanitaria se adopta un enfoque médico y se facilita información sobre las enfermedades, su detección y prevención, los servicios de medicina del trabajo y las actividades de promoción de la salud.

- En Gestión y política se abordan los aspectos jurídicos, éticos y sociales del campo, así como los recursos educativos, informativos e institucionales.

- En H erramientas y enfoques se describen las disciplinas relacionadas con el estudio y la aplicación de la salud y la seguridad en el trabajo: ingeniería, ergonomía, higiene industrial, epidemiología y estadística e investigación de laboratorio.

\section{Volumen II}

- En R iesgos se describen los distintos riesgos químicos, físicos y sociales, los accidentes y los métodos de gestión de la seguridad que pueden encontrarse en el mundo. Se describe también la naturaleza de los riesgos y se facilita información técnica sobre su identificación, evaluación y control. 


\section{Volumen III}

- En Sustancias químicas se presenta información básica sobre los usos industriales y las propiedades químicas, físicas y toxicológicas de más de 2.000 sustancias químicas clasificadas por familias químicas.

- En Sectores de la industria y profesiones se explica "cómo funcionan las cosas" y "cómo se controlan los riesgos" en los principales sectores de la industria. Los riesgos asociados a determinadas profesiones que abarcan distintos sectores de la industria, se presentan en forma de una ficha de riesgos.

\section{Volumen IV}

- En Indices y G uías se brinda una guía para utilizar la E nciclopedia. Esta sección incluye una lista de tablas y figuras, así como de las instituciones que han colaborado en esta publicación, e índices de sustancias químicas, referencias cruzadas, temas y autores citados.

Varios miles de expertos de prestigio internacional procedentes de las principales instituciones del mundo han contribuido en calidad de autores o revisores a esta E nciclopedia. H emos intentado asegurarnos de que estuvieran representadas las perspectivas internacionales, ya que las perspectivas no son las mismas en todas partes y la Organización Internacional del Trabajo es responsable de promover el libre intercambio de ideas diferentes. Por otra parte, los problemas y las soluciones son diferentes en cada país, y es conveniente conocer de primera mano la opinión de los que tratan los problemas de manera directa.

En esta Enciclopedia hemos plantado el jardín de la salud y la seguridad en el trabajo con datos, cifras e interpretaciones, para ayudar a que florezcan unas condiciones de trabajo saludables y seguras en todo el mundo. $\mathrm{H}$ emos plantado las semillas en grupos más o menos ordenados por disciplinas, de manera que el lector, una vez que se familiarice con los senderos del jardín, pueda formar cualquier ramo de datos que desee. Los índices del volumen IV proporcionan un mapa más detallado, incluido un valioso índice de referencias cruzadas básicas. El lector experimentado sabrá averiguar con rapidez qué se ha plantado y dónde, y podrá elegir el camino más rápido. La versión electrónica de este trabajo incluye otras ayudas a la navegación, incorporando hiperenlaces y funciones de búsqueda especializada. Con las claves de búsqueda adecuadas, el astuto usuario de CD-ROM podrá incluso plantar él solo un jardín totalmente nuevo y reorganizado.

Por supuesto, la E nciclopedia no está completa al cien por cien. Faltan datos aislados. Es posible que algunos conceptos se hayan quedado desfasados incluso antes de que se publique, señal de que se trata de un campo dinámico y creativo del esfuerzo humano. Esta Enciclopedia no podría haberse escrito sin las incontables horas de trabajo de numerosas personas en todo el mundo. El lector encontrará los nombres de nuestros colaboradores en la lista de autores y directores de edición, así como en el Directorio de Expertos que se incluye en la versión electrónica de la obra. La mayoría de las personas han contado con el pleno respaldo y ayuda de las instituciones a las que pertenecen. EI Volumen IV contiene también una lista (no exhaustiva) de las instituciones que han colaborado.

D eseamos expresar nuestro agradecimiento por el gran apoyo que hemos recibido para este proyecto mundial. Por último conviene aclarar que las opiniones que se expresan son responsabilidad exclusiva de los autores y no implican en modo alguno a las instituciones que los encuadran, ni a la 0 ficina Internacional del Trabajo. Esperamos que este compendio de ideas que les presentamos sirva para adelantar el día en que las muertes y las enfermedades relacionadas con el trabajo lleguen a ser acontecimientos excepcionales en el mundo. 


\section{AUTORES Y DIRECTORES}

P.K. Abeytunga, PhD, MSc

Vice President, D irector G eneral

Canadian $\mathrm{C}$ entre for $\mathrm{O}$ ccupational $\mathrm{H}$ ealth and Safety

$\mathrm{H}$ amilton, $\mathrm{O}$ ntario

Canadá

\section{Sheila H. Akabas, PhD, MBA}

Professor, Director

Workplace C enter

School of Social W ork

Columbia U niversity

Nueva Y ork, N ueva Y ork

Estados U nidos

Munehira Akita, PhD, MA

Profesor de psicología

Facultad de Ciencias Sociales y de la Información

U niversidad de Nihon Fukushi

K ioto

Japón

\section{Lorenzo Alessio, MD}

Profesor, Director

Instituto de M edicina del T rabajo

Universidad de Brescia

Brescia

Italia

\section{Peter Arlien-Soborg, MD}

Profesor adjunto, J efe

Departamento de N eurología

$\mathrm{H}$ ospital de $\mathrm{H}$ vidovre,

Universidad de Copenhague

Copenhague

Dinamarca

\section{Bruce K. Armstrong, MB, D Phil}

Director

Cancer Control Information Centre

New South Wales Cancer Council

Sidney

Australia

\section{Pat Armstrong, PhD, MA}

Professor, D irector

School of $C$ anadian Studies

Carleton U niversity

O ttawa, O ntario

Canadá

\section{Thomas J. Armstrong, PhD, MPH}

Professor

$\mathrm{O}$ ccupational $\mathrm{H}$ ealth and Industrial and

$O$ perations Engineering

$U$ niversity of $M$ ichigan

Ann Arbor, M ichigan

Estados U nidos
Ian M.F. Arnold, MD, MSc

Director

$\mathrm{O}$ ccupational $\mathrm{H}$ ealth and Safety

Alcan Aluminium Ltd.

M ontreal, Q uebec

Canadá

Gordon Atherley, MB, ChB, MD

President

O beron C omposer Software

0 akville, 0 ntario

Canadá

Michael D. Attfield, PhD

Division of R espiratory D isease Studies

$N$ ational Institute for $O$ ccupational Safety and $\mathrm{H}$ ealth

M organtown, W est $V$ irginia

Estados U nidos

\section{Rahmat Awang, Phar MD}

Profesor asociado, J efe

U nidad de I nformación sobre Fármacos y Sustancias Tóxicas

C entro Nacional de T oxicología

U niversidad Sains de M alaisia

Penang

M alaisia

\section{Olav Axelson, MD}

Profesor

División de M edicina del T rabajo y A mbiental

D epartamento de Salud y M edio A mbiente

U niversidad de Linköping

Linköping

Suecia

\section{Dean B. Baker, MD, MPH}

Professor, Director

Center for $O$ ccupational and

Environmental $\mathrm{H}$ ealth

U niversity of California-I rvine

Irvine, California

Estados U nidos

\section{Robin Baker, MPH}

Director

L abor $\mathrm{O}$ ccupational $\mathrm{H}$ ealth Program

U niversity of C alifornia-Berkeley

Berkeley, California

Estados Unidos

\section{Isabelle Balty, MS}

Consultora técnica

Dirección de A plicaciones para Prevención Instituto $\mathrm{N}$ acional de Investigación sobre Seguridad y Prevención de Riesgos Profesionales

París

Francia
Randal D. Beaton, PhD

Clinical Psychologist,

R esearch A ssociate P rofessor

School of N ursing

U niversity of Washington

Seattle, W ashington

Estados U nidos

\section{Margaret R. Becklake, MD}

Professor

Departments of M edicine, Epidemiology and Biostatistics and $\mathrm{O}$ ccupational

$\mathrm{H}$ ealth

M cG ill U niversity

M ontreal, Q uebec

Canadá

\section{Raymond Bégin, MD}

Professor of M edicine

U niversity H ospital

U niversity of Sherbrooke

Sherbrooke, Q uebec

Canadá

Vladimír Bencko, MD, PhD

Profesor, Director

Instituto de H igiene y Epidemiología

U niversidad de $C$ harles

Praga

República Checa

\section{Irene K. Berezesky, BA}

Instructor

Department of Pathology

School of M edicine

U niversity of $\mathrm{M}$ aryland

Baltimore, $M$ aryland

Estados U nidos

\section{Elliott H. Berger, MS}

Senior Scientist

Auditory R esearch Department

E-A-R / A earo Company

Indianapolis, Indiana

Estados U nidos

Joan Bertin, JD

School of Public Health

Columbia U niversity

Nueva Y ork, NuevaY ork

Estados Unidos

\section{Marco Biagi}

Profesor de derecho del trabajo

Departamento de Administración de Empresas

U niversidad de M ódena

Bolonia

Italia 


\section{Elyce Anne Biddle}

National Institute for O ccupational Safety and $\mathrm{H}$ ealth

M organtown, V irginia occidental

Estados U nidos

\section{Annibale Biggeri, MD \\ P rofesor de estadística médica \\ Facultad de M edicina \\ U niversidad de Florencia \\ Florencia \\ Italia}

\section{Donald Birmingham, MD}

Professor E meritus

D epartment of D ermatology

W ayne State U niversity

$D$ etroit, M ichigan

Estados U nidos

\section{Helmut Blome, Dr rer nat}

Subdirector

Berufsgenossenschaftliches I nstitute für Arbeitssicherheit

$\mathrm{H}$ auptverband der gewerblichen

Berufsgenossenschaften

Sankt A ugustin

Alemania

\section{Sheila B. Blume, MD, CAC}

M edical D irector

Alcoholism, Chemical D ependency and

C ompulsive $\mathrm{G}$ ambling Programs

South $\mathrm{O}$ aks $\mathrm{H}$ ospital

A mityville, Nueva Y ork

Estados U nidos

\section{Frank Bochmann, Dr}

fe de sección

Berufsgenossenschaftliches Institute für Arbeitssicherheit

$\mathrm{H}$ auptverband der gewerblichen

Berufsgenossenschaften

Sankt A ugustin

Alemania

\section{Paolo Boffetta, MD, MPH}

I fe

Unidad de E pidemiología de

Cáncer A mbiental

Agencia Internacional para

la Investigación sobre el Cáncer

Lyon

Francia

\section{Marcel-André Boillat, MD, MS}

Profesor asociado

Instituto de Ciencias de M edicina del Trabajo

U niversidad de L ausanne

L ausanne

Suiza

\section{Carole Brabant, PhD}

Subdirectora de edición

E nciclopedia de salud y seguridad en el trabajo

O ficina Internacional del T rabajo

Ginebra

Suiza

\section{Mario Braga, MD}

Subdirector

U nidad de Evaluación Epidemiológica

A gencia de Servicios R egionales de Salud

R oma

Italia

Paul Brandt-Rauf, MD, ScD, Dr PH

Professor, D irector

O ccupational and Environmental

M edicine

School of Public Health

Columbia U niversity

N uevaY ork, NuevaY ork

Estados U nidos

\section{Sherry I. Brandt-Rauf, JD, M Phil} Assistant Professor of Social M edicine

Columbia U niversity

N ueva Y ork, Nueva Y ork

Estados U nidos

\section{Mark Braverman, PhD, M Ed}

Principal

$C$ risis $M$ anagement $G$ roup Inc.

N ewton U pper Falls, M assachusetts

Estados U nidos

William B. Bunn, MD, JD, MPH

$D$ irector of $\mathrm{H}$ ealth

W orkers' Compensation and Safety

$\mathrm{N}$ avistar Corporation

Chicago, Illinois

Estados U nidos

\section{Wayne N. Burton, MD}

First Vice-P resident, Corporate M edical Director

First C hicago N BD

Chicago, Illinois

Estados U nidos

\section{Martin Butz, PhD}

lefe de sección

$\mathrm{H}$ auptverband der gewerblichen

Berufsgenossenschaften

Sankt Augustin

Alemania

\section{LaMont Byrd, MSc}

$D$ irector of Safety and $\mathrm{H}$ ealth

International Brotherhood of T eamsters

Washington, DC

Estados U nidos

\section{D. Calnan}

Institute of Dermatology

St. John's H ospital for D iseases of the Skin Londres

Reino U nido

Barry I. Castleman, ScD, MSE

E nvironmental $C$ onsultant

Baltimore, $\mathrm{M}$ aryland

Estados U nidos

\section{Chaiyuth Chavalitnitikul, PhD,} MPH

Director

Instituto Nacional para la M ejora de las $\mathrm{C}$ ondiciones y el M edio A mbiente de Trabajo

Bangkok

Tailandia

\section{Haim Chayon, MJ}

Antiguo director

Departamento de Incapacidad L aboral Instituto Nacional del Seguro Jerusalén

srae

Kee-Seng Chia, MD, MBBS, MSc

Profesor asociado

Departamento de M edicina Comunitaria, del Trabajo y de Familia

U niversidad Nacional de Singapur

Singapur

\section{Gerolamo Chiappino, MD}

Profesor, Director

Centro de M edicina del T rabajo

Instituto de M edicina del Trabajo

Milán

I talia

\section{K.S. Cho, MD*}

Director

Instituto de H igiene Industrial

Escuela Católica de M edicina

Seúl

República de Corea

Emmert Clevenstine, PhD, MS

Centro Internacional de Información sobre Seguridad y Salud en el T rabajo

O ficina Internacional del Trabajo

Ginebra

Suiza

\section{W. Coenen, Dipl Ing}

D irector de prevención

$\mathrm{H}$ auptverband der gewerblichen Berufsgenossenschaften

Sankt Augustin

Alemania

* Colaborador de la 3a edición de esta Enciclopedia. Esta información bibliográfica no se ha actualizado. 


\section{Edward Cohen-Rosenthal, Ed M}

Director

W ork and Environment I nitiative

School of Industrial and L abor R elations

C ornell U niversity

I thaca, N ueva Y ork

Estados U nidos

\section{Paula Coleman, BS}

Curriculum Specialist

$\mathrm{C}$ arpenters $\mathrm{H}$ ealth and Safety Fund

Washington, DC

E stados U nidos

\section{Georges H. Coppée, MD}

J efe de sección médica

$R$ ama de Seguridad y Salud en

$$
\text { el Trabajo }
$$

O ficina Internacional del T rabajo

Ginebra

Suiza

\section{Wayne Corneil, ScD}

Director

$O$ perations E astern R egion

$\mathrm{H}$ ealth Canada

O ttawa, O ntario

Canadá

James Corry, PhD, MS

Director

Corporate W ellness and Fitness Services $M$ etropolitan Life Insurance Company

N ueva Y ork, Nueva Y ork

Estados U nidos

\section{Maureen P. Corry, MPH}

General Director

$M$ aternity Center Association

N ueva Y ork, Nueva Y ork

Estados U nidos

John W.F. Cowell, MD, MSc

P resident, C hief E xecutive 0 fficer

W orkers' Compensation Board of Alberta

Edmonton, A lberta

Canadá

\section{Breen Creighton, LLB, PhD}

Special C ounse

Corrs $C$ hambers W estgarth

M elbourne

Australia

\author{
Marie L. Cros-Courtial, Dr d'Etat \\ en droit \\ Profesora de derecho \\ D epartamento A.E.S. \\ U niversidad de Paul V aléry \\ M ontpellier \\ Francia
}

Mark R. Cullen, MD

P rofessor of $M$ edicine and $P$ ublic $H$ ealth

$\mathrm{Y}$ ale $\mathrm{U}$ niversity $\mathrm{Sch}$ ool of $\mathrm{M}$ edicine

$\mathrm{N}$ ew $\mathrm{H}$ aven, Connecticut

Estados U nidos

\section{Ellen Cutler, MPA}

National Director

Program Services

$M$ arch of D imes Birth D efects Foundation

White Plains, N ueva Y ork

Estados U nidos

\section{Monica Dahlqvist, PhD}

P rofesora adjunta

Departamento de T ecnología

A mbiental y Ciencias del Trabajo

Real Instituto de T ecnología

Estocolmo

Suecia

\section{Antonio J. Dajer, MD}

Neuilly-sur-Seine

Francia

Louis Damphousse, MD, MSc

M edical C onsultant

$M$ aclaren Inc.

$M$ asson, Q uebec

Canadá

\section{Frank Darby, MSc}

Consultant in E rgonomics

Wellington

Nueva Zelanda

\section{Alois David, MD, PhD}

Profesor asociado

Departamento de M edicina del T rabajo

Escuela de Estudios M édicos

Postuniversitarios

Praga

República C heca

\section{Véronique De Keyser, PhD}

Profesora de psicología del trabajo, D ecana de F acultad

Universidad de Lieja

Lieja

Bélgica

\section{David M. DeMarini, PhD}

Environmental Carcinogenesis D ivision

US Environmental Protection Agency

R esearch T riangle Park, Carolina

del Norte

Estados U nidos
Dušan Djurić DSc, ChE

Instituto de M edicina del T rabajo y

R adiológica

Belgrado

Yugoslavia

\section{Mel Doyle, MPhil}

$D$ eputy General Secretary

W orkers' E ducational A ssociation

Londres

R eino Unido

\section{Louis-Philippe Durocher, MD,} FRCPC

Professor of $D$ ermatology

N otre D ame H ospital

$\mathrm{H}$ ead

Dermatology T raining Programme

U niversity of $\mathrm{M}$ ontreal

M ontreal, Q uebec

Canadá

\section{Robert W. Dykes, PhD}

Director

Center for R esearch

R ehabilitation Institute of $M$ ontreal

U niversity of $\mathrm{M}$ ontreal

M ontreal, Q uebec

Canadá

\section{Lawrence D. Eicher, PhD}

Secretario general

O rganización Internacional de N ormalización

Ginebra

Suiza

\section{G. Enderlein, Dr rer nat}

J efe de grupo

D epartamento de E valuación de R iesgos y Diseño de Estudios Epidemiológicos

Instituto Federal de Seguridad y Salud en el Trabajo

Berlín

Alemania

John W. Farquhar, MD

Professor of M edicine, D irector

Stanford Center for R esearch in Disease Prevention

Stanford U niversity School of M edicine Palo Alto, California

Estados U nidos

Igor A. Fedotov, MD, MSc

E specialista en medicina del trabajo

O ficina Internacional del T rabajo

Ginebra

Suiza 
Ilise Levy Feitshans, Esq JD, ScM Trustee

Society of M edical Jurisprudence

G lobal Alliance for W omen's $\mathrm{H}$ ealth

Riverdale, Nueva Y ork

Estados U nidos

\section{Robert G. Feldman, MD \\ Professor, Chair \\ Department of N eurology \\ School of M edicine \\ Professor \\ School of Public H ealth \\ Boston U niversity \\ Boston, M assachusetts \\ Estados U nidos}

\author{
Adalberto Ferioli, MD, PhD \\ Científico \\ D epartamento de T oxicología del T rabajo \\ Centro Internacional para la Seguridad \\ de los Plaguicidas \\ Busto $\mathrm{G}$ arolfo \\ Italia
}

Jonathan E. Fielding, MD, MBA, MPH

Professor of $H$ ealth Sciences and Pediatrics

U niversity of C alifornia- L os Angeles

Los Angeles, California

Estados U nidos

\section{John Finklea, MD, Dr PH}

M edical Officer

Center to Protect W orkers' R ights

F ormer D irector

National Institute for $\mathrm{O}$ ccupational

Safety and $\mathrm{H}$ ealth

W ashington, DC

Estados U nidos

\section{Vito Foà, MD}

Profesor de higiene industrial

Instituto de M edicina del T rabajo

U niversidad de M ilán

M ilán

Italia

\section{G. Frada, Dr Prof}

Director

Instituto de M edicina del T rabajo

U niversidad de Palermo

Palermo

Italia

\section{John R. Franks, PhD}

Chief

Bioacoustics and $O$ ccupational Vibration Section

$\mathrm{N}$ ational Institute for $\mathrm{O}$ ccupational Safety and $\mathrm{H}$ ealth

Cincinnati, $\mathrm{O}$ hio

Estados U nidos
T.M. Fraser, MD, Msc, P Eng

Professor E meritus

Systems D esign Engineering

University of Waterloo

W aterloo, 0 ntario

Canadá

Herbert J. Freudenberger, PhD

Psychologist, P sychoanalyst

N ueva Y ork, Nueva Y ork

Estados U nidos

\section{George Friedman-Jiménez, MD}

Director

Bellevue $O$ ccupational and Environmental

$M$ edicine $\mathrm{Clinic}$

Bellevue H ospital C enter

N ueva Y ork, Nueva Y ork

Estados U nidos

\section{Howard Frumkin, MD, Dr PH, MPH}

Associate Professor, Chair

D epartment of Environmental and

$O$ ccupational $\mathrm{H}$ ealth

$\mathrm{R}$ ollins School of Public H ealth

Emory U niversity

Atlanta, G eorgia

Estados U nidos

\section{Lawrence Garfinkel, MA}

F ormer V ice P resident for E pidemiology and Statistics

American Cancer Society

N ueva Y ork, Nueva Y ork

Estados U nidos

\section{Otto Geiecker, Dkfm}

Antiguo subdirector general

D epartamento de R ehabilitación Interna

Allgemeine U nfall V ersicherungsanstalt

Viena

Austria

\section{Issachar Gilad, PhD}

Profesor de ingeniería industrial y ergonomía Instituto de T ecnología de I srael $\mathrm{H}$ aifa

Israel

William. I. Glass, MB ChB, DIH, DPH

$O$ ccupational M edicine Specialist

Christchurch

N ueva Zelanda

\section{F. Gobbato*}

Instituto de M edicina del T rabajo

U niversidad de T rieste

Trieste

Italia
Berenice I. Ferrari Goelzer, CIH, MPH

$H$ igienista industrial

O ficina de M edicina del T rabajo

O rganización M undial de la Salud

Ginebra

Suiza

Kristan D. Goldfein, Ed D

$M$ anager of $C$ orporate $W$ ellness

$M$ errill Lynch Inc.

A djunct Assistant P rofessor

T eacher's College

Columbia U niversity

Nueva Y ork, N ueva Y ork

Estados U nidos

\section{Bernard D. Goldstein, MD}

D irector

Environmental and $\mathrm{O}$ ccupational $\mathrm{H}$ ealth Sciences Institute

Chair

Department of Environmental and Community $M$ edicine

U M DN J-R obert W ood Johnson M edical School

Piscataway, Nueva J ersey

Estados U nidos

\section{David Gompert, MD, PhD}

Senior L ecturer (H onorary)

Institute of $\mathrm{O}$ ccupational $\mathrm{H}$ ealth

U niversity of Birmingham

Birmingham

Reino U nido

Joke H. Grady-van den Nieuwboer, MSc

Centro R oessingh de R ehabilitación

$\mathrm{H}$ aáksbergen

Países Bajos

E. Grandjean, Dr med (fallecido)*

Antiguo director

Instituto de H igiene y Fisiología del Trabajo

Zurich

Suiza

Philippe Grandjean, MD, DMSc

Profesor

M edicina Ambiental

U niversidad de 0 dense

$O$ dense

Dinamarca

\footnotetext{
* Colaborador de la 3a edición de esta Enciclopedia. Esta información bibliográfica no se ha actualizado.
} 
Peter Greenwald, MD, Dr PH

Director

Division of $\mathrm{C}$ ancer Prevention and $\mathrm{C}$ ontrol

$\mathrm{N}$ ational $\mathrm{C}$ ancer Institute

Bethesda, M aryland

Estados U nidos

\section{Dieter Greiner, Dr jur}

Director general adjunto

$H$ auptverband der gewerblichen

Berufsgenossenschaften

Sankt Augustin

Alemania

\section{Gudela Grote, PhD}

Profesor

Psicología del Trabajo y las

O rganizaciones

Instituto Federal Suizo de T ecnología

Zurich

Suiza

\section{Saul G. Gruner, MS}

SG G runer A ssociates Inc.

W estport, Connecticut

Estados U nidos

\author{
Per Gustavsson, MD, PhD \\ Profesor asociado \\ D epartamento de M edicina del T rabajo \\ $\mathrm{H}$ ospital de $\mathrm{K}$ arolinska \\ Estocolmo \\ Suecia
}

Winfried Hacker, Dr rer nat habil

Profesor, Catedrático

Psicología G eneral

U niversidad T ecnológica de

D resde

Alemania

\section{Mats Hagberg, MD, PhD}

Profesor

División de Fisiología del T rabajo y

A mbiental

Instituto $\mathrm{N}$ acional del Trabajo

Solna

Suecia

\section{David Hamerman, MD}

U niversity P rofessor of $M$ edicine

Albert E instein College of $M$ edicine

N ueva Y ork, Nueva Y ork

Estados U nidos

\section{Takashi Haratani, PhD}

I nvestigador

Instituto $\mathrm{N}$ acional de $\mathrm{H}$ igiene Industrial K awasaki

Japón
Jillian Haslehurst, MB, ChB

M edical Advisor

$M$ arks and Spencer PLC

Londres

R eino U nido

\section{Fengsheng $\mathrm{He}$, MD}

Profesor de medicina del trabajo y

neurotoxicología, D irector honorario

Instituto de M edicina del Trabajo

A cademia China de M edicina Preventiva

Pekín

China

Catherine A. Heaney, PhD, MPH

Associate P rofessor

School of Public H ealth

O hio State U niversity

Columbus, $\mathrm{O}$ hio

Estados U nidos

\section{Steven Hecker, MSPH}

Associate P rofessor

Labor E ducation and R esearch Center

$U$ niversity of $O$ regon

Eugene, Oregon

Estados U nidos

Dick Heederik, PhD, MSc

Profesor asociado de epidemiología del trabajo

U niversidad de $W$ ageningen

Wageningen

Países Bajos

Lothar A.J. Heinemann, MD, DSc

Director

Centro de E pidemiología e Investigaciones M édicas

Zepernick

Alemania

Adjunct P rofessor for E pidemiology and Biostatistics

M CG ill U niversity

M ontreal, Q uebec

Canadá

\section{Rolf Helbig, Dr-Ing}

Ingeniero jefe

Institut für Arbeitswissenschaft

T echnische H ochschule D armstadt

Darmstadt

Alemania

George P. Hemstreet III, MD, PhD

Professor of U rology

College of M edicine

U niversity of $\mathrm{O}$ klahoma

O klahoma City, O klahoma

Estados U nidos

\section{Sven Hernberg, MD}

P rofesor emérito, Antiguo director

D epartamento de E pidemiología y

Bioestadística

Instituto Finés de M edicina del

Trabajo

H elsinki

Finlandia

\section{Robert F. Herrick, ScD}

L ecturer on I ndustrial $\mathrm{H}$ ygiene

D epartment of Environmental $\mathrm{H}$ ealth

$\mathrm{H}$ arvard School of Public $\mathrm{H}$ ealth

Boston, M assachusetts

Estados U nidos

Raymond Hétu, PhD (fallecido)

F ormer D irector

A coustic Group

M edical Faculty

U niversity of M ontreal

M ontreal, Q uebec

Canadá

\section{Gerd E. Heuchert, MD, Dr med sci}

Profesor, I efe

D epartamento de E pidemiología

Instituto Federal de Seguridad y Salud en el Trabajo

Berlín

Alemania

\section{Herbert Heuer, Dr rer nat}

Profesor, J efe

D epartamento de Psicología

del Trabajo y Experimental

Institut für Arbeitsphysiologie

D ortmund

Alemania

\section{Penny D. Higgins, RN, BS}

President

$\mathrm{OH}$ A ssociates, Ltd.

D es Plaines, Illinois

Estados U nidos

Michael J. Hodgson, MD, MPH

A ssociate P rofessor of $M$ edicine

U niversity of $\mathrm{C}$ onnecticut $\mathrm{H}$ ealth $\mathrm{C}$ enter

Farmington, Connecticut

Estados U nidos

Perrine Hoet, MD, MIH, MSc

Investigadora asociada

U nidad de T oxicología I ndustrial y M edicina del Trabajo

Facultad de M edicina

Universidad C atólica de L ovaina

Bruselas

Bélgica 


\author{
Burkhard Hoffmann, DPhil \\ lefe de sección \\ D ocumentación y Estadísticas \\ $\mathrm{H}$ auptverband der gewerblichen \\ Berufsgenossenschaften \\ Sankt Augustin \\ Alemania
}

\section{Johan Högberg, MD, PhD \\ Profesor de toxicología \\ Instituto Nacional del Trabajo \\ Solna \\ Suecia}

\section{Judith C. Holder, PhD}

Assistant $D$ irector of $O$ ccupational

$M$ ental $H$ ealth Programs

Duke U niversity M edical C enter

Durham, Carolina del Norte

Estados U nidos

\section{Bo Holmberg, PhD}

Profesor emérito

D epartamento de T oxicología

Instituto Nacional del T rabajo

Solna

Suecia

\section{Irene L.D. Houtman, PhD}

Investigadora

NIA TNO

Amsterdam

Países Bajos

Ann F. Hubbs, DVM, PhD, MS

$\mathrm{H}$ ealth $\mathrm{E}$ ffects $L$ aboratory Division

N ational Institute for $\mathrm{O}$ ccupational Safety and $\mathrm{H}$ ealth

$M$ organtown, $V$ irginia occidental

Estados U nidos

\section{James Huff, PhD, MS}

Environmental $\mathrm{C}$ arcinogenesis Program National Institute of Environmental $\mathrm{H}$ ealth Sciences

R esearch T riangle Park

Carolina del Norte

Estados U nidos

\section{Vilma Hunt, BDS, AM}

Adjunct Professor

D epartment of Work Environment

$U$ niversity of M assachusetts-L owell

L owell, M assachusetts

Estados U nidos
Joseph J. Hurrel, Jr., PhD

Senior R esearch E pidemiologist

$H$ azard Evaluation and T echnical A ssistance Branch

$\mathrm{N}$ ational Institute for $\mathrm{O}$ ccupational Safety and $\mathrm{H}$ ealth

Cincinnati, Ohio

Estados U nidos

\section{Robert Husbands}

$R$ ama de $R$ ehabilitación Profesional

O ficina Internacional del T rabajo

Ginebra

Suiza

Masayuki Ikeda, MD, PhD

Profesor enérito de salud pública

U niversidad de $\mathrm{K}$ ioto

$\mathrm{K}$ ioto

Japón

\section{Terence G. Ison, LLD}

Professor E meritus

$\mathrm{O}$ sgoode $\mathrm{H}$ all Law School

Y ork U niversity

$\mathrm{N}$ orth $\mathrm{Y}$ ork, $\mathrm{O}$ ntario

Canadá

\section{Masaaki Iuchi, BL}

Subdirector

División de Planificación de Políticas

D epartamento de M edidas para la

Promoción del Empleo entre las

Personas de E dad A vanzada y

D iscapacitadas

M inisterio de T rabajo

Tokio

Japón

\section{Nikolai Izmerov, PhD}

Profesor de medicina, D irector

Instituto R AM S de M edicina del Trabajo

M oscú

Federación R usa

\section{Regina Jäckel, MD}

D epartamento de E fectos en la Salud de Sustancias Peligrosas

Instituto Federal de Seguridad y Salud en el Trabajo

Berlín

Alemania

\section{Peter Jacobsen, MD}

Inspector médico

Centro de M edicina del T rabajo

Rigshospitalet

Copenhague

Dinamarca
Marek Jakubowski, PhD, MSc

Profesor, J efe

División de M edicina del T rabajo y

Sanidad A mbiental

Instituto $\mathrm{N}$ ofer de M edicina del T rabajo

Lodz

Polonia

Jerry Jeyaratnam, PhD, MSc

J efe

División de M edicina del T rabajo

U niversidad Nacional de Singapur

Singapur

\section{Gunnar Johanson, Dr med sci}

I nvestigador

D epartamento de T oxicología

Instituto $\mathrm{N}$ acional del Trabajo

Solna

Profesor asociado

U niversidad de U ppsala

U ppsala

Suecia

\section{Barry L. Johnson, PhD}

Assistant Surgeon General, A ssistant

Administrator

A gency for T oxic Substances and Disease Registry

A tlanta, G eorgia

Estados U nidos

T. K. Joshi, MS, MSc

O ficina Internacional del T rabajo (Bhután e India)

Nueva Delhi

India

\section{Roland Kadefors, PhD}

Profesor

Departamento de Prevención de Accidentes

U niversidad T ecnológica de Chalmers G öteborg

Suecia

\section{Jeffrey P. Kahn, MD}

President

Center for W ork Stress R eduction

Farmington, Connecticut

W orkPsych A ssociates Inc.

Scarsdale, Nueva Y ork

Estados Unidos

\section{Craig Karpilow, MD}

President

International Professional Associates, Ltd.

Seattle, Washington

Estados U nidos 
Timo Kauppinen, PhD

J efe de la U nidad de R egistros

Instituto Finlandés de M edicina

del Trabajo

$\mathrm{H}$ elsinki

Finlandia

\section{George Kazantzis, FRCP, FFCM, FFOM*}

L ondon School of $\mathrm{H}$ ygiene and T ropical $M$ edicine

T U C C entenary Institute of O ccupational $\mathrm{H}$ ealth

Londres

R eino U nido

\section{Homayoun Kazemi, MD}

Professor of M edicine

$\mathrm{H}$ arvard M edical School

Chief

Pulmonary and Critical $\mathrm{C}$ are U nit

$M$ assachusetts $G$ eneral H ospital

Boston, M assachusetts

Estados U nidos

\section{Ása Kilbom, MD}

Profesor, Director

Departamento de Ergonomía

Instituto $\mathrm{N}$ acional del T rabajo

Solna

Suecia

\section{Kikuzi Kimura, Dr med sci}

Instituto de Ciencias del T rabajo

K awasaki

Japón

\section{Howard M. Kipen, MD, MPH}

Associate $P$ rofessor, D irector

Division of $\mathrm{O}$ ccupational $\mathrm{H}$ ealth

Environmental and $\mathrm{O}$ ccupational $\mathrm{H}$ ealth

Science Institute

U M D NJ-R obert Woods J ohnson M edical School

Piscataway, N ueva Jersey

Estados U nidos

\section{George R. Kliesch}

Antiguo director

Condiciones de Trabajo y M edio Ambiente

O ficina Internacional del T rabajo

Ginebra

Suiza

Manolis Kogevinas, MD, PhD, MSc

Profesor asociado

U nidad de Investigación de la Salud

R espiratoria y Ambiental

Institut M unicipal d'Investigació M édica

Barcelona

España

\author{
Kazutaka Kogi, MD, Dr med sci \\ Director \\ Instituto de Ciencias del T rabajo \\ K awasaki \\ Japón
}

\section{David Koh, MBBS, PhD, MSc}

Profesor asociado

D epartamento de M edicina Comunitaria, del Trabajo y de Familia

U niversidad $\mathrm{N}$ acional de

Singapur

\section{Michie A. J. Kompier, PhD}

Profesor

D epartamento de Psicología del T rabajo y de las 0 rganizaciones

U niversidad de Nijmegen

$\mathrm{N}$ ijmegen

Países Bajos

\section{Lawrence D. Kornreich, PhD,} M SPH

President

EnviroH ealth and Safety $M$ anagement

$M$ t A rlington, N ueva Jersey

Estados U nidos

\section{Andreas Kranig, Dr jur}

J efe de sección

Legislación Alemana sobre el Seguro de Accidente

$H$ auptverband der gewerblichen Berufsgenossenschaften

Sankt Augustin

Alemania

\section{Richard S. Kraus, PE, CSP}

Principal

Petroleum Safety Consultants

Annandale, Virginia

Estados U nidos

\section{Leon Kreitzman, DSc, MSc}

Director

$M$ aturity $M$ arketing $L t d$.

Londres

R eino U nido

\section{Penny M. Kris-Etherton, PhD, RD}

Professor

D epartment of $\mathrm{N}$ utrition

Pennsylvania State U niversity

University Park, Pensilvania

Estados U nidos

\footnotetext{
${ }^{*}$ Colaborador de la 3a edición de esta Enciclopedia. Esta información bibliográfica no se ha actualizado.
}

Karl H.E. Kroemer, Dr-Ing

Professor, Director

Industrial Ergonomics L aboratory H uman Factors Engineering C enter

ISE D epartment

$\checkmark$ irginia T ech

Blacksburg, V irginia

Estados Unidos

\section{Ilkka Kuorinka, MD, PhD}

D irector

Safety and Ergonomics Division

Institute for $\mathrm{O}$ ccupational $\mathrm{H}$ ealth and Safety R esearch

$M$ ontreal, Q uebec

Canadá

\section{Joseph LaDou, MD, MS}

D irector

International C enter for O ccupational $M$ edicine

U niversity of California-San Francisco

San Francisco, California

Estados U nidos

\section{Jay Lasser, MD}

President

C enter for W ork Stress R eduction

Farmington, Connecticut

Estados U nidos

Patricia A. Last, FRCS, FRCOG

Consultant, W omen's $H$ ealth

$\mathrm{H}$ ertfordshire

R eino U nido

\section{Aishah A. Latiff, PhD}

D irector

Centro de Control del Doping

U niversidad Sains de M alaisia

Penang

M alaisia

\section{Wolfgang Laurig, Dr-Ing}

Profesor, D irector

D epartamento de Ergonomía Institut für Arbeitsphysiologie

U niversidad de D ortmund

D ortmund

Alemania

\footnotetext{
Robert R. Lauwerys, MD, DSC, MIH, MSc

Profesor

U nidad de T oxicología Industrial y

M edicina del T rabajo

Facultad de M edicina

U niversidad Católica de L ovaina

Bruselas

Bélgica
} 


\section{Antoine Laville}

Professor, Director

Laboratoire d'Ergonomie

Physiologique-Cognitive

É cole Pratique des H autes Études

París

Francia

\section{Marjatta Leirisalo-Repo, MD}

Consultora de reumatología

D epartamento de M edicina

H ospital Central de la U niversidad de $\mathrm{H}$ elsinki

$\mathrm{H}$ elsinki

Finlandia

\section{Grace Kawas Lemasters \\ Professor \\ D epartment of Epidemiology and Environmental $\mathrm{H}$ ealth \\ $U$ niversity of $\mathrm{C}$ incinnati \\ Cincinnati, $\mathrm{O}$ hio \\ Estados U nidos}

Richard A. Lemen, PhD, MS

F ormer Assistant Surgeon G eneral, D eputy

$D$ irector

$\mathrm{N}$ ational Institute for $\mathrm{O}$ ccupational Safety and $\mathrm{H}$ ealth

A tlanta, Georgia

Estados U nidos

\section{Michel Lesage, MD, CSPQ}

E specialista en medicina del trabajo O ficina Internacional del T rabajo

G inebra

Suiza

\section{Lennart Levi, MD, PhD}

Profesor emérito, Antiguo director

D epartamento de Investigación del Estrés Instituto $\mathrm{K}$ arolinska

Estocolmo

Suecia

\section{Linnéa Lillienberg, PhD \\ $H$ igienista industrial \\ D epartamento de M edicina del T rabajo \\ U niversidad de Sahlgrenske \\ G öteborg \\ Suecia}

\section{Morton Lippmann, PhD}

Professor of E nvironmental M edicine

$N$ elson Institute of Environmental

M edicine

N ew Y ork U niversity M edical C enter

T uxedo, Nueva Y ork

Estados U nidos
James E. Lockey, MD, MS

Professor, Director

D epartment of O ccupational and Environmental $M$ edicine

U niversity of $\mathrm{C}$ incinnati

Cincinnati, $\mathrm{O}$ hio

Estados U nidos

\section{Veikko Louhevaara, PhD}

P rofesor de ergonomía, I nvestigador

U nidad de Ergonomía

D epartamento de Fisiología

U niversidad de K uopio

Instituto Finlandés de M edicina del Trabajo

Kuoppio

Finlandia

\section{Michelle Madelien}

Paulson and Cooper Inc.

Chicago, Illinois

Estados U nidos

\section{Mohd Isa Abd Majid, PhD \\ I fe \\ U nidad del Laboratorio de T oxicología \\ Centro Nacional de T oxicología \\ U niversidad Sains de M alaisia \\ Penang \\ $M$ alaisia}

\section{Nicole Mamelle, PhD}

D irectora de investigación

Instituto $\mathrm{N}$ acional de Investigaciones

Sanitarias y M édicas

$$
\text { Lyon }
$$

Francia

\section{Norman M. Mann, MD}

Chemosensory Clinical R esearch C enter

D epartment of M edicine

U niversity of C onnecticut

Farmington, Connecticut

Estados U nidos

\section{S. Zack Mansdorf, PhD \\ $M$ anaging $D$ irector \\ Liberty International R isk Services \\ Boston, $M$ assachusetts \\ Estados U nidos}

\section{Alfred C. Marcus, PhD}

Director

Division of Behavioral Science R esearch

AM C C ancer R esearch Center

Denver, Colorado

Estados U nidos
Kazimier J. Marek, MD, PhD

Profesor, I efe

D epartamento Clínico

Instituto de M edicina del T rabajo y

Sanidad A mbiental

Sosnowiec

Polonia

\section{Anthony A. Marfin, MD, MPH}

Division of R espiratory Disease Studies

$\mathrm{N}$ ational Institute for O ccupational Safety and $\mathrm{H}$ ealth

M organtown, $V$ irginia occidental

Estados U nidos

\section{Steven B. Markowitz, MD}

Associate Professor, D eputy D irector

Division of Environmental and O ccupational M edicine

$M$ ount Sinai School of M edicine

N ueva Y ork, N ueva Y ork

Estados U nidos

\section{Marco Maroni, MD}

Director

C entro Internacional para la Seguridad de los Plaguicidas

Instituto de M edicina del T rabajo

Milán

Italia

\section{Masali*}

Instituto de Antropología y Etnología

U niversidad de T urín

Turín

Italia

\section{Donald R. Mattison, MD, MS}

Professor, D ean

Graduate School of Public H ealth

U niversity of Pittsburgh

Pittsburgh, Pensilvania

Estados U nidos

\section{A. Mayer, Eng}

J efe

Departamento de $M$ aquinaria y

Dispositivos de Protección

C entro de Investigación

Instituto $\mathrm{N}$ acional de Investigaciones sobre la Seguridad

$\checkmark$ andoeuvre

Francia

\section{Alan Maynard, BA, B Phil}

D epartment of E conomics

$U$ niversity of $Y$ ork

H eslington, Y ork

$R$ eino U nido

\footnotetext{
${ }^{*}$ Colaborador de la 3a edición de esta Enciclopedia. Esta información bibliográfica no se ha actualizado.
} 


\section{Daniel McBain, MA}

$\mathrm{H}$ amilton, $\mathrm{O}$ ntario

Canadá

\section{Michael McCann, PhD, CIH}

Senior Associate E ditor

E ncycl opaedia of $O$ ccupational $H$ ealth and Safety

International L abour $O$ ffice

N ueva Y ork, Nueva Y ork

Estados Unidos

\section{Robert J. McCunney, MD, MPH}

Director

Environmental M edical Service

$M$ assachusetts I nstitute of T echnology

C ambridge, M assachusetts

Estados U nidos

\section{Ross A. McKinnon, PhD}

Lecturer in Pharmaceutical Biotechnology

School of Pharmacy and M edical Sciences

U niversity of South Australia

Adelaide

Australia

Thomas H. McQuiston, MS

University of N orth Carolina

Chapel H ill, Carolina del Norte

Estados U nidos

\section{Dick J. Meertens, Engsaf}

Director de programa

$R$ ama de Estudios y A ctividades relacionadas con la Prevención y

el Seguro de Accidentes

A sociación Internacional de la

Seguridad Social

Ginebra

Suiza

Heather Menzies, BA

School of Canadian Studies

C arleton U niversity

O ttawa, O ntario

Canadá

\section{Donna Mergler, PhD}

Professor

Centre for the Study of Biological Interactions in $\mathrm{H}$ ealth and Environment U niversity of Q uebec-M ontreal M ontreal, Q uebec

Canadá

Franco Merletti, MD, MSc

Profesor de estadística médica

D epartamento de Ciencias M édicas

Universidad de T urín

T urín

Italia
Jacqueline Messite, MD

Clinical Professor

Department of Environmental M edicine

$\mathrm{N}$ ew Y ork U niversity C ollege of M edicine

Nueva Y ork, Nueva Y ork

Estados U nidos

Jean-Jacques Meyer, PhD

Profesor de ergonomía, J efe de laboratorio

Laboratorio de Ergonomía de la V isión

Instituto de Ciencias de la M edicina del Trabajo

Lausanne

Suiza

Jarl-Erik Michelsson, MD, PhD

Loviisa

Finlandia

\section{H. Mierzecki*}

Antiguo jefe

Instituto de D ermatología

Academia de M edicina

Wroclaw

Polonia

\section{R. Rita Misra, PhD}

Laboratory of Comparative

Carcinogenesis

National Cancer Institute

Frederick, $\mathrm{M}$ aryland

Estados U nidos

Toyohiko Miura, MD

Instituto de C iencias del T rabajo

K awasaki

Japón

\section{Willi Momm, MA}

lefe

Rama de R ehabilitación Profesiona

O ficina Internacional del Trabajo

Ginebra

Suiza

John S. Morawetz, ScM

Director

ICWU Center for Worker $\mathrm{H}$ ealth and Safety Education

Cincinnati, 0 hio

Estados U nidos

\section{Vivian K. Morgan, BS}

Acting Chief

Information R esources Branch

National Institute for $\mathrm{O}$ ccupational

Safety and $\mathrm{H}$ ealth

Cincinnati, O hio

Estados U nidos
Sharon L. Morris, BA

Assistant C hair for $\mathrm{C}$ ommunity $\mathrm{O}$ utreach

$D$ epartment of Environmental $\mathrm{H}$ ealth

U niversity of W ashington

Seattle, W ashington

Estados U nidos

April E. Mott, MD

$M$ edical Director

Chemosensory Clinical R esearch $\mathrm{C}$ enter

U niversity of $\mathrm{C}$ onnecticut $\mathrm{H}$ ealth $\mathrm{C}$ enter

Farmington, Connecticut

Estados U nidos

\section{Sonia Muchnick-Baku, MA, ScM}

Director

W ashington Business $\mathrm{G}$ roup on $\mathrm{H}$ ealth

W ashington, DC

Estados U nidos

Vladimir M. Munipov, MS

C atedrático, Profesor de ergonomía

Instituto de Ingeniería R adioeléctrica,

Electrónica y Automatización de M oscú

M oscú

Federación R usa

\section{Lawrence R. Murphy, PhD}

R esearch P sychologist

Applied Psychology and Ergonomics Branch

National Institute for $O$ ccupational Safety and $\mathrm{H}$ ealth

Cincinnati, 0 hio

Estados U nidos

Karl J. Musgrave, DVM, MPH

Wyoming State $\mathrm{H}$ ealth D epartment Cheyenne, W yoming

Estados U nidos

Melvin L. Myers, BS, MPA

D eputy Director

O ffice of Extramural Coordination and Special Projects

$\mathrm{N}$ ational Institute for $\mathrm{O}$ ccupational Safety and $\mathrm{H}$ ealth

Atlanta, G eorgia

Estados U nidos

Friedhelm Nachreiner, Dr rer nat

Profesor de psicología aplicada

U nidad de Psicología del T rabajo y las 0 rganizaciones

U niversidad de Carl von 0 ssietzky

O ldenburg

Alemania 
Pranab Kumar Nag, PhD, DSc, MSc

Subdirector

Consejo de Investigaciones M édicas de la India

Instituto Nacional de M edicina

del Trabajo

Ahmedabad

India

Danie W. Nebert, MD, MS

Professor, Director

Center for Environmental G enetics

U niversity of $\mathrm{C}$ incinnati $\mathrm{M}$ edical $\mathrm{C}$ enter

Cincinnati, O hio

Estados U nidos

\section{Carolyn Needleman, PhD}

Professor, Director

O ccupational/ E nvironmental $\mathrm{H}$ ealth Program

G raduate School of Social Work and Social R esearch

Bryn M awr College

Bryn M awr, Pensilvania

Estados U nidos

\section{Thomas J. Nelson, BS, CIH}

NIHS Inc.

Ardentown, D elaware

Estados U nidos

\section{Toshiteru Okubo, MD, Dr Med Sc}

Profesor, Director

D epartamento de E pidemiología Ambiental

U niversidad de M edicina del T rabajo y Sanidad Ambiental

K itakyushu

Japón

\section{Shauna Olney, LLB, BCL}

Director jurídico

R ama de Libertad de A sociación

$O$ ficina Internacional del T rabajo

Ginebra

Suiza

\section{Peter Orris, MD, MPH}

Associate P rofessor of $M$ edicine

Cook County H ospital

U niversity of Illinois

Chicago, Illinois

Estados U nidos

\section{Dave W. Ortlieb, BS}

Director

Safety and H ealth Department

U nited Paperworkers I nternational U nion

Nashville, T ennessee

Estados U nidos
M. Gerald Ott, PhD, MS

$D$ irector of E pidemiology

BASF Corporation

$M$ ount O live, N ueva J ersey

Estados U nidos

\section{Heinz Otten, Dr rer nat}

J efe de sección

$\mathrm{H}$ auptverband der gewerblichen Berufsgenossenschaften

Sankt Augustin

Alemania

\section{Muneto Ozaki}

R ama de $D$ erecho del T rabajo y R elaciones $L$ aborales

O ficina Internacional del T rabajo

Ginebra

Suiza

Freda L. Paltie, CSW, MPH, CM

F ormer Senior Advisor, Status of W omen

Consultant in $\mathrm{H}$ ealth and Social Policy

$\mathrm{H}$ ealth Canada

O ttawa, O ntario

Canadá

\section{Sheila Pantry, OBE, BA, FLA,} FIInf Sci

Sheila Pantry A ssociates-I nformation Services Consultancy

\section{Sheffield}

R eino U nido

\section{John E. Parker, MD}

Chief

Examination Processing Branch

Division of R espiratory Disease Studies

$\mathrm{N}$ ational Institute for O ccupational Safety and $\mathrm{H}$ ealth

M organtown, V irginia occidental

Estados U nidos

Timo Partanen, PhD, MSc, MPH

Departamento de E pidemiología y Bioestadística

Instituto Finlandés de M edicina del Trabajo

$\mathrm{H}$ elsinki

Finlandia

\section{Glenn Paulson, PhD}

President

Paulson and Cooper Inc.

Jackson H ole, W yoming

Estados U nidos

Dennis J. Paustenbach, PhD, MS

President, Chief E xecutive 0 fficer

$\mathrm{M} \mathrm{CL}$ aren $\mathrm{H}$ art/ Chem Risk ${ }^{\circledR}$

Alameda, California

Estados U nidos
Neil Pearce, PhD

Associate P rofessor

W ellington Asthma R esearch G roup

W ellington School of M edicine

Wellington South

N ueva Zelanda

Daniela Pelclová, MD, PhD

Profesora asociada, I efa

D epartamento de Enfermedades

Profesionales

U niversidad de $\mathrm{C}$ harles

Praga

R epública Checa

Peter L. Pelmear, MD, FFOM

A ctive Staff C onsultant

Department of $O$ ccupational and Environmental $\mathrm{H}$ ealth

St. M ichael's H ospital

T oronto, 0 ntario

Canadá

\section{Edith Perlebach, MD}

I efa de sección

M edicina del T rabajo

$H$ auptverband der gewerblichen

Berufsgenossenschaften

Sankt Augustin

Alemania

\section{Debra A. Perry, M Ed}

President

Perry, Winans and Company

Washington, DC

Estados U nidos

\section{Edward L. Petsonk, MD, CM}

Chief, Clinical Section

Division of R espiratory Disease Studies

$\mathrm{N}$ ational Institute for $\mathrm{O}$ ccupational Safety and $\mathrm{H}$ ealth

M organtown, V irginia occidental

Estados U nidos

\section{Wai-On Phoon, MB, DIH}

P rofessor, $\mathrm{H}$ ead

D epartment of O ccupational $\mathrm{H}$ ealth

U niversity of Sydney

Sidney

Australia

\section{Simon Pickvance, BA}

$O$ ccupational $\mathrm{H}$ ealth $\mathrm{Advisor}$

Sheffield $\mathrm{O}$ ccupational $\mathrm{H}$ ealth Project

Sheffield

R eino U nido 


\section{Robert Ransom, MA}

E specialista

R ama de R ehabilitación Profesional

$O$ ficina I nternacional del T rabajo

Ginebra

Suiza

\section{Jorma Rantanen, MD, PhD}

Director genera

Instituto Finlandés de M edicina del Trabajo

H elsinki

Finlandia

\section{Carl Raskin, BA, Dip Ed}

Coordinator

G lobal Applied Disability R esearch and Information N etwork on Employment and $T$ raining

Canadian L abour Force D evelopment Board

$\mathrm{N}$ epean, $\mathrm{O}$ ntario

Canadá

\section{Dzulkifli Abdul Razak, MSc}

Profesor, Director

Centro Nacional de T oxicología

U niversidad Sains de M alaisia

Penang

M alaisia

\section{Paule Rey, MD, MPH}

Profesora emérita

Facultad de M edicina

U niversidad de Ginebra

Ginebra

Suiza

\section{Annie Rice, BSc}

Directora

H ealth Safety Environment Consultants

Petit Bornand

Francia

Peter Richter, Dr rer nat

Profesor

Institut für Arbeits, 0 rganisations und Sozialpsychologie

U niversidad T ecnológica de Dresde

Dresde

Alemania

\section{Wolfgang von Richthofen}

E specialista en inspección del trabajo $R$ ama de $A$ dministración del T rabajo

O ficina I nternacional del T rabajo

Ginebra

Suiza
Hilkka Riihimäki, MD, Dr med sci

D irector

Departamento de Epidemiología y

Bioestadística

Instituto Finlandés de M edicina del Trabajo

$\mathrm{H}$ elsinki

Finlandia

\section{Sally Roberts, PhD}

Clinical Scientist

Centre for Spinal Studies

Robert J ones and Agnes H unt $\mathrm{O}$ rthopaedic and District H ospital

O swestry, Shropshire

Reino Unido

\section{Dilys Robertson, BA}

Consultant

$\mathrm{O}$ ccupational $\mathrm{H}$ ealth and Safety

Toronto, 0 ntario

Canadá

\section{Walter Rohmert, Prof Dr-Ing}

Profesor emérito

Institut für Arbeitswissenschaft

T echnische H ochschule Darmstadt

Darmstadt

Alemania

\section{William N. Rom, MD, MPH}

Professor of $M$ edicine

Division of Pulmonary and Critical Care $M$ edicine

N ew Y ork U niversity

Nueva Y ork, Nueva Y ork

Estados U nidos

\section{Linda Rosenstock, MD, MPH}

Director

National Institute for 0 ccupational Safety and $\mathrm{H}$ ealth

Washington, DC

Estados U nidos

\section{Clara Sue Ross, MD, JD}

President

Environmental and $\mathrm{O}$ ccupational $\mathrm{H}$ ealth Consultants Inc.

Cincinnati, O hio

Estados U nidos

\section{John Rudge, MBA}

Senior L ecturer and OH S P rogrammes Coordinator

School of $M$ anagement

University of South Australia

Adelaide

Australia
Jon Rudnick, MD, MPh, MSc

Corporate M edical Director

D ow Corning Corporation

$M$ idland, M ichigan

Estados U nidos

John W. Ruser, PhD, MA

Chief

Compensation R esearch Group

U nited States Bureau of $L$ abor Statistics

W ashington, DC

Estados U nidos

\section{Ragnar Rylander, MD, PhD}

Profesor

D epartamento de M edicina A mbiental

U niversidad de G öteborg

Göteborg

Suecia

\section{David L.S. Ryon, MD}

Division of Pulmonary and Critical Care M edicine

New Y ork U niversity

Nueva Y ork, N ueva Y ork

Estados U nidos

\section{Sheldon W. Samuels, AB}

$F$ ormer D irector of $\mathrm{H}$ ealth, Safety and $E$ nvironment

Industrial U nion D epartment

A merican Federation of $L$ abor and

C ongress of I ndustrial 0 rganizations

Washington, DC

Estados U nidos

\section{Andries F. Sanders, PhD}

P rofesor de psicología cognitiva

D epartamento de Psiconomía

U niversidad Pública

Amsterdam

Países Bajos

\section{Rodolfo Saracci, MD}

Director de investigación

Consejo $\mathrm{N}$ acional de Investigación

Pisa

Italia

Annie J. Sasco, MD, Dr PH

J efa

Programa de Epidemiología para la

Prevención del Cáncer

Agencia Internacional para la

Investigación sobre el Cáncer

Lyon

Francia 
Denis Sasseville, MD, FRCPC Associate $P$ rofessor of $M$ edicine ( $D$ ermatology) M cG ill U niversity

M ontreal, Q uebec

Canadá

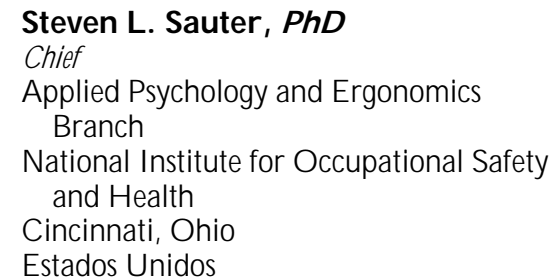

\section{Marianne Saux, MD}

J efa

D epartamento de M edicina del T rabajo

Directora del Servicio de Inspección $M$ édica

M inisterio de T rabajo

París

Francia

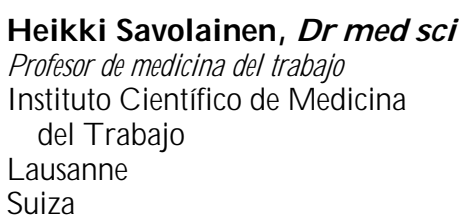

Richard Schilling, MD, DSc

0 ccupational $\mathrm{H}$ ealth Consultant

Londres

R eino U nido

William J. Schneider, MD, MPH

Director of $\mathrm{H}$ ealth Services

J.P. M organ and $\mathrm{Co}$. Inc.

Nueva Y ork, N ueva Y ork

Estados U nidos

Wolfram D. Schneider, Prof Dr med

I fe

D epartamento de E fectos en la Salud de Sustancias Peligrosas

Instituto Federal de Seguridad y Salud en el Trabajo

Berlín

Alemania

Steven M. Schrader, PhD
Chief
Functional T oxicology Section
National Institute for O ccupational Safety
and H ealth
Cincinnati, O hio
Estados U nidos

Horst Schulz, Dipl Volkswirt

I efe

Departamento de Informática y D ocumentación

$\mathrm{H}$ auptverband der gewerblichen Berufsgenossenschaften

Sankt Augustin

Alemania

\section{Susan Scott-Parker, BA}

Chief Executive

Employers' Forum on Disability

Londres

R eino U nido

\section{Patrick Sébastien, PhD}

Scientific D irector

Institute of $\mathrm{O}$ ccupational $\mathrm{H}$ ealth and Safety R esearch

M ontreal, Q uebec

Canadá

\section{Marie-Claire Séguret}

$\mathrm{R}$ ama de Condiciones de T rabajo y Servicios de Bienestar

O ficina Internacional del T rabajo

Ginebra

Suiza

Anna Maria Seppäläinen, MD, PhD Jefa

División de N eurofisiología Clínica

U niversidad de $\mathrm{H}$ elsinki

H elsinki

Finlandia

\section{Lowell E. Sever, PhD}

Program D irector for Public $\mathrm{H}$ ealth Sciences Battelle Seattle R esearch C enter

Seattle, Washington

Estados U nidos

\section{Erwin Seyfried, PhD}

Profesor de psicología social, D irector

U nidad de Investigación sobre

Formación Profesional,

M ercado de T rabajo y Evaluación

Berlín

Alemania

\section{Behrouz Shahandeh, MA}

A sesor de drogas y al cohol

$R$ ama de $R$ ehabilitación Profesional

O rganización Internacional del T rabajo

Ginebra

Suiza
Houshang Shahnavaz, PhD, MSc

Profesor de ergonomía industrial

Director

Centro de E rgonomía de los Países en Vías de D esarrollo

U niversidad T ecnológica de Luleå

Luleå

Suecia

\section{Steven Short, DO}

M edical 0 fficer

Division of R espiratory Disease Studies

National Institute for $O$ ccupational Safety and $\mathrm{H}$ ealth

M organtown, V irginia occidental

Estados U nidos

Donald E. Shrey, PhD

Associate Professor

Department of Physical M edicine and R ehabilitation

$U$ niversity of $\mathrm{C}$ incinnati $\mathrm{M}$ edical $\mathrm{C}$ enter

Cincinnati, O hio

Estados Unidos

Joel Shufro, PhD

Executive D irector

$\mathrm{NYCOSH}$

Nueva Y ork, Nueva Y ork

Estados U nidos

\section{Ellen Silbergeld, PhD}

Professor of E pidemiology and Pathology

$U$ niversity of $M$ aryland at Baltimore Baltimore, $\mathrm{M}$ aryland

Estados U nidos

\section{Leif Simonsen, PhD}

Departamento de T oxicología y Biología Instituto $\mathrm{N}$ acional de $\mathrm{M}$ edicina del

Trabajo

Copenhague

Dinamarca

William T. Singleton, DSc, MA

Professor E meritus of A pplied Psychology

Aston U niversity

Birmingham

Northumberland

Reino U nido

\section{Susan Sink, MFA}

Artist

Chicago, Illinois

Estados Unidos 


\section{Gisela Sjøgaard, PhD, Dr med sci}

Directora

Departamento de Fisiología

Instituto Nacional de M edicina del

Trabajo

Copenhague

Dinamarca

\section{Juhani Smolander, PhD \\ Investigador \\ Instituto Finlandés de M edicina del Trabajo \\ Vantaa \\ Finlandia}

\section{David Snowball, PhD}

Deputy D irector G eneral's O ffice

$\mathrm{H}$ ealth and Safety Executive

$L$ ondres

Reino U nido

\section{Marja Sorsa, PhD}

Directora

M inisterio de E ducación

$\mathrm{H}$ elsinki

Finlandia

Colin L. Soskolne, PhD

P rofessor, D irector of $G$ raduate $T$ raining Department of Public H ealth Services U niversity of Alberta

Edmonton, Alberta

Canadá

\section{Jerry Spiegel, MA, MSc}

Director

Pollution Prevention

$M$ anitoba Environment

Winnipeg, M anitoba

Canadá

Heide Stark, Dr med

Departamento de Epidemiología

Instituto Federal de Seguridad y Salud en el Trabajo

Berlín

Alemania

\section{Jeanne M. Stellman, PhD}

Directora de edición

Enciclopedia de salud y seguridad en el trabajo

O ficina Internacional del Trabajo

Ginebra

Suiza

School of Public H ealth

Columbia U niversity

Nueva Y ork, Nueva Y ork

Estados U nidos

\section{Steven D. Stellman, PhD, MPH}

Chief

Division of Epidemiology

American $\mathrm{H}$ ealth Foundation

Nueva Y ork, N ueva Y ork

Estados U nidos

\section{Craig R. Stenberg, PhD}

Director

O ccupational/ M ental $\mathrm{H}$ ealth Programs

D epartments of Psychiatry and

Community and Family $M$ edicine

Duke U niversity M edical School

Durham, C arolina del N orte

Estados U nidos

\section{James H. Stewart, PhD, CIH}

School of Public H ealth

$\mathrm{H}$ arvard U niversity

Boston, M assachusetts

Estados U nidos

B.J. Stiles, BD, BA

President, Chief Executive 0 fficer

National AIDS Fund

Washington, DC

Estados U nidos

\section{Phillip W. Strine, BA}

Special Assistant to the Assistant Surgeon General and $\mathrm{D}$ eputy Director, Public $\mathrm{H}$ ealth Advisor

$N$ ational Institute for $O$ ccupational Safety and $\mathrm{H}$ ealth

Atlanta, G eorgia

Estados U nidos

\section{Zhi Su, MD, MPH}

Director

D epartamento de Inspección y Supervisión Sanitaria

M inisterio de Sanidad

Pekín

China

\section{Haruko Suzuki}

División de Información Científica

Instituto de Ciencias del Trabajo

K awasaki

Japón

\section{Ken Takahashi, MD, D MSc, MPH}

Profesor asociado

Departamento de Epidemiología

Ambiental

U niversidad de M edicina del T rabajo y Ambiental

K itakyushu

Japón
Jukka Takala, Dr Tech, MSc

Je efe

R ama de Seguridad y Salud en el Trabajo

O ficina Internacional del T rabajo

Ginebra

Suiza

Krishna Talluri, MB

D epartment of Psychiatry

Duke U niversity M edical Center

Durham, Carolina del N orte

Estados U nidos

\section{Rachael F. Taylor, LLB}

Consultora

O ficina Internacional del T rabajo

Ginebra

Suiza

Spomenka Telišman, DSc, MSc

Consultor científico

Instituto de Investigaciones M édicas y

M edicina del T rabajo

Zagreb

Croacia

\section{Benedetto Terracini, MD}

Antiguo jefe

U nidad de Epidemiología del Cáncer

H ospital U niversitario y U niversidad de Turín

Turín

Italia

\section{Ulrike Tittel bach, Dr med}

D epartamento de Efectos en la Salud de Sustancias Peligrosas

Instituto Federal de Seguridad y

Salud en el T rabajo

Berlín

Alemania

\section{Lori Todd, PhD, MS}

Associate P rofessor

D epartment of Environmental Science and Engineering

U niversity of N orth Carolina Chapel H ill, Carolina del Norte Estados U nidos

\section{Angela K. Traiforos, M Ed}

E xecutive $D$ irector

Center for Administration, R ehabilitation and Employment Services

International Association of $M$ achinists

U pper M arlboro, M aryland

Estados U nidos 
Anne Trebilcock, JD

D irectora jurídica

O ficina de A sesoramiento Jurídico

O ficina Internacional del T rabajo

Ginebra

Suiza

\section{Benjamin F. Trump, MD}

Professor, Chair

D epartment of Pathology

School of M edicine

$U$ niversity of $\mathrm{M}$ aryland

Baltimore, $M$ aryland

Estados U nidos

\section{Ulf Ulfvarson, PhD}

P rofesor de ergonomía industrial

D epartamento de T ecnología

A mbiental y Ciencias del Trabajo

R eal Instituto de T ecnología

Estocolmo

Suecia

\section{Eberhard Ulich, Prof Dr, Dr hc \\ Profesor \\ D epartamento de Psicología del T rabajo y las 0 rganizaciones \\ Instituto Federal Suizo de Tecnología \\ Zurich \\ Suiza}

Jill P.G. Urban, PhD

Senior R esearch F ellow

Laboratory of Physiology

U niversity of 0 xford

Oxford

R eino U nido

\section{Antero Vähäpassi, MSc}

A sesor técnico

R ama de Administración del T rabajo

O ficina Internacional del T rabajo

Ginebra

Suiza

\section{Harri Vainio, MD, PhD \\ J efe \\ U nidad de Q uimioprevención \\ Agencia I nternacional para la Investigación sobre el Cáncer \\ Lyon \\ Francia}

\section{José A. Valciukas, PhD}

Associate P rofessor, D irector

Psychology Internship T raining Program

$L$ incoln $M$ edical and $M$ ental $H$ ealth

Center

N ueva Y ork, N ueva Y ork

Estados U nidos
Kees A. van der Heijden, Dr

Director

División de Bilthoven

Centro Europeo de M edio Ambiente

y Salud de la O rganización M undial de la Salud

Bilthoven

Países Bajos

\section{Henk van Loveren, PhD}

J efe

Sección de Inmunobiología y H ematología

Laboratorio de Patología e Inmunobiología

Instituto $\mathrm{N}$ acional de Salud Pública y M edio Ambiente

Bilthoven

Países Bajos

Joachim Vedder, Dipl-Ing, MS

Departamento de Ergonomía

Institut für A rbeitsphysiologie

U niversidad de D ortmund

Dortmund

Alemania

\section{María Luz Vega Ruiz, Lab Law}

E specialista en derecho del trabajo y relaciones laborales

O ficina Internacional del T rabajo

Ginebra

Suiza

\section{Marc Vericel, Dr d’État en droit}

Profesor

Facultad de D erecho

Universidad de Saint-Etienne

Saint-Etienne

Francia

\section{Eira Viikari-Juntura, MD,}

\section{Dr med sci}

U nidad de Investigación

M usculosquelética

D epartamento de Fisiología

Instituto Finlandés de M edicina del Trabajo

$\mathrm{H}$ elsinki

Finlandia

\section{Paolo Vineis, MD}

Subdirector

U nidad de E pidemiología del Cáncer

$\mathrm{H}$ ospital C entral y U niversidad

Turín

Italia

Eva Vingård, MD, PhD

M édica, I nvestigadora

Instituto $\mathrm{N}$ acional del T rabajo

Solna

Suecia

\section{Serge Volkoff}

D irector

Centro de Investigación y Estudios sobre

la Edad y la Población Activa

París

Francia

Joseph G. Vos, DVM, PhD

efe

Laboratorio de Patología e

Inmunobiología

Instituto N acional de Salud Pública y

M edio A mbiente

Bilthoven

Países Bajos

\section{Michael P. Waalkes, PhD}

Chief

Inorganic Carcinogenesis Section

$\mathrm{N}$ ational Cancer Institute

Frederick, $\mathrm{M}$ aryland

Estados U nidos

\section{Gregory R. Wagner, MD}

D irector

Division of R espiratory Disease Studies

N ational Institute for $\mathrm{O}$ ccupational Safety and $\mathrm{H}$ ealth

M organtown, V irginia occidental

Estados U nidos

Nina B. Wallerstein, Dr PH, MPH

Associate P rofessor

Department of Family and C ommunity

M edicine

U niversity of $\mathrm{New} \mathrm{M}$ exico

Albuquerque, N uevo M éxico

Estados U nidos

Jung-Der Wang, MD, ScD, MIH

Profesor, Director

Instituto de M edicina del T rabajo e

$\mathrm{H}$ igiene Industrial

Escuela de Salud Pública de la

U niversidad Nacional de T aiwán

Taipei

China

Leon J. Warshaw, MD

Clinical Professor

D epartment of Environmental M edicine

N ew Y ork U niversity

N ueva Y ork, Nueva Y ork

Estados U nidos

Philip G. Watanabe, PhD, DABT

T oxicology C onsultant

Blaine, Washington

Estados U nidos 
David Howe Wegman, MD, MS

Professor, Chair

D epartment of W ork Environment U niversity of M assachusetts-L owell

L owell, M assachusetts

Estados U nidos

Elisabete Weiderpass, MD, MSc

Departamento de Epidemiología del Cáncer

U niversidad de U ppsala

Uppsala

Suecia

\section{Merri Weinger, MPH}

O ficina de Sanidad A mbiental G lobal e Integrada

O rganización M undial de la Salud

Ginebra

Suiza

Peter J.M. Westerholm, MD

Profesor de epidemiología del trabajo

Instituto $\mathrm{N}$ acional del T rabajo

Solna

Suecia

\section{Julian Wilbourn, BSc}

Científico

Unidad de Identificación y Evaluación de $C$ arcinógenos

A gencia Internacional para la Investigación sobre el Cáncer

Lyon

Francia

\section{Mary S. Wolff, PhD}

Professor of Community M edicine

$M$ ount Sinai School of M edicine

Nueva Y ork, Nueva Y ork

Estados U nidos

\section{Patrisha Woolard, BA}

M ount Sinai School of M edicine

Nueva Y ork, Nueva Y ork

Estados U nidos

\section{Frank B. Wright}

Director

European $\mathrm{O}$ ccupational $\mathrm{H}$ ealth and Safety Law U nit

U niversity of Salford

$M$ anchester

Reino U nido

\section{H. Beric Wright, MB, BS}

F ormer M edical D irector

British U nited Provident Association

Bucks

R eino U nido

\section{Michael J. Wright, MS}

D irector

$H$ ealth, Safety and Environment Department

U nited Steelworkers of America

Pittsburgh, Pensilvania

Estados U nidos

\section{Lucy Yardley, PhD, MSc}

Senior L ecturer in P sychology

D epartment of Psychology

U niversity C ollege-L ondon

Londres

R eino U nido

\section{Annalee Yassi, MD, MSc}

Director

O ccupational and Environmental M edicine

$\mathrm{H}$ ealth Sciences $\mathrm{C}$ entre and $\mathrm{U}$ nit

$U$ niversity of $M$ anitoba

Winnipeg, M anitoba

Canadá

\section{Shelia Hoar Zahm, ScD}

D eputy Chief

O ccupational Epidemiology Branch

National $C$ ancer Institute

R ockville, M aryland

Estados U nidos

\section{Jan E. Zejda, MD, PhD}

J efe

D epartamento de E pidemiología Instituto de M edicina del Trabajo y

Sanidad A mbiental

Sosnowiec

Polonia

\section{Joanne Zurlo, PhD}

Associate Director

Johns $\mathrm{H}$ opkins Center for Alternatives to Animal T esting

Baltimore, M aryland

Estados U nidos 



\title{
Para la versión inglesa original
}

\author{
Sarah Alvarez \\ $M$ aria Arteta \\ $\mathrm{M}$ ay Ballerio-H ofman \\ Lillian Benjamin \\ M ichel Berka \\ Walter Benjamin \\ Christian Bolufer \\ Claude Chaperon \\ $\mathrm{K}$ yle $\mathrm{Creane}$ \\ D enis Cullinan \\ Johanna de V ries \\ $R$ obert $D$ ees \\ $M$ argaret Fennessy \\ $R$ aymond Figuières \\ Betty G oldman \\ Susan G uthridge \\ $\mathrm{K}$ athleen Susan H urst \\ Claudia H ommel \\ R achael H orner \\ Sanna Immonen \\ $\mathrm{L}$ isa $\mathrm{K}$ ellner \\ Diana Signe K line \\ Nana-Ekua L eigh \\ R obert L euze \\ Elizabeth $M$ ahiga \\ Christiane M elin \\ Jacky M erteau
}

\author{
John M cK enna \\ Julie N ayler \\ Catherine $\mathrm{H}$. Perring \\ Peter Perring \\ Bodhani Pieris \\ Giles R eed \\ $K$ irsten R eed \\ John G. Rodwan, Jr. \\ N ancy J. R odwan \\ David R osenweig \\ David Rowley \\ $O$ riele $\mathrm{R}$ ovaletti \\ $D$ aniel $R$ uffieux \\ Jacques $P$. T remblet \\ Steven Sacks \\ Barbara Sandi \\ Gabor Sandi \\ Anneliese Shulte \\ Jonathon Stampf \\ Fred Stanton \\ Prabha Sundaram \\ Juan T enorio \\ Jennifer $V$ aldes \\ Tracy W eber \\ Berit W iding-Pry \\ Sydney G. Williams \\ Su Zen
}

\section{Para la versión española}

$\mathrm{H}$ an colaborado de forma desinteresada en las diversas fases de correcciones técnicas los/ las siguientes expertos/ expertas.

Por el Instituto Nacional de Seguridad e Higiene en el Trabajo (E spaña), coordinados por D ña. M a Carmen Guardiola H uertas:

\author{
I gnacio Cáceres A rmendariz \\ Dolores Carreño M artín \\ Pilar Casla Benito \\ R osa Cuenca Alvarez \\ Antonio De la I glesia \\ $M \stackrel{a}{a}$ Angeles Del $\mathrm{H}$ oyo Delgado \\ $R$ afael $D$ enia $C$ andel \\ $M$ anuel $F$ idalgo $V$ ega \\ $X$ avier Guardino Solá \\ Andrés $\mathrm{H}$ arto Castaño \\ J esús L edesma de M iguel \\ Jerónimo M aqueda Blasco \\ Luis V icente M artín M artín \\ Esther M artín de Dios \\ L ourdes Pacheco R eyna \\ Pilar Pancorbo Aguilera \\ Joaquín Pérez Nicolás \\ Javier Pinilla García \\ Jesús Portillo G arcía-Pintos \\ T omás Sancho Figueroa \\ Alberto Sanz M erinero \\ M a D olores Solé G ómez \\ M a Félix Villar Fernández
}

Por el Instituto Nacional de M edicina y Seguridad en el Trabajo (España), coordinados por D. E duardo M ascías Saracho:
$M$ anuel Callejas Berdonés
Luis C onde Salazar
M anuel Domínguez Carmona
José $M$ anuel Fernández $O$ nieva
Carlos $\mathrm{G}$ onzalo G uisande
Javier $M$ ascías $C$ adavid
Javier Sanz G onzález
José M iguel Seoane R uiz 



\section{SUMARIO}

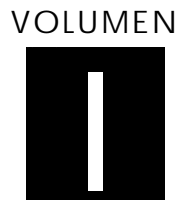

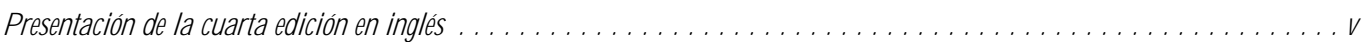

Extractos de presentaciones de ediciones anteriores $\ldots \ldots \ldots \ldots \ldots \ldots \ldots \ldots \ldots \ldots \ldots \ldots \ldots \ldots \ldots \ldots \ldots \ldots \ldots$

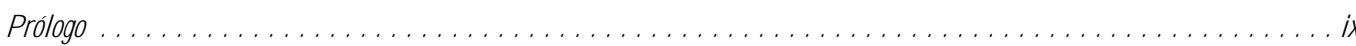

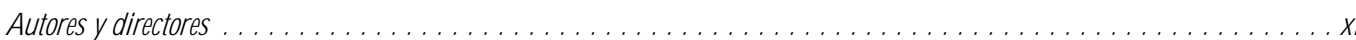

PARTE I. EL CUERPO HUMANO

\section{Sangre}

Bernard D. Goldstein, Director del capítulo

Sistema hematopoyético y linfático B ernard D. Goldstein 1.2

Leucemia, linfomas malignos y mieloma múltiple . ................ T imo Partanen, Paolo B offetta, E lisabete W eiderpass

\section{Cáncer}

Paolo Boffetta, Director del capítulo

Introducción.

N eil Pearce, Paolo B offetta y M anolis Kogevinas 2.2

Cancerígenos profesionales .............. . Paolo B offetta, R odolfo Saracci, M anolis Kogevinas, J ulian W ilbourn y H arri Vainio 2.4

Cáncer de origen ambiental . .................... B ruce K. Armstrong y Paolo B offetta

Prevención. . Per Gustavsson

\section{Sistema cardiovascular}

\section{y G erd H euchert, Directo}

Introducción

M orbilidad y mortalidad cardiovascular

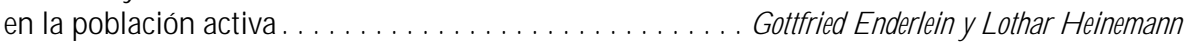

El concepto de factor de riesgo en la enfermedad cardiovascular. . . . . . . . . . . . . . . . . . . L othar $\mathrm{H}$ énemann, Gottfried E nderlein y $\mathrm{H}$ éde Stark 3.5

Programas de rehabilitación y prevención . . . . . . . . . . L L othar H énemann y Gottfried E nderlein 3.9

\section{PELIGROS FISICOS, QUIMICOSY BIOLOGICOS}

Factores físicos $\mathrm{H}$ eide Stark y $\mathrm{G}$ erd $\mathrm{H}$ euchert 3.11

M ateriales químicos peligrosos. . U Irike T ittelbach y W olfram D ietmar Schneider

Peligros biológicos R egina J äckel, U Irike T ittelbach y W olfram D ietmar Schneider

4. Aparato digestivo

H eikki Savolainen, Director del capítulo

A parato digestivo . G. Frada 4.2

Boca y dientes. F. Gobbato 4.3

Hígado. G eorge Kazantzis 4.5

U Icera péptica. K.S. Cho 4.8

Cáncer hepático T imo Partanen, T imo Kauppinen, Paolo B offetta y E lisabete W eiderpass

Cáncer pancreático T imo Partanen, T imo Kauppinen, Paolo B offetta y E lisabete W eiderpass 
5. Salud Mental

Joseph J. H urrell, Lawrence R. Murphy, Steven L. Sauter y Lennart Levi, D irectores del capítulo

Trabajo y salud mental . . I rene L.D. H outman y M ichie A.J. Kompier 5.2

Psicosis relacionadas con el trabajo . Craig Stenberg, J udith $\mathrm{H}$ older y K rishna Tallu

EST ADO DE ANIMO Y AFECTO

Depresión J ay L asser y J effrey P. Kahn

Ansiedad relacionada con el trabajo ... Randal D. B eaton

Trastorno por estrés postraumático y su relación con la salud laboral y la prevención de lesiones. $M$ ark B raverman

El estrés y el agotamiento, y sus implicaciones en el medio ambiente de trabajo H erbert I. F reudenberger 5.17

Trastornos cognitivos . Catherine A. H eaney 5.19

$\mathrm{K}$ aroshi: muerte por exceso de trabajo. Takashi $\mathrm{H}$ aratani

6. Sistema musculosquelético

Hilkka Riihimäki y Eira Viikari-juntura, Directores del capítulo

Visión general . H ilkka Riihimäki 6.2

M úsculos. Gisela Sjøgaard 6.2

Tendones. T homas J. Armstrong 6.4

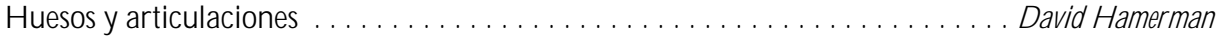
6.6

Discos intervertebrales Sally R oberts y J ill P.G. U rban

Región lumbar .. . H ilkka Riihimäki 6.11

Región de la columna dorsal

J arl-E rik M ichelsson

Cuello . Asa Kilbom 6.16

Hombro $M$ ats $\mathrm{H}$ agberg 6.19

Codo. E ira Viikari-J untura 6.23

Antebrazo, muñeca y mano E ira Viikari-J untura

Cadera y rodilla E va Vingård

Pierna, tobillo y pie. . J arl-E rik M ichelsson

0 tras enfermedades.

$M$ arjatta L érisalo-R epo

\section{Sistema nervioso}

Donna Mergler, Directora del capítulo

Sistema nervioso: visión general . . . . . . . . . . . . . . . . . D onna M ergler y $J$ osé A. Valciukas A natomía y fisiología

A gentes químicos neurotóxicos Peter A rlien-Søborg y Leif Simonsen 7.9

M anifestaciones de intoxicación aguda y crónica precoz. . . . . . . . . . . . . . D onna M ergler 7.15

Síndromes clínicos asociados a neurotoxicidad . . . . . . . . . . . . . . . . . . . . Robert G. Feldman 7.18

D eterminación de los déficit neurotóxicos ...................... D onna M ergler 7.22

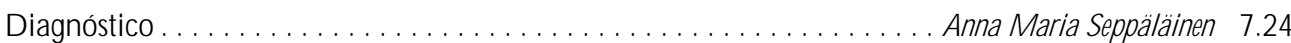

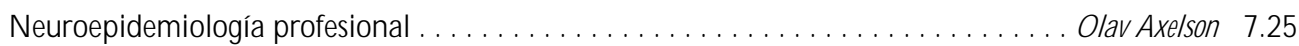

8. Sistemas renal y urinario G eorge $P$. H emstreet, Director del capítulo Los sistemas renal y urinario. . . . . . . . . . . . . . . . . . . . G eorge P. H emstreet 8.2 Cánceres renales y urinarios ....... . T imo Partanen, H arri Vainio, Paolo B offetta y E lisabete W eiderpass 8.11

\section{Sistema reproductor G Gace Kawas Lemasters, Directora del capítulo}

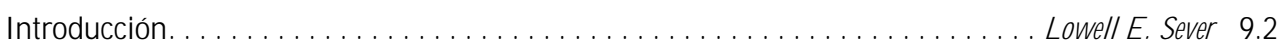
Introducción a la función reproductora masculina y femenina . . . . . . . . . . . D onald R. M attison 9.4 
El sistema reproductor masculino y la toxicología Steven Schrader y Grace Kaw as L emasters

L a estructura del sistema reproductor femenino y la vulnerabilidad de los órganos diana . . . . . . . . . . . . . . . . . . . . . . . . D onald R. M attison 9.9

Exposiciones profesionales maternas y resultados adversos en el embarazo Grace Kawas L emasters 9.11

El parto pretérmino o prematuro y el trabajo . . . . . . . . . . . . . . . Nicole M amelle 9.16

Exposiciones del recién nacido a sustancias tóxicas de origen industrial y ambiental . ........................ W ary S. W olff y Patrisha M. Woolard 9.19

La protección de la maternidad en la legislación . . . . . . . . . . . . . . M arie Claire Séguret 9.25

Recomendaciones de Estados U nidos en relación con el embarazo y el trabajo Leon J. W arshaw

10. Aparato respiratorio Alois David y G regory $R$. Wagner, D irectores del capítulo Estructura y función ..................................... orton Lippmann

Examen de la función pulmonar..................... U If U Ifvarson y M onica $D$ ahlquist

Enfermedades causadas por irritantes respiratorios y productos químicos tóxicos....................... D avid L.S. R yon y W illiam N. R om

Asma ocupacional . George F riedman-J iménez y E dward L. Petsonk 10.20

E nfermedades causadas por polvos orgánicos. .......... R agnar R ylander y R ichard $S$. F. Schilling

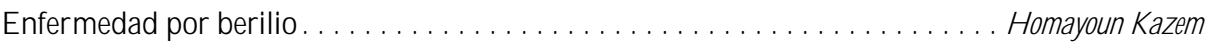
10.31

Neumoconiosis: definición Alois D avid

Clasificación internacional de radiografías de neumoconiosis de la O IT . ........ M ichel Lesage 10.37 E tiopatogenia de la neumoconiosis. . . . . . . . . . . . . . . . . . Patrick Sébastien y R aymond Bégin 10.40 Silicosis . . . . . . . . . . . . . . . . . . . . . . . . . . . . . . . . ohn E. Parker y G regory R. W agner 10.48

Enfermedades pulmonares de los mineros del carbón

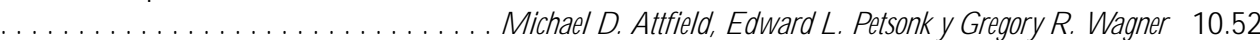
Enfermedades relacionadas con el amianto . . . . . . . . . . . . . . . . . . . . . M argaret $R$. B ecklake 10.57 Enfermedades por metales pesados. . . . . . . . . . . . . . . . . . . G erolamo Chiappino 10.71 A parato respiratorio: la variedad de las neumoconiosis. . . . . . . Steven R. Short y E dward L. Petsonk 10.75 Enfermedad pulmonar obstructiva crónica................ Kazimierz M arek y J an E. Z ejda E fectos de las fibras artificiales sobre la salud ............... ames $E$. L ockey y C lara S. R oss 10.79 Cáncer respiratorio . . . . . . . . . . . . . . . . . . . . . . . . . Paolo $B$ offetta y $E$ lisabete W eiderpass Infecciones pulmonares de origen ocupacional M arcel-André B oillat

Trastornos auditivos inducidos por productos químicos .. Peter J acobsen

Trastornos auditivos provocados por agentes físicos Peter L. Pelmear

Equilibrio... . Lucy Yardley

Visión y trabajo .............................. Paule R ey y $\mathrm{J}$ ean- $\mathrm{J}$ acques $M$ eyer

Gusto A pril E. M ott y N orman M ann

O Ifato A pril E. M ott

Receptores cutáneos. R obert $D$ ykes y $D$ anied $M C B$ ain

\section{Enfermedades de la piel Louis-Philippe Durocher, Director del capítulo} Visión general: enfermedades profesionales de la piel. . . . . . . . . . . . . D onald $]$. B irmingham Cáncer de piel no melanocítico . . . . . . . . . . . . E lisabete W eiderpass, T imo Partanen, Paolo B offetta M elanoma maligno . . . . . . . . . . . . . . . . T imo Partanen, Paolo B offetta, E lisabete W eiderpass 
Dermatitis de contacto profesionales.

D enis Sasseville

Prevención de las dermatosis profesionales.

L ouis-Phillipe D urocher

Distrofia ungüeal profesional .

C.D. Calnan

Estigmas

H. M ierzecki

13. Condiciones del entorno

H oward M. Kipen, Director del capítulo

Condiciones del entorno: introducción . ..................... oward M . Kipen

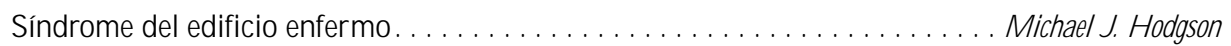

M ultisensibilidad química

. M ark R. Cullen

\section{PARTE II. ASISTENCIA SANITARIA}

\section{Primeros auxilios y servicios médicos de urgencia}

\section{Antonio J. Dajer,}

Primeros auxilios . Antonio J. Dajer

Lesiones craneoencefálicas .

\section{Protección y promoción de la salud}

Jacqueline Messite y Leon J. Warshaw, Directores del capítulo

Protección y promoción de la salud: visión general .......... L eon J. W arshaw y J acqueline M essite Promoción de la salud en el lugar de trabajo . . . . . . . . . . . . . . . onathan $E$. Fielding Promoción de la salud en el lugar de trabajo: Inglaterra Leon Kreitzman 15.13

Promoción de la salud en las pequeñas organizaciones: experiencia de Estados $U$ nidos................. Sonia M uchnick-Baku y L eon J. W arshaw

Función del servicio de salud de los empleados en los programas de prevención . J ohn W.F. Cowell

Programas de mejora de la salud en M aclaren Industries, Inc.: estudio de caso.

Función del servicio de salud en el trabajo en los programas de prevención:

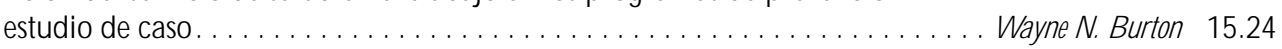

Promoción de la salud en el lugar de trabajo en Japón . . . . . . . . . . . . . Toshiteru 0 kubo 15.27

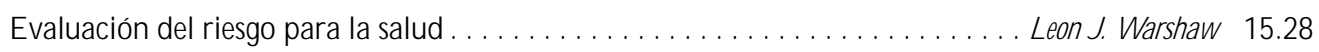

Programas de ejercicio físico y de mantenimiento de la capacidad física para el trabajo: un activo de la organización ...................... ames Corry 15.32

Programas de nutrición en el lugar de trabajo . . . . . . . . Penny M . Kris-E therton y J ohn W. Farquhar 15.37

Control del tabaco en el lugar de trabajo. . . . . . . . . . . . . . . . . . on R udnick 15.42

Los programas de control del tabaco en M errill Lynch and Company, Inc.: estudio de caso . . . . . . . . . . . . . . . . . . . . . . . . . . . . Kristan D. Goldfein 15.47

Prevención y control del cáncer.................... Peter $G$ reenwald y L eon J. W arshaw 15.48

La salud de la mujer . . . . . . . . . . . . . . . . . . . . . . . Patricia A. Last 15.54

Estudio de caso: el programa de mamografías de M arks and Spencer . . . . . . . . . illian H aslehurst 15.60

Estrategias en el lugar de trabajo para la mejora de la salud maternal e infantil: experiencias de los trabajadores en Estados U nidos . . . . . M aureen P. Corry y E llen C utler 15.62

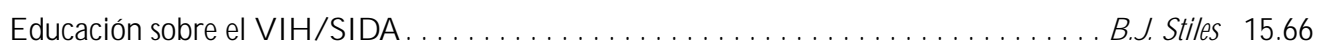
Protección y promoción de la salud: enfermedades infecciosas . . . . . . . . . W illiam J. Schneider 15.69

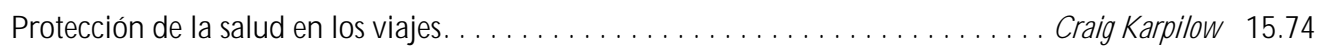

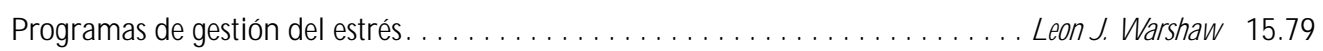

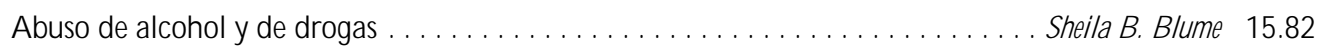


Programas de asistencia a los empleados . . . . . . . . . . . . . . . Sheila $H$. A kabas

L a salud en la tercera edad: programas de prejubilación. . . .

H. B eric W right

15.91

Recolocación.

Saul G. G runer y L eon J. W arshaw

16. Servicios de salud en el trabajo

Igor A. Fedotov, Marianne Saux y Jorma Rantanen, D irectores del capítulo

N ormas, principios y enfoques de los servicios de salud

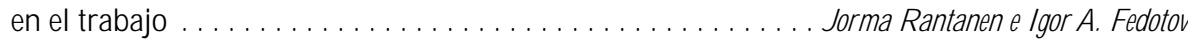

Los servicios de la salud en el trabajo y la práctica ................. Georges $H$. Coppée 16.2

Inspección médica del trabajo en Francia . . . . . . . . . . . . . . . . . . . . . M arianne Saux

Los servicios de salud en el trabajo en la pequeña empresa .... . . J orma $R$ antanen y $L$ eon J. W arshaw 16.25

El seguro de accidentes y los servicios de salud en el trabajo

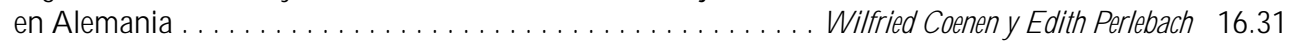

Los servicios de salud en el trabajo en Estados U nidos:

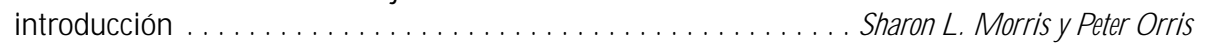

O rganismos públicos de salud en el trabajo en Estados U nidos. . . . . . . . . . . . . . . . . . . . . . . . Sharon $L$. M orris y $L$ inda R osenstock

Servicios de salud en el trabajo en las empresas de Estados U nidos: servicios prestados internamente. . . . . . . . . . . . . . . W illiam B. B unn y R obert J. M cC unney 16.38

Servicios de salud en el trabajo mediante contrato en Estados U nidos. . Penny H iggins 16.41

Actividades sindicales en Estados U nidos . Lamont B yrd 16.43

Servicios académicos de salud en el trabajo en Estados U nidos. . . . . . . . . . . . . D ean B. Baker

Los servicios de salud en el trabajo en Japón ..................... Ken Takahashi 16.45

La protección de los trabajadores en la Federacion Rusa: legislación y prácticas. . . . . . . . . . . . . . . . . . . N ikolai F. I zmerov el gor A. F edotov 16.49

La práctica de los servicios de salud en el trabajo en la República Popular China. .............................. Zhi Su

Salud y seguridad en el trabajo en la R epublica Checa. . . . . . . . . V Vladimír B encko y D aniela Peldová La práctica de la salud en el trabajo en la India

\section{PARTE III. GESTION Y POUTICA}

\section{Discapacidad y trabajo Willi Momm y Robert Ransom, D irectores del capítulo}

D iscapacidad: conceptos y definiciones. . . . . . . . . . . . . . W illi M omm y 0 tto $G$ eiecker

Estudio de caso: clasificación legal de las personas discapacitadas

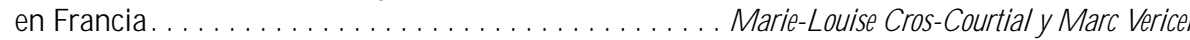

Política social y derechos humanos: conceptos de la discapacidad. . . . . . . . . . . C arl R askin

N ormas laborales internacionales y legislación nacional de empleo en

favor de las personas discapacitadas . . . . . . . . . . . . . . W illi M omm y M asaaki I uchi

Servicios de rehabilitación profesional y de apoyo a los trabajadores. . . . . . . . . . . E rwin Seyfried

Gestión de la discapacidad en el lugar de trabajo: visión de conjunto

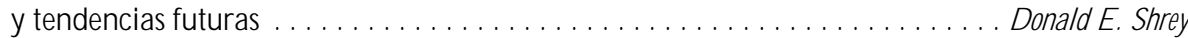

Rehabilitación y pérdida auditiva inducida por el ruido $\ldots \ldots \ldots \ldots \ldots \ldots \ldots$ R aymond $\mathrm{H}$ étu

D erechos y obligaciones: el punto de vista de la empresa . . . . . . . . . . . . . . Susan Scott-Parker

Derechos y obligaciones: el punto de vista de los trabajadores . . . . Angela Traiforos y D ebra A. Perry 


\section{ESTUDIOS DE CASO}

Evaluación de la formación sobre salud y seguridad: estudio de caso de la educación de los trabajadores de residuos peligrosos del Sindicato Internacional de Trabajadores Q uímicos . . . . . . . . . . . . . . T homas H . M cQ uiston, Paula Coleman, Nina W allerstein,

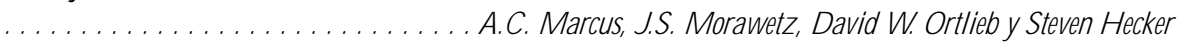

Educación y formación ambiental: situación de la educación de los trabajadores que manejan materiales peligrosos

en Estados U nidos . . . . . . . . . . . . . . G lenn Paul son, M ichelle M adelien, Susan Sink y Steven H ecker 18.15

La educación de los trabajadores y la mejora ambiental . . . . . . . . . . . Edward Cohen-R osenthal 18.17

Formación sobre salud y seguridad de los directivos ................. J ohn Rudge 18.20

Formación de los profesionales en materia de salud y seguridad ............ Wai-0 n Phoon 18.25

Un nuevo enfoque del aprendizaje y la formación: estudio de caso del Proyecto Africano de Salud y Seguridad de la OIT-FIN NIDA ................ Antero Vahapassi y $M$ erri W einger

\section{Cuestiones relacionadas con la ética G eorges H. Coppée, Director del capítulo}

Códigos y directrices .................................. Colin L. Soskolne

Ciencia y responsabilidad: normas éticas y conducta moral en la medicina del trabajo. ....................... Richard A. Lemen y Phillip W. Strine

Aspectos éticos de la investigación sobre la salud y la seguridad en el trabajo ..................... Paul W. B randt-R auf y Sherry I. B randt-R auf 19.8

La ética en el lugar de trabajo: marco para el juicio moral. . . . . . . . . . . . . Sheddon W. Samuels 19.10

Vigilancia del medio ambiente de trabajo . . . . . . . . . . . . . . . . . . . . . L aw rence D. Kornreich 19.13

Aspectos éticos de la información y la confidencialidad ............... Peter J. M. W esterholm 19.14

Etica en la protección y promoción de la salud ............. D. W ayne Corneil y Annalee Yassi 19.20

Estudio de caso: consideraciones éticas sobre el consumo de drogas y alcohol en el lugar de trabajo ................... B ehrouz Shahandeh y R obert $\mathrm{H}$ usbands 19.25

Código deontológico internacional para los profesionales de la salud en el trabajo. .................... . Comisión I nternacional de M edicina de Trabajo

\section{Desarrollo, tecnología y comercio}

Tendencias de la salud en el trabajo en el ámbito de los países en desarrollo..... . e ery J eyaratnam Países industrializados y salud y seguridad en el trabajo .................. Toshiteru 0 kubo

Estudios de caso sobre cambio tecnológico ........................ M ichael J. W right

Pequeñas empresas y salud y seguridad en el trabajo . . Bill Glass

Transferencia de tecnología y elección tecnológica . J oseph LaD ou 20 Acuerdos de libre comercio ............................... ow ard F rumkin

Responsabilidad respecto a los productos y traslado de riesgos industriales ...... Barry Castleman

Aspectos económicos de la salud y la seguridad en el trabajo................ Alan M aynard

\section{Relaciones laborales y gestión de recursos humanos}

Anne Trebilcock, Directora del capítulo

Relaciones laborales y gestión de recursos humanos: visión general . . . . . . . . . . Anne T rebilcock Derechos de asociación y representación. ........................ B reen C réghton 
Cooperación tripartita y bipartita a escala nacional en materia de salud

y seguridad en el trabajo . . . . . . . . . . . . . . . . . . . . R obert $H$ usbands

Formas de participación de los trabajadores ................. uneto 0 zaki y Anne T rebilcock

Consulta e información sobre salud y seguridad.

Aspectos de la formación vinculados a las relaciones laborales . . . M arco Biagi 21.28

Aspectos de la inspección de trabajo vinculados a las relaciones laborales ... M aría L uz Vega Ruiz 21.31

Conflictos colectivos por cuestiones de salud y seguridad . . . . . . . . . . . Shauna $L$. O Iney

C onflictos individuales por cuestiones de salud y seguridad . . Anne Trebilcock

\section{Recursos: información y salud y seguridad en el trabajo}

\section{Jukka T akala, Director del capítulo}

La información: una condición previa para la acción . J ukka Takala

Acceso a la información .......... P.K. A beytunga, E mmert Clevenstine, Vivian M organ y Sheila Pantry 22.2

Gestión de la información Gordon A therley 22.5

Estudio de caso: servicio de información de M alaisia sobre toxicidad de pesticidas. .............. D.A. Razak, A.A. L atiff, M .I. A. M ajid y R. Awang

Estudio de caso: una experiencia de gestión de información eficaz en Tailandia. .

\section{Recursos institucionales, estructurales y jurídicos Rachael F. T aylor} y Simon Pickvance, D irectores del capitulo

O rígenes, medios institucionales, estructurales y

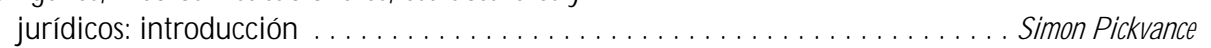

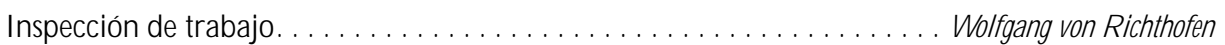
23.2

R esponsabilidad civil y penal en el campo de la salud y seguridad en el trabajo Felice M orgenstern (adaptación)

L a salud en el trabajo como derecho humano I lise L evy Feitshans

AM BITO COMUNITARIO

O rganizaciones de ámbito comunitario Simon Pickvance

Derecho de saber: función de las organizaciones de ámbito comunitario . . . . . . C arolyn N eedleman 23.34

EI movimiento COSH y el derecho a conocer. J oel Shufro 23.35

EJEM PLOS DE AMBITO REGIONAL Y NACIONAL

Salud y seguridad en el trabajo: la U nión Europea . . . . . . . . . . . . . . Frank B. W right 23.37 Legislación tutelar de los derechos de los trabajadores en China . . Su Z hi

Estudio de caso: normas de exposición rusas. Nikolai F. I zmerov

ORGANIZACIONES INTERNACIONALES GUBERNAM ENTALES Y NO GUBERNAMENTALES

Cooperación internacional en la salud laboral: función de las organizaciones internacionales ........................ Georges H. Coppée 23.42

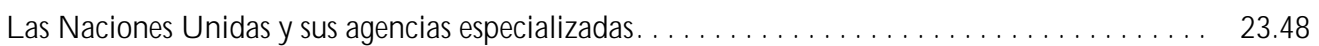

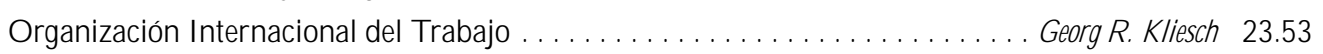

Convenios de la O IT : procedimiento ejecutivo ................... Anne T rebilcock 23.58

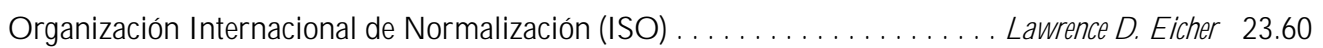

A sociación Internacional de la Seguridad Social (AISS) . . . . . . . . . . . . . D ick J. M eertens 23.63

Comisión Internacional de M edicina del Trabajo (CIM T) . . . . . . . . . . . erry J eyaratnam 23.67

A sociación Internacional de Inspectores de Trabajo (IALI) . . . . . . . . . . D avid Snowball 23.69 
24. Trabajo y trabajadores

Jeanne Mager Stellman y Leon J. Warshaw, Directores del capítulo

Trabajo y trabajadores. Freda L. Paltie 24.2

Cambio de paradigmas y políticas. Freda L. Paltiel 24.2

Salud, seguridad e igualdad en el lugar de trabajo .................. oan B ertin 24.6

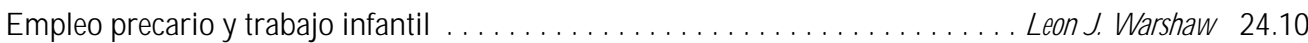

Transformación de los mercados y la mano de obra. . . . . . . . . . . . . . . . . Pat Armstrong 24.17

Tecnologías mundializadoras y reducción/ transformación del trabajo. . . . . . . . . H eather M enzies 24.20

25. Indemnización a los trabajadores, visión general Terence G. I son, Director del capítulo Sistemas de indemnización a los trabajadores por accidentes de trabajo, visión general

PARTE PRIMERA: INDEM NIZACION A LOSTRABAJADORES

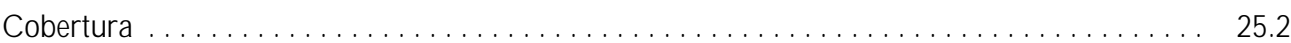

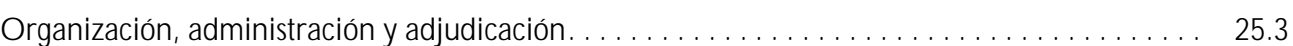

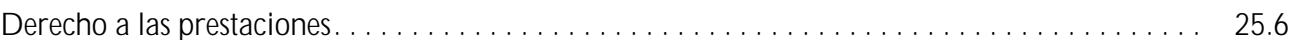

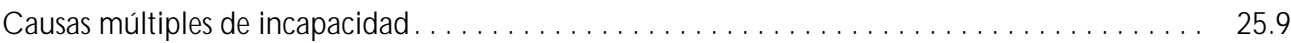

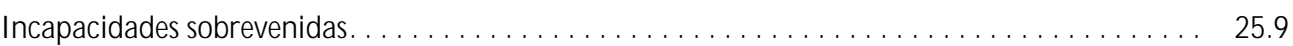

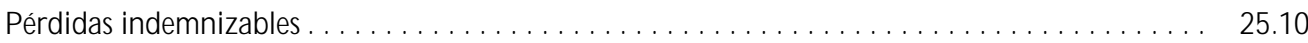

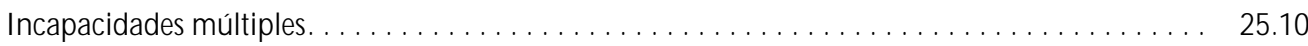

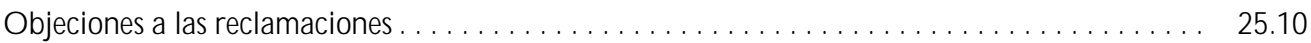

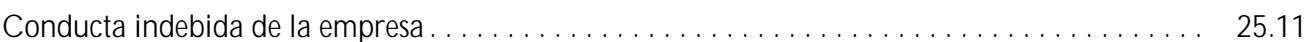

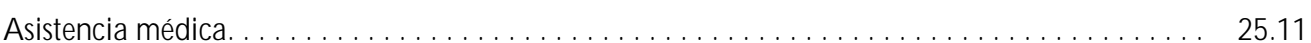

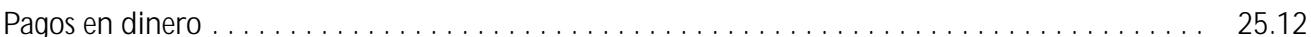

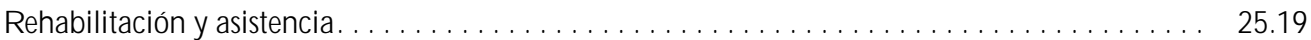

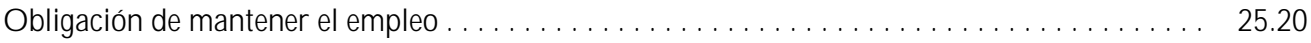

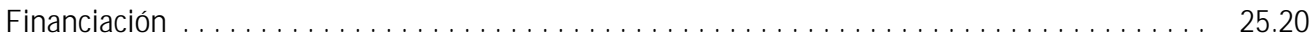

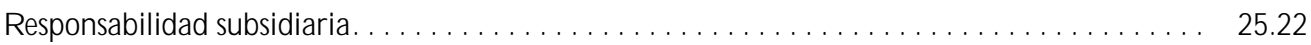

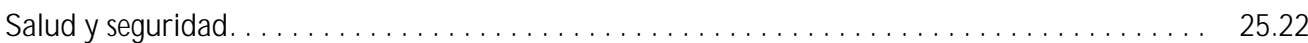

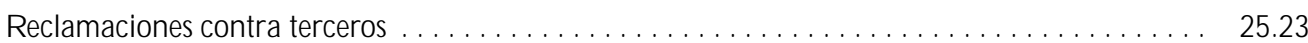

PARTE SEGUNDA: OTROSREGIMENES

Seguros sociales y seguridad social $\ldots \ldots \ldots \ldots \ldots \ldots \ldots \ldots \ldots \ldots \ldots \ldots \ldots \ldots \ldots \ldots \ldots \ldots \ldots$

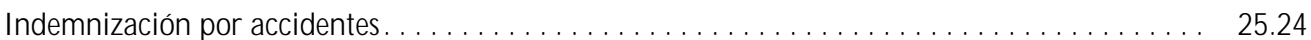

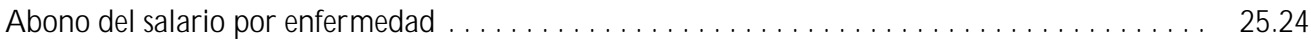

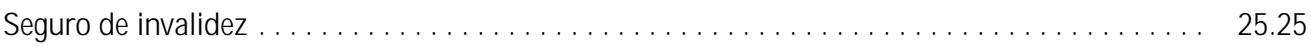

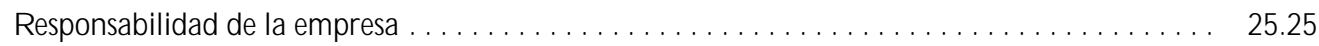

\section{Indemnización a los trabajadores: temas relacionados Paule Rey y}

Michel Lesage, Directores del capítulo

Enfermedades relacionadas con el trabajo y enfermedades profesionales:

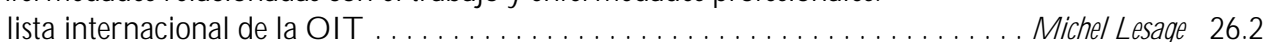

Indemnización por accidentes de trabajo: tendencias y perspectivas . . . . . . . . . . Paule R ey 26.6

Prevención, rehabilitación e indemnización en el sistema alemán de seguro de accidentes. . . . . . . . . . . . . . . . . . . . . . . D ieter G réner y A ndreas K ranig 26.17

Seguro e indemnización de las lesiones profesionales en I srael . . . . . . . . . . . . H aim Chayon 26.22

La indemnización por accidentes de trabajo en Japón. . . . . . . . . . Kazutaka Kogi y H aruko Suzuki 26.26 Estudio de caso: Suecia . . . . . . . . . . . . . . . . . . . . . . . . . . . . . . . Peter W esterholm 26.30 


\section{PARTE IV. HERRAMIENTAS Y ENFOQUES}

27. Control biológico

Principios generales.

G arantía de calidad.

M etales y compuestos organometálicos.

Disolventes orgánicos

Sustancias químicas genotóxicas

Pesticidas.
Robert Lauwerys, Director del capítulo

... V ito $F$ oà y L orenzo Alessio . D avid Gompertz

Perrine $H$ oet y $R$ obert $L$ auw erys ...M asayuki I keda

. M arja Sorsa

$\mathrm{M}$ arco $\mathrm{M}$ aroni y $\mathrm{A}$ dal berto Ferioli

\section{Epidemiología y estadística}

M étodo epidemiológico aplicado a la salud y seguridad en el trabajo.

Franco Merletti, Colin L. Soskolne y Paolo Vineis, Directores del capítulo M. Gerald 0 tt

Evaluación de la exposición M edidas que resumen la exposición durante toda una vida laboral Colin L. Soskolne M edición del efecto de una exposición . . . . . . . . . . . . . . . . . . . . . Shelia H oar Z ahm Tipos de diseño de los estudios . . . . . . . . . . . . . . . . . . . . . . . . . Sven $\mathrm{H}$ ernberg

A spectos relacionados con la validez del diseño del estudio . AnnieJ. Sasco C onsecuencias del error de medida aleatorio ................. Paolo V ineis y Col in L. Soskolne M étodos estadísticos Annibale B iggeri y $M$ ario Braga Paolo Vinés

Evaluación de la causalidad y ética en la investigación epidemiológica.

las enfer medades profesionales $\ldots \ldots \ldots \ldots \ldots \ldots \ldots \ldots \ldots \ldots \ldots \ldots \ldots \ldots \ldots \ldots \ldots$ ung $D$ er $W$ ang

Estudio de caso que ilustra los problemas metodológicos en la vigilancia de

C uestionarios en la investigación epidemiológica

Steven D. Stellman y Colin L. Soskolne

A mianto: perspectiva histórica

L aw rence G arfinkel

29. Ergonomía

\section{Wolfgang L auring y Joachim Vedder, Directores del capítulo}

Introducción . Wolfgang L aurig y Joachim Vedder

\section{OBJETIVOS, PRINCIPIOS Y METODOS}

$\mathrm{N}$ aturaleza y objetivos de la ergonomía . . . . . . . . . . . . . . . W illiam T. Singleton

A nálisis de actividades, tareas y sistemas de trabajo

Véronique D e Keyser

Ergonomía y normalización Friedhelm Nachreiner

\section{ASPECTOS FISICOSY PSICOLOGICOS}

A ntropometría .....................................

Trabajo muscular . J uhani Smolander y Veikko L ouhevaara

Postura en el trabajo Ilkka Kuorinka

Biomecánica. . . . Frank $D$ arby

Fatiga general . É tienne Grandjean

Fatiga y recuperación R olf $\mathrm{H}$ ebig y Walter R ohmert

\section{ASPECTOS PSICOLOGICOS}

C arga mental de trabajo. 
Vigilancia H erbert H euer 29.46

Fatiga mental Peter Richter

ASPECT OS ORGANIZATIVOS DEL TRABAJO

O rganización del trabajo . . . . . . . . . . . . . . . . . . . E berhard U lich y Gudela G rote 29.52

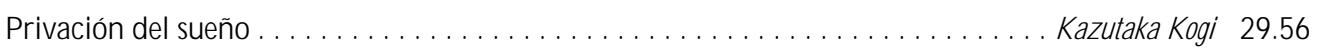

DISEÑO DE LOS SISTEMAS DE TRABAJO

Puestos de trabajo . . . . . . . . . . . . . . . . . . . . . . . . Roland Kadefors 29.61

Herramientas ................................... Fraser 29.66

Controles, indicadores y paneles . . . . . . . . . . . . . . . . . . . Karl H. E. Kroemer 29.69

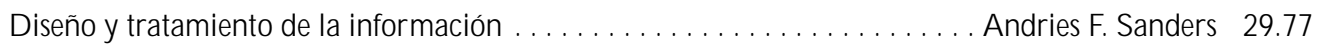

DISEÑO PARA TODOS

Diseño para grupos específicos . . . . . . . . . . . . . . . . . . oke H . G rady-van den N ieuwboer 29.82

Diferencias culturales. . . . . . . . . . . . . . . . . . . . . . . . . oushang Shahnavaz 29.86

Trabajadores de edad avanzada. . . . . . . . . . . . . . . . . . Antoine L aville y Serge Volkoff 29.91

Trabajadores con necesidades especiales................. oke H. G rady-van den N ieuwboer 29.94

DIVERSIDAD E IMPORTANCIA DE LA ERGONOMIA: DOS EJEMPLOS

Diseño de sistemas en la fabricación de diamantes. . . . . . . . . . . . . . . . I ssachar Gilad 29.99

Violación de los principios del diseño ergonómico:

Chernobil. .

Vladimir M . M unipov 29.102

\section{0. $\mathrm{H}$ igiene industrial}

Robert F. Herrick, Director del capítulo

O bjetivos, definiciones e información general. ............... B erenice I. Ferrari G oelzer

Identificación de riesgos. . Linnéa Lillienberg 30.11

Evaluación del medio ambiente de trabajo. Lori A. Todd 30.15

H igiene industrial: control de las exposiciones mediante la intervención . . . . . . . . . . ames Stew art Fundamentos biológicos para evaluar la exposición .................. Dick H eederik Límites de exposición profesional.

. D ennis J . Paustenbach 30.25 30.27 30.31

\section{Protección personal}

Robert F. H errick, Director del capítulo

Aspectos generales y principios de la protección personal $\ldots \ldots \ldots \ldots \ldots \ldots$. obert $F$. H errick

Protectores de ojos y cara . . . . . . . . . . . . . . . . . . . . . Kikuzi Kimura

Protección de pies y piernas Toyohiko M iura

Protección de la cabeza I sabelle Balty y Alain M ayer 31.9

Protección de los oídos J ohn R. Franks y E lliott H . B erger 31.11

Ropa protectora . S. Zack M ansdorf 31.17

Protección respiratoria T homas J. Neson 31.22

32. Sistemas de notificación y vigilancia Steven D. Stellman, Director del capítulo Sistemas de vigilancia y notificación de enfermedades profesionales ........ Steven B. M arkowitz 32.2 Vigilancia de los riesgos profesionales. D avid $H$. W egman y Steven D. Stellman V igilancia en los países en vías de desarrollo. D avid Koh y Kee Seng Chia 32.11

Desarrollo y aplicación de un sistema de clasificación de lesiones y enfermedades profesionales Elyce Biddle 32.13 
A nálisis del riesgo de lesiones y enfermedades no mortales en el lugar de trabajo. .J ohn W. R user 32.20

Estudio de caso: protección del trabajador y estadísticas sobre accidentes y enfermedades profesionales- HVBG, Alemania. . M artin B utz y B urkhard H offmann 32.22

Estudio de caso: Wismut- las consecuencias de la exposición

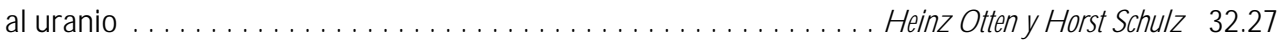

Estrategias y técnicas de medición para la evaluación de la exposición en epidemiología. Frank B ochmann y $\mathrm{H}$ elmut B lome 32.31

Estudio de caso: encuestas de higiene industrial en China . . . . . . . . . . . . . . Z hi Su 32.34

\section{Toxicología}

Introducción.
Ellen K. Silbergeld, Directora del capítulo E llen K. Silbergeld 33.2

PRINCIPIOS GENERALES DE LA TOXICOLOGIA

D efiniciones y conceptos. . . . . . . . . . . . . . . . . B B H ol mberg, J ohan $\mathrm{H}$ ögberg y $\mathrm{G}$ unnar J ohanson 33.3

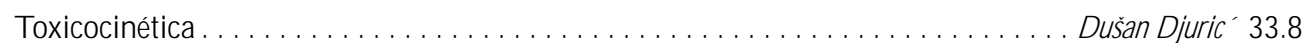

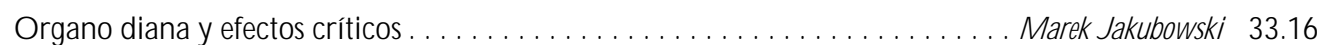

E fectos de la edad, el sexo y otros factores . . . . . . . . . . . . . . . . . . Spomenka Telišman 33.18

D eterminantes genéticos de la respuesta tóxica. . . . . . . . . . . . . D aniel W. N ebert y R oss A. M cK innon 33.21

MECANISM OS DE LA TOXICIDAD

Introducción y conceptos. . . . . . . . . . . . . . . . . . . . . . . . . Philip G. W atanabe 33.29

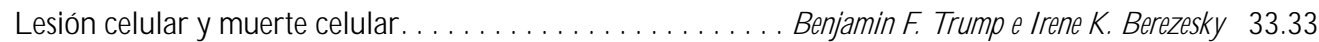

Toxicología genética ........................... R ita M isra y M ichael P. W aalkes 33.35

Inmunotoxicología ........................... oseph $G$. Vos y $H$ enk van $L$ overen 33.39

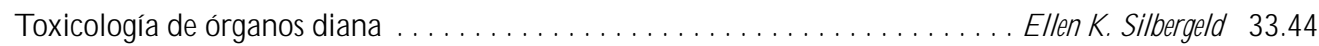

\section{METODOSDE ENSAYO EN TOXICOLOGIA}

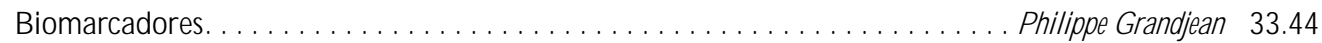

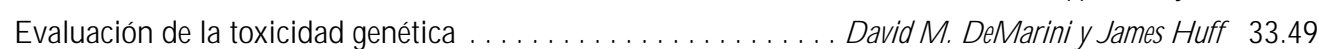

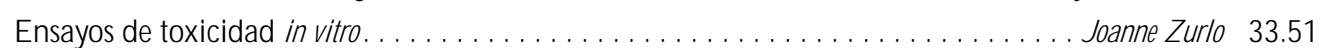

R elaciones estructura-actividad . . . . . . . . . . . . . . . . . . . . . E llen K. Silbergeld 33.55

TOXICOLOGIA REGULADORA

La toxicología en la regulación de la salud y la seguridad . . . . . . . . . . . . . . . E Ellen K. Silbergeld 33.57

Principios de la identificación de los peligros: el enfoque japonés . . . . . . . . . M asayuki l keda 33.57

El enfoque estadounidense de la evaluación del riesgo de los tóxicos para

la reproducción y agentes neurotóxicos. . . . . . . . . . . . . . . . . . E Ellen K. Silbergeld 33.60

Enfoques en la identificación de los peligros: la IARC . . . . . . . . . . H arri Vainio y J ulian W ilbourn 33.65

A péndice: evaluaciones globales de carcinogenicidad para los

humanos: monografías de la IARC, volúmenes $1-69(836) \ldots \ldots \ldots \ldots \ldots \ldots \ldots \ldots \ldots . \ldots \ldots$

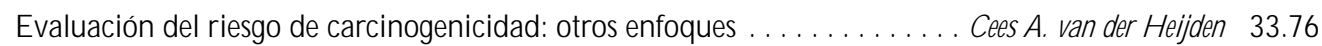


A nálisis del riesgo de lesiones y enfermedades no mortales en el lugar de trabajo. .J ohn W. R user 32.20

Estudio de caso: protección del trabajador y estadísticas sobre accidentes y enfermedades profesionales- HVBG, Alemania. . M artin B utz y B urkhard H offmann 32.22

Estudio de caso: Wismut- las consecuencias de la exposición

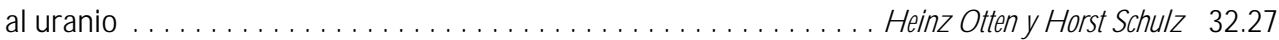

Estrategias y técnicas de medición para la evaluación de la exposición en epidemiología. Frank B ochmann y $\mathrm{H}$ elmut B lome 32.31

Estudio de caso: encuestas de higiene industrial en China . . . . . . . . . . . . . . Z hi Su 32.34

\section{Toxicología}

Introducción.
Ellen K. Silbergeld, Directora del capítulo E llen K. Silbergeld 33.2

PRINCIPIOS GENERALES DE LA TOXICOLOGIA

D efiniciones y conceptos. . . . . . . . . . . . . . . . . B B H ol mberg, J ohan $\mathrm{H}$ ögberg y $\mathrm{G}$ unnar J ohanson 33.3

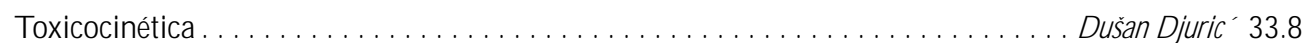

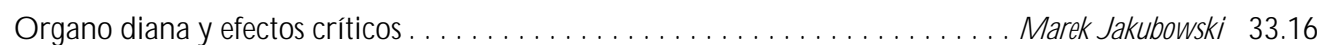

E fectos de la edad, el sexo y otros factores . . . . . . . . . . . . . . . . . . Spomenka Telišman 33.18

D eterminantes genéticos de la respuesta tóxica. . . . . . . . . . . . . D aniel W. N ebert y R oss A. M cK innon 33.21

MECANISM OS DE LA TOXICIDAD

Introducción y conceptos. . . . . . . . . . . . . . . . . . . . . . . . . Philip G. W atanabe 33.29

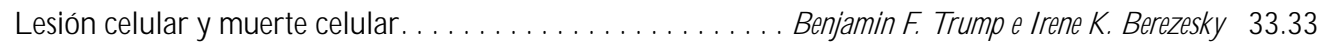

Toxicología genética ........................... R ita M isra y M ichael P. W aalkes 33.35

Inmunotoxicología ........................... oseph $G$. Vos y $H$ enk van $L$ overen 33.39

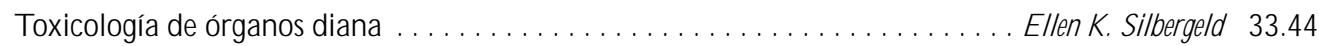

\section{METODOSDE ENSAYO EN TOXICOLOGIA}

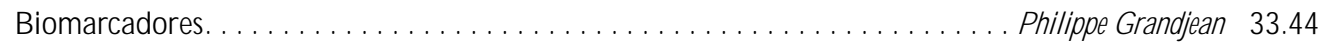

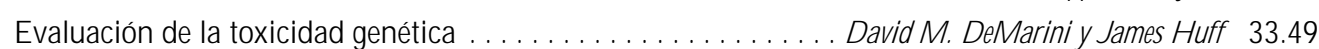

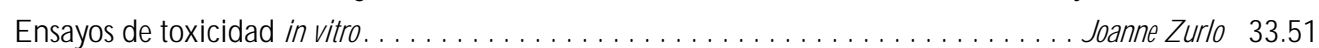

R elaciones estructura-actividad . . . . . . . . . . . . . . . . . . . . . E llen K. Silbergeld 33.55

TOXICOLOGIA REGULADORA

La toxicología en la regulación de la salud y la seguridad . . . . . . . . . . . . . . . E Ellen K. Silbergeld 33.57

Principios de la identificación de los peligros: el enfoque japonés . . . . . . . . . M asayuki l keda 33.57

El enfoque estadounidense de la evaluación del riesgo de los tóxicos para

la reproducción y agentes neurotóxicos. . . . . . . . . . . . . . . . . . E Ellen K. Silbergeld 33.60

Enfoques en la identificación de los peligros: la IARC . . . . . . . . . . H arri Vainio y J ulian W ilbourn 33.65

A péndice: evaluaciones globales de carcinogenicidad para los

humanos: monografías de la IARC, volúmenes $1-69(836) \ldots \ldots \ldots \ldots \ldots \ldots \ldots \ldots \ldots . \ldots \ldots$

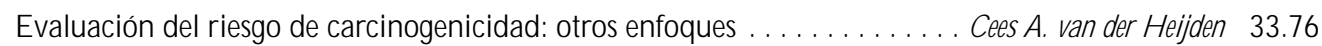




\section{SANGRE}

Director del capítulo

B ernard D. Goldstein

\section{Sumario}

Sistema hematopoyético y linfático

B ernard D. Goldstein. . . . . . . . . . . . . . . . . . . . . . . . . . 1.2

Leucemia, linfomas malignos y mieloma múltiple

T imo Partanen, Paolo B offetta, E lisabete W eiderpass . . . . . . . . . . 1.3

A gentes 0 condiciones de trabajo que afectan a la sangre

B ernard D. Goldstein. . . . . . . . . . . . . . . . . . . . 1.6 


\section{SISTEMA HEMATO POYETICO Y LINFATICO}

\section{Bernard D. G oldstein}

El sistema linfohematopoyético está constituido por la sangre, la médula ósea, el bazo, el timo, los vasos y los ganglios linfáticos. En conjunto, la sangre y la médula ósea forman el sistema hematopoyético. La médula ósea es el lugar en el que se producen las células para reponer constantemente los elementos celulares de la sangre (eritrocitos, neutrófilos y plaquetas). Esta producción está controlada estrechamente por un grupo de factores del crecimiento. Los neutrófilos y las plaquetas se consumen a medida que realizan sus funciones fisiológicas, mientras que los eritrocitos acaban por envejecer y tienen una supervivencia superior a su período de utilidad. Para cumplir adecuadamente sus funciones, los elementos celulares de la sangre deben circular en las cantidades apropiadas y mantener su integridad estructural y fisiológica. Los eritrocitos contienen hemoglobina, que les permite captar oxígeno y suministrarlo a los tejidos para mantener el metabolismo celular. Normalmente, los eritrocitos sobreviven en la circulación unos 120 días cumpliendo estas funciones. LoS neutrófilos aparecen en la sangre cuando se dirigen a los tejidos para participar en la respuesta inflamatoria a los microbios y otros agentes. Las plaquetas circulantes desempeñan un papel esencial en la hemostasia.

La médula ósea tiene una capacidad de producción asombrosa. Cada día, la médula sustituye 3.000 millones de eritrocitos por cada kilogramo de peso corporal. Los neutrófilos tienen una vida media en la circulación de sólo 6 horas, y cada día deben producirse 1.600 millones de neutrófilos por kg de peso corporal. La población plaquetaria debe renovarse completamente cada 9,9 días. Debido a esta necesidad de producir grandes cantidades de células funcionales, la médula ósea es muy sensible a cualquier agresión infecciosa, química, metabólica 0 ambiental que altere la síntesis del ADN o interrumpa la formación de la maquinaria subcelular vital de los eritrocitos, los leucocitos o las plaquetas. Además, como las células hemáticas derivan de la médula ósea, la sangre periférica constituye un indicador sensible y muy exacto de la actividad medular. Es muy fácil obtener sangre para su análisis mediante venopunción, y el estudio de la sangre puede proporcionar indicios precoces de la existencia de enfermedades de etiología ambiental.

Puede considerarse al sistema hematológico como un conducto para las sustancias que penetran en el organismo y como un sistema en el que puede influir negativamente la exposición laboral a agentes potencialmente nocivos. L as muestras de sangre pueden servir como control biológico de la exposición y ofrecer un medio de valorar los efectos de la exposición laboral sobre el sistema linfohematopoyético y otros órganos del cuerpo.

\section{Tabla 1.1 - Agentes seleccionados relacionados con la metahemoglobinemia de etiología ambiental y profesional.}

\footnotetext{
- Agua de pozo contaminada por nitratos

- Clorato potásico

- Gases nitrosos (en soldadura y silos)

- Nitrobencenos

- Tintes de anilina

- Alimentos ricos en nitratos o nitritos

- Fenilendiamina

- Bolitas matapolillas (que contienen naftaleno)
}

L os agentes ambientales pueden interferir en el sistema hematopoyético de varias formas: inhibición de la síntesis de la hemoglobina, inhibición de la producción o la función celulares, leucemogénesis y aumento de la destrucción de los eritrocitos.

Las anomalías del número o la función de las células sanguíneas causadas directamente por riesgos profesionales pueden dividirse en aquéllas en las que el problema hematológico es el efecto más importante, como la anemia aplásica inducida por el benceno, y aquellas otras en las que se observa un efecto hematológico directo pero de menor importancia que los efectos sobre otros sistemas u órganos, como la anemia inducida por el plomo. En ocasiones, las alteraciones hematológicas son un efecto secundario de un riesgo laboral. Por ejemplo, la policitemia secundaria puede deberse a una neumopatía de origen laboral. En la Tabla 1.1 se enumeran los riesgos sobre los que existe una certeza razonable de que tienen un efecto directo en el sistema hematológico.

\section{Ejemplos de riesgos laborales que afectan fundamentalmente al sistema hematológico}

\section{Benceno}

A finales del siglo pasado se determinó que el benceno era un tóxico laboral que producía anemia aplásica (Goldstein 1988). Existen pruebas concluyentes de que el responsable de esta toxicidad hematológica no es el propio benceno, sino uno o varios de sus metabolitos, aunque todavía no se han identificado claramente esos metabolitos y sus objetivos subcelulares (Snyder, Witz y Goldstein 1993).

El reconocimiento de que el metabolismo del benceno tiene un protagonismo en su toxicidad, así como estudios recientes sobre los procesos metabólicos que intervienen en el metabolismo de compuestos como el benceno, presupone la probabilidad de que existan diferencias en la sensibilidad humana al benceno, basadas en diferencias en los índices metabólicos condicionadas por factores ambientales o genéticos. Existen algunas pruebas de una cierta tendencia familiar a la anemia aplásica inducida por el benceno, aunque no se ha podido demostrar con claridad. Parece que el citocromo P-450(2E1) desempeña un papel importante en la formación de metabolitos hematotóxicos del benceno, y estudios recientes realizados en China sugieren que existe un mayor riesgo en los trabajadores que presentan una mayor actividad de este citocromo. Asimismo, se ha sugerido que la talasanemia menor, y presumiblemente otros trastornos en los que aumenta el recambio medular, pueden predisponer al individuo a la anemia aplásica inducida por el benceno ( $Y$ in y cols. 1996). Aunque existen indicios de algunas diferencias en la sensibilidad al benceno, la impresión general que se desprende de la literatura es que, a diferencia de lo que ocurre con otros agentes, como el cloranfenicol, para el que la sensibilidad varía considerablemente, hasta el punto de observarse reacciones idiosincrásicas que producen anemia aplásica con niveles de exposición relativamente insignificantes, la respuesta a la exposición al benceno es prácticamente universal, y se traduce en toxicidad medular $y$, finalmente, anemia aplásica en función de la dosis.

Por consiguiente, el efecto del benceno sobre la médula ósea es análogo al producido por los alquilantes quimioterapéuticos utilizados para tratar la enfermedad de H odgkin y otras neoplasias (T ucker y cols. 1988). A medida que aumenta la dosis disminuyen progresivamente todos los elementos formes de la sangre, lo que a veces se manifiesta inicialmente con anemia, leucopenia o trombocitopenia. Conviene señalar que sería muy raro observar trombocitopenia en una persona que no presentase además unos niveles normales bajos de los demás elementos formes de la sangre. Además, es probable que esa citopenia 
aislada no fuera muy intensa. En otras palabras, un recuento leucocitario aislado de 2.000 por $\mu$ l (cuando el intervalo normal es de 5.000-10.000) indicaría claramente que la leucopenia no se debía al benceno (Goldstein 1988).

La médula ósea tiene una gran capacidad de reserva. I ncluso después de una hipoplasia importante como consecuencia de la quimioterapia, el recuento sanguíneo suele recuperar con el tiempo los valores normales. No obstante, las personas sometidas a esos tratamientos no pueden responder produciendo tantos leucocitos cuando su médula ósea se enfrenta a algún desafío, como una endotoxina, como los individuos que nunca han recibido esos fármacos. C abe deducir razonablemente que, a determinadas dosis, un agente como el benceno puede destruir las células precursoras medulares y, por consiguiente, alterar la capacidad de reserva de la médula sin causar daños suficientes para reducir los recuentos sanguíneos por debajo de los valores normales. $D$ ado que las pruebas médicas habituales pueden no descubrir alteraciones en trabajadores que pueden haber sufrido esa exposición, la protección debe centrarse en la prevención y basarse en principios básicos de higiene industrial. Aunque se ignora el grado de toxicidad medular asociado a la exposición al benceno en los lugares de trabajo, no parece que una sola exposición aguda pueda producir anemia aplásica. Esta observación podría reflejar el hecho de que las células precursoras medulares sólo corren riesgos durante determinadas fases de su ciclo celular, quizá durante su división, y no todas esas células se encontrarán en esa fase durante una exposición aguda aislada. La rapidez de aparición de la citopenia depende en parte de la vida del tipo celular en la circulación. La interrupción completa de la producción medular provocaría primero leucopenia, ya que los leucocitos, y en particular los granulocitos, persisten en la circulación menos de un día. A continuación disminuirían las plaquetas, que tienen una supervivencia de unos diez días. Por último, disminuirían los eritrocitos, que sobreviven un total de 120 días.

El benceno no sólo destruye las células progenitoras pluripotenciales, responsables de la producción de eritrocitos, plaquetas y granulocitos; también se ha observado que reducen rápidamente los linfocitos circulantes tanto en animales de laboratorio como en las personas. Esto sugiere que el benceno puede tener un efecto perjudicial sobre el sistema inmunitario de los trabajadores expuestos, un efecto que no se ha podido demostrar todavía (Rothman y cols. 1996).

Se ha relacionado la exposición al benceno con la anemia aplásica, que a menudo es un trastorno mortal. La muerte suele deberse a alguna infección, ya que la reducción de los leucocitos (leucopenia), compromete el sistema defensivo del organismo, 0 a una hemorragia secundaria debido a la disminución de las plaquetas necesarias para la coagulación normal. U na persona expuesta al benceno en el trabajo que desarrolla una anemia aplásica grave debe considerarse como una señal de alarma de posibles efectos similares en sus compañeros. Estudios basados en el descubrimiento de un individuo centinela han permitido a menudo identificar grupos de trabajadores con signos evidentes de hematotoxicidad por benceno. En la mayor parte de los casos, los individuos que no sucumban con relativa rapidez a la anemia aplásica se recuperarán generalmente tras la supresión de la exposición al benceno. En un estudio de seguimiento de un grupo de trabajadores que habían presentado una importante pancitopenia (disminución de todos los tipos de células hemáticas) inducida por el benceno sólo se encontraron pequeñas anomalías hematológicas residuales diez años después (Hernberg y cols. 1966). Sin embargo, algunos trabajadores de estos grupos, con una pancitopenia inicial relativamente intensa, desarrollaron primero una anemia aplásica, atravesaron después por una fase preleucémica mielodisplásica $y$, finalmente, desarrollaron una leucemia mielógena aguda (Laskin y Goldstein 1977). No debe sorprender esta progresión de la enfermedad, ya que parece que los individuos con anemia aplásica de cualquier etiología tienen un riesgo de desarrollar leucemia mielógena aguda mayor de lo normal (De Planque y cols. 1988).

\section{Otras causas de anemia aplásica}

Se ha relacionado la anemia aplásica con otros agentes presentes en el lugar de trabajo, de los que el más notable es la radiación. Los efectos de la radiación sobre las células progenitoras medulares han sido aprovechados en el tratamiento de la leucemia. Asimismo, diversos alquilantes quimioterapéuticos producen aplasia y representan un riesgo para los trabajadores encargados de fabricar 0 administrar estos compuestos. Parece que la radiación, el benceno y los agentes alquilantes tienen un umbral por debajo del cual no producen anemia aplásica.

La protección de los trabajadores encargados de la producción plantea mayores problemas cuando el agente tiene un mecanismo de acción idiosincrásico y puede producir aplasia en cantidades mínimas, como el cloranfenicol. Se ha asociado el trinitrotolueno, que se absorbe fácilmente por la piel, con la aparición de anemia aplásica en trabajadores de fábricas de munición. También se han asociado otros productos químicos con la anemia aplásica, pero a menudo es difícil establecer una relación causal. Un buen ejemplo es el del plaguicida lindano (hexacloruro de gamma-benceno). Se han publicado algunos casos, generalmente tras una exposición a niveles relativamente elevados, en los que se ha asociado al lindano con aplasia. Este hallazgo no se produce ni mucho menos en todas las personas, y no existen informes de toxicidad medular inducida por lindano en animales de laboratorio tratados con dosis elevadas de este producto. También se ha asociado la hipoplasia de médula ósea con la exposición a éteres de etilenglicol, a diversos plaguicidas y al arsénico (F lemming y T immeny 1993).

\section{LEUCEMIA, LINFO MAS MALIG NOS Y MIELOMA MULTIPLE}

Timo Partanen, Paolo B offetta, Elisabete Weiderpass

\section{Leucemias}

Las leucemias constituyen el $3 \%$ de las neoplasias en todo el mundo (Linet 1985). Son un grupo de neoplasias malignas de las células precursoras hemáticas que se clasifican en función del tipo celular de origen, el grado de diferenciación celular y el comportamiento clínico y epidemiológico. Los cuatro tipos más corrientes son la leucemia linfocítica aguda (LLA), la leucemia linfocítica crónica (LLC), la leucemia mielocítica aguda (LM A) y la leucemia mielocítica crónica (LMC). La LLA tiene un desarrollo rápido, es la forma más frecuente de leucemia infantil y se origina en los corpúsculos leucocitarios de los ganglios linfáticos. La LLC deriva de los linfocitos medulares, se desarrolla muy lentamente y es más frecuente en personas mayores. La LM A es la forma común de leucemia aguda en adultos. Existen tipos poco frecuentes de leucemia aguda: monocítica, basófila, eosinófila, de plasmocitos, de eritrocitos y de células pilosas. Estas formas menos frecuentes de leucemia aguda se agrupan a veces bajo la denominación de leucemia no linfocítica aguda ( $L N L A)$, debido en parte a la creencia de que derivan de una célula progenitora común. La mayoría de los casos de LM C se caracterizan por una anomalía cromosómica específica, el cromosoma Filadelfia. La 
LM C suele evolucionar con el tiempo a LM A tras una transformación leucémica. También puede producir una transformación a LM A en la policitemia vera y la trombocitopenia esencial, trastornos neoplásicos con niveles elevados de eritrocitos o plaquetas, así como mielofibrosis y displasia mieloide. Por tal motivo, estos trastornos se han clasificado como enfermedades mieloproliferativas relacionadas.

El cuadro clínico varía dependiendo del tipo de leucemia. La mayoría de los pacientes experimentan fatiga y malestar general. Las anomalías del recuento hematológico y las células atípicas indican la presencia de una leucemia y obligan a efectuar un estudio de médula ósea. Los signos típicos de la leucemia aguda son la anemia, la trombocitopenia, la neutropenia, el recuento leucocitario elevado y el número elevado de blastocitos.

Incidencia: La incidencia global anual ajustada según la edad oscila entre el 2 y el 12 por 100.000 en los varones y entre el 1 y el 11 por 100.000 en las mujeres en diferentes poblaciones. Las cifras son elevadas en las poblaciones de N orteamérica, E uropa occidental e Israel, y bajas en las poblaciones de Asia y A frica. La incidencia varía en función de la edad y el tipo de leucemia. Aumenta notablemente con la edad, y también se observa un pico en los niños de dos a cuatro años de edad. Los diferentes subgrupos de leucemia presentan diferentes patrones de edades. La LLC es unas dos veces más frecuente en hombres que en mujeres. La incidencia y la mortalidad de las leucemias adultas se han mantenido relativamente estables durante los últimos decenios.

Factores de riesgo: Se ha sugerido que existen factores familiares en el desarrollo de la leucemia, pero las pruebas no son concluyentes. Parece que determinadas condiciones inmunológicas, algunas de ellas hereditarias, predisponen a la leucemia. EI síndrome de D own es un factor predictivo de la leucemia aguda. Se han identificado dos retrovirus oncogénicos (virus I de la leucemia de células T humana, virus II T-linfotropo humano) relacionados con el desarrollo de leucemias. Se cree que estos virus son cancerígenos de etapas tempranas y, como tales, causas insuficientes de leucemia (K eating, E stey y K antarjian 1993).

La exposición a las radiaciones ionizantes y al benceno es causa ambiental y profesional de leucemia demostrada. No obstante, no se ha asociado la incidencia de LLC con la exposición a las radiaciones. En varios países se considera que las leucemias inducidas por radiaciones y por el benceno son enfermedades profesionales.

De manera mucho menos concluyente se ha comunicado una mayor incidencia de leucemia en los siguientes grupos de trabajadores: conductores; electricistas; instaladores de teléfonos e ingenieros electrónicos; granjeros; empleados de molinos de harina; jardineros; mecánicos; soldadores y metalúrgicos; trabajadores textiles; trabajadores de papeleras, y trabajadores de la industria del petróleo y la distribución de derivados petrolíferos. Se ha establecido una relación firme entre determinados agentes del medio ambiente de trabajo y un aumento del riesgo de leucemia: butadieno, campos electromagnéticos, escapes de motores, óxido de etileno, insecticidas y herbicidas, líquidos de máquinas, disolventes orgánicos, derivados del petróleo (incluida la gasolina), el estireno y virus sin identificar. Se ha señalado que la exposición paterna y materna a estos agentes antes de la concepción aumenta el riesgo de leucemia en los descendientes, pero las pruebas disponibles no bastan para establecer la causalidad de esa exposición.

Tratamiento y prevención: Es posible prevenir hasta el $75 \%$ de los casos de leucemia en varones (Agencia Internacional para la Investigación sobre el Cáncer 1990). La supresión de la exposición a las radiaciones y al benceno reduce el riesgo de leucemia, pero no se ha podido calcular la reducción potencial a nivel mundial. El tratamiento de las leucemias incluye la quimioterapia (con uno o varios fármacos), los trasplantes de médula ósea y el interferón. En la LLA y la LM A el trasplante medular permite una supervivencia sin enfermedad del 25-60 \% . El pronóstico es sombrío en pacientes en los que no se consigue la remisión o que recidivan. De los que recidivan, alrededor del $30 \%$ consiguen una segunda remisión. La causa fundamental de que no se produzca la remisión es la muerte por infección y hemorragia. La supervivencia de los pacientes con leucemia aguda no tratada es del $10 \%$ en el año siguiente al diagnóstico. La media de supervivencia de los pacientes con LLC antes del inicio del tratamiento es de 6 años. La supervivencia depende del estadio de la enfermedad en el momento de establecer el diagnóstico.

L as leucemias pueden aparecer tras el tratamiento médico de otras neoplasias malignas (como la enfermedad de Hodgkin, los linfomas, los mielomas y los carcinomas de ovario y de mama) con radiaciones y determinados agentes quimioterapéuticos. La mayoría de estos casos secundarios de leucemia son leucemias no linfocíticas agudas o síndromes mielodisplásicos (un proceso preleucémico). En las leucemias secundarias a un tratamiento y las asociadas a la exposición a radiaciones y benceno parecen ser más frecuentes las anomalías cromosómicas. Estas leucemias agudas suelen ser también más resistentes al tratamiento. Se ha publicado que en los pacientes con LM A con profesiones consideradas con alto riesgo de exposición a leucemógenos es más frecuente la activación del oncogén ras (Taylor y cols. 1992).

\section{Linfomas malignos y mieloma múltiple}

Los linfomas malignos son un grupo heterogéneo de neoplasias que afectan fundamentalmente a los tejidos y órganos linfoides. Los linfomas malignos se dividen en dos tipos celulares principales: la enfermedad de Hodgkin (EH) (Clasificación Internacional de Enfermedades, CIE-9 201) y linfomas no Hodgkin (LNH) (CIE-9 200, 202). El mieloma múltiple (M M ) (CIE-9 203) es una neoplasia maligna de células plasmáticas de la médula ósea responsable de menos del $1 \%$ de las neoplasias malignas (Agencia Internacional para la Investigación sobre el Cáncer 1993). En 1985, los linfomas malignos y el mieloma múltiple ocupaban el séptimo lugar entre todas las neoplasias a nivel mundial. Representaban el 4,2\% de los nuevos casos de cáncer, lo que equivalía a 316.000 nuevos casos (Parkin, Pisani y Ferlay 1993).

La mortalidad y la incidencia de los linfomas malignos no siguen un patrón constante entre las diferentes categorías socioeconómicas en todo el mundo. La EH infantil suele ser más frecuente en los países menos desarrollados, y alcanza niveles relativamente elevados en los adultos jóvenes de regiones más desarrolladas. En algunos países parece que los L NH afectan más a los grupos socioeconómicos más elevados, mientras que en otros países no se observa un gradiente tan claro.

La exposición profesional puede aumentar el riesgo de linfomas malignos, pero la evidencia epidemiológicas no son concluyentes todavía. El amianto, el benceno, las radiaciones ionizantes, los disolventes de hidrocarburos clorados, el serrín y los productos químicos usados en la fabricación del cuero y los neumáticos son ejemplos de agentes con mayor riesgo de producir linfomas malignos sin especificar. Los LNH son más frecuentes entre los granjeros. Más adelante incluimos otros posibles agentes profesionales relacionados con la $E H$, los $L N H$ y el MM.

\section{E nfermedad de H odgkin}

L a enfermedad de H odgkin es un linfoma maligno caracterizado por la presencia de células gigantes multinucleadas (de ReedSternberg). Afecta a los ganglios linfáticos del mediastino y el cuello en cerca del $90 \%$ de los casos, pero puede aparecer en 
otros puntos. Los subtipos histológicos de la $\mathrm{EH}$ difieren en su comportamiento clínico y epidemiológico. El sistema de clasificación de Rye incluye cuatro subtipos: de predominio linfocítico, de esclerosis nodular, de celularidad mixta y de depleción linfocítica. El diagnóstico de la EH se basa en la biopsia, y el tratamiento consiste en la radioterapia sola o combinada con quimioterapia.

El pronóstico de los pacientes con EH depende del estadio de la enfermedad en el momento del diagnóstico. Entre el 85 y el $100 \%$ de los pacientes sin afectación mediastínica masiva sobreviven unos 8 años desde el comienzo del tratamiento sin recidivas. Cuando existe afectación masiva del mediastino, aproximadamente un $50 \%$ de los casos sufren una recidiva. La radioterapia y la quimioterapia pueden producir diversos efectos secundarios, como la leucemia mielocítica aguda secundaria antes comentada.

La incidencia de la $\mathrm{EH}$ no ha experimentado variaciones importantes con el tiempo, con algunas excepciones, como la de las poblaciones de los países nórdicos, en los que han disminuido las tasas (Agencia Internacional para la Investigación sobre el Cáncer 1993).

Los datos disponibles demuestran que en la década de 1980 las poblaciones de Costa Rica, Dinamarca y Finlandia tenían medianas de incidencia anual de EH de 2,5 casos por cada 100.000 varones y de 1,5 casos por cada 100.000 mujeres (normalizadas para la población mundial); estas cifras daban un cociente entre sexos de 1,7. Las tasas más altas en varones se registraban en las poblaciones de I talia, Estados U nidos, Suiza e Irlanda, mientras que en las mujeres se daban en Estados Unidos y Cuba. En Japón y China se han comunicado tasas de incidencia bajas (Agencia Internacional para la Investigación sobre el Cáncer 1992).

Se ha sospechado que la intervención de las infecciones víricas podría intervenir en la etiología de la $\mathrm{EH}$. Se ha comprobado que la mononucleosis infecciosa, inducida por el virus de Epstein-Barr (un herpesvirus), va acompañada de un aumento del riesgo de $E H$. En una misma familia pueden coincidir varios casos de la enfermedad de Hodgkin, y también se han observado otras coincidencias temporoespaciales, pero las pruebas de que existen factores etiológicos comunes detrás de tales casos son poco consistentes.

No se ha establecido en qué medida los factores profesionales pueden aumentar el riesgo de EH. Existen tres agentes sospechosos fundamentales: los disolventes orgánicos, los herbicidas fenoxi, y el polvo de madera, pero las pruebas epidemiológicas son limitadas y controvertidas.

\section{Linfoma no H odgkin}

A proximadamente un $98 \%$ de los LNH son linfomas linfocíticos. Se utilizan habitualmente al menos cuatro clasificaciones diferentes de los linfomas linfocíticos (Longo y cols. 1993). Además, existe una neoplasia maligna, el linfoma de Burkitt, que es endémica en deter minadas zonas de Africa tropical y Nueva Guinea.

La quimioterapia y/o la radioterapia permiten curar un 30-50\% de los LNH. También pueden ser necesarios trasplantes de médula ósea.

Incidencia: Durante el decenio de 1980 se han notificado incidencias anuales elevadas de LNH (superiores al 12 por 100.000, normalizadas para una población mundial estándar) en la población blanca norteamericana, especialmente de San Francisco y Nueva York, así como en algunos cantones suizos, en Canadá, en Trieste (Italia) y en Porto Alegre (Brasil, en hombres). La incidencia de LNH suele ser mayor en los hombres que en las mujeres, generalmente en un 50-100 \%. Sin embargo, en Cuba y la población blanca de Bermudas la incidencia es algo mayor en las mujeres (A gencia Internacional para la Investigación sobre el Cáncer 1992).
$\mathrm{La}$ incidencia y la mortalidad de los $\mathrm{LNH}$ han aumentado en algunos países de todo el mundo (Agencia Internacional para la Investigación sobre el Cáncer 1993). En 1988 la incidencia anual media en los varones blancos norteamericanos aumentó en un $152 \%$. Parte de este aumento se debe a cambios en los medios de diagnóstico disponibles y otra parte a un aumento de los trastornos inmunosupresores inducidos por el virus de la inmunodeficiencia humana (VIH, asociado con el SIDA), por otros virus y por la quimioterapia inmunosupresora. Estos factores no explican la totalidad del aumento, y una parte considerable del incremento residual puede explicarse por los hábitos dietéticos, la exposición ambiental a productos como los tintes para el cabello y, posiblemente, por tendencias familiares, así como por algunos otros factores raros (H artge y D evesa 1992).

Se ha sospechado la participación en el desarrollo de LNH de factores laborales determinantes. Actualmente se calcula que un $10 \%$ de los LNH diagnosticados en Estados U nidos guardan relación con exposiciones profesionales (H artge y D evesa 1992), pero ese porcentaje varía con el período de tiempo y la zona. N o se conocen bien las causas profesionales. Se ha asociado un exceso de riesgo de LNH con el trabajo en centrales eléctricas, granjas, manipulación de cereales, metalurgia, refinerías de petróleo y ebanistería, y también con la industria química. Entre las exposiciones profesionales asociadas a un aumento del riesgo de LNH destacan el óxido de etileno, los clorofenoles, los fertilizantes, los herbicidas, los insecticidas, los tintes para el cabello, los disolventes orgánicos y las radiaciones ionizantes. Se han comunicado varios hallazgos positivos en relación con la exposición a herbicidas con ácido fenoxiacético (Morrison y cols. 1992). Algunos de los herbicidas implicados estaban contaminados con 2,3,7,8-tetraclorodibenzo-para-dioxina (TCDD). Sin embargo, las pruebas epidemiológicas de etiologías profesionales de los LNH son todavía limitadas.

\section{Mieloma múltiple}

EI mieloma múltiple (M M) afecta fundamentalmente al hueso (especialmente al cráneo), la médula ósea y el riñón. Representa una proliferación maligna de células derivadas de los linfocitos B que sintetizan y secretan inmunoglobulinas. El diagnóstico se basa en la radiología, en una prueba para la proteinuria de Bence-Jones específica del $M \mathrm{M}$, en la determinación de la presencia de células plasmáticas anormales en la médula ósea y en la inmunoelectroforesis. EI tratamiento del M M se basa en los trasplantes de médula ósea, la radioterapia, la quimioterapia convencional o la poliquimioterapia y la inmunoterapia. LoS pacientes tratados sobreviven 28-43 meses por término medio (Ludwig y K uhrer 1994).

La incidencia del M M aumenta de forma acentuada con la edad. En la población negra norteamericana, en la M artinica y entre los maoríes de Nueva Zelanda se ha observado una elevada tasa de incidencia anual normalizada por edades (5-10 por 100.000 en hombres y 4-6 por 100.000 en mujeres). N umerosas poblaciones chinas, indias, japonesas y filipinas tienen tasas bajas (menos de 10 por 100.000 personas-año en hombres y menos de 0,3 por 100.000 personas-año en mujeres) (Agencia Internacional para la Investigación sobre el Cáncer 1992). La incidencia del mieloma múltiple ha ido aumentando en Europa, A sia, 0 ceanía y en las poblaciones blanca y negra de Estados U nidos desde la década de 1960, pero el incremento ha tendido a estabilizarse en varios países europeos (A gencia Internacional para la I nvestigación sobre el Cáncer 1993).

En todo el mundo se observa de modo casi uniforme una incidencia mayor de MM en los varones. Este exceso suele ser del orden del $30-80 \%$

Se han publicado agrupamientos de casos familiares y de otros tipos de $M M$, pero las pruebas sobre la causa de esos 
agrupamientos no son concluyentes. La mayor incidencia en los negros norteamericanos que en la población blanca indica una posible diferencia en la sensibilidad del huésped entre esos grupos de población, que podría ser de tipo genético. En ocasiones se han asociado trastornos inmunológicos crónicos con un mayor riesgo de M M . L os datos sobre la distribución del M M por clases sociales son limitados y poco fiables, y no permiten extraer conclusiones sobre posibles gradientes.

Factores profesionales: Las pruebas epidemiológicas de un riesgo elevado de M M en los trabajadores expuestos a la gasolina y de refinerías sugiere un papel etiológico del benceno (Infante 1993). Se ha observado repetidas veces un exceso de mielomas múltiples en granjeros y trabajadores de granjas. Los plaguicidas representan un posible grupo de agentes causales. Sin embargo, las pruebas de carcinogenicidad de los herbicidas de ácido fenoxiacético son insuficientes (M orrison y cols. 1992). A veces, los herbicidas de ácido fenoxiacético contienen dioxinas como impurezas. Se ha observado un exceso significativo de M M en mujeres que residían en una zona contaminada con 2,3,7,8-tetraclorodibenzo-para-dioxina tras un accidente producido en una fábrica cercana a Seveso, en Italia (Bertazzi y cols. 1993). Los resultados de Seveso se basaban en dos casos que se produjeron durante 10 años de seguimiento, y es necesario seguir investigando para confirmar esta asociación. 0 tra posible explicación del mayor riesgo de los granjeros y los empleados de granjas es la exposición a determinados virus (Priester y M ason 1974).

0 tras profesiones y factores profesionales que se han asociado con un mayor riesgo de M M son los pintores, los conductores de camiones, el amianto, los escapes de motores, los tintes para el cabello, las radiaciones, el estireno, el cloruro de vinilo y el polvo de madera. Las pruebas de esta causalidad son poco concluyentes.

\section{- AgENTES 0 CONDICIONES DE TRABAJO QUE AFECTAN A LA SANGRE}

Bernard D. G oldstein

\section{Eritrocitos circulantes} Interferencia en el suministro de oxígeno hemoglobínico por
alteraciones del grupo heme

La principal función de los eritrocitos es suministrar oxígeno a los tejidos y eliminar el anhídrido carbónico. La fijación del oxígeno en el pulmón y su liberación en los tejidos en función de las necesidades dependen de una serie de reacciones fisicoquímicas cuidadosamente equilibradas. El resultado es una compleja curva de disociación que en el individuo sano sirve para saturar al máximo el eritrocito con oxígeno en condiciones atmosféricas normales, y para liberar ese oxígeno a los tejidos dependiendo del nivel de oxígeno, del pH y de otros indicadores de la actividad metabólica. El aporte de oxígeno depende también de la velocidad de flujo de los eritrocitos oxigenados, que está en función de la viscosidad y de la integridad vascular. D entro de los límites normales del hematócrito (volumen de eritrocitos condensados), el equilibrio es tal que cualquier descenso del recuento sanguíneo se compensa con una disminución de la viscosidad, que mejora el flujo. Si el aporte de oxígeno disminuye, no suele producir síntomas hasta que el hematócrito disminuye al $30 \%$ o menos; por el contrario, si el hematócrito aumenta por encima de los valores normales, como ocurre en la policitemia, puede disminuir el aporte de oxígeno debido a los efectos del aumento de la viscosidad sobre el flujo sanguíneo. La excepción es la ferropenia, que produce síntomas de debilidad y lasitud, debido fundamen- talmente a la falta de hierro, más que a la anemia asociada (Beutler, Larsh y Gurney 1960).

El monóxido de carbono es un gas ubicuo que puede tener efectos graves, posiblemente letales, sobre la capacidad de transporte de oxígeno de la hemoglobina. Del monóxido de carbono se habla más detalladamente en la sección de sustancias químicas de esta E nciclopedia.

Compuestos productores de metahemoglobina. La metahemoglobina es otra forma de la hemoglobina que no puede suministrar oxígeno a los tejidos. En la hemoglobina, el átomo de hierro situado en el centro del grupo heme de la molécula debe encontrarse en la forma ferrosa reducida para poder participar en el transporte del oxígeno. U na parte del hierro de la hemoglobina es oxidada continuamente a su forma férrica. Así, aproximadamente el $0,5 \%$ de la hemoglobina total de la sangre es metahemoglobina, que es la forma química oxidada de la hemoglobina que no puede transportar oxígeno. La metahemoglobina reductasa, una enzima que depende del $\mathrm{NADH}$, reduce el hierro férrico y vuelve a formar hemoglobina ferrosa.

Algunas sustancias químicas presentes en los lugares de trabajo pueden inducir niveles de metahemoglobina clínicamente significativos; por ejemplo, en las industrias en las que se usan tintes de anilina. 0 tros productos químicos que han sido encontrados frecuente, como causa de metahemoglobinemia en el lugar de trabajo son los nitrobencenos, otros nitratos y nitritos orgánicos e inorgánicos, las hidracinas y diversas quinonas (K iese 1974). Algunos de estos productos se incluyen en la Tabla 1.1, y serán analizados con mayor detalle en la sección sobre sustancias químicas de esta E ncicl opedia. L os síntomas habituales de la metahemoglobinemia son cianosis, confusión y otros signos de hipoxia. Las personas que sufren una exposición crónica a esas sustancias pueden tener los labios azules cuando los niveles de hemoglobina alcanzan o superan el $10 \%$, aproximadamente. Pueden no presentar ningún otro efecto manifiesto. La sangre con metahemoglobinemia tiene un color chocolate característico. El tratamiento consiste en evitar la exposición. Pueden aparecer síntomas importantes, sobre todo cuando la metahemoglobinemia alcanza niveles superiores al $40 \%$. El tratamiento con azul de metileno o ácido ascórbico puede acelerar la disminución del nivel de metahemoglobina. Los individuos con deficiencia de glucosa-6-fosfato deshidrogenasa pueden experimentar una aceleración de la hemólisis al ser tratados con azul de metileno (véase más adelante el comentario sobre la deficiencia de glucosa-6-fosfato deshidrogenasa).

Existen trastornos hereditarios que dan lugar a una metahemoglobinemia persistente, ya sea debida a una forma heterocigótica relacionada con hemoglobina anormal o a una forma homocigótica relacionada con una deficiencia de metahemoglobina reductasa eritrocitaria dependiente del NADH. Los individuos heterocigotos para esta deficiencia enzimática no podrán reducir los niveles elevados de metahemoglobina inducidos por la exposición a determinadas sustancias químicas con la misma rapidez que los individuos con niveles enzimáticos normales.

Además de oxidar el hierro hemoglobínico, muchos de los productos causantes de metahemoglobinemia o sus metabolitos son agentes oxidantes relativamente inespecíficos, y a niveles elevados pueden causar una anemia hemolítica con cuerpos de Heinz. Este proceso se caracteriza por una desnaturalización oxidativa de la hemoglobina, que da lugar a la formación de inclusiones puntiformes unidas a la membrana de los eritrocitos, denominadas cuerpos de $\mathrm{Heinz}$, que pueden identificarse con tinciones especiales. También se producen daños oxidativos en la membrana de los eritrocitos. Aunque este proceso puede provocar una hemólisis importante, los compuestos incluidos en la Tabla 1.1 producen sus efectos adversos fundamentalmente a través de la formación de metahemoglobina, que puede poner 
Figura 1.1 • Enzimas eritrocíticas de la defensa oxidativa y reacciones relacionadas.

$$
\begin{aligned}
& \mathrm{GSH}+\mathrm{GSH}+(\mathrm{O}) \underset{\text { Glutatión peroxidasa }}{\longleftrightarrow} \mathrm{GSSG}+\mathrm{H}_{2} \mathrm{O} \\
& \mathrm{GSSG}+2 \mathrm{~N} \mathrm{ADPH} \underset{\text { G lutatiónreductasa }}{\stackrel{\text { G }}{\longleftrightarrow} \mathrm{GH}+2 \mathrm{~N} \mathrm{ADP}}
\end{aligned}
$$$$
\text { G lucosa }-6 \text { - fosfato +N ADP } \underset{G 6 P D}{\longleftrightarrow 6} \text {-fosfogluconato + N ADPH }
$$

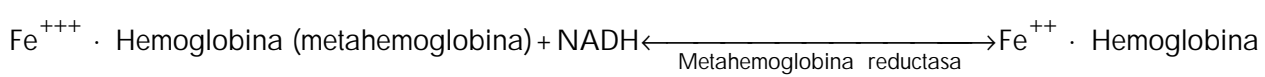

en peligro la vida del individuo, y no mediante hemólisis, que suele ser un proceso limitado.

En esencia, intervienen dos formas de defensa eritrocitaria: 1) la metahemoglobina reductasa dependiente de NADH necesaria para reducir la metahemoglobina a hemoglobina normal y 2) el proceso dependiente de NADPH a través del shunt del monofosfato de hexosa (MPH), que conduce al mantenimiento del genera glutatión reducido como medio de defensa contra sustancias oxidadas capaces de producir anemia hemolítica con cuerpos de Heinz (Figura 1.1). La hemólisis con cuerpos de $\mathrm{H}$ einz puede exacerbarse con el tratamiento con azul de metileno en los pacientes con metahemoglobinemia, ya que requiere NADPH para poder reducir la metahemoglobina. La hemólisis será también un elemento más destacado del cuadro clínico en las personas con: 1) deficiencias de una de las enzimas de la vía defensiva oxidativa del NADPH , o 2) una hemoglobina inestable hereditaria. A excepción de la deficiencia de glucosa-6-fosfato deshidrogenasa (G 6PD), que se describe más adelante en este mismo capítulo, éstos son trastornos relativamente infrecuentes.

0 tra forma de alteración de la hemoglobina producida por agentes oxidantes es una especie desnaturalizada conocida como sulfahemoglobina. Este producto irreversible puede encontrarse en la sangre de individuos con una metahemoglobinemia importante producida por productos oxidantes. También se denomina sulfahemoglobina, y con mayor propiedad, a un producto específico formado durante la intoxicación por sulfuro de hidrógeno.

Agentes hemolíticos: En los lugares de trabajo pueden encontrarse diversos agentes hemolíticos. La toxicidad más grave de muchos de ellos es la metahemoglobinemia. O tros agentes hemolíticos son el naftaleno y sus derivados. Además, algunos metales, como el cobre, y organometales, como el estaño tributilo, reducen la supervivencia de los eritrocitos, al menos en modelos animales. También puede producirse una ligera hemólisis durante el effuerzo físico traumático (hemoglobinuria de la marcha); recientemente se ha observado un aumento del número de leucocitos con el ejercicio prolongado (leucocitosis de los corredores). EI metal más importante que altera la formación y la supervivencia de los eritrocitos en los trabajadores es el plomo, que describimos detalladamente en la sección de sustancias químicas de esta E nciclopedia.

Arsenamina: Un eritrocito normal sobrevive en la circulación durante 120 días. Si se reduce esta supervivencia, puede aparecer anemia si no se compensa con un aumento de la producción medular de eritrocitos. Existen fundamentalmente dos tipos de hemólisis: 1) hemólisis intravascular, en la que se produce una liberación inmediata de hemoglobina a la circulación, y 2) hemólisis extravascular, en la que los eritrocitos son destruidos en el bazo o el hígado.

Una de las hemolisinas intravasculares más potentes es la arsenamina $\left(\mathrm{AsH}_{3}\right)$. La inhalación de cantidades relativamente pequeñas de este agente provoca hinchazón y explosión final de los eritrocitos en la circulación. Puede resultar difícil establecer la relación causal entre la exposición profesional a la arsenamina y un episodio de hemólisis aguda (Fowler y Wiessberg 1974). Esto se debe en parte a que a menudo se produce una demora entre la exposición y el comienzo de los síntomas, pero especialmente a que a menudo no es evidente la fuente de la exposición. $L a$ arsenamina se fabrica y utiliza comercialmente, a menudo en la industria electrónica. Sin embargo, la mayor parte de los informes publicados de episodios hemolíticos agudos se refieren a la liberación inesperada de arsenamina como subproducto no deseado de un proceso industrial: por ejemplo, si se añade ácido a un recipiente fabricado de metal contaminado con arsénico. Cualquier proceso que induzca la reducción química del arsénico, como la acidificación, puede liberar arsenamina. Dado que el arsénico puede ser un contaminante de muchos metales y materiales orgánicos, como el carbón, la exposición al arsénico es a menudo inesperada. Parece que la estibina, o hidruro de antimonio, produce un efecto hemolítico similar al de la arsenamina.

La muerte puede producirse directamente como consecuencia de una pérdida completa de eritrocitos. (Se ha publicado un caso con un hematócrito de cero.) Sin embargo, a niveles de arsenamina inferiores a los que producen una hemólisis completa una preocupación importante: es la insuficiencia renal aguda debida a la liberación masiva de hemoglobina a la circulación. A niveles mucho más elevados, la arsenamina puede producir edema pulmonar agudo y, posiblemente, efectos renales directos. EI episodio agudo puede acompañarse de hipotensión. Suele existir un plazo mínimo de algunas horas entre la inhalación de arsenamina y la aparición de los síntomas. Además del enrojecimiento de la orina debido a la hemoglobinuria, el paciente suele quejarse de dolor abdominal y náuseas, síntomas que aparecen al mismo tiempo que la hemólisis intravascular aguda por diferentes causas ( $N$ eilsen 1969).

El tratamiento va dirigido a mantener la perfusión renal, e incluye la transfusión de sangre normal. D ado que los eritrocitos circulantes afectados por la arsenamina parecen en alguna medida condenados a la hemólisis intravascular, parece que el tratamiento óptimo sería una exanguinotransfusión que sustituyese los eritrocitos expuestos a la arsenamina por células no expuestas. Al igual que en una hemorragia muy intensa y peligrosa, es importante que las células de sustitución tengan unos niveles adecuados de ácido 2,3-difosfoglicérico (DPG) para que puedan suministrar oxígeno a los tejidos.

\section{Otros trastornos hematológicos}

\section{Leucocitos}

Existen algunos fármacos, como la propiltiourea (PTU), que alteran la producción o la supervivencia de los leucocitos polimorfonucleares circulantes de manera relativamente selectiva. Por el contrario, toxinas medulares inespecíficas afectan también 
a los precursores de los eritrocitos y las plaquetas. $\mathrm{H}$ ay que considerar en riesgo a los trabajadores que intervienen en la preparación o la administración de tales fármacos. Se ha publicado un informe de granulocitopenia completa en un trabajador intoxicado con dinitrofenol. Cada vez se presta mayor atención a las alteraciones del número y la función de los linfocitos, y particularmente de la distribución en subtipos, ya que podrían ser un mecanismo sutil de los efectos producidos por diferentes productos químicos en los lugares de trabajo 0 en entornos normales, en especial los hidrocarburos clorados, las dioxinas y compuestos relacionados. Es necesario confirmar las repercusiones sanitarias de tales cambios.

\section{Coagulación}

Al igual que en el caso de la leucopenia, existen muchos fármacos que reducen selectivamente la producción o la supervivencia de las plaquetas circulantes, lo que podría plantear problemas en los trabajadores que intervienen en la preparación o la administración de tales productos. Por lo demás, sólo se han publicado algunos informes aislados de trombocitopenia en trabajadores. Un estudio sugiere que el diisocianato de tolueno (DIT) puede provocar púrpura trombocitopénica. Generalmente no se observan anomalías de los diferentes factores de coagulación de la sangre como consecuencia del trabajo. Las personas con anomalías preexistentes de la coagulación, como la hemofilia, suelen tener problemas para encontrar trabajo. Sin embargo, aunque es razonable una exclusión sopesada cuidadosamente de algunos trabajos muy concretos, esas personas suelen ser capaces de desempeñar muchos otros trabajos normalmente.

\section{Exploración selectiva y vigilancia hematológicas en el lugar de trabajo}

\section{M arcadores de sensibilidad}

Debido en parte a la facilidad de obtención de muestras, se sabe más de las variaciones hereditarias de los componentes de la sangre humana que de las que se producen en cualquier otro órgano. Estudios exhaustivos impulsados por el descubrimiento de anemias familiares han permitido conocer las consecuencias funcionales y estructurales de algunas alteraciones genéticas. Son importantes para la salud en el trabajo las variaciones hereditarias que pueden originar una mayor sensibilidad a los peligros en el lugar de trabajo. Para la exploración selectiva de los trabajadores se han considerado o se utilizan varias de esas variaciones cuantificables. EI rápido avance de nuestros conocimientos sobre la genética humana nos permite asegurar que cada vez conoceremos mejor las bases hereditarias de las variaciones en la respuesta humana, y podremos predecir mejor el grado de sensibilidad individual mediante pruebas de laboratorio.

Antes de analizar la utilidad potencial de los marcadores de sensibilidad disponibles en la actualidad, hay que subrayar las principales consideraciones éticas relativas al uso de esas pruebas en los trabajadores. Se ha cuestionado si esas pruebas favorecen la exclusión de los trabajadores de un centro en lugar de mejorar las condiciones de los centros de trabajo en beneficio de los trabajadores. Como mínimo, antes de empezar a usar un indicador de sensibilidad en un centro de trabajo, todas las partes interesadas deben tener claros los objetivos de las pruebas y las consecuencias de sus resultados.

Los dos marcadores de sensibilidad hematológica cuya exploración selectiva más se ha practicado son el rasgo de la drepanocitosis y la deficiencia de G6PD. El primero tiene a lo sumo un valor marginal en contadas situaciones, y el segundo carece de valor en la mayoría de las situaciones en las que se ha preconizado (Goldstein, Amoruso y Witz 1985).
La drepanocitosis, o anemia de células falciformes, en la que existe una homocigosidad para la hemoglobina $\mathrm{S}(\mathrm{HbS})$, es un trastorno bastante corriente entre los individuos de origen africano. Es una enfermedad relativamente grave que con frecuencia (aunque no siempre) impide el acceso a un puesto de trabajo. El gen $\mathrm{HbS}$ puede heredarse junto con otros genes, como el $\mathrm{H}$ bC, que pueden limitar la gravedad de sus efectos. EI defecto básico en los individuos con drepanocitosis es la polimerización de la $\mathrm{HbS}$, que ocasiona microinfartos. Los microinfartos pueden producirse en episodios, conocidos como crisis drepanocíticas, que pueden ser desencadenados por factores externos, especialmente los que producen hipoxia y, en menor medida, deshidratación. Teniendo en cuenta la variación razonablemente amplia en la evolución clínica y el bienestar de los afectados por esta enfermedad, la evaluación laboral debe centrarse en cada caso concreto. No son adecuados los trabajos en los que pueden producirse exposiciones hipóxicas, como los que obligan a volar a menudo, o los trabajos que pueden inducir una deshidratación significativa.

M ucho más frecuente que la drepanocitosis es el rasgo drepanocítico, una alteración heterocigota en la que se hereda un gen para la H bS y otro para la H bA. Se ha señalado que los individuos que presentan este patrón genético sufren crisis drepanocíticas en condiciones de hipoxia extrema. Se ha considerado a veces la posibilidad de excluir a los individuos con este rasgo de los lugares de trabajo en los que la hipoxia es un riesgo frecuente, que probablemente se limitan a los trabajos en aviones o submarinos militares, y quizá en aviones comerciales. Sin embargo, hay que señalar que los individuos con rasgo drepanocítico responden muy bien en casi todas las demás circunstancias. Por ejemplo, los deportistas con rasgo drepanocítico no sufrieron efectos adversos al competir a la altitud de M éxico $(2.200 \mathrm{~m})$ durante los Juegos 0 límpicos de 1968. Por consiguiente, con las contadas excepciones mencionadas previamente, no existen razones para considerar la exclusión o la modificación de las pautas laborales para las personas con el rasgo drepanocítico.

0 tra variante genética frecuente de un componente eritrocitario es la forma $A^{-}$de deficiencia de G6PD. Se hereda con el cromosoma $X$ como un gen recesivo ligado al sexo y se encuentra aproximadamente en uno de cada siete varones negros y una de cada 50 mujeres negras en Estados U nidos. En Africa, este gen es especialmente prevalente en zonas de mucho paludismo. Al igual que el rasgo drepanocítico, la deficiencia de G6PD representa una ventaja que protege contra el paludismo. En condiciones normales, los individuos con esta forma de deficiencia de G 6PD tienen unos recuentos y unos índices eritrocitarios dentro de los límites normales. Sin embargo, debido a la incapacidad para regenerar el glutatión reducido, sus eritrocitos son propensos a la hemólisis tras la ingestión de fármacos oxidantes y en determinados estados patológicos. Esta sensibilidad a los agentes oxidantes ha llevado a efectuar controles selectivos en los lugares de trabajo en la idea equivocada de que los individuos con la frecuente variante $\mathrm{A}^{-}$de deficiencia de G6PD corren un gran riesgo en caso de inhalar gases oxidantes. De hecho, se necesitaría una exposición muy por encima de los niveles a los que esos gases provocan un edema mortal para que los eritrocitos de los individuos con esta deficiencia sufrieran una oxidación que pudiese causarles problemas (G oldstein, A moruso y Witz 1985). La deficiencia de G6PD aumenta las probabilidades de una hemólisis de cuerpos de $\mathrm{H}$ einz manifiesta en las personas expuestas a colorantes de anilina y otros agentes causantes de metahemoglobina (Tabla 1.1), pero en tales casos el principal problema clínico sigue siendo la metahemoglobinemia, muy peligrosa para la vida de los pacientes. Aunque el conocimiento de la deficiencia de G6PD puede ser de utilidad en estos 
casos, sobre todo para orientar el tratamiento, no debe usarse esta información para excluir a los trabajadores de los lugares de trabajo.

Existen muchas otras formas de deficiencia familiar de G 6PD, todas ellas mucho menos frecuentes que la variante $A$ - (Beutler 1990). A lgunas de esas variantes, en especial en individuos de la cuenca mediterránea y de Asia central, presentan unos niveles de actividad de la G 6PD mucho menores en sus eritrocitos. Por consiguiente, los individuos afectados pueden verse gravemente comprometidos por una anemia hemolítica continua. También se ha informado de deficiencias de otras enzimas que participan en la defensa contra los agentes oxidantes, así como de hemoglobinas inestables que sensibilizará a los eritrocitos al estrés oxidativo del mismo modo que en la deficiencia de G6PD.

\section{Vigilancia}

La vigilancia difiere considerablemente de las pruebas clínicas tanto para la valoración de los pacientes enfermos como para la exploración selectiva periódica de los individuos presumiblemente sanos. El objetivo de todo programa de vigilancia correctamente diseñado es prevenir la enfermedad manifiesta descubriendo cambios sutiles precoces mediante las pruebas de laboratorio pertinentes. Por consiguiente, un resultado ligeramente anormal debe desencadenar automáticamente una respuesta (o al menos una revisión) por parte de los médicos.

En la revisión inicial de los datos de vigilancia hematológica de trabajadores potencialmente expuestos a una hematotoxina como el benceno, existen fundamentalmente dos enfoques que son especialmente útiles para descartar falsos positivos. EI primero es el grado de diferencia con los valores normales. A medida que el recuento se va alejando de los límites normales, disminuye rápidamente la posibilidad de que sólo represente una anomalía estadística. En segundo lugar, hay que aprovechar todos los datos de ese individuo, incluidos los valores normales, teniendo presente el amplio espectro de efectos que puede producir el benceno. Por ejemplo, es mucho más probable que el benceno haya producido un efecto si un descenso leve del recuento plaquetario va acompañado de un recuento bajonormal de leucocitos, un recuento bajo-normal de eritrocitos y un volumen corpuscular medio (VCM ) eritrocitario alto-normal. Por el contrario, puede descartarse la importancia de ese mismo recuento plaquetario como relacionado con una posible hematotoxicidad por el benceno si los demás recuentos tienen unos valores opuestos dentro del espectro normal. Estas dos mismas consideraciones son válidas para juzgar si el individuo debe abandonar el trabajo mientras se esperan los resultados de otras pruebas y si las pruebas adicionales sólo deben consistir en una repetición del hemograma completo.

Si existe alguna duda acerca de la causa de la disminución del recuento, debe repetirse el hemograma. Si la disminución se debe a la variabilidad de las técnicas de laboratorio o alguna variabilidad biológica individual a corto plazo, es poco probable que el recuento sanguíneo vuelva a dar valores bajos. La comparación con los recuentos previos a la contratación y otros recuentos disponibles debe ayudar a distinguir a los individuos con una tendencia intrínseca a situarse en la zona baja de la distribución. La identificación de un trabajador con un efecto debido a una toxina hematológica debe considerarse una señal de alerta sanitaria, que debe poner en marcha una meticulosa investigación de las condiciones de trabajo y de los demás trabajadores (G oldstein 1988).

Los amplios márgenes de los valores analíticos normales de los recuentos sanguíneos representa un desafío aún mayor, ya que puede producirse un efecto considerable sin que los recuentos se desvíen de los límites normales. Por ejemplo, puede ocurrir que un trabajador expuesto al benceno 0 a radiaciones ionizantes sufra un descenso del 40-50\% del hematócrito, un descenso del recuento leucocitario de 10.000 a 5.000 células por milímetro cúbico y un descenso del recuento plaquetario de 350.000 a 150.000 por milímetro cúbico (es decir, un descenso del número de plaquetas superior al $50 \%$ ); sin embargo, estos valores se mantienen dentro de los "límites normales" de los recuentos hemáticos. Por consiguiente, un programa de vigilancia que se base únicamente en recuentos sanguíneos "anormales" puede pasar por alto efectos importantes. Por lo tanto, hay que prestar especial atención a los recuentos sanguíneos que disminuyen a lo largo del tiempo manteniéndose dentro de los límites normales.

O tro problema complicado que plantea la vigilancia en los lugares de trabajo es la detección de un ligero descenso del recuento sanguíneo medio de toda una población expuesta: por ejemplo, un descenso de 7.500 a 7.000 leucocitos por milímetro cúbico debido a una exposición generalizada al benceno o las radiaciones ionizantes. La detección y correcta valoración de una observación de ese tipo requiere una atención muy meticulosa para la normalización de las pruebas de laboratorio, la disponibilidad de un grupo de control adecuado y un análisis estadístico detenido.

\section{Referencias}

Agencia Internacional para la Investigación sobre el Cáncer (IAR C). 1990. Cancer: Causes, 0 ccurrence and Control. IARC Scientific Publications, no. 100 Lyon: IARC.

- - 1992. Cancer Incidence in Five Continents. V ol. VI. IARC Scientific Publications, no. 120. Lyon: IARC.

- - 1993. T rends in Cancer Incidence and M ortality. IARC Scientific Publications, no. 121. Lyon: IARC.

Bertazzi, A, AC Pesatori, D Consonni, A T ironi, M T Landi, C Zocchetti. 1993. Cancer incidence in a population accidentally exposed to 2,3,7,8-tetrachlorodibenzo-para-dioxin, Seveso, I talia. E pide miology 4(5): 398-406

Beutler, E, SE Larsh, CW Gurney. 1960. Iron therapy in chronically fatigued nonanemic women: a double-blind study. Ann Intern M ed 52:378.
Beutler, E. 1990. Genetics of glucose-6-phosphate dehydrogenase deficiency. Sem H ematol 27:137.

De Planque, M M , HC K luin-Nelemans, HJ Van $K$ rieken, M P K luin, A Brand, GC Beverstock, $R$ Willemze, JJ van Rood. 1988. Evolution of acquired severe aplastic anaemia to myelodysplasia and subsequent leukaemia in adults. B rit ] $\mathrm{H}$ aematol 70:55-62.

Flemming, LE, W T immeny. 1993. A plastic anemia and pesticides. J M ed 35(1):1106-1116

Fowler, BA, JB Wiessberg. 1974. Arsine poisoning. New Engl J M ed 291:1171-1174.

Goldstein, BD, MA Amoruso, G Witz. 1985. Erythrocyte glucose-6-phosphate dehydrogenase deficiency does not pose an increased risk for Black Americans exposed to oxidant gases in the workplace or general environment. Toxicol Ind H ealth 1:75-80.

Goldstein, BD. 1988. Benzene toxicity. O ccup M ed: State Art R ev 3(3):541-554.
Hartge P SS Devesa 1992. Quantification of the impact of known risk factors on time trends in non-H odgkin's lymphoma incidence. Cancer Res 52:5566S-5569S

Hernberg, S et al. 1966. Prognostic aspects of benzene poisoning. B rit J Ind M ed 23:204.

Infante, P. 1993. State of the science on the carcinogenicity of gasoline with particular reference to cohort mortality study results. E nviron $H$ ealth Persp 101 Suppl. 6:105-109.

K eating, MJ, E Estey, H K antarjian. 1993. Acute leukaemia. En Cancer: Principles and Practice of Oncology, dirigido por VTJ DeVita, S Hellman y SA R osenberg. Filadelfia: JB Lippincott.

K iese, M. 1974. M ethemoglobinemia: A Comprehensive T reatise Cleveland: CR C Press.

Laskin, sincerely, BD Goldstein. 1977. Benzene toxicity, a clinical evaluation. I T oxicol Environ H ealth Suppl. 2. 
Linet, MS. 1985. The Leukemias, E pidemiologic Aspects. N ueva Y ork: O xford U niv. Press.

Longo, DL, VTJ DeV ita, ES Jaffe, P M auch, W Urba. 1993. Lymphocytic lymphomas. En Cancer: Principles and Practice of Oncology, dirigido por VTJ D eV ita, S H ellman y SA R osenberg. Filadelfia: JB Lippincott

Ludwig, H, I Kuhrer. 1994. The treatment of multiple myeloma. Wien klin Wochenschr 106:448-454

Morrison, $\mathrm{HI}, \mathrm{K}$ Wilkins, R Semenciw, Y M ao, Y Wigle. 1992. Herbicides and cancer. J Natl Cancer Inst 84:1866-1874.

N eilsen, B. 1969. Arsine poisoning in a metal refinery plant: fourteen simultaneous cases. Acta M ed Scand Suppl. 496.

Parkin, D M , P Pisani, J Ferlay. 1993. Estimates of the worldwide incidence of eighteen major cancers in 1985. Int J Cancer 54:594-606.

Priester, WA, TJ Mason. 1974. Human cancer mortality in relation to poultry population, by county, in 10 southeastern states. I Natl Cancer Inst 53:4549.

Rothman, N, G-L Li, M Dosemeci, WE Bechtold, GE M arti, Y -Z Wang, M Linet, L X i, W Lu, M T Smith, N Titenko-Holland, L-P Zhang, W Blot, S-N Y in, RB Hayes. 1996. Hematoxicity among
Chinese workers heavily exposed to benzene. Am J Ind $M$ ed 29:236-246.

Snyder, R, G Witz, BD Goldstein. 1993. The toxicology of benzene. Environ $H$ ealth Persp 100:293-306.

Taylor, JA, DP Sandler, CD Bloomfield, DL Shore, ED Ball, A N eubauer, OR M cIntyre, E Liu. 1992. [r]as Oncogene activation and occupational exposures in acute myeloid leukemia. J Natl Cancer Inst 84:1626-1632

T ucker, M A, CN Coleman, R S C ox, A V arghese, SA R osenberg. 1988. Risk of second cancers after treatment for Hodgkin's disease. New Engl J $M$ ed 318:76-81.

Y in, S-N , R B H ayes, M S Linet, G -L Li, M Dosemeci, LB Travis, C-Y Li, Z-N Zhang, D-G Li, W-H Chow, S Wacholder, Y -Z Wang, Z-L Jiang, T-R Dai, W-Y Zhang, $X$-I Chao, P-Z Y e, Q-R K ou, $X-C$ Zhang, $X-F$ Lin, J-F M eng, C-Y Ding, J-S Zho, W-J Blot. 1996. A cohort study of cancer among benzene-exposed workers in China: 0 verall results. Am J Ind M ed 29:227-235.

\section{O tras lecturas recomendadas}

Agencia Internacional para la Investigación sobre el Cáncer (IARC). 1994. Occupational Cancer in
Developing Countries. IARC Scientific Publications no. 129. Lyon: IARC.

Deisseroth, $A B, M$ Andreeff, $R$ Champlin, $M J$ K eating, $H$ Kantarjian, IF K houri, M Talpaz. 1993. Chronic leukaemias. En Cancer: Principles and Practice of Oncology, dirigido por VTJ DeVita, S Hellman y SA Rosenberg. Filadelfia: JB Lippincott.

DeV ita, VJ, S Hellman, ES Jaffe. 1993. Hodgkin's disease. En Cancer: Principles and Practice of Oncology, dirigido por VTJ DeVita, S Hellman y SA R osenberg. Filadelfia: JB Lippincott.

H igginson, J, CS Muir, B M unoz. 1992. H uman Cancer: Epidemiology and Environmental Causes. Cambridge M onographs on Cancer Research. C ambridge: $C$ ambridge $U$ niv. Press.

Saez, RA, RB Slease, GB Selby, C Puckett, RB Epstein, RA M andaras, DL Confer. 1994 Autologous bone marrow transplantation fo non-H odgkin lymphoma. I Oklahoma State M ed Assoc 87:358-363.

Siemiatycki, J, M Gerin, R Dewar, L Nadon, R Lakhani, D Begin, L Richardson. 1991. Associations between occupational circumstances and cancer. En Risk Factors for Cancer in the W orkplace, dirigido por J Siemiatycki. Boca R aton: CRC Press. 


\section{CANCER}

Director del capítulo

Paolo B offetta

\section{Sumario}

Introducción

$\mathrm{N}$ eil Pearce, Paolo B offetta

y M anolis Kogevinas . . . . . . . . . . . . . . . . . . . . . . . . . . . . . . . 2.2

Cancerígenos profesionales

Paolo B offetta, Rodolfo Saracci, M anolis Kogevinas, J ulian W ilbourn

y $\mathrm{H}$ arri Vainio. . . . . . . . . . . . . . . . . . . . . . 2.4

Cáncer de origen ambiental

B ruce K. Armstrong y Paolo B offetta . . . . . . . . . . . . . . . . . . . . 2.8

Prevención

Per Gustavsson . . . . . . . . . . . . . . . . . . . . . . . . . . . . . . . . 2.15 


\section{INTRODUCCION}

\section{Neil Pearce, Paolo B offetta y M anolis Kogevinas}

\section{Magnitud del problema}

L a primera prueba evidente del origen causal de un cáncer se obtuvo para un cancerígeno profesional (Checkoway, Pearce y Crawford-Brown 1989). Pott (1775) identificó el hollín como la causa del cáncer escrotal en deshollinadores londinenses y describió gráficamente las penosas condiciones en que trabajaban, que exigían a los niños escalar por estrechas chimeneas todavía calientes. A pesar de estas pruebas, los informes sobre la necesidad de prevenir incendios en las chimeneas se utilizaron para retrasar la adopción de disposiciones sobre el trabajo de los niños en este sector hasta 1840 (Waldron 1983). N o se demostró un modelo experimental de carcinogénesis por hollín hasta el decenio de 1920 (D ecoufle 1982), 150 años después de la observación epidemiológica original.

Con posterioridad se han demostrado otras causas profesionales de cáncer en estudios epidemiológicos (aunque, por lo general, la primera observación de la asociación con el cáncer se debe a un médico del trabajo o a los trabajadores), como el arsénico, el amianto, el benceno, el cadmio, el cromo, el níquel y el cloruro de vinilo. Estos cancerígenos profesionales presentan una gran importancia desde el punto de vista de la salud pública, dadas las posibilidades de prevención que ofrecen la normativa y las mejoras de la higiene industrial (Pearce y $M$ atos 1994). En la mayor parte de los casos, aumentan notablemente el riesgo relativo de determinados tipos de cáncer; es posible que existan otros cancerígenos profesionales que no se han detectado todavía debido a que sólo suponen un pequeño aumento del riesgo, o simplemente porque no han sido estudiados (D oll y Peto 1981). En la Tabla 2.1 se recogen algunos de los factores clave acerca del cáncer profesional.

Las causas profesionales del cáncer han recibido una gran atención en los estudios epidemiológicos realizados. Se discute, no obstante, la proporción de cánceres atribuibles a exposiciones profesionales, ya que los cálculos oscilan entre un 4 y un $40 \%$ (H igginson 1969, H igginson y M uir 1976, Wynder y Gori 1977,

Tabla 2.1 - Cáncer profesional: factores clave.

- Unos 20 productos y mezclas son cancerígenos profesionales establecidos; hay un número similar de sustancias químicas sobre las que existen sospechas muy fundadas de que son profesionales.

- En los países industrializados, el trabajo está ligado causalmente al 2-8 \% de los cánceres; sin embargo, entre los trabajadores expuestos esta cifra es más elevada.

- No se dispone de cálculos fiables sobre la carga que supone el cáncer profesional ni sobre el grado de exposición a los cancerígenos en el lugar del trabajo en los países en vías de desarrollo.

- La carga global relativamente baja del cáncer profesional en los países industrializados es el resultado de las estrictas disposiciones adoptadas sobre varios cancerígenos conocidos'; sin embargo, aún se permite la exposición a otros agentes que se sabe o se sospecha que son cancerígenos.

- Aunque en muchos países existen varios cánceres profesionales clasificados como enfermedades profesionales, sólo una pequeñísima fracción de casos se reconocen y reciben indemnización.

- El cáncer profesional es en gran medida una enfermedad prevenible.

\section{La Clasificación Internacional de Enfermedades}

Las enfermedades humanas se clasifican de acuerdo con la Clasificación Internacional de Enfermedades (CIE), un sistema que se empezó a utilizar en 1893 y que se actualiza periódicamente bajo la coordinación de la 0 rganización Mundial de la Salud. La CIE se utiliza en casi todos los países para tareas como los certificados de defunción, el registro de los casos de cáncer y los diagnósticos de altas hospitalarias. La décima revisión (CIE-10), aprobada en 1989 (OMS, 1992) difiere considerablemente de las tres revisiones anteriores, parecidas entre sí y que se han venido utilizando desde la década de 1950 . Por consiguiente, es probable que en muchos países se siga utilizando durante los próximos años la novena revisión (C IE-9, O M S, 1978), o incluso revisiones anteriores.

Higginson y M uir 1979, Doll y Peto 1981, Hogan y Hoel 1981, Vineis y Simonato 1991, Aitio y K auppinen 1991). El riesgo atribuible de cáncer expresa el exceso de cáncer en una población producido por la exposición profesional considerada. Puede calcularse tanto para la población expuesta como para una población más amplia. En la Tabla 2.2 se resumen los datos existentes de acuerdo con la Clasificación Internacional de Enfermedades aplicada universalmente (véase el recuadro).

La gran variabilidad en los cálculos se debe a las diferencias en las series de datos utilizadas y en las hipótesis aplicadas. La mayor parte de los cálculos publicados acerca de la proporción de cánceres atribuidos a factores de riesgo profesional se basan en premisas bastante simples. Además, aunque el cáncer sea relativamente menos frecuente en los países en vías de desarrollo, debido a que su estructura de edad es más joven (Pisani y Parkin 1994), la proporción de cánceres de origen profesional posiblemente sea mayor en ellos, debido a las exposiciones relativamente altas existentes (K ogevinas, Boffetta y Pearce 1994).

L as estimaciones más generalmente aceptados de los cánceres de origen profesional son los que figuran en una detallada revisión de las causas de cáncer en la población de Estados U nidos en 1980 (D oll y Peto 1981). Doll y Peto llegaron a la conclusión de que alrededor del $4 \%$ de las muertes debidas a cáncer pueden ser causadas por cancerígenos profesionales dentro de los "límites aceptables" (esto es, plausibles a la vista de todas las pruebas disponibles) del 2 y el $8 \%$. Al ser estos cálculos de carácter porcentual, dependen de la forma en que contribuyan a la producción de los cánceres causas distintas a la exposición en el trabajo. Por ejemplo, la proporción sería más elevada en una población que no ha consumido nunca tabaco (como los Adventistas del Séptimo Día) y más baja en otra población constituida, por ejemplo, en un $90 \%$ por fumadores. De igual forma, los cálculos no se aplican de modo uniforme a los dos sexos ni a las diferentes clases sociales. Además, si no se considera la población completa (a la que se refieren los cálculos), sino los segmentos de la población adulta en los que se produce de forma casi exclusiva la exposición a cancerígenos profesionales (los trabajadores manuales de la minería, la agricultura y la industria, tomados en términos generales, que suponían en EE.UU. 31 millones de una población total de 20 o más años de 158 millones), la proporción del $4 \%$ de la población global aumentaría a cerca del $20 \%$ en los expuestos.

Vineis y Simonato (1991) estimaron el número de casos de cáncer de pulmón y de vejiga de origen profesional, obtenidos de una revisión detallada de estudios de casos-controles, que demuestran que, en poblaciones específicas situadas en zonas industriales, la proporción de cáncer de pulmón o de vejiga 
debida a exposiciones profesionales puede elevarse hasta el $40 \%$ (dependiendo no sólo de las exposiciones predominantes a nivel local, sino también en cierto grado del método utilizado para definir y valorar la exposición).

\section{Mecanismos y teorías de la carcinogénesis}

Los estudios sobre el cáncer profesional son complicados porque no existen cancerígenos "completos"; las exposiciones en el trabajo aumentan el riesgo de desarrollar cáncer, no significa que este desarrollo futuro de cáncer sea seguro. Además, pueden transcurrir 20-30 años (y como mínimo 5) entre la exposición profesional y la inducción posterior del cáncer, y algunos más hasta que éste sea clínicamente detectable y se produzca la muerte (M oolgavkar y cols. 1993). Esta situación, que se da también con los cancerígenos no profesionales, es compatible con las teorías actuales sobre la causalidad del cáncer.

Se han propuesto varios modelos matemáticos de carcinogénesis (p. ej., Armitage y Doll 1961), pero el más sencillo y más compatible con los conocimientos biológicos actuales es el de M oolgavkar (1978). En él se plantea la hipótesis de la mutación ocasional de una célula madre sana (inicio); si una exposición concreta estimula la proliferación de células intermedias (promoción), aumentan las posibilidades de que al menos una célula experimente una 0 más nuevas mutaciones y produzca un cáncer maligno (progresión) (Ennever 1993).

Así pues, las exposiciones profesionales pueden aumentar el riesgo de desarrollar cáncer al causar mutaciones en el ADN 0 por diversos mecanismos "epigenéticos" de promoción (los que no implican lesiones en el ADN), incluido el aumento de la proliferación celular. La mayor parte de los cancerígenos profesionales descubiertos hasta este momento son mutágenos y, por tanto, parecen ser iniciadores del cáncer. Esto explica el largo período de "latencia" necesario para que tengan lugar nuevas mutaciones; en muchos casos, es posible que éstas no se produzcan nunca y que, por tanto, no se desarrolle el cáncer.

En los últimos años ha aumentado el interés por las exposiciones profesionales (p. ej., benceno, arsénico, herbicidas fenoxi) que no parecen ser mutágenas, pero que pueden actuar como promotoras. La promoción se puede producir en una fase relativamente tardía del proceso cancerígeno y, por tanto, los períodos de latencia de los promotores pueden ser más cortos que los de los iniciadores. Sin embargo, las pruebas epidemiológicas sobre la promoción del cáncer siguen siendo muy limitadas en estos momentos (Frumkin y Levy 1988).

\section{Transferencia de riesgos}

Una preocupación importante en las últimas décadas ha sido el problema del traslado de las industrias peligrosas a los países en vías de desarrollo (Jeyaratnam 1994). Estos traslados se han producido en parte debido a la rigurosa normativa sobre los cancerígenos y a los costes laborales cada vez más elevados en los países industrializados, y en parte a la mano de obra más barata, al desempleo y al impulso de industrialización en los países en vías de desarrollo. Por ejemplo, en la actualidad, Canadá exporta casi la mitad de su amianto a los países en vías de desarrollo, habiéndose trasladado algunas de las industrias que utilizan este compuesto a países como Brasil, India, Pakistán, Indonesia y Corea del Sur (Jeyaratnam 1994). Estos problemas se complican aún más por la magnitud del sector informal, el gran número de trabajadores con escaso apoyo de los sindicatos y otras organizaciones de trabajadores, la falta de seguridad en el trabajo, la ausencia de protección legislativa o su cumplimiento deficiente, el control nacional cada vez menor sobre los recursos y el efecto de la deuda del Tercer $\mathrm{M}$ undo y los programas de ajuste estructural de ella derivados (Pearce y cols. 1994).

Como resultado, no se puede decir que el problema del cáncer profesional haya disminuido en los últimos años, ya que en muchos casos simplemente se ha transferido la exposición desde los países industrializados a los que están en vías de desarrollo, habiendo aumentado incluso en algunos casos la exposición total. Con todo, la historia reciente de la prevención del cáncer profesional en países industrializados ha demostrado que es posible utilizar sustitutos de los compuestos cancerígenos en los procesos industriales sin provocar la ruina de la industria, de

Tabla 2.2 - Porcentajes calculados de cáncer (PAR) atribuible a la profesión en estudios seleccionados.

\begin{tabular}{|c|c|c|c|}
\hline Estudio & Población & PAR y localización del cáncer & Comentarios \\
\hline Higginson 1969 & No indicada & $\begin{array}{l}1 \% \text { cáncer oral } \\
1-2 \% \text { cáncer de pulmón } \\
10 \% \text { cáncer de vejiga } \\
2 \% \text { cáncer de piel }\end{array}$ & Presentación no detallada de los niveles de exposición y de otras hipótesis \\
\hline Higginson y Muir 1976 & No indicada & 1-3 \% cáncer total & Presentación no detallada de las hipótesis \\
\hline Wynder y Gori 1977 & No indicada & $\begin{array}{l}4 \% \text { cáncer total en varones, } \\
2 \% \text { en mujeres }\end{array}$ & Basado en un PAR para el cáncer vesical y dos comunicaciones personales \\
\hline Higginson y Muir 1979 & $\begin{array}{l}\text { West Midland, } \\
\text { Reino Unido }\end{array}$ & $\begin{array}{l}6 \% \text { cáncer total en varones, } \\
2 \% \text { cáncer total }\end{array}$ & $\begin{array}{l}\text { Basado en un } 10 \% \text { de cáncer de pulmón no relacionado con el tabaco, } \\
\text { mesotelioma, cáncer vesical (30\%) y leucemia en mujeres (30\%) }\end{array}$ \\
\hline Doll y Peto 1981 & $\begin{array}{l}\text { Estados Unidos, principios } \\
\text { del decenio de } 1980\end{array}$ & $\begin{array}{l}4 \% \text { (límites } 2.8 \% \text { ) } \\
\text { Cáncer total }\end{array}$ & $\begin{array}{l}\text { Basado en todas las localizaciones de cáncer estudiadas; presentado como } \\
\text { cálculo "provisional" }\end{array}$ \\
\hline Hogan y Hoel 1981 & Estados Unidos & $\begin{array}{l}3 \% \text { (límites } 1,4-4 \%) \\
\text { Cáncer total }\end{array}$ & Riesgo asociado a la exposición profesional al amianto \\
\hline Vineis y Simonato 1991 & Varias & $\begin{array}{l}1-5 \% \text { cáncer de pulmón, } \\
16-24 \% \text { cáncer vesical }\end{array}$ & $\begin{array}{l}\text { Cálculos basados en datos de estudios de casos-controles. El porcentaje } \\
\text { del cáncer de pulmón considera sólo la exposición al amianto. En un } \\
\text { estudio con una elevada proporción de sujetos expuestos a radiación } \\
\text { ionizante, se calculó un PAR del } 40 \% \text {. Los cálculos del PAR en algunos } \\
\text { estudios sobre el cáncer vesical estaban entre el } 0 \text { y el } 3 \% \text {. }\end{array}$ \\
\hline
\end{tabular}


Tabla 2.3 - Evaluación de las pruebas de carcinogenicidad en el programa de monografías de la IARC.

1. Se consideran las pruebas de la inducción de cáncer en seres humanos, que desempeñan evidentemente un papel importante en la identificación de los cancerígenos humanos. Tres tipos de estudios epidemiológicos contribuyen a la valoración de la carcinogenicidad en los seres humanos: los estudios de cohorte, los estudios de casos-controles y los estudios de correlación (o ecológicos). También pueden revisarse informes de casos en seres humanos.

Las pruebas relevantes para la carcinogenicidad procedentes de estudios en seres humanos se clasifican en una de las siguientes categorías:

- Prueba suficiente de carcinogenicidad: Se ha establecido una relación causal entre la exposición al agente, la mezcla o la circunstancia de la exposición y el cáncer en el ser humano. Es decir, se ha observado una relación positiva entre la exposición y el cáncer en estudios en los que se pudieron descartar con una confianza razonable la casualidad, el sesgo y los elementos de confusión.

- Prueba limitada de carcinogenicidad: Se ha observado una asociación positiva entre la exposición al agente, la mezcla o la circunstancia de la exposición y el cáncer, considerándose creible una interpretación causal, sin que sea posible descartar con una confianza razonable la casualidad, el sesgo o los elementos de confusión

- Prueba insuficiente de carcinogenicidad: Los estudios disponibles carecen de la calidad, coherencia o potencia estadística suficientes para llegar a una conclusión en relación con la presencia 0 ausencia de asociación causal, o no se dispone de datos sobre cáncer en seres humanos.

- Pruebas indicativas de ausencia de carcinogenicidad: Existen varios estudios adecuados que abarcan la gama completa de niveles de exposición a los que se sabe que se someten los seres humanos que coinciden entre sí en no mostrar una asociación positiva entre la exposición al agente y el cáncer estudiado con ninguno de los niveles de exposición observados.

2. Se revisan los estudios en los que se ha expuesto de forma crónica a animales de experimentación (principalmente roedores) a cancerígenos potenciales y se han investigado en ellos las pruebas de cáncer, y se clasifican las pruebas de carcinogenicidad en categorías similares a las utilizadas para los datos en seres humanos.

3. Se revisan los datos sobre los efectos biológicos en seres humanos y en animales de experimentación que tengan especial importancia. Pueden ser consideraciones toxicológicas, cinéticas y metabólicas e indicios de fijación al ADN, de persistencia de lesiones del ADN o de lesiones genéticas en seres humanos expuestos. Se utilizan asimismo información toxicológica, como la relacionada con la citotoxicidad y la regeneración, la unión a receptores y los efectos hormonales e inmunológicos, y datos sobre la relación entre estructura y actividad cuando se consideran relevantes para explicar el posible mecanismo de la acción cancerígena del agente.

4. Se consideran todas las pruebas de forma conjunta, con el fin de realizar una evaluación global de la carcinogenicidad para el ser humano de un agente, mezcla o circunstancia de exposición (véase la Tabla 2.4).

lo que se infiere la posibilidad de conseguir éxitos similares en los países en vías de desarrollo si existieran una normativa adecuada y un control de los cancerígenos profesionales.

\section{Prevención del cáncer profesional}

Swerdlow (1990) enunció una serie de opciones para prevenir la exposición a las causas profesionales de cáncer. La más interesante es la que consiste en evitar el uso de cancerígenos humanos reconocidos en el lugar de trabajo. Esta opción rara vez se ha considerado en los países industrializados, puesto que la mayor parte de los cancerígenos profesionales se han identificado por estudios epidemiológicos de poblaciones ya sometidas a exposición en el trabajo. Sin embargo, al menos en teoría, los países en vías de desarrollo podrían aprender de esta experiencia e impedir la introducción de los productos químicos y de los procesos de producción de peligrosidad demostrada.

La mejor opción siguiente es la eliminación de los cancerígenos una vez establecida o sospechada la carcinogenicidad. Como ejemplos pueden mencionarse el cierre de las plantas productoras de los cancerígenos vesicales 2-naftilamina y bencidina en el Reino U nido (A non 1965), la finalización de la fabricación de gas en el Reino U nido mediante la carbonización de la hulla, el cierre de las fábricas de gas mostaza japonesas y británicas una vez finalizada la segunda Guerra Mundial (Swerdlow 1990) y la eliminación progresiva del uso del benceno en la industria del calzado en Estambul (Aksoy 1985).

Sin embargo, en muchos casos la eliminación total de un cancerígeno (sin el cierre de la industria) no es posible (porque no se dispone de productos alternativos) o resulta política 0 económicamente inaceptable. Por tanto, habrá que reducir los niveles de exposición modificando los procesos de producción y mediante prácticas de higiene industrial. Por ejemplo, las exposiciones a cancerígenos reconocidos como el amianto, el níquel, el arsénico, el benceno, los pesticidas y las radiaciones ionizantes se han reducido progresivamente en los países industrializados durante los últimos años (Pearce y M atos 1994).

U n enfoque afín consiste en reducir o eliminar las actividades que implican las exposiciones más intensas. Por ejemplo, tras la aprobación en 1840 de una ley en Inglaterra y Gales que prohibía la entrada de deshollinadores en las chimeneas, disminuyó el número de casos de cáncer escrotal (Waldron 1983). La exposición puede también reducirse al mínimo mediante el uso de equipos de protección personal, como mascarillas y ropas protectoras, o imponiendo medidas de higiene industrial más estrictas.

Por lo general, una estrategia global eficaz para el control y la prevención de la exposición a cancerígenos profesionales exige la combinación de varios enfoques. Un ejemplo eficaz es el de un registro finlandés destinado a aumentar la conciencia respecto a los cancerígenos, evaluar la exposición en puestos de trabajo concretos y estimular las medidas de prevención (Kerva y Partanen 1981). Contiene información tanto sobre los lugares de trabajo como sobre los trabajadores expuestos, y se exige a todas las empresas que mantengan y actualicen sus archivos y que faciliten información al registro. Parece que el sistema ha conseguido, al menos parcialmente, reducir las exposiciones a cancerígenos en el lugar de trabajo (A hlo, K auppinen y Sundquist 1988).

\section{CANCERIGEN OS PROfesionales}

\section{Paolo Boffetta, Rodolfo Saracci, Manolis Kogevinas, Julian Wilbourn y Harri Vainio}

El control de los cancerígenos industriales se basa en la revisión crítica de investigaciones científicas llevadas a cabo tanto en seres humanos como en sistemas experimentales. En la actualidad hay en curso varios programas en diferentes países con objeto de revisar y controlar las exposiciones profesionales potencialmente cancerígenas para el ser humano. Los criterios utilizados en ellos no son totalmente coincidentes, lo que origina en ocasiones diferencias en el control de los productos. Por ejemplo, la 4,4-metileno-bis-2-cloroanilina (M O CA) fue clasificada como cancerígeno 


\section{Tabla 2.4 - Grupos de clasificación del programa de monografías de la IARC.}

Se describe el agente, mezcla o circunstancia de exposición según la redacción de una de las siguientes categorías:
Grupo 1- El agente (mezcla) es cancerígeno para el ser humano. La circunstancia de la exposición supone exposiciones que son cancerígenas para el ser humano.

Grupo 2A- El agente (mezcla) es probablemente cancerígeno para el ser humano. La circunstancia de la exposición supone exposiciones que son probablemente cancerígenas para el ser humano.

Grupo 2B- El agente (mezcla) es posiblemente cancerígeno para el ser humano. La circunstancia de la exposición supone exposiciones que son posiblemente cancerígenas para el ser humano.

Grupo 3- El agente (mezcla, circunstancia de la exposición) no puede clasificarse en cuanto a su carcinogenicidad para el ser humano.

Grupo 4 - El agente (mezcla, circunstancia de la exposición) no es probablemente cancerígeno para el ser humano.

industrial en Dinamarca y los Países Bajos en 1976 y 1988, respectivamente, pero sólo recientemente la Conferencia Americana de Higienistas Industriales del Gobierno (ACGIH) lo ha considerado en Estados U nidos "supuesto cancerígeno para el ser humano".

La Agencia Internacional para la Investigación sobre el Cáncer (IARC) ha establecido, dentro de su programa de monografías, una serie de criterios para evaluar las pruebas de carcinogénesis de agentes específicos. De hecho, este programa de monografías de la IARC representa uno de los mayores esfuerzos de revisión sistemática y consistente de los datos sobre el cáncer, que goza de gran reputación entre la comunidad científica y ha servido de base para la información contenida en este artículo. Ejerce además un efecto importante sobre las actividades de control del cáncer profesional nacionales e internacionales. En la Tabla 2.3 se explica el sistema de evaluación. En las monografías de la IARC se evalúan las sustancias, mezclas y circunstancias de exposición siempre que existan pruebas de exposición humana y haya datos sobre la carcinogenicidad (ya sea en seres humanos 0 en animales de experimentación) (véanse los grupos de clasificación de la I ARC en la Tabla 2.4).

\section{Cancerígenos industriales conocidos y sospechados}

En la actualidad existen 22 sustancias químicas, grupos de sustancias químicas o mezclas a las que la exposición es principalmente profesional (excluidos los pesticidas y los fármacos), que son cancerígenos establecidos para el ser humano (Tabla 2.5). M ientras que algunos agentes, como el amianto, el benceno y los metales pesados, se utilizan en la actualidad ampliamente en muchos países, otros tienen principalmente un interés histórico (p. ej., el gas mostaza y la 2-naftilamina).

0 tros 20 productos se clasifican como probablemente cancerígenos para el ser humano (grupo 2A); se enumeran en la Tabla 2.6 e incluyen exposiciones muy habituales en la actualidad en muchos países, como la sílice cristalina, el formaldehído y el 1,3-butadieno. Un gran número de sustancias se clasifican como posibles cancerígenos para el ser humano (grupo 2B, Tabla 2.7); por ejemplo, el acetaldehído, el diclorometano 0 los compuestos de plomo inorgánicos. Las pruebas de
Tabla 2.5 - Sustancias químicas, grupos de sustancias químicas o mezclas a las que la exposición es fundamentalmente profesional (excluidos los pesticidas y los fármacos): Grupo 1: cancerígenos para los seres humanos ${ }^{1}$.

\begin{tabular}{|c|c|c|}
\hline Exposición ${ }^{2}$ & $\begin{array}{l}\text { Organos diana } \\
\text { humanos }\end{array}$ & Sector/ aplicación \\
\hline $\begin{array}{l}\text { 4-aminobifenilo } \\
{[92-67-1]}\end{array}$ & Vejiga & Fabricación de caucho \\
\hline $\begin{array}{l}\text { Arsénico [7440-38-2] } \\
\text { y sus derivados }\end{array}$ & Pulmón, piel & Vidrio, metales, pesticidas \\
\hline Amianto [1332-21-4] & $\begin{array}{l}\text { Pulmón, pleura, } \\
\text { peritoneo }\end{array}$ & $\begin{array}{l}\text { Aislamiento, material } \\
\text { para filtros, textiles }\end{array}$ \\
\hline Benceno [71-43-2] & Leucemia & Disolvente, combustible \\
\hline Bencidina [ $92-87-5$ ] & Vegija & $\begin{array}{l}\text { Fabricación de tintes/ } \\
\text { pigmento, producto de } \\
\text { laboratorio }\end{array}$ \\
\hline $\begin{array}{l}\text { Berilio [ } 7440-41-7] \\
\text { y sus compuestos }\end{array}$ & Pulmón & $\begin{array}{l}\text { Industria aerospaciall } \\
\text { metales }\end{array}$ \\
\hline $\begin{array}{l}\text { Bis( clorometil)éter } \\
\text { [542-88-11] }\end{array}$ & Pulmón & $\begin{array}{l}\text { Producto intermedio/ } \\
\text { subproducto químico }\end{array}$ \\
\hline $\begin{array}{l}\text { Clorometil metil } \\
\text { éter [107-30-2] } \\
\text { (grado técnico) }\end{array}$ & Pulmón & $\begin{array}{l}\text { Producto intermedio/ } \\
\text { subproducto químico }\end{array}$ \\
\hline $\begin{array}{l}\text { Cadmio [ } 7440-43-9] \\
\text { y sus compuestos }\end{array}$ & Pulmón & $\begin{array}{l}\text { Fabricación de tintes/ } \\
\text { pigmentos }\end{array}$ \\
\hline $\begin{array}{l}\text { Compuestos de } \\
\text { Cromo [VI] }\end{array}$ & Cavidad nasal, pulmón & $\begin{array}{l}\text { Chapado de metales, } \\
\text { fabricación/ de } \\
\text { tintes/ pigmentos }\end{array}$ \\
\hline $\begin{array}{l}\text { Brea de alquitranes de } \\
\text { hulla [65996-93-2] }\end{array}$ & Piel, pulmón, vejiga & $\begin{array}{l}\text { Material de construcción, } \\
\text { electrodos }\end{array}$ \\
\hline $\begin{array}{l}\text { Alquitranes de hulla } \\
\text { [8007-45-2] }\end{array}$ & Piel, pulmón & Combustible \\
\hline $\begin{array}{l}\text { Oxido de etileno } \\
{[75-21-8]}\end{array}$ & Leucemia & $\begin{array}{l}\text { Intermediario químico, } \\
\text { esterilizante }\end{array}$ \\
\hline $\begin{array}{l}\text { Aceites minerales, } \\
\text { sin procesar y } \\
\text { ligeramente procesados }\end{array}$ & Piel & Lubricantes \\
\hline $\begin{array}{l}\text { Gas mostaza (mostaza } \\
\text { sulfúrica) [505-60-2] }\end{array}$ & Faringe, pulmón & Gas de guerra \\
\hline $\begin{array}{c}\text { 2-naftilamina } \\
\text { [91-59-8] }\end{array}$ & Vejiga & $\begin{array}{l}\text { Fabricación de } \\
\text { tintes/ pigmentos }\end{array}$ \\
\hline Compuestos de níquel & Cavidad nasal, pulmón & $\begin{array}{l}\text { Metalurgia, aleaciones, } \\
\text { catalizador }\end{array}$ \\
\hline $\begin{array}{l}\text { Aceites de esquisto } \\
\text { [68308-34-9] }\end{array}$ & Piel & Lubricantes, combustibles \\
\hline Hollines & Piel, pulmón & Pigmentos \\
\hline $\begin{array}{l}\text { Talco con fibras } \\
\text { amiantiformes }\end{array}$ & Pulmón & Papel, pinturas \\
\hline $\begin{array}{l}\text { Cloruro de vinilo } \\
{[75-01-4]}\end{array}$ & $\begin{array}{l}\text { Hígado, pulmón, } \\
\text { vasos sanguíneos }\end{array}$ & Plásticos, monómero \\
\hline Polvo de madera & Cavidad nasal & Industria maderera \\
\hline
\end{tabular}

1 Evaluados en las monografías de la IARC, volúmenes 1-63 (1972-1995) (excluidos pesticidas y fármacos).

2 El número entre paréntesis es el no de registro CAS.

${ }^{3}$ Esta evaluación se aplica al grupo de sustancias químicas en conjunto, y no necesariamente a todas las que componen el grupo. 
Tabla 2.6 - Sustancias químicas, grupos de sustancias químicas o mezclas a las que la exposición es fundamentalmente profesional (excluidos pesticidas y fármacos):

G rupo 2A: probablemente cancerígenos para los seres humanos ${ }^{1}$.

\begin{tabular}{|c|c|c|}
\hline Exposición ${ }^{2}$ & $\begin{array}{l}\text { Organos diana } \\
\text { humanos sospechados }\end{array}$ & $\begin{array}{l}\text { Sector/ aplicación } \\
\text { principal }\end{array}$ \\
\hline Acrilonitrilo [107-13-1] & $\begin{array}{l}\text { Pulmón, próstata, } \\
\text { linfoma }\end{array}$ & $\begin{array}{l}\text { Plásticos, caucho, textiles, } \\
\text { monómero }\end{array}$ \\
\hline Tintes bencidímicos & - & Papel, cuero, tintes textiles \\
\hline 1,3-butadieno [106-99-0] & Leucemia, linfoma & $\begin{array}{l}\text { Plásticos, caucho, } \\
\text { monómero }\end{array}$ \\
\hline $\begin{array}{l}\text { p-cloro-0-toluidina } \\
\text { [95-69-2] y sus sales } \\
\text { ácidas fuertes }\end{array}$ & Vejiga & $\begin{array}{l}\text { Fabricación de tintes } \\
\text { pigmentos, textiles }\end{array}$ \\
\hline Creosotas [8001-58-9] & Piel & Conservación de maderas \\
\hline Dietilsulfato [64-67-5] & - & Intermediario químico \\
\hline $\begin{array}{l}\text { Cloruro de dimetilcarbamilo } \\
\text { [79-44-7] }\end{array}$ & - & Intermediario químico \\
\hline $\begin{array}{l}\text { Dimetilsulfato } \\
\text { [77-78-1] }\end{array}$ & - & Intermediario químico \\
\hline $\begin{array}{l}\text { Epiclorohidrina } \\
\text { [106-89-8] }\end{array}$ & - & $\begin{array}{l}\text { Monómero de plás- } \\
\text { ticos/ resinas }\end{array}$ \\
\hline $\begin{array}{l}\text { Dibromuro de etileno } \\
{[106-93-4]}\end{array}$ & - & $\begin{array}{l}\text { Intermediario químico, } \\
\text { fumigante, combustibles }\end{array}$ \\
\hline Formaldehído [50-0-0] & Nasofaringe & $\begin{array}{l}\text { Plásticos, textiles, } \\
\text { producto de } \\
\text { laboratorio }\end{array}$ \\
\hline $\begin{array}{l}\text { 4,4'-metilo- bis- } \\
\text { 2-cloroanilina (MOCA) } \\
{[101-14-4]}\end{array}$ & Vejiga & Fabricación de caucho \\
\hline $\begin{array}{l}\text { Bifenilos policlorados } \\
\text { [1336-36-3] }\end{array}$ & $\begin{array}{l}\text { Hígado, vías biliares, } \\
\text { leucemia, linfoma }\end{array}$ & Componentes eléctricos \\
\hline $\begin{array}{l}\text { Sílice [14808-60-7], } \\
\text { cristalina }\end{array}$ & Pulmón & $\begin{array}{l}\text { Tallado de piedras, minería, } \\
\text { vidrio, papel }\end{array}$ \\
\hline $\begin{array}{l}\text { Oxido de estireno } \\
{[96-09-3]}\end{array}$ & - & $\begin{array}{l}\text { Plásticos, intermediario } \\
\text { químico }\end{array}$ \\
\hline $\begin{array}{l}\text { Tetracloroetileno } \\
\text { [127-18-4] }\end{array}$ & $\begin{array}{l}\text { Esófago, } \\
\text { linfoma }\end{array}$ & $\begin{array}{l}\text { Disolvente, limpieza en } \\
\text { seco }\end{array}$ \\
\hline $\begin{array}{l}\text { Tricloroetileno } \\
{[79-01-6]}\end{array}$ & Hígado, linfoma & $\begin{array}{l}\text { Disolvente, limpieza en } \\
\text { seco, metales }\end{array}$ \\
\hline $\begin{array}{l}\text { Tris(2,3-dibromopropil } \\
\text { fosfato [126-72-7] }\end{array}$ & - & $\begin{array}{l}\text { Plásticos, textiles, } \\
\text { retardador de la } \\
\text { combustión }\end{array}$ \\
\hline $\begin{array}{l}\text { Bromuro de vinilo } \\
\text { [593-60-2] }\end{array}$ & - & $\begin{array}{l}\text { Plásticos, textiles, } \\
\text { monómero }\end{array}$ \\
\hline $\begin{array}{l}\text { Fluoruro de vinilo } \\
\text { [75-02-5] }\end{array}$ & - & Intermediario químico \\
\hline
\end{tabular}

carcinogénesis de la mayor parte de ellos proceden de estudios en animales de experimentación.

Pueden producirse asimismo exposiciones profesionales durante la producción y utilización de algunos pesticidas y fármacos. En la Tabla 2.8 se presenta la evaluación de la carcinogenicidad de los pesticidas; dos de ellos, el captafol y el

Tabla 2.7 - Sustancias químicas, grupos de sustancias químicas o mezclas a las que la exposición es fundamentalmente profesional (excluidos pesticidas y fármacos):

$\mathrm{G}$ rupo $2 \mathrm{~B}$ : Posiblemente cancerígenos para los seres humanos ${ }^{1}$.

Exposición ${ }^{2}$

Acetaldehído [75-07-0]

Acetamida [60-35-5]

Acrilamida [79-06-1]

p-aminoazatolueno [60-09-3]

o-aminoazatolueno [97-56-3]

0-anisidina [90-04-0]

Trióxido de antimonio [1309-64-4]

Auramina [492-80-8] (grado técnico)

Violeta de bencilo 4B [1694-09-3]

Betunes [8052-42-4], extractos de

refinados al vapor $y$ al aire

Bromodiclorometano [75-27-4]

$\beta$-butirolactona [3068-88-0]

Extractos de negro de humo

Tetracloruro de carbono [ 56-23-5]

Fibras cerámicas

Acido cloréndico [115-28-6]

Parafinas cloradas de cadenas de carbono de longitud media $\mathrm{C} 12$ y grado medio

de cloración aproximado $60 \%$

Toluenos alfa-clorados

p-cloroanilina [106-47-8]

Cloroformo [67-66-3]

4-cloro-o-fenilendiamina [95-83-9]

Cl Rojo Acido 114 [6459-94-5]

Cl Rojo Básico 9 [569-61-9]

Cl Azul Directo 15 [2429-74-5]

Cobalto [ 7440-48-4] y compuestos

de cobalto

p-cresidina [120-71-8]

$N, N^{\prime}$-diacetilbencidina [ 613-35-4]

2,4-diaminoanisol [615-05-4]

4,4'-diaminodifenil éter [101-80-4]

2,4-diaminotolueno [95-80-7]

p-Diclorobenceno [106-46-7]

3,3'-Diclorobenceno [91-94-1]

3,3'-dicloro-4,4'-diaminodifenil éter [28434-86-8]
Sector/ aplicación principal

Fabricación de plásticos, sabores

Disolvente, intermediario químico

Plásticos, agente de lechada

Fabricación de tintes/ pigmentos

Tintes/ pigmentos, textiles

Fabricación de tintes/ pigmentos

Retardador de la combustión, vidrio, pigmentos

Tintes/ pigmentos

Tintes/ pigmentos

Material de construcción

Intermediario químico

Intermediario químico

Tintas de impresión

Disolvente

Plásticos, textiles, industria aerospacial

Retardador de la combustión

Retardador de la combustión

Fabricación de tintes/ pigmentos, intermediario químico

Fabricación de tintes/ pigmentos

Disolvente

Tintes/ pigmentos, tintes para el cabello

Tintes/ pigmentos, textiles, cuero

Tintes/ pigmentos, tintas

Tintes/ pigmentos, textiles, pape

Vidrio, pinturas, aleaciones

Fabricación de tintes/ pigmentos Fabricación de tintes/ pigmentos Fabricación de tintes/ pigmentos, tintes para el cabello

Fabricación de plásticos

Fabricación de tintes/ pigmentos,

tintes para el cabello

Intermediario químico

Fabricación de tintes/ pigmentos No se utiliza

Evaluado en las monografías de la IARC, volúmenes 1-63 (1972-1995)

(excluidos pesticidas y fármacos).

2El número entre paréntesis es el no de registro CAS

Continúa en la página siguiente. 
Tabla 2.7 - Sustancias químicas, grupos de sustancias químicas o mezclas a las que la exposición es fundamentalmente continuación profesional (excluidos pesticidas y fármacos): Grupo 2B: Posiblemente cancerígenos para los seres humanos ${ }^{1}$.

Exposición $^{2}$
1,2-dicloroetano [107-06-2]
Diclorometano [75-09-2]
Diepoxibutano [1464-53-5]
Combustible diesel, marino
Di(2-etilhexill)ftalato [117-81-7]
1,2-dietilhidrazina [1615-80-1]
Diglicidil resorcinol éter [101-90-6]
Sulfato de diisopropilo [29973-10-6]
3,3'-dimetoxibencidina
(0-dianisidina) [119-90-4]
p-Dimetilaminoazobenceno [60-11-7]
2,6-dimetilanilina (2,6-xilidina) [87-62-7]
3,3'-Dimetilbencidina (0-tolidina)[119-93-7]
Dimetilformamida [ 68-12-2]
1,1-dimetilhidrazina [ $57-14-7]$
1,2-dimetilhidrazina [540-73-8]
1,4-dioxano [123-91-1]
Azul disperso 1 [2475-45-8]
Acrilato de etilo [140-88-5]
Tiourea de etileno [96-45-7]
Aceites combustibles, residuales (pesados)
Furano [110-00-9]
Gasolina
Lana de vidrio
Glicidaldehído [765-34-4]
Azul HC no 1 [2784-94-3]
Hexametilfosforamida [680-31-9]
Hidrazina [302-01-2]
Plomo [7439-92-1] y compuestos de
plomo, inorgánicos
2-metilaziridina [75-55-8]
[838-metileno-bis-2-metilanilina
[83-0]

Sector/ aplicación principal
Disolvente, combustibles
Disolvente
Plásticos/ resinas
Combustible
Plásticos, textiles
Reactivo de laboratorio
Plásticos/ resinas
Contaminante
Fabricación de tintes/ pigmentos

Tintes/ pigmentos

Intermediario químico

Fabricación de tintes/ pigmentos

Disolvente

Combustible para cohetes

Sustancia química experimental

Disolvente

Tinte/ pigmento, tintes para el cabello

Plásticos, adhesivos, monómero

Sustancia química para el caucho

Combustible

Intermediario químico

Combustible

Aislamiento

Textiles, fabricación de cuero

Tintes para el cabello

Disolvente, plásticos

Combustible para cohetes,

intermediario químico

Pinturas, combustibles

Tintes, papel, fabricación

de plásticos

Fabricación de tintes/ pigmentos
Exposición ${ }^{2}$

4,4'-metilenodianilina[101-77-9]

Compuestos de metilmercurio

2-M etil-1-nitroantraquinona [129-15-7]

(pureza incierta)

Níquel metálico [7440-02-0]

Acido nitrilotriacético [139-13-9] y sus sales

5-nitroacenafteno [602-87-9]

2-nitropropano [79-46-9]

N-nitrosodietanolamina [1116-54-7]

Aceite naranja SS [2646-17-5]

Fenil glicidil éter [122-60-1]

Bifenilos polibromados

[Firemaster BP-6] [59536-65-1]

Ponceau MX [3761-53-3]

Ponceau 3R [3564-09-8]

1,3-propano sulfona [1120-71-4]

$\beta$-propiolactona [57-57-8]

Oxido de propileno [75-56-9]

Lana mineral

Lana de escoria

Estireno [100-42-5]

2,3,7,8-tetraclorodibenzo-p-dioxina

(TCDD) [1746-01-6]

Tioacetamida [62-55-5]

4,4'-tiodianilina [139-65-1]

Tiourea [62-56-6]

Diisocianatos de tolueno [26471-62-5]

o-toluidina [95-53-4]

Azul tripano [72-57-1]

Acetato de vinilo [108-05-4]

Vapores de fundición
Sector/ aplicación principal

Plásticos/ resinas, fabricación

de tintes/ pigmentos

Fabricación de pesticidas

Fabricación de tintes/ pigmentos

Catalizador

Quelante, detergente

Fabricación de tintes/ pigmentos

Disolvente

Líquidos diluyentes, impureza

Tintes/ pigmentos

Plásticos/ adhesivos/ resinas

Retardador de la combustión

Tintes/ pigmentos, textiles

Tintes/ pigmentos, textiles

Fabricación de tintes/ pigmentos

Intermediario químico;

fabricación de plásticos

Intermediario químico

Aislamiento

Aislamiento

Plásticos

Contaminante

Textiles, papel, cuero,

fabricación de caucho

Fabricación de tintes/ pigmentos

Textiles, ingrediente del caucho

Plásticos

Fabricación de tintes/

pigmentos

Tintes/ pigmentos

Intermediario químico

Metalurgia dibromuro de etileno, se clasifican como probables cancerígenos para el ser humano, mientras que un total de otros 20 compuestos, incluidos el DDT, la atrazina y los clorofenoles, se clasifican como posibles cancerígenos.

Varios fármacos son cancerígenos para el ser humano (Tabla 2.9): se trata sobre todo de agentes alquilantes y hormonas; otros 12 fármacos, como el cloranfenicol, el cisplatino y la fenacetina, que se clasifican como probables cancerígenos para el ser humano (grupo 2A). La exposición profesional a estos cancerígenos conocidos o supuestos, utilizados principalmente en quimioterapia, puede tener lugar en farmacias y durante su administración por el personal de enfermería.
En la Tabla 2.10 se relacionan varios agentes ambientales que son causantes demostrados o supuestos de cáncer en el ser humano; aunque la exposición a ellos no tiene carácter primordialmente profesional, existen grupos de personas expuestas a ellos a causa de su trabajo: son ejemplos los mineros del uranio expuestos a los productos de la degradación del radón, los trabajadores de hospitales expuestos al virus de la hepatitis B, los manipuladores de alimentos expuestos a las aflatoxinas de alimentos contaminados, los trabajadores al aire libre expuestos a la radiación UV o a los gases de escape de motores diesel y el personal o los camareros de los bares expuestos al humo del tabaco del ambiente. 
En el programa de monografías de la IARC se han abordado la mayor parte de las causas de cáncer conocidas o sospechadas; sin embargo, existen algunos grupos importantes de agentes que no han sido evaluados por la IARC, como la radiación ionizante y los campos eléctricos y magnéticos.

\section{Sectores industriales y profesiones}

El conocimiento actual de la relación entre las exposiciones profesionales y el cáncer dista de ser completo; de hecho, sólo hay 22 sustancias establecidas como cancerígenos industriales (Tabla 2.5), siendo muchos más los cancerígenos experimentales de los que no existen pruebas claras obtenidas en trabajadores expuestos. En muchos casos, hay pruebas importantes de aumento del riesgo asociado a determinadas industrias y profesiones, pero no ha sido posible identificar agentes concretos como factores etiológicos. En las Tablas 2.11 y 2.12 se relacionan profesiones e industrias asociados a riesgos de cáncer superiores a lo normal, junto a las localizaciones correspondientes del cáncer y a los agentes causales conocidos (o sospechados).

En la Tabla 2.11 se presentan las exposiciones, profesiones e industrias en las que se considera establecida la presencia de un riesgo cancerígeno, mientras que en la Tabla 2.12 se presentan las exposiciones, profesiones y procesos industriales en los que se ha notificado un riesgo de cáncer superior al normal, pero no existen pruebas de carácter definitivo. Se incluyen también en ella algunas profesiones e industrias ya mencionadas en la Tabla 2.11, para las que existen pruebas no concluyentes de asociación con cánceres distintas a las citadas en esta última. Por ejemplo, la industria de producción de amianto figura en la Tabla 2.11 en relación con el cáncer pulmonar y el mesotelioma pleural peritoneal, y también en la Tabla 2.12 en relación con las neoplasias gastrointestinales. Varios de los sectores y profesiones incluidos en las Tablas 2.11 y 2.12 también se han evaluado en el programa de monografías de la IARC. Por ejemplo, "la exposición profesional a neblina ácida inorgánica intensa que contiene ácido sulfúrico" se clasificó dentro del grupo 1 (cancerígeno para los seres humanos).

La creación e interpretación de este tipo de listas de agentes cancerígenos químicos o físicos y su asociación con profesiones e industrias concretas se complica a causa de varios factores: 1) a menudo, la información sobre los procesos y exposiciones es escasa, y no permite una evaluación completa de la importancia de exposiciones cancerígenas específicas en diferentes profesiones o industrias; 2) las exposiciones a cancerígenos perfectamente conocidos, como el cloruro de vinilo o el benceno, se producen a diferentes intensidades en distintas situaciones profesionales; 3) en una determinada situación profesional se producen cambios en la exposición a lo largo del tiempo a causa de la sustitución de agentes cancerígenos identificados por otros agentes o (lo que es más frecuente) por la introducción de nuevos materiales o procesos industriales; 4) cualquier lista de exposiciones profesionales sólo puede referirse al número relativamente pequeño de exposiciones químicas que se han investigado en relación con la presencia de un riesgo cancerígeno.

Todos los problemas anteriores ponen de manifiesto la limitación básica de una clasificación de este tipo, y en particular de su generalización a todas las partes del mundo: la presencia de un cancerígeno en una situación profesional no significa necesariamente que los trabajadores estén expuestos a él y, por el contrario, la ausencia de cancerígenos identificados no excluye la presencia de causas de cáncer todavía no identificadas.

Un problema especial de los países en vías de desarrollo es que gran parte de la actividad industrial está muy fragmentada y tiene lugar en ámbitos locales. Estas pequeñas industrias se suelen caracterizar por el empleo de maquinaria vieja, edificios poco seguros y trabajadores con formación y educación
Tabla 2.8 • Pesticidas evaluados en las monografías de la IARC, volúmenes 1-63 (1972-1995).

\begin{tabular}{|c|c|}
\hline Grupo IARC & Pesticida ${ }^{1}$ \\
\hline $\begin{array}{l}2 \mathrm{~A} \text { - Probablemente } \\
\text { cancerígenos para seres } \\
\text { humanos }\end{array}$ & $\begin{array}{l}\text { Captafol [2425-06-1] } \\
\text { Dibromuro de etileno [106-93-4] }\end{array}$ \\
\hline $\begin{array}{l}\text { 2B- Posiblemente } \\
\text { cancerígenos para seres } \\
\text { humanos }\end{array}$ & $\begin{array}{l}\text { Amitrol [61-82-5] } \\
\text { Aramita [140-57-8] } \\
\text { Atrazina [1912-24-9] } \\
\text { Clordano [57-74-9] } \\
\text { Clordecona (Kepone) [143-50-0] } \\
\text { Clorofenoles } \\
\text { Herbicidas clorofenoxi } \\
\text { DDT [50-29-3] } \\
\text { 1,2-Dibromo-3-cloropropano [96-12-8] } \\
\text { 1,3-dicloropropeno [542-75-6] } \\
\text { (grado-técnico) } \\
\text { Diclorvos [62-73-7] } \\
\text { Heptaclor [76-44-8] } \\
\text { Hexaclorobenceno [118-74-1] } \\
\text { Hexaclorociclohexanos (HCH) } \\
\text { Mirex [2385-85-5] } \\
\text { Nitrofeno [1836-75-5], grado técnico } \\
\text { Pentaclorofenol [87-86-5] } \\
\text { o-fenilfenato sódico [132-27-4] } \\
\text { Sulfalato [95-06-7] } \\
\text { Toxafeno (canfenos policlorados) } \\
\text { [8001-35-2] }\end{array}$ \\
\hline
\end{tabular}

1 El número entre paréntesis es el $n-0$ de registro CAS

limitadas; además, las empresas tienen recursos económicos limitados. Rara vez se utilizan ropas protectoras, respiradores, guantes u otro material de seguridad. Las pequeñas empresas suelen estar geográficamente dispersas y ser inaccesibles a las inspecciones de los organismos competentes en materia de salud y seguridad en el trabajo.

\section{CANCER DE ORIGEN AMBIENTAL}

\section{Bruce K. Armstrong y Paolo B offetta}

EI cáncer es una enfermedad común en todos los países del mundo. La probabilidad de que una persona lo desarrolle cuando llega a los 70 años, supuesta la supervivencia a esa edad, oscila entre un 10 y un $40 \%$ en ambos sexos. En promedio, en los países desarrollados alrededor de una persona de cada cinco morirá de cáncer. Esta probabilidad es de uno de cada 15 en los países en vías de desarrollo. En este artículo, el cáncer de origen ambiental se define como el causado (o evitado) por factores no genéticos, como el comportamiento, los hábitos y el estilo de vida de las personas, así como por factores externos sobre los cuales el individuo no tiene control. En ocasiones se utiliza una definición más estricta, limitada al efecto de factores como la contaminación del aire y del agua y los residuos industriales. 
Tabla 2.9 - Fármacos evaluados en las monografías de la IARC, volúmenes 1-63 (1972-1995).

\begin{tabular}{|c|c|}
\hline Fármaco ${ }^{1}$ & Organo diana ${ }^{2}$ \\
\hline \multicolumn{2}{|c|}{ GRUPO 1 de la IARC- Cancerígenos para los seres humanos } \\
\hline Mezclas analgésicas con fenacetina & Riñón, vejiga \\
\hline Azatioprina [446-86-6] & $\begin{array}{l}\text { Linfoma, sistema } \\
\text { hepatobiliar, piel }\end{array}$ \\
\hline $\begin{array}{l}\text { N,N-bis(2-cloroetil)- } \beta \text {-naftilamina } \\
\text { (clornafacina) [494-03-1] }\end{array}$ & Vejiga \\
\hline $\begin{array}{l}\text { 1,4-butanodiol dimetanosulfonato (Myleran) } \\
\text { [55-98-1] }\end{array}$ & Leucemia \\
\hline Clorambucilo [305-03-3] & Leucemia \\
\hline $\begin{array}{l}\text { 1-(2-cloroetil)-3-(4-metilciclohexil)-1- } \\
\text { nitrosourea (Metil-CCNU) [13909-09-6] }\end{array}$ & Leucemia \\
\hline Ciclosporina [ 79217-60-0] & Linfoma, piel \\
\hline Ciclofosfamida [50-18-0] [6055-19-2] & Leucemia, vejiga \\
\hline Dietilestilbestrol [56-53-1] & Cérvix, vagina, mama \\
\hline Melfalán [148-82-3] & Leucemia \\
\hline $\begin{array}{l}\text { 8-metoxipsoraleno (Methoxsalen) } \\
\text { [298-81-7] más radiación UVA }\end{array}$ & Piel \\
\hline $\begin{array}{l}\text { MOPP y otros quimioterápicos combinados, } \\
\text { incluidos agentes alquilantes }\end{array}$ & Leucemia \\
\hline Estrógenos de sustitución & Utero \\
\hline Estrógenos no esteroideos & Cérvix, vagina, mama \\
\hline Estrógenos esteroideos & Utero \\
\hline Anticonceptivos orales combinados & Hígado \\
\hline Anticonceptivos orales secuenciales & Utero \\
\hline Tiotepa [52-24-4] & Leucemia \\
\hline Treosulfán [299-75-2] & Leucemia \\
\hline \multicolumn{2}{|c|}{ GRUPO 2A de la IARC- Probablemente cancerígenos para los seres humanos } \\
\hline Adriamicina [23214-92-8] & - \\
\hline Esteroides androgénicos (anabolizantes) & (Hígado) \\
\hline Azacitidina [320-67-2] & - \\
\hline Biscloroetil nitrosourea (BCNU) [154-93-8] & (Leucemia) \\
\hline Cloranfenicol [56-75-7] & (Leucemia) \\
\hline $\begin{array}{l}\text { 1-(2-cloroetil)-3-ciclohexil-1-nitrosourea } \\
\text { (CCNU) [13010-47-4] }\end{array}$ & - \\
\hline Clorozotocina [ 54749-90-5] & - \\
\hline Cisplatino [15663-27-1] & - \\
\hline 5-Metoxipsoraleno [484-20-8] & - \\
\hline Mostaza nitrogenada [51-75-2] & (Piel) \\
\hline Fenacetina [62-44-2] & (Riñón, vejiga) \\
\hline Clorhidrato de procarbazina [366-70-1] & - \\
\hline
\end{tabular}

\section{Variación geográfica}

La variación en las tasas de tipos concretos de cáncer según la región geográfica puede ser mucho mayor que la del cáncer en general. En la Tabla 2.13 se resumen las variaciones conocidas en la incidencia de los cánceres más comunes. La incidencia de carcinoma nasofaríngeo, por ejemplo, varía unas 500 veces entre el sureste asiático y Europa. Esta gran variación de la frecuencia ha dado lugar a la opinión de que gran parte de los cánceres del ser humano son causados por factores presentes en el medio ambiente. En particular, se ha aducido que la tasa más baja de un cáncer observada en cualquier población es indicativa de la tasa mínima, posiblemente espontánea, registrada en ausencia de factores causales. Por lo tanto, la diferencia entre la tasa de un cáncer en una población determinada y la tasa mínima observada en cualquier población se corresponde con la tasa atribuible a factores ambientales en la primera. Sobre esta base se ha calculado que, de forma muy aproximada, entre el 80 y el $90 \%$ de los cánceres humanos están determinados por factores ambientales (A gencia Internacional para la Investigación sobre el Cáncer 1990).

Obviamente, existen otras explicaciones de la variación geográfica de las tasas de cáncer. Es posible que el registro insuficiente de los casos de cáncer en algunas poblaciones exagere el margen de variación, pero no puede explicar en modo alguno diferencias del grado mostrado en la Tabla 2.13. Pueden influir factores genéticos. Sin embargo, se ha observado que cuando las poblaciones se desplazan a lo largo de un gradiente de incidencia de cáncer, suelen adquirir una tasa de cáncer intermedia entre la de su país de origen y la del de acogida. Esto sugiere que un cambio en el medio ambiente, sin cambios genéticos, ha modificado la incidencia de cáncer. Por ejemplo, cuando los japoneses emigran a Estados U nidos, sus tasas de cáncer de colon y mama, que son bajas en Japón, se elevan, mientras que las de cáncer de estómago, que son altas en Japón, descienden. Estas variaciones pueden retrasarse hasta la primera generación posterior a la emigración, pero se producen sin que tengan lugar cambios genéticos. En algunos cánceres, sin embargo, no se producen cambios con la emigración. Por ejemplo, los habitantes del sur de C hina mantienen una elevada tasa de cáncer de nasofaringe independientemente de dónde vivan, lo que indicaría que es la presencia de factores genéticos 0 de algunos hábitos culturales que cambian poco con la emigración la responsable de esta enfermedad.

\section{Tendencias a lo largo del tiempo}

La observación de las tendencias a lo largo del tiempo ha aportado nuevas pruebas sobre el papel que desempeñan los factores ambientales en la incidencia del cáncer. El cambio más espectacular y conocido ha sido el aumento de las tasas de cáncer de pulmón en ambos sexos en paralelo a la adquisición del hábito de fumar, aunque de 20 a 30 años después, observado en muchas regiones del mundo. M ás recientemente, en algunos países, como E stados U nidos, parece que se apunta un descenso de las tasas en los varones, como resultado del descenso del consumo de tabaco. Se sabe menos sobre los importantes descensos observados en la incidencia de los cánceres de estómago, esófago, cérvix y otros que se han producido de forma paralela al desarrollo económico en muchos países. Son de difícil explicación, salvo por una disminución de la exposición a factores causales ambientales 0 , quizás, por aumento de la exposición a factores protectores, también ambientales.

\section{Principales agentes cancerígenos ambientales}

La importancia de los factores ambientales como causas del cáncer en el ser humano ha quedado también demostrada por estudios epidemiológicos que relacionaban determinados agentes 
Tabla 2.10 - Agentes y exposiciones ambientales que se sabe o se sospecha que causan cáncer en los seres humanos

\begin{tabular}{|c|c|c|}
\hline Agente/ exposición & Organo diana ${ }^{2}$ & $\begin{array}{l}\text { Valor de las } \\
\text { pruebas }^{3}\end{array}$ \\
\hline \multicolumn{3}{|l|}{ Contaminantes del aire } \\
\hline Erionita & Pulmón, pleura & 1 \\
\hline Amianto & Pulmón, pleura & 1 \\
\hline $\begin{array}{l}\text { Hidrocarburos aromáticos } \\
\text { policíclicos }\end{array}$ & (Pulmón, vejiga) & $S$ \\
\hline \multicolumn{3}{|l|}{ Contaminantes del agua } \\
\hline Arsénico & Piel & 1 \\
\hline Subproductos de la cloración & (Vejiga) & $S$ \\
\hline Nitrato y nitrito & (Esófago, estómago) & $S$ \\
\hline \multicolumn{3}{|l|}{ Radiación } \\
\hline $\begin{array}{l}\text { Radón y sus productos } \\
\text { de degradación }\end{array}$ & Pulmón & 1 \\
\hline Radio, torio & Hueso & E \\
\hline Otras radiaciones $X$ & Leucemia, mama, tiroides, otros & $E$ \\
\hline Radiación solar & Piel & 1 \\
\hline Radiación ultravioleta A & (Piel) & $2 A$ \\
\hline Radiación ultravioleta B & ( Piel) & $2 A$ \\
\hline Radiación ultravioleta C & ( Piel) & $2 A$ \\
\hline $\begin{array}{l}\text { Utilización de lámparas } \\
\text { y cabinas solares }\end{array}$ & ( Piel) & $2 A$ \\
\hline Campos eléctricos y magnéticos & (Leucemia) & $S$ \\
\hline \multicolumn{3}{|l|}{ Agentes biológicos } \\
\hline $\begin{array}{l}\text { Infección crónica por el } \\
\text { virus de la hepatitis B }\end{array}$ & Hígado & 1 \\
\hline $\begin{array}{l}\text { Infección crónica por el } \\
\text { virus de la hepatitis C }\end{array}$ & Hígado & 1 \\
\hline $\begin{array}{l}\text { Infección por Helicobacter } \\
\text { pylori }\end{array}$ & Estómago & 1 \\
\hline $\begin{array}{l}\text { Infección por Opistorchis } \\
\text { viverrini }\end{array}$ & Conductos biliares & 1 \\
\hline $\begin{array}{l}\text { Infección por Chlonorchis } \\
\text { sinensis }\end{array}$ & (Hígado) & $2 A$ \\
\hline $\begin{array}{l}\text { Papillomavirus humano } \\
\text { tipos } 16 \text { y } 18\end{array}$ & Cérvix & 1 \\
\hline $\begin{array}{l}\text { Papillomavirus humano } \\
\text { tipos } 31 \text { y } 33\end{array}$ & (Cérvix) & $2 \mathrm{~A}$ \\
\hline $\begin{array}{l}\text { Papillomavirus humano } \\
\text { otros tipos distintos al } 16 \text {, } \\
18,31 \text { y } 33\end{array}$ & (Cérvix) & $2 B$ \\
\hline $\begin{array}{l}\text { Infección por Schistosoma } \\
\text { haematobium }\end{array}$ & Vejiga & 1 \\
\hline $\begin{array}{l}\text { Infección por Schistosoma } \\
\text { japonicum }\end{array}$ & (Hígado, colon) & $2 B$ \\
\hline
\end{tabular}

\begin{tabular}{|c|c|c|}
\hline Agente/ exposición & Organo diana ${ }^{2}$ & $\begin{array}{l}\text { Valor de las } \\
\text { pruebas }^{3}\end{array}$ \\
\hline \multicolumn{3}{|c|}{ Tabaco alcohol y sustancias relacionadas } \\
\hline Bebidas alcohólicas & $\begin{array}{l}\text { Boca, faringe, esófago, } \\
\text { hígado, laringe }\end{array}$ & 1 \\
\hline Humo del tabaco & $\begin{array}{l}\text { Labio, boca, faringe, } \\
\text { esófago, pancreas, } \\
\text { laringe, pulmón, riñón, } \\
\text { vejiga, (otros) }\end{array}$ & 1 \\
\hline Productos de tabaco sin humo & Boca & 1 \\
\hline Mascada de betel con tabaco & Boca & 1 \\
\hline \multicolumn{3}{|l|}{ Factores dietéticos } \\
\hline Aflatoxinas & Hígado & 1 \\
\hline Aflatoxina M1 & (H'́gado) & $2 B$ \\
\hline Ocratoxina A & (Riñón) & $2 B$ \\
\hline $\begin{array}{l}\text { Toxinas de } \\
\text { Fusarium moniliforme }\end{array}$ & (Esófago) & $2 B$ \\
\hline Pescado salado al estilo chino & Nasofaringe & 1 \\
\hline $\begin{array}{l}\text { Verduras en escabeche } \\
\text { (tradicionales en Asia) }\end{array}$ & (Esófago, estómago) & $2 B$ \\
\hline Helecho & (Esófago) & $2 B$ \\
\hline Safrol & - & $2 B$ \\
\hline Café & (Vejiga) & $2 B$ \\
\hline Acido cafeico & - & $2 B$ \\
\hline Mate caliente & (Esófago) & $2 A$ \\
\hline $\begin{array}{l}\text { Frutas y hortalizas frescas } \\
\text { (protectoras) }\end{array}$ & $\begin{array}{l}\text { Boca, esófago, estómago, } \\
\text { colon, recto, laringe, pulmón } \\
\text { (otros) }\end{array}$ & $\mathrm{E}$ \\
\hline Grasa & (Colon, mama, endometrio) & S \\
\hline Fibra ( protectora) & (Colon, recto) & $S$ \\
\hline Nitratos y nitritos & (Esófago, estómago) & S \\
\hline Sal & (Estómago) & S \\
\hline $\begin{array}{l}\text { Vitamina A, } \beta \text {-carotenos } \\
\text { (protectores) }\end{array}$ & $\begin{array}{l}\text { (Boca, esófago, pulmón, } \\
\text { otros) }\end{array}$ & $S$ \\
\hline Vitamina C ( protectora) & (Esófago, estómago) & $S$ \\
\hline lQ & (Estómago, colon, recto) & $2 A$ \\
\hline MelQ & - & $2 B$ \\
\hline MelQx & - & $2 B$ \\
\hline PhlP & - & $2 B$ \\
\hline \multicolumn{3}{|c|}{ Comportamiento reproductor y sexual } \\
\hline $\begin{array}{l}\text { Edad avanzada en el primer } \\
\text { embarazo }\end{array}$ & Mama & $E$ \\
\hline Baja paridad & $\begin{array}{l}\text { Mama, ovario, } \\
\text { cuerpo uterino }\end{array}$ & E \\
\hline Edad temprana del primer coito & Cérvix & E \\
\hline Número de parejas sexuales & Cérvix & $\mathrm{E}$ \\
\hline
\end{tabular}

1 Se excluyen los agentes y exposiciones así como los medicamentos que se producen principalmente en el marco profesional.

2 Entre paréntesis aparecen los órganos diana sospechados.

3 Evaluación de la monografía de la IARC notificada siempre que se disponía de ella (1: cancerígeno humano; $2 \mathrm{~A}$ : probable cancerígeno humano; $2 \mathrm{~B}$ : posible cancerígeno humano); en caso contrario $\mathrm{E}$ : cancerígeno establecido, S: cancerígeno sospechado.

con cánceres concretos. L os principales agentes que se han identificado se resumen en la T abla 2.10, en la que no se incluyen los fármacos para los que se ha establecido una relación causal con el cáncer en el ser humano, como el dietilestilbestrol y varios agentes alquilantes, o en los que se sospecha tal relación, como sucede con la ciclofosfamida (véase también la T abla 2.9). En estos casos hay que sopesar el riesgo de cáncer frente a las ventajas del tratamiento. De modo análogo, no se incluyen en la T abla 2.10 
Tabla 2.11 - Industrias, profesiones y exposiciones reconocidas como causantes de un riesgo cancerígeno.

\begin{tabular}{|c|c|c|c|}
\hline Industria (código ISIC) & Profesión/ proceso & Localización/ tipo de cáncer & $\begin{array}{l}\text { Agente causal confirmado } 0 \\
\text { sospechado }\end{array}$ \\
\hline $\begin{array}{l}\text { Agricultura, silvicultura } \\
\text { y pesca (1) }\end{array}$ & $\begin{array}{l}\text { Vinicultores que usan insecticidas arseniales } \\
\text { Pescadores }\end{array}$ & $\begin{array}{l}\text { Pulmón, piel } \\
\text { Piel, labio }\end{array}$ & $\begin{array}{l}\text { Compuestos arseniales } \\
\text { Radiación ultravioleta }\end{array}$ \\
\hline \multirow[t]{5}{*}{ Minería y canteras (2) } & Minería del arsénico & Pulmón, piel & Compuestos arseniales \\
\hline & Minería del hierro (hematita) & Pulmón & Productos de degradación del radón \\
\hline & Minería del amianto & $\begin{array}{l}\text { Pulmón, mesotelioma pleural } \\
\text { y peritoneal }\end{array}$ & Amianto \\
\hline & Minería del uranio & Pulmón & Productos de degradación del radón \\
\hline & Minería y molinos de talco & Pulmón & Talco con fibras amiantiformes \\
\hline \multirow[t]{7}{*}{ Industrias químicas (35) } & $\begin{array}{l}\text { Trabajadores y usuarios de bis (clorometil) éter } \\
\text { (BCME) y clorometil-metil éter (CMME) }\end{array}$ & $\begin{array}{l}\text { Pulmón (carcinoma de células } \\
\text { de avena) }\end{array}$ & BCME, CMME \\
\hline & Producción de cloruro de vinilo & Angiosarcoma hepático & Monómero de cloruro de vinilo \\
\hline & $\begin{array}{l}\text { Fabricación de alcohol isopropílico (proceso con } \\
\text { ácidos fuertes) }\end{array}$ & Sinonasal & No identificado \\
\hline & Producción de pigmentos de cromato & Pulmón, sinonasal & Compuestos de cromo (VI) \\
\hline & Fabricantes y usuarios de tintes & Vejiga & $\begin{array}{l}\text { Bencidina, 2-naftilamina, } \\
\text { 4-aminobifenilo }\end{array}$ \\
\hline & Fabricación de auramina & Vejiga & $\begin{array}{l}\text { Auramina y otras aminas aromáticas } \\
\text { usadas en el proceso }\end{array}$ \\
\hline & Producción de p-cloro-o-toluidina & Vejiga & $\begin{array}{l}\text { p-cloro-o-toluidina y sus sales } \\
\text { ácidas fuertes }\end{array}$ \\
\hline Cuero (324) & Fabricación de botas y zapatos & Sinonasal, leucemia & Polvo de cuero, benceno \\
\hline Madera y derivados (33) & Ebanistas & Sinonasal & Polvo de madera \\
\hline $\begin{array}{l}\text { Producción de pesticidas } \\
\text { y herbicidas (3512) }\end{array}$ & Producción y empaquetado de insecticidas arseniales & Pulmón & Compuestos arseniales \\
\hline \multirow[t]{6}{*}{ Industria del caucho (355) } & Fabricación de caucho & Leucemia & Benceno \\
\hline & & Vejiga & Aminas aromáticas \\
\hline & $\begin{array}{l}\text { Calandrado, vulcanizado de neumáticos, fabricación } \\
\text { de neumáticos }\end{array}$ & Leucemia & Benceno \\
\hline & Molineros, mezcladores & Vejiga & Aminas aromáticas \\
\hline & $\begin{array}{l}\text { Producción de látex sintético, vulcanizado de } \\
\text { neumáticos, calandrado, regeneración del caucho, } \\
\text { fabricación de cables }\end{array}$ & Vejiga & Aminas aromáticas \\
\hline & Producción de caucho laminado & Leucemia & Benceno \\
\hline Producción de amianto (3699) & $\begin{array}{l}\text { Producción de materiales aislantes (tuberías, fundas, } \\
\text { textiles, ropas, mascarillas, productos de cemento } \\
\text { de amianto) }\end{array}$ & $\begin{array}{l}\text { Pulmón, mesotelioma } \\
\text { pleural y peritoneal }\end{array}$ & Amianto \\
\hline \multirow[t]{8}{*}{ Metales (37) } & Producción de aluminio & Pulmón, vejiga & $\begin{array}{l}\text { Hidrocarburos aromáticos policíclicos, } \\
\text { alquitrán }\end{array}$ \\
\hline & Fundición de cobre & Pulmón & Compuestos arseniales \\
\hline & Producción de cromatos, cromado & Pulmón, sinonasal & Compuestos de cromo (VI) \\
\hline & Fundición de hierro y acero & Pulmón & No identificado \\
\hline & Refinado de níquel & Sinonasal, pulmón & Compuestos de níquel \\
\hline & Operaciones de desoxidado & Laringe, pulmón & $\begin{array}{l}\text { Neblinas de ácidos inorgánicos que } \\
\text { contienen ácido sulfúrico }\end{array}$ \\
\hline & $\begin{array}{l}\text { Producción y refinado de cadmio; fabricación de baterías } \\
\text { de níquel-cadmio; fabricación de pigmentos de cadmio; } \\
\text { producción de aleaciones de cadmio; electrogalvanizado; } \\
\text { fundidores de zinc; soldadura y compuestos de cloruro } \\
\text { de polivinilo }\end{array}$ & Pulmón & Cadmio y compuestos de cadmio \\
\hline & $\begin{array}{l}\text { Refinado y mecanizado del berilio; fabricación } \\
\text { de productos que contienen berilio }\end{array}$ & Pulmón & Berilio y compuestos de berilio \\
\hline
\end{tabular}


Tabla 2.11 - Industrias, profesiones y exposiciones reconocidas como causantes de un riesgo cancerígeno. Continuación

\begin{tabular}{|c|c|c|c|}
\hline Industria (código ISIC) & Profesión/ proceso & Localización/ tipo de cáncer & $\begin{array}{l}\text { Agente causal confirmado } 0 \\
\text { sospechado }\end{array}$ \\
\hline $\begin{array}{l}\text { Astilleros, fabricación de } \\
\text { equipos para automóviles } \\
\text { y ferrocarriles (385) }\end{array}$ & $\begin{array}{l}\text { Astilleros, trabajadores de fábricas de } \\
\text { automóviles y ferrocarriles }\end{array}$ & $\begin{array}{l}\text { Pulmón, mesotelioma pleural } \\
\text { y peritoneal }\end{array}$ & Amianto \\
\hline \multirow[t]{3}{*}{$\operatorname{Gas}(4)$} & Trabajadores de plantas de coque & Pulmón & Benzo[a]pireno \\
\hline & Trabajadores del gas & Pulmón, vejiga, escroto & $\begin{array}{l}\text { Productos de carbonización del } \\
\text { carbón, 2-naftilamina }\end{array}$ \\
\hline & Trabajadores de plantas de gas & Vejiga & Aminas aromáticas \\
\hline \multirow[t]{2}{*}{ Construcción (5) } & Aislamiento y cubiertas de conducciones & $\begin{array}{l}\text { Pulmón, mesotelioma pleural } \\
\text { y peritoneal }\end{array}$ & Amianto \\
\hline & Techadores, trabajadores del asfalto & Pulmón & Hidrocarburos aromáticos policíclicos \\
\hline \multirow[t]{2}{*}{ Otras } & Personal médico (9331) & Piel, leucemia & Radiación ionizante \\
\hline & $\begin{array}{l}\text { Pintores (construcción, industria del automóvil } \\
\text { y otros usuarios) }\end{array}$ & Pulmón & No identificado \\
\hline
\end{tabular}

agentes presentes principalmente en entornos industriales, como el cromo, el níquel y las aminas aromáticas. Para un comentario más detallado al respecto, véase el artículo anterior sobre cancerígenos profesionales. La importancia relativa de los agentes enumerados en la Tabla 2.10 varía mucho dependiendo de su potencia y del número de personas a las que afectan. Las pruebas de carcinogenicidad de varios agentes ambientales se han evaluado en el programa de monografías de la IARC (A gencia Internacional para la Investigación sobre el Cáncer 1995) (véase al respecto el artículo sobre cancerígenos profesionales); la Tabla 2.10 se basa principalmente en evaluaciones de las monografías de la IARC. L os agentes más importantes de los citados en ella son aquéllos a los que se expone una parte importante de la población en cantidades relativamente grandes, y son especialmente las radiaciones ultravioleta (solares), el tabaquismo, el consumo de alcohol, el mascado de betel, los virus de la hepatitis B, la hepatitis C y el papilomavirus humano, las aflatoxinas, posiblemente las grasas de la dieta y el déficit de fibras y de vitaminas A y $\mathrm{C}$ en la dieta, el amianto y el retraso de la maternidad.

Se ha intentado cuantificar las aportaciones respectivas de estos factores al 80 ó $90 \%$ de los cánceres que podrían atribuirse a factores ambientales. Por supuesto, el patrón varía de una población a otra en función de diferencias en la exposición y, posiblemente, en la susceptibilidad genética en diversos cánceres. Sin embargo, en muchos países industrializados es probable que el tabaquismo y ciertos factores dietéticos sean responsables cada uno de ellos de casi una tercera parte de los cánceres de origen ambiental (Doll y Peto 1981); por el contrario, en los países en vías de desarrollo es probable que tengan gran importancia los agentes biológicos, y menos el tabaquismo (aunque la de éste último esté aumentando, debido al incremento del tabaquismo en los últimos años).

\section{Interacciones entre cancerígenos}

0 tro aspecto que debe considerarse es la existencia de interacciones entre cancerígenos. Así, por ejemplo, en el caso del alcohol y el tabaco, y el cáncer de esófago, se ha demostrado que un consumo creciente de alcohol multiplica la tasa de cáncer originada por un nivel determinado de consumo de tabaco. El alcohol puede facilitar por sí mismo el transporte de cancerígenos del tabaco, o de otros, a las células de tejidos sensibles. Se aprecia asimismo una interacción sinérgica entre los cancerígenos iniciadores, como sucede entre el radón y sus productos de degradación y el consumo de tabaco en los mineros del uranio. Algunos agentes ambientales pueden actuar estimulando cánceres que han sido iniciados por otro agente; éste es el mecanismo más probable de un efecto de la grasa de la dieta sobre el desarrollo del cáncer de mama (probablemente a través del aumento de la producción de las hormonas que estimulan la mama). También puede suceder lo contrario, como por ejemplo en el caso de la vitamina $A$, que tiene probablemente un efecto antipromotor sobre el cáncer de pulmón y, posiblemente, sobre otros cánceres iniciados por el tabaco. Pueden producirse interacciones similares entre factores ambientales y constitucionales. En particular, el polimorfismo genético para las enzimas que intervienen en el metabolismo de agentes cancerígenos o en la reparación del $A D N$ es probablemente un requisito importante para la sensibilidad individual al efecto de los cancerígenos ambientales.

Desde el punto de vista del control del cáncer, las interacciones entre cancerígenos suponen que la supresión de la exposición a uno o dos (o más) factores que interactúan mutuamente puede originar una reducción en la incidencia de cáncer mayor de lo que cabría esperar al considerar el efecto del agente por sí solo. Así, por ejemplo, la supresión del consumo de cigarrillos puede eliminar casi por completo la tasa excesiva de cáncer de pulmón en trabajadores del amianto (aunque no influiría en las tasas de mesotelioma).

\section{Consecuencias para la prevención}

La percepción de que los factores ambientales son responsables de un gran porcentaje de cánceres en los seres humanos ha sentado las bases para la prevención primaria del cáncer mediante la modificación de la exposición a los factores identificados. Esta modificación puede incluir la eliminación de un único cancerígeno importante; la reducción, como se ha comentado anteriormente, de la exposición a uno de varios cancerígenos que interactúan; el aumento de la exposición a agentes protectores, 0 diversas combinaciones de estos enfoques. Aunque estos efectos pueden conseguirse en parte, por ejemplo, a través de la legislación sobre el medio ambiente, la importancia aparente de los factores ligados al estilo de vida indica que gran parte de la prevención primaria continuará siendo responsabilidad de los individuos. Con todo, la administración pública puede crear un clima que haga más fácil para éstos la toma de decisiones correctas. 
Industria (código ISIC)

Agricultura, silvicultura y pesca (1)

Minas y canteras (2)

Industria alimentaria (3111)

Industria de bebidas (3131)

Fabricación textil (321)

Cuero (323)

Madera y derivados (33), industria de la celulosa (341)

Imprentas (342)

Productos químicos (35)
Profesión/ proceso
Agricultores, trabajadores agrarios

Aplicación de herbicidas

Aplicación de insecticidas

Minería de cinc-plomo

Carbón

Minería de metales

Minería del amianto

Carniceros y trabajadores del sector cárnico

Cerveceros

Tintoreros

Tejedores

Curtidores y procesadores

Fabricación y reparación de botas y zapatos Leñadores y trabajadores de aserraderos

Trabajadores de la celulosa

Carpinteros, ebanistas

Trabajadores de la madera, sin especificar

Producción de contrachapado, producción de conglomerado

Trabajadores de rotativas, encuadernadores, trabajadores de impresión, trabajadores de salas de máquinas y otros trabajos

Producción de 1,3-butadieno

Producción de acrilonitrilo

Producción de cloruro de vinilideno

Fabricación de alcohol isopropílico (procesado con ácidos fuertes)

Producción de policloropreno

Producción de dimetilsulfato

Producción de epiclorohidrina

Producción de óxido de etileno

Producción de dibromuro de etileno

Producción de formaldehído

Empleo de retardadores de la combustión y plastificantes

Producción de cloruro de benzoilo
Localización/ tipo de cáncer

Sistemas linfático y hematopoyético

(leucemia, linfoma)

Linfomas malignos, sarcomas de tejidos blandos

Pulmón, linfoma

Pulmón

Estómago

Pulmón

Tubo digestivo

Pulmón

Tramos altos de aparatos respiratorio y digestivo

Vejiga

Vejiga, sinonasal, oral

Vejiga, páncreas, pulmón

Sinonasal, estómago, vejiga

Cavidad nasal, linfoma de Hodgkin, piel

Tejido linfopoyético, pulmón

Cavidad nasal, linfoma de Hodgkin Linfomas

Nasofaringe, sinonasal

Sistemas linfático y hematopoyético, boca, pulmón, riñón

Sistemas linfático y hematopoyético

Pulmón, colon

Pulmón

Laringe

Pulmón

Pulmón

Pulmón, sistemas linfático y hematopoyético (leucemia)

Sistemas linfático y hematopoyético (leucemia), estómago

Sistema digestivo

Nasofaringe, sinonasal

Piel (melanoma)

Pulmón
Agente causal conocido (o sospechado)

No identificado

Herbicidas clorofenoxi, clorofenoles (presumiblemente contaminados con dibenzodioxinas policloradas) Insecticidas no arseniales Productos de degradación del radón Polvo de carbón Sílice cristalina

Amianto

Virus, HAP1

Consumo de alcohol

Tintes

Polvos de fibras e hilos

Polvo de cuero, otros productos químicos, cromo

No identificado

Polvo de madera, clorofenoles, creosotas

No identificado

Polvo de madera, disolventes

No identificado

Formaldehído

Vapores de aceite, disolventes

1,3-butadieno

Acrilonitrilo

Cloruro de vinilideno (exposición mixta con acrilonitrilo)

No identificado

Cloropreno

Dimetilsulfato

Epiclorohidrina

Oxido de etileno

Dibromuro de etileno

Formaldehído

Bifenilos policlorados

Cloruro de benzoilo

1 HAP, hidrocarburos aromáticos policíclicos.

Continúa en la página siguiente. 
Tabla 2.12 - Industrias, profesiones y exposiciones en las que se ha informado de una incidencia excesiva de cáncer, pero Continuación en las que la valoración del riesgo cancerígeno no es definitiva.

\begin{tabular}{|c|c|c|c|}
\hline Industria (código ISIC) & Profesión/ proceso & Localización/ tipo de cáncer & Agente causal conocido (o sospechado) \\
\hline Producción de herbicidas (3512) & Producción de herbicidas clorofenoxi & Sarcoma de tejidos blandos & $\begin{array}{l}\text { Herbicidas clorofenoxi, clorofenoles } \\
\text { (contaminados con dibenzodioxinas } \\
\text { policloradas) }\end{array}$ \\
\hline Petróleo (353) & Refinado del petróleo & Piel, leucemia, cerebro & $\begin{array}{l}\text { Benceno, HAP, aceites minerales sin } \\
\text { procesar y ligeramente procesados }\end{array}$ \\
\hline \multirow[t]{2}{*}{ Caucho (355) } & $\begin{array}{l}\text { Diversas ocupaciones en la fabricación del } \\
\text { caucho }\end{array}$ & $\begin{array}{l}\text { Linfoma, mieloma múltiple, } \\
\text { estómago, cerebro, pulmón }\end{array}$ & Benceno, MOCA, ${ }^{2}$ otros no identificados \\
\hline & Producción de caucho de estireno-butadieno & Sistemas linfático y hematopoyético & 1,3-Butadieno \\
\hline \multirow{2}{*}{$\begin{array}{l}\text { Cerámica, vidrio y ladrillos refractarios } \\
(36)\end{array}$} & Trabajadores de cerámica y alfarería & Pulmón & Sílice cristalina \\
\hline & $\begin{array}{l}\text { Trabajadores del vidrio (vidrio artístico, } \\
\text { recipientes y loza) }\end{array}$ & Pulmón & $\begin{array}{l}\text { Oxido de arsénico y otros metales, } \\
\text { sílice, HAP }\end{array}$ \\
\hline Producción de amianto (3699) & $\begin{array}{l}\text { Producción de materiales de aislamiento } \\
\text { (tuberías, fundas, textiles, ropas, } \\
\text { mascarillas, productos de cemento } \\
\text { de amianto) }\end{array}$ & Laringe, tubo digestivo & Amianto \\
\hline \multirow[t]{3}{*}{ Metales $(37,38)$} & Fundición de plomo & Aparatos respiratorio y digestivo & Compuestos de plomo \\
\hline & $\begin{array}{l}\text { Producción y refinado del cadmio; fabricación } \\
\text { de baterías de níquel-cadmio; fabricación } \\
\text { de pigmentos de cadmio; producción de } \\
\text { aleaciones de cadmio; electrogalvanizado; } \\
\text { fundición de zinc; soldadura y compuestos } \\
\text { de cloruro de polivinilo }\end{array}$ & Próstata & Cadmio y compuestos de cadmio \\
\hline & Fundición de hierro y acero & Pulmón & Sílice cristalina \\
\hline Astilleros (384) & Trabajadores de astilleros & Laringe, sistema digestivo & Amianto \\
\hline $\begin{array}{l}\text { Fabricación de vehículos a motor } \\
(3843,9513)\end{array}$ & Mecánicos, soldadores, etc. & Pulmón & $\begin{array}{l}\text { HAP, vapores de soldaduras, escapes de } \\
\text { motores }\end{array}$ \\
\hline \multirow[t]{2}{*}{ Electricidad $(4101,9512)$} & $\begin{array}{l}\text { Generación, producción, distribución, } \\
\text { reparación }\end{array}$ & Leucemia, tumores cerebrales & $\begin{array}{l}\text { Campos magnéticos de muy baja } \\
\text { frecuencia }\end{array}$ \\
\hline & & Hígado, vías biliares & $\mathrm{BPCs}^{3}$ \\
\hline \multirow[t]{2}{*}{ Construcción (5) } & $\begin{array}{l}\text { Trabajadores de aislamientos y cubiertas } \\
\text { de conducciones }\end{array}$ & Laringe, tubo digestivo & Amianto \\
\hline & Techadores, trabajadores del asfalto & $\begin{array}{l}\text { Boca, faringe, laringe, esófago, } \\
\text { estómago }\end{array}$ & AHP, alquitrán de hulla, brea \\
\hline \multirow[t]{2}{*}{ Transportes (7) } & $\begin{array}{l}\text { Trabajadores del ferrocarril, empleados de } \\
\text { gasolineras, conductores de autobuses y } \\
\text { camiones, conductores de excavadoras }\end{array}$ & Pulmón, vejiga & Escapes de motores diesel \\
\hline & & Leucemia & $\begin{array}{l}\text { Campos magnéticos de muy baja } \\
\text { frecuencia }\end{array}$ \\
\hline \multirow[t]{7}{*}{ Otras } & Empleados de gasolineras (6200) & Leucemia y linfoma & Benceno \\
\hline & $\begin{array}{l}\text { Químicos y otros trabajadores de laboratorios } \\
\text { (9331) }\end{array}$ & Leucemia y linfoma, páncreas & $\begin{array}{l}\text { No identificado (virus, sustancias } \\
\text { químicas) }\end{array}$ \\
\hline & Embalsamadores, personal médico (9331) & Sinonasal, nasofaringe & Formaldehído \\
\hline & Trabajadores de sanidad (9331) & Hígado & Virus de la hepatitis B \\
\hline & $\begin{array}{l}\text { Empleados de lavanderías y limpieza en seco } \\
\text { (9520) }\end{array}$ & Pulmón, esófago, vejiga & $\begin{array}{l}\text { Tri y tetracloroetileno y tetracloruro } \\
\text { de carbono }\end{array}$ \\
\hline & Peluqueros (9591) & Vejiga, leucemia y linfoma & Tintes para el cabello, aminas aromáticas \\
\hline & Trabajadores con contadores de radiación & Mama & Radón \\
\hline
\end{tabular}


Tabla 2.13 - Variación de la incidencia de cánceres comunes en distintas poblaciones en las que existen registros de cáncer ${ }^{1}$.

\begin{tabular}{|c|c|c|c|c|c|}
\hline Cáncer (código CIE9) & Area de alta incidencia & $T A^{2}$ & Area de baja incidencia & $T A^{2}$ & Límites de variación \\
\hline Boca $(143-5)$ & Francia, Bas Rhin & 2 & Singapur (Malasia) & 0,02 & 80 \\
\hline Nasofaringe (147) & Hong Kong & 3 & Polonia, Varsovia (rural) & 0,01 & 300 \\
\hline Esófago (150) & Francia, Calvados & 3 & Israel (judíos nacidos en Israel) & 0,02 & 160 \\
\hline Estómago (151) & Japón, Yamagata & 11 & EE.UU., Los Angeles (Filipinos) & 0,3 & 30 \\
\hline Colon (153) & EE.UU. Hawai (japoneses) & 5 & India, Madrás & 0,2 & 30 \\
\hline Recto (154) & EE.UU. Los Angeles (japoneses) & 3 & Kuwait (no kuwaitíes) & 0,1 & 20 \\
\hline Hígado (155) & Tailandia, Khon Khaen & 11 & Paraguay, Asunción & 0,1 & 110 \\
\hline Páncreas (157) & EE.UU. Alameda C. (California) (negros) & 2 & India, Ahmedabad & 0,1 & 20 \\
\hline Pulmón (162) & Nueva Zelanda (maoríes) & 16 & Mali, Bamako & 0,5 & 30 \\
\hline Melanoma cutáneo (172) & Australia, Capital Terr. & 3 & EE.UU., Bay Area (California) (negros) & 0,01 & 300 \\
\hline Otros cánc. cutáneos (173) & Australia, Tasmania & 25 & España, País Vasco & 0,05 & 500 \\
\hline Mama (174) & EE.UU. Hawai (hawaianos) & 12 & China, Qidong & 1,0 & 10 \\
\hline Cérvix (180) & Perú, Trujillo & 6 & EE.UU., Hawai (chinos) & 0,3 & 20 \\
\hline Cuerpo uterino (182) & EE.UU. Alameda C. (California) (blancos) & 3 & China, Qidong & 0,05 & 60 \\
\hline Ovario (183) & Islandia & 2 & Mali, Bamako & 0,09 & 20 \\
\hline Próstata (185) & EE.UU. Atlanta (negros) & 12 & China, Qidong & 0,09 & 140 \\
\hline Vejiga (188) & Italia, Florencia & 4 & India, Madrás & 0,2 & 20 \\
\hline Riñón (189) & Francia, Bas Rhin & 2 & China, Qidong & 0,08 & 20 \\
\hline
\end{tabular}

1 Los datos de los registros de cáncer se incluyen en IARC 1992. Sólo se incluyen las localizaciones del cáncer con tasas acumuladas iguales 0 superiores al $2 \%$ en el área de alta incidencia. Las tasas se refieren a varones, excepto en los cánceres de mama, cérvix, cuerpo uterino y ovario.

2 Porcentaje de tasa acumulada entre 0 y 74 años de edad.

Fuente: Agencia Internacional para la Investigación sobre el Cáncer, 1992.

\section{- Prevencion}

\section{Per G ustavsson}

Las exposiciones profesionales sólo explican un pequeño porcentaje del número total de cánceres en el conjunto de la población. Se ha calculado que el $4 \%$ de los cánceres puede atribuirse a exposiciones profesionales, tomando como base datos procedentes de Estados U nidos, con un margen de duda del 2 al $8 \%$. Esto significa que incluso la prevención total de los cánceres profesionales sólo conseguiría una disminución marginal de las tasas nacionales de cáncer.

Existen, sin embargo, varias razones para no cejar en los esfuerzos por evitar los cánceres de origen profesional. En primer lugar, el cálculo del $4 \%$ es una cifra media para toda la población, incluidas las personas no expuestas. Entre las personas realmente expuestas a los cancerígenos industriales, la proporción de tumores profesionales es mucho mayor. En segundo lugar, las exposiciones profesionales son peligros evitables a los que los individuos se exponen de forma no voluntaria. $\mathrm{N}$ adie tiene por qué aceptar un mayor riesgo de cáncer en el trabajo, especialmente si la causa es conocida. En tercer lugar, los cánceres profesionales pueden evitarse mediante la adopción de las disposiciones pertinentes, al contrario que los cánceres asociados a factores del estilo de vida.

La prevención de los cánceres de origen profesional comprende al menos dos fases: primero, la identificación de un compuesto o de un entorno profesional concretos como cancerígenos, y segundo, la imposición de un control reglamentario adecuado. Los principios y la práctica del mencionado control de riesgos de cáncer conocidos o sospechados en el medio ambiente de trabajo presentan considerables diferencias, no sólo entre diferentes partes de los países desarrollados y en vías de desarrollo, sino también entre países con un desarrollo socioeconómico similar.

La Agencia Internacional para la Investigación sobre el Cáncer (IARC), con sede en Lyón, Francia, recopila y evalúa de forma sistemática datos epidemiológicos y experimentales sobre cancerígenos sospechados o conocidos. Las evaluaciones se presentan en una serie de monografías, que ofrecen una base para tomar decisiones sobre las disposiciones nacionales que deben adoptarse respecto a la producción y utilización de compuestos cancerígenos (véase el artículo anterior sobre cancerígenos profesionales).

\section{Antecedentes}

La historia del cáncer profesional se remonta al menos a 1775 , año en que Sir Percivall Pott publicó su clásico informe sobre el cáncer escrotal en deshollinadores, relacionando la exposición al hollín con la incidencia del cáncer. EI hallazgo tuvo cierto efecto inmediato, puesto que se concedió a los deshollinadores de algunos países del mundo el derecho a bañarse al finalizar la jornada de trabajo. Los estudios actuales sobre los deshollinadores indican que los cánceres de escroto y de piel están controlados, aunque subsiste un riesgo elevado de otros cánceres.

En el decenio de 1890, un cirujano notificó la aparición de un grupo de cánceres de vejiga en una fábrica de colorantes alemana cercana a su hospital. M ás adelante, los compuestos 
causantes fueron identificados como aminas aromáticas, que desde entonces están clasificadas como sustancias cancerígenas en la mayor parte de los países. Como ejemplos posteriores hay que mencionar el cáncer de piel en los pintores que utilizaban radio, el cáncer de nariz y de senos paranasales entre los trabajadores de la madera provocado por la inhalación de serrín y la "enfermedad de los hilanderos", esto es, el cáncer de escroto en los trabajadores de la industria del algodón provocado por los vapores de aceites minerales. La leucemia inducida por exposición al benceno en la industria de reparación y fabricación de calzado representa otro peligro que se ha reducido tras la identificación de los cancerígenos en el lugar de trabajo.

El caso de la relación del amianto con el cáncer ejemplifica un episodio de retraso importante entre la identificación del riesgo y la adopción de medidas reguladoras. Ya en el decenio de 1930 comenzaron a acumularse resultados epidemiológicos que indicaban que la exposición al amianto estaba asociada a un mayor riesgo de cáncer de pulmón. H acia 1955 había ya pruebas más convincentes, pero hasta mediados del decenio de 1970 no se dieron los pasos necesarios para la adopción de medidas legales.

La identificación de los peligros asociados al cloruro de vinilo es la otra cara de la moneda, pues en este caso la identificación del cancerígeno fue seguida de la adopción inmediata de medidas legales. En el decenio de 1960, la mayor parte de los países habían adoptado un límite de exposición para el cloruro de vinilo de 500 ppm. En 1974, tras los primeros informes sobre una mayor frecuencia de un raro tumor hepático, el angiosarcoma, en las personas que trabajaban con cloruro de vinilo se inició inmediatamente la realización de estudios en animales de experimentación, que dieron resultados positivos. U na vez identificado el cloruro de vinilo como cancerígeno, se adoptaron medidas legales para la reducción inmediata de la exposición al límite actual de 1-5 ppm.

\section{Métodos utilizados para la identificación de los cancerígenos profesionales}

Los métodos seguidos en los ejemplos históricos precedentes varían desde la observación de agrupamientos de enfermedades por parte de clínicos avispados hasta la realización de estudios epidemiológicos más serios, como las investigaciones de la tasa de una enfermedad (tasa de cáncer) en los seres humanos. L os resultados de estos estudios epidemiológicos tienen gran importancia para las evaluaciones del riesgo para los seres humanos. Su mayor inconveniente es que suele requerirse un largo período de tiempo, por lo general un mínimo de 15 años, para demostrar y evaluar los efectos de una exposición a un cancerígeno potencial. De ahí que deban aplicarse otros métodos para conseguir una evaluación más rápida de sustancias introducidas recientemente. Desde comienzos de este siglo, se han utilizado a tal fin los estudios sobre potencial cancerígeno en animales. Sin embargo, la extrapolación de datos obtenidos en animales a los seres humanos introduce dudas importantes. O tra limitación es la necesidad de realizar un seguimiento de un gran número de animales durante varios años.

La necesidad de métodos con una respuesta más rápida quedó parcialmente cubierta en 1971, cuando se introdujo la prueba de mutagenicidad a corto plazo (prueba de Ames). En ella se utilizan bacterias para medir la actividad mutágena de una sustancia (su capacidad para provocar cambios irreparables en el material genético celular, el ADN). No obstante, la interpretación de los resultados de las pruebas bacterianas plantea el problema de que no todas las sustancias que provocan cáncer en el ser humano son mutágenas, y que no todos los mutágenos bacterianos se consideran peligrosos para la producción de cáncer en el ser humano. Con todo, el hallazgo de que una sustancia es mutágena suele considerarse indicativo de que representa al menos un riesgo de cáncer para el ser humano.

En los últimos 15 años se han desarrollado nuevos métodos de biología genética y molecular para la detección de peligros de cáncer en el ser humano. Esta disciplina se denomina "epidemiología molecular". Se estudian fenómenos genéticos y moleculares para aclarar el proceso de formación del cáncer y desarrollar así métodos para su detección precoz, o indicios de aumento del riesgo de desarrollo de cáncer. Entre estos métodos figura el análisis de la lesión del material genético y de la formación de enlaces químicos (aductos) entre los contaminantes y el material genético. La presencia de aberraciones cromosómicas indica claramente la existencia de efectos sobre el material genético que pueden asociarse al desarrollo de cáncer. Sin embargo, todavía queda por establecer el papel que desempeñan los hallazgos epidemiológicos moleculares en la valoración del riesgo de cáncer humano, y ya hay en curso distintas investigaciones para determinar de manera más clara y exacta cómo deben interpretarse los resultados de estos análisis.

\section{Vigilancia y exploración selectiva}

La estrategia para la prevención de los cánceres de origen profesional es diferente a la aplicada para el control del cáncer asociado al estilo de vida o a otras exposiciones ambientales. En el ámbito profesional, la principal estrategia para el control del cáncer ha sido la disminución o la eliminación total de la exposición a los agentes causantes de cáncer. L os métodos basados en la detección precoz mediante programas de exploración selectiva, como los aplicados para el cáncer de cérvix o de mama, tienen una importancia muy limitada en la salud en el trabajo.

\section{Vigilancia}

Para la vigilancia de la frecuencia del cáncer en diversas profesiones puede utilizarse información procedente de los registros de población sobre tasas de cáncer y profesión. Se han aplicado varios métodos para obtener esta información, en función de los registros disponibles. Las limitaciones y posibilidades existentes dependen en gran medida de la calidad de la información de los registros. La información sobre las tasas de enfermedad (frecuencia de cáncer) suele obtenerse de los registros locales 0 nacionales de cáncer (véase más adelante), o de los certificados de defunción, mientras que la información sobre la composición por edades y el tamaño de los grupos profesionales se obtiene de los registros de población.

El ejemplo clásico de este tipo de información son los "Suplementos decenales sobre mortalidad profesional", publicados en el Reino U nido desde finales del siglo XIX. Estas publicaciones utilizan la información de los certificados de defunción sobre la causa de la muerte y la profesión, junto a datos del censo sobre frecuencias de profesiones en el conjunto de la población, para calcular las tasas de muerte por una causa concreta en diferentes profesiones. Este tipo de estadística es una herramienta útil para controlar la frecuencia del cáncer en profesiones con riesgos conocidos, pero su capacidad para detectar riesgos no conocidos previamente es limitada. Puede adolecer también de problemas asociados a diferencias sistemáticas en la codificación de las profesiones en los certificados de defunción y en los datos del censo.

La utilización de números de identificación personal en los países nórdicos ha ofrecido una oportunidad especial para vincular los datos del censo relativos a la profesión con los datos de los registros de cáncer, y para calcular así directamente las tasas de cáncer en diferentes profesiones. En Suecia se ha puesto a disposición de los investigadores una conexión permanente entre los censos de 1960 y 1970 y la incidencia de cáncer 
durante los años posteriores, que ha sido utilizada por un gran número de estudios. Este registro ambiental y del cáncer sueco ha permitido llevar a cabo una revisión general de determinados cánceres tabulados según la profesión, iniciada por un comité gubernamental que investigaba los peligros en el entorno profesional. Se han realizado conexiones similares en los demás países nórdicos.

Por lo general, las estadísticas basadas en la incidencia de cánceres registrada de forma habitual y en los datos del censo tienen la ventaja de que facilitan abundante información. Esta información versa sobre las frecuencias de cáncer relacionadas con la profesión, no con exposiciones concretas, lo que origina una considerable dilución de las asociaciones, ya que la exposición puede variar considerablemente entre unas personas y otras con la misma profesión. Los estudios epidemiológicos de cohortes (en los que se compara a un grupo de trabajadores expuestos con otro de trabajadores no expuestos equiparables en edad, sexo y otros factores) o los de casos-controles (en los que se compara la experiencia de exposición de un grupo de personas con la de una muestra de la población general) ofrecen mejores oportunidades para una descripción detallada de la exposición y, por tanto, mejores oportunidades para la investigación de la coherencia de cualquier aumento del riesgo observado, analizando, por ejemplo, la relación exposición-respuesta.

En un estudio prospectivo canadiense de casos-controles se investigó la posibilidad de obtener datos más refinados sobre la exposición junto a notificaciones de cáncer recopiladas de forma sistemática. Se llevó a cabo en la zona metropolitana de Montreal en 1979. Higienistas especializados obtuvieron el historial profesional de los varones incluidos en el registro local de cánceres y codificaron después esas historias según la exposición a determinados productos químicos. M ás adelante, se calcularon y publicaron los riesgos de cáncer en relación con varias sustancias (Siemiatycki 1991).

En conclusión, la producción continua de datos de vigilancia basados en información registrada ofrece una forma eficaz y comparativamente sencilla de controlar la frecuencia de cánceres por profesión. El principal objetivo que se consigue es la vigilancia de factores de riesgo conocidos, aunque las posibilidades de identificación de nuevos riesgos son limitadas. No deben utilizarse estudios basados en registros para sacar conclusiones relacionadas con la ausencia de riesgo en una profesión, a menos que la proporción de individuos significativamente expuestos se conozca de forma más exacta. Es bastante frecuente que sólo un porcentaje relativamente pequeño de miembros de una profesión estén realmente expuestos; para ellos, la sustancia puede representar un peligro importante, que no será observable (es decir, se diluirá estadísticamente) cuando se analice de forma conjunta el grupo profesional completo.

\section{Exploración selectiva}

La exploración selectiva del cáncer profesional en poblaciones expuestas con fines de diagnóstico precoz se aplica raras veces, pero ha sido analizada en algunos contextos en los que ha resultado difícil eliminar la exposición. Por ejemplo, se han aplicado métodos para la detección precoz del cáncer de pulmón en personas expuestas al amianto. En el caso de la exposición al amianto, persiste un aumento del riesgo durante largo tiempo, incluso después de cesar la exposición. Por tanto, en los individuos expuestos está justificada la evaluación continua del estado de salud. Se han utilizado radiografías de tórax y estudios citológicos del esputo. Por desgracia, cuando se analizan en condiciones comparables, ninguno de estos métodos reduce significativamente la mortalidad, aunque puedan detectarse algunos casos de forma más precoz. Este resultado negativo se debe, en parte, a que el diagnóstico precoz tiene escaso efecto sobre el pronóstico del cáncer de pulmón. O tro problema es que las propias radiografías representan un peligro de cáncer que, aunque pequeño para el individuo, puede ser significativo cuando se aplica a un gran número de personas (es decir, a todos los estudiados).

También se ha propuesto la exploración selectiva para el cáncer de vejiga en determinadas profesiones, como la industria del caucho. Se han notificado investigaciones de los cambios citológicos de las células en la orina, o de análisis de mutagenicidad de la orina de los trabajadores. Sin embargo, se ha puesto en duda el valor del control de los cambios citológicos para la exploración selectiva de la población, y el valor de los análisis de mutagenicidad requiere una nueva evaluación científica, dado que no se conoce el valor pronóstico de un aumento de la actividad mutágena en la orina.

L os juicios sobre el valor de la exploración selectiva dependen también de la intensidad de la exposición y, por tanto, de la magnitud del riesgo de cáncer esperado. La exploración selectiva podría estar más justificada en grupos pequeños expuestos a niveles altos de cancerígenos que en grupos grandes expuestos a niveles bajos.

Para resumir, no se pueden recomendar métodos de exploración selectiva sistemáticos basándose en los conocimientos actuales. El desarrollo de nuevas técnicas epidemiológicas moleculares puede mejorar las perspectivas de la detección precoz del cáncer, aunque se necesita más información para poder sacar conclusiones.

\section{Registro del cáncer}

Durante este siglo se han establecido registros del cáncer en varios lugares de todo el mundo. La Agencia Internacional para la Investigación sobre el Cáncer (IARC) (1992) ha recopilado datos sobre la incidencia del cáncer en diferentes partes del mundo, en una serie de publicaciones tituladas, "Incidencia del cáncer en cinco continentes". En el volumen 6 de esta publicación se ofrece una lista de 131 registros de cáncer de 48 países.

D os características principales determinan la posible utilidad de un registro del cáncer: una buena definición de la zona de captación (con definición de la región geográfica abarcada) y la calidad y cantidad de la información del registro. M uchos de los registros creados inicialmente no cubren un área geográfica delimitada, sino que se limitan a la zona de influencia de un hospital.

En la prevención del cáncer de origen profesional se pueden hacer varios usos de los registros del cáncer. Un registro completo, de alcance nacional y alta calidad informativa puede ofrecer excelentes oportunidades para controlar la frecuencia del cáncer en la población. Para ello se requiere el acceso a los datos de la población, a fin de calcular las frecuencias de cáncer normalizadas por edades. Algunos registros contienen también datos sobre la profesión, lo que permite controlar el riesgo de cáncer en cada una de éstas.

L os registros pueden servir también como fuente de identificación de casos para estudios epidemiológicos tanto de cohortes como de casos-controles. En el estudio de cohortes, se comparan los datos de identificación personal de la cohorte con los del registro para obtener información sobre el tipo de cáncer (es decir, como en los estudios de comparación de registros). Para ello se requiere un sistema de identificación fiable, como el representado por los números de identificación personal en los países nórdicos, y que las leyes sobre confidencialidad no impidan utilizar el registro para ese fin. Para los estudios de casos-controles puede utilizarse el registro como fuente de casos, aunque se plantean algunos problemas prácticos. En primer lugar, por razones metodológicas, los registros del cáncer no pueden estar totalmente actualizados en lo referente a los casos 
recién diagnosticados. El sistema de notificación, y los necesarios controles y correcciones de la información obtenida, provocan un retraso de algunos años. En los estudios concurrentes o prospectivos de casos-controles, en los que es deseable ponerse en contacto con los propios individuos poco después del diagnóstico de cáncer, suele ser preciso establecer una forma alternativa de identificación de casos, por ejemplo por medio de los registros de los hospitales. En segundo lugar, en algunos países las leyes sobre protección de la intimidad prohíben la identificación de los sujetos del estudio con los que se va a establecer contacto personal.

Los registros suponen también una fuente excelente para el cálculo de tasas de cáncer antiguas que vayan a utilizarse para la comparación de la frecuencia de cáncer en estudios de cohorte de ciertas profesiones o industrias.

En el estudio del cáncer, los registros del cáncer tienen varias ventajas sobre los registros de mortalidad habituales. Con frecuencia, la precisión del diagnóstico del cáncer es mejor en aquéllos que en éstos, que habitualmente se basan en los datos de los certificados de defunción. 0 tra ventaja es que los registros del cáncer a menudo contienen información sobre tipos histológicos de tumores, y permiten además el estudio de personas vivas con cáncer, sin limitarse a los fallecidos. Por encima de todo, los registros incluyen datos sobre la morbilidad del cáncer, lo que permite el estudio de los cánceres que no provocan la muerte con rapidez y/ o que no son mortales.

\section{Control ambiental}

Existen tres estrategias principales para la reducción de las exposiciones en el lugar de trabajo a cancerígenos conocidos o sospechados: la eliminación de la sustancia, la reducción de la exposición mediante la disminución de la emisión o la ventilación y la protección personal de los trabajadores.

D esde hace mucho se discute sobre la existencia de un umbral real para la exposición a cancerígenos, por debajo del cual no existe riesgo. A menudo se supone que el riesgo debería ser extrapolado linealmente, bajando el riesgo a cero con una exposición cero. Si así fuera, ningún límite de exposición, por bajo que fuera, se consideraría totalmente libre de riesgo. Con todo, muchos países han definido límites de exposición para algunas sustancias cancerígenas, aunque no para otras.

La eliminación de un compuesto puede originar problemas cuando se introducen sustancias para sustituirlo, cuya toxicidad debe ser inferior a la de la sustancia sustituida.

La reducción de la exposición en su origen puede llevarse a cabo con relativa facilidad en el caso de sustancias químicas para procesos, mediante la encapsulación del proceso y la ventilación. Por ejemplo, cuando se descubrieron las propiedades cancerígenas del cloruro de vinilo, el límite de exposición al mismo se redujo en un factor de cien o más en varios países. Aunque al principio este patrón se consideró imposible de cumplir por parte de la industria, técnicas posteriores lo hicieron posible. $L$ a reducción de la exposición en su origen puede ser difícil de aplicar a sustancias que se utilizan en condiciones menos controladas o que se forman durante el trabajo (por ejemplo, los gases de escape de los motores). El cumplimiento de los límites de exposición exige el control periódico de los niveles de aire en la sala de trabajo.

Cuando no es posible controlar la exposición eliminando ni reduciendo las emisiones, la única solución que queda es utilizar instrumentos de protección personal, desde mascarillas con filtro hasta cascos con suministro de aire y ropas protectoras. Para decidir la modalidad de protección más adecuada, habrá que considerar la principal vía de exposición a las sustancias. Sin embargo, muchos instrumentos de protección personal causan molestias al usuario, y las mascarillas con filtro suponen un aumento de la resistencia respiratoria que puede ser muy importante en trabajos que exigen esfuerzo físico. Por lo general, el efecto protector de los respiradores no es previsible y depende del grado de ajuste de la mascarilla a la cara, de la frecuencia de cambio de los filtros, etc. La protección personal debe considerarse el último recurso, y únicamente se intentará cuando fracasen formas más eficaces de reducir la exposición.

\section{Enfoques experimentales}

Resulta llamativo el escaso número de investigaciones realizadas para evaluar el efecto de los programas o estrategias para reducir riesgos de cáncer profesional conocidos en los trabajadores. Con la posible excepción del amianto, son escasas las evaluaciones de este tipo realizadas. La mejora de los métodos para el control del cáncer profesional debería incluir una evaluación del uso real que se hace de los conocimientos existentes.

La mejora del control de los cancerígenos profesionales en el lugar de trabajo exige el desarrollo de diferentes áreas de salud y seguridad en el trabajo. En primer lugar, el proceso de identificación de los riesgos es un requisito previo fundamental para reducir la exposición a los cancerígenos en el lugar de trabajo. La identificación del riesgo en el futuro deberá resolver ciertos problemas metodológicos. Si se desea detectar riesgos más pequeños, habrá que adoptar métodos epidemiológicos más refinados. Se necesitarán datos más precisos sobre la exposición tanto para la sustancia estudiada como para posibles exposiciones generadoras de confusión. La mejora de los métodos para la descripción de la dosis exacta del cancerígeno que llega al órgano diana aumentará también la potencia de los cálculos de la relación exposición-respuesta. En la actualidad no es infrecuente la utilización de sustitutivos muy toscos para la determinación real de la dosis, como el número de años trabajados en la industria. Es muy evidente que tales estimaciones de la dosis se clasifican muy erróneamente cuando se utilizan como sustitutivo de la dosis. $\mathrm{H}$ abitualmente, la presencia de una relación exposición-respuesta se considera una prueba firme de una relación etiológica. Sin embargo, lo contrario, la no demostración de una relación exposición-respuesta, no demuestra necesariamente la ausencia de riesgo, sobre todo cuando se utilizan determinaciones toscas de la dosis soportada por órganos diana. Si se pudiese determinar la dosis recibida por el órgano diana, las tendencias dosis-respuesta reales tendrían todavía más peso como pruebas de causalidad.

La epidemiología molecular es un área de la investigación en rápido crecimiento. Cabe esperar que se logren nuevos conocimientos de los mecanismos de desarrollo del cáncer, y la posibilidad de la detección precoz de efectos cancerígenos llevará a un tratamiento más precoz. Además, los indicadores de exposición a cancerígenos permitirán mejorar la identificación de nuevos riesgos.

El desarrollo de métodos para la supervisión y el control mediante la adopción de medidas legales del ambiente de trabajo son tan necesarios como los métodos para la identificación de riesgos. Los métodos para el control mediante medidas legales presentan importantes diferencias, incluso entre los países occidentales. Los sistemas de regulación utilizados en cada país dependen en gran medida de factores sociopolíticos y de la situación de los derechos del trabajador. La regulación de las exposiciones tóxicas implica, evidentemente, decisiones políticas. Sin embargo, la investigación objetiva de los efectos de diferentes tipos de sistemas normativos puede servir como guía a los políticos y a los responsables de la toma de decisiones.

También es necesario aclarar algunas cuestiones concretas de la investigación. Deben desarrollarse métodos para describir el efecto esperado de la supresión o disminución de la exposición a una determinada sustancia cancerígena (es decir, hay que 
valorar el efecto de las intervenciones). El cálculo del efecto preventivo de esta reducción del riesgo plantea ciertos problemas cuando se estudian sustancias que interactúan, como en el caso del amianto y el humo del tabaco. El efecto preventivo de la eliminación de una de dos sustancias que interactúan es comparativamente mayor que cuando una y otra presentan sólo un simple efecto añadido.

L as consecuencias de la teoría multifásica de la carcinogénesis en el efecto esperado de la supresión de un cancerígeno suponen una complicación añadida. Dicha teoría afirma que el desarrollo de cáncer es un proceso en el que participan varios acontecimientos celulares (etapas). Las sustancias cancerígenas pueden actuar en etapas precoces o tardías, o en ambas. Por ejemplo, se cree que la radiación ionizante afecta principalmente a las etapas precoces en la inducción de determinados tipos de cáncer, mientras que el arsénico actúa principalmente en etapas tardías del desarrollo de cáncer de pulmón. El humo del tabaco afecta tanto a las etapas precoces como a las tardías del proceso cancerígeno. El efecto de la supresión de una sustancia que participa en una etapa precoz no se reflejaría en una disminución de la tasa de cáncer en la población durante un tiempo prolongado, mientras que la eliminación de un cancerígeno "de acción tardía" se reflejaría en una disminución de la tasa de cáncer al cabo de algunos años. Se trata de un aspecto muy importante que se ha de tener en cuenta cuando se evalúan los efectos de los programas de intervención de reducción del riesgo.

Por último, recientemente se ha intensificado el interés por los efectos de nuevos factores preventivos. En los últimos cinco años se han publicado un gran número de informes sobre el efecto preventivo de la ingesta de frutas y hortalizas sobre el cáncer de pulmón. El efecto parece ser muy constante y potente. Por ejemplo, se ha notificado que el riesgo de cáncer de pulmón es doble en las personas que consumen pocas frutas y hortalizas que entre las que presentan un consumo elevado. Por tanto, futuros estudios sobre el cáncer de pulmón profesional tendrían una mayor precisión y validez si se incluyeran en el análisis datos sobre el consumo de frutas y hortalizas.

En conclusión, las mejoras en la prevención del cáncer profesional comprenden tanto un perfeccionamiento de los métodos de identificación del riesgo como la realización de nuevas investigaciones sobre los efectos del control mediante la adopción de medidas legales. Para la identificación del riesgo, los avances de la epidemiología deben ir dirigidos principalmente a una mejor información sobre la exposición, mientras que en el campo experimental es necesaria la validación de los resultados de los métodos epidemiológicos moleculares relacionados con el riesgo de cáncer.

\section{Referencias}

Agencia Internacional para la Investigación sobre el Cáncer (IAR C). 1972-1995. I AR C M onographs on the Evaluation of $C$ arcinogenic $R$ isks to $H$ umans. V ol. 1-63. Lyon: IARC

- 1990. Cancer: Causes, O ccurrence and Control. IAR C Scientific Publication, N o. 100. Lyon: IAR C.

-. 1992. Cancer Incidence in Five Continents. Vol. VI. IARC Scientific Publications, No. 120. Lyon: IARC

Aitio, A, T K auppinen. 1991. O ccupational cancer as occupational disease. En O ccupational Diseases. $\mathrm{H}$ elsinki: Instituto de M edicina del T rabajo.

Aksoy, M. 1985. M alignancies due to occupational exposure to humans. Am J Ind M ed 7:395-402.

Alho, M, T K auppinen, E Sundquist. 1988. U se of exposure registration in the prevention of occupational cancer in Finland. $\mathrm{Am}\rfloor$ Ind $\mathrm{M} \mathrm{ed}$ 13:581-592.

Anon. Bladder tumours in industry. 1965. Lancet 2:1173

Armitage, P, R Doll. 1961. Stochastic models for carcinogenesis. En Proceedings of the Fourth B erkeley Symposium on $M$ athematical Statistics and Probability, dirigido por J Neyman. Berkeley: Univ. of California Press.

Checkoway, H, NE Pearce, DJ Crawford-Brown 1989. Research M ethods in Occupational E pidemiology. N ueva Y ork: O xford U niv. Press.

Decoufle, P. 1982. O ccupation. En Cancer E pidemiology and Prevention, dirigido por D Schottenfeld $y$ JF Fraumenti. Filadelfia: WB Saunders.

Doll, R, R Peto. 1981. The causes of cancer. I Natl Cancer Inst 66:1191-1308.

Ennever, FK. 1993. Biologically based mathematical models of lung cancer risk. E pidemiology 4:193-194.

Frumkin, H, BS Levy. 1988. Carcinogens. En $O$ ccupational $H$ ealth, dirigido por BS Levy y $\mathrm{DH}$ Wegman. Boston: Little, Brown \& C 0.

Higginson, J, CS Muir. 1976. The role of epidemiology in elucidating the importance of environmental factors in human cancer. Cancer D etec Prev 1:79-105.
—. 1979. Environmental carcinogenesis: M isconceptions and limitations to cancer control. I Natl C ancer I nst 63:1291-1298.

Higginson, J. 1969. Present trends in cancer epidemiology. Proc Canadian Cancer Res Conf 8:40-75.

H ogan, M D, DG H oel. 1981. Estimated cancer risk associated with occupational asbestos exposure. Risk Anal 1:67-76.

Jeyaratnam, J. 1994. T ransfer of hazardous industries. En Occupational Cancer in Developing Countries, dirigido por NE Pearce, E Matos, $\mathrm{H}$ Vainio, $\mathrm{P}$ Boffetta y M K ogevinas. Lyon: IAR C.

Kerva, A, T Partanen. 1981. Computerizing occupational carcinogenic data in Finland. Am Ind H yg Assoc f 42:529-533.

Kogevinas, M, P Boffetta, N Pearce. 1994. O ccupational exposure to carcinogens in developing countries. En O ccupational Cancer in Developing Countries, dirigido por NE Pearce, E $M$ atos, $H$ Vainio, $P$ Boffetta y $M$ Kogevinas. Lyon: A gencia Internacional para la Investigación sobre el Cáncer (IAR C).

Moolgavkar, S. 1978. The multistage theory of carcinogenesis and the age distribution of cancer in man. J Natl Cancer Inst 61:49-52.

Moolgavkar, SH, EG Luebeck, D K rewski, JM Zielinski. 1993. Radon, cigarette smoke and lung cancer: A re-analysis of the Colorado Plateau uranium miners' data. E pidemiology 4:204-217.

O rganización Mundial de la Salud (OM S). 1978. Clasificación Internacional de Enfermedades. Ginebra: OMS.

- . 1992. International Classification of D iseases and R elated $H$ ealth Problems. Ginebra: O M S.

Pearce, NE, E M atos, M K oivusalo, S Wing. 1994. Industrialization and health. En $O$ ccupational $C$ ancer in Developing Countries, dirigido por NE Pearce, $\mathrm{E}$ $M$ atos, $H$ Vainio, $P$ Boffetta y $M$ Kogevinas Lyon: Agencia Internacional para la Investigación sobre el Cáncer (IARC)

Pearce, NE, E M atos. 1994. Strategies for prevention of occupational cancer in developing countries. En 0 ccupational Cancer in Developing Countries, dirigido por NE Pearce, E M atos, H Vainio, P Boffetta y $M$ Kogevinas. Lyon: Agencia Internacional para la Investigación sobre el Cáncer (IARC).

Pisani, P, M Parkin. 1994. Burden of cancer in developing countries. En Occupational Cancer in Developing Countries, dirigido por NE Pearce, E $M$ atos, $\mathrm{H}$ Vainio, $\mathrm{P}$ Boffetta y $M$ Kogevinas. Lyon: Agencia Internacional para la Investigación sobre el Cáncer (IARC).

Pott, P. 1775. Chirugical Observations. Londres: H awes, Clarke and Collins.

Siemiatycki, J. 1991. Risk Factors for Cancer in the W orkplace. Londres: CR C Press.

Swerdlow, AJ. 1990. Effectiveness of primary prevention of occupational exposures on cancer risk. En E valuating $E$ ffectiveness of P rimary Prevention of Cancer, dirigido por M Hakama, V Veral, JW Cullen y DM Parkin. IARC Scientific Publications, No. 103. Lyon: Agencia Internacional para la Investigación sobre el Cáncer (IARC).

Vineis, P, L Simonato. 1991. Proportion of lung and bladder cancers in males resulting from occupation: A systematic approach. Arch Environ $H$ ealth 46:6-15.

Waldron, HA. 1983. A brief history of scrotal cancer. $B$ r J Ind $M$ ed 40:390-401.

Wynder, EJ, GB Gori. 1977. Contribution of the environment to cancer incidence: An epidemiologic exercise. I N atl Cancer I nst 58:825-832.

\section{0 tras lecturas recomendadas}

Alderson, M. 1986. Occupational Cancer. Londres: Butterworths.

Drever, F. (dir.). 1995. 0 ccupational $H$ ealth, T he R egistrar $G$ eneral's D ecennial Supplement for England and W ales. Londres: $\mathrm{H}$ er M ajesty's Stationary $\mathrm{O}$ ffice.

Flamm, WG, RJ Scheuplein. 1988. U se of short-term test data in risk analysis of chemical carcinogens. En Carcinogen Risk Assessment, dirigido por CC T ravis. Londres: Plenum Press. 
Hakama, M, V Beral, JW Cullen, DM Parkin. 1990. $E$ valuating $E$ ffectiveness of Primary Prevention of $C$ ancer. IARC Scientific Publications, No. 103. Lyon: Agencia Internacional para la Investigación sobre el Cáncer (IARC).

M uir, C, J Waterhouse, T M ack, J Powell, S Whelan. 1987. Cancer Incidence in Five Continents. Vol. V.

IARC Scientific Publications, No. 88. Lyon: Agencia Internacional para la Investigación sobre el Cáncer (IARC).
O ffice of Population Censuses and Surveys. 1982 Cancer M ortality by $O$ ccupation and Social Class 1851-1971. IARC Scientific Publications, N o. 36. L ondres: $\mathrm{H}$ er $\mathrm{M}$ ajesty's Stationery $\mathrm{O}$ ffice.

-. 1986. O ccupational M ortality 1979-1980, 1982-1983. Suplemento decenal. Londres: Her Majesty's Stationery 0 ffice.

Parkin, D M , G Wagner, C M uir. 1985. The R ole of the Registry in Cancer Control. IARC Scientific Publications, N o. 66. Lyon: Agencia Internacional para la Investigación sobre el Cáncer (IARC).
Pearce, NE, E Matos, $H$ Vainio, $P$ Boffetta, M K ogevinas. 1994. O ccupational Cancer in D eveloping Countries. Lyon: Agencia Internacional para la Investigación sobre el Cáncer (IARC)

Pearce, NE. 1988. Multistage modeling of lung cancer mortality in asbestos textile workers. Int J E pidemiol 17:747-752.

Schottenfeld, D, JF Fraumeni. 1982. Cancer E pidemiology and Prevention. Londres: WB Saunders.

Vainio, H, J Wilbourn. 1992. Identification of carcinogens within the IARC monograph programme. Scand J W ork Environ H ealth 18 Supl. 1:64-73. 
Directores del capítulo

Lothar H einemann

y $\mathrm{G}$ erd $\mathrm{H}$ euchert

\section{Sumario}

Introducción

Lothar $\mathrm{H}$ enemann y $\mathrm{G}$ erd $\mathrm{H}$ euchert . . . . . . . . . . . . . . . . . 3.2

M orbilidad y mortalidad cardiovascular en la

población activa

Gottfried $E$ nderlen $y L$ othar $H$ einemann . . . . . . . . . . . . . . 3.2

El concepto de factor de riesgo en la enfermedad

cardiovascular

L othar $\mathrm{H}$ einemann, G ottfried E nderlen y $\mathrm{H}$ eide Stark . . . . . . . . . . . . . . 3.5

Programas de rehabilitación y prevención

$L$ othar $\mathrm{H}$ enemann y $\mathrm{G}$ ottfried $\mathrm{E}$ nderlein ...

PELIGROS FISICOS, QUIMICOSYBIOLOGICOS

Factores físicos

$H$ eide Stark y $\mathrm{G}$ erd $\mathrm{H}$ euchert . . . . . . . . . . . . . . . . . . 3.11

$M$ ateriales químicos peligrosos

U Irike T ittelbach y W olfram D ietmar Schneider. .

Peligros biológicos

R egina J äckel, U Irike T ittelbach y W olfram D ietmar Schneider 


\section{INTRODUCCION}

Lothar Heinemann y G erd H euchert

Las enfermedades cardiovasculares (ECV) son unas de las causas más frecuentes de morbilidad y mortalidad en la población activa, sobre todo de los países industrializados. En los países subdesarrollados también está aumentando su frecuencia (Wielgosz 1993). En los países industrializados, entre el 15 y el $20 \%$ de toda la población activa sufre un trastorno cardiovascular alguna vez durante su vida laboral y la incidencia aumenta de forma radical con la edad. Entre 45 y 64 años, más de la tercera parte de las muertes de los varones y más de la cuarta parte de las muertes de las mujeres están causadas por este grupo de enfermedades (véase la Tabla 3.1). En los últimos años, las ECV se han convertido en la causa más frecuente de muerte en mujeres posmenopáusicas.

\section{Tabla 3.1 - Mortalidad por enfermedades cardiovascu- lares en 1991 y 1990 en los grupos de edades comprendidas entre 45-54 años y 55-64 años en países seleccionados.}

\begin{tabular}{lccccccccc} 
País & \multicolumn{4}{c}{ Varones } & \multicolumn{4}{c}{ Mujeres } \\
& $45-54$ & $55-64$ & \multicolumn{2}{c}{$45-54$} & \multicolumn{2}{c}{$55-64$} \\
& Años & \multicolumn{2}{c}{ Años } & \multicolumn{2}{c}{ Años } & \multicolumn{2}{c}{ Años } \\
& Tasa & $\%$ & Tasa & $\%$ & Tasa & $\%$ & Tasa & $\%$ \\
Rusia** & 528 & 36 & 1.290 & 44 & 162 & 33 & 559 & 49 \\
Polonia** & 480 & 38 & 1.193 & 45 & 134 & 31 & 430 & 42 \\
Argentina* & 317 & 40 & 847 & 44 & 131 & 33 & 339 & 39 \\
Gran Bretaña** & 198 & 42 & 665 & 47 & 59 & 20 & 267 & 32 \\
EE.UU.* & 212 & 35 & 623 & 40 & 83 & 24 & 273 & 31 \\
Alemania** & 181 & 29 & 597 & 38 & 55 & 18 & 213 & 30 \\
Italia* & 123 & 27 & 404 & 30 & 41 & 18 & 148 & 25 \\
México** & 128 & 17 & 346 & 23 & 82 & 19 & 230 & 24 \\
Francia** & 102 & 17 & 311 & 22 & 30 & 12 & 94 & 18 \\
Japón** & 111 & 27 & 281 & 26 & 48 & 22 & 119 & 26
\end{tabular}

* 1990. ** 1991. Tasa $=$ Muertes por 100.000 habitantes. El \% se refiere a todas las causas de muerte en el grupo de edad.

A causa de su compleja etiología, sólo una proporción muy pequeña de los casos de enfermedad cardiovascular se reconocen como enfermedad profesional. Muchos países, sin embargo, admiten que la exposición laboral contribuye al desarrollo de ECV (algunas veces se definen como enfermedades relacionadas con el trabajo). Las condiciones de trabajo y las exigencias del puesto de trabajo desempeñan un papel importante en el proceso multifactorial que origina estas enfermedades, pero diferenciar el papel de los componentes causales individuales es muy difícil. Estos interactúan relacionándose entre sí de forma estrecha y cambiante y la enfermedad suele desencadenarse por una combinación o acumulación de diferentes factores causales, incluidos los relacionados con el trabajo.
El lector debe consultar los textos convencionales de cardiología para obtener información sobre la epidemiología, fisiopatología, diagnóstico y tratamiento de las enfermedades cardiovasculares. Este capítulo se centrará en los aspectos de la enfermedad cardiovascular de especial importancia en el lugar de trabajo y sobre los que influyen probablemente factores relacionados con el puesto de trabajo y con el medio ambiente del trabajo.

\section{MORBILIDAD Y MORTALIDAD CARDIOVASCULAR EN LA POBLACION ACTIVA}

\section{G ottfried Enderlein y L othar H einemann}

En el artículo siguiente, el término enfermedades cardiovasculares (ECV) se refiere a los trastornos orgánicos y funcionales del sistema cardíaco y circulatorio, incluidas las lesiones resultantes en otros sistemas orgánicos, clasificadas con los números 390 a 459 en la 9a revisión de la Clasificación Internacional de Enfermedades (CIE) [Organización Mundial de la Salud (OMS) 1975]. Basándose sobre todo en datos estadísticos internacionales recogidos por la OMS y en datos de Alemania, en el artículo se comentan la prevalencia de ECV, las nuevas tasas de enfermedad y la frecuencia de fallecimientos, morbilidad e incapacidades.

\section{Definición y prevalencia en la población en edad detrabajar}

Las coronariopatías (CIE 410-414) que provocan isquemia del miocardio probablemente sean la ECV más significativa de la población activa, sobre todo en los países industrializados. Este trastorno se produce por una constricción del sistema vascular que suministra la sangre al músculo cardíaco, un problema causado sobre todo por la arteriosclerosis. Afecta al 0,9-1,5\% de los varones en edad de trabajar y al 0,5-1,0 \% de las mujeres.

Las enfermedades inflamatorias (CIE 420-423) pueden afectar al endocardio, las válvulas cardíacas, el pericardio o al propio músculo cardíaco (miocardio). Son menos comunes en los países industrializados, donde su frecuencia es menor del 0,01\% de la población adulta, pero se observan con más frecuencia en los países en vías de desarrollo, lo que quizás refleja la mayor prevalencia de trastornos nutricionales y de enfermedades infecciosas.

Los trastornos del ritmo cardíaco (CIE 427) son relativamente raros, aunque se ha prestado una gran atención a los casos recientes de incapacidad y de muerte súbita en atletas profesionales destacados. Aunque pueden tener un impacto significativo sobre la capacidad de trabajo, con frecuencia son asintomáticos y transitorios.

Las miocardiopatías (CIE 424) son trastornos en los que se produce un aumento o engrosamiento del músculo cardíaco, con lo que se estrechan los vasos y se debilita el corazón. En los últimos años se les ha prestado más atención, en parte por la mejora de los métodos diagnósticos, aunque su patogenia en numerosos casos no está clara. Se ha atribuido su origen a infecciones, enfermedades metabólicas, trastornos inmunológicos, enfermedades inflamatorias que afectan a los vasos capilares y a factores, de particular importancia en este volumen, como la 
exposición a sustancias tóxicas en el lugar de trabajo. Se dividen en tres tipos:

- dilatada: es la forma más frecuente (de 5 a 15 casos por 100.000 habitantes) y se asocia al debilitamiento funcional del corazón;

- hipertrófica: engrosamiento y aumento del tamaño del miocardio que provoca una insuficiencia relativa de las arterias coronarias;

- restrictiva: es un tipo raro en el que están limitadas las contracciones miocárdicas.

La hipertensión (CIE 401-405) (aumento de la tensión arterial sistólica y/ o diastólica) es la enfermedad circulatoria más frecuente, ya que afecta al 15-20 \% de la población activa de los países industrializados. Se comenta con más detalle más adelante.

Las alteraciones ateroscleróticas en los principales vasos sanguíneos (CIE 440), asociadas a menudo a hipertensión, causan enfermedad de los órganos a los que aportan el suministro sanguíneo. La principal de ellas es la enfermedad cerebrovascular (CIE 430-438), que puede provocar un ictus por infarto $\mathrm{y} / \mathrm{o}$ hemorragia. Esto sucede en el $0,3-1,0 \%$ de la población activa, sobre todo en los mayores de 40 años.

Las enfermedades ateroscleróticas, incluida la coronariopatía, el ictus y la hipertensión, con diferencia las enfermedades cardiovasculares más comunes en la población activa, son de origen multifactorial y se inician en etapas más tempranas de la vida. Tienen importancia en el lugar de trabajo por los siguientes motivos:

- una proporción muy elevada de la plantilla padece una forma asintomática o no reconocida de enfermedad cardiovascular;

- las exigencias del puesto de trabajo y las condiciones de trabajo pueden agravar el desarrollo de esta enfermedad o precipitar acontecimientos sintomáticos agudos;

- el inicio agudo de una fase sintomática de la enfermedad cardiovascular se atribuye con frecuencia al trabajo y/o al medio ambiente del lugar del trabajo;

- la mayoría de los individuos que padecen una enfermedad cardiovascular establecida son capaces de trabajar de forma productiva, aunque en algunos casos esto sólo es posible después de un proceso de rehabilitación eficaz y de una formación de reconversión profesional;

- el lugar de trabajo presenta unas condiciones únicas muy propicias para el desarrollo de los programas de prevención primaria y secundaria.

Los trastornos circulatorios funcionales de las extremidades (CIE 443), como la enfermedad de Raynaud o la palidez pasajera de los dedos de la mano, son relativamente raros. Estos trastornos pueden ser provocados por algunas enfermedades profesionales, como las congelaciones, la exposición prolongada al cloruro de vinilo y la exposición de las manos a las vibraciones.

$L$ as varicosidades venosas de las piernas (CIE 454), que suelen considerarse inadecuadamente sólo como un problema estético y afectan con frecuencia a las mujeres, sobre todo durante el embarazo. Aunque la tendencia hereditaria a la debilidad de las paredes venosas puede ser un factor favorable al desarrollo de la enfermedad, suelen producirse por permanecer de pie sin moverse durante períodos prolongados en los que aumenta la presión estática en las venas. Con frecuencia es necesario el cambio de puesto de trabajo o la modificación del tipo de trabajo como consecuencia de las molestias y el edema de la pierna causados por este trastorno.

\section{Tasas de incidencia anual}

Entre las ECV, la hipertensión tiene el mayor índice anual de casos nuevos en los trabajadores de 35 a 64 años. A parecen casos nuevos en el $1 \%$ aproximadamente de esta población cada año. Los siguientes trastornos en frecuencia son la cardiopatía coronaria (8-92 casos nuevos de ataque cardíaco agudo por 10.000 varones al año y 3-16 casos nuevos por 10.000 mujeres al año) y el ictus (12-30 casos por 10.000 varones al año y 6-30 casos por 10.000 mujeres al año). Como se ha demostrado por los datos globales recogidos por el proyecto Monica de la OMS (OMSM O NICA 1994; O M S-M O NICA 1988), las tasas de incidencia más bajas de ataque cardíaco se hallaron en varones en China y mujeres en España, mientras que las tasas más elevadas se hallaron en varones y mujeres en Escocia. Según estos datos, en la población en edad de trabajar, el 40-60 \% de las víctimas de los ataques cardíacos y el $30-40 \%$ de los afectados por ictus no sobreviven a los episodios iniciales de la enfermedad.

Tabla 3.2 - Tasas de mortalidad de grupos diagnósticos cardiovasculares especiales en los años 1991 y 1990 en el grupo de edades comprendidas entre 55-64 años en países seleccionados.

\begin{tabular}{|c|c|c|c|c|c|c|c|c|c|c|}
\hline \multirow[t]{2}{*}{ Grupo de diagnósticos (CIE 9ª Rev.) } & \multicolumn{2}{|c|}{ Rusia (1991) } & \multicolumn{2}{|c|}{ EE.UU. (1990) } & \multicolumn{2}{|c|}{ Alemania (1991) } & \multicolumn{2}{|c|}{ Francia (1991) } & \multicolumn{2}{|c|}{ Japón (1991) } \\
\hline & H & M & $H$ & M & H & M & $H$ & M & H & M \\
\hline 393-398 & 16,8 & 21,9 & 3,3 & 4,6 & 3,6 & 4,4 & 2,2 & 2,3 & 1,2 & 1,9 \\
\hline 401- 405 & 22,2 & 18,5 & 23,0 & 14,6 & 16,9 & 9,7 & 9,4 & 4,4 & 4,0 & 1,6 \\
\hline 410 & 160,2 & 48,9 & 216,4 & 79,9 & 245,2 & 61,3 & 100,7 & 20,5 & 45,9 & 13,7 \\
\hline 411- 414 & 586,3 & 189,9 & 159,0 & 59,5 & 99,2 & 31,8 & 35,8 & 6,8 & 15,2 & 4,2 \\
\hline $415-429$ & 60,9 & 24,0 & 140,4 & 64,7 & 112,8 & 49,2 & 73,2 & 27,0 & 98,7 & 40,9 \\
\hline $430-438$ & 385,0 & 228,5 & 54,4 & 42,2 & 84,1 & 43,8 & 59,1 & 26,7 & 107,3 & 53,6 \\
\hline 440 & & & 4,4 & 2,1 & 11,8 & 3,8 & 1,5 & 0,3 & 0,3 & 0,1 \\
\hline 441- 448 & {$[30,0$} & & 18,4 & 6,7 & 15,5 & 4,2 & 23,4 & 3,8 & 3,8 & 2,6 \\
\hline Total $390-459$ & 1.290 & 559 & 623 & 273 & 597 & 213 & 311 & 94 & 281 & 119 \\
\hline
\end{tabular}

Muertes por 100.000 habitantes; $H=$ hombre; $M=$ mujer. 


\section{M ortalidad}

Dentro de los límites principales de la edad laboral, de 15 a 64 años, sólo el 8-18 \% de los fallecimientos por ECV se produjeron antes de los 45 años. La mayoría de las muertes se produjeron después de esta edad y las tasas anuales de mortalidad aumentan con la edad. Las tasas cambian con el tiempo y varían de forma considerable de un país a otro (O M S 1994b).

En la Tabla 3.1 se muestran las tasas de mortalidad en varones y mujeres de 45 a 54 y de 55 a 64 años en algunos países. 0 bsérvese que las tasas de mortalidad de los varones son sistemáticamente superiores a las tasas de las mujeres de la misma edad.

En la Tabla 3.2 se comparan las tasas de mortalidad de varias ECV en personas de 55 a 64 años en cinco países.

\section{Incapacidad laboral y jubilación anticipada}

Los datos estadísticos relacionados con el diagnóstico sobre el tiempo de trabajo perdido representan un aspecto importante del impacto de la morbilidad de la población activa, aunque las denominaciones diagnósticas suelen ser menos precisas que en los casos de jubilación anticipada por incapacidad. Las tasas de casos, expresadas generalmente en casos por 10.000 trabajadores, proporcionan un índice de la frecuencia de las distintas categorías de enfermedad, mientras que el número medio de días perdidos por caso indica la gravedad de las diferentes enfermedades. Por tanto, de acuerdo con los datos estadísticos relativos a 10 millones de trabajadores de Alemania occidental recopilados por la Allgemeinen O rtskrankenkasse, las ECV representaron el 7,7 \% de la incapacidad total en 1991-92, aunque el número de casos para

Tabla 3.3 - Tasa de enfermedad cardiovascular en jubilados precoces* debido a la reducción de la capacidad para trabajar ( $\mathrm{N}=576,079)$ y discapacidad laboral en relación con el diagnóstico en Alemania occidental, $1990-92$

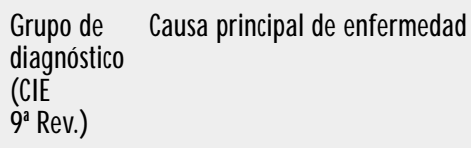

Acceso a la jubilación anticipada; total por 100.000 personas jubiladas anticipadamente Hombres Mujeres

$\begin{array}{rr}16 & 24 \\ 604 & 605 \\ 4.158 & 4.709\end{array}$

4.158

4.709

9.635

2.981

2.293

621

2.183

6.932

248

124

3.434

1.947

141

118

108

1.257

119

402

86

734

981

4.415

3.785

2.453

219

464

16

29

37

26.843
Incapacidad laboral media anual 1990- 92

$\begin{array}{cc}\text { Casos por } 100.000 & \text { Duración (días) } \\ \text { trabajadores } & \text { por caso }\end{array}$

Hombres Mujeres Hombres Mujeres

$\begin{array}{llll}49 & 60 & 28,1 & 32,8\end{array}$

$24 \quad 20 \quad 67,5 \quad 64,5$

$982 \quad 1.166 \quad 24,5 \quad 21,6$

$\begin{array}{llll}1.176 & 529 & 51,2 & 35,4\end{array}$

$\begin{array}{llll}276 & 73 & 85,8 & 68,4\end{array}$

$\begin{array}{llll}337 & 135 & 50,8 & 37,4\end{array}$

$\begin{array}{llll}23 & 26 & 58,5 & 44,8\end{array}$

$\begin{array}{llll}645 & 544 & 36,3 & 25,7\end{array}$

$\begin{array}{llll}20 & 12 & 49,4 & 48,5\end{array}$

$\begin{array}{llll}22 & 18 & 45,6 & 38,5\end{array}$

$\begin{array}{llll}38 & 14 & 66,8 & 49,2\end{array}$

$\begin{array}{llll}12 & 7 & 39,6 & 45,0\end{array}$

$\begin{array}{llll}291 & 274 & 29,3 & 21,8\end{array}$

$\begin{array}{llll}82 & 61 & 62,4 & 42,5\end{array}$

$172 \quad 120 \quad 75,6 \quad 58,9$

$\begin{array}{llll}238 & 90 & 59,9 & 44,5\end{array}$

$\begin{array}{llll}27 & 10 & 71,7 & 47,6\end{array}$

$\begin{array}{llll}63 & 25 & 50,6 & 33,5\end{array}$

$\begin{array}{llll}113 & 34 & 63,3 & 49,5\end{array}$

$\begin{array}{llll}1.020 & 1.427 & 22,9 & 20,3\end{array}$

$\begin{array}{llll}142 & 132 & 10,4 & 14,2\end{array}$

$\begin{array}{llll}616 & 1.501 & 9,4 & 9,5\end{array}$

$\begin{array}{llll}1.056 & 2.094 & 11,5 & 10,2\end{array}$

$\begin{array}{llll}6.143 & 7.761 & 29,6 & 18,9\end{array}$

* Personas jubiladas anticipadamente: seguro de pensión obligatorio de la antigua República Federal de Alemania. 
ese período fue sólo del 4,6 \% del total (Tabla 3.3). En algunos países, donde se concede la jubilación anticipada si una enfermedad disminuye la capacidad de trabajo, el patrón de incapacidad refleja las tasas de las diferentes categorías de ECV.

\section{- El CONCEPTO DE FACTOR DE RIESGO EN LA EN FERMEDAD CARDIOVASCULAR}

\author{
Lothar Heinemann, Gottfried Enderlein y \\ H eide Stark
}

Los factores de riesgo son características genéticas, fisiológicas, del comportamiento y socioeconómicas de los individuos que les sitúan dentro de una cohorte de la población en la que es más probable el desarrollo de un problema sanitario o enfermedad concretos que en el resto de la población. Este concepto suele aplicarse para enfermedades multifactoriales en las que no se conoce una causa única precisa y ha resultado particularmente útil para identificar personas candidatas a seguir las medidas de prevención primaria y para valorar la eficacia de los programas de prevención en el control de los factores de riesgo estudiados. Este concepto se ha desarrollado gracias a estudios prospectivos de población a gran escala, como el estudio Framingham de ictus y coronariopatías realizado en Framingham, M assachussets, en Estados U nidos y a otros estudios epidemiológicos, de intervención y experimentales.

D ebe señalarse que los factores de riesgo son simplemente expresiones de probabilidad, esto es, no son términos absolutos ni diagnósticos. Presentar uno o más factores de riesgo de una enfermedad concreta no significa necesariamente que un individuo vaya a desarrollar esa enfermedad ni que un individuo sin ningún factor de riesgo nunca la vaya a padecer. Los factores de riesgo son características individuales que influyen sobre las probabilidades de un individuo de sufrir una enfermedad particular 0 un grupo de enfermedades en un período de tiempo futuro definido. Los factores de riesgo pueden clasificarse en las categorías siguientes:

- factores somáticos, como hipertensión arterial, trastornos del metabolismo lipídico, sobrepeso y diabetes mellitus;

- factores del comportamiento, como tabaquismo, malnutrición, falta de actividad física, personalidad del tipo A, consumo excesivo de alcohol y abuso de drogas;

- factores de tensión en los campos laboral, social y privado.

Desde luego, los factores predisponentes y genéticos desempeñan también un papel en la hipertensión arterial, la diabetes mellitus y los trastornos del metabolismo lipídico. M uchos de los factores de riesgo facilitan el desarrollo de arteriosclerosis, que es una condición previa significativa para el comienzo de la cardiopatía coronaria.

A causa de algunos factores de riesgo el individuo puede sufrir más de una enfermedad; por ejemplo, el consumo de cigarrillos se asocia a coronariopatías, ictus y cáncer de pulmón. Un individuo puede presentar al mismo tiempo factores de riesgo múltiples de sufrir una enfermedad particular; estos factores pueden sumarse, aunque lo más frecuente es que al combinarse sus efectos se multipliquen. Los factores somáticos y del estilo de vida se han identificado como los factores de riesgo principales de cardiopatía coronaria y de ictus.

\section{Hipertensión}

La hipertensión (aumento de la tensión arterial), enfermedad con entidad propia, es una de los principales factores de riesgo de cardiopatía coronaria (CC) y de ictus. Según define la O M S, la tensión arterial es normal cuando la diastólica es inferior a $90 \mathrm{~mm} \mathrm{H}$ g y la sistólica es inferior a $140 \mathrm{~mm} \mathrm{Hg}$. En la hipertensión umbral o límite, la tensión arterial diastólica es de 90 a $94 \mathrm{~mm} \mathrm{H}$ g y la sistólica de 140 a 159 mm H g. Los individuos con tensiones diastólicas iguales o superiores a $95 \mathrm{~mm} \mathrm{H}$ g y tensiones sistólicas iguales o superiores a $160 \mathrm{~mm} \mathrm{H} \mathrm{g}$ se consideran hipertensos. N o obstante, en diversos estudios se ha demostrado que estos criterios tan estrictos no son completamente correctos. Algunos individuos tienen una tensión arterial "lábil", es decir, que oscila entre los niveles de normalidad y de hipertensión según las circunstancias del momento. Además, sin tener en cuenta las categorías específicas, existe una progresión lineal del riesgo relativo al aumentar la tensión por encima del nivel normal.

En Estados Unidos, por ejemplo, la incidencia de CC y de ictus en los varones de 55 a 61 años fue del $1,61 \%$ por año en los varones con tensión arterial normal, en comparación con el $4,6 \%$ por año en los que sufrían hipertensión (National H eart, Lung and Blood Institute 1981). Según el estudio M O NICA de la OMS, se hallaron tensiones diastólicas superiores a $94 \mathrm{~mm}$ $\mathrm{H} \mathrm{g}$ en el 2-36 \% de la población de 35 a 64 años. En numerosos países de Europa central, septentrional y oriental (como Rusia, la República Checa, Finlandia, Escocia, Rumania, Francia y algunas partes de Alemania, así como $M$ alta) el $30 \%$ de la población de 35 a 54 años es hipertensa, mientras que en países como España, Dinamarca, Bélgica, Luxemburgo, Canadá y Estados U nidos, la cifra correspondiente fue menor del $20 \%$ (O M S-M O NICA 1988). Las tasas tienden a aumentar con la edad y se observaron diferencias raciales (al menos en Estados U nidos, la hipertensión afecta con más frecuencia a los afroamericanos que a la población blanca).

\section{Riesgo de desarrollo de hipertensión}

Los factores de riesgo importantes de desarrollo de hipertensión son el peso corporal excesivo, la ingesta elevada de sal, diversos factores dietéticos, la inactividad física y factores psicosociales, como el estrés (Levi 1983). Además, hay un componente genético cuyo significado relativo no se conoce con certeza (O M S 1985). L a frecuencia de aparición familiar de hipertensión debe considerarse un peligro y hay que prestar especial atención al control de los factores de que depende el estilo de vida.

Se sabe que los factores psicosociales y psicofísicos, junto con el puesto de trabajo, pueden influir en el desarrollo de la hipertensión, sobre todo en los aumentos pasajeros de la tensión arterial. Se ha observado que la concentración de determinadas hormonas (adrenalina y noradrenalina) y del cortisol (Levi 1972) está elevada, lo cual puede provocar, por sí mismo, o asociado a un consumo excesivo de sal, la hipertensión. El estrés en el trabajo parece relacionarse también con la hipertensión. Se ha observado una relación dosis-efecto con la intensidad del tráfico aéreo (Levi 1972; O M S 1985) al comparar grupos de controladores de tráfico aéreo con tensiones psíquicas diferentes.

\section{Tratamiento de la hipertensión}

La hipertensión puede y debe tratarse, aunque el paciente no presente ningún síntoma. L os cambios en el estilo de vida, como el control del peso, la disminución de la ingesta de sodio y el ejercicio físico regular, asociados si es necesario a medicamentos hipotensores, consiguen en muchos casos reducir la tensión arterial, incluso hasta niveles normales. Por desgracia, muchos individuos hipertensos no reciben un tratamiento adecuado. Según el estudio MONICA de la OMS (1988), menos del $20 \%$ de las mujeres hipertensas de R usia, M alta, Alemania oriental, Escocia, Finlandia e I talia, recibían un tratamiento adecuado a mediados del decenio de 1980 y en los varones de Irlanda, Alemania, 
China, Rusia, M alta, Finlandia, Polonia, Francia e Italia, esta proporción no alcanzaba el $15 \%$.

\section{Prevención de la hipertensión}

La prevención de la hipertensión debe basarse en la identificación de los individuos con la tensión arterial aumentada mediante detección selectiva o programas de exploración médica periódicos, comprobaciones repetidas para verificar la amplitud y la duración de la elevación, e instauración de una pauta terapéutica apropiada que se mantendrá de forma indefinida. Los pacientes con antecedentes familiares de hipertensión deben controlarse la tensión arterial con más frecuencia y ser asesorados para eliminar o controlar cualquier factor de riesgo que puedan presentar. EI control del abuso de alcohol, el entrenamiento físico que mantenga la capacidad física para el trabajo, el control del peso y los esfuerzos encaminados a reducir el estrés psicológico son elementos importantes de los programas de prevención. La mejoría de las condiciones en el lugar de trabajo, como la reducción del ruido y del calor excesivo, son otras medidas preventivas.

El lugar de trabajo es un entorno muy propicio para realizar programas dirigidos a detectar y controlar la hipertensión en la plantilla de trabajadores. La comodidad y el coste bajo o nulo atraen a los participantes y los efectos positivos de la estrecha presión ejercida por los compañeros tiende a aumentar el cumplimiento del tratamiento y el éxito del programa.

\section{Hiperlipidemia}

Numerosos estudios internacionales a largo plazo han mostrado una relación convincente entre las anormalidades del metabolismo de los lípidos y el aumento del riesgo de CC e ictus. Esto es cierto sobre todo cuando están elevados los niveles de colesterol total y LDL (lipoproteínas de baja densidad) y/ o están reducidos los niveles de HDL (lipoproteínas de alta densidad). En estudios recientes se han hallado más datos que relacionan el exceso de riesgo con diferentes fracciones de las lipoproteínas (O M S 1994a).

En los estudios M ONICA de la OMS realizados a mediados del decenio de 1980, se ha observado que la frecuencia de los niveles elevados de colesterol total $(>6,5 \mathrm{mmol} / \mathrm{l})$ varía de forma considerable en los grupos de población de todo el mundo (O M S-M O NICA 1988). La tasa de hipercolesterolemia en las poblaciones en edad de trabajar (35 a 64 años) osciló entre el 1,3 y el $46,5 \%$ en los varones y entre el 1,7 y el $48,7 \%$ en las mujeres. Aunque los límites fueron en general similares, los niveles medios de colesterol en los grupos de estudio de diferentes países variaron de forma significativa: en Finlandia, Escocia, Alemania oriental, los países del Benelux y $M$ alta se halló un promedio superior a $6 \mathrm{mmol} / \mathrm{l}$, mientras que los valores medios fueron inferiores en los países de Asia oriental, como China $(4,1 \mathrm{mmol} / \mathrm{l})$ y Japón $(5,0 \mathrm{mmol} / \mathrm{l})$. En ambas regiones, las medias fueron inferiores a $6,5 \mathrm{mmol} / \mathrm{l}(250 \mathrm{mg} / \mathrm{dl})$, el nivel seleccionado como límite de la normalidad; sin embargo, como se mencionó antes en el caso de la tensión arterial, el riesgo aumenta de forma progresiva según se eleva el nivel, en vez de existir una delimitación clara entre los niveles normales y anormales. D e hecho, algunas autoridades sanitarias han señalado un nivel de colesterol total de $180 \mathrm{mg} / \mathrm{dl}$ como el nivel óptimo que no debe superarse.

$\mathrm{H}$ ay que subrayar que el sexo es un factor determinante porque las mujeres presentan niveles medios de LDL inferiores. Este puede ser uno de los motivos por los que las mujeres en edad de trabajar tienen un índice de mortalidad por C C inferior.

Salvo por el número relativamente escaso de individuos con hipercoletesterolemia hereditaria, los niveles de colesterol suelen reflejar el consumo con la dieta de alimentos ricos en colesterol y grasas saturadas. Las dietas basadas en frutas, productos vegetales y pescado, en las que se reduce la ingesta total de grasas y se sustituyen las grasas poliinsaturadas se asocian en general a niveles bajos de colesterol. Aunque su papel no se conoce con certeza, se cree que el consumo de antioxidantes (vitamina $E$, carotenos, selenio, etc.) influye también en los niveles de colesterol.

Los factores asociados al aumento de los niveles de colesterol de las HDL, la forma "protectora" de las lipoproteínas, son la raza (negra), el sexo (femenino), el peso normal, el ejercicio físico y la ingesta moderada de alcohol.

L os factores socioeconómicos también desempeñan al parecer un papel, al menos en los países industrializados, como Alemania occidental, en los que se hallaron niveles elevados de colesterol en grupos de población de ambos sexos de bajo nivel educativo (menos de diez años de escuela) en comparación con los que completaron 12 años de educación (H einemann 1993).

\section{Consumo de cigarrillos}

El consumo de cigarrillos es uno de los factores de riesgo más importante de ECV. EI riesgo se relaciona de forma directa con el número de cigarrillos que se fuman, el período de tiempo que se ha fumado, la edad a la que se comenzó a fumar, la cantidad de humo que se inhala y el contenido de alquitrán, nicotina y monóxido de carbono del humo inspirado. En la Figura 3.1 se muestra el llamativo aumento de la mortalidad por C C en los fumadores en comparación con los no fumadores. Se ha demostrado que el riesgo aumenta en varones y mujeres y en todas las clases socioeconómicas.

El riesgo relativo del consumo de cigarrillos disminuye después de abandonar el hábito. Esta disminución es progresiva; después de aproximadamente diez años sin fumar, el riesgo disminuye casi hasta el mismo nivel que en las personas que nunca fumaron.

Estudios recientes muestran que las personas que inhalan un "humo de segunda mano" (es decir, la inhalación pasiva de

Figura 3.1 - Riesgo de mortalidad relativa por enfermedades cardiovasculares en los fumadores (incluidos los ex fumadores), según la clase social, en comparación con trabajadores cualificados (varones) de peso normal y no fumadores, basado en los exámenes médicos realizados en el trabajo en Alemania oriental, mortalidad 1985-89, $\mathrm{N}=2,7$ millones de años-persona.

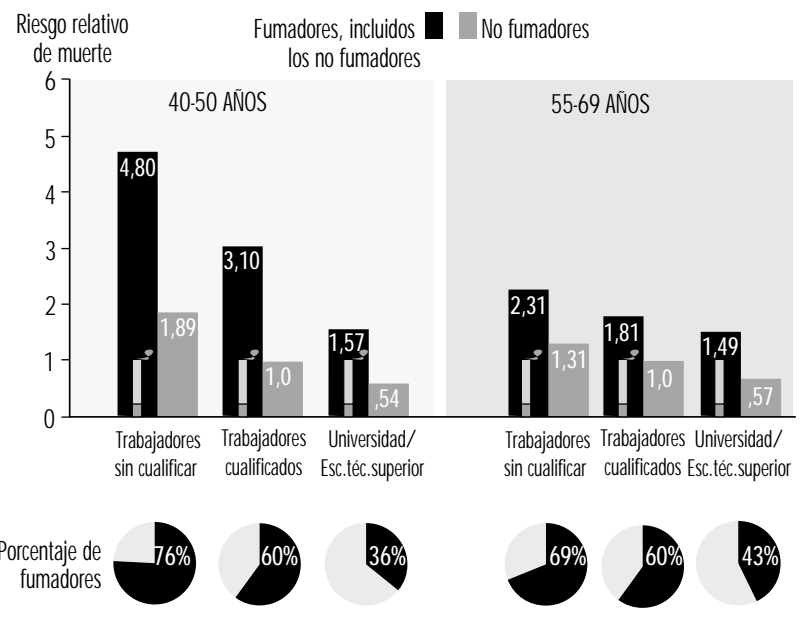


humo de cigarrillos fumados por otras personas) sufren también un riesgo significativo (Wells 1994; G lantz y Parmley 1995).

Las tasas de consumo de cigarrillos varía, según los países, como se demostró en el estudio internacional MONICA de la O M S (1988). Las tasas más elevadas en varones de 35 a 64 años se determinaron en Rusia, Polonia, Escocia, H ungría, I talia, M alta, Japón y C hina. En Escocia, D inamarca, Irlanda, Estados Unidos, H ungría y Polonia fuman más mujeres que varones (los datos recientes de Polonia se limitan a grandes ciudades).

El estado social y el nivel de ocupación son factores que influyen en la intensidad del consumo de cigarrillos en los trabajadores. En la Figura 3.1, por ejemplo, se observa que la proporción de fumadores entre los varones de Alemania oriental era más alta en las clases sociales más bajas. L o contrario se observa en países con un número relativamente escaso de fumadores, en los que los índices más altos se encuentran en los niveles sociales más elevados. En Alemania oriental, el consumo de cigarrillos es un hábito más frecuente en las personas que trabajan por turnos en comparación con las que tienen un horario de trabajo "normal".

Figura 3.2 - Prevalencia de la hipertensión por edad, sexo y seis niveles de peso corporal relativo según el índice de masa corporal (IMC) en los exámenes médicos realizados en el trabajo en Alemania oriental (los valores normales del IMC están subrayados).
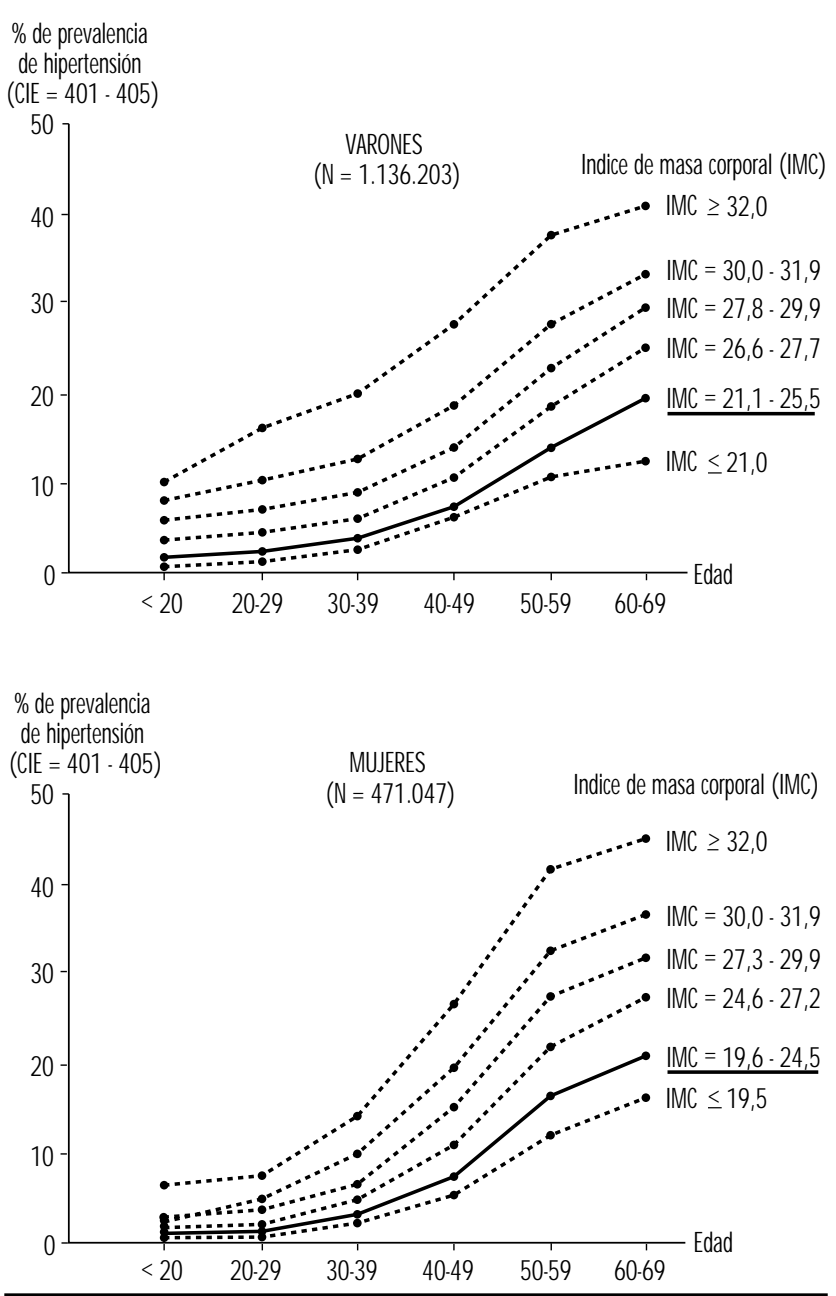

\section{Nutrición desequilibrada, consumo de sal}

En la mayoría de los países industrializados, las dietas tradicionales de bajo contenido de grasas se han sustituido por dietas demasiado dulces o saladas, de contenido bajo en hidratos de carbono y elevado en grasas y calorías. Esto contribuye al desarrollo de sobrepeso, hipertensión y al aumento del nivel de colesterol, con el consiguiente aumento del riesgo cardiovascular. EI consumo excesivo de grasas de origen animal, con su elevada proporción de ácidos grasos saturados, aumenta el nivel de colesterol de las LDL y con ello el riesgo cardiovascular. Las grasas de origen vegetal tienen una cantidad muy inferior de estas sustancias (OM S 1994a). Los hábitos dietéticos se asocian también estrechamente al nivel socioeconómico y a la actividad profesional.

\section{Sobrepeso}

El sobrepeso (exceso de grasa u obesidad más que aumento de la masa muscular) es un factor de riesgo cardiovascular de menor significación directa. Se sabe que el patrón de distribución del exceso de grasa en el varón (obesidad abdominal) se asocia a un riesgo mayor de problemas cardiovasculares y metabólicos que el patrón de distribución de la grasa en la mujer (pélvico).

El sobrepeso se asocia a hipertensión, hipercolesterolemia y diabetes mellitus y, en una medida muy superior en las mujeres que en los hombres, tiende a aumentar con la edad (H euchert y Enderlein 1994) (Figura 3.2).

Es también un factor de riesgo de problemas musculoesqueléticos y de osteoartritis y dificulta la práctica de ejercicio físico. La frecuencia de sobrepeso significativo varía de forma considerable según los países. En encuestas aleatorias de población realizadas en el proyecto MONICA de la OMS se halló sobrepeso en más del $20 \%$ de las mujeres de 35 a 64 años de la República Checa, Alemania oriental, Finlandia, Francia, H ungría, Polonia, Rusia, España y Yugoslavia, y de las personas de ambos sexos de Lituania, M alta y Rumania. En China, Japón, Nueva Zelanda y Suecia, tenían un sobrepeso significativo menos del $10 \%$ de los habitantes de ambos sexos de este grupo de edad.

La causas habituales del sobrepeso son los factores familiares (estos pueden ser en parte genéticos, pero en general reflejan hábitos dietéticos comunes), la ingesta excesiva de alimentos, las dietas de alto contenido en grasas e hidratos de carbono y la falta de ejercicio físico. El sobrepeso tiende a ser más habitual en las capas socioeconómicas más bajas, sobre todo en las mujeres en las que, entre otros factores, las limitaciones económicas impiden seguir una dieta más equilibrada. Estudios de población realizados en A lemania muestran que la proporción de personas con sobrepeso entre aquellos con niveles más bajos de educación es entre 3 y 5 veces mayor que la observada en personas con una educación superior; y que en algunas actividades profesionales, sobre todo la preparación de comidas, la agricultura y, en alguna medida, el trabajo por turnos, la proporción de personas con sobrepeso es mayor (Figura 3.3) (H einemann 1993).

\section{Inactividad física}

La estrecha asociación entre la hipertensión, el sobrepeso y la diabetes mellitus con la falta de ejercicio en el trabajo y/o el tiempo libre ha convertido a la inactividad física en un factor de riesgo significativo de CC e ictus (Briazgounov 1988; OMS 1994a). En varios estudios se ha demostrado que, manteniendo constantes todos los demás factores de riesgo, la tasa de mortalidad en las personas que realizan de forma regular ejercicios muy intensos es inferior que en las personas con un estilo de vida sedentaria. 
Figura 3.3 - Riesgo relativo del sobrepeso según la duración del período de educación (años de escolaridad) espacio en Alemania (población entre 25 a 64 años).
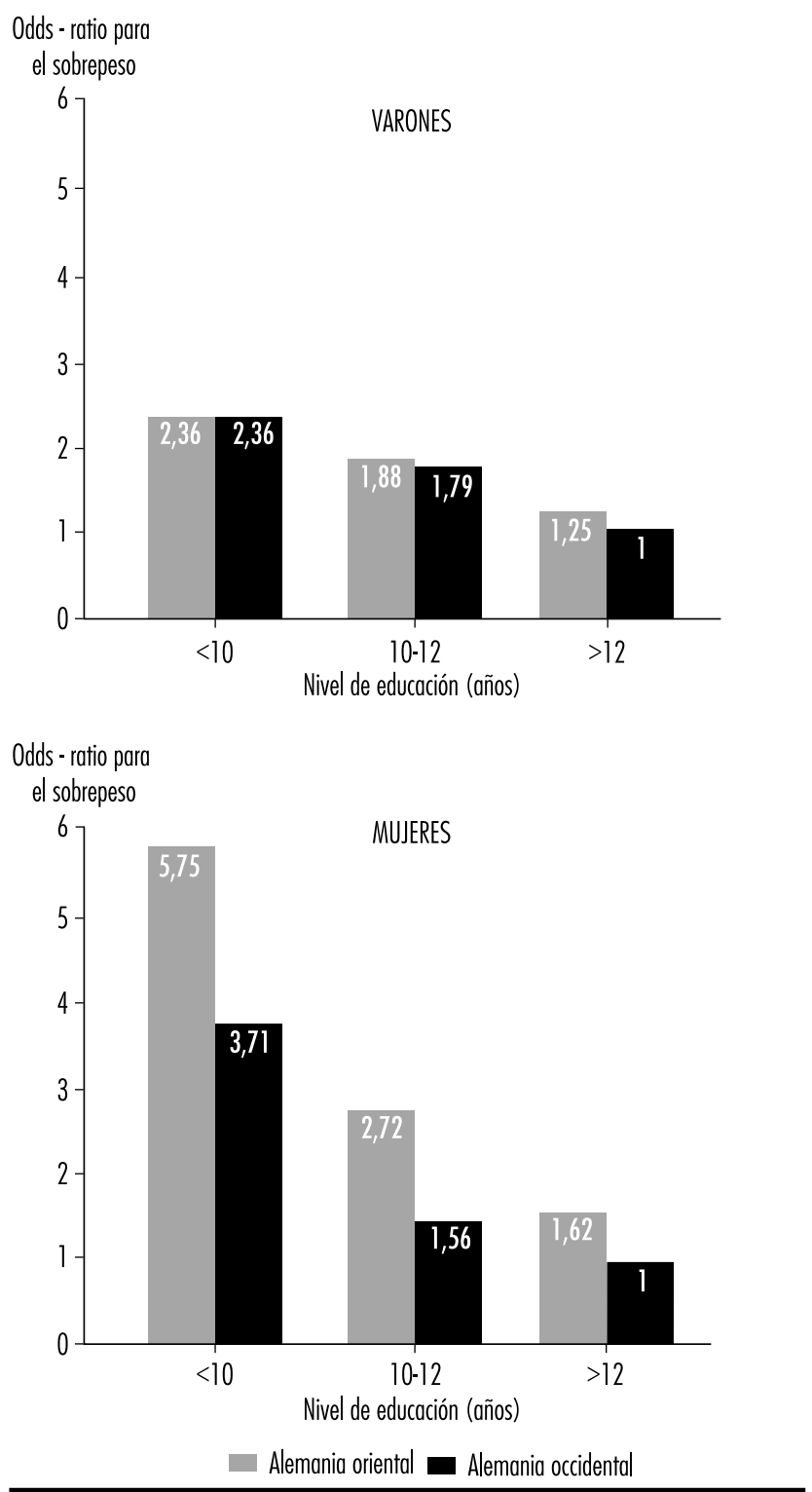

La cantidad de ejercicio se mide fácilmente registrando su duración y la cantidad de trabajo físico realizado o la amplitud del aumento de la frecuencia cardíaca inducido por el ejercicio, así como el tiempo necesario para que esta frecuencia cardíaca vuelva a los niveles normales. Este último parámetro es también útil como indicador del estado cardiovascular: si se practica ejercicio físico de forma regular, la frecuencia cardíaca aumentará menos y volverá de forma más rápida al nivel de reposo con una intensidad determinada de ejercicio.

Los programas de ejercicio físico en el lugar de trabajo son eficaces para mejorar la capacidad física del sistema cardiovascular. Los participantes en estos programas tienden también a dejar de fumar y a prestar mayor atención a seguir una dieta apropiada, con lo que disminuye de forma significativa el riesgo de CC y de ictus.

\section{Alcohol}

El consumo excesivo de alcohol, sobre todo de bebidas de alta graduación, se ha asociado a un riesgo elevado de hipertensión, ictus y miocardiopatía, mientras que el consumo moderado de alcohol, sobre todo de vino, reduce el riesgo de $\mathrm{CC}$ (OM S 1994a). Este hecho se ha asociado a la menor mortalidad por CC en las capas sociales altas de los países industrializados, que generalmente prefieren el vino a los licores "fuertes". C onviene señalar también que, aunque la ingesta de alcohol sea similar a la de los bebedores de vino, los bebedores de cerveza tienden al sobrepeso, lo que, como ya se ha comentado, puede aumentar el riesgo cardiovascular.

\section{Factores socioeconómicos}

Se ha hallado una estrecha relación entre la situación socioeconómica y el riesgo de ECV en estudios de mortalidad con registros de fallecimientos realizados en Gran Bretaña, Escandinavia, Europa occidental, Estados U nidos y Japón. Por ejemplo, en Alemania oriental, la tasa de muerte de origen cardiovascular es muy inferior en las clases sociales altas que en las bajas (véase la Figura 3.1) ( $M$ armot y Theorell 1991). En Inglaterra y Gales, donde las tasas de mortalidad general están disminuyendo, la diferencia relativa entre las clases sociales altas y bajas está aumentando.

La situación socioeconómica se define típicamente por indicadores como la profesión, la cualificación y la posición profesional, el nivel de educación y, en algunos casos, por el nivel de ingresos. Estos indicadores reflejan bien el nivel de vida, los patrones de alimentación, las actividades en el tiempo libre, el tamaño de la familia y el acceso a los servicios médicos. Como se indicó antes, los factores de riesgo del comportamiento (como el consumo de tabaco y la dieta) y los factores de riesgo somáticos (como el sobrepeso, la hipertensión y la hiperlipidemia) varían de forma considerable según las clases sociales y los grupos profesionales (M ielck 1994; Helmert, Shea y Maschewsky Schneider 1995).

\section{Factores psicosociales profesionales y estrés}

\section{Estrés profesional}

Los factores psicosociales en el lugar de trabajo comprenden el efecto combinado del medio ambiente de trabajo, el objeto del trabajo, las exigencias del trabajo, las condiciones tecnológicas y de organización y también factores personales como capacidad, sensibilidad psicológica y, por último, también los indicadores de salud (K arasek y T heorell 1990; Siegrist 1995).

El efecto del estrés agudo sobre las personas que ya sufren una enfermedad cardiovascular es irrefutable. El estrés provoca episodios de angina de pecho, trastornos del ritmo e insuficiencia cardíaca y puede precipitar también un ictus y/o un ataque cardíaco. En este contexto, el estrés se entiende en general como estrés físico agudo. Sin embargo, cada vez hay más datos a favor de que el estrés psicosocial agudo puede tener también estos efectos. Estudios del decenio de 1950 mostraron que las personas que tienen dos trabajos o que trabajan demasiado durante períodos prolongados de tiempo, tienen un mayor riesgo relativo de ataque cardíaco, incluso a menor edad. En otros estudios se ha demostrado que en el mismo trabajo, la persona que trabaja más, con mayor presión temporal y con problemas frecuentes en el puesto de trabajo sufre un riesgo significativamente superior (M ielck 1994).

En los últimos 15 años, los resultados de los estudios sobre el estrés en el trabajo indican una relación causal entre el estrés laboral y la incidencia de enfermedad cardiovascular. Esto es cierto tanto para la mortalidad cardiovascular como para la 
frecuencia de enfermedad coronaria y de hipertensión (Schnall, Lysbergis y Baker 1994). En el modelo de tensión laboral de $K$ arasek se definen dos factores que pueden aumentar la incidencia de enfermedad cardiovascular:

- grado de exigencia del puesto de trabajo;

- amplitud del margen de toma de decisiones.

Posteriormente, Johnson añadió como tercer factor el grado de respaldo social (K ristensen 1995), comentado con más detalle en otra parte de esta Enciclopedia. En el capítulo Factores psicosociales y de organización se incluyen comentarios sobre los factores individuales, como la personalidad del tipo A, así como el respaldo social y otros mecanismos para superar los efectos del estrés.

L os efectos de los factores, individuales o circunstanciales, que aumentan el riesgo de enfermedad cardiovascular pueden reducirse mediante "mecanismos de afrontamiento", es decir, reconociendo el problema y superándolo para sacar el mejor partido posible de la situación.

$\mathrm{H}$ asta ahora, las medidas centradas en el individuo han sido las más habituales para prevenir los efectos negativos del estrés laboral sobre la salud. En la actualidad se utilizan cada vez más las mejoras en la organización del trabajo y la ampliación del margen de toma de decisiones de los trabajadores (p. ej., investigación y negociación colectiva; en Alemania, calidad profesional y círculos sanitarios) para aumentar la productividad y humanizar el trabajo mediante la reducción de la carga de estrés (L andsbergis y cols. 1993).

\section{Trabajo nocturno y por turnos}

N umerosas publicaciones internacionales se ocupan de los riesgos para la salud que suponen el trabajo nocturno y por turnos. Se suele admitir que el trabajo por turnos es un factor de riesgo que, junto con otras exigencias relevantes (incluidas las indirectas) relacionadas con el trabajo y otros factores relacionados con las expectativas profesionales, provoca efectos negativos.

En la última década, la investigación sobre el trabajo por turnos se ha centrado sobre todo en los efectos a largo plazo del trabajo nocturno y por turnos en la frecuencia de enfermedad cardiovascular, sobre todo de cardiopatía isquémica y de infarto de miocardio, así como en los factores de riesgo cardiovascular. L os resultados de estudios epidemiológicos, sobre todo los realizados en Escandinavia, indican que el riesgo de cardiopatía isquémica y de infarto de miocardio es mayor en los trabajadores por turnos (Alfredsson, K arasek y Theorell 1982; Alfredsson, Spetz y Theorell 1985; Knutsson y cols. 1986; Tüchsen 1993). En Dinamarca se ha llegado a estimar que el $7 \%$ de las enfermedades cardiovasculares, tanto en varones como en mujeres, pueden guardar relación con el trabajo por turnos (O Isen y K ristensen 1991).

La hipótesis de que los trabajadores nocturnos y por turnos tienen un riesgo mayor (el riesgo relativo estimado es 1,4 ) de enfermedad cardiovascular es respaldada por otros estudios que consideran factores de riesgo cardiovascular, como la hipertensión o los niveles de ácidos grasos, en los trabajadores por turnos en comparación con los trabajadores en turno fijo de día. En varios estudios se ha demostrado que el trabajo nocturno y por turnos puede provocar hipertensión y aumentar los niveles de triglicéridos y/o de colesterol séricos (así como fluctuaciones dentro de los límites normales de colesterol de las HDL en un nivel de colesterol total aumentado). Estos cambios, junto con otros factores de riesgo (como el consumo de cigarrillos intenso y el sobrepeso en los trabajadores por turnos) pueden aumentar la mortalidad y la morbilidad por enfermedad aterosclerótica (De Backer y cols. 1984; DeBacker y cols. 1987; H ärenstam y cols. 1987; K nutsson 1989; Lavie y cols. 1989; Lennernäs, Åkerstedt y Hambraeus 1994; O rth-Gomer 1983; Romon y cols. 1992).

Globalmente, en el momento actual no pueden establecerse con certeza posibles relaciones causales entre el trabajo por turnos y la aterosclerosis, porque el mecanismo patogénico no está lo suficientemente claro. Entre los mecanismos posibles descritos en las publicaciones figuran los cambios en los hábitos dietéticos y el consumo de cigarrillos, la mala calidad del sueño, el aumento de los niveles de lípidos, el estrés crónico por las exigencias psicológicas y sociales y la alteración de los ritmos circadianos. K nutsson (1989) ha propuesto un mecanismo patogénico interesante para los efectos a largo plazo del trabajo por turnos sobre la morbilidad crónica.

L os efectos de la asociación de diversas variables sobre la estimación del riesgo apenas se han estudiado, ya que en el campo laboral existen otras condiciones de trabajo inductoras de estrés (ruido, materiales químicos peligrosos, estrés psicosocial, monotonía, etc.) relacionadas con el trabajo por turnos. De la observación del hecho de que los hábitos dietéticos perjudiciales para la salud y los hábitos de consumo de tabaco se relacionan con frecuencia con el trabajo por turnos, se suele concluir que el aumento del riesgo de enfermedad cardiovascular en los trabajadores por turnos se explica más por el resultado indirecto de este comportamiento de efectos negativos para la salud que por la influencia directa del trabajo nocturno o por turnos (Rutenfranz, Knauth y Angersbach 1981). Además, hay que comprobar la hipótesis evidente de si el trabajo por turnos favorece este tipo de conductas o si la diferencia se explica por la elección del lugar de trabajo y la profesión. Con independencia de las preguntas sin respuesta, hay que prestar una atención especial a los programas de prevención cardiovascular en los trabajadores nocturnos y por turnos como grupo de riesgo.

\section{Resumen}

En resumen, los factores de riesgo constituyen una amplia variedad de características psicosociales, de comportamiento, fisiológicas, somáticas y genéticas que pueden evaluarse de forma individual en sujetos y en grupos de sujetos. En conjunto, reflejan la probabilidad de que se desarrolle una ECV o, más precisamente en el contexto de este artículo, una CC o un ictus. Además de servir para comprender las causas y la patogenia de enfermedades multifactoriales, su principal importancia radica en que identifican a los individuos que deben incluirse en programas de eliminación o control de factores de riesgo, una acción para la que el lugar de trabajo es un sitio idóneo, según muestran las valoraciones repetidas del riesgo en el tiempo, en las que suele confirmarse el éxito de las medidas preventivas.

\section{PROGRAMAS DE REHABILITACION Y PREVENCION}

\section{Lothar H einemann y G ottfried Enderlein}

La mayoría de los individuos con ECV diagnosticadas pueden trabajar de forma eficaz y productiva en la mayoría de los puestos de trabajo en los lugares de trabajo modernos. H ace sólo unas décadas, los individuos que sobrevivían a un infarto de miocardio agudo eran controlados durante semanas y meses bajo una supervisión estrecha y permanecían en inactividad forzosa. La confirmación de laboratorio del diagnóstico era suficiente para etiquetar la individuo como "discapacitado de forma total y permanente". Los nuevas tecnologías diagnósticas permiten 
evaluar con mayor exactitud la evolución del estado cardíaco y las experiencias favorables de los que no pudieron o no quisieron aceptar esta etiqueta pronto demostraron que no sólo era posible, sino deseable la vuelta precoz al trabajo y a un nivel óptimo de actividad (Edwards, M CCallum y Taylor 1988; Theorell y cols. 1991; T heorell 1993). En la actualidad, los pacientes comienzan la actividad física supervisada tan pronto como los efectos agudos del infarto desaparecen y suelen salir del hospital en pocos días en vez de permanecer las 6-8 semanas obligatorias, con lo que en escasas semanas pueden reiniciar su actividad laboral. Cuando es posible y deseable, los procedimientos quirúrgicos como la angioplastia, las implantaciones de by-pass e incluso el trasplante cardíaco pueden mejorar el flujo sanguíneo coronario, mientras que un régimen a base de una dieta adecuada, ejercicio y el control de los factores de riesgo de CC puede reducir al mínimo (o incluso invertir) la progresión de la aterosclerosis coronaria.

Una vez que las fases agudas, con frecuencia potencialmente mortales, de la ECV se han superado, debe iniciarse la movilización pasiva seguida de ejercicios activos precoces durante la estancia en el hospital o centro hospitalario. En los ataques cardíacos, esta fase finaliza cuando el individuo puede subir escaleras sin dificultad. Al mismo tiempo, hay que enseñar al paciente un régimen de prevención del riesgo que incluya una dieta adecuada, ejercicios de acondicionamiento cardiovascular, suficiente descanso y relajación y control del estrés. Durante estas fases de la rehabilitación, el apoyo de los familiares, amigos y compañeros de trabajo puede resultar especialmente útil (Brusis y Weber-Falkensammer 1986). El programa puede llevarse a cabo en centros de rehabilitación o en "grupos cardíacos" ambulatorios bajo la supervisión de un médico experto (H alhubar y Traencker 1986). Se ha demostrado que si las acciones se centran en el control del estilo de vida, de los factores de riesgo de comportamiento y del estrés, puede reducirse de forma mensurable el riesgo de reinfarto y de otros problemas cardiovasculares.

Durante todo el programa el médico asistente debe mantener el contacto con la empresa (sobre todo con el médico de la empresa, si lo hay) para comentar las perspectivas de recuperación y la probable duración del período de discapacidad, y para valorar la viabilidad de cualquier disposición especial que sea necesaria para permitir la vuelta rápida al trabajo. Si el trabajador sabe que se espera su vuelta al trabajo, ello constituye un poderoso factor de motivación que acelera el proceso de recuperación. La experiencia ha demostrado ampliamente que el éxito del esfuerzo de rehabilitación disminuye según se prolonga el período de ausencia laboral.

En los casos en que no es posible o viable realizar los ajustes deseables en el puesto de trabajo y/o el lugar de trabajo, la formación de reconversión y la colocación en un puesto de trabajo adecuado pueden evitar una incapacidad innecesaria. Las áreas de trabajo con protección especial suelen ser útiles para reintegrar al lugar de trabajo a personas que han faltado de su puesto durante períodos prolongados mientras reciben tratamiento para los graves efectos del ictus, la insuficiencia cardíaca congestiva o la angina de pecho discapacitantes.

Tras el retorno al trabajo, el médico que atiende al paciente y el médico del trabajo deben vigilar de cerca al paciente. Los controles médicos periódicos, a intervalos frecuentes al principio y más espaciados después, cuando es segura la recuperación, sirven para evaluar el estado cardiovascular del trabajador, ajustar las medicaciones y otros elementos de la pauta de mantenimiento y controlar el estilo de vida y las recomendaciones relacionadas con el comportamiento. L os hallazgos satisfactorios en estos exámenes permiten eliminar de forma gradual cualquier limitación o restricción en el trabajo hasta que el trabajador se incorpore plenamente a su centro laboral.

\section{Programas de prevención y promoción de la salud en el lugar de trabajo}

La prevención de las enfermedades y las lesiones profesionales es uno de los objetivos principales de los programas de seguridad y salud en el trabajo de la organización. Esto incluye la prevención primaria (es decir, la identificación y eliminación o el control de los peligros y las tensiones potenciales mediante cambios del medio ambiente de trabajo o del puesto de trabajo). Se complementa con las medidas de prevención secundaria que protegen a los trabajadores de los efectos de la tensión y de los peligros existentes que no pueden eliminarse (es decir, los equipos de protección personal y los reconocimientos médicos periódicos). LoS programas de prevención y promoción de la salud en el lugar de trabajo (PPS) van más allá de estos objetivos. Prestan especial atención al comportamiento consciente en relación con la salud y se centran en el estilo de vida, los factores de riesgo asociados al comportamiento y la eliminación o superación del estrés, etc. Tienen gran valor, sobre todo en la prevención de la ECV. Los objetivos de los PPS, formulados por la Comisión de Control A mbiental y de la Salud en el Trabajo de la O M S se extienden más allá de la simple ausencia de enfermedad y lesiones e incluyen el bienestar y la capacidad funcional (O M S 1973).

EI diseño y la ejecución de los programas de PPS se comentan con más detalle en otra parte del capítulo. En la mayoría de los países, los programas se centran sobre todo en la prevención de las ECV. Por ejemplo, en Alemania, el programa "Cuida tu corazón" complementa las medidas de los círculos de enfermedad de salud cardíaca organizados por las empresas de seguros de enfermedad (M urza y Laaser 1990 1992), mientras que el movimiento "Ten corazón" en Gran Bretaña y Australia tiene objetivos similares (G lasgow y cols. 1955).

En el decenio de 1980 se comprobó la eficacia de estos programas en el Ensayo Cooperativo para la Prevención de Cardiopatías de la OMS, realizado en 40 pares de fábricas de cuatro países europeos y en el que participaron unos 61.000 varones de 40 a 59 años. Las medidas preventivas consistieron en gran parte en actividades de educación sanitaria, realizadas sobre todo por los servicios de salud de los empleados de la empresa, centradas en dietas para reducir el nivel de colesterol, el abandono del tabaco, el control del peso, el aumento de la actividad física y el control de la hipertensión. El estudio aleatorio de un $10 \%$ de los trabajadores que reunían las condiciones para participar en el proyecto en las fábricas designadas como centros de control demostró que durante los 4-7 años que duró el estudio, el riesgo global de ECV pudo reducirse un $11,1 \%$ (el $19,4 \%$ en los que sufrían un riesgo elevado al principio). En las fábricas del estudio, la mortalidad por ECV se redujo un 7,4 \%, mientras que la mortalidad global disminuyó un 2,7\%. Los mejores resultados se obtuvieron en Bélgica, donde la intervención se realizó de forma continua durante todo el período del estudio, mientras que los peores resultados se observaron en Gran Bretaña, donde las actividades de prevención disminuyeron de forma radical antes del último examen de seguimiento. Esta disparidad señala la relación del éxito del programa con la duración del esfuerzo de educación sanitaria; para inculcar los cambios deseados en el estilo de vida se necesita tiempo. La intensidad del esfuerzo docente fue un factor relevante también en Italia, donde trabajaron en el programa seis educadores a tiempo completo y se consiguió reducir un $28 \%$ el perfil global de factores de riesgo, mientras que en Gran Bretaña, donde sólo tres educadores se encargaron de un número de trabajadores tres veces superior, sólo se logró reducir el factor de riesgo un $4 \%$.

Aunque el tiempo necesario para detectar una reducción de la mortalidad y la morbilidad por ECV es un factor limitante muy importante en los estudios epidemiológicos que tienen como 
objetivo evaluar los resultados de los programas de salud en el trabajo (M annebach 1989), se han demostrado reducciones de los factores de riesgo Janssen 1991; Gomel y cols. 1993; Glasgow y cols. 1995). Se ha descrito una reducción temporal del número de días de trabajo perdidos y un descenso de las tasas de hospitalización (H arris 1994). Parece existir un acuerdo general en que las actividades de los PPS realizadas en la comunidad y, sobre todo, en el lugar de trabajo, han contribuido de forma significativa a reducir la mortalidad cardiovascular en Estados U nidos y en otros países industrializados.

\section{Conclusión}

Las ECV desempeñan un papel importante en el lugar de trabajo, no tanto porque el sistema cardiovascular sea especialmente vulnerable a los peligros ambientales y relacionados con el puesto de trabajo, sino porque estos trastornos son muy comunes en la población en edad de trabajar. El lugar de trabajo es un contexto idóneo para la detección de ECV asintomáticas no diagnosticadas, para eliminar los factores dependientes del lugar de trabajo que podrían acelerarlas o agravarlas, para identificar los factores que aumentan el riesgo de ECV y para ejecutar programas que los eliminen o controlen. $C$ uando se producen ECV, la atención rápida para controlar las circunstancias relacionadas con el puesto de trabajo que pueden prolongar o aumentar su gravedad reducirá al mínimo la extensión y la duración de la discapacidad, mientras que los esfuerzos de rehabilitación precoces supervisados por profesionales permitirán restaurar la capacidad de trabajo y reducir el riesgo de recidivas.

\section{PEUGROS FISICOS, QUIMICOS Y BIOLOGICOS}

El sistema cardiovascular intacto es notablemente resistente a los efectos perniciosos de los peligros físicos, químicos y biológicos que se encuentran en el puesto o lugar de trabajo. Salvo escasas excepciones, estos peligros rara vez causan de forma directa una ECV. Por otro lado, una vez que la integridad del sistema cardiovascular se halla comprometida, y esto puede suceder de forma totalmente silente y pasar desapercibido, la exposición a estos peligros puede contribuir al desarrollo continuo de un proceso patológico o acelerar la aparición de síntomas que reflejan la alteración funcional. Este hecho obliga a identificar de forma precoz a los trabajadores con ECV incipiente y a modificar sus trabajos o el ambiente de trabajo para reducir el riesgo de sufrir efectos perjudiciales. En los siguientes apartados se incluirán comentarios breves sobre algunos de los peligros profesionales que se encuentran con más frecuencia y que pueden afectar al sistema cardiovascular. Todos los peligros que se indican más adelante se comentan con más detalle en otras partes de la E nciclopedia.

\section{FACTORES FISICOS}

H eide Stark y G erd H euchert

\section{Ruido}

La pérdida de audición debido al ruido en el lugar de trabajo se reconoce como enfermedad profesional desde hace muchos años. L as enfermedades cardiovasculares son el centro del estudio sobre los posibles efectos crónicos extrauditivos del ruido. Se han realizado estudios epidemiológicos dentro del campo de ruido en los lugares de trabajo (con indicadores de niveles altos de ruido), así como en el campo de ruido circundante (con indicadores de niveles bajos de ruido). Los mejores estudios se han realizado sobre la relación entre la exposición al ruido y la hipertensión. En numerosos estudios recientes, los investigadores del ruido han evaluado los resultados disponibles de la investigación y resumido el estado actual de los conocimientos (K ristensen 1994; Schwarze y Thompson 1993; van Dijk 1990).

Los estudios muestran que el factor de riesgo del ruido para las enfermedades del sistema cardiovascular es menos significativo que los factores de riesgo relacionados con el comportamiento como el consumo de cigarrillos, la malnutrición o la inactividad física (Aro y Hasan 1987; Jegaden y cols. 1986; Kornhuber y Lisson 1981).

Los resultados de los estudios epidemiológicos no permiten explicar de forma clara los efectos adversos cardiovasculares de la exposición crónica al ruido en el lugar de trabajo o ambiental. EI conocimiento experimental de los efectos hormonales del estrés y de los cambios en la vasoconstricción periférica, por un lado, y la observación de que, por otro lado, un nivel alto de ruido en el lugar de trabajo ( $>85 \mathrm{dBA}$ ) induce el desarrollo de hipertensión, nos permite incluir el ruido como un estímulo de estrés inespecífico en un modelo de riesgo multifactorial de enfermedad cardiovascular, con un alto grado de fiabilidad biológica.

Según los estudios recientes sobre el estrés, aunque los aumentos de la tensión arterial durante el trabajo se relacionan con la exposición al ruido, el nivel de tensión arterial per se depende de una asociación compleja de factores ambientales y relacionados con la personalidad (Theorell y cols. 1987). La personalidad y los factores ambientales desempeñan un papel muy importante para determinar la carga total de estrés en el lugar de trabajo.

Por este motivo, parece una tarea urgente estudiar el efecto de las múltiples cargas en el lugar de trabajo y aclarar los efectos cruzados, la mayoría de ellos desconocidos hasta ahora, entre la combinación de los factores exógenos y las diversas características endógenas de riesgo.

\section{E studios experimentales}

En la actualidad se acepta en general que la exposición al ruido es un factor de estrés psicofísico. N umerosos estudios experimentales realizados con animales y seres humanos permiten extender la hipótesis sobre el mecanismo patogénico del ruido en el desarrollo de enfermedades cardiovasculares. Existe una imagen relativamente uniforme respecto a las reacciones periféricas agudas a los estímulos ruidosos. Los estímulos ruidosos provocan claramente vasoconstricción periférica, que puede medirse como un descenso de la amplitud del pulso digital y de la temperatura de la piel y un aumento de la tensión arterial diastólica y sistólica. Casi todos los estudios confirman el aumento de la frecuencia cardíaca (Carter 1988; Fisher y Tucker 1991; M ichalak, I sing y Rebentisch 1990; M illar y Steels 1990; Schwarze y Thompson 1993; Thompson 1993). La intensidad de estas reacciones se modifica por factores como el tipo de ruido, la edad, el sexo, el estado de salud, el estado nervioso y las características personales (H arrison y K elly 1989; Parrot y cols. 1992; Petiot y cols. 1988).

Se están realizando numerosos estudios acerca de los efectos del ruido sobre el metabolismo y los niveles de hormonas. $L a$ exposición al ruido alto casi siempre provoca cambios rápidos en Ios niveles hemáticos de cortisona, adenosinmonofosfato cíclico (AM PC ), colesterol, algunas fracciones de lipoproteínas, glucosa, 
fracciones de proteínas, hormonas (p. ej., ACT H, prolactina), adrenalina y noradrenalina. En la orina pueden encontrarse niveles elevados de catecolaminas. Todo esto muestra con claridad que estímulos ruidosos inferiores al nivel de sordera por ruido pueden provocar la hiperactividad del sistema de la corteza suprarrenal hipofisaria (I sing y K ruppa 1993; Rebentisch, L ange-A sschenfeld y I sing 1994).

Se ha demostrado que la exposición crónica al ruido alto reduce el contenido de magnesio en el suero, los eritrocitos y en otros tejidos, como el miocardio (Altura y cols. 1992), aunque los resultados del estudio son contradictorios (Altura 1993; Schwarze y T hompson 1993).

El efecto del ruido en el lugar de trabajo sobre la tensión arterial es equívoco. En diversos estudios epidemiológicos, la mayoría diseñados como estudios de corte, se ha observado que los trabajadores expuestos durante mucho tiempo al ruido alto presentan cifras más altas de tensión sistólica y diastólica que los trabajadores que realizan sus actividades en condiciones menos ruidosas. Sin embargo, otros estudios muestran que la asociación estadística entre la exposición prolongada al ruido y el aumento de la tensión arterial o hipertensión es mínima o nula (Schwarze y T hompson 1993; T hompson 1993; van Dijk 1990). En estudios en los que la pérdida auditiva se considera un marcador indirecto del ruido se han obtenido resultados variables. En cualquier caso, la pérdida auditiva no es un indicador biológico adecuado de la exposición al ruido (K ristensen 1989; van Dijk 1990). Cada vez hay más datos a favor de que el ruido y los factores de riesgo, aumento de la tensión arterial y del nivel de colesterol sérico (Pillsburg 1986) y consumo de cigarrillos (Baron y cols. 1987), ejercen un efecto sinérgico sobre el desarrollo de la pérdida auditiva inducida. La diferenciación entre la pérdida auditiva por el ruido y la pérdida auditiva por otros factores es difícil. En los estudios (Talbott y cols. 1990; van Dijk, Veerbeck y de Vries 1987), no se halló ninguna relación entre la exposición al ruido y la hipertensión, aunque la pérdida auditiva y la hipertensión se relacionan de forma positiva después de realizar una corrección teniendo en cuenta los factores de riesgo habituales, sobre todo la edad y el peso corporal. L os riesgos relativos de tensión arterial elevada oscilan entre 1 y 3,1 cuando se compara la exposición con el ruido más y menos alto. En los estudios realizados con métodos más exactos se encuentra una relación menor. Las diferencias entre las medias de tensión arterial de los grupos son relativamente escasas, con valores entre 0 y $10 \mathrm{~mm} \mathrm{H} \mathrm{g}$.

En la investigación sobre el efecto del ruido tiene una importancia fundamental un amplio estudio epidemiológico realizado con trabajadoras de la industria textil de China (Zhao, Liu y Zhang 1991). Z hao comprobó una relación dosis-efecto entre los niveles de ruido y la tensión arterial en mujeres trabajadoras de la industria que estuvieron expuestas durante muchos años a diferentes tipos de ruidos. Al aplicar un modelo logístico aditivo, los factores "refería el uso de sal de mesa", "antecedentes familiares de hipertensión" y "nivel de ruido" $(p<0,05)$ se relacionaron de forma significativa con la probabilidad de sufrir hipertensión. Los autores consideraron que el sobrepeso no interfería con la valoración. El factor del nivel de ruido, no obstante, supuso la mitad del riesgo de hipertensión de los dos primeros factores mencionados. U n aumento del nivel de ruido de 70 a 100 dBA aumentó el riesgo de hipertensión 2,5 veces. $L a$ cuantificación del riesgo de hipertensión empleando niveles de exposición más elevados fue posible en este estudio porque las trabajadoras no utilizaban protectores para el ruido. El estudio se centró en mujeres no fumadoras de $35 \pm 8$ años, así, de acuerdo con los resultados de V. Eiff (1993), el riesgo de hipertensión asociado al ruido en los varones pudo ser significativamente más elevado.
La protección frente al ruido se prescribe en los países industrializados cuando el nivel de ruido supera los 85-90 dBA. En numerosos estudios realizados en estos países no se ha demostrado un riesgo claro con ese nivel de ruido, por lo que puede concluirse, según Gierke y H arris (1990), que la limitación del nivel de ruido a los límites establecidos previene la mayoría de los efectos extraauditivos.

\section{Trabajo físico intenso}

L os efectos de la "falta de movimiento", como factor de riesgo de enfermedad cardiovascular, y de la actividad física en la mejora de la salud se han descrito en publicaciones clásicas como las de M orris, Paffenbarger y cols. en los decenios de 1950 y 1960 y en numerosos estudios epidemiológicos (Berlin y Colditz 1990; Powell y cols. 1987). En estudios previos no pudo demostrarse una relación directa causa-efecto entre la falta de movimiento y las tasas de enfermedad o mortalidad cardiovasculares. Sin embargo, los estudios epidemiológicos señalan los efectos positivos y protectores de la actividad física, ya que reduce la incidencia de diversas enfermedades crónicas, como la cardiopatía coronaria, la hipertensión, la diabetes mellitus no insulino dependiente, la osteoporosis y el cáncer de colon, así como de la ansiedad y la depresión. La conexión entre la inactividad física y el riesgo de cardiopatía coronaria se ha observado en numerosos países y grupos de población. El riesgo relativo de cardiopatía coronaria entre las personas inactivas en comparación con el de las personas activas oscila entre 1,5 y 3,0 y se obtiene una relación más estrecha cuanto mejor es la calidad de los métodos empleados en los estudios. Este aumento del riesgo puede compararse al determinado para la hipercolesterolemia, la hipertensión y el tabaquismo (Berlin y Colditz 1990; Centers for Disease Control and Prevention 1993; K ristensen 1994; Powell y cols. 1987).

La actividad física regular practicada en el tiempo libre parece reducir el riesgo de cardiopatía coronaria mediante varios mecanismos fisiológicos y metabólicos. En estudios experimentales se ha demostrado que el entrenamiento de movimiento regular influye de forma positiva sobre los factores de riesgo conocidos y otros factores relacionados con la salud. Así, por ejemplo, aumenta los niveles de colesterol de las HDL y reduce el nivel de triglicéridos séricos y la tensión arterial (Bouchard, Shepard y Stephens 1994; Pate y cols. 1995).

En una serie de estudios epidemiológicos, iniciada por los estudios de $\mathrm{M}$ orris y cols. sobre el riesgo coronario en conductores de autobús de Londres (M orris, Heady y Raffle 1956; Morris y cols. 1966), y el estudio de Paffenbarger y cols. (1970) en trabajadores portuarios norteamericanos, se investigó la relación entre el nivel de dificultad del trabajo físico y la incidencia de enfermedades cardiovasculares. Según los resultados de estudios previos de los decenios de 1950 y 1960, se tenía la idea de que la actividad física en el trabajo podía ejercer un cierto efecto protector sobre el corazón. El mayor riesgo relativo de enfermedades cardiovasculares se encontró en personas con trabajos en los que no desarrollaban ninguna actividad física (p. ej., personas que trabajan sentadas), en comparación con las personas que realizan trabajos físicos duros. Sin embargo, en estudios recientes no se han hallado diferencias en la frecuencia de enfermedad coronaria entre los grupos activos e inactivos, y en algunos estudios se ha encontrado incluso una prevalencia e incidencia más elevada de factores de riesgo cardiovascular en las personas que realizan trabajos físicos duros (I Imarinen 1989; K annel y cols. 1986; K ristensen 1994; Suurnäkki y cols. 1987). La contradicción entre el efecto favorable para la salud de la actividad física practicada en el tiempo libre y la falta de este 
efecto en los trabajos físicos duros puede explicarse por varios motivos:

- Los procesos de selección primaria y secundaria (efecto del trabajador sano) pueden distorsionar de forma notable los estudios epidemiológicos en medicina del trabajo.

- La relación entre el trabajo físico y la aparición de enfermedades cardiovasculares puede modificarse por la interferencia de diversas variables (como la situación social, la educación y los factores de riesgo relacionados con el comportamiento).

- La evaluación de la carga física sobre la única base de las descripciones del trabajo no es un método adecuado de evaluación

A causa del desarrollo social y tecnológico sostenido desde el decenio de 1970, sólo queda un escaso número de trabajos con "actividad física dinámica". La actividad física en el lugar de trabajo moderno a menudo se reduce al levantamiento o transporte de cargas pesadas, y una gran parte del trabajo se realiza mediante trabajo muscular estático. Por esto, no sorprende que la actividad física en profesiones de este tipo no tenga un efecto protector frente a las enfermedades coronarias: carece de la intensidad, duración y frecuencia suficientes para optimizar la carga física sobre los grandes grupos musculares. El trabajo físico suele ser intensivo, pero no tiene un efecto significativo sobre el sistema cardiovascular. La combinación de un trabajo físico duro y una actividad física intensa en el tiempo libre podría suponer la situación más favorable para el perfil de factores de riesgo cardiovascular y la aparición de CC (Saltin 1992).

Los resultados de los estudios realizados hasta la fecha no aclaran la cuestión de si el trabajo físico pesado se relaciona con la aparición de hipertensión arterial.

El trabajo físico intenso se asocia a cambios en la tensión arterial. En el trabajo dinámico en el que se emplean grandes masas musculares, el suministro de sangre se ajusta al esfuerzo de forma equilibrada. En el trabajo dinámico en el que se utilizan los músculos de pequeño y mediano tamaño, el corazón puede bombear más sangre de la necesaria para el trabajo físico total y puede aumentar de forma considerable la tensión sistólica y diastólica (Frauendorf y cols. 1986).

Incluso cuando se combina la tensión física y mental o la tensión física que provoca el ruido, se observa un notable aumento de la tensión arterial y de la frecuencia cardíaca en un porcentaje (aproximadamente el $30 \%$ ) de las personas (Frauendorf, K obryn y G elbrich 1992; Frauendorf y cols. 1995).

En la actualidad no hay estudios sobre los efectos crónicos de este aumento de la actividad circulatoria en el trabajo muscular local, con o sin ruido o tensión mental.

En dos estudios independientes publicados recientemente por investigadores norteamericanos y alemanes ( $\mathrm{M}$ ittleman y cols. 1993; Willich y cols. 1993) se investiga la cuestión de si el trabajo físico intenso puede originar un infarto agudo de miocardio. En estos estudios, de 1.228 y 1.194 personas con infarto agudo de miocardio, respectivamente, se comparó la tensión física una hora antes del infarto con la situación de los pacientes 25 horas antes. Se calcularon los siguientes riesgos relativos para el inicio de un infarto agudo de miocardio en la hora siguiente al esfuerzo físico intenso en comparación con la actividad ligera o con el reposo: 5,9 (IC $95 \%: 4,6-7,7)$ en el estudio norteamericano y 2,1 (IC $95 \%: 1,6-3,1)$ en el estudio alemán. EI riesgo era superior en las personas que no estaban en buena forma física. No obstante, una observación limitante importante fue que la actividad física intensa se produjo una hora antes del infarto sólo en el 4,4 y $7,1 \%$ de los pacientes con infarto, respectivamente.

Estos estudios implican cuestiones acerca de la significación de la tensión física o del aumento de catecolaminas inducido por el estrés en cuanto al riesgo sanguíneo coronario, al desencadenamiento de espasmos coronarios o a un efecto nocivo inmediato de las catecolaminas sobre los receptores beta-adrenérgicos de la membrana del músculo cardíaco como causa de las manifestaciones de infarto o de muerte cardíaca aguda. En un sistema coronario sano con un miocardio intacto no se producirían estas consecuencias (Fritze y M üller 1995).

Según estas observaciones, está claro que la posible relación causal entre el trabajo físico intenso y los efectos sobre la morbilidad cardiovascular no se establecen fácilmente. El problema con este tipo de estudio radica sin duda en la dificultad que entraña determinar con exactitud qué es un "trabajo intenso" y en excluir las preselecciones (efecto del trabajador sano). Se necesita realizar estudios de cohortes prospectivos sobre los efectos crónicos de formas seleccionadas de trabajo físico y también sobre los efectos del estrés combinado físico-mental o por ruido sobre áreas funcionales seleccionadas del sistema cardiovascular.

Es paradójico que la consecuencia de reducir el trabajo muscular dinámico intenso, hasta ahora considerado como una mejoría significativa en relación con el nivel de tensión en el lugar de trabajo moderno, sea posiblemente la aparición de un problema de salud significativo en la sociedad industrial moderna. Desde el punto de vista de la medicina del trabajo, según los resultados de los estudios realizados hasta ahora, cabe concluir que la actividad física estática sobre el sistema musculoesquelético sin movimiento supone un riesgo para la salud muy superior al que se le atribuía previamente.

Cuando no puedan evitarse tensiones monótonas inadecuadas, estas deben compensarse con actividades deportivas de duración comparable en el tiempo libre (p. ej., natación, bicicleta, marcha y tenis).

\section{Calor y frío}

Se cree que la exposición al calor o al frío extremos influye sobre la morbilidad cardiovascular (K ristensen 1989; K ristensen 1994). Los efectos agudos de las temperaturas externas muy elevadas 0 muy frías sobre el sistema circulatorio están bien documentados. Se ha observado un aumento de la mortalidad por enfermedades cardiovasculares, la mayoría ataques cardíacos e ictus, con las temperaturas invernales bajas (inferiores $a+10^{\circ} \mathrm{C}$ ) en países septentrionales (Curwen 1991; Douglas, Allan y Rawles 1991; K ristensen 1994; K unst, Looman y M ackenbach 1993). Pan, Li y Tsai (1995) describieron una impresionante relación en forma de $\mathrm{U}$ entre la temperatura externa y las tasas de mortalidad por cardiopatía coronaria e ictus en Taiwan, un país subtropical con un gradiente descendente similar entre $+10^{\circ} \mathrm{C}$ y $+29^{\circ} \mathrm{C}$ y un aumento marcado después con temperaturas superiores $\mathrm{a}+32^{\circ} \mathrm{C}$. La temperatura a la que se observó la menor mortalidad cardiovascular es superior en Taiwan que en otros países de climas más fríos. Según K unst, Looman y M ackenbach, en los Países Bajos existe una relación en forma de $\mathrm{V}$ entre la mortalidad total y la temperatura externa; la menor mortalidad se observó a $17^{\circ} \mathrm{C}$. La mayoría de las muertes relacionadas con el frío se produjeron en personas con enfermedades cardiovasculares y la mayoría de las muertes relacionadas con el calor se asociaron a enfermedades del aparato respiratorio. En estudios realizados en Estados Unidos (Rogot y Padgett 1976) y otros países (Wyndham y Fellingham 1978) se ha observado una relación similar en forma de $U$, donde la menor mortalidad por ictus y ataque cardíaco se produjo con temperaturas externas alrededor de 25 a $27^{\circ} \mathrm{C}$

No está claro cómo deben interpretarse estos resultados. Algunos autores han concluido que puede existir una relación causal entre el estrés térmico y la patogenesia de las enfermedades cardiovasculares (Curwen y Devis 1988; Curwen 1991; Douglas, Allan y Rawles 1991; K haw 1995; K unst, Looman y 
Mackenbach 1993; Rogot y Padgett 1976; Wyndham y Fellingham 1978). K haw respaldó esta hipótesis con las siguientes observaciones:

- La temperatura fue el factor predictivo agudo (día a día) más asociado a la mortalidad cardiovascular entre una serie de parámetros que se evaluaron de forma independiente, como las variaciones ambientales estacionales y factores como la contaminación atmosférica, la exposición a la luz solar, la incidencia de gripe y la nutrición. Esto se opone a la suposición de que la temperatura sólo actúa como una variable sustitutiva de otras condiciones ambientales adversas.

- Un hecho convincente es que esta relación se mantiene en varios países y grupos de población y persiste en el tiempo y en diferentes grupos de edad.

- Los datos obtenidos en los estudios clínicos y de laboratorio indican varios mecanismos biopatológicos posibles, como los efectos del cambio de temperatura sobre la homeostasis, la viscosidad de la sangre, los niveles de lípidos, el sistema nervioso simpático y la vasoconstricción (Clark y Edholm 1985; Gordon, Hyde y Trost 1988; K eatinge y cols. 1986; Lloyd 1991; Neild y cols. 1994; Stout y Grawford 1991; Woodhouse, Khaw y Plummer 1993b; Woodhouse y cols. 1994).

La exposición al frío aumenta la tensión arterial, la viscosidad sanguínea y la frecuencia cardíaca (K unst, L ooman y M ackenbach 1993; Tanaka, K onno y Hashimoto 1989; K awahara y cols. 1989). En los estudios realizados por Stout y Grawford (1991) y Woodhouse y colaboradores (1993; 1994) se muestra que los niveles de fibrinógeno, del factor de coagulación VIIc y de los lípidos eran más elevados en las personas mayores durante el invierno.

En las personas expuestas a temperaturas elevadas se observó que la viscosidad sanguínea y el nivel de colesterol estaban aumentados (Clark y E dholm 1985; G ordon, H yde y Trost 1988; Keatinge y cols. 1986). Según Woodhouse, K haw y Plummer (1993a), hay una correlación inversa muy estrecha entre la tensión arterial y la temperatura.

Todavía no se sabe con certeza si la exposición prolongada al frío 0 al calor aumenta de forma duradera el riesgo de padecer una enfermedad cardiovascular, ni si la exposición al calor o al frío aumenta el riesgo de sufrir una manifestación aguda de enfermedad cardiovascular (p. ej., un ataque cardíaco, un ictus) en relación con la exposición real (el "efecto gatillo"). K ristensen (1989) concluye que la hipótesis del aumento del riesgo agudo de complicaciones de una enfermedad cardiovascular en personas sin enfermedades orgánicas de base está confirmado, mientras que la hipótesis de un efecto crónico del calor o del frío no puede confirmarse ni rechazarse.

Existen pocos o ningún dato epidemiológico que respalde la hipótesis de que el riesgo de enfermedad cardiovascular es mayor en las poblaciones con una exposición profesional prolongada a temperaturas elevadas (Dukes-Dobos 1981). Se realizaron dos estudios recientes de corte horizontal en trabajadores del metal del Brasil (K loetzel y cols. 1973) y de una fábrica de vidrio de Canadá (Wojtczak-Jaroszowa y Jarosz 1986). En ambos se determinó una prevalencia significativamente alta de hipertensión entre los sujetos sometidos a temperaturas altas, que aumentó con la duración del trabajo en ambiente caluroso. Se excluyó la influencia previsible de la edad y la nutrición. Lebedeva, A limova y Efendiev (1991) estudiaron la mortalidad en los trabajadores de una compañía metalúrgica y hallaron un riesgo de mortalidad elevado entre las personas expuestas a un nivel de calor superior al indicado por los límites legales. Los resultados fueron estadísticamente significativos en relación con enfermedades hemáticas, hipertensión, cardiopatía isquémica y enfermedades del tracto respiratorio. Karnaukh y cols. (1990) describieron un aumento de la incidencia de cardiopatía isquémica, hipertensión y hemorroides en los trabajadores de fundiciones metalúrgicas. Se desconoce el diseño de este estudio. Wild y cols. (1995) evaluaron los índices de mortalidad entre 1977 y 1987 en un estudio de cohorte realizado con mineros de la potasa franceses. La mortalidad por cardiopatía isquémica fue superior en los mineros que trabajaban bajo tierra que en los que ejercían su actividad al aire libre (riesgo relativo $=1,6$ ). Entre las personas que abandonaron la empresa por motivos de salud, la mortalidad por cardiopatía isquémica fue cinco veces superior en el grupo expuesto en comparación con los trabajadores al aire libre. En un estudio de cohorte de mortalidad realizado en Estados Unidos se determinó una mortalidad cardiovascular un $10 \%$ inferior en los trabajadores expuestos al calor en comparación con el grupo de control no expuesto. En cualquier caso, entre los trabajadores expuestos al calor durante menos de seis meses, la mortalidad cardiovascular fue relativamente alta (Redmon, Gustin y K amon 1975, Redmond y cols. 1979). M oulin y cols. (1993) mencionaron resultados comparables en un estudio de cohorte de trabajadores franceses del acero. Estos resultados se atribuyeron a un posible efecto del trabajador sano entre los trabajadores expuestos al calor.

$\mathrm{N}$ o se conocen estudios epidemiológicos realizados con trabajadores expuestos al frío (p. ej. en frigoríficos, mataderos o pesquerías). Hay que señalar que el estrés por frío no sólo depende de la temperatura. Los efectos descritos en las publicaciones parecen depender de una combinación de factores como actividad muscular, ropa, humedad y, posiblemente, viviendas en malas condiciones. En los lugares de trabajo fríos debe prestarse especial atención a la ropa y evitarse las humedades ( $\mathrm{K}$ ristensen 1994).

\section{Vibraciones}

\section{Estrés por vibración de la mano y el brazo}

Se sabe desde hace mucho tiempo que las vibraciones transmitidas a la mano por herramientas vibradoras pueden causar trastornos vasculares periféricos además de lesiones del sistema musculoesquelético y trastornos de la función nerviosa periférica en la zona de la mano y el brazo (D upuis y cols. 1993, Pelmear, Taylor y Wasserman 1992). La "enfermedad de los dedos blancos", descrita primero por Raynaud, aparece con más frecuencia en las poblaciones expuestas y se reconoce como enfermedad profesional en numerosos países.

El fenómeno de R aynaud se caracteriza por un ataque en el que se reduce el flujo sanguíneo por un vasoespasmo que afecta a todos 0 algunos todos o algunos dedos, salvo los dedos pulgares, y que se acompaña de trastornos de la sensibilidad en los dedos afectados, con sensación de frío, palidez y parestesias. Después de finalizar la exposición, la circulación comienza otra vez y se acompaña de hiperemia dolorosa.

Se admite que tanto los factores endógenos (p. ej., un fenómeno de Raynaud primario), como la exposición exógena pueden provocar la aparición de un síndrome vasoespástico relacionado con la vibración (SVV). EI riesgo es claramente mayor con las vibraciones de máquinas de frecuencias más altas (de 20 a $800 \mathrm{~Hz}$ ) que con las máquinas de vibraciones más bajas. La cantidad de tensión estática (fuerza de agarre y de presión) parece ser un factor contribuyente. Todavía no se sabe con certeza el papel relativo del frío, el ruido, otros factores psicológicos productores de estrés y el tabaquismo intenso en el desarrollo del fenómeno de R aynaud.

Desde el punto de vista patogénico, el fenómeno de R aynaud se basa en un trastorno vasomotor. A pesar de que hay un gran número de estudios en los que se han empleado métodos de 
exploración funcional y diagnósticos no invasivos (termografía, pletismografía, capilaroscopia y test del frío) e invasivos (biopsia, arteriografía), la fisiopatología del fenómeno de Raynaud relacionado con la vibración todavía no se conoce con claridad. En la actualidad no se sabe con certeza si la vibración lesiona directamente la musculatura vascular (un "efecto local") o si se produce una vasoconstricción a consecuencia de la hiperactividad simpática, o bien si es necesario que estén presentes a la vez estos dos factores (G emne 1994; G emne 1992).

El síndrome del martillo hipotenar $(\mathrm{SM} \mathrm{H})$ relacionado con el trabajo debe distinguirse en el diagnóstico diferencial del fenómeno de R aynaud causado por la vibración. D esde el punto de vista patogenético, se trata de una lesión traumática crónica de la arteria cubital (lesión de la íntima con posterior trombosis) en la zona en que la arteria discurre a nivel superficial por encima del hueso unciforme (os hamatum). La causa del SM H es el efecto mecánico a largo plazo de la presión externa continuada, de los golpes o de la tensión súbita en forma de vibraciones mecánicas corporales parciales (a menudo combinadas con una presión persistente y con los efectos de los impactos). Por este motivo, el SM H puede presentarse como una complicación o relacionado con un SV V (K aji y cols. 1993; M arshall y Bilderling 1984).

A demás de los efectos vasculares periféricos precoces (y específicos en el caso de la exposición a la vibración del brazo y de la mano), también son de particular interés científico las denominadas alteraciones crónicas inespecíficas de la regulación autónoma de los sistemas orgánicos, por ejemplo, del sistema cardiovascular, quizá provocadas por la vibración (Gemme y Taylor 1983). L os escasos estudios experimentales y epidemiológicos sobre los posibles efectos crónicos de la vibración del brazo y la mano no aportan resultados claros que confirmen la hipótesis de la relación de la vibración con trastornos de la función endocrina y cardiovascular o con trastornos de los procesos metabólicos, las funciones cardíacas o la tensión arterial (Färkkilä, Pyykkö y Heinonen 1990; Virokannas 1990) no asociados a la estimulación del sistema adrenérgico por la exposición a la vibración (Bovenzi 1990; O Isen 1990). Esto puede aplicarse también a la vibración sola o en combinación con otros factores de tensión, como el ruido o el frío.

\section{Estrés por vibración de todo el organismo}

Si las vibraciones de todo el organismo tienen efectos sobre el sistema cardiovascular, varios parámetros como la frecuencia cardíaca, la tensión arterial, el gasto cardíaco, el electrocardiograma, el pletismograma y algunos parámetros metabólicos deben mostrar las reacciones correspondientes. Resulta difícil extraer ninguna conclusión por la razón metodológica de que estos sistemas de cuantificación relativos al sistema circulatorio no reaccionan de forma específica a las vibraciones y también pueden variar por efecto de otros factores simultáneos. La frecuencia cardíaca sólo aumenta si la carga de vibración es muy intensa; el efecto sobre la tensión arterial no es constante y las variaciones electrocardiográficas (ECG) no pueden diferenciarse de forma significativa.

Los trastornos circulatorios periféricos producidos por la vasoconstricción se han estudiado menos y son más débiles y de menor duración que los causados por las vibraciones de la mano y el brazo, que tienen un efecto marcado sobre la fuerza prensil de los dedos (D upuis y Zerlett 1986).

En la mayoría de los estudios, los efectos agudos de las vibraciones corporales totales sobre el sistema cardiovascular de los conductores de vehículos fue relativamente débil y temporal (D upius y Christ 1966; G riffin 1990).

Wikström, K jellberg y Lyström (1994), en una revisión muy completa, citan ocho estudios epidemiológicos realizados desde 1976 a 1984 en los que se investigó la conexión entre las vibraciones corporales totales y las enfermedades y trastornos cardiovasculares. Sólo en dos de estos estudios se halló una prevalencia mayor de estas enfermedades en el grupo expuesto a las vibraciones, pero en ninguno de los casos se atribuyó el aumento de la prevalencia al efecto de las vibraciones sobre todo el organismo.

En general, se admite que los cambios de las funciones fisiológicas producidos por la vibración de todo el organismo tienen un efecto muy limitado sobre el sistema cardiovascular. Todavía no se conocen bien las causas ni los mecanismos de reacción del sistema cardiovascular a las vibraciones de todo el organismo. En la actualidad, no disponemos de datos claros que permitan afirmar que las vibraciones de todo el organismo per se aumentan el riesgo de sufrir enfermedades del sistema cardiovascular. No obstante, hay que tener en cuenta que este factor suele combinarse con la exposición al ruido, la inactividad (trabajo sentado) y el trabajo por turnos.

\section{Radiación ionizante, campos electromagnéticos, ondas de radio y microondas, ultra e infrasonidos}

En numerosos estudios de caso y en algunos estudios epidemiológicos se ha llamado la atención sobre la posibilidad de que la radiación ionizante que se emplea para tratar el cáncer y otras enfermedades pueda inducir el desarrollo de arteriosclerosis y aumentar así el riesgo de cardiopatía coronaria y de otras enfermedades cardiovasculares (K ristensen 1989, K ristensen 1994). No se dispone de estudios sobre la incidencia de enfermedades cardiovasculares en los grupos profesionales expuestos a la radiación ionizante.

K ristensen (1989) aporta información sobre tres estudios epidemiológicos realizados desde comienzos del decenio de 1980 sobre la relación entre las enfermedades cardiovasculares y la exposición a los campos electromagnéticos. Los resultados son contradictorios. En los decenios de 1980 y 1990, los posibles efectos de los campos eléctricos y magnéticos sobre la salud humana han atraído considerable atención en los campos de la medicina del trabajo y la medicina ambiental. U nos estudios epidemiológicos parcialmente contradictorios, en los que se buscaron relaciones entre la exposición profesional y/o ambiental a campos magnéticos y eléctricos débiles de baja frecuencia, por un lado, y la aparición de trastornos de salud por otro, atrajeron un interés especial. En el primer plano de los numerosos estudios experimentales y los pocos estudios epidemiológicos se hallaban posibles efectos a largo plazo como la carcinogénesis y la teratogénesis, efectos sobre los sistemas inmunológico y endocrino, sobre la reproducción (con especial atención a los abortos y defectos congénitos), así como la "hipersensibilidad a la electricidad" y las reacciones neurofisiológicas relacionadas con el comportamiento. En el momento actual no se plantea el posible riesgo cardiovascular ( $\mathrm{G}$ amberale 1990; K nave 1994).

En relación con este tema, deben mencionarse algunos efectos inmediatos de los campos magnéticos de baja frecuencia sobre el organismo documentados de forma científica mediante estudios in vitro $\mathrm{e}$ in vivo con potencias de campo bajas y altas (PNUMA/ O M S/ IRPA 1984; PNUMA/ O M S/IRPA 1987). En el campo magnético, como ocurre en el torrente sanguíneo o durante una contracción cardíaca corta, los portadores cargados inducen campos y corrientes eléctricas. Por tanto, el voltaje eléctrico que se crea en un campo magnético estático intenso sobre la aorta en las proximidades del corazón durante la actividad coronaria puede alcanzar los $30 \mathrm{mV}$, con un grosor de flujo de 2 Tesla (T), y en el ECG se han detectado valores de inducción superiores a $0,1 \mathrm{~T}$. 
Sin embargo, no se hallaron efectos, por ejemplo, sobre la tensión arterial. Los campos magnéticos que oscilan con el tiempo (campos magnéticos intermitentes) inducen campos eléctricos en remolino en los objetos biológicos que pueden, por ejemplo, excitar las células nerviosas y musculares del organismo. Este efecto no aparece con los campos eléctricos o las corrientes inducidas inferiores a $1 \mathrm{~mA} / \mathrm{m}^{2}$. Se han descrito efectos visuales (inducidos con magnetofosfeno) y nerviosos con dosis de 10 a $100 \mathrm{~mA} / \mathrm{m}^{2}$. Si el nivel supera los $1 \mathrm{~A} / \mathrm{m}^{2}$ aparecen extrasístoles y fibrilación en las cámaras cardíacas. Según los datos disponibles en la actualidad, la exposición a corto plazo de todo el organismo no supone ningún riesgo directo para la salud hasta 2 T (PNUMA/OM S/IRPA 1987). Sin embargo, el límite peligroso de aparición de efectos indirectos (p. ej., por la acción de las fuerzas del campo magnético sobre materiales ferromagnéticos) es menor que el límite para los efectos directos. Por tanto, hay que adoptar medidas preventivas en las personas con implantes ferromagnéticos (marcapasos unipolares, clips aneurismáticos imantables, hemoclips, porciones de válvulas cardíacas artificiales, otros implantes eléctricos y, también, fragmentos de metales). El límite peligroso para los implantes ferromagnéticos empieza entre 50 y 100 mT. El riesgo radica en que el desplazamiento o los movimientos pivotales pueden causar lesiones o hemorragias y pueden alterarse las capacidades funcionales ( $p$. ej., de las válvulas cardíacas, de marcapasos, etc.). En las instalaciones industriales y de centros de investigación sometidas a campos magnéticos intensos, algunos autores aconsejan realizar exploraciones médicas de control a las personas con enfermedades cardiovasculares, incluida la hipertensión, en los puestos de trabajo en los que el campo magnético supera los 2 T (Bernhardt 1986; Bernhardt 1988). La exposición corporal total a $5 \mathrm{~T}$ supone un riesgo para la salud, sobre todo en las personas con enfermedades cardiovasculares, como la hipertensión (Bernhardt 1988; PNUM A/ O M S/ IRPA 1987).

En los estudios sobre los diversos efectos de las ondas de radio y las microondas no se han observado efectos perniciosos para la salud. La posibilidad de efectos cardiovasculares por los ultrasonidos (intervalo de frecuencias entre $16 \mathrm{kHz}$ y $1 \mathrm{GHz}$ ) o los infrasonidos (intervalo de frecuencias $>20 \mathrm{kHz}$ ) se comentan en las publicaciones, pero la evidencia empírica es muy débil (K ristensen 1994).

\section{- Materiales Quimicos Peligrosos}

\section{Ulrike Tittel bach y Wolfram Dietmar Schneider}

A pesar de los numerosos estudios, el papel de los factores químicos en las enfermedades cardiovasculares todavía se discute, aunque probablemente sea de escasa importancia. El papel etiológico de los materiales químicos en las enfermedades cardiovasculares profesionales de la población danesa se estimó en menos del $1 \%$ (K ristensen 1994). En general, se reconoce el efecto sobre el sistema cardiovascular de algunos materiales como el disulfuro de carbono y los compuestos orgánicos nitrogenados (K ristensen 1994). El plomo parece influir sobre la tensión arterial y la morbilidad cerebrovascular. EI monóxido de carbono (Weir y Fabiano 1982) tiene, sin duda, efectos agudos y provoca principalmente angina de pecho en personas con isquemia previa, pero no es probable que aumente el riesgo de arteriosclerosis subyacente, como se sospechaba desde hacía tiempo. El papel de otros materiales como el cadmio, el cobalto, el arsénico, el antimonio, el berilio, los fosfatos orgánicos y los disolventes no está claro y
Tabla 3.4 • Selección de actividades y de ramas industriales que pueden asociarse a riesgos cardiovasculares.

\section{Material peligroso Rama profesional afectada/ uso \\ Disulfuro de carbono $\left(\mathrm{CS}_{2}\right)$ Industrias de fabricación de rayón y fibras sintéticas, caucho, cerillas, explosivos y celulosa \\ Se utiliza como disolvente en la fabricación de productos farmacéuticos, cosméticos e insecticidas \\ Compuestos orgánicos- nitrogenados \\ Fabricación de explosivos y municiones, industria farmacéutica}

Monóxido de carbono (CO) Trabajadores de grandes instalaciones de combustión industrial (altos hornos, hornos de coque) Fabricación y utilización de mezclas de gas que contienen CO (instalaciones de producción de gas) Reparación de gaseoductos

Trabajadores de fundiciones, bomberos, mecánicos de automóviles (en espacios mal ventilados) Exposiciones a accidentes (gases de explosiones, fuegos en construcciones de túneles 0 en obras subterráneas)

Plomo

Fundición de mineral de plomo y de materiales secundarios en bruto que contienen plomo

Industria del metal (producción de diversas aleaciones), corte y soldadura de metales que contengan plomo 0 de materiales recubiertos con materiales que contengan plomo

Fábricas de baterías

Industria de cerámica y de porcelana ( producción de esmaltes que contienen plomo

Producción de vidrio con plomo

Industria de pinturas, aplicación y eliminación de pinturas con plomo

\section{Hidrocarburos, $\quad$ Disolventes (pinturas, lacas)}

hidrocarburos Pegamentos (zapatos, industrias del caucho)

halogenados

Agentes limpiadores y desengrasantes

Materiales básicos para la síntesis química

Refrigerantes

Medicina ( narcóticos)

Exposición al cloruro de metilo en actividades en las que se utilizan disolventes

todavía no se dispone de una documentación suficiente para poder evaluarlos. K ristensen $(1989,1994)$ realiza una revisión crítica sobre el tema. En la Tabla 3.4 se presenta una selección de las actividades y de las ramas industriales relevantes.

Los datos de los estudios importantes relativos a la exposición y los efectos del disulfuro de carbono $\left(\mathrm{CS}_{2}\right)$, el monóxido de carbono ( $\mathrm{CO}$ ) y la nitroglicerina se muestran en la sección química de la Enciclopedia. En esta lista puede apreciarse con claridad que los problemas relacionados con la inclusión, la exposición combinada, la variabilidad en la consideración de los factores determinantes, las diferencias en los tamaños de las muestras y las estrategias de valoración desempeñan un papel considerable en los hallazgos, por lo que las conclusiones de estos estudios epidemiológicos son inciertas.

En estas situaciones, el conocimiento y la comprensión clara de los mecanismos patogénicos puede respaldar las relaciones sospechadas y contribuir, por tanto, a valorar las consecuencias y adoptar las medidas preventivas pertinentes. Se conocen los efectos del disulfuro de carbono sobre el metabolismo de los lípidos y los hidratos de carbono, sobre el funcionamiento del 
tiroides (produce hipotiroidismo) y sobre el metabolismo de la coagulación (favorece la agregación plaquetaria e inhibe el plasminógeno y la actividad de plasmina). Los cambios en la tensión arterial, como la hipertensión, se atribuyen más bien a las variaciones de origen vascular en el riñón; todavía no se ha excluido una relación causal directa entre la hipertensión y el disulfuro de carbono y se sospecha un efecto tóxico directo (reversible) sobre el miocardio o una interferencia con el metabolismo de las catecolaminas. En un estudio de intervención de 15 años completado con éxito (Nurminen y Hernberg 1985) se documenta la reversibilidad del efecto cardíaco: tras reducir la exposición disminuyó de forma casi inmediata la mortalidad cardiovascular. En las personas expuestas al $\mathrm{CS}_{2}$, además de los efectos cardiotóxicos directos, se han demostrado alteraciones arterioscleróticas en los vasos cerebrales, oculares, renales y coronarios que pueden causar encefalopatías, aneurismas en la zona de la retina, nefropatía y cardiopatía isquémica crónica. Los componentes étnicos y dietéticos interfieren con los mecanismos patogénicos, como se demostró en los estudios comparativos de trabajadores finlandeses y japoneses del sector del rayón viscoso. En Japón, se hallaron alteraciones vasculares en la zona de la retina, mientras que en Finlandia predominaron los efectos cardiovasculares. Se observaron alteraciones aneurismáticas en la vascularización retiniana con concentraciones de disulfuro de carbono inferiores a 3 ppm (Fajen, Albright y Leffingwell 1981). Tras reducir la exposición a 10 ppm, disminuyó claramente la mortalidad cardiovascular. Esto no aclara si los efectos cardiotóxicos pueden excluirse de forma definitiva con dosis inferiores a $10 \mathrm{ppm}$.

L os efectos tóxicos agudos de los nitratos orgánicos son ensanchamiento de los vasos acompañado de descenso de la tensión arterial, aumento de la frecuencia cardíaca, eritema macular (enrojecimiento), mareos ortostáticos y cefalea. Como la vida media de los nitratos orgánicos es corta, los trastornos desaparecen pronto. En condiciones normales, no cabe esperar problemas sanitarios graves con la intoxicación aguda. El denominado síndrome de abstinencia aparece tras un período de latencia de 36 a 72 horas cuando se interrumpe la exposición a los nitratos orgánicos en los trabajadores expuestos durante períodos prolongados. Estas personas pueden sufrir desde episodios de angina de pecho hasta infarto de miocardio agudo y casos de muerte súbita. En las muertes investigadas se documentaron con frecuencia cambios escleróticos coronarios. Se sospecha, por tanto, un "vasoespasmo de rebote". Si desaparece el efecto de ensanchamiento vascular de los nitratos, se produce en los vasos, incluidas las arterias coronarias, un aumento autorregulador de la resistencia, con los resultados descritos anteriormente. En algunos estudios epidemiológicos, la sospecha de la asociación entre la duración e intensidad de la exposición a los nitratos orgánicos y la cardiopatía isquémica se considera incierta y no se ha establecido una teoría patogénica convincente.

En relación con el plomo, cabe destacar la importancia del plomo metálico en forma de polvo, las sales de plomo divalentes y los compuestos orgánicos de plomo. El plomo afecta al mecanismo contráctil de las células musculares de los vasos y provoca espasmos vasculares, que se consideran la causa de varios de los síntomas asociados a la intoxicación por plomo. Entre estos se encuentra la hipertensión pasajera que aparece en el cólico por plomo. La hipertensión duradera asociada al saturnismo crónico puede explicarse por los vasoespasmos y las alteraciones renales. En estudios epidemiológicos con tiempos de exposición más prolongados se ha observado una relación entre la exposición al plomo y el aumento de la tensión arterial, así como un aumento de la incidencia de enfermedades cerebrovasculares, mientras que hubo pocos datos indicativos de un aumento de la incidencia de enfermedades cardiovasculares.

Los datos epidemiológicos y las investigaciones sobre la patogenia realizadas hasta la fecha no ofrecen resultados claros sobre la toxicidad cardiovascular de otros metales como el cadmio, el cobalto y el arsénico. Sin embargo, se considera cierta la hipótesis de que el hidrocarburo halogenado actúa como un irritante miocárdico. El mecanismo por el que estos materiales pueden desencadenar arritmias que en ocasiones suponen una amenaza para la vida depende, probablemente, de la sensibilidad miocárdica a la adrenalina, que actúa como un portador natural del sistema nervioso autónomo. En la actualidad se discute todavía si existe un efecto cardíaco directo, como disminución de la contractilidad, supresión de los centros de formación de impulsos o de la transmisión de impulsos, o una alteración refleja a través de la irrigación de la zona de las vías respiratorias superiores. El potencial de sensibilización de los hidrocarburos depende al parecer del grado de halogenación y del tipo de halógeno que contienen; se supone que los hidrocarburos clorosustituidos tienen un efecto sensibilizante más potente que los compuestos fluorados. El efecto miocárdico máximo de los hidrocarburos que contienen cloruros aparece cuando hay cuatro átomos de cloro por molécula. Los hidrocarburos no sustituidos de cadena corta son más tóxicos que los de cadena larga.

Se tienen pocos datos sobre la dosis desencadenante de arritmia de las sustancias individuales, ya que las publicaciones referidas a seres humanos son sobre todo descripciones de casos de exposición a concentraciones elevadas (exposición accidental e "inhalación por fosas nasales"). Según R einhardt y cols. (1971), el benceno, el heptano, el cloroformo y el tricloroetileno son sustancias con especial poder de sensibilización, mientras que el tetracloruro de carbono y el halotano tienen un efecto arritmogénico inferior.

Los efectos tóxicos del monóxido de carbono se producen por la hipoxemia tisular resultante del aumento de la formación de $\mathrm{CO}-\mathrm{H}$ b (el $\mathrm{CO}$ tiene una afinidad por la hemoglobina 200 veces superior a la del oxígeno). Además del tejido nervioso, el corazón es uno de los órganos más sensibles a esta hipoxemia. Los trastornos cardíacos agudos provocados se han estudiado repetidas veces y se han descrito sus características según el tiempo de exposición, la frecuencia de respiración, la edad y las enfermedades previas. M ientras que en los sujetos sanos, los efectos cardiovasculares aparecen cuando la concentración de $\mathrm{CO}-\mathrm{H}$ b es del $35-40 \%$, los pacientes con cardiopatía isquémica pueden sufrir episodios de angina de pecho con una concentración de $\mathrm{CO}-\mathrm{Hb}$ del 2-5\%, durante la exposición física (K leinman y cols. 1989; $\mathrm{H}$ inderliter y cols. 1989). En pacientes con trastornos previos se han observado infartos mortales a concentraciones de $\mathrm{CO}-\mathrm{H}$ b del $20 \%$ (Atkins y Baker 1985).

Los efectos de la exposición a largo plazo a concentraciones bajas de $\mathrm{CO}$ todavía son controvertidos. Aunque en los estudios experimentales realizados con animales se ha observado un posible efecto aterogénico mediado por la hipoxia en las paredes de los vasos o por un efecto directo del CO sobre las paredes de los vasos (aumento de la permeabilidad vascular), las características del flujo sanguíneo (aumento de la agregación plaquetaria), o el metabolismo de los lípidos, no está demostrado que esto mismo ocurra en el ser humano. El aumento de la mortalidad por enfermedades cardiovasculares en los trabajadores de túneles (SM R 1,35; $95 \%$ Cl 1,09-1,68) puede explicarse mejor por la exposición aguda que por los efectos crónicos del CO (Stern y cols. 1988). Tampoco se ha aclarado la influencia del CO sobre los efectos cardiovasculares del consumo de cigarrillos. 


\section{- Peligros biologicos}

\section{Regina Jäckel, U Irike Tittelbach y Wolfram Dietmar Schneider}

“Un material biológicamente peligroso puede definirse como un material biológico capaz de autorreplicarse y que puede provocar efectos dañinos en otros organismos, sobre todo en humanos" (A merican Industrial H ygiene Association 1986).

Bacterias, virus, hongos y protozoos se encuentran entre los materiales biológicos peligrosos que pueden lesionar el sistema cardiovascular mediante un contacto intencional (introducción de materiales biológicos asociada a procedimientos técnicos) 0 no intencional (contaminación de materiales de trabajo no relacionada con procedimientos técnicos). Las endotoxinas y las micotoxinas pueden desempeñar un papel añadido al potencial infeccioso de los microorganismos. Pueden ser la causa o un factor contribuyente en el desarrollo de una enfermedad.

El sistema cardiovascular puede reaccionar con una participación orgánica localizada como complicación de una infección; de esta forma se producen vasculitis (inflamación de los vasos sanguíneos), endocarditis (inflamación del endocardio, sobre todo por bacterias, pero también por hongos y protozoos; la forma aguda se presenta como una sepsis; las formas subagudas, como la generalización de una infección), miocarditis (inflamación del músculo cardíaco, causada por bacterias, virus y protozoos), pericarditis (inflamación del pericardio, acompaña generalmente a la miocarditis), o pancarditis (aparición simultánea de endocarditis, miocarditis y pericarditis) o puede afectarse en el curso de una enfermedad sistémica generalizada (sepsis, shock tóxico o séptico).

El corazón puede participar durante o después de la infección. Entre los posibles mecanismos patogénicos hay que

Tabla 3.5 - Visión global de enfermedades infecciosas posiblemente relacionadas con el trabajo y que afectan al sistema cardiovascular.

\begin{tabular}{|c|c|c|c|}
\hline Enfermedad & Efecto en el corazón & Aparición/ frecuencia de efectos cardíacos en caso de enfermedad & Grupos de riesgo profesional \\
\hline SIDA/ VIH & $\begin{array}{l}\text { Miocarditis, } \\
\text { Endocarditis, } \\
\text { Pericarditis }\end{array}$ & $\begin{array}{l}42 \% \text { (Blanc y cols. 1990); infecciones oportunistas, pero también } \\
\text { miocarditis linfocítica producida por el propio VIH (Beschorner y } \\
\text { cols. 1990) }\end{array}$ & $\begin{array}{l}\text { Personal de los servicios sanitarios y de asis- } \\
\text { tencia social }\end{array}$ \\
\hline Aspergilosis & Endocarditis & Poco frecuente; aparece en personas inmunodeprimidas & Trabajadores del sector agrario \\
\hline Brucelosis & $\begin{array}{l}\text { Endocarditis, } \\
\text { Miocarditis }\end{array}$ & $\begin{array}{l}\text { Poco frecuente (Groß, Jahn y Schölmerich 1970; Schulz y } \\
\text { Stobbe 1981) }\end{array}$ & $\begin{array}{l}\text { Trabajadores de empresas de empaquetado de } \\
\text { carne y cría de animales, trabajadores del } \\
\text { sector agrario, veterinarios }\end{array}$ \\
\hline $\begin{array}{l}\text { Enfermedad de } \\
\text { Chagas }\end{array}$ & Miocarditis & $\begin{array}{l}\text { Datos variables: } 20 \text { \% en Argentina (Acha y Szyfres 1980); } 69 \% \\
\text { en Chile (Arribada y cols. 1990); } 67 \text { \% (Higuchi y cols. 1990); } \\
\text { enfermedad crónica de Chagas siempre con miocarditis (Gross, } \\
\text { Jahn y Schölmerich 1970) }\end{array}$ & $\begin{array}{l}\text { Personas que viajan por motivos de negocios por } \\
\text { América central y del sur }\end{array}$ \\
\hline Virus Coxsackie & $\begin{array}{l}\text { Miocarditis, } \\
\text { Pericarditis }\end{array}$ & 5 al $15 \%$ con el virus Coxsackie-B (Reindell y Roskamm 1977) & $\begin{array}{l}\text { Personal de los servicios sanitarios y de asis- } \\
\text { tencia social, personas que trabajan con aguas } \\
\text { residuales }\end{array}$ \\
\hline Citomegalovirus & $\begin{array}{l}\text { Miocarditis, } \\
\text { Pericarditis }\end{array}$ & $\begin{array}{l}\text { Sumamente poco frecuente; aparece sobre todo en personas } \\
\text { inmunodeprimidas }\end{array}$ & $\begin{array}{l}\text { Personal que trabaja con niños ( sobre todo niños } \\
\text { pequeños), en diálisis y departamentos de } \\
\text { trasplantes }\end{array}$ \\
\hline Difteria & $\begin{array}{l}\text { Miocarditis, } \\
\text { Endocarditis }\end{array}$ & $\begin{array}{l}10 \text { al } 20 \% \text { con difteria localizada, más común en la forma progresiva } \\
\text { D. (Gross, Jahn y Schölmerich 1970), especialmente en la que se } \\
\text { desarrolla de forma tóxica }\end{array}$ & $\begin{array}{l}\text { Personal que trabaja con niños y en servicios } \\
\text { sanitarios }\end{array}$ \\
\hline Equinococosis & Miocarditis & Poco frecuente (Riecker 1988) & Trabajadores de la silvicultura \\
\hline $\begin{array}{l}\text { Infecciones por } \\
\text { el virus de } \\
\text { Epstein-Barr virus }\end{array}$ & $\begin{array}{l}\text { Miocarditis, } \\
\text { Pericarditis }\end{array}$ & Poco frecuente; sobre todo en las personas inmunodeprimidas & $\begin{array}{l}\text { Personal sanitario y de los servicios de asistencia } \\
\text { social }\end{array}$ \\
\hline Erisipeloide & Endocarditis & $\begin{array}{l}\text { Los datos varían desde una incidencia escasa (Gross, Jahn y } \\
\text { Schölmerich 1970; Riecker 1988) hasta un } 30 \% \\
\text { (Azofra y cols. 1991) }\end{array}$ & $\begin{array}{l}\text { Trabajadores de empresas de envasado de carne, } \\
\text { procesamiento de pescado, pescadores, } \\
\text { veterinarios }\end{array}$ \\
\hline
\end{tabular}

Continúa en la página siguiente. 
Tabla 3.5 - Visión global de enfermedades infecciosas posiblemente relacionadas con el trabajo y que afectan al sistema continuación cardiovascular.

\begin{tabular}{|c|c|c|c|}
\hline Enfermedad & Efecto en el corazón & Aparición/ frecuencia de efectos cardíacos en caso de enfermedad & Grupos de riesgo profesional \\
\hline Filariasis & Miocarditis & Poco frecuente (Riecker 1988) & $\begin{array}{l}\text { Personas que viajan por motivos de negocios a } \\
\text { zonas endémicas }\end{array}$ \\
\hline $\begin{array}{l}\text { Tifus entre otras } \\
\text { ricketsiosis } \\
\text { (excluida la } \\
\text { fiebre Q) }\end{array}$ & $\begin{array}{l}\text { Miocarditis, } \\
\text { Vasculitis de los vasos } \\
\text { pequeños }\end{array}$ & $\begin{array}{l}\text { Los datos son variables, por la acción directa del patógeno, un efecto } \\
\text { tóxico o la reducción de la resistencia durante la resolución de } \\
\text { la fiebre }\end{array}$ & $\begin{array}{l}\text { Personas que viajan por motivos de negocios a } \\
\text { zonas endémicas }\end{array}$ \\
\hline $\begin{array}{l}\text { Meningoencefalitis de } \\
\text { principios del } \\
\text { verano }\end{array}$ & Miocarditis & Poco frecuente (Sundermann 1987) & Trabajadores de la silvicultura, jardineros \\
\hline Fiebre amarilla & $\begin{array}{l}\text { Lesión tóxica de los vasos } \\
\text { (Gross, Jahn y Schölme- } \\
\text { rich, 1970), Miocarditis }\end{array}$ & Poco frecuente; con casos graves & $\begin{array}{l}\text { Personas que viajan por motivos de negocios a } \\
\text { zonas endémicas }\end{array}$ \\
\hline $\begin{array}{l}\text { Fiebre hemorrágica } \\
\text { (Ebola, Marburg, } \\
\text { Lassa, Dengue, } \\
\text { etc.) }\end{array}$ & $\begin{array}{l}\text { Miocarditis y hemorragias } \\
\text { endocárdicas en el } \\
\text { contexto de un síndrome } \\
\text { hemorrágico generali- } \\
\text { zado, insuficiencia } \\
\text { cardiovascular }\end{array}$ & No se dispone de información & $\begin{array}{l}\text { Trabajadores de servicios sanitarios en zonas } \\
\text { afectadas y laboratorios especiales, y } \\
\text { trabajadores de la cría de animales }\end{array}$ \\
\hline Gripe & $\begin{array}{l}\text { Miocarditis, } \\
\text { Hemorragias }\end{array}$ & Los datos varían entre raros y frecuentes (Schulz y Stobbe 1981) & Trabajadores de los servicios de salud \\
\hline Hepatitis & $\begin{array}{l}\text { Miocarditis (Gross, } \\
\text { Willens } \\
\text { y Zeldis 1981; Schulz } \\
\text { y Stobbe 1981) }\end{array}$ & Poco frecuente (Schulz y Stobbe 1981) & $\begin{array}{l}\text { Trabajadores de los servicios de salud y de } \\
\text { asistencia social }\end{array}$ \\
\hline Legionelosis & $\begin{array}{l}\text { Pericarditis, } \\
\text { Miocarditis, } \\
\text { Endocarditis }\end{array}$ & $\begin{array}{l}\text { Si se produce, suele ser poco frecuente raros (Gross, Willens y } \\
\text { Zeldis 1981) }\end{array}$ & $\begin{array}{l}\text { Personal de mantenimiento de equipos de aire } \\
\text { acondicionado, humidificadores jacuzzis }\end{array}$ \\
\hline Leishmaniasis & $\begin{array}{l}\text { Miocarditis (Reindell y } \\
\text { Roskamm 1977) }\end{array}$ & Con leishmaniasis visceral & Viajeros de negocios a zonas endémicas \\
\hline $\begin{array}{l}\text { Leptospirosis } \\
\text { (forma ictérica) }\end{array}$ & Miocarditis & Efecto tóxico o infección directa del patógeno (Schulz y Stobbe 1981) & $\begin{array}{l}\text { Trabajadores de empresas de tratamiento de } \\
\text { residuos y de aguas residuales, trabajadores de } \\
\text { mataderos }\end{array}$ \\
\hline Listeriosis & Endocarditis & $\begin{array}{l}\text { Muy poco frecuente (la listeriosis cutánea es la forma predominante de } \\
\text { enfermedad profesional) }\end{array}$ & $\begin{array}{l}\text { Trabajadores del sector agrario, veterinarios, traba- } \\
\text { jadores de empresas de envasado de carne }\end{array}$ \\
\hline Enfermedad de Lyme & $\begin{array}{l}\text { En estadio 2: } \\
\text { Miocarditis } \\
\text { Pancarditis } \\
\text { En estadio 3: } \\
\text { Carditis crónica }\end{array}$ & 8 \% (Mrowietz 1991) o 13 \% (Shadick y cols. 1994) & Trabajadores de la silvicultura \\
\hline Malaria & Miocarditis & $\begin{array}{l}\text { Relativamente frecuente con el paludismo tropical } \\
\text { (Sundermann 1987); infeccion directa de los capilares }\end{array}$ & Viajeros de negocios en zonas endémicas \\
\hline Sarampión & $\begin{array}{l}\text { Miocarditis, } \\
\text { Pericarditis }\end{array}$ & Poco frecuente & $\begin{array}{l}\text { Personal de servicios sanitarios y que trabaja } \\
\text { con niños }\end{array}$ \\
\hline Enfermedad pie-boca & Miocarditis & Muy poco frecuente & $\begin{array}{l}\text { Trabajadores del sector agrario, granjas de } \\
\text { animales, (sobre todo con animales de pezuñas } \\
\text { hendidas) }\end{array}$ \\
\hline
\end{tabular}

Continúa en la página siguiente. 


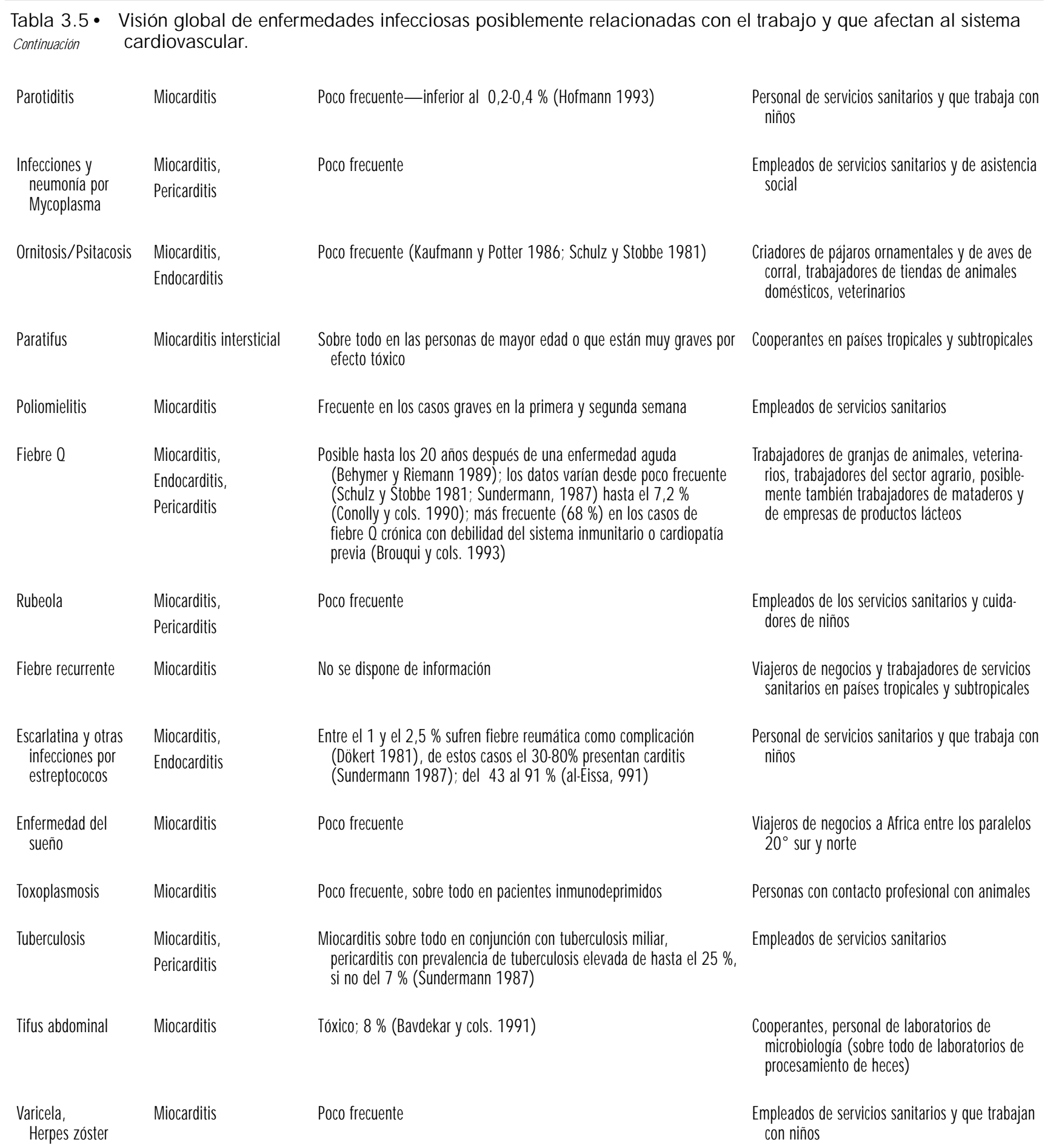

considerar la colonización directa por gérmenes o procesos alérgicos o tóxicos. Además del tipo y virulencia del patógeno, la eficiencia del sistema inmunitario desempeña un papel en la forma en que reacciona el corazón frente a una infección. A partir de heridas infectadas por microorganismos como los estafilococos y los estreptococos puede producirse una miocarditis 0 endocarditis. Esto puede sucederle a la práctica totalidad de los grupos profesionales tras un accidente en el lugar de trabajo.
EI noventa por ciento de todos los casos estudiados de endocarditis pueden atribuirse a estafilococos o estreptococos, pero sólo una pequeña parte de estos casos son infecciones relacionadas con accidentes.

En la Tabla 3.5 se ofrece un resumen de las enfermedades infecciosas de posible origen profesional que afectan al sistema cardiovascular. 


\section{Referencias}

Acha, P, B Szyfres. 1980. Zoonoses and Communicable $D$ iseases Common to $M$ an and Animals. Washington, DC: O ficina R egional de la OMS.

al-Eissa, YA. 1991. Acute rheumatic fever during childhood in Saudi Arabia. Ann Trop Paediat 11(3):225-231.

Alfredsson, L, C-L Spetz, T Theorell. 1985. Type of occupation and near-future hospitalization for myocardial infarction (MI) and some other diagnoses. Int J E pidemiol 14:378-388.

Alfredsson, L, R Karasek, T Theorell. 1982 $M$ yocardial infarction risk and psychosocial work environment: An analysis of male Swedish working force. Soc Sci M ed 16:463-467.

Altura, BM, BT Altura, A Gebrewold, H Ising T Gunther. 1992. Noise-induced hypertension and magnesium in rats: Relationship to microcirculation and calcium. I Appl Physiol 72:194-202.

Altura, BM . 1993. Extraaural effects of chronic noise exposure on blood pressure, microcirculation and electrolytes in rats: M odulation by $\mathrm{M} \mathrm{g}^{2+}$. En Lärm und $\mathrm{K}$ rankheit [Ruido y enfermedad], dirigido por $\mathrm{H}$ I sing y B K ruppa. Stuttgart: G ustav Fischer.

American Industrial $\mathrm{H}$ ygiene Association (AIHA) 1986. Biohazards- $R$ eference $M$ anual. Akron, O hio: AIH A.

Aro, S, J Hasan. 1987. O ccupational class, psychosocial stress and morbidity. Ann Clin Res 19:62-68.

Arribada, A, W Apt, X Aguilera, A Solari, y J Sandoval. 1990. Chagas cardiopathy in the first region of Chile. Clinical, epidemiologic and parasitologic study. Revista M édica de Chile 118(8):846-854

Atkins, EH, EL Baker. 1985. Exacerbation of coronary artery disease by occupational carbon monoxide exposure: A report of two fatalities and a review of the literature. Am I Ind M ed 7:73-79.

Azofra, J, R Torres, JL Gómez Garcés, M Górgolas, ML Fernández Guerrero, y M Jiménez Casado. 1991. Endocarditis por erysipelothrix rhusiopathiae. Estudio de due casos y revisión de la literatura. Enfermedades Infecciosas y M icrobiologia Clinica 9(2):102-105.

Baron, JA, JM Peters, DH Garabrant L Bernstein, R K rebsbach. 1987. Smoking as a risk factor in noise-induced hearing loss. J O ccup M ed 29:741-745.

Bavdekar, A, M Chaudhari, S Bhave, A Pandit. 1991. Ciprofloxacin in typhoid fever. Ind J Pediatr 58(3):335-339.

Behymer, D, H P Riemann. 1989. Coxiella burnetil infection ( $Q$-fever). J Am Vet Med Assoc 194:764-767.

Berlin, JA, GA Colditz. 1990. A meta-analysis of physical activity in the prevention of coronary heart disease. Am J E pidemiol 132:612-628.

Bernhardt, JH. 1986. Biological Effects of Static and Extremely Low Frequency M agnetic Fields. M unich: M M V M edizin V erlag.

- . 1988. The establishment of frequency dependent limits for electric and magnetic fields and evaluation of indirect effects. Radiat E nviron Biophys 27: 1-27.

Beschorner, WE, K Baughman, RP Turnicky, GM Hutchins, SA Rowe, AL KavanaughM CH ugh, DL Suresch, A Herskowitz. 1990. HIV associated myocarditis pathology and immunopathology. Am J Pathol 137(6):1365-1371.

Blanc, P, P H offman, JF M ichaels, E Bernard, H Vinti, P M orand, R Loubiere. 1990. Cardiac involvement in carriers of the human immunodeficiency virus. Report of 38 cases. Annales de cardiologie et d'angiologie 39(9):519-525.

Bouchard, C, RJ Shephard, T Stephens. 1994. Physical Activity, Fitness and $\mathrm{H}$ ealth. Champaign, III: $\mathrm{H}$ uman $\mathrm{K}$ inetics.

Bovenzi, M. 1990. Autonomic stimulation and cardiovascular reflex activity in the hand-armvibration syndrome. Kurume M ed | 37:85-94.

Briazgounov, IP. 1988. The role of physical activity in the prevention and treatment of noncommunicable diseases. W orld H ealth Stat Q 41:242-250.

Brouqui, P, HT Dupont, M Drancourt, Y Berland, J Etienne, C Leport, F Goldstein, P M assip, M Micoud, A Bertrand 1993. Chronic Q fever. Ninety-two cases from France, including 27 cases without endocarditis. Arch Int M ed 153(5):642-648.

Brusis, OA y H Weber-Falkensammer (dirs.). 1986. $H$ andbuch der Koronargruppenbetreuung [M anual de tratamiento de enfermedades coronarias]. Erlangen: Perimed.

Carter, NL. 1988. Heart rate and blood pressure response in medium artillery gun crews. M ed J Austral 149:185-189.

Centers for Disease Control and Prevention. 1993. Public health focus: Physical activity and the prevention of coronary heart disease. M orb M ortal W eekly R ep 42:669-672.

Clark, RP, OG Edholm. 1985. M an and his Thermal E nvironment. Londres: Edward Arnold.

Conolly, JH, PV Coyle, AA Adgey, HJ O 'N eill, DM Simpson. 1990. Clinical Q-fever in Northern Ireland 1962-1989. U Ister M ed J 59(2):137-144.

Curwen, M. 1991. Excess winter mortality: A British phenomenon? $\mathrm{H}$ ealth T rends 22:169-175.

Curwen, M, T Devis. 1988. Winter mortality, temperature and influenza: $\mathrm{H}$ as the relationship changed in recent years? Population $T$ rends 54:17-20.

DeBacker, G, M K ornitzer, H Peters, M Dramaix. 1984. Relation between work rhythm and coronary risk factors. E ur H eart J 5 Suppl. 1:307.

DeBacker, G, M K ornitzer, M Dramix, H Peeters, F K ittel. 1987. Irregular working hours and lipid levels in men. $\mathrm{En} \mathrm{Expanding} \mathrm{H}$ orizons in Atherosclerosis Research, dirigido por G Schlierf y H M örl. Berlín: Springer.

Dökert, B. 1981. Grundlagen der Infektionskrankheiten für medizinische $B$ erufe [P rincipios de enfermedades infecciosas para la profesión médica]. Berlín: V olk und W issen.

Douglas, AS, TM Allan, JM Rawles. 1991. Composition of seasonality of disease. Scott M ed I 36:76-82.

Dukes-D obos, FN. 1981. Hazards of heat exposure Scand I W ork Environ $\mathrm{H}$ ealth 7:73.

Dupuis, H, E Christ, DJ Sandover, W Taylor, A O kada. 1993. Actas de la 6 a Conferencia internacional sobre vibración mano-brazo, B onn, República Federal de Alemania, 19-22 de mayo de 1992. Essen: D ruckzentrum Sutter \& Partner.

Dupuis, H, G Zerlett. 1986. T he E ffects of W hole B ody Vibration. Berlín: Springer.

Dupuis, H, W Christ. 1966. On the vibrating behavior of the stomach under the influence of sinusoidal and stochastic vibration. Int J Appl Physiol 0 ccup Physiol 22:149-166.

Edwards, FC, RI M cCallum, PJ T aylor. 1988. Fitness for W ork: The M edical Aspects. O xford: O xford U niv. Press.

Eiff, AW v. 1993. Selected aspects of cardiovascular responses to acute stress. Lärm und Krankheit [R uido y enfermedad ], dirigido por $\mathrm{H}$ Ising y B K ruppa. Stuttgart: Gustav Fischer.
Fajen, J, B Albright, SS Leffingwell. 1981. A cross-sectional medical and industrial hygiene survey of workers exposed to carbon disulfide. Scand I W ork E nviron H ealth 7 Suppl. 4:20-27.

Färkkilä, M , I Pyykkö, E H einonen. 1990. Vibration stress and the autonomic nervous system. Kurume $M$ ed ] 37:53-60.

Fisher, LD, DC T ucker. 1991. Air jet noise exposure rapidly increases blood pressure in young borderline hypertensive rats. | $\mathrm{H}$ ypertension 9:275-282.

Frauendorf, H G Caffier, G K aul, M Wawrzinoszek 1995. M odelluntersuchung zur $E$ rfassung und $B$ ew ertung der $W$ irkung kombinierter physischer und psychischer B elastungen auf $\mathrm{Funktionen}$ des $\mathrm{H}$ erz-Kresilauf-Systems (Schlußbericht) [Investigación modelo de la consideración y valoración de los efectos de la tensión física y psíquica combinadas sobre las funciones del sistema cardiovascular (F inal Report)]. Bremerhaven: Wirtschaftsverlag NW

Frauendorf, H, U Kobryn, W Gelbrich. 1992. [R eacciones circulatorias a las tensiones físicas de os efectos del ruido relevantes para la medicina del trabajo (en alemán)]. En Arbeitsmedizinische Aspekte der Arbeits (-zeit) organisation [Aspectos médico-laborales de la organización del (tiempo de) trabajo], dirigido por R K reutz y C Piekarski. Stuttgart: Gentner.

Frauendorf, H, U K obryn, W Gelbrich, B H offman, U Erdmann. 1986. [Exploraciones ergométricas de los diferentes grupos musculares y sus efectos sobre la frecuencia cardíaca y la presión arterial (en alemán).] Z eitschrift für klinische M edizin 41:343-346.

Fritze, E, KM M üller. 1995. Herztod und akuter $M$ yokardinfarkt nach psychischen oder physischen Belastungen $-K$ ausalitätsfragen und Versicherungsrecht. Versicherungsmedizin 47:143-147.

Gamberale, F. 1990. Physiological and psychological effects of exposure to extremely low-frequency and magnetic fields on humans. Scand J W ork Environ H ealth 16 Suppl. 1:51-54.

Gemne, G. 1992. Pathophysiology and pathogenesis of disorders in workers using hand-held vibrating tools. En $\mathrm{H}$ and-Arm Vibration: A Comprehensive Guide for $O$ ccupational $\mathrm{H}$ ealth Professionals, dirigido por PL Pelmear, W Taylor y DE Wasserman. Nueva Y ork: $V$ an N ostrand R einhold.

-.1994 . Where is the research frontier for hand-arm vibration? Scand J W ork E nviron $\mathrm{H}$ ealth 20, número especial:90-99.

Gemne, G, W T aylor. 1983. H and-arm vibration and the central autonomic nervous system. Actas de un simposio internacional, Londres, 1983. J L ow F req $\mathrm{N}$ oise Vib número especial.

Gierke, HE, CS Harris. 1990. On the potential association between noise exposure and cardiovascular disease. En Noise As a Public $\mathrm{H}$ ealth Problem, dirigido por B Berglund y $T$ Lindvall. Estocolmo: Swedish Council for Building R esearch.

Glantz, SA, WW Parmley. 1995. Passive smoking and heart disease. J AM A 273:1047-1053.

Glasgow, RE, JR Terborg, JF H ollis, HH Severson, M B Shawn. 1995. Take Heart: R esults from the initial phase of a work site wellness program. Am J Public H ealth 85: 209-216.

Gomel, M, B Oldenberg, JM Sumpson, N O wen. 1993. Work site cardiovascular risk reduction: A randomized trial of health risk assessment, education, counseling and incentives. Am J Public $H$ ealth 83:1231-1238.

Gordon, DJ, J H yde, DC T rost. 1988. Cyclic seasonal variation in plasma lipid and lipoprotein levels: The Lipid Research Clinics Coronary Primary 
Prevention Trial placebo group. J Clin Epidemiol 41:679-689.

Griffin, MJ, 1990. Handbook of $H$ uman Vibration. Londres: Academic.

Gross, D, H Willens, St Zeldis. 1981. M yocarditis in L egionnaire's disease. Chest 79(2):232-234.

Gross, R, D Jahn, P Schölmerich (dirs). 1970. Lehrbuch der Inneren Medizin [M anual de medicina interna]. Stuttgart: Schattauer.

Halhuber, C, K Traencker (eds). 1986. Die Koronare $\mathrm{H}$ erzkrankheit- eine $\mathrm{H}$ erausforderung an Politik und $G$ esellschaft [ $L$ a cardiopatía coronaria, un desafío político y social]. Erlangen: Perimed.

$\mathrm{H}$ ärenstam, $\mathrm{A}, \mathrm{T}$ Theorell, $\mathrm{K}$ O rth-Gomer, U-B Palm, A-L Unden. 1987. Shift work, decision latitude and ventricular ectopic activity: A study of 24-hour electrocardiograms in Swedish prison personnel. W ork Stress 1:341-350

$\mathrm{H}$ arris, JS. 1994. Health promotion in the workplace. En O ccupational M edicine, dirigido por C Zenz. St. Louis: M osby.

Harrison, DW, PL K elly. 1989. Age differences in cardiovascular and cognitive performance under noise conditions. Perceptual and M otor Skills 69:547-554.

Heinemann, L. 1993. M ONICA East Germany Data Book. Berlín: ZEG

H elmert, U, S Shea, U M aschewsky-Schneider. 1995. Social class and cardiovascular disease risk factor changes in West Germany 1984-1991. Eur J Pub $H$ ealth 5:103-108.

Heuchert, G, G Enderlein. 1994. O ccupational registers in Germany-diversity in approach and setout. En Quality Assurance of Occupational $\mathrm{H}$ ealth Services. Bremerhaven: W irtschaftsverlag N W.

Higuchi, M de L, CF DeM orais, NV Sambiase, AC Pereira-Barretto, G Bellotti, F Pileggi. 1990. $\mathrm{H}$ istopathological criteria of myocarditis-A study based on normal heart, chagasic heart and dilated cardiomyopathy. J apan Circul J 54(4):391-400.

$\mathrm{H}$ inderliter, AL, AF Adams, CJ Price, MC Herbst, $G$ K och, DS Sheps. 1989. Effects of low-leve carbon monoxide exposure on resting and exercise-induced ventricular arrhythmias in patients with coronary artery disease and no baseline ectopy. Arch E nviron $\mathrm{H}$ ealth 44(2):89-93.

H ofmann, F (ed). 1993. I nfektiologie- Diagnostik T herapie Prophylaxe- $\mathrm{H}$ andbuch und Atlas für Klinik und Praxis [Enfermedades infecciosas-Diagnóstico, tratamiento profilaxis- $M$ anual y atlas de la clínica y la práctica]. Landsberg: Ecomed.

IImarinen, J. 1989. Work and cardiovascular health $V$ iewpoint of occupational physiology. Ann $M$ ed 21:209-214.

Ising, H, B K ruppa. 1993. Lärm und Krankheit [R uido y enfermedad]. Actas del simposio internacional sobre "Ruido y enfermedad", Berlín, 26-28 de septiembre de 1991. Stuttgart: Gustav Fischer.

Janssen, $H$. 1991. Zur F rage der E ffektivität und E ffizienz betrieblicher Gesundheitsförderung- E rgebnisse einer Literatur recherche [Sobre el tema de la eficacia y la eficiencia del fomento de la salud a escala de la empresa- Resultados de una búsqueda bibliográfica]. Z eitschrift für Präventivmedizin und Gesundheitsförderung 3:1-7.

Jegaden, D, C LeFuart, Y M arie, P Piquemal. 1986 Contribution à l'étude de la relation bruit-hypertension artérielle à propos de 455 marins de commerce agés de 40 à 55 ans. Arch mal prof (Paris) 47:15-20.

Kaji, H, H Honma, M Usui, Y Y asuno, K Saito. 1993. Analysis of 24 cases of $\mathrm{H}$ ypothenar $\mathrm{H}$ ammer Syndrome observed among vibration exposed workers. En Actas de la 6 a Conferencia internacional sobre vibración mano-brazo, dirigido por $\mathrm{H}$ Dupuis, $\mathrm{E}$ Christ, DJ Sandover, W T aylor y A O kade. Essen: Druckzentrum Sutter.
K annel, WB, A Belanger, R D'Agostino, I I srael. 1986. Physical activity and physical demand on the job and risk of cardiovascular disease and death The Framingham Study. A m H eart I 112:820-825.

K arasek, RA, T Theorell. 1990. H ealthy W ork. Nueva Y ork: Basic Books.

K arnaukh, NG, GA Petrow, CG M azai, M N Zubko, ER Doroklin. 1990. [La pérdida temporal de la capacidad de trabajo en los trabajadores de las plantas metalúrgica como consecuencia de enfermedades circulatorias (en ruso)]. V racebnoe delo 7:103-106.

K aufmann, AF, ME Potter. 1986. Psittacosis. Occupational Respiratory Diseases, dirigido por JA M erchant. Publication No. 86-102. Washington, DC: NIOSH.

Kawahara, J, H Sano, H Fukuzaki, H Saito J H irouchi. 1989. Acute effects of exposure to cold on blood pressure, platelet function and sympathetic nervous activity in humans. Am J $H$ ypertension 2:724-726.

K eatinge, WR, SR W Coleshaw, JC Eaton et al. 1986. Increased platelet and red cell counts, blood viscosity and plasma cholesterol levels during heat stress, and mortality from coronary and cerebral thrombosis. Am J M ed 81: 795-800.

K haw, K-T. 1995. Temperature and cardiovascular mortality. Lancet 345: 337-338.

Kleinman, $M T$, DM Davidson, RB Vandagriff, VJ Caiozzo, JL Whittenberger. 1989. Effects of short-term exposure to carbon monoxide in subjects with coronary artery disease. Arch Environ $H$ ealth 44(6):361-369.

K loetzel, K, AE deAndrale, J Falleiros, JC Pacheco. 1973. Relationship between hypertension and prolonged exposure to heat. J O ccup M ed 15: 878-880.

K nave, B. 1994. Electric and magnetic fields and health outcomes-an overview. Scand I W ork E nviron $\mathrm{H}$ ealth 20, número especial: 78-89.

K nutsson, A. 1989. Relationships between serum triglycerides and gamma-glutamyltransferase among shift and day workers. J Int $\mathrm{Med}$ 226:337-339.

Knutsson, A, T Åkerstedt, BG Jonsson, K Orth-Gomer. 1986. Increased risk of ischemic heart disease in shift workers. Lancet 2:89-92.

Kornhuber, HH, G Lisson. 1981. Bluthochdruck-sind Industriestressoren, Lärm oder Akkordarbeit wichtige U rsachen? Deutsche medizinische W ochenschrift 106:1733-1736.

K ristensen, TS. 1989. Cardiovascular diseases and the work environment. Scand J W ork Environ $H$ ealth 15:245-264.

-. 1994. Cardiovascular disease and the work environment. In Encyclopedia of Environmental Control T echnology, dirigido por PN Cheremisinoff. H ouston: Gulf.

- 1995. The demand-control-support model: $M$ ethodological challenges for future research. Stress M edicine 11:17-26.

K unst, AE, CWN Looman, JP M ackenbach. 1993. Outdoor air temperature and mortality in the Netherlands: A time series anlaysis. Am | E pidemiol 137:331-341.

Landsbergis, PA, SJ Schurman, BA Israel, PL Schnall, MK Hugentobler, J Cahill, D Baker. 1993. Job stress and heart disease: Evidence and strategies for prevention. N ew Solutions :42-58.

Lavie, P, N Chillag, R Epstein, 0 Tzischinsky, R Givon, S Fuchs, B Shahal. 1989. Sleep disturbance in shift-workers: As marker for maladaptation syndrome. W ork Stress 3:33-40.

Lebedeva, NV, ST Alimova, FB Efendiev. 1991. [Estudio de la mortalidad entre trabajadores expuestos a microclimas calientes (en ruso)]. Gigiena truda i professionalnye zabolevanija 10:12-15.
Lennernäs, M, T Åkerstedt, L H ambraeus 1994. Nocturnal eating and serum cholesterol of three-shift workers. Scand J W ork Environ $\mathrm{H}$ ealth 20:401-406.

Levi, L. 1972. Stress and distress in response to psychosocial stimuli. Acta M ed Scand Suppl. 528.

-. 1983. Stress and coronary heart disease-causes, mechanisms, and prevention. Act Nerv Super 25:122-128

Lloyd, EL. 1991. The role of cold in ischaemic heart disease: A review. Public $\mathrm{H}$ ealth 105:205-215.

$M$ annebach, H. 1989. [ $\mathrm{iH}$ an mejorado en los 10 últimos años las probabilidades de prevención de las cardiopatías coronarias? (en alemán)]. J Prev $M$ ed $H$ ealth R es 1:41-48.

Marmot, M, T Theorell. 1991. Social class and cardiovascular disease: The contribution of work. En The Psychosocial W ork Environment, dirigido por TV Johnson y $G$ J ohannson. A mityville: Baywood.

M arshall, M, P Bilderling. 1984. [El síndrome del martillo hipotenar, un importante diagnóstico diferencial en la enfermedad del dedo blanco relacionado con la vibración (en alemán)]. En N eurotoxizität von Arbeitsstoffen. Kausalitätsprobleme beim Berufskrebs. Vibration. [Neurotoxicidad de las sustancias del lugar de trabajo. P roblemas de causalidad en el cáncer de origen profesional], dirigido por $\mathrm{H}$ K onietzko y F Schuckmann. Stuttgart: G entner.

M ichalak, R, H Ising, E Rebentisch. 1990. Acute circulatory effects of military low altitude flight noise. Int A rch 0 ccup E nviron $\mathrm{H}$ ealth 62:365-372.

Mielck, A. 1994. Krankheit und soziale Ungleichheit. O pladen: L eske \& Budrich.

Millar, K, MJ Steels. 1990. Sustained peripheral vasoconstriction while working in continuous intense noise. A viat Space E nviron M ed 61:695-698.

Mittleman, MA, M Maclure, GH Tofler, JB Sherwood, RJ Goldberg, JE Muller. 1993. Triggering of acute myocardial infarction by heavy physical exertion. N ew E ngl J M ed 329:1677-1683.

Morris, JN, A Kagan, DC Pattison, MJ Gardner, PAB R affle. 1966. Incidence and prediction of ischaemic heart-disease in London busmen. Lancet 2:553-559.

M orris, JN , JA H eady, PAB R affle. 1956. Physique of London busmen: Epidemiology of uniforms. Lancet 2:569-570.

Moulin, J, P Wild, B M antout, M Fournier-Betz, JM M ur, G Smagghe. 1993. M ortality from lung cancer and cardiovascular diseases among stainless-steel producing workers. Cancer Causes Control 4:75-81.

M rowietz, U. 1991. Klinik und Therapie der $L$ yme B orreliose Informationen über Infektionen [Clínica y tratamiento de la borreliosis de L yme. Información sobre las infecciones. Conferencia científica, B onn, 28-29 de junio de 1990]. Basilea: Editiones R oches

M urza, G, U Laaser. 1990, 1992. H ab en $H$ erz für $D$ ein $\mathrm{H}$ erz [Quiere a tu corazón]. Gesundheitsförderung. Vol. 2 y 4 . Bielefeld: IDIS

National Heart, Lung and Blood Institute. 1981. Control for Blood Pressure in the W ork Setting, U niversity of M ichigan. Washington, DC: US Government Printing 0 ffice.

Neild, PJ, P Syndercombe-Court, WR K eatinge, GC Donaldson, M M attock, M Caunce. 1994 Cold-induced increases in erythrocyte count, plasma cholesterol and plasma fibrinogen of elderly people without a comparable rise in protein $C$ or factor X. Clin Sci M ol M ed 86:43-48.

Nurminen, M , S Hernberg. 1985. Effects of intervention on the cardiovascular mortality of workers exposed to carbon disulphide: A 15 year follow up. Brit J Ind M ed 42:32-35.

Olsen, N. 1990. Hyperreactivity of the central sympathetic nervous system in vibration-induced white finger. Kurume M ed J 37:109-116. 
O Isen, N, TS K ristensen. 1991. Impact of work environment on cardiovascular diseases in Denmark. J E pidemiol Community $H$ ealth 45:4-10.

Organización Mundial de la Salud (OM S). 1973. Report of a W H O Expert Committee on E nvironmental and $\mathrm{H}$ ealth $\mathrm{M}$ onitoring in $\mathrm{O}$ ccupation $\mathrm{H}$ ealth. Technical R eport Series, N 0. 535. Ginebra: O M S

- 1975. Clasificación internacional de enfermedades, 9ạ edición. G inebra: O M S.

- 1985. Identification and control of work-related diseases T echnical R eport Series, N o. 714. G inebra: O M S.

- . 1994a. Cardiovascular disease risk factors: $N$ ew areas for research. T echnical R eport Series, N 0. 841.G inebra: OMS.

—. 1994b. W orld H ealth Statistics Annual 1993. Ginebra: OMS.

Organización Mundial de la Salud, Proyecto MONICA. 1988. Geographical variation in the major risk factors of coronary heart disease in men and women aged $35-64$ years. W orld $\mathrm{H}$ ealth Stat $\mathrm{Q}$ 41:115-140

-. 1994. M yocardial infarction and coronary deaths in the World Health Organization MONICA project. Registration procedures, event rates, and case-fatality in 38 populations from 21 countries in four continents. Circulation 90:583-612.

O rth-G omer, K. 1983. Intervention on coronary risk factors by adapting a shift work schedule to biologic rhythmicity. P sychosom M ed 45:407-415.

Paffenbarger, RS, M E Laughlin, AS Gima, RA Black. 1970. Work activity of longshoremen as related to death from coronary heart disease and stroke. $N$ ew Engl J M ed 282:1109-1114.

Pan, W-H, L-A Li, M-J T sai. 1995. Temperature extremes and mortality from coronary heart disease and cerebral infarction in elderly Chinese L ancet 345:353-355.

Parrot, J, JC Petiot, JP Lobreau, HJ Smolik. 1992. Cardiovascular effects of impulse noise, road traffic noise, and intermittent pink noise at $L A e q=75$ $\mathrm{dB}$, as a function of sex, age and level of anxiety: A comparative study. Int Arch Occup Environ $H$ ealth 63:477-484;485-493.

Pate, RR, M Pratt, SN Blair, WL H askell, et al. 1995. Physical activity and public health. A recommendation from the Centers for Disease Control and Prevention and the A merican College of Sports M edicine. J AM A 273:402-407.

Pelmear, PL, W T aylor, DE W asserman (dirs.). 1992. $\mathrm{H}$ and-Arm Vibration: A Comprehensive Guide for $O$ ccupational $H$ ealth Professionals. Nueva Y ork: $V$ an N ostrand R einhold.

Petiot, JC, J Parrot, JP Lobreau, JH Smolik. 1988. Individual differences in cardiovascular responses to intermittent noise in human females. Int J Psychophysiol 6:99-109;111-123.

Pillsburg, HC. 1986. Hypertension, hyperlipoproteinemia, chronic noise exposure: Is there synergism in cochlear pathology? Laryngoscope 96:1112-1138.

Powell, KE, PD Thompson, CJ Caspersen, JS Kendrick. 1987. Physical activity and the incidence of coronary heart disease. Ann Rev Pub $H$ ealth 8:253-287.

Programa de las Naciones Unidas para el Medio Ambiente (PNUM A), O rganización M undial de la Salud (O M S) e International R adiation Protection Association (IRPA). 1984. Extremely low frequency (ELF) fields. Environmental $\mathrm{H}$ ealth Criteria, N o. 35. Ginebra: O M S.

-. 1987. M agnetic fields. Environmental $\mathrm{H}$ ealth Criteria, N o. 69. Geneva: WHO

Rebentisch, E, H Lange-Asschenfeld, H Ising (eds). 1994. G esundheitsgefahren durch Lärm: Kenntnisstand der W irkungen von arbeitslärm, U mweltlärm und lanter M usik [Peligros para la salud derivados del ruidoEstado de los conocimientos sobre los efectos del ruido en e lugar de trabajo el ruido ambiental y la música fuerte]. M unich: M M V, M edizin V erlag.

Redmond, CK , J Gustin, E K amon. 1975. Long-term mortality experience of steelworkers: VIII. M ortality patterns of open hearth steelworkers. J 0 ccup M ed 17:40-43.

Redmond, CK, IJ Emes, S M azumdar, PC M agee, E $K$ amon. 1979. M ortality of steelworkers employed in hot jobs. J Environ Pathol T oxicol 2:75-96.

Reindell, H, H Roskamm (eds). 1977. H erzkrankheiten: Pathophysiologie, Diagnostik, Therapie [Enfermedades cardíacas: Fisiopatología, diagnóstico y tratamiento]. Berlín: Springer.

Riecker, G (dir.). 1988. Therapie innerer Krankheiten [T ratamiento de las enfermedades internas]. Berlín: Springer.

Rogot, E, SJ Padgett. 1976. Associations of coronary and stroke mortality with temperature and snowfall in selected areas of the United States 1962-1966. Am J E pidemiol 103:565-575.

Romon, M , M -C Nuttens, C Fievet, P Pot, JM Bard, D Furon, JC Fruchart. 1992. Increased triglyceride levels in shift workers. Am J M ed 93:259-262.

R utenfranz, J, P K nauth, D Angersbach. 1981. Shift work research issues. En Biological R hythms, Sleep and Shift W ork, dirigido por LC Johnson, DI Tepas, WP Colquhoun y MJ Colligan. Nueva York: Spectrum.

Saltin, B. 1992. Sedentary lifestyle: An underestimated health risk. I Int M ed 232:467-469.

Schnall, PL, PA Landsbergis, D Baker. 1994. Job strain and cardiovascular disease. Ann Rev Pub $H$ ealth 15:381-411.

Schulz, F-H y H Stobbe (dirs.). 1981. Grundlagen und Klinik innerer E rkrankungen [Principios y clínica de las enfermedades internas]. Vol. III. Berlin: Volk and G esundheit.

Schwarze, S, SJ Thompson. 1993. Research on non-auditory physiological effects of noise since 1988: R eview and perspectives. En B ruit et Santé dirigido por $M$ Vallet. Arcueil: Inst. national de recherche sur les transports et leur securité.

Shadick, NA, CB Phillips, EL Logigian, AC Steere, RF K aplan, VP Berardi, PH Duray, MG Larson, EA W right, KS Ginsburg, JN K atz, MH Liang. 1994. The long-term clinical outcomes of Lyme disease-A population-based retrospective cohor study. Ann Intern M ed 121:560-567.

Siegrist, J. 1995. Crisis sociales y salud (en alemán) Gottingen: H ogrefe.

Stern, FB, WE Halperin, RW Hornung, VL $R$ ingenburg, CS M CC ammon. 1988. H eart disease mortality among bridge and tunnel officers exposed to carbon monoxide. Am J Epidemiol 128(6): 1276-1288

Stout, RW, V Grawford. 1991. Seasonal variations in fibrinogen concentrations among elderly people. Lancet 338:9-13.

Sundermann, A (ed). 1987. Lehrbuch der Inneren M edizin [M anual de medicina interna ]. Jena: G ustav Fischer.

Suurnäkki, T, J Ilmarinen, G Wägar, E Järvinen, K Landau. 1987. Municipal employees' cardiovascular diseases and occupational stress factors in Finland. Int Arch Occup Environ $\mathrm{H}$ ealth 59:107-114

Talbott, E, PC Findlay, LH Kuller, LA Lenkner, KA Matthews, RA Day, EK Ishii. 1990. Noise-induced hearing loss: A posssible marker for high blood pressure in older noise-exposed populations. J O ccup M ed 32:690-697.

Tanaka, S, A Konno, A Hashimoto. 1989. The influence of cold temperatures on the progression of hypertension: An epidemiological study. I $H$ ypertension 7 Suppl. 1:549-551.

Theorell, T. 1993. Medical and psychological aspects of job interventions. Int Rev Ind Organ Psychol 8: 173-192.
Theorell, T, A Perski, K O rth-Gomér, U deFaire. 1991. The effects of the strain of returning to work on the risk of cardiac death after a first myocardial infraction before the age of 45 . Int J Cardiol 30: 61-67.

Theorell, T, G Ahlberg-Hulten, L Alfredsson, A Perski y $\mathrm{F}$ Sigala. 1987. B ullers E ffekter $\mathrm{Pa} M$ änniskor. Stress Research Reports, No. 195. Estocolmo: National Institute of Psychosocial Factors and $\mathrm{H}$ ealth.

Thompson, SJ. 1993. Review: Extraaural health effects of chronic noise exposure in humans. En $L$ ärm und Krankheit [Ruido y enfermedad], dirigido por $\mathrm{H}$ I sing y B K ruppa. Stuttgart: G ustav Fischer.

Tüchsen, F. 1993. Working hours and ischaemic heart disease in Danish men: A 4-year cohort study of hospitalization. Int J E pidemiol 22:215-221.

van Dijk, FJH. 1990. Epidemiological research on non-auditory effects of occupational noise exposure. E nviron Int 16 (número especial):405-409.

van Dijk, FJH, JHA Verbeek, FF de Vries. 1987. Non-auditory effects of occupational noise in industry. V. A field study in a shipyard. Int Arch $O$ ccup E nviron $H$ ealth 59:55-62;133-145.

Virokannas, H. 1990. Cardiovascular reflexes in workers exposed to hand-arm vibration. Kurume $M$ ed J 37:101-107.

Weir, FW, VL Fabiano. 1982. Reevaluation of the role of carbon monoxide in production or aggravation of cardiovascular disease processes. J 0 ccup M ed 24(7):519-525

Wells, AJ. 1994. Passive smoking as a cause of heart disease. J AM A 24:546-554.

Wielgosz, AT, 1993. The decline in cardiovascular health in developing countries. W orld $\mathrm{H}$ ealth Stat $\mathrm{Q}$ 46:90-150.

Wikström, B-O, A K jellberg, U Landström. 1994. $\mathrm{H}$ ealth effects of long-term occupational exposure to whole-body vibration: A review. Int J Ind Erg 14:273-292.

Wild, P, J-J Moulin, F-X Ley, P Schaffer. 1995 Mortality from cardiovascular diseases among potash miners exposed to heat. Epidemiology 6:243-247.

Willich, SN, M Lewis, H Löwel, H-R Arntz, F Schubert, R Schröder. 1993. Physical exertion as a trigger of acute myocardial infarction. $\mathrm{N} \mathrm{ew} \mathrm{Engl} \mathrm{J}$ M ed 329:1684-1690.

Wojtczak-Jaroszowa, J, D Jarosz. 1986. Health complaints, sicknesses and accidents of workers employed in high environmental temperatures. Canad J Pub H ealth 77:132-135.

Woodhouse, PR, KT K haw, M Plummer. 1993a. Seasonal variation in blood pressure in relation to temperature in elderly men and women. $\mathrm{H}$ ypertension 11:1267-1274.

-. 1993b. Seasonal variation of lipids in an elderly population. Age Ageing 22:273-278.

Woodhouse, PR, KT K haw, TW M eade, Y Stirling, M Plummer. 1994. Seasonal variations of plasma fibrinogen and factor VII activity in the elderly: Winter infections and death from cardiovascular disease. L ancet 343:435-439.

Wyndham, CH, SA Fellingham. 1978. Climate and disease. S Afr M ed J 53:1051-1061.

Zhao, Y, S Liu, S Zhang. 1994. Effects of short-term noise exposure on heart rate and ECG ST segment in male rats. $\mathrm{En} \mathrm{H}$ ealth $\mathrm{H}$ azards from $\mathrm{N}$ oise State of the Knowledge of the E ffects of W orkplace Noise, Environmental Noise, and Loud M usic, dirigido por $\mathrm{E}$ Rebentisch, $\mathrm{H}$ Lange-Asschenfeld y $\mathrm{H}$ Ising M unich: M M V , M edizin V erlag.

\section{O tras lecturas recomendadas}

A hlman, K, R-S K oskela, P K uikka, M K oponen, M Annanmäki. 1991. M ortality among sulfide ore miners. Am J Ind M ed 19:603-617. 
Babisch, W, H Ising, B K ruppa, D Wiens. 1994. The incidence of myocardial infarction and its relation to road traffic noise-The Berlin case control studies. Environ Int 20:469-474.

Babisch, W, JEJ Gallacher, D Bainton, IA Baker, et al. 1988. Traffic noise, work noise and cardiovascular risk factors-The Caerphilly and Speedwell collaborative heart disease studies. En Noise As a Public $\mathrm{H}$ ealth Problem, dirigido por B Berglund, J Berglund, J Karlsson y T Lindvall. Estocolmo, Suecia.

Babisch, W, PC Elwood, H Ising. 1993. Road traffic noise and heart disease risk: Results of the epidemiological studies in Caerphilly, Speedwel and Berlin. In Bruit et Santé dirigido por M V allet. Arcueil: Inst. national de recherche sur les transports et leur securité

Balcarová, O J Halik. 1991. Ten-year epidemiological study of ischaemic heart disease (IHD) in workers exposed to carbon disulphide. Sci T otal Environ 101:97-99.

Belaich, S. 1995. La maladie de Lyme [Lyme disease]. La Presse M édicale 24(2):81-87.

Brüschke (ed). 1988. Innere M edizin [I nternal M edicine]. Jena: G ustav Fischer.

Craig, R, CR Gillis, DJ Hole, GM Paddle. 1985. Sixteen year follow up of workers in an explosives factory. I Soc 0 ccup M ed 35:107-110.

Dejoy, DM, DJ Soutern. 1993. An integrative perspective on worksite health promotion. J 0 ccup M ed 35:1221-1230.

Dibbs, E, HE Thomas, ST Weiss, D Sparrow. 1982. Fire fighting and coronary heart disease. Circulation 65(5):943-946.

Edling, C, C-G Anjou, O Axelson, H K ling. 1987. $M$ ortality among personnel exposed to diese exhaust. Int Arch $O$ ccup E nviron $H$ ealth 59:559-565.

Edling, C, O Axelson. 1984. R isk factors of coronary heart disease among personnel in a bus company. Int Arch $O$ ccup E nviron $\mathrm{H}$ ealth 54:181-183.

Egeland, GM, GA Burkhart, TM Schnorr, RW H ornung, JM Fajen, ST Lee. 1992. Effects of exposure to carbon disulphide on low density lipoprotein cholesterol concentration and diastolic blood pressure. Brit J Ind M ed 49:287-293.

Eliopulos, E, BK Armstrong, JT Spcikett, F Heyworth. 1984. Mortality of fire fighters in Western Australia. B rit J Ind M ed 41:183-187.

Fielding, JE, PV Piserchia. 1989. Frequency of work site health promotion activities. Am 」 Public $\mathrm{H}$ ealth 798:16-20.

Fielding, JE. 1984. Health promotion and disease prevention at the work site. Ann Rev Pub $\mathrm{H}$ ealth 5:237-266.

Forman, SA, JC Helmkamp, CM Bone. 1987 Cardiac morbidity and mortality associated with occupational exposure to 1,2 propylene glycol dinitrate. I O ccup M ed 29(5):445-450.

Germer, WD, H Lode, H Stickl (eds). 1987. Infektionsund Tropenkrankheiten, AIDS, Schutzimpfungen [Enfermedades infecciosas y tropicales, SIDA, vacunaciones]. Berlín: Springer.

Guidotti, TL. 1993. M ortality of urban firefighters in Alberta, 1927-1987. Am J Ind M ed 23:921-940.

Gurney, M , J Gorstein. 1988. The global prevalence of obesity-An initial review of available data. W orld $H$ ealth Stat Q 41:251-254.

$\mathrm{H}$ ansen, ES. 1989. M ortality of auto mechanics. Scand J W ork Environ $H$ ealth 15:43-46.

H eart: Results from the initial phase of a work site wellness program. 1995. Am J Public $H$ ealth 85:209-216.

H ein, H O , P Suadicani, F Gyntelberg. 1992. Physical fitness or physical activity as a predictor of ischaemic heart disease? A seventeen-year follow-up in the Copenhagen male study. J Int M ed 232:471-479.
Helcamp, JC, SA Forman, MS M CN ally, CM Bone N.d. M orbidity and M ortality Associated with Exposure to Otto Fuel II in the US Navy 1966-1979. Report No. 84-35. San Diego, Calif: US Navy $H$ ealth R esearch Center.

Hernberg, S, M Tolonen, M Nurminen. 1976. Eight-year follow-up of viscose rayon workers exposed to carbon disulfide. Scand I W ork E nviron $H$ ealth 2:27-30.

H ernberg, S, T Partanen, CH N ordman, P Sumari. 1970. Coronary heart disease among workers exposed to carbon disulphide. Brit I Ind $M$ ed 27:313-325

Heyer, N, NS Weiss, P Demers, L R osenstock. 1990. Cohort mortality study of Seattle fire fighters: 1945-1983. Am J Ind M ed 17:493-504.

$\mathrm{H}$ offmeister, H, H H üttner, H Stolzenberg, H L opez, J Winkler. 1992. Social Status and $H$ ealth. M unich M M V M edizin V erlag

Hofmann, F y F-W Tiller. 1993. Infektiologie in Stichworten [Palabras clave en enfermedades infecciosas ]. L andsberg: Ecomed.

Hogstedt, C, K Andersson. 1979. A cohort study on mortality among dynamite workers. I O ccup $M$ ed 21(8):553-556.

Idzoir-Walus, B. 1987. Coronary risk factors in men occupationally exposed to vibration and noise. E ur $H$ eart ] 8:1040-1046.

Ilmarinen, J. 1992a. Job design for the aged with regard to decline in their maximal aerobic capacity: Part I: Guidelines for the practitioner. Int J Ind E rg 10:53-63.

- 1992b. Job design for the aged with regard to decline in their maximal aerobic capacity: Part II: The scientific basis for the guide. Int J Ind Erg 10:65-77.

Ising, H, W Babisch, B Kruppa, D Wiens. 1995 Chronic work noise exposure-An important risk factor for myocardial infarction. Presentado en e 1er Simposio internacional sobre el medio ambiente de trabajo y las enfermedades cardiovasculares, Copenhague, 31 mayo - 2 junio 1995.

Jacobs, F, D Abramowicz, P Vereerstraeten, JL Le Clerc, F Zech, JP Thys. 1990. Brucella endocarditis: The role of combined medical and surgical treatment. R ev Infect D is 12(5):740-744.

K alimo, R, J K arvonen. 1982. M O N ICA Project- Social Structure and Behaviour. Documento WH O / M NC/ WP/ 82.9. Ginebra: O M S.

K napikowa, D, Z Andreasik, S K wiatkowski, M O krojek, R Smolik, K Szczerba. 1988. Application of the Minnesota Code in evaluation of electrocardiographic features of ischemic heart disease in patients exposed to carbon disulphide. Int Arch 0 ccup E nviron $H$ ealth 60:351-353.

K nutsson, A, H Anderson, U Berglund. 1990. Serum lipoproteins in day and shift workers. A prospective study. B rit J Ind $M$ ed 47:132-134.

K nutsson, A, T Åkerstedt, BG Jonsson. 1988. Prevalence of risk factors for coronary artery disease among day and shift workers. Scand J W ork Environ $H$ ealth 14:317-321.

Knutsson, A. 1989b. Shift work and coronary heart disease. Scand J Soc M ed 44 Suppl. 1:1-36.

$\mathrm{K}$ ramer, M D, SE M oter, $\mathrm{H}$ H ofmann, UE Schaible, M M Simon, R Wallich. 1993. Symptomatik und Diagnostik der Lyme-Borreliose [Síntomas y diagnóstico de la borreliosis]. D eutsche medizinische W ochenschrift 118:423-427.

Laaser, U (ed). 1993. Krankheitsverhütung und Früherkennung: $H$ andbuch der Prävention [Prevención y detección precoz de enfermedades: $M$ anual de prevención]. Berlín: Springer

Lang, T, C Fouriaud, M D Jacquinet-Salord. 1992. Length of occupational noise exposure and blood pressure. Int Arch 0 ccup E nviron $\mathrm{H}$ ealth 63:369-372.
Levine, RJ, DA Andjelkovich, SL K ersteter, EW Arp, SA Balogh, PB Blunden, JM Stanley. 1986. Heart disease in workers exposed to dinitrotoluene. J 0 ccup M ed 28(9):811-816.

M acM ahon, B, R R M onson. 1988. M ortality in the US rayon industry. J O ccup M ed 30(9):698-705.

M anson, JE, H T osteson, PM Ridker, S Satterfield, $P$ Herbert, GT O'Connor, JE Burring, $\mathrm{CH}$ Hennekens. 1992. The primary prevention of myocardial infarction. New Engl । $M$ ed 326:1406-1416.

M asironi, R, K Rothwell. 1988. Smoking trends and effects world wide. W orld $H$ ealth Stat Q 41:228-241.

M auff, AC. 1980. Acute brucellosis in Johannisburg. S Afr M ed I 58(12):477-479.

N urminen, M , P M utanen, M T olonen, S H ernberg. 1982. Q uantitated effects of carbon disulfide exposure, elevated blood pressure and ageing on coronary mortality. Am J E pidemiol 115(1):107-118.

O'D onnel, MP, TH Ainsworth (dirs.). 1984. H ealth Promotion in the W orkplace. N ueva Y ork: Wiley.

O liver, LC, RP Weber. 1984. Chest pain in rubber chemical workers exposed to carbon disulphide and methaemoglobin formers. Brit J Ind $M e d$ 41:296-304.

O rganización M undial de la Salud (OM S). 1987 M ONICA M anual-Version 1.1. Ginebra: OM S

- . 1995. International Classification of Diseases. 10th R evision. G inebra: O M S.

O verzier, C. 1983. Systematik der Inneren M edizin [Systematics of Internal M edicine]. Stuttgart: Georg Thieme.

Pluto, R, J Brecht, I Hildebrand, A Zober. 1993. Betriebssport und aktive Bewegungsprogramme in einem Großbetrieb der Chemischen Industrie [Programa de deporte y de movimiento activo en una gran empresa del sector químico]. Arbeitsmedizin, Sozialmedizin, U mweltmedizin 28:203-205.

Prerovská, I, J Picková. 1979. Vliv kyslicníku uhelnatého na rozvoi arteriosklerózy u profesionálné exponovanych osob. Pracovni Lékarstvi 31(5):166-171.

Reeve, G, T Bloom, R R insky, A Smith. 1983. Cardiovascular disease among nitroglycerin-exposed workers. Am J E pidemiol 118(3):418.

Reinhardt, CF, A Azar, ME M axfield, PE Smith, LS Mullin. 1971. Cardiac arrhythmias and aerosol sniffing. Arch E nviron $\mathrm{H}$ ealth 22(2):265-279.

R ose, G. 1981. Strategy of prevention: Lessons from cardiovascular disease. B rit M ed J 282:1847-1852.

Rosengren, A, K Anderson, L Wilhelmsen. 1991. Risk of coronary heart disease in middle-aged male bus and tram drivers compared to men in other occupations: A prospective study. Int J Epidemio 20(1):82-87.

Sakurai, H. 1982. A morbidity study of viscose rayon workers exposed to carbon disulphide. B rit J Ind $M$ ed 39:39-44.

Sardinas, A, JW M iller, H H ansen. 1986. Ischaemic heart disease mortality of firemen and policemen. Am J Public H ealth 76(9):1140-1141.

Schwarze, S. 1991. Langjährige Lärmbelastung und Gesundheit ... [Exposición al ruido de larga duración y salud: Estado de la investigación médica sobre el ruido y artículos experimentales y epidemiológicos sobre el inicio de los trastornos patológicos relacionados con el ruido]. Bremerhaven: Wirtschaftsverlag N W.

Sharp, DS, CE Becker, AH Smith. 1987. Chronic low-level lead exposure: Its role in the pathogenesis of hypertension. M ed T oxicol 2:210-232.

Smith, GD, JN M orris. 1992. Assessment of physical activity, and physical fitness, in population surveys. E pidemiol Community H ealth 46:89-91. 
Snyder, R. 1987. E thel Browning's Toxicity and M etabolism of Industrial Solvents. Vol. I: $\mathrm{H}$ ydrocarbons. Amsterdam: Elsevier.

Sprößig, M y G Anger (dirs.). 1988. M ikrobiologisches Vademekun [M anual de microbiología]. Jena: Gustav Fischer.

Stayner, L, AL Dannenberg, M Thun, G Reeve TF Bloom, M Boeniger, W H alperin. 1992 Cardiovascular mortality among munitions workers exposed to nitroglycerin and dinitrotoluene. Scand I W ork Environ $H$ ealth 18:34-43.

Stern, FB, RA Curtis. 1981. Exposure of motor vehicle examiners to carbon monoxide: A historical prospective mortality study. Arch Environ $H$ ealth 36:59-66.

Stobbe, $H$ (dir.). 1988. Allgemeine und spezielle Therapie innerer E rkrankungen [T ratamiento general y especial de las enfermedades internas]. Jena: G ustav Fischer.

Sugimoto, K, S Goto, S K anda, H Taniguchi, K Nakamura, T Baba. 1978. Studies on angiopathy due to carbon disulfide. Scand I W ork E nviron $\mathrm{H}$ ealth 4:151-158.

Sweetnam, PM, SW Taylor, PC Elwood. 1987. Exposure to carbon disulphide and ischaemic heart disease in a viscose rayon factory. B rit J Ind $M$ ed 44:220-227.
T alijancic, A, M M ustac. 1989. Arterial hypertension in workers exposed to occupational noise. Archiv za H igijenu Rada/ T oksik 40:415-420.

Thériault, GP, CG Tremblay, BG Armstrong. 1988. $R$ isk of ischaemic heart disease among primary aluminum production workers. Am J Ind $\mathrm{Med}$ 13:659-666.

Tiller, JR, RSF Schilling, JN Morris. 1968. $O$ ccupational toxic factor in mortality from coronary heart disease. B rit M ed J 4:407-411.

Tolonen, M, M Nurminen, S Hernberg. 1979 T en-year coronary mortality of workers exposed to carbon disulfide. Scand J W ork Environ $\mathrm{H}$ ealth 5:109-114.

Tolonen, $\mathrm{M}$, S Hernberg, $\mathrm{M}$ Nurminen, $\mathrm{K}$ Tiitola. 1975. A follow-up study of coronary heart disease in viscose rayon workers exposed to carbon disulphide. Brit J Ind $M$ ed 32:1-10.

U emura, K, Z Pisa. 1988. T rends in cardiovascular disease mortality in industrialized countries since 1950. W orld $H$ ealth Stat Q 41:155-178.

US Department of $\mathrm{Health}$ and Human Services (DH H S) and Public H ealth Service. 1991. H ealthy People. National $H$ ealth Promotion and D isease Prevention $O$ bjectives. W ashington, DC: DH HS

US Preventive Services Task Force. 1989. Guide to Clinical Preventive Services: An Assessment of the
E ffectiveness of 169 Interventions. Baltimore: Williams $\&$ Wilkins.

V allet, M. 1993 (dir.). Bruit et Santé . V ol. 1-3. Actas del 60 Congreso internacional, 5-9 de julio, $\mathrm{Niza}$. Arcueil: Inst. national de recherche sur les transports et leur sécurité

Vanhoorne, M, D de Bacquer, G de Backer. 1992. Epidemiological study of the cardiovascular effects of carbon disulphide. Int I E pidemiol 21(4):745-752.

Vena, JE, RC Fiedler. 1987. Mortality of a municipal-worker cohort: IV. Fire fighters. Am J Ind $M$ ed 11:671-684.

Vermel', $A E, G M$ Zinenko, EM Kochanova, LT Suares, KM Bogatov. 1988. Intensity of industrial noise and the incidence of arterial hypertension (according to data from a prospective epidemiological study of organized female populations in Moscow). Terapevticheskii Arkhiv 60:88-91.

Wilcosky, TC, HA Tyroler. 1983. M ortality from heart disease among workers exposed to solvents. I 0 ccup M ed 25(12):879-885.

Willich, SN. 1992. Der Herzinfarkt [E] infarto de miocardio(en alemán)]. Darmstadt: Steinkopff Verlag.

Zhao, YM, SZ Zhang, S Selvin, RC Spear. 1991. A dose-response relation for noise induced hypertension. B rit J Ind M ed 48:179-184. 

Director del capítulo

H eikki Savolainen

\section{Sumario}

A parato digestivo

G. Frada . . . . . . . . . . . . . . . . . . . . . . . . . 4.2

Boca y dientes

F. Gobbato ............................... 4.3

Hígado

G eorge Kazantzis........................ 4.5

Ulcera péptica

K.S. Cho ................................. 4.8

Cáncer hepático

T imo Partanen, T imo Kauppinen, Paolo B offetta

y E lisabete $W$ eiderpass. . . . . . . . . . . . . . . . . . . . . . . . 4.9

Cáncer pancreático

T imo Partanen, T imo Kauppinen, Paolo B offetta y E lisabete W eiderpass. . . 4.11 


\section{- Aparato digestivo}

\section{G . Frada*}

EI aparato digestivo ejerce una influencia considerable en la eficiencia y capacidad de trabajo del organismo y sus enfermedades, agudas o crónicas, son algunas de las causas más frecuentes de absentismo y discapacidad. En este contexto, puede solicitarse al médico del trabajo de alguna de las siguientes maneras para que haga sugerencias relativas a las necesidades de higiene y nutrición específicas de una profesión dada: para evaluar la posible influencia de los factores propios de una profesión en el desarrollo de ciertos procesos de enfermedad del aparato digestivo 0 en el agravamiento de otros preexistentes 0 independientes de la profesión, o para que dé su opinión acerca de la idoneidad general o específica de una persona para la profesión.

M uchos de los factores perjudiciales para el aparato digestivo pueden tener un origen profesional; no es raro que varios factores actúen en concierto y que su acción se vea facilitada por la predisposición individual. A continuación se reseñan algunos de los factores laborales más importantes: tóxicos industriales, agentes físicos y estrés profesional, como la tensión, la fatiga, las posturas anormales, los cambios frecuentes del ritmo de trabajo, el trabajo por turnos, el trabajo nocturno y los malos hábitos alimenticios (cantidad, calidad y horario de las comidas).

\section{Peligros químicos}

El aparato digestivo puede ser la puerta de entrada de numerosas sustancias químicas al organismo, si bien a este respecto su papel es mucho menos importante que el del aparato respiratorio, que tiene un área de superficie de absorción de 80-100 m², mientras que la cifra correspondiente del aparato digestivo no supera $20 \mathrm{~m}^{2}$. Además, los vapores y gases que penetran en el cuerpo por inhalación alcanzan el torrente sanguíneo, y por tanto el encéfalo, sin encontrar sistemas de defensa interpuestos; por el contrario, las sustancias tóxicas ingeridas son filtradas y hasta cierto punto metabolizadas por el hígado antes de alcanzar el árbol vascular. No obstante, pueden producirse lesiones orgánicas y funcionales tanto durante su introducción como durante su eliminación del organismo, o como consecuencia de su acumulación en ciertas vísceras. Estas lesiones pueden ser debidas a la acción de la propia sustancia tóxica o de sus metabolitos, 0 al hecho de que el organismo carezca de ciertos compuestos esenciales. También pueden intervenir la idiosincrasia y los mecanismos alérgicos. La ingestión de cáusticos es todavía un accidente relativamente frecuente. En un estudio retrospectivo realizado en Dinamarca, la incidencia anual de quemaduras esofágicas se calculó en 1/100.000, y la de hospitalización por esta causa, en 0,8/100.000 adultos/año. Muchos de los productos utilizados en la limpieza del hogar son cáusticos.

Los mecanismos tóxicos son muy complejos y varían considerablemente de unas sustancias a otras. Algunos de los elementos y compuestos utilizados en la industria producen lesiones locales del aparato digestivo que afectan, por ejemplo, a la cavidad oral y zonas vecinas, al estómago, al intestino, al hígado 0 al páncreas.

Los disolventes muestran una afinidad especial por los tejidos ricos en lípidos. Su acción tóxica es por lo general compleja, y en ella participan diversos mecanismos. En el caso del tetracloruro de carbono, se cree que la lesión hepática se debe sobre todo a sus metabolitos tóxicos. En el del disulfuro de carbono, la afectación gastrointestinal se atribuye a la acción

*A daptado de la tercera edición, E nciclopedia de Salud y Seguridad en el Trabajo. neurotropa específica de esta sustancia en el plexo intramural, mientras que el daño hepático parece debido, sobre todo, a la acción citotóxica del compuesto, que induce cambios del metabolismo de las lipoproteínas.

La lesión hepática forma una parte importante de la patología de los compuestos tóxicos exógenos, puesto que el hígado es el órgano fundamentalmente encargado de metabolizar los agentes tóxicos, y colabora con los riñones en los procesos de desintoxicación. La bilis recibe del parénquima hepático, directamente 0 tras su conjugación, diversas sustancias que pueden ser reabsorbidas en la circulación enterohepática (por ejemplo, cadmio, cobalto, manganeso). Los hepatocitos participan en los procesos de oxidación (p. ej., alcoholes, fenoles, tolueno), reducción (p. ej., compuestos nitrogenados), metilación (p. ej., ácido selénico), conjugación con los ácidos sulfúrico o glucurónico (p. ej., benceno) y acetilación (p. ej., aminas aromáticas). Las células de Kupffer pueden intervenir también, por ejemplo mediante fagocitosis de los metales pesados.

Los síndromes gastrointestinales graves, como los provocados por el fósforo, el mercurio o el arsénico, se manifiestan con vómitos, dolores cólicos y heces mucosanguinolentas y pueden asociarse a lesión hepática (hepatomegalia, ictericia). Estos cuadros son relativamente raros en la actualidad, y han sido superados por intoxicaciones profesionales, de instauración lenta e incluso insidiosa: en consecuencia, la lesión hepática también puede ser insidiosa.

La hepatitis infecciosa merece una atención especial; puede asociarse a varios factores profesionales (agentes hepatotóxicos, calor o trabajo con calor, frío o trabajo con frío, actividad física intensa, etc.), puede mostrar un curso clínico desfavorable (hepatitis crónica prolongada o persistente) y puede causar fácilmente una cirrosis. Suele asociarse a ictericia y, por tanto, plantear dificultades diagnósticas. Además, plantea problemas de pronóstico y de valoración del grado de restablecimiento y, por tanto, de la recuperación física para la reanudación del trabajo.

Aunque el aparato digestivo está colonizado por una microflora abundante que tiene funciones fisiológicas importantes para la salud humana, la exposición profesional puede dar lugar a infecciones profesionales. Así ocurre, por ejemplo, con los trabajadores de mataderos, que pueden correr riesgo de contraer una infección por H elicobacter, a menudo asintomática. 0 tras infecciones importantes son las debidas a especies de Salmonella y Shigella, que también es preciso controlar para conservar la seguridad de los alimentos, como ocurre en la industria alimentaria y en los servicios de restauración.

En los países industrializados, los principales riesgos de cáncer de esófago proceden del tabaco y del alcohol, siendo la etiología profesional de importancia mucho menor. Sin embargo, los carniceros y sus cónyuges parecen correr un alto riesgo de cáncer colorrectal.

\section{Factores físicos}

Distintos agentes físicos pueden causar síndromes digestivos, como sucede con los traumatismos directa o indirectamente discapacitantes, las radiaciones ionizantes, las vibraciones, la aceleración rápida, el ruido, las temperaturas muy altas o muy bajas o los cambios climáticos bruscos y repetidos. Las quemaduras, sobre todo cuando son extensas, pueden dar lugar a ulceraciones gástricas y lesiones hepáticas, quizá con ictericia. Las posturas o movimientos anormales pueden causar trastornos digestivos, especialmente cuando se asocian a trastornos predisponentes, como la hernia paraesofágica, la visceroptosis o la relaxatio diaphragmatica; además, pueden aparecer reflejos extradigestivo scomo el ardor epigástrico cuando los trastornos digestivos van acompañados de alteraciones del sistema nervioso 
autónomo o neuropsicológicas. Estos trastornos son frecuentes en las modernas circunstancias de trabajo y pueden ser ellos mismos causa de disfunción gastrointestinal.

\section{Estrés profesional}

El cansancio físico también puede alterar la función digestiva, y el trabajo pesado puede causar trastornos secretomotores y cambios distróficos, sobre todo del estómago. Las personas con procesos gástricos, sobre todo las que han sido sometidas a intervenciones quirúrgicas, presentan limitaciones en cuanto a la cantidad de trabajo pesado que pueden hacer, aunque sólo sea porque estas tareas requieren mayores grados de nutrición.

El trabajo por turnos causa importantes cambios de los hábitos alimenticios, con la consiguiente aparición de problemas gastrointestinales. Los turnos pueden asociarse también a un aumento de las concentraciones sanguíneas de colesterol y triglicéridos y a una mayor actividad de la gamma-glutamiltransferasa sérica.

La dispepsia gástrica nerviosa (o neurosis gástrica) no parece tener una causa gástrica ni extragástrica, ni ser debida a un trastorno metabólico o humoral; en consecuencia, se considera que se debe a un trastorno primitivo del aparato nervioso autónomo, a veces asociado a un esfuerzo mental excesivo 0 al estrés emocional o psicológico. El cuadro gástrico suele manifestarse por hipersecreción neurótica o por una neurosis hipercinética 0 atónica (esta última, asociada a menudo a gastroptosis). Bajo este epígrafe podrían incluirse también el dolor epigástrico, la regurgitación y la aerofagia. La erradicación de los factores psicológicos perjudiciales del medio ambiente de trabajo puede inducir la remisión de los síntomas.

Diversas observaciones indican un aumento de la frecuencia de úlcera péptica en las personas con mayores responsabilidades, como supervisores y ejecutivos, personas que realizan trabajos muy pesados, recién llegados a una industria, emigrantes, marineros y trabajadores sometidos a importantes tensiones socioeconómicas. Sin embargo, son muchas las personas que, aun con este mismo trastorno, llevan vidas profesionales normales, y carecemos de pruebas estadísticas. A demás de las condiciones de trabajo, el consumo de alcohol, el hábito de fumar, los hábitos alimenticios y las circunstancias de la vida social y familiar contribuyen también al desarrollo y perpetuación de la dispepsia, lo que hace difícil establecer la parte que cada uno desempeña en la etiología de esta enfermedad.

También se ha dicho que los trastornos digestivos se relacionarían con el trabajo por turnos como consecuencia de la frecuente variación de los horarios de las comidas y de las malas condiciones de alimentación en los lugares de trabajo. Estos factores pueden agravar una alteración digestiva preexistente e inducir una dispepsis neurótica. En consecuencia, los trabajadores sólo deberían ser asignados a un trabajo por turnos después de ser sometidos a una exploración médica.

\section{Supervisión médica}

Puede verse que el profesional de la salud del trabajo se enfrenta a numerosos problemas en el diagnóstico y la valoración de las molestias digestivas (debidas entre otras cosas el papel desempeñado por los factores nocivos no profesionales) y que tiene una responsabilidad considerable en la prevención de los trastornos de origen profesional.

EI diagnóstico precoz es sumamente importante y supone la realización de exploraciones médicas periódicas y supervisión del medio ambiente de trabajo, sobre todo en los casos de alto nivel de riesgo.

La educación sanitaria de la población en general, y de los trabajadores en particular, es una medida preventiva de gran valor que puede proporcionar importantes resultados. Debe prestarse atención a las necesidades nutritivas, a la elección y preparación de los alimentos, a los horarios y tamaños de las comidas, a la masticación adecuada y a la moderación en el consumo de los alimentos ricos en calorías, alcohol y bebidas frías, suprimiéndolos incluso de la dieta.

\section{BOCA Y DIENTES}

\section{F. G obbato*}

La boca es la puerta de entrada al aparato digestivo, y sus funciones son fundamentalmente la masticación y la deglución de los alimentos y la digestión parcial de los almidones por medio de las enzimas salivales. También participa en la vocalización, y puede sustituir o complementar a la nariz en la respiración. Dados lo expuesto de su localización y las funciones que cumple, es mucho más que una simple puerta de entrada, actuando como área de absorción, retención y excreción de las sustancias tóxicas a las que se expone el organismo. Los factores que favorecen la respiración bucal (estenosis nasal, situaciones emocionales) y el aumento de la ventilación pulmonar durante el esfuerzo facilitan la penetración de sustancias extrañas por esta vía o su acción directa en los tejidos de la cavidad bucal.

La respiración bucal favorece:

- una mayor penetración del polvo en el árbol respiratorio, ya que la cavidad bucal tiene un cociente de retención (atrapamiento) de partículas sólidas muy inferior al de la cavidad nasal;

- la abrasión dental en los trabajadores expuestos a partículas de polvo de gran tamaño, la erosión dental en los expuestos a los ácidos fuertes, la caries en los expuestos a polvos de harina 0 azúcar, etc.

La boca puede ser la vía de entrada de sustancias tóxicas al interior del organismo, ya sea por ingestión accidental o por absorción lenta. La superficie de las membranas mucosas orales es relativamente pequeña (en comparación con la del aparato respiratorio o gastrointestinal), por lo que las sustancias extrañas permanecen en contacto con ella sólo durante breves períodos. Estos factores limitan considerablemente la absorción hasta de las sustancias muy solubles, pero esta posibilidad de absorción existe e incluso se utiliza con fines terapéuticos (absorción perlingual de fármacos).

Los tejidos de la cavidad oral pueden ser un foco de acumulación de sustancias tóxicas, no sólo por absorción directa y local, sino también por transporte a través de la circulación sanguínea. La investigación con isótopos radiactivos demuestra que incluso los tejidos que parecen metabólicamente más inertes (como el esmalte y la dentina del diente) poseen cierta capacidad de acumulación y muestran un recambio relativamente activo de ciertas sustancias. Son ejemplos clásicos de depósito los diversos cambios de color de las membranas mucosas (líneas gingivales), que a menudo proporcionan una información diagnóstica de gran valor (p. ej., plomo).

La excreción salival no contribuye a la eliminación de las sustancias tóxicas del organismo, puesto que la saliva se traga y las sustancias contenidas en ella se absorben de nuevo, con el consiguiente círculo vicioso. Por otra parte, esta secreción posee cierto valor diagnóstico (determinación de sustancias tóxicas en la saliva); también puede ser importante en la patogenia de algunas lesiones, puesto que la saliva renueva y prolonga la acción de las sustancias tóxicas en las membranas bucales. Las

\footnotetext{
*A daptado de la tercera edición, E nciclopedia de Salud y Seguridad en el Trabajo.
} 
sustancias siguientes se excretan por la saliva: varios metales pesados, los halógenos (la concentración de yodo puede llegar a ser 7-700 veces mayor que la del plasma), los tiocianatos (fumadores, trabajadores expuestos al ácido cianhídrico y a los compuestos cianogenados) y una amplia gama de compuestos orgánicos (alcoholes, alcaloides, etc.).

\section{Etiopatogenia y clasificación clínica}

Las lesiones de la boca y de los dientes (también llamadas lesiones estomatológicas) de origen profesional pueden ser debidas a:

- agentes físicos (traumatismos agudos y microtraumatismos crónicos, calor, electricidad, radiaciones, etc.);

- agentes físicos que alteran los tejidos de la cavidad oral, directamente 0 a través de cambios sistémicos;

- agentes biológicos (virus, bacterias, micetos).

Sin embargo, al tratar de las lesiones de la boca y los dientes de origen profesional, es preferible una clasificación basada en la localización topográfica o anatómica que otra basada en los principios etiopatogénicos.

Labios y mejillas. La exploración de labios y mejillas puede revelar palidez debida a anemia (benceno, intoxicación por plomo, etc.), cianosis por insuficiencia respiratoria aguda (asfixia) o crónica (enfermedades profesionales del pulmón), cianosis por metahemoglobinemia (nitritos y compuestos orgánicos nitrogenados, aminas aromáticas), color rojo cereza secundario a la intoxicación aguda por monóxido de carbono, pigmentación amarillenta en caso de intoxicación aguda por ácido pícrico o dinitrocresol 0 en la ictericia hepatotóxica (fósforo, pesticidas con hidrocarburos clorados, etc.). En la argirosis aparece una coloración parda o gris azulada causada por la precipitación de la plata 0 de sus compuestos insolubles, sobre todo en las zonas expuestas a la luz solar.

Los trastornos profesionales de los labios son: disqueratosis, fisuras y ulceraciones por acción directa de las sustancias cáusticas y corrosivas; dermatitis alérgica de contacto (níquel, cromo) que puede incluir también la dermatitis de los trabajadores del tabaco, eczemas microbianos secundarios al uso de equipo respiratorio protector sin respetar las normas elementales de higiene, lesiones debidas al carbunco y al muermo (úlcera cancroide y pústulas malignas) de los que trabajan con animales, inflamación causada por la radiación solar en los trabajadores agrícolas y los pescadores, neoplasias en los que manejan sustancias carcinógenas, lesiones traumáticas y chancros de los labios en los sopladores de vidrio.

Dientes. La coloración debida al depósito de sustancias inertes o a la impregnación del esmalte por compuestos solubles tiene un interés casi exclusivamente diagnóstico. L os cambios de coloración importantes son los siguientes: pardo, por depósito de compuestos de hierro, níquel y manganeso; pardoverdoso, debido al vanadio; pardoamarillento, debido al yodo y al bromo; amarillo dorado, con frecuencia limitado a la línea gingival, debido al cadmio.

Mayor importancia tiene la erosión dental de origen mecánico o químico. Incluso en la actualidad, es posible encontrar erosiones de origen mecánico en ciertos artesanos (debidas a la costumbre de sujetar clavos o cuerdas, etc., con los dientes), tan características que pueden considerarse estigmas profesionales. Se han descrito lesiones causadas por polvos abrasivos en fresadores, lijadores, canteros y talladores de piedras preciosas. $L a$ exposición prolongada a los ácidos orgánicos e inorgánicos provoca a menudo lesiones dentales, que afectan sobre todo a la superficie labial de los incisivos (más rara vez a los caninos); estas lesiones comienzan por ser superficiales y limitadas al esmalte, pero se van haciendo más profundas y amplias, alcanzando la dentina y provocando la solubilización y movilización de las sales de calcio. Su localización en la superficie anterior de los dientes se debe a que, cuando la boca está abierta, son estos dientes los que resultan más expuestos y privados de la protección natural del efecto tampón de la saliva.

La caries dental es una enfermedad tan común y difundida que sería necesario un detallado estudio epidemiológico para poder determinar si, de hecho, tiene un origen profesional. El ejemplo más típico es la caries de los trabajadores expuestos a los polvos de harina y azúcar (molineros, panaderos, pasteleros, trabajadores de la industria azucarera). Se trata de una caries blanda que se desarrolla con rapidez, comienza en la base del diente (caries rampante) y progresa de inmediato hacia la corona. Las caras afectadas adquieren un color negruzco, el tejido se ablanda y se produce una importante pérdida de sustancia; en última instancia, la pulpa también se ve afectada. Estas lesiones comienzan a aparecer al cabo de algunos años de exposición y su gravedad y extensión aumentan con la duración de aquélla. Los rayos $X$ también pueden dar lugar a caries dentales de desarrollo rápido que suelen comenzar en la base de los dientes.

A demás de las pulpitis debidas a la caries y erosión dental, un aspecto interesante de la patología de la pulpa es la odontalgia por barotraumatismo, es decir, el dolor dental inducido por la presión. Este trastorno se debe a la rápida acumulación del gas disuelto en el tejido de la pulpa después de una descompresión brusca. Se trata de una de las manifestaciones más frecuentes del ascenso rápido en aeroplano. En las personas que sufren pulpitis sépticas-gangrenosas, en las que ya existe un contenido gaseoso, este dolor dental puede comenzar ya a los 2.000-3.000 m de altitud.

La fluorosis profesional no causa patología dental, como sucede con la fluorosis endémica; el flúor sólo induce cambios distróficos (esmalte moteado) cuando el período de exposición precede a la erupción de la dentición permanente.

Cambios de las membranas mucosas y estomatitis. Los distintos cambios de coloración de las membranas mucosas debidos a la impregnación o precipitación de metales y sus compuestos insolubles (plomo, antimonio, bismuto, cobre, plata, arsénico) tienen un valor diagnóstico definitivo. U n ejemplo típico es la línea de Burton en la intoxicación por plomo, que se debe a la precipitación del sulfuro de plomo tras el desarrollo de ácido sulfhídrico en la cavidad oral como consecuencia de la putrefacción de los restos alimenticios. No ha sido posible reproducir experimentalmente esta línea de Burton en animales hervíboros.

Existe un cambio de coloración muy peculiar de la membrana mucosa de la lengua de los trabajadores expuestos al vanadio. Se debe a la impregnación por pentóxido de vanadio, que posteriormente se reduce a trióxido. Esta coloración no puede eliminarse, pero desaparece espontáneamente algunos días después de concluir la exposición.

La mucosa oral puede ser asiento de lesiones corrosivas graves debidas a ácidos, álcalis u otras sustancias corrosivas. L os álcalis producen maceración, supuración y necrosis del tejido, con formación de lesiones que se desprenden con facilidad. La ingestión de productos cáusticos o corrosivos provoca úlceras grandes y muy dolorosas en la boca, el esófago y el estómago, que pueden evolucionar hacia la perforación y a menudo dejan cicatrices. La exposición crónica favorece el desarrollo de inflamación, físuras, úlceras y descamación epitelial de la lengua, el paladar y otras partes de la mucosa oral. L os ácidos inorgánicos y orgánicos coagulan las proteínas y causan lesiones ulceradas, necróticas, que curan con cicatrices estenosantes. LoS cloruros de mercurio y de zinc, algunas sales de cobre, los cromatos alcalinos, el fenol y otras sustancias cáusticas provocan lesiones similares. 
Un ejemplo básico de estomatitis crónica es la secundaria al mercurio. Tiene un comienzo gradual, con síntomas poco prominentes y curso clínico prolongado. Los síntomas son salivación excesiva, sabor metálico en la boca, halitosis y ligero enrojecimiento y tumefacción de las encías. Se trata de la primera fase de una periodontitis que termina por causar la caída de los dientes. En la estomatitis debida al arsénico, el bismuto, el oro, etc. se observa un cuadro clínico similar.

Glándulas salivales. Se ha observado un aumento de la secreción salival en las situaciones siguientes:

- en distintas estomatitis agudas y crónicas, debido sobre todo a la acción irritante de las sustancias tóxicas; a veces es de gran intensidad. Por ejemplo, en la intoxicación crónica por derivados del mercurio, el síntoma es tan marcado y aparece en una fase tan precoz, que los trabajadores ingleses lo han denominado "enfermedad de la saliva";

- en casos de intoxicación con afectación del sistema nervioso central, como sucede en la secundaria al manganeso. Sin embargo, incluso en la intoxicación crónica por mercurio, se cree que la hiperactividad de las glándulas salivales es, al menos en parte, de origen nervioso;

- en casos de intoxicación aguda por pesticidas organofosforados que inhiben las colinesterasas.

Existe disminución de la secreción salival en los trastornos graves de la termorregulación (golpe de calor, intoxicación aguda por dinitrocresol) y en la alteración grave del equilibrio hidroelectrolítico durante el fracaso hepatorrenal de origen tóxico.

En los casos de estomatitis aguda o crónica, el proceso inflamatorio puede afectar también, a veces, a las glándulas salivales. En el pasado, se comunicaron casos de "parotiditis saturnina", pero este proceso es tan raro hoy día que parece justificado dudar de su existencia real.

H uesos maxilares. Los agentes químicos, físicos y biológicos pueden causar cambios degenerativos, inflamatorios y proliferativos del esqueleto de la boca. De los agentes químicos, probablemente sea el fósforo blanco o amarillo el más importante, ya que causa la necrosis por fósforo de la mandíbula, tan temida en un tiempo por los trabajadores de la industria fosforera. La absorción de fósforo aumenta en caso de lesiones gingivales y dentales y produce, al principio, una reacción perióstica productiva, seguida de fenómenos destructivos y necróticos, activados por la infección bacteriana. El arsénico también causa una estomatitis ulceronecrótica que puede complicarse con lesión ósea. La afectación se limita a las raíces de la mandíbula y lleva al desarrollo de pequeñas láminas de hueso muerto. Cuando el diente cae y el hueso muerto se elimina, la evolución del proceso es favorable y la lesión cicatriza casi siempre.

EI radio fue la causa de los procesos osteonecróticos maxilares observados durante la primera Guerra M undial en los trabajadores que manejaban compuestos luminosos. Además, la lesión ósea también puede ser debida a infección.

\section{Medidas preventivas}

Todo programa de prevención de las enfermedades bucodentales debe basarse en los cuatro principios fundamentales siguientes:

- aplicación de medidas de higiene industrial y medicina preventiva, incluidos control del medio ambiente de trabajo, análisis de los procesos de producción, eliminación de los peligros medioambientales y, cuando sea necesario, uso de equipo de protección personal;

- educación de los trabajadores acerca de la necesidad de una higiene oral escrupulosa; se ha comprobado en muchos casos que la ausencia de una buena higiene oral puede reducir la resistencia a las enfermedades profesionales generales y locales;

- exploración meticulosa de la boca y los dientes cuando se realizan a los trabajadores exploraciones médicas previas al empleo o periódicas;

- detección precoz y tratamiento de todas las enfermedades bucodentales, sean o no de origen profesional.

\section{HIGADO}

\section{G eorge Kazantzis*}

EI hígado actúa como una enorme fábrica de productos químicos y ejerce varias funciones de importancia vital. Desempeña un papel esencial en el metabolismo de las proteínas, los hidratos de carbono y las grasas y participa en la absorción y depósito de las vitaminas y en la síntesis de la protrombina y otros factores relacionados con la coagulación de la sangre. Es el responsable de la inactivación de las hormonas y de la desintoxicación de muchas sustancias químicas tóxicas, exógenas o endógenas. También excreta los productos de degradación de la hemoglobina, que son los componentes principales de la bilis. Estas funciones, tan variadas, se deben a las células parenquimatosas, de estructura uniforme, que contienen numerosos sistemas enzimáticos complejos.

\section{Fisiopatología}

U na característica importante de las enfermedades hepáticas es el aumento de la concentración de bilirrubina en la sangre que, si alcanza la magnitud suficiente, tiñe los tejidos y da lugar a ictericia. El mecanismo de este proceso se muestra en la Figura 4.1. La hemoglobina liberada a partir de los hematíes viejos se degrada a hemo y luego, por eliminación del hierro, a bilirrubina, antes de llegar al hígado (bilirrubina prehepática). Durante su paso por los hepatocitos, la bilirrubina se conjuga por actividad enzimática para dar glucurónidos hidrosolubles (bilirrubina posthepática) y se secreta luego al intestino en forma de bilis. La mayor parte de este pigmento pasa en última instancia a las heces, pero una fracción es reabsorbida por la mucosa intestinal y secretada de nuevo por las células hepáticas a la bilis (circulación enterohepática). No obstante, una pequeña proporción de este pigmento reabsorbido se excreta en la orina en forma de urobilinógeno. Cuando la función del órgano es normal, la orina no contiene bilirrubina, ya que la forma prehepática se halla unida a las proteínas; sí contiene, en cambio, una pequeña cantidad de urobilinógeno. Puede producirse una obstrucción del sistema biliar en el árbol biliar, o a nivel celular por tumefacción de los hepatocitos en caso de lesión, con la consiguiente obstrucción de los pequeños canalículos biliares. La bilirrubina posthepática se acumula entonces en la circulación sanguínea y produce ictericia, además de pasar a la orina. La secreción de pigmento biliar al intestino disminuye, y no hay excreción urinaria de urobilinógeno. Por tanto, las heces son pálidas por falta de pigmento, mientras que la orina adquiere un color oscuro, y la bilirrubina conjugada del suero se eleva por encima de su valor normal, lo que origina ictericia obstructiva.

La lesión de los hepatocitos, que puede aparecer tras la inyección o exposición a los agentes tóxicos, también provoca acumulación de la bilirrubina conjugada posthepática (ictericia hepatocelular), que puede ser lo bastante grave y prolongada para originar un cuadro obstructivo pasajero en el que existe

*A daptado de la tercera edición, E nciclopedia de Salud y Seguridad en el Trabajo. 
Figura 4.1 Excreción de la bilirrubina por el hígado, mostrando la circulación enterohepática.

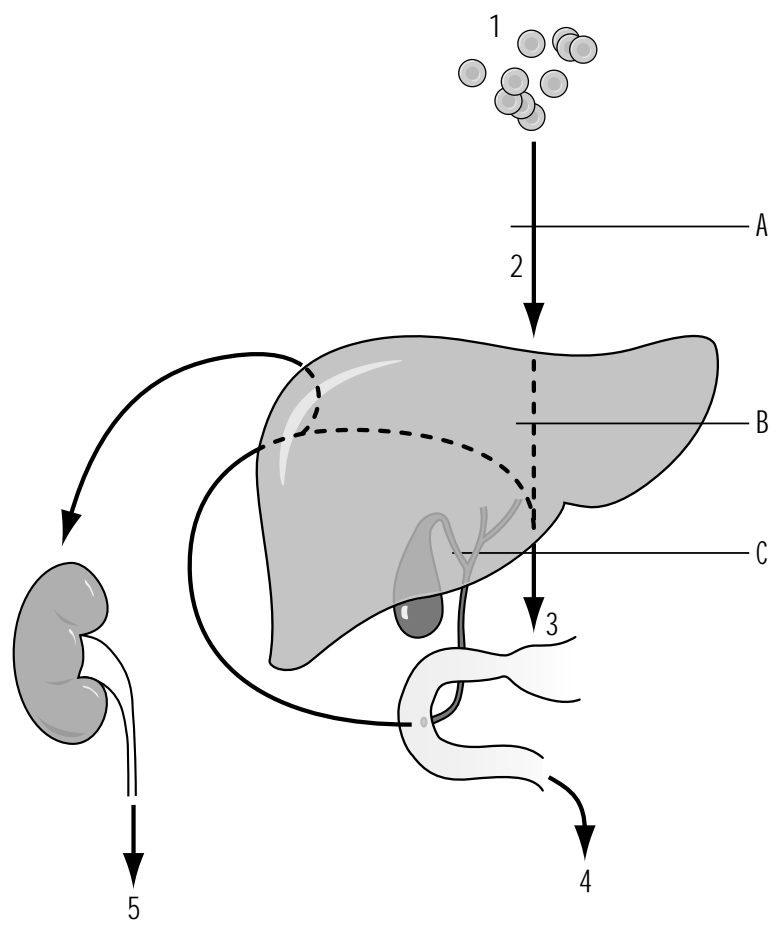

A. Lugar de origen de la ictericia hemolítica $B$. Lugar de origen de la ictericia hepatocelular C. Lugar de origen de la ictericia obstructiva

1. Hemoglobina

2. Bilirrubina prehepática

3. Bilirrubina posthepática

4. Estercobilinógeno

5. Urobilinógeno

bilirrubina en la orina pero no urobilinógeno. Sin embargo, en los estadios precoces de la lesión hepatocelular, y en ausencia de obstrucción, el hígado no puede reexcretar la bilirrubina reabsorbida, por lo que se encuentra una cantidad excesiva de urobilinógeno urinario.

Cuando la destrucción de los hematíes se produce a un ritmo acelerado, como sucede en las anemias hemolíticas, el hígado sufre una sobrecarga de bilirrubina prehepática no conjugada y la concentración de ésta en la sangre aumenta, lo que también da lugar a ictericia. Sin embargo, la bilirrubina prehepática no puede excretarse en la orina. Ello hace que pase en gran cantidad al intestino y tiña las heces de color oscuro. Puesto que la cantidad reabsorbida hacia la circulación enterohepática es mayor, también lo es la cantidad de urobilinógeno que se elimina con la orina (ictericia hemolítica).

\section{Diagnóstico}

Las pruebas de función hepática se emplean para confirmar una sospecha de enfermedad hepática, para evaluar su evolución y para facilitar el diagnóstico diferencial de la ictericia. Suelen utilizarse distintas pruebas para examinar las diferentes funciones del hígado. Las de valor demostrado son:

1. Investigación de la presencia de bilirrubina y urobilinógeno en la orina: La primera indica una lesión hepatocelular o una obstrucción biliar. La presencia de un exceso de urobilinógeno puede preceder a la instauración de la ictericia y constituye una demostración sencilla y sensible de la existencia de lesión hepatocelular mínima o de hemólisis.

2. Cálculo de la bilirrubina total en el suero: Valor normal 5-17 $\mu \mathrm{mol} / \mathrm{I}$.

3. Cálculo de la concentración sérica de enzimas : La lesión hepatoceIular se asocia a la elevación de varias enzimas en el suero, particularmente de $\gamma$-glutamil transpeptidasa, alanina aminotransferasa (transaminasa glutámico pirúvica) y aspartato aminotransferasa (transaminasa glutámico oxaloacética), y a elevaciones más moderadas de la fosfatasa alcalina. El aumento de la concentración en suero de esta última indica una lesión obstructiva.

4. Determinación de la concentración de proteínas plasmáticas y de su patrón electroforético: La lesión hepatocelular va acompañada de descenso de la albúmina plasmática y elevación diferencial de las fracciones de globulinas, especialmente de la globulina $\gamma$. E stos cambios constituyen la base de las pruebas hepáticas de floculación.

5. Prueba de excreción de bromosulftaléna: Se trata de una prueba sensible de la lesión hepatocelular precoz, y es útil para detectar su presencia en ausencia de ictericia.

6. Pruebas inmunológicas: La determinación de las concentraciones de inmunoglobulinas y la detección de autoanticuerpos son de gran valor en el diagnóstico de ciertas formas de hepatopatía crónica. La presencia del antígeno de superficie de la hepatitis B indica una hepatitis sérica, mientras que la presencia de alfa-fetoproteína sugiere un hepatocarcinoma.

7. D eterminación de hemoglobina, índices eritrocitarios y fórmula sanguínea.

O tras pruebas utilizadas en el diagnóstico de las hepatopatías comprenden los estudios ecográficos o por captación de isótopos radiactivos, la biopsia mediante trocar con estudio histológico del tejido y la laparoscopia. La ecografía es una técnica segura, sencilla y no agresiva, pero exige habilidad en su aplicación.

\section{Enfermedades profesionales}

Infecciones. La esquistosomiasis es una infección parasitaria grave y muy extendida que puede dar lugar a una hepatopatía crónica. L os huevos del parásito producen una inflamación de los espacios porta del hígado que va seguida de fibrosis. La infección es una enfermedad profesional de los trabajadores que entran en contacto con aguas contaminadas por larvas del parásito.

La hidatidosis hepática es frecuente en las comunidades dedicadas a la cría de ovejas y con escasa higiene, en las que la población se halla en íntimo contacto con el perro, el huésped definitivo, y con las ovejas, huéspedes intermedios del parásito, E chinococcus granulosus. Cuando una persona se convierte en el huésped intermedio, el parásito puede formar un quiste hidatídico hepático que causa dolor y tumefacción, seguidos a veces de infección o rotura del quiste.

La enfermedad de Weil puede producirse tras contacto con agua o tierra húmeda contaminadas por ratas portadoras del microorganismo causal, Leptospira icterohaemorrhagiae. Es una enfermedad profesional de los trabajadores del alcantarillado, mineros, agricultores de los campos de arroz y pescaderos y carniceros. La aparición de ictericia pocos días después del comienzo de fiebre constituye sólo una fase de la enfermedad, que también afecta al riñón.

Son varios los virus que causan hepatitis, pero los más frecuentes son el virus de tipo $\mathrm{A}(\mathrm{VH} A)$, que produce una hepatitis infecciosa aguda, y el virus de tipo $B(\mathrm{VHB})$, que causa la hepatitis sérica. El primero es responsable de epidemias mundiales y se contagia por vía fecal-oral; produce una enfermedad caracterizada por ictericia febril con lesión hepatocelular que suele resolverse sin secuelas. La hepatitis de tipo $B$ es una enfermedad de pronóstico más serio. El virus se transmite con 
facilidad tras la punción de la piel o de una vena o por transfusión de sangre o hemoderivados contaminados; también se transmite por vía parenteral en los drogadictos y por vía sexual, sobre todo en contactos homosexuales o contactos personales íntimos. También los artrópodos hematófagos pueden transmitirlo. Se han producido epidemias en unidades de diálisis y de trasplante y en laboratorios y salas de hospitales. Los pacientes en hemodiálisis y los de las unidades oncológicas muestran gran propensión a hacerse portadores crónicos, por lo que constituyen un reservorio de la infección. El diagnóstico se confirma mediante la identificación en el suero de un antígeno que solía conocerse como antígeno en Australia, pero que hoy se denomina antígeno de superficie de la hepatitis B, HBsA g. El suero que contiene este antígeno es muy infeccioso. La hepatitis de tipo $B$ es un importante riesgo profesional del personal sanitario, sobre todo de los que trabajan en laboratorios clínicos y en unidades de diálisis. Se han encontrado grandes tasas de positividad en patólogos y cirujanos, y bajas en los médicos que no tienen contacto con pacientes. Se conoce también un virus no A, no $\mathrm{B}$ de la hepatitis, identificado como virus C (VHC). Es muy probable que existan otros virus de la hepatitis aún no identificados. El virus delta no puede causar hepatitis por sí solo, sino que actúa en combinación con el de la hepatitis $B$. La hepatitis vírica crónica es una etiología importante en la cirrosis hepática y en el cáncer de hígado (hepatocarcinoma).

L a fiebre amarilla es una enfermedad febril aguda debida a la infección por un arbovirus del grupo B transmitido por los mosquitos culicinios, sobre todo Aedes aegypti. Es endémica en muchas regiones de Africa occidental y central, en las zonas tropicales de Sudamérica y en algunas regiones de las Antillas. C uando la ictericia es muy intensa, el cuadro clínico remeda una hepatitis infecciosa. El paludismo falciparum y la fiebre recurrente también producen fiebre alta e ictericia y exigen un diagnóstico diferencial meticuloso.

Procesos tóxicos. La destrucción excesiva de hematíes con la consiguiente ictericia hemolítica puede deberse a la exposición al gas arsina 0 a la ingestión de agentes hemolíticos, como la fenilhidrazina. En la industria, el gas se debe a la formación de hidrógeno naciente en presencia de arsénico, que puede ser un contaminante ignorado de muchos procesos metalúrgicos.

M uchos tóxicos exógenos interfieren en el metabolismo de los hepatocitos por inhibición de los sistemas enzimáticos o pueden lesionar e incluso destruir las células parenquimatosas, con los que obstaculizan la excreción de bilirrubina conjugada y provocan ictericia. La lesión secundaria al tetracloruro de carbono puede considerarse un modelo de hepatotoxicidad directa. En los casos leves puede haber síntomas dispépticos sin ictericia, pero la presencia de lesión hepática se deduce del hallazgo de un exceso de urobilinógeno en la orina, de la elevación de las concentraciones séricas de aminotransferasas (transaminasas) y de la alteración de la excreción de bromosulftaleína. En los casos más graves aparece un cuadro clínico similar al de la hepatitis infecciosa aguda, con anorexia, náuseas, vómitos y dolor abdominal, seguidos de hepatomegalia dolorosa y de ictericia, con heces pálidas y orina oscura. Una característica bioquímica importante es el gran aumento de la aminotransferasa (transaminasa) sérica común en estos casos. El tetracloruro de carbono se ha utilizado ampliamente para la limpieza en seco, como componente de los extintores y como disolvente industrial.

0 tros muchos hidrocarburos halogenados tienen propiedades hepatotóxicas similares. En la serie alifática, los que lesionan el hígado son el cloruro de metilo, el tetracloroetano y el cloroformo; en la serie aromática, los nitrobencenos, el dinitrofenol, el trinitrotolueno y, más rara vez, el tolueno, los naftalenos clorados y el difenil clorado pueden ser hepatotóxicos. Estos compuestos se utilizan como disolventes, desengrasantes y refrigerantes, así como en pulimentos, tintes y explosivos. Si bien la exposición a ellos puede causar una lesión parenquimatosa hepática no muy distinta de la hepatitis infecciosa, en ciertos casos ( $p$. ej., tras la exposición al trinitrotolueno 0 al tetracloroetano) el cuadro clínico puede ser muy grave, con fiebre alta, ictericia de intensidad rápidamente creciente, confusión mental y coma, con evolución fatal por necrosis hepática masiva.

El fósforo amarillo es un metaloide muy tóxico cuya ingestión produce una ictericia que puede desembocar en la muerte. EI arsénico, el antimonio y los compuestos de hierro ferrosos también pueden causar lesión hepática.

La exposición al cloruro de vinilo durante el proceso de polimerización utilizado en la producción del cloruro de polivinilo se ha asociado asimismo al desarrollo de una fibrosis hepática no cirrótica, junto con esplenomegalia e hipertensión portal. En una pequeña proporción de trabajadores expuestos se han encontrado también angiosarcomas hepáticos, un tipo raro de tumor sumamente maligno. La exposición al monómero de cloruro de vinilo en los cerca de 40 años que precedieron a la identificación del angiosarcoma en 1974 había sido muy alta, sobre todo en los trabajadores que limpiaban los vasos de reacción, en quienes se produjeron casi todos los casos descritos. Durante ese período, el T LV del cloruro de vinilo era 500 ppm y en la actualidad se ha reducido a $5 \mathrm{ppm}\left(10 \mathrm{mg} / \mathrm{m}^{3}\right)$. Si bien las lesiones hepáticas fueron descritas primero en trabajadores rusos en 1949, no se prestó atención a los efectos nocivos de la exposición a este producto hasta el descubrimiento de casos de síndrome de R aynaud con cambios esclerodermiformes y osteólisis acra en el decenio de 1960.

La fibrosis hepática de los trabajadores del cloruro de vinilo puede ser silente, pues la función del parénquima hepático puede conservarse, y las pruebas convencionales mostrar alteraciones funcionales. M uchos casos han sido diagnosticados tras la aparición de hematemesis secundarias a la hipertensión portal asociada, el hallazgo de una trombocitopenia con esplenomegalia asociada o el desarrollo de un angiosarcoma. En la vigilancia de los trabajadores expuestos a cloruro de vinilo debe recogerse una historia completa que incluya datos sobre el consumo de alcohol y drogas y determinación de la presencia del antígeno de superficie y el anticuerpo del virus de la hepatitis B. La hepatoesplenomegalia puede establecerse clínicamente mediante radiografía 0 , más exactamente, con una ecografía en escala de grises. En estos casos, la fibrosis es de tipo periportal, con una obstrucción de predominio presinusoidal al flujo portal que se atribuye a la alteración de las raicillas de la vena porta 0 de los sinusoides hepáticos y que causa hipertensión portal. Es probable que la evolución favorable de los trabajadores sometidos a derivaciones portocavas después de la hematemesis pueda atribuirse a la no afectación de las células parenquimatosas en este trastorno.

Se han descrito menos de 200 casos de angiosarcoma hepático que cumplan los criterios diagnósticos actuales. M enos de la mitad de ellos se han producido en trabajadores con cloruro de vinilo tras exposiciones medias de 18 años, con límites de 4-32 años. En el Reino Unido, un registro iniciado en 1974 contiene 34 casos con criterios diagnósticos aceptables. Dos de ellos se produjeron en trabajadores con cloruro de vinilo, con posible exposición de otros cuatro, mientras que 8 pueden atribuirse a exposición anterior a thorotrast y otro al efecto de una medicación arsenical. El dióxido de torio, usado en épocas pasadas como medio de contraste diagnóstico, es ahora responsable de algunos casos de angiosarcoma y hepatocarcinoma. La intoxicación crónica por arsénico, de origen yatrógeno o como enfermedad profesional en los viticultores del M osela, también 
ha sido asociada a angiosarcoma. Al igual que en los trabajadores con cloruro de vinilo, esta intoxicación provoca una fibrosis perisinusoidal no cirrótica.

La aflatoxina, derivada de un grupo de mohos, sobre todo de A spergillus flavus, provoca lesiones hepáticas, cirrosis y carcinomas del hígado en los animales de experimentación. La frecuente contaminación de las cosechas de cereales por A. flavus, sobre todo cuando se almacenan en condiciones de calor y humedad, permite explicar la elevada incidencia de hepatocarcinomas en algunas partes del mundo, sobre todo en Africa tropical. En los países industrializados, el hepatocarcinoma es un tumor raro que suele desarrollarse sobre hígados cirróticos; en cierta proporción de casos se ha identificado el antígeno HBsAg en el suero, y otros se han producido tras tratamientos con andrógenos. En las mujeres que toman algunas formas de anticonceptivos orales se han descrito adenomas hepáticos.

Alcohol y cirrosis. La enfermedad parenquimatosa crónica del hígado puede adoptar la forma de hepatitis crónica o de cirrosis. Esta última se caracteriza por lesión celular, fibrosis y regeneración nodular. Si bien en muchos casos se desconoce la etiología, la cirrosis puede aparecer después de una hepatitis vírica o de una necrosis hepática masiva debida, a su vez, a la ingestión de fármacos $u$ otras sustancias o a una exposición industrial. En países industrializados como Francia, Reino Unido o Estados Unidos, muchos casos de cirrosis portal se asocian al consumo excesivo de alcohol, si bien es posible la participación de varios factores de riesgo, lo que explicaría las evidentes variaciones de susceptibilidad. Aunque el modo de acción del alcohol se desconoce, la lesión hepática se asocia fundamentalmente con la magnitud y duración del consumo. L os trabajadores con fácil acceso al alcohol corren mayor riesgo de desarrollar cirrosis. Entre las profesiones que presentan mayores tasas de mortalidad por esta causa se encuentran los camareros, taberneros y cocineros, los marineros, los directores de empresa y los médicos.

$\mathrm{H}$ ongos. $\mathrm{H}$ ongos de la especie Amanita (p. ej., A manita phalloides) son muy tóxicos. Su ingestión va seguida de síntomas gastrointestinales, con diarrea acuosa y, después de un intervalo, insuficiencia hepática aguda por necrosis centrozonal del parénquima.

Fármacos y drogas. Antes de atribuir una lesión hepática a la exposición industrial es preciso recoger una historia clínica muy meticulosa, pues son muchos los fármacos y sustancias que no sólo ejercen efectos tóxicos, sino que pueden provocar una inducción enzimática que altere la respuesta del hígado a otros agentes exógenos. Los barbitúricos son inductores potentes de las enzimas microsomales hepáticas, al igual que algunos aditivos alimenticios y el DDT.

EI popular analgésico paracetamol produce necrosis hepática en casos de sobredosis. O tros fármacos con una acción tóxica directa sobre los hepatocitos predecible y proporcional a la dosis son la hicantona, los citotóxicos y las tetraciclinas (aunque con mucha menor potencia). También ciertos tuberculostáticos, sobre todo la isoniazida y el ácido paraaminosalicílico, varios inhibidores de la monoamino oxidasa y el gas anestésico halotano pueden resultar hepatotóxicos en personas hipersensibles.

La fenacetina, las sulfamidas y la quinina son ejemplos de fármacos que pueden originar una ictericia hemolítica leve, aunque sólo en personas sensibles. Ciertos fármacos causan ictericia no por lesión de los hepatocitos, sino por alteración de los pequeños conductos biliares que los separan, con lo que provocan una obstrucción biliar (ictericia colestásica). Las hormonas esteroideas metiltestosterona y otros compuestos con sustitución C -17 alquil de la testostetona ejercen hepatotoxicidad por este mecanismo. Así pues, en la evaluación de una trabajadora con ictericia es importante establecer si está tomando anticonceptivos orales. El endurecedor de resinas epoxi 4,4-diamino-difenilmetano produjo una epidemia de ictericia colestática en Inglaterra tras la ingestión de pan contaminado.

Son varios los fármacos que han originado lo que parece ser una colestasis intrahepática por hipersensibilidad, ya que no es proporcional a la dosis. El grupo de las fenotiazinas, y sobre todo la clorpromazina, se asocian a esta reacción.

\section{Medidas preventivas}

L os trabajadores con trastornos del hígado o de la vesícula biliar o con antecedentes de ictericia no deben manejar agentes hepatotóxicos potenciales ni verse expuestos a ellos. De igual modo, los que estén recibiendo algún fármaco con capacidad para lesionar el hígado no deben exponerse a otros tóxicos hepáticos, y los que hayan recibido cloroformo o tricloroetileno como anestésico deben evitar la exposición durante un cierto período posterior. El hígado es especialmente sensible a las lesiones durante el embarazo, por lo que durante él deben evitarse todos los agentes con potencial hepatotóxico. LoS trabajadores expuestos a estos agentes deben evitar también el consumo de alcohol. El principio general a seguir es la evitación de un segundo agente potencialmente hepatotóxico cuando ha existido exposición a uno. U na dieta equilibrada, con una ingesta suficiente de proteínas de primera clase y factores esenciales, ofrece protección frente a la elevada incidencia de cirrosis de algunos países tropicales. En la educación sanitaria debe subrayarse la importancia de la moderación del consumo de alcohol para la protección del hígado frente a la esteatosis y la cirrosis. El seguimiento de unas buenas normas de higiene general es de enorme valor para proteger frente a las infecciones del hígado, como la hepatitis, la hidatidosis y la esquistosomiasis.

En los hospitales, lasmedidas de control de la hepatitis de tipo B consisten en precauciones para el manejo de las muestras de sangre en las salas; etiquetado adecuado y envío seguro al laboratorio; precauciones de laboratorio, con prohibición de pipetear con la boca; uso de batas y guantes protectores; prohibición de comer, beber o fumar en lugares donde pueda haber pacientes 0 muestrasinfecciosos; precauciones extremas durante el manejo de las partes no desechables de los equipos de diálisis; detección de la hepatitis en los enfermos y en el personal y exploración selectiva obligatoria, a intervalos periódicos, del antígeno H BsAg . La vacunación contra los virus $A$ y $B$ de la hepatitis es un método eficaz para prevenir la infección en las profesiones de alto riesgo.

\section{ULCERA PEPTICA}

\section{K.S. Cho*}

Las úlceras gástricas y duodenales - denominadas colectivamente "úlceras pépticas" - son soluciones de continuidad, circunscritas del tejido, que afectan a la mucosa, la submucosa y la muscular propia del estómago o del duodeno expuestos al jugo gástrico rico en ácido y pepsina. La úlcera péptica es una causa frecuente de dolor abdominal recurrente o persistente, sobre todo en los varones jóvenes. $L$ as úlceras duodenales suponen alrededor del $80 \%$ de las úlceras pépticas y son más frecuentes en los varones que en las mujeres, mientras que las gástricas muestran un cociente entre sexos de alrededor de 1. Es importante diferenciar las úlceras pépticas gástricas de las duodenales porque su diagnóstico, tratamiento y pronóstico son distintos. La causa de la úlcera péptica no se ha establecido por completo, y se cree que en

*A daptado de la tercera edición, E nciclopedia de Salud y Seguridad en el Trabajo 
su patogenia intervienen muchos factores, sobre todo la tensión nerviosa, el uso de ciertos fármacos (como los salicilatos y corticoides) y ciertas influencias hormonales .

\section{Personas con riesgo}

Aunque no puede decirse que la úlcera péptica sea una enfermedad profesional específica, muestra una incidencia superior a la media en las profesiones liberales y en los que trabajan en condiciones de estrés. Se cree que el estrés, ya sea físico o emocional, es un factor importante en la etiología de la enfermedad ulcerosa; el estrés emocional prolongado de determinadas profesiones podría incrementar la secreción de ácido clorhídrico y la propensión de la mucosa gastroduodenal a la lesión.

Los resultados de muchas investigaciones efectuadas sobre la relación entre úlcera péptica y profesión revelan claramente la existencia de importantes variaciones en la incidencia de enfermedad ulcerosa en las distintas profesiones. Muchos estudios señalan la alta probabilidad de que los trabajadores del transporte, como los conductores, mecánicos, empleados de tranvías y ferroviarios sufran úlceras. Así, en una encuesta sobre 3.000 trabajadores del ferrocarril, se encontró una mayor proporción de úlceras entre el personal de trenes, operadores de señales y revisores que en el de mantenimiento y administración; se consideró que el trabajo por turnos, los riesgos y la responsabilidad eran factores contribuyentes. Sin embargo, en otra encuesta a gran escala, los trabajadores del transporte mostraron tasas "normales" de úlcera péptica, cuya incidencia fue máxima en los médicos y en un grupo de trabajadores no cualificados. LoS pescadores y pilotos de barco también tienden a desarrollar úlceras, sobre todo de localización gástrica. Por último, en un estudio sobre mineros del carbón se vio que la incidencia de úlceras pépticas era proporcional a la dureza de las condiciones laborales, siendo máxima en los picadores. L os casos descritos en soldadores y en trabajadores de una planta de refinado de magnesio sugieren que los vapores metálicos pueden inducir el trastorno (aunque en este caso parece que la causa no sería el estrés, sino un mecanismo tóxico). Se han observado igualmente incidencias elevadas en supervisores y ejecutivos, es decir, en personas con cargos de responsabilidad en la industria o en el comercio; conviene señalar que, en estos grupos, la frecuencia se debe casi exclusivamente a las úlceras duodenales, mientras que las gástricas tienen una incidencia normal.

Por otra parte, se han encontrado incidencias bajas en los trabajadores agrícolas y, aparentemente, en los trabajadores sedentarios, estudiantes y artesanos.

Así pues, si bien las pruebas acerca de la incidencia profesional de la úlcera péptica parecen hasta cierto punto contradictorias, existe acuerdo en al menos un aspecto, a saber, en que cuanto mayor sea el estrés de una profesión, mayor será la tasa de úlceras. Esta relación general existe también en los países en vías de desarrollo donde, durante el proceso de industrialización y modernización, muchos trabajadores caen progresivamente bajo la influencia del estrés y la tensión, debidos a factores como la congestión del tráfico rodado y la dificultad del transporte, la introducción de maquinaria, sistemas y tecnologías complejos, mayores sobrecargas de trabajo y jornadas más largas, todo lo cual conduce, como se ha visto, al desarrollo de la úlcera péptica.

\section{Diagnóstico}

El diagnóstico de la úlcera péptica se basa en la obtención de una historia de dolor ulceroso característico, que se alivia con la ingesta de alimentos 0 álcalis, o de otras manifestaciones, como una hemorragia digestiva. La técnica diagnóstica más útil es un estudio radiológico concienzudo del aparato digestivo alto.

Los intentos de reunir datos sobre la prevalencia de este proceso se han visto seriamente dificultados por el hecho de que no se trata de una enfermedad notificable, porque muchos trabajadores con úlcera péptica omiten consultar a sus médicos acerca de sus síntomas y porque, cuando lo hacen, los criterios aplicados al diagnóstico no son uniformes. La detección de la úlcera péptica en la población activa no es, por tanto, fácil. De hecho, algunos investigadores excelentes han tenido que confiar en los datos procedentes de registros de autopsia, cuestionarios a médicos y estadísticas de las compañías de seguros.

\section{Medidas preventivas}

D esde la perspectiva de la medicina del trabajo, la prevención de la úlcera péptica - considerada como un trastorno psicosomático con connotaciones profesionales- debe basarse sobre todo en el alivio, siempre que sea posible, del exceso de estrés y de la tensión nerviosa debidos directa o indirectamente a factores de tipo laboral. Dentro del amplio marco de este principio general hay lugar para muchas medidas como, por ejemplo, actuar en el plano colectivo para reducir las jornadas de trabajo, introducir 0 mejorar las instalaciones destinadas al descanso, mejorar las condiciones económicas y la seguridad social y (en colaboración con las autoridades locales) mejorar las condiciones de transporte y facilitar un alojamiento adecuado a una distancia razonable del lugar de trabajo, por no hablar de las acciones directamente dirigidas a erradicar determinadas situaciones generadoras de estrés en el medio ambiente de trabajo.

A nivel personal, el éxito de la prevención depende en igual medida de un asesoramiento médico apropiado y de la cooperación inteligente del trabajador, que debe disponer de la oportunidad para solicitar consejo sobre sus problemas laborales y de otro tipo.

La probabilidad del individuo de sufrir una úlcera péptica aumenta cuando se asocian distintos factores profesionales y características personales. Si fuera posible identificar y comprender tales factores $y$, sobre todo, si pudiera demostrarse definitivamente la razón de la aparente correlación entre determinadas profesiones y tasas elevadas de enfermedad ulcerosa, las probabilidades de prevenir su desarrollo y de tratar sus recaídas serían mucho mayores. También debe erradicarse una posible infección por $\mathrm{H}$ elicobacter. M ientras tanto, y como precaución general, es preciso tener presentes las implicaciones de los antecedentes de úlcera péptica en toda persona sometida a una exploración previa al ingreso en la empresa o periódica y no situar - ni dejar-a los trabajadores afectados en puestos 0 situaciones en los que se vean expuestos a grandes tensiones, sobre todo de carácter nervioso o psicológico.

\section{CANCER HEPATICO}

Timo Partanen, Timo Kauppinen, Paolo Boffetta y Elisabete Weiderpass

El tumor maligno más frecuente del hígado (CIE-9 155) es el hepatocarcinoma (carcinoma hepatocelular, hepatoma; $\mathrm{CHC}$ ), es decir, un tumor maligno de los hepatocitos. LOS colangiocarcinomas son neoplasias de los conductos biliares intrahepáticos y constituyen alrededor del $10 \%$ de los cánceres hepáticos en Estados U nidos, si bien pueden llegar a alcanzar 
proporciones de hasta el $60 \%$ en otras zonas, como en las poblaciones del noreste de Tailandia (IARC 1990). LoS angiosarcomas del hígado son tumores muy raros y agresivos que aparecen sobre todo en varones. Los hepatoblastomas son cánceres embrionarios raros de la primera época de la vida y de escasa variación geográfica o étnica.

El pronóstico del CHC depende del tamaño del tumor y de la existencia de cirrosis, metástasis, afectación de los ganglios linfáticos, invasión vascular y existencia o no de cápsula. Estas neoplasias tienden a recidivar después de la resección quirúrgica. LOS CHC pequeños pueden extirparse, con supervivencias a los 5 años del 40-70\%. El trasplante hepático hace posible una supervivencia de alrededor del $20 \%$ a los dos años en los pacientes con $\mathrm{CHC}$ avanzado. En los que tienen tumores menos extendidos, el pronóstico es más favorable. En cuanto a los hepatoblastomas, puede lograrse la ablación completa en el $50-70 \%$ de los niños. Las tasas de curación después de la resección oscilan entre el 30 y el $70 \%$. Puede utilizarse quimioterapia pre y postoperatoria. EI trasplante hepático puede ser una alternativa en los hepatoblastomas inextirpables.

Los colangiocarcinomas son tumores multifocales en más del $40 \%$ de los pacientes ya en el momento del diagnóstico. En el $30-50 \%$ de estos casos existen metástasis a ganglios linfáticos. La respuesta a la quimioterapia es muy variable, pero la tasa de éxitos suele ser inferior al $20 \%$. Sólo algunos pacientes son susceptibles de extirpación quirúrgica. La radioterapia se ha utilizado como tratamiento principal o coadyuvante y puede mejorar la supervivencia de los pacientes que no han podido ser sometidos a una resección completa. Las tasas de supervivencia a los cinco años son inferiores al $20 \%$. Los pacientes con angiosarcomas suelen tener ya metástasis a distancia en el momento del diagnóstico. En casi todos los casos, la extirpación, la radioterapia, la quimioterapia y el transplante hepático son inútiles. En general, la supervivencia desde el diagnóstico es inferior a seis meses (L otze, F lickinger y C arr 1993).

Se calcula que en 1985 se produjeron 315.000 casos nuevos de cáncer hepático en todo el mundo, con una preponderancia evidente, relativa y absoluta, en las poblaciones de los países en vías de desarrollo, excepto en América Latina (IARC 1994a; Parkin, Pisani y Ferlay 1993). La incidencia media anual de cáncer hepático muestra variaciones considerables en los diferentes registros internacionales. Durante el decenio de 1980, esta incidencia media anual osciló desde 0,8 en los varones y 0,2 en las mujeres de M aastricht, Países Bajos, hasta el 90,0 en los varones y 38,3 en las mujeres de $\mathrm{K}$ hon $\mathrm{K}$ aen, Tailandia, por 100.000 habitantes, normalizada para la población mundial. Las tasas de China, Japón, Asia oriental y A frica fueron altas, mientras que en América Latina y del Norte, Europa y O ceanía fueron bajas, excepto en los maoríes de Nueva Zelanda (IARC 1992). Esta distribución geográfica guarda relación con la distribución de la prevalencia de portadores crónicos del antígeno de superficie de la hepatitis $B$ y también con la distribución de los niveles locales de contaminación alimentaria por aflatoxinas (IARC 1990). Los cocientes varón-mujer suelen variar entre 1 y 3 , aunque pueden ser mayores en las poblaciones de alto riesgo.

Las estadísticas de mortalidad e incidencia del cáncer hepático según la clase social indican una tendencia a la concentración del exceso de riesgo en los estratos socioeconómicos más bajos, pero este gradiente no aparece en todas las poblaciones.

L os factores de riesgo establecidos para el carcinoma hepático primitivo, en seres humanos, son los alimentos contaminados por aflatoxinas, la infección crónica por el virus de la hepatitis B (IARC 1994b), la infección crónica por el virus de la hepatitis C (IARC 1994b) y el consumo elevado de bebidas alcohólicas (IARC 1988). Se calcula que el VHB es el responsable de alrededor del 50-90\% de los hepatocarcinomas en las poblaciones de alto riesgo, y del 1-10\% en las de bajo riesgo. 0 tro factor del que también se sospecha es el uso de anticonceptivos orales. N o hay pruebas suficientes para sugerir una relación entre el hábito de fumar y el desarrollo de esta neoplasia (H igginson, M uir y M uñoz 1992).

L as grandes variaciones geográficas en la incidencia del hepatocarcinoma sugieren que una gran proporción de estos tumores pueden evitarse. Las medidas preventivas son la vacunación contra el VHB (en las áreas endémicas, se calcula una reducción teórica potencial de la incidencia de alrededor del $70 \%$ ), la reducción de la contaminación de los alimentos por micotoxinas (reducción del $40 \%$ en las áreas endémicas), la mejora de los procedimientos de recogida y conservación de las cosechas y la disminución del consumo de bebidas alcohólicas (reducción del $15 \%$ en los países occidentales; IARC 1990).

Se han comunicado excesos de cáncer hepático en varios grupos profesionales e industriales de distintos países. Ciertas asociaciones positivas son fáciles de explicar por la exposición laboral, como el mayor riesgo de angiosarcoma hepático en los trabajadores del cloruro de vinilo (véase más adelante). En cuanto a otros trabajos de alto riesgo, como el trabajo del metal, la pintura en la construcción y el procesamiento de piensos para animales, la relación resulta menos clara y no aparece en todos los estudios, aunque muy bien podría existir. En otras profesiones, como en los trabajadores de servicios, agentes del orden, vigilantes o funcionarios, el exceso no puede explicarse por acción directa de los cancerígenos en el lugar de trabajo. Los datos sobre cáncer en agricultores no proporcionan muchos indicios acerca de la etiología profesional del cáncer de hígado. En una revisión de 13 estudios sobre 510 casos o defunciones por esta causa en granjeros (Blair y cols. 1992), se encontró un pequeño déficit (cociente de riesgo agregado 0,89; intervalo de confianza al $95 \%$ 0,81-0,97).

Ciertos datos procedentes de estudios epidemiológicos, específicos de industrias o puestos de trabajo, sugieren que la exposición profesional podría desempeñar un papel en la inducción del cáncer de hígado. Por tanto, para prevenir su desarrollo en las poblaciones con exposición profesional, sería fundamental reducir al mínimo dicha exposición. Como ejemplo clásico, se ha demostrado que la exposición profesional al cloruro de vinilo produce angiosarcoma hepático, una forma rara de cáncer de este órgano (IARC 1987). En consecuencia, la exposición a esta sustancia ha sido regulada en muchos países. Existen cada vez más indicios de que los disolventes constituidos por hidrocarburos clorados también pueden causar cáncer de hígado. LoS estudios epidemiológicos revelan también asociaciones entre estos tumores y las aflatoxinas, los clorofenoles, el etilenoglicol, los compuestos de estaño, los insecticidas y algunos otros agentes. Muchos agentes químicos utilizados en las distintas profesiones producen cáncer de hígado en los animales y, por tanto, puede sospecharse que son cancerígenos para el hombre. Entre ellos se encuentran las aflatoxinas, las aminas aromáticas, los colorantes azoicos, los colorantes derivados de la bencidina, el 1,2-dibromoetano, el butadieno, el tetracloruro de carbono, los clorobencenos, el cloroformo, los clorofenoles, el dietilhexil ftalato, el 1,2-dicloroetano, la hidrazina, el cloruro de metileno, las $\mathrm{N}$-nitrosoaminas, varios pesticidas organoclorados, el percloroetileno, los bifenilos policlorados y el toxafeno. 


\section{- CANCER PANCREATICO}

\section{Timo Partanen, Timo Kauppinen, Paolo} Boffetta y E lisabete Weiderpass

EI cáncer pancreático (CIE-9 157; CIE-10 C 25), un tumor maligno de elevada mortalidad, es uno de los 15 cánceres más frecuentes de todo el mundo, pero se encuentra entre los diez más comunes en las poblaciones de los países desarrollados, en las que supone el 2 a $3 \%$ de todos los nuevos diagnósticos de cáncer (IARC 1993). Se calcula que en 1985 se produjeron 185.000 casos nuevos de esta neoplasia en el mundo (Parkin, Pisani y Ferlay 1993). Sus tasas de incidencia se están elevando en los países industrializados. En Europa, este ascenso se ha estabilizado, excepto en el Reino Unido y algunos países nórdicos (Fernández y cols. 1994). Las tasas de incidencia y mortalidad muestran un brusco ascenso asociado con la edad entre los 30 y los 70 años. El cociente varón/ mujer ajustado a la edad de los casos de cáncer de páncreas de nuevo diagnóstico es 1,6/ 1 en los países desarrollados y sólo 1,1/ 1 en los que se hallan en vías de desarrollo.

Se han registrado elevadas tasas anuales de incidencia de cáncer de páncreas (de hasta $30 / 100.000$ en varones y 20/100.000 en mujeres) durante el período 1960-85 en los maoríes de Nueva Zelanda, hawaianos y poblaciones de raza negra de Estados U nidos. Por regiones, las mayores tasas ajustadas a la edad de 1985 (superiores a 7/ 100.000 en varones y a 4/ 100.000 en mujeres) corresponden a personas de ambos sexos de Japón, Norteamérica, Australia, Nueva Zelanda y Europa septentrional, occidental y oriental. Las tasas más bajas (hasta 2/ 100.000 en ambos sexos) se han descrito en las regiones de Africa central y occidental, sureste asiático, M elanesia y países templados de Sudamérica (IARC 1992; Parkin, Pisani y Ferlay 1993).

Las comparaciones en el tiempo y el espacio entre poblaciones plantean dificultades de interpretación y exigen cautela, dadas las variaciones de los criterios y tecnologías diagnósticas aplicadas (M ack 1982).

La inmensa mayoría de los cánceres pancreáticos se desarroIlan en el páncreas exocrino. Los síntomas principales son dolor abdominal y de espalda y pérdida de peso. Otros síntomas asociados son anorexia, diabetes e ictericia obstructiva. Los pacientes sintomáticos son sometidos a procedimientos como análisis de sangre y orina, ecografía, tomografía computarizada, estudios citológicos y pancreatoscopia. Casi todos ellos tienen metástasis en el momento del diagnóstico, con el consiguiente mal pronóstico.

Sólo el $15 \%$ de los pacientes con cáncer pancreático son operables. Después de la intervención, son frecuentes tanto las recidivas locales como las metástasis a distancia. $\mathrm{N}$ i la radioterapia ni la quimioterapia mejoran significativamente la supervivencia cuando se combinan con la cirugía de los carcinomas localizados. Los procedimientos paliativos son de escasa ayuda. Pese a algunos progresos diagnósticos, la supervivencia sigue siendo escasa. Durante el período 1983-85, la supervivencia media a los 5 años de 11 poblaciones europeas fue del $3 \%$ en los varones y del $4 \%$ en las mujeres (IARC 1995). La eficacia de la cirugía podría mejorar con una detección y diagnóstico muy precoces, o con la identificación de las personas de alto riesgo. La eficacia de la exploración selectiva del cáncer pancreático no se ha establecido.
$\mathrm{Ni}$ la mortalidad ni la incidencia del cáncer de páncreas revelan un patrón constante a escala mundial entre las categorías socioeconómicas.

El cuadro desalentador que surge de los problemas diagnósticos y de la ineficacia del tratamiento se completa por el hecho de que las causas del cáncer de páncreas son en gran parte desconocidas, lo que, de hecho, impide prevenir esta enfermedad mortal. La única causa demostrada es el consumo de tabaco, que justifica alrededor del $20-50 \%$ de los casos, dependiendo del patrón de los hábitos de la población. Se ha calculado que la eliminación del hábito de fumar reduciría la incidencia de cáncer de páncreas en alrededor de un $30 \%$ en todo el mundo (IARC 1990). También se ha sospechado que el consumo de alcohol y café aumenta el riesgo de esta neoplasia. Sin embargo, un estudio más detallado de los datos epidemiológicos revela que no es probable que el café tenga una relación causal con este cáncer. En cuanto a las bebidas alcohólicas, su único nexo causal parece ser la pancreatitis, enfermedad asociada al consumo excesivo de alcohol. La pancreatitis es un factor de riesgo raro pero potente del cáncer pancreático. Es posible que existan algunos factores dietéticos todavía no identificados que expliquen, en parte, la etiología de esta neoplasia.

$L$ as exposiciones en los lugares de trabajo pueden tener una asociación causal con el cáncer de páncreas. Los resultados de varios estudios epidemiológicos en los que se han establecido nexos entre determinadas industrias y empleos con un exceso de cáncer pancreático son heterogéneos e inconstantes, y las exposiciones compartidas por las supuestas tareas de alto riesgo son difíciles de identificar. La fracción etiológica poblacional del cáncer de páncreas debido a exposición profesional en Montreal, Canadá, se ha calculado entre el $0 \%$ (según los cancerígenos conocidos) y el $26 \%$ (según un estudio multicéntrico de casos y controles en la región de Montreal, Canadá) (Siemiatycki y cols. 1991).

No se ha encontrado una exposición profesional única que incremente el riesgo de cáncer pancreático. Casi todos los agentes químicos profesionales que se han asociado con un exceso de riesgo en los estudios epidemiológicos lo fueron en un sólo estudio, lo que sugiere que muchas de estas asociaciones pueden ser artefactos debidos al azar o a factores de confusión. En ausencia de información adicional obtenida, por ejemplo, mediante bioensayos en animales, la distinción entre asociaciones falsas y causales conlleva enormes dificultades, dada la incertidumbre general en relación con los agentes causales que participan en el desarrollo de esta neoplasia. Entre las sustancias que se han asociado a un mayor riesgo se encuentran el aluminio, las aminas aromáticas, el amianto, las cenizas y hollines, el polvo de latón, los cromatos, los productos de combustión del carbón, el gas natural y la madera, los vapores de cobre, el polvo de algodón, los productos de limpieza, el polvo de los cereales, el fluoruro de hidrógeno, el polvo de los aislamientos inorgánicos, las radiaciones ionizantes, los vapores de plomo, los compuestos de níquel, los óxidos de nitrógeno, los disolventes orgánicos y los diluyentes de pintura, los pestidicas, el fenol-formaldehído, el polvo de los plásticos, los hidrocarburos aromáticos policíclicos, las fibras de rayón, el polvo de acero inoxidable, el ácido sulfúrico, los adhesivos sintéticos, los compuestos y vapores de estaño, las ceras y barnices y los vapores de zinc (K auppinen y cols. 1995). De todos ellos, sólo el aluminio, las radiaciones ionizantes y algunos pesticidas no especificados se han asociado a un exceso de riesgo en más de un estudio. 


\section{Referencias}

Agencia Internacional para la Investigación del Cáncer (IARC). 1987. IARC M onographs On the Evaluation of Carcinogenic Risks to $H$ umans. An U pdating of IARC M onographs $V$ olumes 1 to 42 , Suppl. 7. Lyon: IAR C

-. 1988. Alcohol drinking. IARC M onographs on the Evaluation of Carcinogenic Risks to Humans, No. 44. Lyon: IARC.

-. 1990. Cancer: Causes, occurrence and control. IARC Scientific Publications, N o. 100. Lyon: IAR C.

-. 1992. Cancer incidence in five continents. Vol. VI. IARC Scientific Publications, No. 120. Lyon: IARC.

-. 1993. T rends in cancer incidence and mortality. IARC Scientific Publications, N o. 121. Lyon: IAR C.

-. 1994a. H epatitis viruses. IARC M onographs On the Evaluation of $\mathrm{C}$ arcinogenic $\mathrm{R}$ isks to $\mathrm{H}$ umans, N o. 59. Lyon: IARC.

-. 1994b. Occupational cancer in developing countries. IARC Scientific Publications, No. 129. Lyon: IARC

- . 1995. Survival of cancer patients in Europe. The EUROCARE study. Vol. 132. IARC Scientific Publications. Lyon: IARC.

Blair, A, S H oar Zahm, NE Pearce, EF H eineman, and JF Fraumeni. 1992. Clues to cancer aetiology from studies of farmers. Scand J W ork E nviron $\mathrm{H}$ ealth 18:209-215.

Fernandez, E, C LaV ecchia, M Porta, E N egri, F Lucchini, and $F$ Levi. 1994. Trends in pancreatic cancer mortality in Europe, 1955-1989. Int J Cancer 57:786-792.

$\mathrm{H}$ igginson, J, CS M uir, and N M unoz. 1992. Human Cancer: Epidemiology and Environmental C auses. En Cambridge M onographs On Cancer R esearch Cambridge: Cambridge U niv. Press.

K auppinen, $\mathrm{T}, \mathrm{T}$ Partanen, $\mathrm{R}$ Degerth, and $\mathrm{A}$ O jajärvi. 1995. Pancreatic cancer and occupational exposures. E pidemiology 6(5):498-502.

Lotze, MT, JC Flickinger, and BI Carr. 1993. $\mathrm{H}$ epatobiliary N eoplasms. En Cancer: Principles and Practice of Oncology, dirigido por VT DeVita Jr, S Hellman, y SA Rosenberg. Filadelfia: JB Lippincott.

M ack, TM . 1982. Pancreas. En Cancer E pidemiology and Prevention, dirigido por D.Schottenfeld y JF Fraumeni. Filadelfia: WB Sanders.
Parkin, D M , P Pisani, and J Ferlay. 1993. Estimates of the worldwide incidence of eighteen major cancers in 1985. Int J Cancer 54:594-606.

Siemiatycki, J, M Gerin, R Dewar, L Nadon, R Lakhani, D Begin, and L Richardson. 1991. Associations between occupational circumstances and cancer. En Risk Factors for Cancer in the W orkplace, dirigido por J Siemiatycki. Boca Raton: CR C Press.

\section{0 tras lecturas recomendadas}

Balestra, V, B Bogett, and F DeLuca. 1980. Gastroduodenopathy in sailors: Pathogenic A spects I. M edicina 71(3):259-269.

Baxter, PJ, PP Anthony, RNM M acsween, and PJ Scheuer. 1980. Angiosarcoma of the liver: Annual occurrence and aetiology in G reat Britain. B rit J Ind M ed 37(3):213-221.

Ben-Aryeh, H and D Gutman. 1979. The use of biological specimens for the assessment of human exposure to environmental pollutants. En T eeth for Biological M onitoring, dirigido por $\mathrm{A}$ Berlin, $\mathrm{AH}$ W olff y $Y$ H asegawa. La H aya: M artinus $N$ ijhoff.

Brennan, MF, TJ K insella, and ES Casper. 1993. Cancer of the pancreas. En Cancer: Principles and Practice of Oncology, dirigido por VT DeVita Jr, S Hellman y SA Rosenberg. Filadelfia: JB Lippincott.

Cobb, S and RM Rose. 1973. Hypertension, peptic ulcer, and diabetes in air traffic controllers. J AM A 224(4):489-492.

Chronic gastritis and its occupational causes. 1978. Arbeitsmed Sozialmed Praventivmed 13(9):181-196.

Denes, AE, JL Smith, JE M aynard, IL Doto, KR Berquist, and AJ Finkel. 1978. Hepatitis B infection in physicians: Results of a nationwide seroepidemiologic study. J AM A 239(3):210-212.

Dupuy, $R$ and $G$ Vallin. 1975. Social and occupational consequences of partial gastrectomy for gastric or duodenal ulcer. Arch franç mal appareil digest 64(8):653-657.

Ekbom, A, JK MCLaughlin, B-M K arlsson, 0 N yrén, G G ridley, H-O Adami, and JF Fraumeni. 1994. Pancreatitis and pancreatic cancer. I Nat| Cancer Inst 86:625-627.

Frada, G and L Salamone. 1968. Digestive system problems as related to fitness for work. Securitas 53:9-10.
Gaultier, M , P H ousset, and E M artin. 1961. A study of gastric disturbances in industrial workers. Arch mal prof méd trav secur soc 22(3):129-134.

Greene, JC, R Louie, and SJ Wycoff. 263. Preventive dentistry II. Periodontal diseases, malosclusion, trauma and oral cancer. J AM A 263:421-425.

Heinkel, K, K Maier, and I Rehmann. 1978. Problems relating to chronic gastritis in the writing of medical reports. Arbeitsmed Sozialmed Praventivmed 13(9): 193-196

H offman, L. 1978. Morbidity patterns in a non-German population (migrant workers). M edizinische Klinik 73(16):571-578.

K oelsch, K A. 1976. Assessment of fitness for work in cases of gastric disease. Z eitschrift für ärztiliche F ortbildung 70/ 8:397-400.

Lammert, $\mathrm{KH}$ and $\mathrm{H}$ Seifert. 1970. Stomatology and $O$ ccupational $H$ ealth. Berlín: Verlag Volk und Gesundheit.

L'Epée, P, HJ Lazarini, J T oussaint, and J Doignon. 1969. The value of oral and dental examinations as part of the occupational medicine service. Arch mal prof méd trav secur soc 30(7/ 8):428-431.

Mehendale, HM, RA Roth, AJ Gandolfi, JE K launig, JJ Lemasters, and LR Curtis. 1994. $\mathrm{N}$ ovel mechanisms in chemically induced hepatotoxicity. FASE B J 8:1285-1295.

N orthwestern National Life. 1991. Employee Burnout: America's Newest Epidemic. Survey Findings. M inneapolis, M inn: N orthwestern N ational Life.

Partanen, T, T K auppinen, R D egerth, G M oneta, I M earelli, A O jajärvi, S H ernberg, H K oskinen, and E Pukkala. 1994. Pancreatic cancer in industrial branches and occupations in Finland. Am J Ind M ed 25:851-866.

Schmauss, AK. 1976. Assessment of fitness for work after gastric resection for chronic peptic ulcer. Z eitschrift für ärztiliche F ortbildung 70(12):652-654.

Sherlock, SPV. 1975. Diseases of the Liver and Biliary System. O xford: Blackwell Scientific Publications.

Tannock, GW. 1988. The normal microflora: New concepts in health promotion. M icrobiol Sci 5:4-8.

Tietjen, M and DYC Fung. 1995. Salmonellae and food safety. Crit Rev M icrobiol 21:53-83.

Zabinska, O and H O strowska. 1975. Development of leukoplakia, atrophic changes of oral cavity mucosa and paradontium sickness in metal workers. M edycina Pracy 26(6):515-520. 
Directores del capítulo

J oseph J. H urrel

Lawrence R. M urphy

Steven L. Sauter

L ennart L evi

\section{Sumario}

Trabajo y salud mental

I rene L.D. H outman y M ichiel A.J. Kompier

Psicosis relacionadas con el trabajo

Craig Stenberg, J udith H older y K rishna Tallur . . . . . . . . . . . . . . 5.5

ESTADO DE ANIMO Y AFECTO

Depresión

J ay L asser y J effrey P. Kahn.

Ansiedad relacionada con el trabajo

R andal D. B eaton.

Trastorno por estrés postraumático y su relación con la salud laboral y la prevención de lesiones

$M$ ark B raverman . . . . . . . . . . . . . . . . . . . . . . . . . 5.13

El estrés y el agotamiento, y sus implicaciones en el medio ambiente de trabajo

$H$ erbert J. F reudenberger.

Trastornos cognitivos

Catherine A. H eaney . . . . . . . . . . . . . . . . . . . . . . . . . . . . 5.19

$\mathrm{K}$ aroshi: muerte por exceso de trabajo

Takashi $\mathrm{H}$ aratani. 
TRABAJO Y SALUd MENTAL

Irene L.D. H outman y Michiel A.J. Kompier

En este capítulo se revisan los tipos principales de trastornos de la salud mental que pueden asociarse al trabajo: los trastornos del estado de ánimo y del afecto (p. ej., insatisfacción), el agotamiento, el trastorno por estrés postraumático (T EPT), las psicosis, los trastornos cognitivos y el abuso de sustancias psicoactivas. Se definirán el cuadro clínico, las técnicas de evaluación disponibles, los agentes y factores etiológicos y las medidas específicas de prevención y tratamiento de cada uno. Siempre que sea posible, se ilustrarán y comentarán sus relaciones con el trabajo, la profesión 0 el sector industrial.

En este artículo de introducción se ofrecerá una perspectiva general sobre la propia salud mental profesional. Se abordará el concepto de salud mental y se presentará un modelo. A continuación, se comentarán la necesidad de prestar atención a la (mala) salud mental y cuáles son los grupos profesionales que corren mayor riesgo. Por último, presentaremos un marco de intervención general para tratar con éxito los problemas de salud mental relacionados con el entorno laboral.

\section{¿Qué es la salud mental?: un modelo conceptual}

$\mathrm{H}$ ay muchas opiniones acerca de los componentes y procesos de la salud mental. Es un concepto muy cargado de valor, y no es probable que se llegue a una definición unánime de él. Al igual que el concepto, fuertemente asociado, de "estrés", la salud mental se define como:

- un estado: por ejemplo, un estado de bienestar psicológico y social total de un individuo en un entorno sociocultural dado, indicativo de estados de ánimo y afectos positivos (p. ej., placer, satisfacción y comodidad) o negativos (p. ej., ansiedad, estado de ánimo depresivo e insatisfacción);

- un proceso indicativo de una conducta de afrontamiento: por ejemplo, luchar por conseguir la independencia, autonomía (ambos aspectos clave de la salud mental);
- el resultado de un proceso: un estado crónico debido a una confrontación aguda e intensa con un factor estresante, como sucede en el trastorno por estrés postraumático, 0 a la presencia continua de un factor estresante, no necesariamente intenso. Es lo que ocurre en el agotamiento, así como en las psicosis, los trastornos depresivos mayores, los trastornos cognitivos y el abuso de sustancias psicoactivas. No obstante, estos dos últimos se consideran a menudo problemas neurológicos, puesto que pueden existir procesos fisiopatológicos (p. ej., degeneración de las vainas de mielina) debidos a un afrontamiento ineficaz o al propio factor estresante (consumo de alcohol o exposición profesional a disolventes, respectivamente) subyacentes a ellos.

La salud mental puede asociarse también a:

- Características de la persona como los "estilos de afrontamiento": la competencia (incluidos el afrontamiento eficaz, el dominio del entorno y la autoeficacia) y la aspiración son características de una persona mentalmente sana, que se muestra interesada por su entorno, participa en actividades motivadoras y busca su propia proyección por medios personalmente significativos.

Así pues, la salud mental se conceptualiza no sólo como un proceso o una variable de resultado, sino también como una variable independiente; es decir, una característica personal que influye en nuestro comportamiento.

La Figura 5.1 presenta un modelo de salud mental. Esta viene determinada por las características del entorno, tanto fuera como dentro del campo profesional, y por las características propias del individuo. Las características del entorno profesional más importantes se tratan con detalle en el capítulo sobre Factores psicosociales y organizativos, pero aquí comentaremos también algunos aspectos de estos precursores de la (mala) salud mental.

Existen muchos modelos, casi todos ellos procedentes del campo de la psicología laboral y organizativa, que permiten identificar a los precursores de la mala salud mental. Estos precursores reciben a menudo el nombre de "factores estresantes". Los modelos difieren en su ámbito y, en relación

Figura 5.1 - Un modelo para la salud mental.

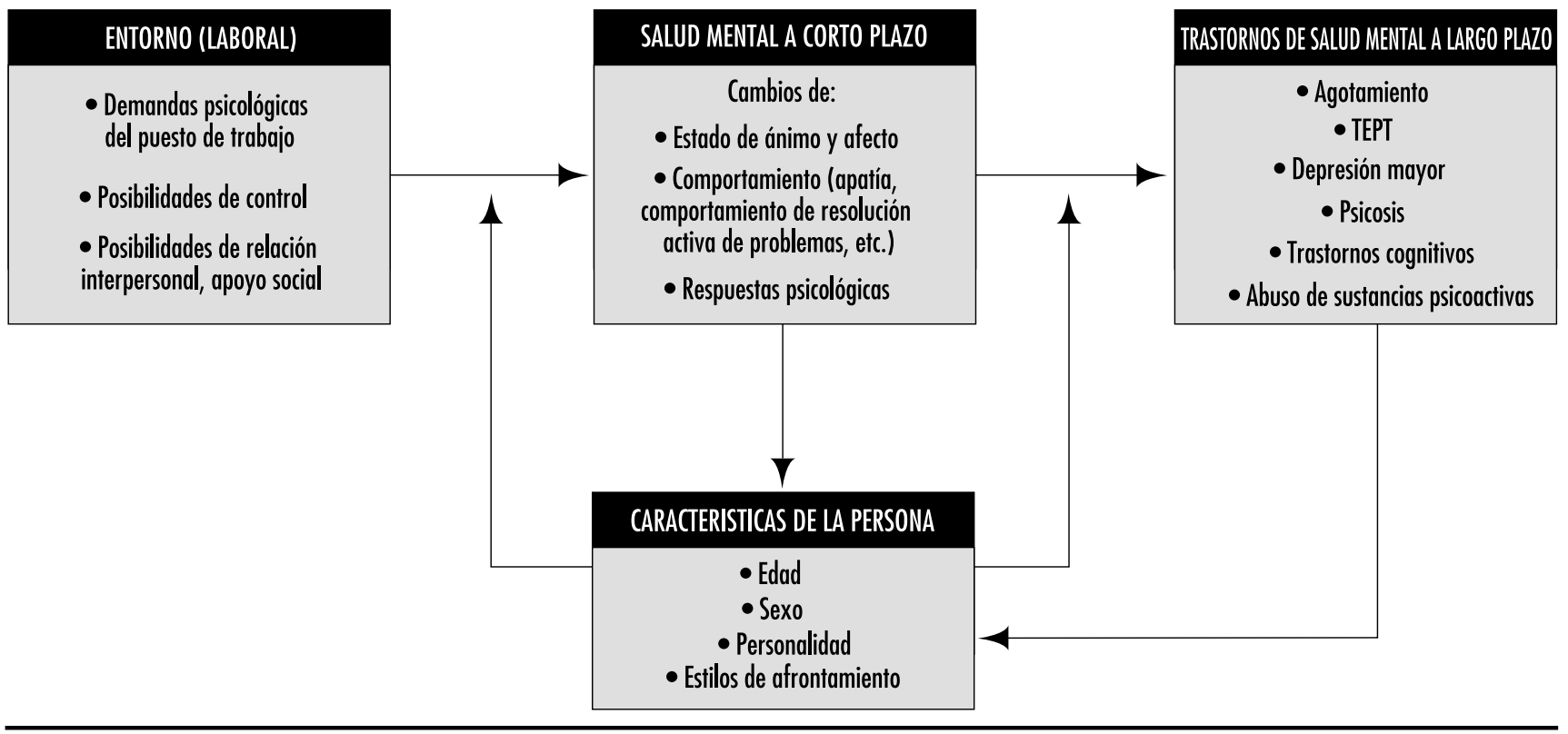


con ello, en el número de dimensiones estresantes identificadas. Un modelo relativamente simple es el de $\mathrm{K}$ arasek ( $\mathrm{K}$ arasek y Theorell 1990), que describe sólo tres dimensiones: demandas psicológicas, amplitud del margen de toma de decisiones (que abarca la discreción respecto al uso de las destrezas y la autoridad de decisión) y el apoyo social. El modelo de Warr (1984) es más elaborado y posee nueve dimensiones: oportunidad de control (autoridad de decisión), posibilidad para el uso de habilidades (discreción respecto al uso de las destrezas), objetivos generados externamente, (demandas cuantitativas y cualitativas), variedad, claridad ambiental (información acerca de las consecuencias del comportamiento, disponibilidad de retroinformación, información sobre el futuro, información sobre el comportamiento exigido), disponibilidad de dinero, seguridad física (escaso riesgo físico, ausencia de peligro), posibilidad de contacto interpersonal (requisito previo para el apoyo social) y posición social valorada (valoración de la posición social desde las perspectivas cultural y por terceros, evaluaciones personales de la importancia). De lo expuesto se deduce que los precursores de la (mala) salud mental son, en general, de carácter psicosocial y guardan relación con el contenido del trabajo, así como con las condiciones de trabajo y de empleo y con las relaciones (formales e informales) en el trabajo.

Los factores de riesgo ambientales de la (mala) salud mental suelen provocar efectos a corto plazo, como cambios del estado de ánimo y del afecto del tipo de sentimientos de placer o entusiasmo o un estado de ánimo depresivo. Estos cambios van acompañados a menudo de cambios de comportamiento. Pensemos en la inquietud, en el afrontamiento paliativo (p. ej., el consumo de alcohol) o en la evitación, así como en los comportamientos de resolución activa de problemas. Estos afectos y comportamientos también van acompañados generalmente de cambios psicológicos, que indican un estado de alerta y, a veces, también una alteración de la homeostasia. Cuando uno o más de estos factores estresantes se mantiene activo, las respuestas reversibles a corto plazo pueden originar modificaciones más estables y menos reversibles de la salud mental, como el agotamiento, las psicosis o un trastorno depresivo mayor. Las situaciones sumamente amenazadoras pueden causar, incluso de forma inmediata, un trastorno mental crónico (p. ej., TPET), difícil de contrarrestrar.

Las características de la persona pueden interactuar con factores psicosociales de riesgo en el trabajo y exacerbar o amortiguar sus efectos. La capacidad (percibida) de afrontamiento puede no sólo moderar o mediar los efectos de los factores de riesgo ambientales, sino también determinar la evaluación por el individuo de dichos factores. Parte del efecto de éstos en la salud mental se debe a este proceso de evaluación.

Las características de la persona (p. ej., su forma física) no solamente pueden actuar como precursores en el desarrollo de la salud mental, sino también cambiar como consecuencia de los efectos. A sí, la capacidad de afrontamiento puede, por ejemplo, aumentar a medida que el proceso de afrontamiento progresa con éxito ("aprendizaje"). Por otra parte, los problemas de salud mental prolongados a menudo reducirán a la larga esa capacidad de afrontamiento.

En la investigación sobre salud mental en el trabajo se ha prestado atención especial al bienestar afectivo: factores como la satisfacción en el trabajo, los estados de ánimo depresivos y la ansiedad. L os trastornos mentales más crónicos, secundarios a la exposición prolongada a factores estresantes y relacionados también, en mayor o menor medida, con trastornos de la personalidad, tienen una prevalencia mucho menor en la población activa. Estos problemas mentales crónicos tienen múltiples
Figura 5.2 - Los tres ejes principales para determinar el bienestar a fectivo.

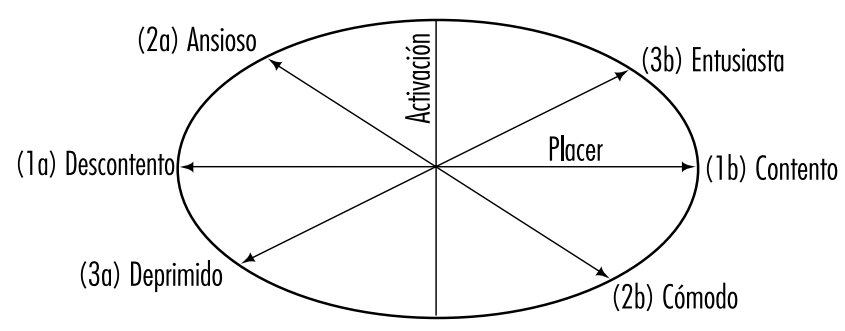

Fuente: Warr 1994.

factores causales. En consecuencia, la responsabilidad de los factores de estrés profesionales será sólo parcial. También sucede que las personas con esos problemas crónicos tendrán grandes dificultades para conservar su empleo, y muchas de ellas están de baja o han abandonado su trabajo durante períodos muy largos (1 año), o incluso de forma permanente. Por tanto, estos problemas crónicos suelen estudiarse desde una perspectiva clínica.

Puesto que los estados de ánimo y los afectos se estudian con tanta frecuencia en el campo profesional, los trataremos con mayor detalle. El bienestar afectivo se ha considerado tanto de forma bastante indiferenciada (distinguiendo sólo entre sentirse bien y sentirse mal) como teniendo en cuenta dos dimensiones, "placer" y "activación" (Figura 5.2). Cuando las variaciones de la activación no guardan relación con el placer, no se consideran por lo general un indicador del bienestar. Sin embargo, cuando existe relación entre activación y placer, pueden distinguirse cuatro cuadrantes:

1. Gran activación y placer indican entusiasmo.

2. Baja activación y placer indican comodidad.

3. G ran activación y desagrado indican ansiedad.

4. Baja activación y desagrado indican estado de ánimo depresivo (W arr 1994).

El bienestar puede estudiarse a dos niveles: un nivel general sin contexto y un nivel específico de contexto. El medio ambiente de trabajo es uno de tales contextos específicos. LoS análisis de datos respaldan la idea general de que la relación existente entre las características del puesto de trabajo y la salud mental no laboral sin contexto está mediada por un efecto sobre la salud mental relacionada con el trabajo. El bienestar afectivo relacionado con el trabajo se ha estudiado habitualmente a lo largo del eje horizontal (Figura 5.2), en términos de satisfacción en el puesto de trabajo. Sin embargo, los afectos relacionados con la comodidad, en particular han sido, ignorados en gran medida, algo lamentable teniendo en cuenta que este afecto puede indicar resignación con el trabajo: es posible que las personas no se quejen de él, pero puedan mostrarse apáticas y desinteresadas (Warr 1994).

\section{¿Por qué hay que prestar atención a los problemas de salud mental?}

Son varios los motivos que demuestran la necesidad de prestar atención a los problemas de salud mental. En primer lugar, las estadísticas de varios países indican que son muchas las personas que abandonan su empleo por problemas de salud mental. Así, 
en los Países Bajos, por ejemplo, los problemas de la tercera parte de los trabajadores diagnosticados cada año de incapacidad laboral están relacionados con la salud mental. La mayor parte de los de este grupo, el $58 \%$, se consideran relacionados con el trabajo (Gründemann, Nijboer y Schellart 1991). Junto con los problemas musculosqueléticos, los de la salud mental son responsables de alrededor de dos terceras partes de todas las bajas anuales de causa médica.

La mala salud mental es también un problema de envergadura en otros países. Según el $\mathrm{H}$ ealth and Safety E xecutive B ooklet, se ha calculado que entre el 30 y el $40 \%$ del absentismo por enfermedad en el Reino Unido puede atribuirse a alguna forma de enfermedad mental (Ross 1989; O 'Leary 1993). En ese país, se ha calculado que uno de cada cinco miembros de la población activa sufre cada año alguna forma de enfermedad mental. Resulta difícil precisar el número de días de trabajo perdidos cada año por esta causa. En el R eino U nido, se acepta una cifra de 90 millones de días de baja certificada, es decir, 30 veces la cantidad perdida por conflictos sindicales (O 'L eary 1993). Puede compararse con los 8 millones de jornadas perdidas por alcoholismo y enfermedades relacionadas con el alcohol y con los 35 millones de jornadas perdidas por cardiopatía coronaria 0 accidente cerebrovascular.

Además de resultar costosa, en términos tanto humanos como económicos, la salud mental tiene un marco legal en la U nión

Figura 5.3 - Riesgo de estrés y mala salud mental en diferentes grupos profesionales, determinados por los efectos combinados del ritmo de trabajo y la discreción respecto al uso de las destrezas.

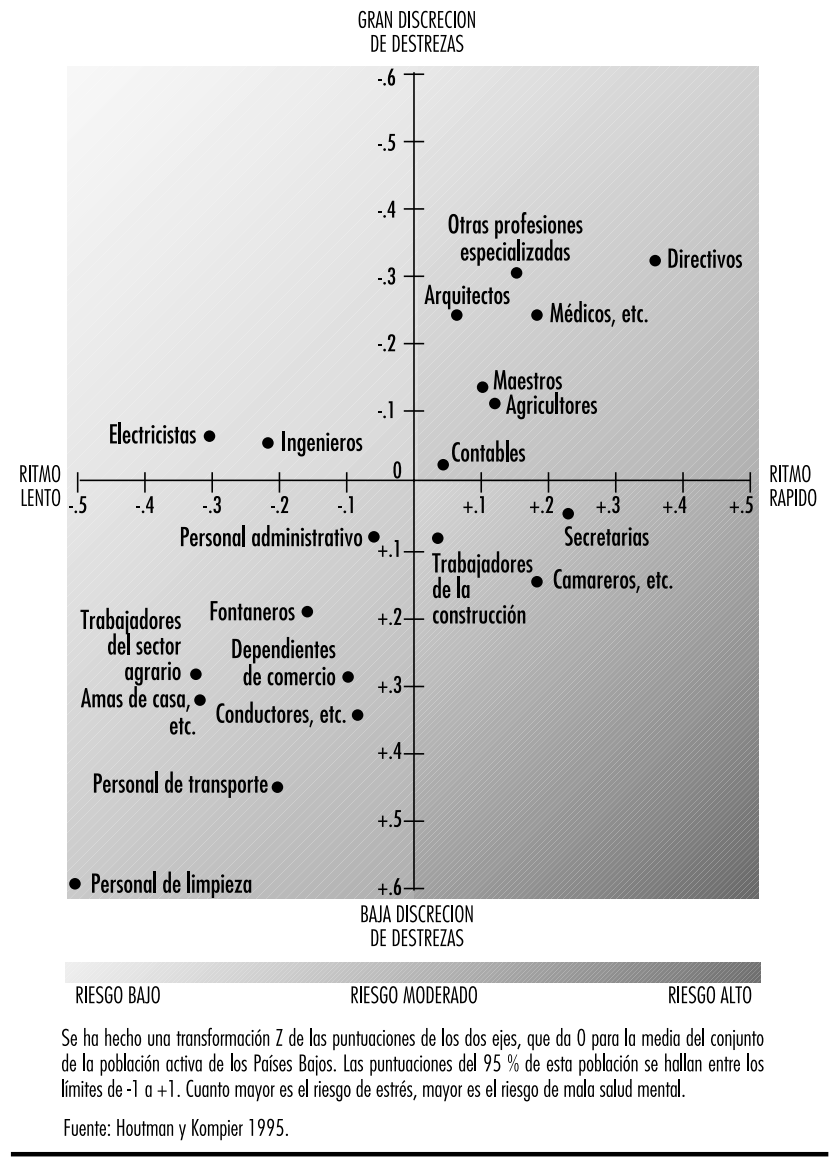

Europea (UE), su directiva sobre salud y seguridad en el trabajo (89/391/EEC), que entró en vigor en 1993. Aunque la salud mental no constituye el núcleo fundamental de la directiva, en su artículo 6 se presta cierta atención a este aspecto de la salud . La directiva marco señala, entre otras cosas, que la empresa tiene el deber de:

[adoptar] las medidas necesarias para la protección de la seguridad y de la salud de los trabajadores [en todos los aspectos relacionados con el trabajo], con arreglo a los siguientes principios generales de prevención: evitar los riesgos; evaluar los riesgos que no se puedan evitar; combatir los riesgos en su origen; adoptar el trabajo a la persona, en particular en lo que respecta a la concepción de los puestos de trabajo, así como a la elección de los equipos de trabajo y los métodos de trabajo y de producción, con miras, en particular, a atenuar el trabajo monótono y el trabajo repetitivo y a reducir los efectos de los mismos en la salud.

Pese a esta Directiva, no todos los países europeos cuentan con un marco legislativo sobre salud y seguridad. En un estudio comparativo de normativas, políticas y prácticas referentes a la salud mental y al estrés profesional en cinco países europeos, los que disponen de leyes marco (Suecia, Países Bajos y Reino Unido) reconocen que los problemas de salud mental en el trabajo son temas importantes para la salud y la seguridad, mientras que los que carecen de tal legislación (Francia, Alemania) no consideran importantes los problemas de salud mental (K ompier y cols. 1994).

Por último, pero no por ello menos importante, la prevención de la mala salud mental (en su origen) es rentable. Son muchos los indicios de que los programas preventivos producen beneficios importantes. Por ejemplo, del total de empresas de una muestra nacional representativa de tres grandes ramas de la industria, el $69 \%$ afirmaron que la motivación aumentó, el $60 \%$, que el absentismo por enfermedad disminuyó, el $49 \%$ que el ambiente laboral mejoró y el $40 \%$ que la productividad se incrementó a consecuencia de un programa de prevención (H outman y cols. 1995).

\section{Grupos profesionales con riesgo para la salud mental}

¿Existen grupos específicos de la población activa con riesgo de sufrir problemas de salud mental? La respuesta a esta pregunta no es sencilla, pues apenas existen sistemas de vigilancia internacionales o nacionales que permitan identificar los factores de riesgo, las consecuencias para la salud mental o los grupos de riesgo. Sólo puede darse un "gráfico de dispersión". En algunos países se dispone de datos sobre la distribución de los grupos profesionales en lo que concierne a los principales factores de riesgo (p. ej., para los Países Bajos, H outman y K ompier 1995; para Estados U nidos, K arasek y Theorell 1990). La distribución de los grupos profesionales en los Países Bajos en las dimensiones de las demandas del puesto de trabajo y la discreción respecto al uso de las destrezas (Figura 5.3) coincide bastante bien con la distribución de Estados U nidos presentada por K arasek y T heorell, para los grupos que se encuentran en ambas muestras. En las profesiones con elevados ritmos de trabajo y/ o baja discreción respecto al uso de las destrezas, el riesgo de trastorno mental es máximo. Al mismo tiempo, en algunos países se dispone de datos sobre resultados de salud mental en relación con grupos profesionales. Los que parecen especialmente proclives a abandonar por motivos de salud mental en los Países Bajos pertenecen al sector servicios, como el personal sanitario y los maestros, así como los empleados de la limpieza, amas de casa y trabajadores del transporte (G ründemann, N ijboer y Schellart 1991). 
Tabla 5.1 - Resumen esquemático de las estrategias de gestión de los problemas de salud mental, con algunos ejemplos.

$\begin{array}{ll}\begin{array}{l}\text { Tipo de } \\ \text { prevención }\end{array} & \text { Nivel de inter } \\ \text { Primaria } & \text { Medio a mbiente de trabajo } \\ & \begin{array}{l}\text { Rediseño del contenido de tareas } \\ \text { Rediseño de la estructura de comunicación }\end{array} \\ \text { Secundaria } & \begin{array}{l}\text { Introducción de políticas sobre medidas en caso de absentismo } \\ \text { (p. ej., formación de supervisores para comentar la ausencia y el } \\ \text { regreso con el trabajador implicado) } \\ \text { Prestación de servicios de empresa, sobre todo para grupos de riesgo } \\ \text { (p. ej., asesor en caso de acoso sexual) }\end{array} \\ & \text { Adaptación del puesto de trabajo individual }\end{array}$

Tipo de

\author{
Características de la persona y/o repercusión en la salud \\ Formación de grupos de trabajadores para identificación y manejo de \\ problemas específicos relacionados con el trabajo ( $p$. ej., actitudes ante \\ premuras de tiempo, robos, etc.) \\ Formación en técnicas de relajación
}

Asesoramiento individual

Tratamiento o terapia individual (también con medicación)
En Estados U nidos, las profesiones más propensas al trastorno depresivo mayor, diagnosticado mediante sistemas de codificación normalizados (es decir, la tercera edición de M anual diagnóstico y estadístico de los trastornos mentales (DSM III)) (A merican Psychiatric Association 1980), son los empleados judiciales y administrativos y los maestros (E aton y cols. 1990).

\section{Actitud ante los problemas de salud mental}

El modelo conceptual (Figura 5.1) sugiere al menos dos objetivos de la intervención en los problemas de salud mental:

1. El medio ambiente (de trabajo).

2. La persona, ya sean sus características o las consecuencias en la salud mental.

La prevención primaria, el tiempo de intervención que debe evitar que se produzca la enfermedad mental, debe orientarse hacia los precursores, eliminando o reduciendo los riesgos del entorno y favoreciendo la capacidad de afrontamiento y otras capacidades del individuo. La prevención secundaria se orienta hacia el mantenimiento de la población activa que ya padece algún tipo de problema de salud (mental). Este tipo de prevención debería abarcar la estrategia de prevención primaria, asociada a estrategias encaminadas a que tanto los trabajadores como sus supervisores puedan reconocer precozmente los signos de la mala salud mental, a fin de reducir sus consecuencias 0 impedir que empeoren. La prevención terciaria va dirigida a la rehabilitación de las personas que han dejado de trabajar por problemas de salud mental. Este tipo de prevención debe dirigirse a la adaptación de los puestos de trabajo a las posibilidades del individuo (lo que a menudo resulta sumamente eficaz), junto con el asesoramiento y tratamiento individuales. La Tabla 5.1 ofrece un marco sistemático sobre la conducta a seguir ante los trastornos mentales en el lugar de trabajo. En principio, todo plan preventivo eficaz debe tomar en consideración los tres tipos de estrategia (prevención primaria, secundaria y terciaria), así como los riesgos, las consecuencias y las características de las personas.

La pauta presentada proporciona un método útil para el análisis sistemático de todas las medidas posibles. Puede discutirse si una medida determinada podría pertenecer a otra categoría de la pauta, pero esta discusión sería un tanto inútil, ya que a menudo sucede que una medida de prevención primaria funciona también como prevención secundaria. El análisis sistemático propuesto puede muy bien producir un gran número de medidas potenciales, de las que pueden adoptarse varias, bien como parte de una política general (de salud y seguridad) o para un caso específico.

En conclusión, aunque la salud mental no es un estado, proceso o resultado claramente definido, cubre un campo generalmente aceptado de la (mala) salud. Parte de este campo puede ser abarcado por los criterios diagnósticos generalmente aceptados (p. ej., psicosis, trastorno depresivo mayor), pero el carácter diagnóstico de otras partes no está claro ni goza de aceptación general. Son ejemplos de estas últimas los estados de ánimo y los afectos, así como el agotamiento. Pese a todo, existen numerosos indicios de que la (mala) salud mental, incluidos los criterios diagnósticos más vagos, es un problema importante que tiene un elevado coste, tanto humano como económico. En los artículos siguientes de este capítulo, se tratarán varios trastornos de la salud mental - los estados de ánimo y los afectos (p. ej., insatisfacción), el agotamiento, el trastorno por estrés postraumático, las psicosis, los trastornos cognitivos y el abuso de sustancias psicoactivas- con mayor profundidad en lo que se refiere al cuadro clínico, las técnicas de evaluación existentes, los factores y agentes etiológicos y las medidas específicas de prevención y tratamiento.

\section{PSICOSIS RELACIONADAS CON EL TRABAJO}

\section{Craig Stenberg, Judith H older y Krishna Tallur}

Psicosis es un término general empleado con frecuencia para describir una alteración grave de la función mental. En general, esta deficiencia es tan importante que el individuo es incapaz de realizar las actividades de la vida cotidiana, incluyendo la mayor parte de las actividades laborales. De modo más formal, Yodofsky, H ales y Fergusen (1991) definen la psicosis como:

Un trastorno mental mayor de origen orgánico 0 emocional en el que la capacidad de la persona para pensar, responder emocionalmente, recordar, comunicar, interpretar la realidad y comportarse correctamente está lo bastante alterada para causar un menoscabo manifiesto de la capacidad para satisfacer las demandas habituales de la vida. [L os síntomas se] caracterizan a menudo por un comportamiento regresivo, un estado de ánimo inadecuado, un menor 
control de los impulsos y un contexto mental anormal, como ideas delirantes y alucinaciones. [p. 618].

Los trastornos psicóticos son comparativamente poco frecuentes en la población general. Su incidencia en el lugar de trabajo es aún menor, probablemente porque muchas de las personas que acaban siendo psicóticas tienen a menudo problemas para conservar un empleo estable (Jorgensen 1987). Ahora bien, su frecuencia real es difícil de calcular. No obstante, se ha sugerido que la prevalencia de las psicosis (p. ej., de la esquizofrenia) en la población general sería inferior al $1 \%$ (Bentall 1990; Eysenck 1982). Las personas que sufren activamente un estado psicótico suelen tener graves dificultades para el desempeño normal de un trabajo y otros aspectos de su vida. A veces, los sujetos con psicosis agudas muestran comportamientos atractivos, sugestivos e incluso humorísticos. Así, algunos individuos con trastorno bipolar se muestran llenos de energía y con grandes planes o ideas cuando entran en la fase maníaca. No obstante, en la mayor parte de los casos las psicosis se asocian a comportamientos que despiertan reacciones de incomodidad, ansiedad, ira o miedo en los compañeros de trabajo, los supervisores y otros.

En este artículo se ofrecerá primero una panorámica de los distintos procesos neurológicos y estados mentales en los que pueden producirse psicosis. A continuación, se revisarán los factores profesionales potencialmente asociados al desarrollo de psicosis. Por último, se resumirán los enfoques terapéuticos orientados tanto al tratamiento del trabajador psicótico como a la conducta a seguir en el entorno de trabajo (p. ej., tratamiento médico, procedimientos de alta para la reincorporación al trabajo, adaptación del puesto de trabajo y consultas con supervisores y compañeros).

\section{Procesos neurológicos y estados mentales en los que aparecen las psicosis}

Las psicosis pueden manifestarse como parte de distintas categorías diagnósticas identificadas en la cuarta edición del $M$ anual diagnóstico y estadístico de los trastornos mentales (DSM IV) (American Psychiatric Association 1994). En la actualidad, no hay todavía un conjunto diagnóstico uniformemente aceptado. A continuación se indican los procesos médicos en los que se admite que surgen las psicosis.

\section{Enfermedades sistémicas y neurológicas}

La sintomatología delirante puede estar causada por distintos trastornos neurológicos que afectan al sistema límbico o a los ganglios basales, mientras el funcionamiento de la corteza cerebral permanece intacto. Las crisis convulsivas parciales complejas van precedidas a menudo de alucinaciones olfatorias de olores peculiares. A un observador externo puede parecerle que la persona con esta actividad convulsiva está simplemente con la vista perdida o soñando despierta. Las neoplasias cerebrales, sobre todo de las regiones temporal y occipital, pueden causar alucinaciones. También los trastornos que producen delirio, como las enfermedades de Parkinson, $\mathrm{H}$ untington, Alzheimer $\mathrm{y}$ Pick, pueden alterar el estado de conciencia. Existen asimismo varias enfermedades de transmisión sexual, como la sífilis terciaria y el SIDA, que pueden dar lugar a psicosis. Por último, ciertas deficiencias de nutrientes, como las de B-12, niacina, ácido fólico y tiamina, se asocian a la posibilidad de causar problemas neurológicos capaces de originar psicosis.

En varios procesos sistémicos también se producen síntomas psicóticos, como alucinaciones e ideas delirantes. Entre ellos se encuentran la encefalopatía hepática, la cetoacidosis diabética y la disfunción endocrina (suprarrenales, tiroides, paratiroides e hipófisis). Se ha demostrado igualmente que la privación sensorial y de sueño causa psicosis.

\section{Estados mentales}

La esquizofrenia es probablemente el mejor conocido de los trastornos psicóticos. Se trata de una enfermedad que causa un deterioro progresivo y que suele tener un comienzo insidioso. Se han identificado varias subcategorías específicas, que comprenden los tipos paranoide, desorganizado, catatónico, indiferenciado y residual. Las personas con este trastorno tienen a menudo historias laborales limitadas y no suelen formar parte de la población activa una vez desarrollada la enfermedad. Tienen frecuentes alteraciones profesionales y pierden el interés o el deseo de trabajar. Salvo en empleos de muy escasa complejidad, suele ser muy difícil que conserven su puesto de trabajo.

El trastorno esquizofreniforme es similar a la esquizofrenia, pero sus episodios son de duración breve, en general inferior a seis meses. El funcionamiento social y profesional previo de las personas que sufren este trastorno suele haber sido bueno $y$, cuando los síntomas ceden, recuperan su rendimiento anterior. En consecuencia, el impacto profesional de este trastorno puede ser notablemente inferior al de la esquizofrenia.

El trastorno esquizoafectivo tiene también mejor pronóstico que la esquizofrenia, aunque peor que el de los trastornos afectivos. La alteración profesional es muy frecuente en este grupo de pacientes. A veces, las psicosis aparecen en los trastornos afectivos mayores. Con el tratamiento adecuado, el funcionamiento laboral de los trabajadores con trastornos afectivos mayores es por lo general mucho mejor que el de los que tienen esquizofrenia o trastornos esquizoafectivos.

Ciertos factores estresantes, como la pérdida del empleo o la muerte de un ser querido, pueden causar psicosis reactivas breves. Parece probable que este trastorno psicótico sea más frecuente en el medio laboral que otras psicosis, sobre todo cuando se asocian a características esquizoides, esquizotípicas 0 limítrofres.

Parece probable que los trastornos delirantes sean relativamente frecuentes en el entorno de trabajo. El sujeto afectado por el tipo erotomaniaco cree típicamente ser amado por otra persona, en general de situación social más alta. A veces, acosa a esa persona con llamadas telefónicas, cartas o incluso espiándola. M uchas de estas personas desempeñan empleos modestos, viven aislados y retirados y tienen contactos sociales y sexuales limitados. El trastorno de tipo grandioso suele asociarse a ideas delirantes de valor, poder, conocimientos o relaciones de alto nivel, o de relación especial con una deidad o algún famoso. EI tipo celoso cree erróneamente que su pareja sexual le es infiel. El tipo persecutorio cree que él mismo (o alguien próximo a él) está siendo engañado, acosado, perseguido o maltratado de alguna otra forma. Estas personas suelen sentirse resentidas y furiosas, y pueden recurrir a la violencia contra aquellos a los que consideran sus enemigos. R ara vez desean buscar ayuda, pues no creen que les ocurra nada. Los tipos somáticos desarroIlan la idea, pese a cualquier prueba en contrario, de que sufren una enfermedad infecciosa. También pueden creer que están desfigurados, o preocuparse obsesivamente por un mal olor corporal. Estos trabajadores con ideas delirantes causan con frecuencia problemas laborales.

\section{Factores químicos relacionados con el trabajo}

Se sabe que ciertas sustancias químicas, como el mercurio, el disulfuro de carbono, el tolueno, el arsénico y el plomo han producido psicosis en trabajadores manuales. Por ejemplo, se ha descubierto que el mercurio induce una psicosis en los trabajadores de la industria del sombrero, que ha recibido el literario nombre de "psicosis del sombrerero loco" (K aplan y 
Sadock, 1995). Stopford (comunicación personal, 6 de noviembre de 1995) sugiere que el disulfuro de carbono indujo psicosis en un grupo de trabajadores franceses en 1856. En Estados U nidos, en 1989, dos hermanos del estado de Nevada compraron este producto para matar ardillas y desarrollaron una psicosis grave tras entrar en contacto con él: uno de los hermanos disparó a un tercero y el otro se disparó a sí mismo durante un cuadro de confusión grave y depresión psicótica. La incidencia de suicidio y homicidio se multiplica por trece tras la exposición al disulfuro de carbono. Además, Stopford señala que se sabe que la exposición al tolueno (utilizado en la fabricación de explosivos y tintes) causa una encefalopatía aguda con psicosis. También puede causar síntomas de pérdida de memoria, cambios del estado de ánimo (p. ej., disforia) deterioro de la coordinación visual-manual y alteraciones del lenguaje. Así pues, varios disolventes orgánicos, utilizados sobre todo en la industria química, ejercen una influencia directa en el sistema nervioso central (SNC), en el que inducen cambios bioquímicos y un comportamiento impredecible (Levi, Frandenhaeuser y Gardell 1986). La Administración para la Salud y la Seguridad en el Trabajo (O ccupational Safety and $\mathrm{H}$ ealth Administration, $\mathrm{OSHA}$ ) y el Instituto Nacional para la Salud y la Seguridad en el Trabajo (N ational Institute for $\mathrm{O}$ ccupational Safety and Health, NIOSH) de Estados Unidos y la industria química han establecido precauciones, procedimientos y protocolos especiales destinados a reducir al mínimo el riego de las personas que trabajan con sustancias químicas tóxicas.

\section{0 tros factores}

Varios medicamentos pueden causar delirio, que, a su vez, puede evolucionar a la psicosis. Entre ellos se encuentran los antihipertensivos, los anticolinérgicos (incluidos algunos de los fármacos utilizados en el tratamiento del resfriado común), los antidepresivos, los tuberculostáticos, los antiparkinsonianos y los antiulcerosos (como la cimetidina). Además, pueden aparecer psicosis relacionadas con el uso de sustancias psicoactivas legales 0 ilegales, como el alcohol, las anfetaminas, la cocaína, el PCP, los esteroides anabolizantes y la marihuana. Estos delirios y alucinaciones suelen ser transitorios. Si bien el contexto es variable, las ideas delirantes de persecución son muy comunes. En las alucinaciones relacionadas con el alcohol, la persona puede oír voces que le amenazan, insultan, critican o condenan. A veces, estas voces hablan en tercera persona. Al igual que sucede con las personas que sufren delirios paranoides o persecutorios, es preciso hacer una evaluación cuidadosa de estos sujetos, pues pueden ser peligrosos para sí mismos o para los demás.

La psicosis posparto es relativamente rara en el mundo del trabajo, pero conviene reseñarla pues son muchas las mujeres que están volviendo a su trabajo antes de lo que solían. Tiende a ocurrir en madres primerizas (0, más rara vez, en padres) y suele instaurarse entre dos y cuatro semanas después del parto.

En distintas culturas pueden desarrollarse psicosis asociadas a creencias comunes. Se han descrito varias reacciones psicóticas de base cultural, como el "koro" en el sur y este de Asia, "la reacción psicótica qi-gong " en poblaciones chinas, el "piblokto" en las comunidades esquimales y el "whitigo" en varios grupos de indios norteamericanos (K aplan and Sadock 1995). No parecen existir estudios sobre la eventual relación de estos fenómenos psicóticos y las variables profesionales.

\section{Factores del puesto de trabajo asociados a la aparición de psicosis}

Aunque la información y la investigación empírica sobre las psicosis relacionadas con el trabajo son muy escasas, en parte a causa de su baja prevalencia en el entorno laboral, varios investigadores han observado relaciones entre los factores psicosociales del entorno laboral y la angustia psicológica (N eff 1968;
Lazarus 1991; Sauter, M urphy and H urrell 1992; Q uick y cols. 1992). Se ha comprobado que factores estresantes psicosociales importantes propios del empleo, como la ambigüedad de las funciones, los conflictos de funciones, la discriminación, los conflictos entre supervisor y supervisado, la sobrecarga de trabajo y el entorno en que éste se desarrolla se asocian a una mayor propensión a las enfermedades relacionadas con el estrés, a la impuntualidad y al absentismo, al rendimiento escaso, a la depresión, a la ansiedad y a otras formas de sufrimiento psicosocial (Levi, Frandenhaeuser y Gardell 1986; Sutherland y Cooper 1988).

Parece que el estrés desempeña un papel fundamental en las complejas manifestaciones de los distintos tipos de trastornos fisiológicos y psicológicos. M argolis y K roes (1974) creen que el estrés en el trabajo aparece cuando algún factor o combinación de factores laborales interactúa con el trabajador y altera su homeostasis psicológica o fisiológica. Estos factores pueden ser externos 0 internos. Entre los primeros se hallan las distintas presiones o demandas del entorno que surgen de la profesión de la persona, de su matrimonio, familia o amigos. Por el contrario, los factores internos son las presiones y demandas que se impone el trabajador a sí mismo, por ejemplo, por ser "ambicioso, materialista, competitivo y agresivo" (Yates, 1989). Son estos factores internos y externos, por separado o en conjunto, los que pueden causar una tensión profesional que induce problemas psicológicos y fisiológicos importantes en el trabajador.

Varios investigadores se han planteado si el estrés intenso o acumulado, conocido como "hiperactivación inducida por el estrés" y derivado del entorno laboral, puede inducir trastornos psicóticos relacionados con el trabajo (Bentall, Dohrenwend y Skodol 1990; Link, Dohrenwend y Skodol 1986). Así, existen pruebas que relacionan las experiencias alucinatorias y delirantes con acontecimientos estresantes específicos. Se ha asociado la aparición de alucinaciones con la hiperactivación inducida por el estrés causada por accidentes en minas, situaciones de retención de rehenes, explosiones en fábricas de productos químicos, la guerra, operaciones militares prolongadas y la pérdida del cónyuge (Comer, M adow y Dixon 1967; H obfoll 1988; Wells 1983).

DeWolf (1986) cree que la exposición o la interacción de múltiples situaciones estresantes durante períodos prolongados de tiempo es un proceso complejo por el que algunos trabajadores sufren problemas psicológicos. Brodsky (1984), en su estudio sobre 2.000 trabajadores que habían sido sus pacientes durante más de 18 años, encontró que: (1) la cromatología, la frecuencia, la intensidad y la duración de las condiciones desagradables de trabajo eran potencialmente dañinas, y opinó que entre el 8 y el $10 \%$ de la población activa sufría problemas de salud psicológicos, emocionales o físicos incapacitantes; y (2) los trabajadores reaccionan al estrés relacionado con el trabajo en parte "en función de sus percepciones, personalidad, edad, situación social, etapa vital, expectativas incumplidas, experiencias previas, sistemas de apoyo social y capacidad para responder adecuadamente o adaptarse." Además, el sufrimiento psicológico puede, en teoría, agudizarse si el trabajador tiene una sensación de imposibilidad de control (p. ej., incapacidad para tomar decisiones) e impredecibilidad en el entorno laboral ( $p$. ej., recortes de plantilla y reorganización de la empresa) (L abig 1995; Link y Stueve 1994).

Se ha prestado escasa atención a los "antecedentes" laborales de los trabajadores que desarrollan psicosis. Los pocos investigadores que han estudiado empíricamente la relación entre los factores psicosociales del entorno laboral y la psicopatología grave han encontrado relaciones entre las condiciones "inclementes" (ruido, peligro, calor, humedad, emanaciones y frío) y las psicosis (Link, Dohrenwend y Skodol 1986; M untaner y 
cols. 1991). Link, D ohrenwend y Skodol (1986) intentaron determinar los trabajos que realizaban los esquizofrénicos cuando experimentaron su primer episodio psicótico. Estudiaron los primeros puestos de trabajo a tiempo completo de los trabajadores que habían desarrollado (a) episodios de esquizofrenia 0 de tipo esquizofrénico; (b) depresión; y (c) ninguna psicopatología. Hallaron una mayor frecuencia de condiciones laborales inclementes en los trabajadores manuales que en los administrativos. Llegaron a la conclusión de que el trabajo en condiciones desagradables constituye un riesgo potencial significativo para la manifestación de los episodios psicóticos (es decir, de esquizofrenia).

M untaner y cols. (1991) reprodujeron los hallazgos de Link, Dohrenwend y Skodol (1986) y analizaron con mayor detalle la posible contribución de los distintos factores estresantes profesionales al riesgo de desarrollar o sufrir psicosis. Para ello, analizaron tres tipos de procesos psicóticos con arreglo a los criterios del DSM III, esquizofrenia; criterio A de la esquizofrenia (alucinaciones e ideas delirantes); y criterio A de la esquizofrenia con episodio afectivo (trastorno psicótico-afectivo). La muestra de su estudio retrospectivo procedía de un estudio más amplio sobre un área de captación epidemiológica (ACE) que investigaba la incidencia de trastornos psiquiátricos en cinco regiones (Connecticut, M aryland, Carolina del Norte, M issouri y California). Encontraron que las características psicosociales del trabajo (grandes demandas físicas, falta de control sobre el trabajo y las condiciones laborales, factores inclementes) aumentaban el riesgo de desarrollo de psicosis.

Como ejemplo, en el estudio de M untaner y cols. (1991), los trabajadores de la industria de la construcción (carpinteros, pintores, techadores, electricistas, fontaneros) tenían 2,58 más probabilidades de sufrir delirios y alucinaciones que los trabajadores administrativos o de gestión; también los empleados domésticos, de lavanderías, tintorerías y otras profesiones similares tenían 4,13 veces más probabilidades de desarrollar esquizofrenia que éstos. Los que se identificaban a sí mismos como escritores, artistas, del espectáculo o deportistas tenían 3,32 veces más probabilidades de sufrir ideas delirantes 0 alucinaciones que los profesionales ejecutivos, administrativos o de gestión. Por último, los que tenían profesiones relacionadas con campos como las ventas, el correo y la mensajería, la docencia, las bibliotecas y el asesoramiento tenían más riesgo de trastornos afectivos psicóticos. Conviene observar que estas asociaciones entre procesos psicóticos y variables profesionales se estudiaron tras controlar el consumo de alcohol y drogas.

Una de las diferencias más importantes existentes entre los trabajadores manuales y administrativos se da en los tipos de demanda psicológica y estrés psicosocial que experimentan cada uno. Así lo demuestran los hallazgos de M untaner y cols. (1993), quienes encontraron una asociación entre la complejidad cognitiva del entorno y las formas psicóticas de enfermedad mental. L os últimos empleos a tiempo completo de los pacientes esquizofrénicos se caracterizaban por la escasa complejidad de sus relaciones con las personas, la información y los objetos (p. ej., celadores, personal de limpieza, jardineros, vigilantes). Algunos investigadores han estudiado algunas de las consecuencias del primer episodio psicótico con respecto al empleo, el rendimiento laboral y la capacidad de trabajo (Jorgensen 1987; M assel y cols. 1990; Beiser y cols. 1994). Por ejemplo, Beiser y cols. examinaron el funcionamiento profesional después de un primer episodio de psicosis y encontraron que, 18 meses después del mismo, la "psicosis [había] comprometido el funcionamiento profesional". En otras palabras, el deterioro posmorboso era mayor en los trabajadores esquizofrénicos que en los que padecían trastornos afectivos. De igual modo, M assel y cols. (1990) encontraron que la capacidad de trabajo de los psicóticos (personas con esquizofrenia, trastornos afectivos con rasgos psicóticos o trastornos psicóticos atípicos) se había visto alterada, en comparación con los no psicóticos (p. ej., personas con trastornos afectivos sin rasgos psicóticos, trastornos por ansiedad, trastornos de la personalidad y trastornos por abuso de sustancias psicoactivas). Los sujetos psicóticos de su estudio presentaban importantes alteraciones del pensamiento, hostilidad y suspicacia que guardaban correlación con un escaso rendimiento laboral.

En resumen, nuestro conocimiento acerca de la relación entre los factores relacionados con el trabajo y las psicosis se halla aún en un estadio embrionario. Como afirma Brodsky (1984), "Ios riesgos físicos y químicos del lugar de trabajo han recibido una considerable atención, pero las tensiones psicológicas asociadas al trabajo no han sido tratadas en la misma medida, excepto en lo que concierne a las responsabilidades de dirección o al patrón de comportamiento con tendencia al infarto de miocardio". Ello implica que es muy necesaria la investigación en el campo de las psicosis relacionadas con el trabajo, sobre todo teniendo en cuenta que cada trabajador destina a su empleo, en promedio, el 42 a $44 \%$ de su vida (H ines, Durham y Geoghegan 1991; Lemen 1995) y que el trabajo se ha asociado con el bienestar psicológico (Warr 1978). Necesitamos comprender mejor qué tipos de factores estresantes profesionales y en qué circunstancias influyen en qué tipo de trastorno psicológico. Por ejemplo, sería necesario estudiar si existen estadios de intensidad, duración 0 frecuencia de la tensión psicosocial por los que pasan los trabajadores en su entorno laboral, junto a factores personales, sociales, culturales y políticos de su vida diaria. Estamos tratando de temas complejos que exigen soluciones ingeniosas junto a análisis profundos.

\section{Tratamiento agudo del trabajador psicótico}

Típicamente, el papel fundamental de las personas que deben responder al trabajador psicótico agudo en el lugar de trabajo consiste en facilitar el traslado seguro de ese trabajador a un servicio de urgencias o a un centro de tratamiento psiquiátrico. El proceso puede ser mucho más fácil si la organización dispone de un programa activo de ayuda a sus empleados y de un plan de respuesta ante las crisis. En condiciones ideales, la organización formará previamente a determinados empleados para que sepan reaccionar ante las crisis y dispondrá de un plan para la coordinación con los recursos de urgencia locales.

Los enfoques terapéuticos del trabajador psicótico dependen del tipo específico de problema subyacente. En general, todos los trastornos psicóticos deben ser objeto de evaluación por un profesional sanitario. A menudo es imprescindible una hospitalización inmediata para garantizar la seguridad del trabajador y de sus compañeros de trabajo. Posteriormente, podrá realizarse una valoración meticulosa para establecer el diagnóstico y desarrollar el plan terapéutico. El objetivo fundamental es el tratamiento de la causa o causas subyacentes. No obstante, incluso antes de llevar a cabo esa valoración global e iniciar el plan terapéutico, es posible que el médico que responde a la urgencia deba aplicar en primer lugar medidas sintomáticas. Siempre es deseable crear un entorno estructurado, de bajo nivel de estrés. Para calmar al paciente pueden utilizarse neurolépticos, y las benzodiacepinas ayudan a reducir la ansiedad aguda.

U na vez resuelta la crisis aguda, la evaluación global puede comprender la recogida de una anamnesis detallada, la realización de tests psicológicos, una valoración del riesgo para establecer el peligro para el propio paciente o para los demás y un control riguroso de la respuesta al tratamiento (incluyendo no sólo la respuesta a la medicación, sino también a las intervenciones psicoterapéuticas). U no de los problemas más difíciles que plantean los enfermos con sintomatología psicótica es la 
observancia del tratamiento. Con frecuencia, estas personas no creen tener dificultades graves 0 , incluso aunque reconozcan su problema, deciden por su cuenta la interrupción prematura del tratamiento. En estos casos, los familiares, colegas, médicos responsables, personal de salud en el trabajo y empresas se ven abocados a situaciones desagradables o difíciles. En ocasiones, por la propia seguridad del trabajador y también del lugar de trabajo, es necesario hacer de la observancia del tratamiento una condición indispensable para reanudar el trabajo.

\section{Reincorporación al trabajo}

D espués del episodio psicótico, el tema fundamental es si el trabajador puede volver a desempeñar su puesto de trabajo en condiciones seguras. A veces, las organizaciones dejan esta decisión en manos de los médicos. Sin embargo, en condiciones ideales, toda organización debería exigir a su sistema de medicina de empresa que realizase una evaluación independiente de la capacidad específica para el puesto de trabajo (H immerstein y Pransky 1988). En ese proceso de evaluación hay que revisar ciertos datos esenciales, como la valoración del médico responsable, su tratamiento y sus recomendaciones, así como el rendimiento previo del trabajador y las características específicas del puesto de trabajo, incluidas las tareas y el entorno organizativo.

Si el médico de la empresa no está capacitado para este tipo de evaluaciones psiquiátricas o psicológicas, debe realizarlas un profesional de la salud mental independiente, distinto al médico responsable. Si el puesto de trabajo puede originar algún riesgo en materia de seguridad, habrá que especificar las correspondientes restricciones, que pueden ir desde pequeños cambios de la actividad o del horario laborales hasta modificaciones más importantes, como el cambio a otro puesto de trabajo (p. ej., asignación de funciones más sencillas o cambio a otro puesto de trabajo). En principio, las restricciones no difieren de las habitualmente indicadas por los médicos de empresa, como la especificación del peso que un trabajador puede manejar después de sufrir una lesión musculosquelética.

Como demuestra el caso presentado como ejemplo más arriba, la reincorporación al trabajo plantea problemas a menudo no sólo para el propio trabajador, sino también para sus compañeros, supervisores y la organización de la empresa. Si bien los profesionales están obligados a respetar la confidencialidad del trabajador afectado en la medida en que la ley lo permita, siempre que el trabajador lo acepte, sea competente y firme el correspondiente permiso, el departamento médico de la empresa podrá proporcionar consultas o intervenciones formativas para facilitar el proceso de reincorporación al trabajo. La coordinación del servicio médico, el programa de asistencia a los trabajadores, los supervisores, los representantes sindicales y los compañeros del trabajor es a menudo decisiva para un resultado satisfactorio.

Al mismo tiempo, el servicio de salud en el trabajo debe controlar periódicamente el ajuste del trabajador a su puesto de trabajo, en colaboración con el supervisor. En algunos casos, puede ser necesario vigilar la observancia del tratamiento recomendado por el médico responsable, por ejemplo, como condición indispensable para participar en alguna tarea con aspectos de seguridad. Además y sobre todo, el sistema de salud en el trabajo debe considerar no sólo lo que es mejor para el trabajador, sino lo que es seguro para el lugar de trabajo. También puede desempeñar un papel esencial ayudando a la organización a cumplir los requisitos legales, como la L ey de norteamericanos con discapacidades, y actuando como intermediario para los tratamientos provistos por el plan de asistencia sanitaria de la organización y/o el sistema de indemnización de los trabajadores.

\section{Gestión del trabajador psicótico y medio ambiente de trabajo}

\section{Ejemplo de caso}

Un trabajador cualificado del tercer turno de una fábrica de productos químicos comenzó a mostrar un comportamiento extraño cuando la empresa inició una serie de cambios de su esquema de producción. Durante algunas semanas, en lugar de marcharse una vez concluido su turno, empezó a quedarse durante varias horas para comentar su preocupación por la mayor demanda laboral, el control de calidad y los cambios del proceso de producción con sus compañeros del turno de mañana. Parecía muy angustiado y se comportaba de forma atípica. Hasta entonces, se había mostrado un tanto tímido y distante, y su historia de rendimiento laboral era excelente. Durante este período, se hizo más hablador. También se acercaba a las personas con las que hablaba y se quedaba de pie junto a ellos de una forma que varios colegas encontraban incómoda. Si bien estos compañeros señalaron más tarde que habían encontrado raro tal comportamiento, ninguno de ellos avisó a los encargados del programa de asistencia a los empleados (PAE) 0 a los supervisores. Algo más tarde, una noche este trabajador empezó a gritar repentinamente de forma incoherente, se dirigió a uno de los almacenes de productos químicos volátiles, se acostó en el suelo y empezó a encender y apagar un encendedor. Ello motivó la intervención de los compañeros y del supervisor $y$, una vez consultado el PAE, el trabajador fue trasladado en ambulancia al hospital más próximo. El médico diagnosticó un estado de psicosis aguda. Después de un breve período de tratamiento, el trastorno se estabilizó con medicación.

Después de varias semanas, el médico consideró que el trabajador podía volver al trabajo. Un médico independiente realizó una evaluación formal previa a la reincorporación, que también resultó positiva. Sin embargo, aunque tanto el médico de empresa como el clínico independiente habían establecido que el trabajador podía volver a su puesto de trabajo, sus compañeros y supervisores expresaron su preocupación al respecto. Algunos de ellos señalaron que podrían resultar lesionados si el episodio se repitiera y el almacén se incendiara. La empresa tomó medidas para aumentar la seguridad de las áreas peligrosas. Entonces, surgió otro problema. Ciertos trabajadores afirmaron que, en su opinión, esta persona podría traer un arma al trabajo y empezar a disparar. $\mathrm{N}$ inguno de los profesionales que habían participado en el tratamiento del trabajador o en su evaluación posterior creía que hubiera riesgo alguno de conducta violenta. La empresa decidió contratar a profesionales de la salud mental que (con el consentimiento del trabajador afectado) aseguraran a sus compañeros que el riesgo de violencia era sumamente escaso, proporcionaran educación sobre las enfermedades mentales e identificaran los pasos proactivos que los trabajadores podrían dar para facilitar el regreso de su compañero. No obstante, en esa situación, e incluso después de haber sido informados sobre las enfermedades mentales, los compañeros se negaron a relacionarse con este trabajador, contribuyendo así a complicar el proceso de reincorporación. Aunque la Ley de norteamericanos con discapacidades contempla específicamente los derechos legales de los trabajadores con trastornos mentales, incluyendo los asociados a estados psicóticos, la conducta a seguir ante la aparición de una psicosis en el centro de trabajo plantea en la práctica retos organizativos a menudo igual de difíciles de resolver o más que el tratamiento médico de los trabajadores con psicosis. 


\section{Programas de prevención}

En la actualidad, no existe bibliografía sobre programas específicos de prevención o de intervención precoz destinados a reducir la incidencia de psicosis en la población activa. Los programas de asistencia a los trabajadores podrían desempeñar un papel fundamental en la identificación precoz y el tratamiento de los trabajadores psicóticos. Puesto que el estrés puede contribuir a la incidencia de episodios de psicosis en la población laboral, seria útil disponer de programas de intervención que permitieran identificar y modificar los estreses secundarios a la organización del trabajo. Estos esfuerzos de programación generales podrían consistir en rediseñar las tareas, establecer ritmos individuales flexibles y equipos de trabajo autodirigidos o permitir microdescansos, así como en actividades específicas para amortiguar el efecto estresante de la reorganización o la reducción de plantilla.

\section{Conclusión}

Si bien la psicosis es un fenómeno comparativamente poco frecuente determinado por diversas causas, su aparición en la población activa plantea importantes desafíos a los compañeros del afectado, a los representantes sindicales, supervisores y profesionales de la salud en el trabajo.

La psicosis puede aparecer como consecuencia de una exposición tóxica de origen laboral. El estrés relacionado con el trabajo puede incrementar también su incidencia en los trabajadores que padecen (o que corren el riesgo de padecer) trastornos mentales que aumentan el riesgo de psicosis. Se necesitarían nuevos estudios para: (1) comprender mejor la relación entre los factores propios del lugar de trabajo y las psicosis, y (2) desarrollar enfoques más eficaces para tratar las psicosis en el lugar de trabajo y reducir su incidencia.

ESTADO DE ANIMO Y AFECTO

\section{- DEPRESION}

\section{Jay Lasser y Jeffrey P. Kahn}

La depresión es un tema de enorme importancia en el campo de la salud mental en el trabajo, no sólo en lo que concierne al impacto que puede tener en el lugar de trabajo, sino también al papel que el lugar de trabajo puede desempeñar como agente etiológico del trastorno.

En un estudio de 1990, Greenberg y cols. (1993a) calcularon que la carga económica de la depresión en Estados U nidos fue en ese año de 43.700 millones de dólares aproximadamente. De ese total, un $28 \%$ era atribuible a los costes directos de la atención médica, pero el $55 \%$ derivaba de la combinación de absentismo laboral y descenso de la productividad. En otro artículo, los mismos autores (1993b) señalan que:

(...) la depresión tiene dos rasgos distintivos: que es muy tratable y que no se identifica ampliamente. EI NIHM ha señalado que entre el $80 \%$ y el $90 \%$ de las personas con trastorno depresivo mayor responden al tratamiento, pero que sólo uno de cada tres afectados recurre al sistema de salud para buscar ayuda (...) Al contrario que en otras enfermedades, una parte muy importante del coste total de la depresión recae sobre las empresas. Ello hace pensar que las empresas, como grupo, deberían tener un interés especial por invertir en programas que permitieran reducir los costes asociados a esta enfermedad.

\section{Manifestaciones}

Todo el mundo se siente triste o "deprimido" de vez en cuando, pero un episodio de depresión mayor, según el M anual diagnóstico y estadístico de los trastornos mentales, $4^{a}$ edición (DSM IV) (American Psychiatric Association 1994), debe cumplir varios criterios. Escapa al ámbito de este capítulo una descripción completa de los mismos, pero conviene reseñar varias partes del C riterio $A$, para tener una idea de lo que sucede en la verdadera depresión mayor:

A. Cinco (o más) de los síntomas siguientes han estado presentes durante un mismo período de 2 semanas y representan un cambio respecto a la conducta previa; al menos, uno de los síntomas se identifica con el número 0 o con el 2 :

1. estado de ánimo deprimido durante la mayor parte del día, casi todos los días:
2. notable disminución del placer 0 interés en todas o casi todas las actividades la mayor parte del día, casi todos días;

3. aumento 0 pérdida significativa de peso sin seguir ningún régimen, o disminución o aumento del apetito casi todos los días;

4. insomnio o hipersomnio casi todos los días;

5. agitación o retraso psicomotores casi todos los días;

6. fatiga o pérdida de energía casi todos los días;

7. sentimientos de inutilidad excesivos o inadecuados de culpabilidad casi todos los días;

8. disminución de la capacidad para pensar o concentrarse, 0 indecisión, casi todos los días;

9. ideas de muerte recurrentes, ideas de suicidio recurrentes, con o sin un plan específico, o intento de suicidio.

A demás de dar una idea sobre los problemas que sufre la persona con depresión, la revisión de estos criterios revela también las muchas formas en que la depresión puede influir negativamente en el lugar de trabajo. También es importante señalar la amplia variedad de los síntomas. U na persona deprimida puede sentirse apenas capaz de salir de la cama, mientras que otra puede estar tan ansiosa que apenas puede permanecer sentada y se describe como "nerviosa" o "volviéndose loca". A veces, la existencia de múltiples malestares y dolores sin explicación médica es un indicio de depresión.

\section{Prevalencia}

El siguiente párrafo de M ental H ealth in the W orkplace (K ahn 1993) describe la penetración (y el aumento) de la depresión en el lugar de trabajo:

La depresión (... ) es uno de los problemas de salud mental más frecuentes en el lugar de trabajo. Las investigaciones recientes... sugieren que, en los países industrializados, la incidencia de depresión ha ido aumentando cada decenio desde 1910, y que la edad a la que las personas tienden a deprimirse ha disminuido con cada generación desde 1940. Las enfermedades depresivas son frecuentes y graves, y suponen una enorme carga tanto para los trabajadores como para los centros de trabajo. Cabe esperar que dos de cada diez trabajadores sufran una depresión en algún momento de su vida, y las mujeres son 1,5 veces más propensas que los varones a desarrollarla. U no de cada diez trabajadores sufrirá una depresión clínica lo bastante grave para exigir la baja laboral. 
Así pues, además de los aspectos cualitativos de la depresión, las características cuantitativas/ epidemiológicas de esta enfermedad hacen de ella uno de los grandes problemas del lugar de trabajo.

\section{Trastornos relacionados}

La depresión mayor es sólo uno de varios trastornos relacionados, que se agrupan en la categoría "trastornos del estado de ánimo". El mejor conocido de ellos es la enfermedad bipolar (o trastorno "maníaco-depresivo"), en la que el paciente alterna períodos de depresión y de manía, esta última con sentimientos de euforia, menor necesidad de dormir, energía excesiva y rapidez del habla, y que puede progresar a la irritabilidad y a la paranoia.

Existen varias versiones distintas del trastorno bipolar, dependiendo de la frecuencia y la gravedad de los episodios depresivos y maníacos, de la presencia o ausencia de rasgos psicóticos (delirio, alucinaciones), etc. De igual modo, la depresión es también variable en función de su gravedad, la presencia o ausencia de psicosis y los tipos de síntomas más destacados. U na vez más, escapa al ámbito de este artículo describir todos estos aspectos, pero el lector puede consultar el DSM IV para hallar un listado completo de todas las formas de trastorno del estado de ánimo.

\section{Diagnóstico diferencial}

El diagnóstico diferencial de la depresión mayor comprende tres áreas fundamentales: otros trastornos médicos, otros trastornos psiquiátricos y otros cuadros de origen farmacológico.

Tan importante como el hecho de que muchos pacientes con depresión acuden a sus médicos generales con molestias físicas es la circunstancia de que otros que acuden al profesional de la salud mental con síntomas depresivos pueden tener una enfermedad orgánica subyacente causante de esa sintomatología. De éstas, las más frecuentes son las endocrinas (hormonales), como el hipotiroidismo, las alteraciones suprarrenales o los cambios relacionados con el embarazo o el ciclo menstrual. Sobre todo en los pacientes de mayor edad, los procesos neurológicos como la demencia, los accidentes cerebrovasculares o la enfermedad de Parkinson deben formar parte fundamental del diagnóstico diferencial. 0 tras enfermedades que pueden causar síntomas depresivos son la mononucleosis, el SIDA, el síndrome de fatiga crónica y algunos cánceres y enfermedades articulares,

Desde el punto de vista psiquiátrico, los trastornos que comparten rasgos comunes con la depresión son los trastornos por ansiedad (incluyendo la ansiedad generalizada, el trastorno por angustia y el trastorno por estrés postraumático), la esquizofrenia y el abuso de alcohol y drogas. La lista de medicamentos que pueden inducir cuadros depresivos es muy grande y comprende analgésicos, algunos antibióticos, muchos antihipertensivos y algunos medicamentos para el corazón, así como los esteroides y los agentes hormonales.

Para más detalles sobre las tres áreas del diagnóstico diferencial de la depresión, el lector debe consultar el manual de K aplan y Sadock Synopsis of P sychiatry (1994), o el más detallado Comprehensive Textbook of Psychiatry (K aplan y Sadock 1995).

\section{Etiologías relacionadas con el trabajo}

Gran parte de lo que se sabe en relación con el estrés en el lugar de trabajo puede encontrarse en otros capítulos de esta Enciclopedia, pero en este artículo nos centraremos en la forma en que ciertos aspectos del estrés pueden llevar a la depresión. Hay muchas escuelas de pensamiento acerca de la etiología de la depresión, incluidas la biológica, la genética y la psicosocial. M uchos de los factores relacionados con el lugar de trabajo se asocian a este último aspecto.
Los problemas de pérdida o riesgo de pérdida del empleo pueden dar lugar a depresión y, en el contexto actual de recortes de plantilla, las fusiones y el continuo cambio de la descripción de los puestos de trabajo son problemas frecuentes en el entorno laboral. 0 tro resultado del frecuente cambio de las tareas a desempeñar y de la constante introducción de nuevas tecnologías es que el trabajador se siente incompetente 0 insuficiente. Según la teoría psicodinámica, la depresión se desarrolla a medida que se amplía la distancia entre la autoimagen actual y el "yo ideal".

También puede utilizarse un modelo experimental animal conocido como "desamparo aprendido" para explicar los nexos ideológicos entre los entornos laborales estresantes y la depresión. En estos experimentos, se expuso a los animales a corrientes eléctricas de las que no podían escapar. Cuando aprendían que ninguno de sus intentos de actuación influía en su destino, estos animales desarrollaban una conducta cada vez más pasiva y depresiva. No es difícil extrapolar este modelo al centro de trabajo moderno, donde tantos trabajadores sienten una progresiva pérdida de control sobre sus actividades cotidianas y sus planes a largo plazo.

\section{Tratamiento}

D ada la relación etiológica antes descrita entre el lugar de trabajo y la depresión, una forma de considerar su tratamiento sería el uso de la prevención primaria, secundaria y terciaria. La prevención primaria, consistente en el intento de eliminar la raíz del problema, supone la realización de cambios organizativos fundamentales para mejorar algunos de los factores estresantes ya descritos. La prevención secundaria, que consistiría en intentar "inmunizar" al individuo frente a la enfermedad, comprendería intervenciones como la formación para el afrontamiento del estrés y los cambios del estilo de vida. La prevención terciaria, 0 la tarea de ayudar a la persona a recuperar su salud, supone un tratamiento psicoterapéutico y psicofarmacológico.

El clínico de hoy dispone de una gama creciente de enfoques psicoterapéuticos. Las estrategias psicodinámicas estudian las luchas y conflictos del paciente en un formato poco estructurado que permite explorar todos los materiales que van surgiendo en la sesión, por muy marginales que parezcan ser al principio. Se han hecho ciertas modificaciones de este modelo, limitando el número de sesiones o la amplitud del foco, con el fin de crear muchas formas nuevas de terapia breve. La terapéutica interpersonal se centra de modo más exclusivo en los patrones de las relaciones entre el paciente y los demás. 0 tra terapéutica, de popularidad creciente, es la cognitiva, basada en el precepto " $L O$ que piensas es lo que sientes". En este caso, se aplica un formato muy estructurado se analizan, cuestionan y modifican los "pensamientos automáticos" del paciente ante ciertas situaciones para obtener una respuesta emocional menos inadaptada.

Aunque las psicoterapias se han desarrollado con gran rapidez, el arsenal psicofarmacológico lo está haciendo más aún. En los últimos decenios previos a 1990, los medicamentos más utilizados en el tratamiento de la depresión eran los tricíclicos (imipramina, amitripitilina y nortriptilina, por ejemplo) y los inhibidores de la monoaminooxidasa (Nardil, Marplan y Parnate). Todos ellos actúan sobre los sistemas neurotransmisores que se cree intervienen en la depresión, pero afectan también a otros receptores, lo que origina diversos efectos secundarios. A comienzos del decenio de 1990 se introdujeron varios fármacos nuevos (fluoxetina, sertralina, Paxil, Effexor, fluvoxamina y nefazodona), que han logrado una gran difusión por ser "más limpios" (al unirse de forma más específica a las localizaciones relacionadas con la depresión) y permitir, de este modo, un tratamiento eficaz con muchos menos efectos secundarios. 


\section{Resumen}

La depresión es sumamente importante en el campo de la salud mental en el trabajo, tanto por su impacto en el lugar de trabajo como por el impacto de éste en la salud mental del trabajador. Su prevalencia es muy grande y puede tratarse con facilidad, pero por desgracia muchas veces pasa inadvertida, con graves consecuencias tanto para el enfermo como para la empresa. En consecuencia, un mayor énfasis en la detección y el tratamiento de la depresión permitirían ayudar a reducir el sufrimiento individual y las pérdidas empresariales.

\section{- ANSIEDAD RELACIONADA CON EL TRABAJO}

Randal D. Beaton

Los trastornos por ansiedad, al igual que el miedo, la preocupación y la aprensión subclínicos y los trastornos relacionados con el estrés asociados, como el insomnio, parecen tener una gran penetrancia y mostrar una prevalencia cada vez mayor en los centros de trabajo en el decenio de 1990, tanto que, de hecho, el Wall Street J ournal ha dicho que este decenio es la "Edad del Angst" laboral (Zachary y O rtega 1993). Los recortes de plantilla, la amenaza a los derechos adquiridos, los despidos, los rumores de despido inminente, la competencia a nivel mundial, la obsolescencia de las cualificaciones y la pérdida de éstas, las reestructuraciones, reconversiones, adquisiciones, fusiones y otras fuentes de confusión organizativa han erosionado la sensación de seguridad laboral de los trabajadores y han contribuido a crear una "ansiedad relacionada con el trabajo" evidente, aunque difícil de medir (Buono y Bowditch 1989). Aunque parecen existir ciertas diferencias y variables moderadoras situacionales, Kuhnert y Vance (1992) señalaron que los trabajadores manuales y los empleados administrativos que comunicaban mayor "inseguridad laboral" presentaban también una ansiedad y una sintomatología obsesiva-compulsiva significativamente mayor en una lista de comprobación de síntomas psiquiátricos. Durante gran parte del decenio de 1980 y cada vez más en el de 1990, el paisaje organizativo transicional del mercado de Estados U nidos (u "oleaje permanente", como también ha sido descrito) ha contribuido, sin duda, a esta epidemia de trastornos relacionados con el estrés profesional, incluidos, por ejemplo, los trastornos por ansiedad (Jeffreys 1995; N orthwestern N ational Life 1991).

Los problemas de estrés profesional y trastornos psicológicos relacionados en el trabajo parecen existir en todo el mundo, pero son pocas las estadísticas que documenten su naturaleza y extensión fuera de Estados U nidos (Cooper y Payne 1992). Los datos internacionales de que se dispone, casi todos ellos procedentes de países europeos, parecen confirmar los efectos negativos para la salud mental de la inseguridad laboral y de los empleos de gran tensión, similares a los observados en los trabajadores estadounidenses (K arasek y Theorell 1990). Sin embargo, el estigma, muy real, que se asocia a las enfermedades mentales en muchos otros países y culturas hace que muchos síntomas psicológicos, por no decir todos, incluyendo la ansiedad relacionada con el trabajo no se notifiquen, descubran ni traten (fuera de Estados U nidos) (C ooper y Payne 1992). En ciertas culturas, se somatizan estos trastornos psicológicos para que se manifiesten como síntomas físicos "más aceptables" (K aton, K leinman y Rosen 1982). U n estudio sobre funcionarios del gobierno japonés identificó los factores estresantes profesionales, como la sobrecarga de trabajo y el conflicto de funciones, como variables significativamente relacionadas con la enfermedad mental en estos trabajadores (M ishima y cols. 1995). Se necesitan nuevos estudios de este tipo para documentar el impacto de los factores estresantes laborales psicosociales en la salud mental de los trabajadores asiáticos, así como en los países en vías de desarrollo y en los antiguos países del Este.

\section{Definición y diagnóstico de la ansiedad}

Evidentemente, los trastornos por ansiedad figuran entre los problemas de salud mental más prevalentes y afectan en algún momento de su vida a cerca del 7 al $15 \%$ de la población adulta de Estados U nidos (Robins y cols. 1981). Estos trastornos constituyen una familia de procesos que comprenden la agorafobia (temor a los espacios abiertos), las fobias (temores irracionales), el trastorno obsesivo-compulsivo, las crisis de angustia y la ansiedad generalizada. Según el M anual diagnóstico y estadístico de los trastornos mentales, 4 à edición (D SM IV), de la American Psychiatric Association, los síntomas de trastorno por ansiedad generalizada comprenden "inquietud 0 sensación de estar en tensión 0 al borde de un ataque de nervios", fatiga, dificultades para concentrarse, tensión muscular excesiva y alteración del sueño (American Psychiatric Association 1994). El trastorno obsesivocompulsivo se caracteriza por pensamientos persistentes 0 conductas repetitivas que son excesivas/ irrazonables, causan marcado malestar, consumen gran cantidad de tiempo e interfieren en el funcionamiento del individuo. También, según el DSM IV, los ataques de angustia, definidos como períodos breves de miedo o inquietud intensos, no son en realidad trastornos en sí mismos, sino que pueden aparecer en relación con otros trastornos por ansiedad. Técnicamente, el diagnóstico de trastorno por ansiedad sólo puede ser hecho por un profesional de la salud mental debidamente formado y que emplee los criterios diagnósticos aceptados.

\section{Factores de riesgo profesional de los trastornos por ansiedad}

Son pocos lo datos acerca de la incidencia y prevalencia de los trastornos por ansiedad en el lugar de trabajo. Además, puesto que la etiología de la mayor parte de ellos es multifactorial, no podemos descartar la contribución de factores genéticos, del desarrollo y no profesionales individuales a la génesis de los mismos. Parece probable que exista una mutua influencia de los factores organizativos relacionados con el trabajo y los propiamente personales, y que esta interacción determine la aparición, progresión y evolución de estos trastornos.

La expresión ansiedad relacionada con el trabajo implica que hay situaciones, tareas y demandas laborales o factores estresantes profesionales relacionados que se asocian a la instauración 0 cronicidad de la ansiedad 0 de sus manifestaciones. Estos factores pueden ser una carga de trabajo abrumadora, el ritmo de trabajo, los plazos y una falta percibida de control personal. El modelo demanda-control predice que los trabajadores que desem- peñan tareas con escaso control personal y exposición a elevados niveles de demanda psicológica serían los más expuestos a sufrir problemas de salud mental, incluyendo los trastornos por ansiedad (K arasek y Theorell 1990). Un estudio sobre el consumo de comprimidos (tranquilizantes en su mayor parte) por varones suecos empleados en trabajos de gran tensión ha venido a respaldar esta hipótesis (K arasek 1979). Desde luego, en Estados U nidos existen hoy pruebas abrumadoras de que algunas profesiones de gran tensión se asocian a una mayor prevalencia de depresión (Eaton y cols. 1990). Ciertos estudios epidemiológicos más recientes, sumados a los modelos teóricos y bioquímicos de ansiedad y depresión, han establecido el nexo entre estos trastornos, no sólo en lo que se refiere a su comorbilidad $(40$ a $60 \%)$, sino también en cuanto a otros aspectos comunes más básicos (Ballenger 1993). En consecuencia, el 
capítulo de la Enciclopedia que trata de los factores profesionales asociados a la depresión puede proporcionar claves importantes acerca de los factores de riesgo profesionales e individuales que se asocian también a los trastornos por ansiedad. A demás de los factores de riesgo asociados al trabajo de gran tensión, se han identificado otras variables del lugar de trabajo que contribuyen a la angustia psicológica de los trabajadores, incluyendo la mayor prevalencia de los trastornos por ansiedad, y se resumen a continuación.

L as personas que, como los agentes del orden y los bomberos, desempeñan tareas peligrosas caracterizadas por la probabilidad de verse expuestas a un producto dañino o a una actividad lesiva, parecen correr también mayor riesgo de sufrir estados de sufrimiento psicológico mayores y más prevalentes, como la ansiedad. Sin embargo, hay datos de que ciertos trabajadores empleados en profesiones peligrosas consideran su trabajo "estimulante", en lugar de peligroso, y que lo afrontan mejor, en lo que a sus respuestas emocionales al trabajo se refiere ( $\mathrm{M} \mathrm{clntosh}$ 1995). N o obstante, un análisis de la sintomatología del estrés de un gran grupo de bomberos profesionales y empleados de ambulancias identificó un rasgo central de aprensión o temor. Esta "vía de estrés de la ansiedad" comprendía notificaciones subjetivas de "estar en tensión y saltar a la primera" y "estar inquieto y aprensivo". Estas y otras molestias similares asociadas a la ansiedad fueron más prevalentes y frecuentes en el grupo de bomberos/ trabajadores de ambulancias que en una muestra comparativa de varones de otras profesiones (Beaton y cols. 1995)

0 tra profesión que corre evidentemente un gran riesgo de sufrir niveles de ansiedad altos y a veces incapacitantes son los músicos profesionales. Estos profesionales, y su trabajo, se hallan expuestos a un severo escrutinio por parte de sus directores, deben trabajar en público y deben enfrentarse a la ansiedad tanto antes de su actuación como durante ésta ("miedo escénico"), esperándose de ellos (tanto por parte de los demás como de sí mismos) que den "notas perfectas" (Sternbach 1995). O tros grupos profesionales, como los actores de teatro e incluso los maestros, pueden sufrir también síntomas de ansiedad aguda y crónica en relación con su trabajo, pero los datos acerca de la prevalencia 0 importancia reales de estos trastornos por ansiedad laboral son muy escasos.

0 tro tipo de ansiedad laboral de la que tenemos pocos datos es la "fobia a los ordenadores", observada en las personas que desarrollan respuestas de ansiedad ante la tecnología informática (Stiles 1994). Aunque supuestamente cada generación de programas es más fácil de manejar que la anterior, son muchos los trabajadores que se sienten incómodos y otros incluso sienten, literalmente, pánico ante los retos del "tecnoestrés". Algunos temen al fracaso personal y profesional asociado a su incapacidad de adquirir la habilidad necesaria para enfrentarse a cada generación tecnológica sucesiva. Por último, hay pruebas de que los trabajadores sometidos a vigilancia informatizada de su rendimiento consideran su trabajo más estresante y notifican mayor número de síntomas psicológicos, incluida ansiedad, que los no sometidos a este tipo de supervisión (Smith y cols. 1992).

\section{Interacción de los factores de riesgo de ansiedad individuales y profesionales}

Es probable que los factores de riesgo individuales interactúen con muchos de los profesionales citados y potencien su influencia en el comienzo, progresión y evolución de los trastornos por ansiedad. Por ejemplo, un trabajador con "personalidad de tipo A" puede ser más propenso a sufrir ansiedad y otros problemas de salud mental en entornos profesionales de gran tensión (Shima y cols. 1995). Para dar un ejemplo más gráfico, un trabajador de ambulancias con gran sentido de la responsabilidad y "personalidad de rescate" podría hallarse más en tensión e hipervigilante durante sus horas de trabajo que otro trabajador con una actitud más filosófica ante la vida, del tipo "no puedes salvarlos a todos" (M itchell y Bray 1990). Las variables de la personalidad de cada trabajador pueden servir asimismo para atenuar los factores de riesgo profesionales. Así, K obasa, Maddi y K ahn (1982) señalaron que los directivos de empresa con "personalidad firme" parecen más capaces de afrontar los factores de estrés relacionados con su trabajo en lo que a su salud se refiere. Así pues, es preciso tener en cuenta las variables individuales de la personalidad del trabajador en el contexto de las demandas específicas de su profesión, antes de predecir su probable impacto interactivo en la salud mental del mismo.

\section{Prevención y remedio de la ansiedad relacionada con el trabajo}

Es probable que muchas de las tendencias laborales existentes hoy tanto en Estados U nidos como en el resto del mundo, citadas al principio de este artículo, persistan en años venideros. Estas tendencias influirán desfavorablemente en la salud psicológica y física de los trabajadores. La mejora psicológica del puesto de trabajo, por medio de intervenciones y nuevo diseño de los lugares de trabajo, podría erradicar o prevenir muchos de estos efectos adversos. En consonancia con el modelo de demandacontrol, sería posible mejorar el bienestar de los trabajadores diseñando e implantado, por ejemplo, una estructura más horizontal (K arasek y Theorell 1990). M uchas de las recomendaciones hechas por los investigadores del NIO SH, como aumentar la sensación de seguridad en el empleo y reducir la ambigüedad de roles en el trabajo, reducirían también considerablemente, si se aplicaran las tensiones laborales y los trastornos psicológicos asociados al trabajo, incluidos los trastornos por ansiedad (Sauter, M urphy y H urrell 1992).

Además de los cambios de política organizativa, existe también la responsabilidad personal del trabajador moderno de manejar su propio estrés o ansiedad. Algunas de las estrategias más frecuentes y eficaces utilizadas hoy por los trabajadores de Estados U nidos consisten en separar las actividades laborales y no laborales, lograr los suficientes reposo y ejercicio y aplicar el propio ritmo de trabajo (salvo, claro está, que el ritmo venga impuesto por una máquina). 0 tras alternativas cognitivas y de comportamiento útiles para afrontar y prevenir la ansiedad son las técnicas de respiración profunda de biorretroalimentación y relajación, y la meditación (Rosch y Pelletier 1987). En ciertos casos, puede ser necesaria la medicación para tratar un trastorno por ansiedad grave. En general, estos fármacos, incluidos los antidepresivos y otros ansiolíticos, sólo pueden conseguirse por prescripción médica.

\section{TRASTORNO POR ESTRES} POSTRAUMATICO Y SU RELACION CON LA SALUD LABORAL Y LA PREVEN CION DE LESIONES

$M$ ark Braverman

Excepto en lo que se refiere al concepto general de estrés y a su relación con los aspectos generales de la salud, poca ha sido la atención prestada al papel del diagnóstico psiquiátrico en la prevención y el tratamiento de las consecuencias psicológicas de 
las lesiones de origen laboral. G ran parte de la investigación realizada acerca del estrés laboral se refiere a los efectos de la exposición prolongada a los estreses propios del trabajo, y no a los problemas asociados a acontecimientos específicos, como una lesión traumática o con riesgo para la vida o la observación de un accidente industrial o un acto de violencia. Al mismo tiempo, el diagnóstico de trastorno por estrés postraumático (TEPT), proceso que ha sido objeto de credibilidad e interés crecientes desde mediados del decenio de 1980, se aplica cada vez con mayor frecuencia en contextos distintos a los de la guerra y las víctimas de actos delictivos. En lo que al lugar de trabajo se refiere, el TEPT comienza a aparecer como diagnóstico clínico en casos de accidente laboral y como resultado emocional de la exposición a situaciones traumáticas ocurridas en el lugar de trabajo. Es a menudo objeto de controversia y de cierta confusión en lo que concierne a su relación con las condiciones de trabajo y a la responsabilidad de la empresa cuando se formulan reclamaciones por daños psicológicos. Cada vez se pide con mayor frecuencia a los médicos de empresa que ayuden a definir las políticas empresariales en el manejo de estas demandas por exposición o lesión, y que den su opinión profesional acerca del diagnóstico, tratamiento y situación laboral definitiva del trabajador afectado. Por tanto, estos profesionales están obligados a familiarizarse con el TEPT y procesos asociados.

En este artículo se revisarán los temas siguientes:

- diagnóstico diferencial del TEPT con otros trastornos, como la depresión primaria y los trastornos por ansiedad;

- relación entre el TEPT y las molestias somáticas relacionadas con el estrés;

- prevención de las reacciones de estrés postraumático en los supervivientes de acontecimientos psicológicamente traumáticos ocurridos en el lugar de trabajo;

- prevención y tratamiento de las complicaciones de los accidentes de trabajo relacionados con el estrés postraumático.

EI trastorno por estrés postraumático afecta a las personas que se han visto expuestas a accidentes 0 situaciones traumatizantes. Se caracteriza por síntomas de entumecimiento, retraimiento psicológico y social, dificultades para controlar las emociones, sobre todo la ira, y recuerdo vivo e intrusivo de las experiencias de la situación traumática. Por definición, un acontecimiento traumatizante es aquél que es ajeno a la variedad normal de acontecimientos de la vida cotidiana y que el individuo vive como abrumador. Suele suponer una amenaza para la vida propia o la de alguien cercano, o la contemplación de una muerte o lesión grave, sobre todo si se produce de forma repentina o violenta.

Los antecedentes psiquiátricos de nuestro concepto actual del TEPT se remontan a las descripciones de la "fatiga de combate" durante las Guerras M undiales. Sin embargo, las causas, sintomatología, curso clínico y tratamiento efectivo de este trastorno, a menudo incapacitante, se conocían todavía mal cuando decenas de miles de ex combatientes en Vietnam comenzaron a poblar los hospitales de la Veterans Administration estadounidense, las consultas de los médicos de familia, las cárceles y los refugios para vagabundos durante el decenio de 1970. Gracias, en gran parte, al esfuerzo organizado de grupos de ex combatientes en colaboración con la American Psychiatric Association, el TPET fue identificado y descrito, por primera vez, en la 3a edición del $M$ anual diagnóstico y estadístico de los trastornos mentales (DSM III) (American Psychiatric A ssociation 1980). Se sabe hoy que el trastorno afecta a muchas personas que han padecido traumas, incluidos supervivientes de desastres, víctimas de delitos, tortura o terrorismo, o personas que han sufrido malos tratos durante su infancia y en su hogar. Aunque el manual diagnóstico actual (DSM IV) refleja ciertos cambios en la clasificación del trastorno, los criterios diagnósticos y los síntomas no han variado sustancialmente (American Psychiatric Association 1994).

\section{Criterios diagnósticos del trastorno por estrés postraumático}

A. La persona se ha visto expuesta a un acontecimiento traumático en el que concurrieron las dos circunstancias siguientes:

(1) La persona experimentó, presenció o se enfrentó a un acontecimiento 0 acontecimientos que supusieron una amenaza real para la vida o la integridad física de ella misma o de otros.

(2) La persona respondió al acontecimiento con miedo intenso, impotencia u horror.

B. El acontecimiento traumático se reexperimenta persistentemente por lo menos de una de las tres formas siguientes:

(1) Recuerdos angustiosos, recurrentes e invasores del acontecimiento, incluyendo imágenes, pensamientos 0 percepciones.

(2) Sueños angustiosos y recurrentes sobre el acontecimiento.

(3) Conductas y sentimientos que aparecen como si el acontecimiento traumático estuviera sucediendo de nuevo.

(4) M alestar psicológico intenso al verse expuesto a acontecimientos que simbolizan o recuerdan algún aspecto del suceso traumático.

(5) Reactividad psicológica ante la exposición a claves internas o externas que simbolizan o recuerdan algún aspecto del acontecimiento traumático.

C. Evitación persistente de los estímulos asociados al trauma y embotamiento de la capacidad general de respuesta (no existente antes del acontecimiento), puestas de manifiesto por tres (o más) de los siguientes:

(1) Esfuerzos para evitar los pensamientos, sensaciones o conversaciones asociadas al trauma.

(2) Esfuerzos por evitar las actividades, lugares o personas que despiertan recuerdos del trauma.

(3) Incapacidad para recordar alguno de los aspectos importantes del trauma.

(4) Notable disminución del interés o participación en actividades significativas.

(5) Sensación de distanciamiento 0 extrañamiento respecto a los demás.

(6) Restricción de la gama de afectos (p. ej., incapaz de sentir amor).

(7) Sensacion de acortamiento del futuro (no se espera terminar una carrera, casarse, tener hijos o una larga vida).

D. Síntomas persistentes de aumento de la activación (no existentes antes del traumatismo), puestos de manifiesto por al menos dos de los siguientes;

(1) D ificultad para conciliar o mantener el sueño.

(2) Irritabilidad o explosiones de ira

(3) Dificultad para la concentración

(4) H ipervigilancia

(5) Respuesta de alarma exagerada

E. Duración del trastorno (síntomas de los criterios B, C , D) superior a 1 mes.

F. La alteración causa una angustia significativa o altera la actividad social o laboral, u otros campos importantes del funcionamiento.

Especificar si:

Agudo: duración de los síntomas es inferior a 3 meses 
Crónico: duración de los síntomas es igual o superior a 3 meses

Especificar si:

Comienzo reardado: si el inicio de los síntomas se produjo al menos seis meses después del acontecimiento desencadenante.

$\mathrm{H}$ oy se reconoce cada vez con mayor frecuencia que el estrés psicológico es una de las consecuencias de los riesgos asociados al trabajo. El nexo entre estos riesgos y el estrés postraumático fue establecido inicialmente en el decenio de 1970, cuando se descubrieron las grandes tasas de incidencia de TEPT en los cuerpos de seguridad, personal sanitario de urgencia y bomberos.

Se han desarrollado estrategias específicas para prevenir el TEPT en los trabajadores expuestos a factores de estrés traumático de origen laboral, como los accidentes con mutilación, la muerte y el uso de la fuerza con resultado de muerte. Estas intervenciones subrayan la importancia de proporcionar a los trabajadores expuestos tanto una educación acerca de las reacciones de estrés normales, como la posibilidad de manifestar libremente sus sentimientos ante sus compañeros. Se trata de técnicas bien conocidas en los ámbitos laborales afectados de Estados U nidos, Australia y muchos países de Europa. Sin embargo, el estrés traumático asociado al trabajo no afecta sólo a estos trabajadores de alto riesgo. M uchos de los principios de la intervención preventiva desarrollados para estas profesiones pueden aplicarse también a los programas destinados a reducir o prevenir las reacciones de estrés traumático en la población activa general.

\section{Aspectos del diagnóstico y el tratamiento}

\section{Diagnóstico}

La clave del diagnóstico diferencial del TEPT y de los procesos relacionados con el estrés traumático es la presencia del factor estresante. Aunque el acontecimiento desencadenante debe cumplir el criterio $A$, es decir, ser un acontecimiento o situación ajeno a la gama de experiencias normal, las personas responden de distinta forma ante estímulos similares.

Un suceso que precipita una reacción clínica de estrés en una persona puede no afectar significativamente a otra. Por tanto, la ausencia de síntomas en otros trabajadores que hayan sufrido una experiencia similar no permite descartar la posibilidad de una auténtica reacción de estrés postraumática en un sujeto dado. La vulnerabilidad individual al TEPT depende en tan gran medida del impacto emocional y cognitivo que la experiencia ejerce en la víctima como de la intensidad del propio acontecimiento desencadenante. Un factor de vulnerabilidad fundamental es el antecedente de trauma psicológico debido a una exposición traumática previa o una pérdida personal de algún tipo. Ante una sintomatología sugestiva de TEPT, es necesario determinar si se ha producido un acontecimiento que cumpla el criterio de traumático. Este aspecto es de la mayor importancia, puesto que la propia víctima puede no haber establecido la conexión entre sus síntomas y el suceso. Esta incapacidad suele ser consecuencia de la reacción de "embotamiento" habitual, que puede causar el olvido o la disociación del acontecimiento, y también de que los síntomas aparecen a menudo semanas o incluso meses después de aquél. En ausencia del diagnóstico y tratamiento adecuados, suelen manifestarse una depresión crónica y a veces grave, ansiedad y trastornos somáticos. En consecuencia, el diagnóstico precoz es especialmente importante, tanto a causa de la naturaleza con frecuencia oculta del proceso, incluso para el propio afectado, como por las implicaciones terapéuticas del mismo.

\section{Tratamiento}

Si bien los síntomas de ansiedad y depresión del TEPT pueden responder al tratamiento habitual, p. ej., con fármacos, el tratamiento eficaz difiere de los habitualmente recomendados para estos trastornos. EI TEPT es quizá el más fácil de prevenir de todos los procesos psiquiátricos y, en el campo de la salud laboral, tal vez sea el más previsible de todas las lesiones relacionadas con el trabajo. Puesto que su aparición tiene un nexo tan evidente con el acontecimiento desencadenante específico, el tratamiento puede centrarse en la prevención. Proporcionando una educación y asesoramiento preventivos poco después de la exposición al trauma, las reacciones de estrés posteriores pueden reducirse al mínimo, o incluso evitarse. Q ue la intervención sea preventiva 0 terapéutica dependerá en gran parte del momento en que se produzca, pero la metodología aplicable es básicamente idéntica. El primer paso del tratamiento o de la prevención consiste en hacer que la víctima establezca la conexión entre el acontecimiento desencadenante y su sintomatología. Esta identificación y "normalización" de lo que son normalmente reacciones de miedo y confusión es importante para aliviar o prevenir los síntomas. Una vez lograda la normalización de la respuesta de estrés, el tratamiento puede orientarse hacia el procesamiento controlado del impacto emocional y cognitivo de la experiencia.

EI TEPT o los procesos relacionados con estrés traumático se producen cuando la persona afectada sella en su mente las reacciones emocionales y cognitivas inaceptables o intolerablemente intensas provocadas por factores estresantes traumáticos. En general, se admite que el síndrome de estrés puede prevenirse si puede disponerse de la oportunidad de controlar el procesamiento de las reacciones antes de que éstas hayan sido selladas. En consecuencia, la prevención efectuada mediante una intervención oportuna y diestra es la clave del tratamiento de este trastorno. Puede pensarse que estos principios terapéuticos se desvían del enfoque psiquiátrico tradicional aplicado a muchos procesos. En consecuencia, es importante que los trabajadores con riesgo de reacciones de estrés postraumáticas sean tratados por profesionales de la salud mental especialmente formados y experimentados en el tratamiento de los procesos relacionados con traumas. La duración de este tratamiento es variable. Depende del momento en que se efectúe la intervención, de la intensidad del factor estresante, de la gravedad de los síntomas y de la posibilidad de que una exposición traumática desencadene una crisis emocional asociada a experiencias previas o relacionadas. 0 tro aspecto del tratamiento se refiere a la importancia de las modalidades de terapéutica de grupo. Las víctimas de tales acontecimientos pueden obtener grandes beneficios del apoyo de otros que hayan compartido experiencias traumáticas iguales o semejantes. Este aspecto adquiere una importancia especial en el contexto laboral, cuando un grupo de trabajadores o la totalidad de la plantilla resulta afectada por un accidente, un acto violento 0 una pérdida traumática.

\section{Prevención de las reacciones de estrés postraumático después de incidentes traumáticos en el lugar de trabajo.}

En los centros de trabajo, distintas situaciones o acontecimientos pueden implicar un riesgo de reacciones de estrés postraumático. Entre ellos se encuentran la violencia o la amenaza de violencia, incluyendo el suicidio, la violencia y el delito entre trabajadores, como el robo a mano armada, los accidentes mortales o graves y la muerte repentina o la crisis médica, como un ataque cardíaco. A menos que se adopten las medidas adecuadas, estas situaciones pueden dar lugar a resultados negativos, como reacciones de estrés postraumático que lleguen a niveles clínicos y otros efectos relacionados con el estrés que afecten a la salud y al rendimiento laboral del trabajador, 
incluyendo la evitación del lugar de trabajo, los problemas para concentrarse, las alteraciones del estado de ánimo, el retraimiento social, el abuso de sustancias psicoactivas y los problemas familiares. Estas consecuencias afectan no sólo a los trabajadores manuales, sino también al personal administrativo. Los directivos corren un riesgo especial a causa de los conflictos entre sus responsabilidades operativas, su sentimiento de responsabilidad personal por los empleados a su cargo y su propia sensación de shock y dolor. En ausencia de políticas de empresa y de pronta asistencia por parte del personal sanitario para ayudar a afrontar las consecuencias del traumatismo, los directivos de todos los niveles pueden desarrollar sentimientos de impotencia que complican sus propias reacciones de estrés postraumático.

Los acontecimientos traumáticos en el centro de trabajo requieren una respuesta definida de la alta dirección en colaboración con el personal de asistencia sanitaria, seguridad, comunicaciones y otras funciones implicadas. Un plan de respuesta a las crisis debe cumplir tres objetivos fundamentales:

(1) prevención de las reacciones de estrés postraumáticas llegando a las personas y grupos afectados antes de que se instaure el proceso;

(2) comunicación de la información relacionada con la crisis, a fin de limitar y controlar los rumores;

(3) transmitir confianza en que los directivos pueden controlar la crisis y demostrar preocupación por el bienestar de los empleados.

La metodología de la puesta en práctica de un plan de este tipo ha sido ya descrita (Braverman 1992a, b; 1993b). En ella se subraya la importancia de la comunicación entre directivos y empleados, reuniendo a los afectados y asesorando precozmente a los que corren mayor riesgo de reacción postraumática a causa de sus niveles de exposición o de sus factores de vulnerabilidad personales.

El personal directivo y sanitario de la empresa debe funcionar como un solo equipo y mantenerse alerta ante la posibilidad de reacciones de estrés continuas o tardías que aparezcan semanas o meses después del acontecimiento traumático. Estas reacciones pueden ser difíciles de identificar tanto para los primeros como para los segundos, puesto que a menudo aparecen con retraso y pueden estar enmascaradas como otros problemas. Para un supervisor, una enfermera o un consejero involucrados, la observación de signos de estrés emocional como irritabilidad, retraimiento o descenso de la productividad pueden ser signos de reacción a un factor de estrés traumático. Cualquier cambio de comportamiento, incluyendo un aumento del absentismo, o incluso un aumento importante de las horas de trabajo (adición al trabajo) puede ser una señal. Es preciso explorar todos los indicios de abuso de alcohol o sustancias psicoactivas y todo cambio del estado de ánimo posiblemente relacionados con un estrés postraumático. Todo plan de respuesta a crisis debe incluir la formación de directivos y profesionales sanitarios para que se mantengan alerta ante estos signos, de forma que la intervención se lleve a cabo lo más precozmente posible.

\section{Complicaciones relacionadas con el estrés de los accidentes de trabajo}

Al revisar las demandas de indemnización de los trabajadores hasta cinco años después de un accidente de trabajo, hemos podido comprobar que el síndrome de estrés postraumático es una consecuencia frecuente de los accidentes de trabajo que ponen en peligro la vida y producen lesiones con desfiguración, o de las agresiones y otros delitos violentos. Es típico que el trastorno permanezca inadvertido durante años, sin que su origen sea sospechado por los profesionales de la medicina, los que resuelven las reclamaciones o los responsables de recursos humanos, e incluso por el propio trabajador. Cuando ello ocurre, la recuperación de la lesión física puede ser mucho más lenta, o incluso imposible.

Las discapacidades y lesiones asociadas al estrés psicológico figuran entre las lesiones de origen laboral más costosas y difíciles de tratar. Al solicitar una "indemnización por estrés", el trabajador sostiene que ha sufrido una lesión emocional por un acontecimiento o circunstancia de su trabajo. Costosas y difíciles de combatir, las demandas de indemnización por estrés suelen terminar en los juzgados y en el despido del trabajador. Existe, sin embargo, una fuente muchísimo más frecuente pero pocas veces reconocida de demandas por estrés. En estos casos, una lesión grave o la exposición a una situación que pone en peligro la vida dan lugar a un proceso de estrés psicológico no diagnosticado y no tratado que influye significativamente en la evolución de la lesión física.

Basándonos en nuestro trabajo sobre lesiones traumáticas y episodios de violencia en centros de trabajo, calculamos que al menos la mitad de las demandas de indemnización objeto de litigio se refieren a procesos de estrés postraumático que no se han identificado ni tratado, u otros componentes psicosociales. En el intento por resolver los problemas médicos y establecer la situación del trabajador, y dado el miedo y desconfianza de muchos sistemas ante las intervenciones de salud mental, los problemas de estrés emocional y psicosociales siempre ocupan un lugar secundario. Cuando no se afronta, el estrés puede adoptar la forma de distintos procesos médicos, que pasan inadvertidos para la empresa, el gestor de riesgos, el profesional sanitario y el propio trabajador. El estrés relacionado con los traumatismos también origina característicamente la evitación del lugar de trabajo, con el consiguiente aumento del riesgo de conflicto y desacuerdo en torno a la reincorporación al trabajo y la incapacidad laboral.

Muchas empresas y compañías de seguros creen que el contacto con los profesionales de la salud mental se asocia directamente a una demanda costosa e insoluble. Por desgracia, así sucede en muchos casos. Las estadísticas confirman que las demandas por estrés mental son más costosas que las debidas a cualquier otra lesión. A demás, aumentan con mayor rapidez que las de cualquier otro tipo. En el supuesto típico de una demanda "físico-mental", el psiquiatra o psicólogo aparece sólo en el momento - por lo general, meses o incluso años después del acontecimiento- en que se le necesita para hacer una evaluación experta en un litigio. En ese momento, el daño psicológico ya está hecho. La reacción de estrés relacionada con el traumatismo puede haber impedido que el trabajador vuelva a su trabajo, aunque físicamente parezca curado. A lo largo del tiempo, la reacción de estrés a la lesión original no tratada ha causado una ansiedad o depresión crónicas, una enfermedad somática o un trastorno por abuso de sustancias. De hecho, es raro que la intervención de salud mental se ejecute en el momento en que puede prevenir la reacción de estrés y, por tanto, ayudar al trabajador a recuperarse plenamente del trauma originado por un accidente o agresión graves.

Con un mínimo grado de planificación y oportunidad, los costes y el sufrimiento asociados al estrés originado por el accidente se hallarían en el grupo de las más fácilmente prevenibles de todas las lesiones. A continuación se indican los componentes de un plan eficaz después del acontecimiento lesivo (Braverman 1993a):

\section{Intervención precoz}

Todas las empresas deberían exigir una breve intervención de salud mental cuando sus empleados se vieran afectados por un accidente grave, agresión u otro acontecimiento traumático. E sta evaluación debe considerarse preventiva, y no ligada al procedimiento de 
reclamación habitual. D ebe prestarse incluso en ausencia de pérdida de tiempo, lesión o necesidad de tratamiento médico. La intervención debe centrarse en la educación y la prevención, más que en un enfoque exclusivamente clínico que puede hacer que esos trabajadores se sientan estigmatizados. La empresa, quizá junto al asegurador, debe hacerse responsable del coste, relativamente pequeño, de este servicio. $\mathrm{H}$ ay que intentar que sólo participen profesionales con experiencia o formación especiales en los procesos relacionados con el estrés postraumático.

\section{Reincorporación al trabajo}

Toda actividad de asesoramiento o evaluación debe coordinarse con un plan de reincorporación al trabajo. Los trabajadores que han sufrido un traumatismo temen o dudan, con frecuencia, ante la vuelta al lugar de trabajo. La combinación de unas breves sesiones de educación y asesoramiento con visitas al centro del trabajo durante la fase de recuperación ha resultado muy beneficiosa para lograr esta transición y acelerar la reincorporación. Los profesionales sanitarios pueden trabajar en equipo con los supervisores o directivos para lograr una reincorporación progresiva al pleno rendimiento en el puesto de trabajo. Incluso en ausencia de secuelas físicas, los factores emocionales pueden precisar adaptaciones, como permitir que el cajero que ha sido objeto de robo trabaje en otra zona del banco durante parte del día, hasta que se sienta cómodo de nuevo en su ventanilla, de cara al público.

\section{Seguimiento}

Con frecuencia, las reacciones postraumáticas son tardías. Es importante hacer un seguimiento de los trabajadores que se han reincorporado al cabo de 1 y 6 meses. También es importante facilitar a los supervisores información que les permita identificar los eventuales problemas demorados o a largo plazo asociados al estrés postraumático.

\section{Resumen: nexo entre los estudios sobre el estrés postraumático y la salud en el trabajo}

Q uizá más que cualquier otro campo de las ciencias de la salud, la medicina del trabajo se ocupa de la relación entre el estrés y la enfermedad. De hecho, gran parte de la investigación sobre el estrés humano efectuada en este siglo ha tenido lugar en el campo de la salud en el trabajo. A medida que las ciencias de la salud, en general, se orientaban más hacia la prevención, el lugar de trabajo se ha convertido en un campo cada vez más importante para el estudio de la influencia del entorno físico y psicosocial en la enfermedad y a la salud, y de los métodos que permiten prevenir los procesos relacionados con el estrés. Al mismo tiempo, desde 1980 se ha producido una revolución en el estudio del estrés postraumático que ha permitido grandes avances en el conocimiento de la respuesta del ser humano al estrés. El profesional de la higiene industrial se encuentra en la intersección entre estos campos, de importancia cada vez mayor.

A medida que el paisaje laboral experimenta esta transformación revolucionaria, y a medida que aprendemos más sobre la productividad, el afrontamiento y el impacto estresante del cambio continuo, se va borrando la línea que separa el estrés crónico del estrés agudo o traumático. La teoría clínica del estrés traumático tiene mucho que aportar a la prevención y el tratamiento del estrés psicológico relacionado con el trabajo. Como en todas las ciencias de la salud, el conocimiento de las causas de un síndrome puede ayudar a su prevención. En el campo del estrés postraumático, el centro de trabajo ha resultado ser un lugar ideal para promocionar la salud y la curación. Los profesionales de la salud familiarizados con los síntomas y causas de las reacciones de estrés postraumático serán más eficaces como agentes de su prevención.

\section{EL ESTRES Y EL AG OTAMIENTO, Y SUS IMPLICACIONES EN EL MEDIO AMBIENTE DE TRABAJO}

H erbert J. Freudenberger

“La naciente economía mundial exige prestar una atención científica seria a los descubrimientos que favorecen el aumento de la productividad humana en un mundo laboral siempre cambiante y tecnológicamente perfeccionado" (H uman Capital Initiative 1992). Los cambios económicos, sociales, psicológicos, demográficos, políticos y ecológicos que tienen lugar en todo el mundo nos obligan a evaluar de nuevo los conceptos de trabajo, estrés y agotamiento en la población activa

El trabajo productivo "exige centrarse en una realidad externa a sí mismo. Por tanto, el trabajo destaca los aspectos racionales de las personas y su capacidad para resolver problemas" (Lowman 1993). Las facetas afectivas y del estado de ánimo del trabajo son objeto de una preocupación cada vez mayor, a medida que el medio ambiente de trabajo se hace más complejo.

U no de los conflictos que pueden surgir entre el individuo y el mundo del trabajo es la exigencia al trabajador que ocupa su primer empleo de una transición desde el egocentrismo de la adolescencia a la subordinación disciplinada de las necesidades personales a las demandas del puesto de trabajo. M uchos trabajadores necesitan aprender a adaptarse al hecho de que sus sentimientos y valores tienen a menudo escasa importancia 0 pertinencia en el centro de trabajo.

Para poder seguir tratando del estrés relacionado con el trabajo, es preciso definir este término, tan utilizado en la bibliografía de las ciencias del comportamiento y con tan variados significados. EI estrés supone una interacción entre la persona y el medio ambiente de trabajo. Algo sucede en el campo laboral que plantea al individuo una demanda, obstáculo, exigencia u oportunidad de comportamiento y respuesta consiguiente. "Existe potencial de estrés cuando una situación del entorno se percibe como una demanda que amenaza superar las capacidades y recursos de la persona para satisfacerla, en condiciones en las que él o ella esperan una diferencia sustancial en las recompensas y costes de satisfacer 0 no esa demanda" (M cG rath 1976).

Conviene señalar que el grado en el que la demanda excede la expectativa percibida y el grado de recompensa diferencial esperado del cumplimiento 0 no de esa demanda reflejan la magnitud del estrés a que la persona se ve sometida. M CG rath sugiere, además, que el estrés puede manifestarse de la siguiente forma: "Valoración cognitiva en la que el estrés experimentado subjetivamente depende de la percepción de la situación por la persona. En esta categoría, en las respuestas emocional, fisiológica y del comportamiento influye significativamente la interpretación que hace la persona de la situación de estrés "objetiva" 0 "externa".

O tro componente del estrés es la experiencia previa del individuo ante un situación similar y su respuesta empírica. A ello se asocia el factor de refuerzo, positivo o negativo, los éxitos o fracasos que pueden intervenir para reducir o aumentar, respectivamente, los niveles de estrés subjetivo experimentado. 
El agotamiento es una forma de estrés. Es un proceso definido como una sensación de deterioro y cansancio progresivos con eventual pérdida completa de energía. También va acompañado a menudo por una falta de motivación, un sentimiento que sugiere "ya basta, no más". Es una sobrecarga que tiende, a lo largo del tiempo, a afectar a las actitudes, al estado de ánimo y a la conducta general (Freudenberger 1975; Freudenberger y Richelson 1981). Se trata de un proceso sutil, que se desarrolla lentamente y que a veces evoluciona por fases. $M$ uchas veces no es percibido por la persona más afectada, que es la última en creer que el proceso se está produciendo.

Los síntomas del agotamiento se manifiestan a nivel físico como molestias psicosomáticas difusas, alteraciones del sueño, fatiga excesiva, trastornos gastrointestinales, dolores de espalda, cefaleas, distintos procesos cutáneos o dolores cardíacos vagos inexplicables (Freudenberger y N orth 1986).

Los cambios mentales y del comportamiento son más sutiles. "El agotamiento se manifiesta a menudo por una facilidad para la irritación, problemas sexuales (p. ej., impotencia, frigidez), empeño en encontrar defectos, ira y un bajo umbral de frustración" (Freudenberger 1984a).

0 tros signos afectivos y del estado de ánimo pueden ser un distanciamiento progresivo, pérdida de la confianza en sí mismo y menor autoestima, depresión, grandes oscilaciones del estado de ánimo, incapacidad para concentrarse o prestar atención, mayor cinismo y pesimismo, y una sensación general de futilidad. A lo largo del tiempo, la persona contenta se hace malhumorada, la afectiva se vuelve silenciosa y distante y el optimista se convierte en pesimista.

Las alteraciones más frecuentes de los afectos parecen ser la ansiedad y la depresión. La primera se asocia sobre todo al rendimiento laboral. Las características de las condiciones de trabajo que parecen más importantes en el desarrollo de esta forma de ansiedad son la ambigüedad de rol y la sobrecarga de rol (Srivastava 1989).

Wilke (1977) indicó que "un campo en el que existe una oportunidad especial de conflicto para el sujeto con trastornos de personalidad es la naturaleza jerarquizada de la organización del trabajo. El origen de estas dificultades puede estar en el propio individuo, en la organización o en alguna combinación interactiva de ambos".

Los rasgos depresivos forman parte a menudo de los síntomas de presentación de los problemas relacionados con el trabajo. Los cálculos realizados a partir de datos epidemiológicos sugieren que la depresión afecta al 8 a $12 \%$ de los varones y al 20 a $25 \%$ de las mujeres. La esperanza de vida de las reacciones depresivas graves garantiza prácticamente que los aspectos laborales de la vida de muchas personas se verán afectados por la depresión en algún momento (Charney y Weissman 1988).

La gravedad de estas observaciones quedó validada en un estudio realizado por la N orthwestern $N$ ational Life Insurance Company, "Employee Burnout: America's Newest Epidemic" (1991), efectuado en un total de 600 trabajadores de todo el país y en el que se identificaron la extensión, causas, costes y soluciones relacionados con el estrés del lugar de trabajo. Los hallazgos más llamativos de esta investigación fueron que, en 1990, uno de cada tres norteamericanos pensaba seriamente en dejar su trabajo a causa del estrés, y que una proporción similar preveía experimentar agotamiento laboral en el futuro. Casi la mitad de los 600 entrevistados consideraban sus niveles de estrés "muy altos o extraordinariamente altos". Los cambios laborales, como los recortes de las prestaciones de los trabajadores, el cambio de propiedad, la frecuente necesidad de horas extraordinarias o la reducción de plantilla tienden a acelerar la aparición del estrés.
M acL ean (1986) ha estudiado con mayor detalle los factores de estrés laboral, como las condiciones de trabajo incómodas 0 inseguras, la sobrecarga cuantitativa o cualitativa, la ausencia de control sobre el proceso y el ritmo de trabajo, y también la monotonía y el aburrimiento.

A demás, las empresas informan de que un número creciente de sus trabajadores padecen problemas de abuso de alcohol 0 sustancias psicoactivas (Freudenberger 1984b). Entre los factores de estrés más comunes se encuentran el divorcio o los problemas matrimoniales, junto a otros de carácter familiar agudos 0 crónicos, como la necesidad de cuidar de un pariente anciano 0 discapacitado.

La evaluación y clasificación destinadas a reducir la posibilidad de agotamiento pueden enfocarse desde los puntos de vista relacionados con los intereses vocacionales, las elecciones 0 preferencias vocacionales y las características de las personas con preferencias distintas (Holland 1973). Podrían utilizarse sistemas informatizados de orientacion profesional o equipos de simulación laboral (K rumboltz 1971).

Los factores bioquímicos influyen en la personalidad, y los efectos de su equilibrio o desequilibrio en el estado de ánimo y en el comportamiento quedan claramente demostrados por los cambios de personalidad que aparecen durante la menstruación. Durante los últimos 25 años, se ha prestado gran atención a las catecolaminas suprarrenales, adrenalina y noradrenalina, y a otras aminas biógenas. Se han establecido relaciones entre estas sustancias y las sensaciones de miedo, ira y depresión (Barchas y cols. 1971).

Los instrumentos de evaluación psicológica más utilizados son:

- Inventario de la personalidad de Eysenck e Inventario de la Personalidad de M ardsley

- Perfil de personalidad de G ordon

- Cuestionario de la Escala de Ansiedad del IPAT

- Estudio de valores

- Inventario de Preferencia Vocacional de H olland

- Test de Interés Vocacional de M innesota

- Test de las manchas de tinta de R orschach

- Prueba de A percepción Temática

Ninguna discusión sobre el agotamiento estaría completa sin una breve referencia al cambiante sistema familia-trabajo. Shellenberger, H offman y Gerson (1994) indicaron que "Las familias pugnan por sobrevivir en un mundo cada vez más complejo y desconcertante. Con más elecciones de las que pueden considerar, las personas intentan encontrar un equilibrio entre el trabajo, el ocio, el amor y la responsabilidad familiar".

AI mismo tiempo, los papeles de la mujer en el mundo laboral son cada vez más amplios, y más del $90 \%$ de las mujeres de Estados U nidos citan el trabajo como una fuente de identidad y autovaloración. Además del cambiante papel de varones y mujeres, la conservación de dos fuentes de ingresos obliga a veces a efectuar cambios en la vida cotidiana, como mudarse para ocupar un puesto de trabajo, desplazarse diariamente a larga distancia o vivir en lugares distintos. Todos estos factores pueden causar graves tensiones en las relaciones interpersonales y en el trabajo.

Para reducir el agotamiento y el estrés a nivel individual, pueden ofrecerse las siguientes soluciones:

- Aprende a equilibrar tu vida

- Comparte tus pensamientos y comunica tus preocupaciones

- Limita el consumo de alcohol

- Reconsidera tus actitudes personales

- A prende a establecer prioridades

- Desarrolla intereses ajenos al trabajo 
- H az trabajo voluntario

- Reconsidera tu necesidad de perfeccionismo

- A prende a delegar y a pedir ayuda

- Tómate tiempo libre

- H az ejercicio y sigue una alimentación nutritiva

- A prende a no tomarte tan en serio a tí mismo.

A mayor escala, es imprescindible que el gobierno y las empresas tengan en cuenta las necesidades familiares. Para reducir o amortiguar el estrés en el sistema familia-trabajo, será preciso llevar a cabo una importante reorganización de toda la estructura de la vida familiar y laboral. "U na distribución más equitativa de las relaciones entre ambos sexos y el posible escalonamiento de los tiempos de trabajo y no trabajo a lo largo de la vida, de forma que los permisos por maternidad y paternidad y los años sabáticos se conviertan en circunstancias habituales" (Shellenberger, H offman y Gerson 1994).

Como señaló Entin (1994), el aumento de la diferenciación del yo, ya sea en el seno de la familia o en la empresa, tiene una importante repercusión en la reducción del estrés, la ansiedad y el agotamiento.

Las personas necesitan mayor control sobre sus propias vidas y tener la responsabilidad de sus acciones, y tanto los individuos como las empresas deben volver a estudiar sus sistemas de valores. Es preciso que se produzcan cambios espectaculares. Si no prestamos atención a las estadísticas, es seguro que el agotamiento y el estrés seguirán siendo los grandes problemas que hoy son para toda la sociedad.

\section{TRASTORNOS COGNITIVOS}

Catherine A. H eaney

Los trastornos cognitivos se definen como un deterioro significativo de la capacidad del individuo para procesar y recordar la información. En el DSM IV (American Psychiatric Association 1994) se describen tres tipos fundamentales de estos trastornos: delirio, demencia y trastorno por amnesia. EI delirio se desarrolla durante un breve período de tiempo y se caracteriza por afectación de la memoria reciente, desorientación y problemas del lenguaje y de la percepción. El trastorno por amnesia se define por una alteración tal de la memoria, que los afectados no pueden aprender ni recordar la información nueva, si bien no presentan ningún otro deterioro asociado de la función cognitiva. $\mathrm{H}$ abitualmente, ambos trastornos se deben a los efectos fisiológicos de una enfermedad sistémica (p. ej., lesiones craneoencefálicas, fiebre alta) 0 al uso de sustancias psicoactivas. No hay apenas razones para sospechar que los factores laborales intervengan directamente en la génesis de los mismos.

Sin embargo, ciertas investigaciones sugieren que los factores profesionales podrían influir en la probabilidad de sufrir las múltiples deficiencias cognitivas que constituyen la demencia. E sta se caracteriza por afectación de la memoria y al menos uno de los problemas siguientes: (a) disminución de la función de lenguaje; (b) deterioro de la capacidad de pensamiento abstracto, o (c) incapacidad para reconocer los objetos familiares, aunque no exista alteración de los sentidos ( $p$. ej., visión, tacto). La enfermedad de Alzheimer es el tipo más frecuente de demencia.

La prevalencia de la demencia aumenta con la edad. A proximadamente el $3 \%$ de todos los mayores de 65 años sufrirán un grave déficit cognitivo durante cualquier año dado. Estudios recientes sobre poblaciones de edad avanzada han demostrado la existencia de un nexo entre la historia laboral de la persona y su probabilidad de desarrollar demencia. Por ejemplo, un estudio sobre ancianos del medio rural efectuado en Francia (Dartigues y cols. 1991) comprobó que los que se habían dedicado fundamentalmente a trabajos agrícolas, al servicio doméstico o a trabajar como obreros manuales corrían un riesgo significa- tivamente superior de alteración cognitiva grave que los que habían sido maestros, gerentes, ejecutivos o profesionales liberales. Además, este aumento del riesgo no se debía a diferencias entre grupos de trabajadores en lo referente a edad, sexo, educación, consumo de bebidas alcohólicas, alteraciones sensoriales o uso de agentes psicotropos.

La demencia es sumamente rara en personas menores de 65 años, por lo que no se ha hecho ningún estudio sobre la profesión como factor de riesgo en esta población. No obstante, una gran investigación efectuada en Estados U nidos (Farmer y cols., 1995) demostró que los menores de 65 años con altos niveles educativos tenían menos probabilidades de sufrir alteraciones del funcionamiento cognitivo que las personas de edad similar y menor grado de educación. L os autores de este estudio comentaron que el nivel educativo podría ser una "variable indicadora" que reflejara, en realidad, el efecto de la exposición profesional. En este momento, esta conclusión no pasa de ser una hipótesis.

Aunque son varios los estudios que han encontrado asociación entre la profesión principal del individuo y el desarrollo de demencia en la ancianidad, la explicación o mecanismo subyacente a este fenómeno se desconocen. Es posible que en ciertas profesiones existan mayores niveles de exposición a sustancias tóxicas y disolventes que en otras. Por ejemplo, existen cada vez más pruebas de que la exposición tóxica a pesticidas y herbicidas puede tener efectos desfavorables para el sistema nervioso. De hecho, se ha sugerido que tales exposiciones podrían explicar el mayor riesgo de demencia de los trabajadores agrícolas franceses comentado más arriba. Además, hay también indicios de que la ingestión de ciertos minerales (p. ej., aluminio y calcio como componentes del agua potable) podría influir en el riesgo de afectación cognitiva. Ciertas profesiones implicarían una exposición diferencial a estos minerales. Sería necesario investigar con mayor detalle los posibles mecanismos fisiopatológicos.

L os niveles de estrés psicosocial de ciertas profesiones podrían contribuir asimismo a crear el nexo entre profesión y demencia. Los trastornos cognitivos no suelen considerarse problemas de salud mental relacionados con el estrés. U na revisión sobre la relación entre estrés y enfermedad psiquiátrica se centró en los trastornos por ansiedad, la esquizofrenia y la depresión sin hacer mención alguna de los procesos cognitivos (R abkin 1993). Existe un tipo de trastorno, denominado amnesia disociativa, que se caracteriza por la imposibilidad de recordar un acontecimiento traumático 0 angustioso vivido, sin ninguna otra alteración de la memoria. Este trastorno está, evidentemente, ligado al estrés, pero no se clasifica dentro de los trastornos cognitivos en el DSM IV.

Si bien no se ha establecido una relación explícita entre el estrés y el desarrollo de los trastornos cognitivos, se ha demostrado que la vivencia de un estrés psicosocial afecta a la forma en que las personas procesan la información y a su capacidad para recordarla. La activación del sistema nervioso autónomo, componente común de reacción a los factores de estrés, alerta al individuo ante el hecho de que "las cosas no son lo que parecen o deberían ser" (M andler 1993). Al principio, este estado de alerta mejora la capacidad del sujeto para dirigir su atención a los aspectos fundamentales y resolver los problemas. Sin embargo, el aspecto negativo es que la activación consume parte de la "capacidad consciente disponible", o los recursos de que el individuo dispone para procesar la información que le llega. Así pues, un alto grado de estrés psicosocial tendrá, en última 
instancia, las consecuencias siguientes: (1) limitar la capacidad para examinar toda la información importante disponible de forma ordenada (2) interferir en la capacidad para detectar con rapidez las claves periféricas, (3) reducir la capacidad para mantener la atención en el problema, y (4) menoscabar ciertos aspectos del rendimiento de la memoria. $\mathrm{H}$ asta la fecha, si bien se ha comprobado que esta disminución de la capacidad de procesar la información puede dar lugar a síntomas similares a los asociados a los trastornos cognitivos, no se ha establecido relación alguna entre estas alteraciones leves y la probabilidad de desarrollar un trastorno cognitivo de importancia clínica.

Un tercer factor que puede contribuir a la relación entre profesión y alteración cognitiva sería el grado de estimulación mental exigido por el trabajo. En el estudio sobre ancianos del medio rural francés antes descrito, las profesiones asociadas al riesgo más bajo de demencia fueron las que exigían mayores grados de actividad intelectual ( $p$. ej., médico, maestro, abogado). U na hipótesis plausible es que la actividad intelectual - la estimulación mental propias de estas profesiones produzcan ciertos cambios biológicos en el encéfalo que, a su vez, protege al trabajador frente al deterioro de la función cognitiva. El bien conocido efecto protector de la educación a este respecto sería compatible con esta hipótesis.

Es prematuro extraer conclusiones para la prevención o el tratamiento de los hallazgos aquí resumido. De hecho, la asociación entre la profesión principal de las personas y la instauración de la demencia en la ancianidad puede no deberse a la exposición profesional ni al tipo de trabajo realizado. Por el contrario, podría deberse a diferencias en las características propias de los trabajadores de cada profesión. Por ejemplo, las diferencias entre las actitudes hacia la propia salud o en el acceso a una atención médica de calidad pueden explicar, al menos, parte del efecto de la profesión. Ninguno de los estudios descriptivos publicados permite descartar esta posibilidad. Se necesitan nuevas investigaciones para explorar la eventual contribución de los tipos específicos de exposición psicosocial, química y física del entorno profesional a la etiología de este trastorno cognitivo.

\section{- Karo SH I: MUERTE POR EXCESO DE TRABAJO}

Takashi Haratani

\begin{abstract}
¿Qué es el karoshi?
Karoshi es una palabra japonesa que significa muerte por exceso de trabajo. Este fenómeno fue reconocido inicialmente en Japón, y el término ha sido adoptado en todo el mundo (D rinkwater 1992). U ehata (1978) comunicó 17 casos en la 51ạ reunión anual de la A sociación Japonesa de Salud Industrial. De ellos, en siete se concedió una indemnización como enfermedades laborales, pero no diez restantes. En 1988, un grupo de abogados creó el Consejo Nacional de Defensa de Víctimas del K aroshi (1990) y estableció una consulta telefónica para responder a las preguntas acerca de las indemnizaciones por muertes relacionadas con este trastorno. U ehata (1989) utilizó la palabra karoshi como término medicosocial que comprende los fallecimientos o incapacidades laborales de origen cardiovascular (como accidente cerebrovascular, infarto de miocardio o insuficiencia cardíaca aguda) que pueden producirse cuando el trabajador con una enfermedad arteriosclerótica hipertensiva se ve sometido a una fuerte sobrecarga de trabajo. El karoshi no es un término exclusivamente médico. Los medios de comunicación lo utilizan con frecuencia porque subraya el hecho de que la muerte súbita (0 la
\end{abstract}

incapacidad) se deben al exceso de trabajo y debe ser objeto de indemnización. El karoshi se ha convertido en un importante problema social en Japón.

\section{Investigación sobre el karoshi}

U ehata (1991a) realizó un estudio en 203 trabajadores japoneses (196 varones y 7 mujeres) que habían sufrido episodios cardiovasculares. Ellos, o sus familiares, le habían consultado acerca la posibilidad de recibir indemnizaciones entre 1974 y 1990. Se habían producido un total de 174 muertes; 55 casos habían recibido ya indemnización por enfermedad profesional. Un total de 123 trabajadores habían sufrido accidentes cerebrovasculares (57 hemorragias subaracnoideas, 46 hemorragias cerebrales, 13 infartos cerebrales y 7, no clasificados); se habían producido 50 casos de insuficiencia cardíaca aguda, 27 infartos de miocardio y 4 disecciones aórticas. Sólo se hizo autopsia en 16 casos. M ás de la mitad de los trabajadores tenían antecedentes de hipertensión, diabetes u otros problemas arterioscleróticos. Un total de 131 sujetos habían hecho horarios prolongados, más de 60 horas a la semana, más de 50 horas extra al mes o más de la mitad de sus turnos de vacaciones. En 88 trabajadores se encontraron acontecimientos desencadenantes identificables en las 24 horas previas al suceso. U ehata llegó a la conclusión que los afectados eran fundamentalmente varones con horarios de trabajo muy prolongados y otras sobrecargas generadoras de estrés, y que estos estilos de trabajo exacerbaban sus otros hábitos de vida y originaban los ataques, desencadenados en última instancia por pequeños sucesos o problemas laborales.

\section{El modelo de Karasek y el karoshi}

Según el modelo demanda-control de K arasek (1979), un empleo que entraña una alta tensión - en el que se da una combinación de demanda elevada y bajo control (amplitud del margen de toma de decisiones) - aumenta el riesgo de tensión psicológica y enfermedad física; un empleo activo - que combine una gran demanda y un gran control- exige una motivación de aprendizaje para desarrollar nuevos patrones de comportamiento. U ehata (1991b) señaló que puestos de trabajo de los casos de karoshi se caracterizaban por un mayor grado de demanda laboral y un menor apoyo social, mientras que el grado de control sobre el trabajo era muy variable. Según su descripción, los casos de karoshi eran trabajadores entusiastas y dedicados, por lo que tendían a olvidar su necesidad de descanso periódico, e incluso la necesidad de atención médica. Se ha sugerido que el riesgo puede ser alto no sólo en los puestos de trabajo que generan gran tensión, sino también en los más activos. Los directivos y técnicos tienen un gran margen de toma de decisiones. Si sus demandas son muy altas y se muestran entusiastas en su trabajo, pueden no controlar sus horas de trabajo, en cuyo caso serían un grupo de riesgo para el karoshi.

\section{Conducta de comportamiento tipo A en Japón}

Friedman y Rosenman (1959) propusieron el concepto de patrón de comportamiento tipo a (PCTA). Son muchos los estudios en los que se ha demostrado una relación entre el PCTA y la prevalencia o incidencia de cardiopatía coronaria (CC).

$\mathrm{H}$ ayano y cols. (1989) investigaron las características del PCTA en trabajadores japoneses usando la encuesta de actividad de Jenkins (JAS). En su trabajo, analizaron las respuestas de 1.682 empleados varones de una compañía telefónica. La estructura de factores de la JAS en esta población fue, en muchos aspectos, similar a la encontrada en el Western Collaborative G roup Study (WCGS). Sin embargo, la puntuación media del factor $\mathrm{H}$ (dedicación y competitividad) fue considerablemente inferior en los japoneses que en la población del WCGS. 
M onou (1992) revisó la investigación del PCTA realizada en Japón y llegó a las siguientes conclusiones: en Japón, el PCTA es menos prevalente que en Estados U nidos; en ese país, la relación entre el PCTA y la cardiopatía coronaria parece ser significativa, pero más débil que en Estados Unidos; en los japoneses, el PCTA se caracteriza más que en Estados U nidos por la adición al trabajo y la "capacidad de dirección del grupo"; el porcentaje de individuos muy hostiles es menor en Japón; no hay relación entre la hostilidad y la CC.

L a cultura japonesa es muy distinta a la de los países occidentales. Se encuentra muy influida por el budismo y el confucionismo En términos generales, los trabajadores japoneses están centrados en la organización, y se presta más importancia a la cooperación con los colegas que a la competencia. En Japón, la competitividad es un factor menos importante en las conductas propensas a la isquemia miocárdica que la dedicación al puesto de trabajo o la tendencia al exceso de trabajo. La sociedad japonesa suprime la expresión directa de la hostilidad. Esta se expresa de distinta forma que en las sociedades occidentales.

\section{Horas de trabajo de los trabajadores japoneses}

Se sabe que los empleados japoneses trabajan muchas más horas que sus colegas de los países industrializados occidentales. En 1993, la jornada anual normal de los trabajadores de producción fue de 2.017 horas en Japón, mientras que en Estados U nidos fue de 1.904 horas, en Francia de 1.763 horas y en el Reino U nido, de 1.769 horas (O IT 1995). Sin embargo, en Japón se está produciendo una reducción paulatina de las jornadas de trabajo. En 1960, el promedio de horas trabajadas en las empresas de 300 más trabajadores fue de 2.484 horas, pero en 1994 había disminuido a 1.957 horas. El artículo 32 de la Ley de reglamentación laboral, que fue revisado en 1987, establece una semana de 40 horas. Se prevé que esta jornada se introduzca progresivamente durante el decenio de 1990. En 1985, se concedió la semana de 5 días laborables al $27 \%$ de los trabajadores de empresas con plantillas de 30 empleados o más; en 1993, alcanzaba ya al $53 \%$ de ellos. El trabajador medio tenía derecho a 16 días de vacaciones pagadas en 1993, pero en realidad sólo disfrutaba de 9 días por término medio. En Japón, los días de vacaciones pagadas son pocos, y los trabajadores tienden a destinarlos a cubrir los días de baja por enfermedad.

¿Por qué trabajan tantas horas los japoneses? Deutschmann (1991) señaló tres condiciones estructurales subyacentes al patrón actual de jornada laboral prolongada en Japón. En primer lugar, la necesidad permanente de los trabajadores de mejorar sus ingresos; en segundo, la estructura centrada en la empresa de las relaciones laborales, y en tercero, el estilo holístico de la gestión de personal en el país. Estas condiciones se deben a factores históricos y culturales. En 1945, Japón sufrió la primera derrota de su historia y, después de la guerra, fue un país de bajos salarios. Los japoneses se acostumbraron a trabajar muchas horas para subsistir. Puesto que los sindicatos colaboran con las empresas, los conflictos laborales son relativamente raros. Las empresas del país adoptaron un sistema de salarios basado en la antigüedad y en el empleo fijo. EI número de horas mide la lealtad y la cooperación del trabajador y se convierte en un criterio de promoción. Los trabajadores no son obligados a trabajar muchas horas, sino que desean trabajar para sus empresas, como si fueran su propia familia. La vida laboral tiene prioridad sobre la familiar. Estas jornadas tan largas han contribuido al espectacular desarrollo económico de Japón.

\section{Encuesta nacional sobre la salud de los trabajadores}

EI M inisterio de Trabajo de Japón llevó a cabo encuestas sobre el estado de salud de los trabajadores en 1982, 1987 y 1992. En la encuesta de 1992, se identificaron 12.000 empresas privadas con 10 o más empleados, de las que se extrajo al azar una muestra nacional de 16.000 trabajadores de todo el país, representativos de las distintas industrias y empleos, que debían completar ciertos cuestionarios. Estos cuestionarios se enviaron por correo a un representante del centro de trabajo, que posteriormente seleccionaba a los que debían contestarlos.

EI $65 \%$ de estos trabajadores se quejaban de cansancio físico debido a su trabajo habitual, y el $48 \%$ manifestaban fatiga mental. EI $57 \%$ afirmaban sufrir una fuerte ansiedad, preocupación o estrés en relación con su trabajo o su vida laboral. Se descubrió una prevalencia creciente de trabajadores con estrés, que había sido del $55 \%$ en 1987 y del $51 \%$ en 1982. Las causas principales del estrés fueron: relaciones insatisfactorias en el lugar de trabajo, $48 \%$; calidad del trabajo, $41 \%$; cantidad de trabajo, $34 \%$.

EI $86 \%$ de estos centros de trabajo efectuaban exploraciones sanitarias periódicas. En el $44 \%$ de ellos se llevaban a cabo actividades de promoción de la salud. De estos últimos, el $48 \%$ tenían actividades deportivas, el $46 \%$ realizaban programas de ejercicio físico y el $35 \%$ disponían de asesoramiento sobre salud.

\section{Política nacional de protección y promoción de la salud de los trabajadores}

EI objetivo de la Ley de Salud y Seguridad Industrial de Japón es garantizar la seguridad y la salud de los trabajadores en el lugar de trabajo, así como facilitar el desarrollo de entornos laborales confortables. La ley señala que la empresa no sólo debe cumplir las normas mínimas para prevenir los accidentes y enfermedades laborales, sino que también debe intervenir activamente para garantizar la seguridad y salud de los trabajadores en el puesto de trabajo mediante la creación de un entorno laboral cómodo y la mejoría de las condiciones de trabajo.

El artículo 69 de la ley, modificado en 1988, señala que la empresa debe hacer esfuerzos continuos y sistemáticos en favor del mantenimiento y la promoción de la salud de sus trabajadores, tomando para ello las medidas oportunas, como proporcionar servicios de educación para la salud y asesoramiento. En 1988, el M inisterio de Trabajo de Japón anunció las directrices en que debían basarse las medidas adoptadas por las empresas para la promoción y el mantenimiento de la salud de sus trabajadores. En ellas, se recomienda la instauración de programas de promoción de la salud en los lugares de trabajo, según el denominado Plan Total de Promoción de la Salud: ejercicio (entrenamiento y asesoramiento), educación para la salud, asesoramiento psicológico y asesoramiento nutricional basado en el estado de salud de los trabajadores.

En 1992, el M inisterio de Trabajo de Japón publicó las directrices para la creación de entornos laborales confortables. En ellas recomendaban las medidas siguientes: el entorno laboral debe mantenerse siempre en condiciones de comodidad; las condiciones de trabajo deben mejorarse para reducir la sobrecarga laboral, y deben facilitarse instalaciones para el bienestar de los trabajadores que necesiten recuperarse de la fatiga. Se han establecido préstamos a bajo interés y ayudas para las pequeñas y medianas empresas para que mejoren las condiciones de los centros de trabajo y aumenten su comodidad.

\section{Conclusión}

Todavía no se ha demostrado de manera fehaciente que el exceso de trabajo produzca la muerte repentina. Son necesarios nuevos estudios para dilucidar esta relación causal. Es preciso reducir el número de horas trabajadas para prevenir el karoshi. La política laboral nacional japonesa se ha centrado en los peligros del trabajo y en la atención sanitaria a los trabajadores con 
problemas. Es preciso mejorar el entorno laboral psicológico como paso imprescindible para lograr un entorno laboral confortable. Debe estimularse la puesta en práctica de las exploraciones de salud y de los programas de promoción de la salud de todos los trabajadores. Estas actividades permitirán prevenir el karoshi y reducir el estrés.

\section{Referencias}

American Psychiatric Association (APA). 1980 Diagnostic and Statistical $M$ anual of $M$ ental Disorders (DSM III). 3a edición. Washington, DC: APA Press.

- 1994. Diagnostic and Statistical M anual of M ental D isorders (DSM IV). 4th edition. Washington, DC APA Press.

Ballenger, J. 1993. The co-morbidity and etiology of anxiety and depression. U pdate on Depression. Smith-K line Beecham Workshop. Marina de Rey, Calif., 4 April.

Barchas, JD, JM Stolk, RD Ciaranello, DA $\mathrm{H}$ amberg. 1971. Neuroregulatory agents and psychological assessment. En Advances in Psychological Assessment, dirigido por P M cR eynolds. Palo Alto, Calif.: Science and Behavior Books.

Beaton, R, S M urphy, K Pike, M Jarrett. 1995 Stress-symptom factors in firefighters and paramedics. En Organizational Risk Factors for $I$ ob Stress, dirigido por S Sauter y L M urphy. Washington, DC: APA Press.

Beiser, M , G Bean, D Erickson, K Zhan, W G Iscono, NA Rector. 1994. Biological and psychosocia predictors of job performance following a firs episode of psychosis. Am J Psychiatr 151(6):857-863.

Bentall, RP. 1990. The illusion or reality: A review and integration of psychological research on hallucinations. Psychol Bull 107(1):82-95.

Braverman, M. 1992a. Post-trauma crisis intervention in the workplace. En Stress and W ell-Being at W ork: Assessments and Interventions for $O$ ccupational $M$ ental $H$ ealth, dirigido por JC Q uick, LR M urphy y JJ Hurrell. Washington, DC: APA Press.

- . 1992b. A model of intervention for reducing stress related to trauma in the workplace. Cond W ork D ig 11(2).

-. 1993a. Preventing stress-related losses: M anaging the psychological consequences of worker injury. Compens B enefits $M$ anage 9(2) (Spring).

-. 1993b. Coping with trauma in the workplace. Compens B enefits M anage 9(2) (Spring).

Brodsky, CM. 1984. Long-term workstress. Psychomatics 25 (5):361-368.

Buono, A , J Bowditch. 1989. T he $H$ uman Side of $M$ ergers and Acquisitions. San Francisco: Jossey-Bass.

Comer, NL, L M adow, JJ Dixon. 1967. O bservation of sensory deprivation in a life-threatening situation. Am J Psychiatr 124:164-169.

Cooper, C, R Payne. 1992. International perspectives on research into work, well-being and stress management. En Stress and W ell-Being at Work, dirigido por J Quick, L Murphy y J Hurrell. Washington, DC: APA Press.

Charney, EA, M W W eissman. 1988. Epidemiology of depressive and manic syndromes. En D epression and $\mathrm{M}$ ania, dirigido por A Georgotas y $\mathrm{R}$ Cancro. N ueva Y ork: Elsevier.

Dartigues, JF, M Gagnon, L Letenneur, $P$ Barberger-Gateau, D Commenges, M Evaldre, $R$ Salamon. 1991. Principal lifetime occupation and cognitive impairment in a French elderly cohort (Paquid). Am J E pidemiol 135:981-988.

Deutschmann, C. 1991. The worker-bee syndrome in Japan: An analysis of working-time practices. En W orking T ime in Transition: The Political E conomy of W orking Hours in Industrial Nations, dirigido por $\mathrm{K}$
Hinrichs, W Roche y C Sirianni. Filadelfia: Temple Univ. Press.

DeW olf, CJ. 1986. M ethodological problems in stress studies. En The Psychology of W ork and O rganizations, dirigido por G Debus y HW Schroiff. North Holland: Elsevier Science.

D rinkwater, J. 1992. Death from overwork. Lancet 340: 598

Eaton, WW, JC Anthony, W M andel, R Garrison. 1990. O ccupations and the prevalence of major depressive disorder. O ccup $M$ ed 32(111):1079-1087.

Entin, AD. 1994. The work place as family, the family as work place. Documento inédito presentado en la American Psychological Association, Los Angeles, California.

Eysenck, HJ. 1982. The definition and measurement of psychoticism. Personality Indiv D iff 13(7):757-785.

Farmer, ME, SJ Kittner, DS Rae, JJ Bartko, DA Regier. 1995. Education and change in cognitive function. The epidemiological catchment area study. Ann E pidemiol 5:1-7.

Freudenberger, HJ. 1975. The staff burn-out syndrome in alternative institutions. Psycother Theory, Res Pract 12:1.

- 1984a. Burnout and job dissatiffaction: Impact on the family. En Perspectives on W ork and Family, dirigido por JC Hammer y SH Cramer. R ockville, $\mathrm{M} d$ : Aspen

- . 1984b. Substance abuse in the work place. Cont D rug P rob 11(2):245.

Freudenberger, HJ. G North. 1986. W omen's Burnout: $\mathrm{H}$ ow to Spot It, $\mathrm{H}$ ow to R everse It and $\mathrm{H}$ ow to Prevent It. Nueva Y ork: Penguin Books.

Freudenberger, $\mathrm{HJ}$ and $\mathrm{G}$ Richelson. 1981. Burnout: $\mathrm{H}$ ow to $\mathrm{B}$ eat the $\mathrm{H}$ igh Cost of Success. N ueva Y ork: Bantam Books.

Friedman, M, RH Rosenman. 1959. Association of specific overt behavior pattern with blood and cardiovascular findings. J Am Med Assoc 169:1286-1296.

Greenberg, PE, LE Stiglin, SN Finkelstein, ER Berndt. 1993a. The economic burden of depression in 1990. I Clin Psychiatry 54(11):405-418.

-. 1993b. Depression: A neglected major illness. J Clin Psychiatry 54(11):419-424.

Gründemann, RWM, ID Nijboer, AJM Schellart. 1991. T he W ork- R elatedness of D rop- $O$ ut from $W$ ork for M edical Reasons. La Haya: M inisterio de Asuntos Sociales y T rabajo.

Hayano, J, S Takeuchi, S Yoshida, S Jozuka, N M ishima, T Fujinami. 1989. Type A behavior pattern in Japanese employees: Cross-cultural comparison of major factors in Jenkins Activity Survey (JAS) responses. J B ehav M ed 12(3):219-231.

H immerstein, IS, GS Pransky. 1988. O ccupational $M$ edicine: W orker Fitness and Risk E valuations. Vol. 3. Filadelfia: $H$ anley $\&$ Belfus.

Hines, LL, TW Durham, GR Geoghegan. 1991. Work and self-concept: The development of a scale. J Soc B ehav Personal 6:815-832.

H obfoll, WE. 1988. T he E cology of Stress. Nueva Y ork: H emisphere.

H olland, JL. 1973. M aking Vocational Choices: A T heory of $\mathrm{C}$ areers. Englewood C liffs, $\mathrm{N}$ J: Prentice $\mathrm{H}$ all.

Houtman, I, A Goudswaard, S Dhondt, M van der Ginten, V Hildebrandt, M Kompier. 1995.
E valuation of the M onitor on Stress and Physical L oad. La Haya: VU GA

Houtman, ILD, MAJ Kompier. 1995. Risk factors and occupational risk groups for work stress in the Netherlands. En Organizational Risk Factors for I ob Stress, dirigido por SL Sauter y LR Murphy. Washington, DC: APA Press

Human Capital Initiative $(\mathrm{HCl})$. 1992. Changing nature of work. APS O bserver número especial.

J effreys, J. 1995. Coping W ith W orkplace Change: D ealing W ith L oss and Grief. M enlo Park, Calif.: C risp.

Jorgensen, P. 1987. Social course and outcome of delusional psychosis. Acta Psychiatr Scand 75:629-634.

$\mathrm{K}$ ahn, JP. 1993. M ental $\mathrm{H}$ ealth in the W orkplace $-A$ Practical Psychiatric Guide. Nueva York: Van N ostrand R einhold.

Kaplan, HI, BJ Sadock. 1994. Synopsis of Psychiatry- Behavioral Sciences Clinical Psychiatry. Baltimore: Williams \& Wilkins.

K aplan, HI, BJ Sadock. 1995. Comprehensive T extbook of Psychiatry. Baltimore: Williams \& Wilkins.

K arasek, R. 1979. Job demands, job decision latitude, and mental strain: Implications for job redesign. Adm Sci Q 24:285-307.

K arasek, R, T T heorell. 1990. H ealthy W ork. Londres: Basic Works.

K aton, W, A K leinman, G Rosen. 1982. Depression and somatization: A review. Am J M ed 72:241-247.

K obasa, S, S M addi, S K ahn. 1982. H ardiness and health: A prospective study. J Personal Soc Psychol 45:839-850.

K ompier, M, E de Gier, P Smulders, D Draaisma. 1994. Regulations, policies and practices concerning work stress in five European countries. W ork Stress 8(4):296-318.

K rumboltz, JD. 1971. J ob Experience Kits. Chicago: Science R esearch A ssociates.

Kuhnert, K, R Vance 1992. Job insecurity and moderators of the relation between job insecurity and employee adjustment. En Stress and W ell-Being at W ork, dirigido por J Quick, L M urphy y J H urrell Jr. W ashington, DC: APA Press.

Labig, CE. 1995. Preventing Violence in the W orkplace. Nueva Y ork: AM ACON.

Lazarus, RS. 1991. Psychological stress in the workplace. J Soc B ehav Personal 6(7):114.

Lemen, R. 1995. Welcome and opening remarks. Presentado en la Conferencia, "Work Stress and $\mathrm{H}$ ealth '95: Creating $\mathrm{H}$ ealthier Workplaces", 15 de septiembre de 1995, Washington, DC.

Levi, L, M Frandenhaeuser, B Gardell. 1986. The characteristics of the workplace and the nature of its social demands. En $\mathrm{O}$ ccupational Stress: $\mathrm{H}$ ealth and Performance at Work, dirigido por SG Wolf y AJ Finestone. Littleton, M ass: PSG

Link, BG, A Stueve. 1994. Psychotic symptoms and the violent/illegal behaviour of mental patients compared to community controls. En Violence and $M$ ental Disorders: Development in Risk Assessment, dirigido por J M ohnhan y HJ Steadman. Chicago, Illinois: U niv. of Chicago.

Link, BP, PB Dohrenwend, AE Skodol. 1986. Socio-economic status and schizophrenia: Noisome occupational characteristics as a risk factor. Am Soc R ev 51 (A pril):242-258.

Lowman, RL. 1993. Counseling and Psychotherapy of W ork D ysfunctions. Washington, DC: APA Press. 
M acLean, AA, 1986. H igh T ech Survival Kit: M anaging Y our Stress. N ueva Y ork: John Wiley \& Sons.

$M$ andler, G. 1993. Thought, memory and learning: Effects of emotional stress. En $H$ andbook of Stress: Theoretical and Clinical Aspects, dirigido por $L$ Goldberger y S Breznitz. N ueva Y ork: Free Press.

M argolis, BK, WH K roes. 1974. O ccupational stress and strain. En Occupational Stress, dirigido por A M CL ean. Springfield, III: Charles C. Thomas.

M assel, HK, RP Liberman, J M intz, HE Jacobs, RV Rush, CA Giannini, R Zarate. 1990. Evaluating the capacity to work of the mentally ill. Psychiatry 53:31-43.

MCGrath, JE. 1976. Stress and behavior in organizations. En $\mathrm{H}$ andbook of Industrial and Organizational Psychology, dirigido por MD D unnette. Chicago: R and $\mathrm{M} \mathrm{CN}$ ally College.

M clntosh, N. 1995. Exhilarating work: An antidote for dangerous work. En Organizational Risk Factors for J ob Stress, dirigido por S Sauter y L M urphy. Washington, DC: APA Press.

M ishima, N, S Nagata, T H aratani, N Nawakami, S Araki, J Hurrell, S Sauter, and N Swanson. 1995. Mental health and occupational stress of Japanese local government employees. Presentado en la Conferencia "Work, Stress, and H ealth '95: Creating Healthier Workplaces", 15 de septiembre de 1995, Washington, DC.

M itchell, J, G Bray. 1990. Emergency Service Stress. Englewood Cliffs, NJ: Prentice H all.

M onou, H. 1992. Coronary-prone behavior pattern in Japan. En Behavioral M edicine: An Integrated Biobehavioral Approach to $\mathrm{H}$ ealth and IIIness, dirigido por S A raki. Amsterdam: Elsevier Science.

M untaner, C, A T ien, WW Eaton, R Garrison. 1991. $O$ ccupational characteristics and the occurrence of psychotic disorders. Social Psych Psychiatric E pidemiol 26:273-280.

M untaner, C, AE Pulver, J M CG rath, WW Eaton. 1993. Work environment and schizophrenia: An extension of the arousal hypothesis to occupational self-selection. Social Psych Psychiatric E pidemiol 28:231-238.

National Defense Council for Victims of $\mathrm{K}$ aroshi. 1990. Karoshi. T okyo: M ado Sha.

N eff, WS. 1968. W ork and Human Behavior. Nueva Y ork: Altherton

Northwestern National Life. 1991. Employee Burnout: America's Newest Epidemic. Survey Findings. M inneapolis, M inn: N orthwestern $N$ ational Life.

O 'Leary, L. 1993. Mental health at work. Occup $H$ ealth R ev 45:23-26.

O rganización Internacional del Trabajo (OIT ). 1995 EI trabajo en el mundo. N o. 8. G inebra: OIT.

Q uick, JC, LR M urphy, JJ H urrell, D O rman. 1992. The value of work, the risk of distress and the power of prevention. En Stress and W ell-Being: Assessment and Interventions for $O$ ccupational $M$ ental $\mathrm{H}$ ealth, dirigido por JC Quick, LR Murphy y JJ H urrell. Washington, DC: APA Press.
Rabkin, JG. 1993. Stress and psychiatric disorders En $\mathrm{H}$ andbook of Stress: Theoretical and Clinical Aspects, dirigido por $L$ Goldberger y S Breznitz. Nueva York: Free Press.

Robins, LN, JE H eltzer, J Croughan, JBW Williams, RE Spitzer. 1981. NIMH Diagnostic Interviews Schedule: Version III. Final report on contract no. 278-79-00 17D B and Research O ffice grant no. 33583. R ockville, $\mathrm{M} \mathrm{d}$ : D epartment of $\mathrm{H}$ ealth and $H$ uman Services.

Rosch, P, K Pelletier. 1987. Designing workplace stress management programs. En Stress $M$ anagement in W ork Settings, dirigido por L M urphy y $T$ Schoenborn. Rockville, M d: US Department of $H$ ealth and H uman Services.

R oss, DS. 1989. M ental health at work. 0 ccup $H$ ealth Safety 19(3):12

Sauter, SL, LR M urphy, JJ H urrell. 1992. Prevention of work-related psychological disorders: A national strategy proposed by the National Institute for $O$ ccupational Safety and Health (NIOSH). En W ork and W ell-Being: An Agenda for 1990's, dirigido por SL Sauter y G Puryear K eita. Washington, DC: APA Press.

Shellenberger, S, SS H offman, R Gerson. 1994 Psychologists and the changing family-work system. Documento inédito presentado en la American Psychological Association, Los Angeles, California.

Shima, S, H Hiro, M Arai, T Tsunoda, T Shimomitsu, O Fujita, L Kurabayashi, A Fujinawa, M K ato. 1995. Stress coping style and mental health in the workplace. Presentado en la Conferencia "Work, Stress and Health '95: Creating Healthier Workplaces", 15 de septiembre de 1995, W ashington, DC.

Smith, M, D Carayon, K Sanders, S Lim, D LeGrande. 1992. Employee stress and health complaints in jobs with and without electronic performance monitoring. Appl E rgon 23:17-27.

Srivastava, AK. 1989. Moderating effect of $n$-self actualization on the relationship of role stress with ob anxiety. Psychol Stud 34:106-109.

Sternbach, D. 1995. M usicians: A neglected working population in crisis. En O rganizational R isk Factors for ob Stress, dirigido por S Sauter y L Murphy. Washington, DC: APA Press.

Stiles, D. 1994. Video display terminal operators T echnology's biopsychosocial stressors. I Am Assoc 0 ccup $H$ ealth N urses 42:541-547.

Sutherland, VJ, CL Cooper. 1988. Sources of work stress. En 0 ccupational Stress: I ssues and D evelopment in Research, dirigido por JJ Hurrell Jr, LR M urphy, SL Sauter y CL Cooper. Nueva York: Taylor \& Francis.

U ehata, T. 1978. A study on death from overwork. (I) Considerations about 17 cases. Sangyo I gaku (| ap ] Ind $\mathrm{H}$ ealth) 20:479.

-. 1989. A study of $K$ aroshi in the field of occupational medicine. Bull Soc M ed 8:35-50.
_. 1991a. Long working hours and occupational stress-related cardiovascular attacks among middle-aged workers in Japan. I H um Ergol 20(2):147-153.

- . 1991b. K aroshi due to occupational stress-related cardiovascular injuries among middle-aged workers in Japan. J Sci Labour 67(1):20-28.

Warr, P. 1978. W ork and W ell-Being. Nueva Y ork: Penguin.

-. 1994. A conceptual framework for the study of work and mental health. W ork Stress 8(2):84-97.

Wells, EA. 1983. Hallucinations associated with pathological grief reaction. I Psychiat T reat Eval 5:259-261.

Wilke, HJ. 1977. The authority complex and the authoritarian personality. I Anal Psychol 22:243-249.

Yates, JE. 1989. M anaging Stress. Nueva Y ork: AMACON.

Yodofsky, S, RE H ales, T Fergusen. 1991. W hat You $\mathrm{N}$ eed to Know about Psychiatric D rugs. Nueva Y ork: $G$ rove W eidenfeld.

Zachary, G, B O rtega. 1993. Age of Angst-W orkplace revolutions boost productivity at cost of job security. W all Street J, 10 de marzo.

\section{0 tras lecturas recomendadas}

Bickel, H, B Cooper. 1994. Incidence and relative risk of dementia in an urban elderly population: findings of a prospective field study. Psycholog $M$ ed 24:179-192.

Gagnon, M, JF Dartigues, JM M azaux, L Dequae, $L$ Letenneur, JM Giroire, $P$ Barberger-Gateau. 1994. Self-reported memory complaints and memory performance in elderly French community residents: Results of the PAQIID research program. N euroepidemiol 13:145-154.

Jacqmin, H, D Commenges, $L$ Letenneur, $P$ Barberger-Gateau, JF Dartigues. 1994. Components of drinking water and risk of cognitive impairment in the elderly. Am J E pidemiol 139:48-57.

M angione, CM , JM Seddon, EF Cook, JH K rug Jr, CR Sahagian, EW Campion, RJ Glynn. 1993. Correlates of cognitive function scores in elderly outpatients. I Am G eriat Soc 41:491-497.

Warr, P. 1986. A vitamin model of jobs and mental health. En The Psychology of W ork and Organization, dirigido por G Debus y HW Schroiff. North $\mathrm{H}$ olland: Elsevier Science.

White, L, R K atzman, K Losonczy, M Salive, R Wallace, L Berkman, J Taylor, G Fillenbaum, $\mathrm{R}$ Havlik. 1994. Association of education with incidence of cognitive impairment in three established populations for epidemiologic studies of the elderly. J Clin E pidemiol 47:363-374.

Zyzanski, SJ, CD Jenkins. 1970. Basic dimensions within coronary-prone behavior pattern. J Chron $D$ is 22:781-795. 

Directores del capítulo

H ilkka R iihimäki y E ira Viikari-J untura

\section{Sumario}

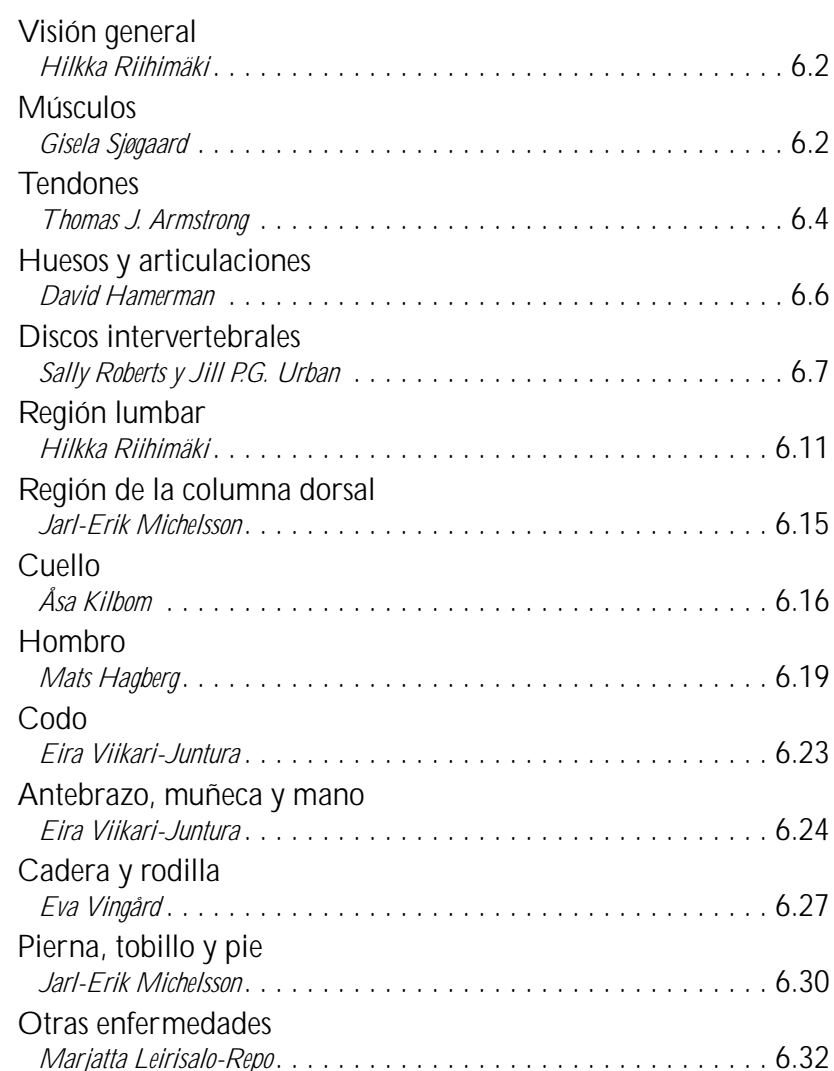




\section{- VISION GENERAL}

\section{Hilkka Riihimäki}

Los trastornos musculosqueléticos se encuentran entre los problemas más importantes de salud en el trabajo, tanto en los países desarrollados como en los en vías de desarrollo. Afectan a la calidad de vida de la mayoría de las personas durante toda su vida, y su coste anual es grande. En los países nórdicos, por ejemplo, se calcula que oscila entre el 2,7 y el $5,2 \%$ del Producto Nacional Bruto (Hansen 1993; Hansen y Jensen 1993). Se cree que la proporción de las enfermedades musculosqueléticas atribuibles al trabajo es de alrededor del $30 \%$. Por tanto, su prevención sería muy rentable. Para alcanzar este objetivo es preciso conocer a fondo el sistema musculosquelético sano, sus enfermedades y los factores de riesgo de los trastornos musculosqueléticos.

La mayor parte de las enfermedades musculosqueléticas producen molestias o dolor local y restricción de la movilidad, que pueden obstaculizar el rendimiento normal en el trabajo o en otras tareas de la vida diaria. Casi todas las enfermedades musculosqueléticas guardan relación con el trabajo, en el sentido de que la actividad física puede agravarlas o provocar síntomas, incluso aunque las enfermedades no hayan sido causadas directamente por el trabajo. En la mayor parte de los casos no es posible señalar un único factor causal. Los procesos causados únicamente por lesiones accidentales son una excepción; en casi todos los casos intervienen varios factores. En muchas enfermedades musculosqueléticas, la sobrecarga mecánica en el trabajo y en el tiempo libre constituye un factor causal importante. Una sobrecarga brusca, o una carga repetida y mantenida, pueden lesionar diversos tejidos del sistema musculosquelético. Por otra parte, un nivel de actividad demasiado bajo puede llevar al deterioro de los músculos, tendones, ligamentos, cartílagos e incluso huesos. Para mantener a estos tejidos en buenas condiciones es necesaria la utilización adecuada del sistema musculosquelético.

El sistema musculosquelético está formado en esencia por tejidos similares en las diferentes partes del organismo que presentan un extenso panorama de enfermedades. Los músculos son la localización más frecuente del dolor. En la región lumbar, los discos intervertebrales son los tejidos que habitualmente presentan problemas. En el cuello y las extremidades superiores son frecuentes los trastornos de tendones y nervios, mientras que en las extremidades inferiores es la osteoartritis el proceso patológico más importante.

Para comprender estas diferencias corporales es necesario conocer las características anatómicas y fisiológicas básicas del sistema musculosquelético, así como la biología molecular de los diversos tejidos, sus recursos nutritivos y los factores que afectan a su funcionamiento normal. También son fundamentales las propiedades biomecánicas de los diversos tejidos. Es necesario conocer tanto la fisiología del funcionamiento normal como la fisiopatología, es decir, lo que funciona mal. Estos aspectos se describen en los primeros artículos sobre discos intervertebrales, huesos y articulaciones, tendones, músculos y nervios. En los artículos siguientes se describen los trastornos musculosqueléticos de las diferentes regiones anatómicas. Se reseñan los síntomas y signos de las enfermedades más importantes y se describe la incidencia de los trastornos en las poblaciones. Se presentan los conocimientos actuales de los factores de riesgos relacionados tanto con el trabajo como con las personas, basados en la investigación epidemiológica. En muchos trastornos existen datos muy convincentes de la existencia de factores de riesgo relacionados con el trabajo, aunque hasta la fecha sólo se dispone de datos limitados acerca de las relaciones de causalidad entre los factores de riesgo y los trastornos, datos que son necesarios para establecer directrices para el diseño de trabajos más seguros.

A pesar de la falta de conocimientos cuantitativos, pueden proponerse orientaciones para la prevención. El método primario para la prevención de los trastornos musculosqueléticos relacionados con el trabajo es volver a diseñarlo para optimizar la carga de trabajo y hacerla compatible con la capacidad de rendimiento físico y mental de los trabajadores. También es importante estimularles para que se mantengan en forma mediante el ejercicio físico regular.

No todas las enfermedades musculosqueléticas descritas en este capítulo guardan una relación causal con el trabajo. No obstante, es importante que el personal responsable de la salud y seguridad en el trabajo sea consciente de tales enfermedades y considere también la carga de trabajo en relación con ellas. La adecuación del trabajo a la capacidad de rendimiento del trabajador ayudará a éste a realizarlo con éxito y de forma segura.

\section{Musculos}

\section{Gisela Sjøgaard}

La actividad física puede aumentar la fuerza muscular y la capacidad de trabajo mediante cambios como el aumento del volumen muscular y de la capacidad metabólica. Los diferentes patrones de actividad producen diversas adaptaciones bioquímicas y morfológicas en los músculos. En general, un tejido debe ser activo para poder seguir viviendo. La inactividad produce atrofia, sobre todo en el tejido muscular. La medicina deportiva y las investigaciones científicas han demostrado que las diversas pautas de entrenamiento pueden producir cambios musculares muy específicos. El entrenamiento de fuerza, que aplica fuerzas intensas a los músculos, aumenta el número de filamentos contráctiles (miofibrillas) y el volumen del retículo sarcoplásmico (véase la Figura 6.1). El ejercicio de alta intensidad aumenta la actividad enzimática muscular. Las fracciones de enzimas glucolíticas y oxidativas están estrechamente relacionadas con la intensidad del trabajo. Además, el ejercicio intenso y prolongado aumenta la densidad de los capilares.

En ocasiones, el ejercicio excesivo puede producir dolor muscular, fenómeno bien conocido por cualquiera que haya demandado un rendimiento muscular superior a su capacidad. Cuando un músculo es utilizado en exceso, se producen en primer lugar procesos de deterioro, seguidos de procesos de reparación. Si se permite un tiempo suficiente para la reparación, el tejido muscular puede acabar con unas capacidades aumentadas. Por otra parte, la utilización excesiva sin tiempo suficiente para la reparación produce fatiga y altera el rendimiento muscular. Esta utilización excesiva prolongada puede dar lugar a cambios degenerativos crónicos en los músculos.

0 tros aspectos del uso y abuso de los músculos son los patrones de control motor en las diversas actividades laborales, que dependen del nivel de la fuerza, del ritmo de desarrollo de la fuerza, del tipo de contracción, de la duración y de la precisión de la tarea muscular (Sjøgaard y cols. 1995). Para estas tareas se "reclutan" determinadas fibras musculares, y algunos patrones de reclutamiento pueden inducir una carga elevada sobre determinadas unidades motoras, aunque la carga sobre el conjunto del músculo sea pequeña. El reclutamiento extenso de una determinada unidad motora producirá inevitablemente fatiga, que puede ir seguida de dolor y lesión muscular profesional, que fácilmente podrían estar relacionados con la fatiga causada por un aporte 
Figura 6.1 - Representación esquemática de los principales componentes de una célula muscular que participan en el acoplamiento excitación-contracción, así como del lugar de producción de ATP, la mitocondria.

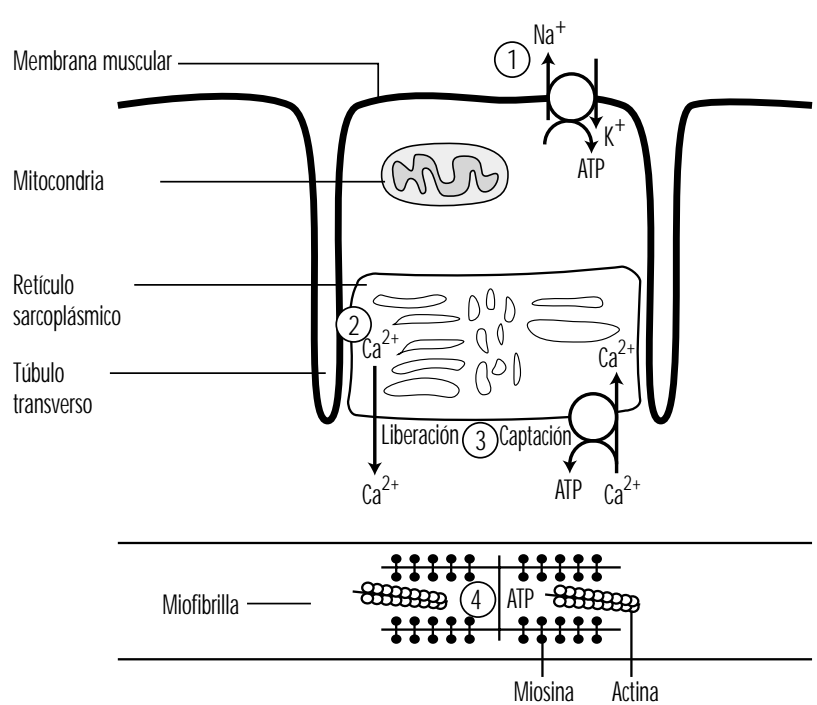

Los números indican las posibles localizaciones de la fatiga muscular e incluyen:

(1) Potencial de acción discurriendo a través de la superficie y de la membrana del túbulo en T;

(2) Mecanismo desconocido que acopla el movimiento de cargas en el túbulo en T con la liberación de $\mathrm{Ca}^{2+}$ en el retículo sarcoplásmico;

(3) Liberación y captación de $\mathrm{Ca}^{2+}$ en el retículo sarcoplásmico;

(4) Hidrólisis de ATP en el complejo actina-miosina y reciclado de puentes cruzados

sanguíneo insuficiente al músculo y por los cambios bioquímicos intramusculares debidos a esta demanda elevada (E dwards 1988). L as altas presiones en el tejido muscular pueden impedir también el flujo sanguíneo muscular, lo que reducirá la capacidad de las sustancias químicas esenciales para alcanzar el músculo, así como la capacidad de la sangre para eliminar los productos de desecho, lo que puede causar crisis de energía en los músculos. El ejercicio puede dar lugar a la acumulación de calcio, y la formación de radicales libres puede favorecer también procesos degenerativos como la rotura de la membrana muscular y la alteración del metabolismo normal (recambio energético mitocondrial) (Figura 6.2). Estos procesos pueden originar finalmente cambios degenerativos en el propio tejido muscular. La presencia de fibras con marcadas características degenerativas es más frecuente en las biopsias musculares de los pacientes con dolor muscular (mialgia) crónico relacionado con el trabajo, que en los sujetos normales. Es interesante señalar que las fibras musculares degeneradas así identificadas son "fibras de contracción lenta", que conectan con nervios motores de bajo umbral. Estos son los nervios reclutados normalmente, con fuerzas bajas mantenidas, no tareas relacionadas con una fuerza elevada. La percepción de fatiga o de dolor puede tener un papel importante en la prevención de la lesión muscular. L os mecanismos protectores inducen a los músculos a relajarse y recuperarse para recuperar la fuerza (Sjøgaard 1990). Si se ignora este mecanismo de biorretroalimentación procedente de los tejidos periféricos, la fatiga y el dolor pueden dar lugar finalmente a dolor crónico.

En ocasiones, después de un uso excesivo frecuente diversas sustancias químicas celulares normales no sólo producen dolor por sí mismas, sino que aumentan la respuesta de los receptores musculares a otros estímulos, reduciendo así el umbral de
Figura 6.2 - Ampliación de la membrana muscular y de las estructuras del interior del músculo de la Figura 6.1. Se ilustra la cadena de acontecimientos en la patogenia de la lesión de las células musculares inducida por el calcio $\left(\mathrm{Ca}^{2+}\right)$.

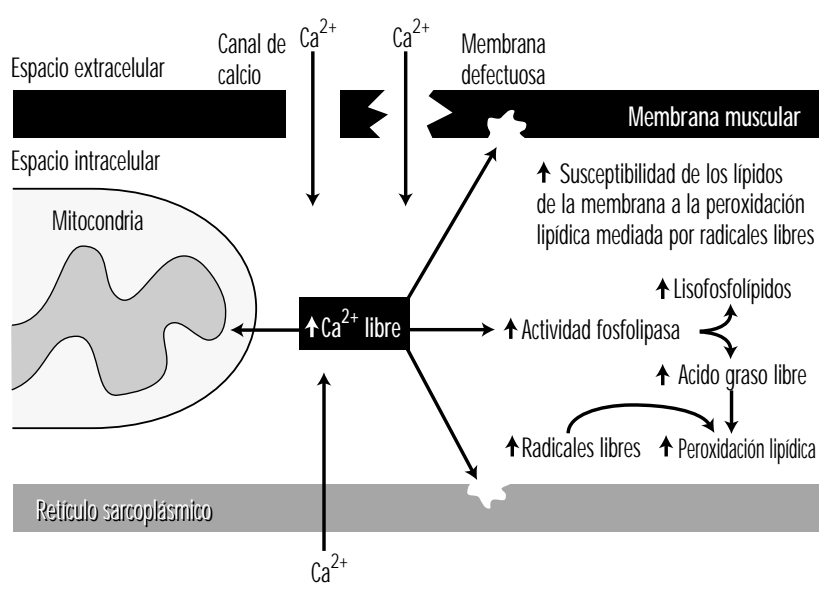

activación (M ense 1993). En consecuencia, los nervios que transportan las señales de los músculos al cerebro (aferentes sensitivos) pueden sensibilizarse con el tiempo, lo que significa que una dosis dada de sustancias causantes de dolor desencadena una respuesta de excitación más potente. Es decir, se reduce el umbral de activación, y exposiciones más pequeñas pueden producir respuestas mayores. Es interesante señalar que las células que normalmente sirven como receptores del dolor (nociceptores) en el tejido no lesionado se mantienen silentes, pero estos nervios pueden desarrollar también una actividad dolorosa continua que puede persistir incluso una vez terminada la causa del dolor. Este efecto puede explicar los estados crónicos de dolor presentes después de curada la lesión inicial. Cuando el dolor persiste después de la curación, los cambios morfológicos originales en los tejidos blandos pueden ser difíciles de identificar, incluso cuando la causa primaria o inicial del dolor está localizada en estos tejidos periféricos. Así, a veces es imposible encontrar la "causa" real del dolor.

\section{Factores de riesgo y estrategias preventivas}

Los factores de riesgo de los trastornos musculares relacionados con el trabajo son: la repetición, fuerza, carga estática, postura, precisión, demanda visual y la vibración. Los ciclos inadecuados de trabajo/ descanso son un factor de riesgo potencial de trastornos musculosqueléticos si no se permiten suficientes períodos de recuperación antes del siguiente período de trabajo, con lo que nunca se da un tiempo suficiente para el descanso fisiológico. También pueden intervenir factores ambientales, socioculturales o personales. Los trastornos musculosqueléticos son multifactoriales $y$, en general, es difícil detectar relaciones causa-efecto simples. No obstante, es importante documentar el grado de relación causal entre los factores profesionales y los trastornos, puesto que sólo en el caso de que exista causalidad se podrán prevenir los trastornos mediante la eliminación o la reducción al mínimo de la exposición. Desde luego, dependiendo del tipo de tarea se deberán implantar diferentes estrategias preventivas. En el caso de trabajo de alta intensidad, el objetivo será reducir la fuerza y la intensidad del trabajo, mientras que en caso de trabajo monótono y repetitivo será más importante introducir alguna variación en él. En resumen, el objetivo es optimizar la exposición. 


\section{Enfermedades profesionales}

El dolor muscular relacionado con el trabajo se presenta casi siempre en la zona del cuello y los hombros, el antebrazo y de la región lumbar. Aunque es una causa importante de baja laboral, existe una gran confusión en cuanto a la clasificación del dolor y a los criterios diagnósticos específicos. Los términos utilizados habitualmente se presentan en tres categorías (véase la Figura 6.3).

Cuando se supone que el dolor muscular está relacionado con el trabajo, se puede clasificar en uno de los siguientes trastornos:

- Trastornos profesionales cervicobraquiales (TPC).

- Lesión por tensión de repetición (LTR).

- Trastornos traumáticos acumulados (TTA).

- Síndrome de (lesión por) uso excesivo.

- Trastornos del cuello y de las extremidades superiores relacionados con el trabajo.

La taxonomía de los trastornos del cuello y de las extremidades superiores relacionados con el trabajo demuestra claramente que la etiología incluye cargas mecánicas externas, que bien pueden ocurrir en el lugar de trabajo. Además de los trastornos en el propio tejido muscular, en esta categoría se incluyen también los de otros tejidos blandos del sistema musculosquelético. H ay que de destacar que los criterios diagnósticos quizá no permitan identificar la localización del trastorno específicamente en uno de estos tejidos blandos. De hecho, es probable que en la percepción del dolor muscular influyan cambios morfológicos en las uniones músculotendinosas. Esto hace recomendable la utilización del término fibromialgia para los tras tornos musculares locales (véase la Figura 6.3)

Por desgracia, para procesos médicos esencialmente iguales se utilizan términos diferentes. En los últimos años, la comunidad científica internacional ha prestado una atención creciente a la clasificación y a los criterios diagnósticos de los trastornos musculosqueléticos. Se distingue entre dolor generalizado y dolor local o regional (Yunus 1993). El síndrome de fibromialgia es un proceso de dolor generalizado, pero no se considera relacionado con el trabajo. Por otra parte, es probable que los

Figura 6.3 - Clasificación de las enfermedades musculares.

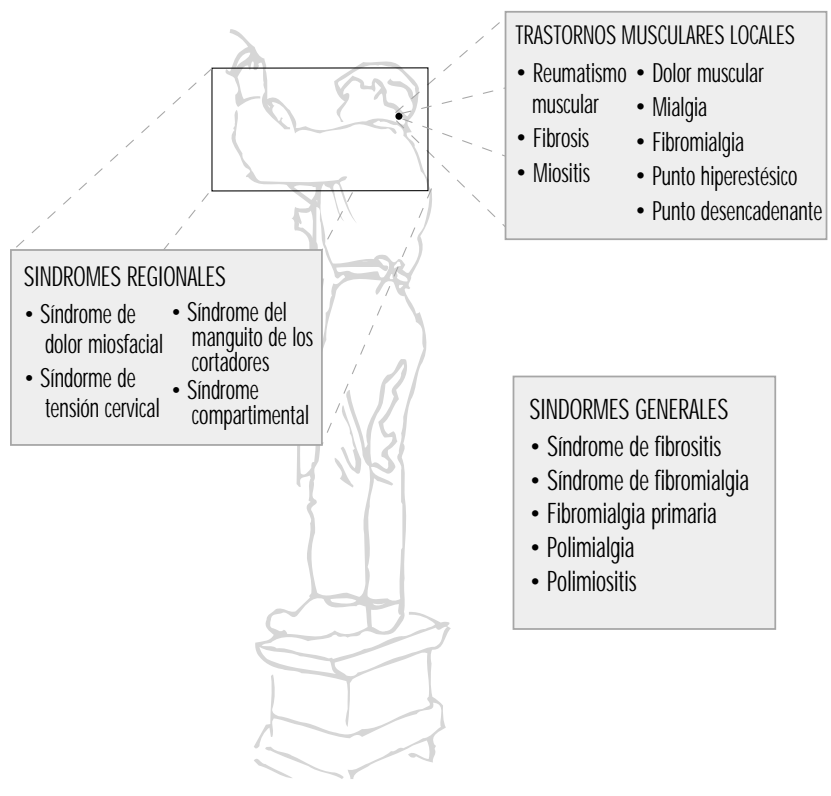

trastornos dolorosos localizados estén relacionados con tareas profesionales específicas. El síndrome de dolor miofascial, el síndrome de tensión cervical (en el cuello) y el síndrome del manguito de los rotadores son trastornos dolorosos localizados que pueden considerarse enfermedades relacionadas con el trabajo.

\section{TENDONES}

Thomas J. Armstrong

La deformación que se produce al aplicar y retirar una fuerza se denomina deformación "elástica". La producida después de la aplicación o la retirada de una fuerza se denomina deformación "viscosa". Debido a que los tejidos del organismo presentan propiedades tanto elásticas como viscosas, se denomina "viscoelásticos". Si el tiempo de recuperación entre esfuerzos sucesivos no es lo bastante largo para una fuerza y duración dadas, la recuperación no será completa y el tendón sufrirá un estiramiento adicional con cada esfuerzo sucesivo. Goldstein y cols. (1987) observaron que cuando los tendones del flexor de los dedos eran sometidos a cargas fisiológicas de 8 segundos (s) y reposo de $2 \mathrm{~s}$, la tensión viscosa acumulada después de 500 ciclos era igual a la tensión elástica. Cuando los tendones eran sometidos a $2 \mathrm{~s}$ de trabajo y $8 \mathrm{~s}$ de reposo, la tensión viscosa acumulada después de 500 ciclos era mínima. Todavía no se han determinado los tiempos de recuperación crítica para unos perfiles trabajo-reposo dados.

Los tendones pueden definirse como estructuras compuestas con haces paralelos de fibras de colágeno dispuestas en una matriz gelatinosa de mucopolisacárido. Las fuerzas de tracción en los extremos del tendón eliminan las ondulaciones y causan el enderezamiento de las bandas de colágeno. Cargas adicionales producen el estiramiento de las bandas enderezadas. En consecuencia, el tendón se hace más rígido a medida que se alarga. Fuerzas de compresión perpendiculares al eje largo del tendón hacen que las bandas de colágeno se aproximen entre sí, lo que ocasiona el aplanamiento del tendón. Fuerzas de cizallamiento laterales al tendón producen el desplazamiento de las bandas de colágeno más próximas a la superficie con respecto a las más alejadas, lo que da un aspecto sesgado al perfil del tendón.

\section{Los tendones como estructuras}

A través de los tendones se transmiten las fuerzas que mantienen el equilibrio estático y dinámico en los diversos requerimientos del trabajo. Los músculos, al contraerse, tienden a rotar las articulaciones en una dirección, mientras que el peso del cuerpo y de los objetos del trabajo tiende a rotarlas en la opuesta. No es posible la determinación exacta de estas fuerzas de los tendones, ya que alrededor de cada estructura articular actúan numerosos músculos y tendones; no obstante, es posible demostrar que las fuerzas musculares que actúan sobre los tendones son mucho mayores que el peso o las fuerzas de reacción de los objetos del trabajo.

Las fuerzas ejercidas por los músculos al contraerse se denominan fuerzas de tracción porque estiran el tendón. Estas fuerzas pueden demostrarse tirando de los extremos de una banda de goma. Los tendones también están sujetos a fuerzas compresoras y de cizallamiento, y a presiones de líquidos, ilustradas en la Figura 6.4 para los tendones flexores de los dedos en la muñeca.

El esfuerzo de los dedos para asir o manipular los objetos del trabajo requiere la acción de músculos del antebrazo y de la mano que, al contraerse, tiran de los extremos de sus respectivos 
Figura 6.4 - Diagrama esquemático de un tendón estirado alrededor de una superficie anatómica o polea, con las correspondientes fuerzas de tracción $\left(F_{t}\right)$, de compresión $\left(F_{c}\right)$ y de fricción $\left(F_{f}\right)$ y la presión hidrostática 0 del líquido $\left(P_{f}\right)$.

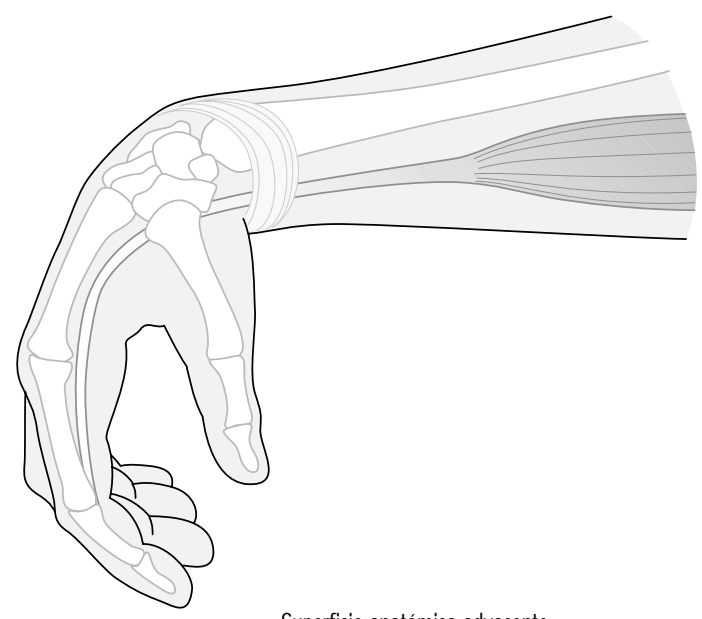

Superficie anatómica adyacente

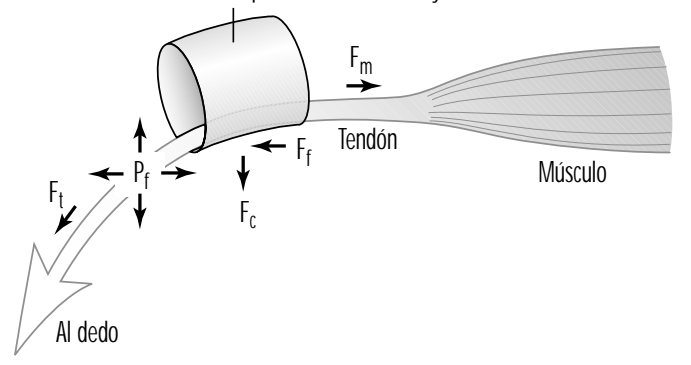

tendones, que pasan a través del centro y de la circunferencia de la muñeca. Si esta última no se mantiene en una posición tal que los tendones estén perfectamente rectos, estos presionarán contra las estructuras adyacentes. Los tendones flexores de los dedos presionan contra los huesos y ligamentos situados en el interior del túnel del carpo. Durante el pellizco forzado con la muñeca flexionada puede verse cómo estos tendones sobresalen bajo la piel hacia la palma. Del mismo modo es posible observar el abultamiento de los tendones extensores y abductores sobre el dorso y la parte lateral de la muñeca cuando se extiende con los dedos estirados.

Las fuerzas de fricción o de cizallamiento están causadas por esfuerzos dinámicos en los que los tendones rozan contra las superficies anatómicas adyacentes. Estas fuerzas actúan sobre la superficie del tendón y en paralelo a ella. Las fuerzas de fricción pueden notarse presionando y deslizando la mano simultáneamente sobre una superficie plana. El deslizamiento de los tendones sobre una superficie anatómica adyacente es análogo al de una cinta deslizándose por una polea.

La presión de líquido está causada por esfuerzos o posturas que desplazan líquido fuera de los espacios situados alrededor de los tendones. Los estudios sobre presión en el túnel del carpo demuestran que el contacto de la muñeca con las superficies externas y ciertas posturas producen presiones lo bastante altas para alterar la circulación y amenazar la viabilidad del tejido (Lundborg 1988).

La contracción de un músculo produce un estiramiento inmediato de su tendón. Los tendones agrupan a los músculos. Si el esfuerzo es mantenido, el tendón continuará estirándose. La relajación del músculo producirá una recuperación rápida del tendón, seguida de una recuperación más lenta. Si el estiramiento inicial estaba dentro de ciertos límites, el tendón se recuperará hasta volver a su longitud inicial sin carga (Fung 1972).

\section{Los tendones como tejidos vivos}

La fuerza de los tendones contradice la fragilidad de los mecanismos fisiológicos subyacentes por los que se nutren y curan. Intercaladas dentro de la matriz del tendón hay células vivas, terminaciones nerviosas y vasos sanguíneos. Las terminaciones nerviosas proporcionan información al sistema nervioso central para el control motor y para advertir de sobrecargas agudas. Los vasos sanguíneos desempeñan un papel importante en la nutrición de ciertas zonas del tendón. Algunas zonas de los tendones son avasculares y dependen de la difusión del líquido secretado por los revestimientos sinoviales de las vainas externas de los tendones (Gelberman y cols. 1987). El líquido sinovial lubrica también los movimientos de los tendones. Las vainas sinoviales se encuentran en las localizaciones donde los tendones entran en contacto con las superficies anatómicas adyacentes.

La excesiva deformación elástica o viscosa del tendón puede lesionar estos tejidos y alterar su capacidad de curación. Se ha formulado la hipótesis de que la deformación puede impedir o frenar la circulación y la nutrición de los tendones ( $\mathrm{H}$ agberg 1982; Viikari-Juntura 1984; Armstrong y cols. 1993). Sin una circulación adecuada, la viabilidad celular se verá alterada y la capacidad de curación del tendón estará reducida. La deformación del tendón puede ocasionar pequeños desgarros que contribuyen a una mayor lesión celular e inflamación. Si se restaura la circulación y se permite que el tendón tenga un tiempo de recuperación adecuado, los tejidos lesionados se curarán (Gelberman y cols. 1987; D aniel y Breidenbach 1982; Leadbetter 1989).

\section{Trastornos de los tendones}

Se ha demostrado que los trastornos de los tendones se producen según patrones previsibles (Armstrong y cols. 1993). Se localizan en las partes del organismo con altas concentraciones de tensión (p. ej., en los tendones del supraespinoso, el bíceps y los flexores y extensores de los dedos). A simismo, existe una asociación entre la intensidad del trabajo y la prevalencia de trastornos tendinosos. Este patrón también se ha demostrado en deportistas aficionados y profesionales (Leadbetter 1989). Los factores comunes, tanto en los trabajadores como en los deportistas, son los esfuerzos repetidos y la sobrecarga de las unidades musculotendinosas.

Dentro de ciertos límites, las lesiones producidas por sobrecarga mecánica se curarán. El proceso de curación se divide en tres fases: inflamatoria, proliferativa y de remodelación (Gelberman y cols. 1987; Daniel y Breidenbach 1982). La fase inflamatoria se caracteriza por infiltración de polimorfonucleares, brote y exudación capilar, y dura varios días. La fase proliferativa se caracteriza por la proliferación de fibroblastos y de fibras de colágeno orientadas aleatoriamente entre las zonas de la herida y los tejidos adyacentes, y dura varias semanas. La fase de remodelación se caracteriza por la alineación de las fibras de colágeno en la dirección de la carga, y dura varios meses. Si los tejidos se vuelven a lesionar antes de que se haya completado la curación, la recuperación puede retrasarse y el proceso empeorar (L eadbetter 1989). La curación normalmente da lugar a un reforzamiento o adaptación del tejido a la tensión mecánica.

Los efectos de la carga repetida son evidentes en los tendones del flexor de los dedos en el antebrazo, en el punto donde contactan con las paredes interiores del túnel de carpo (Louis 1992; Armstrong y cols. 1984). Se ha demostrado que existe un engrosamiento progresivo del tejido sinovial entre los bordes del túnel del carpo y el centro, donde las tensiones de 
contacto sobre los tendones son máximas. El engrosamiento de los tendones va acompañado de hiperplasia sinovial y proliferación del tejido conjuntivo. El engrosamiento de las vainas tendinosas es un factor muy citado en los casos de compresión del nervio mediano en el interior del túnel del carpo. Se puede argumentar que el engrosamiento de los tejidos sinoviales es una adaptación de los tendones al traumatismo mecánico. Si no fuera por el efecto secundario sobre la compresión del nervio mediano que origina el síndrome del túnel del carpo, podría considerarse un resultado favorable.

$\mathrm{H}$ asta que se determinen las pautas de carga óptima de los tendones, las empresas deben controlar la aparición en los trabajadores de signos o síntomas de trastornos tendinosos, de modo que puedan intervenir modificando el trabajo para evitar nuevas lesiones. Deben inspeccionarse los puestos de trabajo en busca de factores de riesgo manifiestos siempre que se identifiquen 0 sospechen problemas en las extremidades superiores. También se inspeccionarán los puestos de trabajo siempre que se produzca un cambio en los estándares, los métodos o las herramientas de trabajo para asegurarse de que se reducen al mínimo los factores de riesgo.

\section{- HUESOSY ARTICULACIONES}

\section{David H amerman}

EI hueso y el cartílago forman parte de los tejidos conjuntivos especializados que constituyen el sistema esquelético. El hueso es un tejido vivo que se repone a sí mismo continuamente. Su dureza es la adecuada para la tarea de proporcionar una función de soporte mecánico, mientras que la elasticidad del cartílago lo es para proporcionar a las articulaciones la capacidad de moverse. Tanto el cartílago como el hueso están formados por células especializadas que producen y controlan una substancia intercelular de material en su exterior. Esta substancia es abundante en colágenos, proteoglucanos y proteínas no colágenas. En la misma también están presentes minerales.

La parte externa del hueso se denomina corteza, y está formada por hueso compacto. La parte interna es más esponjosa (hueso trabecular) está rellena de médula ósea formadora de sangre (hematopoyética). Las partes interna y externa del hueso poseen diferentes índices de recambio metabólico, lo que tiene consecuencias importantes para la osteoporosis en etapas posteriores de la vida. El hueso trabecular se regenera a mayor velocidad que el hueso compacto, motivo por el que la osteoporosis se observa primero en los cuerpos vertebrales de la columna, que poseen grandes cantidades de hueso trabecular.

El hueso del cráneo y de otras zonas específicas se forma directamente mediante formación ósea (osificación intramembranosa), sin pasar por fase intermedia de cartílago. Los huesos largos de las extremidades se desarrollan a partir de cartílago, por un proceso denominado osificación endocondral. Este proceso es el que da lugar al crecimiento normal de los huesos largos, a la reparación de las fracturas y, en la vida adulta, a la formación específica de hueso nuevo en las articulaciones con osteoartritis.

El osteoblasto es un tipo de célula ósea responsable de la síntesis de los componentes de la substancia intercelular en el hueso: el colágeno específico (tipo I) y los proteoglucanos. Los osteoblastos sintetizan también otras proteínas no colágenas del hueso, algunas de las cuales pueden medirse en suero para determinar el índice del recambio óseo.
La otra célula ósea específica se denomina osteoclasto, y es la responsable de la resorción ósea. En circunstancias normales, se reabsorbe el tejido óseo viejo al tiempo que se genera tejido óseo nuevo. El hueso es reabsorbido mediante la producción de enzimas que disuelven las proteínas. El recambio óseo se denomina remodelación y en condiciones normales es un proceso equilibrado y coordinado de resorción y formación. La remodelación está influida por hormonas corporales y por factores de crecimiento locales.

Las articulaciones móviles (diartrodiales) se forman entre dos huesos que se ajustan entre sí. Las superficies articulares están diseñadas para el soporte de peso y para admitir una cierta amplitud de movimiento. La articulación está dentro de una cápsula fibrosa, cuya superficie interna es una membrana sinovial, que secreta líquido sinovial. La superficie articular está formada por cartílago hialino, bajo el cual existe un fondo de hueso duro (subcondral). Dentro de la articulación, los ligamentos, tendones y estructuras fibrocartilaginosas (meniscos en ciertas articulaciones, como la rodilla) proporcionan estabilidad y una adaptación exacta entre las superficies articulares. Las células especializadas de estos componentes articulares sintetizan y mantienen las macromoléculas de la substancia intercelular cuyas interacciones son las responsables del mantenimiento de la resistencia a la tracción de ligamentos y tendones, el tejido conjuntivo laxo que soporta los vasos sanguíneos y los elementos celulares de la membrana sinovial, el líquido sinovial viscoso, la elasticidad del cartílago hialino y la resistencia rígida del hueso subcondral. Estos componentes articulares son interdependientes, y sus relaciones se muestran en la Tabla 6.1.

\section{Enfermedades específicas de huesos y articulaciones} 0 steopenia es el término general utilizado para describir la reducción de la sustancia ósea detectada radiológicamente. A menudo asintomática en las primeras fases, puede manifestarse finalmente como debilitamiento de los huesos. Casi todos los

\begin{tabular}{|c|c|c|}
\hline abla 6.1 • & $\begin{array}{l}\text { Relaciones estruc } \\
\text { interdependencia } \\
\text { articulares. }\end{array}$ & $\begin{array}{l}\text { ctura-función e } \\
\text { a de los componentes }\end{array}$ \\
\hline Componentes & Estructura & Funciones \\
\hline $\begin{array}{r}\text { Ligamentos y } \\
\text { tendones }\end{array}$ & $\begin{array}{l}\text { Tejido conjuntivo } \\
\text { denso, fibroso }\end{array}$ & $\begin{array}{l}\text { Impide la hiperextensión de las articula- } \\
\text { ciones, proporciona estabilidad y } \\
\text { fuerza }\end{array}$ \\
\hline $\begin{array}{l}\text { Membrana } \\
\text { sinovial }\end{array}$ & $\begin{array}{c}\text { Areolar, vascular } \\
\text { y celular }\end{array}$ & $\begin{array}{l}\text { Secreta líquido sinovial, disuelve } \\
\text { (fagocitosis) el material en } \\
\text { partículas en el líquido sinovial }\end{array}$ \\
\hline Líquido sinovial & Líquido viscoso & $\begin{array}{l}\text { Proporciona nutrientes para el cartílago } \\
\text { de las articulaciones, lubrica el } \\
\text { cartílago durante el movimiento } \\
\text { articular }\end{array}$ \\
\hline Cartílago & Cartílago hialino firme & $\begin{array}{l}\text { Constituye la superficie articular, } \\
\text { soporta peso, responde elástica- } \\
\text { mente a la compresión }\end{array}$ \\
\hline $\begin{array}{l}\text { Línea de } \\
\text { osificación }\end{array}$ & Cartílago calcificado & $\begin{array}{l}\text { Separa el cartílago articular del hueso } \\
\text { subyacente }\end{array}$ \\
\hline $\begin{array}{l}\text { Hueso } \\
\text { subcondral }\end{array}$ & $\begin{array}{l}\text { Hueso duro con } \\
\text { espacios medulares }\end{array}$ & $\begin{array}{l}\text { Proporciona la base para la superficie } \\
\text { articular; la cavidad medular propor- } \\
\text { ciona nutrientes para la base del } \\
\text { cartílago y es la fuente de células } \\
\text { con potencial para la formación de } \\
\text { hueso nuevo }\end{array}$ \\
\hline
\end{tabular}

Fuente: Hamerman y Taylor 1993. 
procesos reseñados a continuación producen osteopenia, aunque difieren los mecanismos. Por ejemplo, el exceso de hormona paratiroidea estimula la resorción ósea, mientras que el déficit de calcio y fosfato, que puede producirse por múltiples causas y que a menudo es debido a déficit de vitamina $D$, da lugar a una mineralización deficiente. Al envejecer la persona, existe un desequilibrio entre la formación y la resorción óseas. En las mujeres alrededor de la edad de la menopausia a menudo predomina la resorción, proceso que recibe el nombre de osteoporosis de tipo I. En edades avanzadas, la resorción puede dominar de nuevo y dar lugar a osteoporosis de tipo II. La osteoporosis de tipo I suele producir pérdidas óseas y hundimientos vertebrales, mientras que en el tipo II predomina en la fractura de cadera.

La osteoartritis es el principal trastorno crónico de ciertas articulaciones móviles, y su incidencia aumenta con la edad. $\mathrm{H}$ acia los 80 años, casi todas las personas presentan aumento de tamaño de las articulaciones de los dedos (nódulos de Heberden), cuyo significado clínico suele ser muy escaso. Las principales articulaciones que soportan carga propensas a la osteoartritis son la cadera, la rodilla, los pies y las articulaciones de la columna vertebral. El hombro, aunque no soporta peso, también puede sufrir diversas alteraciones artríticas, como desgarro del manguito de los rotadores, subluxación de la cabeza humeral y un derrame rico en enzimas proteolíticas, un cuadro clínico a menudo conocido como "hombro de M ilwaukee" que va acompañado de dolor importante y de limitación de la movilidad. La principal alteración en la artrosis es sobre todo la degradación del cartílago, aunque radiológicamente suele observarse la formación de hueso nuevo, los denominados osteofitos.

\section{DISCOS INTERVERTEBRALES}

Sally R oberts y Jill P.G. U rban

L os discos intervertebrales ocupan alrededor de la tercera parte de la columna. Dado que no sólo proporcionan flexibilidad a ésta, sino que también transmiten carga, su comportamiento mecánico posee una gran influencia sobre la mecánica de toda la columna. Una elevada proporción de casos de dolor lumbar guardan relación con el disco, ya sea directamente a través de una hernia de disco, o indirectamente porque los discos degenerados someten a una tensión excesiva a otras estructuras de la columna. En este artículo revisaremos la estructura y la composición del disco en relación con su función mecánica, y comentaremos los cambios que sufre en la enfermedad.

\section{Anatomía}

En la columna vertebral del ser humano existen 24 discos intervertebrales, intercalados entre los cuerpos vertebrales, con los que forman el componente anterior (frontal) de la columna vertebral, mientras que las superficies articulares, las apófisis transversas y espinosas forman los elementos posteriores (traseros). El tamaño de los discos aumenta según se va descendiendo por la columna, hasta alcanzar unos $45 \mathrm{~mm}$ en sentido anteroposterior, $64 \mathrm{~mm}$ en sentido lateral y $11 \mathrm{~mm}$ de altura en la región lumbar.

EI disco está formado por tejido cartilaginoso y consta de tres regiones diferenciadas (véase la Figura 6.5). La región interna (núcleo pulposo) es una masa gelatinosa, sobre todo en las personas jóvenes. La región externa del disco (anillo fibroso) es firme y en forma de banda. Las fibras del anillo están entrelazadas de tal forma que le permiten resistir fuerzas elevadas de
Figura 6.5 - Proporciones relativas de los tres componentes principales del disco intervertebral y de la placa basal de cartílago en un adulto normal humano.

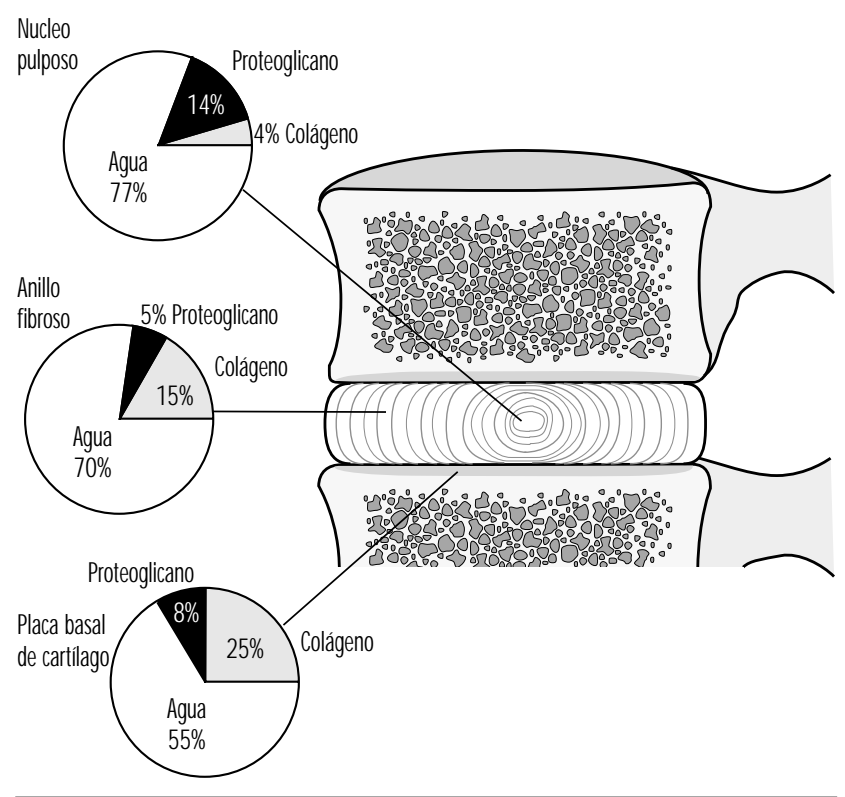

flexión y de torsión. Al aumentar la edad el núcleo pierde agua, aumenta su firmeza y la diferencia entre las dos regiones resulta menos clara que en edades anteriores. EI disco está separado del hueso por una fina capa de cartílago hialino, la tercera región. En la edad adulta, tanto la placa basal de cartílago como el propio disco carecen normalmente de vasos sanguíneos propios, y dependen del aporte sanguíneo de los tejidos adyacentes, como los ligamentos y los cuerpos vertebrales, para el transporte de nutrientes y la eliminación de productos de desecho. Sólo está inervada la porción externa del disco.

\section{Composición}

El disco, al igual que otros cartílagos, está formado fundamentalmente por una matriz de fibras colágenas (incluidas en un gel de proteoglucano) y agua que, en conjunto, constituyen el 90-95\% de la masa tisular total, aunque las proporciones varían según la localización en el interior del disco y la edad y el estado de degeneración. Dispersas por toda la matriz existen células responsables de la síntesis y el mantenimiento de sus distintos componentes (Figura 6.6). Puede encontrarse una revisión de la bioquímica del disco en U rban y Roberts 1994.

Proteoglucanos: El principal proteoglucano del disco, el agrecano, es una gran molécula formada por un núcleo proteico central al que están unidos numerosos glucosaminoglucanos (cadenas repetidas de disacáridos) (véase la Figura 6.7). Estas cadenas laterales poseen una gran densidad de cargas negativas asociadas, lo que las hace atraer moléculas de agua (hidrófilas), propiedad descrita como presión de hinchamiento y que es muy importante para el funcionamiento del disco.

Cuando las moléculas individuales se unen a una cadena de otra sustancia química, el ácido hialurónico, pueden formarse enormes agregados de proteoglucanos. EI tamaño de los agrecanos varía (con pesos moleculares que van desde 300,000 a 7 millones de dalton) dependiendo del número de las moléculas que constituyen el agregado. Recientemente se han encontrado también en el disco y en la placa terminal de cartílago otros tipos de proteoglucanos más pequeños (p. ej., decorina, 
Figura 6.6 - Representación esquemática de la estructura del disco, donde se muestran las fibras de colágeno en bandas intercaladas con numerosas moléculas de proteoglicano en forma de botella y cepillo y algunas células.

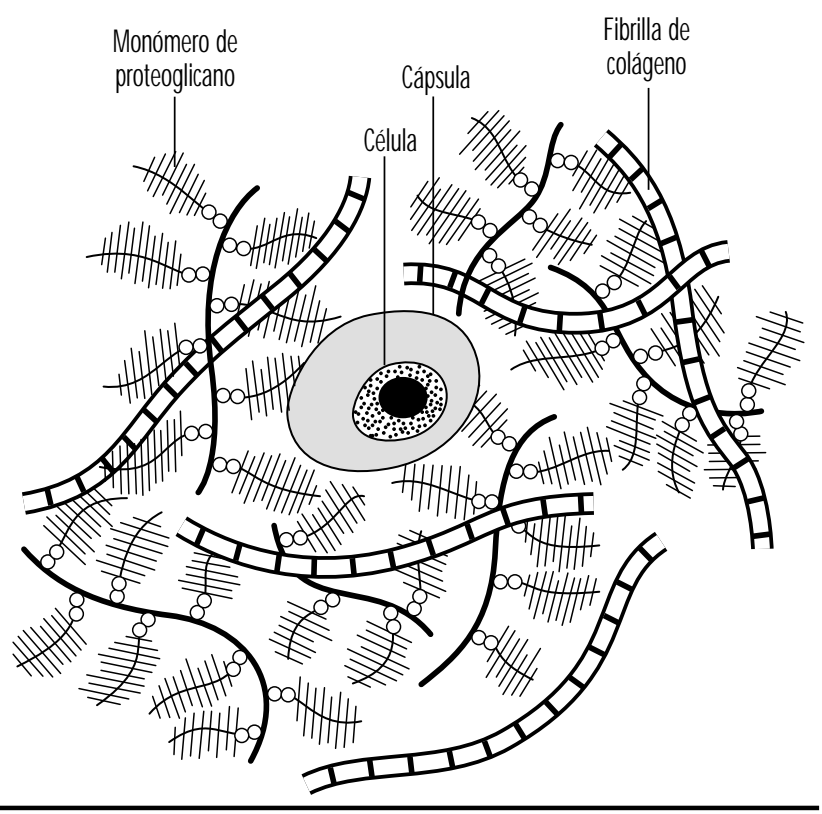

biglucano, fibromodulina y lumicano). Su función es en general desconocida, aunque la fibromodulina y la decorina pueden participar en la regulación de la formación de la red de colágeno.

Agua: El agua es el componente principal del disco y constituye hasta el 65-90 \% del volumen tisular, dependiendo de la edad y de la región del disco. Existe una correlación entre la cantidad de proteoglucano y el contenido de agua de la matriz. La cantidad de agua también varía dependiendo de la carga aplicada al disco; por ello, el contenido de agua es diferente de noche y de día, ya que la carga será muy diferente durante el sueño. El agua es importante tanto para el funcionamiento mecánico del disco como para proporcionar el medio de transporte de las sustancias disueltas dentro de la matriz.

Colágeno: El colágeno es la principal proteína estructural del organismo y está constituido por una familia de al menos 17 proteínas diferentes. Todos los colágenos poseen regiones helicoidales y están estabilizados por una serie de enlaces cruzados intra e intermoleculares, que refuerzan la resistencia de las moléculas ante las tensiones mecánicas y la degradación enzimática. La longitud y la forma de los diferentes tipos de moléculas de colágeno varían, así como su proporción helicoidal. EI disco está formado por varios tipos de colágeno, con predominio del tipo I en el anillo externo y del tipo II en el núcleo y en la placa terminal de cartílago. Ambos tipos forman fibrillas que constituyen el andamiaje estructural del disco. Las fibrillas del núcleo son mucho más finas $\approx 0,05 \mu \mathrm{m}$ de diámetro) que las del anillo $(0,1$ a $0,2 \mu \mathrm{m}$ de diámetro). Las células del disco a menudo están rodeadas por una cápsula de alguno de los otros tipos de colágeno, como el tipo VI.

Células: La densidad celular del disco intervertebral es muy baja en comparación con la de otros tejidos. Aunque la densidad celular es baja, su actividad continua es vital para la salud del disco, ya que las células producen macromoléculas durante toda la vida para sustituir a las que se degradan y se pierden con el paso del tiempo.

\section{Función}

La principal función del disco es mecánica. El disco transmite la carga a lo largo de la columna vertebral y también permite su curvatura y torsión. Las cargas sobre el disco proceden del peso corporal y de la actividad muscular, y se modifican con la postura (véase la Figura 6.8). D urante las actividades diarias el disco está sometido a cargas complejas. La extensión o la flexión de la columna producen sobre todo fuerzas de tracción y de compresión sobre el disco, que aumentan de magnitud según se desciende por la columna, debido a las diferencias en el peso y en la geometría corporal. La rotación de la columna produce tensiones transversales (de cizallamiento).

Los discos están sometidos a presión, que varía con la postura desde alrededor de 0,1 a 0,2 M Po en reposo hasta alrededor de 1,5 a 2,5 M Po con la curvatura y la elevación. La presión en el disco normal se debe fundamentalmente a la presión de agua a través del núcleo y del anillo interno. Cuando aumenta la carga que soporta el disco, la presión se distribuye de modo uniforme a través de la placa terminal y por todo el disco.

Durante la carga, el disco se deforma y pierde altura. La placa basal y el anillo se abomban, aumentando la tensión sobre estas estructuras y, en consecuencia, se eleva la presión del núcleo. El grado de deformación del disco depende de la velocidad de producción de la carga. El disco puede experimentar una deformidad considerable, comprimiéndose 0 extendiéndose en un 30 a un $60 \%$ durante la flexión y la extensión. Las distancias entre las apófisis espinosas adyacentes pueden aumentar en más de un $300 \%$. Si la carga se retira en unos segundos, el disco vuelve rápidamente a su estado anterior, pero si la carga se mantiene, el disco continúa perdiendo altura. Este "aplastamiento" es consecuencia de la deformación continua de las estructuras del disco, y también de la pérdida de líquidos, ya que el disco pierde líquido como consecuencia del aumento de presión. Durante las actividades diarias, cuando el disco está sometido a presiones mucho mayores, se pierde lentamente entre el 10 y el $25 \%$ del líquido del disco, que se recupera al descansar tumbados. Esta pérdida de agua puede dar lugar a

Figura 6.7 - Diagrama de parte de un disco agregado de proteoglicano. G1, G 2 y G 3 son regiones globulosas insertadas en una proteína nuclear central.

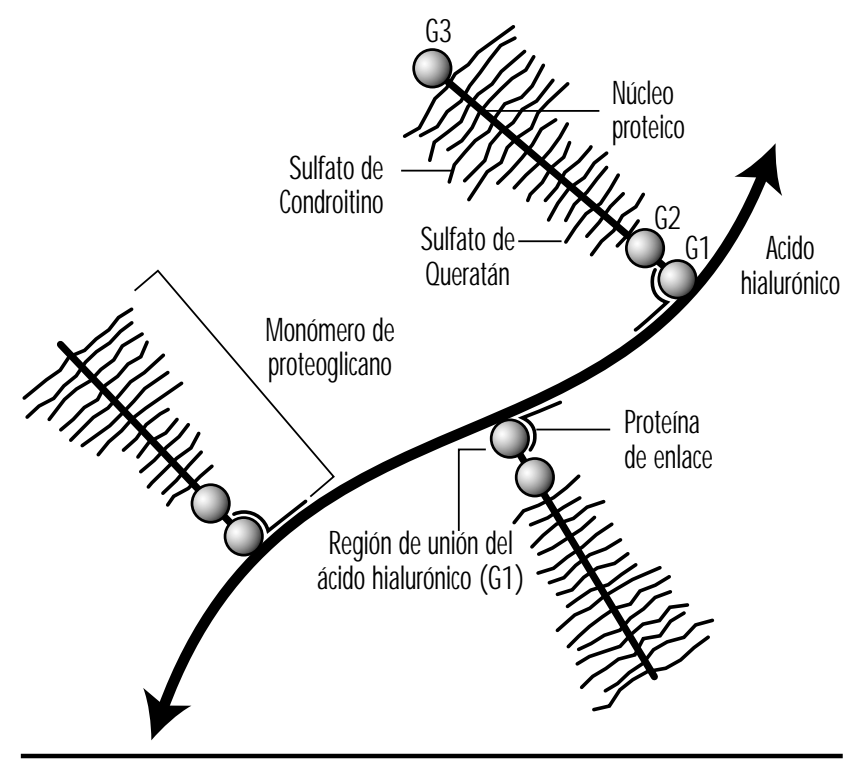


Figura 6.8 - Presiones intradiscales relativas en diferentes posturas, en comparación con la presión en bipedestación erecta $(100 \%)$.

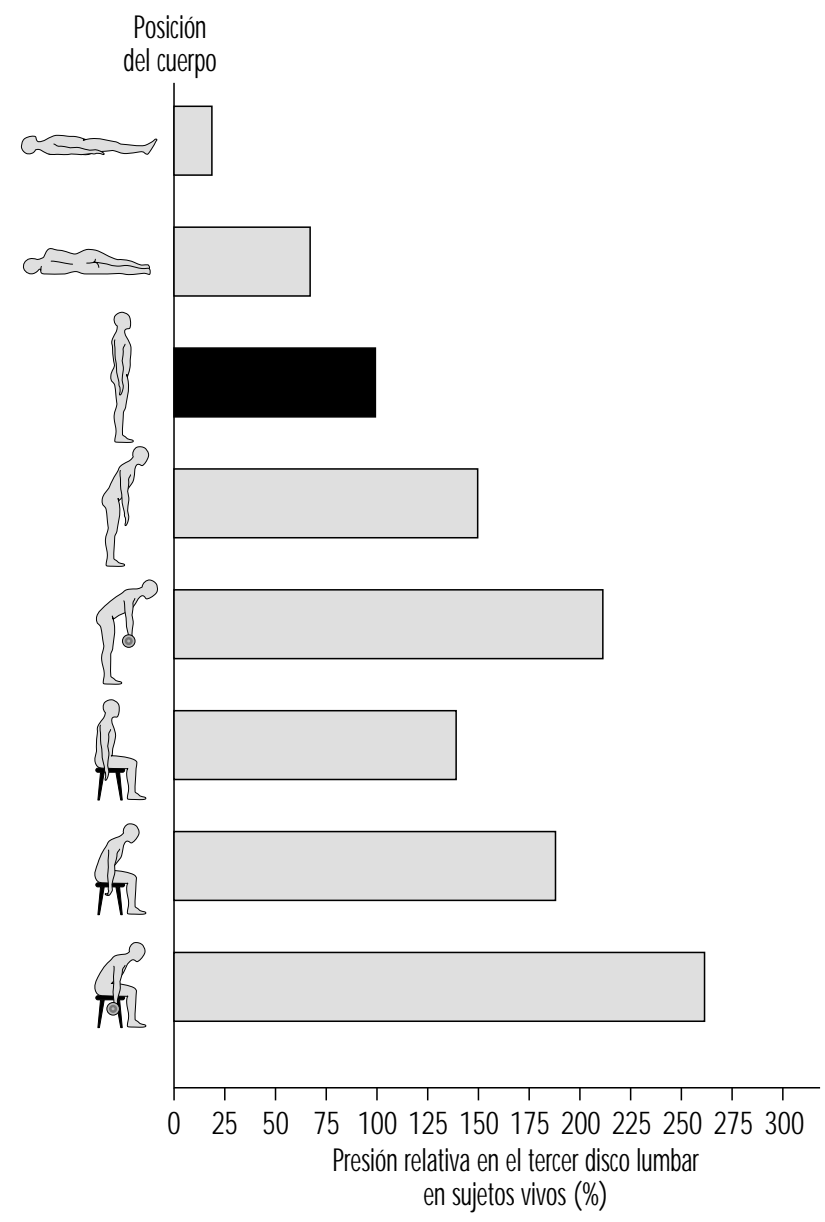

Fuente: Adaptado de Nachemson 1992

una disminución de 1 a $2 \mathrm{~cm}$ de estatura desde la mañana hasta la noche en los trabajadores de día.

A medida que cambia la composición del disco a causa de la edad o de la degeneración, también cambia su respuesta a las cargas mecánicas. Con la pérdida de proteoglucanos y, por tanto, del contenido de agua, el núcleo ya no puede responder de forma tan eficaz. Este cambio da lugar a tensiones no uniformes a través de la placa terminal y de las fibras del anillo $y$, en los casos de degeneración grave, a la protrusión hacia adentro de las fibras internas cuando el disco recibe una carga, lo que a su vez puede generar tensiones anormales sobre otras estructuras del disco, lo que finalmente ocasiona su fracaso. La velocidad de "aplastamiento" también está aumentada en los discos degenerados, que de esta forma pierden altura más rápidamente que los discos normales sometidos a la misma carga. EI estrechamiento del espacio del disco afecta a otras estructuras de la columna, como los músculos y ligamentos y, en particular, conduce a un aumento de la presión en las facetas articulares, que puede ser la causa de los cambios degenerativos que se observan en ellas en las columnas con discos anormales.

\section{Contribución de los componentes principales a la función}

\section{Proteoglucanos}

La función del disco depende del mantenimiento de un equilibrio en el que la presión del agua está equilibrada con la presión de hinchamiento del disco. Esta presión depende de la concentración de los iones atraídos al disco por los proteoglucanos cargados negativamente y, por tanto, depende directamente de la concentración de proteoglucanos. Si aumenta la carga sobre el disco, la presión de agua aumenta y se altera el equilibrio. Para compensarlo, sale líquido del disco, lo que aumenta la concentración de proteoglucanos y la presión osmótica del disco. Tal expresión de líquido continúa hasta que se restablece el equilibrio o se retira la carga sobre el disco.

Los proteoglucanos también afectan al movimiento de los líquidos de otras maneras. D ebido a su elevada concentración en el tejido, los espacios entre las cadenas son muy pequeños $(0,003$ a $0,004 \mu \mathrm{m})$. El flujo de líquido a través de estos poros tan pequeños es muy lento por lo que, incluso ante una gran presión diferencial, la velocidad a la que se pierde el líquido y, por tanto, la velocidad de "aplastamiento" del disco, es lenta. Sin embargo, dado que los discos degenerados tienen menores concentraciones de proteoglucanos, el líquido puede fluir más rápido a través de la matriz. Esta puede ser la causa de que los discos degenerados pierdan altura con más rapidez que los normales. La carga y la elevada concentración de proteoglucanos controlan la entrada y el movimiento de otras sustancias disueltas en el disco. Las moléculas pequeñas (nutrientes como glucosa, oxígeno) pueden penetrar fácilmente en el disco y moverse a través de la matriz. L as sustancias químicas electropositivas y los iones, como $\mathrm{Na}^{+} 0 \mathrm{Ca}^{2+}$, están en concentraciones más altas en el disco cargado negativamente que en el líquido intersticial circundante. Las moléculas grandes, como la seroalbúmina o las inmunoglobulinas, son demasiado voluminosas para entrar en el disco, y sólo están presentes en concentraciones muy bajas. L os proteoglucanos pueden afectar también a la actividad y el metabolismo celulares. Los proteoglucanos pequeños, como el biglucano, se pueden unir a factores de crecimiento y a otros mediadores de la actividad celular, liberándolos cuando la matriz es degradada.

\section{Agua}

El agua es el componente principal del disco, y la rigidez del tejido se mantiene por las propiedades hidrófilas de los proteoglucanos. Con la pérdida inicial de agua, el disco se hace más fláccido y deformable al relajarse la red de colágeno. Sin embargo, una vez que el disco ha perdido una fracción significativa de agua, sus propiedades mecánicas cambian drásticamente; el tejido se comporta más como un sólido que como un material compuesto sometido a carga. El agua también proporciona el medio a través del cual se intercambian nutrientes y productos de desecho entre el disco y la corriente sanguínea circundante.

\section{Colágeno}

La red de colágeno, que puede soportar altas cargas de tracción, proporciona un entramado para el disco y lo ancla a los cuerpos vertebrales vecinos. La red está inflada por el agua captada por los proteoglucanos; a su vez, contiene a los proteoglucanos e impide que escapen del tejido. Estos tres componentes en conjunto forman por tanto una estructura capaz de soportar altas cargas compresivas

La organización de las fibrillas de colágeno proporciona al disco su flexibilidad. Las fibrillas están dispuestas en capas; el ángulo que forman las fibrillas de cada capa entre los cuerpos vertebrales vecinos tiene una dirección alternante. Este tejido 
Figura 6.9 • Las principales vías de nutrición del disco intervertebral son la difusión a partir de la vascularización del interior del cuerpo vertebral (V), a través de la placa basal (E) hasta el núcleo (N) 0 a partir del riego sanguíneo del exterior del anillo (A).

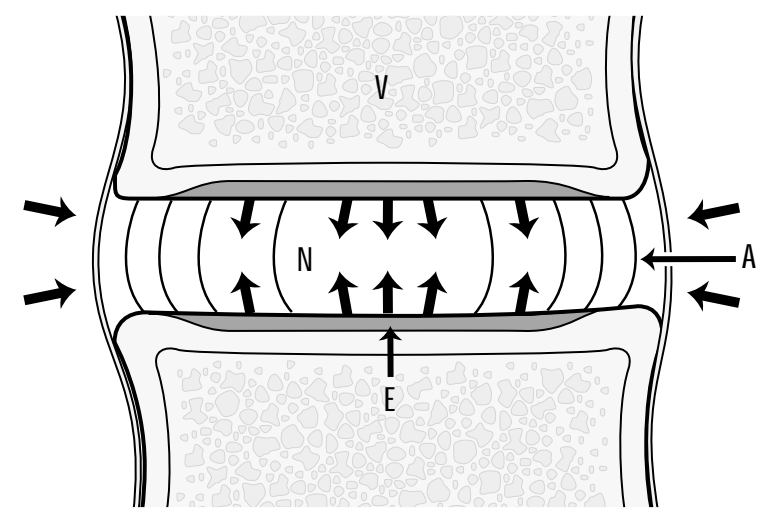

altamente especializado permite al disco un extenso movimiento en cuña, lo que posibilita la curvatura de la columna, aunque las fibras de colágeno por sí mismas sólo pueden extenderse alrededor de un $3 \%$.

\section{Metabolismo}

Las células del disco producen tanto moléculas grandes como enzimas que degradan los componentes de la matriz. En el disco sano, las tasas de producción y de degradación de la matriz están equilibradas. Si se trastorna el equilibrio, debe cambiar en última instancia la composición del disco. Durante el crecimiento, las tasas de síntesis de moléculas nuevas y de reposición son más altas que las de degradación, y se acumulan materiales de la matriz alrededor de las células. Con el envejecimiento y la degeneración ocurre lo contrario. Los proteoglucanos suelen durar unos dos años. El colágeno dura muchos más años. Si se trastorna el equilibrio, o si desciende la actividad celular, el contenido de proteoglucanos de la matriz finalmente disminuye, lo que afecta a las propiedades mecánicas del disco.

Las células del disco también responden a los cambios de la tensión mecánica. La carga afecta al metabolismo del disco, aunque los mecanismos no están claros. En el momento actual es imposible predecir cuáles son las demandas mecánicas que favorecen un equilibrio estable, y cuáles pueden favorecer la degradación de la matriz en lugar de la síntesis.

\section{Aporte de nutrientes}

Debido a que el disco recibe nutrientes procedentes del aporte sanguíneo de los tejidos adyacentes, los nutrientes como el oxígeno o la glucosa deben difundirse a través de la substancia intercelular hasta las células situadas en el centro del disco, que a veces están alejadas hasta 7 u $8 \mathrm{~mm}$ del aporte sanguíneo más próximo. Se desarrollan gradientes pronunciados. En la interfase entre el disco y el cuerpo vertebral, la concentración de oxígeno es de alrededor del $50 \%$, mientras que en el centro del disco es inferior al $1 \%$. El metabolismo del disco es principalmente anaerobio. Cuando el oxígeno desciende por debajo del $5 \%$, el disco aumenta la producción de lactato, un producto de desecho metabólico. La concentración de lactato en el centro del núcleo llega a ser de seis a ocho veces más alta que en la sangre o en el intersticio. (V éase la Figura 6.9.)
A menudo se ha sugerido que la disminución del aporte de nutrientes es una causa importante de la degeneración del disco. La permeabilidad de la placa basal del disco disminuye con la edad, lo que puede dificultar el transporte de nutrientes al interior del disco y podría ocasionar la acumulación de sustancias de desecho como el lactato. En los discos en los que se ha reducido el transporte de nutrientes, las concentraciones centrales de oxígeno descienden hasta niveles muy bajos. Aquí el metabolismo anaerobio $y$, en consecuencia, la producción de lactato aumentan, y la acidez en el centro del disco puede descender hasta cifras de $\mathrm{pH}$ bajas, del orden de 6,4. Estos valores bajos de $\mathrm{pH}$, al igual que las bajas tensiones de oxígeno, reducen la tasa de síntesis de la matriz, lo que da lugar a un descenso del contenido de proteoglucanos. Además, las propias células quizá no sobrevivan a la exposición prolongada a un pH ácido. En los discos humanos se ha encontrado un elevado porcentaje de células muertas.

La degeneración del disco conduce a una pérdida de proteoglucanos y a un cambio de su estructura, a la desorganización de la red de colágeno y a una involución de los vasos sanguíneos. Existe la posibilidad de que algunos de estos cambios sean reversibles. Se ha demostrado que el disco tiene cierta capacidad de recuperación.

\section{Enfermedades}

Escoliosis: La escoliosis es una curvatura lateral de la columna vertebral en la que tanto los discos intervertebrales como los cuerpos vertebrales están acuñados. Se suele asociar a torsión o rotación de la columna. Debido a la forma en que las costillas están unidas a las vértebras, ello da lugar a una "joroba costal", visible cuando el individuo afectado se inclina hacia adelante. La escoliosis puede ser debida a un defecto congénito de la columna, como en el caso de las hemivértebras en forma de cuña, o surgir secundariamente a trastornos como la distrofia neuromuscular. Sin embargo, en la mayor parte de los casos la causa es desconocida, por lo que se denomina escoliosis idiopática. El dolor rara vez constituye un problema, y el tratamiento se realiza sobre todo para detener el desarrollo posterior de la curvatura lateral de la columna. (Para más detalles acerca del tratamiento clínico de ésta y de otras patologías de la columna, véase T idswell 1992.)

E spondilolistesis: La espondilolistesis es un desplazamiento horizontal hacia adelante de una vértebra con relación a otra. Puede ser consecuencia de una fractura en el puente óseo que conecta las porciones frontal y posterior de la vértebra. 0 bviamente, el disco intervertebral situado entre estas dos vértebras está estirado y sometido a cargas anormales. La matriz de este disco y, en menor grado, de los discos adyacentes, muestra cambios degenerativos típicos en su composición - pérdida de agua y de proteoglucanos. Este proceso se puede diagnosticar radiológicamente.

$D$ isco roto o prolapsado: La rotura del anillo posterior es bastante frecuente en los jóvenes 0 adultos de edad mediana físicamente activos. No se puede diagnosticar por radiología a menos que se realice discografía, con inyección de un material radiopaco en el centro del disco; siguiendo el recorrido del líquido es posible demostrar la existencia de un desgarro. En ocasiones, fragmentos aislados y secuestrados de material del disco atraviesan este desgarro y llegan hasta el canal vertebral. La irritación o la compresión del nervio ciático produce dolor intenso y parestesias (ciática) en la extremidad inferior.

E nfermedad degenerativa del disco: Es la denominación dada a un grupo mal definido de pacientes que presentan dolor lumbar. Pueden mostrar cambios radiológicos, como disminución de la altura del disco y posiblemente formación de osteofitos en el borde de los cuerpos vertebrales. Este grupo de pacientes podría representar el estado final de varios estados fisiopatológicos. Por 
ejemplo, los desgarros anulares no tratados pueden adoptar finalmente esta forma.

E stenosis espinal: El estrechamiento del canal vertebral que se produce en la estenosis espinal ocasiona compresión mecánica de las raíces de los nervios espinales y de su aporte sanguíneo, con lo que puede dar lugar a síntomas como debilidad, alteración de los reflejos, dolor o pérdida de la sensibilidad (parestesias) 0 , en ocasiones, no presentar síntomas. El estrechamiento del canal puede, a su vez, estar causado por diversos factores, incluida la protrusión del disco intervertebral en el espacio del canal, la formación de hueso nuevo en las superficies articulares (hipertrofia de las facetas) y la presencia de artritis con inflamación de otros tejidos conjuntivos blandos.

La interpretación de las más recientes técnicas de imagen en relación con la patología discal no está completamente establecida. Por ejemplo, los discos degenerados en la imagen por resonancia magnética (RM) dan una señal alterada respecto a la observada en los discos "normales". Sin embargo, la correlación entre un disco de aspecto "degenerado" en la R M y los síntomas clínicos es mala, y existe un $45 \%$ de discos degenerados en la RM que son asintomáticos y un $37 \%$ de pacientes con dolor lumbar que presentan una RM de columna normal.

\section{Factores de riesgo}

\section{Carga}

La carga sobre los discos depende de la postura. Las mediciones intradiscales demuestran que la posición sedente da lugar a presiones cinco veces mayores que las alcanzadas con la columna en reposo (véase la Figura 6.8). EI levantamiento de pesos externos puede aumentar en gran medida la presión intradiscal, sobre todo si el peso se mantiene separado del cuerpo. O bviamente, un aumento de la carga puede dar lugar a la rotura de discos que de otra manera permanecerían intactos.

L as investigaciones epidemiológicas revisadas por Brinckmann y Pope (1990) concuerdan en un aspecto: la elevación o el transporte repetidos de objetos pesados o la realización de trabajos en posición de flexión o hiperextensión representan factores de riesgo para la aparición de problemas lumbares. Asimismo, ciertos deportes, como la halterofilia, pueden asociarse a una mayor incidencia de dolor lumbar que, por ejemplo, la natación. El mecanismo no está claro, aunque podrían influir los diferentes patrones de carga.

\section{Tabaquismo}

La nutrición del disco es muy precaria, y basta una pequeña reducción del flujo de nutrientes para que resulte insuficiente para el metabolismo normal de sus células. El consumo de cigarrillos puede producir tal reducción debido a su efecto sobre el sistema circulatorio fuera del disco intervertebral. El transporte de nutrientes como oxígeno, glucosa o sulfato al interior del disco se reduce significativamente tras sólo 20 a 30 minutos del consumo de tabaco, lo que puede explicar la mayor incidencia de dolor lumbar en los fumadores en comparación con los no fumadores (R ydevik y H olm 1992).

\section{Vibración}

Estudios epidemiológicos han demostrado que existe una mayor incidencia de dolor lumbar en los sujetos expuestos a niveles altos de vibración. La columna vertebral es susceptible a las lesiones a sus frecuencias naturales, sobre todo desde 5 a $10 \mathrm{~Hz}$. N umerosos vehículos provocan vibraciones a estas frecuencias. Estudios comunicados por Brinckmann y Pope (1990) han demostrado la existencia de una relación entre tales vibraciones y la incidencia de dolor lumbar. Puesto que se ha demostrado que las vibraciones afectan a los pequeños vasos sanguíneos en otros tejidos, éste podría ser también el mecanismo de este efecto en la columna vertebral.

\section{REGION LUMBAR}

\section{H ilkka Riihimäki}

El dolor lumbar es un achaque frecuente en las poblaciones en edad laboral. Alrededor del $80 \%$ de las personas experimentan dolor lumbar en algún momento de su vida, y se trata de una de las causas más importantes de discapacidad de corta o de larga duración en todos los grupos profesionales. Según la etiología, el dolor lumbar se puede clasificar en seis grupos: mecánico, infeccioso (p. ej., tuberculosis), inflamatorio (p. ej., espondilitis anquilopoyética), metabólico (p. ej., osteoporosis), neoplásico (p. ej., cáncer) y visceral (dolor causado por enfermedades de los órganos internos).

En la mayoría de las personas, el dolor lumbar tiene causas mecánicas, entre las que se encuentran el esguince/ distensión lumbosacra, la enfermedad degenerativa del disco, la espondilolistesis, la estenosis espinal y la fractura. Aquí sólo se comentará el dolor lumbar mecánico, también denominado dolor lumbar regional, que puede ser local 0 irradiado a una 0 ambas piernas (ciática). U na característica del dolor lumbar mecánico es que aparece de forma episódica, y en la mayor parte de los casos la evolución natural es favorable. En cerca de la mitad de los casos agudos, el dolor cede en dos semanas, y en casi el $90 \%$ lo hace en dos meses. Se calcula que se cronifica uno de cada diez casos, y es este grupo de pacientes con dolor lumbar el responsable de la mayor proporción de los costes debidos a trastornos lumbares.

\section{Estructura y función}

D ebido a la postura erecta, la estructura de la parte inferior de la columna vertebral (columna lumbosacra) del ser humano difiere anatómicamente de la de la mayoría de los restantes vertebrados. La posición erecta también hace aumentar las fuerzas mecánicas que actúan sobre las estructuras de la columna lumbosacra. N ormalmente, la columna lumbar posee cinco vértebras. EI sacro es rígido, y el coxis carece de función en el ser humano, como se muestra en la Figura 6.10.

Figura 6.10 - La columna, sus vértebras y curvaturas.

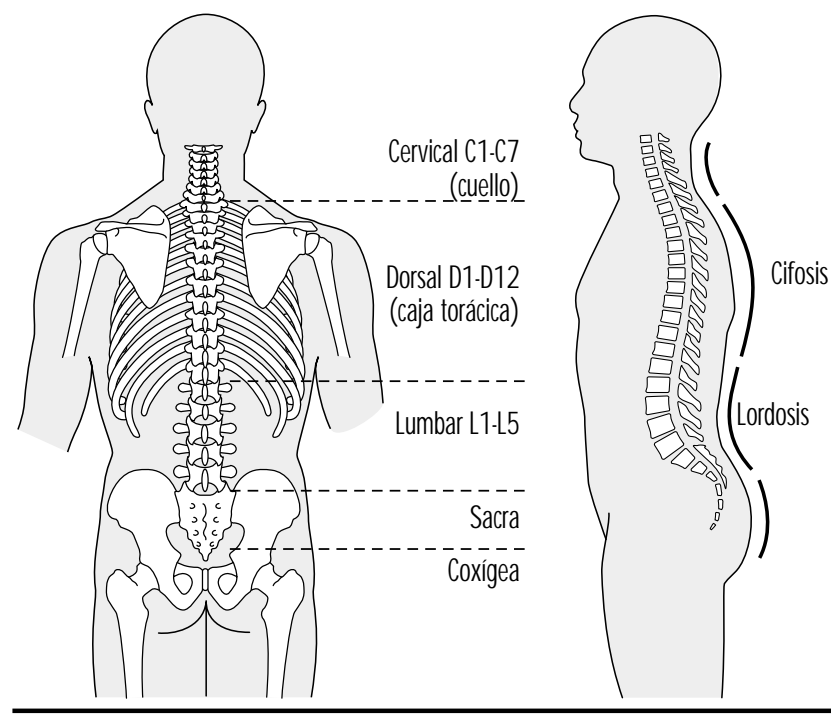


Figura 6.11 - La unidad funcional básica de la columna.

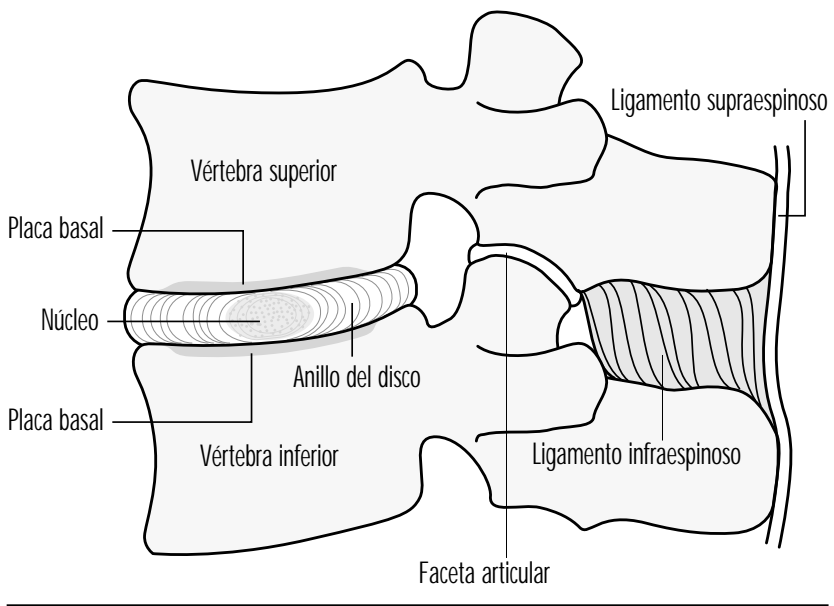

L as vértebras están unidas entre si por discos intervertebrales situados entre los cuerpos vertebrales, así como por ligamentos y músculos. Estas uniones mediante tejidos blandos hacen que la columna sea flexible. Dos vértebras adyacentes forman una unidad funcional, como se muestra en la Figura 6.11. Los cuerpos y los discos vertebrales son los elementos que soportan el peso de la columna. Las partes posteriores de las vértebras forman el arco neural, que protege a los nervios en el canal vertebral. Los arcos vertebrales están unidos entre sí mediante facetas articulares (articulaciones cigoapofisarias) que determinan la dirección del movimiento. Los arcos vertebrales también están unidos entre sí por numerosos ligamentos que determinan el grado de movilidad o amplitud de movimiento en la columna. Los músculos que extienden el tronco hacia atrás (extensores) están unidos a los arcos vertebrales. Importantes puntos de unión son las tres proyecciones óseas (dos apófisis laterales y la apófisis espinosa) de los arcos vertebrales.

La médula espinal termina a la altura de las vértebras lumbares más altas (L 1-L 2). El canal vertebral lumbar está lleno por la extensión de la médula espinal denominada cola de caballo, formada por las raíces de los nervios espinales. Las raíces de los nervios salen por pares del canal vertebral a través de los agujeros intervertebrales. Cada una de las raíces de los nervios espinales da una rama que inerva los tejidos de la espalda. Se trata de terminaciones nerviosas que transmiten sensaciones dolorosas (terminaciones nociceptivas) de músculos, ligamentos y articulaciones. En un disco intervertebral sano no existen tales terminaciones nerviosas, excepto en las porciones más externas del anillo. Sin embargo, el disco se considera la fuente más importante de dolor lumbar. Se sabe que las roturas del anillo son dolorosas. Como secuela de la degeneración del disco puede producirse una herniación de la porción interna semigelatinosa del disco intervertebral, el núcleo, hacia el interior del canal vertebral, lo que causa compresión y/ o inflamación de un nervio espinal acompañada de signos y síntomas de ciática, como se muestra en la Figura 6.12.

Los músculos son los responsables de la estabilidad y del movimiento de la espalda. Los músculos de la espalda doblan el tronco hacia atrás (extensión), mientras que los músculos abdominales lo doblan hacia adelante (flexión). La fatiga debida a la carga mantenida o repetitiva 0 al esfuerzo excesivo brusco de músculos o ligamentos puede ocasionar dolor lumbar, aunque el origen exacto de este dolor es difícil de localizar. Existe controversia acerca del papel de las lesiones de tejidos blandos en los trastornos lumbares.
Figura 6.12 • Herniación del disco intervertebral.

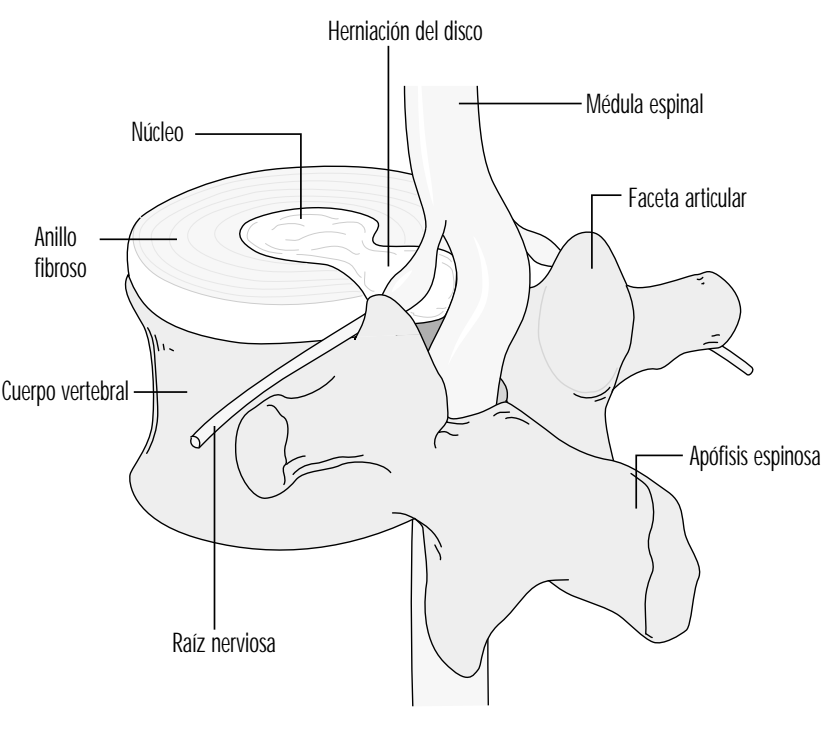

\section{Dolor lumbar}

\section{Incidencia}

Las estimaciones sobre la prevalencia del dolor lumbar varían dependiendo de las definiciones utilizadas en las diferentes investigaciones. Las tasas de prevalencia de los síndromes dolorosos lumbares en la población general finlandesa de más de 30 años se muestran en la Tabla 6.2. Tres de cada cuatro personas han experimentado dolor lumbar (y una de cada tres, dolor ciático) en algún momento de su vida. Cada mes, una de cada cinco personas padece dolor lumbar o ciático y, en un momento dado, una de cada seis personas padece un síndrome doloroso lumbar clínicamente verificable. La ciática o hernia del disco intervertebral es menos frecuente y afecta al $4 \%$ de la población. Alrededor de la mitad de las personas con síndrome de dolor lumbar presentan alteraciones funcionales, que son graves en el $5 \%$. La ciática es más frecuente en los varones, aunque otros trastornos lumbares son igualmente frecuentes en ambos sexos. EI dolor

Tabla 6.2 - Prevalencia de los trastornos de espalda en la población finlandesa de más de 30 años de edad en porcentajes.

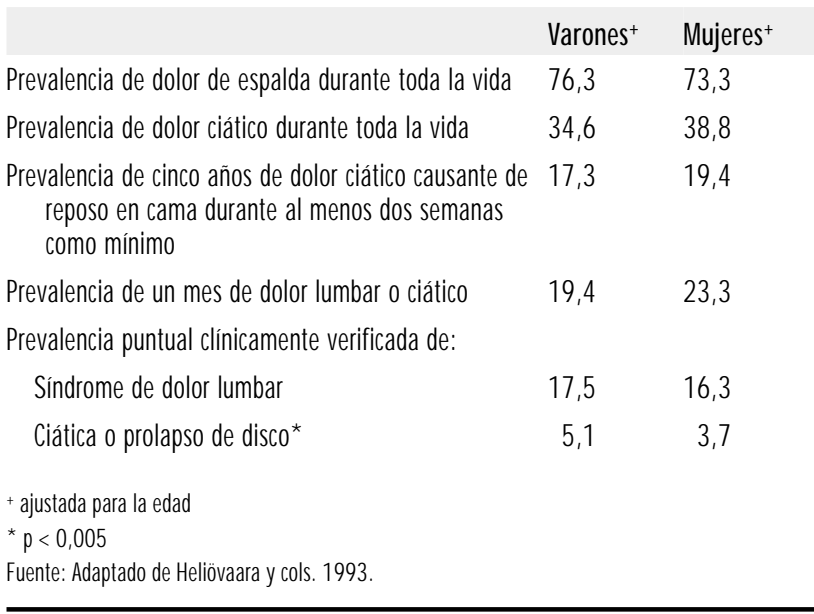


lumbar es relativamente raro antes de los 20 años de edad, pero a partir de entonces se produce un aumento continuo de la prevalencia hasta los 65 años de edad, cuando comienza a descender.

La prevalencia de cambios degenerativos en la columna lumbar aumenta con la edad. Alrededor de la mitad de los varones de 35 a 44 años y nueve de cada diez varones de 650 más años de edad presentan signos radiográficos de degeneración discal en la columna lumbar. Se observa degeneración grave en el 5 y el $38 \%$, respectivamente. L os cambios degenerativos son algo más frecuentes en los varones. Las personas con cambios degenerativos en la columna lumbar presentan dolor lumbar con más frecuencia que las que no los presentan, aunque también entre las personas asintomáticas son frecuentes los cambios degenerativos. En la imagen por resonancia magnética (RM) se ha encontrado degeneración discal en el $6 \%$ de las mujeres asintomáticas de menos de 20 años de edad y en el $79 \%$ de aquellas con edades iguales o superiores a 60 años.

En general, el dolor lumbar es más frecuente en los trabajadores manuales que en los no manuales. En Estados U nidos, las personas que manipulan materiales, los ayudantes de enfermería y los conductores de camiones presentan las mayores tasas de lesiones de espalda objeto de indemnizaciones.

\section{Factores de riesgo en el trabajo}

En los estudios epidemiológicos se ha encontrado de forma bastante constante que el dolor lumbar, la ciática o la hernia de disco intervertebral y los cambios degenerativos de la columna lumbar se asocian al trabajo físico pesado. Se sabe poco, no obstante, sobre los límites aceptables de carga física que puede soportar la espalda.

El dolor lumbar se relaciona con el levantamiento, el transporte, el empuje o la tracción de cargas frecuentes o pesadas Se producen fuerzas de tracción elevadas dirigidas contra los músculos y ligamentos, así como una elevada compresión sobre las superficies óseas y articulares. E stas fuerzas pueden producir lesiones mecánicas de los cuerpos vertebrales, los discos intervertebrales, los ligamentos y las partes posteriores de las vértebras. Las lesiones pueden estar causadas por sobrecargas bruscas 0 por fatiga debida a la carga repetitiva. Los microtraumatismos repetidos, que pueden ocurrir incluso sin que la persona sea consciente de ello, han sido propuestos como causa de la degeneración de la columna lumbar.

El dolor de espalda también se asocia a las torsiones, curvaturas u otras posturas no neutras del tronco adoptadas de forma frecuente 0 prolongada. El movimiento es necesario para la nutrición del disco intervertebral, y las posturas estáticas pueden alterar la nutrición. En otros tejidos blandos puede aparecer fatiga. A simismo, la posición sedente prolongada en una postura (por ejemplo, en las costureras o en los conductores de vehículos a motor) aumenta el riesgo de padecer dolor lumbar.

Se ha observado que la conducción prolongada de vehículos de motor aumenta el riesgo de padecer dolor lumbar y ciática o hernia discal. Los conductores están expuestos a una vibración de todo el cuerpo que posee un efecto adverso sobre la nutrición del disco. También pueden contribuir al riesgo los impulsos súbitos de carreteras bacheadas, la tensión postural y la manipulación de materiales por parte de los conductores profesionales.

Una causa evidente de lesiones en la espalda es el traumatismo directo causado por accidentes como caídas o resbalones. Además de a las lesiones agudas, existen pruebas de que las lesiones traumáticas de la espalda contribuyen de forma sustancial al desarrollo de síndromes lumbares crónicos.

El dolor lumbar se asocia a diversos factores psicosociales laborales, como el trabajo monótono y el realizado con agobio de tiempo, así como el escaso apoyo social por parte de los compañeros y superiores. Los factores psicosociales afectan a la comunicación y a la recuperación del dolor lumbar, pero existe controversia acerca de su papel etiológico.

\section{Factores de riesgo individuales}

E statura y sobrepeso: Las pruebas de una posible relación del dolor lumbar con la estatura y el sobrepeso son contradictorias. No obstante, existen pruebas bastante convincentes de la relación entre la ciática o la hernia de disco y la talla. Las personas altas pueden tener una desventaja nutricional debida al mayor volumen del disco, y quizá presenten también problemas ergonómicos en el lugar de trabajo.

A ptitud física: Los resultados de los estudios sobre la asociación entre aptitud física y dolor lumbar son inconstantes. El dolor lumbar es más frecuente en las personas que poseen menos fuerza que la requerida por su trabajo. En algunos estudios no se ha observado que una mala capacidad aerobia sea predictiva de un futuro dolor lumbar o de indemnizaciones por lesiones. Las personas menos aptas pueden presentar un riesgo global mayor de lesiones de espalda, pero las personas más aptas quizá padezcan las lesiones más costosas. En un estudio se observó que la buena resistencia de los músculos de la espalda prevenía la aparición inicial de dolor lumbar.

Existe una variación considerable en cuanto a la movilidad de la columna lumbar en las distintas personas. Las que tienen dolor lumbar agudo y crónico presentan una movilidad reducida, pero en estudios prospectivos la movilidad no ha resultado un factor de predicción de la incidencia de dolor lumbar.

Tabaquismo: Diversos estudios han demostrado que el consumo de tabaco se asocia a un aumento del riesgo de padecer dolor lumbar y hernia de disco. El tabaquismo también parece favorecer la degeneración discal. En estudios experimentales se ha observado que el consumo de tabaco altera la nutrición del disco.

Factores estructurales: Los defectos congénitos de las vértebras, así como las diferencias de longitud entre las piernas, pueden dar lugar a cargas anormales sobre la columna. Sin embargo, tales factores no se consideran muy importantes como causa de dolor lumbar. La existencia de un canal vertebral estrecho predispone a la compresión de las raíces nerviosas y a padecer ciática.

Factores psicológicos: El dolor lumbar crónico se asocia a factores psicológicos (p. ej., depresión), pero no todas las personas que lo sufren presentan problemas psicológicos. Se han utilizado diversos métodos para diferenciar el dolor lumbar causado por factores psicológicos del ocasionado por factores físicos, pero los resultados han sido contradictorios. Los síntomas de tensión mental son más frecuentes en las personas con dolor lumbar que en las asintomáticas, e incluso parece que la tensión mental pueda ser un factor de predicción de la incidencia de dolor lumbar en el futuro.

\section{Prevención}

El conocimiento acumulado a partir de estudios epidemiológicos sobre los factores de riesgo es en gran medida cualitativo y, por tanto, sólo proporciona directrices amplias para la planificación de programas preventivos. Existen tres métodos principales para la prevención de los trastornos lumbares relacionados con el trabajo: diseño ergonómico del trabajo, educación y formación y selección del trabajador.

\section{Diseño del trabajo}

Es creencia extendida que el medio más eficaz para prevenir los trastornos lumbares relacionados con el trabajo es el diseño de éste. Una intervención ergonómica debería tener en cuenta los siguientes parámetros (mostrados en la Tabla 6.3). 
Tabla 6.3 • Parámetros que deben considerarse para reducir los riesgos de dolor lumbar en el trabajo.

$\begin{array}{ll}\text { Parámetro } & \text { Ejemplo } \\ \text { 1. Carga } & \begin{array}{c}\text { El peso del objeto manipulado, el tamaño del } \\ \text { objeto manipulado }\end{array}\end{array}$

2. Diseño del objeto La forma, situación y tamaño de las asas

3. Técnica de La distancia desde el centro de gravedad del objeto levantamiento y el trabajador, movimientos de giro

4. Distribución del lugar de trabajo

Las características espaciales de la tarea, como la distancia de transporte, la amplitud de movimiento, los obstáculos como escaleras

\section{Diseño de la tarea Frecuencia y duración de las tareas}

6. Psicología

Satisfacción en el trabajo, autonomía y control, expectativas

7. Ambiente

Temperatura, humedad, ruido, tracción con el pie, vibración corporal total

8. Organización del Trabajo en equipo, incentivos, turnos, rotación de tareas, trabajo ritmo de la máquina, seguridad en el trabajo.

Fuente: Adaptado de Halpern 1992.

La mayor parte de las intervenciones ergonómicas modifican las cargas, el diseño de los objetos manipulados, las técnicas de levantamiento, la disposición del lugar de trabajo y el diseño de la tarea. La eficacia de estas medidas para controlar la aparición de dolor lumbar o de los costes médicos no se ha demostrado claramente. Q uizá lo más eficaz sea reducir las cargas máximas. Se ha sugerido un método que consiste en diseñar un trabajo de modo que entre dentro de la capacidad física de un gran porcentaje de la población trabajadora (Waters y cols. 1993). En los trabajos estáticos, puede lograrse la restauración de la movilidad mediante la reestructuración, la rotación o el enriquecimiento del puesto de trabajo.

\section{Educación y formación}

Los trabajadores deben recibir formación para realizar su trabajo adecuadamente y con seguridad. La educación y la formación de los trabajadores en el levantamiento seguro de pesos están muy implantadas, pero los resultados no han sido convincentes. Existe acuerdo general en que es beneficioso mantener la carga próxima al cuerpo y evitar las sacudidas y torsiones, pero en cuanto a las ventajas de realizar el effuerzo con las piernas o con la espalda, las opiniones de los expertos son contradictorias.

$\mathrm{Si}$ se aprecia un desequilibrio entre los las exigencias del trabajo y la fuerza de los trabajadores y no es posible un nuevo diseño del trabajo, debe facilitarse a los trabajadores un programa de preparación física.

En la prevención de la discapacidad debida a dolor o cronicidad lumbar, la educación de la espalda se ha mostrado eficaz en los casos subagudos, y la preparación física general en los casos subcrónicos.

Es preciso extender también la formación al personal directivo en aspectos como la intervención precoz, el tratamiento conservador inicial, el seguimiento del paciente, la asignación de puestos de trabajo y la aplicación de las normas de seguridad.
Los programas activos pueden reducir significativamente las indemnizaciones por discapacidad prolongada y las tasas de accidentes.

El personal médico debe recibir formación acerca de los beneficios de las técnicas de intervención precoz, tratamiento conservador, seguimiento del paciente y asignación al puesto de trabajo. EI informe del grupo de Q uebec (Q uebec Task Force) sobre el control de los trastornos de columna relacionados con la actividad y otras directrices de clínica práctica ofrece una orientación sólida para un tratamiento adecuado. (Spitzer y cols. 1987; A HCPR 1994.)

\section{Selección del trabajador}

En general, la selección de los trabajadores previa al empleo no se considera una medida adecuada de prevención del dolor lumbar relacionado con el trabajo. $\mathrm{Ni}$ los antecedentes de problemas lumbares previos, ni las radiografías de la columna lumbar, ni las pruebas generales de fuerza y de aptitud física han demostrado una sensibilidad ni una especificidad suficientes para identificar a las personas con un mayor riesgo de padecer futuros problemas lumbares. La utilización de estas medidas en la selección previa al empleo puede dar lugar a una discriminación indebida de ciertos grupos de trabajadores. Existen, no obstante, algunos grupos profesionales especiales (p. e.., bomberos y policías) en los que la selección previa al empleo se puede considerar adecuada.

\section{Características clínicas}

A menudo no es posible determinar el origen exacto del dolor lumbar, lo que se refleja en las dificultades para la clasificación de los trastornos lumbares. En gran medida, la clasificación se basa en las características de los síntomas, apoyadas por la exploración física clínica y por los resultados de las técnicas de imagen. Básicamente, en la exploración clínica es posible diagnosticar a los pacientes con ciática causada por compresión y/ o inflamación de una raíz nerviosa espinal. En cuanto a otras muchas entidades clínicas, como el síndrome facetario, la fibrositis, los espasmos musculares, el síndrome compartimental lumbar o el síndrome sacroilíaco, la verificación clínica se ha mostrado poco fiable.

En un intento de resolver la confusión, el grupo de trastornos espinales de Q uebec (Q uebec Task Force on Spinal Disorders) llevó a cabo una revisión completa y crítica de la literatura y terminó recomendando utilizar la clasificación de los pacientes con dolor lumbar que se muestra en la Tabla 6.4.

En el informe se presentan las medidas terapéuticas adecuadas para cada categoría, de acuerdo con la revisión crítica de la bibliografía.

\section{Espondilólisis y espondilolistesis}

Espondilólisis significa defecto en el arco vertebral (pars interarticularis o istmo), mientras que espondilolistesis indica un desplazamiento hacia adelante del cuerpo vertebral con relación a la vértebra situada por debajo. EI trastorno es más frecuente en la quinta vértebra lumbar.

La espondilolistesis puede estar causada por anomalías congénitas, por una fractura por fatiga o aguda, por inestabilidad entre dos vértebras adyacentes debida a degeneración y por enfermedades infecciosas o neoplásicas.

La prevalencia de espondilólisis y espondilolistesis oscila entre el 3 y el $7 \%$, aunque en ciertos grupos étnicos es considerablemente mayor (lapones, $13 \%$; esquimales de Alaska, 25 a $45 \%$; ainus de Japón, $41 \%$ ), lo que indica una predisposición genética. La espondilólisis es igualmente frecuente en las personas con o sin dolor lumbar, aunque las personas con espondilolistesis son propensas a padecer dolor lumbar recurrente. 
Tabla 6.4 - Clasificación de los trastornos lumbares según el grupo de trabajo sobre trastornos espinales de Q uebec (Q uebec Task Force on Spinal Disorders).

1. Dolor
2. Dolor con irradiación a la parte proximal de la extremidad inferior
3. Dolor con irradiación a la parte distal de la extremidad inferior
4. Dolor con irradiación a la extremidad inferior y signos neurológicos
5. Supuesta compresión de la raíz de un nervio espinal en la radiografía simple (es
decir, inestabilidad o fractura vertebral)
6. Compresión de una raíz nerviosa espinal confirmada por:
Técnicas de imagen específicas (tomografía computadorizada, mielografía o
resonancia magnética)
Otras técnicas diagnósticas ( $p$. ej., electromiografía, venografía)
7. Estenosis espinal
8. Situación posquirúrgica, 1-6 semanas después de la intervención
9. Situación posquirúrgica, más de 6 semanas después de la intervención
9.1. Asintomático
9.2. Sintomático
10. Síndrome de dolor crónico
11. Otros diagnósticos
Para las categorías 1-4, la clasificación adicional está basada en
(a) Duración de los sintomas (< 7 días; 7 días-7 semanas; >7 semanas),
(b) Situación laboral (trabajando; ocioso, es decir, ausente del trabajo, desempleo o inactivo).
Fuente: Spitzer y cols. 1987.

Puede aparecer una espondilolistesis traumática aguda debida a un accidente de trabajo. La prevalencia es mayor en los deportistas de ciertas especialidades, como fútbol americano, atletismo, lanzamiento de jabalina, judo y levantamiento de peso, aunque no existen pruebas de que el esfuerzo físico en el trabajo pueda producir espondilólisis o espondilolistesis.

\section{Síndrome del piramidal}

El síndrome del piramidal es una causa rara y controvertida de ciática caracterizada por síntomas y signos de compresión del nervio ciático en la región del músculo piramidal, en el punto donde atraviesa la escotadura ciática mayor. No existen datos epidemiológicos sobre la prevalencia de este síndrome. El conocimiento actual se basa en informes de casos aislados y series de casos. Los síntomas se agravan con la flexión prolongada de la cadera, la aducción y la rotación interna. Recientemente se ha comprobado, mediante tomografía computadorizada y resonancia magnética un aumento de tamaño del músculo piramidal en algunos casos de este síndrome, que puede ser resultado de una lesión del músculo piramidal.

\section{- REgiOn DE LA COLUMNA DORSAL}

\section{JarlE rik Michelsson}

Los síntomas y signos más comunes en la región superior de la espalda y la columna son dolor, hiperestesia, debilidad, rigidez y/ o deformidad de la espalda. El dolor es mucho más frecuente en la región inferior de la espalda (lumbar) y en el cuello que en la porción superior del tronco (dorsal). Además de los síntomas locales, los trastornos dorsales pueden ocasionar dolor que se irradia a la región lumbar y a las extremidades inferiores, al cuello y los hombros, a la caja torácica y al abdomen.

\section{Trastornos dolorosos de los tejidos blandos}

Las causas de dolor en la región dorsal de la columna son multifactoriales y a menudo oscuras. Los síntomas surgen en muchos casos debido a un uso excesivo, a un estiramiento excesivo y/ o habitualmente a roturas leves de los tejidos blandos. Existen también, no obstante, numerosos trastornos específicos que pueden ocasionar dolor de espalda, como la escoliosis intensa (joroba) o la cifosis de diferentes etiologías, el mal de Sheuermann (osteocondritis de la columna dorsal, en ocasiones dolorosa, que aparece en adolescentes pero rara vez en adultos), y otras deformidades que pueden seguir a traumatismos 0 a algunas enfermedades neurológicas y musculares. La infección de la columna (espondilitis) a menudo está limitada a la región dorsal. Existen muchos tipos de microorganismos que pueden causar espondilitis, como el causante de la tuberculosis. Puede aparecer dolor de la columna dorsal en las enfermedades reumáticas, sobre todo en la espondilitis anquilopoyética y en la osteoporosis grave. También otras muchas enfermedades intraespinales, intratorácicas e intraabdominales, como los tumores, pueden ocasionar síntomas en la espalda. En general, es frecuente que el dolor se note en la columna dorsal (dolor referido). Las metástasis esqueléticas del cáncer de otras localizaciones con frecuencia se localizan en la columna dorsal, sobre todo en los cánceres metastáticos de mama, riñón, pulmón y tiroides. La rotura de un disco de la columna dorsal es extremadamente rara, siendo su incidencia del 0,25 al $0,5 \%$ de todas las roturas de discos intervertebrales.

Exploración: Durante la exploración es preciso tener en cuenta numerosos trastornos intra y extraespinales causantes de síntomas en la columna dorsal. Cuanto mayor es el paciente, más frecuentes son los síntomas dorsales procedentes de tumores primarios o de metástasis. Por tanto, es muy importante realizar una entrevista exhaustiva y una exploración cuidadosa, cuyo objetivo será aclarar la etiología de la enfermedad. La exploración clínica comprenderá métodos ordinarios, como inspección, palpación, comprobación de la fuerza muscular, de la movilidad articular, del estado neurológico, etc. En los casos de síntomas y signos prolongados e intensos, y cuando las radiografías simples hagan sospechar una enfermedad específica, otras pruebas radiológicas como la $\mathrm{RM}$, la $\mathrm{TC}$, las imágenes obtenidas con radioisótopos y la ENM G pueden contribuir a aclarar el diagnóstico etiológico y a localizar el proceso patológico. En la actualidad, la R M suele ser el método radiológico de elección en los casos de dolor dorsal.

\section{Trastornos degenerativos de la columna dorsal}

Todos los adultos sufren cambios degenerativos de la columna que progresan con la edad, aunque la mayoría no presentan síntomas debidos a tales cambios, que a menudo se encuentran durante la investigación de otras enfermedades y suelen carecer de importancia clínica. En raras ocasiones, los cambios degenerativos en la región dorsal dan lugar a síntomas locales e irradiados, como dolor, hipersensibilidad, rigidez y signos neurológicos.

El estrechamiento del canal vertebral, o estenosis espinal, puede ocasionar una compresión de tejidos vasculares y neurológicos que causa dolor local y/ o irradiado y déficit neurológico. El prolapso de un disco dorsal casi nunca provoca síntomas. En muchos casos, la detección radiológica de un prolapso de disco es un hallazgo casual que no provoca síntomas.

Los principales signos de los trastornos degenerativos de la columna torácica son la hipersensibilidad, el espasmo o debilidad musculares y la disminución local de la movilidad de 
la columna. En algunos casos puede haber trastornos neurológicos- paresias musculares, déficit de reflejos y de la sensibilidad locales y/ o distales a los tejidos afectados.

El pronóstico en el prolapso del disco dorsal suele ser bueno. Los síntomas remiten en unas semanas, al igual que en las regiones lumbar y cervical.

Exploración. Resulta fundamental una exploración adecuada, sobre todo en las personas de edad avanzada, en caso de dolor intenso y prolongado y de paresias. Además de una historia clínica detallada se deberá realizar una exploración clínica adecuada con inspección, palpación, comprobación de la movilidad, de la fuerza muscular y del estado neurológico. Entre las exploraciones radiológicas, la radiografía simple, la TC y, especialmente, la $\mathrm{R} M$ resultan útiles para evaluar el diagnóstico etiológico y la localización de los cambios patológicos en la columna. La ENMG y la imagen con radioisótopos pueden contribuir al diagnóstico. En el diagnóstico diferencial pueden resultar útiles las pruebas de laboratorio. En el prolapso de disco puro y en los cambios degenerativos no se observan anomalías específicas en las pruebas de laboratorio.

\section{- Cuello}

\section{Åsa Kilbom}

El dolor y las molestias en el cuello son algunos de los síntomas más comunes asociados al trabajo. A parecen tanto en el trabajo manual duro como en el trabajo sedentario, y los síntomas a menudo persisten durante períodos prolongados; de hecho, en al gunos casos durante toda la vida. De ello se deduce que los trastornos del cuello son difíciles de curar una vez que han aparecido, por lo que se debe prestar la máxima atención a la prevención primaria. Tres son las principales razones por las que los trastornos del cuello son frecuentes en la vida laboral:

1. La carga sobre las estructuras del cuello se mantiene durante períodos prolongados debido a las elevadas demandas visuales del trabajo y a la necesidad de estabilización de la región del cuello-hombros cuando se trabaja con los brazos.

2. Los trabajos psicológicamente exigentes, con grandes demandas en cuanto a concentración y a calidad y cantidad de trabajo son frecuentes, y producen una mayor actividad de los músculos del cuello. Esta tensión aumenta más si el trabajo es en general psicológicamente estresante, debido por ejemplo a malas relaciones laborales, a la escasa influencia sobre la organización del trabajo y a motivos similares.

3. Los discos y las articulaciones del cuello son a menudo asiento de cambios degenerativos, cuya prevalencia aumenta con la edad. Ello reduce la capacidad de soportar las sobrecargas de trabajo. También es probable que la velocidad de degeneración aumente como consecuencia de las demandas físicas del trabajo.

\section{Anatomía y biomecánica del cuello}

La parte musculosquelética del cuello está formada por siete cuerpos vertebrales, seis discos intervertebrales (formados por cartílago), ligamentos que los mantienen unidos y los conectan al cráneo y a la columna dorsal, y músculosque rodean a la columna. Aunque cada articulación de la columna cervical posee una amplitud de movimiento muy limitada, el cuello se puede doblar, extender, girar y bascular con una amplitud de movimiento relativamente grande (véase la Tabla 6.5). En posición erecta normal y con la mirada dirigida hacia adelante, el centro de gravedad de cabeza y cuello está realmente situado por delante del centro de
Tabla 6.5 - Amplitud de movimiento normal ${ }^{1}$ y permisible ${ }^{2}$ para conducción prolongada, en grados, de la cabeza.

$\begin{array}{lcl} & \text { Normal } & \text { Permisible para conducción prolongada } \\ \text { Flexión lateral } & 45 & - \\ \text { Giro } & 60 & 0-15 \\ \text { Flexión } & 45 & 0-25 \\ \text { Extensión } & -45 & 0-5\end{array}$

1American Academy of Orthopaedic surgeons 1988.

2Hansson 1987.

apoyo, por lo que necesita ser equilibrado por los músculos dorsales, es decir, por los situados detrás de los cuerpos vertebrales. C uando se inclina la cabeza hacia adelante se necesita más fuerza muscular para equilibrar la cabeza, y cuando esta inclinación hacia adelante se mantiene durante períodos prolongados puede aparecer una fatiga muscular notable. Además de la fatiga muscular, la inclinación y la basculación de la cabeza dan lugar a una mayor compresión de los discos intervertebrales, lo que puede acelerar los procesos degenerativos.

Los músculos que rodean el cuello actúan también en el trabajo de los brazos, a fin de estabilizar el complejo hombro/ brazo. El trapecio y otros varios músculos se originan en la columna cervical y se extienden hacia abajo y hacia afuera para insertarse en el hombro. Estos músculos suelen ser asiento de disfunciones y de trastornos, sobre todo en las tareas estáticas 0 repetitivas con los brazos elevados y la visión fija.

Las estructuras que estabilizan el cuello son muy robustas, lo que sirve para proteger el tejido nervioso situado dentro del canal vertebral y los nervios que salen de los agujeros intervertebrales para inervar el cuello, la extremidad superior y la parte superior del tórax. Los discos intervertebrales, las partes adyacentes de los cuerpos vertebrales y las facetas articulares de los agujeros intervertebrales son a menudo asiento de cambios degenerativos, que pueden ejercer presión sobre los nervios y estrechar su espacio. (V éase la Figura 6.13.)

Como se ha mencionado en la introducción, los síntomas como dolor, molestias e incomodidad en el cuello son muy frecuentes. Dependiendo de los criterios utilizados y del método de investigación, las tasas de prevalencia de los trastornos del cuello varían. Si se utiliza una encuesta por correo o una entrevista centrada en los trastornos musculosqueléticos, la prevalencia de los trastornos suele ser mayor que cuando se realiza una investigación completa que comprenda también una exploración física. Por tanto, las comparaciones entre grupos sólo deben hacerse cuando se haya utilizado la misma técnica de investigación. En la Figura 6.14 se presentan las cifras de prevalencia anual para una muestra representativa de la población de Islandia que respondió a una encuesta por correo, el denominado cuestionario "Nórdico" sobre trastornos musculosqueléticos (K uorinka y cols. 1987). Los problemas del cuello (dolor, molestias 0 incomodidad) ocuparon el tercer puesto en frecuencia (un promedio del $38 \%$ de toda la muestra), después de los problemas de hombro (43\%) y lumbares $(56 \%)$. Los problemas cervicales fueron más frecuentes en el sexo femenino, con un aumento de la prevalencia hasta los 25-30 años de edad, en que las tasas se estabilizaban, para descender algo a los 50-55 años. En una muestra representativa de 200 varones y mujeres de Estocolmo de edades comprendidas entre 16 y 65 años, la prevalencia a los 12 meses era de alrededor del $30 \%$ en los 
Figura 6.13 - Dibujo esquemático de un corte transversal de tres de los cuerpos vertebrales cervicales inferiores (1) con discos intervertebrales (2), agujeros intervertebrales (3) y raíces nerviosas; (4) vista lateral.

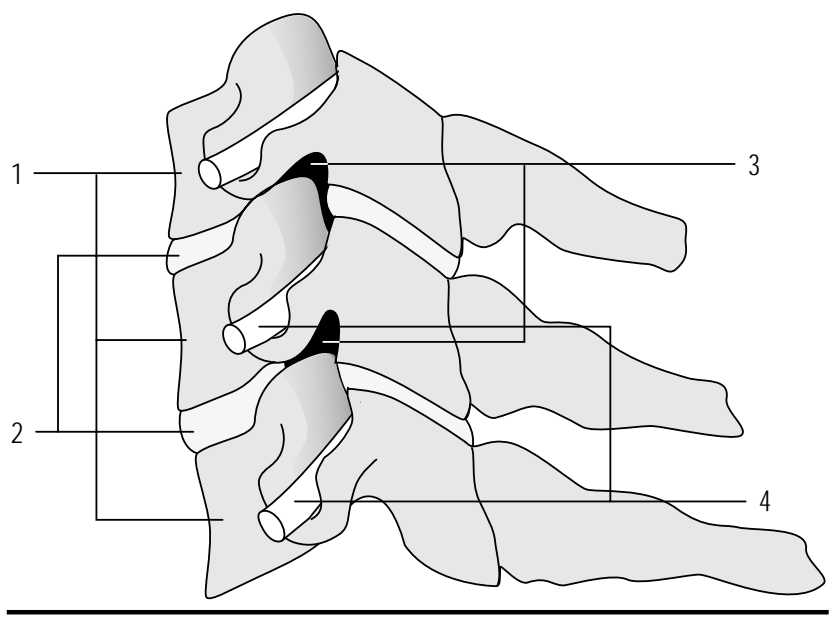

varones y del $60 \%$ en las mujeres. Se encontró experiencia de dolor reciente en el cuello de un mes como mínimo de duración en el $22 \%$ de una muestra de población de Gotemburgo, Suecia, donde también fue la tercera más común después del dolor de hombro y lumbar.

\section{Factores de riesgo en el trabajo}

Los trastornos cervicales tienen una prevalencia considerablemente mayor en ciertos grupos profesionales. U tilizando el cuestionario nórdico (K uorinka y cols. 1987), los servicios suecos de salud en el trabajo han recopilado datos de varias profesiones. Los resultados indican que el riesgo de problemas cervicales (dolor, molestias o incomodidad) es muy alto en los trabajadores con monitores de representación visual y de máquinas de coser, costureras y trabajadores en montajes electrónicos, con una prevalencia en 12 meses superior al $60 \%$. Además, más de una tercera parte de las personas que manifiestan trastornos afirman

Figura 6.14 - Prevalencia en doce meses de síntomas de problemas del cuello en una muestra aleatoria de la población islandesa $(n=1000)$.

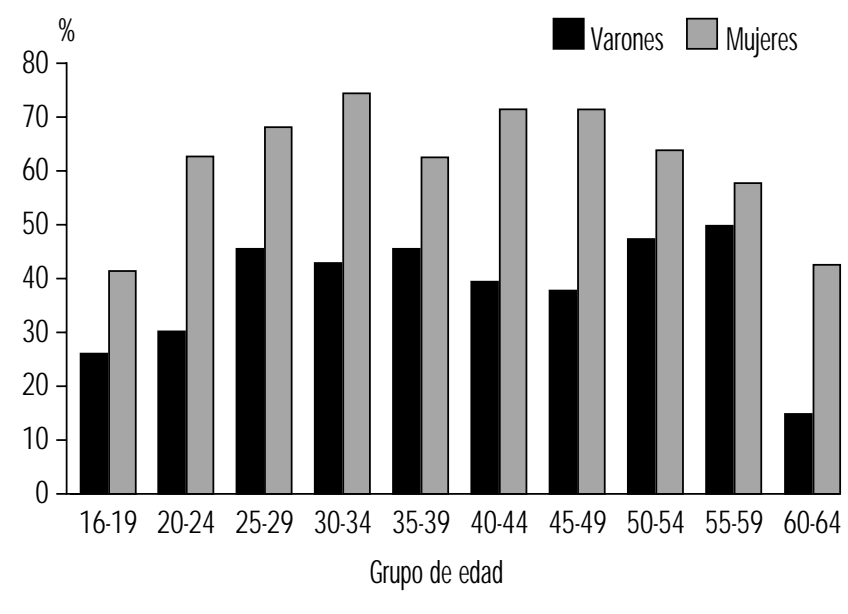

también que los problemas repercuten en su vida laboral, ya sea provocando bajas laborales o haciendo necesario un cambio de trabajo o de las tareas a realizar en el mismo.

Se han revisado los estudios epidemiológicos sobre los trastornos de cuello y hombros, y se han agrupado los diferentes estudios según el tipo de exposición (trabajo repetitivo y trabajo por encima de la altura de los hombros, respectivamente). Los trastornos de los tejidos blandos del cuello, como tensión cervical y otras mialgias, estaban considerablemente aumentados en varias tareas profesionales como introducción de datos, mecanografía, fabricación de tijeras, montaje de lámparas y enrollado de películas.

L os trastornos degenerativos de los discos intervertebrales del cuello son más frecuentes en los mineros del carbón, dentistas y trabajadores de la industria cárnica (H agberg y Wegman 1987).

\section{Postura}

La flexión, extensión, curvatura lateral y torsión prolongadas del cuello producen fatiga muscular y pueden dar lugar a lesiones musculares crónicas y cambios degenerativos de la columna cervical. La actividad muscular necesaria para contrarrestar el peso de la cabeza en la flexión hacia adelante del cuello aumentan con el ángulo de flexión, como se muestra en la Figura 6.15. La fatiga y el dolor son frecuentes en la flexión del cuello cuando se realiza un trabajo prolongado. Cuando se bascula la cabeza hacia adelante hasta el límite de su amplitud de movimiento, la carga principal se transfiere desde los músculos hasta los ligamentos y las cápsulas articulares que rodean a la columna cervical. Se ha calculado que si se flexiona al máximo toda la columna cervical, el par de torsión ejercido por la cabeza y el cuello sobre el disco situado entre el séptimo cuerpo vertebral cervical y el primero

Figura 6.15 • Porcentaje de la fuerza de extensión máxima del cuello necesario al aumentar la inclinación (flexión) del cuello.

\section{$\%$ de la fuerza de extensión} máxima del cuello en una mujer promedio

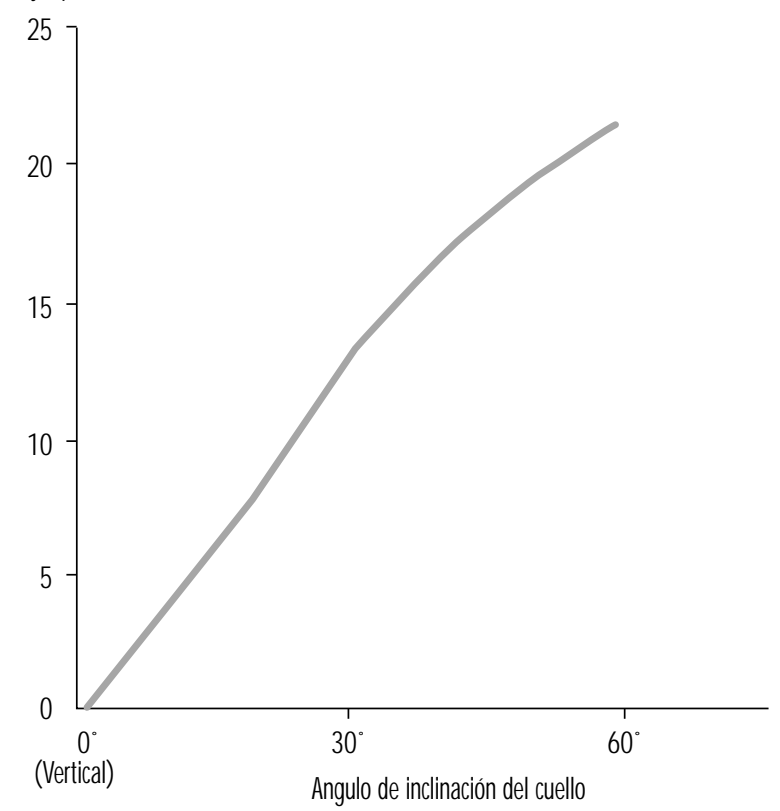

Adaptado de Chaffin y Anderson 1991 
dorsal se multiplica por un factor de 3,6. Tales posturas ocasionan dolor transcurridos sólo unos 15 minutos, y por lo general es preciso normalizar la postura en 15 a 60 minutos debido al intenso dolor. Posturas en las que se mantiene el cuello curvado hacia adelante durante períodos prolongados varias horas son frecuentes en los trabajos de montaje de la industria, en el trabajo con monitores y en las tareas de empaquetado e inspección cuando los lugares de trabajo están mal diseñados. Tales posturas a menudo están causadas por un compromiso entre la necesidad de realizar el trabajo con las manos, sin elevar los brazos, y la necesidad simultánea de control visual. Para una revisión de los mecanismos que llevan desde la fatiga muscular hasta la lesión, véase el artículo sobre "M úsculos".

La extensión del cuello durante períodos prolongados, como es el trabajo realizado sobre la cabeza en la construcción, puede ser muy agotadora para los músculos situados delante de la columna cervical. Sobre todo cuando se llevan equipos protectores pesados, como los cascos de seguridad, el nivel de torsión que inclina la cabeza hacia atrás puede ser alto.

\section{M ovimientos repetitivos}

Los movimientos repetitivos de las manos aumentan las demandas para la estabilización de la región del cuello y hombros, aumentando así el riesgo de problemas cervicales. Factores como las altas demandas de velocidad y precisión de movimientos, así como las grandes demandas de fuerza ejercida por las manos, implican demandas aún mayores de estabilización de las regiones proximales del cuerpo. Los movimientos repetitivos de la cabeza son menos frecuentes. Los cambios rápidos y repetidos de objetivo visual suelen realizarse mediante movimientos oculares, a menos que la distancia entre los objetos observados sea bastante grande. Esto puede ocurrir, por ejemplo, en los grandes puestos de trabajo informáticos.

\section{Vibración}

La vibración local de las manos, como ocurre al trabajar con taladros y otras máquinas vibratorias sujetadas con las manos, se transmite a lo largo del brazo, pero la fracción transferida hasta la región del cuello-hombros es mínima. Sin embargo, el hecho de sostener una herramienta vibratoria puede producir contracciones musculares en los músculos proximales del cuello-hombros para estabilizar la mano y la herramienta, lo que puede ejercer un efecto fatigoso sobre el cuello. Los mecanismos y la prevalencia de tales trastornos producidos por la vibración no son bien conocidos.

\section{Organización del trabajo}

La organización del trabajo en este contexto se define como la distribución de las tareas en el tiempo y entre los trabajadores, la duración de las mismas y la duración y distribución de los períodos de descanso y las pausas. La duración de los períodos de trabajo y de descanso tiene un profundo efecto sobre la fatiga y la recuperación tisular. Se han realizado pocos estudios específicos acerca del efecto de la organización del trabajo sobre los trastornos del cuello. En un gran estudio epidemiológico realizado en Suecia, se observó que el trabajo con monitores durante más de cuatro horas al día, se asociaba a unos altos índices de síntomas cervicales (Aronsson, Bergkvist y Almers 1992). Estos hallazgos han sido confirmados posteriormente en otros estudios.

\section{Factores psicológicos y sociales}

La asociación entre los factores psicológicos y sociales en el trabajo y los trastornos de la región del cuello se han demostrado en varios estudios. Se han destacado especialmente factores como el estrés psicológico percibido, el mal control de la organización del trabajo, las malas relaciones con los superiores y los compañeros y de trabajo y las altas demandas de exactitud y rapidez en el trabajo. Estos factores se han asociado a un aumento del riesgo (hasta el doble) de trastornos en estudios transversales. EI mecanismo probablemente sea un aumento de la tensión en el trapecio y otros músculos que rodean el cuello, como parte de una reacción general de "estrés". Dado que los estudios longitudinales bien controlados son escasos, todavía no está claro si estos factores son causales o agravantes. Además, a menudo se dan malas condiciones psicológicas y sociales en trabajos también caracterizados por posturas incómodas prolongadas.

\section{Factores individuales}

Características individuales como la edad, sexo, fuerza y resistencia muscular, la capacidad física para el trabajo, tamaño corporal, personalidad, inteligencia, hábitos en el tiempo libre (actividad física, consumo de tabaco, alcohol, dieta) y trastornos musculosqueléticos anteriores han sido tenidos en cuenta, como factores que podrían modificar la respuesta a las exposiciones físicas y psicosociales. La edad como factor de riesgo se ha comentado antes y aparece en la Figura 6.14.

Las mujeres suelen presentar una mayor prevalencia de síntomas en el cuello que los varones. La explicación más probable es que la exposición a los factores de riesgo físicos y psicosociales es mayor en el sexo femenino, como ocurre en los trabajos con monitores, el montaje de pequeños componentes y la costura a máquina.

Los estudios de grupos musculares distintos a los del cuello no indican de modo consistente que una fuerza estática baja implique un riesgo elevado de aparición de trastornos. No existen datos relativos a los músculos del cuello. En un estudio reciente en una población aleatoria de Estocolmo, la baja resistencia a la extensión del cuello mostraba una asociación débil con el desarrollo posterior de trastornos del cuello (Schüldt y cols. 1993). Se han comunicado resultados similares para los trastornos lumbares.

En un estudio longitudinal realizado en Suecia se observó que el tipo de personalidad era un factor de riesgo para el desarrollo de trastornos del cuello-hombros (Hägg, Suurküla y K ilbom 1990). Los trabajadores con una personalidad de tipo A (es decir, ambiciosos e impacientes) presentaban problemas más serios que los otros, y estas asociaciones no estaban relacionadas con la productividad individual.

Se sabe poco acerca de la asociación entre otras características individuales y los trastornos del cuello.

\section{Prevención}

\section{Diseño del puesto de trabajo}

El puesto de trabajo se debe organizar de modo que la cabeza no esté estáticamente curvada, extendida o girada más allá de los límites dados para la amplitud de movimiento permisible que se presentan para la conducción prolongada en la Tabla 6.5. De vez en cuando, son aceptables los movimientos que estén dentro de los límites de la amplitud del movimiento normal, así como el movimiento ocasional hasta los extremos individuales. Estudios experimentales han demostrado que la carga de los músculos del cuello es menor cuando el tronco está ligeramente basculado hacia atrás que con una postura totalmente recta, que a su vez es mejor que el tronco basculado hacia adelante (Schüldt 1988).

La disposición del puesto de trabajo y la colocación del objeto de trabajo requieren un estudio cuidadoso y un acuerdo entre las demandas de una postura óptima de la cabeza y de los hombros-brazos. Por lo general, el objeto se sitúa algo por debajo de la altura del codo, lo que no obstante puede producir una fuerte tensión sobre los músculos del cuello ( $p$. ej., en el 
trabajo de montaje). Esto requiere puestos de trabajo ajustables individualmente.

El esfuerzo visual aumentará la tensión de los músculos del cuello, por lo que se deberá prestar atención a la iluminación y a los contrastes del puesto de trabajo y a la legibilidad de la información dada en los monitores y en el material impreso. Para el trabajo en monitores de representación visual, la distancia de visión debe ser optimizada a unos $45-50 \mathrm{~cm}$, y el ángulo de visión debe ser de 10 a 20 grados. La visión del trabajador se optimizará con ayuda de gafas.

\section{Organización del trabajo}

En el trabajo con cargas estáticas sobre el cuello, como ocurre en el montaje y en los monitores para introducción de datos, deben hacerse pausas frecuentes para permitir la recuperación de la fatiga. En algunos lugares se han establecido recomendaciones de hacer una pausa de unos 10 minutos por hora y de limitar el trabajo en monitores a un máximo de cuatro horas al día. Como se ha señalado antes, la base científica de estas recomendaciones en lo que respecta al cuello es relativamente débil.

\section{Características clínicas y tratamiento de los trastornos del cuello}

\section{Trastor nos dolorosos de los tejidos blandos}

\section{Tensión cervical y otras mialgias}

La localización más frecuente de la tensión cervical y otras mialgias es la parte superior del músculo trapecio, aunque a menudo se afectan simultáneamente otros músculos originados en el cuello. Los síntomas son rigidez del cuello y molestias en el trabajo y en reposo. Con frecuencia se percibe una fatiga muscular excesiva, incluso durante períodos de trabajo de corta duración y bajo nivel. Los músculos están hipersensibles, y a menudo se encuentran "puntos dolorosos" a la palpación. La tensión cervical es habitual en los trabajos con cargas estáticas prolongadas sobre el cuello y los hombros. El examen microscópico del tejido ha demostrado cambios en la morfología del músculo, pero los mecanismos no se conocen por completo y probablemente impliquen tanto a la circulación sanguínea como a la regulación nerviosa.

\section{Tortícolis aguda}

Este estado de dolor agudo y rigidez del cuello puede ser provocado por un giro brusco de la cabeza con extensión del brazo opuesto. En ocasiones no es posible identificar un acontecimiento desencadenante. Se cree que la tortícolis aguda está causada por distensión y roturas parciales de los ligamentos del cuello. Por lo general, el dolor y la rigidez remiten después de una semana de reposo, soporte externo del cuello (collarín) y administración de relajantes musculares.

\section{Trastor nos degenerativos}

\section{Trastorno agudo (hernia de disco)}

La degeneración de la columna cervical afecta a los discos, que pierden parte de su resistencia incluso a tensiones débiles. $L a$ herniación del disco con extrusión de su contenido, o la protrusión del mismo, puede comprometer al tejido nervioso y a los vasos sanguíneos laterales y posteriores al disco. Un trastorno degenerativo agudo del disco es la compresión de las raíces nerviosas que se extienden desde la médula espinal e inervan el cuello, los brazos y la porción superior del tórax. D ependiendo de la altura de la compresión (disco entre la segunda y la tercera vértebras cervicales, entre la tercera y la cuarta, etc.), aparecen síntomas sensitivos y motores agudos de las regiones inervadas por los nervios. La investigación de los síntomas agudos de cuello y brazos incluye una exploración neurológica completa para identificar la altura del posible prolapso del disco y una exploración radiológica simple, por lo general complementada con TC y RM.

\section{Trastornos crónicos (espondilosis cervical y síndrome cervical)}

La degeneración de la columna cervical implica el estrechamiento del disco, la formación de hueso nuevo (los denominados osteofitos) a partir de los bordes de las vértebras cervicales y el engrosamiento de los ligamentos como en un trastorno agudo. Cuando los osteofitos se extienden a los agujeros intervertebrales, pueden comprimir las raíces nerviosas. E spondilosis es el término utilizado para describir los cambios radiológicos en el cuello, cambios que en ocasiones se asocian a síntomas locales crónicos. Los cambios radiológicos pueden ser avanzados, sin síntomas graves, y a la inversa. Los síntomas suelen consistir en molestias y dolor en el cuello, que en ocasiones se extienden a la cabeza y a la región de los hombros, y movilidad reducida. Cuando están comprimidas las raíces nerviosas se utiliza el diagnóstico de síndrome cervical. Sus síntomas son molestias y dolor en el cuello, disminución de la movilidad del cuello y síntomas sensitivos y motores en el lado de la raíz nerviosa comprimida. Síntomas como la reducción de la sensibilidad táctil, hormigueo, entumecimiento y disminución de la fuerza son frecuentes en la mano y el brazo. Por tanto, los síntomas son similares a los que aparecen en caso de prolapso agudo del disco, aunque el comienzo suele ser más gradual y la intensidad puede fluctuar dependiendo de la carga de trabajo externa. Tanto la espondilosis cervical como el síndrome cervical son frecuentes en la población general, sobre todo en las personas de edad avanzada. El riesgo de espondilosis cervical es elevado en grupos profesionales que soportan una carga biomecánica alta en las estructuras del cuello, como los mineros del carbón, los dentistas y los trabajadores de las industrias cárnicas.

\section{Trastornos traumáticos (lesiones por latigazo)}

En los accidentes de automóvil por alcance, la cabeza (si no dispone de un apoyo posterior) es basculada hacia atrás a gran velocidad y con gran fuerza. En los accidentes menos graves sólo se producen roturas musculares parciales, mientras que los accidentes graves pueden lesionar seriamente los músculos y ligamentos situados por delante de la columna cervical y dañar asimismo las raíces nerviosas. Los casos más graves se producen cuando se luxan las vértebras cervicales. Las lesiones por latigazo precisan una exploración y un tratamiento cuidadosos, ya que si la lesión no se atiende adecuadamente pueden persistir síntomas duraderos, como cefaleas.

\section{HOMBRO}

\section{Mats $\mathrm{H}$ agberg}

Los trastornos de la región del hombro son problemas frecuentes tanto en la población general como en la laboral. H asta un tercio de las mujeres y una cuarta parte de los varones se quejan de sensación de dolor en cuello y hombros a diario o cada dos días. Se calcula que la prevalencia de tendinitis de hombro en la población general es de alrededor del $2 \%$. En los trabajadores de ambos sexos de Estados U nidos, la prevalencia de tendinitis del hombro se ha calculado hasta en un $8 \%$ en los expuestos a movimientos muy repetitivos o de gran fuerza con las manos, en comparación con el $1 \%$ aproximadamente en los no sometidos a este tipo de estrés musculosquelético. 
Figura 6.16 - Visión esquemática de las partes esqueléticas de la cintura escapular (hombro).

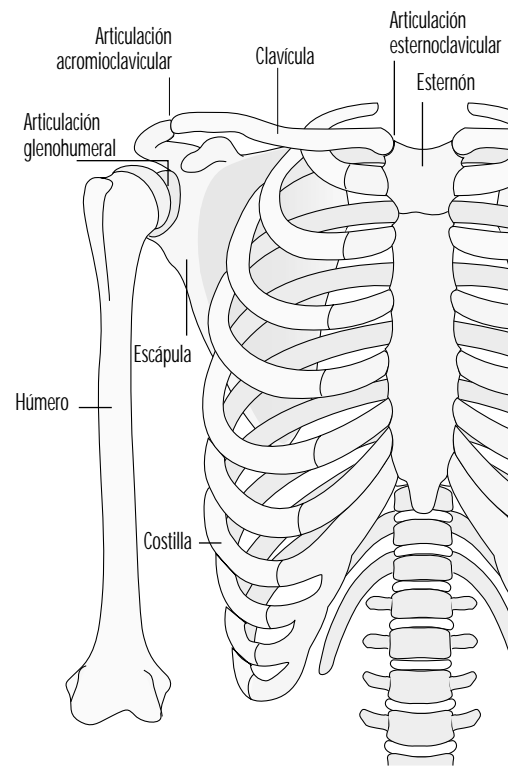

\section{Anatomía}

Los huesos que forman el hombro son la clavícula, la escápula (omóplato) y la articulación glenohumeral, como se muestra en la Figura 6.16. La clavícula está conectada al cuerpo mediante la articulación esternoclavicular, y a la escápula mediante la articulación acromioclavicular. La articulación esternoclavicular es la única conexión entre la extremidad superior y el resto del cuerpo. La escápula carece de conexión directa propia, por lo que, el hombro depende de los músculos para su fijación al tronco. La parte superior del brazo está conectada a la escápula por la articulación glenohumeral.

La función del hombro es proporcionar una plataforma para la extremidad superior y para algunos de sus músculos. A unque la articulación glenohumeral posee una amplitud de movimiento mayor que, por ejemplo, la extremidad inferior en la cadera, esta flexibilidad se ha desarrollado a expensas de la estabilidad. M ientras que la articulación de la cadera posee ligamentos muy fuertes, los de la articulación glenohumeral son escasos y débiles. Para compensar esta debilidad relativa, la articulación glenohumeral está rodeada por músculos del hombro que forman un manguito, el denominado manguito de los rotadores.

\section{Biomecánica}

El brazo representa alrededor del $5 \%$ del peso corporal total, y su centro de gravedad está aproximadamente a medio camino entre la articulación glenohumeral y la muñeca. Cuando el brazo se eleva y se dobla, ya sea para alejarlo o acercarlo al cuerpo (abducción o flexión), se crea una palanca en la que aumenta la distancia desde el centro de gravedad y, por tanto, la fuerza de torsión y la torsión de carga sobre la articulación glenohumeral. El índice en el cual la torsión, aumenta sin embargo, no es simplemente directamente proporcional al ángulo al que se dobla el brazo, ya que la función matemática que describe las fuerzas mecánicas no es lineal, sino es una función sinusoidal del ángulo de abducción. La torsión sólo disminuye en un $10 \%$ aproximadamente cuando el ángulo de flexión o de abducción disminuye de 90 a 60 grados. Sin embargo, si el ángulo disminuye de 60 a 30 grados, la torsión se reduce hasta en un $50 \%$.

La fuerza de flexión en la articulación glenohumeral es de alrededor de 40 a $50 \mathrm{Nm}$ en las mujeres y de 80 a $100 \mathrm{Nm}$ en los varones. Cuando se mantiene el brazo en flexión de 90 grados hacia adelante y no se coloca sobre él ninguna carga externa, es decir, la persona no sostiene ningún peso ni usa el brazo para ejercer una fuerza, la carga estática es todavía de alrededor del 15 al $20 \%$ de la capacidad voluntaria máxima (CVM) en las mujeres y de alrededor del 10 al $15 \%$ de la CVM en los varones. Si se sujeta una herramienta de $1 \mathrm{~kg}$ de peso en la mano con el brazo extendido, la carga correspondiente en el hombro será de alrededor del $80 \%$ de la CVM en las mujeres, como aparece en la Figura 6.17.

Los músculos más importantes para la abducción - 0 elevación del brazo separándolo lateralmente del cuerpo- son el músculo deltoides, los músculos del manguito de los rotadores y la cabeza larga del bíceps. Los músculos más importantes para la flexión hacia adelante - elevación del brazo separándolo del cuerpo hacia adelante- son la parte anterior del músculo deltoides, los músculos del manguito de los rotadores, el músculo coracobraquial y la cabeza corta del músculo bíceps braquial. La rotación interna se realiza mediante el músculo pectoral mayor, el músculo subescapular, la parte arterior del músculo deltoides y el músculo dorsal ancho. La rotación externa se realiza mediante la parte posterior del músculo deltoides, el músculo infraespinoso y los músculos redondo menor y mayor.

Los músculos del manguito de los rotadores intervienen en todos los movimientos de la articulación glenohumeral o, lo que es lo mismo, en todos los movimientos del brazo. Tienen su origen en la escápula, y sus tendones están dispuestos alrededor del húmero formando un manguito, de ahí su nombre. L os cuatro músculos del manguito de los rotadores son el supraespinoso, el infraespinoso, el redondo menor y el subescapular. Estos músculos actúan como ligamentos de la articulación

Figura 6.17 - Fuerza en la mujer y el varón; se muestran los resultados de sostener una herramienta de 1 kilogramo en la mano manteniendo el brazo recto a diferentes ángulos de flexión del hombro.

Porcentaje de la

capacidad máxim

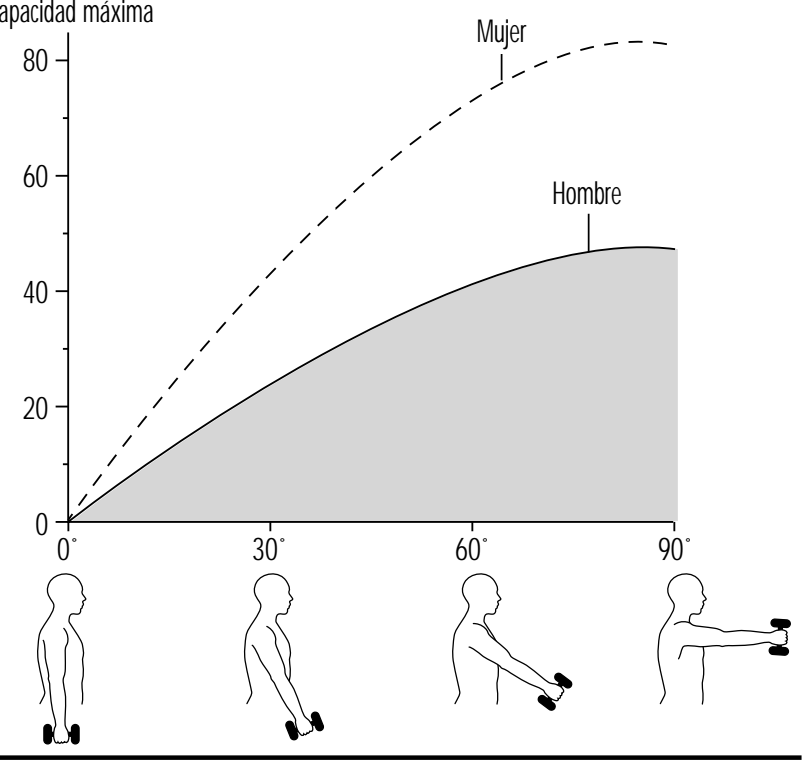


glenohumeral y también mantienen a la cabeza humeral contra la escápula. U na rotura del manguito de los rotadores (p. ej., del tendón del supraespinoso) producirá una reducción de la fuerza de abducción, que afectará sobre todo a las posiciones en las que el brazo está doblado y separado del cuerpo. Cuando se pierde la función de los músculos deltoides, la fuerza de abducción puede reducirse hasta en un $50 \%$, con independencia del ángulo en que esté doblado el brazo.

En todo momento en que exista flexión hacia adelante 0 abducción del brazo se producirá una carga sobre el sistema. $\mathrm{N}$ umerosos movimientos producen también una fuerza o carga de torsión. Dado que el brazo está conectado a la escápula por la articulación glenohumeral, cualquier carga aplicada sobre esta articulación se transmitirá a la escápula. La carga en la articulación glenohumeral, medida en \% de la CVM, es casi directamente proporcional a la carga aplicada sobre el músculo que fija la escápula en posición, la parte superior del trapecio.

\section{Principales enfermedades específicas relacionadas con el trabajo}

\section{Trastornos del manguito de los rotadores y tendinitis del bíceps}

Las tendinitis y tenosinovitis son inflamaciones de un tendón y de la membrana sinovial de una vaina tendinosa. Los tendones de los músculos del manguito de los rotadores (supraespinoso, infraespinoso, subescapular y redondo menor), junto con la cabeza larga del bíceps braquial, son localizaciones habituales de inflamación en el hombro. En estas localizaciones están implicados grandes movimientos de los tendones. D urante la elevación, dado que los tendones pasan a la articulación del hombro y bajo la estructura ósea (el arco coracoacromial), pueden resultar comprimidos, con la consiguiente inflamación. Estos trastornos reciben en ocasiones el nombre de síndromes de impactación. La inflamación de un tendón puede ser parte de una enfermedad inflamatoria generalizada, como ocurre en la artritis reumatoide, pero también estar causada por inflamación local a consecuencia de irritación y fricción mecánicas.

\section{0 steoartritis de las articulaciones del hombro y acromioclavicular}

L as osteoartritis (OA) de la articulación del hombro y de la articulación acromioclavicular son cambios degenerativos del cartílago y del hueso en las articulaciones y los discos intervertebrales.

\section{Epidemiología}

Existe una alta prevalencia de tendinitis del hombro entre los soldadores y los laminadores de acero, con tasas del 18 y del $16 \%$, respectivamente. En un estudio comparativo entre soldadores y laminadores de acero, por un lado, y oficinistas varones por otro, los primeros tenían de 11 a 13 veces más posibilidades de padecer el trastorno, según los índices obtenidos. Se encontró una relación similar, de 11, en un estudio de casos-controles sobre trabajadores varones de la industria que trabajaban con las manos elevadas aproximadamente a la altura del hombro. Los montadores de automóviles que padecían dolor agudo y tendinitis del hombro se veían obligados a elevar los brazos más a menudo y durante más tiempo que los no sometidos a tales exigencias laborales.

Estudios realizados en trabajadores industriales en Estados U nidos han demostrado una prevalencia del 7,8\% de tendinitis del hombro y enfermedad articular degenerativa (hombro) a causa de trastornos traumáticos acumulados (TTA) en los trabajadores cuyas tareas implicaban el empleo de fuerza, movimientos repetitivos o ambos, sobre la muñeca y las manos. En un estudio, estudiantes del sexo femenino que realizaban movimientos repetitivos del hombro desarrollaron una tendinitis reversible con un ritmo de flexión durante una hora de 15 flexiones hacia adelante por minuto y un ángulo de flexión entre 0 y 90 grados. Entabladores, plegadores y costureras sufrían el doble de tendinitis del hombro que las personas que tricotaban. Entre los lanzadores profesionales de beisbol, alrededor de un $10 \%$ han experimentado tendinitis del hombro. U na investigación en nadadores de clubes canadienses encontró que el $15 \%$ informaban de una discapacidad significativa del hombro, debida fundamentalmente a impactación. El problema se relacionaba en particular con los estilos mariposa y libre. Se encontró tendinitis del bíceps braquial en el $11 \%$ de los 84 mejores tenistas del mundo.

O tro estudio demostró que la osteoartritis de la articulación del hombro era más frecuente en los dentistas que en los agricultores, aunque no se ha identificado la exposición ergonómica relacionada con la $O A$ de la articulación del hombro. Se ha observado un mayor riesgo de OA acromioclavicular en los trabajadores de la construcción. Se ha sugerido que el levantamiento de grandes pesos y el manejo de herramientas pesadas con vibración de mano-brazo podrían ser las exposiciones relacionadas con la OA de la articulación acromioclavicular.

\section{Mecanismos y factores de riesgo de la enfermedad}

\section{Fisiopatología de la tendinitis de hombro}

La degeneración tendinosa es a menudo el factor predisponente para el desarrollo de la tendinitis de hombro. Tal degeneración del tendón puede estar causada por una alteración de la circulación del tendón, que interrumpe el metabolismo. También el estrés mecánico puede ser una causa. La muerte de las células dentro del tendón, que produce restos en los que se puede depositar calcio, quizá sea la forma inicial de degeneración. Los tendones del supraespinoso, el bíceps braquial (la cabeza larga) y las porciones superiores del infraespinoso poseen una zona en la que no existen vasos sanguíneos (avascular), y es en esta zona en la que se localizan predominantemente los signos de degeneración, incluida la muerte de células, los depósitos de calcio y las roturas microscópicas. C uando se altera la circulación sanguínea, como ocurre con la compresión y la carga estática de los tendones del hombro, la degeneración puede acelerarse, ya que el mantenimiento normal del organismo no funcionará de forma óptima.

Cuando se eleva el brazo se produce compresión de los tendones. Un proceso, a menudo denominado impactación, consiste en el paso forzado de los tendones a través de los conductos óseos del hombro, como se refleja en la Figura 6.18. Se produce la compresión de los tendones del manguito de los rotadores (en especial del tendón del supraespinoso) porque el espacio entre la cabeza humeral y el ajustado arco coracoacromial es estrecho. Las personas que padecen discapacidad prolongada debida a bursitis crónica 0 a desgarros completos 0 parciales de los tendones del manguito de los rotadores o del bíceps braquial suelen presentar también síndrome de impactación.

La circulación de la sangre hasta el tendón también depende de la tensión muscular. En el tendón, la circulación será inversamente proporcional a la tensión. Con tensiones muy altas, la circulación puede cesar por completo. Estudios recientes han demostrado que la presión intramuscular en el músculo supraespinoso puede superar los $30 \mathrm{~mm} \mathrm{H} \mathrm{g} \mathrm{a} 30$ grados de flexión hacia adelante o de abducción de la articulación del hombro, como se muestra en la Figura 6.19. A esta presión se produce 
Figura $6.18 \cdot$ Impactación.

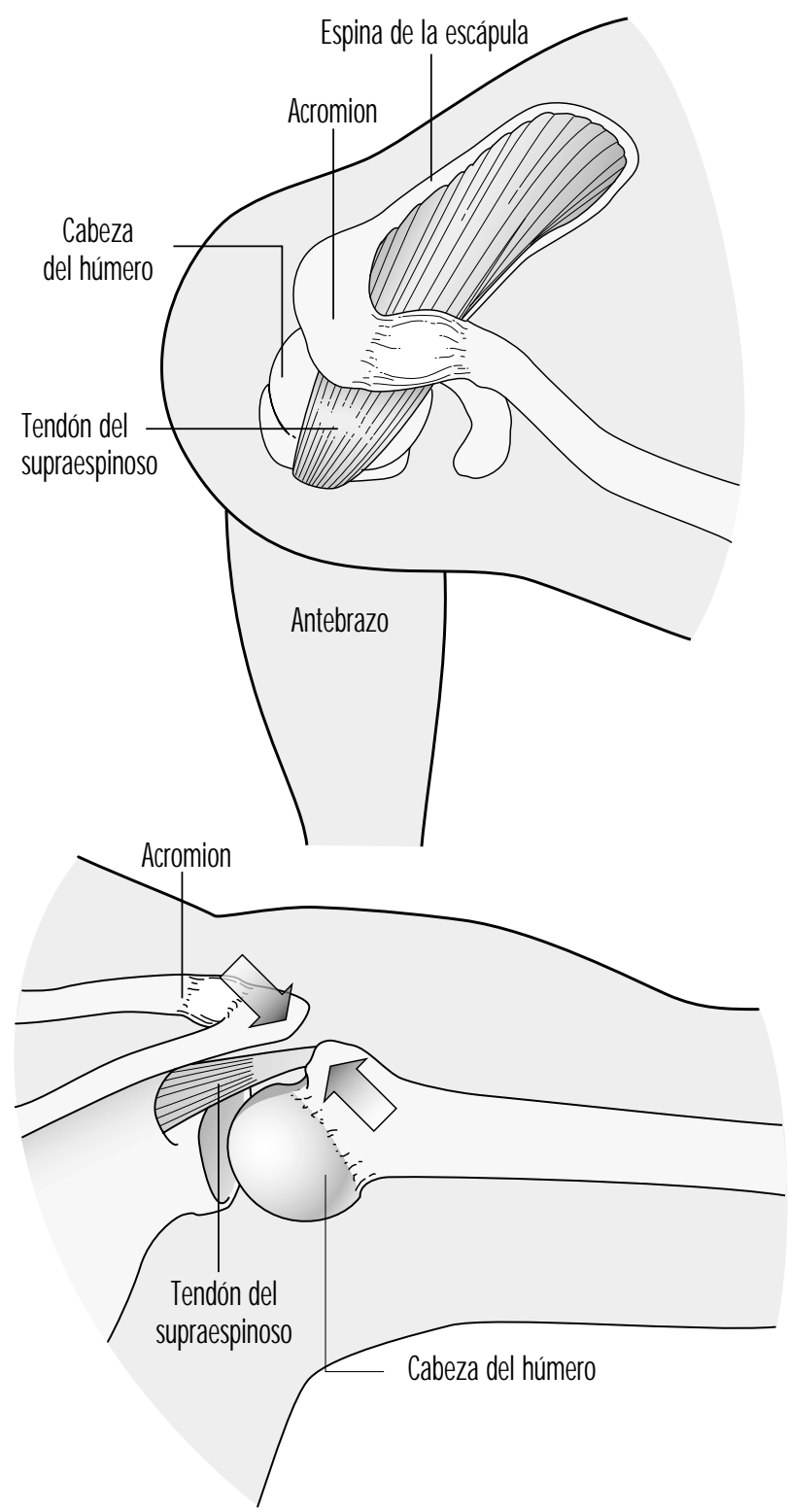

El extremo distal del tendón del supraespinoso se desliza por debajo de la parte trasera del acromion (flecha negra) y/ 0 a través del arco formado por el acromion; el ligamento entre el acromion y la apófisis coracoides. Durante este proceso se produce una impactación contra la superficie inferior de la parte trasera del acromion y la presión y la fricción mecánica se centran en el tendón del supraespinoso.

alteración de la circulación sanguínea. Dado que el principal vaso sanguíneo que irriga el tendón del supraespinoso discurre a través del músculo supraespinoso, es probable que la circulación hasta el tendón se altere incluso a 30 grados de flexión hacia adelante o de abducción de la articulación del hombro.

Debido a estos efectos biomecánicos, no es sorprendente encontrar un riesgo alto de lesiones de los tendones del hombro en las personas que realizan actividades que requieren contracciones estáticas del músculo supraespinoso o flexiones hacia adelante 0 abducciones repetitivas del hombro. Los soldadores, laminadores de metal y costureras se encuentran entre los grupos profesionales cuyo trabajo lleva aparejada tensión estática de estos músculos. Los trabajadores de la línea de montaje
Figura 6.19 - La elevación del brazo a diferentes alturas y en distintos ángulos ejerce diferentes presiones intramusculares sobre el músculo supra espinoso.

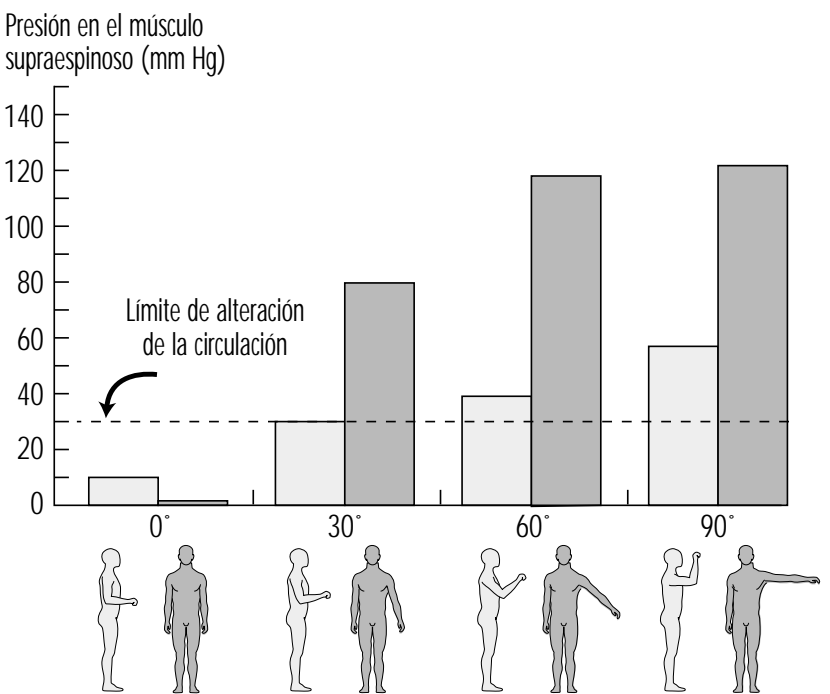

Fuente: Järnholm y cols. 1988.

en la industria automovilística, los pintores, los carpinteros y deportistas como los nadadores son otros grupos profesionales que realizan movimientos repetitivos de la articulación del hombro.

En el tendón degenerado, el esfuerzo puede desencadenar una respuesta inflamatoria a los restos de las células muertas, que ocasiona una tendinitis activa. También las infecciones (p. ej., víricas, urogenitales) o la inflamación sistémica pueden predisponer a una persona a padecer una tendinitis reactiva en el hombro. Una hipótesis es que la infección, que activa el sistema inmunitario, aumenta la posibilidad de una respuesta de cuerpo extraño a las estructuras degenerativas del tendón.

\section{Patogenia de la artrosis}

La patogenia de la artrosis se desconoce. El diagnóstico de artrosis primaria (idiopática) es el más frecuente en ausencia de factores predisponentes, como fracturas previas. Cuando existe un factor predisponente, la artrosis se denomina secundaria. Existen controversias entre los autores que afirman que la artrosis primaria es un trastorno metabólico o genético y quienes aseguran que los traumatismos mecánicos acumulados también pueden tener un papel en la patogenia de la artrosis primaria. Un mecanismo patogénico de la artrosis relacionada con la carga pueden ser las microfracturas debidas a un impacto brusco o a impactos de carga repetitivos.

\section{Tratamiento y prevención}

En esta sección se considera el tratamiento no médico de los trastornos del hombro. Si se considera que la tendinitis es debida a una elevada carga local sobre el hombro, será necesario un cambio en el diseño del puesto de trabajo o de la tarea a desempeñar. El antecedente de tendinitis del hombro hace que un trabajador que realiza un trabajo repetitivo o encima de la cabeza sea propenso a una recaída. D ebe reducirse al mínimo la carga sobre la articulación artrósica mediante la optimización ergonómica del trabajo. 


\section{Prevención primaria}

La prevención de los trastornos musculosqueléticos del hombro relacionados con el trabajo se puede lograr mejorando las posturas del trabajo, los movimientos, el manejo del material y la organización del trabajo, y eliminando los factores externos peligrosos, como las vibraciones en mano-brazo o en todo el cuerpo. Una metodología que puede resultar ventajosa para mejorar las condiciones ergonómicas del trabajo es la ergonomía participativa, con un enfoque macroergonómico.

- Posturas en el trabajo: Dado que la compresión de los tendones del hombro se produce a los 30 grados de elevación (abducción) del hombro, se diseñará el trabajo de modo que se procure mantener la parte superior del brazo próxima al tronco.

- Movimientos: Las elevaciones repetitivas del brazo pueden desencadenar una tendinitis del hombro, por lo que se deberá diseñar el trabajo de forma que se eviten los movimientos muy repetitivos del brazo.

- M anejo de material: El manejo de herramientas y objetos puede provocar cargas intensas sobre los tendones y músculos del hombro. Las herramientas y objetos sujetos por la mano tendrán el menor peso posible y se utilizarán con soportes para ayudar a levantarlas.

- Organización de trabajo: La organización del trabajo se diseñará de forma que permita pausas y descansos. Las vacaciones, las rotaciones y la ampliación del trabajo son todas ellas técnicas que pueden evitar la carga repetitiva de músculos o estructuras aislados.

- Factores externos: La vibración y otros impactos de las herramientas eléctricas pueden ocasionar distensiones tanto de los tendones como de las estructuras articulares, aumentando el riesgo de artrosis. Se reducirán al mínimo los niveles de vibración de las herramientas eléctricas y se evitarán la vibración y otros tipos de exposición a impactos utilizando diferentes tipos de soporte o palancas. Las vibraciones de todo el cuerpo pueden causar contracciones reflejas de los músculos del hombro y aumentar la carga sobre él.

- Ergonomía participativa: Este método implica a los propios trabajadores en la definición de los problemas y sus soluciones, y en la evaluación de éstas. La ergonomía participativa comienza a partir de una visión macroergonómica, que implica el análisis de todo el sistema de producción. Los resultados de este análisis podrían dar lugar a cambios a gran escala en los métodos de producción, cambios que podrían aumentar tanto la salud y la seguridad como el beneficio y la productividad. El análisis podría llevar también a cambios en menor escala, como el diseño de los puestos de trabajo.

- Exámenes precolocación: La información disponible actualmente no apoya la idea de que la selección de precolocación sea eficaz para reducir la aparición de trastornos del hombro relacionados con el trabajo.

- Control y vigilancia médicos: La vigilancia de los síntomas del hombro se realiza fácilmente mediante cuestionarios normalizados y visitas de inspección de los centros de trabajo.

\section{- CODO}

\section{Eira Viikari-Juntura}

\section{Epicondilitis}

L a epicondilitis es un proceso doloroso que se produce en el codo, en donde los músculos que permiten el movimiento de la muñeca y los dedos contactan con el hueso. C uando este proceso doloroso

se produce en la parte externa, se denomina codo de tenista (epicondilitis externa). C uando tiene lugar en la parte interna de la articulación del codo, se denomina codo de golfista (epicondilitis interna). El codo de tenista es una enfermedad bastante frecuente en la población general, y en algunos estudios se ha observado una alta incidencia en algunos grupos profesionales con tareas manuales intensivas (Tabla 6.6); es más frecuente que la epicondilitis interna.

Se cree que la epicondilitis está causada por esfuerzos repetitivos e intensos de la muñeca y de los dedos; no obstante, estudios controlados han dado resultados contradictorios con respecto al papel de las tareas manuales intensivas en el desarrollo de la enfermedad. Los traumatismos también pueden tener su papel, y la proporción de casos ocurridos después de un traumatismo ha oscilado entre el 0 y el $26 \%$ en diferentes estudios. La epicondilitis suele aparecer a partir de los 40 años de edad, y es rara antes de los 30 años. Se sabe poco acerca de otros factores de riesgo individuales. U na idea común acerca de su fisiopatología es la existencia de un desgarro en la inserción de los músculos. Los síntomas consisten en dolor, especialmente durante los ejercicios de la mano y la muñeca; la prensión de un objeto con el codo extendido puede ser sumamente dolorosa.

Existen varios conceptos sobre la patogenia de la epicondilitis. La duración suele oscilar entre varias semanas y algunos meses, tras lo cual suele producirse una recuperación completa. Entre los trabajadores con tareas intensivas, la duración de la baja laboral por epicondilitis se ha situado alrededor de las dos semanas o ligeramente por encima.

\section{Bursitis del olécranon}

La bursitis del olécranon es una inflamación del saco lleno de líquido que está situado en el lado dorsal del codo (bolsa del olécranon). Puede estar causada por traumatismos mecánicos repetidos (bursitis traumática o "del estudiante"). También puede ser debida a infección o asociarse a la gota. Existen tumefacción local y movimiento ondulante a la palpación debido a la acumulación de líquido en la bolsa. El aumento de la temperatura cutánea indica la existencia de un proceso infeccioso (bursitis séptica).

\section{Artrosis}

La artrosis, o enfermedad degenerativa resultante de la degradación del cartílago, casi nunca se observa en el codo en personas

Tabla 6.6 - Incidencia de epicondilitis en diversas poblaciones.

Población del estudio

Tasa por 100 Referencia personas-año

5.000 trabajadores de diversas industrias

1,5 Manz y Rausch

15.000 sujetos de una población normal

$<1,0 \quad$ Allander 1974

7.600 trabajadores de diversas industrias

102 carniceros varones

0,6 Kivi 1982

107 mujeres fabricantes de embutidos

6,4 Kurppa y cols. 1991

118 empaquetadoras

11,3 Kurppa y cols. 1991

7,0 Kurppa y cols. 1991

141 varones en trabajos ligeros

0,9 Kurppa y cols. 1991

197 mujeres en trabajos ligeros 
menores de 60 años. Sin embargo, se ha encontrado una prevalencia excesiva de artrosis en algunos grupos profesionales cuyo trabajo conlleva la utilización intensiva de herramientas de mano u otros trabajos manuales pesados, como los mineros del carbón y los trabajadores de la construcción. También se han publicado estudios válidos que no encuentran un riesgo excesivo en tales trabajos. La artrosis del codo se ha asociado a la vibración, aunque se cree que no es específica de la vibración.

Los síntomas son dolor local, al principio durante el movimiento y después también en reposo, y limitación de la amplitud de movimientos. En presencia de cuerpos libres en la articulación, puede producirse el bloqueo de la misma. La pérdida de la capacidad de extender la articulación por completo resulta especialmente discapacitante. L as anomalías radiológicas observadas consisten en el crecimiento de tejido óseo nuevo en los sitios en que los ligamentos y tendones están en contacto con el hueso. A veces es posible observar fragmentos sueltos de cartílago 0 de hueso. La lesión del cartílago articular puede dar lugar a la destrucción del tejido óseo subyacente y a la deformación de las superficies articulares

En la prevención y el tratamiento de la artrosis del codo destaca la optimización de la carga de trabajo mediante la mejora de las herramientas y de los métodos de trabajo, a fin de disminuir las cargas mecánicas impuestas a la extremidad superior, y reducir al mínimo la exposición a la vibración. Se puede realizar tratamiento con movimientos activos y pasivos para reducir al mínimo las limitaciones de la amplitud de movimiento.

\section{- ANTEBRAZO, MUÑECA Y MANO}

\section{Eira Viikari-Juntura}

\section{Tenosinovitis y peritendinitis}

\section{Extensores y flexores de la muñeca y de los dedos}

En la muñeca y en la mano, los tendones están rodeados por vainas tendinosas, estructuras tubulares que contienen líquido para proporcionar lubricación y protección al tendón. La inflamación de la vaina tendinosa se denomina tenosinovitis. La que se produce en el punto en que el músculo se une al tendón se denomina peritendinitis. La tenosinovitis de la muñeca se localiza en la zona de la vaina tendinosa de la muñeca, mientras que la peritendinitis lo hace por encima de la zona de la vaina tendinosa en el antebrazo. Se denomina tendinitis de inserción a una inflamación del tendón en el lugar de unión al hueso (Figura 6.20).

La terminología de las enfermedades del tendón y de sus estructuras adyacentes a menudo se utiliza laxamente, y en ocasiones se ha empleado el término "tendinitis" para referirse a todos los procesos dolorosos de la región del antebrazo-muñecamano, con independencia del tipo de presentación clínica. En Estados U nidos se ha utilizado un diagnóstico de amplio contenido, el de "trastornos traumáticos acumulados" (TTA), para denominar a todos los trastornos de los tejidos blandos de la extremidad superior que se cree están causados, precipitados 0 agravados por esfuerzos repetitivos de la mano. En Australia y en algunos otros países se ha utilizado el diagnóstico de "Iesión por distensión repetitiva" (LTR ) o "lesión por sobreuso", mientras que en Japón, el concepto de "trastorno profesional cervicobraquial" (TPC) ha servido para abarcar los trastornos de los tejidos blandos de la extremidad superior. Los dos últimos diagnósticos incluyen también los trastornos de hombro y cuello.

La aparición de tenosinovitis o peritendinitis es muy variable según el tipo de trabajo. Se han descrito de modo característico
Figura 6.20 - La unidad musculotendinosa.

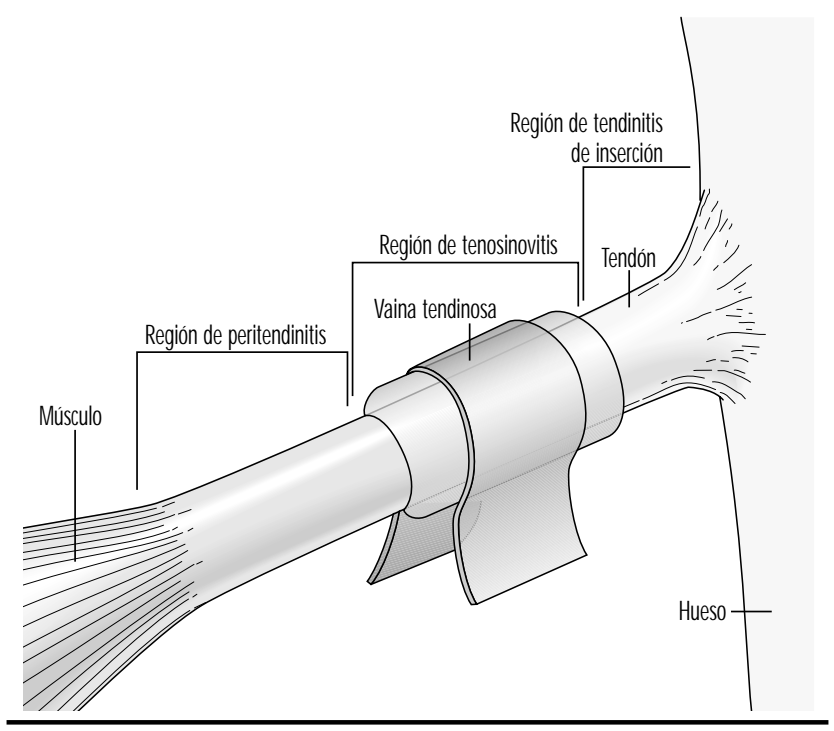

incidencias altas en trabajadores de fabricación como procesadores de alimentos, carniceros, envasadores y montadores. Algunos estudios recientes demuestran la existencia de altas tasas de incidencia incluso en las industrias modernas, como se muestra en la Tabla 6.7. Los trastornos de los tendones son más frecuentes en la región dorsal que en la cara flexora de la muñeca. El dolor y otros síntomas de la extremidad superior son frecuentes también en otros tipos de tareas, como el trabajo moderno con teclado. No obstante, los signos clínicos que presentan estas personas rara vez son compatibles con una tenosinovitis o una peritendinitis.

La repetición frecuente de movimientos en el trabajo y las demandas elevadas de fuerza en la mano son poderosos factores de riesgo, sobre todo cuando se dan conjuntamente (Silverstein, Fine y Armstrong 1986). Sin embargo, todavía no existen valores aceptados generalmente con relación a la repetitividad y el uso de fuerza aceptables (H agberg y cols. 1995). La falta de costumbre de realizar un trabajo manual intensivo, ya sea como trabajador nuevo o después de una ausencia del trabajo, aumenta el riesgo. Las posturas desviadas o dobladas de la muñeca en el trabajo y la baja temperatura ambiental también

Tabla 6.7 - Incidencia de tenosinovitis/ peritendinitis en diversas poblaciones.

Población del estudio

$\begin{array}{ll}\text { Tasa } & \text { Referencia } \\ \text { por } 100 & \\ \text { personas-año } & \end{array}$

700 empaquetadores de té moscovitas $40,5 \quad$ Obolenskaja y Goljanitzki 1927

12.000 trabajadores de fábricas de $\quad 0,3 \quad$ Thompson y cols. 1951 automóviles

7.600 trabajadores de diversas industrias $\quad 0,4$

102 carniceros varones

12,5

107 mujeres fabricantes de embutidos

118 empaquetadoras

16,8

141 varones en trabajos ligeros 25,3

197 mujeres en trabajos ligeros
Kivi 1982

Kurppa y cols. 1991

Kurppa y cols. 1991

Kurppa y cols. 1991

Kurppa y cols.1991

Kurppa y cols. 1991 
se han considerado factores de riesgo, aunque las pruebas epidemiológicas que lo apoyan son débiles. La tenosinovitis y la peritendinitis se producen a todas las edades. Existen algunas pruebas de que las mujeres podrían ser más susceptibles que los varones (Silverstein, Fine y Armstrong 1986). N o obstante, esto ha sido difícil de investigar, ya que en muchas industrias los trabajos que realizan hombres y mujeres son muy diferentes. $L a$ tenosinovitis puede ser debida a infección bacteriana, y algunas enfermedades sistémicas, como la artritis reumatoide y la gota, a menudo se asocian a tenosinovitis. Se sabe poco acerca de otros factores de riesgo individuales.

En la tenosinovitis, la zona de la vaina tendinosa es dolorosa, sobre todo en sus extremos. Los movimientos del tendón están restringidos o bloqueados, y la prensión es débil. L os síntomas a menudo empeoran por la mañana, con mejoría de la capacidad funcional después de realizada cierta actividad. La zona de la vaina tendinosa presenta hiperestesia a la palpación, y también se pueden encontrar nódulos hiperestésicos. El acto de doblar la muñeca aumenta el dolor. La zona de la vaina tendinosa puede estar asimismo hinchada, y el acto de doblar la muñeca hacia atrás 0 adelante produce crepitación o crujidos. En la peritendinitis a menudo es posible observar una tumefacción fusiforme en la cara posterior del antebrazo.

La tenosinovitis de los tendones flexores de la cara palmar de la muñeca puede producir el atrapamiento del nervio mediano en su trayecto a través de la muñeca, dando lugar al síndrome del túnel del carpo.

La fisiopatología en la fase aguda de la enfermedad se caracteriza por la acumulación de líquido y de una sustancia llamada fibrina en la vaina del tendón en la tenosinovitis, y en el paratendon y entre las células musculares en la peritendinitis. Posteriormente se observa crecimiento celular (M oore 1992).

Es preciso resaltar que la tenosinovitis o la peritendinitis clínicamente identificables como profesionales sólo suponen una proporción pequeña de los casos de dolor de muñeca y de antebrazo en las poblaciones de trabajadores. La mayoría de ellos buscan atención médica cuando el único hallazgo clínico es la hipersensibilidad a la palpación. No se sabe muy bien si la fisiopatología en tales procesos es similar a la de la tenosinovitis o la peritendinitis.

Para prevenir la tenosinovitis y la peritendinitis es preciso evitar los movimientos muy repetitivos y de fuerza en el trabajo. Además de prestar atención a los métodos de trabajo, los factores de organización del trabajo (la cantidad y el ritmo, las pausas y las rotaciones) también determinan la carga local impuesta a la extremidad superior, por lo que debe considerarse asimismo la posibilidad de introducir variabilidad en el trabajo mediante la modificación de estos factores. Los trabajadores nuevos y los que vuelven al trabajo después de una baja o que cambian de tarea se deben acostumbrar gradualmente al trabajo repetitivo.

En los trabajadores industriales con tareas manuales grandes, la duración típica de la baja laboral por tenosinovitis o peritendinitis ha sido de unos diez días. El pronóstico de ambos procesos suele ser bueno, y la mayoría de los trabajadores pueden reanudar sus tareas laborales previas.

\section{Tenosinovitis de De Quervain}

La tenosinovitis de D e Q uervain es una tenosinovitis estenosante (o constrictora) de las vainas tendinosas de los músculos que extienden y separan (abducen) el pulgar en la cara externa de la muñeca. El proceso aparece al principio de la niñez y en cualquier edad posterior. Suele ser más frecuente en el sexo femenino. Se han sugerido como factores causales los movimientos repetitivos de la muñeca y los traumatismos contusos, aunque no se ha realizado una investigación epidemiológica.
Los síntomas son dolor local en la muñeca y debilidad para la prensión. El dolor se extiende en ocasiones al pulgar 0 al antebrazo. Existe hipersensibilidad y finalmente un engrosamiento a la palpación en el lugar de la constricción. En ocasiones son visibles engrosamientos nodulares. Al doblar la muñeca hacia el meñique con el pulgar flexionado hacia la palma (prueba de Finkelstein) se agudizan los síntomas. En algunos casos se observa engatillado o chasquido al mover el pulgar.

L os cambios anatomopatológicos consisten en engrosamiento de las capas externas de las vainas tendinosas. EI tendón puede estar constreñido y mostrar un aumento de tamaño más allá del punto de constricción.

\section{Tenosinovitis estenosante de los dedos}

Las vainas tendinosas de los tendones flexores de los dedos se mantienen próximas a los ejes de las articulaciones mediante bandas tensas denominadas pol eas. L as poleas pueden engrosarse, y el tendón mostrar una tumefacción nodular más allá de la polea, lo que ocasiona una tenosinovitis estenosante, a menudo acompañada de bloqueo doloroso o de dedo en resorte. Para referirse a estas situaciones se han utilizado las denominaciones de dedo en resorte o pulgar en resorte.

Las causas del dedo en resorte son en gran parte desconocidas. Algunos casos producidos en la primera infancia es probable que sean congénitos, y otros parecen surgir después de un traumatismo. Se ha postulado que el dedo en resorte está causado por movimientos repetitivos, aunque no se han realizado estudios epidemiológicos para comprobarlo.

El diagnóstico se basa en la presencia de tumefacción local, engrosamiento nodular eventual y chasquido 0 bloqueo. El proceso a menudo se encuentra en la palma, a nivel de las cabezas de los metacarpianos (los nudillos), aunque puede ocurrir también en cualquier otro lugar y en localizaciones múltiples.

\section{Artrosis}

La prevalencia de artrosis detectable radiológicamente en la muñeca y la mano es rara en la población normal menor de 40 años, y más frecuente en varones (K ärkkäinen 1985). A partir de los 50 años, la artrosis de la mano es más frecuente en las mujeres. El trabajo manual pesado, con o sin exposición a vibraciones de baja frecuencia (menos de $40 \mathrm{~Hz}$ ), se ha asociado, aunque no de forma constante, a una prevalencia excesiva de artrosis de muñeca y mano. No se ha informado de un exceso de patología articular para frecuencias de vibración más altas (Gemne y Saraste 1987).

La artrosis de la primera articulación entre la base del pulgar y la muñeca (articulación carpometacarpiana) es bastante frecuente en la población general, y más en el sexo femenino. La artrosis es menos frecuente en los nudillos (articulaciones metacarpofalángicas), con la excepción de la articulación metacarpofalángica del pulgar. No se conoce bien la etiología de estos trastornos

Los cambios artrósicos son frecuentes en las articulaciones más próximas a la punta de los dedos (articulaciones interfalángicas distales de los dedos), en las que la prevalencia ajustada para la edad de cambios detectables radiológicamente (leves a intensos) en los diferentes dedos oscila entre el 9 y el $16 \%$ para los varones y entre el 13 y el $22 \%$ en las mujeres de una población normal. La artrosis interfalángica distal puede detectarse en la exploración clínica como crecimientos nodulares de las articulaciones, denominados nódulos de $\mathrm{Heberden.} \mathrm{En} \mathrm{un} \mathrm{estudio}$ sueco de población realizado en mujeres y varones de 55 años de edad se detectaron nódulos de Heberden en el $5 \%$ de los varones y en el $28 \%$ de las mujeres. La mayoría de los sujetos mostraron cambios en ambas manos. La presencia de nódulos 
de Heberden mostró una correlación con el trabajo manual pesado (Bergenudd, Lindgärde y Nilsson 1989).

La carga articular asociada a la manipulación de herramientas, los movimientos repetitivos de la mano y el brazo, posiblemente junto con traumatismos menores, la carga de las superficies articulares en las posturas extremas y el trabajo estático se han considerado posibles factores causales de la artrosis de muñeca y mano. Aunque no se ha considerado a la artrosis específica de la vibración de baja frecuencia, es posible que los siguientes factores también intervengan: lesión del cartílago articular por choques de la herramienta, carga articular adicional asociada a una mayor necesidad de estabilización de la articulación inducida por la vibración, el reflejo de vibración tónica y una prensión más fuerte de la herramienta inducida cuando la sensibilidad táctil está disminuida por la vibración (Gemne y Saraste 1987).

Los síntomas de artrosis consisten en dolor durante el movimiento en las fases iniciales, y posteriormente también durante el reposo. La limitación del movimiento en la muñeca no interfiere de forma acusada las actividades laborales ni otras actividades de la vida diaria, mientras que la artrosis de las articulaciones de los dedos puede interferir en la capacidad de prensión.

Para evitar la artrosis deben desarrollarse herramientas que ayuden a disminuir el trabajo manual pesado. También debe reducirse al mínimo la vibración de las herramientas.

\section{Síndrome compartimental}

Los músculos, nervios y vasos sanguíneos del antebrazo y de la mano está situados en compartimientos específicos limitados por huesos, membranas y otros tejidos conjuntivos. Se entiende por síndrome compartimental un proceso en el que la presión intracompartimental aumenta de forma constante o repetida hasta un punto en que las estructuras compartimentales pueden resultar lesionadas (M ubarak 1981). Esto puede ocurrir después de un traumatismo, como una fractura o una lesión por aplastamiento del brazo. El síndrome compartimental después de un ejercicio intenso de los músculos es una enfermedad bien conocida de la extremidad inferior. También se han descrito algunos casos de síndrome compartimental por el ejercicio en el antebrazo y la mano, aunque la causa de estos procesos se desconoce. $\mathrm{N}$ o se han definido criterios diagnósticos aceptados en general ni indicaciones terapéuticas. L os trabajadores afectados han realizado por lo general un trabajo manual intenso, aunque no se han publicado estudios epidemiológicos sobre la asociación entre el trabajo y estas enfermedades.

Los síntomas del síndrome compartimental son tensión de los límites aponeuróticos del compartimiento, dolor durante la contracción muscular y, posteriormente, también durante el reposo, y debilidad muscular. A la exploración clínica, la zona del compartimiento está hipersensible, dolorosa al estiramiento pasivo, y puede haber una disminución de la sensibilidad en la distribución de los nervios que pasan por el compartimiento. Para confirmar el diagnóstico se han realizado mediciones de la presión intracompartimental durante el reposo, en actividad y después de ella, aunque no existe un acuerdo completo en cuanto a los valores normales.

La presión intracompartimental aumenta cuando lo hace el volumen del contenido en el compartimiento rígido. Ello va seguido de un aumento de la presión venosa y de una disminución de la diferencia entre las presiones arterial y venosa, lo que a su vez afecta al aporte de sangre al músculo. A continuación existen producción anaerobia de energía y lesión muscular.

La prevención del síndrome compartimental por esfuerzo consiste en evitar o restringir la actividad causante de los síntomas hasta un nivel tolerable

\section{Trombosis de la arteria cubital (síndrome del martillo} hipotenar)

La arteria cubital puede sufrir daño, con la consiguiente trombosis y oclusión del vaso, en el canal de Guyon, situado en la cara interna (cubital) de la palma. A menudo la enfermedad va precedida de una historia de traumatismos repetidos sobre la cara cubital de la palma (eminencia hipotenar), como pueden ser el martilleo intenso o la utilización de la eminencia hipotenar como si fuera un martillo (Jupiter y K leinert 1988).

L os síntomas consisten en dolor y calambres, así como intolerancia al frío de los dedos cuarto y quinto. También puede haber trastornos dolorosos del tipo de dolor sordo, hormigueo y entumecimiento, pero el rendimiento de los músculos suele ser normal. A la exploración clínica es posible observar frialdad y palidez del cuarto y quinto dedos, así como cambios nutricionales de la piel. La prueba de Allen suele ser positiva, lo que indica que tras la compresión de la arteria radial no se produce flujo sanguíneo a la palma a través de la arteria cubital. En la región hipotenar se puede encontrar una masa hiperestésica palpable.

\section{Contractura de Dupuytren}

La contractura de Dupuytren es un acortamiento progresivo (fibrosis) de la aponeurosis palmar (tejido conjuntivo que une los tendones flexores de los dedos) de la mano, que da lugar a una contractura permanente de los dedos en flexión. Es un proceso frecuente en las personas del norte de Europa, que afecta al $3 \%$ aproximadamente de la población general. La prevalencia suele ser el doble en los varones que en las mujeres, llegando hasta el $20 \%$ en los varones mayores de 60 años. La contractura de Dupuytren se asocia a epilepsia, diabetes tipo I, consumo de alcohol y tabaquismo. Existen pruebas de una relación entre la exposición a la vibración procedente de herramientas manuales y la contractura de Dupuytren. La presencia de la enfermedad se ha asociado también a lesiones aisladas y al trabajo manual pesado. Existen algunos datos en apoyo de una asociación entre este último y la contractura de D upuytren, mientras que el papel de la lesión aislada no se ha investigado adecuadamente (Liss y Stock 1996).

La modificación fibrótica aparece primero como un nódulo. Posteriormente, la aponeurosis se engrosa y acorta, formando una unión en forma de cordón con el dedo. Al avanzar el proceso, los dedos quedan en flexión permanente. Los primeros en afectarse suelen ser el quinto y cuarto dedos, aunque también pueden serlo otros. En la cara posterior de los dedos pueden verse abultamientos en los nudillos.

\section{$Q$ uistes sinoviales de muñeca y mano}

Un ganglión es un pequeño saco blando lleno de líquido; los quistes sinoviales representan la mayor parte de todos los tumores de tejidos blandos de la mano. Los quistes sinoviales son frecuentes, aunque no se conoce su prevalencia en poblaciones; en poblaciones clínicas, las mujeres han mostrado una prevalencia algo mayor que los varones, y han estado representados tanto los niños como los adultos. Existe controversia acerca de las causas de los quistes sinoviales. Algunos autores los consideran congénitos, mientras que otros opinan que en su desarrollo pueden intervenir los traumatismos agudos o repetidos. También existen diversas opiniones en cuanto al proceso de su desarrollo (Angelides 1982).

La localización más típica del ganglión es en la cara exterior del dorso de la muñeca (ganglión dorsorradial), donde se puede presentar como una formación blanda claramente visible. Un ganglión dorsal más pequeño puede pasar inadvertido si no se flexiona marcadamente la muñeca. El ganglión palmar de la muñeca (situado en la cara palmar de ésta) se localiza 
típicamente en el lado exterior del tendón del flexor radial de la muñeca. El tercer tipo de ganglión en cuanto a frecuencia se sitúa en la polea de la vaina del tendón flexor de los dedos, a nivel de los nudillos. Un ganglión palmar de la muñeca puede producir el atrapamiento del nervio mediano en la muñeca, dando lugar a un síndrome del túnel de carpo. En raros casos, un ganglión puede localizarse en el canal cubital (canal de Guyon) en la parte interior de la palma y causar el atrapamiento del nervio cubital.

Los síntomas de los tumores sinoviales de la muñeca son dolor local típico durante el esfuerzo, así como posturas desviadas de la muñeca. Los tumores sinoviales de la palma y de los dedos suelen resultar dolorosos durante la prensión.

\section{Trastornos del control motor de la mano (calambre del escritor)}

El temblor y otros movimientos incontrolados pueden alterar las funciones de la mano que requieren una alta precisión y control, como la escritura, el montaje de piezas pequeñas y el tañido de instrumentos musicales. La forma clásica del trastorno es el calambre del escritor cuya tasa de aparición se desconoce. Afecta a ambos sexos y parece ser habitual en los decenios tercero, cuarto y quinto de la vida.

No se conocen por completo las causas del calambre del escritor y de los trastornos relacionados. Se ha sugerido una predisposición hereditaria. Estos procesos se consideran en la actualidad una forma de distonía específica de la tarea. (Las distonías son un grupo de trastornos caracterizados por contracciones musculares involuntarias permanentes, que provocan movimientos de giro repetitivos o posturas anormales.) En los pacientes con calambre del escritor no se han descrito pruebas anatomopatólogicas de enfermedad cerebral. Investigaciones electrofisiológicas han revelado una activación anormalmente prolongada de los músculos que participan en la escritura, así como una activación excesiva de los músculos que no intervienen directamente en ella ( $M$ arsden y Sheehy 1990).

En el calambre del escritor aparece un espasmo muscular, por lo general indoloro, inmediatamente o poco después de comenzar a escribir. Los dedos, la muñeca y la mano pueden adoptar posturas anormales, y la pluma a menudo se sujeta con una fuerza excesiva. La situación neurológica puede ser normal. En algunos casos se observa una mayor tensión o temblor del brazo afectado.

Algunas de las personas que padecer este proceso aprenden a escribir con la mano no dominante, y una pequeña proporción de estos presentan también calambres en dicha mano no dominante. La curación espontánea del calambre del escritor es rara.

\section{CADERAY RODILLA}

\section{E va Vingård}

La articulación de la cadera es una enartrosis rodeada de ligamentos, músculos potentes y bolsas. La articulación soporta peso y posee una elevada estabilidad intrínseca junto con una gran amplitud de movimiento. En las personas jóvenes, el dolor en la región de la cadera se suele originar en los músculos, las inserciones tendinosas o las bolsas, mientras que en las personas de más edad el principal trastorno causante de dolor de cadera es la artrosis.

La rodilla es una articulación de carga de gran importancia para caminar, mantenerse en pie, doblarse, encorvarse y acuclillarse. La rodilla es bastante inestable, y depende para el apoyo de ligamentos y músculos potentes, como se muestra en la Figura 6.21. En la rodilla existen dos articulaciones, la femorotibial y la femororrotuliana. En los lados interno y externo de la articulación existen fuertes ligamentos, y en el centro de la articulación femorotibial se encuentran los ligamentos cruzados, que proporcionan estabilidad y ayudan a la función mecánica normal de la rodilla. Los meniscos son estructuras fibrocartilaginosas curvas situadas entre el fémur (cóndilos femorales) y la tibia (platillo tibial). La articulación de la rodilla es estabilizada y fortalecida por músculos que se originan por encima de la articulación de la cadera y en la diáfisis femoral y que se insertan en estructuras óseas situadas debajo de la articulación. Alrededor de la articulación de la rodilla existe una cápsula sinovial, y la articulación está protegida por varias bolsas.

Todas estas estructuras se lesionan fácilmente por traumatismos o por el uso excesivo, y el tratamiento médico por dolor de rodilla es bastante frecuente. $L a$ artrosis de la rodilla es un

Figura 6.21 - La rodilla.

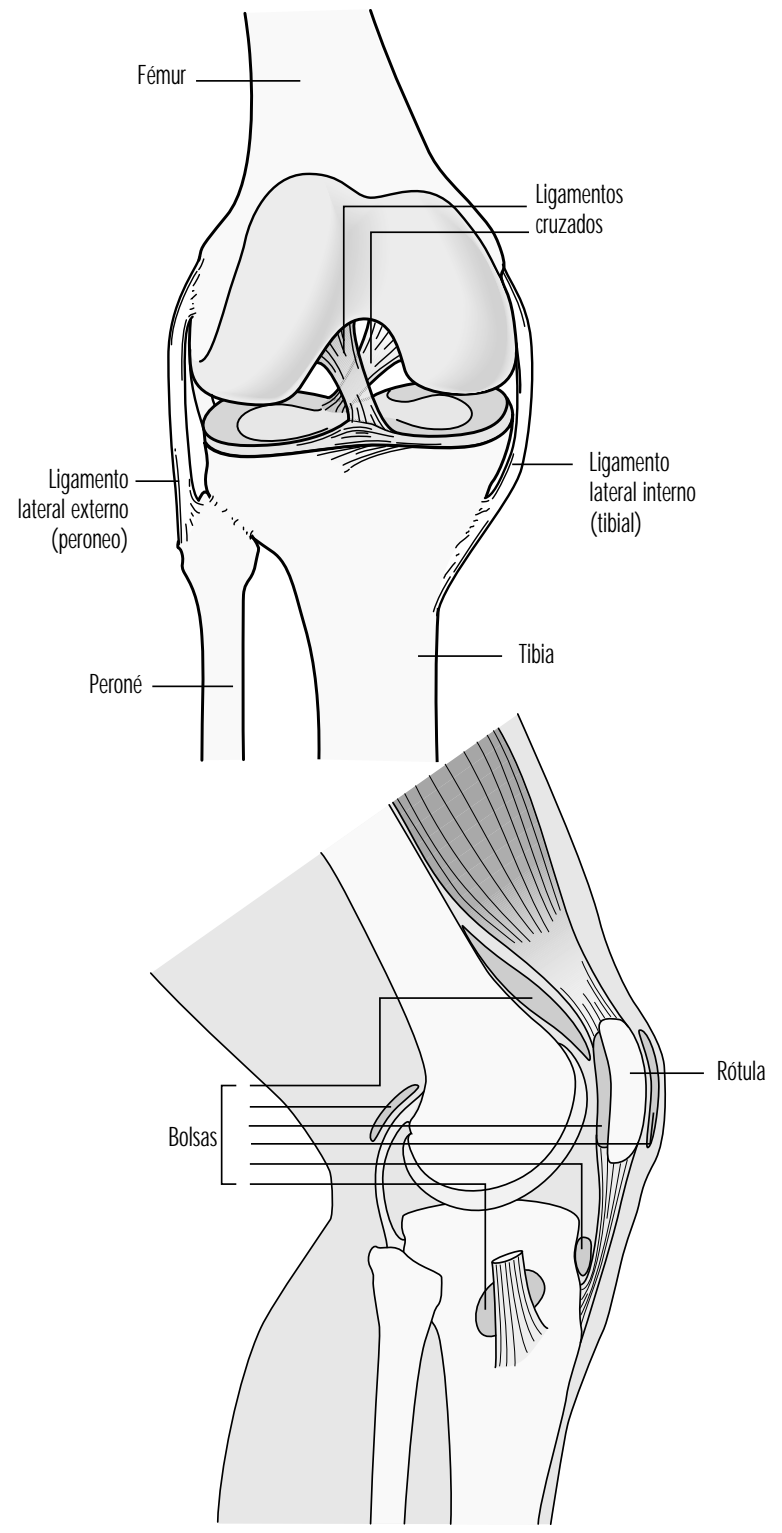


trastorno común en el anciano que causa dolor y discapacidad. En las personas jóvenes son bastante frecuentes la bursitis rotuliana y los síndromes de dolor femororrotuliano como el pes anserinus doloroso.

\section{Artrosis}

La artrosis es un trastorno articular degenerativo frecuente, en el cual el cartílago resulta más o menos destruido y la estructura del hueso subyacente está afectada. En ocasiones se acompaña de pocos síntomas, pero por lo general se produce dolor, cambios en la capacidad de trabajo y una menor calidad de vida. Es posible observar cambios articulares en las radiografías, y la persona que la padece suele acudir al médico por dolor, presente incluso en reposo, y disminución de la amplitud de movimiento. En los casos graves, la articulación puede quedar totalmente rígida, e incluso destruida. En la actualidad está bien desarrollado el tratamiento quirúrgico para sustituir la articulación destruida por una prótesis.

El estudio de las causas de la artrosis de cadera es difícil. EI comienzo del trastorno suele ser difícil de determinar, y el desarrollo es por lo general lento e insidioso (es decir, la persona no sabe necesariamente que está ocurriendo). El criterio de valoración, con fines de investigación, puede ser diferente, y oscilar desde pequeños cambios radiológicos hasta trastornos sintomáticos que precisen cirugía. De hecho, los criterios de valoración utilizados para identificar el proceso pueden diferir debido a las diferentes tradiciones existentes en los distintos países, e incluso entre las diferentes clínicas en la misma ciudad. Estos factores causan problemas al interpretar los estudios de investigación.

La investigación epidemiológica trata de identificar asociaciones entre exposiciones como la carga física y consecuencias como la artrosis. Cuando se combinan con otros conocimientos, es posible encontrar asociaciones que podrían considerarse causales, aunque la cadena causa-efecto es complicada. La artrosis es frecuente en todas las poblaciones, y es preciso recordar que el proceso se da en personas sin exposiciones de riesgo conocidas, mientras que existen sujetos sanos en el grupo sometido a exposiciones de mucho riesgo y bien conocidas. Algunos de los contribuyentes a esta situación pueden ser las vías desconocidas entre la exposición y el trastorno, los factores sanitarios desconocidos, los factores genéticos y las fuerzas de selección.

\section{Factores de riesgo individuales}

E dad: La aparición de artrosis aumenta con la edad. Se ha realizado investigación radiológica de la artrosis de diferentes articulaciones, sobre todo de rodilla y de cadera, en diferentes poblaciones, y se ha encontrado que la incidencia varía. La explicación podría radicar en diferencias étnicas o en variaciones de las técnicas de investigación y de los criterios diagnósticos.

Enfermedades y cambios congénitos y del desarrollo: Los cambios precoces sufridos por la articulación, como las malformaciones congénitas, los causados por infecciones y similares, dan lugar a una progresión más temprana y rápida de la artrosis de cadera. $L$ as piernas en $O$ (genu varum) y las piernas en $X$ (genu valgum) producen una distribución no uniforme de fuerzas sobre la articulación de la rodilla, por ejemplo, que puede tener cierta importancia para el desarrollo de artrosis.

H erencia: En la artrosis están presentes factores hereditarios. Por ejemplo, la artrosis de cadera es una enfermedad rara en la personas de origen asiático, pero es más frecuente en la raza blanca, lo que sugiere un factor hereditario. La artrosis de tres 0 más articulaciones se denomina artrosis generalizada y presenta un patrón hereditario. Las vías hereditarias de la artrosis de rodilla no se conocen bien.
Sobrepeso: El sobrepeso probablemente cause artrosis de rodilla y de cadera. La relación entre sobrepeso y artrosis de rodilla se ha demostrado en grandes estudios epidemiológicos realizados en la población general, como la encuesta nacional de análisis de la salud y la nutrición de Estados U nidos ( $N$ ational $\mathrm{H}$ ealth and Nutrition Examination Survey, (NHANES) y el estudio de Framingham. La asociación era máxima en las mujeres, aunque existía incluso en los varones (Anderson y Felson 1988; Felson y cols. 1988).

Traumatismos: Los accidentes o las causas de traumatismos 0 lesiones, en especial los que interfieren en la mecánica y la circulación de la articulación y sus ligamentos, pueden dar lugar a artrosis precoz.

Sexo y utilización de estrógenos: La artrosis de cadera y rodilla parece tener una distribución similar en ambos sexos. A partir de un estudio en participantes femeninas del estudio de Framingham, se llegó a la conclusión de que la utilización de estrógenos en las mujeres se asociaba a un efecto protector moderado, pero no significativo, frente a la artrosis de la rodilla (H annan y cols. 1990).

\section{Carga mecánica}

Estudios experimentales en monos, conejos, perros y ovejas han demostrado que las fuerzas de compresión sobre una articulación, en especial cuando se mantiene en una posición extrema, con o sin cargas de desplazamiento simultáneas pueden dar lugar a cambios en el cartílago y el hueso similares a los de la artrosis en el ser humano.

Actividades deportivas: La práctica de deportes puede aumentar la carga sobre diferentes articulaciones. También está aumentado el riesgo de traumatismos. Por otra parte, no obstante, al mismo tiempo se desarrollan una buena función y coordinación musculares. Se dispone de pocos datos sobre si la participación en deportes previene los traumatismos 0 es perjudicial para las articulaciones. LOS datos obtenidos de estudios científicos solventes son muy limitados, y algunos se describen aquí. Algunos estudios realizados en jugadores de fútbol han demostrado que tanto los profesionales como los aficionados presentan más artrosis de cadera y rodilla que la población masculina general. Por ejemplo, en un estudio sueco realizado en varones de 50 a 70 años con artrosis grave en comparación con varones sanos del mismo grupo de edad, se demostró que los varones con artrosis habían participado más en actividades deportivas en su juventud. Los más perjudiciales parecían ser los deportes en pista y campo, los de raqueta y el fútbol (Vingård y cols. 1993). En la literatura científica existen otros estudios que no han demostrado diferencias entre los deportistas y las personas que no realizan deporte. Sin embargo, la mayoría están realizados en deportistas todavía en activo y, por tanto, no son concluyentes.

\section{Factores de carga de trabajo}

La etiología de la artrosis de la rodilla y la cadera es, como en todas las enfermedades, compleja y multifactorial. Estudios recientes bien realizados han demostrado que la carga física sobre la articulación provocada por exposiciones laborales desempeñará un papel como causa contribuyente al desarrollo de una artrosis prematura.

La mayor parte de los estudios epidemiológicos relativos a la carga de trabajo físico son transversales y realizados en grupos profesionales, sin evaluación de las exposiciones individuales. Estos graves problemas metodológicos hacen extremadamente difícil la generalización de los resultados de tales estudios. En varios estudios se ha observado que los agricultores presentan más artrosis de cadera que otros grupos profesionales. En un estudio realizado en Suecia en 15.000 agricultores, se preguntó a sus esposas y a otros trabajadores agrícolas por anteriores 
exploraciones radiológicas en las que se pudiera ver la articulación de la cadera. Se estudiaron las articulaciones de la cadera de los 565 varones y 151 mujeres que habían sido examinados, utilizando los mismos criterios y el mismo investigador que en un estudio de población realizado en Suecia en 1984. La distribución de la artrosis de cadera en los agricultores varones y en la población masculina de Malmoe se muestra en la Tabla 6.8 (Axmacher y Lindberg 1993).

Se ha observado que, además de los agricultores, los trabajadores de la construcción, procesadores de alimentos (trabajadores en molinos de grano, carniceros y preparadores de carne), bomberos, carteros, trabajadores de astilleros y bailarines profesionales de ballet presentan un mayor riesgo de artrosis de cadera. Es importante tener en cuenta que una denominación profesional no describe adecuadamente por sí sola el estrés ejercido sobre una articulación, ya que el mismo tipo de trabajo puede significar cargas diferentes para distintos trabajadores. Además, la carga que interesa en un estudio es la presión exacta ejercida sobre una articulación. En un estudio realizado en Suecia se ha cuantificado retrospectivamente la carga de trabajo físico mediante entrevistas individuales (Vingård y cols. 1991). Los varones muy expuestos a cargas físicas debido a sus ocupaciones hasta los 49 años de edad presentaban un riesgo mayor del doble de padecer artrosis de cadera que aquellos con exposición baja. Tanto las exposiciones dinámicas, como el levantamiento de grandes pesos, como la exposición estática, en forma de permanencia prolongada en posición sentada y girada, parecieron ser igualmente perjudiciales para la articulación.

Se ha observado que el riesgo de artrosis de rodilla está aumentado en los mineros del carbón, estibadores, trabajadores de astilleros, soladores e instaladores de moquetas y otros trabajadores de la construcción, bomberos, agricultores y limpiadores. Las exigencias físicas de moderadas a intensas en el trabajo, la flexión las rodillas y las lesiones traumáticas aumentan el riesgo.

En otro estudio inglés realizado en 1968 se observó que los estibadores padecían más artrosis de la rodilla que los funcionarios con ocupaciones sedentarias (Partridge y D uthie 1968).

En Suecia, Lindberg y M ontgomery investigaron a los trabajadores de un astillero y los compararon con oficinistas y maestros (Lindberg y M ontgomery 1987). Padecían gonartrosis el $3,9 \%$ de los trabajadores de astilleros, en comparación con el $1,5 \%$ de los oficinistas y maestros.

Tabla 6.8 - Prevalencia de osteoartrosis primaria de cadera en agricultores y poblaciones de varones de diferentes grupos de edad de la ciudad de Malmoe.

Agricultores varones Población masculina de Malmoe

$\begin{array}{lrrrrrr}\begin{array}{l}\text { Grupo de } \\ \text { edad }\end{array} & \text { N } & \text { Casos } & \text { Prevalencia } & \text { N } & \text { Casos } & \text { Prevalencia } \\ 40-44 & 96 & 1 & 1,0 \% & 250 & 0 & 0,0 \% \\ 45-49 & 127 & 5 & 3,9 \% & 250 & 1 & 0,4 \% \\ 50-54 & 156 & 12 & 6,4 \% & 250 & 2 & 0,8 \% \\ 55-59 & 127 & 17 & 13,4 \% & 250 & 3 & 1,2 \% \\ 60-64 & 59 & 10 & 16,9 \% & 250 & 4 & 1,6 \%\end{array}$

$\mathrm{N}=$ Número de varones estudiados; $\operatorname{casos}=$ varones con osteoartrosis de cadera. Fuente: Axmacher y Lindberg 1993.
En Finlandia, Wickström comparó trabajadores del hormigón armado con pintores, pero no encontró diferencias en cuanto a discapacidad de las rodillas (Wickström y cols. 1983). En un estudio finlandés posterior se compararon los trastornos de rodilla en soladores e instaladores de moqueta y en pintores (K ivimäki, Riihimäki y Hänninen 1992). Tanto el dolor como los accidentes de rodilla y las formas de uso (tratamiento) de las rodillas, así como la presencia de osteofitos alrededor de la rótula, fueron más frecuentes en los soladores e instaladores de moqueta que en los pintores. L os autores sugieren que el trabajo arrodillado aumenta el riesgo de padecer trastornos de rodilla, y que los cambios radiográficos observados podrían ser un signo inicial de degeneración de la rodilla.

En Estados U nidos se examinaron los factores asociados al proceso en la primera encuesta nacional de análisis de la salud y la nutrición (NHANES 1) para un total de 5.193 varones y mujeres de 35 a 74 años de edad, de los cuales 315 contaban con diagnóstico radiográfico de artrosis de rodilla, (Anderson 1988). Al investigar la carga en el trabajo, los autores caracterizaron las demandas físicas y la tensión por inflexión de las rodillas a partir de las denominaciones profesionales del diccionario de profesiones del Departamento de Trabajo de Estados U nidos. En ambos sexos, las personas en las que la descripción de sus trabajos incluía la flexión frecuente de las rodillas tenían un riesgo de desarrollar una artrosis de rodilla más de dos veces superior al de las que no realizaban tales trabajos. Al controlar la edad y el peso en el análisis estadístico, los autores observaron que el $32 \%$ de las artrosis de rodilla que se producían en estos trabajadores eran atribuible al tipo de trabajo.

En el estudio de Framingham de Estados U nidos se realizó un seguimiento epidemiológico durante más de 40 años a personas de Framingham, ciudad situada en las afueras de Boston (Felson 1990). Se comunicó la situación laboral en los períodos 1948-51 y 1958-61, y los resultados de los estudios radiológicos de búsqueda de artrosis de rodilla durante los años 1983-85. Se caracterizó el trabajo de cada persona por su nivel de demanda física y según estuviera asociado o no a la flexión de las rodillas. En este estudio también se observó que el riesgo de desarrollar artrosis de rodilla era doble en las personas que flexionaban mucho las rodillas y soportaban unas demandas físicas al menos medias en su trabajo.

En un estudio realizado en California se evaluaron los papeles de la actividad física, la obesidad y las lesiones de rodillas en el desarrollo de artrosis grave de rodilla (Kohatsu y Schurman 1990). En el estudio se analizaron 46 personas con gonartrosis y 46 personas sanas de la misma comunidad. Las personas con artrosis tenían una probabilidad dos o tres veces mayor que los controles de haber realizado un trabajo moderado o pesado en etapas anteriores de su vida, y una probabilidad 3,5 veces mayor de haber sido obesos a los 20 años de edad. Presentaban también una probabilidad cinco veces mayor de haber padecido una lesión de rodilla. No se observaron diferencias en las actividades de tiempo libre en los dos grupos.

En un estudio sueco de cohorte basado en registros (Vingärd y cols. 1991) fueron estudiados sujetos nacidos entre 1905 y 1945 , residentes en 13 de los 24 condados de Suecia en 1980 y que figuraban que habían desempeñado la misma profesión manual en los censos de 1960 y 1970. Las ocupaciones manuales desarrolladas fueron clasificadas a continuación según se asociaran a una carga alta (superior a la media) o baja (inferior a la media) de la extremidad inferior. Durante 1981, 1982 y 1983 se determinó si la población del estudio solicitó atención hospitalaria por artrosis de rodilla. Entre los varones, los bomberos, 
agricultores y trabajadores de la construcción presentaron un riesgo relativo elevado de desarrollar artrosis de rodilla. Entre las mujeres, se observó que el mayor riesgo lo presentaban las limpiadoras.

\section{Condromalacia rotuliana}

Un tipo especial de artrosis es la condromalacia rotuliana, que casi siempre comienza en la juventud. Se trata de un cambio degenerativo del cartílago de la superficie posterior de la rótula. Los síntomas son dolor de rodilla, sobre todo al flexionarla. La rótula está muy sensible a la percusión, y sobre todo si se ejerce presión sobre ella. El tratamiento es el entrenamiento del músculo cuádriceps y, en los casos graves, la cirugía. No está clara su conexión con las actividades laborales.

\section{Bursitis rotuliana}

En la rodilla existe una bolsa entre la piel y la rótula. La bolsa (bursa), que es un saco que contiene líquido, puede verse sometida a presión mecánica al arrodillarse y, por tanto, resultar inflamada. L os síntomas consisten en dolor y tumefacción. Se puede aspirar una cantidad importante de líquido seroso de la bolsa. Este trastorno es bastante frecuente en los grupos profesionales que se arrodillan con frecuencia. K ivimäki (1992) ha investigado mediante ecografía los cambios en los tejidos blandos de la parte anterior de la rodilla en dos grupos profesionales. Entre los soladores e instaladores de moqueta, el $49 \%$ presentaba engrosamiento de la bolsa prerrotuliana o infrarrotuliana superficial, en comparación con el 7 \% observado entre los pintores.

\section{Bursitis del pes anserinus (pata de ganso)}

El pes anserinus o pata de ganso está formado por los tendones de los músculos sartorio, semimembranoso y recto interno en la cara interna de la articulación de la rodilla. Bajo el punto de inserción de estos tendones existe una bolsa que se puede inflamar. El dolor aumenta con la extensión forzada de la rodilla.

\section{Bursitis trocantérea}

La cadera tiene numerosas bolsas que la rodean. La bolsa trocantérea se sitúa entre el tendón del glúteo mayor y la prominencia posterolateral del trocánter mayor (al otro lado de la cadera). EI dolor en esta zona suele recibir el nombre de bursitis trocantérea. En ocasiones se trata de una verdadera bursitis. El dolor puede irradiarse hacia el muslo y simular un dolor ciático.

En teoría es posible que una postura laboral especial ocasione el trastorno, pero no existen investigaciones científicas en este sentido.

\section{Meralgia parestésica (enfermedad de Bernhardt)}

La meralgia parestésica pertenece a los trastornos por atrapamiento, y su causa probablemente sea un atrapamiento del nervio femorocutáneo lateral en el punto de salida de éste entre los músculos y las aponeurosis por encima del borde de la pelvis (espina iliaca anterosuperior). El paciente presentará dolor en la cara frontal y lateral del muslo. Este trastorno puede ser realmente difícil de curar. Se han utilizado diferentes remedios, desde analgésicos hasta cirugía, con éxito variable. Dada la existencia de exposiciones profesionales que pueden ocasionar presión contra el nervio, este proceso puede ser una enfermedad profesional. Aunque existen casos puntuales, no se han realizado investigaciones epidemiológicas para comprobarlo.

\section{PIERNA, TOBILLO Y PIE}

Jarl-Erik M ichelsson

En general, el dolor es el síntoma principal en los trastornos de la pierna, el tobillo y el pie. A menudo sigue al ejercicio y puede ser agravado por éste. Son problemas frecuentes en estos trastornos la debilidad muscular, el déficit neurológico, los problemas para la adaptación del calzado, la inestabilidad o rigidez de las articulaciones y las dificultades para caminar y correr.

Las causas de los problemas suelen ser multifactoriales, aunque casi siempre proceden de factores biomecánicos, infecciones y/ o enfermedades sistémicas. Las deformidades del pie, la rodilla o la pierna, los cambios óseos y/ o de los tejidos blandos que siguen a una lesión, la tensión excesiva como las producidas por el uso repetitivo, la inestabilidad o la rigidez y el calzado inadecuado son causas habituales de estos síntomas. Pueden producirse infecciones óseas 0 de tejidos blandos. La diabetes, las enfermedades reumáticas, la psoriasis, la gota y los trastornos de la circulación sanguínea a menudo producen estos síntomas en la extremidad inferior.

A demás de la historia, siempre es necesaria una exploración clínica adecuada. Se examinarán cuidadosamente las posibles deformidades y alteraciones de la función, la circulación sanguínea y la situación neurológica. También puede estar indicado el análisis de la marcha. Los estudios mediante radiografías simples, TC, RM, ecografía, ENMG, imágenes vasculares y pruebas sanguíneas pueden contribuir al diagnóstico anatomopatológico y etiológico, así como al tratamiento.

Principios de tratamiento . El tratamiento irá dirigido siempre a la eliminación de la causa. Excepto en los traumatismos, el tratamiento principal suele ser conservador. Si es posible, se corregirán las deformidades mediante el calzado y/o las ortosis adecuadas. A menudo resulta beneficioso el consejo ergonómico adecuado, incluida la corrección de la mala forma de caminar 0 de correr. Pueden estar indicadas la disminución de la carga excesiva, la fisioterapia, los antiinflamatorios y, en raros casos, una corta inmovilización, así como el rediseño del trabajo.

También puede estar indicada la cirugía en algunos traumatismos agudos, sobre todo para algunos síntomas persistentes que no han mejorado con el tratamiento conservador, aunque es necesaria la valoración médica específica en cada caso.

\section{Tendinitis del tendón de Aquiles}

El trastorno suele ser debido a un uso excesivo del tendón de Aquiles, que es el tendón más fuerte del cuerpo humano y se encuentra en la pierna/tobillo. EI tendón está expuesto a una carga excesiva, sobre todo en los deportes, lo que da lugar a cambios anatomopatológicos inflamatorios y degenerativos del tendón y de los tejidos circundantes, bolsas y paratendon. En los casos graves puede producirse una rotura completa. Son factores predisponentes el calzado inadecuado, la mala alineación y las deformidades del pie, la debilidad o rigidez de los músculos de la pantorrilla, la carrera sobre superficies duras o irregulares y el entrenamiento intensivo. 0 casionalmente se produce tendinitis del tendón de Aquiles en algunas enfermedades reumáticas, después de fracturas de la pierna o el pie, en algunas enfermedades metabólicas y después de un trasplante renal.

El dolor y la tumefacción en la región del tendón del calcáneo, el tendón de Aquiles, son síntomas bastante frecuentes, sobre todo en los deportistas. El dolor está localizado en el tendón o en su unión al calcáneo. 
La tendinitis del tendón de Aquiles es más frecuente en los varones. L os síntomas son más habituales en los deportes recreativos que en las competiciones profesionales. Los deportes de carrera y salto en especial son los más proclives a causar tendinitis del tendón de Aquiles.

El tendón está hiperestésico, a menudo nodular, con tumefacción, y es fibrótico. También puede haber microrrupturas. La exploración clínica se puede apoyar sobre todo en la RM y la ecografía. Ambas son superiores a la TC para la visualización de la región y de la calidad de los cambios en los tejidos blandos.

El calzado adecuado en caso de mala alineación, los dispositivos de ortosis y el consejo sobre un correcto entrenamiento biomecánico pueden prevenir el desarrollo de la tendinitis del tendón de Aquiles. En presencia de síntomas a menudo tiene éxito el tratamiento conservador: evitar el entrenamiento excesivo, utilizar calzado adecuado que eleve el talón y amortigüe los choques, fisioterapia, antiinflamatorios, estiramiento y fortalecimiento de los músculos de la pantorrilla.

\section{Bursitis calcánea}

EI dolor detrás del talón, que por lo general se agrava al caminar, casi siempre está causado por una bursitis calcánea, a menudo asociada a una tendinitis del tendón de Aquiles. El trastorno se puede encontrar en ambos talones y aparecer a cualquier edad. En los niños, la bursitis calcánea a menudo se combina con una exostosis o una osteocondritis del calcáneo.

La causa de este trastorno es en la mayor parte de los casos un calzado inadecuado con un talón estrecho o duro. En los deportistas, la carga excesiva de la región del talón, como ocurre durante la carrera, puede provocar una tendinitis del tendón de Aquiles y una bursitis retrocalcánea. La deformidad de la parte posterior del pie es un factor predisponente. No suele haber infección.

A la exploración, el talón hiperestésico está engrosado y la piel puede estar roja. A menudo existe una curvatura hacia dentro de la parte posterior del pie. Las radiografías son importantes, en especial para el diagnóstico diferencial, y pueden revelar cambios en el calcáneo (p. ej., enfermedad de Sever, fracturas osteocondrales, osteofitos, tumores óseos y osteítis). En casi todos los casos la historia y la exploración clínica se apoyarán en una R M o una ecografía. U na bursografía retrocalcánea proporcionará más datos en los casos crónicos.

Los síntomas pueden desaparecer sin tratamiento. En los casos leves suele tener éxito el tratamiento conservador. Se protegerá el talón doloroso con vendas y con calzado adecuado de talones blandos. Puede resultar útil una ortosis para corregir la mala posición de la parte posterior del pie. A menudo resulta eficaz la corrección del comportamiento durante la marcha y la carrera.

La escisión quirúrgica de la bolsa y de la parte impactada del calcáneo sólo está indicada cuando ha fracasado el tratamiento conservador.

\section{Metatarsalgia de Morton}

$M$ etatarsalgia significa dolor en el antepié. Puede ser debida a un neuroma del nervio digital plantar, o neuroma de Morton. EI dolor típico aparece en el antepié, por lo general con irradiación al tercer y cuarto dedos y, rara vez, al segundo y tercero. El dolor aparece estando de pie o caminando a cualquier edad, aunque es más frecuente en las mujeres de mediana edad. Con el reposo, el dolor desaparece.

El proceso a menudo guarda relación con un pie plano y con la presencia de callosidades. La compresión lateral de las cabezas de los metatarsianos, así como la compresión de los espacios entre ellas, pueden desencadenar el dolor. En la radiografía simple no se observa el neuroma, aunque pueden ser visibles otros cambios (p. ej., deformidades óseas causantes de metatarsalgia). La imagen por R M puede revelar el neuroma.

El tratamiento conservador, calzado y plantillas adecuadas, para soportar el arco anterior a menudo resulta adecuado.

\section{Síndrome del túnel del tarso}

Todos los síntomas del síndrome del túnel del tarso son un dolor de tipo urente a lo largo de la planta del pie y de todos los dedos, que puede ser debido a la compresión del nervio tibial posterior en el interior del túnel fibroóseo situado bajo el retináculo flexor del tobillo. La compresión del nervio puede ser debida a muchos factores, siendo las causas más comunes las irregularidades óseas, las fracturas y luxaciones de tobillo, la presencia de ganglios 0 tumores locales o el empleo de calzado inadecuado.

Puede haber pérdida de sensibilidad en las zonas correspondientes a los nervios plantares interno y externo, debilidad y parálisis de los músculos del pie, sobre todo de los flexores, un signo de Tinel positivo e hiperestesia en la región del trayecto del nervio.

Resulta esencial una adecuada exploración clínica de la función y de la situación neurológica y vascular. El síndrome también puede diagnosticarse mediante pruebas electrofisiológicas.

\section{Síndromes compartimentales de la extremidad inferior}

Un síndrome compartimental es el resultado de una presión elevada mantenida en un espacio muscular intraaponeurótico cerrado, que da lugar a una circulación sanguínea marcadamente reducida en los tejidos. La elevada presión intracompartimental suele ser debida a traumatismos (lesiones por aplastamiento, fracturas y luxaciones), aunque también puede ser consecuencia de uso excesivo, de tumores y de infecciones. U n enyesado apretado puede ocasionar un síndrome compartimental, al igual que la diabetes y los trastornos de los vasos sanguíneos. Los primeros síntomas son tumefacción con tensión, dolor y restricción de la función, que no se alivian al elevar, inmovilizar o tratar la pierna con los fármacos habituales. Posteriormente habrá parestesias, entumecimiento y paresias. En las personas en edad de crecimiento, un síndrome compartimental puede ocasionar trastornos del crecimiento y deformidades en la región afectada.

Si se sospecha un síndrome compartimental, debe realizarse una buena exploración clínica que comprenda la valoración de la situación vascular, neurológica y muscular, la movilización activa y pasiva de la articulación, etc. Se medirá la presión mediante cateterismo múltiple de los compartimientos. La R M, la exploración Doppler y la ecografía pueden ser útiles para el diagnóstico.

\section{Tenosinovitis de la región del pie y el tobillo}

De los numerosos síntomas del pie, el dolor secundario a tenosinovitis es bastante frecuente, sobre todo en la región del tobillo y en el arco longitudinal. Las causas de la sinovitis pueden ser deformidades del pie, como el planovalgo, estrés excesivo, ajuste inadecuado del calzado, o secuelas de fracturas y otros traumatismos, trastornos reumatológicos, diabetes, psoriasis y gota. La sinovitis puede aparecer en muchos tendones, aunque el más frecuentemente afectado es el tendón de Aquiles. Sólo en raras ocasiones la tendinitis implica infección. Para el diagnóstico son esenciales la anamnesis y la exploración clínica. Los principales síntomas son dolor local, hiperestesia y movimientos dolorosos. Se necesitan radiografías simples que muestren los cambios óseos, y una R M , sobre todo para los cambios de los tejidos blandos.

Es necesario el consejo ergonómico. El calzado adecuado, la corrección de los hábitos de carrera y marcha y la prevención de las situaciones de estrés excesivo en el trabajo suelen ser beneficiosas. A menudo están indicados un corto período 
de reposo, la inmovilización con enyesado y los fármacos antiinflamatorios.

\section{H allux valgus}

EI hallux valgus es una desviación extrema de la primera articulación del dedo gordo del pie hacia la línea media. A menudo se asocia a otros trastornos del pie (varo del primer metatarsiano; pie plano, pie planotransverso o planovalgo). El hallux valgus puede aparecer a cualquier edad, y se observa más a menudo en las mujeres. El proceso es casi siempre familiar, y a menudo se debe a la utilización de calzado inadecuado, por ejemplo, con tacones altos y punta estrecha.

La articulación metatarsiana es prominente, la cabeza del primer metatarsiano está aumentada de tamaño y puede haber un juanete de la bolsa (a menudo inflamado) sobre la cara interna de la articulación. El primer dedo a menudo se monta sobre el segundo. Los tejidos blandos del dedo sufren cambios con frecuencia debido a la deformidad. La amplitud de la extensión y la flexión de la articulación metatarsofalángica suele ser normal, aunque puede haber rigidez debido a la osteoartritis (hallux rígido). En la inmensa mayoría de los casos, el hallux valgus es indoloro y no precisa tratamiento. En algunos casos, sin embargo, provoca problemas de ajuste del calzado y dolor.

El tratamiento se adaptará en cada caso según la edad del paciente, el grado de deformidad y los síntomas. Sobre todo en los adolescentes y en los casos con síntomas leves, se recomienda el tratamiento conservador: calzado adecuado, plantillas, almohadillas para proteger el juanete y similares.

La cirugía se reserva sobre todo para los pacientes adultos con graves problemas para calzarse y con dolor, cuyos síntomas no se alivian con el tratamiento conservador. Los métodos quirúrgicos no siempre tienen éxito $y$, por tanto, los meros factores estéticos no deben constituir una indicación real para la cirugía; sin embargo, las opiniones acerca de la utilidad de los alrededor de los 150 métodos quirúrgicos diferentes para el hallux valgus son muy variadas.

\section{Fascitis plantar}

El paciente nota dolor debajo del talón, sobre todo después de caminar o permanecer de pie mucho tiempo. El dolor se irradia a menudo a la planta del pie. La fascitis plantar puede aparecer a cualquier edad, pero su frecuencia máxima se da en personas de edad mediana y, a menudo, obesas. También es un trastorno bastante frecuente en los aficionados a practicar deporte. A menudo el pie presenta un arco longitudinal aplanado.

Existe hiperestesia local, sobre todo debajo del calcáneo, a nivel de la unión de la aponeurosis plantar. Toda la aponeurosis puede estar hiperestésica. Radiológicamente se observa un espolón óseo en el calcáneo en cerca del $50 \%$ de los pacientes, aunque también está presente en el 10 al $15 \%$ de los pies asintomáticos.

Las causas de la fascitis plantar no siempre están claras. U na infección, en particular la gonorrea, la artritis reumatoide y la gota, puede causar los síntomas. La mayor parte de las veces no existen enfermedades específicas relacionadas con el proceso. La principal causa de la hiperestesia puede ser el aumento de presión y la tensión de la aponeurosis. El espolón calcáneo puede ser una consecuencia del uso excesivo de la aponeurosis plantar. Probablemente no sea la causa principal de la hiperestesia calcánea, ya que muchos pacientes con esos síntomas no presentan espolón calcáneo y, a la inversa, muchos con espolón calcáneo carecen de síntomas.

\section{O TRAS ENFERMEDADES}

M arjatta Leirisalo-Repo

\section{Fibromialgia primaria}

La causa de la fibromialgia se desconoce. En algunos pacientes se asocian traumatismos e infecciones con la aparición de los síntomas, aunque no existen pruebas firmes en favor de tales episodios desencadenantes. Sin embargo, se sabe que existen muchos factores que agravan los síntomas existentes. El frío, el tiempo húmedo, los trastornos mentales, el estrés físico o mental y también la inactividad física se han asociado con la fibromialgia (Wolfe 1986).

U na característica importante es que los pacientes se levantan cansados por la mañana. Existe un metabolismo anormal de la serotonina asociado tanto con el trastorno del sueño como con la disminución del umbral doloroso típicos en estos pacientes (G oldberg 1987).

Los síntomas de fibromialgia tienen un comienzo insidioso, con dolores musculosqueléticos difusos y persistentes, síntomas generales múltiples como fatiga, rigidez, tumefacción subjetiva de los dedos que no observa el médico explorador, sueño no reparador y dolor muscular después del esfuerzo. Alrededor de un tercio de los pacientes presentan síntomas adicionales, como síndrome de intestino irritable, cefaleas de tensión, síndrome premenstrual, entumecimiento y hormigueos de las extremidades, sequedad de boca y ojos y constricción de los vasos sanguíneos de los dedos con la exposición al frío (fenómeno de R aynaud).

El paciente clásico con fibromialgia presenta una gran variedad de síntomas que, a excepción de los puntos hiperestésicos, carecen de componente objetivo. La fibromialgia desarrolla una evolución crónica. Casi todos los pacientes continúan presentando síntomas de intensidad variable. La remisión completa es una excepción. En la fibromialgia primaria no hay datos de laboratorio sugestivos de artritis inflamatoria. LoS pacientes con esta última enfermedad (p. ej., artritis reumatoide) también pueden presentar síntomas fibromiálgicos, en cuyo caso se aplica la denominación fibromial gia secundaria.

No existe una prueba específica para la fibromialgia. El diagnóstico se basa en la historia clínica y en la observación clínica de los puntos hiperestésicos (Figura 6.22). La prevalencia de fibromialgia en la población general es del 0,5 al $1 \%$. Casi todos los pacientes (75 a $90 \%$ ) son mujeres, por lo general entre 25 y 45 años de edad; los niños se afectan rara vez.

El American College of R heumatology ha establecido los criterios para la clasificación de la fibromialgia (Figura 6.23).

\section{Diagnóstico}

Es preciso excluir otros procesos con síntomas similares. El dolor diseminado debe estar presente durante tres meses como mínimo. Además, debe haber dolor a la presión ejercida por el dedo del explorador en 11 de los 18 puntos hiperestésicos que se muestran en la Figura 6.22

\section{Artritis reumatoide}

Alrededor del $1 \%$ de la población adulta padece artritis reumatoide. EI comienzo de la enfermedad se suele situar entre los $30 \mathrm{y}$ los 50 años de edad, con un riesgo tres veces mayor en el sexo femenino. La prevalencia de la enfermedad aumenta en las poblaciones de más edad.

La causa de la artritis reumatoide se desconoce. No es hereditaria, aunque los factores genéticos aumentan el riesgo de desarrollar la enfermedad. Además de uno o varios factores genéticos, se cree que algunos factores desencadentes ambientales 
Figura 6.22 - Puntos hiperestésicos en la fibromialgia.
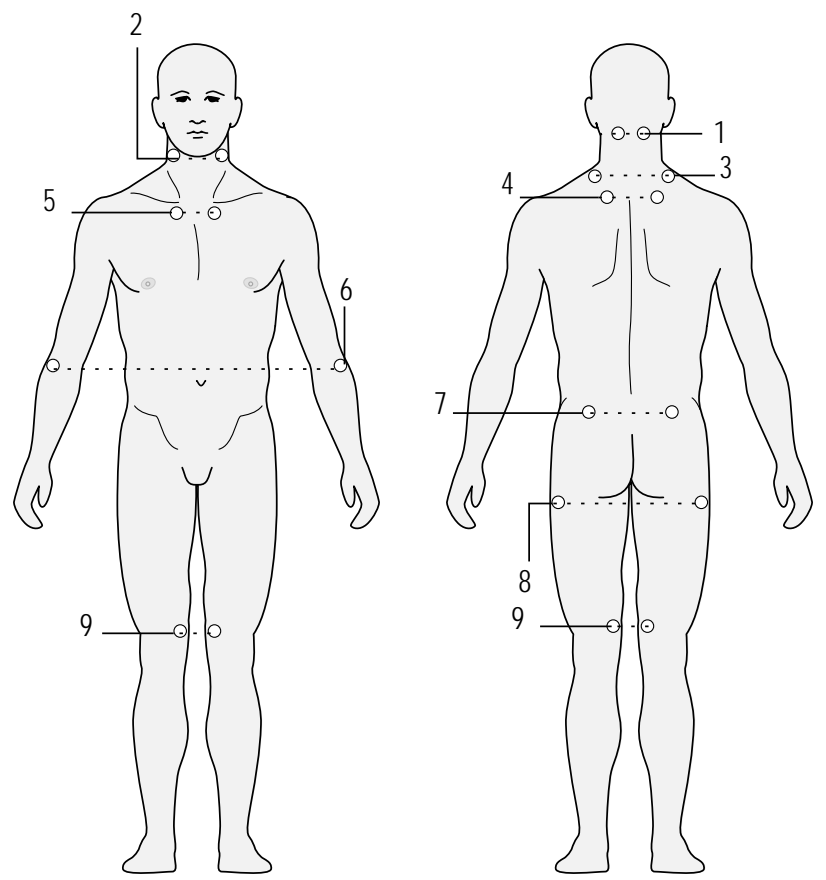

1. Occipital; bilateral, en las inserciones musculares suboccipitales.

2. Cenvical bajo; bilateral, en las superficies anteriores de los espacios intertransversos C5-C7.

3. Trapecio; bilateral, en el punto medio del borde superior.

4. Supraespinoso; bilateral, en sus orígenes, encima de la espina de la escápula cerca del borde interno.

5. Segunda costilla; bilateral, en las segundas uniones condrocostales, inmediatamente lateral a las uniones en las superficies superiores.

6. Epicóndilo lateral; bilateral, $2 \mathrm{~cm}$ distal a los epicóndilos.

7. Glúteo; bilateral.

8. Trocánter mayor; bilateral, posterior a las prominencias trocantéreas.

9. Rodilla; bilateral, en la almohadilla grasa interna, proximal a la línea articular.

pueden intervenir en su patogenia, y se sospecha muy especialmente de las infecciones víricas o bacterianas.

$\mathrm{La}$ artritis reumatoide suele tener un comienzo gradual. Es típico que el paciente presente una hinchazón leve de las pequeñas articulaciones de los dedos, así como hiperestesia de los pies, manifestada de forma simétrica. Por ejemplo, si están afectadas las articulaciones de una mano, es probable que también lo estén las mismas articulaciones de la otra mano. EI principal síntoma es la rigidez matinal de manos y pies. EI paciente a menudo tiene fatiga, y puede presentar febrícula. Los datos de laboratorio muestran signos de inflamación (velocidad de eritrosedimentación y nivel de proteína $C$ reactiva elevados) $y$, a menudo, de anemia ligera. Alrededor del $70 \%$ de los pacientes tienen factor reumatoide circulante (autoanticuerpo frente a la inmunoglobulina de clase IgG ). En los casos precoces, la exploración radiológica de manos y pies a menudo es normal, pero posteriormente la mayoría de los pacientes presentan signos radiológicos de destrucción articular (erosiones). EI diagnóstico de artritis reumatoide se basa en una mezcla de hallazgos clínicos, analíticos y radiológicos (véase la Figura 6.24). Las enfermedades que con más frecuencia causan problemas de diagnóstico diferencial son las enfermedades articulares degenerativas de las manos, las artritis secundarias a infecciones, las espondiloartropatías y algunas enfermedades raras del tejido conjuntivo (G uidelines 1992).
Figura 6.23 - Criterios de 1990 del American College of Rheumatology para el diagnóstico de fibromialgia.
1. Antecedentes de dolor meses como mínimo). El dolor se considera generalizado en presencia de todo lo siguiente: dolor en ambos lados del cuerpo por encima y por debajo de la cintura. Además, debe haber dolor en el esqueleto axial. generalizado (presente durante 3

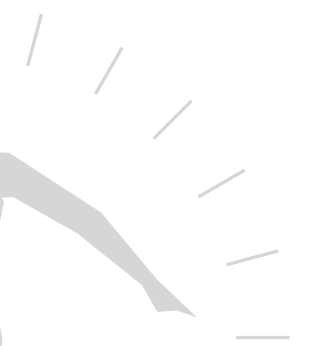

2. Dolor a la palpación digital en 11 de los 18 puntos hiperestésicos (véase la Figura 6.22).

Si se cumplen ambos criterios se dirá que el paciente padece una fibromialgia.

Fuente: Wolfe y cols. 1990
La educación del paciente para disminuir la carga de trabajo en las articulaciones, la utilización de dispositivos ergonómicos, el empleo de calzado adecuado y el tratamiento correcto de las infecciones constituyen la base de las medidas preventivas. Las directrices del tratamiento se dan en la Tabla 6.9.

\section{Espondiloartropatías}

\section{E pidemiología y etiología}

Las espondiloartropatías comprenden entidades clínicas típicas como la espondilitis anquilopoyética y algunas formas de artritis asociadas a psoriasis, enfermedades intestinales inflamatorias crónicas o infecciones bacterianas del tracto urogenital 0 del intestino (las denominadas artritis reactivas). Son enfermedades frecuentes. La prevalencia de la forma más crónica, la espondilitis anquilopoyética, en las poblaciones occidentales oscila entre el 0,1 y el $1,8 \%$ (Gran y H usby 1993). Se calcula que, en una población de 10.000 personas, se producen anualmente tres casos nuevos de artritis transitoria como artritis reactiva por cada paciente con espondilitis anquilopoyética. La mayoría de los pacientes que desarrollan una espondiloartropatía son adultos jóvenes de entre 20 y 40 años de edad. Existen pruebas de que el promedio de comienzo de los síntomas en los pacientes con espondilitis anquilopoyética está aumentando (Calin y cols. 1988).

Figura 6.24 - Criterios para el diagnóstico de artritis reuma toide.

Deben estar presentes cuatro o más de los siguientes:

1. Rigidez matinal (60
minutos como mínimo)
en manos o pies
2. Artitis en tres o
más zonas articulares
3. Artitis de las
articulaciones de las
manos
4. Artititis simétrica


Tabla 6.9 - Directrices para el tratamiento de la artritis reumatoide.

1. Tratamiento del dolor articular

2. Tratamiento de la inflamación articular ( fármacos antirreumáticos modificadores de la enfermedad)

3. Inyecciones locales

4. Cirugía

5. Rehabilitación
Antiinflamatorios no esteroideos Paracetamol (Dextropropoxifeno)

Oro intramuscular

Sulfasalazina

Auranofin

Antipalúdicos

D-penicilamina

Metotrexato

Azatioprina

Ciclosporina (Ciclofosfamida)

Tratamiento glucocorticosteroideo

Glucocorticosteroides

Sinoviectomía química con tetraóxido de osmio

Inyección de isótopos radiactivos

Cirugía reparadora precoz (sinoviectomía, tenosinovectomía) Cirugía reconstructora

Terapia ocupacional

Fisioterapia

Educación

Evaluación de las necesidades de ayudas y dispositivos

Las espondiloartropatías poseen un fuerte componente genético, ya que la mayoría de los pacientes presenta un marcador genético hereditario, el HLA-B27. La frecuencia de este marcador es del 7 al $15 \%$ en las poblaciones occidentales; el 90-100\% de los pacientes con espondilitis anquilopoyética y el $70-90 \%$ de los pacientes con artritis reactiva son HLA-B27 positivos. Sin embargo, a niveles de población, la mayoría de los sujetos con este marcador están sanos. Por tanto, se cree que son necesarios factores exógenos además de la susceptibilidad genética para el desarrollo de la enfermedad. Tales factores desencadenantes incluyen infecciones bacterianas en el aparato urogenital 0 en el intestino (Tabla 6.10), lesiones cutáneas y enfermedades intestinales inflamatorias crónicas. Las pruebas a favor de las infecciones son más claras en el caso de la artritis reactiva. Las infecciones por salmonellas están aumentando mucho, como consecuencia de lo cual es de esperar un aumento de los casos con complicaciones articulares. La agricultura y la avicultura pueden ser las fuentes de estas infecciones. En cuanto a las infecciones por yersinias, los cerdos portan bacterias yersinia en sus amígdalas. Se ha sugerido que el sacrificio de animales seguido de la conservación de los productos cárnicos en frío podría contribuir a la dispersión de las infecciones en los seres humanos. En los pacientes con espondilitis anquilopoyética, sin embargo, no suele ser posible atribuir a infecciones precedentes el acontecimiento desencadenante. Resultados recientes, no obstante, se han centrado en el hallazgo de que los pacientes con espondilitis anquilopoyética a menudo presentan una inflamación intestinal crónica asintomática, que podría servir como factor desencadenante o como foco inflamatorio contribuyente a la cronicidad de la enfermedad.

\section{Signos y síntomas}

La artritis periférica es asimétrica, afecta a las grandes articulaciones y posee predilección por las extremidades inferiores. A menudo, los pacientes presentan también dolor lumbar inflamatorio, que empeora por la noche y se alivia con el movimiento, no con el reposo. U na característica típica es la tendencia a la inflamación de la unión entre tendones y huesos (entesopatía), que puede manifestarse como dolor debajo del talón o en el calcáneo, en la inserción del tendón de Aquiles. A demás de la inflamación de las articulaciones y de las inserciones ligamentosas, los pacientes pueden presentar también síntomas inflamatorios oculares (iritis o conjuntivitis), cutáneos (psoriasis, lesiones cutáneas en palmas y plantas o induración de la pierna) y, a veces, cardíacos

Los siguientes son los criterios diagnósticos de la espondiloartropatía (D ougados y cols., 1991).

\section{Dolor lumbar inflamatorio}

0

\section{Inflamación articular (sinovitis):}

- asimétrica

- predilección por las extremidades inferiores

al menos uno de los siguientes:

- antecedentes familiares positivos de espondiloartropatía

- psoriasis

- enfermedad intestinal inflamatoria

- dolor en los glúteos que cambia de un lado a otro

- dolor en la unión entre tendón y hueso (entesopatía).

Los pacientes con espondilitis anquilopoyética presentan dolor lumbar que empeora por la noche e hiperestesia entre la columna y la pelvis, a nivel de las articulaciones sacroilíacas. Pueden tener una movilidad limitada de la columna con hiperestesia torácica. U n tercio de los pacientes presentan artritis periférica y entesopatía. La clave del diagnóstico de espondilitis anquilopoyética es la presencia de cambios radiológicos en las articulaciones sacroilíacas; existe una pérdida de espacio entre las articulaciones y excesivo crecimiento óseo. Tales cambios aumentan la exactitud diagnóstica en los pacientes con espondiloartropatía, pero sólo son necesarios en el caso de la espondilitis anquilopoyética.

\section{Gota}

\section{Epidemiología y etiología}

La gota es un trastorno metabólico que constituye la causa más común de artritis inflamatoria en el varón. Su prevalencia en el adulto oscila entre el 0,2 y el 0,3 por 1000 , y es del $1,5 \%$ en los

\begin{tabular}{ll}
\hline Tabla $6.10 \cdot \begin{array}{l}\text { Infecciones conocidas como } \\
\text { desencadenantes de la artritis reactiva. }\end{array}$ \\
Foco & Bacteria \\
Aparato respiratorio superior & Chlamydia pneumoniae \\
& Streptococcus beta-hemolítico \\
& (por lo general produce fiebre reumática) \\
Intestino & Salmonella \\
& Shigella \\
& Yersinia enterocolitica \\
& Yersinia pseudotuberculosis \\
& Campylobacter jejuni \\
Aparato urogenital & Chlamydia trachomatis \\
& Neisseria gonorrhoeae
\end{tabular}


varones adultos. La prevalencia de la gota aumenta con la edad y con la elevación de los niveles séricos de uratos.

La hiperuricemia (niveles elevados de ácido úrico en suero) es un factor de riesgo. Son factores contribuyentes a ella las enfermedades renales crónicas que ocasionan insuficiencia renal, la hipertensión, el empleo de diuréticos, la ingesta elevada de alcohol, la exposición al plomo y la obesidad. Los ataques de gota son precipitados por la hipersaturación del líquido articular con ácido úrico; los cristales precipitados irritan la articulación, con aparición de artritis aguda.

\section{Signos y síntomas}

La evolución natural de la gota pasa por varias fases, desde una hiperuricemia asintomática hasta una artritis gotosa aguda, períodos asintomáticos y una gota tofácea crónica (gota con nódulos).

La artritis gotosa aguda a menudo se manifiesta como inflamación aguda en una articulación, habitualmente en la base del primer dedo del pie. La articulación presenta una gran hiperestesia, tumefacción y dolor intenso; a menudo está enrojecida. EI ataque agudo puede ceder espontáneamente en unos días. Si no se trata, pueden producirse ataques repetidos, que en algunos pacientes continúan (durante los años siguientes), dando lugar al desarrollo de una artritis crónica. En estos pacientes es posible observar depósitos de urato en los pabellones auriculares, los codos o los tendones de Aquiles, donde forman masas subcutáneas indoloras palpables (tofos).

\section{Artritis infecciosa}

\section{Epidemiología y etiología}

En la infancia, la artritis infecciosa a menudo se desarrolla en un niño previamente sano, pero los adultos con frecuencia presentan algún factor predisponente como diabetes, artritis crónica, uso de glucocorticosteroides o inmunosupresores, o infecciones o traumatismos previos de la articulación. Los pacientes con endoprótesis también son susceptibles a las infecciones en la articulación operada.

Las bacterias son las causas más frecuentes de artritis infecciosa. En los pacientes inmunosuprimidos pueden encontrarse hongos. Aunque la infección bacteriana de la articulación es rara, es muy importante su diagnóstico ya que, si no se trata, la infección destruye rápidamente la articulación. Los microbios pueden alcanzar la articulación por medio de la circulación (infección séptica), por heridas penetrantes directas o durante una inyección intraarticular, o a partir de un foco infeccioso adyacente.

\section{Signos y síntomas}

En el caso típico, el paciente presenta una inflamación articular aguda, por lo general en una sola articulación, que está dolorida, caliente, roja y con hiperestesia al movimiento. Existen síntomas generales de infección (fiebre, escalofríos) y signos analíticos de inflamación aguda. El aspirado de la articulación es turbio, y al examen microscópico se observan leucocitos, con tinciones y cultivos positivos para bacterias. El paciente puede presentar signos de un foco de infección en cualquier otro lugar, como una neumonía.

\section{0 steoporosis}

\section{Epidemiología y etiología}

La masa ósea aumenta desde la infancia hasta la adolescencia. Las mujeres ganan un $15 \%$ menos de densidad ósea que los varones. El valor máximo se alcanza entre los 20 y los 40 años, tras lo cual existe una disminución progresiva. La osteoporosis es un proceso en el que la masa ósea disminuye y los huesos se hacen más susceptibles a las fracturas. La osteoporosis es una causa importante de morbilidad en las personas de edad avanzada. La manifestación más importante son las fracturas lumbares y de cadera. Alrededor del $40 \%$ de las mujeres que han alcanzado los 70 años han padecido fracturas.

El valor máximo de la masa ósea está influido por factores genéticos. En las mujeres, desciende después de la menopausia. La disminución de la masa ósea en el varón es menos manifiesta. A demás de la falta de estrógenos, existen otros factores que influyen en la tasa de pérdida ósea y en el desarrollo de osteoporosis, como la inactividad física, la dieta baja en calcio, el consumo de tabaco, el consumo de café y el bajo peso corporal. El tratamiento corticosteroideo sistémico también se asocia a un mayor riesgo de osteoporosis.

\section{Signos y síntomas}

La osteoporosis puede ser asintomática. Por otra parte, la manifestación más diferenciada de osteoporosis es la fractura ósea, siendo las más típicas las de cadera, vértebras (columna) y muñeca. Las fracturas de cadera y de muñeca suelen ser consecuencia de caídas, pero las fracturas vertebrales se pueden desarrollar de forma insidiosa después de un traumatismo trivial. El paciente presenta dolor lumbar, cifosis y pérdida de estatura.

\section{Cáncer óseo}

\section{E pidemiología y etiología}

Los tumores óseos malignos primarios son raros. A parecen casi siempre en niños y adultos jóvenes. El osteosarcoma es el más frecuente. Casi siempre se observa en el segundo decenio de la vida, y en los adultos de más edad puede ser secundario a una enfermedad ósea (enfermedad de Paget). El sarcoma de Ewing también se observa casi siempre en niños, con cambios destructivos en la pelvis o los huesos largos. Los tumores malignos originados en el cartílago (condrosarcomas) pueden aparecer en muchas zonas de cartílago. En los adultos, las lesiones óseas malignas son a menudo metastáticas (es decir, la enfermedad primaria está situada en otro punto del organismo).

La mayor parte de los tumores malignos primarios carecen de etiología conocida. Sin embargo, la enfermedad ósea de Paget, la osteomielitis, la osteonecrosis y las lesiones por radiación se han asociado a transformaciones malignas. Las metástasis óseas son frecuentes en los cánceres primarios de mama, pulmón, próstata, riñón o tiroides.

\section{Signos y síntomas}

En los pacientes con osteosarcoma hay dolor, limitación del movimiento y tumefacción. Además del dolor óseo, los pacientes con sarcoma de E wing a menudo presentan síntomas sistémicos como fiebre, malestar y escalofríos. Los condrosarcomas pueden ocasionar síntomas variados, dependiendo de la localización del tumor y de sus características histológicas.

\section{0 steomielitis}

\section{Epidemiología y etiología}

La osteomielitis es una infección ósea, habitualmente bacteriana, aunque puede ser fúngica 0 vírica. En las personas por lo demás sanas, la osteomielitis es un acontecimiento raro, pero en los pacientes con enfermedades crónicas como diabetes 0 artritis reumatoide, una infección del organismo puede diseminarse por la corriente sanguínea o por invasión directa de los huesos. En los niños, la localización más favorable para la diseminación es la 
diáfisis de los huesos largos, pero en los adultos la infección se produce a menudo en la columna vertebral. Un punto focal desde el que una infección puede diseminarse por la corriente sanguínea o por invasión directa, un traumatismo penetrante o contuso, y una cirugía ortopédica previa (inserción de una prótesis) pueden complicarse por una osteomielitis.

\section{Signos y síntomas}

La infección aguda de los huesos largos va acompañada de fiebre, escalofríos y dolor óseo. La osteomielitis espinal puede ocasionar síntomas más vagos, con dolor progresivo y febrícula. Las infecciones alrededor de una prótesis ocasionan dolor e hiperestesia al movilizar la articulación intervenida.

\section{Referencias}

Agency for Health Care Policy and Research (AHCPR). 1994. Acute low-back problems in adults. Clinical Pratice Guidelines 14. Washington, DC: AHCPR .

Allander, E. 1974. Prevalence, incidence and remission rates of some common rheumatic diseases or syndromes. Scand I Rheumatol 3:145-153.

American Academy of O rthopaedic Surgeons. 1988. J oint M otion. Nueva Y ork: Churchill Livingstone.

Anderson, JAD. 1988. Arthrosis and its relation to work. Scand J W ork E nviron H ealth 10:429-433.

Anderson, JJ, DT Felson. 1988. Factors associated with osteoarthritis of the knee in the first $\mathrm{N}$ ational $\mathrm{H}$ ealth and Nutrition Survey (HANES 1): Evidence for an association with overweight, race and physical demands of work. Am J E pidemio 128:179-189.

Angelides, AC. 1982. Ganglions of the hand and wrist. En Operative $\mathrm{H}$ and Surgery, dirigido por DP Green. Nueva Y ork: Churchill Livingstone.

Armstrong, T J, WA Castelli, G Evans, R Diaz-Perez. 1984. Some histological changes in carpal tunnel contents and their biomechanical implications. J 0 ccup M ed 26(3):197-201.

Armstrong, TJ, P Buckle, L Fine, $M$ Hagberg, B Jonsson, A K ilbom, I K uorinka, B Silverstein, B Sjøgaard, E Viikari-Juntura. 1993. A conceptual model for work-related neck and upper-limb musculoskeletal disorders. Scand J W ork Environ $\mathrm{H}$ ealth 19:73-84.

Arnett, FC, SM Edworthy, DA Bloch, DJ M CShane, JF Fries, NS Cooper, LA H ealey, SR K aplan, M H Liang, HS Luthra, TAJ M edsger, DM M itchell, DH Neustadt, RS Pinals, JG Schaller, JT Sharp, RL Wilder, GG Hunder. 1988. The American Rheumatism Association 1987 revised criteria for the classification of rheumatoid arthritis. Arthritis R heum 31:315-324.

Aronsson, G, U Bergkvist, S Almers. 1992 O rganización del trabajo y trastornos musculoesqueléticos en el trabajo con terminales de visualización en pantalla (en sueco con resumen en inglés). Solna: Instituto $\mathrm{N}$ acional de M edicina del T rabajo.

Axmacher, B, H Lindberg. 1993. Coxarthrosis in farmers. Clin O rthop 287:82-86.

Bergenudd, H, F Lindgärde, B Nilsson. 1989. Prevalence and coincidence of degenerative changes of the hands and feet in middle age and their relationship to occupational work load intelligence, and social background. Clin Orthop 239:306-310.

Brinckmann, P, M H Pope. 1990. Effects of repeated loads and vibration. En The L umbar Spine, dirigido por J Weinstein y SW Weisel. Filadelfia: WB Saunders.

Calin, A, J Elswood, S Rigg, SM Skevington. 1988 Ankylosing spondylitis - an analytical review of 1500 patients: The changing pattern of disease. J R heumatol 15:1234-1238.

Chaffin, D, GBJ Andersson. 1991. Occupational Bio-mechanics. N ueva Y ork: Wiley.

Daniel, RK, WC Breidenbach. 1982. Tendon: structure, organization and healing. Capítulo 14 en T he M usculoskeletal System: E mbryology, B iochemistry and Physiology, dirigido por RL Cruess. Nueva Y ork: Churchill Livingstone.

Dougados, M, S van der Linden, R Juhlin, B $\mathrm{H}$ uitfeldt, B Amor, A Calin, A Cats, B Dijkmans, I Olivieri, G Pasero, E Veys, H Zeidler. 1991. The European Spondylarthropathy Study Group preliminary criteria for the clasification of spondylarthropathy. Arthritis R heum 34:1218-1227.

Edwards, RHT. 1988. H ypotheses of peripheral and central mechanisms underlying occupational muscle pain and injury. Eur I Appl Physiol 57(3):275-281.

Felson, DT. 1990. The epidemiology of knee osteoarthritis: R esults from the Framingham 0 steoarthritis Study. Sem Arthrit R heumat 20:42-50.

Felson, DT, JJ Anderson, A Naimark, AM Walker, RF M eenan. 1988. O besity and knee osteoarthritis: The Framingham study. Ann Intern M ed 109:18-24.

Fung, YB. 1972. Stress-strain history relations of soft tissues in simple elongation. Capítulo 7 en Biomechanics: Its $\mathrm{F}$ oundations and $\mathrm{O}$ bjectives, dirigido por YC Fung, $\mathrm{N}$ Perrone y $\mathrm{M}$ Anliker. Englewood C liffs, N ueva J ersey: Prentice $H$ all.

Gelberman, R, V Goldberg, K An, A Banes. 1987. Tendon. Capítulo 1 en Injury and Repair of the M usculoskeletal Soft T issue, dirigido por SL Woo y J A Buckwalter. Park Ridge, Illinois: American A cademy of O rthopaedic Surgeons.

Gemne, G, H Saraste. 1987. Bone and joint pathology in workers using hand-held vibrating tools. Scand J W ork E nviron H ealth 13:290-300.

Goldberg, DL. 1987. Fibromyalgia syndrome. An emerging but controversial condition. JAM A 257:2782-2787.

Goldstein, SA, TJ Armstrong, DB Chaffin, LS $M$ atthews. 1987. Analysis of cumulative strain in tendons and tendon sheaths. I Biomech 20(1):1-6.

Gran, JT , G H usby. 1993. The epidemiology of ankylosing spondylitis. Sem Arthrit R heumat 22:319-334.

Guidelines and audit measures for the specialist supervision of patients with rheumatoid arthritis. R eport of a Joint Working Group of the British Society for R heumatology and the R esearch U nit of the R oyal College of Physicians. 1992. J R oyal Coll Phys 26:76-82

H agberg, M. 1982. Local shoulder muscular strain -symptoms and disorders. J H um E rgol 11:99-108.

Hagberg, M, DH Wegman. 1987. Prevalence rates and odds ratios of shoulder neck diseases in different occupational groups. Brit J Ind $M$ ed 44:602-610.

H agberg, M , H H endrick, B Silverstein, M J Smith, R Well, P Carayon. 1995. W ork Related M usculoskeletal Disorders (W M SD s): A Reference B ook for Prevention, dirigido por I Kuorinka, y L Forcier. Londres: T aylor \& Francis.

Hägg, GM , J Suurküla, A K ilbom. 1990. Factores de predicción de las afecciones del hombro y el cuello relacionadas con el trabajo (en sueco con resumen en inglés). Solna: Instituto nacional de M edicina del T rabajo.

H alpern, M . 1992. Prevention of low back pain: Basic ergonomics in the workplace and the clinic. Bailliere's Clin R heum 6:705-730.
$\mathrm{H}$ amerman, D, S T aylor. 1993. H umoral factors in the pathogenesis of osteoarthritis. En Humoral Factors in the Regulation of $\mathrm{T}$ issue $\mathrm{G}$ rowth, dirigido por PP Foá. N ueva Y ork: Springer.

H annan, MT, DT Felson, JJ Anderson, A Naimark, WB K annel. 1990. Estrogen use and radiographic osteoarthritis of the knee in women. Arthritis $R$ heum 33:525-532.

$\mathrm{H}$ ansen, SM . 1993. Arbejdsmiljø $0 \mathrm{~g}$ Samfundsøkonomi - E n $M$ etode Til Konsekvensbeskrivning. Nord: Nordisk $M$ inisterråd.

$H$ ansen, SM, PL Jensen. 1993. Arbejdsmiljø Og Samfundsøkonomi -R egneark Og Dataunderlag. N ord: Nordisk M inisterråd. (Nordiske Seminar - og Arbejdsrapporter 1993:556.)

Hansson, JE. 1987. Förararbetsplatser [Puestos de trabajo al volante de un vehículo, en sueco]. En M änniskan I Arbete, dirigido por N Lundgren, G Luthman y K Elgstrand. Estocolmo: Almqvist \& Wiksell.

H eliövaara, M, M M äkelä, K Sievers. 1993. Enferme dades musculoesqueléticas en Finlandia (en finlandés). $\mathrm{H}$ elsinki: $\mathrm{K}$ ansaneläkelaitoksen julkaisuja $\mathrm{AL}$.

Järvholm U, G Palmerud, J Styf, P Herberts, R $K$ adefors. 1988. Intramuscular pressure in the supraspinatus muscle. J Orthop R es 6:230-238.

Jupiter, JB, HE K leinert. 1988. V ascular injuries of the upper extremity. En The H and, dirigido por R T ubiana. Filadelfia: W B Saunders.

K ärkkäinen, A. 1985. Osteoartritis de la mano en la población finlandesa de 30 o más años de edad(en finlandés con resumen en inglés). Finlandia: Publicaciones del Instituto de la Seguridad Social.

K ivi, P. 1982. T he etiology and conservative treatment of humeral epicondylitis. Scand I Rehabil M ed 15:37-41.

K ivimäki, J. 1992. O ccupationally related ultrasonic findings in carpet and floor layers knees. Scand I W ork Environ $\mathrm{H}$ ealth 18:400-402.

K ivimäki, J, H Riihimäki, K H änninen. 1992. K nee disorders in carpet and floor layers and painters. Scand J W ork E nviron H ealth 18:310-316.

K ohatsu, ND, D Schurman. 1990. Risk factors for the development of osteoarthrosis of the knee. Clin Orthop 261:242-246.

Kuorinka, I, B Jonsson, A K ilbom, H Vinterberg, $\mathrm{F}$ Biering-Sørensen, G Andersson, $\mathrm{K}$ Jørgensen. 1987. Standardised Nordic questionnaires for the analysis of musculoskeletal symptoms. Appl Ergon 18:233-237.

Kurppa, K, E Viikari-Juntura, E K uosma, M Huus-konen, P K ivi. 1991. Incidence of tenosynovitis or peritendinitis and epicondylitis in a meat-processing factory. Scand J W ork Environ $H$ ealth 17:32-37.

Leadbetter, WB. 1989. Clinical staging concepts in sports trauma. Capítulo 39 en Sports-Induced nflammation: Clinical and Basic Science Concepts, dirigido por WB L eadbetter, JA Buckwalter y SL Gordon. Park Ridge, Illinois: American A cademy of O rthopaedic Surgeons.

Lindberg, H , F M ontgomery. 1987. H eavy labor and the occurence of gonarthrosis. Clin Orthop 214:235-236. 
Liss, GM, S Stock. 1996. Can Dupuytren's contracture be work-related?: R eview of the evidence. Am J Ind M ed 29:521-532.

Louis, DS. 1992. The carpal tunnel syndrome in the work place. Capítulo 12 en 0 ccupational Disorders of the U pper Extremity, dirigido por LH M illender, DS Louis y BP Simmons. Nueva York: Churchill Livingstone.

Lundborg, G. 1988. Nerve Injury and Repair. Edimburgo: Churchill Livingstone.

Manz, A, W Rausch. 1965. Zur Pathogenese und Begutachtung der Epicondylitis humeri. M ünch M ed W ochenshcr 29:1406-1413.

M arsden, CD, M P Sheehy. 1990. Writer's cramp. T rends N eurosci 13:148-153.

M ense, S. 1993. Peripheral mechanisms of muscle nociception and local muscle pain. J M usculoskel Pain 1(1):133-170.

M oore, JS. 1992. Function, structure, and responses of the muscle-tendon unit. O ccup M ed: State Art Rev 7(4):713-740.

Mubarak, SJ. 1981. Exertional compartment syndromes. En Compartment Syndromes and Volkmann's Contracture, dirigido por SJ Mubarak y AR $\mathrm{H}$ argens. Filadelfia: WB Saunders.

Nachemson, A. 1992. Lumbar mechanics as revealed by lumbar intradiscal pressure measurements. En The L umbar Spine and Back Pain, dirigido por MIV Jayson. Edimburgo: Churchill Livingstone.

O bolenskaja, AJ, Goljanitzki, JA. 1927. Die seröse Tendovaginitis in der $\mathrm{K}$ linik und im Experiment. D tsch Z Chir 201:388-399.

Partridge, REH, JJR Duthie. 1968. R heumatism in dockers and civil servants: A comparison of heavy manual and sedentary workers. Ann Rheum Dis 27:559-568.

Rafusson $\mathrm{V}, \mathrm{OA}$ Steingrímsdóttir, $\mathrm{MH}$ O lafsson, $\mathrm{T}$ Sveinsdóttir. 1989. M uskuloskeletala besvär bland islänningar. N ord M ed 104: 1070

R oberts, S. 1990. Sampling of the intervertebral disc. En M ethods in Cartilage Research, dirigido por A $\mathrm{M}$ aroudas y $\mathrm{K}$ K uettner. Londres: Academic Press.

Rydevik, BL, S Holm. 1992. Pathophysiology of the intervertebral disc and adjacent structures. En The Spine, dirigido por RH Rothman y FA Simeone. Filadelfia: WB Saunders.

Schüldt, K. 1988. On neck muscle activity and load reduction in sitting postures. Tesis doctoral, Instituto de K arolinska, Estocolmo.

Schüldt, K, J Ekholm, J Toomingas, K $\mathrm{H}$ arms-R ingdahl, M K öster, Grupo de Estudio MUSIC de Estocolmo 1. 1993. A sociación entre resistencia/ esfuerzo de los extensores del cuello y afecciones del cuello (en sueco). En Stockholm Investigation 1, dirigido por M Hagberg y C H ogstedt. Estocolmo: M U SIC Books.

Silverstein, BA, LJ Fine, T J Armstrong. 1986. H and wrist cumulative trauma disorders in industry. $B$ rit J Ind $M$ ed 43:779-784.

Sjøgaard, G. 1990. Exercise-induced muscle fatigue: The significance of potassium. Acta Physiol Scand 140 Supl. 593:1-64.

Sjøgaard, G, O M Sejersted, J Winkel, J Smolander, K Jørgensen, R Westgaard. 1995. Exposure assessment and mechanisms of pathogenesis in work-related musculoskeletal disorders: Significant aspects in the documentation of risk factors. En $\mathrm{W}$ ork and $\mathrm{H}$ ealth. Scientific Basis of Progress in the W orking Environment, dirigido por O Svane y $C$ Johansen. Luxemburgo: Comisión Europea, Dirección General V

Spitzer, WO, FE LeBlanc, M Dupuis y cols. 1987. Scientific approach to the assessment and management of activity-related spinal disorders. Spine 12(7S).
Tidswell, M. 1992. Cash's T extbook of Orthopaedics and R heumatology for Physiotherapists. Europa: M osby.

Thompson, AR, LW Plewes, EG Shaw. 1951. Peritendinitis crepitans and simple tenosynovitis: A clinical study of 544 cases in industry. B rit J Ind $M$ ed 8:150-160.

U rban, JPG, S Roberts. 1994. Chemistry of the intervertebral disc in relation to functional requirements. En Grieve's M odern M anual Therapy, dirigido por JD Boyling y N Palastanga. Edimburgo: Churchill Livingstone.

Viikari-Juntura, E. 1984. Tenosynovitis, peritendinitis and the tennis elbow syndrome. Scand J W ork Environ $\mathrm{H}$ ealth 10:443-449.

Vingård, E, L Alfredsson, I Goldie, C Hogstedt. 1991. O ccupation and osteoarthrosis of the hip and knee. Int J E pidemiol 20:1025-1031.

Vingård, E, L Alfredsson, I Goldie, C Hogstedt. 1993. Sports and osteoarthrosis of the hip. Am Sports M ed 21:195-200.

Waters, TR, V Putz-Anderson, A Garg, LJ Fine. 1993. Revised NIOSH equation for design and evaluation of manual lifting tasks. Ergonomics 36:739-776.

Wickström, G, K H änninen, T M attsson, T Niskanen, H Riihimäki, P Waris, A Zitting. 1983. $K$ nee degeneration in concrete reinforcement workers. B rit J Ind M ed 40:216-219.

Wolfe, F. 1986. The clinical syndrome of fibrositis. Am J M ed 81 Suppl. 3A:7-14.

Wolfe, F, HA Smythe, M B Y unus, RM Bennett, C Bombardier, DL Goldenberg, $P$ T ugwell, SM Campbell, M Abeles, P Clark, AG Fam, SJ Farber, JJ Fiechtner, CM Franklin, RA Gatter, D Hamaty, J Lessard, AS Lichtbroun, AT M asi, GA M CCain, W J Reynolds, T J R omano, If Russell, R P Sheon. 1990. The American College of R heumatology criteria for the classification of fibromyalgia. Report of the multicenter criteria committee. Arthritis R heum 33:160-172.

Y unus, MB. 1993. Research in fibromyalgia and myofascial pain syndromes: Current status, problems and future directions. J M usculoskel Pain $1(1): 23-41$.

\section{0 tras lecturas recomendadas}

Adams, JC. 1976. O utline of Orthopaedics. Edimburgo: Churchill Livingstone.

Altman, RD. 1991. Criteria for classification of clinical osteoarthritis. J R heumatol 18:10-12.

Andersson, S, T Hessel, A Norén, B Nilsson, M Saraste, D Rydholm. 1989. Degenerative joint disease in ballet dancers. Clin 0 rthop 238:233-236.

A pley, AG. 1997. System of Orthopaedics and F ractures. Londres: Butterworths.

Armstrong, TJ, P Buckle, LJ Fine, $M$ Hagberg, B Jonsson, $\AA$ Kilbom, IAA Kuorinka, BA Silverstein, G Sjøgaard, E V iikari-Juntura. 1993. A conceptual model for work-related neck and upper-limb disorders. Scand J W ork E nviron $\mathrm{H}$ ealth 19(2):73-84.

Armstrong, TJ, RG Radwin, DJ Hansen, KW $\mathrm{K}$ ennedy. 1986. Repetitive trauma disorders. Job evaluation and design. $\mathrm{H}$ um $\mathrm{F}$ actors 28:325-336.

A violi, LV, SM K rane. 1990. M etabolic B one Disease and Clinical Related Disorders. Filadelfia: WB Saunders.

Baylink, DJ, JC Jennings, ME K raenzlin. 1994. Calcium and bone homeostasis and changes with aging. En Principles of Geriatric M edicine and Gerontology, dirigido por WR Hazzard, EL Bierman, JP Blass, WH Ettinger y JB Holter. 3a edición. Nueva Y ork: M cG raw-H ill.

Beltran, J, DS Campanini, C K night, M M CCalla. 1990. The diabetic foot: Magnetic resonance imaging evaluation. Sketetal Radiol 19(1):37-41.
Bland, JH. 1991. Cervical and thoracic pain. Curr 0 pin R heumatol 3(2):218-225.

Brown, CW, PAJ Deffer, J Akmakjian, DH Donaldson, IL Brugman. 1992. The natural history of thoracic disc herniation. Spine 17 Supl. 6:S97-102.

Cailliet, R. 1991. Neck and Arm Pain. Filadelfia: FA Davis.

Cailliet, R. 1983. F oot and Ankle Pain. Filadelfia: FA Davis.

Cheung, Y, ZS Rosenberg, T Magee, L Chinitz. 1992. N ormal anatomy and pathologic conditions of ankle tendons: Current imaging techniques. Radiographics 12(3):429-444.

Christiansen, C. 1992. Prevention and treatment of osteoporosis: A review of current modalities. B one 13:S35-S39.

Clain, M R, DE Baxter. 1992. Achilles tendinitis. F oot Ankle 13(8):482-487.

Crenshaw, AH. 1992. Campbell's 0 perative 0 rthopaedics. Vol. 5. St. Louis: M osby.

Croft, P, D Coggon, M Cruddas, C Cooper. 1992a. O steoarthritis of the hip: An occupational disease in farmers. B rit M ed J 304:1269-1272.

Croft, P, C Cooper, C Wickham, D Coggon. 1992b. $O$ steoarthritis of the hip and occupational activity. Scand J W ork E nviron H ealth 18:59-63.

Danielsson, L. 1964. Incidence and prognosis of coxarthrosis. Acta Orthopaed Scand Suppl 66 Supl. 35:1-61.

Dayton, P, FD Goldman, E Barton. 1990 Compartment pressure in the foot. Analysis of normal values and measurement technique. J Am Podiatr M ed Assoc 80(10):521-525.

Dupuis, H, G Zerlett. 1987. Whole-body vibration and disorders of the spine. Int Arch 0 ccup Environ $H$ ealth 59(4):323-336.

Duthie, RB, ABJ Ferguson. 1973. M ercer's Orthopaedic Surgery. Londres: Edward Arnold.

Fakhouri, AJ, A 2d Manoli. 1992. Acute foot compartment syndromes. I Orthopaed Trauma $6(2): 223-228$

Favus, MJ. 1993. Primer on the M etabolic B one D iseases and $D$ isorders of $M$ ineral $M$ etabolism. 2a edición. Filadelfia: JB L ippincott.

Felson, DT . 1990. O steoarthritis. R heum D is Clin N Am 16:499-512.

Ferguson, H, M Raskowsky, RL Blake, JA Denton. 1991. T L -61 versus $R$ ohadur orthoses in heel spur syndromes. I Am Podiatr M ed Assoc 81(8):439-442.

Fund, DA, JR Cass, KA Johnson. 1986. Acquired adult flat foot secondary to posterior tibial-tendon pathology. J B one J oint Surg Am 68(1):95-102.

Furey, JG. 1975. Plantar fasciitis: The painful heel syndrome. J B one J oint Surg Am 57:672-673.

Galloway, MT, P Jokl, OW Dayton. 1992. Achilles tendon overuse injuries. Clin Sport $M$ ed 11(4):771-782.

Garg, A, JS M oore. 1992. Epidemiology of low-back pain in industry. State Art R ev O ccup M ed 7:593-609.

Goldenstein-Schainberg, C, C Homsi, RM Rodrigues-Pereira, W Cossermelli. 1992. R etrocalcaneal bursitis in juvenile chronic arthritis. Ann R heum D is 51(10):1162-1163.

Goulet, MJ. 1984. Role of soft orthosis in treating plantar fasciitis. Phys T herapy 64(10).

Gower, W, RC Johnston. 1971. Legg-Perthes disease: L ong term follow-up of thirty six patients. I B one oint Surg 53:759-768.

Grandjean, E. 1988. Fitting the Task to the $M$ an. Londres: T aylor \& Francis.

Hadler, NM. 1993. O ccupational M usculoskeletal $D$ isorders. Nueva Y ork: R aven Press.

Hagberg, M. 1987. Shoulder pain pathogenesis. En Clinical Concepts of Regional M usculoskeletal Illness, 
dirigido por NM Hadler. Nueva York: Grune \& Stratton.

—. 1992. Exposure variables in ergonomic epidemiology. Am J Ind M ed 21:91-100.

- . 1994. N eck and shoulders disorders. En T extbook of $O$ ccupational and Environmental M edicine, dirigido por L Rosenstock y MR Cullen. Filadelfia: W B Saunders.

$\mathrm{H}$ arju, V , JE M ichelson. 1988. The subjective results of 443 surgical procedures for hallux valgus. Acta Orthopaed Scand 59(6):751.

$\mathrm{H}$ arms-R ingdahl, K. 1986. O n assessment of shoulder exercise and load-elicited pain in the cervical spine. Tesis doctoral, Instituto de $\mathrm{K}$ arolinska, Estocolmo.

Helfet, AJ. 1984. Disorders of the Foot. Filadelfia: JB Lippincott.

Herberts, P, R Kadefors, C Högfors, G Sigholm. 1984. Shoulder pain and heavy manual labor. Clin Orthop 191:166-178.

Hernandez, PA, WA Hernandez, A Hernandez. 1991. Clinical aspects of bursae and tendon sheaths of the foot. I Am Podiatr M ed Assoc 81(7):366-372.

Hoaglund, FT, ACMC Yau, WL Wong. 1973 $O$ steoarthrosis of the hip and other joints in southern Chinese in $\mathrm{H}$ ong $\mathrm{K}$ ong. Incidence and related factors. J B one J oint Surg 55:545-557.

Jahss, M H. 1992. Foot and ankle pain resulting from rheumatic conditions. Curr Opin Rheumatol 4(2):233-240.

Järvholm, U, G Palmerud, J Styf, P Herberts, R K adefors. 1988. Intramuscular pressure in the supraspinatus muscle. J Orthopaed Res 6:230-238.

Jones, DA, JM Round. 1990. Skeletal muscle in health and disease. En A T extbook of M uscle Physiology. $M$ anchester: $M$ anchester U niv. Press.

K ainberger, F, A Engel, S T rattnig, D Polzleitner, HP K utschera, Seidl.G. 1992. Sonographic structural analysis of the Achilles tendon and biomechanical implications. Ultraschall M edicin 13(1):28-30.

K eenan, MA, TD Peabody, JK Gronley, J Perry. 1991. Valgus deformities of the feet and characteristics of gait in patients who have rheumatoid arthritis. I Bone J oint Surg Am 73(2):237-247.

Kennedy, JC, R Hawkins, WB K rissoff. 1978. Orthopaedic manifestations of swimming. Am J Sports M ed 6:309-322.

K elsey, J. 1982. E pidemiology of musculoskeletal disorders. M onographs in Epidemiology and Biostatistics. Oxford: O xford U niv. Press.

K err, R, C Frey. 1991. M R imaging in tarsal tunnel syndrome. J Comput Assist T omo 15(2):280-286.

K ilbom, §. 1988. Intervention programs for work-related neck and upper limb disorders. Strategies and evaluation. E rgoa 31:435-747.

Klünder, KB, B Rud, J H ansen. 1981. O steoarthritis of the hip and knee joint in retired football players. Acta O rthopaed Scand 51:925-927.

K neeland, JB, M K Dalinka. 1992. M agnetic resonance imaging of the foot and ankle. $M$ agnet Reson 0 8(2):97-115.

K ozin, F. 1991. Medical and surgical treatment of seronegative spondyloarthropathies. Curr 0 pin R heumatol 3:592-596.

Lane, NE, DA Bloch, PD Wood, JF Freis. 1987. Aging, long-distance running and the development of musculoskeletal disability. Am । M ed 82:772-780.

Langenskiöld, A, J-E M ichelsson, T Videman. 1979. $O$ steoarthritis of the knee in the rabbit produced by immobilization. Acta O rthopaed Scand 50:1-14.

Lawrence, JS. 1977. Rheumatism in Populations. Londres: William H einemann M edical Books.
Leach, RE, AA Schepsis, H Takai. 1992. Long term results of surgical management of Achilles tendinitis in runners. Clin Orthop 282 (septiembre):208-212.

Leirisalo-Repo, M, H Repo. 1992. Gout and spondyloarthropathies. Rheum Dis Clin N Am 18:23-35.

Leppilahti, J, S O rava, J K arpakka, T Takala. 1991. $O$ veruse injuries of the A chilles tendon. Ann C hirurg Gynaecol F enni 80(2):202-207.

Lindberg, H, L Danielsson. 1984. The relation between labor and coxarthrosis. Clin Orthop 191:159-161.

Lindberg, H, H Roos, P Gärdsell. 1993. Prevalence of coxarthrosis in former soccer players. Acta Orthopaed Scand 64(2):165-167.

Lohrer, H. 1991. Rare causes and differential diagnoses of Achilles tendinitis. Sportverletz Sportschaden 5(4):182-185.

M alawski, SK, S Lukawski. 1991. Pyogenic infection of the spine. Clin Orthop 272:58-66.

M ann, RA. 1987. Pain in the foot. 2. Causes of pain in the hindfoot, midfoot, and forefoot. Postgrad $M$ ed 82(1):167-171,174.

M anoli, A, T G Weber. 1990. Fasciotomy of the foot: An anatomical study with special reference to release of the calcaneal compartment. F oot Ankle 11(1):54-55

M arti, B, M K nobloch, A T schopp, A Jucker, H H owald. 1989. Is excessive running predictive of degenerative hip disease? B rit M ed J 299:91-93.

M cM ichel, AJ, R Spirtas, LL K upper. 1974. An epidemiological study of mortality within a cohort of rubber workers. J 0 ccup M ed 74:458-464.

McNab, I, J M cCulloch. 1994. Neck Ache and Shoulder Pain. Baltimore: Williams \& Wilkins.

Moskowitz, RW, DS Howell, VM Goldberg, HJ Mankin. 1984. Osteoarthritis Diagnosis and $M$ anagement. Filadelfia: WB Saunders.

Neale, D, IM Adams. 1985. Common F oot Disorders: Diagnosis and $M$ anagement. Edimburgo: Churchill Livingstone.

Neer, CS. 1983. Impingement lesions. Clin Orthop 173:70-77.

Nichols, AW. 1989. Achilles tendinitis in running athletes. J Am B oard F am Pract 2(3):196-203.

Nuki, G. 1980. The Aetiopathogenesis of 0 steoarthrosis. T unbridge W ells, R eino U nido: Pitman M edical.

O rava, S, I Saarela. 1978. Exertion injuries to young athletes. Am J Sports M ed 6.

O xenburgh, M. 1991. Increasing Productivity and Profit through $\mathrm{H}$ ealth and Safety. Chicago: Commerce Clearing $\mathrm{H}$ ouse.

Panush, RS y cols. 1986. Is running associated with degenerative joint disease? I Am M ed Assoc 255:1152-1154.

Pope, M H, G Andersson, JF Frymoyer, DB Chaffin (dirs.) 1991. O ccupational Low Back Pain. St. Louis: M osby

Priest, JD, DA Nagel. 1976. Tennis shoulder. Am J Sports M ed 4:28-42.

Puranen, J, L Ala-K etola, P Peltokallio, J Saarela. 1975. Running and primary osteoarthrosis of the hip. Brit M ed I 285:424-425

Radin, EL. 1976. M echanical aspects of osteoarthritis. B R heum D is 26:862-865.

-. 1976. A etiology of osteoarthritis. Clin R heum D is 2:509-522.

R amazzini, B. 1990. De moribus artificium diatriba (D iseases of W orkers). 1713. Allergic P roc. 11:51-55.

Riel, KA, P Bernett. 1990. Therapy-resistant heel pain -An indication for surgery in sports traumatology. Sportverletz Sportschaden 4(3):121-124.
Riihimân, H. 1995. Back and limb disorders. En E pidemiology of W ork Related Disorders, dirigido por JC M CD onald. Londres: BM J.

Rissanen, A, M H eliövaara, P K nekt, A Aromaa, J $M$ aatela. 1990. R isk of disability and mortality due to overweight in a Finnish population. B rit M ed J 301:835-837.

Romana, M C, AC M aswuelet, K K laue. 1991. Soft tissue preservation and reconstruction in non-supporting foot parts. Therapeutische U mschau 48(12):836-841.

Rosenberg, ZS, F Feldman, RD Singson, GJ Price. 1987. Peroneal tendon injury associated with calcaneal fractures: CT findings. Am J R oentgenol 149(1):125-129.

Rosenfield, AL, E Bartal. 1992. Bilateral spontaneous lateral compartment syndrome in the legs of a patient who received a kidney and heart transplant. A case report. J Bone J oint Surg Am 74(5):775-776.

Ryan, PJ, P Evans, T Gibson, I Fogelman. 1992. O steoporosis and chronic back pain: A study with single-photon emission computed tomography bone scintigraphy. J B one M iner Res 7(12):14551460

Rydell, N. 1973. Biomechanics of the hip joint. Clin Orthop 92:6-15.

van Saase, JL. 1989. O steoarthrosis in the general population. A follow-up study of osteoarthrosis of the hip. T esis, U niversidad de Erasmo, D ordrecht, R oterdam.

Salter, R, P Field. 1960. The effects of continuous compression on living articular cartilage. J B one l oint Surg 42A:31-49.

Schepsis, AA, RE Leach. 1987. Surgical management of Achilles tendinitis. Am J Sports M ed 15(4):308315.

Silverstein, BA. 1985. The prevalence of upper extremity cumulative trauma disorders in industry. Tesis doctoral, Universidad de Michigan, Ann Arbor, M ichigan.

Skeith, KJ, P Davis. 1992. New horizons in the medical treatment of rheumatoid arthritis. Curr 0 pin R heumatol 4:365-371.

Snook, SH . 1988. Approaches to the control of back pain in industry: Job design, job placement and education/training. State Art $\mathrm{Rev} O \mathrm{O}$ ccup $\mathrm{Med}$ 3:45-59.

Sohn, RS, MJ Lyle. 1987. The effect of running on the pathogenesis of osteoarthritis of the hips and knees. Clin Orthop 198:106-109.

Stenlund, B, I Goldie, M H agberg, C Hogstedt, 0 $M$ arions. 1992. Radiographic osteoarthrosis in the acromioclavicular joint resulting from manual work or exposure to vibration. B rit I Ind $M$ ed 49:588-593

Sundaresan, N, GV Digiacinto, JE Hughes, M C afferty, A V allejo. 1991. T reatment of neoplastic spinal cord compression: R esults of a prospective study. N eurosurgery 29(5):645-650.

Supple, K M , JR H anft, BJ M urphy, CJ Janecki, GF Kogler. 1992. Posterior tibial tendon dysfunction. Sem Arthrit R heumat 22(2):106-113.

Thackrah, CT 1957. The effects of arts, trades, and professions, and of civil status and habits of living, on health and longevity. En The Life, W ork and $T$ imes of Charles Turmer Thackrah, dirigido por A M eiklejohn. Edimburgo: $E$ \& S Livingstone.

Thelin, A. 1990. Hip joint arthrosis: An occupational disorder among farmers. Am J Ind M ed 18:339343.

Travell, J. 1984. Myofascial Pain and Dysfunction. Baltimore: Waverly Press

Travell, J G, D G Simons. 1985. M yofascial Pain and Dysfunction. The Trigger Point Manual. Baltimore: Williams \& Wilkins. 
Triano, II, MA Hondras, M M CGregor, 1992. Differences in treatment history with manipulation for acute, subacute, chronic and recurrent spine pain. I M anipul Physiol Therap 15(1) :24-30.

Typpö, T. 1985. Osteoarthritis of the hip: Radiological findings and etiology. Ann Chirurg Gynaecol $F$ enni 74:5-38.

Videman, T. 1982. Experimental osteoarthritis in the rabbit. Acta 0 rthopaed Scand 53:339-347.

-. 1982. The effect of running on osteoarthritic joint: An experimental matched-pair study with rabbits. R heumatol R ehab 21:1-8.

Viikari-Juntura E. 1995. The role of physical stressors in the development of hand/wrist and elbow disorders. En Repetitive M otion Disorders of the U pper Extremity, dirigido por SL Gordon, SJ Blair y LJ Fine. Rosemont, Illinois: American Academy of O rthopaedic Surgeons.

Vingård, E. 1991. O verweight predisposes to cox-arthrosis. Body mass index studied in 239 males with hip arthroplasty. Acta Orthopaed Scand 62:106-109.

Vingård, E, L Alfredsson, E Fellenius, I Goldie C Hogstedt, M Köster. 1991. Coxarthrosis and physical load from occupation. Scand J W ork Environ $\mathrm{H}$ ealth 17:104-109.

Warren, BL. 1984. Anatomical factors associated with predicting plantar fasciitis in long-distance runners. M ed Sci Sport 16(1).

Waris, P. 1980. O ccupational cervicobrachial syndromes. Scand J W ork Environ Health Supl. 3:3-14.

Wedge, JH, MJ Wasylenko, SC Houston. 1991. $M$ inor anatomic abnormalities of the hip joint persisting from childhood and their possible relationship to idiopathic osteoarthrosis. Clin Orthop 264:122-128.

Wegman, DH , LJ Fine. 1990. 0 ccupational health in the 1990s. Ann R ev Pub H ealth 11:89-103.
Weinstein, SL. 1985. Legg-Calvé-Perthes disease: Results of long term follow-up. En The Hip, dirigido por R HJ Fitzgerald. St. Louis: M osby.

Wiesel, SW, JN Weinstein, H Harkowitz, J Dvorak, $G$ Bell (dirs). The Lumbar Spine 2 a edición. Filadelfia: WB Saunders.

Wilson, M , CJ Michet, D Ilstrup, J M elton. 1990. Idiopathic symptomatic osteoarthritis of the hip and knee: $A$ population based incidence study. $M$ ayo $C$ lin Proc 65:1214-1221.

Winkel, J, R Westgaard. 1992. O ccupational and individual risk factors for shoulder-neck complaints: Part II -T he scientific basis (literature review) for the guide. Int I Ind E rg 10:85-104.

Wu, KK. 1986. Surgery of the Foot. Philadelphia: Lea \& Febiger.

Zippel, R, D Lorenz, W Kocher, A Domagk. 1992. Das Druckverhalten in den Muskellogen des Fusses bei definierter Belastung an Tarsal - und Sprunggelenksfrakturen. Chirurg 63(4):310-315. 

Directora del capítulo

D onna M ergler

\section{Sumario}

Sistema nervioso: visión general

D onna M ergler y $\mathrm{J}$ osé Valciukas ........................ 7.2

Anatomía y fisiología

J osé A. Valciukas ......................... 7.3

Agentes químicos neurotóxicos

Peter A rlien-Søborg y L eif Simonsen. . . . . . . . . . . . . . . . . . . . 7.9

M anifestaciones de intoxicación aguda y crónica precoz

Donna $M$ ergler ............................. 7.15

Síndromes clínicos asociados a neurotoxicidad

Robert G. Feldman . . . . . . . . . . . . . . . . . . . . . . . 7.18

Determinación de los déficit neurotóxicos

D onna M ergler

Diagnóstico

Anna M aria Seppäläinen ........................ 7.24

Neuroepidemiología profesional

Olav A xelson. 


\section{SISTEMA NERVIOSO : VISION GENERAL}

\section{D onna M ergler y José Valciukas}

El conocimiento del sistema nervioso en general y del cerebro y el comportamiento humano en particular tiene una importancia capital para quienes se dedican a conseguir un entorno seguro y sano. Las condiciones de trabajo y las exposiciones que afectan directamente a las funciones del cerebro influyen en la mente y en el comportamiento. Para evaluar la información, tomar decisiones y reaccionar de forma adecuada y razonable ante las percepciones del mundo exterior, es necesario que el sistema nervioso funcione adecuadamente y que el comportamiento no resulte afectado por situaciones peligrosas, como accidentes (p. ej., una caída de una escalera mal diseñada) o la exposición a niveles peligrosos de productos químicos neurotóxicos.

La lesión del sistema nervioso puede provocar alteraciones de las aferencias sensoriales (pérdida de visión, de la audición, del olfato, etc.), mermar la capacidad para controlar el movimiento y las funciones del organismo y/ o afectar a la capacidad del cerebro para tratar o almacenar la información. Además, la alteración del funcionamiento del sistema nervioso puede originar trastornos del comportamiento o psicológicos. L os cambios del estado de ánimo o de la personalidad son un acontecimiento frecuente después de lesiones físicas u orgánicas del cerebro. A medida que avanzan nuestros conocimientos, aprendemos más acerca de la forma en que se modifican los procesos del sistema nervioso. Las sustancias neurotóxicas pueden atravesar la barrera natural del cerebro e interferir directamente en su complejo funcionamiento. A unque algunas sustancias tienen una especial afinidad por determinadas regiones del sistema nervioso, la mayor parte de las neurotoxinas tienen efectos generalizados que afectan a los procesos celulares que participan en el transporte de membrana, en las reacciones químicas intracelulares, en la liberación de sustancias secretoras, etc.

La lesión de los distintos componentes del sistema nervioso puede producirse de diferentes formas:

- lesión física directa por objetos que caen, choques, golpes o presión excesiva sobre los nervios;

- cambios en el medio interno, como falta de oxígeno debida a productos asfixiantes y exposición al calor;

- interferencia en los procesos celulares debida a la acción química de sustancias como metales, disolventes orgánicos y pesticidas.

El desarrollo insidioso y polifacético de numerosos trastornos del sistema nervioso exige que las personas que trabajan en el campo de la salud laboral adopten enfoques diferentes, pero complementarios, del estudio, el conocimiento, la prevención y el tratamiento del problema. Pueden descubrirse alteraciones precoces en grupos de trabajadores activos expuestos, utilizando mediciones sensibles del deterioro. L a identificación de la disfunción inicial puede permitir la adopción de medidas preventivas. En etapas más tardías es necesario un buen conocimiento clínico, y es fundamental el diagnóstico diferencial para el tratamiento y asistencia adecuados de los trabajadores discapacitados.

Aunque las sustancias químicas se estudian casi siempre una por una, es preciso recordar que en muchos lugares de trabajo se utilizan mezclas de productos químicos potencialmente neurotóxicos, lo que expone a los trabajadores a lo que podemos llamar un "cóctel". En procesos como la impresión, la pintura, la limpieza, en oficinas mal ventiladas, en laboratorios, en la aplicación de pesticidas, en la microelectrónica y en otros muchos sectores, los trabajadores están expuestos a mezclas de productos químicos. Aunque quizá exista información sobre cada una de las sustancias por separado, tenemos que considerar la nocividad combinada y los posibles efectos aditivos, e incluso sinérgicos, sobre el sistema nervioso. En algunos casos de exposición múltiple, cada sustancia química puede estar presente en una cantidad muy pequeña, incluso inferior al nivel de detección de las técnicas de evaluación de la exposición; sin embargo, cuando se suman todas, la concentración total puede ser muy elevada.

El lector debe ser consciente de tres importantes dificultades que surgen al revisar los aspectos relacionados con el sistema nervioso, que se sitúan en el ámbito de esta E nciclopedia.

En primer lugar, el conocimiento de las enfermedades profesionales que afectan al sistema nervioso y al comportamiento ha cambiado notablemente a medida que se han desarrollado nuevos enfoques de las relaciones entre cerebro y comportamiento. El principal interés de la caracterización de las alteraciones morfológicas macroscópicas que se producen a causa de traumatismos mecánicos del sistema nervioso (especialmente del cerebro, pero no exclusivamente) fue seguido por el interés en la absorción de productos neurotóxicos por el sistema nervioso, por el interés en el estudio de los mecanismos celulares de la patología del sistema nervioso, y finalmente, cobró auge la búsqueda de la base molecular de estos procesos patológicos. Estos enfoques coexisten en la actualidad, y todos ellos aportan información para evaluar las condiciones de trabajo que afectan al cerebro, a la mente y al comportamiento.

En segundo lugar, la información aportada por los científicos es asombrosa. La tercera edición del libro Principles of $\mathrm{N}$ eural Sciences, dirigido por K andel, Schwartz y K essell y publicado en 1991- una de las más valiosas revisiones en este campo- , pesa $3,5 \mathrm{~kg}$ y tiene más de 1.000 páginas.

En tercer lugar, resulta muy difícil revisar los conocimientos sobre la organización funcional del sistema nervioso, en su aplicación a todas las parcelas de la salud y la seguridad en el trabajo. Hasta hace aproximadamente 25 años, las opiniones teóricas en las que se apoyaban los expertos sanitarios especializados en la detección, vigilancia, prevención y tratamiento clínico de los trabajadores que habían absorbido un producto neurotóxico no coincidían en ocasiones con las opiniones teóricas relativas a los traumatismos cerebrales de los trabajadores y las manifestaciones en el comportamiento de lesiones cerebrales mínimas. Las manifestaciones del comportamiento que se suponían consecuencia de la interrupción de reacciones químicas específicas en el cerebro eran competencia exclusiva de los neurotoxicólogos; la lesión hística estructural de regiones concretas del cerebro y de estructuras neurales distantes ligadas a la zona en la que se produjeron las lesiones eran las explicaciones aducidas por los neurólogos. Sólo en los últimos años han ido apareciendo opiniones convergentes.

Teniendo presente todo esto, en este capítulo se abordan temas importantes para el conocimiento del sistema nervioso y de los efectos de las condiciones del lugar de trabajo sobre su funcionamiento. Comienza con una descripción de la anatomía y la fisiología, seguida de una sección sobre neurotoxicidad en la que se revisan la exposición, sus resultados y su prevención.

D ado que el sistema nervioso es fundamental para el bienestar del organismo, numerosos peligros no químicos pueden igualmente afectar a su funcionamiento normal. M uchos de ellos se abordan en diferentes capítulos en los que se tratan estos peligros. Las lesiones craneoencefálicas de origen traumático se incluyen en Primeros auxilios, el estrés por calor se considera en el artículo sobre efectos del estrés por calor y del calor en el trabajo y el mareo por descompresión se revisa en el artículo sobre el estrés por la gravedad. La vibración mano-brazo (vibración transmitida por la mano) y los movimientos repetitivos (Secuelas musculosqueléticas crónicas) abordados en el capítulo 
Sistema M usculosquel ético, que son factores de riesgo de neuropatías periféricas, se consideran igualmente en estas secciones de la Enciclopedia.

El capítulo termina con una revisión de temas especiales y de las perspectivas de futuras vías de investigación.

\section{- AN AT O MIA Y FISIO LO gIA}

José A. Valciukas

Las células nerviosas son las unidades funcionales del sistema nervioso. Se cree que el sistema nervioso tiene diez mil millones de estas células, llamadas neuronas y células gliales, siendo mayor el número de células gliales que de neuronas.

\section{La neurona}

L a Figura 7.1 es un esquema teórico de una neurona con sus tres características estructurales más importantes: el cuerpo celular, las dendritas y el axón terminal.

Las dendritas son prolongaciones finamente ramificadas que se originan cerca del cuerpo celular de una neurona. Reciben impulsos excitadores 0 inhibidores a través de mensajeros químicos llamados neurotransmisores. EI citoplasma es el material del cuerpo celular en el que se encuentran las organelas, incluido el núcleo celular, y otras inclusiones (Figura 7.2). El núcleo contiene la cromatina de la célula, o material genético.

Figura 7.1 - Anatomía de la neurona.

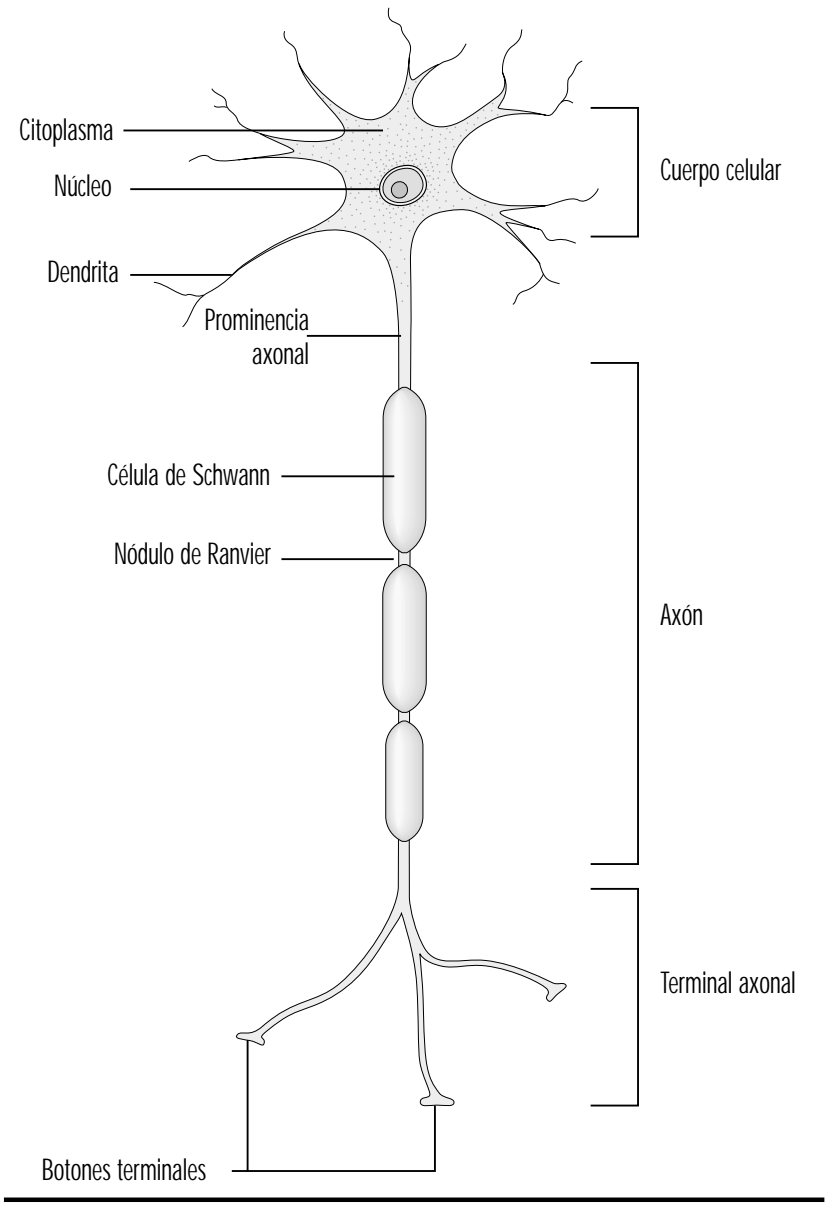

El núcleo de la célula nerviosa es atípico en comparación con el de otras células ya que, aunque contiene el material genético (ácido desoxirribonucléico [ADN]), este no participa en el proceso de división celular; es decir, después de alcanzar la madurez, las células nerviosas no se dividen. (U na excepción a esta regla la constituyen las neuronas del revestimiento de la nariz (epitelio olfatorio).) EI núcleo es rico en ácido ribonucleico (AR N ), necesario para la síntesis de proteínas. Se han identificado tres tipos de proteínas: proteínas citosólicas, que forman los elementos fibrilares de la célula nerviosa; proteínas intramitocondriales, que generan energía para la actividad celular, y proteínas que forman membranas y productos secretores. En la actualidad, las neuronas se consideran células secretoras modificadas. Forman gránulos secretores que se almacenan en vesículas sinápticas y se liberan después como sustancias neurotransmisoras, los mensajeros químicos entre las células nerviosas.

Los elementos fibrilares, que forman el esqueleto de la neurona, participan en la función trófica de esta, actuando como vehículos de transmisión. El transporte axonal puede ser anterógrado (del cuerpo celular al axón terminal) y retrógrado (del axón terminal al cuerpo celular). Se distinguen tres tipos de elementos fibrilares, de mayor a menor grosor: microtúbulos, neurofilamentos y microfilamentos.

\section{Células gliales}

A diferencia de las neuronas, las células gliales no transportan mensajes eléctricos por sí mismas. $\mathrm{H}$ ay dos tipos de células gliales: la macroglia y la microglia. M acroglia es el nombre dado al menos a tres tipos de células: astrocitos, oligodendrocitos y células ependimarias. L as células microgliales son principalmente células depuradoras que eliminan los restos que se producen después de lesiones o infecciones neurales.

Las células gliales tienen también características microscópicas y ultramicroscópicas típicas. Sirven de apoyo físico a las neuronas, aunque se están empezando a conocer también algunas propiedades fisiológicas. Entre las interacciones más importantes de neuronas y células gliales se encuentra el papel de las células gliales como proveedores de nutrientes a las neuronas, la eliminación de fragmentos de neuronas después de su muerte y, lo que es más importante, la contribución al proceso de comunicación química. Las células gliales, en claro contraste con las neuronas, pueden dividirse y, por tanto, reproducirse. Los tumores del sistema nervioso, por ejemplo, se producen por una reproducción anómala de las células gliales.

\section{Mielina}

Lo que en la observación macroscópica del tejido neural aparece como "sustancia gris" y "sustancia blanca" tiene una base microscópica y bioquímica. A nivel microscópico, la sustancia gris contiene los cuerpos de las células neuronales, mientras que la sustancia blanca es donde se encuentran las fibras neurales 0 axones. EI aspecto "blanco" se debe a una vaina, formada por una sustancia grasa llamada mielina, que cubre estas fibras. La mielina de los nervios periféricos tiene su origen en la membrana de la célula de Schwann que envuelve al axón. La mielina de las fibras del sistema nervioso central procede de las membranas de los oligodendrocitos (una variedad de células gliales). H abitualmente, los oligodendrocitos mielinizan varios axones, mientras que la célula de Schwann se asocia a un solo axón. Entre las células de Schwann u oligodendrocitos contiguos existen soluciones de continuidad de la vaina de mielina, los llamados nódulos de R anvier. Se calcula que en la vía motora central más larga, la cubierta de mielina está formada por hasta 2.000 células de Schwann. La mielina, cuya función es facilitar la propagación del potencial de acción, puede ser un objetivo específico de las 
Figura 7.2 - Las organelas.

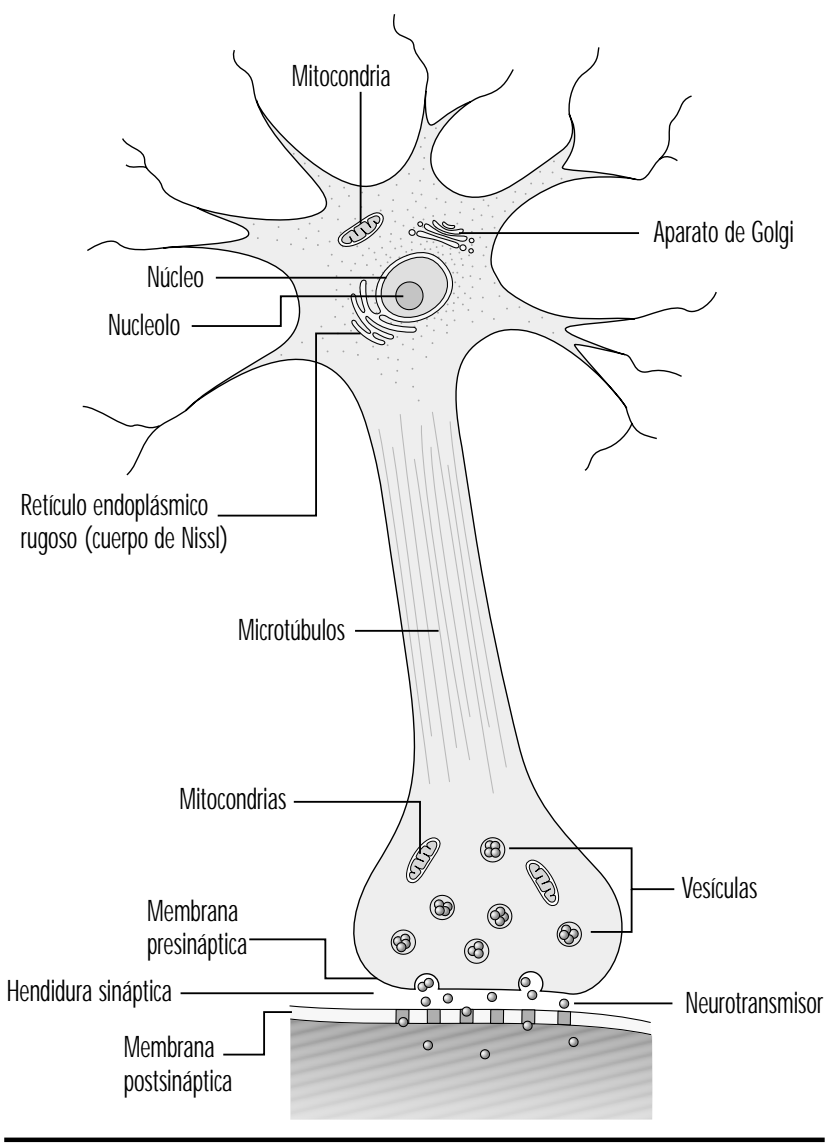

sustancias neurotóxicas. U na clasificación morfológica de las sustancias neurotóxicas describe las alteraciones neuropatológicas características de la mielina como mielinopatías.

\section{Función trófica de la neurona}

Las funciones normales de las neuronas son la síntesis de proteínas, el transporte axonal, la generación y conducción del potencial de acción, la transmisión sináptica y la formación y el mantenimiento de la mielina. Algunas de las funciones tróficas básicas de la neurona se describieron ya en el siglo XIX mediante el corte de los axones (axotomía). De los procesos descubiertos, uno de los más importantes fue la degeneración walleriana, llamada así por Waller, el fisiólogo inglés que la describió.

La degeneración walleriana ofrece una buena oportunidad para describir los conocidos cambios de las organelas a causa de lesiones traumáticas o tóxicas. Señalemos de paso que los términos utilizados para describir la degeneración walleriana producida por la axotomía traumática son los mismos que se utilizan para describir las alteraciones producidas por productos neurotóxicos. A nivel celular, las alteraciones neuropatológicas producidas por la lesión tóxica del tejido neural son mucho más complejas que las originadas por la lesión traumática. H asta hace poco tiempo no ha sido posible observar las alteraciones producidas en las neuronas afectadas por productos neurotóxicos.

Veinticuatro horas después de cortar el axón, la característica más destacada es la hinchazón producida a ambos lados del traumatismo mecánico, que se debe a la acumulación de líquidos y elementos membranosos a ambos lados del lugar de la lesión. Estas alteraciones no son diferentes de las observadas en una carretera de doble sentido inundada por la lluvia en la que los vehículos están detenidos a ambos lados del lugar inundado. En esta comparación, los vehículos atascados son la hinchazón. Al cabo de unos días, se produce la regeneración de los axones envainados (es decir, cubiertos de mielina). Se producen brotes de crecimiento desde el muñón proximal, que se mueven a una velocidad de 1 a $3 \mathrm{~mm}$ por día. En condiciones favorables, los brotes alcanzan el muñón distal (el más alejado del cuerpo celular). Cuando la reinervación (unión de los muñones) se ha completado, se restablecen las características fundamentales de la transmisión normal. El cuerpo celular de la neurona lesionada experimenta profundos cambios estructurales en la síntesis de proteínas y el transporte axonal.

Si la neurobiología molecular es una disciplina joven, la neurobiología de los procesos neurotóxicos es aún más reciente, ya que todavía está en su infancia. Es cierto que en la actualidad se conoce bien el mecanismo de acción de muchas neurotoxinas y productos farmacológicos. Pero con algunas excepciones notables (p. ej., plomo, metil mercurio, acrilamida), la base molecular de la toxicidad de la gran mayoría de los agentes ambientales y neurotóxicos se desconoce. Esta es la razón por la que, en lugar de describir la neurobiología molecular de un grupo selecto de agentes neurotóxicos profesionales y ambientales, nos vemos todavía obligados a referirnos a las comparativamente abundantes estrategias y ejemplos de la neurofarmacología clásica 0 de las investigaciones de la fabricación de fármacos modernos.

\section{Neurotransmisores}

Un neurotransmisor es una sustancia química que, cuando es liberada de las terminales de los axones por el potencial de acción, produce un cambio momentáneo del potencial eléctrico cuando se estimula otra fibra nerviosa. Los neurotransmisores estimulan 0 inhiben neuronas adyacentes u órganos efectores, como músculos y glándulas. En la actualidad se están estudiando intensivamente neurotransmisores conocidos y sus vías neurales, y constantemente se están descubriendo otros nuevos. Se sabe que algunas enfermedades neurológicas y psiquiátricas se deben a alteraciones químicas de la neurotransmisión, como por ejemplo la miastenia grave, la enfermedad de Parkinson, ciertas formas de trastornos afectivos como la depresión, deformaciones graves de los procesos cognitivos como la esquizofrenia y la enfermedad de Alzheimer. Aunque se han publicado excelentes informes aislados sobre el efecto de varios agentes neurotóxicos ambientales y profesionales sobre la neurotransmisión, el conjunto de conocimientos es escaso en comparación con el existente sobre las enfermedades neuropsiquiátricas. Los estudios farmacológicos de fármacos comerciales exigen el conocimiento de la forma en que afectan a la neurotransmisión. Por tanto, la fabricación de fármacos y la investigación de la neurotransmisión están íntimamente relacionadas. LoS conocimientos actuales sobre la acción de los fármacos han sido resumidos por Feldman y Q uenzer (1984).

Los efectos de los agentes neurotóxicos sobre la neurotransmisión se clasifican por el lugar del sistema nervioso en el que actúan, por sus receptores químicos, por la evolución en el tiempo de sus efectos, por el hecho de si los agentes neurotóxicos facilitan, bloquean o inhiben la neurotransmisión o por si los agentes neurotóxicos alteran la terminación o la eliminación de la acción farmacológica del neurotransmisor.

U na dificultad a la que se enfrentan los neurocientíficos es la necesidad de relacionar procesos conocidos que ocurren a nivel molecular en la neurona con acontecimientos a nivel celular, lo que a su vez puede explicar cómo se producen los cambios neuropsicológicos normales y patológicos, como se expresa claramente en la siguiente afirmación, que sigue siendo válida en gran medida: "A nivel molecular, a menudo es posible una 
Figura 7.3 - Las divisiones centrales y periféricas del sistema nervioso.

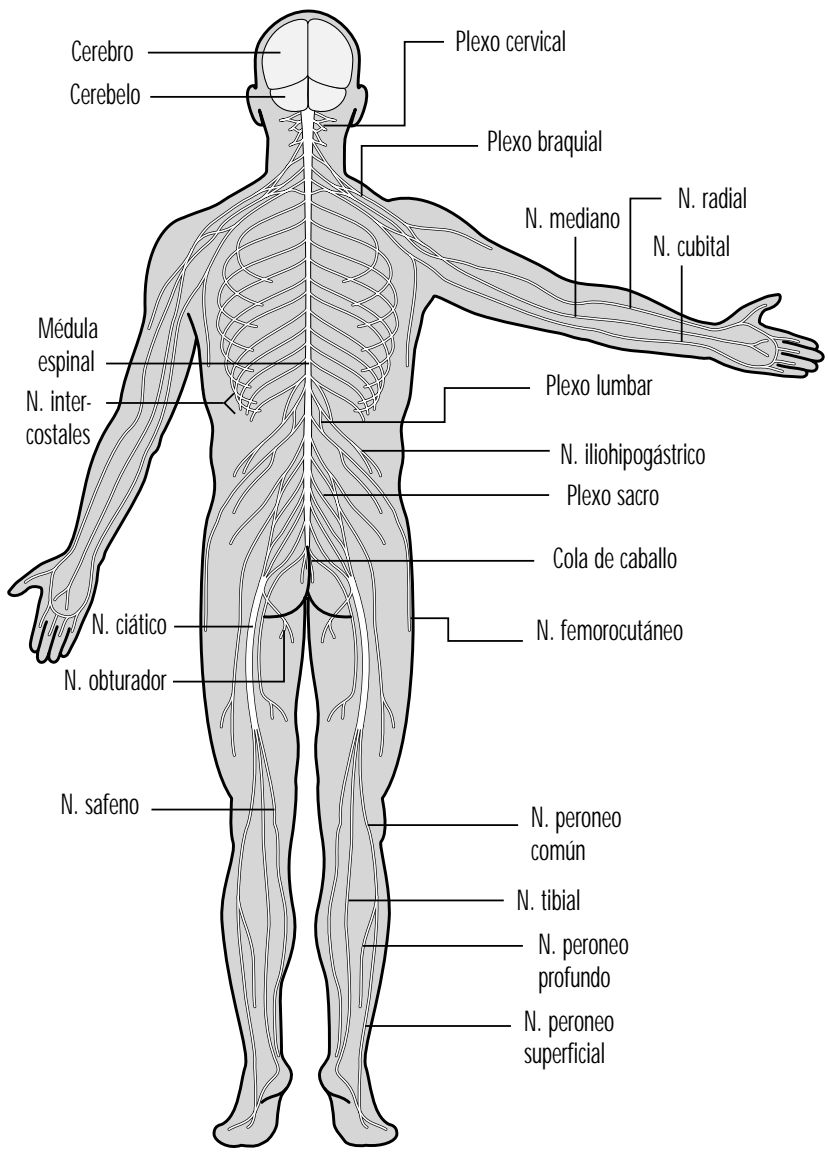

explicación de la acción de un fármaco; a nivel celular, a veces es posible una explicación, pero a nivel del comportamiento, nuestra ignorancia es abismal" (C ooper, Bloom y Roth 1986).

\section{Los principales componentes del sistema nervioso}

El conocimiento de los principales componentes del sistema nervioso es fundamental para comprender las manifestaciones neuropsicológicas más visibles de las enfermedades neurotóxicas, la justificación del uso de técnicas concretas para la valoración de las funciones del sistema nervioso y el conocimiento de los mecanismos farmacológicos de la acción neurotóxica. D esde un punto de vista funcional, el sistema nervioso puede dividirse en dos compartimientos principales: el sistema nervioso somático transmite información sensitiva (tacto, temperatura, dolor y posición de los miembros, incluso con los ojos cerrados) desde los segmentos corporales y transporta las vías neurales que inervan y controlan el movimiento de los músculos esqueléticos, como los de los brazos, manos, piernas y pies. El sistema nervioso visceral controla los órganos internos que no están normalmente bajo la influencia de los vasos sanguíneos, la dilatación y la contracción de las pupilas de los ojos, etc.

Desde un punto de vista anatómico, es necesario identificar cuatro componentes principales: el sistema nervioso central, el sistema nervioso periférico, que incluye los pares craneales, el sistema autónomo y el sistema neuroendocrino.

\section{El sistema nervioso central}

El sistema nervioso central está formado por el cerebro y la médula espinal (Figura 7.3). El cerebro se encuentra en la cavidad craneal y está protegido por las meninges. Se divide en tres componentes principales que son, en orden ascendente, es decir, desde la parte caudal (cola) a la cervical (cabeza) del sistema nervioso, el cerebro posterior (también llamado rombencénfalo), el cerebro medio (el mesencéfalo) y el cerebro anterior (el prosencéfalo).

\section{EI cerebro posterior}

Los tres componentes principales del cerebro posterior son el bulbo raquídeo, la protuberancia y el cerebelo (Figura 7.4).

El bulbo raquídeo contiene estructuras neurales que controlan la frecuencia cardíaca y la respiración, que en ocasiones son el objetivo de agentes neurotóxicos y de fármacos que causan la muerte. Situada entre el bulbo raquídeo y el cerebro medio, la protuberancia (puente) debe su nombre al gran número de fibras que atraviesan su cara anterior en su camino a los hemisferios cerebelosos. El cerebelo (en latín, cerebro pequeño) tiene un aspecto arrugado característico. Recibe información sensitiva y envía mensajes motores esenciales para la coordinación motora. Es el responsable (entre otras funciones) de la ejecución de los movimientos finos. Esta organización, o programación, exige una coordinación adecuada de las aferencias sensitivas y de las respuestas motoras. El cerebelo es a menudo el objetivo de muchos agentes neurotóxicos (por ejemplo bebidas alcohólicas, muchos disolventes industriales, plomo) que afectan a las respuestas motoras.

\section{El cerebro medio}

El cerebro medio es una parte estrecha del cerebro que conecta el cerebro posterior con el anterior. Sus estructuras son el acueducto cerebral, el tectum, los pedúnculos cerebrales, la sustancia negra y el núcleo rojo. El acueducto cerebral es un canal que conecta el tercer y cuarto ventrículos (cavidades del cerebro llenas de líquido); el líquido cefalorraquídeo (LCR ) fluye por esta abertura.

\section{El cerebro anterior}

Esta parte del cerebro se subdivide en diencéfalo ("entre el cerebro") y cerebro propiamente dicho. Las principales regiones del diencéfalo son el tálamo y el hipotálamo. "T álamo" significa "habitación interior". Los tálamos están formados por

Figura 7.4 • Visión lateral del cerebro.

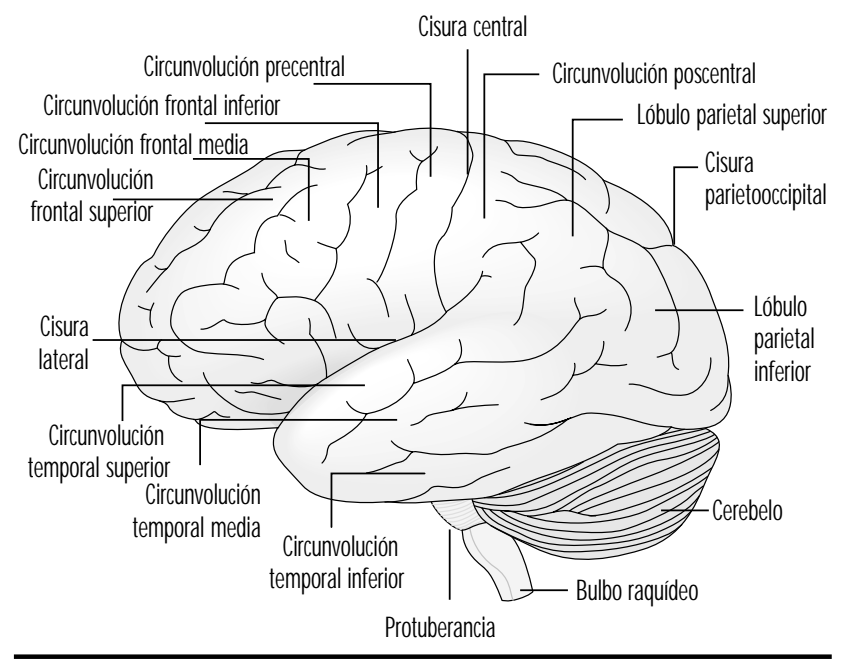


agrupaciones neuronales, Ilamadas núcleos, que tienen cinco funciones principales:

- recibir información sensitiva y enviarla a las áreas primarias de la corteza cerebral;

- enviar información sobre el movimiento en el momento en que se produce a las áreas motoras de la corteza cerebral;

- enviar información sobre la actividad del sistema límbico a las áreas de la corteza cerebral relacionadas con este sistema;

- enviar información sobre la actividad intratalámica a las áreas de asociación de la corteza cerebral;

- enviar información de la actividad de la formación reticular del tronco encefálico a áreas dispersas de la corteza cerebral.

Hipotálamo significa "debajo del tálamo". Forma la base del tercer ventrículo, un punto de referencia importante para la representación por imagen del cerebro. El hipotálamo es una estructura neural compleja y diminuta responsable de muchos aspectos del comportamiento, como los impulsos biológicos básicos, la motivación y la emoción. Es la conexión entre los sistemas nervioso y neuroendocrino, que se revisa más adelante. La hipófisis (también llamada glándula pituitaria) está conectada por neuronas a los núcleos hipotalámicos. Se sabe que las células nerviosas hipotalámicas realizan numerosas funciones neurosecretoras. El hipotálamo está conectado con otras muchas regiones importantes del cerebro, como el rinencéfalo (la corteza primitiva asociada originalmente al olfato) y el sistema límbico, incluido el hipocampo.

La corteza cerebral es el mayor componente del cerebro, y está formada por dos hemisferios cerebrales conectados por una masa de sustancia blanca llamada cuerpo calloso. La corteza cerebral es la capa superficial de cada uno de los hemisferios cerebrales. Los profundos surcos de la corteza cerebral - las cisuras central y lateral (Figura 7.4)- se toman como puntos de referencia para separar regiones anatómicas del cerebro. El lóbulo frontal se sitúa por delante de la cisura central . El lóbulo parietal comienza por detrás de la cisura central, y se sitúa junto al lóbulo occipital, que ocupa la parte posterior del cerebro. El lóbulo temporal comienza bastante dentro del pliegue de la cisura lateral y se extiende a las caras ventrales de los hemisferios cerebrales. Dos componentes importantes del cerebro son los ganglios basales y el sistema límbico.

Los ganglios basales son núcleos-es decir, agrupaciones de células nerviosas- situados hacia el centro del cerebro y constituyen centros importantes del sistema motor extrapiramidal. (El sistema piramidal, con el que se contrasta el término, participa en el control voluntario del movimiento.) El sistema extrapiramidal es afectado de forma selectiva por numerosos agentes neurotóxicos (p. ej., manganeso). En las dos últimas décadas se han realizado importantes descubrimientos en relación con el papel que desempeñan estos núcleos en varias enfermedades

Figura 7.5 • Distribución segmentaria de los nervios espinales (metameras).

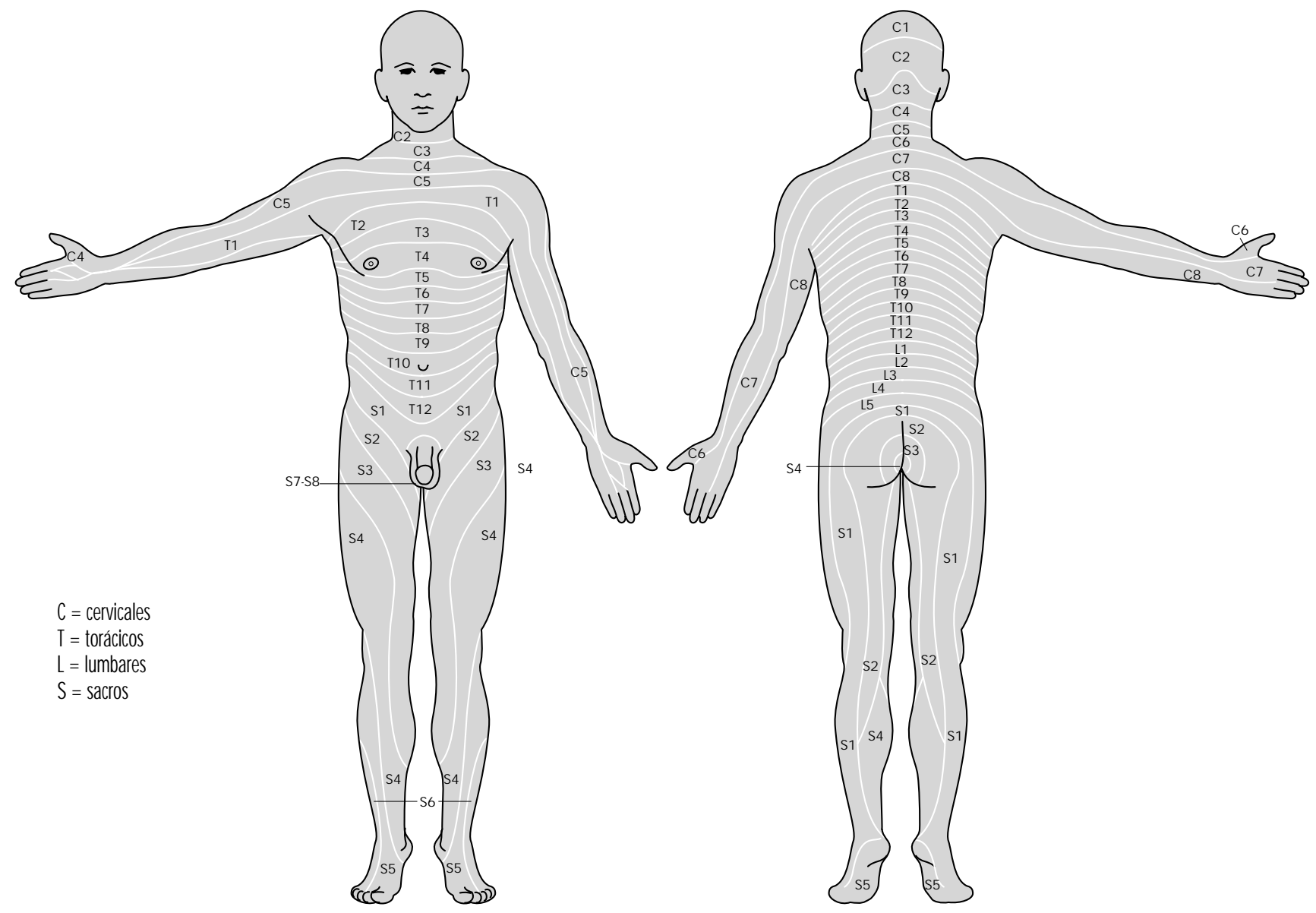

Fuente: Adaptado de Kandel, Schwartz y Kessel 1991. 
degenerativas neurales (p. ej., enfermedad de Parkinson, corea de H untington).

El sistema límbico está formado por estructuras neurales contorneadas que se ramifican en muchas direcciones y establecen conexiones con muchas regiones "arcaicas" del cerebro, especialmente con el hipotálamo. Participa en el control de la expresión emocional. Se cree que el hipocampo es una estructura en la que tienen lugar muchos procesos de la memoria.

\section{La médula espinal}

La médula espinal es una estructura blanquecina situada dentro del canal vertebral. Se divide en cuatro regiones: cervical, torácica, lumbar y sacrococcígea. Las dos zonas de la médula espinal que se reconocen con mayor facilidad son la sustancia gris que contiene los cuerpos celulares de las neuronas y la sustancia blanca que contiene los axones mielinizados. La región ventral de la sustancia gris de la médula espinal contiene células nerviosas que regulan la función motora; la región media de la médula espinal dorsal se asocia a funciones autónomas. La porción dorsal recibe información sensitiva de los nervios raquídeos.

\section{El sistema nervioso periférico}

El sistema nervioso periférico está formado por las neuronas situadas fuera del sistema nervioso central. El adjetivo periférico describe la distribución anatómica de este sistema, pero funcionalmente es artificial. Los cuerpos celulares de las fibras motoras periféricas, por ejemplo, están situados en el sistema nervioso central. En neurotoxicología experimental, clínica y epidemiológica, la denominación de sistema nervioso periférico (SNP) describe un sistema que es vulnerable de forma selectiva a los efectos de los agentes tóxicos y que es capaz de regenerarse.

\section{Los nervios raquídeos}

Las raíces ventral y dorsal son los lugares en los que los nervios periféricos entran y salen de la médula espinal en todo su recorrido. Las vértebras adyacentes tienen orificios para permitir que las fibras de las raíces que forman los nervios raquídeos salgan del conducto vertebral. $\mathrm{H}$ ay 31 pares de nervios raquídeos, que reciben su nombre según la región de la columna vertebral con la que están asociados: 8 cervicales, 12 torácicos, 5 lumbares, 5 sacros y 1 coccígeo. U na metámera es una región del cuerpo inervada por un nervio raquídeo (Figura 7.5).

M ediante una exploración meticulosa de las funciones motora y sensitiva de las metámeras, los neurólogos pueden deducir la localización de las lesiones.

\section{Los pares craneales}

El tronco encefálico es una denominación general que designa la región del sistema nervioso que incluye el bulbo raquídeo, la protuberancia y el cerebro medio. Es una continuación de la médula espinal hacia arriba y hacia delante (ventralmente). Es en esta región por donde entran y salen la mayor parte de los pares craneales. $\mathrm{H}$ ay 12 pares de nervios craneales; en la Tabla 7.1 se describen el nombre y la función principal de cada par, y en la Figura 7.6 se muestran los puntos de entrada y salida de algunos pares craneales en el cerebro.

\section{El sistema nervioso autónomo}

El sistema nervioso autónomo es la parte del sistema nervioso que controla la actividad de los componentes viscerales del cuerpo humano. Se denomina "autónomo" porque realiza sus funciones de forma automática, lo que significa que su funcionamiento no puede controlarse fácilmente a voluntad. Desde un punto de vista anatómico, el sistema autónomo tiene dos componentes principales: el sistema nervioso simpático y el parasimpático. Los nervios simpáticos que controlan la actividad visceral proceden
Figura 7.6 - Visión inferior del cerebro, con la entrada y salida de los nervios craneales.

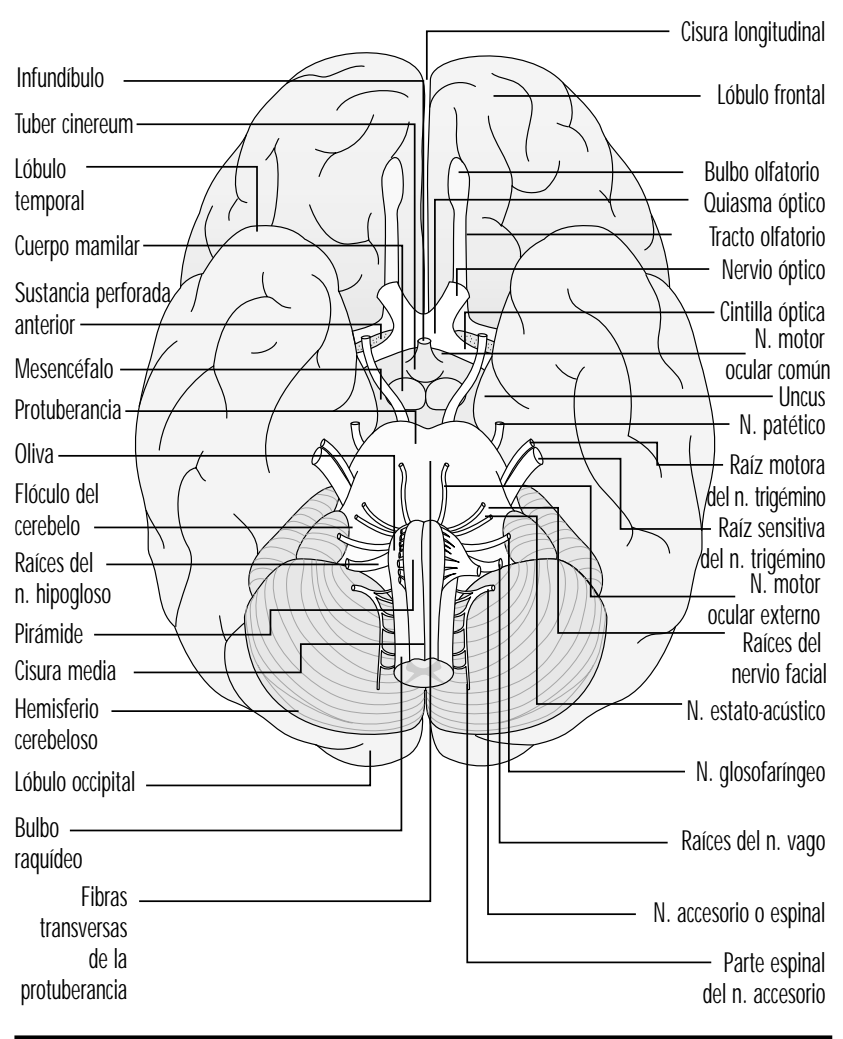

de las porciones torácica y lumbar de la médula espinal; los nervios parasimpáticos proceden del tronco encefálico y de la porción sacra de la médula espinal.

Desde un punto de vista fisiológico, no puede hacerse una generalización única que se aplique a la forma en que los sistemas nerviosos simpático y parasimpático controlan diferentes órganos corporales. En la mayor parte de los casos, los órganos viscerales están inervados por ambos sistemas, y cada uno de ellos tiene un efecto opuesto en un sistema de controles y equilibrios. El corazón, por ejemplo, está inervado por nervios simpáticos cuya excitación produce una aceleración del ritmo cardíaco, y también por nervios parasimpáticos cuya excitación produce un retardo del mismo. Cada sistema puede estimular 0 inhibir los órganos que inerva. En otros casos, los órganos son controlados de forma predominante o exclusiva por uno de los dos sistemas. U na función vital del sistema nervioso autónomo es el mantenimiento de la homeostasia (estado estable de equilibrio) y la adaptación del organismo animal a su medio ambiente externo. La homeostasia es el estado de equilibrio de las funciones corporales conseguido por un proceso activo; el control de la temperatura corporal, del agua y de los electrólitos son ejemplos de procesos homeostáticos.

D esde el punto de vista farmacológico, no hay un neurotransmisor único asociado a funciones simpáticas o parasimpáticas, como se creyó en tiempos. La antigua creencia de que la acetilcolina era el transmisor predominante del sistema autónomo tuvo que abandonarse cuando se encontraron nuevas clases de neurotransmisores y neuromoduladores (p. ej., dopamina, serotonina, purinas y diversos neuropéptidos).

Recientemente, los científicos han resucitado el enfoque conductual del sistema nervioso autónomo. El sistema nervioso autónomo participa en la reacción instintiva de lucha o huida, 
Tabla 7.1 - N ombres y principales funciones de los pares craneales.

\begin{tabular}{|c|c|c|}
\hline Nervio & Conduce impulsos & Funciones \\
\hline I. Olfatorio & De la nariz al cerebro & Sentido del olfato \\
\hline II. Optico & Del ojo al cerebro & Visión \\
\hline $\begin{array}{l}\text { III. Motor ocular } \\
\text { común }\end{array}$ & $\begin{array}{l}\text { Del cerebro a los músculos } \\
\text { del ojo }\end{array}$ & Movimientos oculares \\
\hline IV. Patético & $\begin{array}{l}\text { Del cerebro a los músculos } \\
\text { externos del ojo }\end{array}$ & Movimientos oculares \\
\hline $\begin{array}{l}\text { V. Trigémino } \\
\text { (o trifacial) }\end{array}$ & $\begin{array}{l}\text { De la piel y membranas } \\
\text { mucosas de la cabeza y de } \\
\text { los dientes al cerebro; } \\
\text { también del cerebro a los } \\
\text { músculos de la masticación }\end{array}$ & $\begin{array}{l}\text { Sensibilidad de la cara, } \\
\text { cuero cabelludo y dientes; } \\
\text { movimientos de la } \\
\text { masticación }\end{array}$ \\
\hline
\end{tabular}

VI. Motor ocular Del cerebro a los músculos Vuelve los ojos hacia fuera externo

VII. Facial De las papilas gustativas de externos del ojo la lengua al cerebro; del cerebro a los músculos de la cara

VIII. Estato acústico Del oído al cerebro

IX.Glosofaríngeo

De la garganta y las papilas gustativas de la lengua al cerebro; también del la garganta y glándulas salivales

X.Vago

De la garganta, laringe y órganos de las cavidades torácica y abdominal al cerebro; también del cerebro a los músculos de la garganta y a los órganos de las cavidades torácica y abdominal
XI. Espinal
Del cerebro a determinados músculos del hombro y del cuello
XII. Hipogloso
Movimientos del hombro; movimientos de giro de la cabeza

\section{Del cerebro a los músculos Movimientos de la lengua} de la lengua de la laringe y de los de la voz, reducción de la ción del peristaltismo cerebro a los músculos de

A diferencia de los músculos esqueléticos, no presentan la organización regular en sarcolemas, la unidad contráctil de la fibra muscular. El corazón tiene la singularidad de que puede generar actividad miógena, es decir, incluso después de haberse seccionado sus inervaciones neurales, puede contraerse y relajarse durante varias horas por sí mismo.

El acoplamiento neuromuscular en los músculos lisos es diferente al de los músculos esqueléticos. En los músculos esqueléticos, la unión neuromuscular es la conexión entre el nervio y las fibras musculares. En el músculo liso no hay unión neuromuscular; las terminaciones nerviosas entran en el músculo, y se extienden en todas direcciones. Por tanto, los acontecimientos eléctricos en el interior del músculo liso son mucho más lentos que en los músculos esqueléticos. Finalmente, el músculo liso tiene la característica exclusiva de presentar contracciones espontáneas, como las mostradas por el intestino. En gran parte, el sistema nervioso autónomo regula la actividad espontánea de los músculos lisos.

\section{L os componentes centrales del sistema nervioso autónomo}

El principal papel del sistema nervioso autónomo es regular la actividad de los músculos lisos, del corazón, de las glándulas del aparato digestivo, de las glándulas sudoríparas y de las suprarrenales y otras glándulas endocrinas. EI sistema nervioso autónomo tiene un componente central, el hipotálamo, situado en la base del cerebro, donde se integran muchas funciones autónomas. Y lo que es más importante, los componentes centrales del sistema nervioso autónomo participan directamente en la regulación de los impulsos biológicos (regulación de la temperatura, del hambre, de la sed, del impulso sexual, de la micción, de la defecación y otros), la motivación, la emoción y, en gran medida, de funciones "psicológicas" como el estado de ánimo, la afectividad y los sentimientos.

\section{Sistema neuroendocrino}

Sensibilidad de la garganta, órganos torácicos y abdominales; deglución, producción frecuencia cardíaca, acelera-
Las glándulas son los órganos del sistema endocrino. Se llaman glándulas endocrinas porque liberan sus mensajes químicos en el interior del organismo, directamente a la circulación sanguínea (a diferencia de las glándulas exocrinas, como las glándulas sudoríparas, cuyas secreciones aparecen en la superficie externa del cuerpo). El sistema endocrino proporciona un control lento pero duradero de órganos y tejidos, a través de mensajeros químicos llamados hormonas. Las hormonas son los principales reguladores del metabolismo corporal. Sin embargo, debido a las íntimas conexiones entre los sistemas nerviosos central, periférico y autónomo, el sistema neuroendocrino - un término que engloba estas complejas conexiones- se considera actualmente un potente modificador de la estructura y función del cuerpo y del comportamiento humanos.

Las hormonas se han definido como mensajeros químicos que son liberados de las células a la circulación sanguínea para ejercer su acción sobre células efectoras situadas a cierta distancia. Hasta hace poco, las hormonas se distinguían de los neurotransmisores, comentados anteriormente. Estos últimos son mensajeros químicos liberados por las neuronas en una sinapsis entre las terminales nerviosas y otra neurona 0 un efector (músculo o glándula). Sin embargo, con el descubrimiento de que neurotransmisores clásicos, como la dopamina, pueden actuar también como hormonas, la distinción entre neurotransmisores y hormonas está cada vez menos clara. Por tanto, basándose en consideraciones puramente anatómicas, las hormonas que proceden de células nerviosas pueden llamarse neurohormonas. Desde un punto de vista funcional, el sistema nervioso puede considerarse un verdadero sistema neurosecretor.

\section{El control autónomo de los músculos lisos}

Los músculos de las vísceras, exceptuando los del corazón, son músculos lisos. El músculo cardíaco tiene características de músculo esquelético y liso al mismo tiempo. Al igual que los músculos esqueléticos, los músculos lisos contienen también las dos proteínas actina y, en menor proporción, miosina. 
Tabla 7.2 • Agrupación de los efectos neurotóxicos para reflejar su potencia relativa en el establecimiento de la neurotoxicidad.

\begin{tabular}{|c|c|c|}
\hline Nivel & Grupo & Explicación/ Ejemplos \\
\hline 6 & $\begin{array}{l}\text { Alteraciones } \\
\text { morfológicas }\end{array}$ & $\begin{array}{l}\text { Comprenden muerte celular y axonopatía, así } \\
\text { como alteraciones morfológicas subcelulares. }\end{array}$ \\
\hline 5 & $\begin{array}{l}\text { Alteraciones } \\
\text { neurológicas }\end{array}$ & $\begin{array}{l}\text { Abarcan hallazgos anómalos en las explora- } \\
\text { ciones neurológicas en individuos concretos. }\end{array}$ \\
\hline 4 & $\begin{array}{l}\text { Alteraciones fisioló- } \\
\text { gicas/ del } \\
\text { comportamiento }\end{array}$ & $\begin{array}{l}\text { Comprenden hallazgos experimentales en } \\
\text { grupos de animales o seres humanos, como } \\
\text { variaciones de los potenciales evocados y los } \\
\text { EEG o alteraciones en las pruebas psicológicas y } \\
\text { del comportamiento. }\end{array}$ \\
\hline 3 & $\begin{array}{l}\text { Alteraciones } \\
\text { bioquímicas }\end{array}$ & $\begin{array}{l}\text { Incluyen alteraciones de importantes parámetros } \\
\text { bioquímicos (p. ej., nivel del transmisor, conte- } \\
\text { nido de proteína-AFG (proteína ácida fibrilar } \\
\text { glial) } 0 \text { actividades enzimáticas). }\end{array}$ \\
\hline $2^{1}$ & $\begin{array}{l}\text { Síntomas } \\
\text { subjetivos } \\
\text { irreversibles }\end{array}$ & $\begin{array}{l}\text { Síntomas subjetivos. Ausencia de indicios de } \\
\text { anomalías en las exploraciones neurológica, } \\
\text { psicológica o cualquier otra exploración médica . }\end{array}$ \\
\hline $1^{1}$ & $\begin{array}{l}\text { Síntomas } \\
\text { subjetivos } \\
\text { reversibles }\end{array}$ & $\begin{array}{l}\text { Síntomas subjetivos. Ausencia de indicios de } \\
\text { anomalías en las exploraciones neurológica, } \\
\text { psicológica o cualquier otra exploración médica. }\end{array}$ \\
\hline
\end{tabular}

1 Sólo en seres humanos.

Fuente: Modificado de Simonsen y cols. 1994

EI hipotálamo controla las funciones endocrinas a través de una conexión con la hipófisis (también llamada glándula pituitaria, una diminuta glándula situada en la base del cerebro). $\mathrm{H}$ asta mediados de los 50, las glándulas endocrinas se consideraban un sistema diferente, gobernado por la hipófisis, a menudo llamada la "glándula maestra". En aquel momento se formuló una hipótesis neurovascular que establecía el papel funcional de factores hipotalámicos/ hipofisarios en el control de la función endocrina. Según esta visión, el hipotálamo endocrino proporciona la vía neuroendocrina final común en el control del sistema endocrino. Hoy en día está claramente demostrado que el propio sistema endocrino es regulado por el sistema nervioso central y por las aferencias endocrinas. Por tanto, neuroendocrinología es actualmente el término adecuado para describir la especialidad que estudia las funciones integradas recíprocas de los sistemas nervioso y endocrino en el control de los procesos fisiológicos.

A medida que aumenta nuestro conocimiento sobre la neuroendocrinología, desaparecen las divisiones originales. EI hipotálamo, situado encima de la hipófisis y conectado a ella, es la conexión entre los sistemas nervioso y endocrino, y muchas de sus células nerviosas llevan a cabo funciones secretoras. También está conectado con otras regiones importantes del cerebro, como el rinencéfalo (la corteza primitiva originalmente asociada a la olfación o sentido del olfato) y el sistema límbico, asociado a las emociones. Es en el hipotálamo donde se producen las hormonas liberadas por la hipófisis posterior. EI hipotálamo produce también sustancias que reciben el nombre de hormonas liberadoras e inhibidoras. Estas actúan sobre la adenohipófisis para que aumente 0 inhiba la producción de hormonas de la hipófisis anterior, que actúan sobre glándulas situadas en otros lugares (tiroides, corteza suprarrenal, ovarios, testículos y otras).

\section{AgENTES QUIMICOS NEUROTOXICOS}

\author{
Peter Arlien-Søborg y Leif Simonsen
}

\section{Definición de neurotoxicidad}

Se entiende por neurotoxicidad la capacidad de inducir efectos adversos en el sistema nervioso central, los nervios periféricos 0 los órganos de los sentidos. Se considera que un producto químico es neurotóxico cuando es capaz de inducir un patrón constante de disfunción neural o cambios en la química o la estructura del sistema nervioso.

Por lo general, la neurotoxicidad se manifiesta como un continuo de síntomas y efectos que dependen de la naturaleza del producto químico, de la dosis, de la duración de la exposición y de las características del individuo expuesto. La gravedad de los efectos observados, así como los indicios de neurotoxicidad, aumentan del nivel 1 hasta el 6 , mostrados en la Tabla 7.2. Las exposiciones a sustancias químicas neurotóxicas de corta duración 0 a dosis bajas pueden causar síntomas subjetivos como cefaleas y mareos, pero el efecto suele ser reversible. A medida que aumenta la dosis, pueden aparecer alteraciones neurológicas, y eventualmente producirse alteraciones morfológicas irreversibles. El grado de disfunción necesario para suponer la neurotoxicidad de un producto químico es un tema discutido. Según la definición, se considera un patrón constante de disfunción neural o de alteraciones de la química o la estructura del sistema nervioso si existen pruebas documentadas de efectos persistentes en los niveles 3, 4, 5 ó 6 de la Tabla 7.2. Estos niveles reflejan el peso de las pruebas proporcionadas por diferentes signos de neurotoxicidad. L as sustancias neurotóxicas comprenden elementos naturales como el plomo, el mercurio y el manganeso; compuestos biológicos, como la tetrodotoxina (del pez globo, un manjar japonés) y el ácido domoico (de mejillones contaminados), y compuestos sintéticos, como muchos pesticidas, disolventes industriales y monómeros.

\section{Figura 7.7 Efectos neurológicos y comportamentales de la exposición a agentes químicos neurotóxicos.}

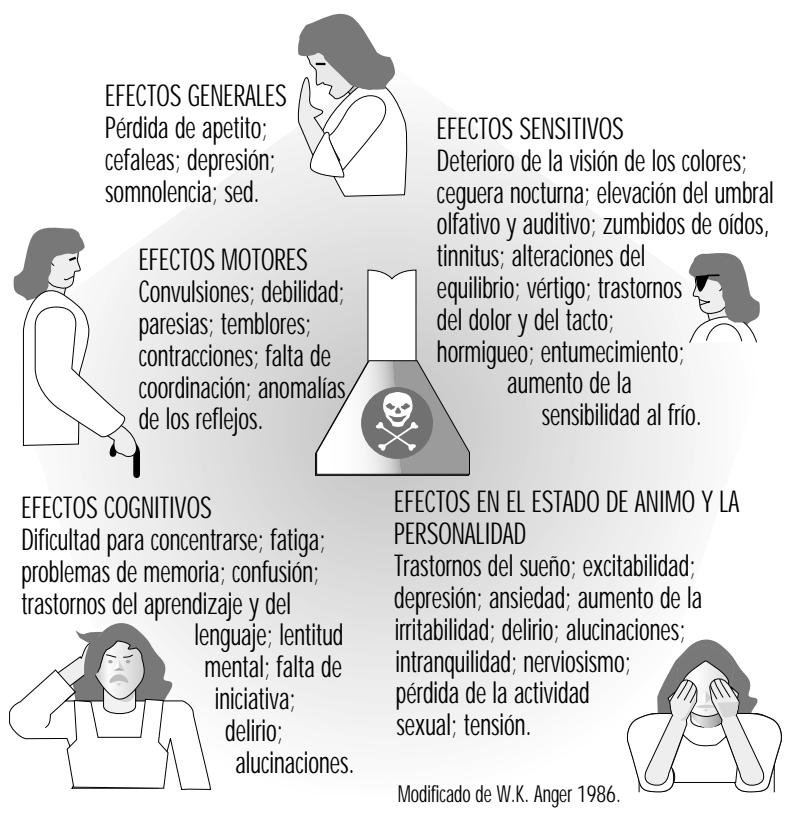


Tabla 7.3 - Gases asociados a efectos neurotóxicos.

\begin{tabular}{|c|c|c|c|}
\hline Producto químico & Ejemplos de fuentes de exposición & Selección de industrias con riesgo & Efectos $^{1}$ \\
\hline Anhídrido carbónico $\left(\mathrm{CO}_{2}\right)$ & $\begin{array}{l}\text { Soldadura; fermentación; fabricación, alma- } \\
\text { cenamiento y uso de hielo seco }\end{array}$ & $\begin{array}{l}\text { Industria metalúrgica; minería; fábricas } \\
\text { de cervezas }\end{array}$ & $\begin{array}{l}\text { M: Vasodilatación } \\
\text { A: Cefaleas; disnea; temblor; pérdida de conciencia } \\
\text { C: Prácticamente ninguno }\end{array}$ \\
\hline Monóxido de carbono (CO) & $\begin{array}{l}\text { Reparación de coches; soldadura; fundición } \\
\text { de metales; conductores; bomberos }\end{array}$ & $\begin{array}{l}\text { Industria metalúrgica; minería; } \\
\text { transportes; centrales eléctricas }\end{array}$ & $\begin{array}{l}\text { M: Privación de oxígeno } \\
\text { A: Cefaleas; somnolencia; pérdida de conciencia }\end{array}$ \\
\hline Acido sulfhídrico $\left(\mathrm{H}_{2} \mathrm{~S}\right)$ & $\begin{array}{l}\text { Fumigación de invernaderos; abonos; pesca- } \\
\text { dores; descarga de pescado; manipulación } \\
\text { de alcantarillado }\end{array}$ & $\begin{array}{l}\text { Agricultura; pesca; trabajo en } \\
\text { alcantarillas }\end{array}$ & $\begin{array}{l}\text { M: Bloqueo del metabolismo oxidativo } \\
\text { A: Pérdida de conciencia } \\
\text { C: Encefalopatía }\end{array}$ \\
\hline Cianuro (HCN) & $\begin{array}{l}\text { Electrosoldadura; galvanoplastia con níquel; } \\
\text { cobre y plata; fumigación de barcos, casas, } \\
\text { alimentos y suelos de invernaderos }\end{array}$ & $\begin{array}{l}\text { Industria metalúrgica; industrias } \\
\text { químicas; viveros; minería; fábricas } \\
\text { de gas }\end{array}$ & $\begin{array}{l}\text { M: Bloqueo de enzimas respiratorias } \\
\text { A: Disnea; descenso de la tensión arterial; } \\
\text { convulsiones; pérdida de conciencia; muerte } \\
\text { C: Encefalopatía; ataxia; neuropatía (p.ej., después } \\
\text { de comer cavasava) } \\
\text { Alteración profesional incierta }\end{array}$ \\
\hline Oxido nitroso $\left(\mathrm{N}_{2} \mathrm{O}\right)$ & $\begin{array}{l}\text { Anestesia general durante cirugía; narcosis } \\
\text { ligera en asistencia dental y parto }\end{array}$ & $\begin{array}{l}\text { Hospitales (anestesia); dentistas; } \\
\text { comadronas }\end{array}$ & $\begin{array}{l}\text { M: Alteración aguda de la membrana de la célula } \\
\text { nerviosa; degeneración de células nerviosas después } \\
\text { de exposición prolongada } \\
\text { A: Mareos; somnolencia; pérdida de conciencia } \\
\text { : Entumecimiento de los dedos de manos y pies; } \\
\text { disminución de la coordinación; encefalopatía }\end{array}$ \\
\hline
\end{tabular}

1 M: mecanismo; A: efectos agudos; C: efectos crónicos.

Neuropatía: disfunción de fibras nerviosas periféricas motoras y sensitivas. Encefalopatía: disfunción cerebral debida a deterioro generalizado del cerebro. Ataxia: deterioro de la coordinación motora.

En Estados U nidos, existen entre 50.000 y 100.000 productos químicos comercializados, y cada año se someten a evaluación entre 1.000 y 1.600 nuevas sustancias químicas. Se sospecha que más de 750 sustancias y varias clases 0 grupos de compuestos químicos son neurotóxicos (0 'D onoghue 1985), aunque nunca se han estudiado las propiedades neurotóxicas de la mayor parte de ellos. La mayoría de los productos químicos neurotóxicos conocidos en la actualidad se han identificado por informes de casos o por accidentes.

Aunque los productos químicos neurotóxicos a menudo se fabrican para usos concretos, la exposición puede tener su origen en varias fuentes: uso casero, en la agricultura y en

Tabla 7.4 - Metales y sus compuestos inorgánicos a sociados a neurotoxicidad.

\section{Producto químico Ejemplos de fuentes de exposición \\ Plomo Fundición; soldadura; molienda; repara- ciones; vidriado; plastificado}

\section{Mercurio elemental}

Calomel $\mathrm{Hg}_{2} \mathrm{Cl}_{2}$

$\mathrm{HgCl}_{2}$ sublimado Desinfección

Manganeso

Fundición (aleación de acero); corte; solda-

Aluminio dura de acero; pilas

Electrólisis; instrumentos eléctricos (giroscopio; manómetro; termómetro; pilas; bombillas eléctricas; tubos, etc.); empastes de amalgama

Metalurgia; molienda; pulimentado

Selección de industrias con riesgo
Metalurgia; minería; fábricas de acumu-
ladores; reparación de coches; astilleros;
trabajadores del vidrio; cerámica;
alfarería; plásticos

Plantas de cloroalcalinos; minería; electrónica; dentistas; producción de polímeros; industria papelera y de la celulosa

Laboratorios

Hospitales; clinicas; laboratorios

Minas de manganeso; producción de acero y aluminio; industria metalúrgica; producción de pilas; industrias químicas; fábricas de ladrillos

Industria del metal

\section{Efectos $^{1}$}

M: Deterioro del metabolismo oxidativo de células nerviosas y glía

A: Dolor abdominal; cefaleas; encefalopatía; convulsiones

C: Encefalopatía; polineuropatía, incluida mano péndula

M: Deterioro en varios lugares de las células nerviosas A: Inflamación pulmonar; cefaleas; trastornos del lenguaje

C: Inflamación de las encías; pérdida de apetito; encefalopatía; temblor; irritabilidad

A: Toxicidad aguda baja, efectos tóxicos crónicos, véase más arriba

M: Degeneración renal tubular y glomerular aguda. Muy tóxico incluso en dosis orales pequeñas, letal hasta

$30 \mathrm{mg} / \mathrm{kg}$ de peso

$C:$ Véase más arriba.

M: Desconocido, posibles cambios de dopamina y catecolaminas en los ganglios basales del centro del cerebro : Disforia

C: Encefalopatía, incluido parkinsonismo; psicosis; pérdida de apetito; irritabilidad; cefaleas; debilidad

$M$ : Desconocido

C: Posiblemente encefalopatía

1 M: mecanismo; A: efectos agudos; C: efectos crónicos. Neuropatía: disfunción de fibras nerviosas periféricas motoras y sensitivas. Encefalopatía: disfunción cerebral debido a un deterioro generalizado del cerebro. 
Tabla 7.5 • Monómeros neurotóxicos.

\begin{tabular}{|c|c|c|c|}
\hline Compuesto & Ejemplos de fuentes de exposición & Selección de industrias con riesgo & Efectos $^{1}$ \\
\hline Acrilamida & Trabajadores expuestos al monómero & $\begin{array}{l}\text { Producción de polímeros; túneles y } \\
\text { perforaciones }\end{array}$ & $\begin{array}{l}\text { M: Deterioro del transporte axonal } \\
\text { C: Polineuropatía; mareos; temblores y ataxia }\end{array}$ \\
\hline Acrilonitrilo & $\begin{array}{l}\text { Accidentes en laboratorios e industrias; fumi- } \\
\text { gación de casas }\end{array}$ & $\begin{array}{l}\text { Producción de polímeros y caucho; } \\
\text { síntesis de productos químicos }\end{array}$ & $\begin{array}{l}\text { A: Hiperexcitabilidad; salivación; vómitos; cianosis; } \\
\text { ataxia; dificultad para respirar }\end{array}$ \\
\hline Disulfuro de carbono & Producción de caucho y rayón viscoso & Industrias de caucho y rayón viscosa & $\begin{array}{l}\text { M: Es probable un deterioro del transporte axonal y de } \\
\text { la actividad enzimática } \\
\text { C: Neuropatía periférica; encefalopatía; cefaleas; } \\
\text { vértigo; trastornos gastrointestinales }\end{array}$ \\
\hline Estireno & $\begin{array}{l}\text { Producción de plásticos reforzados con vidrio; } \\
\text { fabricación y transporte de monómeros; uso } \\
\text { de resinas y baños que contienen estireno }\end{array}$ & $\begin{array}{l}\text { Industrias químicas; producción de fibra } \\
\text { de vidrio; industria de los polímeros }\end{array}$ & $\begin{array}{l}\text { M: Desconocido } \\
\text { A: Depresión del sistema nervioso central; cefaleas } \\
\text { C: Polineuropatía; encefalopatía; pérdida de audición }\end{array}$ \\
\hline Viniltolueno & $\begin{array}{l}\text { Producción de resinas; compuestos } \\
\text { insecticidas }\end{array}$ & $\begin{array}{l}\text { Industrias de productos químicos y } \\
\text { polímeros }\end{array}$ & $\begin{array}{l}\text { C: Polineuropatía; reducción de la velocidad de conduc- } \\
\text { ción nerviosa motora }\end{array}$ \\
\hline
\end{tabular}

1 M: mecanismo; A: efectos agudos; C: efectos crónicos.

Neuropatía: disfunción de las fibras nerviosas periféricas motoras y sensitivas. Encefalopatía: disfunción cerebral debido a deterioro generalizado del cerebro. Ataxia: deterioro de la coordinación motora.

industrias, agua potable contaminada, etc. En consecuencia, las ideas preconcebidas sobre qué compuestos neurotóxicos cabe esperar encontrar en determinadas profesiones deben contemplarse con cautela, y deben consultarse las referencias siguientes como posibles ejemplos que incluyen algunos de los productos químicos neurotóxicos más comunes (Arlien-Søborg 1992; O 'D onoghue 1985; Spencer y Schaumburg 1980; O M S 1978).

\section{Síntomas de neurotoxicidad}

Por lo general, el sistema nervioso reacciona de forma bastante estereotipada ante la exposición a sustancias neurotóxicas (Figura 7.7). A continuación se exponen algunos síndromes típicos.

\section{Polineuropatía}

Se produce por una alteración de la función motora y sensitiva que origina debilidad muscular; la paresia suele ser más intensa a nivel periférico, en las extremidades superiores e inferiores (manos y pies). Antes 0 al mismo tiempo pueden producirse parestesias (hormigueo o entumecimiento de los dedos de manos y pies). Esto puede provocar dificultades para caminar o para la coordinación fina de las manos y sus dedos. Algunos metales pesados, disolventes y pesticidas, entre otros productos químicos, pueden ocasionar este síndrome, aunque el mecanismo tóxico de estos compuestos pueda ser totalmente diferente.

\section{Encefalopatía}

Esta enfermedad se debe a una alteración difusa del cerebro, y puede provocar fatiga; deterioro del aprendizaje, de la memoria y de la capacidad de concentración; ansiedad, depresión, aumento de la irritabilidad e inestabilidad emocional. Estos síntomas pueden ser indicativos de un trastorno degenerativo difuso precoz del cerebro, y también de una encefalopatía tóxica crónica profesional. A menudo, puede encontrarse también una mayor frecuencia de cefaleas, mareos, alteraciones del patrón del sueño y disminución de la actividad sexual desde las etapas precoces de la enfermedad. Estos síntomas pueden aparecer después de una exposición prolongada de bajo nivel a varios productos químicos diferentes, como disolventes, metales pesados o ácido sulfhídrico, y también se observan en varios trastornos causantes de demencia no relacionados con el trabajo. En algunos casos pueden encontrarse síntomas neurológicos más concretos (p. ej., parkinsonismo con temblor, rigidez de los músculos y lentitud de los movimientos, o síntomas cerebelosos como temblor y disminución de la coordinación de los movimientos de las manos y de la marcha). Estos cuadros clínicos se observan después de la exposición a productos químicos concretos, como el manganeso o la M PT P (1-metil-4-fenil-1,2,3,6-tetrahidropiridina) en el primer caso, y el tolueno o el mercurio en el segundo caso.

\section{G ases}

Una amplia variedad de productos químicos con estructuras químicas totalmente diferentes son gases a temperatura normal y tienen una neurotoxicidad demostrada (véase Tabla 7.3). Algunos de ellos son sumamente tóxicos incluso en dosis muy pequeñas, y se han utilizado como gases de guerra (fosgeno y cianuro); otros necesitan dosis más altas durante periodos más largos para originar síntomas (p. ej., anhídrido carbónico). Algunos se utilizan para la anestesia general (p. ej., óxido nitroso); otros son ampliamente utilizados en la industria y en productos para la desinfección (p. ej., formaldehído). Los primeros pueden inducir alteraciones irreversibles del sistema nervioso después de exposiciones repetidas de bajo nivel, mientras que los segundos sólo provocan aparentemente síntomas agudos. La exposición en habitaciones pequeñas con mala ventilación resulta particularmente arriesgada. Algunos de los gases son inodoros, lo que los hace especialmente peligrosos (p. ej., el monóxido de carbono). Como se muestra en la Tabla 7.3, algunos gases son componentes importantes en la producción industrial, mientras que otros son el resultado de una combustión incompleta o completa (p. ej., CO y $\mathrm{CO}_{2}$, respectivamente). Esta situación se da en la minería, la siderurgia, centrales eléctricas, etc., pero también pueden encontrarse en hogares con ventilación insuficiente. Para el tratamiento es fundamental interrumpir la exposición y proporcionar aire fresco u oxígeno, y en los casos graves ventilación artificial.

\section{Metales}

Por regla general, la toxicidad de los metales aumenta con el peso atómico, resultando especialmente tóxicos el plomo y el mercurio. Los metales se encuentran habitualmente en la naturaleza en concentraciones bajas, pero en determinadas industrias se utilizan en grandes cantidades (véase Tabla 7.4), y pueden dar lugar a riesgos profesionales para los trabajadores. Además, se encuentran cantidades importantes de metales en las aguas residuales, 
Tabla 7.6 - Disolventes orgánicos asociados a neurotoxicidad.

\begin{tabular}{|c|c|c|c|}
\hline Producto químico & Ejemplos de fuentes de exposición & Selección de industrias con riesgo & Efectos ${ }^{1}$ \\
\hline $\begin{array}{l}\text { Hidrocarbonos clorados: } \\
\text { tricloroetileno; } \\
\text { 1,1,1-tricloroetano; } \\
\text { tetracloroetileno }\end{array}$ & $\begin{array}{l}\text { Desengrasado; galvanización; pintura; impre- } \\
\text { sión; limpieza; anestesia general y ligera }\end{array}$ & $\begin{array}{l}\text { Industria metalúrgica; industria gráfica; } \\
\text { industria electrónica; limpiezas en seco; } \\
\text { anestesistas }\end{array}$ & $\begin{array}{l}\text { M: Desconocido } \\
\text { A: Síntomas prenarcóticos } \\
\text { C: Encefalopatía; polineuropatía; afectación } \\
\text { trigeminal (TRI); pérdida de audición }\end{array}$ \\
\hline Cloruro de metileno & $\begin{array}{l}\text { Extracción, incluida la extracción de cafeína; } \\
\text { decapante de pinturas }\end{array}$ & $\begin{array}{l}\text { Industria alimentaria; pintores; industria } \\
\text { gráfica }\end{array}$ & $\begin{array}{l}\text { M: Metabolismo } \rightarrow \text { CO } \\
\text { A: Síntomas prenarcóticos; coma } \\
\text { C: Encefalopatía }\end{array}$ \\
\hline Cloruro de metilo & Producción y reparación de frigoríficos & $\begin{array}{l}\text { Producción de frigoríficos; industria del } \\
\text { caucho; industria de los plásticos }\end{array}$ & $\begin{array}{l}\text { M: Desconocidos } \\
\text { A: Síntomas prenarcóticos; pérdida de conciencia; } \\
\text { muerte } \\
\text { C: Encefalopatía }\end{array}$ \\
\hline Tolueno & $\begin{array}{l}\text { Impresión; limpieza; desengrasado; galvani- } \\
\text { zación; pintura; pintura con pistola }\end{array}$ & Industria gráfica; industria electrónica & $\begin{array}{l}\text { M. Desconocido } \\
\text { A: Síntomas prenarcóticos } \\
\text { C: Encefalopatía; disfunción cerebelosa; } \\
\text { polineuropatía; pérdida de audición; } \\
\text { polineuropatíatrastornos visuales }\end{array}$ \\
\hline Xileno & $\begin{array}{l}\text { Impresión; síntesis de anhídrido ftálico; } \\
\text { pinturas; técnicas histológicas de laboratorio }\end{array}$ & $\begin{array}{l}\text { Industria gráfica; industria de los plás- } \\
\text { ticos; laboratorios de histología }\end{array}$ & $\begin{array}{l}\text { M: Desconocido } \\
\text { A: Síntomas prenarcóticos } \\
\text { C: Encefalopatía; trastornos visuales; pérdida } \\
\text { polineuropatíade audición }\end{array}$ \\
\hline Estireno & Polimerización; moldeado & $\begin{array}{l}\text { Industria de los plásticos; producción de } \\
\text { fibra de vidrio }\end{array}$ & $\begin{array}{l}\text { M: Desconocido } \\
\text { A: Síntomas prenarcóticos } \\
\text { C: Encefalopatía; polineuropatía; pérdida de audición }\end{array}$ \\
\hline $\begin{array}{l}\text { Hexacarbonos: n-hexano; } \\
\text { metil butil cetona (MBK); } \\
\text { metil etil cetona (MEK) }\end{array}$ & $\begin{array}{l}\text { Encolado; impresión; revestimientos plás- } \\
\text { ticos; pinturas; extracción }\end{array}$ & $\begin{array}{l}\text { Industria del cuero y del calzado; indus- } \\
\text { tria gráfica; pintores; laboratorios }\end{array}$ & $\begin{array}{l}\text { M: Deterioro del transporte axonal } \\
\text { A: Síntomas prenarcóticos } \\
\text { C: Polineuropatía; encefalopatía }\end{array}$ \\
\hline $\begin{array}{l}\text { Disolventes diversos: } \\
\text { Freón } 113\end{array}$ & $\begin{array}{l}\text { Producción y reparación de frigoríficos; } \\
\text { limpieza en seco; desengrasado }\end{array}$ & $\begin{array}{l}\text { Producción de frigoríficos; industria } \\
\text { metalúrgica; industria electrónica; } \\
\text { limpieza en seco }\end{array}$ & $\begin{array}{l}\text { M: Desconocido } \\
\text { A: Síntomas prenarcóticos leves } \\
\text { C: Encefalopatía }\end{array}$ \\
\hline Dietiléter; halotano & $\begin{array}{l}\text { Anestésicos generales (personal de enfer- } \\
\text { mería; médicos) }\end{array}$ & Hospitales; clinicas & $\begin{array}{l}\text { M: Desconocido } \\
\text { A: Síntomas prenarcóticos } \\
\text { C: Encefalopatía }\end{array}$ \\
\hline Disulfuro de carbono & Véase monómeros & Véase monómeros & Véase monómeros \\
\hline $\begin{array}{l}\text { Mezclas: aguarrás y } \\
\text { diluyentes }\end{array}$ & $\begin{array}{l}\text { Pintura; desengrasante; limpieza; impresión; } \\
\text { impregnación; tratamiento superficial }\end{array}$ & $\begin{array}{l}\text { Industria metalúrgica; industria gráfica; } \\
\text { industria de la madera; pintores }\end{array}$ & $\begin{array}{l}\text { M: Desconocido } \\
\text { A: Síntomas prenarcóticos } \\
\text { C: Encefalopatía }\end{array}$ \\
\hline
\end{tabular}

que pueden dar lugar a riesgos ambientales para quienes viven cerca de las industrias, pero también para los que están a mayor distancia de ellas. A menudo, los metales (o, por ejemplo, los compuestos de mercurio orgánicos) entran en la cadena alimentaria y se irán acumulando en peces, aves y animales, lo que representa un riesgo para los consumidores. La toxicidad y la forma en que el organismo procesa los metales puede depender de la estructura química. Los metales puros pueden ser absorbidos por inhalación o por contacto de vapores con la piel (mercurio) o partículas pequeñas (plomo), o por vía oral (plomo). Los compuestos de mercurio inorgánico ( $\mathrm{p}$. ej., $\mathrm{H} \mathrm{gCl}_{2}$ ) son absorbidos principalmente por la boca, mientras que los compuestos metálicos orgánicos (p. ej., tetraetilo de plomo) son absorbidos principalmente por inhalación o por contacto con la piel. La carga corporal puede reflejarse en cierto grado en la concentración del metal en la sangre 0 en la orina. Esta es la base del control biológico. Para el tratamiento, hay que recordar que sobre todo el plomo se libera muy lentamente de los depósitos del organismo. La cantidad de plomo en los huesos sólo se reducirá normalmente en un $50 \%$ a los 10 años. Esta liberación puede acelerarse utilizando agentes quelantes: BAL (dimercapto-1-propanol), Ca-EDTA o penicilamina.

\section{Monómeros}

Los monómeros constituyen un gran grupo heterogéneo de productos químicos reactivos utilizados para la síntesis química y la producción de polímeros, resinas y plásticos. Los monómeros comprenden compuestos aromáticos polihalogenados, como el p-clorobenceno y el 1,2,4-triclorobenceno; disolventes orgánicos no saturados, como el estireno y el viniltolueno, la acrilamida y compuestos relacionados, fenoles, $\varepsilon$-caprolactam y $\gamma$-aminobutirolactam. En la Tabla 7.5 se enumeran algunos de los monómeros 
Tabla 7.7 - Clasificación de pesticidas neurotóxicos comunes, exposición, efectos y síntomas asociados.

\section{Compuesto \\ Compuestos organofosforados: beomil; demeton; diclorvos; etil paratión;} mevinfos; fosfolán; terbufos; malatión

Carbamatos: aldicarb; carbaril; carbofurano; propoxur

Organoclorados: aldrin; dieldrin; Véase más arriba DDT; hendrin; heptaclor;

lindano; metoxidor; mirex; toxafeno

Piretroides

Véase más arriba Ejemplos de fuentes de exposición Manipulación; tratamiento de cultivos; trabajo con cultivos tratados; trabajadores de muelles

\section{Selección de industrias con riesgo \\ Agricultura; silvicultura; productos químicos; jardinería}

Véase más arriba

Véase más arriba

$\begin{array}{lll}\text { 2,4-D } & \text { Herbicidas } & \text { Agricultura } \\ \text { Hidróxido de trietiltina } & \begin{array}{l}\text { Tratamiento superficial; manipulación de } \\ \text { madera tratada }\end{array} & \text { Madera y derivados } \\ \text { Bromuro de metilo } & \text { Fumigación } & \begin{array}{l}\text { Invernaderos; insecticidas; fábricas de } \\ \text { frigoríficos }\end{array}\end{array}$

\section{Efectos $^{1}$}

M: Inhibición de la acetilcolinesterasa

A: Hiperactividad; parálisis neuromuscular; deterioro visual; dificultad para respirar; nerviosismo; debilidad; vómitos; convulsiones

M: Axonopatía por neurotoxicidad diferida ${ }^{2}$

C: Polineuropatía; entumecimiento y hormigueo en los pies; debilidad muscular; trastornos sensitivos; parálisis

A: Excitabilidad; aprensión; mareos; cefaleas; confusión; pérdida de equilibrio; debilidad; ataxia; temblores; convulsiones; coma C: Encefalopatía

M: Alteración del flujo de iones sodio a través de la membrana de la célula nerviosa

A: Descarga repetida de la célula nerviosa; temblor; convulsiones

C: Polineuropatía

A: Cefaleas; debilidad; parálisis; trastornos visuales C: Polineuropatía; efectos sobre el SNC

M: Desconocido

A: Trastornos visuales y del lenguaje; delirio; convulsiones

C: Encefalopatía

1 M: mecanismo; A: efectos agudos; C: efectos crónicos.

Neuropatía: disfunción de fibras nerviosas periféricas motoras y sensitivas. Encefalopatía: disfunción cerebral debida a deterioro generalizado del cerebro. Ataxia: deterioro de la coordinación motora.

2 Principalmente fosfatos o fosfonatos.

neurotóxicos más utilizados, junto a su efecto sobre el sistema nervioso. La exposición profesional a monómeros neurotóxicos puede tener lugar en industrias que fabrican, transportan y utilizan productos químicos y plásticos. Durante la manipulación de polímeros que contienen monómeros y durante el moldeado en astilleros y en clínicas dentales, se produce una importante exposición a monómeros neurotóxicos. Tras la exposición a estos monómeros, se puede absorber por inhalación (p. ej., disulfuro de carbono y estireno) o por contacto con la piel (p. ej., acrilamida). Como los monómeros son un grupo heterogéneo de productos químicos, es probable que existan varios mecanismos diferentes de toxicidad, lo que se refleja en las diferencias en los síntomas (Tabla 7.5).

\section{Disolventes orgánicos}

Disolventes orgánicos es una denominación común para un gran grupo de más de 200 compuestos químicos lipófilos capaces de disolver grasas, aceites, ceras, resinas, goma, asfalto, filamentos de celulosa y materiales plásticos. Suelen ser líquidos a temperatura ambiente, con puntos de ebullición por debajo de 200 a $250^{\circ} \mathrm{C}$, y se evaporan con facilidad. Se absorben principalmente a través de los pulmones, aunque algunos pueden atravesar también la piel. D ebido a su carácter lipófilo, se distribuyen en órganos ricos en grasas. Por ello, se encuentran concentraciones elevadas en la grasa corporal, la médula ósea, el hígado y el cerebro, que pueden actuar también como reservorios. El coeficiente de distribución octanol/ agua puede indicar si cabe esperar concentraciones altas en el cerebro. Todavía no se conoce el mecanismo de la toxicidad, pero se han apuntado varias posibilidades: bloqueo de importantes enzimas en la degradación metabólica de la glucosa y, por tanto, reducción de la energía disponible para el funcionamiento neuronal; reducción de la formación de energía en las mitocondrias; alteraciones de las membranas neuronales que causan deterioro de la función de los canales iónicos; retardo del flujo axonal. El cloruro de metileno se metaboliza a $\mathrm{CO}$, que bloquea el transporte de oxígeno en la sangre. G randes grupos de trabajadores en una amplia variedad de profesiones sufren exposiciones a diario, o al menos frecuentemente (véase Tabla 7.6). En algunos países, el consumo de disolventes orgánicos ha descendido en algunas profesiones debido a las mejoras higiénicas y su sustitución (p. ej., pintores de brocha gorda, trabajadores de industrias gráficas, trabajadores del metal), mientras que en otras profesiones el patrón de la exposición ha cambiado, pero la cantidad total de disolventes orgánicos no se ha modificado. Por ejemplo, el tricloroetileno ha sido sustituido por el 1,1,1-tricloroetano y el freón. Así pues, los disolventes siguen siendo un problema de higiene importante en muchos lugares de trabajo. Las personas corren un riesgo especial cuando sufren las exposiciones en habitaciones pequeñas con escasa ventilación y con elevadas temperaturas, lo que aumenta la evaporación. El trabajo físico aumenta la absorción pulmonar de disolventes. En varios países (sobre todo en los nórdicos) se han concedido indemnizaciones a trabajadores que han desarrollado encefalopatía tóxica crónica después de exposiciones prolongadas de bajo nivel a disolventes.

\section{Pesticidas}

Pesticidas es una denominación genérica para todos los productos químicos utilizados para destruir grupos de plantas 0 animales 
Tabla 7.8 - 0 tros productos químicos asociados a neurotoxicidad.

\begin{tabular}{|c|c|c|c|}
\hline Producto químico & Ejemplos de fuentes de exposición & Selección de industrias con riesgo & Efectos $^{1}$ \\
\hline Acido bórico & Soldaduras; flujos; conservación & Metal; vidrio & $\begin{array}{l}\text { A: Delirio; convulsiones } \\
\text { C: Depresión del SNC. }\end{array}$ \\
\hline Disulfiram & Farmacéutica & Caucho & C: Fatiga; neuropatía periférica; somnolencia \\
\hline Hexaclorofeno & Jabones antibacterianos & Químicas & C: Edema del SNC; lesión de nervios periféricos \\
\hline Hidrazina & Agentes reductores & Química; ejército & A: Excitación; pérdida de apetito; temblor; convulsión \\
\hline Fenol/ Cresol & Antisépticos & $\begin{array}{l}\text { Plásticos; resinas; productos químicos; } \\
\text { hospitales; laboratorios }\end{array}$ & $\begin{array}{l}\text { M: Desnaturaliza proteínas y enzimas } \\
\text { A: Pérdida de reflejos; debilidad; temblor; sudoración; coma } \\
\text { C: Pérdida de apetito; trastornos mentales; zumbidos en } \\
\text { los oídos }\end{array}$ \\
\hline Piridina & Desnaturalización del etanol & Química; textil & $\begin{array}{l}\text { A: depresión del SNC; depresión mental; fatiga; pérdida } \\
\text { de apetito } \\
\text { C: Irritabilidad; trastornos del sueño; polineuropatía; } \\
\text { visión doble }\end{array}$ \\
\hline Tetraetilo de plomo & Aditivo de la gasolina & Química; transporte & C: Irritabilidad; debilidad; temblor; dificultades de visión \\
\hline Arsina & Pilas; insecticidas; fundición & $\begin{array}{l}\text { Fundición; fábricas de vidrio; cerámica; } \\
\text { fábricas de papel }\end{array}$ & $\begin{array}{l}\text { M: Deterioro de la función enzimática } \\
\text { A: Disminución de la sensibilidad; paresias; convulsiones; } \\
\text { coma } \\
\text { C: Deterioro motor; ataxia; pérdida de la sensibilidad } \\
\text { vibratoria; polineuropatía }\end{array}$ \\
\hline Litio & Aditivo de aceites; farmacéutica & Petroquímica & $\begin{array}{l}\text { A/ C: Pérdida de apetito; zumbidos de oídos; visión borrosa; } \\
\text { temblor; ataxia }\end{array}$ \\
\hline Selenio & $\begin{array}{l}\text { Fundición; produccion de rectificadores; } \\
\text { vulcanización; lubricante para cuchillas; } \\
\text { antioxidantes }\end{array}$ & $\begin{array}{l}\text { Electrónica; fábricas de vidrio; industria } \\
\text { metalúrgica; industria del caucho }\end{array}$ & $\begin{array}{l}\text { A: Delirio; anosmia } \\
\text { C: Olor a ajo; polineuropatía; nerviosismo }\end{array}$ \\
\hline Talio & Raticida & Vidrio; productos de vidrio & $\begin{array}{l}\text { A: Pérdida de apetito; cansancio; somnolencia; sabor } \\
\text { metálico; entumecimiento; ataxia }\end{array}$ \\
\hline Telurio & $\begin{array}{l}\text { Fundición; producción de caucho; } \\
\text { catalizador }\end{array}$ & Metal; química; caucho; electrónica & $\begin{array}{l}\text { A: Cefaleas; somnolencia ; neuropatía } \\
\text { C: Olor a ajo; sabor metálico; parkinsonismo; depresión }\end{array}$ \\
\hline Vanadio & Fundición & Minería; siderurgia; industria química & $\begin{array}{l}\text { A: Pérdida de apetito; zumbidos de oídos; somnolencia, } \\
\text { temblor } \\
\text { C: Depresión; temblor; ceguera }\end{array}$ \\
\hline
\end{tabular}

I M: mecanismo; A: efectos agudos; C: efectos crónicos

Neuropatía: disfunción de las fibras nerviosas periféricas motoras y sensitivas.

Encefalopatía: disfunción cerebral debida a deterioro generalizado del cerebro.

Ataxia: trastorno de la coordinación motora

que constituyen un peligro para la salud humana o que pueden causar pérdidas económicas. Se engloban en ella insecticidas, fungicidas, raticidas, fumigantes y herbicidas. Anualmente se utilizan en la agricultura en todo el mundo unos 2.500 millones de kilos de productos pesticidas, que contienen más de 600 componentes activos. L os pesticidas con organofosforados, carbamato y organoclorados, junto a los piretroides, los herbicidas clorofenoxidos y los compuestos de metales orgánicos utilizados como fungicidas tienen propiedades neurotóxicas (Tabla 7.7). Entre los numerosos productos químicos utilizados como raticidas, algunos (p. ej., estricnina, fosfuro de zinc y talio) son también neurotóxicos. La exposición profesional a pesticidas neurotóxicos está asociada principalmente con trabajos agrícolas como la manipulación de pesticidas y el trabajo con cultivos tratados, aunque los exterminadores, los trabajadores en la fabricación y formulación de pesticidas, los trabajadores de carreteras y ferrocarriles y los de invernaderos, silvicultura y viveros, pueden tener también un riesgo importante de exposición a pesticidas neurotóxicos. Los niños, que son una parte importante de la mano de obra en la agricultura, son especialmente vulnerables porque su sistema nervioso todavía no está completamente desarrollado. Los efectos agudos de los pesticidas están por lo general bien descritos, y se ven con frecuencia efectos duraderos tras la exposición repetida o exposiciones únicas a dosis altas (T abla 7.7), aunque el efecto de la exposición subclínica repetida es incierto.

\section{Otros productos químicos}

Varios productos químicos diferentes que no pertenecen a ninguno de los grupos mencionados anteriormente poseen también neurotoxicidad. Algunos de ellos se utilizan como pesticidas, y también en distintos procesos industriales. Algunos tienen efectos neurotóxicos agudos y crónicos documentados; otros tienen efectos agudos evidentes, pero sus efectos crónicos apenas se han analizado. En la Tabla 7.8 se ofrecen ejemplos de estos productos químicos, de sus usos y sus efectos. 


\section{MANIFESTACIONES DE INTOXICACION AGUDA Y CRONICA PRECOZ}

\section{Donna Mergler}

Los conocimientos actuales de las manifestaciones a corto y largo plazo de la exposición a sustancias neurotóxicas proceden de estudios con animales de experimentación y de estudios de cámara humanos, de estudios epidemiológicos de trabajadores activos y jubilados o enfermos, de estudios e informes clínicos y también de catástrofes a gran escala, como las ocurridas en Bhopal, después de un escape de metilisocianato, y en M inamata por intoxicación con metilmercurio.

La exposición a sustancias neurotóxicas puede producir efectos inmediatos (agudos) o a largo plazo (crónicos). En ambos casos, los efectos pueden ser reversibles y desaparecer con el paso del tiempo tras la reducción o el cese de la exposición, u originar una lesión permanente irreversible. La gravedad del deterioro agudo y crónico del sistema nervioso dependerá de la dosis de la exposición, referida tanto a la cantidad como a la duración. Al igual que el alcohol y las drogas, muchas sustancias neurotóxicas pueden ser inicialmente excitantes, produciendo una sensación de bienestar o euforia y/ o una aceleración de las funciones motoras; a medida que aumenta la dosis, ya sea en cantidad o en tiempo, estas mismas neurotoxinas deprimirán el sistema nervioso. De hecho, un gran número de sustancias neurotóxicas, que alteran la mente y deprimen el sistema nervioso central, inducen narcosis (un estado de estupor o insensibilidad).

\section{Intoxicación aguda}

Los efectos agudos reflejan la respuesta inmediata a la sustancia química. La gravedad de los síntomas y los trastornos resultantes dependen de la cantidad que llegue al sistema nervioso. Con exposiciones leves, los efectos agudos son leves y transitorios, y desaparecen al cesar la exposición. C efaleas, cansancio, mareos, dificultad para concentrarse, sensación de embriaguez, euforia, irritabilidad, vértigo y disminución de los reflejos son los tipos de síntomas experimentados durante la exposición a productos químicos neurotóxicos. Aunque estos síntomas son reversibles, cuando la exposición se repite día tras día, los síntomas también recurren. Además, como la sustancia neurotóxica no es eliminada inmediatamente del organismo, los síntomas persisten después del trabajo. Los síntomas comunicados en un determinado puesto de trabajo son un buen reflejo de interferencia química con el sistema nervioso y deben considerarse un signo de aviso de posible exposición excesiva; deben instaurarse medidas preventivas para reducir los niveles de exposición.

Si la exposición es muy elevada, como puede suceder en casos de fugas, escapes, explosiones y otros accidentes, los síntomas y signos de intoxicación son debilitantes (cefaleas intensas, confusión mental, náuseas, mareos, incoordinación, visión borrosa, pérdida de conciencia); si la exposición es lo bastante alta, los efectos pueden ser duraderos, conduciendo posiblemente al coma y la muerte.

Los trastornos agudos relacionados con pesticidas son un fenómeno común entre los agricultores de países productores de alimentos, en los que se utilizan grandes cantidades de sustancias tóxicas como insecticidas, fungicidas, nematicidas y herbicidas. Organofosfatos, carbamatos, organoclorados, piretro, piretrina, paraquat y diquat son algunas de las principales clases de pesticidas; sin embargo, existen miles de formulaciones, que contienen cientos de principios activos. Algunos pesticidas, como el maneb, contienen manganeso, mientras que otros se disuelven en disolventes orgánicos. Además de los síntomas antes mencionados, la intoxicación aguda por organofosfatos y carbamatos puede ir acompañada de sialorrea, incontinencia, convulsiones, sacudidas musculares, diarrea y trastornos de la visión, así como dificultad respiratoria y taquicardia; estos síntomas se deben a un exceso del neurotransmisor acetilcolina, que se produce cuando estas sustancias atacan a una enzima llamada colinesterasa. La colinesterasa en sangre disminuye proporcionalmente al grado de intoxicación aguda por organofosfatos o carbamatos.

Con algunas sustancias, como los pesticidas organofosforados y el monóxido de carbono, exposiciones agudas de alto nivel pueden causar un efecto nocivo retardado en determinadas partes del sistema nervioso. Con el primero, pueden producirse entumecimiento y hormigueo, debilidad y pérdida del equilibrio algunas semanas después de la exposición, mientras que con el último puede tener lugar un deterioro neurológico retardado, con síntomas de confusión mental, ataxia, incoordinación motora y paresias. La repetición de episodios agudos de

Figura 7.8 - Espectro del deterioro de salud con el aumento de la dosis.

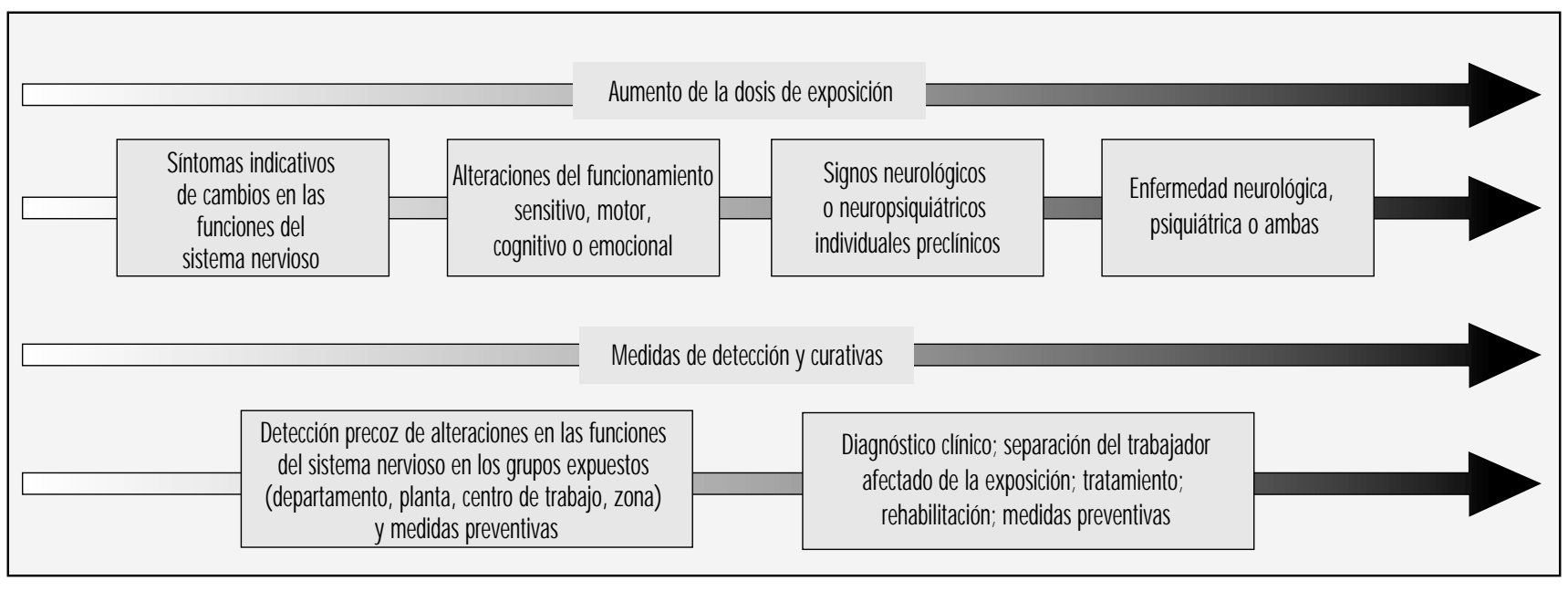


exposición a niveles altos de monóxido de carbono se ha asociado a parkinsonismo en épocas tardías de la vida. Es posible que exposiciones elevadas a determinados productos químicos neurotóxicos puedan ir asociadas a un mayor riesgo de trastornos neurodegenerativos en épocas posteriores de la vida.

\section{Intoxicación crónica}

El reconocimiento de los peligros de los productos químicos neurotóxicos ha llevado a muchos países a reducir los niveles de exposición permisibles. Sin embargo, para la mayoría de éstos productos todavía se desconoce el nivel con el que no se producirán efectos adversos tras la exposición prolongada. La exposición repetida a niveles bajos o medios de sustancias neurotóxicas durante muchos meses 0 años puede alterar las funciones del sistema nervioso de forma insidiosa y progresiva. La interferencia continua con los procesos moleculares y celulares hace que las funciones neurofisiológicas y psicológicas experimenten lentas alteraciones, que inicialmente pueden pasar inadvertidas debido a la existencia de grandes reservas en los circuitos del sistema nervioso, por lo que en las primeras etapas el daño puede compensarse mediante nuevos aprendizajes.

Por lo tanto, la lesión inicial del sistema nervioso no va necesariamente acompañada de trastornos funcionales y puede ser reversible. Sin embargo, a medida que el daño progresa, los síntomas y signos, a menudo de naturaleza inespecífica, se hacen evidentes y es posible que los individuos soliciten atención médica. Finalmente, el deterioro puede llegar a ser tan grave que se manifieste un síndrome clínico evidente, generalmente irreversible.

En la Figura 7.8 se esquematiza el deterioro continuado de la salud asociado a la exposición a sustancias neurotóxicas. La progresión de la disfunción neurotóxica depende tanto de la duración como de la concentración de la exposición (dosis), y pueden influir en ella otros factores del lugar de trabajo, el estado de salud y la sensibilidad de cada persona y el estilo de vida, especialmente el consumo de alcohol y la exposición a sustancias neurotóxicas utilizadas en actividades de ocio, como las colas utilizadas para el montaje de muebles o la construcción de maquetas de plástico, las pinturas y los disolventes de pintura.

Para la identificación de enfermedades relacionadas con neurotoxinas en cada trabajador se adoptan diferentes estrategias, así como para la vigilancia del deterioro precoz del sistema nervioso en trabajadores activos. El diagnóstico clínico se basa en una constelación de signos y síntomas, junto a la historia médica y de exposición de un individuo; deben descartarse de forma sistemática otras etiologías distintas a la exposición. Para la vigilancia del deterioro precoz en los trabajadores activos, es importante un retrato colectivo de la disfunción. Lo más frecuente es que el patrón de disfunción observado para el grupo sea similar al patrón de deterioro clínico observado en la enfermedad. Es algo parecido a sumar las alteraciones leves precoces para obtener un cuadro de lo que está sucediendo en el sistema nervioso. El patrón o perfil de la respuesta global precoz da una indicación de la especificidad y el tipo de acción de la sustancia o mezcla neurotóxica concreta. En lugares de trabajo con exposición potencial a sustancias neurotóxicas, la vigilancia sanitaria de grupos de trabajadores puede resultar especialmente útil para la prevención y la adopción de medidas en el lugar de trabajo que eviten el desarrollo de una enfermedad más grave (véase la Figura 7.9). Estudios realizados en lugares de trabajo de todo el mundo con trabajadores activos expuestos a sustancias neurotóxicas concretas, o a mezclas de varios productos químicos, han proporcionado información valiosa sobre las manifestaciones precoces de diffunción del sistema nervioso en grupos de trabajadores expuestos.
Figura 7.9 - Prevención de la neurotoxicidad laboral.

Un trabajador no expuesto a una sustancia neurotóxica nunca presentará efectos adversos neurotóxicos sobre la salud. Una exposición nula supone una protección total frente a los efectos neurotóxicos. Esta es la esencia de todas las medidas preventivas primarias.

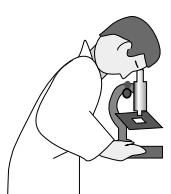

PRUEBAS DE TOXICIDAD

Cuando se introducen nuevos compuestos químicos en un lugar de trabajo y en entornos profesionales ya debe haberse estudiado su neurotoxicidad. La inexistencia de estudios de toxicidad previos a la comercialización puede originar el contacto con los trabajadores, con posibles efectos adversos graves sobre la salud. La introducción de la metil n-butil cetona en un centro de trabajo en Estados Unidos es un ejemplo clásico de los posibles riesgos de la introducción de productos neurotóxicos no ensayados en el lugar de trabajo (Spencer y Schaumburg 1980).

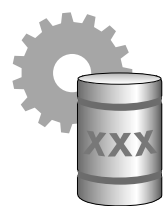

CONTROLES TECNICOS

Los controles técnicos ( $p$. ej., sistemas de ventilación, instalaciones de producción cerradas) son el mejor medio para mantener las exposiciones de los trabajadores por debajo de los límites de exposición permisibles. Lo ideal es el uso de procesos químicos cerrados que impidan la liberación de cualquier producto tóxico al medio ambiente del centro de trabajo. Si esto no es posible, son útiles los sistemas de ventilación cerrados que extraen los vapores del aire ambiental y están diseñados para alejar el aire contaminado de los trabajadores, siempre que estén bien diseñados, mantenidos adecuadamente y bien manejados.

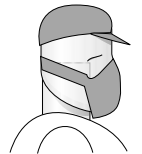

EQUIPO DE PROTECCION PERSONAL

En situaciones en las que no se dispone de controles técnicos para reducir el contacto de los trabajadores con productos neurotóxicos, debe facilitarse equipo de protección personal. Dada la cantidad de productos neurotóxicos presentes en los lugares de trabajo, y las diferentes vías de exposición según el centro y las condiciones de trabajo, habrá que seleccionar cuidadosamente el tipo de equipo de protección personal para cada situación. Por ejemplo, el plomo puede ejercer su toxicidad al respirar partículas de polvo cargadas 0 al ingerirlas con los alimentos o el aqua. Por tanto, el equipo de protección personal debe proteger frente a ambas vías de exposición. Ello implicaría un equipo de protección respiratoria y la adopción de medidas de higiene personal para evitar el consumo de alimentos 0 bebidas contaminados por plomo. Para muchos productos neurotóxicos (como los disolventes industriales), la absorción de la sustancia por la piel intacta es una vía principal de exposición. Por tanto, habrá que proporcionar guantes impermeables, delantales y demás material oportuno para impedir la absorción cutánea. Estas medidas se añadirían a los controles técnicos 0 al equipo de protección respiratoria personal. Es necesaria una planificación detenida para adaptar el equipo de protección personal al trabajo concreto que se vaya a realizar.

\section{CONTROLES ADMINISTRATIVOS}

Los controles administrativos consisten en los esfuerzos de la empresa

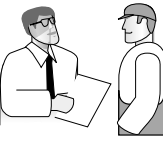
para reducir los peligros del lugar de trabajo a través de la planificación, a formacion, la rotacion de los trabajadores en los puestos de trabajo, los cambios en los procesos de producción y la sustitución de productos (Urie 1992), aś como la observancia estricta de todas las normas existentes.

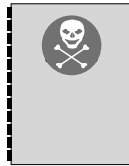

\section{DERECHOS DE INFORMACION DE LOS TRABAIADORES}

Mientras que la empresa tiene la responsabilidad de facilitar un lugar de trabajo 0 una experiencia de trabajo que no sea dañina para la salud de los trabajadores, éstos tienen la responsabilidad de seguir las normas del centro que están pensadas para su protección. Los trabajadores han de conocer qué medidas deben adoptar para protegerse. Esto significa que tienen derecho a conocer la neurotoxicidad de las sustancias con las que entran en contacto y las medidas que pueden adoptar para protegerse.

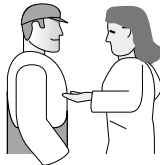

VIGILANCIA DE LA SALUD DEL TRABA|ADOR

Cuando las condiciones lo permitan, los trabajadores deben ser sometidos a exploraciones médicas periódicas. La vigilancia de la salud del trabajador consiste en la realización periódica de una evaluación por parte de médicos del trabajo u otros especialistas. En el caso de trabajadores que entran en contacto con sustancias neurotóxicas conocidas, los médicos deben conocer los efectos de dicha exposición. Por ejemplo, las exposiciones de bajo nivel a muchos disolventes orgánicos producirán síntomas de fatiga, trastornos del sueño, cefaleas y trastornos de la memoria. Ante dosis elevadas de plomo, serían signos indicativos de toxicidad la mano péndula y los trastormos nevviosos períéricos. Cualquier signo y síntoma de intoxicación neurotóxica debería llevar al cambio del trabajador a una zona libre de productos neurotóxicos, y a adoptar medidas para reducir los niveles de dicha sustancia en el lugar de trabajo.

Barry L. Johnson 
Tabla 7.9 • Lista de control de las síntomas crónicos.

\section{Síntomas experimentados en el último mes}

1. ¿ Se ha cansado con más facilidad de lo esperado para el tipo de actividad que realiza?

2. ¿ Se ha sentido mareado o con vértigo?

3. $i$ Ha tenido dificultades para concentrarse?

4. ¿ Se ha sentido confuso o desorientado?

5. ¿ Ha tenido problemas para recordar cosas?

6. ¿ Han notado sus familiares que tiene problemas para recordar las cosas?

7. ¿ Ha tenido que anotar las cosas para recordarlas?

8. ¿ Ha notado dificultades para entender lo que dicen los periódicos?

9. ¿ Se ha sentido irritable?

10. ¿ Se ha sentido deprimido?

11. ¿ Ha notado palpitaciones del corazón incluso cuando no estaba haciendo ejercicio?

12. ¿ Ha tenido convulsiones?

13. ¿ Ha dormido más de lo habitual?

14. ¿ Ha tenido dificultades para conciliar el sueño?

15. ¿ Se ha sentido molesto por falta de coordinación o pérdida del equilibrio?

16. ¿ Ha notado pérdida de fuerza muscular en las piernas o los pies?

17. ¿ Ha notado pérdida de fuerza muscular en los brazos o las manos?

18. $i$ Ha tenido dificultades para mover los dedos de las manos o para coger cosas?

19. ¿ Ha notado entumecimiento y hormigueo en los dedos de las manos de más de un día de duración?

20. ¿ Ha notado entumecimiento y hormigueo en los dedos de los pies de más de un día de duración?

21. ¿ Ha tenido cefaleas al menos una vez a la semana?

22. ¿ Ha tenido dificultades para conducir del trabajo a su casa porque se haya sentido mareado o cansado?

23. ¿ Se ha sentido "eufórico" por los productos químicos utilizados en el trabajo?

24. ¿ Ha observado si tiene una menor tolerancia al alcohol (se emborracha con mayor facilidad)?

Fuente: Tomado de Johnson 1987.

\section{Síntomas precoces de intoxicación crónica}

Las alteraciones del estado de ánimo son casi siempre los primeros síntomas de los cambios iniciales del funcionamiento del sistema nervioso. Irritabilidad, euforia, cambios bruscos del estado de ánimo, cansancio exagerado, sentimientos de hostilidad, inquietud, depresión y tensión se encuentran entre los estados de ánimo asociados con mayor frecuencia a exposiciones neurotóxicas. 0 tros síntomas son problemas de memoria, dificultad de concentración, cefaleas, visión borrosa, sensación de embriaguez, mareos, lentitud, sensación de hormigueo en las manos y los pies, pérdida de la libido y otros. Aunque en las etapas iniciales estos síntomas no suelen ser lo bastante graves para interferir en el trabajo, reflejan una disminución del bienestar y afectan a la capacidad de la persona para disfrutar plenamente de la familia y de las relaciones sociales. A menudo, debido a la naturaleza inespecífica de estos síntomas, trabajadores, empresas y profesionales de la salud laboral suelen ignorarlos y buscan causas distintas a la exposición en el lugar de trabajo. De hecho, estos síntomas pueden contribuir a una situación personal ya difícil o agravarla.

En lugares de trabajo en los que se utilizan sustancias neurotóxicas, trabajadores, empresas y personal de salud y seguridad laboral deben estar especialmente atentos a la sintomatología de intoxicación inicial, indicativa de la vulnerabilidad del sistema nervioso a la exposición. Se han ideado cuestionarios sobre los síntomas para estudios de los puestos de trabajo y vigilancia de los lugares en los que se utilizan sustancias neurotóxicas. En la Tabla 7.9 se ofrece un ejemplo de este tipo de cuestionario.

\section{Alteraciones motoras, sensitivas y cognitivas precoces de la} intoxicación crónica

A medida que aumenta la exposición, pueden observarse cambios en las funciones motora, sensitiva y cognitiva de los trabajadores expuestos a sustancias neurotóxicas, que no presentan signos clínicos. Dada la complejidad del sistema nervioso, y la

\begin{tabular}{|c|c|c|c|c|c|c|}
\hline & $\begin{array}{l}\text { Mezclas } \\
\text { de disol- } \\
\text { ventes } \\
\text { orgánicos }\end{array}$ & $\begin{array}{l}\text { Disulfuro } \\
\text { de } \\
\text { carbono }\end{array}$ & Estireno & $\begin{array}{l}\text { Organo- } \\
\text { fosfo- } \\
\text { rados }\end{array}$ & Plomo & Mercurio \\
\hline Aprendizaje & + & & & & + & \\
\hline Afectividad & + & & + & & + & \\
\hline Categorización & + & & & & & \\
\hline Codificación & + & + & & & + & + \\
\hline $\begin{array}{l}\text { Visión de los } \\
\text { colores }\end{array}$ & + & & + & & & \\
\hline $\begin{array}{l}\text { Distinción de } \\
\text { conceptos }\end{array}$ & + & & & & & \\
\hline Distracción & & & & & + & \\
\hline Inteligencia & + & + & & + & + & + \\
\hline Memoria & + & + & + & + & + & + \\
\hline $\begin{array}{l}\text { Coordinación } \\
\text { motora }\end{array}$ & + & + & + & & + & + \\
\hline Velocidad motora & + & + & + & & + & + \\
\hline $\begin{array}{l}\text { Sensibilidad al } \\
\text { contraste visual } \\
\text { cercano }\end{array}$ & + & & & & & \\
\hline $\begin{array}{l}\text { Umbral de percep- } \\
\text { ción de olores }\end{array}$ & + & & & & & \\
\hline $\begin{array}{l}\text { Identificación de } \\
\text { olores }\end{array}$ & + & & & & + & \\
\hline Personalidad & + & + & & & & t \\
\hline $\begin{array}{l}\text { Relaciones } \\
\text { espaciales }\end{array}$ & + & + & & & + & \\
\hline Umbral vibrotáctil & + & & & + & & + \\
\hline Vigilancia & + & + & & & + & \\
\hline Campo visual & & & & & + & + \\
\hline Vocabulario & & & & & + & \\
\hline
\end{tabular}

Fuente: Adaptado de Anger 1990. 
vulnerabilidad de ciertas áreas a productos químicos concretos, mientras que otras son sensibles a la acción de un gran número de productos tóxicos, un único producto tóxico o una mezcla de neurotoxinas pueden afectar a una amplia gama de funciones del sistema nervioso. El tiempo de reacción, la coordinación visuomotora, la memoria a corto plazo, las memorias visual y auditiva, la atención y la vigilancia, la destreza manual, el vocabulario, la desviación de la atención, la fuerza de prensión, la velocidad motora, la firmeza de la mano, el estado de ánimo, la visión de los colores, la percepción vibrotáctil, la audición y el olfato se encuentran entre las numerosas funciones cuya alteración por diversas sustancias neurotóxicas se ha demostrado.

La comparación del rendimiento de los trabajadores expuestos y no expuestos con respecto al grado de exposición ofrece información importante sobre el tipo de déficit precoces producidos por la exposición. Anger (1990) ofrece una excelente revisión de la investigación neurológica del comportamiento en los lugares de trabajo hasta 1989. En la Tabla 7.10, adaptada de este artículo, se ofrece un ejemplo del tipo de déficit neurofuncionales que se han observado de forma constante en grupos de trabajadores activos expuestos a algunas de las sustancias neurotóxicas más comunes.

Aunque en esta etapa del continuo entre bienestar y enfermedad, la pérdida no puede situarse dentro de los límites de la anormalidad clínica, tales alteraciones pueden ir acompañadas de consecuencias relacionadas con la salud. Por ejemplo, la disminución del estado de vigilia y de los reflejos puede aumentar el peligro de accidentes laborales. Para la identificación de escapes se utiliza el olfato, por lo que la saturación de las mascarillas (rotura del cartucho) y la pérdida aguda o crónica del olfato hacen que una persona esté menos capacitada para identificar una situación potencialmente peligrosa. Los cambios del estado de ánimo pueden perturbar las relaciones interpersonales en el trabajo, sociales y en el hogar. Estas etapas iniciales de deterioro del sistema nervioso, que se pueden observar explorando a grupos de trabajadores expuestos y comparándolos con trabajadores no expuestos o en relación con su grado de exposición, reflejan la disminución del bienestar y pueden predecir un riesgo de problemas neurológicos más graves en el futuro.

\section{Salud mental en la intoxicación crónica}

Los trastornos neuropsiquiátricos se han atribuido desde hace tiempo a la exposición a sustancias neurotóxicas. Las descripciones clínicas varían desde trastornos afectivos, incluidas ansiedad y depresión, hasta manifestaciones de comportamiento psicótico y alucinaciones. La exposición aguda a niveles altos de muchos metales pesados, disolventes orgánicos y pesticidas puede producir delirio. La "locura del manganeso" se ha descrito en personas con exposiciones prolongadas al manganeso, y el conocido síndrome del "sombrerero loco" se debe a intoxicación por mercurio. La encefalopatía tóxica del tipo $2 a$, caracterizada por alteraciones mantenidas de la personalidad consistentes en fatiga, labilidad emocional, alteración del control de los impulsos y del estado de ánimo y motivación general, se ha asociado a exposición a disolventes orgánicos. Cada vez son más las pruebas obtenidas de estudios clínicos y de la población que muestran la persistencia de los trastornos de la personalidad con el paso del tiempo, mucho después de cesar la exposición, aunque otros tipos de deterioro pueden mejorar.

En el continuo que va del bienestar a la enfermedad, los cambios del estado de ánimo, la irritabilidad y la fatiga excesiva son a menudo los primeros indicios de sobreexposición a sustancias neurotóxicas. Aunque en los estudios en los centros de trabajo se revisan de forma sistemática los síntomas neuropsiquiátricos, rara vez se presentan como un problema de salud mental con posibles consecuencias sobre el bienestar mental y social. Por ejemplo, las alteraciones del estado de salud mental afectan al comportamiento, contribuyendo a la dificultad de las relaciones interpersonales y a las desavenencias en el hogar; estas pueden agravar a su vez el estado mental. En lugares de trabajo con programas de ayuda a los empleados, dirigidos a ayudar a los trabajadores con problemas personales, la ignorancia de los potenciales efectos sobre la salud mental de la exposición a sustancias neurotóxicas puede hacer que el tratamiento vaya dirigido a los efectos, y no a las causas. Es interesante señalar que entre los numerosos brotes comunicados de "histeria masiva" o enfermedades psicógenas, las industrias con exposición a sustancias neurotóxicas están exageradamente representadas. Es posible que estas sustancias, que en su mayor parte no se cuantificaron, contribuyeran a los síntomas comunicados.

Las manifestaciones en la salud mental de la exposición a neurotoxinas pueden ser similares a las causadas por los factores de estrés psicosociales asociados a una mala organización del trabajo, así como a las reacciones psicológicas a accidentes, acontecimientos muy estresantes e intoxicaciones graves, que se denominan trastorno por estrés postraumático (comentado en otro lugar de esta E nciclopedia). Un buen conocimiento de la relación entre los problemas de salud mental y las condiciones de trabajo es importante para instaurar medidas preventivas y curativas adecuadas.

\section{Consideraciones generales en la evaluación de la disfunción neurotóxica precoz}

Al evaluar la disfunción precoz del sistema nervioso entre trabajadores activos deben tenerse en cuenta varios factores. En primer lugar, muchas de las funciones neuropsicológicas y neurofisiológicas que se exploran disminuyen con la edad; en algunas de ellas influyen la cultura o el nivel educativo. Se deben tener en cuenta estos factores al considerar la relación entre exposición y alteraciones del sistema nervioso. Para ello pueden compararse grupos con situaciones sociodemográficas similares o utilizar métodos de ajuste estadísticos. Sin embargo, existen ciertos escollos que hay que evitar. Por ejemplo, los trabajadores de más edad quizá tengan historiales de trabajo más largos, y se ha sugerido que algunas sustancias neurotóxicas pueden acelerar el envejecimiento. La segregación laboral puede limitar a los trabajadores con escasa educación, a las mujeres y a las minorías a los trabajos con exposiciones más altas. En segundo lugar, el consumo de alcohol, de tabaco y de drogas, que contienen sustancias neurotóxicas, puede afectar también a los síntomas y al rendimiento. Para desenmarañar los diferentes factores que contribuyen a la disfunción del sistema nervioso y para la implantación de medidas preventivas es importante un buen conocimiento del lugar de trabajo.

\section{SINDROMES CLINICOS ASO CIADOS A NEUROTOXICIDAD}

Robert G. Feldman

Los síndromes neurotóxicos, producidos por sustancias que afectan de forma adversa al tejido nervioso, figuran entre las diez principales enfermedades profesionales en Estados U nidos. LoS efectos neurotóxicos constituyen la base para establecer los criterios del límite de exposición para el $40 \%$, aproximadamente, de los agentes considerados peligrosos por el $\mathrm{N}$ ational Institute for $\mathrm{O}$ ccupational Safety and $\mathrm{H}$ ealth (NIOSH) de Estados U nidos.

U na neurotoxina es cualquier sustancia capaz de interferir en la función normal del tejido nervioso y causar daño celular 
Tabla 7.11 - Exposiciones a productos químicos y síndromes neurotóxicos asociados.

$\begin{array}{ll}\text { Neurotoxina } & \text { Fuentes de exposición } \\ \text { Metales } & \\ \text { Arsénico } & \text { Pesticidas; pigmentos; pintura antimanchas; } \\ & \text { galvanoplastia; marisco; } \\ & \text { fundidores; semiconductores } \\ \text { Plomo } & \text { Soldadura; perdigones; whisky ilegal; } \\ & \text { insecticidas; taller de chapa; } \\ & \text { fabricación de acumuladores; } \\ & \text { fundiciones, fundidores; pinturas con plomo; } \\ & \text { tuberías de plomo } \\ \text { Hierro, siderurgia; operaciones de soldadura; } & \\ \text { operaciones de acabado de metales; fertili- } & \text { zantes; pirotecnia, cerillas; } \\ & \text { fabricantes de pilas secas } \\ & \text { Instrumental científico; equipo eléctrico; } \\ \text { amalgamas; galvanoplastia; } & \text { fotografía; fabricación de fieltro } \\ \text { Mercurio } & \text { Industria conservera; soldadores; } \\ & \text { componentes electrónicos; plásticos de polivi- } \\ \text { Estaño } & \text { nilo; fungicidas }\end{array}$

Disolventes

Disulfuro de carbono

n-hexano, metil butil cetona

Percloroetileno

Tolueno

Tricloroetileno

$\begin{array}{ll}\text { Insecticidas } & \text { Industria agrícola } \\ \text { Organofosforados } & \text { fabricación y aplicación } \\ \text { Carbamatos } & \begin{array}{l}\text { Industria agrícola } \\ \text { fabricación y aplicación } \\ \text { polvos para pulgas }\end{array}\end{array}$

Diagnóstico clínico

Agudo: encefalopatía

Crónico: neuropatía periférica

Agudo: encefalopatía

Crónico: encefalopatía y neuropatía

periférica

\section{Agudo: encefalopatía}

Crónico: parkinsonismo

Agudo: cefaleas, náuseas, inicio de temblor

Crónicos: ataxia, neuropatía periférica, encefalopatía

Agudo: defectos de la memoria,

encefalopatía convulsiones, desorientación

crónico: encefalomielopatía

Agudo: encefalopatía

Crónico: neuropatía periférica, parkinsonismo textiles; pegamento de caucho; barnices; galvanoplastia

Pinturas; lacas; barnices; compuestos para la limpieza de metales; tintas de secado rápido; decapantes de pintura; pegamentos, adhesivos

Decapantes de pintura; desengrasantes; agentes de extracción; industria de la limpieza en seco; industria textil

Disolventes de caucho; productos de limpieza; pegamentos; fabricantes de benceno; gasolina, combustible para aviación; pinturas, diluyentes de pintura; lacas Desengrasantes; industria de la pintura; barnices; quitamanchas; proceso de descafeinización; industria de la limpieza en seco; disolventes de caucho

Crónico: encefalopatía, neuropatía craneal

\section{Agudo: narcosis}

Crónico: neuropatía periférica

desconocido (a)

Axón (c)

Agudo: narcosis

Crónico: neuropatía periférica, encefalopatía

Agudo: narcosis

Crónico: ataxia, encefalopatía

Agudo: narcosis

Desconocida (c)

Axón (c)

Desconocida (a)

Axón (c)

Desconocida

Desconocida (a)

Cerebelo (c)

Desconocida

Desconocida (a)
Localización de la patología ${ }^{1}$

Desconocida (a)

Axón (c)

Vasos sanguíneos (a)

Axón (c)

Desconocida (a)

Neuronas de los ganglios basales (c)

\section{Desconocida (a)}

Axón (c)

Desconocida (c)

Neuronas del sistema límbico (a y c)

Mielina (c)

Desconocida (a)

Axon (c)

Desconocida

Acetilcolinesterasa (a)

Vías largas de la médula espinal (c)

Axón (c)

Acetilcolinesterasa (a)

Sistema dopaminérgico (c)

1 (a), agudo; (c), crónico

Fuente: Modificado de Feldman 1990, con permiso del editor.

irreversible, muerte celular o ambas cosas. Dependiendo de sus propiedades concretas, una neurotoxina determinada atacará puntos seleccionados o elementos celulares específicos del sistema nervioso. Los compuestos que no son polares tienen una mayor solubilidad en lípidos y, por lo tanto, tienen mayor acceso al tejido nervioso que las sustancias químicas muy polares y menos liposolubles. EI tipo y tamaño de las células y los diversos sistemas neurotransmisores afectados en distintas regiones del cerebro, los mecanismos desintoxicantes protectores innatos y la integridad de las membranas celulares y de las organelas intracelulares son todos elementos que influyen en las respuestas a los neurotóxicos.

Las neuronas (la unidad celular funcional del sistema nervioso) tienen una elevada tasa metabólica y corren un gran 
riesgo de lesión neurotóxica, seguidas por los oligodendrocitos, los astrocitos, la microglia y las células del endotelio capilar. Las alteraciones de la estructura de la membrana celular deterioran la excitabilidad e impiden la transmisión de impulsos. Los efectos de los tóxicos alteran la estructura proteica, el contenido líquido y la capacidad de intercambio iónico de las membranas, provocando la hinchazón de neuronas y astrocitos y lesionando las delicadas células que revisten los capilares sanguíneos. La interrupción de los mecanismos neurotransmisores bloquea el acceso a los receptores postsinápticos, produce falsos efectos neurotransmisores, y altera la síntesis, almacenamiento, liberación, recaptación o inactivación enzimática de los neurotransmisores naturales. Por tanto, las manifestaciones clínicas de neurotoxicidad están determinadas por varios factores diferentes: las características físicas de la sustancia neurotóxica, la dosis de la exposición a ella, la vulnerabilidad de la célula diana, la capacidad del organismo para metabolizar y excretar la toxina, y por la capacidad reparadora de las estructuras y mecanismos afectados. En la Tabla 7.11 se ofrece una lista de varias exposiciones a sustancias químicas y sus síndromes neurotóxicos.

El establecimiento de un diagnóstico de síndrome neurotóxico y el diagnóstico diferencial con enfermedades neurológicas de etiología no neurotóxica exige el conocimiento de la patogenia de los síntomas neurológicos y de los signos y síntomas observados; el conocimiento de que determinadas sustancias son capaces de afectar al tejido nervioso; la documentación de la exposición; pruebas de la presencia de neurotoxinas o metabolitos en los tejidos de un individuo afectado, y la delimitación cuidadosa de una relación temporal entre la exposición y la aparición de síntomas, con remisión posterior de los síntomas una vez finalizada la exposición.

Después de la aparición de los síntomas, habitualmente no hay pruebas de que una sustancia determinada ha alcanzado una dosis tóxica. A menos que exista un programa de vigilancia medioambiental, es necesario un elevado índice de sospecha para reconocer los casos de lesión neurotoxicológica. $L a$ identificación de síntomas atribuibles a los sistemas nerviosos central o periférico puede ayudar al médico a centrarse en determinadas sustancias, que tienen una mayor predilección por una parte u otra del sistema nervioso, como posibles culpables. Convulsiones, debilidad, temblor/ sacudidas, anorexia (pérdida de peso), trastornos del equilibrio, depresión del sistema nervioso central, narcosis (estado de estupor o inconsciencia), trastornos visuales, trastornos del sueño, ataxia (incapacidad para coordinar movimientos musculares voluntarios), fatiga y alteraciones del tacto son síntomas referidos habitualmente después de la exposición a determinados productos químicos. Estos grupos de síntomas forman síndromes asociados a la exposición a neurotóxicos.

\section{Alteraciones del comportamiento}

En algunos trabajadores se han descrito enfermedades con síntomas que afectan principalmente al comportamiento, como psicosis aguda, depresión y apatía crónica. Es fundamental distinguir el deterioro de la memoria asociado a otras enfermedades neurológicas, como la enfermedad de Alzheimer, la arteriosclerosis o la presencia de un tumor cerebral, de los déficit cognitivos asociados a la exposición tóxica a disolventes orgánicos, metales o insecticidas. Las alteraciones pasajeras de la conciencia o las convulsiones epilépticas, con afectación motora asociada o sin ella, deben identificarse como diagnóstico principal, diferenciándolas de trastornos de la conciencia aparentemente similares relacionados con los efectos neurotóxicos. Los síndromes tóxicos subjetivos y del comportamiento, como cefaleas, vértigo, fatiga y alteraciones de la personalidad, se manifiestan como encefalopatías leves con sensación de embriaguez, y pueden indicar la exposición a monóxido de carbono, anhídrido carbónico, plomo, zinc, nitratos o mezclas de disolventes orgánicos. Es necesario realizar pruebas neuropsicológicas estandarizadas para documentar elementos de deterioro cognitivo en pacientes con sospecha de encefalopatía tóxica, que es preciso distinguir de los síndromes demenciantes causados por otras patologías. Las pruebas específicas utilizadas en las baterías diagnósticas deben incluir una amplia muestra de pruebas de función cognitiva que proporcionarán predicciones sobre la funcionalidad y la vida diaria del paciente, así como pruebas que previamente hayan demostrado sensibilidad a los efectos de neurotoxinas conocidas. Estas baterías normalizadas deben incluir pruebas han sido validadas en pacientes con tipos concretos de lesión cerebral y déficit estructurales, para separar claramente estos procesos de los efectos neurotóxicos. A demás, las pruebas deben incluir medidas de control interno para detectar la influencia de la motivación, la hipocondría, la depresión y las dificultades del aprendizaje, y deben utilizar un lenguaje que tenga en cuenta los efectos culturales y los antecedentes educativos.

En los pacientes expuestos a sustancias tóxicas existe un continuo desde el deterioro leve del sistema nervioso central al grave:

- Síndrome afectivo orgánico (efecto de tipo I), en el que predominan los trastornos leves del estado de ánimo como principal síntoma del paciente, con características más compatibles con las de los trastornos afectivos orgánicos de tipo depresivo. Este síndrome parece ser reversible después del cese de la exposición al agente agresor.

- Encefalopatía crónica tóxica leve, en la que, además de los trastornos en el estado de ánimo, el deterioro del sistema nervioso central es más llamativo. Los pacientes presentan indicios de trastornos de la función psicomotora y de la memoria, que pueden confirmarse mediante pruebas neuropsicológicas. Además, pueden verse signos de deterioro visuespacial y de la formación de conceptos abstractos. Las actividades de la vida diaria y el rendimiento laboral están mermados.

- Pueden observarse cambios de personalidad o del estado de ánimo mantenidos (efecto de tipo IIA) o deterioro de la función intelectual (tipo II). En la encefalopatía tóxica crónica leve, el curso es insidioso. Los síntomas pueden persistir tras el cese de la exposición y desaparecer progresivamente, mientras que en algunos individuos puede observarse un deterioro funcional persistente. Si la exposición continúa, la encefalopatía puede progresar a una etapa de mayor gravedad.

- En la encefalopatía tóxica crónica grave (efecto de tipo III) se observan demencia con deterioro global de la memoria y otros problemas cognitivos. Los efectos clínicos de la encefalopatía tóxica no son específicos de un determinado agente. La encefalopatía crónica asociada a tolueno, plomo y arsénico no es diferente a la de otras etiologías tóxicas. Sin embargo, la presencia de otros hallazgos asociados (trastornos visuales con alcohol metílico) puede ayudar a distinguir los síndromes según la etiología química de cada uno.

Los trabajadores expuestos a disolventes durante largos periodos de tiempo pueden mostrar trastornos permanentes de la función del sistema nervioso central. Como se han comunicado una cantidad exagerada de síntomas subjetivos, como cefaleas, fatiga, trastornos de la memoria, pérdida de apetito y dolores torácicos difusos, a menudo resulta difícil confirmar este efecto en cada caso. Un estudio epidemiológico en el que se compararon pintores de brocha gorda expuestos a disolventes con trabajadores industriales no expuestos demostró, por ejemplo, que los pintores presentaban puntuaciones medias significativamente más bajas que los sujetos de referencia en las pruebas psicológicas que medían la capacidad intelectual y la 
coordinación psicomotora. Los pintores presentaban también rendimientos significativamente más bajos de lo esperado en las pruebas de memoria y de tiempo de reacción. También resultaron evidentes las diferencias entre trabajadores expuestos durante varios años al combustible para aviones y trabajadores no expuestos en las pruebas que exigían una estrecha atención y una velocidad motora sensitiva alta. Se han comunicado asimismo deterioro del rendimiento psicológico y cambios de la personalidad en los pintores de coches, con afectación de la memoria visual y verbal, reducción de la reactividad emocional y mal rendimiento en las pruebas de inteligencia verbal.

Ultimamente, se ha descrito un síndrome neurotóxico discutible, la sensibilidad química múltiple. Estos pacientes desarrollan diversos síntomas que afectan a varios sistemas orgánicos cuando sufren exposición incluso a niveles bajos de varios productos químicos encontrados en el lugar de trabajo y el medio ambiente. Los trastornos del estado de ánimo se caracterizan por depresión, fatiga, irritabilidad y falta de concentración. Estos síntomas recidivan tras la exposición a estímulos predecibles, siendo desencadenados por productos químicos de diversas clases estructurales y toxicológicas, y a niveles muy inferiores a los que causan respuestas adversas en la población general. Muchos de los síntomas de sensibilidad química múltiple son compartidos por individuos que únicamente muestran una forma leve de trastornos del estado de ánimo, cefaleas, fatiga, irritabilidad y falta de memoria cuando se encuentran en edificios con escasa ventilación y emanación de sustancias volátiles de materiales y moquetas sintéticas. Los síntomas desaparecen cuando abandonan estos ambientes.

\section{Trastor nos de la conciencia, convulsiones y coma}

Cuando el cerebro se ve privado de oxígeno, por ejemplo, en presencia de monóxido de carbono, anhídrido carbónico, metano o agentes que bloquean la respiración de los tejidos, como el ácido cianhídrico, o que causan impregnación masiva del sistema nervioso, como determinados disolventes orgánicos, pueden producirse trastornos de la conciencia. La pérdida de conciencia puede ir precedida de convulsiones en trabajadores con exposición a sustancias anticolinesterásicas, como los insecticidas organofosforados. También pueden producirse convulsiones en la encefalopatía por plomo, asociadas a edema cerebral. Las manifestaciones de toxicidad aguda después de la intoxicación por organofosforados incluyen signos del sistema nervioso autónomo que preceden a la aparición de mareos, cefaleas, visión borrosa, miosis, dolor torácico, aumento de las secreciones bronquiales y convulsiones. Estos efectos parasimpáticos tienen su explicación en la acción inhibidora de estas sustancias tóxicas sobre la actividad colinesterásica.

\section{Trastornos del movimiento}

Lentitud de movimientos, aumento del tono muscular y anomalías posturales son algunos de los signos encontrados en trabajadores expuestos al manganeso, al monóxido de carbono, al disulfuro de carbono y a la toxicidad de un subproducto de la meperidina, la 1-metil-4-fenil-1,2,3,6-tetrahidropiridina (M PT P). En ocasiones parece que estos individuos tienen la enfermedad de Parkinson. El parkinsonismo secundario a exposición tóxica tiene características de otros trastornos neurológicos, como la corea y la atetosis. El temblor característico no se ve en estos casos, y no suelen responder bien al tratamiento con levodopa. La discinesia (deterioro de la potencia de la movilidad voluntaria) puede ser un síntoma común de la intoxicación por bromometano. Pueden observarse movimientos espasmódicos de los dedos de las manos, de la cara, de los músculos peribucales y del cuello, así como espasmos de las extremidades. EI temblor es frecuente después de la intoxicación por mercurio. Un temblor más evidente asociado a ataxia (falta de coordinación de la acción muscular) se observa en individuos después de la inhalación de tolueno.

El opsoclonus es un movimiento anormal de los ojos en forma de sacudidas en todas direcciones. Se observa a menudo en la encefalitis del tronco encefálico, aunque puede ser un síntoma que aparece también después de la exposición a la clordecona. La anomalía consiste en ráfagas irregulares de sacudidas bruscas involuntarias rápidas y simultáneas de ambos ojos, de forma conjugada, posiblemente multidireccionales, en individuos con afectación grave.

\section{Cefaleas}

La aparición frecuente de dolor de cabeza después de la exposición a varios gases de metales, como el zinc y otros vapores de disolventes, puede deberse a vasodilatación (ensanchamiento de los vasos sanguíneos) y a edema cerebral (hinchazón). La experimentación de dolor es un síntoma común de estos trastornos, así como de los provocados por monóxido de carbono, hipoxia (falta de oxígeno) o anhídrido carbónico. Se cree que el "síndrome del edificio enfermo" provoca cefaleas debido a la presencia de un exceso de anhídrido carbónico en una zona mal ventilada.

\section{Neuropatía periférica}

Las fibras nerviosas periféricas que realizan funciones motoras comienzan en las neuronas motoras del asta ventral de la médula espinal. Los axones motores se extienden periféricamente hacia los músculos que inervan. U na fibra nerviosa sensitiva tiene su cuerpo celular en el ganglio de la raíz dorsal o en la sustancia gris dorsal de la médula espinal. Tras haber recibido información de la periferia detectada en receptores distales, los impulsos nerviosos son conducidos en dirección central a los cuerpos de las células nerviosas, donde conectan con vías de la médula espinal que transmiten información al tronco encefálico y a los hemisferios cerebrales. Algunas fibras sensitivas tienen conexiones inmediatas con fibras motoras de la médula espinal, proporcionando una base para la actividad refleja y las respuestas motoras rápidas a estímulos nociceptivos. Estas relaciones sensitivo-motoras existen en todas las partes del organismo; los pares craneales son los equivalentes de los nervios periféricos que proceden de las neuronas del tronco encefálico, en lugar de la médula espinal. Las fibras nerviosas sensitivas y motoras discurren juntas en haces y se denominan nervios periféricos.

Los efectos tóxicos en las fibras nerviosas periféricas pueden dividirse en los que afectan principalmente a los axones (axonopatías), los que causan pérdidas sensitivo-motoras distales y los que afectan principalmente a la vaina de mielina y a las células de Schwann. Las axonopatías resultan evidentes en etapas precoces en las extremidades inferiores, donde los axones tienen mayor longitud y están más alejados del cuerpo de la célula nerviosa. Se produce desmielinización aleatoria en segmentos entre los nódulos de R anvier. Si se produce un daño axonal suficiente, a continuación tiene lugar una desmielinización secundaria; mientras los axones estén conservados, pueden producirse regeneración de las células de Schwann y remielinización. Un patrón observado a menudo en neuropatías tóxicas es la axonopatía distal con desmielinización segmentaria secundaria. La pérdida de mielina reduce la velocidad de conducción de los impulsos nerviosos. Así, la lesión de fibras motoras y sensitivas provoca la aparición progresiva de hormigueo intermitente y entumecimiento que evolucionan a la ausencia de sensibilidad y sensaciones desagradables, debilidad muscular y atrofia. La disminución o ausencia de reflejos tendinosos y los patrones de pérdida sensitiva anatómicamente congruentes, que afectan a las extremidades inferiores más que a las superiores, son características de la neuropatía periférica. 
Puede observarse debilidad motora distal en las extremidades que evoluciona hacia una marcha inestable e incapacidad para coger objetos. Se produce una afectación mayor de las partes distales de las extremidades, aunque en los casos graves también aparecen debilidad muscular proximal 0 atrofia. Se afectan antes los grupos de músculos extensores que los flexores. En ocasiones los síntomas evolucionan durante algunas semanas, incluso después de suspender la exposición. El deterioro de la función nerviosa puede persistir durante varias semanas después de suspendida la exposición.

Dependiendo del tipo y gravedad de la neuropatía, resulta útil realizar una exploración electrofisiológica de los nervios periféricos para documentar el deterioro funcional. Se pueden observar disminución de la velocidad de conducción, amplitudes reducidas de los potenciales de acción sensitivos 0 motores 0 períodos de latencia prolongados. La disminución de las velocidades de conducción motoras o sensitivas se asocia por lo general con desmielinización de las fibras nerviosas. L a conservación de valores normales de velocidad de conducción en presencia de atrofia muscular indica neuropatía axonal. Se producen excepciones cuando existe una pérdida progresiva de fibras nerviosas motoras y sensitivas en la neuropatía axonal que afecta a la velocidad de conducción máxima a causa de la desaparición de las fibras nerviosas de mayor diámetro y de conducción más rápida. En las etapas precoces de la recuperación en las axonopatías aparecen fibras en regeneración, en las que la conducción es más lenta, especialmente en los segmentos distales.

El estudio electrofisiológico de pacientes con neuropatías tóxicas debe incluir determinaciones de la velocidad de conducción motora y sensitiva en las extremidades superiores e inferiores. $\mathrm{H}$ ay que prestar especial atención a las características de conducción sensitiva del nervio sural de la pierna. Esto tiene gran valor cuando se utiliza luego este nervio para obtener una biopsia, al ofrecer una correlación anatómica entre la histología de las fibras nerviosas dañadas y las características de la conducción. El estudio electrofisiológico diferencial de las capacidades de conducción de los segmentos proximales y distales de un nervio es útil para identificar una axonopatía tóxica distal, o para localizar un bloqueo de conducción neuropático, probablemente debido a desmielinización.

El conocimiento de la fisiopatología de una supuesta polineuropatía neurotóxica tiene un gran valor. Por ejemplo, en pacientes con neuropatía provocada por n-hexano y metilbutil cetona disminuyen las velocidades de conducción de los nervios motores, pero en algunos casos los valores pueden entrar dentro de los márgenes normales si únicamente se estimulan y utilizan como resultado medido las fibras de descarga más rápida. Dado que los disolventes hexacarbonados neurotóxicos causan degeneración axonal, se producen alteraciones secundarias de la mielina que explican la reducción global de la velocidad de conducción a pesar del valor dentro de los límites normales producido por las fibras de conducción conservadas.

Entre las técnicas electrofisiológicas se encuentran pruebas especiales además de los estudios de la velocidad de conducción directa, de la amplitud y de la latencia. Los potenciales evocados somatosensitivos, auditivos y visuales son formas de estudiar las características de los sistemas de conducción sensitivos, así como de pares craneales específicos. Los circuitos aferentes-eferentes pueden explorarse mediante la prueba del reflejo del parpadeo, en el que intervienen las respuestas del $\mathrm{V}$ par craneal a músculos inervados por el VII par craneal; los reflejos H valoran las vías de los reflejos motores segmentarios. La estimulación vibratoria separa las afectaciones de fibras de mayor y menor tamaño. Se dispone de técnicas electrónicas bien controladas para medir el umbral necesario para desencadenar una respuesta, y después para determinar la velocidad a la que se desplaza dicha respuesta, así como la amplitud de la contracción muscular o la amplitud y el patrón de un potencial de acción sensitivo evocado. Todos los resultados fisiológicos deben evaluarse a la luz del cuadro clínico y con el conocimiento de los procesos fisiopatológicos subyacentes.

\section{Conclusión}

EI diagnóstico diferencial entre un síndrome neurotóxico y una enfermedad neurológica primaria plantea un enorme reto a los médicos que trabajan en el marco laboral. La obtención de una buena historia, el mantenimiento de un elevado grado de sospecha y el seguimiento adecuado de un individuo, así como de grupos de individuos, es necesario y gratificante. El reconocimiento precoz de enfermedades relacionadas con agentes tóxicos en su medio ambiente 0 con una exposición profesional determinada es fundamental, ya que un diagnóstico adecuado puede conducir a la separación inmediata de un individuo de los peligros de la exposición continua a una sustancia tóxica, evitando posibles lesiones neurológicas irreversibles. Además, el reconocimiento de los primeros casos afectados en un entorno determinado puede conseguir que se produzcan cambios que protegerán a otros todavía no afectados.

\section{DETERMINACION DE LOS DEFICIT NEUROTOXICOS}

\section{Donna Mergler}

\section{Baterías de pruebas neurofuncionales}

Desde hace mucho tiempo se han observado síntomas y signos neurológicos subclínicos en trabajadores activos expuestos a neurotoxinas; sin embargo, hasta mediados de los 60 no se centraron los esfuerzos de la investigación en el desarrollo de baterías de pruebas sensibles capaces de descubrir alteraciones sutiles, leves de las funciones perceptivas, psicomotoras, cognitivas, sensitivas y motoras, y en la afectividad presentes en las primeras etapas de la intoxicación.

La primera batería de pruebas neurológicas del comportamiento concebida para ser utilizada en estudios en centros de trabajo fue desarrollada por $\mathrm{H}$ elena $\mathrm{H}$ änninen, una pionera en el campo de los déficit del comportamiento asociados a la exposición a productos tóxicos (Batería de pruebas de $\mathrm{H}$ änninen) ( $H$ änninen y Lindstrom 1979). D esde entonces, se han realizado esfuerzos en todo el mundo para desarrollar, perfeccionar y, en algunos casos, informatizar baterías de pruebas neurológicas del comportamiento. Anger (1990) describe cinco baterías de pruebas para centros de trabajo desarrolladas en Australia, Suecia, Gran Bretaña, Finlandia y Estados U nidos, además de dos baterías de detección selectiva de neurotoxicidad procedentes de Estados Unidos, que se han utilizado en estudios de trabajadores expuestos a neurotoxinas. Además, el Sistema computarizado de evaluación neurológica del comportamiento (Neurobehavioral Evaluation System, NES) y el Sistema sueco de evaluación del rendimiento (Swedish Performance Evaluation System, SPES) han sido ampliamente utilizados en todo el mundo. Existen también baterías de pruebas diseñadas para evaluar funciones sensoriales, como mediciones de la visión, del umbral de percepción vibrotáctil, del olfato, de la audición y del equilibrio (M ergler 1995). Los estudios sobre varios agentes neurotóxicos en los que se han utilizado alguna de estas baterías han contribuido en gran medida a nuestro conocimiento del deterioro neurotóxico precoz; sin embargo, ha sido difícil 
Tabla 7.12 - Ejemplos de baterías "nucleares" para la evaluación de los efectos neurotóxicos precoces.

\begin{tabular}{|c|c|c|c|c|}
\hline \multicolumn{2}{|c|}{ Batería de pruebas nucleares neurológicas del comportamiento (NCTB) } & \multirow[t]{2}{*}{$\begin{array}{l}\text { Orden de las } \\
\text { pruebas }\end{array}$} & \multicolumn{2}{|c|}{$\begin{array}{l}\text { Batería de pruebas neurológicas del comportamiento en relación con } \\
\text { factores ambientales para adultos (AENTB) de la Agency for toxic } \\
\text { Substances and Disease Registry }\end{array}$} \\
\hline Dominio funcional & Prueba & & Dominio funcional & Prueba \\
\hline Continuidad motora & Persecución (Pursuit Aiming II) & 1 & Visión & $\begin{array}{l}\text { Agudeza visual, sensibilidad al contraste } \\
\text { de cerca }\end{array}$ \\
\hline $\begin{array}{l}\text { Atención/ velocidad de } \\
\text { respuesta }\end{array}$ & Tiempo de reacción simple & 2 & & $\begin{array}{l}\text { Visión de colores (prueba desaturada } \\
\text { Lanthony D-15) }\end{array}$ \\
\hline $\begin{array}{l}\text { Velocidad motora } \\
\text { perceptual }\end{array}$ & Dígitos-símbolos (WAIS-R) & 3 & Somatosensitivo & Umbral de percepción vibrotáctil \\
\hline Destreza manual & Santa Ana (versión de Helsinki) & 4 & Fuerza motora & $\begin{array}{l}\text { Dinamómetro (incluye evaluación de } \\
\text { la fatiga) }\end{array}$ \\
\hline Percepción visual/ memoria & Retención visual de Benton & 5 & Coordinación motora & Santa Ana \\
\hline Memoria auditiva & Separación de dígitos (WAIS-R, WMS) & 6 & $\begin{array}{l}\text { Funciones intelectuales } \\
\text { superiores }\end{array}$ & Matrices progresivas de Raven (Revisada) \\
\hline \multirow[t]{6}{*}{ Afectividad } & POMS (perfil de los estados de ánimo) & 7 & Coordinación motora & $\begin{array}{l}\text { Prueba de tabaleo con los dedos } \\
(\text { (una mano) })^{1}\end{array}$ \\
\hline & & 8 & $\begin{array}{l}\text { Atención mantenida } \\
\text { (cognitiva), velocidad } \\
\text { (motora) }\end{array}$ & $\begin{array}{l}\text { Tiempo de reacción simple (TRS) } \\
(\text { ampliada })^{1}\end{array}$ \\
\hline & & 9 & Codificación cognitiva & Símbolos-digitos con recuerdo diferido ${ }^{1}$ \\
\hline & & 10 & Aprendizaje y memoria & Aprendizaje de dígitos seriados ${ }^{1}$ \\
\hline & & 11 & Indice de nivel educativo & Vocabulario ${ }^{1}$ \\
\hline & & 12 & Estado de ánimo & Escala del estado de ánimo \\
\hline
\end{tabular}

1 Disponible en versión informática; WAIS = Escala de inteligencia del adulto de Wechsler (Wechsler Adult Intelligence Scale); WMS = Escala de la memoria de Wechsler (Wechsler Memory Scale).

realizar comparaciones entre los estudios, debido a la utilización de diferentes pruebas o a la utilización de pruebas con nombres similares, pero que se han aplicado utilizando un protocolo diferente.

En un intento de normalizar la información de los estudios sobre sustancias neurotóxicas, un comité de trabajo de la O rganización M undial de la Salud (OMS) propuso la idea de una batería "nuclear" (Johnson 1987). Basándose en los conocimientos existentes en el momento de la reunión (1985), se seleccionaron una serie de pruebas que constituyeran la batería nuclear de pruebas neurológicas del comportamiento (N eurobehavioral Core Test Battery, NCT B), una batería relativamente económica para la que no se precisa equipo complejo y que se ha utilizado con éxito en muchos países (Anger y cols. 1993). Las pruebas que forman esta batería se eligieron para cubrir ámbitos concretos del sistema nervioso con sensibilidad demostrada a la lesión neurotóxica. U na batería nuclear más reciente, que comprende pruebas sencillas e informatizadas ha sido propuesta por un grupo de trabajo de la Agency for Toxic Substances and Disease Registry de Estados U nidos (H utchison y cols. 1992). A mbas baterías se presentan en la Tabla 7.12.

Los autores de ambas baterías nucleares resaltan que, aunque éstas son útiles para normalizar los resultados, de ningún modo proporcionan una evaluación completa de las funciones del sistema nervioso. Será necesario utilizar pruebas suplementarias, dependiendo del tipo de exposición; por ejemplo, una batería de pruebas para evaluar la disfunción del sistema nervioso en trabajadores expuestos al manganeso debería incluir más pruebas de funciones motoras, especialmente de las que exigen movimientos alternantes rápidos, mientras que las dirigidas a trabajadores expuestos al metilmercurio deberían incluir estudios del campo visual. La elección de pruebas para un centro de trabajo concreto debe realizarse basándose en el conocimiento actual sobre la acción de la toxina o toxinas a las que está expuesto el sujeto.

L as baterías de pruebas más sofisticadas, aplicadas e interpretadas por psicólogos expertos, forman una parte importante de la evaluación clínica de la intoxicación por neurotóxicos (H art 1988). Incluyen pruebas sobre capacidad intelectual, atención, concentración y orientación, memoria, destrezas de percepción visual, constructivas y motoras, lenguaje, funciones conceptual y ejecutiva y bienestar psicológico, además de una evaluación de posibles enfermedades simuladas. El perfil del rendimiento del paciente se estudia a la vista de la historia médica y psicológica pasada y presente, así como de la historia de exposiciones. El diagnóstico final se basa en una constelación de déficit interpretados en relación con el tipo de exposición.

\section{Mediciones del estado emocional y de la personalidad}

Los estudios de los efectos de sustancias neurotóxicas suelen incluir mediciones de los trastornos afectivos o de la personalidad, en forma de cuestionarios de síntomas, escalas de los estados de ánimo o índices de personalidad. La NCT B, descrita 
anteriormente, incluye el Perfil de estados de ánimo (Profile of M ood States, POM S), una determinación cuantitativa del estado de ánimo. Con la utilización de 65 adjetivos calificativos de los estados de ánimo durante los últimos 8 días, se obtienen los grados de tensión, depresión, hostilidad, vigor, fatiga y confusión. La mayor parte de los estudios comparativos de exposiciones neurotóxicas en lugares de trabajo indican la existencia de diferencias entre sujetos expuestos y no expuestos. Un estudio reciente de trabajadores expuestos al estireno muestra relaciones entre dosis y respuesta entre el nivel urinario de ácido mandélico, un indicador biológico del estireno, después del turno y las puntuaciones en la escala de tensión, hostilidad, fatiga y confusión (Sassine y cols. 1996).

Pruebas más largas y sofisticadas de afectividad y de la personalidad, como el Indice de personalidad multifásico de M innesota ( $M$ innesota Multiphasic Personality Index, MMPI), que reflejan tanto estados emocionales como rasgos de la personalidad, han sido utilizados principalmente para la evaluación clínica, pero también para estudios en lugares de trabajo. Asimismo, el M M PI proporciona una evaluación de la exageración de los síntomas y de las respuestas incoherentes. En un estudio de trabajadores de la microelectrónica con antecedentes de exposición a sustancias neurotóxicas, los resultados del M MPI indicaron niveles clínicamente significativos de depresión, ansiedad, trastornos somáticos y alteraciones del pensamiento (Bowler y cols. 1991).

\section{Mediciones electrofisiológicas}

La actividad eléctrica generada por la transmisión de información a lo largo de las fibras nerviosas y de una célula a otra puede registrarse y utilizarse en la determinación de lo que está sucediendo en el sistema nervioso de personas con exposiciones a productos tóxicos. La interferencia en la actividad neuronal puede hacer más lenta la transmisión o modificar el patrón eléctrico. LOS registros electrofisiológicos exigen instrumentos precisos, por lo que se realizan casi siempre en un laboratorio o en el marco hospitalario. Sin embargo, se ha intentado desarrollar equipos portátiles para ser utilizados en estudios en el lugar de trabajo.

Las mediciones electrofisiológicas registran una respuesta global de un gran número de fibras nerviosas, por lo que debe existir un daño considerable antes de que se pueda registrar adecuadamente. Por tanto, con la mayor parte de las sustancias neurotóxicas suele ser posible detectar los síntomas, así como las alteraciones sensitivas, motoras y cognitivas, en grupos de trabajadores expuestos antes de observar diferencias electrofisiológicas. Para la exploración clínica de personas con sospecha de trastornos neurotóxicos, los métodos electrofisiológicos proporcionan información relacionada con el tipo y grado de lesión del sistema nervioso. Seppalaïnen (1988) ha realizado una revisión de las técnicas electrofisiológicas utilizadas en la detección de neurotoxicidad precoz en seres humanos.

La velocidad de conducción nerviosa de los nervios sensoriales (que van hacia el cerebro) y de los nervios motores (que salen del cerebro) se mide mediante la electroneurografía (ENG). Si se estimulan diferentes puntos anatómicos y se obtiene un registro en otros, es posible calcular la velocidad de conducción. Esta técnica puede proporcionar información sobre las grandes fibras mielinizadas; en presencia de desmielinización la velocidad de conducción será más lenta. Con frecuencia se ha observado una reducción de la velocidad de conducción en trabajadores expuestos al plomo sin síntomas neurológicos (M aizlish y Feo 1994). También se han asociado velocidades de conducción lentas en los nervios periféricos a otras neurotoxinas, como mercurio, hexacarbonos, disulfuro de carbono, estireno, metil-n-butil cetona, metiletil cetona y determinadas mezclas de disolventes. El nervio trigémino (un nervio de la cara) resulta afectado por la exposición a tricloroetileno. Sin embargo, si la sustancia tóxica actúa principalmente sobre fibras escasamente mielinizadas o no mielinizadas, la velocidad de conducción suele permanecer normal.

La electromiografía (EM G) se utiliza para medir la actividad eléctrica en los músculos. Se han observado anomalías electromiográficas entre trabajadores con exposición a sustancias como n-hexano, disulfuro de carbono, metil-n-butil cetona, mercurio y determinados pesticidas. Estas alteraciones a menudo van acompañadas de cambios en la ENG y de síntomas de neuropatía periférica.

$L$ as alteraciones de las ondas cerebrales se ponen de manifiesto en la electroencefalografía (EEG). En pacientes con intoxicación por disolventes orgánicos se han observado anomalías consistentes en ondas lentas locales y difusas. Algunos estudios presentan pruebas de alteraciones de la EEG proporcionales a la dosis entre trabajadores activos con exposición a mezclas de disolventes orgánicos, estireno y disulfuro de carbono. Los pesticidas organoclorados pueden provocar convulsiones epilépticas, con anomalías en el EEG. Se han comunicado alteraciones en el EEG con la exposición prolongada a pesticidas organofosforados y con fosfuro de zinc.

Los potenciales evocados (PE) son otro medio de estudiar la actividad del sistema nervioso en respuesta a un estímulo sensitivo. Se colocan electrodos de registro en la zona específica del cerebro que responde a los estímulos concretos, y se registran la latencia y la amplitud del potencial lento relacionado con el acontecimiento. Se han observado aumento del periodo de latencia y/ o reducción de las amplitudes máximas en respuesta a estímulos visuales, auditivos y somatosensitivos para una amplia gama de sustancias neurotóxicas.

La electrocardiografía (ECG) registra los cambios en la conducción eléctrica del corazón. Aunque no suele utilizarse en estudios de sustancias neurotóxicas, se han observado alteraciones en las ondas del ECG entre las personas con exposición al tricloroetileno. Los registros electrooculográficos (EOG) de los movimientos oculares han mostrado alteraciones en los trabajadores expuestos al plomo.

\section{Técnicas de imagen cerebral}

En los últimos años se han desarrollado diferentes técnicas para la obtención de imágenes del cerebro. Las imágenes obtenidas por tomografía computarizada (TC) revelan la anatomía del cerebro y de la médula espinal. Se han utilizado para el estudio de la atrofia cerebral en trabajadores y pacientes expuestos a disolventes; sin embargo, los resultados no son consistentes. La resonancia magnética ( $\mathrm{R} M$ ) estudia el sistema nervioso utilizando un poderoso campo magnético. Resulta especialmente útil en la clínica para descartar un diagnóstico alternativo, como pueden ser los tumores cerebrales. La tomografía por emisión de positrones (TEP), que proporciona imágenes de los procesos bioquímicos, se ha utilizado con éxito para estudiar las alteraciones del cerebro inducidas por la intoxicación por manganeso. La tomografía computarizada por emisión de fotón único (TCEFU) ofrece información sobre el metabolismo cerebral y puede llegar a ser una herramienta importante en el conocimiento de la forma en que las neurotoxinas actúan sobre el cerebro. Todas estas técnicas son muy costosas, y no se dispone de ellas fácilmente en la mayor parte de los hospitales o laboratorios. 


\section{DIAGNOSTICO}

\section{Anna Maria Seppäläinen}

El diagnóstico de enfermedad neurotóxica no es fácil. Los errores suelen ser de dos tipos: o bien no se reconoce que un agente neurotóxico es la causa de síntomas neurológicos, o los síntomas neurológicos (y especialmente los relacionados con el comportamiento) se diagnostican erróneamente como debidos a exposición neurotóxica profesional. Ambos errores pueden ser peligrosos, dada la importancia de un diagnóstico precoz en el caso de las enfermedades neurotóxicas, y que el mejor tratamiento es evitar nuevas exposiciones para cada caso en particular, además de la vigilancia de la situación de otros trabajadores para evitar su exposición al mismo peligro. Por otro lado, a veces puede generarse una alarma exagerada en el lugar de trabajo cuando un trabajador afirma tener síntomas graves y sospecha que la causa es una exposición química cuando, en realidad, el trabajador está equivocado o el riesgo no está realmente presente para los demás. Existen razones prácticas para aplicar los procedimientos diagnósticos correctos, ya que en muchos países el diagnóstico y tratamiento de las enfermedades profesionales y la pérdida de la capacidad de trabajo y la invalidez provocadas por éstas están cubiertas por seguros; así, la compensación económica puede ser cuestionada si los criterios diagnósticos no son sólidos. En la Tabla 7.13 se ofrece un ejemplo de un árbol de decisión para la evaluación neurológica.

\section{Exposición y síntomas}

Los síndromes neurotóxicos agudos se producen principalmente en situaciones accidentales, cuando los trabajadores quedan expuestos durante breves periodos de tiempo a niveles muy elevados de un producto químico o de una mezcla de ellos, generalmente por inhalación. Los síntomas habituales son vértigo, malestar general y posible pérdida de conciencia a causa de la depresión del sistema nervioso central. Cuando se retira al sujeto de la exposición, los síntomas desaparecen con bastante rapidez, a menos que la exposición haya sido tan intensa que ponga en peligro la vida, caso en el que pueden producirse coma y la muerte. En estas situaciones, el reconocimiento del peligro debe producirse en el lugar de trabajo, y hay que sacar a la persona afectada a respirar aire fresco inmediatamente.

Por lo general, los síntomas neurotóxicos aparecen después de exposiciones breves o prolongadas, y a menudo con niveles de exposición profesional relativamente bajos. En estos casos, pueden haberse producido síntomas agudos en el lugar de trabajo, pero no es necesaria su presencia para hacer el diagnóstico de encefalopatía tóxica crónica o de neuropatía tóxica. Sin embargo, a menudo los pacientes comunican cefaleas, mareos 0 irritación de las mucosas al final de un día de trabajo, aunque inicialmente estos síntomas desaparecen por la noche, el fin de semana o las vacaciones. En la Tabla 7.10 se puede encontrar una lista de control de gran utilidad.

Suponiendo que el paciente ha estado expuesto a productos químicos neurotóxicos, el diagnóstico de enfermedad neurotóxica comienza con los síntomas. En 1985, un grupo de trabajo conjunto de la O rganización M undial de la Salud y del Consejo de M inistros de los Estados Nórdicos, comentó la cuestión de la intoxicación crónica por disolventes orgánicos y encontró una serie de síntomas cardinales, que se descubren en la mayor parte de los casos (O M S/ Consejo Nórdico 1985). Tales síntomas son fatigabilidad, pérdida de memoria, dificultad de concentración y pérdida de la iniciativa, y suelen comenzar después de una alteración fundamental de la personalidad, que se desarrolla progresivamente y afecta a la energía, al intelecto, a la emoción y la
Tabla 7.13 • Arbol de decisión para las enfermedades neurotóxicas.

I. Exposición significativa
nivel, duración y tipo
II. Síntomas oportunos
aumento insidioso de los síntomas del sistema nervioso central (SNC) o
periférico (SNP)
III. Signos y otras pruebas
disfunción del SNC: neurología, pruebas psicológicas
disfunción del SNP: prueba sensitiva cuantitativa, estudios de
conducción nerviosa
IV. Exclusión de otras enfermedades en el diagnóstico diferencial.

motivación. Entre otros síntomas de encefalopatía tóxica crónica se encuentran depresión, disforia, labilidad emocional, cefaleas, irritabilidad, trastornos del sueño y mareos (vértigo). Si existe también afectación del sistema nervioso periférico, se desarrollarán entumecimiento $y$, posiblemente, debilidad muscular. Estos síntomas crónicos persisten durante al menos un año después de finalizada la exposición.

\section{Exploración clínica y pruebas complementarias}

La exploración clínica debe incluir una exploración neurológica, que debe prestar atención a la presencia de deterioro de funciones nerviosas superiores como la memoria, el conocimiento, el razonamiento y las emociones; deterioro de funciones cerebelosas, como temblor, marcha, bipedestación y coordinación, y de funciones nerviosas periféricas, especialmente de la sensibilidad a la vibración y de otras pruebas sensitivas. Las pruebas psicológicas pueden proporcionar mediciones objetivas de funciones superiores del sistema nervioso, como la psicomotricidad, la memoria a corto plazo, el razonamiento verbal y no verbal y las funciones de percepción. En el diagnóstico individual, las pruebas deben incluir algunas que ofrezcan datos del nivel intelectual premórbido de la persona. La historia del rendimiento escolar y en trabajos anteriores, así como las posibles pruebas psicológicas realizadas con anterioridad, por ejemplo con ocasión del servicio militar, pueden ser útiles en la evaluación del nivel de rendimiento normal de la persona.

El sistema nervioso periférico se puede estudiar con pruebas cuantitativas de modalidades sensitivas, de la vibración y de la termosensibilidad. Los estudios de la velocidad de conducción nerviosa y la electromiografía a menudo pueden revelar la presencia de una neuropatía en una etapa precoz. En estas pruebas debe insistirse especialmente en las funciones de los nervios sensitivos. La amplitud del potencial de acción sensitivo (PAS) disminuye con mayor frecuencia que la velocidad de conducción sensitiva en las neuropatías axonales, y la mayor parte de las neuropatías tóxicas son de carácter axonal. Estudios neurorradiológicos como la tomografía computarizada (T C) y la resonancia magnética $(\mathrm{R} M)$ no suelen revelar ningún dato relacionado con la encefalopatía tóxica crónica, pero pueden ser útiles para el diagnóstico diferencial.

En el diagnóstico diferencial deben considerarse otras enfermedades neurológicas y psiquiátricas. $\mathrm{H}$ ay que descartar la demencia de otras etiologías, así como la depresión y los síntomas de estrés provocados por diversas causas. En ocasiones es necesaria una consulta psiquiátrica. El consumo exagerado de alcohol es un factor de confusión importante; por un lado provoca síntomas similares a los de la exposición a disolventes, y por otro hay informes que indican que la exposición a 
disolventes puede inducir al alcoholismo. También hay que descartar otras causas de neuropatía, especialmente las neuropatías por atrapamiento, la diabetes y las enfermedades renales; también el alcohol causa neuropatías. La combinación de encefalopatía y neuropatía tiene más posibilidades de ser de origen tóxico que cualquiera de las dos patologías por separado.

A la hora de tomar la decisión final, será necesario evaluar de nuevo la posibilidad de exposición. ¿Se produjo una exposición importante, teniendo en cuenta el nivel, la duración y el tipo de exposición? Los disolventes tienen mayores posibilidades de inducir síndromes psicoorgánicos o encefalopatía tóxica; sin embargo, los hexacarbonos suelen causar primero neuropatía. EI plomo y algunos metales provocan neuropatía, aunque más adelante se puede detectar afectación del SNC.

\section{- NEUROEPIDEMIOLOGIA PROFESIONAL}

\section{Olav Axelson*}

Los primeros conocimientos acerca de los efectos neurotóxicos de las exposiciones profesionales se obtuvieron por las observaciones clínicas. Los efectos observados fueron más o menos agudos y se referían a la exposición a metales como plomo o mercurio, o a disolventes como el disulfuro de carbono y el tricloroetileno. Sin embargo, con el paso del tiempo y los modernos métodos de exploración y los estudios sistemáticos de grupos mayores, se han evaluado efectos de agentes neurotóxicos más crónicos y clínicamente menos evidentes. Aun así, la interpretación de los hallazgos ha sido discutible y discutida, como en el caso de los efectos crónicos de la exposición a disolventes (Arlien-Søborg 1992).

Las dificultades encontradas en la interpretación de los efectos neurotóxicos crónicos dependen tanto de la diversidad y vaguedad de los síntomas y signos como del problema asociado de definir una entidad patológica propiamente dicha para estudios epidemiológicos concluyentes. Por ejemplo, en la exposición a disolventes, los efectos crónicos podrían ser problemas de la memoria y la concentración, cansancio, falta de iniciativa, tendencia a la afectación, irritabilidad y, en ocasiones, mareos, cefaleas, intolerancia al alcohol y disminución de la libido. Los métodos neurofisiológicos han revelado también varios trastornos funcionales que también son difíciles de agrupar en una sola entidad patológica.

De forma similar, parece que también se producen diversos efectos sobre el comportamiento a causa de otras exposiciones profesionales, como la exposición moderada al plomo o la soldadura con cierta exposición al aluminio, plomo y manganeso o la exposición a pesticidas. Existen también signos neurofisiológicos o neurológicos, entre otros, polineuropatía, temblor y trastornos del equilibrio, en individuos expuestos a organoclorados, organofosforados y otros insecticidas.

A la vista de los problemas epidemiológicos que entraña la definición de una entidad patológica a partir de los numerosos tipos de efectos neurológicos sobre el comportamiento mencionados, parece natural considerar algunos trastornos neuropsiquiátricos clínicamente más o menos bien definidos en relación con exposiciones profesionales.

D esde los años 70, varios estudios se han centrado de forma específica en la exposición a disolventes y el síndrome psicoorgánico, cuando éste alcanzaba una gravedad discapacitante. $M$ ás recientemente, también la demencia de Alzheimer, la esclerosis

*A daptado de Axelson 1996. múltiple, la enfermedad de Parkinson, la esclerosis lateral amiotrófica y enfermedades relacionadas han atraído el interés de la epidemiología profesional.

En lo que respecta a la exposición a los disolventes y el síndrome psicoorgánico (o la encefalopatía crónica tóxica en medicina clínica del trabajo, cuando se tiene en cuenta la exposición para el diagnóstico), el problema de definir una entidad patológica era evidente y llevó a considerar primero en bloque los diagnósticos de encefalopatía, demencia y atrofia cerebral, aunque también se incluyeron la neurosis, la neurastenia y el nerviosismo como no necesariamente diferenciados entre sí en la práctica médica (Axelson, Hane y Hogstedt 1976). Recientemente, entidades patológicas más específicas, como la demencia orgánica y la atrofia cerebral, se han asociado también a la exposición a disolventes (Cherry, Labréche y M CD onald 1992). Sin embargo, los hallazgos no han sido totalmente uniformes, ya que en un estudio a gran escala de casos-controles realizado en Estados U nidos, con hasta 3.565 casos de diversos trastornos neuropsiquiátricos y 83.245 controles hospitalarios no apareció un exceso de "demencia presenil" (Brackbill, Maizlish y Fischbach 1990). Sin embargo, en comparación con los albañiles, se registró un exceso aproximado del $45 \%$ de trastornos neuropsiquiátricos incapacitantes entre los pintores varones y de raza blanca, excepto en los pintores con pistola.

Parece que las exposiciones profesionales también desempeñan un papel en trastornos más específicos que el síndrome psicoorgánico. Así, en 1982 se describió por primera vez una asociación entre la esclerosis múltiple y la exposición a disolventes procedentes de pegamentos en la industria del calzado italiana (Amaducci y cols. 1982). Esta relación se ha visto considerablemente reforzada por otros estudios realizados en Escandinavia (Flodin y cols. 1988; Landtblom y cols. 1993; G rönning y cols. 1993) y en otros lugares, lo que permitió que en una revisión pudieran incluirse 13 estudios con cierta información sobre exposición a disolventes ( $L$ andtblom y cols. 1996). Diez de estos estudios ofrecían datos suficientes para su inclusión en un metaanálisis, que mostró aproximadamente el doble de riesgo de esclerosis múltiple en los individuos expuestos a disolventes. En algunos estudios también se asocian la esclerosis múltiple con la exposición a radiación, la soldadura y el trabajo con herbicidas fenoxi (Flodin y cols. 1988; Landtblom y cols. 1993). La enfermedad de Parkinson parece ser más frecuente en zonas rurales (Goldsmith y cols. 1990), especialmente en edades más tempranas (Tanner 1989). U n dato más interesante es el ofrecido por un estudio de Calgary, Canadá, que mostraba un riesgo tres veces mayor con la exposición a herbicidas (Semchuk, Love y Lee 1992).

En todos los casos de personas que recordaron exposiciones concretas se comunicaron exposiciones a herbicidas fenoxi 0 tiocarbamatos. U no de ellos recordó la exposición al paraquat, que es químicamente similar a la MPTP (N-metil-4-fenil-1,2,3,6-tetrahidropiridina), un inductor de un síndrome de tipo parkinsoniano. Sin embargo, todavía no se ha podido comprobar si los sujetos que trabajan con paraquat padecen dicho síndrome (H oward 1979). Estudios de casos-controles de C anadá, C hina, E spaña y Suecia han señalado una relación con la exposición a productos químicos industriales no especificados, pesticidas y metales, especialmente manganeso, hierro y aluminio (Zayed y cols. 1990).

En un estudio norteamericano, apareció un mayor riesgo de enfermedad de las neuronas motoras (que abarca la esclerosis lateral amiotrófica, la parálisis bulbar progresiva y la atrofia muscular progresiva) en relación con la soldadura (Armon y cols. 1991), que aparecía también como factor de riesgo, igual que el trabajo con electricidad y con agentes de impregnación, en un estudio sueco (Gunnarsson y cols. 1992). El carácter 
hereditario de algunos trastornos neurodegenerativos y tiroideos, combinado con la exposición a disolventes y el sexo masculino, presentaba un riesgo hasta 15,6 veces mayor. 0 tros estudios indican también que la exposición a plomo y disolventes podría tener importancia (Campbell, Williams y Barltrop 1970; Hawkes, Cavanagh y Fox 1989; Chio, Tribolo y Schiffer 1989; Sienko y cols. 1990).

Para la enfermedad de Alzheimer, no se encontraron indicios claros de riesgo profesional en un metaanálisis de 11 estudios de casos-controles (G raves y cols. 1991), aunque recientemente se ha encontrado un mayor riesgo asociado al trabajo manual (Fratiglioni y cols. 1993). O tro estudio reciente, que incluía también a personas de edades más avanzadas, indicaba que la exposición a disolventes podría ser un factor de riesgo bastante importante (K ukull y cols. 1995). La reciente sugerencia de que la enfermedad de Alzheimer podría estar relacionada con la exposición a campos electromagnéticos resultó aún más sorprendente (Sobel y cols. 1995). Es probable que estos dos estudios estimulen el interés por la realización de nuevas investigaciones en las líneas indicadas.

Así pues, a la vista de las perspectivas actuales de la neuroepidemiología profesional, reseñadas brevemente, parece que existen razones para realizar nuevos estudios sobre la relación con el trabajo de diferentes trastornos neurológicos y neuropsiquiátricos más o menos descuidados hasta ahora. N o sería raro que apareciesen algunos efectos añadidos de diversas exposiciones profesionales, de la misma forma que se ha visto para muchos tipos de cáncer. Además, como en la investigación etiológica del cáncer, con la epidemiología del trabajo pueden obtenerse nuevas claves que sugieran las causas últimas o los mecanismos desencadenantes que se encuentran detrás de los trastornos neurológicos graves.

\section{Referencias}

Amaducci, L, C Arfaioli, D Inzitari, M M archi. 1982 $M$ ultiple sclerosis among shoe and leather workers: An epidemiological survey in Florence. Acta Neurol Scand 65:94-103.

Anger, KW. 1990. Worksite neurobehavioral research: Result, sensitive methods, test batteries and the transition from laboratory data to human health. N eurotoxicology 11:629-720.

Anger, WK, MG Cassitto, Y Liang, R Amador Hooisma, DW Chrislip, D Mergler, M K eifer, J Hörtnagel. 1993. Comparison of performance from three continents on the W H O -recommended neurobehavioral core test battery (NCT B). Environ $R$ es 62:125-147.

Arlien-Søborg, P. 1992. Solvent Neurotoxicity. Boca Ratón: CR C Press.

Armon, C, LT K urland, JR Daube, PC O 'Brian. 1991. Epidemiologic correlates of sporadic amyotrophic lateral sclerosis. N eurology 41:1077-1084.

Axelson, 0. 1996. Where do we go in occupational neuroepidemiology? Scand J W ork Environ $H$ ealth 22: 81-83.

Axelson, O, M Hane, C Hogstedt. 1976. A case-referent study on neuropsychiatric disorders among workers exposed to solvents. Scand J W ork E nviron $\mathrm{H}$ ealth 2:14-20.

Bowler, R, D M ergler, S R auch, R H arrison, J Cone 1991. Affective and personality disturbance among women former microelectronics workers. J Clin Psychiatry 47:41-52

Brackbill, RM, N M aizlish, T Fischbach. 1990. Risk of neuropsychiatric disability among painters in the U nited States. Scand I W ork Environ $\mathrm{H}$ ealth $16: 182-188$

Campbell, AM G, ER Williams, D Barltrop. 1970 $M$ otor neuron disease and exposure to lead. N eurol N eurosurg P sychiatry 33:877-885.

Cherry, NM, FP Labrèche, JC M CD onald. 1992. O rganic brain damage and occupational solvent exposure. Br I Ind M ed 49:776-781.

Chio, A, A Tribolo, D Schiffer. 1989. M otorneuron disease and glue exposure. $L$ ancet 2:921.

Cooper, JR, FE Bloom, RT Roth. 1986. The Biochemical Basis of Neuropharmacology. N ueva Y ork: 0 xford U niv. Press.

Dehart, RL. 1992. Multiple chemical sensitivity-What is it? Multiple chemical sensitivities. Apéndice de: Biologic markers in immunotoxicology. Washington, DC: National Academy Press.

Feldman, RG. 1990. Effects of toxins and physical agents on the nervous system. En N eurology in
Clinical Practice, dirigido por WG Bradley, RB Daroff, GM Fenichel y CD M arsden. Stoneham, $M$ assachussetts: Butterworth.

Feldman, RG, LD Q uenzer. 1984. Fundamentals of Neuropsychopharmacology. Sunderland, $M$ assachussetts: Sinauer Associates.

Flodin, U, B Söderfeldt, H Noorlind-Brage, M Fredriksson, O Axelson. 1988. Multiple sclerosis, solvents and pets: A case-referent study. Arch N eurol 45:620-623.

Fratiglioni L, A Ahlbom, M Viitanen, B Winblad. 1993. Risk factors for late-onset Alzheimer's disease: a population-based case-control study. Ann N eurol 33:258-66.

Goldsmith, JR, Y Herishanu, JM Abarbanel, Z Weinbaum. 1990. Clustering of Parkinson's disease points to environmental etiology. Arch Environ $\mathrm{H}$ ealth 45:88-94.

Graves, AB, CM van Duijn, V Chandra, L Fratiglioni, A Heyman, AF Jorm y cols. 1991. $O$ ccupational exposure to solvents and lead as risk factors for Alzheimer's disease: A collaborative re-analysis of case-control studies. Int J E pidemiol 20 Supl. 2:58-61.

Grönning, M, G Albrektsen, G K våle, B M oen, JA Aarli, $H$ Nyland. 1993. O rganic solvents and multiple sclerosis. Acta N eurol Scand 88:247-250.

Gunnarsson, L-G, L Bodin, B Söderfeldt, 0 Axelson. 1992. A case-control study of motor neuron disease: Its relation to heritability and occupational exposures, particularly solvents. $\mathrm{Br} J$ Ind $\mathrm{Med}$ 49:791-798.

H änninen, H , K Lindstrom. 1979. N eurobehavioral T est Battery of the Institute of $\mathrm{O}$ ccupational $\mathrm{H}$ ealth. $\mathrm{H}$ elsinki: Instituto de $M$ edicina del T rabajo.

H agberg, M , H M orgenstem, M K elsh. 1992. Impact of occupations and job tasks on the prevalence of carpal tunnel syndrome. Scand I W ork Environ $H$ ealth 18:337-345.

H art, DE. 1988. N europsychological T oxicology: Identification and Assessment of $\mathrm{H}$ uman Neurotoxic Syndromes. N ueva Y ork: Pergamon Press.

Hawkes, CH, JB Cavanagh, AJ Fox. 1989. M otorneuron disease: A disorder secondary to solvent exposure? $L$ ancet 1:73-76.

Howard, JK. 1979. A clinical survey of paraquat formulation workers. Br I Ind M ed 36:220-223.

Hutchinson, LJ, RW Amsler, JA Lybarger, W Chappell. 1992. Neurobehavioral T est B atteries for U se in E nvironmental $\mathrm{H}$ ealth Field Studies. Atlanta: Agency for Toxic Substances and Disease Registry (ATSDR)

Johnson, BL. 1987. Prevention of Neurotoxic Illness in W orking Populations. Chichester: Wiley.
Kandel, ER HH Schwartz, TM Kessel 1991. Principles of N eural Sciences. N ueva Y ork: Elsevier.

Kukull, WA, EB Larson, JD Bowen, WC McCormick, L Teri, ML Pfanschmidt y cols. 1995. Solvent exposure as a risk factor for Alzheimer's disease: A case-control study. Am J E pidemiol 141:1059-1071.

Landtblom, A-M , U Flodin, M K arlsson, S Pålhagen, O Axelson, B Söderfeldt. 1993. Multiple sclerosis and exposure to solvents, ionizing radiation and animals. Scand I W ork E nviron H ealth 19:399-404.

Landtblom, A-M , U Flodin, B Söderfeldt, C W olfson, O Axelson. 1996. Organic solvents and multiple sclerosis: A synthesis of the cement evidence. E pidemiology 7: 429-433.

M aizlish, D, O Feo. 1994. Alteraciones neuropsicológicas en trabajadores expuestos a neurotóxicos. Salud de los T rabajadores 2:5-34.

Mergler, D. 1995. Behavioral neurophysiology: Q uantitative measures of sensory toxicity. En Neurotoxicology: Approaches and M ethods, dirigido por L Chang y W Slikker. N ueva Y ork: A cademic Press.

O 'D onoghue, JL. 1985. Neurotoxicity of Industrial and Commercial Chemicals. Vol. I \& II. Boca Ratón: CRC Press.

Sassine, M P, D M ergler, F Larribe, S Bélanger. 1996. Détérioration de la santé mentale chez des travailleurs exposés au styrène. R ev epidmiol med soc santé publ 44:14-24.

O rganización M undial de la Salud (WHO) 1978. Principles and $M$ ethods of $E$ valuating the $T$ oxicity of Chemicals, Part 1 and 2. EHC, N o. 6, Partes 1 y 2. Ginebra: OM S.

Organización Mundial de la Salud y Consejo Nórdico de Ministros. 1985. Chronic Effects of Organic Solvents On the Central Nervous System and Diagnostic Criteria. EH C, N o. 5. Ginebra: O M S.

Semchuk, K M , EJ Love, RG Lee. 1992. Parkinson's disease and exposure to agricultural work and pesticide chemicals. N eurology 42:1328-1335.

Seppäläinen, AMH. $1988 . \quad$ Neurophysiological approaches to the detection of early neurotoxicity in humans. Crit Rev T oxicol 14:245-297.

Sienko, DG, JD Davis, JA T aylor, BR Brooks. 1990. Amyotrophic lateral sclerosis: A case-control study following detection of a cluster in a small Wisconsin community. Arch N eurol 47:38-41.

Simonsen, L, H Johnsen, SP Lund, E M atikainen, U M idtgård, A Wennberg. 1994. Evaluation of neurotoxicity data: A methodological approach to classification of neurotoxic chemicals. Scand I W ork Environ $H$ ealth 20:1-12.

Sobel, E, Z Davanipour, R Sulkava, T Erkinjuntti, J Wikström, VW Henderson y cols. 1995. 
O ccupations with exposure to electromagnetic fields: A possible risk factor for Alzheimer's disease. Am J E pidemiol 142:515-524.

Spencer, PS, H H Schaumburg. 1980. Experimental and Clinical Neurotoxicology. Baltimore: Williams \& Wilkins.

T anner, CM . 1989. The role of environmental toxins in the etiology of Parkinson's disease. Trends Neurosci 12:49-54.

U rie, RL. 1992. Personal protection from hazardous materials exposures. En $\mathrm{H}$ azardous $\mathrm{M}$ aterials T oxicology: Clinical Principles of Environmental $\mathrm{H}$ ealth, dirigido por JB Sullivan y GR K rieger. Baltimore: Williams \& Wilkins

Zayed, J, G Ducic, G Campanella, JC Panisset, P André, H Masson y cols. 1990. Facteurs environnementaux dans l'étiologie de la maladie de Parkinson. Can J N eurol Sci 17:286-291.

\section{0 tras lecturas recomendadas}

Agee, JM, HJ M CCarroll, RD Tortosa, DA Berry, RM Szabo, CA Peimer. 1992. Endoscopic release of the carpal tunnel: A randomized prospective multicenter study. J $\mathrm{H}$ and Surg 17(6):987-995.

Anger, WK. 1986. Workplace exposures. En Neurobehavioral Toxicology, dirigido por Z Ammau. Baltimore: Johns H opkins U niv. Press.

Baker, EL, R Ehrenberg. 1990. Preventing the work-related carpal tunnel syndrome: Physician reporting and diagnostic criteria. Ann Intern M ed 112(5):317-319.

Baker, EL, RG Feldman, JG French. 1990 Environmentally related disorders of the nervous system. M ed Clin N Am 74(2):325-345.

Baker, EL, A Schotherfeld. 1995. Disorders of the nervous system. In $O$ ccupational $H$ ealth: Recognizing and Preventing $W$ ork R elated D isease, dirigido por BS Levy e IH Wegman. Boston: Little, Brown \& Co.

Beaglehole, R, R Bonita, T K jellstrom. 1993. Basic E pidemiology. Ginebra: O M S.

Bleecker, ML. 1994. O ccupational Neurology and Clinical N eurotoxicology. Baltimore: Williams \& W Wilkins.

Bleecker, M , J Agnew. 1987. N ew techniques for the diagnosis of carpal tunnel syndrome. Scand J W ork E nviron $H$ ealth 13:385-388.

Bleecker, ML, M Bohlman, R M oreland, A Tipton. 1985. Carpal tunnel syndrome: Role of carpal canal size. N eurology 35:1599-1604.

Chang, L, W Slikker. 1995. Neurotoxicology: Approaches and $M$ ethods. Nueva Y ork: A cademic Press.

Chow, JC. 1993. The Chow technique of endoscopic release of the carpal ligament for carpal tunne syndrome: Four years of clinical results. Arthroscopy 9(3):301-314.
Clarkson, TW. 1987. M etal toxicity in the central nervous system. E nviron $H$ ealth Persp 75:59-64.

Cullen, MR . 1987. The worker with multiple chemical sensitivities: An overview. O ccup $\mathrm{M}$ ed 2:655-661.

Dawson, DM . 1993. Entrapment neuropathies of the upper extremities. New Engl । M ed 329(27):2013-2018.

Ecobichon, DJ, RM Joy. 1991. Pesticides and N eurological D iseases. Boston: CRC Press.

Feldman, RG. 1993. M anganese. En $H$ andbook of Clinical Neurology, dirigido por PJ Vinken, GW Bruyn y H L Flawans. Amsterdam: Elsevier.

Feldman, RG, PH T ravers. 1984. Environmental and occupational neurology. En N eurology: T he Physicians Guide, dirigido por RG Feldman. Nueva York: Thieme-Stratton.

Foà, V, R Gilioli, M M aroni. 1983. Nervous system, peripheral. En Encicopledia de salud y seguridad en $e$ trabajo, 3a edición, dirigido por L Parmeggiani. Ginebra: OIT

Gamberale, F, A Iregren, A K jellberg. 1989. SPES Computerized Swedish Performance Evaluation System. Solna, Suecia: Arbetsmiljo Institutet.

Girlanda, P, R Dattola, C V enuto, R M angiapane, C Nicolosi, C M essina. 1993. Local steroid treatment in idiopathic canal tunnel syndrome: Short-long-term efficacy. J N eurol 240(3):187-190.

$\mathrm{H}$ änninen, $\mathrm{H}, \mathrm{K}$ Eskelinen, $\mathrm{K}$ Husman, M Nurninen. 1979. Behavioral effects of long-term exposure to a mixture of organic solvents. Scand J W ork Environ $H$ ealth 4:240-255.

$\mathrm{H}$ ane, M, O Axelson, J Blume, C Hogstedt, L Sundell, B Y drevorg. 1977. Psychological function changes among house painters. Scand J W ork E nviron $\mathrm{H}$ ealth 3:91-99.

Hutchinson, LJ, RW Amsler, JA Lybarger, W Chappell. 1992. Neurobehavioral Test Batteries for U se in E nvironmental $\mathrm{H}$ ealth Field Studies. Atlanta: Agency for Toxic Substances and Disease Registry (ATSDR).

Knave, B, B Anshlem-O Ison, S Elofsson, F Gamberale, A I saksson, P M undus, H Persson, G Struwe, A Wennberg, P Westerholm. 1978. Long-term exposure to jet fuel II: A cross sectional epidemiological investigation on occupationally exposed industry workers with special reference to the nervous system. Scand I W ork Environ $H$ ealth 4(1):19-45.

K reiss, $K, D H$ Wegman, CA Niles, M B Siroky, R K rane, RG Feldman. 1980. Neurologic dysfunction of the bladder in workers exposed to dimethylaminopropionitrile. J AM A 243:741-745.

K uschner, SH, E Ebramzadeh, D Johnson, WW Brien, Sherman. 1992. T inel's sign and Phalen's test in carpal tunnel syndrome. Orthopaedics 15:1297-1302

Letz, R. 1990. The neurobehavorial evaluation system (NES): An international effort. En Advances in Neurobehavioural Toxicology: Applications in Environmental and $O$ ccupational $\mathrm{H}$ ealth, dirigido por BL Johnson, WK Anger, A Durao y C X intaris. Chelsea, M ichigan: L ewis Publishers.

Lippmann, M. 1990. Review. Lead and human health: Background and recent findings. Environ Res 51:1-24.

Murphy, RXJ, MA Chernofsky, MA O sborne, AH Wolson. 1993. M agnetic resonance imaging in the evaluation of persistent carpal tunnel syndrome. J $H$ and Surg 18(1):113-120.

Norton, S. 1986. Toxic responses of the central nervous system. En Casarett and D oull's T oxicology, dirigido por CD K lassen, DO Amdur y J Doull. N ueva Y ork: M acM illan.

Planguwes, J. 1983. Nervous system, central and autonomous. En Enciclopedia de salud y seguridad en el trabajo, dirigido por L Parmeggiani (3a edición). Ginebra: OIT.

Preston, DC, EL Logigian. 1992. Lumbrical and interossei recording in carpal tunnel syndrome. M uscle N erve 16(11):1253-1257.

Proceedings of the International Conference on O rganic Solvent Toxicity. 1985. Scand J W ork Environ $\mathrm{H}$ ealth 11 Supl. 1.

Proceedings on the workshop on neurobehavioural effects of solvents. 1986. N eurotoxicology 7(4).

Spaans, F. 1987. Compression and entrapment neuropathies. En $\mathrm{H}$ andbook of Clinical Neurology, dirigido por WB M atthew. Amsterdam: Elsevier.

Taylor, J. 1992. Disorders of the nervous system. Capítulo 13 en Principles and Practice of Environmental $M$ edicine, dirigido por AB T archer. Nueva York: Plenum M ed. Book.

Valciukas, JA. 1991. Foundations of Environmental and O ccupational Neurotoxicology. Nueva Y ork: Van N ostrand R einhold.

- 1993. The effect of exposure to industrial solvents on the developing brain and behavior of children. En Prenatal Exposure to Toxicants: D evelopmental Consequences, dirigido por $\mathrm{HL}$ Needleman y $\mathrm{D}$ Bellinger. Baltimore: J ohns H opkins U niv. Press.

Virchow, R. 1986. Post-M ortem Examinations and the Position of Pathology Among Biological Studies. Publicado por primera vez en 1873. Metuchen, Nueva Jersey: Scarecrow R eprint.

White, RF, RG Feldman, SP Proctor. 1992. Neurobehavioral effects of toxic exposures, clinical syndromes in adult neuropsychology. En The Practitioner's $\mathrm{H}$ andbook, dirigido por RF White. Amsterdam: Elsevier. 
Director del capítulo

G eorge P. H emstreet

\section{Sumario}

Los sistemas renal y urinario

G eorge P. H emstreet. . . . . . . . . . . . . . . . . . . . . . . . 8.2

Cánceres renales y urinarios

T imo Partanen, H arri Vainio, Paolo B offetta y E lisabete W eiderpass . . . . . 8.11 


\section{- LOS SISTEMAS RENAL Y URINARIO}

\section{G eorge P. H emstreet}

Los sistemas renal y urinario están constituidos por un grupo complejo de órganos que en conjunto se encargan de filtrar los productos residuales de la sangre y de fabricar, almacenar y eliminar la orina. Estos órganos son esenciales para la hemostasia, ya que mantienen el equilibrio hídrico, el equilibrio acidobásico y la presión arterial. Los órganos fundamentales del sistema nefrourinario son los dos riñones y la vejiga urinaria. Durante el proceso de filtración de los productos residuales de la sangre, los riñones pueden exponerse a concentraciones elevadas de sustancias tóxicas endógenas y exógenas. De este modo, algunas células renales están expuestas a concentraciones mil veces superiores a las sanguíneas.

Los problemas que causan daños en los riñones pueden ser prerrenales (afectan al aporte sanguíneo a los riñones), renales (afectan al propio riñón) o posrenales (afectan a cualquier punto de la ruta que sigue la orina desde el riñón hasta la salida de la uretra o el pene). Los problemas posrenales suelen ser de tipo obstructivo; un punto de obstrucción muy frecuente es la próstata, que se encuentra entre la vejiga y la uretra. C ualquier trastorno preexistente de la próstata, la vejiga o los uréteres, en particular las infecciones, las obstrucciones o los cuerpos extraños (como los cálculos), puede comprometer la función renal y aumentar la sensibilidad a los defectos adquiridos 0 genéticos.

Conviene conocer la microanatomía y los mecanismos moleculares del riñón y la vejiga para valorar la sensibilidad a las exposiciones laborales profesionales y controlarlas y prevenirlas. Parece que las sustancias tóxicas se dirigen a partes específicas del riñón o la vejiga e inducen la expresión de marcadores biológicos específicos directamente relacionados con el segmento lesionado. $\mathrm{H}$ istóricamente, se ha considerado la predisposición a la enfermedad desde la perspectiva epidemiológica de la identificación de un grupo de trabajadores con riesgo. Actualmente, al conocerse mejor los mecanismos fundamentales de la enfermedad, puede llegar a valorarse el riesgo individual mediante el empleo de marcadores biológicos de la sensibilidad, la exposición, el efecto y la enfermedad. Se plantean nuevos problemas éticos debido a las presiones para desarrollar estrategias rentables para proteger a los trabajadores de los peligros laborales. La presión deriva en parte del hecho de que las pruebas genéticas tienen cada vez mayor aceptación para valorar la predisposición a la enfermedad, y a que los marcadores biológicos de la exposición y el efecto pueden servir como criterios de valoración intermedios que marquen el momento para intervenir de forma provechosa. Este capítulo pretende ofrecer una revisión médica de los sistemas renal y urinario como base sobre la que puedan establecerse unas pautas para valorar y reducir el riesgo individual en el entorno laboral teniendo debidamente en cuenta los aspectos éticos oportunos.

\section{Anatomía y fisiopatología del riñón}

El riñón humano es un órgano complejo cuya función consiste en filtrar los productos residuales de la sangre y producir orina. Los dos riñones desempeñan además otras funciones vitales, como el mantenimiento de la homeostasia y la regulación de la presión arterial, la presión osmótica y el equilibrio acidobásico. Los riñones reciben el $25 \%$ del gasto cardíaco total, lo que supone una exposición potencial a las toxinas endógenas y exógenas.

Los riñones se sitúan a ambos lados de la columna vertebral en la parte inferior de la espalda. Cada uno de ellos pesa unos $150 \mathrm{~g}$ y tiene aproximadamente el tamaño de una naranja. El riñón consta de tres capas: la corteza (capa exterior), la médula y la pelvis renal. La sangre fluye a la corteza y la médula a través de la arteria renal, que se ramifica en arterias cada vez más pequeñas. Cada una de las arterias termina en una unidad de filtración sanguínea denominada nefrona. Un riñón sano contiene aproximadamente 1.200 .000 nefronas, estratégicamente situadas dentro de la corteza y la médula.

U na nefrona está formada por el glomérulo (un grupo de vasos sanguíneos muy finos), rodeado por la cápsula de Bowman (una membrana de dos capas), que desemboca en un túbulo contorneado. El plasma, la fracción líquida de la sangre, es empujado a través del glomérulo al interior de la cápsula de Bowman y pasa después, en forma de plasma filtrado, al túbulo contorneado. Alrededor del $99 \%$ del agua y los nutrientes esenciales filtrados son reabsorbidos por las células tubulares y pasan a los capilares que rodean el túbulo contorneado. La sangre sin filtrar que permanece en el glomérulo, fluye también a los capilares y vuelve al corazón a través de la vena renal.

Las nefronas son conductos largos y serpenteantes compuestos por varios segmentos, cada uno de los cuales desempeña diversas funciones relacionadas con el mantenimiento de los mecanismos homeostásicos del organismo. En la Figura 8.1 se ilustra una nefrona y su orientación dentro de la corteza y la médula renales. Cada uno de los segmentos de la nefrona tiene un aporte sanguíneo diferenciado que regula el gradiente iónico. D eterminadas sustancias químicas pueden influir directamente sobre segmentos específicos de la nefrona de forma aguda 0 crónica, dependiendo del tipo y la dosis de la exposición

Figura 8.1 - Relaciones entre el aporte vascular, el glomérulo y los túbulos de la nefrona, y orientación de estos componentes dentro de la corteza y la médula renales.

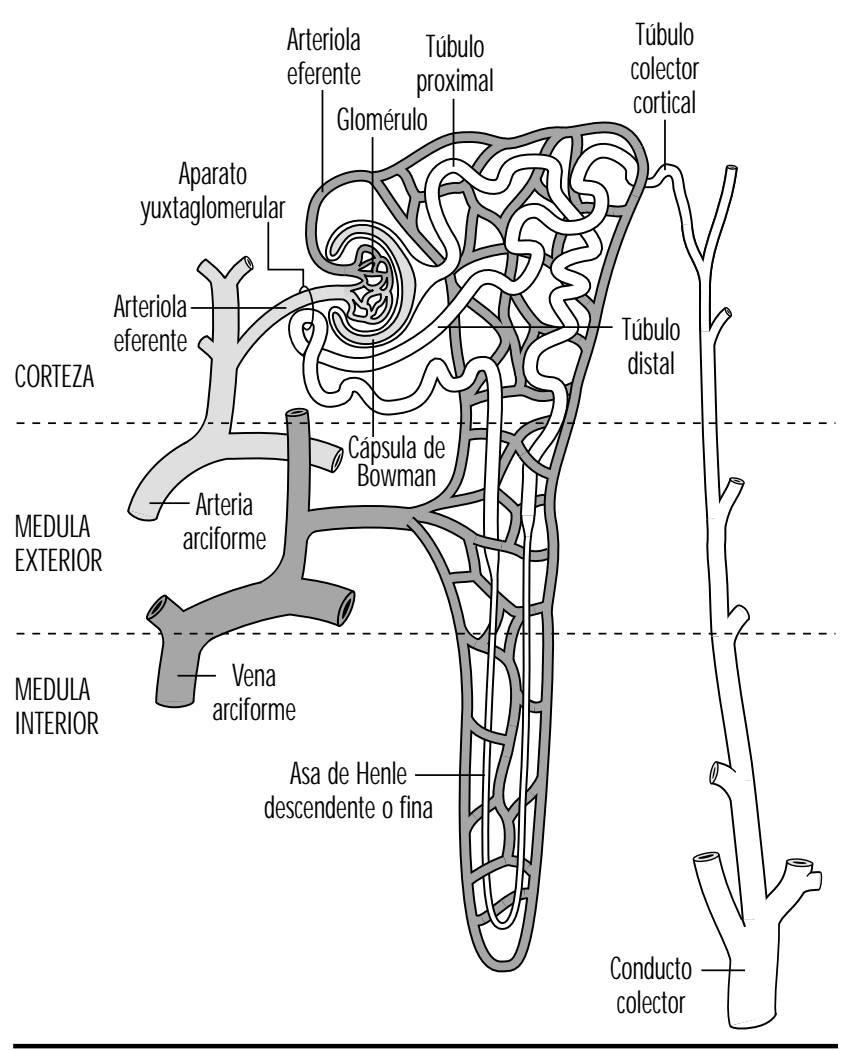


xenobiótica. Según el segmento de la microanatomía sobre el que actúe, pueden afectarse diferentes aspectos de la función renal.

L os vasos sanguíneos renales sólo irrigan los elementos glomerulares y tubulares, aportando los productos residuales que hay que filtrar y absorbiendo nutrientes, proteínas y electrólitos, además de suministrar el oxígeno necesario para la viabilidad del órgano. El 90 \% del flujo sanguíneo se dirige a la corteza, y el aporte disminuye gradualmente hacia la médula. Esa diferencia de flujo y la situación de las nefronas son esenciales para el mecanismo de contracorriente, que concentra aún más la orina y las posibles nefrotoxinas.

El glomérulo se encuentra entre las arteriolas aferentes y eferentes. Las arteriolas eferentes forman una red de capilares alrededor de cada unidad nefronal, con la excepción de la yuxtaposición del túbulo distal junto a la irrigación aferente del glomérulo. Los túbulos aferentes y eferentes, inervados por los nervios simpáticos, responden a la estimulación vegetativa y a mediadores hormonales como la vasopresina y la hormona antidiurética (ADH). U na zona conocida como mácula densa, que forma parte del aparato yuxtaglomerular, produce renina, un mediador de la presión arterial, en respuesta a los cambios osmóticos y de la presión arterial. Las enzimas hepáticas convierten la renina en angiotensina II, un octapéptido que regula el flujo sanguíneo a los riñones, actuando preferentemente sobre las arteriolas aferentes y las células mesangiales del glomérulo.

El glomérulo sólo permite durante la filtración el paso de proteínas de tamaño determinado con una carga definida. La filtración del plasma está controlada por un equilibrio de las presiones oncótica e hidrostática. Los glucosaminoglucanos, unos azúcares especializados, proporcionan una carga aniónica negativa que inhibe, por fuerzas electrostáticas, la filtración de las moléculas con carga negativa. El estrato tricelular de la membrana basal glomerular presenta numerosos podocitos que aumentan la superficie de absorción y forman los poros por los que pasa el filtrado. La lesión de la membrana basal especializada o del endotelio capilar puede permitir el paso a la orina de albúmina (un tipo de proteína) en grandes cantidades. La presencia en la orina de un exceso de albúmina o de otras microproteínas es un indicador de lesión glomerular o tubular.

El intersticio renal es el espacio que existe entre las nefronas, y es mayor en la zona medular central que en la corteza exterior. En el intersticio hay células intersticiales muy próximas a los vasos medulares y a las células tubulares. $C$ on el envejecimiento pueden proliferar las células intersticiales de la corteza, con la formación de fibrosis y cicatrices. Las células intersticiales contienen gotitas de lípidos y pueden participar en el control de la presión arterial mediante la liberación de factores de relajación o constricción vasculares. Las alteraciones crónicas del intersticio pueden afectar al glomérulo y los túbulos, y a la inversa. Por consiguiente, en las nefropatías terminales cuesta a veces definir con exactitud los mecanismos histopatológicos de la insuficiencia renal.

Los túbulos colectores proximales absorben un $80 \%$ del sodio, el agua y el cloruro, y el $100 \%$ de la urea. Cada túbulo proximal consta de tres segmentos, de los que el último (P-3) es el más vulnerable a las exposiciones a xenobióticos (sustancias tóxicas extrañas). Cuando las células proximales resultan dañadas por metales pesados como el cromo, el riñón pierde capacidad de concentración y la orina puede salir más diluida. L a toxicidad para el segmento P-3 causa la liberación a la orina de enzimas como la fosfatasa alcalina intestinal, la $\mathrm{N}$-acetil-beta-D-glucosaminidasa (NAG) o la proteína de Tamm-H orsfall, que guarda relación con el aumento de la superficie efectiva de absorción del borde en cepillo de las células de los túbulos proximales.

\section{Diagnóstico y pruebas de la nefrotoxicidad}

La creatinina es otra sustancia filtrada por el glomérulo pero que apenas se absorbe a través de los túbulos proximales. Si el glomérulo sufre daños, es incapaz de eliminar las toxinas producidas por el organismo, y se acumula la creatinina sérica. Dado que la creatinina sérica es un producto derivado del metabolismo muscular y depende de la masa muscular del individuo, es una medida poco sensible y específica de la función renal, pero se usa a menudo debido a su comodidad. U na prueba más sensible y específica consiste en cuantificar el filtrado midiendo el aclaramiento de creatinina $(\mathrm{Cr})$; para calcular el aclaramiento urinario de la creatinina sérica se emplea la fórmula general $\mathrm{CCr}=\mathrm{U} \mathrm{Cr}$ V/PCr, en donde U CrV es la cantidad de $\mathrm{Cr}$ excretada por unidad de tiempo y PCr es la concentración plasmática de la $\mathrm{Cr}$. Sin embargo, el aclaramiento de la creatinina es más complejo, debido a las dificultades para obtener las muestras para la prueba, y no resulta práctico en el medio laboral. También son eficaces las pruebas de aclaramiento de isótopos basadas en el etiquetado radiactivo de compuestos, como el orto-yodohipurato, que también son eliminadas por el riñón, pero no resultan prácticas ni rentables en el entorno laboral. Para determinar la función diferencial de cada uno de los riñones puede utilizarse la gammagrafía renal diferencial o el cateterismo selectivo de ambos riñones mediante la introducción de una sonda por la vejiga y el uréter hasta el riñón. Sin embargo, tampoco es fácil utilizar estos métodos a gran escala en el entorno laboral. Dado que la función renal puede disminuir un $70-80 \%$ antes de que se aprecie una elevación de la creatinina sérica, y como las demás pruebas que existen son poco prácticas o muy costosas, se necesitan marcadores biológicos no invasivos para detectar las exposiciones renales intermitentes, agudas y a dosis reducidas. En la sección sobre los marcadores biológicos se comentan diversos indicadores para detectar los daños renales producidos a dosis reducidas o los cambios derivados de la carcinogénesis.

Aunque las células de los túbulos proximales absorben un $80 \%$ de los líquidos, el mecanismo de contracorriente y los conductos colectores distales ajustan las cantidades de líquidos absorbidos mediante la regulación de la ADH. La ADH es liberada por la hipófisis cerebral y responde a las presiones osmóticos y al volumen de líquidos hídricos. Algunos compuestos exógenos, como el litio, pueden dañar los conductos colectores distales y producir una diabetes insípida renal (eliminación de orina diluida). Este defecto puede deberse también a alteraciones genéticas hereditarias. L os xenobióticos afectan normalmente a los dos riñones, pero es difícil interpretar la situación cuando no se puede demostrar una exposición o cuando existe nefropatía previa. Por consiguiente, las exposiciones accidentales a dosis elevadas han servido de marcadores para identificar compuestos nefrotóxicos en muchos casos. La mayoría de las exposiciones profesionales se producen a dosis reducidas, y quedan enmascaradas por la capacidad de filtración de reserva y de reparación compensadora (hipertrofia) del riñón. Sigue siendo un problema la detección de las exposiciones a dosis reducidas que no son descubiertas por los métodos clínicos actuales.

\section{Anatomía y fisiopatología de la vejiga}

La vejiga urinaria es una bolsa hueca en la que se almacena la orina; normalmente, se contrae a demanda para su vaciado controlado a través de la uretra. La vejiga está situada en la parte anteroinferior de la cavidad pélvica, y unida por ambos lados a los riñones mediante los uréteres, unos tubos musculares 
peristálticos que transportan la orina de los riñones a la vejiga. La pelvis renal, los uréteres y la vejiga están recubiertos por epitelio de transición. La capa externa del urotelio está formado por células en sombrilla recubiertas por una capa de glucosaminoglucano (GAG), un carbohidrato. Las células de transición llegan hasta la membrana basal de la vejiga. De este modo, las células basales profundas quedan protegidas por las células en sombrilla, pero si se daña la capa protectora de GAG, las células basales quedan expuestas a la agresión de los componentes urinarios. La microanatomía del epitelio de transición le permite expandirse y contraerse, e incluso tras el desprendimiento normal de las células en sombrilla se mantiene la integridad protectora de las células basales.

El sistema neurológico equilibrado que regula el almacenamiento y el vaciado puede resultar dañado debido a descargas eléctricas u otros traumatismos, como las lesiones medulares, que pueden producirse en el entorno laboral. U na causa importante de mortalidad de los tetrapléjicos es la pérdida de la función vesical como consecuencia de una lesión renal crónica secundaria a las infecciones y la formación de cálculos. Son frecuentes las infecciones crónicas por un vaciado incompleto debido a causas neurógenas u obstructivas, como la fractura de pelvis u otros traumatismos uretrales y la posterior formación de estenosis. Las infecciones bacterianas persistentes o la formación de cálculos que dan lugar a procesos inflamatorios crónicos y malignos de la vejiga pueden deberse a una disminución de la resistencia (es decir, una mayor sensibilidad) a las exposiciones exógenas en el lugar de trabajo.

Las moléculas relacionadas con la lesión y la reparación vesicales sirven de marcadores terminales intermedios potenciales de trastornos tóxicos y malignos, ya que durante los cambios relacionados con el desarrollo del cáncer se producen numerosas alteraciones bioquímicas. Al igual que el riñón, las células vesicales poseen sistemas enzimáticos activos, como el del citocromo P-450, que los xenobióticos pueden activar o desactivar. La actividad funcional de las enzimas viene determinada por la herencia genética y muestra polimorfismo genético. La orina eliminada contiene células exfoliadas del riñón, los uréteres, la vejiga, la próstata y la uretra. Estas células sirven de diana, mediante el uso de marcadores biológicos, para valorar posibles cambios en la patología vesical y renal. Recordando el comentario de Virchow de que todas las enfermedades comienzan en las células, centraremos nuestra atención en la importancia de las células, que son el espejo molecular de los episodios de exposición.

\section{Toxicología ambiental y laboral}

Un volumen considerable de datos epidemiológicos confirma la relación causal del cáncer de vejiga con la exposición profesional, pero es difícil calcular la contribución exacta de las exposiciones en el lugar de trabajo a la insuficiencia y las neoplasias renales. En un estudio reciente se calculaba que hasta un $10 \%$ de las nefropatías terminales podían atribuirse a las exposiciones profesionales, pero no es fácil confirmar estos datos debido a los cambios en los riesgos ambientales y químicos, a las variaciones en los criterios de diagnóstico y al período de latencia frecuentemente prolongado entre la exposición y la aparición de enfermedad. Se calcula que puede perderse la función de dos tercios de las nefronas de ambos riñones antes de que sea clínicamente evidente la lesión renal. Sin embargo, cada vez existen más pruebas de que lo que antes se pensaba que eran causas socioeconómicas o étnicas de nefrotoxicidad pueden ser en realidad causas ambientales, lo que respalda el protagonismo de las sustancias tóxicas en el desarrollo de la patología.
Tabla 8.1 - Enzimas renales metabilizadoras de fárma $\cos ^{1}$.

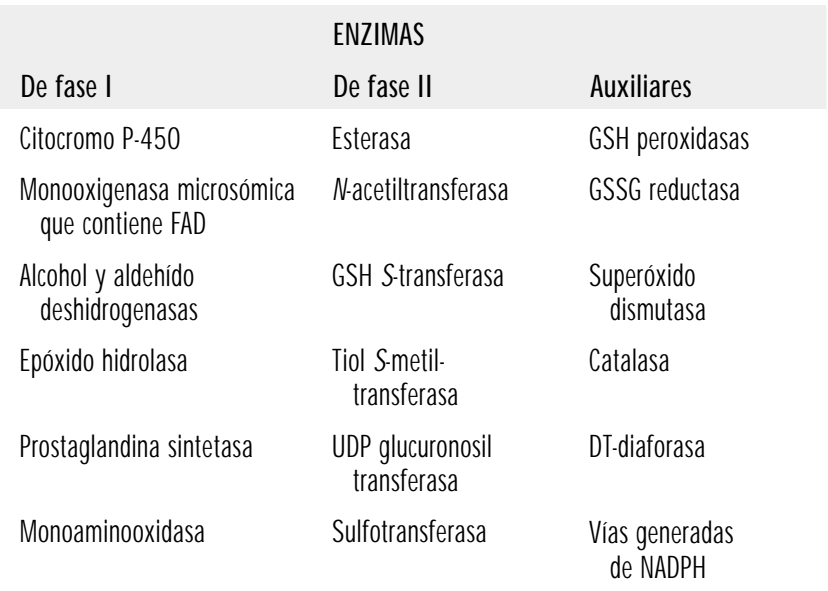

LLas enzimas de fase I catalizan reacciones de oxidación, reducción o hidrólisis.

Las enzimas de fase II catalizan generalmente reacciones de conjugación.

Las enzimas auxiliares tienen una función secundaria 0 de apoyo para facilitar el metabolismo de fármacos.

Fuente: National Research Council 1995.

La nefrotoxicidad puede tener una relación directa con los xenobióticos, o los xenobióticos pueden experimentar activación o inactivación en uno o varios pasos en el riñón o el hígado. La activación de los xenobióticos está regulada por un complejo grupo de enzimas identificados como de fase I, de fase II y auxiliares. U na de las enzimas de fase I es el sistema oxidativo P-450, que actúa por mecanismos de reducción o hidrólisis. Las enzimas de fase II catalizan la conjugación, mientras que las auxiliares regulan el metabolismo de fármacos (la Tabla 8.1 recoge estas enzimas). M ediante diversos modelos animales se han podido estudiar los mecanismos metabólicos, y los estudios de cortes renales y de microdisección de las nefronas renales en cultivos tisulares han permitido mejorar el conocimiento de los mecanismos patológicos. Sin embargo, son notables las variables individuales y entre especie y, aunque los mecanismos pueden ser parecidos, conviene ser muy cautos al extrapolar los resultados a los seres humanos en un entorno laboral. Lo más importante ahora es determinar qué xenobióticos son nefrotóxicos y/ o cancerígenos, y sobre qué tejidos actúan, y desarrollar métodos para identificar con mayor exactitud su toxicidad subclínica sobre el sistema nefrourinario.

\section{Trastornos renales y urinarios no malignos}

La glomerulonefritis es una reacción inflamatoria de la membrana basal glomerular o del endotelio capilar. Las formas agudas y crónicas de esta enfermedad son secundarias a diferentes procesos infecciosos, autoinmunes 0 inflamatorios, 0 a una exposición a agentes tóxicos. La glomerulonefritis se asocia a vasculitis, ya sea sistémica o limitada a los riñones. También se produce una lesión crónica secundaria del glomérulo durante un ciclo intenso de agresión nefrotóxica al intersticio de las células tubulares. L os signos típicos de la glomerulonefritis en las muestras de biopsia renal son las semilunas glomerulares epiteliales 0 formas proliferativas. Los síntomas de glomerulonefritis son la hipertensión y la presencia de sangre, cilindros de hematíes 0 proteínas en la orina. Puede variar el contenido proteico de la sangre, con un descenso de determinadas fracciones del 
complemento sérico, un grupo complejo de proteínas interrelacionadas del sistema inmunitario, las defensas del huésped y los factores de coagulación. Existen pruebas directas e indirectas que confirman la importancia de los xenobióticos como factor causal de glomerulonefritis.

El glomérulo impide el paso de los hematíes portadores del oxígeno a través de su filtro. Tras la centrifugación, el estudio al microscopio óptico de gran aumento muestra un solo eritrocito en $10 \mathrm{ml}$. de orina normal. Cuando los eritrocitos atraviesan el filtro glomerular y quizá adquieren dismorfismos individuales, se forman moldes eritrocíticos que adoptan la configuración cilíndrica de las nefronas colectoras.

Como confirmación de la importancia de las toxinas como factor etiológico en la glomerulonefritis, los estudios epidemiológicos han mostrado pruebas crecientes de exposición tóxica en pacientes sometidos a diálisis o diagnosticados de glomerulonefritis. Las pruebas de una lesión glomerular por exposición aguda a hidrocarburos son escasas, pero se han podido observar en estudios epidemiológicos, con unos porcentajes de probabilidad del 2,0 al 15,5. U n ejemplo de toxicidad aguda es la enfermedad de G oodpasture, en la que los hidrocarburos estimulan la producción de anticuerpos contra proteínas hepáticas y pulmonares que tienen reacciones cruzadas con la membrana basal. También se ha observado una exacerbación del síndrome nefrótico, con grandes cantidades de proteínas en la orina, en individuos que han sufrido una exposición repetida a disolventes orgánicos, mientras que otros estudios revelan una relación histórica con una amplia gama de trastornos renales. 0 tros disolventes, como los productos desengrasantes, las pinturas y los pegamentos, guardan relación con formas más crónicas de la enfermedad. El conocimiento de los mecanismos de excreción y reabsorción de los disolventes ayuda a identificar los posibles marcadores biológicos, ya que incluso una lesión glomerular mínima da lugar a un aumento del paso de hematíes a la orina. Aunque los hematíes urinarios son un signo cardinal de lesión glomerular, es importante descartar otras posibles causas de hematuria.

$N$ efritis intersticial y tubular. Como ya se ha indicado, a menudo es difícil determinar la etiología de una nefropatía crónica terminal. Puede ser primordialmente de origen glomerular, tubular o intersticial, y aparecer como consecuencia de numerosos episodios agudos o de procesos crónicos a dosis reducidas.

La nefritis intersticial crónica incluye fibrosis y atrofia tubular. En su forma aguda, este trastorno se manifiesta por un marcado infiltrado inflamatorio con acumulación de líquido en los espacios intersticiales. La nefritis intersticial puede afectar fundamentalmente al intersticio, manifestarse como un fenómeno secundario a una lesión tubular crónica o ser consecuencia de alguna causa posrenal, como una obstrucción. La prostaglandina A sintetasa es una enzima que se encuentra fundamentalmente en el intersticio y guarda relación con el retículo endoplásmico, integrante de la maquinaria proteica celular. Algunos xenobióticos, como la bencidina y los nitrofuranos, son cosubstratos reductores de la prostaglandina sintetasa y resultan tóxicos para el intersticio tubular.

Las lesiones tubulares e intersticiales pueden deberse a una exposición al cadmio, el plomo o diferentes disolventes orgánicos. La mayoría de las exposiciones son crónicas y a dosis reducidas, y la toxicidad queda enmascarada por la capacidad de reserva y de recuperación funcional del riñón. La nefritis intersticial puede deberse también a una lesión vascular como la causada, por ejemplo, por una exposición crónica al monóxido de carbono. $L$ as células tubulares proximales son las más vulnerables a las sustancias tóxicas de la sangre, debido a la intensa exposición a las toxinas que se filtran por el glomérulo, a los sistemas enzimáticos que activan los tóxicos y al transporte selectivo de sustancias tóxicas. El epitelio de los diferentes segmentos del túbulo proximal tiene cualidades de las peroxidasas lisosómicas y de otros compuestos de la maquinaria genética ligeramente diferentes. De este modo, la exposición al cromo puede provocar lesiones intersticiales y tubulares. Los túbulos colectores pueden quedar dañados cuando enzimas específicas activan diversos xenobióticos como el cloroformo, el paracetamol y el p-aminofenol, y antibióticos como Loradine. Un efecto secundario de la lesión de los conductos colectores es la incapacidad renal para acidificar la orina y la consiguiente aparición de una acidosis metabólica.

La diabetes insípida nérógena, el proceso en el que la orina aparece diluida, puede ser genética 0 adquirida. En la forma genética existen mutaciones de los receptores de ADH situados en la membrana lateral basal de los conductos colectores, en el asa descendente de Henle. La ADH ajusta delicadamente la reabsorción de agua y determinados iones, como el potasio. La diabetes insípida adquirida puede afectar a las células tubulares 0 al intersticio asociado; ambas estructuras pueden verse afectadas por diferentes trastornos. La diabetes insípida nefrógena puede acompañar a una nefropatía terminal como consecuencia de una afectación intersticial difusa. Debido a ello, el intersticio no puede mantener un medio hipertónico para el desplazamiento pasivo del agua desde los túbulos colectores. LoS procesos que pueden causar cambios intersticiales difusos son la pielonefritis, la anemia drepanocítica y las uropatías obstructivas. La posible relación de estos procesos con una exposición laboral es un aumento de la sensibilidad del riñón a los xenobióticos. Se ha identificado un número limitado de compuestos nefrotóxicos que atacan especialmente a las células de los túbulos colectores. Los síntomas de la diabetes insípida nefrógena son la frecuencia, la nicturia (micciones más frecuentes durante la noche) y la polidipsia (sed crónica). El movimiento de los líquidos a través de las células de los conductos colectores da lugar a la aparición de canales que se forman en respuesta a la $A D H, y$ que alteran la función microtubular de las células; por consiguiente, fármacos como la colchicina pueden afectar a la ADH. La hidroclorotiacida y la indometacina (un inhibidor de la prostaglandina sintetasa) son dos fármacos que parecen modificar el efecto de la ADH mediante mecanismos ligeramente diferentes.

La diabetes insípida inducida por litio guarda relación con la duración del tratamiento con litio, con los niveles séricos medios de litio y con la dosis total de carbonato de litio. $\mathrm{H}$ ay que señalar que el litio se concentra en los conductos colectores y afecta al AM P cíclico, que forma parte de la vía de la bomba metabólica de energía. La exposición a otros compuestos como el metoxiflurano y la demeclociclina (esta última utilizada para tratar el acné) también puede producir diabetes insípida nefrógena a través de una vía alternativa que insensibiliza las células epiteliales a la ADH.

La hipertensión, o presión arterial elevada, es la segunda causa de nefropatía terminal y guarda relación con numerosos mecanismos etiológicos. Puede deberse a una nefropatía diabética, a una nefropatía obstructiva, a una glomerulonefritis, a una poliquistosis renal, a una pielonefritis y a una vasculitis, y muchas de estas enfermedades están relacionadas con la exposición a compuestos tóxicos. La hipertensión guarda una relación directa con un número limitado de exposiciones laborales. U na de ellas es la exposición al plomo, que provoca isquemia y lesiones vasculares renales. Es probable que el mecanismo de la hipertensión inducida por el plomo esté regulado por el aparato yuxtaglomerular, la liberación de renina y la conversión de la renina en angiotensina II por las enzimas hepáticas. La hipertensión puede deberse a fármacos como las anfetaminas, los estrógenos y los anticonceptivos orales, los esteroides, el cisplatino, el 
alcohol y los antidepresivos tricíclicos. La hipertensión puede tener un comienzo gradual 0 agudo, y ser de naturaleza maligna. La hipertensión maligna, en la que la presión diastólica supera los $110 \mathrm{~mm} \mathrm{H} \mathrm{g}$, va acompañada de náuseas, vómitos y cefaleas, y representa una urgencia médica. Existen numerosos fármacos para el tratamiento de la hipertensión, pero un tratamiento excesivo puede mermar la perfusión renal y reducir aún más la función renal. Siempre que sea posible, el tratamiento de elección consistirá en la supresión del nefrotóxico.

\section{Diagnóstico diferencial de la hematuria y la proteinuria}

La hematuria (hematíes en la orina) y la piuria (leucocitos en la orina) son síntomas primordiales de muchas enfermedades del sistema nefrourinario, y con fines de clasificación pueden considerarse marcadores biológicos celulares inespecíficos. Dada su importancia, las analizamos por separado en esta sección. EI médico del trabajo tiene que determinar si la hematuria significa que existe un proceso médico subyacente permanente que puede poner en peligro la vida del paciente 0 si se puede atribuir a alguna exposición profesional. Para la valoración clínica de la hematuria se requiere una normalización y determinar si es de origen prerrenal, renal o posrenal.

La hematuria puede deberse a lesiones del propio riñón o de algún punto de la vía de salida de la orina. Puede tener su origen en el riñón, la pelvis renal colectora, los uréteres, la vejiga, la próstata y la uretra. Dado que la hematuria puede asociarse a enfermedades graves, un solo episodio justifica una exploración médica 0 urológica. La presencia de más de un eritrocito por campo de gran aumento puede ser un signo de alteración, pero en el análisis microscópico puede pasarse por alto una hematuria importante en presencia de la orina hipotónica (diluida), que puede lisar los hematíes. La seudohematuria puede deberse a la ingestión de remolacha, bayas, colorantes vegetales y uratos concentrados. La hematuria inicial sugiere un origen uretral, la hematuria terminal suele ser de origen prostático, y la sangre presente en toda la micción procede de la vejiga, el riñón o el uréter. La hematuria macroscópica se asocia a tumores vesicales en un $21 \%$ de los casos, pero esta asociación es mucho menos frecuente en el caso de la hematuria microscópica (2,2-12,5\%).

EI hallazgo de células dismórficas al valorar cuantitativamente la hematuria sugiere que tiene su origen en las vías altas, especialmente cuando va acompañado de cilindros de hematíes. $L a$ presencia de hematuria junto con proteinuria proporciona información adicional. El sistema de filtración glomerular excluye casi completamente las proteínas con un peso molecular de más de 250.000 Daltons, mientras que las de menor peso molecular se filtran libremente y son absorbidas normalmente por las células tubulares. La presencia de proteínas de peso molecular elevado en la orina indica una hemorragia de vías inferiores, mientras que la aparición de proteínas de bajo peso molecular sugiere una lesión tubular. La evaluación de los cocientes $\alpha-1$-microglobulina/ albúmina y $\alpha$-2-macroglobulina/ albúmina ayuda a diferenciar la nefropatía glomerular de la intersticial tubular y la hemorragia de vías inferiores potencialmente asociada con una neoplasia urotelial y otras causas posrenales como las infecciones urinarias.

Se plantea un problema diagnóstico especial cuando coinciden dos o más procesos patológicos que producen los mismos síntomas. Por ejemplo, tanto las neoplasias uroteliales como las infecciones urinarias producen hematuria. En un paciente con ambos trastornos, si se trata y se suprime la infección, persistiría el cáncer. Por consiguiente, es importante identificar la verdadera causa de los síntomas. Existe hematuria en un $13 \%$ de las poblaciones sometidas a controles selectivos; aproximadamente un $20 \%$ de los individuos tienen trastornos renales o vesicales
Tabla 8.2 - Causas más frecuentes de hematuria, según el sexo y la edad.

\begin{tabular}{|c|c|}
\hline 0 - 20 años & 40- 60 años (mujeres) \\
\hline Glomerulonefritis aguda & Infecciones urinarias agudas \\
\hline Infecciones urinarias agudas & Cálculos \\
\hline $\begin{array}{c}\text { Anomalías congénitas de vías } \\
\text { urinarias con obstrucción }\end{array}$ & Tumores vesicales \\
\hline 20-40 años & Más de 60 años (varones) \\
\hline Infecciones urinarias agudas & Hiperplasia prostática benigna \\
\hline Cálculos & Tumores vesicales \\
\hline Tumores vesicales & Infecciones urinarias agudas \\
\hline 40- 60 años (varones) & Más de 60 años (mujeres) \\
\hline Tumores vesicales & Tumores vesicales \\
\hline Cálculos & Infecciones urinarias agudas \\
\hline
\end{tabular}

Infecciones urinarias agudas

Fuente: Wyker 1991

importantes, y un $10 \%$ de ellos desarrollarán una neoplasia maligna. Por consiguiente, la hematuria es un importante marcador biológico de enfermedad que debe valorarse adecuadamente.

El conocimiento de la edad y el sexo del paciente facilita la interpretación clínica de la hematuria, como puede verse en la Tabla 8.2, en la que se recogen las causas de hematuria en relación con la edad y el sexo de los pacientes. 0 tras causas de hematuria son la trombosis de la vena renal, la hipercalciuria y la vasculitis, así como los traumatismos como los producidos por la carrera y otros deportes, y los acontecimientos 0 exposiciones profesionales. Para la valoración clínica de la hematuria se debe recurrir a la radiografía renal, la pielografía intravenosa (PIV) para descartar trastornos de vías altas como cálculos y tumores, y la cistoscopia (visualización del interior de la vejiga mediante un instrumento con iluminación) para descartar neoplasias vesicales, prostáticas o uroteliales. En las mujeres deben descartarse las causas vaginales sutiles. Independientemente de la edad del paciente, estará indicada una exploración clínica en caso de que presente hematuria y, dependiendo de la etiología identificada, pueden estar indicados controles periódicos de seguimiento.

El empleo de marcadores biológicos recientemente identificados en combinación con la citología convencional para valorar la hematuria nos permite confirmar que no hemos pasado por alto ninguna neoplasia maligna oculta o incipiente (véase el apartado siguiente sobre marcadores biológicos). Para el especialista en medicina del trabajo es muy importante determinar si la hematuria se debe a una exposición tóxica o a una neoplasia maligna oculta. El conocimiento de la exposición y la edad del paciente son parámetros críticos para adoptar una decisión terapéutica responsable. U n estudio reciente ha demostrado que la hematuria y el análisis de marcadores biológicos en las células urinarias exfoliadas de la vejiga eran los dos mejores indicadores para detectar lesiones vesicales premalignas. La hematuria aparece en todos los casos de lesión glomerular, en un $60 \%$ de los pacientes con cáncer de vejiga y sólo en un $15 \%$ de los pacientes con neoplasias malignas renales. Por consiguiente, la hematuria sigue siendo un síntoma cardinal de los trastornos renales y posrenales, aunque el diagnóstico definitivo puede ser complicado. 
Figura 8.2 - Categorías de marcadores biológicos.

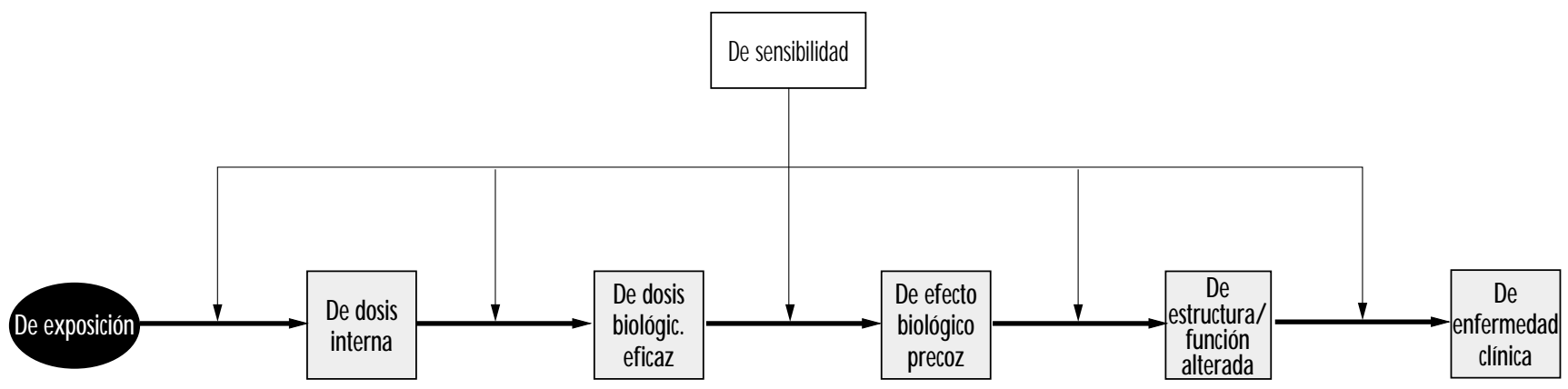

Los marcadores biológicos representan un cambio continuo, aunque sus diversas clases se muestran como categorías diferenciadas. Las flechas gruesas indican progresión, en caso de producirse, y las líneas finas indican el impacto de la sensibilidad en conjunción con otros factores.

Fuente: Committee on Biological Markers 1987

\section{Pruebas de nefrotoxicidad: marcadores biológicos}

$\mathrm{H}$ istóricamente, la detección de toxinas en el entorno laboral ha sido el principal método para identificar posibles riesgos. Sin embargo, no se conocen todas las sustancias tóxicas y, por consiguiente, no es posible controlarlas. Por otra parte, la sensibilidad de los individuos es un factor que influye en el posible efecto de los xenobióticos.

Los marcadores biológicos proporcionan más oportunidades para definir el riesgo individual. Para su descripción y su correcta interpretación, los marcadores biológicos se han clasificado según el esquema que presentamos en la Figura 8.2. Al igual que en otras alteraciones, es posible establecer una relación entre los marcadores biológicos de toxicidad renal y genitourinaria y la sensibilidad, la exposición, los efectos o la enfermedad. Los marcadores biológicos pueden ser genotípicos o fenotípicos, y pueden ser funcionales, celulares o solubles en orina, sangre u otros líquidos corporales. Son ejemplos de marcadores solubles las proteínas, las enzimas, las citocinas y los factores de crecimiento. Para estudiar los marcadores biológicos puede buscarse el gen, el mensajero o la proteína producida. Estos sistemas variables complican aún más la valoración y la selección de los marcadores biológicos. El estudio de las proteínas tiene la ventaja de que son las moléculas funcionales. El gen puede no transcribirse, y la cantidad de mensajero puede no corresponderse con la proteína producida. En la Tabla 8.3.se ofrece una lista de criterios para la selección de los marcadores biológicos.

El esfuerzo de los científicos internacionales para cartografiar el genoma humano, posibilitado por los avances de la biología molecular, estableció las bases para identificar marcadores biológicos de sensibilidad. En la mayoría de las enfermedades humanas, en especial las que se deben a la exposición a tóxicos ambientales, interviene una constelación de genes que presentan una considerable diversidad genética (polimorfismo genético). Como ya hemos señalado, un ejemplo de este producto genético es el sistema enzimático oxidativo P-450, que puede metabolizar xenobióticos en el hígado, el riñón o la vejiga. Existen factores de sensibilidad que pueden controlar también los mecanismos de reparación del ADN, influir en la sensibilidad de diversas vías de señalización importantes en la carcinogénesis (es decir, los factores de crecimiento) o guardar relación con procesos hereditarios que predisponen a la enfermedad. Un ejemplo claro de factor de sensibilidad heredado es el fenotipo de acetilación lenta o rápida, que regula la acetilación e inactivación de determinadas aminas aromáticas que se sabe causan cáncer de vejiga. L os marcadores biológicos de sensibilidad no incluyen sólo genes

que regulan la activación de xenobióticos, sino también protooncogenes y oncogenes supresores. En el control del crecimiento de las células tumorales intervienen diferentes sistemas interrelacionados muy complejos, como un equilibrio entre los (proto) oncogenes positivos y los oncogenes negativos (supresores). LoS protooncogenes controlan el crecimiento y desarrollo celulares normales, mientras que los oncogenes supresores controlan la división y diferenciación celulares normales. O tros genes pueden contribuir a procesos preexistentes, como la propensión a la insuficiencia renal secundaria a alteraciones subyacentes como la poliquistosis renal.

También pueden ser marcadores biológicos los propios xenobióticos, los metabolitos o marcadores como los aductos del ADN. En algunos casos el marcador biológico puede estar unido a una proteína. L os marcadores biológicos de exposición pueden ser también marcadores de efecto, si el efecto es pasajero. Si un marcador biológico persiste, puede convertirse en un marcador biológico de enfermedad. Los marcadores biológicos de efecto útiles tienen una relación muy estrecha con una sustancia tóxica y son indicadores de exposición. Para la detección de una enfermedad, un marcador biológico tiene su máxima especificidad si se expresa inmediatamente después del comienzo de la enfermedad. Las sensibilidad y especificidad previsibles de un marcador biológico dependerán de los riesgos y las ventajas de

Tabla 8.3 - Criterios de selección de los marcadores biológicos.

Utilidad clínica

Marcador biológico potente

Sensibilidad

Especificidad

Valor predictivo negativo

Valor predictivo positivo

Papel funcional

Secuencia en la oncogénesis

Fuente: Hemstreet y cols. 1996

\section{Consideraciones analíticas}

Estabilidad del reactivo

Precio del reactivo

Necesidades de fijación

Reproducibilidad del ensayo

Parámetros sensibles a aparatos

Contribución al perfil del marcador biológico

Adaptabilidad a sistemas automáticos 
la intervención. Por ejemplo, un marcador biológico como la F-actina, indicadora de diferenciación de las proteínas citosqueléticas, que aparece alterado en las fases precoces de la carcinogénesis, puede tener poca especificidad para la detección de estados precancerosos debido a que no todos los individuos que presentan un marcador anormal desarrollan la enfermedad. No obstante, puede ser útil para seleccionar a los individuos y controlarles mientras se les somete a quimioprevención, siempre que el tratamiento no resulte tóxico. Es muy importante conocer la relación cronológica y funcional entre los marcadores biológicos para poder valorar el riesgo individual y comprender los mecanismos de carcinogénesis y nefrotoxicidad.

\section{Marcadores biolócicos de nefrotoxicidad}

Los marcadores biológicos de nefrotoxicidad pueden guardar relación con la etiología de la insuficiencia renal (prerrenal, renal o posrenal) y con los mecanismos que intervienen en la patogenia del proceso. Este proceso comprende la lesión y la reparación de las células. U na lesión tóxica puede afectar a las células, el glomérulo, el intersticio o los túbulos, con la liberación de los correspondientes marcadores biológicos. Los xenobióticos pueden afectar a más de un compartimiento o provocar cambios en los marcadores biológicos debido a la interdependencia de las células dentro del compartimiento. Los cambios inflamatorios, los procesos autoinmunes y los fenómenos inmunológicos potencian todavía más la liberación de biomarcadores. Los xenobióticos pueden atacar un compartimiento en algunos casos, y actuar sobre otro en circunstancias diferentes. U n buen ejemplo es el del mercurio, que en condiciones agudas es nefrotóxico para el túbulo proximal y en condiciones crónicas afecta a las arteriolas. La respuesta a la agresión puede dividirse en varias categorías fundamentales: hipertrofia, proliferación, degeneración (necrosis y apoptosis, o muerte celular programada) y alteraciones de las membranas.

La mayoría de los factores de sensibilidad están relacionados con nefropatías no asociadas a xenobióticos. Sin embargo, un $10 \%$ de los casos de insuficiencia renal se atribuyen a la exposición ambiental a compuestos tóxicos 0 a inducción yatrógena por diversos compuestos, los antibióticos, 0 a intervenciones como la administración de contraste radiológico renal a un diabético. En el lugar de trabajo puede resultar muy útil la detección de una insuficiencia renal subclínica antes de una posible exposición nefrotóxica adicional. Si se sospecha que un compuesto es xenobiótico e incide específicamente en la vía causal de la enfermedad, es posible intervenir para anular sus efectos. Así pues, los marcadores biológicos de efecto eliminan muchos de los problemas que entrañan el cálculo de la exposición y la definición de la sensibilidad individual. El análisis estadístico de los marcadores biológicos de efecto en relación con los marcadores biológicos de sensibilidad y exposición debería mejorar la especificidad de los marcadores. Cuanto más específico sea el marcador biológico del efecto, menor tendrán que ser las muestras para poder identificar científicamente las posibles toxinas.

Los marcadores biológicos de efecto son el tipo más importante de marcadores, y relacionan la exposición con la sensibilidad y la enfermedad. Ya hemos comentado la combinación de marcadores biológicos celulares y solubles para distinguir entre la hematuria de vías altas y la de vías bajas. En la Tabla 8.4 se incluye una lista de marcadores biológicos solubles que pueden provocar nefrotoxicidad celular. $\mathrm{H}$ asta la fecha, ninguno de ellos, solos 0 en batería, permite detectar la toxicidad subclínica con una sensibilidad aceptable. Algunos problemas que plantea el uso de marcadores biológicos solubles son la falta de especificidad, la inestabilidad enzimática, el efecto diluyente de la orina, las variaciones de la función renal y las interacciones con
Tabla 8.4 Marcadores biológicos potenciales asociados a daños celulares.
Factores inmunológicos:

- Humorales: anticuerpos y fragmentos de anticuerpos; componentes de la cascada del complemento, y factores de coagulación

- Celulares: linfocitos, fagocitos mononucleares, y otros efectores derivados de la médula ósea (eosinófilos, basófilos, neutrófilos y plaquetas)

Linfocinas

Principales antígenos de histocompatibilidad

Factores de crecimiento y citocinas: factor de crecimiento de origen plaquetario, factor de crecimiento epidémico, factor de crecimiento transformador,factor de necrosis tumoral, interleucina 1 , etc.

Mediadores lipídicos: prostaglandinas

Endotelina
Componentes de la

matriz extracelular:

Colágenos

Procolágeno

Laminina

Fibronectina
Fuente: Finn, Hemstreet y cols. en National Research Council 1995.

proteínas inespecíficas que pueden enturbiar la especificidad del análisis.

U n factor de crecimiento soluble que puede tener aplicación clínica es el factor de crecimiento epidérmico urinario ( $F C E)$, que puede ser excretado por el riñón y también está alterado en pacientes con carcinoma vesical de células de transición. Se ha investigado la cuantificación de las urinarias, pero su utilidad es limitada debido a la imposibilidad de determinar el origen de la enzima y a la falta de reproducibilidad de los ensayos. El empleo de enzimas urinarias y su aceptación universal avanzan con gran lentitud debido a los criterios restrictivos que acabamos de mencionar. Las enzimas evaluadas son la alaminopeptidasa, la NAG y la fosfatasa alcalina intestinal. La NAG es quizá el marcador más aceptado para el control de las lesiones de las células de los túbulos proximales, debido a su localización en el segmento S3 del túbulo. No es fácil interpretar los resultados, ya que no se conocen la célula exacta de origen ni la causa patológica de la actividad de la enzima urinaria. Además, algunos fármacos, pruebas diagnósticas y trastornos concomitantes (como el infarto de miocardio) pueden dificultar la interpretación.

0 tra posibilidad consiste en utilizar anticuerpos monoclonales como marcadores biológicos para identificar y cuantificar las células tubulares presentes en la orina procedentes de diferentes zonas de la nefrona. La utilidad de este método dependerá del mantenimiento de la integridad de la célula que se vaya a cuantificar, para lo que habrá que fijar y manipular adecuadamente las muestras. Actualmente se dispone de anticuerpos monoclonales que actúan sobre células tubulares específicas y distinguen, por ejemplo, entre las células de los túbulos proximales, de los túbulos distales o de los túbulos contorneados. El microscopio de transmisión no permite distinguir adecuadamente las diferencias 
Figura 8.3 - Cuatro marcadores biológicos, G -actina, P-300, DD23 y ADN, en relación con la progresión tumoral y la respuesta al tratamiento quirúrgico y la quimioprevención.

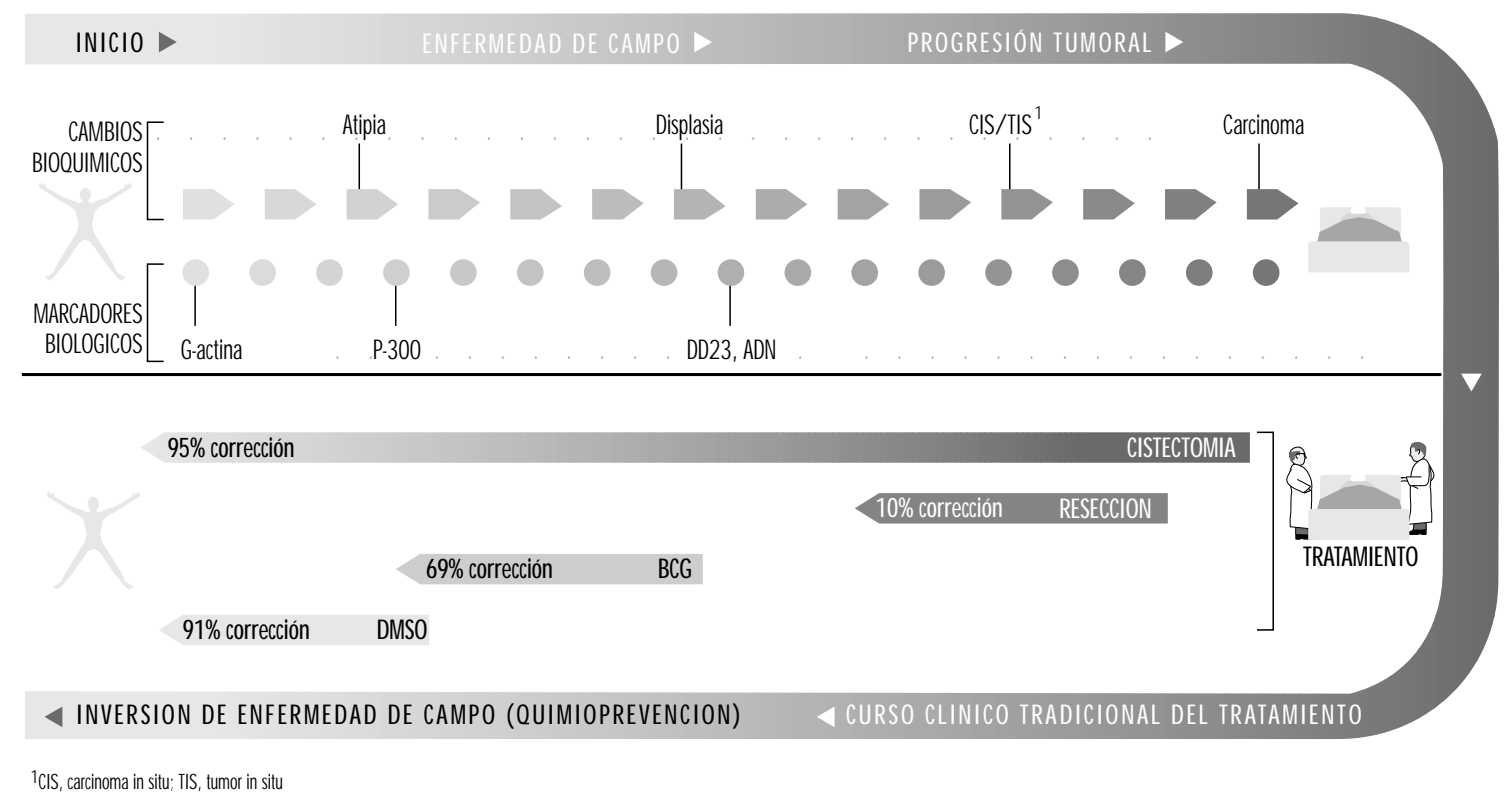

Fuente: Hemstreet y cols. 1996.

entre los leucocitos y diversos tipos de células tubulares, mientras que el microscopio electrónico permite detectar el rechazo de un trasplante. Este problema debería resolverse con técnicas como el análisis cuantitativo de alta velocidad de imágenes de fluorescencia de las células tubulares teñidas con anticuerpos monoclonales. En un futuro no muy lejano será posible detectar la nefrotoxicidad subclínica con una gran certidumbre tras producirse la exposición.

\section{Marcadores biológicos de enfermedades malignas}

En muchos casos los tumores sólidos derivan de una serie de células con alteraciones bioquímicas que pueden o no presentar alteraciones histológicas o citológicas. Algunas tecnologías, como el análisis cuantitativo de imágenes de fluorescencia, que pueden detectar con certeza marcadores biológicos asociados a alteraciones premalignas permitirán la quimioprevención dirigida. Pueden producirse alteraciones bioquímicas en un trastorno variado u ordenado. Fenotípicamente, estos cambios se expresan mediante una progresión morfológica gradual de la atipia a la displasia, y por último a una degeneración maligna manifiesta. Conociendo el "papel funcional" de un marcador biológico y "el momento de la secuencia de carcinogénesis en el que se expresa" se puede concretar mejor su utilidad para identificar un trastorno premaligno, para establecer un diagnóstico precoz y para desarrollar una batería de marcadores biológicos para predecir las recidivas y la evolución de los tumores. Se está desarrollando un paradigma para la valoración de los marcadores biológicos que exige la identificación de los perfiles de marcadores biológicos aislados y múltiples.

Parece que el cáncer vesical sigue dos vías de desarrollo diferentes: una vía de bajo grado aparentemente relacionada con alteraciones del cromosoma 9 , y una segunda vía relacionada con una alteración del gen supresor P-53 en el cromosoma 17. Es evidente que en el desarrollo del cáncer intervienen numerosos factores genéticos, y que resulta muy difícil definir los factores genéticos en cada individuo, especialmente cuando hay que establecer una relación entre la vía genética y una complejidad de exposiciones, quizá numerosas. En los estudios epidemiológicos realizados ha costado mucho reconstruir las exposiciones durante períodos prolongados. Se están identificando baterías de marcadores fenotípicos y genotípicos para definir a los individuos de riesgo en cohortes laborales. En la Figura 8.3 presentamos un perfil de marcadores biológicos fenotípicos y su relación con el cáncer de vejiga; en esta figura puede verse que la $\mathrm{G}$-actina, un precursor proteico de la proteína citosquelética F-actina, es un marcador de diferenciación precoz y puede seguirse mediante las alteraciones secuenciales de otros marcadores terminales intermedios como M 344, DD23 y la ploidia del ADN. Todavía están por determinar las baterías de marcadores biológicos más potentes para la detección y el pronóstico de los cuadros premalignos y del cáncer manifiesto. A medida que se establezcan criterios bioquímicos que puedan detectarse con aparatos puede ser posible detectar el riesgo de enfermedad en momentos específicos del proceso patológico.

\section{Diagnóstico y tratamiento de los trastor nos renales y urinarios relacionados con el trabajo}

\section{Nefropatía preexistente}

Los cambios experimentados por los sistemas asistenciales de todo el mundo obligan a plantearse los problemas relacionados con cobertura mediante seguro y la protección de los trabajadores ante una exposición adicional. Una nefropatía previa importante se manifiesta por una creatinina sérica elevada, glucosuria (azúcar en la orina), proteinuria, hematuria y orina diluida. Es necesario descartar inmediatamente causas sistémicas subyacentes, como la diabetes y la hipertensión y, dependiendo de la edad del paciente, deben buscarse otras etiologías congénitas, como los quistes renales múltiples. Por consiguiente, el análisis de orina, tanto con el microscopio como con tiras reactivas, para detectar posibles alteraciones bioquímicas y celulares es muy útil para el médico del trabajo. Las pruebas para medir la creatinina 
sérica y el aclaramiento de creatinina estarán indicadas si la presencia de hematuria, piuria o proteinuria importante sugiere una patología subyacente.

Existen numerosos factores que tienen importancia para valorar el riesgo de progresión a una nefropatía crónica o una insuficiencia renal aguda. El primero de ellos es la limitación intrínseca 0 adquirida del riñón para resistir la exposición a los xenobióticos. En capacidad de respuesta del riñón a los nefrotóxicos, como un aumento de los tóxicos absorbidos o alteraciones en el metabolismo renal, puede influir una anomalía preexistente. Es especialmente importante la disminución de la capacidad de destoxificación en los muy jóvenes o muy ancianos. En un estudio, la sensibilidad a la exposición laboral guardaba una relación muy estrecha con los antecedentes familiares de nefropatía, lo que pone de relieve la importancia de la predisposición hereditaria. Los procesos subyacentes, como la diabetes y la hipertensión, aumentan la sensibilidad. Existen otros factores de sensibilidad mucho menos frecuentes, como el lupus eritematoso y la vasculitis. En la mayoría de los casos, el aumento de la sensibilidad es multifactorial y comprende a menudo una batería de noxas que pueden aparecer solas o simultáneamente. Por consiguiente, el médico laboral debe conocer los antecedentes familiares de nefropatía del paciente y los trastornos preexistentes que alteren la función renal, así como cualquier enfermedad vascular o cardíaca, especialmente en los trabajadores de más edad.

\section{Insuficiencia renal aguda}

La insuficiencia renal aguda puede ser de etiología prerrenal, renal o posrenal. Suele ser consecuencia de una noxa aguda que da lugar a una pérdida rápida y progresiva de la función renal. Cuando se suprime el factor nefrotóxico o la causa desencadenante, la función renal se recupera progresivamente, con un descenso gradual de la creatinina sérica y una mejora de la capacidad renal de concentración. En la Tabla 8.5 presentamos una lista de las causas profesionales de insuficiencia renal aguda. La insuficiencia renal aguda por exposición a dosis elevadas de xenobióticos ha sido muy útil para identificar los posibles factores etiológicos que pueden contribuir también a formas más crónicas de nefropatía progresiva. La insuficiencia renal aguda por obstrucción de la salida de la orina como consecuencia de una alteración benigna 0 una neoplasia maligna es relativamente rara, pero las causas quirúrgicas pueden aumentar su frecuencia. La ecografía de vías urinarias altas permite identificar el problema obstructivo, cualquiera que sea el factor contribuyente. La insuficiencia renal secundaria a fármacos o tóxicos industriales tiene un índice de

Tabla 8.5 - Causas principales de insuficiencia renal aguda de origen profesional.

\begin{tabular}{cll} 
Isquemia renal & Necrosis & Hemoglobinuria, \\
tubular & mioglobinuria \\
Shock traumático & Mercurio & Arsénico \\
Shock anafiláctico & Cromo & Síndrome de aplastamiento \\
Intoxicación aguda por & Arsénico & Impacto de un rayo \\
monóxido de carbono & Acido oxálico & \\
Golpe de calor & Tartratos & \\
& Etilenglicol & \\
& Tetracloruro & \\
& de carbono & \\
Fuente: Crepet 1983. & Tetracloroetano & \\
\hline
\end{tabular}

mortalidad del $37 \%$, aproximadamente; el resto de los afectados mejora en mayor o menor medida.

La insuficiencia renal aguda puede deberse a diversas causas prerrenales que tienen su origen en una isquemia renal como consecuencia de una disminución prolongada de la perfusión renal. D os ejemplos son la insuficiencia cardíaca y la obstrucción de la arteria renal. La necrosis tubular puede deberse a un número cada vez mayor de nefrotóxicos presentes en los lugares de trabajo. Diferentes estudios culpan a los herbicidas y a los plaguicidas. Según un informe reciente, la intoxicación por cicuta causaba el depósito en los túbulos de miosina y actina procedentes de la degradación de las células musculares, así como un descenso agudo de la función renal. El endosulfán, un insecticida, y el acetato de trifeniltina, una organotina, fueron clasificados inicialmente como neurotoxinas, pero recientemente han sido relacionados con la necrosis tubular. Informes anecdóticos sobre otros casos ponen de manifiesto la necesidad de encontrar marcadores biológicos para poder identificar tóxicos subclínicos más sutiles que pueden no haber provocado todavía exposiciones tóxicas a dosis elevadas.

Los signos y síntomas de la insuficiencia renal aguda son: supresión de la excreción urinaria (anuria); oliguria (disminución de la excreción urinaria); disminución de la capacidad de concentración del riñón, y/ o un aumento del potasio sérico que puede detener el corazón en fase de relajamiento (parada diastólica). El tratamiento consiste en medidas de mantenimiento clínico y, siempre que sea posible, en la supresión de la exposición a la sustancia tóxica. El aumento del potasio sérico o la retención excesiva de líquido son los dos indicadores fundamentales para proceder a la hemodiálisis o la diálisis peritoneal, dependiendo la elección de la estabilidad cardiovascular del paciente y del acceso vascular para la hemodiálisis. EI nefrólogo, un especialista en riñón, es la pieza clave en la estrategia de tratamiento de estos pacientes, que pueden necesitar además la intervención de un especialista en cirugía urológica.

Tras una insuficiencia renal, el tratamiento a largo plazo depende en gran medida del grado de recuperación y rehabilitación y del estado de la salud general del paciente. Conviene que éste reanude una actividad laboral limitada y que evite las condiciones que acentúen la patología subyacente. Los pacientes con piuria o hematuria persistente requieren un seguimiento muy cuidadoso, posiblemente con marcadores biológicos, durante los dos años siguientes a su recuperación.

\section{Nefropatía crónica}

Las nefropatías crónicas o terminales suelen ser secundarias a un proceso subclínico crónico continuo en el que intervienen diferentes factores, la mayoría de los cuales no se conocen bien. La glomerulonefritis, las causas vasculares y la hipertensión son factores contribuyentes importantes. Otros factores son la diabetes y las sustancias nefrotóxicas. Los pacientes afectados presentan aumentos progresivos de los niveles séricos de nitrógeno ureico en sangre, creatinina y potasio, así como oliguria (disminución de la excreción urinaria). Se necesitan marcadores biológicos o baterías de marcadores biológicos más perfeccionados para identificar con mayor precisión la nefrotoxicidad subclínica. EI médico del trabajo debe utilizar métodos de valoración no invasivos, muy específicos y reproducibles. Ningún marcador biológico cumple por el momento estos criterios para poder aplicarse a gran escala.

Las nefropatías crónicas pueden deberse a diferentes sustancias nefrotóxicas, y la patogenia se conoce mejor en unos casos que en otros. En la Tabla 8.6 presentamos una lista de sustancias nefrotóxicas y los lugares donde ejercen su toxicidad. Como ya hemos señalado, las toxinas pueden atacar al glomérulo, a diferentes segmentos de los túbulos 0 a las células intersticiales. La 

$\begin{array}{cl}\text { Tabla } 8.6 \text { - } & \begin{array}{l}\text { Segmentos de la nefrona afectados por } \\ \text { sustancias tóxicas seleccionadas. }\end{array}\end{array}$

\begin{tabular}{ll}
\hline Túbulo proximal & Glomérulo \\
Antibióticos & Inmunocomplejos \\
Cefalosporinas & Antibióticos aminoglucósidos \\
Aminoglucósidos & Aminonucleósido de puromicina \\
Antineoplásicos & Adriamicina \\
Nitrosoureas & Penicilamina \\
Cisplatino y análogos & \\
Contrastes radiológicos & Túbulo distal// conducto colector \\
Hidrocarburos halogenados & Litio \\
Clorotrifluoroetileno & Tetraciclinas \\
Hexafluropropeno & Anfotericina \\
Hexaclorobutadieno & Fluoruro \\
Tricloroetileno & Metoxiflurano \\
Cloroformo & \\
Tetracloruro de carbono & \\
Acido maleico & Papila \\
Citrinina & Aspirina \\
Metales & Fenacetina \\
Mercurio & Paracetamol \\
Nitrato de uranilo & Antiinflamatorios no esteroideos \\
Cadmio & 2-Bromoetilamina \\
Cromo & \\
Fuente: Tarloff y Goldstein 1994. & \\
\hline
\end{tabular}

exposición a un xenobiótico puede producir hematuria, piuria, glucosuria, aminoaciduria, frecuencia urinaria y disminución de la excreción urinaria. No se conocen con exactitud los mecanismos de la lesión renal producida por muchos nefrotóxicos, pero la identificación de marcadores biológicos específicos de nefrotoxicidad debería ayudarnos a resolver este problema. Aunque la prevención de la vasoconstricción protege en parte al riñón, en la mayoría de los casos persiste la lesión tubular. A modo de ejemplo, la toxicidad del plomo es fundamentalmente de tipo vascular, mientras que el cromo a dosis reducidas afecta a las células de los túbulos proximales. Parece que estos compuestos alteran la maquinaria metabólica de las células. Se ha observado una relación entre diferentes formas mercuriales y una nefrotoxicidad elemental aguda. El cadmio, a diferencia del mercurio y de otros muchos nefrotóxicos industriales, ataca primero a las células de los túbulos proximales.

\section{- CANCERES RENALES Y URINARIOS}

Timo Partanen, Harri Vainio, Paolo Boffetta y E lisabete Weiderpass

\section{Cáncer de riñón}

\section{E pidemiología}

$H$ istóricamente, dentro del cáncer de riñón se han incluido todas las neoplasias malignas del sistema renal (carcinoma de células renales (CCR ), CIE-9 189.0; de la pelvis renal, CIE-9 189.1, y del uréter, CIE-9 189.2) o únicamente el CCR. Esta clasificación ha originado cierta confusión en los estudios epidemiológicos, lo que ha obligado a revisar los datos publicados previamente. EI CCR representa un 75-80\% del total, y el resto son fundamentalmente carcinomas de células de transición de la pelvis y el uréter. Es conveniente separar estos dos tipos de neoplasias, ya que ambas tienen una patogenia bastante diferente, y también son distintos los factores de riesgo epidemiológico y los signos y síntomas de ambos trastornos. En esta sección nos centraremos en el estudio del CCR.

El principal factor de riesgo conocido de cáncer de riñón es el tabaquismo, seguido por factores de riesgo profesionales y ambientales sospechados pero poco definidos. Se calcula que la supresión del tabaquismo reduciría la incidencia del cáncer de riñón un 30-40\% en los países industrializados, pero no se conocen bien los factores profesionales determinantes de CCR . Se ha calculado que el riesgo para la población atribuible a exposiciones profesionales oscila entre cero, basado en la carcinogénesis reconocida, y el $21 \%$, basado en un estudio de casoscontroles llevado a cabo en diversos centros y lugares de trabajo de la región de Montreal (Canadá). Los marcadores biológicos precoces de efecto en combinación con los marcadores biológicos de exposición deben ayudarnos a aclarar los factores de riesgo importantes. En estudios epidemiológicos se ha descubierto que existe un riesgo aumentado de cáncer de riñón en varias profesiones y sectores. No obstante, las pruebas existentes no son concluyentes, con la posible excepción de los productos empleados en la limpieza en seco y de las exposiciones en el proceso de refinado del petróleo. El análisis estadístico de los datos epidemiológicos de exposición en relación con los marcadores biológicos de sensibilidad y efecto permitirá desentrañar otros factores etiológicos.

En diversos estudios epidemiológicos se han asociado determinadas industrias, profesiones y exposiciones profesionales con un aumento del riesgo de carcinoma de células renales. El patrón que se desprende de esos estudios no es totalmente constante. Las refinerías de petróleo, las imprentas, la limpieza en seco y la conducción de camiones son algunos ejemplos de trabajos asociados a un mayor riesgo de cáncer de riñón. Los granjeros suelen estar menos expuestos al cáncer de riñón, pero un estudio danés ha relacionado la exposición prolongada a los insecticidas y los herbicidas con un riesgo de CCR casi cuatro veces mayor. Es necesario confirmar estos resultados con datos independientes, incluida la especificación de la posible naturaleza causal de esta asociación. O tros productos que podrían guardar alguna relación con el CCR son: diversos disolventes y derivados de hidrocarburos; productos del refinado del petróleo; petróleo, alquitrán y productos de la brea; gases de combustión de la gasolina; combustible para reactores; emisiones de motores diesel y a reacción; compuestos de arsénico; cadmio; compuestos de cromo (VI); compuestos inorgánicos de plomo, y amianto. Algunos estudios epidemiológicos han relacionado la exposición laboral a los vapores de la gasolina con riesgo de cáncer de riñón, en algunos casos del tipo dosis-respuesta, un fenómeno observado en la rata macho expuesta a vapores de gasolina sin plomo. Estos hallazgos adquieren una cierta importancia potencial, dada la exposición generalizada de las personas a los vapores de la gasolina en las estaciones de servicio y el reciente aumento de la incidencia del cáncer de riñón. La gasolina es una mezcla compleja de hidrocarburos y aditivos, incluido el benceno, un conocido cancerígeno humano.

El riesgo de cáncer de riñón no guarda una relación constante con las clases sociales, aunque a veces se ha asociado un aumento del riesgo con las clases socioeconómicas más privilegiadas. Sin embargo, en algunas poblaciones se ha observado un gradiente inverso, y en otras no se ha podido establecer un patrón definido. Posiblemente estas variaciones guarden relación con el estilo de vida. Estudios realizados con emigrantes 
demuestran que el riesgo de C C R se va igualando con los niveles de la población del primer país, lo que sugiere que los factores ambientales son importantes en el desarrollo de esta neoplasia maligna.

Salvo el nefroblastoma (tumor de Wilms), que es una neoplasia infantil, el cáncer de riñón suele aparecer a partir de los 40 años de edad. En conjunto, se calcula que en 1985 se produjeron unos 127.000 nuevos casos de cáncer de riñón (incluyendo el CCR y el carcinoma de células de transición (CCT ) de la pelvis renal y el uréter), lo que equivale al 1,7\% de la incidencia total del cáncer en el mundo. La incidencia del cáncer de riñón varía de unas poblaciones a otras. Se ha medido una incidencia elevada en ambos sexos en Norteamérica, Europa, Australia y Nueva Zelanda, y una incidencia reducida en M elanesia, Africa central y oriental y el este y el sureste asiáticos. La incidencia del cáncer de riñón ha ido aumentando en la mayoría de los países occidentales, pero se ha estancado en algunos de ellos. En 1985, la incidencia normalizada por edades alcanzó valores máximos en Norteamérica y en Europa occidental, septentrional y oriental, y tuvo su menor incidencia en Africa, A sia (con la excepción de los varones japoneses) y el Pacífico. El cáncer de riñón es más frecuente en los hombres que en las mujeres, y en algunos países se encuentra entre las diez neoplasias más frecuentes.

El carcinoma de células de transición (CCT) de la pelvis renal se asocia con agentes etiológicos parecidos a los del cáncer de vejiga, como las infecciones crónicas, los cálculos y los analgésicos que contienen fenacetina. La nefropatía de los Balcanes, una nefropatía crónica lentamente progresiva y mortal prevalente en los países balcánicos, se asocia a una mayor incidencia de tumores de la pelvis renal y el uréter. Se ignoran las causas de esta nefropatía. Se ha relacionado su desarrollo con una exposición excesiva a la ocratoxina $A$, un posible cancerígeno humano, pero no se puede descartar el papel de otros agentes nefrotóxicos. La ocratoxina A es una toxina producida por unos hongos que pueden encontrarse en muchos alimentos, especialmente en los cereales y los derivados del cerdo.

\section{Exploración selectiva y diagnóstico del cáncer de riñón}

El patrón de síntomas del CCR varía de unos pacientes a otros, incluso hasta la fase en la que aparecen metástasis. Debido a la situación de los riñones y a la movilidad de las estructuras contiguas a la masa en expansión, estos tumores son a menudo muy grandes en el momento de su detección clínica. Aunque el síntoma primordial del CCR es la hematuria, ésta aparece más tarde que en los tumores de células de transición debido a la localización intrarenal del C CR. Se ha considerado al CCR como "el sueño médico de los médicos" pero "la maldición de los cirujanos" debido a la interesante constelación de síntomas relacionados con los síndromes paraneoplásicos. Se han encontrado sustancias que aumentan el número de hematíes, calcio y factores que simulan una función suprarrenal anormal, y también se han observado masas abdominales, pérdida de peso, fatiga, dolor, anemia, alteraciones de la función hepática e hipertensión. LoS facultativos solicitan cada vez con más frecuencia tomografías axiales computadorizadas (TAC) y ecografías del abdomen y, debido a ello, se calcula que un $20 \%$ de los CCR se diagnostican de forma casual durante el estudio de otros problemas médicos.

La valoración clínica de un caso de CCR incluye una exploración física para identificar una masa en el costado, que aparece en el $10 \%$ de los pacientes. U na radiografía renal con contraste puede delimitar una masa renal, y la ecografía o el TAC suelen confirmar la naturaleza sólida o quística de la tumoración. Estos tumores están muy vascularizados y presentan un aspecto característico cuando se inyecta un contraste radiopaco en la arteria. Puede realizarse una arteriografía para embolizar el tumor si es muy grande o para definir su aporte arterial si se va a practicar una nefrectomía parcial. Para obtener una muestra de un posible CCR se puede recurrir a la aspiración con aguja fina.

Los CCR localizados se extirpan quirúrgicamente con los ganglios linfáticos regionales; durante la intervención es importante ligar precozmente la arteria y la vena. EI paciente puede mejorar sintomáticamente con la resección de tumores grandes o sangrantes que hayan metastatizado, pero la supervivencia no aumenta. En los tumores metastáticos puede conseguirse un control localizado del dolor mediante la radioterapia, pero el tratamiento de elección para los cuadros metastáticos consiste en la administración de modificadores de la respuesta biológica (interleucina 2 o interferón $\alpha$ ), aunque a veces se utiliza la quimioterapia sola 0 en combinación con otras formas de tratamiento.

Algunos marcadores, como el gen del cáncer que se observa en el cromosoma 3 de las familias con cáncer y en la enfermedad de von Hippel-Lindau pueden servir de marcadores biológicos de sensibilidad. Aunque se han notificado antígenos marcadores tumorales del CCR, actualmente no disponemos de los medios para detectarlos adecuadamente en la orina o la sangre con la sensibilidad y la especificidad adecuadas. D ebido a la escasa prevalencia de esta enfermedad en la población general, hay que utilizar una prueba muy específica y sensible para poder detectarla precozmente. Se podría examinar selectivamente a los grupos de trabajadores en riesgo mediante la ecografía. La detección de estos tumores sigue representando un desafío para los científicos generales, los epidemiólogos moleculares y los médicos.

\section{Cáncer de vejiga}

\section{Epidemiología}

M ás del $90 \%$ de las neoplasias vesicales de Europa y N orteamérica son carcinomas de células de transición (CCT). Los carcinomas de células escamosas y los adenocarcinomas representan el $5 \%$ y el $1 \%$, respectivamente, de los tumores vesicales en esas regiones. Los diversos tipos histopatológicos de los tumores vesicales tienen una distribución muy diferente en regiones como 0 riente Próximo y Africa, zonas en las que el cáncer de vejiga se asocia a la esquistosomiasis. Por ejemplo, en Egipto, donde la esquistosomiasis es endémica y el cáncer de vejiga es el principal problema oncogénico, el tipo más frecuente es el carcinoma de células escamosas, pero la incidencia del CCT está aumentando con el tabaquismo. El siguiente comentario se centra en el CCT.

El cáncer de vejiga sigue siendo una patología muy importante. En 1980 representaba el 3,5\% de las neoplasias malignas diagnosticadas en el mundo. En 1985 ocupaba el puesto número 11 por su frecuencia a nivel mundial, siendo el octavo en frecuencia entre los hombres, con una previsión total de 243.000 nuevos casos. Se observa un pico de incidencia en el séptimo decenio de vida, y a nivel mundial la relación hombres/ mujeres es aproximadamente de tres a uno. La incidencia ha ido aumentando en casi todas las poblaciones europeas, especialmente en los varones. En Dinamarca, que tiene una incidencia anual de las más altas del mundo (45 por 100.000 en hombres y 12 por 100.000 en mujeres), la tendencia ha sido últimamente a un aumento aún mayor del 8-9 \% cada cinco años. En Asia, la incidencia muy elevada medida entre los chinos de $\mathrm{H}$ ong $\mathrm{K}$ ong ha ido disminuyendo de forma sostenida, pero la incidencia del cáncer de vejiga en ambos sexos sigue siendo mucho mayor que en otras zonas asiáticas, y más del doble de la observada en los chinos de Shanghai o Singapur. También es muy alta la incidencia del cáncer de vejiga entre los chinos de $\mathrm{H}$ awai.

El tabaquismo es el factor etiológico más importante en el cáncer vesical, y las exposiciones laborales ocupan el segundo 
lugar en importancia. Se ha calculado que el tabaco es el responsable de un tercio de los casos de cáncer vesical fuera de las regiones en las que la esquistosomiasis es endémica. Se ha cifrado el número de casos de cáncer vesical achacables al tabaquismo en 1985 en más de 75.000 en todo el mundo, y puede causar la mitad de los casos en las naciones occidentales. EI hecho de que no todas las personas que fuman cantidades parecidas desarrollan cáncer de vejiga con la misma frecuencia sugiere que los factores genéticos son importantes en el control de la sensibilidad. Dos aminas aromáticas, el 4-aminobifenilo y la 2-naftilamina, son cancerígenos relacionados con el tabaco; se encuentran en mayores concentraciones en el "tabaco negro" (secado al aire) que en el "tabaco rubio" (secado con humos). EI tabaquismo pasivo aumenta los aductos en la sangre, y se ha establecido una relación dosis-respuesta de la formación de aductos con el aumento del riesgo de cáncer de vejiga. Se han observado niveles más elevados de formación de aductos en los fumadores de cigarrillos que son acetiladores lentos en comparación con los acetiladores rápidos, lo que sugiere que la capacidad de acetilación genéticamente heredada puede ser un marcador biológico de sensibilidad importante. La menor incidencia del cáncer de vejiga en los negros que en los blancos puede atribuirse a la conjugación de los intermediarios metabólicos cancerígenos por sulfotransferasas que producen electrófilos. Los sulfatos fenólicos destoxificados pueden proteger el urotelio. Se ha señalado que la sulfotransferasa hepática tiene una mayor actividad sobre las $\mathrm{N}$-hidroxiarilaminas en los negros que en los blancos. Esto podría dar lugar a una disminución de los N -hidroximetabolitos libres que actúan como cancerígenos.

EI cáncer vesical profesional es uno de los cánceres laborales antes conocidos y mejor documentados. El primer caso identificado de cáncer vesical de origen profesional apareció unos 20 años después del surgimiento de la industria de colorantes sintéticos en Alemania. En los últimos 25 años se han descubierto muchos otros trabajos como riesgos profesionales de cáncer vesical. $L$ as exposiciones profesionales pueden contribuir hasta a un $20 \%$ de los tumores vesicales. Están expuestos en el entorno laboral los trabajadores que manipulan breas de alquitrán de carbón, los que intervienen en la gasificación del carbón y la producción de caucho, aluminio, auramina y magenta, así como los peluqueros y barberos. Se ha comprobado que las aminas aromáticas producen cáncer vesical en trabajadores de muchos países. Entre esos productos destacan la 2-naftilamina, la bencidina, el 4-nitrobifenilo y la 3,3'-diclorobencidina. 0 tras dos aminas aromáticas, la 4,4'-metilendianilina (MD) y la 4,4'-metilen-bis-2-cloroanilina (M O CA) se encuentran entre los posibles cancerígenos vesicales más utilizados. Todavía quedan por identificar otros cancerígenos asociados a las exposiciones industriales; sin embargo, las aminas aromáticas son muy frecuentes en el entorno laboral.

\section{Exploración selectiva y diagnóstico del cáncer de vejiga}

La exploración selectiva del cáncer de vejiga sigue recibiendo atención, en un intento de diagnosticarlo antes de que empiece a producir síntomas y, presumiblemente, responda peor a los tratamientos curativos. Como posibles pruebas selectivas se han considerado la citología de la orina evacuada y la búsqueda de hematuria en el análisis de orina. U na cuestión fundamental en esta exploración selectiva es la forma de identificar los grupos de alto riesgo y a los posibles afectados dentro de estos grupos. Los estudios epidemiológicos permiten identificar los grupos de riesgo, mientras que los marcadores biológicos permiten identificar a los individuos potencialmente afectados dentro de esos grupos. En general, la exploración selectiva para el cáncer vesical de origen profesional mediante las pruebas de hematuria y la citología de Papanicolau no ha resultado muy eficaz.
Se puede mejorar la detección del cáncer vesical utilizando la prueba del hemastick durante 14 días descrita por M essing y sus colaboradores. Se obtuvo un resultado positivo al menos una vez en el $84 \%$ de 31 pacientes con cáncer de vejiga como mínimo dos meses antes del diagnóstico cistoscópico de la enfermedad. Esta prueba da falsos positivos en un $16-20 \%$ de los casos, la mitad de los cuales no presenta ninguna alteración urológica. Su coste reducido puede convertirla en una prueba útil en una exploración selectiva en dos fases en combinación con los marcadores biológicos y la citología (Waples y M essing 1992).

En un estudio reciente, el análisis cuantitativo de imágenes de fluorescencia con el anticuerpo monoclonal DD23 permitió detectar el cáncer de vejiga en células uroteliales exfoliadas. Se consiguió una sensibilidad del $85 \%$ y una especificidad del $95 \%$ en una mezcla de carcinomas de células de transición de grado inferior y elevado, incluidos tumores TaT 1. El antígeno tumoral M 344 combinado con la ploidia de ADN obtuvo una sensibilidad cercana al $90 \%$.

Estudios recientes indican que la mejor opción puede ser la combinación de marcadores biológicos con las pruebas de hematuria. En la Tabla 8.7 se resume una lista de las aplicaciones de la citología urinaria de fluorescencia cuantitativa combinada con marcadores biológicos. Los cambios genéticos, bioquímicos y morfológicos precoces en las células asociados con cuadros premalignos respaldan la idea de que es posible identificar a los individuos en riesgo años antes de que desarroIlen una neoplasia maligna manifiesta. La combinación de marcadores biológicos de sensibilidad y de efecto permitirá seguramente detectar a los individuos de riesgo con una

Tabla 8.7 - Aplicaciones de la citología urinaria.

Detección del CIS y y cáncer de vejiga:

Control del tratamiento quirúrgico:

Control vesical tras RTUTV ${ }^{2}$

Control de vías urinarias altas

Control del remate uretra

Control de derivaciones urinarias

Control del tratamiento intravesical

Elección del tratamiento intravesical

Control de los efectos del tratamiento con láser

Valoración de pacientes con hematuria

Determinación de la necesidad de la cistoscopia

Estudio selectivo de poblaciones de alto riesgo:

Grupos de exposición profesional

Grupos de drogadictos con riesgo de cáncer de vejiga

Criterios de decisión para:

Cistectomía

Resección ureteral segmentaria o nefroureterectomía

Otras indicaciones:

Detección de fístulas enterovesicales

Tumores extraurológicos que invaden las vías urinarias

Definición de quimioterápicos eficaces

Control de la eficacia de la quimioterapia

1 CIS, carcinoma in situ.

2 RTUTV, resección transuretral de un tumor vesical.

Fuente: Hemstreet y cols. 1996. 
precisión aún mayor. Estos avances son posibles gracias a las nuevas tecnologías capaces de cuantificar los cambios moleculares fenotípicos y genotípicos a nivel unicelular y que, por consiguiente, permiten identificar a los individuos en riesgo. $L$ a valoración del riesgo en cada caso facilita el control estratificado y rentable de grupos elegidos para la quimioprevención dirigida.

El cáncer de vejiga tiene unos síntomas parecidos a los de una infección urinaria y puede producir disuria, frecuencia urinaria y aparición de células sanguíneas y purulentas en la orina. Dado que los síntomas de una infección urinaria pueden ser el anuncio de un tumor vesical, especialmente si se acompañan de hematuria macroscópica en pacientes mayores, es necesario confirmar la presencia de bacterias y mantenerse alerta. Si un paciente tratado de una infección urinaria no mejora inmediatamente, hay que remitirlo al urólogo para un estudio más completo.

La valoración diagnóstica del cáncer vesical exige en primer lugar una pielografía intravenosa (PIV) para descartar una posible anomalía de vías altas (pelvis renal o uréteres). Para confirmar el diagnóstico hay que examinar la vejiga con un cistoscopio y obtener varias muestras de biopsia con un instrumento con luz introducido por la uretra para determinar si el tumor es invasivo o no invasivo (es decir, papilar o CIS). Las biopsias aleatorias de la vejiga y la uretra prostática ayudan a definir la cancerización por campos y los cambios de efecto por campos. Los pacientes con trastornos no invasivos requieren un control muy estrecho, ya que están expuestos a posteriores recidivas, aunque no es frecuente que se produzca una progresión en el estadio y el grado de sus lesiones. Los pacientes que presentan un cáncer vesical de grado avanzado o que ha invadido la lámina propia corren el mismo riesgo de recidivas, pero las probabilidades de una progresión en el estadio tumoral son mucho mayores. Debido a ello, se les suele someter a una resección transuretral y a la instilación intravesical de agentes inmuno o quimioterapéuticos. Los pacientes con tumores que han invadido la muscular propia o estructuras más profundas suelen presentar ya metástasis, y raras veces pueden recibir tratamiento conservador. Sin embargo, aunque se les practique una cistectomía total (el tratamiento estándar para el cáncer de vejiga que ha invadido el músculo vesical), un 20-60 \% acaban sucumbiendo a su enfermedad, debido casi siempre a las metástasis. Cuando ya existen metástasis regionales 0 distantes en el momento del diagnóstico, los índices de supervivencia a los 5 años descienden al 35 y al $9 \%$, respectivamente, a pesar de utilizar un tratamiento agresivo. La quimioterapia sistémica del cáncer vesical metastático ha mejorado mucho, y se han comunicado índices de respuesta completa del $30 \%$. Estudios recientes sugieren que el empleo de la quimioterapia antes de la cistectomía puede aumentar la supervivencia en pacientes escogidos.

El estadiaje del cáncer de vejiga permite predecir el potencial biológico de progresión, metástasis o recidiva en el $70 \%$ de los casos. Para dicho estadiaje suele precisarse la TAC para descartar las metástasis hepáticas, la gammagrafía ósea para descartar la diseminación ósea y la radiografía o la TAC de tórax para descartar las metástasis pulmonares. $\mathrm{H}$ ay que seguir buscando marcadores biológicos en el tumor y en la región del cáncer vesical que permitan predecir qué tumores van a metastatizar o recidivar. La accesibilidad de las células vesicales exfoliadas presentes en las muestras de orina seguramente nos permitirá utilizar marcadores biológicos para controlar las recidivas y prevenir el cáncer.
Referencias

Committee on Biological $\mathrm{M}$ arkers of the $\mathrm{Nationa}$ Research Council. 1987. Biological markers in environmental health research. Environ $H$ ealth Persp 74:3-9.

Crepet, M. 1983. En Enciclopedia de la salud y seguridad en el trabajo. Ginebra: OIT).

Hemstreet, G, R Bonner, R Hurst, and G O 'Dowd. 1996. Cytology of bladder cancer. En Comprehensive T extbook of Genitourinary O ncology, dirigido por NJ Vogelzang, Wu Shipley, PT Scardino y DS C offey. Baltimore: Williams \& W ilkins.

National R esearch Council. 1995. Biological M arkers in U rinary Toxicology. Washington, DC: National Academy Press.

Schulte, PA, K Ringen, GP H emstreet, and E W ard. 1987. Exposure: O ccupational cancer of the urinary tract. En Occupational Cancer and Carcinogenesis. Filadelfia: $\mathrm{H}$ anley $\&$ Belfus.

Tarloff, JB and RS Goldstein. 1994. Biochemical mechanisms of renal toxicity. En Introduction to B iochemical T oxicology, dirigido por $\mathrm{E} H$ odgson y $\mathrm{PE}$ Levi. E. Norwalk, Conn.: Appleton and Lange.

Waples, M and EM M essing. 1992. The management of stage T 1, grade 3 transitional cell carcinoma of the bladder. En Advances in U rology. St. Louis: M osby.

Wyker, A. 1991. Standard diagnostic considerations. En Adult and Pediatric U rology, dirigido por JY Gillenwater et al. (3 ed. 1996). St. Louis: M osby.

\section{0 tras lecturas recomendadas}

Agencia Internacional para la Investigación sobre el Cáncer (IARC). 1982. Some industrial chemicals and dyestuffs. IARC M onographs on the Evaluation of Carcinogenic R isk of Chemicals to $\mathrm{H}$ umans, $\mathrm{V}$ ol. 29. Lyon: IARC

-. 1986. T obacco smoking. IARC M onographs on the Evaluation of Carcinogenic R isk of Chemicals to H umans, N o. 38. Lyon: IAR C

-. 1991. M ycotoxins, endemic nephropathy and urinary tract tumour. IARC Scientific Publications. Lyon: IARC.

- . 1993a. 0 ccupational exposures of hairdressers and barbers and personal use of hair colourants: Some hair dyes, cosmetic colourants, industrial dyestuffs and aromatic amines. IARC M onographs on the Evaluation of C arcinogenic R isks to H umans. Lyon: IAR C.

—. 1993b. Some naturally occurring substances: Food items and constituents, heterocyclic aromatic amines and mycotoxins. IARC M onographs on the Evaluation of Carcinogenic R isks to Humans, N o. 56. Lyon: IARC.

-. 1994. Schistosomes, liver flukes and helicobacter pylory. IARC M onographs on the Evaluation of Carcinogenic R isks to $H$ umans. L yon: IAR C.

Bane, B, J Rao, and G Hemstreet. 1996. Pathology and staging of bladder cancer. Semin 0 ncol 2 3(5):546-570.

C atalona, W. 1992. U rothelial tumours of the urinary tract. En Cambell's U rology, dirigido por P Walsc, A R etic y J Stamoy. Filadelfia: WB Saunders.

Commings, KB, JG Barone, and WS Ward. 1992. Diagnosis and staging of bladder cancer. $\mathrm{U}$ rol $\mathrm{Clin}$ N Am 19:455-465.

Fair, W, Z Fuks, and H Scher. 1982. Cancer of bladder. En Cancer: Principles and Practice of O ncology, dirigido por V D eV ita, S H ellman, y S R osenberg. Filadelfia: JB Lippincott.
Hemstreet, G, R H urst, and NR Asal. 1993. Biologic markers in the genitourinary system. En M olecular E pidemiology: Principles and Practices, dirigido por PA Schulte y FP Perera. San Diego, Calif.: Academic Press.

Higginson, J, C M uir, and N M onoz. 1992. Human cancer: Epidemiology and environmental causes. En Cambridge Monographs on Cancer Research. Cambridge: Cambridge U niv. Press.

Holtzman, EJ and DA Ausiello. 1994. Nephrogenic diabetes insipidus: Causes revealed. H osp Pract 29:89-93.

Hook I and W H ewitt. 1986. Toxic responses of the kidney. En T he B asic Science of Poisons. N ueva Y ork: M acmillan.

Linehan, W, W Shipley, and W Parkinson. 1993. Cancer of the kidney and ureter. En Cancer: Principles and Practice of Oncology, dirigido por $\mathrm{V}$ D eV ita, S H ellman y S R osenberg. Filadelfia: JB Lippincott.

Pitha, JV, GP Hemstreet, NR Asal, RL Petrone, BF Trump, and FG Silva. 1987. O ccupational hydrocarbon exposure and renal histopathology. T oxicol Ind $\mathrm{H}$ ealth 3:491-506.

Schulte, P, K Ringen, G Hemstreet, and E Ward. 1995. Exposure: O ccupational medicine. State Art Rev :85-107.

Trump, B, T Jones, and B Heatfield. 1984. The biology of the kidney. En Renal E ffects of Petroleum $\mathrm{H}$ ydrocarbons. Princeton: Scientific Publishers. 
Directora del capítulo

Grace Kawas L emasters

\section{Sumario}

Introducción

Lowell E. Sever .......................... 9.2

Introducción a la función reproductora masculina y

femenina

R. M attison . . . . . . . . . . . . . . . . . . . . . . 9.4

El sistema reproductor masculino y la toxicología

Steven Schrader y G race Kawas $L$ emasters . . . . . . . . . . . . . . 9.4

La estructura del sistema reproductor femenino y la

vulnerabilidad de los órganos diana

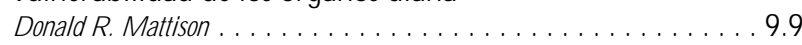

Exposiciones profesionales maternas y resultados

adversos en el embarazo

Grace Kawas $L$ emasters . . . . . . . . . . . . . . . . . . . . . . . . . . . 9.1

El parto pretérmino o prematuro y el trabajo

Nicole M amelle.

Exposiciones del recién nacido a sustancias tóxicas de origen industrial y ambiental

M ary S. Wolff y Patrisha M. W oolard. ............... 9.19

La protección de la maternidad en la legislación

$M$ arie Claire Séguret.

Recomendaciones de Estados U nidos en relación con el embarazo y el trabajo

L eon J. W arshaw . . 


\section{INTRODUCCION}

Lowell E. Sever

La infertilidad de causa tóxica en hombres y mujeres es un tema de creciente interés en el marco de los peligros profesionales. $L a$ toxicidad reproductiva ha sido definida como la aparición de efectos adversos en el sistema reproductor, secundarios a la exposición a agentes ambientales. Se expresa en forma de distintas alteraciones de los órganos reproductivos y/ o del sistema endocrino relacionado. Sus manifestaciones pueden ser:

- alteraciones del comportamiento sexual;

- reducción de la fertilidad;

- resultados adversos del embarazo;

- modificaciones de otras funciones que dependen de la integridad del sistema reproductor.

Los mecanismos subyacentes en la toxicidad reproductiva son complejos. Se han ensayado y demostrado más sustancias tóxicas para el proceso reproductor masculino que para el femenino. Sin embargo, se desconoce si ello se debe a diferencias implícitas en la toxicidad 0 a la mayor facilidad para estudiar el esperma que los ovocitos.

\section{Toxicidad sobre el desarrollo}

La toxicidad para el desarrollo ha sido definida como la aparición de efectos adversos en el organismo en desarrollo, secundarios a una exposición previa a la concepción (de cualquiera de los padres) o producida durante el desarrollo prenatal o durante el período posnatal hasta el momento de la madurez sexual. Se pueden detectar efectos de este tipo en cualquier momento de la vida del organismo. Sus manifestaciones principales son:

- la muerte del organismo en desarrollo;

- anomalías estructurales;

- alteraciones del crecimiento;

- deficiencias funcionales.

En lo que sigue, toxicidad sobre el desarrollo se utiliza con carácter general para designar las exposiciones de la madre, del padre 0 del producto de la concepción que conducen a un desarrollo anormal. Se emplea teratogénesis para referirse más específicamente a la exposición del producto de la concepción que genera una malformación estructural. En este artículo no se examinan los efectos de las exposiciones posnatales sobre el desarrollo.

\section{Mutagénesis}

Además de la toxicidad para la reproducción, la exposición de cualquiera de los padres antes de la concepción puede producir defectos del desarrollo mediante mutagénesis, es decir, mediante algún cambio en el material genético que pasa al descendiente. Estos cambios pueden afectar a genes aislados o producirse a nivel cromosómico. Los primeros pueden producir la transmisión de mensajes genéticos alterados, en tanto que los cambios a nivel cromosómico pueden dar lugar a la transmisión de anomalías en el número o estructura de los cromosomas.

Es interesante señalar que algunas de las pruebas más sólidas sobre el papel de las exposiciones previas a la concepción en las anomalías del desarrollo proceden de estudios de exposiciones profesionales paternas. Por ejemplo, el síndrome de Prader-Willi, una deficiencia congénita caracterizada por hipotonicidad durante el período neonatal y, más adelante, por obesidad pronunciada y trastornos del comportamiento, se ha asociado a las exposiciones paternas a los hidrocarburos. 0 tros estudios han demostrado asociaciones entre distintas exposiciones paternas a agentes físicos previas a la concepción y ciertas malformaciones congénitas y neoplasias malignas de la infancia. Por ejemplo, la exposición profesional paterna a la radiación ionizante se ha asociado a un aumento del riesgo de defectos del tubo neural y de leucemia infantil, y varios estudios han puesto de manifiesto la existencia de asociaciones entre la exposición profesional paterna antes de la concepción a campos electromagnéticos y los tumores cerebrales infantiles (G old y Sever 1994). Al evaluar los peligros de las exposiciones laborales para la reproducción y el desarrollo, se debe prestar mayor atención a los posibles efectos entre los varones.

Es muy probable que algunos defectos de etiología desconocida impliquen un componente genético relacionado con las exposiciones paternas. Dadas las asociaciones demostradas entre la edad del padre y la tasa de mutación, parece lógico que haya otros factores y exposiciones paternas asociados a mutaciones genéticas. La asociación perfectamente establecida entre la edad materna y la ausencia de disyunción cromosómica, que produce anomalías en el número de cromosomas, sugiere que las exposiciones maternas desempeñan un papel significativo en las anomalías cromosómicas.

A medida que aumente nuestro conocimiento del genoma humano es posible que consigamos descubrir más defectos del desarrollo secundarios a cambios mutagénicos en el ADN de genes aislados 0 a cambios estructurales en porciones de cromosomas.

\section{Teratogénesis}

L os efectos adversos derivados de la exposición del producto de la concepción a agentes químicos exógenos están reconocidos desde el descubrimiento de la teratogenicidad de la talidomida, en 1961. Wilson (1973) ha desarrollado seis "principios generales de la teratología" que presentan interés en este campo:

1. Las manifestaciones finales del desarrollo anormal son la muerte, la malformación, el retraso del crecimiento o los trastornos funcionales.

2. La sensibilidad del producto de la concepción a los agentes teratogénicos varía con la fase del desarrollo en el momento de la exposición.

3. Los agentes teratogénicos actúan de modo (mecanismo) específico sobre las células y los tejidos en desarrollo al iniciarse la embriogénesis anormal (patogénesis).

4. Las manifestaciones del desarrollo anormal aumentan gradualmente desde la ausencia de efecto hasta el nivel totalmente letal a medida que aumenta la dosis.

5. El acceso de los factores ambientales adversos a los tejidos en desarrollo depende de la naturaleza del agente.

6. La sensibilidad a un teratógeno depende del genotipo del producto de la concepción y de la manera en que el genotipo interactúa con los factores ambientales.

En lo que sigue se examinan con más atención el primero de estos principios y asimismo la combinación de los principios 1, 2 y 4 (efectos, tiempo de exposición y dosis).

\section{Espectro de resultados adversos asociados a la exposición}

Existe un espectro de resultados adversos potencialmente asociados a la exposición. Los estudios profesionales que se centran en un único resultado corren el riesgo de pasar por alto otros efectos reproductivos importantes.

La Figura 9.1 recoge algunos ejemplos de resultados del desarrollo potencialmente asociados con la exposición a teratógenos profesionales. Algunos estudios sugieren que las malformaciones congénitas y los abortos espontáneos se asocian a unas mismas exposiciones, por ejemplo, a gases anestésicos y a disolventes orgánicos. 
Figura 9.1 - Anomalías del desarrollo y resultados de la reproducción potencialmente asociados con exposiciones profesionales.

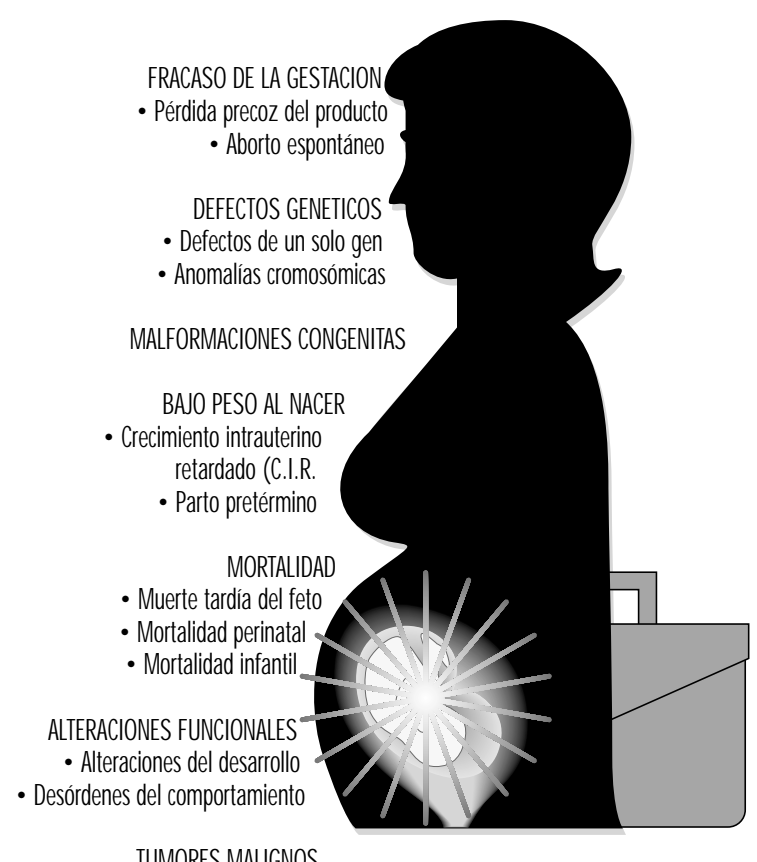

TUMORES MALIGNOS

El aborto espontáneo es un resultado importante que debe tenerse en cuenta, dada la posibilidad de que se produzca por diferentes mecanismos a través de diversos procesos patógenos. Puede deberse a toxicidad para el embrión o el feto, alteraciones cromosómicas, efectos sobre genes aislados o anomalías morfológicas. Es importante tratar de diferenciar entre el producto de la concepción normal y el anormal desde el punto de vista cariotípico en los estudios de abortos espontáneos.

\section{Momento de la exposición}

El segundo principio de Wilson relaciona la sensibilidad al desarrollo anormal con el momento de la exposición, es decir, con la edad gestacional del producto de la concepción. Este principio ha sido perfectamente establecido para la inducción de malformaciones estructurales, y se conocen los períodos sensibles a la organogénesis de muchas estructuras. Considerando un conjunto amplio de resultados, el período sensible durante el cual puede inducirse un efecto dado debe abarcar toda la gestación.

Al evaluar la toxicidad profesional para el desarrollo, se debe determinar y clasificar la exposición para cada período crítico, es decir, la edad o edades de gestación para cada resultado. Por ejemplo, es probable que los abortos espontáneos y las malformaciones congénitas estén relacionados con exposiciones durante el primer y segundo trimestre, mientras que el bajo peso al nacimiento y las alteraciones funcionales, como los trastornos convulsivos y el retraso mental, lo estén con exposiciones durante el segundo y tercer trimestre.

\section{Mecanismos teratogénicos}

El tercer principio exige considerar los mecanismos que pueden iniciar la embriogénesis anormal. Se han señalado varios que pueden conducir a la teratogénesis (Wilson 1977), como:
- Mutaciones en secuencias del ADN .

- Anomalías cromosómicas inductoras de cambios estructurales o cuantitativos en el ADN.

- Alteración o inhibición del metabolismo intracelular, por ejemplo, bloqueos metabólicos y ausencia de coenzimas, precursores o sustratos para la biosíntesis.

- Interrupción de la síntesis del ADN OARN.

- Interferencia en la mitosis.

- Interferencia con la diferenciación celular.

- Fallo en interacciones intercelulares.

- Fallo en migraciones celulares.

- M uerte celular mediante efectos citotóxicos directos.

- Efectos sobre la permeabilidad de la membrana celular y cambios osmolares.

- Rotura física de células o tejidos.

Al considerar los mecanismos, los investigadores pueden agrupar los resultados significativos desde el punto de vista biológico, así como aportar ideas sobre los teratógenos potenciales; por ejemplo, las relaciones entre la carcinogénesis, mutagénesis y teratogénesis han sido motivo de discusión durante algún tiempo. Desde la perspectiva de la evaluación de los peligros reproductivos profesionales, tales relaciones tienen una importancia particular por dos razones distintas: (1) las sustancias que son cancerígenas o mutagénicas tienen más posibilidades de ser teratogénicas, por lo que conviene prestar atención especial a sus efectos reproductivos y (2) los efectos sobre el ácido desoxirribonucleico (ADN) que producen mutaciones somáticas se considera que son mecanismos tanto de carcinogénesis como de teratogénesis.

\section{Dosis y efectos}

EI cuarto principio sobre la teratogénesis concierne a la relación entre el efecto y la dosis. Está perfectamente establecido en muchos estudios con animales, y Selevan (1985) ha señalado su relevancia para el ser humano, indicando la importancia de distintos resultados reproductivos dentro de rangos terapéuticos específicos y sugiriendo que la relación dosis respuesta se podría reflejar en un aumento de la tasa de un efecto determinado con una dosis mayor y/ o un cambio en el espectro de los resultados observados.

En relación con la teratogénesis y la dosis, existe una gran preocupación por las alteraciones funcionales producidas por los posibles efectos en el comportamiento de la exposición prenatal a los agentes ambientales. La teratología en relación con el comportamiento está en rápida expansión en el caso de los animales, mientras que en humanos está en etapas relativamente iniciales de desarrollo. En la actualidad, existen limitaciones críticas en la definición y comprobación de los resultados para la realización de estudios epidemiológicos. Además, es posible que las exposiciones de bajo nivel a tóxicos sobre el desarrollo influyan en algunos efectos funcionales.

\section{Variabilidad de efectos y momento y dosis de la exposición}

L os conceptos de variabilidad de efectos y momento y dosis de la exposición son especialmente importantes para la identificación de peligros para el desarrollo presentes en el lugar de trabajo.

Basándonos en lo que sabemos sobre la biología del desarrollo, está claro que existen relaciones entre los resultados reproductivos, como el aborto espontáneo y el retraso del crecimiento intrauterino y las malformaciones congénitas. Además, se ha demostrado que se produce una pluralidad de efectos con muchos tóxicos (Tabla 9.1). 
Tabla 9.1 - Ejemplos de exposiciones asociadas a múltiples problemas reproductivos.

\begin{tabular}{lcccc} 
Exposición & \multicolumn{5}{c}{ Resultado } \\
& $\begin{array}{l}\text { Aborto } \\
\text { espontáneo }\end{array}$ & $\begin{array}{l}\text { Malformación } \\
\text { congénita }\end{array}$ & $\begin{array}{l}\text { Bajo peso } \\
\text { al nacer }\end{array}$ & $\begin{array}{c}\text { Discapaci- } \\
\text { dades de } \\
\text { desarrollo }\end{array}$ \\
Alcohol & $X$ & $X$ & $X$ & $X$ \\
$\begin{array}{c}\text { Gases } \\
\text { anestésicos }\end{array}$ & $X$ & $X$ & & \\
Plomo & $X$ & & $X$ & $X$ \\
Disolventes & $X$ & $X$ & & $X$ \\
orgánicos & & $X$ & $X$ & \\
Tabaco & $X$ & $X$ &
\end{tabular}

En este sentido, tienen relevancia los tiempos de exposición y las relaciones dosis respuesta. Se sabe desde hace tiempo que el período embrionario, durante el cual se produce la organogénesis (2-8 semanas después de la concepción), es el más sensible a la inducción de malformaciones estructurales. El período fetal, entre las ocho semanas y el término, es el de la histogénesis, con un aumento rápido del número de células y de la diferenciación celular. Es entonces cuando la probabilidad de inducción de anomalías funcionales y retraso del crecimiento es más elevado. Durante este período puede haber relaciones entre la dosis y la respuesta: una dosis elevada puede ocasionar retraso del crecimiento y una dosis más baja acaso induzca alteraciones funcionales o conductuales.

\section{Toxicidad sobre el desarrollo transmitida por el varón}

Aunque la toxicidad sobre el desarrollo se considera producida habitualmente por la exposición de la mujer o del producto de la concepción, es decir, como resultado de los efectos teratogénicos, cada vez son mayores las pruebas procedentes de estudios tanto animales como humanos, de los efectos sobre el desarrollo transmitidos por el varón. L os mecanismos propuestos al efecto son la transmisión de sustancias químicas del padre al producto de la concepción a través del líquido seminal, la contaminación indirecta de la madre o del producto de la concepción por sustancias transportadas desde el lugar de trabajo al ambiente doméstico por medio de la contaminación personal, y - como se ha observado anteriormente - las exposiciones paternas previas a la concepción inductoras de cambios genéticos transmisibles (mutaciones).

\section{- INTRODUCCION A LA FUNCION REPRODUCTORA MASCULINAY FEMENINA}

Donald R. M attison

La toxicidad reproductiva presenta muchas diferencias específicas con la toxicidad relacionada con otros sistemas. Dado que la reproducción requiere la interacción entre dos personas, mientras que otras formas de toxicidad ambiental afectan típicamente al desarrollo de enfermedad en una persona expuesta, la expresión toxicidad reproductiva alude siempre a una unidad reproductiva o pareja. Este aspecto es característico, por mucho que sea obvio.
Por ejemplo, es posible que la exposición a una sustancia tóxica por parte de un miembro de una pareja reproductiva (p. ej., el varón) se manifieste como un resultado reproductivo adverso en el otro miembro de la pareja (p. ej., aumento de la frecuencia de abortos espontáneos). Cualquier intento de análisis de las causas ambientales de la toxicidad reproductiva debe tener en cuenta el dato específico de la pareja.

Existen otros aspectos característicos de la toxicología reproductiva. A diferencia de las funciones renal, cardíaca 0 pulmonar, la función reproductiva se desarrolla de forma intermitente. En consecuencia, las exposiciones profesionales pueden interferir con la reproducción aunque pasen desapercibidas durante los períodos en los que no se desee la fertilidad. Esta característica intermitente puede dificultar la identificación de una sustancia tóxica reproductiva para los seres humanos. 0 tra característica exclusiva de la reproducción, derivada directamente de esa consideración previa, es que la evaluación completa de la integridad funcional del sistema reproductor requiere que la pareja trate de conseguir un embarazo.

\section{EL SISTEMA REPRODUCTOR MASCULINO YLA TOXICOLOGIA}

\section{Steven Schrader y G race Kawas Lemasters}

La espermatogénesis y la espermiogénesis son los procesos celulares que producen células sexuales masculinas maduras. Se desarrollan dentro de los túbulos seminíferos de los testículos del varón sexualmente maduro, como se muestra en la Figura 9.2

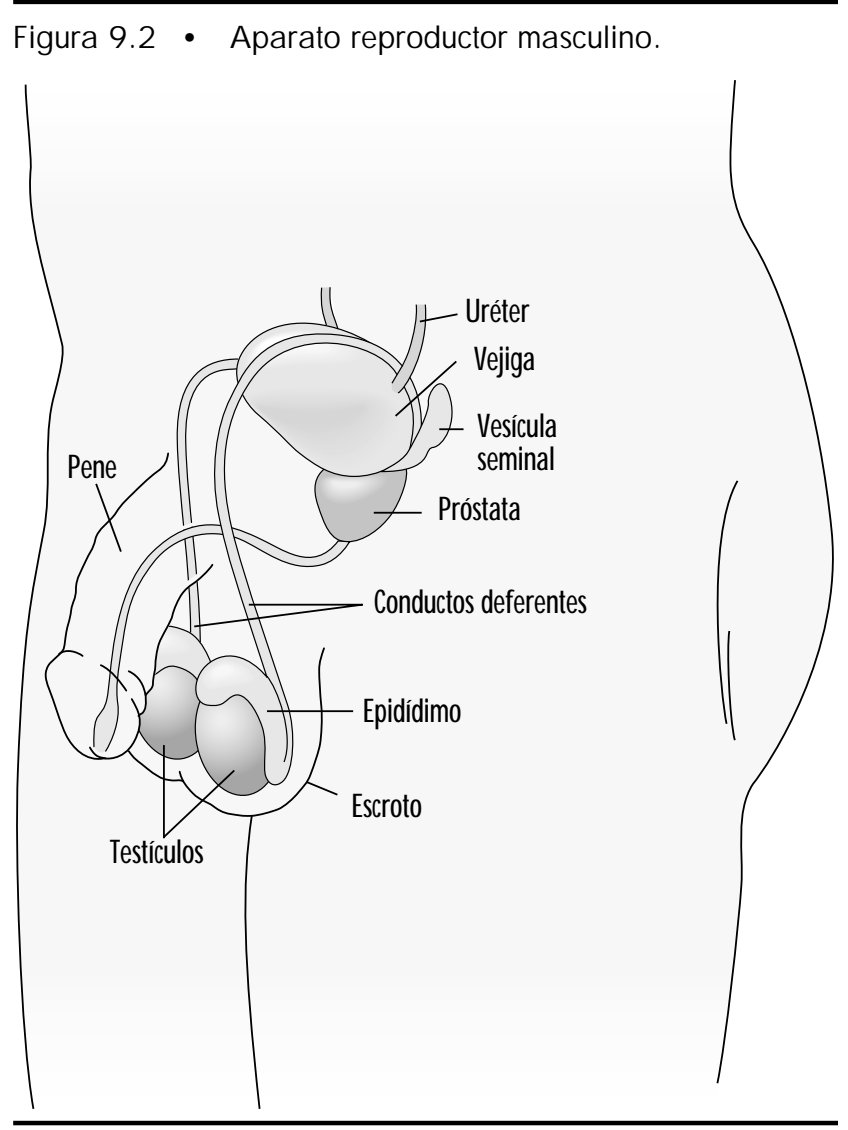


Los túbulos seminíferos humanos tienen una longitud de 30 a $70 \mathrm{~cm}$ y un diámetro de 150 a $300 \mu \mathrm{m}$ (Zaneveld 1978). Las espermatogonias (células madre) se disponen a lo largo de la membrana basal de los túbulos seminíferos y son las células fundamentales para la producción de espermatozoides.

Los espermatozoides maduran a través de una serie de divisiones celulares en las que las espermatogonias proliferan y se convierten en espermatocitos primarios. Estos migran a través de las estrechas uniones formadas por las células de Sertoli hacia el lado luminal de esta barrera testicular. En el momento en el que los espermatocitos alcanzan la membrana de la barrera testicular, la síntesis de ADN, el material genético del núcleo celular, está totalmente finalizada. Cuando los espermatocitos primarios se encuentran de hecho en la luz del túbulo seminífero, sufren una forma de división celular especial que se da sólo en las células germinales y que se conoce como meiosis. La división meiótica da lugar a la separación de los pares de cromosomas del núcleo, con lo cual cada célula germinal resultante contiene sólo una sola copia de cada cromosoma, en vez de un par de cromosomas iguales.

Durante la meiosis, los cromosomas cambian de forma por condensación y adoptan un aspecto filamentoso. En un momento determinado, la membrana nuclear que los rodea se rompe y unos haces microtubulares se fijan a los pares de cromosomas haciendo que se separen. Así se completa la primera división de la meiosis y se forman dos espermatocitos secundarios haploides. Estos sufren a continuación la segunda división de la meiosis, para formar espermátidas que contienen números iguales de cromosomas $X$ e $Y$.

La transformación morfológica de las espermátidas en espermatozoides se denomina espermiogénesis. C uando la espermiogénesis se ha completado, cada espermatozoide se libera de la célula de Sertoli hacia la luz del túbulo seminífero por un proceso que se denomina espermiación. Los espermatozoides migran a lo largo del túbulo hasta la rete testis y la cabeza del epidídimo. Los que abandonan los túbulos seminíferos son inmaduros: no pueden fertilizar un óvulo y no se pueden desplazar. Los que se liberan a la luz del túbulo seminífero se encuentran suspendidos en un líquido producido primariamente por las células de Sertoli. Los espermatozoides concentrados suspendidos en este líquido fluyen de forma continua desde los túbulos seminíferos mediante cambios sutiles del medio iónico en la rete testis, a través de los conductos deferentes, hasta alcanzar el epidídimo. Este último es un tubo muy espiralizado (cinco a seis metros de longitud) en el que los espermatozoides permanecen 12-21 días.

En el epidídimo, los espermatozoides adquieren progresivamente movilidad y capacidad de fecundación. Es posible que esto se deba al cambio de naturaleza de la suspensión líquida del epidídimo. A medida que maduran las células, éste absorbe los componentes del líquido, incluidas las secreciones de las células de Sertoli (p. ej., la proteína fijadora de andrógenos), aumentando de esta forma la concentración de los espermatozoides. EI epidídimo aporta también sus propias secreciones al líquido en suspensión, entre las que se incluyen sustancias químicas como la glicerilfosforilcolina (GPC) y la carnitina.

La morfología del espermatozoide sigue transformándose en el epidídimo. Desaparece la gota citoplasmática y el núcleo se condensa aún más. Aunque el epidídimo es el principal almacén de espermatozoides hasta la eyaculación, aproximadamente el $30 \%$ de los espermatozoides de una eyaculación han estado almacenados en el conducto deferente. L a eyaculación frecuente acelera el paso de espermatozoides a través del epidídimo y puede aumentar el número de espermatozoides inmaduros (infértiles) presentes en la eyaculación (Zaneveld 1978).

\section{Eyaculación}

U na vez en el conducto deferente, los espermatozoides son transportados por las contracciones musculares de la eyaculación, y no tanto por el flujo de líquido. D urante la eyaculación, las glándulas sexuales accesorias expulsan con fuerza los líquidos, formando el líquido seminal, si bien no expulsan sus secreciones simultáneamente. La glándula bulbouretral (de Cowper) expulsa en primer lugar un líquido transparente, después las secreciones prostáticas, los líquidos con una concentración elevada de espermatozoides del epidídimo y de la ampolla del conducto deferente y, por último, la fracción más importante, procedente fundamentalmente de las vesículas seminales. Por ello, el líquido seminal no es un líquido homogéneo.

\section{Acciones tóxicas sobre la espermatogénesis y la espermiogénesis}

Las sustancias tóxicas pueden alterar la espermatogénesis en varios puntos. Las más lesivas, debido a su irreversibilidad, son las que matan 0 alteran genéticamente (fuera del alcance de los mecanismos de reparación) las espermatogonias o las células de Sertoli. Estudios realizados en animales han permitido determinar la fase en la que una sustancia tóxica ataca el proceso de espermatogénesis. Estos estudios emplean exposiciones breves a una sustancia tóxica antes de muestrear para determinar el efecto. Conociendo la duración de cada fase de la espermatogénesis, se puede realizar una extrapolación para estimar la fase afectada.

El análisis bioquímico del líquido seminal aporta datos sobre la función de las glándulas sexuales accesorias. Las sustancias químicas que segregan fundamentalmente cada una de esas glándulas se seleccionan específicamente para actuar como marcadores de las mismas. Por ejemplo, el epidídimo está representado por la GPC, las vesículas seminales por la fructosa y la próstata por el zinc. $\mathrm{H}$ ay que señalar que este tipo de análisis ofrece sólo una información general sobre la función glandular, y poca 0 ninguna sobre los demás componentes secretores. La determinación del pH y la osmolalidad del semen proporciona información general adicional sobre la naturaleza del líquido seminal.

El líquido seminal se puede analizar para determinar la presencia de una sustancia tóxica o de sus metabolitos. Se han detectado en él metales pesados mediante espectrofotometría de absorción atómica, mientras que los hidrocarburos halogenados se han cuantificado mediante cromatrografía en gas tras extracción o filtración de limitación proteica (Stachel y cols. 1989; Zikarge 1986).

La viabilidad y movilidad de los espermatozoides en el líquido seminal representa típicamente la calidad del mismo. Las alteraciones de la viabilidad de los espermatozoides, determinadas mediante exclusión por tinción o por edema hipoosmótico, o las alteraciones de los parámetros de la movilidad del esperma sugieren efectos tóxicos postesticulares.

Los análisis de semen pueden indicar también si la producción de espermatozoides ha resultado afectada por una sustancia tóxica. El recuento y la morfología de los espermatozoides ofrecen índices de la integridad de la espermatogénesis y de la espermiogénesis. Así, el número de espermatozoides presentes en la eyaculación es directamente proporcional al de células germinales por gramo de testículo (Zuckerman y cols. 1978), mientras que la morfología anormal probablemente es consecuencia de una espermiogénesis anormal. La presencia de espermatozoides muertos o inmóviles refleja con frecuencia los efectos de episodios postesticulares. Por tanto, el tipo o el momento de un efecto tóxico pueden indicar el destino de la sustancia tóxica. Así, la exposición de ratas macho a 2-metoxietanol determina 
fertilidad reducida en el curso de cuatro semanas (Chapin y cols. 1985). Esta prueba, corroborada por observaciones histológicas, indica que el destino de la sustancia tóxica son los espermatocitos (Chapin y cols. 1984). Aunque no es ético exponer deliberadamente a seres humanos a sustancias que podrían ser tóxicas para la reproducción, los análisis de semen de series de eyaculaciones de varones expuestos inadvertidamente durante tiempos breves a sustancias potencialmente tóxicas pueden aportar información valiosa similar.

La exposición profesional al 1,2-dibromocloropropano (DBCP) redujo la concentración de espermatozoides en los eyaculados desde un valor medio de 79 millones células/ ml en hombres no expuestos a 46 millones células/ $\mathrm{ml}$ en trabajadores expuestos (Whorton y cols. 1979). Con el traslado de éstos, los que presentaban un recuento reducido experimentaron una recuperación parcial, mientras que los azoospérmicos permanecieron estériles. La biopsia testicular reveló que el objetivo del DBCP eran las espermatogonias. Esto explica la gravedad del efecto resultante cuando el objetivo de las sustancias tóxicas son las células madre. No hubo indicios de que la exposición al $D B C P$ de los varones se asociara a resultados adversos del embarazo (Potashnik y Abeliovich 1985). O tro ejemplo de efecto tóxico sobre la espermatogénesis/ espermiogénesis fue el estudio de los trabajadores expuestos al dibromuro de etileno (EDB). Presentaban más espermatozoides con cabeza fusiforme y un menor número de espermatozoides por eyaculado que los controles (R atcliffe y cols. 1987).

La lesión genética es difícil de detectar en los espermatozoides humanos. Varios estudios realizados en animales utilizando el ensayo letal dominante (Ehling y cols. 1978) indican que la exposición paterna puede dar resultados adversos en el embarazo. Estudios epidemiológicos con grandes poblaciones han demostrado un aumento de la frecuencia de abortos espontáneos entre mujeres cuya pareja trabajaba como mecánico de vehículos de motor (M CD onald y cols. 1989). I ndican así la necesidad de desarrollar métodos de detección de las lesiones genéticas en los espermatozoides humanos. Estos métodos se están desarrollando en varios laboratorios y entre ellos figuran las sondas de ADN para detectar mutaciones genéticas (H echt 1987), el cariotipo de los cromosomas del espermatozoide (M artin 1983) y evaluación de la estabilidad del ADN por citometría de flujo (Evenson 1986).

La Figura 9.3 presenta las exposiciones cuyo efecto sobre la calidad de los espermatozoides es conocido, y la Tabla 9.2 ofrece un resumen de los resultados de los estudios epidemiológicos realizados acerca de los efectos paternos sobre los resultados reproductivos.

\section{El sistema neuroendocrino}

El funcionamiento general del sistema reproductor está controlado por el sistema nervioso y por las hormonas producidas por las glándulas (sistema endocrino). El eje neuroendocrino reproductivo del varón está formado fundamentalmente por el sistema nervioso central (SNC), la hipófisis anterior y los testículos. EI hipotálamo integra las señales procedentes del SNC y de la periferia, y regula directamente la secreción de gonadotropinas a cargo de la hipófisis anterior. A su vez, las gonadotropinas actúan principalmente sobre las células de Leydig del intersticio y las células de Sertoli y las germinales que se encuentran en los túbulos seminíferos para regular la espermatogénesis y la producción hormonal de los testículos.

\section{El eje hipotálamo-hipofisario}

El hipotálamo segrega una neurohormona, la hormona liberadora de gonadotropina $(\mathrm{GnRH})$ al sistema vascular porta
Figura 9.3 - Exposiciones sobradamente asociadas con efectos adversos para la calidad del semen.

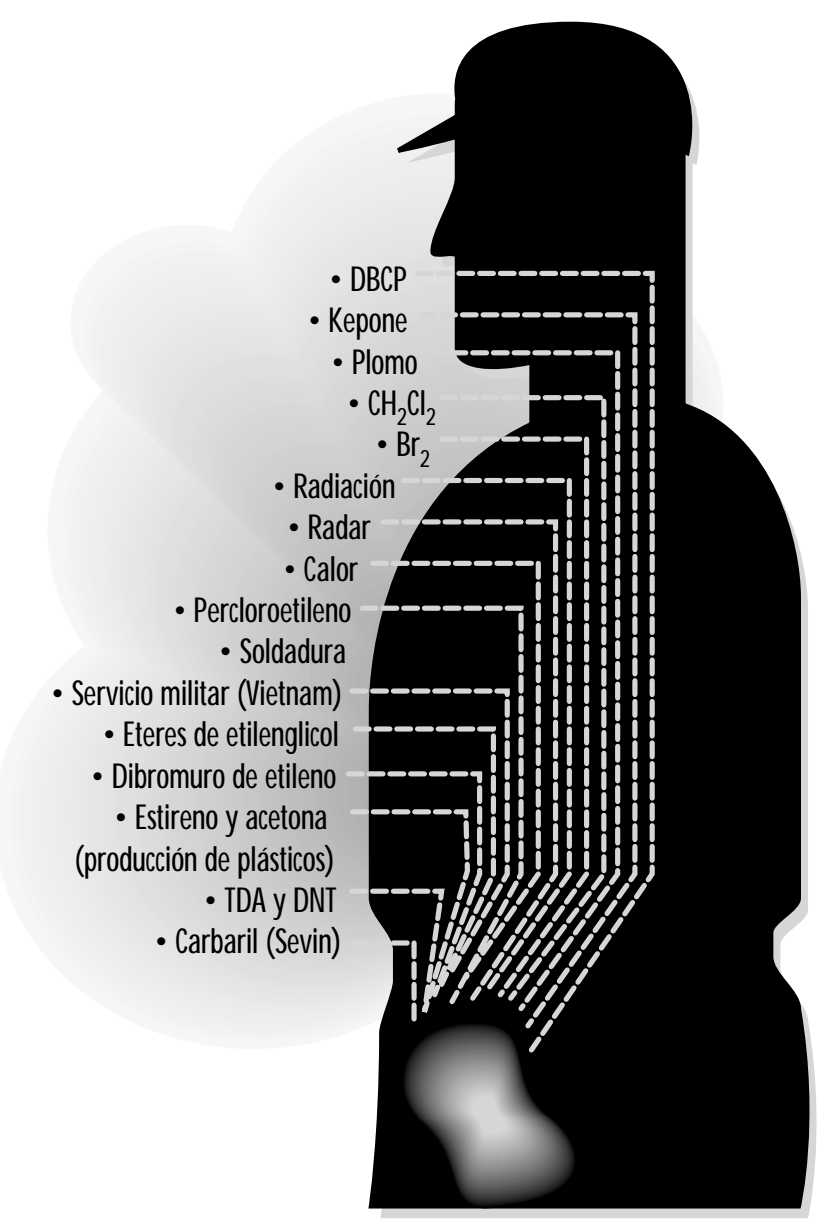

hipofisario para que la transporte a la hipófisis anterior. La secreción pulsátil de este decapéptido provoca la liberación simultánea de hormona luteinizante $(\mathrm{LH})$ y con menor sincronía y la quinta parte de potencia, la de la hormona estimuladora de los folículos (FSH ) (Bardin 1986). Existen pruebas sólidas que apoyan la existencia de otra hormona liberadora de FSH, aunque todavía no ha sido aislada (Savy-M oore y Schwartz 1980; Culler y N egroVilar 1986). Estas hormonas son segregadas por la hipófisis anterior. La LH actúa directamente sobre las células de Leydig estimulando la síntesis y liberación de testosterona, mientras que la FSH estimula la aromatización de la testosterona a estradiol en las células de Sertoli. La estimulación gonadotrópica provoca la liberación de estas hormonas a la vena espermática.

A su vez, la secreción de gonadotropinas está controlada por la testosterona y el estradiol mediante mecanismos de retroalimentación negativa. La testosterona actúa principalmente sobre el hipotálamo para regular la secreción de $\mathrm{GnRH}$, reduciendo de este modo la frecuencia de los pulsos de liberación de LH. Por otro lado, el estradiol actúa sobre la hipófisis para reducir la magnitud de la liberación de gonadotropinas. A través de estos circuitos de retroalimentación endocrina, la función testicular en general y la secreción de testosterona en concreto se mantienen en un nivel relativamente estable. 
Tabla 9.2 - Estudios epidemiológicos de efectos paternos sobre el embarazo.

$\begin{array}{ll}\text { Referencia } & \text { Tipo de exposición o profesión } \\ \text { Estudios de población basados en historias } & \\ \text { Lindbohm y cols. } 1984 & \text { Disolventes } \\ \text { Lindbohm y cols. } 1984 & \text { Estación de servicio } \\ \text { Daniell y Vaughan } 1988 & \text { Disolventes orgánicos } \\ \text { McDonald y cols. } 1989 & \text { Mecánica } \\ \text { McDonald y cols. 1989 } & \text { Procesamiento de alimentos } \\ \text { Lindbohm y cols. 1991a } & \text { Oxido de etileno } \\ \text { Lindbohm y cols. } 1991 \text { a } & \text { Refinería de petróleo } \\ \text { Lindbohm y cols. } 1991 \text { a } & \text { Barnices para madera } \\ \text { Lindbohm y cols. } 1991 \text { a } & \text { Sustancias químicas relacionadas con la goma } \\ \text { Olsen y cols. } 1991 & \text { Metales } \\ \text { Olsen y cols. } 1991 & \text { Maquinistas } \\ \text { Olsen y cols. } 1991 & \text { Herreros } \\ \text { Kristensen y cols. } 1993 & \text { Disolventes } \\ \text { Kristensen y cols. } 1993 & \text { Plomo y disolventes } \\ \text { Kristensen y cols. } 1993 & \text { Plomo } \\ \text { Kristensen y cols. } 1993 & \text { Plomo }\end{array}$

\section{Estudios de casos controles}

Kucera 1968

Kucera 1968

Olsen 1983

Olsen 1983

Sever y cols. 1988

Taskinen y cols. 1989

Taskinen y cols. 1989

Taskinen y cols. 1989

Gardner y cols. 1990

Bonde 1992

Wilkins y Sinks 1990

Wilkins y Sinks 1990

Wilkins y Sinks 1990

Wilkins y Sinks 1990

Lindbohmn y cols. $1991 b$

Sallmen y cols. 1992

Veulemans y cols. 1993

Chia y cols. 1992

Industria de la impresión
Pintura
Pintura
Disolventes
Radiación de bajo nivel
Disolventes orgánicos
Hidrocarburos aromáticos
Polvo
Radiación
Soldadura
Agricultura
Construcción
Procesamiento de alimentos/ tabaco
Metal
Plomo
Plomo
Éter de etilenglicol
Metales

\section{Asociación con la Efecto exposición ${ }^{1}$}

$\begin{array}{ll}- & \text { Aborto espontáneo } \\ + & \text { Aborto espontáneo } \\ - & \text { Aborto espontáneo } \\ + & \text { Aborto espontáneo } \\ + & \text { Defectos de desarrollo } \\ + & \text { Aborto espontáneo } \\ + & \text { Aborto espontáneo } \\ + & \text { Aborto espontáneo } \\ + & \text { Aborto espontáneo } \\ + & \text { Riesgo de cáncer infantil } \\ + & \text { Riesgo de cáncer infantil } \\ + & \text { Riesgo de cáncer infantil } \\ + & \text { Parto pretérmino } \\ + & \text { Parto pretérmino } \\ + & \text { Muerte perinatal } \\ + & \text { Morbilidad del niño varón }\end{array}$

1 - sin asociación significativa; (+) asociación significativa límite; + asociación significativa. Fuente: Adaptado de Taskinen 1993.

\section{El eje hipofisario-testicular}

En general, la FSH y la LH se consideran necesarias para la espermatogénesis. Presumiblemente, el efecto de la LH es secundario a la inducción de concentraciones intratesticulares de testosterona elevadas. Por tanto, la FSH de la hipófisis y la testosterona de las células de Leydig actúan sobre las células de Sertoli dentro del epitelio del túbulo seminífero para iniciar la espermatogénesis. La producción de espermatozoides persiste, aunque está reducida desde el punto de vista cuantitativo, después de eliminar la LH (y presumiblemente las elevadas 
concentraciones intratesticulares de testosterona) o la FSH. La FSH es necesaria para iniciar la espermatogénesis en la pubertad y, en menor grado, para reiniciar una espermatogénesis que se haya detenido (M atsumoto 1989; Sharpe 1989).

EI sinergismo hormonal que sirve para mantener la espermatogénesis puede implicar el reclutamiento, a través de la FSH, de las espermatogonias diferenciadas para iniciar la meiosis, mientras que la testosterona puede controlar fases posteriores específicas de la espermatogénesis. La FSH y la testosterona pueden actuar también sobre la célula de Sertoli estimulando la producción de uno o más factores paracrinos que pueden afectar al número de células de Leydig y a la producción de testosterona de estas células (Sharpe 1989). La FSH y la testosterona estimulan la síntesis de proteínas por las células de Sertoli, como la síntesis de la proteína fijadora de andrógenos (PFA), mientras que la FSH estimula por sí misma la síntesis de aromatasa y de inhibina. La PFA se segrega fundamentalmente en el líquido del túbulo seminífero y se transporta a la región proximal de la cabeza del epidídimo, actuando posiblemente como transportador local de andrógenos (Bardin 1986). La aromatasa cataliza la transformación de la testosterona en estradiol en las células de Sertoli y en otros tejidos periféricos.

La inhibina es una glucoproteína que consta de dos subunidades diferentes, denominadas a y $b$, unidas entre sí por puentes disulfuro. Aunque la inhibina inhibe preferentemente la liberación de FSH, también puede reducir la liberación de LH en presencia de estimulación con GnRH (K otsugi y cols. 1988). La FSH y la LH estimulan la liberación de inhibina aproximadamente con la misma potencia (M CL achlan y cols. 1988). Es interesante señalar que la inhibina se segrega a la sangre de la vena espermática en forma de pulsos que son sincrónicos con los de testosterona (Winters 1990). Probablemente esto no refleje acciones directas de la $\mathrm{LH}$ o de la testosterona sobre la actividad de las células de Sertoli, sino los efectos de otros productos de las células de Leydig segregados a los espacios intersticiales 0 a la circulación.

La prolactina, que se segrega también en la hipófisis anterior, actúa de forma sinérgica con la LH y la testosterona estimulando la función reproductiva masculina. La prolactina se une a receptores específicos presentes en la célula de Leydig y aumenta la cantidad de complejos receptor-andrógeno en el núcleo de los tejidos sensibles a los andrógenos (Baker y cols. 1977). La hiperprolactinemia se asocia a reducciones del tamaño de los testículos y de la próstata, del volumen de semen y de las concentraciones de LH y testosterona circulantes (Segal y cols. 1979). La hiperprolactinemia también se ha asociado a impotencia, aparentemente independiente de la alteración de la secreción de testosterona (T horner y cols. 1977).

Para cuantificar la concentración de los metabolitos de las hormonas esteroideas en orina, se debe tener en cuenta la posibilidad de que la exposición que se esté estudiando altere el metabolismo de los metabolitos excretados. Esta cuestión tiene una importancia especial, ya que la mayoría de los metabolitos se producen en el hígado, uno de los órganos diana de muchas sustancias tóxicas. Por ejemplo, el plomo reduce la cantidad de esteroides sulfatados excretados en la orina (A postoli y cols. 1989). Los niveles sanguíneos de ambas gonadotropinas aumentan durante el sueño a medida que el varón inicia la pubertad, mientras que los niveles de testosterona mantienen este patrón diurno a lo largo de la vida adulta de los varones (Plant 1988). Por ello, las muestras de sangre, orina o saliva se deben recoger aproximadamente a la misma hora del día, para evitar variaciones debidas a los patrones diurnos de secreción.

Los efectos evidentes de una exposición tóxica dirigida al sistema neuroendocrino reproductivo se ponen de manifiesto con más probabilidad mediante la alteración de las manifestaciones biológicas de los andrógenos. Entre las manifestaciones reguladas significativamente por los andrógenos en el varón adulto que se pueden detectar en una exploración física básica figuran los siguientes: 1) retención de nitrógeno y desarrollo muscular, 2) mantenimiento de los genitales externos y órganos sexuales accesorios, 3) mantenimiento del aumento de tamaño de la laringe y del engrosamiento de las cuerdas vocales responsables de la voz varonil, 4) crecimiento de la barba, vello axilar y púbico y recesión temporal del cabello y calvicie, 5) libido y actividad sexual, 6) proteínas específicas de órganos en los tejidos (p. ej., hígado, riñones, glándulas salivares) y 7) conducta agresiva (Bardin 1986). La modificación de cualquiera de estos rasgos puede indicar que la producción de andrógenos está afectada.

\section{Ejemplos de efectos producidos por sustancias tóxicas}

El plomo es un ejemplo clásico de sustancia tóxica que afecta directamente al sistema neuroendocrino. Se observó que las concentraciones séricas de LH estaban elevadas en varones expuestos al plomo durante menos de un año. Este efecto no progresó en varones expuestos durante más de cinco años. Los niveles séricos de FSH no resultaron afectados. Por otra parte, los niveles séricos de PFA estaban elevados y los de testosterona total reducidos en los varones expuestos al plomo durante más de cinco años. Los niveles séricos de testosterona libre estaban significativamente reducidos tras la exposición al plomo durante tres a cinco años (Rodamilans y cols. 1988). Por el contrario, las concentraciones séricas de FSH, LH, testosterona total, prolactina y 17-cetoesteroides neutros totales no estaban alteradas en trabajadores con niveles de plomo circulante menores, aunque la frecuencia de distribución del recuento de espermatozoides estaba alterada (Assennato y cols. 1986).

La exposición de los pintores de astilleros al 2-etoxietanol también redujo el recuento de espermatozoides sin una modificación simultánea de las concentraciones séricas de FSH, L H ni testosterona (Welch y cols. 1988). Por ello, las sustancias tóxicas pueden afectar a la producción de hormonas y al recuento de espermatozoides independientemente.

Los varones que trabajaban en la fabricación del nematocida D BC $P$ experimentaron un ascenso de los niveles séricos de L H y FSH y una reducción del recuento de espermatozoides y de la fertilidad. Estos efectos parecen ser secuelas de las acciones sobre las células de Leydig del DBCP, que altera la producción 0 la acción de los andrógenos (M attison y cols. 1990).

Varios compuestos pueden ejercer toxicidad a través de una semejanza estructural con las hormonas esteroides reproductivas. Así, mediante su unión al receptor endocrino respectivo, las sustancias tóxicas pueden actuar como agonistas o antagonistas, alterando las respuestas biológicas. El clordecono (K epone), insecticida que se une a los receptores de estrógenos, redujo el recuento y la movilidad de los espermatozoides, detuvo la maduración espermática y redujo la libido. Aunque resulta tentador sugerir que estos efectos son consecuencia de la interferencia del clordecono con las acciones de los estrógenos a nivel neuroendocrino o testicular, no se demostró que los niveles séricos de testosterona, LH ni FSH estuvieran alterados en estos estudios de una forma semejante a la de los efectos derivados del tratamiento con estradiol. EI DDT y sus metabolitos también muestran propiedades esteroides y se podría esperar que alterara la función reproductiva masculina interfiriendo con las funciones de las hormonas esteroides. Sustancias xenobióticas como los bifenilos policlorados, polibromados y los plaguicidas organoclorados también pueden interferir con las funciones reproductivas masculinas ejerciendo una actividad agonista/ antagonista estrogénica (M attison y cols. 1990). 


\section{La función sexual}

El concepto de función sexual humana hace referencia a las actividades integradas de los testículos y de las glándulas sexuales secundarias, los sistemas endocrinos de control y los componentes conductuales y psicológicos de la reproducción localizadas en el sistema nervioso central (libido). La erección, la eyaculación y el orgasmo son tres procesos fisiológicos y psicodinámicos diferentes que normalmente aparecen de forma simultánea en los varones.

Se dispone de pocos datos fidedignos acerca de los efectos de la exposición profesional sobre la función sexual debido a los problemas descritos anteriormente. Se ha demostrado que distintos fármacos afectan a cada una de las tres fases de la función sexual del varón (Fabro 1985), lo que indica que las exposiciones profesionales pueden ejercer efectos semejantes. Los antidepresivos, los antagonistas de la testosterona y los estimuladores de la liberación de prolactina reducen eficazmente la libido en los varones. L os fármacos antihipertensivos que actúan sobre el sistema nervioso simpático inducen impotencia en algunos varones $y$, sorprendentemente, priapismo en otros. La fenoxibenzamina, un antagonista de los receptores alfa-adrenérgicos, se ha utilizado a nivel clínico para bloquear la emisión de semen, pero no el orgasmo (Shilon Paz y Homonnai 1984). Los fármacos antidepresivos anticolinérgicos permiten la emisión de semen, aunque bloquean la eyección seminal y el orgasmo, lo que provoca que el líquido seminal rezume por la uretra en vez de ser eyaculado.

Las drogas de abuso también afectan a la función sexual (Fabro 1985). El etanol puede reducir la impotencia aumentando la libido. La cocaína, la heroína y los cannabinoides a dosis elevadas reducen la libido. Los opiáceos también retrasan 0 alteran la eyaculación.

La amplia y variada gama de productos farmacéuticos de los que se ha demostrado que afectan al sistema reproductor masculino apoyan la idea de que las sustancias químicas presentes en el lugar de trabajo también pueden actuar como sustancias tóxicas reproductivas. Es necesario disponer de métodos de investigación fidedignos y prácticos adaptados a las características de los estudios de campo para evaluar esta área importante de la toxicología reproductiva.

\section{- LA ESTRUCTURA DEL SISTEMA REPRODUCTOR FEMENINO Y LA VULNERABILIDAD DE LOS ORGANOS DIANA}

Donald R. M attison

El sistema reproductor femenino está controlado por elementos del sistema nervioso central (SNC), como el hipotálamo y la hipófisis. Está constituido por los ovarios, las trompas de Falopio, el útero y la vagina (Figura 9.4). Los ovarios, que son las gónadas femeninas, son la fuente de los ovocitos y también sintetizan y segregan estrógenos y progestágenos, las principales hormonas femeninas. Las trompas de Falopio transportan los ovocitos desde el ovario hasta el útero y el esperma desde el útero hacia los ovocitos. El útero es un órgano muscular piriforme, cuya región superior comunica con la cavidad abdominal a través de las trompas de Falopio, mientras que su región inferior se continúa, a través del estrecho conducto del cuello uterino, con la vagina, que se comunica con el exterior. La Tabla 9.3 resume los compuestos, manifestaciones clínicas, lugar y mecanismo de acción de las sustancias tóxicas reproductivas potenciales.

\section{EI hipotálamo y la hipófisis}

EI hipotálamo se localiza en el diencéfalo, que se ubica sobre el tronco del encéfalo y está rodeado por los hemisferios cerebrales. EI hipotálamo es el intermediario principal entre los sistemas nervioso y endocrino, los dos principales sistemas de control del organismo. Regula la hipófisis y la producción hormonal.

La función reproductiva del hipotálamo puede resultar alterada por cualquier episodio que sea capaz de modificar la frecuencia o amplitud de la liberación pulsátil de hormona liberadora de gonadotropina $(\mathrm{G} n \mathrm{RH})$. L os procesos que pueden resultar afectados químicamente son los que intervienen en la síntesis y secreción de $\mathrm{GnRH}$, específicamente los de transcripción o traducción, empaquetamiento o transporte axonal y los mecanismos de secreción. Todos ellos representan puntos en los que compuestos químicamente reactivos de acción directa pueden interferir con la síntesis o la liberación hipotalámicas de GnRH. La alteración de la frecuencia o amplitud del pulso de $\mathrm{GnRH}$ puede ser secundaria a trastornos de las vías estimuladoras o inhibidoras que regulan la liberación de $\mathrm{GnRH}$. Al investigar la regulación del generador de pulsos de $\mathrm{GnRH}$, se ha demostrado que las catecolaminas, la dopamina, la serotonina, el ácido $\gamma$-aminobutírico y las endorfinas son capaces de alterar la liberación de GnRH. Por tanto, las sustancias xenobióticas que sean agonistas 0 antagonistas de estos compuestos podrían modificar la liberación de G $\mathrm{nRH}$, interfiriendo así en la comunicación con la hipófisis.

La prolactina, la hormona estimulante del folículo (FSH) y la hormona luteinizante $(\mathrm{LH})$ son tres hormonas proteicas segregadas por la hipófisis anterior que son esenciales para la

Figura 9.4 - A parato reproductor femenino.

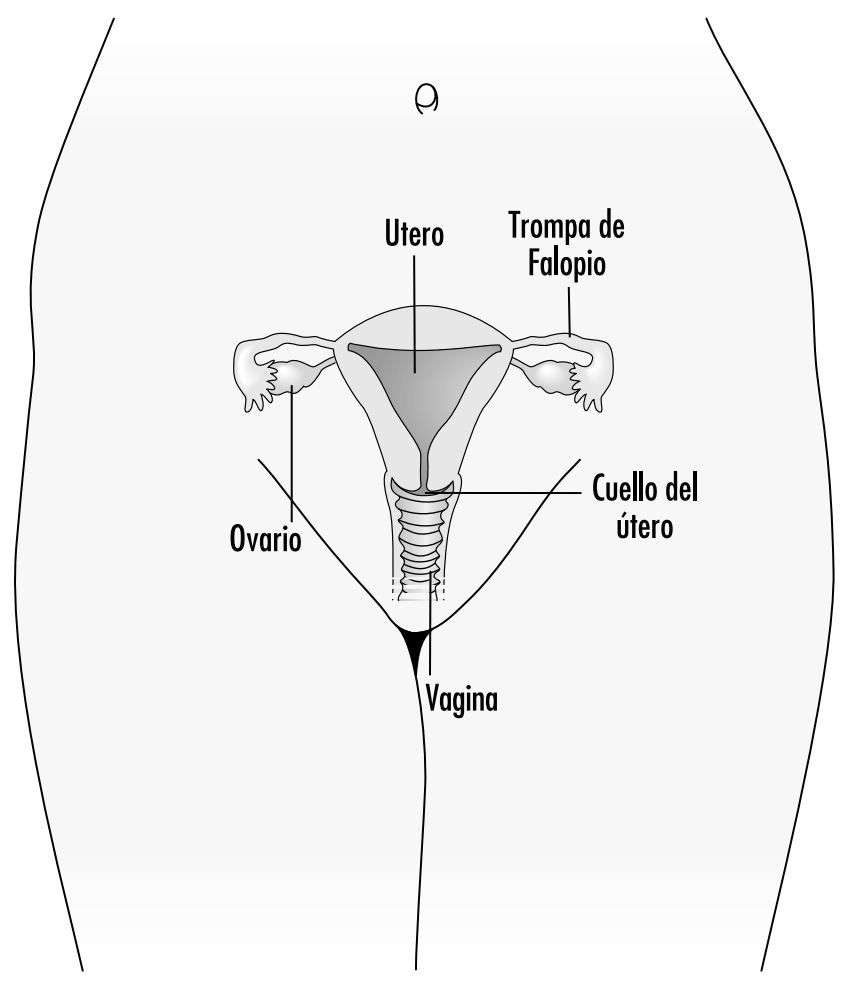


Tabla 9.3 - Sustancias potencialmente tóxicas para la reproducción femenina.

\begin{tabular}{|c|c|c|c|}
\hline Compuesto & $\begin{array}{l}\text { Manifestación } \\
\text { clínica }\end{array}$ & Órgano & Mecanismo/ diana \\
\hline \multicolumn{4}{|c|}{ Reactividad química } \\
\hline \multirow[t]{5}{*}{$\begin{array}{l}\text { Agentes } \\
\text { alquilantes }\end{array}$} & $\begin{array}{l}\text { Menstruación } \\
\text { alterada }\end{array}$ & Ovario & $\begin{array}{l}\text { Citotoxicidad para los } \\
\text { granulocitos }\end{array}$ \\
\hline & Amenorrea & & $\begin{array}{l}\text { Citotoxicidad para los } \\
\text { ovocitos }\end{array}$ \\
\hline & Atrofia ovárica & Útero & $\begin{array}{l}\text { Citotoxicidad para las } \\
\text { células endometriales }\end{array}$ \\
\hline & Fertilidad reducida & & \\
\hline & $\begin{array}{l}\text { Menopausia } \\
\text { prematura }\end{array}$ & & \\
\hline \multirow[t]{3}{*}{ Plomo } & $\begin{array}{l}\text { Menstruación } \\
\text { alterada }\end{array}$ & Hipotálamo & Disminución de FSH \\
\hline & Atrofia ovárica & Pituitaria & $\begin{array}{l}\text { Disminución de } \\
\text { progesterona }\end{array}$ \\
\hline & Fertilidad reducida & Ovario & \\
\hline \multirow[t]{2}{*}{ Mercurio } & $\begin{array}{l}\text { Menstruación } \\
\text { alterada }\end{array}$ & Hipotálamo & $\begin{array}{l}\text { Producción y secreción de } \\
\text { gonadotropina alterada }\end{array}$ \\
\hline & & Ovario & $\begin{array}{l}\text { Toxicidad folicular } \\
\text { Proliferación de } \\
\text { granulocitos }\end{array}$ \\
\hline \multirow[t]{3}{*}{ Cadmio } & Atresia folicular & Ovario & Toxicidad vascular \\
\hline & Diestro persistente & & $\begin{array}{l}\text { Citotoxicidad para los } \\
\text { granulocitos }\end{array}$ \\
\hline & & Hipotálamo & Citotoxicidad \\
\hline \multicolumn{4}{|c|}{ Similitud estructural } \\
\hline \multirow[t]{2}{*}{ Azatioprina } & $\begin{array}{l}\text { Reducción del } \\
\text { número de } \\
\text { folículos }\end{array}$ & Ovario & Análogo de la purina \\
\hline & & Ovogénesis & $\begin{array}{l}\text { Alteración de la } \\
\text { síntesis de ADN/ ARN }\end{array}$ \\
\hline Clordecono & Fertilidad reducida & Hipotálamo & Agonista del estrógeno \\
\hline DDT & $\begin{array}{l}\text { Menstruación } \\
\text { alterada }\end{array}$ & Pituitaria & Alteración de FSH, LH \\
\hline 2,4-D & Infertilidad & & \\
\hline Lindano & Amenorrea & & \\
\hline Toxafeno & Hipermenorrea & & \\
\hline PCB, PBB & $\begin{array}{l}\text { Menstruación } \\
\text { alterada }\end{array}$ & & Alteración de FSH, LH \\
\hline
\end{tabular}

Fuente: De Plowchalk, Meadows y Mattison 1992. Se sugiere que estos compuestos son directamente tóxicos para la reproducción basándose primordialmente en ensayos de toxicidad con animales de experimentación.

reproducción. Desempeñan un papel crítico en el mantenimiento del ciclo ovárico, dirigiendo el reclutamiento y la maduración folicular, la esteroidogénesis, la finalización de la maduración de los ovocitos, la ovulación y la luteinización.

EI control preciso y afinado del sistema reproductor se lleva a cabo en la hipófisis anterior como respuesta a señales de retroalimentación positivas y negativas de las gónadas. La liberación adecuada de FSH y LH durante el ciclo ovárico controla el desarrollo folicular normal, y su ausencia causa amenorrea y atrofia gonadal. Las gonadotropinas desempeñan un papel crítico en la iniciación de cambios en la morfología del folículo ovárico y en sus microambientes esteroideos mediante la estimulación de la producción de esteroides y la inducción de poblaciones de receptores. La liberación precisa y adecuada de estas gonadotropinas también es esencial para los episodios ovulatorios y el desarrollo de una fase lútea funcional. Dado que las gonadotropinas son esenciales para la función ovárica, la alteración de su síntesis, almacenamiento o secreción puede afectar seriamente la capacidad reproductiva. La interferencia de la expresión génica, tanto en las fases de transcripción o traducción como en las posteriores de traducción o empaquetamiento, o en los mecanismos de secreción, puede modificar el nivel de gonadotropinas que llegan a las gónadas. Sustancias químicas que actúan por semejanza estructural o por alteración de la homeostasia endocrina pueden producir efectos por interferencia con los mecanismos normales de retroalimentación. L os antagonistas y agonistas de los receptores esteroideos pueden iniciar una liberación inadecuada de gonadotropinas hipofisarias, induciendo de esta forma enzimas que metabolizan los esteroides, con la reducción consiguiente de la vida media de éstos y, por tanto, del nivel de esteroides circulantes que llegan a la hipófisis.

\section{El ovario}

El ovario de los primates es responsable del control de la reproducción a través de sus productos principales, ovocitos y hormonas esteroideas y proteicas. El proceso por el que se producen los ovocitos y las hormonas se denomina foliculogénesis y depende de mecanismos reguladores tanto intraováricos como extraováricos. El propio ovario tiene tres subunidades funcionales: el folículo, el ovocito y el cuerpo lúteo. Durante el ciclo menstrual normal, estos componentes, bajo la influencia de la FSH y la LH, actúan conjuntamente para producir un ovocito viable para la fertilización y un ambiente adecuado para la implantación y la gestación posterior.

Durante el período preovulatorio del ciclo menstrual, se produce el reclutamiento y desarrollo folicular bajo la influencia de la FSH y la LH. Esta última estimula la producción de andrógenos por las células de la teca, mientras que la FSH estimula la aromatización de los andrógenos a estrógenos por las células de la granulosa y la producción de inhibina, una hormona proteica. La inhibina actúa sobre la hipófisis anterior, disminuyendo la liberación de FSH. Así se evita una estimulación excesiva del desarrollo folicular y se permite el desarrollo ininterrumpido del folículo dominante, el destinado a la ovulación. La producción de estrógenos aumenta, lo que estimula tanto el pico de secreción de LH, que provoca la ovulación, como los cambios celulares y secretores de la vagina, cuello, útero y oviducto, que mejoran la viabilidad y transporte de los espermatozoides.

En la fase postovulatoria, las células de la teca y la granulosa que permanecen en la cavidad folicular del ovocito ovulado forman el cuerpo lúteo y segregan progesterona. Esta hormona estimula al útero para que proporcione un ambiente apropiado para la implantación del embrión si se produce la fertilización. A diferencia de lo que sucede con la gónada masculina, la femenina tiene un número limitado de células germinales en el momento del nacimiento y, por tanto, es especialmente sensible a las sustancias tóxicas para la reproducción. Este tipo de exposición en la mujer puede producir una disminución de la fecundidad, aumento de las gestaciones malogradas, menopausia precoz o infertilidad.

El folículo, como unidad reproductiva básica del ovario, mantiene el delicado ambiente hormonal necesario para que tenga lugar el crecimiento y la maduración del ovocito. Como se 
ha señalado, este proceso complejo se conoce como foliculogénesis e implica una regulación tanto intra como extraovárica. A medida que el folículo progresa desde folículo primordial a folículo preovulatorio (que contiene un ovocito en desarrollo), se producen numerosos cambios morfológicos y bioquímicos, y cada fase del crecimiento folicular presenta patrones característicos de sensibilidad a las gonadotropinas, producción de esteroides y vías de retroalimentación. E stas características sugieren que existe una serie de puntos en los que es posible la interacción con sustancias xenobióticas. A demás, hay distintas poblaciones foliculares dentro del ovario, lo que complica la situación, posibilitando el desarrollo de una toxicidad diferencial. Los patrones de infertilidad inducidos por una sustancia química dependerían, pues, del tipo folicular afectado. Por ejemplo, un episodio de toxicidad sobre los folículos primordiales no produciría signos inmediatos de infertilidad, sino que acortaría el período de vida reproductiva. Por otro lado, un episodio de toxicidad sobre los folículos antrales o preovulatorios traería como consecuencia una pérdida inmediata de la función reproductiva. El complejo folicular consta de tres componentes básicos: las células de la granulosa, las células de la teca y el ovocito. Cada uno de ellos tiene características que lo hacen específicamente sensible a la lesión química.

Varios investigadores han estudiado la metodología de la detección selectiva de sustancias xenobióticas responsables de la toxicidad en las células de la granulosa midiendo los efectos sobre la producción de progesterona por parte de células de la granulosa en cultivo. La supresión con estradiol de la producción de progesterona por parte de las células de la granulosa se ha utilizado para verificar la sensibilidad de estas células. EI plaguicida $p, p^{\prime}-D D T$ y su isómero o, $p^{\prime}$-DDT dan lugar a una supresión de la producción de progesterona con una potencia aparentemente igual a la del estradiol. Por el contrario, plaguicidas como el malatión, el paratión y el dieldrín y el fungicida hexaclorobenceno no ejercen efecto alguno. Es necesario realizar un análisis detallado adicional de las respuestas de las células de la granulosa aisladas a sustancias xenobióticas para definir la utilidad de este sistema de ensayo. El atractivo de los sistemas aislados de este tipo es la economía y la facilidad de uso; sin embargo, es importante recordar que las células de la granulosa representan sólo un componente del sistema reproductor.

Las células de la teca proporcionan los precursores de los esteroides que sintetizan las células de la granulosa. Se cree que son reclutadas a partir de las células del estroma ovárico durante la formación y crecimiento del folículo. El reclutamiento puede implicar la proliferación de las células del estroma, así como la migración a las regiones que rodean al folículo. Las sustancias xenobióticas que alteren la proliferación, migración y comunicación celular afectarán a la función de las células de la teca. Las sustancias xenobióticas que alteran la producción tecal de andrógenos también pueden alterar la función folicular. Por ejemplo, las células de la teca producen los andrógenos que se metabolizan a estrógenos en las células de la granulosa. Se supone que las alteraciones de la producción de andrógenos por las células de la teca, tanto en el sentido de aumentos como de disminuciones, tienen un efecto importante sobre la función folicular. Por ejemplo, se cree que una producción excesiva de andrógenos por las células de la teca conduce a atresia folicular. Además, la alteración de la producción de andrógenos por las células de la teca puede reducir la producción de estrógenos por las células de la granulosa. Cualquiera de estas circunstancias repercutirá claramente sobre el rendimiento reproductivo. En la actualidad se dispone de pocos datos sobre la vulnerabilidad de las células de la teca a las sustancias xenobióticas.
Aunque la información que define la vulnerabilidad de las células del ovario a las sustancias xenobióticas es escasa, existen datos que demuestran claramente que los ovocitos pueden resultar lesionados 0 destruidos por este tipo de agentes. LoS agentes alquilantes destruyen los ovocitos en los seres humanos y en los animales de experimentación. El plomo produce toxicidad ovárica. El mercurio y el cadmio también producen lesión ovárica que puede estar mediada por toxicidad sobre el ovocito.

\section{De la fertilización a la implantación}

La gametogénesis, la liberación y la unión de las células germinales masculinas y femeninas son los acontecimientos preliminares que conducen a la formación de un cigoto. LoS espermatozoides depositados en la vagina deben entrar por el cuello uterino y desplazarse a través del útero hacia la trompa de Falopio para alcanzar al óvulo. El proceso de fertilización comprende la penetración del óvulo por parte del espermatozoide y la fusión de sus respectivos ADN. Tras la fertilización, se inicia la división celular y continúa durante los siguientes tres 0 cuatro días, formando una masa sólida de células denominadas mórula. Las células de la mórula siguen dividiéndose y, en el momento en que el embrión en desarrollo alcanza el útero, se ha transformado en una bola hueca denominada blastocito.

Después de la fertilización, el embrión en desarrollo migra a través de la trompa de Falopio hasta el útero. El blastocito entra en éste y se implanta en el endometrio aproximadamente siete días después de la ovulación. En este momento, el endometrio se encuentra en la fase postovulatoria. La implantación permite al blastocisto absorber nutrientes o sustancias tóxicas a partir de las glándulas y vasos sanguíneos del endometrio.

\section{EXPOSICIONES PRO FESIONALES MATERNAS Y RESULTADOS ADVERSOS EN EL EMBARAZO}

Grace Kawas Lemasters

EI empleo remunerado entre las mujeres crece en todo el mundo. Por ejemplo, casi un $70 \%$ de las mujeres de Estados Unidos trabajan fuera de casa durante sus años fértiles (20 a 34 años de edad). D esde la década de 1940 existe además una tendencia casi lineal en la producción de sustancias químicas orgánicas sintéticas, que aumenta los peligros del ambiente para la trabajadora gestante y su descendencia.

En último extremo, el éxito reproductivo de una pareja depende de un delicado equilibrio fisicoquímico entre el padre, la madre y el feto y dentro de ellos. Los cambios metabólicos que se producen durante el embarazo pueden potenciar la exposición tanto de la trabajadora como del embrión o el feto a sustancias tóxicas peligrosas. Algunos de estos cambios metabólicos son el aumento de la absorción pulmonar y del gasto cardíaco, el retraso del vaciamiento gástrico, y el aumento de la motilidad intestinal y de la grasa corporal. Como se muestra en la Figura 9.5, las consecuencias de la exposición del embrión se pueden manifestar como una serie de efectos variables dependiendo de la fase de desarrollo: embriogénesis precoz o tardía o período fetal.

El período de transporte de un óvulo fecundado antes de la implantación es de dos a seis días. Durante esta fase precoz, el embrión puede estar expuesto a la acción de los compuestos químicos que penetren en los líquidos uterinos. En general, la absorción de compuestos xenobióticos puede ir acompañada de cambios degenerativos, alteración del perfil proteico del 
Figura 9.5 - Consecuencias para la descendencia de la exposición materna a sustancias tóxicas.

\section{EXPOSICION DEL EMBRION DURANTE LA GESTACION}

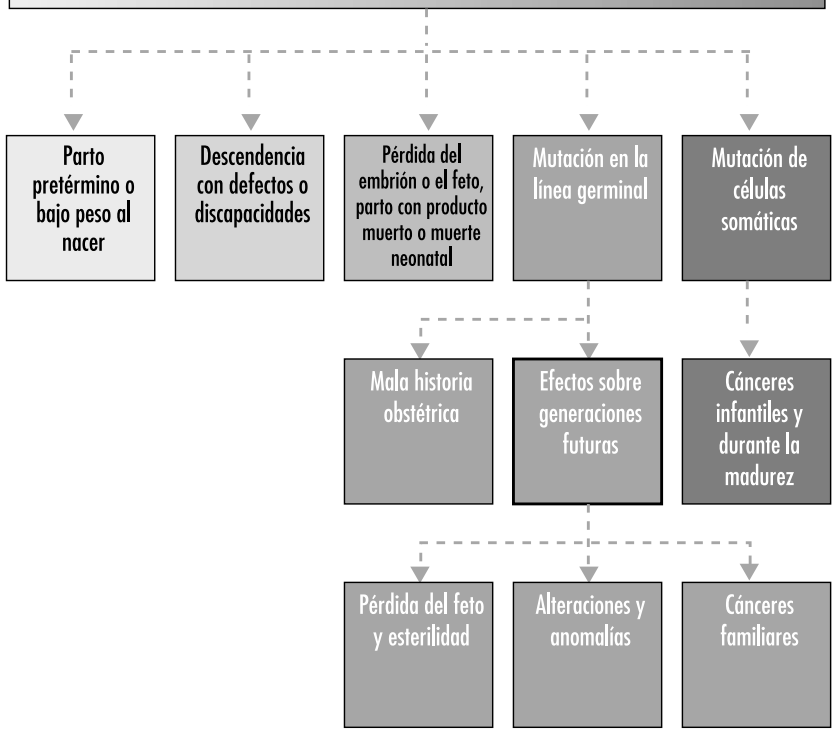

blastocisto 0 ausencia de implantación. Cualquier agresión durante este período tiene muchas probabilidades de producir un aborto espontáneo. Con todo, a partir de los datos experimentales se cree que el embrión es bastante resistente a las agresiones teratógenas en este estadio precoz, dado que las células no han iniciado la compleja secuencia de la diferenciación química.

El período de embriogénesis tardía se caracteriza por la diferenciación, movilización y organización de las células y tejidos en órganos rudimentarios. La patogenia precoz puede inducir muerte celular, fracaso de la interacción celular, reducción de la biosintesis, alteración del movimiento morfogénico, alteración mecánica de las adherencias y edema (Paul 1993). Los factores mediadores que determinan la sensibilidad son la ruta y el nivel de exposición, el patrón de exposición y el genotipo fetal y materno. La respuesta puede verse aún más alterada por factores extrínsecos como las deficiencias nutricionales o los efectos aditivos, sinérgicos o antagonistas asociados a las exposiciones múltiples. Las respuestas adversas durante la embriogénesis tardía pueden culminar en un aborto espontáneo, defectos estructurales macroscópicos, pérdida del feto, retraso del crecimiento 0 anomalías del desarrollo.

El período fetal se extiende desde la embriogénesis hasta el nacimiento y su comienzo se establece hacia los 54-60 días de gestación, cuando el embrión presenta una longitud craneocaudal de $33 \mathrm{~mm}$. Por lo demás, la distinción respecto del período embrionario es en cierto modo arbitraria. El período fetal se caracteriza, en cuanto al desarrollo, por el crecimiento, la histogénesis y la maduración funcional. La toxicidad se puede manifestar por una reducción del tamaño y número de las células. EI cerebro aún es sensible a las lesiones; la mielinización no se completa hasta después del nacimiento. La toxicidad durante este período puede producir retraso del crecimiento, defectos funcionales, interrupción de la gestación, efectos conductuales, carcinogénesis transplacentaria o muerte. A continuación se analizan los aspectos biológicos, sociológicos y epidemiológicos de las exposiciones ambientales/ profesionales de la madre.

\section{Pérdida embrionaria/ fetal}

Las fases evolutivas del cigoto, definidas en días desde la ovulación (DDO), son la fase de blastocito, en los días 15 a 20 (uno a seis DD O), la fase de implantación, en el día 20 ó 21 (seis o siete DDO), el período embrionario, en los días 21 a 62 (siete a 48 DD 0$)$, y el período fetal, desde el día 63 (49+ D OV) hasta el período denominado de viabilidad, que oscila entre los 140 y los 195 días. Las estimaciones de la probabilidad de culminación de la gestación en cada una de estas fases dependen tanto de la definición de pérdida fetal como del método que se utilice para medir el acontecimiento. La definición de pérdida fetal es variable, oscilando entre la que se produce al final de la semana 20 y en la semana 28. Las definiciones de muerte fetal y neonatal recomendadas por la O rganización M undial de la Salud (1977) aparecen en la Tabla 9.4. En Estados U nidos se admiten de forma generalizada las 20 semanas como límite inferior para considerar el feto viable.

Dado que la mayoría de los fetos que sufren un aborto precoz presentan anomalías cromosómicas, se ha propuesto que, a efectos de investigación, se haga una distinción más matizada entre pérdida fetal precoz, antes de las 12 semanas de gestación, y pérdida fetal tardía (K ällén 1988). Al examinar esta última también puede ser apropiado incluir la muerte neonatal precoz, dada la posible similitud de la causa. La O M S define la muerte neonatal precoz como la que afecta a un recién nacido de siete días de vida o menos, y la muerte neonatal tardía como la que se produce entre los siete y los 29 días. En estudios realizados en países en vías de desarrollo es importante distinguir entre las muertes anteparto y las que se producen intraparto. Como consecuencia de las dificultades del parto, éstas representan un porcentaje elevado de los partos de fetos muertos.

En una revisión llevada a cabo por K line, Stein y Susser (1989) de nueve estudios transversales o retrospectivos, las tasas de pérdida fetal antes de las 20 semanas de gestación oscilaban entre el 5,5 y el $12,6 \%$. Cuando se ampliaba la definición para incluir las pérdidas producidas hasta la semana 28 de gestación, la tasa oscilaba entre el 6,2 y el 19,6\%. Sin embargo, las tasas de incidencia de pérdida fetal en embarazos identificados desde el punto de vista clínico en cuatro estudios prospectivos presentaban un margen relativamente estrecho, $11,7-14,6 \%$, en períodos gestacionales de hasta 28 semanas. Esta tasa menor en los diseños prospectivos que en los transversales o los retrospectivos puede ser atribuida a diferencias en las definiciones básicas, a la notificación errónea de abortos inducidos como espontáneos o a la clasificación incorrecta de menstruaciones retrasadas 0 copiosas como casos de pérdida fetal.

Cuando se incluyen los abortos ocultos o las pérdidas "químicas" precoces, identificadas por una elevación de las gonadotropinas coriónicas humanas ( $\mathrm{hCG}$ ), la tasa total de aborto espontáneo aumenta de forma espectacular. En un estudio que utilizaba ensayos de hCG, la incidencia de pérdida subclínica postimplantación de huevos fecundados fue del $22 \%$

Tabla 9.4 - Definición de pérdida fetal y muerte
perinatal.

Aborto espontáneo $\leq 500 \mathrm{~g} 020-22$ semanas $025 \mathrm{~cm}$ de longitud

Feto nacido muerto $500 \mathrm{~g}$ (1000 g Internacional) no viable

Muerte neonatal precoz Muerte de un nacido vivo $\leq 7$ días ( 168 horas)

Muerte neonatal tardía 7 días hasta $\leq 28$ días

Fuente: Organización Mundial de la Salud 1977. 
Tabla 9.5 - Factores asociados al resultado de neonato pequeño para la edad gestacional y pérdida fetal.

\begin{tabular}{|c|c|}
\hline \multicolumn{2}{|c|}{ Pequeño para la edad gestacional } \\
\hline Físicos-genéticos & Ambientales-sociales \\
\hline Parto antes de término & Malnutrición \\
\hline Partos múltiples & $\begin{array}{l}\text { Ingresos reducidos / educación } \\
\text { incompleta }\end{array}$ \\
\hline Feto malformado & Consumo materno de tabaco \\
\hline Hipertensión & Consumo materno de alcohol \\
\hline Anomalía de la placenta o del cordón & Exposición profesional \\
\hline Antecedentes médicos maternos & Estrés psicosocial \\
\hline $\begin{array}{l}\text { Antecedente de resultados adversos } \\
\text { del embarazo }\end{array}$ & Altitud \\
\hline Raza & Antecedentes infecciosos \\
\hline Anomalías cromosómicas & Consumo de cannabis \\
\hline \multicolumn{2}{|l|}{ Sexo } \\
\hline \multicolumn{2}{|l|}{ Talla, peso } \\
\hline \multicolumn{2}{|l|}{ Talla paterna } \\
\hline \multicolumn{2}{|l|}{ Paridad } \\
\hline Duración de la gestación & \\
\hline Intervalo breve entre embarazos & \\
\hline
\end{tabular}

Pérdida fetal

$\begin{array}{ll}\text { Físicos-genéticos } & \text { Ambientales-sociales } \\ \text { Gravidez mayor } & \text { Nivel socioeconómico } \\ \text { Edad materna } & \text { Consumo de tabaco } \\ \text { Orden de nacimiento } & \text { Fármacos recetados y drogas de abuso } \\ \text { Raza } & \text { Consumo de alcohol } \\ \text { Aborto espontáneo de repetición } & \text { Nutrición deficiente } \\ \text { Diabetes insulino-dependiente } & \text { Infecciones/ fiebre materna } \\ \text { Trastornos uterinos } & \text { Espermicidas } \\ \text { Gemelos } & \text { Trabajo } \\ \text { Factor inmunológico } & \text { Exposición química } \\ \text { Factores hormonales } & \text { Radiación }\end{array}$

(Wilcox y cols. 1988). En estos estudios, se determinó la hCG urinaria mediante ensayo inmunorradiométrico utilizando un anticuerpo detector. El ensayo utilizado originalmente por Wilcox empleaba un anticuerpo policlonal de conejo de alta afinidad. Estudios más recientes han utilizado un anticuerpo monoclonal irreabsorbible que requiere menos de $5 \mathrm{ml}$ de orina para muestras dobles. EI principal factor restrictivo para la utilización de estos ensayos en el campo profesional no es sólo el coste y los recursos necesarios para coordinar la recogida, almacenamiento y análisis de la orina, sino también el gran tamaño de la población que se necesita. En un estudio sobre las mujeres trabajadoras expuestas a terminales de pantalla y la interrupción precoz del embarazo, 7.000 de ellas fueron sometidas a exploración selectiva para conseguir una población utilizable de 700 mujeres. Esta necesidad de explorar un número de personas diez veces superior al tamaño de la población para conseguir una muestra de tamaño adecuado se debe a la reducción del número de mujeres disponible por problemas de selección relacionadas con la edad, la esterilidad o la inclusión de algunas que no utilizan métodos anticonceptivos o que emplean métodos relativamente ineficaces.

Estudios ocupacionales más convencionales han utilizado datos registrados o procedentes de cuestionarios para identificar los abortos espontáneos. Entre las fuentes de datos registrados están las estadísticas actuariales, los registros de hospitales o de médicos privados y las historias de las pacientes ambulatorias. Al utilizar sistemas de este tipo se identifica sólo un subgrupo de las pérdidas fetales, en especial las que se producen tras el comienzo de la atención prenatal, normalmente después de dos o tres meses de amenorrea. Los datos procedentes de cuestionarios se recopilan mediante el envío de éstos por correo o mediante entrevistas personales o telefónicas. $L$ as entrevistas ofrecen información más completa sobre las pérdidas identificadas. Entre las preguntas referentes a la historia reproductiva suelen hacerse algunas relativas a los resultados de los embarazos, la atención prenatal, los antecedentes familiares de resultados adversos en el embarazo, la historia sexual, el estado de nutrición, el peso previo a la gestación, la talla, el incremento de peso, el consumo de cigarrillos, de alcohol y de fármacos prescritos y no prescritos, el estado de salud de la madre durante la gestación y antes de ella, y las exposiciones en el hogar y en el lugar de trabajo a agentes químicos y físicos tales como vibraciones, radiaciones, metales, disolventes o plaguicidas. Los datos de las entrevistas sobre abortos espontáneos pueden ser una fuente válida de información, especialmente si el análisis incluye los de gestaciones de ocho semanas o de mayor duración y los que han tenido lugar en los últimos 10 años.

En la Tabla 9.5 se resumen los principales factores físicos, genéticos, sociales y ambientales asociados al aborto espontáneo. Para garantizar que la relación exposición-efecto observado no se debe a otro factor de riesgo, es importante identificar los factores de este tipo que pueden estar asociados. Entre las infecciones que se asocian a pérdida fetal figuran la sífilis, rubéola, infecciones genitales por M ycoplasma, herpes simple, infecciones uterinas e hipertermia en general. U no de los factores de riesgo más importantes de aborto espontáneo identificado desde el punto de vista clínico es el antecedente de embarazo que termina con pérdida fetal. La multiparidad se asocia a un riesgo mayor, pero puede que no sea independiente del antecedente de aborto espontáneo. La interpretación de la paridad como factor de riesgo resulta conflictiva, debido a su asociación con la edad materna, los antecedentes reproductivos y la heterogeneidad de las mujeres con diferentes cifras de paridad. Las tasas de aborto espontáneo son más elevadas en mujeres menores de 16 años y mayores de 36 años. D espués de realizar los ajustes relacionados con la paridad y el antecedente de pérdida gestacional, se demostró que las mujeres mayores de 40 años tenían el doble de riesgo de pérdida fetal que las más jóvenes. El riesgo más elevado de las mujeres de más edad se ha asociado al aumento de las anomalías cromosómicas, especialmente la trisomía. R ecientemente se han revisado los posibles efectos mediados por el varón asociados a la pérdida fetal (Savitz, Sonnerfeld y O Ishaw 1994). Se observó una relación más fuerte con la exposición paterna al mercurio y los gases anestésicos y una exposición sospechosa pero inconstante al plomo, la fabricación de goma, determinados disolventes y al gunos plaguicidas.

La situación laboral puede ser un factor de riesgo, independientemente de cualquier peligro físico o químico específico, que actúe como factor de confusión en la evaluación de la exposición profesional y del aborto espontáneo. Algunos investigadores sugieren que es más probable que las mujeres que siguen trabajando tengan antecedentes de gestaciones adversas $y$, como 
consecuencia, estén en condiciones de continuar trabajando; otros creen que este grupo es una subpoblación con mejor capacidad física debido a los mayores ingresos y a la mejor atención prenatal.

\section{Anomalías congénitas}

Durante los 60 días siguientes a la concepción, el feto puede ser más sensible a las sustancias tóxicas xenobióticas que en cualquiera otra etapa del ciclo de la vida. $\mathrm{H}$ istóricamente, el término malformaciones congénitas hacía referencia a los defectos estructurales presentes en el nacimiento, ya fueran macroscópicos 0 microscópicos, internos o externos, hereditarios o no hereditarios, únicos o múltiples. Sin embargo, el término anomalía congénita es más amplio e incluye las anomalías conductuales, funcionales y bioquímicas. Las malformaciones pueden ser únicas o múltiples; los defectos cromosómicos suelen producir defectos múltiples, mientras que las modificaciones de genes aislados o la exposición a agentes ambientales pueden causar indistintamente defectos únicos o síndromes.

La incidencia de las malformaciones depende del estado del producto de la concepción: nacimiento de feto vivo, aborto espontáneo, nacimiento de feto muerto. En general, la tasa de anomalías presentes en los abortos espontáneos es de aproximadamente un $19 \%$, cifra diez veces mayor que la correspondiente a los nacimientos de feto vivo (Shepard, Fantel y Fitsimmons 1989). Entre los fetos nacidos muertos con peso superior a los $500 \mathrm{~g}$ se detectó una tasa de anomalías del $32 \%$. La incidencia de defectos importantes en los nacidos vivos es de aproximadamente el 2,24 \% (Nelson y Holmes 1989). La prevalencia de defectos menores oscila entre el 3 y el $15 \%$ (con una media de aproximadamente el $10 \%$ ). L as anomalías presentes en el nacimiento se asocian a factores genéticos $(10,1 \%)$, herencia multifactorial $(23 \%)$, factores uterinos $(2,5 \%)$, embarazo gemelar $(0,4 \%)$ o factores teratógenos $(3,2 \%)$. L as causas de los demás casos son desconocidas. Las tasas de malformación son aproximadamente un $41 \%$ más elevadas en los niños que en las niñas, lo que se explica por la incidencia significativamente más elevada de anomalías en los órganos genitales masculinos.

Al estudiar las malformaciones, la forma de agrupar los defectos para su análisis constituye todo un reto. Las anomalías se pueden clasificar en función de diversos parámetros, como la gravedad (mayor, menor), la patogenia (deformación, ruptura), la presentación (asociadas o aisladas), la anatomía (por sistemas orgánicos) y la etiología (por ejemplo, cromosómicas, defectos génicos aislados o inducidas por un teratógeno). A menudo, todas ellas están combinadas o la combinación se basa indistintamente en una clasificación como mayor o menor. M alformación mayor se puede definir como aquélla que produce la muerte, requiere tratamiento médico o quirúrgico, o constituye una minusvalía física o psicológica importante. La justificación para clasificar las anomalías en grandes grupos se basa en que la mayoría se producen aproximadamente en el mismo período durante la organogénesis. Por ello, manteniendo unos tamaños de muestreo más grandes, el número total de casos aumenta con un incremento simultáneo de la potencia estadística. No obstante, si el efecto de la exposición es específico de un tipo particular de malformación (por ejemplo, sistema nervioso central), esta clasificación puede enmascarar el efecto. Por otro lado, las malformaciones se pueden agrupar por sistemas orgánicos. Aunque este método es en ocasiones más adecuado, existe la posibilidad de que ciertos defectos dominen la clase, como las deformaciones en varo de los pies en el sistema musculosquelético. Si disponemos de una muestra suficientemente grande, el enfoque óptimo consiste en dividir los defectos en grupos homogéneos desde el punto de vista embriológico o patogenético (K ällén 1988). Se debe considerar la exclusión o inclusión de determinadas malformaciones, como las que están causadas probablemente por defectos cromosómicos, trastornos autosómicos dominantes o anomalías posturales en el útero. En última instancia, al analizar las anomalías congénitas, hay que mantener un equilibrio entre conservar la precisión y comprometer la potencia estadística.

U na serie de sustancias tóxicas ambientales y profesionales ha sido asociada a las anomalías congénitas de la descendencia. U na de las asociaciones más fuertes es el consumo por parte de la madre de alimentos contaminados con metil mercurio, que produce anomalías morfológicas, del sistema nervioso central y del neurocomportamiento. En Japón, el grupo de casos estaba relacionado con el consumo de pescado y marisco contaminados con mercurio procedente de los vertidos de una planta química. La afectación más grave de la descendencia fueron los niños con parálisis cerebral. La ingestión materna de bifenilos policlorados (BPC) procedentes de aceite de arroz contaminado fue la causa de que varios lactantes presentaran diversas alteraciones, como retraso del crecimiento, pigmentación marrón oscuro de la piel, dentición precoz, hiperplasia gingival, sutura sagital ancha, edema facial y exoftalmos. Los trabajos que implican la exposición a mezclas han sido relacionados con diversos resultados adversos. Los hijos de mujeres que trabajan en la industria papelera, tanto en trabajo de laboratorio como en tareas relacionadas con la "transformación" o refino de papel, también presentaban un riesgo más elevado de defectos del sistema nervioso central, de corazón y de fisura en la cavidad oral. Las mujeres que trabajaban en la industria o en la construcción con exposiciones no especificadas tenían un aumento del $50 \%$ en el riesgo de defectos del SN C, y las que trabajaban en transportes y comunicaciones presentaban el doble de riesgo de tener un hijo con fisura de la cavidad oral. Los veterinarios representan un grupo especial dentro del personal sanitario expuesto a gases anestésicos, radiación, traumatismos por coces de animales, insecticidas y zoonosis. Aunque no se detectó ninguna diferencia en la tasa de abortos espontáneos o en el peso al nacimiento de los hijos entre mujeres veterinarias y mujeres abogados, se observó un exceso significativo de defectos al nacimiento entre las del primer grupo (Schenker y cols. 1990). Existen listas de teratógenos conocidos, posibles e improbables, así como bases de datos informáticas y servicios telefónicos de información sobre riesgos para obtener información actualizada sobre los teratógenos potenciales (Paul 1993). No obstante, la evaluación de las anomalías congénitas en una cohorte profesional presenta una dificultad especial, debido al gran tamaño de la muestra necesario para lograr potencia estadística y a nuestra limitada capacidad para identificar exposiciones específicas que se producen en un intervalo breve de tiempo, fundamentalmente los primeros 55 días de la gestación.

\section{Pequeños para la edad gestacional}

Entre los numerosos factores relacionados con la supervivencia infantil, el subdesarrollo físico asociado al bajo peso al nacimiento (BPN) representa uno de los riesgos más importantes. La ganancia significativa de peso del feto no empieza hasta el segundo trimestre. El embrión pesa $1 \mathrm{~g}$ a las ocho semanas, $14 \mathrm{~g}$ a las 12 semanas y alcanza $1,1 \mathrm{~kg}$ a las 28 semanas. Se produce una ganancia adicional de $1,1 \mathrm{~kg}$ cada 6 semanas hasta el nacimiento. El recién nacido normal pesa aproximadamente $3.200 \mathrm{~g}$ a término. El peso del recién nacido depende de su ritmo de crecimiento y de su edad gestacional en el momento del parto. Se dice que un neonato es pequeño para su edad gestacional (PEG) cuando presenta un retraso del crecimiento. Si el feto nace antes de término, tendrá un peso reducido pero su crecimiento no tiene necesariamente que estar retrasado. Los factores asociados a un parto antes de término se tratan en otro punto, por lo que este 
análisis se centra en el retraso del crecimiento del neonato. LoS términos PEG y BPN se utilizarán indistintamente. EI niño con bajo peso al nacimiento se define como el que pesa menos de $2.500 \mathrm{~g}$, el neonato de muy bajo peso al nacimiento es aquel que pesa menos de $1.500 \mathrm{~g}$, y el de extremadamente bajo peso al nacimiento es el que pesa menos de $1.000 \mathrm{~g}$ (O M S 1969).

Cuando se examinan las causas del retraso del crecimiento, es importante distinguir entre el retraso simétrico y el asimétrico. Este último, es decir, aquél en que el peso está más afectado que la estructura esquelética, se asocia fundamentalmente a un factor de riesgo que actúa durante la última parte de la gestación, mientras que el primero se asocia más probablemente a una etiología que actúa a lo largo de toda la gestación ( $K$ line, Stein y Susser 1989). La diferencia de incidencias entre uno y otro es especialmente evidente cuando se comparan los países en vías de desarrollo con los desarrollados. La tasa de retraso del crecimiento en los países en desarrollo es del 10-43 \% y es básicamente simétrico, siendo el factor de riesgo más importante la alimentación deficiente. En los países desarrollados, la tasa de retraso del crecimiento fetal es habitualmente mucho menor, del 3-8 \%, y es generalmente asimétrico, con una etiología multifactorial. De ahí que, en todo el mundo, el porcentaje de recién nacidos con bajo peso al nacimiento, que lo son por crecimiento intrauterino retardado y no por prematuridad, varía espectacularmente. En Suecia y en Estados U nidos, el porcentaje es de un $45 \%$, mientras que en los países en vías de desarrollo, como la India, varía entre el $79 \%$ y el $96 \%$ aproximadamente (Villar y Belizan 1982).

Estudios sobre la hambruna en los Países Bajos demostraron que el hambre limitada al tercer trimestre frenó el crecimiento fetal de forma asimétrica, afectando especialmente al peso al nacimiento y en menor medida al perímetro craneal (Stein, Susser y Saenger 1975). El crecimiento asimétrico también se ha observado en los estudios de exposiciones ambientales. En un estudio de 202 madres gestantes que residían en zonas de riesgo elevado de exposición al plomo, se tomaron muestras de sangre materna prenatal entre la sexta y la 28a semanas de gestación (Bornschein, Grote y M itchell 1989). Los niveles sanguíneos prenatales de plomo (PbS) se asociaron a un descenso tanto de peso como de la talla al nacimiento, pero no del perímetro craneal después de ajustar otros factores de riesgo importantes, como la duración de la gestación, la situación socioeconómica y el consumo de alcohol y de cigarrillos. La presencia de plomo en la sangre materna como un factor de riesgo para la talla al nacimiento se observó exclusivamente en neonatos de raza blanca. La talla al nacimiento de los niños de raza blanca disminuyó aproximadamente $2,5 \mathrm{~cm}$ por unidad logarítmica de plomo que aumentaba en la sangre materna. Se debe prestar atención especial a las decisiones para seleccionar la variable del resultado. Si sólo se hubiera seleccionado el peso al nacimiento para el estudio, el hallazgo de los efectos del plomo sobre otros parámetros del crecimiento podría haber sido pasado por alto. Además, si se hubieran mezclado los neonatos de raza blanca y los afroamericanos en el análisis citado previamente, los efectos diferentes sobre los de raza blanca, quizás debidos a diferencias genéticas en la capacidad de almacenamiento y fijación del plomo, podían haber pasado desapercibidos. También se observó un factor de confusión importante entre el plomo presente en la sangre materna prenatal y la edad materna y el peso del hijo al nacer, después de ajustar otras covariables. Los resultados indican que, en una mujer de 30 años de edad, con un nivel estimado de plomo en sangre de $20 \mu \mathrm{g} / \mathrm{dl}$, el neonato pesaba $2.500 \mathrm{~g}$, frente a los $3.000 \mathrm{~g}$ del hijo de una mujer de 20 años de edad con niveles de plomo similares. Los investigadores señalan que esta diferencia puede indicar que las mujeres de más edad son más sensibles a la agresión adicional de la exposición al plomo o que han tenido una carga total de plomo más alta debido al mayor número de años de exposición o a los mayores niveles de plomo en el ambiente cuando ellas eran niñas. 0 tro factor puede ser el aumento de la presión arterial. No obstante, la lección más importante es que acaso sea necesario realizar una exploración minuciosa de las subpoblaciones de alto riesgo por razón de edad, raza, situación económica, hábitos de la vida diaria, sexo del neonato y otras diferencias genéticas para descubrir los efectos más sutiles de las exposiciones sobre el crecimiento y el desarrollo fetal.

L os factores de riesgo asociados al bajo peso al nacimiento se resumen en la Tabla 9.5. La clase social, considerada como el nivel de ingresos y/o de educación, persiste como factor de riesgo en los casos en que no existen diferencias étnicas. 0 tros factores que pueden actuar además de la clase social y/ o raza son el consumo de cigarrillos, el trabajo físico, la atención prenatal y la nutrición. Las mujeres de edades comprendidas entre los 25 y los 29 años tienen menos probabilidades de dar a luz un neonato con retraso del crecimiento. El consumo de tabaco por parte de la madre aumenta el riesgo de bajo peso en el neonato al nacimiento aproximadamente en un $200 \%$. Algunos de los trastornos médicos maternos asociados al BPN son las anomalías placentarias, enfermedades cardíacas, neumonía vírica, enfermedades hepáticas, preeclampsia, eclampsia, hipertensión crónica, aumento de peso e hiperemesis. EI antecedente gestacional adverso de pérdida fetal, parto prematuro o hijo anterior con BPN aumenta de dos a cuatro veces el riesgo de que la gestación actual finalice en un neonato prematuro con bajo peso al nacimiento. El intervalo inferior a un año entre partos triplica el riesgo de tener un hijo con bajo peso al nacimiento. Entre las anomalías cromosómicas asociadas a un crecimiento anormal están el síndrome de Down, la trisomía 18 y la mayoría de los síndromes que se acompañan de malformación.

El consumo de cigarrillos es uno de los comportamientos asociados más directamente con el nacimiento de neonatos de bajo peso. Se ha demostrado que el consumo de tabaco por la madre durante el embarazo aumenta de dos a tres veces el riesgo de bajo peso al nacimiento en el hijo y de un déficit global de peso de 150-450 g. Se considera que la nicotina y el monóxido de carbono son los agentes causales más probables, ya que ambos son transferidos rápida y preferencialmente a través de la placenta. La nicotina es un vasoconstrictor potente y se han demostrado diferencias significativas en el tamaño de los vasos umbilicales de las madres fumadoras. Los niveles de monóxido de carbono presentes en el humo de los cigarrillos oscilan entre 20.000 y 60.000 ppm. El monóxido de carbono tiene una afinidad por la hemoglobina 210 veces superior a la del oxígeno y, debido a la disminución de la presión parcial de oxígeno en la sangre arterial, el feto está especialmente comprometido. 0 tros autores señalan que estos efectos no se deben al consumo de tabaco, sino que forman parte de las características de los fumadores. Es cierto que los trabajos con exposición potencial al monóxido de carbono, como los que se desarrollan en la industria papelera, altos hornos, fábricas de acetileno, destilerías, producción de negro de humo, hornos de coque, talleres de reparación, síntesis de productos químicos orgánicos y refinerías de petróleo, parecen tener un riesgo elevado para las empleadas embarazadas.

El etanol se utiliza asimismo ampliamente y ha sido objeto de investigación como agente asociado al retraso de crecimiento fetal (y al desarrollo de anomalías congénitas). En un estudio prospectivo de 9.236 nacimientos, se descubrió que el consumo diario por parte de la madre de más de $4,4 \mathrm{~g}$ de alcohol se asociaba a un aumento de nacimientos de feto muerto y de niños con retraso del crecimiento (K aminski, Rumeau y 
Schwartz 1978). El consumo de alcohol también se relaciona con disminución de la talla y del perímetro craneal.

Al evaluar los posibles efectos de las exposiciones sobre el peso al nacimiento, se deben tener en cuenta algunos aspectos problemáticos. $\mathrm{H}$ ay que considerar el parto antes de término como un resultado intermedio, así como los posibles efectos sobre la edad gestacional. Además, las gestaciones con una duración más prolongada también tienen más posibilidades de exposición. Si existe un número suficiente de mujeres que trabajan en las últimas semanas del embarazo, la exposición acumulada más prolongada puede estar asociada a una edad gestacional más avanzada, considerando los neonatos de mayor peso simplemente como un artefacto. Existen distintos procedimientos para salvar este problema, tales como una variante del modelo de regresión de la tabla de vida de Cox, que permite modificar las covariables dependientes del tiempo.

0 tro de los problemas se centra en la definición del bajo peso al nacimiento. A menudo, los estudios definen este término como una variable dicotómica: menos de 2,500 g. La exposición, sin embargo, debe tener un efecto muy poderoso para provocar una reducción drástica del peso del neonato. El peso al nacimiento definido como una variable continua y analizado mediante un modelo de regresión múltiple permite detectar mejor los efectos sutiles. La relativa escasez de hallazgos significativos relacionados con las exposiciones profesionales y los neonatos pequeños para la edad gestacional puede deberse, en parte, al olvido de estos aspectos relativos al diseño y al análisis

\section{Conclusiones}

Los estudios de los resultados adversos en el embarazo deben caracterizar las exposiciones durante un intervalo de tiempo bastante breve. Si la mujer ha sido trasladada a otro trabajo o ha dejado de trabajar durante un período crítico de tiempo, como la organogénesis, la relación entre la exposición y el efecto ocasionado puede quedar seriamente alterada. Por lo tanto, el investigador ha de identificar la exposición de la mujer durante un breve período crítico de tiempo, mientras que, en otros estudios de enfermedades crónicas, los errores de varios meses, o incluso años, tienen un efecto mínimo.

En los estudios de exposiciones profesionales suelen evaluarse el retraso del crecimiento intrauterino, las anomalías congénitas y los abortos espontáneos. Se dispone de una pluralidad de enfoque para evaluar cada resultado. Estos criterios de valoración tienen importancia para la salud pública, tanto por el coste psicológico para el individuo como por los costes económicos implícitos. Por lo general, se ha observado una inespecificidad de la relación exposición-efecto-exposiciones, como las debidas al plomo, los gases anestésicos o los disolventes. Ante esta posible inespecificidad en la relación exposición-efecto, es necesario diseñar estudios que evalúen los distintos criterios de valoración asociados a un conjunto de mecanismos.

\section{- El parto pretermino 0 PREMATURO Y EL TRABAJO}

Nicole M amelle

Conciliar el trabajo y la maternidad constituye un importante aspecto de la sanidad pública en los países industrializados, en los que más del $50 \%$ de las mujeres en edad fértil trabajan fuera del hogar. Las propias mujeres trabajadoras, los sindicatos, los empresarios, los políticos y los médicos buscan métodos para prevenir los resultados desfavorables del embarazo inducidos por el trabajo. Las mujeres desean continuar trabajando durante el embarazo y es posible incluso que consideren que los consejos que les da el médico sobre las modificaciones de su forma de vida son sobreprotectores e innecesariamente restrictivos.

\section{Consecuencias fisiológicas del embarazo}

Será útil exponer, ante todo, algunas de las consecuencias fisiológicas del embarazo que pueden interferir con el trabajo.

La mujer embarazada experimenta cambios profundos, que permiten su adaptación a las necesidades del feto y que consisten, principalmente, en la modificación de las funciones fisiológicas sensibles a los cambios de la postura o de la actividad física (sistema circulatorio, sistema respiratorio y equilibrio hídrico). Como resultado, si se mantiene físicamente activa, la mujer experimenta reacciones fisiológicas y fisiopatológicas singulares

Entre éstas cabe mencionar las siguientes (Mamelle y cols. 1982):

1. Un aumento de la demanda periférica de oxígeno, que da lugar a una modificación de los sistemas respiratorio y circulatorio. El volumen respiratorio comienza a aumentar en el tercer mes y alcanzar al final incrementos de hasta un $40 \%$ de los valores previos. El aumento del intercambio de gas resultante puede incrementar el peligro de inhalación de sustancias volátiles tóxicas, mientras que la hiperventilación puede dar lugar a disnea de esfuerzo.

2. También el gasto cardíaco aumenta, como consecuencia del incremento del volumen de sangre, reduciéndose así la capacidad del corazón para adaptarse al ejercicio y aumentando la presión venosa en las extremidades inferiores, hasta tal punto que resulta difícil mantenerse de pie durante períodos prolongados.

3. Las modificaciones anatómicas, incluidas la exageración de la lordosis dorso-lumbar, el aumento del polígono de soporte y el incremento del volumen abdominal, afectan a las actividades estáticas.

4. $\mathrm{H}$ ay asimismo otras modificaciones: las náuseas y los vómitos dan lugar a fatiga; la somnolencia durante el día ocasiona falta de atención, cambios del estado de ánimo y sentimientos de ansiedad que pueden originar conflictos interpersonales.

5. Finalmente, es interesante resaltar que las necesidades de energía diaria durante el embarazo son equivalentes a los de dos a cuatro horas de trabajo.

Debido a estos profundos cambios, las exposiciones profesionales pueden tener consecuencias singulares en la mujer embarazada y dar lugar a resultados desfavorables del embarazo.

\section{Estudios epidemiológicos sobre las condiciones de trabajo y su relación con el parto pretérmino} Entre los muchos resultados desfavorables del embarazo que pueden producirse, en este artículo se examinan los referentes al parto antes del término, definido como el que se produce antes de la semana 37 de gestación y que implica bajo peso y complicaciones significativas para el recién nacido. El parto antes del término sigue siendo un importante problema de salud pública y constituye una preocupación de muchos tocólogos.

C uando comenzamos a investigar este asunto a mediados del decenio de 1980, la legislación francesa en vigor tenía un fuerte carácter protector de la salud de la mujer embarazada y obligaba a ésta a tomar el permiso de maternidad seis semanas antes de la fecha prevista del parto. D esde entonces, aunque la tasa de partos antes del término se ha reducido del $10 \%$ al $7 \%$, parece haberse estabilizado en esa cifra. Dado que la prevención médica ha alcanzado, aparentemente, el límite de su eficacia, 
tratamos de determinar los factores de riesgo que admiten una posible intervención social. N uestras hipótesis son las siguientes:

- ¿Es el trabajo en sí mismo un factor de riesgo de parto pretérmino?

- ¿Existen trabajos que se asocian con un aumento del riesgo de parto pretérmino?

- ¿C onstituyen ciertas condiciones de trabajo un peligro para la mujer embarazada y el feto?

- ¿Existen medidas preventivas sociales que puedan ayudar a disminuir el riesgo de parto pretérmino?

En nuestro primer estudio, realizado en los años 1977 y 1978 en dos maternidades, examinamos a 3.400 mujeres, de las cuales 1.900 habían trabajado durante el embarazo y 1.500 habían permanecido en el hogar (Mamelle, Laumon y Lazar 1984). A todas se les entrevistó inmediatamente después del parto y se les pidió que describieran su forma de vida, durante el embarazo, en el hogar y en el trabajo, con la mayor precisión posible.

\section{O btuvimos los siguientes resultados:}

\section{Trabajo en sí mismo}

El hecho de trabajar no puede considerarse un factor de riesgo de parto antes de término, puesto que las mujeres que no habían trabajado fuera del hogar presentaban una tasa de prematuridad más elevada que las restantes $(7,2 \%$ frente al 5,8 \%).

\section{Condiciones de trabajo}

U na semana de trabajo excesivamente prolongada parecía ser un factor de riesgo, puesto que se observó una relación entre el incremento regular de la tasa de parto antes del término y el número de horas de trabajo. La venta al por menor, las profesiones de carácter médico-social o las correspondientes a trabajos especializados y al sector de servicios, mostraron un riesgo de parto antes del término más elevado que otras, como las de empleadas de oficina, profesoras, administrativas, trabajadoras cualificadas o supervisoras. Las tasas de prematuridad de los dos grupos fueron del $8,3 \%$ y el 3,8\%, respectivamente.

EI análisis de los datos permitió identificar cinco causas de fatiga laboral: la postura, el trabajo con máquinas industriales, la cantidad de trabajo físico, la cantidad de trabajo mental y el ambiente laboral. Cada una de estas causas de fatiga laboral

Tabla 9.6 - Fuentes conocidas de fatiga profesional.

$\begin{array}{ll}\begin{array}{l}\text { Índice de fatiga } \\ \text { profesional }\end{array} & \text { Índice "ALTO" si: } \\ \begin{array}{l}\text { Postura } \\ \text { Trabajo con máquinas }\end{array} & \begin{array}{l}\text { De pie durante más de tres horas diarias. } \\ \text { independiente con maquinaria industrial que exija un } \\ \text { esfuerzo agotador. }\end{array} \\ \text { Earga física } & \begin{array}{l}\text { Esfuerzo físico continuo o periódico con cargas superiores } \\ 10 \text { kg. }\end{array} \\ \text { Carga mental } & \begin{array}{l}\text { Trabajo rutinario; tareas variadas que exijan poca aten- } \\ \text { ción, sin estímulo. }\end{array} \\ \text { Medio ambiente } & \begin{array}{l}\text { Nivel de ruido considerable; bajas temperaturas; atmós- } \\ \text { fera muy húmeda; manipulación de sustancias químicas. }\end{array}\end{array}$

Fuente: Mamelle, Laumon y Lazar 1984
Tabla 9.7 - Riesgos relativos (RR) e índices de fatiga para el parto pretérmino.

$\begin{array}{lllll}\text { Indice } & \begin{array}{l}\text { Indice } \\ \text { bajo \% }\end{array} & \begin{array}{l}\text { Indice } \\ \text { elevado \% }\end{array} & \text { RR } & \begin{array}{l}\text { Significación } \\ \text { estadística }\end{array} \\ \text { Postura } & 4,5 & 7,2 & 1,6 & \text { Significativo } \\ \text { Trabajo con máquinas } & 5,6 & 8,8 & 1,6 & \text { Significativo } \\ \text { Carga física } & 4,1 & 7,5 & 1,8 & \text { Altamente significativo } \\ \text { Carga mental } & 4,0 & 7,8 & 2,0 & \text { Altamente significativo } \\ \text { Medio ambiente } & 4,9 & 9,4 & 1,9 & \text { Altamente significativo }\end{array}$

Fuente: Mamelle, Laumon y Lazar 1984.

constituye un factor de riesgo de parto pretérmino (véanse las Tablas 9.6 y 9.7)

La exposición a una pluralidad de causas de fatiga puede dar lugar a resultados desfavorables del embarazo, como queda reflejado por el aumento significativo de la tasa de parto pretérmino a medida que aumentaba el número de causas de fatiga (Tabla 9.8). U n $20 \%$ del total de mujeres, que presentaban una exposición simultánea al menos a tres causas de fatiga, tenían una tasa de parto pretérmino que duplicaba la del resto de la población considerada. La fatiga laboral y la semana laboral excesivamente prolongada dan lugar a una tasa de prematuridad incluso más elevada. Esta aumenta de forma adicional cuando existe además un factor de riesgo médico. La detección de la fatiga laboral es, por tanto, incluso más importante que la detección de los factores de riesgo médico.

Estudios europeos y norteamericanos han confirmado nuestros resultados y se ha demostrado que nuestra escala de la fatiga es reproducible en otras encuestas y países.

En un estudio de seguimiento de casos y controles realizado en Francia en la misma maternidad pocos años después (M amelle y M unoz 1987), sólo dos de los cinco índices de fatiga ya señalados se relacionaron significativamente con el parto antes del término. No obstante, habría que señalar que las mujeres tenían más oportunidades de sentarse durante el trabajo y que habían sido retiradas de las tareas que precisaban esfuerzos en virtud de las medidas preventivas adoptadas por entonces en los lugares de trabajo. En todo caso, la escala de la fatiga siguió siendo predictiva del parto pretérmino.

Tabla 9.8 - Riesgo relativo de nacimiento prematuro en función de los índices de fatiga profesional.

$\begin{array}{ccc}\begin{array}{c}\text { Número de índices de } \\ \text { fatiga elevados }\end{array} & \begin{array}{c}\text { Proporción de mujeres } \\ \text { expuestas } \\ \%\end{array} & \begin{array}{l}\text { Riesgo relativo } \\ \text { estimado }\end{array} \\ 0 & 24 & 1,0 \\ 1 & 28 & 2,2 \\ 2 & 25 & 2,4 \\ 3 & 15 & 4,1 \\ 4-5 & 8 & 4,8\end{array}$

Fuente: Mamelle, Laumon y Lazar 1984. 
En M ontreal, Q uebec, se efectuó un estudio ( $M$ acD onald y cols. 1988) sobre 22.000 mujeres embarazadas mediante una encuesta retrospectiva sobre las condiciones de trabajo. En él se demostró que las semanas de trabajo prolongadas, los cambios alternativos de turno y el transporte de cargas pesadas tenían una influencia significativa. Los restantes factores estudiados no parecían estar relacionados con el parto antes de término, aunque se observó aparentemente una asociación significativa entre este último y una escala basada en el número total de causas de fatiga.

Con la excepción del trabajo con máquinas industriales, no se observó ninguna asociación significativa entre las condiciones de trabajo y el parto antes del término en un estudio retrospectivo francés realizado sobre una muestra significativa de 5.000 mujeres embarazadas (Saurel-C ubizolles y K aminski 1987). En cambio, se advirtió esa asociación entre una escala de fatiga inspirada en la muestra y el parto antes del término.

En Estados U nidos, H omer, Bereford y James (1990) confirmaron en un estudio histórico de cohortes la existencia de una asociación entre la carga de trabajo físico y el riesgo creciente de prematuridad. Teitelman y colaboradores (1990), en un estudio prospectivo efectuado sobre 1.200 mujeres embarazadas cuyo trabajo se clasificó como sedentario, activo o en bipedestación basándose en la descripción del puesto de trabajo, demostró la existencia de una asociación entre el trabajo en bipedestación y el parto antes del término.

Recientemente, Barbara Luke y colaboradores (en prensa) han llevado a cabo un estudio retrospectivo en enfermeras norteamericanas, utilizando nuestra misma escala de riesgo laboral. Los resultados han sido similares a los nuestros, es decir, la existencia de una asociación entre el parto antes del término y las semanas laborales prolongadas, el trabajo de pie, una cantidad de trabajo excesiva y un ambiente laboral desfavorable. Además, se observa un riesgo de parto pretérmino significativamente mayor entre las mujeres expuestas de forma simultánea a tres o cuatro causas de fatiga. D ebe resaltarse que en este ensayo participaron más de la mitad de todas las enfermeras de Estados Unidos.

Por otra parte, también se han notificado resultados contradictorios. Las causas podrían encontrarse en el empleo de tamaños de muestra pequeños (Berkowitz 1981), la utilización de definiciones de prematuridad diferentes (Launer y cols. 1990) 0 la clasificación de las condiciones de trabajo en función de las descripciones de los puestos de trabajo y no de un análisis real de éstos en sí (K lebanoff, Shiono y Carey 1990). En algunos casos, el puesto de trabajo se define de forma teórica, según la descripción del médico de empresa, por ejemplo, y no la de las propias mujeres (Peoples-Sheps y cols. 1991). Nosotros estimamos que es importante tener presente en los análisis la fatiga subjetiva, es decir, la que describen y experimentan éstas.

Finalmente, es posible que los resultados negativos se deban a la adopción de medidas preventivas. Así ocurre en el estudio prospectivo de Ahlborg, Bodin y Hogstedt (1990), en el que se pidió a 3.900 mujeres suecas que cumplimentasen un cuestionario durante su primera visita prenatal. El único factor de riesgo de parto pretérmino que pudo registrarse fue el transporte de pesos de más de $12 \mathrm{~kg}$ con una frecuencia superior a 50 veces a la semana y, aun en ese caso, el riesgo relativo de 1,7 no fue significativo. El propio Ahlborg señala que se habían adoptado medidas preventivas, tales como la instauración del permiso remunerado por maternidad y el reconocimiento del derecho a realizar trabajos menos fatigosos durante los dos meses previos a la fecha prevista para el parto. Las bajas habían sido cinco veces más frecuentes entre las mujeres que describían su trabajo como agotador y que implicaban el transporte de cargas pesadas. A hlborg concluye que la disminución del riesgo de parto antes del término pudo deberse a la implantación de medidas preventivas de este tipo.

\section{Intervenciones preventivas: ejemplos de Francia}

¿Son los resultados de los estudios etiológicos lo suficientemente convincentes para permitir la aplicación y evaluación de medidas preventivas? La primera cuestión que debe contestarse es si existe una justificación de salud pública para la aplicación de medidas preventivas sociales destinadas a disminuir la tasa de parto prematuro.

U tilizando datos de estudios previos nuestros, hemos estimado la tasa de nacimientos pretérmino por razones laborales. Considerando una tasa del $10 \%$ en la población expuesta a fatiga intensa y una tasa del $4,5 \%$ en la población restante, estimamos que el $21 \%$ de los nacimientos prematuros se deben a factores laborales. Reduciendo la fatiga laboral podrían excluirse, por tanto, un quinto de todos los nacimientos antes de término en las mujeres trabajadoras francesas. Estos datos justifican por sí solos la adopción de medidas preventivas sociales.

¿Cuáles son estas medidas preventivas? Los resultados de todos los estudios permiten concluir que es posible disminuir las horas de trabajo, reducir la fatiga mediante la modificación del puesto de trabajo, permitir interrupciones temporales del trabajo o prolongar el permiso por maternidad. Existen tres alternativas con un coste económico equivalente:

- disminuir la semana laboral a 30 horas a partir de la semana 20 de gestación;

- prescribir una interrupción laboral de una semana al mes a partir de la semana 20 de gestación;

- comenzar el permiso por maternidad en la semana 28 de gestación.

Es importante resaltar que la legislación francesa obliga a la adopción de las siguientes medidas preventivas en las mujeres embarazadas:

- garantía del empleo después del nacimiento del hijo;

- disminución de la jornada laboral de 30 a 60 minutos, en virtud de convenio colectivo;

- modificación del puesto de trabajo en los casos de incompatibilidad con el embarazo;

- interrupciones temporales del trabajo durante el embarazo en caso de prescripción por el médico;

- permiso prenatal de maternidad de seis semanas antes de la fecha prevista para el parto, con dos semanas adicionales en caso de complicaciones;

- permiso posnatal de maternidad de diez semanas.

En un estudio observacional prospectivo de un año de duración realizado en 23.000 mujeres que trabajaban en 50 empresas de la región francesa de Ródano-Alpes (Bertucat, $M$ amelle y $M$ unoz 1987) se examinaron los efectos de las condiciones de trabajo fatigosas sobre el parto prematuro. Durante el período de estudio, nacieron 1.150 niños en la población considerada. Analizamos las modificaciones de las condiciones de trabajo debidas al embarazo y la relación de estas modificaciones con el parto pretérmino (Mamelle, Bertucat y M unoz 1987), y observamos lo siguiente:

- Unicamente se había modificado el puesto de trabajo en el $8 \%$ de los casos.

- El 33 \% de las mujeres habían trabajado su turno normal, y el resto habían disminuido su jornada laboral en 30 a 60 minutos.

- El 50 \% de las mujeres se habían acogido al menos a una interrupción temporal del trabajo, aparte del permiso prenatal de maternidad, debida a la fatiga en un tercio de los casos. 
- El $90 \%$ de las mujeres habían interrumpido el trabajo antes de lo previsto en el régimen del permiso de maternidad y habían obtenido al menos las dos semanas de permiso adicionales que se permiten en caso de complicaciones del embarazo; en la mitad de los casos, la causa había sido la fatiga.

- En conjunto, considerando las seis semanas del permiso de maternidad anteriores a la fecha prevista para el parto (con dos semanas adicionales en algunos casos), la duración real del permiso había sido de 12 semanas en esta población de mujeres sometidas a condiciones de trabajo fatigosas.

¿T ienen estas modificaciones del trabajo algún efecto sobre el resultado del embarazo? La modificación del puesto de trabajo y la ligera reducción de la jornada laboral (30 a 60 minutos) se asociaron con disminuciones no significativas del riesgo de parto antes de término. Consideramos que las disminuciones adicionales de la semana laboral podrían tener un efecto mayor (véase la Tabla 9.9).

Para analizar la relación existente entre el permiso prenatal de maternidad, las interrupciones temporales del trabajo y el parto antes de término es necesario distinguir entre las interrupciones temporales del trabajo preventivas y las curativas. Para ello hay que restringir el análisis a los casos de embarazo sin complicaciones. Nuestro análisis de este subgrupo reveló una disminución de la tasa de parto pretérmino en las mujeres que se habían acogido a interrupciones temporales del trabajo durante su embarazo, pero no en las que habían prolongado el permiso prenatal de maternidad (T abla 9.9).

Los resultados de este estudio observacional muestran que las mujeres que trabajan en condiciones fatigosas se acogen a más interrupciones temporales del trabajo durante su embarazo y que estas interrupciones, especialmente las motivadas por fatiga intensa, se asocian con disminuciones del riesgo de parto antes del término ( $M$ amelle, Bertucat y M uñoz 1989).

Tabla 9.9 - Riesgo relativo de nacimiento prematuro asociado con la modificación de las condiciones de trabajo.

\begin{tabular}{|c|c|c|c|}
\hline $\begin{array}{l}\text { Modificaciones de } \\
\text { las condiciones } \\
\text { de trabajo }\end{array}$ & $\begin{array}{l}\text { Número de } \\
\text { mujeres }\end{array}$ & $\begin{array}{l}\text { Tasas de naci- } \\
\text { mientos pretér- } \\
\text { mino }(\%)\end{array}$ & $\begin{array}{l}\text { Riesgo relativo } \\
\text { (95\% intervalos } \\
\text { de confianza) }\end{array}$ \\
\hline \multicolumn{4}{|c|}{ Cambio de la situación de trabajo } \\
\hline No & 1.062 & 6,2 & $0,5(0,2-1,6)$ \\
\hline Sí & 87 & 3,4 & \\
\hline \multicolumn{4}{|c|}{$\begin{array}{l}\text { Reducción de las horas de } \\
\text { trabajo semanales }\end{array}$} \\
\hline No & 388 & 7,7 & $0,7(0,4-1,1)$ \\
\hline Sí & 761 & 5,1 & \\
\hline \multicolumn{4}{|c|}{ Episodios de baja por enfermedad ${ }^{1}$} \\
\hline No & 357 & 8,0 & $0,4(0,2-0,7)$ \\
\hline Sí & 421 & 3,1 & \\
\hline \multicolumn{4}{|c|}{$\begin{array}{l}\text { Aumento de la baja } \\
\text { prenatal por maternidad }\end{array}$} \\
\hline $\begin{array}{l}\text { Ninguno o sólo } \\
\text { dos semanas más }\end{array}$ & 487 & 4,3 & $1,7(0,9-3,0)$ \\
\hline Sí & 291 & 7,2 & \\
\hline
\end{tabular}

Elección de las estrategias preventivas en Francia Como epidemiólogos, nos gustaría ver estas observaciones verificadas en estudios preventivos experimentales. Con todo, tendríamos que preguntarnos qué es más razonable: esperar a la realización de dichos estudios o recomendar desde ahora la adopción de medidas sociales dirigidas a la prevención del parto antes de término.

En Francia se ha decidido recientemente la inclusión de una guía sobre "trabajo y embarazo", idéntica a nuestra escala sobre la fatiga, en cada gráfica médica de las mujeres embarazadas. Estas pueden calcular así su propia puntuación de fatiga y, si las condiciones de trabajo son difíciles, pedir al médico de empresa 0 al responsable de seguridad en el trabajo que introduzca las modificaciones pertinentes para reducir su volumen de trabajo. En caso de que sus deseos no sean atendidos, pueden pedir al médico que les prescriba reposo durante el embarazo o incluso que prolongue el permiso prenatal de maternidad.

El mayor desafío actual consiste en establecer las estrategias preventivas más idóneas para las condiciones legislativas y sociales de cada país. Para ello hay que aplicar un enfoque económico de la salud dirigido a la valoración y comparación de las estrategias preventivas. Antes de considerar aplicable con carácter general cualquier medida preventiva, han de tenerse en cuenta numerosos factores, tales como la eficacia, por supuesto, pero también un bajo coste para el sistema de seguridad social, la creación de empleo resultante, las preferencias de las mujeres y su aceptación por parte de los empresarios y los sindicatos.

Este tipo de problema puede resolverse utilizando métodos multicriterio, como el denominado Electra, que permiten clasificar las estrategias preventivas en función de distintos criterios y ponderar éstos a partir de consideraciones políticas, dando, por ejemplo, una importancia especial a la obtención de un bajo coste para el sistema de seguridad social o a la capacidad de elegir de las mujeres (M amelle y cols. 1986). A unque las estrategias resultantes de la aplicación de estos métodos varían en función de los responsables de la toma de decisiones y de las opciones políticas, la eficacia debe sustentarse siempre en criterios de salud pública.

\section{EXPOSICIONES DEL RECIEN NACIDO A SU STANCIAS TOXICAS DE ORIGEN IN DU ST RIAL Y AMBIENTAL}

\author{
M ary S. Wolff y Patrisha M. Woolard
}

Los peligros de origen ambiental suponen un riesgo especial para lactantes y niños pequeños. Los niños no son "adultos en miniatura", ni por la forma en que absorben y eliminan los compuestos químicos ni por su respuesta a la exposición a sustancias tóxicas. La exposición neonatal puede ejercer una influencia mayor, pues la superficie del cuerpo es desproporcionadamente grande y la capacidad metabólica (la aptitud para eliminar compuestos químicos) está relativamente infradesarrollada. Al mismo tiempo, aunque los efectos tóxicos potenciales son mayores, porque el cerebro, los pulmones y el sistema inmunitario se encuentran en fase de desarrollo durante los primeros años de vida.

$\mathrm{H}$ ay posibilidades de exposición en casa, en guarderías y en zonas de juego:

- Los niños pequeños absorben agentes ambientales del aire (por inhalación) 0 a través de la piel.

- La ingestión es una importante vía de exposición, en especial cuando el niño empieza a desplegar la actividad de manos a la boca. 
- Las sustancias presentes en el pelo, la ropa o las manos de los padres pueden transferirse a los niños.

- La leche materna es otra fuente potencial de exposición para el lactante, los beneficios potenciales de la nutrición materna sobrepasan con creces los potenciales efectos tóxicos de los compuestos químicos presentes en la leche.

En algunos de los efectos sobre la salud examinados en relación con la exposición neonatal, es difícil diferenciar entre episodios pre y postnatales. Exposiciones que se inician antes del nacimiento (por vía placentaria) pueden continuar activas durante la primera infancia. El plomo y el humo de tabaco del medio ambiente se han asociado con deficiencias del desarrollo cognitivo y la función pulmonar, tanto antes como después del nacimiento. En la presente revisión tratamos de centrarnos en las exposiciones postnatales y en sus efectos sobre la salud de los niños muy pequeños.

\section{Plomo y otros metales pesados}

Entre los metales pesados, el plomo (Pb) constituye para el hombre la exposición elemental más importante, tanto en el medio ambiente como en el lugar de trabajo. Se producen importantes exposiciones de origen industrial en trabajos como fabricación de baterías, fundición, soldadura, construcción y decapado. Se sabe desde hace tiempo que las personas empleadas en industrias de este tipo llevan en la ropa polvo que pueden absorber sus hijos. Para éstos, la vía de absorción primordial es la ingestión de partículas de pintura, polvo y agua contaminadas con plomo. La absorción respiratoria es eficaz y la inhalación constituye una vía importante de exposición en presencia de aerosoles de plomo 0 alquil plomo (Clement International Corporation 1991).

La intoxicación por plomo puede dañar prácticamente todos los órganos del cuerpo, pero, en los niños, los niveles de exposición actuales se han asociado sobre todo con trastornos neurológicos y del desarrollo. También se han observado afecciones renales y hematológicas en adultos y niños expuestos a concentraciones elevadas de plomo. L as enfermedades cardiovasculares y las disfunciones de la reproducción son secuelas conocidas en la madurez de la exposición al plomo. Se sospecha que la exposición crónica a concentraciones más bajas de plomo tiene efectos renales, cardiovasculares y reproductivos de gravedad subclínica, y hay datos limitados que apoyan esta sugerencia. Los datos obtenidos en animales apoyan las observaciones hechas en el hombre (Sager y Girard 1994).

En términos de dosis mensurable, los efectos neurológicos abarcan desde deficiencias del $\mathrm{Cl}$ a bajas exposiciones $(10 \mu \mathrm{g} / \mathrm{dl}$ de plomo en sangre) hasta encefalopatías ( $80 \mu \mathrm{g} / \mathrm{dl}$ ). En 1985, se consideró que la concentración preocupante para los niños era de $25 \mu \mathrm{g} / \mathrm{dl}$, valor que se rebajó a $10 \mu \mathrm{g} / \mathrm{dl}$ en 1993.

En 1978, Chisholm describió la exposición neonatal debida a la aportación de polvo a casa por los padres trabajadores. Desde entonces, una serie de medidas preventivas, como la ducha y el cambio de ropa antes de abandonar el lugar de trabajo, han reducido la carga de polvo transportada a casa. Sin embargo, el plomo de origen industrial continúa siendo una importante fuente potencial de exposición neonatal. U na investigación realizada en Dinamarca determinó que la concentración de plomo en sangre en hijos de trabajadores expuestos era aproximadamente el doble que en niños que vivían en hogares expuestos a contaminación de origen no industrial (Grandjean y Bach 1986). Se ha documentado exposición de niños a plomo de origen industrial entre empalmadores de cables eléctricos (R inehart y Yanagisawa 1993) y trabajadores de fábricas de condensadores (K aye, N ovotny y Tucker 1987).

Las fuentes no industriales de exposición ambiental al plomo siguen constituyendo un peligro grave para los niños pequeños.
Desde que en Estados Unidos se inició la prohibición gradual del plomo tetraetilo como aditivo para combustibles (1978), las concentraciones medias de plomo en sangre han disminuido en los niños desde 13 hasta $3 \mu \mathrm{g} / \mathrm{dl}$ (Pirkle y cols. 1994). Las partículas y el polvo de pintura son ahora la causa principal de intoxicación por plomo entre los niños en Estados Unidos (Roper 1991). Así, según un informe, los niños más pequeños (neonatos de menos de 11 meses) con cantidades excesivas de plomo en sangre habían estado expuestos a un riesgo máximo de exposición a través del polvo y el agua, mientras que, para niños algo mayores (24 meses), el riesgo procedía de la ingestión de partículas de pintura (pica) (Shannon y Graef 1992). La disminución del plomo por medio de la eliminación de pintura ha logrado proteger a los niños de la exposición al polvo y las partículas de pintura (Farfel, C hisholm y Rohde 1994); paradójicamente, se ha demostrado que los trabajadores encargados de esta operación llevan a sus hogares polvo de plomo pegado a la ropa. Además, se ha observado que la exposición continua al plomo afecta de manera desproporcionada a los niños pequeños económicamente desfavorecidos (Brody y cols. 1994; G oldman y Carra 1994). Parte de esta desigualdad deriva de las malas condiciones de vivienda; ya en 1982 se demostró que la magnitud del deterioro de las viviendas guardaba relación directa con las concentraciones de plomo en sangre durante la infancia (C lement International Corporation 1991).

0 tra fuente potencial de exposición de origen industrial para el recién nacido es la leche materna. Las concentraciones elevadas de plomo en la leche materna se han asociado con fuentes de contaminación industriales y ambientales (Ryu, Ziegler y Fomon 1978; Dabeka y cols. 1986). Las concentraciones de plomo en la leche son pequeñas en relación con las presentes en la sangre (aproximadamente 1/5 a 1/2) (Wolff 1993), pero el gran volumen de leche materna que ingiere el niño puede aportar a su organismo cargas del orden de miligramos. En comparación, normalmente hay menos de $0,03 \mathrm{mg}$ de $\mathrm{Pb}$ en la sangre circulante del lactante, y la ingesta habitual es inferior a $20 \mu \mathrm{g}$ al día (Clement International Corporation 1991). De hecho, la absorción procedente de la leche materna se refleja en la concentración de plomo en sangre del lactante (Rabinowitz, Leviton y Needleman 1985; Ryu y cols. 1983; Ziegler y cols. 1978). H ay que señalar que las concentraciones normales de plomo en la leche materna no son excesivas, y que la lactancia aporta una cantidad similar a otras fuentes de nutrición infantil. En cambio, una diminuta partícula de pintura puede contener más de $10 \mathrm{mg}(10,000 \mu \mathrm{g})$ de plomo.

El retraso en el desarrollo infantil se ha vinculado con exposiciones prenatales y postnatales al plomo. La exposición prenatal se considera causante de deficiencias del desarrollo mental y conductual vinculadas con el plomo observadas en niños hasta la edad de 2 a 4 años (Landrigan y Campbell 1991; Bellinger y cols. 1987). Los efectos de la exposición postnatal al plomo, como la de origen profesional, pueden detectarse en niños de 2 a 6 años o más; entre tales efectos se dan trastornos del comportamiento y disminución de la inteligencia (Bellinger y cols. 1994). Estos efectos no se limitan a exposiciones elevadas, sino que se han observado también a concentraciones relativamente bajas, con valores en sangre del orden de $10 \mu \mathrm{g} / \mathrm{dl}$ (Needleman y Bellinger 1984).

La exposición ambiental al mercurio $(\mathrm{Hg})$ se debe a la presencia de compuestos tanto inorgánicos como orgánicos (sobre todo derivados metilados). Se han descubierto exposiciones industriales recientes a este metal en la fabricación de termómetros y en la reparación de material eléctrico de alta tensión que contiene mercurio. 0 tros empleos con potencial de exposición son: pintura, odontología, fontanería y fabricación de cloro (Agency for Toxic Substance and D isease R egistry 1992). 
La intoxicación prenatal y postanal por mercurio está bien documentada. Los niños son más sensibles a los efectos del mercurio metilo que los adultos; esto se debe en gran medida a que el sistema nervioso central humano en desarrollo es "notablemente sensible" al mercurio metilo, efecto también observado a concentraciones bajas en animales (Clarkson, Nordberg y Sager 1985). La exposición infantil al mercurio metilo se centra primordialmente en la ingestión de pescado o leche materna contaminados; en cambio, la absorción de mercurio elemental es de origen industrial. Se ha señalado exposición en el hogar derivada de la exposición profesional (Zirschky y Wetherell 1987). En años recientes se han documentado casos de exposición accidental en el hogar en industrias domésticas ( $M$ eeks, K eith y Tanner 1990; R owens y cols. 1991) y en un vertido accidental de mercurio metálico (Florentine y Sanfilippo 1991). La exposición al mercurio elemental se produce sobre todo por inhalación, mientras que el alquil mercurio puede absorberse por ingestión, inhalación o contacto dérmico.

En el episodio de intoxicación mejor estudiado, se descubrió disfunción motriz y retraso mental después de exposiciones muy elevadas a mercurio metilo, tanto en el útero como por medio de la leche materna (Bakir y cols. 1973). La exposición materna fue consecuencia de la ingestión de mercurio metilo utilizado como fungicida en cereales.

\section{Plaguicidas y compuestos químicos afines}

A nualmente se producen en todo el mundo varios centenares de millones de toneladas de plaguicidas. Herbicidas, fungicidas e insecticidas se emplean sobre todo en los países desarrollados para mejorar el rendimiento y la calidad de los cultivos. Los conservantes de la madera constituyen una parte mucho menor, pero también importante, del mercado. Las aplicaciones domésticas y de jardinería representan una proporción relativamente menor del consumo total, pero, desde el punto de vista de la toxicidad neonatal, las intoxicaciones domésticas son probablemente las más numerosas. También la exposición profesional es fuente potencial de exposición indirecta para el lactante si el trabajo de los padres supone el manejo de plaguicidas. La exposición a los plaguicidas se produce por absorción dérmica, inhalación e ingestión. M ás de 50 plaguicidas se han declarado cancerígenos para los animales (M cC onnell 1986).

LoS plaguicidas organoclorados comprenden compuestos aromáticos, como el DDT [bis(4-clorofenil)-1,1,1-tricloroetano], y ciclodienos, como el dieldrín. EI DDT empezó a utilizarse a principios del decenio de 1940 y se mostró muy eficaz en la erradicación del mosquito portador de la malaria, aplicación que sigue siendo común en los países en desarrollo. El lindano es un organoclorado muy utilizado para controlar los piojos del cuerpo y en la agricultura, en especial en los países en desarrollo. Los bifenilos policlorados (PCB), otra mezcla de organoclorados liposolubles utilizada desde el decenio de 1940, suponen un riesgo potencial para la salud de los niños, que quedan expuestos a través de la leche materna y otros alimentos contaminados. Tanto el lindano como los PCB se examinan en otros apartados de este capítulo. También se han detectado en la leche materna, pero casi exclusivamente en $\mathrm{M}$ ichigan, bifenilos polibromados (PBB); en ese lugar se mezcló inadvertidamente un ignífugo con pienso en 1973-1974, y se dispersó por todo el estado con los productos lácteos y cárnicos.

El clordano se ha utilizado como plaguicida y como termiticida en viviendas, donde ha resultado eficaz durante decenios, sin duda por su persistencia. La exposición a este compuesto tiene lugar a través de la dieta y por absorción directa respiratoria y dérmica. En Japón se ha establecido una relación entre la concentración en la leche materna y la dieta y el momento en que se ha tratado la vivienda; las mujeres que vivían en casas tratadas más de dos años antes presentaban concentraciones de clordano en la leche tres veces superiores a las halladas en mujeres que ocupaban viviendas sin tratar (Taguchi y Yakushiji 1988).

La dieta es la principal fuente de organoclorados persistentes, pero el consumo de tabaco, el aire y el agua pueden también contribuir a la exposición. Esta clase de plaguicidas, también Ilamados hidrocarburos halogenados, son muy persistentes en el medio, ya que son lipófilos, resistentes al metabolismo y la biodegradación y poco volátiles. Se han hallado varios centenares de ppm en la grasa de personas y animales muy expuestos. Por su toxicidad reproductiva para la vida animal y por su tendencia a la bioacumulación, los organoclorados están en su mayor parte prohibidos o limitados en los países desarrollados.

A dosis muy altas, los organoclorados provocan neurotoxicidad, pero para el hombre son más preocupantes los efectos potenciales a largo plazo. Aunque los efectos crónicos no están muy documentados, en animales de experimentación y salvajes se han observado hepatotoxicidad, cáncer y disfunciones de la reproducción. Los motivos de preocupación derivan sobre todo de las observaciones en animales de carcinogénesis y alteraciones profundas del hígado y el sistema inmunitario.

L os organofosfatos y los carbamatos son menos persistentes que los organoclorados, y son los insecticidas más utilizados en todo el mundo. Esta clase de plaguicidas se degradan relativamente deprisa en el medio y en el organismo. Algunos organofosfatos y carbamatos presentan una elevada toxicidad aguda, y también se han observado casos de neurotoxicidad crónica. La dermatitis es otro síntoma muy documentado de exposición a plaguicidas.

También son motivo de inquietud los productos derivados del petróleo utilizados para aplicar algunos plaguicidas. Se han asociado efectos crónicos, como cánceres infantiles hematopoyéticos y de otro tipo, con exposiciones parentales o residuales a plaguicidas, aunque los datos epidemiológicos son muy limitados. No obstante, los datos de estudios animales indican que debe evitarse la exposición a los plaguicidas.

Para el recién nacido se ha documentado un amplio espectro de posibilidades de exposición y efectos tóxicos. La mayor parte de los niños hospitalizados por intoxicación aguda habían ingerido inadvertidamente plaguicidas, y un número considerable se había expuesto a sus efectos jugando en céspedes tratados (Casey, Thompson y Vale 1994; Zwiener y Ginsburg 1988). $\mathrm{H}$ ace tiempo que se ha reconocido la contaminación de la ropa de los trabajadores por polvo o líquido plaguicida. Por tanto, esta vía abre el camino a la exposición doméstica, salvo que los trabajadores adopten medidas higiénicas adecuadas después del trabajo. Así, una familia completa presentaba concentraciones elevadas de clordecona (K epone) en sangre, atribuidas al hecho de lavar en casa la ropa de un trabajador (Grandjean y Bach 1986). Se ha documentado exposición doméstica a TCDD (dioxina) por la aparición de cloracne en el hijo y la esposa de dos trabajadores expuestos después de una explosión (Jensen, Sneddon y Walker 1972).

La mayor parte de las posibles exposiciones de lactantes son consecuencia de la aplicación de plaguicidas dentro del hogar y en sus inmediaciones (Lewis, Fortman y Camann 1994). Se ha observado que el polvo de las moquetas está muy contaminado por numerosos plaguicidas (Fenske y cols. 1994). G ran parte de la contaminación documentada en viviendas se ha atribuido al exterminio de pulgas 0 al tratamiento de jardines con plaguicidas (Davis, Bronson y Garcia 1992). Según algunas predicciones, la absorción de clorpyrifos por parte de niños lactantes después del tratamiento de la vivienda para erradicar las pulgas supera los valores de inocuidad; de hecho, las concentraciones en el aire del 
interior después de una fumigación de este tipo no siempre disminuyen rápidamente a valores inocuos.

La leche materna es fuente potencial de exposición neonatal a los plaguicidas. $\mathrm{H}$ ace décadas que se conoce la contaminación de la leche humana por plaguicidas, en especial organoclorados. $\mathrm{L}$ as exposiciones industriales y ambientales pueden inducir una contaminación considerable de la leche materna (D'Ercole y cols. 1976; M cConnell 1986). Los organoclorados, que hace algunos años estaban presentes en la leche materna a concentraciones excesivas, están disminuyendo en los países desarrollados, paralelamente a la reducción de su concentración en el tejido adiposo observada después de limitar el uso de estos compuestos. Por tanto, la contaminación por DDT de la leche materna es ahora máxima en los países en desarrollo. H ay pocos indicios de organofosfatos en la leche humana; esto puede atribuirse a la solubilidad en el agua y a la rápida metabolización de estos compuestos en el organismo.

La ingestión de agua contaminada con plaguicidas es también un riesgo potencial para la salud del recién nacido. Este problema es más acusado cuando los alimentos infantiles deben prepararse con agua. En otros casos, los preparados comerciales están relativamente exentos de contaminantes ( $\mathrm{N}$ ational Research Council 1993). También la contaminación de los alimentos con plaguicidas puede causar exposición infantil. $L a$ contaminación con plaguicidas, a concentraciones muy bajas, de la leche, las frutas y las verduras, es un hecho incluso en los países desarrollados, donde las leyes y la vigilancia son más estrictas (T he R eferee 1994). Aunque la leche es el elemento más importante de la dieta infantil, los niños pequeños consumen también cantidades considerables de frutas (en especial manzanas) y hortalizas (en especial zanahorias) que, por tanto, constituyen una fuente posible de exposición a los plaguicidas.

En países industrializados, como Estados Unidos y los de Europa occidental, el uso de casi todos los plaguicidas organoclorados, como el DDT, clordano, dieldrín y lindano, está prohibido, suspendido o limitado desde el decenio de 1970 (M axcy Rosenau-Last 1994). Los plaguicidas utilizados con fines agrícolas y no agrícolas están regulados en cuanto a su concentración en los alimentos, el agua y los productos farmacéuticos. Gracias a ello, las concentraciones de plaguicidas en el tejido adiposo y la leche humana han disminuido sustancialmente a lo largo de los cuatro últimos decenios. Sin embargo, los organoclorados siguen utilizándose de forma generalizada en los países en desarrollo; en ellos, el lindano y el DDT, por ejemplo, se encuentran entre los plaguicidas más utilizados en la agricultura y en el control de la malaria (Awumbila y Bokuma 1994).

\section{Lindano}

El lindano es el isómero $\gamma$ y el principio activo del hexacloruro de benceno $(\mathrm{BHC})$ de calidad técnica. EI BHC, también llamado hexaclorociclohexano $(\mathrm{HCH})$ contiene un $40-90 \%$ de isómeros $\alpha, \beta$ y $\delta$. Este insecticida organoclorado se ha utilizado como plaguicida agrícola y no agrícola en todo el mundo desde 1949. Las exposiciones industriales pueden producirse durante la fabricación, la formulación y la aplicación. En forma de cremas, lociones y champús, el lindano se usa también en farmacia para tratar la sarna y combatir los piojos. Como estas parasitosis afectan habitualmente a lactantes y niños pequeños, el tratamiento médico puede provocar la absorción de BHC a través de la piel. La exposición neonatal puede ocurrir también por inhalación de vapor o polvo transportado al hogar por uno de los padres o suspendido en el aire después de una aplicación doméstica del compuesto. La ingesta es otra posible vía de exposición para el lactante, ya que el BHC se ha detectado en la leche materna, en los productos lácteos y en otros alimentos, al igual que muchos insecticidas organoclorados. La exposición por medio de la leche materna tuvo más importancia en Estados Unidos antes de la prohibición de la producción comercial de lindano. Según la IARC (Agencia I nternacional para la Investigación sobre el Cáncer 1987), es posible que el hexaclorociclohexano sea cancerígeno para el hombre. Sin embargo, las pruebas de influencia adversa en la salud infantil se han materializado sobre todo en efectos sobre los sistemas neurológico y hematopoyético.

Se ha descrito un caso de exposición doméstica al lindano que afectó a la esposa de un formulador de plaguicidas, y que demuestra el potencial para exposiciones neonatales por igual conducto. La mujer presentaba $5 \mathrm{ng} / \mathrm{ml}$ de $\gamma-\mathrm{BHC}$ en sangre, concentración inferior a la de su esposo (Tabla 9.10) (Starr y cols. 1974). Probablemente, el $\gamma$-BH C entró en casa adherido a la ropa y el cuerpo del trabajador. Las concentraciones de $\gamma$-BHC en la mujer y en su cónyuge eran superiores a las documentadas en niños tratados con lociones que contenían entre un 0,3 y un $1,0 \%$ de $B H C$.

$\mathrm{El} \mathrm{BHC}$ se encuentra en la leche materna sobre todo en forma de isómero $\beta$ (Smith 1991). La semivida del isómero $\gamma$ en el cuerpo humano es de aproximadamente 1 día, mientras que el isómero $\beta$ se acumula.

La absorción dérmica de lindano a partir de productos farmacéuticos depende de la cantidad aplicada a la piel y de la duración de la exposición. Los lactantes y los niños pequeños parecen más sensibles a los efectos tóxicos del lindano que los adultos (Clement International Corporation 1992). U na causa puede ser que la absorción dérmica se ve favorecida por la mayor permeabilidad de la piel infantil y la elevada relación superficie-volumen. En el recién nacido, las concentraciones elevadas pueden mantenerse durante más tiempo, porque el metabolismo del BHC es menos eficaz en lactantes y niños pequeños. Además, la exposición del recién nacido puede aumentar si éste lame o chupa superficies tratadas ( $\mathrm{K}$ ramer y cols. 1990). U na ducha o un baño con agua caliente antes de la aplicación de productos medicinales pueden favorecer la absorción dérmica y, por tanto, acentuar la toxicidad.

En varios casos de intoxicación accidental con lindano se han descrito efectos claramente tóxicos, algunos en niños pequeños. En uno de ellos, un niño de dos meses murió después de varias exposiciones a una loción de lindano al $1 \%$, entre ellas una aplicación a todo el cuerpo después de un baño caliente (Davies 1983).

La producción y el uso de lindano están limitados en casi todos los países desarrollados. El lindano continúa utilizándose mucho en otros países con fines agrícolas, como se ha señalado en un estudio de uso de plaguicidas en explotaciones de G hana, donde el lindano suponía entre el $35 \%$ y el $85 \%$ de todos los plaguicidas utilizados por agricultores y ganaderos, respectivamente (Awumbila y Bokuma 1994).

\section{Bifenilos policlorados}

Los bifenilos policlorados se utilizaron desde mediados del decenio de 1940 hasta finales del de 1970 como líquidos aislantes en la fabricación de condensadores y transformadores eléctricos. Todavía quedan en el medio residuos de la contaminación, debida sobre todo a eliminación incorrecta y vertidos accidentales. Los equipos que siguen en uso o que se guardan en almacenes continúan siendo una fuente potencial de contaminación. Se ha documentado el caso de un niño con concentraciones detectables de PCB en sangre después de quedar expuesto a este producto por jugar con unos condensadores (Wolff y Schecter 1991). También se ha documentado la exposición de la esposa de un trabajador expuesto (Fishbein y Wolff 1987). 
Tabla 9.10 - Fuentes potenciales y niveles de exposición para el recién nacido.

\begin{tabular}{|c|c|c|}
\hline & Fuente de exposición & $\begin{array}{l}\gamma \text {-BHC en sangre } \\
\text { (ng/ ml; ppb) }\end{array}$ \\
\hline \multirow[t]{2}{*}{ Exposiciones profesionales } & Exposición baja & 5 \\
\hline & Exposición elevada & 36 \\
\hline Varón adulto & Intento de suicidio & 1300 \\
\hline Niño & Intoxicación aguda & $100-800$ \\
\hline Niños & $\begin{array}{l}1 \% \text { Loción de BHC } \\
\text { (media) }\end{array}$ & 13 \\
\hline \multirow{2}{*}{$\begin{array}{l}\text { Informe de casos de exposición } \\
\text { doméstical }\end{array}$} & Esposo & 17 \\
\hline & Esposa & 5 \\
\hline \multirow{4}{*}{$\begin{array}{l}\text { Poblaciones no expuestas } \\
\text { desde } 1980\end{array}$} & Yugoslavia & $5^{2}$ \\
\hline & Africa & $7^{2}$ \\
\hline & Brasil & $g^{2}$ \\
\hline & India & $75^{2}$ \\
\hline
\end{tabular}

En dos estudios de exposición ambiental, se asoció la exposición pre y postnatal a PCB con efectos ligeros, pero apreciables, en niños. En un estudio se detectó un ligero deterioro del desarrollo motor entre niños cuyas madres presentaban concentraciones de PCB en la leche postnatal inmediata situados en el percentil 95 del grupo de estudio (Rogan y cols. 1986). En el otro, se apreciaron deficiencias sensoriales (además de menor tamaño gestacional) entre niños con concentraciones en sangre situadas aproximadamente entre el $25 \%$ superior (Jacobson y cols. 1985; Fein y cols. 1984). Estos niveles de exposición se encontraban en el intervalo superior de los estudios (por encima de $3 \mathrm{ppm}$ en la leche materna (base grasa) y por encima de $3 \mathrm{ng} / \mathrm{ml}$ en la sangre de los niños), pero, con todo, no son excesivamente altos. Las exposiciones industriales comunes determinan concentraciones entre 10 y 100 veces superiores (Wolff 1985). En ambos estudios, los efectos se atribuyeron a exposición prenatal. En cualquier caso, estos estudios deben servir como advertencia frente a la exposición indebida de neonatos a estos compuestos, tanto antes como después del nacimiento.

\section{Disolventes}

Los disolventes son un grupo de líquidos volátiles o semivolátiles utilizados sobre todo para disolver otras sustancias. Puede producirse exposición a disolventes en operaciones de fabricación, como la exposición al hexano durante la destilación de derivados del petróleo. En casi todas las personas, la exposición a los disolventes se produce en el acto de utilizarlos en el trabajo o en casa. Son aplicaciones industriales comunes la limpieza en seco, el desengrasado, la aplicación y eliminación de pinturas y los trabajos de impresión. En el hogar, el contacto directo con disolventes puede ocurrir al utilizar productos como limpiametales, compuestos de limpieza en seco, diluyentes de pintura y pulverizadores.

Las principales vías de exposición a disolventes, tanto para adultos como para niños lactantes, son la absorción respiratoria y dérmica. La ingestión con la leche materna es un medio de exposición neonatal a los disolventes derivado del trabajo de los padres. Como la semivida de casi todos los disolventes es corta, también lo es su duración en la leche materna. Sin embargo, después de la exposición de la madre, algunos disolventes permanecen en la leche durante cierto tiempo (al menos su semivida); en ella se han detectado tetracloroetileno, disulfuro de carbono y halotano (un anestésico). U n estudio detallado de la exposición potencial del lactante al tetracloroetileno (TCE) ha concluido que las concentraciones presentes en la leche materna pueden superar fácilmente las recomendaciones de riesgo para la salud (Schreiber 1993). El exceso de riesgo era máximo para lactantes cuyas madres podían quedar expuestas en el lugar de trabajo (58 a 600 por millón de personas). En cuanto a las exposiciones máximas de carácter no profesional, se estimó que había 36 a 220 por 10 millones de personas sujetas a riesgo excesivo; estas exposiciones pueden darse en hogares situados inmediatamente encima de locales de limpieza en seco. Se estimó también que las concentraciones lácteas de TCE volverían a valores "normales" (anteriores a la exposición) entre cuatro y ocho semanas después de la inter rupción de ésta.

El lactante puede verse sometido en el hogar a exposiciones de origen no profesional cuando se usan disolventes o productos con disolventes. La atmósfera de los ambientes interiores arroja concentraciones muy bajas, pero siempre detectables, de disolventes, como el tetracloroetileno. También el agua puede contener compuestos orgánicos volátiles del mismo tipo.

\section{Polvos y fibras minerales: amianto, fibra de vidrio, lana mineral, zeolitas, talco}

La exposición a polvos y fibras minerales en el lugar de trabajo provoca en los trabajadores enfermedades respiratorias, entre ellas cáncer de pulmón. La exposición al polvo es un problema potencial para el recién nacido si alguno de sus padres lleva a casa partículas adheridas a la ropa o al cuerpo. En el caso del amianto, se han encontrado fibras del lugar de trabajo en el hogar; la exposición de los miembros de la familia por esta causa se ha descrito como exposición pasiva o familiar. La documentación de la enfermedad familiar por amianto ha sido posible por la formación de un tumor indicador llamado mesotelioma, asociado primordialmente con la exposición a dicho material. El mesotelioma es un cáncer de la pleura o el peritoneo (las membranas que envuelven los pulmones y el abdomen, respectivamente) que se manifiesta después de un prolongado período de latencia, típicamente de 30-40 años después de la primera exposición al amianto. La etiología de esta enfermedad parece vinculada sólo con la duración del tiempo transcurrido desde la exposición inicial, no con la intensidad o la duración, ni con la edad en el momento de la primera exposición (Nicholson 1986, 0 tte, Sigsgaard y K jaerulff 1990). También se han atribuido anomalías respiratorias a la exposición pasiva al amianto ( $G$ randjean y Bach 1986). N umerosos experimentos con animales apoyan las observaciones hechas en el hombre.

Casi todos los casos de mesotelioma familiar se han descrito en viudas de mineros, molineros, fabricantes y aisladores. Sin embargo, también se han asociado con la enfermedad algunas exposiciones infantiles. No pocos de estos niños habían tenido un contacto inicial precoz (Dawson y cols. 1992; Anderson y cols. 1976; Roggli y Longo 1991). Así, en una investigación de 24 contactos familiares con mesotelioma que vivían en una ciudad dedicada a la minería de amiantos de crocidolita, se identificaron 7 casos de edades comprendidas entre 29 y 39 años en el momento del diagnóstico o de la muerte y cuya exposición inicial había ocurrido a una edad inferior a uno $(n=5) 0$ tres $(n=2)$ años (H ansen y cols. 1993).

La exposición al amianto es causa clara de mesotelioma, pero se ha propuesto además un mecanismo epigenético para explicar la inusual acumulación de casos en el seno de ciertas 
familias. Así, el desarrollo de mesotelioma en 64 personas de 27 familias sugiere un rasgo genético que puede hacer a determinados individuos más sensibles a las lesiones causadas por el amianto que inducen la enfermedad (Dawson y cols. 1992; Bianchi, Brollo y Zuch 1993). Pero también se ha señalado que la exposición puede por sí sola explicar suficientemente la agregación familiar documentada (Alderson 1986).

La fibra de vidrio, la zeolita y el talco son otras sustancias inorgánicas pulverulentas asociadas con enfermedades profesionales. El amianto y la fibra de vidrio se han usado mucho como aislantes. Con el primero y, de forma mucho menos clara, también con la segunda, se han asociado fibrosis pulmonar y cáncer. Se ha documentado mesotelioma en áreas de Turquía expuestas a zeolitas naturales. La exposición al amianto puede tener también carácter no profesional. Los pañales con fibra de amianto se han citado como fuente de exposición infantil a este material (Li, D reyfus y Antman 1989), pero en ese informe no se excluyó la ropa de los padres como origen del contacto. Se ha encontrado también amianto en cigarrillos, secadores de pelo, baldosas para suelos y algunos tipos de polvo de talco. En muchos países se ha eliminado su uso; sin embargo, un motivo de inquietud para los niños son los aislantes de amianto que aún quedan en algunas escuelas y que se han investigado ampliamente como fuente potencial de riesgo para la salud pública.

\section{Humo de tabaco ambiental}

El humo de tabaco ambiental (HTA) es una combinación de humo exhalado y humo emitido por la brasa del cigarrillo. Aunque el HTA no es por sí solo fuente de exposición profesional que pueda afectar al neonato, se estudia aquí por su potencial para afectar adversamente a la salud y porque es buen ejemplo de otras exposiciones a aerosoles. La exposición de los no fumadores al HTA suele describirse como consumo de tabaco pasivo o involuntario. La exposición prenatal al HTA se asocia claramente con deficiencias o deterioros del desarrollo fetal. Es difícil diferenciar los resultados postnatales de los efectos del HTA en el período prenatal, puesto que el consumo de tabaco por parte de los padres raramente se limita a uno u otro de estos períodos. Sin embargo, hay pruebas que apoyan una relación entre exposición postnatal al HTA y patologías respiratorias y deterioro de la función pulmonar. La similitud de estas observaciones con la experiencia de los adultos refuerza la asociación.

EI HTA está bien caracterizado y se ha estudiado ampliamente desde el punto de vista de la exposición humana y los efectos sobre la salud. Es cancerígeno para el hombre (US Environmental Protection Agency 1992). La exposición al HTA puede evaluarse midiendo las concentraciones de nicotina (un componente del tabaco) y cotinina (su principal metabolito), en líquidos biológicos, como la saliva, sangre y orina. También se ha detectado nicotina y cotinina en la leche materna. La cotinina se ha detectado en sangre y orina de lactantes expuestos al HTA sólo por intermedio de la leche materna (Charlton 1994; National Research C ouncil 1986).

Se ha establecido con claridad que la exposición neonatal al HTA es consecuencia del consumo de tabaco paterno y materno en el hogar. La madre fumadora es la fuente de exposición más importante. Así, en varios estudios se ha demostrado que la concentración urinaria de cotinina en niños tiene correlación con el número de cigarrillos diarios consumidos por la madre (M arbury, $\mathrm{H}$ ammon y $\mathrm{H}$ aley 1993). L as principales vías de exposición del neonato al HTA son la respiración y la dieta (por medio de la leche materna). Las guarderías representan otra fuente potencial de exposición, pues en muchas de ellas no se ha establecido una política de limitación del consumo de tabaco (Sockrider y Coultras 1994).
La hospitalización por afecciones respiratorias es más común entre recién nacidos de padres fumadores. Además, la duración de las estancias en el hospital es mayor entre lactantes expuestos al HTA. En términos causales, la exposición al HTA no se ha asociado con enfermedades respiratorias concretas. No obstante, hay pruebas de que el consumo de tabaco pasivo incrementa la gravedad de enfermedades previas, como bronquitis y asma (Charlton 1994; Chilmonczyk y cols. 1993; Rylander y cols. 1993). Los niños y lactantes expuestos al HTA sufren también con mayor frecuencia infecciones respiratorias. Además, los padres fumadores que padecen enfermedades respiratorias pueden transmitir la infección a sus hijos con la tos.

Los niños expuestos al HTA después del nacimiento sufren pequeñas deficiencias de la función pulmonar que parecen independientes de la exposición prenatal (Frischer y cols. 1992). Aunque las alteraciones vinculadas con el HTA son pequeñas (disminución del 0,5\% anual del volumen pulmonar de reserva) y se trata de efectos sin trascendencia clínica, son sugestivos de cambios en las células del pulmón en desarrollo que podrían suponer riesgos en el futuro. El consumo de tabaco por parte de los padres se ha asociado también con un mayor riesgo de otitis media o supuración del oído medio entre la lactancia y los nueve años; esta afección es causa común de sordera infantil, y puede retrasar la educación. Esta asociación está apoyada por estudios que atribuyen un tercio de todos los casos de otitis media al consumo de tabaco por parte de los padres (C harlton 1994).

\section{Exposición a radiaciones}

La exposición a radiaciones ionizantes es un peligro para la salud bien establecido, generalmente como resultado de una exposición intensa, sea accidental o con fines médicos. Puede dañar las activas células en fase de proliferación y, por tanto, resultar muy nociva para el feto o el recién nacido en desarrollo. La exposición necesaria para establecer un diagnóstico por rayos $X$ suele ser de muy bajo nivel y se considera inocua. Una fuente potencial de exposición a radiaciones ionizantes en el hogar es el radón, gas presente en las formaciones rocosas de ciertas regiones geográficas.

Son efectos prenatales y postnatales de la radiación el retraso mental, la merma de la inteligencia, el retraso en el desarrollo, las malformaciones congénitas y el cáncer. La exposición a dosis elevadas de radiaciones ionizantes se asocia también con una mayor frecuencia de cáncer. La incidencia de esta exposición depende de la dosis y la edad; en efecto, el máximo riesgo relativo de cáncer de mama observado $(\sim 9)$ se da entre mujeres expuestas precozmente a radiaciones ionizantes.

Recientemente se ha prestado atención a los posibles efectos de las radiaciones no ionizantes o campos electromagnéticos (EM F). EI fundamento de la relación entre la exposición a EM F y el cáncer todavía no se conoce, y las pruebas epidemiológicas son poco claras. No obstante, en varios estudios internacionales se ha documentado una relación entre EM $\mathrm{F}$ y leucemia y cáncer de mama en el varón.

La exposición infantil excesiva a la luz solar se ha asociado con cáncer de piel y melanoma (M arks 1988).

\section{Cáncer infantil}

Aunque todavía no se han identificado sustancias concretas, se han vinculado algunas exposiciones profesionales parentales con cáncer infantil. El período de latencia para que se declare una leucemia infantil puede ser de dos a 10 años después del inicio de la exposición, lo cual indica que las exposiciones en el útero o en el primer período postnatal pueden ser causa de dicha enfermedad. Provisionalmente se ha asociado la exposición a diversos plaguicidas organoclorados (BHC, DDT, clordano) con la leucemia, aunque estos datos no se han confirmado en estudios 
más detallados. A demás, se ha documentado el elevado riesgo de cáncer y leucemia a que están expuestos los hijos de padres que trabajan con plaguicidas y compuestos y vapores químicos (O 'Leary y cols. 1991). Asimismo, el riesgo de sarcoma óseo de Ewing durante la infancia se ha asociado con el trabajo familiar en la agricultura o con la exposición a herbicidas y plaguicidas (H olly y cols. 1992).

\section{Resumen}

Muchos países tratan de definir concentraciones inocuas de compuestos químicos tóxicos en el aire ambiental, en productos alimenticios y en el lugar de trabajo. N o obstante, las oportunidades de exposición abundan, y los niños son particularmente sensibles a la absorción y a los efectos de los tóxicos. Se ha señalado que "muchas de las 40.000 muertes infantiles que se producen cada día en el mundo en desarrollo son consecuencia del deterioro del medio ambiente, manifestado en la contaminación de las aguas, las enfermedades y la malnutrición" (Schaefer 1994). M uchas de las exposiciones de origen ambiental son evitables. Por tanto, la prevención de las enfermedades de origen ambiental debe gozar de prioridad elevada para evitar los efectos adversos sobre la salud infantil.

\section{- LA PROTECCION DE LA MATERNIDAD EN LA LEGISLACION}

\section{M arie-Claire Séguret}

La exposición a ciertos peligros para la salud y la seguridad en el trabajo 0 en el entorno laboral puede tener, durante el embarazo, efectos perjudiciales para la trabajadora y para su hijo no nacido. La mujer necesita también, antes y después de dar a luz, un período razonable de tiempo libre de trabajo para recuperarse, alimentar a su hijo y establecer con él lazos afectivos. M uchas mujeres necesitan y desean volver a su trabajo tras el nacimiento de su hijo, lo que va siendo progresivamente reconocido como un derecho fundamental, en un mundo en el que la tasa de actividad de la mujer crece continuamente y se aproxima ya, en muchos países, a la del hombre. EI mantenimiento de los ingresos de las mujeres durante la maternidad es vital, dado que la mayoría de ellas han de contribuir al sostenimiento económico propio y de su familia.

A lo largo del tiempo, los Estados han promulgado distintas medidas para proteger a la mujer trabajadora durante el embarazo y en el nacimiento de su hijo. U na característica de las medidas más recientes es la prohibición de la discriminación en el empleo por razón de embarazo. 0 tra tendencia actual es la de permitir a los padres y madres compartir el permiso de paternidad y maternidad tras el nacimiento, de manera que cualquiera de ellos pueda ocuparse del niño. En muchos países, los convenios colectivos contribuyen a la mejora y a la aplicación más efectiva de estas medidas. Las empresas desempeñan también un papel importante en la ampliación de la protección a la maternidad, a través de las cláusulas de los contratos individuales de trabajo y las políticas de empresa.

\section{Los límites de la protección}

Las normas reguladoras de la protección a la mujer trabajadora están normalmente restringidas al sector formal de la economía, que en algunos casos representa sólo una pequeña parte de ésta, no siendo de aplicación a las trabajadoras de actividades no registradas de la economía informal o "sumergida", que en muchos países son la mayoría. Persiste así, dentro de la tendencia mundial a mejorar y ampliar la protección a la maternidad, un reto importante: dar cobertura a un extenso sector de la población que vive y trabaja fuera de la economía formal.

En muchos países, la legislación laboral otorga protección a la maternidad para las mujeres que trabajan en empresas, sean industriales o no, del sector privado y, también a menudo, del sector público, pero excluye con frecuencia a las que trabajan en el hogar, a las empleadas domésticas y a las que lo hacen por cuenta propia o en empresas que utilizan sólo a miembros de una misma familia. Es importante la exclusión, bastante frecuente, de las empresas con una plantilla inferior a un cierto número de trabajadores (por ejemplo, en la República de Corea, cinco empleados fijos), ya que son muchas las mujeres que trabajan en pequeñas empresas.

En varios países, muchas mujeres con trabajos precarios, como los empleos temporales o eventuales en Irlanda, están excluidas de la legislación social, como también las trabajadoras a tiempo parcial, según el número de horas de trabajo, o, en ciertos casos, las que ocupan puestos directivos (por ejemplo, en Singapur o Suiza), las que tienen una remuneración superior a un determinado máximo (por ejemplo, en $M$ auricio) o las que cobran según el rendimiento (por ejemplo, en Filipinas). En algunos casos, poco frecuentes, no se concede permiso por maternidad a las mujeres solteras (por ejemplo, a las profesoras, en Trinidad y Tabago), mientras que en Australia (federal) se concede ese permiso a las trabajadoras y a sus cónyuges, incluyendo en este término a las parejas de hecho. Cuando se establecen límites de edad (por ejemplo, en Israel, para las mujeres menores de 18 años), no suelen resultar excluidas demasiadas mujeres, ya que estos límites se fijan en torno al inicio de la edad fértil.

Los empleados públicos disfrutan a menudo de regímenes especiales, que les otorgan, a veces, condiciones más favorables que las del sector privado, como, por ejemplo, permisos de maternidad más largos, prestaciones en metálico por el importe del salario completo y no de un porcentaje de éste, permisos de paternidad más frecuentes o derechos de reincorporación al puesto de trabajo más claramente establecidos. En muchos países, estas buenas condiciones de los empleados públicos son un factor de progreso, ya que los convenios colectivos del sector privado suelen negociarse por referencia a sus normas de protección de la maternidad.

De manera similar a la legislación laboral, aunque de forma aún más restrictiva, las normas de seguridad social limitan, en ocasiones, su aplicación a determinados sectores o categorías de trabajadores, aun cuando pueden también permitir el acceso a las prestaciones en metálico por maternidad a grupos sociales no cubiertos por aquélla, como las mujeres que trabajan en régimen autónomo o para sus maridos incluidos en este régimen. En muchos países en vías de desarrollo, la legislación de seguridad social se extiende sólo a un número limitado de sectores, debido a la falta de recursos del Estado.

En las últimas décadas, la cobertura de la legislación se ha extendido a un mayor número de sectores económicos y de categorías de trabajadores, aunque, pese a esta cobertura, el disfrute de ciertas ventajas, especialmente los permisos de maternidad y las prestaciones en metálico, pueden depender de ciertos requisitos de aplicabilidad, lo que determina que, a pesar de que la mayoría de los países protejan la maternidad, las mujeres trabajadoras no disfruten un derecho universal a esta protección.

\section{El permiso por maternidad}

El tiempo de descanso por parto varía entre unas pocas semanas y varios meses, dividido a menudo en dos partes, antes y después del nacimiento del hijo. En algunos países, se establece dentro de este período un plazo en el que se prohíbe el trabajo, para garantizar que la mujer disfrute un descanso suficiente. El período de 
permiso se amplía normalmente en los casos de enfermedad, parto prematuro o tardío y nacimientos múltiples, y se reduce en caso de aborto espontáneo, alumbramiento de un feto muerto 0 fallecimiento del niño.

\section{La duración normal del permiso}

EI Convenio OIT relativo a la protección de la maternidad 1919 (no 3), establecía que "no se permitirá el trabajo de la mujer durante las seis semanas siguientes al parto; (y) tendrá derecho a dejar de trabajar si aporta un certificado médico en el que se declare que el parto tendrá probablemente lugar dentro de las seis semanas siguientes". El Convenio O IT relativo a la protección de la maternidad (revisado), 1952 (no 103), confirma el permiso de 12 semanas, incluyendo la prohibición de trabajo en las seis semanas siguientes al parto, pero no determina de modo imperativo la utilización de las seis semanas restantes. La Recomendación sobre la protección de la maternidad, 1952 (no 95), propone un permiso de 14 semanas. La mayor parte de los países estudiados cumplen el criterio de las doce semanas, y al menos un tercio garantiza un período aún más largo.

En varios países se permite elegir la distribución del permiso de maternidad. En algunos de ellos, la ley no prescribe su distribución (por ejemplo, en Tailandia) y las mujeres tienen derecho a iniciarlo cuando lo deseen, mientras que en otros se establece el número de días que deben tomarse tras el parto, pudiéndose disponer del resto antes o después de éste.

0 tros países no permiten ninguna flexibilidad: la ley establece dos períodos de descanso, antes y después del parto, que pueden ser iguales, especialmente cuando el tiempo total de descanso es relativamente corto. Cuando éste excede de 12 semanas, el período prenatal es a menudo más corto que el posnatal (por ejemplo, en Alemania, seis semanas antes y ocho semanas después del parto).

En un número relativamente pequeño de países (por ejemplo, Benin, Chile o Italia) está prohibido el empleo de las mujeres durante todo el período de permiso por maternidad. En otros, se establece un tiempo obligatorio de permiso, a menudo después del parto, normalmente de seis semanas (por ejemplo, Barbados, I rlanda, India o M arruecos). EI número de países que establecen algún plazo imperativo de permiso antes del parto ha aumentado en la última década. En algunos países, por el contrario, no hay período de permiso obligatorio (por ejemplo, en Canadá), por considerarse que el permiso es un derecho que debe ejercitarse libremente y que el tiempo concedido debe disponerse del modo que mejor convenga a los intereses y necesidades personales de cada mujer.

\section{Los requisitos para disfrutar del permiso por maternidad}

La legislación de la mayoría de los países reconoce el derecho de la mujer a disfrutar de un permiso por maternidad mediante el establecimiento de su período de duración, de modo que basta con que una mujer se encuentre trabajando en el momento del inicio del permiso para tener derecho a ello. Sin embargo, en cierto número de países se exige que la mujer haya trabajado durante un plazo mínimo antes de la fecha de libranza, plazo que va desde las 13 semanas, en 0 ntario o Irlanda, a los dos años, en Zambia.

En varios países, se exige que la mujer haya trabajado un determinado número de horas semanales o mensuales para tener derecho al permiso y a otras prestaciones por maternidad, lo que puede dar lugar, cuando el umbral que se fija es alto (como las 35 horas semanales requeridas en $\mathrm{M}$ alta), a la exclusión de un gran número de mujeres, que representan la mayoría de los trabajadores a tiempo parcial. En algunos casos, estos umbrales se han reducido recientemente (por ejemplo, en I rlanda, de 16 a ocho horas semanales).
Un pequeño grupo de países limita el número de veces que una mujer puede solicitar el permiso por maternidad dentro de un determinado período (por ejemplo, dos años), o mientras trabaja para una misma empresa, o aun a lo largo de toda la vida de la trabajadora (por ejemplo, en Egipto o M alasia). En Zimbabwe, por ejemplo, pueden beneficiarse del permiso una vez cada 24 meses, hasta un máximo de tres veces, mientras trabajen para una misma empresa. En otros países, no se limita el número de permisos, pero sí las prestaciones en metálico (por ejemplo, en Tailandia), o bien se conceden permisos de una duración menor con prestaciones (por ejemplo, en Sri Lanka, 12 semanas para los primeros dos hijos y seis para el tercero y restantes). Parece estar aumentando el número de países que limitan el derecho a los permisos y prestaciones por maternidad a un cierto número de embarazos, de hijos nacidos o de hijos supervivientes (entre dos y cuatro), aunque no está claro en absoluto que la duración del permiso sea un factor decisivo en las decisiones de los padres sobre el tamaño de la familia.

\section{El preaviso a la empresa}

En la mayoría de los países, el único requisito para la concesión del permiso por maternidad es la presentación de un certificado médico, pero, en algunos casos, se exige también notificar con anterioridad a la empresa el propósito de tomar el permiso. EI plazo de preaviso varía desde el momento del conocimiento del embarazo (por ejemplo, en Alemania), hasta una semana antes de iniciar el permiso (por ejemplo, en Bélgica), y su falta puede determinar la pérdida del derecho, como en Irlanda, donde la notificación debe realizarse tan pronto como sea razonablemente posible, pero en ningún caso después de las cuatro semanas previas al comienzo del permiso. En Canadá (federal), la mujer puede eximirse por causa justificada del requisito del preaviso, cuyo plazo, a nivel provincial, varía entre cuatro meses y dos semanas. En M anitoba, la mujer conserva su derecho al permiso aunque no cumpla este requisito, mientras que en la mayoría de las restantes provincias se reduce, en este caso, la duración del permiso (a seis semanas normalmente, frente a las 17 ó 18 semanas ordinarias) y en algunos otros países no se establecen con claridad las consecuencias de la falta de preaviso.

\section{Las prestaciones en metálico}

La mayoría de las mujeres no pueden permitirse dejar de percibir sus ingresos durante el permiso por maternidad y, si tuvieran que hacerlo, renunciarían a una parte de este período. Dado que el nacimiento de niños sanos beneficia al conjunto de la nación, las empresas no deberían, por razones de equidad, soportar la totalidad del coste generado por la ausencia de sus trabajadoras. Desde 1919, la OIT ha propugnado la concesión de prestaciones en metálico durante el permiso por maternidad, con cargo a fondos públicos o mediante un sistema de seguro. El Convenio no 103 exige que las contribuciones de los sistemas obligatorios de seguridad social se sufraguen en relación con el número total de hombres y mujeres empleados en la empresa, sin distinciones por razón de sexo. Aunque en unos pocos países las prestaciones por maternidad constituyen sólo un porcentaje relativamente pequeño del salario, la proporción de los dos tercios propuesta en el Convenio no 103 se alcanza en varios y se supera en muchos otros. En más de la mitad de los países investigados, las prestaciones por maternidad suponen la totalidad del salario mínimo 0 del salario completo.

M uchas legislaciones de seguridad social prevén una prestación específica por maternidad, reconociéndola en sí misma como una contingencia independiente, mientras que otras aplican a este caso prestaciones de enfermedad o desempleo. Esta asimilación de la maternidad a una incapacidad, o del permiso a una situación de desempleo, podría considerarse un 
trato discriminatorio, ya que, por lo general, tales prestaciones sólo se conceden por un período determinado, y la mujer que las utiliza por razón de su maternidad puede encontrarse en el futuro sin cobertura suficiente para una auténtica enfermedad 0 una situación de desempleo real. Cuando se elaboró la Directiva del Consejo Europeo (1992), hubo una fuerte oposición a la propuesta de conceder prestaciones de enfermedad durante el permiso por maternidad, por considerarse que la igualdad de trato entre hombres y mujeres exigía reconocer la maternidad como causa independiente de prestaciones. Como solución transaccional, se ha definido la prestación económica por maternidad como un ingreso garantizado equivalente al que la trabajadora en cuestión recibiría en caso de enfermedad.

En casi 80 países estudiados, las prestaciones se pagan por los sistemas nacionales de seguridad social, quedando, en más de otros 40, a cargo de la empresa, y repartiéndose, en alrededor de 15 países, entre ésta y la seguridad social, ya sea al cincuenta por ciento (por ejemplo, en Costa Rica) o en otras proporciones (por ejemplo, en $\mathrm{H}$ onduras: dos tercios a cargo de la seguridad social y un tercio a cargo de la empresa). En otros casos, cuando el importe cubierto por la seguridad social está basado en unos ingresos legalmente garantizados que representan una pequeña parte del salario total de la mujer, se impone a la empresa el pago del resto (por ejemplo, en Burkina Faso). En muchos convenios colectivos y contratos individuales de trabajo se contempla también de forma voluntaria el pago de cantidades adicionales por la empresa. La participación de ésta en el pago de las prestaciones en metálico por maternidad puede ser una solución realista para el problema de la carencia de otras fuentes de financiación.

\section{La protección de la salud de la mujer embarazada y lactante}

En la línea marcada por la Recomendación sobre la protección de la salud de la maternidad, 1952 ( $n$ ㅇ 95), muchos países prevén medidas para la protección de la mujer embarazada y su hijo, dirigidas a reducir los esfuerzos que ha de realizar, mediante la adaptación de los horarios de trabajo 0 a protegerla frente a trabajos peligrosos o perjudiciales para la salud.

En unos pocos países (por ejemplo, los Países Bajos o Panamá) se especifica legalmente la obligación de la empresa de organizar el trabajo de modo que no afecte al buen desarrollo del embarazo. Este enfoque, propio del tratamiento moderno de la salud y seguridad en el trabajo, es el más satisfactorio, porque permite adaptar a las necesidades de cada mujer las correspondientes medidas preventivas. Pero lo más frecuente es la protección vía prohibición o limitación del trabajo perjudicial para la salud de la madre o el hijo, establecida en términos generales 0 sólo para ciertos tipos de trabajos peligrosos. En M éxico, la prohibición no se aplica si se adoptan, a juicio de la autoridad competente, las medidas de protección necesarias, ni tampoco en el caso de las mujeres que ocupan puestos directivos o que poseen un título universitario, una diplomatura técnica o los conocimientos y experiencia necesarios para proseguir su trabajo.

En muchos países se prohíbe legalmente que la mujer embarazada 0 en período de lactancia realice trabajos "superiores a sus fuerzas", "que supongan peligro", "que sean peligrosos para su salud o la de su hijo" o "que exijan un esfuerzo físico inadecuado para su estado". Este tipo de prohibición genérica puede implicar problemas de aplicación: ¿quién y cómo debe determinar si un determinado trabajo está por encima de las fuerzas de una persona: el trabajador afectado, la empresa, el inspector de trabajo, el médico especialista en salud en el trabajo o el médico personal de la mujer? Las diferencias de apreciación pueden conducir a que una mujer sea apartada de un trabajo que, de hecho, sí podría realizar, manteniendo, en cambio, a otra en un trabajo excesivamente gravoso.

En otros países se establecen listas, a veces muy detalladas, de los tipos de trabajos prohibidos para las mujeres embarazadas 0 lactantes (por ejemplo, en Austria o Alemania). Suele incluirse el manejo de objetos pesados; en algunos casos se prohíbe expresamente la exposición a ciertas sustancias químicas (como el benceno), los agentes biológicos, el plomo o la radiación; en Japón se prohíbe el trabajo subterráneo durante el embarazo y el primer año posterior al parto; en Alemania, el trabajo a destajo y en líneas de montaje de ritmo fijo; en unos pocos países, no se permite asignar trabajos a las embarazadas fuera de su lugar de residencia estable (por ejemplo, en Ghana, después del cuarto mes); en Austria, está prohibido fumar en los lugares de trabajo con mujeres embarazadas.

En varios países (por ejemplo, Angola, Bulgaria, $\mathrm{H}$ aití 0 A lemania), se exige a la empresa trasladar a la embarazada a un puesto de trabajo adecuado, garantizándose, en muchos casos, el mantenimiento del salario anterior aunque el correspondiente al nuevo puesto sea inferior, garantía que, en la República Democrática Popular Lao, se concede sólo durante un período de tres meses, y, en la Federación de Rusia, se extiende también al período de búsqueda de este nuevo puesto; en algunos países (por ejemplo, en Rumania), la seguridad social cubre la diferencia entre estos dos salarios, lo que es preferible, dado que el coste de la protección de la maternidad no debe, en la medida de lo posible, ser soportado por la empresa afectada.

También puede preverse el traslado en el caso de trabajos no peligrosos en sí mismos, cuando un médico certifica que resulta perjudicial para el estado de salud de una mujer determinada (por ejemplo, en Francia), o a petición del propio trabajador (por ejemplo, en Suiza o Canadá). En algunos casos, se faculta legalmente a la empresa para proponer el traslado, recurriéndose, en caso de desacuerdo del trabajador, a la decisión de un médico del trabajo con respecto a la necesidad médica del cambio y a la capacidad física de la mujer para realizar el nuevo trabajo propuesto.

En un reducido número de países, se especifica que la transferencia tiene carácter temporal y que la trabajadora ha de ser reasignada a su trabajo anterior al término de su permiso por maternidad o de un determinado plazo posterior (por ejemplo, en Francia). Cuando no es posible el traslado, algunos países establecen que se habrá de conceder un permiso de enfermedad (por ejemplo, en Seychelles), o, como se ha analizado anteriormente, que se anticipará el comienzo del permiso por maternidad (por ejemplo, en Islandia).

\section{La no discriminación}

En un número cada vez mayor de países se han adoptado medidas para garantizar que la mujer no sufra discriminación por razón de su embarazo, con objeto de asegurar que reciba un trato igual al de los hombres y al de las demás mujeres en el acceso al empleo y durante su trabajo, y, especialmente, que no sea relegada, pierda su antigüedad o se le deniegue un ascenso por la mera causa de su gestación. $\mathrm{H}$ oy es cada vez más habitual que las legislaciones nacionales prohíban la discriminación por razón de sexo, lo que puede interpretarse por los tribunales, como se ha hecho ya en muchos casos, como una prohibición de la discriminación por razón de embarazo. Este ha sido el enfoque seguido por el Tribunal de Justicia de las Comunidades Europeas, que, en una sentencia de 1989, resolvió que una empresa que despide o se niega a contratar a una mujer por estar embarazada infringe la Directiva 76/207/ CEE del Consejo Europeo sobre igualdad de trato. La importancia de esta sentencia radica en que establece con claridad que existe discriminación por razón de 
sexo cuando se adoptan decisiones relativas al empleo por razón de embarazo, aunque las leyes no citen de manera específica esta circunstancia entre las causas prohibidas de discriminación. Es habitual, en los juicios por discriminación sexual, comparar el trato recibido por la mujer con el equivalente para un hipotético hombre. Pues bien, el Tribunal resolvió que esta comparación no es procedente en el caso de la mujer embarazada, ya que la gestación es una circunstancia exclusiva de la mujer, por lo que el trato desfavorable por esta causa es, por definición, un caso de discriminación por razón de sexo. Esta interpretación coincide con la postura de la Comisión de Expertos de la O IT para la A plicación de Convenios y Recomendaciones respecto al alcance del Convenio sobre la discriminación (empleo y ocupación), 1958 (no 111), que señala el carácter discriminatorio de las distinciones por razón de embarazo, parto y circunstancias médicas derivadas (OIT 1988).

Varios países han establecido prohibiciones explícitas de la discriminación por causa de embarazo (por ejemplo, Australia, Italia, Estados Unidos, Venezuela), mientras que otros (por ejemplo, Finlandia) definen la discriminación por razón de sexo en términos que incluyen la que se basa en la gestación o en la ausencia por permiso de maternidad. En Estados Unidos se garantiza la protección al equiparar el embarazo a una discapacidad: en las empresas con más de 15 trabajadores se prohíbe la discriminación de la mujer por causa de embarazo, parto 0 problemas médicos derivados, y las políticas y prácticas relativas a la gestación y otros aspectos relacionados han de aplicarse en los mismos términos y condiciones que a las demás discapacidades.

Las legislaciones de varios países contienen normas específicas que señalan casos de discriminación por embarazo. En la Federación de Rusia, por ejemplo, las empresas no pueden negarse a contratar a una mujer por razón de su embarazo y, si lo hacen, deben manifestar por escrito las razones por las que no se la contrata. En Francia, es ilegal tener en cuenta la gestación para negar un empleo a una mujer, resolver su contrato durante el período de prueba o trasladarla, así como tratar de averiguar si una candidata a un puesto está embarazada, o pedir a la mujer que lo revele, sea al solicitar un nuevo empleo o estando ya empleada, excepto en el caso de que ésta solicite la aplicación de alguna de las ventajas legales o reglamentarias de protección de la mujer embarazada.

La imposición unilateral y arbitraria del traslado a otro puesto de trabajo de una gestante puede suponer una discriminación, como es el caso en Bolivia y otros países de la región, donde esta protección se extiende además durante un año tras el nacimiento del hijo.

La combinación del derecho de la mujer trabajadora a la protección de su salud durante el embarazo y de su derecho a no ser objeto de discriminación resulta particularmente complicada en el momento de su contratación. ¿D ebe la mujer embarazada revelar su estado, especialmente cuando se presenta para un puesto que implica trabajos prohibidos para gestantes? EI Tribunal Federal de Trabajo de Alemania sostuvo, en una sentencia de 1988, que la mujer embarazada que concurre a un puesto de trabajo exclusivamente nocturno, prohibido para gestantes por la legislación alemana, debe informar de su estado a la empresa potencialmente contratante. Esta sentencia fue revocada por el Tribunal de Justicia de las Comunidades Europeas como contraria a la Directiva CEE sobre igualdad de trato, de 1976. El Tribunal consideró que la Directiva no permite sostener la nulidad de un contrato por razón de la prohibición legal del trabajo nocturno, ni su resolución por parte de la empresa alegando el error de cualquiera de las partes con respecto a una característica personal esencial de la mujer en el momento de su celebración, ya que, al no haberse otorgado el contrato por tiempo determinado, y siendo sólo temporal la discapacidad por embarazo de la empleada para realizar el trabajo para el que fue contratada, tal interpretación sería contraria a los objetivos de la D irectiva.

\section{Estabilidad del empleo}

Son muchas las mujeres que han perdido su empleo a causa del embarazo. La estabilidad del empleo es en la actualidad, pese a la variedad de las disposiciones en vigor, un aspecto muy importante de las políticas de protección de la maternidad.

Las normas laborales internacionales abordan el tema de dos maneras distintas. Los convenios sobre protección de la maternidad prohíben el despido durante dicho permiso por maternidad o su prolongación, en los términos previstos en el artículo 4 del Convenio no 3 y el artículo 6 del Convenio no 103, 0 cuando el plazo establecido en la notificación de despido expire durante el permiso. No está permitido el despido por causas de otro modo lícitas durante este período (O IT 1965). En el caso de que una mujer sea despedida antes de tomar su permiso de maternidad, deberá suspenderse la notificación durante su ausencia y continuar a su vuelta. La Recomendación sobre la protección de la maternidad, 1952 ( $n$ - 95) reclama la protección del empleo de la mujer embarazada a partir del día en que a la empresa le haya sido notificado el embarazo y hasta un mes después de la terminación del período de permiso por maternidad, y considera como causas justas de despido en este período la comisión de una falta grave por la mujer empleada, la cesación de las actividades de la empresa y la terminación del contrato de trabajo temporal. En las letras d) y e) del artículo 5 del Convenio sobre la terminación de la relación de trabajo, 1982 (no 158), no se prohíbe el despido, pero se establece que el embarazo o la ausencia del trabajo durante el permiso por maternidad no constituirá causa justificada para esta terminación.

En la U nión Europea, la Directiva de 1992 prohíbe el despido desde el comienzo del embarazo hasta el final del permiso por maternidad, excepto en casos excepcionales no relacionados con el estado de la trabajadora.

La mayoría de los países disponen dos grupos de normas con respecto al despido. En casos como los de cierre de la empresa, exceso de mano de obra o incapacidad del trabajador, por diversas razones, para realizar la tarea para la que fue contratado o para hacerlo a satisfacción de la empresa, se aplica el despido con preaviso. Cuando el trabajador es culpable de negligencia, mala conducta u otras faltas de comportamiento graves, normalmente previstas de modo exhaustivo en la legislación, se aplica el despido sin preaviso.

En los casos de despido con preaviso, resulta claro que la empresa podría decidir de manera arbitraria que el embarazo es incompatible con las tareas de la trabajadora y despedirla por razón de su gestación. Si quisiera eludir sus obligaciones con respecto a las mujeres embarazadas, o simplemente evitar su presencia en el lugar de trabajo, podría buscar un pretexto para despedirlas sin recurrir, para esquivar las normas antidiscriminatorias, al embarazo como causa del despido. Son muchos los que coinciden en que es legítimo proteger a las trabajadoras frente a estas decisiones discriminatorias: en gran número de países se aplica, como principio de equidad, la prohibición del despido con preaviso por razón de embarazo durante la gestación y durante el permiso por maternidad.

La Comisión de Expertos para la A plicación de Convenios y Recomendaciones de la OIT considera que la prohibición del despido durante el permiso por maternidad no impide a la empresa dar por terminada una relación de trabajo cuando comprueba una falta grave de una trabajadora, sino que cuando hay, como en este caso, razones justificadas, está obligada a 
ampliar el plazo legal de preaviso hasta completar el período de protección previsto en los convenios. Esta situación se da, por ejemplo, en Bélgica, donde puede efectuarse el preaviso de modo que expire tras la vuelta de la mujer al trabajo.

La protección de la mujer embarazada frente al despido en caso de cierre de la empresa o ajuste de plantilla por causas económicas constituye también un problema. Para la empresa que deja de operar, supone sin duda una carga continuar pagando el sueldo de quien ya no trabaja para ella, aunque sea por un corto período, pero las perspectivas de empleo son más adversas para la mujer embarazada que para la que no lo está o para el hombre, y aquélla necesita especialmente la estabilidad económica y emocional que implica conservar el empleo, así como posponer la búsqueda del nuevo trabajo hasta después del parto. Por este motivo, en los países en que la legislación establece un orden de despido para las distintas categorías de trabajadores en casos de ajustes de plantilla, las mujeres embarazadas se encuentran en el último o penúltimo grupo (por ejemplo, en Etiopía)

\section{Los permisos y prestaciones para el padre y para ambos progenitores}

M ás allá de la protección de la salud y del estatuto laboral de la mujer embarazada o lactante, muchos países establecen permisos de paternidad (un corto período de permiso en el momento del nacimiento $\mathrm{O}$ en torno a éste). $\mathrm{H}$ ay otros tipos de permisos en función de las necesidades del niño, como el que se concede por adopción o para la crianza del hijo. Este último se prevé en muchos países, con distintos enfoques: un grupo de países establece la libranza de la madre de niños muy pequeños (permiso opcional por maternidad), mientras que otros contemplan permisos adicionales para ambos padres (permiso conjunto de paternidad y maternidad para la educación). Esta idea de que tanto el padre como la madre han de estar disponibles para el cuidado de los niños pequeños se plasma en estos permisos conjuntos de paternidad y maternidad, que permiten un largo período de descanso para ambos progenitores.

\section{- RECOMENDACIONES DE ESTADOS UNIDOSEN RELACION CON EL EMBARAZO Y EL TRABAJO}

\section{Leon J. Warshaw}

Los cambios producidos en la vida familiar en las últimas décadas han incidido fuertemente en la relación entre trabajo y embarazo. Entre ellos habría que incluir los siguientes:

- Las mujeres, especialmente las que se encuentran en edad fértil, siguen siendo una parte importante de la mano de obra.

- Se advierte entre ellas una tendencia a aplazar la formación del hogar hasta una edad más tardía, una vez que han alcanzado puestos de responsabilidad y han afianzado su situación como miembros importantes del aparato productivo.

- Al mismo tiempo, aumenta el número de embarazos juveniles, muchos de ellos de alto riesgo.

- Debido al aumento de las tasas de separación, de divorcio y a la elección de nuevas formas de vida, así como al incremento del número de familias en que trabajan el padre y la madre, las presiones financieras obligan a muchas mujeres a seguir trabajando en lo posible durante el embarazo.

La incidencia del absentismo laboral y la pérdida o el deterioro de la productividad relacionados con el embarazo, así como la preocupación por la salud y el bienestar de las madres y de sus hijos, han llevado a las empresas a tratar de hacer frente al problema del embarazo y el trabajo. Cuando ellas mismas pagan la totalidad o parte de las primas de los seguros de enfermedad, la perspectiva de impedir los costes (asombrosamente elevados en algunos casos) de los embarazos complicados y los problemas neonatales actúa como un poderoso incentivo adicional. Algunas medidas están previstas en las disposiciones legales y reglamentarias, como las referentes a la protección contra los peligros ambientales y profesionales, al permiso de maternidad 0 a otras prestaciones. 0 tras medidas son de carácter voluntario: por ejemplo, las relativas a la educación prenatal y los programas de asistencia, a la modificación de las condiciones de trabajo, como los regímenes de horario flexible 0 de jornadas especiales, o el cuidado de personas a cargo y a otras prestaciones.

\section{Atención durante el embarazo}

Es fundamental para la mujer embarazada, y para su empresa, independientemente de que aquélla siga o no trabajando, que se le brinde la ocasión de acogerse a un programa de atención de la salud destinado a identificar y evitar o disminuir los riesgos para la madre y el feto, permitiéndole así mantenerse laboralmente activa sin problemas. En cada una de las visitas prenatales programadas, el médico o la comadrona deben valorar la información médica (natalidad y otros antecedentes médicos, molestias actuales, exploración física y pruebas de laboratorio) y los datos sobre su trabajo y medio ambiente laboral, y realizar las recomendaciones apropiadas.

Es importante que los profesionales sanitarios no confíen en las descripciones sencillas del trabajo efectuadas por las pacientes, dado que con frecuencia son inapropiadas e incorrectas. Deben recabarse detalles sobre la actividad física, la exposición a sustancias químicas y de otro tipo y el estrés emocional, información que puede obtenerse, sin duda, de la propia mujer. Sin embargo, en ocasiones, es preciso, para obtener una visión más completa del peligro o de las tareas desarrolladas, así como sobre la posibilidad de controlar las lesiones potenciales, dirigirse a un supervisor, a menudo a través del departamento de seguridad o del servicio de salud de los empleados (en los casos en los que exista). Por este conducto puede comprobarse también la información inadecuada que los pacientes, de forma inadvertida o deliberada, dan al médico; es posible que exageren los riesgos 0 , si consideran que es importante continuar trabajando, que los subestimen.

\section{Recomendaciones para el trabajo}

Las recomendaciones respecto al trabajo durante el embarazo pueden encuadrarse en tres categorías:

L a mujer puede seguir trabajando sin cambiar sus actividades ni el medio ambiente de trabajo. Es lo que ocurre en la mayoría de los casos. D espués de una amplia deliberación, el grupo especial sobre la discapacidad del embarazo compuesto por tocólogos, médicos y enfermeras de empresa y representantes de las mujeres pertenecientes al ACOG (American College of O bstetricians and G ynecologists) y el NIOSH (National Institute for O ccupational Safety and $\mathrm{H}$ ealth) concluyó que "la mujer normal con un embarazo no complicado y cuyo trabajo no presenta mayores peligros que los existentes en la vida cotidiana normal de la comunidad puede seguir trabajando sin interrupción hasta el anuncio del parto y volver al trabajo a las pocas semanas de éste, si no ha sido un parto complicado" (I senman y Warshaw 1977).

La mujer puede seguir trabajando, pero sólo con determinadas modificaciones del medio ambiente de trabajo o de sus tareas. Esas modificaciones pueden ser "deseables" o "esenciales" (en el último caso, la 
mujer deberá interrumpir el trabajo si no pueden llevarse a cabo).

La mujer no debe trabajar. Es lo que sucede si el médico o la comadrona consideran que cualquier trabajo sería probablemente perjudicial para la salud de la mujer o la del feto en desarrollo.

Las recomendaciones no sólo deben detallar la necesidad de realizar modificaciones en el trabajo, sino también el período de tiempo en el que deben efectuarse y la fecha para el próximo examen profesional.

\section{Aspectos no médicos}

Las recomendaciones mencionadas se basan exclusivamente en los aspectos referentes a la salud de la madre y del feto en relación con los requisitos del trabajo. No tienen en cuenta la carga de las actividades extralaborales, como el desplazamiento al centro de trabajo, el trabajo realizado en el hogar o el cuidado de los niños y otros miembros de la familia, que pueden ser en algunos casos incluso más exigentes que el propio trabajo. Cuando es preciso realizar una modificación o una restricción del trabajo, se debe considerar si ésta es pertinente en el trabajo, en el domicilio 0 en ambos.

Además, existen distintos aspectos no médicos que influyen a favor o en contra de la decisión de seguir trabajando, tales como la disponibilidad de prestaciones, la posibilidad de disfrutar de un permiso retribuido o la garantía de la conservación del empleo. A este respecto, es fundamental la cuestión de si la mujer se considera discapacitada. Algunas empresas parecen entender que todas las trabajadoras embarazadas están discapacitadas y tratan de excluirlas de sus plantillas, aun cuando muchas estén en condiciones de seguir trabajando. 0 tras parecen pensar que todas las trabajadoras embarazadas tienden a exagerar su discapacidad para acogerse a cualquier prestación a su alcance. $Y$ algunas piensan incluso que un embarazo, sea 0 no discapacitante, no es algo que les concierna necesariamente en absoluto. De ahí que el concepto de discapacidad sea complejo y, aunque basado fundamentalmente en descubrimientos médicos, implique aspectos legales y sociales.

\section{Embarazo y discapacidad}

En muchas jurisdicciones es importante distinguir entre la discapacidad derivada del embarazo y el embarazo como período de la vida que faculta para obtener prestaciones y dispensas especiales. La discapacidad derivada del embarazo puede encuadrarse en las tres categorías siguientes:

1. Discapacidad después del parto. Desde un punto de vista estrictamente médico, la recuperación que sigue a la finalización de un embarazo mediante un parto no complicado dura sólo unas semanas, pero tradicionalmente se amplía hasta seis u ocho semanas, ya que es el plazo en el que la mayoría de los tocólogos programan la primera consulta posnatal. Por lo demás, desde un punto de vista práctico y sociológico, muchos consideran que sería deseable disfrutar de un permiso más prolongado para fomentar las relaciones familiares, facilitar la alimentación mediante lactancia materna y otros aspectos.

2. Discapacidad resultante de complicaciones de salud. Las complicaciones de salud, como la eclampsia, la amenaza de aborto, los problemas cardiovasculares y renales y demás, exigen el establecimiento de períodos de actividad reducida o incluso de hospitalización mientras persistan aquéllos o hasta que la madre se haya recuperado del problema de salud y el embarazo.

3. Discapacidad derivada de la necesidad de impedir la exposición a peligros de toxicidad o estrés físico anómalo. D ebido a la mayor sensibilidad del feto a muchos peligros ambientales, la mujer embarazada puede ser considerada discapacitada aunque su propia salud no esté en peligro.

\section{Conclusión}

El desafío de compaginar las responsabilidades familiares y el trabajo fuera del hogar no es nuevo para las mujeres. Lo que puede ser novedoso es una sociedad moderna que valora la salud y el bienestar de la mujer y de su descendencia, y que plantea a ésta el desafío dual de conseguir una realización personal a través del trabajo y de alcanzar unas condiciones económicas que le permitan mantener un nivel de vida aceptable. El número cada vez mayor de familias monoparentales y de parejas casadas en las que deben trabajar ambos componentes impide ignorar las cuestiones relacionadas con la familia y el trabajo. Muchas trabajadoras embarazadas deben, simplemente, seguir trabajando aunque estén embarazadas.

¿De quién es la responsabilidad de que se vean atendidas sus necesidades? Algunos podrían argumentar que se trata de un problema estrictamente personal, al que debe hacer frente exclusivamente la mujer 0 la familia. 0 tros consideran que es una responsabilidad de la sociedad, y están a favor de la promulgación de leyes y de la concesión de apoyo financiero y otras prestaciones de carácter básicamente social.

¿Q ué porción debe corresponder a la empresa? Depende fundamentalmente de la naturaleza, emplazamiento $y$, a menudo, tamaño de ésta. La empresa tiene en cuenta dos series de aspectos: las imposiciones de las leyes y reglamentos $(y$, algunas veces, de la necesidad de atender demandas sindicales) y los dictados de la responsabilidad social y la necesidad práctica de mantener una producción óptima. En última instancia, depende de que se conceda un alto valor a los recursos humanos y se reconozca la interdependencia de las responsabilidades laborales y las obligaciones familiares y sus efectos, algunas veces compensados, la salud y la productividad. 


\section{Referencias}

Agencia Internacional para la Investigación sobre e Cáncer (IARC). 1987. M onographs On the Evaluation of $\mathrm{Carcinogenic} \mathrm{R}$ isks to $\mathrm{H}$ umans, Overall $\mathrm{E}$ valuations of Carcinogenicity: An U pdating of IARC M onographs. Vol. 1-42, Supl. 7. Lyon: IAR C.

Agency for Toxic Substance and Disease Registry. 1992. Mercury toxicity. Am Fam Phys 46(6): 1731-1741.

Ahlborg, JR, L Bodin, C Hogstedt. 1990. Heavy lifting during pregnancy-A hazard to the fetus? A prospective study. Int J E pidemiol 19:90-97.

Alderson, M. 1986. Occupational Cancer. Londres: Butterworths

Anderson, HA, R Lilis, SM Daum, AS Fischbein, I] Selikoff. 1976. Household contact asbestos neoplastic risk. Ann NY Acad Sci 271:311-332.

A postoli, P, L Romeo, E Peroni, A Ferioli, S Ferrari, F Pasini, F Aprili. 1989. Steroid hormone sulphation in lead workers. $\mathrm{Br}$ J Ind $\mathrm{Med}$ 46:204-208.

Assennato, G, C Paci, ME Baser, R M olinini, RG Candela, BM Altmura, R Giogino. 1986. Sperm count suppression with endocrine dysfunction in lead-exposed men. Arch Environ $H$ ealth 41:387-390.

A wumbila, B, E Bokuma. 1994. Survey of pesticides used in the control of ectoparasites on farm animals in Ghana. Tropic Animal Health Prod 26(1):7-12

Baker, HWG, TJ Worgul, RJ Santen, LS Jefferson, CW Bardin. 1977. Effect of prolactin on nuclear androgens in perifused male accessory sex organs. $\mathrm{En} T$ he T estis in N ormal and Infertile M en, dirigido por P y H N Troen. Nueva Y ork: R aven Press.

Bakir, F, SF Damluji, L Amin-Zaki, M Murtadha, A K halidi, NY Al-Rawi, S Tikriti, HT Dhahir, TW Clarkson, JC Smith, RA Doherty. 1973. Methyl mercury poisoning in Iraq. Science 181:230-241.

Bardin, CW. 1986. Pituitary-testicular axis. En Reproductive Endocrinology, dirigido por SSC Y en y $R B$ J affe. Filadelfia: W B Saunders.

Bellinger, D, A Leviton, C W aternaux, $\mathrm{H}$ Needleman, M R abinowitz. 1987. Longitudinal analyses of prenatal and postnatal lead exposure and early cognitive development. New Engl J M ed 316:1037-1043.

Bellinger, D, A Leviton, E Allred, M Rabinowitz. 1994. Pre- and postnatal lead exposure and behavior problems in school-aged children. E nviron Res 66:12-30.

Berkowitz, GS. 1981. An epidemiologic study of preterm delivery. Am J E pidemiol 113:81-92.

Bertucat, I, N M amelle, F M unoz. 1987. Conditions de travail des femmes enceintes-étude dans cinq secteurs d'activité de la région $\mathrm{R}$ hône-Alpes. Arch mal prof méd trav secur soc 48:375-385.

Bianchi, C, A Brollo, C Zuch. 1993. Asbestos-related familial mesothelioma. Eur J Cancer 2(3) (mayo):247-250.

Bonde, JPE. 1992. Subfertility in relation to welding-A case referent study among male welders. D anish M ed Bull 37:105-108.

Bornschein, RL, J Grote, T M itchell. 1989. Effects of prenatal lead exposure on infant size at birth. En $L$ ead Exposure and Child Development, dirigido por $M$ Smith y L G rant. Boston: K luwer A cademic.

Brody, DJ, IL Pirkle, RA K ramer, KM Flegal, T D M atte, EW Gunter, DC Pashal. 1994. Blood lead levels in the US population: Phase one of the Third $\mathrm{N}$ ational $\mathrm{H}$ ealth and Nutrition Examination survey (NHANES III, 1988 to 1991). J Am M ed Assoc 272:277-283.

Casey, PB, JP Thompson, JA Vale. 1994. Suspected paediatric poisoning in the UK; I-H ome accident surveillance system 1982-1988. H um Exp T oxicol 13:529-533

Chapin, RE, SL Dutton, MD Ross, BM Sumrell, JC Lamb IV. 1984. The effects of ethylene glycol monomethyl ether on testicular histology in F344 rats. J Androl 5:369-380.

Chapin, RE, SL Dutton, MD Ross, IC Lamb IV. 1985. Effects of ethylene glycol monomethyl ether (EGME) on mating performance and epididymal sperm parameters in F344 rats. Fund Appl Toxicol 5:182-189.

Charlton, A. 1994. Children and passive smoking. J Fam Pract 38(3)(M arch):267-277.

Chia, SE, CN Ong, ST Lee, FHM T sakok. 1992. Blood concentrations of lead, cadmium, mercury, zinc, and copper and human semen parameters. Arch Androl 29(2):177-183.

Chisholm, JJ Jr. 1978. Fouling one's nest. Pediatrics 62:614-617.

Chilmonczyk, BA, LM Salmun, KN M egathlin, LM Neveux, GE Palomaki, GJ K night, AJ Pulkkinen, JE H addow. 1993. A ssociation between exposure to environmental tobacco smoke and exacerbations of asthma in children. New Engl J $M$ ed 328:1665-1669.

Clarkson, TW, GF Nordberg, PR Sager. 1985. Reproductive and developmental toxicity of metals. Scand J W ork E nviron H ealth 11:145-154.

Clement International Corporation. 1991. T oxicological Profile for Lead. Washington, DC: US Department of $\mathrm{H}$ ealth and Human Services, Public Health Service Agency for Toxic Substances and Disease R egistry.

- - 1992. Toxicological Profile for A-, B-, G-, and D-H exachlorocyclohexane. Washington, DC: US Department of $\mathrm{H}$ ealth and Human Services, Public Health Service Agency for Toxic Substances and D isease R egistry.

Culler, M D, A N egro-Vilar. 1986. Evidencethatpulsatile follicle-stimulating hormone secretion is independent of endogenous luteinizing hormone-releasing hormone. Endocrinology 118:609-612.

Dabeka, RW, KF Karpinski, AD M cK enzie, CD Bajdik. 1986. Survey of lead, cadmium and flouride in human milk and correlation of levels with environmental and food factors. Food Chem T oxicol 24:913-921.

Daniell, WE, TL Vaughn. 1988. Paternal employment in solvent related occupations and adverse pregnancy outcomes. $\mathrm{Br}$ J Ind $\mathrm{Med}$ 45:193-197.

Davies, JE, HV Dedhia, C M orgade, A Barquet, HI $M$ aibach. 1983. Lindane poisonings. Arch D ermatol 119 (febrero):142-144.

Davis, JR, RC Bronson, R Garcia. 1992. Family pesticide use in the home, garden, orchard, and yard. Arch E nviron Contam T oxicol 22(3):260-266.

Dawson, A, A Gibbs, K Browne, F Pooley, M G riffiths. 1992. Familial mesothelioma. Details of seventeen cases with histopathologic findings and mineral analysis. Cancer 70(5):1183-1187.

D'Ercole, JA, RD Arthur, JD Cain, BF Barrentine. 1976. Insecticide exposure of mothers and newborns in a rural agricultural area. Pediatrics 57(6):869-874.

Ehling, UH, L M achemer, W Buselmaier, J Dycka, H Froomberg, J Dratochvilova, R Lang, D Lorke D M uller, I Peh, G Rohrborn, $R$ Roll, $M$ Schulze-Schencking, H Wiemann. 1978. Standard protocol for the dominant lethal test on male mice. Arch T oxicol 39:173-185.

Evenson, DP. 1986. Flow cytometry of acridine orange stained sperm is a rapid and practical method for monitoring occupational exposure to genotoxicants. En M onitoring of O ccupational
Genotoxicants, dirigido por M Sorsa y H Norppa. Nueva Y ork: Alan R Liss.

Fabro, S. 1985. Drugs and male sexual function. Rep T oxicol M ed Lettr 4:1-4.

Farfel, MR, JJ Chisholm Jr, CA Rohde. 1994. The long-term effectiveness of residential lead paint abatement. Environ Res 66:217-221.

Fein, G, JL Jacobson, SL Jacobson, PM Schwartz, JK Dowler. 1984. Prenatal exposure to polychlorinated biphenyls: effects on birth size and gestational age. J Pediat 105:315-320.

Fenske, RA, KG Black, KP Elkner, C Lee, MM M ethner, R Soto. 1994. Potential exposure and health risks of infants following indoor residential pesticide applications. Am J Public Health 80(6):689-693.

Fischbein, A, M S Wolff. 1987. Conjugal exposure to polychlorinated biphenyls (PCBs). $\mathrm{Br} J$ Ind $\mathrm{Med}$ 44:284-286.

Florentine, MJ, DJ II Sanfilippo. 1991. Elemental mercury poisoning. Clin Pharmacol 10(3):213-221.

Frischer, $T$, I K uehr, $R$ M einert, $W$ K armaus, $R$ Barth, E Hermann-K unz, R U rbanek. 1992. $M$ aternal smoking in early childhood: A risk factor for bronchial responsiveness to exercise in primary-school children. J Pediat 121 (julio):17-22.

Gardner, M J, AJ H all, M P Snee. 1990. M ethods and basic design of case-control study of leukemia and lymphoma among young people near Sellafield nuclear plant in West Cumbria. $\mathrm{Br} \mathrm{Med}$ । 300:429-434.

Gold, EB, LE Sever. 1994. Childhood cancers associated with parental occupational exposures. 0 ccup M ed .

Goldman, LR, I Carra. 1994. Childhood lead poisoning in 1994. J Am M ed Assoc 272(4):315-316.

Grandjean, P, E Bach. 1986. Indirect exposures: the significance of bystanders at work and at home. Am Ind H yg Assoc f 47(12):819-824.

Hansen, J, NH de-K lerk, JL Eccles, AW Musk, M S H obbs. 1993. M alignant mesothelioma after environmental exposure to blue asbestos. Int J Cancer 54(4):578-581.

H echt, NB. 1987. Detecting the effects of toxic agents on spermatogenesis using DNA probes. Environ $H$ ealth Persp 74:31-40.

H olly, EA, DA Aston, DK Ahn, J] K ristiansen. 1992 Ewing's bone sarcoma, paternal occupational exposure and other factors. Am J Epidemiol 135:122-129.

Homer, CJ, SA Beredford, SA James. 1990. Work-related physical exertion and risk of preterm, low birthweight delivery. Paediat Perin E pidemiol 4:161-174.

Isenman, AW, LJ Warshaw. 1977. Guidelines On Pregnancy and W ork. Chicago: American College of $O$ bstetricians and $G$ ynecologists.

Jacobson, SW, G Fein, JL Jacobson, PM Schwartz, JK Dowler. 1985. The effect of intrauterine PCB exposure on visual recognition memory. Child D evelopment 56:853-860.

Jensen, NE, IB Sneddon, AE Walker. 1972. T etrachlorobenzodioxin and chloracne. Trans St J ohns H osp D ermatol Soc 58:172-177.

Källén, B. 1988. E pidemiology of $H$ uman Reproduction. Boca $R$ atón: $C R C$ Press

K aminski, M , C R umeau, D Schwartz. 1978. Alcohol consumption in pregnant women and the outcome of pregnancy. Alcohol, Clin Exp Res 2:155-163.

Kaye, WE, TE Novotny, M Tucker. 1987. New ceramics-related industry implicated in elevated blood lead levels in children. Arch Environ $\mathrm{H}$ ealth 42:161-164.

K lebanoff, MA, PH Shiono, JC Carey. 1990. The effect of physical activity during pregnancy on 
preterm delivery and birthweight. Am । Obstet Gynecol 163:1450-1456

K line, J, Z Stein, M Susser. 1989. Conception to birth-epidemiology of prenatal development. $\mathrm{Vol} .14$ $M$ onograph in Epidemiology and Biostatistics. Nueva Y ork: $O$ xford U niv. Press.

$K$ otsugi, $F$, SJ Winters, HS K eeping, B Attardi, H O shima, P Troen. 1988. Effects of inhibin from primate sertoli cells on follicle-stimulating hormone and luteinizing hormone release by perifused rat pituitary cells. Endocrinology 122:2796-2802

K ramer, MS, TA Hutchinson, SA Rudnick, JM Leventhal, AR Feinstein. 1990. O perational criteria for adverse drug reactions in evaluating suspected toxicity of a popular scabicide. Clin Pharmacol Ther 27(2):149-155.

K ristensen, $\mathrm{P}, \mathrm{LM}$ Irgens, AK Daltveit, A Andersen. 1993. Perinatal outcome among children of men exposed to lead and organic solvents in the printing industry. Am J E pidemiol 137:134-144.

K ucera, J. 1968. Exposure to fat solvents: A possible cause of sacral agenesis in man. I Pediat 72:857-859.

Landrigan, PJ, CC Campbell. 1991. Chemical and physical agents. Capítulo 17 en $\mathrm{F}$ etal and Neonatal $E$ ffects of $M$ aternal $D$ isease, dirigido por AY Sweet $y$ EG Brown. St. L ouis: M osby Y ear Book.

Launer, LJ, J Villar, E K estler, M de O nis. 1990. The effect of maternal work on fetal growth and duration of pregnancy: a prospective study. $\mathrm{Br}$ । O bstet Gynaec 97:62-70.

Lewis, RG, RC Fortmann, DE Camann. 1994. Evaluation of methods for monitoring the potential exposure of small children to pesticides in the residential environment. Arch E nviron Contam T oxico 26:37-46.

Li, FP, MG Dreyfus, KH Antman. 1989. Asbestos-contaminated nappies and familial mesothelioma. Lancet 1:909-910.

Lindbohm, M L, K Hemminki, P Kyyronen. 1984. Parental occupational exposure and spontaneous abortions in Finland. Am J E pidemiol 120:370-378.

Lindbohm, ML, K Hemminki, MG Bonhomme, A Anttila, K Rantala, P H eikkila, MJ Rosenberg. 1991a. Effects of paternal occupational exposure on spontaneous abortions. Am 」 Public $\mathrm{H}$ ealth 81:1029-1033.

Lindbohm, M L, M Sallmen, A Antilla, H T askinen K Hemminki. 1991b. Paternal occupational lead exposure and spontaneous abortion. Scand I W ork E nviron $H$ ealth 17:95-103.

Luke, B, N M amelle, L K eith, F M uñoz. 1995. The association between occupational factors and preterm birth in US nurses' survey. Obstet Gyneco Ann 173(3):849-862.

M amelle, N, I Bertucat, F M uñoz. 1989. Pregnant women at work: Rest periods to prevent preterm birth? P aediat Perin E pidemiol 3:19-28.

Mamelle, N, B Laumon, PH Lazar. 1984. Prematurity and occupational activity during pregnancy. Am I E pidemiol 119:309-322.

M amelle, N, F M unoz. 1987. O ccupational working conditions and preterm birth: A reliable scoring system. Am J E pidemiol 126:150-152.

$M$ amelle, $N$, J Dreyfus, $M$ Van Lierde, $R$ Renaud. 1982. M ode de vie et grossesse. J Gynecol O bstet Bio Reprod 11:55-63.

Mamelle, N, I Bertucat, JP Auray, G Duru. 1986. $Q$ uelles mesures de la prevention de la prématurite en milieu professionel? Rev Epidemiol Santé Publ 34:286-293.

Marbury, MC, SK Hammon, NJ Haley. 1993. $M$ easuring exposure to environmental tobacco smoke in studies of acute health effects. Am J E pidemiol 137(10):1089-1097.
Marks, R. 1988. Role of childhood in the development of skin cancer. Aust Paediat । 24:337-338.

M artin, RH. 1983. A detailed method for obtaining preparations of human sperm chromosomes Cytogenet Cell G enet 35:252-256.

$M$ atsumoto, AM . 1989. H ormonal control of human spermatogenesis. En The Testis, dirigido por $\mathrm{H}$ Burger y D de K retser. Nueva Y ork: R aven Press.

Mattison, DR, DR Plowchalk, MI Meadows, AZ Al-Juburi, J Gandy, A M alek. 1990. Reproductive toxicity: male and female reproductive systems as targets for chemical injury. M ed Clin N Am 74:391-411.

M axcy R osenau-Last. 1994. Public $\mathrm{H}$ ealth and Preventive $M$ edicine. N ueva Y ork: A ppleton-C entury-C rofts.

McConnell, R. 1986. Pesticides and related compounds. En Clinical Occupational Medicine dirigido por $L$ R osenstock y M R Cullen. Filadelfia: WB Saunders.

MCD onald, AD, JC MCD onald, B Armstrong NM Cherry, AD Nolin, D Robert. 1988 Prematurity and work in pregnancy. $\mathrm{Br}$ । Ind $\mathrm{M} \mathrm{ed}$ 45:56-62.

- - 1989. Fathers' occupation and pregnancy outcome. Br I Ind M ed 46:329-333.

M cLachlan, RL, AM M atsumoto, HG Burger, DM de $\mathrm{K}$ retzer, WJ Bremner. 1988. Relative roles of follicle-stimulating hormone and luteinizing hormone in the control of inhibin secretion in normal men. I Clin Invest 82:880-884.

M eeks, A, PR K eith, MS T anner. 1990. Nephrotic syndrome in two members of a family with mercury poisoning. I T race Elements E lectrol $H$ ealth $D$ is 4(4):237-239.

National Reasearch Council. 1986. Environmental Tobacco Smoke: M easuring Exposures and Assessing $\mathrm{H}$ ealth $\mathrm{E}$ ffects. W ashington, DC: N ational Academy Press.

- - 1993. Pesticides in the D iets of Infants and Children W ashington, DC: N ational A cademy Press.

Needleman, HL, D Bellinger. 1984. The developmental consequences of childhood exposure to lead. Adv Clin Child Psychol 7:195-220.

Nelson, K, LB Holmes. 1989. M alformations due to presumed spontaneous mutations in newborn infants. N ew Engl J M ed 320(1):19-23.

Nicholson, WJ. 1986. Airborne Asbestos $\mathrm{H}$ ealth Assessment U pdate Documento núm. EPS/600/8084/003F. Washington, DC: Environmental Criteria and Assessment.

O 'L eary, LM , AM Hicks, JM Peters, S London. 1991 Parental occupational exposures and risk of childhood cancer: a review. Am J Ind $M$ ed 20:17-35.

Olsen, J. 1983. Risk of exposure to teratogens amongst laboratory staff and painters. Danish $\mathrm{M} \mathrm{ed}$ Bull 30:24-28.

OIsen, JH, PDN Brown, G Schulgen, OM Jensen. 1991. Parental employment at time of conception and risk of cancer in offspring. Eur J Cance 27:958-965.

O rganización Internacional del Trabajo (OIT). 1965 $M$ aternity Protection: $A$ W orld Survey of N ational Law and Practice. Extracto del Informe de la 35a Sesión de Comité de Expertos sobre la Aplicación de Convenios y R ecomendaciones, apart. 199, nota 1, pág. 235. Ginebra: OIT.

- 1988. Equality in Employment and Occupation Report III (4B). Conferencia Internacional de Trabajo, 75a Sesión. Ginebra: OIT.

Organización Mundial de la Salud (OMS). 1969. Prevention of perinatal morbidity and mortality. Public H ealth Papers, N 0. 42. G inebra: O M S.

- - . 1977. M odification Recommended by FIGO WHO recommended definitions, terminology and format for statistical tables related to the perinatal period and use of a new certificate for cause of perinatal death. Acta Obstet Gynecol Scand 56:247-253.

O tte, KE, TI Sigsgaard, J K jaerulff. 1990. M alignant mesothelioma clustering in a family producing asbestos cement in their home. $\mathrm{Br}$ J Ind $\mathrm{Med}$ 47:10-13.

Paul, M. 1993. Occupational and Environmental Reproductive $\mathrm{H}$ azards: A Guide for Clinicians. Baltimore: Williams \& Wilkins.

Peoples-Sheps, MD, E Siegel, CM Suchindran, H Origasa, A' Ware, A Barakat. 1991. Characteristics of maternal employment during pregnancy: Effects on low birthweight. Am J Public $H$ ealth 81:1007-1012.

Pirkle, JL, DJ Brody, EW Gunter, RA Kramer, DC Paschal, KM Flegal, TD M atte. 1994. The decline in blood lead levels in the U nited States. J Am M ed Assoc 272 (julio):284-291.

Plant, TM. 1988. Puberty in primates. En The Physiology of Reproduction, dirigido por E K nobil y JD $N$ eill. Nueva Y ork: R aven Press.

Plowchalk, DR, MJ Meadows, DR M attison. 1992. Female reproductive toxicity. En Occupational and Environmental Reproductive $\mathrm{H}$ azards: A Guide for Clinicians, dirigido por M Paul. Baltimore: Williams and Wilkins.

Potashnik, G, D Abeliovich. 1985. Chromosomal analysis and health status of children conceived to men during or following dibromochloropropaneinduced spermatogenic suppression. Andrologia 17:291-296.

Rabinowitz, M, A Leviton, H Needleman. 1985 Lead in milk and infant blood: A dose-response model. Arch E nviron $\mathrm{H}$ ealth 40:283-286.

R atcliffe, JM, SM Schrader, K Steenland, DE Clapp T T urner, RW Hornung. 1987. Semen quality in papaya workers with long term exposure to ethylene dibromide. Br J Ind M ed 44:317-326.

R eferee (T he). 1994. J Assoc A nal Chem 18(8):1-16.

Rinehart, RD, Y Y anagisawa. 1993. Paraoccupational exposures to lead and tin carried by electric-cable splicers. Am Ind $\mathrm{H}$ yg Assoc J 54(10):593-599.

Rodamilans, M, MJM O saba, J To-Figueras, F Rivera Fillat, JM M arques, P Perez, J Corbella. 1988. Lead toxicity on endocrine testicular function in an occupationally exposed population. H um T oxicol 7:125-128.

Rogan, WJ, BC Gladen, JD M cK inney, N Carreras, P H ardy, I Thullen, I T ingelstad, M Tully. 1986. Neonatal effects of transplacental exposure to PCBs and DDE.J Pediat 109:335-341.

Roggli, VL, WE Longo. 1991. M ineral fiber content of lung tissue in patients with environmental exposures: household contacts vs. building occupants. Ann NY Acad Sci 643 (31 de diciembre):511-518.

Roper, WL. 1991. Preventing Lead Poisoning in Young Children: A Statement by the $C$ enters for $D$ isease Control. Washington, DC: US Department of $\mathrm{H}$ ealth and H uman Services.

Rowens, B, D Guerrero-Betancourt, CA Gottlieb, RJ Boyes, MS Eichenhorn. 1991. Respiratory failure and death following acute inhalation of mercury vapor. A clinical and histologic perspective. Chest 99(1):185-190.

Rylander, E, G Pershagen, M Eriksson, L N ordvall. 1993. Parental smoking and other risk factors for wheezing bronchitis in children. Eur J Epidemiol 9(5):516-526.

R yu, JE, EE Ziegler, JS Fomon. 1978. M aternal lead exposure and blood lead concentration in infancy. J Pediat 93:476-478.

Ryu, JE, EE Ziegler, SE Nelson, JS Fomon. 1983. Dietary intake of lead and blood lead 
concentration in early infancy. Am । D is Child 137:886-891.

Sager, DB, DM Girard. 1994. Long term effects on reproductive parameters in female rats after translactional exposure to PCBs. Environ Res 66:52-76.

Sallmen, M, ML Lindbohm, A Anttila, H Taskinen, K Hemminki. 1992. Paternal occupational lead exposure and congenital malformations. I E pidemiol Community $H$ ealth 46(5):519-522.

Saurel-Cubizolles, M J, M K aminski. 1987. Pregnant women's working conditions and their changes during pregnancy: A national study in France. $\mathrm{Br}$ J Ind $M$ ed 44:236-243.

Savitz, DA, NL Sonnerfeld, AF Olshaw. 1994. Review of epidemiologic studies of paternal occupational exposure and spontaneous abortion. Am J Ind M ed 25:361-383.

Savy-M oore, RJ, NB Schwartz. 1980. Differential control of FSH and LH secretion. Int Rev Physiol 22:203-248.

Schaefer, M. 1994. Children and toxic substances: Confronting a major public health challenge. E nviron H ealth Persp 102 Supl. 2:155-156.

Schenker, M B, SJ Samuels, RS Green, P Wiggins. 1990. Adverse reproductive outcomes among female veterinarians. Am J E pidemiol 132 (enero):96-106.

Schreiber, JS. 1993. Predicted infant exposure to tetrachloroethene in human breastmilk. Risk Anal 13(5):515-524

Segal, S, H Yaffe, N Laufer, M Ben-David. 1979. $M$ ale hyperprolactinemia: Effects on fertility. Fert Steril 32:556-561.

Selevan, SG. 1985. Design of pregnancy outcome studies of industrial exposures. En Occupational $\mathrm{H}$ azards and Reproduction, dirigido por $\mathrm{K} \mathrm{H}$ emminki, $M$ Sorsa y $\mathrm{H}$ Vainio. Washington, DC: $\mathrm{H}$ emisphere.

Sever, LE, ES Gilbert, NA Hessol, JM M clntyre. 1988. A case-control study of congenital malformations and occupational exposure to low-level radiation. Am J E pidemiol 127:226-242.

Shannon, M W, JW Graef. 1992. Lead intoxication in infancy. Pediatrics 89:87-90.

Sharpe, R M . 1989. Follicle-stimulating hormone and spermatogenesis in the adult male. I Endocrinol 121:405-407.

Shepard, T, AG Fantel, I Fitsimmons. 1989. Congenital defect abortuses: Twenty years of monitoring. T eratology 39:325-331.

Shilon, M , GF Paz, ZT H omonnai. 1984. The use of phenoxybenzamine treatment in premature ejaculation. F ert Steril 42:659-661.

Smith, AG. 1991. Chlorinated hydrocarbon insecticides. En $\mathrm{H}$ andbook of Pesticide Toxicology, dirigido por WJ Hayes y ER Laws. Nueva York: Academic Press.

Sockrider, M M , DB Coultras. 1994. Environmental tobacco smoke: a real and present danger. J Resp $D$ is 15(8):715-733.

Stachel, B, RC Dougherty, U Lahl, M Schlosser, $B$ Zeschmar. 1989. T oxic environmental chemicals in human semen: analytical method and case studies. Andrologia 21:282-291.

Starr, HG, FD Aldrich, WD MCDougall III, LM M ounce. 1974. Contribution of household dust to the human exposure to pesticides. Pest $M$ onit] 8:209-212

Stein, ZA, M W Susser, G Saenger. 1975. Famine and $H$ uman Development. The Dutch $H$ unger $W$ inter of 1944/ 45. N ueva Y ork: O xford U niv. Press.

Taguchi, S, T Yakushiji. 1988. Influence of termite treatment in the home on the chlordane concentration in human milk. Arch Environ Contam T oxicol 17:65-71.
Taskinen, HK. 1993. Epidemiological studies in monitoring reproductive effects. Environ $\mathrm{H}$ ealth Persp 101 Supl. 3:279-283.

T askinen, H, A Antilla, ML Lindbohm, M Sallmen, $\mathrm{K}$ Hemminki. 1989. Spontaneous abortions and congenital malformations among the wives of men occupationally exposed to organic solvents. Scand J W ork E nviron $\mathrm{H}$ ealth 15:345-352.

Teitelman, AM, LS Welch, KG Hellenbrand, M B Bracken. 1990. The effects of maternal work activity on preterm birth and low birth weight. Am E pidemiol 131:104-113.

Thorner, MO, CRW Edwards, JP Hanker, G Abraham, GM Besser. 1977. Prolactin and gonadotropin interaction in the male. En T he T estis in $\mathrm{N}$ ormal and Infertile $\mathrm{M}$ en, dirigido por $\mathrm{P}$ T roen y $\mathrm{H}$ $\mathrm{N}$ ankin. N ueva $\mathrm{Y}$ ork: $\mathrm{R}$ aven Press.

US Environmental Protection Agency (US EPA). 1992. R espiratory $\mathrm{H}$ ealth $\mathrm{E}$ ffects of Passive Smoking: L ung Cancer and 0 ther Disorders. Publicación núm. EPA/ 600/ 6-90/ 006F. Washington, DC: US EPA.

Veulemans, $H, O$ Steeno, $R$ M asschelein, $D$ Groesneken. 1993. Exposure to ethylene glycol ethers and spermatogenic disorders in man: A case-control study. Br J Ind M ed 50:71-78.

Villar, J, JM Belizan. 1982. The relative contribution of prematurity and fetal growth retardation to low birth weight in developing and developed societies. Am J Obstet Gynecol 143(7):793-798.

Welch, LS, SM Schrader, TW Turner, MR Cullen. 1988. Effects of exposure to ethylene glycol ethers on shipyard painters: ii. male reproduction. Am J Ind $M$ ed 14:509-526.

Whorton, D, TH M ilby, RM K rauss, HA Stubbs. 1979. Testicular function in DBCP exposed pesticide workers. J 0 ccup M ed 21:161-166.

Wilcox, AJ, CR W einberg, JF O 'C onnor, DD BBaird, JP Schlatterer, RE C anfield, EG Armstrong, BC $N$ isula. 1988. Incidence of early loss of pregnancy. New Engl J M ed 319:189-194.

Wilkins, J, T Sinks. 1990. Parental occupation and intracranial neoplasms of childhood: Results of a case-control interview study. Am J Epidemiol 132:275-292.

Wilson, JG. 1973. Environment and Birth D efects. Nueva Y ork: Academic Press.

- - 1977. current status of teratology-general principles and mechanisms derived from animal studies. En $\mathrm{H}$ andbook of T eratology, Volume 1, General Principles and E tiology, dirigido por JG Fraser y FC Wilson. N ueva Y ork: Plenum.

Winters, SJ. 1990. Inhibin is released together with testosterone by the human testis. I Clin Endocrinol M etabol 70:548-550.

Wolff, MS. 1985. O ccupational exposure to polychlorinated biphenyls. Environ $H$ ealth Persp 60:133-138.

- - 1993. Lactation. En Occupational and Environmental Reproductive $\mathrm{H}$ azards: A Guide for Clinicians, dirigido por M Paul. Baltimore: Williams $\&$ Wilkins.

Wolff, M S, A Schecter. 1991. Accidental exposure of children to polychlorinated biphenyls. Arch Environ Contam T oxicol 20:449-453.

Zaneveld, LJD. 1978. The biology of human spermatozoa. O bstet Gynecol Ann 7:15-40.

Ziegler, EE, BB Edwards, RL Jensen, KR M ahaffey, JS Fomon. 1978. Absorption and retention of lead by infants. Pediat Res 12:29-34.

Zikarge, A. 1986. Cross-Sectional Study of Ethylene DibromideInduced Alterations of Seminal Plasma B iochemistry as a Function of Post- T esticular T oxicity with Relationships to Some Indices of Semen Analysis and Endocrine Profile. Tesis doctoral, H ouston, T exas: U niv. de T exas, $\mathrm{H}$ ealth Science $\mathrm{C}$ enter.

Zirschky, J, L Wetherell. 1987. Cleanup of mercury contamination of thermometer workers' homes. Am Ind H yg Assoc f 48:82-84.
Zukerman, Z, LJ Rodríguez-Rigau, DB Weiss, AK Chowdhury, KD Smith, E Steinberger. 1978. Q uantitative analysis of the seminiferous epithelium in human testicular biopsies, and the relation of spermatogenesis to sperm density. F ert Steril 30:448-455.

Zwiener, RJ, CM Ginsburg. 1988. O rganophosphate and carbamate poisoning in infants and children. Pediatrics 81(1):121-126.

\section{0 tras lecturas recomendadas}

Baird, DD, AJ Wilcox. 1985. Cigarette smoking associated with delayed conception. I Am M ed Assoc 253:2979-2983.

--.1986 . Effects of occupatonal exposures on the fertility of couples. 0 ccup M ed 1:361-374.

Giroux, D, G Lapointe, M Baril. 1992. Toxicological index and the presence in the workplace of chemical hazards for workers who breast-feed infants. Am Ind H yg Assoc f 53(7):471-474.

Haustein, UF. 1991. Pyrethrin and pyrethroid (permethrin) in the treatment of scabies and pediculosis. $H$ autarzt 42(1):9-15.

K atz, DF. 1991. H uman sperm as biomarkers of toxic risk and reproductive health. J NIH Res 3(5):63-67.

Levine, RJ, MJ Symons, SA Balogh, DM Arndt, NT K aswandik, IW Gentile. 1980. A method for monitoring the fertility of workers: 1 . M ethod and pilot studies. J O ccup M ed 22:781-791.

Lindbohm, M L, M Sallmen, A Antilla. 1991. Paternal occupational lead exposure and spontaneous abortion. Scand I W ork E nviron $H$ ealth 17:95-103.

Lindbohm, ML, M Sallmen, A Anttila, H Taskinen, K Hemminki. 1992. Paternal occupational lead exposure and congenital malformations. E pidemiol Community $\mathrm{H}$ ealth 46(5):519-522.

M attison, DR. 1995. Female reproductive system. En Environmental M edicine, dirigido por SM Brooks, $M$ Gochfeld, J Herzstein, RJ Jackson y M B Schenker. St. L ouis: M osby Y ear Book.

Mattison, DR, MR Cullen. 1994. Disorders of reproduction and development. En T extbook of Clinical Occupational and Environmental M edicine, dirigido por L R osenstock y M R Cullen. Filadelfia: WB Saunders.

M attison, DR, PJ Thomford. 1989. M echanisms of action of reproductive toxicants. En T oxicology of the $M$ ale and $F$ emale $R$ eproductive Systems, dirigido por PK W orking. Nueva Y ork: $\mathrm{H}$ emisphere.

National Research Council. 1989. Biologic M arkers in Reproductive T oxicology. Washington, DC: National Academy Press.

O rganización Internacional del Trabajo (OIT). 1994. $\mathrm{M}$ aternity and $\mathrm{W}$ ork, Conditions of $\mathrm{W}$ ork D igest. V ol. 13. Ginebra: OIT.

Sever, LE, NA Hessol. 1984. O verall design considerations in male and female occupational reproductive studies. En Reproduction: The $\mathrm{New}$ Frontier in Occupational and Environmental $\mathrm{H}$ ealth Research, dirigido por JE Lockey, G LeM asters y WRJ K eye. Nueva Y ork: Alan R Liss.

Silvaggio, T, DR M attison. 1992. A comparative approach to toxicokinetics. En O ccupational and Environmental Reproductive $\mathrm{H}$ azards: $\mathrm{A}$ Guide for Clinicians, dirigido por M Paul. Baltimore: Williams $\&$ Wilkins.

Working, PK, DR M attison. 1992. Reproductive and development toxicity testing methods in animals. En Occupational and Environmental Reproductive $\mathrm{H}$ azards: A Guide for Clinicians, dirigido por M Paul. Baltimore: Williams \& Wilkins.

Zenick, H, ED Clegg. 1989. Assessment of male reproductive toxicity: A risk assessment approach. C apítulo 10 en Principles and M ethods of Toxicology, dirigido por AW H ayes. Nueva Y ork: R aven Press. 

Directores del capítulo

Alois $D$ avid y

G regory R. W agner
Enfermedad pulmonar obstructiva crónica

Kazimierz M arek y J an E. Z ejda . . . . . . . . . . . . . . 10.79

E fectos de las fibras artificiales sobre la salud

J ames E. L ockey y Clara S. R oss . . . . . . . . . . . . . . . . . . . . . . 10.84

$C$ áncer respiratorio

Paolo B offetta y E lisabete W eiderpass. . . . . . . . . . . . . . . 10.88

Infecciones pulmonares de origen ocupacional

Anthony A. M arfin, Ann F. H ubbs, Karl J. M usgrave y J ohn E. Parker . . 10.92

Enfermedades causadas por irritantes respiratorios y productos químicos tóxicos

D avid L.S. R yon y W illiam N. Rom

Asma ocupacional

George F riedman-J imenez y $E$ dward L. Petsonk. .

Enfermedades causadas por polvos orgánicos

R agnar R ylander y R ichard S. F. Schilling . .

Enfermedad por berilio

H omayoun Kazemi

Neumoconiosis: definición

Alois D avid

Clasificación internacional de radiografías de

neumoconiosis de la O IT

$M$ ichel Lesage .

Etiopatogenia de la neumoconiosis

Patrick Sébastien y R aymond B égin . . . . . . . . . . . . . . . . . . . 10.40

Silicosis

J ohn E. Parker y G regory R. W agner . . . . . . . . . . . . . . 10.48

Enfermedades pulmonares de los mineros del carbón

M ichael D. Attfield, E dward L. Petsonk y G regory R. W agner . . . . . . . 10.52

Enfermedades relacionadas con el amianto

$M$ argaret R. B ecklake

Enfermedades por metales pesados

Gerolamo Chiappino .......................... 10.71

A parato respiratorio: la variedad de las neumoconiosis

Steven R. Short y E dward L. Petsonk. 


\section{ESTRUCTURA Y FUNCION}

\section{M orton Lippmann}

EI aparato respiratorio se extiende desde la zona de respiración, situada justo por fuera de la nariz y la boca, a través de las vías aéreas conductoras situadas dentro de la cabeza y el tórax, hasta los alveolos, donde tiene lugar el intercambio respiratorio de gases entre los alveolos y la sangre capilar que fluye a su alrededor. Su principal función es llevar el oxígeno $\left(\mathrm{O}_{2}\right)$ hasta la región de intercambio de gases del pulmón, donde el oxígeno puede difundir hasta y a través de las paredes de los alveolos para oxigenar la sangre que circula por los capilares alveolares en función de las necesidades, dentro de unos amplios límites de trabajo o de actividad. Además, el aparato respiratorio también debe: 1) eliminar un volumen equivalente de dióxido de carbono, que entra en los pulmones desde los capilares alveolares; 2) mantener la temperatura corporal y la saturación de vapor de agua en el interior de las vías aéreas pulmonares (para mantener la viabilidad y las capacidades funcionales de las células y los líquidos de la superficie); 3) mantener la esterilidad (para prevenir las infecciones y sus consecuencias adversas); y 4) eliminar el exceso de líquidos y productos de desecho de la superficie, como partículas inhaladas y células fagocíticas y epiteliales senescentes. D ebe cumplir todas estas exigentes tareas de forma continua durante toda la vida, y hacerlo de manera muy eficaz en términos de rendimiento y utilización de la energía. El aparato respiratorio puede verse maltratado y superado por agresiones graves como las concentraciones elevadas de humo de tabaco y polvo industrial, o las concentraciones bajas de patógenos específicos que atacan o destruyen sus mecanismos de defensa o causan una alteración de su función. Su capacidad para superar o compensar tales agresiones de forma tan competente como suele hacerlo es una prueba de su impecable combinación de estructura y función.

\section{Transferencia de masa}

La compleja estructura y las numerosas funciones del aparato respiratorio del ser humano han sido resumidas de manera concisa por un grupo de trabajo de la Comisión Internacional sobre Protección R adiológica (International Comission on R adiological Protection, ICRP, 1994), como se muestra en la Figura 10.1. Las vías aéreas conductoras, conocidas también

Figura 10.1 - Morfometría, citología, histología, función y estructura del aparato respiratorio y regiones utilizadas en el modelo de dosimetría de la ICRP de 1994.

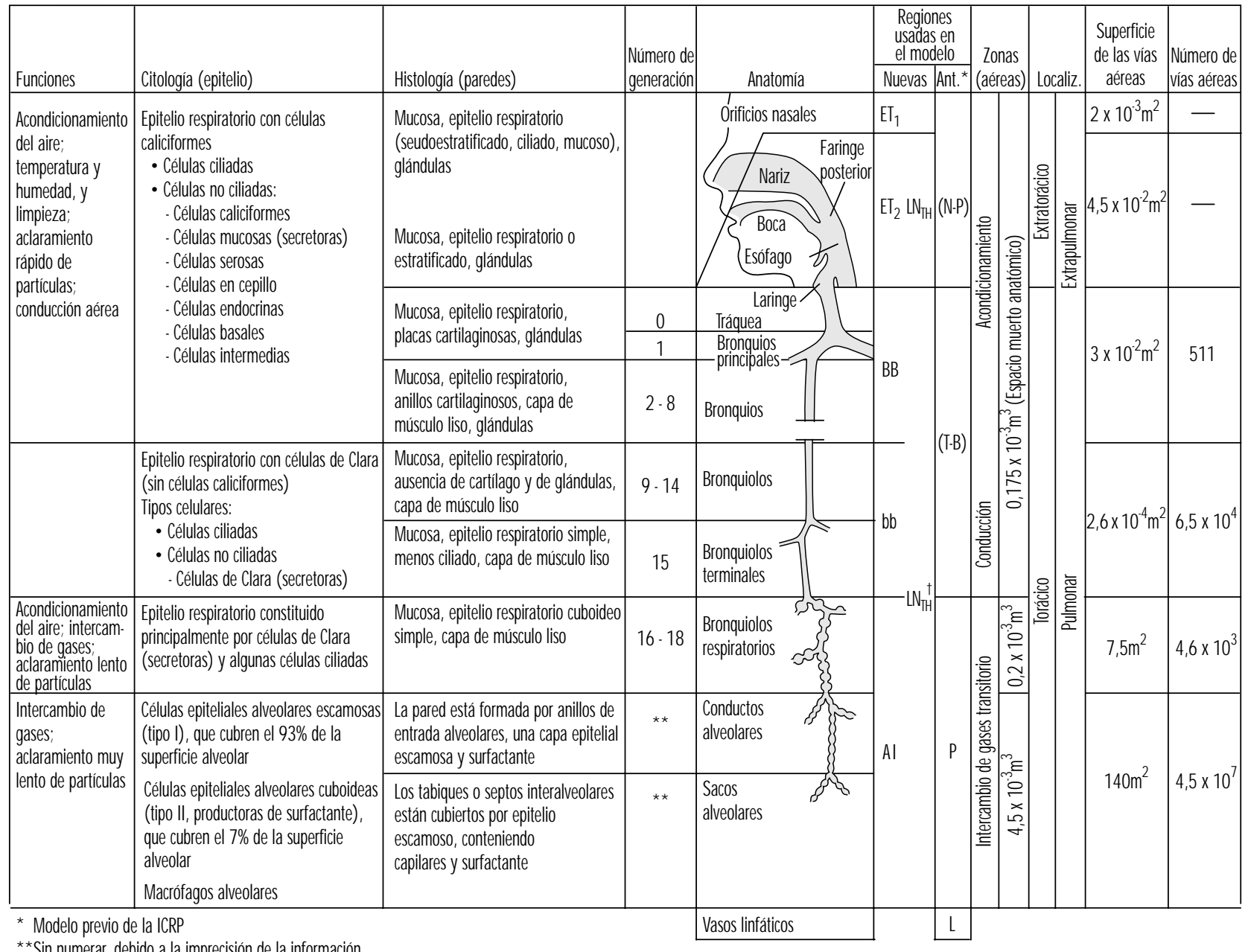

† Los ganglios linfáticos están situados únicamente en la región BB, pero drenan las regiones intersticiales bronquiales y alveolares, así como la región bronquial. 
Figura 10.2 • Mecanismos de depósito de partículas en las vías aéreas pulmonares.

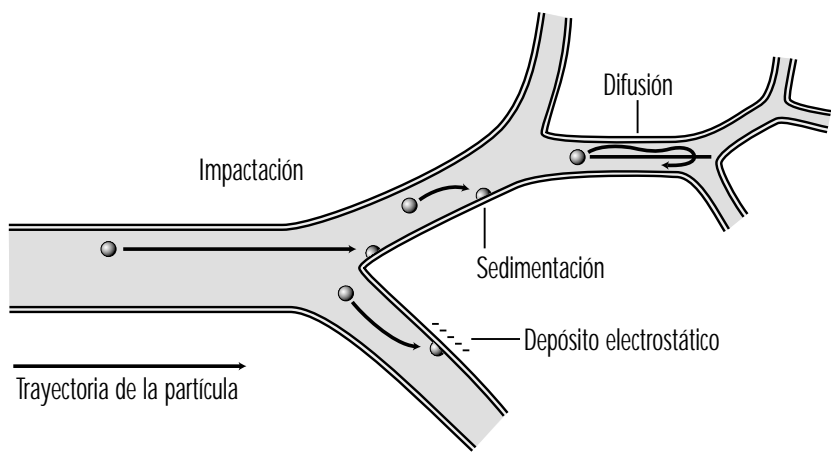

como espacio muerto respiratorio, ocupan unos 0,2 litros. Acondicionan el aire inhalado y lo distribuyen, mediante flujo convectivo, a los aproximadamente 65.000 acinos respiratorios originados de los bronquiolos terminales. A medida que aumenta el volumen corriente, el flujo convectivo domina el intercambio de gases a nivel más profundo en los bronquiolos respiratorios. En cualquier caso, dentro del acino respiratorio, la distancia desde el frente corriente convectivo hasta las superficies alveolares es lo suficientemente corta como para que tenga lugar un intercambio eficaz de $\mathrm{CO}_{2}-\mathrm{O}_{2}$ por difusión molecular. Por el contrario, las partículas transmitidas por el aire con coeficientes de difusión inferiores en órdenes de magnitud a los de los gases, tienden a permanecer suspendidas en el aire corriente, y pueden exhalarse sin que se depositen.

No obstante, una fracción importante de las partículas inhaladas se deposita en el aparato respiratorio. Los mecanismos responsables del depósito de partículas en las vías aéreas pulmonares durante la fase inspiratoria de una respiración a volumen corriente se resumen en la Figura 10.2. Las partículas con un diámetro aerodinámico (diámetro de una esfera de densidad uno con la misma velocidad de depósito terminal (Stokes)) superior a unos $2 \mu \mathrm{m}$ pueden tener un momento importante y depositarse por impactación a las velocidades relativamente altas existentes en las vías aéreas de mayor tamaño. Las partículas superiores a aproximadamente $1 \mu \mathrm{m}$ pueden depositarse por sedimentación en las vías aéreas conductoras, más pequeñas, donde las velocidades de flujo son muy bajas. Por último, las partículas con diámetros comprendidos entre 0,1 y $1 \mu \mathrm{m}$, que tienen una probabilidad muy baja de depositarse durante una única respiración corriente, pueden quedar retenidas en el $15 \%$ del aire corriente inspirado que se intercambia con el aire pulmonar residual en cada ciclo a volumen corriente. Este intercambio volumétrico tiene lugar debido a las variables constantes de tiempo para el flujo aéreo en los diferentes segmentos pulmonares. A consecuencia de los tiempos de estancia mucho mayores del aire residual en los pulmones, los pequeños desplazamientos intrínsecos de las partículas de 0,1 a $1 \mu \mathrm{m}$ en estos volúmenes atrapados de aire a volumen corriente inhalado son suficientes para causar el depósito por sedimentación y/ o difusión en el curso de respiraciones sucesivas.

EI aire pulmonar residual prácticamente libre de partículas, que representa alrededor del $15 \%$ del flujo corriente espiratorio, tiende a actuar como una cubierta de aire limpio alrededor del núcleo axial de aire corriente que se mueve en sentido distal, de forma que el depósito de partículas en el acino respiratorio se concentra en las superficies interiores, como las
Figura 10.3 - Modelo compartimental para representar el transporte de partículas en el tiempo para cada región del modelo de la ICRP de 1994.

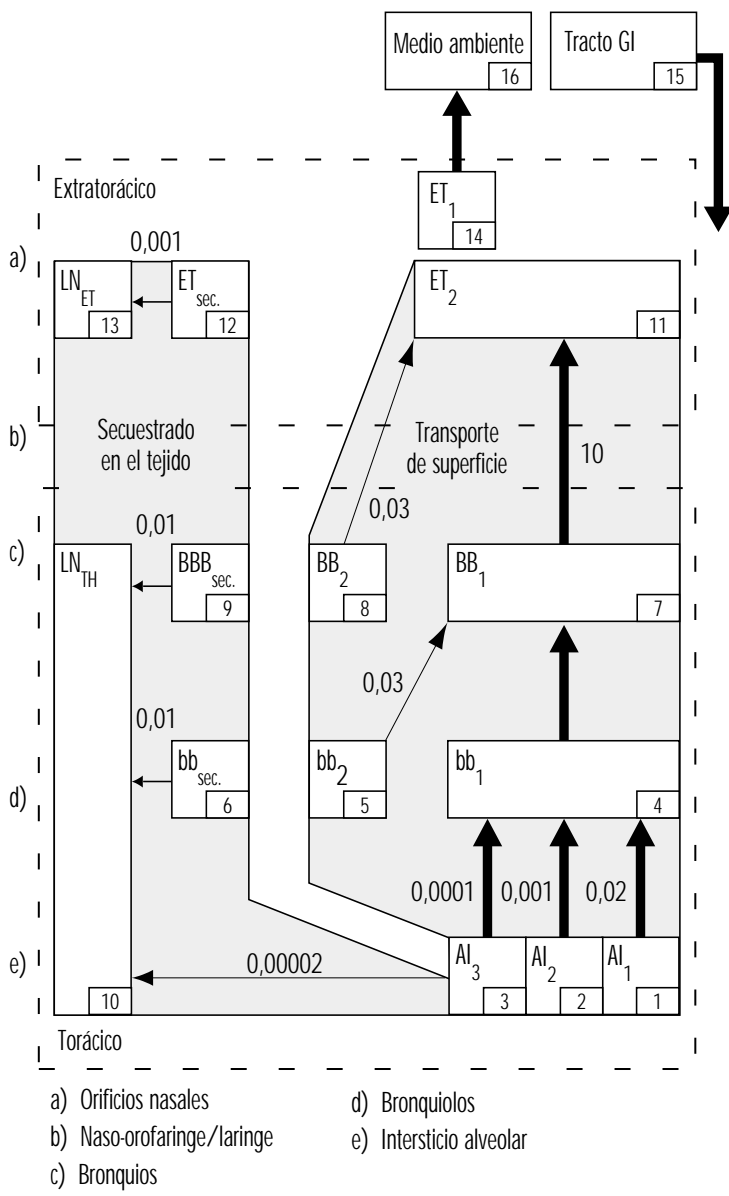

Las constantes de velocidad de transporte de partículas mostradas junto a las flechas son valores de referencia en $d^{1}$. Los números de compartimento (mostrados en la esquina inferior derecha de cada recuadro de compartimento) se utilizan para definir las vías de aclaramiento. Así, la velocidad de transporte de partículas desde $b b^{1}$ a $B^{1}$ se expresa como $m 4,7$, y tiene el valor $2 \mathrm{~d}^{1}$.

bifurcaciones de las vías aéreas, mientras que las paredes aéreas de los segmentos situados entre ramificaciones muestran un depósito escaso.

El número de partículas depositadas y su distribución a lo largo de las superficies del tracto respiratorio son, junto con las propiedades tóxicas de los materiales depositados, los determinantes fundamentales del potencial patogénico. Las partículas depositadas pueden lesionar las células epiteliales y/ o fagocíticas móviles ubicadas en el sitio de depósito o próximas a él, o pueden estimular la secreción de líquidos y mediadores de origen celular que poseen efectos secundarios sobre el sistema. Los materiales solubles depositados como partículas, sobre ellas 0 en su interior, pueden difundir al interior de los líquidos y células de la superficie y a su través, y ser transportados rápidamente por la circulación sanguínea a todo el organismo.

La solubilidad acuosa de los materiales voluminosos apenas sirve como referencia para la solubilidad de partículas en el tracto respiratorio. La solubilidad suele estar muy aumentada debido a la enorme relación superficie/ volumen de las partículas lo suficientemente pequeñas como para entrar en los 
Tabla 10.1 • Regiones del tracto respiratorio definidas según el mecanismo de deposición particulada.

\begin{tabular}{|c|c|c|c|c|}
\hline Estructuras anatómicas incluidas & Región de la ACGIH & $\begin{array}{l}\text { Regiones de la ISO } \\
\text { y el CEN }\end{array}$ & $\begin{array}{l}\text { Región del Grupo de Trabajo } \\
\text { de la ICRP de } 1966\end{array}$ & $\begin{array}{l}\text { Región del Grupo de Trabajo } \\
\text { de la ICRP de } 1994\end{array}$ \\
\hline $\begin{array}{l}\text { Nariz, nasofaringe } \\
\text { Boca, orofaringe, laringofaringe }\end{array}$ & $\begin{array}{l}\text { Vías aéreas de la cabeza } \\
\text { (RVC) }\end{array}$ & Extratorácica (E) & Nasofaringe (NF) & $\begin{array}{l}\text { Orificios nasales }\left(\mathrm{ET}_{1}\right) \\
\text { Resto de regiones extratorácicas }\left(\mathrm{ET}_{2}\right)\end{array}$ \\
\hline Tráquea, bronquios & Traqueobronquial ( TBR) & Traqueobronquial (B) & Traqueobronquial (TB) & Tráquea y bronquios mayores (BB) \\
\hline $\begin{array}{l}\text { Bronquiolos (hasta bronquiolos } \\
\text { terminales) }\end{array}$ & & & & Bronquiolos (bb) \\
\hline $\begin{array}{l}\text { Bronquiolos respiratorios, conductos } \\
\text { alveolares, sacos alveolares, alveolos }\end{array}$ & Intercambio de gas (GER) & Alveolar (A) & Pulmonar (P) & Alveolo-intersticial (Al) \\
\hline
\end{tabular}

pulmones. A demás, el contenido iónico y lipídico de los líquidos de superficie presentes en el interior de las vías aéreas es complejo y muy variable, y puede dar lugar a una mayor solubilidad 0 a la precipitación rápida de solutos acuosos. Por otro lado, las vías de aclaramiento y los tiempos de permanencia de las partículas en la superficie de las vías aéreas son muy diferentes en las diversas partes funcionales del tracto respiratorio.

EI modelo de aclaramiento revisado por el Grupo de Trabajo de la ICR P identifica las principales vías de aclaramiento dentro del tracto respiratorio que son importantes para la determinación de la retención de diversos materiales radiactivos y, por tanto, de las dosis de radiación recibidas por los tejidos respiratorios y por otros órganos tras la traslocación. El modelo de depósito de la ICR P se utiliza para estimar la cantidad de material inhalado que entra en cada vía de aclaramiento. Estas vías, claramente definidas, están representadas en el modelo compartimental mostrado en la Figura 10.3. Se corresponden con los compartimentos anatómicos representados en la Figura 10.1, y se resumen en la Tabla 10.1, junto con los de otros grupos que proporcionan una orientación sobre la dosimetría de partículas inhaladas.

\section{Vías aéreas extratorácicas}

Como se muestra en la Figura 10.1, la ICR P (1994) dividió las vías aéreas extratorácicas en dos regiones de aclaramiento y dosimétricas claramente diferenciadas: los orificios nasales $\left(\mathrm{ET}_{1}\right)$ y las demás vías aéreas extratorácicas $\left(E T_{2}\right)$, es decir, las aberturas nasales posteriores, la nasofaringe, la orofaringe y la laringe. Se supone que las partículas depositadas sobre la superficie de la piel que reviste los orificios nasales $\left(E T_{1}\right)$ sólo se eliminan por medios extrínsecos (sonarse o limpiarse la nariz, etc.). La mayor parte del material depositado en la naso-orofaringe o en la laringe $\left(E_{2}\right)$ es objeto de un aclaramiento rápido en la capa de líquido que recubre estas vías. EI nuevo modelo supone que el depósito por difusión de partículas ultrafinas en las vías aéreas extratorácicas puede ser importante, a diferencia de los modelos anteriores.

\section{Vías aéreas torácicas}

EI material radiactivo depositado en el tórax suele dividirse entre la región traqueobronquial (TB), en la que las partículas depositadas son objeto de un aclaramiento mucociliar relativamente rápido, y la región alveolo-intersticial (AI), en la que el aclaramiento de partículas es mucho más lento.

Con fines dosimétricos, la ICR P (1994) dividió el depósito de material inhalado en la región T B entre la tráquea y los bronquios (BB), por una parte, y las vías aéreas pequeñas más distales, los bronquiolos (bb), por otra. Sin embargo, la eficacia subsiguiente con la que los cilios de cualquier tipo de vía aérea son capaces de eliminar las partículas depositadas es un aspecto controvertido. Para asegurarse de que no se infravalorarían las dosis recibidas por los epitelios bronquial y bronquiolar, el Grupo de Trabajo asumió que hasta la mitad del número de partículas depositadas en estas vías aéreas es objeto de un aclaramiento mucociliar relativamente "Iento". La probabilidad de que una partícula sea eliminada de forma relativamente lenta por el sistema mucociliar parece depender de su tamaño físico.

EI material depositado en la región $\mathrm{Al}$ se subdivide entre tres compartimentos $\left(\mathrm{Al}_{1}, \mathrm{Al}_{2}\right.$ y $\mathrm{Al}_{3}$ ), en los que el aclaramiento, con velocidades características diferentes en las diversas subregiones, es más lento que en la región $T$ B.

La Figura 10.4 representa las predicciones del modelo de la ICRP (1994) en términos de depósito fraccional en cada región en función del tamaño de las partículas inhaladas. Refleja el depósito pulmonar mínimo entre 0,1 y $1 \mu \mathrm{m}$, rango en el que el depósito está determinado en gran medida por el intercambio que tiene lugar en las regiones profundas de los pulmones entre el volumen corriente y el residual. El depósito aumenta por debajo de 0,1 $\mu \mathrm{m}$, a medida que aumenta la eficacia de la difusión al disminuir el tamaño de las partículas. El depósito

Figura 10.4 - Depósito fraccional en cada región del tracto respiratorio para personas de referencia que realizan un trabajo físico leve (respiración nasal normal) en el modelo de la ICRP de 1994.

Depósito

regional (\%)

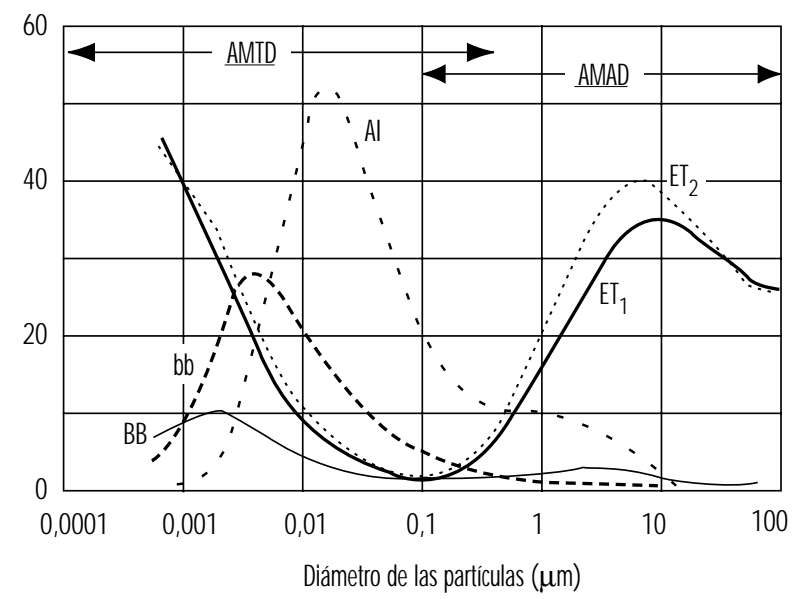

La deposición se expresa como una fracción de la actividad presente en el volumen de aire que se inspira, y la actividad se asume que es el logaritmo normalmente distribuido en función del tamaño de la partículas (para partículas de densidad de 2,25 $\mathrm{g} / \mathrm{cm}^{3}$ y factor de configuración de 1,5). Para las partículas de mayor tamaño se emplea AMAD (activity median particle diameter), mientras que para las pequeñas, donde la deposición es por difusión, se usa el AMTD(activity median thermal diameter). 
Tabla 10.2 - Criterios para el polvo inhalable, torácico y respirable de la ACGIH, la ISO y el CEN, y de la MP10 de la US EPA.

\begin{tabular}{|c|c|c|c|c|c|c|c|}
\hline Inhalable & & Torácico & & Respirable & & $M P_{10}$ & \\
\hline $\begin{array}{l}\text { Diámetro aerodi- } \\
\text { námico de las } \\
\text { partículas (mm) }\end{array}$ & $\begin{array}{l}\text { Masa particulada } \\
\text { inhalable } \\
\text { (MPI) (\%) }\end{array}$ & $\begin{array}{l}\text { Diámetro aerodi- } \\
\text { námico de las } \\
\text { partículas }(\mu \mathrm{m})\end{array}$ & $\begin{array}{l}\text { Masa particulada } \\
\text { torácica } \\
\text { (MPT) (\%) }\end{array}$ & $\begin{array}{l}\text { Diámetro aerodi- } \\
\text { námico de las } \\
\text { partículas }(\mu \mathrm{m})\end{array}$ & $\begin{array}{l}\text { Masa particulada } \\
\text { respirable } \\
\text { (RPM) (\%) }\end{array}$ & $\begin{array}{l}\text { Diámetro aerodi- } \\
\text { námico de las } \\
\text { partículas }(\mu \mathrm{m})\end{array}$ & $\begin{array}{l}\text { Masa particulada } \\
\text { torácica } \\
\text { (MPT) }(\%)\end{array}$ \\
\hline 0 & 100 & 0 & 100 & 0 & 100 & 0 & 100 \\
\hline 1 & 97 & 2 & 94 & 1 & 97 & 2 & 94 \\
\hline 2 & 94 & 4 & 89 & 2 & 91 & 4 & 89 \\
\hline 5 & 87 & 6 & 80,5 & 3 & 74 & 6 & 81,2 \\
\hline 10 & 77 & 8 & 67 & 4 & 50 & 8 & 69,7 \\
\hline 20 & 65 & 10 & 50 & 5 & 30 & 10 & 55,1 \\
\hline 30 & 58 & 12 & 35 & 6 & 17 & 12 & 37,1 \\
\hline 40 & 54,5 & 14 & 23 & 7 & 9 & 14 & 15,9 \\
\hline 50 & 52,5 & 16 & 15 & 8 & 5 & 16 & 0 \\
\hline \multirow[t]{3}{*}{100} & 50 & 18 & 9,5 & 10 & 1 & & \\
\hline & & 20 & 6 & & & & \\
\hline & & 25 & 2 & & & & \\
\hline
\end{tabular}

también es mayor al aumentar el tamaño de las partículas por encima de $1 \mu \mathrm{m}$, debido a la creciente eficacia de la sedimentación y la impactación.

Los profesionales y los organismos dedicados a la salud profesional y a la contaminación del aire de la comunidad han adoptado modelos menos complejos para el depósito selectivo en función del tamaño, que se han utilizado para desarrollar unos límites de exposición por inhalación dentro de rangos de tamaño de partículas específicos. Se distingue entre:

1. Partículas que no se aspiran por la nariz o la boca y que, por consiguiente, no representan un riesgo de inhalación

2. La masa particulada inhalable (MPI) (también conocida como inspirable), constituida por las partículas que se inhalan y son peligrosas si se depositan en algún lugar del tracto respiratorio

3. La masa particulada torácica (MPT), constituida por las partículas que penetran en la laringe y son peligrosas si se depositan en algún lugar dentro del tórax, y

4. La masa particulada respirable (M PR), constituida por las partículas que penetran a través de los bronquiolos terminales y que son peligrosas si se depositan dentro de la región de intercambio gaseoso de los pulmones.

A comienzos del decenio de 1990, tuvo lugar una armonización internacional de las definiciones cuantitativas de $\mathrm{MPI}$, M PT y M PR. L as especificaciones de toma de aire selectiva por tamaño para los muestreadores de aire que cumplen los criterios de la Conferencia Americana de Higienistas Industriales del Gobierno (American Conference of Governmental Industrial H ygienists, ACGIH,1993), la O rganización Internacional para la Normalización (International O rganization for Standardization, ISO, 1991) y el Comité Europeo de Normalización (European Standardization Committee, CEN, 1991), se enumeran en la Tabla 10.2. Son diferentes de las fracciones de depósito de la ICRP (1994), especialmente con respecto a las partículas de mayor tamaño, ya que adoptan la actitud conservadora de que la protección debe proporcionarse en los casos en que esté implicada la inhalación oral, y donde se elude, por tanto, la mayor eficacia de filtración de las fosas nasales.

La norma de la US Environmental Protection A gency (EPA 1987) para la concentración de partículas en el aire ambiente se conoce como $\mathrm{PM}_{10}$, es decir, materia particulada inferior a $10 \mu \mathrm{m}$ de diámetro aerodinámico. Tiene un criterio de toma de entrada de muestreador similar (funcionalmente equivalente) a la M PT pero, como se muestra en la Tabla 10.2, especificaciones numéricas algo diferentes.

\section{Contaminantes atmosféricos}

L os contaminantes pueden dispersarse en el aire a temperaturas y presiones ambientes normales en formas gaseosa, líquida y sólida. Las dos últimas representan suspensiones de partículas en el aire, y Gibbs les asignó el término genérico de aerosoles (1924) por analogía con el término hidrosol, utilizado para describir sistemas dispersados en agua. Los gases y los vapores, presentes como moléculas claramente definidas, forman verdaderas soluciones en el aire. Las partículas formadas por materiales con presión de vapor moderada a alta tienden a evaporarse rápidamente, ya que las que son lo suficientemente pequeñas como para permanecer suspendidas en el aire durante más de algunos minutos (es decir, las inferiores a unas $10 \mu \mathrm{m}$ ) presentan relaciones superficie/ volumen grandes. Algunos materiales con presiones de vapor relativamente bajas pueden tener fracciones apreciables en formas de vapor y aerosol de manera simultánea.

\section{Gases y vapores}

U na vez dispersados en el aire, los gases y vapores contaminantes generalmente forman mezclas tan diluidas que sus propiedades físicas (como la densidad, la viscosidad, la entalpía, etc.) son indistinguibles de las del aire limpio. Puede considerarse que estas mezclas siguen las relaciones de las leyes de los gases ideales. $\mathrm{No}$ existen diferencias prácticas entre un gas y un vapor, salvo que este último se considera generalmente la fase gaseosa de una sustancia que puede existir en forma sólida o líquida a temperatura ambiente. M ientras están dispersadas en el aire, todas las 
moléculas de un compuesto dado son básicamente equivalentes con respecto a su tamaño y a las probabilidades de captura por las superficies del medio ambiente, del tracto respiratorio y de muestreadores o colectores de contaminantes.

\section{Aerosoles}

Los aerosoles, dispersiones de partículas sólidas o líquidas en el aire, tienen la variable adicional muy importante del tamaño de las partículas. El tamaño afecta al movimiento de las partículas y, por tanto, a las probabilidades de que tengan lugar fenómenos físicos como coagulación, dispersión, sedimentación, impactación en las superficies, fenómenos de interfase y propiedades de dispersión de la luz. No es posible identificar una partícula dada por un único parámetro del tamaño. Por ejemplo, las propiedades aerodinámicas de una partícula dependen de la densidad y la forma, además de las dimensiones lineales, y el tamaño eficaz para la dispersión de la luz depende del índice de refracción y de la forma.

En algunos casos especiales, prácticamente todas las partículas tienen el mismo tamaño. Estos aerosoles se consideran monodispersos. Algunos ejemplos son los pólenes naturales y algunos aerosoles fabricados en laboratorios. Con mayor frecuencia, los aerosoles están compuestos de partículas de tamaños muy diferentes, por lo que se denominan heterodispersos o polidispersos. Diferentes aerosoles tienen diferentes grados de dispersión por tamaño. Por consiguiente, es necesario especificar al menos dos parámetros para identificar el tamaño de un aerosol: una medida de la tendencia central, como la media o la mediana, y una medida de la dispersión, como la desviación aritmética 0 geométrica estándar.

Las partículas generadas por una única fuente o proceso generalmente tienen diámetros que siguen una distribución logarítmica normal; es decir, los logaritmos de sus diámetros individuales presentan una distribución gaussiana. En este caso, la medida de dispersión es la desviación geométrica estándar, que es la relación del tamaño del percentil 84,1 con el tamaño del percentil 50. Cuando hay más de una fuente de partículas importante, generalmente el aerosol mixto resultante no seguirá una distribución logarítmica normal, y podría ser necesario caracterizarlo por la suma de varias distribuciones.

\section{Características de las partículas}

M uchas propiedades de las partículas, aparte del tamaño lineal, pueden influir de manera importante en su comportamiento en el aire y sus efectos sobre el medio ambiente y la salud. Estas propiedades son:

SuperficiePara las partículas esféricas, la superficie varía según el cuadrado del diámetro. Sin embargo, para un aerosol con una concentración de masa dada, la superficie total del aerosol aumenta de manera inversamente proporcional al tamaño de las partículas. Para las partículas no esféricas o agregadas, y para las partículas con hendiduras o poros internos, la relación de la superficie respecto al volumen puede ser mucho mayor que para las esferas.

Volumen. El tamaño de las partículas varía según el cubo del diámetro; por tanto, las pocas partículas más grandes de un aerosol tienden a dominar su concentración de volumen (o masa).

Forma. La forma de una partícula afecta a su resistencia aerodinámica además de a su área de superficie y, por tanto, a sus probabilidades de movimiento y depósito.

$D$ ensidad. L a velocidad de una partícula en respuesta a fuerzas gravitatorias o de inercia aumenta según la raíz cuadrada de su densidad.
D iámetro aerodinámico. El diámetro de una esfera de densidad uno que tiene la misma velocidad de sedimentación terminal que la partícula en estudio es igual a su diámetro aerodinámico. La velocidad de sedimentación terminal es la velocidad de equilibrio de una partícula que está cayendo bajo la influencia de la gravedad y la resistencia de los líquidos. El diámetro aerodinámico está determinado por el tamaño real de la partícula, por su densidad y por un factor de forma aerodinámico

\section{Tipos de aerosoles}

Los aerosoles suelen clasificarse en función de sus procesos de formación. Aunque la siguiente clasificación no es precisa ni exhaustiva, es de uso habitual y está aceptada en los campos de la higiene industrial y de contaminación del aire.

Polvo. Aerosol formado mediante subdivisión mecánica de material voluminoso en partículas menudas transportadas por el aire y con la misma composición química. Las partículas de polvo suelen ser sólidas y de forma irregular, y sus diámetros son superiores a $1 \mu \mathrm{m}$.

Vapor. Aerosol de partículas sólidas formadas por la condensación de vapores originados por combustión o sublimación a temperaturas elevadas. Las partículas primarias son generalmente muy pequeñas (menos de $0,1 \mu \mathrm{m}$ ) y tienen formas esféricas 0 cristalinas características Pueden ser químicamente idénticas al material del que se originan, 0 bien estar formadas de un producto de oxidación, como un óxido de metal. Dado que pueden formarse en concentraciones elevadas, a menudo se coagulan rápidamente, formando agregados de baja densidad global.

H umo. A erosol formado por la condensación de productos de combustión, generalmente de materiales orgánicos. Las partículas suelen ser gotitas de líquido de diámetros inferiores a $0,5 \mu \mathrm{m}$.

N eblina. Aerosol de gotitas formado por cizallamiento mecánico de un líquido voluminoso, por ejemplo, mediante atomización, nebulización, formación de burbujas o pulverización. El tamaño de las gotitas oscila en un amplio rango, generalmente desde $2 \mu \mathrm{m}$ hasta más de $50 \mu \mathrm{m}$.

$\mathrm{N}$ iebla. A erosol acuoso formado por condensación de vapor de agua en núcleos atmosféricos a humedades relativas elevadas. EI tamaño de las gotitas suele ser mayor de $1 \mu \mathrm{m}$.

Smog. Término inglés de uso popular que describe un aerosol contaminante y que deriva de una combinación de los términos ingleses "smoke"(humo) y "fog"(niebla). En la actualidad se utiliza de forma habitual para hacer referencia a cualquier mezcla de contaminación atmosférica.

Calina. Aerosol de tamaño submicrométrico formado por partículas higroscópicas que captan vapor de agua a humedades relativas relativamente bajas.

Aitken o núcleos de condensación (NC). Partículas atmosféricas muy pequeñas (la mayoría menores de $0,1 \mu \mathrm{m}$ ) formadas por procesos de combustión y por conversión química a partir de precursores gaseosos.

M odo de acumulación. T érmino con el que se designan las partículas del aire ambiente cuyo diámetro oscila entre 0,1 hasta aproximadamente $1 \mu \mathrm{m}$. Suelen ser partículas esféricas (con superficies líquidas) y se forman por coagulación y condensación de partículas de menor tamaño que derivan de precursores gaseosos. Al ser demasiado grandes para coagularse rápidamente y demasiado pequeñas para sufrir una sedimentación eficaz, tienden a acumularse en el aire ambiental

M odo de partícula gruesa Partículas del aire ambiental cuyo diámetro aerodinámico es superior a unos $2,5 \mu \mathrm{m}$ y que generalmente se forman mediante procesos mecánicos y resuspensión de polvo de superficie. 


\section{Respuestas biológicas del aparato respiratorio a los contaminantes atmosféricos}

L as respuestas a los contaminantes atmosféricos oscilan desde las leves molestias hasta la necrosis y muerte tisulares, desde efectos sistémicos generalizados hasta ataques sumamente específicos sobre tejidos aislados. Los factores del huésped y los factores ambientales actúan modificando los efectos de las sustancias químicas inhaladas, y la respuesta final es el resultado de su interacción. L os principales factores del huésped son los siguientes:

1. Edad: por ejemplo, las personas de más edad, especialmente las que presentan una reducción crónica de las funciones respiratoria y cardiovascular, que pueden no ser capaces de hacer frente a un estrés pulmonar adicional.

2. Estado de salud: por ejemplo, una enfermedad o diffunción concomitantes

3. Estado nutricional

4. Estado inmunológico.

5. Sexo y otros factores genéticos: por ejemplo, diferencias enzimáticas en los mecanismos de biotransformación, como vías metabólicas deficientes, y la incapacidad para sintetizar ciertas enzimas destoxificantes.

6. Estado psicológico: por ejemplo, estrés, ansiedad.

7. Factores culturales: por ejemplo, consumo de tabaco, que puede afectar a las defensas normales o potenciar el efecto de otras sustancias químicas.

Los factores ambientales incluyen la concentración, estabilidad y propiedades fisicoquímicas del agente en el medio de exposición y la duración, frecuencia y vía de exposición. Las exposiciones aguda y crónica a una sustancia química pueden provocar diferentes manifestaciones patológicas.

Cada órgano sólo es capaz de responder en un número restringido de formas, y hay numerosas etiquetas calificativas para las enfermedades resultantes. En las siguientes secciones se analizarán los tipos amplios de respuestas del aparato respiratorio que pueden aparecer tras la exposición a contaminantes ambientales.

\section{Respuesta a los agentes irritantes}

L os agentes irritantes producen un patrón de inflamación tisular generalizada e inespecífica, con posibilidad de destrucción en el área de contacto con el contaminante. Algunos agentes irritantes no provocan efectos sistémicos debido a que la respuesta irritante es mucho mayor que cualquier efecto sistémico, mientras que otros poseen también efectos sistémicos importantes tras su absorción (por ejemplo, el sulfuro de hidrógeno absorbido a través de los pulmones).

A concentraciones elevadas los agentes iritantes pueden provocar una sensación de quemazón en la nariz y la garganta (y generalmente también en los ojos), dolor torácico y tos que provoca inflamación de la mucosa (traqueítis, bronquitis). Son ejemplos de agentes irritantes los gases como cloro, flúor, dióxido de azufre, fosgeno y óxidosdenitrógeno; nieblas deácidoso álcalis; vapores de cadmio; polvo de cloruro de zinc y pentaóxido de vanadio. Las concentraciones elevadas de irritantes químicos también pueden penetrar en la profundidad de los pulmones y provocar edema pulmonar (los alveolos quedan ocupados por líquido) o inflamación pulmonar (neumonitis química).

Las concentraciones muy elevadas de polvos que carecen de propiedades irritativas químicas también tienen la capacidad de provocar irritación mecánica de los bronquios y, tras penetrar en el tracto gastrointestinal, pueden también contribuir al desarrollo de cáncer de estómago y de colon.

La exposición a agentes ir ritantes puede provocar la muerte si resultan afectados gravemente órganos críticos. Por otro lado, la lesión puede ser reversible, o dar lugar a la pérdida permanente de cierto grado de función, como puede ser el deterioro de la capacidad de intercambio de gases.

\section{Respuesta fibrótica}

Diversos polvos provocan el desarrollo de un conjunto de trastornos pulmonares crónicos denominados neumoconiosis.Este término general engloba muy diversas afecciones fibróticas de los pulmones, es decir, enfermedades caracterizadas por la formación de cicatrices en el tejido conectivo intersticial. Las neumoconiosis son consecuencia de la inhalación y retención selectiva subsiguiente de ciertos polvos en los alveolos, en los cuales son objeto de secuestro intersticial.

Las neumoconiosis se caracterizan por lesiones fibróticas específicas, que difieren en cuanto a tipo y patrón en función del polvo responsable. Por ejemplo, la silicosis, causada por el depósito de ślice no cristalino, se caracteriza por una fibrosis de tipo nodular, mientras que en la asbestosis se encuentra una fibrosis difusa debida a la exposición a fibras de amianto. Ciertos polvos, como el óxido de hierro, producen exclusivamente un patrón radiológico alterado (siderosis) sin deterioro funcional, mientras que los efectos de otros tipos de polvo oscilan desde una discapacidad mínima hasta la muerte

\section{Respuesta alérgica}

Las respuestas alérgicas implican el fenómeno conocido como sensibilización. La respuesta inicial al alergeno conduce a la inducción de la síntesis de anticuerpos; una exposición subsiguiente del individuo ahora "sensibilizado" provoca una respuesta inmunitaria, es decir, una reacción antígeno-anticuerpo (el antígeno es el alergeno combinado con una proteína endógena). Esta reacción inmunitaria puede tener lugar inmediatamente después de la exposición al alergeno, o bien puedetratarse deuna respuesta diferida.

Las reacciones alérgicas respiratorias primarias son el asma bronquial, reacciones del tracto respiratorio superior que implican la liberación de histamina o de mediadores de tipo histamínico secundarias a reacciones inmunitarias que tienen lugar en la mucosa, y un tipo de neumonitis (inflamación pulmonar) conocido como alveolitis alérgica extrínseca. Además de estas reacciones locales, tras la exposición a ciertos alergenos químicos puede producirse una reacción alérgica sistémica (shock anafiláctico).

\section{Respuesta infecciosa}

Los agentes infecciosos pueden provocar tuberculosis, carbunco, ornitosis, brucelosis, histoplasmosis, enfermedad del legionario y muchas otras.

\section{Respuesta cancerígena}

Cáncer es un término genérico que describe un conjunto de enfermedades relacionadas que se caracterizan por un crecimiento tisular descontrolado. Su desarrollo es consecuencia de un complejo proceso de interacción entre múltiples factores del huésped y del medio ambiente.

Una de las grandes dificultades a la hora de establecer una correlación entre la exposición a un agente específico y el desarrollo de cáncer en el ser humano es el largo período de latencia, típicamente de 15 a 40 años, entre el comienzo de la exposición y la manifestación de la enfermedad.

Son ejemplos de contaminantes atmosféricos capaces de provocar cáncer pulmonar el arsénico y sus compuestos, los cromatos, el sílice, las partículas que contienen hidrocarburos aromáticos policíclicos y ciertos polvos a base de níquel. Las fibras de amianto pueden provocar cáncer bronquial y mesotelioma de la pleura y el peritoneo. Las fibras radiactivas depositadas pueden exponer el tejido pulmonar a elevadas dosis de radiación ionizante y provocar cáncer.. 


\section{Respuesta sistémica}

M uy diversas sustancias químicas del medio ambiente provocan una enfermedad generalizada sistémica debida a sus efectos sobre diversos lugares diana. Los pulmones no sólo son el objetivo de numerosos agentes nocivos, sino que también son el punto de entrada de sustancias tóxicas que penetran en el torrente circulatorio a su través sin lesionarlos en absoluto. Sin embargo, cuando se distribuyen por la circulación sanguínea a diversosórganos, pueden lesionarlos o provocar una intoxicación general con efectos sistémicos. Este papel específico de los pulmones en patología del trabajo no constituye el objetivo de este capítulo. No obstante, debemos mencionar el efecto de las partículas finamente dispersas (vapores) de diversosóxidos de metal que a menudo se asocian a un síndrome sistémico agudo conocido como fiebre de los vapores de metal.

\section{- EXAMEN de LA funcion PULMONAR}

\section{Ulf Ulfvarson y M onica Dahlqvist}

La función pulmonar puede medirse de diversas formas. Sin embargo, el objeto de las mediciones debe estar claro antes del examen, con el fin de interpretar correctamente los resultados. En este artículo comentaremos el examen de la función pulmonar prestando especial atención a su relación con el ámbito ocupacional. Es importante recordar las limitaciones de las diversas medidas de la función pulmonar. Los efectos temporales agudos sobre la función pulmonar pueden no ser diferenciables en caso de exposición a polvo fibrogénico, como el cuarzo y el amianto, pero es posible observar efectos crónicos sobre la función pulmonar después de una exposición prolongada (>20 años). Esto se debe a que los efectos crónicos tienen lugar años después de la inhalación y el depósito del polvo en los pulmones. Por otro lado, no resulta difícil el estudio de los efectos temporales agudos del polvo orgánico e inorgánico, así como de mohos, vapores de soldadura y gases de escape. Esto se debe a que el efecto irritante de estos polvos tiene lugar algunas horas después de la exposición. Los efectos agudos o crónicos sobre la función pulmonar también pueden ser identificables en casos de exposición a concentraciones de gases irritantes (dióxido de nitrógeno, aldehidos, ácidos y cloruros ácidos) próximas a los valores límite documentados especialmente si el efecto está potenciado por contaminación atmosférica particulada.

L as mediciones de la función pulmonar deben ser seguras para los sujetos explorados, y el equipo de función pulmonar debe ser seguro para el explorador. Se dispone de un resumen de los requisitos específicos para diferentes tipos de equipos de función pulmonar (p. ej., Q uanjer y cols. 1993). Por supuesto, el equipo debe calibrarse de acuerdo con normas independientes. Esto puede ser difícil de conseguir, especialmente cuando se utiliza equipo computarizado. El resultado de la prueba de función pulmonar depende del sujeto y del explorador. Para obtener resultados satisfactorios, los técnicos deben estar bien formados y ser capaces de comunicar al sujeto cuidadosamente las indicaciones necesarias y de animarle a realizar la prueba correctamente. EI explorador también debe tener conocimientos sobre las vías aéreas y los pulmones para interpretar correctamente los resultados de los registros.

Se recomienda que los métodos utilizados tengan una reproducibilidad bastante alta entre sujetos e intrasujeto. La reproducibilidad puede medirse como el coeficiente de variación, es decir, la desviación estándar multiplicada por 100 y dividida por el valor medio. Se consideran aceptables valores inferiores al $10 \%$ en mediciones repetidas en el mismo sujeto.
Para determinar si los valores medidos son patológicos o no, deben compararse con ecuaciones predictivas. Generalmente, las ecuaciones predictivas para variables espirométricas se basan en la edad y la estatura, estratificadas por el sexo. L os varones tienen en promedio valores de función pulmonar mayores que las mujeres de la misma edad y estatura. La función pulmonar disminuye con la edad y aumenta con la estatura. Por consiguiente, un sujeto alto tendrá volúmenes pulmonares mayores que un sujeto bajo de la misma edad. El resultado de las ecuaciones predictivas puede variar considerablemente entre diferentes poblaciones de referencia. La variación en la edad y la estatura en la población de referencia también influirán en los valores previstos. Esto significa que, por ejemplo, no debe utilizarse una ecuación predictiva si la edad o la estatura del sujeto examinado se encuentra fuera de los rangos para la población que constituye la base de la ecuación predictiva.

El tabaquismo también disminuirá la función pulmonar, y su efecto podría potenciarse en sujetos expuestos profesionalmente a agentes irritantes. La función pulmonar no suele considerarse patológica si los valores obtenidos se sitúan dentro del $80 \%$ del valor previsto, derivado de una ecuación predictiva.

\section{Mediciones}

Las mediciones de la función pulmonar se realizan para evaluar el estado de los pulmones. Estas mediciones pueden referirse a uno 0 varios volúmenes pulmonares medidos 0 a las propiedades dinámicas de las vías aéreas y los pulmones. Estas últimas generalmente se determinan mediante maniobras de esfuerzo. EI estado de los pulmones también puede examinarse con respecto a su función fisiológica, es decir, la capacidad de difusión, la resistencia de las vías aéreas y la complianza (véase más adelante).

Las mediciones relacionadas con la capacidad ventilatoria se obtienen por espirometría. La maniobra de respiración suele realizarse como una inspiración máxima seguida de una espiración máxima, la capacidad vital (VC, medida en litros). Deben obtenerse al menos tres registros técnicamente satisfactorios (es decir, esfuerzo inspiratorio y espiratorio máximos y ausencia de escapes), e informarse del valor más alto. El volumen puede medirse directamente con una campana sellada al agua 0 de baja resistencia, o indirectamente por neumotacograafía (es decir, integración de una señal de flujo en el tiempo). Llegado este punto, es importante señalar que todos los volúmenes pulmonares medidos deben expresarse en BTPS, es decir, temperatura corporal y presión ambiente, saturado con vapor de agua.

La capacidad vital espiratoria forzada (FVC, en litros) se define como una medida de la VC realizada con un esfuerzo espiratorio forzado máximo. D ebido a la sencillez de la prueba y a que el equipo necesario es relativamente barato, el espirograma forzado se ha convertido en una prueba útil para el control de la función pulmonar. Sin embargo, esto ha dado lugar a numerosos registros deficientes, cuyo valor práctico es discutible. Para realizar registros satisfactorios, pueden ser útiles las normas actualizadas para la obtención y uso del espirograma forzado, publicadas por la American T horacic Society en 1987.

Pueden medirse flujos instantáneos en curvas de flujo-volumen o de flujo-tiempo, mientras que los tiempos y flujos promedio se calculan a partir del espirograma. Las variables asociadas que pueden calcularse a partir del espirograma forzado son el volumen espiratorio forzado en un segundo $\left(F V_{1}\right.$, en litros por segundo), en porcentaje de la FVC $(\mathrm{FEV}, \%)$, flujo máximo ( $\mathrm{PEF}, \mathrm{l} / \mathrm{s})$, flujos máximos al $50 \%$ y al $75 \%$ de la capacidad vital forzada (MEF $\mathrm{M}_{50}$ y $\mathrm{MEF}_{25}$, respectivamente). En la Figura 10.5 se ilustra el cálculo del FEV 1 a partir del espirograma forzado. En sujetos sanos, los flujos máximos a volúmenes pulmonares grandes (es decir, al comienzo de la 
$\begin{aligned} \text { Figura 10.5 - } & \text { Espirometría forzada mostrando la } \\ & \text { derivación del FEV } \text { F de la FVC de }_{1} \text { acuerdo al principiode extrapolación. } \\ & \text { acuerdo al }\end{aligned}$

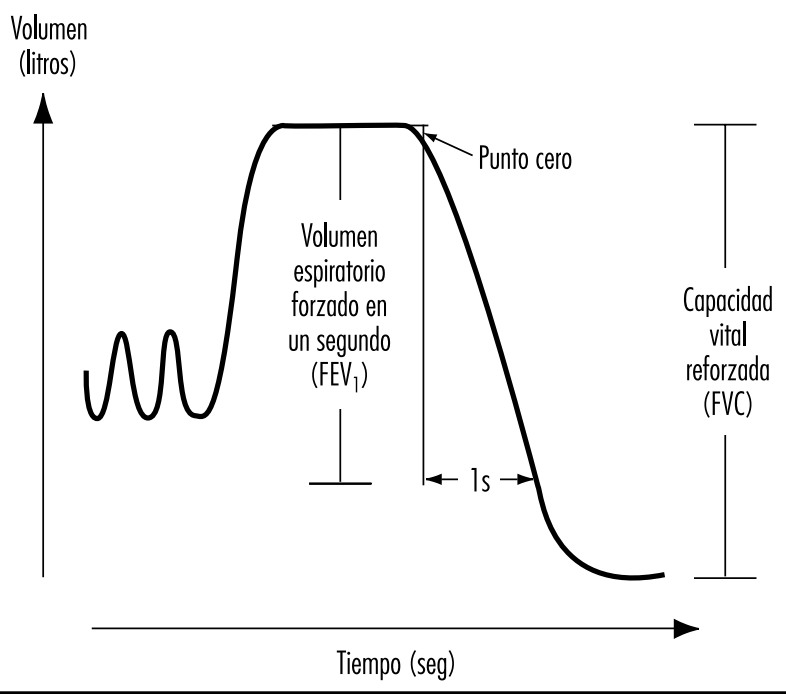

espiración) reflejan principalmente las características de flujo de las vías aéreas grandes, mientras que los flujos máximos a volúmenes pulmonares pequeños (es decir, al final de la espiración) suelen reflejar las características de las vías aéreas pequeñas, Figura 10.6. En estas últimas, el flujo es laminar, mientras que en las vías aéreas grandes puede ser turbulento.

EI PEF también puede medirse con un pequeño aparato portátil, como el desarrollado por Wright en 1959. U na ventaja de este equipo es que el sujeto puede realizar mediciones seriadas, por ejemplo, en el lugar de trabajo. Sin embargo, para obtener registros útiles es necesario enseñar a los sujetos a utilizar bien el aparato. A demás, debe tenerse en cuenta que las mediciones del PEF con, por ejemplo, un medidor de Wright, y las obtenidas mediante espirometría convencional no deben compararse, debido a las diferentes técnicas de soplado utilizadas.

Las variables espirométricas VC, FVC y $\mathrm{FEV}_{1}$ muestran una variación razonable entre sujetos, siendo la edad, la estatura y el sexo los causantes habituales del 60 al $70 \%$ de la variación. Los trastornos restrictivos de la función pulmonar dan lugar a valores más bajos de la VC, la FVC y el FEV ${ }_{1}$. Las mediciones de los flujos durante la inspiración muestran una gran variación individual, ya que los flujos medidos dependen del esfuerzo y del tiempo. Esto significa, por ejemplo, que un sujeto tendrá un flujo extremadamente alto en caso de disminución del volumen pulmonar. Por el otro lado, el flujo puede ser extremadamente bajo en caso de un volumen pulmonar muy alto. Sin embargo, el flujo suele disminuir en caso de enfermedad obstructiva crónica (p. ej., asma, bronquitis crónica).

La proporción del volumen residual (RV), es decir, el volumen de aire que queda en los pulmones después de una espiración máxima, puede determinarse mediante dilución de gas 0 mediante pletismografía corporal. La técnica de dilución de gas requiere un equipo menos sofisticado, por lo que resulta más adecuada para los estudios realizados en el lugar de trabajo. En la Figura 10.7 se ha representado el principio de la técnica de dilución de gas. Esta técnica se basa en la dilución de un gas indicador en un circuito de reinspiración. El gas indicador apenas debe ser soluble en los tejidos biológicos, a fin de que no sea captado por los tejidos y la sangre pulmonares. I nicialmente se utilizó el hidrógeno, pero debido a su capacidad de formar
Figura 10.6 • Curva de flujo-volumen que muestra la derivación del flujo espiratorio máximo (PEF), los flujos máximos al $50 \%$ y el $75 \%$ de la capacidad vital forzada $\left(\mathrm{MEF}_{50}\right.$ y $\mathrm{MEF}_{25}$, respectivamente).

Flujio

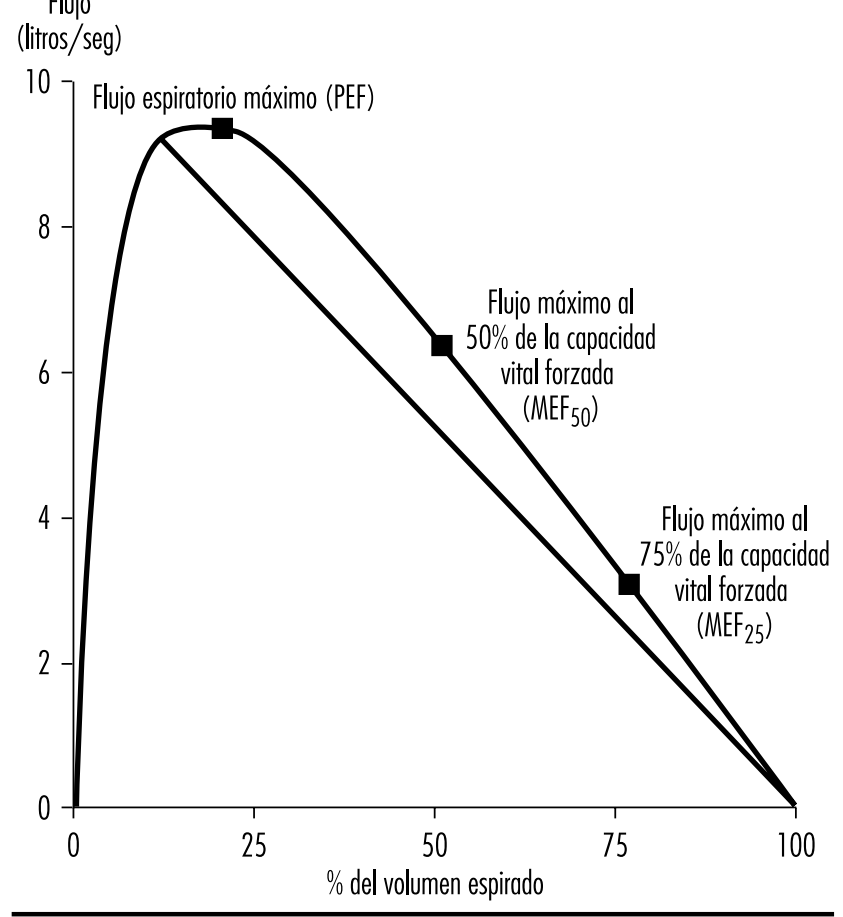

mezclas explosivas con el aire, fue sustituido por helio, que se detecta fácilmente por medio del principio de conductividad térmica.

El sujeto y el aparato forman un sistema cerrado, de forma que la concentración inicial del gas se reduce cuando se diluye en el volumen de gas de los pulmones. Una vez alcanzado el equilibrio, la concentración del gas indicador es la misma en los pulmones y en el aparato, y la capacidad funcional residual (FRC) puede calcularse mediante una sencilla ecuación de dilución. El volumen del espirómetro (incluida la adición de la mezcla de gas al espirómetro) se designa como $V_{S}, V_{L}$ es el volumen pulmonar, $F_{i}$ es la concentración inicial del gas y $F_{f}$ es la concentración final.

$$
F R C=V_{L}=\left[\left(V_{S} \cdot F_{j}\right) / F_{f}\right]-V_{S}
$$

Se realizan dos a tres maniobras de $V C$ a fin de proporcionar una base fiable para el cálculo de la T LC (en litros). L as subdivisiones de los diferentes volúmenes pulmonares se muestran en la Figura 10.8.

Debido al cambio en las propiedades elásticas de las vías aéreas, el RV y la FRC aumentan con la edad. En las enfermedades obstructivas crónicas, suelen observarse valores elevados del RV y de la FRC, mientras que la VC está disminuida. Sin embargo, en sujetos con áreas pulmonares mal ventiladas (por ejemplo, sujetos con enfisema), la técnica de dilución de gas puede infravalorar el RV, la FRC y la TLC. Esto se debe al hecho de que el gas indicador no comunicará con las vías aéreas bloqueadas, por lo que la disminución de su concentración producirá valores erróneamente bajos.

Las mediciones del volumen de cierre y de la distribución del gas en los pulmones pueden obtenerse en una maniobra única mediante la técnica de lavado de nitrógeno con respiración única, Figura 10.9. El equipo consta de un espirómetro 
Figura 10.7 - Esquema principal del equipo para la determinación de la capacidad pulmonar to tal (TLC) de acuerdo con la técnica de dilución de helio.
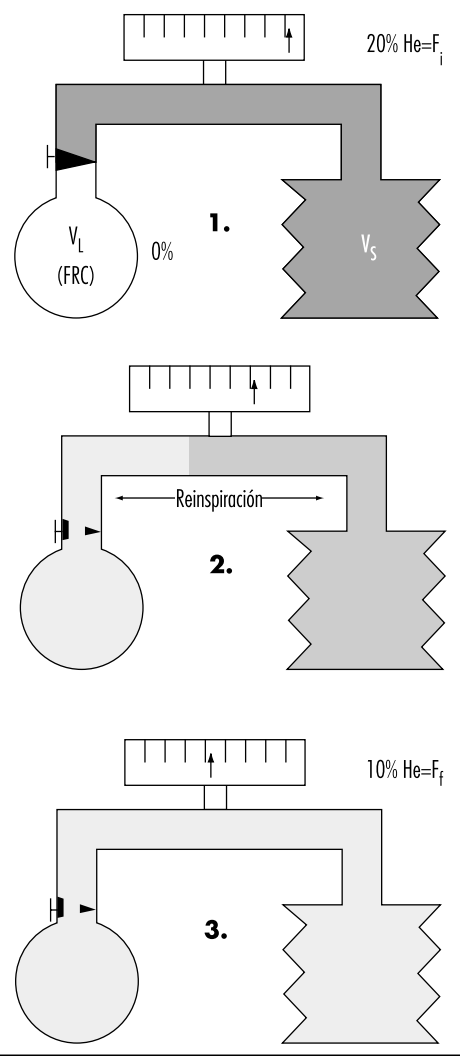

conectado a un sistema de bolsa en receptáculo y un registrador para mediciones continuas de la concentración de nitrógeno. La maniobra se realiza mediante una inspiración máxima de oxígeno puro procedente de la bolsa. Al comienzo de la espiración, la concentración de nitrógeno aumenta debido al vaciado del espacio muerto del sujeto, que contiene oxígeno puro. La espiración continúa con el aire procedente de las vías aéreas y los alveolos. Finalmente, se espira el aire procedente de los alveolos, que contiene un 20-40 \% de nitrógeno. Cuando aumenta la espiración procedente de las partes basales de los pulmones, la concentración de nitrógeno se eleva bruscamente en caso de cierre de la vía aérea en las regiones pulmonares declives, Figura 10.9. Este volumen por encima del RV, con el que las vías aéreas se cierran durante una espiración, suele expresarse como volumen de cierre (CV) en porcentaje de la VC (CV \%). La distribución del aire inspirado en los pulmones se expresa como la pendiente de la meseta alveolar $\left(\% \mathrm{~N}_{2} 0\right.$ fase III, \% $\mathrm{N}_{2} /$ I). Se obtiene tomando la diferencia de la concentración de nitrógeno entre el punto en el que se espira el $30 \%$ del aire y el punto de cierre de las vías aéreas, y dividiendo este valor por el volumen correspondiente.

El envejecimiento y los procesos obstructivos crónicos producen un aumento de los valores del CV \% y la fase III. Sin embargo, ni siquiera los sujetos sanos presentan una distribución uniforme de gas en los pulmones, lo que resulta en valores ligeramente elevados para la fase III, es decir, 1 a $2 \% \mathrm{~N}_{2} /$ I. Se considera que las variables CV \% y fase III reflejan las condiciones de las vías aéreas pequeñas periféricas con un diámetro interno de unos $2 \mathrm{~mm}$. N ormalmente, las vías aéreas periféricas contribuyen a una pequeña parte (10 a $20 \%$ ) de la resistencia total de las vías
Figura 10.8 - Espirograma etiquetado para mostrar las subdivisiones de la capacidad total.

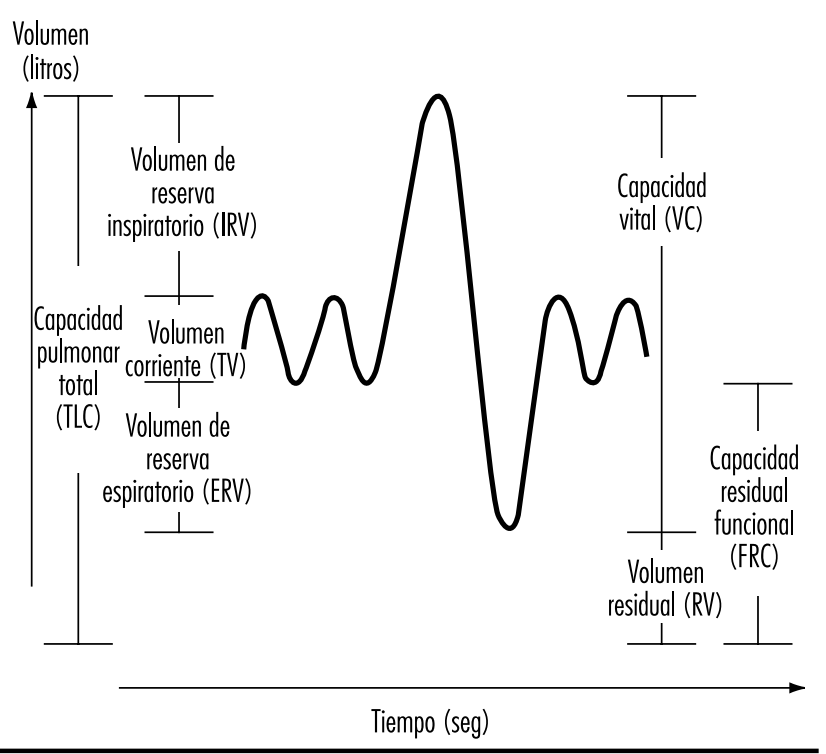

aéreas. Pueden producirse cambios bastante extensos que no son detectables por pruebas convencionales de la función pulmonar como la espirometría dinámica, por ejemplo, como resultado de una exposición de las vías aéreas periféricas a sustancias irritantes del aire. Esto sugiere que la obstrucción de las vías aéreas comienza en las vías pequeñas. Los resultados de diversos estudios también han mostrado alteraciones del CV \% y de la fase III antes de que se produjera ningún otro cambio en la espirometría dinámica y estática. Estos cambios precoces pueden remitir una vez desaparecida la exposición a los agentes nocivos.

El factor de transferencia del pulmón ( $\mathrm{mmol} / \mathrm{min}$; $\mathrm{kPa}$ ) es una expresión de la capacidad de difusión de transporte de oxígeno a Ios capilares pulmonares. EI factor de transferencia puede determinarse utilizando técnicas de respiración única o repetida; la técnica de respiración única se considera más adecuada para los estudios en el lugar de trabajo. Se utiliza el monóxido de

Figura 10.9 - Esquema principal del registro del cierre de la vía aérea y pendiente de la meseta alveolar $\left(\% \mathrm{~N}^{2}\right)$.

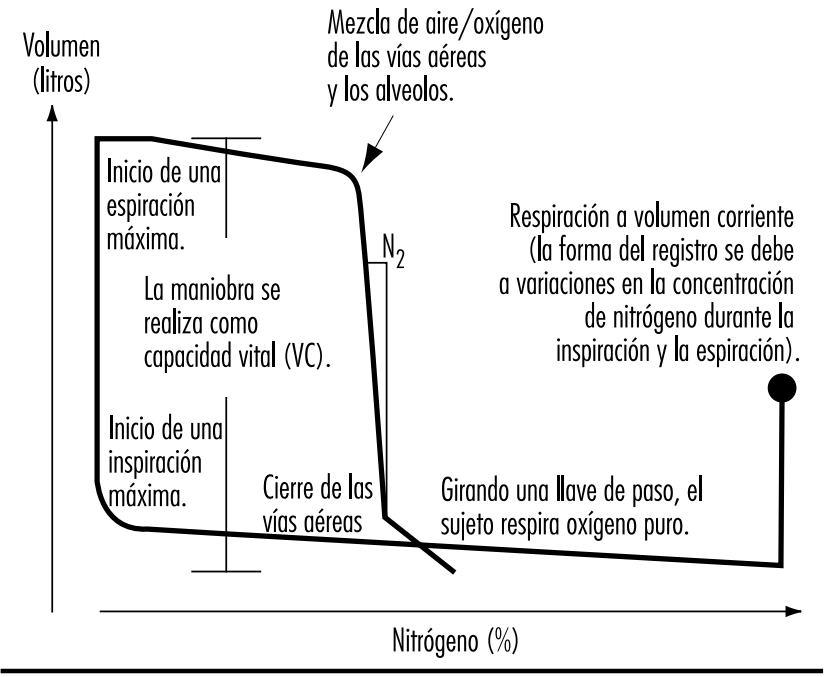


Figura 10.10 - Esquema principal del registro del factor de transferencia.

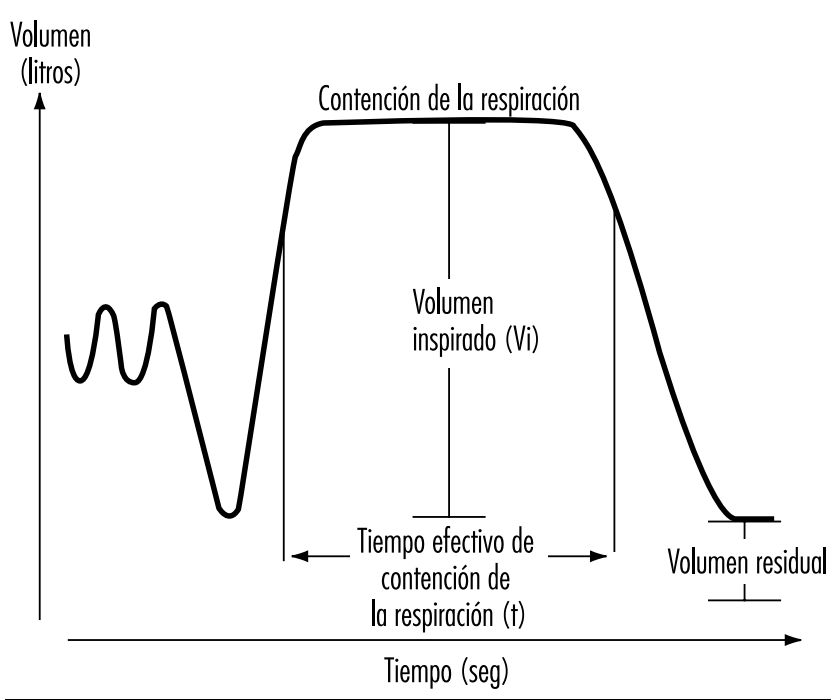

carbono ( $\mathrm{CO}$ ), debido a que la presión de retorno este gas es muy baja en la sangre periférica, a diferencia de la de oxígeno. Se supone que la captación de $\mathrm{CO}$ sigue un modelo exponencial, y esta suposición puede utilizarse para determinar el factor de transferencia pulmonar.

$L$ a determinación del $T L_{c o}$ (factor de transferencia medido con $\mathrm{CO}$ ) se realiza mediante una maniobra respiratoria que incluye una espiración máxima, seguida de una inspiración máxima de una mezcla de gas que contiene monóxido de carbono, helio, oxígeno y nitrógeno. Después de un período de contención de la respiración, se realiza una espiración máxima, que refleja el contenido del aire alveolar, Figura 10.10. Para la determinación del volumen alveolar $\left(V_{A}\right)$ se utiliza helio. Suponiendo que la dilución del $\mathrm{CO}$ es similar a la del helio, puede calcularse la concentración inicial de $\mathrm{CO}$ antes de que se inicie la difusión. EI T $L_{\text {co }}$ se calcula mediante la ecuación expresada más adelante, donde $k$ depende de las dimensiones de los componentes, t es el tiempo eficaz para la contención de la respiración y log es el logaritmo de base 10 . El volumen inspirado se designa como $\mathrm{V}_{i}$ y las fracciones $\mathrm{F}$ de $\mathrm{CO}$ y helio se designan como i y a para las fracciones inspirada y alveolar, respectivamente.

$$
T L_{C O}=k V_{i}\left(F_{a, H e} / F_{i, H e}\right) \log \left(F_{i, C O} F_{a, H e} d F_{a, C O} F_{i, H e}\right)(t)^{-1}
$$

$L$ a magnitud del $T L_{c o}$ dependerá de diversas condiciones, como la cantidad de hemoglobina disponible, el volumen de alveolos ventilados y de capilares pulmonares perfundidos y su relación entre sí. Los valores del $T L_{c o}$ disminuyen con la edad y aumentan con la actividad física y con los volúmenes pulmonares elevados. Se observa un $T L_{\text {co }}$ bajo en los procesos pulmonares restrictivos y obstructivos.

La complianza (I/ $\mathrm{kPa})$ es una función, entre otras, de la propiedad elástica de los pulmones. Estos tienen una tendencia intrínseca a colapsarse. La fuerza necesaria para mantener los pulmones distendidos dependerá del tejido pulmonar elástico, de la tensión superficial en los alveolos y de la musculatura bronquial. Por el otro lado, las paredes torácicas tienden a expandirse a volúmenes pulmonares de 1 a 2 litros por encima del nivel de la FRC. A volúmenes pulmonares mayores, debe aplicarse fuerza para expandir más la pared torácica. AI nivel de la FRC, la tendencia correspondiente en los pulmones se equilibra con la tendencia a expandirse. Por esta razón, se designa al nivel de la FRC como nivel de reposo de los pulmones.

La complianza pulmonar se define como el cambio en el volumen dividido por el cambio en la presión transpulmonar, es decir, la diferencia entre las presiones en la boca (atmosférica) y en el pulmón, como resultado de una maniobra de respiración. Las mediciones de la presión pulmonar no son fáciles de realizar, por lo que se sustituyen por mediciones de la presión en el esófago. La presión en el esófago es prácticamente igual a la presión en el pulmón, y se mide mediante un catéter de polietileno con un balón que cubre los $10 \mathrm{~cm}$ distales. Durante las maniobras inspiratorias y espiratorias, los cambios en el volumen y en la presión se registran mediante un espirómetro y un transductor de presión, respectivamente. Cuando las mediciones se realizan durante la respiración corriente, es posible medir la complianza dinámica. La complianza estática se obtiene cuando se realiza una maniobra de VC lenta. En este último caso, las mediciones se llevan a cabo en un pletismógrafo corporal, y la espiración se interrumpe de forma intermitente mediante un obturador. Sin embargo, las mediciones de la complianza son difíciles de realizar cuando se examinan los efectos de la exposición sobre la función pulmonar en el lugar de trabajo, motivo por el cual esta técnica se considera más apropiada en el marco del laboratorio..

En la fibrosis se observa una disminución de la complianza (aumento de la elasticidad). Para que se produzca un cambio en el volumen, se requieren grandes cambios en la presión. Por otro lado, se observa una complianza elevada, por ejemplo, en el enfisema como resultado de una pérdida de tejido elástico y, por consiguiente, también de la elasticidad en el pulmón.

La resistencia de las vías aéreas depende fundamentalmente del radio y de la longitud de las vías aéreas, pero también de la viscosidad del aire. La resistencia de las vías aéreas $\left(R_{L}\right.$ en $(\mathrm{kPa} / \mathrm{l}) / \mathrm{s})$ puede determinarse con un espirómetro, un transductor de presión y un neumotacógrafo (para medir el flujo). Las mediciones también pueden realizarse utilizando un pletismógrafo corporal para registrar los cambios en el flujo y en la presión durante las maniobras de respiración jadeante. M ediante la administración de un fármaco broncoconstrictor, puede identificarse a los sujetos sensibles, debido a que sus vías aéreas son hiperreactivas. Los sujetos con asma suelen presentar valores elevados de $R_{L}$

\section{Efectos agudos y crónicos de la exposición ocupacional sobre la función pulmonar}

La determinación de la función pulmonar puede utilizarse para descubrir el efecto de una exposición ocupacional sobre los pulmones. Sin embargo, la exploración de la función pulmonar previa a la contratación de una persona no debe utilizarse para excluir a los aspirantes. Esto es debido a que la función pulmonar de los individuos sanos presenta unos amplios límites de variabilidad, de tal forma que resulta difícil establecer una línea divisoria por debajo de la cual pueda afirmarse con seguridad que el pulmón en cuestión es patológico. 0 tra razón es que el medio ambiente de trabajo debe ser lo suficientemente bueno como para permitir que incluso las personas que presentan un leve deterioro de la función pulmonar trabajen con seguridad.

L os efectos crónicos sobre los pulmones de las personas sometidas a exposición ocupacional pueden detectarse de diversas formas. Sin embargo, las técnicas se han diseñado para determinar efectos pasados, por lo que son menos adecuadas para servir como pautas destinadas a prevenir el deterioro de la función pulmonar. Un diseño de estudio habitual consiste en comparar los valores actuales en individuos expuestos con los valores de función pulmonar obtenidos en una población de referencia sin exposición ocupacional. Los individuos de 
referencia pueden reclutarse del mismo lugar de trabajo (o un lugar cercano) o de la misma ciudad.

Se ha utilizado el análisis multivariable en ciertos estudios para valorar las diferencias entre personas expuestas y personas de referencia no expuestas de características similares. Los valores de la función pulmonar en personas expuestas también pueden normalizarse mediante una ecuación de referencia basada en los valores de función pulmonar de los individuos no expuestos.

0 tro enfoque consiste en estudiar la diferencia entre los valores de función pulmonar en trabajadores expuestos y no expuestos tras el ajuste según la edad y la talla utilizando valores externos de referencia, calculados mediante una ecuación de predicción basada en sujetos sanos. También se puede intentar que la población de referencia tenga características similares a la de los sujetos expuestos en cuanto a grupo étnico, sexo, edad, talla y hábito de fumar, con el fin de controlar aún más estos factores que pueden ejercer una influencia.

Sin embargo, el problema es decidir si una reducción es lo suficientemente marcada como para ser clasificada como patológica cuando se utilizan factores externos de referencia. Aunque los instrumentosutilizados en los estudios deben ser portátiles y sencillos, debe prestarse atención tanto a la sensibilidad del método escogido para detectar pequeñas anomalías de las vías aéreas y los pulmones como a la posibilidad de combinar diferentes métodos. $\mathrm{H}$ ay ciertos datos que indican que las personas con síntomas respiratorios, como disnea de esfuerzo, presentan un mayor riesgo de sufrir un deterioro acelerado de la función pulmonar. Esto significa que la presencia de síntomas respiratorios es importante y no debe dejarse de lado.

También se puede llevar a cabo un seguimiento de la persona mediante espirometría, por ejemplo, una vez al año, durante un cierto número de años, con el fin de obtener un aviso del desarrollo de la enfermedad. No obstante, hay limitaciones a este planteamiento, ya que consume mucho tiempo y la función pulmonar puede haberse deteriorado ya de forma permanente para cuando sea posible observar la disminución. Por consiguiente, este enfoque no debe ser una excusa para retrasar la puesta en marcha de medidas destinadas a reducir las concentraciones nocivas de contaminantes atmosféricos.

Finalmente, los efectos crónicos sobre la función pulmonar también pueden estudiarse examinando los cambios individuales en la función pulmonar en personas expuestas y no expuestas a lo largo de varios años. U na ventaja del diseño de estudio longitudinal es que se elimina la variabilidad entre sujetos; sin embargo, se considera que este diseño consume demasiado tiempo y es caro.

También es posible identificar a las personas susceptibles comparando sus funciones pulmonares con y sin exposición durante los turnos de trabajo. Con el fin de reducir al mínimo los posibles efectos de las variaciones diurnas, la función pulmonar se determina a la misma hora del día, en una ocasión sin exposición y en otra en situación expuesta. La situación de ausencia de exposición puede conseguirse, por ejemplo, trasladando temporalmente al trabajador a un área no contaminada 0 mediante el uso de un respirador adecuado durante todo el turno, o en algunos casos realizando las determinaciones de la función pulmonar del trabajador por la tarde de un día libre.

Un aspecto de especial preocupación es el hecho de que los efectos temporales repetidos pueden desembocar en efectos crónicos. U na disminución aguda de la función pulmonar puede ser no sólo un indicador de exposición biológica, sino también un factor de predicción de un descenso crónico de la función pulmonar. La exposición a contaminantes atmosféricos puede provocar efectos agudos discernibles sobre la función pulmonar, aunque los valores medios de contaminantes ambientales medidos se encuentren por debajo de los valores límite saludables. Por este motivo se plantea la pregunta de si estos efectos realmente son dañinos a largo plazo. Se trata de una pregunta que resulta difícil responder de forma directa, especialmente dado que la contaminación atmosférica en los lugares de trabajo a menudo tiene una composición compleja y la exposición no se puede describir en tér minos de concentraciones medias de compuestos individuales. El efecto de una exposición ocupacional es también en parte el resultado de la sensibilidad de la persona. Esto significa que ciertos individuos reaccionan antes o en mayor medida que otros. L a base fisiopatológica subyacente $a$ un descenso temporal agudo de la función pulmonar no se conoce por completo. Sin embargo, la reacción adversa tras la exposición a un contaminante atmosférico irritante constituye una medida objetiva, a diferencia de las experiencias subjetivas, como son los síntomas de diferentes orígenes.

La ventaja de detectar cambios precoces en las vías aéreas y los pulmones causados por contaminantes ambientales peligrosos es evidente: la exposición existente se puede reducir con el fin de prevenir afecciones más graves. Por lo tanto, un objetivo importante a este respecto es utilizar las medidas de los efectos temporales agudos sobre la función pulmonar como un sistema sensible y precoz de aviso que puede aplicarse al estudio de grupos de trabajadores sanos.

\section{Control de irritantes}

La irritación es uno de los criterios más frecuentes para establecer valores límite de exposición. Sin embargo, no existe la certeza de que el cumplimiento de un límite de exposición así establecido proteja contra la irritación. D ebe tenerse en cuenta que un límite de exposición para un contaminante atmosférico habitualmente consta al menos de dos partes: un límite medio ponderado en el tiempo (T WAL) y un límite de exposición a corto plazo (ST EL), o al menos contiene reglas relativas a los casos en que se excede el límite medio ponderado en el tiempo, "límites de expansión". En el caso de sustancias muy irritantes, como el dióxido de azufre, la acroleína y el fosgeno, es importante limitar la concentración incluso durante períodos muy cortos, por lo que ha sido una práctica habitual fijar los valores límite de exposición ocupacional en forma de límites tope, con un período de muestreo tan breve como las instalaciones de medición lo permitan.

Los valores del límite medio ponderado en el tiempo para un día de ocho horas combinados con reglas relativas a la expansión más allá de dichos valores quedan recogidos para la mayoría de las sustancias en la lista de Valores Límite U mbral ( $T$ LV ) de la Conferenecia A mericana de $\mathrm{H}$ igienistas Industriales del Gobierno (ACGIH). La lista TLV de 1993-94 contiene la siguiente afirmación en relación con los límites de expansión para los valores que exceden del límite:

Para la inmensa mayoría de sustancias con un T LV-T WA, no se dispone de suficientes datos toxicológicos para justificar un STEL (= límite de exposición a corto plazo). No obstante, las expansiones por encima del TLV-TWA deben controlarse incluso cuando la TWA de ocho horas se encuentra dentro de los límites recomendados.

Las mediciones de exposición de contaminantes atmosféricos conocidos y la comparación con valores límite de exposición bien documentados debe llevarse a cabo de forma sistemática. Sin embargo, hay situaciones en las que la determinación del cumplimiento de los valores límite de exposición no es suficiente. E ste es el caso en las siguientes circunstancias (entre otras):

1. Cuando el valor límite es demasiado elevado para proteger contra la irritación.

2. Cuando se desconoce el irritante. 
3. Cuando el irritante es una mezcla compleja y no se conoce un indicador adecuado.

Como se ha recomendado anteriormente, en estos casos se puede utilizar la medición de los efectos temporales agudos sobre la función pulmonar como aviso contra la sobreexposición a irritantes.

En los casos 2) y 3), los efectos temporales agudos sobre la función pulmonar podrían aplicarse también para valorar la eficiencia de las medidas de control destinadas a reducir la exposición a la contaminación atmosférica o en investigaciones científicas, por ejemplo, para atribuir efectos biológicos a los componentes de los contaminantes atmosféricos. A continuación se presenta una serie de ejemplos en que los efectos temporales agudos sobre la función pulmonar se han utilizado con éxito en investigaciones relativas a higiene industrial.

\section{Estudios de los efectos temporales agudos sobre la función pulmonar}

A finales del decenio de 1950 se registró un descenso temporal, relacionado con el trabajo, de la función pulmonar a lo largo de un turno en trabajadores de la industria del algodón. Posteriormente, diversos autores informaron acerca de cambios temporales agudos de la función pulmonar relacionados con el trabajo en trabajadores textiles y de cáñamo, mineros del carbón, trabajadores expuestos a diisocianato de tolueno, bomberos, procesadores de caucho, moldeadores y macheros, soldadores, enceradores de esquíes, trabajadores expuestos a polvos orgánicos e irritantes en pinturas a base de agua.

No obstante, hay diversos casos en los que las mediciones anteriores y posteriores a la exposición, habitualmente durante un turno, no han podido demostrar ningún efecto agudo, a pesar de haber tenido lugar una exposición elevada. Esto probablemente se deba al efecto de la variación circadiana normal, principalmente en las variables pulmonares que dependen del calibre de la vía aérea. Así, el descenso temporal de estas variables debe superar la variación circadiana normal para poder ser identificado. Sin embargo, este problema se puede solucionar determinando la función pulmonar a la misma hora del día en cada momento de estudio. U tilizando al empleado expuesto como su propio control se consigue reducir aún más la variabilidad interindividual. De esta forma fueron estudiados soldadores y, aunque la diferencia media entre los valores de la FVC en individuos expuestos y no expuestos fue inferior al $3 \%$ en 15 soldadores examinados, esta diferencia fue significativa a un nivel de confianza del $95 \%$ con una potencia superior al $99 \%$.

Los efectos reversibles transitorios sobre los pulmones se pueden utilizar como un indicador de exposición de componentes irritativos complicados. En el estudio anteriormente mencionado, las partículas en el ambiente de trabajo resultaron cruciales en relación con los efectos irritantes sobre las vías respiratorias y los pulmones. Se extrajeron dichas partículas por medio de un respirador consistente en un filtro acoplado a un casco de soldar. Los resultados indicaron que los efectos sobre los pulmones estaban causados por las partículas contenidas en los vapores de soldadura, y que el uso de un respirador para partículas podría prevenir dicho efecto.

L a exposición a gases de escape diesel también genera efectos irritantes mensurables en los pulmones, que se ponen de manifiesto como una reducción temporal aguda de la función pulmonar. El uso de filtros mecánicos acoplados a los tubos de escape de los camiones durante las operaciones de carga Ilevadas a cabo por estibadores aliviaron los trastornos subjetivos y redujeron la disminución temporal aguda de la función pulmonar observada en los casos en los que no se utilizaba un sistema de filtración. Estos resultados indican que la presencia de partículas en el ambiente de trabajo desempeña un papel en el efecto irritante sobre las vías aéreas y los pulmones, efecto que es posible valorar mediante mediciones de los cambios agudos de la función pulmonar..

La existencia de múltiples exposiciones y el cambio continuo de ambiente de trabajo pueden plantear dificultades a la hora de dilucidar la relación causal de los diferentes agentes presentes en dicho medio. El marco de exposición encontrado en los aserraderos es un ejemplo esclarecedor de este hecho. En este medio ambiente de trabajo no resulta posible (por razones económicas) llevar a cabo mediciones de exposición de todos los posibles agentes (terpenos, polvos, mohos, bacterias, endotoxinas, micotoxinas, etc.). Un método factible puede ser realizar un seguimiento longitudinal de la función pulmonar. En un estudio sobre trabajadores de un aserradero asignados a la sección de corte de madera se examinó la función pulmonar antes y después de una semana de trabajo, y no se observó una disminución estadísticamente significativa. Sin embargo, un estudio de seguimiento realizado varios años después reveló que los trabajadores que habían presentado una reducción numérica de la función pulmonar durante una semana de trabajo también tenían un descenso acelerado a largo plazo en la función pulmonar. Este dato puede indicar que es posible detectar a las personas vulnerables realizando una medición de los cambios de la función pulmonar durante una semana de trabajo.

\section{ENFERMEDADES CAU SADAS POR IRRITANTES RESPIRATORIOS Y PRODUCTOS QUIMICOSTOXICOS}

\author{
David L.S. R yon y William N. Rom
}

La presencia de irritantes respiratorios en el lugar de trabajo puede ser desagradable y un factor de distracción y conducir a una situación de baja moral y menor productividad. Ciertas exposiciones son peligrosas e incluso pueden resultar letales. En cualquiera de los extremos, el problema de los irritantes respiratorios y de las sustancias químicas tóxicas inhaladas es frecuente; muchos trabajadores se enfrentan diariamente a la amenaza de la exposición a los mismos. Estos compuestos son capaces de causar daños mediante muy diversos mecanismos, y el alcance de la lesión puede variar de forma considerable, dependiendo del grado de exposición y de las propiedades bioquímicas del agente inhalado. En cualquier caso, todos comparten la característica de su inespecificidad; es decir, por encima de cierto nivel de exposición suponen una amenaza para su salud de prácticamente todas las personas.

Existen otras sustancias inhaladas que sólo provocan problemas respiratorios en las personas susceptibles; es más adecuado enfocar este tipo de dolencias como enfermedades de origen alérgico e inmunológico. Ciertos compuestos, como los isocianatos, los anhídridos ácidos y las resinas epoxi, no sólo son capaces de actuar como irritantes inespecíficos a elevadas concentraciones, sino que también pueden predisponer a ciertas personas a una sensibilización alérgica. Tales compuestos provocan síntomas respiratorios a muy bajas concentraciones en personas sensibilizadas.

Los irritantes respiratorios son sustancias que producen inflamación de las vías aéreas tras su inhalación. La lesión puede afectar a las vías aéreas superiores e inferiores. $M$ ás peligrosa resulta la inflamación aguda del parénquima pulmonar, como 
ocurre en la neumonitis química o en el edema pulmonar no cardiogénico. Los compuestos capaces de causar lesión del parénquima se consideran sustancias químicas tóxicas. M uchas sustancias químicas tóxicas inhaladas también actúan como irritantes respiratorios, avisando del peligro que entrañan por medio de su desagradable olor y de síntomas de irritación nasal y faríngea asociada a tos. La mayoría de los irritantes respiratorios son también tóxicos para el parénquima pulmonar si se inhalan en cantidad suficiente.

M uchas sustancias inhaladas tienen efectos tóxicos sistémicos después de ser absorbidas por inhalación. Puede no haber efectos inflamatorios sobre el pulmón, como en los casos del plomo, el monóxido de carbono y el cianuro de hidrógeno. Se observa habitualmente una inflamación pulmonar mínima en las fiebres por inhalación (p. ej., síndrome tóxico por polvos orgánicos, fiebre de los vapores de metal y fiebre de los vapores de polímeros). Se produce una grave lesión pulmonar y de órganos distales con la exposición importante a toxinas como el cadmio y el mercurio.

Las propiedades físicas de las sustancias inhaladas predicen el lugar de depósito; los irritantes producen síntomas en esos lugares. Las partículas grandes (10 a $20 \mu \mathrm{m})$ se depositan en la nariz y vías aéreas superiores, las partículas más pequeñas ( 5 a $10 \mu \mathrm{m})$ se depositan en la tráquea y los bronquios, y las partículas de menos de $5 \mu \mathrm{m}$ pueden alcanzar los alveolos. L as partículas de menos de $0,5 \mu \mathrm{m}$ son tan pequeñas que se comportan como gases. Los gases tóxicos se depositan de acuerdo con su solubilidad. Los gases hidrosolubles son absorbidos por la mucosa húmeda de las vías aéreas superiores; los gases con una menor solubilidad se depositan de forma más aleatoria por todo el tracto respiratorio.

\section{Irritantes respiratorios}

Los irritantes respiratorios provocan una inflamación inespecífica del pulmón tras ser inhalados. Estas sustancias, sus fuentes de exposición, sus propiedades físicas y otras propiedades, así como sus efectos sobre la persona afectada se describen en la Tabla 10.3. Los gases irritantes tienden a ser más hidrosolubles que los gases de mayor toxicidad para el parénquima pulmonar. Los vapores tóxicos son más peligrosos cuando tienen un umbral irritante alto; es decir, apenas hay aviso de que se está inhalando el vapor porque la irritación es escasa.

La naturaleza y el alcance de la reacción a un irritante depende de las propiedades físicas del gas o aerosol, de la concentración y el momento de la exposición, y de otras variables como son la temperatura, la humedad y la presencia de agentes patógenos 0 de otros gases ( $\mathrm{M}$ an y $\mathrm{H}$ ulbert 1988). Factores del huésped como la edad (C abral-Anderson, Evans y Freeman 1977; Evans, Cabral-Anderson y Freeman 1977), la exposición previa (Tyler, Tyler y Last 1988), el nivel de antioxidantes (M CM illan y Boyd 1982) y la presencia de infección pueden desempeñar un papel en la determinación de los cambios observados. Este amplio espectro de factores es el responsable de la dificultad de estudiar los efectos patogénicos de los irritantes respiratorios de una forma sistemática.

Los irritantes que mejor se conocen son aquellos que causan una lesión de tipo oxidativo. La mayoría de los irritantes inhalados, incluidos los principales contaminantes, actúan mediante oxidación u originan compuestos que actúan a través de este mecanismo. La mayoría de los vapores de metal son de hecho los óxidos del metal calentado; estos óxidos causan una lesión oxidativa. Los oxidantes lesionan las células principalmente mediante peroxidación de lípidos, y pueden participar otros mecanismos. A nivel celular, se produce inicialmente una pérdida relativamente específica de las células ciliadas del epitelio de la vía aérea y de células del epitelio alveolar de tipo I, con la consiguiente ruptura de la estrecha unión entre las células epiteliales ( $M$ an y H ulbert 1988; Gordon, Salano y K leinerman 1986; Stephens y cols. 1974). Esto ocasiona una lesión subepitelial y submucosa, con estimulación del músculo liso y de las terminaciones nerviosas aferentes sensitivas parasimpáticas, lo que provoca vasoconstricción (Holgate, Beasley y Twentyman 1987; Boucher 1981). A continuación tiene lugar una respuesta inflamatoria (H ogg 1981), y los neutrófilos y eosinófilos liberan mediadores que provocan una lesión oxidativa adicional (Castleman y cols. 1980). Los neumocitos de tipo II y las células cuboideas actúan como células madre para la reparación (Keenan, Combs y McDowell 1982; Keenan, Wilson y M cD owell 1983).

O tros mecanismos de lesión pulmonar con el tiempo implican finalmente a la vía oxidativa de lesión celular, en particular una vez se ha dañado la capa protectora de células epiteliales y se ha generado una respuesta inflamatoria. Los mecanismos descritos con mayor frecuencia se reseñan en la Tabla 10.4.

L os trabajadores expuestos a niveles bajos de iritantes respiratorios pueden presentar síntomas subclínicos cuyo origen es atribuible a irritación de las mucosas, como epífora, faringitis, moqueo y tos. Cuando la exposición es importante, la aparición adicional de disnea a menudo generará atención médica. Es importante recabar una buena historia clínica con el fin de determinar la composición probable de la exposición, la cantidad de la misma y el período de tiempo durante el cual tuvo lugar. Deben buscarse signos de edema laríngeo, como ronquera y estridor, y deben explorarse los pulmones para detectar signos de afectación de las vías aéreas inferiores o del parénquima pulmonar. Para el tratamiento a corto plazo es importante llevar a cabo una valoración de la vía aérea y de la función pulmonar junto con una radiografía de tórax. La laringoscopia puede estar indicada para evaluar la vía aérea.

Si la vía aérea está comprometida, debe intubarse al paciente y suministrársele cuidados de soporte. En caso de que exista edema laríngeo se mantendrá al paciente en observación durante al menos 12 horas para asegurarse de que se trata de un proceso autolimitado. El broncospasmo debe tratarse con $\beta$-agonistas y, en caso de no obtenerse respuesta, con corticoides intravenosos. Deben irrigarse a conciencia las mucosas oral y ocular irritadas. Se debe hospitalizar para observación a los pacientes que presenten crepitantes en la exploración o anomalías en la radiografía de tórax, dada la posibilidad de neumonitis o edema de pulmón. Estos pacientes están en riesgo de desarrollar una sobreinfección bacteriana; sin embargo, no se ha demostrado que la profilaxis antibiótica sea beneficiosa. .

La inmensa mayoría de los pacientes que sobreviven a la agresión inicial se recupera por completo de la exposición al irritante. Cuanto más importante fuera la lesión inicial, más probable es que se produzcan secuelas a largo plazo. EI término síndrome de disfunción reactiva de las vías aéreas (SDRVA) se ha aplicado a la persistencia de síntomas de tipo asmático tras una exposición aguda a irritantes respiratorios (Brooks, Weiss y Bernstein 1985).

Se cree que este trastorno es consecuencia de una inflamación persistente, con reducción de la permeabilidad de la capa de células epiteliales o disminución del umbral de conductancia para las terminaciones nerviosas subepiteliales.

Las exposiciones elevadas a álcalis o ácidos pueden causar quemaduras del tracto respiratorio superior e inferior que provocan enfermedad crónica. Se sabe que el amoníaco origina bronquiectasias (K ass y cols. 1972); se ha informado de que el gas de cloro (que se convierte en $\mathrm{HCl}$ en la mucosa) provoca enfermedad pulmonar obstructiva (D onelly y Fitzgerald 1990; Das y Blanc 1993). 
Tabla 10.3 - Resumen de los irritantes respiratorios.

\begin{tabular}{|c|c|c|c|c|}
\hline Sustancia química & Fuentes de exposición & Propiedades importantes & Lesiones producidas & $\begin{array}{l}\text { Nivel peligroso } \\
\text { de exposición } \\
\text { por debajo de } \\
15 \text { minutos } \\
\text { (PPM) }\end{array}$ \\
\hline Acetaldehído & $\begin{array}{l}\text { Plásticos, industria del caucho sintético, } \\
\text { productos de combustión }\end{array}$ & $\begin{array}{l}\text { Presión de vapor elevada; hidrosolubi- } \\
\text { lidad elevada }\end{array}$ & $\begin{array}{l}\text { Vías aéreas superiores; rara vez causa } \\
\text { edema pulmonar diferido }\end{array}$ & \\
\hline $\begin{array}{l}\text { Acido acético, ácidos } \\
\text { orgánicos }\end{array}$ & $\begin{array}{l}\text { Industria química, electrónica, productos } \\
\text { de combustión }\end{array}$ & Hidrosoluble & $\begin{array}{l}\text { Lesiones oculares y de vías aéreas } \\
\text { superiores }\end{array}$ & \\
\hline Anhídridos ácidos & $\begin{array}{l}\text { Industrias químicas, de pinturas y } \\
\text { plásticos; componentes de las resinas } \\
\text { epoxi }\end{array}$ & $\begin{array}{l}\text { Hidrosoluble, muy reactivo, puede } \\
\text { provocar sesibilización alérgica }\end{array}$ & $\begin{array}{l}\text { Lesión ocular, lesión de vías aéreas } \\
\text { superiores, broncoespasmo; hemorragia } \\
\text { pulmonar tras exposición masiva }\end{array}$ & \\
\hline Acroleína & $\begin{array}{l}\text { Plásticos, textiles, fabricación de } \\
\text { productos famacéuticos, productos de } \\
\text { combustión }\end{array}$ & $\begin{array}{l}\text { Presión de vapor elevada, hidrosolubi- } \\
\text { lidad intermedia, sumamente irritante }\end{array}$ & $\begin{array}{l}\text { Lesión difusa parenquimatosa y de vías } \\
\text { aéreas }\end{array}$ & \\
\hline Amoníaco & $\begin{array}{l}\text { Fertilizantes, piensos animales, } \\
\text { sustancias químicas, y fabricación de } \\
\text { productos farmacéuticos }\end{array}$ & $\begin{array}{l}\text { Gas alcalino, hidrosolubilidad muy } \\
\text { elevada }\end{array}$ & $\begin{array}{l}\text { Principalmente quemaduras oculares y } \\
\text { de vías aéreas superiores; la exposición } \\
\text { masiva puede provocar bronquiectasias }\end{array}$ & 500 \\
\hline $\begin{array}{l}\text { Tricloruro de antimonio, } \\
\text { penta-cloruro de } \\
\text { antimonio }\end{array}$ & Aleaciones, catalizadores orgánicos & $\begin{array}{l}\text { Escasa solubilidad, lesión probable } \\
\text { debida a iones halogenuro }\end{array}$ & $\begin{array}{l}\text { Neumonitis, edema pulmonar no } \\
\text { cardiogénico }\end{array}$ & \\
\hline Berilio & $\begin{array}{l}\text { Aleaciones ( con cobre), cerámicas; } \\
\text { equipo electrónico, aerospacial y de } \\
\text { reactores nucleares }\end{array}$ & $\begin{array}{l}\text { Metal irritante, también actúa como } \\
\text { antígeno para promover una reacción } \\
\text { granumomatosa a largo plazo }\end{array}$ & $\begin{array}{l}\text { Lesión aguda de vías aéreas superiores, } \\
\text { traqueobronquitis, neumonitis química }\end{array}$ & $25 \mu \mathrm{g} / \mathrm{m}^{3}$ \\
\hline Boranos (diborano) & $\begin{array}{l}\text { Combustible de avión, fabricación de } \\
\text { fungicidas }\end{array}$ & Gas hidrosoluble & $\begin{array}{l}\text { Lesión de vías aéreas superiores, } \\
\text { neumonitis en caso de exposición masiva }\end{array}$ & \\
\hline Bromuro de hidrógeno & Refinado del petróleo & & $\begin{array}{l}\text { Lesión de vías aéreas superiores, } \\
\text { neumonitis en caso de exposición masiva }\end{array}$ & \\
\hline Metilbromuro & Refrigeración, producto de fumigación & Gas moderadamente soluble & $\begin{array}{l}\text { Lesión de vías aéreas superiores e } \\
\text { inferiores, neumonitis, depresión del } \\
\text { SNC y convulsiones }\end{array}$ & \\
\hline Cadmio & $\begin{array}{l}\text { Aleaciones con Zn y Pb, electrochapado, } \\
\text { acumuladores, insecticidas }\end{array}$ & Efectos respiratoris agudos y crónicos & $\begin{array}{l}\text { Traqueobronquitis, edema pulmonar (a } \\
\text { menudo comienzo diferido } 24 \text { - } 48 \text { horas); } \\
\text { un nivel bajo de exposición crónica } \\
\text { produce cambios inflamatorios y enfisema }\end{array}$ & 100 \\
\hline $\begin{array}{l}\text { Oxido de calcio, } \\
\text { hidróxido de calcio }\end{array}$ & Cal, fotografía, curtido, insecticidas & $\begin{array}{l}\text { Moderadamente cáustico, son necesarias } \\
\text { dosis muy altas para provocar toxicidad }\end{array}$ & $\begin{array}{l}\text { Inflamación de vías aéreas superiores e } \\
\text { inferiores, neumonitis }\end{array}$ & \\
\hline Cloro & $\begin{array}{l}\text { Blanqueado, formación de compuestos } \\
\text { clorados, limpiadores para el hogar }\end{array}$ & Hidrosolubilidad intermedia & $\begin{array}{l}\text { Inflamación de vías aéreas superiores e } \\
\text { inferiores, neumonitis y edema pulmonar } \\
\text { no cardiogénico }\end{array}$ & $5-10$ \\
\hline Cloroacetofenona & $\begin{array}{l}\text { Agente de control de masas, } \\
\text { "gas lacrimógeno" }\end{array}$ & $\begin{array}{l}\text { Sus cualidades irritativas se utilizan } \\
\text { para incapacitar; agente alquilante }\end{array}$ & $\begin{array}{l}\text { Inflamación ocular y de vías aéreas } \\
\text { superiores, lesión de vías aéreas inferiores } \\
\text { y parenquimatosa en caso de exposición } \\
\text { masiva }\end{array}$ & $1-10$ \\
\hline $\begin{array}{l}\text { o-Clorobenzomalo- } \\
\text { nitrilo }\end{array}$ & $\begin{array}{l}\text { Agente de control de masas, } \\
\text { "gas lacrimógeno" }\end{array}$ & $\begin{array}{l}\text { Sus cualidades irritativas se utilizan } \\
\text { para incapacitar }\end{array}$ & $\begin{array}{l}\text { Inflamación ocular y de vías aéreas } \\
\text { superiores, lesión de vías aéreas inferiores } \\
\text { en caso de exposición masiva }\end{array}$ & \\
\hline Eteres clorometílicos & $\begin{array}{l}\text { Disolventes, utilizados en la fabricación } \\
\text { de otros compuestos orgánicos }\end{array}$ & & $\begin{array}{l}\text { Irritación de vías aéreas superiores e } \\
\text { inferiores, también cancerígeno del tracto } \\
\text { respiratorio }\end{array}$ & \\
\hline Cloropicrina & $\begin{array}{l}\text { Fabricación de sustancias químicas, } \\
\text { componente de fumigantes }\end{array}$ & Antiguo gas de la I Guerra Mundial & $\begin{array}{l}\text { Inflamación de vías aéreas superiores e } \\
\text { inferiores }\end{array}$ & 15 \\
\hline Acido crómico ( Cr(IV)) & Soldadura, chapado & $\begin{array}{l}\text { Irritante hidrosoluble, sensibilizante } \\
\text { alérgico }\end{array}$ & $\begin{array}{l}\text { Inflamación y ulceración nasales, rinitis, } \\
\text { neumonitis en caso de exposición masiva }\end{array}$ & \\
\hline Cobalto & $\begin{array}{l}\text { Aleaciones de alta temperatura, imanes } \\
\text { permanentes, herramientas de metales } \\
\text { pesados (con carburo de tungsteno) }\end{array}$ & $\begin{array}{l}\text { Irritante inespećifico, también sensibili- } \\
\text { zante alergénico }\end{array}$ & $\begin{array}{l}\text { Broncospasmo agudo y/ o neumonitis; la } \\
\text { exposición crónica puede provocar fibrosis } \\
\text { pulmonar }\end{array}$ & \\
\hline
\end{tabular}


Tabla 10.3 - Resumen de los irritantes respiratorios.

Continuación.

\begin{tabular}{|c|c|c|c|c|}
\hline Sustancia química & Fuentes de exposición & Propiedades importantes & Lesiones producidas & $\begin{array}{l}\text { Nivel peligroso } \\
\text { de exposición } \\
\text { por debajo de } \\
15 \text { minutos } \\
\text { (PPM) }\end{array}$ \\
\hline Formaldehído & $\begin{array}{l}\text { Fabricación de aislamientos de espuma, } \\
\text { madera en capas, textiles, papel, } \\
\text { fertilizantes, resinas; agentes de } \\
\text { embalsamamiento; productos de } \\
\text { combustión }\end{array}$ & $\begin{array}{l}\text { Muy hidrosoluble, rápidamente } \\
\text { metabolizado; actúa principalmente } \\
\text { vía estimulación de nervios sensitivos; } \\
\text { se ha comunicado sensibilización }\end{array}$ & $\begin{array}{l}\text { Irritación ocular y de vías aéreas } \\
\text { superiores; broncospasmo en caso de } \\
\text { exposición intensa; dermatitis de contacto } \\
\text { en personas sensibilizadas }\end{array}$ & 3 \\
\hline Acido clorhídrico & $\begin{array}{l}\text { Refinado de metales, fabricación de } \\
\text { caucho, fabricación de compuestos } \\
\text { orgánicos, materiales de fotografía }\end{array}$ & Muy hidrosoluble & $\begin{array}{l}\text { Inflamación de vías aéreas superiores, } \\
\text { inflamación de vías aéreas inferiores sólo } \\
\text { en caso de exposición masiva }\end{array}$ & 100 \\
\hline Acido fluorhídrico & $\begin{array}{l}\text { Catalizador químico, pesticidas, } \\
\text { blanqueado, soldadura, aguafuertes }\end{array}$ & $\begin{array}{l}\text { Muy hidrosoluble, oxidante potente y } \\
\text { rápido, reduce el calcio sérico } \\
\text { en caso de exposición masiva }\end{array}$ & $\begin{array}{l}\text { Inflamación ocular y de vías aéreas } \\
\text { superiores, traqueobronquitis y neumonitis } \\
\text { en caso de exposición masiva }\end{array}$ & 20 \\
\hline Isocianatos & $\begin{array}{l}\text { Producción de poliuretano; pinturas; } \\
\text { herbicidas y productos insecticidas; } \\
\text { laminación, muebles, esmaltación, } \\
\text { trabajo con resina }\end{array}$ & $\begin{array}{l}\text { Compuestos orgánicos de bajo peso } \\
\text { molecular, irritantes, provocan } \\
\text { sensibilización en personas susceptibles }\end{array}$ & $\begin{array}{l}\text { Irritación ocular y de vías aéreas } \\
\text { superiores e inferiores; asma, neumonitis } \\
\text { por hipersensibilidad en personas } \\
\text { sensibilizadas }\end{array}$ & 0,1 \\
\hline Hidruro de litio & $\begin{array}{l}\text { Aleaciones, cerámicas, electrónica, } \\
\text { catalizadores químicos }\end{array}$ & Baja solubilidad, muy reactivo & $\begin{array}{l}\text { Neumonitis, edema pulmonar no } \\
\text { cardiogénico }\end{array}$ & \\
\hline Mercurio & $\begin{array}{l}\text { Electrólisis, extracción de minerales y } \\
\text { amalgamas, fabricación de productos } \\
\text { de electrónica }\end{array}$ & $\begin{array}{l}\text { Sin síntomas respiratorios con bajos } \\
\text { niveles, exposición crónica }\end{array}$ & $\begin{array}{l}\text { Inflamación ocular y del tracto } \\
\text { respiratorio, neumonitis, efectos } \\
\text { sistémicos, sobre el SNC y el riñón }\end{array}$ & $1,1 \mathrm{mg} / \mathrm{m}^{3}$ \\
\hline Niquel carbonilo & $\begin{array}{l}\text { Refinado de niquel, electrochapado, } \\
\text { reactivos químicos }\end{array}$ & Toxina potente & $\begin{array}{l}\text { Irritación respiratoria inferior, neumonitis, } \\
\text { efectos tóxicos sistémicos diferidos }\end{array}$ & $8 \mu \mathrm{g} / \mathrm{m}^{3}$ \\
\hline Dióxido de nitrógeno & $\begin{array}{l}\text { Silos después del almacenaje de nuevo } \\
\text { grano, fabricación de fertilizante, } \\
\text { soldadura por arco, productos } \\
\text { de combustión }\end{array}$ & $\begin{array}{l}\text { Baja hidrosolubilidad, gas pardo a } \\
\text { elevada concentración }\end{array}$ & $\begin{array}{l}\text { Inflamación ocular y de vías aéreas } \\
\text { superiores, edema pulmonar no } \\
\text { cardiogénico, bronquiolitis de comienzo } \\
\text { retardado }\end{array}$ & 50 \\
\hline $\begin{array}{l}\text { Mostazas nitrogenadas; } \\
\text { mostazas de azufre }\end{array}$ & Gases del ejército & $\begin{array}{l}\text { Provoca lesiones graves, propiedades } \\
\text { vesicantes }\end{array}$ & $\begin{array}{l}\text { Inflamación ocular y de vías aéreas } \\
\text { superiores e inferiores, neumonitis }\end{array}$ & $\begin{array}{l}20 \mathrm{mg} / \mathrm{m}^{3}(\mathrm{~N}) \\
1 \mathrm{mg} / \mathrm{m}^{3}(\mathrm{~S})\end{array}$ \\
\hline Tetraóxido de osmio & $\begin{array}{l}\text { Refinado de cobre, aleación con iridio, } \\
\text { catalizador para la síntesis de esteroides } \\
\text { y formación de amoníaco }\end{array}$ & $\begin{array}{l}\text { El osmio metálico es inerte, el } \\
\text { tatraóxido se forma al calentarse en aire }\end{array}$ & $\begin{array}{l}\text { Grave irritación ocular y de vías aéreas } \\
\text { superiores; lesión renal transitoria }\end{array}$ & $1 \mathrm{mg} / \mathrm{m}^{3}$ \\
\hline Ozono & $\begin{array}{l}\text { Soldadura por arco, máquinas } \\
\text { copiadoras, blanqueado de papel }\end{array}$ & $\begin{array}{l}\text { Gas de olor dulce, hidrosolubilidad } \\
\text { moderada }\end{array}$ & $\begin{array}{l}\text { Inflamación de vías aéreas superiores e } \\
\text { inferiores; asmáticos más susceptibles }\end{array}$ & 1 \\
\hline Fosgeno & $\begin{array}{l}\text { Fabricación de pesticidas y de otras } \\
\text { sustancias químicas, soldadura por arco, } \\
\text { eliminación de pintura }\end{array}$ & $\begin{array}{l}\text { Escasa hidrosolubilidad, no irrita las } \\
\text { vías aéreas a bajas dosis }\end{array}$ & $\begin{array}{l}\text { Inflamación de vías aéreas superiores y } \\
\text { neumonitis; edema pulmonar diferido a } \\
\text { bajas dosis }\end{array}$ & 2 \\
\hline Sulfuros fosfóricos & $\begin{array}{l}\text { Producción de insecticidas, compuestos } \\
\text { de ignición, cerillas }\end{array}$ & & $\begin{array}{l}\text { Inflamación ocular y de las vías aéreas } \\
\text { superiores }\end{array}$ & \\
\hline Cloruros fosfóricos & $\begin{array}{l}\text { Fabricación de compuestos orgánicos } \\
\text { clorados, tintes, aditivos de gasolina }\end{array}$ & $\begin{array}{l}\text { Forma ácido fosfórico y ácido clorhídrico } \\
\text { en contacto con las mucosas }\end{array}$ & $\begin{array}{l}\text { Inflamación ocular y de vías aéreas } \\
\text { superiores }\end{array}$ & $10 \mathrm{mg} / \mathrm{m}^{3}$ \\
\hline Dióxido de selenio & $\begin{array}{l}\text { Fundición de cobre o niquel, } \\
\text { calentamiento de aleaciones de selenio }\end{array}$ & $\begin{array}{l}\text { Potente vesicante, forma ácido selenioso } \\
\left(\mathrm{H}_{2} \mathrm{SeO}_{3}\right) \text { sobre las mucosas }\end{array}$ & $\begin{array}{l}\text { Inflamación ocular y de vías aéreas } \\
\text { superiores, edema pulmonar en caso } \\
\text { de exposición masiva }\end{array}$ & \\
\hline Seleniuro de hidrógeno & $\begin{array}{l}\text { Refinado de cobre, producción de ácido } \\
\text { sulfúrico }\end{array}$ & $\begin{array}{l}\text { Hidrosoluble; la exposición a compuestos } \\
\text { de selenio produce aliento con olor a ajo }\end{array}$ & $\begin{array}{l}\text { Inflamación ocular y de vías aéreas } \\
\text { superiores, edema pulmonar retardado }\end{array}$ & \\
\hline Estireno & $\begin{array}{l}\text { Fabricación de poliestireno y resinas, } \\
\text { polímeros }\end{array}$ & Muy irritante & $\begin{array}{l}\text { Inflamación ocular y de vías aéreas } \\
\text { superiores e inferiores, deficiencias } \\
\text { neurológicas }\end{array}$ & 600 \\
\hline Dióxido de azufre & $\begin{array}{l}\text { Refinado de petróleo, trituradoras de } \\
\text { papel, plantas de refrigeración, } \\
\text { fabricación de sulfito sódico }\end{array}$ & Gas muy hidrosoluble & $\begin{array}{l}\text { Inflamación de vías aéreas superiores, } \\
\text { broncoconstricción, neumonitis en caso } \\
\text { de exposición masiva }\end{array}$ & 100 \\
\hline
\end{tabular}


Tabla 10.3 • Resumen de los irritantes respiratorios.

Continuación

\begin{tabular}{|c|c|c|c|c|}
\hline Sustancia química & Fuentes de exposición & Propiedades importantes & Lesiones producidas & $\begin{array}{l}\text { Nivel peligroso } \\
\text { de exposición } \\
\text { por debajo de } \\
15 \text { minutos } \\
\text { (PPM) }\end{array}$ \\
\hline Tetracloruro de titanio & Tintes, pigmentos, publicidad & Los iones cloro forman $\mathrm{HCl}$ en la mucosa & Lesión de vías aéreas superiores & \\
\hline Hexafluoruro de uranio & $\begin{array}{l}\text { Limpiadores de revestimientos de } \\
\text { metal, selladores de suelo, pintura } \\
\text { por pulverización }\end{array}$ & Toxicidad probable de los iones cloro & $\begin{array}{l}\text { Lesión de vías aéreas superiores e } \\
\text { inferiores, broncospasmo, neumonitis }\end{array}$ & \\
\hline Pentaóxido de vanadio & Tanques de aceite limpiador, metalurgia & & $\begin{array}{l}\text { Síntomas oculares y de vías aéreas } \\
\text { superior e inferior }\end{array}$ & 70 \\
\hline Cloruro de zinc & Granadas de humo, artillería & $\begin{array}{l}\text { Más grave que la exposición a óxido } \\
\text { de zinc }\end{array}$ & $\begin{array}{l}\text { Irritación de vías aéreas superiores e } \\
\text { inferiores, fiebre, neumonitis de } \\
\text { comienzo retardado }\end{array}$ & 200 \\
\hline Tetracloruro de circonio & Pigmentos, catalizadores & Toxicidad por iones cloro & $\begin{array}{l}\text { Irritación de vías aéreas superiores e } \\
\text { inferiores, neumonitis }\end{array}$ & \\
\hline
\end{tabular}

Las exposiciones crónicas de bajo nivel a los irritantes pueden provocar síntomas persistentes oculares y de las vías aéreas superiores (K orn, D ockery y Speizer 1987), pero no se ha documentado de forma concluyente un deterioro de la función pulmonar. Los estudios sobre los efectos de los irritantes crónicos de bajo nivel sobre la vía aérea se ven dificultados por la falta de un seguimiento a largo plazo, por el factor de confusión que entraña el consumo de tabaco, por el "efecto del trabajador sano" y por el mínimo o nulo efecto clínico (Brooks y K alica 1987).

Una vez que el paciente se ha recuperado de la lesión inicial es necesario un seguimiento médico regular del mismo. 0 bviamente, debe hacerse todo lo posible por investigar el lugar de trabajo y evaluar las precauciones respiratorias, la ventilación y la contención de los irritantes responsables.

\section{Sustancias químicas tóxicas}

Cuando la exposición es lo suficientemente elevada, la mayor parte de los irritantes respiratorios son tóxicos para el pulmón, aunque hay muchas sustancias químicas que causan lesiones importantes del parénquima pulmonar a pesar de tener propiedades irritantes leves o moderadas. Estos compuestos ejercen sus efectos a través de los mecanismos que se revisan en la Tabla 10.3 y que se han descrito anteriormente. Las toxinas pulmonares tienden a ser menos hidrosolubles que los irritantes de las vías respiratorias superiores. En la Tabla 10.5 se relacionan ejemplos de toxinas pulmonares y de sus fuentes de exposición.

Un grupo de toxinas inhalables recibe el nombre de asfixiantes. Cuando están presentes a elevadas concentraciones, los asfixiantes dióxido de carbono, metano y nitrógeno desplazan al oxígeno y de hecho sofocan a la víctima. El cianuro de

Tabla 10.4 - Mecanismos de lesión pulmonar por sustancias inhaladas.

$\begin{array}{ll}\text { Mecanismo de lesión } & \text { Compuestos de ejemplo } \\ \text { Oxidación } & \text { Ozono, dióxido de nitrógeno, } \\ & \text { dióxido de azufre, cloro, óxidos }\end{array}$

Formación de ácidos Dióxido de azufre, cloro, haluros

Formación de álcalis Amoníaco, óxido de calcio, hidróxidos

Unión a proteínas $\quad$ Formaldehído

Estimulación nerviosa aferente Amoníaco, formaldehído

Antigenicidad

Estimulación de la respuesta inflamatoria del huésped

Formación de radicales libres

Depuración diferida de partículas
Platino, anhídridos ácidos

Oxidos de cobre y zinc, lipoproteínas

Paracuat

Toda inhalación prolongada de polvo mineral
Lesión que se produce

Lesión en placas del epitelio de las vías aéreas, con aumento de la permeabilidad y exposición de las terminaciones de las fibras nerviosas; pérdida de cilios de las células ciliadas; necrosis de neumocitos de tipo I; formación de radicales libres y unión subsiguiente a proteínas y peroxidación lipídica

El gas se disuelve en el agua para formar ácido que lesiona las células epiteliales mediante oxidación; acción principalmente en las vías aéreas superiores

El gas se disuelve en agua para formar una solución alcalina que puede causar licuefacción tisular; lesión predominante de las vías aéreas superiores, vías aéreas inferiores en las exposiciones intensas

Las reacciones con aminoácidos dan lugar a intermediarios tóxicos con lesión de la capa de células epiteliales

La estimulación directa de las terminaciones nerviosas produce síntomas

Las moléculas de bajo peso molecular actúan como haptenos en personas sensibilizadas

Estimulación de citoxinas y de mediadores de la inflamación sin lesión celular directa evidente

Promoción de la formación o del retraso de la depuración de radicales superóxido, que conduce a peroxidación de lípidos y lesión oxidativa

Sobrecarga con partículas de los mecanismos de depuración mucociliar y de macrófagos alveolares, que conduce a una respuesta inflamatoria inespecífica 
Tabla 10.5 - Compuestos con capacidad de toxicidad pulmonar despúes de una exposición leve o moderada.

\begin{tabular}{|c|c|}
\hline Compuesto & Fuentes de exposición \\
\hline Acroleína & $\begin{array}{l}\text { Plásticos, textiles, fabricación de productos farmacéuticos, } \\
\text { productos de combustión }\end{array}$ \\
\hline $\begin{array}{l}\text { Tricloruro de antimonio; } \\
\text { pentacloruro de antimonio }\end{array}$ & Aleaciones, catalizadores orgánicos \\
\hline Cadmio & $\begin{array}{l}\text { Aleaciones con zinc y plomo, electrochapado, acumuladores, } \\
\text { insecticidas }\end{array}$ \\
\hline Cloropicrina & Fabricación de sustancias químicas, componentes de fumigantes \\
\hline Cloro & $\begin{array}{l}\text { Blanqueo, formación de compuestos clorados, limpiadores para } \\
\text { el hogar }\end{array}$ \\
\hline Sulfuro de hidrógeno & Pozos de gas natural, minas, estiércol \\
\hline Hidruro de litio & Aleaciones, cerámicas, electrónica, catalizadores químicos \\
\hline Isocianato de metilo & Síntesis de pesticidas \\
\hline Mercurio & $\begin{array}{l}\text { Electrólisis, extracción de minerales y amalgama, fabricación } \\
\text { de productos de electrónica }\end{array}$ \\
\hline Níquel carbonilo & Refinado del níquel, electrochapado, reactivos químicos \\
\hline Dióxido de nitrógeno & $\begin{array}{l}\text { Silos después del almacenaje de nuevo grano, fabricación de } \\
\text { fertilizante, soldadura por arco; productos de combustión }\end{array}$ \\
\hline $\begin{array}{l}\text { Mostazas nitrogenadas, } \\
\text { mostazas de azufre }\end{array}$ & Agentes del ejército, vesicantes \\
\hline Paracuat & Herbicidas (ingerido) \\
\hline Fosgeno & $\begin{array}{l}\text { Fabricación de pesticidas y de otras sustancias químicas, soldadura } \\
\text { por arco, eliminación de pintura }\end{array}$ \\
\hline Cloruro de zinc & Granadas de humo, artillería \\
\hline
\end{tabular}

Toxicidad
Lesión difusa de las vías aéreas y el parénquima

Neumonitis, edema pulmonar no cardiogénico

Traqueobronquitis, edema pulmonar (a menudo de comienzo diferido 24- 48 horas), lesión renal: proteinuria tubular

Inflamación de vías aéreas superiores e inferiores

Inflamación de las vías aéreas superiores e inferiores, neumonitis y edema pulmonar no cardiogénico

Irritación ocular y de vías aéreas superior e inferior, edema pulmonar diferido, asfixia por hipoxia tisular sistémica

Neumonitis, edema pulmonar no cardiogénico

Irritación del tracto respiratorio superior e inferior, edema pulmonar

Inflamación ocular y del tracto respiratorio, neumonitis, efectos sistémicos y sobre el SNC y el riñón

Irritación respiratoria inferior, neumonitis, efectos tóxicos sistémicos diferidos o retardados

Inflamación ocular y de vías aéreas superiores, edema pulmonar no cardiogénico, bronquiolitis de comienzo retardado

Inflamación ocular y del tracto respiratorio, neumonitis

Lesión selectiva de los neumocitos tipo II que conduce a SDRVA (síndrome de disfunción reactiva de la vía aérea), fibrosis pulmonar, insuficiencia renal, irritación GI

Inflamación de las vías aéreas superiores y neumonitis; edema pulmonar retardado a bajas dosis

Irritación de vías aéreas superiores e inferiores, fiebre, neumonitis de comienzo retardado hidrógeno, el monóxido de carbono y el sulfuro de hidrógeno actúan inhibiendo la respiración celular a pesar de que el aporte de oxígeno a los pulmones sea suficiente. Las toxinas inhaladas no asfixiantes lesionan órganos diana provocando una amplia variedad de problemas de salud y son responsables de mortalidad.

El tratamiento médico de las toxinas pulmonares inhaladas es similar al de los irritantes respiratorios. Estas toxinas a menudo no provocan su efecto clínico máximo hasta transcurridas varias horas de la exposición; en los compuestos capaces de provocar edema pulmonar diferido puede estar indicada la monitorización nocturna. Dado que el tratamiento de las toxinas sistémicas excede los objetivos de este capítulo, se remite al lector a las descripciones de las toxinas individuales recogidas en otras partes de esta Enciclopedia y en otros textos sobre este tema (G oldfrank y cols. 1990; Ellenhorn y Barceloux 1988).

\section{Fiebres por inhalación}

Ciertas exposiciones por inhalación que tienen lugar en diferentes entornos profesionales pueden conducir a enfermedades debilitantes seudogripales de unas horas de duración. Tales trastornos se denominan colectivamente fiebres por inhalación. A pesar de la gravedad de lo síntomas, la toxicidad parece ser autolimitada en la mayoría de los casos, y hay pocos datos que sugieran la existencia de secuelas a largo plazo. La exposición masiva a compuestos desencadenantes es capaz de causar una reacción más grave con neumonitis y edema de pulmón; estos casos infrecuentes se consideran más complicados que la simple fiebre por inhalación.

Las fiebres por inhalación tienen en común la característica de la inespecificidad: el síndrome puede aparecer en prácticamente cualquier persona, dada una exposición suficiente al agente desencadenante. $\mathrm{N}$ o es necesaria la sensibilización, como tampoco lo es la exposición previa. Algunos de estos síndromes muestran el fenómeno de la tolerancia; es decir, con la exposición regular repetida los síntomas no aparecen. Se cree que este efecto está relacionado con un aumento de la actividad de los mecanismos de aclaramiento, aunque no se ha estudiado lo suficiente.

\section{Síndrome del polvo orgánico tóxico}

EI término síndrome del polvo orgánico tóxico (SPOT) es un concepto amplio que hace referencia a los síntomas seudogripales autolimitados que aparecen tras una exposición importante a polvos orgánicos. Este síndrome engloba una amplia gama de enfermedades febriles agudas cuyos nombres derivan de las tareas específicas que conducen a la exposición al polvo. Los síntomas aparecen exclusivamente tras la exposición masiva a un polvo orgánico, y la mayoría de los individuos expuestos desarrollará el síndrome. 
El síndrome del polvo orgánico tóxico recibió anteriormente el nombre de micotoxicosis pulmonar, debido a la supuesta acción etiológica de las esporas de mohos y actinomicetos. En algunos pacientes es posible cultivar especies de Aspergillus, Penicillium, y actinomicetos mesófilos y termófilos (Emmanuel, Marx y Ault 1975; E mmanuel, M arx y Ault 1989). M ás recientemente, se ha propuesto que las endotoxinas bacterianas desempeñan un papel al menos tan importante. Se ha provocado experimentalmente el síndrome mediante la inhalación de la endotoxina derivada de E nterobacter agglomerans, un componente principal del polvo orgánico (Rylander, Bake y Fischer 1989). Se han determinado los niveles de endotoxina en el medio ambiente de las granjas, y los niveles oscilaron entre 0,01 a $100 \mu \mathrm{g} / \mathrm{m}^{3}$. En muchas muestras el nivel fue superior al $0,2 \mu \mathrm{g} / \mathrm{m}^{3}$, que es el nivel al que se sabe aparecen efectos clínicos (M ay, Stallones y Darrow 1989). Se especula acerca de la posibilidad de que las citoquinas, como la IL-1, puedan mediar en los efectos sistémicos, a la vista de lo que ya se conoce sobre la liberación de IL-1 de los macrófagos alveolares en presencia de endotoxinas (R icherson 1990). No es probable que participe un mecanismo alérgico, puesto que no se requiere la sensibilización previa y dado que es necesaria una exposición elevada al polvo.

Desde el punto de vista clínico el paciente suele presentar síntomas entre 2 y 8 horas después de la exposición a grano, heno, lino, cáñamo o astillas de madera (todos ellos habitualmente mohosos), o tras la manipulación de cerdos (Do Pico 1992). L os síntomas a menudo comienzan con irritación ocular y de mucosas asociada a tos seca, que evolucionan a fiebre, malestar, opresión torácica, mialgias y cefalea. EI paciente tiene aspecto de enfermo, pero por lo demás la exploración física es normal. Con frecuencia hay leucocitosis, que puede llegar hasta los 25.000 leucocitos/ $\mathrm{mm}^{3}$. La radiografía de tórax casi siempre es normal. La espirometría puede poner de manifiesto un defecto obstructivo moderado. En los casos en que se realizó fibrobroncoscopia y se realizaron lavados bronquiales se encontró una elevación de los leucocitos en el líquido de lavado. EI porcentaje de neutrófilos era significativamente superior al normal (Emmanuel, M arx y Ault 1989; Lecours, Laviolette y Cormier 1986). La broncoscopia realizada 1 a 4 semanas después del acontecimiento muestra una celularidad elevada persistente, de predominio linfocitario.

En función de la naturaleza de la exposición, el diagnóstico diferencial puede incluir la exposición a gases tóxicos (como dióxido de nitrógeno o amoníaco), en particular si el episodio tuvo lugar en un silo. Debe considerarse la neumonitis por hipersensibilidad, en particular si hay anomalías significativas en la radiografía de tórax o en las pruebas de función pulmonar. Es importante diferenciar la neumonitis por hipersensibilidad (NH) del SPOT: la NH requerirá una evitación estricta de la exposición y tiene peor pronóstico, mientras que el SPOT tiene un curso benigno y autolimitado. EI SPOT se diferencia también de la $\mathrm{NH}$ en que ocurre con mayor frecuencia, requiere niveles más elevados de exposición al polvo, no provoca la liberación de anticuerpos precipitantes del suero y no origina (inicialmente) la alveolitis linfocitaria que es característica de la NH

El tratamiento consiste en la administración de antipiréticos. $\mathrm{N}$ o se ha aconsejado el empleo de esteroides, dada la naturaleza autolimitada de esta enfermedad. Se debe instruir a los pacientes acerca de la necesidad de evitar la exposición masiva. El efecto a largo plazo de los cuadros repetidos se cree que es insignificante. No obstante, este aspecto no se ha estudiado de forma suficiente.

\section{Fiebre por vapores de metal}

L a fiebre por vapores de metal (FVM ) es otra enfermedad seudogripal autolimitada que se desarrolla tras una exposición por inhalación, en este caso a vapores de metal. Este síndrome se produce con mayor frecuencia tras la inhalación de óxido de zinc, como sucede en las fundiciones de latón, y en el fundido o soldadura de metal galvanizado. L os óxidos de cobre y hierro también provocan FVM, y en ocasiones se han visto implicados los vapores de aluminio, arsénico, cadmio, mercurio, cobalto, cromo, plata, manganeso, selenio y estaño (R ose 1992). Los trabajadores desarrollan taquifilaxia; es decir, los síntomas sólo aparecen cuando la exposición tiene lugar después de varios días en ausencia de la misma, no en situación de exposiciones regulares repetidas. La O ccupational Safety and $\mathrm{H}$ ealth Administration (O SH A) ha establecido un T LV de ocho horas de $5 \mathrm{mg} / \mathrm{m}^{3}$ para el óxido de zinc, pero se han provocado síntomas de forma experimental tras una exposición de dos horas a esta concentración (Gordon y cols. 1992).

La patogenia de la FVM sigue sin conocerse con exactitud. El inicio reproducible de los síntomas con independencia del sujeto expuesto es un argumento en contra de una sensibilización inmunitaria o alérgica específica. La falta de síntomas asociados a la liberación de histamina (rubor, prurito, sibilancias, habones) también va en contra de la probabilidad de que participe un mecanismo alérgico. Paul Blanc y colaboradores han desarrollado un modelo que implica a la liberación de citoquinas (Blanc y cols. 1991; Blanc y cols.1993). Estos autores midieron los niveles de factor de necrosis tumoral (TNF), y de las interleuquinas IL-1, IL-4, IL-6 e IL-8 en el líquido de lavado de los pulmones de 23 voluntarios que habían sido expuestos de forma experimental a vapores de óxido de zinc (Blanc y cols. 1993). L os voluntarios desarrollaron niveles elevados de T NF en el lavado broncoalveolar (BAL) a las 3 horas de la exposición. Veinte horas después se observaron niveles elevados en el líquido de BAL de IL-8 (un potente atrayente de neutrófilos) y una marcada alveolitis neutrófila. Se ha comprobado que los monocitos de cultivos expuestos al zinc liberan TNF, una citoquina capaz de causar fiebre y de estimular a las células inmunitarias (Scuderi 1990). En concordancia, la presencia de niveles aumentados de TNF en el pulmón es responsable de la aparición de los síntomas observados en la FVM M. Se sabe que el TNF estimula la liberación de IL-6 y de IL-8, en un período de tiempo que se correlacionaba con los niveles máximos de citoquinas en el líquido de BAL de estos voluntarios. El reclutamiento de estas citoquinas puede ser responsable de la alveolitis neutrofílica resultante y de los síntomas seudogripales que caracterizan la FV M. EI por qué la alveolitis remite con tal rapidez sigue siendo un misterio.

Los síntomas comienzan entre 3 y 10 horas después de la exposición. Inicialmente puede haber un sabor metálico dulce en la boca, asociado a tos seca y disnea progresivas. A menudo el trabajador desarrolla fiebre y escalofríos y se siente enfermo. La exploración física no presenta por lo demás ningún dato destacable. La evaluación de laboratorio muestra la existencia de leucocitosis; la radiografía de tórax es normal. Los estudios de función pulmonar pueden mostrar una leve reducción del FEF $_{25-75}$ y de los niveles de DLCO (N emery 1990; R ose 1992).

Con una buena historia el diagnóstico se establece fácilmente y puede tratarse de forma sintomática al trabajador con antipiréticos. Los síntomas y las anomalías clínicas se resuelven en 24 a 48 horas. Si no es así debe considerarse la posibilidad de que los síntomas tengan una etiología vírica o bacteriana. En casos de exposición extrema, o de exposición relacionada con contaminación por toxinas como el cloruro de zinc, cadmio o mercurio, la FVM puede ser el presagio de una neumonitis química clínica que evolucionará a lo largo de los 2 días siguientes (Blount 1990). Tales casos pueden mostrar infiltrados difusos en la radiografía de tórax y signos de edema pulmonar e insuficiencia respiratoria. Aunque esta posibilidad debe 
considerarse en la evaluación inicial de un paciente expuesto, este curso fulminante es poco frecuente y no es característico de la FV M no complicada.

La FVM no requiere una sensibilidad especial del sujeto afectado a los vapores de metal; más bien indica la existencia de un control ambiental insuficiente. Debe abordarse el problema de la exposición con el fin de evitar la recurrencia de los síntomas. Aunque se considera un síndrome benigno, los efectos a largo plazo de los ataques repetidos de FVM no se ha investigado de forma suficiente.

\section{Fiebre por vapores de polímeros}

La fiebre por vapores de polímeros es una enfermedad febril autolimitada similar a la FV M, pero causada por la inhalación de productos derivados de la pirólisis de fluoropolímeros, incluido el politetrafluoroetano. (PT FE; nombres comerciales Teflon, Fluon, Halon). EI PTFE es muy utilizado por sus propiedades lubricantes, de estabilidad térmica y de aislamiento eléctrico. Es inocuo a menos que se caliente por encima de $300^{\circ} \mathrm{C}$, momento en que comienza a liberar productos de degradación (Shusterman 1993). Esto sucede cuando se sueldan materiales con revestimiento de PTFE, al calentar PTFE con el filo de una herramienta durante el mecanizado a alta velocidad, al manejar máquinas de moldeo o extrusión (R ose 1992) y, rara vez, durante la cirugía endotraqueal con láser (R om 1992a).

Se descubrió una causa frecuente de fiebre por vapores de polímeros después de un período de investigación clásica de salud pública durante los primeros años del decenio de 1970. (Wegman y Peters 1974; K untz y M cC ord 1974). L os trabajadores de la industria textil estaban desarrollando afecciones febriles autolimitadas con la exposición a formaldehído, amoníaco y fibra de nailon; no estaban expuestos a vapores de fluropolímeros, pero manipulaban el polímero triturado. Tras comprobar que los niveles de exposición a los restantes agentes etiológicos posibles se encontraban dentro de límites aceptables, se examinó con más detalle el trabajo con el fluoropolímero. Resultó que sólo presentaban síntomas los fumadores que trabajaban con el mismo. Se planteó la hipótesis de que los cigarrillos estaban siendo contaminados con el fluoropolímero presente en las manos del trabajador, y que a continuación el producto sufría combustión en el cigarrillo cuando éste se fumaba, exponiendo al trabajador a vapores tóxicos. Tras prohibir el consumo de cigarrillos en el lugar de trabajo y establecer estrictas normas de lavado de manos no se comunicaron más enfermedades (Wegman y Peters 1974). Desde entonces, se ha descrito este fenómeno después de trabajar con compuestos impermeabilizantes, compuestos para liberación de moldes (Albrecht y Bryant 1987) y después de utilizar ciertos tipos de ceras para esquíes. (Strom y A lexandersen 1990).

Se desconoce la patogenia de la fiebre por vapores de polímeros. Se cree que es similar a la de otras fiebres por inhalación, debido a su presentación similar y a su aparente respuesta inmunitaria inespecífica. No se han llevado a cabo estudios experimentales con seres humanos; sin embargo, tanto las ratas como las aves desarrolla una grave lesión del epitelio alveolar tras la exposición a productos de la pirólisis del PTFE. (Wells, Slocombe y Trapp 1982; Blandford y cols. 1975). N o se ha realizado una medición exacta de la función pulmonar ni del los cambios en el líquido de BAL.

Los síntomas aparecen varias horas después de la exposición $y$, a diferencia de lo que sucede en la FVM, en este caso no se produce tolerancia, o efecto taquifiláctico. A la debilidad y las mialgias siguen fiebre y escalofríos. A menudo hay opresión torácica y tos. La exploración física es por lo demás normal. Con frecuencia existe leucocitosis, y la radiografía de tórax suele ser normal. Los síntomas se resuelven de forma espontánea en 12 a 48 horas. $\mathrm{Ha}$ habido algunos casos de personas que han desarrollado edema pulmonar tras la exposición; en general, los vapores de PTFE se consideran más tóxicos que los vapores de zinc y de cobre en la génesis de la FVM (Shusterman 1993; Brubaker 1977). Se ha descrito una diffunción crónica de las vías aéreas en personas que habían sufrido episodios múltiples de fiebre por vapores de polímeros (Williams, Atkinson y Patchefsky 1974).

El diagnóstico de la fiebre por vapores de polímeros requiere la realización de una historia meticulosa con un elevado nivel de sospecha clínica. D espués de averiguar la fuente de los productos de pirólisis del PT FE, se debe hacer todo lo posible por prevenir nuevas exposiciones. El lavado de manos obligatorio y la supresión del consumo de tabaco en el lugar de trabajo han eliminado de forma eficaz los casos relacionados con cigarrillos contaminados. Los trabajadores que han sufrido episodios múltiples de fiebre por vapores de polímeros o un edema pulmonar asociado deben someterse a un seguimiento médico a largo plazo.

\section{ASMA OCUPACIONAL}

\section{George Friedman-Jimenez y E dward L. Petsonk}

EI asma es una enfermedad respiratoria caracterizada por obstrucción de las vías aéreas parcial o totalmente reversible, ya sea de forma espontánea o con tratamiento; inflamación de las vías aéreas; y aumento de la reactividad de las vías aéreas a diversos estímulos (NAEP 1991). El asma ocupacional (AO ) es un asma provocada por exposición ambiental en el lugar de trabajo. Se han descrito varios cientos de agentes causantes de AO. La existencia previa de asma o hiperreactividad de las vías aéreas, con síntomas que empeoran con la exposición durante el trabajo a irritantes 0 a estímulos físicos, suele clasificarse de forma independiente como asma agravada por el trabajo (AAT). Se acepta de forma generalizada que el AO se ha convertido en la enfermedad pulmonar ocupacional más prevalente en los países en desarrollo, aunque los cálculos de sus prevalencia e incidencia reales son bastante variables. Es evidente, sin embargo, que en muchos países el asma de etiología ocupacional es responsable de una carga en su mayor parte no reconocida de enfermedad y discapacidad, con unos elevados costes, tanto económicos como no económicos. Gran parte de esta carga de salud pública y económica puede prevenirse en potencia mediante la identificación y el control o la eliminación de las exposiciones en el lugar de trabajo que causan el asma. Este artículo resume los enfoques actuales destinados a identificar, tratar y prevenir el AO. Diversas publicaciones recientes analizan estos aspectos con mayor profundidad. (C han-Yeung 1995; Bernstein y cols. 1993).

\section{Alcance del problema}

La prevalencia del asma en adultos suele oscilar entre el 3 y el $5 \%$, dependiendo de la definición de asma y de variaciones geográficas, y puede ser considerablemente más elevada en ciertas poblaciones urbanas de nivel económico bajo. Se ha comunicado que la proporción de casos de asma del adulto en la población general que guarda relación con el ambiente de trabajo oscila entre el 2 y el $23 \%$, y los cálculos recientes tienden hacia el límite superior. Se han estimado las prevalencias del asma y del AO en pequeñas cohortes y estudios transversales de grupos de alto riesgo ocupacional. En una revisión de 22 estudios seleccionados de lugares de trabajo con exposiciones a sustancias específicas, las prevalencias de asma o de $\mathrm{AO}$, definidas de diferentes 
formas, oscilaron entre el 3 y el $54 \%$, con prevalencias superiores al $15 \%$ en 12 de los estudios (Becklake, en Bernstein y cols. 1993). Este amplio rango refleja variaciones verdaderas de la prevalencia real (debida a diferentes tipos y niveles de exposición). También refleja diferencias en los criterios diagnósticos, y variaciones en la potencia de los sesgos, como el "sesgo del superviviente", que puede deberse a la exclusión de los trabajadores que desarrollaron AO y abandonaron el lugar de trabajo antes de realizarse el estudio. Los cálculos de incidencia en la población oscilan entre 14 por millón de adultos empleados por año en Estados U nidos y 140 por millón de adultos empleados por año en Finlandia (M eredith y N ordman 1996). El descubrimiento de los casos fue más completo y los métodos de diagnóstico generalmente más rigurosos en Finlandia. La evidencia aportada por estas distintas fuentes coincide en su inferencia de que el $\mathrm{AO}$ a menudo se infradiagnostica y/ o se infracomunica y constituye un problema de salud pública de un alcance mayor del que generalmente se reconoce.

\section{Causas del asma ocupacional}

Se ha comunicado más de 200 agentes (sustancias específicas, profesiones o procesos industriales) causantes de $\mathrm{AO}$, según datos epidemiológicos y/ o clínicos. En el AO, la inflamación de las vías aéreas y la broncoconstricción pueden estar causadas por una respuesta inmunitaria a agentes sensibilizantes, por efectos irritantes directos o por otros mecanismos no inmunitarios. Algunos agentes ( $p$. ej., los insecticidas organofosforados) también pueden provocar broncoconstricción por acción farmacológica directa. Se cree que la mayor parte de los agentes descritos inducen una respuesta de sensibilización. L os irritantes respiratorios a menudo empeoran los síntomas en los trabajadores con asma preexistente (es decir, AAT ) y, a niveles elevados de exposición, pueden causar una nueva aparición de asma (denominada síndrome de disfunción reactiva de las vías aéreas (SDRVA) 0 asma inducida por irritantes) (Brooks, Weiss y Bernstein 1985; A lberts y Do Pico 1996).

EI AO puede aparecer con o sin un período de latencia. EI período de latencia hace referencia al tiempo que transcurre entre la exposición inicial y el desarrollo de síntomas, y es sumamente variable. A menudo es inferior a 2 años, pero en cerca del $20 \%$ de los casos es de 10 o más años. EI AO con latencia suele estar causada por sensibilización a uno o más agentes. EI SDRVA es un ejemplo de AO sin latencia.

Los agentes sensibilizantes de alto peso molecular (5.000 daltons ( $\mathrm{Da}$ ) o más) a menudo actúan mediante un mecanismo dependiente de IgE. Los agentes sensibilizantes de bajo peso molecular (menos de 5.000 Da), entre los que se incluyen sustancias químicas altamente reactivas como los isocianatos, pueden actuar a través de mecanismos dependientes de IgE o pueden actuar como haptenos, combinándose con proteínas corporales. Una vez que un trabajador se sensibiliza a un agente, la reexposición (a menudo a niveles muy inferiores al que causó la sensibilización) provoca una respuesta inflamatoria de las vías aéreas, con frecuencia asociada a un aumento de la limitación al flujo aéreo y a una hiperactividad bronquial inespecífica (H R B).

En estudios epidemiológicos sobre el $\mathrm{AO}$, las exposiciones en el lugar de trabajo son de forma constante los determinantes más potentes de la prevalencia del asma, y el riesgo de desarroIlar AO con latencia tiende a incrementarse con la intensidad estimada de la exposición. En estudios de agentes que actúan mediante un mecanismo dependiente de IgE, la atopia es un determinante importante y el tabaco un determinante algo menos constante de aparición de asma. Ninguno de los dos parece ser un determinante importante en los estudios de agentes que actúan mediante mecanismos independientes de IgE.

\section{Presentación clínica}

El espectro de síntomas del AO es similar al del asma no ocupacional: sibilancias, tos, opresión torácica y disnea. En ocasiones los pacientes presentan la variante tusígena o asma nocturna. EI AO ocupacional puede ser grave y discapacitante, y se han comunicado casos de muerte a consecuencia de esta enfermedad. El inicio del AO ocurre debido a un entorno de trabajo específico, de forma que la identificación de las exposiciones que tuvieron lugar en el momento de la aparición de los síntomas de asma es crucial para establecer un diagnóstico exacto. En el AAT, las exposiciones en el lugar de trabajo provocan un aumento significativo de la frecuencia y/ o de la gravedad de los síntomas del asma preexistente.

D iversas características de la historia clínica pueden indicar la existencia de una etiología ocupacional (C han-Yeung 1995). Los síntomas con frecuencia empeoran en el trabajo o por la noche después del trabajo, mejoran en los días libres y recidivan al regresar al trabajo. Pueden empeorar de forma progresiva hacia el final de la semana laboral. El paciente puede advertir que ciertas actividades 0 agentes específicos del lugar del trabajo desencadenan de forma reproducible los síntomas. La irritación ocular y la rinitis relacionadas con el trabajo pueden asociarse a síntomas asmáticos. Estos patrones sintomáticos típicos pueden estar presentes sólo en las fases iniciales del AO. Al principio de la evolución del $\mathrm{AO}$ es habitual la resolución parcial o total durante los fines de semana o las vacaciones, pero con las exposiciones repetidas el tiempo necesario para la recuperación puede aumentar a una o dos semanas, o no producirse la recuperación. La mayoría de los pacientes con $\mathrm{AO}$ en los que se interrumpen las exposiciones siguen teniendo asma sintomática incluso años después de que terminara la exposición, con deterioro y discapacidad permanentes. La continuación de la exposición se asocia a un mayor empeoramiento del asma. La duración breve de los síntomas y el carácter leve de los mismos en el momento de interrumpir la exposición son factores de buen pronóstico y reducen la probabilidad de que la persona sufra asma permanente.

Se han comunicado diversos patrones sintomáticos temporales característicos en el $\mathrm{AO}$. Las reacciones asmáticas precoces ocurren típicamente poco después (menos de una hora) de comenzar el trabajo o la exposición específica responsable del asma. Las reacciones asmáticas tardías comienzan de 4 a 6 horas después de comenzar la exposición, y pueden durar 24 a 48 horas. 0 curren combinaciones de estos patrones en forma de reacciones asmáticas duales con resolución espontánea de los síntomas entre una reacción precoz y otra tardía, o bien como reacciones asmáticas continuas sin resolución de los síntomas entre las fases. $C$ on excepciones, las reacciones precoces tienden a estar mediadas por I gE y las tardías suelen ser independientes de IgE.

El aumento de la HRB, medido en general mediante provocación con metacolina o histamina, se considera una característica cardinal del asma ocupacional. El curso temporal y el grado de HRB pueden ser de utilidad en el diagnóstico y la monitorización. La HR B puede disminuir a las semanas de interrumpir la exposición, aunque a menudo persiste una HRB anómala durante meses 0 años después de interrumpir la exposición. En los sujetos con asma ocupacional inducida por irritantes no cabe esperar que la H R B varíe con la exposición y/ los síntomas.

\section{Identificación y diagnóstico}

Es importante realizar un diagnóstico exacto de AO, dadas las importantes consecuencias negativas tanto de la infravaloración como de la sobrevaloración diagnóstica. En los pacientes con AO o con riesgo de desarrollarla, la identificación, la detección y el control a tiempo de las exposiciones ocupacionales que causan el 
Tabla 10.6 • Definición de caso médico de asma ocupacional del ACC ${ }^{1}$.

Criterios diagnósticos del asma profesional (se requieren los 4, A-D):

(A) Diagnóstico médico de asma y/ 0 pruebas fisiológicas de hiperreactividad de las vías aéreas

(B) La exposición profesional precedió el comienzo de los síntomas de asma ${ }^{1}$

(C) Asociación entre los síntomas de asma y el trabajo

(D) Exposición y/ o pruebas fisiológicas de la relación del asma con el ambiente del trabajo (El diagnóstico de A0 requiere uno 0 más de D2-D5, probablemente el $\mathrm{AO}$ sólo requiera $\mathrm{D1}$ )

(1) Exposición en el lugar de trabajo al agente señalado como causante de AP

(2) Cambios relacionados con el trabajo en el FEV 1 y/ o el PEF

(3) Cambios relacionados con el trabajo en las pruebas seriadas de reactividad bronquial inespecífica ( $p$. ej., prueba de provocación con metacolina)

(4) Prueba de provocación bronquial específica positiva

(5) Comienzo del asma claramente asociado a una exposición sintomática a un irritante inhalado en el lugar de trabajo (generalmente SDRVA)

Criterios diagnósticos de SDRVA (deben cumplirse los 7):

(1) Ausencia documentada de molestias preexistentes de tipo asmático

(2) Comienzo de los síntomas después de un único incidente 0 accidente de exposición

(3) Exposición a un gas, humo, vapor o polvo con propiedades irritantes presente en concentraciones elevadas

(4) Comienzo de los síntomas en las 24 horas siguientes a la exposición con persistencia de síntomas durante al menos 3 meses

(5) Síntomas compatibles con asma: tos, sibilancias, disnea

(6) Presencia de obstrucción al flujo aéreo en las pruebas de función pulmonar y/ o presencia de hiperreactividad bronquial inespecífica (las pruebas deben realizarse poco después de la exposición)

(7) Se han descartado otras enfermedades pulmonares

Criterios diagnósticos del asma agravada por el trabajo (AAT):

(1) Cumple los criterios $A$ y $C$ de la definición de caso médico de AO del ACCP

(2) Asma preexistente o historia de síntomas asmáticos, [ con síntomas activos durante el año anterior al comienzo del empleo 0 de la exposición de interés]

(3) Aumento claro de los síntomas o de las necesidades de medicación, 0 documentación de cambios relacionados con el trabajo del PEF $_{R} 0$ del $\mathrm{FEV}_{1}$ después de comenzar el empleo o la exposición de interés

1 Una definición de caso que requiera A, C y cualquiera de D1 a D5 puede ser de utilidad en la vigilancia del AP, el AAT y el SDRVA.

Fuente: Chan-Yeung 1995

asma aumentan la probabilidad de prevenirla o de obtener una recuperación completa. Esta prevención primaria reduce de forma importante los costes económicos y humanos del asma crónica discapacitante. A la inversa, dado que un diagnóstico de AO puede obligar a un cambio total de profesión, o a costosas actuaciones en el lugar de trabajo, la diferenciación exacta entre el AO y el asma no ocupacional puede prevenir costes sociales y económicos innecesarios tanto a la empresa como a los trabajadores.

$\mathrm{Se}$ han propuesto varias definiciones de caso de $\mathrm{AO}$, adecuadas a diferentes circunstancias. Las definiciones que se consideran de utilidad para la exploración selectiva o la vigilancia del trabajador (H offman y cols. 1990) pueden no ser de todo aplicables desde el punto de vista clínico o con vistas a una compensación. U n consenso de investigadores ha definido el AO
Tabla 10.7 • Pasos en la evaluación diagnóstica del asma en el lugar de trabajo.

Paso 1 Historia médica y profesional completa y exploración física dirigida.

Paso 2 Evaluación fisiológica para detectar una obstrucción reversible de las vías aéreas y/ 0 hiperreactividad bronquial inespecífica.

Paso 3 Valoración inmunológica.

Valoración de la situación laboral:

Trabaja en la actualidad: Proceda primero con el Paso 4

No trabaja en la actualidad, ensayo diagnóstico de vuelta al trabajo factible: Paso 5 primero, a continuación Paso 4.

No trabaja en la actualidad, ensayo diagnóstico de vuelta al trabajo no factible: Paso 6.

Paso 4 Evaluación clínica del asma en el trabajo o ensayo diagnóstico de vuelta al trabajo.

Paso 5 Evaluación clínica del asma alejado del trabajo o ensayo diagnóstico de retirada del trabajo.

Paso 6 Provocación en el lugar de trabajo o pruebas de provocación bronquial específica. Si está disponible para exposiciones causales sospechadas, este paso puede realizarse antes del Paso 4 en cualquier paciente.

Esta pauta pretende ser una guía general para facilitar una evaluación diagnóstica práctica y eficiente Se recomienda que los médicos que diagnostican y tratan el AO consulten también la literatura clínica actual.

como una "enfermedad caracterizada por una limitación al flujo aéreo y/o hiperreactividad de la vía aérea variables, debida a causas y situaciones atribuibles a un ambiente profesional particular y no a estímulos encontrados fuera del lugar de trabajo" (Bernstein y cols. 1993). Esta definición se ha utilizado como una definición de caso médico, resumida en la Tabla 10.6 (ChanYeung 1995).

La evaluación clínica meticulosa del AO puede llevar un tiempo considerable y ser cara y complicada. Puede requerir la realización de ensayos diagnósticos de retirada y reincorporación al trabajo, y a menudo es necesario que el paciente recoja de forma fiable en una gráfica medidas seriadas del máximo flujo espiratorio (PEF). Algunos componentes de la evaluación clínica (p. ej., pruebas específicas de provocación bronquial 0 pruebas cuantitativas para la HRB) pueden no ser fácilmente accesibles para muchos médicos. 0 tros componentes pueden sencillamente ser inalcanzables (p. ej., el paciente ya no trabaja, no se dispone de recursos diagnósticos, las mediciones seriadas del PEF son insuficientes). Es probable que la exactitud diagnóstica aumente si la evaluación clínica es más completa. En cada paciente, las decisiones relativas al alcance de la evaluación médica deberán sopesar los costes de dicha evaluación frente a las consecuencias clínicas, sociales, económicas y de salud pública de realizar un diagnóstico incorrecto o descartar un $\mathrm{AO}$.

Teniendo en cuenta estas dificultades, la Tabla 10.7 presenta un método escalonado para el diagnóstico del AO. Su finalidad es actuar como una guía general que facilite una evaluación diagnóstica exacta, práctica y eficiente, admitiendo que ciertos procedimientos diagnósticos sugeridos en ella pueden no estar disponibles en determinados entornos. El diagnóstico de $A O$ conlleva establecer tanto el diagnóstico de asma como la relación de la misma con exposiciones en el lugar de trabajo. Después de cada paso, y para cada paciente, el médico debe determinar si el nivel de certeza diagnóstica alcanzado es suficiente para apoyar las decisiones necesarias, o si la evaluación 
debe continuar hasta el siguiente paso. Si se dispone de las instalaciones y los recursos necesarios, el tiempo y el coste de continuar la evaluación se suelen ver justificados por la importancia de llevar a cabo una determinación exacta de la relación del asma con el trabajo. Se resumirán los aspectos clave de los procedimientos diagnósticos del $\mathrm{AO}$; se encontrarán detalles en varias de las referencias (Chan-Yeung 1995; Bernstein y cols. 1993). Puede considerarse la consulta con un médico experimentado en $\mathrm{AO}$, dado que el proceso diagnóstico puede ser complicado.

EI SDRVA, cuando está causado por una exposición ocupacional, suele considerarse como una subclase de AO. Se diagnostica clínicamente, utilizando los criterios de la Tabla 10.6. En los pacientes que han experimentado una lesión respiratoria sustancial por inhalaciones de irritantes de alto nivel se debe realizar una evaluación con el fin de detectar la persistencia de síntomas y la presencia de obstrucción al flujo aéreo poco después del acontecimiento. Si la historia clínica es compatible con un SDRVA, la evaluación posterior debe incluir pruebas cuantitativas de HR B, si no están contraindicadas.

EI AAT puede ser frecuente, y causar una importante carga evitable de discapacidad, pero lo publicado en relación con el diagnóstico, tratamiento y pronóstico es escaso. Como se resume en la Tabla 10.6, el AAT se reconoce cuando los síntomas de asma son previos a la exposición causal sospechosa, pero se agravan claramente por el ambiente de trabajo. El empeoramiento en el trabajo puede documentarse, ya sea mediante datos fisiológicos o mediante la evaluación de los registros médicos y la utilización de la medicación. La decisión de diagnosticar de AO 0 de AAT la enfermedad de un paciente con una historia de asma en remisión que presenta una recidiva de síntomas asmáticos y que por lo demás cumple los criterios de $\mathrm{AO}$ es un juicio clínico. Se ha propuesto un año como un período lo suficientemente largo como para que la aparición de síntomas represente probablemente un proceso nuevo provocado por exposición en el lugar de trabajo, aunque todavía no existe consenso al respecto.

\section{Paso 1: H istoria médica y ocupacional completas y exploración física dirigida.}

La sospecha inicial de una posible AO en situaciones clínica y de lugar de trabajo apropiadas es un elemento clave, dada la importancia de un diagnóstico y una intervención precoces para mejorar el pronóstico. El diagnóstico de AO o de AAT debe considerarse en todos los pacientes asmáticos que desarrollaron los síntomas siendo trabajadores adultos. (especialmente de aparición reciente) 0 en quienes la gravedad del asma ha aumentado de forma sustancial. También debe considerarse el AO en cualquier otro sujeto que presente síntomas de tipo asmático y que desempeñe un trabajo en el que se encuentre expuesto a agentes causantes de asma, o en aquellos que sospechen que sus síntomas están relacionados con el trabajo.

Se debe pedir a los pacientes con posible AO que proporcionen una historia profesional/ medioambiental completa, con una cuidadosa documentación de la naturaleza y la fecha del inicio de los síntomas y del diagnóstico de asma, así como de posibles exposiciones causales en ese momento. Debe evaluarse la compatibilidad de la historia médica con la presentación clínica del AO descrita anteriormente, en particular el patrón temporal de los síntomas en relación con el horario de trabajo y con cambios en las exposiciones profesionales. Debe tomarse nota de las pautas de utilización de las medicaciones para el asma y de sus modificaciones, así como del período de tiempo mínimo fuera del trabajo necesario para obtener una mejoría de los síntomas. Son datos de interés a tener en cuenta las enfermedades respiratorias previas, las alergias/atopia, el hábito de fumar y otras exposiciones a agentes tóxicos, así como una historia familiar de alergia.

La exposición ocupacional y otras exposiciones ambientales a posibles agentes o procesos causantes de asma debe estudiarse a conciencia, con una documentación objetiva de las exposiciones si es posible. Las exposiciones sospechadas deben compararse con una lista exhaustiva de agentes documentados como causantes de AO (Harber, Schenker y Balmes 1996; ChanYeung y Malo 1994; Bernstein y cols. 1993; Rom 1992b), aunque la incapacidad para identificar agentes específicos no es infrecuente y la inducción de asma por agentes no descritos previamente también es posible. Algunos ejemplos ilustrativos se muestran en la Tabla 10.8. La historia profesional debe incluir detalles de empleos actuales y pasados de interés, con fechas, cargos desempeñados, tareas y exposiciones, sobre todo en relación con el trabajo actual y con el que desempeñaba el paciente en el momento de iniciarse los síntomas. Otros datos de la historia ambiental deben comprender una revisión de las exposiciones en el hogar o la comunidad que podrían causar asma. Resulta de utilidad comenzar la historia de la exposición de forma abierta, preguntando acerca de categorías amplias de agentes transportados por el aire: polvos (especialmente polvos

Tabla 10.8 - Agentes sensibilizantes que pueden causar asma ocupacional.

\section{Clasificación \\ Antígenos de proteínas de alto} peso molecular

Sustancias derivadas de plantas

Bajo peso molecular / sensibilizantes químicos

Plastificadores, pinturas de 2 partes, adhesivos, espumas

Metales

Polvos de madera

Productos farmacéuticos, medicamentos
Ejemplos de sustancias

Animales de laboratorio, cangrejo/ marisco, ácaros, insectos

Polvos de harina y grano, guantes de látex de caucho natural, enzimas bacterianas, polvo de ricino, gomas vegetales

Isocianatos, anhídridos ácidos, aminas

Sales de platino, cobalto

Cedro (ácido plicático), roble

Psilio, antibióticos

Cloramina T, vapores de polivinil cloruro, insecticidas organofosforados
Ejemplos de trabajos e industrias

Manipuladores de animales, y cultivo y preparación de los alimentos

Panaderías, trabaiadores de asistencia sanitaria, fabricación de detergente, preparación de alimentos

Pintura con autopulverización, barnizado, trabajo con madera

Refinerías de platino, molienda de metal

Trabajo de serrería, carpintería

Fabricación y envasado de productos farmacéuticos

Trabajo de conserjería, envasado de carne 
orgánicos de origen animal, vegetal o microbiano), sustancias químicas, productos farmacéuticos y gases o vapores irritantes 0 visibles. Puede que el paciente identifique agentes específicos, procesos laborales o categorías genéricas de agentes que hayan desencadenado los síntomas. El pedir al paciente que describa paso a paso las actividades y exposiciones relacionadas con la jornada laboral sintomática más reciente puede proporcionar pistas útiles. Los materiales utilizados por compañeros de trabajo, o los liberados en altas concentraciones a partir de un vertido 0 de otra fuente pueden ser importantes. A menudo se puede obtener información adicional sobre el nombre del producto, los ingredientes y el nombre del fabricante, su dirección y número de teléfono. Es posible identificar agentes específicos llamando al fabricante 0 a través de diversas otras fuentes, como libros de texto, bases de datos en CD ROM o en centros de control de intoxicaciones. Dado que el AO es causada con frecuencia por niveles bajos de alergenos transportados por el aire, las inspecciones de higiene industrial en el lugar de trabajo que evalúan de forma cualitativa las exposiciones y las medidas de control a menudo son de mayor utilidad que la medición cuantitativa de los contaminantes atmosféricos.

La historia clínica parece ser más adecuada para excluir que para confirmar el diagnóstico de $\mathrm{AO}$, y una historia abierta realizada por un médico es mejor que un cuestionario cerrado. En un estudio se compararon los resultados de una historia clínica abierta realizada por especialistas en AO con un "patrón oro" de prueba de provocación bronquial específica en 162 pacientes remitidos para evaluación de una posible AO. Los investigadores comunicaron que la sensibilidad de una historia clínica indicativa de AO era del $87 \%$, la especificidad del $55 \%$, el valor predictivo positivo del $63 \%$ y el valor predictivo negativo del $83 \%$. En este grupo de pacientes remitidos, la prevalencia de asma y de AO fue del $80 \%$ y el $46 \%$ respectivamente (M alo y cols. 1991). En otros grupos de pacientes remitidos, los valores predictivos positivos de un cuestionario cerrado oscilaron entre el 8 y el $52 \%$ para diferentes exposiciones en el lugar de trabajo. (Bernstein y cols. 1993). L a aplicabilidad de estos resultados a otros entornos debe ser valorada por el médico.

La exploración física en ocasiones resulta de utilidad, y deben anotarse los hallazgos relacionados con el asma (p. ej., sibilancias, pólipos nasales, dermatitis eccematosa), irritación o alergia respiratoria (p. ej., rinitis, conjuntivitis) u otras posibles causas de síntomas.

\section{Paso 2: Evaluación fisiológica para determinar una obstrucción reversible de las vías aéreas y/o hiper reactividad bronquial inespecífica}

Si el registro médico contiene suficientes datos fisiológicos que apoyen el diagnóstico de asma (NAEP 1991) es posible prescindir del Paso 2. En caso contrario, debe realizarse una espirometría dirigida por un técnico, a ser posible después de un turno de trabajo en un día en que el paciente esté experimentando síntomas de asma. Si la espirometría pone de manifiesto la existencia de una obstrucción de las vías aéreas que revierte con broncodilatador se confirma el diagnóstico de asma. En los pacientes que no presentan datos claros de obstrucción al flujo aéreo en la espirometría deben realizarse pruebas cuantitativas de HRB utilizando metacolina o histamina, a ser posible el mismo día. Dichas pruebas de HRB en esta situación son un procedimiento crucial por dos motivos. En primer lugar, a menudo son capaces de identificar a los pacientes que presentan un $\mathrm{AO}$ leve 0 en sus primeras fases, que son los que más probabilidades tienen de curarse, pero que se pasarían por alto si las pruebas se detuvieran al obtener una espirometría normal. En segundo lugar, si la HRB es normal en un trabajador que está sometido a exposición continuada en el medio ambiente de trabajo asociada a los síntomas, en general puede descartarse el AO sin realizar más pruebas. Si es anormal, la evaluación puede continuar a los Pasos 304 , y el grado de HR B puede ser de utilidad para monitorizar al paciente y detectar una mejoría después de realizar un ensayo diagnóstico de retirada del sujeto de la exposición causal sospechada (Paso 5). Si la espirometría revela una limitación significativa del flujo aéreo que no mejora con el broncodilatador por vía inhalatoria, debe considerarse la realización de una reevaluación después de un ensayo de tratamiento más prolongado que incluya la administración de corticoides. (AT S 1995; NAEP 1991).

\section{Paso 3: Valoración inmunológica, si procede}

L as pruebas cutáneas o serológicas (p. ej., R AST ) permiten demostrar una sensibilización inmunológica a un agente específico del lugar de trabajo. Estas pruebas inmunológicas se han usado para confirmar la relación del asma con un trabajo dado y, en algunos casos, eliminan la necesidad de realizar pruebas específicas de provocación por inhalación. Por ejemplo, entre un conjunto de pacientes expuestos al psilio y con una historia clínica compatible con AO, asma documentada o hiperreactividad de las vías aéreas y evidencias de sensibilización inmunológica al psilio, en cerca del $80 \%$ se confirmó la existencia de AO mediante pruebas específicas de provocación bronquial (M alo y cols. 1990). En la mayoría de los casos, la importancia diagnóstica de las pruebas inmunológicas negativas es menos clara. La sensibilidad diagnóstica de las pruebas inmunológicas depende fundamentalmente de que estén incluidos en las pruebas todos los antígenos causales probables del lugar de trabajo o los complejos hapteno-proteína. Aunque no se ha definido con exactitud la implicación de la sensibilización para un paciente asintomático, el análisis de los resultados agrupados puede ser de utilidad para evaluar los controles ambientales. L a utilidad de la evaluación inmunológica es mayor para los agentes para los que existen test estandarizados in vitro o reactivos cutáneos para Prick-Test, como sales de platino y detergentes enzimáticos. Por desgracia, la mayoría de los alergenos profesionales de interés no se encuentran en la actualidad disponibles en el mercado. La utilización de soluciones no comerciales en las pruebas de punción cutánea (Prick-Test) se ha asociado en ocasiones a reacciones graves, entre ellas anafilaxia, por lo que es preciso actuar con precaución.

Si los resultados de los Pasos 1 y 2 son compatibles con $A O$, debe procederse a realizar una evaluación adicional si es posible. EI orden y el alcance de la misma dependen de la disponibilidad de recursos diagnósticos, de la situación laboral del paciente y de la posibilidad de realizar ensayos diagnósticos de retirada y reincorporación al trabajo, según se indica en la Tabla 10.7. Si no es posible realizar una evaluación adicional, el diagnóstico debe basarse en la información disponible en este momento.

\section{Paso 4: Evaluación clínica del asma en el trabajo, o ensayo diagnóstico de reincorporación al trabajo.}

Con frecuencia, la prueba fisiológica más asequible de obstrucción de las vías aéreas es la espirometría. Con el fin de mejorar la reproducibilidad, la espirometría debe ser dirigida por un técnico preparado. Por desgracia, la espirometría de un solo día realizada antes y después del turno de trabajo no es sensible ni específica para determinar la obstrucción de las vías aéreas asociada al trabajo. Es probable que si se realizaran espirometrías múltiples cada día durante y después de varios días laborales, la exactitud diagnóstica mejoraría, aunque este aspecto no se ha evaluado adecuadamente todavía.

Debido a las dificultades de la espirometría realizada antes y después del turno de trabajo, la medición seriada del PEF se ha convertido en una importante técnica diagnóstica para el AO. U tilizando un medidor portátil de bajo costo, las mediciones de PEF se registran cada dos horas durante las horas de vigilia. Para 
mejorar la sensibilidad, las mediciones deben realizarse durante un período en el que el trabajador esté expuesto a los agentes causales sospechados en el trabajo y esté experimentando un patrón de síntomas relacionados con el trabajo. Las mediciones se repiten tres veces cada una de las ocasiones, y se realizan cada día en el trabajo y fuera de él. D eben continuarse durante un mínimo de 16 días consecutivos ( $p$. ej., dos semanas laborales de cinco días y tres fines de semana libres) si el paciente tolera sin riesgos el continuar trabajando. Las mediciones del PEF se registran en un diario junto con anotaciones sobre las horas laborales, los síntomas, el uso de medicaciones broncodilatadoras y las exposiciones importantes. Para facilitar la interpretación, los resultados del diario se deben representar a continuación en un gráfico. Ciertos patrones sugieren $\mathrm{AO}$, pero ninguno es patognomónico, y a menudo es de utilidad la colaboración de un lector experto en la interpretación de los datos. L as ventajas de las pruebas seriadas de PEF son su bajo coste y su razonable correlación con los resultados de las pruebas de provocación bronquial. Las desventajas son el grado importante de colaboración requerido por parte del paciente, la incapacidad para confirmar definitivamente que los datos son exactos, la ausencia de un método de interpretación normalizado y la necesidad de que ciertos trabajadores se ausenten durante 1 ó 2 semanas consecutivas del trabajo para mostrar una mejoría significativa. L os espirómetros electrónicos portátiles diseñados para la automonitorización del paciente, si se dispone de ellos, pueden resolver algunos de los inconvenientes de las pruebas seriadas de PEF.

Las medicaciones contra el asma tienden a reducir el efecto de las exposiciones laborales sobre las mediciones del flujo aéreo.Sin embargo, no es recomendable interrumpir la medicación durante la monitorización del flujo aéreo en el trabajo. Es mejor que el paciente se mantenga con una dosis mínima constante de seguridad de fármacos antiinflamatorios durante todo el proceso diagnóstico, con una estrecha monitorización de los síntomas y de las vías aéreas, anotando en el diario la utilización de broncodilatadores de acción corta.

La no observación de cambios en el PEF relacionados con el trabajo mientras un paciente está trabajando sus horas habituales no excluye el diagnóstico de $\mathrm{AO}$, ya que muchos pacientes necesitan más de un fin de semana de dos días para mostrar una mejoría significativa del PEF. En este caso, debe considerarse la posibilidad de una prueba diagnóstica de retirada del trabajo ampliada (Paso 5). Si el paciente todavía no se ha sometido a pruebas cuantitativas de HRB y no existen contraindicaciones médicas, éste es el momento de realizarlas, inmediatamente después de al menos dos semanas de exposición en el lugar de trabajo.

\section{Paso 5: Evaluación clínica del asma fuera del lugar de trabajo} o ensayo diagnóstico de alejamiento prolongado del trabajo.

En este paso se completa el diario de medición seriada diaria del PEF cada 2 horas durante al menos 9 días consecutivos fuera del trabajo (p. ej., 5 días sin acudir al trabajo más los fines de semana previo y siguiente a dichos días). Si este registro, comparado con el diario de medición seriada del PEF en el trabajo, no es suficiente para diagnosticar $\mathrm{AO}$, debe continuarse durante una segunda semana consecutiva fuera del trabajo. Después de 20 más semanas sin acudir al trabajo, se pueden llevar a cabo las pruebas cuantitativas de HRB, que se compararán con las pruebas de HRB en el trabajo. Si todavía no se han realizado las pruebas seriadas de PEF durante al menos dos semanas en el trabajo, puede llevarse a cabo un ensayo diagnóstico de reincorporación al trabajo (véase Paso 4) después de un asesoramiento detallado y en estrecho contacto con el médico encargado del tratamiento. EI Paso 5 tiene a menudo una importancia fundamental para la confirmación o exclusión del diagnóstico de AO, aunque puede ser el paso más complicado y de mayor coste económico. Si se intenta una retirada del trabajo prolongada, conviene potenciar al máximo el rendimiento diagnóstico y la eficiencia incluyendo pruebas de PEF, FEV y HRB en una sola evaluación completa. L as visitas semanales al médico para asesoramiento y para revisar la gráfica de PEF pueden ayudar a asegurar unos resultados completos y exactos. Si, después de monitorizar al paciente durante al menos dos semanas en el trabajo y dos semanas fuera de él, las evidencias diagnósticas siguen siendo insuficientes, debe considerarse el Paso 6, si es asequible y factible.

\section{Paso 6: Pruebas de provocación bronquial específica 0 de provocación en el trabajo}

Las pruebas de provocación bronquial específica utilizando una cámara de exposición y niveles de exposición normalizados se ha denominado el "patrón oro" del diagnóstico del AO. Las ventajas consisten en la obtención de la confirmación definitiva de $A O$, con la capacidad de identificar una respuesta asmática a niveles subirritantes de agentes sensibilizantes específicos, que a partir de entonces pueden ser escrupulosamente evitados. De todos los métodos diagnósticos, es el único que permite distinguir de forma fidedigna el asma inducida por un sensibilizante de la provocación por irritantes. Este método ha presentado diversos problemas, como el alto coste económico del procedimiento, la necesidad general de una estrecha observación o de hospitalización durante varios días y la disponibilidad del mismo en muy escasos centros especializados. Pueden producirse falsos negativos si no se dispone de metodología normalizada para todos los agentes sospechosos, si se sospecha de agentes equivocados o si ha transcurrido demasiado tiempo entre la última exposición y la realización de las pruebas. Pueden producirse falsos positivos si se alcanzan inadvertidamente niveles irritantes de exposición. Por estos motivos las pruebas de provocación bronquial específica para el AO siguen siendo un procedimiento de investigación en la mayoría de los lugares.

Las pruebas de provocación en el lugar de trabajo consisten en una espirometría dirigida por un técnico en el lugar de trabajo, realizada a intervalos frecuentes (p. ej., cada hora), antes y durante el curso de la exposición en un día laboral a los agentes o procesos causales sospechados. Puede ser más sensible que las pruebas de provocación bronquial específica, ya que implica exposiciones "de la vida real" pero, dado que la obstrucción de las vías aéreas puede verse desencadenada por irritantes además de por agentes sensibilizantes, la positividad de las pruebas no indica necesariamente sensibilización. También requiere la colaboración de la empresa y mucho tiempo del técnico utilizando un espirómetro portátil. Ambos procedimientos conllevan cierto riesgo de precipitar una grave crisis asmática, por lo que deben realizarse bajo estrecha supervisión de especialistas experimentados en ellos.

\section{Tratamiento y prevención}

EI tratamiento del AO consiste en intervenciones médicas y preventivas individualizadas para cada paciente, así como medidas de salud pública en lugares de trabajo identificados como de alto riesgo para el AO. El tratamiento médico es similar al utilizado para el asma no ocupacional y se analiza en detalle en otras partes (N AEP 1991). El tratamiento médico aislado rara vez es suficiente para controlar de forma óptima los síntomas, y la intervención preventiva mediante el control o la interrupción de la exposición forma parte integral del tratamiento Este proceso comienza con un diagnóstico exacto y con la identificación de las exposiciones y situaciones causales. En el AO inducida por sensibilizantes, la reducción de la exposición al sensibilizante no suele conducir a la resolución completa de los síntomas. Las 
exposiciones a concentraciones muy bajas del agente pueden provocar episodios asmáticos graves o un empeoramiento progresivo de la enfermedad, por lo que se recomienda la interrupción permanente y completa de la exposición. El envío oportuno del paciente a un programa de rehabilitación laboral y de reconversión profesional puede ser un componente necesario del tratamiento en algunos pacientes. Si no es posible interrumpir por completo la exposición, una alternativa puede ser la reducción sustancial de la exposición, asociada a un estrecho control y tratamiento médicos, aunque la reducción de la exposición no siempre es factible y no se ha comprobado la seguridad a largo plazo de este método. Por poner un ejemplo, sería difícil justificar la toxicidad del tratamiento a largo plazo con corticosteroides sistémicos con el fin de permitir que el paciente continuara en el mismo empleo. En el caso del asma inducida y/o desencadenada por irritantes, la respuesta a la dosis puede ser más previsible, y la reducción de los niveles de exposición a irritantes, asociado a una monitorización médica estrecha, puede ser menos arriesgado y tiene más probabilidades de ser eficaz que en el caso del AO inducida por sensibilizantes. Si el paciente continúa trabajando en condiciones modificadas, el seguimiento debe incluir visitas frecuentes al médico con una revisión del diario de PEF, un acceso bien planificado a los servicios de urgencias y espirometría seriada y/o pruebas de provocación con metacolina, según proceda.

Cuando se sospecha que un determinado lugar de trabajo es de alto riesgo, ya sea debido a la aparición de un caso centinela de AO o por el uso de agentes con capacidad conocida de causar asma, los métodos de salud pública pueden ser de gran utilidad. La identificación precoz y el tratamiento y la prevención eficaces de la discapacidad de los trabajadores con un AO existente, así como la prevención de nuevos casos, son objetivos prioritarios evidentes. Es importante identificar al (los) agente(s) causal(es) específico(s) y los procesos de trabajo específicos. U n método inicial práctico consiste en realizar una investigación del lugar de trabajo con un cuestionario, evaluando los criterios $A$, $B, C$ y D1 o D 5 en la definición de caso de AO. Este método permite identificar sujetos en los que podría estar indicada una evaluación clínica adicional y ayuda a identificar posibles agentes o circunstancias causales. La evaluación de los resultados de grupo puede ayudar a decidir si es necesario continuar investigando el lugar de trabajo o si está indicada la intervención $y$, en tal caso, proporcionar una guía útil para centrar futuros esfuerzos de prevención de la forma más eficaz y eficiente posible. Sin embargo, la investigación con cuestionario no es suficiente para establecer diagnósticos médicos individuales, ya que los valores predictivos positivos de los cuestionarios del $A O$ no son lo suficientemente elevados. Si se necesita un nivel más alto de certeza diagnóstica se puede considerar también la detección selectiva médica utilizando procedimientos diagnósticos como la espirometría, pruebas cuantitativas de HRB, registro seriado del PEF y pruebas inmunológicas. En lugares de trabajo con problemas conocidos, la vigilancia continuada y los programas de detección selectiva pueden ser de utilidad. Sin embargo, la exclusión diferencial de los trabajadores asintomáticos con historia de atopia u otros factores potenciales de susceptibilidad de lugares de trabajos considerados de alto riesgo conduciría a la retirada de un elevado número de trabajadores para prevenir relativamente pocos casos de AO, y la literatura médica actual no la respalda.

El control o la eliminación de las exposiciones causales y la evitación y el control adecuado de los vertidos o de los episodios de exposiciones de alto nivel pueden llevar a una prevención primaria eficaz de la sensibilización y del AO en los compañeros del caso centinela. La jerarquía habitual de control de la exposición mediante controles de sustitución, ingeniería y administrativos, junto con el equipo de protección personal, así como la formación de los trabajadores y los directivos, debe ponerse en práctica según proceda. Las empresas proactivas iniciarán o participarán en algunos de estos métodos, pero en caso de que se tomen medidas preventivas insuficientes y los trabajadores sigan encontrándose en situación de alto riesgo, los organismos gubernamentales pueden ser de utilidad.

\section{Menoscabo e incapacidad}

M enoscabo médico o disfunción; se define como una anomalía funcional debida a un trastorno médico. D iscapacidad; hace referencia al efecto total de la deficiencia médica sobre la vida del paciente, y se ve influida por numerosos factores no médicos, como la edad y el estado socioeconómico (ATS 1995).

La valoración del menoscabo médico corresponde al médico y puede incluir un índice de menoscabo calculado, así como otras consideraciones clínicas. El índice de menoscabo se basa en: 1) el grado de limitación al flujo aéreo tras la administración de un broncodilatador, 2) el grado de reversibilidad de la limitación al flujo aéreo con el broncodilatador o el grado de hiperreactividad en las pruebas cuantitativas de HRB, y 3) la medicación mínima necesaria para controlar el asma. El otro componente principal de la valoración del menoscabo médico es el criterio del médico respecto a la capacidad del paciente para trabajar en el lugar de trabajo causante de asma. Por ejemplo, un paciente con $\mathrm{AO}$ inducida por un sensibilizante puede presentar un menoscabo médico sumamente específico para el agente al cual se ha sensibilizado. El trabajador que sólo experimenta síntomas cuando se expone a ese agente puede ser capaz de trabajar en otros puestos de trabajo, pero será permanentemente incapaz de trabajar en el puesto específico para el cual tiene mayor formación y experiencia.

En la valoración de la incapacidad debida a asma (incluida el AO) se requiere tener en cuenta el menoscabo médico además de otros factores no médicos que afectan a la capacidad laboral y funcional en la vida diaria. La valoración de la incapacidad la realiza inicialmente el médico, quien debe identificar todos los factores que influyen en el impacto del menoscabo sobre la vida del paciente. Muchos factores, como la profesión, el nivel de educación, la posesión de otras aptitudes de valor comercial, condiciones económicas y otros factores sociales, pueden conducir a niveles variables de incapacidad en individuos con el mismo nivel de menoscabo médico. Los administradores pueden entonces utilizar esta información para determinar la incapacidad de cara a la indemnización.

El menoscabo y la incapacidad se pueden clasificar como temporales o permanentes, dependiendo de la probabilidad de que se produzca una mejoría significativa, así como de si se están poniendo en práctica controles de exposición eficaces en el lugar de trabajo. Por ejemplo, se suele considerar que una persona con $\mathrm{AO}$ inducida por un sensibilizante presenta un menoscabo permanente y total para cualquier trabajo que conlleve la exposición al agente causal. Si los síntomas se resuelven de forma parcial o completa después de la interrupción de la exposición, tales personas pueden clasificarse con menor o ningún menoscabo para otros trabajos. A menudo esto se considera un menoscabo/ incapacidad permanente parcial, aunque la terminología puede variar. Un individuo con asma que se desencadena dependiendo de la dosis de irritantes presentes en el lugar de trabajo se consideraría que tiene un menoscabo temporal mientras estuviera sintomático, menoscabo que sería menor o nulo si se instalaran controles de exposición suficientes y éstos fueran eficaces para reducir o eliminar lo síntomas. Si no se ponen en práctica controles de exposición eficaces, el mismo individuo tendría que ser clasificado en el grupo de los menoscabos permanentes para trabajar en ese 
puesto particular, con una recomendación de ser retirado del trabajo por causas médicas. Si es necesario, puede llevarse a cabo una valoración repetida del menoscabo/ incapacidad a largo plazo, dos años después de reducida o interrumpida la exposición, cuando sería de esperar que se hubiera estabilizado la mejoría del AO. Si el paciente continúa trabajando, debe realizarse una monitorización médica continuada y la nueva valoración del menoscabo/ incapacidad debe repetirse según sea necesario.

Los trabajadores que quedan discapacitados a consecuencia de AO o de AAT pueden ser aptos para recibir una indemnización económica por gastos médicos y/ o salarios perdidos. Además de reducir de forma directa el impacto económico de la incapacidad sobre los trabajadores y sus familias, la indemnización puede ser necesaria para proporcionar tratamiento médico adecuado, poner en marcha intervenciones preventivas y obtener una rehabilitación profesional. El conocimiento, por parte del trabajador y de su médico, de determinados aspectos medicolegales puede ser importante para asegurarse de que la evaluación diagnóstica cumple los requerimientos locales y no compromete los derechos del trabajador afectado.

Aunque las discusiones en torno al ahorro de costes a menudo se centran en la insuficiencia de los sistemas de compensación, la reducción genuina de la carga económica y de salud pública impuesta a la sociedad por el AO y el AAT no sólo depende de las mejoras de los sistemas de compensación sino, lo que es más importante, de la eficacia de los sistemas desplegados para identificar, rectificar o prevenir por completo las exposiciones en el lugar de trabajo, que son las responsables de la aparición de nuevos casos de asma.

\section{Conclusiones}

EI AO se ha convertido en la enfermedad respiratoria de origen ocupacional más prevalente en muchos países. Es más frecuente de lo que generalmente se admite, puede ser grave y discapacitante, y en general se puede prevenir. La identificación precoz y las intervenciones preventivas eficaces pueden reducir de forma sustancial el riesgo de incapacidad permanente y los elevados costes humanos y económicos asociados al asma crónica. Por numerosas razones, el AO merece una atención más extendida entre los médicos, los especialistas en salud y seguridad, los investigadores, los creadores de la política sanitaria, los higienistas industriales y todas las personas y organismos interesados en la prevención de las enfermedades relacionadas con el trabajo.

\section{- EN FER MEDADES CAUSADAS POR POLVOS ORGANICOS}

\section{Ragnar R ylander y Richard S. F. Schilling}

\section{Polvos orgánicos y enfermedad}

Los polvos de origen vegetal, animal y microbiano siempre han formado parte del medio ambiente del ser humano. Cuando los primeros organismos acuáticos se trasladaron a la tierra hace unos 450 millones de años, pronto desarrollaron sistemas de defensa frente a las numerosas sustancias nocivas presentes en el medio ambiente terrestre, la mayoría de origen vegetal. Las exposiciones a este medio ambiente no suelen causar problemas específicos, aunque las plantas contienen diversas sustancias extremadamente tóxicas, en particular las presentes en los mohos o producidas por ellos.

Durante el desarrollo de la civilización, las condiciones climáticas de ciertas partes del mundo hicieron necesario desarrollar determinadas actividades a cubierto. En los países escandinavos las labores de trillado se llevaban a cabo en el interior de las casas durante el invierno, una práctica mencionada por los cronistas de la antigüedad. La realización de procesos relacionados con polvos en recintos cerrados condujo al desarrollo de enfermedades entre las personas expuestas. U na de las primeras descripciones publicadas de este hecho procede del obispo danés O laus M agnus (1555, según cita de Rask-Andersen 1988), el cual describió una enfermedad que aquejaba a los trilladores escandinavos en los siguientes términos:

"Al separar el grano de la barcia ha de tenerse cuidado de elegir un momento en el que sople un viento adecuado que se lleve de nuestro lado el polvo del grano, de tal forma que no dañe los órganos vitales de los trilladores. Es un polvo tan fino que de forma casi imperceptible penetra en la boca y se acumula en la garganta. Si esta situación no se resuelve rápidamente bebiendo cerveza fresca, es posible que el trillador nunca vuelva a comer lo que ha trillado o sólo tenga oportunidad de probarlo durante un corto tiempo."

Con la introducción del procesamiento mecanizado de los materiales orgánicos, el tratamiento de grandes cantidades de materiales en un espacio cerrado y con una ventilación insuficiente condujo a niveles elevados de polvos transportados por el aire. A las descripciones del obispo O laus M agnus y posteriormente de Ramazzini (1713) siguieron diversos informes sobre enfermedades y polvos orgánicos en el siglo XIX, particularmente entre trabajadores de hilanderías de algodón (Leach 1863; Prausnitz 1936). Posteriormente también se describió la enfermedad pulmonar específica de los granjeros que manipulaban materiales mohosos (C ampbell 1932).

Durante los últimos decenios se han publicado un gran número de informes sobre enfermedades que afectaban a personas expuestas a polvos orgánicos. En un primer momento la mayoría se basaba en sujetos que solicitaban asistencia médica. Los nombres de las enfermedades, cuando se publicaban, a menudo estaban relacionados con el medio ambiente particular en el que se identificó por primera vez la enfermedad, lo que dio lugar a un conjunto desconcertante de nombres tales como pulmón del granjero, pulmón del cultivador de setas, pulmón pardo y fiebre por humidificador.

Tabla 10.9 - Ejemplos de fuentes de riesgo de exposición a polvo orgánico.

$\begin{array}{ll}\text { Agricultura } & \text { Industria } \\ \text { Manipulación de grano, heno } & \text { Preparación de la fibra vegetal } \\ \text { y otros cultivos } & \text { (algodón, lino, cáñamo, yute, } \\ \text { Preparación de la caña de azúcar } & \text { pita) } \\ \text { Invernaderos } & \text { Fermentación } \\ \text { Silos } & \text { Preparación de troncos y madera } \\ \text { Animales } & \text { Panaderías } \\ \text { Edificios de confinamiento de } & \text { Tratamiento en biotecnología } \\ \text { cerdos/ ganado lechero } & \\ \text { Gallineros y plantas procesadoras } & \text { Edificios } \\ \text { Animales de laboratorio, animales } & \text { Agua contaminada de los } \\ \text { de granja y mascotas } & \text { humidificadores } \\ \text { Tratamiento de los desechos } & \text { Crecimiento microbiano en } \\ \text { Aguas cloacales y sedimentos } & \text { estructuras o en conductos de } \\ \text { Basura doméstica } & \text { ventilación } \\ \text { Compostado } & \end{array}$


Con el advenimiento de la epidemiología moderna, se han obtenido cifras más fidedignas sobre la incidencia de las enfermedades respiratorias profesionales relacionadas con polvos orgánicos (Rylander, Donham y Peterson 1986; Rylander y Peterson 1990). También se avanzó en la comprensión de los mecanismos anatomopatológicos subyacentes a estas enfermedades, en particular en lo concerniente a la respuesta inflamatoria. (Henson y M urphy 1989). Estos acontecimientos prepararon el terreno para el planteamiento de una concepción más coherente de las enfermedades causadas por polvos orgánicos. (Rylander y Jacobs 1997).

A continuación se describirán los diferentes ambientes de polvos orgánicos en los que se han descrito enfermedades, las entidades morbosas en sí, la clásica enfermedad de la bisinosis y medidas preventivas específicas.

\section{Ambientes}

Los polvos orgánicos son partículas transportadas por el aire de origen vegetal, animal o microbiano. En la Tabla 10.9 se relacionan ejemplos de ambientes, procesos de trabajo y agentes que conllevan un riesgo de exposición a polvos orgánicos.

\section{Agentes}

Se sabe en la actualidad que los agentes específicos presentes en los polvos son la principal razón por la cual se desarrolla la enfermedad. Los polvos orgánicos contienen numerosísimos agentes con posibles efectos biológicos. Algunos de los principales se encuentran en la Tabla 10.10

El papel relativo de cada uno de estos agentes, de forma aislada o en combinación con otros, se desconoce en su mayor parte. L a mayoría de la información disponible está relacionada con endotoxinas bacterianas presentes en todos los polvos orgánicos.

Las endotoxinas son compuestos de lipopolisacáridos que se fijan a la superficie celular externa de las bacterias gramnegativas. Las endotoxinas tienen un amplia gama de propiedades biológicas. Tras ser inhaladas causan una inflamación aguda (Snella y Rylander 1982; Brigham y M eyrick 1986). La clave de esta reacción es la entrada de neutrófilos (leucocitos) en el pulmón, que se acompaña de activación de otras células y de secreción de mediadores de la inflamación. Después de exposiciones repetidas la inflamación se reduce (adaptación). La reacción se limita a la mucosa de las vías aéreas y no hay afectación extensa del parénquima pulmonar.

0 tro agente específico del polvo orgánico es el $(1 \rightarrow 3)-\beta-D$-glucano. Se trata de un compuesto poliglucosado presente en la estructura de la pared celular de los mohos y de algunas bacterias. Potencia la respuesta inflamatoria causada por las endotoxinas y altera la función de las células inflamatorias, en particular de los macrófagos y las células T (Di Luzio 1985; Fogelmark y cols. 1992).

Tabla 10.10 - Agentes principales en los polvos orgánicos con actividad biológica potencial.

\begin{tabular}{ll} 
Agentes vegetales & Agentes animales \\
Taninos & Proteínas \\
Histamina & Enzimas \\
Acido plicático & Agentes microbianos \\
Alcaloides (p. ej., nicotina) & Endotoxinas \\
Citocalasinas & $(1 \rightarrow 3)-\beta$ - D-glucanos \\
& Proteasas \\
& Micotoxinas \\
\hline
\end{tabular}

Tabla 10.11 • Enfermedades inducidas por polvos orgánicos y sus códigos de la ICD.

Bronquitis y neumonitis (ICD J 40)

Neumonitis tóxica (fiebre por inhalación, síndrome del polvo orgánico tóxico)

Inflamación de las vías aéreas (inflamación de la mucosa)

Bronquitis crónica (ICD J42)

Neumonitis por hipersensibilidad (alveolitis alérgica) (ICD J67)

Asma(ICD J 45)

Rinitis, conjuntivitis

0 tros agentes específicos presentes en los polvos orgánicos son proteínas, taninos, proteasas y otras enzimas, y toxinas procedentes de mohos. Se dispone de muy pocos datos sobre sus concentraciones en los polvos orgánicos. Varios de estos agentes específicos de los polvos orgánicos, como las proteínas y las enzimas, son alergenos.

\section{Enfermedades}

L as enfermedades causadas por polvos orgánicos se muestran en la Tabla 10.11 con los correspondientes números de las C lasificación Internacional de Enfermedades (CIE) (Rylander y Jacobs 1994).

La ruta primaria de exposición para los polvos orgánicos es la inhalatoria y, por consiguiente, los efectos sobre el pulmón han recibido la mayor parte de la atención, tanto en la investigación como en el trabajo clínico. Sin embargo, cada vez es mayor el número de datos procedentes de estudios epidemiológicos y de informes de casos, así como de informes aislados, que indican que también se producen efectos sistémicos. El mecanismo implicado parece ser una inflamación local en el lugar diana, el pulmón, y la subsiguiente liberación de citocinas, ya sea con efectos sistémicos (Dunn 1992; M ichel y cols. 1991) o con un efecto sobre el epitelio intestinal (Axmacher y cols. 1991). LoS efectos clínicos no respiratorios consisten en fiebre, dolores articulares, efectos neurosensoriales, problemas cutáneos, enfermedad intestinal, fatiga y cefalea.

Las diferentes entidades morbosas tal y como se describen en la Tabla 10.11 son fáciles de diagnosticar en los casos típicos, y la anatomía patológica subyacente es claramente distinta. Sin embargo, en la vida real un trabajador que padece una enfermedad por exposición a polvo orgánico a menudo presenta una mezcla de diferentes entidades morbosas. Una persona puede tener una inflamación de las vías aéreas durante varios años y de repente desarrollar asma y además presentar síntomas de neumonitis tóxica durante una exposición particularmente elevada. 0 tra persona puede tener una neumonitis subclínica por hipersensibilidad, con linfocitosis de las vías aéreas, y desarrollar neumonitis tóxica durante una exposición particularmente intensa.

Un buen ejemplo de la mezcla de entidades morbosas que podemos encontrarnos es la bisinosis. Esta enfermedad fue descrita por primera vez en las hilanderías de algodón, pero las entidades morbosas individuales también se encuentran en otros ambientes de polvos orgánicos, A continuación se presenta una descripción general de esta enfermedad.

\section{Bisinosis}

\section{La enfermedad}

La bisinosis fue descrita por primera vez a principios del siglo XIX, y Prausnitz (1936) elaboró un informe clásico que aborda 
aspectos tanto clínicos como experimentales, y en el que describió los síntomas de los trabajadores del algodón de la forma siguiente:

D espués de haber trabajado durante años sin problemas apreciables excepto una leve tos, los trabajadores de las hilanderías de algodón advierten un empeoramiento de su tos, que se vuelve seca y extremadamente irritativa (...) Estos ataques suelen ocurrir los lunes (...), pero gradualmente los síntomas comienzan a extenderse a lo largo de los siguientes días de la semana; con el tiempo deja de haber diferencias y sufren los síntomas de forma continua.

Las primeras investigaciones epidemiológicas se realizaron en Inglaterra en el decenio de 1950 (Schilling y cols. 1955; Schilling 1956). El diagnóstico inicial se basaba en la aparición de una típica opresión torácica el lunes por la mañana, diagnosticado por medio de un cuestionario (Roach y Schilling 1960). Se desarrolló un esquema para graduar la gravedad de la bisinosis en función del tipo y de la periodicidad de los síntomas (M ekky, Roach y Schilling 1967; Schilling y cols. 1955). La duración de la exposición se utilizó como una medida de la dosis y ésta se relacionó con la intensidad de la respuesta. En función de entrevistas clínicas de un gran número de trabajadores, este esquema de gradación se modificó posteriormente con el fin de que reflejara con mayor exactitud los intervalos de tiempo para la reducción del FEV 1 (Berry y cols. 1973).

En un estudio se observó una diferencia en la prevalencia de la bisinosis en las hilanderías que preparaban distintos tipos de algodón (Jones y cols. 1979). Las hilanderías que utilizaban algodón de alta calidad para producir hilos más finos tenían una prevalencia menor de bisinosis que las que producían hilos gruesos y utilizaban algodón de una calidad inferior. De esta forma, además de la intensidad y la duración de la exposición, ambas variables dependientes de la dosis, el tipo de polvo se convertía en una variable importante para valorar la exposición. M ás adelante se demostró que las diferencias de respuesta entre los trabajadores expuestos a algodones gruesos y medios dependía no sólo del tipo de algodón, sino también de otras variables que afectan a la exposición, como son: variables de la preparación como la velocidad de cardado, variables ambientales como la humidificación y la ventilación, y variables de la fabricación como los diferentes tratamientos de los hilos. (Berry y cols. 1973).

El siguiente paso para definir la relación entre la exposición al polvo de algodón y la respuesta (ya fueran síntomas o mediciones objetivas de la función pulmonar) fueron los estudios realizados en Estados U nidos, en los que se comparaban los sujetos que trabajaban con algodón $100 \%$ con trabajadores que utilizaban el mismo algodón pero en una mezcla 50:50 con materiales sintéticos y con trabajadores que no estaban expuestos al algodón. (M erchant y cols. 1973). L os trabajadores expuestos al algodón $100 \%$ presentaban la prevalencia más alta de bisinosis, con independencia del consumo de tabaco, uno de los factores de confusión en la exposición al polvo de algodón. Esta relación semicuantitativa entre dosis y respuesta al polvo de algodón se definió aún más en un grupo de trabajadores de la industria textil estratificado por sexo, hábito de fumar, área de trabajo y tipo de hilandería. En cada una de estas categorías se observó una relación entre la concentración de polvo en los rangos inferiores y la prevalencia de bisinosis y/ o cambios en el volumen espiratorio forzado en un segundo $\left(\mathrm{FEV}_{1}\right)$.

En investigaciones posteriores, la reducción del $\mathrm{FEV}_{1}$ a lo largo del turno de trabajo se ha utilizado para valorar los efectos de la exposición, y forma parte también del US Cotton Dust Standard
Durante mucho tiempo se consideró que la bisinosis era una enfermedad peculiar con una mezcla de síntomas diferentes y sin una anatomía patológica específica conocida. Algunos autores sugirieron que se trataba de un asma profesional (Bouhuys 1976). U na reunión de un grupo de trabajo en 1987 analizó la sintomatología y la anatomía patológica de esta enfermedad. (Rylander y cols. 1987). Se llegó al acuerdo de que la enfermedad comprendía diversas entidades clínicas, generalmente relacionadas con exposición a un polvo orgánico.

La neumonitis tóxica puede aparecer la primera vez que un empleado trabaja en la hilandería, particularmente cuando trabaja en las secciones de abertura, aireación y cardado (Trice 1940). Aunque se desarrolla habituación, los síntomas pueden reaparecer más adelante, después de una exposición inusualmente elevada.

La inflamación de las vías aéreas es la enfermedad más extendida y presenta diferentes grados, desde una irritación leve de la nariz y las vías aéreas hasta una tos seca asociada a dificultad para respirar. La inflamación provoca constricción de las vías aéreas y una reducción del $\mathrm{FEV}_{1}$. La reactividad de las vías aéreas está aumentada, según queda determinado con una prueba de provocación con metacolina o histamina. Se ha discutido si la inflamación de las vías aéreas debería aceptarse como una entidad morbosa en sí misma, o si simplemente representa un síntoma. Dado que los hallazgos clínicos de tos intensa con estrechamiento de las vías aéreas puede conducir a una reducción de la capacidad de trabajo, está justificado considerarla como una enfermedad profesional.

La inflamación continuada de las vías aéreas a lo largo de varios años puede convertirse en una bronquitis crónica, en particular entre los trabajadores sometidos a una exposición elevada en las secciones de aireación y cardado. El cuadro clínico sería el de una enfermedad pulmonar obstructiva crónica (EPOC).

El asma profesional se desarrolla en un pequeño porcentaje de la plantilla, pero habitualmente no se diagnostica en estudios transversales, ya que los trabajadores se ven forzados a abandonar el trabajo a causa de la enfermedad. La neumonitis por hipersensibilidad no se ha detectado en ninguno de los estudios epidemiológicos llevados a cabo, ni tampoco ha habido informes de casos relacionándola con la exposición al polvo de algodón. La ausencia de neumonitis por hipersensibilidad puede deberse a la cantidad relativamente baja de mohos presentes en el algodón, ya que el algodón mohoso no es aceptable para su preparación.

El síntoma clásico de la exposición al polvo de algodón es una sensación subjetiva de opresión torácica, más frecuente los lunes (Schilling y cols. 1955). Sin embargo, no se trata de una característica exclusiva de la exposición al polvo de algodón, ya que también aparece en personas que trabajan con otros tipos de polvos orgánicos (D onham y cols. 1989). La opresión torácica se desarrolla lentamente a lo largo de varios años, pero también puede ser inducida en personas previamente no expuestas, siempre que el nivel de dosis sea elevado ( $\mathrm{H}$ aglind y Rylander 1984). La presencia de opresión torácica no se relaciona directamente con un descenso del FEV $\mathrm{F}_{1}$.

Todavía no se ha explicado la anatomía patológica que subyace a la opresión torácica. Se ha sugerido que los síntomas se deben a un aumento de la adhesividad de las plaquetas, que se acumulan en los capilares pulmonares y aumentan la presión de la arteria pulmonar. Es probable que la opresión torácica implique algún tipo de sensibilización celular, ya que son necesarias exposiciones repetidas para que aparezca. Esta hipótesis se ve apoyada por los resultados obtenidos en estudios de monocitos sanguíneos procedentes de trabajadores del algodón (Beijer y cols. 1990). Se encontró una mayor capacidad para producir factor procoagulante, indicativo de sensibilización celular entre 
los trabajadores de algodón en comparación con los sujetos de control.

\section{EI medio ambiente}

Esta enfermedad fue descrita originalmente entre los trabajadores de hilanderías de algodón, liño y cáñamo. En la primera fase del tratamiento del algodón en el interior de las hilanderías - la apertura de los fardos, la aireación y el cardado- más de la mitad de los trabajadores puede presentar síntomas de opresión torácica e inflamación de las vías aéreas. La incidencia disminuye a medida que el algodón es preparado, lo que refleja la sucesiva eliminación del agente causal presente en la fibra. La bisinosis se ha descrito en todos los países en los que se han llevado investigaciones en hilanderías de algodón. Sin embargo, algunos países como Australia tienen cifras de incidencia inusualmente bajas ( $G$ un y cols. 1983).

En la actualidad existen pruebas concluyentes de que las endotoxinas bacterianas son el agente causal de la neumonitis tóxica y de la inflamación de las vías aéreas (Castellan y cols. 1987; Pernis y cols. 1961; Rylander, $\mathrm{H}$ aglind y Lundholm 1985; Rylander y H aglind 1986; H erbert y cols. 1992; Sigsgaard y cols. 1992). Se han descrito relaciones dosis-respuesta y se han inducido los síntomas típicos mediante inhalación de la toxina purificada (Rylander y cols. 1989; M ichel y cols. 1995). A unque esto no excluye la posibilidad de que otros agentes pudieran contribuir a la patogenia, las endotoxinas pueden servir como marcadores del riesgo de padecer la enfermedad. Es improbable que las endotoxinas estén relacionadas con el desarrollo de asma profesional, pero podrían actuar como un coadyuvante de alergenos potenciales en el polvo de algodón.

\section{El caso}

El diagnóstico de bisinosis se establece clásicamente utilizando cuestionarios con la pregunta específica "¿Siente opresión torácica, y de ser así, qué día de la semana?". Las personas con opresión torácica el lunes por la mañana se clasifican como bisinóticos de acuerdo con el esquema sugerido por Schilling (1956). Puede realizarse una espirometría y, en función de las diferentes combinaciones de opresión torácica y reducción del $\mathrm{FEV}_{1}$, se ha desarrollado el esquema diagnóstico ilustrado en la Tabla 10.12.

\section{Tratamiento}

El tratamiento de las fases leves de la bisinosis es sintomático, y la mayoría de los trabajadores aprende a vivir con la ligera opresión torácica y la broncoconstricción que experimentan los lunes 0 cuando limpian maquinaria o desempeñan tareas similares con una exposición mayor de lo normal. En fases más avanzadas de inflamación de las vías aéreas o en casos de opresión torácica habitual varios días por semana, es necesario el traslado a operaciones con una menor exposición al polvo. La presencia de asma profesional requiere fundamentalmente un cambio de trabajo.

Tabla 10.12 • Criterios diagnósticos de bisinosis.

Grado 1/2. Opresión torácica el primer día de algunas semanas laborales

Grado 1. Opresión torácica el primer día de todas las semanas laborales

Grado 2. Opresión torácica el primer día y otros días de la semana laboral

Grado 3. Síntomas de Grado 2 acompañados de pruebas de incapacidad permanente en forma de disminución de la tolerancia al esfuerzo y/ 0 de la capacidad ventilatoria

\section{Prevención}

La prevención en general se describe con detalle en otras partes de esta Enciclopedia. Los principios básicos de la prevención en términos de sustitución del producto, limitación de la exposición, protección del trabajador y detección selectiva de la enfermedad también se aplican a la exposición al polvo de algodón.

Con respecto a los sustitutos de productos, se ha sugerido utilizar algodón con un bajo nivel de contaminación bacteriana. Una prueba inversa de este concepto se encuentra en los informes que datan de 1863, según los cuales, el cambio a algodón sucio provocaba un aumento de la prevalencia entre los trabajadores expuestos (Leach 1863). También existe la posibilidad de cambiar a otras fibras, en particular a fibras sintéticas, aunque esto no siempre es factible desde el punto de vista del producto. En la actualidad no existe ninguna técnica aplicada a la producción destinada a reducir el contenido en endotoxinas de las fibras de algodón.

En cuanto a la reducción del polvo, se han puesto en práctica con éxito programas en Estados U nidos y en otros países (Jacobs 1987). Tales programas son caros y los costes de la eliminación eficaz del polvo pueden ser prohibitivos para los países en desarrollo (C orn 1987).

En lo que respecta al control de la exposición, el nivel de polvo no constituye una medida suficientemente precisa del riesgo de exposición. Dependiendo del grado de contaminación por bacterias gramnegativas $y$, por tanto, de endotoxinas, un determinado nivel de polvo puede estar o no asociado a un riesgo. Para las endotoxinas no se han establecido directrices oficiales. Se ha sugerido que un nivel de $200 \mathrm{ng} / \mathrm{m}^{3}$ es el umbral para la neumonitis tóxica, 100 a $200 \mathrm{ng} / \mathrm{m}^{3}$ para la constricción aguda de las vías aéreas durante un turno de trabajo y $10 \mathrm{ng} / \mathrm{m}^{3}$ para la inflamación de las vías aéreas (Rylander y Jacobs 1997).

El conocimiento de los factores de riesgo y de las consecuencias de la exposición es importante para la prevención. La base de información se ha expandido rápidamente en los últimos años, pero gran parte de ella todavía no está recogida en los libros de texto ni en otras fuentes de fácil acceso. 0 tro problema es que los síntomas y los hallazgos en las enfermedades respiratorias inducidas por polvos orgánicos son inespecíficos y aparecen de forma normal en la población, por lo que quizá no sean correctamente diagnosticados en sus primeras fases.

La propagación adecuada de los conocimientos relativos a los efectos del algodón y de otros polvos orgánicos requiere la puesta en marcha de programas de formación apropiados, dirigidos no sólo a los trabajadores con una posible exposición, sino también a las empresas y al personal sanitario, en particular a ingenieros e inspectores de salud en el trabajo. La información debe incluir la identificación de la fuente, los síntomas y la descripción de la enfermedad, así como los métodos de protección. Un trabajador informado será capaz de reconocer más fácilmente síntomas relacionados con el trabajo y de comunicarlos con mayor eficacia a los profesionales sanitarios. En lo relativo a la vigilancia y detección selectiva sanitarias, los cuestionarios son una herramienta principal a utilizar. Se han descrito en la literatura médica diversas versiones de cuestionarios diseñadas específicamente para diagnosticar enfermedades inducidas por polvos orgánicos (Rylander, Peterson y Donham 1990; Schwartz y cols. 1995).

Las pruebas de función pulmonar también son una herramienta útil para la vigilancia y el diagnóstico. Se ha comprobado que las mediciones de la reactividad de la vía aéreas son útiles (Rylander y Bergström 1993; Carvalheiro y cols. 1995). 0 tras herramientas diagnósticas, como las mediciones de los mediadores de la inflamación o de la actividad celular, siguen en fase de investigación. 
Tabla 10.13 - Propiedades del berilio y sus compuestos.

\begin{tabular}{|c|c|c|c|c|c|}
\hline & Peso de la fórmula & Densidad & $\begin{array}{l}\text { Punto de fusión/ } \\
\text { ebullición }\left({ }^{\circ}\right)\end{array}$ & Solubilidad & Descripción \\
\hline Berilio(Be) & 9,01 (a.w.) & 1,85 & $1.298 \pm 5 / 2.970$ & - & $\begin{array}{l}\text { Metal de color gris a } \\
\text { plateado }\end{array}$ \\
\hline Oxido de berilio (BeO) & 25 & 3,02 & $2.530 \pm 30 /-$ & $\begin{array}{l}\text { Soluble en ácidos y álcalis; } \\
\text { insoluble en agua }\end{array}$ & Polvo blanco amorfo \\
\hline $\begin{array}{l}\text { Fluoruro de berilio }{ }^{1} \\
\left(\mathrm{BeF}_{2}\right)\end{array}$ & 47,02 & 1,99 & Se sublima a $800 \stackrel{\circ}{\circ}$ & $\begin{array}{l}\text { Rápidamente hidrosoluble; } \\
\text { escasamente soluble en } \\
\text { alcohol etílico }\end{array}$ & Sólido higroscópico \\
\hline $\begin{array}{l}\text { Cloruro de berilio } \\
\left(\mathrm{BeCl}_{2}\right)\end{array}$ & 79,9 & 1,90 & $405 / 520$ & $\begin{array}{l}\text { Muy hidrosoluble; soluble } \\
\text { en alcohol etílico, benzeno, } \\
\text { éter etílico y disulfuro de } \\
\text { carbono }\end{array}$ & $\begin{array}{l}\text { Cristales delicuescentes } \\
\text { blancos } 0 \text { amarillentos }\end{array}$ \\
\hline $\begin{array}{l}\text { Nitrato de berilio }{ }^{3} \\
\left(\mathrm{Be}\left(\mathrm{NO}_{3}\right)_{2} \cdot 3 \mathrm{H}_{2} \mathrm{O}\right)\end{array}$ & 187,08 & 1,56 & $60 / 142$ & $\begin{array}{l}\text { Soluble en agua y en alcohol } \\
\text { etílico }\end{array}$ & $\begin{array}{l}\text { Cristales delicuescentes } \\
\text { blancos a ligeramente } \\
\text { amarillos }\end{array}$ \\
\hline $\begin{array}{l}\text { Nitruro de berilio } \\
\left(\mathrm{Be}_{3} \mathrm{~N}_{2}\right)\end{array}$ & 55,06 & - & $2.200 \pm 100 /-$ & - & $\begin{array}{l}\text { Cristales duros, blancos, } \\
\text { refractarios }\end{array}$ \\
\hline $\begin{array}{l}\text { Hidrato de sulfato } \\
\text { de berilio }\left(\mathrm{BeSO}_{4} \cdot 4 \mathrm{H}_{2} \mathrm{O}\right)\end{array}$ & 177,2 & 1,71 & $100 /-$ & $\begin{array}{l}\text { Hidrosoluble; insoluble en } \\
\text { alcohol etílico }\end{array}$ & Cristales incoloros \\
\hline
\end{tabular}

${ }^{1}$ El fluoruro de berilio se produce por la descompensación a $900-950 \stackrel{0}{C}$ del fluoruro de berilio amónico. Su principal uso es la producción de metal de berilio mediante reducción con magnesio. 2 El cloruro de berilio se fabrica haciendo pasar cloro sobre una mezcla de óxido de berilio y carbono. ${ }^{3}$ El nitrato de berilio se produce por la acción del ácido nítrico sobre el óxido de berilio. Se utiliza como reactivo químico y como endurecedor del manto de gas. ${ }^{4}$ El nitruro de berilio se prepara calentando polvo de metal de berilio en una atmósfera de nitrógeno sin oxígeno a 700 - 1.400 ㄷ. Se utiliza en las reacciones de energía atómica, incluida la producción del isótopo de carbono radiactivo carbono-14 ${ }^{5} \mathrm{El}$ hidrato de sulfato de berilio se produce tratando el mineral fritado con ácido sulfúrico concentrado. Se utiliza en la producción de berilio metálico por el proceso del sulfato.

\section{ENFERMEDAD POR BERILIO*}

\section{H omayoun Kazemi}

La enfermedad por berilio es un proceso sistémico que afecta a múltiples órganos, siendo las manifestaciones pulmonares las más llamativas y frecuentes. Está causada por la exposición al berilio en su forma de aleación o en uno de sus diversos compuestos químicos. La vía de exposición es por inhalación, y la enfermedad puede ser aguda o crónica. La enfermedad aguda es extremadamente rara en la actualidad, y no se ha comunicado ningún caso desde el primer uso industrial generalizado del berilio en el decenio de 1940 tras la implantación de medidas higiénicas industriales para limitar las exposiciones a dosis altas. $L$ a enfermedad crónica por berilio continúa produciéndose actualmente.

\section{Berilio, aleaciones y compuestos}

El berilio, una sustancia industrial de la que se sospecha que tiene potencial cancerígeno, es notable por su ligereza de peso, su elevada resistencia a la tensión y su resistencia a la corrosión. La Tabla 10.13 resume las propiedades del berilio y sus compuestos.

\section{Fuentes}

El berilo ( $3 \mathrm{BeO} \cdot \mathrm{Al}_{2} \mathrm{O}_{3} \cdot 6 \mathrm{SiO}_{2}$ ) es la principal fuente comercial de berilio, el más abundante de los minerales que contienen concentraciones elevadas de óxido de berilio (10 a $13 \%$ ). Las fuentes principales de berilo se encuentran en Argentina, Brasil, India, Zimbabwe y la República de Sudáfrica. En Estados U nidos, el

*Este artículo se basa parcialmente en un artículo sobre la enfermedad por berilio de H.L. Hardy, L.B. Tepper y R.I. Chamberlin, publicado en la 3a edición de la Enciclopedia de Salud y Seguridad en el Trabajo. berilo se encuentra en Colorado, Dakota del Sur, Nuevo M éjico y Utah. Actualmente, se está extrayendo y procesando en Utah bertrandita, un mineral de baja calidad $(0,1$ a $3 \%)$ que contiene berilio soluble en ácido.

\section{Producción}

Los dos métodos más importantes de extracción de berilio del mineral son el proceso de sulfato y el proceso de fluoruro.

En el proceso de sulfato, se funde berilo triturado en un horno de $\operatorname{arco}$ a $1.650{ }^{\circ} \mathrm{C}$ y se vierte a través de un chorro de agua a alta velocidad para formar un frito. Tras el tratamiento con calor, el frito se deposita en una trituradora de bolas y se mezcla con ácido sulfúrico concentrado para formar un compuesto en suspensión, que se pulveriza en forma de chorro a una trituradora sulfatante rotatoria de calentamiento directo. EI berilio, ahora en forma hidrosoluble, se separa del sedimento y se añade hidróxido de amonio al sedimento líquido, que es introducido en un cristalizador donde el alumbre de amonio cristaliza. Se añaden agentes quelantes al líquido para mantener el hierro y el níquel en solución, se añade hidróxido sódico y el berilato sódico formado se hidroliza para precipitar hidróxido de berilio. Este último producto puede convertirse en fluoruro de berilio para la reducción por magnesio a berilio metálico, o a cloruro de berilio para reducción electrolítica.

En el proceso de fluoruro (Figura 10.11), se aglomera una mezcla en bloque de mineral de tierra, silicofluoruro sódico y ceniza de sosa en un horno de crisol/ chimenea rotatorio. El material aglomerado se aplasta, tritura y separa. Se añade hidróxido sódico a la solución de fluoruro de berilio obtenida y el precipitado de hidróxido de berilio se filtra en un filtro rotatorio. El berilio metálico se obtiene de igual forma que en el proceso anterior, mediante reducción con magnesio del fluoruro de berilio o por electrólisis del cloruro de berilio. 
Figura 10.11 Producción de óxido de berilio por el proceso de fluoruro.

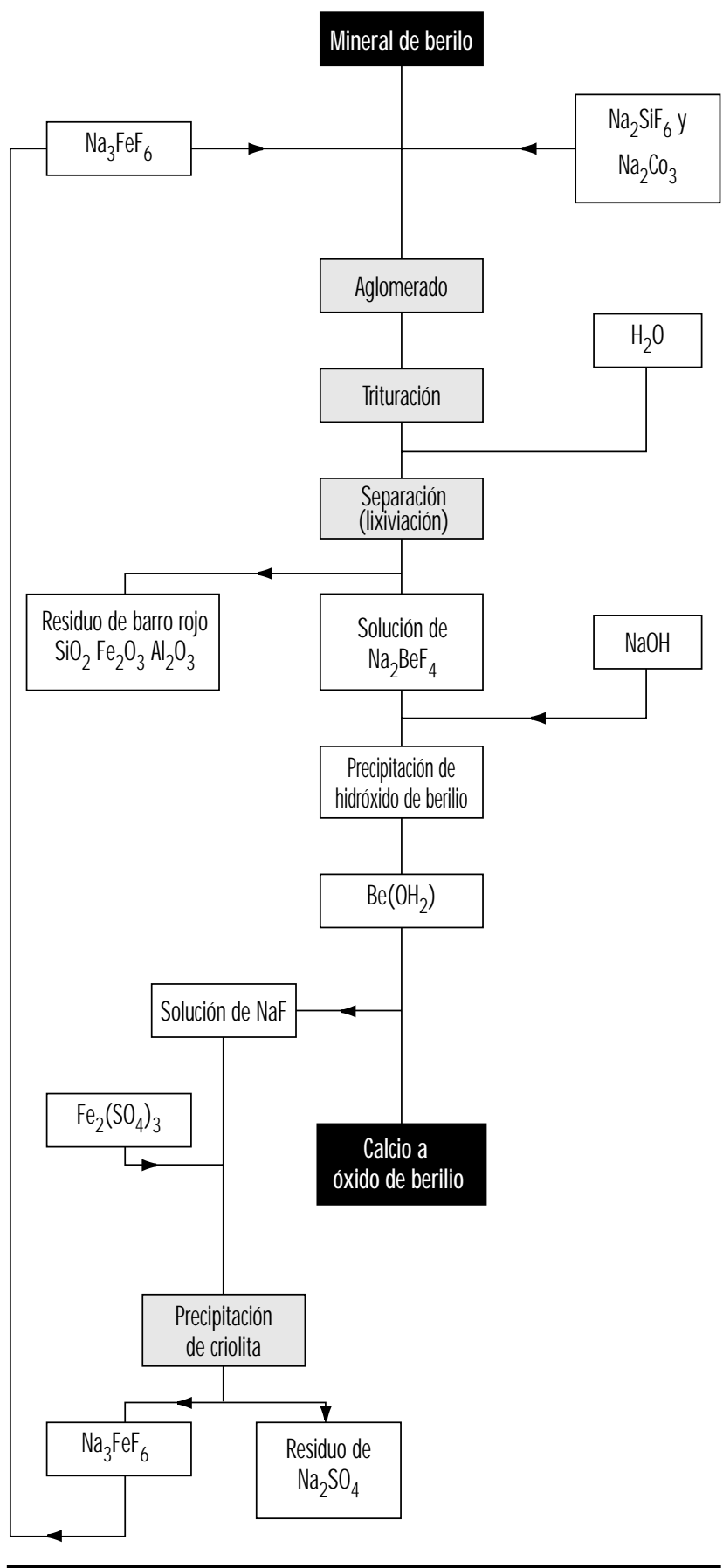

Usos

El berilio se utiliza en aleaciones con diversos metales, como acero, níquel, magnesio, zinc y aluminio; la aleación más utilizada es la de berilio y cobre - apropiadamente denominada "un bronce" - que presenta una alta resistencia a la tensión y la capacidad de endurecerse por el tratamiento con calor. Los bronces de berilio se utilizan en herramientas que no producen chispas, partes de interruptores eléctricos, resortes de relojes, diafragmas, cuñas, levas y cojinetes.
U no de los principales usos del metal es como moderador de neutrones térmicos en reactores nucleares y como reflector para reducir el escape de neutrones del núcleo del reactor. A menudo se utiliza una fuente mixta de uranio-berilio como fuente de neutrones. Como lámina, el berilio se utiliza como material de ventana en tubos de rayos $x$. Su luminosidad, su elevado módulo elástico y su estabilidad al calor hacen de él un material muy atractivo para la industria aeronáutica y aerospacial.

El óxido de berilio se obtiene calentando nitrato o hidróxido de berilio.

Se utiliza en la fabricación de cerámicas, materiales refractarios y otros compuestos de berilio. Antiguamente se utilizó para la fabricación de fósforo para lámparas fluorescentes, hasta que la incidencia de enfermedad por berilio en la industria motivó el abandono de su uso para este propósito (en 1949 en Estados Unidos).

\section{Peligros}

Los procesos en los que interviene el berilio se asocian a riesgo de incendio y riesgo para la salud. El polvo de berilio finamente dividido arde, y el grado de combustibilidad depende del tamaño de las partículas. Se han producido incendios en unidades de filtración de polvo y durante la soldadura de conductos de ventilación en los que había berilio finamente dividido.

El berilio y sus compuestos son sustancias muy tóxicas. EI berilio puede afectar a todos los sistemas del organismo, aunque el más afectado es el pulmón. El berilio causa enfermedad sistémica por inhalación y puede distribuirse extensamente por todo el cuerpo tras su absorción en los pulmones. En el tracto gastrointestinal se absorben cantidades pequeñas de berilio. EI berilio puede causar irritación cutánea, y su introducción traumática en el tejido subcutáneo puede causar irritación local y formación de granulomas.

\section{Patogenia}

El berilio se ha asociado a enfermedad en todas sus formas, excepto la del mineral berilo. La vía de entrada es por inhalación, y en la enfermedad aguda existe un efecto tóxico directo sobre la mucosa nasofaríngea y la de todo el árbol traqueobronquial, causando edema e inflamación, En el pulmón causa una neumonitis química aguda. la principal forma de toxicidad del berilio en el momento actual es la enfermedad crónica por berilio. La vía más importante de enfermedad crónica es un tipo de hipersensibilidad tardía específica del berilio. La entrada de berilio en el sistema a través de los pulmones conduce a la proliferación de linfocitos CD $4^{+}$específicos, en la que el berilio actúa como antígeno específico, bien solo o bien como hapteno a través de una vía de receptores de la interleucina-2 (IL 2). De esta forma, la sensibilidad individual al berilio puede explicarse basándose en la respuesta $C D 4^{+}$individual. La liberación de linfocinas por los linfocitos activados puede causar la formación de un granuloma y el reclutamiento de macrófagos. El berilio puede transportarse a sitios extrapulmonares, donde puede dar lugar a la formación de granulomas. EI berilio se libera lentamente desde diferentes sitios y se excreta por los riñones. Esta liberación lenta puede producirse durante un período de 20 a 30 años. La cronicidad y la latencia de la enfermedad probablemente puedan explicarse sobre la base del lento fenómeno de metabolismo y liberación. Los mecanismos inmunológicos involucrados en la patogenia de la enfermedad por berilio también permiten métodos específicos de diagnóstico, que se comentarán más adelante.

\section{Histopatología}

El principal hallazgo anatomopatológico en la enfermedad por berilio es la formación de granulomas no caseificantes en los pulmones, los ganglios linfáticos y otras localizaciones. LoS 
estudios histopatológicos pulmonares de pacientes con enfermedad aguda por berilio han mostrado un patrón inespecífico de bronquitis aguda y subaguda y neumonitis. En la enfermedad crónica por berilio, existen varios grados de infiltración linfocítica del intersticio pulmonar y formación de granulomas no caseificantes (Figura 10.12).

M uchos de los granulomas se localizan en áreas peribronquiolares. Además, puede haber histiocitos, células plasmáticas y células gigantes con cuerpos de inclusión calcificados. Si sólo se forma un granuloma, el pronóstico a largo plazo es mejor. La histología pulmonar en la enfermedad crónica por berilio es indiferenciable de la de la sarcoidosis. También pueden encontrarse granulomas no caseificantes en ganglios linfáticos, hígado, bazo, músculo y piel.

\section{Manifestaciones clínicas}

\section{Lesiones cutáneas}

L as sales ácidas del berilio causan dermatitis alérgica de contacto. Estas lesiones pueden ser eritematosas, papulosas o papulovesiculares, generalmente son pruriginosas, y se encuentran en las partes expuestas del cuerpo. $\mathrm{H}$ abitualmente existe una diferencia de dos semanas entre la primera exposición y la aparición de la dermatitis, excepto en el caso de exposiciones intensas, en las que puede producirse una reacción irritativa inmediata. Este período de retraso se considera el tiempo necesario para desarrollar el estado de hipersensibilidad.

L a implantación accidental de metales de berilio o cristales de un compuesto de berilio soluble en una abrasión, una solución de continuidad de la piel o bajo las uñas puede ocasionar la formación de un área indurada con supuración central. También pueden formarse granulomas en estos sitios.

La conjuntivitis y la dermatitis pueden desarrollarse de forma aislada o juntas. En los casos de conjuntivitis, el edema periorbitario puede ser intenso.

\section{Enfermedad aguda}

La nasofaringitis por berilio se caracteriza por mucosas tumefactas e hiperémicas, puntos hemorrágicos, fisuras y ulceración. Se ha descrito perforación del tabique nasal. La retirada de la exposición produce la reversión de este proceso inflamatorio en 3 a 6 semanas.

La afectación de la tráquea y del árbol bronquial tras la exposición a niveles más altos de berilio causa tos no productiva, dolor subesternal y disnea moderada. Pueden escucharse roncus y/ o estertores, y la radiografía del tórax puede mostrar un aumento de la trama broncovascular. El carácter, la velocidad de aparición y la gravedad de estos signos y síntomas dependen de la calidad y la cantidad de la exposición. D ebe esperarse la recuperación en 1 a 4 semanas si el trabajador evita nuevas exposiciones.

EI uso de esteroides es bastante útil en el tratamiento de la enfermedad aguda. No se han comunicado nuevos casos de enfermedad aguda al US Beryllium Case Registry en más de 30 años. Este registro, iniciado por $\mathrm{H}$ arriet $\mathrm{H}$ ardy en 1952, tiene casi 1.000 registros de casos, de los que 212 son agudos. Casi todos ellos se produjeron en la industria de fabricación de lámparas fluorescentes. Cuarenta y cuatro sujetos con enfermedad aguda desarrollaron posteriormente enfermedad crónica.

\section{E nfermedad crónica por berilio}

La enfermedad crónica por berilio es una enfermedad granulomatosa pulmonar y sistémica causada por la inhalación de berilio. La latencia de la enfermedad puede oscilar entre 1 y 30 años, pero generalmente se produce 10 a 15 años después de la primera

\section{Figura 10.12 - Tejido pulmonar en un paciente con} enfermedad crónica por berilio.

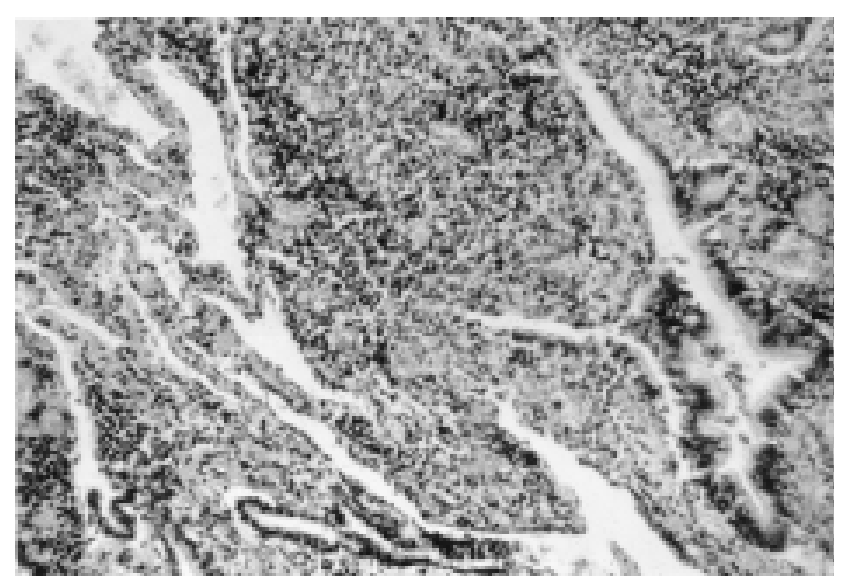

Se observan granulomas e infiltración de células redondeadas.

exposición. Presenta un curso variable, con agudizaciones y remisiones de sus manifestaciones clínicas. Sin embargo, la enfermedad suele ser progresiva. Se han descrito algunos casos con anomalías en la radiografía de tórax pero con un curso clínico estable y ausencia de síntomas importantes.

La disnea de esfuerzo es el síntoma más frecuente de la enfermedad crónica por berilio. O tros síntomas son tos, fatiga, pérdida de peso, dolor torácico y artralgias. Los hallazgos físicos pueden ser completamente normales o consistir en crepitantes bibasales, adenopatías, lesiones cutáneas, hepatoesplenomegalia y acropaquias. Pueden observarse signos de hipertensión pulmonar en casos de enfermedad grave de larga evolución.

Pueden producirse nefrolitiasis e hiperuricemia en algunos pacientes, y se han comunicado algunos casos de aumento de tamaño de las glándulas parótidas y afectación del sistema nervioso central. Las manifestaciones clínicas de enfermedad crónica por berilio son muy similares a las de la sarcoidosis.

\section{Características radiológicas}

El patrón radiológico en la enfermedad crónica por berilio es inespecífico y similar al observado en la sarcoidosis, fibrosis pulmonar idiopática, tuberculosis, micosis y enfermedad por polvo (Figura 10.13). En las primeras fases de la enfermedad, las radiografías pueden mostrar densidades granulares, nodulares 0 lineales. Estas anomalías pueden aumentar, disminuir o no variar, con 0 sin fibrosis. Es frecuente la afectación del lóbulo superior. La adenopatía hiliar, observada en aproximadamente una tercera parte de los pacientes, suele ser bilateral y acompañarse de moteado de los campos pulmonares. La ausencia de cambios pulmonares en presencia de adenopatía es una consideración diferencial relativa, pero no absoluta, a favor de la sarcoidosis en oposición a la enfermedad crónica por berilio. Se ha descrito adenopatía hiliar unilateral, per es bastante rara.

El cuadro radiológico no se correlaciona bien con el estado clínico, y no refleja aspectos cualitativos ni cuantitativos particulares de la exposición causal.

\section{Pruebas de función pulmonar}

Los datos del R egistro de $C$ asos de Berilio muestran que pueden encontrarse 3 patrones de afectación en la enfermedad crónica por berilio. De los 41pacientes estudiados durante un período promedio de 23 años tras la exposición inicial al berilio, el $20 \%$ 
Figura 10.13 - Radiografía de tórax de un paciente con enfermedad crónica por berilio, en la que se observan infiltrados fibronodulares difusos e hilios prominentes.

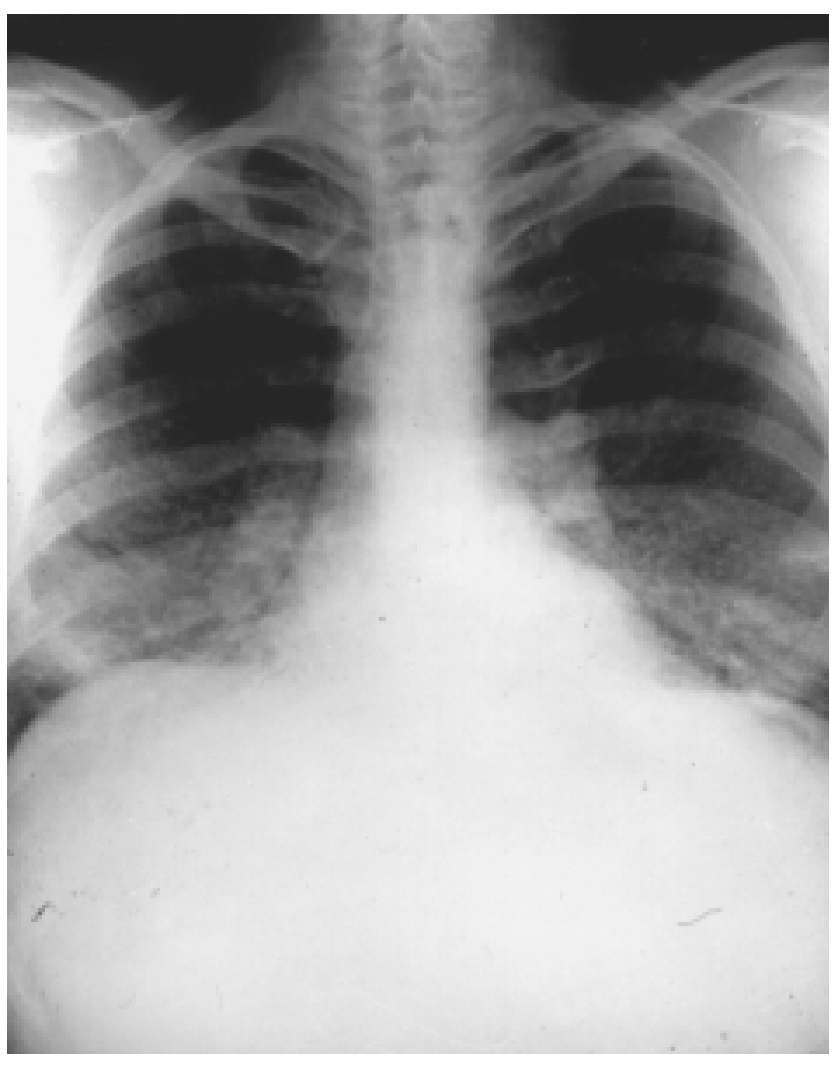

presentaba un defecto restrictivo, el $36 \%$ un defecto intersticial (volúmenes pulmonares y flujos aéreos normales, pero reducción de la capacidad de difusión para el monóxido de carbono), el $39 \%$ un defecto obstructivo y el $5 \%$ eran normales. El patrón obstructivo, observado en fumadores y no fumadores, se asoció a granulomas en la región peribronquial. Este estudio indicó que el patrón de afectación influye en el pronóstico. Los pacientes con defecto intersticial mostraron una mejor evolución, con un deterioro menor durante un intervalo de 5 años. Los pacientes con defectos obstructivo y restrictivo experimentaron un agravamiento de su afectación a pesar del tratamiento con corticosteroides.

Los estudios de la función pulmonar en los trabajadores de extracción de berilio que estaban asintomáticos mostraron la presencia de hipoxemia arterial leve, que se producía generalmente en los primeros 10 años de exposición. En los trabajadores expuestos al berilio durante 20 años o más, se observó una reducción de la capacidad vital forzada (FVC) y del volumen espiratorio forzado en un segundo $\left(F E V_{1}\right)$. E stos hallazgos sugieren que la hipoxemia leve inicial podría deberse a la alveolitis precoz, y que, con una mayor exposición y transcurso de tiempo, la reducción del $F E V_{1}$ y la FVC podría representar fibrosis y formación de granulomas.

\section{Otras pruebas de laboratorio}

Se han descrito pruebas de laboratorio anormales inespecíficas en la enfermedad crónica por berilio, como elevación de la velocidad de sedimentación, eritrocitosis, elevación de los niveles de gammaglobulinas, hiperuricemia e hipercalcemia.
La prueba cutánea de K veim es negativa en la enfermedad por berilio, mientras que puede ser positiva en la sarcoidosis. El nivel de la enzima de conversión de la angiotensina (ECA) suele ser normal en la enfermedad por berilio, pero puede elevarse en el $60 \%$ o más de los pacientes con sarcoidosis activa.

\section{Diagnóstico}

El diagnóstico de la enfermedad crónica por berilio se basó durante muchos años en los criterios desarrollados a través del Registro de C asos de Berilio, que incluían:

1. $\mathrm{H}$ istoria de exposición importante al berilio.

2. Signos de enfermedad de las vías respiratorias inferiores.

3. R adiografía de tórax anormal con enfermedad fibronodular intersticial.

4. Pruebas de función pulmonar anormales con disminución de la capacidad de difusión del monóxido de carbono (DLCO).

5. Cambios anatomopatológicos compatibles con exposición al berilio en el pulmón o en los ganglios torácicos.

6. Presencia de berilio en los tejidos.

Debían cumplirse cuatro de los seis criterios, y debían incluir el criterio 1 ó 6. D esde el decenio de 1980, los avances en inmunología han hecho posible el diagnóstico de la enfermedad por berilio sin necesidad de muestras tisulares para examen histológico 0 análisis de berilio. Newman y cols. (1989) han propuesto la transformación de los linfocitos sanguíneos en respuesta a la exposición al berilio (como en el test de transformación linfocítica, TTL) o de los linfocitos del lavado broncoalveolar (BAL) como herramientas diagnósticas útiles para establecer el diagnóstico de enfermedad por berilio en sujetos expuestos. Sus datos sugieren que una TTL sanguínea positiva es un signo de sensibilización. Sin embargo, datos recientes muestran que la TTL sanguínea no se correlaciona bien con la enfermedad pulmonar. La transformación linfocítica en el BAL se correlaciona mucho mejor con una función pulmonar anormal, pero no se correlaciona bien con las anomalías concurrentes en la TTL sanguínea. Por tanto, para establecer un diagnóstico de enfermedad por berilio, se necesita una combinación de anomalías clínicas, radiológicas y funcionales junto con una $T \mathrm{~T} L$ positiva en el BAL. Esta última no es diagnóstica de forma aislada. EI análisis de berilio por microsonda en muestras tisulares pequeñas es otra innovación reciente que podría contribuir al diagnóstico de la enfermedad en pequeñas muestras de tejido pulmonar obtenidas por biopsia pulmonar transbronquial.

La sarcoidosis es la enfermedad con mayor parecido a la enfermedad crónica por berilio, y su diferenciación puede resultar difícil. Hasta ahora, no se ha comunicado ninguna enfermedad ni afectación ósea quística, ni ocular, ni de la amígdala en la enfermedad crónica por berilio. A simismo, la prueba de $K$ veim es negativa en la enfermedad por berilio. No se recomienda la realización de pruebas cutáneas para demostrar la sensibilización al berilio, ya que la propia prueba es sensibilizante y posiblemente podría desencadenar reacciones sistémicas en personas sensibilizadas y no permite establecer por sí misma que la enfermedad observada esté relacionada necesariamente con el berilio.

M étodos inmunológicos más sofisticados en el diagnóstico diferencial deberían permitir en el futuro una mejor diferenciación respecto a la sarcoidosis.

\section{Pronóstico}

El pronóstico de la enfermedad crónica por berilio ha variado de forma favorable en los últimos años; se ha sugerido que los retrasos más prolongados en la aparición de la enfermedad entre 
los trabajadores del berilio podrían reflejar una exposición menor o una carga corporal de berilio menor, que daría lugar a un curso clínico más leve. Existen pruebas clínicas de que el tratamiento esteroideo, administrado en el momento de aparición de una discapacidad mensurable y a dosis adecuadas durante períodos de tiempo suficientemente largos, ha mejorado el estado clínico de muchos pacientes, permitiendo a algunos de ellos reincorporarse a trabajos útiles. No existen pruebas claras de que los esteroides hayan curado la intoxicación crónica por berilio.

\section{Berilio y cáncer}

En animales, el berilio administrado de forma experimental es cancerígeno y causa sarcoma osteogénico tras la inyección intravenosa en conejos y cáncer de pulmón tras inhalación en ratas y monos. Un tema controvertido es si el berilio podría ser cancerígeno para el ser humano. Algunos estudios epidemiológicos han sugerido una asociación, en particular después de padecer enfermedad aguda por berilio. Este hallazgo ha sido rebatido por otros estudios. Puede concluirse que el berilio es cancerígeno en animales y que podría existir una conexión ente el cáncer de pulmón y el berilio en el ser humano, particularmente en las personas con la enfermedad aguda.

\section{Medidas de seguridad y salud}

L as precauciones de seguridad y de salud deben cubrir el riesgo de incendio, así como el peligro mucho más grave de la toxicidad.

\section{Prevención de incendios}

Deben tomarse las disposiciones pertinentes para prevenir posibles fuentes de ignición, como la formación de chispas o arcos de luz en aparatos eléctricos, fricción, etc, en la proximidad de polvo de berilio finamente dividido. El equipo en el que ha estado presente este polvo debe vaciarse y limpiarse antes de usar en él acetileno $o$ un aparato de soldadura. El polvo de berilio ultrafino libre de óxido preparado en gas inerte es propenso a la ignición espontánea ante la exposición al aire.

Para extinguir un incendio por berilio debe utilizarse un polvo desecado adecuado, no agua. Deberá llevarse un equipo de protección personal completo, que incluya equipo de protección respiratoria, y los bomberos deberán bañarse después y disponer su ropa para que sea lavada por separado.

\section{Protección de la salud}

Los procesos del berilio deben realizarse de manera cuidadosamente controlada para proteger al trabajador y a la población general. El riesgo más importante consiste en la contaminación a través del aire, por lo que el proceso y la planta deben diseñarse con el objetivo de que se forme la menor cantidad posible de polvo o vapores. Deben utilizarse procesos en húmedo en lugar de procesos en seco, y los componentes de las preparaciones que contienen berilio deben unificarse como suspensiones acuosas en lugar de como polvos desecados; siempre que sea posible, la planta se diseñará en grupos de unidades cerradas aisladas. La concentración permisible de berilio en la atmósfera es tan baja que deberá aplicarse el cerramiento incluso a los procesos en húmedo, ya que de lo contrario podrían desecarse los vertidos y salpicaduras producidos y el polvo podría entrar en la atmósfera.

Las operaciones a partir de las cuales puede producirse polvo deben realizarse en áreas con el máximo grado de cerramiento compatible con las necesidades de manipulación. Algunas operaciones se llevan a cabo en cajas selladas, pero son muchos más los que se realizan en cerramientos con aspiración similares a los instalados en las cámaras de vapores químicos. Las operaciones mecanizadas pueden ventilarse por sistemas de aspiración local de alta velocidad y bajo volumen o mediante encoframientos con aspiración.

Para comprobar la eficacia de estas medidas de precaución, el control atmosférico debe realizarse de tal forma que pueda calcularse la exposición promedio diaria de los trabajadores al berilio respirable. El área de trabajo debe limpiarse de forma regular con una aspiradora apropiada o una fregona húmeda. L os procesos del berilio deben separarse de las otras operaciones de la fábrica.

Debe proporcionarse un equipo protector personal a los trabajadores que intervengan en procesos del berilio. Si trabajan a tiempo completo en procesos relacionados con la manipulación de compuestos de berilio o en procesos asociados a la extracción del metal a partir del mineral, deben tomarse las disposiciones necesarias para que se cambien completamente de ropa y no vuelvan a sus casas con la misma con la que han estado trabajando. También deberán tomarse las disposiciones pertinentes para el lavado seguro de las ropas de trabajo, y deberán proporcionarse guardapolvos protectores a los trabajadores de la lavandería para asegurar que no tengan una exposición excesiva al riesgo. Estas disposiciones no deben limitarse a los procedimientos de lavado doméstico normales. Los casos de intoxicación por berilio en las familias de los trabajadores se han atribuido a que éstos llevaban a casa la ropa contaminada o bien la llevaban puesta en casa.

Actualmente continúa aplicándose un estándar de salud profesional de $2 \mu \mathrm{g} / \mathrm{m}^{3}$, propuesto en 1949 por un comité que operaba bajo el auspicio de la Comisión de Energía A tómica de Estados U nidos. Las interpretaciones existentes permiten en general fluctuaciones hasta un techo de $5 \mu \mathrm{g} / \mathrm{m}^{3}$, siempre que no se supere el promedio ponderado en el tiempo. También es permisible un "pico máximo aceptable superior a la concentración techo para un turno de ocho horas" de $25 \mu \mathrm{g} / \mathrm{m}^{3}$ durante 30 minutos como máximo. Estos niveles profesionales son factibles en la práctica industrial actual, y no hay pruebas de experiencias sanitarias adversas entre las personas que trabajan en un entorno así controlado. Debido a la posible asociación entre el berilio y el cáncer de pulmón, se ha sugerido la reducción del límite permisible a $1 \mu \mathrm{g} / \mathrm{m}^{3}$, pero no se ha emprendido ninguna acción oficial sobre esta sugerencia en Estados U nidos.

La población en riesgo de desarrollar enfermedad por berilio es la que de alguna manera trata con berilio, en su extracción o en su uso posterior. Sin embargo, se han comunicado algunos casos "vecinos" a una distancia de 1 a $2 \mathrm{~km}$ de plantas de extracción de berilio.

En diversos países es obligatoria la realización de exámenes médicos previos a la contratación y periódicos de los trabajadores expuestos al berilio y sus compuestos. La evaluación recomendada incluye anualmente un cuestionario respiratorio, una radiografía de tórax y pruebas de función pulmonar. Con los avances en inmunología, la TTL podría convertirse en una evaluación habitual, aunque en este momento no se dispone de suficientes datos para recomendar su uso sistemático. U na vez determinada la presencia de enfermedad por berilio, no es aconsejable que el trabajador continúe expuesto a la sustancia, aunque el lugar de trabajo cumpla los criterios umbral de concentración de berilio en el aire.

\section{Tratamiento}

EI paso más importante en el tratamiento es evitar que continúe la exposición al berilio. Los corticosteroides constituyen el principal modo de tratamiento en la enfermedad crónica por berilio; parecen modificar favorablemente el curso de la enfermedad, aunque no la "curan".

El tratamiento con corticosteroides debe iniciarse a una dosis diaria relativamente alta de prednisona, 0,5 a $1 \mathrm{mg}$ por $\mathrm{kg} 0$ 
superior, y mantenerse hasta la mejoría de la enfermedad o hasta frenar deterioro de las pruebas funcionales y clínicas pulmonares lo que se suele producir a las 4 a 6 semanas de tratamiento. Se recomienda una reducción lenta de los esteroides, y con el tiempo podría ser posible un tratamiento a días alternos. El tratamiento con esteroides generalmente se convierte en una necesidad de por vida.

0 tras medidas de soporte, como suplemento de oxígeno, diuréticos, digital y antibióticos (cuando existe infección), podrían estar indicados en función del estado clínico del paciente. También debe considerarse la inmunización frente al virus de la gripe y al neumococo, como en el caso de todo paciente con enfermedad respiratoria crónica.

\section{- NEUMOCONIOSIS: DEFINICION}

\section{Alois David}

La expresión neumoconiosis, del griego pneuma (aire, viento) y konis (polvo) fue acuñada en Alemania por Zenker en 1867 para señalar los cambios pulmonares causados por la retención de polvo inhalado. Progresivamente, se hizo evidente la necesidad de distinguir entre los efectos de diversos tipos de polvo. Era necesario diferenciar entre el polvo mineral o vegetal y su componente microbiológico. En consecuencia, la 3a Conferencia Internacional de Expertos sobre Neumoconiosis, organizada por la OIT en Sydney en 1950, adoptó la siguiente definición: "La neumoconiosis es una enfermedad pulmonar diagnosticable causada por la inhalación de polvo, entendiéndose por el término 'polvo' una materia particulada en fase sólida, excluyendo a los organismos vivos".

Sin embargo, la palabra enfermedad parece implicar cierto grado de alteración de la salud, lo que puede no ser el caso en las neumoconiosis no relacionadas con el desarrollo de fibrosis/ cicatrización pulmonar. En general, la reacción del tejido pulmonar a la presencia de polvo varía con los diferentes tipos de éste. Los polvos no fibrogénicos provocan una reacción tisular en los pulmones caracterizada por una reacción fibrótica mínima y por ausencia de afectación de la función pulmonar. Estos polvos, algunos ejemplos de los cuales son los polvos purificados de caolinita, dióxido de titanio, óxido estannoso, sulfato de bario y óxido férrico, a menudo son conocidos como polvos biológicamente inertes.

Los polvos fibrogénicos, como el sílice o el amianto, causan una reacción fibrógena más pronunciada que da lugar a la formación de cicatrices en el tejido pulmonar y a enfermedad evidente. La división de los polvos en fibrogénicos y no fibrogénicos no es clara, ya que existen numerosos minerales, principalmente los silicatos, que tienen una capacidad intermedia de producir lesiones fibróticas en los pulmones. No obstante, demostró ser útil con fines clínicos y está reflejada en la clasificación de las neumoconiosis.

En la 4ạ Conferencia Internacional sobre Neumoconiosis, Bucarest, 1971, se adoptó una nueva definición de neumoconiosis: "La neumoconiosis es la acumulación de polvo en los pulmones y las reacciones tisulares provocadas por su presencia. A los fines de esta definición, 'polvo' es un aerosol compuesto por partículas inanimadas sólidas".

Con el fin de evitar errores de interpretación, en ocasiones se añade la expresión no neoplásica a las palabras "reacción tisular".

El grupo de trabajo de la conferencia elaboró la siguiente definición global:

D efinición de neumoconiosis
Hace tiempo, en 1950, se estableció una definición de neumoconiosis en la 3 a Conferencia Internacional de Expertos sobre Neumoconiosis, que ha estado en uso hasta el presente.

M ientras tanto, el desarrollo de nuevas tecnologías ha aumentado los riesgos profesionales, en particular los relacionados con la inhalación de contaminantes suspendidos en el aire.

El crecimiento del conocimiento en el campo de la medicina del trabajo ha permitido la identificación de nuevas enfermedades pulmonares de origen ocupacional, pero también ha demostrado la necesidad de un nuevo examen de la definición de neumoconiosis establecida en 1950.

Por este motivo, la OIT organizó un grupo de trabajo dentro del marco de la 4a Conferencia Internacional sobre Neumoconiosis con el fin de examinar el problema de la definición de neumoconiosis.

El grupo de trabajo mantuvo un debate general sobre este tema y procedió a examinar una serie de propuestas presentadas por sus miembros. Finalmente adoptó una nueva definición de neumoconiosis, que se elaboró junto con un comentario. Este texto está reproducido más adelante.

En los últimos años, y por motivos socioeconómicos, diversos países han incluido bajo el término neumoconiosis algunos procesos que evidentemente no lo son, pero que sí son enfermedades pulmonares profesionales. Bajo el término "enfermedad" se incluyen por motivos de prevención las primeras manifestaciones, que no son necesariamente discapacitantes ni reducen el tiempo de vida.

Por este motivo, el grupo de trabajo ha decidido volver a definir la neumoconiosis como la acumulación de polvo en los pulmones y las reacciones tisulares provocadas por su presencia. A los fines de esta definición, "polvo" es un aerosol compuesto por partículas inanimadas sólidas.

Desde el punto de vista anatomopatológico, las neumoconiosis pueden dividirse por conveniencia en formas colagenosas o no colagenosas.

Una neumoconiosis no colagenosa está causada por un polvo no fibrogénico, y presenta las siguientes características:

i. La arquitectura alveolar permanece íntegra

ii. La reacción estromal es mínima y consta principalmente de fibras de reticulina

iii. La reacción al polvo es potencialmente reversible.

Son ejemplos de neumoconiosis no colagenosas las causadas por polvos puros de óxido de estaño (estannosis) y sulfato bárico (baritosis).

Las neumoconiosis colagenosas se caracterizan por:

i. Alteración permanente o destrucción de la arquitectura alveolar

ii. Reacción estromal colagenosa de grado moderado a máximo, y

iii. Cicatrización permanente del pulmón.

Estas neumoconiosis colagenosas pueden estar causadas por polvos fibrogénicos o por una respuesta tisular alterada a un polvo no fibrogénico.

Son ejemplos de neumoconiosis colagenosa causada por polvos fibrogénicos la silicosis y la asbestosis, mientras que la neumoconiosis de los mineros del carbón complicada y la fibrosis masiva progresiva (FMP) son una respuesta tisular alterada a un polvo relativamente no fibrogénico.

En la práctica, la distinción entreneumoconiosiscolagenosa y no colagenosa es difícil de establecer. La exposición continua al mismo polvo, como el polvo decarbón, puede causar la transición de una forma no colagenosa a una forma colagenosa. Además, la exposición a un único polvo es cada vez menos común, y las exposicionesa polvosmixtoscon diferentesgrados 
de potencial fibrogénico pueden producir neumoconiosis, que varia desde la forma no colagenosa a la forma colagenosa.

Además, existen enfermedades pulmonares crónicas de origen ocupacional que, aunque se desarrollan a partir de la inhalación de polvo, se excluyen de las neumoconiosis debido a que no se ha demostrado que las partículas se acumulen en los pulmones.

L os siguientes son ejemplos de enfermedades pulmonares crónicas de origen ocupacional potencialmente discapacitantes: bisinosis, beriliosis, pulmón del granjero y enfermedades relacionadas. Todas ellas tienen un denominador común, a saber, que el componente etiológico del polvo ha sensibilizado al tejido pulmonar o bronquial de forma que, si es el tejido pulmonar el que responde, la inflamación tiende a ser de carácter granulomatoso, y si es el tejido bronquial el que responde, hay tendencia a la broncoconstricción.

Las exposiciones a materiales inhalados nocivos en ciertas industrias se asocian a un aumento del riesgo de mortalidad por carcinoma de las vías respiratorias. Algunos ejemplos de estos materiales son los minerales radiactivos, el amianto y los cromatos.

A doptado en la $4 \stackrel{a}{a}$ Conferencia Internacional sobre N eumoconiosis. B ucarest, 1971

\section{- CLASIFICACION INTERNACIONAL DE RADIO GRAFIAS DE NEUMOCONIOSIS DE LA OIT}

M ichel Lesage

A pesar de todos los esfuerzos nacionales e internacionales dedicados a su prevención, las neumoconiosis continúan estando presentes en países industrializados y en países en vías de desarrollo, y son responsables de la discapacidad y el deterioro de muchos trabajadores. Esta es la razón por la que la O ficina Internacional del Trabajo, la Organización Mundial de la Salud (O M S) y numerosos institutos nacionales para la salud y la seguridad profesional, continúan luchando contra estas enfermedades y proponiendo programas adecuados para su prevención. Por ejemplo, la O IT, la O M S y el Instituto N acional para la Salud y la Seguridad Profesional de Estados U nidos (US National Institute for $\mathrm{O}$ ccupational Safety and $\mathrm{H}$ ealth, NIOSH ) han propuesto en sus programas trabajar en cooperación en una lucha global contra la silicosis. Parte de este programa se basa en la vigilancia médica, que incluye la evaluación de radiografías de tórax para ayudar al diagnóstico de esta neumoconiosis. Este es un ejemplo que explica por qué la OIT, en cooperación con muchos expertos, ha desarrollado y actualizado de forma continua una clasificación de las radiografías de las neumoconiosis que proporciona un medio para registrar de forma sistemática las anomalías radiográficas torácicas provocadas por la inhalación de polvo. EI esquema está diseñado para clasificar el aspecto de las radiografías de tórax postero-anteriores.

El objeto de la clasificación es codificar las anomalías radiográficas de las neumoconiosis de manera sencilla y reproducible. La clasificación no define entidades patológicas ni tienen en cuenta la capacidad para trabajar. Tampoco implica definiciones legales de neumoconiosis con fines de indemnización ni implica un nivel en el que sea aplicable una indemnización. No obstante, se ha comprobado que la clasificación tiene un uso más amplio de lo previsto. Actualmente se utiliza de forma extensa a nivel internacional para investigaciones epidemiológicas, para la vigilancia de esas profesiones industriales y con fines clínicos. El uso de este esquema podría conducir a una mejor comparabilidad internacional de las estadísticas sobre neumoconiosis. También se utiliza para describir y registrar, de forma sistemática, parte de la información necesaria para valorar las indemnizaciones.

La condición más importante para usar este sistema de clasificación con un valor máximo desde un punto de vista científico y ético es la lectura, en todo momento, de las placas a clasificar haciendo una referencia sistemática a las 22 placas estándar proporcionadas en el juego de placas estándar de la Clasificación Internacional de la OIT. Si el lector intenta clasificar una placa sin hacer referencia a alguna de las placas estándar, no debe realizar ninguna mención del examen en relación con dicha Clasificación Internacional. La posibilidad de desviación respecto a la clasificación por exceso o por defecto es tan arriesgada que esta lectura no debe utilizarse, al menos para investigaciones epidemiológicas o para comparabilidad internacional de estadísticas sobre neumoconiosis.

La primera clasificación se propuso para la silicosis en la 1 a Conferencia Internacional de Expertos sobre N eumoconiosis, que tuvo lugar en Johanesburgo en 1930. Combinó las imágenes radiográficas y el deterioro de la funcion pulmonar. En 1958, se estableció una nueva clasificación basada únicamente en los cambios radiográficos (Clasificación de Ginebra, 1958). Desde entonces, se ha revisado varias veces, la última en 1980 , siempre con el objetivo de proporcionar versiones mejoradas para usar de forma extensa con fines clínicos y epidemiológicos. Cada nueva versión de la clasificación propuesta por la OIT ha dado lugar a modificaciones y cambios basados en la experiencia internacional adquirida en el uso de clasificaciones previas.

Con el fin de proporcionar instrucciones claras para el uso de esta clasificación, la O IT presentó en 1970 una publicación titulada International Classification of Radiographs of Pneumoconioses/ 1968 en las O ccupational Safety and Health Series (N o. 22). Esta publicación se revisó en 1972 como ILO U/C International Classification of Radiographs of Pneumoconioses/ 1971 y de nuevo en 1980 como Guidelines for the use of ILO International Classification of Radiographs of Pneumoconioses, edición revisada 1980. La descripción de las radiografías estándar se incluye en la Tabla 10.14.

\section{Clasificación de 1980 de la OIT}

La revisión de 1980 fue llevada a cabo por la OIT en cooperación con la Comisión de Comunidades Europeas, la NIOSH y el American College of Radiology. El resumen se muestra en la Tabla 10.15. Conservó el principio de anteriores clasificaciones (1968 y 1971).

La clasificación se basa en una serie de radiografías estándar, un texto escrito y una serie de notas (OHS No 22). No hay ninguna características que pueda observarse en una radiografía de tórax que sea patognomónica de exposición al polvo. El principio básico es que deben clasificarse todos los aspectos compatibles con los definidos y representados en las radiografías estándar y la guía para el uso de la Clasificación Internacional de la OIT. Si el examinador considera que un aspecto está probable o claramente no relacionado con el polvo, la radiografía no debe clasificarse, pero debe añadirse un comentario apropiado. Las 22 radiografías estándar han sido seleccionadas después de ensayos internacionales con el fin de ilustrar las normas de categorías intermedias de profusión de pequeñas opacidades y para proporcionar ejemplos de las normas de las categorías A, B y C para opacidades grandes. Las anomalías pleurales (engrosamiento pleural difuso, placas y obliteración del ángulo costofrénico) también se ilustran en diferentes radiografías. 
Tabla 10.14 - Descripción de radiografías estándar.

\begin{tabular}{|c|c|c|c|c|c|c|c|c|c|c|c|c|}
\hline \multirow[b]{2}{*}{$\begin{array}{l}1980 \\
\text { Radiografías } \\
\text { estándar que } \\
\text { muestran }\end{array}$} & \multicolumn{4}{|c|}{ Opacidades pequeñas } & \multirow[b]{2}{*}{$\begin{array}{l}\frac{y}{8} \\
8 \\
\frac{8}{8} \\
\frac{8}{8} \\
8 \\
8\end{array}$} & \multicolumn{4}{|c|}{ Engrosamiento pleural } & \multirow[b]{2}{*}{$\begin{array}{l}\frac{0}{0} \\
\frac{0}{0} \\
\frac{0}{6} \\
\frac{0}{0} \\
\frac{0}{0} \\
\frac{0}{0}\end{array}$} & \multirow[b]{2}{*}{$\frac{8}{\frac{8}{8}}$} & \multirow[b]{2}{*}{ Comentarios } \\
\hline & $\begin{array}{l}\frac{0}{6} \\
\frac{9}{8} \\
\frac{8}{0} \\
\frac{8}{0}\end{array}$ & $\begin{array}{l}\delta \\
0 \\
0 \\
1\end{array}$ & 密 & $\begin{array}{l}6 \\
0 \\
0 \\
0 \\
0\end{array}$ & & $\begin{array}{l}\frac{8}{6} \\
\frac{8}{8} \\
\frac{8}{0}\end{array}$ & torácica & $\frac{2}{8}$ & 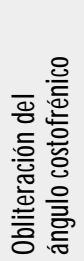 & & & \\
\hline $\begin{array}{l}\text { 0/ } 0 \\
\text { (ejemplo 1) }\end{array}$ & 1 & $0 / 0$ & - & - & No & No & No & No & No & No & Ninguno & El patrón vascular se visualiza bien \\
\hline $\begin{array}{l}\text { 0/ } 0 \\
\text { (ejemplo 2) }\end{array}$ & 1 & $0 / 0$ & - & - & No & No & No & No & No & No & Ninguno & $\begin{array}{l}\text { También muestra el patrón vascular, pero no } \\
\text { tan claramente como en el ejemplo } 1\end{array}$ \\
\hline $1 / 1 ; p / p$ & 1 & $1 / 1$ & $p / p$ & $\begin{array}{ll}R & L \\
X & X \\
X & X \\
X & X\end{array}$ & A & No & No & No & No & No & rp. & $\begin{array}{l}\text { Neumoconiosis reumatoide en la zona } \\
\text { inferior izquierda. Se observan opacidades } \\
\text { pequeñas en todas las zonas, pero la profu- } \\
\text { sión en la zona superior derecha es típica de } \\
\text { (algunos autores dirían un poco más profusa } \\
\text { que) la clasificable como categoría 1/ 1 }\end{array}$ \\
\hline $2 / 2 ; p / p$ & 2 & $2 / 2$ & $p / p$ & $\begin{array}{ll}R & L \\
X & X \\
X & X \\
X & X\end{array}$ & No & No & No & No & No & No & pi; th. & $\begin{array}{l}\text { Defecto de calidad: la radiografía es } \\
\text { demasiado clara }\end{array}$ \\
\hline $3 / 3 ; p / p$ & 1 & $3 / 3$ & $p / p$ & $\begin{array}{ll}R & L \\
X & X \\
X & X \\
X & X\end{array}$ & No & No & No & No & $\begin{array}{l}\text { Sí } \\
R L \\
x-\end{array}$ & No & $a x$. & Ninguno \\
\hline $1 / 1 ; q / q$ & 1 & $1 / 1$ & $q / q$ & $\begin{array}{ll}R & L \\
X & X \\
X & X \\
- & -\end{array}$ & No & No & No & No & No & No & Ninguno & $\begin{array}{l}\text { Muestra profusión } 1 / 1 \text { mejor que la forma } 0 \\
\text { el tamaño }\end{array}$ \\
\hline $2 / 2 ; q / 9$ & 1 & $2 / 2$ & $q / q$ & $\begin{array}{ll}R & L \\
X & X \\
X & X \\
X & X\end{array}$ & No & No & $\begin{array}{lll}S i ́ & R & \\
& x & x \\
\text { anchura: } & a & a \\
\text { extensión: } & 1 & 1\end{array}$ & No & $\begin{array}{l}\text { Sí } \\
R \quad L \\
x \quad x\end{array}$ & No & Ninguno & Ninguno \\
\hline $3 / 3 ; q / 9$ & 2 & $3 / 3$ & $q / q$ & $\begin{array}{ll}R & L \\
X & X \\
X & X \\
X & X\end{array}$ & No & No & No & No & No & No & pi. & $\begin{array}{l}\text { Defectos de calidad: mala definición de la } \\
\text { pleura y ángulos basales cortados }\end{array}$ \\
\hline $1 / 1 ; r / r$ & 2 & $1 / 1$ & $r / r$ & $\begin{array}{ll}R & L \\
X & X \\
X & X \\
- & -\end{array}$ & No & No & No & No & $\begin{array}{l}\text { Sí } \\
R L \\
-x\end{array}$ & No & Ninguno & $\begin{array}{l}\text { Defecto de calidad: movimiento del sujeto. } \\
\text { Profusión de opacidades pequeñas más } \\
\text { marcada en el pulmón derecho }\end{array}$ \\
\hline $2 / 2 ; r / r$ & 2 & $2 / 2$ & $r / r$ & $\begin{array}{ll}R & L \\
X & X \\
X & X \\
X & X\end{array}$ & No & No & No & No & No & No & Ninguno & $\begin{array}{l}\text { Defectos de calidad: radiografía demasiado } \\
\text { clara y contraste excesivo. La sombra } \\
\text { cardíaca está ligeramente desplazada hacia } \\
\text { la izquierda }\end{array}$ \\
\hline $3 / 3 ; r / r$ & 1 & $3 / 3$ & $r / r$ & $\begin{array}{ll}R & L \\
X & X \\
X & X \\
X & X\end{array}$ & No & No & No & No & No & No & $a x ;$ ih. & Ninguno \\
\hline $1 / 1 ; s / t$ & 2 & $1 / 1$ & $s / t$ & $\begin{array}{l}R \quad L \\
X- \\
X \quad X \\
X \quad X\end{array}$ & No & No & No & No & No & No & $\mathrm{kl}$. & $\begin{array}{l}\text { Defecto de calidad: bases cortadas. Líneas } \\
\text { de Kerley en la zona inferior derecha }\end{array}$ \\
\hline
\end{tabular}


Tabla 10.14 • Descripción de radiografías estándar.

Continuación.

\begin{tabular}{|c|c|c|c|c|c|c|c|c|c|c|c|c|}
\hline \multirow[b]{2}{*}{$\begin{array}{l}1980 \\
\text { Radiografías } \\
\text { estándar que } \\
\text { muestran }\end{array}$} & \multicolumn{4}{|c|}{ Opacidades pequeñas } & \multirow[b]{2}{*}{$\begin{array}{l}\frac{y}{0} \\
8 \\
0 \\
0 \\
\frac{0}{8} \\
0 \\
8 \\
8\end{array}$} & \multicolumn{4}{|c|}{ Engrosamiento pleural } & \multirow[b]{2}{*}{$\begin{array}{l}\frac{0}{0} \\
\frac{0}{0} \\
\frac{0}{6} \\
\frac{8}{0} \\
\frac{0}{0} \\
\frac{0}{0}\end{array}$} & \multirow[b]{2}{*}{$\frac{8}{\frac{8}{8}}$} & \multirow[b]{2}{*}{ Comentarios } \\
\hline & $\begin{array}{l}\frac{\theta}{6} \\
\frac{9}{8} \\
\frac{8}{0} \\
\frac{0}{0}\end{array}$ & $\begin{array}{l}6 \\
0 \\
0 \\
8\end{array}$ & 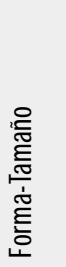 & $\begin{array}{l}6 \\
0 \\
0 \\
0 \\
0\end{array}$ & & $\begin{array}{l}\frac{9}{6} \\
\frac{8}{8} \\
\frac{8}{\theta}\end{array}$ & $\sum_{0}^{8}$ & $\frac{8}{8}$ & 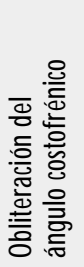 & & & \\
\hline $2 / 2 ; s / s$ & 2 & $2 / 2$ & $s / s$ & $\begin{array}{ll}R & L \\
- & - \\
x & X \\
X & X\end{array}$ & No & No & No & No & No & No & em. & $\begin{array}{l}\text { Defecto de calidad: deformación de las } \\
\text { bases debido a retracción. Enfisema en } \\
\text { zonas superiores }\end{array}$ \\
\hline $3 / 3 ; s / 5$ & 2 & $3 / 3$ & $s / s$ & $\begin{array}{ll}R & L \\
X & X \\
X & X \\
X & X\end{array}$ & No & No & $\begin{array}{l}\text { Sí } \\
\begin{array}{rl}R & L \\
x & x\end{array} \\
\text { anchura: a a } \\
\text { extensión:3 } 3\end{array}$ & No & No & No & $\begin{array}{l}\text { ho; ih; } \\
\text { pi. }\end{array}$ & $\begin{array}{l}\text { Defecto de calidad: radiografía demasiado } \\
\text { clara. Aspecto de pulmón "en panal de } \\
\text { abejas" no marcado }\end{array}$ \\
\hline $\begin{array}{l}\text { 1/ } 1 ; t / t \\
\text { Obliteración } \\
\text { del ángulo } \\
\text { costofrénico }\end{array}$ & 1 & $1 / 1$ & $t / t$ & $\begin{array}{ll}R & L \\
- & - \\
X & X \\
X & X\end{array}$ & No & No & $\begin{array}{lll}\text { Sí } & \\
& R & L \\
& x & x \\
\text { anchura: } & a & a \\
\text { extensión:2 } & 2\end{array}$ & No & $\begin{array}{ll}S i ́ & \\
R & L \\
x & -\end{array}$ & $\begin{array}{l}\text { Sí } \\
R \quad L \\
-\quad x \\
\text { exten- } \\
\text { sión: } 2\end{array}$ & Ninguno & $\begin{array}{l}\text { Esta radiografía define el límite inferior } \\
\text { para la obliteración del ángulo costofrénico. } \\
\text { Obsérvese la retracción de los campos } \\
\text { pulmonares inferiores }\end{array}$ \\
\hline $2 / 2 ; t / t$ & 1 & $2 / 2$ & $t / t$ & $\begin{array}{ll}R & L \\
X & X \\
X & X \\
X & X\end{array}$ & No & No & $\begin{array}{lll}\text { Sí } & \\
& R & L \\
& x & x \\
\text { anchura: } & a & a \\
\text { extensión: } & 1 & 1\end{array}$ & No & No & No & ih. & $\begin{array}{l}\text { Se observa engrosamiento pleural en los } \\
\text { vértices pulmonares }\end{array}$ \\
\hline $3 / 3 ; t / t$ & 1 & $3 / 3$ & $t / t$ & $\begin{array}{ll}R & L \\
X & X \\
X & X \\
X & X\end{array}$ & No & No & No & No & No & No & $\begin{array}{l}\text { hi; ho; } \\
\text { id; ih; } \\
\text { tb. }\end{array}$ & Ninguno \\
\hline $\begin{array}{l}1 / 1 ; u / u \\
2 / 2 ; u / u \\
3 / 3 ; u / u\end{array}$ & - & - & - & - & - & - & - & - & - & - & - & $\begin{array}{l}\text { Esta radiografía compuesta muestra las } \\
\text { categorías de profusión medias de } \\
\text { opacidades pequeñas clasificables por el } \\
\text { tamaño y la forma como u/ u. }\end{array}$ \\
\hline A & 2 & $2 / 2$ & $p / q$ & $\begin{array}{ll}R & L \\
X & X \\
X & X \\
X & X\end{array}$ & A & No & No & No & No & No & No & $\begin{array}{l}\text { Defectos de calidad: la radiografía es } \\
\text { demasiado clara y la definición pleural } \\
\text { es mala }\end{array}$ \\
\hline B & 1 & $1 / 2$ & $p / q$ & $\begin{array}{ll}R & L \\
X & X \\
X & X \\
X & X\end{array}$ & B & No & No & No & No & No & $a x ; c 0$. & $\begin{array}{l}\text { La definición de la pleura es ligeramente } \\
\text { imperfecta }\end{array}$ \\
\hline C & 1 & $2 / 1$ & $q / t$ & $\begin{array}{ll}R & L \\
X & X \\
X & X \\
X & X\end{array}$ & C & No & No & No & No & No & $\begin{array}{l}\text { bu; di; } \\
\text { em; es; } \\
\text { hi; ih. }\end{array}$ & $\begin{array}{l}\text { Las opacidades pequeñas son difíciles } \\
\text { de clasificar debido a la presencia de } \\
\text { opacidades grandes. Obsérvese la } \\
\text { obliteración del ángulo costofrénico } \\
\text { izquierdo. Esta no es clasificable debido } \\
\text { a que no alcanza el límite inferior definido } \\
\text { por la radiografía estándar } 1 / 1 ; \mathrm{t} \text { t }\end{array}$ \\
\hline $\begin{array}{l}\text { Engrosamiento } \\
\text { pleural } \\
\text { (circunscrito) }\end{array}$ & - & - & - & - & - & Sí & No & No & No & No & & $\begin{array}{l}\text { El engrosamiento pleural visualizado } \\
\text { frontalmente es de anchura indeterminada } \\
\text { y de extensión } 2\end{array}$ \\
\hline
\end{tabular}


Tabla 10.14 • Descripción de radiografías estándar.

Continuación.

\begin{tabular}{|c|c|c|c|c|c|c|c|c|c|c|c|c|}
\hline \multirow[b]{2}{*}{$\begin{array}{l}1980 \\
\text { Radiografías } \\
\text { estándar que } \\
\text { muestran }\end{array}$} & \multicolumn{4}{|c|}{ Opacidades pequeñas } & \multirow[b]{2}{*}{$\begin{array}{l}\frac{1}{2} \\
8 \\
0 \\
8 \\
8 \\
8 \\
8 \\
8\end{array}$} & \multicolumn{4}{|c|}{ Engrosamiento pleural } & \multirow[b]{2}{*}{$\begin{array}{l}\frac{0}{0} \\
\frac{0}{0} \\
\frac{0}{8} \\
8 \\
\frac{9}{0} \\
\frac{0}{0}\end{array}$} & \multirow[b]{2}{*}{$\frac{\frac{8}{8}}{\frac{8}{n}}$} & \multirow[b]{2}{*}{ Comentarios } \\
\hline & 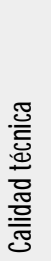 & $\begin{array}{l}0 \\
0 \\
0 \\
2\end{array}$ & 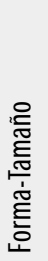 & $\begin{array}{l}0 \\
0 \\
0 \\
0 \\
0\end{array}$ & & $\begin{array}{l}\frac{8}{6} \\
\frac{6}{6} \\
\frac{8}{6} \\
\frac{8}{2}\end{array}$ & torácica & $\begin{array}{l}\frac{1}{8} \\
\frac{8}{0} \\
\frac{0}{0}\end{array}$ & 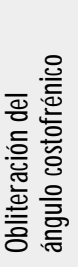 & & & \\
\hline $\begin{array}{l}\text { Engrosamiento } \\
\text { pleural } \\
\text { (difuso) }\end{array}$ & - & - & - & - & - & No & Sí & No & No & Sí & & $\begin{array}{l}\text { El engrosamiento pleural visualizado de } \\
\text { perfil es de anchura a y extensión } 2 \text {. } \\
\text { No se asocia a calcificaciones pequeñas }\end{array}$ \\
\hline $\begin{array}{l}\text { Engrosamiento } \\
\text { pleural } \\
\text { (calcificación) } \\
\text { diafragma }\end{array}$ & - & - & - & - & - & No & No & Sí & No & Sí & & $\begin{array}{l}\text { Engrosamiento pleural circunscrito, } \\
\text { calcificado, de extensión } 2\end{array}$ \\
\hline $\begin{array}{l}\text { Engrosamiento } \\
\text { pleural } \\
\text { (calcificación) }\end{array}$ & - & - & - & - & - & Sí & No & No & No & Sí & & $\begin{array}{l}\text { Engrosamiento pleural calcificado y no } \\
\text { calcificado visualizado frontalmente, de } \\
\text { anchura indeterminada y extensión } 2\end{array}$ \\
\hline
\end{tabular}

El debate, en particular el sostenido en la 7 a Conferencia Internacional sobre Neumoconiosis, que tuvo lugar en Pittsburgh en 1988, indicó la necesidad de mejoría en algunas partes de la clasificación, en particular las relativas a cambios pleurales. La O IT convocó en G inebra en noviembre de 1989 a un grupo de debate para la revisión de la Clasificación Internacional de R adiografías de N eumoconiosis de la O IT.

Los expertos sugirieron que esta corta clasificación no era útil y que, por tanto, podía dejar de usarse. Con respecto a las anomalías pleurales, el grupo acordó que esta clasificación se dividiría a partir de ahora en tres partes: "Engrosamiento pleural difuso"; "Placas pleurales"; y "O bliteración del ángulo costofrénico".

El engrosamiento pleural difuso podría dividirse a su vez en pared torácica y diafragma. Se identificaron con relación a las seis zonas: superior, media e inferior de ambos pulmones. Si un engrosamiento pleural es circunscrito, podría identificarse como una placa.

Todas las placas deben medirse en centímetros. La obliteración del ángulo costofrénico debe señalarse de forma sistemática (su presencia o ausencia). Es importante identificar si el ángulo costofrénico es visible o no, debido a su especial importancia en relación al engrosamiento pleural difuso. La clasificación o no de placas debe señalarse simplemente con un símbolo.

El aplanamiento del diafragma debe registrarse por un símbolo adicional, ya que es una característica muy importante en los casos de exposición al amianto. La presencia de placas debe registrarse en estos cuadros utilizando el símbolo correspondiente " $c$ " (calcificada) 0 " $h$ " (hialina).

En la publicación se presenta una descripción completa de la clasificación, incluidas sus aplicaciones y limitaciones (OIT 1980). La revisión de la clasificación de radiografías es un proceso que la OIT lleva a cabo de forma constante, y deberá publicarse una guía revisada en un futuro muy cercano (1997-1998), que tendrá en cuenta las recomendaciones de estos expertos.

\section{ETIO PAT O GENIA DE LAS NEUMOCONIOSIS}

Patrick Sébastien y Raymond Bégin

Las neumoconiosis se han considerado enfermedades profesionales durante mucho tiempo. Se han realizado grandes esfuerzos dirigidos a la investigación, la prevención primaria y el tratamiento médico. Pero los médicos y los higienistas informan de que el problema sigue presente, tanto en países industrializados como en vías de industrialización (Valiante, Richards y K insley 1992; $M$ arkowitz 1992). Dado que existen pruebas importantes de que los tres minerales industriales responsables de las neumoconiosis (amianto, carbón y ślice) continuarán teniendo cierta importancia económica, con la posible exposición que supone, se prevé que el problema continuará teniendo cierta importancia en todo el mundo, en particular entre las poblaciones con menos recursos de las pequeñas industrias y pequeñas instalaciones mineras. L as dificultades prácticas en la prevención primaria, o el conocimiento insuficiente de los mecanismos responsable de la inducción y la progresión de la enfermedad, son factores que posiblemente podrían explicar la presencia continua del problema.

La etiopatogenia de las neumoconiosis puede definirse como la evaluación y la comprensión de todos los fenómenos que ocurren en el pulmón después de la inhalación de partículas de polvo fibrogénicas. A menudo se encuentra en la literatura sobre este tema la expresión cascada de acontecimientos. La cascada es una serie de acontecimientos que comienza con la exposición y que, en último término, progresa hasta las formas más graves de la enfermedad. Si exceptuamos las formas raras de silicosis acelerada, que pueden desarrollarse después de sólo algunos meses de exposición, la mayoría de las neumoconiosis se desarrolla tras períodos de exposición de décadas más que de años. Esto es especialmente cierto en la actualidad en los lugares de trabajo que adoptan medidas modernas de prevención. 


\begin{tabular}{|c|c|c|}
\hline Características & Códigos & Definiciones \\
\hline \multicolumn{3}{|l|}{ Calidad técnica } \\
\hline & 1 & Buena. \\
\hline & 2 & $\begin{array}{l}\text { Aceptable, sin defectos técnicos que probablemente afectaran a la clasificación de la radiografía de } \\
\text { neumoconiosis. }\end{array}$ \\
\hline & 3 & Deficiente, con algún defecto técnico, pero todavía aceptable con fines de clasificación. \\
\hline & 4 & Inaceptable. \\
\hline
\end{tabular}

Anomalías del parénquima

Opacidades Profusión
pequeñas
pequeñas

$\begin{array}{llll} & 0 /-0 / 0 & 0 / 1 \\ & 1 / 0 & 1 / 1 & 1 / 2 \\ & 2 / 1 & 2 / 2 & 2 / 3 \\ & 3 / 2 & 3 / 3 & 3 /+ \\ \text { Extensión } & R U & R M & R L \\ & L U & L M & L L\end{array}$

Forma y tamaño

Redondeada $p / p \quad q / q \quad r / r$

Irregular $s / s \quad t / t \quad u / u$

Mixta $\quad p / s p / t p / u p / q p / r$ $q / s$ q/ $t$ q/ $u$ q/p $q / r$ r/s $r / t$ r/ u r/p r/q $s / p s / q s / r s / t \quad s / u$ $t / p t / q t / r \quad t / s \quad t / u$ $u / p u / q u / r u / s \quad u / t$

Opacidades

grandes

La categoría de profusión se basa en la valoración de la concentración de opacidades por comparación con las radiografías estándar.

Categoría 0 - ausencia de opacidades pequeñas, o éstas son menos profusas que el límite inferior de la categoría 1.

Categorías 1, 2 y 3-creciente profusión de pequeñas opacidades definida por las radiografías estándar correspondientes.

Se registran las zonas en las que se observan opacidades. Los hemotórax derecho (R) e izquierdo (L) se dividen en tres zonas- superior (U), media (M) e inferior ( $L$ ).

La categoría de la profusión se determina considerando la profusión en conjunto en las zonas afectadas en comparación con la de las radiografías estándar.

Las letras $p$, a y r indican la presencia de opacidades pequeñas redondeadas. Según el aspecto en las radiografías estándar se definen tres tamaños:

$p=$ diámetro igual o inferior a $1,5 \mathrm{~mm}$

$q=$ diámetro superior a $1,5 \mathrm{~mm}$ e igual 0 inferior a $3 \mathrm{~mm}$

$r=$ diámetro superior a $3 \mathrm{~mm}$ e igual 0 inferior a $10 \mathrm{~mm}$

Las letras $s$, t y u indican la presencia de opacidades pequeñas irregulares. Según el aspecto en las radiografías estándar se definen tres tamaños:

$\mathrm{s}=$ ancho igual 0 inferior a $1,5 \mathrm{~mm}$

$t=$ ancho superior a $1,5 \mathrm{~mm}$ e igual 0 inferior a $3 \mathrm{~mm}$

$u=$ ancho superior a $3 \mathrm{~mm}$ e igual 0 inferior a $10 \mathrm{~mm}$

Para las formas ( 0 tamaños) mixtas de las opacidades pequeñas, se regista en primer lugar la forma 0 tamaño predominante. La presencia de un número importante de otros tamaños y formas se registra tras la barra inclinada.

Las categorías se definen con respecto a las dimensiones de las opacidades.

Categoría A - opacidad con un diámetro mayor superior a $10 \mathrm{~mm}$ e igual 0 inferior a $50 \mathrm{~mm}, 0$ varias opacidades cada una superior a $10 \mathrm{~mm}$, no siendo la suma de sus diámetros mayores superior a $50 \mathrm{~mm}$.

Categoría B - una o más opacidades de mayor tamaño o más numerosas que en la categoría A cuya área combinada no es superior al equivalente de la zona superior derecha.

Categoría C - una o más opacidades cuya área combinada es superior al equivalente de la zona superior derecha.

Se reconocen dos tipos de engrosamiento pleural de la pared torácica: circunscrito (placas) y difuso. Ambos tipos pueden coexistir

Localización $R \quad L$

Anchura $a$ b $c$

El engrosamiento pleural de la pared torácica se registra por separado para los hemitórax derecho (R) e izquierdo ( 1 ).

Para el engrosamiento pleural observado a lo largo de la pared torácica lateral, la medición de la anchura máxima se realiza desde la línea más interna de la pared torácica hasta el margen más interno de la sombra observada con mayor nitidez en el límite parénquima-pleura. La anchura máxima suele estar localizada en el margen más interno de la sombra costal en su punto más externo.

a = anchura máxima inferior 0 igual a $5 \mathrm{~mm}$

$\mathrm{b}=$ anchura máxima superior a $5 \mathrm{~mm}$ e igual 0 inferior a $10 \mathrm{~mm}$

$c=$ anchura máxima superior a $10 \mathrm{~mm}$ 
Tabla 10.15 - Clasificación Internacional de 1980 de la O IT de Radiografías de N eumoconiosis: resumen de los detalles de la clasificación.

Continuación.

\begin{tabular}{|c|c|c|c|c|}
\hline \multicolumn{2}{|l|}{ Características } & \multicolumn{2}{|c|}{ Códigos } & Definiciones \\
\hline \multicolumn{5}{|c|}{ Engrosamiento pleural (continuación) } \\
\hline & Frontal & Y & N & $\begin{array}{l}\text { La presencia de engrosamiento pleural observado frontalmente se registra aunque pueda verse también de } \\
\text { perfil. Si el engrosamiento pleural sólo se observa frontalmente, la anchura por lo general no puede } \\
\text { medirse. }\end{array}$ \\
\hline & Extensión & 1 & 3 & $\begin{array}{l}\text { La extensión del engrosamiento pleural se define como la longitud máxima de la afectación pleural, o } \\
\text { como la suma de las longitudes máximas, observadas de perfil o frontalmente. } \\
1 \text { = longitud total igual o inferior a la cuarta parte de la proyección de la pared torácica lateral } \\
2 \text { = longitud total superior a la cuarta parte pero igual o inferior a la mitad de la proyección de la } \\
\text { pared torácica lateral } \\
3 \text { = longitud total superior a la mitad de la proyección de la pared torácica lateral }\end{array}$ \\
\hline \multirow[t]{2}{*}{ Diafragma } & Presencia & Y & N & $\begin{array}{l}\text { Una placa que afecta a la pleura diafragmática se registra como presente }(Y) \text { o ausente }(N) \text {, por separado } \\
\text { para los hemitórax derecho }(R) \text { e izquierdo }(L) \text {. }\end{array}$ \\
\hline & Localización & $R$ & $\mathrm{~L}$ & \\
\hline \multirow[t]{2}{*}{$\begin{array}{l}\text { Obliteración } \\
\text { del ángulo } \\
\text { costofrénico }\end{array}$} & Presencia & Y & N & $\begin{array}{l}\text { La presencia }(Y) \text { o ausencia }(N) \text { de obliteración del ángulo costofrénico se registra por separado del } \\
\text { engrosamiento sobre otras áreas, para los hemitórax derecho }(\mathrm{R}) \text { e izquierdo }(\mathrm{L}) \text {. El límite inferior para } \\
\text { esta obliteración se define por una radiografía estándar }\end{array}$ \\
\hline & Localización & $R$ & $L$ & $\begin{array}{l}\text { Si el engrosamiento se extiende hasta la pared torácica, deben registarse obliteración del ángulo } \\
\text { costofrénico y engrosamiento pleural. }\end{array}$ \\
\hline \multirow[t]{5}{*}{$\begin{array}{l}\text { Calcificación } \\
\text { pleural }\end{array}$} & Localización & & & $\begin{array}{l}\text { La localización y la extensión de la calcificación pleural se registran por separado para los dos pulmones, } \\
\text { y la extensión se define en términos de dimensiones. }\end{array}$ \\
\hline & $\begin{array}{l}\text { Pared } \\
\text { torácica }\end{array}$ & $\mathrm{R}$ & $L$ & \\
\hline & Diafragma & $R$ & $L$ & \\
\hline & Otras & $R$ & $L$ & "Otras" incluye la calcificación de la pleura mediastínica y pericárdica. \\
\hline & Extension & 1 & 23 & $\begin{array}{l}1 \text { = un área de pleura calcificada con un diámetro mayor igual o inferior a } 20 \mathrm{~mm}, 0 \text { varias áreas cuya } \\
\text { suma de los diámetros mayores es inferior o igual a } 20 \mathrm{~mm} \text {. } \\
2 \text { = un área de pleura calcificada con un diámetro mayor superior a } 20 \mathrm{~mm} \text { e igual o inferior a } 100 \mathrm{~mm} \text {, } \\
\text { o varias áreas cuya suma de los diámetros mayores es superior a } 20 \mathrm{~mm} \text { pero igual o inferior a } 100 \mathrm{~mm} \text {. } \\
3 \text { = un área de pleura calcificada con un diámetro mayor superior a } 100 \mathrm{~mm} \text {, o varias áreas } \\
\text { cuya suma de los diámetros mayores es superior a } 100 \mathrm{~mm} \text {. }\end{array}$ \\
\hline
\end{tabular}

Símbolos

Debe suponerse que la definición de cada uno de los símbolos está precedida por una palabra o frase apropiada como "sospechoso", "cambios sugestivos de", u "opacidades sugestivas de", etc.

Coalescencia de opacidades neumoconióticas pequeñas

Bulla(s)

Cáncer de pulmón o pleura

Calcificación en opacidades neumoconióticas pequeñas

Anomalía del tamaño o la forma del corazón

Cor pulmonale

Cavidad

Distorsión marcada de los órganos intratorácicos

Derrame

Enfisema claramente definido

Calcificación en cáscara de huevo de ganglios hiliares o mediastínicos

Fractura(s) costal(es)

Adenopatías hiliares o mediastínicas

Pulmón "en panal"

Diafragma mal definido

Borde cardíaco mal definido

Líneas septales (de Kerley)

Otras anomalías importantes

Continúa en la página siguiente. 
Tabla 10.15 - Clasificación Internacional de 1980 de la O IT de Radiografías de N eumoconiosis: resumen de los detalles de la clasificación.

Continuación.

$\begin{array}{lll}\text { Características } & \text { Códigos } & \text { Definiciones } \\ \text { Símbolos (continuación) } & & \\ & \mathrm{pi} & \text { Engrosamiento pleural de la cisura interlobar del mediastino } \\ \mathrm{px} & \text { Neumotórax } \\ \mathrm{rp} & \text { Neumoconiosis reumatoide } \\ \text { tb } & \text { Tuberculosis }\end{array}$

Comentarios

Presencia Y N

Deben registrarse comentarios relativos a la clasificación de la radiografía, en particular si se cree que existe alguna otra causa responsable de una sombra que podría ser interpretada por otros examinadores como debida a neumoconiosis; también para identificar radiografías en las que la calidad técnica puede haber afectado a su interpretación.

Por esto, los fenómenos etiopatogénicos deben analizarse con respecto a su dinámica a largo plazo.

En los últimos 20 años se ha obtenido gran cantidad de información sobre las numerosas y complejas reacciones pulmonares involucradas en la fibrosis pulmonar intersticial inducida por varios agentes, incluidos los polvos minerales. Estas reacciones se describieron a nivel bioquímico y celular (Richards, M asek y Brown 1991). En estas investigaciones no sólo han intervenido físicos y anatomopatólogos experimentales, sino también clínicos que utilizaron ampliamente el lavado broncoalveolar como nueva técnica pulmonar de investigación. Estos estudios permitieron caracterizar la etiopatogenia como una entidad muy compleja que, no obstante, puede descomponerse en varias facetas: (1) la propia inhalación de partículas de polvo y la subsiguiente constitución e importancia de la carga pulmonar (relaciones exposición-dosis-respuesta), (2) las características fisicoquímicas de las partículas fibrogénicas, (3) las reacciones bioquímicas y celulares que inducen las lesiones fundamentales de las neumoconiosis, y (4) los determinantes de la progresión y las complicaciones. No debe ignorarse esta última faceta, ya que las formas más graves de neumoconiosis son las que conllevan deterioros y discapacidades.

Un análisis detallado de la etiopatogenia de las neumoconiosis escapa a los objetivos de este artículo. Sería necesario distinguir los diversos tipos de polvo y profundizar en numerosas áreas especializadas, algunas de las cuales todavía son objeto de investigación activa. Pero del conocimiento actualmente disponible sobre el tema surgen nociones generales muy interesantes, que presentaremos en las cuatro "facetas" previamente mencionadas, y la bibliografía remitirá a los lectores interesados a textos más especializados. Se darán ejemplos esenciales de las tres neumoconiosis más importantes y documentadas: la asbestosis, las neumoconiosis de los mineros del carbón (N M C) y la silicosis. También se comentarán las posibles repercusiones sobre la prevención.

\section{Relaciones exposición-dosis-respuesta}

Las neumoconiosis están causadas por la inhalación de ciertas partículas de polvo fibrogénico. En la física de los aerosoles, el término polvo tiene un significado muy preciso (H inds 1982). Se refiere a partículas en suspensión en el aire obtenidas por la pulverización mecánica de un material original en estado sólido. Por tanto, este término no debe utilizarse para las partículas generadas por otros procesos. $L$ as nubes de polvo de diversos marcos industriales (p. ej., explotación minera, construcción de túneles y galerías, fabricación y limpieza con chorro de arena) contienen generalmente una mezcla de varios tipos de polvo. Las partículas de polvo en suspensión en el aire no tienen un tamaño uniforme, y muestran una distribución por tamaños. El tamaño y otros parámetros físicos (densidad, forma y carga eléctrica en la superficie) determinan el comportamiento aerodinámico de las partículas y la probabilidad de su penetración y depósito en los diversos compartimentos del sistema respiratorio.

En el campo de las neumoconiosis, el compartimento de interés es el alveolar. Las partículas en suspensión en el aire suficientemente pequeñas para alcanzar este compartimento reciben el nombre de partículas respirables. No todas las partículas que alcanzan los compartimentos alveolares se depositan sistemáticamente, sino que algunas están presentes en el aire espirado. Actualmente se conocen bien los mecanismos físicos responsables del depósito de las partículas isométricas (R aabe 1984) y de las partículas fibrosas (Sébastien 1991). Se han determinado las funciones que relacionan la probabilidad de depósito con los parámetros físicos. Las partículas respirables y las partículas depositadas en el compartimento alveolar tienen características de tamaño ligeramente diferentes. En el caso de las partículas no fibrosas, se utilizan instrumentos de toma de muestras del aire selectivos con respecto al tamaño e instrumentos de lectura directa para medir las concentraciones ponderales de las partículas respirables. Para las partículas fibrosas, el método es diferente. La técnica de medición se basa en el atrapamiento en filtro del "polvo total" y el recuento de fibras al microscopio óptico. En este caso, la selección por el tamaño se realiza excluyendo del recuento las fibras "no respirables" con dimensiones superiores a criterios predeterminados.

Tras el depósito de partículas sobre las superficies alveolares, comienza en éstas el denominado proceso de depuración o aclaramiento alveolar. EI reclutamiento quimiotáctico de macrófagos y la fagocitosis constituyen las primeras fases. Se han descrito varias vías de depuración; la eliminación de macrófagos cargados de polvo hacia las vías aéreas ciliadas, la interacción con las células epiteliales y la transferencia de partículas libres a través de la membrana alveolar, la fagocitosis por macrófagos intersticiales, el secuestro en el área intersticial y el transporte a los ganglios linfáticos (Lauweryns y Baert 1977). Las vías de depuración tienen características cinéticas específicas. No sólo es el régimen de exposición el que desencadena la activación de las diferentes vías responsables de la retención de las partículas depositadas en los pulmones, sino también las características fisicoquímicas de estos contaminantes. 
El concepto de un patrón de retención específico para cada tipo de polvo es bastante reciente, pero actualmente está suficientemente establecido para ser integrado en los esquemas de la etiopatogenia. Por ejemplo, este autor ha observado que tras la exposición a largo plazo al amianto, las fibras se acumulan en el pulmón si son del tipo anfibólico, pero no si son del tipo crisotílico (Sébastien 1991). Se ha demostrado que las fibras cortas se depuran con mayor rapidez que las más largas. Se sabe que el cuarzo muestra cierto tropismo por la linfa y que penetra rápidamente en el sistema linfático. También se ha demostrado que la modificación de las características químicas de superficie de las partículas de cuarzo afecta a su depuración alveolar (H emenway y cols. 1994; Dubois y cols. 1988). La exposición concomitante a varios tipos de polvo también puede influir en la depuración alveolar (D avis, Jones y M iller 1991).

Durante la depuración alveolar, las partículas de polvo pueden sufrir ciertos cambios químicos y físicos. Algunos ejemplos de estos cambios son el revestimiento con material ferruginoso, la separación de algunos componentes fundamentales y la adsorción de algunas moléculas biológicas.

0 tro concepto recientemente derivado de experimentos con animales es el de la "sobrecarga pulmonar" (M ermelstein y cols. 1994). R atas expuestas intensamente por inhalación a diversos polvos insolubles desarrollaron respuestas similares: inflamación crónica, aumento del número de macrófagos cargados con partículas, aumento del número de partículas en el intersticio, engrosamiento septal, lipoproteinosis y fibrosis. Estos hallazgos no se atribuyeron a la reactividad del polvo ensayado (dióxido de titanio, cenizas volcánicas, coque del petróleo, polivinil cloruro, tóner, negro de humo y partículas de escapes diesel), sino a una exposición excesiva de los pulmones. Se desconoce si debe tenerse en cuenta la sobrecarga pulmonar en el caso de la exposición humana a polvos fibrogénicos.

Entre las vías de depuración, la transferencia hacia el intersticio sería especialmente importante en las neumoconiosis. $L a$ depuración de partículas secuestradas en el intersticio es mucho menos eficaz que la depuración de partículas atrapadas por los macrófagos en el espacio alveolar y eliminadas por las vías aéreas ciliadas (V incent y D onaldson 1990). En seres humanos, se observó que tras la exposición a largo plazo a diversos contaminantes inorgánicos en suspensión en el aire, el depósito fue mucho mayor en los macrófagos intersticiales que en los alveolares (Sébastien y cols. 1994). También se expresó la idea de que en la fibrosis pulmonar inducida por sílice interviene la reacción de las partículas con los macrófagos intersticiales más que con los macrófagos alveolares (Bowden, Hedgecock y Adamson 1989). La retención es responsable de la "dosis", una medida del contacto entre las partículas de polvo y su entorno biológico. Para hacer una descripción apropiada de la dosis se requeriría saber en cada momento la cantidad de polvo depositado en las diversas estructuras y células pulmonares, los estados fisicoquímicos de las partículas (incluidos los estados de la superficie) y las interacciones entre las partículas y las células y líquidos pulmonares.

La valoración directa de la dosis en seres humanos es, evidentemente, una tarea imposible, aún disponiendo de métodos para medir las partículas de polvo en diversas muestras biológicas de origen pulmonar, como el esputo, el líquido de lavado boncoalveolar o los tejidos obtenidos por biopsia o autopsia (Bignon, Sébastien y Bientz 1979). Estos métodos se utilizaron con diversos propósitos: proporcionar información sobre los mecanismos de retención, validar cierta información sobre la exposición, estudiar el papel de varios tipos de polvo en el desarrollo patogénico (p. ej., exposición anfibólica frente a crisotílica en la asbestosis, o cuarzo frente a carbón en la NM C) y contribuir al diagnóstico.
Pero estas medidas directas sólo proporcionan una idea puntual de la retención en el momento de la toma de muestra y no permiten al investigador reconstruir los datos referentes a las dosis. Los nuevos modelos dosimétricos ofrecen interesantes perspectivas a este respecto (K atsnelson y cols. 1994; Smith 1991; Vincent y D onaldson 1990). Estos modelos tienen como objetivo valorar la dosis a partir de información sobre la exposición considerando la probabilidad de depósito y la cinética de las diferentes vías de depuración. Recientemente se introdujo en estos modelos el interesante concepto de la "distribución nociva" (Vincent y Donaldson 1990). Este concepto tiene en cuenta la reactividad específica de las partículas depositadas, considerando a cada partícula como una fuente que libera algunas entidades tóxicas al medio pulmonar. Por ejemplo, en el caso de las partículas de cuarzo, podría teorizar que algunos sitios de la superficie podrían ser la fuente de especies de oxígeno activo. Los modelos desarrollados en estas líneas también podrían perfeccionarse para tener en cuenta la gran variación interindividual observada en general con la depuración alveolar. Esto se documentó experimentalmente con el amianto, observándose que los "animales con alta retención" tenían un riesgo mayor de desarrollar asbestosis (Bégin y Sébastien 1989).

$\mathrm{H}$ asta ahora, estos modelos fueron utilizados exclusivamente por anatomopatólogos experimentales. Pero también podrían ser útiles para los epidemiólogos (Smith, 1991). La mayoría de los estudios epidemiológicos centrados en las relaciones entre la exposición y la respuesta se basaron en la "exposición acumulada", un índice de exposición obtenido integrando en el tiempo las concentraciones estimadas de polvo en suspensión en el aire a las que los trabajadores habían estado expuestos (producto de la intensidad y la duración). EI uso de la exposición acumulada presenta algunas limitaciones. LoS análisis basados en este índice suponen de forma simplista que la duración y la intensidad tienen efectos equivalentes sobre el riesgo (Vacek y M cD onald 1991).

Q uizá el uso de estos modelos dosimétricos sofisticados podría proporcionar alguna explicación para una observación común en la epidemiología de las neumoconiosis: "Ias considerables diferencias interpersonales", fenómeno observado claramente en la asbestosis (Becklake 1991) y en la N M C (Attfield y M orring 1992). Cuando se relacionó la prevalencia de la enfermedad con la exposición acumulada, se observaron grandes diferencias - de hasta 50 veces - en el riesgo entre algunos grupos profesionales. El origen geológico del carbón (rango del carbón) proporcionó una explicación parcial de la NMC, de forma que los depósitos de minería de carbón de alto rango (un mineral con un contenido elevado de carbón, como la antracita) conllevaban un riesgo mayor. El fenómeno todavía no se ha explicado en el caso de la asbestosis. Las dudas sobre la idoneidad de la curva de exposición-respuesta guardan cierta relación - al menos en teoría - con el resultado, incluso con las normas de exposición actuales.

De forma más general, las medidas de la exposición son esenciales en el proceso de la valoración del riesgo y el establecimiento de límites de control. Los nuevos modelos dosimétricos podrían mejorar el proceso de valoración del riesgo en las neumoconiosis, con el objetivo último de aumentar el grado de protección ofrecido por los límites de control (K riebel 1994).

\section{Características fisicoquímicas de las partículas de polvo fibrogénicas}

EI concepto probablemente más importante surgido progresivamente durante los últimos 20 años ha sido el de la toxicidad específica de cada tipo de polvo, relacionada con las características químicas de las partículas (incluidas las más sutiles, como son las características de la superficie). En las primeras fases de la 
investigación, no se realizó ninguna diferenciación entre los "polvos minerales". Posteriormente se introdujeron categorías genéricas: amianto, carbón, fibras inorgánicas, filosilicatos y ślice. Pero se observó que esta clasificación no era suficientemente precisa para caracterizar los diversos efectos biológicos observados. En la actualidad se utiliza una clasificación mineralógica. Por ejemplo, se distinguen los diversos tipos mineralógicos de amianto: crisotila serpentina, amosita anfibólica, crocidolita anfibólica y tremolita anfibólica. Para el sílice, generalmente se distingue entre cuarzo (con mucho el más prevalente), otros polimorfos cristalinos y variedades amorfas. En el campo del carbón, deben tratarse por separado los carbones de alto rango y de bajo rango, ya que existen pruebas importantes de que el riesgo de NM C y, especialmente, el riesgo de fibrosis progresiva masiva, es mucho mayor tras la exposición al polvo producido en las minas de carbón de alto rango.

Pero la clasificación mineralógica también tiene algunas limitaciones. Existen pruebas experimentales y epidemiológicas (teniendo en cuenta las "diferencias interpersonales") de que se puede modular la toxicidad intrínseca de un solo tipo mineralógico de polvo actuando sobre las características fisicoquímicas de las partículas. Esto planteó la difícil cuestión de la importancia toxicológica de cada uno de los numerosos parámetros que pueden usarse para describir una partícula de polvo y una nube de polvo. A nivel de partícula individual, pueden considerarse varios parámetros: características químicas generales, estructura cristalina, forma, densidad, tamaño, superficie, propiedades químicas de superficie y carga de superficie. Al considerar las nubes de polvo se añade otro nivel de complejidad debido a la distribución de estos parámetros (p. ej., la distribución por tamaño y la composición del polvo mixto).

El tamaño de las partículas y las propiedades químicas de su superficie fueron los parámetros más estudiados para explicar el efecto modulador. Como se comentó anteriormente, los mecanismos de retención están relacionados con el tamaño. Pero el tamaño también puede modular la toxicidad in situ, como se demostró en numerosos estudios en animales e in vitro.

En el campo de las fibras minerales, el tamaño se consideró de tal importancia que constituyó la base de una teoría patogénica que atribuía la toxicidad de las partículas fibrosas (naturales y artificiales) a la forma y al tamaño de las partículas, sin tener en cuenta su composición química. Al considerar las fibras, el tamaño debe descomponerse en longitud y diámetro. D ebe utilizarse una matriz bidimensional para informar las distribuciones de tamaño, y los rangos útiles son de 0,03 a $3 \mu \mathrm{m}$ de diámetro y de 0,3 a $300 \mu \mathrm{m}$ de longitud (Sébastien 1991). Integrando los resultados de los numerosos estudios, Lippman (1988) asignó un índice de toxicidad a varias células de la matriz. Existe una tendencia general a creer que las fibras largas y finas son las más peligrosas. D ebido a que las normas utilizadas actualmente en la higiene industrial se basan en el uso del microscopio óptico, ignoran las fibras más finas. Si la valoración de la toxicidad específica de cada célula de la matriz tiene cierto interés académico, su interés práctico está limitado por el hecho de que cada tipo de fibra se asocia a una distribución por tamaños específicos relativamente uniforme. Para las partículas compactas, como el carbón y el sílice, existen pruebas dudosas sobre un posible papel específico de las diferentes subfracciones de tamaño de las partículas depositadas en la región alveolar del pulmón.

Teorías patogénicas más recientes en el campo del polvo mineral sugieren la existencia de sitios químicos activos (o funcionalidades) en la superficie de las partículas. Cuando se origina la partícula por separación de su matriz material, algunos enlaces químicos se rompen, ya sea de forma heterolítica u homolítica. L os acontecimientos que tienen lugar durante la rotura y las posteriores recombinaciones o reacciones con moléculas del aire o moléculas biológicas determinan las propiedades químicas de superficie de las partículas. Con respecto a las partículas de cuarzo, por ejemplo, se han descrito varias funcionalidades químicas de especial interés: puentes de siloxano, grupos silanol, grupos parcialmente ionizados y radicales basados en silicona.

Estas funcionalidades pueden iniciar reacciones acidobásicas y redox. Sólo recientemente se ha prestado atención a estas últimas (Dalal, Shi y Vallyathan 1990; Fubini y cols. 1990; Pézerat y cols. 1989; K amp y cols. 1992; K ennedy y cols. 1989; Bronwyn, Razzaboni y Bolsaitis 1990). Actualmente existen pruebas convincentes de que las partículas con radicales de superficie pueden producir especies de oxígeno reactivo, incluso en el medio celular. No se ha establecido aún si debe atribuirse toda la producción de especies de oxígeno a los radicales de superficie. Se especula que estos sitios podrían desencadenar la activación de las células pulmonares (H emenway y cols. 1994). 0 tros sitios podrían estar relacionados con reacciones como la atracción iónica, la unión por medio de enlaces de hidrógeno y la unión hidrófoba (N olan y cols. 1981; H eppleston 1991).

Tras la identificación de las propiedades químicas de la superficie como un determinante importante de la toxicidad del polvo, se realizaron varios intentos para modificar las superficies naturales de partículas de polvo mineral a fin de reducir su toxicidad, valorados en modelos experimentales.

Se observó que la adsorción de aluminio en partículas de cuarzo reduce su fibrogenicidad y favorece la depuración alveolar (Dubois y cols. 1988). El tratamiento con polivinilpiridina-N-óxido (PVPNO) también tuvo cierto efecto profiláctico (Goldstein y Rendall 1987; H eppleston 1991). Se utilizaron otros varios procesos modificadores: pulverización, tratamiento térmico, grabado ácido y adsorción de moléculas orgánicas (Wiessner y cols. 1990). Las partículas de cuarzo recién fracturadas mostraron la actividad de superficie más alta (Kuhn y Demers 1992; Vallyathan y cols. 1988). Llama la atención el hecho de que cualquier desviación con respecto a esta "superficie fundamental" causa una disminución de la toxicidad del cuarzo (Sébastien 1990). La pureza de la superficie de diversas variedades de cuarzo formadas de modo natural podría ser responsable de algunas diferencias observadas en cuanto a la toxicidad (Wallace y cols. 1994). Algunos datos apoyan la idea de que la cantidad de superficie de cuarzo no contaminada es un parámetro importante (K riegseis, Scharman y Serafin 1987).

La multiplicidad de los parámetros, junto con su distribución en la nube de polvo, da lugar a varias formas posibles de describir las concentraciones atmosféricas: concentración ponderal, concentración numérica, concentración de superficie y concentración en varias categorías de tamaño. Por tanto, pueden construirse numerosos índices de exposición, de cada uno de los cuales debe valorarse la importancia toxicológica. Las normas actuales en higiene profesional reflejan esta multiplicidad. Para el amianto, las normas se basan en la concentración numérica de partículas fibrosas incluidas en cierta categoría de tamaño geométrico. Para el sílice y el carbón, las normas se basan en la concentración ponderal de partículas respirables. También se han desarrollado algunas normas para la exposición a mezclas de partículas que contienen cuarzo. Ninguna norma se basa en características de la superficie.

\section{Mecanismos biológicos que inducen las lesiones fundamentales}

L as neumoconiosis son enfermedades pulmonares fibrosas intersticiales, en las que la fibrosis puede ser difusa o nodular. En la reacción fibrótica interviene la activación de los fibroblastos pulmonares (Goldstein y Fine 1986) y la producción y el metabolismo de los componentes del tejido conectivo (colágeno, elastina 
y glucosaminoglicanos). Se considera que representa una fase de cicatrización tardía tras la lesión pulmonar ( $\mathrm{N}$ iewoehner y $\mathrm{H}$ oidal 1982). Aunque varios factores, fundamentalmente relacionados con las características de la exposición, pueden modular la respuesta anatomopatológica, es interesante señalar que cada tipo de neumoconiosis se caracteriza por lo que podría denominarse una lesión fundamental. $L a$ alveolitis fibrosante alrededor de las vías aéreas periféricas constituye la lesión fundamental de la exposición al amianto (Bégin y cols. 1992). El nódulo silicótico es la lesión fundamental de la silicosis (Ziskind, Jones y Weil 1976). La NM C simple está compuesta por máculas y nódulos de polvo (Seaton 1983).

La patogenia de la neumoconiosis se suele presentar como una cascada de acontecimientos cuya secuencia discurre de la siguiente forma: alveolitis por macrófagos alveolares, señalización por citocinas de células inflamatorias, lesión oxidativa, proliferación y activación de fibroblastos y del metabolismo del colágeno y la elastina. La alveolitis por macrófagos alveolares es una reacción característica a la retención de polvo mineral fibrosante (Rom 1991). La alveolitis se define por un aumento del número de macrófagos alveolares activados, que liberan cantidades excesivas de mediadores tales como oxidantes, quimiotaxinas, factores de crecimiento de fibroblastos y proteasas. Las quimiotaxinas atraen a los neutrófilos y, junto con los macrófagos, pueden liberar oxidantes capaces de oxidar las células epiteliales alveolares. Los factores de crecimiento de fibroblastos consiguen acceder al intersticio, donde estimulan a los fibroblastos para que se repliquen y aumenten la producción de colágeno.

La cascada comienza en el momento del primer encuentro de las partículas que se depositan en los alveolos. En el caso del amianto, por ejemplo, la lesión pulmonar inicial ocurre casi inmediatamente después de la exposición, a nivel de las bifurcaciones de los conductos alveolares. Después de sólo una hora de exposición en experimentos en animales, se produce una captación activa de fibras por las células epiteliales de tipo I (Brody y cols. 1981). En 48 horas, se acumula un número elevado de macrófagos alveolares en los lugares de depósito. En casos de exposición crónica, este proceso puede conducir a una alveolitis fibrosante peribronquiolar.

Se desconoce el mecanismo exacto por el cual las partículas depositadas producen una lesión bioquímica primaria en el revestimiento alveolar, en una célula específica o en cualquiera de sus organelas. Es posible que reacciones bioquímicas complejas y extremadamente rápidas conduzcan a la formación de radicales libres, a la peroxidación de lípidos o a la depleción de algunas especies de moléculas protectoras de células vitales. Se ha demostrado que las partículas minerales son capaces de actuar como sustratos catalíticos para la generación de radicales hidroxilo y superóxido (G uilianelli y cols. 1993).

A nivel celular, disponemos de más información. Después del depósito a nivel alveolar, las células epiteliales de tipo I, sumamente delgadas, se lesionan con facilidad (Adamson, Young y Bowden 1988). L os macrófagos y otras células inflamatorias son atraídas al lugar de la lesión y la respuesta inflamatoria se ve amplificada por la liberación de metabolitos del ácido araquidónico, como prostaglandinas y leucotrienos, junto con la exposición de la membrana basal (H oltzman 1991; K uhn y cols. 1990; Engelen y cols. 1989). En esta fase de la lesión primaria, la arquitectura pulmonar se desorganiza y muestra edema intersticial.

Durante el proceso inflamatorio crónico, tanto la superficie de las partículas de polvo como las células inflamatorias activadas liberan mayores cantidades de especies de oxígeno reactivas en las vías respiratorias inferiores. El esfuerzo oxidativo al que está sometido el pulmón tiene ciertos efectos detectables sobre el sistema de defensa antioxidante (H effner y Repine 1989), con expresión de enzimas antioxidantes como la superóxido dismutasa, la catalasa y las glutatión peroxidasas (Engelen y cols. 1990). Estos factores se localizan en el tejido pulmonar, el fluido intersticial y los eritrocitos circulantes. Los perfiles de enzimas antioxidantes pueden depender del tipo de polvo fibrogénico (Janssen y cols. 1992). Los radicales libres son conocidos mediadores de lesiones tisulares y de enfermedad (K ehrer 1993).

La fibrosis intersticial deriva de un proceso de reparación. Se han propuesto numerosas teorías para explicar cómo funciona este proceso. La interacción macrófago-fibroblasto es el proceso que ha recibido mayor atención. Los macrófagos activados segregan una red de citoquinas fibrogénicas proinflamatorias: TNF, IL-I, factor de crecimiento transformador y factor de crecimiento derivado de las plaquetas. También producen fibronectina, una glucoproteína de superficie celular que actúa como un atrayente químico y, en ciertas condiciones, como estimulante del crecimiento de las células mesenquimatosas. Algunos autores consideran que ciertos factores son más importantes que otros. Por ejemplo, en la patogenia de la silicosis se concedió especial importancia al TNF. En animales de experimentación, se demostró que el depósito de colágeno después de la instilación de sílice en ratones se prevenía prácticamente por completo mediante anticuerpos anti-T N F (Piguet y cols. 1990). La liberación de factor de crecimiento derivado de las plaquetas y de factor de crecimiento transformador se presentó como un elemento que desempeñaba un papel importante en la patogenia de la asbestosis (Brody 1993).

Por desgracia, muchas de las teorías relativas a la interacción macrófagos-fibroblastos tienden a ignorar el equilibrio potencial entre las citocinas fibrógenas y sus inhibidores (K elley 1990). De hecho, el desequilibrio resultante entre agentes oxidantes y antioxidantes, proteasas y antiproteasas, los metabolitos del ácido araquidónico, elastasas y colagenasas, así como los desequilibrios entre las diversas citocinas y factores de crecimiento, determinarían la remodelación anormal del componente intersticial hacia las distintas formas de neumoconiosis (Porcher y cols. 1993). En las neumoconiosis, el equilibrio está claramente dirigido hacia un efecto abrumador de las actividades lesivas de las citocinas.

Debido a que las células de tipo I son incapaces de dividirse, después de la agresión primaria la barrera epitelial es sustituida por células de tipo II (Lesur y cols. 1992). Existen ciertos datos que sugieren que si este proceso de reparación epitelial tiene éxito y ya no se lesionan en mayor medida las células de tipo II regeneradoras, no es probable que la fibrogénesis continúe. En ciertas circunstancias, la reparación por células de tipo II es excesiva y conduce a proteinosis alveolar. Este proceso se demostró claramente después de la exposición al sílice (H eppleston 1991). Se desconoce hasta qué punto las alteraciones de las células epiteliales influyen sobre los fibroblastos. Así, parecería que la fibrogénesis se inicia en áreas de lesión epitelial extensa a medida que los fibroblastos se replican, se diferencian y producen más colágeno, fibronectina y otros componentes de la matriz extracelular.

Existen numerosas publicaciones sobre la bioquímica de los diversos tipos de colágeno formado en las neumoconiosis (R ichards, M asek y Brown 1991). El metabolismo del colágeno y su estabilidad en el pulmón son importantes elementos del proceso de la fibrogénesis. Esta misma consideración probablemente pueda aplicarse también a los otros componentes del tejido conectivo lesionado. El metabolismo del colágeno y la elastina es especialmente interesante en la fase de cicatrización, dada la gran importancia de estas proteínas para la función y la estructura pulmonares. Se ha demostrado de forma muy elegante que las alteraciones de la síntesis de estas proteínas podrían determinar el desarrollo de enfisema o fibrosis después 
de la lesión pulmonar (N iewoehner y H oidal 1982). En el estado de enfermedad, mecanismos como el aumento de la actividad de la transglutaminasa podrían favorecer la formación de masas de proteínas estables. En algunas lesiones fibróticas de la NM C, los componentes proteicos son responsables en una tercera parte de la lesión, y el resto corresponde a polvo y a fosfato cálcico.

Si consideramos únicamente el metabolismo del colágeno, son posibles diversas fases de fibrosis, algunas de las cuales son potencialmente reversibles, mientras que otras son progresivas. $\mathrm{H}$ ay datos experimentales que indican que, a menos que se supere una exposición crítica, las lesiones primarias pueden remitir y es improbable que se produzca una fibrosis irreversible. Por ejemplo, en la asbestosis, se describieron distintos tipos de reacciones pulmonares (Bégin, C antin y $M$ assé 1989): una reacción inflamatoria transitoria sin lesión, una reacción de retención baja con cicatriz fibrótica limitada a las vías aéreas distales, una reacción inflamatoria alta debida a la exposición continuada y a la escasa depuración de las fibras más largas.

A partir de estos estudios se puede llegar a la conclusión de que la exposición a partículas de polvo fibrótico es capaz de activar diversas vías bioquímicas y celulares complejas que participan en la lesión y reparación pulmonares. El régimen de exposición, las características fisicoquímicas de las partículas de polvo $y$, posiblemente, factores de susceptibilidad individual, parecen ser los determinantes del delicado equilibrio entre las distintas vías. Las características fisicoquímicas determinarán el tipo de la lesión fundamental final. El régimen de exposición parece determinar el curso temporal de los acontecimientos. Ciertos datos indican que los regímenes de exposición suficientemente bajos son capaces en la mayoría de los casos de limitar la reacción pulmonar a lesiones no progresivas sin discapacidad ni deterioro.

La vigilancia médica y la detección selectiva siempre han formado parte de las estrategias para la prevención de las neumoconiosis. En ese contexto, la posibilidad de detectar ciertas lesiones precoces resulta ventajosa. El mayor conocimiento de la patogenia preparó el camino para el desarrollo de diversos marcadores biológicos (Borm 1994) y para el perfeccionamiento y la utilización de técnicas de investigación pulmonar "no clásicas", como la medición de la tasa de depuración del pentacetato de dietilentriamina de tecnecio-99 (99 Tc-DTPA) para valorar la integridad del epitelio pulmonar ( 0 'Brodovich y Coates 1987), y la gammagrafía pulmonar cuantitativa con galio-67 para valorar la actividad inflamatoria (Bisson, Lamoureux y Bégin 1987).

En el campo de las neumoconiosis, se consideraron diversos marcadores biológicos: macrófagos del esputo, factores de crecimiento del suero, péptido procolágeno sérico tipo III, antioxidantes eritrocitarios, fibronectina, elastasa leucocitaria, metaloendopeptidasa neutra y péptidos de elastina en el plasma, hidrocarburos volátiles en el aire espirado, y liberación de T NF por los monocitos de sangre periférica. Los marcadores biológicos son conceptualmente elementos muy interesantes, pero es necesario realizar muchos más estudios para valorar su importancia con exactitud. Este esfuerzo de validación será bastante intenso, ya que requerirá de los investigadores la realización de estudios epidemiológicos prospectivos. Tal esfuerzo fue llevado a cabo recientemente para la liberación de T N F por los monocitos de sangre periférica en las N M C. Se comprobó que el T NF era un marcador interesante de la progresión de la NMC (Borm 1994). Además de los aspectos científicos del significado de los marcadores biológicos en la patogenia de las neumoconiosis, es preciso examinar cuidadosamente otros aspectos relacionados con el uso de los marcadores biológicos (Schulte 1993), como son las oportunidades de prevención, el impacto sobre la medicina del trabajo y problemas éticos y legales.

\section{Progresión y complicaciones de las neumoconiosis}

En los primeros decenios de este siglo, la neumoconiosis se consideraba como una enfermedad que discapacitaba a los jóvenes y provocaba muerte prematura. En la actualidad, en los países industrializados no suele considerarse más que una anomalía radiológica sin deterioro ni discapacidad (Sadoul 1983). Sin embargo, a esta afirmación optimista deben contraponerse dos observaciones. En primer lugar, y aunque en condiciones de exposición limitada la neumoconiosis sigue siendo una enfermedad relativamente silente y asintomática, debe saberse que puede evolucionar hacia formas más graves y discapacitantes. L oS factores que afectan a esta progresión son sin duda importantes en la etiopatogenia de este proceso. En segundo lugar, existen actualmente datos que indican que algunas neumoconiosis son capaces de afectar al estado de salud general, y pueden ser un factor contribuyente al desarrollo de cáncer de pulmón.

La naturaleza crónica y progresiva de la asbestosis se ha documentado desde la lesión subclínica inicial hasta la asbestosis clínica (Bégin, Cantin y M assé 1989). Las técnicas modernas de investigación pulmonar (BAL, TC, captación pulmonar de galio-67) pusieron de manifiesto que la inflamación y la lesión eran continuas desde el momento de la exposición, pasando por una fase de latencia o subclínica, hasta el desarrollo de la enfermedad clínica. Se ha comunicado (Bégin y cols. 1985) que el $75 \%$ de los sujetos que presentaban inicialmente una gammagrafía con galio-67 positiva pero sin asbestosis clínica en ese momento, evolucionaron hasta una asbestosis clínica franca en un período de 4 años. En seres humanos y en animales de experimentación, la asbestosis puede progresar después de identificada la enfermedad e interrumpida la exposición. Es sumamente probable que la historia de exposición previa a la identificación sea un determinante importante de la progresión. Ciertos datos experimentales apoyan el concepto de la asbestosis no progresiva asociada a una exposición de inducción leve y a una interrupción de la exposición al identificarse la enfermedad (Sébastien, Dufresne y Bégin 1994). Suponiendo que el mismo concepto pueda aplicarse al ser humano, sería de importancia capital establecer con exactitud los parámetros de "exposición de inducción leve". A pesar de todos los esfuerzos dirigidos a la exploración selectiva de poblaciones trabajadoras expuestas al amianto, todavía no se dispone de esta información.

Es bien sabido que la exposición al amianto puede provocar un riesgo muy elevado de cáncer de pulmón. Aunque admitamos que el amianto es un carcinógeno per se, hace tiempo que se debate el hecho de si el riesgo de cáncer de pulmón entre los trabajadores del amianto está relacionado con la exposición al amianto o con la fibrosis pulmonar (H ughes y Weil 1991), tema que aún no se ha resuelto.

D ebido a las continuas mejoras de las condiciones de trabajo en las instalaciones de las minas modernas, la NMC es una enfermedad que en la actualidad afecta básicamente a mineros retirados. Si la NMC simple es un proceso asintomático y que no presenta un efecto demostrable sobre la función pulmonar, la fibrosis masiva progresiva (FM P) es un proceso mucho más grave que provoca alteraciones estructurales importantes, déficit de la función pulmonar y una reducción de la esperanza de vida. M uchos estudios han intentado identificar los determinantes de la progresión hacia FMP (retención intensa de polvo en el pulmón, rango de carbón, infección por micobacterias o estimulación inmunológica). Se propuso una teoría unificadora (Vanhee y cols. 1994) basada en una inflamación alveolar continua e intensa con activación de los macrófagos alveolares y producción sustancial de especies de oxígeno reactivas, factores quimiotácticos y fibronectina. 0 tras complicaciones de la NM C son la infección por micobacterias, el síndrome de Caplan y la 
esclerodermia. No hay pruebas de que exista un mayor riesgo de cáncer de pulmón entre los mineros del carbón.

La forma crónica de la silicosis sigue a la exposición, medida en décadas más que en años, a polvo respirable que contiene generalmente menos del $30 \%$ de cuarzo. Pero en el caso de la exposición incontrolada a polvo rico en cuarzo (exposiciones históricas con explosiones de tierra, por ejemplo), pueden encontrarse formas agudas y aceleradas después de sólo algunos meses de exposición. Los casos de enfermedad aguda y acelerada presentan un riesgo especialmente alto de complicarse con una tuberculosis (Ziskind, Jones y Weil 1976). También puede producirse la progresión, con desarrollo de grandes lesiones que obliteran la estructura pulmonar, y que reciben el nombre de silicosis complicada o F M P.

Algunos estudios examinaron la progresión de la silicosis en relación con la exposición y obtuvieron resultados discordantes acerca de las relaciones entre progresión y exposición, antes y después del comienzo (H essel y cols. 1988). Recientemente, Infante-R ivard y cols. (1991) estudiaron los factores pronósticos que influyen en la supervivencia de los pacientes con silicosis compensada. L os pacientes con pequeñas opacidades aisladas en la radiografía de tórax y que no presentaban disnea, expectoración ni ruidos respiratorios anormales, tenían una supervivencia similar a la de los sujetos de referencia. Los otros pacientes presentaban una supervivencia peor. Finalmente, debemos mencionar la reciente preocupación que ha surgido en torno al sílice, la silicosis y el cáncer de pulmón. Existen datos a favor y en contra del planteamiento de que el sílice per se es cancerígeno (A gius 1992). El sílice puede actuar de forma sinérgica con cancerígenos ambientales potentes, como los presentes en el humo del tabaco, a través de un efecto promotor relativamente leve sobre la carcinogénesis o mediante un deterioro de su depuración. Es más, este proceso asociado a la silicosis o resultante en ella, podría conllevar un mayor riesgo de padecer cáncer de pulmón.

En la actualidad, la progresión y la complicación de las neumoconiosis podría considerarse un aspecto clave para el tratamiento médico. La utilización de técnicas clásicas de investigación pulmonar se ha perfeccionado para la identificación precoz de esta enfermedad (Bégin y cols. 1992), en una fase en la que la neumoconiosis se limita a su manifestación radiológica, sin deterioro ni discapacidad. En un futuro cercano, es probable que dispongamos de una batería de marcadores biológicos para documentar fases incluso más precoces de esta enfermedad. La cuestión de si se debería permitir que un trabajador que ha sido diagnosticado de neumoconiosis - 0 del que se ha documentado que se encuentra en las fases precoces de esta enfermedad- continuara su trabajo ha confundido durante algún tiempo a los encargados de tomar las decisiones en el ámbito de la salud del trabajo. Se trata de una cuestión de difícil respuesta en la que intervienen consideraciones éticas, sociales y científicas. Aunque se dispone de abundante información en la literatura médica sobre la inducción de la neumoconiosis, la información sobre la progresión de que disponen los responsables de las decisiones es bastante escasa y en cierta medida confusa. Se hicieron algunos intentos de estudiar los papeles de variables como la historia de exposición, la retención de polvo, y el estado médico al inicio de la enfermedad. Las relaciones entre todas estas variables sin duda complican el problema. Existen recomendaciones para la detección selectiva y la vigilancia de la salud de los trabajadores expuestos a polvos minerales (Wagner 1996), y ya hay programas en marcha-o lo estarán-de acuerdo con ellas. Estos programas se beneficiarían claramente de un mejor conocimiento científico de la progresión, y en especial de la relación entre la exposición y las características de la retención.

\section{Discusión}

La información proporcionada por muchas disciplinas científicas sobre la etiopatogenia de las neumoconiosis es muy abundante. La principal dificultad actualmente reside en conjuntar los elementos dispersos del rompecabezas en vías de unificación de mecanismos que conduzcan a las lesiones fundamentales de las neumoconiosis. Sin esta necesaria integración, nos quedaríamos con el contraste entre unas cuantas lesiones fundamentales y muy numerosas reacciones bioquímicas y celulares.

N uestro conocimiento de la etiopatogenia sólo ha tenido hasta la fecha una influencia limitada en la práctica de la higiene del trabajo, a pesar de la fuerte determinación de los higienistas de actuar de acuerdo a estándares con alguna importancia biológica. Se incorporaron dos conceptos principales: la selección del tamaño de las partículas de polvo respirable y la dependencia de la toxicidad según el tipo de polvo. Este último concepto dio lugar a ciertos límites específicos de cada tipo de polvo. La valoración cuantitativa del riesgo, paso necesario para definir los límites de exposición, constituye un proceso complicado por varias razones, como son la diversidad de posibles índices de exposición, la escasa información acerca de exposiciones anteriores, los problemas que nos encontramos con los modelos epidemiológicos al trabajar con múltiples índices de exposición y la dificultad para estimar la dosis a partir de la información sobre la exposición. Los límites de exposición actuales, que en ocasiones conllevan un grado considerable de incertidumbre, son probablemente suficientemente bajos para ofrecer buena protección. Sin embargo, las diferencias entre trabajadores observadas en las relaciones de exposición-respuesta reflejan nuestro control incompleto de este fenómeno.

El impacto del moderno concepto de la cascada de acontecimientos en la patogenia de la neumoconiosis no ha modificado el método tradicional de vigilancia de los trabajadores, pero ha mejorado de forma significativa la capacidad de diagnóstico médico precoz de la enfermedad (neumoconiosis), en un momento en que ésta sólo ha tenido un impacto limitado sobre la función pulmonar. Son sin duda los sujetos que se encuentran en las fases precoces los que deben ser identificados y retirados de exposiciones importantes adicionales si queremos conseguir prevenir la discapacidad mediante la vigilancia médica.

\section{SILICOSIS}

\section{John E. Parker y G regor y R. Wagner}

La silicosis es una enfermedad fibrótica de los pulmones causada por la inhalación, retención y reacción pulmonar al sílice cristalino. A pesar de conocer la causa de este proceso - exposiciones respiratorias a polvos que contienen ślice-, esta enfermedad pulmonar profesional grave y potencialmente mortal sigue siendo prevalente en todo el mundo. El ślice, o dióxido de silicio, es el componente predominante de la corteza terrestre. La exposición ocupacional a partículas de sílice de tamaño respirable (diámetro aerodinámico de 0,5 a $5 \mu \mathrm{m}$ ) se asocia a los trabajos de minería, canteras, perforación, construcción de túneles y limpieza mediante abrasión a chorro con materiales que contienen cuarzo (limpieza con arena). La exposición al sílice también supone un riesgo para los canteros y los trabajadores de cerámicas, fundiciones, tierras de sílice y materiales refractarios. D ebido a que la exposición al ślice cristalino es muy extensa y a que la arena de sílice es un componente barato y versátil de numerosos procesos de fabricación, millones de trabajadores de todo el mundo están en riesgo de desarrollar la enfermedad, cuya verdadera prevalencia se desconoce. 


\section{Definición}

La silicosis es una enfermedad pulmonar profesional atribuible a la inhalación de dióxido de silicio, comúnmente denominado sílice, en formas cristalinas, generalmente como cuarzo, pero también en otras formas cristalinas importantes de sílice, como la cristobalita y la tridimita. Estas formas también reciben el nombre de "sílice libre" para diferenciarlas de los silicatos. EI contenido en sílice de las diferentes formaciones de roca, como la piedra arenisca, el granito y la pizarra, varía entre el $20 \%$ y casi el $100 \%$.

\section{Trabajadores de profesiones e industrias de alto riesgo}

Aunque la silicosis es una enfermedad antigua, todavía se comunican nuevos casos en los países desarrollados y en desarrollo. A principios de siglo, la silicosis era una causa importante de morbilidad y mortalidad. Los trabajadores contemporáneos todavía están expuestos al polvo de sílice en diversas profesiones, y cuando las nuevas tecnologías carecen de un control adecuado del polvo, las exposiciones pueden llegar a ser más peligrosas que en un entorno de trabajo no mecanizado. Siempre que se altera la corteza terrestre o se utilizan o procesan rocas o arena que contiene sílice, existen riesgos respiratorios potenciales para los trabajadores. Siguen apareciendo informes de silicosis procedentes de industrias y entornos de trabajo no reconocidos previamente como de riesgo, lo que refleja la presencia prácticamente ubicua del ślice. De hecho, debido a la latencia y la cronicidad de este proceso, incluidos el desarrollo y la progresión de la silicosis una vez interrumpida la exposición, es posible que algunos trabajadores con exposiciones actuales no manifiesten enfermedad hasta el próximo siglo. En muchos países del mundo, los trabajos de minería, canteras, construcción de túneles y galerías, limpieza por abrasión a chorro y fundición continúan presentando riesgos importantes de exposición al sílice, y siguen produciéndose epidemias de silicosis, incluso en los países desarrollados.

\section{Formas de silicosis: historia de exposición y descripciones anatomoclínicas}

Se describen habitualmente formas crónicas, aceleradas y agudas de silicosis. Estas expresiones clínicas y anatomopatológicas de la enfermedad reflejan diferentes intensidades de exposición, períodos de latencia e historias naturales. La forma crónica 0 clásica suele seguir a uno o más decenios de exposición a polvo respirable que contiene cuarzo, y puede evolucionar a fibrosis masiva progresiva (FMP). La forma acelerada se produce tras exposiciones más breves e intensas y evoluciona con mayor rapidez. La forma aguda puede ocurrir después de exposiciones intensas y breves a niveles elevados de polvo respirable con un contenido de ślice alto durante períodos que pueden medirse en meses más que en años.

La silicosis crónica (o clásica) puede ser asintomática o conducir a disnea de esfuerzo o tos insidiosamente progresivas (a menudo atribuidas erróneamente al proceso de envejecimiento). Se presenta como una anomalía radiográfica con opacidades redondeadas pequeñas $(<10 \mathrm{~mm})$ en los lóbulos superiores. Es habitual que el inicio de la exposición tuviera lugar hace 15 años o más. La característica anatomopatológica fundamental de la forma crónica es el nódulo silicótico, que se caracteriza por un área central acelular constituida por fibras de colágeno hialinizado concéntricas dispuestas en espiral, rodeadas por tejido conectivo celular con fibras de reticulina. La silicosis crónica puede evolucionar a FMP (en ocasiones denominada silicosis complicada), incluso después de haberse interrumpido la exposición al polvo con sílice.

La fibrosis masiva progresiva es más probable que se presente con disnea de esfuerzo. Esta forma de la enfermedad se caracteriza por opacidades nodulares mayores de $1 \mathrm{~cm}$ en la radiografía de tórax, y habitualmente conlleva una disminución de la capacidad de difusión del monóxido de carbono, disminución de la tensión arterial de oxígeno en reposo o con el ejercicio, y una importante restricción en la espirometría o en la medición de los volúmenes pulmonares. La distorsión del árbol bronquial también puede conducir a obstrucción de las vías aéreas y a tos productiva. Pueden producirse infecciones bacterianas recidivantes similares a las observadas en la bronquiectasias. La pérdida de peso y la cavitación de las opacidades grandes debe plantear la posibilidad de una tuberculosis o de otra infección por micobacterias. EI neumotórax puede ser una complicación que amenace la vida, ya que el pulmón fibrótico puede resultar difícil de reexpandir. La insuficiencia respiratoria hipoxémica con cor pulmonale es un acontecimiento terminal frecuente.

La silicosis acelerada puede aparecer tras exposiciones más intensas y de menor duración (5 a 10 años). Los síntomas, los hallazgos radiológicos y las mediciones fisiológicas son similares a los que se encuentran en la forma crónica. EI deterioro de la función pulmonar es más rápido, y muchos trabajadores con enfermedad acelerada pueden desarrollar una infección por micobacterias. En la silicosis, a menudo en la de tipo acelerado, se observan enfermedades autoinmunitarias, entre ellas esclerodermia y esclerosis sistémica. La progresión de las anomalías radiológicas y del deterioro funcional pueden ser muy rápidas en los casos de enfermedad autoinmunitaria asociada a silicosis.

La silicosis agudas puede desarrollarse entre los dos meses y los dos años siguientes a una exposición masiva al sílice. A menudo, los síntomas de presentación son disnea, debilidad y pérdida de peso espectaculares. Los hallazgos radiológicos de llenado alveolar difuso difieren de los observados en las formas más crónicas de silicosis. Se han descrito hallazgos histológicos similares a la proteinosis alveolar pulmonar, y en ocasiones se han comunicado anomalías extrapulmonares (renales y hepáticas). La evolución habitual es la progresión rápida hasta una insuficiencia ventilatoria hipoxémica grave.

La tuberculosis puede complicar todas las formas de silicosis, pero las personas que presentan las formas aguda y acelerada son las que tienen el riesgo más alto. La exposición aislada al sílice, incluso sin silicosis, también puede predisponer a esta infección. M. tuberculosis es el microorganismo habitual, pero también se observan micobacterias atípicas.

Incluso en ausencia de silicosis radiográfica, los trabajadores expuestos al sílice pueden padecer también otras enfermedades asociadas a la exposición ocupacional al polvo, como bronquitis crónica y el enfisema asociado. Estas anomalías se asocian a numerosas exposiciones profesionales a polvos minerales, incluidos los polvos que contienen sílice.

\section{Patogenia y asociación a la tuberculosis}

No se conoce con exactitud la patogenia precisa de la silicosis, pero numerosos datos indican que está implicada la interacción entre los macrófagos alveolares pulmonares y las partículas de sílice depositadas en el pulmón. Las propiedades de superficie de las partículas de ślice parecen promover la activación de los macrófagos. Estas células liberan entonces factores quimiotácticos y mediadores de la inflamación que conducen a una mayor respuesta celular por parte de los leucocitos polimorfonucleares, los linfocitos y otros macrófagos. Se liberan factores estimulantes de los fibroblastos, los cuales promueven la hialinización y el depósito de colágeno. La lesión silicótica anatomopatológica resultante es el nódulo hialino, que contiene una zona central acelular con ślice libre rodeada por espirales de colágeno y fibroblastos, y una zona periférica activa compuesta de macrófagos, fibroblastos, células plasmáticas y más sílice libre, tal como se muestra en la Figura 10.14. 
Figura 10.14 • N ódulo silicótico típico, corte microscópico.

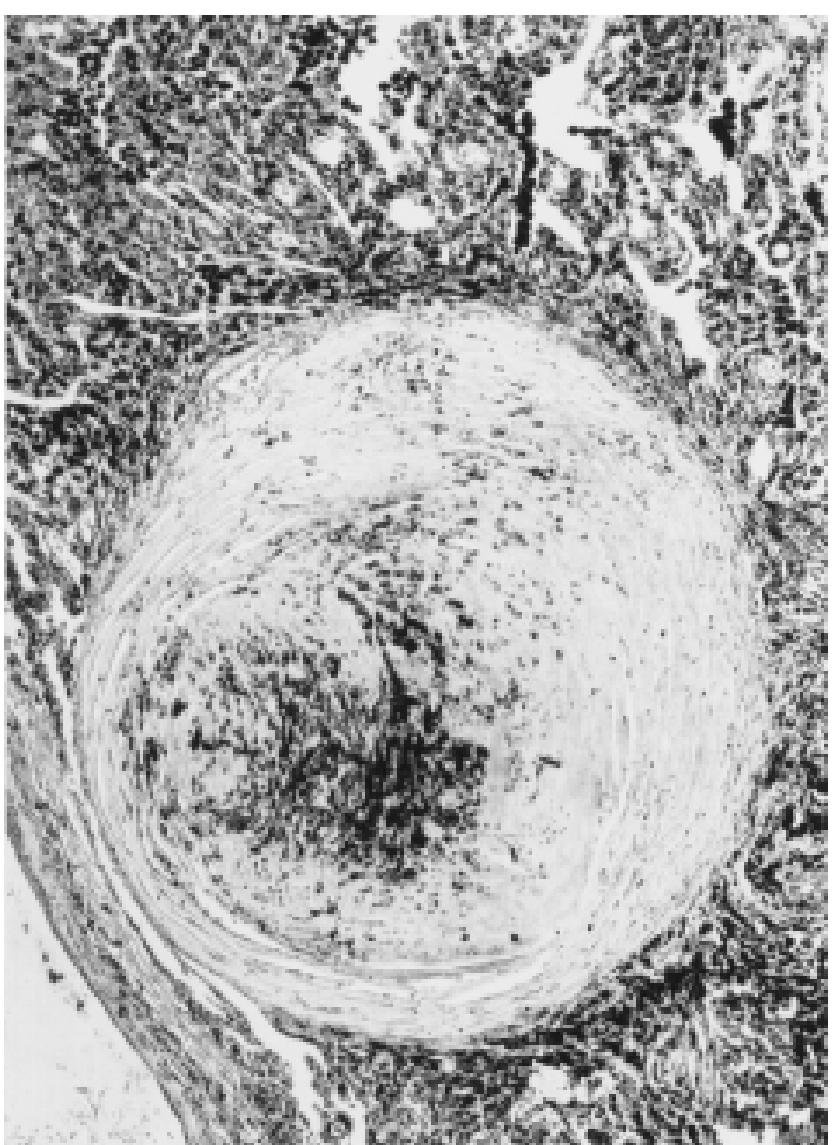

Por cortesía del Dr. V. Vallyathan.

No se conocen las propiedades exactas de las partículas de sílice que provocan la respuesta pulmonar descrita anteriormente, pero pueden ser importantes las características de superficie. La naturaleza y el alcance de la respuesta biológica están relacionados en general con la intensidad de la exposición; sin embargo, cada vez hay más pruebas que indican que el sílice recién fracturado pude ser más tóxico que el polvo envejecido que contiene sílice, un efecto quizá relacionado con los grupos radicales reactivos presentes en los planos de escisión del sílice recién fracturado.

Este dato puede ofrecer una explicación patogénica de la observación de casos de enfermedad avanzada en trabajadores de chorro de arena y de perforación de roca, en los que las exposiciones a sílice recientemente fracturado son particularmente intensas.

La agresión tóxica iniciadora puede ocurrir con una reacción inmunológica mínima; sin embargo, una respuesta inmunológica sostenida a la agresión puede ser importante en algunas de las manifestaciones crónicas de la silicosis. Por ejemplo, en la silicosis acelerada pueden aparecer anticuerpos antinucleares y esclerodermia, así como otras enfermedades del colágeno, en trabajadores que han estado expuestos al sílice. La susceptibilidad de los trabajadores con silicosis a las infecciones, como la tuberculosis y la infección por Nocardia asteroides, probablemente esté relacionada con el efecto tóxico del sílice sobre los macrófagos pulmonares.
La asociación entre silicosis y tuberculosis se conoce desde hace casi un siglo. La tuberculosis activa en los trabajadores con silicosis puede superar el $20 \%$ en los casos en los que la prevalencia de la tuberculosis en la comunidad es elevada. U na vez más, las personas con silicosis aguda parecen presentar un riesgo considerablemente más alto.

\section{Cuadro clínico de la silicosis}

El síntoma primario suele ser la disnea, que se advierte en primer lugar con la actividad o el ejercicio y más adelante en reposo, a medida que se pierde la reserva pulmonar. Sin embargo, en ausencia de otra enfermedad respiratoria, este síntoma puede estar ausente, y en este caso la presentación es la de un trabajador asintomático con una radiografía de tórax anormal, que en ocasiones puede mostrar una enfermedad bastante avanzada con sólo mínimos síntomas. La aparición o la progresión de la disnea puede anunciar el desarrollo de complicaciones, entre ellas tuberculosis, obstrucción de las vías aéreas y FMP. El paciente a menudo presenta tos, que aparece de forma secundaria a la bronquitis crónica debida a exposición ocupacional a polvo, al consumo de tabaco o a ambos. En ocasiones, la tos puede atribuirse también a la presión de grandes masas de ganglios linfáticos silicóticos sobre la tráquea o los bronquios principales.

O tros síntomas torácicos son menos habituales que la disnea y la tos. La hemoptisis es infrecuente y debe plantear la sospecha de que la enfermedad se haya complicado con otros procesos. Puede haber sibilancias y opresión torácica, habitualmente formando parte de una enfermedad obstructiva de las vías aéreas 0 de una bronquitis. El dolor torácico y las acropaquias no son característicos de la silicosis. Los síntomas sistémicos, como fiebre y pérdida de peso, sugieren complicación por una infección o una enfermedad neoplásica. Las formas avanzadas de silicosis se asocian a insuficiencia respiratoria progresiva, con o sin cor pulmonale. Pueden observarse escasos signos físicos, a menos que haya complicaciones.

\section{Patrones radiográficos y anomalías de la función pulmonar}

L os signos radiológicos más precoces de la silicosis no complicada suelen ser opacidades redondeadas de pequeño tamaño. Estas pueden describirse según la Clasificación Internacional de R adiografías de la N eumoconiosis de la OIT por el tamaño, la forma y la categoría de profusión. En la silicosis, predominan las opacidades de tipo " $q$ " y " $r$ ". También se han descrito otros patrones, entre ellos sombras lineales o irregulares. Las opacidades que se observan en la radiografía representan la suma de los nódulos silicóticos anatomopatológicos. Suelen encontrarse de forma predominante en las zonas superiores y pueden más tarde progresar para afectar a otras zonas. En ocasiones, también se advierte una adenopatía hiliar previa a las sombras parenquimatosas nodulares. La calcificación en cáscara de huevo es muy indicativa de silicosis, aunque es una característica que se observa con poca frecuencia. La FM P se caracteriza por la formación de grandes opacidades. Estas lesiones de gran tamaño pueden describirse en función de su tamaño, utilizando la clasificación de la O IT en las categorías A, B o C. L as opacidades grandes o las lesiones de la FM P tienden a contraerse, habitualmente hacia los lóbulos superiores, dejando áreas de enfisema compensador en sus bordes y, a menudo, en las bases pulmonares. D ebido a ello, las opacidades pequeñas previamente evidentes pueden desaparecer en un momento determinado o ser menos llamativas. Pueden aparecer anomalías pleurales, pero no son una característica radiográfica frecuente en la silicosis. Las opacidades grandes también pueden plantear ciertas dudas diagnósticas en relación con las neoplasias, y su diferenciación radiográfica puede ser difícil en ausencia de 
Figura 10.15 - Radiografía de tórax, silicoproteinosis aguda en un perforador de una mina de carbón de superficie.

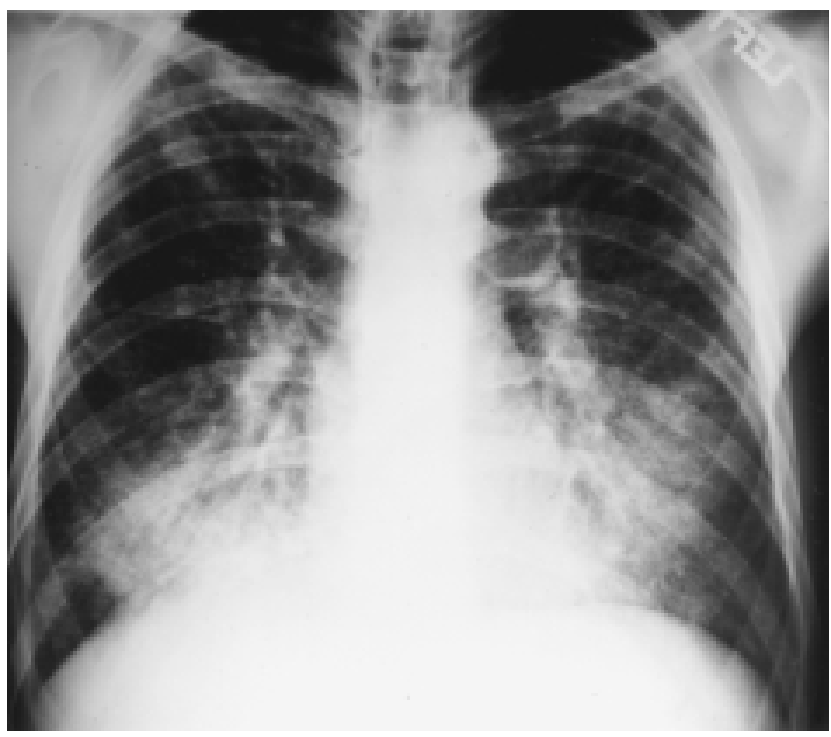

Por cortesía del Dr. N.L Lapp y Dr. DE Banks.

radiografías antiguas. Todas las lesiones que se cavitan o cambian rápidamente deben evaluarse con el fin de descartar una tuberculosis activa. La silicosis aguda puede presentarse con un patrón radiológico de llenado alveolar con desarrollo rápido de FM P 0 lesiones de masa complicadas. V éanse las Figuras 10.15 y 10.16.

Las pruebas de función pulmonar, como la espirometría y la capacidad de difusión, son útiles para la evaluación clínica de las personas con sospecha de silicosis. La espirometría también puede ser de utilidad para la detección precoz de los efectos sobre la salud derivados de la exposición ocupacional a polvos, ya que permite detectar anomalías fisiológicas que pueden preceder a los cambios radiológicos. No hay un patrón característico exclusivo de deterioro ventilatorio en la silicosis. La

Figura 10.16 - Radiografía de tórax, silicosis complicada que muestra fibrosis masiva progresiva.

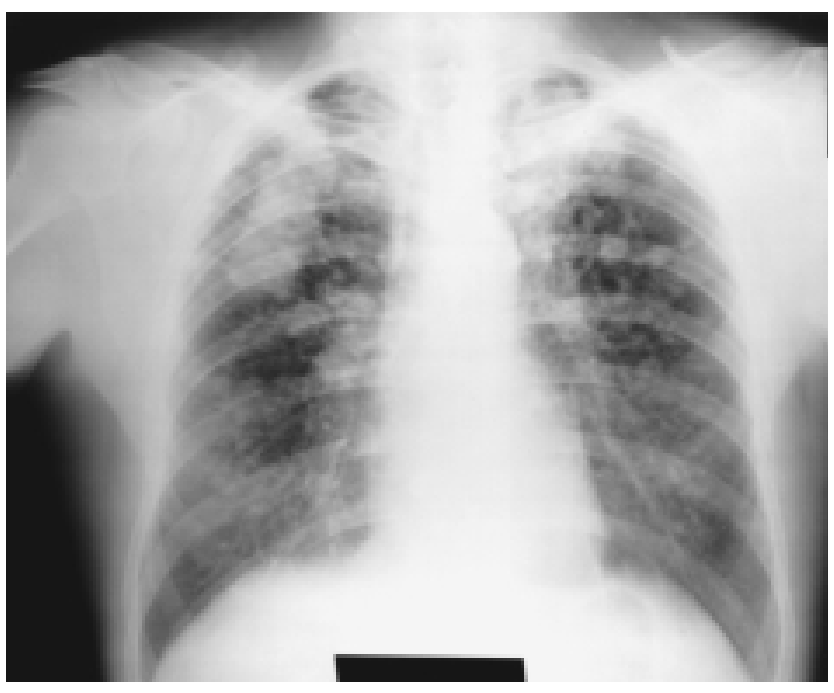

espirometría puede ser normal o, cuando es anormal, las gráficas pueden mostrar obstrucción, restricción 0 un patrón mixto. La obstrucción puede, de hecho, ser el hallazgo más frecuente. Estos cambios tienden a ser más marcados a medida que se avanza en las categorías radiológicas. Sin embargo, existe una mala correlación entre las anomalías radiográficas y el deterioro ventilatorio. En las silicosis acelerada y aguda, los cambios funcionales son más manifiestos y la progresión es más rápida. En la silicosis aguda, la progresión radiológica se asocia a un deterioro ventilatorio progresivo y a anomalías crecientes del intercambio de gases, que conducen a insuficiencia respiratoria $y$, finalmente, a la muerte por hipoxemia refractaria.

\section{Complicaciones y aspectos diagnósticos especiales}

El diagnóstico de silicosis no suele ser difícil de establecer en presencia de una historia de exposición y una radiografía característica. L os problemas sólo se plantean cuando las características radiológicas son raras o no se conoce el antecedente de exposición. Rara vez es necesario realizar una biopsia de carbón para establecer el diagnóstico. Sin embargo, las muestras de tejido son útiles en ciertos entornos clínicos en los casos complicados o en los que el diagnóstico diferencial incluye la tuberculosis, una neoplasia o FM P. EI material de biopsia debe enviarse para cultivo, y en los entornos de investigación el análisis del polvo puede ser una medida adicional de utilidad. Cuando se necesite tejido, suele ser necesaria la biopsia pulmonar abierta para obtener material adecuado para su examen.

N unca se insistirá lo suficiente sobre la necesidad de vigilar las posibles complicaciones infecciosas, y los síntomas de cambio en las características de la tos o hemoptisis, así como la fiebre o la pérdida de peso, deben poner en marcha un estudio con el fin de excluir este problema tratable.

La gran preocupación e interés por la relación entre exposición al sílice, silicosis y cáncer de pulmón, sigue promoviendo el debate y nuevas investigaciones. En octubre de 1996, un comité de la Agencia Internacional para la Investigación del Cáncer ( $T$ he International Agency for R esearch on C ancer, IARC) clasificó el sílice cristalino como un cancerígeno del Grupo I; alcanzó esta conclusión en función de "suficientes pruebas de su carcinogenicidad en seres humanos". $\mathrm{H}$ ay cierta incertidumbre acerca de los mecanismos patogénicos responsables del desarrollo del cáncer de pulmón en las poblaciones expuestas al sílice, y la posible relación entre silicosis (o fibrosis pulmonar) y cáncer en trabajadores expuestos sigue en estudio. Con independencia del mecanismo que pueda ser responsable de los acontecimientos neoplásicos, la conocida asociación ente las exposiciones al sílice y la silicosis obliga a controlar y reducir las exposiciones de los trabajadores en situación de riesgo de padecer esta enfermedad.

\section{Prevención de la silicosis}

La prevención sigue siendo la pieza clave de la eliminación de esta enfermedad pulmonar profesional. La mejoría de los sistemas de ventilación y aspiración, el aislamiento del proceso, las técnicas húmedas, la protección personal incluida la selección adecuada de respiradores $y$, cuando sea posible, la sustitución industrial por agentes de menor riesgo que el sílice, reducen la exposición. También es importante instruir a los trabajadores y a la empresa sobre los peligros de la exposición al polvo de sílice y las medidas destinadas a controlar dicha exposición.

Si se identifica un caso de silicosis en un trabajador, es aconsejable retirarlo de la exposición. Por desgracia, la enfermedad puede progresar incluso en ausencia de más exposición al sílice. Además, el hallazgo de un caso de silicosis, en particular de las formas aguda 0 acelerada, debe poner en marcha una 
evaluación del lugar de trabajo para proteger a otros trabajadores que también se encuentren en situación de riesgo.

\section{Exploración selectiva y vigilancia}

Los trabajadores expuestos al sílice y a otros polvos minerales deben someterse a exploraciones selectivas periódicas para detectar efectos adversos para la salud, como complemento, pero no como sustituto, del control de la exposición al polvo. Esta exploración selectiva incluye evaluaciones destinadas a detectar síntomas respiratorios, anomalías de la función pulmonar y enfermedad neoplásica. También deben realizarse evaluaciones para detectar una infección tuberculosa. Además de realizar una exploración selectiva de cada trabajador individual, deben recogerse datos de grupos de trabajador es para actividades de vigilancia y prevención. Las directrices para estos tipos de estudios se incluyen en la lista de lecturas recomendadas.

\section{Tratamiento, conducta a seguir ante complicaciones y control de la silicosis}

Cuando la prevención no ha tenido éxito y se ha desarrollado silicosis, el tratamiento se dirige fundamentalmente a las complicaciones de la enfermedad. Las medidas terapéuticas son similares a las utilizadas comúnmente en el tratamiento de la obstrucción de las vías aéreas, infección, neumotórax, hipoxemia e insuficiencia respiratoria que complican otra enfermedad pulmonar. $\mathrm{H}$ istóricamente, la inhalación de aluminio en aerosol no ha tenido éxito como tratamiento específico de la silicosis. $\mathrm{La} \mathrm{N}$-óxido polivinil piridina, un polímero que ha protegido a animales de experimentación, no está disponible para su uso en seres humanos. Un trabajo de laboratorio reciente con tetrandina ha demostrado una reducción in vivo de la fibrosis y de la síntesis de colágeno en animales expuestos a sílice y tratados con este fármaco. Sin embargo, en la actualidad faltan pruebas sustanciales de su eficacia en seres humanos, y existe cierta preocupación por su potencial toxicidad, incluida su mutagenicidad. Debido a la elevada prevalencia de esta enfermedad en ciertos países, continúan las investigaciones con combinaciones de fármacos y otras intervenciones. Hasta la fecha no se ha desarrollado ningún método satisfactorio, y la investigación de un tratamiento específico de la silicosis sigue sin dar fruto.

No es deseable continuar la exposición, y debe aconsejarse al paciente que abandone o cambie su trabajo actual, proporcionándole información acerca de las condiciones de exposición pasadas y presentes.

En lo que respecta a la conducta médica a seguir ante la silicosis, la vigilancia de posibles complicaciones infecciosas, en particular de la tuberculosis, es de importancia capital. No se recomienda la utilización de BCG en el paciente con silicosis tuberculín-negativo, pero se recomienda el uso de tratamiento profiláctico con isoniazida (INH) en el paciente con silicosis tuberculín-positivo en los países en los que la prevalencia de la tuberculosis es baja. El diagnóstico de infección tuberculosa activa en los pacientes con silicosis puede ser difícil. Los síntomas clínicos de pérdida de peso, fiebre, sudoración y malestar deben llevar a la realización de una evaluación radiográfica, así como de tinciones del esputo para detectar bacilos acidoalcohol resistentes, y cultivos del esputo. Los cambios radiográficos, incluido el aumento de tamaño de una cavitación en lesiones conglomeradas u opacidades nodulares, son especialmente preocupantes. Los estudios bacteriológicos del esputo expectorado pueden no siempre ser fiables en la silicotuberculosis. La fibrobroncoscopia con el fin de obtener muestras adicionales para cultivo y estudio a menudo puede ser de utilidad para establecer el diagnóstico de enfermedad activa. EI tratamiento con múltiples fármacos ante la sospecha de enfermedad activa en los pacientes silicóticos está justificado para un nivel inferior de sospecha que en el sujeto sin silicosis, debido a la dificultad para establecer claramente pruebas de infección activa. El tratamiento con rifampicina parece haber aumentado la tasa de éxitos del tratamiento de la silicosis complicada con tuberculosis, y en algunos estudios recientes la respuesta al tratamiento a corto plazo era comparable en casos de silicotuberculosis al obtenido en casos de características similares de tuberculosis primaria.

El soporte ventilatorio de la insuficiencia respiratoria está indicado cuando la misma está precipitada por una complicación tratable. El neumotórax, tanto espontáneo como relacionado con el ventilador, suele tratarse mediante la colocación de un tubo torácico. Puede desarrollarse una fístula broncopleural, en cuyo caso debe considerarse una consulta y un tratamiento quirúrgicos.

La silicosis aguda puede evolucionar rápidamente a insuficiencia respiratoria. Cuando esta enfermedad se asemeja a una proteinosis alveolar pulmonar y existe una hipoxemia grave, se ha realizado un tratamiento enérgico mediante lavado pulmonar masivo total con el paciente bajo anestesia general, en un intento de mejorar el intercambio de gases y eliminar los productos de desecho alveolares. Aunque conceptualmente interesante, no se ha demostrado la eficacia del lavado pulmonar total. El tratamiento con glucocorticoides también se ha utilizado para la silicosis aguda; sin embargo, todavía no se ha demostrado que tenga un efecto beneficioso.

A lgunos pacientes jóvenes con silicosis terminal pueden considerarse candidatos para un trasplante de corazón o de corazónpulmón realizado en centros con experiencia en este procedimiento, caro y de alto riesgo. Puede ofrecerse a pacientes seleccionados el envío y la evaluación precoces para esta intervención.

La posibilidad de una intervención terapéutica enérgica y de alta tecnología como es el trasplante, sirve para destacar de forma espectacular la naturaleza grave y potencialmente mortal de la silicosis, al tiempo que enfatiza el papel crucial de la prevención primaria. El control de la silicosis depende en último término de la reducción y del control de la exposición al polvo en el lugar de trabajo, lo que se consigue mediante la aplicación rigurosa y concienzuda de los principios fundamentales de la higiene del trabajo y de las medidas de ingeniería, con el compromiso de preservar la salud del trabajador.

\section{EN FERMEDADES PULMONARES DE LOS MINEROS DEL CARBON}

\author{
Michael D. Attfield, E dward L. Petsonk y \\ Gregory R. Wagner
}

L os mineros del carbón sufren diversas enfermedades y procesos pulmonares debidos a su exposición al polvo de las minas de carbón. Entre éstas se incluyen la neumoconiosis, la bronquitis crónica y la enfermedad pulmonar obstructiva crónica. La aparición y la gravedad de la enfermedad dependen de la intensidad y de la duración de la exposición al polvo. La composición específica del polvo de las minas de carbón también influye en cierta medida sobre las consecuencias para la salud.

En los países desarrollados, en los que en el pasado existieron elevadas prevalencias de enfermedad pulmonar, las reducciones de los niveles de polvo generadas por las normativas han conducido a un descenso sustancial en la prevalencia de la enfermedad desde el decenio de 1970. Además, las importantes reducciones del número de mineros en la mayoría de estos países en los últimos decenios, debida en parte a cambios en la tecnología y a 
las mejoras resultantes en la productividad, conducirán a mayores reducciones en los niveles globales de enfermedad. Los mineros de otros países, donde la minería del carbón es un fenómeno más reciente y los controles del polvo son menos enérgicos, no han tenido tanta suerte. Este problema se ve exacerbado por el elevado coste de la tecnología minera moderna que obliga a emplear a un elevado número de trabajadores, muchos de los cuales presentan un alto riesgo de desarroIlar enfermedades.

En el siguiente texto, cada enfermedad o proceso se considerará por separado. Los procesos específicos de la minería del carbón, como la neumoconiosis de los mineros del carbón, se describen en detalle. La descripción de otros, como la enfermedad pulmonar obstructiva, se limita a aquellos aspectos relacionados con los mineros del carbón y la exposición al polvo.

\section{Neumoconiosis de los mineros del carbón}

La neumoconiosis de los mineros del carbón (NM C) es la enfermedad más frecuentemente asociada con la minería del carbón. No es una enfermedad de desarrollo rápido, y suele tardar al menos diez años en manifestarse, a menudo mucho más cuando las exposiciones son bajas. En sus fases iniciales, es un indicador de una excesiva retención pulmonar de polvo, y puede asociarse a escasos síntomas y signos propios. Sin embargo, a medida que avanza, sitúa al minero en un riesgo cada vez mayor de desarrollar fibrosis masiva progresiva (FMP), un proceso mucho más grave.

\section{Anatomía patológica}

La lesión clásica de la NM C es la mácula de carbón, una acumulación de polvo y de macrófagos cargados de polvo en torno a la periferia de los bronquiolos respiratorios. Las máculas contienen una cantidad mínima de colágeno, por lo que habitualmente no son palpables. Tienen un tamaño de 1 a $5 \mathrm{~mm}$, y a menudo se asocian a un aumento de tamaño de los espacios aéreos adyacentes, lo que se denomina enfisema focal. Aunque a menudo son muy numerosas, no suelen ser evidentes en la radiografía de tórax.

O tra lesión asociada a la NM C es el nódulo de carbón. Esta lesión, de mayor tamaño es palpable y contiene una mezcla de macrófagos cargados de polvo, colágeno y reticulina. La presencia de nódulos de pulmón con o sin nódulos silicóticos (véase más adelante), indica fibrosis pulmonar, y es responsable en gran medida de las opacidades observadas en las radiografías de tórax. L os macronódulos (de 7 a $20 \mathrm{~mm}$ de tamaño) pueden coalescer para formar fibrosis masiva progresiva (véase más adelante), que también puede desarrollarse a partir de un único macronódulo.

Se han encontrado nódulos silicóticos (descritos en el apartado silicosis) en una importante minoría de mineros del carbón que realizan trabajos subterráneos. En la mayoría de los casos, la causa puede ser simplemente el sílice presente en el polvo del carbón, aunque la exposición al sílice puro en algunos trabajos es, sin duda, un factor importante (p.ej., entre perforadores de superficie, maquinistas subterráneos y empernadores de techos).

\section{Radiografía}

El indicador más útil de N M C en los mineros durante su vida se obtiene mediante la radiografía de tórax de rutina. Los depósitos de polvo y las reacciones tisulares nodulares atenúan el haz de rayos $X$ y conducen a la aparición de opacidades en la película. La profusión de estas opacidades se puede valorar sistemáticamente utilizando un método normalizado de descripción radiográfica como el difundido por la O IT y descrito en otro punto de este capítulo. En este método, se comparan radiografías anteroposteriores individuales con radiografías estándar que muestran una profusión creciente de pequeñas opacidades, y cada radiografía se clasifica en una de cuatro categorías principales $(0,1,2$ y $3)$, en función de su similitud con la radiografía estándar. Se ha desarrollado una clasificación secundaria, dependiendo de la valoración que hace el examinador de las similitudes de la radiografía con categorías adyacentes de la O IT. También se tienen en cuenta otros aspectos de las opacidades, como el tamaño, la forma y la región de aparición en el pulmón. Algunos países, como China y Japón, han desarrollado sistemas similares para la descripción o interpretación sistemática de las radiografías. E stos sistemas son particularmente adecuados para sus necesidades específicas.

Tradicionalmente, se han asociado los tipos de opacidades redondeadas pequeñas con la minería del carbón. Sin embargo, datos más recientes indican que también pueden producirse formas más irregulares a consecuencia de la exposición al polvo del carbón. Las opacidades de la NMC y de la silicosis a menudo son indistinguibles en la radiografía. Sin embargo, existen ciertos datos que indican que las opacidades de mayor tamaño (tipo r) indican con mayor frecuencia silicosis.

Es importante señalar que pueden existir abundantes anomalías anatomopatológicas relacionadas con la neumoconiosis antes de que pueda detectarse en las radiografías de rutina. Esto es particularmente cierto para el depósito macular, certeza que va disminuyendo al aumentar la profusión y el tamaño de los nódulos. El enfisema concomitante también puede reducir la visibilidad de las lesiones en la radiografía de tórax. La tomografía computadorizada (TC) - particularmente la de alta resolución (TCAR - - permite visualizar anomalías que no son claramente evidentes en las radiografías de tórax de rutina, aunque no es necesaria para el diagnóstico clínico habitual de las enfermedades pulmonares de los mineros y no está indicada para su vigilancia médica.

\section{Aspectos clínicos}

El desarrollo de N M C, aunque es un marcador de excesiva retención pulmonar de polvo, en sí misma a menudo no se acompaña de ningún signo clínico manifiesto. Sin embargo, no debe considerarse que esto implica que la inhalación de polvo de las minas de carbón carece de riesgos, ya que es bien sabido en la actualidad que la exposición al polvo puede originar otras enfermedades pulmonares. La hipertensión pulmonar se observa con mayor frecuencia en mineros que desarrollan una obstrucción al flujo aéreo asociada a la NM C. Además, una vez que se ha desarrollado la NMC, suele progresar a menos que se interrumpa la exposición, y también a partir de entonces. Asimismo, aumenta el riesgo del minero de desarrollar FM P de mal pronóstico clínico con probabilidad de deterioro, discapacidad y muerte prematura subsiguientes.

\section{M ecanismos de la enfermedad}

EI desarrollo del cambio más precoz de la NM C, la mácula de polvo, representa los efectos del depósito y acumulación de polvo. L a fase subsiguiente, es decir, el desarrollo de nódulos, se produce por la reacción inflamatoria y fibrótica al polvo. En este sentido, se han discutido durante mucho tiempo los papeles de los polvos con y sin sílice. Por un lado, se sabe que el polvo de sílice es considerablemente más tóxico que el polvo de carbón. Sin embargo, por otro lado, los estudios epidemiológicos han demostrado que no hay datos sustanciales que impliquen la exposición al ślice en la prevalencia o la incidencia de la N M C. De hecho, parece que casi existe una relación inversa, en el sentido de que los niveles de enfermedad tienden a estar elevados cuando los niveles de sílice son menores (p.ej., en áreas en las que se extrae antracita). Recientemente, se ha llegado a entender en cierta medida esta paradoja gracias a estudios de las características de las partículas. 
Estos estudios indican que no sólo la cantidad de sílice presente en el polvo (determinada convencionalmente mediante espectrometría por infrarrojos o difracción de rayos $X$ ) puede estar relacionada con la toxicidad, sino también la biodisponibilidad de la superficie de las partículas de sílice. Por ejemplo, el revestimiento (oclusión) con arcilla puede desempeñar un papel modificador importante. 0 tro factor importante en investigación en la actualidad hace referencia a los cambios de superficie en forma de radicales libres y los efectos de los polvos que contienen sílice "recién fracturado" frente a sílice "envejecido".

\section{Vigilancia y epidemiología}

La prevalencia de NMC entre los mineros subterráneos varía según el tipo de trabajo, la ocupación y la edad. Un estudio reciente en mineros del carbón de Estados U nidos reveló que, desde 1970 hasta 1972, del 25 al $40 \%$ de los mineros activos tenían opacidades redondeadas pequeñas de categoría 1 o superior después de 30 años o más de trabajo en las minas. Esta prevalencia refleja la exposición a niveles de $6 \mathrm{mg} / \mathrm{m}^{3} 0$ más de polvo respirable entre los trabajadores del frente de extracción de carbón antes de ese momento. La introducción de un límite de polvo de $3 \mathrm{mg} / \mathrm{m}^{3}$ en 1969, con una reducción a $2 \mathrm{mg} / \mathrm{m}^{3}$ en 1972, ha reducido la prevalencia de esta enfermedad a la mitad aproximadamente de las cifras previas. Se han observado en otros lugares reducciones en relación con el control del polvo, por ejemplo, en el Reino Unido y en Australia. Por desgracia, estos logros se han visto contrarrestados por aumentos temporales de la prevalencia en otros lugares.

En diversos estudios se ha demostrado una relación entre exposición-respuesta para la prevalencia o la incidencia de N M C y la exposición al polvo. Estos estudios han demostrado que la variable significativa primaria de exposición al polvo es la exposición al polvo de mina mixto. Estudios intensivos realizados por investigadores británicos no han podido revelar ninguna influencia importante de la exposición al sílice, siempre que el porcentaje de éste fuera inferior a aproximadamente el $5 \%$. EI rango de carbón (porcentaje de carbón) es otro factor pronóstico importante del desarrollo de NMC. Estudios realizados en Estados U nidos, Reino Unido, Alemania y otros países, han proporcionado claras indicaciones de que la prevalencia y la incidencia de NMC aumentan de forma marcada con el rango de carbón, y que son sustancialmente mayores en los lugares en los que se extrae antracita (rango elevado). No se han encontrado otras variables medioambientales que ejerzan efectos importantes sobre el desarrollo de NMC. La edad del minero parece tener cierta influencia sobre el desarrollo de la enfermedad, dado que los mineros de más edad parecen tener mayor riesgo. Sin embargo, no queda totalmente claro si esto implica que los mineros de más edad son más susceptibles, si se trata de un efecto del tiempo de permanencia o si es simplemente un artefacto (el efecto de la edad podría reflejar, por ejemplo, una infravaloración de los cálculos de exposición para los mineros de más edad). EI consumo de tabaco no parece aumentar el riesgo de desarrollar NM C. Investigaciones en las que se hizo un seguimiento de los mineros mediante radiografías de tórax cada cinco años demuestran que el riesgo de desarrollar FM P a lo largo de cinco años está claramente relacionado con la categoría de N M C, basada en la radiografía de tórax inicial. D ebido a que el riesgo en la categoría 2 es mucho mayor que el de la categoría 1, en el pasado existía el criterio convencional de que debía evitarse que los mineros alcanzaran la categoría 2 siempre que fuera posible. Sin embargo, en la mayoría de las minas hay habitualmente muchos más mineros con NM C de categoría 1 que de categoría 2 . A sí, el menor riesgo de la categoría 1 en comparación con la categoría 2 se contrarresta en cierta medida por el mayor número de mineros que pertenecen a la categoría 1. En función de estos datos, ha quedado claro que deben prevenirse todos los tipos de neumoconiosis.

\section{Mortalidad}

Se ha observado que los mineros como grupo presentan un mayor riesgo de morir a consecuencia de enfermedades respiratorias no malignas, y hay ciertas pruebas que indican que la mortalidad entre los mineros con NMC está en cierta medida aumentada respecto a la de los mineros de edades similares que no padecen esta enfermedad. Sin embargo, el efecto es inferior al observado en los mineros con FM P (véase más adelante).

\section{Prevención}

La única protección frente a la NMC consiste en reducir al mínimo la exposición al polvo. Siempre que sea posible, esto debe conseguirse mediante métodos de supresión de polvo, como ventilación y pulverización con agua, en vez de con el uso de respiradores 0 de controles administrativos, como por ejemplo la rotación del trabajador. En este sentido, existen en la actualidad pruebas claras de que las acciones reguladoras de algunos países destinadas a reducir el nivel de polvo, iniciadas en torno al decenio de 1970, han reducido de forma marcada los niveles de esta enfermedad. El traslado de los trabajadores con signos precoces de N M C a trabajos con una menor exposición al polvo es una acción prudente, aunque existen escasas pruebas prácticas que indiquen que tales programas hayan tenido éxito en la prevención de la progresión de la enfermedad. Por esta razón, la supresión del polvo debe seguir siendo el método primario de prevención de la enfermedad.

La monitorización continuada y enérgica de la exposición al polvo y la aplicación concienzuda de medidas de control pueden complementarse mediante la vigilancia con detección selectiva del estado de salud de los mineros. Si se descubre que desarroIlan enfermedades relacionadas con el polvo, deben intensificarse las medidas de control de la exposición en todos los lugares de trabajo, y debe ofrecerse, a los mineros que presenten efectos derivados de la exposición al polvo, trabajo en áreas de baja concentración de polvo en el entorno de la mina.

\section{Tratamiento}

Aunque se ha intentado diversas formas de tratamiento, incluida la inhalación de polvo de aluminio y la administración de tetrandina, no se conoce ningún tratamiento que revierta de forma eficaz o detenga el proceso fibrótico pulmonar. En la actualidad, y principalmente en $\mathrm{C}$ hina pero también en otros países, se está en sayando el lavado pulmonar total para reducir la carga de polvo total del pulmón. Aunque este procedimiento puede conducir a la eliminación de una cantidad considerable de polvo, no están claros sus riesgos, sus efectos beneficiosos ni su papel en el tratamiento de la salud de los mineros.

En otros aspectos, el tratamiento debe dirigirse hacia la prevención de las complicaciones, potenciando al máximo el estado funcional de los mineros y aliviando sus síntomas, ya sean éstos debidos a la NMC o a otras enfermedades respiratorias concomitantes. En general, los mineros que desarrollan enfermedades pulmonares inducidas por polvo, deben evaluar sus exposiciones actuales al polvo y utilizar los recursos del gobierno y de las organizaciones de trabajo para encontrar los caminos disponibles destinados a reducir todas las exposiciones respiratorias adversas. En el caso de los mineros fumadores, el abandono del tabaco es un paso inicial en el control personal de la exposición. Se sugiere la prevención de las complicaciones infecciosas de la enfermedad pulmonar crónica con vacunas neumocócicas y anuales de la gripe. También se recomienda la investigación precoz de los síntomas de infección pulmonar, prestando especial atención a la enfermedad por micobacterias. Los tratamientos 
de la bronquitis aguda, el broncospasmo y la insuficiencia cardíaca congestiva son similares a los de los pacientes que no presentan enfermedad relacionada con el polvo.

\section{Fibrosis masiva progresiva}

La FM P, en ocasiones denominada neumoconiosis complicada, se diagnostica cuando se encuentran una o más lesiones fibróticas extensas (cuya definición depende del modo de detección) en uno 0 ambos pulmones. Como su nombre indica, la FM $P$ a menudo aumenta de gravedad con el tiempo, incluso en ausencia de una nueva exposición al polvo. También puede desarrollarse después de haberse interrumpido la exposición, y a menudo puede causar discapacidad y muerte prematura.

\section{Anatomía patológica}

L as lesiones de la FM P pueden ser uni o bilaterales, y se encuentran con mayor frecuencia en los lóbulos pulmonares superiores 0 medios. Estas lesiones están formadas por colágeno, reticulina, polvo de las minas de carbón y macrófagos cargados de polvo, mientras que su centro puede contener un líquido negro que en ocasiones se cavita. Los estándares anatomopatológicos de Estados U nidos exigen que las lesiones tengan una lesión igual 0 superior a $2 \mathrm{~cm}$ para ser identificadas como entidades de FM $P$ en muestras quirúrgicas o de autopsia.

\section{Radiología}

Se considera que la presencia de opacidades grandes $(>1 \mathrm{~cm})$ en la radiografía, asociadas a una historia de exposición extensa a polvo de minas de carbón, implica la presencia de FMP. Sin embargo, es importante considerar otras enfermedades como el cáncer de pulmón, la tuberculosis y los granulomas. Lo habitual es observar grandes opacidades en un fondo de pequeñas opacidades, pero se ha observado el desarrollo de FM P a partir de una profusión de categoría 0 a lo largo de un período de cinco años.

\section{Aspectos clínicos}

En todo minero con opacidades torácicas grandes deben evaluarse apropiadamente las posibilidades diagnósticas. Los mineros clínicamente estables con lesiones bilaterales que siguen la distribución típica en los campos pulmonares superiores y con NMC simple preexistente no plantean grandes problemas diagnósticos. Sin embargo, los mineros que tienen síntomas progresivos, factores de riesgo de otros procesos (p.ej., tuberculosis) o características clínicas atípicas, deben someterse a una exploración adecuada exhaustiva antes de atribuir las lesiones a una FM P.

La disnea y otros síntomas respiratorios a menudo acompañan a la FM P, pero no necesariamente son debidos a la propia enfermedad. La insuficiencia cardíaca congestiva (debida a hipertensión pulmonar y cor pulmonale) no es una complicación infrecuente

\section{M ecanismos de la enfermedad}

A pesar de que se han realizado investigaciones extensas, la causa real del desarrollo de FM P sigue siendo incierta. A lo largo de los años, se han propuesto varias hipótesis, pero ninguna es totalmente satisfactoria. U na teoría destacada planteaba que la tuberculosis intervenía en el proceso. Es cierto que la tuberculosis a menudo está presente en los mineros con $\mathrm{FM} P$, particularmente en los países en vías de desarrollo. Sin embargo, se ha comprobado que la FM P se desarrolla en mineros en los que no había ningún signo de tuberculosis, y no se ha observado una elevación de la reactividad a la tuberculina entre los mineros con neumoconiosis. A pesar de las investigaciones realizadas, sigue sin haber pruebas consistentes del papel del sistema inmunitario en el desarrollo de la FM P.

\section{Vigilancia y epidemiología}

Como en el caso de la NM C, los niveles de FM P han ido disminuyendo en los países que tienen normativas y programas estrictos de control del polvo. Un reciente estudio en mineros de Estados Unidos reveló que cerca del $2 \%$ de los mineros del carbón que trabajaban bajo tierra presentaban FM P después de 30 o más años en este trabajo (aunque esta cifra podría estar sesgada debido a los mineros afectados que abandonaron la plantilla).

Las investigaciones sobre la exposición-respuesta de la FM P han demostrado que la exposición al polvo de minas de carbón, la categoría de la NM C, el rango de carbón y la edad son los determinantes primarios del desarrollo de la enfermedad. Como sucede con la NM C, los estudios epidemiológicos no han encontrado un efecto importante del polvo de sílice. Aunque hace tiempo se pensó que la FM P se desarrollaba sólo sobre un fondo de pequeñas opacidades de NM C, recientemente se ha comprobado que éste no es el caso. Se ha comprobado que mineros con una radiografía de tórax inicial que mostraba una N M C de categoría 0 desarrollaron FM P a lo largo de 5 años, y el riesgo aumentaba con la exposición acumulada al polvo. Además, se puede desarrollar FM P una vez interrumpida la exposición al polvo.

\section{M ortalidad}

La FM P conduce a muerte prematura, y el diagnóstico empeora cuanto más avanzada es la fase de la enfermedad. U n reciente estudio demostró que los mineros con FM P de categoría $C$ tenían una tasa de supervivencia a los 22 años de sólo la cuarta parte en comparación con los mineros que no padecían neumoconiosis. Este efecto se manifestó en todos los grupos de edad.

\section{Prevención}

Evitar la exposición al polvo es la única forma de prevenir la FMP. Dado que el riesgo de desarrollarla aumenta de forma marcada con categorías más avanzadas de NMC simple, una estrategia de prevención secundaria de la FM P consiste en que los mineros se sometan a radiografías de tórax periódicas y que se interrumpa o se reduzca su exposición si se detecta una NM C simple. Aunque este enfoque parece válido y ha sido adoptado en algunas jurisdicciones, su eficacia no se ha evaluado de forma sistemática.

\section{Tratamiento}

No hay tratamiento conocido para la FMP. El tratamiento médico debe centrarse en mejorar el estado clínico y las enfermedades pulmonares asociadas, protegiendo al mismo tiempo al paciente de complicaciones infecciosas. A unque mantener la estabilidad funcional puede ser más difícil en los pacientes con FM P, en otros aspectos el tratamiento es similar al de la N M C simple.

\section{Enfermedad pulmonar obstructiva}

En la actualidad se dispone de pruebas consistentes y convincentes de la existencia de una relación entre la pérdida de función pulmonar y la exposición al polvo. Diversos estudios realizados en diferentes países han analizado la influencia de la exposición al polvo sobre los valores absolutos y los cambios temporales de las mediciones de la función ventilatoria, como el volumen espiratorio forzado en un segundo ( $F E V_{1}$ ), la capacidad vital forzada (FVC) y las tasas de flujo. Todos ellos han encontrado pruebas de que la exposición al polvo produce una reducción de la función pulmonar, y los resultados han sido llamativamente similares en diversas investigaciones británicas y norteamericanas. Estas indican que, en el curso de un año, la exposición al polvo en el frente de extracción del carbón provoca, en promedio, una reducción de la función pulmonar equivalente a fumar medio paquete de cigarrillos al día. Los estudios también demuestran que los 
efectos son variables, y un minero puede desarrollar efectos semejantes, o peores, a los esperados con el consumo de tabaco, en particular si el sujeto ha experimentado exposiciones al polvo más elevadas.

Los efectos de la exposición al polvo se han encontrado tanto en personas que nunca han fumado como en fumadores activos. Además, no existen pruebas de que el consumo de tabaco exacerbe el efecto de la exposición al polvo. Por el contrario, los estudios han demostrado generalmente un efecto ligeramente menor en los fumadores activos, un resultado que puede deberse a la selección de trabajadores sanos. Es importante señalar que la relación entre la exposición al polvo y la disminución de la ventilación parece ocurrir con independencia de la neumoconiosis, es decir, no es necesario que la neumoconiosis esté presente para que se produzca una reducción de la función pulmonar. Al contrario, más bien parece que el polvo inhalado actua por múltiples vías diferentes, y conduce a neumoconiosis en algunos mineros, a obstrucción en otros y a múltiples consecuencias en otros. A diferencia de los mineros que sólo presentan N M C aislada, los mineros con síntomas respiratorios tienen una función pulmonar significativamente menor, tras la normalización en función de la edad, el tabaquismo, la exposición al polvo y otros factores.

Recientes trabajos sobre los cambios de la función pulmonar han abordado la exploración de los cambios longitudinales. Los resultados indican que puede existir una tendencia no lineal de descenso en el tiempo en los nuevos mineros, con una tasa elevada de pérdida inicial seguida de un deterioro más moderado con la exposición continuada. A demás, existen pruebas de que los mineros que reaccionan ante el polvo pueden decidir, cuando les es posible, evitar las exposiciones más intensas.

\section{Bronquitis crónica}

Los síntomas respiratorios, como la tos crónica y la producción crónica de esputos, son una consecuencia frecuente del trabajo en las minas de carbón, y la mayoría de los estudios muestran una mayor prevalencia en comparación con grupos de control no expuestos. Además, se ha demostrado que la prevalencia y la incidencia de los síntomas respiratorios aumenta con la exposición acumulada al polvo, después de tener en cuenta la edad y el consumo de tabaco. La presencia de síntomas parece estar asociada a una reducción de la función pulmonar por encima de la debida a la exposición al polvo y otras supuestas causas. Esto sugiere que la exposición al polvo puede ser fundamental para iniciar ciertos procesos patológicos que posteriormente progresan con independencia de si existe o no una nueva exposición. Se ha demostrado desde el punto de vista anatomopatológico la existencia de una relación entre el tamaño de las glándulas bronquiales y la exposición al polvo, y se ha comprobado que la mortalidad debida a bronquitis y enfisema aumenta al aumentar la exposición acumulada al polvo.

\section{Enfisema}

Los estudios anatomopatológicos han encontrado de forma repetida una mayor incidencia de enfisema en los mineros del carbón en comparación con los grupos de control. Además, se ha comprobado que el grado de enfisema está relacionado con la cantidad de polvo presente en los pulmones y con las valoraciones anatomopatológicas de neumoconiosis. Además, es importante conocer la existencia de pruebas indicativas de que la presencia de enfisema está relacionada con la exposición al polvo y con el porcentaje del $\mathrm{FEV}_{1}$ previsto. Así, estos resultados concuerdan con la idea de que la exposición al polvo puede conducir a discapacidad al causar enfisema.

La forma de enfisema que se asocia con mayor claridad a la minería del carbón es el enfisema focal, consistente en zonas de espacios aéreos aumentados de tamaño, de 1 a $2 \mathrm{~mm}$, adyacentes a las máculas de polvo que rodean los bronquiolos respiratorios. La idea actual es que el enfisema se forma por destrucción tisular, más que por distensión o dilatación. A parte del enfisema focal, hay pruebas de que el enfisema centroacinar tiene un origen ocupacional y de que el enfisema total (es decir, el conjunto de todos los tipos) está correlacionado con la ocupación en las minas, tanto en los trabajadores que nunca han fumado como en los fumadores. No existen pruebas que indiquen que el consumo de tabaco potencie la relación exposición al polvo-enfisema. Sin embargo, algunos datos indican que existe una relación inversa entre el contenido de sílice de los pulmones y la presencia de enfisema.

El tema del enfisema ha sido durante mucho tiempo motivo de controversia. Algunos autores afirman que el sesgo de selección y el consumo de tabaco dificultan la interpretación de los estudios anatomopatológicos. Además, algunos consideran que el enfisema focal sólo tiene efectos triviales sobre la función pulmonar. Sin embargo, los estudios de anatomía patológica realizados desde el decenio de 1980 han respondido a críticas anteriores, e indican que el efecto de la exposición al polvo puede ser más importante para la salud de los mineros de lo que se pensaba previamente. Este punto de vista se ve apoyado por hallazgos recientes, que indican que la mortalidad derivada de la bronquitis y del enfisema está relacionada con la exposición acumulada al polvo.

\section{Silicosis}

La silicosis, aunque se asocia más a otras industrias, también puede producirse en los mineros del carbón. En las minas subterráneas se encuentra con mayor frecuencia en trabajadores que ocupan ciertos puestos en los que es típica la exposición a sílice puro. Estos trabajadores son los empernadores de tejados, que perforan el techo, que a menudo es de arenisca u otro tipo de roca con un contenido elevado en ślice; los maquinistas, conductores de transporte ferroviario que están expuestos al polvo generado por la arena colocada en las vías para proporcionar tracción; y los perforadores de roca, que participan en el avance de la mina. Se ha demostrado que los perforadores de roca de las minas de carbón de superficie presentan un riesgo particular en Estados U nidos, y algunos desarrollan silicosis aguda después de sólo algunos años de exposición. En función de las pruebas anatomopatológicas, como se indica más adelante, cierto grado de silicosis puede aquejar a muchos más mineros del carbón de los que realizan los trabajos anteriormente comentados.

Los nódulos silicóticos presentes en los mineros del carbón son de naturaleza similar a los observados en otros lugares, y consisten en un patrón en espiral de colágeno y reticulina. Un estudio de autopsias a gran escala ha demostrado que cerca del $13 \%$ de los mineros del carbón tenía nódulos silicóticos en sus pulmones. Aunque un trabajo (el de maquinista) destacó por tener una prevalencia de nódulos silicóticos mucho más elevada (25\%), hubo escasa variación en la prevalencia entre los mineros que realizaban otros trabajos, lo que sugiere que el responsable era el sílice presente en el polvo mixto de la mina.

La silicosis no puede diferenciarse de forma fiable de la neumoconiosis de los mineros del carbón en una radiografía. Sin embargo, hay algunas pruebas que sugieren que el tipo más grande de las opacidades pequeñas (tipo $r$ ) es indicativo de silicosis.

\section{Neumoconiosis reumatoide}

La neumoconiosis reumatoide, una de cuyas variantes se denomina síndrome de Caplan, es el término utilizado para un proceso que afecta a los trabajadores expuestos al polvo que desarrollan múltiples sombras radiográficas de gran tamaño. Desde el punto de 
vista anatomopatológico, estas lesiones se parecen a los nódulos reumatoides más que a las lesiones de la FM $P$, y a menudo se originan en un corto intervalo de tiempo. Se suelen encontrar una artritis activa o la presencia de factor reumatoide circulante, pero estos hallazgos en ocasiones están ausentes.

\section{Cáncer de pulmón}

Entre las exposiciones profesionales que sufren los mineros del carbón se incluyen las debidas a diversas sustancias que son cancerígenos potenciales. Algunas de ellas son el sílice y los benzopirenos. Sin embargo, no se dispone de pruebas claras de la existencia de un mayor número de muertes por cáncer de pulmón entre los mineros del carbón. U na explicación evidente de este hecho es la prohibición de fumar bajo tierra, debido al peligro de incendios y explosiones. Sin embargo, el hecho de que no se haya detectado una relación exposición-respuesta entre el cáncer de pulmón y la exposición al polvo indica que el polvo de las minas de carbón no es una causa principal de cáncer de pulmón en la industria.

\section{Límites reguladores de la exposición al polvo}

La O rganización M undial de la Salud (OM S) ha recomendado un "límite de exposición provisional basado en la salud" para el polvo respirable de las minas de carbón (con menos del $6 \%$ de polvo respirable) que oscila entre 0,5 y $4 \mathrm{mg} / \mathrm{m}^{3}$. La OM S sugiere un riesgo de FM P de 2 por 1.000 a lo largo de una vida laboral como criterio, y recomienda que los límites se establezcan teniendo en cuenta los factores medioambientales basados en la mina, incluidos el rango de carbón, el porcentaje de cuarzo y el tamaño de las partículas

En la actualidad, entre los principales países productores de carbón, los límites se basan en la regulación exclusiva del polvo de carbón (p. ej., 3,8 mg/ $\mathrm{m}^{3}$ en el Reino U nido, $5 \mathrm{mg} / \mathrm{m}^{3}$ en Australia y Canadá) o en la regulación de una mezcla de carbón y sílice como en Estados U nidos $\left(2 \mathrm{mg} / \mathrm{m}^{3}\right.$ cuando el porcentaje de cuarzo es igual o inferior a $5,0\left(10 \mathrm{mg} / \mathrm{m}^{3}\right) /$ por ciento de $\mathrm{SiO}_{2}$ ), o en Alemania ( $4 \mathrm{mg} / \mathrm{m}^{3}$ cuando el porcentaje de cuarzo es igual o inferior a $5,00,15 \mathrm{mg} / \mathrm{m}^{3}$ cuando no lo sea), o en la regulación del cuarzo puro (p. ej., Polonia, con un límite de $0,05 \mathrm{mg} / \mathrm{m}^{3}$ )

\section{ENFERMEDADES RELACIO NADAS CON EL AMIANTO}

M argaret R. Becklake

\section{Perspectiva histórica}

A mianto es un término utilizado para describir un grupo de minerales fibrosos naturales muy extensamente distribuidos en afloramientos y depósitos de rocas en todo el mundo. La explotación de las propiedades de tensión y de termorresistencia del amianto para uso humano se remonta a la antigüedad. Por ejemplo, en el siglo III AC el amianto se utilizaba en Finlandia para endurecer las ollas de arcilla. En la época clásica, se utilizaban mortajas tejidas de amianto para preservar las cenizas de los muertos famosos. $M$ arco Polo regresó de sus viajes por $C$ hina con descripciones de un material mágico que podía convertirse en una tela resistente al fuego. En los primeros años del siglo XIX, se conocía la existencia de depósitosen diversas partes del mundo, entre ellas losU rales, el norte de I talia y otras áreas mediterráneas, Sudáfrica y Canadá, pero su explotación comercial no comenzó hasta la segunda mitad del siglo XIX. Para entonces, la revolución industrial creó no sólo la demanda (p.ej., para el aislamiento de la máquina de vapor), sino que también facilitó la producción al mecanizarse la separación manual de fibras de la roca original. La industria moderna comenzó en Italia y en el Reino U nido después de 1860, y se aceleró con el desarrollo y la explotación de los extensos depósitos de amianto crisotilo (blanco) en Q uebec (Canadá) en el decenio de 1880. L a explotación de los también extensos depósitos de crisotilo de los U rales fue modesta hasta el decenio de 1920. Las largas y delgadas fibras de crisotilo eran particularmente adecuadas para el hilado de telas y fieltros, uno de los primeros usos comerciales de este mineral. La explotación de los depósitos de amianto crocidolita (azul) del NO de EI C abo, Sudáfrica, una fibra más resistente al agua que el crisotilo y más adecuada para el uso marítimo, y de amianto amosita (marrón), también en Sudáfrica, comenzó en los primeros años de este siglo. La explotación de los depósitos finlandeses de amianto antofilita, la única fuente comercial importante de esta fibra, se desarrolló entre 1918 y 1966, mientras que los depósitos de crocidolita de Wittenoom, Australia O ccidental, se explotaron entre 1937 y 1966.

\section{Tipos de fibras}

Los minerales de amianto se clasifican en dos grupos: el grupo de las serpentinas, que incluye el crisotilo, y los anfíboles, que incluyen la crocidolita, la tremolita, la amosita y la antofilita (Figura 10.17). La mayor parte de los depósitos de minerales son heterogéneos desde el punto de vista mineralógico, al igual que la mayoría de las formas comerciales del mineral (Skinner, Roos y Frondel 1988). El crisotilo y los diversos minerales de amianto anfíboles difieren en su estructura cristalina, en las características químicas y de superficie y en las características físicas de sus fibras, habitualmente descritas en términos de la relación longitud-diámetro (o aspecto). También se diferencian en características que distinguen su uso comercial y su grado. A destacar en el presente contexto es la existencia de pruebas que indican que las distintas fibras se diferencian en su potencia biológica (tal y como se considerará más adelante en las secciones correspondientes a las distintas enfermedades).

\section{Producción comercial}

El crecimiento de la producción comercial, ilustrado en la Figura 10.18, fue lento a principios de siglo. Por ejemplo, la producción canadiense superó las 100.000 toneladas americanas por año por primera vez en 1911 y las 200.000 toneladas en 1923. EI crecimiento entre las dos guerras mundiales fue estable, y aumentó considerablemente para responder a las demandas de la segunda guerra mundial y de forma espectacular para responder a las demandas de los tiempos de paz (incluidas las de la guerra fría), hasta alcanzar un máximo de 5.708 .000 toneladas americanas en 1976 (Selikoff y L ee 1978). D espués, la producción decayó a medida que los efectos perjudiciales de la exposición sobre la salud se convirtieron en un motivo creciente de preocupación para la población en Norteamérica y Europa, y se mantuvieron en unos 4.000.000 de toneladas americanas por año hasta 1986, para disminuir aún más en el decenio de 1990. También tuvo lugar un desplazamiento en los usos y fuentes de fibras en el decenio de 1980; En Europa y Norteamérica, las demandas disminuyeron al irse introduciendo sustitutos para muchas aplicaciones, mientras que en los continentes africano, asiático y sudamericano, la demanda del amianto aumentó para responder a las necesidades de un material duradero y barato para usar en la construcción y la reticulación del agua. En 1981, Rusia se había convertido en el principal productor mundial, con un aumento en la explotación comercial de extensos depósitos en China y Brasil. En 1980, se estimó que se había extraído en todo el mundo un total de más de 100 millones de toneladas de amianto, el $90 \%$ del cual era crisotila, del que a su vez aproximadamente el $75 \%$ procedía de cuatro áreas mineras de crisotilo localizadas en Q uebec (C anadá), Sudáfrica y los U rales 
Figura 10.17 - Tipos de fibras de amianto.
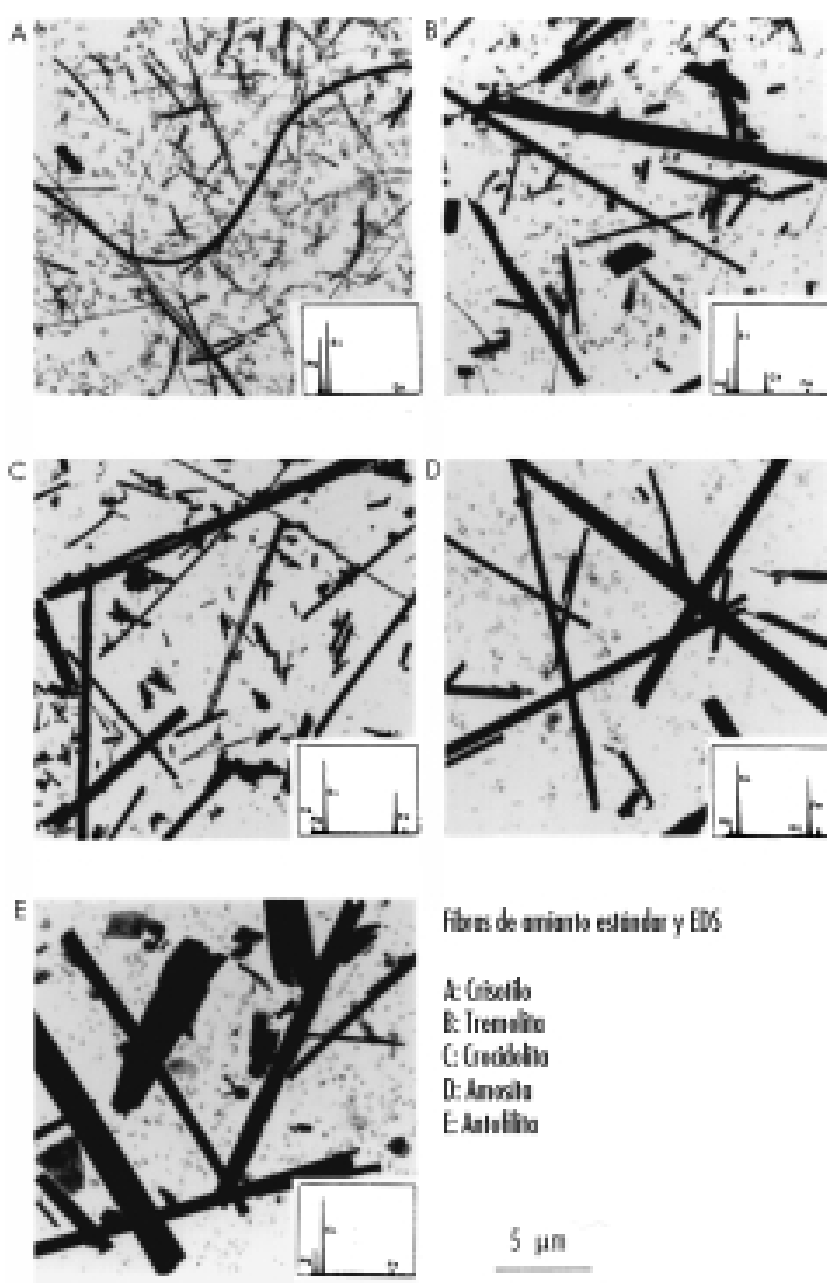

Fitun de ariabs edintar y ECS

A. Gisulb

E. Trenalio

C:Godblis

D:-lnwil

Elanition

5 un

Visión al microscopio electrónico junto con espectros de dispersión de energía de ravos que permite la identificación de fibras individuales.

Por cortesía de A. Dufresne y M. Harrigan, McGill University.

centrales y meridionales. Entre el 2 y el $3 \%$ de la producción mundial correspondía a crocidolita, procedente del norte de EI Cabo, Sudáfrica, y de Australia O ccidental, y otro 2-3\% era amosita, procedente del este del Transvaal, Sudáfrica (Skinner, Ross y Frondel 1988).

\section{Enfermedades y procesos relacionados con el amianto}

Al igual que el sílice, el amianto tiene la capacidad de provocar reacciones cicatriciales en todos los tejidos biológicos, tanto humanos como animales. Además, el amianto genera reacciones malignas, lo que añade un nuevo elemento de preocupación para la salud, además de constituir un reto para la ciencia respecto a la forma en que ejerce este mineral sus efectos nocivos. La primera enfermedad identificada como relacionada con el amianto, la fibrosis o cicatrización pulmonar intersticial difusa, más tarde denominada asbestosis, fue tema de informes de casos en el R eino U nido a principios del siglo XX. M ás adelante, en el decenio de 1930, aparecieron en la literatura médica informes de casos de cáncer de pulmón en relación con la asbestosis, aunque no fue hasta los siguientes decenios cuando se reunieron las pruebas científicas que identificaban al amianto como el factor cancerígeno. En 1960, el informe de un conjunto de estos tumores en 33 sujetos, todos los cuales trabajaban o vivían en el área minera del amianto del NO de EI Cabo, llamó espectacularmente la atención sobre la asociación entre la exposición al amianto y otro cáncer mucho menos común, el mesotelioma maligno, que afecta a la pleura (una membrana que cubre los pulmones y reviste la pared torácica) (Wagner 1996). L a asbestosis fue el objetivo de los niveles de control de polvo introducidos y puestos en práctica con un rigor creciente en los decenios de 1960 y 1970, y en muchos países industrializados, a medida que disminuyó la frecuencia de esta enfermedad, la enfermedad pleural relacionada con el amianto se convirtió en la manifestación más frecuente de la exposición y en el proceso que con mayor frecuencia llevó a solicitar asistencia médica. En la Tabla 10.16 se reseñan las enfermedades y los procesos que en la actualidad se sabe que están relacionados con el amianto. Las enfermedades en negrita son las que aparecen con mayor frecuencia y cuya relación causal directa está bien establecida, mientras que, con el fin de ofrecer información completa, se presentan ciertos otros procesos, cuya relación no se ha establecido con tanta exactitud (véase la nota a pie de página de la Tabla 10.16 y las secciones siguientes del texto bajo los epígrafes de las diversas enfermedades).

\section{Usos}

En la Tabla 10.17 se reseñan las fuentes, productos y usos principales de los minerales de amianto. Aunque necesariamente incompleta, esta tabla destaca los siguientes aspectos:

1. H ay depósitos en muchas partes del mundo, la mayoría de los cuales han sido explotados de forma comercial o no comercial en el pasado, y algunos de los cuales están siendo explotados en la actualidad.

2. Existen numerosos productos, fabricados en la actualidad 0 en el pasado, que contienen amianto, en particular en las industrias de la construcción y el transporte.

3. La desintegración de estos productos o su retirada conlleva el riesgo de resuspensión de las fibras y de una nueva exposición para el ser humano.

Figura 10.18 - Producción mundial de amianto en miles de toneladas 1900-92.

Producción mundial de amianto en miles de toneladas

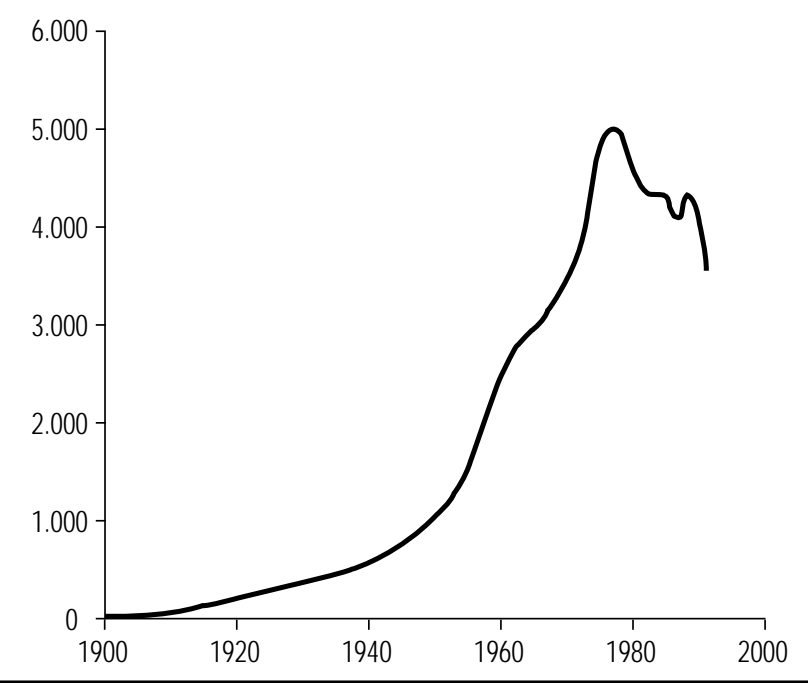


Tabla 10.16 - Enfermedades y procesos relacionados con el amianto. ${ }^{1}$

\begin{tabular}{|c|c|c|}
\hline $\begin{array}{l}\text { Anatomía } \\
\text { patológica }\end{array}$ & Organos afectados & Enfermedad/ proceso \\
\hline \multirow[t]{3}{*}{ No maligna } & Pulmones & $\begin{array}{l}\text { Asbestosis (fibrosis intersticial difusa) } \\
\text { Enfermedad de las pequeñas vías aéreas }{ }^{2} \text { (fibrosis limitada a la región peribronquiolar) } \\
\text { Enfermedad crónica de las vías aéreas }{ }^{3}\end{array}$ \\
\hline & Pleura & $\begin{array}{l}\text { Placas pleurales } \\
\text { Reacciones visceroparietales, incluidos el derrame pleural benigno, la fibrosis pleural difusa y la atelectasia } \\
\text { redondeada }\end{array}$ \\
\hline & Piel & Callos de amianto 4 \\
\hline \multirow[t]{5}{*}{ Maligna } & Pulmones & $\begin{array}{l}\text { Cáncer de pulmón (todos los tipos celulares) } \\
\text { Cáncer de laringe }\end{array}$ \\
\hline & Pleura & Mesotelioma pleural \\
\hline & $\begin{array}{l}\text { Otras cavidades revestidas por } \\
\text { mesotelio }\end{array}$ & Mesotelioma del peritoneo, pericardio y escroto (en orden decreciente de frecuencia) \\
\hline & Tracto gastrointestinal ${ }^{5}$ & Cáncer de estómago, esófago, colon, recto \\
\hline & Otros & Ovario, vesícula biliar, vías biliares, páncreas, riñón \\
\hline
\end{tabular}

1 Las enfermedades o procesos indicados en negrita son los encontrados con mayor frecuencia y para los cuales se ha demostrado claramente o se reconoce de forma general una relación causal.

2 La fibrosis de las paredes de las pequeñas vías aéreas del pulmón (incluidos los bronquiolos membranosos y respiratorios) se cree que representa la respuesta inicial del parénquima pulmonar al amianto retenido (Wright y cols. 1992), que progresará a asbestosis si la exposición continúa o es intensa, pero si ésta es limitada o leve, la respuesta pulmonar puede limitarse a esas áreas (Becklake en Liddell \& Miller 1991)

${ }^{3}$ Se incluyen la bronquitis, la enfermedad pulmonar obstructiva crónica (EPOC) y el enfisema. Se ha demostrado que todos ellos están asociados al trabajo en entornos cargados de polvo. Las pruebas de causalidad se revisan en la seccion Enfermedades crónicas de las vías aéreas y Becklake (1992).

4 Relacionados con la manipulación directa de amianto, y de interés histórico más que actual.

${ }^{5}$ Datos no coincidentes en todos los estudiosa (Doll y Peto 1987); algunos de los mayores riesgos se comunicaron en una cohorte de más de 17.000 trabajadores de aislamiento con amianto de Estados Unidos y Canadá (Selikoff 1990), seguidos desde el 1 de enero de 1967 al 31 de diciembre de 1986, y en los que la exposición había sido particularmente intensa.

Fuentes: Becklake 1994; Liddell y Miller 1992; Selikoff 1990; Doll y Peto en Antman y Aisner 1987; Wright y cols. 1992.

$\mathrm{H}$ abitualmente se ha cifrado en más de 3.000 el número de usos del amianto, lo que sin duda llevó a denominarlo como "el mineral mágico" en el decenio de 1960. U na lista industrial de 1953 contiene hasta 50 usos para el amianto en bruto, además de su empleo en la fabricación de los productos reseñados en la Tabla 10.17, cada uno de los cuales tiene muchas otras aplicaciones industriales. En 1972, el consumo de amianto en un país industrializado como Estados U nidos se atribuía a los siguientes tipos de productos: construcción (42\%); materiales de fricción, fieltros, envasado y juntas (20\%); baldosas para suelo $(11 \%)$; papel (9\%); aislamiento y textiles (3\%) y otros usos (15\%) (Selikoff y Lee 1978). Por el contrario, una lista industrial de las principales categorías de productos en 1995 muestra una importante redistribución a nivel mundial de la siguiente forma: cemento de amianto (84\%); materiales de fricción $(10 \%)$; textiles (3\%); sellos y juntas (2\%); y otros usos (1\%) (A sbestos Institute 1995)

\section{Exposiciones profesionales pasadas y actuales}

La exposición ocupacional, sin duda alguna en los países industrializados, siempre ha sido y sigue siendo la fuente más probable de exposición del ser humano (véase la Tabla 10.17 y las referencias citadas en su pie de página; otras secciones de esta E nciclopedia contienen información adicional). Sin embargo, se han producido importantes cambios en los procesos y procedimientos industriales destinados a reducir la liberación de polvo en el ambiente de trabajo (Browne 1994; Selikoff y Lee 1978). En los países en los que se realizan operaciones mineras, la trituración suele tener lugar en el frente de extracción. La mayoría de las minas de crisotilo son abiertas, mientras que las minas de anfíboles suelen utilizar métodos subterráneos que generan más polvo. La trituración conlleva la separación de la fibra de la roca mediante aplastamiento y cribado, procesos que producían gran cantidad de polvo hasta la introducción de los métodos húmedos y/ o de aislamiento en la mayoría de las trituradoras durante los decenios de 1950 y 1960. La manipulación de los productos de desecho también era una fuente de exposición del ser humano, al igual que el transporte de amianto en sacos, tanto en la carga y descarga en los camiones y vagones como durante el trabajo en los almacenes. Estas exposiciones han disminuido desde la introducción de los sacos impermeables y la utilización de contenedores sellados.

L os trabajadores han tenido que usar amianto en bruto directamente en el embalaje y el revestimiento, particularmente en las locomotoras y en la pulverización de paredes, techos y conductos de aire, y en la industria marítima, las cubiertas y los mamparos. Algunos de estos usos han quedado desfasados de forma voluntaria o han sido prohibidos. En la fabricación de productos de cemento de amianto, la exposición se produce al recibir y abrir los sacos que contienen amianto en bruto, al preparar la fibra para mezclar en la pasta, en la fabricación mecánica de los productos terminales y en el tratamiento de los productos de desecho. En la fabricación de suelos y baldosas vinílicas, el amianto se utilizaba como agente de refuerzo y rellenado para mezclar con resinas orgánicas, pero en la actualidad se ha sustituido en su mayor parte por fibra orgánica en Europa y N orteamérica. En la fabricación de hilos y textiles, la exposición a la fibra tiene lugar al recibir, preparar, mezclar, cardar, hilar, tejer y calandrar la fibra, procesos que hasta hace poco tiempo eran secos y potencialmente generadores de una gran cantidad de polvo. La exposición al polvo se ha reducido de forma considerable en las fábricas modernas mediante el uso de una suspensión coloidal de fibra extruida mediante un coagulante para formar hebras húmedas para los tres últimos procesos mencionados. En la fabricación de los productos de papel de amianto, la exposición humana al polvo de amianto es más 
Tabla 10.17 - Principales fuentes, productos y usos comerciales.

$\begin{array}{ll}\text { Tipo de fibra } & \text { Localización de los principales depósitos } \\ \text { Crisotil } & \text { Rusia, Canadá (Québec, también Columbia Británica, } \\ \text { (blanco) } & \text { Newfoundland), China (provincia de Szechwan); países medi- } \\ & \text { terráneos (Italia, Grecia, Córcega, Chipre); países del sur de } \\ & \text { Africa (Sudáfrica, Zimbabue, Suazilandia); Brasil; depósitos } \\ & \text { más pequeños en Estados Unidos (Vermont, Arizona, Cali- } \\ & \text { fornia) y en Japón }\end{array}$

Tipo de fibra Localización de los principales depositos

Crisotil Rusia, Canadá (Québec, también Columbia Británica,

Newfoundland), China (provincia de Szechwan); paises mediAfrica (Sudáfrica, Zimbabue, Suazilandia); Brasil; depósitos fornia) y en Japón

$\begin{array}{ll}\text { Crocidolita } & \text { Sudáfrica (NO de El Cabo, Transvaal Oriental), Australia } \\ \text { (azul) } & \text { Occidental }^{1} \\ \text { Amosita } & \text { Sudáfrica (norte de Transvaal) }{ }^{1} \\ \text { (marrón) } & \end{array}$

Antofilita

Tremolita

Actinolita

Contamina los depósitos de amosita, y con menor frecuencia,
Finlandia ${ }^{1}$

Italia, Corea y algunas islas del Pacífico; se extrae en pequeña escala en Turquía, China y otros países; contamina la roca que contiene el mineral en algunas minas de amianto, hierro,

talco y vermiculita; también presente en suelos agrícolas de la Península de los Balcanes y en Turquía

\section{Productos y/ o usos comerciales}

Materiales de construcción (baldosas, ripias, canalones y cisternas; techumbre, laminado, y taludes)

Tuberías de presión y de otros tipos

Materiales refractarios (marinos y otros)

Aislamiento e insonorización

Productos pásticos reforzados (hojas de ventilador, interruptores)

Materiales de fricción generalmente en combinación con resinas en frenos, embragues y otras piezas

Textiles (usados en cinturones, prendas de vestir, revestimientos, cortafuegos, autoclaves, hilos y empaquetado)

Productos de papel (usados en cubiertas de libros, aislantes, juntas, fieltro para cubiertas, recubrimientos de paredes, etc.)

Flota en pinturas, revestimientos y varas de soldadura

Usada principalmente en combinación en productos de cemento (en particular en tuberías de presión), pero también en los otros productos antes reseñados

Usado principalmente en cemento, aislamiento térmico y productos para techumbre, en particular en Estados Unidos², pero también en combinación en muchos de los productos reseñados para la crisotil

Relleno en las industrias del caucho, plástico y químicas

Usado como relleno en el talco; puede eliminarse o no en el procesamiento del mineral, por lo que puede aparecer en los productos finales los de crisotil, talco y vermiculita

No suele explotarse comercialmente

${ }^{1}$ Evidentemente, una lista como ésta no es exhaustiva, y los lectores deberán consultar las fuentes citadas y otros capítulos de esta Enciclopedia para obtener una información más completa.

2 Fuera de funcionamiento.

Fuentes: Asbestos Institute (1995); Browne (1994); Liddell y Miller (1991); Selikoff y Lee (1978); Skinner y cols. (1988).

probable que ocurra en la recepción y preparación de las mezclas de material y en el corte de los productos finales, que en el decenio de 1970 contenían entre un 30 y un $90 \%$ de amianto. En la fabricación de productos de fricción de amianto (moldeado mixto en seco, formación de bobinas, tejido o devanado sin fin), la exposición humana al polvo de amianto también es más probable durante los procesos de manipulación y mezcla iniciales, así como en el acabado del producto final, que en el decenio de 1970 contenía entre un 30 y un $80 \%$ de amianto. En la industria de la construcción, antes del uso de un sistema de ventilación apropiado (introducido en el decenio de 1960), el aserrado de alta velocidad, la perforación y el pulido de tableros o baldosas con amianto condujo a la liberación de polvo que contenía fibra cerca del área de respiración del operador, particularmente en los casos en los que tales procedimientos se realizaban en espacios cerrados (por ejemplo, en edificios elevados en construcción). En el período posterior a la II Guerra M undial, una fuente importante de exposición al amianto fue la utilización, retirada o sustitución de materiales que contenían amianto durante la demolición o restauración de edificios o barcos. Una de las principales razones de esta situación era el desconocimiento de la composición de estos materiales (es decir, del hecho de que contenían amianto) y de que la exposición al amianto podía ser perjudicial para la salud. La mejor formación del trabajador, las mejores prácticas de trabajo y la mejor protección personal han reducido los riesgos en el decenio de 1990 en algunos países. En la industria del transporte, las fuentes de exposición eran la retirada y sustitución de revestimientos de motores de locomotoras y de material para frenos en camiones y coches en la industria de reparación del automóvil. Otras fuentes de exposición antiguas que causaron, en particular, enfermedad pleural, continúan siendo centro de atención, incluso en el decenio de 1990, generalmente sobre la base de informes de caso, como los descritos en trabajadores que utilizan cuerdas de amianto en la fabricación de varillas de soldadura, en la formación de cuerda de amianto para hornos de enlechado y en el mantenimiento de sistemas de tracción por cable en las minas.

\section{Otras fuentes de exposición}

La exposición de los individuos cuyas ocupaciones no conllevan la utilización o manipulación directas del amianto, pero que trabajan en la misma área que los que manipulan el amianto de forma directa, se denomina exposición paraocupacional. Esta ha sido una fuente importante de exposición no sólo en el pasado sino también en casos que acudieron a consulta para diagnóstico en el decenio de 1990. Pueden clasificarse dentro de este grupo los electricistas, soldadores y carpinteros de las industrias de la construcción y la reparación y construcción de buques; el personal de mantenimiento de las fábricas de amianto; ajustadores, fogoneros y otros profesionales de centrales hidroeléctricas, barcos y caldererías en los que existe un revestimiento de amianto u otro tipo de aislamiento, y el personal de mantenimiento de los edificios altos de la posguerra que incorporaban diversos materiales que contenían amianto. En el pasado, la exposición doméstica derivaba fundamentalmente del lavado en el hogar de la ropa de trabajo cubierta de polvo; el polvo liberado quedaba atrapado en las alfombras y los muebles y se resuspendía en el aire con las 
Figura $10.19 \cdot$ Cuerpo de amianto.

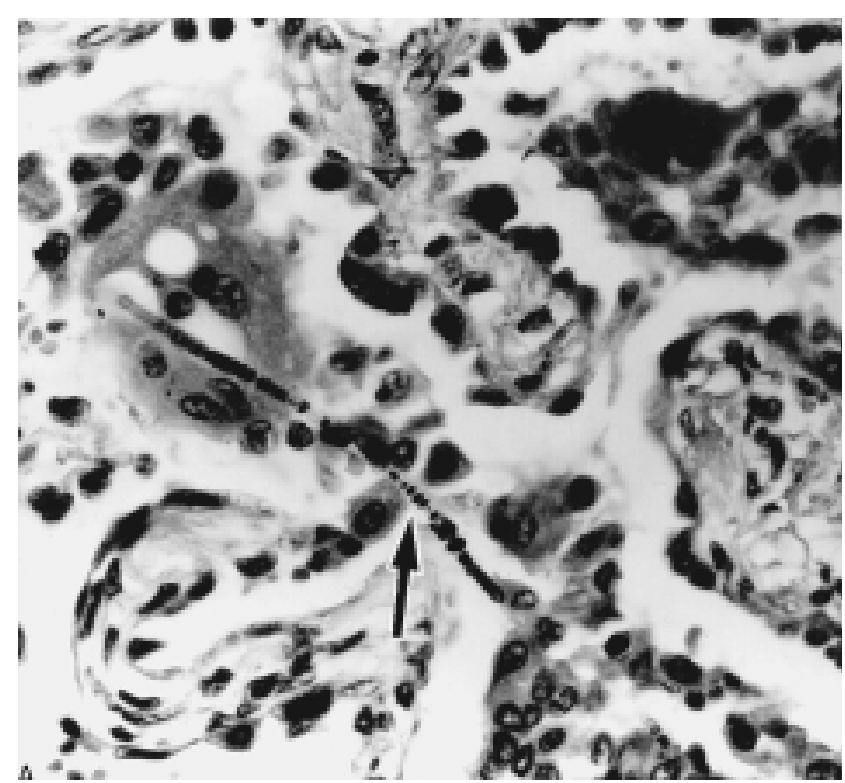

Ampliación x 400, observado en un corte microscópico del pulmón como una estructura alargada ligeramente curvada con una cubierta ferroproteica finamente arrosariada. La fibra de amianto puede identificarse como la fina línea próxima a un extremo del cuerpo de amianto (flecha).

Fuente: Fraser y cols. 1990

actividades de la vida diaria. Los niveles de fibras en suspensión en el aire no sólo podían alcanzar valores de hasta 10 fibras por mililitro (f/ $\mathrm{ml}$ ), es decir, 10 veces el límite de exposición ocupacional, 1 f/ ml, propuesto en una reunión de la O M S (1989), sino que además las fibras tendían a permanecer en el aire durante varios días. Desde el decenio de 1970, la práctica de conservar toda la ropa de trabajo en el centro para su lavado ha sido adoptada de forma extensa pero no universal. También en el pasado, se producía una exposición residencial a partir de la contaminación del aire procedente de fuentes industriales. Por ejemplo, se han documentado niveles elevados de amianto suspendido en el aire en la vecindad de fábricas y minas de amianto, y estos niveles están determinados por los niveles de producción, los controles de emisión y el tiempo. Dado el largo intervalo de tiempo para la enfermedad pleural relacionada con el amianto en particular, estas exposiciones todavía serán probablemente responsables del diagnóstico de algunos casos en el decenio de 1990. En los decenios de 1970 y 1980, con la mayor concienciación pública de las consecuencias nocivas para la salud de la exposición al amianto y del hecho de que en la construcción moderna se utilizan a menudo materiales que lo contienen (particularmente en la forma friable utilizada para pulverización en paredes, techos y conductos de ventilación), una de las principales causas de preocupación fue el hecho de si, a medida que estos edificios envejecen y sufren el desgaste diario, es posible que se liberen fibras de amianto al aire en cantidades suficientes como para resultar una amenaza para la salud de los que trabajan en los modernos rascacielos (véase más adelante una estimación de riesgos). 0 tras fuentes de contaminación del aire en las áreas urbanas son la liberación de fibras de los frenos de los vehículos y la redispersión de fibras liberadas por los vehículos en movimiento (Bignon, Peto y Saracci 1989).

Las fuentes no industriales de exposición ambiental son las fibras naturales del suelo, por ejemplo, en la Europa del este y en afloramientos rocosos en la región mediterránea, incluidos
Córcega, Chipre, Grecia y Turquía (Bignon, Peto y Saracci 1989). O tra fuente de exposición en el ser humano deriva del uso de tremolita para la lechada y el estuco en G recia y Turquía y, según informes más recientes, en N ueva Caledonia en el Pacífico Sur (Luce y cols. 1994). Además, en diversas poblaciones rurales de Turquía se ha comprobado que se utiliza una fibra de zeolita, la erionita, en el estuco y en la construcción doméstica, a la que se ha relacionado con la aparición de mesotelioma (Bignon, Peto y Saracci 1991). Finalmente, puede producirse exposición humana a través el agua potable, principalmente por contaminación natural y, dada la distribución natural extensa de la fibra en afloramientos, la mayor parte de las fuentes de agua contienen cierta cantidad de fibra, correspondiendo los niveles más elevados a las áreas mineras (Skinner, R oos y Frondel 1988).

\section{Etiopatología de la enfermedad relacionada con el amianto}

\section{Destino de las fibras inhaladas}

L as fibras inhaladas se alinean con la corriente de aire y su capacidad de penetrar en los espacios pulmonares más profundos depende de su tamaño, de tal forma que las fibras de diámetros aerodinámico igual o inferior a $5 \mu \mathrm{m}$ muestran una penetración superior al $80 \%$, pero también una retención inferior al 10-20\%. L as partículas de mayor tamaño pueden impactar en la nariz y en las principales vías aéreas a nivel de las bifurcaciones, donde tienden a acumularse. Las partículas depositadas en las vías aéreas principales son depuradas por la acción de las células ciliadas y transportadas por el moco. Las diferencias individuales asociadas a lo que parece ser la misma exposición son debidas, al menos en parte, a diferencias individuales en la penetración y retención de las fibras inhaladas (Bégin, Cantin y M assé 1989). L as partículas pequeñas depositadas más allá de las vías aéreas principales son fagocitadas por los macrófagos alveolares, células depuradoras que ingieren material extraño. Las fibras de mayor tamaño, es decir, las que tienen más de $10 \mu \mathrm{m}$, a menudo son atacadas por más de un macrófago, y lo más probable es que acaben siendo revestidas y formen el núcleo de un cuerpo de asbesto, una estructura característica conocida desde principios del siglo XX como un marcador de la exposición (véase la Figura 10.19). EI revestimiento de una fibra se considera parte de la defensa del pulmón para hacerla inerte y no inmunogénica. Los cuerpos de asbesto es más probable que se formen en fibras de anfíboles que en fibras de crisotilo, y su densidad en el material biológico (esputo, lavado broncoalveolar, tejido pulmonar) es un marcador indirecto de la carga pulmonar. Las fibras revestidas pueden persistir en el pulmón durante largos períodos, para ser recuperadas del esputo o del líquido de lavado broncoalveolar hasta 30 años después de la última exposición. La depuración de las fibras no revestidas depositadas en el parénquima pulmonar se realiza hacia la periferia pulmonar y las regiones subpleurales $y$, posteriormente, a los ganglios linfáticos hiliares. L as teorías planteadas para explicar cómo provocan las fibras las diversas reacciones pleurales asociadas a la exposición al amianto son las siguientes:

1. Penetración directa en el espacio pleural y drenaje con el líquido pleural a los poros de la pleura que reviste la pared torácica

2. Liberación de mediadores al espacio pleural desde linfáticos subpleurales

3. Flujo retrógrado desde los ganglios linfáticos hiliares hasta la pleura parietal (Browne 1994)

También puede haber flujo retrógrado a través del conducto torácico hasta los ganglios linfáticos abdominales, lo cual explicaría la aparición del mesotelioma peritoneal. 


\section{E fectos celulares de las fibras inhaladas}

Los estudios realizados en animales indican que los acontecimientos iniciales que siguen a la retención de amianto en el pulmón son:

1. Una reacción inflamatoria con acumulación de leucocitos seguida de alveolitis macrofágica con liberación de fibronectina, factor de crecimiento y diversos factores quimiotácticos de los neutrófilos y, con el tiempo, liberación de ion superóxido y

2. Proliferación de células alveolares, epiteliales, intersticiales y endoteliales (Bignon, Peto y Saracci 1989).

Estos acontecimientos se reflejan en el material recuperado por lavado broncoalveolar en animales y en seres humanos (Bégin, Cantin y M assé 1989). Las dimensiones de las fibras y sus características químicas parecen determinar la potencia biológica de fibrogénesis, y se cree que estas características, junto con las propiedades de superficie, también son importantes para la carcinogénesis. Las fibras delgadas y largas son más activas que las cortas, aunque la actividad de estas últimas no puede infravalorarse, y los anfíboles son más activos que el crisotilo, una propiedad atribuida a su mayor persistencia biológica (Bégin, Cantin y M assé 1989). Las fibras de amianto también pueden afectar al sistema inmunológico humano y cambiar la población circulante de linfocitos sanguíneos. Por ejemplo, puede resultar alterada la inmunidad celular humana ante los antígenos celulares (como se muestra en una prueba cutánea de tuberculina) (Browne 1994). Además, dado que las fibras de amianto parecen ser capaces de inducir anomalías cromosómicas, se ha propuesto que también pueden ser capaces de inducir cáncer además de promoverlo (Jaurand en Bignon, Peto y Saracci 1989).

\section{Relaciones ente la dosis y la respuesta a la exposición}

En las ciencias biológicas, como la farmacología y la toxicología en las que las relaciones dosis-respuesta se utilizan para calcular la probabilidad de los efectos deseados y el riesgo de los efectos no deseados, el concepto de dosis corresponde a la cantidad de agente suministrado al órgano diana y que permanece en contacto con él durante el tiempo suficiente como para provocar una reacción. En medicina del trabajo, los cálculos del riesgo se suelen basar en ciertos marcadores sustitutivos de la dosis, como son diversas mediciones de la exposición. Sin embargo, en estudios basados en grupos de trabajadores por lo general es posible demostrar relaciones entre exposición-respuesta; no obstante, la medida de exposición más adecuada puede variar según las enfermedades. Resulta algo desconcertante el hecho de que, aunque las relaciones de exposición-respuesta difieran entre los trabajadores, estas diferencias sólo pueden explicarse en parte por la fibra, el tamaño de la partícula y al proceso industrial. Con todo, estas relaciones de exposición-respuesta han constituido la base científica para la valoración de riesgos y para el establecimiento de límites de exposición permisibles, que se centraron originalmente en el control de la asbestosis (Selikoff y Lee 1978). A medida que ha disminuido la prevalencia y/ o la incidencia de este trastorno, la preocupación se ha desplazado a la protección de la salud humana frente a los cánceres relacionados con el amianto. A lo largo del último decenio, se han desarrollado técnicas para la medición cuantitativa de la carga pulmonar de polvo o directamente de la dosis biológica en términos de fibras por gramo de tejido pulmonar seco. Además, el análisis radiológico de liberación de energía (EDX A) permite realizar una caracterización precisa de cada fibra en función del tipo de fibra (Churg 1991). Aunque no se ha conseguido todavía una normalización de los resultados entre los distintos laboratorios, las comparaciones de los resultados obtenidos en un laboratorio dado resultan de utilidad, y las mediciones de carga pulmonar han proporcionado una nueva herramienta para la evaluación de casos. Además, la aplicación de estas técnicas a los estudios epidemiológicos

1. Ha confirmado la persistencia biológica de las fibras de anfíboles en el pulmón en comparación con las fibras de crisotilo

2. Ha identificado la carga de fibras en los pulmones de determinados sujetos en los que la exposición se había olvidado, era remota o se consideraba carente de importancia

3. H a demostrado un gradiente en la carga pulmonar asociado a la residencia rural y urbana y a la exposición ocupacional, y

4. Ha confirmado un gradiente de fibra en la carga pulmonar de polvo asociada a las principales enfermedades relacionadas con el amianto (Becklake y Case 1994).

\section{Asbestosis}

\section{Definición e historia}

Asbestosis es el nombre dado a la neumoconiosis subsiguiente a la exposición al polvo de amianto. El término neumoconiosis se utiliza aquí en el sentido en que se define en el artículo "N eumoconiosis: definiciones" de esta Enciclopedia como una enfermedad en la que existe una "acumulación de polvo en los pulmones y respuestas tisulares al polvo". En el caso de la asbestosis, la reacción tisular es colagenosa, y causa una alteración permanente de la arquitectura alveolar con cicatrización. Ya en 1898, el Annual R eport of $\mathrm{H}$ er $M$ ajesty's Chief Inspector of Factories contenía una referencia al informe de un inspector de fábricas con personal femenino acerca de las consecuencias adversas para la salud de la exposición al amianto, y el R eport de 1898 contenía detalles de un caso de esta naturaleza en un varón que había trabajado durante 12 años en una de las fábricas textiles recién establecidas en L ondres, I nglaterra. La autopsia reveló una fibrosis grave difusa del pulmón, y en subsiguientes exámenes histológicos de los cortes se observaron estructuras que posteriormente recibirían el nombre de cuerpos de asbesto. Dado que la fibrosis pulmonar es un proceso poco frecuente, se consideró que la asociación era causal y el caso se presentó a un comité como prueba para lograr una indemnización por enfermedad profesional en 1907 (Browne 1994). A pesar de la aparición de informes de naturaleza similar registrados por inspectores del Reino Unido, Europa y Canadá en la siguiente década, el papel de la exposición al amianto en el origen del proceso no se reconoció de forma general hasta la publicación de un informe de caso en el British M edical J ournal en 1927. En este informe, se utilizó por primera vez el término asbestosis pulmonar para describir esta neumoconiosis particular, y se comentó lo destacado de las reacciones pleurales asociadas, a diferencia de, por ejemplo, la silicosis, la principal neumoconiosis reconocida en esa época (Selikoff y Lee 1978). En el decenio de 1930, dos estudios basados en grupos de trabajadores de la industria textil, uno en el Reino Unido y otro en Estados Unidos, proporcionaron pruebas de la existencia de una relación exposición-respuesta (y, por consiguiente, probablemente causal) entre el nivel y la duración de la exposición y los cambios radiográficos indicativos de asbestosis. Estos informes constituyeron la base de las primeras regulaciones de control en el R eino U nido, promulgadas en 1930, y de los primeros valores límite umbral para el amianto publicados por la Conferencia A mericana de $\mathrm{H}$ igienistas Industriales del Gobierno (American Conference of Government and Industrial H ygienists) en 1938 (Selikoff y Lee 1978).

\section{Anatomía patológica}

L os cambios fibróticos que caracterizan a la asbestosis son consecuencia de un proceso inflamatorio provocado por las fibras retenidas en los pulmones. La fibrosis en este proceso es de tipo 
intersticial, difusa, tiende a afectar fundamentalmente a los lóbulos inferiores y las zonas periféricas y, en los casos avanzados, se asocia a obliteración de la arquitectura normal del pulmón. Es frecuente la fibrosis de la pleura adyacente. $\mathrm{N}$ inguna de las características histológicas de la asbestosis la diferencia de la fibrosis intersticial debida a otras causas, salvo la presencia de amianto en el pulmón en forma de cuerpos de asbesto, visibles al microscopio óptico, o de fibras no recubiertas, la mayoría de las cuales son demasiado finas para ser visualizadas salvo por microscopia electrónica. Por tanto, la ausencia de cuerpos de asbesto en las imágenes obtenidas al microscopio óptico no descarta ni la exposición ni el diagnóstico de asbestosis. En el otro extremo del espectro de gravedad de la enfermedad, la fibrosis puede limitarse a zonas relativamente escasas y afectar principalmente a las regiones peribronquiolares (véase la Figura 10.20), dando origen a la que se ha denominado enfermedad de las pequeñas vías aéreas relacionada con el amianto. También en este caso, salvo quizá por la afectación más extensa de las pequeñas vías aéreas membranosas, ninguno de los cambios histológicos de este proceso lo distingue de la enfermedad de las pequeñas vías aéreas debida a otras causas (como el consumo de tabaco o la exposición a otros polvos minerales) salvo por la presencia de amianto en el pulmón. $L a$ enfermedad de las pequeñas vías aéreas puede ser la única manifestación de la fibrosis pulmonar relacionada con el amianto, o puede coexistir con grados variables de fibrosis intersticial, es decir, de asbestosis (Wright y cols. 1992). Se han publicado criterios cuidadosamente considerados para la clasificación anatomopatológica de la asbestosis (C raighead y cols. 1982). En general, la extensión y la intensidad de la fibrosis pulmonar está relacionada con la carga pulmonar de polvo medida (Liddell y M iller 1991).

\section{Características clínicas}

La disnea, que es el síntoma más precoz, el referido con mayor frecuencia y el más molesto, es la responsable de que la asbestosis reciba el nombre de enfermedad monosintomática (Selikoff y Lee 1978). La disnea precede a otros síntomas como tos seca, a menudo molesta, y opresión torácica, que se cree asociada a reacciones pleurales. En la auscultación se escuchan estertores 0 crepitantes inspiratorios tardíos que persisten después de la tos, primero en la axila y después en las bases pulmonares, antes de hacerse más generalizados a medida que el proceso evoluciona. Se cree que se deben a la apertura explosiva de las vías aéreas que se cierran en la espiración. En los casos en que se escuchan estertores rudos y roncus, se cree que reflejan una bronquitis, ya sea en respuesta al trabajo en un ambiente polvífero o causada por el consumo de tabaco.

\section{E studios de imagen del tórax}

Tradicionalmente, la radiografía de tórax ha sido la herramienta diagnóstica aislada más importante para establecer la presencia de asbestosis. Esto se ha visto facilitado por la utilización de la clasificación radiológica de la OIT (1980) que gradúa las pequeñas opacidades irregulares características de la asbestosis en un todo continuo desde la ausencia de enfermedad hasta la enfermedad más avanzada, tanto en cuanto a la gravedad (descrita como profusión en una escala de 12 puntos desde - / 0 a $3 /+$ ) como a su extensión (descrita como el número de zonas afectadas). A pesar de la existencia de diferencias entre examinadores, incluso entre aquellos que han realizado cursos de formación en interpretación de radiografías, esta clasificación ha demostrado ser particularmente útil en los estudios epidemiológicos, y también se ha utilizado clínicamente. Sin embargo, puede haber cambios anatomopatológicos de asbestosis
Figura 10.20 Enfermedad de las pequeñas vías aéreas relacionadas con el amianto.

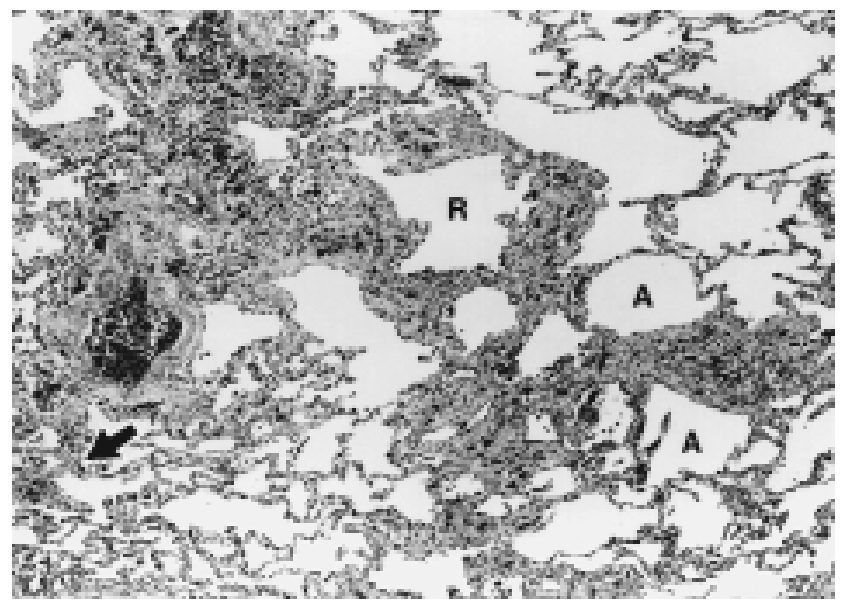

Se observa fibrosis peribronquiolar e infiltración por células inflamatorias en un corte histológico de un bronquiolo respiratorio (R) y sus divisiones distales 0 conductos alveolares (A). El pulmón circundante es prácticamente normal, pero presenta engrosamiento focal del tejido intersticial (flecha), que representa asbestosis precoz.

Fuente: Fraser y cols. 1990.

hasta en un $20 \%$ de sujetos con radiografía de tórax normal. Además, las pequeñas opacidades irregulares de baja profusión (p.ej., 1/0 en la escala de la OIT) no son específicas de la asbestosis, sino que pueden observarse en relación con otros tipos de exposición, como por ejemplo, la exposición al humo de los cigarrillos (Browne 1994). La tomografía computadorizada (TC) ha revolucionado el diagnóstico por imagen de la enfermedad pulmonar intersticial, incluida la asbestosis, y la tomografía computadorizada de alta resolución (TCAR) ha añadido una mayor sensibilidad a la detección de la enfermedad intersticial y pleural (Fraser y cols. 1990). Las características de la asbestosis que pueden identificarse mediante TCAR son líneas centrales interlobulillares (septales) e intralobulillares engrosadas, bandas parenquimatosas, líneas subpleurales curvilíneas y densidades declives subpleurales, de las que las dos primeras son las más específicas de la asbestosis (Fraser y cols. 1990). La TCAR también permite identificar estos cambios en los casos en los que existe déficit de función pulmonar y la radiografía de tórax no es concluyente. En función de los datos de la TCAR posmórtem, se ha demostrado que las líneas intralobulillares se correlacionan con la fibrosis peribronquiolar, y las líneas interlobulillares engrosadas con la fibrosis intersticial (Fraser y cols. 1990). H asta la fecha, no se ha desarrollado ningún método de interpretación para la utilización de la TCAR en la enfermedad relacionada con el amianto. A demás de su coste, el hecho de que los aparatos de TC estén limitados a los hospitales hace improbable que sustituya a la radiografía de tórax para la vigilancia y los estudios epidemiológicos; su papel permanecerá probablemente limitado a la investigación de casos individuales o a estudios planificados diseñados para evaluar aspectos específicos. En la Figura 10.21 se ilustra el uso de las técnicas de imagen del tórax para el diagnóstico de la enfermedad pulmonar relacionada con el amianto; el caso presentado muestra asbestosis, enfermedad pleural relacionada con el amianto y cáncer de pulmón. Las opacidades de gran tamaño, una complicación de otras neumoconiosis, en particular de la silicosis, son poco frecuentes en la asbestosis y suelen deberse a otros procesos como el cáncer de pulmón (véase el caso descrito en la Figura 10.21) o la atelectasia redondeada. 
Figura 10.21 - Imágenes del tórax en la enfermedad pulmonar relacionada con el amianto.

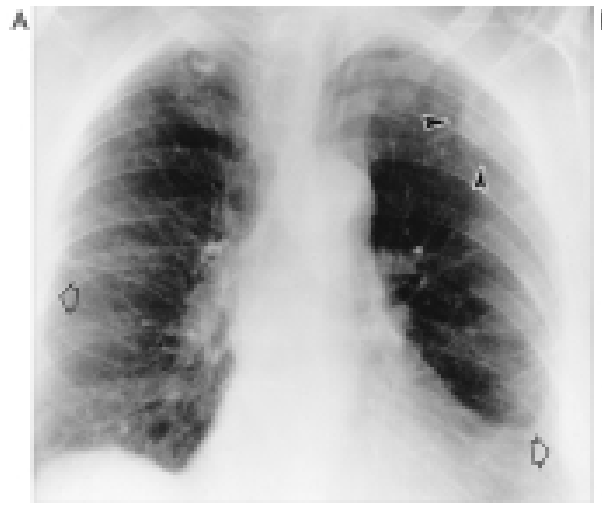

Radiografía de tórax posteroanterior (A) que muestra una asbestosis que afecta a ambos pulmones(A), valorada como de categoría $1 / 1$ de la OIT, asociada a engrosamiento pleural bilateral (flechas huecas) y una opacidad vagamente definida ( puntas de flecha) en el lóbulo superior izquierdo. En la imagen de TCAR (B), esta lesión se visualizó como una masa densa (M) que limita con la pleura, y la biopsia
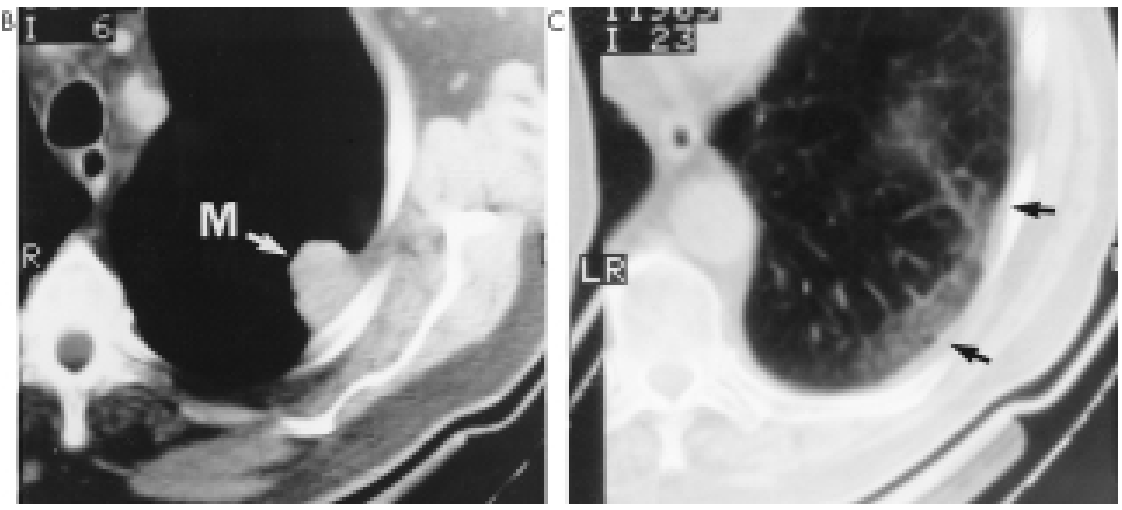

transtorácica con aguja reveló un adenocarcinoma de pulmón. En la imagen de TC (C) de alta atenuación pueden observarse placas pleurales (puntas de flecha) y una opacidad curvilínea delgada en el parénquima subyacente a las placas, con anomalía intersticial en el pulmón entre la opacidad y la pleura.

Fuente: Fraser y cols. 1990.

\section{Pruebas de función pulmonar}

La fibrosis pulmonar intersticial establecida debida a la exposición al amianto, como la debida a otras causas, suele estar asociada (aunque no siempre) a un patrón restrictivo de la función pulmonar (Becklake 1994). Sus características incluyen volúmenes pulmonares reducidos, en particular la capacidad vital (VC) con preservación de la relación del volumen espiratorio forzado en 1 segundo respecto a la capacidad vital forzada $\left(\mathrm{FEV}_{1} / \mathrm{FVC} \%\right.$ ), complianza pulmonar reducida y deterioro del intercambio de gases. Sin embargo, también puede existir una limitación del flujo aéreo con un $\mathrm{FEV}_{1} / \mathrm{FVC}$ reducido en respuesta a un ambiente de trabajo rico en polvo 0 al consumo de tabaco. En las fases precoces de la asbestosis, cuando los cambios anatomopatológicos se limitan a fibrosis peribronquiolar, e incluso antes de que las pequeñas opacidades irregulares sean evidentes en una radiografía de tórax, el deterioro de las pruebas que refleja una disfunción de las pequeñas vías aéreas, como el flujo mesoespiratorio máximo, puede ser el único signo de disfunción respiratoria. También pueden deteriorarse en las fases precoces de la enfermedad las respuestas al estrés producido por el ejercicio, con un aumento de la ventilación en relación con las necesidades de oxígeno del ejercicio (debido a una mayor frecuencia respiratoria y a la respiración superficial) y con deterioro del intercambio de $\mathrm{O}_{2}$. A medida que avanza la enfermedad, cada vez es necesario menos ejercicio para comprometer el intercambio de oxígeno. Dado que el trabajador expuesto al amianto puede presentar al mismo tiempo características de patrones de función pulmonar restrictivo y obstructivo, el médico avisado debe interpretar dicho patrón como lo que es, es decir, una medida del deterioro, más que como una ayuda al diagnóstico. Las funciones pulmonares, en particular la capacidad vital, proporcionan una herramienta útil para el seguimiento individual de los sujetos 0 , en los estudios epidemiológicos, por ejemplo, una vez interrumpida la exposición, para monitorizar la historia natural de la asbestosis o de la enfermedad pleural relacionada con el amianto.

\section{Otras pruebas de laboratorio}

El lavado broncoalveolar se utiliza cada vez más como herramienta clínica en la investigación de la enfermedad pulmonar relacionada con el amianto:

1. Para descartar otros diagnósticos
2. Para valorar la actividad de las reacciones pulmonares en estudio, como la fibrosis, 0

3. Para identificar al agente en forma de cuerpos o fibras de asbesto.

También se utiliza para estudiar los mecanismos de la enfermedad en seres humanos y en animales (Bégin, $C$ antin y M assé 1989). La captación de Galio-67 se utiliza como medida de la actividad del proceso pulmonar, y también se han investigado los anticuerpos antinucleares (ANA) y el factor reumatoide (FR) del suero como factores capaces de influir en la progresión de la enfermedad y/ o responsables de diferencias entre individuos en respuesta a lo que parece ser el mismo nivel y dosis de exposición.

\section{Epidemiología, incluida la historia natural}

La prevalencia de la asbestosis radiológica documentada en estudios basados en grupos de trabajadores varía considerablemente y, como cabría esperar, estas diferencias están relacionadas con diferencias en la duración y la intensidad de la exposición más que con diferencias entre los lugares de trabajo. Sin embargo, incluso cuando se tienen en cuenta estos factores, restringiendo la comparación de las relaciones de respuesta a la exposición a aquellos estudios en los que los cálculos de exposición se individualizaron para cada miembro de la cohorte y se basaron en la historia laboral y en mediciones de higiene industrial, son evidentes marcadas diferencias relacionadas con la fibra y con el proceso (Liddell y M iller 1991). Por ejemplo, hubo una prevalencia del $5 \%$ de pequeñas opacidades irregulares (1/ 00 más en la clasificación de la OIT) a consecuencia de la exposición acumulada a aproximadamente 1.000 fibras-año en mineros de crisotilo de Quebec, a aproximadamente 400 fibras-año en mineros de crisotilo de Córcega y por debajo de 10 fibras-año en mineros de crocidolita de Sudáfrica y Australia. Por el contrario, en los mineros textiles expuestos a crisotilo en Q uebec, se produjo una prevalencia del $5 \%$ de pequeñas opacidades irregulares a partir de una exposición acumulada a menos de 20 fibras-año. Los estudios de la carga pulmonar de polvo también concuerdan con la existencia de una diferencia en la carga de fibra para la provocación de asbestosis: en 29 varones que trabajaban en astiIleros del Pacífico y que presentaban asbestosis asociada principalmente a exposición a amosita, la carga pulmonar media encontrada en el material de autopsia fue de 10 millones de fibras de amosita por gramo de tejido pulmonar desecado, en 
comparación con una carga de crisotilo promedio de 30 millones de fibras por gramo de tejido pulmonar desecado observada en 23 mineros y laminadores de Q uebec (Becklake y C ase 1994). La distribución del tamaño de las fibras contribuye a estas diferencias, pero no las explica por completo, lo que indica la posible influencia de otros factores específicos de cada fábrica, como pueden ser otros contaminantes del lugar de trabajo.

La asbestosis puede permanecer estable o progresar, pero probablemente no experimenta regresión. Las tasas de progresión aumentan con la edad, con la exposición acumulada y con la extensión de la enfermedad existente, y la progresión es más probable en los casos de exposición a crocidolita. La asbestosis radiológica puede progresar o aparecer mucho después de interrumpida la exposición. También se puede producir un deterioro de la función pulmonar una vez cesada la exposición (Liddell y M iller 1991). Un tema importante (y en el que las pruebas epidemiológicas no concuerdan) es el hecho de si la exposición continuada aumenta las probabilidades de progresión una vez desarrollados los cambios radiológicos (Browne 1994; Liddell y M iller 1991). En algunas jurisdicciones, por ejemplo, en el Reino U nido, el número de casos de asbestosis presentados para indemnización se ha reducido en los últimos decenios, lo que refleja los controles en el lugar de trabajo establecidos en el decenio de 1970 (M eredith y M CD onald 1994). En otros países, por ejemplo, en Alemania (Gibbs, Valic y Browne 1994), las tasas de asbestosis siguen aumentando. En Estados U nidos, las tasas de mortalidad relacionada con el amianto ajustadas según la edad (basadas en la mención de la asbestosis en el certificado de defunción como causa de muerte o como factor contributivo) para los sujetos de edad 15+ aumentaron desde menos de 1 por millón en 1960 hasta más de 2,5 en 1986 y hasta 3 en 1990 (U S Dept. of $\mathrm{H}$ ealth and $\mathrm{H}$ uman Services, 1994).

\section{Diagnóstico y tratamiento del caso}

El diagnóstico clínico depende de:

1. Establecer la presencia de enfermedad

2. Establecer si hubo exposición, y

3. Evaluar si es probable que la exposición causara la enfermedad.

La radiografía de tórax sigue siendo la herramienta clave para establecer la presencia de enfermedad, suplementada por la TCAR si está disponible en los casos en que existan dudas. 0 tras características objetivas son la presencia de crepitantes basales, mientras que el nivel de función pulmonar, incluida la prueba de provocación por el esfuerzo, resulta de utilidad para establecer un deterioro, un paso necesario para la evaluación de indemnizaciones. Dado que la anatomía patológica, los cambios radiológicos, los síntomas y los cambios en la función pulmonar asociados a la asbestosis no son diferentes a los observados en la fibrosis pulmonar intersticial debida a otras causas, establecer la exposición resulta fundamental para el diagnóstico. Además, los numeroso usos de los productos de amianto, cuyo contenido a menudo el usuario desconoce, hacen que la historia de la exposición resulte aún más difícil de obtener de lo que se pensaba previamente. Si la historia de exposición parece insuficiente, la identificación del agente en muestras biológicas (esputo, lavado broncoalveolar y, cuando esté indicada, biopsia), puede corroborar la exposición. La dosis puede valorarse cuantitativamente en forma de carga pulmonar mediante autopsia o a partir de los pulmones extraídos quirúrgicamente. Las pruebas de actividad de la enfermedad (a partir de una gammagrafía con galio-67 o de lavado broncoalveolar) pueden ayudar al pronóstico, un aspecto clave en este proceso irreversible. Incluso en ausencia de pruebas epidemiológicas consistentes que indiquen que la progresión se enlentece una vez interrumpida la exposición, este enfoque puede ser prudente $y$, sin duda alguna, aconsejable. Sin embargo, no es una decisión fácil de tomar ni de recomendar, particularmente en el caso de los trabajadores de más edad que tienen escasas oportunidades de reconversión. No cabe duda de que la exposición no debe continuar en los lugares de trabajo que no cumplan los actuales niveles permisibles de exposición. Los criterios diagnósticos de la asbestosis con fines epidemiológicos son menos exigentes, en particular para los estudios de corte transversal basados en grupos de trabajadores que incluyen a aquellos que se encuentran suficientemente bien para trabajar. Estos estudios suelen abordar aspectos de causalidad y, a menudo, utilizan marcadores que indican enfermedad mínima, basados en el nivel de función pulmonar o en cambios en la radiografía de tórax. Por el contrario, los criterios para el diagnóstico con fines medicolegales son considerablemente más estrictos y varían de acuerdo con los sistemas administrativos legales bajo los que operan, siendo diferentes entre estados dentro de cada país, así como entre los distintos países.

\section{Enfermedad pleural relacionada con el amianto}

\section{Perspectiva histórica}

L as primeras descripciones de la asbestosis mencionan la fibrosis de la pleura visceral como parte del proceso de la enfermedad (véase "A natomía patológica"). En el decenio de 1930, también se comunicaron informes de placas pleurales circunscritas, a menudo calcificadas, en la pleura parietal (que reviste la pared torácica y cubre la superficie del diafragma), y que aparecían en sujetos con exposición medioambiental no profesional. Un estudio de trabajadores realizado en 1955 en una fábrica alemana comunicó una prevalencia del $5 \%$ de cambios pleurales en la radiografía de tórax, llamando así la atención sobre el hecho de que la enfermedad pleural podría ser la manifestación primaria, si no la única, de la exposición. Las reacciones pleurales visceroparietales, incluida la fibrosis pleural difusa, el derrame pleural benigno (comunicado por primera vez en el decenio de 1960) y la atelectasia redondeada (comunicada por primera vez en el decenio de 1980), son reacciones actualmente consideradas como interrelacionadas, que resulta útil distinguir de las placas pleurales basándose en la anatomía patológica y probablemente en la patogenia, así como en las características clínicas y la presentación. En jurisdicciones en las que las tasas de prevalencia y/ o incidencia de asbestosis están disminuyendo, las manifestaciones pleurales, cada vez más frecuentes en los estudios, constituyen cada vez más la base de la detección de la exposición pasada y la razón de que los sujetos soliciten atención médica.

\section{Placas pleurales}

L as placas pleurales son lesiones lisas, blancas, elevadas e irregulares cubiertas por mesotelio y presentes en la pleura parietal o en el diafragma (Figura 10.22). Tienen un tamaño variado, a menudo son múltiples y tienden a calcificarse con la edad (Browne 1994). Sólo una pequeña proporción de las placas detectadas en la autopsia se observan en la radiografía de tórax, aunque la mayoría pueden detectarse por TCAR. En ausencia de fibrosis pulmonar, las placas pleurales pueden no causar síntomas y detectarse sólo en estudios de exploración selectiva mediante radiografía de tórax. No obstante, en estudios de trabajadores, se asocian de forma constante a un deterioro de la función pulmonar, modesto pero mensurable, principalmente en la VC y la FVC (Ernst y Zejda 1991). En estudios radiológicos realizados en Estados U nidos, se comunican tasas del $1 \%$ en varones sin exposición conocida, y del 2,3 \% en varones con exposición ocupacional, incluidas las poblaciones urbanas. Las tasas también son más altas en las comunidades con industrias del amianto 0 utilizaciones elevadas del mismo, mientras que en algunos grupos 
Figura 10.22 - Enfermedad pleural relacionada con el amianto.
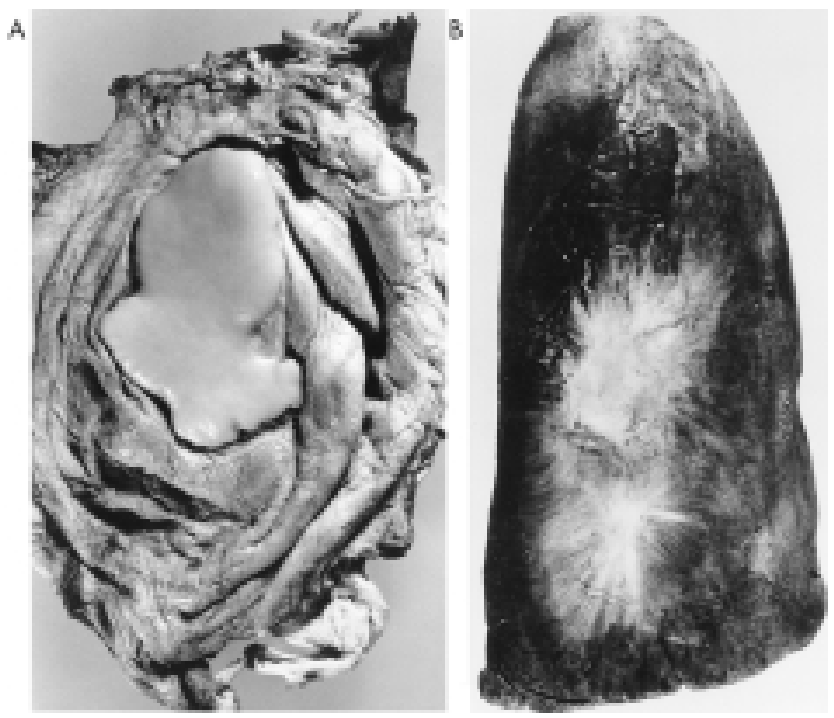

Muestra de autopsia en la que se observa una placa pleural diafragmática (A) visualizada como un foco uniforme bien definido de fibrosis sobre el diafragma de un trabajador de la construcción con exposición accidental al amianto y cuerpos de amianto en el pulmón. Se observa una fibrosis pleural visceral (B) en una muestra de autopsia de pulmón insuflado, que irradia desde dos focos centrales en la pleura visceral del pulmón de un trabajador de la construcción con exposición a amianto que también presentaba varias placas pleurales parietales.

Fuente: Fraser y cols. 1990

de trabajadores, como los trabajadores de láminas de metal, aislantes, fontaneros y trabajadores del ferrocarril, las tasas pueden superar el $50 \%$. En un estudio finlandés de 1994 realizado en autopsias de 288 varones de 35 a 69 años de edad que fallecieron súbitamente, se detectaron placas pleurales en el $58 \%$, y una tendencia a aumentar con la edad, con la probabilidad de exposición (basada en la historia), con la concentración de fibras de amianto en el tejido pulmonar y con el consumo de tabaco ( $K$ arjalainen y cols. 1994). La fracción etiológica de las placas atribuible a una carga pulmonar de polvo de 0,1 millones de fibras por gramo de tejido pulmonar se estimó en un $24 \%$ (se considera que este valor está infraestimado). L os estudios de carga pulmonar de polvo también coinciden con el gradiente de fibras en cuanto a la potencia para provocar reacciones pleurales; en 103 varones con exposición a amosita en astilleros del Pacífico, todos ellos con placas pleurales, la carga pulmonar promedio en la autopsia fue de 1,4 millones de fibras por gramo de tejido pulmonar, en comparación con 15,5 y 75 millones de fibras por gramo de tejido pulmonar para el crisotilo y la tremolita, respectivamente, en 63 mineros y laminadores de crisotilo de Quebec examinados de la misma forma (Becklake y Case 1994).

\section{Reacciones pleurales visceroparietales}

Aunque la anatomía patológica y la patogenia de las diferentes formas de reacción visceroparietal a la exposición al amianto están interrelacionadas casi con absoluta seguridad, sus manifestaciones clínicas y la forma de detección son diferentes. Pueden producirse reacciones pleurales exudativas agudas en forma de derrames en sujetos cuyos pulmones no manifiestan otra enfermedades relacionadas con el asbesto, o como exacerbación de la gravedad y la extensión de las reacciones pleurales existentes. Estos derrames pleurales se denominan benignos para diferenciarlos de los derrames asociados al mesotelioma maligno. Los derrames pleurales benignos se producen típicamente 10 a
15 años después de la primera exposición (o después de una exposición pasada limitada) en sujetos en la tercera y cuarta décadas de la vida. Suelen ser transitorios, pero pueden recidivar, afectar a uno o ambos lados del tórax de forma simultánea o secuencial, y ser silentes 0 asociarse a síntomas como opresión torácica y/ 0 dolor pleural y disnea. El líquido pleural contiene leucocitos, a menudo sangre, y es rico en albúmina; sólo en raras ocasiones contiene cuerpos o fibras de amianto que, sin embargo, pueden encontrarse en el material de biopsia de la pleura o del pulmón subyacente. La mayoría de los derrames pleurales benignos se resuelven de forma espontánea, aunque en una pequeña proporción de sujetos (del orden del $10 \%$ en una serie) pueden evolucionar a fibrosis pleural difusa (véase la Figura 10.22), con o sin fibrosis pulmonar. Las reacciones pleurales locales también pueden plegarse sobre sí mismas, atrapando tejido pulmonar y causando lesiones bien delimitadas conocidas como atelectasia redonda o seudotumor, debido a que tienen el aspecto radiológico del cáncer de pulmón. A diferencia de las placas pleurales, que rara vez causan síntomas, las reacciones pleurales visceroparietales suelen asociarse a cierto grado de disnea, así como a deterioro de la función pulmonar, en particular cuando existe obliteración del ángulo costofrénico. Por ejemplo, el déficit promedio de la FVC en un estudio fue de 0,07 I cuando existía afectación de la pared torácica y de 0,50 I cuando existía afectación del ángulo costofrénico (Ernst y Zejda en Liddell y M iller 1991). Como ya se ha comentado, la distribución y los determinantes de las reacciones pleurales varían considerablemente entre los grupos de trabajadores, y las tasas de prevalencia aumentan:

1. Con el tiempo de permanencia estimado de las fibras en el pulmón (determinado como tiempo desde la primera exposición)

2. Con las exposiciones principalmente debidas $a, 0$ que incluyen, anfíboles y

3. Posiblemente con la intermitencia de la exposición, dadas las elevadas tasas de contaminación en profesiones en las que el uso de materiales de amianto es intermitente, pero la exposición probablemente sea intensa.

\section{Cáncer de pulmón}

\section{Perspectiva histórica}

El decenio de 1930 fue testigo de la publicación, en Estados Unidos, Reino U nido y Alemania, de diversos informes de casos clínicos de cáncer de pulmón (una enfermedad mucho menos frecuente entonces que hoy día) en trabajadores del amianto, la mayoría de los cuales presentaban asbestosis de diversa gravedad. En el Annual Report of $\mathrm{H}$ is $\mathrm{M}$ ajesty's C hief Inspector of Factories de 1947 se proporcionaron pruebas de la asociación entre los dos procesos; en ese informe se indicó que se había comunicado cáncer de pulmón en el 13,2 \% de las muertes de varones atribuidas a asbestosis en el período de 1924 a 1946, y sólo en el $1,3 \%$ de las muertes de varones atribuidas a silicosis. El primero que trató la hipótesis causal fue un estudio de mortalidad en cohortes de una fábrica textil de amianto del Reino Unido (Doll 1955), uno de los primeros estudios basados en grupos de trabajadores, y en 1980, después de que al menos ocho estudios de este tipo en otros tantos grupos de trabajadores hubieran confirmado una relación exposición-respuesta, esta asociación se aceptó de forma general como causal ( $M$ CD onald y M cD onald en Antman y Aisner 1987).

\section{Características clínicas y anatomía patológica}

En ausencia de otras enfermedades asociadas relacionadas con el amianto, las características clínicas y los criterios para el diagnóstico del cáncer de pulmón asociado al amianto no eran diferentes 
de las del cáncer de pulmón no asociado a dicha exposición. O riginalmente, los cánceres de pulmón asociados al amianto se consideraron cánceres de cicatriz, similares a los observados en otras formas de fibrosis pulmonar como la esclerodermia. Las características que apoyaban este enfoque eran su localización en los lóbulos pulmonares inferiores (donde la asbestosis suele ser más marcada), su origen en ocasiones multicéntrico y un predominio de adenocarcinoma en algunas series. Sin embargo, en la mayoría de los estudios basados en grupos de trabajadores, la distribución de los tipos celulares no fue diferente de la observada en estudios de poblaciones no expuestas al amianto, lo que apoya la teoría de que el propio amianto podría ser un cancerígeno humano, conclusión a la que llegó la A gencia Internacional para la Investigación del Cáncer (O rganización M undial de la Salud: Agencia Internacional para la I nvestigación del Cáncer 1982). La mayoría, pero no todos, de los cánceres pulmonares relacionados con el amianto están asociados a asbestosis radiológica (véase más adelante).

\section{E pidemiología}

Los estudios de cohortes confirman que el riesgo de cáncer de pulmón aumenta con la exposición, aunque la tasa fraccional de aumento por cada fibra por milímetro por año de exposición es variable y está relacionada con el tipo de fibra y con el proceso industrial (H ealth Effects Institute-A sbestos R esearch 1991). Por ejemplo, principalmente para las exposiciones a crisotilo en la minería, la industria de las laminadoras y la fabricación de productos de fricción, el aumento osciló desde aproximadamente 0,01 a $0,17 \%$, y en la industria textil desde 1,1 a 2,8 \%, mientras que para la exposición a productos de aislamiento de amosita y a algunos productos de cemento que contienen fibras mixtas, se han registrado tasas de hasta el 4,3 y el 6,7 \% ( $\mathrm{N}$ icholson 1991). Los estudios de cohortes en trabajadores del amianto también confirman que el riesgo de cáncer es demostrable en no fumadores y que aumenta (más cerca de un ritmo multiplicativo que aditivo) con el consumo de tabaco ( $M$ CD onald y $M$ cDonald en Antman y Aisner 1987). El riesgo relativo de cáncer de pulmón disminuye tras la interrupción de la exposición, aunque esta disminución parece más lenta que la ocurrida al dejar de fumar. L os estudios de la carga pulmonar de polvo también son compatibles con un gradiente de fibras en la producción de cáncer de pulmón; 32 varones que trabajaban en astilleros del Pacífico con exposición principalmente a amosita presentaban una carga pulmonar de polvo de 1,1 millones de fibras de amosita por gramo de tejido pulmonar desecado en comparación con 36 mineros del crisotilo de $Q$ uebec que tenían una carga pulmonar de polvo media de 13 millones de fibras de crisotilo por gramo de tejido pulmonar (Becklake y C ase 1994).

\section{Relación con la asbestosis}

En el estudio de autopsias de 1955 sobre causas de muerte en 102 trabajadores de la fábrica textil de amianto del Reino Unido citada anteriormente (D oll 1955), se encontró cáncer de pulmón en 18 sujetos, 15 de los cuales también presentaban asbestosis. Todos los sujetos en los que se encontraron ambas patologías habían trabajado durante al menos 9 años antes de 1931, año en el que se introdujeron las regulaciones nacionales para el control del polvo de amianto. Estas observaciones sugerían que, a medida que disminuye la exposición, el riesgo subsiguiente de muerte por asbestosis también disminuye y que los trabajadores vivían el tiempo suficiente para el desarrollo de cáncer. En la mayoría de los estudios basados en grupos de trabajadores, los de mayor edad con servicios más prolongados presentaban algunos signos anatomopatológicos de asbestosis (o enfermedad de las pequeñas vías aéreas relacionada con el amianto) en la autopsia, aunque éstos podían ser mínimos o no detectables en la radiografía de tórax en vida ( $M$ cD onald y M CD onald en Antman y Aisner 1987). Varios estudios de cohortes, pero no todos, son compatibles con la idea de que no todo el exceso de cáncer de pulmón de las poblaciones expuestas a amianto está relacionado con la asbestosis. De hecho, es posible que haya más de un mecanismo patogénico responsable del cáncer de pulmón en los sujetos expuestos al amianto, dependiendo de la localización y del depósito de las fibras. Por ejemplo, se cree que las fibras largas y finas, que se depositan fundamentalmente en las bifurcaciones de las vías aéreas, se concentran y actúan como inductores del proceso de carcinogénesis a través de lesiones cromosómicas. Entre los promotores de este proceso se pueden incluir la exposición continuada a fibras de amianto o al humo del tabaco (Lippman 1995). Estos cánceres es más probable que sean del tipo celular escamoso. Por el contrario, en los pulmones asiento de fibrosis, la carcinogénesis puede deberse al proceso fibrótico: estos cánceres es más probable que sean adenocarcinomas.

\section{Implicaciones y causabilidad}

Aunque los determinantes del aumento del riesgo de cáncer pueden derivarse a partir de poblaciones expuestas, no es éste el caso de la causabilidad individual. Evidentemente, la causabilidad a la exposición al amianto es más probable y creíble en un sujeto expuesto con asbestosis que nunca ha fumado que en un sujeto expuesto sin asbestosis que es fumador. Esta probabilidad tampoco puede modelarse razonablemente. L as determinaciones de la carga pulmonar de polvo pueden complementar una valoración clínica meticulosa, pero cada caso debe evaluarse por separado (Becklake 1994).

\section{Mesotelioma maligno}

\section{Anatomía patológica, diagnóstico, confirmación y características clínicas}

L os mesoteliomas malignos se originan en la cavidades serosas del organismo. A proximadamente dos terceras partes se originan en la pleura y cerca de una quinta parte en el peritoneo, mientras que en el pericardio y en la túnica vaginal son mucho menos frecuentes ( $M$ CD onald y M cDonald en Lidell y M iller 1991). Dado que las células mesoteliales son pluripotenciales, las características histológicas de los tumores mesoteliales pueden variar; en la mayoría de las series, las formas epitelial, sarcomatosa y mixta representan alrededor del 50 , el 30 y el $10 \%$ de los casos, respectivamente. EI diagnóstico de este raro tipo de tumor, incluso para anatomopatólogos experimentados, no resulta sencillo, y grupos de trabajo anatomopatológicos sobre mesoteliomas a menudo sólo confirman un pequeño porcentaje, que en algunos estudios es inferior al $50 \%$, de los casos presentados para revisión. Se han desarrollado diversas técnicas citológicas e inmunohistoquímicas para ayudar a diferenciar el mesotelioma maligno de los principales diagnósticos clínicos alternativos, es decir, el cáncer secundario y la hiperplasia mesotelial reactiva; éste continúa siendo un campo de investigación activa, en el que las expectativas son elevadas pero en el que los hallazgos no son concluyentes (Jaurand, Bignon y Brochard 1993). Por todas estas razones, la confirmación de los casos para estudios epidemiológicos no resulta sencilla, e incluso cuando se basan en registros de cáncer, puede ser incompleta. Además, es necesaria la confirmación por grupos de expertos que utilicen criterios anatomopatológicos específicos para garantizar la comparabilidad de los mismos para su registro.

\section{Características clínicas}

El dolor suele ser el síntoma de presentación. En los tumores pleurales, este comienza en el tórax y/ o en los hombros, y puede ser intenso. Se sigue de disnea, asociada a derrame pleural y/ o 
atrapamiento progresivo del pulmón por el tumor, con pérdida de peso. En los tumores peritoneales, el dolor abdominal suele acompañarse de tumefacción. Las características de imagen se muestran en la Figura 10.23. El curso clínico suele ser rápido y la mediana de los tiempos de supervivencia, seis meses en un informe de 1973 y ocho meses en un informe de 1993, ha variado poco en las últimas dos décadas, a pesar del mayor concienciamiento público y médico que a menudo conduce a un diagnóstico más precoz, y a pesar de los avances en las técnicas diagnósticas y al aumento en el número de opciones terapéuticas para el cáncer.

\section{Epidemiología}

En los 15 años siguientes al informe de 1960 sobre la serie de casos de mesotelioma del noroeste de EI C abo, Sudáfrica (Wagner 1996), la confirmación internacional de la asociación provino de informes de otras series de casos en Europa (Reino Unido, Francia, Alemania, Países Bajos), Estados Unidos (Illinois, Pennsylvania y N ueva Jersey) y Australia, y de estudios de casos y controles en el Reino U nido (4 ciudades), Europa (I talia, Suecia, Países Bajos) y Estados U nidos y C anadá. Las odds ratios en estos estudios variaron entre 2 y 9 . En Europa en particular, la asociación con trabajos en astilleros fue fuerte. Además, los estudios de mortalidad proporcional en cohortes expuestas al amianto sugirió que el riesgo estaba asociado al tipo de fibra y al proceso industrial, y las tasas atribuibles al mesotelioma variaron desde el 0,3\% en las minas de crisotilo al $1 \%$ en las fábricas de crisotilo, en comparación con el 3,4\% en la minería y la fabricación de anfíboles y de hasta el 8,6 \% para la exposición a fibras mixtas en los aislamientos (M CDonald y M CD onald en Liddell y M iller 1991). Se observan gradientes de fibras similares en estudios de mortalidad de cohortes que, dados los cortos tiempos de supervivencia de estos tumores, constituyen un reflejo razonable de la incidencia. Estos estudios también muestran períodos de latencia más largos para la exposición a crisotilo en comparación con los anfíboles. La variación geográfica de la incidencia se ha documentado utilizando tasas canadienses específicas de la edad y del sexo desde 1966 a 1972 para calcular las tasas previstas (M CD onald y M CD onald en Liddell y M iller 1991). Las relaciones de las tasas (valores reales observados con respecto a los previstos) fueron de 0,8 para Estados U nidos (1972), 1,1 para Suecia (1958 a 1967), 1,3 para Finlandia (1965 a 1969), 1,7 para el Reino U nido (1967 a 1968) y 2,1 para los Países Bajos (1969 a 1971). Aunque diversos factores técnicos, incluida la confirmación, puede contribuir evidentemente a la variación registrada, los resultados sugieren tasas más altas en Europa que en N orteamérica.

Las tendencias en el tiempo y las diferencias por sexo en la incidencia del mesotelioma se han utilizado como medida del impacto sobre la salud de la exposición de las poblaciones al amianto. Las mejores estimaciones para las tasas globales en los países industrializados antes de 1950 se encuentran por debajo de 1 por millón para varones y mujeres ( $M$ CD onald y M CD onald en Jaurand y Bignon 1993). Posteriormente, las tasas aumentan de forma uniforme en los varones pero no, o al menos no en la misma medida, en las mujeres. Por ejemplo, se comunicaron tasas globales por millón, en varones y mujeres respectivamente, de 11 y de menos de 2 en Estados U nidos en 1982, de 14,7 y 7 en Dinamarca para el período $1975-80$, de 15,3 y 3,2 en el Reino Unido para el período $1980-83$, y de 20,9 y 3,6 en los Países Bajos para el período 1978-87. Se comunicaron tasas más altas en varones y mujeres, pero no en sujetos jóvenes, para los países con minería de crocidolita: 28,9 y 4,7 , respectivamente, en Australia (mayores de 20 años) en 1986, y 32,9 y 8,9, respectivamente, en los sujetos de raza blanca de Sudáfrica (mayores de 15 años) en 1988 ( $\mathrm{H}$ ealth Effects Institute-A sbestos Research 1991). L as tasas crecientes en los varones probablemente reflejen la exposición ocupacional, y en ese caso, deberían estabilizarse 0 disminuir en el período de "incubación" de 20 a 30 años tras la introducción de controles en los lugares de trabajo y la reducción de los niveles de exposición en la mayoría de los lugares de trabajo en la mayor parte de los países industrializados en el decenio de 1970. En los países en los que están aumentando las tasas en mujeres, este aumento podría deberse a la mayor

Figura 10.23 - Mesotelioma maligno.

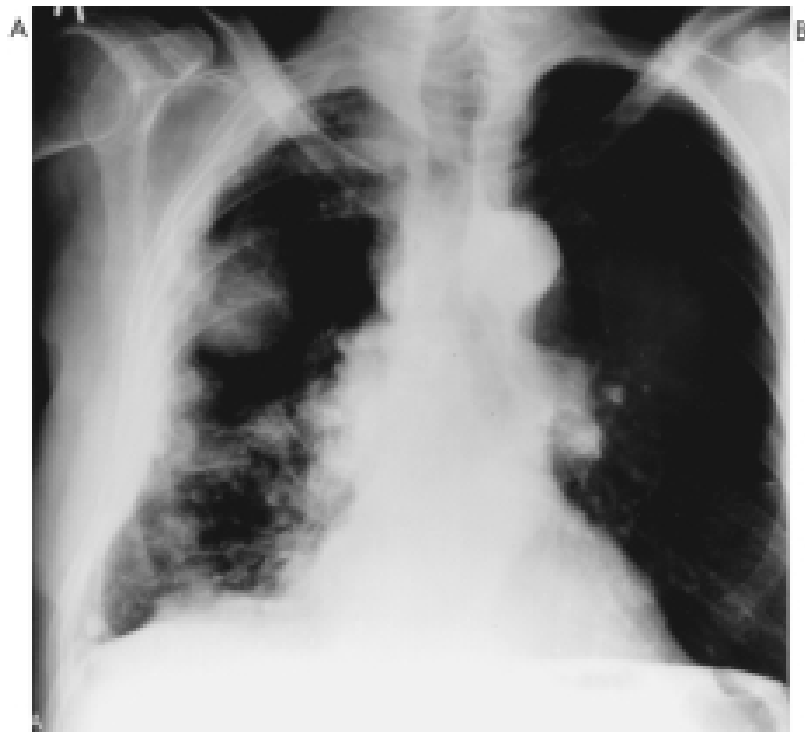

Visualizado en una radiografía de tórax hiperpenetrada (A) como una masa de gran tamaño en la región axilar. Obsérvese la reducción asociada del volumen del hemitórax derecho con un marcado engrosamiento nodular irregular de la pleura de todo el pulmón derecho. La imagen de TC (B) confirma

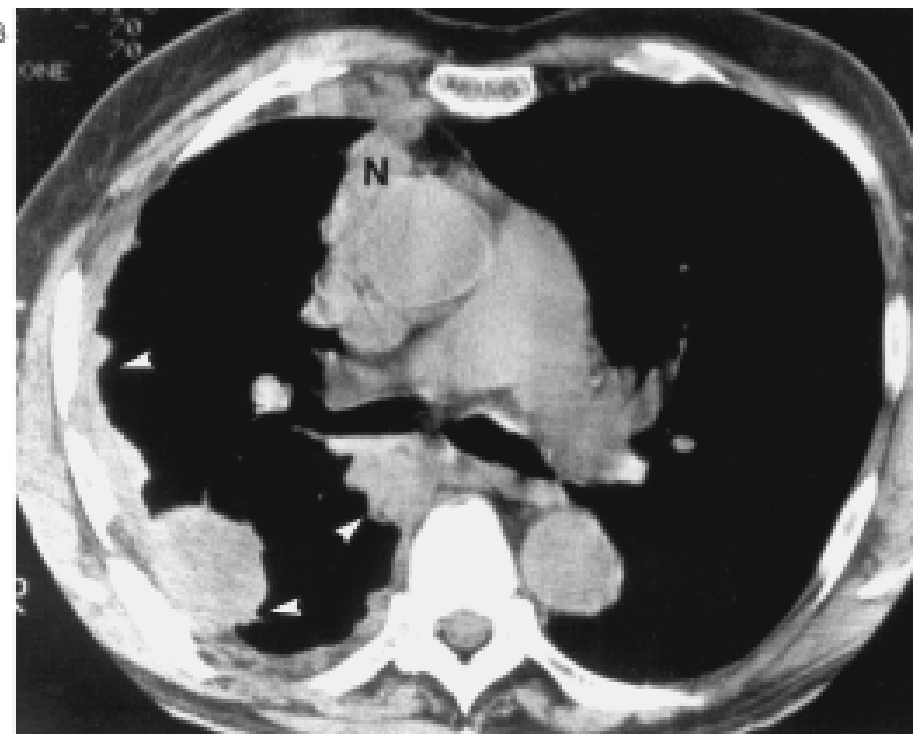

el extenso engrosamiento pleural que afecta a las pleuras parietal y mediastínica (puntas de flecha) en las costillas y a su alrededor.

Fuente: Fraser y cols. 1990 
participación de éstas en ocupaciones con riesgo de exposición, 0 a la creciente contaminación medioambiental o domiciliaria del aire urbano (M cD onald 1985).

\section{Etiología}

Los factores medioambientales son claramente los principales determinantes del riesgo de mesotelioma, siendo la exposición al amianto el más importante, aunque la aparición de grupos familiares mantiene el interés por el posible papel de factores genéticos. Todos los tipos de fibras de amianto han sido involucrados en la producción del mesotelioma, incluida la antofilita por primera vez en un informe reciente de Finlandia (Meurman, Pukkala y H akama 1994). Sin embargo, se dispone de un importante conjunto de pruebas, obtenidas a partir de estudios de mortalidad proporcional y de cohortes y de estudios de carga pulmonar, que sugiere la intervención de un gradiente de fibras en la producción del mesotelioma, siendo el riesgo mayor para las exposiciones principalmente a anfíboles o a mezclas de crisotilo y anfíboles, en comparación con las exposiciones en las que predomina el crisotilo. Sobre todo, existen diferencias de tasa entre los grupos de trabajadores para el mismo tipo de fibra al que parece ser el mismo nivel de exposición; estas diferencias todavía no han podido explicarse, aunque la distribución por el tamaño de las fibras probablemente sea un factor contributivo.

El papel de la tremolita ha sido muy discutido, debate éste suscitado por la evidencia de su persistencia biológica en el tejido pulmonar, animal y humano, en comparación con el crisotilo. U na hipótesis convincente es que las numerosas fibras cortas que alcanzan las pequeñas vías aéreas periféricas y los alveolos y que se depositan en estas estructuras, son eliminadas hasta los ganglios linfáticos, donde se acumulan; su potencia en la producción del mesotelioma dependen de su persistencia biológica en contacto con las superficies pleurales (Lippmann 1995). En estudios en seres humanos, las tasas de mesotelioma son inferiores en las poblaciones expuestas laboralmente a crisolita relativamente no contaminada por tremolita (por ejemplo, en las minas de Zimbabwe), que en las expuesta a crisotilo muy contaminado (por ejemplo, en las minas de Q uebec), hallazgos que han sido reproducidos en estudios en animales (Lippmann 1995). Además, en un análisis multivariante de la carga pulmonar de fibras en material procedente de un estudio de casos y controles del mesotelioma realizado en Canadá (M CD onald y cols. 1989), los resultados sugirieron que la mayoría de los mesoteliomas, si no todos, podrían explicarse por la carga pulmonar de fibras de tremolita. Finalmente, un análisis reciente de la mortalidad en la cohorte de más de 10.000 mineros y laminadores de crisotilo de Q uebec nacidos entre 1890 y 1920, a los que se siguió hasta 1988 (M cD onald y M CD onald 1995), apoya esta teoría: en casi 7.300 muertes, las 37 debidas a mesotelioma se concentraron en ciertas minas del área de Thetford, aunque la carga pulmonar de los 88 miembros de la cohorte de las minas implicadas no se diferencia de la de los mineros de otras minas con respecto a la carga de fibras de crisotilo, salvo en lo referente a la carga de tremolita (M cD onald y cols. 1993).

La denominada cuestión de la tremolita es, quizá, el aspecto científico más importante actualmente debatido, y también tiene consecuencias sobre la salud pública. D ebe llamarse la atención sobre el importante hecho de que en todas las series y jurisdicciones, una determinada proporción de los casos se produjo sin exposición comunicada al amianto, y que sólo en algunos de estos casos los estudios de la carga pulmonar de polvo indican una exposición medioambiental o profesional previa. 0 tras exposiciones profesionales han sido implicadas en la producción del mesotelioma, como en la minería del talco, la vermiculita y posiblemente la mica, pero en estos casos, el mineral contenía tremolita u otras fibras (Bignon, Peto y Saracci 1989). Debe continuarse una investigación de diseño abierto sobre otras exposiciones, profesionales o no, a fibras inorgánicas y orgánicas, y a otros agentes que podrían asociarse a la producción del mesotelioma.

\section{Otras enfermedades relacionadas con el amianto}

\section{Enfermedad crónica de las vías aéreas}

Bajo este término generalmente se incluyen la bronquitis crónica y la enfermedad pulmonar obstructiva crónica (EPOC), las cuales pueden diagnosticarse clínicamente, y el enfisema, hasta hace poco tiempo diagnosticado únicamente por examen anatomopatológico del tejido pulmonar extirpado en la autopsia o en otros procedimientos (Becklake 1992). U na causa fundamental es el consumo de tabaco, y en las últimas décadas, la mortalidad y la morbilidad debidas a enfermedad crónica de las vías aéreas han aumentado en la mayoría de los países industrializados. Sin embargo, con el descenso de la neumoconiosis en muchos grupos de trabajadores, han surgido pruebas que implican a las exposiciones profesionales en la producción de la enfermedad crónica de las vías aéreas, una vez considerado el papel dominante del consumo de tabaco. Se ha demostrado que todas las formas de enfermedad crónica de las vías aéreas se asocian al trabajo en diversas ocupaciones en entornos con polvo, como aquellas en las que un importante componente del polvo contaminante del lugar de trabajo era el amianto (Ernst y Zejda en Liddell y M iller 1991). Se cree que la implicada en este proceso es la carga contaminante total, más que la exposición a alguno de sus componentes, en este caso al polvo de amianto, de forma muy similar a la manera en que se observa el efecto de la exposición al tabaco en las enfermedades crónicas de las vías aéreas, es decir, en términos de carga de exposición total (p.ej., como paquetesaños), y no de exposición a alguno de los más de 4.000 componentes del humo del tabaco. (Consúltense otros apartados de este volumen para más comentarios sobre la relación entre exposiciones profesionales y enfermedad crónica de las vías aéreas.)

\section{Otros cánceres}

En varios de los primeros estudios de cohortes de trabajadores expuestos al amianto, la mortalidad atribuible a todos los cánceres superó la prevista, según estadísticas vitales nacionales 0 regionales. Aunque el cáncer de pulmón fue el responsable de la mayor parte de este exceso, otros cánceres implicados fueron los cánceres gastrointestinales, el cáncer laríngeo y el cáncer ovárico, en ese orden de frecuencia. Para los cánceres gastrointestinales (incluidos los que afectan al esófago, al estómago, al colon y al recto), se cree que la exposición relevante en las cohortes profesionales tiene lugar por deglución de esputo cargado de amianto procedente de las vías aéreas principales del pulmón, y en tiempos antiguos (antes de la instauración de medidas de protección frente a la exposición en los comedores), la contaminación directa de los alimentos en los lugares de trabajo que carecían de comedores separados de las áreas de trabajo de fábricas y factorías. También podría producirse un flujo retrógrado a través del conducto torácico desde los ganglios linfáticos que drenan el pulmón (véase "Destino de las fibras inhaladas"). Debido a que la asociación fue inconstante en las diferentes cohortes estudiadas, y a que no siempre se observaron relaciones exposición-respuesta, ha existido una resistencia a aceptar la evidencia de la asociación entre la exposición ocupacional y la exposición al amianto como causal (Doll y Peto 1987; Liddell y M iller 1991).

El cáncer de laringe es mucho menos frecuente que el cáncer gastrointestinal o el pulmonar. Ya en el decenio de 1970, hubo informes de una asociación entre el cáncer de laringe y la exposición al amianto. Al igual que en el cáncer de pulmón, un factor 
de riesgo principal y causa del cáncer laríngeo es el consumo de tabaco. También existe una estrecha asociación entre cáncer de laringe y consumo de alcohol. Dada la localización de la laringe (un órgano expuesto a todos los contaminantes inhalados a los que están expuestos los pulmones), y dado que está revestida por el mismo epitelio que los bronquios principales, es ciertamente convincente desde el punto de vista biológico que el cáncer de laringe se produzca como resultado de la exposición al amianto. Sin embargo, las pruebas globales disponibles hasta ahora no son constantes, ni siquiera las obtenidas a partir de estudios de cohortes a gran escala como los de los mineros de crisotilo de Q uebec y Balangero (I talia), posiblemente debido a que se trata de un cáncer poco frecuente y a que existe cierta resistencia a considerar esta asociación como causal (Liddell y M iller 1991), a pesar de su posibilidad biológica. Se ha registrado cáncer ovárico en cifras superiores a las previstas en tres estudios de cohortes (O M S 1989). Los errores en el diagnóstico, en particular como mesoteliomas peritoneales, podrían explicar la mayoría de los casos (D oll y Peto 1987).

\section{Prevención, vigilancia y valoración}

\section{Enfoques histórico y actual}

La prevención de las neumoconiosis, incluida la asbestosis, se ha realizado tradicionalmente a través de los siguientes puntos:

1. Prácticas industriales y laborales para mantener los niveles de fibras en suspensión en el aire lo más bajos posible, 0 al menos de conformidad con los niveles de exposición permisibles generalmente establecidos por leyes o regulaciones.

2. V igilancia, realizada para registrar tendencias de marcadores de enfermedad en poblaciones expuestas y controlar los resultados de las medidas de control.

3. Educación y etiquetado de los productos con el objetivo de ayudar a los trabajadores y al público general a evitar la exposición no profesional.

Los niveles de exposición permisibles estaban dirigidos originalmente al control de la asbestosis, y se basaban en mediciones de higiene industrial en millones de partículas por pie cúbico, tomadas utilizando los mismos métodos que para el control de la silicosis. Al desplazarse el foco de atención biológica a las fibras, en particular a las fibras largas y delgadas, como causa de asbestosis, se desarrollaron métodos más apropiados para su identificación y su medición en el aire $y_{1}$ dados estos métodos, disminuyó la atención sobre las fibras cortas, más abundantes, que contaminan la mayoría de los lugares de trabajo. Las relaciones entre la longitud y el diámetro para la mayoría de las partículas del amianto crisotilo triturado se encuentran dentro del rango 5:1 a 20:1, ascendiendo hasta 50:1, en contraste con la mayoría de las partículas de amianto de anfíboles triturado (incluidos los fragmentos de escisión), cuyos valores descienden por debajo de 3:1. La introducción del filtro de membrana para el recuento de fibras de las muestras de aire condujo a una definición de higiene industrial y médica arbitraria de una fibra como una partícula de al menos $5 \mu \mathrm{m}$ de longitud, $3 \mu \mathrm{m} 0$ menos de grosor y con una relación longitud-anchura de al menos 3:1. Esta definición, utilizada en muchos de los estudios de exposición-respuesta, constituye la base científica para el establecimiento de los estándares medioambientales.

Por ejemplo, se utilizó en una reunión patrocinada por la O rganización M undial de la Salud (1989) para proponer límites de exposición ocupacional, y ha sido adoptada por agencias como la U S O ccupational Safety and H ealth Administration; se ha conservado principalmente por razones de comparabilidad. En la reunión de la OMS, presidida por Sir Richard Doll, aunque se reconoció que el límite de exposición ocupacional de cualquier país sólo puede ser establecido por el cuerpo legislativo nacional correspondiente, se recomendó que los países con límites elevados tomaran medidas urgentes para reducir la exposición ocupacional para un trabajador individual a $2 \mathrm{f} / \mathrm{ml}$ (media ponderada en el tiempo de ocho horas) y que todos los países deberían alcanzar lo antes posible el límite de $1 \mathrm{f} / \mathrm{ml}$ (media ponderada en el tiempo de ocho horas) si no lo habían hecho ya. Con la reducción de las tasas de asbestosis en algunos países industrializados, y con la preocupación por los cánceres relacionada con el amianto desatada en todos los países, la atención se ha desplazado actualmente a determinar si los mismos parámetros de fibra - es decir, longitud de al menos $5 \mu \mathrm{m}$, grosor igual o inferior a $3 \mu \mathrm{m}$ y relación longitud-anchura de al menos 3:1- también son apropiados para controlar la carcinogénesis (Browne 1994). U na teoría actual sobre la carcinogénesis por amianto implica tanto a las fibras cortas como a las largas (Lippmann 1995). Además, dadas las pruebas de que existe un gradiente de fibra en la producción del mesotelioma y del cáncer de pulmón y, en menor medida, en la producción de asbestosis, podría argumentarse el que los niveles de exposición permisible se fijaran teniendo en cuenta el tipo de fibra. Algunos países han abordado este tema prohibiendo el uso (y así la importación) de crocidolita, y estableciendo niveles de exposición más restrictivos para la amosita, específicamente $0,1 \mathrm{f} / \mathrm{I}$ (M cD onald y M CD onald 1987).

\section{Niveles de exposición en el lugar de trabajo}

Los niveles de exposición permisibles en el lugar de trabajo engloban la hipótesis, basada en todas las pruebas disponibles, de que la salud humana se preservará si se mantiene la exposición dentro de esos límites. La revisión de los límites de exposición permisibles, cuando se produce, se dirige invariablemente hacia una mayor restricción (como se describe en el párrafo anterior). Sin embargo, a pesar del buen cumplimiento de los controles en el lugar de trabajo, siguen apareciendo casos de esta enfermedad debido a susceptibilidad personal ( $p$. ej., tasas de retención de fibras superiores a la media) o debido a un fracaso de los controles en el lugar de trabajo para procesos o tareas específicos. En las instalaciones de mayor tamaño se han puesto en práctica a escala internacional controles técnicos, mejores prácticas en el lugar de trabajo y la utilización de sustitutos descritos en otras partes de este capítulo (G ibbs, Valic y Browne 1994) a través de la industria, los sindicatos y otras iniciativas. Por ejemplo, según una revisión mundial de la industria de 1983, el cumplimiento del estándar recomendado actual de $1 \mathrm{f} / \mathrm{ml}$ se ha alcanzado en el $83 \%$ de los lugares de producción (minas y laminadoras), cubriendo a 13.499 trabajadores en 6 países, en el $96 \%$ de 167 fábricas de cemento que operaban en 23 países; en el $71 \%$ de 40 fábricas textiles que cubrían a más de 2.000 trabajadores que operaban en 7 países; y en el $97 \%$ de 64 fábricas de materiales de fricción que cubrían a 10.190 trabajadores en 10 países (Bouige 1990). Sin embargo, una proporción no despreciable de tales lugares de trabajo sigue sin cumplir las normativas, no todos los países fabricantes participaron en este estudio, y los efectos beneficiosos previstos para la salud son evidentes sólo en algunas estadísticas nacionales ("D iagnóstico y tratamiento de casos"). El control de los procesos de demolición y de las pequeñas empresas que utilizan amianto sigue sin tener demasiado éxito, incluso en muchos países industrializados.

\section{Vigilancia}

La radiografía de tórax es la principal herramienta para la vigilancia de la asbestosis, los registros de cáncer y las estadísticas nacionales de los cánceres relacionados con el amianto. Una iniciativa digna de encomio en la vigilancia internacional de la 
minería de construcción de túneles y galerías y de las canteras, emprendida por la OIT mediante comunicación voluntaria por parte de fuentes gubernamentales, se centra en la minería del carbón y de rocas duras, pero podría incluir al amianto. Por desgracia, el seguimiento ha sido escaso, y el último informe, basado en datos de 1973-77, fue publicado en 1985 (OIT 1985). Diversos países proporcionan datos sobre mortalidad y morbilidad, un ejemplo excelente de lo cual lo constituye el Work-related Lung D isease Surveillance Report for the U nited States, un informe citado anteriormente (USDHSS 1994). Estos informes proporcionan información para interpretar tendencias y evaluar el impacto de los niveles de control a nivel nacional. Las industrias más grandes deberían (y muchas lo hacen) llevar sus propias estadísticas de vigilancia, como hacen muchos sindicatos. La vigilancia de las industrias más pequeñas puede requerir estudios específicos a intervalos adecuados. 0 tras fuentes de información son programas tales como el Surveillance of Work-related Respiratory Diseases (SWORD) del R eino U nido, que recoge regularmente informes de una muestra de los neumólogos y médicos del trabajo del país (M eredith y M cD onald 1994), así como informes de juntas de indemnización (las cuales a menudo, sin embargo, no proporcionan información sobre los trabajadores en situación de riesgo).

\section{Etiquetado de productos, educación y la autopista de la información}

El etiquetado obligatorio de los productos, junto con la educación del trabajador y del público general, son poderosas herramientas de prevención. M ientras que en el pasado esto se realizaba en el contexto de las organizaciones de trabajadores, los comités de gestión del trabajador y los programas sindicales de educación, los enfoques futuros podrían explotar las autopistas electrónicas para crear bases de datos accesibles sobre salud y seguridad en toxicología y medicina.

\section{Exposición en edificios y a partir de suministros de agua}

En 1988, el Congreso de Estados U nidos ordenó una revisión de los riesgos potenciales para la salud asociados al trabajo en edificios construidos con materiales que contenían amianto (H ealth Effects I nstitute- A sbestos R esearch 1991). Para calcular el riesgo se utilizaron los resultados de un amplio número de estudios de toma de muestras de interior procedentes de Europa, Estados Unidos y C anadá. Se estimó que el riesgo de muerte prematura por cáncer a lo largo de la vida era de 1 por millón para los sujetos expuestos durante 15 años en los colegios (para niveles de exposición estimados entre 0,0005 y 0,005f/ ml) y de 4 por millón para los expuestos durante 20 años en los edificios de oficinas (para niveles de exposición estimados entre 0,0002 y 0,002 f/ ml). En comparación, el riesgo de exposición ocupacional a 0,1f/ ml (es decir, de acuerdo con el límite de exposición permisible propuesto por la US O ccupational Safety y Health Administration) durante 20 años se estimó en 2.000 por millón de sujetos expuestos. Las mediciones en el agua potable en las comunidades urbanas muestran gran variación, desde niveles indetectables hasta niveles altos, que varían desde 0,7 millones $\mathrm{f} / \mathrm{I}$ en Connecticut, EE.UU., hasta niveles que varían entre 1,1 millones y 1.300 millones $\mathrm{f} / \mathrm{I}$ en las áreas mineras de $\mathrm{Q}$ uebec (Bignon, Peto $\mathrm{y}$ Saracci 1989). También puede producirse cierto grado de contaminación a partir de las tuberías de cemento con amianto por las que se realiza la mayor parte de la distribución del agua urbana en el mundo. Sin embargo, un grupo de trabajo que revisó los datos en 1987 no descartó el riesgo asociado potencial, aunque no consideró los riesgos para la salud asociados a la ingestión de amianto como "uno de los riesgos para la salud pública más urgentes" (U SDH HS 1987), un punto de vista que coincide con las conclusiones de un monográfico de la IARC (OM S) sobre la exposición no profesional a fibras minerales (Bignon, Peto y Saracci 1989).

\section{Asbestos y otras fibras en el siglo XXI}

L a primera mitad del siglo XX se caracterizó por lo que podría describirse como un descuido manifiesto de las enfermedades relacionadas con el amianto. No se conocen las razones de este hecho antes de la II Guerra M undial; existía la base científica para el control, pero quizá no existieran ni la voluntad ni la agresividad del trabajador. D urante la guerra, había otras prioridades nacionales e internacionales, y después tenían prioridad las presiones para urbanizar, ejercidas por una población mundial en rápido crecimiento, y es posible que la fascinación causada en una era industrial por la versatilidad del mineral "mágico" distrajera la atención de sus peligros. Tras la 1a Conferencia Internacional sobre los Efectos Biológicos del Amianto celebrada en 1964 (Selikoff y Churg 1965), la enfermedad relacionada con al amianto se convirtió en una causa célebre, no sólo por mérito propio, sino también porque marcó un período de confrontación entre mano de obra y dirección en relación con los derechos del trabajador a conocer los peligros de su lugar de trabajo, la protección de la salud y una indemnización digna por las lesiones 0 enfermedades. En los países con sistema de compensación no dolosa del trabajador, la enfermedad relacionada con el amianto recibió globalmente un reconocimiento y tratamiento correctos. En los países en los que la demanda de responsabilidad por el producto y los procesos de demanda eran más frecuentes, se concedieron grandes indemnizaciones a algunos trabajadores afectados (y a sus abogados), mientras que otros quedaron desamparados y sin apoyo. Aunque no es probable que disminuya la necesidad de fibras en las sociedades modernas, el papel de las fibras minerales con respecto al de otras fibras puede variar. Ya se ha producido un desplazamiento en los usos tanto dentro de los países como entre ellos (véase "Otras fuentes de exposición"). Aunque disponemos de la tecnología necesaria para disminuir las exposiciones en el lugar de trabajo, siguen existiendo lugares en los que ésta no se ha aplicado. Dados los conocimientos actuales, la comunicación internacional y el etiquetado de productos, así como la formación del trabajador y el compromiso de la industria, debería ser posible utilizar este mineral para proporcionar productos baratos y duraderos para la construcción y para la distribución del agua con carácter internacional sin riesgos para el usuario, el trabajador, el fabricante o el minero, ni para el público general.

\section{ENFERMEDADES POR METALES PESADOS}

\section{G erolamo Chiappino}

Poco después de la Primera Guerra M undial, mientras llevaba a cabo unas investigaciones para descubrir un material que pudiera sustituir al diamante en las toberas para extracción de metales, $\mathrm{K}$ arl Schoeter patentó en Berlín un proceso de aglomerado (presurización con calentamiento a $1.500{ }^{\circ} \mathrm{C}$ ) de una mezcla de polvo de carburo de tungsteno puro (WC) con un $10 \%$ de cobalto para producir "metal pesado". Las principales características de este aglomerado son su excepcional dureza, sólo ligeramente inferior a la del diamante, y el hecho de que conserve sus propiedades mecánicas a altas temperaturas; estas características 
Figura 10.24 - (A) Ejemplos de algunos insertos móviles de moldeado de metales pesados, chapados con nitruro de tungsteno dorado;

(B) Inserto soldado a la herramienta trabajando en moldeado de acero.
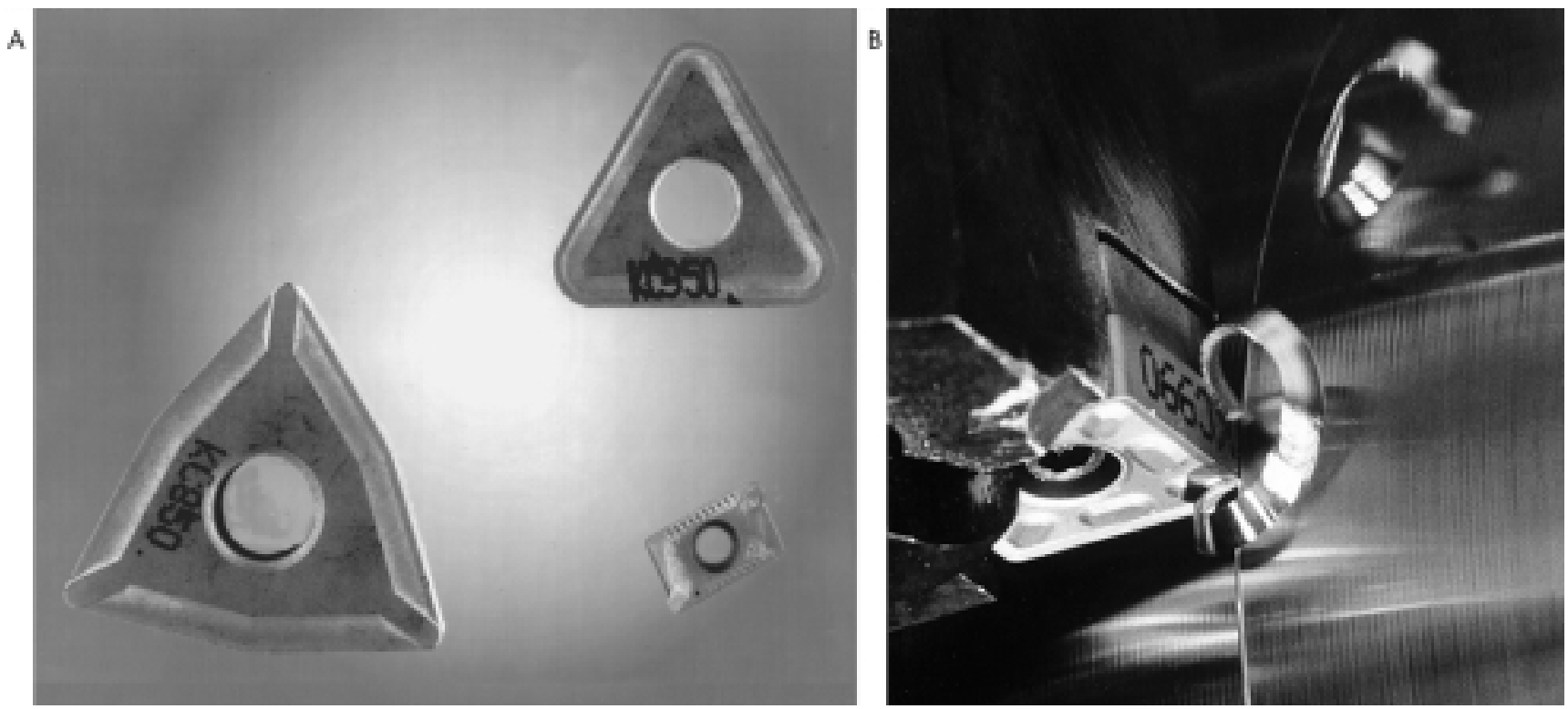

lo hacen adecuado para su uso en la extracción de metales, para insertos de soldaduras y para herramientas de alta velocidad usadas en el tratamiento mecánico de metales, piedras, madera y materiales que ofrecen una elevada resistencia al desgaste 0 al calor, dentro de los campos de la mecánica, la aeronáutica y la balística. El uso del metal pesado está en continua expansión por todo el mundo. En 1927, K rupp extendió su uso al campo de las herramientas cortadoras y lo llamó "Widia" (wie Diamant: como el diamante), nombre que todavía se usa hoy en día.

El aglomerado continúa siendo la base de toda la producción de metales pesados: se mejoran las técnicas introduciendo otros carburos metálicos - carburo de titanio (TiC) y carburo de tantalio $(\mathrm{TaC})$ - y tratando las partes de metal pesado para insertos de corte móviles con una o más capas de nitruro de titanio u óxido de aluminio y de otros compuestos muy duros aplicados mediante depósito de vapor químico (DVQ ) o depósito de vapor físico (DVF). Los insertos fijos soldados a las herramientas no se pueden metalizar, pero se afilan repetidamente con una muela de diamante (Figuras 10.24 y 10.25).
El aglomerado de metal pesado está formado por partículas de carburos metálicos incorporadas a una matriz constituida por cobalto, que se funde durante el aglomerado, estableciendo una interacción y ocupando los intersticios. Por tanto, el cobalto es el material que fija la estructura, que adopta características de cerámica metálica (Figuras 10.26, 10.27 y 10.28).

El proceso de aglomerado emplea polvos muy finos de carburos metálicos (con un diámetro medio de 1 a $9 \mu \mathrm{m}$ ) y polvos de cobalto (con un diámetro medio de 1 a $4 \mu \mathrm{m}$ ) que se mezclan, se tratan con una solución de parafina, se estampan a presión, se les quita la cera a baja temperatura, se preaglomeran a una temperatura entre 700 y $750{ }^{\circ} \mathrm{C}$ y se aglomeran a $1.500{ }^{\circ} \mathrm{C}$ (Brookes 1992).

Cuando el aglomerado se realiza con métodos inadecuados, técnicas incorrectas y mala higiene industrial, los polvos pueden contaminar la atmósfera del ambiente de trabajo: por ello, los trabajadores quedan expuestos al riesgo de inhalar polvos de carburos metálicos y polvos de cobalto. Junto con el proceso primario, hay otras actividades que pueden exponer a los

Figura 10.25 - Insertos fijos soldados a (A) una perforadora de rocas y (B) a un disco de sierra.
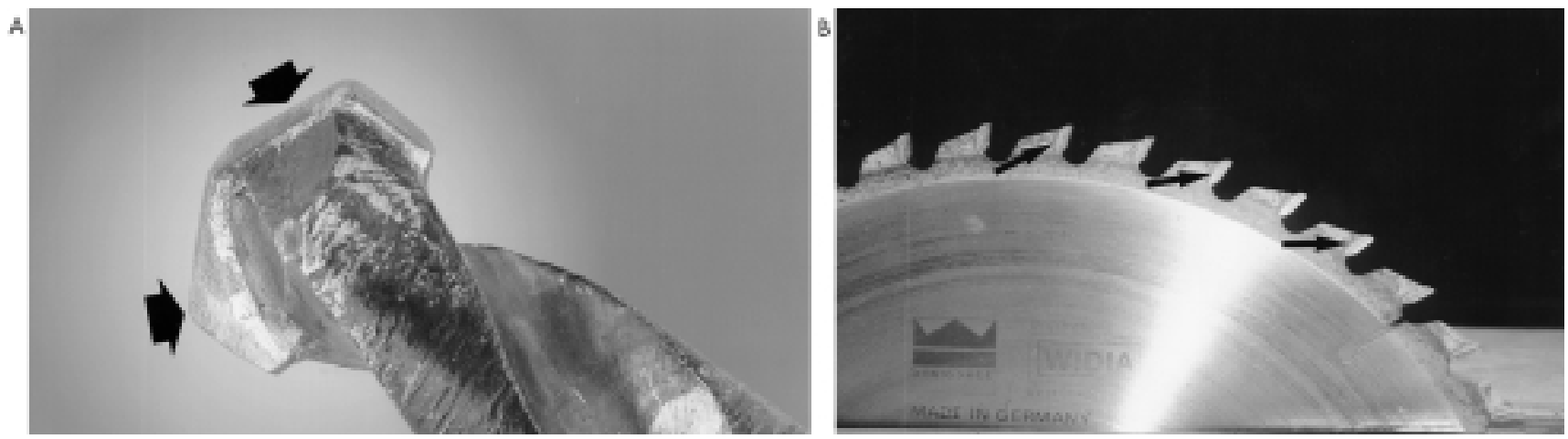
Figura 10.26 - Microestructura de un aglomerado de W C/ Co; las partículas de W C están incorporadas a la matriz clara de $\mathrm{Co}$ (x 1.500).

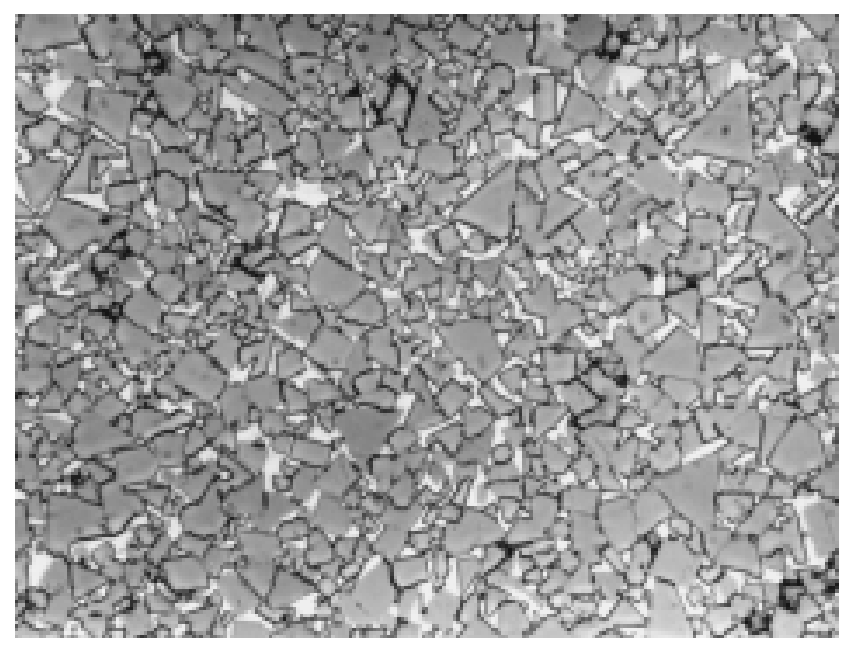

trabajadores al riesgo de inhalar aerosoles de metales pesados. EI proceso de afilar insertos fijos soldados a herramientas se lleva a cabo normalmente amolándolos en seco con diamante 0 , más a menudo, enfriándolos con líquidos de distintas clases, lo cual produce polvos o vapores formados por gotas muy pequeñas que contienen partículas metálicas. Las partículas de metal pesado también se usan para crear una capa de gran resistencia en superficies de acero sometidas a desgaste, aplicada con unos métodos (metalización por chorro de plasma y otros) basados en la combinación de un chorro de polvo con un arco eléctrico o una explosión controlada de una mezcla de gases a alta temperatura. EI arco eléctrico o el flujo explosivo del gas determinan la fusión de las partículas metálicas y su impacto sobre la superficie que se está metalizando.

Las primeras observaciones de "enfermedades por metales pesados" se describieron en Alemania en el decenio de 1940. Informaban de una fibrosis pulmonar difusa y progresiva, Ilamada $\mathrm{H}$ artmetallungenfibrose. Durante los 20 años siguientes se observaron y describieron casos similares en todos los países industrializados. En la mayoría de los casos, los trabajadores afectados estaban a cargo del aglomerado. Desde 1970 hasta nuestros días, varios estudios indican que la patología del aparato respiratorio está causada por la inhalación de partículas de metales pesados. Afecta únicamente a los sujetos propensos y presenta los siguientes síntomas:

- Agudos: rinitis, asma

- Subagudos: alveolitis fibrosante

- Crónicos: fibrosis intersticial difusa y progresiva.

A fecta no sólo a los trabajadores a cargo del aglomerado, sino a cualquier persona que inhale aerosoles que contengan metales pesados y especialmente cobalto. Está causada principal y tal vez exclusivamente por el cobalto.

La definición de enfermedad por metales pesados incluye ahora un grupo de procesos del aparato respiratorio, distintos unos de otros en cuanto a su gravedad clínica y su pronóstico, pero que tienen en común una reactividad individual variable frente al factor etiológico, el cobalto.

La información epidemiológica y experimental más reciente acepta el papel causal del cobalto para los síntomas agudos de
Figura 10.27 - Microestructura de un aglomerado de W C + TiC + TaC + Co. Junto a las partículas globulosas formadas por una solución sólida de TiC + TaC. La matriz está formada por Co (x1.500).

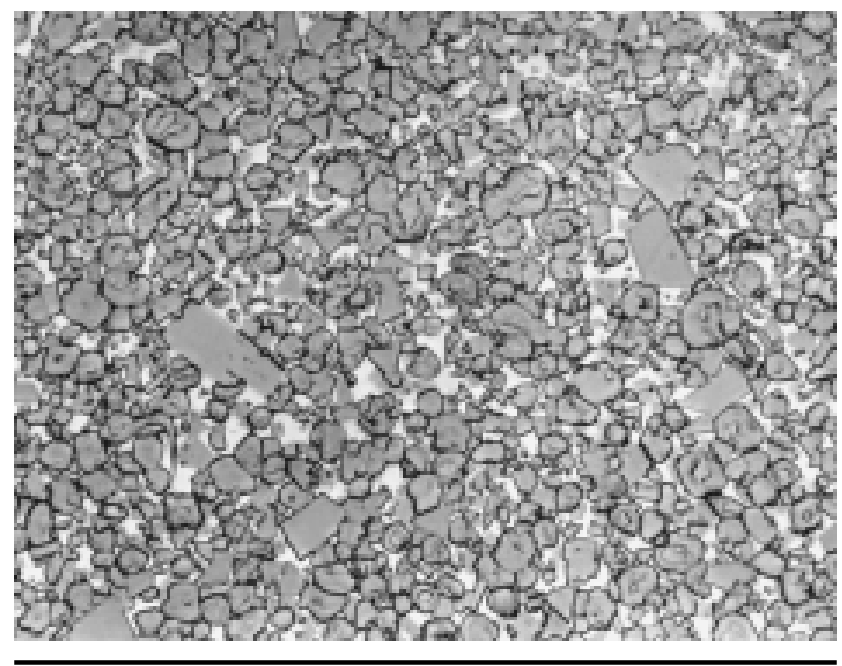

las vías respiratorias superiores (rinitis, asma) y para los síntomas subagudos y crónicos del parénquima bronquial (alveolitis fibrosante y fibrosis intersticial crónica).

El mecanismo patogénico se basa en la inducción de una inmunorreacción de hipersensibilidad causada por Co: de hecho, sólo algunos de los sujetos presentan trastornos tras breves exposiciones a una concentración relativamente baja 0 incluso después de exposiciones más prolongadas e intensas. Las concentraciones de $\mathrm{Co}$ en muestras biológicas (sangre, orina, piel) no se diferencian de manera significativa entre aquellos sujetos que presentan el trastorno y los que no lo presentan; no existe una correlación entre la dosis y la respuesta a nivel tisular; se han detectado anticuerpos específicos (inmunoglobinas IgE e IgG ) frente a un compuesto de Co-albúmina en asmáticos, y la prueba del parche para detectar Co es positiva en los sujetos con alveolitis o fibrosis; las características citológicas de la alveolitis

Figura 10.28 - Microestructura de aglomerado chapada con múltiples capas muy pesadas (x2.000).

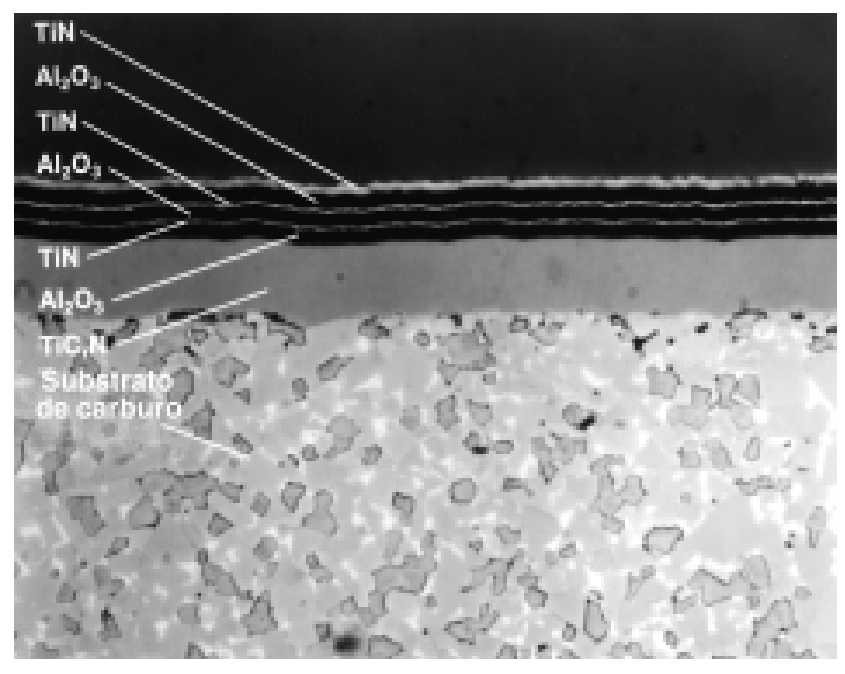


Figura 10.29 - BAL citológico en un caso de alveolitis macrofágica mononuclear de células gigantes causada por metales pesados. Entre los macrófagos mononucleares y el linfocito, se observa una célula gigante de tipo cuerpo extraño (x 400).

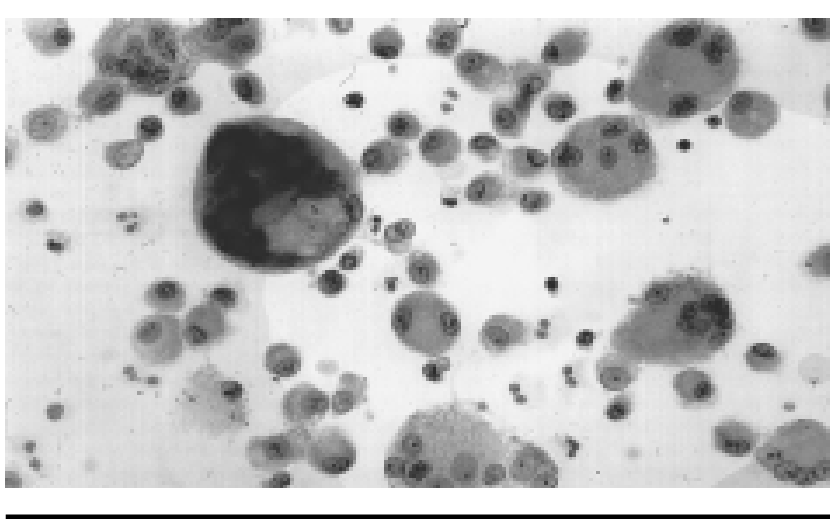

de células gigantes son compatibles con una inmunorreacción y los síntomas agudos o subagudos suelen remitir cuando los sujetos dejan de estar expuestos al Co (Parkes 1994).

Todavía no se ha encontrado una explicación satisfactoria para la base inmunológica de la hipersensibilidad al $\mathrm{Co}$; no es posible, por tanto, identificar un marcador fiable de la susceptibilidad individual.

También se observaron trastornos idénticos a los encontrados en los sujetos expuestos a metales pesados en los talladores de diamantes, que usan discos formados por microdiamantes fijados con $\mathrm{C} 0$ y que por tanto inhalan únicamente $\mathrm{Co}$ y partículas de diamante.

Todavía no se ha demostrado plenamente que el Co puro (excluyendo todas las demás partículas inhaladas) sea capaz por sí mismo de provocar los trastornos y, sobre todo, la fibrosis intersticial difusa: las partículas inhaladas junto con el $\mathrm{Co}$ podrían tener un efecto sinérgico además de modulador. Los estudios experimentales parecen demostrar que la reactividad biológica frente a una mezcla de partículas de $\mathrm{C}$ o y de tungsteno es más fuerte que la causada por Co aislado, y no se observan trastornos importantes en los trabajadores a cargo de la producción de polvo de Co puro (Science of the Total Environment 1994).

Los síntomas clínicos de la enfermedad por metales pesados, que, teniendo en cuenta los actuales conocimientos etiopatogénicos, debería denominarse con mayor precisión "enfermedad por cobalto", son, como ya se ha mencionado, agudos, subagudos y crónicos.

Entre los síntomas agudos se incluye una irritación respiratoria específica (rinitis, laringotraqueítis, edema pulmonar) causada por la exposición a concentraciones elevadas de polvo o humo de $\mathrm{C} 0$; se observan únicamente en casos excepcionales. Es más frecuente el asma. A parece en un porcentaje que oscila entre el 5 y el $10 \%$ de los trabajadores expuestos a concentraciones de cobalto de $0,05 \mathrm{mg} / \mathrm{m}^{3}$, el actual Valor Límite U mbral (TLV) en Estados U nidos. Síntomas como opresión torácica con disnea y tos suelen aparecer al final del turno de trabajo o durante la noche. Se puede sospechar un diagnóstico de asma alérgica bronquial ocupacional debida al cobalto en función de la historia clínica, pero la confirmación se realiza mediante una prueba específica de estimulación bronquial que determina la aparición de una respuesta broncospástica inmediata, diferida o dual. También las pruebas de capacidad respiratoria realizadas al principio y al final del turno de trabajo pueden ayudar a establecer el diagnóstico. Los síntomas de asma debidos al cobalto suelen desaparecer cuando el sujeto deja de estar expuesto, pero, al igual que en todas las demás formas de asma alérgica profesional, los síntomas pueden hacerse crónicos e irreversibles cuando la exposición es continua durante un largo período de tiempo (años), a pesar de la presencia de alteraciones respiratorias. Los sujetos muy broncorreactivos pueden presentar síntomas de asma de etiología no alérgica, con una respuesta inespecífica a la inhalación de cobalto y otros polvosirritantes. En un elevado porcentaje de casos de asma bronquial alérgica, se descubrió en el suero de IgE una reacción específica hacia un compuesto humano de Co-seroalbúmina. El hallazgo radiológico no varía: sólo en raros casos se encuentran formas mixtas de asma unida a alveolitis con una alteración radiológica causada específicamente por la alveolitis. EI tratamiento con broncodilatadores, junto con la interrupción inmediata de la exposición en el trabajo, da lugar a una recuperación completa en los casos de inicio reciente y que todavía no se han hecho crónicos.

Entre los síntomas subagudos y crónicos se incluyen la alveolitis fibrosante y la fibrosis intersticial difusa y progresiva (FIDP) crónica. La experiencia clínica parece indicar que la transición de alveolitis a fibrosis intersticial es un proceso que evoluciona lenta y gradualmente con el tiempo: se pueden encontrar casos de alveolitis inicial pura reversible al apartar al sujeto de la exposición y aplicar tratamiento con corticosteroides; o casos en los que ya ha aparecido un componente de fibrosis, que pueden mejorar, pero no llegar a una recuperación completa, ni siquiera con tratamiento adicional, al apartar al sujeto de la exposición; y, por último, casos en los que la situación predominante es la de una FIDP irreversible. EI porcentaje de estos casos es bajo en los trabajadores expuestos, mucho más bajo que el porcentaje de casos de asma alérgica.

La alveolitis es fácil de estudiar hoy en día en sus componentes citológicos a través del lavado broncoalveolar (BAL); se caracteriza por un gran aumento del número total de células, formado principalmente por macrófagos, con numerosas células gigantes multinucleadas y el típico aspecto de células gigantes de cuerpo extraño que a veces contienen células citoplásmicas (Figura 10.29); incluso un aumento absoluto o relativo de linfocitos es frecuente, con una disminución del cociente CD 4/ CD 8 asociada a un gran aumento de eosinófilos y mastocitos. En raras ocasiones, la alveolitis es fundamentalmente linfocítica, con una inversión del cociente CD4/CD8, como ocurre en las neumopatías por hipersensibilidad.

Los sujetos con alveolitis refieren disnea unida a fatiga, pérdida de peso y tos seca. Se observan crepitantes en la porción inferior del pulmón, con una alteración funcional de tipo restrictivo y opacidad radiológica difusa redondeada o irregular. La prueba del parche de cobalto es positiva en la mayoría de los casos. En los sujetos susceptibles la alveolitis aparece al cabo de un período relativamente corto de exposición en el lugar de trabajo, de uno a pocos años. En sus fases iniciales esta forma es reversible hasta alcanzar la recuperación completa por el simple método de apartar al sujeto de la exposición, con mejores resultados si esta medida se combina con un tratamiento con cortisona.

El desarrollo de fibrosis intersticial difusa agrava los síntomas clínicos con aumento de la disnea, que aparece incluso después de un esfuerzo mínimo y a veces incluso en reposo, con un empeoramiento de la deficiencia ventilatoria restrictiva que va unido a una reducción de la difusión alveolo-capilar, y con la aparición de opacidades radiográficas de tipo lineal y en panal de abejas (Figura 10.30). La situación histológica es la de una alveolitis fibrosante de "tipo mural".

La evolución es rápidamente progresiva; los tratamientos no son eficaces y el pronóstico es dudoso. Uno de los casos 
diagnosticados por el autor necesitó finalmente un transplante de pulmón.

El diagnóstico del origen ocupacional se basa en los antecedentes médicos, el patrón citológico del BAL y la prueba del parche de cobalto.

Las medidas para prevenir la enfermedad por metales pesados o, con mayor precisión, la enfermedad por cobalto, son ahora principalmente técnicas: protección de los trabajadores mediante la eliminación del polvo, los humos o los vapores con una adecuada ventilación de las zonas de trabajo. D e hecho, la falta de conocimiento acerca de losfactores que determinan la hipersensibilidad individual al cobalto imposibilita la identificación de las personas susceptibles, por lo que se debe realizar el máximo esfuerzo para reducir las concentraciones atmosféricas.

El cálculo del número de personas que se encuentran en situación de riesgo está infravalorado, porque muchas actividades de afilado se realizan en pequeñas industrias o por artesanos. En estos lugares de trabajo, se sobrepasa con frecuencia el TLV estadounidense de $0,05 \mathrm{mg} / \mathrm{m}^{3}$. Existe también cierta controversia en cuanto a la suficiencia del TLV para proteger a los trabajadores de la enfermedad por cobalto, ya que no se conocen plenamente las relaciones dosis-efecto en las enfermedades en las que interviene la hipersensibilidad.

La vigilancia de rutina debe ser lo bastante exacta como para identificar los trastornos por cobalto en sus etapas más precoces. Se debe realizar un cuestionario anual dirigido principalmente a síntomas temporales, junto con una exploración médica que incluya pruebas de función pulmonar y otras exploraciones médicas adecuadas. Puesto que se ha demostrado que existe una sólida correlación entre las concentraciones de cobalto en el ambiente de trabajo y la excreción del metal por vía urinaria, es conveniente realizar mediciones semestrales de cobalto en orina $(\mathrm{COO})$ en muestras tomadas al final de la semana laboral. C uando la exposición alcanza el nivel del TLV, se calcula que el índice de exposición biológica (IEB) es igual a $30 \mu \mathrm{g} \mathrm{Co/litro} \mathrm{de}$ orina.

Las exploraciones médicas previas a la exposición para detectar la presencia de enfermedades respiratorias preexistentes e hipersensibilidad bronquial pueden ser útiles para aconsejar y distribuir a los trabajadores. Las pruebas de metacolina resultan un indicador útil de hiperreactividad bronquial inespecífica y pueden ser valiosas en ocasiones.

Se recomienda encarecidamente la estandarización internacional de los métodos de vigilancia medioambiental y médica de los trabajadores expuestos al cobalto.

\section{- APARATO RESPIRATO RIO : LA VARIEDAD DE LAS NEUMOCONIOSIS}

\section{Steven R. Short y Edward L. Petsonk}

En este artículo se lleva a cabo un estudio de las neumoconiosis relacionadas con una serie de sustancias concretas no fibrosas; las exposiciones a estos polvos no se abordan en otros apartados de este volumen. Para cada material capaz de generar una neumoconiosis por exposición, se hace una breve descripción de su mineralogía y de su importancia comercial, seguida de la información relacionada con la salud pulmonar de los trabajadores expuestos

\section{Aluminio}

El aluminio es un metal ligero con muchos usos comerciales, tanto en estado metálico como combinado. (Abramson y cols. 1989; K ilburn y Warshaw 1992; Kongerud y cols. 1994.) Los minerales que contienen aluminio, principalmente la bauxita y la criolita, están formados por combinaciones del metal con oxígeno, flúor y hierro. Es frecuente que los minerales estén contaminados de sílice. De la bauxita se extrae alúmina $\left(\mathrm{Al}_{2} \mathrm{O}_{3}\right)$, que se puede tratar para usarla como abrasivo o como catalizador. El aluminio metálico se obtiene de la alúmina por reducción electrolítica en presencia de fluoruro. La electrólisis de la mezcla se realiza usando electrodos de carbono a una temperatura de unos $1.000{ }^{\circ} \mathrm{C}$ en unos vasos llamados crisoles. A continuación, se vacía el aluminio metálico para colarlo. Las exposiciones a polvos, vapores y gases en las salas de crisoles, entre los que se incluyen carbono, alúmina, fluoruros, dióxido de azufre, monóxido de carbono e hidrocarburos aromáticos, se acentúan durante la ruptura de la corteza y otras operaciones de mantenimiento. A partir de láminas, ralladuras, gránulos y piezas fundidas de aluminio se fabrican numerosos productos, lo cual aumenta las posibilidades de exposiciones profesionales. EI aluminio metálico y sus aleaciones se usan en la industria aeronáutica, la construcción de barcos y la industria automovilística, en la fabricación de contenedores y de aparatos eléctricos y mecánicos, así como en una amplia variedad de aplicaciones para construcción y estructuras. En pinturas, explosivos y bombas incendiarias se usan pequeñas partículas de aluminio. Para mantener la separación de las partículas, se añaden aceites minerales de estearina; la mayor toxicidad pulmonar de las ralladuras de aluminio se ha asociado al uso de aceites minerales.

\section{Salud pulmonar}

Puede producirse inhalación de polvos y vapores que contienen aluminio en los trabajadores encargados de la minería, extracción,

Figura 10.30 - Radiografía de tórax de un sujeto afectado por fibrosis intersticial causada por metales pesados. Se observan una opacidad lineal y difusa y un patrón en panal de abejas.

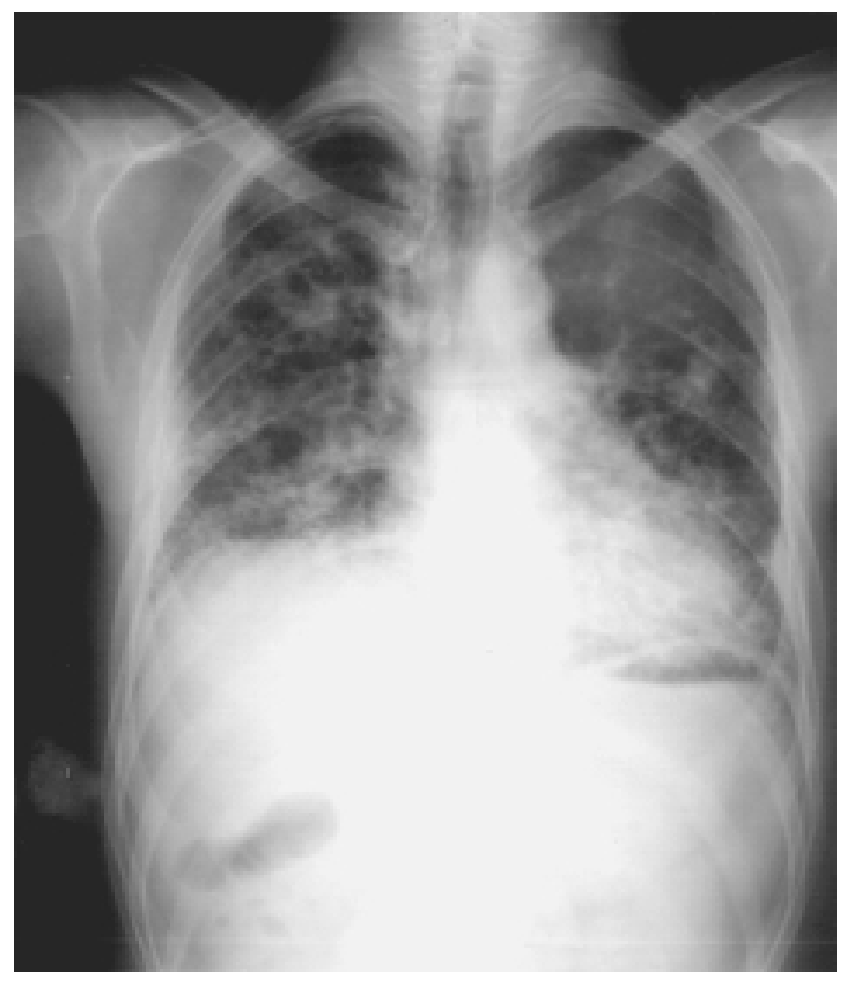


preparación, fabricación y uso final de materiales que contienen aluminio. Se ha descrito fibrosis pulmonar, con síntomas y hallazgos radiológicos, en trabajadores con diferentes grados de exposición a sustancias que contenían aluminio. La enfermedad de Shaver es una grave neumoconiosis descrita entre trabajadores relacionados con la fabricación de abrasivos de alúmina. Se han comunicado varias muertes debidas a esta enfermedad. L as zonas afectadas con mayor frecuencia son los lóbulos superiores del pulmón, y una complicación frecuente es la aparición de neumotórax. Se han encontrado altos niveles de dióxido de silicio en el entorno de las salas de crisoles, así como en los pulmones de los trabajadores durante las autopsias, lo cual indica que el sílice puede contribuir al cuadro clínico de la enfermedad de Shaver. También se han observado altas concentraciones de partículas de óxido de aluminio. La anatomía patológica del pulmón puede presentar vesículas y bullas, y en ocasiones se observa paquipleuritis. La fibrosis es difusa, con zonas de inflamación en los pulmonesy en los ganglios linfáticos asociados.

Los polvos de aluminio se usan para hacer explosivos, y ha habido una serie de informes de fibrosis grave y progresiva en trabajadores relacionados con este proceso. También se ha descrito en ocasiones una afectación pulmonar en trabajadores encargados de soldar o pulir aluminio y de empaquetar material para camas de gatos que contiene silicato de aluminio (alunita). Sin embargo, se ha producido una considerable variación en la comunicación de enfermedades pulmonares relacionadas con exposiciones al aluminio. Los estudios epidemiológicos de trabajadores expuestos a la reducción del aluminio han demostrado por lo general una baja prevalencia de alteraciones neumoconióticas y ligeras reducciones medias en la función pulmonar ventilatoria. En diversos entornos laborales, los compuestos de alúmina pueden presentarse con varias formas y, en los estudios con animales, estas formas parecen tener distintas toxicidades pulmonares. El sílice y otros polvos mixtos también pueden contribuir a esta toxicidad variable, así como los materiales usados para revestir las partículas de aluminio. Un trabajador, que desarrolló una enfermedad pulmonar granulomatosa tras ser expuesto a óxidos y metal de aluminio, presentó una transformación de los linfocitos sanguíneos tras la exposición a sales de aluminio, lo cual indicaba que podrían estar implicados factores inmunológicos.

Se ha observado con frecuencia un síndrome asmático entre los trabajadores expuestos a vapores en las salas de crisoles para la reducción del aluminio. $\mathrm{H}$ an estado implicados fluoruros encontrados en el ambiente de los crisoles, aunque no se ha descubierto el agente 0 agentes causales del síndrome asmático. Al igual que en otros tipos de asma profesional, a menudo los síntomas tardan en aparecer de 4 a 12 horas tras la exposición y entre ellos se incluyen tos, disnea, opresión torácica y sibilancias. También se puede observar una reacción inmediata. La atopia y unos antecedentes familiares de asma no parecen ser factores de riesgo para desarrollar el asma del crisol. Tras el cese de la exposición, es de esperar que los síntomas desaparezcan en la mayoría de los casos, aunque dos tercios de los trabajadores afectados muestran una reactividad bronquial inespecífica persistente $y$, en el caso de algunos trabajadores, los síntomas y la hiperreactividad de las vías aéreas continúan durante años incluso después de haberse interrumpido la exposición. El pronóstico del asma del crisol parece ser mejor en las personas que son apartadas inmediatamente de la exposición cuando los síntomas asmáticos se hacen manifiestos. El trabajo en las salas de crisoles también se ha asociado a una obstrucción fija al flujo aéreo.

En el proceso de reducción del aluminio se usan electrodos de carbono, y en el entorno de las sales de crisoles se han identificado conocidos cancerígenos humanos. Varios estudios de mortalidad han revelado un número excesivo de casos de cáncer de pulmón entre los trabajadores expuestos de esta industria.

\section{Tierra de diatomeas}

Los depósitos de tierra de diatomeas se producen por la acumulación de esqueletos de organismos microscópicos. (C ooper y Jacobson 1977; Checkoway y cols. 1993.) La tierra de diatomeas se puede usar en las fundiciones y en el mantenimiento de filtros, abrasivos, lubricantes y explosivos. Ciertos depósitos se componen de hasta un $90 \%$ de ślice libre. Los trabajadores expuestos pueden desarrollar alteraciones pulmonares con neumoconiosis simple o complicada. El riesgo de muerte, tanto por enfermedades respiratorias no malignas como por cáncer de pulmón, se ha asociado a la permanencia de los trabajadores en un trabajo que implica la creación de grandes cantidades de polvo, así como a la acumulación de exposiciones a sílice cristalino durante la minería y la preparación de la tierra de diatomeas.

\section{Carbono elemental}

A parte del carbón, las dos formas comunes del carbono elemental son el grafito (carbono cristalino) y el negro de humo. ( $\mathrm{H}$ anoa 1983; Petsonk y cols. 1988.) El grafito se usa en la fabricación de minas de lápiz, revestimientos de fundiciones, pinturas, electrodos, pilas y crisoles para fines metalúrgicos. El grafito muy molido tiene propiedades lubricantes. EI negro de humo es una forma parcialmente descompuesta usada para neumáticos de automóviles, pigmentos, plásticos, tintas y otros productos. EI negro de humo se fabrica a partir de combustibles fósiles mediante diversos procesos en los que intervienen la combustión parcial y la descomposición térmica.

Puede producirse inhalación de carbono, así como de polvos asociados, durante la minería y la trituración de grafito natural y durante la fabricación de grafito artificial. El grafito artificial se produce calentando carbón o coque de petróleo y generalmente no contiene sílice libre.

\section{Salud pulmonar}

La neumoconiosis se produce por la exposición del trabajador al grafito, tanto natural como artificial. Clínicamente, los trabajadores con neumoconiosis por carbono 0 grafito presentan hallazgos radiológicos similares a los de los hulleros. En el pasado se comunicaban graves casos sintomáticos con fibrosis pulmonar masiva, especialmente relacionados con la fabricación de electrodos de carbono para la metalurgia, aunque los informes recientes destacan que es probable que los materiales implicados en las exposiciones que provocan este tipo de proceso sean polvos mixtos.

\section{Gilsonita}

La gilsonita, también conocida como uintaite, es un hidrocarburo solidificado. (K eimig y cols. 1987). Se da en vetas en el oeste de Estados U nidos. Entre sus usos actuales están la fabricación de sustancias selladoras para las juntas de la carrocería de los automóviles, tintas, pinturas y esmaltes. Es un ingrediente de los líquidos de perforación de pozos de petróleo y de los cementos; se usa como aditivo en los moldes de arena de las fundiciones; se encuentra como componente del asfalto, de la madera para construcción y de los explosivos; y se emplea en la producción de grafito de grado nuclear. Los trabajadores expuestos a polvo de gilsonita han referido síntomas como tos y producción de esputo. De noventa y nueve trabajadores examinados, cinco mostraron signos radiológicos de neumoconiosis. No se ha establecido ninguna anomalía de la función pulmonar relacionada con exposiciones a polvo de gilsonita. 


\section{Yeso}

El yeso es sulfato cálcico hidratado $\left(\mathrm{C} \mathrm{SSO}_{4} \cdot 2 \mathrm{H}_{2} \mathrm{O}\right)(\mathrm{O}$ akes y cols. 1982). Se usa como componente del cartón de yeso y fieltro, del yeso mate y del cemento Portland. Los depósitos se encuentran en varias formas y a menudo se asocian a otros minerales, como el cuarzo. Se ha observado neumoconiosis en los mineros del yeso y se ha atribuido a contaminación por sílice. Las exposiciones a polvo de yeso no se han asociado a anomalías ventilatorias.

\section{Aceites y lubricantes}

L os líquidos que contienen aceites de hidrocarburos se usan como refrigerantes, aceites de corte y lubricantes (C ullen y cols. 1981). Los aceites vegetales se encuentran en algunos productos comerciales y en una amplia variedad de alimentos. Estos aceites pueden adoptar forma de aerosol y ser inhalados cuando se trituran o someten a manipulación mecánica los metales revestidos con aceites, o si se usan pulverizadores que contengan aceites para limpiar o lubricar. L as mediciones medioambientales realizadas en talleres y fábricas de maquinaria han documentado niveles de aceite en el aire de hasta $9 \mathrm{mg} / \mathrm{m}^{3}$. En un informe se señaló una exposición a aceite en suspensión en el aire debida a la quema de grasas animales y vegetales en un edificio cerrado.

\section{Salud pulmonar}

En ocasiones, se ha comunicado que los trabajadores expuestos a estos aerosoles han desarrollado una neumonía lipoidea, parecida a la que se observa en pacientes que han aspirado gotas nasales de aceite mineral $u$ otros materiales oleaginosos. Este proceso se asocia a síntomas como tos y disnea, crepitantes pulmonares inspiratorios y alteraciones de la función pulmonar, generalmente leves. Se han comunicado algunos casos que muestran cambios radiográficos más extensos y graves alteraciones pulmonares. L a exposición a aceites minerales también se ha asociado en varios estudios a un riesgo mayor de cáncer de las vías respiratorias.

\section{Cemento Portland}

El cemento Portland se fabrica con silicatos de calcio hidratados, óxido de aluminio, óxido magnésico, óxido de hierro, sulfato cálcico, arcilla, esquisto y arena (A brons y cols. 1988; Yan y cols. 1993). La mezcla se tritura y se calcina a altas temperaturas añadiendo yeso. El cemento tiene muchos usos en la construcción de carreteras y edificios.

\section{Salud pulmonar}

La silicosis parece ser el mayor riesgo en los trabajadores del cemento, seguida de una neumoconiosis por polvos mixtos. (En el pasado, se añadía amianto al cemento para mejorar sus características.) Se han observado hallazgos anormales en las radiografías de tórax, entre los que se incluyen pequeñas opacidades redondeadas e irregulares y alteraciones de la pleura. En ocasiones, se han comunicado casos de trabajadores que han desarrollado proteinosis alveolar pulmonar tras la inhalación de polvo de cemento. Se han observado cambios obstructivos del flujo aéreo en algunos estudios de trabajadores del cemento, pero no en todos.

\section{Tierras raras}

L as tierras raras o "lantánidos" tienen números atómicos que van del 57 al 71. L os más comunes del grupo son el lantano (número atómico 57), el cerio (58) y el neodimio (60). L os demás elementos de este grupo son el praseodimio (59), el prometeo (61), el samario (62), el europio (63), el gadolinio (64), el terbio (65), el disprosio (66), el holmio (67), el erbio (68), el tulio (69), el iterbio (70) y el lutecio (71). (H ussain, Dick y K aplan 1980; Sabbioni, Pietra y Gaglione 1982; Vocaturo, Colombo y Zanoni 1983; Sulotto, Romano y Berra 1986; Waring y Watling 1990; Deng y cols. 1991.) Los elementos de las tierras raras se encuentran de forma natural en la arena de monacita, de la cual se extraen. Se usan en una serie de metales de aleación, como abrasivos para pulir espejos y lentes, para la cerámica a alta temperatura, en los fuegos artificiales y en las piedras de los encendedores. En la industria electrónica se usan en electrosoldadura y se encuentran en diversos componentes electrónicos, como el fósforo de los televisores, pantallas radiográficas, láseres, aparatos de microondas, aislantes, condensadores y semiconductores.

EI uso de lámparas de arco de carbono está muy extendido en la imprenta, el fotograbado y la litografía, y también para iluminación con focos, iluminación con reflectores y proyección de películas antes de que se adoptaran de forma generalizada las lámparas de argón y xenón. L os óxidos de tierras raras se incorporaban al núcleo central de las varillas del arco de carbono, para estabilizar la corriente del arco. Los vapores que se desprenden de las lámparas son una mezcla de material gaseoso y partículas compuestos de aproximadamente un $65 \%$ de óxidos de tierras raras, un $10 \%$ de fluoruros y carbono e impurezas sin quemar.

\section{Salud pulmonar}

La neumoconiosis de los trabajadores expuestos a tierras raras se ha presentado principalmente como infiltrados nodulares bilaterales en la radiografía de tórax. La anatomía patológica pulmonar en los casos de neumoconiosis por tierras raras se ha descrito como una fibrosis intersticial acompañada de una acumulación de finas partículas granulosas de polvo 0 de alteraciones granulomatosas.

Se han descrito alteraciones variables de la función pulmonar, desde un patrón restrictivo hasta un patrón mixto restrictivoobstructivo. Sin embargo, todavía no se ha definido el espectro de enfermedades pulmonares relacionadas con la inhalación de elementos de tierras raras y los datos en cuanto al patrón y la progresión de la enfermedad y las alteraciones histológicas proceden principalmente de unos pocos informes de casos.

Se ha sugerido la existencia de un potencial neoplásico para los isótopos de tierras raras a partir del informe de un caso de cáncer de pulmón, posiblemente relacionado con la radiación ionizante de los radioisótopos de tierras raras producidos de forma natural.

\section{Compuestos sedimentarios}

Los depósitos de roca sedimentaria se forman a partir de procesos físicos y químicos de desgaste, erosión, transporte, depósito y diagénesis. Se pueden dividir en dos grandes clases: Clásticos, que son rocalla procedente de la erosión que se ha depositado mecánicamente, y precipitados químicos, que son carbonatos, caparazones de esqueletos orgánicos y depósitos salinos. Los carbonatos, sulfatos y haluros sedimentarios proporcionan minerales relativamente puros que se han cristalizado a partir de soluciones concentradas. Debido a la elevada solubilidad de muchos de los compuestos sedimentarios, éstos se eliminan rápidamente de los pulmones y generalmente provocan una escasa patología pulmonar. Por el contrario, los trabajadores expuestos a ciertos compuestos sedimentarios, fundamentalmente clásticos, han presentado alteraciones neumoconióticas.

\section{Fosfatos}

EI mineral de fosfato, $\mathrm{Ca}_{5}(\mathrm{~F}, \mathrm{Cl})\left(\mathrm{PO}_{4}\right)_{3}$, se usa en la producción de fertilizantes, suplementos de la alimentación, pasta de dientes, conservantes, detergentes, pesticidas, venenos para roedores y municiones (D utton y cols. 1993). La extracción y tratamiento de ese mineral puede provocar una serie de exposiciones irritantes. L os estudios realizados con trabajadores de la minería y la extracción de fosfatos han documentado aumento de síntomas como tos 
y producción de esputo, así como signos radiográficos de neumoconiosis, pero escasos signos de función pulmonar anómala.

\section{Esquisto}

El esquisto es una mezcla de material orgánico compuesto principalmente de carbono, hidrógeno, oxígeno, azufre y nitrógeno (Rom, Lee y Craft 1981; Seaton y cols. 1981). El componente mineral (kerogeno) se encuentra en la roca sedimentaria llamada marga, de color marrón grisáceo y dispuesta en capas. El esquisto bituminoso se ha usado como fuente de energía desde 1850 en Escocia. $\mathrm{H}$ ay importantes depósitos en Estados U nidos, E scocia y Estonia. El polvo disperso en la atmósfera de las minas de esquisto bituminoso es relativamente fino, ya que hasta un $80 \%$ de las partículas tiene un tamaño inferior a $2 \mu \mathrm{m}$.

\section{Salud pulmonar}

La neumoconiosis relacionada con el depósito de polvo de esquisto en el pulmón se denomina esquistosis. El polvo crea una reacción granulomatosa y fibrótica en los pulmones. E sta neumoconiosis se parece clínicamente a la neumoconiosis y la silicosis de los mineros del carbón y puede progresar a fibrosis masiva incluso después de que el trabajador haya abandonado la industria.

Las alteraciones anatomopatológicas identificadas en pulmones enfermos de esquistosis se caracterizan por una deformación vascular y bronquial, con engrosamiento irregular de los tabiques interalveolares e interlobulillares. A demás de la fibrosis intersticial, las muestras pulmonares con neumoconiosis por esquisto han presentado sombras hiliares aumentadas de tamaño, relacionadas con el transporte de polvos de esquisto y el posterior desarrollo de alteraciones escleróticas bien definidas en los ganglios linfáticos hiliares.

Se ha observado en los trabajadores del esquisto una prevalencia de bronquitis crónica dos veces y media superior a la de controles de sus mismas edades. El efecto de las exposiciones a polvo de esquisto sobre la función pulmonar no se ha estudiado de manera sistemática.

\section{Pizarra}

La pizarra es una roca metamórfica, formada por diversos minerales, arcillas y materia carbonosa (M CD ermott y cols. 1978). Los componentes principales de la pizarra son: moscovita, clorita, calcita y cuarzo, junto con grafito, magnetita y rutilo. Estos componentes han sufrido una metamorfosis para formar una densa roca cristalina que posee fuerza, pero que se parte con facilidad, características que explican su importancia económica. La pizarra se usa para tejados, piedras a medida, baldosas, enlosados, formas estructurales como paneles y alféizares, encerados, lápices, mesas de billar y superficies de mesas de laboratorio. La pizarra triturada se usa para la construcción de carreteras, superficies de pistas de tenis y como gránulos para cubiertas ligeras.

\section{Salud pulmonar}

Se ha observado neumoconiosis en un tercio de los trabajadores estudiados en la industria pizarrera del norte de $\mathrm{G}$ ales y en un $54 \%$ de los fabricantes de lápices de pizarra de la India. Se han identificado diversas alteraciones radiológicas en los trabajadores de la pizarra. Dado el elevado contenido en cuarzo de algunas pizarras y de los estratos rocosos adyacentes, la neumoconiosis de los trabajadores de la pizarra puede presentar rasgos de silicosis. La prevalencia de síntomas respiratorios entre los trabajadores de la pizarra es alta, y la proporción de trabajadores con síntomas aumenta en función de la categoría de la neumoconiosis, con independencia de que sean fumadores o no. A una categoría de neumoconiosis mayor se asocian valores decrecientes del volumen espiratorio forzado en un segundo $\left(\mathrm{FEV}_{1}\right)$ y de la capacidad vital forzada (FVC).
Los pulmones de los mineros expuestos al polvo de pizarra revelan zonas localizadas de fibrosis perivascular y peribronquial, que se extienden hasta provocar la formación de máculas y fibrosis intersticial extensa. Son lesiones típicas las máculas fibróticas de configuración variable íntimamente asociadas a pequeños vasos sanguíneos pulmonares.

\section{Talco}

EI talco se compone de silicatos de magnesio y se encuentra en una amplia variedad de formas. (Vallyathan y Craighead 1981; Wegman y cols. 1982; Stille y Tabershaw 1982; Wergeland, Andersen y Baerheim 1990; Gibbs, Pooley y G riffith 1992.)

Los depósitos de talco están frecuentemente contaminados por otros minerales, entre los que se cuentan la tremolita fibrosa y no fibrosa y el cuarzo. Los efectos sobre la salud pulmonar de los trabajadores expuestos pueden relacionarse tanto con el propio talco como con los otros minerales asociados.

La producción de talco se realiza principalmente en Australia, Austria, China, Francia y Estados Unidos. EI talco se usa como componente en cientos de productos y se emplea en la fabricación de pintura, productos farmacéuticos, cosméticos, cerámica, neumáticos de automóviles y papel.

\section{Salud pulmonar}

En las radiografías de tórax de los trabajadores expuestos al talco se observan opacidades redondeadas e irregulares difusas del parénquima pulmonar y anomalías de la pleura. Dependiendo de las exposiciones concretas sufridas, las sombras radiográficas se pueden imputar al talco mismo o a contaminantes en él presentes. La exposición al talco se ha asociado a síntomas como tos, disnea y producción de esputo, junto con signos de obstrucción al flujo aéreo en los estudios de la función pulmonar. La anatomía patológica del pulmón ha revelado diversas formas de fibrosis pulmonar: se han comunicado alteraciones granulomatosas y cuerpos ferruginosos, así como macrófagos cargados de polvo acumulados alrededor de los bronquiolos respiratorios, mezclados con haces de colágeno. La exploración mineralógica del tejido pulmonar de los trabajadores del talco también ofrece resultados variables y puede mostrar sílice, mica o silicatos mixtos.

Dado que los depósitos de talco pueden estar asociados a amianto y otras fibras, no es de sorprender que se haya comunicado un riesgo mayor de carcinoma broncógeno entre los mineros y molineros del talco. U nas investigaciones recientes llevadas a cabo en trabajadores expuestos al talco sin fibras de amianto asociadas revelaron una tendencia a una mortalidad más elevada por enfermedades respiratorias no malignas (silicosis, silicotuberculosis, enfisema y neumonía), pero no se observó que el riesgo de cáncer broncógeno estuviera aumentado.

\section{Laca para el cabello}

La exposición a lacas para el cabello se produce tanto en el hogar como en los centros de peluquería comerciales (Rom 1992b). Las mediciones medioambientales realizadas en los salones de belleza han indicado la posibilidad de que se produzcan exposiciones a aerosoles respirables. Varios informes de casos han relacionado la exposición a la laca con el desarrollo de una neumonitis, la tesaurosis, en personas sometidas a una fuerte exposición. L os síntomas clínicos en estos casos fueron generalmente leves y se resolvieron al eliminar la exposición. La histología mostraba por lo general un proceso granulomatoso en el pulmón y un crecimiento de los ganglios linfáticos hiliares, con engrosamiento de las paredes alveolares y numerosos macrófagos granulosos en los espacios aéreos. Como posibles agentes, se han señalado las macromoléculas de las lacas, incluidas las gomas lacas y la polivinilpirrolidona. En contraste con los informes de casos clínicos, las 
crecientes sombras radiográficas del parénquima pulmonar observadas en las exploraciones radiológicas de peluqueros comerciales no se han relacionado de forma concluyente con la exposición a lacas para el cabello. Aunque los resultados de estos estudios no permiten establecer conclusiones definitivas, parece, efectivamente, que la enfermedad pulmonar clínicamente grave por exposiciones a lacas es infrecuente.

\section{- ENFERMEDAD PULMONAR OBSTRUCTIVA CRONICA}

Kazimierz Marek y Jan E. Zejda

L os trastornos respiratorios crónicos caracterizados por diferentes grados de disnea, tos, expectoración y deterioro de la función respiratoria se incluyen en el concepto general de enfermedad pulmonar crónica inespecífica (EPCI). La definición original de EPCI, aceptada en el Simposio Cyba en 1959, incluía la bronquitis crónica, el enfisema y el asma. Posteriormente, se redefinió la terminología diagnóstica de la bronquitis crónica de acuerdo con el concepto de que la limitación al flujo aéreo discapacitante representa la fase final de un proceso en evolución constante, que comienza como una expectoración benigna causada por la inhalación prolongada o recurrente de irritantes bronquiales ("hipótesis inglesa"). Este concepto se cuestionó en 1977, y a partir de entonces la hipersecreción y la obstrucción del flujo aéreo se consideran procesos no relacionados. La hipótesis alternativa, conocida como "hipótesis alemana", aunque acepta el papel del consumo de tabaco y de la contaminación atmosférica en la etiología de la limitación crónica al flujo aéreo, señala el papel clave y posiblemente causal de la susceptibilidad individual, que se manifiesta, por ejemplo, como una predisposición asmática. Estudios posteriores han demostrado que ambas hipótesis pueden contribuir a la comprensión de la historia natural de la enfermedad crónica de las vías aéreas. Aunque en general se ha aceptado como bastante sólida la conclusión acerca del insignificante valor pronóstico del síndrome de hipersecreción, estudios recientes muestran una asociación significativa entre el trastorno hipersecretor y el aumento del riesgo de desarrollar una limitación al flujo aéreo y la mortalidad de causa respiratoria.

Actualmente, el término $\mathrm{EPCl}$ reúne dos categorías principales de trastornos respiratorios crónicos: el asma (tratada en un artículo independiente de este capítulo), y la enfermedad pulmonar obstructiva crónica (E PO C).

\section{Definición}

En un documento publicado por la American Thoracic Society (AT S) (1987), la EPO C se define como un trastorno caracterizado por una anomalía en las pruebas de flujo espiratorio, que no se modifica de forma destacable tras un periodo de observación de varios meses. Teniendo en cuenta las causas funcionales y estructurales de limitación al flujo aéreo, la definición incluye los siguientes procesos no asmáticos de las vías aéreas: bronquitis crónica, enfisema y enfermedad de las vías aéreas periféricas. Las principales características comunes de la EPOC son anomalías fisiopatológicas importantes, manifestadas principalmente por grados variables de limitación crónica al flujo aéreo (LCFA). La limitación crónica al flujo aéreo se puede ver en un sujeto con cualquier enfermedad de las recogidas bajo el término EPOC.

La bronquitis crónica se define como un trastorno de las vías respiratorias, caracterizado por una tos productiva persistente y excesiva, que refleja la hipersecreción de moco en el interior de las vías aéreas. Con fines epidemiológicos, el diagnóstico de bronquitis crónica se ha basado en las respuestas al conjunto de preguntas estándar incluidas en el M edical Research Council (M RC) 0 en el cuestionario ATS sobre síntomas respiratorios. Este proceso se define como tos y expectoración que aparece la mayoría de los días de al menos tres meses del año, durante un mínimo de dos años consecutivos.

El enfisema se define como una alteración anatómica del pulmón caracterizada por un aumento anómalo del tamaño de los espacios aéreos distales al bronquiolo terminal, acompañada de destrucción de la arquitectura acinar. Con frecuencia el enfisema coexiste con la bronquitis crónica.

EI término enfermedad de las vías aéreas periféricas o enfermedad de las pequeñas vías aéreas se utiliza para describir los trastornos de las vías aéreas de menos de 2 a $3 \mathrm{~mm}$ de diámetro. La inflamación, la obstrucción y la producción excesiva de moco en esta zona del árbol bronquial se observa en varias entidades clínicas, incluidas la bronquitis crónica y el enfisema. Las pruebas anatomopatológicas de la existencia de anomalías estructurales locales y el concepto de que los cambios observados pueden representar una fase temprana en la historia natural de la enfermedad crónica de las vías aéreas ha estimulado en los últimos años del decenio de 1960 y en el decenio de 1970 un rápido desarrollo de pruebas funcionales diseñadas para estudiar las propiedades fisiopatológicas de las vías aéreas periféricas. En consecuencia, generalmente se entiende que el término enfermedad de las vías aéreas periféricas se refiere a anomalías estructurales 0 a un defecto funcional.

La LCFA es un marcador funcional de la EPOC. Este término hace referencia a un aumento de la resistencia al flujo aéreo, que produce un enlentecimiento continuo durante la espiración forzada. Esta definición y el conocimiento clínico y fisiopatológico subyacente implican dos importantes claves diagnósticas. En primer lugar, se debe demostrar que el proceso tiene un curso crónico, y la primera recomendación de 1958 exigía la presencia de LCFA durante más de un año para cumplir los criterios diagnósticos. EI margen temporal propuesto recientemente es menos riguroso y se refiere a la demostración de una deficiencia a lo largo de un período de tres meses. En la vigilancia de la LCFA relacionada con el trabajo, la evaluación espirométrica estándar proporciona suficientes medios de identificación, basándose en la disminución del volumen espiratorio forzado en un segundo $\left(F E V_{1}\right)$ y/ o en la relación de $F E V_{1}$ con la capacidad vital forzada (FVC).

$\mathrm{H}$ abitualmente, se diagnostica LCFA cuando el valor de FEV desciende por debajo del $80 \%$ del previsto. De acuerdo con la clasificación funcional de LCFA recomendada por la American Thoracic Society:

1. Existe deterioro leve cuando el valor de $\mathrm{FEV}_{1}$ está por debajo del $80 \%$ y por encima del $60 \%$ del previsto.

2. Existe deterioro moderado cuando el $\mathrm{FEV}_{1}$ está en el rango del $40 \%$ al $59 \%$ del valor previsto.

3. Existe deterioro grave cuando el valor de $\mathrm{FEV}_{1}$ se encuentra por debajo del $40 \%$ del previsto.

Cuando el grado de deterioro se evalúa mediante el valor de la relación $F E V_{1} / F V C$, se diagnostica un déficit leve si la relación se encuentra entre el $60 \%$ y el $74 \%$; moderado si oscila entre el $41 \%$ y el $59 \%$; y grave si es menor o igual al $40 \%$.

\section{Prevalencia de la EPOC}

Las pruebas acumuladas indican que la EPOC es un problema frecuente en muchos países. Su prevalencia es mayor en varones, y aumenta con la edad. La bronquitis crónica, una forma diagnóstica de EPOC bien estandarizada, es dos a tres veces más frecuente en varones. Estudios extensos informan que habitualmente entre el $10 \%$ y el $20 \%$ de los varones adultos en la 
Tabla 10.18 - Prevalencia de la EPOC en varíos países: resultados de estudios a gran escala.

\begin{tabular}{lllllllll} 
País & Año & Población & Varones & \multicolumn{5}{c}{ Mujeres } \\
& & & FUM (\%) & BC (\%) & EPOC/ LCFA (\%) & FUM (\%) & BC (\%) & EPOC/ LCFA (\%) \\
EE.UU. & 1978 & 4.699 & 56,6 & 16,5 & n.C. & 36,2 & 5,9 & n.C. \\
EE.UU. & 1982 & 2.540 & 52,8 & 13,0 & 5,2 & 32,2 & 4,1 & 2,5 \\
Reino Unido & 1961 & 1.569 & & 17,0 & n.C. & n.C. & 8,0 & n.C. \\
Italia & 1988 & 3.289 & 49,2 & 13,1 & n.C. & 26,9 & 2,8 & n.C. \\
Polonia & 1986 & 4.335 & 59,6 & 24,2 & 8,5 & 26,7 & 10,4 & 4,9 \\
Nepal & 1984 & 2.826 & 78,3 & 17,6 & n.C. & 58,9 & 18,9 & n.C. \\
Japón & 1977 & 22.590 & n.C. & 5,8 & n.C. & n.C. & 3,1 & n.C. \\
Australia & 1968 & 3.331 & n.C. & 6,3 & n.C. & n.C. & 2,4 & n.C.
\end{tabular}

Leyendas: FUM = hábito fumador; $B C=$ bronquitis crónica; EPOC/ LCFA = enfermedad pulmonar obstructiva crónica/ limitación crónica al flujo aéreo; n.c. = no comunicado. Modificado con autorización de: Woolcock 1989.

población general reúnen los criterios diagnósticos de bronquitis crónica (Tabla 10.18). La enfermedad es mucho más frecuente entre fumadores, tanto varones como mujeres. La frecuencia de la EPOC en la población laboral se comenta más adelante.

\section{Factores de riesgo de E POC, incluido el efecto de la exposición ocupacional}

La EPO C es un trastorno de etiología multifactorial. N umerosos estudios han proporcionado pruebas de la existencia de una dependencia causal de la misma con respecto a muchos factores de riesgo, clasificados como factores del huésped y factores medioambientales. En la génesis de la EPO C, se ha documentado el papel de la exposición ocupacional entre los factores de riesgo medioambientales tras la acumulación de pruebas epidemiológicas publicadas en el periodo de 1984 a 1988. Recientemente se han confirmado los efectos independientes del consumo de tabaco y de la exposición ocupacional, en función de los resultados de los estudios publicados desde 1966 hasta 1991. En la Tabla 10.19 se resume el estado de conocimientos actual sobre la etiología multifactorial de la EPOC.

La aparición de bronquitis crónica en la población laboral es un marcador potencial de exposición importante a irritantes laborales. Se ha comunicado un efecto importante de la exposición al polvo industrial sobre el desarrollo de bronquitis crónica en trabajadores de las minas de carbón, de la industria del hierro y del acero, así como de la industria textil, la construcción y la agricultura. En general, los ambientes con más polvo se asocian a una mayor prevalencia de síntomas de expectoración crónica. Sin embargo, los estudios de prevalencia están sujetos al "efecto del trabajador sano", un sesgo que conduce a una infravaloración del impacto de la exposición ocupacional nociva sobre la salud. M ás concluyentes, pero menos accesibles, son los datos sobre la incidencia de esta enfermedad. En ciertas ocupaciones, la tasa de incidencia de la bronquitis crónica es alta y oscila desde 197-276/ 10.000 en agricultores a 380/ 10.000 en trabajadores de la ingeniería y $724 / 10.000$ en mineros y canteros, en comparación con 108/ 10.000 en trabajadores no manuales.

Este patrón, y también el efecto causal del tabaco, está en concordancia con la idea de que la bronquitis crónica representa una respuesta común a la inhalación crónica de irritantes respiratorios.

Se cree que un efecto nocivo de la carga de polvo pulmonar conduce a una inflamación inespecífica de la pared bronquial. Se ha comunicado este tipo de respuesta inflamatoria en trabajadores expuestos a polvo orgánico y a sus componentes, como por ejemplo grano y endotoxina, ambos responsables de inflamación neutrofílica. No se puede descartar el papel de la susceptibilidad individual, y entre los factores del huésped conocidos se incluyen infecciones respiratorias pasadas, la eficacia de los mecanismos de depuración y factores genéticos insuficientemente determinados, mientras que el consumo de cigarrillos se convierte en la causa medioambiental aislada de bronquitis crónica más potente.

No se conoce con exactitud la contribución de las exposiciones ocupacionales a la etiología del enfisema. Los supuestos factores causales son el óxido de nitrógeno, el ozono y el cadmio, tal y como sugieren las observaciones experimentales. Los datos proporcionados por la epidemiología laboral son menos convincentes y pueden ser difíciles de obtener a causa de los habitualmente bajos niveles de exposición ambiental y debido al efecto predominante del consumo de tabaco. Este hecho tiene particular importancia en el caso del llamado enfisema centroacinar. La otra forma anatomopatológica de la enfermedad, el enfisema panacinar, se considera hereditaria y relacionada con el déficit de alfa ${ }_{1}$-antitripsina.

En diversas enfermedades con síntomas de EPOC, en diferentes estadios de la historia natural, se puede observar una inflamación bronquiolar y peribronquiolar, acompañada de un estrechamiento progresivo del segmento del árbol bronquial afectado (enfermedad de las vías aéreas periféricas o bronquiolitis obliterante). En el entorno laboral, la enfermedad suele verse precedida de una lesión pulmonar aguda producida por la inhalación de humos tóxicos, como dióxido de azufre, amoniaco, cloro y óxido de nitrógeno. Sin embargo, la epidemiología profesional de la bronquiolitis obliterante muchas veces resulta poco clara. A parentemente, sus estadios precoces son difíciles de identificar debido a la sintomatología inespecífica y a la limitación del procedimiento diagnóstico. Se sabe más de los casos que aparecen tras accidentes industriales. De otra forma, la enfermedad puede continuar indetectada hasta el desarrollo de síntomas evidentes y de un deterioro respiratorio objetivo ( $p$. ej. limitación crónica al flujo aéreo).

No es raro encontrar LCFA en distintos grupos laborales $y$, como se ha documentado en estudios controlados, su prevalencia en trabajadores manuales puede sobrepasar la observada en trabajadores no manuales. Los primeros estudios sobre la asociación de la limitación crónica al flujo aéreo con la exposición ocupacional no fueron concluyentes debido a la compleja etiología de la LCFA, que incluye el efecto del consumo de tabaco y de factores de riesgo relacionados con el huésped. $L a$ 
Tabla 10.19 - Factores de riesgo implicados en la EPO C

$\begin{array}{lll}\begin{array}{l}\text { Factor } \\ \text { relacionado con }\end{array} & \text { Demostrado } & \text { Supuesto } \\ \text { Huésped } & \text { Sexo } & \text { Atopia } \\ & \text { Edad } & \text { Factores familiares } \\ & \text { Déficit de antitripsina } & \begin{array}{l}\text { Aumento de la reactividad de } \\ \text { las vías aéreas }\end{array} \\ & & \text { Historia de salud } \\ \text { Medio ambiente } & \text { Humo del tabaco (personal) } & \begin{array}{l}\text { Humo del tabaco } \\ \text { (medioambiental) } \\ \end{array} \\ & & \text { Contaminación atmosférica } \\ & \text { Exposición ocupacional }\end{array}$

Reproducido con autorización de: Becklake y cols. 1988.

moderna epidemiología profesional, utilizando diseños orientados al objetivo y modelos de relación exposición-respuesta, ha proporcionado pruebas de la asociación entre la capacidad del flujo aéreo y la exposición a polvos minerales y orgánicos, a vapores y a gases.

Estudios longitudinales basados en grupos de trabajadores, realizados en trabajadores expuestos a polvos minerales y orgánicos y a vapores y gases, muestran que la exposición ocupacional se asocia a la pérdida de función pulmonar. Los resultados resumidos en la Tabla 10.20 demuestran la existencia de un efecto importante de la exposición al polvo en minas de carbón y de hierro, en la industria del cemento de amianto, en los trabajadores del acero y de fundición y en los trabajadores de trituradoras. Algunas de las exposiciones analizadas son las producidas por polvos y vapores (como hidrocarburos no halogenados, pinturas, resinas o barnices) así como por gases (como el dióxido de azufre o los óxidos de nitrógeno). De acuerdo con los resultados de una revisión exhaustiva, limitada a los artículos más válidos y que han sido analizados sistemáticamente, sobre EPOC y exposición ocupacional al polvo, se puede calcular que 80 de cada 1.000 mineros del carbón no fumadores desarroIlarán al menos un $20 \%$ de pérdida de FEV 1 tras 35 años de trabajo con una concentración media de polvo respirable de $2 \mathrm{mg} / \mathrm{m}^{3}$, y que el riesgo respectivo podría ser tres veces mayor en los trabajadores de minas de oro no fumadores.

Estudios seleccionados realizados en trabajadores del grano muestran el efecto de la exposición ocupacional al polvo orgánico sobre la producción de cambios longitudinales en la función pulmonar. Aunque el número de casos y la duración del seguimiento son limitados, los hallazgos muestran una relación independiente del consumo de tabaco con la pérdida anual de función pulmonar (respecto de la exposición al polvo de grano).

\section{Patogenia}

La alteración fisiopatológica clave de la EPOC es la limitación crónica al flujo aéreo. Esta alteración se produce por el estrechamiento de las vías aéreas - el cual tiene un mecanismo complejo en la bronquitis crónica- , mientras que en el enfisema la obstrucción de las vías aéreas se produce principalmente por disminución del retroceso elástico del tejido pulmonar. Con frecuencia, ambos mecanismo coexisten.

Las anomalías estructurales y funcionales observadas en la bronquitis crónica comprenden hipertrofia e hiperplasia de las glándulas submucosas asociadas con hipersecreción de moco. Los cambios inflamatorios conducen a hiperplasia del músculo liso y tumefacción de la mucosa. La hipersecreción de moco y el estrechamiento de las vías aéreas favorecen las infecciones bacterianas y víricas de las vías respiratorias, lo cual puede aumentar más la obstrucción de las vías aéreas.

La limitación al flujo aéreo en el enfisema refleja la pérdida del retroceso elástico como consecuencia de la destrucción de las

Tabla 10.20 - Pérdida de función ventilatoria en relación a exposiciones ocupacionales: resultados de varios estudios longitudinales basados en grupos de trabajadores.

\begin{tabular}{|c|c|c|c|c|c|c|}
\hline \multirow[t]{2}{*}{ País (año) } & \multirow[t]{2}{*}{ Sujetos y exposiciones } & \multirow[t]{2}{*}{ Prueba usada } & \multicolumn{4}{|c|}{ Pérdida funcional anual* } \\
\hline & & & $N E$ & $E$ & NF & $\mathrm{F}$ \\
\hline $\begin{array}{l}\text { Reino Unido } \\
\text { (1982) }\end{array}$ & 1.677 mineros del carbón & $\mathrm{FEV} \mathrm{ml}$ & 37 & $\begin{array}{l}41 \text { (av) } \\
57 \text { (max) }\end{array}$ & 37 & 48 \\
\hline EE.UU. (1985) & 1.072 mineros del carbón & $\mathrm{FEV} \mathrm{ml}$ & 40 & 47 & 40 & 49 \\
\hline Italia (1984) & 65 trabajadores de cemento de amianto & $\mathrm{FEV} \mathrm{ml}$ & 9 & 49 & No facilitado & No facilitado \\
\hline Suecia (1985) & 70 trabajadores de cemento de amianto & FEV\% & 4,2 & 9,2 & 3,7 & 9,4 \\
\hline Francia (1986) & 871 mineros del hierro & FEV\% & 6 & 8 & 5 & 7 \\
\hline Francia (1979) & 159 trabajadores del acero & FEV\% & 0,6 & 7,4 & No facilitado & No facilitado \\
\hline Canadá (1984) & 179 mineros y fundidores & FEV/ FVC\% & 1,6 & 3,1 & 2 & 3,4 \\
\hline Francia (1982) & 556 trabajadores de fábricas & $\mathrm{FEV} \mathrm{ml}$ & 42 & $\begin{array}{l}50 \\
52 \text { (polvo) } \\
47 \text { (gases) } \\
55 \text { (calor) }\end{array}$ & 40 & 48 \\
\hline Finlandia (1982) & 659 trabajadores de trituradoras de pasta & $\mathrm{FEV} \mathrm{ml}$ & Sin efecto & Sin efecto & 37 & 49 \\
\hline Canadá (1987) & 972 mineros y fundidores & $\mathrm{FEV} \mathrm{ml}$ & & $\begin{array}{l}69 \text { (asador) } \\
49 \text { (horno) } \\
33 \text { (mina) }\end{array}$ & 41 & 54 \\
\hline
\end{tabular}

* La tabla muestra la pérdida anual media de la función pulmonar en sujetos expuestos (E) y no expuestos (NE), y en fumadores (F) y no fumadores (NF). Los efectos independientes del consumo de tabaco (F) y/ o la exposición (E) se mostraron significativos en los análisis realizados por los autores de todos los estudios, salvo del finlandés.

Modificado con autorización de: Becklake 1989. 
fibras de elastina y el colapso de la pared bronquiolar debido a la alta distensibilidad pulmonar. Se considera que la destrucción de las fibras de elastina se produce por un desequilibrio en el sistema proteolítico-antiproteolítico, en un proceso conocido como déficit de inhibidores de las proteasas. $\mathrm{La}$ alfa $_{1}$-antitripsina es el mas potente inhibidor del efecto de la elastasa sobre los alveolos en el ser humano. Los neutrófilos y macrófagos, que liberan elastasas, se acumulan en respuesta a los mediadores inflamatorios locales y a la inhalación de varios irritantes respiratorios, incluido el humo del tabaco. 0 tros inhibidores menos potentes, liberados por las glándulas submucosas, son la $\alpha_{2}$-macroglobulina y el inhibidor de la elastasa de bajo peso molecular.

Recientemente se ha estudiado la hipótesis del déficit de antioxidantes, con el fin de determinar su papel en los mecanismos patogénicos del enfisema. La hipótesis sostiene que los oxidantes, si no son inhibidos por los antioxidantes, producen lesiones en el tejido pulmonar, y ello conduce al enfisema. Entre los oxidantes conocidos hay factores exógenos (ozono, cloro, óxidos de nitrógeno y humo del tabaco), y factores endógenos como los radicales libres. Entre los factores antioxidantes más importantes se encuentran los antoxidantes naturales como las vitaminas $\mathrm{E}$ y $\mathrm{C}$, la catalasa, la superóxido dismutasa, el glutatión, la ceruloplasmina, y los antioxidantes sintéticos como la $\mathrm{N}$-acetilcisteína y el alopurinol. C ada vez es mayor el número de datos que indican la existencia de sinergismo entre los mecanismos del déficit de antioxidantes y el déficit de inhibidores de las proteasas en la patogenia del enfisema.

\section{Anatomía patológica}

La anatomía patológica de la bronquitis crónica se caracteriza por hipertrofia e hiperplasia de las glándulas situadas en la submucosa de las grandes vías aéreas. Como consecuencia, aumenta la relación entre el espesor de las glándulas bronquiales y el espesor de la pared bronquial (el llamado índice de R eyd). 0 tras anomalías anatomopatológicas son la metaplasia del epitelio ciliado, la hiperplasia del músculo liso y los infiltrados de neutrófilos y linfocitos. Los cambios en las grandes vías aéreas se acompañan frecuentemente de anomalías anatomopatológicas de los bronquiolos pequeños.

L os cambios anatomopatológicos en los bronquiolos pequeños se han documentado constantemente como un proceso inflamatorio de intensidad variable en las paredes de las vías aéreas. Tras la introducción del concepto de enfermedad de las pequeñas vías aéreas, la atención se ha centrado en la morfología de diferentes segmentos bronquiolares. La evaluación histológica de los bronquiolos membranosos, ampliada después a los bronquiolos respiratorios, muestra inflamación de la pared, fibrosis, hipertrofia muscular, depósito de pigmento, metaplasia del epitelio caliciforme y escamoso, y presencia de macrófagos intraluminales. Las anomalías anatomopatológicas del tipo descrito anteriormente se han denominado "enfermedad de las vías aéreas inducida por polvo mineral". Un proceso asociado demostrado en este segmento de las vías respiratorias es la alveolitis fibrosante peribronquiolar, la cual se cree que representa la reacción precoz del tejido pulmonar a la inhalación de polvo mineral.

Los cambios anatomopatológicos del enfisema se pueden clasificar como enfisema centroacinar o enfisema panacinar. La primera entidad está limitada en su mayor parte al centro del acino, mientras que la segunda conlleva cambios en todas las estructuras del mismo. Aunque se cree que el enfisema panacinar refleja un déficit hereditario de inhibidores de las proteasas, ambas formas pueden coexistir. En el enfisema, los bronquiolos terminales muestran signos de inflamación y los espacios aéreos distales están anormalmente aumentados de tamaño. La destrucción estructural afecta a alveolos y capilares, y puede llevar a la formación de grandes espacios aéreos anómalos (enfisema bulloso). El enfisema centroacinar tiende a estar localizado en los lóbulos pulmonares superiores, mientras que el enfisema panacinar se suele encontrar en los inferiores.

\section{Síntomas clínicos}

Los dos síntomas principales de la bronquitis crónica son la tos y la expectoración, en tanto que la disnea (falta de aire), es una característica clínica del enfisema. En los casos avanzados, suelen coexistir los síntomas de expectoración crónica y disnea. La aparición y la progresión de la disnea indican el desarrollo de una limitación crónica al flujo aéreo. D e acuerdo con los síntomas y la situación fisiopatológica, la presentación clínica de la bronquitis crónica incluye tres formas de enfermedad: bronquitis crónica simple, mucopurulenta y obstructiva.

La auscultación pulmonar en la bronquitis crónica puede mostrar ruidos pulmonares normales. En los casos evolucionados puede existir una prolongación del tiempo espiratorio, sibilancias y estertores, que se oyen durante la espiración. En los casos avanzados de bronquitis crónica es frecuente la cianosis.

El diagnóstico clínico de enfisema es difícil en sus fases precoces, y la disnea puede ser el único hallazgo. El paciente con enfisema evolucionado puede tener tórax en tonel y signos de hiperventilación. Como resultado de la hiperinsuflación pulmonar, aparecen otros hallazgos, como hiperresonancia (en la percusión), disminución de los movimientos diafragmáticos y ruidos pulmonares atenuados; la cianosis es poco frecuente.

El diagnóstico diferencial de la bronquitis crónica respecto del enfisema puede ser difícil, debido a que los factores causales son similares (predominantemente el efecto del humo del tabaco) y a que la presentación es parecida, sobre todo si la limitación crónica al flujo aéreo domina el cuadro. La Tabla 10.21 proporciona algunas claves útiles para el diagnóstico. La forma evolucionada de EPOC puede tomar dos formas extremas: predominio de bronquitis ("blue bloater" o "abotargado azul") 0 de enfisema ("pink puffer" o "soplador rosado").

La radiografía de tórax tiene un valor diagnóstico limitado en la bronquitis crónica y en las fases iniciales del enfisema. LoS casos avanzados de este último muestran un patrón radiológico de radiotransparencia aumentada (hiperinsuflación). La tomografía computadorizada permite una mejor visualización de la

\begin{tabular}{lll}
\hline Tabla 10.21 & $\begin{array}{l}\text { Clasifica ción diagnóstica de los dos tipos } \\
\text { clínicos de EPO C, la bronquitis crónica y el } \\
\text { enfisema. }\end{array}$ \\
Signos/ síntomas & $\begin{array}{l}\text { Bronquitis predominante } \\
\text { ["Blue Bloater"(Abotar- } \\
\text { gado azul)] }\end{array}$ & $\begin{array}{l}\text { Enfisema predominante } \\
\text { ["Pink Puffer"(Soplador } \\
\text { rosado)] }\end{array}$ \\
Masa corporal & Aumentada & Disminuida \\
Cianosis & Frecuente & Infrecuente \\
Tos & Síntoma predominante & Intermitente \\
Esputo & Gran cantidad & Raro \\
Disnea & $\begin{array}{l}\text { Generalmente marcada } \\
\text { durante el ejercicio }\end{array}$ & Síntoma predominante \\
Murmullo vesicular & $\begin{array}{l}\text { Normal o ligeramente } \\
\text { disminuido, } \\
\text { ruidos pulmonares }\end{array}$ & Disminuido \\
& adventicios & \\
Cor Pulmonale & Frecuente & Infrecuente \\
Infecciones & Frecuentes & Infrecuentes \\
respiratorias & & \\
\hline
\end{tabular}


localización y de la magnitud de los cambios enfisematosos, incluida la diferenciación entre enfisema centroacinar y panacinar.

Las pruebas de función pulmonar tienen una posición relevante en la evaluación diagnóstica de la EPOC (Tabla 10.22). La batería de pruebas con importancia práctica en la valoración funcional de la bronquitis crónica y el enfisema comprende la capacidad residual funcional (FRC), el volumen residual (RV), la capacidad pulmonar total (TLC), el $\mathrm{FEV}_{1}$ y la relación $F E V_{1} / V C$, la resistencia de las vías aéreas $\left(R_{\text {aw }}\right)$, la complianza estática $\left(C_{s t}\right)$, la retracción elástica $\left(P_{L, e l}\right)$, los gases arteriales $\left(\mathrm{PaO}_{2}, \mathrm{PaCO}_{2}\right)$ y la capacidad de difusión ( $\left.\mathrm{D}_{\mathrm{LCO}}\right)$.

$\mathrm{N}$ o es posible establecer un diagnóstico clínico de enfermedad de las vías aéreas periféricas. $M$ uy a menudo esta enfermedad acompaña a la bronquitis crónica o al enfisema, 0 incluso precede a la presentación clínica de estas dos formas de EPO C. L a forma aislada de la enfermedad de las vías aéreas periféricas se puede investigar por medio de pruebas de función pulmonar, aunque la situación funcional de las vías aéreas periféricas es difícil de valorar. Esta zona del árbol bronquial contribuye a menos del $20 \%$ de la resistencia del flujo aéreo total, y se considera que las anomalías leves aisladas de las pequeñas vías aéreas están por debajo del nivel de detección de la espirometría convencional. O tros métodos más sensibles diseñados para medir la función de las vías aéreas periféricas comprenden diversas pruebas, de las que las siguientes son las más usadas: flujo mesoespiratorio máximo $\left(F E F_{25-75}\right)$, tasas de flujo a volúmenes pulmonares bajos $\left(\mathrm{MEF}_{50}, \mathrm{MEF}_{25}\right)$, índice de nitrógeno de una sola respiración $\left(\mathrm{SBN}_{2} / \mathrm{I}\right)$, capacidad de cierre $(\mathrm{CC})$, conductancia del flujo aéreo contracorriente $\left(G_{u s}\right)$ y complianza dependiente de la frecuencia $\left(C_{\mathrm{fd}}\right)$. En general, se considera que estas pruebas tienen una especificidad baja. En teoría, $F F_{25-75}$ y $\mathrm{MEF}_{50,25}$ deberían reflejar en primer lugar los mecanismos limitantes de calibre, mientras que $\mathrm{SBN}_{2}$ / I sería más específico de las propiedades mecánicas de los espacios aéreos. Los primeros índices se usan casi exclusivamente en epidemiología ocupacional.

\section{Diagnóstico diferencial}

En las Tablas 10.21 y 10.22 se muestran las diferencias básicas entre la bronquitis crónica y el enfisema. Sin embargo, en casos individuales el diagnóstico diferencial es difícil y a veces imposible de llevar a cabo con un grado razonable de confianza. En ocasiones también es difícil diferenciar entre EPOC y asma. En la práctica, ambas entidades carecen de límites bien definidos, y hay un amplio grado de solapamiento entre las dos. En el asma, la obstrucción de las vías aéreas suele ser intermitente, mientras que en la EPOC es constante. La evolución de la limitación al flujo aéreo es más variable en el asma que en la EPO C.

\section{Tratamiento de casos}

El tratamiento de los casos de EPOC conlleva el abandono del consumo de tabaco, la medida aislada más eficaz. Se debe interrumpir o evitar la exposición ocupacional a irritantes respiratorios. El control clínico se debe centrar en el tratamiento apropiado de las infecciones respiratorias y debe incluir vacunaciones antigripales periódicas. En los pacientes que presenten limitación al flujo aéreo está justificado el tratamiento broncodilatador con agonistas $\beta_{2}$-adrenérgicos y anticolinérgicos, administrados como monoterapia o en combinación, preferiblemente en forma de aerosoles. La teofilina todavía se utiliza, aunque su papel en el tratamiento de la EPOC es controvertido. El tratamiento con corticoides a largo plazo puede ser eficaz en algunos casos. La hipersecreción bronquial se trata a menudo con fármacos mucoactivos que afectan a la producción de moco, a su
Tabla 10.22 - Pruebas de función pulmonar en el diagnóstico diferencial de los dos tipos clínicos de EPO C, la bronquitis crónica y el enfisema.

\begin{tabular}{|c|c|c|}
\hline $\begin{array}{l}\text { Prueba de } \\
\text { función } \\
\text { pulmonar }\end{array}$ & $\begin{array}{l}\text { Bronquitis predominante } \\
\text { ["Blue Bloater" (Abotargado } \\
\text { azul)] }\end{array}$ & $\begin{array}{l}\text { Enfisema predominante } \\
\text { ["Pink Puffer"(Soplador } \\
\text { rosado)] }\end{array}$ \\
\hline RV, FRC, TLC & $\begin{array}{l}\text { Normal o levemente } \\
\text { aumentador }\end{array}$ & Marcadamente aumentador \\
\hline $\mathrm{FEV}_{1}, \mathrm{FEV}_{1} / \mathrm{VC}$ & Disminuido & Disminuido \\
\hline $\mathrm{R}_{\mathrm{aw}}$ & Marcadamente aumentada & Levemente aumentada \\
\hline$C_{s t}$ & Normal & Marcadamente aumentada \\
\hline$P_{L, e l}$ & Normal & Marcadamente aumentada \\
\hline $\mathrm{PaO}_{2}$ & Marcadamente aumentada & Levemente disminuida \\
\hline $\mathrm{PaCO}_{2}$ & Aumentada & Normal \\
\hline$D_{\text {LCO }}$ & $\begin{array}{l}\text { Normal o levemente } \\
\text { disminuida }\end{array}$ & Disminuida \\
\hline
\end{tabular}

RV $=$ volumen residual; $F R C=$ capacidad residual funcional; $T L C=$ capacidad pulmonar total; $\mathrm{FEV}_{1}=$ volumen espiratorio forzado en el primer segundo y VC $=$ capacidad vital; $R_{a w}=$ resistencia de las vías aéreas; $C_{s t}=$ compliance estática; $P_{L, e l}=$ elastancia; $\mathrm{PaO}_{2}$ y $\mathrm{PaCO}_{2}=$ gases arteriales; $D_{1 c 0}=$ capacidad de difusión.

estructura o a su aclaramiento mucociliar. Es difícil valorar los efectos del tratamiento mucolítico, porque estos fármacos no se usan como monoterapia en la EPO C. En los pacientes con hipoxemia ( $\mathrm{PaO}_{2}$ inferior o igual a $55 \mathrm{mmH}$ g) está justificada la oxigenoterapia prolongada, un tratamiento que se ve facilitado por el acceso a los aparatos de oxigenoterapia portátiles. Se puede considerar la posibilidad de administrar tratamiento sustitutivo con alfa $a_{1}$-antitripsina en el enfisema con déficit confirmado de alfa $_{1}$-antitripsina (fenotipo PiZZ). Se está investigando el efecto de los fármacos antioxidantes (como las vitaminas E y C) sobre la progresión del enfisema.

\section{Prevención}

La prevención de la EPOC debe comenzar con campañas antitabaco dirigidas a la población general y a los grupos profesionales de riesgo. En el ámbito laboral, el control y la prevención de las exposiciones a irritantes respiratorios son esenciales y siempre prioritarios. Estas actividades deben dirigirse a la reducción eficaz de la contaminación atmosférica hasta niveles seguros, lo que se suele definir por los llamados valores de exposición permisible. Puesto que el número de contaminantes atmosféricos no está regulado o no lo está de forma suficiente, está justificado cualquier esfuerzo encaminado a reducir la exposición. En las circunstancias en las que tal reducción sea imposible, es necesaria la protección respiratoria personal para disminuir el riesgo de exposición a agentes nocivos.

La prevención médica de la EPOC en el entorno laboral comprende dos pasos importantes: un programa de vigilancia de la salud respiratoria, y un programa de formación dirigido a los trabajadores.

El programa de vigilancia de la salud respiratoria supone una evaluación periódica de la misma; comienza con la valoración inicial (historia clínica, exploración, radiografía de tórax y pruebas estándar de función pulmonar) y se sigue realizando periodicamente durante el tiempo que dure la actividad laboral. EI programa tiene por objeto valorar la salud respiratoria inicial de los trabajadores (y detectar a los que presentan un deterioro respiratorio subjetivo y/ o objetivo) antes de iniciar su actividad laboral, así como detectar signos precoces de deficiencia 
respiratoria durante la vigilancia continuada.Los trabajadores con hallazgos positivos deben ser apartados de la exposición y remitidos para una valoración diagnóstica más exhaustiva.

El programa de educación de los trabajadores debe estar basado en el reconocimiento fiable de peligros para la salud respiratoria presentes en el ambiente laboral, y debe ser diseñado por profesionales de la salud, higienistas industriales, ingenieros de seguridad y también por la dirección de la empresa. EI programa debe proporcionar a los trabajadores información exacta sobre los peligros para la salud respiratoria en el lugar de trabajo, los efectos respiratorios potenciales de las exposiciones y la normativa correspondiente. Tambien debe conllevar la promoción de prácticas laborales seguras y un estilo de vida saludable.

\section{- EFECTOS DE LAS FIBRAS ARTIFICIALES SOBRE LA SALUD}

\section{James E. Lockey y Clara S. R oss}

La utilización industrial de diversos tipos de fibras artificiales ha ido en aumento, en particular desde que se impusieron restricciones al uso del amianto debido a sus peligros conocidos para la salud. EI potencial de efectos adversos para la salud relacionados con la producción y utilización de fibras artificiales sigue siendo objeto de estudio. Este artículo proporcionará un resumen de los principios generales relativos al potencial de toxicidad en relación con estas fibras, un resumen de los distintos tipos de fibras en producción (tal como se reseñan en la Tabla 10.23) y una actualización de los estudios existentes y en marcha sobre sus efectos potenciales para la salud.

\section{Determinantes de la toxicidad.}

Los principales factores relacionados con la toxicidad potencial de la exposición a fibras son:

1. Dimensión de la fibra.

2. Durabilidad de la fibra.

3. D osis que alcanza en el órgano diana.

Generalmente, las fibras largas y delgadas (pero de tamaño respirable) y duraderas tienen el mayor potencial de causar efectos adversos si alcanzan los pulmones en concentración suficiente. En estudios de inhalación a corto plazo con animales, la toxicidad de la fibra se ha correlacionado con inflamación, citotoxicidad, función macrocitaria alterada y persistencia biológica. EI potencial carcinogénico es más probable que esté relacionado con una lesión del DNA celular a través de la formación de radicales libres de oxígeno, la formación de factores clastogénicos 0 defectos en la segregación de los cromosomas en las células en mitosis (aislados o en combinación). Las fibras de tamaño respirable son aquellas cuyo diámetro es inferior a 3,0-3,5 $\mu \mathrm{m}$ y cuya longitud es inferior a $200 \mu \mathrm{m}$.D e acuerdo con la "hipótesis de Stanton", el potencial cancerígeno de las fibras (determinado por estudios de implantación pleural en animales) está relacionado con su dimensión (el mayor riesgo se asocia a las fibras de diámetro inferior a 0,25 $\mu \mathrm{m}$ y de longitud superior a $8 \mu \mathrm{m}$ ) y su durabilidad (Stanton y cols. 1981). Las fibras minerales naturales, como el amianto, existen en forma de estructura policristalina que tiene propensión a escindirse a lo largo de planos longitudinales, creando fibras más finas con relaciones longitudanchura más elevadas, y que tienen mayor potencial de toxicidad. La inmensa mayoría de las fibras artificiales son no cristalinas o amorfas, y se fracturan perpendicularmente a su plano longitudinal, originando fibras más cortas. Esta es una diferencia
Tabla 10.23 • Fibras sintéticas.

\begin{tabular}{|c|c|c|}
\hline \multirow[t]{4}{*}{ Fibras artificiales } & \multicolumn{2}{|l|}{ Oxido de aluminio } \\
\hline & \multicolumn{2}{|l|}{ Carbono/ grafito } \\
\hline & \multicolumn{2}{|l|}{ Para-arámido Kevlar ${ }^{\circledR}$} \\
\hline & \multicolumn{2}{|l|}{$\begin{array}{l}\text { Fibras y pelos de carburo de } \\
\text { silicio }\end{array}$} \\
\hline \multirow[t]{2}{*}{$\begin{array}{l}\text { Fibras vítreas } \\
\text { artificiales }\end{array}$} & Fibra de vidrio & $\begin{array}{l}\text { Lana de vidrio } \\
\text { Filamento de vidrio continuo } \\
\text { Fibra de vidrio especializada }\end{array}$ \\
\hline & Lana mineral & $\begin{array}{l}\text { Lana de roca } \\
\text { Lana de escoria }\end{array}$ \\
\hline
\end{tabular}

Fibra de cerámica refractaria

importante entre el amianto y los silicatos de fibra no compuestos de amianto y las fibras artificiales. La durabilidad de las fibras depositadas en el pulmón depende de la capacidad de éste para depurarlas, así como de las propiedades físicas y químicas de éstas. La durabilidad de las fibras artificiales puede modificarse en el proceso de producción, de acuerdo con las necesidades del uso definitivo del producto, mediante la adicción de ciertos estabilizantes como el $\mathrm{Al}_{2} \mathrm{O}_{3}$. D ebido a esta variabilidad en los constituyentes químicos y en el tamaño de las fibras artificiales, su toxicidad potencial debe evaluarse para cada tipo de fibra.

\section{Fibras artificiales}

\section{Fibras de óxido de aluminio}

El informe de un caso de fibrosis pulmonar en un trabajador empleado en la fundición de aluminio durante 19 años (Jederlinic y cols. 1990) ha sugerido la existencia de toxicidad debida a las fibras de óxido de aluminio cristalino. La radiografía de tórax de este paciente revelaba una fibrosis intersticial. El análisis del tejido pulmonar mediante técnicas de microscopia electrónica demostró $1,3 \times 10^{9}$ fibras cristalinas por gramo de tejido pulmonar desecado, o sea, diez veces más fibras que el número de fibras de amianto encontradas en el tejido pulmonar de mineros de amianto crisotilo que padecían asbestosis. Es necesario un estudio más exhaustivo para determinar el papel de las fibras de óxido de aluminio cristalino (Figura 10.31) y la fibrosis pulmonar. Este informe, sin embargo, indica que tiene lugar un potencial de fibrización cuando coexisten las condiciones ambientales adecuadas como, por ejemplo, un aumento del flujo aéreo a través de materiales fundidos. En los casos en que existan hallazgos clínicos compatibles con una neumoconiosis inducida por fibras deben utilizarse la microscopia óptica con contraste de fase y la microscopia electrónica con análisis $\mathrm{R} x$ de dispersión de energía para identificar posibles fibras transportadas por el aire, tanto en el ambiente de trabajo como en muestras de tejido pulmonar.

\section{Fibras de carbono/grafito}

Las fibras de brea carbonácea, rayón o poliacrilonitrilo, calentadas hasta $1.200{ }^{\circ} \mathrm{C}$ forman fibras de carbono amorfo y, cuando se calientan por encima de $2.200^{\circ} \mathrm{C}$ forman fibras de grafito cristalino (Figura 10.32). Pueden añadirse aglomerantes de resina para aumentar la resistencia y para permitir el moldeamiento y la mecanización del material. G eneralmente estas fibras tienen un diámetro de 7 a $10 \mu \mathrm{m}$, aunque existen variaciones de tamaño debidas al proceso de fabricación y a la manipulación mecánica. 
Figura 10.31 - Microfotografía electrónica de barrido (MEB) de fibras de óxido de aluminio.

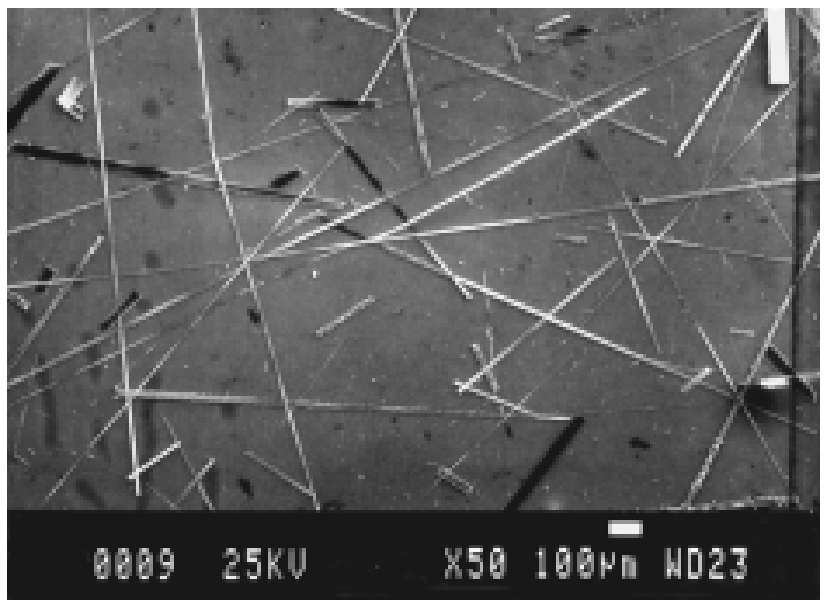

Por cortesía de T. Hesterberg.

Los compuestos de carbono/ grafito se utilizan en las industrias aeronáutica, automovilística y de materiales deportivos. La exposición a partículas de carbono/grafito de tamaño respirable puede producirse durante el proceso de fabricación y a consecuencia de la manipulación mecánica. Además, se pueden generar pequeñas cantidades de fibras de tamaño respirable cuando se calientan los compuestos hasta 900 a $1.100{ }^{\circ} \mathrm{C}$. Los conocimientos existentes acerca de estas fibras son insuficientes para proporcionar respuestas definitivas sobre su potencial de provocar efectos adversos para la salud. Estudios consistentes en la inyección intratraqueal de polvos de diferentes compuestos de fibras de grafito en ratas produjeron resultados heterogéneos. Tres de las muestras de polvo examinadas generaron una toxicidad mínima, y dos de las muestras dieron lugar a una toxicidad constante, manifestada por citotoxicidad para los macrófagos alveolares y por diferencias en el número total de células recuperadas del pulmón (M artin, M eyer y Luchtel 1989). Se han observado efectos clastogénicos en estudios de mutagenicidad de fibras a base de brea, pero no en los estudios de las fibras de carbono a base de poliacrilonitrilo. Un estudio de diez años de duración

Figura 10.32 - MEB de fibras de carbono.

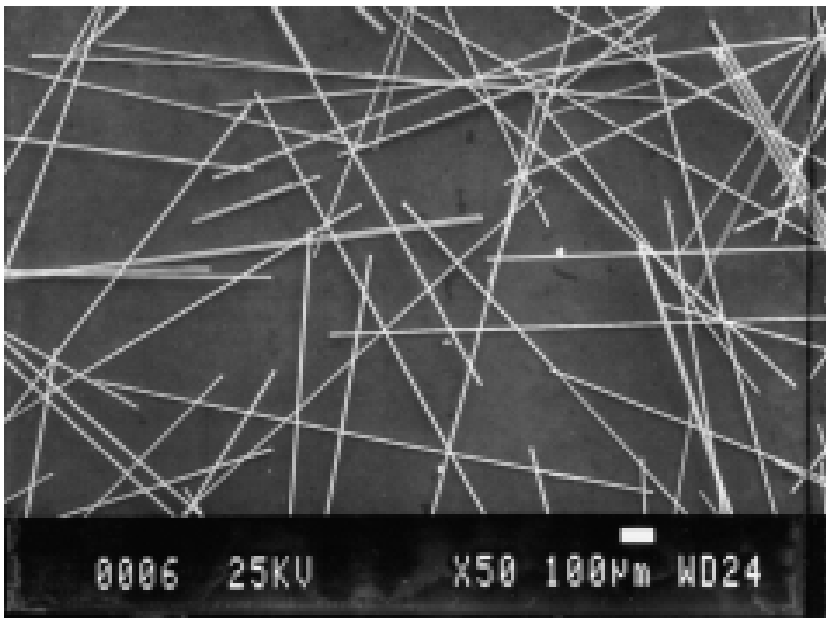

realizado en trabajadores de producción de fibras de carbono, que fabricaban fibras de 8 a $10 \mu \mathrm{m}$ de diámetro, no reveló ninguna anomalía (Jones, Jones y Lyle 1982). Hasta que se disponga de nuevos estudios, se recomienda que la exposición a las fibras de tamaño respirable de carbono/grafito sea de 1 fibra/ $\mathrm{ml}$ (f/ ml) o menos, y que la exposición a los compuestos particulados de tamaño respirable se mantenga por debajo del estándar actual de polvos respirables para polvos nocivos

\section{Fibras de para-arámido Kevlar}

L as fibras de paraarámido Kevlar tienen un diámetro aproximado de $12 \mu \mathrm{m}$ y las fibrillas curvas semejantesa cintas de la superficie de las fibras tienen una anchura inferior a $1 \mu \mathrm{m}$ (Figura 10.33). Las fibrillas se despegan parcialmente de las fibras y se entrecruzan con otras fibrillas para formar agregados de tamaño no respirable. Las propiedades físicas de las fibras K evlar consisten en una resistencia térmica y una fuerza de tensión importantes. T ienen muy diferentes usos, y actúan como agente de refuerzo en plásticos, telas y goma, así como de material de fricción para frenos de automóvil. La media ponderada en el tiempo (TWA) de ocho horas de los niveles de fibrillas durante la fabricación y las aplicaciones finales oscila entre 0,01 a 0,4 f/ ml (M erriman 1989). Cuando se utilizan en materiales de fricción se convierten en polvo cantidades muy bajas de fibras de arámido Kevlar. Los únicos datos disponibles respecto a sus efectos sobre la salud proceden de estudios en animales. Los estudios de inhalación realizados con ratas durante períodos de uno a dosaños y con exposiciones a fibrillas de 25, 100 y $400 \mathrm{f} / \mathrm{ml}$ revelaron la existencia de una bronquiolarización alveolar proporcional a la dosis. También se advirtieron una leve fibrosis y cambios fibróticos de los conductos alveolares con los niveles de exposición más elevados. La fibrosis puede haber estado relacionada con una sobrecarga de los mecanismos de depuración pulmonar. En un pequeño grupo de animales del estudio se desarrolló un tipo de tumor exclusivo de las ratas, el tumor quístico queratinizante de células escamosas (L ee y cols. 1988). L os estudios de inhalación a corto plazo realizados con ratas indican que las fibrillas tienen una baja durabilidad en el tejido pulmonar y que se depuran rápidamente (Warheit y cols. 1992). No se dispone de estudios relativos a los efectos de la exposición a las fibras de paraarámido K evlar sobre la salud en seres humanos. Sin embargo, a la vista de las pruebas que indican una reducción de la persistencia biológica y, dada la estructura física del K evlar, los riesgos para la

Figura 10.33 - MEB de fibras para-arámidas de Kevlar.

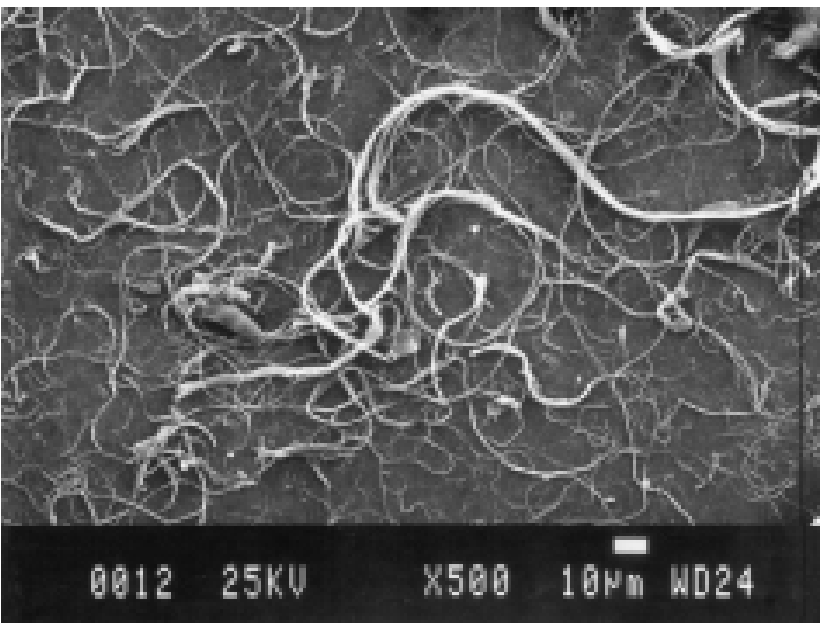


Figura 10.34 - MEB de fibras (A) y pelos (B) de carburo de silicio.
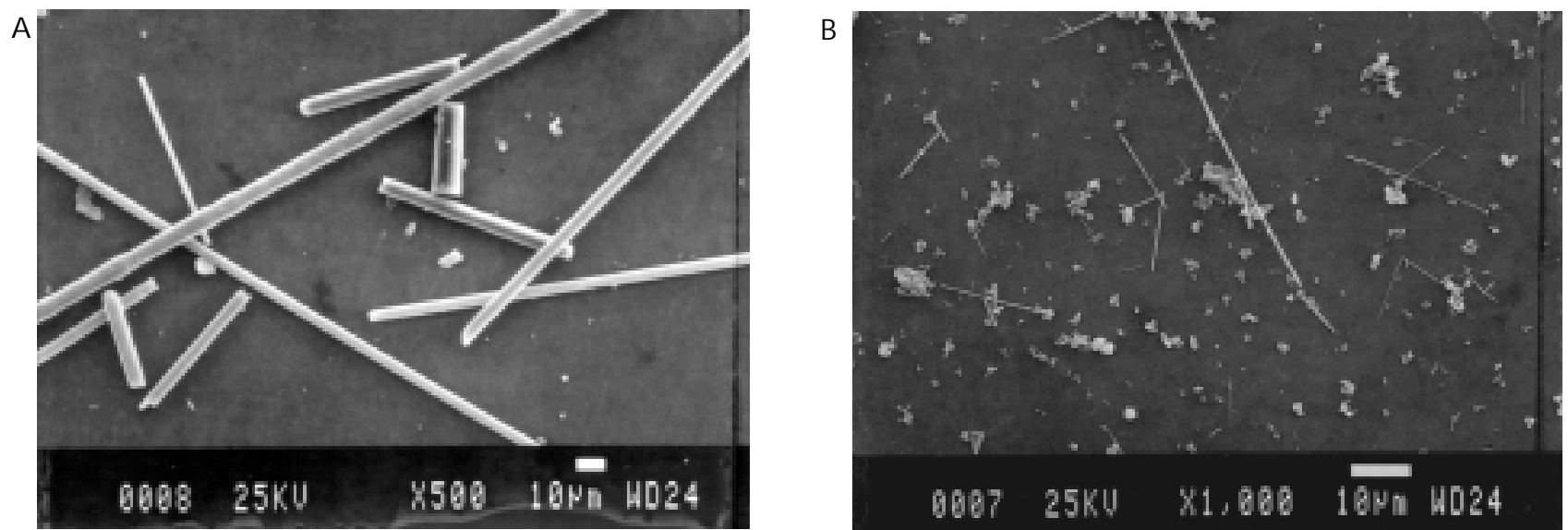

salud deberían ser mínimos si se mantienen las exposiciones a las fibrillas a niveles iguales o inferiores a $0,5 \mathrm{f} / \mathrm{ml}$, como es el caso en la actualidad en sus aplicaciones comerciales.

\section{Fibras y pelos de carburo de silicio}

El carburo de silicio (carborundo) es un material abrasivo y refractario ampliamente utilizado que se fabrica combinando sílice y carbono a $2.400{ }^{\circ} \mathrm{C}$. Las fibras y los pelos de carburo de silicio - Figura 10.34 (H arper y cols. 1995) - pueden generarse como subproductos en la fabricación de cristales de carburo de silicio o producirse de forma intencionada como fibras policristalinas o como pelos monocristalinos. Las fibras suelen tener un diámetro inferior a 1 ó $2 \mu \mathrm{m}$ y su longitud oscila entre 3 y $30 \mu \mathrm{m}$. Los pelos tienen un diámetro medio de $0,5 \mu \mathrm{m}$ y una longitud media de $10 \mu \mathrm{m}$. La incorporación de fibras y pelos de carburo de silicio aumenta la resistencia de productos como los compuestos de matriz de metal, cerámicas y componentes cerámicos. Puede producirse exposición a las fibras y los pelos durante los procesos de producción y fabricación, y potencialmente también durante los procesos de mecanización y acabado. Por ejemplo, se ha demostrado que la exposición a corto plazo durante la manipulación de materiales reciclados alcanza niveles de hasta $5 \mathrm{f} / \mathrm{ml}$. La mecanización de compuestos de matriz de metal y cerámica ha dado lugar a concentraciones de exposición de TWA de ocho horas de $0,03 \mathrm{f} / \mathrm{ml}$ y de hasta $0,76 \mathrm{f} / \mathrm{ml}$, respectivamente (Scansetti, Piolatto y Botta 1992; Bye 1985).

Datos procedentes de estudios en animales y seres humanos indican un claro potencial fibrogénico y posiblemente cancerígeno. Los estudios de cultivos de células de ratón in vitro con pelos de carburo de silicio revelaron la existencia de una citotoxicidad igual o superior a la resultante con amianto crocidolita (Johnson y cols. 1992; Vaughan y cols. 1991). En un estudio de inhalación subaguda (Lapin y cols. 1991) se demostró la existencia de hiperplasia adenomatosa persistente en los pulmones de las ratas. Estudios de inhalación de polvo de carburo de silicio en ovejas pusieron de manifiesto que las partículas eran inertes. Sin embargo la exposición a fibras de carburo de silicio condujo a alveolitis fibrosante y a un incremento de la actividad de crecimiento fibroblástico (Bégin y cols. 1989). Los estudios de muestras de tejido tisular procedente de trabajadores empleados en la fabricación de carburo de silicio revelaron la presencia de nódulos silicóticos y cuerpos ferruginosos e indicaron que las fibras de carburo de silicio son duraderas y que pueden existir en concentraciones elevadas en el parénquima pulmonar. Las radiografías de tórax también han sido compatibles con la existencia de cambios intersticiales irregulares y placas pleurales.

Las fibras y los pelos de carburo de silicio son de tamaño respirable, duraderas y poseen un potencial fibrogénico claro en el tejido pulmonar. U n fabricante de pelos de carburo de silicio ha establecido un estándar internacional de 0,2 f/ ml como TWA de ocho horas (Beaumont 1991). Esta es una recomendación prudente en funcion de la información sobre la salud existente en la actualidad

\section{Fibras vítreas artificiales}

La fibras vítreas artificiales (FVA) se suelen clasificar de la siguiente forma:

1. Fibra de vidrio (lana de vidrio, filamento de vidrio continuo y fibra de vidrio especializada).

2. Lana mineral (lana de roca y lana de escoria).

3. Fibra de cerámica (fibra textil de cerámica y fibra de cerámica refractaria).

El proceso de fabricación comienza con la fundición de los materiales en bruto y el subsiguiente enfriamiento rápido, que da como resultado la producción de fibras no cristalinas (o vítreas). Ciertos procesos de fabricación permiten amplias variaciones del tamaño de las fibras, siendo el límite inferior igual o inferior a $1 \mu \mathrm{m}$ de diámetro (Figura 10.35). Se pueden añadir estabilizantes (como $\mathrm{Al}_{2} \mathrm{O}_{3}, \mathrm{~T} \mathrm{iO}_{2}$ y $\mathrm{ZnO}$ ) y modificadores (como $\mathrm{MgO}, \mathrm{Li}_{2} \mathrm{O}, \mathrm{BaO}, \mathrm{CaO}, \mathrm{Na}_{2} \mathrm{O}$ y $\mathrm{K}_{2} \mathrm{O}$ ) para modificar propiedades físicas y químicas como resistencia a la tensión, elasticidad, durabilidad y ausencia de transferencia térmica.

La fibra de vidrio se fabrica a partir de dióxido de silicio y de diversas concentraciones de estabilizantes y modificadores. $L a$ mayoría de la lana de vidrio se produce utilizando un sistema de rotación que genera fibras discontinuas de un diámetro medio de 3 a $15 \mu \mathrm{m}$ con variaciones iguales o inferiores a $1 \mu \mathrm{m}$ en el diámetro. Las fibras de lana de vidrio se unen, habitualmente con resinas de formaldehído fenólico, y a continuación se someten a un proceso de polimerización por calor. También pueden añadirse otros agentes, entre ellos lubricantes y agentes humectantes, dependiendo del proceso de producción. EI proceso de producción de filamentos de vidrio continuo da lugar a menores variaciones en el diámetro medio de las fibras que la lana de vidrio y la fibra de vidrio especializada. El diámetro de las fibras de filamento de vidrio continuo oscila entre 3 y $25 \mu \mathrm{m}$. La producción de la fibra de vidrio especializada conlleva un 
Figura 10.35 - MEB de lana de escoria.

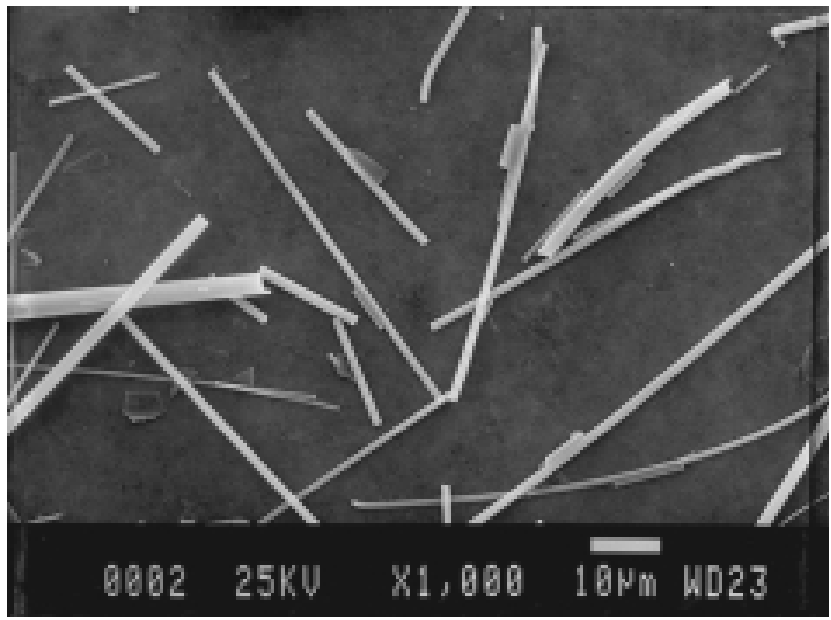

La lana de roca, las fibras de vidrio y las fibras de cerámica refractarias tienen el mismo aspecto.

proceso de fibrización con atenuación de llama que produce fibras cuyo diámetro medio es inferior a $3 \mu \mathrm{m}$.

La producción de lana de escoria y de lana de roca conlleva la fundición y fibrización de escoria procedente de minerales de metal y de roca ígnea, respectivamente. La producción consta de un proceso de centrifugado de muelas y de muelas con forma de disco. Genera fibras discontinuas cuyo diámetro medio oscila entre 3,5 y $7 \mu \mathrm{m}$ y cuyo tamaño puede oscilar dentro del rango respirable. La lana mineral puede manufacturarse con 0 sin aglomerante, dependiendo de sus aplicaciones finales.

La fibra de cerámica refractaria se fabrica mediante un proceso de fibrización con centrifugado de muela o de vapor a chorro utilizando arcilla de caolín fundida, alúmina/ ślice o alúmina/ ślice/ circonio. Los diámetros medios de la fibra oscilan entre 1 y $5 \mu \mathrm{m}$. Cuando se calientan a temperaturas superiores a los $1.000^{\circ} \mathrm{C}$, las fibras de cerámica refractaria pueden transformarse en cristobalita (un ślice cristalino)

Las FVA, con diferentes diámetros y composiciones químicas, se utilizan en más de 35.000 aplicaciones. La lana de vidrio se usa en aplicaciones de aislamiento acústico y térmico, tanto residencial como comercial, así como en los sistemas de manipulación del aire. Los filamentos de vidrio continuo se utilizan en telas y como agentes de refuerzo en plásticos como los utilizados en piezas de automóviles. La fibra de vidrio especializada se utiliza en aplicaciones especiales, como por ejemplo en aviación, que requieren propiedades de aislamiento térmico y acústico elevadas. Las lanas de roca y de escoria se utilizan como aislamiento contra explosiones y en las tejas. Las lanas de roca y de escoria con un aglomerante de resina fenólica se utilizan en materiales de aislamiento, como mantas aislantes y baterías. La fibra de cerámica refractaria constituye del 1 al $2 \%$ de la producción mundial de FVA. Este tipo de fibra se utiliza en aplicaciones industriales especializadas de alta temperatura, como los hornos. La lana de vidrio, el filamento de vidrio continuo y la lana mineral son los que más se fabrican.

Se cree que las FVA tienen menor potencial de producir efectos adversos para la salud que los silicatos fibrosos naturales (como el amianto) debido a su estado no cristalino y a su tendencia a fracturarse en fibras de menor longitud. $\mathrm{H}$ ay datos que sugieren que la FVA más utilizada, la lana de vidrio, es la que conlleva el menor riesgo de producir efectos adversos para la salud, seguida de las lanas de roca y de escoria y a continuación por la fibra de vidrio especializada de durabilidad aumentada, junto con la fibra de cerámica refractaria. La fibra de vidrio especializada y la fibra de cerámica refractaria tienen el mayor potencial de existir como fibras de tamaño respirable, ya que su diámetro es generalmente inferior a $3 \mu \mathrm{m}$. La fibra de vidrio especializada (con concentraciones aumentadas de estabilizantes tales como el $\mathrm{Al}_{2} \mathrm{O}_{3}$ ) y la fibra de cerámica refractaria también son duraderas en los líquidos fisiológicos. Los filamentos de vidrio continuo son de tamaño no respirable $y$, por tanto, no representan un riesgo potencial para la salud pulmonar.

Los datos sanitarios disponibles se han reunido a partir de estudios de inhalación realizados en animales y de estudios de morbilidad y mortalidad realizados en trabajadores relacionados con la fabricación de FVA. Los estudios de inhalación consistieron en la exposición de ratas a dos materiales de aislamiento de lana de vidrio comercial con un diámetro promedio de $1 \mu \mathrm{m}$ y una longitud promedio de $20 \mu \mathrm{m}$. Estos estudios revelaron una leve respuesta celular pulmonar que se invirtió parcialmente al interrumpir la exposición. U n estudio de inhalación realizado en animales con un tipo de lana de escoria proporcionó hallazgos similares. Se ha demostrado la existencia de una fibrosis mínima en animales con la exposición por inhalación a la lana de roca. L os estudios de inhalación de fibra de cerámica refractaria pusieron de manifiesto la existencia de cáncer de pulmón, mesotelioma y fibrosis pulmonar y pleural en ratas, y de mesotelioma y fibrosis pulmonar y pleural en hámsters a una dosis máxima tolerada de $250 \mathrm{f} / \mathrm{ml}$. A dosis de $75 \mathrm{f} / \mathrm{ml} \mathrm{y}$ $120 \mathrm{f} / \mathrm{ml}$ se demostró la existencia de un mesotelioma y fibrosis mínima en las ratas, y a dosis de $25 \mathrm{f} / \mathrm{ml}$ hubo una respuesta pulmonar celular (Bunn y cols. 1993).

Se puede producir irritación cutánea, ocular y de las vías respiratorias superiores e inferiores, que depende de los niveles de exposición y de las tareas de cada trabajo. La irritación cutánea ha sido el efecto para la salud observado con mayor frecuencia y puede hacer que hasta el $5 \%$ de los nuevos trabajadores de la planta de fabricación de FVA abandone su trabajo a las pocas semanas. Está causado por el traumatismo mecánico de la piel provocado por fibras de diámetro superior a 4 a $5 \mu \mathrm{m}$. Se puede prevenir con medidas de control ambiental adecuadas, como evitar el contacto directo de la piel con las fibras, utilizar prendas de manga larga poco ajustadas y lavar por separado la ropa de trabajo. Los síntomas de las vías respiratorias superiores e inferiores pueden ocurrir en situaciones en la que hay cantidades inusualmente elevadas de polvo, en particular durante la fabricación de productos de FVA y en las aplicaciones finales, así como en entornos residenciales en los que las FVA no se manipulan, instalan o reparan correctamente

Los estudios de morbilidad respiratoria, determinada por los síntomas, las radiografías de tórax y las pruebas de función pulmonar, realizados entre los trabajadores de la planta de fabricación no han observado en general efecto adverso alguno. Si embargo, un estudio actualmente en curso, realizado en trabajadores de una planta de fabricación de fibra de cerámica refractaria, ha demostrado un aumento de la prevalencia de placas pleurales (Lemasters y cols. 1994). L os estudios en trabajadores de producción secundaria y usuarios finales de FVA son limitados y se ven dificultados por la probabilidad de que exista un factor de confusión por exposiciones previas al amianto.

En Europa y Estados U nidos se están llevando a cabo estudios de mortalidad en trabajadores de plantas de fabricación de fibra de vidrio y lana mineral. Los datos del estudio de Europa revelaron un aumento global de la mortalidad por cáncer de pulmón basado en tasas de mortalidad nacionales, pero no locales. Se observó una tendencia creciente del cáncer de pulmón en las cohortes de lana de vidrio y lana mineral, relacionada con el 
tiempo transcurrido desde el primer empleo, pero no con la duración del empleo. Utilizando tasas de mortalidad local, se observó un aumento de la mortalidad por cáncer de pulmón en la primera fase de la producción de lana mineral (Simonato, Fletcher y Cherrie 1987; Boffetta y cols. 1992). L os datos procedentes del estudio de Estado U nidos demostraron un aumento del riesgo de cáncer respiratorio estadísticamente significativo, pero no encontraron una asociación entre el desarrollo de cáncer y los índices de exposición a diversas fibras. ( $M$ arsh y cols. 1990). Estos datos concuerdan con los de otros estudios de casos y controles de trabajadores de plantas de fabricación de lana de escoria y fibra de vidrio que han revelado un aumento del riesgo de cáncer de pulmón asociado al consumo de tabaco, pero no al grado de exposición a FVA (Wong, Foliart y Trent 1991; C hiazze, Watkins y Fryar 1992). U n estudio de mortalidad en trabajadores de la fabricación de filamento de vidrio continuo no reveló un aumento del riesgo de mortalidad (Shannon y cols. 1990). En estos momentos está en marcha en Estados U nidos un estudio de mortalidad en trabajadores con fibra de cerámica refractaria. Los estudios de mortalidad en trabajadores relacionados con la fabricación del producto y en usuarios finales de las FVA son muy limitados.

En 1987, la Agencia Internacional para la Investigación del Cáncer (International Agency for Research on Cancer, IARC) clasificó la lana de vidrio, las lanas de roca y de escoria y las fibras de cerámica como posibles cancerígenos humanos (grupo 2B). Estudios en animales y estudios de morbilidad y mortalidad actualmente en curso, realizados en trabajadores relacionados con las FVA, ayudarán a definir con mayor exactitud cualquier riesgo potencial para la salud. En función de los datos disponibles, el riesgo para la salud derivado de la exposición a las FVA es sustancialmente inferior al que conlleva la exposición al amianto, tanto desde el punto de vista de la morbilidad como de la mortalidad. Sin embargo, la inmensa mayoría de los estudios realizados en seres humanos procede de instalaciones de fabricación de FVA en las que los niveles de exposición se han mantenido generalmente por debajo de un valor de 0,5 a $1 \mathrm{f} / \mathrm{ml}$ durante un día de trabajo de 8 horas. La ausencia de datos de morbilidad y mortalidad en usuarios secundarios y finales de FVA hace que sea prudente controlar la exposición a fibras respirables en niveles iguales o inferiores a éstos mediante medidas de control medioambiental, prácticas laborales, formación de los trabajadores y programas de protección respiratoria. Esto es especialmente aplicable en los casos de exposición a cerámica refractaria duradera y a FVA de vidrio especializada, así como a cualquier otro tipo de fibra artificial respirable duradera en medios biológicos y que, por consiguiente, pueda depositarse y quedar retenida en el parénquima pulmonar.

\section{- CANCER RESPIRATO RIO}

\section{Paolo B offetta y Elisabete Weiderpass}

\section{Cáncer de pulmón}

El cáncer de pulmón es el más frecuente en todo el mundo. Se calcula que en 1985 se produjeron 676.500 casos en varones y 219.300 casos en mujeres, lo que representa un $11,8 \%$ de todos los nuevos casos de cáncer ocurridos ese año, cifra que está aumentando a un ritmo aproximado de un $0,5 \%$ por año (Parkin, Pisani y Ferlay 1993). Cerca del $60 \%$ de estos casos tienen lugar en países industrializados, en muchos de los cuales el cáncer de pulmón es la principal causa de muerte por cáncer entre los varones. Tanto en los países industrializados como en aquellos en vías de desarrollo, los varones presentan una incidencia mayor que las mujeres, y la relación entre ambos sexos varía entre 2 y 10 veces. Las variaciones internacionales entre sexos en cuanto a la incidencia de cáncer de pulmón se explican en gran medida por la variación en los patrones de consumo de tabaco, tanto actuales como pasados.

Se ha observado de forma constante un riesgo mayor de cáncer de pulmón en las áreas urbanas en comparación con las áreas rurales. En los países industrializados se observa una relación inversa entre la incidencia de cáncer de pulmón y la mortalidad según la clase social en los varones, mientras que lasmujeres muestran patrones menos claros y constantes. Las diferencias entre clases sociales en los varones reflejan principalmente un patrón de consumo de tabaco diferente. Sin embargo, en los países en desarrollo parece existir un mayor riesgo en los varones de la clase social superior que en otros varones: este patrón probablemente refleja la adopción másprecoz dehábitosoccidentalespor parte de los grupos más prósperos de la población.

Los datos de incidencia del SEER Program del U nited States $N$ ational Cancer Institute para el período 1980-86 indican, de forma similar a años anteriores, que los varones de raza negra presentan una incidencia mayor que los varones de raza blanca, mientras que la incidencia en las mujeres no difiere con la raza. Estas diferencias entre grupos étnicos en Estados U nidos pueden atribuirse en realidad a las diferencias socioeconómicas existentes entre ambos grupos (Baquet y cols. 1991).

La incidencia del cáncer de pulmón aumenta de forma casi lineal con la edad, tal como se observa al representarla en una escala logarítmica; sólo en los grupos de mayor edad puede observarse una curva descendente. La incidencia y la mortalidad del cáncer de pulmón han aumentado rápidamente en este siglo, y continúan haciéndolo en la mayoría de los países.

Existen cuatro tipos histológicos principales del cáncer de pulmón: carcinoma escamocelular, adenocarcinoma, carcinoma de células grandes y carcinoma de células pequeñas (CPCP). L oS tres primeros tipos también se conocen como cáncer de pulmón de células no pequeñas (CPCNP). Las proporciones de los diferentes tipos histológicos varían en función del sexo y de la edad.

El carcinoma escamocelular presenta una fuerte asociación con el consumo de tabaco, y representa el tipo de cáncer de pulmón más común en muchas poblaciones. Se origina con mayor frecuencia en los bronquios proximales.

El adenocarcinoma presenta una asociación menos intensa con el consumo de tabaco. Este tumor es de origen periférico y puede presentarse como un nódulo solitario periférico, una enfermedad multifocal o una forma neumónica rápidamente progresiva que se disemina de lóbulo a lóbulo.

El carcinoma de células grandes representa una proporción más pequeña de todos los cánceres de pulmón y tiene un comportamiento similar al del adenocarcinoma.

EI CPCP representa una proporción pequeña (10 a $15 \%$ ) de todos los cánceres pulmonares. Se origina típicamente en localizaciones endobronquiales centrales y tiende a desarrollar metástasis precoces.

Los signos y síntomas del cáncer de pulmón dependen de la localización del tumor, de su diseminación y de los efectos del crecimiento metastásico. Muchos pacientes se presentan con unas lesión asintomática descubierta casualmente en una radiografía. Entre los pacientes con CPCNP, son frecuentes la fatiga, la disminución de la actividad, la tos persistente, la disnea, la disminución del apetito y la pérdida de peso. También pueden desarrollarse sibilancias o estridor en fases avanzadas de la enfermedad.

El crecimiento continuo puede producir atelectasia, neumonía y formación de absceso. Los signos clínicos son menos pronunciados en los pacientes con CPCP que en los pacientes con 
CPNCP, y generalmente están relacionados con la localización endobronquial.

EI cáncer de pulmón puede metastatizar a prácticamente cualquier órgano. Las localizaciones más frecuentes de las lesiones metastásicas son la pleura, los ganglios linfáticos, el hueso, el cerebro, las glándulas suprarrenales, el pericardio y el hígado. En el momento del diagnóstico, la mayoría de los pacientes con cáncer de pulmón presentan metástasis.

El pronóstico varía según el estadio de la enfermedad. La supervivencia global a los cinco años para los pacientes con cáncer de pulmón en Europa (en el período 1983-85) se encontraba entre el 7 y el $9 \%$ (Berrino y cols. 1995).

Actualmente no se dispone de ningún método de detección selectiva en la población para el cáncer de pulmón.

\section{Cáncer nasofaríngeo}

El cáncer nasofaríngeo es raro en la mayoría de las poblaciones, pero frecuente en ambos sexos en áreas como el sudeste asiático, el sur de China y el norte de Africa. Los emigrantes del sur de China conservan en gran medida este riesgo elevado, pero los emigrantes chinos de segunda y tercera generación a Estados U nidos tienen un riesgo inferior a la mitad con respecto a de los de primera generación.

Los cánceres de nasofaringe generalmente se originan en el epitelio escamoso. De acuerdo con la OM S, estos tumores se clasifican como: tipo 1, carcinoma escamocelular queratinizante; tipo 2, carcinoma no queratinizante; y tipo 3, carcinoma indiferenciado, que es el tipo histológico más frecuente. El tipo 1 tiene un crecimiento local incontrolado,, y se observa diseminación metastásica en el $60 \%$ de los pacientes. Los tipos 2 y 3 presentan diseminación metastásica en el 80 al $90 \%$ de los pacientes

Se detecta una masa en el cuello en alrededor del $90 \%$ de los pacientes con carcinoma de nasofaringe. Pueden encontrarse alteraciones de la audición, otitis media serosa, acúfenos, obstrucción nasal, dolor y síntomas relacionados con el crecimiento del tumor hacia estructuras anatómicas adyacentes.

La supervivencia global a los cinco años para los pacientes con cáncer nasofaríngeo en Europa entre 1983 y 1985 fue de alrededor del $35 \%$, variando en función del estadio del tumor y de su localización (Berrino y cols. 1995).

El consumo de pescado salado al estilo chino es un factor de riesgo de cáncer nasofaríngeo; el papel de otros factores nutricionales y de virus, en particular del virus de Epstein-Barr, aunque sospechado, no se ha confirmado. No se conoce ningún factor profesional que cause cáncer nasofaríngeo, y en la actualidad no se dispone de medidas preventivas. (H igginson, $M$ uir y M uñoz 1992).

\section{Cáncer nasosinusal}

L as neoplasias de la nariz y de las cavidades nasales son relativamente raras. En conjunto, el cáncer de nariz y de senos paranasales - incluidos los senos maxilares, etmoidales, esfenoidales y frontales- representan menos del $1 \%$ de todos los cánceres. En la mayoría de los casos, estos tumores se clasifican como carcinomas escamosos. En los países occidentales, los cánceres de nariz son más frecuentes que los de senos paranasales (H igginson, M uir y M uñoz 1992).

Se producen con mayor frecuencia en varones y entre las poblaciones de raza negra. La incidencia más alta se observa en Kuwait, Martinica e India. El pico de desarrollo de la enfermedad se produce durante la sexta década de la vida. La principal causa conocida del cáncer nasosinusal es la exposición al polvo de madera, en particular de las maderas duras. EI consumo de tabaco no parece asociarse a este tipo de cáncer.
La mayoría de los tumores de la cavidad nasal y de los senos paranasales son bien diferenciados y de crecimiento lento. LoS síntomas pueden incluir úlcera no cicatrizante, hemorragia, obstrucción nasal y síntomas relacionados con el crecimiento en la cavidad oral, la órbita y la fosa pterigoidea. La enfermedad suele estar avanzada en el momento del diagnóstico.

La supervivencia global a los cinco años para los pacientes con cáncer de nariz y de senos paranasales en Europa entre 1983 y 1985 era de alrededor del $35 \%$, variando en función del tamaño dela lesión en el momento del diagnóstico (Berrino y cols. 1995).

\section{Cáncer de laringe}

La incidencia más alta de cáncer de laringe se comunica en Sao Paolo (Brasil), N avarra (E spaña) y Varese (I talia). También se ha comunicado una mortalidad elevada en Francia, U ruguay, H ungría, Yugoslavia, Cuba, O riente Próximo y norte de Africa. EI cáncer de laringe afecta predominantemente a los varones: en 1985 se produjeron aproximadamente 120.500 casos en varones y 20.700 en mujeres (Parkin, Pisani y Ferlay 1993). En general, la incidencia es mayor en las poblaciones de raza negra que en las de raza blanca, y en las áreas urbanas en comparación con las rurales.

Prácticamente todos los cánceres de laringe son carcinomas escamosos. La mayor parte se localizan en la glotis, pero también pueden desarrollarse en la supraglotis 0, raramente, en la subglotis.

Los síntomas pueden estar ausentes o ser muy leves. Puede aparecer dolor, sensación de aspereza, alteración de la tolerancia a alimentos calientes o fríos, tendencia a la broncoaspiración de líquidos, alteración de las vías aéreas, un cambio leve en la voz durante varias semanas y adenopatía cervical, dependiendo de la localización y el estadio de la lesión.

L a mayoría de los cánceres de laringe son visibles a la inspección o la endoscopia laríngea. En la laringe de los fumadores pueden identificarse lesiones preneoplásicas (Higginson, M uir y M uñoz 1992).

La supervivencia global a los cinco años para los pacientes con cáncer de laringe en Europa entre 1983 y 1985 era de alrededor del 55 \% (Berrino y cols. 1995).

\section{Mesotelioma pleural}

Los mesoteliomas pueden originarse en la pleura, el peritoneo y el pericardio. EI mesotelioma maligno representa el tumor pleural más importante; se produce principalmente entre la quinta y la séptima décadas de la vida.

El mesotelioma pleural fue en el pasado un tumor raro, y continúa siéndolo en la mayoría de las poblaciones femeninas, pero en los varones de los países industrializados su incidencia ha aumentado en un 5 a un $10 \%$ por año durantelasúltimas décadas. En general, los varones resultan afectados .0 veces más que las mujeres. La obtención de cálculos precisos sobre su incidencia y mortalidad resulta problemática debido a las dificultades en el diagnóstico histológico y a los cambios en la Clasificación Internacional de Enfermedades (International C lassification of Diseases, ICD) (H igginson, M uir y M uñoz 1992). Sin embargo, las tasas de incidencia parecen presentar variaciones localesmuy importantes: son muy elevadas en áreas en las que existe minería del amianto (p.ej., provincia del NO de EI Cabo en Sudáfrica), en las principales ciudades con astilleros y en regiones con contaminación medioambiental por fibras, como ocurre en ciertas áreas de la parte central de Turquía.

L os pacientes pueden estar asintomáticos y ser diagnosticados casualmente por una radiografía de tórax, o bien presentar disnea y dolor torácico.

Los mesoteliomas tienden a ser invasivos. La supervivencia media es de 4 a 18 meses en varias series. 

Tabla 10.24 - Cancerígenos respiratorios humanos
demostrados según el IARC.

\begin{tabular}{ll} 
Agentes & Organos diana \\
Agentes individuales & \\
Amianto & Pulmón, laringe, pleura \\
Arsénico y compuestos de arsénico & Pulmón \\
Berilio y compuestos de berilio & Pulmón \\
Eter de bis (clorometilo) & Pulmón \\
Cadmio y compuestos de cadmio & Pulmón \\
Eter metilico de clorometilo (grado técnico) & Pulmón \\
Compuestos de cromo [VI] & Nariz, pulmón \\
Gas mostaza & Pulmón, laringe \\
Compuestos de níquel & Nariz, pulmón \\
Talco que contiene fibras asbestiformes & Pulmón, pleura \\
Mezclas complejas & \\
Breas de hulla & Pulmón \\
Alquitranes de brea de hulla & Pulmón \\
Hollines & Pulmón \\
Humo de tabaco & Nariz, pulmón, laringe \\
Circunstancias de exposición & \\
Producción de aluminio & Pulmón \\
Fabricación y reparación de calzado & Nariz \\
Gasificación de carbón & Pulmón \\
Producción de coque & Pulmón \\
Fundición de hierro y acero & Pulmón \\
Fabricación de muebles y cabinas & Nariz \\
Nieblas de ácidos inorgánicos fuertes que & Laringe \\
contienen ácido sulfúrico & \\
(exposiciones profesionales a) & \\
Pintores (exposición profesional como) & \\
Radón y sus productos de degradación & \\
Minas subterráneas de hematita & (con exposición a radón) \\
\hline
\end{tabular}

Fuente: IARC, 1971-1994

\section{Factores de riesgo ocupacionales de cáncer respiratorio}

Aparte del humo del tabaco, se ha demostrado una asociación causal con el cáncer respiratorio, según la Agencia Internacional para la Investigación del Cáncer (International Agency for Research on ( ancer, IARC), para 13 agentes o mezclas y nueve circunstancias de exposición (véase la Tabla 10.24). Además, existen ocho agentes, mezclas o circunstancias de exposición que, de acuerdo con la IARC, son probables cancerígenos para uno 0 más órganos del tracto respiratorio (Tabla 10.25). Todos ellos, excepto la azatioprina, un fármaco inmunosupresor, son exposiciones principalmente profesionales (IARC 1971-94).

Los grupos profesionales que demuestran un aumento del riesgo de cáncer de pulmón tras la exposición a compuestos de arsénico son los trabajadores de fundiciones no ferrosas, manipuladores de pieles, fabricantes de desinfectantes para ovejas y trabajadores de viñedos (IARC 1987).

Se ha realizado un gran número de estudios epidemiológicos sobre la asociación entre los compuestos de cromo (VI) y la aparición de cáncer de pulmón y nasal en las industrias de chapado con cromatos, pigmentos de cromatos y cromo (IARC 1990a). La constancia de los hallazgos y la magnitud de los aumentos han demostrado el potencial cancerígeno de los compuestos de cromo (VI).

Los trabajadores de las refinerías de níquel de muchos países han mostrado un aumento sustancial del riesgo de cáncer de pulmón y nasal; otros grupos profesionales expuestos al níquel entre los que se ha detectado un aumento del riesgo de cáncer de pulmón son los mineros del sulfuro de níquel y los trabajadores en la fabricación de aleaciones con una alta proporción de níquel (IARC 1990b).

Los trabajadores expuestos al berilio presentan un riesgo elevado de cáncer de pulmón (IARC 1994a). Los datos más informativos derivan del US Beryllium Case Registry, en el que se recogieron casos de enfermedades pulmonares relacionadas con el berilio en diferentes industrias.

Se ha observado un aumento de la incidencia de cáncer de pulmón en cohortes de fundidores de cadmio y en fabricantes de pilas de níquel-cadmio (IARC 1994b). La exposición concurrente al arsénico entre los fundidores y al níquel entre los fabricantes de pilas no puede explicar este aumento de la incidencia.

El amianto es un importante cancerígeno industrial. El cáncer de pulmón y el mesotelioma son las principales neoplasias relacionadas con el amianto, pero también se han comunicado cánceres en otras localizaciones como el tracto gastrointestinal, la laringe y el riñón, en trabajadores del amianto. Todas las formas de amianto han sido relacionadas causalmente con el cáncer de pulmón y el mesotelioma. Además, se ha demostrado que las fibras de amianto que contienen talco son cancerígenas para el pulmón humano (IARC 1987). U na característica distintiva del cáncer de pulmón inducido por el amianto es su relación sinérgica con el consumo de cigarrillos.

Diversos estudios en trabajadores de minas, canteras, fundiciones, cerámica, granito y cortadores de piedras han mostrado que los sujetos diagnosticados de silicosis tras la exposición a

Tabla 10.25 - Carcinógenos respiratorios humanos probables de acuerdo con el IARC.

$\begin{array}{ll}\text { Agentes } & \text { Organos diana sospechados } \\ \text { Agentes individuales } & \\ \text { Acrilonitrilo } & \text { Pulmón } \\ \text { Azatioprina } & \text { Pulmón } \\ \text { Formaldehído } & \text { Nariz, laringe } \\ \text { Sílice (cristalino) } & \text { Pulmón } \\ \text { Mezclas complejas } & \\ \text { Gases de escape de motores diesel } & \text { Pulmón } \\ \text { Vapores de soldadura } & \text { Pulmón } \\ \text { Circunstancias de exposición } & \\ \text { Industria del caucho } & \\ \text { Pulverización y aplicación de insecticidas } & \text { Pulmón }\end{array}$

(exposiciones profesionales en)

Fuente: IARC, 1971-1994. 
polvo que contiene sílice cristalino presentan un aumento del riesgo de cáncer de pulmón (IARC 1987).

Los hidrocarburos aromáticos polinucleares (HAP) se forman principalmente como resultado de procesos pirolíticos, especialmente por la combustión incompleta de materiales orgánicos. Sin embargo, los seres humanos están expuestos exclusivamente a mezclas de HAP, como hollín, brea de hulla y terrenos de brea de hulla. Los estudios de cohortes de mortalidad entre los deshollinadores han mostrado un aumento del riesgo de cáncer de pulmón, que se ha atribuido a la exposición al hollín. Varios estudios epidemiológicos han mostrado un aumento de la incidencia de cáncer respiratorio en los trabajadores expuestos a vapores de brea en la producción de aluminio, la producción de carburo cálcico y trabajos de techado. En estas industrias, también se produce exposición a alquitrán, y en particular a la brea de hulla. 0 tras industrias en las que existe un aumento de la incidencia de cáncer respiratorio debido a la exposición a vapores de brea de hulla son la gasificación del carbón y la producción de coque (IARC 1987). Se encontró un aumento del riesgo de cáncer respiratorio (principalmente de pulmón) en algunos estudios, pero no en todos, que intentaron analizar la exposición a los gases de escape de motores diesel por separado de otros productos de combustión; los grupos profesionales estudiados fueron trabajadores del ferrocarril, estibadores, trabajadores de garajes de autobuses, empleados de compañías de autobuses y camioneros profesionales (I ARC 1989a). O tras mezclas de H AP estudiadas por su carcinogenicidad en seres humanos son los negros de carbón, los gases de escape de los motores de gasolina, los aceites minerales, el petróleo de esquisto y los betunes. Los petróleos de esquisto y los aceites minerales no tratados y levemente tratados son cancerígenos para el ser humano, mientras que los gases de escape de los motores de gasolina posiblemente lo sean y los aceites minerales muy refinados, los betunes y los negros de carbón no son clasificables con respecto a su carcinogenicidad para el ser humano (IARC 1987, 1989a). Aunque estas mezclas contienen H AP, no se ha demostrado un efecto carcinógeno sobre el pulmón humano para ninguna de ellas, y las pruebas de carcinogenicidad de los aceites minerales no tratados y levemente tratados y del petróleo de esquisto se basan en el aumento del riesgo de cánceres en localizaciones diferentes a los órganos respiratorios (principalmente piel y escroto) entre los trabajadores expuestos.

EI bis(b-cloroetil)sulfuro, conocido como gas mostaza, se utilizó ampliamente durante la I Guerra M undial, y los estudios de soldados expuestos al gas mostaza, así como de trabajadores relacionados con su fabricación, han revelado el desarrollo subsiguiente de cáncer de pulmón y nasal (IARC 1987).

N umerosos estudios epidemiológicos han demostrado que los trabajadores expuestos al éter metílico de clorometilo y/ o éter bis(clorometílico) presentan un mayor riesgo de cáncer de pulmón, principalmente de CPCP (IARC 1987).

Se ha observado que los trabajadores expuestos al acrilonitrilo presentan un mayor riesgo de cáncer de pulmón en algunos estudios, pero no en todos, realizados en trabajadores dedicados a la fabricación de fibras textiles, la polimerización del acrilonitrilo y la industria del caucho (IARC 1987).

Se ha comunicado un aumento de la incidencia en los trabajadores expuestos al formaldehído, como son los trabajadores de la industria química y de la madera y los productores y usuarios de formaldehído (IARC 1987). La evidencia es mayor para el cáncer nasal y nasofaríngeo: la incidencia de estos cánceres mostró un gradiente dosis-respuesta en más de un estudio, aunque el número de casos expuestos a menudo era pequeño. 0 tras neoplasias con un posible aumento del riesgo son los cánceres de pulmón y de cerebro y la leucemia.
Se ha observado un aumento del riesgo de cáncer laríngeo en varios estudios realizados en trabajadores expuestos a nieblas y vapores de ácido sulfúrico y de otros ácidos inorgánicos fuertes, como son los encargados de operaciones de desoxidación química del acero y de la fabricación de jabones y los trabajadores petroquímicos (IARC 1992). El riesgo de cáncer de pulmón también estaba aumentado en algunos de estos estudios, aunque no en todos. A demás, se observó un aumento del cáncer nasosinusal en una cohorte de trabajadores de la fabricación de isopropanol en la que se utiliza un proceso de ácido fuerte.

L os trabajadores de la madera presentan un mayor riesgo de cáncer nasal, en particular de adenocarcinoma (IARC 1987). EI riesgo está confirmado en los trabajadores de la industria del mueble y de cámaras; los estudios en trabajadores de carpintería sugirieron un aumento del riesgo similar, pero algunos estudios produjeron resultados negativos. O tras industrias madereras, como serrerías y fábricas de papel y cartón, no fueron clasificables con respecto a su riesgo cancerígeno. Aunque la carcinogenicidad del polvo de madera no fue evaluada por la IARC, es admisible considerar que es responsable de al menos parte del aumento del riesgo de adenocarcinoma nasal entre los trabajadores de la madera. Estos no parecen presentar un aumento del riesgo de cáncer de otros órganos respiratorios.

El adenocarcinoma nasal también ha sido causado por el trabajo en la fabricación y reparación de calzado (IARC 1987). Por otro lado, no se dispone de pruebas claras de que los trabajadores encargados de la fabricación de productos de piel y del curtido y procesamiento de pieles presenten un mayor riesgo de cáncer respiratorio. No se sabe actualmente si el aumento de la incidencia de adenocarcinoma nasal en la industria del calzado se debe al polvo de las pieles 0 a otras exposiciones. La carcinogenicidad del polvo de las pieles no ha sido evaluada por la IARC.

El cáncer de pulmón ha sido frecuente entre los mineros del uranio, los mineros subterráneos de la hematita y varios otros grupos de mineros del metal (IARC 1988; BEIR IV Committee on the Biological Effects of I onizing Radiation 1988). Un factor común entre estos grupos profesionales es la exposición a la radiación $\alpha$ emitida por partículas de radón inhaladas. La fuente principal de datos sobre el cáncer tras exposición a radiación ionizante deriva del seguimiento de supervivientes de bombas atómicas (Preston y cols. 1986; Shimizu y cols. 1987). El riesgo de cáncer de pulmón es elevado en este grupo, así como en las personas que han recibido radioterapia (Smith y Doll 1982). Sin embargo, en la actualidad no se dispone de pruebas convincentes sobre la existencia de una elevación del riesgo de cáncer de pulmón en los trabajadores expuestos a radiaciones ionizantes de bajo nivel, como las que tienen lugar en la industria nuclear (Beral y cols. 1987; BEIR V, Committee on the Biological Effects of Ionizing Radiation 1990). La carcinogenicidad de la radiación ionizante no ha sido evaluada por la IARC.

Se encontró un aumento del riesgo de cáncer de pulmón en pintores en tres estudios de cohortes a gran escala y en ocho estudios de pequeñas cohortes, así como en once estudios de controles de casos de diferentes países. Por otro lado, se encontraron escasas pruebas de que el riesgo de cáncer de pulmón aumente en los trabajadores relacionados con la fabricación de pinturas (IARC 1989b).

Diversos compuestos químicos, mezclas, profesiones e industrias evaluadas por la IARC como cancerígenas para el ser humano (IARC Grupo 1) no tienen el pulmón como órgano diana principal. No obstante, se ha planteado la posibilidad de un aumento del riesgo de cáncer de pulmón con algunos de estos compuestos químicos, como el cloruro vinílico (IARC 1987), y algunas profesiones, como la pulverización y aplicación de insecticidas (IARC 1991a), aunque las pruebas no son consistentes. 
Además, se ha considerado como posibles cancerígenos humanos a varios agentes que tienen al pulmón como uno de los órganos diana principales (IARC Grupo 2B), basándose en la actividad cancerígena en animales de experimentación y/o en datos epidemiológicos limitados. Entre ellos se encuentran los compuestos inorgánicos de plomo (IARC 1987), cobalto (IARC 1991b), fibras vítreas artificiales (lana de roca, lana de escoria y lana de vidrio) (IARC 1988b) y vapores de soldadura (IARC 1990C).

\section{- INFECCIONES PULMONARES DE ORIGEN OCUPACIONAL}

\author{
Anthony A. Marfin, Ann F. Hubbs, Karl J. \\ M usgrave y John E. Parker
}

Aunque los estudios epidemiológicos sobre la neumonía de origen ocupacional ( $\mathrm{NO} O$ ) son limitados, se cree que la frecuencia de las infecciones pulmonares relacionadas con el trabajo está disminuyendo en todo el mundo. Por contraste, en los países desarrollados es posible que las N 00 estén aumentando en profesiones relacionadas con la investigación médica o la asistencia sanitaria. Entre el personal hospitalario la NOO es en gran parte un reflejo de los patógenos prevalentes adquiridos en la comunidad, pero la reaparición de la tuberculosis, el sarampión y la tos ferina en entornos sanitarios supone riesgos adicionales para las profesiones del sector sanitario. En los países en vías de desarrollo y en profesiones concretas de los países desarrollados, muchas N 00 están causadas por patógenos infecciosos muy específicos que no se encuentran habitualmente en la comunidad.

Atribuir la infección a la exposición ocupacional y no a la comunitaria puede resultar difícil, especialmente para el personal hospitalario. En el pasado, el riesgo ocupacional sólo quedaba documentado con certeza en las situaciones en las que el personal era infectado por agentes presentes en el lugar de trabajo, pero que no se encontraban en la comunidad. En el futuro, el uso de técnicas moleculares para localizar clones microbianos específicos en el lugar de trabajo y las comunidades permitirá identificar los riesgos con más claridad.

Al igual que la neumonía de origen comunitario, la NOO se produce por microaspiración de bacterias que colonizan la orofaringe, inhalación de partículas infecciosas respirables 0 siembra hematógena de los pulmones. La mayoría de las neumonías adquiridas en la comunidad se produce por microaspiración, pero la NOO se debe generalmente a la inhalación de partículas infecciosas de 0,5 a $10 \mu \mathrm{m}$ transmitidas por el aire en el lugar de trabajo. Las partículas de mayor tamaño no consiguen llegar a los alveolos porque impactan o se sedimentan en las paredes de las grandes vías aéreas y más tarde se eliminan. Las partículas de menor tamaño permanecen en suspensión durante el flujo inspiratorio y espiratorio y rara vez se depositan en los alveolos. En el caso de algunas enfermedades, como la fiebre hemorrágica con síndrome renal asociada a la infección por hantavirus, el modo principal de transmisión es la inhalación, aunque es posible que el foco primario de la enfermedad no sean los pulmones. L os patógenos de origen ocupacional que no se transmiten por inhalación pueden afectar secundariamente a los pulmones, pero no se abordarán en estas páginas.

En este artículo se analizan brevemente algunos de los patógenos de origen ocupacional más importantes. En la Tabla 10.26 se ofrece una relación más extensa de trastornos respiratorios de origen ocupacional, clasificados por etiologías concretas.

\section{Infecciones de origen ocupacional en los agricultores}

Además de los gases y polvos orgánicos que afectan al tracto respiratorio e imitan enfermedades infecciosas, varias enfermedades zoonóticas (patógenos comunes a animales y seres humanos) y otras enfermedades infecciosas asociadas a la vida rural afectan de forma específica a los agricultores. Estas enfermedades se adquieren por inhalación de aerosoles infecciosos y rara vez se transmiten de persona a persona. Entre las enfermedades que afectan a los agricultores se incluyen el carbunco, la brucelosis, la fiebre $Q$, la ornitosis, la tuberculosis y la peste (Tabla 10.26). Entre los patógenos micóticos se incluyen los agentes causaes de histoplasmosis, blastomicosis, coccidioidomicosis, paracoccidioidomicosis y criptococosis (Tabla 10.26). Salvo en el caso de las enfermedades por hantavirus, los procesos víricos no son una causa importante de enfermedad pulmonar de origen ocupacional en los agricultores.

Se cree que algunas de estas enfermedades son más comunes, pero su incidencia es difícil de determinar porque: 1) la mayoría de las infecciones son subclínicas, 2) la enfermedad clínica es leve o de difícil diagnóstico por la inespecificidad de sus síntomas, 3) los servicios médicos y diagnósticos rara vez están al alcance de la mayoría de los agricultores, 4) no hay un sistema organizado para informar sobre muchas de estas enfermedades y 5) muchas de éstas son enfermedades raras en la comunidad general y el personal médico no las diagnostica. Por ejemplo, aunque la nefritis epidémica debida al virus de Puumala, un hantavirus, rara vez se comunica en Europa occidental, las vigilancias serológicas realizadas en agricultores han demostrado una prevalencia de anticuerpos frente a hantavirus situada entre el 2 y el $7 \%$.

Las infecciones zoonóticas en los países desarrollados están disminuyendo debido a los enérgicos programas de control de enfermedades dirigidos a las poblaciones de animales. A pesar de estos controles, los agricultores y las personas que trabajan en campos relacionados con la agricultura (como veterinarios, envasadores de carne, trabajadores de las industrias avícolas y trabajadores de la lana o el cuero) permanecen en situación de riesgo de contraer muchas enfermedades.

\section{Infección por Hantavirus}

La infección por hantavirus, que causa fiebre hemorrágica con síndrome renal (FHSR) o nefritis epidémica (NE), se ha descrito clínicamente en agricultores, personal militar y personal de laboratorio en zonas endémicas de A sia y Europa desde hace más de 50 años. La infección se produce por inhalación de aerosoles de orina, saliva y heces de roedores infectados. La enfermedad hemorrágica y la disminución de la función renal se desarrollan durante la mayoría de las enfermedades por hantavirus antes que la neumonía, aunque se han descrito casos de edema pulmonar por aumento de la permeabilidad vascular en la FHSR y la NE. $L$ as profundas consecuencias pulmonares de las infecciones por hantavirus no se apreciaron plenamente hasta un reciente brote del síndrome pulmonar por Hantavirus (SPH) asociado a infección por un hantavirus recientemente aislado en el oeste de Estados U nidos (virus de M uerto $\mathrm{C}$ anyon, virus de Four C orners 0 virus Sin Nombre).

Los hantavirus son miembros de la familia Bunyaviridae, una familia de virus R NA. Cinco de ellos se han asociado a enfermedades humanas. La FH SR se ha asociado al virus de $\mathrm{H}$ antaan en Asia oriental, al virus de Dobrava en los Balcanes y al virus de Seúl, que está extendido por todo el mundo. La NE se ha asociado al virus de Puumala en Europa occidental. EI SPH se ha asociado a un hantavirus recientemente aislado en el oeste de Estados U nidos. De 1951 a 1983, se comunicaron 12.000 casos de FHSR en la República de Corea. Se informa de que la 
Tabla 10.26 - Enfermedades infecciosas de origen ocupacional contraídas por microaspiración 0 inhalación de partículas infecciosas.

Enfermedad (patógeno)

Bacterias, chlamydia, mycoplasma y rickettsia

Brucelosis (Brucella spp.)

Carbunco por inhalación (Bacillus anthracis)

Peste neumónica ( Yersinia pestis)

Tosferina (Bordatella pertussis)

Enfermedad del legionario ( Legionella spp.)

Melioidosis (Pseudomonas pseudomallei)

Streptococcus pneumoniae

Neisseria meningitidis

Pasteurelosis (Pasteurella multocida)

Tularemia respiratoria (Francisella tularensis)

Ornitosis (Chlamydia psittaci)

Neumonía TWAR (Chlamydia pneumoniae)

Fiebre Q (Coxiella burnetii)

Neumonía atípica (Mycoplasma pneumoniae)

Hongos/ Micobacterias

Histoplasmosis ( Histoplasma capsulatum)

Coccidioidomicosis (Coccidioides immitis)

Blastomicosis (Blastomyces dermatitidis)

Paracoccidioidomicosis (Paracoccidioides brasiliensis)

Esporotricosis (Sporothrix schenkii)

Tuberculosis (Mycobacterium tuberculosis, M. Bovis, M. africanum)

Micobacteriosis diferentes a la tuberculosis

(Mycobacterium spp.)

Virus

Hantavirus

Sarampión

Rubéola

Gripe

Varicela zóster

Virus respiratorio sincitial

Adenovirus

Virus parainfluenza

Virus de la coriomeningitis linfocítica (arenavirus)

Fiebre de Lassa (arenavirus)

Virus Marburgo y Ebola (filovirus)
Reservorio

Poblaciones en riesgo

Ganado (vacas, cabras, cerdos)

Productos animales (lanas, pieles)

Roedores salvajes

Ser humano

Fuentes de agua contaminada ( $p . e j$., torres de refrigeración, condensadores evaporadores)

Suelo, agua estancada, campos de arroz

Ser humano

Ser humano

Diversos animales domésticos (gatos, perros) y salvajes

Roedores salvajes y conejos

Pájaros

Ser humano

Animales domesticados (vacas, ovejas, cabras)

Ser humano

Suelo; excremento de pájaros o murciélagos (endémica en el este de Norteamérica)

Suelo (endémica en el oeste de Norteamérica)

Suelo (endémica en el este de Norteamérica)

Suelo (endémica en Venezuela, Colombia, Brasil)

Desechos de plantas, corteza de árboles y plantas de jardín

Ser humano y primates, ganado vacuno

Suelo

Roedores

Ser humano

Ser humano

Ser humano

Ser humano

Ser humano

Ser humano

Ser humano

Roedores

Roedores

Ser humano y primates no humanos, posiblemente murciélagos
Veterinarios, agricultores, personal de laboratorio, trabajadores de mataderos

Agricultores, curtidores, trabajadores de mataderos, trabajadores de la industria textil, personal de laboratorio

Veterinarios, cazadores/ tramperos, personal de laboratorio

Trabajadores de residencias, personal sanitario

Personal sanitario, personal de laboratorio, personal de laboratorio industrial, excavadores de pozos de agua

Personal militar, agricultores

Personal sanitario, agricultores, mineros subterráneos Personal sanitario, personal de laboratorio, personal militar Agricultores, veterinarios

Trabajadores manuales, personal militar, personal de laboratorio, cazadores/ tramperos, agricultores

Trabajadores de tiendas de animales, avicultores, veterinarios, personal de laboratorio

Personal sanitario, personal militar

Personal de laboratorio, trabajadores de la industria textil, trabajadores de mataderos, trabajadores con vacas lecheras, veterinarios

Personal militar, personal sanitario, trabajadores de instituciones

Agricultores, personal de laboratorio, trabajadores manuales

Personal militar, agricultores, trabajadores manuales, trabajadores de la industria textil, personal de laboratorio

Personal de laboratorio, agricultores, trabajadores manuales, trabajadores forestales

Agricultores

Jardineros, floristas, mineros

Mineros de rocas duras, trabajadores de la fundición, personal sanitario y de laboratorio, trabajadores de mataderos, veterinarios, personal militar, taberneros

Trabajadores expuestos al sílice, incluidos los trabajadores en la limpieza con chorro de arena

Agricultores, pastores, desratizadores

Personal sanitario y de laboratorio

Personal sanitario y de laboratorio

Personal sanitario y de laboratorio

Personal sanitario y de laboratorio, personal militar

Personal sanitario y de laboratorio

Personal sanitario y de laboratorio, personal militar

Personal sanitario y de laboratorio

Personal de laboratorio, veterinarios

Personal sanitario

Personal de laboratorio, veterinarios, personal sanitario, trabajadores en fábricas de algodón 
incidencia de esta enfermedad en China está aumentando, con epidemias en centros rurales y urbanos, y en 1980 se atribuyeron a la FH RS 30.500 casos con 2.000 muertes.

\section{Presentación clínica}

En el caso de los virus que causan la FH SR o la NE, la infección generalmente provoca un desarrollo asintomático de anticuerpos frente a hantavirus. Las personas que enferman no presentan en la primera fase signos ni síntomas específicos y la infección por hantavirus sólo se puede diagnosticar mediante pruebas serológicas. L o normal es que se produzca una lenta recuperación, pero algunas personas desarrollan FH SR o NE con proteinuria, hematuria microscópica, hiperazoemia y oliguria. Las personas que padecen FHSR también desarrollan hemorragias profundas debidas a coagulación intravascular diseminada, aumento de la permeabilidad vascular y shock. La mortalidad en los casos de síndrome de FH SR completo oscila entre el 5 y el $20 \%$.

EI SPH se caracteriza por infiltrados pulmonares intersticiales difusos y por la brusca aparición de dificultad respiratoria aguda y shock. Se puede producir una leucocitosis marcada como consecuencia del aumento de citocinas que caracteriza a las enfermedades por hantavirus. En el SPH, la mortalidad puede ser superior al $50 \%$. La incidencia de la infección asintomática o del SPH no reconocido no se ha investigado en profundidad.

\section{Pruebas diagnósticas}

El diagnóstico se realiza demostrando la presencia de inmunoglobulina $M \quad 0$ de un título creciente de inmunoglobulina $G$ mediante inmunofluorescencia indirecta de alta especificidad y sensibilidad y análisis de neutralización de anticuerpos. 0 tros métodos diagnósticos son la reacción en cadena de la polimerasa para ácido ribonucleico vírico y técnicas inmunohistoquímicas para antígenos víricos.

\section{Epidemiología}

La infección se produce por inhalación de aerosoles de orina, saliva y heces de roedores infectados. Los roedores infectados no tienen ninguna enfermedad aparente. La transmisión se puede producir por inoculación percutánea de orina, saliva o heces de roedores infectados, pero no hay pruebas de que se transmita de persona a persona.

L os estudios seroepidemiológicos en seres humanos y roedores han demostrado que los hantavirus son endémicos y están distribuidos en todo el mundo en entornos rurales y urbanos. En entornos rurales endémicos, la interacción entre seres humanos y roedores aumenta cuando estos últimos invaden cíclicamente los hogares 0 aumenta la actividad humana en áreas con elevada densidad de roedores. Las personas que trabajan en ambientes rurales corren mayor riesgo de infección. En estudios de poblaciones rurales asintomáticas de I talia, entre el 4 y el $7 \%$ de los trabajadores forestales, guardabosques, granjeros y cazadores tenían anticuerpos frente a hantavirus, en comparación con el $0,7 \%$ de los soldados. En los agricultores asintomáticos de I rlanda y Checoslovaquia, la presencia de anticuerpos de hantavirus se situaba entre el 1 y el $2 \%$ y entre el 20 y el $30 \%$, respectivamente. La siembra, la cosecha, la trilla, el pastoreo y la silvicultura son factores de riesgo para las infecciones por virus. En el oeste de Estados U nidos se están realizando vigilancias serológicas para determinar el riesgo ocupacional de infección por hantavirus, aunque en un estudio realizado en personal de asistencia sanitaria (PAS) al cuidado de pacientes de SPH, no se detectó ninguna infección. De los datos procedentes de las primeras 68 personas con SPH, parece deducirse que las actividades agrícolas en entornos con roedores infectados son factores de riesgo para la infección. La mayoría de los pacientes se dedicaba al arado a mano, a la limpieza de zonas de almacenaje de alimentos, a la siembra, a la limpieza de cobertizos de animales y al pastoreo. El portador más importante del SPH es el ratón ciervo Peromyscus maniculatus.

\section{0 tras profesiones afectadas}

En entornos urbanos, el portador del virus de Seúl entre los roedores es la rata común. L os trabajadores urbanos, como son los trabajadores portuarios, de los silos, de los zoológicos y de los servicios de desratización, corren el riesgo de contraer una infección por hantavirus. Los laboratorios de investigación que utilizan roedores para investigaciones no relacionadas con este virus han sido en ocasiones focos insospechados de infecciones por hantavirus entre el personal de laboratorio. 0 tras profesiones, como el personal militar y los biólogos de campo, también corren el riesgo de contraer infección por hantavirus.

\section{Tratamiento}

La ribavirina ha demostrado actividad in vitro frente a varios hantavirus y eficacia clínica contra la infección por el virus de $\mathrm{H}$ antaan, y se ha utilizado para tratar a personas con SPH .

\section{Controles de salud pública}

No se dispone de vacuna, aunque se están realizando continuos esfuerzos para desarrollar vacunas de virus vivos o muertos. $L a$ reduccción al mínimo del contacto humano con roedores y la reducción de las poblaciones de roedores en los entornos humanos disminuyen el riesgo de contraer la enfermedad. En laboratorios de investigación de hantavirus, las instalaciones de seguridad biológica de alto nivel limitan el riesgo de que se propaguen virus en cultivos celulares 0 al manipular materiales con concentraciones elevadas de virus. En otros laboratorios de investigación que usan roedores, se puede plantear la vigilancia serológica periódica para prevenir la infección de las colonias de roedores por hantavirus.

\section{Coriomeningitis linfocítica (CML)}

$\mathrm{La} C M \mathrm{~L}$, al igual que las infecciones por hantavirus, es, en su entorno natural, una infección de roedores silvestres que en ocasiones se contagia al hombre. EI virus de la CM L es un arenavirus, pero la transmisión se produce generalmente por aerosolización. Entre los huéspedes naturales se incluyen los ratones silvestres, aunque está bien demostrada la infección persistente de hámsters sirios domésticos. Por tanto, la infección es posible en la mayoría de las profesiones relacionadas con la aereosolización de orina de roedores. El brote profesional más reciente de esta enfermedad del que existe documentación se produjo entre el personal de un laboratorio expuesto a ratones sin pelo con déficit de células T persistentemente infectados como resultado de la inoculación de líneas de células tumorales contaminadas.

\section{Presentación clínica}

La mayoría de los casos de CML son asintomáticos o están asociados a enfermedades seudogripales inespecíficas y, por tanto, no se diagnostican. Aunque las vías respiratorias son el lugar de entrada, los síntomas respiratorios suelen ser inespecíficos y autolimitados. En un pequeño porcentaje de los pacientes se desarrolla meningitis o meningoencefalitis, que puede conducir a un diagnóstico específico.

\section{Pruebas diagnósticas}

EI diagnóstico se realiza generalmente mediante la demostración serológica de un título creciente frente al virus en presencia de los signos clínicos apropiados. También se recurre en ocasiones al aislamiento del virus y a la inmunofluorescencia tisular. 


\section{Epidemiología}

A proximadamente el $20 \%$ de los ratones silvestres está infectado por este virus. La transmisión transplacentaria del virus en roedores susceptibles conduce a tolerancia de células $T$ y a ratones (o hamsters) con infección congénita que persisten infectados durante toda su vida. Del mismo modo, los ratones con déficit de células $T$, como los ratones sin pelo, pueden quedar persistentemente infectados por el virus. Los seres humanos se infectan por transmisión de aerosoles. A demás, las líneas celulares de roedores pueden contaminarse por el virus y propagarlo. Por lo general, los seres humanos se infectan por aerosoles, aunque puede haber transmisión directa o a través de insectos vectores.

\section{Otras profesiones afectadas}

Cualquier profesión expuesta a polvos contaminados por excrementos de roedores silvestres corre el riesgo de contraer CML. Los cuidadores de animales en instalaciones de laboratorio, los trabajadores de las tiendas de animales y el personal de laboratorio que trabaja con líneas celulares de roedores pueden infectarse.

\section{Tratamiento}

Generalmente, la infección de CM L es autolimitada. En los casos graves puede ser necesario un tratamiento de soporte.

\section{Controles de salud pública}

No se dispone de vacuna. La vigilancia de ratones, hamsters y líneas celulares para investigación ha limitado la mayoría de las infecciones adquiridas en los laboratorios. En el caso de los ratones con déficit de células $T$, las pruebas serológicas requieren el uso de ratones centinela inmunocompetentes. Está indicado el uso de medidas rutinarias de seguridad de laboratorio como guantes, protección ocular y batas de laboratorio. La reducción del número de roedores silvestres en el medio ambiente del ser humano es importante para controlar la CM L, los hantavirus y la peste.

\section{Clamidiasis respiratoria}

La clamidiasis respiratoria debida a Chlamydia psittaci es la causa más frecuente de NOO asociada a la matanza de animales (pollos) y a las industrias cárnicas. La clamidiasis y otras enfermedades se asocian con frecuencia a la exposición a animales enfermos, a veces la única pista que señala el origen y el tipo de infección. La manipulación de animales infectados crea aerosoles que infectan a personas ajenas a las industrias cárnicas, y el hecho de trabajar cerca de plantas de preparación de carne puede dar una pista sobre el tipo de infección. La clamidiasis respiratoria puede estar asociada a una exposición a loros (psitacosis) 0 a aves que no pertenezcan a la familia de las psitácidas (ornitosis). Las fuentes de Chlamydia psittaci no relacionadas con las aves no suelen considerarse orígenes posibles de zoonosis, aunque se ha informado de abortos espontáneos y conjuntivitis en seres humanos expuestos a cepas de ovejas y cabras. La neumonía debida a C. pneumoniae es una causa común recientemente descrita de neumonía adquirida en la comunidad distinta de las infecciones por C. psittaci. Dado su reciente descubrimiento, el papel de $C$. pneumoniae en las NOO no se ha investigado en profundidad y no se abordará más en este artículo.

\section{Presentación clínica}

La ornitosis oscila entre una leve enfermedad seudogripal y una neumonía grave con encefalitis que, en los tiempos en los que no existían los antibióticos, tenía una tasa de mortalidad por casos (T M C ) superior al $20 \%$. La fiebre prodrómica, los escalofríos, las mial gias, las cefaleas y la tos no productiva pueden preceder hasta tres semanas antes de que se diagnostique la neumonía. Son frecuentes las alteraciones neurológicas, hepáticas y renales. Los hallazgos radiológicos incluyen condensación del lóbulo inferior con adenopatías hiliares. La sospecha clínica después de determinar una exposición a aves, ya sea relacionada con el trabajo o de otro tipo, es crucial para el diagnóstico porque no hay hallazgos patognomónicos.

\section{Pruebas diagnósticas}

Por lo general, la ornitosis provoca un título elevado de anticuerpos de fijación del complemento ( $F C$ ), aunque un tratamiento precoz con tetraciclinas puede suprimir la formación de anticuerpos. Para establecer el diagnóstico se puede usar un título sérico agudo único $\geq 1: 16$ de dilución de anticuerpos FC con una presentación clínica compatible o un aumento de cuatro veces en el título de anticuerpos FC. L as muestras séricas inadecuadamente emparejadas y el elevado nivel basal de anticuerpos frente a Chlamydia en los grupos de riesgo reducen la utilidad de los análisis de anticuerpos para diagnosticar la mayoría de las enfermedades por clamidias.

\section{Epidemiología}

C. psittaci se encuentra en prácticamente todas las especies de aves y es frecuente en los mamíferos. La infección está provocada generalmente por transmisión zoonótica, aunque se ha informado de transmisión persona a persona. La infección asintomática es frecuente y hasta un $11 \%$ de los agricultores sin historia de enfermedades presenta anticuerpos frente a C. psittaci. Sigue habiendo brotes intermitentes, pero la pandemia más reciente asociada al comercio de aves exóticas ocurrió en 1930. En Estados U nidos se comunican anualmente entre 70 y 100 casos de ornitosis, casi un tercio de ellas de origen ocupacional. La mayoría de las infecciones de origen ocupacional ocurre en trabajadores de pajarerías o de industrias avícolas y se relacionan con la aerosolización de tejidos o heces de aves. En países donde es frecuente tener aves como mascotas y las cuarentenas de importación no se cumplen debidamente, los brotes son más frecuentes, pero la ocupación es un factor de riesgo menor.

\section{Otras ocupaciones afectadas}

Esta enfermedad aparece con mayor frecuencia en los trabajadores de las industrias avícolas, pero también corren riesgo las personas que trabajan en la distribución de aves exóticas y en instalaciones de cuarentena para aves, criaderos de aves y clínicas veterinarias

\section{Tratamiento}

La administración de tetraciclina o eritromicina durante 10 ó 14 días debería ser un tratamiento adecuado, pero es frecuente la recidiva clínica cuando la duración del tratamiento es insuficiente.

\section{Controles de salud pública}

En Estados U nidos, las aves exóticas son sometidas a cuarentena para profilaxis con tetraciclinas. En otros países en los que existe comercio de aves exóticas se usan métodos parecidos. No se ha desarrollado una vacuna para la ornitosis. Se han puesto en marcha programas destinados a aumentar la ventilación, a fin de diluir la concentración de aerosoles, reducir la aerosolización o inhalación de partículas infecciosas o tratar a las aves enfermas en las plantas comerciales de preparación de carne, pero no se ha demostrado su eficacia.

\section{Brucelosis}

Anualmente se producen unos 500.000 casos de brucelosis en todo el mundo, causados por varias especies de Brucella. La patogenicidad de las infecciones por Brucella depende de las especies 
que causen la infección, las cuales suelen tener distintos huéspedes reservorio. $L$ os reservorios de $B$ rucella abortus, $B$. suis, $B$. melitensis, B. ovis, B. canis, y B. neotomae suelen ser vacas, cerdos, cabras, ovejas, perros y ratas, respectivamente.

La brucelosis puede producirse por infección a través de distintas rutas, incluida la aerosolización. Sin embargo, casi todos los casos de esta enfermedad se producen por ingestión de productos lácteos de cabra no pasteurizados. La enfermedad sistémica resultante está causada por B. melitensis, pero no se asocia a profesiones concretas. Un $1 \%$ de los casos desarrolla neumonía, aunque la tos es un hallazgo frecuente.

En los países desarrollados, la brucelosis profesional está causada generalmente por B rucella abortus y se produce por ingestión 0 inhalación de aerosoles infecciosos asociados a las placentas de los cerdos y las vacas. La infección subclínica es frecuente; hasta un $1 \%$ de los agricultores presenta anticuerpos frente a B. abortus. La enfermedad se desarrolla en cerca del $10 \%$ de las personas infectadas. A diferencia de la enfermedad debida a B. melitensis, la enfermedad asociada a B. abortus es normalmente de origen ocupacional y de menor gravedad. Las personas que padecen brucelosis aguda presentan fiebre alta diaria, artralgias y hepatoesplenomegalia. En la neumonía primaria por Brucella, la condensación neumónica es muy poco frecuente y entre los hallazgos pulmonares se pueden incluir roncus o sibilancias, adenopatía hiliar, infiltrados peribronquiales, nódulos parenquimatosos o un patrón miliar. Se puede efectuar el aislamiento en la médula ósea en el $90 \%$ de los casos agudos y en la sangre entre el 50 y el $80 \%$ de los casos. Se puede establecer un diagnóstico serológico con diversos análisis de anticuerpos. Se deben usar tetraciclinas durante cuatro a seis semanas y se puede añadir rifampicina para obtener un efecto sinérgico. Los criadores de vacas, cabras, ovejas y cerdos, los trabajadores de las industrias lecheras y de los mataderos, los veterinarios y los carniceros son los principales grupos de riesgo. Las pruebas de Brucella y los programas de erradicación han reducido en gran medida el número de animales infectados y han identificado los rebaños que ofrecen mayor riesgo de transmisión de la enfermedad. Cuando se trabaja con animales infectados por B rucella, su evitación o la utilización de medios de protección personal, especialmente después de un aborto o un parto, son los únicos métodos eficaces para controlar la enfermedad.

\section{Carbunco por inhalación}

El carbunco por inhalación se produce en todo el mundo, pero es menos común que el carbunco cutáneo. El carbunco es una enfermedad sistémica en muchos animales y normalmente se transmite a los seres humanos por infección percutánea al trabajar con carne contaminada o al ingerirla. El carbunco por inhalación se produce por inhalación de esporas de Bacillus anthracis procedentes de los huesos, el pelo o el cuero de ovejas, cabras o vacas ("enfermedad de los cardadores de lana") o en raras ocasiones al trabajar con carne infectada. L as esporas son fagocitadas por los macrófagos alveolares y transportadas a los ganglios linfáticos mediastínicos, donde germinan. Esto produce una mediastinitis hemorrágica, pero rara vez se presenta como neumonía primaria. Esta enfermedad se caracteriza por ensanchamiento del mediastino, edema pulmonar, derrames pleurales, esplenomegalia y una evolución rápida hasta la insuficiencia respiratoria. La tasa de mortalidad por casos es del $50 \%$ o superior, a pesar de los antibióticos y del soporte ventilatorio. Son frecuentes los hemocultivos positivos, pero se pueden emplear pruebas serológicas de análisis por inmunoensayo (inmunoblot). Las personas enfermas reciben tratamiento con dosis elevadas de penicilina, o bien ciprofloxacino por vía intravenosa como alternativa en caso de alergia a la penicilina. Los criadores de animales, veterinarios, personal de asistencia veterinaria, trabajadores de la lana y el cuero y trabajadores de los mataderos corren un alto riesgo. En las zonas endémicas, se pueden realizar vacunaciones anuales de los animales, así como de los seres humanos con elevado riesgo de contraer la enfermedad. Entre las medidas de control específicas contra el carbunco por inhalación se incluyen la descontaminación con formaldehídos, la esterilización al vapor o la irradiación de lanas y cueros; la prohibición de importar cuero procedente de zonas endémicas y la protección personal respiratoria para los trabajadores.

\section{Peste neumónica}

La peste, causada por Yersinia pestis, es principalmente una enfermedad endozoótica de los roedores silvestres transmitida por pulgas. Por lo general, los seres humanos se infectan al ser picados por una pulga infectada y con frecuencia desarrollan septicemia. En Estados Unidos, de 1970 a 1988, alrededor del $10 \%$ de las personas con septicemia desarrolló neumonía secundaria por diseminación hematógena. L os animales y los seres humanos que padecen peste neumónica producen aerosoles infecciosos. En los seres humanos, se puede producir una neumonía primaria por inhalación de un aerosol infeccioso creado en torno a los animales agonizantes a consecuencia de una neumonía secundaria. Pese a las amplias posibilidades de diseminación neumónica, la transmisión de persona a persona es muy poco frecuente y no se ha producido en E stados U nidos desde hace casi 50 años. Los controles de la enfermedad incluyen el aislamiento de las personas enfermas de peste neumónica y el uso de protección personal respiratoria por parte del PAS. La transmisión de aerosoles al personal hospitalario es posible, y se debe plantear el tratamiento profiláctico con tetraciclina para cualquier persona que esté en contacto con seres humanos 0 animales con peste neumónica. U na serie de profesiones corren riesgo por transmisión de aerosoles, incluido el personal de laboratorios biomédicos y de hospitales y, en zonas endémicas, también una serie de profesiones rurales, como veterinarios, trabajadores de los servicios de desratización, cazadores o tramperos, expertos en mamíferos, biólogos especializados en fauna salvaje y agricultores. Se recomienda una vacuna de virus muertos para las personas que ejercen profesiones de alto riesgo.

\section{Fiebre Q}

Causada por inhalación de Coxiella burnetii, la fiebre Q es una enfermedad sistémica que provoca una neumonía atípica en el 10 al $60 \%$ de las personas infectadas. Son muchos los aislados diferentes de $C$. burnetii que provocan la enfermedad, y existe cierta polémica en torno a las teorías sobre la virulencia dependiente de plásmidos. $C$. burnetii infecta a muchos animales domésticos (por ejemplo, ovejas, vacas, cabras, gatos) en todo el mundo; adopta forma de aerosol a partir de la orina, las heces, la leche, la placenta o los tejidos del útero; forma una endospora muy resistente que continúa siendo infecciosa durante años; y es extremadamente infecciosa.

\section{Presentación clínica}

Al cabo de un período de incubación de 4 a 40 días, la fiebre $\mathrm{Q}$ aguda provoca una enfermedad seudogripal que progresa hasta convertirse en una neumonía atípica similar a la causada por M ycoplasma. La enfermedad aguda dura unas dos semanas, pero puede persistir hasta nueve semanas. La enfermedad crónica, caracterizada principalmente por endocarditis y hepatitis, puede desarrollarse hasta 20 años después de la enfermedad aguda.

\section{Pruebas diagnósticas}

El aislamiento primario de $C$. burnetii rara vez se realiza, ya que requiere un alto nivel de confinamiento para seguridad biológica. EI diagnóstico se establece serológicamente demostrando un título 
de anticuerpos de FC igual o superior a 1:8 en un entorno clínico adecuado, o bien un aumento de cuatro veces en el título de FC.

\section{0 tras profesiones afectadas}

Los agricultores (especialmente los trabajadores de las industrias lecheras y de la lana), el personal de laboratorio de los hospitales y el personal de investigaciones biomédicas corren riesgo de infectarse.

\section{Tratamiento}

No existe una vacuna eficaz contra $C$. burnetii. Para tratar la enfermedad aguda se recurre a un ciclo de dos semanas con tetraciclinas o ciprofloxacino.

\section{Controles de salud pública}

A causa de su amplia distribución geográfica, la gran cantidad de animales portadores y su resistencia a la inactivación, la protección personal respiratoria y los controles técnicos de los aerosoles infecciosos son las únicas medidas preventivas eficaces. Sin embargo, estos métodos de control son difíciles de poner en práctica en muchos entornos agrícolas (por ejemplo, en el pastoreo de ovejas y vacas). Se puede facilitar el diagnóstico precoz de la fiebre Q por parte del personal de asistencia sanitaria mediante la educación de los trabajadores que corren un alto riesgo de contraer esta rara enfermedad. Es posible la transmisión al personal hospitalario y el aislamiento puede limitar la propagación de la neumonía por fiebre $\mathrm{Q}$ en los hospitales.

\section{NOO bacterianas diversas en los agricultores}

Pseudomonas pseudomallè es un microorganismo asociado al suelo y a los roedores, que se encuentra principalmente en el sureste de Asia y que causa melioidosis. Esta enfermedad está asociada a la exposición al suelo y tiene un período de latencia que puede ser largo. En Estados U nidos, las víctimas principales de la melioidosis han sido el personal militar durante la guerra de V ietnam y después de ésta. La forma pulmonar de la melioidosis se caracteriza por una neumonía multifocal, nodular, supurada 0 granulomatosa.

F rancisella tularensis, el agente etiológico de la tularemia, es una zoonosis asociada a los roedores y lagomorfos silvestres. Es una posible enfermedad ocupacional de los biólogos especializados en fauna salvaje, los expertos en mamíferos, los trabajadores de los servicios de desratización, los cazadores, los tramperos y los veterinarios. La tularemia puede producirse por inhalación, inoculación directa, contacto cutáneo o ingestión, o ser transmitida por vectores. La enfermedad pulmonar se produce ya sea por exposición a una inhalación directa o por diseminación hematógena de una enfermedad septicémica. Las lesiones pulmonares de la tularemia son agudas, multifocales, supuradas y necrotizantes.

\section{Histoplasmosis}

La histoplasmosis está causada por H istoplasma capsulatum, un moho libre del suelo asociado a las heces de aves o murciélagos. La histoplasmosis es la causa más importante de $\mathrm{N} O \mathrm{O}$ micóticas en los agricultores. Las diversas neumonías micóticas de los agricultores se describen en la siguiente sección.

\section{Presentación clínica}

Después de la exposición, las tasas de incidencia y la gravedad de la histoplasmosis varían en función del inóculo infeccioso y de los niveles de anticuerpos del huésped desarrollados tras una infección anterior. Después de una exposición fuerte, desarrolla una enfermedad respiratoria autolimitada hasta el $50 \%$ de las personas, mientras que las demás continúan asintomáticas. El síndrome sintomático menos grave incluye síntomas "seudogripales", tos no productiva y dolor torácico. La exploración física puede revelar eritema nudoso o eritema multiforme. La radiografía de tórax revela inflitrados irregulares y segmentarios, pero ningún hallazgo radiológico permite diferenciar específicamente la histoplasmosis de otras infecciones pulmonares. La adenopatía hiliar o mediastínica es frecuente en todas las fases de histoplasmosis primaria.

La histoplasmosis neumónica primaria progresiva se caracteriza por profundas molestias sistémicas, tos productiva de esputos purulentos y hemoptisis. Los cambios radiográficos progresivos incluyen nódulos múltiples, condensación lobular y densos infiltrados intersticiales multilobulares. Un mayor grado de exposición aumenta la intensidad del cuadro y provoca una grave enfermedad respiratoria, el síndrome del distrés respiratoria del adulto (SDRA), o atelectasias debidas a obstrucción por las adenopatías mediastínicas.

Alrededor del $20 \%$ de las personas enfermas desarrolla otros síndromes de histoplasmosis, que son idiosincráticos y no se deben a una mayor exposición 0 al progreso de la enfermedad primaria. Entre ellos se incluyen : artritis-eritema nudoso, pericarditis e histoplasmosis pulmonar crónica (infiltrados pulmonares apicales fibróticos con cavitación). En un pequeño porcentaje de pacientes, especialmente en los inmunodeprimidos, se desarrolla histoplasmosis diseminada.

\section{Pruebas diagnósticas}

El diagnóstico definitivo se establece aislando o demostrando histopatológicamente el microorganismo en una muestra clínica adecuada. Por desgracia, el microorganismo está presente en bajas concentraciones y la sensibilidad de estos métodos es baja. Con frecuencia se establecen diagnósticos de presunción basándose en la situación geográfica, los antecedentes de exposiciones y los hallazgos radiográficos en los pulmones o las calcificaciones del bazo.

\section{Epidemiología}

$H$. capsulatum se encuentra por todo el mundo asociado a condiciones concretas del suelo, pero se informa de la existencia de la enfermedad principalmente en los valles de los ríos 0 hio y $M$ ississippi en Estados U nidos. Se encuentran elevadas concentraciones de esporas en perchas para aves, edificios viejos, gallineros, cuevas o patios de colegio; se alteran por la actividad laboral.

La concentración de microconidias es mayor en las zonas derruidas y cerradas (por ejemplo, demolición de edificios) y provoca mayores niveles de inóculo para las personas que trabajan allí que en la mayoría de los lugares al aire libre. En zonas endémicas, las personas que limpian perchas de aves, realizan la demolición de edificios antiguos o llevan a cabo excavaciones para la construcción de carreteras o edificios corren mayor riesgo que el resto de la población. En Estados U nidos, cada año son hospitalizadas entre 15.000 y 20.000 personas por histoplasmosis y, de ellas, muere aproximadamente el $3 \%$.

\section{Otras profesiones afectadas}

Atribuir un riesgo ocupacional de infección por $\mathrm{H}$ istoplasma es difícil porque el microorganismo vive libremente en el suelo y la concentración de esporas en forma de aerosol aumenta con el viento y en condiciones en que se forman grandes cantidades de polvo. La infección se debe principalmente a la situación geográfica. En las zonas endémicas, las personas del campo, independientemente de su profesión, tienen una prevalencia de pruebas cutáneas positivas frente a antígenos de $\mathrm{H}$. capsulatum que oscila entre el 60 y el $80 \%$. La enfermedad declarada se produce por un gran inóculo infeccioso y generalmente se limita a los trabajadores que participan en el levantamiento del suelo o la destrucción de edificios contaminados. 


\section{Tratamiento}

El tratamiento antifúngico de la histoplasmosis y otras infecciones micóticas de origen ocupacional no está indicado para la enfermedad pulmonar aguda autolimitada. La terapia con anfotericina B (con una dosis total de 30 a $35 \mathrm{mg} / \mathrm{kg}$ ) o ketoconazol (400 mg/ día durante seis meses) o regímenes de tratamiento con ambos agentes están indicados para la histoplasmosis diseminada, la histoplasmosis pulmonar crónica, la histoplasmosis pulmonar aguda con SDRA o el granuloma mediastínico con obstrucción sintomática, y pueden ser útiles para la enfermedad primaria prolongada y moderadamente grave. EI tratamiento ofrece una tasa de respuesta que oscila entre el 80 y el $100 \%$, pero las recidivas son frecuentes y pueden llegar al $20 \%$ con anfotericina B y al $50 \%$ con ketoconazol. No se ha determinado la eficacia de medicamentos azólicos más recientes (por ejemplo, itraconazol y fluconazol) para las infecciones micóticas profesionales.

\section{Controles de salud pública}

No se ha desarrollado una vacuna eficaz. Se puede reducir la infección mediante descontaminación química con formaldehído al $3 \%$, mojando previamente el suelo o las superficies contaminadas para reducir la aerosolización y adoptando protección personal respiratoria para reducir la inhalación de esporas en forma de aerosol, pero la eficacia de estos métodos no está demostrada.

\section{Neumonías micóticas diversas}

Entre las diversas neumonías micóticas de los agricultores se incluyen la aspergilosis, la blastomicosis, la criptococosis, la coccidioidomicosis y la paracoccidioidomicosis (Tabla 10.26). Estas enfermedades están causadas por A spergillus spp., B lastomyces dermatitidis, Cryptococcus neoformans, Coccidioides immitis y Paracoccidioides brasiliensis, respectivamente. Aunque estos hongos tienen una amplia distribución geográfica, por lo general la enfermedad se comunica en zonas endémicas. En comparación con las causas víricas y bacterianas de la neumonía, estos trastornos son muy poco frecuentes y a menudo insospechados en principio. Los trastornos de las células T aumentan la propensión a la histoplasmosis, la blastomicosis, la criptococosis, la coccidioidomicosis y la paracoccidioidomicosis. Sin embargo, una gran exposición inicial puede provocar la enfermedad en el trabajador inmunocompetente. Las infecciones por A spergillus y hongos relacionados suelen producirse en pacientes neutropénicos. La aspergilosis es casi siempre una N 00 que afecta a los pacientes inmunodeprimidos y se tratará en la sección dedicada a las infecciones en los sujetos inmunodeprimidos.

$\mathrm{Cr}$. neoformans, al igual que $\mathrm{H}$. capsulatum, es un habitante común del suelo contaminado por heces de aves y la exposición ocupacional a éstos $u$ otros polvos contaminados por $\mathrm{Cr}$. neoformans puede provocar la enfermedad. La blastomicosis ocupacional se asocia a profesiones al aire libre, especialmente en el este y el centro de Estados Unidos. La coccidioidomicosis se produce por exposición a polvos contaminados en zonas endémicas del suroeste de Estados U nidos (de ahí el sinónimo de fiebre del valle de San Joaquín). La exposición ocupacional a suelos contaminados en Sudamérica y A mérica C entral se asocia con frecuencia a la paracoccidioidomicosis. Dado que en el caso de esta última el período de latencia puede ser largo, es posible que esta exposición se produzca mucho tiempo antes de que aparezcan los síntomas.

\section{Presentación clínica}

La presentación clínica de la coccidioidomicosis, la blastomicosis - la paracoccidioidomicosis es parecida a la de la histoplasmosis. La exposición a aerosoles de estos hongos puede producir NO O si el inóculo inicial es lo bastante elevado. Sin embargo, factores del huésped, como una exposición anterior, limitan la enfermedad en la mayoría de los individuos. En la coccidioidomicosis, los signos pulmonares y sistémicos de la enfermedad son evidentes en un pequeño porcentaje de las personas infectadas; la enfermedad progresiva con diseminación a múltiples órganos es muy poco frecuente si no hay inmunosupresión. Aunque el origen de la enfermedad es generalmente el pulmón, la blastomicosis puede presentarse como enfermedad pulmonar, cutánea o sistémica. La presentación clínica más común de la blastomicosis es una tos crónica con neumonía indistinguible de la tuberculosis. Sin embargo, la mayoría de los pacientes con blastomicosis clínicamente evidente sufrirá lesiones extrapulmonares que afectarán a la piel, los huesos o el aparato genitourinario. La paracoccidioidomicosis es una enfermedad de M éxico, América Central y Sudamérica, que se produce casi siempre como reactivación de una infección anterior tras un período de latencia largo pero variable. La enfermedad puede estar asociada al envejecimiento de los individuos infectados y la reactivación puede estar provocada por inmunosupresión. La presentación pulmonar es parecida a la de otras neumonías micóticas, pero en la paracoccidioidomicosis es frecuente la enfermedad extrapulmonar, que afecta especialmente a las mucosas.

El pulmón es el lugar habitual de la infección primaria por Cryptococcus neoformans. Al igual que en el caso de los hongos arriba descritos, las infecciones pulmonares pueden ser asintomáticas, autolimitadas o progresivas. Sin embargo, puede producirse la diseminación del microorganismo, en especial a las meninges y el cerebro, sin que haya una enfermedad respiratoria sintomática. La meningoencefalitis criptocócica sin signos de criptococosis pulmonar, aunque poco frecuente, es la manifestación clínica más común de la infección por $\mathrm{C}$. neoformans .

\section{Pruebas diagnósticas}

La demostración directa de la forma tisular del microorganismo permite establecer un diagnóstico definitivo en biopsias y preparados citológicos. La inmunofluorescencia puede ser un método útil de confirmación si los detalles morfológicos resultan insuficientes para determinar el agente etiológico. También se puede realizar un cultivo a partir de lesiones sospechosas. U na prueba positiva de aglutininas criptocócicas al látex en el líquido cefalorraquídeo es compatible con meningoencefalitis criptopcócica. Sin embargo, es posible que la demostración de los microorganismos no baste para diagnosticar la enfermedad. Por ejemplo, se puede producir un crecimiento saprofítico de $\mathrm{Cr}$. neoformans en las vías aéreas.

\section{Otras profesiones afectadas}

El personal de laboratorio que trabaja en el aislamiento de estos hongos corre el riesgo de quedar infectado.

\section{Tratamiento}

El tratamiento antifúngico es similar al utilizado para la histoplasmosis.

\section{Controles de salud pública}

Los controles técnicos están indicados para reducir el riesgo del personal de laboratorio. La protección respiratoria al trabajar con suelos fuertemente contaminados por heces de aves reducirán la exposición a Cr. neoformans.

\section{Infecciones de origen ocupacional en el personal sanitario y de laboratorio}

La inhalación de aerosoles infecciosos es la causa más común de infección en el personal hospitalario y se han atribuido muchas neumonías víricas y bacterianas a una transmisión relacionada con el trabajo (Tabla 10.26). La mayoría de las infecciones son 
víricas y autolimitadas. Sin embargo, se ha informado de brotes potencialmente graves de tuberculosis, sarampión, tos ferina y neumonía neumocócica entre el personal hospitalario. Al final de esta sección se abordarán las infecciones en trabajadores inmunocomprometidos.

El personal de los laboratorios de diagnóstico corre el riesgo de contraer infecciones de origen ocupacional provocadas por transimisión aérea. La transmisión se produce cuando los patógenos adoptan forma de aerosol durante la preparación inicial de las muestras clínicas de pacientes con enfermedades infecciosas dudosas y rara vez se diagnostica. Por ejemplo, en un reciente brote comunitario de brucelosis, un tercio de los técnicos de laboratorio desarrolló la enfermedad. El hecho de trabajar en el laboratorio fue el único factor de riesgo identificado. No se pudo demostrar que la transmisión de persona a persona entre los empleados del laboratorio o el contacto con una muestra clínica concreta fueran factores de riesgo. La rubéola, la tuberculosis, la varicela-zóster y el virus respiratorio sincitial son enfermedades profesionales que los técnicos adquieren de igual forma en el laboratorio.

A pesar de los rigurosos cuidados veterinarios, las medidas de confinamiento para seguridad biológica y el uso de animales de laboratorio criados comercialmente y carentes de patógenos, la inhalación continúa siendo el modo principal de transimisión de enfermedades infecciosas en el personal de investigación biomédica. Además, se pueden encontrar microorganismos recién descubiertos o reservorios zoonóticos no identificados hasta ahora, todo lo cual puede socavar estas medidas de control de enfermedades.

\section{Sarampión}

El sarampión, como enfermedad de origen ocupacional, se ha convertido en un problema creciente entre el personal hospitalario de los países desarrollados. D esde 1989, se ha producido un resurgimiento del sarampión en Estados U nidos, debido a un inadecuado cumplimiento de las recomendaciones de vacunación y al fracaso de la inmunización primaria en los receptores de la vacuna. En vista de la elevada morbilidad y posible mortalidad asociadas al sarampión en los trabajadores susceptibles, debe prestarse una atención especial al sarampión en cualquier programa de salud laboral. De 1985 a 1989, se comunicaron más de 350 casos de sarampión de origen ocupacional en Estados Unidos, lo cual representa un $1 \%$ de todos los casos comunicados. Casi el $30 \%$ del personal hospitalario con sarampión de origen ocupacional tuvo que ser hospitalizado. EI mayor grupo de personal hospitalario con sarampión estaba formado por enfermeros y médicos y el $90 \%$ de ellos contrajo el sarampión de sus pacientes. Aunque el $50 \%$ de estas personas enfermas era candidato a la vacunación, ninguna de ellas se había vacunado. El incremento de la morbilidad y la mortalidad por sarampión en los adultos ha aumentado la preocupación de que los trabajadores infectados puedan infectar a los pacientes y a sus compañeros de trabajo.

En 1989, el Immunization Practices Advisory Committee recomendó la administración de dos dosis de vacuna del sarampión o la aportación de pruebas que demostraran inmunidad frente a esta enfermedad a la hora de realizar contratos laborales en un medio sanitario. La situación serológica y de vacunación de los trabajadores debe documentarse. A demás, cuando se presenten pacientes con sarampión, es conveniente volver a realizar una evaluación de la situación inmunológica del PAS. EI cumplimiento de estas recomendaciones y el adecuado aislamiento de los pacientes en los que se sepa o se sospeche que padecen sarampión restringe la transmisión de la enfermedad en los medios sanitarios.

\section{Presentación clínica}

Además de la presentación común del sarampión en adultos no inmunes, se deben tener en cuenta las presentaciones atípicas y modificadas como consecuencia de que muchos trabajadores hospitalarios han recibido previamente vacunas de virus muertos o son parcialmente inmunes. En el sarampión clásico, tras la infección sigue un período de incubación de dos semanas con leves síntomas de las vías respiratorias superiores. Durante este período, el trabajador es virémico e infeccioso. A este período le sigue otro de siete a diez días de duración con tos, coriza y conjuntivitis, y el desarrollo de una erupción morbiliforme y manchas de Koplik (lesiones blancas elevadas de la mucosa bucal), que son patognomónicas del sarampión. La radiografía pone de manifiesto infiltrados reticulonodulares difusos con adenopatías hiliares bilaterales, a menudo con una bronconeumonía bacteriana superpuesta. Estos signos aparecen mucho después de que la persona haya tenido la oportunidad de infectar a otras personas susceptibles. Las complicaciones pulmonares causan el $90 \%$ de las muertes por sarampión en los adultos. N o existe un tratamiento antivírico eficaz para ninguna forma de sarampión, aunque la inmunoglobulina antisarampionosa a títulos altos puede mejorar algunos síntomas en los adultos.

En el sarampión atípico, que se produce en personas vacunadas con una vacuna de virus muertos desarrollada en los años 60 , es frecuente que los pulmones se vean gravemente afectados. La erupción es atípica y las manchas de K oplik son muy poco frecuentes. En el sarampión modificado, que se produce en personas que previamente han recibido una vacuna de virus vivos, pero que han desarrollado una inmunidad parcial, los signos y síntomas son parecidos a los del sarampión clásico, pero más leves, y a menudo pasan desapercibidos. Las personas con sarampión atípico y modificado son virémicas y pueden propagar el virus del sarampión.

\section{Diagnóstico}

En el personal hospitalario, el sarampión es con frecuencia atípico o modificado y rara vez se sospecha. Se debería pensar en esta enfermedad en toda persona que presente una erupción eritematosa maculopapulosa precedida de un pródromo febril de tres a cuatro días de duración. En el caso de personas que se hayan infectado por primera vez en su vida y que no estén previamente inmunizadas, resulta difícil aislar el virus o detectar los antígenos, pero se pueden usar análisis de inmunoabsorción ligado a enzimas 0 un análisis de anticuerpos fluorescentes para establecer un diagnóstico rápido. En el caso de personas previamente inmunizadas, es difícil interpretar estos análisis, pero las tinciones de anticuerpos inmunofluorescentes en las células exfoliadas pueden ser de ayuda.

\section{Epidemiología}

Los enfermeros y médicos susceptibles tienen nueve veces más probabilidades de contraer sarampión que las personas dela misma edad que no sean PAS. Al igual que con todas las infecciones por virusdel sarampión, la transmisión de persona a persona se produce mediante la inhalación de un aerosol infeccioso. El personal hospitalario contrae sarampión a partir de sus pacientes y de sus compañeros de trabajo y, a su vez, transmite el sarampión a sus pacientes, compañeros de trabajo y familiares susceptibles.

\section{Otras profesiones afectadas}

Se han producido epidemias de sarampión en instituciones académicas de países desarrollados y entre los agricultores que viven en alojamientos colectivos en plantaciones.

\section{Controles de salud pública}

Las estrategias de intervención en salud pública incluyen programas de inmunización así como programas de control de 
infecciones para hacer un seguimiento de la enfermedad por este virus y de la situación de anticuerpos de los trabajadores. Si no se puede documentar una infección natural o una vacunación adecuada en dos dosis, deben realizarse análisis de anticuerpos. La vacunación de las trabajadoras embarazadas está contraindicada. La vacunación de otros trabajadores de riesgo es una importante ayuda para prevenir la enfermedad. Tras una exposición al sarampión, el evitar que los trabajadores susceptibles entren en contacto con pacientes durante 21 días puede reducir la propagación de la enfermedad. También se puede limitar su transmisión restringiendo la actividad de los trabajadores enfermos de sarampión durante 7 días después de la aparición de la erupción. Por desgracia, se han dado casos de trabajadores adecuadamente vacunados que han desarrollado sarampión a pesar de los niveles de anticuerpos de protección que estaban documentados antes de contraer la enfermedad. En consecuencia, muchos autores recomiendan protección personal respiratoria cuando se está a cargo de pacientes con sarampión.

\section{Infecciones víricas diversas de las vías respiratorias}

La causa más común de NOO en el personal sanitario es una serie de virus que no son exclusivos del entorno sanitario. Los agentes etiológicos son los que causan NOO adquiridas en la comunidad y entre los que se incluyen los adenovirus, los citomegalovirus, el virus de la gripe, el virus de la parainfluenza y el virus respiratorio sincitial. Dado que estos microorganismos están también presentes en la comunidad, es difícil establecer que sean la causa de una determinada NOO. Sin embargo, los estudios serológicos indican que el personal sanitario y los cuidadores de día corren un mayor riesgo de exposición a estos patógenos respiratorios. Estos virus son también responsables de brotes de enfermedad en muchas situaciones en las que los trabajadores se reúnen en un espacio confinado. Por ejemplo, los brotes de infección por adenovirus son comunes entre los reclutas del ejército.

\section{Tos ferina}

La tos ferina, al igual que el sarampión, se está comunicando cada vez más entre el personal hospitalario de los países desarrollados. En 1993, se comunicaron cerca de 6.000 casos de tos ferina en Estados U nidos, lo cual supone un aumento del $80 \%$ con respeto a 1992. Al contrario que en años anteriores, el $25 \%$ de los casos comunicados se produjo en personas mayores de diez años. Se desconoce el número de enfermedades de origen ocupacional entre el personal hospitalario, pero se piensa que en los países desarrollados no se están comunicando todos los casos. A causa de la disminución de la inmunidad en los adultos y de las posibilidades de que el personal hospitalario infecte a los lactantes susceptibles, se está haciendo mayor hincapié en el diagnóstico y la vigilancia de la tos ferina.

\section{Presentación clínica}

La tos ferina no tratada puede durar de seis a diez semanas. En la primera semana, cuando el enfermo es más contagioso, aparecen tos seca, coriza, conjuntivitis y fiebre. En adultos vacunados previamente, la tos persistente y productiva puede durar varias semanas y rara vez se plantea que se pueda tratar de tos ferina. EI diagnóstico clínico es difícil, y debe plantearse la sospecha clínica ante todo trabajador con una tos que dure más de siete días. La única anomalía detectada en el laboratorio puede ser un recuento leucocitario superior a 20.000 con predominio de linfocitos, aunque rara vez se advierte en adultos. Las radiografías de tórax muestran bronconeumonía confluyente en los lóbulos inferiores que se irradia desde el corazón para dar el característico signo del "corazón velloso", y el $50 \%$ de los casos desarrolla atelectasia. Dada la extremada contagiosidad de este agente, es necesario un estricto aislamiento respiratorio hasta que se haya aplicado un tratamiento con eritromicina o trimetoprima/sulfametoxazol durante cinco días. Cuando se produzcan contactos estrechos entre la persona infectada y personal hospitalario que no haya adoptado precauciones respiratorias, el personal debe recibir profilaxis antibiótica durante 14 días, con independencia de su estado de inmunización.

\section{Diagnóstico}

EI diagnóstico definitivo se establece mediante el aislamiento de B ordetella pertussis, la tinción inmunofluorescente directa de secreciones nasales o el desarrollo de una respuesta de anticuerpos frente $a B$. pertussis.

\section{Epidemiología}

B. pertussis es muy contagiosa, se transmite de persona a persona a través de la inhalación de aerosoles infecciosos y presenta una tasa de incidencia situada entre el 70 y el $100 \%$. En el pasado, no era una enfermedad de adultos y no se consideraba como una NO O. D urante un brote comunitario de tos ferina en el oeste de Estados U nidos, muchos trabajadores hospitalarios quedaron expuestos en el trabajo y desarrollaron tos ferina a pesar del tratamiento profiláctico con antibióticos. A causa de la disminución de los niveles de anticuerpos protectores en adultos que nunca han tenido la enfermedad clínica, pero que recibieron una vacuna celular después de 1940, en los países desarrollados está aumentando la población de personal hospitalario propenso a la tos ferina.

\section{Controles de salud pública}

La identificación, el aislamiento y el tratamiento son las principales medidas de control de la enfermedad en los hospitales. No está claro el papel de la vacuna acelular de la tos ferina para el personal hospitalario sin niveles adecuados de anticuerpos protectores. Durante el reciente brote ocurrido en el oeste de Estados Unidos, un tercio del personal hospitalario vacunado comunicó efectos secundarios leves o moderados a la vacuna, pero un $1 \%$ presentó síntomas sistémicos "graves". Aunque estos trabajadores más gravemente afectados faltaron unos días al trabajo, no se comunicaron síntomas neurológicos.

\section{Tuberculosis}

Durante el decenio de 1950, se reconoció de forma generalizada que el personal sanitario de los países desarrollados corría mayor riesgo de contraer tuberculosis (TB: enfermedad granulomatosa debida a M ycobacterium tuberculosis o a microorganismos íntimamente relacionados $M$. bovis) que la población general. A partir del decenio de 1970 y hasta principios del decenio de 1980, los estudios indicaban que el riesgo sólo había aumentado ligeramente. A finales del decenio de 1980, un marcado aumento del número de casos de TB ingresados en los hospitales de Estados U nidos provocó la transmisión insospechada de $M$. tuberculosis al personal hospitalario. La elevada prevalencia de una prueba cutánea de la tuberculina (PCT) positiva en ciertos grupos socioeconómicos o de inmigrantes de los que procedían muchos trabajadores hospitalarios y la escasa asociación de la conversión de la PCT con exposiciones a la TB relacionadas con el trabajo dificultaron la cuantificación del riesgo de transmisión ocupacional de TB a los trabajadores. En 1993, en Estados U nidos, se calculó que un 3,2 \% del total comunicado de personas con T B era personal sanitario. A pesar de los problemas que existen para definir el riesgo, se debe pensar en una infección relacionada con el trabajo cuando el personal hospitalario desarrolla TB o se produce una conversión de su PCT

$M$. tuberculosis se propaga casi exclusivamente de persona a persona a través de partículas infecciosas con un diámetro de 1 a 
$5 \mu \mathrm{m}$ producidas al toser, hablar o estornudar. El riesgo de infección está directamente relacionado con la intensidad de la exposición a aerosoles infecciosos (espacios pequeños compartidos, aumento de la densidad de partículas infecciosas, reciclaje de aire que contiene partículas infecciosas, deficiente eliminación de partículas infecciosas y tiempo de contacto prolongado). En entornos sanitarios, procedimientos como la broncoscopia, la intubación endotraqueal y el tratamiento con aerosoles nebulizados aumentan la densidad de los aerosoles infecciosos. A proximadamente el $30 \%$ de las personas que establecen un contacto estrecho - personas que comparten un espacio común con una persona infecciosa - queda infectado y sufre una conversión de la prueba cutánea. Tras la infección, entre el 3 y el $10 \%$ de las personas desarrollará TB durante los primeros 12 meses (es decir, enfermedad primaria) y entre un 5 y un $10 \%$ más desarrollará TB en algún momento de su vida (es decir, enfermedad por reactivación). Estas tasas más altas se dan en los países en vías de desarrollo y en situaciones en las que la desnutrición es más prevalente. Las personas infectadas por VIH sufren reactivación tuberculosa con mayor frecuencia, aproximadamente entre el 3 y el $8 \%$ por año. La tasa de mortalidad por casos varía: en los países desarrollados oscila entre el 5 y el $10 \%$, pero en los países en vías de desarrollo se eleva hasta situarse entre el 15 y el $40 \%$.

\section{Presentación clínica}

Antes de la epidemia por VIH, entre el 85 y el $90 \%$ de las personas con TB sufría afectación pulmonar. La tos crónica, la producción de esputo, la fiebre y la pérdida de peso continúan siendo los síntomas deTB pulmonar declarados con más frecuencia. Salvo en el caso de un soplo anfórico, poco frecuente, 0 de crepitantes tras la tos en los lóbulos superiores, la exploración física no es de gran ayuda. Las radiografías de tórax son anormales en casi todos los casos, y éste suele ser el primer hallazgo que indica la existencia de TB. En la TB primaria, es frecuente un infiltrado de los lóbulos inferiores 0 medios, con adenopatía hiliar ipsolateral y atelectasia. La T B por reactivación produce generalmente un infiltrado y cavitación de los lóbulos pulmonares superiores. Aunque sensible, la radiografía de tórax tiene escasa especificidad, y no permite establecer un diagnóstico definitivo de TB.

\section{Diagnóstico}

Sólo se puede establecer un diagnóstico definitivo de TB pulmonar aislando $M$. tuberculosis a partir de esputos o de tejido pulmonar, aunque es posible establecer un diagnóstico de presunción si se encuentran bacilos acidoalcohol-resistentes (BAAR) en los esputos de personas con cuadros clínicos compatibles. Se debe comsiderar el diagnóstico de TB en función de los signos y síntomas clínicos; no se debe retrasar el aislamiento y tratamiento de personas con enfermedades compatibles mientras se espera el resultado de una PCT. En los países en vías de desarrollo donde no se dispone de reactivos para la PCT ni de radiografías de tórax, la OM S propone que se evalúe para detectar una posible TB a las personas que presenten cualquier síntoma respiratorio de tres semanas de duración, hemoptisis de cualquier duración 0 una pérdida de peso importante. Se deben examinar al miscrocopio los esputos de estas personas para detectar BAAR .

\section{Otras profesiones afectadas}

Se ha documentado la transmisión aérea de $M$. tuberculosis de trabajador a trabajador y de cliente a trabajador entre personal hospitalario, tripulaciones de vuelo de las líneas aéreas, cuidadores de animales, trabajadores de astilleros, empleados de colegios y obreros de fábricas de contrachapados. Se debe prestar especial atención a ciertas profesiones como los trabajadores agrícolas, los cuidadores de animales, los trabajadores manuales, las amas de casa, los porteros y los manipuladores de alimentos, aunque la mayor parte del riesgo se puede deber a la situación socioeconómica o de inmigración de los trabajadores.

Se debe prestar especial atención a la TB pulmonar entre los mineros y otros grupos expuestos al sílice. Además de un aumento del riesgo de contraer una infección primaria a partir de otros mineros, las personas enfermas de silicosis tienen más probabilidades de desarrollar TB y tienen una tasa de mortalidad por TB más elevada que los trabajadores que no tienen silicosis. Al igual que en la mayoría de las personas, la TB se desarrolla por reactivación entre las personas con silicosis a partir de antiguas infecciones por $M$. tuberculosis que anteceden a la exposición al ślice. En sistemas experimentales, se ha demostrado que la exposición al ślice empeora el progreso de la infección de forma proporcional a la dosis, pero no está claro si los trabajadores expuestos al sílice que no han desarrollado silicosis corren mayor riesgo de desarrollar TB. Los trabajadores de fundiciones expuestos al sílice sin silicosis radiográfica corren un riesgo de muerte por TB tres veces superior al de trabajadores de características similares que no han sufrido exposición al sílice. O tras exposiciones profesionales a polvos no se han asociado a un aumento de la progresión de la T B.

Los jornaleros agrícolas tienen más probabilidades de desarrollar TB por reactivación que el resto de la población. Se calcula que las PCT positivas en jornaleros oscilan entre aproximadamente el $45 \%$ en personas de 15 a 34 años de edad y cerca del $70 \%$ en trabajadores de más de 34 años.

El personal de laboratorios clínicos corre un mayor riesgo de contraer TB de origen ocupacional por transmisión aérea. En un reciente estudio llevado a cabo durante diez años en una selección de hospitales de Japón, desarrolló T B el 0,8 \% del personal de laboratorio. No se identificó ningún origen comunitario y sólo se identificaron exposiciones relacionadas con el trabajo en el $20 \%$ de los casos. Casi todos los casos se produjeron entre trabajadores de los laboratorios de anatomía patológica y bacteriología y de las salas de autopsia.

\section{Tratamiento}

Varios regímenes de tratamiento han demostrado su eficacia en distintos entornos ambulatorios. En los pacientes colaboradores de los países desarrollados, se ha convertido en tratamiento estándar la administración de dosis diarias de cuatro fármacos (entre los que se incluyen isoniazida y rifampicina) durante dos meses, seguidas de dosis diarias de isoniazida y rifampicina durante los cuatro meses siguientes. Bajo observación directa, la administración dos veces a la semana de los mismos medicamentos es una alternativa eficaz en los pacientes menos colaboradores. En los países en vías de desarrollo y en situaciones en las que no se puede disponer fácilmente de fármacos antituberculosos, se han empleado dosis diarias de isoniazida y rifampicina durante un período de 9 a 12 meses. El régimen de tratamiento debe ser compatible con la política nacional y tener en cuenta la sensibilidad del microorganismo a los fármacos antituberculosos estándar disponibles y la duración del tratamiento. D ada la limitación de recursos para controlar la TB en los países en vías de desarrollo, los esfuerzos se pueden dirigir a los orígenes primarios de la infección: los pacientes con frotis de esputo que demuestran BAAR .

En entornos sanitarios, está indicada la ausencia al trabajo en el caso de trabajadores infecciosos con TB pulmonar. En otros entornos, simplemente se puede aislar a los trabajadores infecciosos de los demás trabajadores. En general, se considera que las personas ya no son infecciosas tras dos semanas de tratamiento farmacológico antituberculoso adecuado, siempre que 
exista una mejoría sintomática y una disminución de la densidad de BAAR en los frotis de esputo.

\section{Controles de salud pública}

El principal control de salud pública para evitar la transmisión de TB de origen ocupacional o adquirida en la comunidad continúa siendo la identificación, el aislamiento y el tratamiento de las personas con T B pulmonar. La ventilación para diluir aerosoles infecciosos; la filtración y las luces ultravioletas para descontaminar el aire que contenga el aerosol o la protección personal respiratoria son medidas que se pueden usar donde se sepa que el riesgo de transmisión es excepcionalmente alto, pero todavía se desconoce la eficacia de estos métodos. Continúa la controversia sobre la utilidad del BCG para la protección del trabajador.

\section{Infecciones bacterianas diversas en el entorno sanitario}

Se pueden adquirir infecciones bacterianas comunes del pulmón a partir de los pacientes o dentro de la comunidad. Se produce transmisión aérea profesional de patógenos bacterianos como Streptococcus pneumoniae, $\mathrm{H}$ aemophilus influenza, $\mathrm{Nejsseria} \mathrm{meningitidis,}$ M ycoplasma pneumoniae y Legionella spp (Tabla 10.26), y las enfermedades resultantes están incluidas en muchos programas de vigilancia hospitalaria. Las infecciones bacterianas de origen ocupacional que afectan al tracto respiratorio tampoco se limitan al personal sanitario. Las infecciones por Streptococcus spp son, por ejemplo, una causa bien establecida de brotes de enfermedad entre los reclutas del ejército. Sin embargo, en el caso de un trabajador concreto, la prevalencia de estos trastornos fuera del lugar de trabajo complica la distinción entre infecciones de origen ocupacional e infecciones adquiridas en la comunidad. La presentación clínica, las pruebas diagnósticas, la epidemiología y el tratamiento de estos trastornos se describen en los manuales médicos habituales.

\section{Infecciones en el trabajador inmunodeprimido}

Los trabajadores inmunodeprimidos corren un mayor riesgo de contraer muchas NOO. Además, una serie de microorganismos que no causan ninguna enfermedad en individuos normales pueden provocar enfermedades en los sujetos inmunodeprimidos. El tipo de inmunosupresión también afectará a la propensión a la enfermedad. Por ejemplo, la aspergilosis pulmonar invasiva es una complicación más frecuente de la quimioterapia que del síndrome de inmunodeficiencia adquirida (SIDA).

La aspergilosis pulmonar invasiva se observa generalmente en pacientes inmunodeprimidos, especialmente en aquellos con neutropenia. Sin embargo, a veces se comunica esta enfermedad en individuos sin una predisposición aparente a la misma. La aspergilosis pulmonar invasiva se presenta normalmente como una grave neumonía necrotizante, con o sin afectación sistémica, en un paciente neutropénico. Aunque la aspergilosis invasiva se observa casi siempre como una infección nosocomial en pacientes sometidos a quimioterapia, es una enfermedad de elevada mortalidad en cualquier trabajador neutropénico. Las técnicas que reducen la aspergilosis nosocomial - por ejemplo, el control del polvo en los proyectos de construcción- también pueden proteger a los trabajadores susceptibles.

Una serie de patógenos animales se convierten en posibles zoonosis sólo en el paciente inmunodeprimido. Entre las zoonosis transmitidas por exposición a aerosoles observadas únicamente en los inmunodeprimidos se incluyen la encefalitozoonosis (debida a Encephalitozoon cuniculi), la tuberculosis debida a $M$ ycobacterium avium y las infecciones por R hodococcus equi. Estas enfermedades son especialmente preocupantes en la agricultura. Los métodos para proteger a los trabajadores inmunodeprimidos no están suficientemente investigados.
En el trabajador inmunodeprimido, muchos patógenos potenciales causan enfermedades invasivas y graves que no se observan en los pacientes normales. Por ejemplo, las infecciones graves por Candida albicans y Pneumocystis carinii son manifestaciones clásicas del SIDA. Por tanto, el espectro de patógenos profesionales en el trabajador inmunodeprimido puede provocar trastornos que no se presentan en trabajadores inmunológicamente normales. L as enfermedades de los individuos inmunodeprimidos se han estudiado en profundidad en otras partes y no se volverán a abordar en estas páginas.

\section{Controles de salud pública: resumen}

Las NOO se producen principalmente en cinco grupos de trabajadores: personal hospitalario, agricultores, trabajadores de las industrias cárnicas, personal militar y personal de laboratorios biomédicos (Tabla 10.26). El evitar los aerosoles infecciosos es la manera más eficaz de reducir la infección en la mayoría de las situaciones, pero a menudo resulta difícil. Por ejemplo, Coxiella burnetii, el agente etiológico de la fiebre $Q$, puede estar presente en cualquier entorno previamente contaminado por los líquidos biológicos de animales infectados, pero sería poco práctico evitar todos los aerosoles que puedan estar infectados en muchas situaciones de bajo riesgo como en el pastoreo de ovejas o los rodeos. El control de enfermedades concomitantes también reduce el riesgo de contraer $\mathrm{NOO}$. La silicosis, por ejemplo, aumenta el riesgo de reactivación de $T B$, y reducir la exposición al sílice puede reducir el riesgo de T B en los mineros. En el caso de NO O que presentan una morbilidad y mortalidad importantes en la población general, la inmunización puede ser la actuación de salud pública más importante. La educación de los trabajadores sobre el riesgo que corren de contraer NOO contribuye a que éstos colaboren con los programas de control de enfermedades profesionales y también ayuda al diagnóstico precoz de estos procesos.

Entre el personal hospitalario y el personal militar, la transmisión de persona a persona es generalmente la principal vía de infección. La inmunización de los trabajadores puede evitar la enfermedad y contribuir al control de patógenos de elevada morbilidad y/ o mortalidad. Dado que existe un riesgo para las personas que quizá no han sido adecuadamente inmunizadas, la identificación, el aislamiento y el tratamiento de las personas enfermas continúan formando parte del control de estas enfermedades. Cuando la inmunización y el aislamiento respiratorio fracasan o la morbilidad y la mortalidad asociadas alcanzan niveles intolerables, se pueden plantear medidas de protección personal o controles técnicos para reducir la densidad o la contagiosidad de los aerosoles.

En el caso de los agricultores, los trabajadores de las industrias cárnicas y el personal de laboratorios biomédicos, la transmisión de animal a ser humano es un patrón de transmisión común. Además de llevar a cabo la inmunización de las personas susceptibles siempre que sea posible, otras medidas para el control de estas enfermedades pueden ser la inmunización de los animales, la profilaxis con antibióticos, controlada por el veterinario, de animales aparentemente sanos, la cuarentena de los animales recién llegados, el aislamiento y el tratamiento de animales enfermos y la adquisición de animales carentes de patógenos. Cuando estas medidas fracasen o haya un alto nivel de morbilidad y mortalidad, se pueden plantear medidas como la protección personal o los controles técnicos.

La transmisión de agentes infecciosos del medio ambiente a los seres humanos es común entre los agricultores, incluidos muchos jornaleros. Es posible llevar a cabo la inmunización del trabajador cuando se dispone de vacuna, pero en el caso de muchos de estos patógenos, la incidencia de la enfermedad en la población general es baja y las vacunas rara vez son posibles. En 
los entornos agrícolas, los orígenes de la infección están muy extendidos. En consecuencia, rara vez es posible realizar controles técnicos para reducir la densidad o la contagiosidad de los aerosoles. En estos entornos, se puede pensar en aplicar agentes humidificadores $u$ otros métodos para reducir el polvo, agentes descontaminantes y protección personal respiratoria. D ado que el control de las NO 0 en los agricultores es a menudo difícil y que el personal médico rara vez ve estas enfermedades, es esencial educar a los trabajadores y establecer una comunicación entre estos y el personal médico.

\section{Referencias}

Abramson, MJ, JH Wlodarczyk, NA Saunders, MJ $\mathrm{H}$ ensley. 1989. Does aluminum smelting cause lung disease? Am R ev R espir D is 139:1042-1057.

Abrons, HL, MR Peterson, WT Sanderson, AL Engelberg, P H arber. 1988. Symptoms, ventilatory function, and environmental exposures in Portland cement workers. Brit I Ind M ed 45:368-375.

Adamson, IYR, L Young, DH Bowden. 1988. Relationship of alveolar epithelial injury and repair to the indication of pulmonary fibrosis. Am J Pathol 130(2):377-383.

Agencia Internacional para la Investigación sobre el Cáncer (IARC). 1971-1994. M onographs on the E valuation of $\mathrm{C}$ arcinogenic R isks to $\mathrm{H}$ umans. $\mathrm{V}$ ol. 1-58. Lyon: IARC.

-. 1987. M onographs on the Evaluation of Carcinogenic Risks to $\mathrm{H}$ umans, $O$ verall $E$ valuations of $C$ arcinogenicity: An U pdating of IARC M onographs. Vol. 1-42. Lyon: IAR C. (Suplemento 7.)

-. 1988. M an-made mineral fibres and radon. IARC M onographs on the Evaluation of Carcinogenic Risks to H umans, N o. 43. Lyon: IARC.

1988. Radon. IARC Monographs on the Evaluation of $\mathrm{C}$ arcinogenic R isks to $\mathrm{H}$ umans, $\mathrm{No}$. 43. Lyon: IARC.

-. 1989a. Diesel and gasoline engine exhausts and some nitroarenes. IARC M onographs on the Evaluation of Carcinogenic Risks to Humans, No. 46. Lyon: IARC.

-. 1989b. Non-occupational exposure to mineral fibres. IARC Scientific Publications, No. 90. Lyon: IARC.

-. 1989c. Some organic solvents, resin monomers and related compounds, pigments and occupational exposure in paint manufacture and painting. IARC M onographs on the Evaluation of $\mathrm{C}$ arcinogenic $\mathrm{R}$ isks to $\mathrm{H}$ umans, $\mathrm{No}$. 47. Lyon: IARC.

-. 1990a. Chromium and chromium compounds. IARC $M$ onographs on the Evaluation of Carcinogenic Risks to H umans, N o. 49. Lyon: IARC.

-. 1990b. Chromium, nickel, and welding. IARC $M$ onographs on the Evaluation of $\mathrm{C}$ arcinogenic Risks to H umans, N o. 49. Lyon: IAR C.

-. 1990c. Nicke and nickel compounds. IARC $M$ onographs on the Evaluation of $\mathrm{C}$ arcinogenic R isks to H umans, N 0. 49. Lyon: IARC.

- 1991a. Chlorinated drinking-water; Chlorination by-products; Some other halogenated compounds; C obalt and cobalt compounds. IARC Monographs on the Evaluation of $C$ arcinogenic R isks to $H$ umans, $\mathrm{No}$. 52. Lyon: IAR C

-. 1991b. Occupational exposures in spraying and application of insecticides and some pesticides. IARC $M$ onographs on the Evaluation of $C$ arcinogenic Risks to H umans, N 0. 53. Lyon: IARC.

-. 1992. Occupational exposures to mists and vapours from sulfuric acid, other strong inorganic acids and other industrial chemicals. IARC Monographs on the Evaluation of $\mathrm{C}$ arcinogenic $\mathrm{R}$ isks to $\mathrm{H}$ umans, $\mathrm{No}$. 54. Lyon: IARC.

- 1994a. Beryllium and beryllium compounds. IARC Monographs on the Evaluation of Carcinogenic Risks to H umans, N o. 58. Lyon: IAR C.

-. 1994b. B eryllium, cadmium and cadmium compounds, mercury and the glass industry. IARC M onographs on the Evaluation of $\mathrm{C}$ arcinogenic $\mathrm{R}$ isks to H umans, No. 58. Lyon: IARC

-. 1995. Survival of cancer patients in Europe The EUROCARE study. IARC Scientific Publications, N 0.132. Lyon: IARC

Agius, R. 1992. Is silica carcinogenic? 0 ccup M ed 42: 50-52.

Alberts, WM , GA Do Pico. 1996. Reactive airways dysfunction syndrome (revisión). Chest 109:1618-1626.

Albrecht, WN , CJ Bryant. 1987. Polymer fume fever associated with smoking and use of a mold release spray containing polytetraflouroethylene. I 0 ccup $M$ ed 29:817-819.

American Conference of Governmental Industrial H ygienists (ACGIH). 1993. 1993-1994 Threshold Limit Values and Biological Exposure Indices. Cincinnati, O hio: ACGIH.

American Thoracic Society (ATS). 1987 Standards for the diagnosis and care of patients with chronic obstructive pulmonary disease (COPD) and asthma. Am R ev R espir D is 136:225-244.

-.1995. Standardization of Spirometry: 1994 update. Amer | Resp C rit Care M ed 152: 1107-1137.

Antman, K , J Aisner. 1987. A sbestos-R elated M alignancy. O rlando: G rune \& Stratton.

Antman, K H, FP Li, HI Pass, J Corson, T Delaney. 1993. Benign and malignant mesothelioma. En Cancer: Principles and Practice of Oncology, dirigido por VTJ DeVita, S Hellman y SA Rosenberg. Filadelfia: JB Lippincott.

Asbestos Institute. 1995. Centro de documentación: M ontreal, C anadá

Attfield, M D, K M orring. 1992. An investigation into the relationship between coal workers' pneumoconiosis and dust exposure in US coal miners. Am Ind H yg Assoc J 53(8):486-492.

Attfield, MD. 1992. British data on coal miners' pneumoconiosis and relevance to US conditions. Am J Public $H$ ealth 82:978-983.

Attfield, MD, RB Althouse. 1992. Surveillance data on U S coal miners' pneumoconiosis, 1970 to 1986. Am J Public $\mathrm{H}$ ealth 82:971-977.

Axmacher, B, O Axelson, T Frödin, R Gotthard, J H ed, L M olin, H N oorlind Brage, M Ström. 1991. Dust exposure in coeliac disease: A case-referent study. B rit J Ind M ed 48:715-717.

Baquet, CR, JW H orm, T G ibbs, P G reenwald. 1991. Socioeconomic factors and cancer incidence among blacks and whites. I Natl Cancer Inst 83: 551-557.

Beaumont, GP. 1991. Reduction in airborne silicon carbide whiskers by process improvements. Appl $O$ ccup E nviron $H$ yg 6(7):598-603.

Becklake, MR. 1989. O ccupational exposures: Evidence for a causal association with chronic obstructive pulmonary disease. Am Rev Respir Dis. 140: S85-S91.

— . 1991. The epidemiology of asbestosis. En M ineral Fibers and $\mathrm{H}$ ealth, dirigido por $\mathrm{D}$ Liddell y $\mathrm{K} \mathrm{M}$ iller. Boca R atón: CR C Press.

- . 1992. O ccupational exposure and chronic airways disease. Capítulo 13 en Environmental and 0 ccupational M edicine Boston: Little, Brown \& Co.
-. 1993. En Asthma in the workplace, dirigido por IL Bernstein, M Chan-Y eung, J-L Malo y D Bernstein. M arcel Dekker.

- . 1994. Pneumoconioses. Capítulo 66 en A T extbook of Respiratory M edicine, dirigido por JF M urray y J Nadel. Filadelfia: WB Saunders.

Becklake, MR, B Case. 1994. Fibre burden and asbestos-related lung disease: Determinants of dose-response relationships. Am J Resp Critical Care $M$ ed 150:1488-1492.

Becklake, M R y cols. 1988. T he relationships between acute and chronic airways responses to occupational exposures. In C urrent Pulmonology. V ol. 9, dirigido por DH Simmons. Chicago: Y ear Book $M$ edical Publishers.

Bégin, R, A Cantin, S M assé. 1989. R ecent advances in the pathogenesis and clinical assessment of mineral dust pneumoconioses: Asbestosis, silicosis and coal pneumoconiosis. E ur Resp | 2:988-1001.

Bégin, R, P Sébastien. 1989. Alveolar dust clearance capacity as determinant of individual susceptibility to asbestosis: Experimental observations. Ann 0 ccup H yg 33:279-282.

Bégin, $R, A$ Cantin, $Y$ Berthiaume, $R$ Boileau, $G$ Bisson, G Lamoureux, M Rola-Pleszczynski, G Drapeau, S Massé, M Boctor, I Breault, S Péloquin, D Dalle. 1985. Clinical features to stage alveolitis in asbestos workers. Am J Ind $\mathrm{Med}$ 8:521-536.

Bégin, R, G O stiguy, R Filion, S Groleau. 1992. Recent advances in the early diagnosis of asbestosis. Sem R oentgenol 27(2):121-139.

Bégin, T, A Dufresne, A Cantin, S M assé, P Sébastien, G Perrault. 1989. Carborundum pneumoconiosis. Chest 95(4):842-849.

Beijer L, M Carvalheiro, PG Holt, R R ylander. 1990. Increased blood monocyte procoagulant activity in cotton mill workers. J. Clin Lab Immunol 33:125-127.

Beral, V, P Fraser, M Booth, L Carpenter. 1987. Epidemiological studies of workers in the nuclear industry. En Radiation and $\mathrm{H}$ ealth: The Biological Effects of Low-Level Exposure to Ionizing Radiation, dirigido por $\mathrm{R}$ Russell Jones y $\mathrm{R}$ Southwood. Chichester: Wiley.

Bernstein, IL, M Chan-Yeung, J-L Malo, D Bernstein. 1993. Asthma in the $W$ orkplace. Marcel Dekker.

Berrino F, M Sant, A Verdecchia, R Capocaccia, T $\mathrm{H}$ akulinen, J Esteve. 1995. Survival of Cancer Patients in Europe: The EUROCARE Study. IARC Scientific Publications, No 132. Lyon: IARC.

Berry, G, CB M CK errow, MKB Molyneux, CE Rossiter, JBL Tombleson. 1973. A study of the acute and chronic changes in ventilatory capacity of workers in Lancashire Cotton M ills. Br J Ind $M$ ed 30:25-36.

Bignon J, (dir.) 1990. H ealth-related effects of phyllosilicates. NATO ASI Series. Berlín: Springer-V erlag.

Bignon, J, P Sébastien, M Bientz. 1979. R eview of some factors relevant to the assessment of exposure to asbestos dusts. En The use of Biological Specimens for the Assessment of $H$ uman Exposure to Environmental Pollutants, dirigido por A Berlin, $\mathrm{AH}$ W olf y $Y$ H asegawa. D ordrecht: $\mathrm{M}$ artinus Nijhoff para la Comisión Europea. 
Bignon J, J Peto, R Saracci, (dirs.) 1989 Non-occupational exposure to mineral fibres. IARC Scientific Publications, No 90. Lyon: IAR C.

Bisson, G, G Lamoureux, R Bégin. 1987. Q uantitative gallium 67 lung scan to assess the inflammatory activity in the pneumoconioses. Sem Nuclear M ed 17(1):72-80.

Blanc, PD, DA Schwartz. 1994. Acute pulmonary responses to toxic exposures. En Respiratory $M$ edicine, dirigido por JF Murray y JA Nadel. Filadelfia: W B Saunders.

Blanc, P, H Wong, MS Bernstein, HA Boushey. 1991. An experimental human model of a metal fume fever. Ann Intern M ed 114:930-936.

Blanc, PD, HA Boushey, H Wong, SF Wintermeyer, MS Bernstein. 1993. Cytokines in metal fume fever. Am R ev Respir D is 147:134-138.

Blandford, TB, PJ Seamon, R Hughes, M Pattison, MP Wilderspin. 1975. A case of polytetrafluoroethylene poisoning in cockatiels accompanied by polymer fume fever in the owner. $V$ et R ec 96:175-178.

Blount, BW. 1990. T wo types of metal fume fever: mild vs. serious. M ilit M ed 155:372-377.

Boffetta, P, R Saracci, A Anderson, PA Bertazzi, Chang-Claude J, G Ferro, AC Fletcher, R Frentzel-Beyme, MJ Gardner, JH OIsen, L Simonato, L T eppo, P W esterholm, P Winter, C Zocchetti. 1992. Lung cancer mortality among workers in the European production of man-made mineral fibers-a Poisson regression analysis. Scand J W ork E nviron $\mathrm{H}$ ealth 18:279-286.

Borm, PJA. 1994. Biological markers and occupational lung dsease: $M$ ineral dust-induced respiratory disorders. Exp L ung R es 20:457-470.

Boucher, RC. 1981. Mechanisms of pollutant induced airways toxicity. Clin Chest M ed 2:377-392.

Bouige, D. 1990. Dust exposure results in 359 asbestos-using factories from 26 countries. En Seventh International Pneumoconiosis Conference Aug 23-26, 1988. Proceedings Part II. Washington, DC DHS (NIOSH).

Bouhuys A. 1976. Byssinosis: Scheduled asthma in the textile industry. L ung 154:3-16.

Bowden, DH, C Hedgecock, IYR Adamson. 1989. Silica-induced pulmonary fibrosis involves the reaction of particles with interstitial rather than alveolar macrophages. J Pathol 158:73-80.

Brigham, KL, B Mayerick. 1986. Endotoxin and Lung injury. Am R ev Respir D is 133:913-927.

Brody, AR. 1993. Asbestos-induced lung disease. E nviron $H$ ealth Persp 100:21-30.

Brody, AR, LH Hill, BJ Adkins, RW O'Connor 1981. Chrysotile asbestos inhalation in rats: Deposition pattern and reaction of alveolar epithelium and pulmonary macrophages. Am Rev Respir D is 123:670.

Bronwyn, L, L Razzaboni, P Bolsaitis. 1990. Evidence of an oxidative mechanism for the hemolytic activity of silica particles. Environ $\mathrm{H}$ ealth Persp 87: 337-341.

Brookes, KJA. 1992. W orld Directory and $\mathrm{H}$ andbook of $H$ ard $M$ etal and $H$ ard $M$ aterials. Londres: International C arbide Data.

Brooks, SM, AR Kalica. 1987. Strategies for elucidating the relationship between occupational exposures and chronic air-flow obstruction. Am R er Respir D is 135:268-273.

Brooks, SM , M A W eiss, IL Bernstein. 1985. Reactive airways dysfunction syndrome (RADS). Chest 88:376-384.

Browne, K. 1994. Asbestos-related disorders Capítulo 14 en 0 ccupational Lung Disorders, dirigido por WR Parkes. O xford: Butterworth-H einemann.
Brubaker, RE. 1977. Pulmonary problems associated with the use of polytetrafluoroethylene. I 0 ccup M ed 19:693-695.

Bunn, WB, JR Bender, TW H esterberg, GR Chase, JL K onzen. 1993. Recent studies of man-made vitreous fibers: Chronic animal inhalation studies. I O ccup M ed 35(2):101-113.

Burney, MB, S Chinn. 1987. Developing a new questionnaire for measuring the prevalence and distribution of asthma. Chest 91:79S-83S.

Burrell, R, R R ylander. 1981. A critical review of the role of precipitins in hypersensitivity pneumonitis E ur J Resp D is 62:332-343.

Bye, E. 1985. O ccurrence of airborne silicon carbide fibers during industrial production of silicon carbide. Scand I W ork E nviron H ealth 11:111-115.

Cabral-Anderson, LJ, MJ Evans, G Freeman. 1977 Effects of $\mathrm{NO}_{2}$ on the lungs of aging rats I. Exp M ol Pathol 27:353-365.

Campbell, JM . 1932. A cute symptoms following work with hay. B rit M ed I 2:1143-1144.

Carvalheiro MF, Y Peterson, E Rubenowitz, R Rylander. 1995. Bronchial activity and work-related symptoms in farmers. Am J Ind M ed 27: 65-74.

Castellan, RM, SA Olenchock, KB Kinsley, JL $H$ ankinson. 1987. Inhaled endotoxin and decreased spirometric values: An exposure-response relation for cotton dust. $\mathrm{N}$ ew Engl J M ed 317:605-610.

Castleman, WL, DL Dungworth, LW Schwartz, WS Tyler. 1980. Acute repiratory bronchiolitis - An ultrastructural and autoradiographic study of epithelial cell injury and renewal in Rhesus monkeys exposed to ozone. Am J Pathol 98:811-840.

Chan-Y eung, M. 1994. M echanism of occupational asthma due to Western red cedar. Am J Ind M ed 25:13-18.

-. 1995. Assessment of asthma in the workplace ACCP consensus statement. American College of Chest Physicians. Chest 108:1084-1117.

Chan-Y eung, M , J-L M alo. 1994. A etiological agents in occupational asthma. E ur Resp J 7:346-371.

Checkoway, H, NJ Heyer, P Demers, NE Breslow. 1993. Mortality among workers in the diatomaceous earth industry. Brit J Ind $\mathrm{Med}$ 50:586-597.

Chiazze, L, DK Watkins, C Fryar. 1992. A case-control study of malignant and non-malignant respiratory disease among employees of a fibreglass manufacturing facility. B rit J Ind M ed 49:326-331.

Churg, A. 1991. Analysis of lung asbestos content. B rit $J$ Ind $M$ ed 48:649-652.

Cooper, WC, G Jacobson. 1977. A twenty-one year radiographic follow-up of workers in the diatomite industry. J O ccup M ed 19:563-566.

Comisión Internacional de Protección contra la Radiación (ICRP). 1994. H uman Respiratory T ract M odel for Radiological Protection. Publication No. 66. ICRP

Comité Europeo de Normalización (CEN). 1991. Size $F$ raction $D$ efinitions for $M$ easurements of Airborne Particles in the Workplace Informe núm. EN 481. Luxemburgo: CEN

Craighead, JE, JL Abraham, A Churg, FH Green, J Kleinerman, PC Pratt, TA Seemayer, V Vallyathan, H Weill. 1982. The pathology of asbestos associated diseases of the lungs and pleural cavities. Diagnostic criteria and proposed grading system. Arch Pathol L ab M ed 106: 544-596.

Crystal, RG, JB West. 1991. T he Lung. Nueva Y ork: $R$ aven Press.

Cullen, MR, JR Balmes, JM Robins, GJW Smith 1981. Lipoid pneumonia caused by oil mist exposure from a steel rolling tandem mill. Am J Ind $M$ ed 2: 51-58.

Dalal, NA, X Shi, V V allyathan. 1990. R ole of free radicals in the mechanisms of hemolysis and lipid peroxidation by silica: Comparative ESR and cytotoxicity studies. I Tox Environ $\mathrm{H}$ ealth 29:307-316.

Das, R, PD Blanc. 1993. Chlorine gas exposure and the lung: A review. T oxicol Ind $\mathrm{H}$ ealth 9:439-455.

Davis, JMG, AD Jones, BG Miller. 1991. Experimental studies in rats on the effects of asbestos inhalation couples with the inhalation of titanium dioxide or quartz. Int | Exp Pathol 72:501-525.

Deng, JF, T Sinks, L Elliot, D Smith, M Singal, L Fine. 1991. Characterisation of respiratory health and exposures at a sintered permanent magnet manufacturer. B rit J Ind M ed 48:609-615.

De Viottis, JM. 1555. Magnus O pus. Historia de gentibus septentrionalibus. En Aedibus Birgittae. Roma.

Di Luzio, NR. 1985. U pdate on immunomodulating activities of glucans. Springer Semin Immunopathol 8:387-400.

Doll, $R$, J Peto. 1985. Effects on health of exposure to asbestos. Londres, $\mathrm{H}$ ealth and Safety Commission Londres: $\mathrm{H}$ er M ajesty's Stationery $\mathrm{O}$ ffice.

—. 1987. En Asbestos-R dated M alignancy, dirigido por $K$ Antman y J Aisner. O rlando, Florida: Grune $\&$ Stratton.

Donelly, SC, M X Fitzgerald. 1990. R eactive airways dysfunction syndrome (RADS) due to acute chlorine exposure. Int J M ed Sci 159:275-277.

Donham, K, P Haglind, Y Peterson, R Rylander. 1989. Environmental and health studies of farm workers in Swedish swine confinement buildings. B rit J Ind M ed 46:31-37.

Do Pico, GA. 1992. Hazardous exposure and lung disease among farm workers. Clin Chest $M$ ed 13: 311-328.

Dubois, F, R Bégin, A Cantin, S M assé, M M artel, G Bilodeau, A Dufresne, G Perrault, $P$ Sébastien. 1988. Aluminum inhalation reduces silicosis in a sheep model. Am R ev R espir D is 137:1172-1179.

Dunn, AJ. 1992. Endotoxin-induced activation of cerebral catecholamine and serotonin metabolism: Comparison with Interleukin.1. J Pharmacol Exp Therapeut 261:964-969.

Dutton, CB, MJ Pigeon, PM Renzi, PJ Feustel, RE Dutton, GD Renzi. 1993. Lung function in workers refining phosphorus rock to obtain elementary phosphorus. I Occup M ed 35:1028-1033.

Ellenhorn, MJ, DG Barceloux. 1988. M edical T oxicology. Nueva Y ork: Elsevier.

Emmanuel, DA, JJ M arx, B Ault. 1975. Pulmonary mycotoxicosis. Chest 67:293-297.

- 1989. O rganic dust toxic syndrome (pulmonary mycotoxicosis) - A review of the experience in central Wisconsin. En Principles of $H$ ealth and Safety in Agriculture, dirigido por JA Dosman y DW Cockcroft. Boca R atón: CRC Press.

Engelen, JJM, PJA Borm, M Van Sprundel, L Leenaerts. 1990. Blood anti-oxidant parameters at different stages in coal worker's pneumoconiosis. Environ $H$ ealth Persp 84:165-172.

Englen, MD, SM Taylor, WW Laegreid, HD Liggit, RM Silflow, RG Breeze, RW Leid. 1989. Stimulation of arachidonic acid metabolism in silica-exposed alveolar macrophages. Exp L ung R es 15: $511-526$

Environmental Protection Agency (EPA). 1987. Ambient Air M onitoring reference and equivalent methods. Federal Register 52:24727 (1 de julio de 1987). 
Ernst, Zejda. 1991. En M ineral Fibers and $\mathrm{H}$ ealth, dirigido por $\mathrm{D}$ Liddell y $\mathrm{K}$ Miller. Boca Ratón: CRC Press.

Evans, MJ, LJ Cabral-Anderson, G Freeman. 1977 Effects of $\mathrm{NO}_{2}$ on the lungs of aging rats II. Exp $\mathrm{M}$ ol Pathol 27:366-376.

Fogelmark, B, H Goto, K Yuasa, B Marchat, R Rylander. 1992. Acute pulmonary toxicity of inhaled $(1 \rightarrow 3)-B-D-g l u c a n$ and endotoxin. Agents Actions 35:50-56.

Fraser, RG, JAP Paré, PD Paré, RS Fraser. 1990. Diagnosis of $D$ iseases of the Chest. $V$ ol. III. Filadelfia: WB Saunders.

Fubini, B, E Giamello, M V olante, V Bolis. 1990 Chemical functionalities at the silica surface determining its reactivity when inhaled. Formation and reactivity of surface radicals. T oxicol Ind $\mathrm{H}$ ealth 6(6):571-598.

Gibbs, AE, FD Pooley, DM Griffith. 1992. Talc pneumoconiosis: A pathologic and mineralogic study. H um Pathol 23(12):1344-1354.

Gibbs, G, F Valic, K Browne. 1994. Health risk associated with chrysotile asbestos. A report of a workshop held in Jersey, Channel Islands. Ann 0 ccup H yg 38:399-638.

Gibbs, WE. 1924. Clouds and Smokes. Nueva York: Blakiston.

Ginsburg, CM, MG K ris, JG Armstrong. 1993. $\mathrm{N}$ on-small cell lung cancer. En Cancer: Principles \& Practice of Oncology, dirigido por VTJ DeV ita, S H ellman y SA Rosenberg. Filadelfia: JB Lippincott.

Goldfrank, LR, NE Flomenbaum, N Lewin, MA H owland. 1990. Goldfrank's T oxicologic Emergencies. N orwalk, Connecticut: Appleton \& Lange.

Goldstein, B, RE Rendall. 1987. The prophylactic use of polyvinylpyridine-N-oxide (PVNO) in baboons exposed to quartz dust. Environmental R esearch 42:469-481.

Goldstein, RH, A Fine 1986. Fibrotic reactions in the lung: The activation of the lung fibroblast. $E x p$ Lung R es 11:245-261.

Gordon, RE, D Solano, J K leinerman. 1986. Tight junction alterations of respiratory epithelia following long term $\mathrm{NO}_{2}$ exposure and recovery. Exp L ung Res 11:179-193.

Gordon, T, LC Chen, JT Fine, R B Schlesinger. 1992. Pulmonary effects of inhaled zinc oxide in human subjects, guinea pigs, rats, and rabbits. Am Ind $\mathrm{H}$ yg Assoc] 53:503-509.

Graham, D. 1994. Noxious gases and fumes. En T extbook of Pulmonary Diseases, dirigido por GL Baum y E Wolinsky. Boston: Little, Brown \& Co.

Green, J M , R M Gonzalez, N Sonbolian, P R enkopf. 1992. The resistance to carbon dioxide laser ignition of a new endotracheal tube. I Clin Anesthesiaol 4:89-92.

Guilianelli, C, A Baeza-Squiban, E Boisvieux-U Irich, O Houcine, R Zalma, C Guennou, H Pezerat, $F$ $M$ araN o. 1993. Effect of mineral particles containing iron on primary cultures of rabbit tracheal epithelial cells: Possible implication of oxidative stress. Environ $H$ ealth Persp 101(5):436-442

Gun, RT, Janckewicz, A Esterman, D Roder, R Antic, RD M cEvoy, A Thornton. 1983. Byssinosis: A cross-sectional study in an Australian textile factory. I Soc 0 ccup M ed 33:119-125.

$\mathrm{H}$ aglind $\mathrm{P}, \mathrm{R}$ Rylander. Exposure to cotton dust in an experimental cardroom. $\mathrm{Br}$ J Ind $\mathrm{M}$ ed 10 : 340-345.

H anoa, R. 1983. Graphite pneumoconiosis. A review of etiologic and epidemiologic aspects. Scand J W ork E nviron $H$ ealth 9:303-314.
H arber, P, M Schenker, J Balmes. 1996. O ccupational and Environmental Respiratory Disease. St. Louis: M osby.

H ealth Effects Institute - Asbestos Research. 1991. Asbestos in Public and Commercial Buildings: A Literature Review and Synthesis of $C$ urrent Knowledge. $C$ ambridge $M$ assachussetts: $H$ ealth $E$ ffects Institute.

H effner, JE, JE R epine. 1989. Pulmonary strategies of antioxidant defense. Am Rev Respir Dis 140: 531-554.

Hemenway, D, A Absher, B Fubini, L Trombley, P Vacek, M V olante, A Cabenago. 1994. Surface functionalities are related to biological response and transport of crystalline silica. Ann O ccup H yg 38 Supl. 1:447-454

Henson, PM, RC M urphy. 1989. M ediators of the Inflammatory P rocess. N ueva Y ork: Elsevier.

Heppleston, AG. 1991. M inerals, fibrosis and the Lung. E nviron $H$ ealth Persp 94:149-168.

Herbert, A, M Carvalheiro, E R ubenowiz, B Bake, R Rylander. 1992. Reduction of alveolar-capillary diffusion after inhalation of endotoxin in normal subjects. Chest 102:1095-1098.

H essel, PA, GK Sluis-Cremer, E H nizdo, M H Faure, RG Thomas, FJ Wiles. 1988. Progression of silicosis in relation to silica dust exposure. Am 0 ccup H yg 32 Supl. 1:689-696.

Higginson, J, CS Muir, N M uñoz. 1992. Human cancer: Epidemiology and environmental causes. En Cambridge $M$ onographs on Cancer Research. Cambridge: Cambridge U niv. Press.

H inds, WC. 1982. A erosol T echnology: Properties, B ehavior, and $M$ easurement of Airborne Particles. Nueva York: John Wiley.

H offman, RE, K Rosenman, F Watt y cols. 1990. O ccupational disease surveillance: O ccupational asthma. M orb M ortal W eekly R ep 39:119-123.

Hogg, JC. 1981. Bronchial mucosal permeability and its relationship to airways hyperreactivity. I Allergy Clin immunol 67:421-425.

Holgate, ST, R Beasley, OP T wentyman. 1987. The pathogenesis and significance of bronchial hyperresponsiveness in airways disease. Clin Sci 73:561-572.

Holtzman, MJ. 1991. Arachidonic acid metabolism. Implications of biological chemistry for lung function and disease. Am Rev Respir Dis 143:188-203.

H ughes, J M , H Weil. 1991. A sbestosis as a precursor of asbestos related lung cancer: Results of a prospective mortality study. Brit J Ind M ed 48: 229-233.

H ussain, M H , JA Dick, Y S K aplan. 1980. R are earth pneumoconiosis. I Soc O ccup M ed 30:15-19.

Ihde, DC, HI Pass, EJ G latstein. 1993. Small cell lung cancer. En Cancer: Principles and Practice of Oncology, dirigido por VTJ DeVita, S Hellman y SA R osenberg. Filadelfia: JB Lippincott.

Infante-Rivard, C, B Armstrong, $P$ Ernst, $M$ Peticlerc, L-G Cloutier, G Thériault. 1991. Descriptive study of prognostic factors influencing survival of compensated silicotic patients. Am Rev Respir D is 144:1070-1074.

Janssen, YMW, JP Marsh, MP Absher, D Hemenway, PM Vacek, KO Leslie, PJA Borm, BT Mossman. 1992. Expression of antioxidant enzymes in rat lungs after inhalation of asbestos or silica. J Biol Chem 267(15):10625-10630.

Jaurand, M C, J Bignon, P Brochard. 1993. The mesothelioma cell and mesothelioma. Past, present and future. Conferencia internacional celebrada en París los días 20 de septiembre al 2 de octubre de 1991. E ur R esp Rev 3(11):237.

Jederlinic, PJ, JL Abraham, A Churg, JS Himmelstein, GR Epler, EA Gaensler. 1990.
Pulmonary fibrosis in aluminium oxide workers. Am Rev Respir D is 142:1179-1184.

Johnson, NF, MD Hoover, DG Thomassen, YS Cheng, A Dalley, AL Brooks. 1992. In vitro activity of silicon carbide whiskers in comparison to other industrial fibers using four cell culture systems. Am J Ind M ed 21:807-823.

Jones, HD, TR Jones, WH Lyle. 1982. Carbon fibre: Results of a survey of process workers and their environment in a factory producing continuous filament. Am O ccup H yg 26:861-868.

Jones, RN, JE Diem, HW Glindmeyer, V Dharmarajan, YY Hammad, J Carr, H Weill. 1979. M ill effect and dose-response relationships in byssinosis. $\mathrm{Br}$ J Ind $\mathrm{M}$ ed 36:305-313.

Kamp, DW, P Graceffa, WA Prior, A Weitzman. 1992. The role of free radicals in asbestos-induced diseases. F ree $R$ adical B io M ed 12:293-315.

$K$ arjalainen, A, PJ Karhonen, K Lalu, A Pentilla, E Vanhala, P K ygornen, A Tossavainen. 1994. Pleural plaques and exposure to mineral fibres in a male urban necropsy population. O ccup Environ $M$ ed 51:456-460.

Kass, I, N Zamel, CA Dobry, M Holzer. 1972. Bronchiectasis following ammonia burns of the respiratory tract. Chest 62:282-285.

$\mathrm{K}$ atsnelson, BA, LK K onyscheva, YEN Sharapova, LI Privalova. 1994. Prediction of the comparative intensity of pneumoconiotic changes caused by chronic inhalation exposure to dusts of different cytotoxicity by means of a mathematical model. 0 ccup E nviron M ed 51:173-180.

K eenan, KP, JW Combs, EM M CD owell. 1982. R egeneration of hamster tracheal epithelium after mechanical injury I, II, III. Virchows Archiv 41:193-252.

Keenan, KP, TS Wilson, EM M CD owell. 1983. R egeneration of hamster tracheal epithelium after mechanical injury IV . V irchows A rchiv 41:213-240.

K ehrer, JP. 1993. Free radicals as mediators of tissue injury and disease. Crit R ev T oxicol 23:21-48.

Keimig, DG, RM Castellan, GJ Kullman, KB K insley. 1987. Respiratory health status of gilsonite workers. Am J Ind M ed 11:287-296.

K elley, J. 1990. Cytokines of the Lung. Am Rev Respir $D$ is 141:765-788.

Kennedy, TP, R Dodson, NV Rao, H Ky, C Hopkins, M Baser, E Tolley, JR Hoidal. 1989. Dusts causing pneumoconiosis generate $\mathrm{OH}$ and product hemolysis by acting as fenton catalysts. Arch B iochem Biophys 269(1):359-364.

K ilburn, K H, RH Warshaw. 1992. I rregular opacities in the lung, occupational asthma, and airways dysfunction in aluminum workers. Am J Ind $\mathrm{M}$ ed 21:845-853.

Kokkarinen, J, H Tuikainen, EO Terho. 1992. Severe farmer's lung following a workplace challenge. Scand J W ork E nviron $H$ ealth 18:327-328.

K ongerud, I, Boe, V Soyseth, A Naalsund, P $M$ agnus. 1994. Aluminium pot room asthma: The N orwegian experience. E ur Resp J 7:165-172.

K orn, RJ, DW Dockery, FE Speizer. 1987. O ccupational exposure and chronic respiratory symptoms. Am R ev Respir D is 136:298-304.

K riebel, D. 1994. The dosimetric model in occupational and environmental epidemiology. $O$ ccup $H$ yg 1:55-68.

Kriegseis, W, A Scharmann, I Serafin. 1987. Investigations of surface properties of silica dusts with regard to their cytotoxicity. Ann $\mathrm{O}$ ccup $\mathrm{H}$ yg 31(4A):417-427.

K uhn, DC, LM Demers. 1992. Influence of mineral dust surface chemistry on eicosanoid production by the alveolar macrophage. I T ox Environ $\mathrm{H}$ ealth 35. $39-50$ 
K uhn, DC, CF Stanley, N El-Ayouby, LM Demers. 1990. Effect of in vivo coal dust exposure on arachidonic acid metabolism in the rat alveolar macrophage. J T ox E nviron H ealth 29:157-168.

K unkel, SL, SW Chensue, RM Strieter, JP Lynch, DG Remick. 1989. Cellular and molecular aspects of granulomatous inflammation. Am J Respir Cell M ol Biol 1:439-447.

K untz, WD, CP M cC ord. 1974. Polymer fume fever. I 0 ccup M ed 16:480-482.

Lapin, CA, DK Craig, M G Valerio, JB M CC andless, $R$ Bogoroch. 1991. A subchronic inhalation toxicity study in rats exposed to silicon carbide whiskers. F und Appl T oxicol 16:128-146.

Larsson, K, P Malmberg, A Eklund, L Belin, E Blaschke. 1988. Exposure to microorganisms, airway inflammatory changes and immune reactions in asymptomatic dairy farmers. Int Arch Allergy I mm 87:127-133.

Lauweryns, JM, JH Baert. 1977. Alveolar clearance and the role of the pulmonary lymphatics. Am Rer Respir D is 115:625-683.

Leach, J. 1863. Surat cotton, as it bodily affects operatives in cotton mills. Lancet II:648.

Lecours, R, M Laviolette, Y Cormier. 1986. Bronchoalveolar lavage in pulmonary mycotoxicosis (organic dust toxic syndrome). Thorax 41:924-926.

Lee, KP, DP K elly, FO O'Neal, JC Stadler, GL K ennedy. 1988. Lung response to ultrafine kevlar aramid synthetic fibrils following 2-year inhalation exposure in rats. F und Appl T oxicol 11:1-20.

Lemasters, G, J Lockey, C Rice, R M cK ay, K Hansen, J Lu, L Levin, P Gartside. 1994. Radiographic changes among workers manufacturing refractory ceramic fiber and products. Ann 0 ccup H yg 38 Supl 1:745-751.

Lesur, O, A Cantin, AK Transwell, B M elloni, J-F Beaulieu, R Bégin. 1992. Silica exposure induces cytotoxicity and proliferative activity of type II. Exp L ung Res 18:173-190.

Liddell, D, K M illers (dirs.). 1991. M ineral fibers and health. Florida, Boca R atón: CR C Press.

Lippman, M. 1988. Asbestos exposure indices. Environmental R esearch 46:86-92.

-. 1994. Deposition and retention of inhaled fibres: Effects on incidence of lung cancer and mesothelioma. 0 ccup E nviron M ed 5: 793-798.

Lockey, J, E James. 1995. M an-made fibers and nonasbestos fibrous silicates. Capítulo 21 en $O$ ccupational and Environmental Respiratory Diseases, dirigido por $\mathrm{P} H$ arber, M B Schenker y JR Balmes. St. Louis: M osby.

Luce, D, P Brochard, P Q uénel, C Salomon-N ekiriai, $P$ Goldberg, MA Billon-Galland, M Goldberg. 1994. M alignant pleural mesothelioma associated with exposure to tremolite. Lancet 344:1777.

M alo, J-L, A Cartier, J L'A rcheveque, H Ghezzo, F Lagier, C Trudeau, J Dolovich. 1990. Prevalence of occupational asthma and immunological sensitization to psyllium among health personnel in chronic care hospitals. Am Rev Respir Dis 142:373-376.

Malo, J-L, H Ghezzo, J L'Archeveque, F Lagier, B Perrin, A Cartier. 1991. Is the clinical history a satisfactory means of diagnosing occupational asthma? Am R ev R espir D is 143:528-532.

Man, SFP, WC Hulbert. 1988. Airway repair and adaptation to inhalation injury. En Pathophysiology and Treatment of Inhalation Injuries, dirigido por J Locke. N ueva Y ork: M arcel D ekker.

M arkowitz, S. 1992. Primary prevention of occupational lung disease: A view from the U nited States. I srael J M ed Sci 28:513-519.

$M$ arsh, GM, PE Enterline, RA Stone, VL $H$ enderson. 1990. M ortality among a cohort of
US man-made mineral fiber workers: 1985 follow-up. J O ccup M ed 32:594-604.

Martin, TR, SW M eyer, DR Luchtel. 1989. An evaluation of the toxicity of carbon fiber composites for lung cells in vitro and in vivo. E nvironmental R esearch 49:246-261.

M ay, JJ, L Stallones, D Darrow. 1989. A study of dust generated during silo opening and its physiologic effect on workers. En Principles of $\mathrm{H}$ ealth and Safety in Agriculture, dirigido por JA Dosman y DW Cockcroft. Boca R atón: CR C Press.

M cDermott, M, C Bevan, JE Cotes, M M Bevan, PD Oldham. 1978. Respiratory function in slateworkers. B E ur Physiopathol R esp 14:54.

MCDonald, JC. 1995. Health implications of environmental exposure to asbestos. Environ $\mathrm{H}$ ealth Persp 106: 544-96.

M cD onald, JC, AD M CD onald. 1987. Epidemiology of malignant mesothelioma. En Asbestos-R elated $M$ alignancy, dirigido por $\mathrm{K}$ Antman y J Aisner. O rlando, Florida: Grune \& Stratton.

-. 1991. Epidemiology of mesothelioma. En M ineral Fibres and $\mathrm{H}$ ealth. Boca R atón: CR C Press.

- . 1993. M esothelioma: Is there a background? En The M esothelioma $C \mathrm{Cll}$ and $M$ esothelioma: Past, Present and Future, dirigido por M C Jaurand, J Bignon y P Brochard.

-. 1995. Chrysotile, tremolite, and mesothelioma. Science 267:775-776.

M CD onald, JC, B Armstrong, B Case, D Doell, WTE M cCaughey, AD M CD onald, P Sébastien. 1989. Mesothelioma and asbestos fibre type. Evidence from lung tissue analyses. Cancer 63:1544-1547.

$M C D$ onald, JC, FDK Lidell, A Dufresne, AD M cD onald. 1993. The 1891-1920 birth cohort of Q uebec chrystotile miners and millers: mortality 1976-1988. B rit J Ind M ed 50:1073-1081.

McMillan, DD, GN Boyd. 1982. The role of antioxidants and diet in the prevention or treatment of oxygen-induced lung microvascular injury. Ann NY A cad Sci 384:535-543.

Medical Research Council. 1960. Standardized questionnaire on respiratory symptoms. B rit $\mathrm{M}$ ed J 2:1665.

M ekky, S, SA R oach, R SF Schilling. 1967. Byssinosis among winders in the industry. $\mathrm{Br} J$ Ind $\mathrm{Med}$ 24:123-132.

Merchant JA, JC Lumsden, KH Kilburn, WM O 'Fallon, JR Ujda, VH Germino, JD Hamilton. 1973. Dose response studies in cotton textile workers. I O ccup M ed 15:222-230.

M eredith, SK, JC M CD onald. 1994. Work-related respiratory disease in the United Kingdom, 1989-1992. 0 ccup E nviron M ed 44:183-189.

M eredith, S, H Nordman. 1996. O ccupational asthma: M easures of frequency of four countries. Thorax 51:435-440.

M ermelstein, R, RW Lilpper, PE M orrow, H M uhle. 1994. Lung overload, dosimetry of lung fibrosis and their implications to the respiratory dust standard. Ann O ccup H yg 38 Supl. 1:313-322.

M erriman, EA. 1989. Safe use of K evlar aramid fiber in composites. Appl Ind $\mathrm{H}$ yg $\mathrm{Número}$ especial (diciembre):34-36.

M eurman, LO, E Pukkala, M H akama. 1994. Incidence of cancer among anthophyllite asbestos miners in Finland. 0 ccup E nviron M ed 51:421-425.

M ichael, O , R Ginanni, J D uchateau, F V ertongen, B LeBon, R Sergysels. 1991. Domestic endotoxin exposure and clinical severity of asthma. Clin Exp Allergy 21:441-448.

Michel, O,J Duchateau, G Plat, B Cantinieaux, A Hotimsky, J Gerain R Sergysels. 1995. Blood inflammatory response to inhaled endotoxin in normal subjects. Clin Exp Allergy 25:73-79.
Morey, P, JJ Fischer, R Rylander. 1983. Gram-negative bacteria on cotton with particular reference to climatic conditions. Am Ind H yg Assoc) 44: 100-104.

National Academy of Sciences. 1988. Health risks of radon and other internally deposited alpha-emitters. Washington, DC: N ational A cademy of Sciences.

- . 1990. $\mathrm{H}$ ealth effects of exposure to low levels of ionizing radiation. Washington, DC: National Academy of Sciences.

National Asthma Education Program (NAEP). 1991. Expert Panel Report: Guidelines for the Diagnosis and $M$ anagement of Asthma. Bethesda, M aryland: $\mathrm{N}$ ational Institutes of $\mathrm{H}$ ealth $(\mathrm{N} / \mathrm{H})$.

Nemery, B. 1990. M etal toxicity and the respiratory tract. E ur Resp J 3:202-219.

Newman, LS, K K reiss, T K ing, S Seay, PA Campbell. 1989. Pathologic and immunologic alterations in early stages of beryllium disease. Reexamination of disease definition and natural history. Am R ev Respir D is 139:1479-1486.

Nicholson, WJ. 1991. In H ealth E ffects Institute-Asbestos Research: Asbestos in Public and Commercial Buildings. Cambrige, Massachussetts: $\quad H$ ealth Effects Institute-A sbestos R esearch.

Niewoehner, DE, JR H oidal. 1982. L ung Fibrosis and Emphysema: Divergent responses to a common injury. Science 217:359-360.

Nolan, R P, AM Langer, JS H arrington, G O ster, If Selikoff. 1981. Q uartz hemolysis as related to its surface functionalities. E nviron R es 26:503-520.

O akes, D, R Douglas, K K night, M Wusteman, JC $M$ cD onald. 1982. R espiratory effects of prolonged exposure to gypsum dust. Ann 0 ccup $\mathrm{H}$ yg 2:833-840.

O'Brodovich, H, G Coates. 1987. Pulmonary Clearance of $99 \mathrm{mT}$ c-DTPA: A noninvasive assessment of epithelial integrity. L ung 16:1-16.

O rganización Internacional del Trabajo (OIT). 1980. Guidelines for the use of IL 0 international classification of radiographs of pneumoconioses. O ccupational Safety and H ealth Series, N 0. 22. Ginebra: OIT.

-. 1985. Sixth International Report on the Prevention and Suppression of D ust in $M$ ining, T unnelling and $Q$ uarrying 1973-1977. O ccupational Safety and $\mathrm{H}$ ealth Series, N 0.48. Ginebra: OIT.

O rganización Internacional de Normalización (ISO). 1991. Air Q uality - Particle Size F raction D efinitions for $H$ ealth-R elated Sampling. G inebra: ISO.

O rganización M undial de la Salud (O M S) y Agencia Internacional para la Investigación sobre el Cáncer (IARC). 1982. IARC M onographs on the Evaluation of the Carcinogenic Risk of Chemicals to $H$ umans. Lyon: IARC

O rganización M undial de la Salud (O M S) y O ficina de Medicina del Trabajo. 1989. O ccupational Exposure Limit for A sbestos. G inebra: O M S.

Parkes, RW. 1994. Occupational Lung Disorders. L ondres: Butterworth-H einemann.

Parkin, D M , P Pisani, J Ferlay. 1993. Estimates of the worldwide incidence of eighteen major cancers in 1985. Int J Cancer 54:594-606.

Pepys, J, PA Jenkins. 1963. Farmer's lung: Thermophilic actinomycetes as a source of "farmer's lung hay" antigen. Lancet 2:607-611.

Pepys, J, RW Riddell, KM Citron, YM Clayton. 1962. Precipitins against extracts of hay and molds in the serum of patients with farmer's lung, aspergillosis, asthma and sarcoidosis. Thorax 17:366-374

Pernis, B, EC Vigliani, C Cavagna, M Finulli. 1961. The role of bacterial endotoxins in occupational diseases caused by inhaling vegetable dusts. B rit J nd M ed 18:120-129.

Petsonk, EL, E Storey, PE Becker, CA Davidson, K K ennedy, V V allyathan. 1988. Pneumoconiosis in 
carbon electrode workers. J O ccup M ed 30: 887-891.

Pézerat, H, R Zalma, J Guignard, MC Jaurand. 1989. Production of oxygen radicals by the reduction of oxygen arising from the surface activity of mineral fibres. En Non-occupational exposure to mineral fibres, dirigido por J Bignon, ] Peto y R Saracci. IARC Scientific Publications, N 0.90. Lyon: IARC

Piguet, PF, AM Collart, GE Gruaeu, AP Sappino, P $V$ assalli. 1990. Requirement of tumour necrosis factor for development of silica-induced pulmonary fibrosis. Nature 344:245-247.

Porcher, JM , C L afuma, R EI Nabout, M P Jacob, P Sébastien, PJA Borm, S Hannons, G Auburtin. 1993. Biological markers as indicators of exposure and pneumoconiotic risk: Prospective study. Int Arch $\mathrm{O}$ ccup E nviron $\mathrm{H}$ ealth 65:S209-S213.

Prausnitz, C. 1936. Investigations on respiratory dust disease in operatives in cotton industry. M edical Research Council Special Report Series, N o. 212. Londres: $\mathrm{H}$ is $\mathrm{M}$ ajesty's Stationery $\mathrm{O}$ ffice.

Preston, DL, H K ato, KJ Kopecky, S Fujita. 1986. Life Span Study Report 10, Part 1. Cancer M ortality Among A-Bomb Survivors in $\mathrm{H}$ iroshima and Nagasaki, 1950-1982. Technical Report. RERF TR.

Quanjer, PH, GJ Tammeling, JE Cotes, OF Pedersen, R Peslin, J-C Vernault. 1993. Lung volumes and forced ventilatory flows. Informe del Grupo de Trabajo para la Normalización de las Pruebas de la Función Pulmonar, Comunidad Europea del Carbón y del Acero. Declaración oficial de la Sociedad Respiratoria Europea. Eu Resp J 6(supl 16): 5-40.

Raabe, OG. 1984. Deposition and clearance of inhaled particles. En Occupational Lung Disease, dirigido por $\mathrm{BL}$ Gee, WKC Morgan y GM Brooks. Nueva York: R aven Press.

Ramazzini, B. 1713. De M oribis Artificium Diatriba (D iseases of W orkers). En Allergy P roc 1990, 11:51-55.

Rask-Andersen A. 1988. Pulmonary reactions to inhalation of mould dust in farmers with special reference to fever and allergic alveolitis. Acta Universitatis Upsalienses. Tesis doctoral de la Facultad de M edicina 168. U ppsala.

Richards, RJ, LC Masek, RFR Brown. 1991. Biochemical and Cellular Mechanisms of Pulmonary Fibrosis. T oxicol Pathol 19(4):526-539.

Richerson, HB. 1983. H ypersensitivity pneumonitis pathology and pathogenesis. Clin Rev Allergy 1: 469-486.

-. 1990. U nifying concepts underlying the effects of organic dust exposures. Am J Ind M ed 17:139-142.

—. 1994. Hypersensitivity pneumonitis. En Organic Dusts - Exposure, Effects, and Prevention, dirigido por $R$ Rylander y RR Jacobs. Chicago: Lewis Publishing.

Richerson, HB, IL Bernstein, JN Fink, GW H unninghake, HS N ovey, CE R eed, JE Salvaggio, MR Schuyler, HJ Schwartz, DJ Stechschulte. 1989. Guidelines for the clinical evaluation of hypersensitivity pneumonitis. J Allergy Clin immunol 84:839-844.

Rom, WN. 1991. Relationship of inflammatory cell cytokines to disease severity in individuals with occupational inorganic dust exposure. Am J Ind $M$ ed 19:15-27.

-. 1992a. Environmental and Occupational M edicine Boston: Little, Brown \& Co.

-. 1992b. Hairspray-induced lung disease. En Environmental and $O$ ccupational $M$ edicine, dirigido por WN R om. Boston: Little, Brown \& Co.

R om, WN , JS Lee, BF Craft. 1981. O ccupational and environmental health problems of the developing oil shale industry: A review. Am I Ind M ed 2: 247-260.
Rose, CS. 1992. Inhalation fevers. En Environmental and $O$ ccupational Medicine, dirigido por WN Rom. Boston: Little, Brown \& Co.

Rylander R. 1987. The role of endotoxin for reactions after exposure to cotton dust. Am J Ind $M$ ed 12: 687-697.

Rylander, R, B Bake, J-J Fischer, IM H elander 1989. Pulmonary function and symptoms after inhalation of endotoxin. Am Rev Resp $D$ is 140:981-986.

Rylander R, R Bergström 1993. Bronchial reactivity among cotton workers in relation to dust and endotoxin exposure. Ann $\mathrm{O}$ ccup $\mathrm{H}$ yg 37:57-63.

Rylander, R, KJ D onham, Y Peterson. 1986. Health effects of organic dusts in the farm environment. Am J Ind M ed 10:193-340.

Rylander, R, P H aglind. 1986. Exposure of cotton workers in an experimental cardroom with reference to airborne endotoxins. Environ $\mathrm{H}$ ealth Persp 66:83-86.

Rylander R, P H aglind, M Lundholm 1985. Endotoxin in cotton dust and respiratory function decrement among cotton workers. Am Rev Respir $D$ is 131:209-213.

Rylander, R, PG H olt. 1997. M odulation of immune response to inhaled allergen by co-exposure to the microbial cell wall components $(1 \rightarrow 3)$-B-D -glucan and endotoxin. M anuscript.

R ylander, R, R R Jacobs. 1994. O rganic D usts: Exposure, E ffects, and Prevention. Chicago: Lewis Publishing

- 1997. Environmental endotoxin - A criteria document. I O ccup E nviron $\mathrm{H}$ ealth 3: 51-548.

Rylander, R, Y Peterson. 1990. O rganic dusts and lung disease. Am J Ind M ed 17:1148.

—. 1994. Causative agents for organic dust related disease. Am J Ind M ed 25:1-147.

Rylander, R, Y Peterson, KJ Donham. 1990. Q uestionnaire evaluating organic dust exposure Am J Ind M ed 17:121-126.

Rylander, R, RSF Schilling, CAC Pickering, GB Rooke, AN Dempsey, RR Jacobs. 1987. Effects after acute and chronic exposure to cotton dust The $M$ anchester criteria. B rit J Ind $M$ ed 44:557-579.

Sabbioni, E, R Pietra, P Gaglione. 1982. Long term occupational risk of rare-earth pneumoconiosis. Sci T otal E nviron 26:19-32.

Sadoul, P. 1983. Pneumoconiosis in Europe yesterday, today and tomorrow. E ur J Resp D is 64 Supl. 126:177-182.

Scansetti, G, G Piolatto, GC Botta. 1992. Airborne fibrous and non-fibrous particles in a silicon carbide manufacturing plant. Ann Occup $\mathrm{Hyg}$ 36(2):145-153.

Schantz, SP, LB Harrison, WK Hong. 1993. T umours of the nasal cavity and paranasal sinuses, nasopharynx, oral cavity, and oropharynx. En Cancer: Principles \& Practice of Oncology, dirigido por VTJ DeVita, S Hellman y SA Rosenberg. Filadelfia: JB Lippincott.

Schilling, RSF. 1956. Byssinosis in cotton and other textile workers. L ancet 2:261-265.

Schilling, R SF, JPW H ughes, I Dingwall-Fordyce, JC Gilson. 1955. An epidemiological study of byssinosis among L ancashire cotton workers. B rit J Ind $M$ ed 12:217-227.

Schulte, PA. 1993. Use of biological markers in occupational health research and practice. J Tox Environ $\mathrm{H}$ ealth 40:359-366.

Schuyler, M, C C ook, M Listrom, C Fengolio-Preiser. 1988. Blast cells transfer experimental hypersensitivity pneumonitis in guinea pigs. Am Rev Respir D is 137:1449-1455.

Schwartz DA, KJ Donham, SA Olenchock, WJ Popendorf, D Scott Van Fossen, LJ Burmeister, JA M erchant. 1995. Determinants of longitudinal changes in spirometric function among swine confinement operators and farmers. Am J Respir Crit Care M ed 151: 47-53.

Science of the total environment. 1994. Cobalt and $H$ ard $M$ etal D isease 150(N úmero especial):1-273.

Scuderi, P. 1990. Differential effects of copper and zinc on human peripheral blood monocyte cytokine secretion. Cell I mmunol 265:2128-2133.

Seaton, A. 1983. Coal and the lung. Thorax 38:241-243.

Seaton, J, D Lamb, W R hind Brown, G Sclare, WG $M$ iddleton. 1981. Pneumoconiosis of shale miners. Thorax 36:412-418.

Sébastien, P. 1990. Les mystères de la nocivité du quartz. En Conférence Thématique 23 Congrès International De La M édecine Du T ravail Montreal: Comisión Internacional de $M$ edicina del T rabajo.

-. 1991. Pulmonary Deposition and Clearance of Airborne $M$ ineral Fibers. En $M$ ineral $F$ ibers and $\mathrm{H}$ ealth, dirigido por $\mathrm{D}$ Liddell y $\mathrm{K}$ M iller. Boca R atón: CRC Press.

Sébastien, P, A Dufresne, R Bégin. 1994. Asbestos fibre retention and the outcome of asbestosis with or without exposure cessation. Ann $\mathrm{O}$ ccup $\mathrm{H}$ yg 38 Supl. 1:675-682

Sébastien, P, B Chamak, A G audichet, JF Bernaudin, M C Pinchon, J Bignon. 1994. Comparative study by analytical transmission electron microscopy of particles in alveolar and interstitial human lung macrophages. Ann 0 ccup H yg 38 Supl. 1: 243-250.

Seidman, H, IJ Selikoff. 1990. Decline in death rates among asbestos insulation workers 1967-1986 associated with diminution of work exposure to asbestos. Annals of the $\mathrm{New}$ Y ork Academy of Sciences 609:300-318.

Selikoff, IJ, J Churg. 1965. The biological effects of asbestos. Ann NY A cad Sci 132:1-766.

Selikoff, IJ, DHK Lee. 1978. Asbestos and Disease. Nueva Y ork: Academic Press.

Sessions, RB, LB Harrison, VT Hong. 1993. T umours of the larynx, and hypopharynx. En Cancer: Principles and Practice of Oncology, dirigido por VTJ DeVita, S Hellman y SA Rosenberg. Filadelfia: JB Lippincott.

Shannon, HS, E Jamieson, JA Julian, DCF M uir. 1990. M ortality of glass filament (textile) workers. B rit J Ind M ed 47:533-536.

Sheppard, D. 1988. Chemical agents. En Respiratory M edicine, dirigido por JF Murray y JA Nadel. Filadelfia: WB Saunders.

Shimizu, Y, H K ato, WJ Schull, DL Preston, S Fujita, DA Pierce. 1987. Life span study report 11, Part 1. Comparison of R isk Coefficients for Site-Specific Cancer M ortality based on the DS86 and T 65D R Shielded Kerma and Organ Doses. Informe técnico RERF TR 12-87.

Shusterman, DJ. 1993. Polymer fume fever and other flourocarbon pyrolysis related syndromes. 0 ccup $M$ ed: State Art Rev 8:519-531.

Sigsgaard T, OF Pedersen, S Juul, S Gravesen. Respiratory disorders and atopy in cotton wool and other textile mill workers in Denmark. Am J Ind M ed 1992;22:163-184.

Simonato, L, AC Fletcher, JW Cherrie. 1987. The International Agency for Research on Cancer historical cohort study of MMMF production workers in seven European countries: Extension of the follow-up. Ann $\mathrm{O}$ ccup H yg 31:603-623.

Skinner, HCW, M Roos, C Frondel. 1988. Asbestos and $O$ ther Fibrous $M$ inerals. Nueva York: Oxford U niv. Press.

Skornik, WA. 1988. Inhalation toxicity of metal particles and vapors. En Pathophysiology and Treatment of I nhalation I njuries, dirigido por J Locke. Nueva Y ork: $M$ arcel D ekker. 
Smith, PG, R Doll. 1982. M ortality among patients with ankylosing sponchylitis after a single treatment course with $X$-rays. B rit $M$ ed 284:449-460.

Smith, TJ. 1991. Pharmacokinetic models in the development of exposure indicators in epidemiology. Ann $\mathrm{O}$ ccup H yg 35(5):543-560.

Snella, M-C, R Rylander. 1982. Lung cell reactions after inhalation of bacterial lipopolysaccharides. Eur J Resp D is 63:550-557.

Stanton, MF, M Layard, A Tegeris, E Miller, M May, E M organ, A Smith. 1981. Relation of particle dimension to carcinogenicity in amphibole asbestoses and other fibrous minerals. J N atl Cancer Inst 67:965-975.

Stephens, RJ, MF Sloan, MJ Evans, G Freeman 1974. Alveolar type I cell response to exposure to $0.5 \mathrm{ppm} 03$ for short periods. Exp Mol Pathol 20:11-23.

Stille, WT, IR Tabershaw. 1982. The mortality experience of upstate $\mathrm{N}$ ew Y ork talc workers. 0 ccup M ed 24:480-484.

Strom, E, O Alexandersen. 1990. Pulmonary damage caused by ski waxing. Tidsskrift for Den Norske L aegeforening 110:3614-3616.

Sulotto, F, C Romano, A Berra. 1986. Rare earth pneumoconiosis: A new case. Am J Ind M ed 9: 567-575.

Trice, M F. 1940. Card-room fever. Textile W orld 90:68.

Tyler, WS, NK Tyler, JA Last. 1988. Comparison of daily and seasonal exposures of young monkeys to ozone. T oxicology 50:131-144.

Ulfvarson, U, M Dahlqvist. 1994. Pulmonary function in workers exposed to diesel exhaust. En E ncyclopedia of E nvironmental Control T echnology N ueva Jersey: Gulf Publishing.

US Department of $\mathrm{H}$ ealth and $\mathrm{H}$ uman Services. 1987. Report on cancer risks associated with the ingestion of asbestos. Environ $\mathrm{H}$ ealth Persp 72:253-266.

US Department of $\mathrm{Health}$ and Human Services (USDHHS). 1994. W ork-Related L ung Disease Survellance Report. Washington, DC: Public H ealth Services, Center for Disease Control and Prevention.

Vacek, PM, JC M CD onald. 1991. Risk assessment using exposure intensivity: An application to vermiculite mining. B rit J Ind $M$ ed 48:543-547.

Valiante, DJ, TB Richards, KB Kinsley. 1992. Silicosis surveillance in New Jersey: Targeting workplaces using occupational disease and exposure surveillance data. Am I Ind $\mathrm{M} \mathrm{ed}$ 21:517-526.

Vallyathan, NV, JE Craighead. 1981. Pulmonary pathology in workers exposed to nonasbestiform talc. H um Pathol 12:28-35.

Vallyathan, V, X Shi, NS Dalal, W Irr, V Castranova. 1988. Generation of free radicals from freshly fractured silica dust. Potential role in acute silica-induced lung injury. Am R ev Respir D is 138:1213-1219.

Vanhee, D, P Gosset, B Wallaert, C Voisin, AB T onnel. 1994. Mechanisms of fibrosis in coal workers' pneumoconiosis. Increased production of platelet-derived growth factor, insulin-like growth factor type I, and transforming growth-factor beta and relationship to disease severity. Am J Resp Critical Care M ed 150(4):1049-1055.

V aughan, GL, J Jordan, S K arr. 1991. The toxicity, in vitro, of silicon carbide whiskers. Environmenta Research 56:57-67.

Vincent, JH, K Donaldson. 1990. A dosimetric approach for relating the biological response of the lung to the accumulation of inhaled mineral dust. B rit J Ind M ed 47:302-307.
V ocaturo, K G, F Colombo, M Zanoni. 1983. H uman exposure to heavy metals. Rare earth pneumoconiosis in occupational workers. Chest 83:780-783.

Wagner, GR. 1996. Health Screening and Surveillance of M ineral Dust Exposed Workers Recomendación para el Grupo de Trabajadores de la OIT. Ginebra: O M S.

Wagner, JC. 1994. The discovery of the association between blue asbestos and mesotheliomas and the aftermath. B rit J Ind M ed 48:399-403.

Wallace, WE, JC H arrison, R C Grayson, MJ K eane $P$ Bolsaitis, RD Kennedy, AQ Wearden, MD Attfield. 1994. Aluminosilicate surface contamination of respirable quartz particles from coal mine dusts and from clay works dust. Ann 0 ccup H yg 38 Supl. 1:439-445.

Warheit, DB, KA Kellar, MA Hartsky. 1992. Pulmonary cellular effects in rats following aeroso exposures to ultrafine K evlar aramid fibrils: Evidence for biodegradability of inhaled fibrils. T oxicol Appl Pharmacol 116:225-239.

Waring, PM, RJ Watling. 1990. Rare deposits in a deceased movie projectionist. A new case of rare earth pneumoconiosis? M ed J Austral 153:726-730.

Wegman, DH, JM Peters. 1974. Polymer fume fever and cigarette smoking. Ann Intern M ed 81:55-57.

Wegman, DH, JM Peters, MG Boundy, TJ Smith. 1982. Evaluation of respiratory effects in miners and millers exposed to talc free of asbestos and silica. B rit J Ind M ed 39:233-238.

Wells, RE, RF Slocombe, AL Trapp. 1982. Acute toxicosis of budgerigars ( $M$ elopsittacus undulatus) caused by pyrolysis products from heated polytetrafluoroethylene: Clinical study. Am J Vet Res 43:1238-1248.

Wergeland, E, A Andersen, A Baerheim. 1990. M orbidity and mortality in talc-exposed workers. Am J Ind M ed 17:505-513.

White, DW, JE Burke. 1955. The M etal Beryllium. Cleveland, O hio: A merican Society for $M$ etals.

Wiessner, JH, NS M andel, PG Sohnle, A H asegawa GS M andel. 1990. The effect of chemical modification of quartz surfaces on particulate-induces pulmonary inflammation and fibrosis in the mouse. Am R ev R espir D is 141:11-116.

Williams, N, W Atkinson, AS Patchefsky. 1974. Polymer fume fever: Not so benign. J O ccup M ed 19:693-695.

Wong, O, D Foliart, LS T rent. 1991. A case-control study of lung cancer in a cohort of workers potentially exposed to slag wool fibres. B rit J Ind $M$ ed 48:818-824

Woolcock, AJ. 1989. Epidemiology of Chronic airways disease. Chest 96 (Supl): 302-306S

Wright, JL, P Cagle, A Shurg, TV Colby, J M yers. 1992. Diseases of the small airways. Am R ev Respir $D$ is $146: 240-262$

Y an, CY, CC Huang, IC Chang, CH Lee, JT T sai, YC K o. 1993. Pulmonary function and respiratory symptoms of portland cement workers in souther T aiwan. Kaohsiung」 M ed Sci 9:186-192.

Zajda, EP. 1991. Pleural and airway disease associated with mineral fibers. En M ineral Fibers and $\mathrm{H}$ ealth, dirigido por $\mathrm{D}$ Liddell y $\mathrm{K}$ Miller. Boca R atón: CR C Press

Ziskind, M, RN Jones, H Weill. 1976. Silicosis. Am Rev Respir D is 113:643-665.

\section{0 tras lecturas recomendadas}

Agencia Internacional para la Investigación sobre el Cáncer (IARC). 1980. Biological effects of mineral fibres. IAR C Scientific Publications, N o. 30. Lyon: ARC.

Althouse, RB, RM Castellan, GR Wagner. 1992. Pneumoconioses in the U nited States: Highlights of surveillance data from NIOSH and other federal sources. 0 ccup M ed 7:197-208.

Andrews, JL, H K azemi, HL H ardy. 1969. Patterns of lung dysfunction in chronic beryllium disease. Am Rev Respir D is 100:191-800.

Attfield, M D, TK H odous. 1992. Pulmonary function of US coal miners related to dust exposure estimates. Am R ev Respir D is 14:605-609.

Attfield, M D, K M orring. 1992. An investigation into the relationship between coal workers' pneumoconiosis and dust exposure in US coal miners. Am Ind H yg Assoc 5 53:486-492.

Banks, DE, MA Bauer, RM Castellan, NL Lapp. 1983. Silicosis in surface coalmine drillers. Thorax 38: $275-278$

Beckett W, J Abraham, M Becklake, D Christiani, R Cowie, G Davis, R Jones, K K reiss, J Parker, G Wagner. 1997. Adverse effects of crystaline silica exposure. Am J Respir C rit C are M ed 155:761-768.

Binford, CH, DH Conner (dirs.). 1976. Pathology of T ropical and Extraordinary D iseases. Washington, DC. Armed Forces Institute of Pathology.

Centers for Disease Control and Prevention. 1994. Guidelines for preventing the transmission of $M$ ycobacterium tuberculosis in health-care facilities. M M W R M orb M ortal W kly Rep 43 (No. R R-13): 1-132

Chandler, FW, JC Watts. 1988. Fungal infections. En Pulmonary Pathology, dirigido por DH Hail y SP $\mathrm{H}$ ammar. Nueva Y ork: Springer-V erlag.

Cochrane, AL. 1962. The attack rate of progressive massive fibrosis. B rit J Ind M ed 19:52-64.

Cotran, RS, V Kumar, SL Robbins, FJ Schoen, (dirs.). 1994. Pathologic Basis of Disease, 5a ed. Filadelfia: WB Saunders.

Davies, SF. 1994. Fungal pneumonia. M ed Clin N orth Am 78:1049-1065.

Dykewicz, CA, VM Dato, SP FIscher-Hoch, MV H owarth, GI Perez-O ronoz, SM O stroff, H Gary Jr., LB Schonberger, JB M CC ormick. 1992. Lymphocytic choriomeningitis outbreak associated with nude mice in a research institute. J AM A 267: 1349-1353.

Eastes, W. 1993. M an-M ade Vitrteous Fibers: Nomenclature, Chemical and Physical Properties. Stanford, Connecticut: Nomenclature Committee of TIMA.

Eisenbud, ME, J Lisson. 1983. Epidemiological aspects of beryllium-induced nonmalignant lung disease: A 30-year update. I O ccup M ed 25:196-202.

Epstein, PE, JH Dauber, M D R ossman, RP Daniele. 1982. Bronchoalveolar lavage in a patient with chronic berylliosis: Evidence for hypersensitivity pneumonitis. Ann Intern M ed 97:213-216.

Esposito, AL. 1992. Pulmonary infections acquired in the workplace: A review of occupation-associated pneumonia. Clin Chest M ed 13:355-365.

Graman, PS, CB Hall. 1989. Epidemiology and control of nosocomial viral infections. Infect D is Clin N Am 3(4):815-841.

Hardy, HL. 1980. Beryllium disease: A clinical perspective. E nviron Res 21(1):1-9.

Hopewell, PC, BR Bloom. 1994. Tuberculosis and other mycobacterial diseases. En T extbook of Respiratory M edicine, dirigido por JF M urray y JA Nadel. Filadelfia: WB Saunders.

H urley, JF, WM M aclaren. 1987. Dust-R elated Risks of Radiological Changes in Coalminers Over a $40-Y$ ear W orking Life: Report on W ork Commissioned By NIOSH. Informe núm. T M / 79/ 09:1-66. Washington, DC: National Institute for O ccupational Safety and $\mathrm{H}$ ealth $(\mathrm{N} I \mathrm{OSH})$

Hurley, JF, CA Souter. 1986. Can exposure to coalmine dust cause a severe impairment of lung function? B rit J Ind M ed 43:150-157. 
Inhaled particles VII. 1994. Actas de un Simposio internacional sobre inhalación de partículas organizado por la British $\mathrm{H}$ ygiene Society, dirigido por J Dodgson y RI M cCallum. Ann Occup $\mathrm{H}$ yg 38(Supl.1).

Jacobsen, M, S Rae, WH Walton, JM Rogan. 1971. The relation between pneumoconiosis and dust exposure in British coal mines. En Inhaled Particles III, dirigido por WH Walton. O Id Woking, Reino U nido: Unwin Brothers.

Jubb, KVF, PC Kennedy, N Palmer (dirs.). 1985. Pathology of Domestic Animals, 3a ed. San Diego: Academic Press.

K leinerman, J, FHY Green, W Laquer, G T aylor, R Harley, P Pratt. 1979. Pathology standards for coal workers' pneumoconiosis. Arch Pathol Lab M ed 103:375-432.

K reiss, K, LS N ewman, M M M roz, PA Campbell. 1989. Screening blood test identifies subclinical beryllium disease. J 0 ccup M ed 31:603-608.

$\mathrm{K}$ riebel, D, NL Sprince, EA Eisen, IA Greaves, HA Feldman, RE Greene. 1988. Beryllium exposure and pulmonary function: A cross-sectional study of beryllium workers. B rit I Ind M ed 45:167-173.

Landrigan, PJ, H K azemi. 1991. The third wave of asbestos disease: Exposure to asbestos in place Public health control. Ann NY A cad Sci 643:1-628.

Leigh, J, TR Driscoll, BD Cole, RW Beck, BP Hull, J Yang. 1994. Q uantitative relation between emphysema and lung mineral content in coalworkers. B rit J Ind M ed 51:400-407.

Léonard, A, R Lauwerys. 1987. Mutagenicity, carcinogenicity and teratogenicity of beryllium. M utat Res 186:35-42.

Liddel, D, K M iller. 1991. M ineral Fibres and $\mathrm{H}$ ealth. Boca R atón: CR C Press.

- 1990. Man-made mineral fibers (MMMF) Human exposures and health risk assessment. T oxicol Ind $H$ ealth 6:225-246.
Lockey, JE, NK Wiese. 1992. Health effects of synthetic vitreous fibers. Clin Chest $M$ ed 13(2):329-339.

Lowenthal, GL. 1994. O ccupational health programs in clinics and hospitals. En Occupational M edicine dirigido por C Zenz. St. Louis: M osby.

M acM ahon, B. 1994. The epidemiological evidence on the carcinogenicity of beryllium in humans. I 0 ccup M ed 36(1):15-26.

Mancuso, TF. 1970. Relation of duration of employment and prior respiratory illness to respiratory cancer among beryllium workers. Environ Res 3:251-275.

Massé, S, R Bégin, A Cantin. 1988. Pathology of silicon carbide pneumoconiosis. M od Pathol 1(2):104-108.

Merchant, JA (dir.). 1986. O ccupational Respiratory D iseases. Washington, DC: Division of R espiratory Disease Studies, NIOSH, CDC, USPH S, D ept. of $\mathrm{H}$ ealth and $\mathrm{H}$ uman Services.

Miller, BG, M Jacobsen. 1985. Dust exposure, pneumoconiosis, and mortality of coal miners. B rit J Ind $M$ ed 42:723-733.

Murray, R. 1990. Asbestos: A chronology of its origins and health effects. Brit I Ind $M$ ed 47:361-365.

$\mathrm{N}$ ational Institute for $\mathrm{O}$ ccupational Safety and $\mathrm{H}$ ealth (NIOSH) 1972. Criteria for a Recommended Standard. $O$ ccupational Exposure to B eryllium. Washington, DC: US G overnment Printing O ffice.

NIEHS. 1994. Biopersistence of respirable synthetic fibers and minerals. Environmental $\mathrm{H}$ ealth Perspectives Supplements. DH HS publication N 0. 94-218, Supl. 5. Washington, DC: DH S

Organización Mundial de la Salud (OMS). 1986. Recommended $\mathrm{H}$ ealth-Based Limits in $O$ ccupational Exposure to Selected Dusts (Silica, Coal). Ginebra: OMS.

- . 1994. Screening and Surveillance of M ineral Dust Exposed W orkers. Ginebra: O M S.
Organización del Tratado del Atlántico Norte (OTAN ). 1990. H ealth-R elated E ffects of Phyllosilicates. NATO ASI Series, dirigido por J Bignon.

Pappas, GP, LS Newman. 1993. Early pulmonary physiologic abnormalities in beryllium disease. Am Rev R espir D is 148:661-666.

Pott, F, U Ziem, FJ Reiffer, F Huth, H Ernst, U Mohr. 1987. Carcinogenicity studies on fibres, metal compounds, and some other dusts in rats. Exp Pathol 32:129-152.

Pratt, D, J M ay. 1994. Agricultural occupational medicine. En $O$ ccupational M edicine, dirigido por $\mathrm{C}$ Zenz. St. Louis: M osby.

Preuss, O, H O ster. 1980. Modern views on beryllium toxicity. Arbeitsmed Sozialmed Praventivmed 15(11):270-275.

R obbins, JJ, RL W are. 1964. Pulmonary edema from T eflon fumes. N ew Engl J M ed 271:360-361.

Soutar, CA, JF H urley. 1986. Relation between dust exposure and lung function in miners and ex-miners. Brit J Ind M ed 43:307-320.

Sprince, NL, DJ K anarek, A W eber, RI Chamberlin, $\mathrm{H}$ K azemi. 1978. Reversible respiratory disease in beryllium workers. Am Rev Respir Dis 117:1011-1017.

Stein, A, D Raoult. 1993. Lack of pathotype specific gene in human Coxiella burnetii isolates. M icrob Pathog 15:177-185.

Tepper, LB. 1980. B eryllium. M etals in the Environment. Londres: A cademic Press.

Weinberg, AN. 1991. Respiratory infections transmitted from animals. Infect $\mathrm{D}$ is Clin $\mathrm{N} \mathrm{Am}$ 5(3):649-661.

Weinberg, AN, AJ Weber (dirs.). 1991. Animal-associated human infections. Infect D is Clin North Am 5:1-180. 

Director del capítulo

$\mathrm{H}$ eikki Savolainem

\section{Sumario}

El oído

M arcel-André B oillat. ......................... 11.2

Trastornos auditivos inducidos por productos químicos

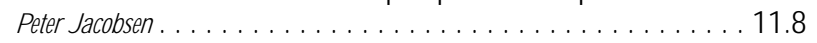

Trastornos auditivos provocados por agentes físicos

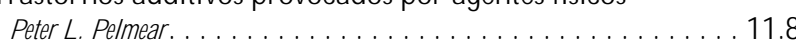

Equilibrio

Lucy Yardley............................... 11.9

Visión y trabajo

Paule R ey y $\mathrm{J}$ ean-J acques $M$ eyer . . . . . . . . . . . . . . . . . . 11.11

Gusto

A pril E. M ott y Norman M ann . . . . . . . . . . . . . . . . . 11.24

O Ifato

April E. M ott ............................ 11.27

Receptores cutáneos

Robert $D$ ykes $y$ D aniel $M C B$ ain 


\section{EL OIDO}

\section{M arcel-André Boillat}

\section{Anatomía}

El oído es el órgano sensorial responsable de la audición y del mantenimiento del equilibrio mediante la detección de la posición corporal y del movimiento de la cabeza. Se compone de tres partes: oído externo, medio e interno; el oído externo se sitúa fuera del cráneo, mientras que las otras dos partes se hallan dentro del hueso temporal (Figura 11.1).

El oído externo está formado por el pabellón auricular, una estructura cartilaginosa recubierta de piel, y por el conducto auditivo externo, un cilindro de forma irregular de unos $25 \mathrm{~mm}$ de largo y recubierto de glándulas que secretan cera.

El oído medio consta de la cavidad timpánica, una cavidad llena de aire cuyas paredes externas forman la membrana timpánica (tímpano) y que se comunica en dirección proximal con la nasofaringe a través de las trompas de Eustaquio, que mantienen el equilibrio de presión a ambos lados de la membrana timpánica. Así, debido a esta comunicación, al tragar se iguala la presión y se recupera la audición perdida por un cambio rápido en la presión barométrica (p. ej., al aterrizar en avión 0 en ascensores muy rápidos). La cavidad timpánica también contiene los huesecillos martillo, yunque y estribo, que son controlados por los músculos del estribo y tensor del tímpano. La membrana timpánica se une al oído interno por los huesecillos, concretamente a través del pie móvil del estribo, que está en contacto con la ventana oval.

El oído interno contiene el aparato sensorial propiamente dicho. Está formado por una cubierta ósea (el laberinto óseo) en la que se encuentra el laberinto membranoso, una serie de cavidades que forman un sistema cerrado lleno de endolinfa, un líquido rico en potasio. El laberinto membranoso está separado del laberinto óseo por la perilinfa, un líquido rico en sodio.

El laberinto óseo consta de dos partes. La porción anterior se conoce como cóclea y es el órgano real de la audición. Tiene una forma espiral que recuerda a la concha de un caracol, apuntada en sentido anterior. La porción posterior del laberinto óseo contiene el vestíbulo y los canales semicirculares y es la parte responsable del equilibrio. Las estructuras neurosensoriales que

Figura 11.1 • Diagrama del oído.

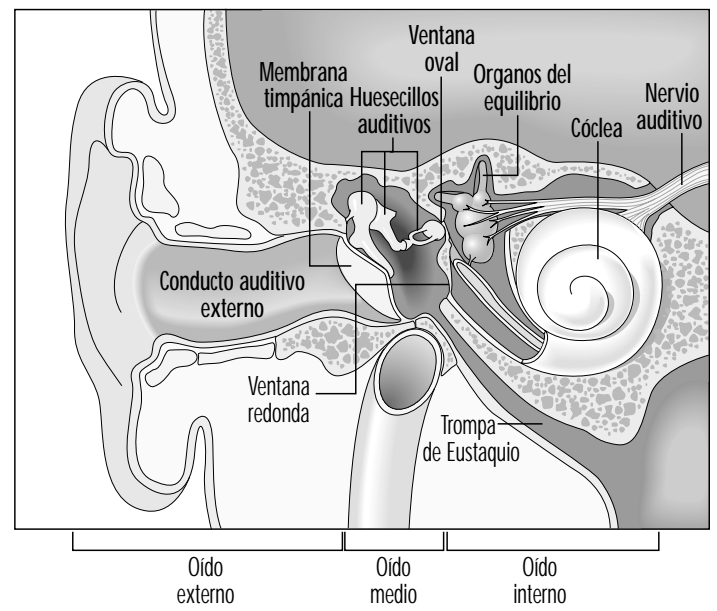

Fuente: Hohmann y Schmucki 1989 participan en la audición y el equilibrio se localizan en el laberinto membranoso: el órgano de Corti se localiza en el canal coclear, mientras que la mácula del utrículo y del sáculo y las ampollas de los canales semicirculares se localizan en la sección posterior.

\section{Organos de la audición}

EI canal coclear es un tubo triangular en espiral de dos vueltas y media que separa la rampa vestibular de la rampa timpánica. U no de los extremos termina en el ligamento espiral, una prolongación de la columna central de la cóclea, mientras que el otro se conecta con la pared ósea de la cóclea.

La rampa vestibular y la timpánica terminan en la ventana oval (el pie del estribo) y la ventana redonda, respectivamente. L as dos cámaras se comunican a través del helicotrema o punta de la cóclea. La membrana basilar forma la superficie inferior del canal coclear y sostiene el órgano de Corti, que es el responsable de la transducción de los estímulos acústicos. Toda la información auditiva es transducida por sólo unas 15.000 células ciliadas (órgano de Corti), de las que unas 3.500, las denominadas células ciliadas internas, son de importancia crítica, ya que establecen sinapsis con alrededor del $90 \%$ de las 30.000 neuronas auditivas primarias (Figura 11.2). L as células ciliadas internas y externas están separadas entre sí por una capa abundante de células se sostén. Los cilios atraviesan una membrana extraordinariamente fina y se incrustan en la membrana tectoria, cuyo extremo libre se localiza por encima de las células. La superficie superior del canal coclear está formada por la membrana de R eissner.

Los cuerpos de las células sensoriales cocleares que descansan sobre la membrana basilar están rodeados de terminaciones nerviosas y de los casi 30.000 axones que forman el nervio coclear. El nervio coclear atraviesa el conducto auditivo interno y se extiende hacia las estructuras centrales del tronco encefálico, la parte más antigua del cerebro. Las fibras auditivas finalizan su camino sinuoso en el lóbulo temporal, la parte de la corteza cerebral responsable de la percepción de los estímulos acústicos.

Figura 11.2 - Corte horizontal de la cóclea. Diámetro aproximado: $1,5 \mathrm{~mm}$.

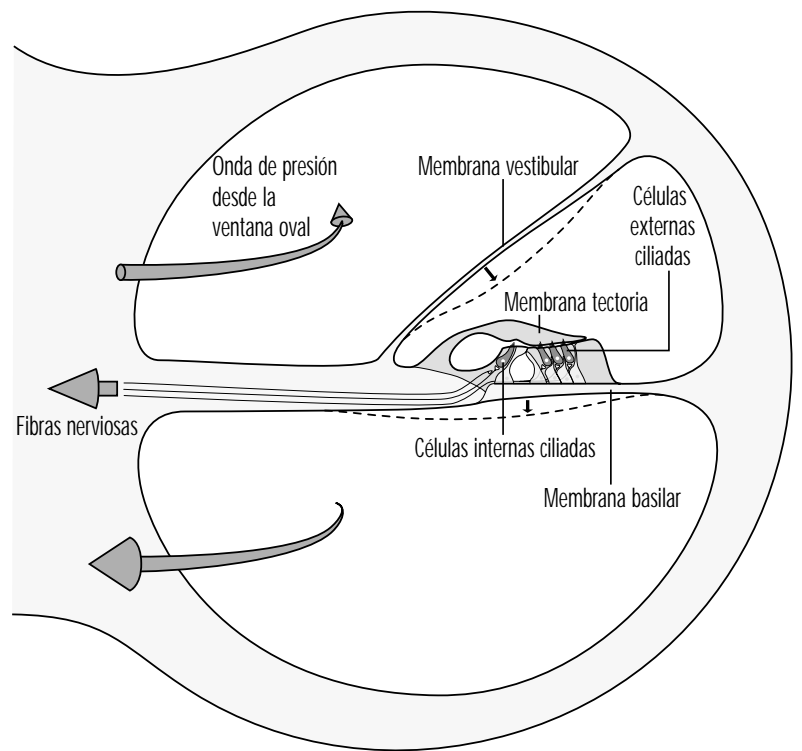

Fuente: Hohmann y Schmuckli 1989. 


\section{Organos del equilibrio}

L as células sensoriales se localizan en las ampollas de los canales semicirculares y en las máculas del utrículo y del sáculo y son estimuladas por la presión transmitida a través de la endolinfa a consecuencia de los movimientos de la cabeza y del cuerpo. Estas células conectan con las células bipolares dotadas de unas prolongaciones periféricas que forman dos tractos, uno procedente de los canales semicirculares anterior y externo y otro del canal semicircular posterior. Estos dos tractos pasan por el conducto auditivo interno y se unen para formar el nervio vestibular, que se prolonga hasta los núcleos vestibulares del tronco encefálico. Las fibras de los núcleos vestibulares, a su vez, se extienden hasta los centros cerebelosos que controlan los movimientos oculares y hasta la médula espinal.

La unión de los nervios coclear y vestibular forma el 8o par craneal, conocido también como nervio vestíbulococlear 0 estatoacústico.

\section{Fisiología de la audición}

\section{Conducción aérea del sonido}

El oído se compone de un sistema de conducción del sonido (el oído medio y externo) y de un receptor (el oído interno).

Las ondas sonoras que atraviesan el conducto auditivo externo inciden sobre la membrana timpánica y la hacen vibrar. Esta vibración se transmite al estribo a través del martillo y del yunque. La superficie de la membrana timpánica es casi 16 veces superior al área del pie del martillo $\left(55 \mathrm{~mm}^{2} / 3,5 \mathrm{~mm}^{2}\right)$, y esto, en combinación con el mecanismo de amplificación de los huesecillos, aumenta 22 veces la presión sonora. Debido a la frecuencia de resonancia del oído medio, el índice de transmisión óptimo se encuentra entre 1.000 y $2.000 \mathrm{~Hz}$. Al moverse el pie del estribo, se forman ondas en el líquido situado en el interior del canal vestibular. Como el líquido no puede comprimirse, cada movimiento del pie del estribo hacia el interior origina un movimiento equivalente de la ventana redonda hacia afuera, en dirección al oído medio.

Durante la exposición a niveles acústicos elevados, el músculo del estribo se contrae para proteger al oído interno (reflejo de atenuación). Además de esta función, los músculos del oído medio amplían también los límites dinámicos del oído, mejoran la localización del sonido, reducen la resonancia en el oído medio y controlan la presión del aire en el oído medio y la presión del líquido en el oído interno.

Entre 250 y $4.000 \mathrm{~Hz}$, el umbral del reflejo de atenuación supera en casi 80 decibelios $(\mathrm{dB})$ al umbral de audición y aumenta unos 0,6 dB/ dB al incrementarse la intensidad de la estimulación. Su latencia es de $150 \mathrm{~ms}$ en el umbral y de 24-35 ms con los estímulos intensos. Para frecuencias menores a la resonancia natural del oído medio, la contracción de los músculos atenúa la transmisión del sonido en unos $10 \mathrm{~dB}$. D ebido a su latencia, el reflejo de atenuación ofrece una protección adecuada frente al ruido generado a una frecuencia superior a 2 ó $3 \mathrm{~Hz}$, pero no frente a los impulsos sonoros discretos.

La velocidad de propagación de las ondas sonoras a través el oído depende de la elasticidad de la membrana basilar. La elasticidad aumenta, y la velocidad de la onda, por tanto, disminuye, desde la base de la cóclea hasta la punta. La transferencia de energía vibratoria hasta la membrana de Reissner y la membrana basilar depende de la frecuencia. Para las frecuencias elevadas, la amplitud de onda es mayor en la base, mientras que con las frecuencias más bajas, es mayor en la punta. Por tanto, el punto de mayor excitación mecánica en la cóclea depende de la frecuencia. Este fenómeno explica la capacidad para detectar diferencias en las frecuencias. El movimiento de la membrana basilar provoca fuerzas de cizallamiento en los estereocilios de las células ciliadas y desencadena una serie de acontecimientos mecánicos, eléctricos y bioquímicos, responsables de la transducción mecánico-sensorial y del procesamiento inicial de las señales acústicas. L as fuerzas de cizallamiento de los estereocilios provocan la apertura de los canales iónicos existentes en las membranas celulares y modifican la permeabilidad de éstas, permitiendo la entrada de iones potasio en las células. Este flujo de iones potasio hacia el interior causa la despolarización y genera un potencial de acción.

Los neurotransmisores liberados en la unión sináptica por la despolarización de las células ciliadas internas desencadenan impulsos neuronales que se transmiten por las fibras aferentes del nervio auditivo hacia los centros nerviosos superiores. La intensidad de la estimulación auditiva depende del número de potenciales de acción por unidad de tiempo y del número de células estimuladas, mientras que la frecuencia percibida depende de la población específica de fibras nerviosas activada. Existe una asociación espacial específica entre la frecuencia del estímulo sonoro y la sección de la corteza cerebral estimulada.

L as células ciliadas internas son mecanorreceptores que transforman las señales generadas en respuesta a la vibración acústica en mensajes eléctricos que se envían al sistema nervioso central. Sin embargo, no depende de ellas el umbral de sensibilidad auditiva ni la extraordinaria selectividad de frecuencias del oído.

L as células ciliadas externas, por otro lado, no envían señales auditivas al cerebro, sino que su función consiste en amplificar unas 100 veces (es decir, 40 dB) la vibración mecánico-acústica en los niveles cercanos al umbral, con lo que se facilita la estimulación de las células ciliadas internas. Se cree que esta amplificación funciona mediante un acoplamiento micromecánico en el que participa la membrana tectoria. L as células ciliadas externas pueden producir más energía de la que reciben de los estímulos externos y, al contraerse de forma activa con frecuencias muy elevadas, pueden funcionar como amplificadores cocleares.

En el oído medio, la interferencia entre las células ciliadas internas y externas crea un sistema de retroalimentación que permite controlar la recepción auditiva, sobre todo el umbral de sensibilidad y la selectividad de frecuencia. Por tanto, las fibras cocleares eferentes pueden ayudar a reducir la lesión coclear causada por la exposición a estímulos acústicos intensos. Las células ciliadas externas pueden sufrir también una contracción refleja en presencia de estímulos intensos. El reflejo de atenuación del oído medio, activo principalmente a frecuencias bajas, y el reflejo de contracción del oído interno, activo a frecuencias altas son, por tanto, complementarios.

\section{Conducción ósea del sonido}

Las ondas sonoras pueden transmitirse también a través del cráneo. Existen dos mecanismos posibles:

En el primero, las ondas de compresión que impactan en el cráneo provocan que la perilinfa, que no es compresible, deforme las ventanas oval o redonda. Como estas dos ventanas tienen una elasticidad diferente, el movimiento de la endolinfa provoca el movimiento de la membrana basilar.

El segundo mecanismo se basa en el hecho de que el movimiento de los huesecillos sólo induce movimiento en la rampa vestibular. En este mecanismo, la membrana basilar se mueve a causa del movimiento de traslación producido por la inercia.

La conducción ósea es habitualmente 30-50 dB menor que la conducción aérea, como puede comprobarse con facilidad si se tapan los dos oídos. No obstante, esto sólo es cierto en los estímulos mediados por el aire, ya que la estimulación ósea directa se atenúa en un grado diferente. 


\section{Límites de sensibilidad}

La vibración mecánica induce cambios de potencial en las células del oído interno, las vías de conducción y los centros nerviosos superiores. Sólo se perciben las frecuencias de

$$
16 \mathrm{~Hz}-25.000 \mathrm{~Hz}
$$

y las presiones de sonido (pueden expresarse en pascales, $\mathrm{Pa}$ ) de

$$
20 \mu \mathrm{Pa} \text { a } 20 \mathrm{~Pa}
$$

La gama de presiones sonoras que pueden percibirse es de una amplitud enorme (pueden variar en 1 millón de veces). Los umbrales de detección de las presiones sonoras dependen de las frecuencias; son mínimos a $1.000-6.000 \mathrm{~Hz}$ y aumentan con las frecuencias extremas.

Con fines prácticos, el nivel de presión sonora se expresa en decibelios ( $\mathrm{dB}$ ), una escala de determinación logarítmica que corresponde a la intensidad de sonido percibida en relación al umbral de audición. Por tanto, $20 \mu \mathrm{Pa}$ equivale a $0 \mathrm{~dB}$. Cuando la presión sonora aumenta diez veces, el nivel de decibelios aumenta $20 \mathrm{~dB}$, según la fórmula siguiente:

donde:

$$
L_{x}=20 \log P_{x} / P_{0}
$$

$L_{x}=$ presión del sonido en $d B$

$P_{x}=$ presión del sonido en pascales

$P_{0}=$ presión del sonido de referencia

$$
\text { ( } 2 \times 10^{-5} \mathrm{~Pa} \text {, el umbral auditivo) }
$$

El umbral de discriminación de frecuencias, que es la diferencia mínima detectable en frecuencia, es de $1,5 \mathrm{~Hz}$ para frecuencias de hasta $500 \mathrm{~Hz}$ y del $0,3 \%$ de la frecuencia del estímulo para frecuencias superiores. Para presiones de sonido cercanas al umbral de audición, el umbral de discriminación se aproxima al $20 \%$, aunque pueden detectarse diferencias de hasta un $2 \%$ con presiones sonoras altas.

Si la frecuencia de dos sonidos se diferencia muy poco, sólo se oirá un tono. La frecuencia percibida será un promedio de los dos tonos de origen, pero su nivel de presión sonora es variable. Si dos estímulos acústicos tienen frecuencias similares con intensidades diferentes se produce un efecto de enmascaramiento. Si la diferencia en la presión sonora es lo suficientemente grande, el enmascaramiento será completo y sólo se percibirá el sonido más alto.

La localización del estímulo acústico depende de la detección de la diferencia temporal entre la llegada del estímulo a cada oído y, por tanto, requiere una audición bilateral intacta. La menor diferencia temporal detectable es $3 \times 10^{-5}$ segundos. El efecto de detección selectiva de la cabeza facilita la localización, ya que se producen diferencias en la intensidad del estímulo en cada oído.

La notable capacidad de resolución de los estímulos acústicos en los seres humanos se explica por la descomposición de frecuencias en el oído interno y el análisis de estas en el cerebro. Estos son los mecanismos que permiten detectar e identificar fuentes individuales de sonido como los instrumentos musicales dentro de las complejas señales acústicas que constituyen la música de una orquesta sinfónica.

\section{Fisiopatología}

\section{Lesión ciliar}

El movimiento ciliar inducido por los estímulos acústicos intensos puede superar la resistencia mecánica de los cilios y provocar la

N ota: 1 pascal $(\mathrm{Pa})=1 \mathrm{~N} / \mathrm{m}^{2}=10 \mu \mathrm{bar}$ destrucción mecánica de las células ciliadas. Como el número de estas células es limitado y no pueden regenerarse, cualquier pérdida celular será permanente y, si la exposición al estímulo sonoro dañino continúa, tendrá un carácter progresivo. En general, el efecto último de la lesión ciliar es el desarrollo de un déficit auditivo.

L as células ciliadas externas son las más sensibles al sonido y a los agentes tóxicos como la anoxia, las medicaciones ototóxicas y los agentes químicos (p. ej., derivados de la quinina, estreptomicina, algunos otros antibióticos y algunos preparados antitumorales) y son, por tanto, las primeras en perderse. En las células ciliadas externas afectadas o con estereocilios dañados sólo permanecen operativos los fenómenos hidromecánicos pasivos. En estas condiciones, sólo es posible el análisis grosero de la vibración acústica. A grandes rasgos, la destrucción de los cilios en las células ciliadas externas hace aumentar el umbral de audición en $40 \mathrm{~dB}$.

\section{Lesión celular}

La exposición al ruido, sobre todo si es reiterada y prolongada, puede afectar también al metabolismo de las células del órgano de Corti y a las sinapsis aferentes localizadas bajo las células ciliadas internas. Entre los efectos extraciliares descritos se encuentran la modificación de la ultraestructura celular (retículo, mitocondria, lisosomas) y, postsinápticamente, hinchazón de las dendritas aferentes. La hinchazón dendrítica probablemente se deba a la acumulación tóxica de neurotransmisores como resultado de la actividad excesiva de las células ciliadas internas. No obstante, la extensión de la lesión estereociliar parece determinar si la pérdida auditiva es temporal o permanente.

\section{Pérdida de audición inducida por el ruido}

El ruido es un serio peligro para la audición en las cada vez más complejas sociedades industriales actuales. Por ejemplo, la exposición al ruido es la causa de alrededor de un tercio de los 28 millones de casos de sordera en Estados U nidos, y el National Institute for O ccupational Safety and $\mathrm{H}$ ealth (NIOSH) informa que el $14 \%$ de los trabajadores americanos están expuestos a niveles de sonido potencialmente peligrosos, es decir, por encima de $90 \mathrm{~dB}$. La exposición al ruido es la exposición profesional dañina más común y constituye la segunda causa, después de los efectos del envejecimiento, de pérdida de audición. Finalmente, no debe olvidarse la contribución de la exposición no profesional, como sucede en algunos talleres domésticos, o con la música demasiado alta, sobre todo con el uso de auriculares, armas de fuego, etc.

Lesión aguda inducida por ruido. Los efectos inmediatos de la exposición a los estímulos sonoros de alta intensidad (por ejemplo, explosiones) son la elevación del umbral de audición, la rotura del tímpano y la lesión traumática del oído medio e interno (luxación de los huesecillos, lesión coclear o fístulas).

Variación temporal del umbral. La exposición al ruido provoca un descenso de la sensibilidad de las células sensoriales auditivas proporcional a la duración e intensidad de la exposición. En los estadios más precoces, este aumento del umbral de audición, conocido como fatiga auditiva o variación temporal del umbral (VTU), es totalmente reversible, pero persiste durante algún tiempo después de finalizar la exposición.

En estudios sobre la recuperación de la sensibilidad auditiva se han identificado varios tipos de fatiga auditiva. La fatiga a corto plazo desaparece en menos de dos minutos y provoca una variación del umbral máximo en la frecuencia de exposición. $L a$ fatiga a largo plazo se caracteriza por la recuperación en más de dos minutos y menos de 16 horas, un límite establecido de forma arbitraria según los resultados de los estudios sobre la exposición al ruido industrial. En general, la fatiga auditiva es 
función de la intensidad, duración, frecuencia y continuidad del estímulo. Por tanto, a una dosis determinada de ruido, obtenida por la integración de la intensidad y la duración, los patrones de exposición intermitente son menos nocivos que los patrones continuos.

La gravedad de la VTU aumenta unos $6 \mathrm{~dB}$ cada vez que se duplica la intensidad del estímulo. Por encima de una intensidad específica de exposición (el nivel crítico), este índice aumenta, sobre todo si la exposición se produce a ruidos por impulsos. La VTU aumenta de forma asintótica con la duración de la exposición; la propia asíntota aumenta con la intensidad del estímulo. Debido a las características de la función de transferencia de oído medio e interno, las frecuencias bajas son las que mejor se toleran.

Los estudios sobre la exposición a tonos puros indican que, según aumenta la intensidad del estímulo, la frecuencia en la que la VTU es mayor cambia de forma progresiva a frecuencias superiores a las del estímulo. Los sujetos expuestos a un tono puro de $2.000 \mathrm{~Hz}$ desarrollan una VTU que es máxima aproximadamente a $3.000 \mathrm{~Hz}$ (un cambio de una semioctava). Se cree que el responsable de este fenómeno es el efecto del ruido sobre las células ciliadas externas.

EI trabajador que muestra una VTU se recupera hasta alcanzar los valores auditivos basales a las pocas horas de cesar la exposición al ruido. Sin embargo, la exposición reiterada disminuye el grado de recuperación y produce una pérdida auditiva permanente.

Variación permanente del umbral. La exposición a estímulos sonoros de alta intensidad durante varios años puede provocar una pérdida auditiva permanente. Esto se conoce como variación permanente del umbral (VPU). Desde el punto de vista anatómico, la V PU se caracteriza por una degeneración de las células ciliadas, que comienza con alteraciones histológicas ligeras pero termina finalmente en una destrucción celular completa. Lo más probable es que la pérdida auditiva afecte a las frecuencias a las que el oído es más sensible, porque en ellas la transmisión de la energía acústica del medio ambiente externo al oído interno es óptima. Esto explica por qué la pérdida auditiva a $4.000 \mathrm{~Hz}$ es el primer signo de pérdida de audición de origen profesional (Figura 11.3). Se ha observado

Figura 11.3 - Audiograma de una pérdida auditiva bilateral inducida por el ruido.

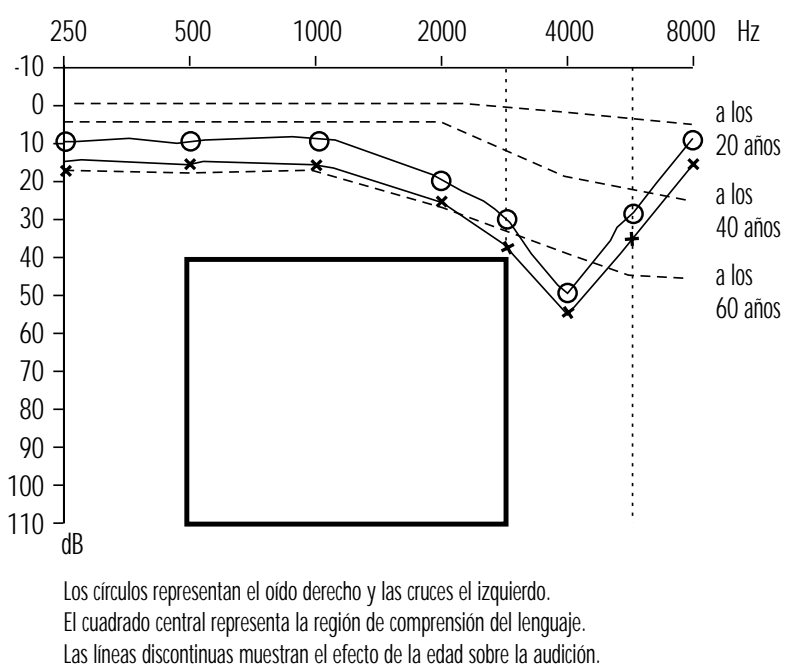

una interacción entre la intensidad del estímulo y la duración, e internacionalmente se acepta que el grado de pérdida de audición está en función de la energía acústica total recibida por el oído (dosis de ruido).

El desarrollo de una pérdida auditiva inducida por el ruido muestra una sensibilidad individual. Se han estudiado diversas variables potencialmente importantes para explicar esta sensibilidad, como edad, sexo, raza, enfermedades cardiovasculares, tabaquismo, etc. Estos datos no fueron concluyentes.

U na cuestión interesante es si la magnitud de la VT U podría utilizarse para predecir el riesgo de V PU. Como se indicó antes, hay una variación progresiva de la VTU hacia frecuencias superiores a la frecuencia de estimulación. Por otro lado, la mayor parte de la lesión ciliar producida con intensidades de estímulo altas afecta a células que son sensibles a la frecuencia del estímulo. Si la exposición persiste, la diferencia entre la frecuencia a la que la VPU es máxima y la frecuencia de estimulación desciende de forma progresiva. La lesión ciliar y la pérdida celular se producen en consecuencia en las células más sensibles a las frecuencias del estímulo. Por tanto, parece que la VTU y la VPU se desarrollan por mecanismos distintos y, por tanto, es imposible predecir la V PU basándose en la VT U observada.

Los individuos con VPU no suelen mostrar síntomas al principio. Según progresa la pérdida auditiva, comienzan a tener dificultades para seguir una conversación en entornos ruidosos como fiestas o restaurantes. La progresión, que al principio suele afectar a la capacidad para percibir sonidos agudos, suele ser indolora y relativamente lenta.

\section{Exploración de los individuos con pérdida auditiva}

\section{Exploración clínica}

Además de recoger la fecha en que se detectó por primera vez la pérdida de audición (si existe) y cómo evolucionó, indicando cualquier asimetría auditiva, el cuestionario médico debe aportar información sobre la edad del paciente, los antecedentes familiares, la utilización de medicamentos ototóxicos o la exposición a otras sustancias químicas ototóxicas, la presencia de tinnitus (es decir, zumbidos, pitidos o "timbrazos" en uno o los dos oídos), vértigo o problemas de equilibrio, y cualquier antecedente de infecciones óticas acompañadas de dolor o supuración en el conducto auditivo externo. Es muy importante obtener una historia detallada de las exposiciones del individuo durante toda su vida a niveles altos de sonido (téngase en cuenta que, para las personas legas en la materia, no todos los sonidos son "ruidos") en el trabajo actual, en los previos y fuera del trabajo. Si presenta antecedentes de episodios de VTU se confirma que el paciente ha estado expuesto a niveles tóxicos de ruido previamente.

La exploración física debe incluir la evaluación de la función de los pares craneales, pruebas de equilibrio y oftalmoscopia para detectar cualquier evidencia de aumento de la presión intracraneal. La exploración visual del conducto auditivo externo servirá para detectar restos de cerumen impactados y, después de eliminarlos con cuidado (no deben utilizarse objetos puntiagudos ni afilados) cualquier signo de perforación o cicatrización de la membrana timpánica. La pérdida auditiva puede determinarse a grandes rasgos comprobando la capacidad del paciente de repetir palabras y frases pronunciadas suavemente 0 susurradas por el explorador desde atrás y fuera de la vista del paciente. La prueba de Weber (colocar un diapasón en el centro de la frente para determinar si el sonido se "oye" en uno o los dos oídos) y la prueba de R inné (colocar un diapasón vibrante sobre la mastoides hasta que el paciente no pueda oír el sonido y después colocar rápidamente el diapasón cerca del conducto auditivo; en condiciones normales el sonido puede escucharse 
durante más tiempo a través del aire que del hueso) permitirán clasificar la pérdida auditiva como de transmisión o neurosensorial.

La audiometría es la prueba normalizada para detectar y evaluar la pérdida auditiva (véase más adelante). En algunos pacientes puede ser necesario realizar estudios complementarios, como timpanometría, pruebas de discriminación de palabras, evaluación del reflejo de atenuación, estudios electrofisiológicos (electrococleograma, potenciales evocados auditivos) y estudios radiológicos (radiografías simples de cráneo complementadas con TAC, RM ).

\section{Audiometría}

En este componente crucial de la evaluación médica se utiliza un aparato conocido como audímetro para determinar el umbral auditivo de los individuos a tonos puros de $250-8.000 \mathrm{~Hz}$ y niveles de sonido entre -10 dB (el umbral de audición de los oídos intactos) y $110 \mathrm{~dB}$ (lesión máxima). Para eliminar los efectos de las VTU, los pacientes no deben haber sido expuestos a ruidos en las 16 horas previas. La conducción aérea se determina con unos auriculares colocados en los oídos y la conducción ósea, colocando un diapasón en el cráneo por detrás del pabellón auricular. La audición de cada oído se determina por separado y los resultados de las pruebas se describen en una gráfica conocida como audiograma (Figura 11.3). El umbral de inteligibilidad, esto es, la intensidad de sonido a la que se entiende el habla, se determina mediante una prueba complementaria conocida como audiometría vocal, basada en la capacidad para entender palabras compuestas de dos sílabas de igual intensidad (por ejemplo, pastor, cena, genial).

La comparación entre la conducción aérea y la ósea permite clasificar las pérdidas auditivas como de transmisión (las que afectan al conducto auditivo externo 0 al oído medio) o neurosensoriales (afectación del oído interno o del nervio auditivo) (Figuras 11.3 y 11.4). El audiograma que se observa en los casos de pérdida auditiva inducida por el ruido se caracteriza por la aparición de pérdida auditiva a $4.000 \mathrm{~Hz}$, visible como un

Figura 11.4 • Ejemplos de audiogramas del oído derecho. Los círculos representan una pérdida auditiva de conducción aérea, y los "<", la conducción ósea.
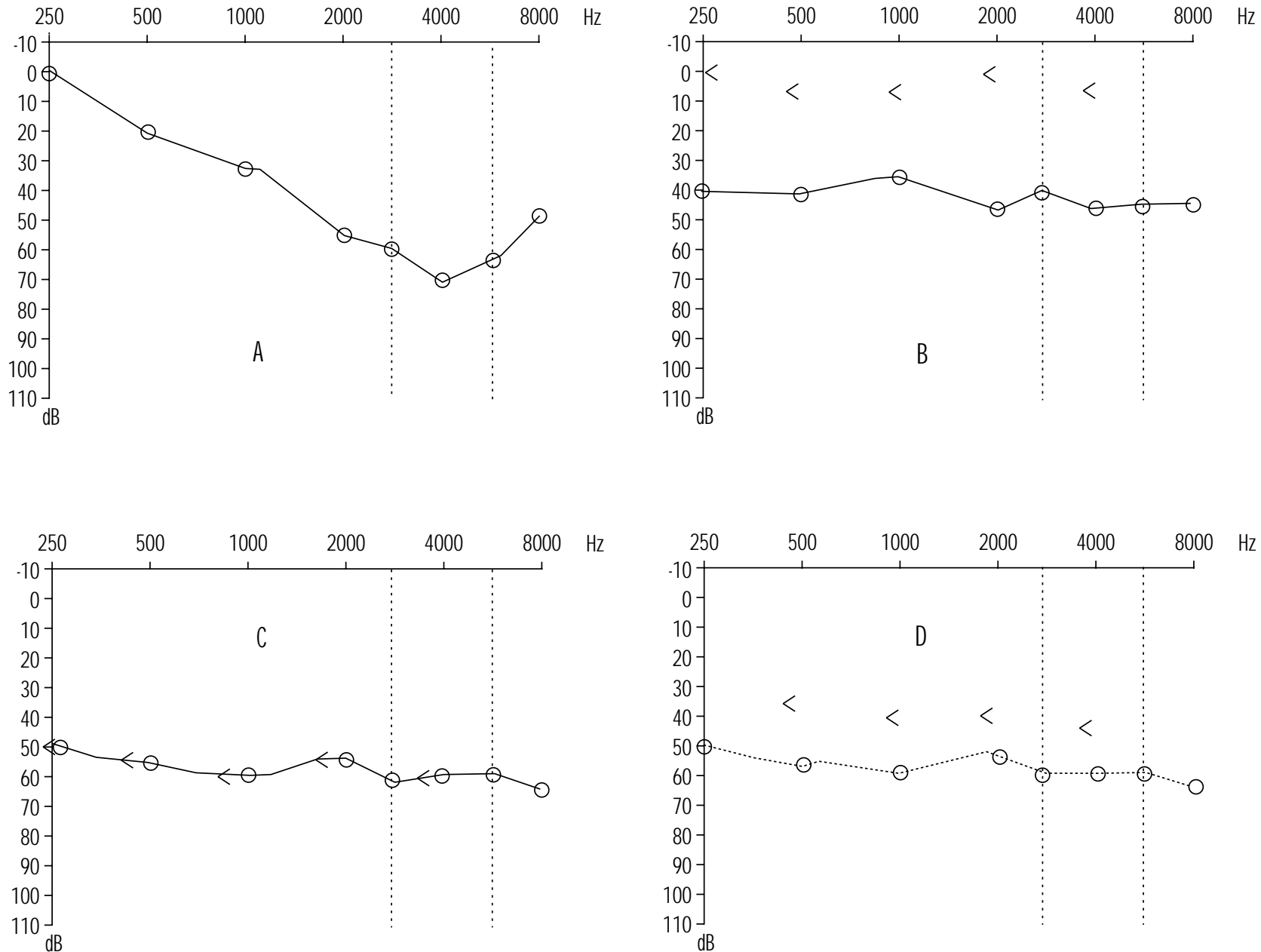

A: Típica pérdida auditiva inducida por el ruido, con afectación de la zona de comprensión del lenguaje hablado. B: Pérdida conductiva

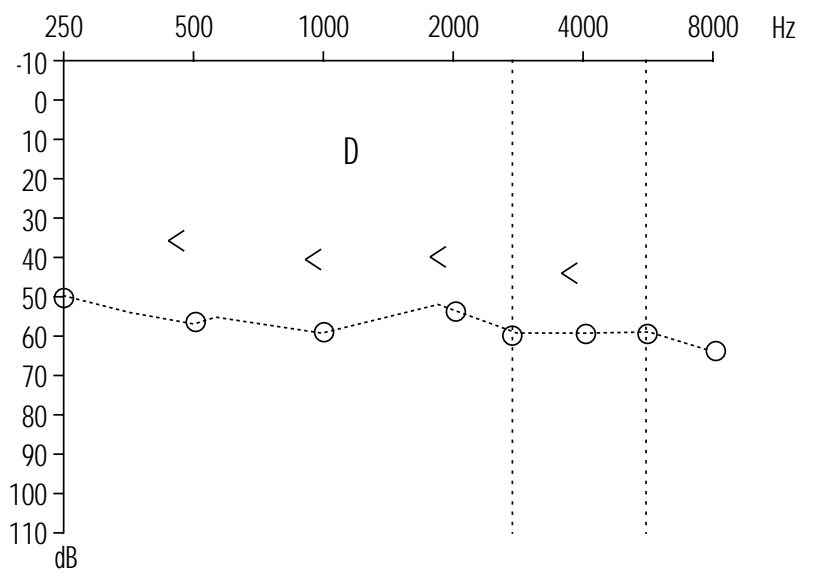

C: Neurosensorial.

D: Pérdida mixta (conductiva y neurosensorial). 
descenso marcado en el audiograma (Figura 11.3). Si la exposición a los niveles excesivos de ruido continúa, las frecuencias cercanas se afectan de forma progresiva y la depresión en la curva se ensancha e incluye frecuencias de hasta $3.000 \mathrm{~Hz}$, con lo que se comprometen las frecuencias esenciales para la comprensión de la conversación. La pérdida auditiva inducida por el ruido suele ser bilateral y muestra un patrón similar en ambos oídos, es decir, la diferencia entre los dos oídos no supera los $15 \mathrm{~dB}$ a $500 \mathrm{~Hz}$, los $1.000 \mathrm{~dB}$ a $2.000 \mathrm{~Hz}$, y los $30 \mathrm{~dB}$ a $3.000,4.000$ y $6.000 \mathrm{~Hz}$. No obstante, puede haber lesión asimétrica en casos de exposición no uniforme, por ejemplo, en los tiradores, en los que la pérdida auditiva es mayor en el lado contrario al del dedo que dispara (el lado izquierdo, en una persona diestra). En la pérdida auditiva no relacionada con la exposición al ruido, la audiometría no muestra la depresión característica a $4.000 \mathrm{~Hz}$ (Figura 11.4).

$\mathrm{H}$ ay dos tipos de exploraciones audiométricas: de detección selectiva y diagnósticas. $L$ a audiometría de detección selectiva se utiliza para la exploración rápida de grupos de individuos en el lugar de trabajo, en escuelas o en otros sitios de la comunidad para identificar a las personas que parecen presentar alguna pérdida auditiva. Casi siempre se utilizan audímetros electrónicos de comprobación automática y, en general, en una zona tranquila, aunque no es necesario emplear una cámara sin vibraciones insonorizada. Se considera que esta última es un requisito obligado para la audiometría diagnóstica destinada a determinar la pérdida auditiva con precisión y exactitud reproducibles. La exploración diagnóstica se realiza de forma apropiada por un audiólogo entrenado (en algunas circunstancias, se requiere una certificación formal de la competencia del audiólogo). La exactitud de ambos tipos de audiometría depende de la comprobación y de la recalibración periódicas del equipo utilizado.

En numerosos marcos jurídicos, los individuos con pérdida auditiva inducida por el ruido relacionada con el trabajo pueden recibir prestaciones por indemnización. Por esto, numerosas empresas están incluyendo la audiometría en la exploración médica previa al comienzo en un puesto de trabajo para detectar cualquier pérdida auditiva que pueda ser

Tabla 11.1 - Cálculo típico de la pérdida funcional a partir de un audiograma.

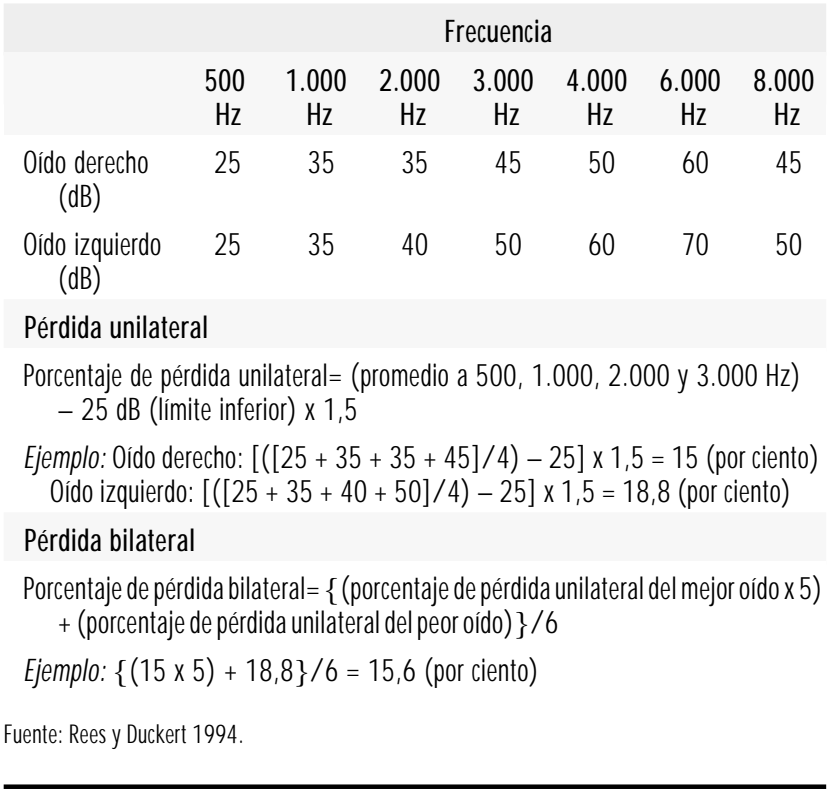

responsabilidad de una empresa previa o que represente una exposición de carácter no profesional.

Los umbrales de audición aumentan de forma progresiva con la edad y se afectan más las frecuencias más altas (Figura 11.3). Con este tipo de pérdida auditiva no se observa el característico descenso a $4.000 \mathrm{~Hz}$ observado en la pérdida auditiva inducida por el ruido.

\section{Cálculo de la pérdida auditiva}

En Estado U nidos, la fórmula más ampliamente aceptada para calcular la limitación funcional relacionada con la pérdida auditiva es la propuesta en 1979 por la American Academy of Otolaryngology (AAO), que fue adoptada por la American $M$ edical Association. Se basa en la media de valores obtenidos a $500,1.000,2.000$ y $3.000 \mathrm{~Hz}$ (Tabla 11.1), en los que el límite inferior de la limitación funcional se estableció en $25 \mathrm{~dB}$.

\section{Presbiacusia}

La presbiacusia o pérdida auditiva relacionada con la edad comienza en general a los 40 años y progresa de forma gradual. Suele ser bilateral. En la presbiacusia no se observa la depresión característica a $4,000 \mathrm{~Hz}$ observada en la pérdida auditiva inducida por el ruido. Sin embargo, es posible que los efectos de la edad se superpongan a la pérdida auditiva relacionada con el ruido.

\section{Tratamiento}

El principal aspecto del tratamiento es evitar cualquier otra exposición a niveles potencialmente tóxicos de ruido (véase más adelante "Prevención"). En general, se considera que, una vez finalizada la exposición al ruido, no se produce más pérdida auditiva de la que cabría esperar por el proceso normal de envejecimiento.

M ientras que las pérdidas de conducción como, por ejemplo, las relacionadas con lesiones traumáticas agudas inducidas por el ruido, pueden tratarse de forma médica o quirúrgica, la pérdida auditiva crónica inducida por el ruido no puede corregirse con el tratamiento. La utilización de un audífono es el único "remedio" posible y sólo está indicada si la pérdida auditiva afecta a las frecuencias críticas para la comprensión del habla (500 a $3.000 \mathrm{~Hz}$ ). N o obstante, también es posible utilizar otros tipos de ayuda, como la lectura labial y los amplificadores de sonido (en los teléfonos, por ejemplo).

\section{Prevención}

Como la pérdida auditiva inducida por ruido es permanente, es muy importante aplicar medidas para reducir la exposición. Esto incluye la reducción del ruido en la fuente (utilizando máquinas y equipos más silenciosos 0 aislándolos mediante cubiertas insonorizadas) 0 el uso de dispositivos protectores individuales como tapones para los oídos y/ o auriculares de insonorización. Si se confía en estos últimos, es imprescindible comprobar que el grado de eficacia que especifica el fabricante es correcto y que los trabajadores expuestos los utilizan de forma correcta en todo momento.

La designación de $85 \mathrm{~dB}$ (A) como el límite de exposición profesional más alto permisible tiene como objetivo proteger al mayor número posible de personas. Sin embargo, como existe una significativa variación interpersonal, deben tomarse todas las medidas posibles para mantener los niveles de exposición por debajo del nivel indicado. En los programas de vigilancia médica deben realizarse audiometrías periódicas para detectar lo más pronto posible cualquier efecto indicativo de toxicidad por ruido. 


\section{TRAST ORNOS AUDITIVOS INDUCIDOS POR PRODUCTOS QUIMICOS}

Peter Ja cobsen

La pérdida de audición producida por la toxicidad coclear de algunos fármacos es bien conocida (Ryback 1993). Sin embargo, hasta la pasada década se ha prestado escasa atención a los efectos audiológicos de los productos químicos industriales. La investigación reciente sobre los trastornos auditivos inducidos por productos químicos se ha centrado en los disolventes, los metales pesados y los productos químicos que producen anoxia.

D isolventes. En estudios realizados con roedores se ha demostrado un descenso permanente de la sensibilidad auditiva a los tonos de alta frecuencia tras varias semanas de exposición intensa al tolueno. En estudios sobre la respuesta histopatológica y auditiva del tronco encefálico se ha observado un efecto importante sobre la cóclea, con lesión de las células ciliadas externas. Se han hallado efectos similares tras la exposición a estireno, xilenos o tricloroetileno. El disulfuro de carbono y el n-hexano pueden alterar también las funciones auditivas, aunque su principal efecto parece tener lugar en vías nerviosas más centrales (J ohnson y Nylén 1995).

Se han comunicado varios casos de lesión del sistema auditivo y anomalías neurológicas graves asociados a la inhalación de disolventes en seres humanos. En series de casos con exposición profesional a mezclas de disolventes, al n-hexano 0 al disulfuro de carbono se han descrito efectos centrales y cocleares sobre las funciones auditivas. En estos grupos la exposición al ruido era frecuente, pero el efecto sobre la audición se consideró superior a lo que cabría esperar por el ruido.

H asta ahora, el problema de la pérdida auditiva asociada a la exposición a disolventes en seres humanos sin exposición a niveles significativos de ruido se ha planteado en pocos estudios controlados. En un estudio danés, se halló un aumento estadísticamente significativo del riesgo de pérdida auditiva de 1,4 (IC del $95 \%: 1,1-1,9$ ) tras la exposición a disolventes durante 5 años o más. En el grupo expuesto tanto a los disolventes como al ruido, no se halló un efecto adicional de la exposición al disolvente. En un subgrupo de la población del estudio se encontró una buena concordancia entre la comunicación de problemas de audición y los criterios audiométricos de pérdida auditiva (Jacobsen y cols. 1993).

En un estudio holandés realizado en trabajadores expuestos a estireno se halló una diferencia proporcional a la dosis en los umbrales de audición encontrados en la audiometría (M uijser y cols. 1988)

En otro estudio realizado en Brasil, se investigó el efecto audiológico de la exposición al ruido, al tolueno combinado con ruido y a mezclas de disolventes en trabajadores de las industrias de la imprenta y la pintura. En comparación con un grupo de control, en los tres grupos expuestos se observó un riesgo significativamente elevado de pérdida auditiva para frecuencias altas en la audiometría. Los riesgos relativos para la exposición al ruido y a las mezclas de disolventes fueron 4 y 5 , respectivamente. En el grupo con exposición mixta al tolueno y al ruido se determinó un riesgo relativo de 11 , lo que sugiere una interacción entre los dos tipos de exposición (M orata y cols. 1993).

$M$ etales. El efecto del plomo sobre la audición se ha investigado en estudios realizados en niños y en jóvenes menores de 20 años en Estados U nidos. Se halló una asociación dosis-respuesta significativa entre la concentración sanguínea de plomo y los umbrales de audición en el intervalo de frecuencias comprendido entre 0,5 y $4 \mathrm{kHz}$, después de controlar la interferencia potencial de otros factores. El efecto del plomo se comprobó en todo el intervalo de exposición y pudo detectarse con niveles sanguíneos de plomo inferiores a $10 \mu \mathrm{g} / 100 \mathrm{ml}$. En niños sin signos clínicos de toxicidad por plomo se halló una relación lineal entre el nivel sanguíneo de plomo y las latencias de las ondas III y $\mathrm{V}$ en los potenciales auditivos encefálicos (PAE), lo que indica un lugar de acción más central que el núcleo coclear (0 tto y cols. 1985).

La pérdida auditiva se describe como una parte habitual del cuadro clínico en el envenenamiento agudo y crónico por metilmercurio. Se ha descrito la participación de lesiones cocleares y postcocleares (O yagani y cols. 1989). El mercurio inorgánico también puede afectar al sistema auditivo, probablemente por lesión de las estructuras cocleares.

La exposición al arsénico inorgánico se ha relacionado con trastornos de la audición en los niños. Se ha observado una frecuencia elevada de pérdida auditiva grave $(>30 \mathrm{~dB})$ en niños alimentados con leche en polvo contaminada con arsénico inorgánico V. En un estudio realizado en Checoslovaquia, la exposición ambiental al arsénico de una central eléctrica de carbón se asoció a una pérdida auditiva audiométrica en niños de diez años. En experimentos con animales, los compuestos inorgánicos de arsénico han provocado importantes lesiones cocleares (O M S 1981).

En el envenenamiento agudo por trimetiltina, entre los primeros síntomas figuraron la pérdida auditiva y el tinnitus. La audiometría mostró una pérdida auditiva pancoclear entre 15 y $30 \mathrm{~dB}$ al iniciarse el cuadro. No se especifica si estas alteraciones fueron reversibles (Besser y cols. 1987). En experimentos con animales, la trimetiltina y la trietiltina provocaron lesiones cocleares parcialmente reversibles (C lerisi y cols. 1991).

$G$ ases asfixiantes. En publicaciones sobre el envenenamiento agudo por monóxido de carbono o sulfuro de hidrógeno en humanos, se han descrito con frecuencia trastornos auditivos asociados a las alteraciones del sistema nervioso central (Ryback 1992). En experimentos realizados con roedores, la exposición al monóxido de carbono tuvo un efecto sinérgico con el ruido sobre los umbrales auditivos y las estructuras cocleares. No se observó ningún efecto tras la exposición aislada al monóxido de carbono (Fetcher y cols. 1988).

\section{Resumen}

En estudios experimentales se ha documentado que diversos disolventes pueden provocar trastornos auditivos en ciertas circunstancias de exposición. Los estudios en seres humanos indican que este efecto puede producirse en exposiciones comunes en el ambiente laboral. Se han observado efectos sinérgicos entre el ruido y los compuestos químicos en algunos estudios experimentales y en seres humanos. Algunos metales pesados pueden alterar la audición, la mayoría de ellos sólo con niveles de exposición que provocan toxicidad sistémica clara. En cuanto al plomo, se han observado efectos menores con niveles de exposición muy inferiores a los profesionales. No se ha documentado un efecto ototóxico de los gases asfixiantes, aunque el monóxido de carbono puede potenciar el efecto audiológico del ruido.

\section{TRASTORNOS AUDITIVOS PROVOCADOS POR AGENTES FISICOS}

Peter L. Pelmear

Debido a su posición en el cráneo, el sistema auditivo está en general bien protegido contra las lesiones físicas externas. Sin 
embargo, existen varios peligros físicos en el lugar de trabajo que pueden afectarlo:

Barotrauma. La variación súbita de la presión barométrica (por descenso o ascenso subacuático rápido o por el descenso súbito en un medio de transporte aéreo) asociada al funcionamiento inadecuado de la trompa de Eustaquio (fallo en la compensación de la presión) puede provocar la rotura de la membrana timpánica, lo que causa dolor y hemorragia en el oído medio y externo. En los casos menos graves, la distensión de la membrana provoca dolor leve o intenso. Se producirá una pérdida auditiva temporal (pérdida de conducción) aunque, en general, el traumatismo tiene un curso benigno y la recuperación funcional es completa.

Vibración. La exposición simultánea a la vibración y al ruido (continuo o por impacto) no aumenta el riesgo ni la gravedad de la pérdida auditiva neurosensorial; sin embargo, la frecuencia de su aparición parece aumentar en los trabajadores con el síndrome de vibración de la mano-brazo (SVM B). Se cree que la circulación coclear se afecta por un espasmo simpático reflejo, durante los episodios de vasoespasmo que sufren estos trabajadores (fenómeno de $R$ aynaud) en los dedos de las manos y de los pies.

Infrasonidos y ultrasonidos. La energía acústica de este origen no es audible para el ser humano. Todas las fuentes habituales de ultrasonidos, por ejemplo, los motores a reacción, las fresas dentales de alta velocidad y los limpiadores y mezcladores ultrasónicos, emiten sonidos audibles, por lo que los efectos de los ultrasonidos en los sujetos expuestos no pueden diferenciarse con facilidad. Se cree que por debajo de $120 \mathrm{~dB}$ son inocuos y no es probable que causen pérdida auditiva inducida por el ruido. De la misma forma, el ruido de baja frecuencia es relativamente seguro, aunque si la intensidad es elevada (119-144 dB) puede producirse una pérdida de audición.

"E I oído del soldador". Las chispas calientes pueden penetrar por el conducto auditivo externo hasta llegar a la membrana timpánica y quemarla. Esto provoca un dolor agudo de oído y, a veces, parálisis del nervio facial. Si las quemaduras son menores no es necesario ningún tratamiento, pero en los casos más graves a veces hay que reparar quirúrgicamente la membrana. El riesgo puede evitarse colocando en una posición correcta el casco del soldador o llevando tapones para los oídos.

\section{EQUILIBRIO}

Lucy Yardley

\section{Funcionamiento del sistema del equilibrio}

\begin{abstract}
Aferencias
La percepción y el control de la orientación y el movimiento corporal en el espacio se consiguen mediante un sistema en el que participan simultáneamente estímulos aferentes de tres fuentes: la visión, el órgano vestibular del oído interno y los sensores musculares, articulares y cutáneos que aportan una información somatosensorial o "propioceptiva" sobre el movimiento del cuerpo y el contacto físico con el medio ambiente (Figura 11.5). La combinación de toda esta información se integra en el sistema nervioso central, donde se generan las acciones apropiadas para restaurar y mantener el equilibrio, la coordinación y el bienestar. La descompensación de cualquier
\end{abstract}

Figura 11.5 - Diagrama de los principales elementos del sistema del equilibrio.
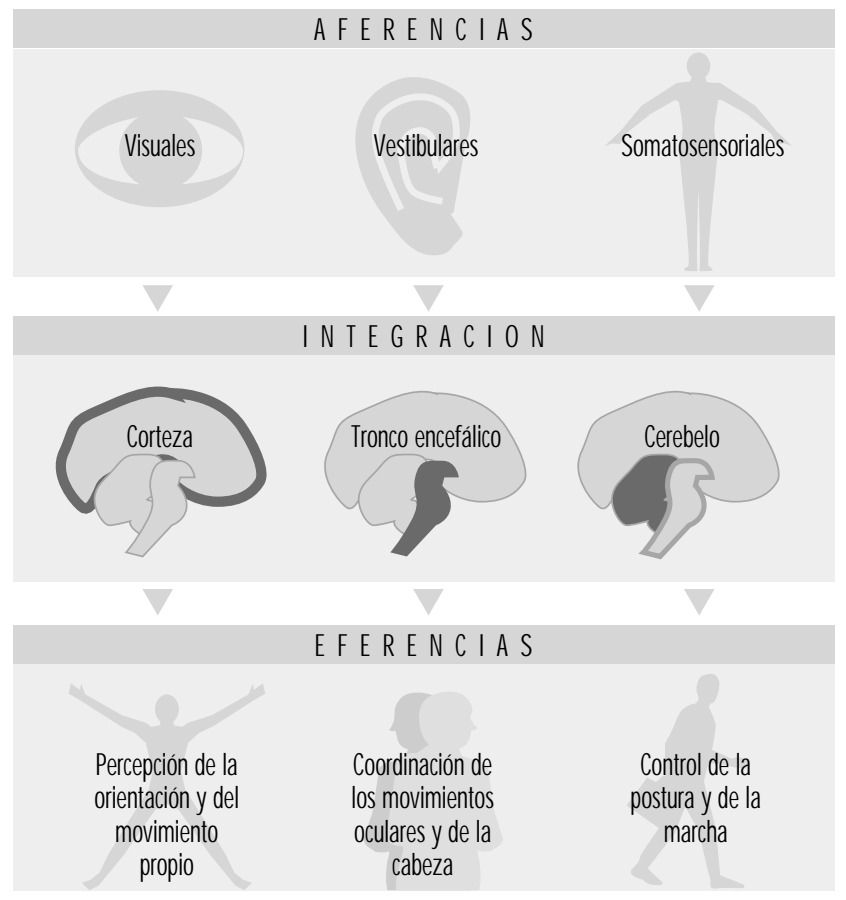

parte del sistema puede provocar malestar, vértigo e inestabilidad, causantes de síntomas y/ o caídas.

El sistema vestibular registra directamente la orientación y el movimiento de la cabeza. El laberinto vestibular es una estructura ósea minúscula localizada en el oído interno que comprende los canales semicirculares llenos de líquido (endolinfa) el utrículo y el sáculo (Figura 11.6). Los tres canales semicirculares se orientan en ángulos rectos, de forma que permiten detectar la aceleración en los tres planos posibles del movimiento angular. En los giros de la cabeza, el movimiento relativo de la endolinfa dentro de los canales (provocado por la inercia)

Figura 11.6 • Diagrama esquemático del laberinto vestibular.

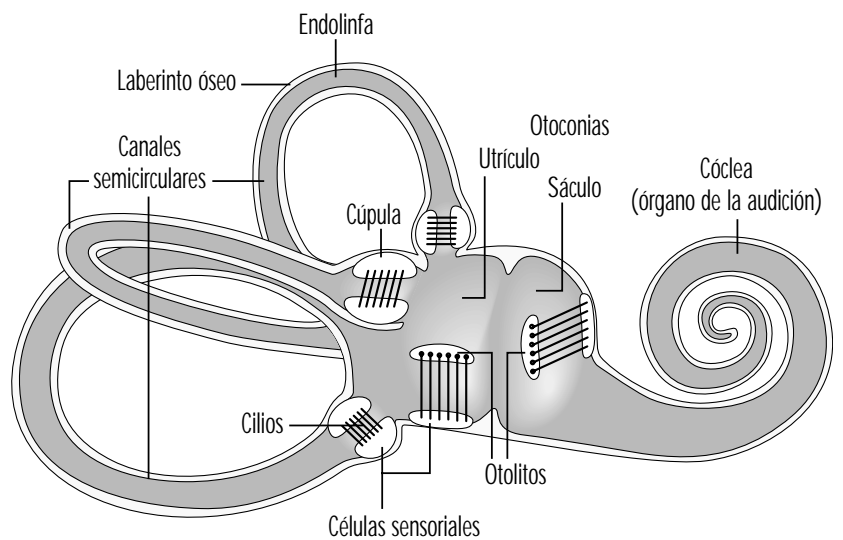

Fuente: Yardley 1994 
Figura 11.7 • Representación esquemática de los efectos biomecánicos de una inclinación de la cabeza de noventa grados (hacia adelante).

Otolito y canal semicircular antes de la inclinación de 90 de la cabeza

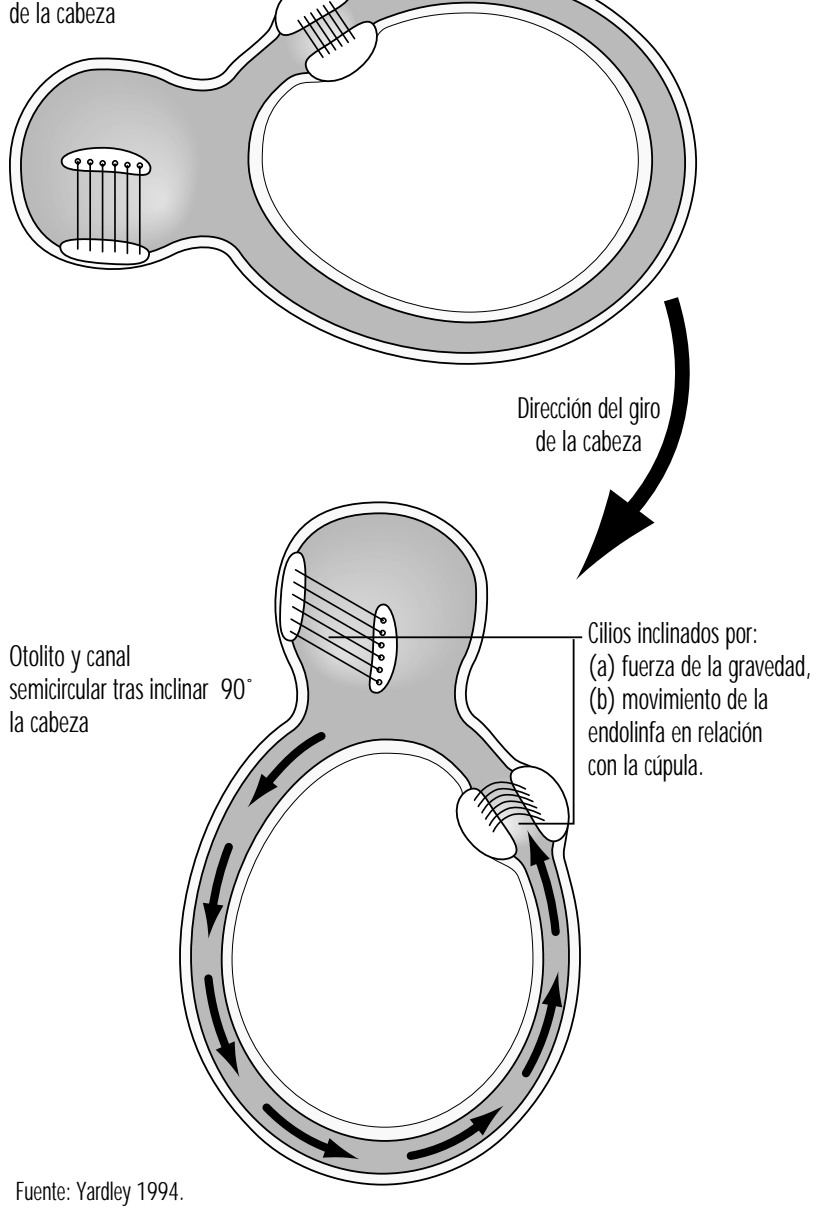

mueve los cilios de las células sensoriales y se produce un cambio en la señal nerviosa procedente de estas células (Figura 11.7). EI utrículo y el sáculo contienen cristales pesados (otolitos) que responden a variaciones en la posición de la cabeza en relación con la fuerza de la gravedad y a la aceleración o deceleración lineal, que también hacen inclinarse a los cilios, con lo que se altera la señal procedente de las células sensoriales a las que están unidos.

\section{Integración}

Las interconexiones centrales dentro del sistema del equilibrio son muy complejas; la información de los órganos vestibulares de ambos oídos se combina con la información procedente de la visión y del sistema somatosensorial a varios niveles del tronco encefálico, del cerebelo y de la corteza cerebral (L uxon 1984).

\section{Eferencias}

Esta información integrada proporciona la base, no sólo de la percepción consciente de la orientación y del propio movimiento, sino también del control preconsciente de los movimientos oculares y de la postura, mediante lo que se conoce como los reflejos vestíbulooculares y vestíbuloespinales. El fin del reflejo vestíbuloocular consiste en mantener un punto estable de fijación visual durante el movimiento de la cabeza, compensando de forma automática el movimiento de ésta con un movimiento ocular equivalente en la dirección opuesta (H oward 1982). Los reflejos vestíbuloespinales contribuyen a la estabilidad y al equilibrio postural (Pompeiano y Allum 1988).

\section{Disfunción del sistema del equilibrio}

En circunstancias nor males, los estímulos aferentes de los sistemas vestibular, visual y somatosensorial son congruentes, pero si se produce un desajuste aparente entre las diferentes aferencias sensoriales al sistema del equilibrio, el resultado es una sensación subjetiva de vértigo, desorientación o una sensación ilusoria de movimiento. Si el vértigo es prolongado o grave se acompaña de síntomas secundarios como náuseas, sudor frío, palidez, fatiga e incluso vómitos. La interrupción del control reflejo de los movimientos oculares y de la postura puede provocar una imagen visual borrosa o vacilante, la tendencia a desviarse hacia un lado al caminar o a tambalearse y caer. El término médico para la desorientación provocada por la disfunción del sistema del equilibrio es "vértigo", y puede tener su origen en cualquier trastorno de los sistemas sensoriales que intervienen en el equilibrio 0 bien en una integración central defectuosa. Sólo el 1 ó $2 \%$ de la población consulta al médico cada año por la aparición de un vértigo, pero la incidencia de la sensación de mareo y desequilibrio aumenta de forma notable con la edad. La "cinetosis" es una forma de desorientación inducida por condiciones ambientales artificiales para las que nuestro sistema del equilibrio no está preparado por la evolución, como el transporte pasivo en coche 0 barco (C rampton 1990).

\section{Causas vestibulares de vértigo}

Las causas más comunes de disfunción vestibular son la infección (laberintitis o neuronitis vestibular) y el vértigo posicional paroxístico benigno (VPPB), que se desencadena sobre todo al yacer sobre un lado. Los ataques recidivantes de vértigo grave que se acompañan de pérdida auditiva y ruidos (tinnitus) en un oído son típicos de un síndrome conocido como enfermedad de $M$ enière. L os trastornos del oído medio (como las infecciones bacterianas, los traumatismos y el colesteatoma), los fármacos ototóxicos (que sólo deben utilizarse en situaciones de urgencia médica) y los traumatismos craneales también pueden provocar lesiones vestibulares.

\section{Causas periféricas no vestibulares de vértigo}

Numerosos clínicos consideran que los trastornos del cuello que alteran la información somatosensorial relacionada con el movimiento de la cabeza o interfieren con el aporte de sangre al sistema vestibular pueden provocar vértigo. Entre las causas más frecuentes se encuentran los traumatismos cervicales por "latigazo" y la artritis. En ocasiones, la inestabilidad se relaciona con una pérdida de sensibilidad en los pies y las piernas que puede estar causada por diabetes, consumo excesivo de alcohol, deficiencias vitamínicas, lesiones de la médula espinal y otros trastornos diversos. A veces, el origen de la sensación de vértigo 0 de movimiento ilusorio del medio ambiente se relaciona con algún trastorno de la información visual. La alteración de la visión puede ser provocada por debilidad de los músculos oculares o producirse durante el período de adaptación a lentes potentes 0 a gafas bifocales.

\section{Causas centrales de vértigo}

Aunque la mayoría de los casos de vértigo se atribuyen a trastornos periféricos (sobre todo vestibulares), los síntomas de 
desorientación pueden tener su origen en el tronco encefálico, el cerebelo o la corteza cerebral. El vértigo por disfunción central se acompaña casi siempre de algún otro síntoma de trastorno neurológico central, como sensación de dolor, hormigueo o entumecimiento en la cara o las extremidades, dificultad para hablar o tragar, cefaleas, alteraciones visuales y pérdida del control motor o de la consciencia. Las causas centrales más comunes de vértigo son los trastornos del aporte sanguíneo al cerebro (desde migrañas a ictus), epilepsia, esclerosis múltiple, alcoholismo y, ocasionalmente, tumores. El vértigo y el desequilibrio pasajeros son un efecto secundario potencial de una amplia serie de fármacos, incluidos analgésicos de uso muy común, anticonceptivos y fármacos empleados en el control de las enfermedades cardiovasculares, la diabetes y la enfermedad de Parkinson y, sobre todo, de los medicamentos de acción central como estimulantes, sedantes, antiepilépticos, antidepresivos y tranquilizantes (Ballantyne y Ajodhia 1984).

\section{Diagnóstico y tratamiento}

Todos los casos de vértigo requieren atención médica para asegurar la detección y el tratamiento adecuado de todos los procesos peligrosos (relativamente raros) que pueden causarlo. Para mejorar los síntomas del vértigo agudo a corto plazo pueden administrarse medicamentos y, rara vez, debe realizarse una intervención quirúrgica. Sin embargo, si la causa del vértigo es un trastorno vestibular, los síntomas suelen desaparecer con el tiempo, al adaptarse los integradores centrales al patrón alterado de aferencias vestibulares, de la misma forma que los marineros continuamente expuestos al movimiento de las olas adquieren de forma gradual sus "piernas de marinero". Para que esto ocurra, es esencial continuar realizando movimientos vigorosos que estimulen el sistema del equilibrio, aunque estos causen al principio molestias y sensación de vértigo. Como los síntomas del vértigo son muy molestos y provocan miedo a los pacientes, a veces conviene aplicar fisioterapia y ofrecer apoyo psicológico para contrarrestar la tendencia natural a restringir las actividades (Beyts 1987; Yardley 1994).

\section{Vértigo en el lugar del trabajo}

\section{Factores de riesgo}

El vértigo y la desorientación, que pueden cronificarse, son síntomas comunes en los trabajadores expuestos a los disolventes orgánicos; además, la exposición prolongada puede provocar signos objetivos de disfunción del sistema del equilibrio (p. ej., control reflejo vestibuloocular anormal), incluso en personas que no sufren síntomas subjetivos de vértigo (G yntelberg y cols. 1986; M öller y cols. 1990). L os cambios de presión en los vuelos o la inmersión pueden producir una lesión del órgano vestibular asociada a vértigo y pérdida de audición súbita, que deben tratarse de forma inmediata ( $\mathrm{H}$ ead 1984). Existe alguna evidencia de que la pérdida de audición inducida por el ruido puede acompañarse de lesión en los órganos vestibulares (van Dijk 1986). Las personas que trabajan durante períodos prolongados con pantallas de ordenador refieren a veces vértigo; la causa de este trastorno no está clara, aunque puede relacionarse con una combinación de rigidez de nuca y percepción de estímulos visuales en movimiento.

\section{Dificultades laborales}

Los ataques inesperados de vértigo, como sucede en la enfermedad de $M$ enière, pueden causar problemas en las personas que trabajan en altura, conducen, manejan maquinaria peligrosa 0 son responsables de la seguridad de otras personas. Un efecto común de la disfunción del sistema del equilibrio que puede dificultar los viajes es el aumento de la sensibilidad a la cinetosis.

\section{Conclusión}

El equilibrio se mantiene por un sistema multisensorial complejo, por lo que una amplia variedad de trastornos pueden provocar desorientación y desequilibrio, sobre todo cualquier proceso que afecte al sistema vestibular o a la integración central de la información perceptiva para la orientación. Si no existe una lesión neurológica central, la flexibilidad del sistema del equilibro permitirá habitualmente que el individuo se adapte a las causas periféricas de desorientación, ya sean trastornos del oído interno que alteren la función vestibular o circunstancias ambientales causantes de cinetosis. Sin embargo, los ataques de vértigo suelen ser impredecibles, alarmantes y discapacitantes, por lo que puede ser necesario realizar rehabilitación para restaurar la confianza y mejorar la función del equilibrio.

\section{VISION Y TRABAJO}

Paule Rey y Jean-Jacques M eyer

\section{Anatomía del ojo}

El ojo es una esfera (Graham y cols. 1965; A dler 1992) de unos $20 \mathrm{~mm}$ de diámetro, situada en la órbita y rodeada de seis músculos (oculares) extrínsecos que lo mueven unido a la esclerótica, su pared externa (Figura 11.8). En la parte anterior, la esclerótica es sustituida por la córnea, que es transparente. Por detrás de la córnea, en la cámara anterior, se encuentra el iris, que regula el diámetro de la pupila, el espacio por el que pasa el eje

Figura 11.8 • Representación esquemática del ojo.

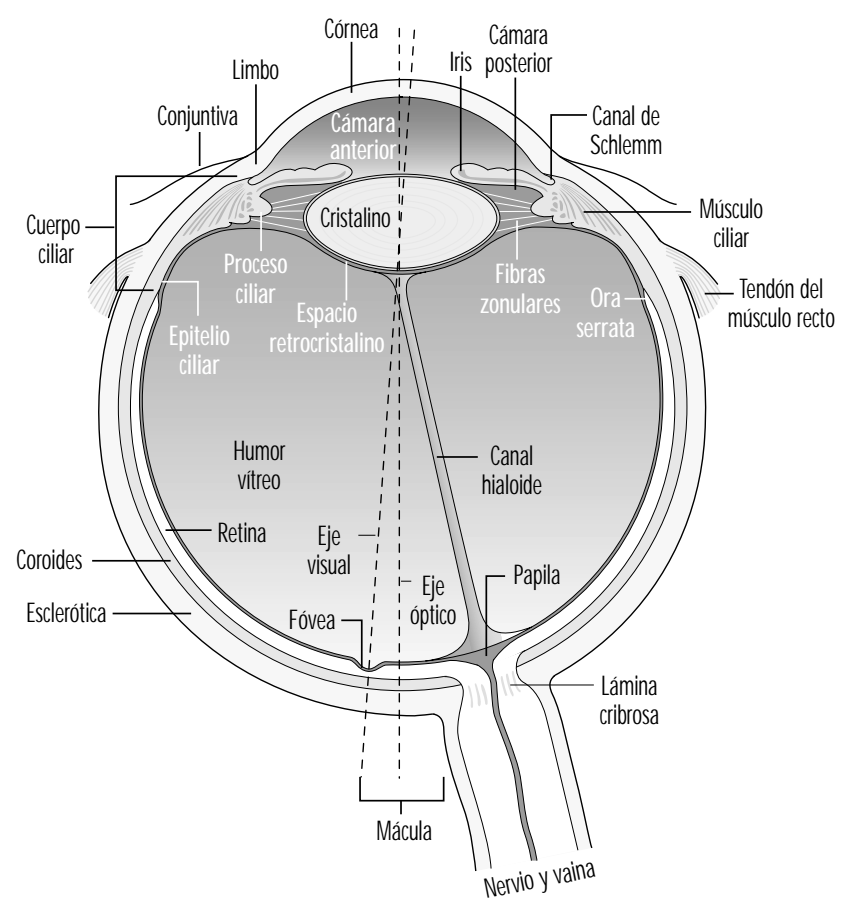


óptico. La parte posterior de la cámara anterior está formada por una lente biconvexa, el cristalino; la curvatura de esta lente está determinada por los músculos ciliares, unidos por delante a la esclerótica y por detrás a la membrana coroidea, que recubre la cámara posterior. La cámara posterior está llena del humor vítreo , un líquido gelatinoso transparente. La coroides, o superficie interna de la cámara posterior, es de color negro para evitar que los reflejos luminosos internos interfieran con la agudeza visual.

Los párpados ayudan a mantener una película de lágrimas, producidas por las glándulas lagrimales, para proteger la superficie anterior del ojo. El parpadeo facilita la diseminación de las lágrimas y su drenaje hacia el canal lagrimal, un conducto que desemboca en la cavidad nasal. La frecuencia de parpadeo, que se utiliza como prueba en ergonomía, varía en gran medida según la actividad realizada (por ejemplo, es más lenta durante la lectura) y las condiciones de iluminación (la velocidad de parpadeo disminuye al aumentar la iluminación).

La cámara anterior contiene dos músculos: el esfínter del iris, que contrae la pupila, y el dilatador, que la ensancha. Cuando se dirige una luz brillante hacia un ojo normal, la pupila se contrae (reflejo pupilar). También se contrae cuando se observa un objeto cercano.

La retina tiene varias capas internas de células nerviosas y una capa externa que contiene dos tipos de células fotorreceptoras, los conos y los bastones. Así, la luz pasa a través de las células nerviosas hasta los conos y los bastones donde, de una forma todavía no aclarada, genera impulsos en las células nerviosas que pasan por el nervio óptico hasta el cerebro. Los conos, cuyo número oscila entre cuatro y cinco millones, son responsables de la percepción de imágenes brillantes y del color. Se concentran en la porción interna de la retina, con mayor densidad en la fóvea, una pequeña depresión situada en el centro de la retina, en la que no hay bastones y donde la visión es más aguda. M ediante espectrofotometría se han identificado tres tipos de conos, con picos de absorción en las zonas amarilla, verde y azul, de los que depende el sentido del color. Los bastones, en número de 80 a 100 millones, son más numerosos hacia la periferia de la retina y son sensibles a la luz débil (visión nocturna). A simismo, desempeñan un papel muy importante en la visión en blanco y negro y en la detección del movimiento.

Las fibras nerviosas, junto con los vasos sanguíneos que irrigan la retina, atraviesan la coroides, la capa media de las tres que forman la pared de la cámara posterior, y abandonan el ojo formando el nervio óptico en un punto ligeramente excéntrico que, debido a la ausencia de fotorreceptores, se conoce como "mancha ciega".

Los vasos retinianos, las únicas arterias y venas visibles de forma directa, pueden visualizarse dirigiendo una luz a través de la pupila y utilizando un oftalmoscopio para enfocar su imagen (estas imágenes pueden también fotografiarse). Este examen retinoscópico forma parte de la exploración médica habitual y es importante para valorar el componente vascular de enfermedades como la arteriosclerosis, la hipertensión y la diabetes, que puede provocar hemorragias y/ o exudados retinianos causantes de defectos en el campo visual.

\section{Propiedades del ojo importantes para el trabajo}

\section{Mecanismo de acomodación}

En el ojo emetrópico (normal), cuando los rayos de luz atraviesan la córnea, la pupila y el cristalino, se enfocan sobre la retina y producen una imagen invertida que es revertida de nuevo por los centros visuales del cerebro.

Cuando se observa un objeto distante, el cristalino se aplana. Si se miran objetos cercanos, el cristalino se acomoda (es decir, aumenta su potencia) mediante la contracción de los músculos ciliares, lo que le permite adoptar una forma más oval y convexa. Al mismo tiempo, el iris contrae la pupila y esto mejora la calidad de la imagen al reducir las aberraciones esféricas y cromáticas del sistema y aumentar la profundidad del campo.

En la visión binocular, la acomodación se acompaña necesariamente de una convergencia proporcional de ambos ojos.

\section{El campo visual y el campo de fijación}

El campo visual (el espacio que abarcan los ojos en reposo) está limitado por los obstáculos anatómicos existentes en el plano horizontal (es más reducido en el lado de la nariz) y en el plano vertical (limitado por el borde superior de la órbita). En la visión binocular, el campo horizontal abarca unos 180 grados y el campo vertical, de 120 a 130 grados. En la visión diurna, la mayoría de las funciones visuales se debilitan hacia la periferia del campo visual; en cambio, mejora la percepción del movimiento. En la visión nocturna se produce una considerable pérdida de agudeza en el centro del campo visual, donde, como se mencionó antes, los bastones son menos numerosos

El campo de fijación se extiende más allá del campo visual gracias a la movilidad de los ojos, la cabeza y el cuerpo; en las actividades laborales lo que importa es el campo de fijación. Las causas de reducción del campo visual, anatómicas o fisiológicas, son muy numerosas: estrechamiento de la pupila; opacidad del cristalino; alteraciones patológicas de la retina, de las vías o de los centros visuales; brillantez del objeto a percibir; monturas de las gafas de corrección o de protección; movimiento y velocidad del objeto a percibir; y otras causas.

\section{Agudeza visual}

"La agudeza visual (AV) es la capacidad de discriminar con precisión los detalles de los objetos del campo visual. Se indica como la dimensión mínima de algunos aspectos críticos de un objeto de prueba que un sujeto puede identificar correctamente" (Riggs, en G raham y cols. 1965). U na buena agudeza visual es la capacidad para distinguir detalles pequeños. La agudeza visual define el límite de la discriminación espacial.

El tamaño retiniano de un objeto depende no sólo de su tamaño físico, sino también de su distancia al ojo; por tanto, se expresa como el ángulo visual (generalmente en minutos de arco). L a agudeza visual es el valor inverso de este arco.

Riggs (1965) describe varios métodos de valoración de la "agudeza visual". En la práctica clínica y laboral, la tarea de reconocimiento, en la que se pide al sujeto que nombre el objeto de prueba y localice algunos detalles de éste, es la que se emplea con más frecuencia. Por comodidad, en oftalmología, la agudeza visual se determina en relación a un valor "normal" utilizando gráficas que presentan una serie de objetos de tamaño diferente, que deben visualizarse a una distancia normalizada.

En la práctica clínica, los gráficos de Snellen son los más utilizados para valorar la agudeza visual; se emplean una serie de objetos de prueba en los que el tamaño y la anchura de los caracteres se ha diseñado para cubrir un ángulo de 1 minuto a una distancia normalizada que varía según los países (en Estados Unidos, 20 pies entre el gráfico y el sujeto de la prueba; en la mayoría de los países europeos, 6 metros). Por tanto, la puntuación normal de Snellen es 20/20. Asimismo, se dispone de objetos de mayor tamaño que forman un ángulo de 1 minuto de arco a distancias mayores.

La agudeza visual de un individuo se expresa como la relación $A V=D^{\prime} / D$, en la que $D^{\prime}$ es la distancia de visualización normalizada y $D$, la distancia a la que el objeto de prueba más pequeño correctamente identificado por el individuo forma un ángulo de 1 minuto de arco. Por ejemplo, la AV de una persona es 20/30 si, a una distancia de visualización de 20 pies, sólo 
Figura 11.9 - Ejemplo de un gráfico de Snellen: anillos de Landlot (agudeza en valores decimales (no se especifica la distancia de lectura)).

\section{0}
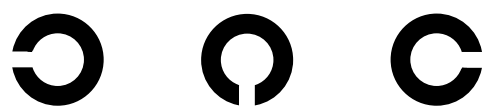

0
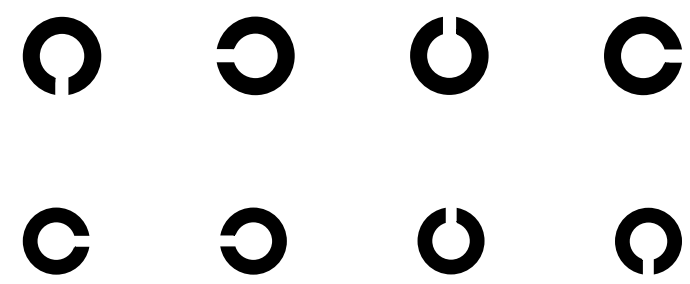

0
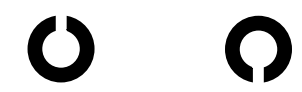

C

0

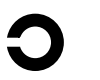

o

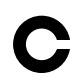

$V=0.6$

o

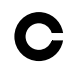

0

0

o

C

0

C

0

O

$V=0.8$

\section{O}

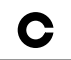

0

0

C

$V=0.9$

puede identificar un objeto que forma un ángulo de 1 minuto a 30 pies.

En la práctica optométrica, los objetos suelen ser letras del alfabeto (u objetos de formas familiares para los niños y las personas analfabetas). Sin embargo, cuando se repite la prueba, los gráficos deben presentarse con caracteres que no puedan aprenderse, para que no intervengan factores culturales ni educativos en el reconocimiento de las diferencias. Este es uno de los motivos por los que en la actualidad se recomienda en todo el mundo el uso de los anillos de Landolt, al menos en los estudios científicos. Los anillos de Landolt son círculos con un hueco y el sujeto debe identificar la posición del mismo. Salvo en las personas de edad avanzada y en los individuos con defectos de la acomodación (presbiopía), la agudeza visual próxima y remota son paralelas. En la mayoría de los trabajos se necesita un buen grado de agudeza visual de cerca y de lejos. Para evaluar la visión cercana existen gráficos de Snellen de diferentes tipos (Figuras 11.9 y 11.10). Este gráfico particular de Snellen debe mantenerse a 16 pulgadas del ojo $(40 \mathrm{~cm})$; en Europa hay gráficos similares para una distancia de lectura de $30 \mathrm{~cm}$ (la distancia adecuada para leer un periódico).

Al extenderse el uso de monitores de representación visual, VDU, ha aumentado el interés en la salud laboral por realizar pruebas a mayor distancia $(60$ a $70 \mathrm{~cm}$, según K rueger (1992), con el fin de corregir de forma adecuada a los operadores que trabajan con VDU.
Dispositivos para pruebas visuales y detección selectiva En salud laboral, existen en el mercado varios tipos de dispositivos para pruebas visuales de características similares: O rthorater, Visiontest, Ergovision, T itmus 0 ptima C Tester, C 45 Glare Tester, M esoptometer, Nyctometer, etc.. Son pequeños; no dependen de la iluminación de la sala en que se realiza la prueba, ya que están dotados de un sistema de iluminación interna; en todos se incluyen varias pruebas, como la agudeza visual binocular y monocular de lejos y de cerca (casi siempre con caracteres que no pueden aprenderse), y también la percepción profunda, la discriminación grosera del color, el equilibrio muscular, etc. Puede determinarse la agudeza visual de cerca, en algunos casos para distancias cortas e intermedias del objeto de prueba. EI dispositivo más reciente está dotado de un sistema electrónico que proporciona de forma automática por escrito las puntuaciones obtenidas en las diferentes pruebas. Además, estos instrumentos pueden ser manejados por personal no sanitario tras un breve período de formación.

Los dispositivos para pruebas visuales están diseñados para la exploración selectiva previa a la contratación de trabajadores, 0 para realizar pruebas algún tiempo después, teniendo en cuenta los requisitos visuales del lugar de trabajo. En la Tabla 11.2 se indica el nivel de agudeza visual necesario para realizar actividades no especializadas y actividades muy especializadas, según el dispositivo de pruebas visuales utilizado (Fox, en Verriest y H ermans 1976).

Los fabricantes recomiendan estudiar la agudeza visual de los trabajadores si estos llevan gafas correctoras. Fox (1965), sin embargo, señala que este procedimiento puede dar lugar a resultados erróneos, por ejemplo, si se realizan pruebas a trabajadores con gafas demasiado antiguas respecto al momento de la prueba actual; por otro lado, los cristales pueden estar deteriorados por la exposición al polvo o a otros agentes nocivos.

Tabla 11.2 - Requisitos visuales para diferentes actividades con un Titmus O ptimal C Tester, con corrección.

\section{Categoría 1: Trabajo de oficina}

Agudeza visual de lejos, 20/ 30 en cada ojo (20/25 para la visión binocular)

Agudeza visual de cerca, 20/25 en cada ojo (20/20 para la visión binocular)

Categoría 2: Inspección y otras actividades en trabajos mecánicos delicados Agudeza visual de lejos, $20 / 35$ en cada ojo (20/30 para la visión binocular)

AV de cerca, 20/25 en cada ojo (20/20 para la visión binocular)

Categoría 3: Operadores de maquinaria móvil

AV de lejos, 20/ 25 en cada ojo (20/ 20 para la visión binocular)

AV de cerca, 20/35 en cada ojo (20/30 para la visión binocular)

Categoría 4: Operadores de maquinaria

AV de lejos y de cerca, 20/ 30 en cada ojo (20/25 para la visión binocular)

Categoría 5: Trabajadores no especializados

AV de lejos, $20 / 30$ en cada ojo (20/ 25 para la visión binocular)

AV de cerca, 20/35 en cada ojo (20/30 para la visión binocular)

\section{Categoría 6: Capataces}

AV de lejos, 20/ 30 en cada ojo (20/25 para la visión binocular)

AV de cerca, 20/25 en cada ojo (20/20 para la visión binocular)

Fuente: Fox, en Verriest y Hermans 1975. 
Figura 11.10 - Ejemplo de un gráfico de Snellen: letras de Sloan para medir la visión de cerca $(40 \mathrm{~cm})$ (agudeza en valores decimales y en equivalentes de distancia).

Cm Pulgadas

$620 \quad 256$
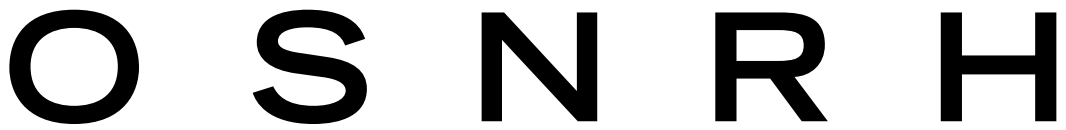

Equivalentes

de distancia

Decimales

$0,06 \quad \frac{20}{333}$
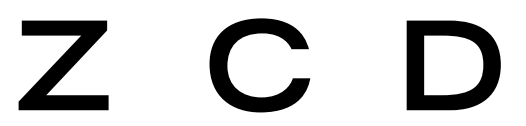

$\mathrm{V}$

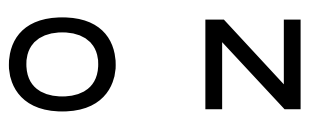

$0,08 \quad \frac{20}{250}$

$400 \quad 160$
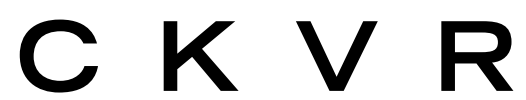

$\mathrm{N}$

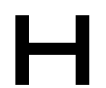

$D$

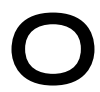

$0,1 \quad \frac{20}{200}$

$310 \quad 128$

D H Z V

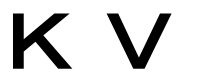

RCOS N

$0,12 \quad \frac{20}{167}$

$\begin{array}{ll}250 & 96\end{array}$

$\begin{array}{llll}\text { K D } \mathbf{Z} ~ V \quad 0,16 & \frac{20}{125}\end{array}$

$200 \quad 80$

V R N H

DCK SO

$0,2 \quad \frac{20}{100}$

$160 \quad 64$

S O Z N

H R V D K

$0,25 \quad \frac{20}{80}$

$125 \quad 48$

N H R O C

C V H R N

V Z S K D

$0,33 \quad \frac{20}{60}$

$100 \quad 40$

$C \vee O R D$

D O S K R

S KHZ N

$0,4 \quad \frac{20}{50}$

$80 \quad 32$

H S V Z O

H Z D O V

R K N C D

$0,5 \quad \frac{20}{40}$

$60 \quad 24$

R C DEN

KRCNE

$0,66 \quad \frac{20}{30}$

$50 \quad 20$

RODEN

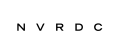

$0,8 \quad \frac{20}{25}$

$40 \quad 16$

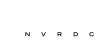

$1,0 \quad \frac{20}{20}$

$30 \quad 13$

\section{.....}

$1,2 \quad \frac{20}{16,7}$

También es muy frecuente el caso de personas que acuden a la sala de pruebas con las gafas erróneas. Fox (1976) sugiere, por tanto, que si "la visión corregida no alcanza un nivel de 20/ 20 en la visión de lejos y de cerca, el trabajador debe ser remitido a un oftalmólogo para que realice una evaluación adecuada y valore la necesidad del empleado en su puesto de trabajo 
actual". En este artículo se mencionan más adelante otras deficiencias de los dispositivos de pruebas visuales.

\section{Factores que influyen en la agudeza visual}

La primera limitación de la agudeza visual se encuentra en la estructura de la retina. En la visión diurna, puede superar los 10/ 10 en la fóvea y disminuir con rapidez al desplazarse algunos grados con respecto al centro de la retina. En la visión nocturna, la agudeza visual es mínima o nula en el centro, pero puede alcanzar la décima parte en la periferia, por la distribución de los conos y los bastones (Figura 11.11).

El diámetro de la pupila actúa sobre la visión de forma compleja. Al dilatarse, la pupila permite que pase más luz al ojo para estimular la retina; se reduce al mínimo la borrosidad causada por la difracción. Una pupila más estrecha, sin embargo, reduce los efectos negativos de las aberraciones del cristalino mencionadas previamente. En general, un diámetro pupilar de 3 a $6 \mathrm{~mm}$ aumenta la claridad de la visión.

Gracias al proceso de adaptación,el ser humano puede ver tan bien con la luz de la luna como con la luz brillante del sol, aunque existe una diferencia de luminosidad de 1 a 10.000.000. La sensibilidad visual es tan amplia que la intensidad luminosa debe representarse en una gráfica a escala logarítmica.

Al entrar en una habitación oscura nos sentimos al principio completamente ciegos; después, comenzamos a percibir los objetos a nuestro alrededor. Al aumentar el nivel luminoso, pasamos de una visión dominada por los bastones a una visión dominada por los conos. La variación asociada de la sensibilidad se conoce como cambio de Purkinje. La retina adaptada a la oscuridad es sensible sobre todo a la luminosidad baja, pero se caracteriza por la ausencia de visión en colores y la escasa resolución espacial (baja AV); la retina adaptada a la luz no es muy sensible a la luminosidad baja (sólo se perciben los objetos bien iluminados), pero se caracteriza por un alto grado de resolución espacial y temporal y por la visión en color. D espués de la desensibilización inducida por la estimulación luminosa intensa, el ojo recupera su sensibilidad de acuerdo con una progresión típica: al principio se produce un cambio rápido que afecta a los conos y a

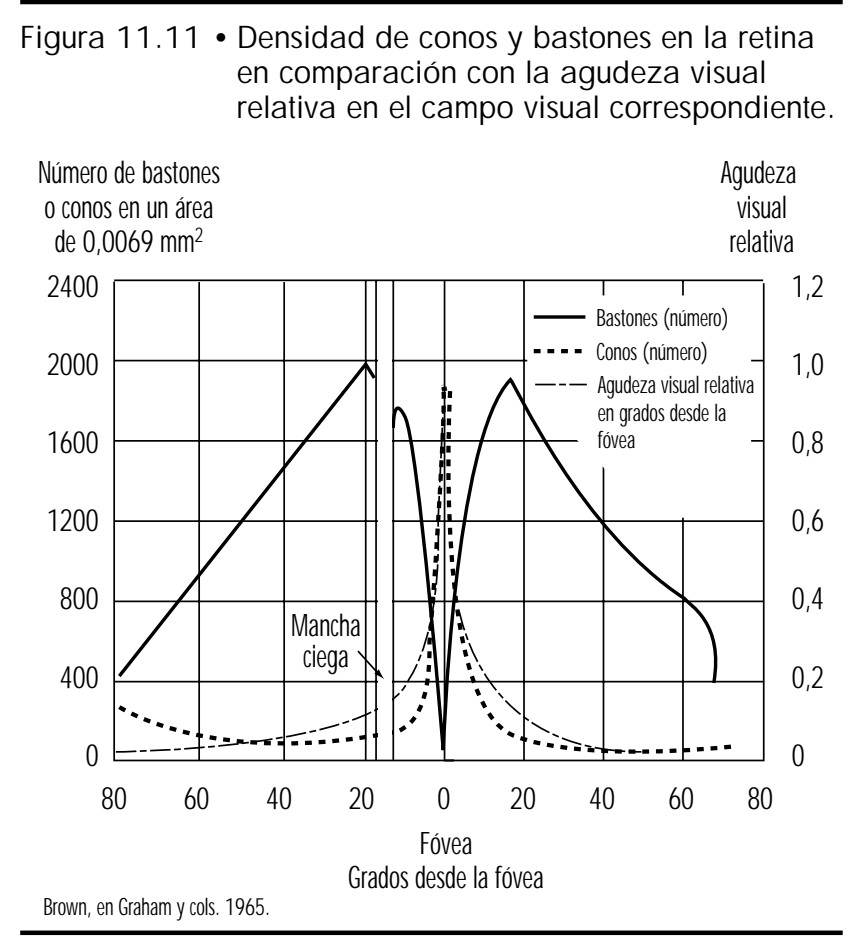

Figura 11.12 • Porcentaje de distribución de la agudeza visual estudiada en trabajadores de oficina.
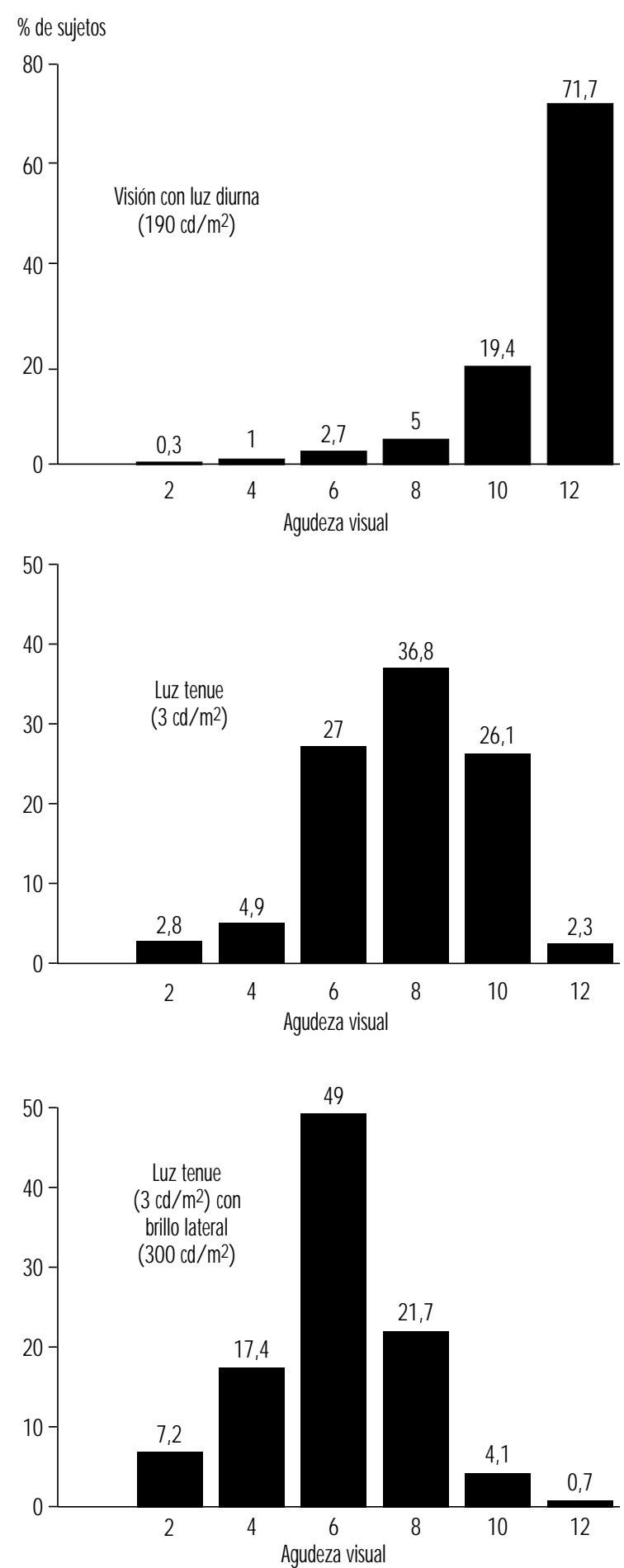

El efecto es una reducción considerable de la agudeza. Con luz brillante, más de la mitad de los trabajadores de oficina superaron los 12 / 10 de agudeza visual; los instrumentos de medición deberían tener esto en cuenta. (Essilor Ergovision tester: distancia de visión $=60 \mathrm{~cm}$, objeto de prueba: letras y números) para tres niveles diferentes de iluminación y condiciones de adaptación. Arriba: nivel con luz diuma; medio: luz tenue; abaj: luz tenue con reflejos ( $N=780$ ) Fuente: Meyer y cols. 1990. 
la adaptación diurna o fotópica, seguido de una fase más lenta en la que participan los bastones y la adaptación nocturna o escotópica; la zona intermedia se relaciona con la luz tenue 0 adaptación mesópica.

En el medio de trabajo, la adaptación nocturna carece de relevancia, salvo en las actividades que tienen lugar en una habitación oscura y para la conducción nocturna (aunque el reflejo de los faros sobre la carretera siempre aporta algo de luz). La adaptación a la luz diurna procedente de la iluminación natural 0 artificial es la más habitual en las actividades industriales 0 administrativas. Sin embargo, en la actualidad, dada la importancia del trabajo con monitores de representación visual, muchos trabajadores prefieren operar con luz tenue.

En la práctica laboral, el comportamiento de los grupos de personas tiene una importancia especial (en comparación con la evaluación individual) a la hora de diseñar el lugar de trabajo apropiado. Los resultados de un estudio realizado con 780 trabajadores en G inebra (M eyer y cols. 1990) muestran la variación del porcentaje de distribución de los niveles de agudeza al cambiar las condiciones de iluminación. Puede observarse que, una vez adaptados a la luz diurna, la mayoría de los trabajadores sometidos a las pruebas visuales (con corrección ocular) alcanzan un nivel de agudeza visual bastante adecuado; en cuanto se reduce el nivel de iluminación circundante, la AV media disminuye y esta reducción es más marcada en algunas personas en las que se reduce mucho la agudeza visual; esta tendencia empeora si la luz tenue se acompaña de alguna fuente de deslumbramiento. (Figura 11.12). En otras palabras, resulta difícil predecir el comportamiento de un sujeto con luz tenue basándose en su puntuación en condiciones óptimas de luz diurna.

D eslumbramiento. Si los ojos se dirigen de un área oscura a un área iluminada y de ésta al área oscura otra vez, o si el sujeto mira un momento a una lámpara o a una ventana (y la iluminación varía de 1.000 a $12.000 \mathrm{~cd} / \mathrm{m}^{2}$ ), las variaciones en la adaptación se producen en un área limitada del campo visual (adaptación local). El tiempo de recuperación tras un deslumbramiento discapacitante puede durar varios segundos, dependiendo del nivel de iluminación y del contraste (Meyer y cols. 1986) (Figura 11.13).

I mágenes residuales. La desadaptación local se acompaña generalmente de la imagen continuada de una mancha brillante, en color o no, que produce un velo o efecto de enmascaramiento (esta es la imagen consecutiva). L as imágenes residuales se han estudiado minuciosamente para comprender mejor algunos fenómenos visuales (Brown, en G raham y cols. 1965). Tras cesar la estimulación visual, el efecto permanece durante algún tiempo; esta persistencia explica, por ejemplo, por qué se produce una percepción continua de la luz cuando se mira a una fuente de luz parpadeante (véase más adelante). Si la frecuencia de parpadeo es lo suficientemente rápida, o cuando se miran los coches por la noche, vemos una línea de luz. Estas imágenes residuales aparecen en la oscuridad cuando se mira a un punto luminoso; también son producidas por áreas de color que dejan imágenes residuales en color. Esto explica por qué los operadores de monitores de representación visual pueden percibir imágenes visuales nítidas después de mirar durante un tiempo prolongado a la pantalla y mover los ojos hacia otra área de la habitación.

Las imágenes residuales son muy complicadas. Por ejemplo, en un experimento sobre imágenes residuales se observó que una mancha azul aparece blanca durante los primeros segundos de observación, después rosa durante unos 30 segundos y después de color rojo brillante al cabo de uno o dos minutos. En otro experimento se comprobó que un campo de color rojo-
Figura 11.13 - Tiempo de respuesta antes y después de la exposición a reflejos para percibir el hueco en un anillo de Landlot: adaptación a la luz tenue.
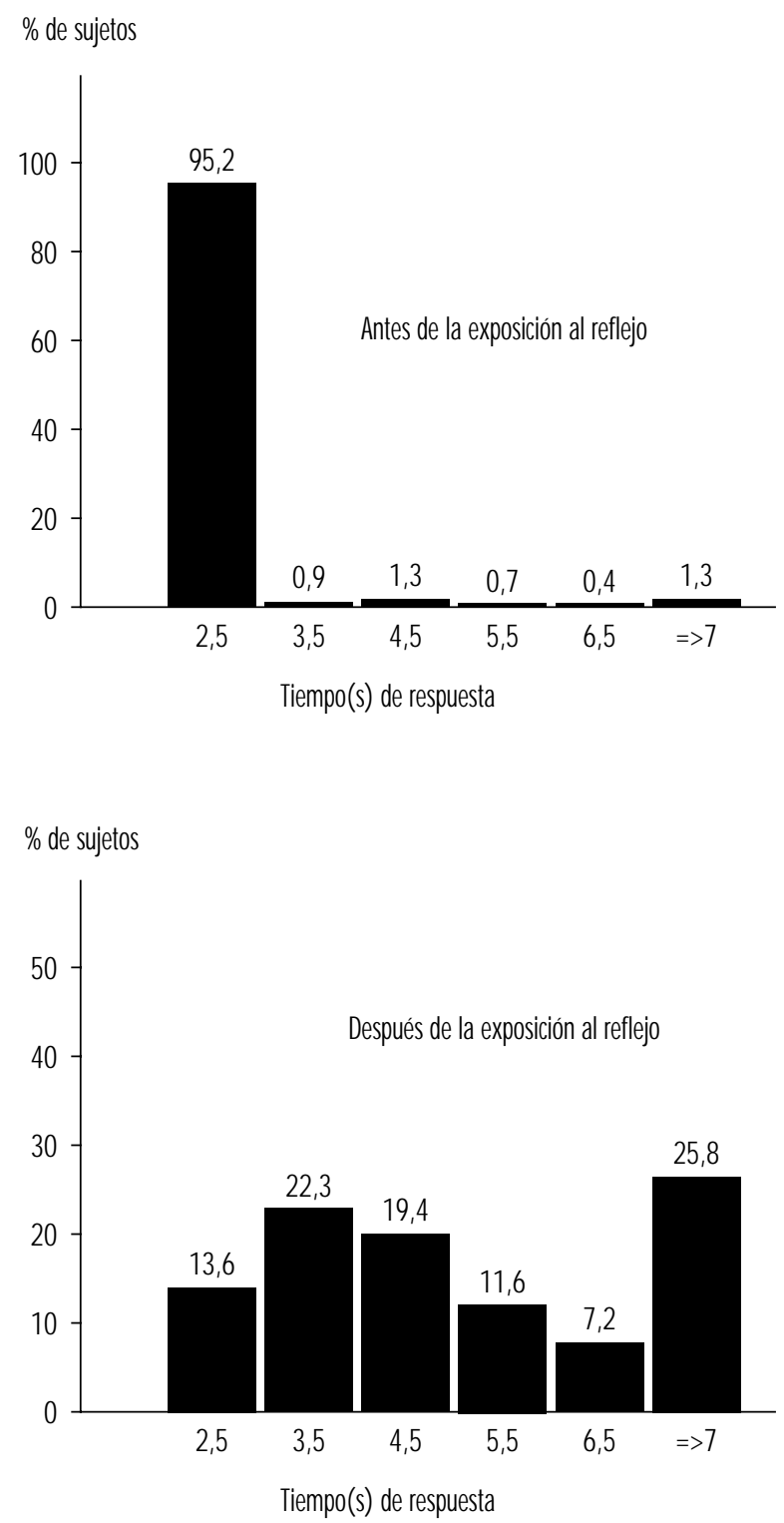

Instrumento Essilor C45 glare tester, modificado por Meyer y Richez. Resultados obtenidos en 670 trabaiadores de oficina.

Fuente: Meyer y cols. 1990.

naranja aparecía momentáneamente en color rosa y, en unos 10-15 segundos, pasaba por el naranja y el amarillo hasta alcanzar un aspecto verde brillante que persistía durante todo el período de observación. Si el punto de fijación se mueve, generalmente se mueve también la imagen residual (Brown en Graham y cols. 1965). Estos efectos podrían causar bastantes molestias a personas que trabajan con monitores.

La luz difusa que emiten las fuentes de deslumbramiento tiene también el efecto de reducir el contraste fondo/ objeto (efecto de velado) y disminuir así la agudeza visual (deslumbramiento discapacitante). Los ergooftalmólogos describen también la molestia por deslumbramiento, que no reduce la agudeza visual 


\section{Tabla 11.3 - Valores de iluminación recomendados para el diseño de la iluminación de algunos puestos de trabajo.}

Limpieza y planchado

Lavanderías y limpieza en seco

500-1.000 lux 0 50-100 bujías-pie

Inspección y revisión

2.000-5.000 lux o 200-500 bujías-pie

Reparación y modificación

1.000-2.000 lux 0 100-200 bujías-pie

Productos lácteos, industria lechera

Almacenamiento de botellas

200-500 lux 0 20-50 bujias-pie

Lavado de botellas

Llenado, inspección

Laboratorios

200-500 lux 0 20-50 bujías-pie

Equipos eléctricos, fabricación

Impregnación

Bobinado aislante

Centrales eléctricas

Equipos de aire acondicionado, precalentador de aire

Auxiliares, bombas, tanques, compresores

Industria de la confección

Revisión ("repasado")

Corte

Plancha

Cosido

Apilado y marcado

Cardado, decatizado, devanado

Banca

General

Area de escritura

Puestos de cajeros

Granjas de productos lácteos

Almacén de heno

Area de lavado

Area de alimentación

Fundiciones

Fabricación de núcleos: pequeños

Fabricación de núcleos: medianos

Moldeado: medianos

Moldeado: grandes

Inspección: pequeños

Inspección: medianos
500-1.000 lux 0 50-100 bujias-pie

500-1.000 lux 0 50-100 bujías-pie

200-500 lux o 20-50 bujías-pie

500-1.000 lux 0 50-100 bujías-pie

\section{0-100 lux 0 50-10 bujias-pie}

100-200 lux o 10-20 bujías-pie

10.000-20.000 lux 0 1.000. 2.000 bujjas-pie

2.000-5.000 lux 0 200-500 bujías-pie

1.000-2.000 lux o 100-200 bujías-pie

2.000-5.000 lux 0 200-500 bujías-pie

500-1.000 lux 0 50-100 bujías-pie

200-500 lux 0 20-50 bujías-pie

100-200 lux o 10-20 bujías-pie

200-500 lux o 20-50 bujías-pie

500-1.000 lux 0 50-100 bujías-pie

20-50 lux o 2-5 bujías-pie

500-1.000 lux 0 50-100 bujías-pie

100-200 lux o 10-20 bujías-pie

1.000-2.000 lux 0 100-200 bujías-pie

500-1.000 lux 0 50-100 bujías-pie

1.000-2.000 lux o 100-200 bujías-pie

500-1.000 lux 0 50-100 bujías-pie

1.000-2.000 lux o 100-200 bujílas-pie

500-1.000 lux 0 50-100 bujías-pie

pero provoca una sensación molesta 0 incluso dolorosa (IESNA 1993).

El nivel de iluminación en el lugar de trabajo debe adaptarse al que requiere la tarea. Si sólo es necesario percibir formas en un ambiente de luminosidad estable, puede bastar una iluminación débil; sin embargo, si es preciso percibir detalles finos con una agudeza visual mayor, o si en el trabajo hay que discriminar los colores, debe aumentarse de forma notable la iluminación retiniana.

En la Tabla 11.3 se muestran los valores de iluminación recomendados en el diseño de algunos puestos de trabajo en diferentes industrias (IESNA 1993).

Contraste de brillo y distribución espacial de la luminosidad en el lugar de trabajo. Desde el punto de vista ergonómico, la relación entre la luminosidad del objeto de prueba, su fondo inmediato y el área circundante se ha estudiado ampliamente y existen recomendaciones sobre este tema para diferentes requerimientos laborales (véanse Verriest y H ermans 1975; G ryjean 1987).

El contraste fondo-objeto se define en la actualidad según la fórmula $\left(L_{f}-L_{0}\right) / L_{f}$, en la que $L_{0}$ es la luminosidad del objeto y $\mathrm{L}_{f}$, la luminosidad del fondo. Por tanto, varía entre 0 y 1.

Como se muestra en la Figura 11.14, la agudeza visual aumenta con el nivel de iluminación (como se indicó previamente) y con el aumento del contraste fondo-objeto (Adrian 1993). Este efecto es particularmente intenso en las personas jóvenes. Un fondo amplio claro y un objeto oscuro, por tanto, proporcionan la mayor eficiencia. Sin embargo, en la vida real, el contraste nunca alcanza la unidad. Por ejemplo, si se imprime una letra negra sobre un hoja de papel blanco, el contraste fondo-objeto sólo alcanza un valor de alrededor del $90 \%$.

En la situación más favorable, esto es, en la presentación positiva (letras oscuras sobre un fondo claro), la agudeza y el contraste están relacionadas, de forma que se puede mejorar la visibilidad modificando uno u otro factor, por ejemplo,

Figura 11.14 - Relación entre la agudeza visual de un objeto oscuro percibido sobre un fondo iluminado de forma creciente con cuatro valores de contraste.

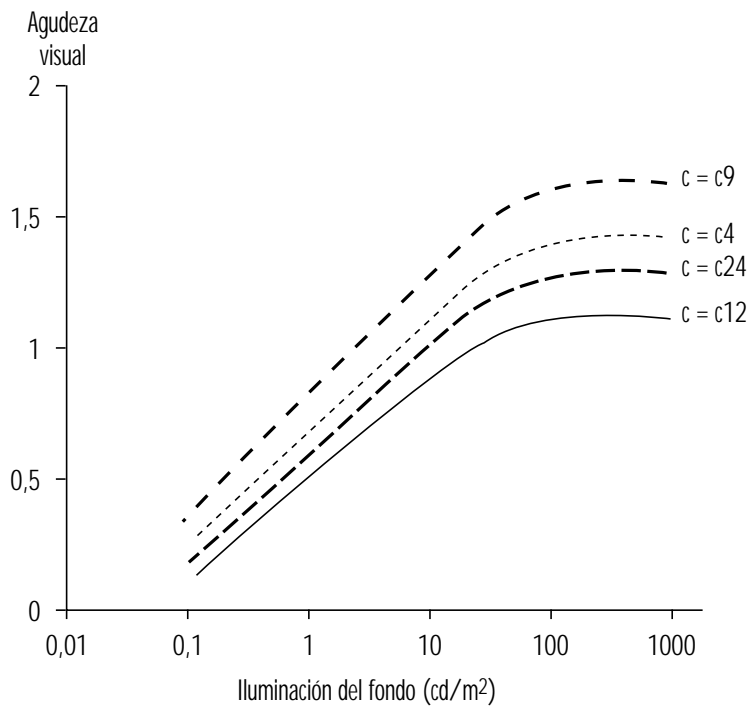

La agudeza visual aumenta con rapidez al principio, después lentamente; los resultados son mejores con todos los niveles de iluminación cuando el nivel de contraste es mayor.

Fuente: Adrian 1993. 
aumentando el tamaño de las letras o su intensidad, como en la tabla de Fortuin (en Verriest y Hermans 1975). Cuando aparecieron en el mercado los monitores de representación visual, las letras o símbolos se presentaban en la pantalla como manchas claras sobre un fondo oscuro. Posteriormente se desarrollaron nuevas pantallas en las que aparecían letras oscuras sobre un fondo claro, y se realizaron numerosos estudios con el fin de comprobar si esta presentación mejoraba la visión. Los resultados de la mayoría de los experimentos subrayan sin lugar a dudas que la agudeza visual aumenta cuando se leen letras oscuras sobre un fondo claro; desde luego, una pantalla oscura favorece los reflejos producidos por fuentes luminosas.

El campo visual funcional se define por la relación entre la luminosidad de las superficies percibidas realmente por el ojo en el puesto de trabajo y las superficies de las áreas circundantes. $\mathrm{H}$ ay que tener cuidado en no crear diferencias de luminosidad demasiado grandes en el campo visual; según el tamaño de las superficies implicadas se producen variaciones en la adaptación general o local que provocan molestias al realizar las tareas. Además, está demostrado que, para obtener un buen rendimiento, los contrastes en el campo deben ser tales que el área de la tarea esté más iluminada que los alrededores inmediatos, y que las áreas más alejadas estén más oscuras.

Tiempo de presentación del objeto. La capacidad de detección de un objeto depende directamente de la cantidad de luz que penetra a través del ojo, lo que a su vez está relacionado con la intensidad lumínica del objeto, la calidad de su superficie y el tiempo durante el que aparece (esto se sabe por las pruebas de presentación taquiscópica). Si la duración de la presentación es inferior a 100-500 ms, disminuye la agudeza.

M ovimientos del ojo o del objeto. Se produce una pérdida de rendimiento sobre todo con el movimiento rápido del ojo; no obstante, no se requiere una imagen totalmente estable para conseguir una resolución máxima. Se ha demostrado que las vibraciones del tipo de las generadas por la maquinaria de construcción o los tractores pueden afectar adversamente a la agudeza visual.

Diplopia. La agudeza visual es mayor en la visión binocular que en la monocular. La visión binocular requiere la unión de los ejes ópticos en el objeto observado, de forma que la imagen se refleje en las áreas correspondientes de la retina de ambos ojos. Esto es posible gracias a la actividad de los músculos externos. Si falla la coordinación de estos, pueden aparecer imágenes más o menos pasajeras, como sucede en la fatiga visual excesiva, causantes de sensaciones molestas (G randjean 1987).

En resumen, el poder discriminatorio del ojo depende del tipo de objeto que debe percibirse y del ambiente luminoso en el que se determina; en la consulta médica, las condiciones son óptimas: contraste alto entre el fondo y el objeto, adaptación a la luz directa del día, caracteres de contornos nítidos, presentación del objeto sin límite de tiempo y cierta redundancia de señales (p. ej., varias letras del mismo tamaño en un gráfico de Snellen). Además, la agudeza visual determinada con fines diagnósticos es una operación máxima y única en ausencia de fatiga de acomodación. La agudeza clínica es, por tanto, una referencia inadecuada del funcionamiento visual en el puesto de trabajo. Además, una agudeza clínica satisfactoria no significa necesariamente la ausencia de molestias en el puesto de trabajo, en el que las condiciones de comodidad visual individual rara vez se alcanzan. Como señala K rueger (1992), en la mayoría de los lugares de trabajo, los objetos que deben percibirse están borrosos y con escaso contraste, la luminosidad de fondo se distribuye de forma desigual y las fuentes de luz producen veladuras y efectos de adaptación local, etc. Según cálculos propios, los resultados clínicos no tienen demasiado valor predictivo respecto a la cantidad y naturaleza de la fatiga visual encontrada, por ejemplo, en el trabajo con monitores de representación visual. En un ensayo de laboratorio más realista, en el que las condiciones de determinación se ajustaron más a las condiciones de las tareas laborales, se obtuvieron resultados algo mejores (Rey y Bousquet 1990; M eyer y cols. 1990).

K rueger (1992) tiene razón cuando afirma que la exploración oftalmológica no es realmente apropiada en los campos de la salud laboral y la ergonomía, y que deberían desarrollarse nuevas pruebas o mejorar las existentes, y que habría que poner a disposición del médico de empresa los métodos de laboratorio existentes en la actualidad.

\section{Visión en relieve, visión estereoscópica}

La visión binocular permite obtener una imagen única mediante la síntesis de las imágenes recibidas por los dos ojos. L as analogías entre estas imágenes dan lugar a la cooperación activa que constituye el mecanismo esencial del sentido de profundidad y del relieve. La visión binocular tiene la propiedad adicional de aumentar la amplitud del campo, mejorando así en general el rendimiento visual, aliviando la fatiga y aumentado la resistencia al deslumbramiento y al brillo.

Si la fusión de ambos ojos no es adecuada, la fatiga ocular aparece antes.

Sin alcanzar la eficiencia de la visión binocular en la apreciación del relieve de objetos relativamente cercanos, la sensación de relieve y la percepción de profundidad son, no obstante, posibles con la visión monocular, mediante fenómenos que no requieren la disparidad binocular. Sabemos que el tamaño de los objetos no varía; por eso, el tamaño aparente desempeña un papel en la apreciación de la distancia; así, las imágenes que aparecen de pequeño tamaño en la retina darán la impresión de objetos distantes y viceversa (tamaño aparente). Los objetos cercanos tienden a ocultar los objetos distantes (lo que se denomina interposición). EI más brillante de dos objetos, o el que tiene un color más saturado, parece estar más cerca. El entorno desempeña también un papel, los objetos más distantes se pierden en una neblina. Dos líneas paralelas parecen encontrarse en el infinito (efecto de la perspectiva). Finalmente, si dos objetos se mueven a la misma velocidad, el que lo hace a menos velocidad en la retina aparecerá más lejos del ojo.

De hecho, la visión monocular no es un obstáculo importante en la mayoría de las situaciones laborales. El sujeto necesita acostumbrarse a la reducción del campo visual y también a la posibilidad bastante excepcional de que la imagen del objeto pueda caer sobre la mancha ciega (en la visión binocular la misma imagen nunca cae sobre la mancha ciega de los dos ojos al mismo tiempo). D ebe señalarse también que una buena visión binocular no se acompaña necesariamente de visión en relieve (estereoscópica), ya que esto depende también de procesos complejos del sistema nervioso.

Por todos estos motivos, deben abandonarse todas las normativas referidas a la necesidad de visión estereoscópica en el puesto de trabajo y sustituirse por una exploración completa de los sujetos llevada a cabo por un oftalmólogo. No obstante, estas normativas o recomendaciones existen y se supone que la visión estereoscópica es necesaria para tareas como la conducción de grúas, la joyería o el tallado. Sin embargo, hay que tener en cuenta que las nuevas tecnologías pueden modificar en gran medida el tipo de tarea; por ejemplo, las modernas máquinas computarizadas requieren probablemente menos visión estereoscópica de lo que antes se creía.

En cuanto a la conducción, las normativas de los distintos países no son iguales. En la Tabla 11.4, se mencionan los 
Tabla 11.4 - Requisitos visuales para obtener el permiso de conducción en Francia.

\section{Agudeza visual (con gafas) \\ Vehículos ligeros Al menos $6 / 10$ para ambos ojos con al menos $2 / 10$ en el peor ojo \\ Vehículos pesados AV de 10/10 con ambos ojos con al menos 6/10 en el peor ojo \\ Campo visual \\ Vehículos ligeros No se concede el permiso si hay reducción periférica en un solo ojo, ni si la agudeza visual del segundo ojo es menor de $2 / 10$ \\ Vehículos pesados Integridad completa de ambos campos visuales (sin reduc- ción periférica, ni escotomas) \\ Nistagmo (movimientos oculares espontáneos) \\ Vehículos ligeros No se concede el permiso si la agudeza visual binocular es menor de $8 / 10$ \\ Vehículos pesados No se aceptan defectos de visión nocturna}

requisitos para conducir vehículos ligeros o pesados en Francia. Las directrices de la American M edical Association son la referencia apropiada para los lectores norteamericanos. Fox (1973) indica que, en 1972, para el Departamento de Transportes de Estados Unidos los conductores de vehículos comerciales a motor debían tener una AV para lejos de 20/ 40 como mínimo, con o sin gafas correctoras; en cada ojo se necesita un campo de visión de 70 grados como mínimo. La capacidad de reconocimiento de los colores de las luces de los semáforos era necesaria también en aquella época, aunque en la mayoría de los países, dichas señales pueden distinguirse no sólo por el color, sino también por la forma.

\section{Movimientos oculares}

Se describen varios tipos de movimientos oculares cuyo objetivo es permitir al ojo aprovechar toda la información que contienen las imágenes. El sistema de fijación nos permite mantener el objeto situado a nivel de los receptores foveolares, donde puede ser examinado en la región retiniana con el máximo poder de resolución. No obstante, los ojos están sometidos continuamente a micromovimientos (temblor). L os movimientos oculares rápidos o "sacadas" (estudiados sobre todo durante la lectura) son movimientos rápidos inducidos de forma intencional con el fin de desplazar la mirada de un detalle a otro de un objeto inmóvil; el cerebro percibe este movimiento no previsto como el movimiento de una imagen que cruza la retina. Esta ilusión de movimiento se cumple en situaciones patológicas del sistema nervioso central o del órgano vestibular. Los movimientos de búsqueda son parcialmente voluntarios cuando se sigue la trayectoria de objetos relativamente pequeños, pero no pueden controlarse cuando se trata de objetos muy grandes. Diversos mecanismos de supresión de imágenes (incluidos los movimientos rápidos) permiten a la retina preparar o recibir información nueva.

Las ilusiones de movimiento (movimientos autocinéticos) de un punto luminoso o de un objeto inmóvil, como el movimiento de un puente sobre un curso de agua, se explican por la persistencia retiniana y por condiciones de visión que no están integradas en nuestro sistema central de referencia. El efecto consecutivo puede consistir en un simple error de interpretación de un mensaje luminoso (a veces dañino en el ambiente laboral) o provocar trastornos neurovegetativos graves. Las ilusiones causadas por figuras estáticas se conocen bien. Los movimientos que se producen durante la lectura se comentan en otro apartado de este capítulo.

\section{Fusión de parpadeo y curva de De Lange}

Cuando el ojo se expone a una sucesión de estímulos cortos, primero percibe el parpadeo y después, al aumentar la frecuencia, se tiene la impresión de luminosidad estable: esta es la frecuencia de fusión crítica. Si la luz estimuladora fluctúa de forma sinusoidal, el sujeto puede experimentar una fusión en todas las frecuencias inferiores a la frecuencia crítica, siempre que esté reducido el nivel de modulación de esta luz. Todos estos umbrales pueden unirse después por una curva que fue descrita primero por D e Lange y que puede alterarse al cambiar el tipo de estimulación: la curva mostrará un descenso si la luminosidad del área parpadeante está reducida o si el contraste entre la mancha parpadeante y su entorno disminuye; cambios similares en la curva pueden observarse en procesos retinianos patológicos 0 después de los traumatismos craneales (M eyer y cols. 1971) (Figura 11.15). Por tanto, hay que ser cauto al interpretar el significado de un descenso en la fusión de parpadeo crítica en relación con la fatiga visual inducida por el trabajo.

En la práctica laboral deberían utilizarse mejor las luces parpadeantes para detectar pequeñas lesiones o disfunciones

Figura 11.15 • Curvas de fusión-parpadeo conectando la frecuencia de la estimulación luminosa intermitente y su amplitud de modulación en el umbral (curvas de De Lange), media y desviación estándar, en 43 pacientes con traumatismo craneal y 57 controles (línea discontinua).

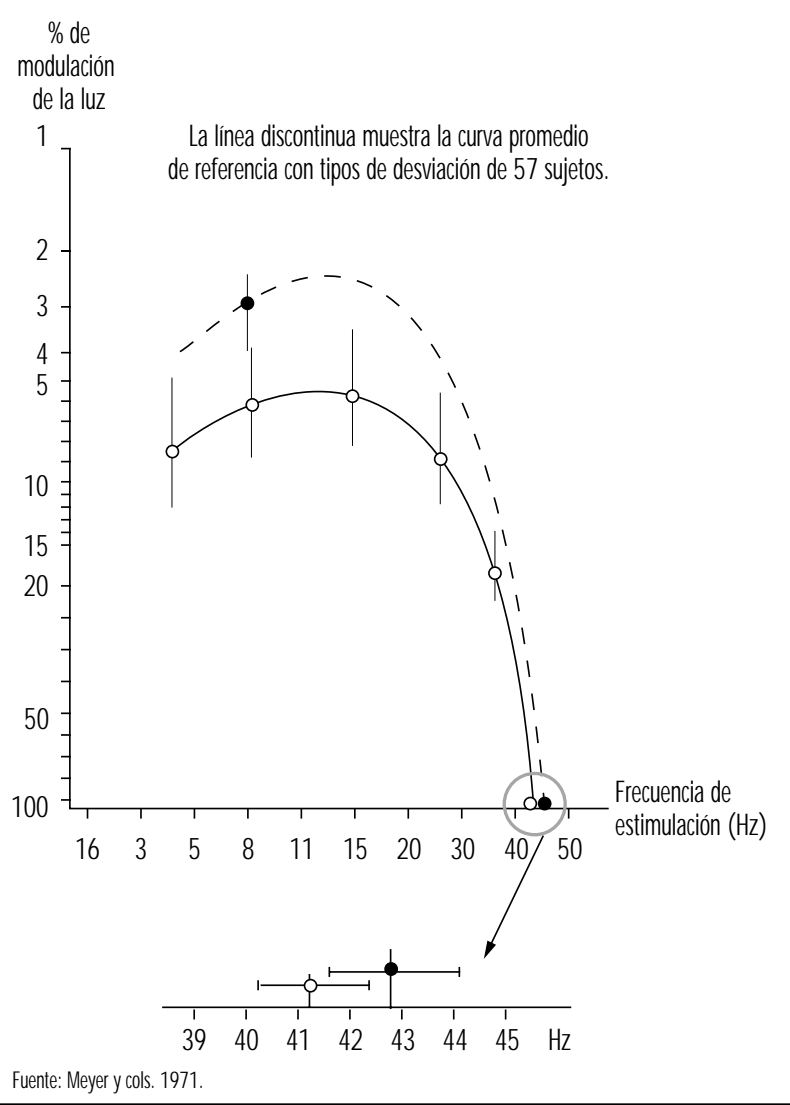


Figura 11.16 - Curva de De Lange en un hombre joven en tratamiento con etambutol; el efecto del medicamento puede deducirse comparando la sensibilidad de parpadeo del sujeto antes y después del tratamiento.

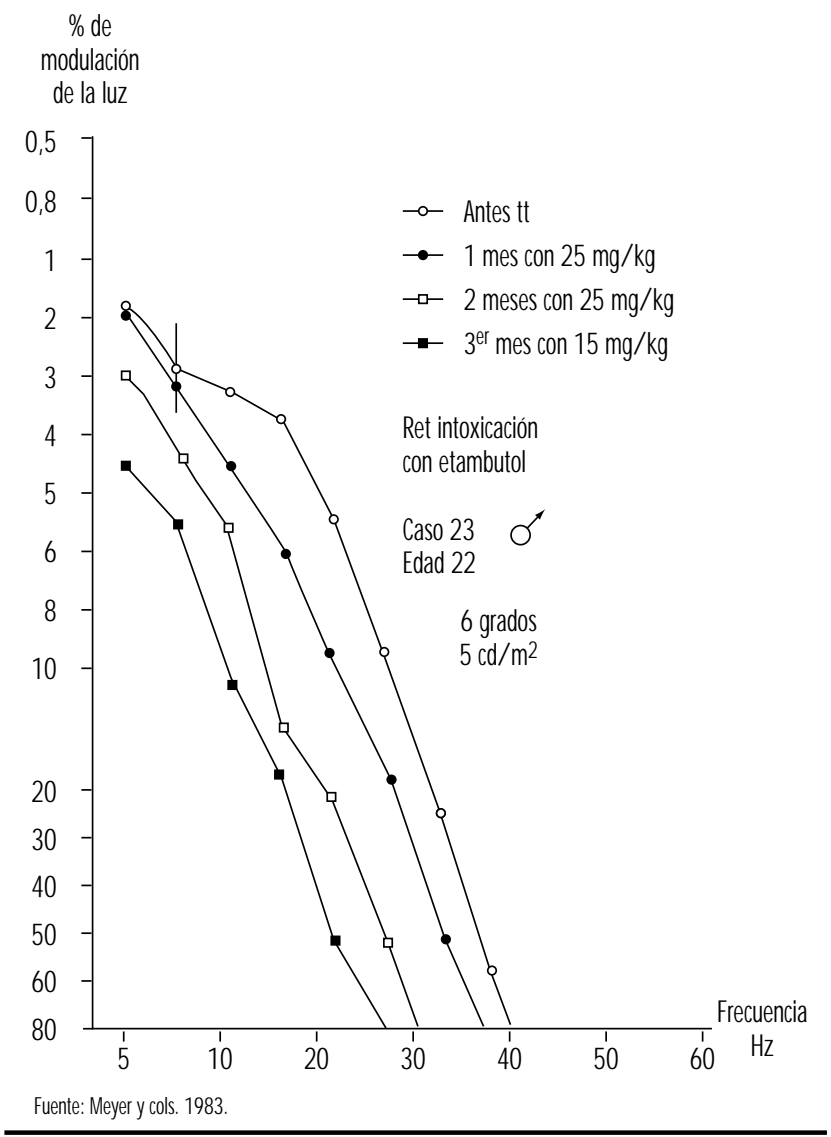

retinianas (p. ej., puede observarse un aumento de la curva en los casos de intoxicación ligera, seguido por un descenso cuando la intoxicación es mayor); este procedimiento de ensayo no altera la adaptación retiniana y no requiere corrección ocular; también es muy útil para el seguimiento de la recuperación funcional durante y después del tratamiento (M eyer y cols. 1983) (Figura 11.16).

\section{Visión en color}

La sensación de color se relaciona con la actividad de los conos y, por tanto, sólo existe en el caso de la luz diurna (límites fotópicos de la luz) 0 en la adaptación mesópica (límites medios de la luz). Para que el sistema de análisis del color funcione de forma satisfactoria, la iluminación de los objetos percibidos debe ser como mínimo de $10 \mathrm{~cd} / \mathrm{m}^{2}$. En general, basta con tres fuentes de color, los denominados colores primarios (rojo, verde y azul), para reproducir el espectro completo de sensaciones de color. Además, se observa un fenómeno de inducción de contraste de color entre dos colores que se refuerzan mutuamente entre sí: el par verderojo y el par amarillo-azul.

Las dos teorías sobre la sensación de color, la tricromática y la dicromática, no son excluyentes; la primera parece aplicarse a nivel de los conos y la segunda a niveles más centrales del sistema visual.

Para entender la percepción de los objetos de color en un fondo luminoso es necesario utilizar otros conceptos. De hecho, el mismo color puede ser producido por diferentes tipos de radiación. Por tanto, para reproducir fielmente un color dado hay que conocer la composición del espectro de las fuentes lumínicas y el espectro de la reflectancia de los pigmentos. El índice de reproducción del color utilizado por especialistas en iluminación permite seleccionar tubos fluorescentes apropiados a las necesidades. Nuestros ojos han desarrollado la facultad de detectar cambios muy ligeros en la tonalidad de una superficie obtenidos mediante la variación de su distribución espectral; los colores espectrales (el ojo puede distinguir más de 200) formados mediante mezclas de luz monocromática representan sólo una pequeña proporción de la sensación de color posible.

Por tanto, no debe exagerarse la importancia de las anomalías de la visión del color en el entorno laboral, salvo en actividades como la inspección del aspecto de los productos y, por ejemplo, en decoradores y profesionales similares, que deben identificar correctamente los colores. Además, incluso en el trabajo de los electricistas, el tamaño, la forma u otro tipo de marcadores pueden sustituir al color.

Las anomalías en la visión del color pueden ser congénitas 0 adquiridas (degeneraciones). En los tricromatismos anómalos, la variación puede afectar a la sensación básica del rojo (tipo Dalton), del verde o del azul (la anomalía más rara). En los dicromatismos, el sistema de tres colores básicos se reduce a dos. En la deuteranopía, falta el color básico verde.

En la protanopía, desaparece el rojo básico; aunque menos frecuente, esta anomalía, al acompañarse de una pérdida de luminosidad en la gama de los rojos, debe tenerse en cuenta en el ambiente laboral, especialmente para evitar la instalación de avisos en rojo, sobre todo si no están muy bien iluminados.

Debe señalarse también que estos defectos de la visión en color pueden encontrarse con distinto grado en el sujeto normal; de ahí la necesidad de ser cautos a la hora de emplear demasiados colores. $\mathrm{H}$ ay que tener en cuenta también que con los dispositivos para pruebas de visión sólo pueden detectarse los defectos importantes en la visión del color.

\section{Errores de refracción}

EI punto próximo (Weymouth 1966) es la distancia más corta a la que puede enfocarse con nitidez un objeto; el punto remoto es la distancia más alejada. En el ojo normal (emétrope), el punto remoto está situado en el infinito. En el ojo miope, el punto remoto está situado delante de la retina, a una distancia finita; este exceso de potencia se corrige con lentes cóncavas. En el ojo hiperópico (hipermétrope), el punto remoto se sitúa detrás de la retina; esta falta de potencia se corrige con lentes convexas. (Figura 11.17). En caso de hiperopía ligera, el defecto se compensa de forma espontánea mediante acomodación y el sujeto puede ignorar el problema. En los miopes que no llevan las gafas, la pérdida de acomodación puede compensarse por el hecho de que el punto remoto está más cerca.

En el ojo ideal, la superficie de la córnea debe ser perfectamente esférica; sin embargo la curvatura del ojo es distinta en los diferentes ejes (el denominado astigmatismo); la refracción es mayor si la curvatura es más acentuada y, en consecuencia, los rayos que salen de un punto luminoso no forman una imagen precisa sobre la retina. Estos defectos, cuando son pronunciados, se corrigen con lentes cilíndricas (véase el diagrama más inferior de la Figura 11.17); en el astigmatismo irregular se recomienda el uso de lentes de contacto.

El astigmatismo resulta particularmente molesto al conducir por la noche 0 al trabajar con monitores, es decir, en situaciones en las que las señales luminosas resaltan sobre un fondo oscuro o al utilizar un microscopio binocular. 
Figura 11.17 • Representación esquemática de los errores de refracción y su corrección.
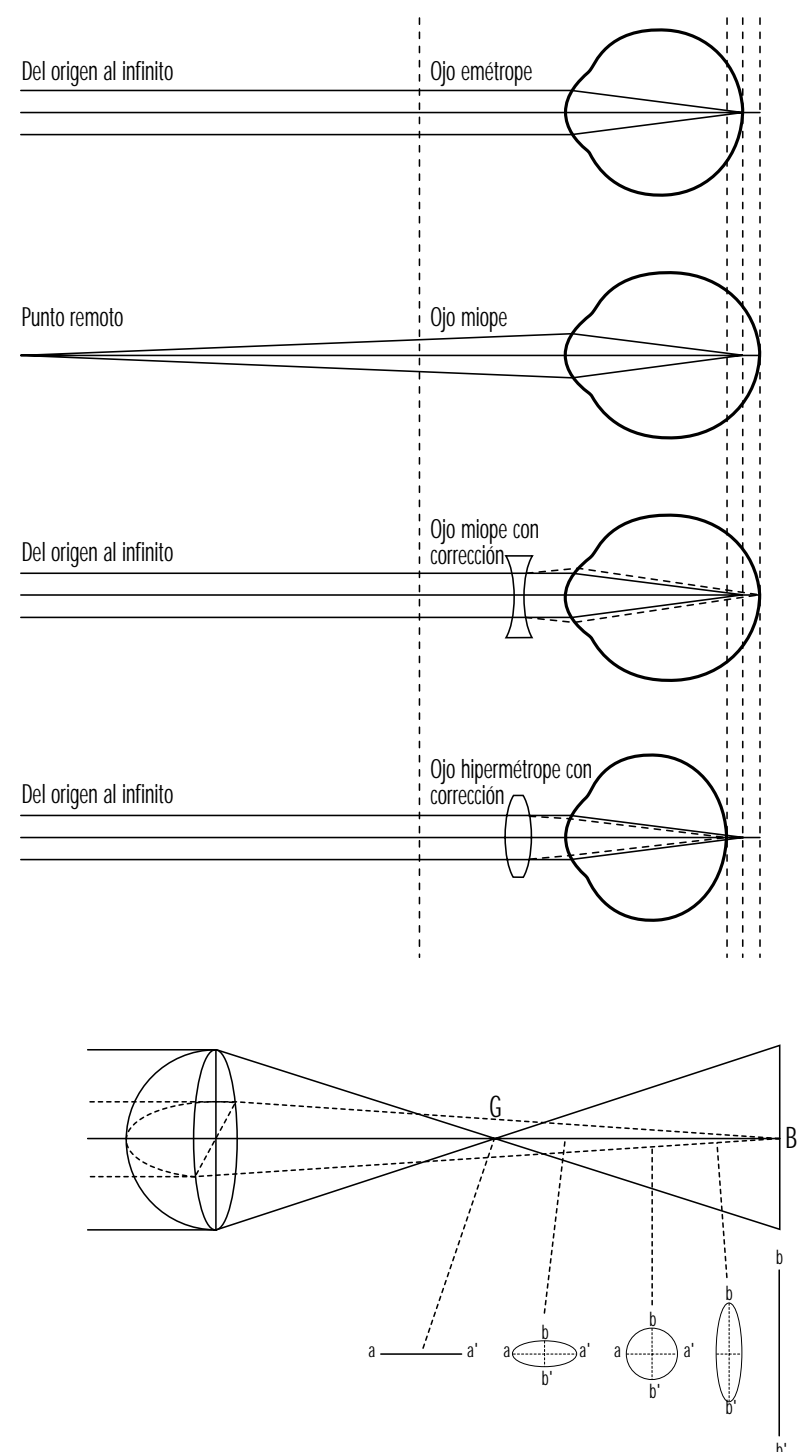

Arriba, errores esféricos; abajo, esquema del astigmatismo regular, que se corrige con lentes cilíndricas.

$B=$ punto de enfoque de los rayos a lo largo del meridiano horizontal;

$G=$ punto de enfoque de los rayos a lo largo del meridiano vertical.

Las figuras inferiores representan cortes horizontales de la luz en los puntos indicados. Obsérvese que la imagen del punto distante de luz nunca es un punto.

Fuente: Weymouth 1966.

Las lentes de contacto no deben utilizarse en los puestos de trabajo en los que el aire es demasiado seco, hay polvo, etc. (Verriest y Hermans 1975).

En la presbiopía (presbicia), un trastorno provocado por la pérdida de elasticidad del cristalino, disminuye la amplitud de la acomodación, esto es, la distancia entre los puntos remoto y próximo; el segundo se va alejando (desde unos $10 \mathrm{~cm}$ a la edad de 10 años) con la edad; la corrección se realiza con lentes convergentes unifocales o multifocales; estas últimas corrigen distancias cada vez más cercanas del objeto (en general hasta $30 \mathrm{~cm}$ ), teniendo en cuenta que los objetos más cercanos se perciben generalmente en la parte inferior del campo visual, mientras que la parte superior de las gafas se reserva para la visión a distancia. En la actualidad se propone el uso de nuevas lentes, distintas a las lentes normales, para trabajar con monitores de representación visual. Estas lentes, conocidas como lentes progresivas, casi borran los límites entre las zonas de corrección. Los usuarios de lentes progresivas deben acostumbrarse más a estos tipos de lentes que a otros, porque su campo de visión es estrecho (véase K rueger 1992).

Si la tarea visual requiere una visión alternativa de lejos y de cerca, se recomienda utilizar lentes bifocales, trifocales o incluso progresivas. Sin embargo, hay que recordar que el uso de lentes multifocales puede obligar a un operador a realizar modificaciones importantes de la postura. Por ejemplo, los operadores de monitores con presbiopía corregida con lentes bifocales tienden a extender el cuello y pueden sufrir dolor cervical y del hombro. Los fabricantes de gafas propondrán entonces el uso de lentes progresivas de diferentes tipos. 0 tra cuestión es la mejoría ergonómica de los puestos de trabajo con monitores, para evitar la colocación de la pantalla en una posición demasiado elevada.

La demostración de los errores de refracción (que son muy comunes en la población trabajadora) depende del tipo de pruebas realizadas. Con los gráficos de Snellen fijados a una pared no tienen por qué obtenerse los mismos resultados que con diversos tipos de aparatos en los que la imagen del objeto se proyecta sobre un fondo cercano. De hecho, en un dispositivo de pruebas visuales (véase más arriba), el sujeto tiene dificultades para relajar la acomodación, sobre todo si se reduce el eje de visión; este hecho se conoce como "miopía instrumental".

\section{Efectos de la edad}

C on la edad, como ya se ha explicado, el cristalino pierde su elasticidad, con lo que el punto próximo se aleja y disminuye el poder de acomodación. Aunque la pérdida de acomodación asociada a la edad puede compensarse con unas gafas, la presbiopía es un verdadero problema de salud pública. K auffman (en Adler 1992) calcula su coste, en relación con las medidas de corrección y la pérdida de productividad, en decenas de miles de millones de dólares al año sólo en Estados U nidos. En los países en vías de desarrollo, hemos observado que algunos trabajadores se veían obligados a renunciar a su puesto de trabajo (en particular, en la fabricación de saris de seda) porque no podían comprar unas gafas. Si además se necesitan gafas protectoras, la combinación de corrección y protección en las mismas gafas resulta muy cara. D ebe recordarse que la amplitud de la acomodación disminuye ya incluso en la segunda década de la vida (y quizás antes) y que desaparece por completo a los 50-55 años (M eyer y cols. 1990) (Figura 11.18).

Existe otro fenómeno asociado al envejecimiento que también hay que tener en cuenta: el hundimiento del ojo en la órbita, que se produce en edades muy avanzadas y varía más o menos según los individuos, reduce el tamaño del campo visual (por la caída del párpado). La dilatación de la pupila es máxima en la adolescencia y después disminuye; en las personas mayores, la pupila se dilata menos y su reacción a la luz se retrasa. La pérdida de transparencia de los medios oculares reduce la agudeza visual (algunos medios tienden hacia el color amarillo, lo que modifica también la visión del color) (véase Verriest y H ermans 1976). El aumento del tamaño de la mancha ciega reduce el campo visual funcional.

Con la edad y las enfermedades se producen variaciones de los vasos retinianos, con la consiguiente pérdida funcional. Incluso se modifican los movimientos oculares; se produce una ralentización y una reducción de la amplitud de los movimientos de exploración.

L os trabajadores de más edad sufren una desventaja doble en condiciones de contraste y de luminosidad ambientales débiles; 


\section{Figura 11.18 • Punto próximo determinado con la regla de Clement y Clark, porcentaje de distribución de 367 trabajadores de oficina de 18 a 35 años (abajo) y 414 trabajadores de oficina de 36 a 65 años (arriba).}
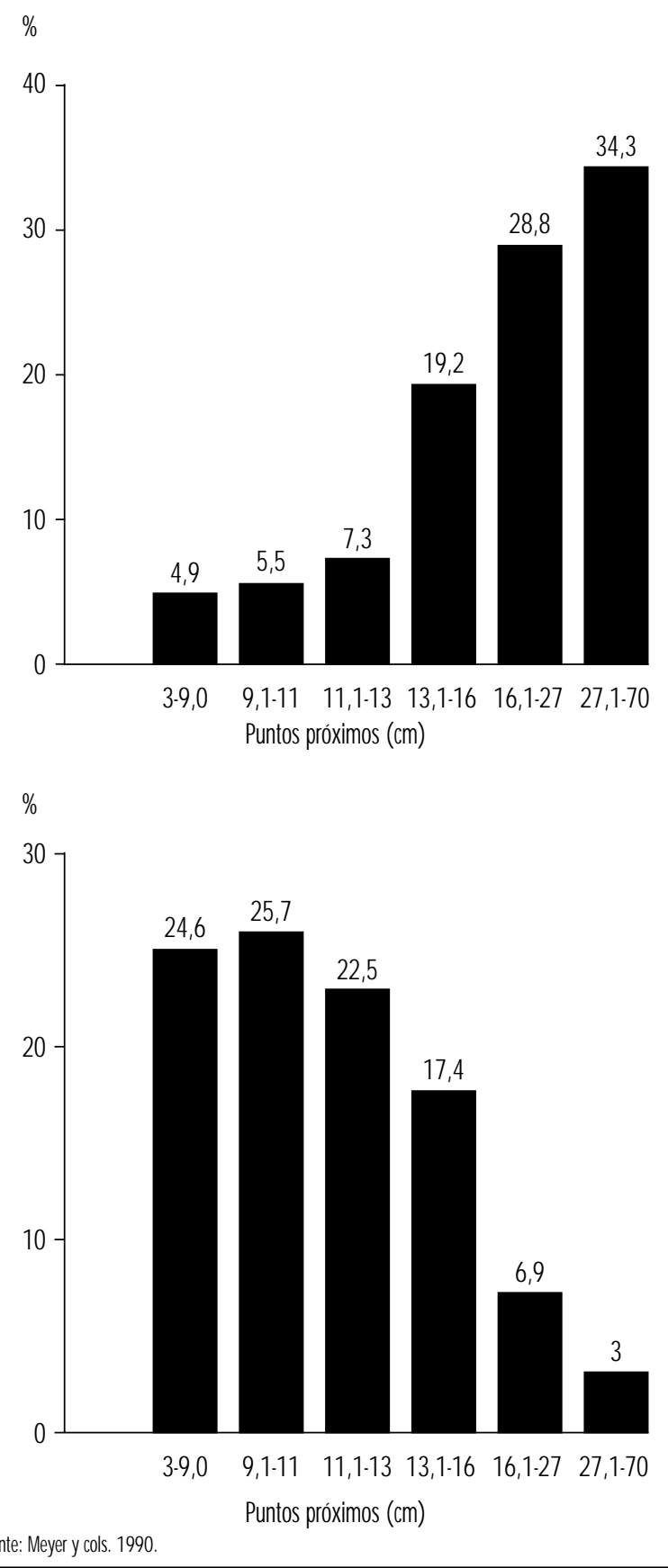

en primer lugar, necesitan más luz para ver un objeto, y a la vez se benefician menos del aumento de la luminosidad, porque se deslumbran con más rapidez por las fuentes lumínicas brillantes. Este inconveniente se explica por las variaciones de los medios transparentes oculares, que dejan pasar menos luz y aumentan su difusión (el efecto de velado descrito antes). Sus molestias visuales se agravan con los cambios demasiado súbitos entre áreas de iluminación intensa y débil (reacción pupilar más lenta, adaptación local más difícil). Todos estos defectos tienen un impacto especial en el trabajo con monitores y resulta muy difícil, de hecho, proporcionar una iluminación correcta en los lugares de trabajo comunes para operadores jóvenes y de mayor edad; puede observarse, por ejemplo, que estos últimos reducirán por todos los medios posibles la luminosidad del entorno, aunque la luz tenue disminuya su agudeza visual.

\section{Riesgos oculares en el trabajo}

E stos riesgos pueden expresarse de distintas formas (R ey y M eyer 1981; Rey 1991): por la naturaleza del agente causal (agente físico, agentes químicos, etc.), por la vía de penetración (córnea, esclerótica, etc.), por la naturaleza de las lesiones (quemaduras, equimosis, etc.), por la gravedad del trastorno (limitado a las capas externas, con afectación de la retina, etc.) y por las circunstancias del accidente (como sucede con cualquier lesión física); estos elementos descriptivos son útiles para diseñar las medidas preventivas. Aquí sólo se mencionarán las lesiones oculares y las circunstancias que se encuentran con más frecuencia en los informes estadísticos de las empresas aseguradoras. Conviene señalar que los trabajadores pueden solicitar indemnizaciones por la mayoría de las lesiones oculares.

\section{Trastornos oculares causados por cuerpos extraños}

Estos trastornos se observan sobre todo en torneros, pulidores, trabajadores de fundiciones, caldereros, albañiles y canteros. LoS cuerpos extraños pueden ser sustancias inertes como la arena, metales irritantes como el hierro y el plomo o materiales orgánicos de origen animal o vegetal (polvos). Por ello, además de las lesiones oculares, pueden producirse complicaciones como infecciones e intoxicaciones si la cantidad de sustancia introducida en el organismo es lo bastante grande. Las lesiones producidas por cuerpos extraños serán más o menos discapacitantes dependiendo de si afectan a las capas externas de ojo o penetran profundamente en el bulbo ocular; el tratamiento, por tanto, será muy diferente y a veces requiere el traslado inmediato de la víctima a una clínica oftalmológica.

\section{Quemaduras oculares}

Diversos agentes producen quemaduras oculares: los fogonazos y las llamas (en una explosión de gas); el metal fundido (la gravedad de la lesión depende del punto de fusión: los metales que funden a temperaturas más altas causan lesiones más graves); y las lesiones químicas causadas, por ejemplo, por ácidos y bases fuertes. Se producen también quemaduras por agua hirviendo, quemaduras eléctricas y de otros muchos tipos.

\section{Lesiones por aire comprimido}

Este tipo de lesiones es muy frecuente. Intervienen dos fenómenos: la fuerza del propio chorro (y los cuerpos extraños acelerados por el flujo de aire) y la forma del chorro: cuanto menos concentrado sea, menos lesión produce.

\section{Trastornos oculares provocados por la radiación}

\section{Radiación ultravioleta (UV)}

L a fuente de los rayos ultravioleta puede ser el sol o cierto tipo de lámparas. El grado de penetración en el ojo (y en consecuencia, el peligro de la exposición) depende de la longitud de onda. La Comisión Internacional de Iluminación ha definido tres zonas: rayos UVC (280 a $100 \mathrm{~nm}$ ), en la que los rayos se absorben a nivel de la córnea y la conjuntiva; rayos UVB (315 a $280 \mathrm{~nm}$ ), que penetran más y alcanzan el segmento anterior del ojo; y los rayos UVA (400 a $315 \mathrm{~nm}$ ), que penetran hasta planos más profundos. 
Se han descrito los efectos característicos de la exposición en los soldadores, como queratoconjuntivitis aguda, fotooftalmía crónica con disminución de la visión, etc. El soldador está sometido a una cantidad considerable de luz visible y es muy importante que proteja los ojos con los filtros adecuados. La ceguera de la nieve es un trastorno muy doloroso que afecta a las personas que trabajan en la montaña y debe evitarse protegiendo los ojos con unas gafas de sol adecuadas.

\section{Radiación infrarroja}

Los rayos infrarrojos se sitúan entre los rayos visibles y las ondas radioeléctricas más cortas. Comienzan, según la Comisión Internacional de Iluminación, a $750 \mathrm{~nm}$. Su penetración en el ojo depende de su longitud de onda; los rayos infrarrojos de mayor longitud pueden alcanzar el cristalino e incluso la retina. Su efecto sobre el ojo se debe a su poder calorífico. El trastorno característico se encuentra en las personas que soplan vidrio enfrente de los hornos. 0 tros trabajadores, como los de los altos hornos, sufren una irradiación térmica con diversos efectos clínicos (como queratoconjuntivitis o engrosamiento membranoso de la conjuntiva).

\section{LASER (Light amplification by stimulated emission of radiation; amplificación de la luz mediante emisión estimulada de radiación)}

La longitud de onda de la emisión depende del tipo de láser (luz visible, ultravioleta e infrarroja). La cantidad de energía proyectada es la que determina principalmente el nivel de peligrosidad.

Los rayos ultravioleta provocan lesiones inflamatorias; los rayos infrarrojos pueden provocar lesiones calóricas; sin embargo, el mayor riesgo es la destrucción del tejido retiniano por el propio haz de rayos, que causa la pérdida de visión en el área afectada.

\section{Radiación de las pantallas catódicas}

Todas las emisiones de las pantallas catódicas que se utilizan habitualmente en las oficinas (rayos X, ultravioleta, infrarrojos y de radio) son inferiores a los niveles autorizados internacionalmente. No hay evidencia de que exista ninguna relación entre el trabajo con las terminales de vídeo y la aparición de cataratas (Rubino 1990)

\section{Sustancias nocivas}

Algunos disolventes, como los ésteres y los aldehídos (el formaldehído se emplea con mucha frecuencia), producen irritación ocular. Los ácidos inorgánicos, cuya acción corrosiva se conoce bien, causan destrucción tisular y quemaduras químicas por contacto. Los ácidos orgánicos son también peligrosos. Los alcoholes son irritantes. La sosa cáustica, una base muy fuerte, es una sustancia corrosiva potente que ataca a los ojos y a la piel. En la lista de sustancias dañinas también se incluyen ciertos materiales plásticos (G rant 1979), así como polvos alergénicos u otras sustancias como maderas exóticas, plumas, etc.

Por último, las enfermedades infecciosas profesionales pueden acompañarse de efectos oculares.

\section{G afas protectoras}

Como las medidas de protección individual (gafas y máscaras) pueden obstaculizar la visión (reducción de la agudeza visual por pérdida de transparencia de las gafas a causa de la proyección de cuerpos extraños; obstáculos en el campo visual como las piezas laterales de las gafas), la higiene industrial también tiende a utilizar otros medios como la extracción de polvo y de partículas peligrosas del aire mediante la ventilación general.
Se acude con frecuencia al médico del trabajo para pedir consejo sobre la calidad de las gafas adaptadas según el riesgo; la elección se realizará se acuerdo con las normativas nacionales e internacionales. Además, ahora se dispone de gafas de mejor calidad, más eficaces y cómodas y de mejor aspecto estético.

En Estados U nidos, por ejemplo, es posible referirse a las normas ANSI (en particular a la ANSI Z87. 1-1979), que tienen el respaldo legal de la ley federal de salud y seguridad en el trabajo (Fox 1973). La norma ISO no 4007-1977 se refiere también a los dispositivos protectores.

En Francia, el INRS de Nancy ofrece recomendaciones y material de protección. En Suiza, la empresa nacional de seguros CNA establece normas y procedimientos para extraer cuerpos extraños en el lugar de trabajo. En las lesiones peligrosas, es preferible enviar al trabajador lesionado al oftalmólogo 0 a una clínica especializada.

Finalmente, las personas con patologías oculares pueden sufrir más riesgo que otras; la discusión de este controvertido problema se halla fuera del marco de este artículo. Como se comentó previamente, el oftalmólogo debe conocer los peligros que pueden encontrarse en el lugar de trabajo e investigarlos cuidadosamente.

\section{Conclusión}

En el lugar de trabajo, la mayor parte de la información y de las señales son de tipo visual, aunque también se utilizan las señales acústicas; tampoco hay que olvidar la importancia de las señales táctiles en el trabajo manual, así como en el trabajo administrativo (por ejemplo, la velocidad de un teclado).

Nuestros conocimientos sobre el ojo y la visión provienen en su mayor parte de dos fuentes: las médicas y las científicas. Para el diagnóstico de los defectos y las enfermedades oculares se han desarrollado técnicas que miden las funciones visuales; estos procedimientos pueden no ser los más eficaces en salud laboral. Las condiciones en que se realizan las exploraciones médicas son, de hecho, muy distintas a las que se encuentran en el lugar de trabajo; por ejemplo, para determinar la agudeza visual, el oftalmólogo utilizará gráficos 0 instrumentos en los que el contraste entre el objeto del ensayo y el fondo sea el máximo posible, donde los contornos de los objetos de la prueba sean nítidos, no se perciban fuentes de luz molestas, etc. En la vida real, las condiciones de iluminación son con frecuencia deficientes y la visión se fuerza durante horas.

Esto subraya la necesidad de utilizar aparatos de laboratorio e instrumentos con un poder predictivo superior para determinar la tensión y la fatiga visual en el lugar de trabajo.

Numerosos experimentos científicos citados en los libros de texto se realizaron para lograr un mejor conocimiento teórico del sistema visual, ya que se trata de un sistema muy complejo. Las referencias de este artículo se han limitado a las que presentan una utilidad directa en el área de la salud en el trabajo.

Aunque los procesos patológicos pueden impedir que algunas personas cumplan todos los requisitos visuales de un trabajo, parece más seguro y justo, con la excepción de trabajos especiales con normativas legales propias (aviación, por ejemplo), dejar al oftalmólogo el poder de decisión, en vez de establecer reglas generales, y esto es así en la mayoría de los países. Si se desea más información, existen directrices sobre este tema.

Por otro lado, existen peligros para el ojo en la exposición a diversos agentes nocivos de tipo químico o físico ya han comentado. Se brevemente los peligros para el ojo en la industria. Según los conocimientos científicos actuales, no hay ningún peligro de cataratas por el hecho de trabajar con monitores de representación visual. 


\section{G UST 0}

\section{April E. Mott y Norman Mann}

Los tres sistemas quimiosensibles, el olfato, el gusto y el sentido químico común, requieren la estimulación directa por sustancias químicas para la percepción sensorial. Su función consiste en vigilar constantemente las sustancias químicas nocivas y beneficiosas que se inhalan e ingieren. Las propiedades irritativas y de hormigueo son detectadas por el sentido químico común. EI sistema del gusto percibe sólo los sabores dulce, salado, agrio, amargo y, posiblemente, el sabor metálico y el del glutamato monosódico (umami). La totalidad de la experiencia sensorial oral se denomina "sabor", es decir, la interacción entre olor, gusto, irritación, textura y temperatura. Como la mayoría de los sabores se derivan del olor, o aroma, de las comidas y bebidas, la lesión del sistema olfativo se notifica con frecuencia como un problema de "gusto". Es más probable que existan déficit de

Tabla 11.5 - Agentes/ procesos descritos que alteran el sistema del gusto.

\begin{tabular}{|c|c|c|}
\hline Agente/ proceso & Trastorno del gusto & Referencia \\
\hline Amalgama & Sabor metálico & $\begin{array}{l}\text { Siblerud 1990; véase el } \\
\text { texto }\end{array}$ \\
\hline $\begin{array}{l}\text { Reparaciones/ } \\
\text { aparatos dentales }\end{array}$ & Sabor metálico & Véase el texto \\
\hline Buceo ( saturación seca) & $\begin{array}{l}\text { Dulce, amargo; salado, } \\
\text { agrio }\end{array}$ & Véase el texto \\
\hline Buceo y soldaduras & Sabor metálico & Véase el texto \\
\hline Fármacos/Medicamentos & Variable & Véase el texto \\
\hline Hidracina & Disgeusia dulce & $\begin{array}{l}\text { Schweisfurth y } \\
\text { Schottes } 1993\end{array}$ \\
\hline Hidrocarbonos & $\begin{array}{l}\text { Hipogeusia, disgeusia a } \\
\text { "pegamento" }\end{array}$ & Hotz y cols. 1992 \\
\hline Intoxicación por plomo & Disgeusia dulce/ metálica & Kachru y cols. 1989 \\
\hline $\begin{array}{l}\text { Metales y humos metá- } \\
\text { licos (también, algunos } \\
\text { metales específicos } \\
\text { enumerados en el } \\
\text { gráfico) }\end{array}$ & Dulce/ Metálico & $\begin{array}{l}\text { Véase el texto; Shus- } \\
\text { terman y Sheedy } 1992\end{array}$ \\
\hline Níquel & Sabor metálico & $\begin{array}{l}\text { Pfeiffer y Schwickerath } \\
1991\end{array}$ \\
\hline $\begin{array}{l}\text { Pesticidas (Organo- } \\
\text { fosforados) }\end{array}$ & $\begin{array}{l}\text { Disgeusia amargo/ metá- } \\
\text { lica }\end{array}$ & + \\
\hline Radiación & UD y UR aumentados & $*$ \\
\hline Selenio & Sabor metálico & Bedwal y cols. 1993 \\
\hline Disolventes & "sabor extraño", H & + \\
\hline Vapores de ácido sulfúrico & "Mal sabor" & $\begin{array}{l}\text { Petersen y Gormsen } \\
1991\end{array}$ \\
\hline Soldadura bajo el agua & Sabor metálico & Véase el texto \\
\hline Vanadio & Sabor metálico & Nemery 1990 \\
\hline $\begin{array}{l}=\text { umbral de detección UR = } \\
=\text { Schiffman \& Nagle } 1992 \\
\text { trastornos espećficicos del gusto }\end{array}$ & cimiento $*=$ & Mott \& Leopold 1991 \\
\hline
\end{tabular}

gusto verificables si se refieren pérdidas específicas de las sensaciones de sabor dulce, agrio, salado y amargo.

Las molestias quimiosensoriales son frecuentes en salud laboral y pueden producirse por la percepción de agentes químicos ambientales por parte de un sistema sensorial normal. Por otro lado, también pueden indicar una lesión del sistema: el contacto obligado con sustancias químicas aumenta la vulnerabilidad de estos sistemas sensoriales a las lesiones (véase la Tabla 11.5). En el contexto laboral, estos sistemas también pueden lesionarse por traumatismos craneales y por agentes distintos de las sustancias químicas (p. ej., radiaciones). Los trastornos del gusto pueden ser temporales o permanentes: pérdida de gusto completa o parcial (ageusia o hipogeusia), exacerbación del gusto (hipergeusia) y gustos distorsionados o fantasmas (disgeusia) (Deems, Doty y Settle 1991; M ott, Grushka y Sessle 1993).

El sistema del gusto se mantiene gracias a su capacidad regenerativa y a su abundante inervación. Por este motivo, los trastornos del gusto de relevancia clínica son menos comunes que los trastornos olfatorios. Las distorsiones del gusto son más frecuentes que la pérdida significativa del mismo y, cuando se producen, es más probable que presenten efectos secundarios adversos como ansiedad y depresión. La pérdida o distorsión del gusto puede interferir con la actividad laboral cuando se necesita una agudeza especial del mismo, como ocurre en las artes culinarias y en la cata de vinos y licores.

\section{Anatomía y fisiología}

L as células receptoras del gusto se reparten por toda la cavidad oral, la faringe, la laringe y el esófago; son células epiteliales modificadas localizadas en las yemas gustativas. Sobre la lengua, las yemas se agrupan en estructuras superficiales denominadas papilas; en el epitelio se encuentran también yemas gustativas extralinguales. Las células gustativas pueden lesionarse debido a su localización superficial. Los agentes nocivos suelen entrar en contacto con la boca mediante ingestión, aunque la respiración bucal asociada a obstrucción nasal o a otras condiciones (p. ej., ejercicio, asma) permite el contacto de la mucosa oral con agentes que se transmiten a través del aire. El promedio de vida de la célula receptora es de diez días, lo que permite una recuperación rápida cuando se produce una lesión superficial. Asimismo, el sentido del gusto depende de cuatro pares de nervios periféricos: la parte anterior de la lengua de la cuerda del tímpano, una rama del séptimo par craneal (VII); la parte posterior de la lengua y la faringe, del nervio glosofaríngeo (IX); el paladar blando de la rama petrosa superficial mayor del VII par; y la laringe/ esófago del nervio vago $(X)$. Por último, las vías centrales del gusto, aunque no se conocen por completo en el ser humano (O gawa 1994), parecen más divergentes que las vías olfatorias centrales.

En el primer paso en la percepción del gusto se produce una interacción entre las sustancias químicas y las células receptoras. Las cuatro cualidades del gusto, es decir, los sabores dulce, agrio, salado y amargo, se expresan por diferentes mecanismos a nivel del receptor (K innamon y Getchell 1991), y generan en último término potenciales de acción en las neuronas gustativas (transducción).

L as sustancias con sabor difunden por las secreciones salivares y también por el moco secretado alrededor de las células gustativas, para interactuar con la superficie de éstas. La saliva asegura el transporte de las sustancias con sabor a las yemas y crea un ambiente iónico óptimo para la percepción gustativa (Spielman 1990). Las alteraciones del gusto pueden demostrarse por los cambios en los componentes inorgánicos de la saliva. La mayoría de las sustancias estimuladoras del gusto son hidrosolubles y difunden con facilidad; otras necesitan proteínas 
portadoras solubles para el transporte hasta el receptor. La cantidad y la composición de la saliva, por tanto, desempeñan un papel esencial en la función del gusto.

El sabor de la sal se estimula por cationes como $\mathrm{Na}^{+}, \mathrm{K}^{+} 0$ $\mathrm{NH}^{4+}$. La mayoría de los estímulos salados se transducen cuando los iones atraviesan un tipo específico de canal del sodio (Gilbertson 1993), aunque pueden intervenir también otros mecanismos ciertas. Variaciones en la composición del moco del poro gustativo o en el entorno de la célula gustativa podrían modificar el sabor salado. Asimismo, los cambios estructurales en las proteínas de los receptores cercanos podrían alterar la función de los receptores de la membrana. El sabor agrio corresponde a la acidez. El bloqueo de los canales específicos del sodio por iones hidrógeno es el fenómeno inductor de este sabor. Sin embargo, como sucede con el sabor salado, se cree que existen otros mecanismos. N umerosos compuestos químicos se perciben con un sabor amargo, incluidos cationes, aminoácidos, péptidos y compuestos de gran tamaño. En la detección de estímulos amargos intervienen, al parecer, mecanismos más diversos, como el transporte de proteínas, los canales del calcio, las proteínas $G$ y otras vías mediadas por un segundo mensajero (Margolskee 1993). Las proteínas salivares pueden ser muy importantes para el transporte de estímulos lipofílicos amargos a las membranas del receptor. Los estímulos dulces se unen a receptores específicos relacionados con los sistemas de segundos mensajeros activados por la proteína G. Según algunos estudios, en los mamíferos los estímulos dulces pueden acceder directamente a los canales iónicos (G ilbertson 1993).

\section{Trastornos del gusto}

\section{Conceptos generales}

La diversidad anatómica y la amplia distribución del sistema del gusto tienen un valor protector suficiente para prevenir su pérdida permanente y total. La pérdida de unas pocas áreas periféricas del gusto, por ejemplo, no afecta a la capacidad gustativa global de la boca (M ott, G rushka y Sessle 1993). El sistema puede ser mucho más vulnerable a la distorsión del gusto o a los sabores fantasma. Por ejemplo, las disgeusias parecen ser más frecuentes en las exposiciones profesionales que las propias pérdidas del gusto. Aunque se piensa que el sentido del gusto se conserva mejor que el sentido del olfato en el proceso de envejecimiento, se han documentado pérdidas en la percepción del sabor con la edad.

Cuando la mucosa oral se irrita, es posible que se produzcan pérdidas pasajeras del gusto. En teoría, podrían inflamarse las células gustativas, cerrarse los poros gustativos 0 alterarse la función en la superficie de las células gustativas. La inflamación puede modificar el aporte sanguíneo a la lengua y afectar así al gusto. EI flujo de saliva también puede alterarse. Los agentes irritantes pueden provocar hinchazón y obstrucción de los conductos salivales. Los tóxicos absorbidos y excretados en las glándulas salivales son capaces de dañar el tejido glandular durante la excreción. Cualquiera de estos procesos podría provocar sequedad oral a largo plazo y tener efectos sobre el gusto. La exposición a sustancias tóxicas podría alterar el índice de recambio de las células gustativas, modificar los canales del gusto en la superficie de la célula gustativa o cambiar el ambiente químico interno o externo de las células. Se sabe que muchas sustancias son neurotóxicas y pueden dañar los nervios periféricos del gusto, ya sea de forma directa o por lesión de las vías superiores del gusto en el cerebro.

\section{Pesticidas}

El uso de pesticidas se ha generalizado y sus residuos pueden contaminar la carne, las verduras, la leche, la lluvia y el agua potable. Aunque los trabajadores expuestos durante la fabricación o el uso de pesticidas son los que sufren más riesgo, la población general también se halla expuesta. Entre los pesticidas más importantes figuran los compuestos organoclorados, los pesticidas organofosforados y los carbamatos. Los compuestos organoclorados son muy estables y persisten en el medio ambiente durante períodos prolongados. Se han demostrado efectos tóxicos directos sobre las neuronas centrales. Los pesticidas organofosforados se utilizan más porque no persisten tanto tiempo en el medio ambiente, pero son más tóxicos; la inhibición de la acetilcolinesterasa puede provocar alteraciones neurológicas y del comportamiento. La toxicidad de los pesticidas con carbamatos es similar a la de los compuestos organofosforados y suelen utilizarse cuando estos fracasan. La exposición a los pesticidas se ha asociado a un sabor amargo o metálico persistente (Schiffman y Nagle 1992), a una disgeusia inespecífica (Ciesielski y cols. 1994) y, con menos frecuencia, a la pérdida del gusto. Los pesticidas pueden alcanzar los receptores del gusto a través del aire, el agua y los alimentos y pueden absorberse por la piel, el tracto gastrointestinal, la conjuntiva y las vías respiratorias. Como muchos pesticidas son liposolubles, penetran con facilidad a través de las membranas lipídidas del organismo. La interferencia con el gusto puede producirse a nivel periférico con independencia de la vía inicial de exposición; en los ratones se ha observado la fijación en la lengua de ciertos insecticidas tras la inyección de la sustancia en el torrente sanguíneo. Se han demostrado alteraciones en la morfología de las yemas gustativas tras la exposición a pesticidas. Asimismo, se han observado alteraciones degenerativas en las terminaciones sensoriales, que podrían explicar los casos comunicados de anomalías de la transmisión nerviosa. La disgeusia metálica puede ser una parestesia sensorial provocada por la acción de los pesticidas sobre las yemas gustativas y sus terminaciones nerviosas aferentes. No obstante, según algunos datos, los pesticidas pueden interferir los neurotransmisores $\mathrm{y}$, por tanto, alterar la transmisión de la información gustativa a un nivel más central (El-Etri y cols. 1992). En los trabajadores expuestos a pesticidas organofosforados pueden demostrarse alteraciones neurológicas en las pruebas electroencefalográficas y neurofisiológicas, que son independientes de la supresión de la colinesterasa en la circulación sanguínea. Se cree que estos pesticidas tienen un efecto neurotóxico sobre el cerebro independiente del efecto sobre la colinesterasa. Aunque se ha descrito una asociación entre la exposición a pesticidas y el aumento del flujo salival, no está claro el efecto que podría tener sobre el gusto.

\section{M etales y fiebre por humos metálicos}

Se han producido alteraciones del gusto tras la exposición a ciertos metales y compuestos metálicos como mercurio, cobre, selenio, telurio, cianuro, vanadio, cadmio, cromo y antimonio. También se ha observado un sabor metálico en los trabajadores expuestos a los humos del zinc o del óxido de cobre, tras la ingestión de sales de cobre en los casos de envenenamiento o por la exposición a las emisiones desprendidas al aplicar sopletes para cortar tuberías de cobre. La exposición a humos recién formados de óxidos metálicos puede provocar un síndrome conocido como la fiebre por humos metálicos (Gordon y Fine 1993). Aunque el óxido de zinc se cita con más frecuencia, este trastorno se ha comunicado también tras la exposición a los óxidos de otros metales (cobre, aluminio, cadmio, plomo, hierro, magnesio, manganeso, níquel, selenio, plata, antimonio y estaño). El síndrome se observó por primera vez en trabajadores de las fundiciones de cobre, pero ahora es más común en las personas que intervienen en las soldaduras de acero galvanizado o durante el proceso de galvanización. U nas horas después de la exposición se produce irritación de garganta y aparece un sabor dulce o una 
disgeusia metálica que pueden preceder a síntomas más generalizados, con fiebre, escalofríos y mialgias. A veces aparecen otros síntomas, como tos o cefalea. El síndrome se caracteriza por su rápida resolución (en menos de 48 horas) y por el desarrollo de tolerancia con las exposiciones reiteradas al óxido metálico. Se han propuesto diferentes mecanismos posibles, como reacciones del sistema inmunitario y un efecto tóxico directo sobre el tejido respiratorio, aunque en la actualidad se cree que la exposición del pulmón a los humos metálicos provoca la liberación a la circulación sanguínea de mediadores específicos denominados citocinas, que provocan los signos y síntomas físicos (Blanc y cols. 1993). Tras la exposición a los aerosoles de cloruro de zinc en las bombas de humo durante las maniobras militares se produce una variedad de la fiebre por humos metálicos más grave y potencialmente mortal (Blount 1990). La presentación de la fiebre por humos de polímeros es similar a la de la fiebre por humos metálicos, salvo por la ausencia de las molestias referidas al sabor metálico (Shusterman 1992).

En los casos de intoxicación por plomo, suelen describirse sabores metálicos dulces. En un informe, un grupo de trabajadores de la joyería de plata con toxicidad confirmada por plomo sufrieron alteraciones del gusto (K achru y cols. 1989). L os trabajadores se expusieron a los humos de plomo al calentar desechos de la joyería de plata en talleres con sistemas de ventilación inadecuados. Los vapores se condensaron sobre la piel y el pelo de los trabajadores y contaminaron también la ropa, la comida y el agua potable.

\section{Soldadura en inmersión}

Los buzos describen trastornos orales, aflojamiento de empastes metálicos y sabor metálico durante las tareas de soldadura y corte eléctricos bajo el agua. En un estudio realizado por Ö rtendahl, Dahlen y Röckert (1985), el 55 \% de 118 buzos que trabajaban bajo el agua con equipos eléctricos describieron la aparición de un sabor metálico. Los buzos sin antecedentes laborales de este tipo no refirieron el sabor metálico. Se reclutaron cuarenta buzos en dos grupos para realizar una evaluación; en el grupo que había practicado soldaduras y cortes bajo el agua se observaron con una diferencia significativa más casos de rotura de amalgama. Al principio, se planteó la teoría de que las corrientes eléctricas intraorales erosionaban la amalgama dental y liberaban iones metálicos que tenían efectos directos sobre las células gustativas. Según datos obtenidos posteriormente, sin embargo, se demostró que la actividad eléctrica intraoral no tenía una intensidad suficiente como para erosionar la amalgama dental, aunque sí podía estimular directamente las células gustativas y provocar un sabor metálico (Ö rtendahl 1987; Frank y Smith 1991). Los buzos que no practican soldaduras pueden sufrir cambios de sabor; se han documentado efectos diferenciales sobre la percepción de la calidad del sabor, con un descenso de la sensibilidad al sabor dulce y amargo y un aumento de la sensibilidad a los sustancias con sabor salado y agrio (O 'R eilly y cols. 1977).

\section{Intervenciones y dispositivos dentales y galvanismo oral}

En un estudio longitudinal amplio y prospectivo sobre intervenciones dentales, alrededor del $5 \%$ de los sujetos refirieron un sabor metálico en algún momento (participantes del SCP Núms. 147/ $242 \&$ M orris 1990). El sabor metálico era más frecuente si había antecedentes de fresado dental, con las prótesis dentales parciales fijas más que con las coronas, y con un número mayor de prótesis dentales parciales fijas. Las interacciones entre las amalgamas dentales y el medio ambiente oral son complejas (M arek 1992) y podrían afectar al gusto mediante diversos mecanismos. Los metales que se unen a las proteínas pueden adquirir antigenicidad (Nemery 1990) y podrían causar reacciones alérgicas asociadas a alteraciones del gusto. En la cavidad oral se liberan iones metálicos y residuos solubles que pueden interactuar con los tejidos blandos. Se ha descrito que el sabor metálico se relaciona con la solubilidad del níquel de los dispositivos dentales en la saliva (Pfeiffer y Schwickerath 1991). R efirieron sabor metálico el $16 \%$ de sujetos con empastes dentales y ninguno de los sujetos sin empastes (Siblerud 1990). En un estudio relacionado de sujetos a los que se retiró la amalgama, el sabor metálico mejoró o desapareció en el 94 \% (Siblerud 1990).

El galvanismo oral, un diagnóstico controvertido (I nforme del Consejo sobre $M$ ateriales D entales 1987), describe la generación de corrientes orales procedentes de la corrosión de la amalgama de las reparaciones dentales o por diferencias electroquímicas entre distintos metales intraorales. Los pacientes con posible galvanismo oral parecen presentar con alta frecuencia disgeusia $(63 \%)$, descrita como sabores salados, metálicos, desagradables o a "pilas eléctricas" (Johansson, Stenman y Bergman 1984). En teoría, las células gustativas podían ser estimuladas de forma directa por corrientes eléctricas intraorales y generar disgeusia. Se determinó que los sujetos con síntomas de quemazón oral, sabor a pila eléctrica, sabor metálico y/ o galvanismo oral tenían umbrales electrogustométricos menores (es decir, más sensibilidad al sabor) en las pruebas sobre el gusto que los sujetos de control (Axéll, N ilner y N ilsson 1983). Con todo, todavía es cuestionable si las corrientes galvánicas relacionadas con los materiales dentales son la causa. Se cree que es posible sentir brevemente un sabor a estaño poco después de una intervención reparadora dental, pero es improbable que se produzcan efectos más permanentes (Consejo sobre Materiales Dentales 1987). Yontchev, Carlsson y H edegård (1987) hallaron frecuencias similares de sabor metálico o quemazón oral en sujetos con estos síntomas, hubiera o no contacto con reparaciones dentales. U na explicación alternativa a las molestias sobre sabores extraños que refirieron los pacientes sometidos a intervenciones reparadoras o con dispositivos dentales es la sensibilidad al mercurio, cobalto, cromo, níquel u otros metales (C onsejo sobre $M$ ateriales Dentales 1987), o la presencia de otros procesos intraorales (p. ej., enfermedad periodontal), xerostomía, alteraciones de la mucosa, trastornos médicos y efectos secundarios de la medicación.

\section{Fármacos y medicamentos}

Numerosos fármacos y medicamentos se han relacionado con alteraciones del gusto (Frank, Hettinger y M ott 1992; M ott, Grushka y Sessle 1993; Della Fera, M ott y Frank 1995; Smith y Burtner 1994) y se mencionan en este artículo por su posible asociación a exposiciones profesionales durante el proceso de fabricación. Se han descrito alteraciones del gusto con los siguientes fármacos: antibióticos, anticonvulsivantes, hipolipemiantes, antineoplásicos, psicofármacos, antiparkinsonianos, antitiroideos, fármacos para la artritis, para las enfermedades cardiovasculares y fármacos para la higiene dental.

El posible lugar de acción de los fármacos sobre el sistema del gusto es variable. A menudo, el fármaco es degustado directamente durante la administración oral; el sabor también puede corresponder al propio fármaco o a sus metabolitos después de excretarse con la saliva. Numerosos fármacos, por ejemplo, los anticolinérgicos 0 algunos antidepresivos, provocan sequedad oral y afectan al gusto por una presentación inadecuada de la sustancia sápida a las células gustativas a través de la saliva. Algunos fármacos pueden afectar a las células gustativas directamente. Como estas últimas tienen un alto índice de recambio, son especialmente vulnerables a los fármacos que interrumpen la síntesis de proteínas, como los fármacos antineoplásicos. Se cree también que puede existir un efecto sobre la transmisión de impulsos por los nervios gustativos o en las células ganglionares, 
0 un cambio en el procesado de los estímulos en los centros gustativos superiores. Se ha descrito disgeusia metálica con el litio, posiblemente a causa de transformaciones en los canales iónicos de los receptores. L os fármacos antitiroideos y los inhibidores de la enzima conversora de la angiotensina (p. ej., captopril y enalapril) son causas bien conocidas de alteraciones del gusto, posiblemente por la presencia de un grupo sulfhidrilo (-SH) (M ott, G rushka y Sessle 1993). O tros fármacos con grupos -SH (p. ej., metimazol, penicilamina) provocan también alteraciones del gusto. Los fármacos que afectan a los neurotransmisores podrían alterar también la percepción del gusto.

N o obstante, los mecanismos de alteración del gusto varían, incluso dentro de la misma clase de fármacos. Por ejemplo, una micosis oral podría causar las alteraciones del gusto posteriores al tratamiento con tetraciclina. De forma alternativa, el aumento de la concentración de nitrógeno ureico en sangre, asociado al efecto catabólico de las tetraciclinas, puede provocar un sabor metálico o parecido al amoníaco.

Entre los efectos secundarios del metronidazol figuran una alteración del gusto, náuseas y una distorsión selectiva del sabor de las bebidas alcohólicas y carbonatadas. A veces se producen neuropatía periférica y parestesias. Se cree que el fármaco y sus metabolitos afectan directamente a la función de los receptores gustativos y a las células sensoriales.

\section{Exposición a la radiación}

El tratamiento radioterápico puede causar una disfunción gustativa por (1) alteraciones de las células gustativas, (2) lesión de los nervios gustativos, (3) disfunción de las glándulas salivales y (4) infecciones orales oportunistas (D ella Fera y cols. 1995). No se han realizado estudios en el ámbito laboral sobre los efectos de la radiación sobre el sistema del gusto.

\section{Traumatismo craneal}

Durante las actividades laborales se producen traumatismos craneales que pueden alterar el sistema del gusto. Aunque quizá sólo el 0,5\% de los pacientes con traumatismos craneales refieren pérdida del gusto, la frecuencia de disgeusia puede ser muy superior (M ott, G rushka y Sessle 1993). La pérdida de sabor, cuando se produce, es probablemente específica o localizada, y a veces el sujeto ni siquiera la percibe. El pronóstico de la pérdida de gusto apreciada de forma subjetiva es mejor que el pronóstico de la pérdida de olfato.

\section{Causas no profesionales}

En el diagnóstico diferencial deben considerarse otras causas de alteraciones del gusto: trastornos congénitos/ genéticos, endocrinos/ metabólicos o gastrointestinales; enfermedades hepáticas; efectos yatrogénicos; infecciones; trastornos orales locales; cáncer; trastornos neurológicos; trastornos psiquiátricos; enfermedad renal; y síndrome de Sjögren/ boca seca. (D eems, D oty y Settle 1991; M ott y L eopold 1991; M ott, G rushka y Sessle 1993).

\section{Pruebas sobre el gusto}

La psicofísica es la medición de la respuesta a un estímulo sensorial aplicado. Las determinaciones de "umbrales", o pruebas para hallar la concentración mínima que puede percibirse con fiabilidad, son menos útiles en el gusto que en el olfato, por la mayor variabilidad que muestra el primero en la población general. Pueden obtenerse umbrales separados para detectar sustancias sápidas y para el reconocimiento del sabor. Las pruebas de supraumbrales evalúan la capacidad del sistema para funcionar en niveles superiores al umbral y pueden aportar más información sobre la experiencia de sabor en el "mundo real". Los ensayos de discriminación, en los que se obtiene información sobre la diferencia entre sustancias, pueden detectar cambios sutiles en la capacidad sensorial. Con las pruebas de identificación pueden obtenerse resultados distintos a los que se determinan con las pruebas de umbral en el mismo individuo. Por ejemplo, una persona con una lesión del sistema nervioso puede ser capaz de detectar y valorar las sustancias sápidas, pero sin identificarlas. En las pruebas de sabor puede valorarse el sabor en toda la boca agitando las sustancias por toda la cavidad oral 0 realizarse el ensayo en áreas de sabor específicas dirigiendo gotas de las sustancias hacia la zona o aplicando papel de filtro empapado estas mismas sustancias.

\section{Resumen}

El sistema del gusto es uno de los tres sistemas quimiosensibles, junto con el olfato y el sentido químico común, y tiene la función de controlar las sustancias dañinas y beneficiosas que se inhalan e ingieren. Las células gustativas se reponen con rapidez, están inervadas por parejas de cuatro nervios periféricos y tienen al parecer vías centrales divergentes en el cerebro. El sistema del gusto es responsable de la apreciación de cuatro sabores básicos (dulce, agrio, salado y amargo) y de los sabores metálico y umami (glutamato monosódico) (estos últimos son cuestionables). Las pérdidas clínicamente significativas del gusto son raras, probablemente a causa de la diversidad y multiplicidad de la inervación. No obstante, es frecuente la alteración o distorsión del gusto, problemas que pueden ser todavía más molestos. Los agentes tóxicos que no destruyen el sistema del gusto ni interrumpen la transducción o transmisión de la información gustativa pueden, no obstante, impedir de diversas formas la percepción de las cualidades normales del gusto. Pueden producirse irregularidades u obstáculos por una o más de las causas siguientes: transporte subóptimo de las sustancias sápidas, alteración de la composición de la saliva, inflamación de las células gustativas, bloqueo de las vías iónicas, alteraciones en la membrana de las células o en las proteínas de los receptores y neurotoxicidad periférica o central. Por otro lado, el sistema del gusto puede estar intacto y funcionar normalmente, pero estar sujeto a una estimulación sensorial desagradable debida a pequeñas corrientes galvánicas o a la percepción de medicamentos, fármacos, pesticidas o metales iónicos intraorales.

\section{O lfato}

April E. M ott

Existen tres sistemas sensoriales construidos específicamente para controlar el contacto con sustancias ambientales: el olfato (olor), el gusto (sabores dulce, salado, agrio y amargo) y el sentido químico común (detección de irritación o picor). Como requieren la estimulación por sustancias químicas, se denominan sistemas "quimiosensibles". Los trastornos olfatorios consisten en alteraciones pasajeras o permanentes: pérdida completa o parcial del olfato (anosmia o hiposmia) y parosmias (disosmia: olores distorsionados; fantosmia: olores fantasma) (M ott y Leopold 1991; M ott, Grushka y Sessle 1993). Tras las exposiciones químicas, algunas personas describen un aumento de la sensibilidad a los estímulos químicos (hiperosmia). El sabor es la experiencia sensible generada por la interacción del olor, el gusto y los componentes irritantes de los alimentos y las bebidas, así como por la textura y la temperatura. Como la mayoría de los sabores dependen del olor, o aroma, de los alimentos que se ingieren, las lesiones del sistema olfatorio se identifican con frecuencia como un problema del "gusto".

Las molestias quimiosensibles son frecuentes en la actividad laboral y pueden producirse a partir de la percepción, por un 
sistema sensorial normal, de las sustancias químicas ambientales. Por otro lado, también pueden indicar una lesión del sistema: el contacto obligado con sustancias químicas aumenta la vulnerabilidad de estos sistemas sensoriales a las lesiones. En el contexto laboral, estos sistemas pueden dañarse también por traumatismos craneales y por agentes no químicos (p. ej., radiación). Los olores ambientales relacionados con los agentes contaminantes pueden exacerbar procesos médicos subyacentes (p. ej., asma, rinitis), precipitar el desarrollo de aversiones a ciertos olores o causar algún tipo de enfermedad relacionada con el estrés. Se ha demostrado que los malos olores reducen la capacidad para realizar tareas complejas (Shusterman 1992).

La identificación precoz de los trabajadores con pérdida del olfato es esencial. En algunas profesiones como las artes culinarias, la crianza de vinos y las relacionadas con la industria del perfume, es un requisito previo indispensable estar dotado de un buen sentido del olfato. En muchos otros trabajos se necesita tener un olfato normal para obtener un rendimiento óptimo o por la propia seguridad. Por ejemplo, los padres o el personal que trabaja en guarderías confían generalmente en el olfato para determinar las necesidad higiénicas de los niños. Los bomberos necesitan detectar agentes químicos y humos. Cualquier trabajador con una exposición continua a productos químicos sufre más riesgos si su capacidad olfativa está reducida.

El olfato proporciona un sistema de aviso precoz frente a numerosas sustancias ambientales dañinas. Si esta capacidad se pierde, los trabajadores no serán conscientes de las exposiciones peligrosas hasta que la concentración del agente sea lo suficientemente alta para producir irritación, lesionar los tejidos respiratorios o ser letal. La detección inmediata puede evitar la progresión de la lesión olfatoria mediante el tratamiento de la inflamación y la reducción de la exposición posterior. Por último, si la pérdida es permanente y grave, puede considerarse una discapacidad que requiera formación para un nuevo trabajo y/ o una indemnización.

\section{Anatomía y fisiología}

\section{Olfato}

Los receptores olfativos primarios se localizan en áreas de tejido, denominadas neuroepitelio olfatorio, situadas en la porción más superior de las fosas nasales (M ott y Leopold 1991). A diferencia de otros sistemas sensoriales, el receptor es el nervio. U na porción de una célula receptora olfatoria se envía a la superficie del epitelio nasal y el otro extremo se conecta directamente a través de un axón largo a uno de los dos bulbos olfatorios del cerebro. Desde aquí, la información se transmite hasta numerosas áreas cerebrales. L as sustancias olorosas son compuestos químicos volátiles que deben contactar con el receptor olfatorio para que se produzca la percepción del olor. Las moléculas olorosas son atrapadas y después se difunden por el moco para unirse a los cilios situados en los extremos de las células del receptor olfatorio. Todavía no se sabe cómo somos capaces de detectar más de diez mil sustancias olorosas, discriminar entre más de 5.000 y valorar la variación de la intensidad del olor. Se ha descubierto recientemente una familia multigénica que codifica los receptores de olor en los nervios olfatorios primarios (Ressler, Sullivan y Buck 1994). Esto ha permitido investigar cómo se detectan los olores y la organización del sistema olfatorio. Cada neurona puede responder ampliamente a concentraciones elevadas de diversas sustancias olorosas, pero sólo responderá a una o a unas pocas si las concentraciones son bajas. Tras la estimulación, las proteínas del receptor de superficie activan los procesos intracelulares que convierten la información sensorial en una señal eléctrica (transducción). No se sabe por qué finaliza la señal sensorial a pesar de la exposición continua al estímulo oloroso. Se han encontrado proteínas solubles que fijan las sustancias olorosas, pero su papel no se conoce con exactitud. Es posible que intervengan proteínas que metabolizan las sustancias olorosas o proteínas que las transportan lejos de los cilios olfatorios o hacia las zonas de catálisis en el interior de las células olfatorias.

Las porciones de los receptores olfatorios que se conectan de forma directa con el cerebro son filamentos nerviosos finos que atraviesan una placa de hueso. Debido a su localización y delicada estructura, estos filamentos son vulnerables a las lesiones por cizallamiento causadas por golpes en la cabeza. A simismo, como el receptor olfatorio es un nervio, entra en contacto físico con las sustancias olorosas y conecta directamente con el cerebro, las sustancias que penetran en las células olfatorias pueden viajar a lo largo del axón hasta el cerebro. Debido a la exposición continuada a compuestos que lesionan las células receptoras olfatorias, podría perderse la capacidad olfatoria en los primeros años de vida, si no fuera por una cualidad de importancia fundamental: los nervios receptores olfatorios pueden regenerarse y sustituirse siempre que el tejido no se haya destruido por completo. Sin embargo, si el sistema se ha lesionado a un nivel más central, los nervios no se pueden regenerar.

\section{Sentido químico común}

EI sentido químico común se inicia por la estimulación de terminaciones nerviosas libres y múltiples del 50 nervio craneal (trigémino) situadas en la mucosa. Con este sentido se perciben las propiedades irritantes de las sustancias inhaladas y se desencadenan reflejos para limitar la exposición a los agentes peligrosos: estornudos, secreción de moco, reducción de la frecuencia respiratoria 0 , incluso, contención de la respiración. Los estímulos de aviso intensos promueven la eliminación de la irritación lo antes posible. Aunque el picor o irritación que producen las sustancias es de intensidad variable, en general, el olor de una sustancia se detecta antes que la irritación (Ruth 1986). Sin embargo, una vez que la irritación se ha detectado, pequeños aumentos de la concentración aumentan la irritación más que la apreciación olorosa. El picor puede evocarse por interacciones químicas 0 físicas con los receptores (Cometto-M uñiz y Cain 1991). Las propiedades de aviso de los gases o vapores tienden a relacionarse con su solubilidad en el agua (Shusterman 1992). Las personas anósmicas requieren, al parecer, concentraciones mayores de agentes químicos picantes para poder detectarlos (ComettoMuñiz y Cain 1994), pero los umbrales de detección no aumentan con la edad (Stevens y Cain 1986).

\section{Tolerancia y adaptación}

La percepción de los agentes químicos puede estar alterada por contactos previos. Se desarrolla tolerancia si la exposición a un producto disminuye la respuesta a exposiciones posteriores. $\mathrm{La}$ adaptación se produce cuando un estímulo constante o que se repite con rapidez se acompaña de una respuesta cada vez menor. Por ejemplo, la exposición breve a disolventes disminuye de forma notable, pero pasajera, la capacidad de detección de los mismos (Gagnon, Mergler y Lapare 1994). La adaptación también tiene lugar cuando se ha producido una exposición prolongada a concentraciones bajas o rápidamente, con algunos agentes químicos, en presencia de concentraciones muy elevadas. Esto último puede provocar una "parálisis" olfatoria rápida y reversible. El picor nasal típicamente muestra menos adaptación y desarrollo de tolerancia que las sensaciones olfatorias. Las mezclas de agentes químicos pueden alterar también las intensidades percibidas. En general, cuando se mezclan sustancias olorosas, la intensidad olorosa total percibida es menor de lo que cabría esperar al sumar las intensidades individuales (hipoaditividad). El picor nasal, sin embargo, muestra en general aditividad con la exposición a múltiples agentes químicos y una sumación 
de la irritación con el tiempo (C ometto-M uñiz y Cain 1994). Con sustancias olorosas e irritantes en la misma mezcla, el olor siempre se percibe con menor intensidad. A causa de la tolerancia, adaptación e hipoaditividad, no debe confiarse en estos sistemas sensoriales para valorar la concentración de agentes químicos en el ambiente.

\section{Trastornos olfatorios}

\section{Conceptos generales}

El olfato se altera cuando las sustancias olorosas no pueden alcanzar los receptores olfatorios o cuando el tejido olfatorio está lesionado. La hinchazón que producen la rinitis, la sinusitis o los pólipos puede impedir el acceso de las sustancias olorosas. Los siguientes trastornos pueden provocar lesiones: inflamación de las cavidades nasales; destrucción del neuroepitelio olfatorio por diversos agentes; traumatismos craneales; y transmisión de agentes a través de los nervios olfatorios hacia el cerebro con la consiguiente lesión del área olfatoria del sistema nervioso central. En las actividades laborales se encuentra una gran variedad de agentes y de situaciones potencialmente dañinas (Amoore 1986; Cometto-M uñiz y Cain 1991; Shusterman 1992; Schiffman y Nagle 1992). Según datos publicados recientemente, obtenidos con las respuestas de 712.000 personas entrevistadas en la Encuesta sobre el $\mathrm{O}$ lor de $\mathrm{National}$ G eographic, el trabajo en las fábricas deteriora el sentido de olfato; se comprobó que en los trabajadores de fábricas, tanto hombres como mujeres, el sentido del olfato se hallaba deteriorado y las pruebas demostraron una disminución de la capacidad olfatoria (Corwin, Loury y Gilbert 1995). Específicamente, se describieron más exposiciones químicas y traumatismos craneales que en los trabajadores de otros ámbitos laborales.

Cuando se sospecha un trastorno olfatorio profesional, puede ser difícil identificar al agente causal. L os conocimientos actuales sobre este tema se han obtenido con series pequeñas e informes de casos aislados. Es importante señalar que en pocos estudios se menciona la exploración de las fosas nasales y de los senos paranasales. La mayoría se basan en los antecedentes olfatorios del paciente, más que en pruebas del sistema del olfato. Un factor adicional que complica la evaluación es la alta prevalencia de trastornos olfatorios no relacionados con la actividad laboral en la población general, la mayoría causados por infecciones víricas, procesos alérgicos, pólipos nasales, sinusitis o traumatismos craneales. Sin embargo, algunos de estos son más comunes en el medio ambiente de trabajo y se comentarán con detalle en este capítulo.

\section{Rinitis, sinusitis y poliposis}

En los sujetos con trastornos olfatorios hay que evaluar en primer lugar la presencia de rinitis, pólipos nasales y sinusitis. Se calcula que el $20 \%$ de la población de Estados U nidos, por ejemplo, padece trastornos alérgicos de las vías respiratorias superiores. $L$ as exposiciones ambientales pueden no relacionase con el trastorno, causar inflamación o exacerbar un proceso subyacente. La rinitis se asocia a la pérdida olfatoria en el ámbito profesional (Welch, Birchall y Stafford 1995). Algunos agentes químicos como los isocianatos, los anhídridos ácidos, las sales de platino y los colorantes (Coleman, H olliday y D earman 1994), así como los metales (Nemery 1990), pueden ser alergénicos. Además, se dispone de una considerable cantidad de datos a favor de que los agentes químicos y las partículas aumentan la sensibilidad a los alergenos no químicos (R usznak, D evalia y Davies 1994). Los agentes tóxicos alteran la permeabilidad de la mucosa nasal, lo que aumenta la penetración de los alergenos y la sintomatología; así, resulta difícil distinguir entre rinitis alérgicas y rinitis por exposición a sustancias tóxicas o en partículas. Si se demuestran inflamación y/ o obstrucción en las fosas nasales o los senos, la función olfatoria puede recuperarse con un tratamiento adecuado. Las opciones terapéuticas son nebulizadores tópicos de corticosteroides, antihistamínicos y descongestionantes por vía sistémica, antibióticos e intervenciones quirúrgicas sinusales 0 polipectomías. Si no existe inflamación ni obstrucción, o el tratamiento no mejora la función olfatoria, el tejido olfatorio puede sufrir un daño permanente. Con independencia de la causa, el individuo debe evitar en el futuro el contacto con la sustancia nociva para que no aumente la lesión del sistema olfatorio.

\section{Traumatismos craneales}

L os traumatismos craneales pueden alterar el olfato por: (1) lesión nasal con cicatrización del neuroepitelio olfatorio, (2) lesión nasal con obstrucción mecánica a los olores, (3) desgarro de los filamentos olfatorios, y (4) contusión o destrucción de las zonas del cerebro responsables de las sensaciones olorosas (M ott y Leopold 1991). A unque los traumatismos son un riesgo en numerosos contextos profesionales (Corwin, Loury y Gilbert 1995), la exposición a ciertos agentes químicos puede aumentar este riesgo.

En un 5-30\% de los pacientes con traumatismos craneales se producen pérdidas de olfato que pueden aparecer sin ninguna otra alteración del sistema nervioso. La obstrucción nasal a las sustancias olorosas puede corregirse por medios quirúrgicos, salvo en los casos que se asocian a una cicatrización intranasal significativa. No hay otras alternativas terapéuticas disponibles para los trastornos del olfato producidos por los traumatismos craneales, aunque es posible la recuperación espontánea. A veces los pacientes mejoran con rapidez al disminuir la hinchazón en el área de la lesión. Si se han desgarrado los filamentos olfatorios, es posible la regeneración de las fibras nerviosas y la recuperación gradual del olfato. Aunque esto ocurre en los animales en un plazo de 60 días, se han descrito mejorías en seres humanos hasta siete años después de la lesión. Las parosmias que se desarrollan según se recupera el paciente de las lesiones pueden indicar el nuevo crecimiento del tejido olfatorio y anunciar una normalización parcial de la función. Las parosmias que se producen en el momento de la lesión o poco después es más probable que se deban a una lesión del tejido cerebral. Las lesiones cerebrales no se reparan y no cabe esperar una mejoría de la capacidad olfatoria. Las lesiones del lóbulo central, la parte del cerebro relacionada con la emoción y el pensamiento, son más frecuentes en los traumatismos craneales con pérdida del sentido del olfato. Los cambios que se producen en los patrones de relación social o de pensamiento pueden ser sutiles, pero de consecuencias familiares y profesionales negativas, por lo que en algunos pacientes está indicado realizar pruebas y tratamientos neuropsiquiátricos formales.

\section{Agentes ambientales}

Los agentes ambientales pueden acceder al sistema olfatorio a través de la circulación sanguínea o del aire inspirado y se han descrito casos de pérdida de olfato, parosmia e hiperosmia. Entre los agentes responsables figuran compuestos metálicos, polvos metálicos, compuestos inorgánicos no metálicos, compuestos orgánicos, polvos de madera y sustancias presentes en diversos ambientes profesionales, como en los centros metalúrgicos y en las fábricas (A moore 1986; Schiffman y N agle 1992) (Tabla 11.6). Tras las exposiciones agudas y crónicas pueden producirse lesiones que serán reversibles o irreversibles, dependiendo de la interacción entre la sensibilidad del huésped y el agente nocivo. Los principales atributos de las sustancias son bioactividad, concentración, capacidad irritativa, duración de la exposición, índice de aclaramiento y sinergismo potencial con otros agentes químicos. 
Tabla 11.6 - Agentes/ procesos asociados a trastornos olfatorios en el ser humano.

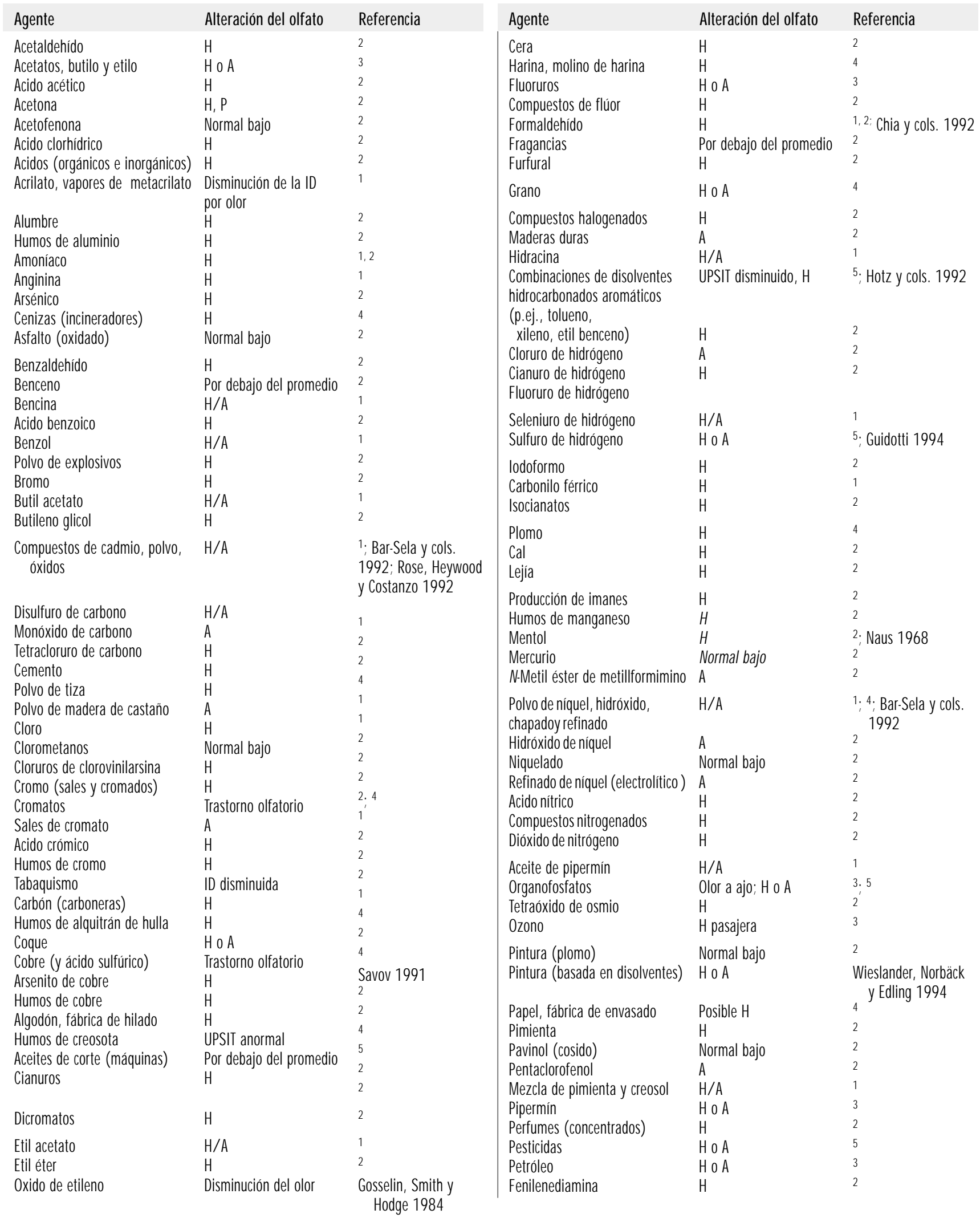

Continúa en la página siguiente. 
Tabla 11.6 - Agentes/ procesos asociados a trastornos olfatorios en el ser humano.

Continuación

$\begin{array}{lll}\text { Agente } & \text { Alteración del olfato } & \text { Referencia } \\ \text { Fosgeno } & H & 2 \\ \text { Oxicloruro de fósforo } & H / \text { A } & 1 \\ \text { Potasa } & H & 1 \\ \text { Imprenta } & \text { Normal bajo } & 2 \\ \text { Vulcanización de caucho } & H & 2 \\ \text { Compuestos de selenio } & H & 2 \\ \text { (volátiles) } & H & \\ \text { Dióxido de selenio } & H & 2 \\ \text { Dióxido de silicona } & \text { H } & 4 \\ \text { Nitrato de plata } & \text { H } & 2 \\ \text { Chapado de plata } & \text { Por debajo de lo normal } & 2 \\ \text { Disolventes } & \text { H, P, Normal bajo } & 1 ; \text { Ahlström, Berglund } \\ & & \text { y Berglund 1986; } \\ & & \text { Schwartz y cols. } \\ & & 1991 ; \text { Bolla y cols. } \\ & & 495\end{array}$

\begin{tabular}{|lll} 
Agente & Alteración del olfato & Referencia \\
Compuestos de azufre & $H$ & 2 \\
Dióxido de azufre & $H$ & 2 \\
Acido sulfúrico & $H$ & 1; Petersen y \\
& & Gormsen 1991 \\
Curtido & $H$ & 2 \\
Tetrabromoetano & Parosmia, H o A & 5 \\
Tetracloroetano & $H$ & 2 \\
Humos de estaño & $H$ & 2 \\
Tabaco & $H$ & $2 ; 4$ \\
Tricloroetano & $H$ & 2 \\
Tricloroetileno & H/ A & 2 \\
Humos de vanadio & $H$ & 2 \\
Barnices & H & 2 \\
Aguas residuales & Normal bajo & 2 \\
Zinc (humos, cromato) y & Normal bajo & 2 \\
\multicolumn{1}{l}{ produción } &
\end{tabular}

$H=$ hiposmia; $A=$ anosmia; $P$ = parosmia; $I D=$ capacidad de identificación del olor

${ }^{1}$ Mott y Leopold 1991. ${ }^{2}$ Amoore 1986. ${ }^{3}$ Schiffman y Nagle 1992. ${ }^{4}$ Naus 1985. $\quad{ }^{5}$ Callendar y cols. 1993

Los trastornos específicos del olfato son los indicados en los artículos citados.

La sensibilidad del huésped varía según el fondo genético y la edad. Existen diferencias, dependientes del sexo, en el olfato, la modulación hormonal del metabolismo de las sustancias olorosas y las diferencias en anosmias específicas. Las diferencias individuales dependen de factores como consumo de tabaco, alergias, asma, estado de nutrición, enfermedades previas (p. ej., síndrome de Sjögren), ejercicio físico en el momento de la exposición, patrones de flujo aéreo nasal y, posiblemente, aspectos psicosociales (Brooks 1994). La resistencia del tejido periférico a la lesión y la presencia de nervios olfatorios funcionantes pueden alterar la sensibilidad. Por ejemplo, la exposición aguda y grave podría destruir el neuroepitelio olfatorio, impidiendo con eficacia la diseminación central de la toxina. Al contrario, la exposición prolongada a bajas concentraciones podría permitir la conservación de tejido periférico funcionante y el tránsito lento, pero continuado, de las sustancias dañinas al cerebro. El cadmio, por ejemplo, tiene una semivida de 15 a 30 años en el ser humano y sus efectos podrían no ser aparentes hasta años después de la exposición (H astings 1990).

L os conductos nasales se ventilan con 10.000 a 20.000 litros de aire al día, que contienen cantidades variables de agentes potencialmente dañinos. Las vías respiratorias superiores absorben o eliminan casi por completo los gases muy reactivos - solubles y las partículas mayores de $2 \mathrm{~mm}$ (Evans y $\mathrm{H}$ astings 1992). Por suerte, diversos mecanismos previenen la lesión tisular. Los tejidos nasales están enriquecidos con vasos sanguíneos, nervios, células especializadas con cilios móviles y glándulas productoras de moco. Las funciones defensivas son la filtración y el aclaramiento de partículas, la eliminación de gases hidrosolubles y la identificación precoz de agentes dañinos mediante la detección mucosa y olfatoria de agentes irritantes que desencadenan una alarma y evitan al sujeto una mayor exposición (Witek 1993). Las concentraciones bajas de agentes químicos se absorben en la capa mucosa, son separadas por los cilios funcionantes (aclaramiento mucociliar) y después se tragan. Los agentes químicos pueden unirse a proteínas 0 metabolizarse con rapidez y convertirse en productos menos dañinos. En la mucosa nasal y en los tejidos olfatorios residen numerosas enzimas metabolizadoras (Bonnefoi, M onticello y M organ 1991; Schiffman y Nagle 1992; Evans y cols. 1995). El neuroepitelio olfatorio, por ejemplo, contiene enzimas del citocromo P-450 que desempeñan un papel muy importante en la detoxificación de sustancias extrañas (G resham, Molgaard y Smith 1993). Este sistema puede proteger a las células olfatorias primarias y detoxificar también sustancias que de otra forma entrarían en el sistema nervioso central a través de los nervios olfatorios. $\mathrm{H}$ ay datos también a favor de que un neuroepitelio olfatorio intacto puede evitar la invasión de algunos microorganismos (p. ej., C riptococcus; véase Lima y Vital 1994). A nivel del bulbo olfatorio, pueden existir también mecanismos de protección que impidan el transporte central de sustancias tóxicas. Por ejemplo, se ha demostrado recientemente que el bulbo olfatorio contiene metalotioneínas, unas proteínas con efecto protector frente a las toxinas (Choudhuri y cols. 1995).

El exceso de protección puede precipitar un ciclo de empeoramiento de la lesión. Por ejemplo, la pérdida de capacidad olfatoria impide el aviso precoz del peligro y permite una exposición continuada. El aumento del flujo sanguíneo nasal y de la permeabilidad de los vasos sanguíneos provoca hinchazón y obstrucción. La función ciliar, necesaria para el aclaramiento mucociliar y para el olfato normal, puede estar alterada. Las variaciones del aclaramiento aumentarán el tiempo de contacto entre los agentes nocivos y la mucosa nasal. Las alteraciones intranasales del moco alteran la absorción de sustancias olorosas o de moléculas irritantes. El exceso de potencia en la capacidad de metabolización de toxinas favorece la lesión tisular, aumenta la absorción de toxinas y, posiblemente, incrementa la toxicidad sistémica. El tejido epitelial lesionado es más vulnerable a exposiciones posteriores. Asimismo existen efectos más directos sobre los receptores olfatorios. Las toxinas pueden alterar el índice de recambio de las células receptoras olfatorias (normalmente, de 30 a 60 días), lesionar los lípidos de la membrana de las células 
receptoras, o modificar su ambiente interno o externo. Aunque es posible la regeneración, el tejido olfatorio lesionado puede mostrar alteraciones permanentes 0 atrofia, o bien la sustitución del tejido olfatorio por tejido no sensorial.

Los nervios olfatorios proporcionan una conexión directa con el sistema nervioso central y pueden servir como vía de entrada de diversos agentes exógenos, como virus, disolventes y algunos metales (Evans y $\mathrm{H}$ astings 1992). Este mecanismo puede intervenir en algunas de las demencias relacionadas con la vía olfatoria (M onteagudo, Cassidy y Folb 1989; Bonnefoi, M onticello y M organ 1991), por ejemplo, mediante la transmisión central de aluminio. El cadmio aplicado por vía intranasal puede detectarse en el bulbo olfatorio ipsilateral (esto no sucede por vía intraperitoneal ni intratecal) (Evans y H astings 1992). Además, según la información disponible, algunas sustancias se captan mejor a través del tejido olfatorio, con independencia de la localización de la exposición inicial (p. ej., sistémica frente a inhalatoria). Por ejemplo, se han hallado concentraciones elevadas de mercurio en la región cerebral olfatoria en sujetos con amalgamas dentales (Siblerud 1990). En la electroencefalografía, el bulbo olfatorio muestra sensibilidad a numerosos contaminantes atmosféricos como la acetona, el benceno, el amoníaco, el formaldehído y el ozono (Bokina y cols. 1976). A causa de los efectos sobre el sistema nervioso central de algunos disolventes hidrocarbonados, los individuos expuestos podrían no reconocer con rapidez el peligro para distanciarse del mismo y así se prolongaría la exposición. Recientemente, Callender y cols. (1993) obtuvieron en sujetos expuestos a neurotoxinas una frecuencia del $94 \%$ de alteraciones en la SPECT, una técnica que permite valorar el flujo cerebral regional, y una alta frecuencia de trastornos de la identificación olfatoria. La localización de las alteraciones en las SPECT coincidió con la distribución de la toxina a través de las vías olfatorias.

La localización de la lesión en el sistema olfatorio es distinta según los agentes (C ometto-M uñiz y C ain 1991). Por ejemplo, el etil acrilato y el nitroetano lesionan de forma selectiva el tejido olfatorio, mientras que el tejido respiratorio nasal se conserva (M iller y cols. 1985). El formaldehído altera la consistencia y el ácido sulfúrico, el pH del moco nasal. Numerosos gases, las sales de cadmio, la dimetilamina y el consumo de tabaco alteran la función ciliar. El dietiléter provoca el escape de algunas moléculas por las uniones intercelulares (Schiffman y Nagle 1992). Los disolventes como el tolueno, el estireno y el xileno alteran los cilios olfatorios; asimismo, parecen transmitirse al cerebro a través de los receptores olfatorios (H otz y cols. 1992). El sulfuro de hidrógeno no sólo irrita la mucosa, sino que tiene un alto potencial neurotóxico al impedir el aporte de oxígeno a las células e inducir una rápida parálisis del nervio olfatorio (G uidotti 1994). EI níquel lesiona directamente las membranas celulares e interfiere también con las enzimas protectoras (Evans y cols. 1995). Se cree que el cobre disuelto interfiere directamente con diferentes fases de transducción a nivel del receptor olfatorio (Winberg y cols. 1992). El cloruro de mercurio se distribuye de forma selectiva en el tejido olfatorio y puede interferir con la función neuronal al modificar los niveles de neurotransmisores (Lakshmana, D esiraju y R aju 1993). Tras la inyección en el torrente sanguíneo, los pesticidas son captados por la mucosa nasal (Brittebo, Hogman y Bryt 1987), y pueden provocar congestión nasal. Sin embargo, el olor a ajo que se nota con los pesticidas organofosforados no se debe a una lesión tisular, sino a la detección de butilomercaptano.

Aunque el tabaquismo puede provocar la inflamación del epitelio nasal y reducir la capacidad olfatoria, puede proteger también frente a otros agentes nocivos. Los agentes químicos que contiene el humo pueden inducir los sistemas enzimáticos microsomales del citocromo P450 (Gresham, M olgaard y Smith
1993), que acelerarían el metabolismo de los productos químicos tóxicos antes de que pudieran lesionar el neuroepitelio olfatorio. Por el contrario, algunos fármacos, como los antidepresivos tricíclicos y los fármacos antipalúdicos, pueden inhibir el citocromo P450.

Las pérdidas olfatorias tras la exposición al polvo de las tablas de madera y de fibra (Innocenti y cols. 1985; H olmström, R osén y Wilhelmsson 1991; M ott y Leopold 1991) pueden explicarse por varios mecanismos. Las rinitis alérgicas y no alérgicas pueden provocar obstrucción a las sustancias olorosas o inflamación. Las alteraciones mucosas pueden ser graves: se han documentado displasias (Boysen y Solberg 1982) y a veces se desarrolla un adenocarcinoma, sobre todo en el área de los senos etmoidales, cerca del neuroepitelio olfatorio. El carcinoma asociado a las maderas duras puede relacionarse con su alto contenido en tanino (Innocenti y cols. 1985). Se ha descrito una incapacidad para eliminar con eficacia el moco nasal, que puede relacionarse con una frecuencia elevada de resfriados (Andersen, Andersen y Solgaard 1977); las infecciones víricas resultantes pueden lesionar todavía más el sistema olfatorio. La pérdida de olfato también se ha relacionado con agentes químicos asociados a los trabajos con madera, incluidos el barnizado y la pintura. L as tablas con fibras de densidad media contienen formaldehído, un conocido irritante respiratorio que altera el aclaramiento mucociliar, provoca una pérdida olfatoria y se asocia a una incidencia elevada de cáncer oral, nasal y nasofaríngeo (Consejo de Asuntos Científicos 1989); todos estos factores justificarían las pérdidas olfatorias inducidas por el formaldehído.

Se ha descrito que la radioterapia causa alteraciones olfatorias (M ott y Leopold 1991), pero se dispone de escasa información sobre las exposiciones profesionales. Cabría esperar que el tejido que se regenera con rapidez, como las células receptoras olfatorias, sea vulnerable. $R$ atones expuestos a radiación en un vuelo espacial mostraron alteraciones en el tejido olfatorio, mientras que el resto del epitelio nasal no se afectó (Schiffman y N agle 1992).

Después de estar sometidos a exposiciones químicas, algunas personas describen un aumento de la sensibilidad a las sustancias olorosas. Para describir trastornos tipificados como "hipersensibilidad" a diversos agentes químicos ambientales, con frecuencia en concentraciones bajas, se han utilizado las etiquetas de "sensibilidad a múltiples agentes químicos" o "enfermedades ambientales" (Cullen 1987; Miller 1992; Bell 1994). Sin embargo, hasta ahora no se han demostrado umbrales más bajos a sustancia olorosas.

\section{Causas no profesionales de problemas olfatorios}

El envejecimiento y el tabaquismo disminuyen la capacidad olfatoria. Las cuatro causas principales de problemas olfatorios en Estados U nidos son las lesiones víricas de las vías respiratorias superiores, los traumatismos craneales, los trastornos idiopáticos ("de causa desconocida") y las enfermedades nasales y sinusales (M ott y Leopold 1991), que deben tenerse en cuenta en el diagnóstico diferencial de cualquier individuo con antecedentes de posibles exposiciones ambientales. Es frecuente la incapacidad congénita para detectar algunas sustancias. Por ejemplo, entre el 40 y el $50 \%$ de la población es incapaz de detectar la androsterona, un esteroide que se encuentra en el sudor.

\section{Pruebas de quimiosensación}

La psicofísica es la medición de la respuesta a un estímulo sensorial aplicado. Las determinaciones de "umbrales", 0 pruebas para hallar la concentración mínima que puede percibirse con fiabilidad, se utilizan con frecuencia. Pueden obtenerse umbrales por separado para detectar e identificar sustancias con 
olor. Las pruebas de supraumbrales evalúan la capacidad del sistema para funcionar en niveles superiores al umbral y también aportan una información útil. Los ensayos de discriminación, en los que se obtiene información sobre la diferencia entre sustancias, pueden detectar cambios sutiles en la capacidad sensorial. Con las pruebas de identificación pueden obtenerse resultados distintos a los que se determinan con las pruebas de umbral en el mismo individuo. Por ejemplo, una persona con una lesión del sistema nervioso central puede ser capaz de detectar sustancias olorosas en los umbrales habituales y ser incapaz de identificar sustancias olorosas normales.

\section{Resumen}

L os conductos nasales se ventilan con 10.000 a 20.000 litros de aire al día, que puede estar contaminado con materiales potencialmente peligrosos en diversa medida. El sistema olfatorio es particularmente vulnerable a la lesión, debido al contacto directo obligado con sustancias químicas volátiles para la percepción de los olores. La pérdida olfatoria, la tolerancia y la adaptación impiden el reconocimiento de la proximidad de agentes químicos peligrosos y pueden contribuir al desarrollo de lesiones locales 0 de toxicidad sistémica. La identificación precoz de los trastornos olfatorios permite iniciar con rapidez estrategias protectoras, asegurar un tratamiento adecuado y evitar la progresión de la lesión. Los trastornos profesionales del olfato pueden manifestarse como anosmia o hiposmia, temporales o permanentes, además de como una percepción distorsionada del olor. Las causas identificables que deben considerarse en el contexto laboral son la rinitis, la sinusitis, el traumatismo craneal, la exposición a las radiaciones y la lesión tisular por compuestos metálicos, polvo metálico, compuestos inorgánicos no metálicos, compuestos orgánicos, polvo de madera y sustancias presentes en procesos metalúrgicos e industriales. Dichas sustancias se diferencian por su lugar de acción o de interferencia con el sistema olfatorio. El organismo dispone de mecanismos potentes para atrapar, eliminar y detoxificar las sustancias extrañas, que protegen así la función olfatoria y previenen la diseminación de agentes dañinos al cerebro desde el sistema olfatorio. El desarrollo excesivo de las capacidades protectoras puede desencadenar un ciclo de empeoramiento de la lesión que termina por aumentar la gravedad y extender la localización de las lesiones, convirtiendo los efectos reversibles temporales en lesiones permanentes

\section{- RECEPTORES CUTANEOS}

\section{Robert Dykes y Daniel M cBain}

La sensibilidad cutánea comparte los elementos principales de todos los sentidos básicos. Los receptores sensoriales, que son las terminaciones de unas células nerviosas especializadas, captan las propiedades del mundo exterior, como el color, el sonido o la vibración, y convierten estos datos en impulsos nerviosos. Estas señales se transmiten entonces al sistema nervioso central, donde se convierten en la base para interpretar el mundo que nos rodea.

Es útil reconocer tres aspectos esenciales de estos procesos. Primero, la energía y los cambios del nivel de energía, sólo pueden percibirse por medio de un órgano sensorial capaz de detectar el tipo específico de energía en cuestión (por esto las microondas, los rayos $X$ y la luz ultravioleta son peligrosas; no estamos preparados para detectarlas, de forma que incluso a niveles letales no podemos percibirlas). En segundo lugar, nuestras percepciones son necesariamente sombras imperfectas de la realidad, porque nuestro sistema nervioso central se limita a reconstruir una imagen incompleta de las señales que transmiten sus receptores sensoriales. Tercero, nuestros sistemas sensoriales nos aportan una información más exacta sobre los cambios en nuestro entorno que sobre las condiciones estáticas. Estamos bien dotados con receptores sensoriales para las luces parpadeantes, o para las pequeñas fluctuaciones de temperatura que provoca una brisa ligera; sin embargo, nuestra capacidad sensorial es menor para recibir información sobre una temperatura constante 0 una presión constante sobre la piel.

Tradicionalmente, la sensibilidad de la piel se divide en dos categorías: cutánea y profunda. M ientras que la sensibilidad profunda se sitúa en receptores localizados en el músculo, los tendones, las articulaciones y el periostio (membrana que rodea los huesos), la sensibilidad cutánea, a la que nos referimos aquí, se relaciona con la información recibida por los receptores localizados en la unión de la dermis con la epidermis o cerca de ella.

Todos los nervios sensoriales que unen los receptores cutáneos al sistema nervioso central tienen una estructura similar. El gran cuerpo celular se sitúa en un grupo de otros cuerpos celulares nerviosos denominado ganglio, cerca de la médula espinal, a la que se conecta por una rama pequeña que parte del tronco de la célula y que se denomina axón. La mayoría de las células nerviosas 0 neuronas que se originan en la médula espinal envían axones a los huesos, músculos, articulaciones 0 , en el caso de la sensibilidad cutánea, a la piel. De la misma forma que un cable aislado, todos los axones están recubiertos en su trayecto y terminaciones por capas protectoras de células conocidas como células de Schwann. Estas células producen una sustancia denominada mielina, que cubre el axón como una vaina. En el recorrido, cada ciertos intervalos existen minúsculos cortes en la mielina denominados nódulos de Ranvier. Finalmente, en el extremo del axón se hallan los componentes especializados en recibir y transmitir información sobre el ambiente externo: los receptores sensoriales (M ountcastle 1974).

Las diferentes clases de receptores cutáneos, como todos los receptores sensoriales, se definen de dos maneras: por sus estructuras anatómicas y por el tipo de señales eléctricas que envían por las fibras nerviosas. Los receptores de estructuras definidas reciben generalmente el nombre de sus descubridores. El número relativamente escaso de clases de receptores sensoriales que se encuentran en la piel puede dividirse en tres categorías principales: mecanorreceptores, receptores térmicos y nociceptores.

Todos estos receptores sólo pueden transmitir información acerca de un tipo de estímulo después de ser codificados en un lenguaje electroquímico particular. Estos códigos utilizan frecuencias y patrones variables de impulsos nerviosos que los científicos sólo han empezado a descifrar. De hecho, una rama importante de la investigación neurofisiológica está dedicada por entero al estudio de los receptores sensoriales y de las formas en que pueden traducir los estados de energía ambientales en códigos nerviosos. U na vez generados los códigos, estos se transmiten al sistema nervioso central por las fibras aferentes, las células nerviosas que conectan con los receptores transmitiendo las señales al sistema nervioso central.

Los mensajes producidos por los receptores pueden subdividirse según la respuesta dada a una estimulación continua no variable: los receptores de adaptación lenta envían impulsos electroquímicos al sistema nervioso central durante el tiempo que dura un estímulo constante, mientras que los receptores de adaptación rápida reducen de forma gradual sus descargas en presencia de un estímulo constante, hasta que alcanzan un nivel basal bajo o cesan por completo, con lo que dejan de informar al sistema nervioso central sobre la presencia continua del estímulo. 
Las sensaciones distintas de dolor, calor, frío, presión y vibración se producen, por tanto, por la actividad sobre distintas clases de receptores sensoriales y sus fibras nerviosas correspondientes. Los términos "aleteo" y "vibración", por ejemplo, se utilizan para distinguir dos sensaciones vibratorias ligeramente distintas codificadas por dos clases diferentes de receptores sensibles a la vibración (M ountcastle y cols. 1967). Las tres categorías importantes de sensación dolorosa conocidas como dolor punzante, quemante y sordo se han asociado con clases distintas de fibras aferentes nociceptivas. Sin embargo, esto no quiere decir que una sensación específica se relacione necesariamente sólo con una clase de receptor; a una sensación determinada puede contribuir más de una clase de receptores y, de hecho, las sensaciones pueden variar dependiendo de la contribución relativa de las diferentes clases de receptores (Sinclair 1981).

EI resumen precedente se basa en la hipótesis de la especificidad de la función sensorial cutánea, formulada en primer lugar por el médico alemán Von Frey en 1906. Aunque en el siglo pasado se propusieron al menos otras dos teorías de igual o mayor aceptación, en la actualidad la hipótesis de Von Frey está respaldada por datos objetivos.

\section{Receptores que responden a la presión cutánea} constante

En la mano emergen, procedentes de una red nerviosa subcutánea denominada plexo nervioso subpapilar, fibras mielinizadas relativamente grandes (de 5 a $15 \mu \mathrm{m}$ de diámetro) que acaban en múltiples terminaciones nerviosas situadas en la unión de la dermis y la epidermis (Figura 11.19). En la piel con vello, estas terminaciones nerviosas terminan en estructuras superficiales visibles denominadas cúpulas táctiles; en la piel lampiña, las terminaciones nerviosas se localizan en la base de las elevaciones cutáneas (como las que forman las huellas dactilares). En la

Figura 11.19 • Ilustración esquemática de un corte de la piel.

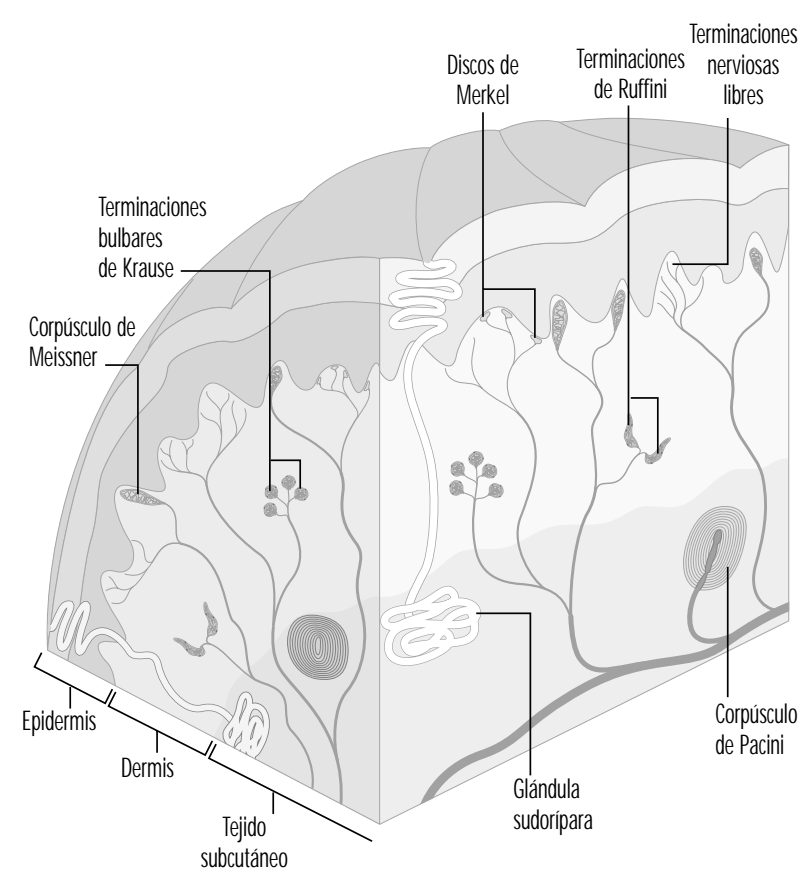

Se muestran los nervios y receptores sensitivos principales. La mayoría de las terminaciones nerviosas se localizan en la unión entre la dermis y la epidermis.
Figura 11.20 • La cúpula táctil de cada región elevada de la piel contiene de 30 a 70 células de M erkel.

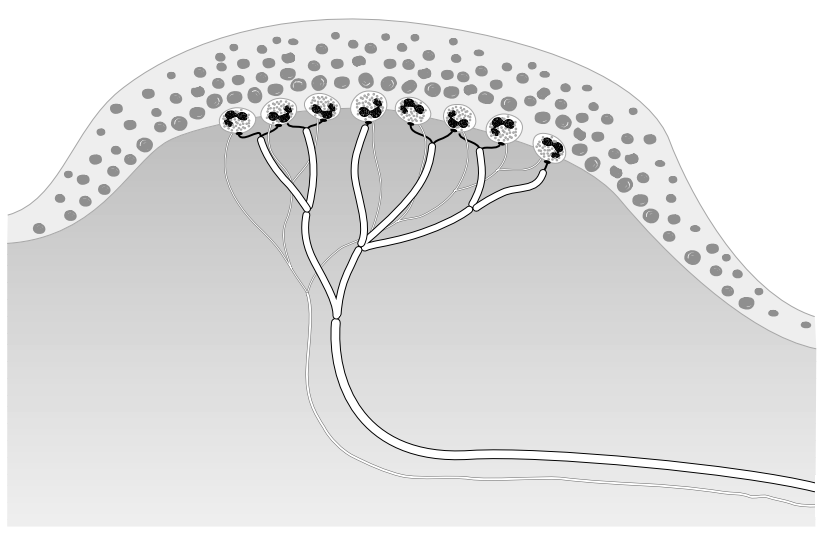

La mayoría de estas células están en contacto con una rama terminal de uno de los tres o cinco axones que terminan en la cúpula. Obsévese que la gran fibra nerviosa mielinizada se acompaña de una fibra desmielinizada más pequeña. Fuente: lggo y Muir 1969

cúpula táctil, cada extremo de la fibra nerviosa, o neurita, está contenida en una célula epitelial especial denominada célula de M erkel (véanse las Figuras 11.20 y 11.21).

El complejo formado por la neurita y la célula de Merkel transduce la energía mecánica en impulsos nerviosos. Aunque se conoce poco sobre el papel de la célula o sobre su mecanismo de transducción, se ha identificado un receptor de adaptación lenta. Esto significa que la presión sobre una cúpula táctil que contiene células de Merkel induce la producción de impulsos nerviosos en los receptores durante el tiempo de acción del estímulo. La frecuencia de estos impulsos aumenta en proporción a la intensidad del estímulo y así se informa al cerebro de la duración y magnitud de la presión sobre la piel.

Al igual que la célula de Merkel, un segundo receptor de adaptación lenta sirve también a la piel para señalar la magnitud

Figura 11.21 - A mayor aumento, con el microscopio electrónico, la célula de Merkel, una célula epitelial especializada, se observa unida a la membrana basal que separa la epidermis de la dermis.

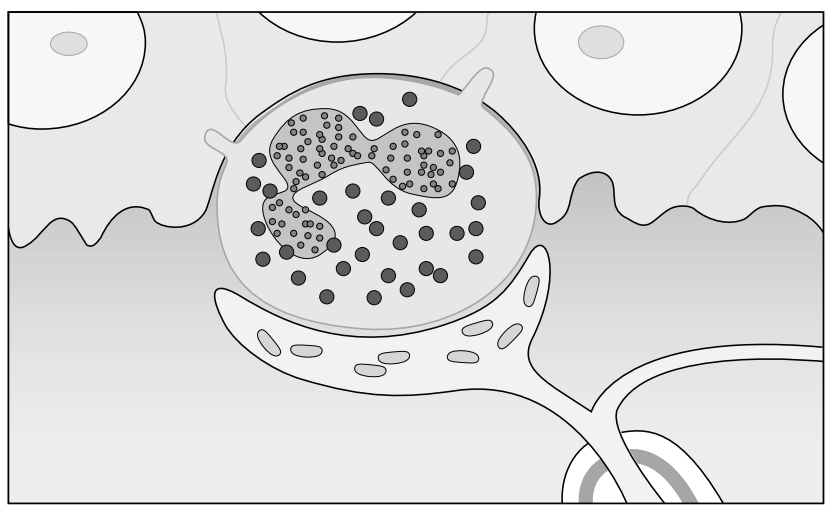

El núcleo de la célula es lobulado y el citoplasma contiene gránulos de función desconocida, similares a los gránulos de secreción. El axón terminal está lleno de mitocondrias y cubierto por una célula de Schwann hasta que penetra en la célula de Merkel. 
y la duración de la presión cutánea constante. Este receptor, de tamaño microscópico y conocido como receptor de Ruffini, está formado por un grupo de neuritas que salen de una fibra mielinizada y están encapsuladas por células de tejido conectivo. Dentro de la estructura capsular hay fibras que aparentemente transmiten sensaciones cutáneas locales distorsionadas a las neuritas, que a su vez producen los mensajes que se envían por las vías nerviosas hasta el sistema nervioso central. La presión sobre la piel provoca una descarga mantenida de impulsos nerviosos; como sucede con la célula de M erkel, la frecuencia de los impulsos es proporcional a la intensidad del estímulo.

A pesar de estas similitudes, existe una diferencia fundamental entre las células de M erkel y los receptores de Ruffini. La estimulación de estos últimos provoca una sensación; en cambio, la estimulación de las cúpulas táctiles que contienen células de M erkel no produce una sensación consciente; la cúpula táctil es, por tanto, un receptor misterioso, porque no se conoce su papel real en la función nerviosa. Por tanto, se cree que los receptores de Ruffini son los únicos capaces de generar las señales nerviosas necesarias para la percepción sensorial de la presión o del tacto constante. Además, se ha demostrado que los receptores de adaptación lenta de Ruffini son los que permiten al ser humano evaluar la presión cutánea en una escala de intensidad.

\section{Receptores que responden a la vibración y al movimiento de la piel}

A diferencia de los mecanorreceptores de adaptación lenta, los receptores de adaptación rápida permanecen silentes durante la indentación cutánea mantenida. Sin embargo, son adecuados para las señales de vibración y de movimiento de la piel. Se señalan dos categorías: los receptores de la piel con vello, que se asocian a cada pelo; y los que forman terminaciones corpusculares en la piel lampiña o sin pelo.

\section{Receptores capilares}

Un pelo típico está cubierto por una red de terminaciones nerviosas ramificadas a partir de cinco a nueve axones mielinizados. (Figura 11.22). En los primates, estas terminales se clasifican en tres categorías: terminaciones lanceoladas, fusiformes y papilares. L os tres tipos son de adaptación rápida, de forma que la inclinación mantenida del pelo sólo causa impulsos nerviosos cuando se produce el movimiento. Por tanto, estos receptores son muy sensibles a los estímulos de movimiento o vibratorios, pero ofrecen escasa o nula información sobre la presión o el tacto constantes.

L as terminaciones lanceoladas salen de una fibra muy mielinizada que forma una red alrededor del pelo. Las neuritas terminales pierden su cobertura habitual de células de Schwann y se abren camino entre las células de la base del pelo.

Los axones rodeados de células de Schwann forman terminales fusiformes. Estas ascienden hasta el tallo del pelo inclinado y terminan en un grupo semicircular justo debajo de un glándula sebácea o productora de grasa. Las terminaciones papilares se diferencian de los terminales fusiformes porque en vez de terminar sobre el tallo del pelo, acaban como terminaciones nerviosas libres alrededor del orificio del pelo.

Es probable que existan diferencias funcionales entre los tipos de receptores capilares. Esto se explica en parte por las diferencias estructurales en relación con la forma en que los nervios terminan sobre el tallo del pelo $y$, en parte, por las diferencias en el diámetro de los axones, ya que los axones de diámetros diferentes conectan con estaciones centrales diferentes. Con todo, las funciones de los receptores en la piel con vello continúan siendo objeto de estudio.

\section{Receptores en la piel lampiña}

La relación de la estructura anatómica de un receptor con las señales nerviosas que genera es más marcada en los receptores grandes fácilmente manipulables y con terminaciones corpusculares o encapsuladas. Los corpúsculos de Pacini y de M eissner se conocen particularmente bien; estos, como las terminaciones capilares comentadas antes, transmiten sensaciones de vibración.

El corpúsculo de Pacini tiene un tamaño suficiente para verlo a simple vista, con lo que resulta sencillo asociar el receptor a una respuesta nerviosa específica. Se localizan en la dermis, generalmente alrededor de tendones 0 articulaciones, en una estructura en forma de cebolla que mide $0,5 \times 1,0 \mathrm{~mm}$. Se continúa con una de las fibras aferentes más largas del organismo, con un diámetro de 8 a $13 \mu \mathrm{m}$ y una velocidad de conducción de 50 a 80 metros por segundo. Su anatomía, estudiada con microscopía óptica y electrónica, es bien conocida.

El principal componente del corpúsculo es un núcleo externo formado por material celular que contiene espacios llenos de líquido. El propio núcleo externo está rodeado por una cápsula

Figura 11.22 - Los tallos pilosos son una plataforma para las terminales nerviosas que detectan el movimiento.

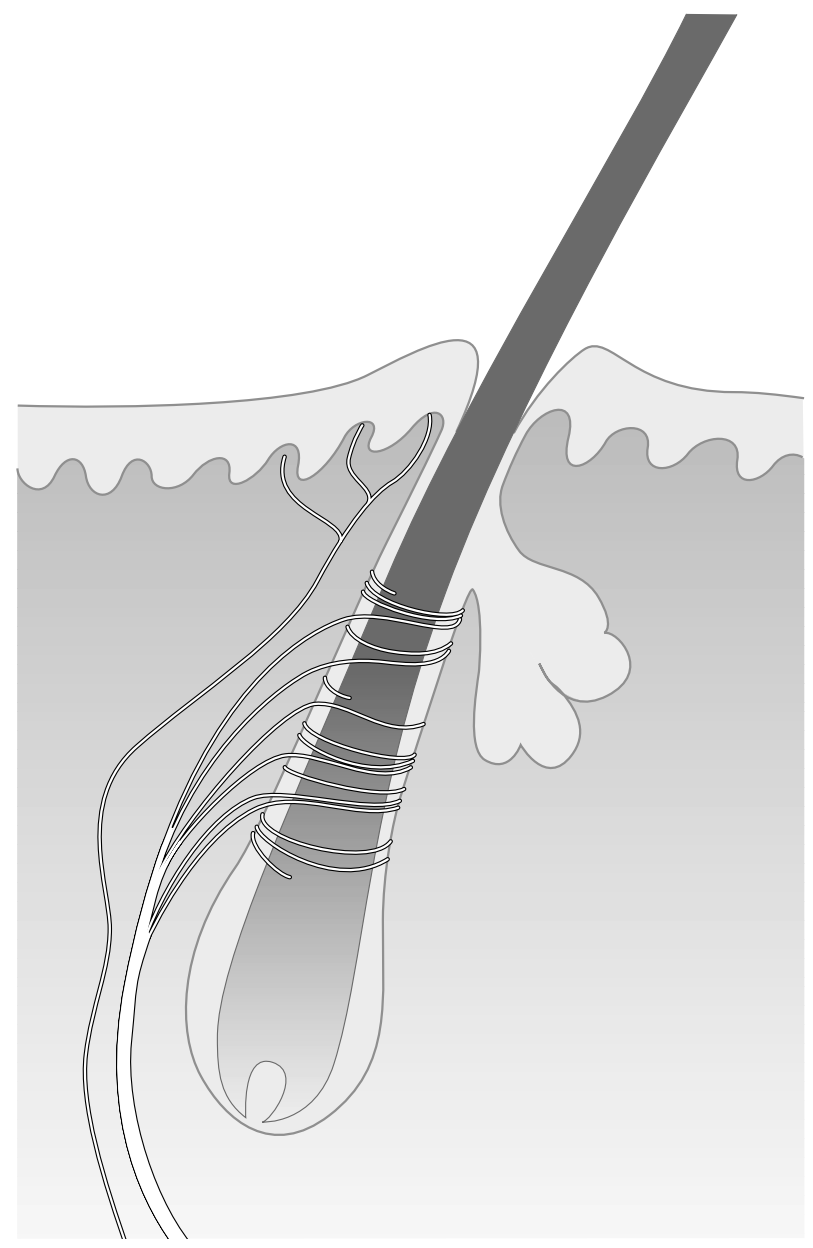

Como se describe en el texto, diversos tipos de axones terminan sobre el tallo del pelo o cerca de él, algunos se elevan e imbrican alrededor del tallo y terminan en disposición vertical. Una fibra ligeramente mielinizada continúa a lo largo del pelo hasta que termina en el orificio del folículo piloso. Fuente: Dykes 1977. 
en la que penetra un canal central y una red capilar. A través del canal pasa una fibra nerviosa mielinizada simple de 7 a $1 \mu \mathrm{m}$ de diámetro, que se convierte en una terminación nerviosa larga no mielinizada que se hunde profundamente en el centro del corpúsculo. El axón terminal es elíptico y posee ramificaciones.

El corpúsculo de Pacini es un receptor de adaptación rápida. Cuando se somete a presión mantenida, produce un impulso sólo al principio y al final del estímulo. Responde a vibraciones de alta frecuencia (de 80 a $400 \mathrm{H}$ z) y es más sensible a las vibraciones de alrededor de $250 \mathrm{~Hz}$. Con frecuencia, estos receptores responden a las vibraciones transmitidas a lo largo de huesos y tendones $y$, debido a su sensibilidad extrema, pueden activarse tan sólo con un soplo de aire sobre la mano (M artin 1985).

Además de los corpúsculos de Pacini, hay otros receptores de adaptación rápida en la piel lampiña. La mayoría de los investigadores creen que son los corpúsculos de M eissner, que se localizan en las papilas dérmicas. Este receptor responde a vibraciones de baja frecuencia, de 2 a $40 \mathrm{~Hz}$, y está formado por las ramas terminales de una fibra mielinizada de mediano tamaño cubierta por una o varias capas de unas células que parecen ser células de Schwann modificadas, denominadas células laminares. Las neuritas del receptor y de las células laminares pueden conectarse con una célula basal de la epidermis (Figura 11.23).

Si el corpúsculo de $\mathrm{M}$ eissner se inactiva de forma selectiva mediante la inyección de un anestésico local a través de la piel, se pierde el sentido de aleteo o de vibración de baja frecuencia. Esto indica un complemento funcional a la capacidad receptora de alta frecuencia de los corpúsculos de Pacini. Juntos, estos dos receptores aportan las señales nerviosas suficientes para que la sensibilidad humana abarque un amplio margen de vibraciones (M ountcastle y cols. 1967).

\section{Receptores cutáneos asociados a terminaciones nerviosas libres}

En la dermis se encuentran numerosas fibras mielinizadas y no mielinizadas que todavía no se han identificado. M uchas de ellas sólo pasan por la dermis camino de la piel, los músculos o el periostio, mientras que otras (mielinizadas y no mielinizadas) parecen terminar en la dermis. Salvo algunas excepciones como el corpúsculo de Pacini, las mayoría de las fibras de la dermis parecen terminar de forma mal definida o simplemente como terminaciones nerviosas libres.

Aunque se necesitan más estudios anatómicos para diferenciar estas terminaciones mal definidas, la investigación fisiológica ha mostrado con claridad que estas fibras codifican varios acontecimientos ambientales. Por ejemplo, las terminaciones nerviosas libres que se encuentran en la unión entre la dermis y la epidermis son responsables de la codificación de los estímulos ambientales que se interpretarán como frío, calor, dolor, picor y cosquilleo. No se sabe por ahora cuál de estas fibras pequeñas transmite las distintas sensaciones.

La aparente similitud anatómica de estas terminaciones nerviosas libres se explica, probablemente, por las limitaciones de las actuales técnicas de investigación, ya que últimamente se están determinando diferencias estructurales entre ellas. Por ejemplo, en la piel lampiña se han distinguido dos formas diferentes de terminaciones nerviosas libres: un patrón corto y grueso y otro largo y fino. Los estudios realizados sobre piel humana con vello han demostrado terminaciones nerviosas reconocibles histoquímicamente que terminan en la unión dermo-epidérmica: las terminaciones papilares y peniciladas. L as primeras surgen de fibras no mielinizadas y forman una red de terminaciones; en cambio, las segundas surgen de fibras mielinizadas y terminan alrededor de los orificios pilosos, como se mencionó antes. Es probable que estas disparidades estructurales correspondan a diferencias funcionales.

Aunque no es todavía posible asignar funciones específicas a entidades estructurales individuales, está claro por los experimentos fisiológicos que existen categorías funcionalmente diferentes de terminaciones nerviosas libres. Se ha descubierto que una fibra mielinizada pequeña responde al frío en el ser humano. 0 tra fibra no mielinizada que acaba en terminaciones nerviosas libres responde al calor. Se desconoce por qué una clase de terminaciones nerviosas libres puede responder de forma selectiva a un descenso de la temperatura, mientras que un aumento de la temperatura cutánea induce a otra clase a emitir una señal de calor. Algunos estudios muestran que la activación de una fibra pequeña con una terminación libre puede ser responsable de las sensaciones de picor o de cosquilleo y se cree que dos clases de fibras pequeñas son específicamente sensibles a los estímulos nocivos mecánicos, químicos o térmicos, lo que proporciona la base neurológica de las sensaciones de dolor quemante y punzante (K eele 1964).

La relación definitiva entre la respuesta anatómica y fisiológica sólo se establecerá cuando se desarrollen técnicas de investigación más avanzadas. Este es uno de los principales obstáculos para el tratamiento de trastornos como la causalgia, las parestesias y la hiperpatía, que continúan siendo un dilema importante para el médico.

\section{Lesiones de los nervios periféricos}

La función de los nervios puede dividirse en dos categorías: sensorial y motora. Las lesiones de los nervios periféricos, generalmente causadas por el aplastamiento o sección de un nervio,

Figura 11.23 - El corpúsculo de M eissner es un receptor sensorial con una cápsula laxa que se localiza en las papilas dérmicas de la piel lampiña.

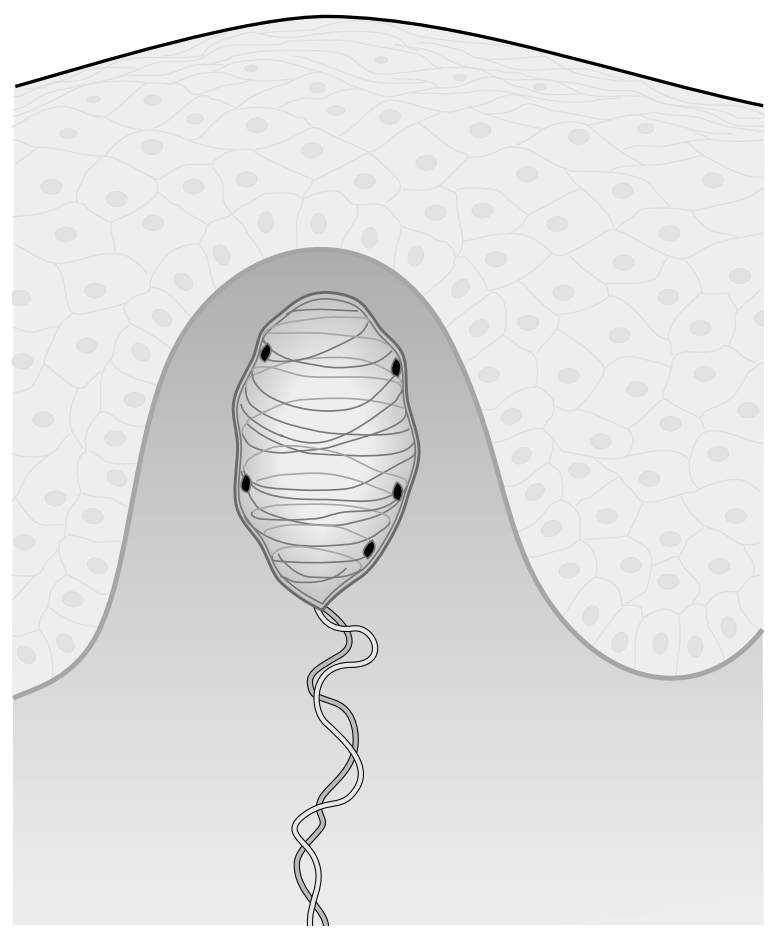

Alrededor de una o más terminaciones nerviosas ramificadas se envuelven células corpusculares no nerviosas. La estructura muestra su máxima sensibilidad a las vibraciones de baja frecuencia. Fuente: Dykes 1977. 
puede afectar a una o ambas funciones, dependiendo de los tipos de fibras del nervio lesionado. Algunos aspectos de la pérdida motora suelen interpretarse mal o pasarse por alto, porque estas señales no alcanzan los músculos, sino que influyen sobre el control autonómico vascular, la regulación de la temperatura, la naturaleza y grosor de la epidermis y el estado de los mecanorreceptores cutáneos. La pérdida de inervación motora no se comentará aquí, ni tampoco la que afecta a otros sentidos diferentes de los responsables de la sensación cutánea.

La pérdida de inervación sensorial de la piel crea un estado de vulnerabilidad a lesiones posteriores, porque la superficie cutánea insensible es incapaz de señalar estímulos potencialmente dañinos. U na vez lesionadas, las superficies de piel insensibles curan con lentitud, en parte a causa de la falta de inervación autonómica que regula normalmente factores claves como la temperatura y la nutrición celular.

En algunas semanas, los receptores sensoriales cutáneos denervados comienzan a atrofiarse, lo cual se observa con facilidad en receptores encapsulados de gran tamaño como los corpúsculos de Pacini y de M eissner. Si la regeneración axonal es posible, la función podrá recuperarse, pero la calidad de la función recuperada dependerá del tipo de lesión original y de la duración de la denervación (M cK innon y D ellon 1988).

La recuperación tras el aplastamiento de un nervio es más rápida, completa y funcional que la recuperación tras la sección neural. D os factores explican el pronóstico favorable en los casos de aplastamiento. En primer lugar, pueden contactar con la piel más axones que en los casos de sección; por otro lado, las conexiones son guiadas en sentido inverso hacia su localización original por las células de Schwann y por las membranas basales, elementos que permanecen intactos en los aplastamientos nerviosos, mientras que después de una sección neural, el nervio suele prolongarse hacia regiones incorrectas de la superficie cutánea siguiendo las vías erróneas de las células de Schwann. Debido a esto, se envía una información espacial distorsionada a la corteza somatosensorial del cerebro. Sin embargo, en los dos casos, los axones en proceso de regeneración parecen capaces de hallar el camino de vuelta hacia el mismo tipo de receptores sensoriales que alcanzaban antes de la lesión.

La reinervación de un receptor cutáneo es un proceso gradual. Cuando el axón en crecimiento alcanza la superficie de la piel, las áreas de recepción sensorial son más pequeñas de lo normal y el umbral de sensibilidad es superior. Estos puntos receptivos se extienden con el tiempo y se unen de forma gradual en campos de mayor tamaño. La sensibilidad a los estímulos mecánicos aumenta y con frecuencia se acerca a la sensibilidad de los receptores sensoriales normales de esa clase. LoS estudios realizados con estímulos táctiles constantes, o en movimiento y con vibraciones han mostrado que las zonas insensibilizadas recuperan a distinto ritmo las modalidades sensoriales atribuidas a diferentes tipos de receptores.

Si se observa al microscopio, se aprecia que la piel lampiña denervada es más fina de lo normal y presenta unas elevaciones cutáneas aplanadas y menos capas de células. Esto confirma que los nervios tienen una influencia trófica o nutricional sobre la piel. Al poco tiempo de recuperarse la inervación, las elevaciones dérmicas se desarrollan mejor, la epidermis aumenta de grosor y pueden hallarse axones que atraviesan la membrana basal. Cuando el axón alcanza de nuevo el corpúsculo de M eissner, éste comienza a aumentar de tamaño y la estructura atrófica previamente aplanada recupera su forma original. Si la denervación fue prolongada, puede formarse un corpúsculo nuevo al lado del esqueleto atrófico original, que continúa denervado (D ellon 1981).

Como se puede observar, para comprender las consecuencias de las lesiones nerviosas periféricas hay que conocer el funcionamiento normal y el grado de recuperación funcional. Aunque se dispone de esta información en algunas células nerviosas, deberán realizarse más estudios, ya que todavía quedan varias áreas oscuras en relación con la función de los nervios cutáneos en la salud y la enfermedad.

\section{Referencias}

Adler, FH. 1992. Physiology of the Eye Clinical Application. St. Louis: M osby N ew Y ork Books.

Adrian, WK. 1993. Visual Performance, Acuity and Age L UX E uropa Proceedings of the VIIth E uropean Lighting Conference Londres: CIBSE.

Ahlström, R, B Berglund, U Berblund. 1986 Impaired odor perception in tank cleaners. Scand ] W ork E nviron $\mathrm{H}$ ealth 12:574-581.

Amoore, JE. 1986. Effects of chemical exposure on olfaction in humans. En Toxicology of the Nasal Passages, dirigido por CS Barrow. Washington, DC: H emisphere Publishing.

Andersen, HC, I Andersen, I Solgard. 1977. Nasa cancers, symptoms and upper airway function in woodworkers. Br J Ind M ed 34:201-207.

- . 1993. Otolaryngol Clin N Am 5(26).

Axéll, T, K Nilner, B Nilsson. 1983. Clinical evaluation of patients referred with symptoms related to oral galvanism. Scand D ent J 7:169-178.

Ballantyne, JC, JM Ajodhia. 1984. Iatrogenic dizziness. En Vertigo, dirigido por MR Dix y JD H ood. C hichester: Wiley.

Bar-Sela, S, M Levy, JB Westin, R Laster, ED Richter. 1992. Medical findings in nickel-cadmium battery workers. I srael | M ed Sc 28:578-583.

Bedwal, RS, N N air, M P Sharma. 1993. Selenium-its biological perspectives. M ed H ypoth 41:150-159.
Bell, IR . 1994. White paper: N europsychiatric aspects of sensitivity to low-level chemicals: A neural sensitization model. T oxicol Ind $\mathrm{H}$ ealth 10:277-312.

Besser, R, G Krämer, R Thümler, J Bohl, L Gutmann, HC Hopf. 1987. A cute trimethyltin limbic cerebellar syndrome. N eurology 37:945-950.

Beyts, JP. 1987. Vestibular rehabilitation. En Adult Audiology, Scott-B rown's O tolaryngology, dirigido por D Stephens. Londres: Butterworths.

Blanc, PD, HA Boushey, H Wong, SF Wintermeyer, MS Bernstein. 1993. Cytokines in metal fume fever. Am R ev Respir D is 147:134-138.

Blount, BW. 1990. Two types of metal fume fever: mild vs. serious. M il M ed (agosto) 155(8):372-7

Bokina, AI, ND Eksler, AD Semenenko. 1976. Investigation of the mechanism of action of atmospheric pollutants on the cenral nervous system and comparative evaluation of methods of study. E nviron $\mathrm{H}$ ealth Persp 13:37-42.

Bolla, KI, BS Schwartz, W Stewart. 1995 Comparison of neurobehavioral function in workers exposed to a mixture of organic and inorganic lead and in workers exposed to solvents. Am J Ind M ed 27:231-246.

Bonnefoi, M, TM M onticello, KT Morgan. 1991. Toxic and neoplastic responses in the nasal passages: Future research needs. Exp Lung Res 17:853-868.

Boysen, M, Solberg. 1982. Changes in the nasal mucosa of furniture workers. Scand I W ork E nviron $H$ ealth :273-282.
Brittebo, EB, PG Hogman, I Brandt. 1987. Epithelial binding of hexachlorocyclohexanes in the respiratory and upper alimentary tracts: A comparison between the alpha-, beta- and gamma-isomers in mice. Food Chem Toxicol 25:773-780.

Brooks, SM . 1994. Host susceptibility to indoor air pollution. J Allergy Clin Immunol 94:344-351.

Callender, TI, L M orrow, K Subramanian, D Duhon, M Ristovv. 1993. Three-dimensional brain metabolic imaging in patients with toxic encephalopathy. E nvironmental R esearch 60:295-319.

Ciesielski, S, DP Loomis, SR M ims, A Auer. 1994. Pesticide exposures, cholinesterase depression, and symptoms among North Carolina migrant farmworkers. Am J Public H ealth 84:446-451.

Clerisi, WJ, B Ross, LD Fechter. 1991. Acute ototoxicity of trialkyltins in the guinea pig. Toxicol Appl Pharmacol :547-566.

Coleman, JW, MR Holliday, RJ Dearman. 1994. Cytokine-mast cell interactions: Relevance to IgE-mediated chemical allergy. Toxicology 88:225-235.

Cometto-M uñiz JE, WS Cain 1991. Influence of airborne contaminants on olfaction and the common chemical sense. En Smell and Taste in $H$ ealth and D isease, dirigido por TV G etchell. N ueva Y ork: R aven Press.

-. 1994. Sensory reactions of nasal pungency and odor to volatile organic compounds: The alkylbenzenes. Am Ind H yg Assoc $55: 811-817$. 
Corwin, J, M Loury, AN Gilbert. 1995. Workplace, age, and sex as mediators of olfactory function: Data from the National G eographic Smell Survey. J ournal of Gerontolgy: Psychiol Sci 50B:P179-P186.

Council on Dental Materials, Instruments and Equipment. 1987. American Dental Association status report on the occurence of galvanic corrosion in the mouth and its potential effects. Am D ental Assoc 115:783-787.

Council on Scientific Affairs. 1989. Council report: Formaldehyde. J AM A 261:1183-1187.

Crampton, GH. 1990. M otion and Space Sickness. Boca R atón: $C R C$ Press.

Cullen, MR. 1987. Workers with multiple chemical sensitivities. 0 ccup M ed: State Art R ev 2(4).

Chia, SE, CN O ng, SC Foo, HP Lee. 1992. Medical student's exposure to formaldehyde in a gross anatomy dissection laboratory. I Am Coll Health 41:115-119.

Choudhuri, S, KK Kramer, NE Berman. 1995. Constitutive expression of metallothionein genes in mouse brain. T oxicol Appl Pharmacol 131:144-154.

Deems, DA, RL Doty, RG Settle. 1991. Smell and taste disorders, a study of 750 patients from the University of Pennsylvania Smell and Taste Center. Arch Otolaryngol $\mathrm{H}$ ead Neck Surg 117:519-528.

Della Fera, MA, AE Mott, ME Frank. 1995 latrogenic causes of taste disturbances: Radiation therapy, surgery, and medication. En $\mathrm{H}$ andbook of Olfaction and Gustation, dirigido por RL Doty. Nueva Y ork: M arcel Dekker.

Dellon, AL. 1981. Evaluation of Sensibility and $\mathrm{ReE}$ ducation of Sensation in the $\mathrm{H}$ and. Baltimore: Williams \& Wilkins.

Dykes, R W. 1977. Sensory receptors. En R econstructive $M$ icrosurgery, dirigido por RK Daniel y JK Terzis. Boston: Little Brown \& Co.

El-Etri, M M, WT Nickell, M Ennis, KA Skau, MT Shipley. 1992. Brain norepinephrine reductions in soman-intoxicated rats: Association with convulsions and AchE inhibition, time course, and relation to other monoamines. Experimental N eurology 118:153-163.

Evans, J, L H astings. 1992. A ccumulation of $\mathrm{Cd}(\mathrm{II})$ in the CNS depending on the route of administration: Intraperitoneal, intratracheal, or intranasal. F und A ppl T oxicol 19:275-278

Evans, JE, M L M iller, A Andringa, L H astings. 1995. Behavioral, histological, and neurochemical effets of nickel(II) on the rat olfactory system. T oxicol Appl Pharmacol 130:209-220.

Fechter, LD, JS Y oung, L C arlisle. 1988. Potentiation of noise induced threshold shifts and hair cell loss by carbon monoxide. $H$ earing $R$ es 34:39-48.

Fox, SL. 1973. Industrial and Occupational 0 pthalmology. Springfield: Charles $\mathrm{C}$. Thomas.

Frank, ME, DV Smith. 1991. Electrogustometry: A simple way to test taste. En Smell and T aste in $\mathrm{H}$ ealth and Disease, dirigido por TV G etchell, RL D oty y LM Bartoshuk. N ueva Y ork: R aven Press.

Frank, M E, TP H ettinger, AE M ott. 1992. The sense of taste: Neurobiology, aging, and medication effects. Critical Reviews in O ral Biology Medicine 3:371-393.

Gagnon, P, D M ergler, S Lapare. 1994. O Ifactory adaptation, threshold shift and recovery at low levels of exposure to methyl isobutyl ketone (M IBK ). N eurotoxicology 15:637-642.

Gilbertson, TA. 1993. The physiology of vertebrate taste reception. Curr 0 pin N eurobiol 3:532-539.

Gordon, T, JM Fine. 1993. M etal fume fever. O ccup M ed: State Art R ev 8:505-517.
Gosselin, RE, RP Smith, HC Hodge. 1984. Clinical Toxicology of Commercial Products. Baltimore: Williams \& Wilkins.

Graham, CH, NR Barlett, JL Brown, Y H sia, CG Mueller, LA Riggs. 1965. Vision and Visual Perception. Nueva Y ork: John W iley and Sons, Inc.

Grandjean, E. 1987. E rgonomics in Computerized Offices. Londres: T aylor \& Francis.

Grant, A. 1979. O ptical danger of fiberglass hardener. M ed J Austral 1:23.

Gresham, LS, CA M olgaard, RA Smith. 1993. Induction of cytochrome P-450 enzymes via tobacco smoke: A potential mechanism for developing resistance to environmental toxins as related to Parkinsonism and other neurologic disease. Neuroepidemiol 12:114-116.

Guidotti, TL. 1994. O ccupational exposure to hydrogen sulfide in the sour gas industry: Some unresolved issues. Int Arch Occup Environ $\mathrm{H}$ ealth 66:153-160.

Gyntelberg, F, S V esterhauge, P Fog, H Isager, K Zillstorff. 1986. Acquired intolerance to organic solvents and results of vestibular testing. Am J Ind M ed 9:363-370.

H astings, L. 1990. Sensory neurotoxicology: use of the olfactory system in the assessment of toxicity. Neurotoxicology and T eratology 12:455-459.

H ead, PW. 1984. V ertigo and barotrauma. En Vertigo, dirigido por MR Dix y JD Hood. Chichester: Wiley.

H ohmann, B, F Schmuckli. 1989. D angers du bruit pour l'ouië et I'emplacement de travail. Lucerne: CNA.

Holmström, M, G Rosén, B Wilhelmsson. 1991. Symptoms, airway physiology and histology of workers exposed to medium-density fiber board. Scand I W ork Environ H ealth 17:409-413.

H otz, P, A T schopp, D Söderström, J H oltz. 1992. Smell or taste disturbances, neurological symptoms, and hydrocarbon exposure. Int Arch O ccup E nviron $\mathrm{H}$ ealth 63:525-530.

Howard, IP. 1982. H uman Visual Orientation. Chichester: Wiley.

Iggo, A, AR M uir. 1969. The structure and function of a slowly adapting touch corpuscle in hairy skin. J Physiol L ond 200(3):763-796.

Illuminating Engineering Society of North America (IESNA). 1993. Vision and perception. En Lighting $H$ andbook: R eference and Application, dirigido por M S Rea y Fies. Nueva Y ork: IESN A.

Innocenti, A, M Valiani, G Vessio, M Tassini, M Gianelli, S Fusi. 1985. Wood dust and nasal diseases: Exposure to chestnut wood dust and loss of smell (pilot study). M ed L avoro 4:317-320.

Jacobsen, P, HO Hein, P Suadicani, A Parving, F Gyntelberg. 1993. Mixed solvent exposure and hearing impairment: An epidemiological study of 3284 men. The Copenhagen male study. O ccup $M$ ed 43:180-184.

Johansson, B, E Stenman, M Bergman. 1984. Clinical study of patients referred for investigation regarding so-called oral galvanism. Scand J D ent Res 92:469-475.

Johnson, A-C, PR Nylén. 1995. Effects of industrial solvents on hearing. O ccup $M$ ed: State of the art reviews. 10:623-640.

K achru, DM, SK T andon, UK M isra, D Nag. 1989. O ccupational lead poisoning among silver jewelry workers. Indian J ournal of M edical Sciences 43:89-91.

Keele, CA. 1964. Substances Producing Pain and Itch. Londres: Edward Arnold.

K innamon, SC, TV Getchell. 1991. Sensory transduction in olfactory receptor neurons and gustatory receptor cells. En Smell and T aste in $\mathrm{H}$ ealth and Disease, dirigido por TV G etchell, RL Doty y LM Bartoshuk. Nueva York: Raven Press.
K rueger, H. 1992. Exigences visuelles au poste de travail: Diagnostic et traitement. Cahiers médico-sociaux 36:171-181.

Lakshmana, MK, T Desiraju, TR Raju. 1993. M ercuric chloride-induced alterations of levels of noradrenaline, dopamine, serotonin and acetylcholine esterase activity in different regions of rat brain during postnatal development. Arch Toxicol 67:422-427.

Lima, C, JP V ital. 1994. O Ifactory mucosa response in guinea pigs following intranasal instillation with Cryptococcus neoformans: A histological and immunocytochemical study. M ycopathologia 126: 65-73.

Luxon, LM . 1984. The anatomy and physiology of the vestibular system. En Vertigo, dirigido por M R Dix y JD Hood. Chichester: Wiley.

Mack innon, SE, AL Dellon. 1988. Surgery of the Peripheral Nerve Nueva York: Thieme Medical Publishers.

Marek, J-J. 1993. The molecular biology of taste transduction. B ioessays 15:645-650.

Marek, M. 1992. Interactions between dental amalgams and the oral environment. Adv D ental Res 6:100-109.

M argolskee, RF. 1993. The biochemistry and molecular biology of taste transduction. Curr 0 pin Neurobiol 3:526-531.

Martin, JH. 1985. Receptor physiology and submodality coding in the somatic sensory system. Principles of Neuroscience, dirigido por ER K andel $y$ JH Schwartz.

M eyer, J-J, A Bousquet, JC Schira, L Zoganas, P R ey. 1986. Light sensitivity and visual strain when driving at night. En Vision in Vehicles, dirigido por AG G ale. Amsterdam: Elsevier Science Publisher.

M eyer, J-J, A Bousquet, L Zoganas, JC Schira. 1990. Discomfort and disability glare in VDT operators. En W ork with Display U nits 89 , dirigido por L Berlinguet y D Berthelette. Amsterdam: Elsevier Science.

Meyer, J-J, P Rey, A Bousquet. 1983. An automatic intermittent light stimulator to record flicker perceptive thresholds in patients with retinal disease. En Advances in Diagnostic Visual Optics, dirigido por GM Brenin y IM Siegel. Berlín: Springer-V erlag.

M eyer, J-J, P R ey, B Thorens, A Beaumanoire. 1971. Examen de sujets atteints d'un traummatisme cranio-cérébral par un test perception visuelle: courbe de Lange. Swiss Arch of N eurol 108:213-221.

M eyer, J-J. 1990. Physiologie de la vision et ambiance lumineuse. D ocument de l'A erospatiale, París.

Miller, CS. 1992. Possible models for multiple chemical sensitivity: conceptual issues and role of the limbic system. T oxicol Ind $\mathrm{H}$ ealth 8:181-202.

M iller, RR, JT Y oung, RJ K ociba, DG K eyes, KM Bodner, LL Calhoun, JA Ayres. 1985. Chronic toxicity and oncogenicity bioassay of inhaled ethyl acrylate in fischer 344 rats and B6C 3F 1 mice. D rug Chem T oxicol 8:1-42

M öller, C, L Ö dkvist, B Larsby, R Tham, T Ledin, L Bergholtz. 1990. O toneurological finding among workers exposed to styrene. Scand I W ork Environ $H$ ealth 16:189-194.

Monteagudo, FSE, MJD Cassidy, PI Folb. 1989. Recent developments in aluminum toxicology. $M$ ed T oxicol 4:1-16.

Morata, TC, DE Dunn, LW K retschmer, GK Lemasters, RW K eith. 1993. Effects of occupational exposure to organic solvents and noise on hearing. Scand J W ork Environ $H$ ealth 19:245-254.

M ott, AE, DA Leopold. 1991. Disorders in taste and smell. M ed Clin N Am 75:1321-1353. 
M ott, AE, M Grushka, BJ Sessle. 1993. Diagnosis and management of taste disorders and burning mouth syndrome. D ental C linics of N orth America 37:33-71.

M ountcastle, VB, WH Talbot, I Darian-Smith, HH K ornhuber. 1967. Neural basis of the sense of flutter-vibration. Science :597-600.

M ountcastle, VB. 1974. M edical Physiology. St. Louis: CV M osby.

M uijser, H, EM G H oogendijk, J H oosima. 1988. The effects of occupational exposure to styrene on high-frequency hearing thresholds. Toxicology :331-340.

N aus, A. 1982. Alterations of the smell acuity caused by menthol. J Laryngol 0 tol 82:1009-1011.

Nemery, B. 1990. M etal toxicity and the respiratory tract. E ur Respir J 3:202-219.

O 'R eilly, JP, BL Respicio, FK K urata. 1977. H ana K ai II: A 17-day dry saturation dive at 18.6 ATA. VII: Auditory, visual and gustatory sensations. Undersea Biomed R es 4:307-314.

O gawa, H. 1994. Gustatory cortex of primates: A natomy and physiology. N eurosci Res 20:1-13.

O rganización Mundial de la Salud (OMS). 1981. Arsenic. Environmental $\mathrm{H}$ ealth Criteria, No.18. Ginebra: OM S.

Örtendahl, TW, G Dahlén, HOE Röckert. 1985. The evaluation of oral problems in divers performing electrical welding and cutting under water. U ndersea B iomed R es 12:55-62.

Örtendahl, TW. 1987. O ral changes in divers working with electrical welding/ cutting underwater. Swedish D ent J Suppl 43:1-53.

Otto, D, G Robinson, S Bauman, S Schroeder, P M ushak, D K leinbaum, L Boone. 1985. \%-years follow-up study of children with low-to-moderate lead absorption: Electrophysiological evaluation. E nviron R esearch 38:168-186.

O yanagi, K, E O hama, F Ikuta. 1989. The auditory system in methyl mercurial intoxication: A neuropathological investigation on 14 autopsy cases in Niigata, Japan. Acta Neuropathol 77:561-568

Participants of SCP N os. 147/ 242, H F M orris. 1990. Veterans administration cooperative studies project no. 147: Association of metallic taste with metal ceramic alloys. J P rosthet D ent 63:124-129.

Petersen, PE, C Gormsen. 1991. O ral conditions among $\mathrm{G}$ erman battery factory workers. Community D entistry and Oral E pidemiology 19:104-106.

Pfeiffer, P, H Schwickerath. 1991. Nickel solubility and metallic taste. Zwr 100:762-764, 766,768-779.

Pompeiano, O, JHJ Allum. 1988. Vestibulospinal Control of Posture and Locomotion. Progress in Brain R esearch, N 0.76. Amsterdam: Elsevier.

R ees, T , L D uckert. 1994. H earing loss and other otic disorders. En T extbook of Clinical, O ccupational and Environmental M edicine, dirigido por C Rosenstock. Filadelfia: WB Saunders.

Ressler, KJ, SL Sullivan, LB Buck. 1994. A molecular dissection of spatial patterning in the olfactory system. Curr 0 pin N eurobiol 4:588-596.

Rey, P, A Bousquet. 1990. M edical eye examination strategies for VDT operators. En W ork W ith D isplay $U$ nits 89, dirigido por $L$ Berlinguet y $D$ Berthelette. Amsterdam: Elsevier Science.

Rey, P. 1991. Précis D e M edecine Du T ravail. Ginebra: $M$ edicine et $H$ ygiène.

Rose, CS, PG Heywood, RM Costanzo. 1934. O Ifactory impairment after chronic occupational cadmium exposure. I O ccup M ed 34:600-605.

Rubino, GF. 1990. Epidemiologic survey of ocular disorders: The Italian multicentric research. En W ork with Display U nits 89 , dirigido por L
Berlinguet y D Berthelette. Amsterdam: Elsevier Science Publishers B.V.

R usznak, C, JL D evalia, RJ Davies. 1994. The impact of pollution on allergic disease. Allergy 49:21-27.

R uth, JH. 1986. O dor thresholds and irritation levels of several chemical substances: A review. Am Ind $H$ yg Assoc J 47:142-151.

R yback, LP. 1992. Hearing: The effects of chemicals. O tolaryngology- $\mathrm{H}$ ead and N eck Surgery 106:677-686.

- . 1993. O totoxicity. O tolaryngol Clin N Am 5(26).

Savov, A. 1991. Damages to the ears, nose and throat in copper production. Problemi na Khigienata 16:149-153.

-. 1994. Changes in taste and smell: Drug interactions and food preferences. Nutr Rev 52(II):S11-S14.

Schiffman, SS, HT Nagle. 1992. Effect of environmental pollutants on taste and smell. O tolaryngology- $\mathrm{H}$ ead and N eck Surgery 106:693-700.

Schiffman, SS. 1994. Changes in taste and smell: Drug interactions and food preferences. Nutr Rev 52(II): S11-S14.

Schwartz, BS, DP Ford, KI Bolla, J Agnew, M L Bleecker. 1991. Solvent-associated olfatory dysfunction: $N$ ot a predictor of deficits in learning and memory. Am J Psychiatr 148:751-756.

Schweisfurth, H, C Schottes. 1993. A cute intoxication of a hydrazine-like gas by 19 workers in a garbage dump. $\mathrm{Zbl} \mathrm{H}$ yg 195:46-54

Shusterman, D. 1992. Critical review: The health significance of environmental odor pollution. Arch E nviron $\mathrm{H}$ ealth 47:76-87.

Shusterman, DJ, JE Sheedy. 1992. O ccupational and environmental disorders of the special senses. 0 ccup M ed: State Art R ev 7:515-542.

Siblerud, RL. 1990. The relationship between mercury from dental amalgam and oral cavity health. Ann D ent 49:6-10.

Sinclair. 1981. M echanisms of Cutaneous Sensation. O xford: O xford U niv. Press.

Spielman, AI. 1990. Interaction of saliva and taste. J D ental Res 69:838.

Stevens, JC, WS Cain. 1986. Aging and the perception of nasal irritation. Physiol Behav 37:323-328.

van Dijk, FJH . 1986. N on-auditory effects of noise in industry. II A review of the literature. Int Arch $O$ ccup $\mathrm{E}$ nviron $\mathrm{H}$ ealth 58.

Verriest, G, G Hermans. 1975. Les aptitudes visuelles professionnelles. Bruselas: Imprimerie médicale et scientifique.

Welch, AR, JP Birchall, FW Stafford. 1995. O ccupational rhinitis - Possible mechanisms of pathogenesis. J Laryngol 0 tol 109:104-107.

Weymouth, FW. 1966. The eye as an optical instrument. En Physiology and Biophysics, dirigido por TC Ruch y HD Patton. Londres: Saunders.

Wieslander, G, D Norbäck, C Edling. 1994. O ccupational exposure to water based paint and symptoms from the skin and eyes. O ccup E nviron M ed 51:181-186.

Winberg, S, R Bjerselius, E Baatrup, KB Doving. 1992. The effect of $\mathrm{Cu}(\mathrm{II})$ on the electro-olfactogram (EOG) of the Atlantic salmon (Salmo salar $L$ ) in artificial freshwater of varying inorganic carbon concentrations. E cotoxicology and Environmental Safety 24:167-178.

Witek, TJ. 1993. The nose as a target for adverse effects from the environment: Applying advances in nasal physiologic measurements and mechanisms. Am J Ind M ed 24:649-657.

Yardley, L. 1994. Vertigo and Dizziness. Londres: R outledge.
Y ontchev, E, GE Carlsson, B Hedegård. 1987. Clinical findings in patients with orofacial discomfort complaints. Int J Oral M axillofac Surg $16: 36-44$

\section{0 tras lecturas recomendadas}

Anniko, M, L Sarkady. 1987. Cochlear pathology following exposure to mercury. Acta 0 to-Laryngol 85:213-224

Anniko, M. 1976. Damage to reissner's membrane in the guinea-pig cochlea foolowing acute atoxyl intoxication. Acta O to-L aryngol 18:415-423.

Baloh, RW, V H onrubia. 1990. Clinical N europhysiology of the V estibular System. Filadelfia: FA D avis.

Barregård, L, A Axelsson. 1984. Is there an ototraumatic interaction between noise and solvents? Scand Audiol 13:151-155

Bencko, V, K Symon, V Chládek, J Pihrt. 1977. $\mathrm{H}$ ealth aspects of burning coal with a high arsenic content. II hearing changes in exposed children. Environmental R esearch 13:386-395.

Brandt, T. 1991. Vertigo: Its M ultisensory Syndromes. Londres: Springer-V erlag.

Dancer, E. 1991. Le traumatisme acoustique. M éd/ sci 7:357-367.

Dobie, RA. 1993. M edical-L egal Evaluation of $\mathrm{H}$ earing L oss. N ueva Y ork: $V$ an N ostrand R einhold.

Fornazzari, L, DA Wilkinson, BM K apur, PL Carlen. 1983. Cerebellar, cortical and functional impairment in toluene abusers. Acta Neurol Scand 67:319-329.

H art, WM. 1992. Adler's Physiology of the Eye: Clinical Application. St. Louis: M osby Y ear Book.

Hudspeth, AJ. 1989. How the ear's works work. N ature 341:397-404

H unter, D, RR Bomford, DS Russell. 1940. Poisoning by methyl mercury compounds. Q J M ed 9:193-214.

Johnson, A-C. 1993. The ototoxic effect of toluene and the influence of noise, acetyl salicylic acid or genotype. Scand Audiol Suppl 39:1-40.

K itada, Y 1994. Enhancing effects of transition metals on the salt taste responses of single fibers of the frog glossopharyngeal nerve: Specificity of and similarities among $\mathrm{Ca} 2+, \mathrm{Mg}+$, and $\mathrm{NA}+$ taste responses. Chemical Senses 19:265-277.

M orata, TC. 1989. Study of the effects of simultaneous exposure to noise and carbon disulfide on workers' hearing. Scand Audiol 18:53-58.

-. 1985. The occupational meaning of smell. J H yg E pidemiol M icrobiol I mmunol 29:29-36.

Peters, HA, RL Levine, CG M atthews, LJ Chapman. 1988. Extrapyramidal and other neurologic manifestations associated with carbon disulfide fumigant exposure. Arch N eurol 45:537-540.

Pryor, GT , C S R ebert, R A H owd. 1987. H earing loss in rats caused by inhalation of mixed xylenes and styrene. J Appl T oxicol 7:55-61.

Pryor, GT , J Dickinson, RA H owd, C S R ebert. 1983. Transient cognitive deficits and high-frequency hearing loss in weanling rats exposed to toluene. N eurobehav T oxicol T eratol 5:53-57.

Pryor, GT, RA Howd, ET Uyeno, Thurber. 1985. Interactions between toluene and alcohol. Pharmacol B iochem B ehav 23:401-410.

R ebert, CS, E Becker. 1986. Effects of inhaled carbon disulfide on sensory-evoked potentials of Long-Evans rats. Neurobehav Toxicol Teratol 8:533-541.

Rebert, CS, MJ M atteucci, GT Pryor. 1990. Acute interactive pharmacologic effects of inhaled toluene and dichloromethane on rat brain electrophysiology. Pharmacol Biochem B ehav 36:351-365. 
Rebert, CS, PW Houghton, RA Howd, GT Pryor. 1982. Effects of $\mathrm{H}$ exane on the brainstem auditory response and caudal nerve action potential. N eurobehav T oxicol T eratol 4:79-85.

Rey, P, J J M eyer. 1981. Vision et travail. En Précis De Physiologie D u T ravail, dirigido por J Scherrer. París: $\mathrm{M}$ asson et $\mathrm{Cie}$.

R ollin, H. 1978. D rug related gustatory disorders. Ann Otolaryngol 87:37-42.

Schwartz, J, D 0 tto. 1987. Blood lead, hearing thresholds and neurobehavioral development in children and youth. Arch Environ $H$ ealth 42:153-160.

—. 1991. Lead and minor hearing impairment. Arch Environ $\mathrm{H}$ ealth 46:300-305.
Sharpe, JA, HO Barber. 1993. The Vestibulo-0 cular $R$ eflex and $V$ ertigo. N ueva Y ork: R aven Press.

Smith, R G, AP Burtner. 1994. O ral side-effects of the most frequently prescribed drugs. Special $C$ are $D$ ent 14:96-102.

Sullivan, MJ, KE Rarey, RB Conolly. 1988. $O$ totoxicity of toluene in rats. Neurotoxic T eratol 10:525-530.

T vedt, B, A Edland, K Skyberg, O Forberg. 1991. Delayed neuropsychiatric sequelae after acute hydrogen sulfide poisoning: Effect on motor function, memory, vision and hearing. Acta $\mathrm{Neurol}$ Scand 84:348-351.
Verriest, G, G H ermans. 1976. Influence de l'âge sur les fonctions visuelles. En Vue Et Profession Bruselas: Imprimerie médicale et scientifique (SA).

Wright, T. 1988. Dizziness: A Guide to Disorders of Balance. London: $\mathrm{Croom} \mathrm{H}$ elm.

Wu, M-F, JR Ison, JR Wecker, LW Lapham. 1985. Cutanaeous and auditory function in rats following methyl mercury poisoning. Toxicol Appl Pharmacol 79:377-388.

Yamamura, K, K Terayama, N Yamamoto, A K ohyama, R K ishi. 1989. Effect of acute lead acetate exposure on adult guinea pigs: Electrophysiological study of the inner ear. Fund Appl T oxicol 13:193-214. 
Director del capítulo

L ouis-P hilippe D urocher

\section{Sumario}

Visión general: enfermedades profesionales de la piel

D onald $\mathrm{J}$. Birmingham ........................ 12.2

Cáncer de piel no melanocítico

E lisabete W eiderpass, T imo Partanen, Paolo B offetta

M elanoma maligno

T imo Partanen, Paolo B offetta, E lisabete Weiderpass

Dermatitis de contacto profesionales

D enis Sasseville . . . . . . . . . . . . . . . . . . . . 12.10

Prevención de las dermatosis profesionales

L ouis-P hillipe D urocher

Distrofia ungüeal profesional

C.D. Calnan.

Estigmas

H. M ierzecki 


\section{- VISION GENERAL: ENFERMEDADES PROFESIONALES DE LA PIEL}

Donald J. Birmingham

El crecimiento de la industria, la agricultura, la minería y las manufacturas han ido en paralelo con el desarrollo de enfermedades profesionales de la piel. Los primeros efectos nocivos descritos fueron ulceraciones de la piel causadas por sales metálicas en la minería. Al desarrollar los distintos pueblos y culturas el uso de materiales nuevos se han creado nuevas técnicas y procesos de fabricación. Estos avances tecnológicos han modificado el medio ambiente de trabajo y en cada período algún aspecto del cambio tecnológico ha alterado la salud de los trabajadores. $L$ as enfermedades profesionales en general y las enfermedades de la piel en particular constituyen desde hace mucho tiempo uno de los efectos indeseables del avance industrial.

H ace cincuenta años en Estados Unidos, por ejemplo, las enfermedades profesionales de la piel representaban como mínimo el $65-70 \%$ de todas las enfermedades profesionales comunicadas. Recientemente, los datos estadísticos recogidos por el Departamento de Trabajo de Estados U nidos indican un descenso en la frecuencia de aproximadamente un $34 \%$. Este descenso en el número de casos se asocia a la creciente automatización, al aislamiento de los procesos industriales y al mejor nivel educativo de los cuadros directivos, los supervisores y los trabajadores respecto a las enfermedades profesionales en general, sin duda, estas medidas preventivas han beneficiado al conjunto de los trabajadores en muchas de las fábricas de gran tamaño en las que se dispone de buenos servicios de prevención, aunque una gran parte de los trabajadores todavía desarrollan su actividad en condiciones que favorecen la aparición de enfermedades profesionales. Por desgracia, en la mayor parte de los países no se ha realizado una valoración exacta del número de casos, factores causales, tiempo perdido o coste real de las enfermedades cutáneas profesionales.

Para denominar la enfermedades cutáneas profesionales se utilizan términos generales, como dermatitis industrial o laboral - eccema profesional, aunque también suelen emplearse nombres relacionados con la causa y el efecto. Dermatitis del cemento, úlceras por cromo, cloracné, prurito de la fibra de vidrio, urticaria del petróleo y urticaria del caucho son algunos ejemplos. Debido a la variedad de los cambios cutáneos inducidos por los agentes 0 por las condiciones de trabajo, estas enfermedades se denominan con acierto dermatosis profesionales, un término que abarca cualquier alteración producida directamente o agravada por el medio ambiente de trabajo. La piel puede servir también como vía de entrada de algunos agentes tóxicos que provocan envenenamiento químico mediante absorción percutánea.

\section{Defensas cutáneas}

Según la experiencia acumulada, se sabe que la piel puede reaccionar frente a un gran número de agentes químicos, físicos y biológicos que actúan solos o en combinación. A pesar de esta vulnerabilidad, la dermatitis profesional no es un problema inevitable en el trabajo. La mayoría de los trabajadores no padecen trastornos cutáneos profesionales, debido en parte a la protección inherente al diseño y función de la piel y en parte a la utilización diaria de medidas protectoras personales que reducen al mínimo el contacto de la piel con sustancias peligrosas en el puesto de trabajo. Sería esperanzador que la ausencia de enfermedad en la mayoría de los trabajadores se debiera también a que los trabajos estuvieran diseñados para reducir al mínimo la exposición a situaciones peligrosas para la piel.
Figura 12.1 • Representación esquemática de la piel.

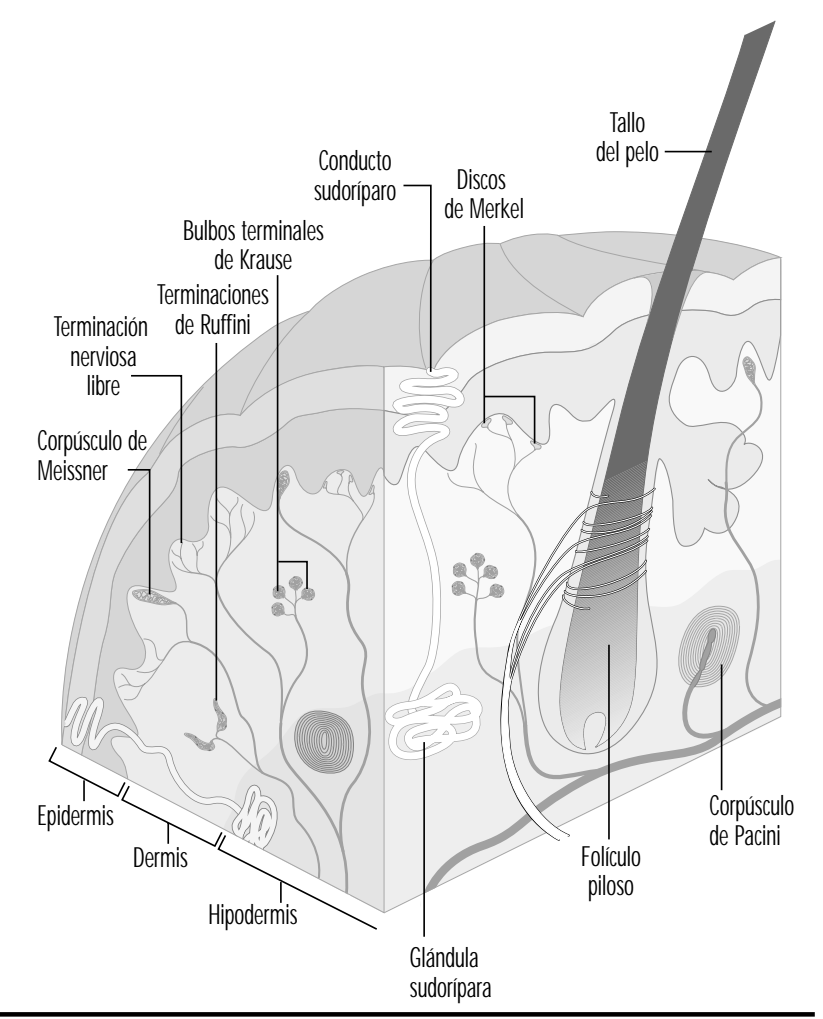

\section{La piel}

La piel humana, salvo en las palmas de las manos y las plantas de los pies, es bastante fina y de grosor variable. Tiene dos capas: la epidermis (externa) y la dermis (interna). La piel funciona como una barrera flexible, gracias a los componentes de colágeno y elásticos de la dermis. La piel proporciona un escudo o defensa única que protege, dentro de ciertos límites, frente a las fuerzas mecánicas y a la penetración de diversos agentes químicos. La piel controla la pérdida de agua del organismo y lo protege contra los efectos de la luz natural y artificial, del calor y del frío. La piel intacta y sus secreciones constituyen una barrera defensiva bastante eficaz frente a los microorganismos, siempre que no se altere por lesiones químicas o mecánicas. En la Figura 12.1 se muestra un esquema de la piel y se describen sus funciones fisiológicas.

La capa epidérmica externa de células muertas (queratina) sirve de escudo contra los elementos del mundo exterior. Si estas células se someten a presiones de fricción, pueden formar un manto protector y también pueden engrosarse por la exposición a los rayos ultravioleta. Los queratinocitos se disponen normalmente en forma de empedrado con capas de 15 ó 16 células y ofrecen una protección limitada para el agua, los materiales hidrosolubles y los ácidos débiles. Su papel defensivo frente al contacto repetido o prolongado con productos alcalinos orgánicos o inorgánicos, incluso a concentraciones bajas, es menor. Los materiales alcalinos ablandan pero no disuelven por completo los queratinocitos. El ablandamiento altera su estructura interna lo suficiente para debilitar la cohesión celular. La integridad de la capa de queratina es un factor que se suma al contenido de agua y este, a su vez, influye en su flexibilidad. Las temperaturas bajas y la humedad, los agentes químicos deshidratantes como los ácidos, los álcalis, los disolventes y los limpiadores fuertes, provocan la pérdida de agua de la capa de queratina y esto, a su vez, hace que las células se curven y se 
rompan. Esto reduce su papel de barrera y compromete su función defensiva frente a la pérdida de agua del organismo y a la penetración de agentes externos.

Los sistemas de defensa cutánea sólo son eficaces dentro de ciertos límites. Cualquier evento que interrumpa uno o más de los elementos defensivos pondrá en peligro toda la cadena defensiva. Por ejemplo, la absorción percutánea aumenta cuando la continuidad de la piel ha sido alterada por lesiones químicas 0 físicas, o por la abrasión mecánica de la capa de queratina. Los materiales tóxicos pueden absorberse no sólo a través de la piel, sino también a través de los folículos pilosos y los orificios y conductos sudoríparos. E stas últimas vías no son tan importantes como la absorción transepidérmica. Varios productos químicos utilizados en la industria y en la agricultura han provocado toxicidad sistémica por absorción a través de la piel. Algunos ejemplos bien conocidos son el mercurio, el tetraetilo de plomo, compuestos aromáticos y aminonitrogenados, y ciertos pesticidas organofosforados e hidroclorados. Debe señalarse que, aunque muchas sustancias causan toxicidad sistémica por vía inhalatoria generalmente, también es posible la absorción percutánea, que no debe dejar de tenerse en cuenta.

U na característica notable de la barrera defensiva cutánea es la capacidad de la piel para sustituir de forma continua las células basales que dotan a la epidermis de su propio sistema interno de replicación y reparación.

La capacidad de la piel para actuar como intercambiador de calor es fundamental para la vida. La función de las glándulas sudoríparas, la dilatación y contracción vascular bajo control nervioso tienen una importancia vital en la regulación del calor corporal, al igual que la evaporación de agua sobre la superficie cutánea. $L$ a contracción de los vasos sanguíneos protege frente a la exposición al frío conservando el calor corporal central. M últiples terminaciones nerviosas situadas en el interior de la piel actúan como sensores de calor, de frío y de otros excitantes, transmitiendo la presencia del estimulo al sistema nervioso que responde al agente provocador.

El pigmento (melanina) que fabrican los melanocitos localizados en la capa de células basales de la epidermis es un factor defensivo de primer orden frente a las lesiones por radiación ultravioleta, un componente potencialmente dañino de la luz solar y de algunas formas de luz artificial. Los gránulos de melanina son captados por las células epidérmicas y sirven de protección añadida frente a los rayos de luz natural o artificial que atraviesan la piel. U na protección adicional, aunque de menor grado, es la conferida por la capa de queratina engrosada tras la exposición a la luz ultravioleta (como se comenta más adelante, es muy importante que las personas que trabajan al aire libre se apliquen en la piel expuesta una crema solar con un agente protector frente los rayos UV-A y UV-B (de un factor 15 como mínimo) y se vistan de forma adecuada para protegerse frente a las lesiones por exposición a la luz solar).

\section{Tipos de enfermedades profesionales de la piel}

Las dermatosis profesionales varían en su aspecto (morfología) y gravedad. Los efectos de una exposición profesional pueden oscilar entre un ligero eritema (enrojecimiento) o alteración del color de la piel y una alteración mucho más compleja, como puede ser un tumor maligno. A pesar de la amplia serie de sustancias productoras de alteraciones cutáneas que se conocen, en la práctica resulta difícil asociar una lesión específica con la exposición a un material concreto. Sin embargo, algunos grupos químicos se asocian a patrones de reacción característicos. La naturaleza de las lesiones y su localización pueden aportar indicios claros de la causa.

Diversos agentes químicos, con o sin efectos tóxicos directos sobre la piel, pueden causar también una intoxicación sistémica tras la absorción cutánea. Para que actúe como toxina sistémica, el agente debe atravesar la queratina y las capas celulares epidérmicas y, después, la unión dermo-epidérmica. A partir de este punto ya puede acceder con rapidez a la circulación sanguínea y al sistema linfático, y puede llegar a órganos diana vulnerables.

\section{Dermatitis de contacto aguda (irritantes 0 alérgica).}

La dermatitis eccematosa de contacto aguda puede ser causada por cientos de sustancias químicas, plantas y agentes fotorreactivos irritantes y sensibilizantes. La mayoría de las dermatosis alérgicas profesionales pueden clasificarse como dermatitis de contacto eccematosas agudas. Los signos clínicos son calor, enrojecimiento, hinchazón, formación de vesículas y exudación. LoS pacientes sufren picores, sensación de quemazón y malestar general. El dorso de las manos y la parte interna de las muñecas y los antebrazos son los puntos afectados con más frecuencia, aunque la dermatitis de contacto puede aparecer en cualquier punto de la piel. Si la dermatosis aparece en la frente, los párpados, los pabellones auriculares, la cara o el cuello, es lógico sospechar que la reacción fue provocada por algún componente del polvo o por un vapor. Si la dermatitis de contacto es generalizada y no se limita a una 0 unas pocas zonas, suele tener su origen en una exposición más general, como vestir una ropa contaminada, o por autosensibilización a partir de una dermatitis previa. La aparición de lesiones vesiculares internas con destrucción de tejidos indica en general la acción de un agente irritante absoluto o muy intenso. Los antecedentes de exposición, que deben investigarse en todo control médico de la dermatitis profesional, pueden revelar el agente causal sospechoso. En un artículo que acompaña a este capítulo se incluye una información más detallada sobre la dermatitis de contacto.

\section{Dermatitis de contacto subaguda}

M ediante un efecto acumulativo, el contacto reiterado con irritantes débiles y moderados puede provocar una forma subaguda de dermatitis de contacto caracterizada por la aparición de placas rojas y secas. Si la exposición continúa, la dermatitis se cronifica.

\section{Dermatitis de contacto eccematosa crónica}

Si una dermatitis de contacto recidiva durante un período prolongado de tiempo se denomina dermatitis de contacto eccematosa crónica. Las zonas afectadas con más frecuencia por las lesiones eccematosas crónicas son las manos, los dedos, las muñecas y los antebrazos; la piel afectada está enrojecida, seca y es descamativa. En algunos casos se producen grietas y fisuras en los dedos y las palmas de las manos. 0 tro hallazgo frecuente es la distrofia ungueal crónica. Con frecuencia, las lesiones rezuman líquido tras una nueva exposición al agente responsable o a causa de un tratamiento o cuidado inapropiados. Numerosos agentes que no fueron responsables de la dermatosis original mantienen este problema cutáneo recidivante crónico.

\section{Dermatitis por fotosensibilidad (fototóxica o fotoalérgica)}

La mayoría de las fotorreacciones sobre la piel son de origen fototóxico. Las fuentes de luz artificiales o naturales, solas o combinadas con varios agentes químicos, plantas o fármacos, pueden inducir una respuesta fototóxica o de fotosensibilidad. La reacción fototóxica suele limitarse a las zonas expuestas a la luz, mientras que la reacción de fotosensibilidad suele desarrollarse en superficies no expuestas. Algunos ejemplos de sustancias químicas fotorreactivas son los productos de destilación del alquitrán de hulla, como la creosota, la brea de alquitrán y el antraceno. Los miembros de la familia de plantas U mbelliferae son productos fotorreactivos bien conocidos. Entre los miembros de la familia figuran la chirivía, el apio, las zanahorias, el hinojo y el eneldo. Los psoralenos son el agente reactivo de estas plantas. 
Foliculitis y dermatosis acneiformes, incluido el cloracné Las personas que desempeñan su trabajo en condiciones de suciedad desarrollan con frecuencia lesiones que afectan a los orificios foliculares. L os comedones (puntos negros) pueden ser el único efecto obvio de la exposición, aunque suelen producirse también infecciones secundarias del folículo. El problema puede agravarse también si la higiene personal y los hábitos de aseo son inapropiados. L as lesiones foliculares suelen aparecer en los antebrazos y, con menos frecuencia, en los muslos y las nalgas, aunque pueden presentarse en cualquier sitio, salvo en las palmas de las manos y las plantas de los pies.

L as lesiones foliculares y acneiformes se producen por la exposición excesiva a líquidos de corte insolubles, a diversos productos del alquitrán, a la parafina y a ciertos hidrocarburos clorados aromáticos. El acné producido por cualquiera de estos agentes puede ser muy extenso. El cloracné es la forma más grave, no sólo por la posible desfiguración (hiperpigmentación y cicatrización), sino también por la lesión hepática, incluida la porfiria cutánea tarda y otros efectos sistémicos que pueden provocar los agentes químicos. Entre los compuestos que causan cloracné se encuentran los cloronaftalenos, los clorodifenilos, los clorotrifenilos, la hexaclorodibenzo-p-dioxina, el tetracloroazoxibenceno y la tetraclorodibenzodioxina (TCDD). Los puntos negros y las lesiones quísticas del cloracné suelen aparecer primero en las zonas laterales de la frente y en los párpados. Si la exposición continúa, pueden aparecer lesiones sobre extensas áreas corporales, salvo en las zonas palmares y plantares.

\section{Reacciones inducidas por el sudor}

Numerosos puestos de trabajo implican exposición al calor; si el calor y la sudoración son excesivas y se siguen de una evaporación insuficiente del sudor de la piel, puede producirse un sarpuIlido. Si la zona afectada se erosiona por el roce de una superficie cutánea con otra, aparecen con frecuencia infecciones bacterianas o fúngicas. Esto sucede sobre todo en el hueco axilar, bajo las mamas, en la ingle y entre las nalgas.

\section{Cambios de pigmentación}

Las alteraciones del color de la piel de origen profesional pueden ser provocadas por colorantes, metales pesados, explosivos, algunos hidrocarburos clorados, alquitranes y la luz solar. La variación del color cutáneo puede producirse por una reacción química en la queratina, como sucede cuando ésta se tiñe con metafenilenodiamina, azul de metileno o trinitrotolueno. A veces se produce un cambio de color permanente en zonas más profundas de la piel, como sucede con la argiria o los tatuajes traumáticos. El aumento de pigmentación inducido por los hidrocarburos clorados, los compuestos de alquitrán, los metales pesados y los aceites derivados del petróleo se produce a consecuencia de la estimulación y la producción excesiva de melanina. Las quemaduras, la dermatitis de contacto, y el contacto con ciertos compuestos de hidroquinona u otros agentes oxidantes utilizados en algunos productos sanitarios y adhesivos (como los aminofenoles terciarios, el catecolbutilo terciario y el fenol butilo terciario) pueden provocar hipopigmentación o despigmentación en zonas cutáneas determinadas.

\section{Neoplasias}

Las lesiones neoplásicas de origen profesional pueden ser malignas o benignas (cancerosas o no cancerosas). El melanoma y el cáncer de piel no melanocítico se comentan en otros dos apartados de este capítulo. Los quistes traumáticos, los fibromas, las verrugas por amianto, petróleo o alquitrán y el queratoacantoma son neoplasias benignas típicas. Los queratoacantomas pueden asociarse a una exposición excesiva a la luz solar y también se han relacionado con el contacto con petróleo, brea de alquitrán y alquitrán.

\section{Alteraciones ulcerosas}

Está demostrada la acción ulcerosa de los siguientes compuestos químicos: ácido crómico, dicromato potásico concentrado, trióxido de arsenio, óxido de calcio, nitrato cálcico y carburo cálcico. L as principales zonas afectadas son los dedos de las manos y los pliegues y grietas palmares. Varios de estos agentes producen también perforación del tabique nasal.

Las quemaduras químicas o térmicas, las heridas contusas 0 las infecciones bacterianas o fúngicas pueden provocar excavaciones ulcerosas de la parte afectada.

\section{Granulomas}

En muchos puestos de trabajo pueden producirse granulomas si se dan las circunstancias apropiadas. La exposición profesional a bacterias, hongos, virus o parásitos puede causar granulomas. Sustancias inertes como fragmentos óseos, astillas de madera, carbonilla, restos de coral o grava y minerales como el berilio, el sílice y el circonio pueden provocar también granulomas tras incrustarse en la piel.

\section{Otros trastornos}

La dermatitis de contacto profesional representa al menos el $80 \%$ de todos los casos de enfermedades cutáneas profesionales. Sin embargo, en la clasificación anterior no se incluyen otras alteraciones que afectan a la piel, el pelo y las uñas. U n ejemplo es la pérdida de pelo provocada por las quemaduras, los traumatismos mecánicos 0 algunos agentes químicos. 0 tro es el enrojecimiento facial que aparece tras el consumo de alcohol combinado con la inhalación de ciertos agentes químicos, como el tricloroetileno y el disulfiram. En los limpiadores de tanques de polimerización de cloruro de polivinilo se ha descrito la aparición de acroosteólisis, un trastorno óseo de los dedos asociado a cambios vasculares de las manos y del antebrazo (con o sin síndrome de Raynaud). Las alteraciones ungueales se tratan en un artículo aparte de este capítulo.

\section{Fisiopatología o mecanismos de las enfermedades profesionales de la piel}

Los mecanismos por los que actúan los irritantes primarios sólo se conocen de forma parcial, por ejemplo, los gases irritantes 0 productores de vesículas (mostaza nitrogenada o bromometano y lewisita, etc) interfieren con ciertas enzimas y, por tanto, bloquean fases selectivas en el metabolismo de los hidratos de carbono, las grasas y las proteínas. No se conoce con exactitud por qué y cómo se producen las vesículas, pero las observaciones sobre la forma en que los agentes químicos reaccionan fuera del organismo aportan algunas ideas sobre los posibles mecanismos biológicos.

En resumen, como los álcalis reaccionan con los ácidos, los lípidos o las proteínas, se supone que también reaccionan con los lípidos y las proteínas de la piel. De este modo, los lípidos de la superficie cutánea se modifican y se altera la estructura de la queratina. Los disolventes orgánicos e inorgánicos disuelven las grasas y las sustancias oleosas y tienen el mismo efecto sobre los lípidos cutáneos. No obstante, además, parece que los disolventes extraen alguna sustancia o modifican la piel de forma que la capa de queratina se deshidrata, con lo que la barrera defensiva de la piel deja de estar intacta. La agresión continuada da lugar a una reacción inflamatoria que puede originar una dermatitis de contacto.

Algunos agentes químicos se combinan rápidamente con el agua de la piel o de la superficie de la piel y provocan una reacción química intensa. Los compuestos de calcio, como el óxido 
de calcio y el cloruro cálcico, producen su efecto irritante de esta forma.

A lgunas sustancias como la brea de alquitrán de hulla, la creosota, el petróleo sin refinar y ciertos hidrocarburos clorados aromáticos, en combinación con la exposición a la luz solar, estimulan a las células productoras de pigmentos y la sobreproducción provoca una hiperpigmentación. La dermatitis aguda también puede provocar hiperpigmentación tras la curación. Por otro lado, las quemaduras, los traumatismos mecánicos, la dermatitis de contacto crónica y el contacto con éter de monobencilo de hidroquinona o con ciertas sustancias fenólicas pueden inducir una hipo o despigmentación cutánea.

El trióxido de arsenio, la brea de alquitrán de hulla, la luz solar y la radiación ionizante, entre otros agentes, pueden lesionar las células de la piel de forma que el crecimiento celular anormal origina un cambio canceroso en la piel expuesta.

A diferencia de lo que sucede con la irritación primaria, la sensibilización alérgica se produce como consecuencia de una alteración específicamente adquirida de la capacidad de reacción, inducida por la activación de las células T. Durante varios años se admitía que la dermatitis de contacto eccematosa alérgica representaba aproximadamente el $20 \%$ de todas las dermatosis profesionales. Probablemente, esta cifra sea demasiado conservadora si se tiene en cuenta la continua introducción de agentes químicos nuevos, muchos de los cuales se ha demostrado que causan dermatitis de contacto alérgica.

\section{Causas de las enfermedades profesionales de la piel}

EI número de materiales o productos que causan enfermedades cutáneas profesionales es ilimitado. En la actualidad, se clasifican en las categorías de agentes mecánicos, físicos, biológicos y químicos, y su número aumenta de año en año.

\section{Agentes mecánicos}

La fricción, la presión y otras formas de traumatismos más intensos pueden inducir cambios que varían entre la formación de callos y vesículas y la provocación de miositis, tenosinovitis, lesiones óseas, lesiones nerviosas, laceraciones, desgarros tisulares o abrasiones. Las laceraciones, las abrasiones, los desgarros tisulares y la formación de vesículas favorecen la aparición de infecciones bacterianas secundarias 0 , con menos frecuencia, fúngicas. Casi todo el mundo se expone todos los días a una o más formas de traumatismos mecánicos leves o moderados. Sin embargo, las personas que utilizan remachadoras, cortadoras, taladradoras 0 martillos neumáticos son las que presentan más riesgo de sufrir lesiones neurovasculares, de partes blandas, fibrosas u óseas en las manos y los antebrazos, debido a los traumatismos repetitivos de la herramienta. El uso de máquinas productoras de vibraciones que operan en ciertos intervalos de frecuencia puede provocar espasmos dolorosos en los dedos de la mano que las sostiene. EI cambio de puesto de trabajo, si es posible, alivia los síntomas. Los equipos modernos están diseñados para reducir la vibración y eliminar así los problemas.

\section{Agentes físicos}

El calor, el frío, la electricidad, la luz solar, la luz ultravioleta, la radiación láser y las fuentes de alta energía como los rayos $X$, el radio y otras sustancias radiactivas son potencialmente nocivas para la piel y para todo el organismo. La humedad y la temperatura elevadas en el lugar de trabajo o en un ambiente de trabajo tropical pueden interferir con el mecanismo de la sudoración y causar efectos sistémicos, produciendo un cuadro clínico conocido como síndrome de retención del sudor. U na exposición más ligera al calor puede inducir sarpullido, intértrigo, maceración cutánea y favorecer las infecciones bacterianas o fúngicas, sobre todo en las personas diabéticas y con sobrepeso.
Las quemaduras térmicas son frecuentes en trabajadores de hornos eléctricos, trabajadores de fundición de plomo, soldadores, químicos de laboratorio y trabajadores de oleoductos, de carreteras, de la construcción y reparación de techos y de las plantas de producción de alquitrán que tienen contacto con el alquitrán líquido.

La exposición prolongada al agua fría o a temperaturas bajas provoca lesiones de intensidad variable que oscilan desde eritema a vesículas, ulceraciones y gangrena. Las congelaciones que afectan a la nariz, las orejas y los dedos de las manos y de los pies de los trabajadores de la construcción, bomberos, carteros, militares y otros trabajadores al aire libre es una forma frecuente de lesión por frío.

La exposición a la electricidad por contacto en cortocircuitos, cables sin aislante o aparatos eléctricos defectuosos provoca quemaduras en la piel y la destrucción de tejidos más profundos.

Pocos son los trabajadores que no se exponen a la luz solar y algunos individuos con exposición repetida sufren graves lesiones actínicas de la piel. La industria moderna tiene también numerosas fuentes de longitudes de onda ultravioleta artificiales potencialmente dañinas, como sucede en los procesos de soldadura, fusión de metal, transferencia de metal fundido, soplado de vidrio, manejo de hornos eléctricos, utilización de sopletes y operaciones con rayo láser. Además de la capacidad natural de los rayos ultravioleta presentes en la luz natural o artificial para lesionar la piel, el alquitrán de hulla y algunos de sus derivados, incluidos ciertos colorantes, algunos componentes de plantas y de frutas (captadores de la luz) y diversos medicamentos tópicos y parenterales contienen agentes químicos nocivos que se activan por ciertas longitudes de onda de los rayos ultravioleta. Estos efectos de fotorreacción pueden producirse por mecanismos fototóxicos o fotoalérgicos.

La energía electromagnética de alta intensidad asociada a los rayos láser puede lesionar los tejidos humanos, sobre todo del ojo. El riesgo de lesión cutánea es mínimo, pero puede ocurrir.

\section{Agentes biológicos}

L as exposiciones profesionales a bacterias, hongos, virus o parásitos pueden provocar infecciones primarias o secundarias de la piel. Antes de disponer de los tratamientos antibióticos modernos, las infecciones bacterianas y fúngicas eran más frecuentes y causaban enfermedades discapacitantes e incluso a veces la muerte. Aunque las infecciones bacterianas pueden producirse en cualquier actividad laboral, en algunos trabajadores, como cuidadores de animales, agricultores y ganaderos, pescadores, procesadores de alimentos y personas que manipulan cueros, el potencial de exposición es mayor. De la misma forma, las infecciones por hongos (levaduras) son comunes en panaderos, camareros, trabajadores de empresas de enlatado, cocineros, friegaplatos y trabajadores de guarderías y de empresas de preparación de alimentos. Las dermatosis debidas a infecciones parasitarias no son frecuentes y suelen observarse en trabajadores agrícolas y ganaderos, personas que manipulan grano o trabajan en la recolección, estibadores y trabajadores de silos.

Las infecciones cutáneas víricas son escasas, pero todavía se comunican casos de nódulos del ordeñador en trabajadores de empresas de productos lácteos, de herpes simple en el personal sanitario, técnicos dentales y estomatólogos, y de viruela ovina en personas que trabajan con ganado.

\section{Agentes químicos}

L os compuestos químicos orgánicos e inorgánicos son la principal fuente de peligro para la piel. Todos los años se incorporan al medio ambiente de trabajo cientos de agentes nuevos, y muchos de ellos provocan lesiones cutáneas al actuar como irritantes primarios o sensibilizadores alérgicos. Se ha calculado que los 
agentes químicos irritantes primarios causan el $75 \%$ de los casos de dermatitis profesionales. Sin embargo, en los centros clínicos donde suelen emplearse pruebas con parches diagnósticos, la frecuencia de dermatitis de contacto alérgica profesional ha aumentado. Por definición, un irritante primario es una sustancia química que dañará la piel de cualquier persona si se produce una exposición suficiente. Los irritantes pueden ser destructivos (fuertes o absolutos), como sucede con los ácidos concentrados, los álcalis, las sales metálicas, algunos disolventes y ciertos gases. Estos efectos tóxicos pueden observarse en escasos minutos, dependiendo de la concentración del agente de contacto y de la duración de la exposición. En cambio, los ácidos y álcalis diluidos, incluidos los polvos alcalinos, varios disolventes y líquidos de corte solubles, entre otros, pueden necesitar varios días de contacto repetido para producir efectos apreciables. Estos materiales se denominan "irritantes acumulativos o débiles".

\section{Plantas y maderas}

Las plantas y las maderas suelen clasificarse como una causa aparte de enfermedad cutánea, aunque pueden también incluirse correctamente en el grupo de agentes químicos. Numerosas plantas provocan irritación mecánica y química y sensibilización alérgica, mientras que otras se caracterizan por su capacidad fotorreactiva. La familia Anacardiaceae, que incluye la hiedra, el roble y el zumaque venenosos, el aceite de cáscara de anacardo y la nuez de areca, es una causa bien conocida de dermatitis profesional debido a sus agentes activos (fenoles polihídricos). La hiedra, el roble y el zumaque venenosos son causas comunes de dermatitis de contacto alérgica. 0 tras plantas que se asocian a dermatitis de contacto profesionales y no profesionales son las siguientes: judías, crisantemo, lúpulo, yute, adelfas, piña, primavera, ambrosía, jacinto y los bulbos de tulipanes. $L$ as frutas y las verduras, como los espárragos, las zanahorias, el apio, la achicoria, los cítricos, el ajo y las cebollas pueden producir dermatitis de contacto en recolectores, envasadores de alimentos y trabajadores de empresas de preparación de comida.

Varios tipos de madera se han relacionado con dermatosis profesionales en madereros y trabajadores de aserraderos, carpinteros y otros grupos de artesanos de la madera. Sin embargo, la frecuencia de enfermedad cutánea es muy inferior a la que tiene lugar por contacto con plantas venenosas. Es probable que algunos de los productos químicos que se emplean para conservar la madera causen más reacciones de dermatitis que las resinas oleosas que contiene la madera. Entre los conservantes que se utilizan para la protección frente a insectos, hongos y el deterioro causado por la suciedad y la humedad se encuentran los difenilos clorados, los naftalenos clorados, el naftenato de cobre, la creosota, los fluoruros, los mercuriales orgánicos, el alquitrán y algunos compuestos arsenicales; todos ellos son causas conocidas de enfermedades cutáneas profesionales.

\section{Factores no profesionales en las enfermedades profesionales de la piel}

Si se tienen en cuenta las numerosas causas directas de enfermedades cutáneas profesionales mencionadas anteriormente, se comprende fácilmente que, en la práctica, en cualquier tipo de trabajo existen peligros evidentes y, con frecuencia, ocultos. D ebe prestarse atención también a los factores predisponentes 0 indirectos. La predisposición puede heredarse y relacionarse con el color y el tipo de piel o puede representar un defecto cutáneo adquirido por otras exposiciones. Con independencia de la causa, algunos trabajadores toleran peor los materiales o las condiciones de trabajo en el ambiente laboral. En las grandes plantas industriales, los programas médicos y de higiene pueden ofrecer la oportunidad de colocar a estos empleados en situaciones laborales que no alteren más su salud. En las industrias pequeñas, sin embargo, a veces no se presta una atención médica adecuada a los factores causales indirectos o predisponentes.

\section{Situaciones cutáneas previas}

Varias enfermedades no profesionales que afectan a la piel pueden empeorar por diversos factores de exposición laboral.

Acné. El acné del adolescente suele empeorar por la exposición a maquinaria, a aceites y al alquitrán. En estas personas, los aceites insolubles, diversas fracciones del alquitrán, la grasas y los agentes químicos productores de cloracné son claros factores de riesgo.

E ccemas crónicos. La detección de la causa de un eccema crónico que afecta a las manos y a veces, a otras localizaciones distantes, puede ser difícil. La dermatitis alérgica, el ponfólix, el eccema atópico, la psoriasis pustulosa y las infecciones fúngicas son algunos ejemplos. Cualquiera que sea la situación, la erupción puede empeorar a causa de una gran cantidad de agentes químicos irritantes como plásticos, disolventes, líquidos para corte y limpiadores industriales, así como por la humedad prolongada. Los trabajadores obligados a continuar en el mismo puesto sufrirán muchas molestias y es probable que disminuya su eficiencia.

D ermatomicosis. Las infecciones fúngicas pueden empeorar por la actividad profesional. Si están afectadas las uñas, puede ser difícil valorar el papel de los agentes químicos o de los traumatismos en el trastorno. La tiña crónica del pie sufrirá empeoramientos periódicos, sobre todo si deben utilizarse calzados especiales cerrados.

$\mathrm{H}$ iperhidrosis. La sudoración excesiva de las palmas de las manos y las plantas de los pies puede ablandar (macerar) la piel, sobre todo si es necesario utilizar guantes o calzados impermeables. Esto aumentará la vulnerabilidad de una persona a los efectos de otras exposiciones.

Situaciones varias. L os trabajadores con erupciones polimórficas ligeras, lupus discoide crónico eritematoso, porfiria o vitíligo tienen mayor riesgo, sobre todo si se exponen simultáneamente a la radiación ultravioleta de la luz natural 0 artificial.

\section{Tipo de piel y pigmentación}

Las personas pelirrojas y las rubias de ojos azules, sobre todo las de origen celta, toleran menos la luz solar que las personas con tipos de piel más oscuros. Este tipo de piel también tolera peor la exposición a productos químicos y a plantas fotorreactivas y se sospecha que es más sensible a la acción de los agentes químicos irritantes primarios, incluidos los disolventes. En general, la piel negra tolera más la luz solar y los agentes químicos fotorreactivos y es menos propensa a la inducción de cáncer de piel. Sin embargo, la piel más oscura tiende a responder a los traumatismos mecánicos, físicos o químicos mostrando una pigmentación postinflamatoria y también es más propensa a formar queloides después de los traumatismos.

Las personas con ciertos tipos de piel, como las muy velludas, grasas y morenas, son más propensas a sufrir acné y foliculitis. Los trabajadores con piel seca y los que padecen ictiosis pueden presentar problemas si deben desarrollar su actividad laboral en ambientes con baja humedad o con agentes químicos que deshidratan la piel. La necesidad de llevar ropa protectora especial puede causar grandes molestias a los trabajadores que sudan de forma profusa. De la misma forma, los individuos con sobrepeso suelen presentar sarpullidos durante los meses cálidos en ambientes laborales con calor excesivo o en los climas tropicales. Aunque el sudor contribuye a enfriar la piel, también puede hidrolizar algunos compuestos químicos que actuarán como irritantes cutáneos. 


\section{Diagnóstico de las enfermedades profesionales de la piel}

El mejor método para determinar la causa y el efecto de las enfermedades cutáneas profesionales es una historia detallada, en la que se investigará el estado de salud pasado y presente y la situación laboral del trabajador. Es importante conocer los antecedentes familiares, sobre todo las alergias y las enfermedades personales pasadas y de la infancia. D eberá registrarse el tipo de trabajo, los materiales que se manipulan y el tiempo de permanencia en ese puesto. Es importante saber cuándo y dónde apareció la erupción, cómo evoluciona ésta fuera del trabajo, si hay otros trabajadores afectados, qué productos se utilizaron para limpiar y proteger la piel y qué fármacos se han empleado en el tratamiento (automedicación y medicamentos prescritos); así como si el trabajador tiene la piel seca, eccema crónico de manos, psoriasis u otros problemas cutáneos; además, hay que comprobar qué medicamentos se utilizaron en el tratamiento de cualquier enfermedad concreta, y, por último, qué materiales se han utilizado en actividades domésticas como la jardinería, el trabajo en madera o la pintura.

L os elementos siguientes son un parte importante del diagnóstico clínico:

- Aspecto de las lesiones. Las dermatosis de contacto eccematosas agudas 0 crónicas son las más comunes. Pueden presentarse lesiones granulomatosas ulcerativas, neoplásicas, pigmentarias, acneiformes o foliculares, y trastornos como el síndrome de R aynaud y la urticaria de contacto.

- A reas afectadas. Las manos, dedos, muñecas y antebrazos son las zonas más afectadas. La dermatosis causada por la exposición al polvo y a los humos suele aparecer en la frente, la cara y la cara anterior del cuello. La autosensibilización (diseminación) puede diseminar una dermatosis profesional o no profesional.

- Pruebas diagnósticas. Si es necesario, deberán realizarse pruebas de laboratorio para detectar bacterias, hongos y parásitos. Si se sospecha la existencia de reacciones alérgicas, pueden utilizarse las pruebas diagnósticas con parches para detectar alergias profesionales y no profesionales, incluida la fotosensibilización. Estas pruebas son un procedimiento muy útil y se comentan en otro artículo de este capítulo. A veces puede obtenerse información práctica mediante el análisis bioquímico de la sangre, la orina o los tejidos (piel, pelo y uñas).

- Evolución. De todas las alteraciones cutáneas inducidas por agentes o por ciertas condiciones de trabajo, las dermatosis de contacto eccematosas crónicas y agudas son las más frecuentes. Las siguientes son la erupciones acneiformes y foliculares. EI resto de trastornos, incluido el cloracné, constituyen un número pequeño, pero aún importante, debido a su naturaleza crónica y a la cicatrización y desfiguración que pueden provocar.

Una dermatitis de contacto eccematosa aguda de origen profesional tiende a mejorar al cesar el contacto. Además, los agentes terapéuticos modernos pueden facilitar el período de recuperación. Sin embargo, si un trabajador vuelve a su puesto de trabajo en las mismas condiciones, sin que la empresa tome las medidas preventivas adecuadas y sin que aquel haya recibido y comprendido las precauciones necesarias, es probable que la dermatosis recidive poco después de la reexposición.

Las dermatosis eccematosas crónicas, las lesiones acneiformes y los cambios pigmentarios responden menos al tratamiento aunque se elimine el contacto. Las ulceraciones suelen mejorar al eliminar la fuente. En las lesiones granulomatosas y tumorales, la eliminación del contacto con el agente causal puede prevenir la aparición de lesiones futuras, pero no cambiará demasiado las alteraciones ya existentes.
Si un paciente con una probable dermatosis profesional no ha mejorado dos meses después de eliminar el contacto con el agente sospechoso, deberán valorarse otras causas que expliquen la persistencia de la enfermedad. Sin embargo, las dermatosis provocadas por metales como el níquel o el cromo tienen una evolución prolongada característica, debido en parte a la ubicuidad de estos elementos. $\mathrm{Ni}$ siquiera la retirada del puesto de trabajo elimina la posibilidad de una exposición profesional como origen de la enfermedad. Si estos y otros alergenos potenciales se descartan como causa del problema, puede concluirse con una seguridad razonable que la dermatitis es de origen no profesional o se produce por contactos no profesionales, como el mantenimiento y reparación de automóviles y barcos, los adhesivos para azulejos, las plantas de jardín o, incluso, tratamientos médicos prescritos o autoadministrados.

\section{CANCER De PIEL No MELANOCITICO}

\section{Elisabete Weiderpass, Timo Partanen, Paolo Boffetta}

Existen tres tipos histológicos de cáncer de piel no melanocítico (CPNM) (CIE-9: 173; CIE-10: C 44): el carcinoma de células basales, el carcinoma de células escamosas y los raros sarcomas de tejidos blandos que afectan a la piel, el tejido subcutáneo, las glándulas sudoríparas, las glándulas sebáceas y los folículos pilosos.

El carcinoma de células basales es el CPN M más común en la población blanca y representa el $75-80 \%$ del total. Se desarrolla generalmente en la cara, crece lentamente y tiene escasa tendencia a metastatizar.

L os cánceres de células escamosas representan el 20-25\% de todos los CPNM . Pueden presentarse en cualquier parte del cuerpo, pero sobre todo en las manos y las piernas, y pueden metastatizar. En las personas de piel oscura los cánceres de células escamosas son la forma más común de CPN M .

L os CPNM primarios múltiples son comunes. La mayoría de Ios CPNM aparecen en la cabeza y el cuello, a diferencia de lo que sucede con la mayoría de los melanomas, que se desarrollan en el tronco y las extremidades. La localización de los CPN M refleja las formas de vestir.

Los CPNM se tratan por diversos métodos como escisión, radiación y quimioterapia local. Responden bien al tratamiento y más del $95 \%$ se curan por escisión (IARC 1990).

Es difícil calcular la incidencia de CPN M, porque muchos de ellos no se comunican y muchos registros tumorales no los incluyen. EI número de casos nuevos en EE.UU. se estimó entre 900.000 y 1.200 .000 en 1994, una frecuencia comparable al número total de todos los cánceres no cutáneos (M iller y Weinstock 1994). Las incidencias comunicadas varían ampliamente y están aumentando en varios tipos de población, p. ej., en Suiza y en EE.UU. Los índices anuales más elevados se han descrito en Tasmania (167/ 100.000 en varones y 89/ 100.000 en mujeres), y los más bajos en Asia y Africa (globalmente, 1/100.000 en varones y 5/ 100.000 en mujeres). El CPN M es el tipo de cáncer más común en la raza caucásica. EI CPNM es unas diez veces más frecuente en la población blanca que en el resto de las poblaciones. Su mortalidad es muy baja (Higginson y cols. 1992).

La propensión al cáncer de piel es inversamente proporcional al grado de pigmentación por melanina, ya que ésta protege frente a la acción cancerígena de la radiación solar ultravioleta (UV ). El riesgo de cáncer de piel no melanocítico en la población blanca aumenta con la proximidad al ecuador. 
En 1992, la A gencia I nternacional para la Investigación sobre el Cáncer (International Agency for Research on C ancer, IARC 1992b) evaluó la carcinogenicidad de la radiación solar y concluyó que hay datos suficientes indicativos de la misma en el ser humano y que la radiación solar causa melanoma maligno y CPNM .

La reducción de la exposición a la luz solar probablemente disminuya la incidencia de CPN M . En personas blancas, entre el 90 y el $95 \%$ de los CPNM pueden atribuirse a la radiación solar (IARC 1990).

LoS CPNM pueden desarrollarse en zonas de inflamación o irritación crónicas, así como en cicatrices de quemaduras. Los traumatismos y las úlceras crónicas cutáneas son factores de riesgo importantes para los cánceres cutáneos de células escamosas, sobre todo en A frica.

La radioterapia, la quimioterapia con mostaza nitrogenada, el tratamiento inmunosupresor, el tratamiento con psoralenos combinado con la radiación UVA y las preparaciones a base de alquitrán de hulla aplicadas sobre lesiones cutáneas se han asociado a un aumento del riesgo de CPNM. Se ha confirmado que la exposición ambiental al arsénico trivalente y a los compuestos arsenicales se acompaña de una incidencia elevada de cáncer de piel en el ser humano (IARC 1987). La exposición al arsénico puede provocar queratosis arsenicales palmares 0 plantares, carcinoma epidermoide y carcinoma superficial de células basales

Los trastornos hereditarios como la ausencia de las enzimas necesarias para reparar el ADN dañado por la radiación UV puede aumentar el riesgo de CPN M . EI X eroderma pigmentosum se incluye dentro de los trastornos hereditarios de este grupo.

U n ejemplo histórico de cáncer de piel profesional es el cáncer de escroto que Sir Percival Pott describió en 1775 en los deshollinadores. La causa de estos tumores era el hollín. A principios del siglo XX, los cánceres de escroto se observaban en los hilanderos de las fábricas textiles de algodón, donde estaban expuestos al aceite de esquisto que se empleaba como lubricante para los husos de algodón. L os cánceres de escroto de los deshollinadores y los hilanderos se asociaron después a los hidrocarburos aromáticos policíclicos (HAP), muchos de los cuales son cancerígenos en animales, en particular algunos H AP con anillo en las posiciones 3-, 4-, y 5-, como el benzopireno y el dibenzoantraceno (IARC 1983, 1984a, 1984b, 1985a). Además de las mezclas que contienen los HAP, el calentamiento de los compuestos orgánicos puede originar la formación de compuestos cancerígenos.

0 tras ocupaciones asociadas a un aumento de la incidencia de CPNM en relación con los HAP son: trabajadores en procesos de reducción del aluminio, trabajadores en la gasificación del carbón, trabajadores de hornos de coque, sopladores de vidrio, ingenieros ferroviarios, trabajadores de la construcción de carreteras y del mantenimiento de autopistas, trabajadores que tienen contacto con el aceite de esquisto, ajustadores y montadores de herramientas (véase la Tabla 12.1). L os alquitranes de hulla, las breas de alquitrán de hulla, otros productos derivados del carbón, el aceite de antraceno, el aceite de creosota y los aceites lubricantes son algunos de los materiales y mezclas que contienen H AP cancerígenos.

0 tros tipos de trabajadores en los que se ha determinado un aumento del riesgo de CPNM son: procesadores de yute, trabajadores al aire libre, técnicos de farmacia, trabajadores de aserraderos, trabajadores que tienen contacto con el aceite de esquisto, personas que desinfectan ovejas, pescadores, montadores de herramientas, trabajadores de viñedos y pescadores. EI exceso de incidencia en pescadores (que participan sobre todo en actividades de pesca tradicionales) se constató en M aryland, EE.UU., y se limitaba a los cánceres de células escamosas. La
Tabla 12.1 - O cupaciones de riesgo.

$\begin{array}{lll}\text { Material o } & \text { Industria o peligro } & \text { Proceso o grupo de riesgo } \\ \text { agente cancerígeno } & & \\ \begin{array}{l}\text { Brea de alquitrán, } \\ \text { alquitrán o }\end{array} & \text { Reducción del aluminio } & \text { Trabajadores de calderas } \\ \text { productos } & & \\ \text { alquitranosos } & & \end{array}$

Industrias de carbón, gas y coque

Fabricación de aglomerados

Industria del asfalto

Usuarios de creosota

Hollín Deshollinadores
Industria del caucho

Aceites lubricantes y Soplado de vidrio

de corte

Refinado de aceite de
esquisto
Industria del algodón
Trabajadores con cera de
parafina
Ingeniería

Ingeniería

Refinerías de petróleo
Centros de desinfección de
ovejas
Insecticidas arsenicales

$\begin{array}{cl} & \text { Minería de arsénico } \\ \text { Radiación ionizante } & \text { Radiólogos } \\ & \text { Otros trabajadores que } \\ & \text { reciben radiaciones }\end{array}$

Radiación ultravioleta Trabajadores al aire libre
Hornos de coque, destilación de alquitrán, producción de gas con carbón, carga de brea de alquitrán

Fabricación de ladrillos

Construcción de carreteras

Trabajadores de empresas fabricantes de ladrillos y de tejas, impermeabilizantes de madera

Mezcladores de negro de carbón (hollín comercial) $y$ de aceite

Hilanderos

Ajustadores de herramientas y operarios ajustadores en talleres de máquinas automáticas (aceites de corte)

Limpiadores de alambiques

Usuarios y trabajadores industriales (jardineros, fruticultores y vendimiadores)

Agricultores y ganaderos, pescadores, trabajadores de viñedos radiación solar probablemente explica el aumento del riesgo en pescadores, trabajadores al aire libre, trabajadores de viñedos y pescadores. L os pescadores también pueden estar expuestos a los aceites y alquitranes y al arsénico inorgánico del pez consumido, lo que puede contribuir al aumento de incidencia de cáncer de piel observado, unas tres veces en un estudio sueco, en comparación con los índices normales de ese país (H agmar y cols. 1992). 
El aumento de incidencia en las personas que desinfectan ovejas puede atribuirse a los compuestos arsenicados, que inducen cáncer de piel por ingestión más que por contacto cutáneo. Aunque los granjeros tienen un riesgo ligeramente aumentado de melanoma, no parecen sufrir un riesgo mayor de CPNM, según las observaciones epidemiológicas realizadas en Dinamarca, Suecia y EE. UU. (Blair y cols. 1992).

La radiación ionizante ha causado cáncer de piel en los primeros radiólogos y trabajadores que manipulaban radio. En ambas situaciones, las exposiciones fueron prolongadas y masivas. Los accidentes profesionales asociados a lesiones cutáneas o irritación cutánea prolongada pueden aumentar el riesgo de CPNM.

\section{Prevención (del cáncer de piel profesional no melanocítico)}

La utilización de una ropa adecuada y de una crema solar con un factor protector UV-B de 15 como mínimo contribuye a proteger a los trabajadores al aire libre expuestos a la radiación ultravioleta. A demás, la sustitución de los materiales cancerígenos (como el almacenaje de alimentos) por alternativas no cancerígenas es otra medida protectora evidente que, sin embargo, no siempre puede aplicarse. EI grado de exposición a los materiales cancerígenos puede reducirse mediante el uso de pantallas protectoras, ropa protectora y medidas higiénicas.

La educación de los trabajadores sobre la naturaleza del peligro y el valor y el sentido de las medidas protectoras es de importancia fundamental.

Finalmente, los cánceres de piel suelen desarrollarse en muchos años y la mayoría pasan por estadios premalignos antes de alcanzar su potencial pleno de malignidad, como sucede con las queratosis arsenicales y las queratosis actínicas. Estas fases iniciales se detectan con rapidez mediante inspección visual. Por este motivo, en los cánceres de piel existe la posibilidad real de reducir la mortalidad en los trabajadores que han estado expuestos a cualquier cancerígeno cutáneo si se realizan exploraciones selectivas periódicas.

\section{- Melan oma maligno}

Timo Partanen, Paolo Boffetta, Elisabete Weiderpass

EI melanoma maligno es menos frecuente que el cáncer de piel no melanocítico. A parte de la exposición a la radiación solar, ningún otro factor ambiental muestra una asociación constante con el melanoma maligno cutáneo. No se ha establecido con seguridad ninguna asociación con la actividad laboral, con la dieta ni con factores hormonales (K oh y cols. 1993).

EI melanoma maligno es un cáncer de piel agresivo (CIE-9 172.0 a 173.9; CIE-10: C 43). Se forma a partir de células cutáneas productoras de pigmento, generalmente, de un nevus preexistente. El tumor tiene un grosor que oscila entre algunos milímetros y varios centímetros, es de color marrón o negro y ha aumentado de tamaño, cambiado de color, y puede sangrar 0 ulcerarse (Balch y cols. 1993).

Los indicadores de mal pronóstico del melanoma maligno de la piel son: subtipo nodular, grosor del tumor, tumores primarios múltiples, metástasis, ulceración, sangrado, larga duración del tumor, localización corporal y, en algunas localizaciones, el sexo masculino. El antecedente de melanoma maligno cutáneo aumenta el riesgo de melanoma secundario. Los índices de supervivencia cinco años después del diagnóstico en las zonas de alta incidencia del tumor son del 80-85\%, pero en las zonas de baja incidencia la supervivencia es menor (Ellwood y K oh 1994; Stidham y cols. 1994).

Existen cuatro tipos histológicos de melanoma maligno cutáneo. Los melanomas de diseminación superficial (MDS) representan el 60-70\% de todos los melanomas en la población blanca y menos en la población de otras razas. L os M DS tienden a progresar con lentitud y son más frecuentes en las mujeres que en los varones. Los melanomas nodulares (M N) constituyen el $15-30 \%$ de los melanomas malignos cutáneos. Son invasivos, crecen con rapidez y son más frecuentes en el varón. Entre el 4 y el $10 \%$ de los melanomas malignos cutáneos son melanomas malignos lentiginosos (MML) o manchas melanóticas de $\mathrm{H}$ utchinson. L os M M L crecen lentamente, suelen aparecer en la cara de personas de edad avanzada y rara vez metastatizan. Los melanomas lentiginosos acros (M LA) representan el 35-60 \% de todos los melanomas malignos del la piel en la población de raza no blanca y el 2-8 \% en la raza blanca. Suelen aparecer en la planta del pie (Bijan 1993).

El tratamiento de los melanomas malignos de la piel consiste en cirugía, radioterapia, quimioterapia y tratamiento biológico (interferón alfa o interleucina-2), aislados o en combinación.

Durante el decenio de 1980, los índices de incidencia anual, estandarizados por edad, de melanoma maligno cutáneo oscilaron entre 0,1 por 100.000 en $\mathrm{K}$ hon $\mathrm{K}$ aen, Tailandia, y alrededor de 30,9 en varones y 28,5 en mujeres en Queensland, Australia (IARC 1992b). Los melanomas malignos de la piel representan menos del 1\% de todos los cánceres en la mayoría de la población. Se ha observado un aumento anual cercano al $5 \%$ en la incidencia de melanoma en la mayoría de la población blanca entre el principio del decenio de 1960 y 1972. La mortalidad por melanoma ha aumentado en las últimas décadas en la mayoría de las poblaciones, pero con menor rapidez que la incidencia, probablemente a causa de la mayor precocidad de los diagnósticos y la toma de conciencia sobre la enfermedad (IARC 1985b, 1992b). Datos más recientes muestran índices diferentes de variación y en algunos casos se observa incluso una tendencia descendente de la incidencia.

Los melanomas malignos de la piel se encuentran entre los diez cánceres más frecuentes en Australia, Europa y Norteamérica, y el riesgo de padecerlos durante la vida es del 1-5\%. La población de piel blanca es más propensa que la población de otras razas. El riesgo de melanoma en la población blanca aumenta con la proximidad al ecuador.

La distribución por sexos de los melanomas cutáneos varía ampliamente en las poblaciones (IARC 1992a). Las mujeres presentan una incidencia menor que los varones en casi todas. Existen diferencias por sexos en los patrones de distribución corporal de las lesiones: el tronco y la cara predominan en los varones y las extremidades en las mujeres.

Los melanomas malignos de la piel son más comunes en las clases socioeconómicas más altas que en los grupos de clase más baja (IARC 1992b).

Los melanomas familiares son raros, pero están bien documentados. Entre el 4 y el $10 \%$ de los pacientes refieren antecedentes de melanoma en sus familiares en primer grado.

La irradiación UV-B solar es probablemente la principal causa del aumento generalizado de la incidencia de melanomas cutáneos (I ARC 1993). N o está claro si el agotamiento de la capa estratosférica de ozono y el consiguiente aumento de la irradiación UV ha provocado el aumento de la incidencia de melanoma maligno (IARC 1993, K ricker y cols. 1993). El efecto de la radiación UV depende de algunas características, como el fenotipo I y II y los ojos azules. Se sospecha que la radiación U V que emana de las lámparas fluorescentes puede desempeñar un papel, pero este aspecto no se ha demostrado de forma definitiva (Beral y cols. 1982) 
Se ha estimado que la reducción de la exposición recreativa al sol y la utilización de cremas de protección solar podrían reducir en un $40 \%$ la incidencia de melanomas malignos en las poblaciones de alto riesgo (IARC 1990). En los trabajadores al aire libre, la aplicación de cremas de protección solar con un factor de protección UV-B de 15 como mínimo y una protección frente a los rayos UV-A, junto con el uso de una ropa adecuada son medidas protectoras prácticas. Aunque el riesgo de las actividades laborales al aire libre es plausible, dada la mayor exposición a la radiación solar, los resultados de los estudios sobre la exposición laboral regular al aire libre son contradictorios. Esto se explica, probablemente, por los hallazgos epidemiológicos que indican que no es la exposición regular, sino la exposición intermitente a dosis elevadas de radiación solar lo que se asocia a un riesgo elevado de melanoma (IARC 1992b).

La inmunosupresión terapéutica puede aumentar el riesgo de melanoma maligno de la piel. Se ha descrito un aumento del riesgo con los anticonceptivos orales, pero no parece probable que aumente el riesgo de melanoma maligno de la piel (H annaford y cols. 1991). Pueden inducirse melanomas con estrógenos en hamsters, aunque no existen indicios de este efecto en los seres humanos

En la población adulta de raza blanca, la mayoría de los tumores malignos intraoculares primarios son melanomas, que se originan por lo general en los melanocitos uveales. L os índices estimados para estos cánceres no muestran las variaciones geográficas y la tendencia al aumento con el tiempo que se observa en los melanomas cutáneos. La incidencia y la mortalidad de los melanomas oculares son muy bajas en las poblaciones asiáticas y de raza negra (IARC 1990, Sahel y cols. 1993). Las causas del melanoma ocular se desconocen (H igginson y cols. 1992).

En estudios epidemiológicos se ha observado un aumento del riesgo de melanoma maligno en administradores y directivos, pilotos de líneas aéreas, trabajadores de fábricas de productos químicos, trabajadores de refinerías y personas expuestas a la gasolina, vendedores y empleados de almacenes. Se ha descrito un aumento del riesgo de melanoma en las siguientes industrias:

Tabla 12.2 Tipos de dermatitis de contacto.

\begin{tabular}{|c|c|c|}
\hline Características & $\begin{array}{l}\text { Dermatitis de contacto por } \\
\text { irritantes }\end{array}$ & $\begin{array}{l}\text { Dermatitis de contacto } \\
\text { alérgica }\end{array}$ \\
\hline $\begin{array}{l}\text { Mecanismo } \\
\text { de producción }\end{array}$ & Efecto citotóxico directo & $\begin{array}{l}\text { Inmunidad celular del tipo } \\
\text { retardado (Tipo IV de Gell y } \\
\text { Coombs) }\end{array}$ \\
\hline $\begin{array}{l}\text { Víctimas } \\
\text { potenciales }\end{array}$ & Cualquiera & Una minoría de individuos \\
\hline Aparición & $\begin{array}{l}\text { Progresiva, tras una exposi- } \\
\text { ción repetida o prolongada }\end{array}$ & $\begin{array}{l}\text { Rápida, en 12- } 48 \text { horas en } \\
\text { los individuos sensibilizados }\end{array}$ \\
\hline Signos & $\begin{array}{l}\text { Eccema subagudo o crónico } \\
\text { con eritema, descamación y } \\
\text { fisuras }\end{array}$ & $\begin{array}{l}\text { Eccema agudo o subagudo con } \\
\text { eritema, edema, ampollas y } \\
\text { vesículas }\end{array}$ \\
\hline Síntomas & $\begin{array}{l}\text { Sensación de dolor y de } \\
\text { quemazón }\end{array}$ & Prurito \\
\hline $\begin{array}{l}\text { Concentración } \\
\text { del agente de } \\
\text { contacto }\end{array}$ & Alta & Baja \\
\hline Investigación & Antecedentes y exploración & $\begin{array}{l}\text { Antecedentes y exploración } \\
\text { Pruebas de parche }\end{array}$ \\
\hline
\end{tabular}

producción de fibra de celulosa, productos químicos, textiles, productos eléctricos y electrónicos, industria del metal, productos minerales no metálicos, petroquímica, impresión y telecomunicaciones. Sin embargo, muchos de estos hallazgos son aislados y no se han confirmado en otros estudios. U na serie de metaanálisis de los riesgos del cáncer en granjeros (Blair y cols. 1992; Nelemans y cols. 1993) indicaron un exceso ligero, pero significativo (índice de riesgo agregado de 1,15 ) de melanoma maligno de la piel en 11 estudios epidemiológicos.

En un estudio multicéntrico de casos controles sobre el cáncer de origen laboral realizado en M ontreal, C anadá (Siemiatycki y cols. 1991), las siguientes exposiciones laborales se asociaron a un aumento significativo del riesgo de melanoma cutáneo: cloro, emisiones de los motores de propano, productos de la pirólisis de los plásticos, polvo de tejidos, fibras de lana, fibras acrílicas, adhesivos sintéticos, "otras" pinturas, barnices, alquenos clorados, tricloroetileno y lejías. Se estimó que el riesgo de la población atribuible a exposiciones profesionales, según las asociaciones significativas en los datos del mismo estudio, era del $11,1 \%$.

\section{DERMATITIS DE CONTACTO PROFESIONALES}

Denis Sasseville

Los términos dermatitis y eccema son intercambiables y se refieren a un tipo particular de reacción inflamatoria de la piel que puede desencadenarse por factores internos o externos. La dermatitis de contacto profesional es un eccema exógeno causado por la interacción de la piel con agentes químicos, biológicos y físicos del medio ambiente de trabajo.

La dermatitis de contacto representa el $90 \%$ de todas las dermatosis profesionales y en el $80 \%$ de los casos afectará a la herramienta más importante de un trabajador: las manos (Adams 1988). El contacto directo con el agente ofensor es la forma habitual de producción de la dermatitis, aunque pueden intervenir otros mecanismos. Las partículas, como el polvo o el humo, o los vapores de las sustancias volátiles, pueden provocar una dermatitis de contacto de transmisión aérea. Algunas sustancias se transfieren desde los dedos a localizaciones distantes del cuerpo y producen una dermatitis de contacto ectópica. Por último, si un agente de contacto es activado por la exposición a la luz ultravioleta puede inducirse una dermatitis por fotocontacto.

La dermatitis de contacto se divide en dos categorías amplias según los diferentes mecanismos de producción. En la Tabla 12.2 se enumeran las características más significativas de la dermatitis de contacto por irritantes y de la dermatitis de contacto alérgica.

\section{Dermatitis de contacto por irritantes}

La dermatitis de contacto por irritantes se produce por una acción citotóxica directa del agente causal. La participación del sistema inmunitario es secundaria a la lesión cutánea y provoca una inflamación visible de la piel. Representa el tipo más común de dermatitis de contacto, causante del $80 \%$ de todos los casos.

La mayoría de los productos irritantes son sustancias químicas que se clasifican como irritantes inmediatos 0 acumulativos. Las sustancias corrosivas, como los ácidos y los álcalis fuertes, son ejemplos de los primeros, porque provocan una lesión cutánea a los pocos minutos u horas de la exposición. En general se identifican bien, por lo que el contacto con estas sustancias suele ser accidental. En cambio, los irritantes acumulativos son de naturaleza más insidiosa y el trabajador no suele reconocerlos como 
Tabla 12.3 - Irritantes comunes.

\begin{tabular}{|c|c|}
\hline \multicolumn{2}{|l|}{ Acidos y álcalis } \\
\hline \multicolumn{2}{|c|}{ Jabones y detergentes } \\
\hline $\begin{array}{l}\text { Disolventes } \\
\text { Alifáticos: } \\
\text { Aromáticos: } \\
\text { Halogenados: } \\
\text { Varios: }\end{array}$ & $\begin{array}{l}\text { Destilados de petróleo (queroseno, gasolina, nafta) } \\
\text { Benceno, tolueno, xileno } \\
\text { Tricloroetileno, cloroformo, cloruro de metileno } \\
\text { Trementina, cetonas, ésteres, alcoholes, glicoles, agua }\end{array}$ \\
\hline \multicolumn{2}{|c|}{$\begin{array}{l}\text { Plásticos } \\
\text { Monómeros epoxi, fenólicos, acrílicos } \\
\text { Aminas catalíticas } \\
\text { Estireno, peróxido de benzoilo }\end{array}$} \\
\hline $\begin{array}{l}\text { Metales } \\
\text { Arsénico } \\
\text { Cromo }\end{array}$ & \\
\hline
\end{tabular}

agentes nocivos porque la lesión aparece días, semanas o meses después de la exposición repetida. Como se muestra en la Tabla 12.3, entre estos irritantes figuran los disolventes, destilados del petróleo, ácidos y álcalis diluidos, jabones y detergentes, resinas y plásticos, desinfectantes e incluso el agua (G ellin 1972).

La dermatitis de contacto por irritantes, que aparece años después de manipular sin problemas una sustancia, puede deberse a una pérdida de tolerancia, cuando la barrera epidérmica falla finalmente después de agresiones subclínicas reiteradas. M ás raramente, el engrosamiento de la epidermis y otros mecanismos adaptativos pueden aumentar la tolerancia a ciertos productos irritantes; este fenómeno se conoce como endurecimiento.

En resumen, la dermatitis de contacto por irritantes se produce en la mayoría de los sujetos expuestos a concentraciones adecuadas del agente agresor durante un espacio de tiempo suficiente.

\section{Dermatitis de contacto alérgica}

EI $20 \%$ de todos los casos de dermatitis de contacto se produce por una reacción alérgica celular de tipo retardado, similar a la que se observa en el rechazo de los injertos. Este tipo de reacción, que se desarrolla en una minoría de sujetos, requiere la participación activa del sistema inmunitario y concentraciones muy bajas del agente causal. Numerosos alergenos son también irritantes, pero el umbral de irritación es generalmente muy superior al de sensibilización. La secuencia de acontecimientos que culminan con la aparición de lesiones visibles se divide en dos fases.

\section{Fase de sensibilización (fase de inducción 0 aferente)}

Los alergenos son agentes químicos heterogéneos, orgánicos 0 inorgánicos, capaces de atravesar la barrera epidérmica por ser lipofílicos (les atrae la grasa de la piel) y de pequeño peso molecular, generalmente inferior a 500 daltons (T abla 12.4). L os alergenos son antígenos incompletos o haptenos, esto es, deben unirse a proteínas de la epidermis para convertirse en antígenos completos.

Las células de Langerhans son células dendríticas presentadoras de antígenos que constituyen menos del $5 \%$ de todas las células epidérmicas; atrapan a los antígenos cutáneos y los procesan antes de volver a expresarlos sobre su superficie externa unidos a proteínas del complejo de histocompatibilidad. A las pocas horas del contacto, las células de $L$ angerhans abandonan la epidermis y migran por los linfáticos hacia los ganglios
Tabla 12.4 - Alergenos cutáneos comunes.

\begin{tabular}{cc} 
Metales & Plantas \\
Níquel & Urusiol (Toxicodendron) \\
Cromo & Lactonas sesquiterpenas (Compositae) \\
Cobalto & Primina (Primula obconica) \\
Mercurio & Tulipalina A (Tulipa, Alstroemeria) \\
Aditivos de caucho & Plásticos \\
Mercaptobenzotiazol & Monómero epoxi \\
Tiurames & Monómero acrilico \\
Carbamatos & Resinas fenólicas \\
Tioureas & Aminas catalíticas \\
Colorantes & Biocidas \\
Diamina parafenileno & Formaldehído \\
Reactivos de fotografía en color & Katon CG \\
Colorantes textiles de dispersión & Timerosal \\
\hline
\end{tabular}

linfáticos. Las linfonas como la interleuna-1 (IL - 1 ) y el factor de necrosis tumoral alfa (TNF- $\alpha$ ) secretado por los queratinocitos son sustancias que intervienen en la maduración y migración de las células de $L$ angerhans.

En la zona paracortical de los ganglios linfáticos regionales, las células de Langerhans entran en contacto con células $T$ cooperadoras CD 4 + que nunca habían tenido contacto previo con el antígeno y les presentan su carga antigénica. La interacción entre las células de $L$ angerhans y las células $T$ cooperadoras implica el reconocimiento del antígeno por los receptores de las células $T$, así como la relación de varías moléculas de adhesión y otras glicoproteínas de superficie. El éxito del reconocimiento antigénico permite una expansión clonal de las células $T$ de memoria, que se diseminan por el torrente sanguíneo y toda la piel. E sta fase requiere entre 5 y 21 días, durante los cuales no se produce ninguna lesión.

\section{Fase de provocación (eferente)}

$L$ a reexposición al alergeno activa las células $T$ sensibilizadas e induce la secreción de linfonas potentes como la IL-1 y la IL-2 e interferón gamma (IFN- $\gamma$ ). Estas sustancias favorecen la transformación blástica de las células T, la generación de células T supresoras y citotóxicas, el reclutamiento y la activación de macrófagos y de otras células efectoras y la producción de otros mediadores de la inflamación como el TNF- $\alpha$ y moléculas de adhesión. En un plazo de 8 a 48 horas, esta cascada de acontecimientos provoca vasodilatación y enrojecimiento (eritema), hinchazón dérmica y epidérmica (edema), formación de vesículas (vesiculación) y la aparición de exudado. Si no se trata, esta reacción puede durar entre dos y seis semanas.

$L$ a respuesta inmune disminuye al degradarse 0 desaparecer el antígeno, al destruirse las células de Langerhans, al aumentar la producción de células T supresoras CD 8+ y al producirse IL-10 en los queratinocitos, lo que inhibe la proliferación de las células T cooperadoras/ citotóxicas.

\section{Presentación clínica}

M orfología. La dermatitis de contacto puede ser aguda, subaguda o crónica. En la fase aguda, las lesiones aparecen con rapidez y se presentan al principio como placas urticariformes pruriginosas, eritematosas y edematosas. El edema puede ser considerable, sobre todo en zonas de piel laxa como los párpados y el área genital. En cuestión de horas, estas placas se agrupan y presentan vesículas pequeñas que pueden aumentar de tamaño o coalescer 
para formar bullas. Cuando se rompen, rezuman un líquido viscoso de color ámbar.

El edema y la vesiculación son menos marcados en la dermatitis subaguda; que se caracteriza por la aparición de eritema, vesiculación, descamación cutánea, exudación de líquido moderada y formación de costras amarillentas.

En la fase crónica, la vesiculación y la exudación se sustituyen por un aumento de la descamación, engrosamiento de la epidermis, que adquiere una coloración grisácea y un aspecto arrugado (liquenificación), y aparición de fisuras profundas dolorosas sobre las zonas de movimiento o traumatismos. Al cabo de varios años de dermatitis persistente puede desarrollarse un linfedema de larga duración.

Distribución. El patrón peculiar y la distribución de las lesiones de una dermatitis permitirán al clínico sospechar su origen exógeno e identificar a veces el agente causal. Por ejemplo, los trazos lineales o serpiginosos de eritema y las vesículas sobre la piel descubierta son prácticamente diagnósticos de dermatitis de contacto por plantas, mientras que una reacción alérgica a los guantes de goma será más intensa en el dorso de las manos y alrededor de las muñecas.

El contacto repetido con el agua y con agentes limpiadores es responsable de la clásica "dermatitis de las amas de casa", caracterizada por eritema, descamación y fisuras de las puntas y el dorso de los dedos, así como afectación de la piel entre los dedos (interdigital). En cambio, la dermatitis causada por la fricción de las herramientas o por el contacto con objetos sólidos tiende a localizarse en las palmas y en la zona inferior o superior de los dedos de las manos.

La dermatitis de contacto por irritantes causada por las partículas de fibra de vidrio afectará a la cara, las manos y los antebrazos y será más intensa en las superficies de flexión, alrededor del cuello y de la cintura, donde el movimiento y la fricción de las ropas fuerzan la penetración de las partículas en la piel. La afectación de la cara, de los párpados superiores, los oídos y el área submentoniana sugiere una dermatitis de contacto transmitida por vía aérea. En una dermatitis por fotocontacto no se afectan las zonas protegidas del sol, como los párpados superiores y las zonas submentonianas y retroauriculares.

Extensión a localizaciones distantes. La dermatitis irritante permanece localizada en el área de contacto. La dermatitis alérgica de contacto, sobre todo si es aguda y grave, destaca por su tendencia a diseminarse más allá de la zona de exposición inicial. Este fenómeno puede explicarse por dos mecanismos. EI primero, la autoeccematización, conocido también como reacción ide o síndrome de la piel excitada, consiste en un estado de hipersensibilidad de toda la piel en respuesta a una dermatitis localizada persistente o grave. La dermatitis de contacto sistémica, se produce cuando un paciente sensibilizado por vía tópica a un alergeno se expone de nuevo al mismo agente por vía oral o parenteral. En ambos casos, se desarrolla una dermatitis diseminada que puede confundirse fácilmente con un eccema de origen endógeno.

\section{Factores predisponentes}

La aparición de una dermatitis profesional depende de la naturaleza del agente de contacto, de su concentración y de la duración del contacto. EI hecho de que en condiciones similares de exposición sólo una minoría de trabajadores desarrolle una dermatitis prueba la importancia de otros factores personales y ambientales predisponentes (Tabla 12.5).

E dad. Los trabajadores jóvenes son más propensos a desarrollar una dermatitis profesional. Es posible que tengan menos experiencia que sus colegas más veteranos, o que sigan con menos rigor las medidas de seguridad. L os trabajadores de más

edad quizá se han endurecido frente a los irritantes suaves o han aprendido a evitar el contacto con sustancias peligrosas; también es posible que sean un grupo autoseleccionado con el tiempo, sin haber sufrido problemas que quizá hicieron a otros abandonar el puesto de trabajo.

T ipo de piel. La mayoría de las pieles de color negro o orientales parecen más resistentes a los efectos de los irritantes de contacto que la piel de la mayoría de las razas caucasianas.

E nfermedad previa. Los trabajadores propensos a los problemas alérgicos (con antecedentes de atopia manifestada por eccema, asma o rinitis alérgica) muestran más propensión a desarrollar dermatitis de contacto por irritantes. La psoriasis y el liquen plano pueden agravarse por la fricción o los traumatismos reiterados; este fenómeno se denomina Furorueno de Koebner. Si estas lesiones se limitan a las palmas de las manos, puede ser difícil distinguirlas de la dermatitis de contacto por irritantes crónica.

Temperatura y humedad. En condiciones de calor extremo, los trabajadores suelen olvidarse de los guantes y de otras ropas de protección adecuadas. La humedad elevada reduce la eficacia de la barrera epidérmica, mientras que las situaciones de sequedad y frío favorecen la formación de grietas y de fisuras.

Condiciones de trabajo. La incidencia de la dermatitis de contacto es más elevada en los centros de trabajo sucios, contaminados con productos químicos, con equipos obsoletos o que carecen de medidas protectoras y de instalaciones para la higiene personal. Algunos trabajadores sufren un riesgo superior porque sus actividades son manuales y se exponen a irritantes 0 alergenos potentes (p. ej., peluqueros, impresores, técnicos dentales).

\section{Diagnóstico}

Después de realizar una cuidadosa historia y una exploración física completa suele ser posible establecer un diagnóstico de dermatitis de contacto profesional.

Antecedentes. D ebe cumplimentarse un cuestionario que incluya el nombre y la dirección de la empresa, el tipo de trabajo y una descripción de las funciones que desempeña el afectado. EI trabajador deberá proporcionar una lista con todos los agentes

Tabla 12.5 - Factores predisponentes de dermatitis profesionales.

Edad

Tipo de piel

Enfermedad previa

Temperatura y humedad

Condiciones de trabajo
Los trabajadores más jóvenes suelen tener escasa experiencia o ser más descuidados y es más probable que sufran dermatitis profesionales que los trabajadores de más edad

Las personas de razas asiáticas y negra son, en general, más resistentes a la irritación que las de raza blanca

La atopia predispone a la dermatitis de contacto por irritantes

La psoriasis o el liquen plano pueden empeorar por el fenómeno de Koebner

La humedad elevada reduce la eficacia de la barrera epidérmica

La humedad baja y el frío pueden causar grietas y desecación de la epidermis

Un lugar de trabajo sucio suele estar más contaminado con sustancias químicas tóxicas 0 alergénicas

Los equipos anticuados y la falta de medidas de protección aumentan el riesgo de dermatitis profesionales

Los movimientos repetitivos y la fricción pueden causar irritación y formar callos 
químicos que manipula y suministrar información sobre ellos, como se específica en las Fichas T écnicas de Seguridad. D eberá registrarse la fecha de comienzo y la localización de la dermatitis. Es importante documentar los efectos de las vacaciones, la baja laboral, la exposición al sol y el tratamiento sobre la evolución de la enfermedad. EI médico deberá obtener información sobre las aficiones del trabajador, sus hábitos personales, los antecedentes de enfermedades cutáneas previas y de otros tipos de enfermedades, así como de los medicamentos que reciba en ese momento.

Exploración física. Las áreas afectadas deben examinarse con cuidado. $\mathrm{H}$ ay que anotar la gravedad y la fase de la dermatitis, su distribución precisa y su grado de interferencia con la función. Debe realizarse una exploración cutánea completa, incluida la búsqueda de signos de psoriasis, dermatitis atópica, liquen plano, tiña, etc., lo que pudiera significar que la dermatitis no es de origen profesional.

\section{E studios complementarios}

La información obtenida por la historia y la exploración física suelen bastar para sospechar la naturaleza profesional de una dermatitis. Sin embargo, en la mayor parte de los casos se necesitan pruebas adicionales para confirmar el diagnóstico e identificar el agente causal.

Prueba del parche. La prueba del parche o epicutánea es la técnica de elección para identificar los alergenos cutáneos y debería realizarse de forma sistemática en todos los casos de dermatitis profesional (R ietschel y cols. 1995). En la actualidad existen más de 300 sustancias disponibles comercialmente. La serie convencional, en la que se incluyen los alergenos más comunes, puede complementarse con series adicionales según los tipos de trabajadores, por ejemplo, para peluqueros, técnicos dentales, jardineros, impresores, etc.

En la Tabla 12.6 se muestran varias sustancias irritantes y sensibilizantes que se encuentran en algunas de estas profesiones.

Los alergenos se mezclan en un vehículo apropiado, como la vaselina, a una concentración que, mediante pruebas de ensayo y error realizadas durante muchos años, han demostrado no tener un efecto irritante, pero que sí es lo suficientemente para demostrar una sensibilización alérgica. Recientemente se han comenzado a utilizar tiras adhesivas con alergenos, preenvasadas y listas para su aplicación, aunque hasta ahora sólo se dispone de 24 alergenos de la serie convencional. El resto de las sustancias deben adquirirse en jeringas individuales.

En el momento de la prueba, el paciente debe hallarse en una fase inactiva de la dermatitis y no tomar corticosteroides por vía sistémica. Se aplica una pequeña cantidad de cada alergeno a unas cámaras poco profundas de aluminio o plástico montadas sobre una cinta adhesiva hipoalergénica porosa. Estas filas de cámaras se fijan a una zona sin dermatitis de la espalda del paciente y se dejan en el sitio durante 24 o, más habitualmente, 48 horas. Se realiza una primera lectura al retirar las tiras y una segunda lectura, y a veces una tercera, al cabo de 4 y de 7 días, respectivamente. L as reacciones se gradúan como sigue:
Nula
sin reacción
? reacción dudosa, eritema maculoso leve
$+\quad$ reacción débil, eritema papuloso leve
++ reacción intensa, eritema, edema, vesículas
$+++\quad$ reacción extrema, ampollosa o ulcerativa
IR reacción irritativa, eritema o erosión que parece una quemadura.

Si se sospecha una dermatitis de fotocontacto (un tipo que requiere la exposición a la luz ultravioleta, UV-A), se realiza una variante de la prueba del parche, denominada fotoparche. LoS alergenos se aplican por duplicado en la espalda. D espués de 24 y 48 horas, un conjunto de alergenos se expone a 5 julios de U V-A y se colocan de nuevo los parches en su sitio durante otras 24 y 48 horas. Si las reacciones son iguales en los dos sitios se trata de una dermatitis de contacto; las reacciones positivas en el lado expuesto a la luz U V indican una combinación de dermatitis de contacto y de fotocontacto.

La técnica de las pruebas del parche es sencilla. La parte más complicada es la interpretación de los resultados, que debe reservarse a un dermatólogo con experiencia. Como regla general, las reacciones irritantes tienden a ser leves, provocan más quemazón que picor, suelen presentarse cuando se quitan los parches y desaparecen con rapidez. Por el contrario, las reacciones alérgicas son pruriginosas, alcanzan la máxima intensidad después de 4 a 7 días y pueden persistir durante semanas. Cuando se ha identificado una reacción positiva, hay que valorar su relevancia: ¿se relaciona con la dermatitis actual 0 simplemente muestra una sensibilización pasada? ¿Está expuesto el paciente a esa sustancia en particular 0 es alérgico a un compuesto diferente, pero relacionado estructuralmente con el que reacciona de forma cruzada?

El número de alergenos potenciales es muy superior a los 300 , más o menos, disponibles en el mercado para las pruebas del parche. Por tanto, suele ser necesario realizar pruebas a los pacientes con las sustancias reales con las que trabajan. M ientras que la mayoría de las plantas pueden emplearse en las pruebas "tal cual", los agentes químicos deben identificarse con precisión y tamponarse si su nivel de acidez $(\mathrm{pH})$ se halla fuera del intervalo de 4 a 8 . T ienen que diluirse hasta alcanzar una concentración apropiada y mezclarse en un vehículo apropiado según las prácticas científicas actuales (de G root 1994). $\mathrm{H}$ ay que practicar la prueba en un grupo de 10 a 20 sujetos de control para detectar las concentraciones irritantes y eliminarlas del protocolo.

La prueba del parche suele ser un procedimiento seguro. Las reacciones positivas intensas pueden exacerbar a veces la dermatitis en estudio. En raras ocasiones, puede producirse una sensibilización activa, sobre todo si las pruebas se realizan con los propios productos de los pacientes. Las reacciones graves pueden dejar marcas de hipo 0 hiperpigmentación, cicatrices 0 queloides.

Biopsia cutánea La principal característica histológica de todos los tipos de eccema es el edema epidérmico intercelular (espongiosis), que expande los puentes entre los queratinocitos hasta que se rompen y se produce una vesiculación intraepidérmica. La espongiosis suele estar presente incluso en las dermatitis más crónicas, en las que no se observan vesículas macroscópicas. En la parte superior de la dermis se encuentra un infiltrado inflamatorio de células linfohistiocíticas que migran hacia la epidermis (exocitosis). Como en una biopsia cutánea no es posible distinguir entre los diversos tipos de dermatitis, este procedimiento rara vez se realiza, salvo en casos excepcionales en los que no está claro el diagnóstico clínico y se desea descartar otros trastornos como la psoriasis o el liquen plano.

0 tros procedimientos. A veces hay que realizar cultivos bacterianos, víricos o fúngicos, así como preparaciones microscópicas con hidróxido potásico para investigar la presencia de hongos o de ectoparásitos. Si se dispone del equipo adecuado, la dermatitis de contacto puede evaluarse y cuantificarse con los siguientes métodos físicos: colorimetría, evaporimetría, velocimetría LáserDoppler, ecografía y determinación de la impedancia, conductancia y capacitancia eléctricas (A dams 1990).

L ugar de trabajo En algunos pacientes, la causa de una dermatitis profesional sólo se descubre después de una observación cuidadosa del centro de trabajo. La visita permite al médico observar cómo se realizan las tareas y cómo podrían modificarse para eliminar el riesgo de dermatitis profesional. Estas visitas 
Tabla 12.6 - Ejemplos de irritantes y sensibilizantes cutáneos en las profesiones en que puede producirse el contacto con la piel.

$\begin{array}{cc}\begin{array}{c}\text { Profesión } \\ \text { Trabajadores de } \\ \text { la construcción }\end{array} & \begin{array}{c}\text { Trementinantes diluyentes, fibra } \\ \text { de vidrio, pegamentos }\end{array} \\ \begin{array}{c}\text { Técnicos } \\ \text { dentales }\end{array} & \text { Detergentes, desinfectantes } \\ & \\ & \\ \text { Agricultores y } & \text { Fertilizantes, desinfectantes, } \\ \text { ganaderos, } & \text { jabones y detergentes } \\ \text { floristas, } & \\ \text { jardineros } & \\ \text { Manipuladores } & \text { Jabones y detergentes, } \\ \text { de alimentos, } & \text { vinagre, frutas, verduras } \\ \text { cocineros, } & \\ \text { panaderos } & \\ \text { Peluqueros, } & \text { Champús, lejía, peróxidos, } \\ \text { esteticistas } & \text { permanentes, acetona }\end{array}$

Personal Desinfectantes, alcohol,
médico jabones y detergentes

Trabajadores del metal, maquinistas y mecánicos

Jabones y detergentes, aceites de corte, destilados del petróleo, abrasivos

Impresores y Disolventes, ácido acético, fotógrafos tinta, monómero acrílico

\section{Sensibilizantes}

Cromatos, resinas epoxi y fenólicas, colofonio, trementina, maderas

Caucho, monómeros epoxi y acrilicos, aminas catalíticas, anestésicos locales, mercurio, oro, níquel, eugenol, formaldehído, glutaraldehído

Plantas, maderas, fungicidas, insecticidas

Verduras, especias, ajo, caucho, peróxido de benzoilo

Parafenilenediamina en tintes para el pelo, glicerilmonotioglicolato en permanentes, persulfato de amonio en la ejía, surfactantes en champús, níquel, perfumes, aceites esenciales, conservantes en cosméticos

Caucho, colofonia, formaldehído, glutaraldehído, desinfectantes, antibióticos, anestésicos locales, fenotiacinas, benzodiacepinas

Níquel, cobalto, cromo, biocidas en los aceites de corte, hidrazina y colofonia en fundente para soldar, resinas epoxi y aminas catalíticas, caucho

Níquel, cobalto, cromo, caucho, colofonia, formaldehído, diaminas parafenileno y colorantes azoicos, hidroquinonas, monómeros epoxi y acrílico, aminas catalíticas, agentes reveladores de color y de blanco y negro

Resinas de formaldehído, colorantes azoicos y antraquinonas, caucho, biocidas

deben programarse siempre de acuerdo con el agente sanitario o el supervisor de la fábrica. La información obtenida será útil tanto para el trabajador como para la empresa. En muchas localidades, los trabajadores tienen el derecho de solicitar estas visitas y en numerosos centros de trabajo existen comités de salud y seguridad que proporcionan una valiosa información.

\section{Tratamiento}

El tratamiento local de una dermatitis aguda vesiculosa consiste en la aplicación, 3 ó 4 veces al día durante 15-30 minutos, de una compresa empapada en solución salina, solución de Burow 0 agua corriente templadas. Tras la colocación de las compresas debe aplicarse un corticosteroide tópico potente. Cuando la dermatitis mejora y se secan las lesiones, las compresas húmedas se aplican a intervalos cada vez mayores y se acaban retirando, y se disminuye progresivamente la potencia del corticosteroide según la parte del cuerpo tratada.

Si la dermatitis es intensa o diseminada, el mejor tratamiento se realiza por vía oral con prednisona, 0,5 a $1,0 \mathrm{mg} / \mathrm{kg} /$ día durante dos o tres semanas. Según el estado clínico del paciente, se administran antihistamínicos sistémicos de primera generación para sedarlo y aliviar el prurito.

La dermatitis subaguda suele responder a las cremas de corticosteroides de potencia media aplicadas dos a tres veces al día, a menudo combinadas con medidas protectoras como la utilización de guantes de algodón bajo los guantes de goma o de vinilo cuando no puede evitarse el contacto con los agentes irritantes 0 los alergenos.

La dermatitis crónica se trata con pomadas de corticosteroides y la aplicación frecuente de emolientes, cuanto más grasos, mejor. En los casos de dermatitis persistente puede ser necesario el tratamiento con psoralenos y la fototerapia con rayos ultravioleta A (PUVA), o con inmunosupresores sistémicos como la azatioprina (Guin 1995).

En todos los casos hay que evitar estrictamente las sustancias causales. Para el trabajador resulta más fácil mantenerse alejado de las mismas si recibe información escrita con los nombres, sinónimos, fuentes de exposición y patrones de las reacciones cruzadas. Este folleto deberá ser claro y conciso y en su redacción deberán emplearse términos que el paciente entienda sin dificultad

\section{Indemnización del trabajador}

Con frecuencia es necesario retirar al paciente de su puesto de trabajo. El médico deberá especificar de la forma más precisa posible la duración aproximada del período de incapacidad, teniendo en cuenta que la recuperación total de la barrera de defensa epidérmica se prolonga entre cuatro y cinco semanas después de la curación clínica de la dermatitis. Los formularios legales que permitirán al trabajador incapacitado recibir una compensación adecuada deben rellenarse con diligencia. Por último, hay que determinar el grado de incapacidad permanente o la presencia de limitaciones funcionales que puedan impedir al paciente la vuelta a su antiguo trabajo o necesiten un tratamiento rehabilitador.

\section{Prevencion de las dermatosis PROFESIONALES}

L ouis-Phillipe D urocher

El objetivo de los programas de salud profesional es permitir a los trabajadores que conserven su puesto de trabajo y su salud durante muchos años. El desarrollo de programas eficaces requiere la identificación de factores de riesgo sectoriales, basados en la población, y específicos del lugar de trabajo. Esta información podrá utilizarse entonces para desarrollar políticas de prevención para grupose individuos.

La Comisión de salud y seguridad en el trabajo de Q uebec ha caracterizado las actividades laborales en 30 sectores de servicios, comerciales e industriales (C ommmision de la santé et de la 
Tabla 12.7 - Dermatosis profesionales en Q uebec en 1989: distribución por período de baja laboral.

\begin{tabular}{|c|c|c|c|c|c|}
\hline $\begin{array}{l}\text { Período de baja laboral } \\
\text { (días) }\end{array}$ & 0 & 1- 14 & $15-56$ & $57-182$ & $>183$ \\
\hline $\begin{array}{l}\text { Número de casos } \\
\text { (total: 735) }\end{array}$ & 10 & 370 & 195 & 80 & $>80$ \\
\hline
\end{tabular}

Fuente: Commission de la santé et de la sécurité au travail, 1993.

securité au travail 1993). Sus estudios muestran que las dermatosis profesionales son más prevalentes en las industrias de alimentación y de bebidas, los servicios médicos y sociales, los servicios comerciales y de personal y en la construcción (incluidos los trabajos públicos). Los trabajadores afectados suelen participar en actividades de servicios, fabricación, montaje, reparación, manipulación de materiales o preparación de alimentos.

Las dermatosis profesionales son particularmente prevalentes en dos grupos de edad: los trabajadores jóvenes sin experiencia que no son conscientes de los riesgos, a veces insidiosos, asociados a su trabajo y los trabajadores de edad próxima a la jubilación para los que puede pasar desapercibida la sequedad progresiva de su piel con el paso de los años, y que aumenta tras varios días consecutivos de trabajo. A causa de esta deshidratación, la exposición reiterada a los productos irritantes o sustancias astringentes que antes toleraban bien puede provocar una dermatitis irritativa en estos trabajadores.

Como se indica en la Tabla 12.7, aunque en la mayoría de las dermatosis profesionales la baja laboral no suele superar dos semanas, en un número significativo de casos las lesiones pueden persistir durante más de dos meses (D urocher y Paquette 1985). En esta Tabla se muestra con claridad la importancia de la prevención de las dermatosis crónicas que requieren bajas laborales prolongadas.

\section{Factores de riesgo}

Numerosas sustancias utilizadas en la industria pueden causar dermatosis, y el riesgo depende de la concentración de la sustancia y de la frecuencia y duración del contacto cutáneo. El esquema de clasificación general que se presenta en la Tabla 12.8 (véase al dorso), basado en la clasificación de los factores de riesgo como mecánicos, físicos, químicos o biológicos, es una herramienta útil para identificar los factores de riesgo en las visitas a los centros. Durante la evaluación en el lugar de trabajo, la presencia de factores de riesgo puede observarse de forma directa o sospecharse por las lesiones cutáneas observadas. En el esquema de clasificación de la Tabla 12.8 se presta especial atención a este aspecto. En algunos casos pueden existir efectos específicos de un factor de riesgo determinado, mientras que en otros, los trastornos cutáneos pueden asociarse a varios factores de una categoría determinada. Los trastornos de este último tipo se conocen como efectos de grupo. Los efectos cutáneos específicos de los factores físicos se enumeran en la Tabla 12.8 y se describen en otras secciones de este capítulo.

Entre los factores mecánicos figuran la fricción repetida, la presión excesiva y prolongada y la acción física de algunos polvos industriales, cuyos efectos dependen de la forma y el tamaño de sus partículas y del grado de fricción con la piel. Las propias lesiones pueden ser mecánicas (sobre todo en los trabajadores expuestos a vibraciones repetidas), químicas o térmicas, e incluyen las lesiones físicas (úlceras, vesículas), la infección secundaria y el isomorfismo (fenómeno de Koebner). Asimismo, pueden desarrollarse cambios crónicos, como cicatrices, queloides, discromías y el fenómeno de R aynaud, que es una alteración neurovascular periférica causada por el uso prolongado de herramientas vibratorias.

L os factores químicos son, con diferencia, la causa más común de dermatosis profesionales. Es prácticamente imposible elaborar una lista exhaustiva con todos los agentes químicos. Estos pueden provocar reacciones alérgicas, irritantes o fotodermatósicas, y a veces dejan secuelas discrómicas. Los efectos de la irritación química varían entre la simple sequedad y la inflamación hasta la necrosis celular completa. En el artículo sobre la dermatitis de contacto se incluye más información sobre este tema. Las Fichas Técnicas de Seguridad, que proporcionan información toxicológica y de otro tipo, son unas herramientas indispensables para desarrollar medidas preventivas eficaces contra la acción de los agentes químicos. De hecho, en varios países, los fabricantes del sector químico deben informar a todos los centros de trabajo que utilizan sus productos sobre los peligros sanitarios laborales asociados.

L as infecciones bacterianas, víricas y fúngicas contraídas en el lugar de trabajo suelen producirse por el contacto con materiales, animales o personas contaminadas. Entre ellas figuran la piodermatitis, la foliculitis, los panadizos, las dermatomicosis, el carbunco y la brucelosis. Los trabajadores del sector de la alimentación pueden desarrollar múltiples verrugas en las

Tabla 12.8 - Factores de riesgo y sus efectos sobre la piel.

\begin{tabular}{ll} 
& \\
Factores mecánicos & Efectos de grupo \\
Traumatismos & Cortes, punciones, ampollas \\
Fricción & Abrasiones, isomorfismo \\
Presión & Liquenificación \\
Polvo & Callos \\
Factores físicos & Efectos espećificos \\
Radiación & Fotodermatitis, radiodermatitis, cáncer \\
Humedad & Maceración, irritación \\
Calor & Erupción por calor, quemaduras, eritema \\
Frío & Congelaciones, xerodermia, urticaria, \\
& paniculitis, \\
& Fenómeno de Raynaud \\
Factores químicos & Efectos de grupo \\
Acidos, bases & Deshidratación \\
Detergentes, disolventes & Inflamación \\
Metales, resinas & Necrosis \\
Aceites de corte & Alergia \\
Colorantes, alquitrán & Fotodermatitis \\
Caucho, etc. & Discromía \\
Factores biológicos & Efectos espećificos \\
Bacterias & Piodermatitis \\
Virus & Verrugas múltiples \\
Dermatofitos & Dermatomicosis \\
Parásitos & Parasitosis \\
Plantas & Fitodermatitis \\
Insectos & Urticaria \\
Cofactores de riesgo & \\
Eccema (atópico, dishidrótico, seborreico, numular) \\
Psoriasis & \\
Xerodermia & \\
Acné & \\
& \\
\hline & \\
\hline
\end{tabular}


manos, aunque esto sólo sucede si han sufrido previamente microtraumatismos y están expuestos a niveles excesivos de humedad durante períodos prolongados (Durocher y Paquette 1985). Los animales, y también las personas que trabajan en guarderías y centros sanitarios, pueden actuar como vectores de infestaciones parasitarias por ácaros y piojos del cuero cabelludo y de la sarna. Algunas plantas (R hus sp.) o flores (A lstroemeria sp., crisantemos, tulipanes) pueden causar fitodermatitis. Por último, algunos extractos de madera provocan dermatitis de contacto.

\section{Cofactores de riesgo}

Algunas alteraciones cutáneas no profesionales pueden exacerbar los efectos de los factores ambientales sobre la piel de los trabajadores. Por ejemplo, desde hace tiempo se sabe que el riesgo de dermatitis de contacto por irritantes aumenta en gran medida en los individuos con antecedentes médicos de atopia, incluso en ausencia de dermatitis atópica. En un estudio de 47 casos de dermatitis de contacto por irritantes de las manos de trabajadores de plantas de procesado de alimentos, el $64 \%$ tenía antecedentes de atopia (Cronin 1987). Los individuos con dermatitis atópica sufren procesos irritativos más graves cuando se exponen al lauril sulfato sódico que se encuentra habitualmente en los jabones (Agner 1991). La predisposición a los trastornos alérgicos (T ipo I) (diátesis atópica), sin embargo, no aumenta el riesgo de sufrir una dermatitis de contacto alérgica retardada (T ipo IV), ni siquiera al níquel (Schubert y cols. 1987), que es el alergeno más investigado. Por otro lado, se ha observado recientemente que la atopia favorece el desarrollo de urticaria de contacto (alergia del Tipo I) al látex de caucho en los trabajadores sanitarios (Turjanmaa 1987; Durocher 1995) y al pescado en los trabajadores de empresas de abastecimiento de comidas (Cronin 1987).

En la psoriasis, la capa más externa de la piel (estrato córneo) está engrosada pero no forma hiperqueratosis (paraqueratótica) y es menos resistente a los irritantes cutáneos y a la tracción mecánica. Las lesiones cutáneas frecuentes pueden empeorar una psoriasis previa y en el tejido cicatricial pueden desarrollarse nuevas lesiones psoriáticas isomórficas.

El contacto repetido con detergentes, disolventes o polvos astringentes puede provocar una dermatitis de contacto por irritantes secundaria en las personas con xerodermia. De la misma forma, la exposición a los aceites de freír puede exacerbar el acné.

\section{Prevención}

Es indispensable que los trabajadores entiendan con claridad los factores de riesgo relevantes para establecer los programas de prevención, que podrán ser institucionales o personales, como, por ejemplo, el empleo de un equipo de protección personal. La eficacia de los programas de prevención depende de la colaboración estrecha de los trabajadores y la empresa durante su desarrollo. En la Tabla 12.9 se ofrece información sobre la prevención.

\section{Prevención en el lugar de trabajo}

El objetivo principal de las medidas preventivas en el lugar de trabajo es la eliminación de los peligros en su origen. Siempre que sea posible, la sustitución de una sustancia tóxica por otra no tóxica es la solución ideal. Por ejemplo, los efectos tóxicos de un disolvente que se utiliza de forma incorrecta para limpiar la piel pueden eliminarse sustituyéndolo por un detergente sintético sin efectos sistémicos y menos irritante. En la actualidad se dispone de varios polvos de cemento no alergénicos en los que se sustituye el cromo hexavalente, un alergeno bien conocido, por sulfato ferroso. En los sistemas de refrigeración con agua, los agentes anticorrosivos que contienen cromato pueden sustituirse por borato de zinc, un alergeno más débil (M athias 1990). Los biocidas alergénicos de los aceites de corte pueden sustituirse por otros agentes conservantes. La utilización de guantes de goma sintética o de PVC puede evitar el desarrollo de alergias al látex en los trabajadores sanitarios. La sustitución de la aminoetanolamina por trietanolamina en los fundentes decapantes que se emplean para soldar los cables de aluminio ha reducido la incidencia de trastornos alérgicos (L achapelle y cols. 1992).

La modificación de los procesos de producción para evitar el contacto de la piel con sustancias peligrosas puede constituir una alternativa aceptable cuando la sustitución es imposible o el riesgo es bajo. Algunas modificaciones simples consisten en el uso de pantallas o de tubos flexibles para eliminar las salpicaduras durante la transferencia de líquidos, o de filtros para retener los residuos y reducir la necesidad de limpieza manual. Asimismo, puede resultar útil dotar a las herramientas y a los equipos de puntos de agarre más naturales para evitar la presión y la fricción excesivas en las manos y prevenir el contacto de la piel con agentes irritantes. 0 tra medida eficaz es la instalación de sistemas de ventilación con captura local y con dispositivos de captura que limiten las nebulizaciones o reduzcan la concentración de las partículas de polvo en el aire. En los centros donde se han automatizado totalmente los procesos para evitar los peligros ambientales, deberá prestarse particular atención a la formación de los trabajadores responsables de la reparación y limpieza de los equipos, y pueden necesitarse medidas preventivas específicas para limitar su exposición (Lachapell y cols. 1992).

Todo el personal debe ser consciente de los peligros presentes en los centros de trabajo y las medidas colectivas sólo serán eficaces si se acompañan de un programa completo de información. Pueden utilizarse Fichas T écnicas de Seguridad para identificar sustancias peligrosas y potencialmente peligrosas. Es posible utilizar también signos de advertencias del peligro para identificar con rapidez estas sustancias. EI nivel de riesgo puede codificarse visualmente con un color simple. Por ejemplo, una pegatina roja podría señalar la presencia de un producto peligroso y la necesidad de evitar el contacto con la piel. Este código sería apropiado para una sustancia corrosiva que ataque con rapidez la piel. De la misma forma, una pegatina amarilla podría indicar la necesidad de proceder con prudencia, por ejemplo, al manipular una sustancia capaz de dañar la piel tras el contacto repetido o prolongado (Durocher 1984). La exhibición periódica de carteles y la utilización ocasional de elementos audiovisuales refuerza la información suministrada y estimula el

Tabla 12.9 - Medidas colectivas (participación en grupos) de prevención.

Medidas colectivas
- Sustitución
- Control ambiental:
Utilización de herramientas para manipular materiales
Ventilación
Sistemas cerrados
Automatización
- Información y programas de formación
- Medidas de precaución en el trabajo
- Seguimiento
Protección personal
- Higiene de la piel
- Agentes protectores


interés por los programas de prevención de las dermatosis profesionales.

A ntes de comenzar el trabajo, debería facilitarse una información completa sobre los peligros asociados a las actividades laborales. En varios países, los trabajadores reciben cursos especiales de formación laboral impartidos por instructores profesionales.

Las actividades de formación en el lugar de trabajo deben repetirse cada vez que se cambie un proceso o tarea y varíen los factores de riesgo. L as buenas relaciones laborales no se favorecen con actitudes alarmistas ni paternalistas. Tanto las empresas como los trabajadores desean que el trabajo se realice con seguridad y la información facilitada sólo será creíble si es realista.

Dada la ausencia de normas de seguridad para las sustancias dermatotóxicas (M athias 1990), las medidas preventivas deben respaldarse con la observación atenta del estado de la piel de los trabajadores. Por suerte, esto resulta fácil, ya que cualquiera puede observar directamente la piel, sobre todo de las manos y la cara. El objetivo de este tipo de observación es identificar los signos precoces de alteraciones cutáneas que indiquen la ruptura del equilibrio corporal natural. Los trabajadores y los especialistas en seguridad y salud deben, por tanto, estar atentos a los siguientes signos de aviso:

- sequedad progresiva

- maceración

- engrosamiento localizado

- traumatismos frecuentes

- enrojecimientos, sobre todo alrededor de los pelos.

Es muy importante identificar y tratar con rapidez los trastornos cutáneos y los factores causales subyacentes para evitar su cronificación.

Si los sistemas de control en el lugar de trabajo no pueden impedir el contacto de la piel con sustancias peligrosas, deberá reducirse al mínimo posible la duración del contacto cutáneo. Con este fin, los trabajadores deben tener un acceso rápido a equipos de higiene apropiados. La contaminación de los agentes limpiadores puede evitarse utilizando recipientes cerrados equipados con un sistema de bombeo que dispense la cantidad adecuada de limpiador con un único movimiento de presión. La selección de los limpiadores debe realizarse manteniendo un equilibrio entre la eficacia limpiadora y el potencial de irritación. Por ejemplo, los limpiadores de alta potencia suelen contener disolventes o sustancias abrasivas que aumentan la irritación. El limpiador seleccionado deberá adaptarse a las características específicas del lugar de trabajo, ya que los trabajadores emplearán un disolvente si los limpiadores disponibles son ineficaces. Los limpiadores pueden ser jabones, detergentes sintéticos, pastas o cremas sin agua, preparaciones abrasivas y agentes antimicrobianos (D urocher 1984).

En diversas actividades laborales, la aplicación de una crema protectora antes del trabajo facilita la limpieza de la piel con independencia del agente limpiador utilizado. En todos los casos, la piel debe enjuagarse por completo y secarse después de cada lavado. Si esto no se realiza, la irritación puede aumentar, por ejemplo, debido a la reemulsificación de los residuos de jabón causada por la humedad en el interior de los guantes impermeables.

Los jabones industriales suelen suministrarse en forma de líquidos que se dispensan mediante presión manual. Se componen de ácidos grasos de origen animal (manteca) o vegetal (aceite), tamponados con una base (p. ej., hidróxido sódico). EI tamponado puede ser incompleto y, en ese caso, deja radicales libres residuales que pueden irritar la piel. Para evitar este problema, conviene que el $\mathrm{pH}$ sea neutro (4 a 10). Estos jabones líquidos son adecuados para muchas tareas.
Los detergentes sintéticos, disponibles en forma líquida y en polvo, emulsionan las grasas. Por tanto, eliminan generalmente el sebo de la piel, que es una sustancia protectora contra la sequedad. La emulsificación de la piel suele ser menos marcada con los jabones que con los detergentes sintéticos y es proporcional a la concentración del detergente. Para contrarrestar este efecto suelen añadirse a los detergentes sustancias emolientes como la glicerina, la lanolina y la lecitina.

Las pastas y las cremas, conocidas también como "jabones para usar sin agua" son emulsiones de sustancias oleosas en agua. Su agente limpiador principal es un disolvente, en general un derivado del petróleo. Se dice que no "necesitan agua" porque pueden emplearse cuando no se dispone de agua corriente. Debido a su dureza, no se consideran como limpiadores de elección. Recientemente se han comercializado "jabones para usar sin agua" que contienen detergentes sintéticos menos irritantes para la piel que los disolventes. La American Association of Soap and Detergent $M$ anufacturers recomienda lavarse con un jabón suave después de utilizar "jabones para usar sin agua" que contengan un disolvente. Los trabajadores que utilizan estos jabones que no necesitan agua tres o cuatro veces al día deberán aplicarse una loción o una crema hidratante al final del día de trabajo para evitar la sequedad.

Las partículas abrasivas que suelen añadirse a los limpiadores antes descritos para aumentar su poder limpiador son irritantes. Estas pueden ser solubles (p. ej., bórax) o insolubles. Los abrasivos insolubles pueden ser minerales (p. ej., piedra pómez), vegetales (p. ej., cáscaras de nuez) o sintéticos (p. ej., poliestireno).

Los limpiadores antimicrobianos sólo deberían emplearse en los lugares de trabajo en los que existe un riesgo real de infección, ya que algunos son alergenos potenciales y los trabajadores no deberían exponerse a ellos de forma innecesaria.

Por la influencia de ciertas sustancias o de lavados repetidos, las manos de los trabajadores tienen a secarse. EI mantenimiento a largo plazo de una buena higiene cutánea en estas condiciones requiere la humidificación diaria, con una frecuencia que dependerá del individuo y del tipo de trabajo. En muchos casos, las lociones o cremas hidratantes, conocidas también como cremas para las manos, son adecuadas. En los casos de sequedad grave 0 si las manos se sumergen durante períodos prolongados, las vaselinas hidrofílicas son más adecuadas. Las cremas denominadas protectoras o de barrera suelen ser cremas hidratantes, a veces contienen silicona, zinc u óxidos de titanio. Las cremas protectoras específicas para el tipo de exposición son raras, salvo las que protegen frente a la radiación ultravioleta. Estas han mejorado de forma notable en los últimos años y ahora ofrecen una protección eficaz frente a los rayos UV-A y UV-B. Se recomienda un factor de protección mínimo del 15 (escala norteamericana). La crema Stokogard ${ }^{\circledR}$ parece ser eficaz contra la dermatitis de contacto causada por la hiedra venenosa. Las cremas de barrera o protectoras nunca deben considerarse como el equivalente a un guante impermeable invisible (Sasseville 1995). Además, las cremas protectoras sólo son eficaces en la piel sana.

Aunque a pocas personas les agrada utilizar equipos de protección, no queda otra elección si las medidas descritas antes son inadecuadas. El equipo de protección consta de botas, delantales, gafas, mangas, batas, zapatos y guantes. Este material se comenta en otra parte de la Enciclopedia.

N umerosos trabajadores se quejan de que los guantes protectores reducen su destreza, pero su uso resulta inevitable en algunas situaciones. Es preciso tratar de reducir al mínimo los inconvenientes que causan. Existen muchos tipos, tanto permeables (algodón, cuero, malla metálica, K evlar ${ }^{\circledR}$ ) como impermeables (látex de caucho, neopreno, nitrilo, cloruro de polivinilo, Viton ${ }^{\circledR}$, alcohol de polivinilo, polietileno) al agua. El tipo 
seleccionado deberá tener en cuenta las necesidades específicas de cada situación. El algodón ofrece una protección mínima y una buena ventilación. El cuero es eficaz frente a la fricción, presión y tracción, y frente a algunos tipos de lesiones. Las mallas de metal protegen contra los cortes. EI K evlar ${ }^{\circledR}$ es ignífugo. El amianto es resistente al fuego y al calor. La resistencia de los guantes impermeables frente a los disolventes es muy variable y depende de su composición y grosor. Para aumentar la resistencia a los disolventes, algunos investigadores han desarrollado guantes con capas múltiples de polímeros.

A la hora de seleccionar guantes deben tenerse en cuenta varias características, como grosor, flexibilidad, longitud, dureza, ajuste a las muñecas y los dedos y resistencia química, mecánica y térmica. En varios laboratorios se han desarrollado técnicas, basadas en la determinación de los tiempos de rotura y las constantes de permeabilidad, para calcular la resistencia de los guantes a productos químicos específicos. Existen listas que sirven de guía para la elección de los guantes (L achapelle y cols. 1992; Berardinelli 1988).

En algunos casos, el uso prolongado de guantes protectores puede provocar una dermatitis de contacto alérgica a los componentes del guante 0 a los alergenos que penetran a través de ellos. El uso de guantes protectores también se asocia a un mayor riesgo de irritación cutánea por la exposición prolongada a niveles altos de humedad dentro del guante o por la penetración de agentes irritantes a través de las perforaciones. Para evitar el empeoramiento de las lesiones, todos los trabajadores que padezcan una dermatitis de la mano, con independencia de su origen, deben evitar el uso de guantes que aumenten el calor y la humedad alrededor de sus lesiones.

Para establecer un programa completo de prevención de las dermatosis profesionales hay que adaptar cuidadosamente los principios y las normas a las características específicas de cada lugar de trabajo. Para asegurar su eficacia, los programas de prevención deben revisarse periódicamente, teniendo en cuenta los cambios en el lugar de trabajo, la experiencia con el programa y los avances tecnológicos.

\section{- Distrofia Ungueal PROfESIONAL*}

\section{C.D. Calnan}

La función del epitelio de la epidermis es formar la superficie o capa córnea de la piel; su principal componente es la queratina, una proteína fibrosa. En ciertas áreas, el epitelio se desarrolla de forma especial para producir un tipo particular de estructura de la queratina, como sucede en el pelo y las uñas. El cuerpo de la uña está formado en parte por el epitelio de la matriz y en parte por el lecho ungueal. La uña crece de la misma forma que el pelo y la capa córnea y se afecta por los mismos mecanismos patogénicos que intervienen en las enfermedades del pelo y de la epidermis. Algunos elementos como el arsénico y el mercurio se acumulan en la uña al igual que en el pelo.

En la Figura 12.2 se observa que la matriz ungueal es una invaginación del epitelio y está cubierta por el pliegue ungueal en su base. Una fina capa córnea denominada cutícula sirve para sellar el espacio periungueal y se extiende desde el pliegue ungueal hasta el lecho de la uña.

Las partes más vulnerables de la uña son el pliegue ungueal y el área situada bajo el extremo del cuerpo de la uña, aunque este último puede sufrir también traumatismos físicos o químicos

*Este artículo se publicó originalmente en la E ncidopedia de salud y seguridad en el trabajo, 3a edición, y ha sido adaptado por el director del capítulo para esta $4^{\mathrm{a}}$ edición.
Figura 12.2 - La estructura de la uña.

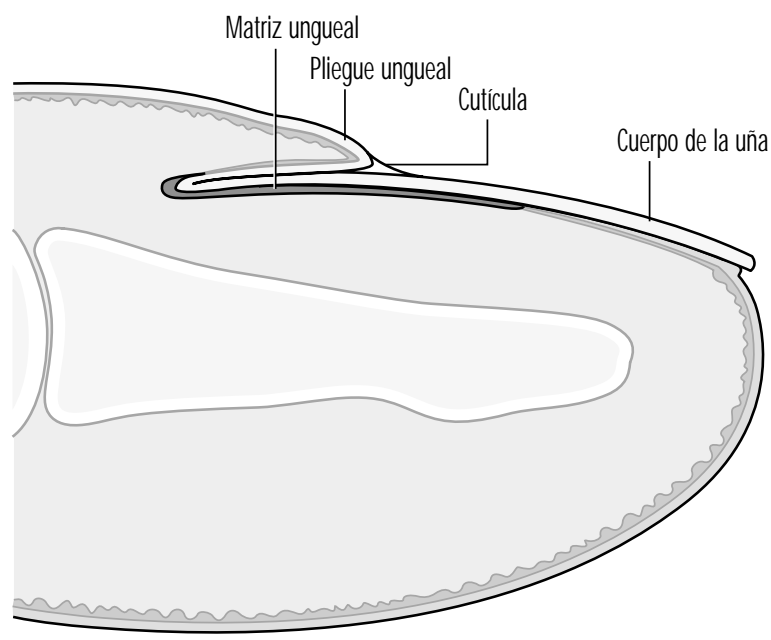

Fuente: Fundación Ciba

directos. Las sustancias químicas o los agentes infecciosos pueden penetrar bajo el cuerpo de la uña por su margen libre. La humedad y los álcalis pueden destruir la cutícula y permitir la entrada de bacterias y de hongos, que causarán inflamación del tejido periungueal y producirán alteraciones secundarias del crecimiento ungueal.

Las causas más frecuentes de enfermedad ungueal son la paroniquia crónica, las dermatofitosis, los traumatismos, la psoriasis, los trastornos circulatorios y el eccema u otros tipos de dermatitis. La paroniquia es una inflamación del pliegue ungueal. La paroniquia aguda es un trastorno supurativo agudo que requiere tratamiento antibiótico $y$, a veces, tratamiento quirúrgico. La paroniquia crónica se produce tras la pérdida de la cutícula, lo cual permite el acceso de agua, bacterias y $C$ andida albicans al espacio periungueal. Es común en las personas con exposición intensa al agua, sustancias alcalinas y detergentes, como personal de cocinas, limpiadores, trabajadores que

Figura 12.3 - O nicodistrofia secundaria a una dermatitis de contacto por irritación crónica.

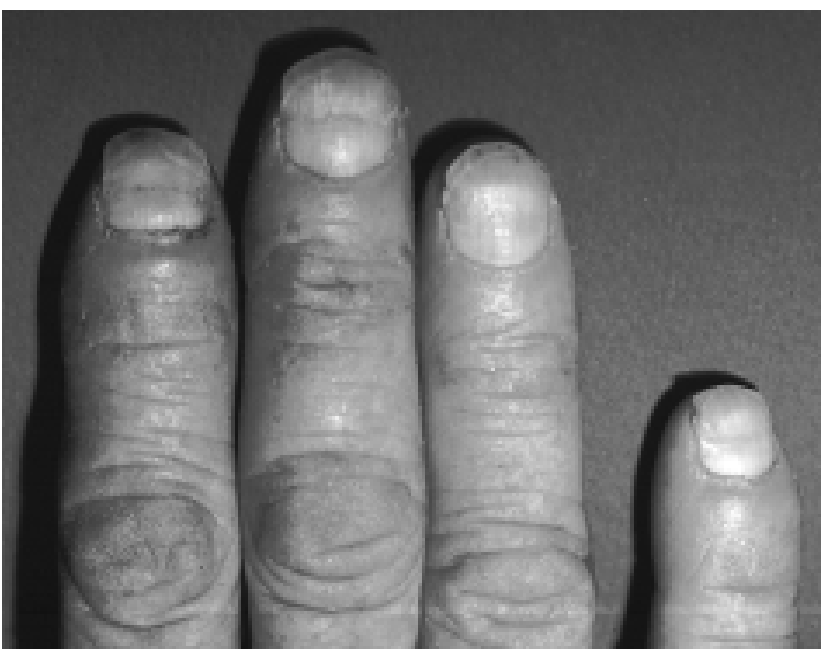


preparan frutas y verduras o de centros de enlatado y amas de casa. No es posible lograr una recuperación completa mientras no se haya restaurado al integridad de la cutícula que sella el espacio periungueal.

La exposición al cemento, la cal y los disolventes orgánicos, y algunos tipos de trabajo como los de carnicero o granjero de aves de corral, pueden dañar la cutícula y los pliegues ungueales.

Cualquier inflamación o enfermedad de la matriz ungueal puede provocar una distrofia (distorsión) del cuerpo de la uña, y esta alteración es el síntoma que suele inducir al paciente a buscar atención médica. La exposición al frío extremo o el fenómeno de espasmos arteriales de Raynaud, pueden lesionar también la matriz y producir distrofia ungueal. A veces, la lesión es temporal y la distrofia ungueal desaparece después de eliminar la causa y de tratar el trastorno inflamatorio (en la Figura 12.3 se muestra un ejemplo).

La uña puede lesionarse por la aplicación directa de ciertas preparaciones cosméticas, como cubrientes de base que se utilizan bajo el barniz, endurecedores ungueales y cubiertas sintéticas.

Algunas profesiones concretas son más propensas a las lesiones ungueales. Se han comunicado casos de distrofia por la manipulación de los pesticidas paraquat y diquat, que contienen dipiridilio concentrado. Durante la fabricación de dióxido de selenio, un polvo fino de esta sustancia puede penetrar bajo el borde del cuerpo ungueal y provocar irritación intensa y necrosis de las yemas de los dedos, con lesión del cuerpo ungueal. Debe prevenirse a los trabajadores de este peligro y aconsejarles que se limpien las zonas subungueales de los dedos todos los días.

Algunos tipos de dermatitis de contacto alérgica de las yemas de los dedos suelen provocar distrofia ungueal secundaria. Seis sustancias sensibilizantes comunes son:

1. ametocaína y otros anestésicos locales químicamente relacionados, utilizados por los cirujanos dentales;

2. formalina empleada por los ayudantes de laboratorio y el personal de depósitos de cadáveres, museos y centros anatómicos;

3. ajos y cebollas utilizados por los cocineros;

4. bulbos de tulipanes y flores, manejados por horticultores y floristas;

5. resina $p$-tert-butilfenol formaldehído, utilizada por los fabricantes de calzados y por los zapateros;

6. aminoetiletanolamina, empleada en algunos flujos de aluminio.

El diagnóstico puede confirmarse con una prueba del parche positiva. Al cesar el contacto, la piel y las uñas recuperan su estado normal.

\section{M edidas protectoras}

En muchos casos, las uñas pueden preservarse con una protección adecuada de las manos. Sin embargo, si la exposición manual se produce, las uñas deben cuidarse correctamente, conservando la cutícula y protegiendo el área subungueal. La piel situada bajo el margen libre de las uñas debe limpiarse todos los días para eliminar las sustancias extrañas o los productos químicos irritantes.

Si se emplean cremas o lociones de barrera, hay que asegurarse de que se cubran la cutícula y el área situada bajo el margen libre.

Para preservar la cutícula intacta es necesario evitar el exceso de manicura o los traumatismos, la maceración y la exposición prolongada al agua, así como la disolución por la exposición repetida a disolventes, álcalis y detergentes.

\section{ESTIGMAS*}

\section{H. M ierzecki}

Las marcas o estigmas profesionales son lesiones anatómicas de origen laboral que no alteran la capacidad de trabajo. Suelen estar causadas por irritaciones mecánicas, químicas o térmicas prolongadas y con frecuencia son características de una profesión determinada. Cualquier tipo de presión o de fricción de la piel puede tener un efecto irritante, mientras que una presión única y violenta puede provocar la rotura de la epidermis y los tejidos subyacentes. Por otro lado, sin embargo, la repetición frecuente 0 la irritación moderada no rompen la piel, pero estimulan las reacciones de defensa (engrosamiento y queratinización de la epidermis). El proceso puede adoptar tres formas:

1. un engrosamiento difuso de la epidermis que aparece en la piel normal, con preservación y acentuación ocasional de los pliegues cutáneos y sin alteración de la sensibilidad;

2. una callosidad circunscrita, formada por láminas córneas lisas, amarillentas, elevadas, con pérdida parcial o completa de los pliegues cutáneos y alteración de la sensibilidad. Las láminas no están bien limitadas; son más gruesas en el centro y más delgadas hacia la periferia, y se mezclan con la piel normal;

3. una callosidad circunscrita, en la mayoría de los casos elevada sobre la piel normal, de $15 \mathrm{~mm}$ de diámetro, de color amarillo marrón a negro, indolora y ocasionalmente asociada a hipersecreción de las glándulas sudoríparas.

Las callosidades se producen generalmente por la acción de agentes mecánicos, a veces con la ayuda de un irritante térmico (como sucede en el caso de los sopladores de vidrio, panaderos, bomberos, procesadores de carne, etc) , en cuyo caso presentan un color entre marrón oscuro y negro y fisuras dolorosas. Sin embargo, si el agente térmico o mecánico se combina con un irritante químico, las callosidades muestran cambios de color, se ablandan y ulceran.

En numerosas profesiones se observan callosidades que representan una reacción profesional característica (sobre todo en la piel de la mano, como se muestra en las Figuras 12.4 y 12.5). Su forma y localización dependen de cómo se ejerce la presión (zona, fuerza, modo y frecuencia), así como de las herramientas y materiales empleados. El tamaño de las callosidades puede revelar también una tendencia congénita a la queratinización cutánea (ictiosis, queratosis palmar hereditaria). Estos factores pueden ser también decisivos en lo que respecta a las variaciones en la localización y tamaño de las callosidades en los trabajadores manuales.

Las callosidades actúan normalmente como mecanismos protectores pero, en ciertas condiciones, adquieren características patológicas, por lo que no deben pasarse por alto en lo que se refiere a la patogenia y, sobre todo, a la prevención de las dermatosis profesionales.

Cuando un trabajador renuncia a un puesto de trabajo en el que se forman habitualmente callosidades, las capas córneas superfluas sufren una exfoliación, la piel se vuelve fina y blanda, la alteración de la coloración desaparece y se restaura el aspecto normal de la piel. El tiempo necesario para la regeneración cutánea varía: las callosidades profesionales de las manos pueden observarse ocasionalmente meses 0 años después de abandonar el trabajo (sobre todo en herreros, sopladores de vidrio y

*Este artículo se publicó originalmente en la E ncidopedia de salud y seguridad en el trabajo, 3 a edición, y ha sido adaptado por el director del capítulo para esta $4^{\mathrm{a}}$ edición. 
Figura 12.4 • Estigmas profesionales en las manos.
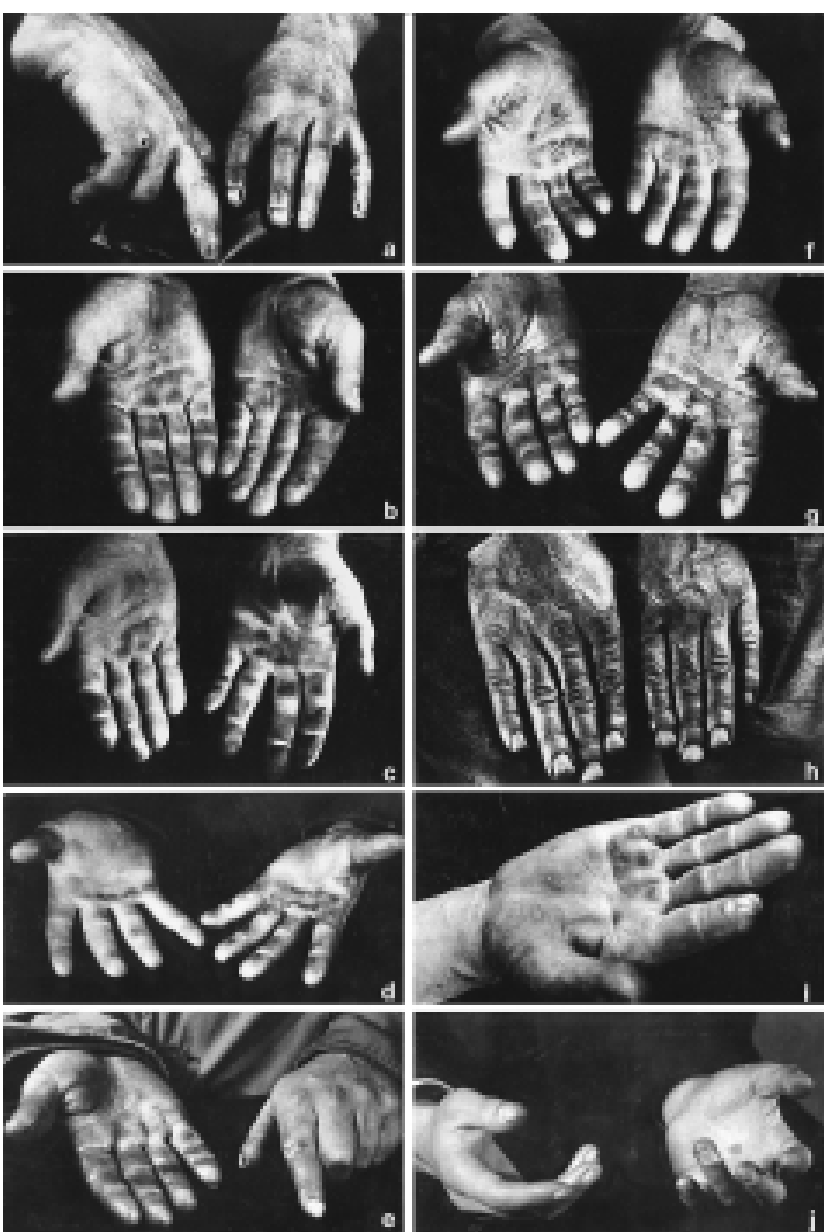

(a) Ulceras de curtidor; (b) Herrero; (c) Trabajador de serrería; (d) Cantero; (e) Albañil;

(f) Marmolista; (g) Trabajador de empresa química; (h) Trabajador de refinería de parafina; (i) Impresor; (j) Violinista.

(Fotos: Janina Mierzecka)

trabajadores de serrerías). Persisten más tiempo en la piel senil y cuando están asociadas a una degeneración del tejido conectivo y a bursitis.

Las fisuras y erosiones de la piel son características de ciertas profesiones (trabajadores ferroviarios, armeros, albañiles,
Figura 12.5 - Callos en puntos de presión sobre la palma de la mano.

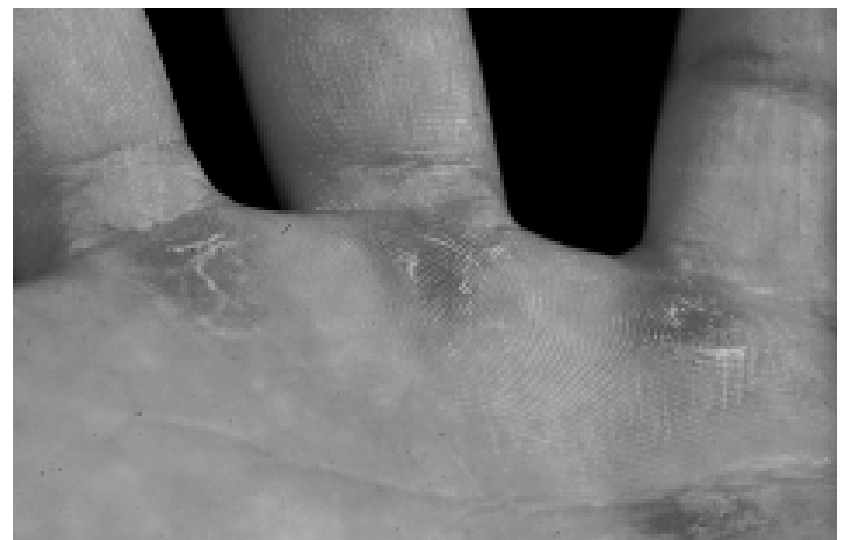

orfebres, tejedores de cestas, etc). La dolorosa "úlcera del curtidor", asociada a la exposición a compuestos de cromo (Figura 12.4) es de forma redonda u oval y de un diámetro de 2-10 mm. La localización de las lesiones profesionales (p. ej., dedos de trabajadores de la confección, dedos y palmas de sastres, etc.) es también característica.

Las manchas de pigmentos se producen por la absorción de colorantes a través de la piel, la penetración de partículas de compuestos químicos sólidos o de metales industriales o la acumulación excesiva del pigmento cutáneo, la melanina, en trabajadores de centrales eléctricas o de coque, al cabo de tres a cinco años. En algunos centros, se ha observado que alrededor del $32 \%$ de los trabajadores muestran signos pigmentarios. Las manchas de pigmentos se encuentran con más frecuencia en los trabajadores de empresas químicas.

Como regla general, los colorantes que se absorben a través de la piel no pueden eliminarse mediante un lavado normal, de ahí su permanencia y su significado como estigma laboral. Las manchas pigmentarias se producen ocasionalmente por la impregnación con compuestos químicos, plantas, suciedad u otras sustancias a las que está expuesta la piel durante el proceso de trabajo.

En la zona de la boca pueden observarse varios estigmas laborales (p. ej., líneas de Burton en las encías de los trabajadores expuestos al plomo, erosiones dentales en los trabajadores expuestos a humos, coloración azul de los labios en las personas que trabajan en la fabricación de anilina). Los olores característicos relacionados con determinadas ocupaciones pueden considerarse también estigmas profesionales.

\section{Referencias}

Adams, RM. 1988. M edicolegal aspects of occupational skin diseases. D ermatol Clin 6:121.

-. 1990. O ccupational Skin Disease. 2a ed. Filadelfia: Saunders.

Agencia Internacional para la Investigación sobre el Cáncer (IARC). 1983. Polynuclear aromatic compounds, Part I, Chemical, environmental and experimental data. M onographs on the Evaluation of the $\mathrm{C}$ arcinogenic Risk of Chemicals to Humans, No. 32. Lyon: IARC

- . 1984a. Polynuclear aromatic compounds, Part 2, Carbon blacks, mineral oils and some Nitroarenes. M onographs on the Evaluation of the Carcinogenic Risk of Chemicals to $\mathrm{H}$ umans, N O. 33. Lyon: IAR C

- 1984b. Polynuclear aromatic compounds, Part 3, Industrial exposures in aluminium production, coal gasification, coke production, and iron and sted founding. Monographs on the Evaluation of the Carcinogenic Risk of Chemicals to Humans, $\mathrm{NO}$. 34. Lyon: IARC

- 1985a. Polynuclear aromatic compounds Part 4 Bitumens, coal tars and derived products, shale oils and soots. M onographs on the Evaluation of the Carcinogenic Risk of Chemicals to $\mathrm{H}$ umans, No. 35. Lyon: IAR C.
$-1985 \mathrm{~b}$. Solar and ultraviolet radiation. M onographs on the Evaluation of the Carcinogenic Risk of Chemicals to H umans, N o. 55. Lyon: IARC.

-. 1987. Overall Evaluations of Carcinogenecity: An updating of IARC M onographs Volumes 1 to 42. Monographs on the Carcinogenic Risks to H umans. Suppl. 7. Lyon: IAR C

-. 1990. Cancer: Causes, occurrence and control. IARC Scientific Publications, N 0. 100. Lyon: IARC.

-. 1992a. Cancer incidence in five continents. Vol. VI. IARC Scientific Publications, No. 120. Lyon: IARC. 
-. 1992b. Solar and ultraviolet radiation. Monographs On the Evaluation of Carcinogenic Risks to H umans, N 0. 55. Lyon: IAR C.

-. 1993. T rends in cancer incidence and mortality. IARC Scientific Publications, N o. 121. Lyon: IAR C.

Agner, T. 1991. Susceptibility of atopic dermatitis patients to irritant dermatitis caused by sodium lauryl sulfate. A D erm-V en 71: 296-300.

Balch, CM, AN Houghton, L Peters. 1993. Cutaneous melanoma. En Cancer: Principles and Practice of Oncology, dirigido por VTJ DeVita, S Hellman y SA Rosenberg. Filadelfia: JB Lippincott.

Beral, V, H Evans, H Shaw, G Milton. 1982. $M$ alignant melanoma and exposure to fluorescent lighting at work. L ancet II:290-293.

Berardinelli, SP. 1988. Prevention of occupational skin disease through use of chemical protective gloves. D ermatol Clin 6:115-119.

Bijan, S. 1993. Cancers of the skin. En Cancer: Principles \& Practice of Oncology, dirigido por VTJ DeV ita, S H ellman y SA R osenberg. Filadelfia: JB Lippincott.

Blair, A, S H oar Zahm, NE Pearce, EF H einerman, J Fraumeni. 1992. Clues to cancer etiology from studies of farmers. Scand I W ork Environ $\mathrm{H}$ ealth 18:209-215.

Commission de la santé et de la sécurité du travail. 1993. Statistiques sur les lesions professionnelles de 1989. Q uebec: CSST

Cronin, E. 1987. Dermatitis of the hands in caterers Contact D ermatitis 17: 265-269.

De Groot, AC. 1994. Patch T esting: T est Concentrations and Vehicles for 3,700 Allergens. 2a ed. Amsterdam Elsevier.
Durocher, LP. 1984. La protection de la peau en milieu de travail. Le M édecin du Q uébec 19:103-105.

—. 1995. Les gants de latex sont-ils sans risque? Le M édecin du T ravail 30:25-27.

Durocher, LP, N Paquette. 1985. Les verrues multiples chez les travailleurs de l'alimentation. L'U nion M édicale du Canada 115:642-646.

Ellwood, JM, HK Koh. 1994. Etiology, epidemiology, risk factors, and public health issues of melanoma. Curr O pin O ncol 6:179-187.

Gellin, GA. 1972. Occupational Dermatoses. Chicago: American M edical Assoc.

Guin, JD. 1995. Practical Contact Dermatitis. Nueva Y ork: M cG raw-H ill.

Hagmar, L, K Linden, A Nilsson, B Norrving, B Akesson, A Schutz, T Moller. 1992. Cancer incidence and mortality among Swedish Baltic Sea fisherman. Scand J W ork E nviron H ealth 18:217-224.

$H$ annaford, PC L Villard M ackintosh, M P Vessey, CR K ay. 1991. O ral contraceptives and malignant melanoma. Brj Cancer 63:430-433.

Higginson, J, CS M uir, M M unoz. 1992. H uman Cancer: Epidemiology and Environmental Causes. Cambridge Monographs on Cancer Research. Cambridge, R eino U nido: CUP.

Koh, HK, TH Sinks, AC Geller, DR Miller, RA Lew. 1993. Etiology of melanoma. Cancer T reat Res 65:1-28.

K ricker, $A$, BK Armstrong, ME Jones, RC Burton. 1993. H ealth, solar UV radiation and environmental change IARC Technical Report, No. 13. Lyon: IARC.

Lachapelle, JM , P Frimat, D T ennstedt, G Ducombs. 1992. D ermatologie professionnelle et de l'environnement. París: M asson.
M athias, T . 1987. Prevention of occupational contact dermatitis. I Am A cad D ermatol 23:742-748.

M iller, D, M A W einstock. 1994. N onmelanoma skin cancer in the U nited States: Incidence. J Am Acad Dermatol 30:774-778.

Nelemans, PJ, R Scholte, H Groenendal, LA Kiemeney, FH Rampen, DJ Ruiter, AL V erbeek. 1993. M elanoma and occupation: results of a case-control study in The $\mathrm{N}$ etherlands. $B$ rit J Ind M ed 50:642-646.

Rietschel, RI, JF Fowler Jr. 1995. Fisher's Contact D ermatitis. $4 \mathrm{a}$ ed. Baltimore: Williams \& Wilkins.

Sahel, JA, JD Earl, DM Albert. 1993. Intraocular melanomas. En Cancer: Principles \& Practice of O ncology, dirigido por VTJ DeV ita, S H ellman, y SA R osenberg. Filadelfia: JB Lippincott.

Sasseville, D. 1995. O ccupational dermatoses: Employing good diagnostic skills. Allergy 8:16-24

Schubert, H, N Berova, A C zernielewski, E H egyi, L Jirasek. 1987. Epidemiology of nickel allergy. Contact D ermatitis 16:122-128.

Siemiatycki J, M Gerin, R Dewar, L Nadon, R Lakhani, D Begin, L Richardson. 1991. Associations between occupational circumstances and cancer. En Risk Factors for Cancer in the W orkplace, dirigido por I Siematycki. Londres, Boca R atón: CR C Press.

Stidham, K R, JL J ohnson, H F Seigler. 1994. Survival superiority of females with melanoma. A multivariate analysis of 6383 patients exploring the significance of gender in prognostic outcome. Archives of Surgery 129:316-324.

T urjanmaa, K. 1987. Incidence of immediate allergy to latex gloves in hospital personnel. Contact Dermatitis 17:270-275. 

Director del capítulo

H oward M . Kipen

\section{Sumario}

Condiciones del entorno: introducción

H oward M. Kipen ........................... 13.2

Síndrome del edificio enfermo

M ichael J. H odgson . .

M ultisensibilidad química

M ark R. Cullen. 


\section{- CONDICIONES DEL ENTORNO: INTRODUCCION}

\section{H oward M. Kipen}

En la última edición de esta E nciclopedia no se incluyó ningún artículo sobre el síndrome del edificio enfermo (SEE) ni sobre la multisensibilidad química (SQ M) (esta última denominación fue acuñada por Cullen en 1987). La mayoría de los profesionales dedicados a la medicina del trabajo no se sienten muy cómodos con estos fenómenos sintomáticos que tienen a menudo connotaciones psicológicas, debido (al menos en parte) a que los pacientes con estos síndromes no responden satisfactoriamente a las actuaciones tradicionales de la medicina del trabajo, principalmente, la reducción de la exposición. Los médicos ajenos a la medicina del trabajo y la práctica médica, en general, también reaccionan de manera parecida: consideran a los pacientes con una patología escasamente verificable, como los que se quejan de un síndrome de fatiga crónica o de fibromialgias, más difíciles de tratar (y que generalmente se consideran a sí mismos más discapacitados) que los que presentan alteraciones deformantes, como la artritis reumatoide. Es evidente que existen muchas menos obligaciones legales en relación con el síndrome del edificio enfermo y las sensibilidades químicas múltiples que con los síndromes profesionales clásicos, como las intoxicaciones por plomo o la silicosis. Esta incomodidad que sienten los facultativos que atienden a esos pacientes y la falta de un marco legal adecuado representan un gran inconveniente, por muy comprensibles que puedan ser, ya que hacen que se minimice la importancia de estas alteraciones cada vez más corrientes, aunque sean en gran medida subjetivas y no amenacen la vida. Dado que muchos trabajadores con estos procesos reclaman la incapacidad total, y son pocos los ejemplos de curación que se pueden encontrar, las sensibilidades químicas múltiples y el síndrome del edificio enfermo representan retos considerables para los sistemas aseguradores.

En los países desarrollados, en los que se controlan mejor muchas tóxicos laborales clásicos, se concede cada vez mayor importancia económica y sanitaria a los síndromes que provocan una sintomatología, como los que se están investigando actualmente y que implican unos niveles de exposición reducidos. Los empresarios se sienten frustrados ante estos trastornos por diferentes razones. Como el hecho de que en la mayoría de las jurisdicciones no existen normas legales claras que hagan referencia a la atmósfera del interior de los edificios o a los individuos con una hipersensibilidad (con la importante excepción de las personas con alergias reconocidas), no pueden saber si están cumpliendo las normas vigentes o no. Los niveles de contaminantes específicos establecidos para la industria, como los niveles de exposición permisible de la Administración para la Seguridad y Salud del Trabajo (O ccupational Safety and Health Administration, OSH A), o los valores límite umbral T LV de la Conferencia Americana de $\mathrm{H}$ igienistas Industriales del Gobierno $(A C G H I)$, son claramente inadecuados para prevenir o predecir los trastornos sintomáticos en administrativos y trabajadores de la educación. Por último, dada la aparente importancia de la sensibilidad individual y de los factores psicológicos como elementos determinantes de la respuesta a niveles reducidos de contaminantes, no resulta tan sencillo como a muchos les gustaría predecir el efecto de las medidas medioambientales antes de adoptar una decisión sobre los escasos recursos para los edificios 0 el mantenimiento. A menudo, tras la aparición de estos trastornos se encuentra un posible culpable, como los niveles elevados de compuestos orgánicos volátiles en relación con la atmósfera exterior, y a pesar de tomar las medidas pertinentes, los trastornos persisten o reaparecen.
L os trabajadores que sufren síntomas del síndrome del edificio enfermo o de sensibilidades químicas múltiples suelen ser menos productivos y a menudo recriminatorios cuando los empresarios o el gobierno son reacios a comprometerse a la adopción de medidas que no pueden garantizar que mejoren dichos síntomas con una total seguridad. Es evidente que los profesionales de la salud laboral son de las pocas personas clave que pueden facilitar unos resultados razonables aceptables para todos y que resulten ventajosos para todos los interesados. Esto es así independientemente de que la causa sean niveles reducidos de contaminantes, incluso en el caso poco frecuente de una verdadera histeria colectiva, que a menudo tiene un desencadenante medioambiental limitado. Es importante que los empresarios utilicen la habilidad y la sensibilidad para aceptar, valorar e incorporar un conjunto de factores en forma de soluciones, como una importante forma de dirigir estos problemas.

El síndrome del edificio enfermo es el trastorno mejor delimitado y definible de los dos, e incluso la O rganización $\mathrm{M}$ undial de la Salud ha establecido definiciones de él (1987). Aunque continúa el debate, tanto en términos generales como en casos específicos, sobre si una lesión determinada puede atribuirse más a los trabajadores de forma individual 0 al edificio, todo el mundo reconoce, basándose en estudios de exposición controlada a compuestos orgánicos volátiles y en controles epidemiológicos, que existen factores ambientales modificables que originan el tipo de síntomas que recogemos en el siguiente artículo titulado síndrome del edificio enfermo. En dicho artículo, M ichael H odgson (1992) detalla la tríada de factores personales, laborales y arquitectónicos que pueden contribuir en diferente medida a los síntomas en población trabajadora. U n problema importante es el de mantener una buena comunicación entre trabajadores y empresarios mientras se desarrolla la investigación y se intentan buscar remedios. N ormalmente, los profesionales de la salud necesitarán el asesoramiento de expertos medioambientales para valorar y remediar los brotes identificados.

La definición de las sensibilidades químicas múltiples plantea más problemas que la del síndrome del edificio enfermo. Algunas organizaciones médicas, como la American Medical Association, han publicado tomas de postura en las que ponen en duda los fundamentos científicos del diagnóstico de este trastorno. No obstante, muchos facultativos en activo, aunque sin una base científica rigurosa han defendido la validez de este diagnóstico. Se basan para ello en pruebas diagnósticas no confirmadas o erróneamente interpretadas, como la activación linfocítica 0 el diagnóstico por imagen del cerebro, y pueden recomendar tratamientos como saunas y megadosis de vitaminas, prácticas que han provocado en parte la animosidad de organizaciones como la Asociación Médica Americana. Sin embargo, nadie niega que existe un grupo de pacientes que se quejan de que experimentan síntomas al estar expuestos a niveles reducidos de sustancias químicas en el medio ambiente. Su sintomatología se solapa a la de otros síndromes subjetivos, como el síndrome de fatiga crónica y la fibromialgia. Esta sintomatología son dolores, fatiga y confusión, se acentúan con la exposición a niveles reducidos de sustancias químicas y parecen afectar a un porcentaje sustancial de pacientes diagnosticados de estos otros síndromes. De gran importancia, aunque todavía sin resolver, es la cuestión de si los síntomas de la sensibilidad química son adquiridos (y en qué medida) a causa de una sobreexposición previa al producto, o si (como ocurre en la mayoría de los casos publicados) aparecen sin que pueda identificarse un factor desencadenante importante.

La hipersensibilidad química es, en ocasiones, invocada como consecuencia en ciertos brotes del síndrome del edificio enfermo (SEE) que no se solucionan ni se mitigan tras una investigación 
rutinaria y la adopción de las medidas pertinentes. En este caso está claro que las SQ M afectan a un individuo o a un grupo reducido de personas, y raras veces a toda una población; de acuerdo con algunas definiciones, lo que caracteriza al síndrome del edificio enfermo es su efecto sobre una población. La SQ M parece ser endémica en las poblaciones afectadas, mientras que el síndrome del edificio enfermo es a menudo epidémico; sin embargo, investigaciones preliminares parecen indicar que pueden producirse algunos brotes epidémicos de sensibilidad química (y fatiga crónica), como se pudo observar entre los combatientes norteamericanos de la Guerra del Golfo. Todavía es necesario efectuar estudios controlados sobre las sensibilidades químicas múltiples, como los estudios controlados de exposición que han permitido esclarecer en gran medida el papel de los irritantes y los compuestos orgánicos volátiles en el síndrome del edificio enfermo.

M uchos facultativos aseguran que reconocen la SQ M cuando la ven, pero no existe una definición consensuada. Se puede incluir como un proceso que se "solapa" a otros síndromes de origen no profesional, como el síndrome de fatiga crónica, la fibromialgia, los trastornos de somatización y otros. Al examinar su relación con los diagnósticos psiquiátricos y con los informes iniciales, parece deducirse que cuando se puede definir aceptablemente el comienzo del síndrome, disminuye notablemente la morbilidad psiquiátrica concomitante diagnosticable (Fiedler y cols. 1996). El fenómeno de los síntomas desencadenados por olores es muy característico, pero evidentemente no exclusivo, y se cuestiona en qué medida puede ser éste un trastorno de origen profesional. Esto es importante, ya que la definición del Dr. Cullen (1987), como la de muchos otros, describe las sensibilidades químicas múltiples como una secuela de un trastorno profesional o ambiental mejor caracterizado. Sin embargo, como hemos señalado anteriormente, los síntomas que aparecen tras la exposición a niveles ambientales de olores son frecuentes entre los individuos con y sin diagnóstico clínico, y podría ser tan importante analizar las similitudes entre la SQM y otros trastornos como definir sus diferencias (K ipen y cols. 1995; Buchwald y Garrity 1994).

\section{- SindROME DEL EDIFICIO ENFERMO}

\section{Michael J. H odgson}

Síndrome de edificio enfermo (SEE) es el nombre que se utiliza para describir una serie de molestias y síntomas clínicos de las personas que trabajan en oficinas y que guardan relación con las características del edificio, la exposición a contaminantes y la organización del trabajo, y que están mediados por factores de riesgo personales. Existe un gran número de definiciones, pero sigue habiendo discrepancias acerca de a) si un solo individuo puede desarrollar este síndrome en un edificio o si se debe utilizar un criterio numérico establecido (proporción afectada), y b) la sintomatología necesaria para el diagnóstico. En la Figura 13.1 se enumeran los síntomas que se suelen incluir en el SEE; en los últimos años, al conocerse mejor este trastorno, se han eliminado de la lista por lo general los síntomas relacionados con los malos olores, y se han incluido los síntomas torácicos dentro de la irritación de las mucosas. Es necesario establecer una diferenciación fundamental entre el SEE y la enfermedad relacionada con el edificio ( $E R E$ ), en la que pueden existir irritación, alergia o patologías comprobables como la neumonitis por hipersensibilidad, el asma o las cefaleas inducidas por monóxido de carbono como un brote relacionado con un edificio. También debe distinguirse el SEE de las sensibilidades químicas múltiples (SQ M ; véase más adelante), que aparecen de modo más esporádico, afectan a menudo a una población con SEE y responden mucho peor a las modificaciones del entorno profesional.

EI SEE debe considerarse y documentarse desde tres perspectivas diferentes. Para los profesionales de la salud, esa perspectiva es la de las ciencias médicas y de la salud en relación con la definición de los síntomas relacionados con el trabajo en el interior de edificios y sus mecanismos fisiopatológicos asociados. La segunda perspectiva es la de la ingeniería, que incluye el diseño, la puesta en marcha, las operaciones, el mantenimiento y la valoración de la exposición a contaminantes específicos. La tercera perspectiva comprende los aspectos organizativos, sociales y psicológicos del trabajo.

\section{Epidemiología}

Desde mediados del decenio de 1970 se vienen estudiando formalmente las quejas cada vez más frecuentes sobre las molestias que sufren las personas que trabajan en oficinas. Se han efectuado estudios epidemiológicos sobre el terreno tomando como muestra un edificio o un puesto de trabajo para tratar de identificar los factores de riesgo y sus causas, estudios de poblaciones para definir la prevalencia, estudios en cámaras con seres humanos para definir los efectos y los mecanismos, y estudios de intervención sobre el terreno.

\section{E studios transversales y de tipo caso-control}

Se han publicado aproximadamente 30 estudios transversales (M endell 1993; Sundell y cols. 1994). En muchos de ellos han incluido fundamentalmente edificios "no problemáticos" elegidos al azar. Estos estudios demuestran en todos los casos una asociación entre la ventilación mecánica y el aumento del número de síntomas comunicados. En varios estudios de caso-control se han definido otros factores de riesgo. En la Figura 13.2 se han agrupado algunos factores de riesgo ampliamente reconocidos asociados con aumento de la incidencia de síntomas.

M uchos de estos factores se solapan; no se excluyen mutuamente. Por ejemplo, la limpieza y el mantenimiento inadecuados, la presencia de fuentes contaminantes interiores intensas y el aumento de la sensibilidad individual pueden originar

Figura 13.1 • Síndrome del edificio enfermo.

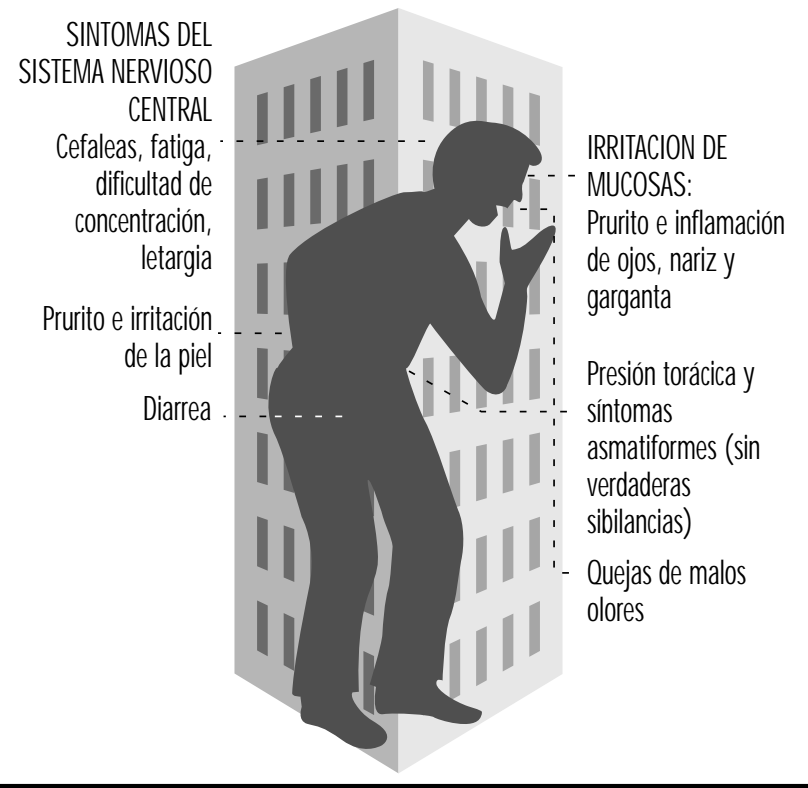


Figura 13.2 - Factores de riesgo y causas del síndrome del edificio enfermo.

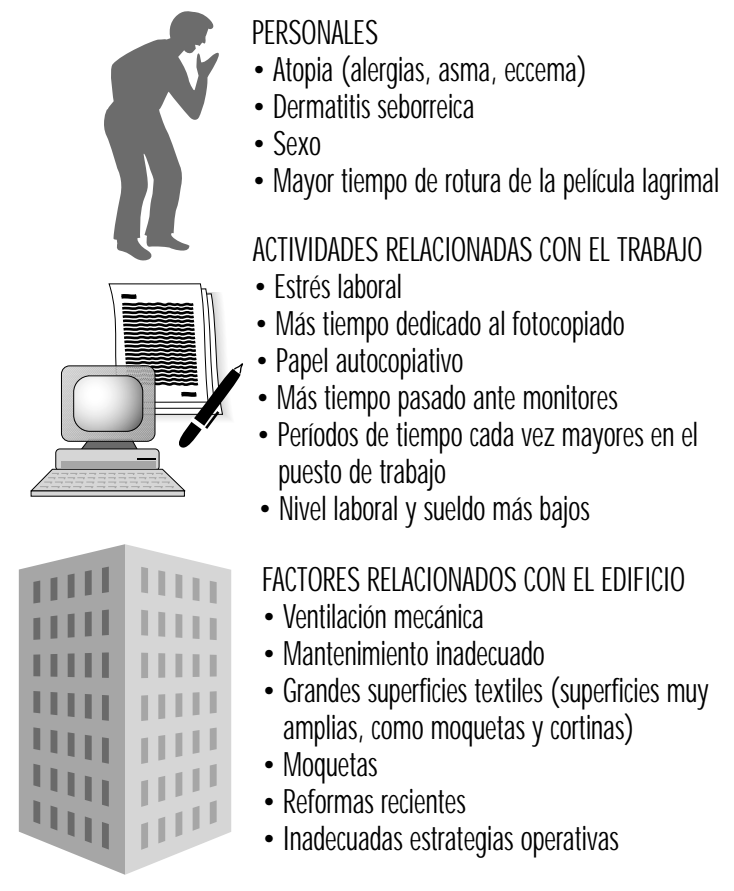

problemas mucho más graves que cualquiera de esos factores por separado.

En los análisis de los factores y los principales componentes de las respuestas obtenidas en los cuestionarios de los estudios transversales se ha explorado la interrelación de diversos síntomas. De modo constante, los síntomas relacionados con sistemas orgánicos únicos se han agrupado con mayor fuerza que los relacionados con diferentes sistemas orgánicos. Es decir, parece que existe una relación muy acusada entre la irritación, el lagrimeo, la sequedad y el picor oculares, y se obtiene muy poco provecho de buscar numerosos síntomas dentro de un sistema orgánico.

\section{Estudios de exposición controlados}

Son ya clásicas las pruebas realizadas con animales para determinar las propiedades y los umbrales de diferentes irritantes. Generalmente se considera como instrumento básico un método de consenso de la American Society for Testing and Materials (1984). Este método ha sido utilizado para establecer relaciones entre estructuras y actividades, para demostrar que puede existir más de un receptor para sustancias irritantes en el nervio trigémino y para analizar las posibles interacciones entre múltiples exposiciones. $M$ ás recientemente se ha empleado para demostrar los efectos irritantes de las emanaciones de gases de los equipos de oficina.

Se han propuesto, por analogía, varios enfoques similares para documentar los métodos y las relaciones dosis-respuesta de la irritación en seres humanos. M ientras tanto, este trabajo sugiere que, al menos en el caso de los compuestos "no reactivos" como los hidrocarburos alifáticos no saturados, el porcentaje de saturación de presión de vapor de un compuesto es un factor predictivo razonable de su potencia como irritante. Ciertas pruebas también respaldan la idea de que el aumento del número de compuestos que forman una mezcla compleja reduce el umbral para las sustancias irritantes. Es decir, a mayor número de agentes, incluso con una masa constante, mayor irritación.

Se han llevado a cabo estudios de exposición controlados con voluntarios en el interior de cámaras de acero inoxidable. En la mayoría de ellos se ha utilizado una mezcla constante de compuestos orgánicos volátiles (COV) (M ølhave y N ielsen 1992). Estos trabajos documentan siempre una relación entre los síntomas y los niveles de exposición crecientes. 0 ficinistas que se consideraban "sensibles" a los efectos de los niveles habituales de COV en interiores demostraron cierta alteración en pruebas estándar de rendimiento neuropsicológico ( $\mathrm{M} ø$ lhave, Bach y Pederson 1986). Por otra parte, voluntarios sanos experimentaron irritación de mucosas y cefaleas con exposiciones entre 10 y $25 \mathrm{mg} / \mathrm{m}^{3}$, pero no mostraron cambios en su rendimiento neuropsicológico. M ás recientemente, trabajadores administrativos manifestaron síntomas parecidos tras un simulacro de trabajo en entornos en los que se generaban contaminantes procedentes de equipos utilizados habitualmente en oficinas. L OS animales reaccionaban de forma parecida cuando se utilizaba una prueba normalizada de potencia irritante.

\section{Estudios de población}

$\mathrm{H}$ asta la fecha se han publicado tres estudios sobre poblaciones en Suecia, Alemania y Estados Unidos. Los cuestionarios utilizados diferían considerablemente entre sí, por lo que no es posible comparar directamente los respectivos cálculos de prevalencia. No obstante, se recogieron quejas de entre un 20 y un $35 \%$ de los encuestados de varios edificios aparentemente no enfermos.

\section{Mecanismos}

Se han identificado varios mecanismos potenciales y medidas objetivas para explicar y examinar los síntomas producidos en determinados sistemas orgánicos. N inguno de ellos tiene un valor predictivo elevado de la presencia de la enfermedad y, por consiguiente, no sirven para el diagnóstico clínico. Son útiles en las investigaciones sobre el terreno y en los estudios epidemiológicos. En muchos de los casos no está claro si deben considerarse mecanismos, marcadores de efecto o medidas de sensibilidad.

\section{Ojos}

Para explicar los síntomas oculares se han propuesto mecanismos alérgicos e irritantes. La disminución del tiempo de rotura de la película lagrimal (una medida de la inestabilidad de la película lagrimal) se asocia a un aumento de los niveles de síntomas. También se han empleado la medición del "espesor de la espuma grasa" y la fotografía para documentar el eritema ocular. A lgunos autores atribuyen los síntomas oculares, al menos en parte, a una mayor sensibilidad individual, medida por estos factores. Por otra parte, se ha demostrado que los trabajadores de oficinas con síntomas oculares parpadean menos cuando trabajan con monitores de vídeo.

\section{Nariz}

Para explicar los síntomas nasales se han propuesto mecanismos alérgicos e irritantes. Como pruebas que se han empleado con éxito cabe destacar la obtención de muestras nasales con torundas de algodón (eosinófilos), el lavado o la biopsia nasal, la rinometría acústica (volumen nasal), la rinomanometría anterior y posterior (pletismografía) y las mediciones de la hiperreactividad nasal.

\section{Sistema nervioso central}

Se han utilizado pruebas neuropsicológicas para documentar la reducción del rendimiento en pruebas normalizadas tanto en 
función de la exposición controlada (M ølhave, Bach y Pederson 1986) como de la presencia de síntomas (M iddaugh, Pinney y Linz 1982).

\section{Factores de riesgo individuales}

Se han analizado dos grupos de factores de riesgo individuales. En primer lugar, se consideran factores predisponentes a presentar síntomas clínicamente definidos, dos diátesis muy habituales: la atopia y la seborrea. En segundo, pueden ser importantes las variables psicológicas. Por ejemplo, rasgos personales como la ansiedad, la depresión o la hostilidad se asocian a sensibilidad al papel de enfermo. Igualmente, el estrés laboral se asocia de modo tan constante con los síntomas relacionados con el edificio que es probable que exista una relación causal. Se ignora cuál de los tres componentes del estrés laboral (los rasgos individuales, la capacidad de afrontar los problemas y la función de organización, como las formas de gestión inadecuadas) es la causa dominante. Se sabe que si no se interviene para solucionar un problema concreto, los trabajadores pueden experimentar sus molestias con una sensación de sufrimiento creciente.

\section{Aspectos técnicos y fuentes}

A partir de finales del decenio de 1970, el Instituto Nacional para la Salud y la Seguridad en el Trabajo de Estados Unidos ( $\mathrm{N}$ ational Institute for $\mathrm{O}$ ccupational Safety and $\mathrm{H}$ ealth, NIOSH) respondió a las peticiones de ayuda para tratar de identificar las causas de los trastornos de los ocupantes de edificios achacando los problemas a los sistemas de ventilación (50\%), a la contaminación microbiológica (3-5 \%), a fuentes importantes de contaminantes en el interior de los edificios (tabaco $3 \%$, otros $14 \%$ ), a contaminantes procedentes del exterior (15\%) y a otras causas. Por otra parte, Woods (1989) y Robertson y cols. (1988) publicaron dos conocidas series de análisis técnicos de los edificios causantes de problemas en las que documentaban la existencia, por término medio, de tres posibles factores causales en cada edificio.

Un estándar actual para la climatización profesional (American Society of $\mathrm{H}$ eating, Refrigerating and Airconditioning Engineers 1989) propone dos métodos para la ventilación: uno basado en la tasa de ventilación y el otro en la calidad del aire. El primero ofrece un enfoque tabular de las necesidades de ventilación: los edificios de oficinas necesitan 560 litros de aire exterior por ocupante y minuto para mantener las molestias medioambientales de los ocupantes por debajo del $20 \%$. En este cálculo se supone la existencia de fuentes de contaminación relativamente débiles. Cuando existen fuentes más potentes, los resultados son menos satisfactorios. Por ejemplo, cuando se permite fumar en las cantidades habituales (según datos de principios del decenio de 1980), aproximadamente un $30 \%$ de los ocupantes se quejarán de molestias medioambientales. EI segundo enfoque exige la selección de una concentración predeterminada en el aire (partículas, COV, formaldehído, etc.), la información sobre los índices de emisiones (contaminante por tiempo y masa o superficie), y deduce las necesidades de ventilación. Aunque éste es un sistema intelectualmente mucho más satisfactorio, es difícil de poner en práctica debido a que los datos sobre emisiones son insuficientes y a que no existe un acuerdo sobre las concentraciones objetivo.

\section{Contaminantes}

G eneralmente, los científicos medioambientales definen la exposición y los efectos sobre la salud basándose en cada contaminante concreto. La American Thoracic Society (1988) ha establecido seis categorías fundamentales, que se enumeran en la Figura 13.3.
Se han establecido criterios medioambientales para muchas de las sustancias que incluyen esos seis grupos. La utilidad y las posibilidades de aplicación de tales criterios en interiores son objeto de controversia por muchas razones. Por ejemplo, los objetivos de los valores límite umbral a menudo no incluyen la prevención de la irritación ocular, una queja muy corriente en edificios en los que el trabajo exige la visión cercana de los monitores de vídeo. Todavía no se ha definido adecuadamente para la mayoría de las categorías de contaminantes el problema de las interacciones, conocido habitualmente como el "problema de los contaminantes múltiples". $\mathrm{Ni}$ siquiera en el caso de los agentes que se cree que afectan al mismo receptor, como los aldehídos, los alcoholes y las cetonas, se han establecido modelos predictivos adecuados. Por último, no está muy clara la definición de "compuestos representativos" para su medición. Es decir, los contaminantes deben ser mensurables, pero la composición de las mezclas complejas es muy variable. No está claro, por ejemplo, si las molestias por olor residual crónico a causa del humo de tabaco en el ambiente se deben a la nicotina, a las partículas emitidas, al monóxido de carbono 0 a otros contaminantes. Se considera interesante el parámetro “compuestos orgánicos volátiles totales", pero carece de aplicación práctica debido a que los diversos componentes tienen efectos radicalmente diferentes (M ølhave y Nielsen 1992; Brown y cols. 1994). Las partículas presentes en el interior de un edificio pueden diferir en su composición de sus equivalentes en el aire exterior, dado que el tamaño de los filtros altera las concentraciones de las sustancias introducidas, y las fuentes interiores de contaminantes pueden diferir de las exteriores. También existen problemas de medición, ya que el tipo de partículas recogidas dependerá del

Figura 13.3 - Principales categorías de contaminantes.

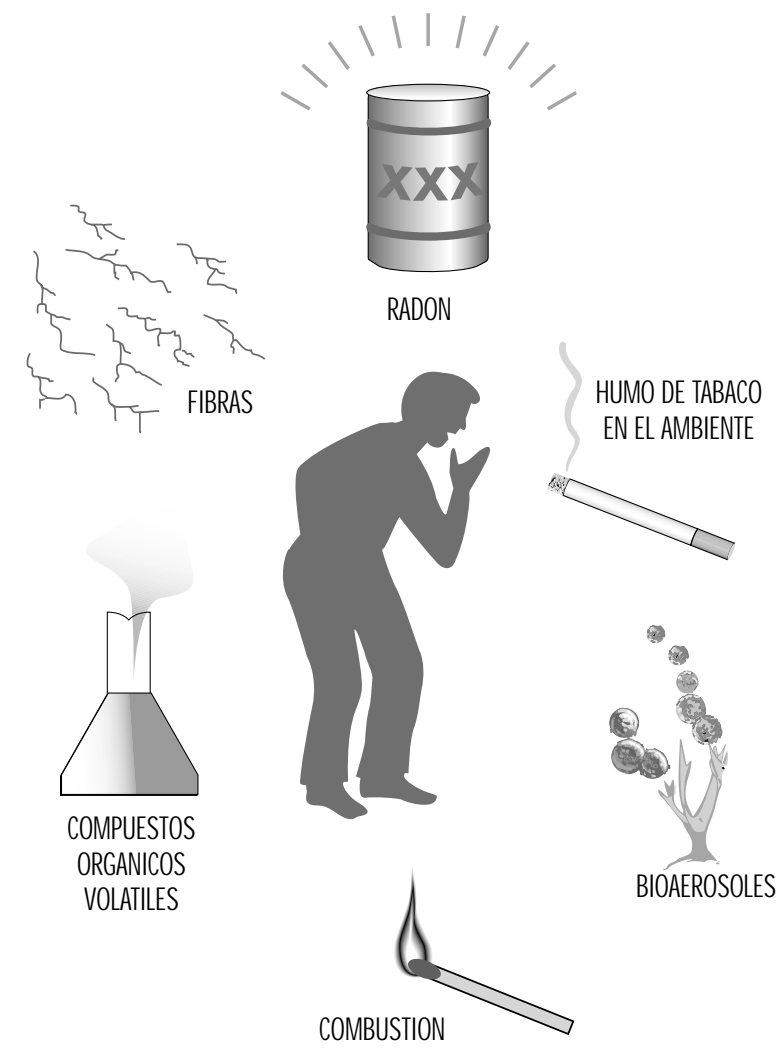

Fuente: American Thoracic Society 1988 
tamaño de los filtros utilizados. Para las mediciones en interiores pueden necesitarse diferentes filtros.

Por último, los datos que siguen apareciendo indican que contaminantes reactivos del interior de los edificios pueden interactuar con otros contaminantes y formar nuevos compuestos. Por ejemplo, el ozono presente (procedente de las máquinas de las oficinas 0 del exterior) puede interactuar con el 4-fenilciclohexeno y producir aldehídos (Wechsler 1992).

\section{Teorías etiológicas primarias}

\section{Disolventes orgánicos}

Para la eliminación de los contaminantes presentes en los edificios se ha confiado siempre en estrategias generales de dilución, pero los diseñadores han asumido que las personas eran la principal fuente de sustancias contaminantes. $M$ ás recientemente, se ha reconocido la contribución de las emisiones de "materiales sólidos" (como las mesas de conglomerado, las moquetas y otros elementos del mobiliario), de productos húmedos (como pegamentos, pinturas de paredes, tóner de máquinas de oficina) y de productos personales (perfumes) a una mezcla compleja de contaminantes individuales a niveles muy reducidos (resumido en Hodgson, Levin y Wolkoff 1994).

Diversos estudios sugieren que la presencia de compuestos orgánicos volátiles reactivos, como aldehídos e hidrocarburos halogenados, se asocia a niveles crecientes de síntomas. Las oficinas con mayores índices de quejas han sufrido una "pérdida" de COV entre el aire que entra y el que sale mayor que las oficinas con menos quejas. En un estudio prospectivo realizado en colegios, se relacionó el desarrollo de síntomas con COV de cadena corta. En otra encuesta, se asociaron con niveles de síntomas más altos las muestras personales más elevadas de COV utilizando un medidor selectivo de muestras que "sobrerreacciona" a los COV reactivos, como los aldehídos y los hidrocarburos halogenados. En dicho estudio, las mujeres tenían mayores niveles de COV en su zona de respiración, Io que sugiere otra posible explicación del mayor índice de quejas entre las mujeres. Los COV podrían adsorberse a los recovecos, como las superficies lanosas, y pasar nuevamente a la atmósfera a partir de esas fuentes secundarias. También respalda esta hipótesis la interacción del ozono con COV relativamente no irritantes para formar aldehídos.

La existencia de múltiples fuentes potenciales, la concordancia entre los efectos en la salud de los COV y los síntomas del SEE y los conocidos problemas relacionados con los sistemas de ventilación convierten a los compuestos orgánicos volátiles en agentes etiológicos atractivos. 0 tras soluciones, aparte de las mejoras en el diseño y el funcionamiento de los sistemas de ventilación, son la elección de contaminantes de emisiones reducidas, una limpieza más profunda y la prevención de la "química de interiores".

\section{Bioa erosoles}

Varios estudios han sugerido que los bioaerosoles pueden contribuir a las molestias en los centros de trabajo. Pueden actuar por varios mecanismos diferentes: emisiones irritantes; liberación de fragmentos, esporas o microorganismos viables que ocasionan alergia y secreción de toxinas complejas. Los datos existentes que respaldan esta teoría son aún menores. No obstante, es evidente que los sistemas de calefacción, ventilación y aire acondicionado pueden ser fuentes de microorganismos.

También se han identificado en materiales de construcción de edificios (como consecuencia de un proceso incorrecto), como resultado de entradas de agua no deseadas y en el polvo de las oficinas. 0 tra posible fuente de exposición es la presencia de sensibilizantes en el entorno de las oficinas, como ácaros del polvo o caspa de gato traídos del domicilio en la ropa. En la medida en que los agentes biológicos contribuyan a este problema, la gestión de la suciedad y las aguas se convierte en una estrategia fundamental de control.

Por otra parte, pueden encontrarse hongos toxigénicos en otros productos porosos presentes en los edificios, como las tejas, las espumas aislantes y las viguetas de madera. Especialmente en los entornos residenciales, se ha observado una relación entre la proliferación de estos hongos debido a un control incorrecto de la humedad y los síntomas de este trastorno.

\section{Aspectos psicosociales del trabajo}

En todos los estudios en los que se ha analizado el "estrés laboral" se ha observado una clara asociación con los síntomas del SEE. La percepción por los trabajadores de las presiones en el trabajo, los conflictos laborales y otros factores estresantes no relacionados con el trabajo, como las exigencias conyugales o filiales, pueden conducir claramente a una sensación subjetiva de una irritación "más intensa" como una función de comportamiento de enfermedad. De hecho, a veces esas percepciones pueden deberse a unas medidas de supervisión deficientes. Por otra parte, se cree que la presencia de irritantes que dan lugar a irritación subjetiva origina "estrés laboral".

\section{Evaluación del paciente}

La exploración debe ir orientada a identificar o descartar algún componente importante de enfermedad relacionada con el edificio $(E R E)$. H ay que identificar los posibles trastornos alérgicos y tomar las medidas terapéuticas más adecuadas. Sin embargo, debe tenerse presente que existen mecanismos no alérgicos que pueden contribuir a una importante carga sintomática residual. A veces se puede tranquilizar al paciente asegurándole que no presenta ninguna alteración clara con la ayuda de pruebas como la medición del flujo máximo con un aparato portátil o las pruebas de la función pulmonar antes y después del esfuerzo. Una vez descartados esos trastornos identificables o patológicamente verificables, es imperativo examinar el edificio, y para ello hay que recurrir a expertos en higiene o ingeniería industrial. De la documentación, el tratamiento y las soluciones para los problemas identificados hablaremos en la sección sobre control del medio ambiente interior de un edificio.

\section{Conclusiones}

EI SEE es un fenómeno que puede afectar a un individuo, pero que se suele observar en grupos, se asocia a deficiencias técnicas y puede deberse a diferentes contaminantes y tipos de contaminantes. Al igual que ocurre en cualquier enfermedad, existe un componente psicológico personal que actúa como modulador del efecto y que puede dar lugar a la aparición de síntomas de intensidad variable con un mismo nivel de exposición.

\section{MULTISENSIBILIDAD QUIMICA}

Mark R. Cullen

\section{Introducción}

Desde el decenio de 1980 se conoce un nuevo síndrome clínico en medicina medioambiental y del trabajo, caracterizado por la aparición de diferentes síntomas tras la exposición a niveles reducidos de sustancias químicas artificiales, aunque todavía no existe una definición ampliamente aceptada. Este trastorno puede afectar a individuos que han sufrido un solo episodio o episodios 
repetidos de un accidente químico, como una intoxicación con un disolvente 0 un pesticida. Posteriormente, muchos tipos de contaminantes medioambientales presentes en el aire, los alimentos 0 el agua pueden provocar una gran variedad de síntomas a dosis inferiores a las que causan reacciones tóxicas en otras personas.

Aunque puede que no exista una alteración cuantificable en órganos específicos, las molestias dan lugar a disfunción y discapacidad. Si bien probablemente estas reacciones idiosincráticas a sustancias químicas no sean un fenómeno nuevo, se cree que los pacientes con sensibilidades químicas múltiples (SQ M ), como se suele denominar a este síndrome, acuden a la consulta de los médicos con mucha mayor frecuencia que antes. Este síndrome está lo bastante extendido para generar una considerable controversia pública acerca de quiénes deben encargarse del tratamiento de los pacientes que sufren este trastorno y quién debe costear dicho tratamiento, pero todavía hay que investigar numerosos aspectos científicos del problema, como su etiología, patogenia, tratamiento y prevención. A pesar de todo, es evidente que la SQ M existe y que causa una importante morbilidad entre los trabajadores y la población general. EI presente artículo pretende exponer lo que se sabe en estos momentos sobre este trastorno, con la esperanza de mejorar su conocimiento y tratamiento a pesar de la incertidumbre que le rodea.

\section{Definición y diagnóstico}

Aunque no existe unanimidad en la definición de la SQ M , ciertos rasgos permiten diferenciarla de otros cuadros bien caracterizados:

- Los síntomas aparecen típicamente tras un incidente laboral o medioambiental perfectamente identificable, como la inhalación de gases o vapores nocivos $u$ otras exposiciones tóxicas. E ste suceso "iniciador" puede ser un episodio aislado, como la exposición a una pulverización de pesticida, o repetitivo, como una exposición excesiva y frecuente a un determinado disolvente. A menudo, el suceso o los sucesos aparentemente desencadenantes tienen efectos leves y pueden fundirse sin una delimitación clara en el síndrome que describimos a continuación.

- Se empiezan a observar síntomas agudos similares a los de la exposición previa al repetirse la exposición a niveles más bajos de diferentes materiales, como derivados del petróleo, perfumes y otros productos comunes en el trabajo y el hogar.

- Los síntomas afectan a varios órganos y sistemas. En la práctica totalidad de los casos se observan manifestaciones en el sistema nervioso central, como fatiga, confusión y cefaleas. Son frecuentes los síntomas respiratorios de vías altas y bajas, cardíacos, dérmicos, gastrointestinales y musculosqueléticos.

- Es frecuente que agentes muy diferentes entre sí desencadenen los síntomas a niveles de exposición muy inferiores a los valores T LV aceptados o recomendados

- Son habituales los síntomas crónicos, como fatiga, dificultades cognitivas y alteraciones gastrointestinales y musculosqueléticas. En algunos casos estos síntomas persistentes pueden predominar sobre las reacciones a las sustancias químicas.

- Normalmente, no existe un trastorno objetivo de los órganos que explique el patrón o la intensidad de las manifestaciones. Los pacientes examinados durante las reacciones agudas pueden presentar hiperventilación o mostrar otras manifestaciones de exceso de actividad simpática.

- No existe ningún diagnóstico establecido que explique de manera sencilla este tipo de respuestas o síntomas.

Aunque no todos los pacientes cumplen estrictamente estos criterios, al diagnosticar la SQ M hay que tener en cuenta todos estos puntos. Cada uno de ellos permite descartar otros trastornos clínicos a los que se puede parecer la SQ M, como el trastorno de somatización, la sensibilización a antígenos medioambientales (como en el caso del asma de origen laboral), las secuelas tardías de una lesión orgánica (p. ej., el síndrome de disfunción reactiva de vías respiratorias tras una inhalación tóxica) o una enfermedad sistémica (p. ej., el cáncer). Por otra parte, la SQM no es un diagnóstico de exclusión, y en la mayoría de los casos no se precisan pruebas exhaustivas. Aunque se producen muchas variaciones, se dice que la SQM tiene un carácter reconocible que facilita su diagnóstico tanto 0 más que los propios criterios específicos.

En la práctica, el diagnóstico de la SQM puede plantear problemas en dos situaciones. La primera es la de un paciente que se encuentra en las fases iniciales del proceso, momento en el que suele ser difícil distinguir la SQM del problema de salud profesional o medioambiental que le precede inmediatamente. Por ejemplo, los pacientes que han sufrido reacciones sintomáticas a la pulverización de pesticidas en interiores pueden observar que sus reacciones persisten, aunque eviten el contacto directo con los materiales o su pulverización. En tales casos, el facultativo puede suponer que todavía están sometidos a una exposición importante e intentar injustificadamente modificar aún más el entorno, generalmente sin conseguir aliviar los síntomas recidivantes. Esto resulta especialmente problemático en una oficina en la que se puede desarrollar una SQ M como complicación del síndrome del edificio enfermo. Si bien la mayoría de los trabajadores mejorarán una vez que se hayan tomado medidas para mejorar la calidad del aire, los pacientes que hayan adquirido una SQM seguirán experimentando síntomas, a pesar de la reducción de la exposición. Los esfuerzos por mejorar aún más la calidad del aire suelen ser frustrantes para el paciente y el empresario.

En fases posteriores de la evolución de la SQ M , el diagnóstico puede plantear dificultades debido a los aspectos crónicos de la enfermedad. Al cabo de muchos meses, el paciente con SQ M suele sentirse deprimido y ansioso, al igual que otros pacientes médicos con enfermedades crónicas nuevas. Esto puede dar lugar a una exageración de las manifestaciones psiquiátricas, que pueden predominar sobre los síntomas estimulados por las sustancias químicas. Sin minimizar la importancia de la identificación y el tratamiento de estas complicaciones de la SQ M, ni siquiera la de la posibilidad de que la propia SQ M sea de origen psicológico (véase más adelante), es necesario reconocer la SQ M subyacente para desarrollar un tratamiento eficaz que resulte aceptable para el paciente.

\section{Patogenia}

Se desconoce la secuencia patogénica que lleva a determinados pacientes desde uno o varios episodios autolimitados de exposición ambiental hasta el desarrollo de SQ M. Actualmente existen varias teorías. Los ecólogos clínicos y sus seguidores han publicado numerosos trabajos en los que señalan que la SQ M representa una disfunción inmunitaria causada por la acumulación en el organismo de sustancias químicas exógenas (Bell 1982; Levin y Byers 1987). Existe, al menos, un estudio controlado que no confirmó estas anomalías inmunitarias (Simon, Daniel y Stockbridge 1993). Según esta hipótesis, los factores de sensibilidad pueden ser deficiencias nutricionales (p. ej., falta de vitaminas 0 antioxidantes) o la presencia de infecciones subclínicas como la candidiasis. En esta teoría es importante el trastorno "iniciador" debido a que contribuye a una sobrecarga de productos químicos de por vida.

Existe un enfoque menos elaborado, aunque muy orientado hacia aspectos biológicos, que postula que la SQ M representa una serie de secuelas biológicas inusuales de una lesión química. Como tal, este trastorno podría representar una nueva forma de 
neurotoxicidad debida a disolventes o pesticidas, lesión de las mucosas respiratorias tras un episodio agudo de inhalación 0 fenómenos similares. Desde esta perspectiva, la SQ M es la vía final en la que desembocan diferentes mecanismos patológicos primarios (Cullen 1994; Bascom 1992).

M ás recientemente, se ha propuesto otra hipótesis biológica sobre las relaciones entre las mucosas de las vías respiratorias altas y el sistema límbico, especialmente en su conexión a nivel de la nariz (M iller 1992). Según esta hipótesis, estimulantes del epitelio nasal relativamente reducidos podrían producir una respuesta límbica amplificada, lo que explicaría las respuestas tan espectaculares, y a menudo estereotípicas, a exposiciones muy reducidas. Esta teoría podría explicar igualmente el papel predominante de los materiales muy olorosos, como los perfumes, en la activación de las respuestas en muchos pacientes.

En cambio, un gran número de clínicos e investigadores experimentados han propuesto mecanismos psicológicos para explicar la SQM, relacionándola con otros trastornos somatoformes (Brodsky 1983; Black, Ruth y Goldstein 1990). Existen otras variaciones, como la teoría que sostiene que la SQM es una variante de un trastorno por estrés postraumático (Schottenfeld y Cullen 1985) o una respuesta condicionada a una experiencia inicial con una sustancia tóxica (Bolle-Wilson, Wilson y Blecker 1988). O tro grupo ha propuesto que la SQM es una respuesta tardía a traumas infantiles precoces, como abusos sexuales (Selner y Strudenmayer 1992). En cada una de estas teorías, la enfermedad precipitante tiene un papel más simbólico que biológico en la patogenia de la SQM. Se considera que los factores del huésped tienen una gran importancia, especialmente la predisposición a somatizar los sufrimientos psicológicos.

Aunque se han publicado muchos trabajos sobre el tema, son pocos los estudios clínicos o experimentales publicados que respaldan de modo concluyente cualquiera de estas teorías. Los investigadores no han definido por lo general las poblaciones estudiadas, ni las han comparado con grupos de control equiparables. L os observadores no ignoraban el estado del sujeto ni las hipótesis de la investigación. Como consecuencia de ello, la mayoría de los datos disponibles son efectivamente descriptivos. Por otra parte, el debate legítimo sobre la etiología de la SQ M se ha visto distorsionado por el dogma. Dado que las decisiones económicas importantes ( $p$. ej., los derechos del paciente a compensaciones y la aceptación del reembolso por el médico) pueden depender de la forma en que se consideren estos casos, muchos facultativos tienen opiniones fuertemente arraigadas sobre esta enfermedad, lo que limita el valor científico de sus observaciones. Para poder prestar asistencia a los pacientes con SQM es necesario que se reconozca el hecho de que los pacientes a veces conocen muy bien estas teorías, y también pueden tener opiniones muy firmes sobre este tema.

\section{Epidemiología}

No se conoce a fondo la epidemiología de la SQ M . Los cálculos sobre su prevalencia en la población estadounidense (de la que aún proceden la mayoría de los informes) difieren en varios puntos porcentuales, pero su base científica sigue siendo confusa, y existen otras pruebas que indican que la SQM , en su forma clínicamente manifiesta, es poco frecuente (Cullen, Pace y Redlich 1992). La mayoría de los datos disponibles proceden de series de casos estudiados por facultativos que tratan a pacientes con SQM. A pesar de estos inconvenientes, pueden realizarse algunas observaciones generales. Aunque se han descrito pacientes de prácticamente todas las edades, la SQM es más frecuente en los sujetos en la edad media de la vida. Parece ser que afecta de manera desproporcionada a las personas que ejecutan trabajos de mayor categoría socioeconómica, y mucho menos a las personas de menos ingresos o que no son de raza blanca; esto podría ser un artefacto de acceso diferencial o de sesgo clínico. A fecta a las mujeres con mayor frecuencia que a los hombres. Existen datos epidemiológicos que responsabilizan claramente a algún factor idiosincrático del huésped como elemento de riesgo, ya que los brotes masivos son poco frecuentes, y sólo parecen desarrollar SQM como secuela una pequeña parte de los afectados por accidentes o sobreexposiciones químicas (Welch y Sokas 1992; Simon 1992). A este respecto quizá sea sorprendente el hecho de que los trastornos alérgicos atópicos, comunes, no son aparentemente un factor de riesgo de SQ M importante en la mayoría de los grupos.

La mayoría de los episodios iniciadores se han atribuido a varios grupos de sustancias químicas; en concreto, a los disolventes orgánicos, los pesticidas y los irritantes respiratorios. Esto podría deberse al uso generalizado de estos materiales en el lugar de trabajo. La otra circunstancia habitual en la que se producen numerosos casos es el síndrome del edificio enfermo; algunos pacientes evolucionan desde una sintomatología típica del SEE a una SQM. Aunque ambos trastornos tienen mucho en común, pueden distinguirse por sus características epidemiológicas. El síndrome del edificio enfermo afecta típicamente a la mayoría de las personas que comparten un mismo ambiente, que mejoran al remediar los problemas medioambientales; la SQ M aparece esporádicamente, y no responde de forma predecible a las modificaciones introducidas en las oficinas.

Por último, existe un gran interés por saber si la SQ M es un trastorno nuevo 0 si se trata de una nueva presentación o percepción de un trastorno que ya existía anteriormente. $\mathrm{H}$ ay disparidad de opiniones acerca de la patogenia propuesta de la SQ M . L os que defienden un papel biológico de agentes ambientales, incluidos los ecólogos clínicos, sostienen que la SQM es una enfermedad de nuestro siglo con una incidencia creciente debido al empleo cada vez mayor de sustancias químicas (A shford y M iller 1991). Por su parte, quienes sostienen una etiología psicosomática consideran que la $\mathrm{SQM}$ es un trastorno somatoforme antiguo con una nueva metáfora social (Brodsky 1983; Shorter 1992). Según este punto de vista, la percepción social de los productos químicos como agentes perjudiciales ha dado lugar a que el problema histórico de la enfermedad psicosomática haya evolucionado hacia un nuevo contenido simbólico.

\section{Historia natural}

Todavía no se ha estudiado la SQ M lo suficiente para definir su evolución o pronóstico. Informes sobre cantidades importantes de pacientes nos han proporcionado algunas pistas. En primer lugar, parece que la enfermedad tiene un patrón general de progresión precoz según se va desarrollando el proceso de generalización, que va seguido de períodos menos predecibles de mejorías y exacerbaciones por incrementos. Aunque el paciente puede pensar que estos ciclos se deben a factores ambientales 0 al tratamiento, no existen pruebas científicas que confirmen esas relaciones.

Se deducen dos conclusiones importantes. En primer lugar, son pocas las pruebas indicativas de que la SQ M sea una enfermedad progresiva. Los pacientes no se deterioran de un año a otro de una forma que pueda cuantificarse físicamente, ni sufren complicaciones como infecciones o insuficiencias orgánicas en ausencia de una enfermedad intercurrente. No hay pruebas de que la SQM sea potencialmente letal, a pesar de las percepciones de los pacientes. Aunque esta base puede servir para establecer un pronóstico esperanzador y para tranquilizar a los pacientes, también se deduce claramente de las descripciones clínicas que las remisiones completas son poco frecuentes. 
Aunque se produce una mejoría significativa, se basa generalmente en una mejoría funcional y en una sensación de bienestar del paciente. Suele persistir la tendencia subyacente a reaccionar a las exposiciones químicas, aunque puede que los síntomas sean lo bastante llevaderos para permitir a la persona afectada reanudar una vida normal.

\section{Tratamiento clínico}

Es muy poco lo que se sabe acerca del tratamiento de la SQ M. Se han probado numerosos métodos tradicionales e innovadores, aunque no se ha podido confirmar su eficacia basándose en los estándares científicos habituales. Como ocurre con muchas otras enfermedades, las opciones terapéuticas han seguido una evolución paralela a las teorías sobre su patogenia. Los ecólogos y quienes consideran que la SQ M se debe a una disfunción inmunitaria secundaria a cantidades excesivas de sustancias químicas exógenas han centrado su atención en la evitación de las sustancias químicas artificiales. Este punto de vista se ha asociado con el empleo de estrategias de diagnóstico para intentar determinar las sensibilidades "específicas" por medio de diversas pruebas no validadas para "desensibilizar" a los pacientes. Paralelamente, se han utilizado estrategias para potenciar la inmunidad subyacente mediante suplementos dietéticos, como vitaminas y antioxidantes, y se ha hecho todo lo posible para erradicar los hongos y otros organismos comensales. Un sistema más radical consiste en intentar eliminar las toxinas del organismo por medio de la quelación o la renovación acelerada de las grasas en las que se almacenan los pesticidas, los disolventes y otros productos químicos orgánicos liposolubles.

Los partidarios de la teoría psicológica de la etiología de la SQM han probado métodos alternativos adecuados. Se han propuesto la terapia de apoyo individual y de grupo y otras técnicas de modificación de la conducta más clásicas, aunque se sigue conjeturando sobre la eficacia de estos enfoques. La mayoría de los observadores se han visto sorprendidos por la intolerancia de los pacientes a los fármacos empleados generalmente para los trastornos afectivos y de ansiedad, impresión que quedó confirmada en una prueba al doble ciego controlada con placebo realizada por el autor con la fluvoxamina y que hubo que interrumpir a consecuencia de los efectos secundarios que se produjeron en cinco de los ocho primeros participantes.

A pesar de las limitaciones de nuestros conocimientos actuales, podemos enunciar algunos principios terapéuticos.

En primer lugar, y en la medida de lo posible, se debe limitar la búsqueda de una "causa" específica de la SQ M en cada caso, ya que es infructuosa y contraproducente. Para cuando se considera la posibilidad de la SQ M muchos pacientes se han sometido ya a numerosas exploracines médicas y consideran que las pruebas presuponen la existencia de una alteración y la posibilidad de que exista un tratamiento específico. Cualquiera que sea la opinión teórica del facultativo, es esencial exponerle al paciente los conocimientos actuales y la incertidumbre que existe en relación con la SQ M , indicando específicamente que se desconoce su causa. $\mathrm{H}$ ay que asegurarle al paciente que la consideración de una posible etiología psicológica no implica que la enfermedad sea menos real, menos grave o menos digna de tratamiento. También se le puede asegurar que no es probable que la SQ M siga progresando o produzca la muerte, y que tiene que comprender que la curación total es improbable con los tratamientos actuales.

D ejando a un lado la incertidumbre acerca de la patogenia, casi siempre es necesario alejar al paciente de los componentes de su medio ambiente de trabajo que desencadenan los síntomas. Aunque la separación radical es sin duda contraproducente para el objetivo de mejorar la capacidad funcional del trabajador, se deben controlar en la medida de lo posible las reacciones sintomáticas frecuentes e intensas, para que se pueda entablar una estrecha relación terapéutica con el paciente. A menudo, es necesario que el paciente cambie de trabajo. Posiblemente existan indemnizaciones para los trabajadores; incluso aunque no se conozca bien la patogenia de la enfermedad, puede caracterizarse debidamente la SQ M como una complicación de una exposición profesional más fácil de identificar (Cullen 1994).

El objetivo de todo el tratamiento posterior es mejorar la actividad del paciente. Deben tratarse los problemas psicológicos, como las dificultades de adaptación, la ansiedad y la depresión, así como los posibles problemas concomitantes, como las típicas alergias atópicas. Dado que los pacientes con SQ M no toleran las sustancias químicas en general, puede que haya que recurrir a soluciones no farmacológicas. La mayoría de los pacientes necesitan que se les oriente, asesore y tranquilice para poder adaptarse a una enfermedad para la que no existe un tratamiento establecido (L ewis 1987). En la medida de lo posible, hay que animarles a que amplíen sus actividades y desaconsejarles la pasividad y la dependencia, que son respuestas muy frecuentes a este trastorno.

\section{Prevención y control}

O bviamente, no es posible desarrollar estrategias de prevención primaria con los conocimientos actuales sobre la patogenia de la enfermedad o de sus factores de riesgo para el huésped predisponentes. Por otra parte, probablemente se reducirá la incidencia de la SQM limitando en el entorno laboral las oportunidades de exposiciones agudas incontroladas que precipitan la SQM en algunos afectados, como las derivadas de irritantes respiratorios, disolventes y pesticidas. También pueden ser de gran ayuda las medidas proactivas dirigidas a mejorar la calidad del aire en las oficinas mal ventiladas.

Parece que la prevención secundaria puede ofrecer mejores posibilidades de control, aunque no se han estudiado medidas específicas. Dado que los factores psicológicos pueden influir en las víctimas de las sobreexposiciones profesionales, conviene tratar cuidadosa y precozmente a las personas expuestas, aunque desde el punto de vista de la exposición sufrida el pronóstico sea favorable. Se debe valorar la manera en que reaccionarán los pacientes atendidos en los servicios de urgencias 0 su clínica inmediatamente después de haberse visto sometidos a una exposición aguda, y probablemente haya que seguirlos muy de cerca para asegurarse de que no sufren recidivas evitables, ya que este tipo de exposición puede ser un importante factor de riesgo de SQ M , con independencia del mecanismo causal. 


\section{Referencias}

American Society of $\mathrm{H}$ eating, R efrigerating, and Airconditioning Engineers (ASHRAE). 1989 Standard 62-89: Ventilation for Acceptable Indoor Air Quality. Atlanta: ASH RAE.

American Society for T esting and M aterials (AST M). 1984. Standard T est M ethod for the E stimation of Sensory I rritancy of Airborne Chemicals. Filadelfia: AST M .

Anon. 1990. Environmental controls and lung disease. (Erratum in Am Rev Respir Dis 143(3):688, 1991 Am R ev R espir D is 142:915-939.

Ashford, NA, CS M iller. 1991. Chemical Exposures: Low Levels and $\mathrm{H}$ igh Stakes. Nueva Y ork: $\mathrm{V}$ an N ostrand Reinhold.

Bascom, R. 1992. Multiple chemical sensitivity: A respiratory disorder? T oxicol Ind $\mathrm{H}$ ealth 8:221-228.

Bell, I. 1982. Clinical E cology. Colinas, California: Common $\mathrm{K}$ nowledge Press.

Black, DW, A Ruth, RB Goldstein. 1990. Environmental illness: A controlled study of 26 subjects with 20 th century disease. J Am M ed Assoc 264:3166-3170.

Bolle-Wilson, K, RJ Wilson, ML Bleecker. 1988 Conditioning of physical symptoms after neurotoxic exposure. I O ccup M ed 30:684-686.

Brodsky, CM. 1983. Psychological factors contributing to somatoform diseases attributed to the workplace. The case of intoxication. I 0 ccup $M$ ed 25:459-464.

Brown, SK, MR Sim, MJ Abramson, CN Gray. 1994. C oncentrations of V O C in indoor air. Indoor Air 2:123-134.

Buchwald, D, D Garrity. 1994. Comparison of patients with chronic fatigue syndrome fibromyalgia, and multiple chemical sensitivities. Arch Int M ed 154:2049-2053.

Cullen, MR. 1987. The worker with multiple chemical sensitivities: An overview. En W orkers with Multiple Chemical Sensitivities, dirigido por M Cullen. Filadelfia: $\mathrm{H}$ anley \& Belfus.

—. 1994. Multiple chemical sensitivities: Is there evidence of extreme vulnerability of the brain to environmental chemicals? En The Vulnerable Brain and Environmental Risks, Vol. 3, dirigido por RL I saacson y K IF J ensen. N ueva Y ork: Plenum.

Cullen, MR, PE Pace, CA Redlich. 1992. The experience of the Yale Occupational and Environmental Medicine Clinics with MCS 1986-1989. T oxicol Ind $\mathrm{H}$ ealth 8:15-19.

Fiedler, N L, H K ipen, J De Luca, K K elly-M cN eil, B Natelson. 1996. A controlled comparison of multiple chemical sensitivities and chronic fatigue syndrome. Psychosom M ed 58:38-49.

Hodgson, MJ. 1992. A series of field studies on the sick-building syndrome. Ann NY Acad Sci 641:21-36

Hodgson, M J, H Levin, P Wolkoff. 1994. Volatile organic compounds and indoor air (revisión). J Allergy Clin Immunol 94:296-303.

K ipen, H M , K H allman, N K elly-M cN eil, N Fiedler. 1995. M easuring chemical sensitivity prevalence. Am J Public H ealth 85(4):574-577.

Levin, AS, VS Byers. 1987. Environmental illness: A disorder of immune regulation. State Art Rev 0 ccup $M$ ed 2:669-682.

Lewis, BM. 1987. Workers with multiple chemical sensitivities: Psychosocial interventions. State Art Rev 0 ccup M ed 2:791-800.

M endell, M J. 1993. Non-specific symptoms in office workers: A review and summary of the literature. Indoor Air 4:227-236.

Middaugh, DA, SM Pinney, DH Linz. 1992. Sick building syndrome: Medical evaluation of two work forces. J O ccup M ed 34:1197-1204.
Miller, CS. 1992. Possible models for multiple chemical sensitivity: Conceptual issues and the role of the limbic system. Toxicol Ind $\mathrm{H}$ ealth :181-202.

M ølhave, L, R Bach, OF Pederson. 1986. Human reactions to low concentrations of volatile organic compounds. Environ Int 12:167-175.

Mølhave, L, GD Nielsen. 1992. Interpretation and limitations of the concept "T otal volatile organic compounds" (TVOC) as an indicator of human responses to exposures of volatile organic compounds (VOC) in indoor air. Indoor Air 2:65-77.

Robertson, A, PS Burge, A Hedge, S Wilson, J Harris-Bass. 1988. Relation between passive cigarette smoke exposure and "building sickness". Thorax 43:263P.

Schottenfeld, RS, MR Cullen. 1985. O ccupationinduced post-traumatic stress disorder. Am J Psychol 142:198-202.

Selner, JC, H Strudenmayer. 1992. Neuropsychophysiologic observations in patients presenting with environmental illness. Toxicol Ind $\mathrm{H}$ ealth 8:145-156.

Shorter, E. 1992. F rom Paralysis to F atigue. N ueva Y ork: The Free Press.

Simon, GE. 1992. Epidemic MCS in an industrial setting. T oxicol I nd $\mathrm{H}$ ealth 8:41-46.

Simon, GE, W Daniel, H Stockbridge. 1993. Immunologic, psychologic, and neuropsychological factors in multiple chemical sensitivity. Ann Intern M ed 19:97-103.

Sundell, J, T Lindvall, B Stenberg, S W all. 1994. SBS in office workers and facial skin symptoms among VDT workers in relation to building and room characteristics: T wo case-referent studies. Indoor Air 2:83-94

Wechsler, CJ. 1992. Indoor chemistry: Ozone, volatile organic compounds, and carpets. Environ Sci T echnol 26:2371-2377.

Welch, LS, P Sokas. 1992. Development of MCS after an outbreak of sick building syndrome. T oxicol Ind H ealth 8:47-50.

Woods, JE. 1989. Cost avoidance and productivity. State Art R ev 0 ccup M ed 4:753-770.

\section{0 tras lecturas recomendadas}

Ahearn, DG, DL Price, RB Simmons, SA Crow. 1992. Colonization Studies of Various H VAC M aterials. Environments for People: IAQ, No. 9. Atlanta: ASHRAE.

Anon. Discomfort from ETS among employees at work sites with minimal smoking restrictions. 1992. M orb M ortal W eekly R ep 41:351-354.

Apter, A, A Bracker, M Hodgson, J Sidman, W-Y Leung. 1994. Epidemiology of the sick building syndrome. I Allergy Clin Immunol 94:277-288.

Bascom, R. 1991. The upper respiratory tract: mucous membrane irritation. Environ $\mathrm{H}$ ealth Persp 95:39-44

Bauer, R, K Greve, EL Besch, CJ Schramke, J Crouch, A Hicks, MR Ware, WB Lyles. 1992. The role of psychological factors in the report of building related symptoms in sick-building syndrome. J Clin Consult N europsychol 60:213-219.

Boswell, RT, L DiBerardinis, A Ducatman. 1994. Descriptive epidemiology of indoor odor complaints at a large teaching institution. Appl $O$ ccup E nviron $\mathrm{H}$ yg 9:281-286.

Burge, $H$. 1993. Characterization of B ioaerosols in the U S. Environments for People: IAQ, N o. 92. Atlanta: ASHRAE.
Burge, PS, A Hedge, S Wilson, JH Bass, A Robertson. 1987. Sick-building syndrome: A study of 4,373 office workers. Ann Occup $\mathrm{H}$ yg 31:493-504.

Cain, WS, BS Leaderer, Isseroff. 1983. V entilation requirements in buildings - control of occupancy odor and tobacco smoke. Atmos Environ 17:1183-1197.

Cometto-M uniz, JE, WS Cain. 1992. Sensory irritation: R elation to indoor air pollution. Sources of indoor contaminants. Ann NY Acad Sci 641:137-151.

Cone, J, MJ Hodgson. 1989. Building-associated illness and problem buildings. State Art Rev 0 ccup $M$ ed 4.

Cullen, M R. 1991. Multiple chemical sensitivities. Development of public policy in the face of scientific uncertainty. N ew Solutions (Fall):16-24.

Finnegan, M, CAC Pickering, PS Burge 1984. The sick-building syndrome: Prevalence studies. $\mathrm{Br} \mathrm{M}$ ed 289:1573-1575.

Flannigan, B. 1993. Approaches to the Assessment of $M$ icrobial Flora of Buildings. Environments for People: IAQ, N 0.92. Atlanta: ASH RAE.

Foarde, K, E Cole, D V an O sdell, D Bush, D Franke, $J$ Chung. 1992. Characterization of Environmental Chambers for $E$ valuating $M$ icrobial Growth on Building $M$ aterials. Indoor Air, N o. 9. Atlanta: ASH RAE.

Franck, C, P Skov. 1991. Evaluation of two different questionnaires used for diagnosing ocular manifestations in the sick-building syndrome on the basis of an objective index. Indoor Air 1:5-11.

Gustafsson, H. 1992. Building M aterials Identified as Sources for Indoor Air Pollutants: A Critical Review and Case Studies. Vol. D10. Consejo Sueco de Investigación de la Construcción.

$H$ ansen, L, GD Nielsen, I Tottrup, A Abildgaard, OF Dahl, GK Hansem, O Nielsen. 1991. Biological determination of emission of irritants from paint and lacquer. Indoor Air 2:95-110.

Hoffman, R, RC Wood, K K reiss. 1993. Building-related asthma in Denver office workers. Am J Public H ealth 83:89-93.

Jarvis, BB. 1990. M ycotoxins and indoor air quality. $B$ io Cont Ind E nv 83:200-210.

K jaergard, S, L M ølhave, OF Pederson. 1991. $H$ uman reactions to a mixture of indoor pollutants. Atmos E nviron A-G en 25:1417-1426.

K jaergard, S, E T audorff, L M ølhave, OF Pederson. 1990. Assessment of changes in eye redness. Int Arch $O$ ccup E nviron $H$ ealth 62:133-137.

K noeppel, H, P Wolkoff. 1992. Chemical, microbiological, health, and comfort aspects of indoor air. En State of the Art in SBS, dirigido por $\mathrm{H}$ K noeppel y P W olkoff. Bruselas: ECSC.

Koren, H, DE Graham, RB Devlin, H K noeppel. 1992. Exposure of humans to a volatile organic mixture. III. Inflammatory response. Arch Environ $H$ ealth 47:39-44.

K roeling, P. 1987. Untersuchungen zum "building-illness" syndrom in klimatisierten gebaeuden. $\mathrm{G}$ esundheits I ngenieur $\mathrm{H}$ austechnik B auphysik U mweltechnik 108:121-130.

$M$ artikainen, $M$, A Asikainen, $A$ Nevalainen, $M$ Jantunen, P Pasanen, P K allikowski. 1990. $\mathrm{M}$ icrobial growth on ventilation filter materials. Proc Indoor Air 3:203-206.

Meggs, WJ. 1993. Neurogenic inflammation and sensitivity to environmental chemicals. Environ $H$ ealth Persp 101:234-238.

M elius, J, K Wallingford, J Carpenter, R K eenlyside. 1984. Indoor air qualtiy: The NIOSH experience. Ann Am Conf G ov Ind H yg 10:3-7. 
M endell, M, AB Smith. 1990. Consistent pattern of elevated symptoms in air-conditioned office buildings: A reanalysis of epidemiologic studies. Am J Public H ealth 80:1193-1199.

Menzies, RI, RM Tamblyn, JP Farant, J H anley, $F$ Nunes, RT Tamblyn. 1993. The effect of varying levels of outdoor air supply on symptoms of the Sick-building Syndrome. New Engl J $M$ ed 328:821-827.

Miller, JD. 1993. Fungi and the Building Engineer Environments for People: IAQ, No. 92. Atlanta: ASHRAE.

Nielsen, GD. 1991. M echanisms of activation of the sensory irritant receptor. CRC Rev Toxicol 21:183-208.

-.1992 . Irritation of the upper airways. M echanisms and structure-activity relationships. En Chem, $\mathrm{M}$ icro, $\mathrm{H}$ ealth and Comfort Aspect of Indoor Air Q uality.

O hm, M, JE Juto, K Andersson. 1993. Nasal $H$ yperreactivity and Sick Building Syndrome Environments for People: IAQ, N o. 92. Atlanta: ASHRAE.

O rganización M undial de la Salud (O M S) 1987. Air Q uality Guidelines for Europe. Copenhague, O ficina R egional de la O M S para Europa.

Otto, DA, HK Hudnell, DE House, L Mølhave, W Counts. 1992. Exposure of humans to a volatile organic mixture. III. Behavioral assessment. Arch Environ $\mathrm{H}$ ealth 47:23-30.

Pasanen, P, A Pasanen, M Jantunen. 1993. Water condensation promotes fungal growth in ventilation ducts. Indoor Air 2:106-112.

Pasanen, PO, I Teijonsalo, O Seppanen, I Ruuskanen, P Kalliokoski. 1994. Increase in perceived odor emissions with loading of ventilation filters. Indoor Air 2:106-113.
Rafferty, E, E Light. 1993. Indoor Air Guidelines: Limitations and Alternatives. Environments for People: IAQ, N 0. 92. Atlanta: ASH RAE.

Raw, GJ, MS Roys, C Whitehead. 1993. Sick-building syndrome: Cleanliness next to healthiness. Indoor Air 4:237-245.

R einikainen, LM , J Jaakola, O Seppanen. 1992. The effect of air humidification on symptoms and perception of indoor air quality in office workers: A six-period cross-over study. Arch E nviron $H$ ealth 47:8-15.

Rylander, R. 1994. A perspective on indoor air microbiological contamination. En ASHRAE Transactions 1994. Atlanta: ASH RAE.

Skov, P, O Valbjorn, The Danish Indoor Study Group. 1987. The sick-building syndrome in the office environment: The Danish T own $\mathrm{H}$ all Study. Environ Int 13:339-349.

Stenberg, B, K Hansson Mild, M Sandstron, J Sundell, S Wall. 1993. A prevalence study of the SBS and facial symptoms among office workers. Indoor Air 2:71-80.

Stolwijk, JAJ. 1992. The sick-building syndrome. E nviron $H$ ealth Persp 95:99-100.

Strom, G, U Palmgren, B Wessen, B H elmstrom, A $\mathrm{K}$ umlin. 1990. The sick-building syndrome: $A n$ effect of microbial growth in building construction. Proc Indoor Air 1:173-178.

Sundell, J, T Andersson, K Andersson, T Lindvall. 1993. V olatile organic compounds in ventilating air in buildings at different sampling points and their relationship with the prevalence of occupant symptoms. Indoor Air 2:82-93.

Tsubota, K, K Nakamuri. 1993. Dry eyes and video-display terminal units. New Engl J M ed 328:584.

Valbjorn, O , S G ravesen, L M ølhave. 1990. Dust in ventilation ducts. Proc Indoor Air 3:361-364.
Walsh, CS, PJ Dudney, E Copenhaever. 1984. Indoor Air Q uality. Boca R atón: CRC Press.

Wilkons, CK, P Wolkoff, F Gyntelberg, P Skov, 0 Valbjorn. 1993. Characterization of office dust by $V O C S$ and TVOC release: Identification of potential irritant VOCs by partial least squares analysis. Indoor Air 4:283-290.

Wolkoff, P, L H ansen, GD Nielsen. 1988. Air-way irritating effect of carbonless copy paper examined by the sensory irritation test in mice. Environ Int 14:43-48.

Wolkoff, P, GD Nielsen, LF H ansen. 1990 Controlled human reactions to building materials in climate chambers. Part II: VOC measurements, mice bioassay, and decipol evaluation. Proc Indoor Air 1:331-336.

Wolkoff, P, GD Nielsen, L H ansen, 0 Albrechtsen, CR Johnsen, JH Heniig, C Franck, PA Nielsen. 1991. A study of human reactions to emissions from building materials in climate chambers. Part II: VOC measurements, mouse bioassay, and decipol evaluation in the $1-2 \mathrm{mg} / \mathrm{m} 3 \mathrm{TVOC}$ range. Indoor Air 4:389-403.

Wolkoff, P, CR Jonssen, C Franck, P Wilhardt, $O$ Albrechtsen. 1992. A study of human reactions to office machines in a climatic chamber. I Expos Anal Environ E pidemiol Supl. 1:1-25.

Wolkoff, P, CK Wilkins, G Clausen, CK Larsen. 1993. Comparison of volatile organic compound from processed paper and toners from office copiers and printers: M ethods, emission rates, and modelled concentrations. Indoor Air 2:113-123.

Wyon, D. 1992. Sick buildings and the experimental approach. Environ T echnol 13:313-322.

Zweers, T, L Preller, B Brunekreef, JSM Boleij. 1992. $\mathrm{H}$ ealth and indoor climate complaints of 7043 office workers in 61 buildings in the Netherlands. Indoor Air 2:127-136. 



\section{PRIMEROS AUXIUOS Y SERVICIOS MEDICOS DE URGENCIA}

Director del capítulo

Antonio J . D ajer

\section{Sumario}

\section{Primeros auxilios}

Antonio J. Dajer........................... 14.2

L esiones craneoencefálicas

Fengsheng $\mathrm{H} \mathrm{e}$ 


\section{- Primeros auXiLIOS}

Antonio J. Dajer

Los primeros auxilios son la asistencia inmediata que se presta a las víctimas de accidentes antes de la llegada de personal médico especializado. Su objetivo es detener y, si es posible, revertir el daño ocasionado. Consisten en una serie de medidas rápidas y sencillas, como liberar la vía aérea, aplicar presión sobre las heridas sangrantes o lavar las quemaduras químicas situadas en los ojos o en la piel.

Los factores principales que definen los servicios de primeros auxilios de un lugar de trabajo son los riesgos específicos de la actividad y la disponibilidad de asistencia médica definitiva. Evidentemente, la asistencia que requiere una lesión causada por una sierra de gran potencia es radicalmente diferente de la que requiere la producida por la inhalación de un producto químico.

Desde la perspectiva de los primeros auxilios, una herida grave en el muslo que se produce cerca de un hospital dotado de servicio quirúrgico requiere poco más que un transporte adecuado; si la misma lesión se produce en una zona rural situada a ocho horas del servicio médico más cercano, los primeros auxilios incluirían, entre otras cosas, el desbridamiento, la ligadura de los vasos sangrantes y la administración de inmunoglobulina antitetánica y antibióticos.

EI concepto de primeros auxilios es flexible, no sólo en cuanto a qué debe hacerse (durante cuánto tiempo, con qué grado de complejidad), sino también por lo que respecta a quién debe hacerlo. Aunque es necesario actuar con mucho cuidado, todo trabajador puede conocer las cinco o diez reglas fundamentales sobre lo que se debe y no se debe hacer en materia de primeros auxilios. En algunas situaciones, la acción inmediata puede salvar la vida, un miembro o la vista. Los compañeros de trabajo de las víctimas no deben quedarse paralizados mientras esperan la llegada de personal especializado. Por otra parte, la lista de las "diez medidas fundamentales" será diferente en cada lugar de trabajo y deberá acompañarse de la formación correspondiente.

\section{Importancia de los primeros auxilios}

En los casos de parada cardíaca por fibrilación ventricular, la desfibrilación realizada durante los cuatro primeros minutos logra unas tasas de supervivencia del 40 al $50 \%$, en comparación con valores inferiores al $5 \%$ si se administra más tarde Quinientas mil personas mueren de parada cardíaca cada año sólo en Estados Unidos. En cuanto a las lesiones químicas oculares, el lavado inmediato con agua puede salvar la vista. En las lesiones de la médula espinal, la inmovilización correcta puede establecer la diferencia entre la recuperación completa y la parálisis. En las hemorragias, la simple aplicación de la punta de un dedo sobre un vaso sangrante puede detener una hemorragia potencialmente mortal.

Con frecuencia, ni siquiera la asistencia médica más avanzada puede reparar los efectos de unos primeros auxilios inadecuados.

\section{Primeros auxilios en el contexto de la organización general de la salud y la seguridad}

La prestación de primeros auxilios debe tener siempre una relación directa con la organización general de la salud y la seguridad, ya que los primeros auxilios propiamente dichos no solucionan nada más que una pequeña parte de la asistencia total de los trabajadores. Los primeros auxilios son una parte de la asistencia sanitaria total de los trabajadores. En la práctica, su aplicación dependerá en gran medida de las personas presentes en el momento del accidente, ya sean compañeros de trabajo 0 personal médico con formación normalizada. Esta intervención inmediata debe completarse con una asistencia médica especializada cuando sea necesario.

En el artículo 5 del Convenio sobre los servicios de salud en el trabajo, de la OIT (no 161), así como en la Recomendación del mismo nombre, se incluyen los primeros auxilios y la atención de urgencia en los casos de accidente e indisposición de los trabajadores en el lugar de trabajo como parte importante de las funciones de los servicios de salud en el trabajo. Ambos instrumentos, adoptados en 1985, regulan el desarrollo progresivo de servicios de salud en el trabajo dirigidos a todos los trabajadores.

Todo programa global sobre salud y seguridad en el trabajo debe incluir primeros auxilios, ya que contribuyen a reducir al mínimo las consecuencias de los accidentes y son, por tanto, uno de los componentes de la prevención terciaria. Existe un nexo de unión entre la identificación de los peligros profesionales, su prevención, los primeros auxilios, el tratamiento de urgencia, la asistencia médica adicional y el tratamiento especializado para la reintegración y la readaptación al trabajo. L os profesionales de la salud en el trabajo pueden desempeñar importantes funciones en este ámbito.

No es infrecuente que se produzcan varios incidentes pequeños 0 accidentes menores antes de que tenga lugar un accidente grave. Los accidentes que sólo requieren primeros auxilios constituyen una señal que deben atender y utilizar los profesionales de la salud y la seguridad en el trabajo para dirigir y promover medidas preventivas.

Relación con otros servicios relacionados con la salud Las instituciones que pueden participar en la organización de los primeros auxilios y en la prestación de asistencia después de un accidente 0 una enfermedad en el trabajo son las siguientes:

- el servicio de salud en el trabajo de la propia empresa u otras entidades de salud en el trabajo;

- otras instituciones que pueden prestar servicios, como: servicios de ambulancia; servicios de salvamento y urgencia públicos; hospitales, clínicas y centros de salud públicos o privados; médicos privados; centros de toxicología; protección civil; servicios de bomberos y policía.

Cada una de estas instituciones tiene diferentes funciones y capacidades, si bien debe comprenderse que lo que se aplica a un tipo de institución - por ejemplo, un centro de toxicologíade un país no tiene que aplicarse necesariamente a un centro de toxicología de otro país. La empresa, tras consultar con el médico de la fábrica o un consultor médico externo, debe garantizar que la capacidad y las instalaciones de las instituciones médicas más próximas son adecuadas para hacer frente a las lesiones que puedan producirse en un accidente grave. Esta evaluación es la base sobre la que se decide qué instituciones participarán en el plan de remisión.

La cooperación entre estos servicios es muy importante para la prestación de unos primeros auxilios adecuados, en especial en el caso de las pequeñas empresas. M uchos de ellos pueden aconsejar sobre la organización de los primeros auxilios y la planificación necesaria para atender una urgencia. Existen prácticas adecuadas que son muy sencillas y eficaces; por ejemplo, incluso una tienda o una pequeña empresa pueden invitar a los bomberos a que visiten sus locales. La empresa o el propietario recibirán asesoramiento sobre prevención y control de incendios, planes de emergencia, extintores, botiquín de primeros auxilios, etc. A su vez, la brigada de bomberos conocerá la empresa y estará preparada para intervenir con mayor rapidez y eficacia.

Existen otras muchas instituciones que pueden intervenir, como las asociaciones industriales y comerciales, las empresas de 
seguridad, las compañías de seguros, las organizaciones de normalización, los sindicatos y otras organizaciones no gubernamentales. Algunas de estas organizaciones pueden tener información sobre salud y seguridad en el trabajo y ser un recurso valioso para la planificación y la organización de los primeros auxilios.

\section{Enfoque organizado de los primeros auxilios}

\section{Organización y planificación}

Los primeros auxilios no pueden planificarse de forma aislada, sino que requieren un enfoque organizado integrado por personas, equipos y materiales, instalaciones, sistemas de apoyo y medios para el transporte de víctimas y no víctimas desde el lugar del accidente. La organización de los primeros auxilios debe ser un esfuerzo de cooperación en el que participen la empresa, los servicios de salud pública y de salud en el trabajo, la inspección de trabajo, los directivos de las fábricas y las organizaciones no gubernamentales pertinentes. La implicación de los trabajadores es esencial: suelen ser el mejor recurso ante un eventual accidente en situaciones específicas.

Con independencia del grado de complejidad o de disponibilidad de instalaciones, la secuencia de acciones que deben realizarse en el caso de un episodio imprevisto debe determinarse con antelación. Para ello, deben tenerse en cuenta los peligros y las circunstancias profesionales y no profesionales potenciales y existentes, así como las formas de obtener de inmediato ayuda adecuada. Las situaciones varían no sólo según el tamaño de la empresa, sino también en función de su localización (ciudad o área rural) y del desarrollo del sistema sanitario y la legislación laboral a escala nacional.

En cuanto a la organización de los primeros auxilios, existen algunas variables fundamentales que deben tenerse en cuenta:

- tipo de trabajo y nivel de riesgo asociado;

- peligros potenciales;

- tamaño y organización de la empresa;

- otras características de la empresa (p. ej., configuración);

- disponibilidad de otros servicios sanitarios.

\section{Tipo de trabajo y nivel de riesgo asociado}

Los riesgos de lesión varían en gran medida por empresas y profesiones. Incluso dentro de una misma empresa, por ejemplo del sector metalúrgico, existen distintos riesgos, en función de si el trabajador se dedica a la manipulación y al corte de láminas de metal (donde los cortes son frecuentes), al soldado (con riesgo de quemaduras y electrocución), al montaje de piezas o al chapado del metal (donde existe la posibilidad de intoxicación y de lesión cutánea). L os riesgos asociados con un tipo de trabajo varían en función de otros muchos factores, como el diseño y la antigüedad de la maquinaria empleada, el mantenimiento del equipo, las medidas de seguridad aplicadas y su control periódico.

La influencia del tipo de trabajo y de los riesgos asociados en la organización de los primeros auxilios se ha reconocido plenamente en la mayor parte de la legislación al respecto. EI equipo y el material necesarios para los primeros auxilios, así como el número de personas dedicadas a ellos y su formación, pueden variar según el tipo de trabajo y los riesgos que conlleva. Los distintos países utilizan modelos diferentes de clasificación con objeto de planificar los primeros auxilios y de fijar unos requisitos más o menos estrictos. En algunas ocasiones se establece una distinción entre tipos de trabajo y riesgos potenciales específicos:

- riesgo bajo: por ejemplo, oficinas o tiendas;
- riesgo alto: por ejemplo, almacenes, explotaciones agrarias y algunas fábricas y talleres;

- riesgos infrecuentes o específicos: por ejemplo, fabricación de acero (especialmente cuando se trabaja con hornos), coquificación, fundición y fabricación de materiales no ferrosos, forja, fundiciones; construcción de buques; trabajo en canteras, minería u otras actividades subterráneas; trabajo con aire comprimido y actividades submarinas; construcción, explotación forestal e industria transformadora de la madera; mataderos y fábricas de extracción de sebo; transporte terrestre y marítimo, y la mayoría de las industrias en las que se utilizan sustancias nocivas o peligrosas.

\section{Peligros potenciales}

Incluso en las empresas que parecen limpias y seguras pueden producirse muchos tipos de lesiones. L as lesiones graves pueden ser la consecuencia de caídas, golpes contra objetos o contacto con bordes afilados o vehículos en movimiento. Los requisitos específicos en materia de primeros auxilios serán diferentes en función de que se produzcan o existan:

- caídas;

- cortes importantes, extremidades seccionadas;

- lesiones por aplastamiento;

- riesgo alto de extensión de incendios y explosiones;

- intoxicación por sustancias químicas en el trabajo;

- otras exposiciones a sustancias químicas;

- electrocución;

- exposición a calor o frío excesivos;

- falta de oxígeno;

- exposición a agentes infecciosos, mordeduras y picaduras de animales.

Esta lista constituye sólo una guía general. La evaluación detallada de los riesgos potenciales en el medio ambiente de trabajo facilita en gran medida la identificación de las necesidades de primeros auxilios.

\section{Tamaño y organización de la empresa}

Toda empresa, independientemente de su tamaño, debe disponer de primeros auxilios, ya que la frecuencia de accidentes es en muchos casos inversamente proporcional al tamaño de la empresa.

En las grandes empresas, la planificación y la organización de los primeros auxilios puede ser más sistemática. Esto se debe a que cada taller tiene funciones diferentes y a que la plantilla está distribuida de un modo más específico que en las empresas más pequeñas. En consecuencia, el equipo, el material y las instalaciones para primeros auxilios, así como el personal de primeros auxilios y su formación, pueden organizarse normalmente de un modo más preciso, como respuesta a los posibles riesgos, en una empresa grande que en otra de tamaño menor. N o obstante, los primeros auxilios también pueden organizarse con eficacia también en las pequeñas empresas.

Los distintos países utilizan diferentes criterios para planificar los primeros auxilios en función del tamaño y otras características de la empresa. No puede establecerse ninguna regla general. En el Reino Unido, las empresas con menos de 150 trabajadores y riesgo bajo 0 aquellas con menos de 50 trabajadores y riesgo alto se consideran pequeñas, y se aplican a la planificación de los primeros auxilios criterios diferentes a los de las empresas en las que el número de trabajadores presentes en el trabajo supera estos límites. En Alemania el enfoque es diferente: cuando hay menos de 20 trabajadores en el lugar de trabajo se aplica un conjunto de criterios, que será distinto si el número de trabajadores es superior a 20. En Bélgica se aplica un conjunto de criterios a las empresas industriales con 20 
trabajadores o menos, otro diferente a aquellas con un número comprendido entre 20 y 500 y un tercero a aquellas con 1.000 trabajadores o más.

\section{Otras características de la empresa}

La configuración de la empresa (es decir, el lugar o lugares en los que los trabajadores realizan su actividad) es importante para la planificación y organización de los primeros auxilios. La empresa puede estar ubicada en un solo lugar o distribuida en varios lugares dentro de una ciudad o región, o incluso por todo el país. Los trabajadores pueden estar asignados a zonas distantes de la central de la empresa, como ocurre en la agricultura, en la explotación forestal, en la construcción y en otras actividades. Este hecho influye en la provisión de equipo y material, en el número y la distribución del personal de primeros auxilios y en los medios dispuestos para el salvamento de los trabajadores lesionados y su transporte a centros médicos más especializados.

Algunas empresas tienen carácter temporal o estacional. Esto significa que algunos lugares de trabajo existen sólo de forma temporal o que en el mismo lugar de trabajo algunas funciones se realizan sólo durante períodos determinados de tiempo y, por consiguiente, pueden conllevar riesgos diferentes. Los primeros auxilios deben estar disponibles siempre que sea necesario, independientemente de que la situación cambie, y han de planificarse de acuerdo con estas circunstancias.

En algunas situaciones, los trabajadores de más de una empresa trabajan juntos en proyectos conjuntos o de forma coyuntural, como ocurre en la construcción. En estos casos, las empresas pueden establecer acuerdos para aunar su prestación de primeros auxilios. Es necesario asignar claramente las responsabilidades y que los trabajadores de cada empresa conozcan adecuadamente cómo está dispuesta la prestación de primeros auxilios. Las empresas deben procurar que la organización de los primeros auxilios para esta situación concreta sea lo más sencilla posible.

\section{Disponibilidad de otros servicios de salud}

El nivel de formación y el grado de organización de los primeros auxilios están determinados, básicamente, por la proximidad de la empresa a servicios sanitarios de fácil acceso y por su integración con ellos. Una relación estrecha, con un flujo adecuado de información, que permita evitar los retrasos en el transporte y en la solicitud de ayuda, puede ser más decisiva para obtener buenos resultados que las habilidades en la aplicación de procedimientos médicos. Todo programa de primeros auxilios en el lugar de trabajo debe adaptarse al servicio médico que proporciona la asistencia definitiva a los trabajadores lesionados y convertirse en una extensión del mismo.

\section{Requisitos básicos de un programa de primeros} auxilios

Los primeros auxilios deben considerarse parte de una buena gestión y de la seguridad en el trabajo. La experiencia de los países en los que los primeros auxilios están plenamente establecidos indica que el modo más adecuado de garantizar su eficacia es que la legislación los considere obligatorios. En los países que han adoptado este criterio, los requisitos principales se establecen en una legislación específica 0 , en la mayoría de los casos, en códigos laborales nacionales 0 disposiciones normativas similares. En estos casos, la normativa complementaria contiene disposiciones más detalladas. En la mayoría de los casos, la responsabilidad global de la empresa respecto de la prestación y la organización de los primeros auxilios está contenida en la legislación básica. Los elementos básicos de un programa de primeros auxilios son los siguientes:

\section{Equipo, material e instalaciones}

- equipo para el salvamento de la víctima en el lugar del accidente a fin de prevenir lesiones adicionales (p. ej., en caso de incendio, emanaciones de gases, electrocución);

- maletines de primeros auxilios, botiquines o equipos similares, con una cantidad suficiente del material y los instrumentos necesarios para la prestación de los primeros auxilios básicos;

- equipo y material especializados que puedan ser necesarios en empresas con riesgos específicos o poco comunes en el trabajo;

- sala de primeros auxilios adecuadamente identificada o instalación similar en la que puedan administrarse los primeros auxilios;

- disposición de medios de evacuación y transporte de urgencia de los heridos hasta el servicio de primeros auxilios o los lugares en los que se disponga de asistencia médica complementaria;

- medios para dar la alarma y comunicar la situación de alerta.

\section{Recursos humanos}

- selección, formación y readaptación profesional de las personas adecuadas para administrar los primeros auxilios, a las que se deberá designar y ubicar en lugares clave de la empresa, y cuya disponibilidad y accesibilidad permanentes deberán garantizarse;

- formación de reconversión, con ejercicios prácticos de simulación de situaciones de emergencia, teniendo en cuenta los peligros profesionales específicos que existen en la empresa.

\section{Otros}

- elaboración de un plan, en el que se prevean acuerdos con los servicios de salud públicos o privados pertinentes, para la prestación de asistencia médica después de los primeros auxilios;

- educación e información de todos los trabajadores sobre la prevención de accidentes y lesiones y las medidas que deben adoptar los propios trabajadores después de una lesión (p. ej., ducharse inmediatamente después de una quemadura química);

- información sobre las disposiciones en materia de primeros auxilios y actualización periódica de esa información;

- difusión de anuncios con información, guías visuales (p. ej., carteles) y normas sobre primeros auxilios, así como de los planes para la prestación de asistencia médica después de los primeros auxilios;

- cumplimentación de un registro: el registro del tratamiento de primeros auxilios es un informe interno que contiene datos sobre la salud de la víctima, así como referencias a la seguridad en el trabajo; debe incluir información sobre el accidente (hora, lugar, circunstancias); el tipo y la gravedad de la lesión; los primeros auxilios prestados; la asistencia médica adicional solicitada; el nombre del afectado y los nombres de los testigos y otros trabajadores relacionados, en especial los que transportaron a la víctima.

Aunque la responsabilidad básica de la ejecución de un programa de primeros auxilios incumbe a la empresa, estos no pueden ser eficaces sin la participación plena de los trabajadores. Por ejemplo, puede ser necesaria la cooperación de los trabajadores en el salvamento y en las operaciones de primeros auxilios; por tanto, deben estar informados de las medidas de primeros auxilios y deben hacer sugerencias basadas en su conocimiento del lugar de trabajo. La empresa debe exponer instrucciones escritas sobre primeros auxilios, preferiblemente en forma de carteles, en lugares estratégicos de sus locales. Además, es aconsejable que organice sesiones informativas dirigidas a todos 
Ios trabajadores. Algunos aspectos esenciales que deben abordarse en una sesión informativa son los siguientes:

- organización de los primeros auxilios en la empresa, incluido el procedimiento previsto para acceder a la asistencia adicional;

- compañeros designados como personal de primeros auxilios;

- formas de comunicación de la información sobre un accidente y destinatarios de esa información;

- ubicación del maletín de primeros auxilios;

- ubicación de la sala de primeros auxilios;

- ubicación del equipo de salvamento;

- acciones que deben realizar los trabajadores en caso de accidente;

- ubicación de las vías de evacuación;

- acciones que deben realizar los trabajadores después de un accidente;

- formas de apoyo al personal de primeros auxilios en el desempeño de su tarea.

\section{Personal de primeros auxilios}

El personal de primeros auxilios está integrado por personas presentes en el lugar de trabajo; normalmente, son trabajadores que conocen las condiciones específicas de trabajo, que no siempre disponen de cualificación médica, pero sí de la formación y la preparación necesarias para realizar tareas muy específicas. No todos los trabajadores cumplen los requisitos para recibir formación sobre la prestación correspondiente. El personal de primeros auxilios debe ser cuidadosamente seleccionado, y deben considerarse atributos como la fiabilidad, la motivación y la capacidad para tratar a las personas en una situación de crisis.

\section{Tipo y número}

La legislación sobre primeros auxilios difiere por países en cuanto al tipo de personal necesario para prestar este servicio y el número de personas que han de integrarlo. En algunos países se basa en el número de personas empleadas en el lugar de trabajo. En otros, los criterios fundamentales son los riesgos potenciales del trabajo. En otros, se consideran estos dos factores en conjunto. En los países con una larga tradición de prácticas de salud y seguridad en el trabajo y en los que la frecuencia de accidentes es baja, se suele prestar más atención al tipo de personal de primeros auxilios. En los países en los que no está regulada la prestación de primeros auxilios, se suele hacer hincapié en el número de personas que integran el personal de primeros auxilios.

En la práctica, puede establecerse una diferencia entre dos tipos de personal de primeros auxilios:

- el personal de primeros auxilios de nivel básico, que recibe una formación básica, como se describe más adelante, y que está cualificado para actuar en los casos en los que el riesgo potencial en el trabajo es bajo;

- el personal de primeros auxilios de nivel avanzado, que debe recibir una formación básica y avanzada, y ha de estar cualificado para actuar en los casos en los que el riesgo potencial sea más alto, especial o poco común.

Los cuatro ejemplos que se exponen a continuación son representativos de las diferencias de planteamiento para determinar el número y el tipo de personal de primeros auxilios aplicado en diferentes países:

\section{Reino Unido}

- Si el trabajo conlleva únicamente peligros relativamente bajos, no se exige que haya personal de primeros auxilios, salvo que haya 150 trabajadores o más presentes en el lugar de trabajo; en este caso, se considera adecuada la proporción de un socorrista por cada 150 trabajadores. Aunque se trate de un lugar en el que haya menos de 150 trabajadores, siempre debe existir una "persona responsable" designada por la empresa.

- Si el trabajo conlleva un riesgo más alto, habitualmente se exige que haya un socorrista cuando el número de trabajadores está comprendido entre 50 y 150. Si hay más de 150 trabajadores, se exige que haya un socorrista más por cada 150 trabajadores y, si el número de trabajadores es menor de 50, deberá designarse una "persona responsable".

- Si el riesgo potencial es especial o poco común, además de la dotación de personal de primeros auxilios ya establecida según los criterios expuestos anteriormente, es necesario que haya otra persona que recibirá formación específica sobre primeros auxilios en caso de accidentes debidos a estos peligros especiales o poco comunes (el socorrista industrial).

\section{Bélgica}

- En principio, se exige la presencia de un socorrista por cada 20 trabajadores presentes en el trabajo. No obstante, se exige que haya un miembro de plantilla dedicado a tiempo completo a la salud en el trabajo, si existen peligros especiales y el número de trabajadores es superior a 500, o en todo caso si se trata de una empresa con 1.000 trabajadores o más en el lugar de trabajo.

- Se prevé cierto grado de flexibilidad ante situaciones particulares.

\section{Alemania}

- Se exige que haya un socorrista en los lugares de trabajo con un máximo de 20 trabajadores.

- Cuando están presentes más de 20 trabajadores, el número de socorristas debe ser del $5 \%$ de la plantilla en oficinas y actividades comerciales en general, y del $10 \%$ en el resto de las empresas. En función de las demás medidas adoptadas por la empresa para hacer frente a las situaciones de emergencia y a los accidentes, estas cifran pueden revisarse.

- Si el trabajo conlleva riesgos específicos o poco comunes (por ejemplo, si se utilizan sustancias peligrosas), es necesario disponer de un personal específico de primeros auxilios debidamente formado; no se establece un número concreto en cuanto a la dotación de personal de estas características (es decir, se aplican las cifras citadas).

- Si en el lugar de trabajo hay más de 500 trabajadores y existen peligros especiales o poco comunes (quemaduras, intoxicaciones, electrocuciones, alteraciones de las funciones vitales, como parada cardíaca o respiratoria), se debe disponer de personal a tiempo completo especialmente formado, que se haga cargo de los casos en los que la llegada de la asistencia no puede demorarse más de 10 minutos. Esta disposición se aplica en casi todas las grandes obras de construcción, en las que diferentes empresas suelen tener empleados a varios centenares de trabajadores.

\section{Nueva Zelanda}

- Si están presentes más de cinco trabajadores, se designa un trabajador como responsable del equipo, el material y las instalaciones de primeros auxilios.

- Si están presentes más de 50 trabajadores, la persona designada debe ser un profesional de la enfermería diplomado 0 titular de un certificado (expedido por la St. John's A mbulance Association o la Cruz Roja de N ueva Zelanda). 


\section{Formación}

La formación del personal de primeros auxilios es el factor más importante para la eficacia de la organización de este servicio. Los programas de formación han de ajustarse a las necesidades de la empresa, en especial al tipo de trabajo y a los riesgos consiguientes.

\section{Formación básica}

Los programas de formación básica suelen tener una duración mínima de 10 horas. Los programas pueden dividirse en dos partes: tareas generales que deben realizarse y práctica concreta de los primeros auxilios. Abarcan las áreas que se citan a continuación:

\section{Tareas generales}

- organización de los primeros auxilios;

- evaluación de la situación, la magnitud y la gravedad de las lesiones y de la necesidad de solicitar asistencia médica adicional;

- protección de la víctima frente a nuevas lesiones, sin riesgo para el socorrista; ubicación y utilización del equipo de salvamento;

- observación e interpretación del estado general de la víctima (p. ej., inconsciencia, alteraciones respiratorias y cardiovasculares, hemorragia);

- ubicación, utilización y mantenimiento del equipo e instalaciones de primeros auxilios;

- plan de acceso a la asistencia adicional.

\section{Prestación de los primeros auxilios}

El objetivo es aportar los conocimientos teóricos y prácticos básicos para la prestación de los primeros auxilios. En este nivel básico se incluyen, entre otras materias:

- heridas;

- hemorragias;

- fracturas óseas o articulares;

- heridas por aplastamiento (p. ej., en el tórax o abdomen);

- inconsciencia, especialmente si se acompaña de dificultad o parada respiratoria;

- lesiones oculares;

- quemaduras;

- hipotensión arterial o shock;

- higiene personal durante la manipulación de las heridas;

- cuidados de los dedos amputados.

\section{Formación avanzada}

El objetivo de la formación avanzada es la especialización, más que la comprensión de conjunto. Tiene especial importancia en las siguientes situaciones (sin embargo, los programas específicos normalmente sólo se ocupan de algunas de ellas, según las necesidades, y su duración varía considerablemente):

- reanimación cardiopulmonar;

- envenenamiento (intoxicación);

- lesiones causadas por la corriente eléctrica;

- quemaduras graves;

- lesiones oculares graves;

- lesiones cutáneas;

- contaminación con material radiactivo (interna, o contaminación de la piel y las heridas);

- otros procedimientos relativos a peligros específicos (p. ej., estrés por frío o calor, situaciones de emergencia por inmersión).

\section{Materiales y centros de formación}

Existen numerosas publicaciones relativas a programas de formación sobre primeros auxilios. Las sociedades nacionales de la Cruz Roja y la M edia Luna Roja y diversas organizaciones de muchos países han publicado materiales que abarcan gran parte del programa de formación básica. D ebe consultarse este material en el momento de diseñar un programa de formación concreto, aunque sea preciso adaptarlo a las necesidades específicas de los primeros auxilios en el trabajo (a diferencia de lo que sucede, por ejemplo, con los primeros auxilios que deben prestarse después de accidentes de tráfico).

Los programas de formación deben ser aprobados por las autoridades competentes o por el organismo técnico autorizado para hacerlo. En muchos casos, puede tratarse de la sociedad nacional de la Cruz Roja o de la M edia Luna Roja o de otras instituciones relacionadas. En algunas ocasiones, las organizaciones de seguridad, las asociaciones industriales o profesionales, los centros sanitarios, algunas organizaciones no gubernamentales y los inspectores de trabajo (o los correspondientes órganos auxiliares) pueden contribuir a diseñar y ejecutar el programa de formación para que se adapte a situaciones específicas.

Esta autoridad debe ser también la responsable de evaluar al personal de primeros auxilios cuando finalice su formación. Deben designarse examinadores independientes de los programas de formación. A los candidatos que superen el examen se les deberá entregar un diploma, que servirá a la empresa para justificar su designación. La certificación debe ser obligatoria y debe entregarse también después de un curso de perfeccionamiento u otro tipo de formación, o después de la participación en trabajos de campo o en demostraciones.

\section{Equipo de primeros auxilios, material e instalaciones} La empresa es la responsable de proporcionar al personal de primeros auxilios el equipo, el material y las instalaciones adecuados.

\section{Maletines de primeros auxilios, botiquines de urgencia y equipos similares}

En algunos países la normativa vigente sólo establece los requisitos principales (es decir, que se disponga de las cantidades adecuadas de material e instrumental convenientes, y que la empresa determine lo que es estrictamente necesario en función del tipo de trabajo, los riesgos asociados y la configuración de la empresa). No obstante, en la mayoría de los países se han establecido requisitos más específicos, que asumen algunas diferencias en función del tamaño de la empresa y el tipo de trabajo y sus riesgos potenciales.

\section{Contenido básico}

El contenido de estos recipientes debe ajustarse a las cualificaciones del personal de primeros auxilios, a la disponibilidad de un médico de empresa o de otro personal sanitario y a la proximidad de un servicio de ambulancias o de urgencias. Cuanto más complejas sean las tareas del personal de primeros auxilios, más completo habrá de ser el contenido de los maletines y los botiquines. Un maletín de primeros auxilios relativamente sencillo suele incluir los siguientes artículos:

- apósitos adhesivos estériles empaquetados individualmente;

- vendas (y vendajes compresivos, cuando sea adecuado):

- diferentes tipos de apósitos;

- apósitos estériles para quemaduras;

- gasas oculares estériles;

- vendajes triangulares;

- imperdibles;

- tijeras; 
- solución antiséptica;

- algodón;

- una tarjeta con las instrucciones de primeros auxilios;

- bolsas de plástico estériles

- posibilidad de obtener hielo.;

\section{Ubicación}

El acceso a los maletines de primeros auxilios debe ser siempre sencillo, y han de estar situados cerca de las áreas en las que puedan producirse accidentes, de modo que se pueda llegar a ellos en uno o dos minutos. Deben estar fabricados con materiales adecuados y proteger el contenido del calor, la humedad, el polvo y los usos inadecuados. Deben estar claramente identificados como material de primeros auxilios; en la mayoría de los países están marcados con una cruz blanca o una media luna blanca sobre un fondo verde con bordes blancos.

Si la empresa está subdividida en departamentos o talleres, cada unidad debe disponer al menos de un maletín de primeros auxilios. No obstante, el número real de maletines necesarios estará determinado por la evaluación de necesidades que realice la empresa. En algunos países, tanto el número de recipientes necesarios como su contenido está establecido en la legislación.

\section{Botiquines auxiliares}

Debe haber siempre pequeños botiquines de primeros auxilios disponibles en aquellos casos en los que los trabajadores están fuera de un establecimiento, en sectores como la explotación forestal, la agricultura o la construcción; cuando trabajan solos, en pequeños grupos o en lugares aislados; cuando el trabajo conlleva el desplazamiento a zonas alejadas, o cuando se utilizan herramientas o piezas de maquinaria muy peligrosas. El contenido de estos botiquines, a los que también deben tener fácil acceso los trabajadores autónomos, varía según las circunstancias, aunque siempre debe incluir:

- varios apósitos de tamaño medio;

- una venda;

- un vendaje triangular;

- imperdibles.

\section{Equipo y material especializados}

En caso de que existan riesgos específicos o poco comunes será necesario disponer de un equipo de primeros auxilios más amplio. Por ejemplo, si existe la posibilidad de intoxicación, se debe disponer de forma inmediata de antídotos introducidos en un recipiente individual, en el que se debe advertir claramente que su administración está sujeta a indicación médica. Existen largas listas de antídotos para muchas situaciones específicas. Los riesgos potenciales determinarán qué antídotos son necesarios.

El equipo y el material especializados siempre deben estar situados cerca de los lugares en los que puedan producirse accidentes y en la sala de primeros auxilios. EI transporte del equipo desde una posición central, como el servicio de salud en el trabajo, hasta el lugar del accidente puede llevar demasiado tiempo.

\section{Equipo de salvamento}

En algunas situaciones de emergencia puede ser necesaria la utilización de un equipo de salvamento especializado para trasladar 0 rescatar a la víctima de un accidente. Aunque resulte difícil hacer predicciones, algunas situaciones de trabajo (como las que se dan en espacios cerrados, en alturas elevadas o debajo del agua) pueden estar unidas a una probabilidad elevada de este tipo de incidentes. El equipo de salvamento puede estar compuesto, entre otros elementos, por ropa protectora, mantas para la extinción de incendios, extintores, respiradores, aparatos de respiración autónomos, instrumentos de corte y gatos hidráulicos o mecánicos, así como cuerdas, arneses y camillas especiales para trasladar a la víctima. Debe incluir además todo el material necesario para proteger al personal de primeros auxilios de las lesiones que pueda sufrir durante su prestación. Aunque las medidas iniciales de primeros auxilios deben aplicarse antes de mover al paciente, deben preverse también medios sencillos para transportar a una persona lesionada o enferma desde el lugar del accidente a las instalaciones de primeros auxilios. Siempre se debe disponer de camillas.

\section{Sala de primeros auxilios}

Se debe disponer de una sala o una zona preparada para la administración de primeros auxilios. En muchos países este tipo de instalaciones están reguladas por la legislación. H abitualmente, las salas de primeros auxilios son obligatorias cuando hay más de 500 trabajadores en el lugar de trabajo o cuando existe un riesgo potencialmente alto o específico en el trabajo. En otros casos, se debe disponer de algún tipo de instalación, aunque no es necesario que sea una sala sino, por ejemplo, una zona preparada con el material mínimo de una sala de primeros auxilios completa, 0 incluso una parte de un despacho con un asiento, un lavabo y un botiquín de primeros auxilios, en el caso de una empresa pequeña. L as características ideales de una sala de primeros auxilios son las siguientes:

- que permita el acceso a camillas y ambulancias o a otros medios de transporte a un hospital;

- que sea lo bastante grande para albergar una cama, con suficiente espacio alrededor para que el personal pueda trabajar en torno a ella;

- que esté limpia, bien ventilada, bien iluminada y que se mantenga ordenada;

- que esté reservada para la administración de primeros auxilios;

- que esté claramente identificada como servicio de primeros auxilios, con la señalización correcta y bajo la responsabilidad del personal de primeros auxilios;

- que disponga de agua corriente, preferiblemente fría y caliente, jabón y un cepillo de uñas. Si no hay agua corriente, deberá haber agua almacenada en recipientes desechables cerca del botiquín de primeros auxilios para el lavado y la irrigación ocular;

- debe estar equipada con toallas, almohadas y mantas, ropa limpia que pueda utilizar el personal de primeros auxilios y un contenedor de residuos.

\section{Sistemas de comunicación y remisión}

\section{M edios de comunicación de la alerta}

Cuando se produce un accidente 0 aparece una enfermedad repentina es importante ponerse en contacto de inmediato con el personal de primeros auxilios. Para ello, es necesario disponer de medios de comunicación entre las zonas de trabajo, el personal de primeros auxilios y la sala de primeros auxilios. Pueden ser preferibles las comunicaciones telefónicas, en especial si las distancias son de más de 200 metros, aunque no en todos los establecimientos se puede disponer de ellas. Los medios acústicos de comunicación, como las sirenas, pueden servir de sustituto, siempre que esté garantizada la llegada rápida del personal de primeros auxilios al lugar del accidente. $L$ as vías de comunicación deben estar establecidas. La solicitud de asistencia médica especializada o avanzada suele realizarse por teléfono, así como la llamada a los servicios de ambulancia o de urgencia. La empresa debe asegurarse de que en todos sus locales, así como en la habitación de primeros auxilios, están clara y visiblemente anotadas las direcciones, los nombres y los números de teléfono 
importantes, y de que el personal de primeros auxilios puede utilizarlos en todo momento.

\section{Acceso a asistencia adicional}

Siempre debe estar prevista la necesidad de remitir a la víctima a un centro de asistencia médica más especializada o avanzada. La empresa debe tener planificada esa remisión, de modo que si se produce la situación todas las personas implicadas sepan exactamente lo que tienen que hacer. En algunos casos los sistemas de remisión son bastante sencillos, pero en otros pueden ser complejos, especialmente cuando existen riesgos especiales 0 poco comunes en el trabajo. En el sector de la construcción, por ejemplo, las remisiones pueden ser necesarias después de caídas o aplastamientos graves, y el destino del traslado será probablemente un hospital general, con servicios quirúrgicos y traumatológicos adecuados. En el caso de las industrias químicas, el destino de la remisión será un centro de toxicología o un hospital dotado de los recursos necesarios para el tratamiento de las intoxicaciones. No existe ningún modelo uniforme. Cada plan de remisión se ajustará a las necesidades de la empresa de que se trate, especialmente si existen riesgos poco comunes, específicos 0 altos. En todo caso, el plan de remisión es una parte importante del plan de emergencias de la empresa.

El plan de remisión precisa del apoyo de un sistema de comunicación y de medios para el transporte de la víctima. En algunos casos, puede tratarse de sistemas de comunicación y transporte organizados por la propia empresa, sobre todo en el caso de las empresas más grandes o complejas. En las empresas pequeñas, el transporte de las víctimas puede realizarse mediante un servicio externo, como los sistemas de transporte públicos, los servicios públicos de ambulancias, taxis, etc. Es aconsejable que se establezcan sistemas alternativos o de alerta.

Los procedimientos previstos para las situaciones de emergencia deben comunicarse a todo el mundo: trabajadores (en el contexto de la información general que se les ha de facilitar sobre salud y seguridad) socorristas, agentes de seguridad, servicios de salud en el trabajo, servicios sanitarios a los que se puede remitir a la víctima, y entidades relacionadas con las comunicaciones y el transporte de las víctimas (p. ej., servicios telefónicos, servicios de ambulancias, empresas de taxis, etc.).

\section{- LESIONES CRANEOENCEFALICAS}

Fengsheng $\mathrm{He}$

\section{Factores etiológicos}

Los traumatismos craneales son las lesiones del cráneo, las lesiones cerebrales focales y las lesiones difusas del tejido cerebral (Gennarelli y Kotapa 1992). En el medio laboral, los traumatismos craneales se deben en la mayoría de los casos a caídas ( $K$ raus y Fife 1985). O tras causas relacionadas con el trabajo son los golpes con el equipo, la maquinaria u otros elementos relacionados, y los vehículos de motor en movimiento. Las tasas de lesión cerebral relacionada con el trabajo son mucho más altas entre los trabajadores jóvenes que entre los de más edad (K raus y Fife 1985).

\section{Profesiones de riesgo}

Los trabajadores que se dedican a actividades de minería, construcción, conducción de vehículos motorizados y agricultura son los más expuestos a riesgo. El traumatismo craneal es frecuente entre deportistas, como los boxeadores y los futbolistas.

\section{Neurofisiopatología}

La fractura de cráneo puede producirse con o sin lesión del cerebro. Todas las formas de lesión cerebral, sean consecuencia de una herida penetrante 0 de un traumatismo craneal cerrado, pueden producir el desarrollo de edema del tejido cerebral. La activación a nivel celular de procesos fisiopatológicos vasógenos y citógenos produce edema cerebral, aumento de la presión intracraneal e isquemia cerebral.

Las lesiones cerebrales focales (hematomas epidurales, subdurales o intracraneales) no sólo pueden producir lesión cerebral local, sino un efecto de masa en el interior del cráneo, que causa desplazamiento de la línea media, herniación y, por último, compresión del tronco encefálico (mesencéfalo, protuberancia y bulbo raquídeo), lo cual produce una disminución del nivel de conciencia y, posteriormente, parada respiratoria y muerte (Gennarelli y K otapa 1992).

Las lesiones cerebrales difusas producen un traumatismo por cizallamiento en numerosos axones del cerebro y pueden manifestarse de múltiples formas, desde una disfunción cognitiva sutil hasta una discapacidad grave.

\section{Datos epidemiológicos}

Existen pocas estadísticas fiables sobre la incidencia de las lesiones producidas como consecuencia de actividades relacionadas con el trabajo.

En Estados U nidos, los cálculos de la incidencia de lesiones craneales indican que al menos 2 millones de personas sufren este tipo de lesión cada año, lo cual da lugar a cerca de 500.000 ingresos hospitalarios (G ennarelli y K otapa 1992). A proximadamente la mitad de estos pacientes sufrieron accidentes de tráfico.

U n estudio sobre lesiones cerebrales realizado en 1981 entre los habitantes del condado de San Diego, California, reveló que la tasa global de lesiones relacionadas con el trabajo era, en los hombres, de 19,8 por 100.000 trabajadores $(45,9$ por 100 millones de horas de trabajo). L as tasas de incidencia de las lesiones cerebrales relacionadas con el trabajo en el personal civil y militar masculino eran de 15,2 y de 37,0 por 100.000 trabajadores, respectivamente. Además, la incidencia anual de estas lesiones era de 9,9 por 100 millones de horas de trabajo en la población activa masculina (18,5 por 100 millones de horas para el personal militar, y 7,6 por 100 millones de horas entre los civiles) (K raus y Fife 1985). En el mismo estudio se observaba que cerca del $54 \%$ de las lesiones cerebrales relacionadas con el trabajo en el personal civil se debían a caídas y que el $8 \%$ estaban relacionadas con accidentes de vehículos motorizados (K raus y Fife 1985).

\section{Síntomas}

Los síntomas varían según las distintas formas de traumatismo craneal (Tabla 14.1) (G ennarelli y K otapa 1992) y las diferentes localizaciones de la lesión cerebral traumática (Gennarelli y Kotapa 1992; Gorden 1991). En algunas ocasiones, un mismo paciente puede presentar varias formas de traumatismo craneal.

\section{Lesiones craneales}

Las fracturas de la bóveda craneal, ya sean lineales o con hundimiento, pueden detectarse mediante exploraciones radiológicas, en las que los factores más importantes desde el punto de vista clínico son la localización y la profundidad de la fractura.

Las fracturas de la base del cráneo, donde no suelen ser visibles en las radiografías convencionales de cráneo, pueden identificarse mejor mediante tomografía computarizada (TC). Asimismo, pueden diagnosticarse a través de los hallazgos clínicos, como la fuga de líquido cefalorraquídeo por la nariz (rinorrea de LCR) o por el oído (otorrea de LCR), o por una 


\section{Tabla 14.1 • Clasificación de las lesiones craneoencefálicas (G ennarelli y Kotapa 1992).}

\begin{tabular}{ccc} 
Lesiones craneales & \multicolumn{2}{c}{ Lesiones del tejido cerebral } \\
Fractura de la bóveda & Focales & Difusas \\
Lineal & Hematoma & Conmoción \\
Deprimida & Epidural & Leve \\
& Subdural & Clásica \\
Fractura basilar & Intracraneal & \\
& Contusión & Coma prolongado \\
& & (lesión axonal difusa)
\end{tabular}

hemorragia subcutánea en las regiones periorbitaria 0 mastoidea, aunque esta puede tardar 24 horas en aparecer.

\section{Lesiones focales del tejido cerebral (G ennarelli y Kotapa 1992; G orden 1991)}

Hematoma: el hematoma epidural se debe habitualmente a hemorragia arterial y puede asociarse a fractura del cráneo. La hemorragia se identifica como una zona densa biconvexa en la imagen de TC. Desde el punto de vista clínico se caracteriza por una pérdida transitoria de la conciencia inmediatamente después de la lesión, seguida de un período de lucidez. La conciencia puede deteriorarse rápidamente debido al aumento de la presión intracraneal.

El hematoma subdural es el resultado de una hemorragia venosa por debajo de la duramadre. La hemorragia subdural puede clasificarse como aguda, subaguda y crónica, en función del curso temporal del desarrollo de los síntomas. Estos se deben a la presión directa que ejerce la sangre contra la corteza. La imagen de TC muestra con frecuencia un déficit de captación en forma de media luna.

El hematoma intracerebral se produce como consecuencia de una hemorragia en el interior del parénquima de los hemisferios cerebrales. Puede aparecer en el momento del traumatismo o varios días después (C ooper 1992). L os síntomas, que suelen ser muy llamativos, son una disminución aguda del nivel de conciencia y signos de aumento de la presión intracraneal, como cefalea, vómitos, convulsiones y coma. La hemorragia subaracnoidea puede aparecer espontáneamente, como resultado de la rotura de un aneurisma congénito sacular o puede deberse al traumatismo craneal.

En los pacientes con cualquier forma de hematoma, el deterioro de la conciencia, la presencia de una pupila dilatada ipsolateral y hemiparesia contralateral indican la existencia de un hematoma en expansión y la necesidad de realizar de inmediato una evaluación neuroquirúrgica. La compresión del tronco encefálico es la causa de aproximadamente el $66 \%$ de las muertes como consecuencia de lesiones craneales ( $G$ ennarelli y Kotapa 1992).

Contusión cerebral: se manifiesta como una pérdida transitoria de la conciencia o por déficit neurológicos. La pérdida de memoria puede ser retrógrada — pérdida de memoria sobre el período de tiempo previo a la lesión-o anterógrada — pérdida de la memoria actual—. En las imágenes de TC se observan numerosas hemorragias aisladas pequeñas en la corteza cerebral. Los pacientes tienen un riesgo alto de desarrollar hemorragia intracraneal en una fase posterior.

\section{Lesiones difusas del tejido cerebral (Gennarelli y Kotapa 1992; G orden 1991)}

Conmoción: la conmoción leve se define como la interrupción de resolución rápida (menos de 24 horas) de una función (como la memoria) que se produce como consecuencia de un traumatismo. Incluye síntomas tan sutiles como la pérdida de memoria y otros tan obvios como la inconsciencia.

La conmoción cerebral clásica se manifiesta como una disfunción neurológica reversible, temporal, de resolución lenta, como la pérdida de memoria, que suele acompañarse de una pérdida importante de conciencia (más de 5 minutos y menos de 6 horas). La imagen de TC es normal.

Lesión axonal difusa: produce un estado comatoso prolongado (más de 6 horas). En la forma leve, el estado de coma tiene una duración de 6 a 24 horas y puede asociarse a déficit cognitivos o neurológicos permanentes 0 prolongados. En la forma moderada el coma dura más de 24 horas y se asocia con una mortalidad del $20 \%$. En la forma grave aparecen disfunciones del tronco encefálico y el estado de coma dura más de 24 horas, 0 incluso meses, debido a la afectación del sistema activador reticular.

\section{Diagnóstico y diagnóstico diferencial}

Además de los antecedentes y las exploraciones neurológicas seriadas y de un instrumento de evaluación normalizado como es la escala del coma de Glasgow (Tabla 14.2), las exploraciones radiológicas son útiles para establecer un diagnóstico definitivo. La prueba diagnóstica más importante que se debe realizar en los pacientes con hallazgos neurológicos después de un traumatismo craneal es una TC del cráneo (Gennarelli y Kotapa 1992; Gorden 1991; Johnson y Lee 1992), ya que permite evaluar con exactitud y rapidez las lesiones quirúrgicas y no quirúrgicas en los pacientes con lesiones graves (Johnson y L ee 1992). La resonancia magnética (R M ) es una técnica complementaria para la evaluación del traumatismo craneoencefálico. M uchas lesiones se identifican mediante RM, como contusiones corticales, hematomas subdurales pequeños y lesiones axonales difusas que pueden pasar desapercibidas en las exploraciones con TC (Sklar y cols. 1992).

Tabla 14.2 - Escala del coma de Glasgow.

\begin{tabular}{|c|c|c|}
\hline Ojos & Respuesta verbal & Respuesta motora \\
\hline No abre los ojos & No emite ningún sonido & $\begin{array}{l}\text { (1) Ninguna respuesta } \\
\text { motora al dolor }\end{array}$ \\
\hline $\begin{array}{l}\text { Abre los ojos a } \\
\text { estímulos dolorosos }\end{array}$ & $\begin{array}{l}\text { Gemidos y sonidos } \\
\text { incomprensibles }\end{array}$ & $\begin{array}{l}\text { (2) Respuesta extensora } \\
\text { (decerebrado) }\end{array}$ \\
\hline $\begin{array}{l}\text { Abre los ojos a } \\
\text { estímulos verbales }\end{array}$ & Palabras sin sentido & $\begin{array}{l}\text { (3) Respuesta flexora } \\
\text { (decorticado) }\end{array}$ \\
\hline \multirow[t]{3}{*}{$\begin{array}{l}\text { Abre los ojos } \\
\text { espontáneamente }\end{array}$} & $\begin{array}{l}\text { Parece confuso } \\
\text { y desorientado }\end{array}$ & $\begin{array}{l}\text { (4) Mueve partes del } \\
\text { cuerpo pero no retira } \\
\text { el miembro al } \\
\text { estímulo doloroso }\end{array}$ \\
\hline & \multirow[t]{2}{*}{ Está alerta y orientado } & $\begin{array}{l}\text { (5) Retira el miembro al } \\
\text { estímulo doloroso }\end{array}$ \\
\hline & & $\begin{array}{l}\text { (6) Obedece órdenes } \\
\text { motoras sencillas }\end{array}$ \\
\hline
\end{tabular}




\section{Tratamiento y pronóstico}

L os pacientes con traumatismo craneoencefálico deben remitirse a un servicio de urgencias, y es importante que se realice una evaluación neuroquirúrgica. Todos los pacientes en los que se haya observado un período de inconsciencia mayor de 10 a 15 minutos, que presenten fractura de cráneo o alguna alteración neurológica requieren ingreso hospitalario y observación, ya que existe la posibilidad de que se produzca un deterioro posterior como consecuencia de lesiones en forma de masa expansivas (Gennarelli y K otapa 1992).

En función del tipo y la gravedad del traumatismo craneal pueden ser necesarias las siguientes medidas: administración de oxígeno complementario, ventilación adecuada, disminución del edema cerebral mediante la administración intravenosa de agentes hiperosmolares de acción rápida (p. ej., manitol), corticosteroides o diuréticos, y descompresión quirúrgica. En fases posteriores se recomienda una rehabilitación adecuada.
U n estudio multicéntrico reveló que el $26 \%$ de los pacientes con lesiones craneales graves tenían una recuperación buena, el $16 \%$ presentaban una discapacidad moderada y el $17 \%$ estaban gravemente discapacitados 0 en estado vegetativo (Gennarelli y Kotapa 1992). En un estudio de seguimiento se encontró también cefalea persistente en el $79 \%$ de los casos leves de lesión craneal y alteraciones de la memoria en el $59 \%$ (G ennarelli y K otapa 1992).

\section{Prevención}

Las empresas deben establecer programas de educación sobre salud y seguridad, para prevenir los accidentes relacionados con el trabajo, dirigidos a los trabajadores y a los directivos. Deben aplicarse medidas preventivas para reducir la aparición y la gravedad de las lesiones craneales producidas por causas relacionadas con el trabajo, como las caídas y los accidentes de transporte.

\section{Referencias}

Cooper, PR. 1992. Delayed traumatic intracerebral haemorrhage. N eurosurg Clin N Am 3(3): 659-665.

Gennarelli, TA, MJ K otapa. 1992. Trauma to the head-general considerations. En Principles and Practice of Emergency $M$ edicine, 3a edición, $V$ ol. 1. dirigido por GR Schwartz, CG Cayten, MA $M$ angelsen, TA Mayer y BK Hanke. Filadelfia/ L ondres: Lea and Febiger.
Gorden, K. 1991. Head and neck trauma. En Emergency Medicine. An Approach to Clinica Problem-solving, dirigido por $\mathrm{GC}$ Hamilton, $A B$ Sanders, GR Strange y AT Trott. Filadelfia: WB Saunders Company.

Jennett, B. 1992. Head trauma. En Diseases of the $\mathrm{N}$ ervous System - Clinical Neurobiology, 2a edición, $\mathrm{V}$ ol. 2, dirigido por AK Asbury, GM M ckhann y WI $M$ cD onald. Filadelfia: WB Saunders Company.
Johnson, MH, SH Lee. 1992. Computed tomography of acute cerebral trauma. Radiol Clin N Am 30(2): 325-352.

K raus, JF, D Fife. 1985. Incidence, external causes, and outcomes of work-related brain injuries in males. J O ccup M ed 27(10):757-760.

Sklar, EM, RM Quencer, BC Bowen, N Altman, PA Villanueva. 1992. M agnetic resonance applications in cerebral injury. Radiol Clin N Am. 30(2): 353-366. 


\section{PROTECCION Y \\ PROMOCION DE LA SALUD}

Directores del capítulo

J acqueline M essite y Leon J. W arshaw

\section{Sumario}

Protección y promoción de la salud: visión general

L eon $\mathrm{J}$. W arshaw y J acqueline $M$ essite.............

Promoción de la salud en el lugar de trabajo

J onathan E . Fielding. .

Promoción de la salud en el lugar de trabajo: Inglaterra

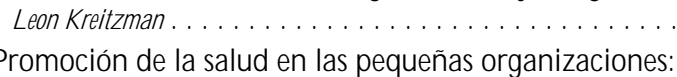
experiencia de Estados U nidos

Sonia M uchnick-B aku y L eon J. W arshaw .

Función del servicio de salud de los empleados en los programas de prevención

J ohn W.F. Cowell.

Programas de mejora de la salud en M aclaren

Industries, Inc.: estudio de caso

I an M .F. Arnold y L ouis D amphousse .

Función del servicio de salud en el trabajo en los programas de prevención: estudio de caso

W ayne N. B urton .

Promoción de la salud en el lugar de trabajo en Japón

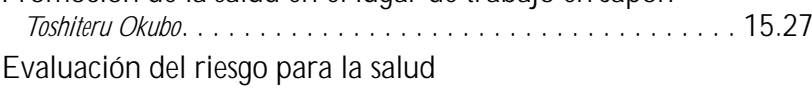

Leon J. W arshaw .

Programas de ejercicio físico y de mantenimiento de la capacidad física para el trabajo: un activo de la organización

J ames Corry .

Programas de nutrición en el lugar de trabajo

Penny M . Kris-E therton y J ohn W. Farquhar

Control del tabaco en el lugar de trabajo

I on Rudnick. ...

L os programas de control del tabaco en M errill Lynch and Company, Inc.: estudio de caso Kristan D. Goldfein. . . . . . . . . . . . . . . . . . . . . . . . . . . . . . . . . 15.47

Prevención y control del cáncer Peter G reenwald y L eon J. W arshaw. . .
La salud de la mujer

Patricia A. Last . . . . . . . . . . . . . . . . . . . . . . . . . 15.54

Estudio de caso: el programa de mamografías de $\mathrm{M}$ arks and Spencer

J illian $\mathrm{H}$ aslehurst. . .

Estrategias en el lugar de trabajo para la mejora de

la salud maternal e infantil: experiencias de los trabajadores en Estados U nidos

M aureen $P$. Corry y E llen Cutler . . . . . . . . . . . . . . . 15.62

Educación sobre el VIH / SIDA

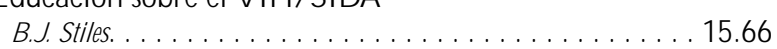

Protección y promoción de la salud:

enfermedades infecciosas

W illiam J. Schneider . . . . . . . . . . . . . . . . . . . . . . . . . . . 15.69

Protección de la salud en los viajes

Craig Karpilow .......................... . 15.74

Programas de gestión del estrés

Leon J. W arshaw ....................... 15.79

A buso de alcohol y de drogas

Shella B. Blume. . . . . . . . . . . . . . . . . . . . . 15.82

Programas de asistencia a los empleados

Shèla $H$. Akabas . . . . . . . . . . . . . . . . . . . . . . . . 15.88

La salud en la tercera edad: programas de prejubilación

H. B eric W right. . . . . . . . . . . . . . . . . . . . . . . 15.91

Recolocación

Saul G. G runer y L eon J. W arshaw . . . . . . . . . . . . . . . . 15.95 


\section{- ProteCCION Y PROMOCION DE LA SALUD: VISION GENERAL}

\section{Leon J. Warshaw y Jacqueline M essite}

Se ha dicho a menudo que la plantilla constituye el elemento esencial del aparato productivo de la organización. Incluso en las fábricas caracterizadas por un alto grado de automatización y un reducido número de trabajadores, el empeoramiento de la salud y el bienestar da lugar tarde o temprano a una pérdida de productividad y, en ocasiones, a situaciones desastrosas.

En virtud de disposiciones legales y administrativas, se ha hecho responsables a las empresas del mantenimiento de la seguridad del entorno de trabajo y de las prácticas laborales, así como del tratamiento, rehabilitación e indemnización de los trabajadores que padecen lesiones y enfermedades profesionales. No obstante, en los últimos decenios las empresas han comenzado a reconocer que las incapacidades y las faltas de asistencia resultan caras incluso cuando se originan fuera del lugar de trabajo. En consecuencia, han empezado a adoptar un número cada vez mayor de programas de protección y promoción de la salud con un carácter más global, destinados no sólo a los trabajadores, sino también a sus familias. En la sesión inaugural de una reunión de la Comisión de Expertos de la Organización M undial de la Salud (O M S) sobre Promoción de la Salud en el Lugar de Trabajo celebrada en 1987, el Dr. Lu Rushan, director general adjunto de la O M S, reiteró que este organismo consideraba la promoción de la salud de los trabajadores como elemento esencial de los servicios de salud en el trabajo (O M S 1988).

\section{¿Por qué el lugar de trabajo?}

Entre las razones que justifican el patrocinio, por parte de las empresas, de los programas de promoción de la salud figuran la prevención de la pérdida de productividad de los trabajadores debido a enfermedades e incapacidades evitables y al absentismo asociado, la mejora del bienestar y el estado de ánimo de las plantillas y el control de los costes de los seguros de enfermedad pagados por las empresas mediante la reducción del alcance de los servicios de asistencia sanitaria requeridos. Consideraciones semejantes han estimulado el interés de los sindicatos por el patrocinio de programas, sobre todo en los casos en que sus afiliados se encuentran repartidos entre muchas organizaciones demasiado pequeñas para llevar a cabo programas eficaces propios.

El lugar de trabajo presenta ventajas incomparables como escenario para la educación sanitaria y la promoción de la salud. Como lugar en que los trabajadores se congregan y pasan la mayor parte de sus horas de vigilia, constituye una localización adecuada para acceder a las plantillas. Además de la afinidad, el compañerismo y la coincidencia de intereses facilitan el ejercicio de presiones homogéneas que estimulen la participación y la permanencia en las actividades de promoción de la salud. La relativa estabilidad de las plantillas (la mayoría de los trabajadores se mantiene en la misma organización durante largos períodos) hace posible la continuidad de comportamientos sanos necesaria para que éstos resulten beneficiosos.

El lugar de trabajo brinda oportunidades únicas para fomentar la mejora de la salud y el bienestar de los trabajadores a través de las medidas siguientes:

- integración de los programas de protección y promoción de la salud en las iniciativas de las organizaciones encaminadas a controlar las enfermedades y accidentes profesionales;
- modificación de la estructura de los puestos de trabajo y de su entorno, de forma que sean menos peligrosos y estresantes;

- adopción de programas financiados por las empresas o los sindicatos y diseñados para que los trabajadores puedan afrontar con mayor eficacia las cargas personales o familiares que perjudiquen su bienestar o su actuación en el trabajo (p. ej., modificación de horarios de trabajo y dotación de prestaciones de asistencia financiera y adopción de programas que aborden el abuso de alcohol y drogas, los embarazos, la atención a la infancia, a los ancianos y a los discapacitados, las dificultades conyugales y la planificación de la jubilación).

\section{¿Da resultados la promoción de la salud?}

No cabe duda de la eficacia de las vacunaciones en la prevención de las enfermedades infecciosas o del valor de los buenos programas de salud y seguridad en el trabajo para la reducción de la frecuencia y gravedad de las enfermedades y lesiones relacionadas con el trabajo. $\mathrm{H}$ ay un acuerdo general en que la detección precoz y el tratamiento adecuado de las enfermedades reducen la mortalidad y la frecuencia y alcance de la incapacidad residual asociada. Cada vez se dispone de más pruebas de que la eliminación o el control de los factores de riesgo evitan 0 , al menos, retrasan considerablemente la aparición de enfermedades que amenazan la vida, como los accidentes cerebrovasculares, las enfermedades coronarias y el cáncer. Pocos dudan de que el mantenimiento de una forma de vida sana y la adopción de una postura adecuada respecto a las cargas psicosociales mejoran el bienestar y la capacidad funcional necesaria para alcanzar el objetivo de bienestar, definido por la O rganización M undial de la Salud como un estado que va más allá de la simple ausencia de enfermedad. Con todo, hay personas que siguen siendo escépticas, incluidos, al menos a juzgar por sus acciones, algunos médicos.

Es posible que el nivel de escepticismo sea mayor respecto al valor de los programas de promoción de la salud en el lugar de trabajo. Esta actitud refleja en gran parte la falta de estudios adecuadamente diseñados y controlados, el efecto desconcertante de episodios tales como el descenso de la incidencia de mortalidad por cardiopatías y accidente cerebrovascular y, lo que es más importante, el período de tiempo requerido para que la mayoría de las medidas preventivas hagan efecto. No obstante, en el informe de Health Project, Freis y cols. (1993) resumen la bibliografía cada vez más abundante que confirma la eficacia de los programas de promoción de la salud en el lugar de trabajo en la reducción de los costes de la asistencia sanitaria. En su revisión inicial de más de 200 programas aplicados en el lugar de trabajo, Health Project, un grupo voluntario formado por directivos de empresas, gestores de seguros de enfermedad, investigadores de la formulación de políticas y miembros de organismos gubernamentales que defienden el papel de la promoción de la salud en la reducción de la demanda de servicios sanitarios, identificó ocho programas para los que existía una documentación convincente sobre ahorro de costes de asistencia sanitaria.

Pelletier (1991) reunió 24 estudios sobre programas globales aplicados en el lugar de trabajo aparecidos entre 1980 y 1990 en publicaciones especializadas en análisis comparativos. (Los informes sobre programas específicos, como el de exploración selectiva de la hipertensión o el de abandono del tabaco, aun cuando se demostró su eficacia, no se incluyeron en él.) Pelletier definió el programa global como el que "constituye un plan continuo e integrado de promoción de la salud y prevención de la enfermedad que une los componentes individuales (abandono del tabaco, gestión del estrés, reducción del riesgo coronario, etc.) en un proyecto progresivo coherente con los objetivos empresariales que prevé su propia evaluación." 
Los 24 programas resumidos en este trabajo dieron lugar a la mejora de las prácticas de salud de los trabajadores, la reducción del absentismo y de la incapacidad y el aumento de la productividad, mientras que todos los estudios en que se analizó la repercusión en los costes de la asistencia sanitaria y la incapacidad, los cambios de la eficacia en función del coste y la relación coste-beneficio revelaron un efecto positivo.

Dos años más tarde, Pelletier analizó otros 24 estudios publicados entre 1991 y principios de 1993 y llegó a la conclusión de que en 23 de ellos se obtuvieron ventajas para la salud $y$, de nuevo, que todos los estudios en que se analizaban la eficacia en función del coste y la relación coste-beneficio ponían de manifiesto un rendimiento positivo (Pelletier 1993). Señaló factores comunes a los programas eficaces, como la fijación de objetivos específicos, la facilidad de acceso al programa y a los servicios, el establecimiento de incentivos a la participación, el respeto y la confidencialidad, el apoyo de la alta dirección y la cultura empresarial que fomenta las iniciativas relacionadas con la promoción de la salud (Pelletier 1991).

Aunque es conveniente disponer de pruebas que confirmen la eficacia y el valor de los programas de promoción de la salud en el lugar de trabajo, son pocas las ocasiones en que se han exigido éstas para adoptar la decisión de emprender un programa. La mayoría de los programas se han basado en la convicción de que la prevención da resultados. En algunos casos, se ha estimulado la adopción de un programa debido al interés demostrado por los trabajadores y, en otros, por la muerte inesperada de un alto directivo 0 un trabajador destacado provocada por el cáncer 0 por una cardiopatía, más con la esperanza que con la certeza de que un programa preventivo evitaría "un segundo golpe".

\section{Estructura de un programa global}

En muchas organizaciones, sobre todo en las más pequeñas, el programa de promoción de la salud y de prevención de enfermedades se limita a una 0 varias actividades en gran parte específicas, relacionadas, en su caso, informalmente entre sí, de escasa o nula continuidad y a menudo impulsadas por un episodio concreto y abandonadas cuando el recuerdo de éste se desvanece. Un programa auténticamente global debe contar con una estructura formal que comprenda varios elementos integrados, como los siguientes:

- clara exposición de objetivos aprobados por la dirección y aceptables para los trabajadores;

- apoyo explícito por parte de la dirección y, en su caso, de las organizaciones de trabajadores, a la continua asignación de recursos adecuada para lograr los objetivos previstos;

- adecuada ubicación en la organización, coordinación eficaz con otras actividades referentes a la salud y comunicación de los planes incluidos en el programa a los mandos intermedios y a los trabajadores de las distintas divisiones y departamentos. Algunas organizaciones han considerado oportuno crear un comité paritario compuesto por representantes de todas las escalas y segmentos de la plantilla por razones "políticas", así como para contribuir al diseño del programa;

- designación de un "director de programa" dotado de las cualificaciones administrativas requeridas, que cuente con formación y experiencia en materia de promoción de la salud o que pueda acceder a consultores que impartan los conocimientos prácticos necesarios;

- adopción de un mecanismo de retroinformación generada por los participantes y, si es posible, también por los que no participan, para confirmar la validez del diseño del programa y comprobar la popularidad y utilidad de determinadas actividades del mismo;
- adopción de procedimientos para mantener la confidencialidad de la información personal;

- utilización de un registro sistemático que permita el seguimiento de las actividades, de la participación y de los resultados como base para su control y potencial evaluación;

- recopilación y análisis de los datos pertinentes disponibles con vistas a la evaluación científica del programa o, cuando ésta no sea factible, presentación de un informe periódico a la dirección que justifique la continuación de la asignación de recursos y sirva como base para la adopción de posibles modificaciones del programa.

\section{Principios y objetivos del programa}

Los objetivos básicos del programa son la mejora y el mantenimiento de la salud y el bienestar de los trabajadores a todos los niveles, la prevención de la enfermedad y la incapacidad, y el alivio de la carga que recae sobre individuos y organizaciones cuando ésta no puede evitarse.

Los programas de salud y seguridad en el trabajo se centran en los factores que, en este entorno, pueden afectar a la salud de los trabajadores. En ellos se considera que las actividades referentes a la salud no pueden limitarse a la fábrica o a la oficina, que los problemas que surgen en el lugar de trabajo repercuten inevitablemente en la salud y bienestar de los trabajadores ( $y$, por extensión, en los de sus familias) en su hogar y en la comunidad y que, del mismo modo, los problemas generados fuera del trabajo influyen en la asistencia y la actuación en el mismo. (El término bienestar puede considerarse equivalente a la expresión protección y promoción de la salud, cada vez más utilizado en este ámbito en los dos últimos decenios, que resume la definición positiva de salud adoptada por la O rganización M undial de la Salud). En consecuencia, es conveniente que los programas de promoción de la salud aborden problemas que, en opinión de algunos, no deberían ser objeto de consideración por parte de la organización.

La necesidad de lograr el bienestar adquiere mayor importancia cuando se reconoce que los trabajadores con sus capacidades disminuidas, independientemente del modo en que hayan llegado a esa situación, representan un peligro potencial para sus compañeros y, en ciertos puestos de trabajo, para el público en general.

De acuerdo con algunos, puesto que la salud es esencialmente una responsabilidad personal del individuo, resulta inadecuado e incluso constituye un ejercicio de intrusismo que las empresas o los sindicatos (o ambos) participen en actividades al respecto. Están en lo cierto si se utilizan enfoques excesivamente paternalistas y coercitivos. En todo caso, la mejora del acceso a las actividades de promoción de la salud y los ajustes de los puestos y los lugares de trabajo basados en ésta proporcionan la conciencia, el conocimiento y las herramientas que permiten a los trabajadores asumir tal responsabilidad personal con mayor eficacia.

\section{Componentes del programa}

\section{Evaluación de las necesidades}

$M$ ientras que el director de un programa de alerta aprovecha los episodios concretos que crean interés por una actividad específica (p. ej., la inesperada enfermedad de una persona muy conocida en la organización, los informes de casos de una enfermedad infecciosa que genera miedo al contagio, las señales de una posible epidemia), el programa global se basa en una evaluación más formal de las necesidades. Puede tratarse simplemente de una comparación de las características demográficas de la población activa basada en los datos de morbilidad y mortalidad 
suministrados por las autoridades sanitarias para las cohortes de población presentes en el área en cuestión, o del análisis global de los datos referentes a la salud de una determinada empresa, como las indemnizaciones concedidas al amparo de un seguro de asistencia sanitaria y las causas del absentismo y la jubilación por incapacidad. La determinación del estado de salud de la plantilla mediante la compilación de resultados de chequeos y reconocimientos médicos periódicos y programas de valoración del riesgo para la salud puede completarse a través de encuestas sobre los intereses de los trabajadores en materia de salud que permitan identificar los objetivos óptimos del programa. (Debe tenerse en cuenta que los problemas de salud que afectan a determinadas cohortes de trabajadores que requieren atención pueden pasarse por alto si sólo se consideran los datos para el total de la plantilla.) Tal evaluación de las necesidades no resulta útil únicamente al seleccionar y dar prioridad a las actividades programadas, sino también al planificar su "venta" a los trabajadores con más probabilidades de considerarlas beneficiosas. Asimismo, constituye un punto de referencia al medir la eficacia del programa.

\section{Elementos del programa}

Un programa global de promoción de la salud y de prevención de enfermedades comprende los elementos siguientes.

\section{Promoción del programa}

Un flujo constante de instrumentos promocionales, como folletos, memorándums, carteles, artículos en la revista de empresa, etc., atraerán la atención sobre la disponibilidad y la conveniencia de participar en el programa. Previo permiso de los interesados, pueden darse a conocer los éxitos alcanzados por determinados trabajadores y los premios acaso concedidos por ello.

\section{Evaluación de la salud}

Cuando sea posible, debe evaluarse el estado de salud de cada trabajador al iniciar el programa, a fin de obtener una base para la "prescripción" de objetivos personales que deben alcanzarse y las actividades específicas indicadas, y periódicamente, para valorar su evolución y sus cambios provisionales. La evaluación de los riesgos para la salud puede utilizarse realizando o no una exploración médica previa tan global como las circunstancias lo permitan, completada con pruebas diagnósticas o de laboratorio. Los programas de cribado pueden permitir la identificación de las personas para las que estén indicadas actividades específicas.

\section{Actividades}

$\mathrm{H}$ ay un gran número de actividades que pueden desarrollarse como parte del programa. Algunas son continuas, otras se llevan a cabo sólo periódicamente. Algunas se destinan a individuos 0 determinadas cohortes de trabajadores, otras al conjunto de la plantilla. La prevención de la enfermedad y la incapacidad constituye el hilo conductor de todas ellas. Estas actividades pueden dividirse en las siguientes categorías, parcialmente coincidentes:

- Asistencia sanitaria. R equieren la intervención de profesionales de la salud e incluyen reconocimientos médicos, programas de cribado, procedimientos diagnósticos como las mamografías, las citologías y la determinación del nivel de colesterol, vacunaciones, etc. Asimismo comprenden el consejo médico y la modificación del comportamiento en lo que respecta al control del peso, la capacidad física para el trabajo, el abandono del tabaco y otros factores relativos a la forma de vida.

- E ducación para la salud. Es necesaria para fomentar la sensibilización respecto a posibles enfermedades, la importancia del control de factores de riesgo y el valor de mantener formas de vida sanas, por ejemplo, a través del control del peso, la preparación física para el trabajo y el abandono del tabaco.
Asimismo, esta actividad debe marcar el camino para la adopción de intervenciones apropiadas.

- O rientación para la gestión de la asistencia médica. D ebe ofrecerse asesoramiento respecto a las cuestiones siguientes: relaciones con el sistema de asistencia sanitaria y consecución de asistencia médica inmediata y de alta calidad, tratamiento de problemas de salud crónicos o recurrentes, rehabilitación y retorno al trabajo después de una enfermedad o accidente, tratamiento del abuso de alcohol y drogas, cuidados prenatales, etc.

- Capacidad de afrontar problemas personales. Entre las cualificaciones necesarias en este ámbito figuran la gestión del estrés y la planificación previa a la jubilación. A simismo, puede prestarse ayuda a los trabajadores que deben resolver problemas laborales y familiares, como la planificación familiar, los cuidados prenatales, la atención a personas a cargo, la paternidad, etc.

- Servicios y políticas en el lugar de trabajo. Los servicios y políticas en el lugar de trabajo que completan los relacionados con actividades de salud y seguridad en el trabajo se refieren a la dotación de instalaciones para el aseo personal y taquillas, la prestación de servicios de lavandería en caso necesario, servicios de restauración que ofrezcan asesoramiento nutricional y una selección de alimentos beneficiosos, garantía de un lugar de trabajo con prohibición del consumo de tabaco y drogas, etc.

En general, a medida que se han desarrollado y difundido los programas y se ha generalizado la convicción de su eficacia, las actividades han aumentado en número y variedad. Con todo, algunas han sido objeto de una menor atención debido a una reducción de recursos provocada por presiones económicas o a su reasignación en áreas nuevas o más populares.

\section{Mecanismos}

Los mecanismos empleados para el desarrollo de las actividades de promoción de la salud dependen del tamaño y la localización de la organización, del grado de centralización de la plantilla respecto a la geografía y los horarios de trabajo, de los recursos económicos, tecnológicos y de cualificación disponibles, de las características de la plantilla (en cuanto a niveles sociales y educativos) y del ingenio del director del programa. Son los siguientes:

- Recogida de información: encuestas a trabajadores; grupos diana.

- M ateriales impresos: libros, folletos (pueden distribuirse mediante expositores), envíos de publicidad, artículos en la revista de empresa, carteles.

- M aterial audiovisual: cintas de audio, mensajes grabados accesibles a través del teléfono, películas, cintas de vídeo para su visionado individual y en grupo. Algunas organizaciones disponen de mediotecas con cintas de audio y de vídeo que los trabajadores pueden tomar prestadas para su utilización en el hogar.

- Asistencia sanitaria: reconocimientos médicos, diagnósticos y pruebas de laboratorio, vacunación, asesoramiento individual

- Formación: primeros auxilios, reanimación cardiopulmonar, compra y cocina sanas.

- R euniones: conferencias, cursos, seminarios

- A contecimientos especiales: ferias de salud, concursos.

- Grupos de autoayuda y apoyo: abuso de alcohol y drogas, cáncer de mama, paternidad, cuidado de ancianos.

- Comités: un grupo especial o comité interno para coordinar los programas referentes a la salud entre los distintos departamentos y divisiones y un comité paritario para determinar la orientación general del programa suelen resultar útiles. Asimismo, pueden crearse comités especiales para ciertas actividades. 
- Programas de deportes: organización de campeonatos internos, patrocinio de la participación individual en programas comunitarios, equipos de empresa.

- Programas informáticos: disponibles en los ordenadores personales individuales o a través de la red de la organización, juegos de ordenador o de vídeo orientados a la promoción de la salud.

- Programas de exploración selectiva: generales (p. ej., evaluación de los riesgos para la salud) o específicos para una enfermedad (p. ej., hipertensión, visión y audición, cáncer, diabetes, colesterol).

- Información y consulta: programas de asistencia a los empleados, asesoramiento personal por teléfono

- Actividades continuas: capacidad física para el trabajo, selección de alimentos sana en los servicios de restauración y en las máquinas expendedoras del lugar de trabajo.

- Prestaciones especiales: tiempo libre para actividades de promoción de la salud, reembolso de los gastos de formación, modificación de horarios de trabajo, permisos para atender cuestiones personales y familiares.

- Incentivos: premios a la participación y a la consecución de objetivos, reconocimiento en publicaciones empresariales y tablones de anuncios, concursos y premios.

\section{Aplicación del programa}

En muchas organizaciones, sobre todo en las más pequeñas, las actividades de promoción de la salud se llevan a cabo de forma específica y ocasional, a menudo en respuesta a una "crisis" sanitaria real o prevista en el lugar de trabajo o en la comunidad. No obstante, transcurrido un cierto tiempo, estas actividades se combinan en las grandes organizaciones en un marco más 0 menos coherente que recibe el nombre de "programa" y se designa como responsable del mismo a una persona conocida como director o coordinador de programa o con otra denominación.

La selección de actividades para el programa puede estar determinada por las respuestas obtenidas en encuestas de opinión entre los trabajadores, por la producción de episodios concretos, por razones de calendario o por la disponibilidad de recursos. En muchos programas se prevén actividades para aprovechar la publicidad generada por las entidades voluntarias de salud en sus campañas anuales de captación de fondos, como el M es del Corazón o la Semana Nacional de la Capacidad Física para el Trabajo y el Deporte. (En Estados Unidos, el Centro Nacional de Información sobre la Salud de la O ficina de Prevención de la Enfermedad y Protección de la Salud publica en septiembre las $\mathrm{N}$ ational $\mathrm{H}$ ealth $\mathrm{O}$ bservances, una lista de los meses, semanas y días dedicados a la promoción de determinadas cuestiones de salud, ya disponible a través del correo electrónico.)

En términos generales, resulta prudente aplicar el programa de forma gradual, añadiendo actividades y cuestiones a medida que se consiguen la credibilidad y el apoyo de los trabajadores y cambiar los temas en los que se hace especial hincapié, con el fin de que el programa no llegue a estancarse. J.P. M organ \& $C_{0 .}$., Inc., gran organización financiera con domicilio en Nueva York, ha incluido un innovador "formato cíclico planificado" en su programa de promoción de la salud para hacer hincapié en un conjunto de cuestiones secuencialmente en períodos de cuatro años (Schneider, Stewart y H aughey 1989). El primer año (Año del Corazón) se centró en la prevención de enfermedades cardiovasculares, el segundo (Año del Cuerpo) se centró en el SIDA y la prevención y detección precoz del cáncer, en el tercero (Año de la M ente) se trataron cuestiones psicológicas y sociales, y en el cuarto (A ño de la Salud) se abordaron cuestiones como la vacunación de adultos, la artritis y la osteoporosis, la prevención de accidentes, la diabetes y el embarazo sano.
Actualmente se repite la secuencia cuatrienal. En opinión de Schneider y sus colaboradores, este enfoque optimiza la utilización de los recursos empresariales y comunitarios disponibles, fomenta la participación de los trabajadores a través de la consideración secuencial de diferentes cuestiones, y brinda la oportunidad de prestar atención a las revisiones y ampliaciones basadas en avances médicos y científicos.

\section{Evaluación del programa}

Siempre es conveniente evaluar el programa para justificar que se le sigan asignando recursos, determinar las necesidades de mejora y apoyar las recomendaciones de expansión. Las evaluaciones pueden adoptar diversas formas, desde simples tabulaciones de participación (incluidos los abandonos), combinadas con la expresión de la satisfacción de los trabajadores (objeto de encuesta o no), hasta encuestas más formales. L os datos obtenidos por estos medios ponen de manifiesto el grado de utilización y la popularidad del programa en conjunto y de sus componentes y suelen estar disponibles a la conclusión del período de evaluación.

En todo caso, son aún más valiosos los datos que reflejan los resultados del programa. En un artículo en que se indica la vía para mejorar la evaluación de los programas de promoción de la salud, Anderson y O 'D onnell (1994) ofrecen una clasificación de áreas en las cuales los programas de promoción de la salud pueden dar lugar a resultados interesantes (véase la Figura 15.1).

Con todo, los datos sobre resultados requieren un esfuerzo de planificación antes del inicio del programa y deben recopilarse en un período de tiempo que permita su desarrollo y evaluación. Por ejemplo, puede contarse el número de individuos que se vacunan contra la gripe y posteriormente realizar un seguimiento de la población total durante un año para demostrar que esas personas presentan una menor incidencia de infecciones respiratorias semejantes a la gripe. El estudio puede ampliarse para comparar las tasas de absentismo de las dos cohortes, y los costes del programa con el ahorro directo e indirecto obtenido por la organización.

Por otra parte, no resulta demasiado difícil demostrar la consecución por parte de una persona de un perfil de factores de riesgo más adecuado en lo que respecta a las enfermedades cardiovasculares. Por el contrario, será necesario al menos un decenio y probablemente varios para demostrar una reducción de la morbilidad y la mortalidad debidas a la incidencia de las enfermedades coronarias en una cohorte de trabajadores. Incluso entonces, es posible que la cohorte no alcance el tamaño necesario para que los datos sean significativos.

L os artículos analíticos citados ponen de manifiesto la posibilidad de desarrollar una investigación sobre evaluación adecuada y las iniciativas emprendidas y la información disponible al respecto. Su utilidad está fuera de duda. Pero, como señalan Freis y sus colaboradores (1993), "se dispone ya de programas modelo que mejoran la salud y reducen los costes. No son conocimientos lo que hace falta, sino la puesta en práctica de estos programas en un mayor número de casos."

\section{Comentarios y advertencias}

Las organizaciones que contemplan la posibilidad de poner en práctica un programa de promoción de la salud deben tener en cuenta ciertas cuestiones potencialmente delicadas desde el punto de vista ético y ciertas dificultades que conviene evitar y a las que ya se ha aludido en algunos casos. Se han clasificado en los siguientes apartados:

\section{Elitismo frente a igualitarismo}

Ciertos programas puede calificarse de elitistas, en cuanto que algunas de las actividades que comprenden son exclusivas para personas de un rango determinado. Así, es posible que las 
Figura 15.1 - Categorías de resultados de la promoción de la salud.

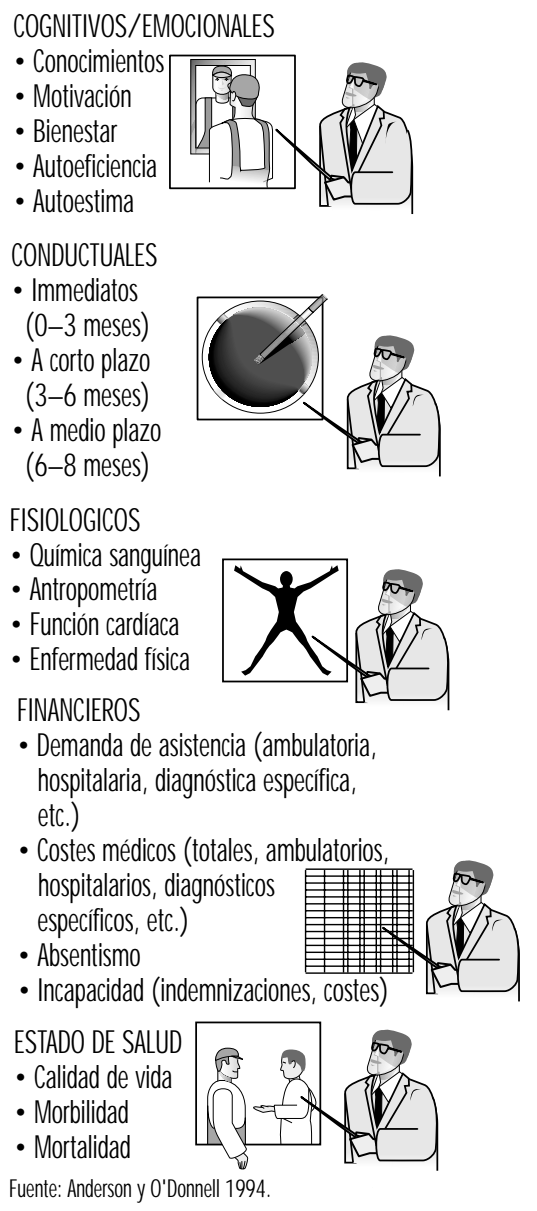

instalaciones internas de capacitación física sólo puedan ser utilizadas por los ejecutivos porque éstos son más importantes para la organización, trabajan más horas y tienen dificultades para disponer del tiempo que les permita asistir a un "gimnasio o club" externo. No obstante, para algunas personas esta medida constituye una gratificación (es decir, un privilegio especial), como la llave para el acceso a los cuartos de baño privados, la admisión en el comedor gratuito para ejecutivos o la utilización de una área de aparcamiento reservada. En ocasiones, esta situación genera resentimientos entre los demás trabajadores, para los que resulta excesivamente caro utilizar instalaciones ajenas a la empresa e imposible disponer de tiempo en la jornada de trabajo para dedicarlo al ejercicio.

En algunas instalaciones internas se observa una forma más sutil de elitismo, consistente en la ocupación de las vacantes disponibles por fanáticos del ejercicio que probablemente encontrarían la forma de desarrollar esta actividad en cualquier caso. Por el contrario, a las personas sedentarias que podrían obtener un beneficio muy superior de la práctica regular y supervisada de ejercicio se les niega el acceso. Incluso cuando consiguen incorporarse al programa de capacitación física, la continuidad de su participación está amenazada por el sentimiento de vergüenza experimentado al comprobar que el rendimiento de trabajadores de inferior categoría es superior al suyo. Es lo que le sucede al directivo que considera su reputación masculina dañada si no es capaz de rendir al mismo nivel que su secretaria.
A lgunas organizaciones son más igualitarias. Sus instalaciones de capacitación física están abiertas a todos en función del orden de llegada, y el mantenimiento de la condición de miembro depende únicamente de su utilización con una frecuencia considerada valiosa para el interesado. O tras adoptan soluciones parciales, reservando cierto número de plazas a los trabajadores en rehabilitación tras un accidente o enfermedad y a los de mayor edad que pueden requerir más incentivos para participar que sus compañeros jóvenes.

\section{Discriminación}

En ciertas áreas, las leyes y reglamentos antidiscriminatorios pueden dar lugar a que las organizaciones reciban quejas e incluso sean llevadas a juicio si se demuestra que los programas de promoción de la salud que aplican discriminan a determinadas personas por razón de edad, sexo o pertenencia a minorías o grupos étnicos. Es poco probable que se produzca esta última circunstancia si la cultura del lugar de trabajo no se encuentra profundamente sesgada, pero tal discriminación puede provocar quejas.

Aunque no se presenten acusaciones formales, el resentimiento y la insatisfacción, que pueden aumentar al comentarse por los miembros de las plantillas, no propician unas buenas relaciones entre los trabajadores ni mejoran su estado de ánimo.

La preocupación por las acusaciones de discriminación sexual puede llevar a exageraciones. Por ejemplo, aunque no se recomienda su utilización habitual en el caso de hombres asintomáticos (Preventive Services Task Force de los Estados U nidos 1989), algunas organizaciones ofrecen la detección de cáncer prostático para compensar las citologías y mamografías que se ponen a disposición de las trabajadoras.

$\mathrm{H}$ an presentado quejas por discriminación personas a las que se ha negado la oportunidad de obtener incentivos a causa de problemas de salud congénitos 0 de enfermedades adquiridas que les impiden participar en las actividades de promoción de la salud o alcanzar los objetivos personales de salud ideales. Al mismo tiempo, se cuestiona la equidad de los premios concedidos a las personas por corregir un problema de salud potencial (p. ej., abandonar el tabaco o perder el exceso de peso), mientras que no se recompensa a las personas que carecen de tales problemas.

\section{"Inculpación de la víctima"}

D el concepto válido de que el estado de salud es una cuestión de responsabilidad personal se deriva la idea de que las personas son culpables cuando se les detectan problemas de salud y deben ser acusadas por no corregirlas por sí mismos. Al razonar de esta forma, no se tiene en cuenta que la investigación genética demuestra cada vez con mayor rotundidad que algunos defectos son hereditarios y, por tanto, aunque pueden modificarse, su corrección queda fuera del alcance del individuo.

Ejemplos de esta "inculpación de la víctima" son: (a) la postura demasiado extendida según la cual el VIH/SIDA es el justo pago por las "imprudencias" sexuales o la utilización de drogas por vía intravenosa, por lo que sus víctimas no merecen compasión ni cuidados, y (b) la imposición de barreras financieras y burocráticas que dificultan a las jóvenes solteras la obtención de cuidados prenatales adecuados cuando quedan embarazadas.

Lo que es más importante, la consideración en el lugar de trabajo de la responsabilidad de las personas respecto a sus propios problemas de salud tiende a ocultar la responsabilidad de las empresas respecto a los factores de la estructura del empleo y del ambiente de trabajo que pueden poner en peligro la salud y el bienestar. Quizá un ejemplo clásico sea el de la organización que ofrece cursos de gestión del estrés para 
enseñar a sus trabajadores a afrontarlo con mayor eficacia, pero no analiza ni corrige las características del lugar de trabajo que generan estrés innecesariamente.

Debe reconocerse que los peligros presentes en el lugar de trabajo pueden no sólo afectar a los trabajadores y a sus familias por extensión, sino también acelerar y agravar problemas de salud generados fuera del puesto de trabajo. El respeto al concepto de responsabilidad individual en materia de salud debe matizarse por la comprensión de que los factores propios del lugar de trabajo de los que la empresa es responsable también pueden influir en cuestiones referentes a la salud. Esta consideración resalta la importancia de la comunicación y la coordinación entre los programas de promoción de la salud y los programas de salud y seguridad en el trabajo y otros afines desarrollados por las empresas cuando éstos no son competencia del mismo departamento de la organización.

\section{Persuasión, no coerción}

Según un principio esencial de los programas de promoción de la salud en el lugar de trabajo, la participación en ellos debe ser voluntaria. Debe instruirse a los trabajadores sobre la conveniencia de las intervenciones sugeridas, garantizarles el acceso y persuadirles para lograr su participación. No obstante, suele haber un estrecho margen entre la persuasión decidida y la obligación, entre el paternalismo bien intencionado y la coerción. En muchos casos, ésta puede ser más o menos sutil: por ejemplo, algunos profesionales de la promoción de la salud tienden a ser excesivamente autoritarios y los trabajadores temen las situaciones embarazosas, el rechazo e incluso el castigo provocados por su negativa a aceptar el consejo que se les da; las opciones de los trabajadores respecto a las actividades de promoción de la salud recomendadas pueden estar muy limitadas y es posible que los ejecutivos dificulten la existencia de aquellos de sus subordinados que no les acompañen en su actividad favorita, como salir a correr a primera hora de la mañana.

Aunque muchas organizaciones recompensan el comportamiento sano a través, por ejemplo, de certificados de méritos, premios y seguros de enfermedad "tarifados en función del riesgo" (que, en Estados U nidos, contemplan una reducción en la proporción de la prima abonada por el trabajador), otras imponen penalizaciones a las personas que no cumplen sus patrones arbitrarios de comportamiento en materia de salud. Entre las penalizaciones figuran la no concesión de un empleo 0 de un ascenso e incluso el despido y la denegación de prestaciones a las que podría tenerse derecho. Un ejemplo de este último tipo de penalización es el caso de E.A. M iller, una fábrica de envasado de carne con sede en $\mathrm{H}$ yrum, U tah, núcleo de 4.000 habitantes situado unos $65 \mathrm{~km}$ al norte de Salt Lake City (M andelker 1994) E.A. Miller es la mayor empresa de esta pequeña comunidad y ofrece seguros de enfermedad colectivos a sus 900 trabajadores y sus 2.300 familiares a cargo. Sus actividades de promoción de la salud son las habituales en muchos sentidos, si bien se distinguen por las penalizaciones impuestas a la no participación:

- A los trabajadores y sus cónyuges que no asisten a los seminarios sobre cuidados prenatales no se les reembolsa el coste de la atención obstétrica o del recién nacido en el hospital. Además, para poder optar a las prestaciones de seguro, las embarazadas deben visitar un médico en el primer trimestre.

- Si los trabajadores o las personas a su cargo fuman, deben contribuir a la prima del seguro de enfermedad colectivo abonando una cuota superior al doble de la ordinaria: 66 dólares al mes, en lugar de 30 dólares. La fábrica sigue una política de prohibición del consumo de tabaco desde 1991 y ofrece cursos en el lugar de trabajo para abandonar el tabaco 0 financia la matrícula de los trabajadores que siguen cursos ajenos a la empresa.

- La empresa no cubre los costes médicos del trabajador o de la persona a su cargo que resulten heridos en accidente de automóvil si conducían bajo los efectos del alcohol o de las drogas o no llevaban puesto el cinturón de seguridad, ni se hace cargo de los costes generados por lesiones producidas en accidentes de moto si el accidentado no llevaba el casco.

Una forma de coerción cada vez más aceptada consiste en amenazar con la pérdida del empleo a los trabajadores cuyo abuso del alcohol o de las drogas haya repercutido en su asistencia al trabajo y en su actuación en el mismo. En este caso, se expone el problema al trabajador y se le comunica que las acciones disciplinarias no se aplicarán siempre que siga un tratamiento prescrito y permanezca en período de abstinencia. Aunque se permite alguna recaída esporádica (algunas organizaciones fijan un número concreto), el incumplimiento de las condiciones establecidas da lugar al despido. La experiencia demuestra que este tipo de amenaza, considerada por algunos como el factor de estrés más importante en el lugar de trabajo, constituye un estimulo efectivo para muchas personas con problemas de tal magnitud que les obligan a tomar parte en un programa para su corrección.

\section{Confidencialidad e intimidad}

O tra característica esencial de un programa de promoción de la salud eficaz consiste en mantener la confidencialidad de la información personal relativa a los trabajadores que participan, o que no participan, en el programa y, en concreto, evitar que sus datos se incluyan en los archivos de personal. Para lograr estos objetivos cuando se utiliza dicha información en las tabulaciones de evaluación y en los procesos de investigación, algunas organizaciones han creado bases de datos en las que se identifica a los trabajadores mediante códigos cifrados o mecanismos semejantes. Esta iniciativa es especialmente pertinente en las exploraciones selectivas a gran escala y los procedimientos de laboratorio, prácticas en las que se producen errores administrativos.

\section{Quién participa}

Los programas de promoción de la salud reciben críticas por la tendencia constatada a que los participantes sean más jóvenes y sanos y estén más interesados en cuestiones de salud que los que no participan (el fenómeno "llueve sobre mojado"). Esta situación plantea a los responsables del diseño y funcionamiento de los programas el reto de incentivar a las personas que tienen más que ganar al participar.

\section{Quién paga}

Los programas de promoción de la salud implican ciertos costes para las organizaciones. Estos costes corresponden a los gastos financieros de administración y gestión y de servicios y materiales, al tiempo restado a la jornada de trabajo y a la distracción de los trabajadores participantes. Como ya se ha indicado, cada vez hay más pruebas de que estos costes quedan compensados con creces por la reducción de gastos de personal y el aumento de la productividad. Asimismo, existen beneficios menos tangibles, consistentes en la mejora de la imagen pública y la reputación de la organización como un buen lugar para trabajar, con lo cual mejoran los procesos de contratación.

En la mayoría de los casos, la organización cubre el coste total del programa. En ocasiones, sobre todo si la actividad se lleva a cabo en instalaciones ajenas a la empresa, se exige a los participantes que asuman parte de los gastos, aunque en algunas organizaciones se reembolsa la proporción abonada por el 
trabajador al culminar con éxito el programa o el curso en cuestión.

Muchos programas de seguros de enfermedad colectivos incluyen servicios preventivos como vacunación, reconocimientos médicos, pruebas e intervenciones de detección, prestados por profesionales de la salud. Con todo, este tipo de cobertura de seguro de enfermedad plantea problemas: puede aumentar el coste del seguro, y los costes ordinarios de los pagos principales y accesorios, habitualmente deducibles, pueden dificultar su utilización por parte de los trabajadores de escasa remuneración. Teniendo estos factores en cuenta, puede que a las empresas les resulte menos gravoso realizar estos pagos directamente, ahorrándose los gastos administrativos generados por la gestión de indemnizaciones y reembolsos.

\section{Conflictos de intereses}

Aunque la mayoría de los profesionales de la salud se caracterizan por una integridad ejemplar, debe ejercerse una estrecha vigilancia para identificar y atajar las actividades de los que se aparten de esta tendencia general. Entre los ejemplos de este tipo de prácticas figuran la manipulación de registros para mejorar los resultados propios y el establecimiento de relaciones con prestadores de servicios externos que ofrecen comisiones y otras ventajas a cambio de consultas. D ebe supervisarse la actuación de los proveedores externos para identificar a los que ofrecen condiciones ventajosas para obtener un contrato y después, para ahorrar, utilizan personal de escasa cualificación para la prestación de servicios.

Un conflicto de intereses más sutil se produce cuando los directivos y los proveedores traicionan las necesidades y los intereses de los trabajadores en favor de los objetivos de la organización 0 de sus gestores. Este tipo de acción censurable puede no ser explícita. Un ejemplo consiste en procurar la participación de los trabajadores con problemas en un programa de gestión del estrés sin hacer todo lo posible para convencer a la organización de la necesidad de reducir los niveles excesivamente elevados de estrés en el lugar de trabajo. Los profesionales experimentados no encontrarían ninguna dificultad para prestar un servicio adecuado tanto a los trabajadores como a la organización, pero deberían estar dispuestos a establecer una situación de mayor rigor respetando los valores éticos en los casos en que las presiones ejercidas por la dirección alcancen niveles excesivos.

0 tro conflicto sutil que puede afectar negativamente a los trabajadores se plantea al establecerse una relación de competencia y no de coordinación y colaboración entre el programa de promoción de la salud y otras actividades referentes a la salud de la organización. Esta situación no es extraña cuando los programas se encuadran en áreas diferentes del esquema organizativo y su competencia corresponde a distintos responsables de la dirección. Como ya se ha dicho, es fundamental, incluso cuando formen parte de la misma entidad, que el programa de promoción de la salud no se desarrolle a costa del programa de salud y seguridad en el trabajo.

\section{Estrés}

Probablemente, el estrés es el peligro para la salud más extendido dentro y fuera del lugar de trabajo. En una encuesta de referencia efectuada por la St. Paul Fire and $\mathrm{M}$ arine Insurance Company en la que participaron casi 28.000 trabajadores de 215 empresas de Estados U nidos, K ohler y K amp (1992) llegan a la conclusión de que el estrés en el trabajo está estrechamente relacionado con los problemas de salud y de actuación de los trabajadores. A simismo, señalan que los problemas personales generados por el trabajo son más importantes y ejercen más influencia que otras cuestiones familiares, jurídicas o financieras. En su opinión, este hecho indica que "algunos trabajadores se ven atrapados en un círculo vicioso de problemas laborales y domésticos: las dificultades en el trabajo repercuten en la vida familiar y viceversa". En consecuencia, aunque la atención primaria debe centrarse en el control de los factores de riesgo psicosociales intrínsecos al trabajo, este esfuerzo debe complementarse mediante actividades de promoción de la salud dirigidas a los factores personales de estrés que repercuten con mayor probabilidad en la actuación en el trabajo.

\section{Acceso a la asistencia sanitaria}

U na cuestión digna de consideración es la educación para utilizar el sistema de prestación de asistencia sanitaria que debe formar parte de los programas con vistas a la satisfacción de futuras demandas de servicios de salud. Esta formación comprende desde la autoasistencia (saber qué hacer cuando aparecen los síntomas y cuándo se requieren servicios profesionales) hasta la selección de un hospital o de un profesional de la salud cualificado. Asimismo, incluye la mejora de la capacidad de distinguir la asistencia sanitaria adecuada de la deficiente y el conocimiento de los derechos de los pacientes.

Para que los trabajadores ahorren tiempo y dinero, algunos servicios médicos de empresa ofrecen prestaciones sanitarias internas de alcance variable (con frecuencia incluyen pruebas radiológicas, de laboratorio y otros procedimientos de diagnóstico) y comunican los resultados a sus médicos personales. 0 tros elaboran una relación de médicos, odontólogos y demás profesionales de la salud cualificados a la que los trabajadores y, en ocasiones, las personas a su cargo pueden remitirse. LoS permisos constituyen un beneficio adicional importante cuando no se dispone de servicios profesionales de salud fuera de la jornada de trabajo.

En Estados U nidos, incluso en los casos en que se aplica un programa de seguro de enfermedad colectivo adecuado, los trabajadores de escasa remuneración y sus familias pueden considerar la parte de los gastos cubiertos correspondiente a la franquicia y el coaseguro como barreras para recibir los servicios sanitarios recomendados en circunstancias prácticamente extremas. Algunas empresas están contribuyendo a superar tales barreras eximiendo a estos trabajadores de la obligación de realizar tales pagos o celebrando acuerdos especiales sobre cuotas con los prestadores de asistencia sanitaria.

\section{"Ambiente" en el lugar de trabajo}

Los programas de promoción de la salud en el lugar de trabajo se plantean, a menudo explícitamente, como una expresión del interés de la empresa en la salud y el bienestar de la plantilla. Se contradice ese mensaje cuando la empresa no atiende las quejas de los trabajadores respecto a las condiciones de trabajo ni hace nada por mejorarlas. No es probable que los trabajadores acepten 0 decidan participar en programas ofrecidos en tales circunstancias o en situaciones de conflicto laboral.

\section{Diversidad de la población activa}

Los programas de promoción de la salud deben diseñarse para su adaptación a la diversidad cada vez más característica de la población activa actual. Las diferencias de antecedentes étnicos y culturales, niveles educativos, edad y sexo deben reflejarse en el contenido y presentación de las actividades comprendidas en dichos programas.

\section{Conclusión}

De las anteriores consideraciones se deduce que los programas de promoción de la salud en el lugar de trabajo constituyen una extensión de los programas de salud y seguridad en el trabajo que, correctamente diseñados y aplicados, pueden beneficiar a los 
trabajadores, a las plantillas y a las organizaciones. Además, pueden impulsar el cambio social en la comunidad.

En los últimos decenios, los programas de promoción de la salud en el lugar de trabajo han aumentado en número y ámbito, tanto en las pequeñas y medianas empresas, como en las grandes de los sectores privado, de beneficiencia y público. Como ponen de manifiesto los artículos incluidos en el presente capítulo, los programas también han aumentado en alcance, pasando de limitarse a los servicios sanitarios como, por ejemplo, los reconocimientos médicos y las vacunaciones, a incluir la atención a problemas personales y familiares cuya vinculación con el lugar de trabajo resulta menos evidente. La selección de elementos y actividades comprendidas en un programa determinado debe basarse en las características concretas de la plantilla, la organización y la comunidad en cuestión, teniendo en cuenta que parte de dichas actividades sólo serán necesarias para cohortes específicas de trabajadores y no para el conjunto de la población.

Al considerar la creación de un programa de promoción de la salud en el lugar de trabajo, se recomienda una planificación detallada, una aplicación gradual que permita el crecimiento y la ampliación, el seguimiento de la actuación y la calidad del programa y, en la medida de lo posible, la evaluación de los resultados. Los artículos contenidos en el presente capítulo deben resultar extremadamente útiles en tal empeño.

\section{- Promocion de LA SALUd EN EL LUGAR DE TRABAJO}

Jonathan E. Fielding

\begin{abstract}
Justificación
El entorno de trabajo constituye un lugar adecuado para avanzar en la consecución de objetivos como la evaluación, la educación, el asesoramiento y la promoción de la salud en general. D esde el punto de vista de la formulación de políticas nacionales, el lugar de trabajo favorece el desarrollo de este tipo de actividades, ya que su aplicación suele requerir una amplia concentración de personas. Además, la mayoría de los trabajadores se encuentran en una ubicación laboral predecible durante un período de tiempo significativo casi todas las semanas. El lugar de trabajo suele ser un entorno controlado en el que las personas o los grupos pueden someterse a una programación educativa o recibir consejos sin las distracciones propias del hogar o la precipitación habitual de los centros médicos.

La salud es una función habilitadora, es decir, permite a las personas alcanzar otras metas, incluida una actuación acertada en el cumplimiento de sus funciones profesionales. Las empresas desean optimizar la salud debido a la vinculación de ésta con la productividad en el trabajo, tanto cuantitativa como cualitativa. Por tanto, reducir la aparición (incidencia) y la existencia (prevalencia) de enfermedades que conllevan absentismo, incapacidad o trabajo deficiente constituye un objetivo prioritario que justifica una inversión considerable. Las organizaciones de trabajadores, creadas para elevar el bienestar de sus miembros, también tienen un interés intrínseco en patrocinar programas que pueden mejorar el estado de salud y la calidad de vida.
\end{abstract}

\section{Patrocinio}

El patrocinio de las empresas suele incluir la financiación total o parcial de los programas. No obstante, algunas empresas financian únicamente la planificación u organización de las actividades de promoción de la salud, que los trabajadores deben sufragar. En ocasiones, los programas patrocinados por las empresas ofrecen incentivos a los trabajadores por la participación, la finalización del programa o la correcta modificación de los hábitos en materia de salud. Tales incentivos pueden consistir en la concesión de permisos y de premios económicos por participación o resultados y en el reconocimiento de la consecución de objetivos referentes a la salud. En sectores con implantación sindical, sobre todo cuando los trabajadores están repartidos en lugares de trabajo demasiado pequeños para organizar un programa, los programas de promoción de la salud pueden estar diseñados y aplicados por las organizaciones sindicales. Aunque las empresas y las organizaciones de trabajadores suelen patrocinar programas de asesoramiento y educación sanitaria en el lugar de trabajo, en ocasiones financian también otros desarrollados total o parcialmente en servicios de la comunidad, ya sean gestionadas por la administración pública o por organizaciones lucrativas o no lucrativas.

El patrocinio financiero debe completarse con el compromiso de la empresa, tanto de la alta dirección como de los mandos intermedios. Las empresas tienen muchas prioridades. Si la promoción de la salud es una de ellas, debe ser apoyada financieramente de forma activa y manifiesta por la dirección y recibir una atención continua, destacando su importancia ante los trabajadores, los accionistas, los directivos y los inversores.

\section{Confidencialidad y derecho a la intimidad}

La salud de los trabajadores determina en gran medida la productividad y la vitalidad de las organizaciones, pero, en esencia, es una cuestión personal. La empresa u organización de trabajadores que desee ofrecer asesoramiento y educación sanitaria debe incorporar a los programas procedimientos que garanticen la confidencialidad y derecho a la intimidad. Los trabajadores estarán dispuestos a participar voluntariamente en tales programas si se convencen de que la información personal sobre su salud no será revelada a terceros sin su permiso. Para ellos y para sus representantes es fundamental que los datos obtenidos en los programas de mejora de la salud no se tengan en cuenta de ningún modo en la evaluación de su actuación en el puesto de trabajo ni en las decisiones de contratación, despido y ascenso.

\section{Evaluación de necesidades}

La planificación de los programas suele comenzar con una evaluación de las necesidades. A menudo se lleva a cabo una encuesta entre los trabajadores para obtener información sobre cuestiones como: a) la frecuencia autodeclarada de los hábitos de salud ( $p$. ej., consumo de tabaco, actividad física, dieta); b) la presencia de otros riesgos para la salud, como el estrés, la hipertensión, la hipercolesterolemia y la diabetes; c) las prioridades personales en cuanto a la reducción de riesgos y la mejora de la salud; d) la actitud ante otras posibles configuraciones del programa; e) los lugares preferidos para la programación de la promoción de la salud; f) la disposición a participar en las actividades programadas y, en ocasiones, g) la disposición a pagar parte del coste. Asimismo, pueden investigarse las actitudes ante las políticas empresariales vigentes o previstas, como la prohibición del consumo de tabaco o la oferta de alimentos más sanos en las máquinas expendedoras y comedores del lugar de trabajo.

En algunos casos, la evaluación de las necesidades comprende el análisis de los problemas de salud de los trabajadores basado en el estudio de los archivos clínicos del departamento médico, los registros de asistencia sanitaria, las indemnizaciones por incapacidad o por accidente de trabajo y los datos sobre absentismo. Este análisis ofrece información epidemiológica sobre la prevalencia y el coste de los diferentes problemas de salud, tanto somáticos como psicológicos, y permite la evaluación de las 
Figura 15.2 - Elementos de un programa de promoción de la salud.

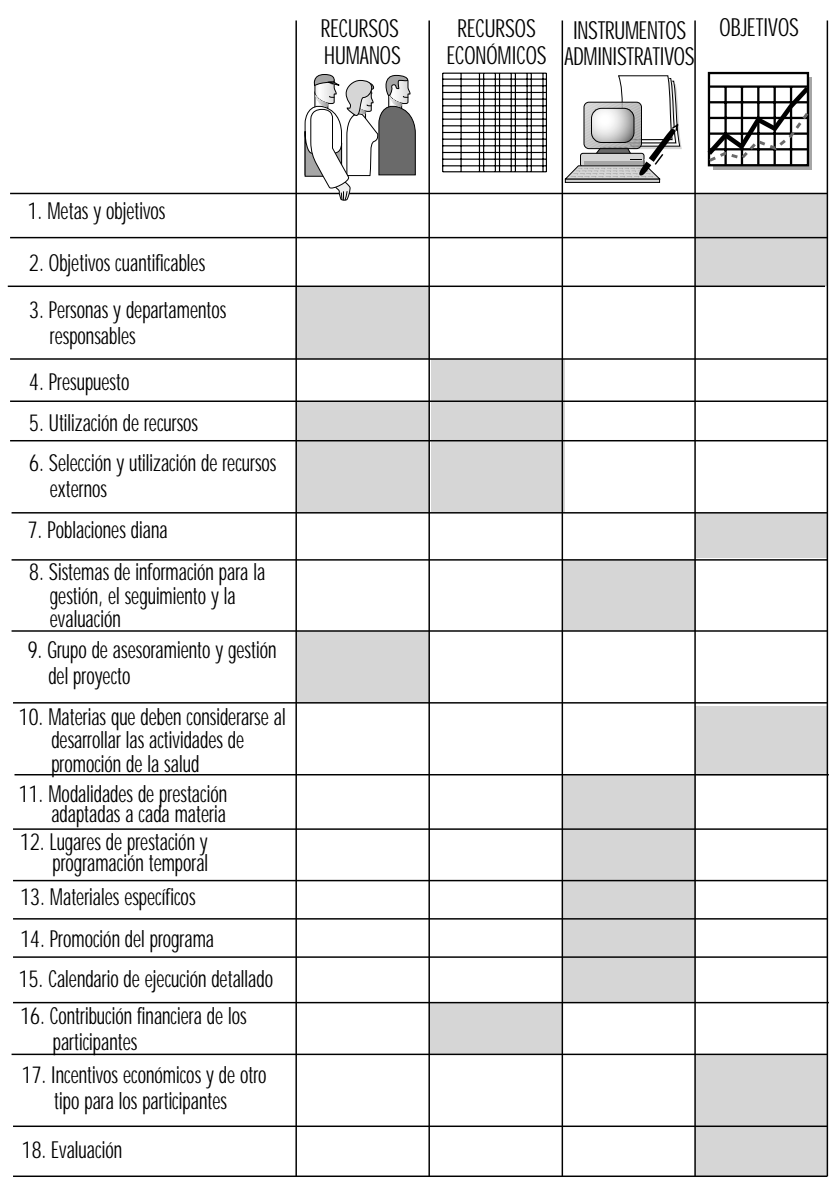

oportunidades existentes en materia de prevención desde un punto de vista programático (planificador) y financiero.

\section{Estructura del programa}

Al considerar los resultados de la evaluación de las necesidades se tienen en cuenta los recursos económicos y humanos disponibles, la experiencia de programas previos, los requisitos reglamentarios y las características de la plantilla. En la Figura 15.2 se enumeran algunos de los elementos clave que deben definirse claramente en el proceso de planificación del programa. Entre las decisiones esenciales figura la determinación de las modalidades efectivas para llegar a la población diana. Por ejemplo, en el caso de una plantilla dispersa, la programación basada en las actividades desarrolladas fuera del lugar de trabajo y en la utilización del teléfono y el correo puede representar la opción más factible y eficaz en función del coste. 0 tra decisión importante hace referencia a la inclusión (defendida por algunos programadores) o exclusión del programa de los jubilados y de los cónyuges e hijos de los trabajadores.

La responsabilidad relativa al programa de promoción de la salud en el lugar de trabajo puede corresponder a alguno de los departamentos ya existentes, como el servicio médico o de salud laboral o los departamentos de recursos humanos y personal, formación, administración, capacidad física para el trabajo, asistencia al trabajador $u$ otros, o bien encomendarse a un departamento de promoción de la salud específico. Esta elección suele ser muy importante para el éxito del programa. Un departamento decidido a hacer todo lo posible por sus usuarios, dotado de una adecuada base de conocimientos, buenas relaciones de trabajo con otras partes de la organización y la confianza de directivos y supervisores, tiene muchas probabilidades de lograr sus objetivos desde el punto de vista organizativo. Las actitudes de los empleados en relación con el departamento al que se asigne el programa y la confianza que tengan en su integridad, sobre todo en lo que afecta a la confidencialidad de la información personal, puede afectar a la aceptación del programa.

\section{Contenido}

La Figura 15.3 muestra la frecuencia con que se abordan diversas cuestiones referentes a la promoción de la salud, según datos derivados de encuestas realizadas en empresas privadas de 50 o más trabajadores. La comparación de los resultados de dos encuestas llevadas a cabo en 1985 y 1992, respectivamente, pone de manifiesto que se ha experimentado un importante aumento en la mayoría de las áreas. En términos generales, en un $66 \%$ de los lugares de trabajo en 1985 se desarrollaba al menos una actividad, mientras que en 1992 la proporción ascendía al 81 \%. Las áreas con un mayor aumento fueron las relacionadas con el ejercicio y la capacitación física para el trabajo, la nutrición, la hipertensión y el control del peso. Algunas de las cuestiones investigadas por primera vez en 1992, como la educación sobre el SIDA, el colesterol, la salud mental, los riesgos en el trabajo y la prevención de accidentes, presentaban frecuencias relativamente altas. Según la encuesta de 1992, en un $36 \%$ de los lugares de trabajo se aplicaban programas educativos o de otro tipo relativos al abuso de alcohol y otras drogas; programas relacionados con el

Figura 15.3 - Información o actividades de promoción de la salud clasificadas por temas (1985 y 1992 ).

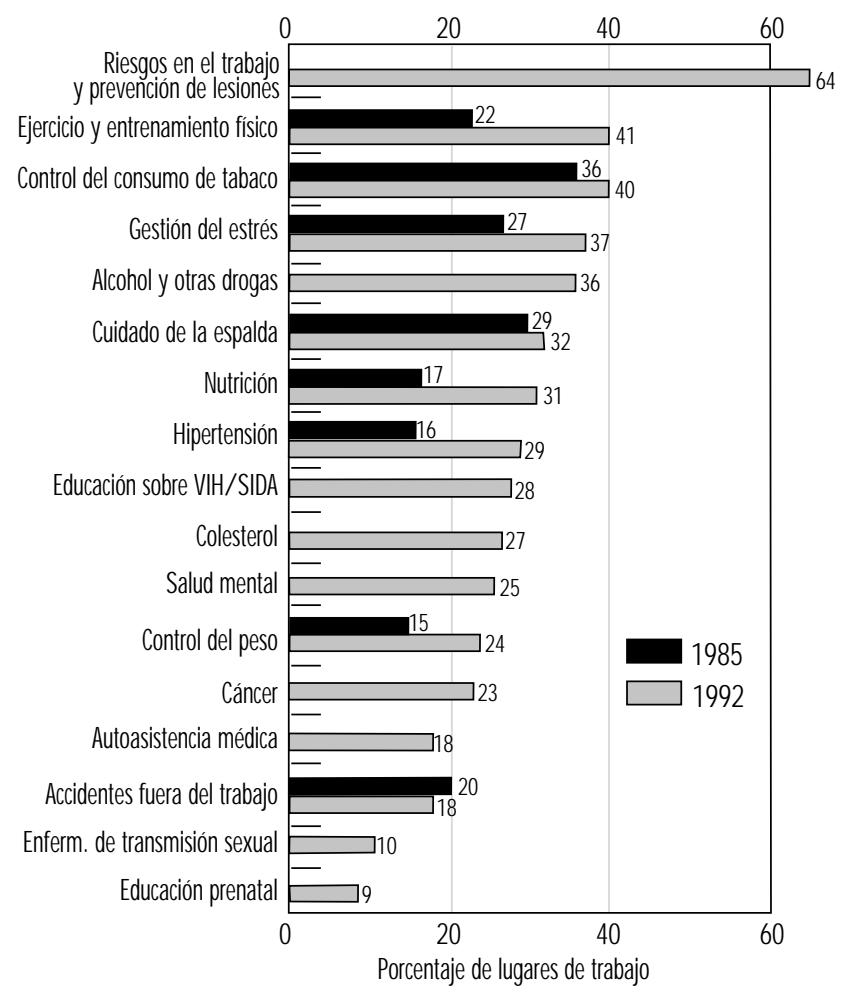

Fuente: US Office of Disease Prevention and Health Promotion 1992 
SIDA en un $28 \%$; programas de prevención de enfermedades de transmisión sexual en un $10 \%$ y en un $9 \%$ programas de educación prenatal, lo que indica la ampliación de las áreas tratadas.

U na amplia categoría de cuestiones que merece una atención cada vez mayor en los programas de promoción de la salud en el lugar de trabajo (un $16 \%$ de los lugares de trabajo en 1992) es la relativa a la asistencia sanitaria basada en programas de autoayuda. Estos programas tienen en común que abordan cómo atender problemas de salud de escasa importancia con la aplicación de normas sencillas para estimar la gravedad de diversos signos y síntomas y así decidir la conveniencia de solicitar ayuda profesional y con qué grado de urgencia.

La mejora de la información de los usuarios de los servicios de asistencia sanitaria constituye un objetivo complementario del programa y requiere su adiestramiento respecto a la elección de médico, las preguntas que deben plantearle, las ventajas e inconvenientes de las diferentes estrategias de tratamiento, la forma de decidir la oportunidad de someterse a un procedimiento diagnóstico o terapéutico recomendado y el lugar conveniente a tal efecto, los tratamientos no tradicionales y los derechos de los pacientes.

\section{Evaluaciones de la salud}

Independientemente de la función, alcance y población diana del programa, se realizan evaluaciones multidimensionales de la salud de los trabajadores participantes durante las fases iniciales y, posteriormente, a intervalos periódicos. En general, se recogen datos sobre los hábitos y el estado de salud, se practican mediciones fisiológicas simples, como la tensión arterial y el perfil lipídico, y (con menor frecuencia) se registran las actitudes ante la salud, las dimensiones sociales de la salud, la utilización de servicios preventivos, las prácticas de seguridad y los antecedentes familiares. L os informes resultantes informatizados se comunican a los trabajadores individualmente y de forma colectiva sirven para la planificación, seguimiento y evaluación del programa, y permiten obtener habitualmente estimaciones del riesgo absoluto o relativo, que van desde la valoración del riesgo absoluto de sufrir un infarto de miocardio en el decenio siguiente (o la comparación del riesgo cuantificable de una persona de sufrirlo con el riesgo medio de las personas de los mismos sexo y edad), hasta la clasificación cualitativa de la salud y los riesgos mediante una escala de deficiente a excelente. También son habituales las recomendaciones específicas. Por ejemplo, se aconseja la actividad física regular a las personas sedentarias y el aumento de los contactos sociales a las personas que se relacionan poco con los familiares y amigos.

En algunos programas se hacen evaluaciones de la salud en el momento de la contratación o en conexión con programas específicos, y posteriormente, a intervalos fijos o con una periodicidad definida por la edad, el sexo y la situación de riesgo para la salud.

\section{Asesoramiento}

0 tro elemento común de la mayoría de programas es el asesoramiento para la modificación de hábitos de salud tan perjudiciales como el consumo de tabaco, las prácticas nutricionales deficientes o el comportamiento sexual de alto riesgo. Existen métodos eficaces para ayudar a las personas a aumentar su motivación y disposición a modificar tales hábitos, no abandonar una vez iniciado el proceso y minimizar las recaídas. Las sesiones de grupo dirigidas por profesionales de la salud o por personal no sanitario con formación específica suelen ser útiles para ayudar a las personas a efectuar los cambios, y el apoyo de los compañeros en el lugar de trabajo puede mejorar los resultados en cuestiones como el abandono del tabaco o la actividad física.
La educación sanitaria de los trabajadores puede comprender aspectos que influyan favorablemente en la salud de otros miembros de su familia. Por ejemplo, en ocasiones se desarrollan programas sobre el embarazo sano, la importancia de la lactancia, la capacitación como padres y el modo de abordar eficazmente la atención sanitaria y otras necesidades de los familiares de edad avanzada. EI asesoramiento efectivo exige evitar la estigmatización de los participantes que presentan dificultades para cambiar o que no siguen las recomendaciones relativas a la modificación del estilo de vida.

\section{Trabajadores con necesidades especiales}

Una parte significativa de la población activa, sobre todo si se incluye un gran número de trabajadores de edad avanzada, padece al menos una enfermedad crónica, como diabetes, artritis, depresión, asma o lumbalgia. Además, otra parte importante de la población se considera expuesta a un alto riesgo de padecer un problema de salud grave, como una enfermedad cardiovascular, debido al agravamiento de factores de riesgo, como el nivel total de colesterol en sangre, la hipertensión, el consumo de tabaco, una obesidad significativa o un alto nivel de estrés.

Es posible que estas poblaciones utilicen los servicios de salud con una frecuencia excesiva, generen costes por sus gastos en prestaciones sanitarias y den lugar a pérdidas de productividad, pero tales efectos pueden atenuarse mediante iniciativas preventivas. De hecho, los programas de educación y asesoramiento destinados a paliar estas enfermedades y riesgos son cada vez más habituales. Suelen basarse en la intervención de personal de enfermería con formación específica (0, más raramente, educadores sanitarios o dietistas) con objeto de ayudar a poner en práctica y mantener los cambios de comportamiento necesarios y colaborar más estrechamente con el médico de atención primaria en la utilización de medidas médicas apropiadas, sobre todo en lo que se refiere al consumo de medicamentos.

\section{Prestación de los programas}

La prestación de los programas de promoción de la salud, ya sean patrocinados por la empresa o por los trabajadores, pueden encomendarse a distintas personas. En las grandes organizaciones, sobre todo en aquéllas en que las concentraciones geográficas de trabajadores son significativas, se encomienda a los propios empleados a tiempo completo y a tiempo parcial (personal de enfermería, educadores sanitarios, psicólogos, fisioterapéutas, etc.) la gestión del programa. 0 tras veces se acude a personal externo, a consultores individuales o a miembros de organizaciones que ofrecen especialistas en una amplia gama de disciplinas, tales como hospitales, organizaciones voluntarias (p. ej., la American $\mathrm{H}$ eart Association), empresas de promoción de la salud que ofrecen programas de detección precoz, de mejora de la capacidad física para el trabajo, de gestión del estrés, de nutrición y otros, y gestoras de la asistencia. L os materiales utilizados en los programas proceden de estas fuentes o se elaboran internamente. En ocasiones, las organizaciones de trabajadores llevan a cabo sus propios programas para sus miembros o prestan ciertos servicios de promoción de la salud en asociación con la empresa.

Son muchos los programas de educación y formación que se han elaborado para preparar a los estudiantes y a los profesionales de la salud en la planificación, ejecución y evaluación de los programas de promoción de la salud en el lugar de trabajo. $M$ uchas universidades ofrecen cursos al respecto y algunas han creado una asignatura o un área de especialización concreta sobre "promoción de la salud en el lugar de trabajo". Tanto instituciones educativas públicas y privadas como organizaciones profesionales imparten un número considerable de cursos de formación continuada sobre el trabajo en el entorno de la 
empresa, la gestión de programas y los avances tecnológicos. Para ser eficaces, los responsables deben comprender el contexto concreto, las limitaciones y las actitudes asociadas con los entornos de trabajo. Al planificar y ejecutar los programas, deben tener en cuenta las políticas específicas del tipo de empleo y del lugar de trabajo, así como las cuestiones pertinentes relativas a las relaciones laborales, los horarios de trabajo, las estructuras organizativas formales e informales, además de la cultura, las normas y las expectativas empresariales.

\section{Tecnología}

Las tecnologías aplicables van desde los materiales de autoayuda, como libros, folletos y cintas de audio y vídeo tradicionales, hasta el software de aprendizaje y CD interactivo. La mayor parte de los programas exigen un contacto interpersonal a través de clases, conferencias o seminarios 0 de la formación y los consejos ofrecidos individualmente en el lugar de trabajo, por vía telefónica o incluso a través del ordenador. Asimismo, en ocasiones se utilizan grupos de autoayuda.

Los sistemas informáticos de recogida de datos son esenciales para la eficacia del programa, ya que se utilizan en diversas funciones de gestión (elaboración de presupuestos y utilización de recursos, cronograma/calendario, seguimiento individual, evaluación de procesos y resultados). 0 tras aplicaciones tecnológicas adoptan modalidades más complejas, tales como un mecanismo de conexión bioinformática para registrar medidas fisiológicas (p. ej., presión arterial, agudeza visual) o incluso la participación del sujeto en el propio programa (p. ej., asistencia a una instalación de capacitación física para el trabajo). Se están probando equipos informáticos de aprendizaje portátiles para evaluar su capacidad de mejora de los cambios de comportamiento.

\section{Evaluación}

Las iniciativas de evaluación abarcan desde los comentarios anecdóticos de los trabajadores hasta el empleo de complejas metodologías cuyas características justifican su inclusión en publicaciones contrastadas. Pueden centrarse en los procesos o en los resultados. Por ejemplo, la evaluación de un determinado proceso permite valorar la ejecución del programa, el número de trabajadores participantes y la opinión de éstos al respecto. Las evaluaciones de resultados tienen como objetivo los cambios en el estado de salud, como la frecuencia o el nivel de un determinado factor de riesgo, ya sea autodeclarado (p. ej., nivel de ejercicio) u objetivamente evaluado (p. ej., hipertensión). La evaluación puede centrarse también en aspectos económicos como los vinculados a la utilización y el coste de los servicios de asistencia sanitaria, al absentismo o a la incapacidad, esté relacionada con el trabajo o no.

La evaluación puede cubrir únicamente a los participantes en el programa o a la totalidad de los trabajadores sometidos a riesgo. En el primer caso permite tratar aspectos relativos a la eficacia de una determinada intervención, mientras que en el segundo determina la eficacia con que se han reducido los factores de riesgo en una población total. M ientras que en algunas evaluaciones (la mayoría) sólo se analizan los esfuerzos dedicados a la modificación de un factor de riesgo, en otras se estudian los efectos simultáneos de diversas intervenciones. Tras examinar 48 estudios publicados en los que se evalúan los resultados de programas globales de promoción de la salud y prevención de la enfermedad en el lugar de trabajo, se observó que 47 de ellos registraban resultados sanitarios positivos (Pelletier 1991). M uchos de estos estudios presentan deficiencias significativas de diseño, metodología o análisis. C on todo, su unanimidad respecto a las conclusiones favorables y los resultados optimistas de los mejor diseñados indican que los efectos reales se aproximan a los deseados. Q ueda por aclarar su reproductibilidad en programas semejantes, la persistencia de los efectos observados inicialmente y la posibilidad de que su valoración estadística alcance significación médica. Además, las pruebas de eficacia son mucho más sólidas para algunos factores de riesgo como el consumo de tabaco y la hipertensión, que para la actividad física, las prácticas nutricionales y los factores de salud mental, incluido el estrés.

\section{Tendencias}

La ampliación de los programas de promoción de la salud en el lugar de trabajo permite abordar cuestiones distintas de las tradicionales, esto es, las referentes al abuso de alcohol y las drogas, la nutrición, el peso, el consumo de tabaco, el ejercicio y el estrés. D e hecho, las actividades se centran actualmente en una gama de cuestiones más amplia, desde el embarazo sano y la menopausia hasta la vida con enfermedades crónicas como la artritis, la depresión o la diabetes. Cada vez se presta más atención a la mejora de la salud mental. Por ejemplo, en el marco de los programas patrocinados por las empresas, se desarrollan cursos 0 actividades de "optimización de la comunicación interpersonal", "consolidación de la autoestima", "mejora de la productividad personal en el trabajo y en el hogar" o "superación de la depresión".

O tra tendencia se refiere a la ampliación de la oferta de servicios de asesoramiento e información sanitaria. EI asesoramiento individual y en grupo puede complementarse con el realizado por compañeros, con el aprendizaje basado en medios informáticos y con la utilización de CD interactivos. El reconocimiento de la multiplicidad de estilos de aprendizaje se ha manifestado en la ampliación de las modalidades de prestación con objeto de aumentar la eficacia y mejorar la coordinación entre dichos estilos, las preferencias individuales y los enfoques pedagógicos. Esta diversificación de la oferta permite a las personas elegir el entorno, la intensidad y el formato educativo que mejor se adaptan a sus hábitos de aprendizaje.

Actualmente, la educación sanitaria y el asesoramiento están al alcance de un número cada vez mayor de trabajadores de grandes empresas, incluidos los que desarrollan su actividad en lugares alejados y tienen pocos compañeros y los que trabajan en su domicilio. Los envíos por correo y la vía telefónica, en su caso, pueden facilitar tales avances. La ventaja de estas modalidades consiste en que mejora la equidad, debido a la armonización de las condiciones de los trabajadores de las filiales y de la sede central. En ocasiones, hay que citar como inconveniente la reducción de los contactos con los profesionales de promoción de la salud.

\section{Políticas para la salud}

Cada vez se reconoce más claramente la importancia de las normas sociales y de la política de las organizaciones para la salud y para la eficacia de las iniciativas emprendidas para su mejora. Por ejemplo, la limitación o la prohibición del consumo de tabaco en el lugar de trabajo puede dar lugar a descensos significativos en el consumo individual de cigarrillos de los trabajadores fumadores. Una política de prohibición de la venta de bebidas alcohólicas en las instalaciones de la empresa pone de manifiesto el comportamiento que se espera de los trabajadores. La oferta de alimentos bajos en grasas y ricos en carbohidratos complejos en el comedor de la empresa constituye otra opción para ayudar a los trabajadores a mejorar su salud.

N o obstante, debe tenerse en cuenta también que las políticas de organización para la salud y las creencias sociales de carácter normativo relativas al concepto de buena salud pueden estigmatizar a quienes optan por seguir ciertos hábitos perjudiciales para la salud, como el consumo de tabaco, o que tienen una 
fuerte predisposición genética a alcanzar estados poco saludables, como la obesidad. No es sorprendente que la mayoría de programas registren mayores tasas de participación entre los trabajadores de hábitos sanos y expuestos a menores riesgos.

\section{Integración con otros programas}

La promoción de la salud presenta múltiples facetas. Son cada vez más las iniciativas encaminadas a mejorar la integración de la educación sanitaria y el asesoramiento, la ergonomía, los programas de asistencia a los empleados y ciertas prestaciones de orientación sanitaria, como los planes de detección precoz y de capacitación física para el trabajo. En países donde las empresas pueden diseñar sus propios planes de prestaciones sanitarias o completar los planes públicos en determinados aspectos, muchas de ellas ofrecen servicios médicos preventivos, sobre todo de detección precoz y de mejora de la salud, como la incorporación de los trabajadores a servicios de salud y de capacitación física ajenos a la organización. Las políticas fiscales que permiten a las empresas deducir estas prestaciones a los trabajadores generan fuertes incentivos económicos a su concesión.

EI diseño ergonómico constituye un importante factor determinante de la salud de la plantilla y va más allá de la simple adecuación física del trabajador a las herramientas utilizadas en el puesto de trabajo. Debe prestarse atención a la adaptación general de la persona a su tarea y al entorno de trabajo global. Así, un entorno sano requiere el equilibrio entre la autonomía y la responsabilidad en el puesto de trabajo y la adaptación efectiva entre el estilo de trabajo individual, las necesidades familiares y la flexibilidad de los requisitos laborales. No debe pasarse por alto la relación entre los factores de estrés en el trabajo y la capacidad personal para afrontarlos. Además, la salud puede promoverse mediante la contribución de los trabajadores a la configuración del contenido del trabajo de forma que se generen sentimientos de autorrealización y éxito.

Los programas de asistencia a los empleados, que, en términos generales, comprenden actividades patrocinadas por las empresas y dirigidas por profesionales que ofrecen evaluación, asesoramiento y remisión a otros medios a trabajadores con problemas personales, deben vincularse estrechamente con los restantes programas de promoción de la salud y actuar como fuente de remisión en casos de depresión, estrés y preocupación excesiva. A su vez, los programas de asistencia a los empleados pueden remitir a los trabajadores que lo requieran a programas de gestión del estrés patrocinados por la empresa, programas nutricionales de sobrepeso, peso insuficiente o sencillamente dieta inadecuada, y grupos de autoayuda para quienes carecen de apoyo social.

\section{Conclusión}

La promoción de la salud en el lugar de trabajo ha alcanzado su mayoría de edad debido en gran medida a los incentivos a la inversión empresarial, a los resultados positivos registrados por la mayoría de los programas y a la aceptación cada vez mayor de esta actividad como parte esencial de los planes globales de prestación. Su alcance se ha ampliado considerablemente, lo que pone de manifiesto una definición más general de la salud y la comprensión de los factores que determinan la salud individual y familiar.

Existen enfoques completos de la planificación y la ejecución de los programas y se dispone de profesionales de la salud cualificados para gestionarlos, así como de una amplia gama de materiales e instrumentos. El éxito de los programas depende de su adaptación a la cultura empresarial, de las oportunidades de promoción de la salud y de las limitaciones organizativas de cada uno de los lugares de trabajo. Los resultados de la mayoría de las evaluaciones apoyan la fijación de objetivos programáticos, si bien se necesitan más evaluaciones basadas en diseños y métodos científicamente válidos.

\section{Promocion de LA SALUd EN EL LUGAR DE TRABAJO : INGLATERRA}

Leon Kreitzman

En su declaración sobre formulación de políticas $\mathrm{H}$ ealth of the Nation, el Gobierno del Reino U nido adoptó una estrategia dual (parafraseando su declaración de intenciones) consistente en (1) "prolongar la vida" a través del aumento de la esperanza de vida y de la reducción del número de muertes prematuras y (2) "mejorar la calidad de vida", incrementando el número de años vividos sin padecer enfermedades, minimizando los efectos adversos de la enfermedad y la discapacidad, fomentando formas de vida sanas y mejorando los entornos físico y social.

Se consideró que los esfuerzos realizados para alcanzar estos objetivos serían más eficaces si se centraban en "entornos" ya existentes; es decir, en escuelas, hogares, hospitales y centros de trabajo.

Aunque se conocía el desarrollo de una considerable actividad de promoción de la salud en el lugar de trabajo (Fundación Europea 1991), no se disponía de información básica completa sobre su nivel y características. Se habían llevado a cabo diversas encuestas a pequeña escala, pero su alcance era escaso, ya sea porque se centraban en una única actividad como el consumo de tabaco, porque se limitaban al estudio de un área geográfica restringida o porque se basaban en un número reducido de centros de trabajo.

Se realizó una encuesta general sobre la promoción de la salud en el lugar de trabajo en Inglaterra, en nombre de la $\mathrm{H}$ ealth Education Authority. Se utilizaron dos modelos para Ilevarla a cabo: la encuesta nacional sobre promoción de la salud en el lugar de trabajo, realizada en Estados U nidos en 1985, (Fielding y Piserchia 1989) y una encuesta de 1984 elaborada por el Policy Studies Institute of Workplaces in Britain (D aniel 1987).

\section{La encuesta}

$\mathrm{H}$ ay más de 2.000.000 de centros de trabajo en Inglaterra (el lugar de trabajo se define como un entorno geográficamente continuo). La distribución es enormemente asimétrica: en el $88 \%$ de los centros de trabajo hay menos de 25 trabajadores, lo que representa un $30 \%$ de la población activa; mientras que sólo un $0,3 \%$ de los centros de trabajo disponen de plantillas de más de 500 personas, aunque absorben un $20 \%$ del total de trabajadores.

Inicialmente, la encuesta se estructuró para reflejar esta distribución, concentrando la toma de muestras en los grandes centros de trabajo, en el marco de un muestreo aleatorio de centros de trabajo de todos los tamaños y de los sectores público y privado; no obstante, se excluyeron de la encuesta los trabajadores por cuenta propia y los que desarrollan su actividad en su domicilio. Tampoco se consideraron los organismos públicos responsables de la prestación de servicios de defensa, policiales y penitenciarios.

Se realizaron encuestas en un total de 1.344 centros de trabajo, en marzo y abril de 1992. Las entrevistas se mantuvieron por teléfono y la duración media de cada entrevista completa fue de 28 minutos. Para contestar a las preguntas se eligió en cada caso al responsable de las actividades referentes a la salud. En los pequeños centros de trabajo, pocas veces se trataba de una persona especializada en cuestiones sanitarias. 
Figura 15.4 - ¿Se han llevado a cabo actividades relacionadas con la salud en los últimos 12 meses?

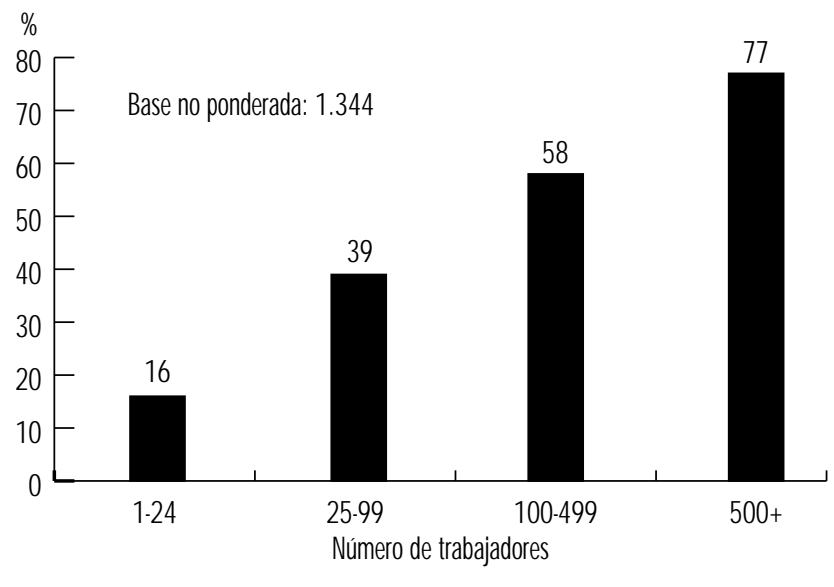

\section{Resultados de la encuesta}

La Figura 15.4 muestra las respuestas espontáneas a la pregunta sobre si se habían realizado en el pasado año actividades referentes a la salud y la acusada relación entre tamaño del lugar de trabajo y tipo de respuesta obtenida.

Una sucesión de preguntas espontáneas y preguntas planteadas en el curso de la entrevista permitieron obtener de los encuestados un volumen de información considerable respecto al alcance y características de las actividades referentes a la salud. La gama e incidencia de estas actividades se muestra en la Tabla 15.1. Algunas de ellas, como la satisfacción en el puesto de trabajo (entendida en Inglaterra como una expresión global que cubre aspectos tales como la responsabilidad respecto al ritmo y al contenido del trabajo, la autoestima, las relaciones laborales, la cualificación y la formación), suelen considerarse ajenas a la promoción de la salud, aunque, en opinión de algunos observadores, estos factores estructurales son sumamente importantes para su mejora.

0 tras cuestiones investigadas fueron el proceso de toma de decisiones, los presupuestos, la consulta a las plantillas, el conocimiento de la información y el asesoramiento disponible, las ventajas de la actividad de promoción de la salud para empresas y trabajadores, las dificultades de ejecución y la percepción de la importancia de dicha actividad. Cabe hacer varias observaciones generales:

1. En conjunto, en el $40 \%$ de los centros de trabajo se había realizado al menos una actividad importante referente a la salud el año anterior al de la encuesta. A parte de la actividad referente al consumo de tabaco en los centros de trabajo con más de 100 trabajadores, no se desarrolla otra actividad concreta de promoción de la salud en una mayoría de los centros de trabajo clasificados por tamaños.

2. En los centros de trabajo pequeños, las únicas actividades directas de promoción de la salud de alguna relevancia están relacionadas con el consumo de tabaco y de alcohol. Incluso en este caso, su incidencia es minoritaria ( $29 \%$ y $13 \%$ ).

3. El entorno físico inmediato, reflejado en factores como la ventilación y la iluminación, se considera una actividad esencial referente a la salud, al igual que la satiffacción en el puesto de trabajo. Con todo, estos factores fueron mencionados por menos del $25 \%$ de los encuestados de centros de trabajo con menos de 100 trabajadores.
4. Con el aumento de tamaño del lugar de trabajo no sólo se observa un porcentaje superior de centros de trabajo en los que se desarrolla alguna actividad, sino que se amplía también la gama de actividades emprendidas. Esta tendencia puede observarse en la Figura 15.5, que muestra la probabilidad de adopción de uno o varios de los programas principales. U nicamente en el $9 \%$ de los grandes centros de

Tabla 15.1 - Actividades relacionadas con la salud en función del tamaño de la plantilla.

\begin{tabular}{|c|c|c|c|c|c|}
\hline & \multicolumn{5}{|c|}{ Tamaño de la plantilla (actividad en \%) } \\
\hline & Todas & $1-24$ & $25-99$ & $100-499$ & $500 t$ \\
\hline Consumo de tabaco & 31 & 29 & 42 & 61 & 81 \\
\hline Alcoholismo y bebida & 14 & 13 & 21 & 30 & 46 \\
\hline Dieta & 6 & 5 & 13 & 26 & 47 \\
\hline Comida sana & 5 & 4 & 13 & 30 & 45 \\
\hline Gestión del estrés & 9 & 7 & 14 & 111 & 32 \\
\hline $\begin{array}{l}\text { VIH/ SIDA y prácticas } \\
\text { sexuales sanas }\end{array}$ & 9 & 7 & 16 & 26 & 42 \\
\hline Control del peso & 3 & 2 & 4 & 12 & 30 \\
\hline $\begin{array}{l}\text { Ejercicio y entrenamiento } \\
\text { físico }\end{array}$ & 6 & 5 & 10 & 20 & 37 \\
\hline $\begin{array}{l}\text { Salud cardíaca y activi- } \\
\text { dades relacionadas con } \\
\text { las patologías cardíacas }\end{array}$ & 4 & 2 & 9 & 18 & 43 \\
\hline Exploración de las mamas & 3 & 2 & 4 & 15 & 29 \\
\hline Citología & 3 & 2 & 5 & 12 & 23 \\
\hline Reconocimiento médico & 5 & 4 & 10 & 29 & 54 \\
\hline $\begin{array}{l}\text { Evaluación del estilo de } \\
\text { vida }\end{array}$ & 3 & 2 & 2 & 5 & 21 \\
\hline Análisis de colesterol & 4 & 3 & 5 & 11 & 24 \\
\hline $\begin{array}{l}\text { Control de la tensión } \\
\text { arterial }\end{array}$ & 4 & 3 & 9 & 16 & 44 \\
\hline $\begin{array}{l}\text { Actividades relacionadas } \\
\text { con el abuso de drogas y } \\
\text { alcohol }\end{array}$ & 5 & 4 & 13 & 14 & 28 \\
\hline $\begin{array}{l}\text { Actividades relacionadas } \\
\text { con la salud de la mujer }\end{array}$ & 4 & 4 & 6 & 14 & 30 \\
\hline $\begin{array}{l}\text { Actividades relacionadas } \\
\text { con la salud del varón }\end{array}$ & 2 & 2 & 5 & 9 & 32 \\
\hline $\begin{array}{l}\text { Prevención de lesiones por } \\
\text { músculotraumatismos } \\
\text { repetitivos }\end{array}$ & 4 & 3 & 10 & 23 & 47 \\
\hline Cuidado de la espalda & 9 & 8 & 17 & 25 & 46 \\
\hline Visión & 5 & 4 & 12 & 27 & 56 \\
\hline Oído & 4 & 3 & 8 & 18 & 44 \\
\hline $\begin{array}{l}\text { Diseño de la oficina y del } \\
\text { mobiliario de trabajo }\end{array}$ & 9 & 8 & 16 & 23 & 45 \\
\hline $\begin{array}{l}\text { Ventilación e iluminación } \\
\text { de interiores }\end{array}$ & 16 & 14 & 26 & 38 & 46 \\
\hline Satisfacción en el empleo & 18 & 14 & 25 & 25 & 32 \\
\hline Ruido & 8 & 6 & 17 & 33 & 48 \\
\hline
\end{tabular}


Figura 15.5 - Probabilidad de que se aplique un número determinado de programas de promoción de la salud, en función del tamaño de la plantilla.

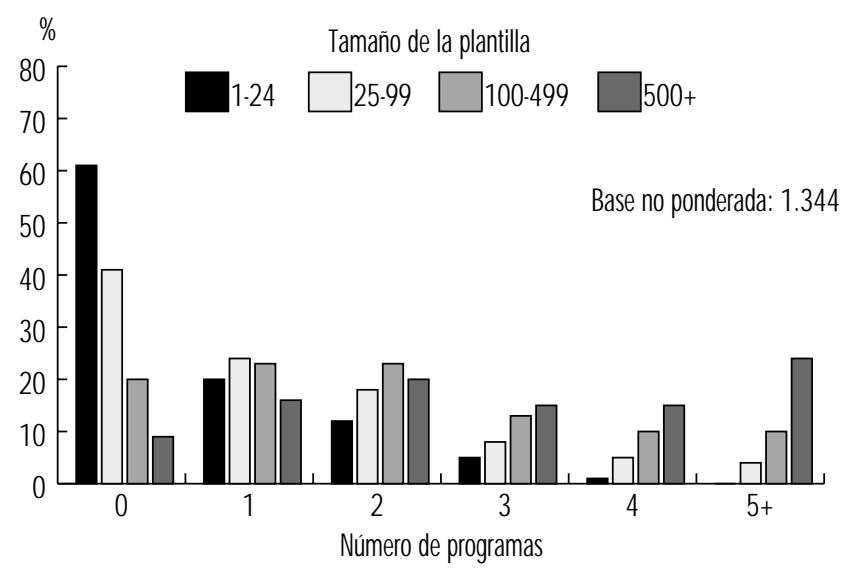

trabajo no se dispone de ningún programa y más del $50 \%$ cuentan con un mínimo de tres. Sólo en el $19 \%$ de los pequeños centros de trabajo se aplican dos o más programas. E sta proporción alcanza el $35 \%$ en los centros de trabajo con plantillas de 25 a 99 trabajadores y el $56 \%$ en los centros de trabajo que concentran de 100 a 499 trabajadores, mientras que en el $33 \%$ de estos centros de trabajo se dispone de tres o más programas. Con todo, sería aventurado deducir de estas cifras que la situación se asemeja a lo que podría denominarse un "lugar de trabajo sano". A un cuando éste se defina como el lugar de trabajo en el que se aplican 50 más programas, deben evaluarse las características e intensidad de los mismos. La realización exhaustiva de entrevistas indica que son pocos los casos en que la actividad referente a la salud se integra en una función planificada de promoción de la salud y menos aún, si los hay, los casos en que se modifican las prácticas o los objetivos del lugar de trabajo para prestar más atención al fomento de la salud.

5. D espués del consumo de tabaco, que alcanza una incidencia del $81 \%$ en los grandes centros de trabajo, y de alcohol, las actividades de mayor incidencia son las pruebas de agudeza visual, las pruebas de cribado y el tratamiento de problemas vertebrales.

6. El cribado del cáncer de mama y de cervix es poco frecuente incluso en los centros de trabajo en que al menos el $60 \%$ de los trabajadores son mujeres (véase la T abla 15.2).

7. En los centros de trabajo del sector público, se observan niveles de incidencia superiores en un $200 \%$ a los alcanzados

Tabla 15.2 - Tasas de participación (espontánea y fomentada) en las actividades de cribado de cáncer de mama y cuello del útero en función del porcentaje de mujeres en la plantilla.

\begin{tabular}{lcc} 
& \multicolumn{2}{c}{ Porcentaje de mujeres en la plantilla } \\
& Más del $60 \%$ & Menos del $60 \%$ \\
Exploración selectiva de mamas & $4 \%$ & $2 \%$ \\
Citología del cuello del útero & $4 \%$ & $2 \%$
\end{tabular}

Base no ponderada $=1.344$ en el sector privado. Esta tendencia se mantiene en todas las actividades.

8. En lo que respecta al consumo de tabaco y de alcohol, las empresas de propiedad extranjera registran una mayor incidencia de actividad en el lugar de trabajo que las del Reino U nido. No obstante, la diferencia es relativamente escasa en la mayoría de las actividades, a excepción del cribado (15\% frente a $5 \%$ ) y actividades auxiliares como el control del colesterol y de la presión arterial.

9. U nicamente en el sector público se lleva a cabo una actividad significativa en relación con el VIH/ SIDA. En la mayoría de actividades, el sector público obtiene mejores resultados que los demás sectores, con la notable excepción del control del consumo de alcohol.

10. En casi todos los casos, los centros de trabajo en que no se desarrollan actividades de promoción de la salud son pequeños o medianos y de titularidad británica, pertenecen al sector privado y prestan servicios de distribución y abastecimiento.

\section{Comentarios}

La encuesta telefónica cuantitativa y las entrevistas personales paralelas revelaron una cantidad considerable de información sobre la intensidad de las actividades de promoción de la salud en los lugares de trabajo de Inglaterra.

En un estudio de esta naturaleza, no es posible desenredar por completo la maraña de variables que tienden a confundir los resultados. No obstante, se observa que el tamaño del lugar de trabajo (en términos de número de empleados), la pertenencia al sector público en lugar de al privado, el grado de implantación sindical y la naturaleza del trabajo son factores importantes.

Los mensajes de promoción de la salud se comunican primordialmente por medio de métodos colectivos, como carteles, prospectos o vídeos. En los lugares de trabajo mayores es mucho más probable que se proporcione asesoramiento personal, sobre todo en cuestiones como el abandono del tabaco, el consumo de alcohol o el tratamiento del estrés. Los métodos de investigación utilizados han puesto de manifiesto que las actividades de promoción de la salud no están "integradas" en el lugar de trabajo y son muy contingentes, lo que significa que en la inmensa mayoría de los casos su efectividad depende de los individuos. $\mathrm{H}$ asta la fecha, la promoción de la salud no ha generado la base de coste/ beneficio necesaria para su aplicación. No hace falta que este cálculo sea un análisis detallado y complejo, sino una mera indicación de valor. Esta indicación puede ser muy beneficiosa para convencer a más lugares de trabajo del sector privado de que intensifiquen su actividad. Los "lugares de trabajo saludables" son muy escasos. En muy pocos casos está integrada la actividad de promoción de la salud en una función de promoción planificada, y todavía hay menos, si es que hay alguno, en que se hayan modificado la práctica o los objetivos del lugar de trabajo para aumentar el énfasis puesto en la mejora de la salud.

\section{Conclusión}

Las actividades de promoción de la salud parecen estar aumentando, y el $37 \%$ de los encuestados afirmaba que dicha actividad se había intensificado en el año anterior. La promoción de la salud se considera una cuestión importante, y en el $41 \%$ de los lugares de trabajo pequeños se afirma que es muy importante. A estas actividades se atribuyen beneficios considerables para la salud de los trabajadores y su buena forma física, así como disminución del absentismo y las enfermedades.

No obstante, apenas se han llevado a cabo evaluaciones formales y, aunque se han propuesto oficialmente medidas políticas escritas, éstas distan de ser universales. Se apoyan los 
objetivos de promoción de la salud y se perciben sus ventajas positivas, pero los indicios de institucionalización de las actividades en la cultura del lugar de trabajo son escasos. Se puede decir que la promoción de la salud en el lugar de trabajo es en Inglaterra contingente y vulnerable.

\section{- Promocion de la Salud en las PEQ UEÑAS ORGANIZACIONES: EXPERIENCIA DE ESTADOS UNIDOS}

\section{Sonia Muchnick-Baku y Leon J. Warshaw}

En otros artículos de este capítulo se examinan la justificación de los programas de promoción y protección de la salud en el lugar de trabajo y los enfoques encaminados a su ejecución. La actividad más intensa a este respecto ha tenido lugar en las grandes organizaciones, que cuentan con recursos para ejecutar programas globales. Sin embargo, la mayor parte de la población activa trabaja en pequeñas organizaciones, en las que la salud y el bienestar de los trabajadores tienen probablemente una incidencia mayor en la capacidad productiva y, en última instancia, en el éxito de la empresa. Conscientes de ello, estas organizaciones han comenzado a prestar más atención a la relación existente entre las prácticas de salud preventiva y la productividad y vitalidad de los trabajadores. Cada vez son más las pequeñas empresas que toman conciencia de que, con la ayuda de las coaliciones empresariales, de los recursos de la comunidad, de los organismos públicos de salud y de voluntariado y de estrategias creativas y modestas, diseñadas para atender sus necesidades concretas, pueden ejecutar programas de bajo coste que den importantes frutos.

En el último decenio se ha producido un crecimiento significativo del número de programas de promoción de la salud. Esta tendencia es importante tanto por el avance que representa en la promoción de la salud en el lugar de trabajo como por lo que implica en el temario futuro de la asistencia sanitaria de la nación. En este artículo se analizan algunos de los múltiples retos que afrontan las pequeñas organizaciones al ejecutar tales programas y se describen determinadas estrategias que han resultado útiles para superar las dificultades. EI texto tiene su origen, en parte, en un artículo redactado en 1992 para un simposio sobre pequeñas empresas y promoción de la salud, patrocinado por el Washington Business Group on $\mathrm{H}$ ealth, la O ficina de Prevención de Enfermedades del Public Health Service y la Small Business Administration de Estados U nidos (M uchnick-Baku y O rrick 1992). En él se hará hincapié en los ejemplos de organizaciones que hayan ejecutado con éxito, a base de ingenio y determinación, programas eficaces con recursos limitados.

\section{Posibles barreras a los programas de las pequeñas empresas}

Aunque muchos propietarios de pequeñas empresas son partidarios del concepto de promoción de la salud en el lugar de trabajo, pueden vacilar a la hora de ejecutar un programa si se encuentran con las siguientes barreras (M uchnick-Baku y O rrick 1992):

- "E s demasiado costoso." Suele considerarse erróneamente que la promoción de la salud en el lugar de trabajo es demasiado costosa para una pequeña empresa. Sin embargo, algunas empresas ofrecen programas mediante la utilización imaginativa de recursos comunitarios gratuitos o de bajo coste. A título de ejemplo, N ew Y ork Business Group, coalición empresarial interesada en temas de salud, con más de 250 organizaciones miembros en el área metropolitana de la ciudad de Nueva Y ork, ofrecía periódicamente un seminario titulado W ellnes 0 n A Shoe String, dirigido principalmente a pequeñas empresas, que hacía hincapié en la documentación que facilitaban los organismos de salud locales a bajo coste o sin coste alguno.

- "Es demasiado complicado." Otra idea errónea es que los programas de promoción de la salud son demasiado complicados para adaptarse a la estructura típica de la pequeña empresa. Sin embargo, las pequeñas empresas pueden comenzar con medidas modestas y ampliarlas gradualmente a medida que vayan detectándose nuevas necesidades. U na ilustración de lo anterior es Sani-D airy, una pequeña empresa de Johnstown, Pensilvania, que comenzó con una publicación mensual de promoción de la salud, dirigida a los trabajadores y a sus familias y elaborada por cuatro trabajadores como una actividad "extracurricular", suplementaria a sus cometidos habituales. Posteriormente, comenzaron a organizar a lo largo del año diferentes acontecimientos de promoción de la salud. A diferencia de muchas pequeñas empresas de sus dimensiones, Sani-D airy hace hincapié en la prevención de enfermedades dentro de su programa médico.

Las pequeñas empresas también pueden reducir la complejidad de los programas de promoción de la salud ofreciendo los servicios con una frecuencia menor que las empresas de mayores dimensiones. Los boletines informativos y el material de educación sanitaria pueden ser distribuidos trimestralmente, en lugar de mensualmente; puede celebrarse un número inferior de seminarios sobre salud en estaciones del año adecuadas o en el marco de campañas nacionales de carácter anual, como H eart M onth, Great American Smoke $O$ ut o Cancer Prevention Week, en Estados U nidos.

- "Aún no se ha demostrado que los programas den resultado." Las pequeñas empresas no tienen, sencillamente, ni el tiempo ni los recursos para realizar análisis formales de la relación coste/ beneficio de sus programas de promoción de la salud. Se ven obligadas a confiar en experiencias esporádicas (que, a menudo, pueden resultar engañosas) 0 en la inferencia a partir de investigaciones realizadas en grandes empresas. "Lo que intentamos hacer es aprender de las empresas más grandes", señala Shawn Connors, Presidente de The International $\mathrm{H}$ ealth Awareness Center, y añade: "Extrapolamos su información. Cuando ponen de manifiesto que están ahorrando dinero, consideramos que lo mismo nos va a suceder a nosotros". Aunque muchas de las investigaciones publicadas que pretenden confirmar la eficacia de la promoción de la salud no estén exentas de fallos, Pelletier ha encontrado pruebas suficientes en los estudios realizados, que corroboran las impresiones sobre su valor (Pelletier 1991 y 1993).

- "Carecemos de los conocimientos prácticos para diseñar un programa." Aunque ello sea cierto en la mayoría de los directivos de pequeñas empresas, no constituye, necesariamente, un obstáculo. M uchos de los organismos de salud de la Administración y de voluntariado facilitan, de forma gratuita o a bajo coste, los medios necesarios con instrucciones detalladas y materiales de muestra (véase la Figura 15.6) para la presentación de un programa de promoción de la salud. Además, muchos ofrecen asesoramiento especializado y servicios de consultoría. Por último, en la mayoría de las comunidades más grandes y en numerosas universidades existen consultores cualificados, con los que pueden negociarse contratos a corto plazo a cambio de unos honorarios relativamente modestos, que cubren la ayuda sobre el terreno para la adaptación de un programa concreto de promoción de la salud a las necesidades y circunstancias de una pequeña empresa, y la orientación sobre su ejecución. 
- "No somos lo bastante grandes - carecemos del espacio necesario." E sto es cierto en la mayoría de las pequeñas organizaciones, pero no debe paralizar un buen programa. La empresa puede "hacerse con" programas ofrecidos al vecindario por hospitales locales, agencias de salud de voluntariado, grupos médicos y organizaciones de la comunidad, subvencionando la totalidad 0 una parte de los honorarios que no queden cubiertos por el plan de seguro de enfermedad colectivo. M uchas de estas actividades deben realizarse fuera del horario de trabajo, por la tarde o los fines de semana, con lo que se evita que los participantes tengan que abandonar el lugar de trabajo.

\section{Ventajas del lugar de trabajo pequeño}

Aunque las pequeñas empresas afrontan importantes desafíos relacionados con los recursos financieros y administrativos, también tienen sus ventajas. Citemos algunas (M uchnick-Baku and O rrick 1992):

- Orientación familiar. Cuanto menor es la organización, más probable es que las empresas conozcan a sus trabajadores y familias. Ello puede facilitar que la promoción de la salud se convierta en un asunto empresa-familia por el que se creen vínculos y se promocione la salud.

- Culturas de trabajo comunes. En las pequeñas organizaciones hay menos diversidad entre los trabajadores que en las organizaciones más grandes, lo que facilita el desarrollo de programas más cohesionados.

- Interdependencia de los trabajadores. Los miembros de las pequeñas unidades son más dependientes entre sí. La ausencia de un trabajador por enfermedad, en especial si es prolongada, va a suponer una disminución sustancial de la productividad y a imponer una carga sobre los compañeros. Al mismo tiempo, la proximidad de los miembros de la unidad hace que la presión del grupo sea un estímulo más eficaz para participar en las actividades de promoción de la salud.

- Accesibilidad de los altos directivos. En una organización más pequeña, la dirección es más accesible y su trato con los trabajadores es más familiar, con lo que es más probable que la dirección sea más consciente de sus problemas y necesidades personales. Además, cuanto menor es la organización, más rápidamente el propietario/consejero delegado se verá envuelto, inmediatamente, en la toma de decisiones sobre las nuevas actividades del programa, evitándose los efectos, a menudo absurdos, de la burocracia que puede encontrarse en las grandes organizaciones. En una pequeña empresa, dicha persona clave está más capacitada para recabar el apoyo de la alta dirección, tan vital para el éxito de los programas de promoción de la salud en el lugar de trabajo.

- Utilización eficaz de los recursos. Debido a que son normalmente limitados, las pequeñas empresas tienden a ser más eficientes en la utilización de sus recursos. Es más probable que acudan a recursos de la comunidad, tales como los ofrecidos por los organismos de salud y sociales de voluntariado, de la Administración y empresariales, hospitales y centros escolares, en busca de medios poco onerosos para facilitar información y educación a los trabajadores y a sus familias (véase la Figura 15.6).

\section{Seguro de enfermedad y promoción de la salud en las pequeñas empresas}

Cuanto más pequeña es la empresa, menor es la probabilidad de que ofrezca seguros de enfermedad colectivos a los trabajadores y a sus familiares. Es difícil para una empresa exigir a sus trabajadores que se preocupen por la salud, como un principio básico para ofrecerles actividades de promoción de la salud, cuando no disfrutan del seguro de enfermedad básico. Incluso si hubiesen
Figura 15.6 - Ejemplos de programas “hágalo usted mismo" de promoción de la salud en el lugar de trabajo que se ofrecen en Estados Unidos.

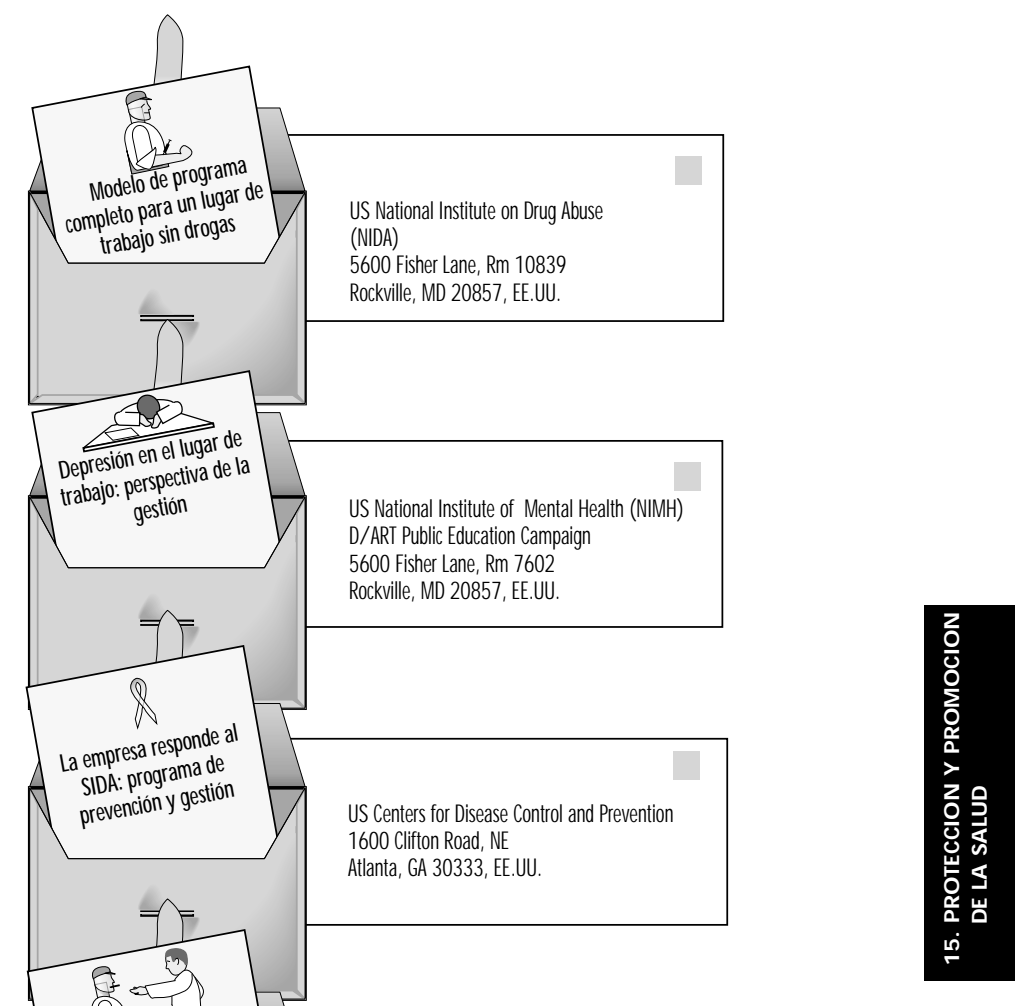


tenido acceso al mismo, los imperativos de costes constriñen a muchas pequeñas empresas a programas de seguros de enfermedad básicos, con coberturas muy reducidas.

Por otro lado, muchos planes colectivos cubren las exploraciones médicas periódicas, las mamografías y citologías, la vacunación y los cuidados adecuados de recién nacidos y niños. L amentablemente, el desembolso económico que hay que hacer, antes de disfrutar de las prestaciones aseguradas, para cubrir los costes de los gastos no cubiertos y los sufragados parcialmente deducibles y las cuotas suele ser un elemento disuasorio de la utilización de los mencionados servicios de prevención. Para salvar este impedimento, algunas empresas han llegado a un acuerdo con los trabajadores para reembolsarles estos gastos; otras juzgan que es menos gravoso y complicado pagarlos como coste de explotación.

Además de incluir medidas de prevención en su cobertura, algunas compañías de seguros de enfermedad ofrecen programas de promoción de la salud para colectivos asegurados, normalmente a cambio de una comisión, aunque a veces no supone un coste suplementario. Por lo general, estos programas comprenden material impreso y/o audiovisual, aunque en determinados casos son más globales. Algunos resultan especialmente apropiados para las pequeñas empresas.

En un número cada vez mayor de áreas, las empresas y otras organizaciones han formado coaliciones de "acción sanitaria" para elaborar información y conocimientos, así como respuestas a problemas de orden sanitario que afectan a tales organizaciones y a su medio social. M uchas de estas coaliciones proporcionan a sus miembros asistencia para diseñar y aplicar programas de promoción de la salud en el lugar de trabajo. Además, están apareciendo grupos operativos en un número creciente de zonas, donde estimulan la aplicación de actividades de promoción de la salud tanto en el lugar de trabajo como en la comunidad en general.

\section{Sugerencias para las pequeñas empresas}

Las siguientes sugerencias contribuirán a garantizar la puesta en marcha y el funcionamiento satisfactorios de un programa de promoción de la salud en una pequeña empresa:

- Integración del programa en otras actividades de la empresa. El programa será más eficaz y menos costoso si se integra en los planes de prestaciones y seguros de enfermedad colectivos de la plantilla, en las políticas de relaciones laborales y el entorno empresarial, así como en la estrategia comercial de la empresa. Y lo que es más importante, deberá coordinarse con las prácticas y políticas de la empresa en materia de seguridad ambiental y laboral.

- Análisis de los costes de la plantilla y de la empresa. Puede haber enormes diferencias entre lo que los trabajadores desean y necesitan y lo que la empresa puede permitirse. La empresa debe ser capaz de asignar al programa los recursos necesarios, tanto en términos de desembolsos económicos como de tiempo y esfuerzo de los trabajadores. Sería inútil lanzar un programa que no pudiese proseguir por falta de recursos. Al mismo tiempo, las planificaciones presupuestarias deberían contemplar incrementos de las asignaciones de recursos para cubrir la expansión del programa, a medida que crezca y se vaya consolidando.

- Participación de la plantilla y de sus representantes. U na representación de todos los niveles jerárquicos de la empresa (es decir, alta dirección, supervisores, trabajadores de base) debería estar presente a la hora de diseñar, ejecutar y evaluar el programa. Cuando exista un sindicato, su líder y los delegados de personal también deberían participar. A veces, el contar con los sindicatos para la ejecución de un programa elimina la oposición latente a la dirección y fomenta los programas de la empresa destinados a la mejora del bienestar del trabajador, si los hay; asimismo, puede estimular al sindicato a promover el programa en otras empresas del mismo sector o de la misma zona.

- Participación de cónyuges y familiares a cargo del trabajador. Normalmente, los hábitos sanitarios son característicos de la familia. Debería enviarse material educativo al domicilio y, en la medida de lo posible, animar a las cónyuges y a otros familiares a participar en algunas de las actividades.

- A probación y participación de la alta dirección. Los altos directivos de la empresa deberían dar su aprobación al programa públicamente y confirmar su valor participando personalmente en alguna de las actividades.

- Colaboración con otras organizaciones. Siempre que sea posible, se deberán fomentar las economías de escala aunando fuerzas con otras organizaciones locales, utilizando las instalaciones de la comunidad, etc.

- Confidencialidad de la información personal. Se deberán realizar esfuerzos por mantener la confidencialidad de la información personal relativa a problemas de salud, resultados de pruebas e, incluso, participación en determinadas actividades, y por evitar la posible estigmatización.

- Imagen positiva de programa y continua actualización. Se deberá fomentar la imagen positiva del programa y difundir sus objetivos entre la opinión pública. Sin abandonar ninguna actividad útil, se deberá modificar el acento del programa para captar un interés renovado y evitar que parezca estancado. U na forma de lograrlo es recurrir a programas nacionales y de la comunidad, tales como National $\mathrm{H}$ eart $\mathrm{M}$ onth y Diabetes Week, en Estados U nidos.

- Facilitar la participación. Las actividades que no puedan realizarse en el lugar de trabajo, deberían llevarse a cabo en lugares apropiados, próximos a la comunidad. Cuando sea inviable programarlas durante el horario laboral, podrán celebrarse a la hora de la comida 0 al término del turno de trabajo; en el caso de algunas actividades, pueden ser más adecuadas las tardes o los fines de semana.

- Considerar la oferta de incentivos y la entrega de premios. Entre los incentivos que suelen utilizarse para estimular la participación en programas y reconocer los logros, se encuentran las horas libres, las bonificaciones, la reducción de la contribución del trabajador a las primas del plan de seguro de enfermedad colectivo (seguro de enfermedad "en función del riesgo"), vales de regalo de comerciantes locales, premios sencillos, como camisetas, relojes y bisutería de poco valor, utilización de plazas de garaje privilegiadas y reconocimiento de los méritos en los boletines de la empresa y en el tablón de anuncios del lugar de trabajo.

- Evaluación del programa. La cifra de participantes y su tasa de abandono pondrán de manifiesto el grado de aceptación de las respectivas actividades. Los cambios cuantificables, tales como el abandono del tabaco, la pérdida o ganancia de peso, la reducción de los niveles de presión arterial o de colesterol, o los índices de capacidad física para el trabajo, demostrarán la eficacia del programa. Las encuestas periódicas a los trabajadores pueden servir para evaluar las actitudes hacia el programa y aportar sugerencias para su mejora. Por último, un análisis de datos tales como el absentismo, la rotación de personal, la evaluación de los cambios cualitativos y cuantitativos en la producción y la utilización de prestaciones de asistencia sanitaria pueden indicar a la organización el valor del programa. 


\section{Conclusión}

Aunque existen importantes retos que superar, no son insalvables. Los programas de promoción de la salud pueden ser más valiosos, y así ocurre a menudo, en las pequeñas empresas que en las grandes. Aunque resulta difícil obtener datos válidos, puede preverse que obtendrán resultados similares de mejora de la salud, del bienestar, del estado de ánimo y de la productividad de su plantilla. Lograrlo con recursos, a menudo limitados, exige una planificación y una ejecución meticulosas, la aprobación y el apoyo de los altos directivos, la participación de los trabajadores y de sus representantes, la integración del programa de promoción de la salud en las prácticas y políticas de la organización en materia de seguridad y salud, un plan de seguro de asistencia sanitaria y políticas y convenios trabajadores-dirección, y la utilización de material y servicios gratuitos y de bajo coste disponibles en la comunidad.

\section{- FunCION DEL SERVICIO DE SALUd DE LOS EMPLEADOSEN LOS PROGRAMAS DE PREVENCION}

John W.F. Cowell

Las principales funciones del servicio de salud de los empleados son el tratamiento de accidentes y enfermedades agudas que ocurren en el lugar de trabajo, la evaluación de la capacidad física para el desarrollo de la actividad laboral (Cowell 1986) y la prevención, detección y tratamiento de accidentes y enfermedades relacionadas con el trabajo. Sin embargo, también pueden desempeñar una función importante en los programas de prevención y mantenimiento de la salud. En este artículo, se dedica una atención especial a los servicios que una unidad corporativa específica puede prestar en este sentido.

D esde su creación, el servicio de salud de los empleados se ha ocupado también de la prevención de problemas de salud no relacionados con el trabajo. Las actividades tradicionales incluían la distribución de materiales de educación sanitaria, la preparación de artículos sobre promoción de la salud escritos por miembros del personal para su publicación en los periódicos de la empresa y, quizá lo más importante, los consejos sobre medidas preventivas que daban los médicos y enfermeras de salud laboral a trabajadores en los que habían detectado incidentalmente problemas de salud potenciales o incipientes. Los reconocimientos médicos periódicos para detectar posibles efectos derivados de las condiciones de trabajo han servido muchas veces para detectar un problema de salud incipiente no relacionado con el trabajo.

EI director médico está estratégicamente situado para desempeñar un papel protagonista en los programas preventivos de la organización. La persona que ocupa este puesto disfruta de importantes ventajas, como la oportunidad de introducir medidas preventivas en servicios relacionados con el trabajo, el elevado respeto que le suelen demostrar los trabajadores y la buena relación que mantiene con la dirección de la empresa, que le permite introducir cambios en la estructura y en el ambiente de trabajo y obtener los recursos necesarios para desarrollar un programa eficaz de prevención.

En algunos casos, los programas preventivos no relacionados con el trabajo se ubican en otras divisiones de la organización, por ejemplo, en los departamentos de personal o recursos humanos. En general, esta separación no es conveniente, pero puede ser necesaria, por ejemplo, cuando los programas se subcontratan a diferentes empresas externas; en ese caso debería existir al menos una coordinación y una estrecha colaboración con el servicio de salud de los empleados.

Dependiendo de la naturaleza y ubicación del lugar de trabajo y el compromiso de la organización con la prevención, estos servicios pueden ser muy completos, abarcando prácticamente todos los aspectos de la asistencia sanitaria, o bastante restringidos, limitándose a distribuir alguna información relacionada con la salud. Los programas globales son convenientes cuando el centro de trabajo está situado en una zona aislada en donde no existen servicios sanitarios; en estos casos, la empresa puede tener la obligación de proporcionar servicios completos de asistencia sanitaria, que suelen cubrir también a las personas a cargo de los trabajadores, para atraer y retener a una mano de obra leal, sana y productiva. El otro extremo suele producirse en situaciones en las que existe un buen sistema de asistencia sanitaria en la comunidad o cuando la organización es pequeña, carece de recursos 0 , con independencia de su tamaño, se muestra indiferente a la salud y el bienestar de sus trabajadores.

En este artículo, ninguno de estos extremos es objeto de consideración; por el contrario, la atención se centra en la situación más común y deseable, cuando las actividades y los programas organizados por el servicio de salud de los empleados complementan y suplen los servicios prestados por la comunidad.

\section{Organización de los servicios de prevención}

N ormalmente, los servicios de prevención en el lugar de trabajo abarcan educación y formación sanitaria, evaluaciones de la salud y reconocimientos médicos periódicos, programas de cribado para determinadas afecciones y asesoramiento en materia de salud.

La participación en cualquiera de estas actividades debe ser de carácter voluntario, y cualquier hallazgo o recomendación a título individual debe mantenerse confidencial entre el personal del servicio de salud laboral y el trabajador afectado, aunque, con su consentimiento, podrá informarse a su médico personal. Si no se respetan estos principios, el programa no podrá ser realmente eficaz. Se han aprendido y se siguen aprendiendo duras lecciones sobre la importancia de estas consideraciones. LoS programas que no disfrutan de la credibilidad y confianza de los trabajadores no consiguen ninguna participación o sólo una participación poco entusiasta. Si los trabajadores creen que la dirección ofrece estos programas de una forma manipuladora 0 interesada, es poco probable que se consigan los objetivos esperados

Desde un punto de vista ideal, el personal asignado al servicio de salud laboral se encarga de los servicios de prevención en el lugar de trabajo, normalmente en colaboración con un departamento interno de educación de los trabajadores (si es que existe). Cuando el personal carece de tiempo o de los conocimientos prácticos necesarios, o cuando se requiere un equipo especial (por ejemplo, en el caso de las mamografías), los servicios pueden obtenerse contratando a un servicio externo. Como consecuencia de las peculiaridades de algunas organizaciones, estos contratos son a veces negociados por un directivo ajeno al servicio de salud laboral. Este suele ser el caso de las organizaciones descentralizadas: los directores locales de las fábricas son los que negocian los contratos de servicios ajenos a la empresa. Sin embargo, es conveniente que el director médico sea el responsable de establecer el marco del contrato, verificar la competencia de los posibles proveedores y vigilar su actuación. En estos casos, aunque pueden facilitarse informes a la dirección, los resultados individuales deben mantenerse en el servicio de salud 0 en ficheros confidenciales del contratista. En ningún 
caso se debe permitir que esta información forme parte del expediente de cada trabajador, en el departamento de recursos humanos. U na de las grandes ventajas de que exista un servicio de salud es precisamente el poder mantener los registros de salud separados de los demás registros de la empresa bajo la supervisión de un profesional de la salud laboral y tener también la oportunidad de utilizar esta información como base para un seguimiento discreto con el fin de asegurar que los trabajadores tienen en cuenta las recomendaciones médicas importantes. Lo ideal sería que el servicio de salud laboral si es posible en colaboración con el médico personal de cada trabajador, proporcionara o supervisara los servicios recomendados de diagnóstico 0 tratamiento. 0 tros miembros del personal del servicio de salud laboral, como fisioterapeutas, masajistas terapéuticos, especialistas en ejercicio físico, dietistas, psicólogos y asesores en materia de salud aportarán también sus conocimientos prácticos cuando sea necesario.

Las actividades de promoción y protección de la salud realizadas por el servicio de salud laboral deben complementar su principal función de prevención y tratamiento de accidentes y enfermedades profesionales. Cuando se introducen y gestionan adecuadamente estas medidas, pueden mejorar mucho el programa básico de salud y seguridad laboral, pero en ningún caso deben desplazarlo o dominarlo. Asignar la responsabilidad de los servicios preventivos al servicio de salud de los empleados facilita la integración sin fisuras de ambos programas y permite la utilización óptima de los recursos.

\section{Elementos del programa}

\section{Educación y formación}

El objetivo en este caso es informar y motivar a los trabajadores y a las personas a su cargo para que elijan y mantengan unas formas de vida sanas. La intención es capacitarles para que puedan cambiar sus hábitos relacionados con la salud y disfrutar de una vida más larga, sana, divertida y productiva.

Pueden utilizarse distintas técnicas de comunicación y estilos de presentación. Cuando existen restricciones presupuestarias, es muy útil preparar una serie de folletos atractivos y de fácil lectura y ofrecerlos en las salas de espera, distribuirlos a través del correo interno de la empresa o enviarlos por correo a los domicilios de los trabajadores. Son quizá más útiles cuando se entregan a los trabajadores al mismo tiempo que se comenta un determinado problema de salud. EI director médico o la persona que dirige el programa de prevención debe hacer un gran esfuerzo para asegurar que su contenido sea pertinente y relevante y que se presente con un lenguaje y unos términos que comprendan los trabajadores (a veces se necesitan ediciones diferentes para distintas cohortes de una plantilla diversa).

Asimismo, pueden organizarse presentaciones en el lugar de trabajo realizadas por un miembro del servicio de salud laboral o por ponentes invitados, sobre temas de salud de interés. Las reuniones a la hora del almuerzo (a las que los trabajadores se llevan comida de su casa y comen mientras escuchan) son un mecanismo popular para celebrar este tipo de encuentros sin interferir en los horarios de trabajo. Los pequeños grupos interactivos dirigidos por un profesional sanitario bien informado son especialmente adecuados para trabajadores que comparten un determinado problema de salud; la presión de los compañeros suele constituir una fuerte motivación para seguir las recomendaciones sobre salud. Los consejos individuales son, por supuesto, excelentes, pero exigen mucho trabajo y deberían reservarse sólo a situaciones especiales. No obstante, siempre debe permitirse el acceso a una fuente de información fiable para responder a las preguntas de los trabajadores.
Algunos temas frecuentes son: abandono del tabaco, tratamiento del estrés, abuso del alcohol y de las drogas, nutrición y control del peso, vacunaciones, consejos para los viajes y enfermedades de transmisión sexual. Suele hacerse hincapié en el control de los factores de riesgo para las enfermedades cardiovasculares y coronarias, como la hipertensión y los perfiles anormales de lípidos en sangre. 0 tros temas frecuentes son el cáncer, la diabetes, las alergias, la autoasistencia para dolencias comunes de escasa importancia y la seguridad doméstica y vial.

Algunos temas se prestan a una demostración y participación activas, como los cursos de reanimación cardiopulmonar o de primeros auxilios, los ejercicios para prevenir dolores de espalda y tensiones repetitivas, los ejercicios de relajación y el aprendizaje de técnicas de autodefensa, que suelen ser de enorme interés para las mujeres.

Finalmente, "las ferias de salud" periódicas, con demostraciones de las agencias locales de salud voluntarias y casetas en las que se realizan reconocimientos a todo el que lo solicita, constituyen una forma popular de generar entusiasmo e interés.

\section{Reconocimientos médicos periódicos}

Además de los reconocimientos médicos periódicos reglamentados o recomendados a los trabajadores expuestos a determinados trabajos o peligros ambientales, muchos servicios de salud laboral ofrecen chequeos médicos periódicos más o menos completos. Cuando el personal y los recursos materiales son escasos, los reconocimientos pueden realizarse, normalmente a expensas de la empresa, en centros locales o en las consultas de médicos privados (es decir, contratados). En el caso de lugares de trabajo situados en comunidades que carecen de estos servicios, debe organizarse la visita a la fábrica de una unidad móvil o instalar furgonetas de exploración en la zona de aparcamiento.

En un principio, la mayoría de las organizaciones ofrecían estos reconocimientos exclusivamente a los ejecutivos y altos directivos. En algunos casos, se extendían a los demás trabajadores que habían prestado un número mínimo de años de servicio o que sufrían un problema médico conocido. Estos reconocimientos solían incluir un historial médico completo y una exploración complementada con toda una batería de pruebas de laboratorio, radiografías, un electrocardiograma y pruebas de esfuerzo, así como exploración de todos los orificios corporales. Siempre que la empresa estuviera dispuesta a pagar los honorarios, los centros privados que realizaban estos reconocimientos no tardaban en añadir pruebas, a medida que iban surgiendo nuevas tecnologías. En las organizaciones preparadas para un servicio más elaborado, los reconocimientos se ofrecían como parte de una breve estancia en algún centro acreditado de cuidados de salud. Aunque con frecuencia se hacían diagnósticos útiles e importantes, los falsos positivos eran también frecuentes $y$, en cualquier caso, los reconocimientos realizados en estos entornos eran costosos.

En las últimas décadas, como consecuencia de las crecientes presiones económicas, la tendencia hacia la equidad y, principalmente, los resultados de las evaluaciones sobre la viabilidad de los reconocimientos, se han impuesto los reconocimientos médicos para toda la plantilla, aunque menos completos que los que se realizaban antes.

EI U S Preventive Services Task G roup publicó una evaluación de la eficacia de 169 intervenciones preventivas (1989). La Figura 15.7 presenta un útil programa de reconocimientos preventivos a lo largo de la vida laboral y las pruebas adecuadas para adultos sanos que ocupan puestos directivos de poco riesgo (Guidotti, C owell y Jamieson 1989). Gracias a estas actividades, los reconocimientos médicos periódicos se han hecho menos costosos y más eficientes. 
Figura 15.7 - Programa de vigilancia de la salud a lo largo de toda la vida.

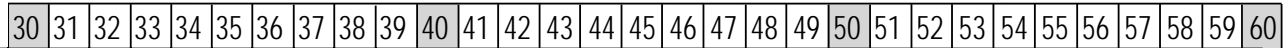

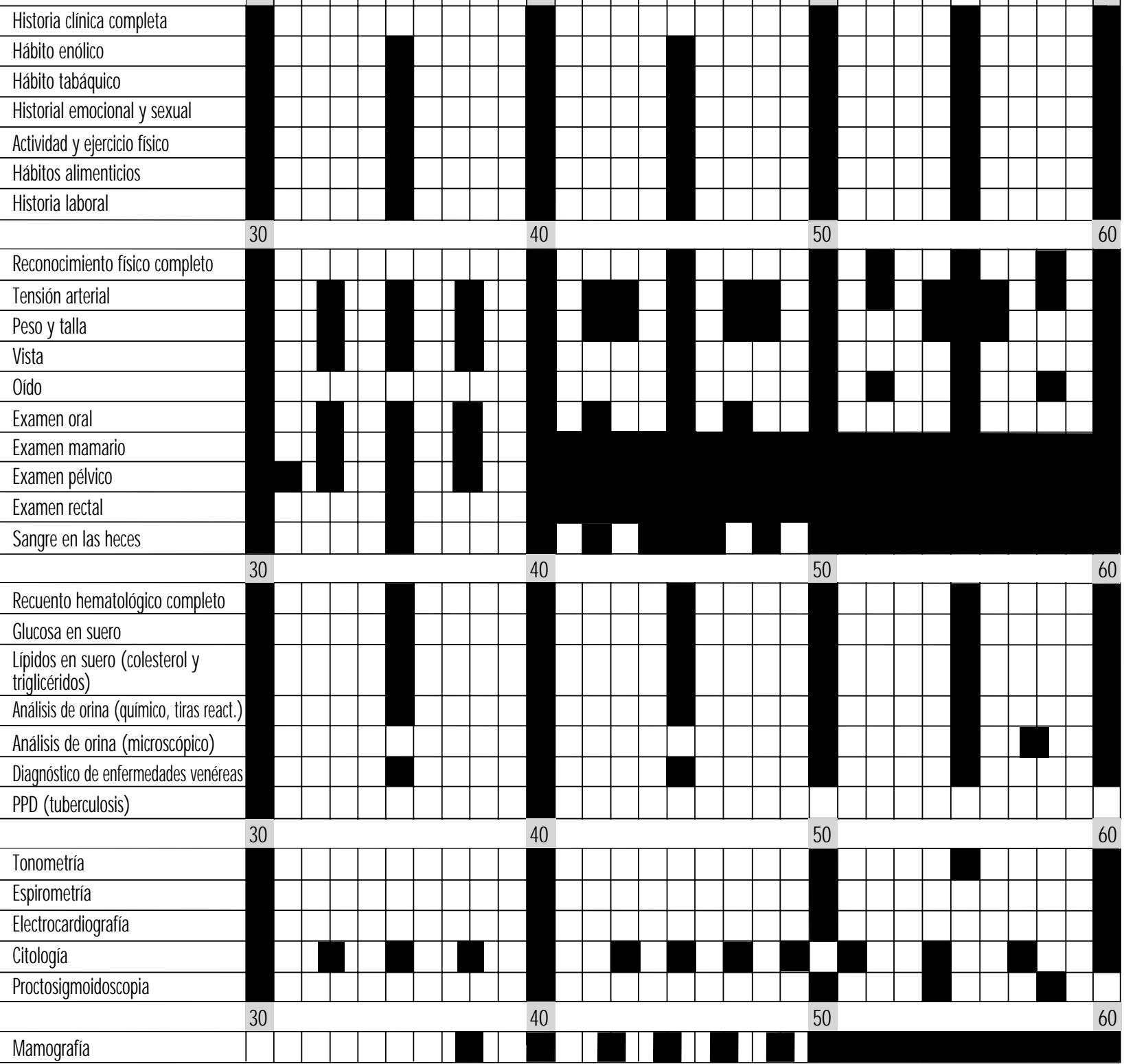

\section{Reconocimientos periódicos}

Estos programas están diseñados para la detección precoz de problemas de salud o enfermedades que permita su curación 0 control y para detectar síntomas precoces relacionados con hábitos nocivos para la salud que, si consiguen modificarse, pueden prevenir o retrasar la aparición de enfermedades 0 un envejecimiento prematuro.

La atención suele centrarse en enfermedades cardiorrespiratorias, metabólicas (diabetes), musculosqueléticas (espalda, microtraumatismos repetitivos) y detección precoz del cáncer (colorrectal, pulmonar y de mama).

Algunas organizaciones ofrecen periódicamente una valoración del riesgo para la salud (VRS) utilizando un cuestionario para averiguar los hábitos relacionados con la salud y los síntomas que podrían tener importancia. Esta valoración suele completarse con mediciones físicas como altura y peso, grosor del pliegue cutáneo, presión arterial, análisis de orina y determinación del nivel de colesterol en sangre mediante un simple "pinchazo en el dedo". 0 tras organizaciones realizan programas masivos de reconocimientos para detectar ciertos problemas de salud; los más frecuentes son los destinados a detectar hipertensión, diabetes, elevados niveles de colesterol en sangre y cáncer. La discusión sobre las pruebas que son más útiles está fuera del ámbito de este artículo. Sin embargo, el director médico puede desempeñar un papel crítico en la selección de los procedimientos más apropiados para la población y evaluar la sensibilidad, especificidad y valores predictivos de las pruebas que se están barajando. Especialmente cuando se contrata a personal temporal o a servicios externos para realizar estos reconocimientos, es importante que el director médico verifique sus 
cualificaciones y su formación para garantizar la calidad de sus actuaciones. De igual importancia es la rápida notificación de los resultados a las personas exploradas, la disponibilidad inmediata de pruebas de confirmación y procedimientos de diagnóstico para las personas que han dado resultados positivos 0 equívocos, el acceso a una fuente de información fiable para los que desean hacer preguntas y un sistema organizado de seguimiento para promover el cumplimiento de las recomendaciones. Cuando no existe un servicio de salud laboral o éste no participa en el programa de cribado, estas consideraciones suelen pasarse por alto, con la consiguiente pérdida de valoración del programa.

\section{Acondicionamiento físico}

En muchas grandes organizaciones, los programas de mantenimiento de la capacidad física para el trabajo constituyen el núcleo del programa de promoción y mantenimiento de la salud. Estos programas incluyen actividades aeróbicas para acondicionar el corazón y los pulmones y ejercicios de fuerza y elasticidad para acondicionar el sistema musculosquelético.

En las organizaciones que disponen de instalaciones deportivas propias, éstas suelen estar bajo la dirección del servicio de salud laboral. En esos casos, las instalaciones pueden utilizarse no sólo para los programas de mantenimiento de la capacidad física para el trabajo sino también para realizar ejercicios de prevención o alivio de dolores de espalda, síndromes de mano y hombro y otras lesiones. Asimismo, se facilita el control médico de los programas especiales de ejercicio para trabajadores que se han reincorporado después de un embarazo, una operación quirúrgica o un infarto de miocardio.

Los programas de acondicionamiento físico pueden ser eficaces, pero requieren la estructuración y dirección de personal debidamente formado, que sepa cómo guiar a una persona con limitaciones físicas para que alcance un estado adecuado para el trabajo. Para evitar posibles efectos secundarios, todas las personas que participen en un programa de mantenimiento de la capacidad física para el trabajo deberían someterse a una evaluación médica apropiada, que puede ser realizada por el servicio de salud laboral.

\section{Evaluación de los programas}

El director médico está en una posición ventajosa para evaluar el programa de educación y promoción de la salud de la organización. Los datos acumulados a partir de valoraciones del riesgo para la salud, reconocimientos médicos y cribado, visitas al servicio de salud laboral, absentismo debido a enfermedades o accidentes, etc., cuando se aplican a una determinada cohorte de trabajadores 0 a la totalidad de la plantilla, pueden ser cotejados con evaluaciones de la productividad, costes de indemnización por accidentes de trabajo, seguros médicos y otros datos para la gestión, con el fin de proporcionar, al cabo del tiempo, una estimación de la eficacia del programa. Este tipo de análisis permite identificar lagunas y deficiencias que sugieran la necesidad de modificar el programa y, al mismo tiempo, demostrar a la dirección la conveniencia de seguir asignando los recursos necesarios. Se han publicado fórmulas para calcular el coste/ beneficio de estos programas (G uidotti, Cowell y Jamieson 1989).

\section{Conclusión}

Existen numerosas pruebas en la literatura mundial de la utilidad de los programas preventivos en el lugar de trabajo (Pelletier 1991 y 1993). El servicio de salud laboral se encuentra en una posición óptima para dirigir estos programas o, como mínimo, para participar en el diseño y la supervisión de su ejecución y sus resultados. El director médico está estratégicamente situado para combinar estos programas con actividades orientadas a la salud y la seguridad laboral y alcanzar ambos objetivos, tanto en beneficio de los trabajadores (y sus familias, cuando se incluyen en el programa) como de la organización.

\section{Programas de Mejora de LA SALUd EN MACLAREN INDUSTRIES, INC.: ESTUDIO DE CASO}

Ian M.F. Arnold y Louis Damphousse

\section{Introducción}

\section{La organización}

James M aclaren Industries Inc., el entorno industrial utilizado para este estudio de caso, es una empresa papelera situada en la región occidental de la provincia de Q uebec (C anadá). Esta filial de N oranda Forest, Inc., tiene tres grandes divisiones: una fábrica de pasta, una fábrica de papel prensa y una central de energía hidroeléctrica. La industria papelera es la industria local predominante y la empresa objeto del estudio tiene más de 100 años de antigüedad. La plantilla, de unos 1.000 trabajadores, pertenece a la localidad y es frecuente encontrar familias cuyas sucesivas generaciones han trabajado para esta empresa. La lengua oficial de trabajo es el francés, pero la mayoría de los trabajadores son funcionalmente bilingües, dominando el francés y el inglés. LOS servicios de salud en el trabajo propios de la compañía tienen una larga historia (más de 40 años). Aunque los servicios eran en un principio de naturaleza "tradicional", se ha producido una tendencia creciente hacia el enfoque preventivo durante los últimos años, en línea con la filosofía de la "mejora continua" adoptada en toda la organización M aclaren.

\section{Prestación de servicios de salud en el trabajo}

El médico del trabajo tiene asignadas tareas a nivel de la compañía y de los distintos centros de trabajo y depende directamente del director de salud, seguridad y mejora continua; este último depende a su vez directamente del presidente de la compañía. En los dos principales centros de trabajo (la fábrica de pasta, con 390 trabajadores y la fábrica de papel prensa, con 520), se han contratado a tiempo completo enfermeras especializadas en salud laboral, que dependen directamente del médico en todas las cuestiones relacionadas con la salud. La enfermera que trabaja en la fábrica de papel prensa se encarga también de la división de energía/ forestal (60 trabajadores) y de la sede central (50 trabajadores). Un higienista contratado a tiempo completo para toda la compañía y el personal de seguridad de los tres centros de trabajo completan el equipo de profesionales de la salud y cuestiones afines.

\section{El enfoque preventivo}

La prevención de enfermedades y accidentes corre a cargo de un equipo de salud laboral e higiene y seguridad industriales, que cuenta con el apoyo de todas las partes interesadas. Los métodos utilizados normalmente no diferencian entre prevención dentro y fuera del ámbito de trabajo. Se considera que la prevención refleja una actitud o cualidad del trabajador, una actitud que no se abandona ni se adopta al salir o entrar de la fábrica. O tra característica de este planteamiento es la idea de que la prevención puede experimentar una mejora continua, idea apoyada por la decisión que ha tomado la empresa de auditar sus distintos programas. 
M ejora continua de los programas de prevención

Los programas de salud, higiene industrial, medio ambiente, preparación para emergencias y auditoría de seguridad constituyen una parte esencial del enfoque de la mejora continua. Los resultados de las auditorías, aunque hacen referencia a problemas relacionados con el cumplimiento de las políticas y la legislación, insisten también en la "mejor práctica de gestión", es decir, en las áreas que se considera que pueden experimentar una mejora. De esta forma, los programas de prevención se evalúan repetidamente y se proponen ideas válidas para conseguir los objetivos preventivos de los programas de salud en el trabajo y otros programas relacionados.

\section{Reconocimientos médicos}

Los nuevos trabajadores que se incorporan a la empresa son sometidos a un reconocimiento médico previo a dicha incorporación. Este reconocimiento está diseñado para poner de manifiesto los efectos de la exposición (química, física o biológica) presente en el lugar de trabajo. Conforme a los resultados de la evaluación previa a la incorporación, se formulan recomendaciones indicando la capacidad física para el trabajo y las restricciones específicas del puesto. Estas recomendaciones tienen como finalidad reducir el riesgo de accidentes y enfermedades de los trabajadores. La educación para la salud forma parte del reconocimiento y su propósito es concienciar a los trabajadores de la posible repercusión en el hombre de los factores de riesgo que existen en el lugar del trabajo. Se hace también hincapié en las medidas para reducir los riesgos, especialmente los relacionados con la salud personal.

Los programas vigentes de evaluación de la salud se basan en la exposición a factores de riesgo en el lugar de trabajo. EI programa de conservación de la audición es un buen ejemplo de un programa diseñado para prevenir un efecto sobre la salud. Se hace hincapié en la necesidad de reducir el ruido en la fuente y los trabajadores participan en la evaluación de las prioridades de reducción de ruidos. C ada cinco años, se realiza una evaluación audiométrica. Esta evaluación ofrece una excelente oportunidad para informar a los trabajadores de los síntomas de la pérdida de audición inducida por el ruido y de las medidas preventivas. Por otra parte, ayuda a evaluar la eficacia del programa de control. Se aconseja a los trabajadores que sigan las mismas recomendaciones fuera del trabajo, es decir, que utilicen protectores auditivos y que disminuyan su exposición al ruido.

A simismo, se realizan evaluaciones de la salud relacionadas con riesgos concretos para trabajadores que realizan tareas especiales, como extinción de incendios, labores de rescate, operaciones en instalaciones de tratamiento de aguas, tareas que requieren una exposición excesiva a elevadas temperaturas, manejo de grúas y conducción de vehículos. Igualmente, los trabajadores que utilizan aparatos de protección de las vías respiratorias tienen que someterse a una evaluación para determinar si su estado de salud les permite utilizar dichos aparatos. También se evalúan los riesgos de exposición a los que se ven expuestos los trabajadores de los contratistas.

\section{Información en materia de riesgos para la salud}

Está establecida legalmente la obligación de facilitar a todos los trabajadores información sobre los peligros y riesgos para la salud. Se trata de una amplia tarea que incluye la educación de los trabajadores acerca de los efectos sobre la salud de determinadas sustancias a las que pueden estar expuestos. Entre los ejemplos de estas sustancias figuran una serie de agentes que afectan a las vías respiratorias, ya sean subproductos de las reacciones de otros materiales 0 un peligro por exposición directa. En este sentido, pueden citarse materiales como el dióxido de azufre, el sulfuro de hidrógeno, el cloro, el dióxido de cloro, el monóxido de carbono, los óxidos de nitrógeno y los gases de soldadura. Las Fichas Técnicas de Seguridad (FTS) constituyen la principal fuente de información sobre este tema. Lamentablemente, las fichas de los proveedores no destacan por la calidad de la información que contienen sobre salud y toxicidad y no siempre están disponibles en las dos lenguas oficiales. Esta deficiencia está siendo solventada en uno de los centros de trabajo de la empresa (y lo mismo se hará en los demás) mediante el desarrollo de fichas de información sobre salud que ocupan una única página, elaboradas a partir de una base de datos extensa y reconocida (utilizando un sistema de software para generar FTS disponible en el mercado). Este proyecto fue puesto en marcha, con el apoyo de la empresa, por los miembros de un comité paritario de salud y seguridad, un proceso que no sólo resolvía un problema de comunicación, sino que fomentaba la participación de todas las partes en el lugar de trabajo.

\section{Programas de detección precoz de la hipercolesterolemia}

La empresa ha introducido un programa voluntario de detección precoz de la hipercolesterolemia para los trabajadores de todos los centros de trabajo. Se ofrecen recomendaciones acerca de los efectos sobre la salud de unos niveles elevados de colesterol, el seguimiento médico en los casos indicados (realizado por médicos de familia) y la nutrición. Los centros de trabajo que disponen de servicio de cafetería ofrecen a los trabajadores dietas alternativas. EI personal de salud prepara también folletos sobre nutrición para los trabajadores y sus familias, con el fin de ayudarles a conocer y reducir sus factores de riesgo para la salud.

\section{Programas de detección precoz de la hipertensión arterial}

Conjuntamente con los programas comunitarios anuales sobre la salud cardiovascular ("M es del Corazón"), y de forma periódica, la empresa insiste en que los trabajadores comprueben su presión arterial $y$, en caso necesario, la controlen. Los trabajadores reciben consejos para que conozcan, tanto ellos como, indirectamente, sus familias, los problemas de salud que produce la hipertensión y para que soliciten ayuda a través de los recursos médicos de su comunidad, en caso de que necesiten un seguimiento o tratamiento posteriores.

\section{Programas de asistencia a los empleados y a sus familias}

Los problemas que repercuten en el rendimiento de un trabajador suelen ser el resultado de dificultades ajenas al lugar de trabajo. En muchos casos, se trata de dificultades relacionadas con el entorno social del trabajador, ya sea su familia o la comunidad en la que reside. Existen sistemas de consultas internas y externas. La empresa aplica desde hace más de cinco años un programa de asistencia a los empleados (ampliado recientemente a sus familias). El programa presta todos los años asistencia a casi el $5 \%$ de los trabajadores. Este programa recibe mucha publicidad y se insiste en que los trabajadores acudan a él tan pronto como lo necesiten. Las opiniones manifestadas por los trabajadores indican que el programa ha sido un factor importante para reducir y prevenir el deterioro del rendimiento laboral. Las razones más frecuentes para utilizar el programa de asistencia reflejan problemas familiares y sociales $(90 \%)$ ); los problemas con el alcohol o las drogas representan sólo un pequeño porcentaje del total de los casos atendidos $(10 \%)$.

En el marco del programa de asistencia a los empleados, el centro ha establecido un proceso de información sobre incidentes que entrañen gravedad. Los accidentes graves o con resultado de muerte pueden tener un efecto extremadamente perturbador en los trabajadores. Existe también la posibilidad de que se produzcan importantes consecuencias a largo plazo, no 
sólo para el funcionamiento eficiente de la compañía, sino, en especial, para las personas involucradas en el incidente.

\section{Programas de bienestar}

Una reciente novedad ha sido la decisión de dar los primeros pasos hacia el desarrollo de un programa de "bienestar" dirigido a la prevención de enfermedades, utilizando un enfoque integrado. Este programa tiene varios componentes: capacidad cardiorrespiratoria, condición física, nutrición, abandono del tabaco, gestión del estrés, cuidados para la espalda, prevención del cáncer y abuso de sustancias. Algunos de ellos ya han sido mencionados en este estudio de caso. Sin embargo, otros (no comentados en este artículo) se irán introduciendo de manera progresiva.

\section{Programas especiales de información}

1. VIH/SIDA. La aparición del VIH/SIDA en la población general determinó la necesidad de facilitar información a la comunidad laboral, por dos razones: disipar el miedo al contagio si se conociera un caso entre los trabajadores y asegurar que los trabajadores conocen las medidas preventivas y los hechos "reales" sobre la posibilidad de transmisión. Para alcanzar estos dos objetivos, se organizó un programa de información que se propuso con carácter voluntario a los trabajadores. Asimismo, se facilitaron folletos y documentación en los centros de salud.

2. Comunicación de los resultados de estudios de investigación. A continuación, se ofrece el ejemplo de dos recientes comunicaciones de los resultados de estudios de investigación de la salud en áreas consideradas de especial interés para los trabajadores.

- E studios sobre radiaciones electromagnéticas. Los resultados del estudio sobre radiaciones electromagnéticas realizado por Electricité (EDF), Hydro Quebec, y Ontario Hydro (T hériault 1994), se dieron a conocer a todos los trabajadores expuestos o potencialmente expuestos. Los objetivos de la comunicación eran prevenir un temor injustificado y facilitar a los trabajadores conocimientos de primera mano sobre cuestiones que afectaban a su lugar de trabajo y, potencialmente, a su salud.

- Estudios sobre los efectos de las condiciones de trabajo. Varios estudios realizados sobre la industria papelera hacen referencia a las consecuencias para la salud derivadas de trabajar en esta industria. Los resultados investigados han sido la incidencia del cáncer y la mortalidad producida por el cáncer. Están previstas comunicaciones dirigidas a los trabajadores para garantizar que conocen la existencia de estos estudios y de sus resultados, cuando se disponga de los mismos. Los objetivos son disipar el miedo y asegurar que los trabajadores tienen la oportunidad de conocer los resultados de estudios pertinentes para su profesión.

3. T emas de interés para la comunidad. Como parte de su enfoque preventivo, la empresa ha contactado con médicos de la comunidad y les ha invitado a visitar el lugar de trabajo y a conocer al personal dedicado a la prevención de riesgos laborales. Al mismo tiempo, se han organizado presentaciones sobre asuntos relacionados con la industria papelera. De esta forma, se ha contribuido a que los médicos locales conozcan las condiciones de trabajo, incluidas las exposiciones potencialmente peligrosas, así como los requisitos de los puestos de trabajo de los trabajadores. Como resultado, la compañía y los médicos han trabajado conjuntamente para reducir los posibles efectos perniciosos de lesiones y enfermedades.
Asimismo, se han celebrado reuniones comunitarias para facilitar información sobre cuestiones ambientales relacionadas con las actividades de la empresa y para ofrecer a los ciudadanos locales la oportunidad de formular preguntas sobre temas que les preocupen (entre ellos, los relacionados con la salud). De esta forma, se ha llevado la prevención al ámbito de la comunidad.

4. Futuras tendencias en la prevención. Se están estudiando técnicas de modificación del comportamiento para mejorar aún más el nivel global de salud de los trabajadores y para reducir lesiones y enfermedades. Estas modificaciones no sólo tendrán un efecto positivo en la salud de los trabajadores en el lugar de trabajo, sino también en su entorno familiar.

La participación de los trabajadores en la toma de decisiones sobre la salud y la seguridad es ya una realidad a través de los Comités Paritarios de Salud y Seguridad. Se está realizando un esfuerzo para extender esta colaboración a trabajadores de otras áreas.

\section{Conclusiones}

Los principales elementos del programa de Maclaren son los siguientes:

- compromiso firme de la dirección con la promoción y protección de la salud:

- integración de los programas de salud en el trabajo con los programas centrados en problemas de salud no relacionados con el trabajo;

- participación de todas las partes implicadas en el lugar de trabajo en la planificación, ejecución y evaluación de los programas;

- coordinación con los centros de asistencia sanitaria de la comunidad, así como con proveedores y organismos públicos;

- enfoque progresivo hacia la expansión de los programas;

- auditorías de la eficacia de los programas para identificar problemas que deban ser resueltos y áreas que pueden mejorarse, junto con planes de acción para asegurar actividades apropiadas de seguimiento;

- integración eficaz de todas las actividades relacionadas con el medio ambiente, la salud, la higiene y la seguridad.

Este estudio de caso se ha centrado en programas vigentes dirigidos a mejorar la salud de los trabajadores y a prevenir efectos nocivos y evitables en la salud. Las posibilidades de mejorar este enfoque son infinitas y especialmente acordes con el planteamiento de mejora continua que ha adoptado la empresa.

\section{FUNCION DEL SERVICIO DE SALUD EN EL TRABAJO EN LOS PROGRAMAS DE PREVENCION: ESTUDIO DE CASO}

\section{Wayne N. Burton}

First Chicago Corporation es la sociedad de cartera del First $N$ ational Bank of Chicago, que ocupa el décimoprimer lugar en la lista de los principales bancos de Estados U nidos. La empresa tiene 18.000 trabajadores, el $62 \%$ de los cuales son mujeres. La media de edad es de 36,6 años. La mayoría de los empleados trabajan en los estados de Illinois, Nueva York, Nueva Jersey y Delaware. El grupo tiene unos 100 centros de trabajo, cuyo tamaño varía desde diez hasta más de 4.000 trabajadores. Los seis centros de trabajo de mayor tamaño, todos ellos con más de 
500 trabajadores (que en total representan el $80 \%$ de la plantilla), poseen servicios de salud laboral, administrados por el D epartamento M édico de la sede central en colaboración con los directores locales de recursos humanos. L os centros de trabajo de menor tamaño son atendidos por enfermeras especializadas en salud laboral y participan en los programas a través de materiales impresos, cintas de vídeo, comunicación telefónica y, en el caso de programas especiales, mediante la contratación de proveedores locales.

En 1982, el Departamento M édico y el de Administración de Prestaciones de la empresa establecieron un Programa de Bienestar global, administrado por el Departamento M édico. Sus objetivos incluyen la mejora de la salud general de los trabajadores y de sus familias para reducir en lo posible los costes innecesarios de asistencia sanitaria y prestaciones por incapacidad.

\section{La necesidad de datos sobre asistencia sanitaria}

Para que First $C$ hicago pudiera adquirir cierto grado de control sobre la escalada de sus costes de asistencia sanitaria, los Departamentos M édicos y de Administración de Prestaciones decidieron que se precisaba un conocimiento detallado del origen de dichos gastos. En 1987, se sentían frustrados por la escasa calidad y cantidad de los datos sobre asistencia sanitaria de que disponían para diseñar, ejecutar y evaluar estratégicamente los programas de promoción de la salud. Decidieron contratar a dos consultores informáticos para que les ayudaran a construir una base de datos interna, que se denominó Sistema de Información sobre M edicina y Enfermería del Trabajo (OMNI) (Burton y Hoy 1991). Para mantener la confidencialidad del sistema, éste se encuentra en el $\mathrm{D}$ epartamento M édico.

La base de datos OMNI contiene información sobre la demanda de servicios sanitarios de carácter hospitalario y ambulatorio, prestaciones por incapacidad y de indemnización por accidentes de trabajo, servicios prestados por el programa de asistencia a los empleados (PAE) del Banco, registros del absentismo laboral, participación en programas de bienestar, valoraciones del riesgo para la salud (V R S), medicamentos prescritos y resultados de las pruebas de laboratorio y las exploraciones físicas. Los datos se analizan periódicamente para evaluar el efecto del Programa de Bienestar y para sugerir cualquier cambio que pueda ser conveniente.

\section{Programa de Bienestar de First Chicago}

El Programa de Bienestar incluye una amplia gama de actividades, entre las que figuran las siguientes:

- Educación para la salud. Los trabajadores reciben folletos sobre una gran variedad de temas. EI Banco publica un boletín sobre bienestar (W ellness N ewsletter) que se envía a todos los trabajadores y se complementa con los artículos que aparecen en otras publicaciones del Banco y en los tablones de anuncios de las cafeterías. En los centros de trabajo, se proyectan cintas de vídeo sobre temas relacionados con la salud, y los trabajadores pueden llevarse muchas de ellas para verlas en su propio domicilio. En los principales centros de trabajo, todas las semanas se organizan al mediodía talleres, seminarios y conferencias sobre temas como salud mental, nutrición, violencia, salud de la mujer y enfermedades cardiovasculares.

- Consejos individuales. Los servicios de salud de los empleados cuentan con enfermeras diplomadas que responden a las preguntas de los trabajadores y les ofrecen consejos individuales, ya sea en persona o por teléfono en el caso de los lugares de trabajo más pequeños.
- Valoración del riesgo para la salud. En los centros de trabajo provistos de un servicio de salud laboral, la mayoría de los nuevos trabajadores, y periódicamente todos los demás, pueden someterse voluntariamente a una valoración del riesgo para la salud realizada por ordenador. Esta valoración también se ofrece periódicamente a los trabajadores de algunos centros satélite del Banco.

- Reconocimientos médicos periódicos. Estas exploraciones se ofrecen con carácter voluntario al personal directivo. En Illinois, las trabajadoras pueden someterse si lo desean a una exploración médica anual que incluye un frotis cervical "Papanicolau" y una exploración de mamas. En los centros de trabajo dotados de un servicio de salud laboral, se realizan cribados para la detección de hipertensión, diabetes, cáncer de mama y niveles elevados de colesterol.

- Préubilación. Todos los trabajadores pueden acceder a reconocimientos médicos de prejubilación cada tres años a partir de los 55 años y hasta su jubilación. El Banco organiza un seminario de prejubilación que incluye sesiones sobre cómo envejecer con buena salud.

- Programas de promoción de la salud. El Banco negocia tarifas reducidas con los proveedores locales para los trabajadores que participan en los programas de mantenimiento de la capacidad física para el trabajo. Asimismo, en los centros de trabajo se ofrecen, con carácter gratuito, programas sobre educación prenatal, abandono del tabaco, educación del estrés, pérdida de peso, bienestar infantil, reducción de los factores de riesgo cardiovascular y educación en relación con el cáncer de piel y la autoexploración de las mamas.

- Cursos de reanimación cardiopulmonar (RCP) y primeros auxilios. Se organizan cursos de RCP para todo el personal de seguridad y los trabajadores designados. Asimismo, se ofrecen clases sobre RCP y primeros auxilios en niños.

- Programas de vacunación. La vacuna de la H epatitis B se ofrece a todos los trabajadores del servicio de salud que puedan entrar en contacto con sangre o fluidos biológicos. Las vacunas que se proporcionan al personal que viaja al extranjero, incluidas las del tétanos y la difteria, dependen del riesgo de infección de las zonas que visiten. Se les explica a los trabajadores la utilidad de la vacuna contra la gripe y se les remite a sus respectivos médicos de atención primaria 0 al departamento local de salud para su vacunación.

\section{Programa de salud para la mujer}

En 1982, el First National Bank of Chicago observó que más del $25 \%$ de los costes de la asistencia sanitaria de los trabajadores y de sus familias estaban relacionados con la salud de la mujer. Por otra parte, más del $40 \%$ de todas las ausencias por incapacidad temporal de los trabajadores (es decir, inferiores a seis meses de duración) se debían a la gestación. Para controlar estos costes y ayudar a asegurar una asistencia sanitaria de alta calidad y bajo coste, se desarrolló un programa global orientado a la prevención y a la detección y control precoces de los problemas de salud de la mujer (Burton, Erikson y Briones 1991). En la actualidad, el programa incluye los siguientes servicios:

- Programa obstétrico y ginecológico en el lugar de trabajo. Desde 1985, un ginecólogo procedente de un importante hospital universitario trabaja a tiempo parcial en la sede central del Banco en Chicago. Periódicamente, se desplaza a otros dos centros de trabajo, y está previsto introducir el programa en otro centro más. EI D epartamento M édico de la sede central ofrece, con carácter voluntario, exploraciones médicas anuales a todas las trabajadoras acogidas al plan de prestaciones con autoaseguramiento del Banco (en el caso de los trabajadores que han optado por una organización de mantenimiento de la salud 
(H M O ), los médicos de la H M O pueden realizar estas exploraciones). La exploración incluye un historial médico, exploración física general y ginecológica, pruebas de laboratorio, como frotis cervical "Papanicolau" para la detección del cáncer cervical y otras pruebas indicadas según el caso.

Además de realizar exploraciones y consultas, el ginecólogo organiza también seminarios sobre problemas de salud de la mujer. Este programa ginecológico en el lugar de trabajo ha demostrado ser una manera práctica y rentable de promover la prevención de los problemas de salud.

- E ducación preconceptiva y prenatal. Estados U nidos ocupa el puesto vigésimocuarto en la lista de mortalidad infantil de los países desarrollados. En First Chicago, las demandas relacionadas con la gestación representaron en torno al $19 \%$ de la totalidad de los costes de asistencia sanitaria pagados en 1992 por el plan médico de los trabajadores y personas a su cargo. Para hacer frente a este reto, el Banco, en cooperación con $M$ arch of Dimes, empezó a ofrecer en 1987 clases impartidas por una enfermera especializada en salud laboral, en las que se tratan temas como atención prenatal, formas de vida sanas, una nutrición adecuada e indicaciones de cesárea. Estas clases se ofrecen durante la jornada laboral y en el propio lugar de trabajo. Al inscribirse en el programa, las trabajadoras rellenan un cuestionario sobre valoración del riesgo para la salud relacionado con la gestación, que se analiza por ordenador. Tanto las mujeres como sus ginecólogos reciben un informe en el que se destacan los posibles factores de riesgo para complicaciones de la gestación, como estilos de vida inadecuados, malformaciones congénitas y problemas médicos.

Para fomentar la participación en el programa, las trabajadoras o los cónyuges que hayan asistido a estas clases antes de la decimoséptima semana de embarazo tienen derecho a una reducción de 400 dólares en los costes médicos aplazados del recién nacido.

Los resultados preliminares del programa de educación prenatal que se ofrece a los trabajadores del área de Chicago (Illinois) son los siguientes:

- El porcentaje de cesáreas fue de un $19 \%$ en las trabajadoras que participaron en el programa de educación prenatal en el lugar de trabajo, frente a un $28 \%$ entre las trabajadoras que no participón prenatal frente a 9.986 dólares en las trabajadoras que no asistieron a las mismas.

- El absentismo laboral relacionado con la gestación (incapacidad temporal) se redujo ligeramente en las trabajadoras que particiaron en el mismo. La tasa media de cesáreas en la región es de aproximadamente el $24 \%$.

- El coste medio del parto en el área de Chicago (I llinois) fue de 7.793 dólares en las trabajadoras que asistieron a las clases de educaciparon en el programa de educación prenatal.

- Programa de lactancia. EI Departamento M édico ofrece una habitación privada y un frigorífico para guardar la leche materna a las trabajadoras que desean dar de mamar a sus hijos. La mayoría de los servicios de salud laboral están equipados con sacaleches eléctricos y ofrecen los materiales necesarios para la lactancia sin coste alguno para las trabajadoras acogidas al plan médico del Banco (o a una H M O ).

- M amografías. Desde 1991, los servicios de salud de Estados U nidos ofrecen con carácter gratuito mamografías para la detección del cáncer de mama. U nidades móviles para la realización de mamografías pertenecientes a proveedores locales debidamente acreditados se desplazan una 0 varias veces al año, dependiendo de la necesidad, a los seis centros de trabajo provistos de servicio de salud laboral. A proximadamente el $90 \%$ de las trabajadoras que pueden participar en este programa se encuentran a una distancia de 30 minutos en coche de un centro en el que se practican mamografías. Además de las trabajadoras, también pueden participar las esposas de los trabajadores y los jubilados.

Las directrices de la American Cancer Society para la exploración mamográfica son las siguientes: en la actualidad, se recomienda la exploración mamográfica a partir de los 40 años, cada uno o dos años entre los 40 y los 49 años, y todos los años a partir de los 50. Las trabajadoras con mamografías anormales reciben un seguimiento tanto escrito como telefónico y se envía una copia a su médico personal. Desde 1991 (hasta 1994, fecha de este informe), se han realizado más de 3.000 mamografías y se han detectado seis casos de cáncer de mama en los primeros estadios.

\section{Programa de asistencia a los empleados y servicios de salud mental}

En 1979, el Banco introdujo un programa de asistencia a los empleados (PAE) que presta servicios de consulta, asesoramiento, consulta y seguimiento para una gran variedad de problemas personales, como trastornos emocionales, conflictos interpersonales, alcoholismo, otras drogadicciones y trastornos adictivos en general. Los trabajadores acuden a estos servicios por iniciativa propia o son remitidos por un supervisor que detecta dificultades en su rendimiento 0 en sus relaciones interpersonales en el trabajo. EI PAE organiza también seminarios sobre una serie de temas, como el control del estrés, los problemas de violencia o la paternidad responsable. El programa, que es una unidad del D epartamento M édico, cuenta ahora con seis psicólogos clínicos a tiempo total y parcial. Estos psicólogos trabajan en cada uno de los seis departamentos médicos y, además, se desplazan a los centros satélite del banco.

Asimismo, el PAE trata casos de incapacidad temporal por motivos psiquiátricos (hasta un máximo de seis meses de ausencia continuada). El objetivo del PAE es garantizar la prestación de una asistencia adecuada a los trabajadores que reciben indemnizaciones por incapacidad por motivos psiquiátricos.

En 1984, se inició un programa global para prestar servicios de salud mental de calidad y eficaces con relación al coste a los trabajadores y a las personas a su cargo (Burton y cols. 1989; Burton y Conti 1991). El programa incluye cuatro componentes:

- PAE para prevención e intervención precoz;

- análisis de la posible necesidad de hospitalización psiquiátrica;

- manejo de casos de incapacidad mental transitoria por el personal del PAE;

- red de profesionales de la salud mental que prestan servicios ambulatorios.

A pesar de la mejora de las prestaciones de los seguros de salud mental, que reembolsan el $85 \%$ (en lugar del $50 \%$ ) de los costes de las alternativas a la hospitalización (por ejemplo, programas de hospitalización parcial y programas ambulatorios intensivos), los costes de los servicios de salud mental de First Chicago se han reducido desde casi un $15 \%$ de los costes médicos totales en 1983 a menos de un $9 \%$ en 1992.

\section{Conclusión}

$\mathrm{H}$ ace más de diez años, First Chicago inició un programa global de bienestar con el lema "First Chicago invierte en su salud". EI Programa de Bienestar es una actividad conjunta del 
Departamento M édico y del de Administración de Prestaciones del banco. Se considera que ha mejorado la salud y la productividad de los trabajadores y que ha reducido costes innecesarios de asistencia sanitaria, tanto para los trabajadores como para el banco. En 1993, el Programa de Bienestar de First Chicago recibió el Premio Nacional de Salud C. Everett K oop, bautizado en honor a este antiguo titular del departamento de sanidad pública de Estados U nidos.

\section{- Promocion de LA SALUd EN EL LUGAR DE TRABAJO EN JAPON}

Toshiteru O kubo

La promoción de la salud en el lugar de trabajo ha mejorado sustancialmente en Japón desde que se modificó la Ley de salud y seguridad en el trabajo, en 1988, fecha en que se ordenó a las empresas que introdujeran programas de promoción de la salud (PPS) en el lugar de trabajo. Aunque la ley modificada no prevé sanciones, el M inisterio de Trabajo empezó entonces a estimular activamente a las empresas para que establecieran programas de promoción de la salud. En este contexto, el M inisterio ha prestado apoyo a iniciativas de formación y de educación encaminadas a incrementar el total de especialistas cualificados para trabajar en esos programas. Entre los especialistas figuran médicos promotores de la salud en el trabajo (M PST), formadores en materia de asistencia sanitaria (FAS), monitores de asistencia sanitaria (MAS), consejeros en materia de salud mental (CSM ), consejeros en materia de dietética (CD) y consejeros en materia de salud en el trabajo (CST). Aunque se fomenta en las empresas la creación de organizaciones internas de promoción de la salud, pueden optar también por recurrir a servicios externos, en especial si la empresa es pequeña y no puede permitirse ofrecer un programa interno; el M inisterio de Trabajo facilita una serie de directrices para el funcionamiento de esas entidades responsables de la prestación servicios. El programa de promoción de la salud recientemente diseñado y de carácter obligatorio, autorizado por el gobierno japonés, se ha denominado plan de "promoción total de la salud" (PTS).

\section{Modelo recomendado de plan de promoción de la salud}

Si una empresa es lo bastante grande para ofrecer los distintos especialistas enumerados, se recomienda a la empresa que organice un comité integrado por esos especialistas, al que se encomendarán las tareas de planificación y ejecución de un programa de promoción de la salud. Ese comité deberá, en primer lugar, analizar el estado de salud de los trabajadores y determinar las máximas prioridades que deberán guiar la planificación efectiva de un programa apropiado de promoción de la salud. El programa debe ser de carácter global, basado en un doble enfoque, de grupo e individual.

Por lo que respecta al enfoque de grupo, pueden ofrecerse diferentes clases de educación sanitaria, por ejemplo, sobre dietética, forma de vida, gestión del estrés y pausas. Se recomiendan actividades realizadas en grupo además de clases teóricas, para estimular la participación práctica de los trabajadores, a fin de que la información facilitada en clase dé lugar a una modificación del comportamiento.

Como primera medida del enfoque individual, los M PST deben realizar un reconocimiento médico. EI M PST entrega entonces un plan a cada trabajador, basado en los resultados del reconocimiento y en la información facilitada por el CST o el CSM (o por ambos). De conformidad con ese plan, los especialistas pertinentes facilitarán las instrucciones o el consejo necesarios. EI FAS diseñará un programa personal de formación física basado en el plan. EI M AS ofrecerá instrucciones prácticas a cada trabajador en el gimnasio. En caso necesario, un CD ofrecerá enseñanza personal en materia de dietética y el CSM 0 el CST se reunirán con el trabajador para facilitarle consejos específicos. EI M PST deberá evaluar periódicamente los resultados de los programas individuales para que puedan mejorarse progresivamente.

\section{Formación de especialistas}

EI M inisterio ha designado a la Asociación de Salud y Seguridad en el Trabajo (ASST) de Japón, organización semipública que promociona actividades voluntarias de salud y seguridad en el sector privado, para que sea el organismo oficial encargado de dirigir los cursos de formación de especialistas en promoción de la salud. Llegar a ser uno de los seis especialistas mencionados requiere determinados conocimientos y la realización de un curso para cada especialidad. EI M PST, por ejemplo, debe tener la autorización nacional para el ejercicio de la medicina y debe haber realizado un curso de 22 horas sobre reconocimientos médicos en el que se basará la planificación del PPS. EI curso dirigido a los FAS dura 139 horas, es el más largo de los seis cursos y, como requisito previo para participar en él, se exige una licenciatura en ciencias de la salud o en educación física. Las personas que tengan tres 0 más años de experiencia práctica como MAS también pueden optar a participar en el curso. El MAS es el monitor encargado de facilitar enseñanza práctica a los trabajadores, de conformidad con las prescripciones elaboradas por el FAS. Para ser MAS se requiere una edad mínima de 18 años y haber realizado el curso pertinente, cuya duración es de 28,5 horas. Para poder seguir el curso de CSM, se requiere alguno de los siguientes títulos o experiencia: una licenciatura en psicología, asistencia social o ciencias de la salud, o un título de enfermería en salud pública o una diplomatura en enfermería. Para ser FAS, debe cumplirse alguno de los requisitos siguientes: haber realizado el Curso a Distancia sobre Salud organizado por la ASST, poseer una cualificación como supervisor sanitario o cinco o más años de experiencia como consejero. La duración del curso de CSM es de 16,5 horas. Sólo los expertos en nutrición cualificados pueden seguir el curso para CD, cuya duración es de 16 horas. El personal de enfermería cualificado en salud pública y el personal de enfermería con tres o más años de experiencia práctica en tareas de consejo puede seguir el curso para CST, cuya duración es de 20,5 horas. Se espera que el CST sea un promotor global del programa de promoción de la salud en el lugar de trabajo. A finales de diciembre de 1996, el total de especialistas registrados en la ASST, previa realización de los cursos asignados, era el siguiente: $\mathrm{MPST}=2.895$; $\mathrm{FAS}=2.800$; MAS $=11.364 ; C S M=8.307 ; C D=3.888 ; C S T=5.233$.

\section{Entidades responsables de la prestación de servicios}

Existen dos tipos de entidades responsables de la prestación de servicios de promoción de la salud aprobadas por la ASST; está a disposición del público una lista de las entidades registradas. Las entidades del primer tipo están autorizadas para realizar reconocimientos médicos, a fin de que el M PST pueda facilitar un plan a cada trabajador. Estas entidades pueden prestar un servicio global de promoción de la salud. Las entidades del segundo tipo únicamente están autorizadas para prestar un servicio de formación física, de conformidad con un programa elaborado por un FAS. A finales de marzo de 1997, el número de entidades que reunían las características del primer tipo era de 72 y el total de entidades del segundo tipo era de 295. 


\section{Apoyo financiero del Ministerio}

El M inisterio de Trabajo dispone de un presupuesto para apoyar los cursos de formación que ofrece la ASST, la aplicación de nuevos programas en las empresas y la adquisición, por parte de las entidades responsables de la prestación de servicios, de equipo para la realización de ejercicios físicos. Cuando una empresa pone en marcha un nuevo programa, el gasto consiguiente cuenta con el apoyo del M inisterio, a través de la ASST, durante un período máximo de tres años. La cantidad asignada depende del tamaño; si el número de trabajadores de una empresa es de menos de 300, dos terceras partes del gasto total corren a cargo del M inisterio; en el caso de las empresas con más de 300 trabajadores, el apoyo financiero cubre un tercio del total.

\section{Conclusión}

Aún es demasiado pronto para hacer una evaluación fiable de la eficacia del proyecto PTS, pero prevalece la opinión general de que debe formar parte de todo programa global de salud en el trabajo. La situación general de los servicios japoneses de salud en el trabajo se caracteriza aún por su mejora progresiva. En los lugares de trabajo avanzados, es decir, sobre todo en las grandes empresas, el nivel de desarrollo del PTS permite evaluar ya el grado de promoción de la salud de los trabajadores alcanzado y la mejora de la productividad. En las empresas más pequeñas, sin embargo, aunque la mayor parte del gasto ligado a la aplicación del PT S puede sufragarse con cargo a fondos públicos, la precariedad de los sistemas de asistencia sanitaria vigentes suele dificultar la introducción de actividades adicionales de mantenimiento de la salud.

\section{- Evaluacion del Riesgo para la SALUD}

Leon J. Warshaw

\section{Introducción}

En los dos últimos decenios, la evaluación de riesgos para la salud (ERS), también denominada evaluación de peligros para la salud, ha incrementado su popularidad, especialmente en Estados Unidos como instrumento para promover la sensibilización respecto a la salud y motivar cambios en el comportamiento. También se utiliza como una introducción al reconocimiento médico periódico o como sustituto del mismo y, cuando se aplica a un grupo de individuos, sirve de base para identificar los objetivos de una educación sanitaria o de un programa de promoción de la salud. Se basa en el siguiente planteamiento:

- Los individuos manifiestamente sanos y asintomáticos pueden hallarse en peligro de contraer una enfermedad que puede causar morbilidad en el futuro y conducir a la muerte prematura.

- Es posible identificar los factores que inducen dicho riesgo.

- Algunos de los factores de riesgo pueden eliminarse o controlarse para evitar 0 atenuar el proceso patológico y prevenir 0 retrasar la morbilidad y la mortalidad.

EI desarrollo de la ERS en los decenios de 1940 y 1950 se atribuye principalmente al Dr. Lewis C. R obbins, que trabajó en el estudio prospectivo de las cardiopatías de Framinghan y posteriormente en el $\mathrm{N}$ ational Cancer Institute (Beery y cols. 1986). En el decenio de 1960 se desarrollaron nuevos modelos de ER S y 1970, R obbins y H all realizaron el trabajo de referencia, en el cual se definía la técnica, se describían los instrumentos de investigación y los cálculos de riesgo y se perfilaba la estrategia de retroinformación al paciente (Robbins y H all 1970).

EI interés por la ERS y por la promoción de la salud en general se vio estimulado por la consciencia cada vez mayor de la importancia de controlar los factores de riesgo como elemento básico para promocionar la salud, el uso generalizado de los ordenadores para reunir datos y analizarlos y, sobre todo en Estados U nidos, la preocupación acerca de los costes cada vez mayores de la asistencia sanitaria, con la esperanza de que la prevención de las enfermedades pudiera frenar esta espiral ascendente. En 1982, Edward Wagner y sus colegas de la Universidad de Carolina del Norte habían identificado 217 proveedores públicos y privados de ER S en Estados U nidos (Wagner y cols. 1982). D esde entonces, muchos de estos proveedores han desaparecido de escena, pero han sido sustituidos, al menos en cierta medida, por otros que se han incorporado a esta parcela del mercado. De acuerdo con un informe de 1989 sobre un estudio de una muestra aleatoria de lugares de trabajo de Estados Unidos, en el $29,5 \%$ se han realizado actividades de ERS; en los lugares de trabajo que contaban con más de 750 trabajadores, esta cifra alcanzó el $66 \%$ (Fielding 1989). EI uso de la ERS en otros países está considerablemente más retrasado.

\section{¿Qué es la ERS?}

En este artículo, la ERS se define como una herramienta para la evaluación de riesgos de la salud, que consta de tres elementos esenciales:

1. Cuestionario con información sobre el perfil demográfico del individuo, su historial médico, su historia familiar, sus hábitos personales y su forma de vida. Esta información se complementa normalmente con mediciones biomédicas, como altura, peso, presión arterial, grosor del pliegue cutáneo, análisis de orina, nivel de colesterol en sangre y otras pruebas de laboratorio, cuyos resultados pueden ser aportados por el individuo u obtenidos como parte del proceso.

2. Cálculo cuantitativo del riesgo futuro de fallecimiento del individuo o de otros resultados adversos debidos a causas específicas, que se obtendrá mediante la comparación de las respuestas del individuo con datos epidemiológicos, estadísticas de mortalidad nacionales y cálculos actuariales. El propio individuo realiza la puntuación de algunos cuestionarios: se asignan puntos a la respuesta de cada pregunta y éstos se suman para obtener la puntuación del riesgo. M ediante un programa informático adecuado, es posible introducir las respuestas en un ordenador para calcular la puntuación automáticamente, aunque en la mayoría de los casos los cuestionarios cumplimentados se envían a una sede central para su procesamiento por lotes y los resultados individuales se envían por correo o se entregan a los participantes.

3. Información posterior al individuo, con propuestas de cambios en su forma de vida y otras acciones que mejorarían su bienestar y reducirían el riesgo de enfermedad o de muerte prematura.

En un principio, la estimación total del riesgo se presentaba en forma de un único número que servía de referencia para lograr su reducción a un valor "normal" o incluso inferior al normal (en comparación con la población en general), mediante la puesta en práctica de los cambios de comportamiento propuestos. Para facilitar la interpretación de los resultados, actualmente el riesgo se expresa a veces como una "edad de salud" o "edad de riesgo" que se ha de comparar con la edad cronológica del individuo para obtener una "edad alcanzable" como meta de las intervenciones. Por ejemplo, un informe podría decir así: "Su edad actual es de 35 años, pero tiene la 
esperanza de vida de una persona de 42 años. Si sigue nuestras recomendaciones, usted podría reducir su edad de riesgo a 32 años, con lo que prolongaría su vida 10 años más".

En lugar de comparar el estado de salud del individuo con la "norma" de la población general, algunas ERS ofrecen una puntuación "de salud óptima": la mejor puntuación que podría obtenerse siguiendo todas las recomendaciones. Este enfoque parece resultar especialmente útil para encaminar a los jóvenes, que puede que todavía no hayan acumulado riesgos importantes para la salud, hacia una forma de vida más satisfactoria.

El uso de una "edad de riesgo" o de un único número para representar el estado global de riesgo del individuo puede resultar engañoso: un factor de riesgo importante puede quedar estadísticamente eclipsado por "buenas" puntuaciones en la mayor parte de las demás áreas y crear una falsa sensación de seguridad. Por ejemplo, una persona con una presión arterial normal, un nivel bajo de colesterol, una buena historia familiar, que practique ejercicio y utilice el cinturón de seguridad puede obtener una buena puntuación de riesgo a pesar de ser fumador. Esto sugiere la conveniencia de centrarse en cada uno de los elementos de riesgo "superiores al promedio", en lugar de confiar en una puntuación global.

No se ha de confundir la ERS con los cuestionarios sobre el estado de salud que se utilizan para clasificar a los pacientes para tratamientos concretos o para evaluar los resultados de los mismos, ni tampoco con los diversos instrumentos que se emplean para evaluar el grado de incapacidad, la salud mental, la alteración de la salud o el funcionamiento social, a pesar de que este tipo de escalas se incorporen a veces en algunas ER S.

\section{Cuestionario sobre ERS}

Aunque la ERS a veces se ofrece como parte de un reconocimiento médico periódico previo al empleo o a la incorporación, normalmente se ofrece independientemente, como ejercicio voluntario. Se utilizan diversos cuestionarios de ERS. Algunos se limitan a preguntas básicas que se utilizan directamente para calcular la edad de riesgo. En otros, estas preguntas básicas se entremezclan con aspectos médicos y de comportamiento adicionales: historial médico más extenso; percepciones de estrés; escalas para medir la ansiedad, la depresión y otras trastornos psicológicos; nutrición; uso de servicios preventivos; estilos de vida, e incluso relaciones interpersonales. Algunos proveedores permiten que los compradores añadan preguntas al cuestionario, si bien las respuestas a éstas no se incorporan normalmente a los cómputos de riesgo para la salud.

A ctualmente, casi todas las ER S utilizan impresos con casillas que han de marcarse o rellenarse a lápiz para su introducción en un ordenador manualmente o mediante un escáner óptico. Por lo general, los cuestionarios cumplimentados se recogen y se procesan por lotes, bien sea internamente o por el proveedor de la ERS. A fin de fomentar la confianza en la confidencialidad del programa, a veces los cuestionarios cumplimentados se envían directamente al proveedor para su procesamiento, y los informes se envían por correo al domicilio del participante. En algunos programas, tan solo se envían los informes a los participantes con resultados "normales", mientras que los que requieren algún tipo de intervención son citados para mantener una entrevista con personal formado que interpreta los resultados y señala las intervenciones correctoras adecuadas. EI uso generalizado de los ordenadores personales ha llevado al desarrollo de programas de software interactivos con los que se introducen directamente las respuestas. De este modo el cálculo y la retroinformación sobre los resultados son inmediatos y es más rápida la formulación de recomendaciones para la reducción de riesgos. Este enfoque permite que sea el individuo quien tome la decisión de solicitar ayuda del personal cuando necesita algún tipo de aclaración sobre los resultados y sus implicaciones. Excepto cuando el programa de software permite el almacenamiento de los datos o su transferencia a una base de datos centralizada, este enfoque no proporciona información para un seguimiento sistemático y excluye el desarrollo de informes consolidados.

\section{Gestión del programa}

$L$ a responsabilidad de la gestión del programa de ERS suele asignarse a los respectivos directores del servicio de salud laboral, del programa de bienestar 0 , con menor frecuencia, del programa de asistencia a los empleados. Sin embargo, es muy habitual que sea el departamento de personal o de recursos humanos el que organice y supervise el programa. En algunos casos se crea un comité de asesoramiento, en el que suelen participar los trabajadores 0 los sindicatos. Los programas que se incorporan a la rutina operativa de la organización parecen funcionar con menos problemas que los que son de alguna manera proyectos aislados (Beery y cols. 1986). El lugar de la organización donde está situado el programa puede influir en su aceptación por parte de los trabajadores, especialmente cuando entra en juego la confidencialidad de la información relativa a la salud personal. A fin de evitar este temor, normalmente se envía el cuestionario cumplimentado en sobre sellado al proveedor, quien procesa los datos y envía el informe individual (también en sobre sellado) directamente al domicilio del participante.

Para potenciar la participación en el programa, la mayoría de las organizaciones lo dan a conocer mediante folletos, pósters y artículos en las publicaciones de las empresas. 0 casionalmente se ofrecen incentivos (camisetas, libros y otros regalos) a cambio de terminar el ejercicio, y se conceden incluso premios económicos (reducción de la aportación del trabajador a las primas del seguro médico) para quienes logran reducir el exceso de riesgo. En algunas organizaciones se preparan reuniones en las que se informa a los trabajadores acerca de los objetivos y procedimientos del programa y se les explica cómo rellenar el cuestionario. Sin embargo, otras veces simplemente se distribuye el cuestionario con instrucciones por escrito para cada trabajador $(y$, en caso de que estuvieran incluidos en el programa, para cada familiar a su cargo). En algunos casos, se distribuyen uno 0 más recordatorios para cumplimentar y enviar el cuestionario, con el fin de aumentar el índice de participación. En cualquier caso, es importante designar a una persona responsable, bien sea en la organización o en la estructura del proveedor de la ER S, a quien se pueda formular preguntas personalmente 0 por teléfono. Es preciso señalar que, aunque el trabajador no llegue a remitir el cuestionario cumplimentado, el simple hecho de haberlo leído puede consolidar la información proveniente de otras fuentes y promover un comportamiento más responsable respecto a la salud en el futuro.

M uchos de los cuestionarios incluyen preguntas sobre datos clínicos que los participantes no pueden responder. En algunas organizaciones, el personal del programa lleva a cabo mediciones de altura, peso, presión arterial y grosor del pliegue cutáneo y toma muestras de sangre y de orina para análisis de laboratorio. Posteriormente, los resultados se incorporan a las respuestas del cuestionario; en los casos en los que no se introducen estos datos, el programa de tratamiento informático puede insertar automáticamente las cifras que representan los "valores normales" en personas de la misma edad y sexo.

El tiempo de retorno (el tiempo que transcurre desde que se cumplimenta el cuestionario hasta que se reciben los resultados) puede ser un factor importante en el valor del programa. La mayoría de los proveedores se comprometen a entregar los resultados en un período que oscila entre 10 días y dos semanas, aunque el procesamiento por lotes y los retrasos del correo 
pueden prolongar este plazo. Para cuando se reciben los resultados, es posible que algunos participantes hayan olvidado cuáles fueron sus respuestas y se hayan desvinculado del proceso; para obviar esta posibilidad, algunos proveedores devuelven el cuestionario cumplimentado 0 incluyen en el informe las respuestas clave del individuo.

\section{Informes que se remiten a los participantes}

Los informes pueden variar, desde una exposición de los resultados y recomendaciones de una extensión de una página, hasta un folleto de más de 20 páginas, repleto de gráficos e ilustraciones a todo color y extensas explicaciones acerca de la relevancia de los resultados y la importancia de las recomendaciones. Algunos informes se basan casi en su totalidad en una información general preimpresa, mientras que otros son informes completamente personalizados realizados por ordenador. En algunos programas, en los que el ejercicio ya se ha hecho anteriormente y se han conservado los datos anteriores, se proporcionan informes comparativos de los resultados actuales con los registrados previamente; esto puede proporcionar un sentimiento de gratificación que sirva de motivación para efectuar cambios de comportamiento.

Un aspecto clave para el éxito del programa es la disponibilidad de un profesional de la salud o de un asesor cualificado, que les explicará la importancia de los descubrimientos y les ofrecerá un programa individualizado de intervenciones. EI consejo especializado de este tipo puede ser extremadamente útil para calmar ansiedades innecesarias por interpretaciones erróneas de los resultados, y para ayudar a los individuos a establecer prioridades en los cambios de comportamiento e informarles sobre los recursos a su alcance.

\section{Informes que se remiten a las empresas}

En la mayoría de los programas, los informes individuales se resumen en un informe consolidado que se envía a la empresa o a la organización patrocinadora. Este tipo de informes tabulan la demografía de los participantes, a veces por localización geográfica y tipo de empleo, y analizan la gama y los niveles de riesgos para la salud que hayan sido detectados. Diversos proveedores de ERS incluyen cálculos estimativos acerca del aumento de los costes de asistencia sanitaria en los que es probable que incurran los trabajadores de alto riesgo. Estos datos son muy valiosos a la hora de designar elementos para el programa de bienestar y de promoción de la salud de la organización y a la hora de estimular cambios en la estructura del empleo, en el entorno del lugar de trabajo y en la cultura corporativa, que promoverán la salud y el bienestar de la plantilla.

$\mathrm{H}$ ay que señalar que la validez del informe consolidado depende del número de trabajadores y del índice de participación en el programa de ERS. Las personas que participan en estos programas suelen estar muy sensibilizadas respecto a su salud y, cuando su número es relativamente pequeño, puede que sus puntuaciones no reflejen con exactitud las características de la totalidad de la plantilla.

\section{Seguimiento y evaluación}

La eficacia del programa de ER S puede verse potenciada por un sistema de seguimiento que recuerde a los participantes las recomendaciones y les anime a cumplirlas. Esto puede hacerse mediante memorandos dirigidos personalmente al participante; consejos personales de un médico, AT S o educador de la salud; 0 mediante reuniones en grupo. Este tipo de seguimiento resulta especialmente importante en el caso de individuos de alto riesgo.

La evaluación del programa ERS debería iniciarse con una tabulación del nivel de participación, analizado preferiblemente en función de características tales como edad, sexo, localización geográfica o unidad de trabajo, puesto de trabajo y nivel educativo. Estos datos pueden servir para identificar diferencias en la aceptación del programa y realizar cambios en la forma de presentarlo o de darlo a conocer.

U n aumento de la participación en las secciones del programa de bienestar que fomenten la reducción de los riesgos (por ejemplo, programa de capacidad física para el trabajo, cursos para dejar de fumar o seminarios de gestión del estrés) puede indicar que se están teniendo en cuenta las recomendaciones de la ERS. No obstante, en último término, la evaluación tendrá que incluir la determinación de cambios en el nivel de riesgo. Para ello podría ser necesario analizar los resultados del seguimiento con los individuos de alto riesgo o la repetición del programa transcurrido un plazo de tiempo adecuado. Estos datos pueden verse reforzados por la correlación con otros, como la utilización de prestaciones sanitarias, el absentismo o las mediciones de productividad. Sin embargo, habrá que tener en cuenta también otros factores que pueden ser significativos (por ejemplo, el sesgo por el tipo de persona que vuelve a hacerse las pruebas, la regresión a la media y las tendencias seculares); una evaluación realmente científica del impacto del programa requerirá un ensayo clínico prospectivo aleatorio (Schoenbach 1987; DeFriese y Fielding 1990).

\section{Validez y utilidad de la ERS}

L os factores que pueden afectar la exactitud y validez de la ER S han sido examinados en otro lugar (Beery y cols. 1986; Schoenback 1987; DeFriese y Fielding 1990), y aquí nos limitaremos a enumerarlos. Representan una lista de comprobación para que los responsables de la toma de decisiones en los lugares de trabajo evalúen diferentes instrumentos, e incluyen los siguientes puntos:

- precisión y coherencia de la información proporcionada por el trabajador:

- integridad y calidad de los datos epidemiológicos y actuariales en los que se basan los cálculos del riesgo;

- limitaciones de los métodos estadísticos para el cálculo del riesgo, teniendo en cuenta la combinación de los factores de riesgo para diferentes problemas en una puntuación consolidada única y las distorsiones producidas al sustituir los "valores medios", en las respuestas sin cumplimentar 0 en las mediciones no efectuadas:

- fiabilidad del cálculo de los beneficios de la reducción del riesgo;

- aplicabilidad de los mismos cálculos de mortalidad a jóvenes con tasas de mortalidad bajas y a individuos cuyo principal factor de mortalidad sea la edad; también debe considerarse desde una perspectiva crítica la validez de la ERS cuando se aplica a poblaciones diferentes de aquellas sobre las que se ha hecho la mayor parte de la investigación, como mujeres, minorías o personas con orígenes culturales y educativos diferentes.

También han surgido preguntas con respecto a la utilidad de la ERS según consideraciones como las siguientes:

1. EI principal aspecto en el que se centra la ERS es la esperanza de vida. $\mathrm{H}$ asta hace poco tiempo, se ha prestado poca o ninguna atención a factores que influyen principalmente en la morbilidad, producto de afecciones que normalmente no son fatales pero que pueden tener un fuerte impacto sobre el bienestar, la productividad y los costes relacionados con la salud (por ejemplo, artritis, transtornos mentales, y efectos secundarios de tratamientos destinados a reducir riesgos específicos). El problema reside en la falta de buenas bases de datos sobre la morbilidad de la población general, y más de subgrupos definidos por su edad, sexo, raza u origen étnico. 
2. Existe preocupación por la ansiedad que generan los informes de estado de alto riesgo en los que se reflejan factores que el individuo no puede modificar, como la edad, los condicionamientos hereditarios o el historial médico anterior; así como por la posibilidad de que los informes de estado "normal" o de bajo riesgo pueden hacer que el individuo no tenga en cuenta síntomas potencialmente importantes que no se incluyeron en el informe o que surgieron después de la ERS.

3. La participación en los programas de ERS es normalmente voluntaria, pero en ocasiones hay personas que se han visto obligadas a participar o a seguir las recomendaciones.

4. Se ha acusado con razón de "culpabilización de la víctima" a empresas que ofrecen la ER S como parte de un programa de promoción de la salud, pero que se esfuerzan poco o nada por controlar los riesgos para la salud en el medio ambiente de trabajo.

5. La confidencialidad de la información personal es una preocupación siempre presente, especialmente en aquellos casos en los que la ER S se lleva a cabo como programa interno y se teme que los resultados anómalos puedan desencadenar acciones discriminatorias.

Cada día hay más pruebas del valor de la reducción de los riesgos para la salud. Por ejemplo, Fielding y sus socios de Johnson and Johnson $\mathrm{H}$ ealth $\mathrm{M}$ anagement Inc. comprobaron que los 18.000 trabajadores que se sometieron a la ERS realizada por sus empresas hicieron uso de los servicios preventivos a una escala mucho mayor que una población similar que cumplimentó la encuesta de la Encuesta Nacional de Salud (National $\mathrm{H}$ ealth Interview) (Fielding y cols. 1991). Un estudio de cinco años de duración realizado sobre casi 46.000 trabajadores de DuPont demostró que los trabajadores que presentaban alguno de los seis factores de riesgo de comportamiento identificados por la ERS (tales como fumar, hipertensión, concentración elevada de colesterol y falta de ejercicio) tenían un nivel de absentismo y de utilización de las prestaciones de la asistencia sanitaria significativamente más elevado que el de los que no presentaban dichos factores de riesgo (Bertera 1991). Además, la aplicación de modelos de regresión múltiple a 12 mediciones relacionadas con la salud, efectuadas principalmente en una ER S, permitió a Yen y a sus colegas del Fitness Research Center de la U niversidad de M ichigan predecir cuáles eran los trabajadores que generarían mayores costes para la empresa debido a indemnizaciones por razones médicas y el absentismo (Yen, Edington y Witting 1991)

\section{Ejecución de un programa ERS}

La ejecución de un programa de ER S no es un ejercicio casual y no debería llevarse a cabo sin una cuidadosa planificación. El coste de un cuestionario individual y de su procesamiento puede que no sea elevado, pero los costes globales para la organización pueden ser considerables si se tienen en cuenta aspectos tales como el tiempo que el personal debe dedicar a la planificación, la ejecución y el seguimiento, el tiempo que necesitan los trabajadores para cumplimentar el cuestionario y los programas de promoción de la salud adjuntos. En la Figura 15.8 se recogen algunos factores que deben considerarse al ejecutar el programa.

\section{¿Es necesario un programa de ERS?}

Cada día son más las empresas, al menos en Estados U nidos, que responden afirmativamente a esta pregunta, incitadas por el número cada vez mayor de proveedores que comercializan agresivamente programas de ERS. LOS medios de comunicación populares y las publicaciones "comerciales" están repletas de anécdotas que describen programas "exitosos"; mientras que, en comparación, hay una gran escasez de artículos en publicaciones profesionales que ofrezcan pruebas de la exactitud de sus resultados, su fiabilidad práctica y su validez científica.

Figura 15.8 • Lista de control de la evaluación del riesgo para la salud (ERS).

\section{$\square$ PLANIFICACION}

1. ¿ Hay alguna declaración escrita de la finalidad del programa que recoja los objetivos, el alcance, la duración y la población destinataria?

2. ¿Cuenta el programa con el apoyo claro de los directivos de nivel superior y dispone de un presupuesto suficiente? i Han intervenido en la planificación del programa los trabajadores y sus sindicatos?

3. ¿ Está el programa correctamente situado dentro de la estructura organizativa? iSe ha nombrado a alguna persona dotada de las capacidades y la autoridad necesarias para que dirija o supenise el programa? ¿ Está la empresa capacitada para organizar y dirigir el programa (internamente o por medio de asesores).

\section{$\square$ EJECUCION}

4. ¿Se ajusta el cuestionario sobre ERS a los objetivos del programa, al presupuesto y a las necesidades de la población destinataria? Esto se refiere no sólo a la amplitud y variedad de los temas cubiertos, el grado de dificultad de lectura, la claridad de las preguntas y el tiempo necesario para cumplimentarlo, sino también a la claridad de las instrucciones y la disponibilidad de versiones en distintas lenguas para grupos minoritarios.

5. ¿ Se basa el método de cálculo del riesgo en la información epidemiológica y actuarial mejor y más actualizada para la población de destino?

6. Si hay que hacer mediciones físicas y análisis de laboratorio, i se dispone de un local adecuado, de personal bien formado y del equipo necesario?

7. ¿Cómo se va a promover el programa dentro de la organización? ¿ Habrá una fuente accesible para responder a preguntas sobre el programa?

8. ¿Se ofrecerán incentivos por participar? ¿De qué tipo? ¿Y por controlar correctamente los factores de riesgo cardíaco?

9. ¿Cómo se protegerá la confidencialidad de los datos personales? ¿Se han adoptado las medidas necesarias para enviar los resultados a los profesionales de la salud autorizados por los participantes para recibirlos?

10. ¿ Estarán los informes individuales atractivamente personalizados, contendrán información suficiente, serán fáciles de leer y comprender y presentarán recomendaciones debidamente organizadas?

$\square$ SEGUIMIENTO

11. ¿Se han adoptado medidas para verificar la corrección de los resultados anormales 0 límites y para afrontar los costes correspondientes?

12. ¿ Se ofrecerá asesoramiento adecuado a los sujetos expuestos a un riesgo elevado y a quienes estén preocupados por los resultados del informe?

13. ¿ Hay programas de intervención internos 0 extemos a los que pueda remitirse a los participantes para que controlen los factores de riesgo? ¿ Cómo se afrontarán los costes correspondientes?

14. ¿ Proporciona el informe resumen un grado significativo de detalle y profundidad de análisis a la organización? ¿ Puede integrarse esta información con otros datos, como los relativos a la productividad, el absentismo y el uso de registros de atención médica?

15. ¿Comprende y acepta la organización el compromiso implíito de realizar cambios en la estructura de puestos de trabajo, el entomo laboral y la cultura empresarial que aceleren y complementen el esfuerzo de los participantes por eliminar o controlar los factores de riesgo?

16. ¿Quién evaluará el programa, y cómo?

17. ¿ Pueden conservarse los datos del programa para comparar las respuestas individuales y globales si se repite en el futuro? 
Parece claro que la definición del estado de riesgo del individuo es una premisa necesaria para la reducción del mismo. Pero ¿es necesario un ejercicio formal de ERS para lograrlo? $\mathrm{H}$ oy en día, prácticamente todas las personas que insisten en seguir fumando cigarrillos conocen perfectamente los efectos adversos de este hábito para la salud; del mismo modo, se ha hecho mucha publicidad sobre los beneficios de la buena forma física y las ventajas de llevar una alimentación adecuada. Quienes abogan por la ERS contraatacan señalando que mediante la entrega de un informe de ERS, se personaliza y describe detalladamente la información acerca de los riesgos, creando así un "momento idóneo" que puede servir de motivación al individuo para adoptar las medidas apropiadas. Añaden además que los informes pueden señalar factores de riesgo de los que los participantes no fueran conscientes, y les indican de forma específica cuáles son sus posibilidades de reducción de riesgos y las prioridades para lograrlo.

Existe acuerdo general respecto a que la ERS tiene un valor limitado cuando se utiliza como ejercicio único (es decir, sin combinarla con otras modalidades) y que su utilidad sólo se aprecia cuando es parte de un programa integral de promoción de la salud. Este programa debería ofrecer no sólo explicaciones y consejos personalizados, sino también acceso a los programas de intervención en respuesta a los riesgos identificados (estas intervenciones pueden efectuarse en el seno de la empresa o en la comunidad). Por tanto, la oferta de ERS debe ampliarse (y quizá su coste aumente) con cursos para dejar de fumar, actividades para aumentar la capacidad física para el trabajo y sesiones informativas sobre nutrición. Un compromiso tan amplio debería especificarse en la exposición de objetivos del programa y en el presupuesto asignado para llevarlo a cabo.

Al planificar un programa ERS, hay que decidir si se ofrecerá a todos los trabajadores o tan sólo a ciertos segmentos (por ejemplo, a trabajadores remunerados por horas o con sueldo, a ambos, o a trabajadores de edades 0 antigüedad determinadas o destinados a lugares o categorías de puesto de trabajo especiales); y la probabilidad de ampliar el programa para que incluya a los cónyuges y a otras personas a cargo del trabajador (quienes, por lo general, suponen más de la mitad del uso de las prestaciones de los seguros de enfermedad). Un factor crítico es que haya al menos una persona de la organización que tenga los conocimientos adecuados y ocupe la posición apropiada para supervisar el diseño y la ejecución del programa, así como la actuación del proveedor y del personal interno.

En algunas empresas en las que se está procediendo a la eliminación de reconocimientos médicos anuales o se realizan con menos frecuencia, se ofrece la ERS como sustituto, como método único o en combinación con una selección de pruebas exploratorias selectivas. Esta estrategia tiene valor para mejorar la relación coste/ beneficio de los programas de promoción de la salud, pero a veces no se basa tanto en el valor intrínseco de la ERS como en el deseo de evitar el malestar que podría generar lo que pudiera percibirse como la eliminación de una prestación del trabajador ya establecida.

\section{Conclusión}

A pesar de las limitaciones y de la escasez de investigaciones científicas que confirmen las afirmaciones respecto a la validez de la ERS, cada día está más generalizada su utilización en Estados U nidos $y$, aunque en menor medida, también en otros lugares. DeFriese y Fielding, cuyos estudios los han convertido en autoridades en esta materia, auguran un futuro brillante para la ERS en consonancia con la predicción de nuevas fuentes de información significativa sobre riesgos y nuevos avances tecnológicos, como mejoras en el software y en el hardware, que permitirán la introducción directa de las respuestas de los cuestionarios en el ordenador y la creación de modelos sobre los efectos de los cambios en el comportamiento sanitario (Defriese y Fielding 1990).

La ERS debería utilizarse como uno más de los elementos de un programa de bienestar o de promoción de la salud bien concebido y continuo. Implica un compromiso implícito de proporcionar actividades y cambios en la cultura del lugar de trabajo, que ofrezcan oportunidades para contribuir al control de los factores de riesgo que el programa identifique. La dirección debe ser consciente de este compromiso y estar dispuesta a asignar las partidas presupuestarias necesarias.

Aunque se requiere todavía mucha investigación, la mayoría de las empresas descubrirán que la ERS es un valioso complemento a sus esfuerzos por mejorar la salud de sus trabajadores. La información de carácter científico que aporta la ERS, el uso de la tecnología informática y el impacto personalizado de los resultados en función de la edad cronológica frente a la edad de riesgo aumentan la motivación de los participantes para adoptar comportamientos saludables que reduzcan los riesgos. $\mathrm{H}$ ay numerosas pruebas de que los trabajadores y las personas a su cargo que mantienen unos perfiles de riesgo saludables presentan un nivel menor de absentismo, ven potenciada su productividad y hacen menos uso de la asistencia sanitaria. Todos estos logros tienen un efecto positivo en el margen de beneficios de las empresas.

\section{Programas de ejer CICIO fisico Y DE MANTENIMIENTO DE LA CAPACIDAD FISICA PARA EL TRABAJO:
UN ACTIVO DE LA ORGANIZACION}

James Corry

Los programas de ejercicio y capacidad física suelen ser el elemento más común de los programas de promoción y protección de la salud en el lugar de trabajo. Son eficaces cuando contribuyen a los objetivos de la organización, promueven la salud de los trabajadores y resultan agradables y útiles para los participantes (D ishman 1988). D ebido a que las empresas y organizaciones de todo el mundo tienen objetivos, y plantillas y recursos muy divergentes, estos programas varían considerablemente en su organización y en los servicios que prestan.

En este artículo se explican las razones que mueven a las empresas a ofrecer programas de ejercicio físico y mantenimiento de la capacidad física para el trabajo, la forma en que estos programas encajan en una estructura administrativa, los servicios que suelen ofrecerse a los participantes, el personal especializado que los presta, y las cuestiones implicadas con mayor frecuencia en la organización de programas de este tipo en el lugar de trabajo, entre ellas las necesidades de poblaciones especiales de la plantilla. Se centra primordialmente en los programas realizados en el lugar de trabajo.

\section{Calidad y programas de ejercicio físico}

En la actualidad, la economía mundial condiciona los objetivos y las estrategias empresariales de decenas de miles de empresas y afecta a millones de trabajadores en todo el mundo. La intensa competencia internacional exige a las empresas una oferta de productos y servicios de mayor valor y menor coste que nunca; es decir, el objetivo perseguido es lo que se denomina "calidad". Las empresas centradas en la calidad esperan que sus trabajadores 
estén "orientados al cliente", que trabajen con energía, entusiasmo y exactitud durante toda la jornada, que se formen y perfeccionen personal y profesionalmente de manera continua y que asuman la responsabilidad de su comportamiento en el lugar de trabajo y su bienestar personal.

L os programas de ejercicio físico y mantenimiento de la capacidad física para el trabajo pueden desempeñar un importante papel en las organizaciones basadas en la calidad, ya que ayudan a los trabajadores a conseguir un elevado nivel de "bienestar". Esto resulta particularmente importante en los sectores con trabajadores no manuales y sedentarios. En la manufactura y en las industrias pesadas el ejercicio físico para adquirir fuerza y elasticidad puede proteger a los trabajadores de lesiones profesionales. Además de mejorar la forma física, las actividades de entrenamiento alivian el estrés e inculcan el sentido de la responsabilidad personal por la propia salud en otros aspectos de la forma de vida, como la nutrición y el control del peso, la abstinencia del consumo de alcohol y drogas y el abandono del tabaco.

Las organizaciones basadas en la calidad suelen ofrecer acondicionamiento aeróbico, clases de relajación y elasticidad, ejercicios para adquirir fuerza, deportes de aventura y competiciones deportivas. Estas ofertas suelen estructurarse en el marco de las iniciativas de las empresas para el bienestar de los trabajadores, ya que ayudan a las personas a aprovechar todo su potencial y a llevar una forma de vida que proteja su salud. Se basan en la convicción de que, como está claramente demostrado que la vida sedentaria es un factor de riesgo, el ejercicio regular constituye un hábito que es importante fomentar.

\section{Servicios básicos de mantenimiento de la capacidad física}

Los trabajadores participantes en los programas de mantenimiento de la capacidad física para el trabajo deben aprender las bases mínimas del entrenamiento físico. La formación comprende los siguientes elementos:

- un número mínimo de sesiones semanales de ejercicio físico para conseguir una buena forma y una buena salud (tres 0 cuatro sesiones a la semana de 30 a 60 minutos de duración);

- formas de calentar y enfriar los músculos antes y después del ejercicio;

- control de la frecuencia cardíaca y cómo elevarla sin riesgos hasta un nivel adecuado para la edad y capacidad física de la persona en cuestión;

- graduación de la intensidad del ejercicio, hasta conseguir una elevada capacidad física para el trabajo;

- técnicas de entrenamiento combinado;

- principios de los ejercicios para adquirir fuerza, alternando resistencia y sobrecarga, y combinando repeticiones y series para conseguir los objetivos establecidos en materia de fuerza;

- técnicas seguras de levantamiento de pesos y descansos estratégicos;

- relajación y estiramiento como parte integrante del programa global de entrenamiento;

- adaptación de los ejercicios a los intereses personales y a la forma de vida de cada persona;

- concienciación respecto del papel que desempeña la nutrición en la forma física y en la salud en general.

Además de la instrucción, estos servicios incluyen evaluación de la forma física y diseño de tablas de ejercicios, orientación sobre las instalaciones y formación en el uso de los equipos, clases y actividades aeróbicas estructuradas, clases de estiramientos y relajación y clases para prevenir dolores de espalda. Algunas organizaciones ofrecen entrenamientos individualizados, pero son bastante costosos, ya que requieren una gran cantidad de personal.

Algunos programas ofrecen técnicas llamadas de "endurecimiento del trabajo" 0 "acondicionamiento" orientadas a reforzar la capacidad de los trabajadores para desempeñar tareas repetitivas o penosas y para rehabilitar a los que se están recuperando de lesiones y enfermedades. Con frecuencia incluyen pausas en el trabajo para realizar ejercicios especiales de relajación y estiramiento de los músculos utilizados en exceso y fortalecimiento de los grupos musculares antagonistas para evitar el abuso y las lesiones causadas por esfuerzos repetitivos. C uando se considera necesario, incluyen sugerencias para modificar el contenido del puesto de trabajo o el equipo utilizado.

\section{Personal responsable del entrenamiento físico y del mantenimiento de la capacidad física para el trabajo}

Ergofisiólogos, profesores de educación física y especialistas en actividades de tiempo libre son los profesionales que suelen trabajar en los programas de ejercico físico en el lugar de trabajo. Los educadores sanitarios y los especialistas en rehabilitación también participan en estos programas.

El ergofisiólogo diseña tablas de ejercicios adaptadas a cada persona, para lo cual se basa en su historial médico, una exploración de los riesgos para la salud y una evaluación de su capacidad física para el trabajo (esencial en el caso de las personas con discapacidades y las que se están recuperando de alguna lesión) y de sus objetivos en este campo. La evaluación de la capacidad física para el trabajo incluye: determinación de la frecuencia cardíaca y la presión arterial en reposo, la constitución, la elasticidad y la fuerza muscular, la eficiencia cardiovascular y, con frecuencia, los perfiles de lípidos en sangre. Los resultados suelen compararse con los valores de referencia correspondientes a personas de la misma edad y sexo.

Ninguno de los servicios prestados por el fisiólogo tiene como finalidad diagnosticar enfermedades. Cuando se detectan anomalías, los trabajadores son remitidos al servicio de salud de los empleados o a su médico de cabecera. De hecho, muchas organizaciones exigen al solicitante que obtenga una autorización médica antes de incorporarse al programa. En el caso de los trabajadores que se estén recuperando de alguna lesión 0 enfermedad, el ergofisiólogo trabaja en estrecho contacto con su médico personal y con los asesores de rehabilitación.

Los profesores de educación física han recibido formación para dirigir sesiones de gimnasia, enseñar los principios de un ejercicio físico saludable y seguro, demostrar y enseñar distintas habilidades deportivas y organizar y administrar un programa variado de ejercicio físico. M uchos de ellos han recibido también formación para evaluar la capacidad física para el trabajo, aunque en este mundo de especialistas, dicha tarea suele ser realizada por el ergofisiólogo.

Los especialistas en actividades de tiempo libre realizan encuestas sobre las necesidades e intereses de los trabajadores, con el fin de conocer las características de su forma de vida y sus requisitos y preferencias durante su tiempo libre. Pueden dirigir clases de ejercicio físico, pero son especialistas en organizar excursiones y actividades que impongan un reto físico y que instruyan y motiven a los participantes para practicar una actividad saludable.

Verificar la formación y las competencias de los responsables del entrenamiento físico suele plantear dificultades a las organizaciones interesadas en designar personal para un programa. La mayoría de los organismos públicos de Estados U nidos y Japón con competencias educativas exigen certificados académicos y un período de prácticas supervisadas a los profesores de educación física que trabajan en centros escolares. La mayoría de los 
gobiernos no exigen ninguna certificación. Por ejemplo, en Estados U nidos, sólo el estado de Wisconsin ha promulgado una legislación que hace referencia a los profesores de educación física. Si se considera la colaboración con clubs de salud externos a la empresa, sean voluntarios, como el YMCA, 0 comerciales, hay que adoptar medidas especiales para verificar las competencias de los profesores, pues muchos son voluntarios o personas escasamente formadas.

$\mathrm{H}$ ay una serie de asociaciones acreditadas que ofrecen certificaciones para los profesionales que trabajan en el campo del entrenamiento físico de adultos. Por ejemplo, el American College of Sports M edicine ofrece un certificado para los profesores de educación física, y la International Dance Education Association ofrece un certificado para instructores de ejercicio aeróbico. No obstante, estos certificados deben considerarse más como una prueba de experiencia y de formación avanzada que como una autorización para ejercer.

\section{Programas de mantenimiento de la capacidad física para el trabajo y estructura de la organización}

Como norma, sólo las organizaciones de tamaño grande 0 mediano (500 a 700 trabajadores suele considerarse el mínimo) pueden abordar la tarea de proporcionar instalaciones de ejercicio físico para los trabajadores en el lugar de trabajo. Además del tamaño, hay que tener en cuenta la capacidad y la disponibilidad para dedicar las partidas presupuestarias necesarias y la existencia de espacio para alojar las instalaciones y el equipo que se requiere, incluidos vestuarios y duchas.

La ubicación del programa dentro de la estructura administrativa de la organización depende de los objetivos establecidos. Por ejemplo, si los objetivos están relacionados principalmente con la salud, por ejemplo la reducción del riesgo cardiovascular, la reducción del absentismo por enfermedad, la prevención de las lesiones y la rehabilitación de los trabajadores lesionados, la reducción del estrés, etc. el programa suele enmarcarse en el departamento médico o como complemento del servicio de salud de los empleados. D ado que los departamentos de recursos humanos se encargan también de la ejecución de los programas de mejora de la calidad, los programas de mantenimiento de la capacidad física para el trabajo enfocados al bienestar y a la calidad suelen ubicarse en estos departamentos.

El departamento de formación no suele encargarse de estos programas, ya que su misión suele limitarse a la adquisición de determinadas cualificaciones y a la formación en el puesto de trabajo. Sin embargo, algunos departamentos de formación organizan deportes de aventura y actividades al aire libre para los trabajadores, para promover el trabajo en equipo, aumentar la autonomía de los trabajadores y su confianza en sí mismos y explorar formas de superar la adversidad. Cuando se trata de trabajos que exigen actividad física, el departamento de formación puede asumir la tarea de enseñar las técnicas de trabajo adecuadas. Estos servicios de formación se encuentran a menudo en organizaciones de bomberos, policía y salvamento, empresas de transporte por carretera y mensajería, operaciones de minería, empresas de exploración petrolífera, empresas de actividades subacuáticas y de socorrismo, empresas constructoras y similares.

\section{Programas de mantenimiento de la capacidad física para el trabajo basados en el lugar de trabajo o en la comunidad}

Si por razones económicas y de espacio no se puede disponer de instalaciones completas de ejercicio físico en el propio lugar de trabajo, siempre se pueden realizar programas más limitados. Cuando no se utilizan para los fines que les son propios, los comedores y salas de reunión, las zonas de recepción y los aparcamientos pueden aprovecharse para impartir clases de ejercicio físico. U na compañía de seguros de N ueva York creó una pista de jogging cubierta en un almacén de grandes dimensiones, definiendo un camino entre estanterías de archivadores que contenían documentos importantes, pero poco consultados. En muchas organizaciones de todo el mundo, se programan pausas en el trabajo durante las cuales los trabajadores realizan tablas de gimnasia y otros ejercicios sencillos sin apartarse de su puesto de trabajo.

Si no hay instalaciones dentro de la empresa (o si no tienen capacidad suficiente para el número de trabajadores que quisieran utilizarlas), las organizaciones recurren a centros externos, como clubs de salud comerciales, escuelas e institutos, iglesias, centros sociales, centros recreativos patrocinados por organizaciones como el YMCA, el ayuntamiento o los sindicatos, etc. A lgunos parques empresariales albergan instalaciones deportivas compartidas por las empresas arrendatarias.

En otro nivel, los programas de ejercicio físico pueden consistir en actividades físicas sencillas y de muy poco riesgo que realizan los trabajadores en su propio domicilio. La reciente investigación científica ha demostrado que incluso unos niveles bajos 0 moderados de actividad física diaria pueden tener efectos positivos sobre la salud. Actividades como pasear, montar en bicicleta o subir escaleras, que permiten a la persona ejercitar dinámicamente grandes grupos de músculos durante 30 minutos cinco veces a la semana, pueden prevenir o retrasar la aparición de enfermedades cardiovasculares y constituyen un agradable alivio del estrés diario. Los programas que promueven el desplazamiento al trabajo a pie 0 en bicicleta pueden introducirse incluso en las empresas más pequeñas y cuestan muy poco.

En algunos países, los trabajadores tienen derecho a permisos que pueden pasar en balnearios o centros de salud que ofrecen programas completos de descanso, relajación, ejercicio, dieta saludable, masajes y otros tratamientos rehabilitadores. El objetivo, por supuesto, es que mantengan una forma de vida saludable cuando vuelvan a su hogar y a su trabajo.

\section{Ejercicio físico para poblaciones especiales}

Los trabajadores de edad más avanzada, los que tienen problemas de obesidad o los que han llevado siempre una vida sedentaria pueden participar en programas de ejercicio físico de menor intensidad e impacto, para evitar lesiones graves y urgencias cardiovasculares. Cuando estos programas se ofrecen en el lugar de trabajo, muchas empresas reservan unas horas determinadas 0 unos espacios independientes de las zonas de trabajo para proteger la dignidad y privacidad de estas poblaciones.

Las mujeres embarazadas que han sido siempre físicamente activas pueden seguir trabajando con el consejo y el consentimiento de su médico personal, sin olvidar los consejos médicos referentes al ejercicio durante la gestación (American College of $O$ bstetricians and $G$ ynecologists 1994). Algunas organizaciones ofrecen programas especiales de mantenimiento para las mujeres que se reincorporan al trabajo después del parto.

Los trabajadores con problemas o discapacidades físicas deben tener facilidades para participar en el programa de mantenimiento de la capacidad física, por razones de equidad y porque pueden obtener del ejercicio físico beneficios todavía mayores que otros. Sin embargo, los responsables del programa deben tener en cuenta las afecciones que pueden poner a estas personas en situación de riesgo de lesión o muerte, por ejemplo, ciertas enfermedades genéticas, como el síndrome de $M$ arfan (una enfermedad congénita) o ciertas cardiopatías. En estos casos es particularmente importante un reconocimiento previo del estado de salud y la supervisión atenta durante el ejercicio. 


\section{Definición de objetivos para el programa de ejercicio físico}

Los objetivos establecidos para un programa de ejercicio físico deben complementar y respaldar los de la organización. La Figura 15.9 contiene una lista de comprobación de los posibles objetivos del programa; clasificándolos en orden de importancia para la organización y combinándolos adecuadamente, pueden servir para diseñar el programa.

\section{Criterios de admisión para participar en el programa de ejercicio físico}

Los administradores del programa de ejercicio físico deben establecer cuidadosamente los criterios para seleccionar a los participantes, ya que la demanda puede superar tanto el presupuesto asignado al programa como el espacio y el tiempo disponibles. Es conveniente conocer por adelantado la razón por la que se ofrece esta prestación y a cuántos trabajadores puede beneficiar. La falta de previsión en este sentido puede tener como resultado la decepción y el descontento si los que desean realizar ejercicio físico no pueden participar en el programa.

Especialmente cuando el programa se desarrolla en el lugar de trabajo, algunas empresas restringen la participación a los directivos situados por encima de un determinado nivel en el organigrama. Justifican esta decisión alegando que, puesto que estas personas están mejor retribuidas y, por consiguiente, su tiempo es más valioso, es conveniente darles prioridad de acceso. De esta forma, el programa se convierte en un "privilegio", como el comedor para directivos o la plaza de aparcamiento reservada y bien situada. 0 tras empresas son más igualitarias y ofrecen el programa a todos los trabajadores por orden de llegada. Cuando la demanda supera la capacidad de las instalaciones, algunas empresas utilizan la antigüedad como criterio de prioridad. Las normas sobre una práctica mínima mensual pueden servir para disuadir al usuario casual o irregular de seguir participando en el programa.

\section{Selección y mantenimiento de los participantes en el programa}

Un problema que se plantea es que la comodidad y el bajo coste de las instalaciones puede hacerlas particularmente atractivas para quienes ya están interesados en el ejercicio físico, los cuales podrían dejar poco espacio para otros que lo necesitarían mucho más. En su mayor parte, los primeros seguirán haciendo ejercicio en cualquier caso, mientras que los segundos se desanimarán ante cualquier dificultad o retraso en la incorporación al programa. Por tanto, es importante simplificar la admisión de participantes y facilitar el proceso de incorporación.

Casi siempre es necesario atraer activamente a los participantes, al menos al principio del programa. Las técnicas para atraer a nuevos participantes incluyen visitas abiertas a las instalaciones en las que se ha de realizar el ejercicio físico, publicidad mediante carteles, folletos y anuncios en los medios de comunicación internos y la posibilidad de participar en el programa de forma experimental o para probar.

El problema de los abandonos constituye un reto importante para los programas de ejercicio físico en el lugar de trabajo. Los trabajadores mencionan el aburrimiento, los dolores y molestias musculares y la falta de tiempo como las principales causas de abandono. Para contrarrestar estos factores negativos, los especialistas en ejercicio físico entretienen a los participantes con música, cintas de vídeo y programas de televisión, juegos de motivación, actos especiales, camisetas y otros premios y certificados de asistencia o de logro de determinados objetivos. U nas tablas de ejercicios debidamente diseñadas y supervisadas por un profesional para prevenir dolores y molestias, y unas sesiones prácticas y eficientes son otras dos estrategias que suelen tener éxito. A lgunos programas de ejercicio físico ofrecen periódicos y revistas de empresa, así como el acceso a emisoras de televisión o cintas de vídeo con programas sobre economía y formación, para ayudar a los trabajadores a justificar el tiempo que dedican a las sesiones de ejercicio físico.

\section{Seguridad y supervisión}

L as organizaciones que ofrecen programas de mantenimiento de la capacidad física para el trabajo en el lugar de trabajo deben

\section{Figura 15.9 - O bjetivos para un programa de ejercicio físico y mantenimiento de la capacidad física para el trabajo}

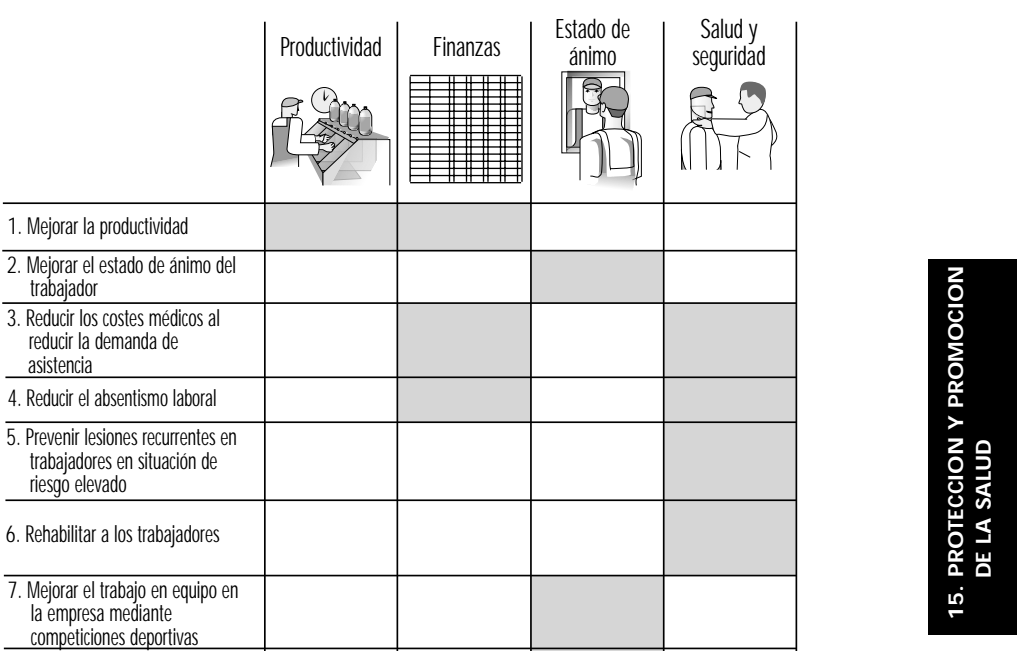


garantizar su seguridad. Los trabajadores que desean participar en los mismos deben someterse a un reconocimiento médico para detectar cualquier afección que pudiera verse agravada por el ejercicio físico. Sólo deben utilizarse equipos con el diseño y el mantenimiento adecuados y se debe enseñar su utilización. Asimismo, deben colocarse carteles con señales y normas de seguridad referentes al uso apropiado de las instalaciones, y todo el personal debe haber recibido formación en primeros auxilios, incluida la reanimación cardiopulmonar. Un profesional del ejercicio físico con la debida formación debe supervisar el funcionamiento de las instalaciones.

\section{Confidencialidad de los registros}

Es preciso mantener registros individuales con información sobre la salud y el estado físico, la evaluación de la capacidad física para el trabajo y los ejercicios recomendados, los objetivos y logros esperados, así como todas las observaciones que se juzguen necesarias. En muchos programas se deja a los participantes que consignen lo que han realizado en cada visita. El acceso al contenido de estos registros debe, como mínimo, estar prohibido a todo el mundo salvo el participante y el personal del programa. Salvo al personal del servicio de salud de los trabajadores, que está obligado por las mismas normas de confidencialidad y, en caso de urgencia, al médico personal del participante, los detalles de la participación y la evolución de cada individuo no deben revelarse a nadie sin la autorización expresa del interesado.

Puede pedirse al personal del programa que elabore informes periódicos para la dirección sobre la participación y los resultados del programa basados en datos agregados.

\section{¿Quién dedica el tiempo y quién paga?}

Puesto que la mayoría de los programas de ejercicio físico en el lugar de trabajo son voluntarios y se organizan en beneficio de los trabajadores, se consideran como una prestación o privilegio adicional. Las empresas, por consiguiente, suelen ofrecer el programa fuera de las horas de trabajo (durante la comida 0 al término de la jornada), y se espera que los participantes abonen la totalidad o una parte de los costes. L os mismos criterios suelen aplicarse a los programas que se ofrecen fuera de la empresa, en instalaciones de la comunidad. En algunas organizaciones, la aportación de los trabajadores es proporcional al salario, y otras ofrecen "becas" a quienes tienen salarios más bajos o pasan por dificultades económicas.

Muchas empresas permiten la participación en horario de trabajo, por lo general a los trabajadores de nivel más elevado, y asumen la mayor parte de los gastos o todos ellos. A lgunas reembolsan las aportaciones de los trabajadores si éstos alcanzan determinados objetivos.

Cuando la participación en el programa es obligatoria, como la formación para prevenir posibles lesiones profesionales 0 preparar a los trabajadores para la realización de determinadas tareas, las leyes y los convenios sindicales exigen que se haga en horario de trabajo y que la empresa corra con todos los gastos.

\section{Tratamiento de los dolores y las molestias de los participantes}

$M$ uchas personas creen que para que el ejercicio físico sea beneficioso tiene que ser doloroso. Es responsabilidad del personal del programa desmentir esta falsa idea modificando la percepción del ejercicio por medio de campañas de información y sesiones educativas orientadas a garantizar que la intensidad del ejercicio aumentará de forma gradual, de modo que las sesiones no resulten dolorosas y sean eficaces para mejorar la capacidad física para el trabajo.
Si los participantes se quejan de dolores y molestias, hay que animarlos para que sigan practicando ejercicio a una intensidad mucho menor o para que descansen hasta recuperarse. Deben conocer los principios del tratamiento de las lesiones deportivas: reposo, aplicación de hielo en la lesión, compresión de cualquier hinchazón y elevación de la parte del organismo lesionada.

\section{Programas deportivos}

M uchas empresas y organizaciones animan a los trabajadores para que participen en competiciones deportivas que ellas mismas patrocinan. Estos acontecimientos varían desde partidos de fútbol o béisbol en la comida al aire libre organizada cada año por la empresa hasta una liga de diversos deportes o competiciones entre empresas, como el Chemical Bank's Corporate C hallenge, una carrera de fondo para equipos de trabajadores de las empresas organizadores que surgió en Nueva York y ahora se ha extendido a otras zonas y a cuyo patrocinio se han unido muchas empresas.

El concepto clave de los programas deportivos en la gestión del riesgo).

Aunque son muchos los beneficios de la competición deportiva, entre otros un mejor estado de ánimo y el fortalecimiento del sentimiento de "equipo", los riesgos también pueden ser importantes. Cuando los trabajadores participan en competiciones, pueden trasladar al campo de juego el "bagaje" psicológico relacionado con el trabajo, lo que a veces ocasiona problemas, especialmente cuando están en mala forma física. Por ejemplo, un directivo de mediana edad y en mala forma física que desea impresionar a los trabajadores más jóvenes puede lesionarse al exceder su capacidad física; o un trabajador que se siente desafiado por otro en su trayectoria profesional puede convertir lo que se supone que es un partido amistoso en un cuerpo a cuerpo peligroso.

La empresa que desee organizar una competición deportiva debería considerar los siguientes consejos:

- Cerciorarse de que los participantes conocen la finalidad del acontecimiento deportivo y recordarles que son trabajadores de una organización, no atletas profesionales.

- Establecer normas y directrices estrictas sobre un juego seguro y limpio.

- Aunque firmar un documento de consentimiento y formularios de renuncia no siempre libera de responsabilidades a la empresa, sirve para que los participantes conozcan la naturaleza del riesgo asociado al deporte.

- O frecer centros de acondicionamiento y sesiones de prácticas antes de comenzar la temporada competitiva, de manera que los participantes se encuentren en una buena forma física antes de comenzar a jugar.

- Exigir, o al menos recomendar, que los participantes se sometan a un reconocimiento físico completo realizado por sus respectivos médicos, si no está previsto en el servicio de salud laboral. (N ota: quizá la organización tenga que correr con los gastos de esta medida.)

- Inspeccionar la seguridad del campo de atletismo y de los equipos deportivos. Suministrar o exigir equipos de protección personal, como cascos, ropas especiales o gafas protectoras.

- Supervisar los encuentros con la participación de árbitros. ropas especiales.

- Disponer de primeros auxilios y establecer con antelación un plan médico de urgencia y evacuación.

- Comprobar si el seguro de responsabilidad e incapacidad de la empresa cubre las competiciones deportivas, es suficiente y está en vigor. ( $N$ ota: debería cubrir a los trabajadores y a quienes asistan como espectadores, además de a los miembros del equipo.) 
En algunas empresas, las competiciones deportivas constituyen la principal causa de incapacidad de los trabajadores. La gestión de los riesgos es importante y se debe pensar seriamente si las actividades deportivas contribuyen a los objetivos que la organización ha establecido para su programa de ejercicio físico.

\section{Conclusión}

Los programas de ejercicio físico en el lugar de trabajo correctamente diseñados y dirigidos por un profesional benefician a los trabajadores, ya que mejoran su salud, su bienestar, su estado de ánimo y su rendimiento laboral. Benefician a las empresas porque mejoran cualitativa y cuantitativamente la productividad, ayudan a prevenir accidentes profesionales, acortan el período de recuperación de los trabajadores que han sufrido una enfermedad 0 un accidente y reducen el absentismo. El diseño y la ejecución de cada programa deberán ajustarse a cada caso concreto, en función de las características de la organización y de su plantilla, de la comunidad en la que opere, y de los recursos que puedan asignarse. El programa debe estar dirigido, 0 al menos supervisado, por un profesional cualificado en mantenimiento de la capacidad física, que sepa lo que el programa puede aportar a los participantes o a la organización y que esté preparado para modificarlo si surgen nuevas necesidades.

\section{- Programas de nutricion en el LUGAR DE TRABAJO}

\section{Penny M. KrisE therton y John W. Farquhar}

La dieta, la actividad física y otras prácticas relacionadas con los estilos de vida, como el abandono del tabaco y la reducción del estrés, son factores importantes en la prevención de las enfermedades crónicas. U na nutrición adecuada y otras prácticas saludables ayudan además a mantener el bienestar individual y la productividad. El centro de trabajo es un lugar idóneo para enseñar a las personas hábitos saludables, como nutrirse de forma adecuada, controlar el peso y realizar ejercicios. Es un foro excelente para la difusión eficiente de la información, en el que es posible controlar y reforzar las modificaciones que se realicen (K aplan y Brinkman-K aplan 1994). EI consejo nutricional figura entre las actividades que se incluyen con más frecuencia en los programas de bienestar patrocinados por las empresas y los sindicatos, y a veces son organizados de forma conjunta por las dos instituciones. Además de las clases y los programas formales, pueden ofrecerse otras actividades educativas de apoyo, como la edición de boletines, memorándums, hojas anexas a las nóminas o carteles, la inclusión de anuncios en los tablones y el correo electrónico. EI material didáctico sobre nutrición se puede enviar también a los familiares de los trabajadores, y es posible organizar clases y seminarios para los que cocinan habitualmente, que son los responsables de la alimentación de la familia. Estas medidas ofrecen una información útil que puede aplicarse fácilmente tanto en el lugar de trabajo como en otro sitio y ayudan a reforzar la instrucción formal y estimulan a los trabajadores a participar en los programas o a utilizar de forma razonable y aprovechar al máximo las instalaciones del lugar de trabajo (como el comedor). Además, las clases y los materiales educativos bien orientados pueden tener un efecto muy significativo en muchas personas, entre ellas los familiares de los propios trabajadores, en particular en sus hijos, que aprenden de este modo hábitos de comida correctos que conservarán durante toda su vida y serán transmitidos a las generaciones futuras.

Para que los programas de intervención en el lugar de trabajo sean eficaces, se necesita un entorno de apoyo que permita a los trabajadores seguir los consejos relacionados con la nutrición. En este contexto, es esencial que se les ofrezca la posibilidad de obtener un tipo de comida apropiado en los comedores y en las máquinas expendedoras. Si guardan su almuerzo en bolsas o en otros tipos de recipientes o fiambreras, habrán de habilitarse sistemas para conservar esas bolsas o recipientes; de este modo, no encontrarán obstáculos para seguir la dieta recomendada. A demás, en los lugares de trabajo alejados de los comedores 0 cafeterías, el almuerzo, preparado por la propia empresa o por un subcontratista, puede transportarse en carritos. Es importante asimismo disponer de instalaciones para que los trabajadores puedan realizar un ligero aseo personal antes de comer. Estas actividades promovidas por la empresa muestran un compromiso claro con la salud y el bienestar de sus trabajadores.

\section{Suministro interno de comidas, máquinas expendedoras y pausas para tomar café}

N umerosas empresas subvencionan servicios internos de suministro de comidas de forma parcial o total, con lo que los trabajadores disponen de una oferta atractiva y cómoda. Incluso en los centros donde sólo hay un turno de trabajo, muchos comedores sirven desayunos y cenas, además de almuerzos y refrescos para las pausas; esta variedad resulta especialmente útil para quienes viven solos o en los casos en que la preparación de la comida en casa no es la adecuada. Algunos de estos comedores pueden ser utilizados por los amigos y familiares de los trabajadores para promover "comidas en el lugar de trabajo", en vez de utilizar otros establecimientos públicos que suelen ser más caros y de menor calidad dietética.

La variedad de la comida que se ofrece en los lugares de trabajo sirve de apoyo y de estímulo a los hábitos de alimentación saludables (G lanz y M ullis 1988). De hecho, las actividades desarrolladas a través del comedor de la empresa representan uno de los programas de nutrición en el lugar de trabajo más difundidos, ya que permiten poner a disposición de los trabajadores los aspectos más relevantes de la información sobre nutrición (G lanz y R ogers 1994). O tras medidas son la inclusión en la oferta de platos con bajo contenido de grasas y de calorías y alto contenido de fibra o la calificación de algunos de ellos como "platos saludables para el corazón" (R ichmond 1986). Pueden aplicarse asimismo políticas saludables de suministro interno de comidas y ofrecer platos muy nutritivos con bajo contenido de grasas, de colesterol y de sodio (American Dietetic Association 1994). Es posible igualmente negociar con los proveedores el suministro de alimentos con bajo contenido de grasas, como fruta, en las máquinas expendedoras. En un programa de estas características, los trabajadores seleccionaron más los productos con bajo contenido de calorías (Wilber 1983). La dirección de los servicios de comidas y los proveedores de los suministros internos de comidas y de las máquinas expendedoras pueden aumentar así sus ventas y su participación en este tipo de actividades, sobre todo si sirven comidas saludables, atractivas y sabrosas (American D ietetic A ssociation 1994).

La oferta de aperitivos muy nutritivos en las pausas para el café 0 el té puede ayudar a los trabajadores a atender sus necesidades dietéticas. En muchos casos, la "hora del almuerzo" dura sólo 30 ó 40 minutos y algunos trabajadores no se sientan a comer porque dedican ese tiempo a ir de compras, ver a otras personas 0 atender asuntos personales. Para obtener un entorno de apoyo quizás haya que prolongar el tiempo de la comida. También el mantenimiento de una higiene adecuada en las 
instalaciones y el control adecuado de la salud y del entrenamiento de todo el personal (aunque las instalaciones estén gestionadas bajo contrato por un proveedor externo) demuestra el compromiso del centro de trabajo con la salud de los trabajadores, con lo que aumentará el interés de éstos en apoyar los establecimientos de servicios de comida internos, así como otros programas.

\section{Orientación general sobre nutrición}

Las recomendaciones dietéticas básicas establecidas por los organismos públicos de diferentes países fomentan la promoción de la salud y la prevención de enfermedades no transmisibles relacionadas con la dieta (FAO, O M S 1992). Esas directrices se sustentan en los siguientes principios:

- Ajustar el aporte al gasto energético para conseguir y mantener un peso corporal adecuado.

- Evitar el consumo excesivo de grasas, sobre todo de grasas saturadas y de colesterol.

- Aumentar el consumo de carbohidratos complejos y de fibra y reducir el consumo de azúcar a un nivel moderado.

- Reducir el consumo de sal a un nivel moderado.

- Reducir el consumo de alcohol.

- Realizar comidas variadas que incluyan todos los grupos de alimentos.

$\mathrm{H}$ ay sólidas pruebas científicas en apoyo de estas recomendaciones. No sólo el peso corporal anormal aumenta el riesgo de padecer numerosas enfermedades crónicas, sino que también es importante para la salud la distribución de las grasa (Bray 1989). La obesidad de tipo masculino, esto es, el exceso de grasa en el abdomen, supone un riesgo para la salud mayor que la obesidad de tipo femenino, esto es, la presencia de grasa por debajo de la cintura (en las caderas y los muslos). Un índice cintura/ cadera igual o superior a 1 se asocia a mayor riesgo de hipertensión, hiperlipidemia, diabetes y resistencia al tratamiento con insulina (Seidell 1992). El índice de masa corporal (IM C), esto es, el peso corporal (kilogramos) dividido por la altura (metros) al cuadrado y el índice cintura/ cadera sirven, pues, para valorar el sobrepeso y, en su caso, la necesidad de perder peso. En la Figura $15.10 \mathrm{se}$ aplica el IM C para distinguir entre las categorías de bajo peso, peso ideal, sobrepeso y obesidad.

Todas las personas, incluso las que tienen un peso ideal, pueden beneficiarse de las recomendaciones dietétitcas destinadas a prevenir el aumento de peso que se produce normalmente con la edad. Para que un programa de control del peso

Figura 15.10 - Clasificación según el índice de masa corporal.

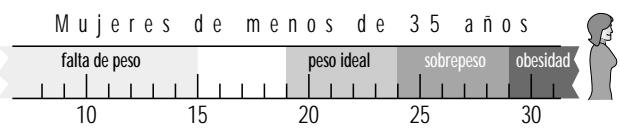
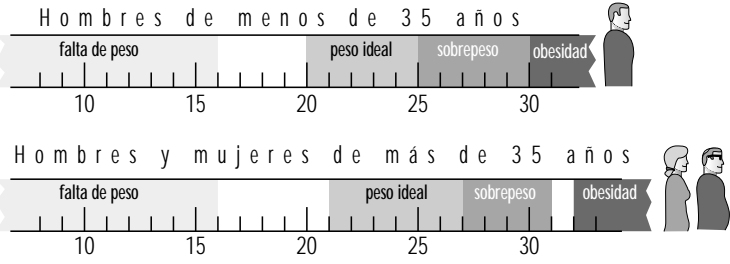

Fuente: US Department of Agriculture: Human Nutrition Information Senvice 1990. sea eficaz, debe atenerse a los principios y técnicas de la nutrición, del ejercicio y de la modificación de conducta.

Para ayudar a mantener un nivel de colesterol deseable (es decir, $200 \mathrm{mg} / \mathrm{dL}$ ) (National Institutes of $\mathrm{H}$ ealth 1993b), se recomienda una dieta en la que menos del $30 \%$ de las calorías se aporten en forma de grasas y menos del $10 \%$ en forma de grasas saturadas, y que tenga menos de 300 miligramos de colesterol al día. El cumplimiento de la recomendación sobre las grasas saturadas se facilita con una dieta relativamente baja en grasas totales. U na dieta de 2.000 calorías puede incluir 67 gramos de grasas en total y menos de 22 gramos de grasas saturadas al día. Una dieta baja en grasas totales permite además reducir las calorías y facilita el control de peso; no impide tomar comidas variadas que permitan atender las necesidades nutritivas sin superar las necesidades calóricas.

Las dietas ricas en carbohidratos complejos (los que se encuentran en los cereales, las legumbres, las verduras y, en cierta medida, las frutas) contienen también una gran variedad de nutrientes (como vitaminas B, vitaminas A y C, zinc e hierro) y su contenido de grasas es bajo. $L$ a recomendación de consumir el azúcar de forma moderada se basa en que este producto, pese a ser una fuente de energía, tiene un escaso valor nutritivo. Por tanto, las personas con escasas necesidades calóricas deberían tomar poco azúcar. En cambio, éste puede emplearse como una fuente de calorías, siempre de forma moderada, en dietas (adecuadas desde el punto de vista nutritivo) de alto contenido calórico. El efecto de formación de caries dental se reduce si el azúcar se toma con las comidas y no en forma de aperitivos frecuentes entre comidas.

D ebido a la asociación entre la ingesta de sodio y la hipertensión sistólica, es aconsejable moderar el consumo de sal y de sodio. Para prevenir la hipertensión se recomienda no tomar más de 2.400 miligramos de sodio al día (National Institutes of $\mathrm{H}$ ealth 1993b). Se ha demostrado también que una dieta con alto contenido de sodio promueve la excreción de calcio y, por tanto, contribuye al desarrollo de osteoporosis, trastorno que afecta más a las mujeres (Anderson 1992). Las principales fuentes de sodio en la dieta son las comidas preparadas y la sal (o los condimentos ricos en sal, como la salsa de soja) que se añade a los platos durante su preparación o en la mesa.

Si se toma alcohol, debe hacerse de forma moderada. EI consumo excesivo de alcohol daña el hígado y el páncreas, provoca hipertensión y produce lesiones cerebrales y cardíacas. 0 tras consecuencias adversas que se asocian al consumo excesivo de alcohol son la adicción, el aumento del riesgo de accidentes y la disminución del rendimiento en el trabajo.

0 tra recomendación habitual consiste en seguir una dieta lo más variada posible. Para mantener un buen estado de salud se necesitan más de 40 nutrientes diferentes. Como ninguna comida sola puede proporcionarlos todos, la dieta debe ser lo más variada posible. Una guía de alimentación típica suele incluir recomendaciones sobre el número de veces que hay que tomar los diferentes grupos de comidas (Figura 15.11). Los valores indicados son mínimos diarios. Si las necesidades energéticas aumentan, esos valores deberán aumentar también de forma correspondiente.

En diferentes países se han elaborado además recomendaciones dietéticas específicas. En algunos se recomiendan la fluoración del agua, la lactancia materna y los suplementos de yodo. En otros muchos se recomienda la inclusión en la dieta de una cantidad adecuada de proteínas, aunque evitando el consumo excesivo. En algunos se establecen directrices sobre la proporción relativa de proteínas animales y vegetales. En otros se hace hincapié en el aporte de vitamina $C$ y de calcio. Todas estas recomendaciones se adaptan a las necesidades específicas del lugar. Son asimismo aspectos nutricionales importantes y 
relevantes para los individuos de todo el mundo los relacionados con el calcio, la hidratación, las vitaminas antioxidantes y los minerales.

El consumo adecuado de calcio es importante durante toda la vida para fortalecer el esqueleto y conseguir una masa ósea máxima (que se alcanza entre 18 y 30 años); además ayuda a retrasar la pérdida de masa ósea asociada a la edad, que suele causar osteoporosis. Se recomienda tomar como mínimo 800 miligramos de calcio desde el primer año de edad hasta la edad avanzada. En los adolescentes, los huesos crecen con rapidez, por lo que el consumo debe elevarse a 1.200 miligramos. Algunos especialistas estiman que la cifra pertinente en los adultos jóvenes, las mujeres postmenopáusicas y los varones mayores de 65 años es de 1.500 miligramos de calcio, frente a 1.000 miligramos el resto de los adultos. Las mujeres embarazadas y las lactantes necesitan 1.200 miligramos de calcio al día. Los productos lácteos son una fuente muy rica de calcio. Es recomendable consumir productos lácteos desnatados para controlar la concentración de colesterol en sangre.

EI mantenimiento de una hidratación adecuada es esencial para lograr un rendimiento máximo en el trabajo. U na consecuencia grave de la deshidratación es la incapacidad para eliminar el calor de forma eficiente, con lo que aumenta la temperatura corporal. La sed suele ser un buen indicador del estado de hidratación, salvo durante el ejercicio físico intenso. Durante el trabajo debe calmarse la sed bebiendo todo el líquido que apetezca. Los líquidos fríos y diluidos reponen las pérdidas hídricas con mayor rapidez. También los trabajadores manuales deben beber todo lo que les apetezca; por cada 0,5 $\mathrm{kg}$ de peso que se pierda al día por el ejercicio, se recomienda tomar medio litro de agua para reponer la pérdida de agua con el sudor.

Recientemente se ha prestado gran atención a los antioxidantes, debido a las pruebas cada vez más amplias de su posible acción protectora frente al cáncer, las cardiopatías y las cataratas y al posible retraso del proceso de envejecimiento. Entre los antioxidantes figuran vitaminas como los beta-carotenos y las vitaminas A, E y C, así como el selenio. Se cree que los antioxidantes previenen la formación de radicales libres nocivos, que con el tiempo destruyen las estructuras celulares en un proceso que provoca el desarrollo de diversas enfermedades. Las pruebas obtenidas hasta hora indican que los antioxidantes pueden proteger frente al desarrollo de cáncer, cardiopatías y cataratas, aunque no se ha establecido una relación causal. Los alimentos

Figura 15.11 - Ejemplo de una buena guía diaria de alimentación.

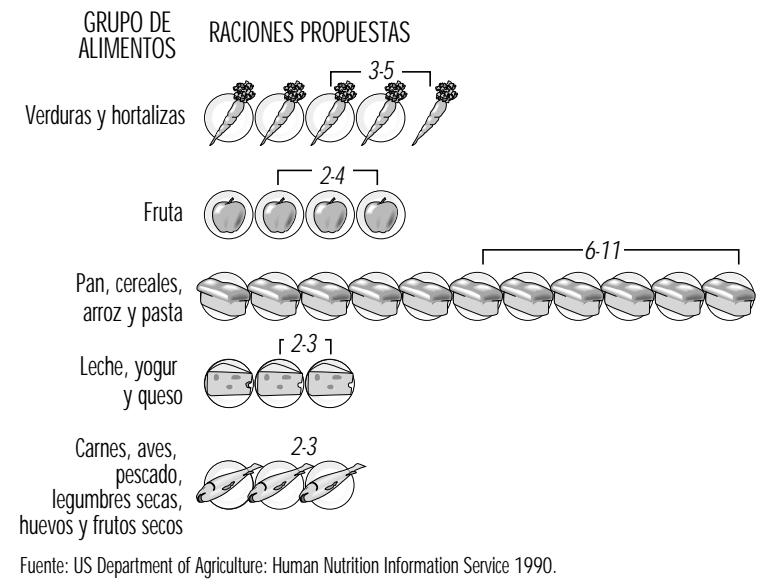

que contienen beta-carotenos y vitamina $\mathrm{A}$ son las verduras de hojas verdes y las frutas y verduras de color amarillo, rojo y naranja. Los cereales y el pescado son fuentes significativas de selenio. L os cítricos son una fuente importante de vitamina $C, y$ la vitamina $E$ se encuentra en las fuentes de grasas poliinsaturadas, como los frutos secos, las semillas, el aceite vegetal y el germen de trigo.

La notable similitud en las recomendaciones dietéticas de los diferentes países subraya el consenso que hay entre los expertos en nutrición sobre la dieta más idónea para promover la salud y el bienestar. El desafío al que se enfrenta el conjunto de profesionales de la nutrición en la actualidad es el de aplicar estas recomendaciones dietéticas para la población y el de garantizar globalmente una nutrición apropiada. Para cumplir estos objetivos, no sólo habrá que ofrecer una fuente segura y adecuada de alimentos a todas las personas en todo el mundo, sino que también habrá que desarrollar y aplicar programas educativos sobre nutrición para que todas las personas conozcan los principios de una dieta sana.

\section{Enfoques culturales y étnicos sobre la comida y la dieta}

Los enfoques de una educación nutricional eficaz deben tener en cuenta los aspectos culturales y los hábitos alimenticios étnicos. Es importante considerar los aspectos culturales al planificar los programas de nutrición y eliminar los obstáculos que impiden una comunicación eficaz en las tareas de asesoramiento. Dada la importancia que se concede actualmente a la diversidad cultural, la exposición a diferentes culturas en el lugar de trabajo y el marcado interés de los individuos por conocer otras culturas, deben acogerse favorablemente los programas de nutrición que tengan en cuenta las diferencias culturales.

Las distintas sociedades tienen unas creencias muy diferentes respecto a la prevención, la causa y el tratamiento de las enfermedades. El valor que se concede a la salud y a la nutrición es muy variable. Para ayudar a las personas a adoptar una forma de vida y unos hábitos dietéticos sanos es necesario comprender sus creencias y su cultura (US Department of $\mathrm{H}$ ealth and H uman Services 1990). Los consejos sobre nutrición deben tener en cuenta las prácticas específicas de cada grupo o población étnicos. Además, la actuación debe planearse de forma que tenga en cuenta las creencias más generales sobre la salud y las prácticas de nutrición. Por ejemplo, algunas culturas no aprueban el consumo de alcohol, mientras que otras lo consideran una parte esencial de la dieta e incluso se toma con las comidas en el lugar de trabajo. Por tanto, las actuaciones sobre la nutrición no sólo deben tener en cuenta las necesidades particulares de un grupo concreto, sino que deben reconocer los valores y creencias específicos de su cultura.

\section{Sobrepeso}

L os principales factores ambientales que determinan el sobrepeso y la obesidad son el consumo excesivo de calorías y la falta de actividad física.

El sobrepeso y la obesidad suelen clasificarse sobre la base del IMC, que se correlaciona con la composición del organismo ( $r=0,7-0,8)$. La clasificación del estado del peso según el IM C en los varones y las mujeres menores y mayores de 35 años se presentan en la Figura 15.10. Los riesgos para la salud asociados al sobrepeso y a la obesidad son claros. Los datos de numerosos estudios han mostrado una relación en forma de J entre el peso corporal y la mortalidad por cualquier causa. Aunque el índice de mortalidad aumenta si el IM C es mayor de 25 , el aumento se hace muy pronunciado si el IMC supera 30 . Curiosamente, el 
Figura 15.12 - Directrices para un programa razonable de reducción de peso.

DIETA

$\|$

- Suficiente desde el punto de vista nutricional

- Variada

- Hipocalórica

- Ajustada a las recomendaciones dietéticas actuales

- Saciante

- Puede seguirse durante un tiempo suficiente para perder peso

- Accesible

- Flexible y adaptable a las necesidades particulares

- Enseña nuevos hábitos de alimentación y facilita su adopción para el control del peso a largo plazo

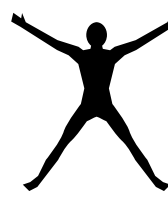

JERCICIO

- Apropiado para el individuo

- Enseña hábitos de ejercicio duraderos

- Cómodo y divertido

- Permite la participación durante todo el año

- Accesible

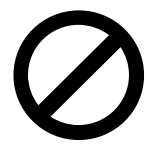

\section{MODIFICACION DEL COMPORTAMIENTO}

- Enseña nuevos hábitos y estrategias de control del peso

- Fomenta el apoyo social

- Proporciona compensaciones

- Enseña a afrontar momentos complejos y difíciles

bajo peso aumenta también el riesgo de mortalidad, aunque no en la medida del sobrepeso. M ientras que los individuos obesos y con sobrepeso tienen un riesgo mayor de fallecer por una enfermedad cardiovascular y de sufrir enfermedades de la vesícula biliar y diabetes mellitus, las personas con bajo peso tienen un riesgo mayor de padecer enfermedades del aparato digestivo y pulmonares (Lew y Garfinkel 1979). La incidencia del sobrepeso y la obesidad de algunos países desarrollados puede llegar a ser del 25 al $30 \%$ de la población; es incluso mayor en ciertos grupos étnicos y en grupos de clase socioeconómica baja.

Para reducir el peso se recomienda una dieta baja en calorías que permita perder entre 0,2 y 0,9 kg por semana. Para reducir el aporte calórico y aumentar la sensación de saciedad se recomienda una dieta baja en grasas (sobre el 30 \% de calorías en grasas o menos) con alto contenido en fibra (15 gramos por 1.000 calorías).

Todo programa para la pérdida de peso debe incluir la práctica de ejercicio y técnicas de modificación de conducta. Se recomienda perder peso lenta y progresivamente para modificar con eficacia los hábitos dietéticos. En la Figura 15.12 se presentan las características que debe reunir un programa razonable de reducción de peso.

U na encuesta telefónica aleatoria realizada en Estados U nidos entre 60.589 adultos reveló que aproximadamente el $38 \%$ de las mujeres y el $24 \%$ de los hombres estaban intentando activamente perder peso. Como reflejo del esfuerzo de marketing de lo que se ha convertido en una verdadera industria de la reducción de peso, los métodos iban desde el ayuno periódico o la participación en programas organizados de reducción de peso, frecuentemente con productos alimenticios y complementos nutritivos especiales elaborados comercialmente, hasta el uso de comprimidos. Sólo la mitad de quienes trataban de perder peso contestaron que estaban siguiendo el método recomendado de reducir la ingesta calórica y hacer ejercicio físico, lo cual demuestra la importancia de los programas de formación nutritiva en el lugar de trabajo (Serdula, Williamson y cols. 1994).
$L$ a reducción de peso en las personas obesas o con sobrepeso es beneficiosa para diversos factores de riesgo de enfermedad crónica (N IH 1993a). Al perder peso disminuyen la presión arterial, los lípidos plasmáticos y las lipoproteínas (es decir, el colesterol total, el colesterol transportado por lipoproteínas de baja densidad (LDL) y los triglicéridos) y aumenta el colesterol transportado por lipoproteínas de alta densidad (HDL); todos estos parámetros son importantes factores de riesgo de cardiopatía coronaria (Figura 15.13). Además, se modifican de forma favorable los niveles de glucosa en sangre, de insulina y de hemoglobina glicosilada. Se han observado mejorías en estos parámetros con pérdidas de peso de sólo $4 \mathrm{~kg}$, aunque después se recupere algo.

El control del peso es esencial para reducir la morbilidad y la mortalidad por enfermedades crónicas. En este principio se sustentan las recomendaciones dietéticas de numerosos grupos establecidas para países desarrollados en los que el sobrepeso y la obesidad son problemas de salud pública de primer orden. Aunque para perder peso se recomienda cumplir una dieta, hacer ejercicio y modificar la conducta, la clave para reducir la incidencia del sobrepeso y la obesidad consiste en aplicar programas de prevención eficaces.

\section{Bajo peso}

El bajo peso (definido como un peso corporal un $15-20 \%$, por lo menos, inferior al peso ideal) es un trastorno grave que provoca pérdida de energía y aumenta la sensibilidad a las lesiones y a las infecciones. El consumo insuficiente de comida, la actividad excesiva, la malabsorción, las comidas inadecuadas, las enfermedades producidas por trastornos en la eliminación y el estrés psicológico pueden ser la causa. Para ganar peso de forma gradual y constante se recomienda seguir dietas de alto contenido energético, que aporten del 30 al $35 \%$ de calorías en forma de grasas y de 500 a 1.000 calorías adicionales. $H$ ay que estimular a las personas con bajo peso a que tomen comidas y aperitivos de alto

Figura 15.13 - Principales factores de riesgo de cardiopatía coronaria.

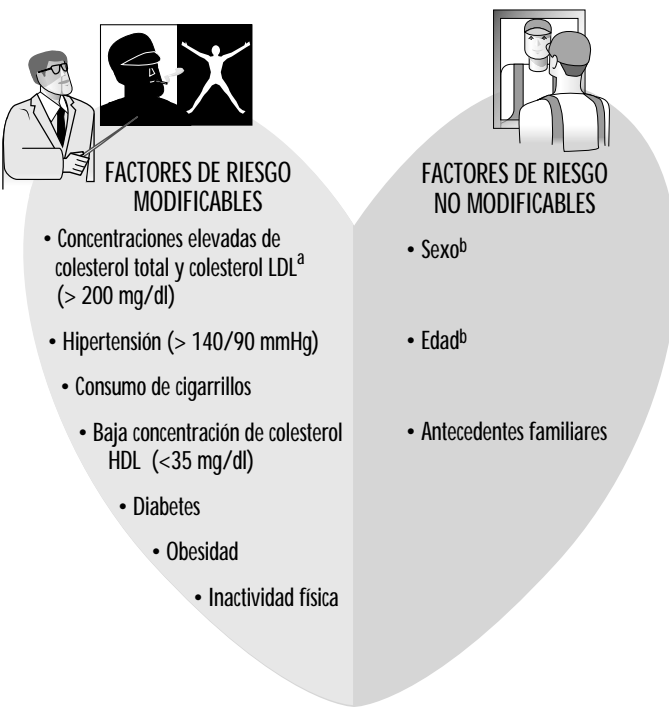

a El objetivo de colesterol LDL se basa en la presencia de factores de riesgo y áreas de cardiopatía coronaria (CPC Los objetivos son: $<160 \mathrm{mg} / \mathrm{dl}$ sin CPC y menos de dos factores de riesgo, $<130 \mathrm{mg} / \mathrm{dl}$ sin $\mathrm{CPC}$ y dos o más factores de riesgo; $y<100 \mathrm{mg} / \mathrm{dl}$ con $C P C$.

hEl riesgo afecta tanto a los hombres como a las mujeres, pero comienza antes en aquéllos. Los hombres están en EE riesgo afecta tanto a los hombres como a las mujeres, pero comienza antes en aquélos. Los hombres están en
peligro a partir de los 45 años, mientras que en las mujeres el riesgo comienza a partir de los 55 años o como peligro a partir de los 45 años, mientras que en las mujeres el riesgo comienza a pattir
consecuencia de una menopausia precoz sin tratamiento de reposición de estrógenos.

fuente: National Institutes of Health, National Heart, Lung, and Blood Institute 1993. 
contenido calórico en el lugar de trabajo ofreciéndoles la posibilidad de consumir productos populares variados de sabor agradable.

\section{Dietas especiales}

Existen dietas especiales para el tratamiento de ciertas enfermedades y trastornos. Además, los programas de nutrición y las formas de vida adecuados deben acompañarse de la modificación de la dieta en diversas etapas de la vida, como el embarazo y la lactancia. Para el éxito de estas dietas especiales es importante reconocer la posibilidad de seguir diferentes estrategias. Así pues, para mantener el cumplimiento a largo plazo y conseguir que se aprecien los beneficios, es necesario individualizar el plan de dieta y adaptarlo a las necesidades personales.

\section{Dieta baja en grasas, en grasas saturadas y en colesterol}

$L$ as dietas recomendadas en el tratamiento de los niveles elevados de colesterol son las que comprenden una sola fase $(30 \%$ de calorías en forma de grasas, 8-10\% de calorías en forma de grasas saturadas y 300 miligramos de colesterol) y las que comprenden dos fases (30\% de calorías en forma de grasas, $7 \%$ de calorías en forma de grasas saturadas, y 200 miligramos de colesterol) ( $\mathrm{N} \mathrm{IH}$ 1993b). A mbas están destinadas a reducir de forma progresiva la ingesta de grasas saturadas y de colesterol, y la de grasas totales. $L$ as principales fuentes de grasas en la dieta son la carne, las aves de corral, los productos lácteos no desnatados y las grasas y los aceites. En general, para la mayoría de las personas de los países desarrollados, seguir la dieta en una sola fase significa reducir las grasas totales y las grasas saturadas en cerca del 20-25\%, mientras que la dieta en dos fases requiere una reducción similar de las grasas totales pero, además, un descenso en las grasas saturadas aproximado del $50 \%$. La dieta en una sola fase puede seguirse fácilmente aplicando una o más de las estrategias de reducción de grasas en la dieta, como la sustitución por la carne magra, las aves de corral y el pescado, las variedades con un contenido de grasas más alto, la sustitución de los productos lácteos con toda la grasa por los productos de leche desnatada y con bajo contenido de grasas, el empleo de menos grasas en la preparación de las comidas y la adicción de menos grasas a éstas antes de consumirlas (p. ej., mantequilla, margarina o aderezo para ensaladas) (Smith-Schneider, Sigman-G rant y K ris-E therton 1992). La dieta en dos fases requiere una planificación más cuidadosa y una educación nutricional intensiva a cargo de un experto cualificado.

\section{Dietas con un contenido muy bajo de grasas}

Algunos expertos en nutrición recomiendan una dieta con un $20 \%$ o menos de calorías en forma de grasas para prevenir algunos cánceres que se han asociado a las dietas ricas en grasas (Henderson, Ross y Pike 1991). Esta dieta es rica en frutas y verduras, cereales, legumbres y productos lácteos desnatados. $L$ as carnes rojas pueden consumirse en pequeñas cantidades, al igual que las grasas y los aceites. Las comidas se preparan añadiendo poca o ninguna grasa y se cocinan al horno, al vapor, cocidas 0 hervidas.

Se ha demostrado la disminución de la aterosclerosis con una dieta que incluye una cantidad mínima de grasas saturadas (3 \% de calorías) y de grasas totales ( $10 \%$ de las calorías), junto con cambios importantes en la forma de vida (abandono del tabaco, ejercicio y meditación) (O rnish y cols. 1990). Esta dieta requiere cambios sustanciales en la forma de vida (es decir, en la forma habitual de cocinar), como adoptar hábitos en gran parte vegetarianos, comer poco o nada de carne, de pescado ni de aves de corral, y tomar más cereales, legumbres, fruta, verduras y productos lácteos desnatados. Para seguirla puede ser necesario comprar alimentos especiales (productos sin grasa) y evitar la mayoría de los que se venden preparados. Aunque representa una opción para algunas personas con un riesgo muy alto de patologías cardiovasculares, sobre todo como alternativa al tratamiento farmacológico, requiere un alto grado de motivación y compromiso.

\section{Dieta para trabajadores diabéticos}

Se recomienda prescribir una dieta individualizada basada en factores metabólicos y nutritivos y en la forma de vida (A merican Dietetic Association 1944). En general, las proteínas de la dieta proporcionan entre el 10 y el $20 \%$ de las calorías. Las grasas saturadas deben aportar menos del $10 \%$. La distribución del resto de las necesidades energéticas entre los carbohidratos y las grasas varía según el estado del paciente y debe basarse en la concentración hemática de lípidos y de glucosa y en el peso que se consideren más idóneos para la persona. En los individuos con un peso ideal, o casi ideal, se recomienda que el $30 \%$ de las calorías sean aportadas en forma de grasas. En las personas con sobrepeso, la reducción del consumo total de grasas facilita la disminución del aporte calórico y, con ello, la pérdida correspondiente de peso. En las personas con un nivel de triglicéridos elevado se recomienda una dieta con alto contenido de grasas totales, sobre todo de grasas monoinsaturadas, junto con una estrecha supervisión; las dietas ricas en grasas pueden prolongar 0 agravar la obesidad. El nuevo modelo para el tratamiento médico dietético de la diabetes incluye la evaluación individual de los parámetros metabólicos y de la forma de vida y un plan de actuación y de control de los resultados terapéuticos.

\section{Dieta para el embarazo y la lactancia}

Durante el embarazo y la lactancia, las necesidades nutritivas y energéticas son altas. En el embarazo, la dieta debe aportar las calorías suficientes para que la embarazada gane peso de forma adecuada (National Research Council 1989). Las calorías y los nutrientes necesarios para conseguir el apoyo nutritivo máximo en mujeres con períodos de embarazo y de lactancia repetidos durante varios años, en los que las necesidades nutritivas aumentan como consecuencia de los embarazos múltiples y de períodos de lactancia prolongados, pueden obtenerse con una dieta que incluya los grupos de alimentos básicos. Se recomienda también a las mujeres embarazadas y a las lactantes la elección de diversos tipos de cada grupo de alimentos, la toma de aperitivos de forma regular y la ingesta de abundante fibra y líquidos. El consumo de alcohol debe evitarse 0 , al menos, reducirse sustancialmente durante el embarazo y la lactancia. Se recomienda también a las mujeres embarazadas que utilicen la sal a su gusto. U na dieta adecuada durante el embarazo y la lactancia es esencial para garantizar el desarrollo y el crecimiento normal del feto y del niño, así como la salud y el bienestar de la madre, y debería fomentarse en los programas de educación nutricional en el lugar de trabajo y en las instalaciones de restauración de la empresa.

\section{Intolerancia a la lactosa y sensibilidad al gluten}

Un gran número de personas adultas, sobre todo las de ciertos grupos étnicos, deben restringir la lactosa en su dieta por una deficiencia de lactasas. La fuente principal de lactosa en la dieta son los productos lácteos y las comidas que se preparan con ellos. Es importante señalar que en numerosos medicamentos se utiliza como excipiente lactosa, que, por tanto, puede ocasionar problemas. En el escaso número personas con sensibilidad al gluten (enfermedad celíaca) hay que eliminar de la dieta los alimentos que contengan gluten, es decir, el trigo, el centeno, la cebada y la avena. M ientras muchos individuos con intolerancia a la lactosa pueden tolerar pequeñas cantidades de lactosa, sobre todo con otros alimentos que no contengan este producto, las personas con sensibilidad al gluten deben evitar cualquier comida 
que lo contenga. Las instalaciones de suministro interno de comidas en el lugar de trabajo deben disponer de platos apropiados si alguno de los trabajadores sufre este trastorno.

\section{Resumen}

El lugar de trabajo es el contexto idóneo para la aplicación de programas de nutrición encaminados a enseñar los principios de los hábitos dietéticos saludables y a ponerlos en práctica. Existen diversos programas para su aplicación en el lugar de trabajo. Además de impartir clases y de ofrecer materiales educativos sobre nutrición a todos los trabajadores, pueden dirigirse programas especiales a los trabajadores de alto riesgo de desarrollo de enfermedades crónicas o a grupos seleccionados basándose en las características demográficas. Para reducir el riesgo de sufrir enfermedades crónicas se necesita el compromiso a largo plazo de los trabajadores y de las empresas. Los programas eficaces de nutrición en el lugar de trabajo reducen el riesgo de enfermedades crónicas en países de todo el mundo.

\section{- CONTROL DEL TABACO EN EL LUGAR DE TRABAJO}

Jon Rudnick

\section{Introducción}

La "concienciación" de los efectos desfavorables que se asocian al consumo de cigarrillos ha ido aumentando desde el decenio de 1960, en que apareció el primer informe del Departamento de Sanidad de EE.UU. sobre el tema. Desde entonces, las actitudes ante el consumo de cigarrillos han ido haciéndose cada vez más negativas y han llevado a la exigencia de imprimir advertencias en los paquetes y anuncios de tabaco, la prohibición de la publicidad de cigarrillos en la televisión en algunos países, la instauración de zonas de no fumadores en algunos lugares públicos y la prohibición completa del tabaco en otras. Los mensajes de salud pública bien fundados acerca de los peligros de los derivados del tabaco se difunden cada vez más, pese a los intentos de la industria tabaquera por negar la existencia del problema. Las personas que intentan "dejar el hábito" gastan al año grandes sumas de dinero. Para ayudar a los que tienen adicción a la nicotina se han elaborado libros, cintas de audio, terapias de grupo, chicles de nicotina y parches cutáneos, e incluso ordenadores de bolsillo, todos con grados variables de éxito. La validación de los efectos cancerígenos del tabaquismo pasivo o indirecto ha añadido impulso a los esfuerzos crecientes por controlar el consumo de tabaco.

Con estos antecedentes, es natural que el consumo de tabaco en los centros de trabajo se haya convertido en un problema creciente tanto para las empresas como para los trabajadores. Al nivel más básico, el consumo de tabaco supone un riesgo de incendio. Desde el punto de vista de la productividad, el tabaco es una distracción o una molestia, según el trabajador sea o no fumador. El consumo de tabaco es una causa importante de morbilidad en la población activa. Supone tanto una pérdida de productividad, en forma de pérdida de horas de trabajo por enfermedad, como una pérdida económica de los recursos de la compañía o empresa a causa del aumento progresivo de los costes relacionados con la salud. Además, el tabaco ejerce una interacción aditiva o multiplicativa con otros riesgos ambientales presentes en algunos centros de trabajo, incrementando significativamente el riesgo de muchas enfermedades profesionales (Figura 15.14)

Este artículo trata de la justificación del control del tabaco en los centros de trabajo y propone una actitud y un enfoque prácticos del mismo, reconociendo que la mera advertencia no es suficiente. Al mismo tiempo, no se olvidan el terrible carácter adictivo de la nicotina ni los problemas asociados al abandono del tabaco. Se ha redactado con la esperanza de ofrecer un enfoque de este complejo problema más realista que algunos de los que nos han precedido.

\section{Consumo de tabaco en el lugar de trabajo}

Son cada vez más las compañías o empresas que relacionan los hábitos insanos, como el consumo de tabaco, con el aumento de

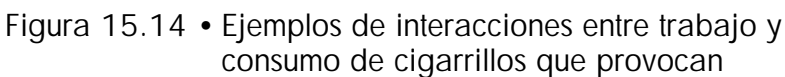
enfermedades.

\begin{tabular}{|c|c|c|c|}
\hline TRABAI0 & EXPOSICION & $\begin{array}{c}\text { ENTRE TABACO Y } \\
\text { TRABAJ } 0\end{array}$ & ENFERMEDAD \\
\hline $\begin{array}{l}\text { Amianto, construcción } \\
\text { y otros trabajos en } \\
\text { contacto con el } \\
\text { amianto }\end{array}$ & Amianto & $+x$ & $\begin{array}{l}\text { - Bronquitis crónica } \\
\text { - Enfermedad } \\
\text { pulmonar crónica }\end{array}$ \\
\hline $\begin{array}{l}\text { Fundición de } \\
\text { aluminio }\end{array}$ & $\begin{array}{l}\text { Hidrocarburos } \\
\text { polinucleados }\end{array}$ & $+0 x$ & Cáncer de vejiga \\
\hline $\begin{array}{l}\text { Industrias de aviación, } \\
\text { minería y otras }\end{array}$ & Ruido & + & $\begin{array}{l}\text { Pérdida de audición y } \\
\text { agudeza auditiva }\end{array}$ \\
\hline Cementos & $\begin{array}{l}\text { Polvo de } \\
\text { cemento }\end{array}$ & + & $\begin{array}{l}\text { - Bronquitis crónica } \\
\text { - Enfermedad pulmonar } \\
\text { obstructiva }\end{array}$ \\
\hline Fabricación de cloro & Cloro & + & $\begin{array}{l}\text { Enfermedad pulmonar } \\
\text { obstructiva crónica }\end{array}$ \\
\hline Minería del carbón & $\begin{array}{l}\text { Polvo de } \\
\text { carbón }\end{array}$ & + & $\begin{array}{l}\text { Enfermedad pulmonar } \\
\text { obstructiva crónica }\end{array}$ \\
\hline \multirow[t]{2}{*}{ Fundición de cobre } & $\begin{array}{l}\text { Dióxido de } \\
\text { azufre }\end{array}$ & + & $\begin{array}{l}\text { Enfermedad pulmonar } \\
\text { obstructiva crónica }\end{array}$ \\
\hline & Arsénico & $+0 x$ & Cáncer de pulmón \\
\hline Cereales & Polvo de cereal & + & $\begin{array}{l}\text { - Bronquitis crónica } \\
\text { - Enfermedad pulmonar } \\
\text { obstructiva }\end{array}$ \\
\hline $\begin{array}{l}\text { Compuestos químicos } \\
\text { orgánicos }\end{array}$ & Cancerígenos & $+0 x$ & $\begin{array}{l}\text { Cáncer de diversos } \\
\text { órganos y tejidos }\end{array}$ \\
\hline $\begin{array}{l}\text { Corte de piedras, } \\
\text { fundición }\end{array}$ & Polvo de sílice & + & $\begin{array}{l}\text { Enfermedad pulmonar } \\
\text { obstructiva crónica }\end{array}$ \\
\hline Textil & $\begin{array}{l}\text { Polvo de } \\
\text { algodón, } \\
\text { cáñamo, lino }\end{array}$ & $x$ & $\begin{array}{l}\text { - Obstrucción aguda } \\
\text { de las vías } \\
\text { respiratorias } \\
\text { - Bronquitis crónica } \\
\end{array}$ \\
\hline $\begin{array}{l}\text { Minería del uranio y } \\
\text { otros entornos } \\
\text { radiactivos }\end{array}$ & $\begin{array}{l}\text { Radiación alfa } \\
\text { (radón) }\end{array}$ & $\mathrm{x}$ & Cáncer de pulmón \\
\hline Soldadura & $\begin{array}{l}\text { Gases irritantes, } \\
\text { vapores metálicos, } \\
\text { polvo (radón) }\end{array}$ & + & $\begin{array}{l}\text { - Bronquitis crónica } \\
\text { - Enfermedad pulmonar } \\
\text { obstructiva }\end{array}$ \\
\hline
\end{tabular}

Fuente: Organización Mundial de la Salud 1992.

$\mathbf{+}=$ Aditiva $\quad \mathbf{X}=$ Multiplicativa $\quad \mathbf{X}=$ Probablemente multiplicativa 
los gastos de explotación, y muchas las que han adoptado medidas para reducir el exceso de costes asociados a los trabajadores que fuman. El coste de las indemnizaciones por motivos de salud de las personas que consumen al menos un paquete de tabaco al día es un $18 \%$ más alto que el de los no fumadores, según un estudio sobre el efecto de los distintos riesgos relacionados con el estilo de vida efectuado por la Ceridian Corporation, una empresa de servicios tecnológicos con domicilio en M inneapolis, M innesota. Según este estudio (Lesmes 1993), los grandes fumadores pasan un $25 \%$ más días hospitalizados y sus probabilidades de recibir indemnizaciones por razones de salud superiores a 5.000 dólares anuales son un $29 \%$ mayores que las de los no fumadores.

El efecto del tabaco en la salud de la población y en el sistema sanitario no tiene equivalentes (US D epartment of $\mathrm{H}$ ealth and Human Services 1989). Según la World Health Association (1992), el tabaco mata al menos a tres millones de personas al año en todo el mundo: en los países en los que es un hábito establecido, provoca alrededor del $90 \%$ de todas las muertes por cáncer de pulmón, el $30 \%$ de todos los cánceres, más del $80 \%$ de todos los casos de bronquitis crónica y enfisema y entre el 20 y el $25 \%$ de todas las muertes por infarto de miocardio 0 accidente cerebrovascular. También pueden atribuirse a él otros muchos trastornos nocivos para la salud, como las enfermedades respiratorias, la úlcera péptica y las complicaciones de la gestación. El tabaco sigue siendo la causa más importante de mortalidad evitable en Estados U nidos, hasta tal punto que provoca alrededor de la sexta parte de las muertes totales (D avis 1987).

El efecto combinado del tabaco y de los riesgos profesionales ha quedado demostrado por las importantes diferencias de morbilidad de los fumadores y no fumadores de muchas profesiones. La interacción de los tipos de peligros aumenta el riesgo de muchos trastornos, sobre todo de las enfermedades obstructivas crónicas del pulmón, del cáncer de pulmón, de las enfermedades cardiovasculares y de distintas discapacidades (Figura 15.14).

En distintas publicaciones técnicas se hallan bien establecidas las complicaciones mejor conocidas de la exposición a los peligros relacionados con el tabaco. R ecientemente, se ha prestado una gran atención a los aspectos siguientes:

- Riesgos para la mujer. Cambio del metabolismo de los estrógenos, trastornos menstruales, menopausia precoz, concepción tardía o infertilidad, cáncer de cuello uterino.

- Riesgos maternofetales. Aborto espontáneo, embarazo ectópico, alteraciones de la placenta, placenta previa, abruptio placentae, hemorragia vaginal, mortalidad fetal, parto pretérmino, retraso del desarrollo fetal, bajo peso al nacimiento, anomalías congénitas e hipoxia crónica.

- Complicaciones infantiles. M ayor mortalidad neonatal, síndrome de muerte súbita del lactante (SM SL), alteración del desarrollo físico e intelectual.

\section{Tabaquismo pasivo e indirecto (TPI)}

El consumo de tabaco no sólo resulta peligroso para el fumador, sino también para los no fumadores. EI T PI constituye un riesgo especial para quienes trabajan en un ambiente cerrado. Como señala la O rganización M undial de la Salud (1992), en los países desarrollados el consumo de tabaco es el principal contaminante del aire interior y suele encontrarse a concentraciones mayores que las de otros contaminantes atmosféricos. R esulta especialmente inconveniente para las personas que sufren problemas de salud preexistentes, como asma, bronquitis, enfermedades cardiovasculares, alergias o infecciones de las vías respiratorias altas. También supone un reto molesto para los que han dejado de fumar recientemente y están intentando persistir en su abstinencia.

El Instituto Nacional de Salud y Seguridad en el Trabajo (NIOSH) de los Estados Unidos ha llegado a la conclusión siguiente (1991):

- EITPI es un carcinógeno potencial.

- La exposición al TPI debe reducirse a la concentración mínima posible.

- Las empresas deben reducir al mínimo la exposición laboral al T PI utilizando todas las medidas de control posibles.

- El control más eficaz y completo de la exposición de los trabajadores al TPI se consigue eliminando el tabaco de los lugares de trabajo.

- Las empresas deben prohibir el consumo de tabaco en los lugares de trabajo y no dar incentivos a quienes no cumplan las normas.

Excepto en los casos en que la legislación prohíbe el tabaco en el lugar de trabajo, la protección de los no fumadores frente a los riesgos para su salud que se asocian a la exposición al TPI sigue siendo un serio problema para muchos trabajadores de los sectores público y privado. Los fumadores, incitados por la industria del tabaco, afirman que fumar es un derecho personal, pese a que la eliminación del humo de los lugares de trabajo exige mejorar los servicios de ventilación, con el consiguiente gasto. LoS precedentes legales han establecido la obligación de estas últimas de ofrecer lugares de trabajo libres de riesgos tales como el TPI y los tribunales de algunos países han considerado que las empresas son responsables de los efectos desfavorables para la salud del TPI durante el trabajo.

L as encuestas sobre conocimientos y actitudes de la población en relación con los riesgos del TPI y la conveniencia de restringir el consumo de tabaco en los lugares de trabajo revelan que tanto los fumadores como los no fumadores demuestran una preocupación creciente por este tipo de exposición y un mayor apoyo a las medidas restrictivas (American Lung Association 1992). Se han adoptado un número cada vez mayor de ordenanzas y disposiciones limitando el consumo de tabaco en los lugares de trabajo públicos y privados (Corporate $\mathrm{H}$ ealth Policies $G$ roup 1993).

\section{Efecto del consumo de tabaco en los costes de las empresas}

$\mathrm{H}$ istóricamente, las actividades de las empresas para reducir el consumo de tabaco en el lugar de trabajo se han debido a problemas relacionados con los costes y la pérdida de productividad asociados a dicho consumo. Distintos estudios han comparado los costes asociados con los trabajadores fumadores y no fumadores. Por ejemplo, en una investigación sobre los trabajadores de un plan de seguro sanitario a gran escala, los fumadores presentaban, como promedio, mayores gastos de atención médica ambulatoria (122 frente a 75 dólares), unos costes médicos asegurados más altos (1.145 frente a 762 dólares), un mayor número de ingresos hospitalarios por 1.000 trabajadores (174 frente a 76), un mayor número de días de hospitalización por 1.000 trabajadores (800 frente a 381) y una mayor duración media de la hospitalización (6,74 frente a 5,03 días) (Penner y Penner 1990).

0 tro estudio, efectuado durante un período de tres años y medio por D ow Chemical Company en un total de 1.400 trabajadores (Fishbeck 1979), demostró que los fumadores faltaban al trabajo 5,5 días más al año que los no fumadores y costaban a la empresa 650.000 dólares anuales per capita sólo en exceso de salarios. Esta cifra no comprendía los costes sanitarios adicionales. A ello debe añadirse que los fumadores tenían 17,4 días de baja por enfermedad al año, en comparación con los 9,7 días de los no fumadores. Asimismo, la frecuencia de los trastornos 
circulatorios era doble en los primeros y la de neumonía, triple; tenían un $41 \%$ más de bronquitis y enfisema y un $76 \%$ más de enfermedades respiratorias de todos los tipos. Por cada dos no fumadores que fallecieron durante el período de estudio, murieron siete fumadores.

Un estudio de U nited States Steel Corporation demostró que los trabajadores que fumaban perdían más días de trabajo que los que nunca habían fumado. También reveló que, en todos los grupos de edad y a medida que aumentaba el número de cigarrillos consumidos por los fumadores confirmados, ascendía asimismo el número de ausencias por enfermedad. Además, los varones fumadores de más de dos paquetes al día tenían casi dos veces más absentismo que sus compañeros no fumadores. En un estudio sobre la magnitud en que los factores de riesgo individuales contribuyen a los costes por discapacidad total y atención sanitaria de una empresa industrial con varios centros de trabajo, los fumadores tenían un $32 \%$ más de absentismo y un exceso de costes anuales por enfermedad de 960 dólares per capita (Bertera 1991).

El informe anual de la Comisión sobre la Atención Sanitari ade los Trabajadores del estado de $K$ ansas señaló que los fumadores tenían un $33 \%$ más de hospitalizaciones que los no fumadores $(106,5$ frente a 71,06 hospitalizaciones por 1.000 personas). Los pagos totales por indemnizaciones per capita ascendieron a 282,62 dólares más en el caso de los fumadores, en comparación con los no fumadores.

Estos y otros resultados similares han llevado a algunas empresas de Estados U nidos a aplicar a sus empleados fumadores un "recargo" de las pólizas de los seguros de enfermedad a fin de cubrir los mayores gastos asociados. R esinoid E ngineering Corporation dejó de contratar a trabajadores fumadores en su planta de $\mathrm{O}$ hio porque sus indemnizaciones por enfermedad eran 6.000 dólares más altas por empleado y año que las de los no fumadores. En Chicago, se impidió una maniobra similar porque la legislación estatal prohíbe la discriminación laboral por razón del estilo de vida.

O tras empresas, usando la "zanahoria" más que el "palo", han ofrecido incentivos económicos o de otro tipo a los trabajadores que consigan dejar de fumar. Un enfoque muy extendido consiste en refinanciar la matrícula exigida para participar en un programa de abandono del tabaco a los que lo hayan completado con éxito 0 , más estrictamente, a los que sigan sin fumar durante un período definido de tiempo después de haber completado el curso.

Además de los mayores costes de atención sanitaria y de los costes relacionados con la pérdida de productividad por enfermedad de los fumadores, existen otros costes asociados al consumo de tabaco que dependen de la productividad perdida durante los descansos para fumar, los mayores costes del seguro contra incendios y de los mayores costes generales de limpieza. Por ejemplo, Air Canada comprobó un ahorro de unos 700.000 dólares anuales al no tener que limpiar los ceniceros y poder reducir la frecuencia de limpieza general de sus aviones de seis a nueve meses después de poner en práctica su política de prohibición del tabaco (O M S 1992).

Un estudio de K ristein (1983) diseñado para tomar en consideración el incremento total de costes relacionados con el tabaco obtuvo un total de 1.300 dólares por fumador y año (ajustado a dólares de 1993). El autor comentó también la existencia de otras áreas de exceso de costes, en especial las correspondientes a un mayor nivel de mantenimiento de ordenadores y otros equipos sensibles y a la instalación y mantenimiento de los sistemas de ventilación. A ello añadió otros costes debidos a la "ineficacia y los errores, de acuerdo con la bibliografía reconocida, en relación con los efectos del aumento de las concentraciones de monóxido de carbono de los fumadores, la irritación ocular, el menor nivel medido de atención, de capacidad cognitiva y de capacidad de esfuerzo".

\section{Políticas y reglamentos sobre el consumo de tabaco}

En el decenio de 1980 se produjo un notable aumento del número de disposiciones legales y políticas privadas destinadas a reducir el consumo de tabaco en el lugar de trabajo. Algunas corresponden sólo a los centros oficiales que, junto a los centros de trabajo en los que hay niños, suelen tomar la delantera en este campo. 0 tras afectan tanto a los centros oficiales como a los privados. Se caracterizan por la prohibición total del tabaco, la limitación del consumo en las zonas comunes, como los comedores y las salas de reunión, la posibilidad de fumar sólo en áreas especialmente destinadas a este fin, y la exigencia de modificaciones para respetar los intereses de fumadores y no fumadores, aunque dando primacía a estos últimos.

Algunos programas regulan el consumo de tabaco en los lugares de trabajo en los que existen materiales peligrosos. Por ejemplo, en 1976, Noruega prohibió destinar fumadores a zonas en las que pudieran verse expuestos al amianto. En 1988, España prohibió fumar en cualquier lugar en que la combinación del tabaco y los riesgos laborales pudiera producir mayores riesgos para la salud de los trabajadores. En este país también está prohibido fumar en cualquier lugar en que se hallen presentes mujeres embarazadas. 0 tros países que han tomado medidas legales para restringir el consumo de tabaco en los lugares de trabajo son Costa R ica, Cuba, Dinamarca, Islandia e Israel (O M S 1992).

Con frecuencia cada vez mayor, las disposiciones relativas al consumo de tabaco en los centros de trabajo se encuadran en una normativa más amplia que afecta a los lugares públicos. Así ocurre en Nueva Zelanda, Noruega y Suecia, mientras que Bélgica, Países Bajos e Irlanda prohíben fumar en casi todos los lugares públicos. La legislación francesa de 1991 prohíbe fumar en cualquier zona de uso colectivo, particularmente en las escuelas y en el transporte público (O M S 1992).

En Estados U nidos y Canadá, aunque los organismos federales han adoptado políticas de control del tabaco, han sido los estados, provincias y municipios los que han promulgado disposiciones al respecto. En 1989, 45 estados de EE.UU. habían adoptado normas limitando el consumo de tabaco en los lugares públicos, mientras que otros 19 estados y el distrito de Columbia habían prohibido también fumar en los lugares de trabajo privados (Bureau of National Affairs 1989). En el estado de California se ha presentado un proyecto de ley que prohíbe fumar en todas las zonas de trabajo cubiertas y obliga a las empresas a tomar medidas razonables para impedir que fumen los visitantes (M askin, Connelly y Noonan 1993). Desde hace algún tiempo, la Administración de Salud y Seguridad en el Trabajo del Departamento de Trabajo de EE.UU. está valorando la normativa sobre el TPI en los centros de trabajo, como tóxico independiente y como componente del aire ambiental (Corporate $\mathrm{H}$ ealth Policies G roup 1993).

0 tro incentivo para que las empresas reduzcan el consumo de tabaco en el lugar de trabajo procede de las sentencias sobre discapacidad secundaria a la exposición al TPI. En 1982, un tribunal federal de apelación reconoció a una trabajadora el derecho a la jubilación por incapacidad por haberse visto obligada a trabajar en un ambiente cargado de humo (Parodi contra Veterans Administration 1982). De igual modo, se ha reconocido a algunos trabajadores el derecho a indemnización por sufrir reacciones adversas al humo de tabaco durante sus horas de trabajo. De hecho, William Reilly, antiguo administrador de la Agencia de Protección del Medio Ambiente de Estados U nidos (EPA), ha manifestado su esperanza de que la amenaza 
de responsabilidad empresarial planteada por el reciente reconocimiento del TPI como importante riesgo para la salud por la EPA evite al gobierno la necesidad de seguir adoptando reglamentos federales (N oah 1993).

0 tro factor que favorece la creación de políticas limitativas del consumo de tabaco en los lugares de trabajo es el cambio de las actitudes de la población, que refleja: (1) el reconocimiento de la progresiva acumulación de pruebas científicas sobre los riesgos del humo de los cigarrillos tanto para los fumadores como para los no fumadores, (2) el descenso de la prevalencia del consumo de tabaco, (3) el descenso de la aceptación social del tabaco y (4) la mayor conciencia de los derechos de los no fumadores. La American Lung Association (1992) ha registrado un incremento constante del porcentaje global de adultos favorables a la limitación del consumo de tabaco en los lugares de trabajo, que ha pasado del $81 \%$ de 1983 al $94 \%$ de 1992, en tanto que los que defienden la prohibición total han aumentado del $17 \%$ al $30 \%$ y los que rechazan cualquier prohibición han descendido del $15 \%$ al $5 \%$.

L os sindicatos apoyan cada vez más las políticas de control del tabaco en sus negociaciones con las empresas (C orporate $\mathrm{H}$ ealth Policies G roup 1993).

Las encuestas más recientes efectuadas en EE.UU. demuestran una clara tendencia no sólo a la adopción de limitaciones al consumo de tabaco, sino también su carácter progresivamente restrictivo (Bureau of National Affairs 1986, 1991). El porcentaje de empresas que han adoptado políticas de este tipo ha aumentado del $36 \%$ de 1986 al $85 \%$ de 1991 y, durante el mismo período, se ha producido un incremento de 16 veces en el porcentaje de prohibiciones totales (Bureau of $\mathrm{N}$ ational Affairs 1991; C oalition on Smoking and $\mathrm{H}$ ealth 1992).

\section{Programas de abandono del tabaco}

Los lugares de trabajo son entornos cada vez más habituales de las actividades de educación y promoción de la salud. U na encuesta tomada de uno de varios estudios citados (C oalition on Smoking and $\mathrm{H}$ ealth 1992) indica que el 35,6 \% de las empresas ofrecen algún tipo de ayuda para dejar de fumar. 0 tro estudio revela que las políticas antitabaco tienden también a prestar apoyo a las personas que lo intentan. Por tanto, la política antitabaco también debe ser considerada como un elemento importante de los programas de abandono del tabaco.

L os métodos para abandonar el consumo de tabaco se dividen en dos categorías:

- M étodos no asistidos, que no utilizan técnica especial alguna: reducir poco a poco el número de cigarrillos diarios, consumir cigarrillos bajos en alquitrán o nicotina, dejar de fumar junto a otros amigos, parientes o conocidos, usar filtros o boquillas especiales, usar otros productos de venta libre o sustituir los cigarrillos por otros derivados del tabaco (rapé, tabaco de mascar, pipa o cigarro puro).

- M étodos asistidos, que implican la asistencia a un programa o curso pagado o gratuito o la consulta a un profesional de la salud mental, la hipnosis, la acupuntura o el uso de chicles o parches de nicotina.

La eficacia de estos distintos métodos es objeto de gran controversia, debida en gran parte a las dificultades y costes asociados con el seguimiento a largo plazo y al evidente interés de sus promotores por defender sus programas y productos. 0 tra limitación importante se refiere a la posibilidad de comprobar el estado de los participantes en los programas con respecto al tabaco (Elixhauser 1990). Los análisis de saliva para medir la cotinina, un metabolito de la nicotina, son un indicador objetivo eficaz de si el individuo ha fumado recientemente, pero resultan moderadamente laboriosos y costosos y, por tanto, no se usan con carácter habitual. En consecuencia, hay que depender de la fiabilidad, cuestionable, de los informes del propio sujeto acerca del éxito 0 el fracaso del abandono o reducción del tabaco. Estos problemas hacen que resulte sumamente difícil comparar los distintos métodos entre sí o incluso utilizar correctamente los grupos de control.

Pese a todos estos problemas, pueden extraerse dos conclusiones generales. En primer lugar, las personas que consiguen dejar de fumar son, en gran parte, las que lo hacen por sí solas, a menudo tras numerosos intentos anteriores. En segundo lugar, si dejamos aparte el enfoque "duro" individual, parece que son las actuaciones múltiples combinadas las que mayor éxito consiguen, particularmente cuando van acompañadas de una ayuda en el mantenimiento de la abstinencia y de un refuerzo del mensaje para abandonar el tabaco (Bureau of $\mathrm{N}$ ational Affairs 1991). La importancia de este último factor ha sido confirmada en un estudio (Sorenson, L ando y Pechacek 1993) en el que se demostró que la tasa global de abandonos más elevada correspondía a los fumadores que trabajaban junto a una gran proporción de no fumadores y a los que se pedía a menudo que dejaran de fumar. Aun así, la tasa de abandono a los seis meses era sólo del $12 \%$, en comparación con el $9 \%$ en el grupo de control. Evidentemente, no debe esperarse que los programas de abandono del tabaco en general produzcan resultados positivos espectaculares, sino que, por el contrario, han de ser considerados como programas que requieren un esfuerzo persistente y paciente dirigido hacia ese objetivo.

Algunos programas de abandono del tabaco en los lugares de trabajo parten de planteamientos demasiado simples o ingenuos, mientras que otros carecen de un compromiso y determinación a largo plazo. L as empresas lo han intentado todo, desde la mera restricción del consumo de tabaco a zonas definidas hasta el anuncio repentino y autócrata de la prohibición total del tabaco, - la oferta de programas costosos e intensivos (aunque, a menudo, de corta duración) contratados con terceros. El problema y el reto consisten en lograr un centro de trabajo en el que no se fume sin sacrificar el estado de ánimo y la productividad de los trabajadores.

En la sección siguiente se presenta un enfoque que incluye nuestros conocimientos actuales sobre las dificultades a las que se enfrentan las personas que desean dejar de fumar y la actitud empresarial que sería necesario adoptar para lograr de la mejor manera posible el objetivo de lograr un centro de trabajo sin tabaco.

\section{Un enfoque alternativo a la prohibición del tabaco en el lugar de trabajo}

L a experiencia demuestra que la simple oferta de programas para dejar de fumar no basta para conseguir el objetivo de un centro de trabajo sin tabaco, porque la mayoría de los trabajadores no participarán en ellos. En un momento dado, sólo un $20 \%$ de los fumadores están dispuestos a dejar de fumar y únicamente una minoría de entre ellos se apuntará a un programa de abandono. EI $80 \%$ restante que no quieren dejar de fumar o que no creen que puedan hacerlo cuando la empresa establezca la prohibición se limitarán a fumar "al aire libre", en las zonas designadas o en algún lugar fuera del edificio durante sus horas de trabajo. Este "problema del $80 \%$ " (el $80 \%$ de los fumadores no van a recibir ayuda y ni siquiera van a considerar su participación en el programa si éste es lo único que se les ofrece) tiene múltiples efectos negativos en las relaciones con la empresa, la productividad, los costes de explotación y los costes relacionados con la salud.

Addiction $\mathrm{M}$ anagement Systems, organización domiciliada en Toronto, Canadá, ha diseñado un enfoque alternativo que ha resultado eficaz y que se basa en el conocimiento de que el 
cambio y la modificación del comportamiento son un proceso que puede planificarse y gestionarse utilizando técnicas organizativas y conductistas. Consiste en considerar el control del consumo del tabaco en los centros de trabajo de la misma forma que los otros grandes cambios de procedimiento o de política de la empresa, en los que la gerencia toma sus decisiones tras recibir la información oportuna de los representantes de los trabajadores. El cambio controlado se consigue respaldando a los directivos responsables de supervisar el cambio y transformando a los fumadores en participantes positivos en ese cambio, proporcionándoles las "herramientas" necesarias para adaptarse al nuevo entorno sin tabaco, aunque sin exigirles que dejen de fumar. El aspecto central es la participación y la educación de todos los afectados por la política de cambio, mediante un proceso de comunicación y de construcción de equipos.

El proceso real de transición al establecimiento de un lugar de trabajo en el que esté prohibido el consumo de tabaco comienza con el anuncio de cambio de política y el inicio de un período de transición de varios meses de duración. En términos del comportamiento, la política prevista actúa como "estímulo para el cambio" y crea un nuevo ambiente en el que el mayor interés de los fumadores será adaptarse a ese nuevo entorno.

El anuncio del cambio de política va seguido de un programa de comunicación destinado a todos los trabajadores, pero centrado en dos grupos principales: los supervisores, que deben ejecutar y vigilar la nueva política antitabaco, y los fumadores, que deben aprender a adaptarse al nuevo entorno. U na parte importante del programa de comunicación consiste en hacer conscientes a los fumadores de que, si bien no se les va a exigir que dejen de fumar si no lo desean, deberán cumplir las nuevas normas que prohíben fumar en el lugar de trabajo durante la jornada laboral. Todos los trabajadores deben recibir la información sobre la nueva política y los futuros cambios.

Durante el período de transición, los supervisores reciben materiales informativos y siguen un programa de formación que les permita entender los cambios de política y prever las preguntas, problemas e inconvenientes a los que deberán enfrentarse durante la fase de cambio o después. Como grupo más directamente afectado cuando la política se establezca, se consulta a los fumadores acerca de sus necesidades específicas y se les imparte su propio programa de formación. Este va destinado a familiarizarles con un programa voluntario de autoayuda para "control del tabaco" que contiene distintas opciones y elecciones que permiten entender el programa y aprender a modificar el hábito a fin de abstenerse de fumar durante la jornada laboral, como exigirá la nueva política cuando se aplique. De este modo, cada trabajador puede personalizar el programa y definir el "éxito" en sus propios términos, tanto si deja de fumar como si aprende a no hacerlo durante las horas de trabajo. En consecuencia, el resentimiento queda neutralizado y la transición al establecimiento de un lugar de trabajo libre de tabaco se convierte en un factor motivador positivo para el individuo.

El resultado final de este enfoque es que, cuando llega la fecha efectiva de implantar la nueva política, la transición se consigue sin traumatismos, es simple y tiene éxito, porque se han construido los cimientos, se ha realizado la comunicación y todos los afectados entienden lo que va a suceder y poseen los medios para efectuar el cambio.

Lo más importante, desde un punto de vista organizativo, es que el cambio se haga de forma que pueda mantenerse con una aportación mínima de la gerencia. También es importante que el efecto del aprendizaje de los fumadores del "grupo del $80 \%$ " a "gestionar" su problema tienda a multiplicarse y les lleve a abandonar por completo el tabaco. Por último, además de los efectos beneficiosos sobre el bienestar y la moral de los trabajadores que participan activamente en la transición al establecimiento de un entorno sin tabaco, la organización consigue beneficios a largo plazo en términos de aumento de la productividad y disminución de los costes relacionados con la atención sanitaria.

\section{Evaluación de la eficacia}

Al evaluar la eficacia del programa, es preciso tener en cuenta dos criterios distintos. El primero es si el lugar de trabajo se ha convertido realmente en un entorno sin tabaco. El éxito con respecto a este objetivo es relativamente fácil de medir: se basa en los informes periódicos de los supervisores sobre las infracciones de la política general durante las horas de trabajo, el seguimiento de las quejas de otros trabajadores y los resultados de las inspecciones imprevistas para comprobar la presencia o ausencia de colillas, cenizas o humo de tabaco.

La segunda medida del éxito, y la más difícil de determinar, es el número de trabajadores que dejan de fumar realmente y que mantienen esta abstinencia. Aunque la postura más práctica quizá sea la que se refiere tan sólo al consumo de tabaco en el lugar de trabajo, este éxito limitado implica mejores beneficios a largo plazo, particularmente en lo que concierne a la reducción de las enfermedades y de los costes de asistencia sanitaria. Aunque los análisis periódicos del contenido en cotinina de la saliva destinados a identificar a los fumadores serían la forma más eficaz y objetiva de evaluar el éxito a largo plazo del programa, esta medida no sólo es compleja y costosa, sino que, además, plantea numerosas cuestiones éticas y legales relacionadas con la intimidad de los trabajadores. Un compromiso puede consistir en usar cuestionarios anónimos anuales o semestrales en los que se pregunte si los hábitos del individuo con respecto al tabaco han sufrido alguna modificación y durante cuánto tiempo han mantenido su abstinencia del tabaco, sondeando al mismo tiempo los posibles cambios de la actitud ante la política y el programa. Estos cuestionarios tienen la ventaja añadida de ser un medio para reforzar el mensaje antitabaco y mantener las puertas abiertas para que los todavía fumadores puedan plantearse abandonar el hábito.

La evaluación final a largo plazo valora el absentismo, las enfermedades y los costes de asistencia sanitaria de los trabajadores. Cualquier cambio que se produzca será inicialmente sutil, pero a lo largo de los años debe adquirir una significación acumulativa. O tro reflejo a largo plazo del éxito del programa podría ser el total de indemnizaciones por muerte pagadas antes de la edad normal de jubilación. Como es natural, todos estos datos deben ajustarse a ciertos factores, como los cambios en la plantilla, las características de los trabajadores, tales como su edad y su sexo, y otros elementos que influyen en la organización. El análisis de estos datos está, desde luego, sujeto a las reglas de la estadística y probablemente sólo sea válido en organizaciones que disponen de plantillas grandes y estables y de una capacidad suficiente de obtención, almacenamiento y estudio de los datos.

\section{Control del consumo de tabaco en todo el mundo}

Cada vez está más extendida en todo el mundo la opinión reacia a soportar la carga del consumo de cigarrillos y de la adicción a la nicotina, debido a sus efectos en el bienestar y la productividad del hombre, en la salud y en los costes de atención sanitaria y en la salud económica de las poblaciones activas y las naciones. Así lo demuestra la creciente participación de los países en el Día M undial sin Tabaco patrocinado cada mes de mayo por la O rganización M undial de la Salud desde 1987 (O M S 1992).

El objetivo de este acontecimiento no es sólo pedir a la gente que deje de fumar durante un día, sino también despertar el interés por el control del consumo de tabaco en las organizaciones públicas y privadas y promover las medidas de presión 
Tabla 15.3 - Temas del "Día mundial sin tabaco".

\section{Lugares de trabajo sin tabaco: más seguros y saludables}

1993 Servicios de salud: nuestra ventana a un mundo sin tabaco

1994 Los medios de comunicación y el tabaco: difundir el mensaje de salud

1995 La economía del tabaco: el tabaco cuesta más de lo que usted piensa

1996 Deporte y arte

1997 Las Naciones Unidas y los organismos especializados contra el tabaco actividades de promoción de la salud a sus trabajadores para el año 2000, "preferiblemente en el marco de un programa global de promoción de la salud de los empleados" (objetivo 8.6). Además, otros dos objetivos señalan, específicamente, la necesidad de prohibir o limitar en gran medida el consumo de tabaco en los puestos de trabajo, elevando el porcentaje de centros que dispongan de una política propia al efecto (objetivo 3.11) y promulgando leyes estatales generales sobre pureza del aire en los recintos cerrados (objetivo 3.12).

En respuesta a estos objetivos y al interés de sus trabajadores, $M$ errill Lynch and Company, Inc. (en adelante, M errill Lynch) diseñó su programa "El bienestar y usted" para los empleados de sus oficinas en la ciudad de Nueva York y en el estado de N ueva Jersey. M errill L ynch es una compañía dedicada al asesoramiento y gestión de recursos financieros que ocupa una posición destacada en este campo, y que tiene como clientes tanto personas físicas como empresas. Sus 42.000 trabajadores en más de 30 países prestan servicios que abarcan la suscripción, contratación e intermediación en valores, la banca de inversión, la contratación en divisas, mercancías y derivados, el negocio bancario y de préstamos, y la venta de seguros y servicios de reaseguros. Su plantilla presenta grandes diferencias desde el punto de vista de la raza, la nacionalidad y los niveles educativos y salarial. Casi la mitad de sus trabajadores trabajan en las oficinas centrales del área metropolitana de Nueva York (que incluye parte de Nueva Jersey) y en dos centros de Florida y Colorado.

\section{Programa "El bienestar y usted" de Merrill Lynch}

El programa "El bienestar y usted" está adscrito al departamento de Servicios de Atención a la Salud y su gestión se ha encomendado a un educador sanitario con título de doctorado que depende del director médico. Su plantilla básica está compuesta por el gerente y un ayudante a tiempo completo, y se completa con médicos, enfermeras y asesores de asistencia al personal y con consultores externos según las necesidades.

En 1993, su primer año de funcionamiento, más de 9.000 trabajadores, equivalentes al $25 \%$ aproximadamente de la plantilla, participaron en las distintas actividades del programa, entre ellas las siguientes:

- Programas de autoayuda y de información escrita, que comprendieron la distribución de folletos sobre numerosos temas relacionados con la salud y asimismo de una guía de salud personal de Merrill Lynch diseñada para alentar a los trabajadores a someterse a las pruebas, vacunas y orientaciones que necesiten para conservar la salud.

- Seminarios y talleres educativos, sobre temas de interés general, tales como el abandono del tabaco, la gestión del estrés, el SIDA y la enfermedad de Lyme.

- Programas generales de detección sistemática, destinados a identificar a los trabajadores con riesgo de enfermedad cardiovascular, cáncer de piel y cáncer de mama. Estos programas fueron aplicados por personal contratado en las propias instalaciones de la empresa, bien en las consultas de atención sanitaria, bien en unidades móviles.

- Programas continuos, como los de ejercicios aeróbicos en el corredor de la empresa y los de control del peso corporal en las salas de conferencias de la misma.

- Atención sanitaria, manifestada en la vacunación contra la gripe, los servicios de dermatología, las exploraciones clínicas periódicas y el consejo dietético en las consultas de atención sanitaria a los trabajadores.

En 1994, el programa se amplió para incluir un programa de detección sistemática ginecológica en los centros de trabajo, que 
comprendía citología vaginal y exploración pelviana y mamaria, un programa mundial de atención médica de urgencia para ayudar a los trabajadores a encontrar médicos que hablen inglés en cualquier parte del mundo. En 1995, los programas de bienestar se ampliarán a las oficinas de Florida y Colorado y cubrirán aproximadamente a la mitad de toda la plantilla. Casi todos los servicios son gratuitos o se ofrecen a un coste nominal.

\section{Programas de abandono del tabaco en Merrill Lynch}

Durante los últimos años, los programas antitabaco han conseguido un lugar preeminente en el campo del bienestar laboral. En 1964, el Departamento de Sanidad de Estados U nidos definió el tabaco como la causa singular de la mayor parte de las enfermedades prevenibles y de la mortalidad prematura (Departamento de Salud, Educación y Bienestar de EE.UU. 1964). Desde entonces, la investigación ha demostrado que el riesgo para la salud implícito en la aspiración del humo de tabaco no afecta sólo al fumador, sino también a los que respiran en la vecindad de éste (D epartamento de Salud y Servicios H umanos de EE.UU. 1991). En consecuencia, muchas empresas han iniciado la adopción de medidas para limitar o restringir el consumo de tabaco por sus trabajadores, tanto en beneficio de la salud de éstos como de sus propios resultados empresariales. En M errill Lynch, el programa "El bienestar y usted" ha incluido tres tipos de actividades para dejar de fumar: (1) distribución de material impreso, (2) programas para el abandono del tabaco y (3) políticas internas para restringir el consumo de tabaco.

\section{M ateriales impresos}

El programa de bienestar mantiene una amplia gama de materiales educativos de gran calidad para informar, ayudar y estimular a sus trabajadores a mejorar su propia salud. En las salas de espera de las consultas de atención sanitaria existe abundante documentación de este tipo, en forma de folletos y cintas de audio, para educar a los empleados acerca de los efectos nocivos del tabaco y sobre las ventajas de dejar de fumar, que también pueden solicitarse por correo interno.

El material impreso se distribuye también en las ferias de salud. Estas suelen celebrarse coincidiendo con las iniciativas nacionales, a fin de aprovechar la atención de los medios de comunicación. Por ejemplo, el tercer jueves de noviembre, la American Cancer Society patrocina el Gran Día Americano sin Tabaco. Esta campaña nacional, destinada a incitar a los fumadores a dejar de fumar durante 24 horas, recibe una cobertura en la televisión, la radio y los periódicos del país. Se parte de la idea de que, si los fumadores pueden demostrarse a sí mismos que son capaces de abandonar el tabaco durante un día, podrán abandonarlo por completo. En 1993, el 20,5\% de los fumadores de Estados U nidos (9,4 millones) dejaron de fumar o redujeron el número de cigarrillos consumidos al día; 8 millones de ellos seguían sin fumar o habían reducido su consumo de uno a 10 días más tarde.

Todos los años, al llegar el tercer jueves de noviembre, los miembros del departamento médico de $M$ errill Lynch levantan stands para el abandono del tabaco en las oficinas de la empresa. Estos stands se sitúan en los lugares de mayor tráfico de empleados (vestíbulos y comedores) y ofrecen información escrita, "equipos de supervivencia" (chicle, barritas de canela y materiales de autoayuda) y tarjetas en las que consta el compromiso sobre del abandono del tabaco, para alentar a los trabajadores a dejar de fumar al menos durante ese día.

\section{Programas de abandono del tabaco}

Puesto que no hay ningún programa para dejar de fumar que sea universalmente útil, se ofrecen a los trabajadores de M errill
Lynch distintas opciones: materiales escritos de autoayuda ("equipos para dejar de fumar"), programas de grupo, cintas de audio, asesoramiento individual e intervenciones médicas. Estas últimas oscilan desde la educación y la modificación clásica del comportamiento hasta la hipnosis, el tratamiento sustitutivo de la nicotina (p. ej., los "parches" y los chicles de nicotina) o distintas combinaciones de los mismos. Casi todas estas opciones son gratuitas y algunas, como las intervenciones de grupo, son patrocinados por el departamento de prestaciones de la empresa.

\section{Políticas a ntita baco}

Además de las actividades específicamente individuales, es cada vez más frecuente encontrar restricciones al consumo de tabaco en los centros de trabajo. En Estados U nidos, muchos estados, como los de Nueva York y Nueva Jersey, han promulgado leyes muy estrictas que, en su mayor parte, limitan el consumo a los despachos privados. En las áreas comunes y las salas de conferencias se puede fumar, pero sólo si todos los presentes lo aceptan. Estas normas obligan, pues, a respetar las preferencias de los no fumadores, hasta el punto de prohibir absolutamente el consumo de tabaco. La Figura 15.15 resume las disposiciones de la ciudad y del estado que se aplican en N ueva York.

En muchas de sus oficinas, M errill Lynch ha puesto en práctica políticas que van más allá de los requisitos establecidos legalmente. Está prohibido fumar en casi todos los comedores de las oficinas centrales de Nueva York y Nueva Jersey. A demás, se ha dictado una prohibición total del consumo de tabaco en algunos edificios de la empresa en Nueva Jersey y Florida y en ciertas áreas de trabajo de la ciudad de Nueva York.

L os efectos del tabaco desfavorables para la salud parecen ser objeto de poca controversia. Sin embargo, al elaborar una política de empresa sobre el tabaco es preciso tomar en consideración otros factores. La Figura 15.16 destaca diversas razones que pueden inducir a una compañía a no limitar el consumo de tabaco más allá de las exigencias legales.

\section{Evaluación de los programas y actividades de abandono del tabaco}

D ada la relativa juventud del programa "EI bienestar y usted", no se ha realizado todavía ninguna evaluación formal para determinar sus efectos en el estado de ánimo o en el hábito de fumar de los trabajadores. Sin embargo, algunos estudios revelan que la mayor parte de los empleados están a favor de las restricciones al consumo de tabaco en sus centros de trabajo (Stave y Jackson 1991), que estas medidas implican un descenso del consumo (Brigham y cols. 1994; Baile y cols. 1991; Woodruff y cols. 1993) y que son eficaces para incrementar las tasas de abandono del tabaco (Sorensen y cols. 1991).

\section{Prevencion y CONTROL Del CANCER}

Peter G reenwald y L eon J. Warshaw

Es previsible que en la próxima década el cáncer se convierta en la principal causa de muerte en muchos países desarrollados, debido no tanto a un incremento de su incidencia sino a una disminución de la mortalidad por causas cardiovasculares, que ocupan actualmente la cabeza de la lista. Además de su elevada tasa de mortalidad, el cáncer es una enfermedad "temible" debido a su carácter incapacitante más o menos rápido y al 
Figura 15.15 • Resumen de las restricciones al tabaco vigentes en la ciudad y el estado de $\mathrm{N}$ ueva York.

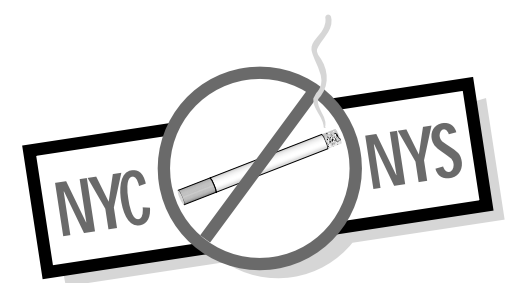

Las empresas están legalmente autorizadas a restringir más o prohibir totalmente e consumo de tabaco en sus edificios e instalaciones. El siguiente reglamento es el mínimo absoluto permitido por la ley. Es aconsejable que la empresa favorezca la salud y el bienestar de la mayoría de sus trabajadores (no fumadores) sobre la voluntad de la minoría (fumadores).

- Está prohibido fumar en áreas de trabajo comunes y salas de conferencias, salvo que todos y cada uno de los presentes en esos lugares acuerden permitirlo. Se entiende por área de trabajo común cualquier espacio ocupado por dos o más personas en el cual los individuos no están separados por tabiques que lleguen desde el suelo hasta el techo. La empresa tiene la responsabilidad de determinar si los trabajadores quieren trabajar y hablar en una zona sin tabaco.

- También está prohibido fumar en auditorios, zonas de recepción, lavabos, salas de espera, salas cerradas y áreas con equipos comunes (salas en las que hay copiadoras, archivos, impresoras y otros aparatos compartidos).

- Puede permitirse fumar en oficinas ocupadas por una sola persona, pero la puerta debe estar cerrada mientras el ocupante fuma. La empresa puede habilitar una sala cerrada para uso exclusivo de fumadores, pero la puerta debe también permanecer cerrada. Además, se puede permitir fumar en una zona que cubra como máximo el $50 \%$ de los asientos 0 el espacio en el comedor de trabajadores, aunque la zona de no fumadores debe ampliarse hasta el $70 \%$ si éstos lo demandan.

Fuente: Título 17 del capítulo 5 del Código Administrativo de la ciudad de Nueva York y artículo 13-E de la Ley de salud pública del estado de Nueva York.

Figura 15.16 - Razones a favor y en contra de la restricción del tabaco en los lugares de trabajo.

RAZONES PARA RESTRINGIR

\section{EL CONSUMO DE TABACO}

- Demanda de los trabajadores

- Absentismo y pérdida de productividad por enfermedad y consumo de tabaco

- Deseo de demostrar el interés de empresa por el bienestar de los trabajadores

- Oportunidad de que la empresa tome la iniciativa antes de que sea obligatorio según la ley

- Puede animar a los fumadores abandonar su hábito

- Encaja en el objetivo de crear un medio ambiente de trabajo seguro y saludable

- Puede reducir ineficacias y errores vinculados con factores como la irritación ocular y las enfermedades contraidas en el trabajo

- Puede ser una fuente de ahorro en prestaciones sanitarias

- Combate la sensación de que hay una "clase privilegiada" derivada de la autorización legal de fumar sólo en los despachos privados

- Ahorra los costes de limpieza y reparación de muebles dañados por las quemaduras y el humo
RAZONES PARA NO RESTINGIR

\section{EL CONSUM O DE TABACO}

- La población cada vez menor de fumadores deja un núcleo de fumadores empedernidos que pueden sufrir síntomas de privación graves

- Los trabajadores que fuman pueden sentirse marginados por la empresa

- Reducción de la productividad a consecuencia del tiempo perdido por los trabajadores que deben salir de la oficina para fumar

- Repercusión negativa en las relaciones con los clientes a consecuencia de los conflictos de intereses económicos (ingresos de empresas tabaqueras)

- Reacción adversa de los clientes que quieren fumar mientras se encuentran en las instalaciones de la empresa

- Dificultad de aplicar y supenisar el cumplimiento de la política de prohibición del tabaco

- La movilidad y la rotación elevadas de la plantilla pueden impedir la realización de las ventajas de esta política

- El tiempo relativamente largo necesario para que el abandono del tabaco tenga consecuencias económicas apreciables forma de disminucín de as enfermedades forma de disminucion de las enfermedades crónicas retrasa el efecto beneficioso sobre los "resultados" elevado índice de sufrimiento que provoca. Por lo demás, esta descripción, un tanto amenazadora, se está suavizando debido a la mejora de los conocimientos actuales sobre el modo de reducir el riesgo mediante técnicas de detección precoz y a los nuevos e importantes avances en el campo del tratamiento. En todo caso, las preocupaciones más recientes hacen referencia a los costes de tipo físico, emocional y económico que implica este proceso, tanto para los pacientes como para las personas que se ocupan de ellos. Según el National Cancer Institute ( $\mathrm{NCI}$ ) de Estados Unidos, es posible conseguir una reducción significativa en las tasas de morbilidad y mortalidad por cáncer si se aplican eficazmente las recomendaciones actuales sobre tabaquismo, cambios dietéticos, control de factores ambientales, cribado y tratamientos modernos.

Para las empresas, el cáncer constituye un problema importante, prescindiendo incluso de la posible responsabilidad por los casos de cáncer profesional. Los trabajadores con cáncer tienen una productividad alterada e incurren en absentismo de repetición, debido tanto a la enfermedad en sí misma como a los efectos secundarios del tratamiento. Se pierden empleados competentes debido a los prolongados períodos de incapacidad y a su fallecimiento prematuro, con el consiguiente aumento de los costes de contratación y formación del nuevo personal.

También la aparición de cáncer en el cónyuge u otro familiar de un empleado sano supone un coste para la empresa. El cuidado de estos familiares puede provocar distracción, cansancio y absentismo; todos estos factores originan una gran tensión en el trabajador que repercute en su productividad, y los gastos médicos derivados, a menudo de magnitud considerable, incrementan el coste del seguro de enfermedad patrocinado por la empresa. Por consiguiente, la prevención del cáncer debe ser un objetivo principal de los programas de bienestar en los lugares de trabajo.

\section{Prevención primaria}

La prevención primaria implica la evitación del tabaco y la modificación de otros factores individuales que pueden influir sobre el desarrollo del cáncer, así como la identificación de cancerígenos potenciales en el ambiente laboral y la eliminación, 0 al menos reducción, de la exposición de los trabajadores a los mismos.

\section{Control de la exposición}

L os cancerígenos, tanto potenciales como demostrados, se identifican mediante la investigación científica básica y a través de estudios epidemiológicos de poblaciones expuestas. Esto último implica la realización de mediciones de la frecuencia, magnitud y duración de la exposición, junto con una vigilancia médica global de los trabajadores expuestos, incluido el análisis de las causas de incapacidad y de fallecimiento. El control de la exposición supone la eliminación de estos cancerígenos potenciales del lugar de trabajo o, cuando no sea posible, la disminución al mínimo de la exposición a los mismos. Implica asimismo el etiquetado correcto de los materiales peligrosos y la educación continua de los trabajadores con respecto a su manejo, contención y eliminación.

\section{Tabaquismo y riesgo de cáncer}

En Estados U nidos, una tercera parte aproximadamente de todos los fallecimientos por cáncer y un $87 \%$ de todos los cánceres de pulmón son atribuibles al consumo de tabaco. El tabaquismo es también la principal causa de cáncer de laringe, cavidad oral y esófago, y contribuye al desarrollo de cáncer de vejiga, páncreas, riñón y cuello del útero. Existe una clara relación dosis-respuesta entre el riesgo de cáncer de pulmón y el consumo diario de 
cigarrillos: los que fuman más de 25 cigarrillos al día tienen un riesgo alrededor de 20 veces superior al de los no fumadores.

Según los expertos, el consumo involuntario del humo del tabaco emitido por los fumadores ("tabaquismo ambiental") constituye un factor de riesgo significativo de cáncer de pulmón en los no fumadores. En enero de 1993, la Environmental Protection Agency (EPA) de Estados Unidos clasificó el humo ambiental de tabaco como un cancerígeno humano conocido que, según sus estimaciones, es responsable de unas 3.000 muertes anuales por cáncer de pulmón entre los no fumadores de Estados U nidos.

El informe de 1990 del Departamento de Sanidad sobre los efectos beneficiosos del abandono del tabaco para la salud aporta pruebas evidentes de esos beneficios a cualquier edad. Así, cinco años después de abandonar el consumo, los ex-fumadores presentan una disminución del riesgo de cáncer de pulmón; no obstante, el riesgo sigue siendo superior al de los no fumadores durante 25 años.

El abandono del tabaquismo mediante la aplicación de programas promovidos por la empresa o por los sindicatos y la prohibición del tabaco representan un elemento fundamental en la mayoría de los programas de bienestar de los centros de trabajo.

\section{M odificación de los factores individuales}

El cáncer es una aberración del proceso normal de división y crecimiento celular, en virtud de la cual algunas células presentan unos índices de división y crecimiento patológicos, emigrando en ocasiones a otras áreas del organismo y afectando la forma y funcionamiento de los órganos implicados, hasta producir, en último lugar, la muerte del organismo. Los continuos avances durante los últimos años en el campo de la biomedicina han aumentado cada vez más los conocimientos sobre el proceso de la carcinogénesis y gracias a ellos se empiezan a identificar los factores genéticos, humorales, hormonales, dietéticos y de otro tipo que pueden acelerar 0 inhibir este proceso, con la posibilidad consiguiente de investigar la forma de detectar procesos precancerosos y contribuir así al restablecimiento de los patrones de crecimiento celular normal.

\section{Factores genéticos}

Los epidemiólogos continúan recopilando datos sobre variaciones familiares en la frecuencia de determinados tipos de cáncer. Estos datos han sido confirmados por los resultados de los estudios de biología molecular en los que se ha conseguido identificar genes que parecen controlar distintas fases de la división y crecimiento celular. Cuando estos genes "supresores de tumores" se alteran por mutaciones de origen natural o por los efectos de un cancerígeno ambiental, el proceso puede quedar sin control e iniciarse el desarrollo del cáncer.

Se han encontrado genes hereditarios en pacientes con cáncer y en los miembros de sus familias, habiéndose establecido una asociación entre un determinado gen y un riesgo elevado de cáncer de colon y cáncer de endometrio u ovario en mujeres; entre otro gen y un riesgo elevado de cáncer de mama y ovario, y entre un tercer gen y una forma determinada de melanoma maligno. Estos hallazgos han suscitado cierto debate sobre los problemas éticos y sociológicos derivados de los estudios del ADN encaminados a identificar a los individuos portadores de dichos genes, dada la posibilidad de que sean excluidos de puestos de trabajo que implican una posible exposición a cancerígenos potenciales 0 reales. Tras estudiar esta cuestión, el National Advisory Council for Human Genome Research de Estados U nidos (1994), teniendo en cuenta la fiabilidad de las pruebas aportadas, la eficacia actual de las posibles intervenciones terapéuticas y la probabilidad de establecer una discriminación genética frente a los individuos en situación de alto riesgo, concluyó que "es prematuro realizar estudios del ADN o exploraciones selectivas de la predisposición a padecer cáncer fuera de un ámbito de investigación cuidadosamente controlado".

\section{Factores humorales}

En un ensayo clínico, no quedó demostrado el valor del antígeno prostático específico (APE) como parámetro para la exploración selectiva del cáncer de próstata en varones ancianos. Sin embargo, en algunos casos se ofrece este tipo de estudio a los trabajadores varones, a veces como muestra de la igualdad de sexos para equilibrar los estudios de mamografía y frotis cervicales realizados a las mujeres. Las clínicas que realizan exploraciones periódicas de rutina ofrecen la prueba del APE como estudio complementario y, en algunos casos, incluso como sustitutivo del tacto rectal tradicional además de la exploración rectal ecográfica recientemente introducida. Aunque el empleo de esta técnica parece ser válido en varones con alteraciones o síntomas prostáticos, los resultados de una reciente revisión multinacional indican que la determinación del APE no debe ser considerada un procedimiento de rutina en la exploración selectiva de poblaciones de varones sanos (A dami, Baron y Rothman 1994).

\section{Factores hormonales}

En distintos estudios de investigación se ha expuesto la hipótesis de la influencia de las hormonas en la génesis de algunos cánceres, habiéndose utilizado las mismas como tratamiento de otros procesos neoplásicos malignos. Sin embargo, las hormonas no parecen recibir gran atención en los programas de promoción de la salud en el lugar de trabajo. La única excepción estaría constituida por las advertencias sobre los posibles riesgos cancerígenos en determinados casos cuando se recomienda el empleo de hormonas para el tratamiento de los síntomas menopáusicos y la prevención de la osteoporosis.

\section{Factores dietéticos}

Los investigadores han estimado que un $35 \%$, aproximadamente, de la mortalidad total por cáncer en Estados Unidos puede estar relacionada con la dieta. En 1988, el Informe sobre nutrición y salud del D epartamento de Sanidad indicó que puede haber una asociación entre los cánceres de pulmón, colon-recto, mama, próstata, estómago, ovario y vejiga y la dieta. Los resultados de distintos estudios de investigación indican que algunos factores dietéticos - grasa, fibra y micronutrientes como beta-caroteno, vitamina $A$, vitamina $C$, vitamina $E$ y selenio_- pueden influir en el riesgo de cáncer. Los datos epidemiológicos y experimentales indican que la modulación de estos factores en la dieta puede reducir la aparición de algunos tipos de cáncer.

\section{Grasa dietética}

La existencia de una asociación entre la ingesta excesiva de grasa en la dieta y el riesgo de distintos cánceres, particularmente de mama, colon y próstata, ha sido demostrada tanto en estudios epidemiológicos como de laboratorio. Los resultados de estudios de correlación internacional han demostrado una fuerte asociación entre la incidencia de cáncer en esos órganos y la ingesta total de grasa dietética, incluso después de haber realizado un ajuste en función de la ingesta calórica total.

A demás de la cantidad de grasa consumida, también el tipo de ésta puede ser un factor de riesgo importante en el desarrollo del cáncer. Diferentes ácidos grasos pueden tener distintas propiedades promotoras 0 inhibidoras de tumores en órganos específicos. La ingesta de grasa total y de grasas saturadas ha sido asociada de forma evidente y positiva con el cáncer de 
colon, próstata y mama en mujeres posmenopáusicas; la ingesta de aceite vegetal poliinsaturado ha sido asociada positivamente con el cáncer de mama posmenopáusico y el cáncer de próstata, pero no con el de colon. Por el contrario, el consumo de ácidos grasos poliinsaturados omega-3, que se encuentran en algunos aceites de pescado, puede no afectar o incluso disminuir el riesgo de cáncer de mama y de colon.

\section{Fibra dietética}

Los datos epidemiológicos señalan la posible disminución del riesgo de algunos cánceres, especialmente de colon y de mama, si se aumenta la ingesta de fibra dietética y de otros constituyentes de la dieta, asociada con una ingesta elevada de verduras, frutas y cereales integrales.

\section{Micronutrientes}

En general, los resultados de los estudios epidemiológicos han demostrado la existencia de una relación inversa entre la incidencia de cáncer y la ingesta de alimentos ricos en distintos nutrientes con propiedades antioxidantes, como beta-caroteno, vitamina C (ácido ascórbico) y vitamina $E$ (alfa-tocoferol). L os resultados de una serie de estudios han demostrado que la ingesta baja de frutas y verduras se asocia con un riesgo elevado de cáncer de pulmón. Las deficiencias de selenio y de zinc también parecen desempeñar un papel en el aumento del riesgo de cáncer.

En una serie de estudios en los que se demostró que el empleo de suplementos de antioxidantes reducía el número esperado de crisis cardíacas e ictus graves, los datos relativos al cáncer no eran tan claros. Sin embargo, los resultados del ensayo clínico sobre Prevención del cáncer de pulmón con alfa-tocoferol, beta caroteno $(\mathrm{AT} B C)$, dirigido por el $\mathrm{NCl}$ en colaboración con el Instituto $\mathrm{N}$ acional de Salud Pública de Finlandia, indicaron que los suplementos de vitamina $\mathrm{E}$ y beta-caroteno no tenían ningún efecto preventivo. La administración de suplementos de vitamina $\mathrm{E}$ dio lugar asimismo a una disminución del $34 \%$ del número de cáncer de próstata y a una disminución del cáncer colorrectal del $16 \%$, pero los individuos tratados con beta-caroteno tuvieron una incidencia de cáncer de pulmón $16 \%$ mayor, cifra estadísticamente significativa, que los que tomaron vitamina $\mathrm{E}$ o placebo, así como un número algo superior de otros tipos de cáncer. N o se observaron indicios en el sentido de que la combinación de vitamina $E$ y beta-caroteno diera resultados superiores o inferiores a la administración aislada de cada suplemento. Los investigadores no han determinado todavía la causa de la mayor incidencia de cáncer de pulmón observada en los individuos tratados con beta-caroteno. Estos resultados sugieren la posibilidad de que uno o varios compuestos presentes en los alimentos con elevado contenido en beta-caroteno o vitamina $E$ puedan ser responsables del efecto protector observado en los estudios epidemiológicos. Los investigadores también han especulado con la posibilidad de que la duración de la administración de los suplementos haya sido demasiado breve para inhibir el desarrollo de cáncer en los fumadores de larga evolución. EI análisis adicional de los resultados del estudio ATBC, así como de otros ensayos en curso, nos ayudará a resolver algunas de las cuestiones derivadas de este ensayo, especialmente la relativa a si las dosis elevadas de beta-caroteno pueden ser peligrosas para los fumadores.

\section{Alcohol}

La ingesta excesiva de bebidas alcohólicas ha sido asociada con el cáncer de recto, páncreas, mama e hígado. Existen pruebas sólidas que apoyan la existencia de una asociación sinérgica entre el consumo de alcohol y de tabaco y el incremento del riesgo de cáncer de boca, faringe, esófago y laringe.

\section{Recomendaciones dietéticas}

En función de las pruebas convincentes disponibles sobre la relación entre dieta y riesgo de cáncer, el $\mathrm{NCl}$ ha establecido una serie de pautas dietéticas, entre las que hay que incluir las siguientes recomendaciones:

- Reducir la ingesta de grasas a un $30 \%$ o menos de las calorías.

- Aumentar la ingesta de fibra a 20-30 g al día, con un límite superior de $35 \mathrm{~g}$.

- Introducir en la dieta diaria verduras y frutas variadas.

- Evitar la obesidad.

- Evitar el consumo de bebidas alcohólicas 0, al menos, disminuir su cantidad.

- Disminuir al mínimo el consumo de alimentos curados en salazón, en salmuera o ahumados (alimentos que se asocian con un aumento de la incidencia de cáncer de estómago y esófago).

El objetivo de estas pautas es incorporarlas a un régimen dietético general que puede ser recomendable para toda la población.

\section{Enfermedades infecciosas}

Cada vez existen más datos sobre la asociación entre ciertos agentes infecciosos y distintos tipos de cáncer: por ejemplo, el virus de la hepatitis B y el cáncer de hígado; el virus del papiloma humano y el cáncer cervical, o el virus de Epstein-Barr y el linfoma de Burkitt. (La frecuencia de cáncer entre los pacientes con SIDA es atribuible al estado de inmunodeficiencia y no a un efecto cancerígeno directo del VIH). En el momento actual se dispone de una vacuna para la hepatitis $B$ que, administrada a los niños, conseguirá reducir el riesgo de cáncer de hígado.

\section{Prevención del cáncer en el lugar de trabajo}

Con objeto de estudiar las posibilidades que ofrece el lugar de trabajo para la promoción de un amplio grupo de comportamientos sobre control y prevención del cáncer, el NCI está patrocinando el proyecto Trabajar bien. Con él se pretende determinar si las intervenciones realizadas en el lugar de trabajo dirigidas a reducir el consumo de tabaco, conseguir modificaciones dietéticas de prevención del cáncer, aumentar la prevalencia de las exploraciones selectivas y disminuir la exposición profesional pueden prepararse y ejecutarse con eficacia en función del coste. El proyecto, concretamente, se inició en septiembre de 1989 en cuatro centros de investigación de los Estados U nidos.

- Centro O ncológico M .D. Anderson, H ouston, T exas

- U niversidad de Florida, Gainesville, Florida

- Instituto O ncológico D ana Farber, Boston, M assachusetts

- Hospital M iriam/ Universidad Brown, Providence, Rhode Island

En él participan unos 21.000 empleados de 114 centros de trabajo de Estados U nidos, que abarcan desde procesos de fabricación hasta parques de bomberos 0 imprentas de periódicos. $L a$ reducción del consumo de tabaco y las modificaciones dietéticas se han examinado en todos los centros, si bien en cada uno de éstos se han fomentado en mayor o menor medida determinados programas de intervención o bien se han incluido aspectos adicionales para adaptarse a las condiciones climáticas y socioeconómicas propias de la zona. Por ejemplo, en los centros de F lorida y de Texas se ha hecho hincapié en la exploración selectiva del cáncer de piel y en el empleo de filtros solares, debido a la mayor exposición solar; en los de Boston y Texas se han ofrecido programas que subrayan la relación entre cáncer y consumo de tabaco; en el centro de Florida se ha intensificado la intervención sobre la modificación dietética fomentando el consumo de cítricos frescos, que se producen abundantemente en este Estado; 
se han establecido en los centros de trabajo de Florida unos comités paritarios (empresario-trabajadores) para colaborar en el servicio de comidas y asegurar el suministro de verduras y frutas frescas. En algunos de los lugares de trabajo que participan en el proyecto se han ofrecido pequeños premios — vales de regalo 0 comidas del comedor - por la participación o por la consecución de alguno de los objetivos deseados, como el abandono del tabaco. La reducción de la exposición a riesgos laborales ha presentado especial interés en los lugares de trabajo en que se producían escapes de gasoil o se utilizaban disolventes o equipos de radiación. Los programas basados en el lugar de trabajo han incluido los aspectos siguientes:

- actividades de grupo para promover el interés, tales como pruebas de degustación de distintos alimentos;

- actividades de grupo dirigidas, tales como la lucha por el abandono del tabaco;

- demostraciones con base médica/ científica, tales como las pruebas de $\mathrm{CO}_{2}$ para verificar el efecto producido por el tabaco sobre el sistema respiratorio;

- seminarios sobre prácticas empresariales y desarrollo de actitudes dirigidas a reducir de forma significativa o a eliminar la exposición profesional a materiales potencial o realmente peligrosos o tóxicos;

- programas de autoayuda y autovaloración informatizados sobre riesgo y prevención del cáncer;

- manuales y clases de autoayuda para reducir o eliminar el consumo de tabaco, conseguir las modificaciones dietéticas y aumentar la realización de exploraciones selectivas del cáncer.

\section{Educación sobre el cáncer}

En los programas de educación sanitaria de los lugares de trabajo se debe incluir información sobre los síntomas sugestivos de cáncer en estadio precoz - por ejemplo, aparición de bultos, hemorragias por el recto u otros orificios, lesiones cutáneas que no curan,- - junto con el consejo de solicitar asistencia médica rápidamente. En estos programas se deben enseñar también, preferiblemente mediante ejercicios prácticos supervisados, las técnicas de autoexploración de la mama.

\section{Cribado del cáncer}

El cribado de lesiones precancerosas o de cáncer en estadio precoz va encaminada a la detección y eliminación lo más precoz posible de este proceso. La educación de las personas para que soliciten asistencia médica ante los primeros signos y síntomas del cáncer constituye una parte importante de la prevención.

En toda exploración médica rutinaria o periódica se debe investigar la existencia de un cáncer en estadio precoz. A demás, siempre es posible el cribado en masa de determinados tipos de cáncer, bien en el lugar de trabajo, bien en un servicio comunitario cercano al mismo. Toda prueba de cribado del cáncer, aceptable y justificada, en una población asintomática debe cumplir los siguientes criterios:

- La enfermedad en cuestión debe tener una importante repercusión en el ámbito de la salud pública y ha de presentar una fase prevalente asintomática y no metastásica.

- La fase asintomática y no metastásica debe ser reconocible.

- El procedimiento de cribado debe presentar una especificidad, sensibilidad y valor predictivo razonables; ha de caracterizarse por el bajo riesgo y el bajo coste económico y ser aceptable tanto para la persona que lo realiza como para el individuo estudiado.

- La detección precoz seguida por el tratamiento adecuado debe ofrecer un potencial de curación sustancialmente mayor que el existente en los casos diagnosticados en fases más avanzadas.
- El tratamiento de las lesiones detectadas mediante la prueba debe ofrecer una mejoría del pronóstico determinada por la morbilidad y mortalidad de causas específicas.

En el lugar de trabajo son particularmente importantes los siguientes criterios adicionales:

- Los trabajadores (y sus familiares, en caso de que estén incluidos en el programa) deben recibir información sobre el objetivo, naturaleza y posibles resultados de la exploración selectiva y ha de obtenerse un "consentimiento informado" formal.

- El programa de cribado debe llevarse a cabo con la debida consideración a la comodidad, dignidad e intimidad de los individuos que dan su consentimiento, y ha de causar la mínima interferencia con los planes de trabajo y los horarios de producción.

- Los resultados de la prueba deben ser comunicados de forma rápida y privada, remitiéndose copia a los médicos particulares designados por los trabajadores. Q uienes deseen más información sobre el resultado deben disponer de asesoramiento a cargo de profesionales sanitarios expertos.

- Debe informarse a los individuos sometidos a la prueba de la posibilidad de falsos negativos y aconsejarles que consulten con un médico si aparece cualquier tipo de síntoma poco después de la misma.

- Debe establecerse una red de consultas predeterminada a la que pueda enviarse a quienes presenten resultados positivos y no puedan o no quieran consultar con médicos particulares.

- Los costes de las exploraciones necesarias para confirmar el proceso, así como los derivados del tratamiento, deben estar cubiertos por el seguro de enfermedad 0, por lo menos, ser razonables.

- Debe establecerse un sistema de seguimiento predeterminado para garantizar una confirmación rápida de los informes con resultados positivos, así como la instauración de las medidas terapéuticas adecuadas.

Existe un último criterio, dotado de gran importancia: el procedimiento de exploración selectiva debe encomendarse a profesionales sanitarios acreditados y suficientemente preparados que dispongan de equipos modernos, y la interpretación y análisis de los resultados debe ser de la mayor calidad y exactitud posible

En 1989, la Preventive Services Task Force de Estados U nidos, formada por 20 expertos en medicina y otros ámbitos relacionados, valoró la eficacia de unas 169 medidas preventivas valiéndose de centenares de "asesores" y otros profesionales de Estados Unidos, Canadá y Reino Unido. En la Tabla 15.4 se resumen sus recomendaciones con respecto al cribado del cáncer. Teniendo en cuenta la actitud algo conservadora de dicha Task Force y los criterios aplicados de forma rigurosa, estas recomendaciones pueden ser diferentes de las establecidas por otros grupos.

\section{Exploración selectiva del cáncer de mama}

Existe un acuerdo general en el sentido de que la exploración selectiva con mamografía, junto con el examen clínico anual o bienal de la mama, puede ahorrar muchas vidas de mujeres entre los 50 y los 69 años, reduciendo las muertes por cáncer de mama en este grupo de edad en hasta un $30 \%$. En cambio, no existe acuerdo entre los expertos sobre el valor de la exploración selectiva del cáncer de mama mediante mamografía en mujeres asintomáticas de 40 a 49 años de edad. EI NCI recomienda que las mujeres de este grupo de edad se sometan a exploración selectiva todos los años o una vez cada dos años, y que las que estén sujetas 
Tabla 15.4 - Cribado de enfermedades neoplásicas.

Tipos de cáncer Recomendaciones del Preventive Services Task Force de EE.UU.*

Mama Todas las mujeres de más de 40 años deben someterse a exploración anual de las mamas. Entre los 50 y los 75 años se recomienda a todas las mujeres que se hagan una mamografía cada año 0 cada dos años, salvo que se detecte algún signo patológico. En mujeres con riesgo elevado de cáncer de mama, puede ser prudente iniciar la exploración mamográfica antes de esa edad. Aunque por el momento no se recomienda de forma específica enseñar a realizar una exploración personal de la mama, no hay datos suficientes para recomendar ningún cambio en la práctica actual (esto significa que quienes ya están enseñando esta técnica deben continuar haciéndolo).

Colorrectal No hay datos suficientes para recomendar ni para desaconsejar los análisis de sangre en heces o la sigmoidoscopia.

Cervical Se recomienda a todas las mujeres que son o han sido activas sexualmente que se hagan pruebas de citología. La citología 0 prueba de Papanicolau debe realizarse al principio de la actividad sexual y repetirse cada dos o tres años.

Próstata No hay pruebas suficientes para recomendar o desaconsejar el examen rectal digital periódico como prueba eficaz de detección selectiva del cáncer de próstata en varones asintomáticos. Las ecografías transrectales y los marcadores séricos de tumores no son recomendables para el examen rutinario de varones asintomáticos.

Pulmón No se recomienda realizar de forma periódica radiografías torácicas ni citología del esputo para la detección selectiva de sujetos asintomáticos.

Piel Se recomiendan las pruebas de cribado en sujetos expuestos a un riesgo elevado. Los médicos deberían aconsejar a todos los pacientes que pasen mucho tiempo al aire libre que utilicen preparados con filtros solares y adopten otras medidas para protegerse de los rayos ultravioletas. Actualmente no hay pruebas a favor ni en contra de que los pacientes se examinen personalmente la piel.

Testículos Se recomiendan las pruebas de cribado del cáncer testicular en varones con antecedentes de criptorquidia, orquipexia 0 atrofia testicular. No hay pruebas de que el cribado sistemático de este tipo de cáncer en otros sujetos sea beneficiosa ni nociva desde el punto de vista clínico. En este momento no hay datos suficientes para aconsejar ni desaconsejar a los pacientes la realización de autoexploraciones periódicas de los testículos.

Ovarios No están recomendadas las pruebas de cribado de cáncer de ovarios. Es prudente examinar los órganos anejos en el momento de realizar reconocimientos ginecológicos por otros motivos.

Páncreas No se recomienda la realización de pruebas de cribado de cáncer de páncreas en sujetos asintomáticos.

Oral No se recomienda la realización de pruebas de cribado de cáncer de boca por parte de los médicos de atención primaria. Debe aconsejarse a todos los pacientes que se sometan a reconocimientos odontológicos regulares, que interrumpan el consumo de cualquier clase de tabaco y que limiten el de alcohol.

Fuente: Preventive Services Task Force 1989. a un riesgo más elevado de cáncer consulten con un médico la conveniencia de iniciar estas exploraciones antes de los 40 años.

La población femenina de la mayoría de las empresas es demasiado pequeña para justificar la instalación in situ de un equipo de mamografía. Por consiguiente, la mayoría de los programas promovidos por las empresas o los sindicatos (o por ambos) otorgan contratos con entidades que llevan al lugar de trabajo unidades móviles o con servicios comunitarios a los que se remite a las trabajadoras bien durante sus horas de trabajo 0 bien en su tiempo libre. Al realizar este tipo de acuerdos, es esencial asegurarse de que el equipo cumple las normas sobre exposición a rayos $X$ y seguridad establecidos por el American C ollege of R adiology, y de que la calidad de las imágenes y su interpretación es satisfactoria. Por otra parte, es obligatorio establecer previamente un centro de referencia al que poder enviar a las mujeres en las que sea necesario realizar una aspiración con aguja fina u otros procedimientos diagnósticos de confirmación.

\section{Cribado del cáncer cervical}

Los datos científicos dan a entender que el estudio periódico del frotis reduce significativamente la mortalidad por cáncer cervical en mujeres sexualmente activas o mayores de 18 años. La supervivencia parece estar directamente relacionada con el estadio de la enfermedad en el momento del diagnóstico. La detección precoz, mediante citología cervical, constituye en el momento actual el único método práctico para detectar un cáncer cervical en estadio localizado o premaligno. El riesgo de desarrollar cáncer cervical invasivo es de tres a diez veces mayor en mujeres que nunca han sido sometidas a exploración selectiva en comparación con las que han sido sometidas a un frotis cada dos o tres años.

En lo que respecta a los costes de los programas de cribado en los lugares de trabajo, es especialmente importante recordar que los frotis para citología cervical pueden ser realizados eficazmente por enfermeras preparadas, no siendo precisa la participación de un médico. Otro aspecto quizá incluso más importante es la calidad del laboratorio al que se envíen las muestras para su análisis.

\section{Cribado del cáncer colorrectal}

Existe un acuerdo general en el sentido de que la detección precoz de pólipos colorrectales precancerosos, así como de cáncer de colon y recto, mediante análisis periódicos de sangre en heces, tacto rectal y exploración sigmoidoscópica, junto con su extirpación oportuna, reduce la mortalidad por cáncer colorrectal en los individuos de 50 años o más. La sustitución del sigmoidoscopio rígido por un instrumento de fibra óptica, flexible y de mayor longitud ha permitido hacer la exploración menos desagradable y más fiable. Sin embargo, todavía no existe acuerdo sobre el tipo de pruebas que son fiables ni sobre la frecuencia con la que deben realizarse.

\section{Puntos a favor y en contra del cribado}

Existe acuerdo general sobre el valor de la exploración selectiva del cáncer en individuos en situación de riesgo debido a antecedentes familiares, aparición previa de cáncer o exposición conocida a cancerígenos potenciales. En cambio, parece haber una preocupación justificada por la realización de exploraciones selectivas en masa de poblaciones sanas.

Los partidarios del cribado en masa para la detección del cáncer se basan en la premisa de que la detección precoz se acompañará de una mejoría de la morbilidad y mortalidad. Es cierto que ha podido demostrarse en algunos casos, pero no siempre. Por ejemplo, aunque el cáncer de pulmón se detecta antes con la utilización de radiografías de tórax y citología de 
esputo, estos métodos no han conseguido mejorar el resultado del tratamiento. Análogamente, se ha expresado cierta preocupación por la posibilidad de que el alargamiento del tiempo de tratamiento del cáncer de próstata en estadio precoz no sólo no produzca resultados beneficiosos, sino que de hecho sea contraproducente, debido al prolongado período de bienestar que presentan los pacientes en los que el tratamiento se instaura en fases más avanzadas.

Al planificar los programas de cribado en masa, se deben tener en cuenta los efectos sobre el sentimiento de bienestar y sobre los recursos de los pacientes con falsos positivos. Por ejemplo, en distintas series de casos, del 3 al $8 \%$ de las mujeres con resultados positivos en la exploración selectiva de mama fueron sometidas a biopsias innecesarias por tratarse de tumores benignos; y en un estudio del cáncer colorrectal mediante determinación de sangre en heces, cerca de una tercera parte de los individuos estudiados fueron remitidos para colonoscopia diagnóstica que demostró resultados negativos en la mayoría de ellos.

Es evidente que se requieren estudios de investigación adicionales. C on objeto de valorar la eficacia de la exploración selectiva, el $\mathrm{NCl}$ ha emprendido un estudio principal. Ensayos de cribado para el cáncer de próstata, pulmón, colorrectal y ovárico (PLCO), para valorar las técnicas de detección precoz de estos cánceres. La inclusión en el ensayo PLCO comenzó en noviembre de 1993 y en él participarán 148.000 varones y mujeres de 60 a 74 años de edad distribuidos de forma aleatoria a grupos de tratamiento 0 de control. En el grupo de tratamiento se realizará una prueba selectiva de cáncer de pulmón, colorrectal y de próstata en los varones, y de pulmón, colorrectal y ovárico en las mujeres; los individuos asignados al grupo control recibirán la asistencia médica habitual. En el caso del cáncer de pulmón se estudiará el valor de una única imagen de la radiografía de tórax anual; para el cáncer colorrectal se realizará sigmosdoscopia con fibra óptica anual; en el cáncer de próstata se llevará a cabo tacto rectal y determinación sanguínea del APE; y para el cáncer de ovario se procederá a exploración física y ecografía transvaginal, complementadas con determinación sanguínea anual del marcador tumoral CA-125. Al cabo de 16 años, y después de gastar 87,8 millones de dólares de EE.UU., se esperan obtener datos sólidos sobre la forma de utilizar los métodos de cribado para obtener diagnósticos precoces que puedan aumentar la vida y reducir la mortalidad.

\section{Tratamiento y atención continua}

En el apartado del tratamiento y la atención continua hay que incluir distintas medidas destinadas a aumentar la calidad de vida tanto de los pacientes con cáncer como de las personas en las que esta enfermedad tiene algún tipo de repercusión. Los servicios de salud en el trabajo y los programas de asistencia a los empleados patrocinados por las empresas y sindicatos pueden ofrecer asesoramiento y apoyo a los trabajadores que están recibiendo tratamiento para el cáncer o que tienen un familiar en esa situación. Este apoyo puede incluir explicaciones sobre la situación actual y futura, información que a veces no es suministrada por los oncólogos y cirujanos, pautas sobre la posibilidad de enviar al paciente a otro médico con el fin de obtener una segunda opinión, e indicaciones sobre el posible acceso a centros de elevada especialización.

Los permisos y la modificación de los horarios de trabajo pueden permitir que los trabajadores sigan siendo productivos aunque estén en tratamiento y retornen a su trabajo lo antes posible una vez conseguida la remisión. En algunos lugares de trabajo se han formado grupos de apoyo paralelos para ofrecer un intercambio de experiencias y apoyo mutuo a los trabajadores que se enfrentan a problemas similares.

\section{Conclusión}

Los programas para la prevención y detección del cáncer pueden contribuir de forma importante al sentimiento de bienestar de los trabajadores afectados y sus familiares, lo que repercutirá positivamente en las empresas y sindicatos que los promueven. Lo mismo que en otras medidas preventivas, estos programas han de ser diseñados de forma adecuada y ejecutados cuidadosamente, y han de llevarse a cabo según un patrón de regularidad, ya que sus efectos beneficiosos solo serán visibles al cabo de muchos años.

\section{LA SALUD DE LA MUJER}

Patricia A. Last

Es común el error de que, dejando aparte las diferencias en la reproducción, las mujeres y los hombres son igualmente sensibles a los riesgos para la salud existentes en el lugar de trabajo y están sujetos a los mismos procedimientos de control. Aunque unas y otros pueden padecer muchos trastornos similares, son diferentes desde el punto de vista físico, metabólico, hormonal, fisiológico y psicológico. Por ejemplo, el menor tamaño y masa muscular promedio de las mujeres obliga a prestar una atención especial a las medidas de las prendas y equipos de protección y a la disponibilidad de instrumentos de funcionamiento manual diseñados de forma adecuada, mientras que la menor masa corporal las hace también más sensibles, por término medio, a los efectos del abuso de alcohol sobre el hígado y sobre el sistema nervioso central.

Existen asimismo diferencias en los tipos de puestos de trabajo y en las circunstancias sociales y económicas que determinan el estilo de vida, así como en la participación y respuesta a las actividades de promoción de la salud. Aunque recientemente se han producido algunos cambios, sigue siendo muy frecuente que las mujeres ocupen puestos de trabajo muy rutinarios en los que están expuestas a lesiones por esfuerzo repetitivo. Las mujeres padecen desigualdades retributivas y, con mucha más frecuencia que los hombres, están sobrecargadas por responsabilidades domésticas y por el cuidado de los hijos y de familiares ancianos.

En los países industrializados, su esperanza de vida es mayor que entre los hombres; esto es aplicable a todos los grupos de edad. A los 45 años, las mujeres japonesas tienen una esperanza de vida de otros 37,5 años y es probable que una mujer escocesa de 45 años viva otros 32,8 años; la mayoría de las mujeres de otros países del mundo desarrollado presentan una esperanza de vida situada entre estos límites. Estos datos nos llevan a la conclusión de que las mujeres son, por lo tanto, personas sanas. Sin embargo, hay que tener en cuenta que durante estos años "extra" es muy común que padezcan enfermedades crónicas y distintos tipos de incapacidad que pueden evitarse en muchos casos. Muchas mujeres tienen un gran desconocimiento de los riesgos para la salud a los que se enfrentan y, por consiguiente, no saben qué tipo de medidas deben adoptar para controlarlos y para protegerse de lesiones o enfermedades graves. Por ejemplo, es muy habitual que muestren una gran preocupación, y con razón, por el cáncer de mama, pero ignoren que las cardiopatías constituyen la principal causa de muerte entre ellas, o que debido fundamentalmente al aumento del tabaquismo, que también es factor de riesgo importante de cardiopatía coronaria, ha aumentado la incidencia de cáncer de pulmón en mujeres.

En 1993 se realizó una encuesta nacional en los Estados Unidos (H arris y cols. 1993) con entrevistas a más de 2.500 mujeres y 1.000 varones adultos, y sus resultados confirmaron que las mujeres padecen graves problemas de salud y muchas de ellas quizá no reciben la atención que necesitan. Entre tres y cuatro mujeres de cada diez están en situación de riesgo en 
relación con enfermedades no detectadas debido a la falta de prestación de los servicios de medicina preventiva adecuados, en gran parte por inexistencia de un seguro o porque su médico nunca les ha comentado que existen este tipo de pruebas y que deben utilizarse. Es más, un número importante de ellas no se sienten satisfechas con su médico: cuatro de cada diez (doble proporción que entre los varones) señalaron que éste no les hablaba claro y el $17 \%$ (frente a un $10 \%$ de los varones) comentaron que su médico insistía en que los síntomas solo existían "en su cabeza".

Aun cuando la incidencia global de enfermedades mentales es más o menos la misma en varones que en mujeres, las pautas son diferentes: en las mujeres son más frecuentes la depresión y la ansiedad, mientras que en los hombres son más comunes el abuso de alcohol y drogas y los trastornos de la personalidad de tipo antisocial (G lied y K ofman 1995). La probabilidad de recibir asistencia médica especializada es mucho mayor en los varones, mientras que las mujeres son tratadas con mucha mayor frecuencia por médicos de atención primaria que en muchos casos carecen de interés, si no de experiencia, en el tratamiento de problemas de salud mental. En las mujeres, especialmente de edad avanzada, se prescribe una cantidad desproporcionada de fármacos psicotrópicos, lo que favorece una utilización excesiva de los mismos. Con demasiada frecuencia, las dificultades que aparecen como consecuencia de un estrés excesivo o de problemas evitables y susceptibles de tratamiento son justificadas por los profesionales sanitarios, miembros de la familia, supervisores y compañeros de trabajo e incluso por las propias mujeres como reflejo del "ciclo menstrual" 0 de un "cambio de vida" y, por consiguiente, se dejan sin tratamiento.

Estas circunstancias son tanto más graves cuanto que las mujeres - -jóvenes y ancianas, en igual medida - creen conocer perfectamente su cuerpo y su funcionamiento. $\mathrm{N}$ ada más lejos de la realidad. Existe una gran ignorancia y una desinformación que se acepta sin sentido crítico. Muchas mujeres se avergüenzan al revelar su falta de conocimientos y se sienten innecesariamente preocupadas por síntomas que, de hecho, son "normales" o fácilmente explicables.

Considerando que las mujeres constituyen un $50 \%$ de la plantilla en muchos ámbitos laborales y una cifra bastante mayor en el sector de servicios, las consecuencias de sus problemas de salud que se pueden prevenir y corregir implican pérdidas importantes y evitables tanto en su propio sentimiento de bienestar como en la productividad y organización de la empresa. Estas pérdidas pueden reducirse considerablemente con un programa específico de promoción de la salud en el lugar de trabajo.

\section{Promoción de la salud de la mujer en el lugar de trabajo}

Los periódicos, las revistas y la televisión ofrecen bastante información sanitaria, pero ésta es en muchos casos incompleta 0 sensacionalista, o está dirigida a la promoción de productos 0 servicios determinados. Es muy habitual que, al informar sobre avances médicos o científicos actuales, los medios de comunicación planteen más incógnitas que respuestas e incluso produzcan ansiedad innecesaria. D ado que los profesionales sanitarios de los hospitales, clínicas y consultas privadas desconocen, con demasiada frecuencia, si sus pacientes tienen información adecuada sobre los trastornos que padecen, es fácil entender que dediquen aún menos tiempo a explicarles diferentes problemas de salud que no están relacionados con sus síntomas.

Un programa de promoción de la salud en el lugar de trabajo diseñado y ejecutado de forma adecuada debe ofrecer información exacta y completa, posibilidad de plantear preguntas en grupo 0 en sesiones individuales, servicios de medicina preventiva, acceso a diferentes actividades de promoción de la salud y asesoramiento sobre las modificaciones pertinentes para evitar o disminuir al mínimo las molestias y la incapacidad. El lugar de trabajo representa un punto de reunión ideal para compartir experiencias e información sanitaria, especialmente cuando éstas son importantes para las circunstancias particulares de cada puesto de trabajo. Permite además aprovechar la presión de los compañeros de trabajo, que refuerza la motivación para participar y para perseverar en las actividades de promoción de la salud y en el mantenimiento de una forma de vida más sana.

Los programas de promoción de la salud para mujeres pueden adoptar distintas modalidades. La empresa de consultoría Ernst \& Young ofreció a sus trabajadores de Londres una serie de seminarios sobre "salud para las mujeres" dirigidos por un consultor externo. A sistieron a ellos empleados de todos los niveles, quienes mostraron su buena acogida. Al ser impartidos por un consultor externo, éste no representaba ninguna amenaza para ellas, por lo cual pudieron esclarecerse de forma conjunta muchas cuestiones confusas sobre la salud de las mujeres.

$M$ arks and Spencer, importante cadena minorista del Reino U nido, aplica un programa a través de su departamento médico, utilizando personal externo para la prestación de servicios a los empleados de sus múltiples centros de trabajo regionales. Este programa ofrece pruebas de cribado y asesoramiento individual a todo el personal, junto con una amplia bibliografía y cintas de vídeo sobre aspectos sanitarios, muchas de ellas de producción propia.

M uchas empresas utilizan asesores sanitarios externos. En el Reino Unido pueden citarse los servicios prestados por los centros médicos BUPA (British U nited Provident Association), que en número de 35 , distribuidos geográficamente y completados con unidades móviles, atienden a miles de mujeres. La mayoría de éstas proceden de los programas de promoción de la salud de sus respectivas empresas; el resto acude de forma independiente.

BU PA fue probablemente la primera entidad, al menos en el R eino U nido, en establecer un centro de salud dedicado a servicios de medicina preventiva para las mujeres. Cada vez son más los centros de este tipo, de origen hospitalario o independientes, que atienden a mujeres descontentas con la atención sanitaria general. Además de asistencia prenatal y obstétrica, estos centros prestan un amplio espectro de servicios de atención primaria, principalmente de carácter preventivo.

La encuesta nacional sobre Centros de Salud para M ujeres, realizada en 1994 por investigadores de la Escuela de H igiene y Salud Pública Johns Hopkins con financiación de la Commonwealth Foundation (Weisman 1995), estimó que en los Estados U nidos existen unas 3.600 unidades de este tipo. Un $71 \%$ están dedicadas fundamentalmente a la asistencia ginecológica y realizan exploraciones ginecológicas ambulatorias y pruebas citológicas, además de prestar servicios de planificación familiar. 0 tros servicios son los siguientes: pruebas de embarazo, asesoramiento sobre el aborto $(82 \%)$ y abortos (50 \%), cribados y tratamiento de las enfermedades de transmisión sexual, exploraciones de mama y determinación de la presión arterial.

EI $12 \%$ son centros de atención primaria (incluidos los específicos para mujeres universitarias) que ofrecen fundamentalmente asistencia a mujeres sanas y servicios de medicina preventiva: exploraciones físicas periódicas, exploraciones ginecológicas de rutina y pruebas citológicas, diagnóstico y tratamiento de problemas menstruales, asesoramiento sobre la menopausia y sobre el tratamiento de sustitución hormonal y servicios de salud mental, que incluyen asesoramiento y/ o tratamiento sobre el abuso de sustancias. 
L os centros dedicados a la mama constituyen un $6 \%$ del total (véase a continuación), mientras que el resto ofrecen distintas combinaciones de servicios. La mayoría han mostrado interés en ofrecer sus servicios a las mujeres trabajadoras de empresas cercanas, en el marco de sus programas de promoción de la salud en el lugar de trabajo.

Independientemente del lugar, el éxito de un programa de promoción de salud para las mujeres en el centro de trabajo radica no solo en la fiabilidad de la información y servicios ofrecidos, sino, lo que es más importante, en la forma en que se presentan. Los programas deben ser sensibles a las actitudes y aspiraciones de las mujeres, así como a sus preocupaciones, y, aunque cumplan una función de apoyo, deben carecer del aire "protector" con el que se enfocan frecuentemente este tipo de problemas.

En lo que resta del artículo nos centraremos en tres procesos considerados como problemas especialmente importantes para la salud de la mujer: los trastornos menstruales, el cáncer cervical y de mama y la osteoporosis. Por lo demás, el programa de promoción de la salud para las mujeres en el lugar de trabajo no debe subestimar ningún problema particularmente importante, aunque no encaje en esta clasificación.

\section{Trastornos menstruales}

Para la inmensa mayoría de las mujeres, la menstruación constituye un proceso "natural" que causa pocos problemas. No obstante, el ciclo menstrual puede alterarse por distintos procesos que, en el caso de la mujer trabajadora, provocan en ocasiones molestias o cierta preocupación, dando lugar incluso a absentismo que sigue un patrón regular y que se justifica a menudo como un "resfriado" o un "dolor de garganta", especialmente cuando el parte de baja debe enviarse a un directivo varón. En todo caso, el patrón de absentismo es evidente y la consulta con un profesional sanitario cualificado permite resolver el problema rápidamente. Los posibles trastornos menstruales que se manifiestan en el lugar de trabajo son amenorrea, menorragia, dismenorrea, síndrome premenstrual (SPM ) y menopausia.

\section{Amenorrea}

Aunque la amenorrea puede inducir cierta preocupación en la mujer, habitualmente no afecta su actuación profesional. La causa más común de amenorrea en mujeres jóvenes es el embarazo y en las de mayor edad la menopausia o una histerectomía. Sin embargo, también puede atribuirse a las siguientes circunstancias:

- Alimentación deficiente 0 bajo peso. La alimentación deficiente puede tener una causa socioeconómica o ser el resultado de un programa de auto-inanición relacionado con trastornos de la alimentación del tipo de la anorexia nerviosa o la bulimia.

- Exceso de ejercicio. En muchos países desarrollados, las mujeres realizan programas de entrenamiento físico o deportivo excesivos. Aunque su ingesta de alimentos sea adecuada, puede presentarse amenorrea.

- Trastornos médicos. El hipotiroidismo, otras enfermedades endocrinas, la tuberculosis, la anemia de cualquier causa y algunas enfermedades graves que amenazan la vida pueden producir asimismo amenorrea.

- M edidas anticonceptivas. Los medicamentos que contienen sólo progesterona dan lugar con mucha frecuencia a amenorrea. Se debe indicar que la esterilización sin ooforectomía no es causa de interrupción de los períodos menstruales de la mujer.

\section{Menorragia}

En ausencia de cualquier determinación objetiva del flujo menstrual, se acepta en general que cualquier pérdida suficientemente importante para interferir con las actividades diarias de una mujer, o que ocasione anemia, es excesiva. Cuando el flujo es lo bastante importante para anular al factor de anticoagulación plasmático, la mujer con "períodos abundantes" puede presentar coágulos de forma pasajera. La incapacidad para controlar el flujo sanguíneo por los medios sanitarios normales puede ser fuente de considerables problemas en el lugar de trabajo y dar lugar a un patrón de absentismo regular de uno o dos días mensuales.

La menorragia puede estar producida por fibromas o pólipos uterinos, o por un dispositivo intrauterino (DIU) y, en raras ocasiones, es el primer indicio de una anemia intensa o de otros trastornos hematológicos graves, como la leucemia.

\section{Dismenorrea}

Aunque la gran mayoría de las mujeres que tienen la menstruación experimentan algún tipo de molestia, sólo algunas presentan dolor de suficiente intensidad para interferir con su actividad normal y, por consiguiente, precisan consulta médica. También aquí puede ser indicativa la presencia de un patrón regular de ausencias mensuales. Estas alteraciones asociadas con la menstruación pueden clasificarse a efectos prácticos como sigue:

1. D ismenorrea primaria. Las mujeres jóvenes sin indicios de enfermedad pueden experimentar, el día anterior o el primer día de su menstruación, dolor lo bastante intenso para abandonar el trabajo durante algún tiempo. Aunque no se han encontrado causas, se sabe que ese dolor está asociado con la ovulación y, por lo tanto, puede evitarse con la píldora anticonceptiva o con otra medicación anovulatoria.

2. D ismenorrea secundaria. El inicio de menstruaciones dolorosas hacia la mitad de la tercera década de la vida o posteriormente es sugestivo de patología pélvica y requiere el examen por un ginecólogo.

Algunos analgésicos, comprados con o sin receta, para la dismenorrea producen somnolencia que puede constituir un problema para las mujeres que trabajan en puestos que requieren una actitud vigilante.

\section{Síndrome premenstrual}

El síndrome premenstrual (SPM), una combinación de síntomas físicos y psicológicos que se da en un porcentaje relativamente escaso de mujeres durante los siete o diez días previos a la menstruación, ha desarrollado su propia mitología. Se le ha considerado, falsamente, como causa del sentimentalismo y del "carácter caprichoso" de las mujeres. En opinión de algunos hombres, todas las mujeres lo padecen, y según las feministas vehementes ninguna mujer lo presenta. En los lugares de trabajo ha sido aducido indebidamente para denegar el acceso de las mujeres a puestos que requieran la toma de decisiones y la emisión de dictámenes, y ha servido como excusa adecuada para negar a éstas la posibilidad de promoción a puestos directivos y ejecutivos. Se le ha responsabilizado de los problemas de relación interpersonal de las mujeres y, de hecho, en Inglaterra se utilizó para obtener una declaración de desequilibrio temporal que permitió a dos mujeres escapar de la acusación de asesinato.

Entre los síntomas físicos del SPM figuran distensión abdominal, sensibilidad de la mama, estreñimiento, insomnio, aumento de peso debido a un incremento del apetito 0 a retención de sodio y líquidos, torpeza en los movimientos finos e inseguridad de criterios. Los síntomas emocionales son llanto excesivo, crisis de mal genio, depresión, dificultad en la toma de decisiones, incapacidad general para hacer frente a distintas situaciones y falta de confianza. Los síntomas aparecen siempre en los días premenstruales y se alivian al empezar la 
menstruación. EI SPM es muy raro en mujeres que toman la píldora anticonceptiva combinada y en las que han sido sometidas a ooforectomía.

EI diagnóstico de SPM se basa en su relación temporal con los períodos menstruales; en ausencia de causas concretas, no existen pruebas diagnósticas. La intensidad del tratamiento, que es fundamentalmente empírico, depende de la gravedad de los síntomas y de su efecto sobre las actividades normales de la mujer. La mayoría de los casos responden a pautas sencillas de autoayuda, entre las que hay que citar la evitación de la cafeína de la dieta (té, café, chocolate y la mayoría de las bebidas de cola sin alcohol que contienen cantidades importantes de cafeína), la ingestión frecuente de pequeñas cantidades de alimento para disminuir al mínimo la tendencia a la hipoglucemia, la restricción de la ingesta de sodio para evitar la retención de líquidos y el aumento de peso, y la realización de ejercicio regular moderado. Cuando estas medidas no consiguen controlar los síntomas, en ocasiones se prescriben diuréticos suaves (sólo durante dos o tres días) para disminuir la retención de sodio y líquidos y hormonas por vía oral para modificar la ovulación y el ciclo menstrual. En general, el SPM es un trastorno susceptible de tratamiento y no debe constituir un problema importante para las mujeres en el lugar de trabajo.

\section{Menopausia}

La menopausia refleja una insuficiencia ovárica que puede aparecer en la tercera década de la vida o bien retrasarse hasta después de los 50 años; hacia los 48 años se presenta en la mitad de las mujeres. El momento real de aparición de la menopausia depende de la situación general de salud y de factores nutricionales y familiares.

Los síntomas principales son la reducción de la frecuencia de los períodos menstruales habitualmente asociada con flujo escaso, los sofocos con o sin sudoración nocturna y la disminución de las secreciones vaginales, con la posibilidad consiguiente de dolor durante las relaciones sexuales. 0 tros síntomas atribuidos asimismo con mucha frecuencia a la menopausia son depresión, ansiedad, tendencia al llanto, falta de seguridad, cefaleas, cambios en la textura de la piel, pérdida del interés sexual, alteraciones urinarias e insomnio. Son muy interesantes los resultados de un estudio controlado en el que se administró un cuestionario sobre diferentes síntomas tanto a varones como a mujeres, observándose que una parte importante de este tipo de molestias eran compartidas por los varones de la misma edad (Bungay, Vessey y M cPherson 1980).

La menopausia, cuando aparece hacia los 50 años, puede coincidir con lo que se ha denominado "transición de la etapa media de la vida" o "crisis de los cuarenta", término acuñado para indicar de forma colectiva las experiencias que parecen compartir tanto varones como mujeres en la época central de la vida (si acaso, parece ser más frecuente en los varones). Esta crisis se manifiesta en pérdida de objetivos, insatisfacción con el trabajo y con la vida en general, depresión, disminución del interés por la actividad sexual y tendencia al retraimiento social. Puede estar precipitada por la pérdida del cónyuge o compañero a causa de separación o fallecimiento, por la imposibilidad de lograr una promoción laboral esperada o por el abandono del trabajo a causa de jubilación, forzosa o voluntaria. A diferencia de la menopausia, no se conoce una base hormonal responsable.

Especialmente en las mujeres, este período puede asociarse al "síndrome del nido vacío", pérdida de objetivos que tiene lugar cuando todos los hijos han abandonado el hogar y se siente como pérdida de la propia razón de ser. En estos casos, el trabajo y los contactos sociales en el lugar de trabajo a menudo ejercen una influencia estabilizadora y terapéutica.
Al igual que sucede con muchos otros "problemas femeninos", la menopausia ha desarrollado su propia mitología. La educación preparatoria para erradicar estos mitos, junto con un asesoramiento sensible y de apoyo, evitará la aparición de alteraciones importantes. Continuar trabajando y manteniendo una actuación laboral satisfactoria puede ser decisivo para fomentar el sentimiento de bienestar de la mujer en esta fase de su vida.

Este es el momento de referirse al tratamiento de sustitución hormonal (TSH). EI TSH, que suscita actualmente cierta controversia, se prescribía en un principio para controlar síntomas menopáusicos excesivamente intensos. Aunque habitualmente es eficaz, las hormonas utilizadas pueden precipitar la aparición de hemorragias vaginales y, lo que es aún más importante, plantean problemas sobre su posible efecto cancerígeno. Como consecuencia, suele prescribirse durante períodos limitados, sólo lo suficiente para controlar los síntomas menopáusicos molestos.

EI TSH no tiene efecto sobre los síntomas asociados con la crisis de la edad media de la vida. Sin embargo, si consigue controlar los sofocos y permitir a la mujer dormir bien, al evitar los sudores nocturnos o si aumenta el deseo de actividad sexual al eliminar el carácter doloroso de ésta entonces sí que actúa sobre otros problemas de las mujeres.

En el momento actual se reconoce cada vez más claramente el valor del TSH a largo plazo para mantener la integridad del hueso en mujeres con osteoporosis (ver a continuación) y para disminuir el riesgo de cardiopatía coronaria, principal causa de mortalidad en las mujeres de los países industrializados. Las combinaciones hormonales más modernas y las pautas de administración secuencial evitan, en general, la aparición de hemorragias vaginales y parecen no tener riesgos, o muy escasos, de carcinogénesis incluso en mujeres con antecedentes de cáncer. Sin embargo, dada la existencia en muchos médicos de una clara actitud a favor o en contra del TSH, es necesario conseguir que las mujeres dispongan de información sobre sus efectos beneficiosos y desventajas, a fin de que puedan tomar parte en la decisión de si deben utilizarlo o no.

Recientemente, el American College of Obstetricians and $G$ ynecologists ( $A C O G$ ), teniendo en cuenta los millones de mujeres nacidas en los años del boom de la natalidad (después de la Segunda Guerra M undial) que llegarán a la edad de la menopausia en la próxima década, ha advertido sobre la posibilidad de un incremento gradual de la incidencia de osteoporosis y cardiopatías a menos que se mejore la educación de las mujeres sobre la menopausia y se implanten medidas para evitar procesos patológicos e incapacitantes y para prolongar la vida después de la menopausia (Voelker 1995). El Dr. William C. Andrews, presidente del $A C O G$, ha propuesto un programa basado en el lanzamiento de una campaña masiva para educar a los médicos sobre la menopausia, en la realización de una "consulta premenopausia" en todas las mujeres mayores de 45 años para realizar una valoración personal del riesgo, y en la prestación de asesoramiento exhaustivo y la participación de los medios de comunicación en la educación de las mujeres y de sus familias sobre los síntomas de la menopausia y los efectos beneficiosos y riesgos que conlleva el empleo de tratamientos como el TSH. EI programa de promoción de la salud en el lugar de trabajo puede contribuir de forma importante a un esfuerzo educacional de esta magnitud.

\section{Cribado del cáncer cervical y de mama}

En relación con las necesidades de las mujeres, un programa de promoción de la salud debe incluir la posibilidad, o al menos la recomendación, de realizar el cribado del cáncer cervical y de mama. 


\section{Patología cervical}

El cribado periódico para la detección de cambios cervicales precancerosos mediante la prueba citológica está bien establecida. En muchas empresas se practica en el propio lugar de trabajo o en una unidad móvil, reduciéndose así el tiempo necesario para desplazarse a un servicio comunitario o para consultar al médico personal. No es necesaria la presencia de un médico para realizar esta prueba; una enfermera o un técnico bien preparado puede obtener frotis adecuados. Lo más importante es la calidad de la lectura del frotis y la integridad de los procedimientos necesarios para el registro de los datos y el informe de los resultados.

\section{Cáncer de mama}

Aunque el cribado del cáncer de mama mediante mamografía es una práctica muy extendida en casi todos los países desarrollados, sólo se ha establecido con carácter nacional en el Reino U nido. En el momento actual, más de un millón de mujeres del Reino Unido son exploradas cada año, realizándose una mamografía cada tres años en las que tienen de 50 a 64 años de edad. Todas las exploraciones, incluidos los posibles estudios diagnósticos adicionales necesarios para esclarecer las alteraciones observadas en las placas iniciales, son gratuitas para las pacientes. La respuesta a la invitación para este ciclo de mamografías cada tres años ha sido superior al $70 \%$. Los informes relativos al período 1993-1994 (Patnick 1995) demuestran que hubo que remitir para valoración adicional a un 5,5\% de los casos. De estas mujeres, 5,5 de cada 1.000 fueron diagnosticadas de cáncer de mama. En este programa, la biopsia quirúrgica presentó un valor predictivo positivo del $70 \%$, frente a un $10 \%$ observado en programas publicados en distintas partes del mundo.

Lo más importante en una mamografía es lo relativo a la calidad del método, en especial la disminución de la exposición a la radiación y la exactitud de la interpretación de las imágenes. En los Estados U nidos, la Food and D rug Administration (FDA) ha adoptado un conjunto de normas de calidad propuestas por el A merican College of R adiology, que se aplican desde el 1 de octubre de 1994 en más de 10.000 servicios médicos que realizan 0 interpretan mamografías por todo el país (Charafin 1994). Según la Mammography Standards Act (que entró en vigor en 1992), todas las instalaciones de mamografía de Estados U nidos (salvo las gestionadas por el Department of Veterans Affairs, que está elaborando sus propias normas) deben obtener el certificado de la FDA a partir de esa fecha. Estas normas se resumen en la Figura 17.17).

Recientemente se ha observado en los Estados Unidos un incremento del número de centros de salud para la mama, un $76 \%$ de los cuales han aparecido a partir de 1985 (Weisman 1995). La mayoría dependen de algún hospital (82\%); el resto han sido establecidos por grupos de médicos que obtienen los correspondientes beneficios económicos. Una quinta parte poseen unidades móviles. O frecen exploraciones selectivas ambulatorias y servicios diagnósticos, entre los que se incluyen la exploración física de la mama, la mamografía de cribado y diagnóstica, la ecografía de la mama, la biopsia con aguja fina y el asesoramiento sobre la técnica de autoexploración. Algo más de una tercera parte de los mismos ofrecen también tratamiento del cáncer de mama. Aunque se nutren fundamentalmente de mujeres que acuden de forma voluntaria o enviadas por médicos del servicio nacional de salud, muchos tratan de llegar a acuerdos con los programas de promoción de la salud patrocinados por empresas o sindicatos para ofrecer sus servicios de exploración selectiva de la mama.

La introducción de este tipo de programas en el lugar de trabajo puede causar ansiedad en algunas mujeres, sobre todo
Figura 15.17 - Criterios de calidad de la mamografía en los Estados Unidos.

LEY DE CRITERIOS SOBRE MAMOGRAFIA DE EE.UU., 1992

Las normas de la Food and Drug Administration (FDA) exigen que:

- El personal que realice la mamografía y los médicos que la

interpreten posean niveles adecuados de formación y experiencia.

- Las instalaciones sean inspeccionadas anualmente por inspectores formados por la FDA.

- Los sevicios de mamografía sean controlados estrechamente para garantizar que los niveles de radiación y el procedimiento en su conjunto sean seguros.

- Las instalaciones establezcan programas de garantía de calidad para asegurar la calidad y seguimiento adecuados de los casos con resultados positivos.

- Las instalaciones expongan, en un lugar perfectamente visible, un certificado en el que se indique que la FDA ha aprobado su acreditación por cumplir estas normas (en 1995 habían recibido la aprobación el American College of Radiology y tres estados: Arkansas, California y lowa).

Fuente: FDA 1995

las que poseen antecedentes personales o familiares de cáncer y las que han dado resultados "patológicos" (o no concluyentes). Esta última posibilidad de obtener resultados no negativos debe ser cuidadosamente explicada al presentar el programa, junto con la garantía de que se adoptarán todas las medidas necesarias en los casos que precisen exploraciones adicionales para el diagnóstico y tratamiento. D ebe educarse a los supervisores para que tengan en cuenta las ausencias al trabajo motivadas por las consultas de seguimiento concertadas fuera de las horas de trabajo.

\section{Osteoporosis}

La osteoporosis es un trastorno metabólico del hueso, mucho más prevalente en mujeres que en varones, caracterizado por una disminución gradual de la masa ósea y el consiguiente aumento de la susceptibilidad a las fracturas, las cuales pueden producirse ante movimientos y accidentes aparentemente inocuos. Representa un importante problema de salud pública en la mayoría de los países desarrollados.

Las localizaciones más frecuentes de fracturas son las vértebras, la zona distal del radio y la porción superior del fémur. Todas las fracturas en estas localizaciones en individuos mayores deben plantear la sospecha de osteoporosis como factor contribuyente.

Aunque las fracturas suelen aparecer en edades más avanzadas, una vez que el individuo ya ha abandonado la empresa, la osteoporosis es un objetivo adecuado en los programas de promoción de la salud en el lugar de trabajo, por distintas razones: (1) las fracturas pueden implicar jubilaciones y contribuir de forma importante a los costes derivados de la asistencia médica de los que la empresa sea responsable; (2) las fracturas pueden afectar a los padres o familiares ancianos de los trabajadores, obligando a éstos a asumir una carga que puede comprometer su asistencia y actuación laboral, y (3) el lugar de trabajo representa una gran oportunidad para educar a los individuos más jóvenes sobre el peligro potencial de la osteoporosis y para recomendarles que implanten los cambios necesarios en su estilo de vida para detener la progresión de este proceso.

Existen dos tipos de osteoporosis primaria:

- Postmenopáusica: se relaciona con la pérdida de estrógenos y, por lo tanto, es más prevalente en mujeres que en varones (proporción 6:1). Se observa frecuentemente en los grupos con edades 
entre 50 y 70 años y se asocia con fracturas vertebrales y de Colles (fractura de la muñeca).

- Senil: ocurre principalmente en individuos mayores de 70 años y es dos veces más frecuente en mujeres que en varones. Se cree debida a cambios en la síntesis de vitamina $D$ relacionados con la edad y se asocia principalmente con fracturas vertebrales y femorales.

A mbos tipos de osteoporosis pueden presentarse simultáneamente en mujeres. A demás, en un pequeño porcentaje de casos la osteoporosis ha sido atribuida a distintas causas secundarias, como el hiperparatiroidismo, la utilización de corticosteroides, L-tiroxina, antiácidos u otros fármacos que contienen aluminio, el reposo en cama prolongado, la diabetes mellitus, el consumo de alcohol y de tabaco y la artritis reumatoide.

La osteoporosis puede estar presente durante años e incluso décadas antes de que aparezcan las fracturas. Su detección es posible mediante determinaciones radiológicas bien estandarizadas de la densidad ósea, calibradas en función de la edad y el sexo y complementadas con la evaluación analítica del metabolismo del calcio y del fósforo. La existencia de una transparencia ósea inusual en las radiografías convencionales puede ser sugestiva, si bien la osteopenia no se detecta habitualmente de forma fiable hasta que se ha perdido más de un $30 \%$ del hueso.

En general, no debe utilizarse el cribado de osteoporosis en individuos asintomáticos como procedimiento de rutina, especialmente en los programas de promoción de la salud en el lugar de trabajo. Se trata de un método con un coste económico elevado, no muy fiable excepto en servicios bien dotados de personal, implica exposición a la radiación y, lo que es aún más importante, no identifica a las mujeres con osteoporosis que tienen mayor probabilidad de presentar fracturas.

Por consiguiente, aunque todos los individuos sufren algún grado de pérdida ósea, el programa de prevención de la osteoporosis se centra en los que presentan mayor riesgo debido a una progresión más rápida y, por lo tanto, más sensibles a las fracturas. Ciertamente, cuanto antes se instauren las medidas de prevención mayor es la eficacia de éstas, pero es difícil motivar a la gente joven para que adopte en su estilo de vida los cambios necesarios para reducir el riesgo de problemas que muchos consideran propios de edades avanzadas. Un factor favorable que se debe tener en cuenta es que muchos de los cambios recomendados también son útiles en la prevención de otros problemas, así como para la promoción general de la salud y del sentimiento de bienestar.

En todo caso, hay factores de riesgo de osteoporosis que no pueden modificarse. Son los siguientes:

- R aza. Los individuos de raza blanca y los orientales tienen, por término medio, menor densidad ósea que los de raza negra cuando se equiparan por edades $y$, por lo tanto, presentan un riesgo más elevado.

- Sexo. Las mujeres presentan huesos menos densos que los varones cuando se equiparan en función de la edad y la raza, y por consiguiente, tienen un riesgo más elevado.

- E dad. Todas las personas experimentan una pérdida de masa ósea con la edad. Cuanto más fuertes sean los huesos en el individuo joven, menor será la probabilidad de que la pérdida de masa ósea alcance niveles potencialmente peligrosos en edades avanzadas.

- H istoria familiar. Existen algunos indicios de la existencia de un factor genético en la consecución de un máximo de masa ósea y en la velocidad de la subsiguiente pérdida de hueso; por tanto, una historia familiar de fracturas sugestivas en distintos miembros de la familia puede representar un factor de riesgo importante.
La imposibilidad de actuar sobre estos factores de riesgo refuerza la importancia de la actuación sobre los que sí pueden modificarse. Entre las medidas que pueden adoptarse para retrasar el inicio de la osteoporosis o para reducir su gravedad están las siguientes:

- Dieta. Si la dieta no contiene cantidades adecuadas de calcio y vitamina $D$, se recomienda utilizar suplementos, sobre todo en los individuos con intolerancia a la lactosa, que tienden a evitar la ingesta de leche y derivados lácteos, principales fuentes del calcio dietético, y de forma mantenida desde la infancia hasta la tercera década, debido a que es entonces cuando se alcanza la densidad ósea máxima. El carbonato de calcio, suplemento utilizado con más frecuencia, origina efectos secundarios como estreñimiento, hiperacidez de rebote, distensión abdominal y otros síntomas gastrointestinales. En función de esto, muchas personas lo sustituyen por preparaciones de citrato de calcio que, a pesar de poseer un contenido de calcio elemental significativamente menor, presenta una mejor absorción y produce menos efectos secundarios. Las cantidades de vitamina D presentes en la preparación multivitamínica habitual son suficientes para retrasar la pérdida de hueso de la osteoporosis. Las mujeres deben tener precaución frente a las dosis excesivas, que pueden originar una hipervitaminosis $D$, síndrome con posible insuficiencia renal aguda y aumento de la resorción ósea.

- Ejercicio. Es aconsejable realizar ejercicio moderado en función del peso y de forma regular: por ejemplo, caminar 45 a 60 minutos al menos tres veces por semana.

- Tabaquismo. Las mujeres fumadoras tienen la menopausia unos dos años antes que las no fumadoras. Sin un tratamiento de sustitución hormonal, la menopausia más precoz acelerará la pérdida ósea posmenopáusica. Es ésta otra razón para oponerse a la tendencia actual al incremento del consumo de tabaco entre las mujeres

- Tratamiento de sustitución hormonal. Si se instaura un tratamiento de sustitución con estrógenos, se debe iniciar en la fase precoz de la menopausia, puesto que la velocidad de pérdida ósea es más elevada en los primeros años siguientes a aquélla. Puesto que la pérdida ósea vuelve a acelerarse al interrumpir el tratamiento estrogénico, éste se debe mantener de forma indefinida.

Una vez diagnosticada la osteoporosis, su tratamiento se centra en tratar de evitar una mayor pérdida de hueso mediante el seguimiento de todas las recomendaciones expuestas. Algunos autores son partidarios del empleo de calcitonina, fármaco que ha demostrado incrementar el contenido de calcio total del organismo. Sin embargo, la administración ha de hacerse por vía parenteral; su coste económico es elevado y todavía no existen pruebas de que retrase o invierta la pérdida de calcio en el hueso 0 de que disminuya la incidencia de fracturas. LoS bisfosfonatos se utilizan cada vez más como agentes contra la resorción ósea.

Se debe recordar que la osteoporosis favorece la aparición de fracturas, pero no las causa. Estas se deben a caídas o a movimientos imprudentes realizados de forma brusca. Aunque la prevención de las caídas debe constituir una parte importante de todos los programas de seguridad en el lugar de trabajo, es especialmente importante para los individuos con osteoporosis. Por consiguiente, deben incluirse en ellos tareas de educación sobre la protección ambiental tanto en el lugar de trabajo como en el domicilio ( $p$. ej. eliminar o sujetar a las partes bajas de la pared los cables eléctricos, pintar los extremos de las escaleras o las irregularidades del piso, sujetar con tachuelas las alfombras resbaladizas, secar rápidamente las superficies húmedas) y hay que sensibilizar a los individuos respecto a los peligros que implica el empleo de calzado y de asientos inseguros de los que 
sea difícil levantarse por ser demasiado bajos o demasiado blandos.

\section{La salud de las mujeres y su trabajo}

Las mujeres constituyen una parte importante de la plantilla de las empresas. De hecho, son el pilar principal de muchas industrias. Deben recibir el mismo tratamiento que los varones en todos los aspectos; sólo algunos aspectos de su situación sanitaria son diferentes. El programa de promoción de la salud debe informarles sobre estas diferencias y permitirles que busquen el tipo y calidad de asistencia sanitaria que necesitan y merecen. Las empresas y sus directivos han de entender que la mayoría de las mujeres no padecen los problemas descritos en este artículo y que, además, éstos pueden evitarse y controlarse en la escasa proporción de mujeres que los presentan. Excepto en casos muy raros, y en cualquier supuesto no más frecuentes que entre varones con problemas de salud similares, tales problemas no constituyen ningún impedimento para que la mujer asista al trabajo de forma adecuada y mantenga una actuación laboral eficaz.

M uchas mujeres consiguen alcanzar una elevada posición no sólo porque realizan un trabajo de gran calidad, sino también porque no presentan ninguno de los problemas de salud femenina comentados. De ahí la posibilidad de que algunas de ellas se vuelvan intolerantes con las que tienen ese tipo de dificultades. U n foco de resistencia muy importante en la lucha por mejorar la situación laboral de las mujeres pueden ser las propias mujeres.

Un programa de promoción de la salud que englobe los problemas de salud de las mujeres y los aborde con la sensibilidad e integridad adecuadas puede tener un impacto positivo e importante no sólo para las mujeres en el lugar de trabajo, sino también para sus familias, para la comunidad y, lo que es más importante, para la empresa.

\section{- ESTUDIO DE CASO: EL PROGRAMA DE MAMOGRAFIAS DE MARKS AND SPEN CER}

\section{Jillian Haslehurst}

Este estudio de caso describe el programa de mamografías de $M$ arks and Spencer, el primero que ofrece una empresa a escala nacional. $M$ arks and Spencer es una empresa minorista internacional con 612 tiendas por todo el mundo, la mayoría de las cuales se encuentran en el Reino U nido, el continente europeo y Canadá. Además de diversas empresas en régimen de franquicia, la compañía posee en Estados U nidos a Brooks Brothers y $\mathrm{K}$ ings Super Markets, y D'Allaird's en Canadá, y realiza numerosas actividades financieras.

La compañía emplea a 62.000 personas, la mayoría de las cuales trabajan en 285 tiendas en el Reino U nido y la R epública de Irlanda. Es legendaria la reputación de la compañía como buena empresa y su política de relaciones humanas con el personal implica la ejecución de programas sanitarios y de bienestar globales y de alta calidad.

Aunque en algunos lugares de trabajo se presta un servicio de tratamiento, esta necesidad es ampliamente satisfecha por los médicos de atención primaria comunitaria. La política sanitaria de la compañía hace hincapié en la detección precoz y prevención de la enfermedad. Por tanto, durante los últimos 20 años se han desarrollado una serie de programas innovadores de cribado, muchos de los cuales tienen proyectos previos en el
$\mathrm{N}$ ational $\mathrm{H}$ ealth Service (N H S). M ás del $80 \%$ de la plantilla son mujeres y este hecho ha influido en la selección de los programas de cribado que incluyen la citología cervical, el cribado del cáncer de ovario y la mamografía.

\section{Cribado del cáncer de mama}

Mediado el decenio de 1970 el estudio New York HIP (Shapiro 1977) probó que la mamografía era capaz de detectar cánceres de mama no palpables, con la esperanza de que la detección precoz reduciría la mortalidad. Como empresa con un número elevado de mujeres de mediana edad, resultaba obvio el atractivo de la mamografía y se inició un programa de exploración selectiva en 1976 (H utchinson y Tucker 1984; H aslehurst 1986). En aquel momento prácticamente no se tenía acceso en el sector público a una mamografía fidedigna de alta calidad y la que existía en las organizaciones sanitarias privadas era costosa y de calidad variable. La primera tarea por tanto consistía en asegurar el acceso a una calidad elevada uniforme, afrontando este reto mediante unidades móviles de detección equipadas con una sala de espera, una cabina de exploración y un equipo de mamografía.

La centralización de la administración y del procesamiento de la película permitía efectuar continuas comprobaciones de todos los aspectos de la calidad, permitiendo que un experimentado grupo de especialistas realizaran la interpretación de las imágenes. Sin embargo esto tenía una desventaja, que consistía en que el radiólogo no podía examinar inmediatamente la película revelada para comprobar la ausencia de errores técnicos, y si los había, se tenía que citar de nuevo al trabajador o realizar las gestiones oportunas para repetir la exploración.

El cumplimiento del programa ha sido siempre excepcionalmente elevado y ha estado por encima del $80 \%$ en todos los grupos de edad. Sin duda esto se debe a la presión de los compañeros de grupo, a la accesibilidad del servicio en o cerca del centro de trabajo y, hasta hace poco, a la ausencia de centros dotados de mamografía en el NHS.

Las mujeres son invitadas a incorporarse al programa de cribado y la participación es completamente voluntaria. Antes de la exploración, el médico o el personal de enfermería de la compañía imparten varias sesiones educativas breves, prestándose a responder las preguntas y explicar las dudas que surjan. Las inquietudes habituales son la preocupación por la dosis de radiación y el temor a que la compresión de la mama produzca dolor. Las mujeres que son citadas por segunda vez para realizar pruebas adicionales son atendidas durante el horario de trabajo y se les reembolsa totalmente sus gastos de viaje y los de un acompañante.

Durante los cinco primeros años del programa se utilizaron tres modalidades: exploración física por un médico-enfermera altamente cualificado, termografía y mamografía. La termografía era una exploración que requería mucho tiempo, con una tasa elevada de falsos positivos y que no mejoraba la tasa de detección de cáncer; por estas razones fue suspendida en 1981. La exploración física, que incluye una revisión detallada de los antecedentes personales y familiares, aunque posee un valor limitado en la detección del cáncer, aporta al radiólogo una información de valor incalculable y proporciona al paciente tiempo para comentar sus temores y otros aspectos sanitarios con un profesional sanitario comprensivo. La mamografía es la más sensible de las tres pruebas - en la exploración inicial se toman proyecciones cráneo-caudal y oblicua lateral, con proyecciones únicas en la revisión intermedia- . La norma es realizar una lectura única de la placa, aunque en los casos difíciles y como control aleatorio de calidad se realiza una lectura doble. La Figura 15.18 muestra la contribución de la exploración física y de la mamografía a la tasa de detección total del cáncer. De los 
Figura 15.18 - Cribado del cáncer de mama. Contribución de la exploración clínica y de la mamografía a la detección del cáncer, por grupos de edad.

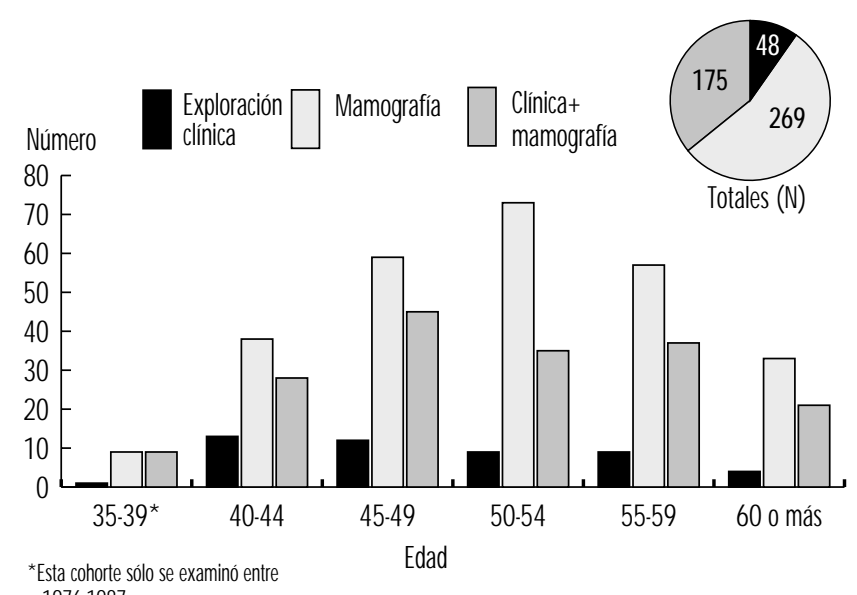
1976-1987

492 cánceres hallados, el $10 \%$ fue detectado por la exploración clínica aislada, el $54 \%$ por la mamografía aislada, y el $36 \%$ por la exploración clínica y la mamografía.

Se ofreció la exploración selectiva a las mujeres con edades comprendidas entre 35 y 70 años al principio del programa, pero la tasa reducida de detección de cáncer y la elevada incidencia de procesos mamarios benignos en las mujeres del grupo de edad de 35 a 39 años condujo a la retirada del servicio a este grupo más joven en 1987. La Figura 15.19 muestra el porcentaje de cánceres detectados por grupos de edad.

De la misma forma se ha modificado el intervalo entre exploraciones, desde una revisión anual (reflejo del entusiasmo inicial) a un intervalo bianual. La Figura 15.20 muestra el número de cánceres detectados por grupos de edad con las cifras correspondientes a los tumores detectados durante el intervalo y a los no detectados. Los casos detectados durante los intervalos se

Figura 15.19 - Distribución por edades de los cánceres detectados mediante cribado.

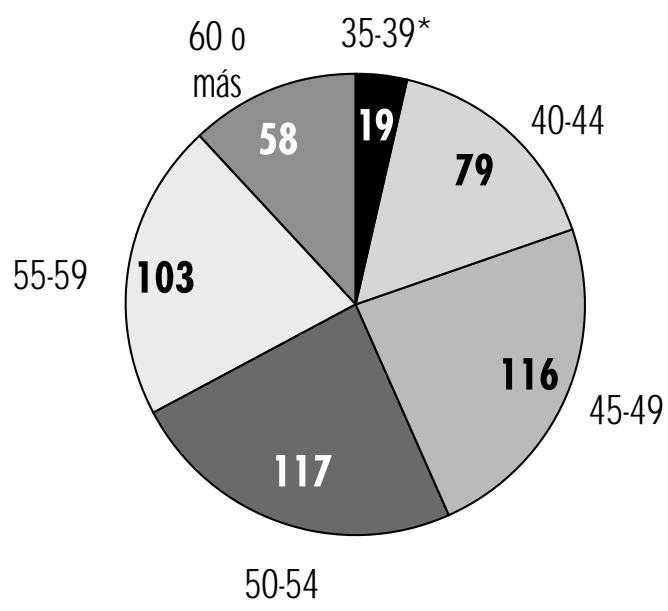

*Esta cohorte sólo se examinó entre 1976 y 1987. definen como aquellos que aparecen después de una exploración realmente negativa durante el período de tiempo transcurrido entre las pruebas de rutina. Los casos no detectados se definen como aquellos tumores malignos que se pueden observar retrospectivamente en las placas pero no fueron identificados en el momento de la realización de la exploración selectiva.

El $76 \%$ de los cánceres de mama de la población estudiada se detectaron en la exploración inicial, con un $14 \%$ adicional de casos que aparecieron durante el intervalo entre exploraciones. Se debe monitorizar cuidadosamente la tasa de tumores durante el intervalo para asegurarse de que no se eleva hasta niveles inaceptables.

No se han podido demostrar los efectos beneficiosos en términos de supervivencia de realizar explosiones a mujeres menores de 50 años, aunque se acepta que se detectan tumores más pequeños y esto permite a algunas mujeres elegir entre mastectomía o tratamiento conservador de la mama, una posibilidad muy valorada por muchas. La Figura 15.21 muestra las dimensiones de los cánceres detectados en la primera exploración, la mayoría de los cuales son menores de $2 \mathrm{~cm}$ y sin adenopatías.

\section{El impacto del Informe Forrest}

A finales de la década de los 80, el profesor Sir Patrick Forrest recomendó que se pusiera a disposición de las mujeres mayores de 50 años una exploración selectiva regular de mama a través del NHS (es decir, sin coste en el momento de la prestación del servicio) (Forrest 1987). Su recomendación más importante fue que el servicio no debería empezar hasta que se hubiera formado adecuadamente al personal especializado en el enfoque interdisciplinario del diagnóstico del cáncer de mama. Este personal está constituido por radiólogos, asesores de enfermería y médicos especialistas en la mama. Desde 1990, el Reino U nido, dispone de un servicio de evaluación y exploración selectiva gratuita de la mama para las mujeres mayores de 50 años

Coincidiendo con este desarrollo en el ámbito público, M arks and Spencer revisó sus datos y se detectó que el programa tenía una grave deficiencia. La tasa de segunda cita tras la exploración de rutina superaba el $8 \%$ entre las mujeres mayores de 50 años y el $12 \%$ entre las mujeres más jóvenes. El análisis de los datos mostró que las razones habituales que dieron lugar a una segunda cita fueron problemas técnicos, como una posición

Figura 15.20 • N úmero de cánceres detectados en la exploración inicial, en el intervalo y de los no detectados, por grupos de edad.

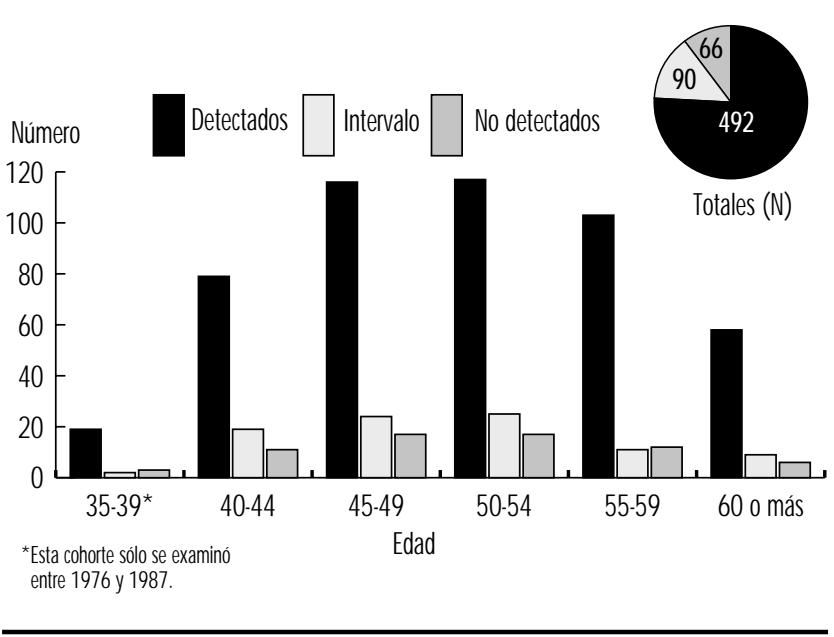


Figura 15.21 - Tamaño de los cánceres detectados en las pruebas de cribado.

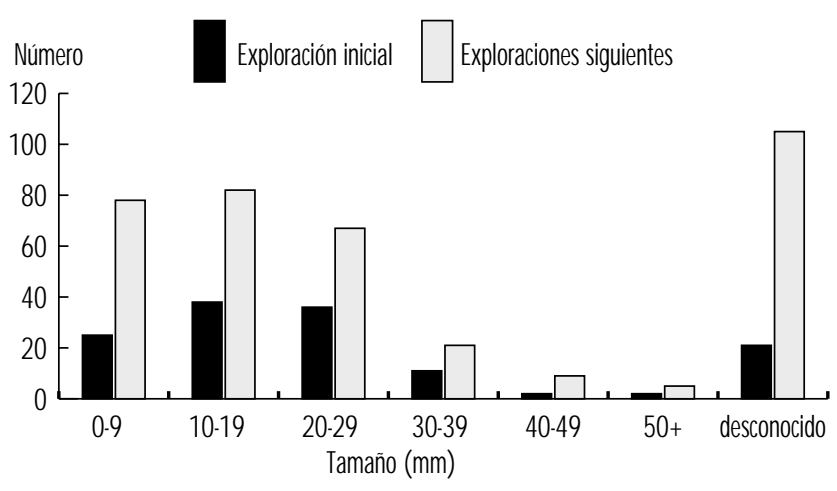

inadecuada, errores de procesamiento, presencia de la cuadrícula o la necesidad de nuevas proyecciones. Además quedó claro que el uso de la ecografía, mamografía especializada y de la citología por aspiración con aguja fina podían disminuir aún más las tasas de segunda cita y de derivación al especialista. Un estudio inicial confirmó estas impresiones y se decidió redefinir el protocolo del programa de exploración de modo que las pacientes que requerían más pruebas no eran remitidas de nuevo a sus médicos de familia, sino que permanecían dentro del programa hasta que se realizara un diagnóstico definitivo. La mayoría de las mujeres volvieron a las citas de rutina después de la realización de las pruebas adicionales, con lo que se redujo al mínimo la tasa oficial de remisión al cirujano.

En vez de duplicar el servicio ofrecido por el $\mathrm{N}$ ational $\mathrm{H}$ ealth Service, se desarrolló una política de cooperación que permitió a $M$ arks and Spencer aprovechar la experiencia del sector público mientras los fondos de la compañía se emplean en mejorar el servicio de forma global. En la actualidad, ofrecen el programa de cribado de la mama una serie de entidades: aproximadamente la mitad de la demanda se atiende con el servicio móvil original, aunque el personal de las tiendas de las grandes ciudades acude a realizar la exploración selectiva a centros especializados, que pueden pertenecer al sector privado 0 al público. Esta cooperación con el $\mathrm{N}$ ational $\mathrm{H}$ ealth Service constituye un proceso estimulante a la vez que un reto, y ha permitido mejorar las normas generales de diagnóstico de los procesos de mama y de atención a la población en general. Complementando los programas laborales privados y los programas del sector público es posible prestar un servicio de una calidad extraordinariamente elevada a una población muy amplia.

\section{- ESTRATEg IAS EN EL LUGAR DE TRABAJO PARA LA MEJORA DE LA SALUD MATERNAL E INFANTIL: EXPERIENCIAS DE LOSTRABAJADORES EN ESTADOS UNIDOS}

\section{Maureen $P$. Corry y Ellen Cutler}

En Estados Unidos, tanto las empresas públicas como las privadas son cada vez más conscientes de que existe una relación entre los partos sanos, la productividad y la situación económica de la empresa. Como consecuencia ha aumentado la preocupación con respecto a los peligros profesionales para la salud reproductora. Nunca habían tenido las empresas razones más válidas para mejorar la salud maternal e infantil de los trabajadores y de sus familias. El incremento de los costes de la asistencia sanitaria, la evolución demográfica de la población activa y la constatación de que unos trabajadores sanos dan lugar a aumentos en la productividad son razones convincentes para que las empresas incluyan la salud maternal e infantil en sus programas de promoción y educación sanitaria.

Estrategia para la salud maternal e infantil es un término utilizado en sentido amplio para definir toda iniciativa cuidadosamente planeada y patrocinada por las empresas o por los sindicatos, con objeto de promover la salud y el bienestar de la mujer, antes, durante y después de la gestación y de apoyar la salud de los niños durante su primer año de vida. No existen una solución o un enfoque únicos para la mejora de la salud maternal e infantil. Para la mayoría de las empresas, el esfuerzo consiste más bien en una serie de actividades combinadas, que se describen a continuación, diseñadas a medida a las características específicas de los distintos lugares de trabajo.

\section{Prestaciones de asistencia sanitaria}

Resulta útil considerar las prestaciones de asistencia sanitaria maternal e infantil como un continuo asistencial que fomenta la sensibilización con respecto a la salud reproductora, facilite consejo en materia de planificación familiar y presta servicios a lo largo del período reproductor. Las prestaciones enumeradas en la Tabla 15.5 son las que un plan de seguros de enfermedad debe cubrir debido a su importancia para la mejora de la salud maternal e infantil.

\section{Diseño de las prestaciones}

Si bien muchos planes de asistencia sanitaria norteamericanos cubren la asistencia prenatal y preconceptiva, existen diversas razones que dificultan el que algunas mujeres tengan acceso a una asistencia de buena calidad y asequible. Por ejemplo, algunos proveedores exigen el pago por adelantado de los servicios relacionados con el parto y la asistencia prenatal, aunque la mayoría de las compañías aseguradoras no hacen efectivo el pago hasta después del parto. Entre otras barreras que dificultan el acceso a una asistencia adecuada figuran la fijación de primas de franquicia muy altas de pagos de coaseguro, la incompatibilidad de horarios, la falta de cobertura para las personas a cargo del trabajador y la inaccesibilidad geográfica. Las empresas no pueden eliminar todas estas barreras, pero sería un excelente comienzo ayudar a eliminar las cargas de los pagos directos y de las elevadas primas de franquicia y prestar apoyo al trabajador para que sea aceptado por un proveedor de asistencia prenatal adecuado.

En Texas Instruments ( $\mathrm{TI}$ ), el objetivo es hacer la asistencia prenatal asequible independientemente de cuál sea el nivel de ingresos del trabajador o el proveedor de asistencia sanitaria. L as madres que solicitan asistencia prenatal dentro de la red de TI pagan sólo el $10 \%$ de una prima de franquicia directa negociada, una carga única que cubre los servicios de asistencia prenatal, así como los partos sin complicaciones y los que requieran cesárea.

H aggar A pparel Company se hace cargo del $100 \%$ del coste del pago directo de la asistencia prenatal si un trabajador o una persona a su cargo se acoge a la asistencia prenatal durante el primer trimestre de gestación. The Home Depot (un detallista de materiales de construcción y de mercancías relacionadas con este sector) renuncia a la franquicia por la atención hospitalaria si las visitas de asistencia prenatal comienzan durante el primer trimestre. 
Tabla 15.5 - Prestaciones del seguro de enfermedad.

\begin{tabular}{|c|c|}
\hline Pregestación & Gestación \\
\hline $\begin{array}{l}\text { Visita anual antes de la concepción o } \\
\text { entre concepciones (incluidos los servicios } \\
\text { de planificación familiar) }\end{array}$ & Asesoramiento genético y pruebas \\
\hline Asesoramiento genético y pruebas & $\begin{array}{l}\text { Atención prenatal; debería ofrecerse sin } \\
\text { pagos deducibles ni copagos }\end{array}$ \\
\hline Prescripción de medicamentos & $\begin{array}{l}\text { El parto en un hospital o una maternidad } \\
\text { debería ofrecerse sin pagos deducibles ni } \\
\text { copagos }\end{array}$ \\
\hline \multirow[t]{5}{*}{ Tratamiento de las toxicomanías } & - Ingreso en un hospital o maternidad \\
\hline & - Servicio de antestesia \\
\hline & $\begin{array}{l}\text { - Prescripción de medicamentos (incluida } \\
\text { la administración prenatal de } \\
\text { vitaminas) }\end{array}$ \\
\hline & $\begin{array}{l}\text { - Servicios de atención médica a } \\
\text { domicilio }\end{array}$ \\
\hline & - Tratamiento de las toxicomanías \\
\hline
\end{tabular}

Postgestación

Atención postparto

Prescripción de medicamentos

Servicios de atención médica a domicilio Prescripción de medicamentos

Tratamiento de las toxicomanías

Servicios de atención médica a domicilio

Fuente: March of Dimes Birth Defects Foundation 1994

Si bien muchos planes ofrecen asistencia adecuada durante los primeros días de vida del recién nacido, la cobertura para la asistencia preventiva del niño tras abandonar el hospital, frecuentemente denominada asistencia para el bienestar del niño, a menudo es inadecuada o no existe.

En el First National Bank de Chicago, las mujeres gestantes que están inscritas en el plan de seguridad y completan un programa de educación prenatal antes de finalizar el cuarto mes de gestación están exentas del pago de 400 dólares deducible de la cobertura del seguro de enfermedad del primer año del recién nacido. T he $M$ onfort Company, una planta empaquetadora de carne de buey con sede en Greeley, Colorado, cubre en su totalidad la asistencia para el bienestar del niño hasta la edad de tres años.

\section{Servicios relacionados con las prestaciones y programas para los empleados}

En la Tabla 15.6 se ofrece una lista de los servicios relacionados con las prestaciones y de los programas que se consideran instrumentos de apoyo importantes de una estrategia para la salud maternal e infantil. Estos servicios y programas puede ofrecerlos directamente la empresa, bien sea en el lugar de trabajo o en un lugar cercano, o mediante un contrato con una agencia o proveedor externo, dependiendo de la estructura, emplazamiento y tamaño de la organización y pueden estar administrados por los departamentos de prestaciones, de salud de los empleados, de promoción de la salud 0 de asistencia a los empleados, por ejemplo.

Pocas compañías pueden ofrecer todos estos elementos; sin embargo, cuanto más completa y global sea la estrategia, mayores serán las posibilidades de mejorar la salud de las madres y de los niños.

\section{Período pregestacional y gestacional}

L os programas de gestión de la maternidad están ganando popularidad debido a los aspectos atractivos que ofrecen tanto a los futuros padres como a la empresa. Si bien no están diseñados con el objeto de reemplazar la asistencia prenatal que ofrecen los profesionales de la asistencia sanitaria, la gestión de la maternidad es un servicio relacionado con las prestaciones que ofrece consejo y asistencia personalizados conforme a las necesidades y a los niveles de riesgo de las madres.

La empresa Levi Strauss \& Company, uno de los mayores productores de prendas de vestir y confección del país, ofrece un programa de gestión de la maternidad administrado por una compañía de seguros. Se anima a las trabajadoras a acogerse al programa tan pronto como quedan embarazadas y reciben 100 dólares en metálico por efectuar una llamada gratuita al número de teléfono del programa de gestión de la maternidad. En 1992, los gastos correspondientes a recién nacidos cuyas madres habían participado en el programa fueron casi la mitad que los correspondientes a aquellos cuyas madres no lo habían hecho.

El First National Bank de Chicago ofrece el programa de promoción de la salud prenatal Babies and You de March of Dimes, como parte de su estrategia para la salud maternal e infantil. Este programa se describe a continuación y en el estudio de caso de la página 15.23.

\section{Babies and You: Un programa de promoción de la salud prenatal}

El programa de promoción de la salud prenatal Babies and You de M arch of Dimes se desarrolló en 1982, en colaboración con especialistas en materia de salud maternal e infantil de todo el país. El programa probado directa y exhaustivamente en los lugares de trabajo de $M$ arch of Dimes, se actualiza y perfecciona constantemente.

Babies and You educa a los adultos acerca de cómo practicar comportamientos ligados a una forma de vida sana antes de la gestación y durante ella, motiva a las mujeres para que soliciten asistencia prenatal desde el principio y de forma regular e influye en las empresas para que apliquen estrategias que favorezcan una gestación y parto sanos.

Las actividades de promoción de la salud prenatal deben contar con la participación de los trabajadores de ambos sexos, de sus parejas y de otros familiares y amigos. Babies and You se adapta a las necesidades específicas de la plantilla. Se tienen en cuenta el nivel de educación, la cultura y la lengua de los futuros 
Tabla 15.6 - 0 tras prestaciones ofrecidas por la empresa.

$\begin{array}{ll}\text { SERVICIOS } & \text { Gestación } \\ \text { Pregestación } & \text { Programa de tratamiento de la } \\ & \text { maternidad } \\ \text { - Servicios de tratamiento por casos de } & \text { embarazo de riesgo elevado (pueden } \\ & \text { formar parte de un programa de trata- } \\ & \text { miento de la maternidad) }\end{array}$

\section{SERVICIOS}

\section{Posgestación}

- Prestaciones compensatorias de la discapacidad por maternidad
Lactancia

- Servicios de tratamiento para recién nacidos de alto riesgo

- Reembolso de gastos causados por el cuidado de personas a cargo

\begin{tabular}{|c|c|}
\hline \multicolumn{2}{|l|}{ PROGRAMAS } \\
\hline Pregestación & Gestación \\
\hline $\begin{array}{l}\text { - Promoción de la salud antes de la } \\
\text { concepción }\end{array}$ & - Promoción de la salud prenatal \\
\hline \multirow[t]{3}{*}{ - Programas de abandono del tabaco } & $\begin{array}{l}\text { - Formación de la sensibilidad para } \\
\text { directivos }\end{array}$ \\
\hline & $\begin{array}{l}\text { - Clases de atención y desarrollo del } \\
\text { lactante dirigidas a los padres }\end{array}$ \\
\hline & - Programas de abandono del tabaco \\
\hline
\end{tabular}

\section{Posgestación}

- Programa de lactancia

\section{Lactancia}

- Centro de atención infantil en la empresa

- Remisión a servicios pediátricos

Fuente: March of Dimes Birth Defects Foundation 1994

participantes así como cualquier limitación que presente el lugar de trabajo y los recursos disponibles de la empresa.

Debido a que en las distintas empresas las actividades de promoción de la salud se encuentran en fases diferentes, Babies and You ofrece tres modalidades de ejecución: campaña de información, seminarios educativos y formación de profesionales de la salud (véase recuadro). Los principales temas más populares del material informativo y de los seminarios educativos son la asistencia preconceptiva y prenatal, el desarrollo fetal, la genética, el papel del hombre durante la gestación, la nutrición durante la gestación y el ejercicio de la paternidad. Los temas tratados en los programas prenatales de 31 empresas encuestadas por el New York Business Group on Health sobre programas prenatales son la comprensión del proceso de la gestación y el parto; la asistencia oportuna por parte de profesionales de la salud cualificados; la práctica de comportamientos sanos relacionados con la gestación y la prevención de peligros que puedan afectar a la madre 0 al feto; el cuidado del recién nacido; y el mantenimiento de unas relaciones familiares y laborales satisfactorias (D uncan, Barr y Warshaw 1992).

\section{Período posgestacional y de la primera infancia}

A demás de la ejecución de programas de promoción de la salud y de otros servicios cuya atención se centra en la salud de la madre antes de la gestación y durante la misma, muchas empresas también ofrecen programas de apoyo a los padres y a los niños después de la gestación, tanto durante los decisivos doce primeros meses como posteriormente. El permiso de maternidad, los programas de lactancia, las cuentas de indemnización de asistencia a personas a cargo (por ejemplo, retenciones del salario antes de impuestos que los trabajadores pueden utilizar para hacer frente a los gastos originados por la asistencia a personas a su cargo), clases de paternidad y asistencia infantil en el lugar de trabajo son sólo algunas de las prestaciones y programas que se ofrecen en la actualidad.

Por ejemplo, con el fin de mantener buenas relaciones con sus trabajadores, Lancaster Laboratories, con sede en Lancaster, Pennsylvania, empresa de investigación de laboratorio bajo contrato y de consultoría para las industrias del medio ambiente, alimentaria y farmacéutica, continúa ofreciendo las prestaciones del seguro de enfermedad durante el permiso de maternidad y durante el permiso parental no retribuido, tanto si la trabajadora tiene o no intención de incorporarse a su puesto de trabajo después de dar a luz. Este enfoque de la gestión de apoyo a la familia ha dado resultados: en una industria en la que la tasa característica de rotación es del $27 \%$, la tasa de Lancaster es de tan sólo el $8 \%$ (M arch of Dimes 1994).

La ejecución de programas de lactancia también resulta fácil y beneficiosa para las empresas. Los beneficios de la lactancia materna para la salud no se limitan tan sólo al niño. Un estudio reciente muestra que la mejora de la salud del niño mediante la lactancia materna tiene un efecto directo sobre la productividad del trabajador. Cuando los niños están más sanos, el número de días de trabajo que los padres pierden por tener que atender las enfermedades de sus hijos es significativamente menor (Ryan y M artinez 1989). Para ofrecer un programa de lactancia sólo es necesario disponer de un espacio en el lugar de trabajo y del equipo para la extracción y el almacenaje de la leche materna.

L os Angeles Department of Water and Power calculó algunos beneficios de su programa de lactancia: por ejemplo, el $86 \%$ de los participantes afirman que el programa facilitó su reincorporación al trabajo; el 71 \% dijo que se ausentaba menos del trabajo desde que participaba en el programa; y la tasa de rotación de los participantes en el programa es del $2 \%$ ( $M$ arch of Dimes 1994).

\section{Políticas de las empresas}

Las empresas pueden poner en marcha muchas políticas en el lugar de trabajo para crear una cultura de apoyo a la salud maternal e infantil. El establecimiento de nuevas políticas y la modificación de las antiguas pueden ser de gran utilidad para que los trabajadores comprendan la cultura corporativa de la empresa.

Algunas políticas se refieren a la salud de todos los trabajadores, como sucede con la creación de un entorno de prohibición del consumo de tabaco. 0 tras atienden a grupos especiales, 


\section{BABIES AND YOU: Etapas de ejecución}

$N$ ivel I: Campaña de información. Tiene por objeto crear en el lugar de trabajo conciencia de la importancia de la atención prenatal precoz y regular. M arch of Dimes aplica esta modalidad por medio de materiales impresos y audiovisuales.

$N$ ivel II: Seminarios educativos. Se organizan en el lugar de trabajo y los imparten profesionales de la salud voluntarios de $M$ arch of Dimes. Hay catorce temas distintos para elegir, entre ellos cuidados previos a la concepción, atención prenatal, nutrición, ejercicio físico y embarazo, gestación después de los 35 años, estrés y embarazo, complicaciones del embarazo, cuidado del bebé, función del varón durante el embarazo y lactancia.

N ivel III: Formación de profesionales de la salud. Permite a la organización instaurar Babies and You como elemento constante de las actividades de bienestar. M arch of Dimes proporciona un día de formación sobre la forma de impartir y aplicar el programa a los profesionales de la salud de la empresa, como ATS de empresas, gestores de prestaciones, directores médicos y especialistas en promoción de la salud.

Sea cual sea la modalidad de Babies and You que una empresa decida aplicar, son ocho los objetivos de promoción de la salud prenatal que este programa intenta alcanzar:

- Compromiso de la dirección

- Planificación interdepartamental del programa

- Participación de los trabajadores

- O ferta de incentivos

- Políticas y prestaciones de apoyo

- Establecimiento de canales de comunicación

- Acceso a los recursos comunitarios

- Evaluación

como las que se centran en los peligros profesionales para la salud reproductora y están dirigidas a atender las necesidades de los hombres y mujeres que tienen intención de ser padres. La aplicación de políticas de flexibilidad en el trabajo, de apoyo a las mujeres gestantes en la organización de las visitas prenatales y el alivio de la carga de los padres que tienen niños recién nacidos y de corta edad aún hacen más en este sentido. Por último, las políticas relativas a la modificación de las tareas laborales en caso de que sea necesario durante la gestación y a las cuestiones relacionadas con el permiso y con la duración del mismo ayudan a proteger la salud de la trabajadora gestante al tiempo que reducen la interferencia con el desarrollo de su actividad laboral.

Cuando la Warner-Lambert Company, empresa líder del sector farmacéutico, de asistencia sanitaria al consumidor y de productos de confitería, puso en marcha sus programas de educación prenatal y de gestión de la maternidad, introdujo también unas directrices globales para la gestión de la salud reproductora. Conforme a estas directrices, se anima a los trabajadores a que cumplimenten unos cuestionarios de evaluación de los peligros potenciales para la salud reproductora ligados a sus puestos o lugares de trabajo. En caso necesario, un técnico de seguridad de la Warner-Lambert llevará a cabo una evaluación para determinar cuáles son, en su caso, las medidas de control de los peligros en el lugar de trabajo o las restricciones laborales que puedan ser necesarias.

Junto con las políticas sobre peligros para la salud reproductora, varias empresas ofrecen políticas flexibles de permisos familiares. Por ejemplo, en AT\&T, el gigante de las comunicaciones, los trabajadores pueden tomarse hasta 12 meses de permiso no retribuido para atender a un niño recién nacido 0 adoptado. M ás del $50 \%$ de los trabajadores que han hecho uso de esta política de permisos desde 1990 volvieron a ocupar su puesto de trabajo en el plazo de tres meses. Al cabo de seis meses, el $82 \%$ de los trabajadores ya se habían reincorporado al trabajo (M arch of Dimes 1994).

$Y$ en PepsiCo Inc., el gran conglomerado de bebidas y alimentos con sede en Purchase, Nueva York, los padres de recién nacidos pueden tomarse hasta ocho semanas de permiso remunerado y otras ocho semanas sin remunerar, con la garantía de volver a ocupar el mismo puesto de trabajo u otro equivalente (M arch of Dimes 1994).

\section{Diseño de una estrategia para la salud maternal e infantil que se ajuste a las necesidades de las empresas}

Cualquier estrategia para la salud maternal e infantil aplicada en las empresas, además de resultar aceptable para los trabajadores, debe ajustarse a determinados objetivos empresariales razonables. En función de cuáles sean los objetivos de la empresa, pueden ser prioritarias diferentes prestaciones, programas para los trabajadores o políticas. L os pasos siguientes son útiles para el desarrollo de una estrategia preliminar:

1. Documentar las prestaciones, programas y políticas existentes que promuevan la salud maternal e infantil, para sentar las bases de una estrategia formal.

2. Averiguar de qué recursos dispone la comunidad para contribuir al effuerzo de la empresa.

3. R edactar una lista con las prioridades en cuanto a iniciativas preliminares para la salud maternal e infantil, en la que se incluyan modificaciones y novedades respecto a prestaciones, programas o políticas.

4. O btener el apoyo preliminar de la dirección antes de seguir adelante.

5. Evaluar las necesidades observadas y probar con los trabajadores las estrategias propuestas para validar las recomendaciones preliminares.

6. Desarrollar una estrategia formal para la salud maternal e infantil, mediante la definición de una misión, la fijación de objetivos, la distribución de los recursos necesarios, la identificación de los posibles obstáculos y de los factores clave, la elaboración de un calendario de ejecución y la obtención del apoyo necesario en todos los niveles de la empresa.

\section{Ejecución de iniciativas para la salud maternal e infantil}

El siguiente paso consiste en ejecutar las prestaciones, los programas y las políticas que integran la estrategia. $\mathrm{H}$ abitualmente, el proceso de ejecución incluye los pasos siguientes:

1. Distribuir las tareas de ejecución.

2. Seleccionar baremos de calidad conforme a los cuales gestionar el programa.

3. Evaluar y seleccionar a los proveedores

4. Estudiar incentivos y otros métodos para fomentar la participación de los trabajadores.

5. Comunicar las iniciativas a los trabajadores y a sus familiares.

Gestión del éxito de una estrategia para la salud maternal e infantil.

U na vez ejecutada, la estrategia para la salud maternal e infantil de una empresa debe revisarse para evaluar su eficacia al ajustarse a los objetivos originales y a las necesidades de la empresa. La evaluación y la retroinformación son esenciales y ayudan a garantizar que las iniciativas para la salud maternal e infantil 


\section{Maternidad y salud infantil en Francia}

Poco después de la segunda Guerra M undial, Francia instituyó el programa Protection maternelle et infantile (PMI), un sistema de cobertura nacional mediante el cual profesionales de Salud pública y privada, en colaboración con los servicios sociales, prestan servicios preventivos básicos de orden sanitario, médico, social y educativo dirigidos a mujeres embarazadas, lactantes y niños de hasta seis años.

En la mayor parte de los casos, las familias y los médicos partculares organizan individualmente el asesoramiento previo a la concepción, la planificación familiar, la atención prenatal precoz y regular y los reconocimientos médicos preventivos y las vacunaciones para niños de hasta seis años. Se estimula la participación en el programa mediante la devolución de la totalidad de los gastos con cargo a la seguridad social nacional (para tener derecho a esta cobertura, las mujeres deben inscribirse en el programa a las quince semanas de gestación), el pago mensual de subsidios (familiares) a partir del cuarto mes de gestación y hasta el tercer mes de vida del niño, como incentivo para que se cumplan las normas nacionales de atención preventiva, y un programa continuo de información y formación.

Las mujeres que no pueden incorporarse al programa por medio del sector privado están cubiertas por 96 centros PMI controlados por la administración local, uno por cada département de Francia. Además de proporcionar clínicas de salud gratuitas en la zona, estos centros se encargan de identificar y localizar a las mujeres y niños expuestos a algún riesgo y que requieran intervención, realizar visitas domiciliarias y supervisar la evolución de todas las mujeres y lactantes para comprobar que se reciben los servicios preventivos que contemplan las normas nacionales.

La función de las empresas en este sistema está regulada por la ley. Proporcionan a las mujeres embarazadas:

- Cambios en el puesto de trabajo, horario flexible para aliviar el esfuerzo del desplazamiento diario y períodos de descanso para reducir el estrés y la fatiga, que podrían inducir un parto prematuro.

- Baja por maternidad con mantenimiento del puesto de trabajo para madres que tienen o adoptan niños con el fin de fa vorecer la unión y el desa rrollo saludable del niño (la seguridad social paga una prestación por maternidad que asciende hasta el $84 \%$ del sueldo, con un tope máximo).

- Trabajo a tiempo parcial y permiso de parternidad no remunerado con mantenimiento del puesto de trabajo, para que los padres puedan compartir el cuidado del niño y las responsabilidad del trabajo (una prestación nacional por paternidad ayuda a compensar el coste de la baja no remunerada) (Richardson $1994)$.

atienden tanto a las necesidades de las empresas como las de los trabajadores.

\section{Conclusión}

La necesidad de ocuparse de la salud maternal e infantil en el lugar de trabajo será mayor a medida que aumente el número de mujeres que se incorporan a la población activa y los asuntos que conciernen a la familia y al lugar de trabajo no puedan separase. Las empresas con proyección de futuro ya han reconocido esta situación y están desarrollando enfoques innovadores. Las empresas reúnen las características y el poder necesarios para ejercer una influencia en favor de la evolución y marcar la pauta en la promoción de la salud de madres y niños.

\section{EDUCACION SOBRE EL VIH/ SIDA}

B.J. Stiles

A medida que se extiende y se agrava la epidemia de la infección por el VIH, cada vez más centros de trabajo, sindicatos, empresas y trabajadores se ven afectados por la amenaza de la infección por el VIH y el SIDA (denominada en conjunto VIH / SIDA). L OS efectos son con frecuencia plenamente visibles, pero otras veces son insidiosos $y$, en cierta manera, ocultos. En la vida relativamente corta de la epidemia VIH, las consecuencias directas e indirectas del SIDA para el sector de la economía y para los entornos laborales (distintos en cuanto a los aspectos sanitarios) siguen siendo por lo general un componente poco reconocido de la gravedad y magnitud del problema del SIDA.

Las actitudes y opiniones de los trabajadores acerca del SIDA son decisivas y deben ser evaluadas si se desea planificar y gestionar de modo eficaz un programa a nivel de trabajo. La ignorancia y falta de información de los trabajadores pueden representar un obstáculo muy importante para un programa educativo y, si se las juzga o gestiona erróneamente, pueden conducir a la desconfianza y a la ruptura, y agravar los malentendidos y temores ya existentes sobre el SIDA.

En Estados U nidos, "el SIDA ha generado más litigios individuales en relación con una amplia gama de cuestiones sanitarias que ninguna otra enfermedad a lo largo de la historia", dice Lawrence Goskin, del HIV Litigation Project. Una encuesta nacional de 1993 sobre las actitudes de los trabajadores ante el SIDA realizada por la $N$ ational Leadership Coalition on AIDS revela que muchos trabajadores siguen teniendo actitudes negativas y potencialmente discriminatorias ante los compañeros infectados con el VIH, y pone de manifiesto que la mayoría de ellos o no saben cómo reaccionaría su empresa en situaciones relacionadas con el VIH (o el SIDA) en su lugar de trabajo, 0 creen que se despediría directamente a un empleado con infección por el VIH a los primeros síntomas de la enfermedad. La discriminación contra los trabajadores basada únicamente en la discapacidad está expresamente prohibida en los Estados U nidos por la Ley sobre ciudadanos con discapacidad, que incluye bajo su protección a las personas con infección por el VIH y SIDA. Esta ley exige a las empresas con más de 15 empleados que "adopten medidas de reorganización razonables" 0 realicen ajustes en el puesto de trabajo en atención a sus empleados con dispacidad, incluidos los afectados por el VIH o el SIDA.

En este sentido, el $32 \%$ de los trabajadores encuestados creían que un trabajador con infección por el VIH sería despedido o dado de baja al primer síntoma de enfermedad. Si así fuere, esa empresa estaría vulnerando la ley. Esa extendida ignorancia de los trabajadores acerca de las obligaciones legales de las empresas hace claramente vulnerables a éstas - y por extensión a sus directivos y trabajadores- ante litigios por discriminación potencialmente costosos, así como ante posibles desórdenes en el trabajo y problemas de estado de ánimo y de productividad de los trabajadores.

U na mala percepción acerca de la epidemia puede alimentar asimismo actitudes y comportamientos discriminatorios entre los directivos y trabajadores y situar a la empresa en una situación de riesgo. Por ejemplo, el $67 \%$ de los trabajadores encuestados pensaban que sus compañeros se sentirían incómodos trabajando junto a alguien con infección por el VIH. Si no se corrigen, estas actitudes y los tipos de comportamiento relacionados con ellas pueden suponer considerables riesgos para las empresas. Los directivos podrían creer erróneamente que es aceptable un trato discriminatorio de quienes tengan infección por el VIH o SIDA o de quienes se crea que padecen estas enfermedades. 


\section{Problemas de la gestión del VIH/ SIDA}

Los aspectos médicos, legales, financieros y laborales relacionados con la epidemia plantean un conjunto de problemas para las personas con infección por el VIH y SIDA, sus familias, sus sindicatos y sus empresas. L os dirigentes sindicales, los directivos de las empresas, los profesionales de recursos humanos y los supervisores se enfrentan a tareas cada vez más complicadas, como las relativas al control de costes, la protección de la confidencialidad de la información médica de los trabajadores y la realización de un cambio de puesto razonable para sus trabajadores con infección por el VIH y SIDA, además de proteger a éstos de cualquier discriminación en la contratación y promoción. En la actualidad, los infectados por el VIH permanecen en el puesto de trabajo durante más tiempo, por lo que las empresas tienen que planificar la mejor forma de gestionar de manera justa y eficaz su situación durante un período de tiempo más largo y a menudo con poca o ninguna formación o asesoramiento. Una gestión eficaz de los trabajadores con SIDA requiere estar al día en lo que respecta a las opciones de asistencia sanitaria disponibles, los costes de los seguros de enfermedad y de la asistencia sanitaria, y las obligaciones legales y reglamentarias existentes. Requiere también un cambio de puesto razonable, así como la gestión de los aspectos relacionados con la confidencialidad e intimidad, la discriminación, los temores de los trabajadores, la persecución de los trabajadores infectados, las inquietudes de los clientes, las interrupciones del trabajo, los litigios y el empeoramiento del estado de ánimo y de la productividad de los trabajadores, al mismo tiempo que se mantiene un centro de trabajo productivo y rentable y se cumplen los objetivos de la empresa.

Todo ello constituye un conjunto importante y en cierta medida complejo de expectativas, y acentúa una necesidad esencial: la de establecer un programa educativo en el propio lugar de trabajo, empezando a formar y motivar a los directivos para que consideren el SIDA en el lugar de trabajo como parte de las estrategias y objetivos a largo plazo.

Entre el cúmulo de interrogantes y preocupaciones acerca de la epidemia y de la forma de gestionar su repercusión en el lugar de trabajo, las empresas pueden adoptar medidas eficaces en función del coste para minimizar los riesgos, recortar los costes de la asistencia sanitaria, proteger su propio futuro y, lo que es más importante, salvar vidas.

\section{Primera etapa: establecer una política sobre el VIH / SIDA en el lugar de trabajo}

El primer paso para gestionar de manera eficaz las cuestiones laborales derivadas de la epidemia del VIH es la puesta en práctica de una política sólida en el lugar de trabajo. Dicha política debe establecer de manera clara las formas en las que una empresa deberá manejar los problemas generados por el VIH/SIDA. ("Una política sólida en el lugar de trabajo, que tenga en cuenta las responsabilidades de una empresa hacia los trabajadores infectados y afectados, contribuirá a evitar que dicha empresa se convierta en un banco de pruebas", según Peter Petesch, abogado laboralista de Washington, D.C. interesado en el tema del SIDA y en sus repercusiones laborales.)

Desde luego, una política laboral en sí misma no eliminará las dificultades inherentes a tratar con un trabajador que padezca una enfermedad terminal y a menudo estigmatizada. Sin embargo, una política laboral formal contribuye en gran medida a preparar a la empresa en sus esfuerzos para gestionar el SIDA, minimizando los riesgos y protegiendo a su plantilla. U na política eficaz formalizada por escrito debe incluir entre sus objetivos la necesidad de:

- establecer unos baremos internos para un programa completo de la empresa respecto al VIH / SIDA;
- normalizar la postura y la comunicación de la empresa respecto al VIH / SIDA;

- establecer un precedente y unas normas para el comportamiento de los trabajadores;

- informar a todos los trabajadores de dónde pueden solicitar información y ayuda;

- enseñar a los mandos intermedios a gestionar el SIDA en sus grupos de trabajo.

Las políticas eficaces sobre el VIH / SIDA deben proporcionar cobertura y orientación con respeto a la ley, la no discriminación, la confidencialidad e intimidad, la seguridad, los niveles de rendimiento, el cambio de puesto razonable, los intereses de los compañeros y la formación de los trabajadores.

Para ser eficaz, una política debe transmitirse a los trabajadores a todos los niveles de la empresa. Es más, es fundamental tener al apoyo franco y visible de la alta dirección y de los ejecutivos, incluso del presidente, para reforzar la urgencia e importancia de los mensajes indicados anteriormente. Sin ese grado de compromiso, una política que exista sólo sobre el papel corre el peligro de convertirse en papel mojado. SIDA:

Existen dos enfoques generales para desarrollar políticas sobre el

1. EI enfoque de la enfermedad con riesgo de muerte. A lgunas empresas optan por llevar a cabo su política sobre el VIH/ SIDA como una más de todas las enfermedades o incapacidades que encierran un peligro de muerte. Estas políticas suelen establecer que el VIH / SID A debe tratarse como las demás enfermedades de larga duración: humanamente, con sensibilidad y sin discriminación.

2. EI enfoque específico VIH / SIDA. Este enfoque del desarrollo de la política reconoce y trata el VIH / SIDA como una cuestión sanitaria fundamental, con posibles repercusiones laborales. Además del establecimiento propiamente dicho de la política, este enfoque incluye con frecuencia un componente educativo que manifiesta que el VIH/SIDA no se transmite por contactos casuales en el trabajo, y los trabajadores con infección por el VIH o con SIDA no suponen un peligro para la salud de los compañeros o de los clientes.

Segunda etapa: formar a directivos y mandos intermedios $L$ os directivos y mandos intermedios deben estar completamente familiarizados con la política de la empresa sobre el VIH / SIDA. $\mathrm{H}$ ay que asegurarse de que cada nivel de dirección dispone de información clara y coherente sobre las realidades médicas y los mínimos riesgos de transmisión en el lugar de trabajo. En los países con leyes contra la discriminación, los directivos tienen que estar profundamente familiarizados con sus obligaciones (por ejemplo, el cumplimiento de la Ley de norteamericanos con discapacidades y lo que establece acerca del cambio de puesto razonable, la no discriminación, la confidencialidad e intimidad, la seguridad en el trabajo y el establecimiento de niveles de rendimiento de los trabajadores en Estados U nidos).

Además, todos los directivos deben estar preparados para afrontar preguntas 0 inquietudes de los trabajadores sobre el VIH/SIDA y el lugar de trabajo.

Con frecuencia, los mandos intermedios son los primeros a los que se solicita información o remisión a otras fuentes, y deben ofrecer respuestas detalladas a preguntas de los trabajadores sobre los motivos de preocupación en relación con la infección por el VIH y el SIDA y sobre cómo se supone que deben comportarse. L os directivos deben recibir formación y preparación antes de que se establezcan programas educativos para los trabajadores. 


\section{Tercera etapa: educar a los trabajadores}

Los programas educativos en el propio lugar de trabajo constituyen una forma económica y eficaz en función del coste de minimizar los riesgos, proteger las vidas de los trabajadores, ahorrar dinero en costes sanitarios y salvar vidas. M acAllister Booth, presidente de la Polaroid Corporation, dijo recientemente que la educación y formación sobre el SIDA para todos los trabajadores de la Polaroid cuesta menos que el tratamiento de un solo caso de SIDA.

Los programas de bienestar y la promoción de la salud en los centros de trabajo son ya una parte consolidada del mundo laboral para una proporción cada vez mayor de trabajadores, especialmente entre organizaciones laborales y grandes empresas. Las campañas para reducir los costes sanitarios y los días perdidos a causa de enfermedades evitables se han concentrado en la importancia de dejar de fumar, hacer ejercicio y adoptar una dieta alimentaria más sana. En un esfuerzo por aumentar la seguridad de los lugares de trabajo y la salud de la plantilla, los programas de bienestar de los lugares de trabajo son ya considerados como medios adecuados y eficaces en función del coste de proporcionar información sanitaria a los trabajadores. Los programas de educación sobre el VIH/ SIDA pueden considerarse integrados en estos esfuerzos de promoción de la salud que se están llevando a cabo.

Además, algunos estudios han demostrado que muchos trabajadores confían en sus empresas en lo referente a proporcionarles información veraz sobre una amplia gama de cuestiones, incluida la formación sanitaria. Las personas que trabajan están preocupadas por el SIDA, y muchas no comprenden los aspectos médicos y legales de la epidemia y desean saber más al respecto.

Conforme a un estudio del New York Business Group on Health (Barr, Waring and Warshaw 1991), los trabajadores suelen tener una opinión positiva de las empresas que ofrecen información sobre el SIDA y, dependiendo del tipo de programa ofrecido, creen que la empresa es una fuente de información más fiable que los medios de comunicación o la Administración. Por otra parte, de acuerdo con la encuesta de la $\mathrm{N}$ ational L eadership C oalition on AIDS sobre las actitudes de los trabajadores norteamericanos ante el SIDA, el $96 \%$ de los trabajadores que recibieron formación en el trabajo sobre el SIDA apoyaron la conveniencia de dicha iniciativa.

Sería ideal que la asistencia a las sesiones de formación de los trabajadores fuese obligatoria, y el programa debería durar al menos hora y media. La sesión debería estar dirigida por un formador experto, y debería presentar la información de manera objetiva y sin prejuicios. El programa habría de permitir también un turno de preguntas y respuestas y la posibilidad de consultas confidenciales. L as iniciativas adoptadas respecto al SIDA en el lugar de trabajo deben ser continuas, no un hecho aislado, y son más eficaces si están ligadas a ciertos reconocimientos públicos de la importancia del problema, tales como la observancia del Día M undial del SIDA. Por último, uno de los métodos más eficaces de tratar el SIDA con los trabajadores es invitar a una persona infectada por el VIH o el SIDA para que se dirija a un auditorio. Escuchar de primera mano cómo alguien vive y trabaja infectado por el VIH o con SIDA ha demostrado tener un efecto muy positivo en la eficacia de las sesiones de formación.

Un programa exhaustivo de educación sobre el SIDA en el lugar de trabajo debe incluir la presentación de las siguientes materias:

- los aspectos médicos: cómo se transmite y cómo no se transmite el VIH, insistiendo en que no se puede contagiar mediante contactos casuales y en que es prácticamente imposible contraerlo en el lugar de trabajo;
- los aspectos jurídicos, incluidas las responsabilidades de la empresa, especialmente la importancia de la confidencialidad y el derecho a la intimidad y de proporcionar cambios de puesto razonables;

- los aspectos psicosociales, incluidas las formas de comportarse con un compañero infectado por el VIH/SIDA y cómo es el vivir y trabajar con la mencionada enfermedad;

- orientaciones sobre las políticas, prestaciones e información de la empresa;

- información para que los trabajadores la transmitan a sus familias con objeto de enseñarles a protegerse;

- información sobre los recursos de la comunidad y los lugares a los que se puede acudir para someterse a pruebas preservando el anonimato.

Los estudios advierten que las actitudes ante el SIDA pueden ser reforzadas negativamente si una sesión educativa o de formación es demasiado breve y no lo suficientemente profunda e interactiva. De modo similar, el limitarse a entregar un folleto se ha demostrado que aumenta la ansiedad sobre el SIDA. En una sesión breve y precipitada, se ha demostrado que los asistentes captan algunas de las realidades, pero que abandonan la sesión con ansiedades sin resolver sobre la transmisión del $\mathrm{VIH}$, ansiedades que han sido despertadas, de hecho, por la forma de presentar la cuestión. Por ello, es importante dejar tiempo suficiente en una sesión de formación para un debate profundo, para preguntas y respuestas, y remitir a otras fuentes de información confidencial. Desde un punto de vista ideal, una sesión de formación debería ser obligatoria, dado que el estigma aún asociado con la infección por el VIH y con el SIDA puede hacer que muchos no asistan a una sesión voluntaria.

\section{Algunas respuestas sindicales sobre el VIH/ SIDA}

Entre algunos ejemplos importantes de iniciativas sindicales de educación y políticas sobre el SIDA, se incluyen los siguientes:

1. EI Sindicato Internacional de Marinos estableció un programa educativo sobre el VIH/SIDA como un componente obligatorio de las asignaturas para los estudiantes de la marina mercante en su Escuela de Marina Lundeberg en Piney Point, $M$ aryland. Las personas que deseen ingresar en la profesión pueden asistir a un curso de formación de 14 semanas en la Escuela, y quienes ya trabajen en el sector asisten a clases gratuitas para mejorar su formación y para obtener diplomas equivalentes al bachillerato 0 a una titulación similar. Los seminarios educativos de los $M$ arinos sobre el VIH/SIDA duran dos horas, y su enfoque global se basa en el reconocimiento de que es precisa una profunda formación para responder a las necesidades de unos trabajadores que viajan al extranjero y trabajan en un entorno aislado. EI curso de prevención del SIDA forma parte de un programa que incluye prácticas laborales, seguridad e higiene en el trabajo, y la contención de los costes sanitarios. La educación se complementa con una variedad de cintas de vídeo sobre el SIDA en el sistema de televisión en circuito cerrado de la Escuela Lundeberg, la publicación de artículos en el periódico de la Escuela y la distribución de folletos en los locales del Sindicato en cada puerto. Se proporcionan también preservativos gratuitos.

2. EI Sindicato Internacional de E mpleados de Servicios (SEIU ) participa en actividades relacionadas con el SIDA desde 1984, cuando empezó a aparecer el temor de transmisión del SIDA entre sus miembros en el Hospital General de San Francisco. Para garantizar que los trabajadores del sector sanitario pudieran seguir proporcionando cuidados humanitarios a sus pacientes, era de la mayor importancia combatir 
el miedo irracional con una información realista, y al mismo tiempo adoptar las precauciones necesarias. Esta coyuntura llevó a la implantación del programa del SIDA del SEIU, un modelo de actuaciones entre compañeros en el que los miembros colaboran entre sí para resolver necesidades de formación y apoyo emocional. El programa incluye realizar un seguimiento del control de la infección en hospitales, responder a las solicitudes individuales de miembros del sindicato para diseñar y llevar a cabo programas de formación sobre el SIDA, así como fomentar la coordinación de los hospitales con el SEIU para asuntos relacionados con el SIDA.

3. Un importante resultado del enfoque del SEIU sobre el VIH/SIDA ha sido el desarrollo de políticas científicas y de programas de educación para sus miembros, que demuestran una genuina preocupación por todas las personas relacionadas con la epidemia, incluidos los trabajadores sanitarios, los pacientes y el público. EI sindicato promueve activamente la toma de conciencia sobre el SIDA a escala nacional e internacional en conferencias y congresos, postura que ha situado al SEIU a la cabeza de la educación de los trabajadores inmigrantes recién llegados, sobre la prevención del $\mathrm{VIH}$ y sobre la seguridad en el lugar de trabajo respecto a todos los agentes patógenos presentes en la sangre. Este esfuerzo educativo tiene en cuenta la lengua materna o la de uso preferente, así como las diferencias culturales entre las poblaciones objetivo.

\section{Conclusión}

Aunque los sindicatos y las empresas que responden de forma constructiva a los desafíos cotidianos que plantea el VIH constituyen aún una minoría, muchos han ayudado a establecer las pautas y un conjunto cada vez mayor de conocimientos para ayudar a otros a enfrentarse con el $\mathrm{VIH}$ como un problema laboral. El conocimiento y la experiencia adquiridos en los 10 últimos años demuestran que las políticas bien planificadas sobre el SIDA, las normas y prácticas en el lugar de trabajo, las iniciativas y los effuerzos continuados, así como la educación que se está impartiendo a los trabajadores, empleados y directivos, constituyen medios eficaces para enfrentarse a los problemas.

A medida que los sindicalistas, los grupos industriales y las asociaciones empresariales reconocen las consecuencias cada vez mayores del SIDA para sus respectivos sectores, están apareciendo otros grupos para combatir la incidencia específica del SIDA para sus intereses. La Coalición Empresarial Tailandesa sobre el SIDA fue creada en 1993, y probablemente servirá de ejemplo para desarrollos similares en otros países del Pacífico. Algunas empresas del A frica central y meridional están tomando la iniciativa de impartir formación en los lugares de trabajo, y se observan realizaciones similares en Brasil y en los países del Caribe.

El I nforme M undial del Desarrollo (1993) se dedicó a "Invertir en Salud", y examinó las relaciones entre la salud humana, la política sanitaria y el desarrollo económico. El informe incluía varios ejemplos de la amenaza que plantea el SIDA para las estrategias y logros de desarrollo. Este informe indica que cada día se abren más posibilidades para utilizar las capacidades y recursos globales financieros y de desarrollo, trabajando en mayor armonía con los líderes de la sanidad pública en todo el mundo, para establecer planes más eficaces y superar los desafíos económicos y empresariales derivados del SIDA (H ammer 1994).

Los sindicatos y las empresas creen que el hecho de poner en marcha políticas sobre el SIDA y programas de educación de los trabajadores antes de encontrarse con un caso de VIH ayuda a reducir problemas en el lugar de trabajo, ahorra dinero al proteger la salud de los trabajadores, evita costosos litigios y prepara a los directivos y trabajadores para responder de forma constructiva a los desafíos del SIDA en el lugar de trabajo. Las herramientas necesarias para gestionar las múltiples y complejas cuestiones relacionadas con la enfermedad son poco costosas y fáciles de adquirir. Por último, pueden salvar vidas y ahorrar dinero.

\section{PROTECCION Y PROMOCION DE LA SALUD: ENFERMEDADES INFECCIOSAS}

\author{
William J. Schneider
}

La prevención y el control de las enfermedades infecciosas es una responsabilidad fundamental del servicio de salud de la empresa en las áreas en que aquéllas son endémicas, en que el trabajo implica la exposición a ciertos agentes infecciosos ante los que la población puede ser especialmente sensible, y en que los servicios de salud comunitarios sean deficientes. En todas estas circunstancias, el director médico debe actuar como el responsable de salud pública de la plantilla, tarea que requiere atención a la higiene, al agua potable y a los alimentos, a los posibles vectores de las infecciones, a las vacunaciones adecuadas cuando sea posible, así como a la detección precoz y al tratamiento rápido de las infecciones cuando ocurran.

En las áreas urbanas bien desarrolladas en que los trabajadores estén relativamente sanos, la inquietud por las enfermedades infecciosas suele estar eclipsada por otros problemas, pero la prevención y el control de las mismas siguen siendo una responsabilidad importante del servicio de salud de la empresa. Debido a su prevalencia en todos los grupos de edad (obviamente incluyendo los que tienen más probabilidad de trabajar) y como consecuencia de su capacidad fundamental de expansión a través de los contactos próximos, característicos del ámbito laboral típico, las enfermedades infecciosas son un objetivo adecuado para cualquier programa de promoción de la salud laboral. Sin embargo, los esfuerzos de las unidades de salud laboral para responder al problema que plantean, con frecuencia no son motivo de discusión. En parte, esta falta de atención se puede atribuir al hecho de que estos esfuerzos se consideren una cuestión de rutina, del estilo, dicen, de los programas estacionales de vacunación antigripal. Además, se pueden pasar por alto porque no son actividades necesariamente asociadas a iniciativas extensas de promoción de la salud sino que forman parte del programa global de salud laboral. Por ejemplo, el asesoramiento y tratamiento individual de los trabajadores sometidos a revisiones periódicas de su estado de salud contiene a menudo intervenciones específicas de promoción de salud dirigidas a las enfermedades infecciosas. Sin embargo, todas esas son actividades significativas, con o sin una denominación formal de "programa", que se pueden combinar en una estrategia coherente para la prevención y control de las enfermedades infecciosas.

Estas actividades se pueden dividir en una serie de componentes: difusión de la información y educación del trabajador, vacunaciones, respuesta a un brote de una infección, protección de la salud de los viajeros, establecimiento de contactos con los miembros de la familia y mantenimiento hasta la jubilación. Este artículo describe el programa de J. P. M organ \& Company, Inc., situada en Nueva York, que ilustra cómo se pueden integrar todas estas medidas en un programa de salud laboral global dirigido a una gran población laboral administrativa urbana. 
Aunque tiene características únicas, no es distinto de los que se realizan en muchas grandes empresas.

\section{J. P. Morgan \& Company}

J. P. M organ \& C ompany, Inc., es una empresa de servicios financieros que actúa en todo el mundo. C on su sede en la ciudad de Nueva York, donde están presentes aproximadamente 7.500 de sus 16.500 trabajadores, mantiene oficinas de diversa magnitud en otras partes de Estados U nidos y Canadá y en grandes ciudades de Europa, Asia, A mérica L atina y Australia.

En cada una de sus empresas matrices existen departamentos médicos propios desde el principio de este siglo y después de la fusión de J. P. M organ con Guaranty Trust Company, la unidad de salud laboral ha evolucionado para ofrecer no solo actividades estándar propias de la medicina ocupacional sino una extensa gama de servicios gratuitos para los trabajadores, como evaluaciones periódicas del estado de salud, vacunaciones, atención primaria ambulatoria, educación sanitaria y promoción de la salud así como un programa de asistencia al trabajador. La eficacia del departamento médico, con sede en la ciudad de Nueva York, está potenciada por la concentración del grueso de la plantilla de Morgan en un número limitado de centros situados céntricamente.

\section{Difusión de la información}

Generalmente, la difusión de la información de interés es la piedra angular de un programa de promoción de la salud y es probablemente el enfoque más sencillo tanto si los recursos son limitados como abundantes. Proporcionar información precisa, significativa y comprensible, modificada en función de la edad, lengua, etnia y nivel de educación del trabajador, sirve no sólo para educar sino también para corregir concepciones equivocadas, inculcar estrategias eficaces de prevención y dirigir a los trabajadores los recursos apropiados tanto dentro como fuera del lugar de trabajo.

Esta información puede adoptar varias formas. Se pueden dirigir comunicados escritos a los trabajadores a sus centros de trabajo 0 a sus domicilios, o se pueden distribuir en las sedes centrales de trabajo. Pueden consistir en boletines o publicaciones obtenidas del gobierno 0 de instituciones sanitarias, compañías farmacéuticas o fuentes comerciales, entre otros, o, si los recursos lo permiten, se pueden desarrollar en la propia empresa.

Puede que las conferencias y seminarios sean incluso más eficaces sobre todo cuando se permite a los trabajadores plantear preguntas sobre sus inquietudes particulares. Por otra parte, presentan el inconveniente de la accesibilidad y un mayor compromiso temporal por parte tanto de la empresa como del personal; también violan el anonimato, lo que a veces puede ser un problema.

\section{$\mathrm{VIH} /$ SIDA}

Un ejemplo de esta actividad puede ser nuestra propia experiencia en J. P. M organ con la difusión de la información sanitaria sobre la infección por el VIH. Los primeros casos de la enfermedad se comunicaron en 1981, siendo conscientes de casos entre nuestros trabajadores en 1985. En 1986, en gran medida por la atención de los medios de comunicación locales al problema, los trabajadores de una de nuestras oficinas en Europa (donde no había aflorado todavía ningún caso de la enfermedad) solicitaron un programa sobre el SIDA. Los conferenciantes fueron el director médico de la compañía y un experto en enfermedades infecciosas de un hospital universitario local. La audiencia estuvo constituida por casi el $10 \%$ de toda la plantilla de aquella unidad, en la que el $80 \%$ eran mujeres. En esa presentación y en las siguientes se hizo mucho énfasis en la transmisión del virus y en las estrategias dirigidas a su prevención. C omo se puede deducir de la composición de la audiencia, existía una considerable preocupación sobre la transmisión heterosexual.

El éxito de esa presentación facilitó el desarrollo de un programa mucho más ambicioso en la sede central de Nueva York al año siguiente. Un boletín y un folleto anticiparon los actos con un breve comentario sobre la enfermedad, se utilizaron posters y otros anuncios para recordar a los trabajadores los lugares y las fechas de las presentaciones y los directivos animaron encarecidamente a la participación. Como consecuencia del compromiso de la administración así como por la preocupación social que suscita el tema, fue posible lograr que el $25-30 \%$ del personal local acudiera a las múltiples presentaciones.

E sas sesiones incluyeron un comentario por parte del director médico de la compañía, que reconocía la presencia de la enfermedad entre los trabajadores y constató que la compañía se comprometía a mantenerlos como empleados todo el tiempo que se encontraran lo suficientemente bien como para seguir trabajando eficazmente. Revisó la política de la compañía sobre las enfermedades potencialmente mortales e informó de que el departamento médico ponía a disposición de los trabajadores pruebas confidenciales del VIH. Se mostró un vídeo educativo sobre la enfermedad, seguido de una conferencia por parte de un experto del departamento local de sanidad municipal. Siguió un período de preguntas y respuestas, y al final de la sesión, se repartió a todo el mundo un lote de material informativo sobre la infección por el VIH y las estrategias de prevención.

$L$ a respuesta a estas sesiones fue muy positiva. M ientras otras empresas estaban teniendo problemas laborales con los trabajadores infectados por el $\mathrm{VIH}, \mathrm{M}$ organ no tuvo ninguno. U na encuesta independiente de los trabajadores (y de otras compañías con programas similares) halló que los participantes en el programa apreciaban profundamente la oportunidad de participar en estas sesiones y consideraban que la información proporcionada era más útil que la que les ofrecían otras fuentes (Barr, Waring y Warshaw 1991).

$\mathrm{M}$ antuvimos sesiones similares sobre la infección por el $\mathrm{VIH}$ en 1989 y 1991, aunque encontramos que la participación disminuía con el tiempo. Atribuimos este hecho, en parte, a la saturación percibida sobre el tema y, en parte, a que la enfermedad estaba modificando su impacto sobre los desempleados de larga duración (en nuestra zona); además, el número de trabajadores infectados recientemente por el VIH que solicitaron atención en nuestro servicio disminuyó bruscamente después de 1991.

\section{Enfermedad de $L$ yme}

$M$ ientras tanto, la enfermedad de Lyme, una enfermedad bacteriana transmitida por la picadura de la garrapata del ciervo en los ámbitos suburbanos y locales de vacaciones, se ha ido haciendo cada vez más prevalente entre nuestros trabajadores. U na conferencia sobre este tema suplementada con información impresa atrajo una atención considerable cuando fue impartida en 1993. Los puntos que se subrayaban en esta presentación eran la identificación de la enfermedad, las pruebas, el tratamiento, y, lo más importante, la prevención.

En general, los programas diseñados para difundir información escrita 0 en forma de conferencia deben ser verosímiles, fácilmente comprensibles, prácticos y oportunos. D eberían servir para aumentar la mentalización, especialmente en lo que respecta a la prevención personal y establecer cuándo y cómo obtener atención profesional. Al mismo tiempo, deberían servir para disipar miedos infundados. 


\section{Programas de vacunación}

Las vacunaciones en el lugar de trabajo constituyen una importante necesidad de la salud pública y probablemente aportan ventajas palpables no sólo a los individuos que las reciben sino también a la organización. M uchas empresas del mundo desarrollado que no tienen su propio servicio médico contratan a personal ajeno para suministrar un programa de vacunación masivo.

Gripe M ientras la mayoría de las vacunaciones proporciona protección durante muchos años, la vacuna de la gripe se debe administrar anualmente como consecuencia de la modificación constante del virus, y en menor grado, por la disminución de la inmunidad del paciente. Dado que la gripe es una enfermedad estacional cuya capacidad infectiva se extiende típicamente en los meses de invierno, la vacuna se debe administrar en otoño. El personal más necesitado de la vacunación son los empleados de mayor edad y los que tienen enfermedades subyacentes o inmunodeficiencias, como la diabetes y los problemas crónicos pulmonares, cardíacos y renales. Se debe animar a los trabajadores de las instituciones sanitarias a vacunarse no solo porque probablemente estén más expuestos a las personas que padecen la infección, sino también porque es esencial que puedan trabajar de forma continuada en caso de que se produzca un brote grave de la enfermedad. Un estudio reciente ha demostrado que la vacunación contra la gripe ofrece ventajas considerables, tanto médicas como económicas, también para los adultos sanos que trabajan. Como la morbilidad asociada a la enfermedad puede generar característicamente una semana o más de discapacidad que a menudo afecta a numerosos trabajadores en la misma unidad al mismo tiempo, hay incentivo suficiente para que las empresas prevengan el impacto resultante sobre la productividad ofreciendo esta forma de inmunización relativamente barata e inocua. Esto adquiere una importancia especial cuando las autoridades sanitarias preven modificaciones importantes en el virus y predicen una epidemia importante en una estación determinada.

Probablemente, la principal barrera contra el éxito de los programas de vacunación contra la gripe (o contra cualquier otra infección) es la aversión de los individuos a participar. Para reducir al mínimo su vacilación, es importante informar a los trabajadores sobre la necesidad y la disponibilidad de la vacuna, facilitando realmente el acceso a la vacunación. Se debe aportar información por todos los medios disponibles, identificando genéricamente a todos los que necesitan especialmente la vacunación, subrayando la relativa seguridad de la vacuna y explicando el procedimiento por el que se puede conseguir.

El tiempo y los inconvenientes de desplazarse para visitar al médico son frenos poderosos para muchos individuos; los programas más eficaces serán los que suministren las vacunas en el lugar de trabajo durante el horario laboral con el mínimo retraso. Por último, el coste, un obstáculo importante, se debería reducir al mínimo o ser enteramente asumido por la empresa 0 por el programa de seguro sanitario colectivo.

Factores adicionales que contribuyen a la aceptación de las vacunaciones por parte del trabajador son la publicidad en la comunidad y programas de incentivos. $\mathrm{H}$ emos encontrado que los reportajes de los medios de comunicación sobre una epidemia amenazadora de gripe aumenta regularmente la aceptación de la vacuna por parte de los trabajadores. En 1993, con el objetivo de animar a todos los trabajadores a revisar su estado de vacunaciones y a recibir las que necesitaran, el departamento médico de M organ ofreció a los que aceptaran esos servicios la participación en una rifa en la que el premio eran acciones de la compañía. El número de trabajadores que solicitaron la vacuna ese año aumentó en un 50 \% respecto al número que fue visto durante el mismo período del año anterior.
Difteria y tétanos. O tras vacunaciones aconsejables en adultos sanos en la edad típica de trabajar son la de la difteria-tétanos y posiblemente sarampión, parotiditis y rubéola. La vacuna de difteria-tétanos (DT) se recomienda cada diez años durante toda la vida, asumiendo que se ha recibido la primera serie de vacunación. Con este intervalo, encontramos que el estado vacunal se confirma más fácilmente y que la vacuna se administra con más facilidad durante las evaluaciones periódicas del estado de salud de nuestros trabajadores (véase más adelante), aunque también se puede lograr mediante una campaña de vacunación a nivel de toda la compañía, como la empleada en el programa de incentivación mencionado anteriormente.

Sarampión. Las autoridades de Salud Pública recomiendan la vacuna contra el sarampión a todos los nacidos después de 1956 que no tengan constancia documental de dos dosis de vacuna contra el sarampión en o después de su primer cumpleaños, un antecedente de sarampión confirmado por un médico o pruebas de laboratorio de inmunidad contra el sarampión. Esta vacunación se puede administrar fácilmente durante el reconocimiento médico previo a la contratación o incorporación a la empresa 0 en una campaña de vacunación realizada a nivel de toda la compañía.

Rubéola. Las autoridades de Salud Pública recomiendan que todos los individuos tengan documentación médica de haber recibido la vacuna contra la rubéola o pruebas de laboratorio de inmunidad frente a esta enfermedad. La inmunización adecuada contra la rubéola es especialmente importante entre los trabajadores del medio sanitario, para los que probablemente sea obligatorio.

De nuevo, se debe determinar la inmunización adecuada frente a la rubéola en el momento de la contratación, o si no fuera posible, mediante campañas periódicas de vacunación 0 durante los reconocimientos médicos periódicos. Se puede conferir una inmunidad eficaz a las personas que precisen la vacuna frente a la rubéola mediante la administración de la vacuna triple vírica (sarampión- rubéola- parotiditis). Se pueden realizar pruebas serológicas para identificar el estado inmunitario de un individuo antes de la vacunación, aunque probablemente no sea rentable.

Hepatitis B. En la medida en que la hepatitis B se transmite a través de contacto sexual y por contacto directo con sangre y otros fluidos corporales, los esfuerzos iniciales de vacunaciones se dirigieron a poblaciones de alto riesgo, como los profesionales sanitarios y los que tenían múltiples parejas sexuales. Además, la elevada prevalencia de la enfermedad y del estado de portador en ciertas áreas geográficas, como Extremo Oriente y el Africa subsahariana, ha dado prioridad a la vacunación de todos los recién nacidos en esas regiones y de los que viajan a las mismas con frecuencia o permanecen en ellas durante largos períodos de tiempo. Más recientemente, se ha propuesto la inmunización universal de todos los recién nacidos en Estados U nidos y en otros países como una estrategia más eficaz para llegar hasta los individuos vulnerables.

En el entorno laboral, el objetivo de la vacunación frente a la hepatitis $B$ han sido los profesionales sanitarios debido al riesgo de exposición a la sangre. De hecho, en Estados Unidos, la normativa gubernamental exige informar a este personal y probablemente a otros profesionales involucrados en la atención de emergencias sanitarias de lo aconsejable que resulta ser vacunado contra la hepatitis $B$ en el contexto de un comentario general sobre las precauciones universales; después se debe suministrar la vacunación. 
Así, en nuestro servicio de Morgan, la información sobre la vacunación frente a la hepatitis $B$ se distribuye en tres contextos: en comentarios sobre las enfermedades de transmisión sexual como el SIDA, en presentaciones para el personal sanitario y de servicios de emergencias sobre los riesgos y precauciones importantes en su trabajo sanitario y en intervenciones con trabajadores individuales y sus familias con prioridad a los que desarrollan su actividad en regiones del mundo en las que la hepatitis B es más prevalente. La vacuna se suministra junto con estos programas.

Hepatitis A. Esta enfermedad, transmitida típicamente por agua o alimentos contaminados, es mucho más prevalente en las naciones en vías de desarrollo que en los países industrializados. Así, los esfuerzos de protección se han dirigido hacia las personas que van a viajar a regiones de riesgo 0 a los que tienen contactos en su domicilio u otros contactos muy íntimos con enfermos recientemente diagnosticados de la enfermedad.

Como ya se ha desarrollado una vacuna que protege frente a la hepatitis A, se administra a las personas que van a viajar a los países en vías de desarrollo y a los contactos íntimos de los casos documentados de hepatitis A de reciente diagnóstico. Si no hay tiempo suficiente para que se desarrollen las concentraciones de anticuerpos antes de la fecha de partida de los viajeros, puede administrarse simultáneamente inmunoglobulina sérica.

Ahora que disponemos de una vacuna segura y eficaz contra la hepatitis A, los esfuerzos de vacunación se suelen dirigir a un grupo diana de mayores dimensiones. Como mínimo, deberían recibir esta vacuna el personal que viaja con frecuencia a las regiones endémicas y los residentes en ellas, y también se debería considerar la vacunación en los manipuladores de alimentos por el riesgo de que transmitan la enfermedad a un número importante de personas.

Antes de realizar cualquier vacunación se debe prestar una atención especial a las posibles contraindicaciones, como la hipersensibilidad a algún componente de la vacuna o, en el caso de las vacunas de virus vivos como los del sarampión, parotiditis y rubéola, a la presencia de una inmunodeficiencia o de embarazo, presente 0 previsto en un plazo breve de tiempo. Se debería distribuir a los trabajadores información adecuada sobre los posibles riesgos de las vacunas y obtener formularios de consentimiento firmado. En todos los programas se deben prever las escasas probabilidades de reacciones vacunales.

Las organizaciones que poseen personal médico pueden utilizar obviamente su propio personal para ejecutar un programa de vacunación. Las que carezcan de este personal pueden conseguir las vacunas a través del personal médico 0 de enfermería de la comunidad, los hospitales o los centros sanitarios y de los servicios sanitarios gubernamentales.

\section{Respuesta a las epidemias}

Pocos acontecimientos suscitan tanto interés y preocupación entre los trabajadores de una unidad laboral concreta 0 de toda una organización como la conciencia de que un compañero de trabajo tiene una enfermedad contagiosa. La respuesta básica del servicio sanitario de la empresa ante este tipo de noticias es la de identificar y aislar adecuadamente a los que estén enfermos, tanto el caso original como cualquier caso secundario, mientras se difunde información sobre la enfermedad que reduzca la angustia de los que creen que pueden haber estado expuestos. Algunas organizaciones, con la esperanza de aminorar la angustia potencial, pueden limitar esta información a los posibles contactos. O tras, siendo consciente de que los "rumores" (comunicación informal entre trabajadores) no solo extienden las noticias sino que probablemente transportan una información errónea que puede dar rienda suelta a la angustia latente, toman el suceso como una oportunidad única para educar a todo el personal sobre la capacidad de diseminación de la enfermedad y el modo de prevenirla. En M organ se han producido varios episodios de este tipo en los que han estado involucradas tres enfermedades distintas: tuberculosis, rubéola y gastroenteritis de origen alimentario.

Tuberculosis. EI miedo a la tuberculosis está justificado por la morbilidad potencialmente significativa de la enfermedad, especialmente con la prevalencia creciente de las bacterias resistentes a múltiples fármacos. En nuestra experiencia, la enfermedad ha suscitado nuestra atención por las noticias sobre la hospitalización y diagnóstico definitivo del caso original; afortunadamente, en $M$ organ los casos secundarios han sido escasos y se han limitado únicamente a conversión de las pruebas cutáneas.

Típicamente, en estos casos se notifica la enfermedad a las autoridades sanitarias y después se insta a los contactos a que se sometan a una prueba cutánea basal de tuberculina o una radiografía; las pruebas cutáneas se repiten diez o doce semanas más tarde. A los que presentan una conversión de la prueba cutánea de negativa a positiva durante el período de seguimiento, se les realiza una radiografía de tórax. Si la radiografía es positiva, se deriva al trabajador para recibir el tratamiento definitivo; si es negativa, se prescribe la profilaxis con isoniazida.

Durante cada fase del proceso, se realizan sesiones informativas en grupo e individuales. $L a$ ansiedad es característicamente desproporcionada al riesgo, y el primer objetivo del asesoramiento es el restablecimiento de la confianza así como la necesidad de realizar un seguimiento prudente.

Rubéola. Los casos de rubéola en M organ se han identificado en las visitas a la unidad de salud laboral. Para evitar contactos posteriores, los trabajadores son enviados a su domicilio incluso si únicamente existe una sospecha clínica de la enfermedad. Después de la confirmación serológica, generalmente en 48 horas, se realiza una supervisión epidemiológica para identificar otros casos mientras se difunde información sobre el acontecimiento. Aunque los objetivos principales de estos programas son las trabajadoras que puedan estar embarazadas y que pudieran haber estado expuestas, las epidemias han servido como oportunidad para verificar el estado de inmunización de todos los trabajadores y para ofrecer la vacuna a todos los que pudieran necesitarla. De nuevo, se avisa del hecho a las autoridades sanitarias y se utiliza su experiencia y asistencia para diseñar las necesidades organizativas.

Infecciones transmitidas por los alimentos. $\mathrm{H}$ ace varios años ocurrió en la sede de M organ una única experiencia de un brote de una enfermedad transmitida por los alimentos. Fue debida a una intoxicación alimentaria por estafilococo que condujo a un manipulador de alimentos que presentaba una lesión cutánea en una de sus manos. $M$ ás de cincuenta trabajadores que utilizaron las instalaciones para cenar desarrollaron una enfermedad autolimitada, caracterizada por náuseas, vómitos y diarrea, que apareció aproximadamente seis horas después de la ingesta de la ensalada fría de pato contaminada y que se resolvió en 24 horas.

En este caso, el ánimo de nuestros esfuerzos de educación sanitaria se centró en sensibilizar a los propios manipuladores de alimentos sobre los signos y síntomas de la enfermedad que deberían inducirles a abandonar el trabajo y solicitar atención médica. Se efectuaron asimismo diversos cambios en los procedimientos y en la gestión: 
- concienciar a los supervisores de su responsabilidad para garantizar que los trabajadores con signos de enfermedad acudan a una revisión médica;

- celebrar sesiones periódicas de formación para todos los trabajadores del servicio de alimentación, con el fin de recordarles las precauciones que deben adoptar;

- garantizar la utilización de guantes desechables.

Recientemente, dos organizaciones vecinas también han sufrido brotes de enfermedades transmitidas por los alimentos. En una de ellas, un manipulador de alimentos del comedor de la compañía transmitió la hepatitis A un número elevado de trabajadores; en la otra, muchos trabajadores desarrollaron una toxiinfección alimentaria por salmonella tras consumir un postre preparado con huevos crudos en un restaurante ajeno a la organización. En el primer caso, la organización dirigió sus esfuerzos educativos a los propios manipuladores de alimentos; en el segundo, se compartió la información con toda la plantilla sobre varios alimentos preparados con huevos crudos y el riesgo potencial que esto entraña.

\section{Intervenciones individuales}

$M$ ientras las tres experiencias descritas anteriormente siguen el típico esquema de promoción sanitaria de llegar a toda la población laboral 0 , al menos, a un sector importante, muchas de las actividades de promoción de salud de organizaciones como $M$ organ se realizan, en lo que respecta a las enfermedades infecciosas, a nivel individual. Esto comprende actuaciones que resultan factibles por las evaluaciones de salud periódicas, previas a la incorporación o a la jubilación, encuestas sobre viajes internacionales y visitas ocasionales al servicio de salud de la empresa.

\section{Reconocimientos médicos previos a la contratación.}

Los individuos examinados en el momento de su contratación son normalmente jóvenes y sanos, y no es probable que hayan precisado recientemente atención médica. Con frecuencia necesitan vacunas como las del sarampión, rubéola o difteria-tétanos. Además, aquellos que van a ser ubicados en áreas de transmisión potencial de enfermedades, como los servicios sanitarios o de alimentación, deberían recibir información adecuada sobre las precauciones que deben observar.

Reconocimientos médicos periódicos. Asimismo, los controles periódicos de salud proporcionan la ocasión de revisar el estado vacunal y de comentar los riesgos asociados potencialmente a ciertas enfermedades crónicas así como las precauciones que se deberían tomar. Son ejemplos de esto último la necesidad de la vacunación anual contra la gripe en los individuos con diabetes 0 asma y las instrucciones a los diabéticos sobre los cuidados adecuados de sus pies para evitar infecciones locales.

Se deberían comentar las noticias recientes sobre enfermedades infecciosas, particularmente con los que presentan problemas de salud conocidos. Por ejemplo, pueden ser importantes para todos las noticias sobre los brotes de infecciones por E. coli atribuidas a la ingestión de carne picada mal cocinada, mientras que el peligro de contraer una criptosporidiosis por bañarse en piscinas públicas puede tener una importancia especial para los enfermos con el $\mathrm{VIH} 0$ con otras inmunodeficiencias.

Reconocimientos médicos prejubilación. Se debe proponer a los trabajadores que son explorados como consecuencia de su jubilación que se vacunen contra el neumococo y se les debe aconsejar sobre la vacunación anual contra la gripe.
Protección previa a los viajes. La progresiva globalización de las tareas laborales junto con el interés creciente por los viajes internacionales de placer han contribuido a un incremento continuo de la población que precisa protección contra enfermedades infecciosas que probablemente no se iban e encontrar en su medio. Una visita previa a un viaje debe incluir una historia clínica que ponga de manifiesto cualquier vulnerabilidad de la salud del individuo que pueda suponer un aumento del riesgo asociado a la tarea o viaje previstos. Un buen ejemplo de lo anterior, y no infrecuente, es la trabajadora embarazada que está considerando un viaje a una región con malaria resistente a la cloroquina, dado que las pautas alternativas de profilaxis frente a la malaria pueden estar contraindicadas en el embarazo.

Se debería proporcionar información global sobre las enfermedades infecciosas prevalentes en las regiones que se van a visitar. Debería incluir los métodos de transmisión de las enfermedades implicadas, las técnicas de prevención y profilaxis y los síntomas típicos y las estrategias para acceder a los cuidados médicos si finalmente aquéllas se desarrollan. $Y$, por supuesto, se deben suministrar las vacunaciones indicadas.

Consultas al servicio de salud laboral. En la mayoría de las unidades de medicina laboral, los empleados pueden recibir los primeros auxilios y el tratamiento para los síntomas de su enfermedad; algunos de ellos, como el de M organ, disponen de muchos servicios de atención primaria. Cada visita ofrece una oportunidad para aconsejar y efectuar actuaciones de prevención. Esto incluye proporcionar las vacunas en los plazos adecuados y alertar a los pacientes trabajadores sobre las precauciones sanitarias relativas a cualquier enfermedad subyacente o posible exposición. U na ventaja particular de esta situación es el hecho de que el trabajador haya buscado esa atención médica, lo que hace pensar que serán más receptivos a los consejos ofrecidos de lo que lo serían si esa misma información la hubieran obtenido en una campaña educativa general. El profesional de la salud debe aprovechar la ocasión para asegurarse de que ofrece una información adecuada y las vacunas o las medicaciones preventivas necesarias.

Establecimiento de contactos con los miembros de la familia. Aunque el objetivo primordial de la salud laboral es asegurar la salud y el bienestar del trabajador, existen muchas razones para pensar que también se realizan esfuerzos eficaces de promoción de la salud dirigidos a la familia del trabajador. O bviamente, la mayoría de los objetivos citados anteriormente son aplicables en la misma medida a los miembros adultos de la casa, y aunque los miembros de la familia generalmente no tienen acceso directo a los servicios de la unidad de salud laboral, se puede hacer llegar la información al hogar a través de boletines y folletos así como por transmisión verbal directa.

Consideración aparte merecen los niños, especialmente a la vista de la importancia de las vacunaciones infantiles precoces. Es bien sabido que a menudo se descuidan estas vacunaciones, al menos en parte, no solamente por los desfavorecidos desde el punto de vista económico, sino incluso en los hijos de los trabajadores más acomodados de las empresas de EE.UU. Para reducir al mínimo esta deficiencia pueden resultar útiles los seminarios sobre la atención correcta de los lactantes y la información impresa sobre este tema, suministrados por la empresa 0 por los responsables del seguro sanitario de la empresa. A demás, la modificación de la cobertura del seguro sanitario para incluir dichas medidas "preventivas" así como las vacunaciones podría servir a su vez para prestar una atención adecuada a este tema.

\section{Mantenerse al día}

Aunque la introducción de los antibióticos a mediados del siglo veinte hizo que algunos pensaran que las enfermedades 
infecciosas pronto serían erradicadas, la experiencia actual ha sido bien distinta. No solo han aparecido nuevas enfermedades infecciosas (p. ej., la infección por el VIH o la enfermedad de Lyme), sino que cada vez más agentes infecciosos han desarrollado resistencias a fármacos eficaces en otro tiempo (p. ej., malaria y tuberculosis). Por lo tanto, es imperativo que los profesionales de la salud laboral actualicen sus conocimientos en el campo de las enfermedades infecciosas y su prevención. Aunque existen muchos modos de hacerlo, son particularmente útiles los informes periódicos y los boletines de la 0 rganización $M$ undial de la Salud y de los agentes nacionales de la salud como los $C$ entros de Control y Prevención de Enfermedades de E stados U nidos (US Centers for D isease Control and Prevention).

\section{Conclusión}

U na de las responsabilidades más importantes de las empresas en cuanto a la salud de su personal es la prevención y control de las enfermedades infecciosas entre los trabajadores. Esto incluye la identificación, el aislamiento y tratamiento adecuado de los individuos que padecen infecciones, junto con la prevención de su diseminación a los compañeros y subordinados y el apaciguamiento de las angustias de los afectados por un posible contacto. Esto también implica la educación y protección adecuada de los trabajadores que puedan entrar en contacto con enfermedades infecciosas durante su trabajo o en la comunidad. El servicio de salud laboral, tal como ha quedado ilustrado en la descripción de las actividades del departamento médico de J. P. M organ and Company, Inc., de la ciudad de Nueva York, puede tener un papel trascendental en el cumplimiento de dicha responsabilidad, con un resultado beneficioso para los trabajadores, para la organización en su totalidad y para la comunidad.

\section{- Proteccion de La SALUd en LOS VIAJES}

\section{Craig Karpilow}

En esta era de organizaciones multinacionales y comercio internacional cada vez más intenso, los trabajadores deben realizar cada vez más viajes de negocios. Además, con frecuencia ellos mismos y sus familias pasan las vacaciones en países lejanos de cualquier parte del mundo. Aunque para la mayoría de las personas estos viajes son causa de disfrute, en ocasiones se convierten en experiencias duras y desagradables que, sobre todo para quienes no se han preparado de forma adecuada, pueden ser peligrosas. En todo caso, aunque a veces se producen situaciones de riesgo mortal, la mayoría de los trastornos asociados a los viajes no son graves, si bien provocan ansiedad, molestias e inconvenientes, junto con la frustración y los costes adicionales que suponen acortar el viaje o reorganizarlo. Para quien hace un viaje de negocios, estos trastornos pueden tener además una influencia considerable en la organización, debido al efecto negativo en las negociaciones y en los otros tipos de gestiones encomendadas, por no decir nada del coste que supondría anular la misión y enviar a otra persona para que la complete.

En este artículo se presenta un programa completo de protección al viajero dirigido a las personas que realizan viajes de negocios de corta duración y se describen de forma resumida las medidas necesarias para evitar los peligros asociados más habituales (se remite al lector a otras fuentes, p. ej., K arpilow 1991, que informan sobre los programas para personas con destinos a largo plazo en el extranjero y sobre los programas para unidades completas o grupos de trabajadores destinados en centros de trabajo lejanos).

\section{Un programa completo de protección en los viajes}

Los programas de promoción de la salud en el puesto de trabajo suelen incluir de forma ocasional la organización de seminarios sobre las medidas adecuadas para prevenir los peligros asociados a los viajes. Estos seminarios suelen celebrarse sobre todo en las organizaciones en las que una parte importante de los trabajadores viaja con frecuencia. En ellas suele existir un departamento interno de viajes que se ocupa de las sesiones y de la distribución de folletos y de otro tipo de publicaciones. En la mayoría de los casos, sin embargo, la educación del futuro viajero y la oferta de cualquier servicio que sea necesario han de realizarse de forma individualizada, no en grupo.

En la situación ideal, esta tarea corresponde al departamento médico 0 al servicio de salud de los empleados que, como es lógico, contarán con un director médico u otro profesional sanitario con los conocimientos adecuados. A parte de la comodidad que suponen, los servicios médicos internos ofrecen la ventaja de que conocen la organización, sus líneas de actuación y las personas que trabajan en ella, y pueden establecer una estrecha colaboración con otros departamentos implicados (como los de viajes y de personal, por ejemplo); además, permiten disponer de una historia clínica con los antecedentes médicos de cada persona y la información sobre cualquier otro trastorno sufrido en un viaje anterior y los datos, como mínimo generales, relativos al tipo y a la intensidad del trabajo que deberá realizarse durante el viaje.

Si no se dispone de un servicio interno de este tipo, debe remitirse a quien vaya a salir de viaje a alguna de las "travel clinics" o clínicas de consejos a los viajeros que dependen de muchos hospitales o de grupos médicos privados en la comunidad. Estas clínicas disponen de personal médico especializado en la prevención y el tratamiento de las enfermedades de los viajeros, prestan información actualizada sobre la situación en las zonas que se van a visitar y suministran las vacunas que estén indicadas.

Para que cualquier programa de prevención sea completo, debe presentar una serie de características que se examinan en los apartados siguientes.

\section{Una política establecida}

C on demasiada frecuencia, pese a que el viaje esté programado desde hace tiempo, las medidas de protección del viajero se toman de forma puntual, en el último minuto 0 , a veces, se omiten por completo. Por tanto, la existencia de una política establecida por escrito es un elemento clave en los programas de protección en el viaje. Como una gran parte de los viajeros son ejecutivos de alto nivel, esta política debe ser adoptada y apoyada por el primer ejecutivo de la organización, de forma que sus disposiciones puedan ser aplicadas por todos los departamentos implicados en la asignación de los viajes y en los preparativos que deban dirigir los directivos de rango inferior. En algunas organizaciones se sigue la política de prohibir de forma expresa cualquier viaje de negocios si el viajero no ha recibido "información médica" adecuada. Algunas políticas son tan detalladas que establecen los criterios mínimos de altura y de peso para autorizar la reserva de pasajes más caros en la clase bussiness, en lugar de en la clase económica o turista de los aviones comerciales, donde los asientos son mucho más pequeños e incómodos, y especifican las circunstancias en las que el cónyuge u otros miembros de la familia pueden acompañar al viajero.

\section{Planificación del viaje}

El director médico o el profesional sanitario responsable deben participar en la planificación del itinerario junto con la agencia de viajes y la persona que va a viajar. $\mathrm{H}$ ay que considerar los 
siguientes aspectos: (1) la importancia de la misión y de sus ramificaciones (incluida la asistencia obligatoria a actividades sociales); (2) las exigencias del viaje y las características de la parte del mundo que se va a visitar, y (3) el estado físico y mental del viajero, junto con su capacidad para soportar las dificultades de la experiencia sin que disminuya su rendimiento. Lo mejor sería que el viajero participara en decisiones tales como si el viaje debe posponerse o cancelarse; si el itinerario debe acortarse o modificarse; si la misión (es decir, el número de personas visitadas, el número o la duración de las reuniones, etc.) debe modificarse; si ha de llevar un asistente, y si en el itinerario deben incluirse períodos de descanso y relajación.

\section{Consulta médica previa al viaje}

Si no se ha realizado recientemente un reconocimiento médico periódico, será necesario practicar una exploración física general y realizar pruebas de laboratorio habituales, incluido un electrocardiograma, para garantizar que las dificultades del viaje y las circunstancias que deban afrontarse durante éste no afectarán de forma negativa a la salud del viajero. Debe conocerse la situación actual de cualquier enfermedad crónica y, en su caso, deben adoptarse las medidas pertinentes en caso de diabetes, enfermedades autoinmunitarias o embarazo. Se ha de entregar un informe por escrito con los hallazgos y las recomendaciones para que pueda ser consultado por cualquier médico que atienda al paciente durante el viaje. Esta exploración inicial también sirve para conocer la situación inicial del viajero y evaluar cualquier posible enfermedad a la vuelta.

En la consulta debe estudiarse la pertinencia de las vacunaciones y sus posible efectos secundarios, distinguiendo claramente entre las vacunas necesarias y las que sólo son recomendables. Se ha de trazar un plan individualizado de vacunaciones adaptado a las necesidades del viajero y a la fecha de salida $y$, por último, se han de administrar las vacunas necesarias.

Debe revisarse cualquier tipo de medicamento que reciba el paciente de forma habitual y deben extenderse las recetas necesarias para que disponga de un suministro adecuado a sus necesidades, incluso algunas de más para el caso de pérdida 0 deterioro. Asimismo, es necesario adaptar la posología de los medicamentos en los viajeros que atraviesen varias zonas horarias (p. ej., en los pacientes con diabetes insulino-dependiente). Según el tipo de trabajo y el modo de transporte, será necesario prescribir ciertos medicamentos para prevenir enfermedades específicas, como la malaria, la diarrea del viajero, el jet-lag y el mal de altura, entre otras. Además, hay que proporcionar 0 recetar medicamentos para el tratamiento sobre la marcha de algunos trastornos leves, como las infecciones de las vías respiratorias superiores (sobre todo, la congestión nasal y la sinusitis), la bronquitis, el mareo, las dermatitis, y otras afecciones razonablemente previsibles.

\section{Botiquín}

Para el viajero que no desea gastar su valioso tiempo buscando una farmacia que esté abierta, un botiquín con medicamentos y otros productos médicos puede tener un valor incalculable. Aunque encontrase la farmacia, puede que el farmacéutico no conozca el medicamento, por no hablar de las dificultades idiomáticas. Además, en algunos casos los medicamentos no son eficaces ni seguros. En un gran número de países no existen leyes estrictas sobre el etiquetado de los fármacos y aun faltan todo tipo de disposiciones legales para garantizar la calidad. En las farmacias pequeñas suelen ignorarse las fechas de caducidad de los medicamentos y, en los países tropicales, las altas temperaturas pueden inactivar algunos medicamentos que se almacenan en estanterías a elevadas temperaturas.
Aunque es posible comprar botiquines con medicamentos de uso común, el contenido debe adaptarse a las necesidades específicas del viajero. Entre los productos más necesarios, además de los medicamentos prescritos para problemas médicos concretos, se encuentran los fármacos para el mareo por movimiento, la congestión nasal, las alergias, el insomnio y la ansiedad, los analgésicos, antiácidos y laxantes, así como la medicación para las hemorroides, los trastornos menstruales y los calambres musculares nocturnos. Pueden incluirse además antisépticos, vendas y algún otro tipo de material de uso quirúrgico.

EI viajero debe llevar una carta firmada por un médico que incluya una lista de los medicamentos que lleva y en la que se especifiquen los trastornos para los que se han prescrito. Esta medida puede evitar al viajero situaciones embarazosas y retrasos, a veces considerables, en las puertas de entrada internacionales en las que los agentes de aduanas ponen especial cuidado en la búsqueda de drogas ilegales.

EI viajero debe llevar además un par de gafas o de lentes de contacto de repuesto y un suministro adecuado de productos como las soluciones de limpieza (se recomendará a los viajeros que visiten zonas demasiado sucias o polvorientas que lleven gafas en vez de lentes de contacto). Es aconsejable llevar una copia de la prescripción de las gafas para facilitar la reposición de éstas en caso de rotura o de pérdida.

Es necesario revisar antes de cada viaje el botiquín de quienes viajan con frecuencia para comprobar que el contenido se ajusta al itinerario particular y no hay productos caducados.

\section{Historias clínicas}

Además de la documentación en la que se indica que los medicamentos que lleva el viajero son adecuados, es necesario entregar una carta o informe en el que se resuman cualquier dato significativo de su historia clínica, los resultados de la evaluación médica previa al viaje y copia de un electrocardiograma reciente y de cualquier dato relevante de las pruebas de laboratorio. U n documento en el que se indiquen las vacunaciones más recientes evitará en algunos casos la vacunación obligatoria en las puertas de entrada internacionales. En ese documento deben incluirse también el nombre, la dirección y los números de teléfono y de fax de un médico que pueda suministrar información adicional sobre el viajero en caso necesario (con este fin pueden resultar útiles una tarjeta del tipo Alerta-M édica o un brazalete).

Existen tarjetas de historia clínica con chips de microfilm para incluir la historia clínica completa del paciente. Aunque suelen ser útiles, es posible que el médico extranjero no disponga de un visualizador de microfilms ni de una lupa con aumentos suficientes para leer la tarjeta. 0 tro problema adicional es la actualización de la información.

\section{Vacunaciones}

Algunos países exigen que todos los viajeros que llegan a ellos estén vacunados contra ciertas enfermedades, como el cólera, la fiebre amarilla o la peste. Aunque la O rganización M undial de la Salud recomienda que únicamente se declare obligatoria la vacuna de la fiebre amarilla, algunos países continúan exigiendo la vacunación contra el cólera. Con ello se pretende proteger no sólo a los viajeros, sino también a los propios ciudadanos contra las enfermedades que aquéllos puedan portar.

Con las vacunas recomendadas se intenta proteger al viajero de contraer enfermedades endémicas. Esta lista es mucho más larga que la lista de vacunas "necesarias" y aumenta todos los años al desarrollarse nuevas vacunas para combatir enfermedades nuevas que se propagan con rapidez. Las recomendaciones sobre una vacuna concreta suelen variar según la 
prevalencia y virulencia de la enfermedad en la zona a la que se viaja. Por este motivo, es esencial disponer de información actualizada. Esta puede obtenerse a través de la O rganización $M$ undial de la Salud y de entidades públicas como los $C$ enters for Disease Control and Prevention de Estados Unidos, el Departamento de Salud y Bienestar de Canadá, y el Departamento de Salud de la Commonwealth en Sidney, Australia. Información similar, en general procedente de estas fuentes, puede obtenerse a través de organizaciones comerciales y de voluntariado locales; también es posible conseguirla en soportes electrónicos que se actualizan de forma periódica.

Las vacunas que se recomiendan a todos los viajeros son las correspondientes a la difteria / tétanos, la polio, el sarampión (en los nacidos después de 1956 que no han sufrido un episodio de sarampión documentado por un médico), la gripe y la hepatitis $B$ (sobre todo si por el tipo de trabajo se corre el riesgo de una exposición).

El tiempo disponible antes de la partida puede influir en el plan de vacunación y en las dosis administradas. Por ejemplo, en las personas que nunca han sido vacunadas contra la fiebre tifoidea, el mayor título de anticuerpos se consigue administrando dos inyecciones con cuatro semanas de intervalo. Si no hay tiempo suficiente, quienes no hayan sido previamente vacunados pueden recibir cuatro comprimidos de la vacuna oral recientemente desarrollada, lo que es considerablemente más eficaz que la administración de una dosis única de la vacuna inyectable. La pauta de vacunación oral puede emplearse también como dosis de recuerdo en quienes han recibido antes las inyecciones.

\section{Seguro de enfermedad y de repatriación}

Numerosos programas de seguros de enfermedad nacionales y privados no cubren los servicios sanitarios que se prestan fuera de la zona especificada. Existe, por tanto, la posibilidad de que se produzcan trastornos y retrasos en la atención y se generen gastos fuera del alcance del bolsillo en caso de accidente 0 de enfermedad aguda durante un viaje. Es prudente, por tanto, comprobar si el seguro de enfermedad cubre toda la zona por la que se va a viajar. En caso contrario, se aconseja contratar un seguro de enfermedad temporal que cubra todo el viaje.

En ciertas circunstancias, sobre todo en las áreas subdesarrolladas, la falta de instalaciones modernas adecuadas y la dudosa calidad de la atención médica disponible pueden obligar a una evacuación. Esta puede hacerse a la ciudad de origen 0 , si la distancia es excesiva, a un centro médico urbano de calidad aceptable situado en la ruta de regreso. Diversas empresas prestan servicios de evacuación de urgencia en todo el mundo; algunas, sin embargo, reducen su cobertura a zonas más limitadas. Como estas situaciones suelen ser muy urgentes y causan gran estrés en la mayoría de las personas implicadas, se aconseja ponerse en contacto con una empresa que ofrezca sus servicios en las áreas que se van a visitar y, como estos servicios pueden ser muy caros, confirmar que se incluyen en el programa de seguro de enfermedad del viajero.

\section{Información posterior al viaje}

Es recomendable consultar al médico al poco tiempo de volver del viaje. De esta forma podrá determinarse cualquier posible problema sanitario e instaurarse el tratamiento adecuado de los trastornos que todavía no hayan desaparecido por completo. Así se obtendrá además información sobre las condiciones y circunstancias de la ruta, la cual podrá emplearse para mejorar las recomendaciones y la organización en viajes futuros de las mismas u otras personas.

\section{Prevencion de los peligros de los viajes}

Los viajes se acompañan casi siempre de peligros sanitarios que, como mínimo, producen inconvenientes y molestias y, en el peor de los casos, pueden provocar enfermedades graves y discapacitantes. En la mayoría de los supuestos pueden controlarse 0 evitarse, pero esto requiere un esfuerzo especial por parte del viajero. El principal objetivo del programa de protección al viajero consiste en sensibilizarle sobre los peligros sanitarios de los viajes y en suministrarle la información y el entrenamiento necesario para evitarlos. A continuación se presentan algunos de los peligros más habituales en los viajes.

Jet lag. EI paso rápido a través de las zonas horarias puede trastornar los ritmos fisiológicos y psicológicos (los ritmos circadianos) que regulan las funciones corporales. Este trastorno se conoce como "jet-lag" porque se presenta de forma casi exclusiva en los viajes en avión y puede provocar alteraciones del sueño, malestar, irritabilidad, disminución del rendimiento mental y físico, apatía, depresión, fatiga, pérdida de apetito, molestias gástricas y alteración del ritmo intestinal. En general, se necesitan varios días hasta que estos ritmos se adaptan otra vez a la nueva situación. En consecuencia, se recomienda a los viajeros que reserven los vuelos de larga distancia días antes del comienzo de compromisos sociales o de negocios importantes, para que dispongan de un período suficiente para recuperar sus energías, el estado de alerta y sus capacidades laborales (lo mismo se recomienda para los viajes de vuelta). Esto es de particular importancia en los viajeros de más edad, ya que los efectos del "jet lag" parecen aumentar con la edad.

Se han utilizado diversas medidas para reducir al mínimo los efectos producidos. A lgunos autores recomiendan la "dieta de jet lag", en la que durante los tres días previos al viaje se alterna el consumo y el ayuno de alimentos muy ricos en carbohidratos 0 en proteínas. 0 tros proponen realizar una cena muy rica en carbohidratos antes de partir de viaje y limitar la alimentación durante éste a ensaladas, fruta y otros platos ligeros, además de beber una gran cantidad de líquido antes y durante el viaje (lo suficiente para necesitar ir al servicio cada hora) y evitar el consumo de bebidas alcohólicas. 0 tros recomiendan utilizar una fuente de luz montada sobre la cabeza que suprima la secreción de melatonina en la glándula pineal, ya que algunos de los síntomas del "jet lag" se han asociado al exceso de esta hormona. Recientemente se ha observado que pequeñas dosis de melatonina en comprimidos ( $1 \mathrm{mg} 0$ menos; las dosis mayores, que se administran frecuentemente con otros fines, producen somnolencia) administradas de acuerdo con una prescripción durante varios días antes y después del viaje minimizan el "jet lag". Aunque todas estas medidas pueden ser útiles, lo mejor es descansar y relajarse de forma adecuada hasta que el organismo se haya adaptado por completo a la nueva situación.

Viajeaérea. Además del "jet lag", el viaje en avión puede presentar otro tipo de problemas. El camino hasta el aeropuerto y su recorrido pueden provocar ansiedad e irritación, sobre todo si hay atascos de tráfico o se lleva un equipaje pesado o voluminoso, se retrasan o se cancelan los vuel os y hay que cruzar las terminales para tomar los vuelos de enlace. Los períodos prolongados de confinamiento en asientos estrechos con espacio insuficiente para las piernas no sólo son incómodos, sino que pueden provocar ataques de flebitis en las piernas. La mayoría de los pasajeros en los aviones modernos bien revisados no tendrán ningún problema para respirar, ya que las cabinas están presurizadas para mantener una altitud inferior a 8.000 pies por encima del nivel del mar. El humo del tabaco puede molestar a los pasajeros sentados en la sección de fumadores o cerca de ella en los aviones en que se permite fumar. 
Figura 15.22 - Ejercicios que pueden realizarse en viajes en avión prolongados.

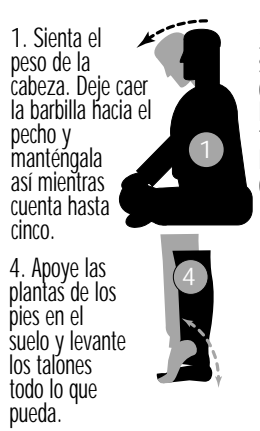

7. Inclinado hacia adelante, con los brazos pegados al cuerpo, deje colgar las manos y haga oscilar los brazos hacia atrás y hacia adelante.

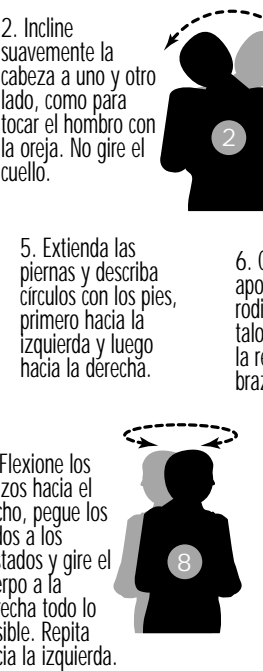

11. Encoja el estómago

10. Eleve los brazos sobre la cabeza despacio y con suavidad. Bájelos despacio. inclínese hacia adelante suba y baje los tobillos. Relaje el estómago y siéntese erguido.
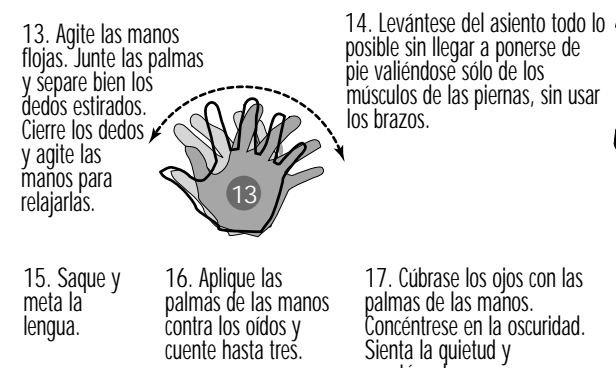

17. Cúbrase los ojos con las palmás de las manos. Sienta la quietud y manténgala.

Para reducir al mínimo estos problemas, pueden adoptarse diversas medidas: preparar con antelación el transporte a los aeropuertos y desde éstos, así como la asistencia con el equipaje; proporcionar carritos eléctricos o sillas con ruedas a quien pueda tener dificultades para recorrer a pie distancias largas entre la entrada de la terminal y las puertas de acceso; realizar comidas ligeras y evitar las bebidas alcohólicas durante el vuelo; beber mucho líquido para prevenir la tendencia a la deshidratación; levantarse del sitio y caminar por la cabina con frecuencia. Si esto no es posible, es muy importante realizar ejercicios de estiramiento y relajación como los que se muestran en la Figura 15.22. U na pieza que cubra los ojos puede resultar útil para intentar dormir durante el vuelo, y se ha demostrado que el uso de tapones de oídos durante éste reduce el estrés y la fatiga.

En unos 25 países, entre ellos Argentina, Australia, la India, $K$ enia, M éxico, M ozambique y Nueva Zelanda, en las cabinas de los aviones que aterrizan se nebulizan insecticidas antes de que los pasajeros abandonen el avión. Con esta medida se pretende impedir la introducción en el país de insectos portadores de enfermedades.

A veces, la nebulización es superficial, pero con frecuencia se realiza por toda la cabina, incluidos los pasajeros y la tripulación. L os viajeros a los que irriten o molesten los carbohidratos que contienen los productos nebulizados deberán cubrirse la cara con un paño mojado y practicar ejercicios respiratorios de relajación.

Estados U nidos se opone a esta práctica. El secretario de Transportes, Federico F. Peña, ha propuesto que se obligue a todas las compañías aéreas y agencias de viajes a comunicarlo a los viajeros cuando van a realizar la nebulización y el D epartamento de Transportes prevé plantear este controvertido tema a la A sociación Internacional de Aviación Civil y copatrocinar un simposio de la O rganización M undial de la Salud sobre la cuestión (Fiorino 1994).

Mosquitos y otros insectos que pican. La malaria y otras enfermedades transmitidas por artrópodos (p. ej., fiebre amarilla, encefalitis vírica, fiebre del dengue, filariasis, leishmaniasis, oncocercosis, tripanosomiasis y enfermedad de Lyme) son endémicas en muchas regiones del mundo. La primera línea de defensa contra ellas consiste en evitar las picaduras de insectos.

Pueden aplicarse sobre la piel y/o los vestidos repelentes de insectos que contengan "DEET" ( $\mathrm{N}, \mathrm{N}$,-dietil-meta-toluamida). Como éste puede absorberse a través de la piel y causar síntomas neurológicos, no se recomienda utilizar preparados con una concentración superior al $35 \%$, sobre todo en los niños. El hexanediol es una alternativa muy útil para las personas sensibles al DEET. El producto comercial humidificante Skin-SoSoft ${ }^{\circledR}$ debe aplicarse cada veinte minutos más o menos para que sea eficaz como repelente.

Todas las personas que viajen por zonas en las que las enfermedades transmitidas por artrópodos sean endémicas deben vestir camisas de manga larga y pantalones largos, sobre todo después del anochecer. En los países cálidos, las prendas sueltas de lino o de algodón son más frescas que llevar la piel expuesta. Deben evitarse los perfumes y los productos cosméticos perfumados, los jabones y las lociones que puedan atraer a los insectos. En las zonas muy infestadas, pueden ser útiles las chaquetas ligeras de malla, las capuchas y los protectores de cara. También es importante el uso de mosquiteras y de mallas protectoras en las ventanas (antes de acostarse, conviene nebulizar un insecticida en el interior para asegurarse de que no han quedado atrapados insectos indeseables.)

Los vestidos protectores y las mallas pueden tratarse con un repelente que contenga DEET o con permetrina, un insecticida disponible en nebulizadores y en formulaciones líquidas.

Malaria. A pesar de los esfuerzos realizados durante décadas para erradicar los mosquitos, la malaria continúa siendo endémica en la mayoría de las regiones tropicales y subtropicales del mundo. Como se trata de una enfermedad peligrosa y debilitante, además de las medidas ya descritas para prevenir las picaduras de los mosquitos es necesario tomar, como profilaxis, uno o más fármacos antipalúdicos. Aunque se han desarrollado numerosos fármacos antipalúdicos eficaces, algunas cepas del parásito de la malaria se han hecho muy resistentes a algunos o incluso a todos los fármacos que se utilizan en la actualidad. Por ejemplo, la cloroquina, el fármaco tradicionalmente más difundido, continúa siendo eficaz frente a las cepas de malaria en algunas partes del mundo, pero es prácticamente inútil en muchas otras. Para las cepas del parásito resistentes a ella se utiliza en general proguanil, mefloquina y doxiciclina. En ciertas áreas se emplea también maloprim, fansidar y sulfisoxazol. La pauta profiláctica se inicia antes de entrar en la zona palúdica y se continúa durante algún tiempo después de salir de ella.

La elección del fármaco debe basarse en recomendaciones "de última hora" para las zonas concretas a las que se dirija el viajero. Deberán considerarse también sus efectos secundarios: por ejemplo, el fansidar está contraindicado durante el embarazo y la lactancia; la mefloquina no debe utilizarse en los 
pilotos de avión ni en las personas en las que los efectos secundarios sobre el sistema nervioso central puedan afectar su rendimiento o poner en peligro la seguridad de otras personas, ni en los viajeros en tratamiento con bloqueadores beta 0 de los canales del calcio o con otros fármacos que alteren la conducción cardíaca.

Agua contaminada. La contaminación del agua puede ser un problema en todo el mundo. Incluso en los centros urbanos modernos, los defectos en las tuberías y en las conexiones de los edificios antiguos o en mal estado de conservación pueden permitir la diseminación de las infecciones. El agua embotellada no siempre es segura, sobre todo si no está intacto el sellado del tapón. Las bebidas carbonatadas son seguras en general siempre que no hayan perdido la fuerza.

El agua puede desinfectarse calentándola a $62{ }^{\circ} \mathrm{C}$ durante 10 minutos 0 añadiendo yodo o cloro después de filtrarla para eliminar los parásitos y las larvas de gusanos y dejarla reposar durante 30 minutos.

Las unidades de filtración que se venden para las excursiones de camping no son apropiadas en general para las zonas en las que el agua puede estar contaminada, ya que no inactivan los virus ni las bacterias. Los filtros Ilamados "Katadyn" se presentan en unidades individuales y permiten filtrar microorganismos de tamaño superior a 0,2 micras, pero después hay que tratar el agua con yodo/ cloro para eliminar los virus. Los filtros "PUR" que se han desarrollado más recientemente combinan filtros de 1,0 micras con la exposición a una matriz de resina triyódica que elimina las bacterias, los parásitos y los virus en un solo proceso.

En las zonas en las que el agua pueda estar contaminada, debe aconsejarse al viajero que no tome hielo ni bebidas granizadas y que no se cepille los dientes con agua no purificada.

0 tra precaución importante es no bañarse ni sumergir los brazos ni las piernas en lagos ni en cursos de agua dulce en los que existan los caracoles portadores de los parásitos de la esquistosomiasis (bilharzia).

Comida contaminada. La comida puede contaminarse en el origen por el uso de residuos humanos como fertilizante, durante el transporte por la falta de refrigeración y la exposición a moscas y otros tipos de insectos, y durante la preparación por la escasa higiene de cocineros y de otros manipuladores de alimentos. Respecto a esto último, la comida servida por un vendedor callejero a quien se ve cocinarla y prepararla puede ser más segura que la de un restaurante de cinco tenedores en el que el ambiente elegante y los limpios uniformes que viste el personal no garantizan que la conservación, la preparación ni la forma de servirla sean las adecuadas. Probablemente, el mejor consejo que pueda darse al viajero es el viejo: "N o comas lo que no puedas hervir ni pelar personalmente".

Diarrea del viajero. L a diarrea del viajero se produce en todo el mundo, tanto en los centros urbanos modernos como en las áreas subdesarrolladas. Aunque la mayoría de los casos se atribuyen a la presencia de microorganismos en la comida y la bebida, en numerosas ocasiones se trata tan sólo del resultado de la ingestión de productos extraños o de comidas elaboradas con procedimientos también extraños, de excesos dietéticos y de la fatiga. Algunos casos se producen después de bañarse 0 de ducharse con agua contaminada 0 de bañarse en lagos, ríos y estanques contaminados.

La mayoría de los casos son autolimitados y responden con rapidez a medidas simples como tomar una cantidad suficiente de líquidos, una dieta blanda y ligera y el descanso.
M edicamentos sencillos como la attapulgita (un producto con arcilla que actúa como absorbente), el subsalicilato de bismuto y los agentes anti-motilidad, como la loperamida o reglan, pueden ayudar a controlar la diarrea. Sin embargo, si ésta es grave, dura más de tres días o se acompaña de vómitos repetidos o de fiebre, se aconseja consultar a un médico y utilizar los antibióticos adecuados. La selección del antibiótico debe guiarse por la identificación en el laboratorio del microorganismo causante de la diarrea 0 , si esto no es posible, del análisis de los síntomas y de la información epidemiológica sobre la prevalencia de las distintas infecciones en el área que se visita. D ebe facilitarse al viajero un folleto como el que ha elaborado la O rganización M undial de la Salud (Figura 15.23), en el que se expliquen de forma clara las medidas que deben tomarse, en un lenguaje sencillo que no provoque alarma.

Se ha propuesto la utilización profiláctica de antibióticos antes de entrar en las áreas en las que se sospecha la contaminación del agua y de la comida, pero esta medida no es aconsejable porque los antibióticos pueden provocar síntomas de diarrea y este tipo de profilaxis favorece que el viajero se relaje e ignore las precauciones que se le han aconsejado.

En algunos casos, la diarrea no se produce hasta la vuelta del viaje. En tal caso puede entenderse que se trata de una enfermedad parasitaria y habrá que realizar las pruebas de laboratorio adecuadas para identificar el microorganismo o descartar este tipo de infección.

Mal dealtura. Las personas que viajan a regiones montañosas como Aspen (Colorado), Ciudad de M éxico o La Paz (Bolivia) pueden sufrir problemas relacionados con la altura, sobre todo si padecen cardiopatías coronarias, insuficiencia cardíaca congestiva o enfermedades pulmonares, como enfisema, bronquitis crónica o asma. En los casos leves, el mal de altura puede causar fatiga, cefaleas, disnea de esfuerzo, insomnio o náuseas. Estos síntomas desaparecen en general al cabo de algunos días de disminución de la actividad física y de descanso.

En los casos más graves, los síntomas pueden progresar hasta producir dificultades respiratorias, vómitos y visión borrosa. Si esto sucede, el viajero debe buscar atención médica y descender a menor altura tan rápido como sea posible e incluso inhalar oxígeno suplementario hasta ese momento.

Delincuencia e inestabilidad social. La mayor parte de los viajeros tienen el sentido común suficiente para evitar las zonas de guerra y de inestabilidad social. No obstante, en ciudades que desconocen pueden adentrarse inadvertidamente en barrios violentos donde los turistas son víctimas habituales. Para evitar situaciones desagradables son útiles las instrucciones sobre la forma segura de guardar joyas y otros objetos valiosos y los mapas con indicación de las rutas seguras para ir desde el aeropuerto al centro y las zonas que deben evitarse.

Fatiga. La fatiga simple suele producir malestar y alterar el rendimiento. U na gran parte de los trastornos que se atribuyen al "jet lag" suelen ser el resultado de las incomodidades que se sufren cuando se viaja en avión, autobús y automóvil, de lo mal que se duerme en camas y en entornos extraños, del consumo excesivo de comida y de alcohol y de una agenda de entrevistas y de compromisos sociales demasiado apretada.

EI viajero de negocios suele tener que resolver gran cantidad de trabajo y realizar los preparativos antes de comenzar el viaje, sin contar con el esfuerzo que necesita para ponerse al día a la vuelta. U n elemento clave de los programas de protección en los 
Figura 15.23 - Ejemplo de un prospecto informativo de la 0 rganización M undial de la Salud sobre la diarrea del viajero.

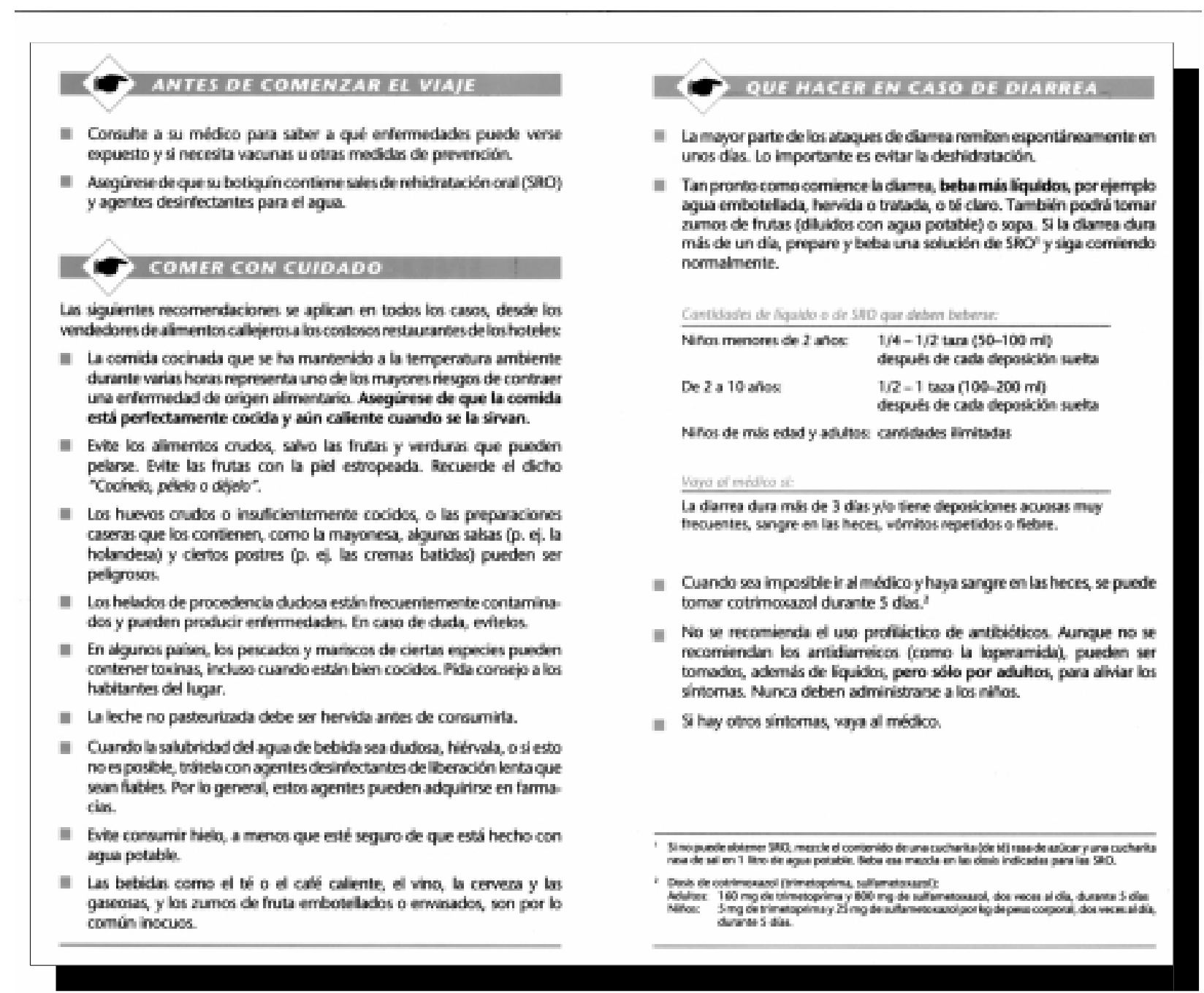

Fuente: Organización Mundial de la Salud, 1994.

viajes es la educación del viajero para prevenir la acumulación de fatiga indebida, así como el adoctrinamiento del superior a quien aquél deba presentar sus informes, para que tenga en cuenta este frecuente peligro al asignar las tareas.

\section{Conclusión}

Al aumentar los viajes a lugares exóticos y lejanos por motivos de ocio o de negocios, la protección del viajero se ha convertido en un elemento importante en los programas de promoción de salud en el puesto de trabajo. A tal fin, hay que sensibilizarle sobre los peligros que puede encontrar y suministrarle la información y los medios necesarios para evitarlos. Estos medios son la consulta previa al viaje, las vacunaciones y el suministro de los medicamentos que pueda necesitar durante el viaje. La participación de la dirección también es importante para que las expectativas de la misión sean razonables y para que puedan realizarse los preparativos adecuados para el viaje y el alojamiento. El objetivo es completar con éxito la misión y que el trabajador vuelva sin ningún problema sanitario.

\section{Programas de GeSTION DEL ESTRES}

Leon J. Warshaw

La misión principal de la salud y seguridad en el trabajo es proteger y mejorar la salud, bienestar y productividad de los trabajadores, tanto individual como colectivamente. Para poder cumplir esta misión es imprescindible comprender el estrés y el mecanismo por el cual afecta a las personas y a las organizaciones, y elaborar un programa bien planificado que disminuya y, lo que es más importante, evite, los perniciosos efectos del estrés.

El estrés es un ingrediente inevitable de la vida de todas las personas en cualquier lugar. M antiene una relación de causa y efecto con la sensación interna de bienestar de las personas, con sus relaciones con la familia, los amigos, los compañeros de trabajo y los desconocidos, y con la capacidad de desenvolverse en el hogar, en el lugar de trabajo y en la vida social. Cuando es excesivo, produce síntomas físicos y psicológicos, si se prolonga demasiado, puede provocar enfermedad e incapacidad. 
M odifica las percepciones de los individuos, así como sus sentimientos, actitudes y comportamientos, y afecta a las organizaciones cuyas actividades dirigen o realizan. El estrés se trata con detenimiento en otros apartados de esta E nciclopedia.

\section{Diseño de un programa de gestion del estrés}

Un programa eficaz de gestión del estrés en el lugar de trabajo debe contener ciertos elementos que se solapan y que operan de forma concurrente. Algunos se sitúan formalmente dentro de los programas de gestión del estrés, mientras que otros son simplemente partes de la gestión organizativa general aun cuando se dirijan de forma explícita al control del estrés. En algunos casos, estos elementos van destinados a los trabajadores de forma individual y en grupos; en otros, se orientan a los factores de estrés que aparecen en el lugar de trabajo, y un tercer tipo de elementos abordan los factores de estrés que influyen negativamente en la organización como entidad en sí misma y que, de forma inevitable, se filtran hasta afectar a algunos 0 a todos los trabajadores. A continuación se verán los elementos que forman un programa de gestión del estrés en el lugar de trabajo.

1. Gestionar los síntomas relativos al estrés. Este elemento se refiere a individuos que ya padecen los efectos del estrés. D enominado "modelo médico", trata de identificar a individuos que presentan síntomas, y convencerlos de que acepten voluntariamente acudir a profesionales que puedan evaluar sus problemas, diagnosticar las causas y ofrecer el tratamiento adecuado. Puede basarse en el servicio de salud de los empleados, el programa de asistencia a éstos, o cualquier otro servicio de asesoramiento prestado por la organización. Los servicios pueden ser diversos, desde entrevistas y exámenes individuales hasta líneas tel efónicas para situaciones de emergencia o centros bien equipados con equipos multidisciplinares de profesionales cualificados. Pueden ser atendidos por profesionales a tiempo completo o parcial, por acuerdos contractuales o caso por caso con profesionales que se desplacen al lugar de trabajo o estén ubicados en instalaciones cercanas de la misma localidad. Algunos servicios se ocupan de todos los problemas, mientras que otros pueden centrarse más o menos en los síndromes específicos relacionados con el estrés, como hipertensión, dolores de espalda, alcoholismo, consumo de drogas o problemas familiares. Las contribuciones de estos elementos de servicio al programa de gestión del estrés se basan en las capacidades siguientes:

- Tomar conciencia de que muchos problemas somáticos recurrentes o persistentes, como dolores musculares, molestias gastrointestinales, etc., se pueden atribuir al estrés. En lugar de limitarse a proporcionar medicaciones y consejos paliativos, el profesional 0 asesor experto reconocerá los síntomas y concentrará su atención en los factores de estrés, que son los verdaderos responsables.

- Reconocer que cuando varios trabajadores de un mismo departamento o sección presentan tales molestias, se debe emprender una investigación para identificar en el ambiente laboral un factor causante e intentar controlarlo para reducir el estrés.

- Localizar a los individuos que hayan padecido un hecho catastrófico o hayan sido testigos de él, como un accidente grave 0 un episodio de violencia.

- A provechar la oportunidad para detener una medida disciplinaria aplicada a un trabajador a causa de un rendimiento inadecuado o de un comportamiento anormal, hasta que se pueda rebajar el nivel de estrés y devolverle su ecuanimidad y capacidad de trabajo normales.
2. Reducir la vulnerabilidad de cada persona. Los elementos más comunes en los programas de gestión del estrés son los que ayudan a las personas a combatirlo reduciendo su vulnerabilidad. Estos elementos pueden consistir en series de seminarios y talleres, complementados con cintas de vídeo y audio y folletos $u$ otras publicaciones que enseñen a los trabajadores a luchar contra el estrés de un modo eficaz. Sus denominadores comunes son:

- Formación en autoconciencia y análisis de problemas para detectar los síntomas de estrés e identificar los factores responsables.

- Formación en positivo para hacer más dinámica la lucha contra tales factores.

- T écnicas para reducir el estrés a niveles más tolerables.

Algunas de las herramientas que se emplean se relacionan en la Figura 15.24. Para quienes no estén familiarizados con la terminología, sesiones de "rap" son reuniones de grupos de trabajadores, con o sin la presencia de supervisores, en las que se discuten experiencias y problemas y donde se expresan libremente las quejas. Son análogas a las "reuniones de taller" auspiciadas por los sindicatos.

3. Relaciones interpersonales en el lugar de trabajo. Las organizaciones están cada vez más sensibilizadas respecto a los factores de estrés que emanan de la heterogeneidad de la plantilla y los problemas interpersonales que se producen. Los prejuicios y la intolerancia no se detienen a las puertas del lugar de trabajo y se combinan a menudo con un comportamiento insensible o discriminatorio por parte de la dirección y los mandos intermedios. El sexo o la cuestión o racial puede materializarse en acoso e incluso producir actos de violencia. Cuando estas actitudes son intensas requieren una corrección rápida mediante la formulación de una política explícita que incluya sanciones disciplinarias contra los culpables y proteja a las víctimas de posibles represalias por denunciar las infracciones.

4. Gestión de los factores laborales de estrés. Es responsabilidad de la organización reducir al mínimo los factores laborales de estrés que puedan influir negativamente en la capacidad de los trabajadores para desempeñar eficazmente sus funciones. Es de importancia capital garantizar que los supervisores y mandos de todos los niveles reciben formación adecuada para reconocer y tratar correctamente los problemas personales que aparecen de forma inevitable en el lugar de trabajo.

5. Gestión del estrés de la organización. La organización como entidad está expuesta a factores de estrés que, si no se tratan adecuadamente, se filtran hacia abajo a través de la plantilla de forma inevitable y acaban afectando negativamente a los trabajadores de todos los niveles. Esta situación exige el establecimiento de objetivos ambiciosos pero realistas, la identificación y evaluación precoz de factores de estrés potenciales que puedan obstaculizar dichos planes, la coordinación de las capacidades de la organización para enfrentarse a ellos, y la comunicación de los resultados de tales esfuerzos al resto de los trabajadores. Esto último es especialmente importante en tiempos de austeridad económica, cuando la colaboración de los trabajadores y una productividad óptima son esenciales para afrontar posibles crisis, como cambios en la alta dirección, amenazas de fusiones y absorciones, cierres de factorías o reubicaciones y reducciones de plantilla.

6. Ayudar a gestionar los factores personales de estrés. A unque la gestión de los factores de estrés que aparecen en el hogar y en la comunidad corresponde principalmente a los individuos, las empresas están descubriendo que el estrés que generan esos factores se traslada de forma inevitable al lugar de trabajo donde, en sí mismos o en combinación con factores de estrés 
Figura 15.24 - Algunas orientaciones para reducir la vulnerabilidad individual.

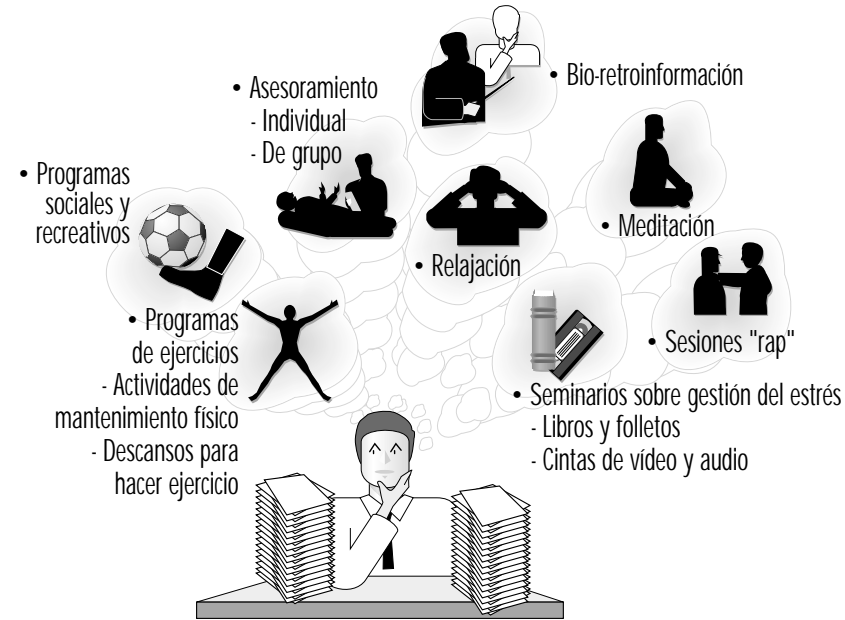

laborales, suelen afectar al bienestar de los trabajadores e influyen negativamente en su rendimiento laboral. En consecuencia, las empresas empiezan a considerar conveniente, y en algunos casos necesario, establecer programas diseñados para ayudar a los trabajadores a combatir dichos factores. En la Figura 15.25 se incluye una lista de los factores personales de estrés más comunes, así como de los programas para combatirlos en el lugar de trabajo.

\section{Principios básicos del programa}

Al establecer un programa de gestión del estrés en el lugar de trabajo, es preciso insistir en algunos principios básicos.

En primer lugar, debe recordarse que no existen diferencias entre el estrés que aparece en el trabajo, en el hogar y en la comunidad. Cada individuo presenta una combinación propia de todos los factores, que traslada consigo a cualquier parte que vaya. Esto significa que mientras el programa se debe concentrar en los problemas que aparecen en el centro de trabajo, debe tener en cuenta que éstos continúan afectando a la vida fuera de él, y tampoco puede ignorar los que se producen fuera del trabajo. Se ha demostrado que el trabajo en sí mismo y el apoyo de los compañeros y de la organización puede tener un valor terapéutico en la lucha contra los problemas personales y familiares. De hecho, la pérdida de ese apoyo es posible que contribuya en gran medida a la incapacidad asociada a la jubilación, incluso cuando ésta es voluntaria.

En segundo lugar, el estrés es muy "contagioso". No sólo afecta a ciertos individuos, sino también a quienes se relacionan y colaboran con ellos. Por tanto, la lucha contra el estrés es al mismo tiempo terapéutica y preventiva.

En tercer lugar, la lucha contra el estrés es una responsabilidad individual. Es posible identificar a los trabajadores con problemas y ofrecerles consejo y orientación. Se les puede ayudar y animar, enseñándoles a mejorar sus habilidades para enfrentarse a determinadas situaciones. Cuando sea necesario, se les puede remitir a profesionales sanitarios cualificados de la localidad para una terapia más intensa o prolongada. Pero, en último término, son imprescindibles el consentimiento y la participación activa de la persona, lo que, a su vez, dependerá de la estructura del programa, la importancia que se conceda a estos aspectos, la profesionalidad y reputación de su personal y la
Figura 15.25 • Factores de estrés que afectan a los trabajadores y programas en el lugar de trabajo que ayudan a neutralizarlos.

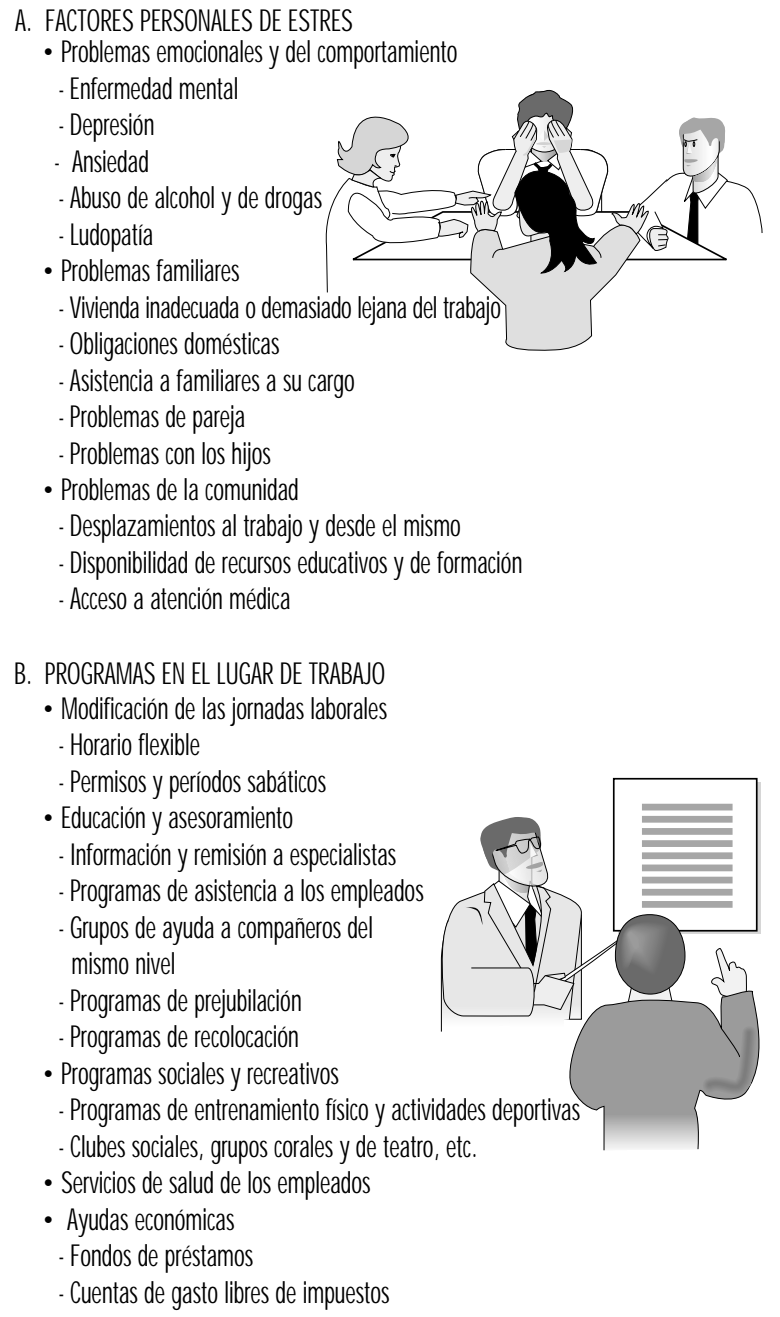

accesibilidad del mismo. Quizá la clave del éxito del programa sea el establecimiento y cumplimiento estricto de una política de respeto a la confidencialidad de la información de carácter personal.

En cuarto lugar, el control del estrés constituye esencialmente una responsabilidad de la dirección. El programa debe basarse en una política organizativa explícita que conceda una gran importancia a la salud y bienestar de los trabajadores. $Y$ esta política debe reflejarse en el trabajo cotidiano, en las actitudes y en el comportamiento de los directivos de todos los niveles.

En quinto lugar, la participación de los trabajadores en el diseño y funcionamiento del programa y, en especial, en la identificación de factores de estrés y el establecimiento de formas de controlarlos constituye un ingrediente fundamental para el éxito del programa. Resulta más fácil en muchos centros de trabajo en los que hay comités conjuntos de salud y seguridad laboral o en los que se fomenta la participación de los trabajadores en el proceso de toma de decisiones empresariales.

Finalmente, para tener éxito un programa de gestión del estrés necesita un conocimiento profundo de los trabajadores y del entorno en que desarrollan su labor. El éxito es mayor 
cuando se pueden identificar y resolver los problemas relacionados con el estrés antes de que se produzca algún perjuicio.

\section{Conclusión}

La misión principal de la salud y seguridad en el trabajo es proteger y mejorar la salud, bienestar y productividad de los trabajadores, tanto individual como colectivamente. Para poder cumplir esta misión es imprescindible comprender el estrés y el mecanismo por el cual afecta a las personas y a las organizaciones, y elaborar un programa bien planificado que minimice $y$, lo que es más importante, evite, los perniciosos efectos del estrés.

\section{- ABUSO DE ALCOHOL Y DE DROGAS}

Sheila B. Blume

\section{Introducción}

A lo largo de la historia, los seres humanos han intentado alterar sus pensamientos, sentimientos y percepciones de la realidad. En muchas culturas se han empleado técnicas de alteración de la mente, como la reducción de los estímulos sensoriales, baile repetitivo, privación de sueño, ayuno y meditación prolongada. Sin embargo, el método más popular para producir cambios en el estado de humor y en la percepción ha sido la utilización de drogas que alteraran la mente. De las 800.000 especies de plantas que existen en nuestro planeta, se conocen alrededor de 4.000 que producen sustancias psicoactivas. A proximadamente 60 de ellas se han empleado de forma continuada como estimulantes o intoxicantes (M alcom 1971). Algunos ejemplos son el café, el té, la amapola del opio, la hoja de coca, el tabaco y el yute indio, al igual que las plantas a partir de las que se fermentan bebidas alcohólicas. Además de las sustancias de origen natural, la investigación farmacéutica moderna ha producido diversos sedantes, opiáceos y tranquilizantes sintéticos. Con frecuencia se emplean drogas derivadas de las plantas y fármacos psicoactivos sintéticos con fines médicos. También se emplean distintas sustancias tradicionales en ritos religiosos y como parte de actos sociales y recreativos. Además, ciertas culturas han incorporado el uso de drogas a prácticas habituales en el lugar de trabajo. Algunos ejemplos son el mascar hojas de coca por los indios peruanos en los A ndes y la práctica de fumar cannabis por los trabajadores jamaicanos de la caña de azúcar. El uso de cantidades moderadas de alcohol durante el trabajo agrícola era una práctica aceptada en el pasado en algunas sociedades occidentales, por ejemplo en Estados Unidos en el siglo XVIII, y a comienzos del $X I X$. Más recientemente, era una costumbre (e incluso una exigencia de algunos sindicatos) entre los trabajadores dedicados a la quema de baterías (trabajadores que quemaban baterías almacenadas descargadas para recuperar su contenido en plomo) y por los pintores domésticos que empleaban pinturas con base de plomo proporcionar a cada trabajador una botella diaria de whisky para mojarse los labios durante la jornada de trabajo con la creencia -errónea- de que prevenía la intoxicación por plomo. A demás, la bebida ha sido un elemento tradicional de algunas ocupaciones como, por ejemplo, los vendedores de licores y destilerías. Se espera de estos representantes de ventas que acepten la hospitalidad del dueño de la taberna al completar su pedido.

Persisten costumbres que relacionan el consumo de alcohol con otros trabajos, como la comida de negocios de "tres martinis" y la suposición de que los grupos de trabajadores deben parar en el bar o taberna de barrio para tomar varias rondas de copas al finalizar la jornada laboral. Esta última práctica supone un riesgo especial para los que regresan conduciendo hasta sus domicilios.

En los centros industriales contemporáneos se siguen usando estimulantes suaves, institucionalizados en los descansos para el café 0 el té. Sin embargo, se han combinado distintos factores históricos para hacer que el uso de sustancias psicoactivas en el lugar de trabajo se convierta en un problema social y económico grave en el mundo contemporáneo. El primero de ellos es la tendencia a la utilización de una tecnología cada vez más sofisticada en el lugar de trabajo. La industria moderna requiere un estado de alerta, unos reflejos inalterados y una percepción exacta por parte de los trabajadores. Los defectos en estos campos pueden producir accidentes graves y pueden interferir con la precisión y eficacia del trabajo. La segunda tendencia importante es el desarrollo de drogas psicoactivas más potentes y medios más rápidos de administración. Algunos ejemplos son la administración intranasal o intravenosa de cocaína y el uso de cocaína purificada fumada ("base libre" 0 "crack"). Estos métodos, que proporcionan unos efectos mucho más potentes de la cocaína que el método tradicional de mascado de hojas de coca, han aumentado en gran medida los peligros del uso de cocaína a nivel laboral.

\section{Efectos del uso de alcohol y otras drogas en el lugar de trabajo}

La Figura 15.26 resume las distintas formas en las que el uso de sustancias psicoactivas puede influir en la actividad de los trabajadores en el puesto de trabajo. El estado de ebriedad (efectos agudos de la ingestión del alcohol) es el riesgo más evidente, siendo responsable de numerosos accidentes laborales, por ejemplo accidentes de tráfico por conducción bajo los efectos del alcohol. Además, la alteración del juicio, la falta de atención y la disminución de los reflejos producidos por el alcohol y otras drogas también interfieren en la productividad a todos los niveles, desde la sala de juntas a la línea de producción. M ás aún, los trastornos en el lugar de trabajo debidos al uso de drogas y alcohol con frecuencia se extienden más allá del período agudo. La resaca relacionada con el alcohol puede producir cefalea, náuseas y fotofobia (sensibilidad a la luz) 24-48 horas después de la última bebida. Los trabajadores que padecen dependencia del alcohol también pueden presentar síntomas de abstinencia al alcohol en el trabajo, con agitación, sudoración y trastornos gastrointestinales. El uso de grandes cantidades de cocaína se acompaña de forma característica de un período de abstinencia con estado depresivo, astenia y apatía, todos los cuales interfieren con el trabajo. Tanto la intoxicación como los efectos posteriores del uso de drogas y de alcohol conducen de forma característica al absentismo y a la impuntualidad. Asimismo, el uso crónico de sustancias psicoactivas está implicado en numerosos problemas de salud que aumentan los costes médicos de la industria de una sociedad y pérdida de tiempo de trabajo. Algunos ejemplos de estos problemas son la cirrosis hepática, la hepatitis, el SIDA y la depre sión clínica.o

Los trabajadores que se convierten en usuarios de alcohol $u$ otras drogas (o ambos) con frecuencia y en gran número pueden desarrollar un síndrome de dependencia que incluye, de forma característica, la preocupación por obtener la droga o el dinero necesario para comprarla. Incluso antes de que otros síntomas inducidos por las drogas o por el alcohol comiencen a interferir con el trabajo, esta preocupación puede comenzar con alterar la productividad. M ás aún, como consecuencia de la necesidad de dinero, el trabajador puede recurrir a robar objetos en el lugar de trabajo o a vender drogas en el trabajo, creando otro grupo de problemas graves. Por último, los amigos íntimos y los familiares de las personas que usan drogas y alcohol (con frecuencia denominadas "allegadas") también ven modificada su capacidad 
Figura 15.26 - Problemas que el consumo de alcohol 0 drogas puede causar en el trabajo.

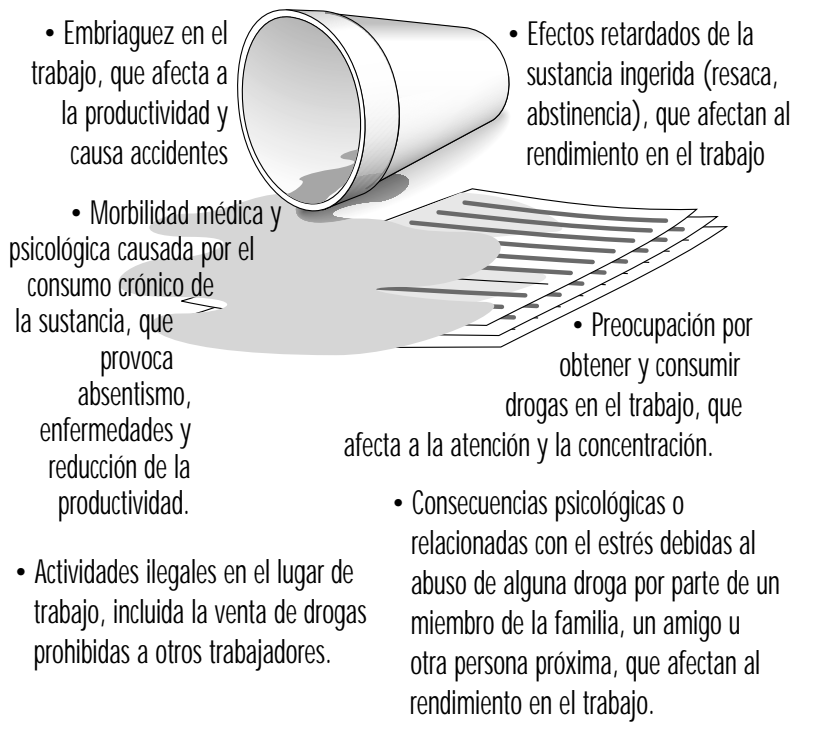

para trabajar como consecuencia de la ansiedad, depresión y distintos síntomas relacionados con el estrés. Estos efectos pueden trasladarse incluso a generaciones posteriores en forma de problemas laborales residuales en los adultos cuyos padres fueron alcohólicos (Woodside 1992). Los gastos sanitarios en trabajadores con problemas graves con el alcohol tienen un valor aproximadamente del doble del de los costes sanitarios de los demás trabajadores (Institute for Health Policy 1993). A simismo, aumentan los costes sanitarios de los miembros de sus familias (Children of Alcoholics Foundation 1990).

\section{Costes para la sociedad}

Por las razones anteriores y por otras, el uso y abuso de drogas y de alcohol han generado una carga económica importante en muchas sociedades. En los Estados U nidos, el coste calculado para la sociedad en el año 1985 fue de 70.300 millones de dólares norteamericanos para el alcohol y de 44.000 millones de dólares norteamericanos para las demás drogas. Del total de costes relacionados con el alcohol, 27.400 millones de dólares (aproximadamente el $39 \%$ del total) fue atribuido a la pérdida de productividad. La cifra correspondiente a las demás drogas fue de 6.000 millones de dólares norteamericanos (aproximadamente el $14 \%$ del total) (US Department of $\mathrm{H}$ ealth and $\mathrm{H}$ uman Services 1990). El resto de los costes añadidos a la sociedad como consecuencia del abuso de drogas y de alcohol son los costes del tratamiento de los problemas médicos (como SIDA y defectos congénitos relacionados con el alcohol), accidentes de tráfico y otros accidentes, crímenes, destrucción de la propiedad, encarcelamiento y los costes sociales de apoyo a la familia. Aunque algunos de estos costes se pueden atribuir al uso socialmente aceptado de sustancias psicoactivas, la inmensa mayoría se asocian al abuso y dependencia de drogas y de alcohol.

\section{Uso, abuso y dependencia de drogas y de alcohol}

U na forma sencilla de clasificar los patrones de uso de sustancias psicoactivas es distinguir entre uso sin riesgo (uso con modelos aceptados socialmente que no produce daño ni implica un riesgo elevado de daño), abuso de drogas y de alcohol (uso con riesgo elevado o con producción de daño) y dependencia de drogas y de alcohol (uso mediante un modelo caracterizado por signos y síntomas del síndrome de dependencia).

Tanto la Clasificación Internacional de Enfermedades, 10a edición ("CIE-10") como el M anual diagnóstico estadístico de la American Psychiatric Association, 4a edición ("D SM -IV ") especifican criterios diagnósticos para los trastornos relacionados con las drogas y el alcohol. EI DSM -IV emplea el término abuso para describir patrones de uso de drogas y de alcohol que producen alteraciones o trastornos, como interferencia con el trabajo, la escuela, el hogar o las actividades recreativas. Esta definición del término también incluye el uso repetido en situaciones de riesgo físico, como conducir en numerosas ocasiones estando bajo la influencia de drogas o alcohol, incluso aunque no haya sufrido todavía ningún accidente. La CIE-10 emplea el término uso nocivo en vez de abuso y lo define como cualquier patrón de uso de drogas o de alcohol que haya causado daño físico o psicológico real en un individuo que no cumpla los criterios diagnósticos de dependencia de drogas o de alcohol. En algunos casos, el abuso de drogas y de alcohol es una fase precoz o prodrómica de la dependencia. En otros, constituye un modelo independiente de conducta patológica.

Tanto la CIE-10 como el DSM-IV emplean el término dependencia de sustancia psicoactiva para describir un grupo de trastornos en los que existe interferencia con el funcionamiento (en el ámbito laboral, familiar y social) y un deterioro de la capacidad del individuo para controlar el uso de la droga. Algunas sustancias desarrollan una dependencia fisiológica, con un incremento de la tolerancia a la droga (se requieren dosis presumiblemente mayores para obtener los mismos efectos) y un síndrome de abstinencia característico cuando cesa de forma brusca el uso de la droga.

Una definición propuesta recientemente por la American Society of Addiction M edicine y el $\mathrm{N}$ ational Council on A lcoholism and Drug Dependence de Estados Unidos describe las características del alcoholismo (un término empleado habitualmente como sinónimo de dependencia del alcohol) como sigue:

El alcoholismo es una enfermedad crónica primaria con factores genéticos, psicosociales y ambientales que influyen su desarrollo y manifestaciones. Con frecuencia la enfermedad es progresiva y mortal. Se caracteriza por una alteración del control sobre la bebida, preocupación por el alcohol, uso de alcohol a pesar de las consecuencias adversas y trastornos del pensamiento, principalmente, negación. Cada uno de estos síntomas puede ser continuo o periódico. (M orse y Flavin 1992)

La definición continúa explicando los términos empleados, por ejemplo, que la calificación de primaria implica que el alcoholismo es una enfermedad concreta, más que un síntoma de otro trastorno, y que alteración del control significa que la persona afectada no puede limitar de una manera consecuente la duración de un episodio de bebida, la cantidad consumida 0 la conducta resultante. La "negación" se describe como un conjunto de maniobras fisiológicas, psicológicas y de base cultural que disminuyen la capacidad de identificación de los problemas relacionados con el alcohol por parte del individuo afectado. Por lo tanto, es frecuente que las personas que padecen alcoholismo valoren el alcohol como una solución para sus problemas más que como una causa.

Las drogas capaces de producir dependencia se dividen habitualmente en varias categorías, que aparecen enumeradas en la Tabla 15.7. Cada categoría corresponde a un síndrome específico de intoxicación aguda y a una combinación característica de efectos destructivos relacionados con el uso intenso y prolongado. Aunque los individuos por lo general padecen un 
Tabla 15.7 - Sustancias que pueden producir dependencia.

Tipo de droga

Alcohol (cerveza, vino, licores)

Depresores (somníferos, sedantes, algunos tranquilizantes)

Opiáceos (morfina, heroína, codeína, algunos analgésicos con receta)

Estimulantes (cocaína, anfetaminas)

Cannabis (marihuana, hachís)

Alucinógenos [ LSD (dietilamida del ácido lisérgico), PCP (feniciclidina, mescalina]

Inhalantes (hidrocarburos, disolventes, gasolina)

Nicotina (cigarrillos, tabaco de mascar, rapé)

\section{Ejemplos de efectos generales}

Deterioro del juicio, reflejos más lentos, deterioro de la función motriz, somnolencia, coma (la sobredosis puede ser mortal)

Falta de atención, lentitud de reflejos, depresión, alteraciones del equilibrio, somnolencia, coma (la sobredosis puede ser mortal)

Pérdida de interés, "pasotismo", (la sobredosis puede ser mortal). La administración subcutánea 0 intravenosa puede difundir la hepatitis B y C y el VIH/ SIDA por el uso en común de agujas

Animo exaltado, hiperactividad, tensión y ansiedad, frecuencia cardíaca elevada, constricción de los vasos sanguíneos

Alteración del sentido del tiempo, deterioro de la memoria, deterioro de la coordinación

Pérdida de atención, ilusiones sensoriales, alucinaciones, desorientación, psicosis

Intoxicación similar a la del alcohol, vahídos, cefaleas

Estimulación inicial seguida de efectos depresivos

\section{Comentarios}

La abstinencia puede ser difícil; riesgo para el feto si se consume en exceso durante el embarazo

La abstinencia puede ser difícil

La absinencia puede ser dificil

El abuso crónico puede inducir psicosis paranoide. La administración subcutánea 0 intravenosa puede difundir la hepatitis B y C y el VIH/ SIDA por el uso en común de agujas

No causan síntomas de abstinencia, pero los consumidores pueden experimentar "recuerdos" Pueden provocar lesiones orgánicas a largo plazo
(cerebro, hígado, riñón)

Pueden causar síntomas de abstinencia. Provoca varios tipos de cáncer y patologías cardíacas y pulmonares síndrome de dependencia relacionado con una única sustancia (p. ej., heroína), también son frecuentes patrones de abuso y dependencia de múltiples drogas.

L os trastornos relacionados con las drogas y el alcohol afectan a menudo las relaciones familiares del trabajador, a las relaciones interpersonales y a la salud antes de que se pongan de manifiesto los trastornos en el trabajo. Por lo tanto, los programas eficaces en el lugar de trabajo no se pueden limitar a esfuerzos por lograr la prevención del abuso de drogas y de alcohol en el trabajo. Estos programas deben combinar educación sanitaria en los trabajadores y prevención con medios adecuados para la intervención, diagnóstico y rehabilitación así como para el seguimiento a largo plazo de los trabajadores afectados después de su reintegración al medio laboral.

\section{Aproximación a los problemas relacionados con las drogas y el alcohol en el puesto de trabajo}

La preocupación por las importantes pérdidas de productividad causadas por el abuso y dependencia de las drogas y del alcohol ha generado distintos enfoques por parte de gobiernos e industrias. Estos enfoques son las denominadas "políticas de puesto de trabajo libre de drogas" (como pruebas analíticas para la detección de drogas) y programas de asistencia a los trabajadores.

Un ejemplo es el enfoque adoptado por los United States M ilitary Services. A principios de la década de los ochenta, se establecieron políticas contra las drogas y programas de detección de drogas con éxito en cada rama del ejército de EE.UU. Como resultado de su programa, la Marina comunicó un descenso significativo en el porcentaje de pruebas aleatorias de orina realizadas a su personal y que fueron positivas para drogas de abuso. Las tasas de pruebas positivas en menores de 25 años disminuyeron del $47 \%$ en 1982 al $22 \%$ en 1984 y al $4 \%$ en 1986 (D eCresce y cols. 1989). En 1986, el Presidente de Estados Unidos firmó una orden ejecutiva requiriendo que todos los trabajadores del gobierno federal se abstuvieran del uso de drogas de abuso, en el trabajo o fuera de él. Como mayor empleador de Estados Unidos, con más de dos millones de trabajadores civiles, el gobierno federal asumió el liderazgo en el desarrollo de un movimiento nacional de puestos de trabajo libres de drogas.

En 1987, después de un accidente ferroviario mortal asociado al abuso de marihuana, el Departamento de Transportes de los EE.UU. ordenó la realización de un programa de detección de drogas y alcohol a todos los trabajadores del transporte, incluyendo a los del medio privado. Posteriormente se han establecido programas en otros ámbitos laborales, con una combinación de supervisión, análisis, rehabilitación y seguimiento en el puesto de trabajo que ha demostrado constantemente resultados positivos.

El componente de identificación de casos y el de seguimiento de esta combinación, el programa de asistencia al empleado $(P A E)$, se ha convertido en una figura cada vez más frecuente de los programas de salud de los trabajadores. Desde el punto de vista histórico, los PAE proceden de programas más concretos de alcoholismo de trabajadores, pioneros en Estados Unidos durante la década de los años veinte, que se expandieron rápidamente en la década de los cuarenta durante y después de la segunda Guerra M undial. LoS PAE actuales se basan habitualmente en una política de empresa perfectamente delimitada, desarrollada habitualmente de forma conjunta entre la dirección y los trabajadores. Esta política incluye normas de comportamiento aceptable en el puesto de trabajo (p. ej., sin alcohol ni drogas de abuso) y el enunciado de que el alcoholismo, otras drogas y la dependencia de alcohol se consideran enfermedades tratables. I gualmente incluye un compromiso de confidencialidad, garantizando la privacidad de la información personal sensible de los trabajadores. El programa también incluye educación preventiva para todos los trabajadores y una 
formación especial para el personal de supervisión para la identificación de los problemas de cumplimiento del trabajo. No se pretende que los supervisores aprendan a diagnosticar los problemas relacionados con las drogas y el alcohol. En cambio, reciben formación para que remitan a los trabajadores con un cumplimiento problemático del trabajo al PAE, donde se realiza una evaluación y se formula un plan de tratamiento y seguimiento, en función de las necesidades. El tratamiento habitualmente corre a cargo de los recursos de la comunidad fuera del puesto de trabajo. Los informes del PAE mantienen la confidencialidad como una característica de la política de la compañía, informando a la dirección únicamente del grado de cooperación del sujeto y el progreso general que realiza, excepto en casos de peligro inminente. $\mathrm{H}$ abitualmente se suspenden las medidas disciplinarias mientras el trabajador coopere en el tratamiento. I gualmente se anima a que los trabajadores acudan espontáneamente al PAE. LoS PAE que ayudan a los trabajadores con un amplio rango de problemas sociales, de salud mental y relacionados con drogas y alcohol se conocen como programas de "brocha gorda" para distinguirlos de los programas que se centran únicamente en el abuso de drogas y alcohol.

No hay duda de que la prohibición de uso de alcohol y otras drogas en el horario de trabajo o en el lugar de trabajo es una medida apropiada. Sin embargo, el derecho de la empresa a prohibir el uso de dichas sustancias fuera del puesto de trabajo durante las horas fuera del trabajo es un tema discutido. Algunas empresas dicen que "no me importa lo que los trabajadores hagan fuera del trabajo, mientras que sean puntuales y sean capaces de realizar el trabajo correctamente", y algunos representantes de los trabajadores se han opuesto a dicha prohibición por considerarla una intromisión en la privacidad de los trabajadores. Sin embargo, como comenté previamente, el uso excesivo de drogas o alcohol durante horas fuera del trabajo puede afectar al cumplimiento del trabajo. Se trata de un hecho reconocido por las líneas aéreas cuando prohíben el uso de alcohol por las tripulaciones durante un número específico de horas antes de la hora del vuelo. Aunque por lo general se aceptan las prohibiciones de uso de alcohol por parte del trabajador antes de volar o de conducir un vehículo, las prohibiciones globales del uso de tabaco, alcohol o de otras drogas fuera del lugar de trabajo es un tema más controvertido.

\section{Programas de detección de drogas en el lugar de trabajo}

Junto con los PAE, un número creciente de empresas también han instituido programas de determinación de drogas en el puesto de trabajo. Algunos de estos programas determinan únicamente drogas ilegales, mientras que otros realizan determinaciones de alcohol en el aliento o en la orina. Los programas de determinación pueden incluir cualquiera de los siguientes componentes:

- determinaciones previas al ingreso en la empresa;

- determinación aleatoria en trabajadores localizados en puestos especiales (p. ej., operadores de reactores nucleares, pilotos, conductores, operadores de maquinaria pesada);

- determinaciones "con causa" (p. ej., después de un accidente 0 si un supervisor tiene razones fundadas para sospechar que el trabajador está intoxicado):

- determinación como parte de un plan de seguimiento de un trabajador que vuelve al trabajo después de haber realizado tratamiento por abuso o dependencia de drogas o alcohol.

L os programas de determinación de drogas generan responsabilidades especiales en las empresas que los realizan (N ew York Academy of M edicine 1989). Este asunto se aborda con más detenimiento en el capítulo sobre cuestiones éticas de esta E nciclopedia. Si las empresas se basan en determinaciones en orina para tomar decisiones disciplinarias en casos relacionados con drogas, los derechos legales tanto de los empresas como de los trabajadores deben ser protegidos mediante una atención meticulosa a los procedimientos de recogida y análisis, así como a la interpretación de los resultados de laboratorio. Las muestras se deben recoger meticulosamente, y etiquetarlas inmediatamente. D ado que los usuarios de drogas pueden intentar evitar la detección sustituyendo una muestra de orina libre de drogas por la suya o diluyendo su orina con agua, la empresa puede requerir que la muestra se recoja bajo observación directa. D ado que esta medida añade tiempo y costes al procedimiento, puede requerirse únicamente en circunstancias especiales más que de forma generalizada. U na vez recogida la muestra, se inicia un procedimiento de custodia en cadena, documentando cada movimiento de la muestra para evitar su pérdida o identificación errónea. Los procedimientos de laboratorio deben garantizar la integridad de la muestra, con un programa eficaz de control de calidad in situ y contando con profesionales que posean la formación y experiencia adecuadas. La prueba utilizada debe emplear un nivel de corte para la determinación de un resultado positivo que reduzca al mínimo la posibilidad de un resultado falso positivo. Por último, los resultados positivos hallados con métodos de detección selectiva ( $p$. ej., cromatografía de capa fina o técnicas inmunológicas) deben ser confirmadas para eliminar los resultados falsos, preferiblemente mediante las técnicas de cromatografía de gases o de espectrometría de masas, o ambos ( $\mathrm{D}$ eC resce y cols 1989). U na vez que se registra un resultado positivo, un médico del trabajo entrenado (conocido en los Estados U nidos como medical review officer) es el responsable de su interpretación, por ejemplo, descartando que la prescripción de algún medicamento sea la causa de los resultados de la prueba. R ealizados e interpretados correctamente, los análisis de orina son precisos y pueden ser útiles. Sin embargo, las empresas deben calcular las ventajas de dichas pruebas en relación con su coste. Las consideraciones a valorar son la prevalencia del abuso y dependencia de drogas y alcohol en la plantilla a investigar, que influirá en el valor de la determinación previa a la incorporación al trabajo, y la proporción de accidentes laborales, las pérdidas de productividad y los costes de los efectos beneficiosos médicos en relación con el abuso de sustancias psicoactivas.

Otros métodos de detección de problemas relacionados con las drogas y el alcohol

Aunque la determinación en orina es un método de detección selectiva establecido para la detección de drogas de abuso, existen otros métodos a disposición de los PAE, los médicos del trabajo y otros profesionales de la salud. L os niveles de alcohol en sangre se pueden calcular mediante su determinación en el aliento. Sin embargo, una prueba analítica negativa de cualquier clase no descarta un problema de drogas y alcohol. El alcohol y algunas drogas se metabolizan rápidamente y sus efectos posteriores pueden seguir afectando al cumplimiento en el trabajo incluso cuando las drogas ya no se pueden detectar con una prueba. Por otro lado, los metabolitos producidos por el cuerpo humano tras la ingestión de ciertas drogas pueden permanecer en la sangre y en la orina muchas horas después de que los efectos agudos y efectos diferidos de las drogas hayan cesado. U na determinación en orina positiva para metabolitos de una droga no demuestra necesariamente que el trabajo del empleado esté alterado por las drogas.

Al realizar una evaluación de los problemas de los trabajadores relacionados con las drogas y el alcohol se pueden utilizar distintos instrumentos clínicos de detección selectiva (Tramm y Warshaw 1989), como pruebas escritas, como el Michigan Alcohol Screening Test (MAST) (Selzer 1971), el Alcohol U se 
Figura 15.27 - Cuestionario CAGE.

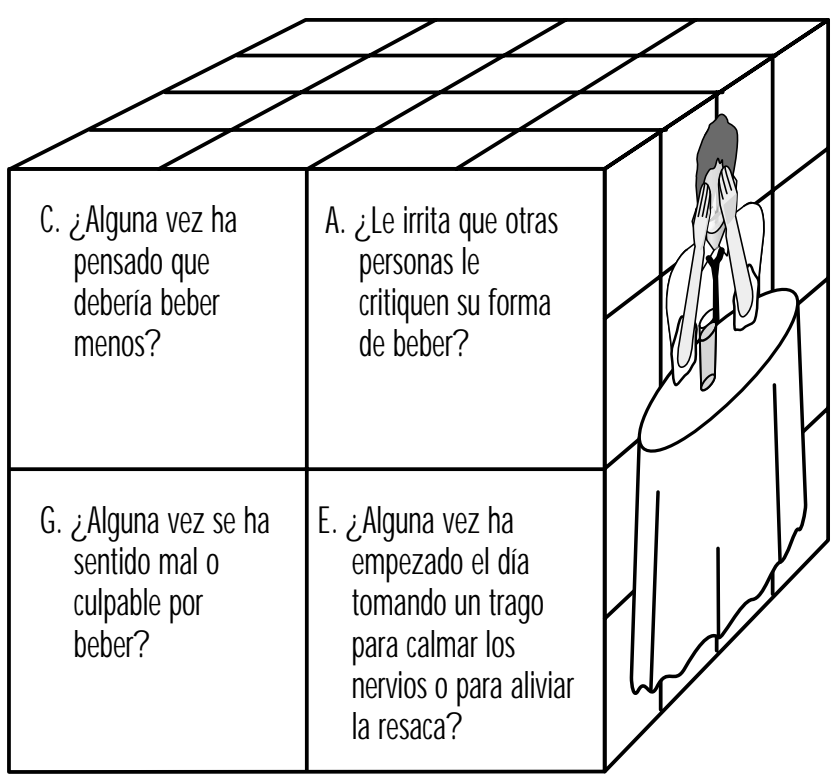

Disorders Identification Test (AUDIT) desarrollado para su uso internacional por la O rganización M undial de la Salud (Saunders y cols 1993) y el Drug Abuse Screening Test (DAST) (Skinner 1982). Además, existen un conjunto de preguntas sencillas que se pueden incorporar a la recopilación de la anamnesis, por ejemplo, las cuatro preguntas CAGE (Ewing 1984), representadas en la Figura 15.27. LoS PAE emplean todos estos métodos para evaluar a los trabajadores que les son remitidos. Los trabajadores remitidos por problemas de cumplimiento de su trabajo, como ausencias, impuntualidad y disminución de la productividad en el trabajo, deben ser evaluados en busca de otros problemas de salud mental, como depresión o ludopatía, que también pueden producir trastornos en el cumplimiento del trabajo y que con frecuencia se asocian a trastornos relacionados con las drogas y el alcohol (Lesieur, Blume y Zoppa 1986). Con respecto a la ludopatía, existe una prueba escrita de detección selectiva, el South $\mathrm{O}$ aks Gambling Screen (SOGS) (Lesieur y Blume 1987).

\section{Tratamiento de los trastornos relacionados con el uso de drogas y de alcohol}

Aunque cada trabajador presenta una combinación única de problemas al profesional encargado del tratamiento de la adicción, el tratamiento de los trastornos relacionados con el uso de drogas y alcohol consiste habitualmente en cuatro fases que se solapan: 1) identificación del problema y (si es necesario) intervención, 2) desintoxicación y evaluación del estado general de salud, 3) rehabilitación y 4) seguimiento a largo plazo.

\section{Identificación e intervención}

La primera fase del tratamiento consiste en confirmar la presencia de un problema causado por el uso de drogas o de alcohol (o ambos), que motiva al individuo afectado a solicitar tratamiento. EI programa de salud de los empleados o el PAE de la compañía tiene la ventaja de utilizar la preocupación de los trabajadores por la salud y la seguridad en el trabajo como factores de motivación. Es probable que los programas del puesto de trabajo entiendan el ambiente de los trabajadores y sus puntos fuertes y débiles, y que por ello puedan elegir la institución terapéutica más adecuada para su derivación. Una consideración importante al remitir a un trabajador para su tratamiento es la naturaleza y extensión de la cobertura del seguro de salud del lugar de trabajo para el tratamiento de los trastornos inducidos por el alcohol y las drogas. Las políticas con cobertura total de los tratamientos hospitalarios ambulatorios ofrecen las fórmulas más flexibles y eficaces. Además, con frecuencia resulta útil involucrar a la familia del trabajador en esta fase de la intervención.

\section{Desintoxicación y evaluación del estado general de salud}

La segunda fase combina el tratamiento adecuado necesario para ayudar al trabajador a lograr un estado libre de drogas y alcohol con una evaluación completa de los problemas físicos, psicológicos, familiares, interpersonales y relacionados con el trabajo del paciente. La desintoxicación requiere un período breve (varios días o varias semanas) de observación y tratamiento para la eliminación del abuso de drogas, la recuperación de sus efectos agudos y el control de cualquier síntoma de abstinencia. Durante el período de desintoxicación y evaluación de actividades, el paciente y sus "allegados" reciben información sobre la naturaleza de la dependencia y la recuperación de las drogas y del alcohol. Se les introduce a ellos y al paciente en los principios de los grupos de autoayuda, cuando se pueda utilizar esa modalidad, y se motiva al paciente a continuar el tratamiento. La desintoxicación se puede realizar de forma ambulatoria u hospitalaria, dependiendo de las necesidades del individuo. Las técnicas terapéuticas que han resultado ser útiles abarcan distintos fármacos, suplementados con asesoramiento, entrenamiento en técnicas de relajación y otras técnicas de comportamiento. Los agentes farmacológicos empleados en la desintoxicación son fármacos que pueden sustituir a la droga de abuso para aliviar los síntomas de abstinencia, reduciendo gradualmente la dosis hasta que el paciente esté libre de la droga. El fenobarbital y las benzodiazepinas de acción prolongada se utilizan con frecuencia de esta forma para conseguir la desintoxicación en el caso de uso de alcohol y de drogas sedantes. Se emplean otros fármacos para aliviar los síntomas de abstinencia sin sustituir la droga de abuso que ejerce un efecto similar. Por ejemplo, en ocasiones se emplea la clonidina para el tratamiento de los síntomas de abstinencia a opiáceos. También se ha empleado la acupuntura como ayuda para la desintoxicación, con algunos resultados positivos (M argolin y cols. 1993).

\section{Rehabilitación}

La tercera fase del tratamiento combina la ayuda al paciente para crear una situación estable o estado permanente de abstinencia continuada de todas las sustancias de abuso (incluidos los fármacos recetados que pueden causar dependencia) y el tratamiento de cualquier problema físico o psicológico asociado a trastorno relacionado con las drogas. EI tratamiento se puede iniciar ingresando al paciente o realizando una terapia ambulatoria intensiva, aunque lo más característico es que continúe de forma ambulatoria durante varios meses. Se puede combinar el asesoramiento de grupo, individual o familiar con técnicas conductuales junto con el tratamiento psiquiátrico, que puede incluir medicación. Los objetivos son ayudar a los pacientes a entender sus patrones de uso de drogas o alcohol, identificar los desencadenantes de la recidiva después de los esfuerzos realizados durante la recuperación, ayudarles a desarrollar patrones de afrontamiento libres de drogas para enfrentarse a los problemas en la vida y ayudarles a integrarse en una red de apoyo social limpia y sobria en la comunidad. En algunos casos de dependencia de opiáceos, el tratamiento de elección es la administración a largo 
plazo de opiáceos sintéticos de larga acción (metadona) o de un fármaco bloqueante de los receptores opiáceos (naltrexona). Algunos médicos recomiendan el mantenimiento de una dosis diaria de metadona, un opiáceo de larga acción, en los individuos con adicción crónica a opiáceos que no desean o son incapaces de conseguir un estado libre de drogas. Los pacientes mantenidos de forma estable con metadona durante períodos prolongados son capaces de actuar correctamente a nivel laboral. En muchos casos, estos pacientes pueden llegar a desintoxicarse y a permanecer libres de drogas. En dichos casos, el mantenimiento se combina con el asesoramiento, los servicios sociales y otros tratamientos rehabilitadores. La recuperación se define en términos de abstinencia estable de todas las drogas, aparte de la de mantenimiento.

\section{Seguimiento a largo plazo}

La fase final del tratamiento continúa de forma ambulatoria durante un año o más después de que se obtiene una remisión estable. El objetivo del seguimiento a largo plazo es prevenir la recidiva, y ayudar al paciente a internalizar los nuevos patrones de afrontamiento de los problemas de la vida. EL PAE o el servicio de salud laboral pueden ser de gran ayuda durante las fases de rehabilitación y de seguimiento vigilando la cooperación con el tratamiento, animando al empleado recuperado a mantener la abstinencia y ayudándoles a readaptarse al puesto de trabajo. Allí donde existan los grupos de soporte al grupo (por ejemplo, Alcohólicos Anónimos o Narcóticos Anónimos) proporcionan un programa de apoyo a lo largo de toda la vida para conservar la recuperación. Dado que la dependencia de las drogas o el alcohol es un trastorno crónico en el que pueden aparecer recidivas, la política de las empresas a menudo exige seguimiento y vigilancia por parte del PAE durante un año o más después de que se establece la abstinencia. Si un trabajador recidiva, el PAE habitualmente reevalúa la situación y realiza alguna modificación en el plan de tratamiento. Dichas recidivas, si son breves y se siguen con una vuelta a la abstinencia, habitualmente no representan un fracaso global del tratamiento. Los trabajadores que no cooperan con el tratamiento, que niegan sus recidivas a pesar de la evidencia o que no pueden mantener una abstinencia estable seguirán mostrando un cumplimiento inadecuado en el trabajo y pueden ser despedidos del trabajo sobre dicha base.

\section{Eficacia de los programas basados en el puesto de trabajo}

En muchas empresas, la inversión en programas basados en el puesto de trabajo para enfrentarse con los problemas relacionados con las drogas y el alcohol ha producido beneficios. Un ejemplo de lo anterior es un estudio de 227 trabajadores de una gran empresa de EE.UU. que fueron enviados por el PAE de la empresa para el tratamiento de alcoholismo. Los empleados fueron aleatoriamente asignados a tres modelos de tratamiento: (1) atención hospitalaria obligatoria; (2) asistencia obligatoria a Alcohólicos A nónimos (AA); o (3) elección entre atención hospitalaria, ambulatoria o AA. El seguimiento al cabo de dos años reveló que solamente el $13 \%$ de los trabajadores habían sido despedidos. Del resto, menos del $15 \%$ presentaba problemas en el trabajo y el $76 \%$ fueron considerados "buenos" o "excelentes" por sus supervisores. El tiempo de ausencia del trabajo disminuyó en más de la tercera parte. Aunque se encontraron ciertas diferencias entre los enfoques terapéuticos, los resultados de trabajo a los dos años fueron similares en los tres modelos (Walsh y cols. 1991).

\section{El abuso de sustancias entre las mujeres}

Aunque los cambios sociales han reducido las diferencias entre hombres y mujeres en algunos aspectos, el abuso de sustancias se ha considerado tradicionalmente un problema masculino, pues se percibía como incompatible con la función social de la mujer. Por tanto, mientras que el abuso de sustancias por parte del hombre podía excusarse y hasta perdonarse, como parte aceptable de la naturaleza del varón, era estigmatizado cuando afectaba a las mujeres. Puede afirmarse que esta actitud ha evitado que muchas mujeres consuman drogas, pero en muchas sociedades también ha dificultado extraordinariamente a las toxicómanas la búsqueda de ayuda.

Las actitudes negativas frente al consumo de drogas por parte de las mujeres, combinadas con la dificultad de éstas a admitir su consumo y dependencia, explican la escasez de datos referidos específicamente a las mujeres. Incluso en países con mucha información sobre consumo de drogas y las toxicomanías suele ser difícil encontrar datos relativos a las mujeres. En los estudios que han analizado la función de las mujeres en el consumo de drogas, el enfoque no es específico a características concretas de este sexo; esto enturbia las conclusiones, pues se contempla el problema de la mujer desde el punto de vista del varón.

0 tro factor vinculado con la idea del abuso de sustancias como problema masculino es la falta de servicios para las mujeres consumidoras (... ). Los servicios de tratamiento y rehabilitación, cuando los hay, suelen basarse en los modelos masculinos de dependencia. Si se crean servicios dirigidos a las mujeres, es evidente que han de ser accesibles, y esto no siempre es fácil cuando el consumo entre las mujeres se estigmatiza y cuado el coste del tratamiento está fuera del alcance de la mayor parte de ellas.

Citado de: O rganización M undial de la Salud 1993.

La M arina de los EE.UU. ha calculado que sus programas de rehabilitación hospitalaria de drogas y alcohol han obtenido una relación global de beneficio económico frente al coste de 12,9 a 1. Esta cifra fue calculada comparando el coste del programa con los costes que habría supuesto la sustitución de los participantes rehabilitados en el programa con personal nuevo (Caliber Associates 1989). La M arina encontró que la relación beneficio-coste fue más elevado en los mayores de 26 años de edad $(17,8$ a 1$)$ en comparación con personal más joven $(8,2$ a 1$)$ y halló que el mayor beneficio se centraba en el tratamiento del alcoholismo (13,8 a 1) frente a otras drogas (10,3 a 1) o al tratamiento de la dependencia de múltiples drogas (6,8 a 1). No obstante, el programa generó ahorros económicos en todas las categorías.

En general, se ha demostrado que los programas basados en el puesto de trabajo para la identificación y rehabilitación de trabajadores que padecen problemas relacionados con el alcohol y otras drogas benefician tanto a las empresas como a los trabajadores. Se han adoptado versiones modificadas de los programas de PAE por parte de organizaciones profesionales como sociedades médicas, asociaciones de enfermería y asociaciones de juristas (asociaciones de abogados). Dichos programas reciben informes confidenciales sobre posibles signos de deterioro de un profesional procedente de sus compañeros, familiares, clientes o trabajadores. La intervención directa (cara a cara) la llevan a cabo compañeros de grupo y si se requiere tratamiento, el programa realiza la derivación adecuada. 
Posteriormente, vigila la recuperación del individuo y ayuda al profesional responsable de la recuperación a enfrentarse con los problemas prácticos y de concesión de permisos (M eck 1992).

\section{Conclusión}

El alcohol y las demás drogas psicoactivas son causas importantes de problemas en el puesto de trabajo en muchos lugares del mundo. Aunque el tipo de droga empleada y la vía de administración pueden variar de un lugar a otro, y en función del tipo de industria, el abuso de drogas y alcohol genera riesgos sanitarios y de seguridad a los usuarios, a sus familias, a los demás trabajadores y, en muchas ocasiones, al público. La comprensión de los tipos de problemas relacionados con el alcohol y las drogas que existen en una empresa dada y de los recursos de intervención y tratamiento presentes en la comunidad permitirá el desarrollo de programas de rehabilitación. Estos programas proporcionan efectos beneficiosos a los trabajadores, empresas, familias y al conjunto de la sociedad en la que surgen dichos problemas.

\section{- Programas de asistencia a los EMPLEADOS}

Sheila H. Akabas

\section{Introducción}

Las empresas contratan trabajadores y los sindicatos aceptan miembros, pero ambos reciben a seres humanos, que trasladan al lugar de trabajo todas las preocupaciones, problemas y sueños característicos de la condición humana. Como el mundo laboral es cada vez más consciente de que la ventaja competitiva en una economía global depende de la productividad de la plantilla, los agentes fundamentales del lugar de trabajo - las empresas y los sindicatos - han prestado especial atención a satisfacer las necesidades de esos seres humanos. En los lugares de trabajo de todo el mundo han aparecido Programas de Asistencia a los Empleados (PAE) y su equivalente en el campo sindical, los Programas de Asistencia a los M iembros (PAM ); a partir de ahora designaremos a ambos, de forma conjunta, como PAE. Estos programas constituyen una respuesta estratégica para satisfacer las diversas necesidades de una plantilla y, en fechas más recientes, para cumplir con la vertiente humanista de las organizaciones a las que pertenecen. En este artículo se describen los orígenes, funciones y organización de los PAE; está escrito desde el punto de vista profesional del trabajador social, que es la principal profesión que impulsa esta evolución en Estados U nidos y la que, por sus conexiones a nivel mundial, desempeña un papel fundamental en el establecimiento de estos programas en todo el mundo.

Los programas de asistencia a los empleados han alcanzado un desarrollo distinto según los países, lo cual refleja, como ha señalado David Bargal (Bargal 1993), las diferencias del nivel de industrialización, el estado de la formación profesional a la que tiene acceso el personal correspondiente, el grado de afiliación sindical de los trabajadores y el compromiso de la sociedad con los problemas sociales, entre otras variables. Comparando la evolución de los PAE en Australia, los Países Bajos, Alemania e Israel, llega a la conclusión de que, si bien es posible que la industrialización sea una condición necesaria para alcanzar un nivel elevado de PAE y PAM en los puestos de trabajo de un país, puede que no sea suficiente. Además, estos programas son característicos de sociedades con un alto grado de afiliación sindical, una intensa cooperación paritaria en las relaciones laborales y un sector de servicios muy desarrollado, en las que la Administración pública desempeña un papel decisivo. Existe además la necesidad de una cultura profesional, apoyada por una especialización académica que promueva y difunda los servicios sociales en el lugar de trabajo. Por último, Bargal afirma que, cuanto mayor sea la suma de estas características en un país determinado, más probabilidades habrá de que exista una amplia oferta de PAE en sus centros de trabajo.

La misma diversidad se observa comparando programas de un mismo país desde el punto de vista de su estructura, dotación de personal, enfoque y alcance. No obstante, todos los PAE tienen un tema común. Las partes que están presentes en el lugar de trabajo pretenden prestar servicios que solucionen los problemas de los trabajadores, que a menudo no guardan una relación causal con su trabajo pero interfieren con su productividad laboral y aun con su bienestar general. Algunos observadores han notado una evolución en las actividades de los PAE que, si bien al principio se dedicaban quizás a controlar el abuso de alcohol y drogas entre los trabajadores, con el tiempo han extendido su interés a todos ellos como individuos, y los propios trabajadores se han convertido en uno de los elementos, en un enfoque doble que abarca también la organización.

Este enfoque organizativo refleja el reconocimiento de que numerosos trabajadores están en "situación de riesgo" de no poder mantener su papel en el trabajo y de que este "riesgo" depende tanto de la forma en que está organizado el mundo laboral como de las características individuales de cada trabajador. Por ejemplo, los trabajadores de más edad están en situación de riesgo si cambia la tecnología relacionada con su puesto de trabajo y, por su edad, se les impide el acceso a la reconversión profesional. Los padres solos y quienes han de cuidar de ancianos "están en situación de riesgo" si su entorno laboral es tan rígido que no admite ninguna flexibilidad de horario en caso de enfermedad de las personas que tienen a su cargo. Una persona discapacitada "está en situación de riesgo" cuando cambia su trabajo y no se le ofrece la posibilidad de adaptarse para actuar de acuerdo con los nuevos requisitos. Al lector se le ocurrirán muchos ejemplos más. Lo significativo es que, ante la posibilidad de cambiar al individuo, el entorno o alguna combinación de ambos, es cada vez más evidente que no se puede lograr una organización laboral productiva y rentable sin tener en cuenta la interacción entre la organización y el individuo.

El trabajo social se apoya en un modelo del individuo en su entorno. La correspondiente definición de la situación de "riesgo" destaca la posible aportación de los profesionales. Tal como indican Googins y Davidson, el PAE aporta una serie de problemas y cuestiones que afectan no sólo a los individuos, sino también a las familias, las empresas y las comunidades respectivas (Googins y Davidson 1993). C uando un trabajador social con una perspectiva organizativa y ambiental trabaja en un $P A E$, se encuentra en una posición única para conceptualizar intervenciones que promuevan no sólo el papel del PAE en la prestación de servicios al individuo, sino también en el asesoramiento sobre políticas organizativas en el lugar de trabajo.

\section{Evolución de los PAE}

La prestación de servicios sociales en el lugar de trabajo se remonta a la época de la industrialización. En los talleres de artesanos que caracterizaban el período anterior, los grupos de trabajo eran reducidos y se establecía una relación íntima entre el maestro artesano y sus oficiales y aprendices. En las primeras fábricas, los grupos ya eran más numerosos y las relaciones entre la empresa y los trabajadores se hicieron más impersonales. A medida que empezaron a aparecer problemas que afectaban el rendimiento de los trabajadores, la empresa comenzó a poner a su disposición personas (que solían recibir el nombre de asistentes sociales) que ayudaban a los trabajadores procedentes de entornos rurales y a veces a los inmigrantes recién llegados 
durante el proceso de adaptación a un lugar de trabajo formalizado.

Esta tendencia al empleo de trabajadores sociales y de otros prestadores de servicios humanos para lograr la adaptación de los nuevos habitantes a las demandas del trabajo fabril prosigue en todo el mundo hasta nuestros días. En varios países, como Perú y la India, en todos los ámbitos laborales que superen un número determinado de empleados debe haber un trabajador social. Estos profesionales han de responder a las necesidades cotidianas de los trabajadores recién contratados, procedentes del medio rural, como las de vivienda y alimentación, además de todo lo relacionado con las enfermedades, accidentes de trabajo, muertes y entierros.

A medida que han ido evolucionado las dificultades inherentes al mantenimiento de una plantilla productiva, han aparecido distintos grupos de cuestiones que requieren un tratamiento algo diferente. Es probable que los PAE representen una ruptura con el antiguo modelo del asistente social, por cuanto es más evidente que son una solución programada a problemas como los del alcoholismo. Presionadas por la necesidad de maximizar la productividad durante la segunda Guerra M undial para hacer frente a las pérdidas provocadas por el abuso de alcohol entre los trabajadores, las empresas establecieron programas profesionales contra el alcoholismo en los principales centros de producción de los aliados. Después de la guerra se reconocieron las enseñanzas de esos esfuerzos y el consiguiente aumento de la productividad de los trabajadores afectados. D esde entonces, ha habido en todo el mundo un incremento lento pero constante de los programas de prestación de servicios que aprovechan el lugar de empleo como centro de apoyo para solucionar problemas que inducen importantes descensos de la productividad.

$\mathrm{H}$ a contribuido a esta tendencia el desarrollo de empresas multinacionales que tienden a reproducir en todas sus instalaciones los effuerzos por la efectividad o los sistemas legalmente exigidos sin apenas considerar la importancia de los programas en sí, o su idoneidad cultural para el país concreto en que se asienta el centro. Por ejemplo, IOS PAE de Sudáfrica son parecidos a los de Estados U nidos; tal estado de cosas es atribuible en parte a que los primeros PAE se establecieron en los puestos de avanzada en empresas multinacionales cuya sede central se encontraba en Estados U nidos. Este cruce cultural ha sido positivo porque ha favorecido la imitación de lo mejor de cada país a escala mundial. Tenemos un ejemplo en el tipo de acción preventiva relacionada con las cuestiones de acoso sexual o de diversidad de las plantillas surgidas en Estados U nidos y que se ha convertido en la norma a la cual se supone que deben adherirse las instalaciones de las empresas estadounidenses en el mundo entero, las cuales, a su vez, sirven de modelo a las empresas locales para establecer iniciativas similares.

\section{La justificación de los PAE}

L OS PAE se diferencian por su grado de evolución, sus principios subyacentes o la definición de los problemas que han de atender y los servicios que se consideran aceptables como respuesta. Sin embargo, la mayoría de los observadores coinciden en que tales actuaciones en el trabajo tienen un alcance más amplio en los países en los que ya se han establecido estos servicios, mientras que son incipientes en los demás. Como ya hemos señalado, un motivo de la expansión puede ser el amplio reconocimiento de que el abuso de drogas y del alcohol en el lugar de trabajo constituye un problema significativo que ocasiona la pérdida de tiempo y cuantiosos gastos médicos y que afecta gravemente a la productividad.

En todo caso, los PAE han evolucionado en respuesta a una amplia variedad de condiciones cambiantes que van más allá de las fronteras nacionales. Obligados a ofrecer ventajas para mantener la fidelidad de sus miembros, los sindicatos les han dado una acogida favorable. La legislación sobre discriminación positiva, permiso familiar, indemnización en caso de accidente de trabajo y reforma asistencial contempla el lugar de trabajo desde la perspectiva de los servicios humanos. La habilitación de la población activa y la búsqueda de la igualdad entre los sexos, que son necesarias para que los trabajadores actúen con eficacia en el ambiente colectivo de la máquina de producción moderna, son objetivos que quedan bien servidos mediante la oferta de sistemas de prestación de servicios sociales universales en el mundo laboral. Estos sistemas contribuyen además a la formación y retención de una plantilla de calidad. Asimismo los PAE han llenado el vacío que existe, y que parece ir en aumento, en los servicios comunitarios de muchos países. La difusión y el deseo de contener el SIDA, así como el creciente interés por la prevención, el bienestar y la seguridad en general, han apoyado el papel educativo de los PAE en los lugares de trabajo del mundo entero.

L OS PAE han demostrado ser un recurso valioso para que los lugares de trabajo respondan a las presiones de las tendencias demográficas. $\mathrm{H}$ a habido que prestar atención a ciertos cambios, como el aumento de los hogares monoparentales, a la expansión del trabajo de la mujer y al incremento del número de familias en que trabajan los dos padres. El envejecimiento de la población y el interés por reducir la dependencia de la beneficencia a través del trabajo de la madre, notorios en la mayoría de los países industrializados, han supuesto la asignación al lugar de trabajo de funciones que requieren la asistencia de entidades responsables de la prestación de servicios humanos. También el problema del abuso de drogas y alcohol, que ha alcanzado proporciones epidémicas en numerosos países, ha sido motivo de gran preocupación para las organizaciones de trabajo. Según una encuesta de opinión acerca de la crisis de las drogas en 1994 en comparación con el lustro anterior, el $50 \%$ de los encuestados opinaba que había aumentado mucho, un $20 \%$ que había aumentado un poco, apenas un $24 \%$ consideraba que no había variado, y al $6 \%$ restante le parecía que había disminuido. Si bien cada una de estas tendencias varía según el país, todas se dan en todos los países. La mayoría son características del mundo industrializado. M uchas se observan en países en vías de desarrollo en los que existe algún grado significativo de industrialización.

\section{Las funciones de los PAE}

El establecimiento de un PAE es una decisión organizativa que representa un desafío para el sistema vigente. $D$ a a entender que en el lugar de trabajo no se ha prestado suficiente atención a las necesidades de los individuos y confirma la obligación, por parte de la empresa y de los sindicatos, por su propio interés organizativo, de responder a las amplias fuerzas que actúan en la sociedad. Se trata de una oportunidad para llevar a cabo un cambio organizativo. Aunque es posible que encuentre resistencias, como ocurre en todas las situaciones que pretenden un cambio global, las tendencias antes descritas justifican la capacidad de los PAE para ofrecer tanto servicios de asesoramiento como de defensa para los individuos y de formular recomendaciones sobre política para las organizaciones.

Los tipos de funciones que brindan IOS PAE son un reflejo de las cuestiones que pretenden solucionar. Es probable que todos los programas existentes hagan referencia al abuso de drogas y al alcohol. En tal sentido, las intervenciones suelen incluir la evaluación, la remisión, la formación de supervisores y el funcionamiento de grupos de apoyo para mantener el empleo y estimular la abstinencia. No obstante, el temario de los servicios de la mayoría de los PAE es más amplio, y los programas ofrecen asesoramiento para las personas que tienen problemas 
conyugales o dificultades con sus hijos, que necesitan ayuda para conseguir guarderías o canguros, o que han de tomar una decisión con respecto a la atención de un familiar de edad avanzada. Algunos PAE abordan también cuestiones relacionadas con el entorno laboral. En consecuencia, ayudan a las familias a adaptarse a un cambio de trabajo, a los empleados de bancos que han sido atracados y precisan ayuda para superar el trauma, a los equipos que trabajan en casos de catástrofes, o a los trabajadores de la salud que han estado expuestos accidentalmente al VIH. También ofrecen asistencia para hacer frente a la "reconversión", tanto respecto a los empleados que han sido despedidos como a los que han sobrevivido al despido. Asimismo se puede recurrir a loS PAE para poner en práctica un cambio organizativo que satisfaga los objetivos de discriminación positiva o que sirva para resolver los casos en que hay que encontrar alojamiento y facilitar el regreso al trabajo de los empleados que sufren alguna discapacidad. Se han utilizado PAE también en actividades preventivas, como en la formación de hábitos de buena alimentación o el abandono del tabaco, la participación en programas de ejercicios u otro tipo de actividades de mejora de la salud, y la oferta de iniciativas educativas que abarcan desde programas sobre la paternidad hasta la preparación para la jubilación.

Si bien estas respuestas de loS PAE son multifacéticas, encontramos características similares en programas tan distantes como algunos de $\mathrm{H}$ ong $\mathrm{K}$ ong y de Irlanda. Estudiando muestras no aleatorias de empresas, sindicatos y contratistas estadounidenses que brindan servicios de PAE sobre el abuso de drogas y de alcohol, por ejemplo, Akabas y $\mathrm{H}$ anson (1991) comprobaron que, en diversas industrias, con distintos antecedentes y diversos auspicios, todos los planes presentan importantes coincidencias. Los investigadores esperaban hallar una amplia variedad de respuestas creativas para atender las necesidades de cada lugar de trabajo $y$, sin embargo, encontraron una uniformidad sorprendente en los programas y prácticas. En una conferencia internacional de la Organización Internacinoal del Trabajo (O IT ) celebrada en Washington D.C. con el fin de comparar las iniciativas nacionales, se confirmó un grado similar de uniformidad en toda Europa occidental (A kabas y H anson 1991).

Los encuestados de empresas y sindicatos de Estados U nidos coincidieron en que la legislación influye significativamente en la determinación de los componentes de sus programas y en los derechos y las expectativas de las poblaciones correspondientes. La mayoría de los gestores de estos programas son profesionales, fundamentalmente trabajadores sociales. Colaboran con tipos de trabajadores muy variados y a menudo también con sus familiares, brindando servicios que ofrecen soluciones diversas a diferentes problemas, aparte de la cuestión fundamental de la rehabilitación de los adictos a las drogas o el alcohol. La mayoría de los programas superan la falta de atención de la alta dirección y la insuficiente preparación y colaboración de los supervisores, logrando una penetración de entre el $3 \%$ y el $5 \%$ del total de trabajadores en el lugar indicado. Los profesionales de los PAE y los PAM parecen coincidir en que la confidencialidad y la confianza son fundamentales para que el servicio resulte efectivo. $\mathrm{H}$ an sido eficaces, afirman, en relación con los problemas de abuso de drogas y de alcohol, aunque apenas pueden indicar unos pocos estudios de evaluación que confirmen la eficacia de su intervención en relación con cualquier aspecto de la prestación de servicios.

Ciertas estimaciones indican que en la actualidad funcionan unos 10.000 PAE sólo en Estados Unidos. Se distinguen dos sistemas principales de prestación de servicios: los que están dirigidos por personal interno y los que gestiona un servicio externo que ofrece servicios a numerosas organizaciones de trabajo (empresas y sindicatos). Los méritos respectivos son objeto de vivos debates. Entre las ventajas de los programas externos cabe mencionar la mayor protección de la confidencialidad y la mayor diversidad de personal con funciones claramente definidas, que no se diluyan en otras actividades. Los defensores de los programas internos señalan la ventaja que les brinda su puesto para llevar a cabo una intervención efectiva a nivel global y la influencia adquirida con respecto a la formulación de políticas como consecuencia de su conocimiento y participación en la organización. Puesto que cada vez se valoran más las iniciativas que afectan a toda una organización, es probable que los programas internos sean mejores para las empresas que cuenten con demanda suficiente (como mínimo, un millar de trabajadores) para justificar un puesto de trabajo a tiempo completo. C omo señalan G oogins y D avidson (1993), este sistema facilita el acceso a los trabajadores, debido a la variedad de servicios que se pueden ofrecer y a la oportunidad de influir en los responsables de la formulación de políticas, y permite la colaboración e integración de la función del PAE con el resto de la organización; todas estas posibilidades refuerzan el valor y el papel de los PAE.

\section{Cuestiones laborales y familiares: relación con Ios PAE}

La interacción de los PAE, a lo largo del tiempo, con cuestiones laborales y familiares brinda un ejemplo informativo de la evolución de estos programas y de su posible influencia a nivel individual y organizativo. En términos históricos, IOS PAE evolucionaron durante el período en que se produjo el acceso masivo al mercado de trabajo de las mujeres, sobre todo madres solteras y madres de niños de corta edad. Estas mujeres experimentaban a menudo una tensión entre las exigencias de cuidado de las personas a su cargo - ya fueran niños o personas de edad avanzada - y los requerimientos del trabajo en un entorno laboral en el que se consideraba que los roles laborales y familiares debían estar separados, y en el que la empresa se mostraba hostil frente a la necesidad de flexibilidad con respecto a las cuestiones laborales y familiares. EI personal de los PAE observó que las mujeres que sufrían estrés se deprimían y a veces, para resolver la situación, recurrían al abuso de drogas o de alcohol. La primera reacción de los PAE fue el asesoramiento sobre este abuso, la educación sobre la organización del tiempo y la remisión a los servicios de cuidados de niños y ancianos.

A medida que aumentó el número de clientes con los mismos problemas, Ios PAE llevaron a cabo una evaluación de necesidades que aconsejó buscar soluciones colectivas en vez de individuales ofreciendo, por ejemplo, sesiones de grupo sobre la gestión del estrés. Sin embargo, tampoco este método sirvió para resolver los problemas. Teniendo en cuenta que las necesidades cambian durante el ciclo vital, los PAE comenzaron a considerar a sus clientes como grupos humanos con distintos requerimientos en función de su edad. Los padres jóvenes precisaban un horario flexible para ocuparse de sus hijos cuando estaban enfermos e información sobre los centros de cuidado de los hijos. Los de más edad, entre treinta y cinco y casi cincuenta años, se identificaban como la "generación intermedia", sujeta a la doble demanda de los hijos adolescentes y los familiares de edad avanzada, con lo cual aumentaba su necesidad de servicios de apoyo variados: educación, remisiones, permisos, asesoramiento familiar y asistencia sobre abstinencia, entre otros. Las crecientes presiones que experimentaban los trabajadores cuando envejecían y se enfrentaban al comienzo de su incapacidad, a la necesidad de adaptarse a un mundo laboral en el cual casi todos los compañeros de trabajo, e incluso los propios supervisores, eran más jóvenes que ellos, mientras se planteaban la jubilación y el cuidado de los familiares ancianos y débiles (y a 
veces de los nietos), creaban otro conjunto de cargas. Como consecuencia del seguimiento de estas necesidades individuales, se llegó a la conclusión de que hacía falta un cambio en la cultura del lugar de trabajo que integrara la vida laboral y familiar de los trabajadores.

Esta evolución ha llevado directamente a la configuración del papel actual de los PAE con respecto al cambio organizativo. Durante el proceso de satisfacción de las necesidades individuales, es probable que el PAE haya adquirido credibilidad dentro del sistema y que se le reconozca como fuente de conocimientos sobre cuestiones laborales y familiares. A simismo, habrá desempeñado un papel educativo e informativo en respuesta a las preguntas planteadas por los directivos en numerosos departamentos afectados por los problemas que surgen cuando estos dos aspectos de la vida humana entran en conflicto entre sí. Es probable que el PAE haya colaborado con muchos sectores, como los responsables de la discriminación positiva, los expertos en relaciones laborales, los representantes sindicales, los especialistas en formación, el personal sanitario y de seguridad, los gestores del riesgo y el resto del personal de recursos humanos, o los supervisores.

EI análisis del campo de fuerzas, técnica propuesta por K urt L ewin (1951) en el decenio de 1950, sirve de marco para definir las actividades que se requieren para suscitar un cambio organizativo. El profesional de la salud en el trabajo debe saber dónde encontrará apoyo para resolver de forma sistemática las cuestiones laborales y familiares, y dónde podría encontrar oposición. El análisis del campo de fuerzas identifica dentro de la empresa, el sindicato o el órgano público las figuras principales que influyen en el cambio y resume las fuerzas impulsoras y restrictivas que influyen sobre ellas en relación con la política laboral y familiar.

En una modalidad más compleja del enfoque organizativo de las cuestiones laborales y familiares, se asigna al PAE la participación en un comité responsable de fijar una política que ha de tener en cuenta el doble interés de los empleados por ser al mismo tiempo trabajadores productivos y participantes familiares efectivos. Esta política debe señalar el compromiso de la organización de establecer un clima y una cultura laboral flexibles para que ambos papeles coexistan en armonía. A continuación se pueden especificar una serie de beneficios y programas para cumplir tal compromiso que incluyan, entre otros, un horario laboral flexible, opciones de trabajo compartido y contratación a tiempo parcial, subsidios para guarderías o guarderías en el lugar de trabajo, y servicios de asesoramiento y remisión para atender otras necesidades de los niños y los ancianos, permisos familiares con y sin sueldo en caso de enfermedad de un familiar, becas para la educación de los hijos y para que los propios trabajadores continúen sus estudios, y sistemas de asesoramiento individual y apoyo grupal para los distintos problemas que afecten a los familiares. Estas múltiples iniciativas relacionadas con cuestiones laborales y familiares se combinan para proponer una respuesta total individual y ambiental a las necesidades de los trabajadores y sus organizaciones laborales.

\section{Conclusiones}

$\mathrm{H}$ ay amplias pruebas empíricas de que estas prestaciones ayudan a los trabajadores a alcanzar la meta del empleo productivo. Sin embargo, tales ventajas corren el riesgo de convertirse en programas costosos y de no ofrecer ninguna garantía de que el trabajo se realice de forma eficaz y eficiente. Al igual que los PAE que las fomentan, las prestaciones laborales y familiares se deben evaluar en función de su contribución a la eficacia de la organización, teniendo en cuenta también el bienestar de las numerosas partes que la componen. La evolución tan uniforme de la que ya hemos hablado se puede interpretar como un apoyo al valor fundamental de los servicios de los PAE en lugares de trabajo, empresas y países diferentes. A medida que el mundo laboral se hace cada vez más exigente, en una época de economía global competitiva, y cuando los conocimientos y las cualificaciones que los trabajadores aportan al puesto de trabajo adquieren mayor importancia que su mera presencia o fuerza física, cabe prever que cada vez se recurrirá más a los PAE para que orienten a las organizaciones hacia el cumplimiento de sus responsabilidades humanitarias respecto a sus empleados o miembros. Incluso con un enfoque individual y ambiental de este tipo para resolver los problemas es previsible que los trabajadores sociales desempeñen un papel fundamental en la prestación de servicios.

\section{LA SALUD EN LA TERCERA EDAD: PROGRAMAS DE PREJUBILACION}

\section{H. Beric Wright}

$\mathrm{H}$ oy se reconoce de manera creciente que el último tercio de la vida - la "tercera edad" - requiere tanto estudio y planificación como la educación y formación (la "primera edad") y el desarrollo de la carrera y la reconversión profesional (la "segunda edad"). Cuando, hace unos treinta años, comenzó el movimiento dirigido a hacer frente a las necesidades de los jubilados, el trabajador masculino medio en los Estados U nidos y en muchos otros países desarrollados se jubilaba a los 65 años, rendido por el trabajo, con una esperanza de vida limitada y una pensión insuficiente, o sin pensión alguna, especialmente en el caso de los obreros o jornaleros agrícolas.

Este panorama ha cambiado profundamente. Muchas personas se jubilan más jóvenes, de manera voluntaria 0 al alcanzar edades distintas a las establecidas en las normas de jubilación obligatoria; algunas se ven forzadas a la jubilación anticipada por causa de enfermedad, incapacidad o despido. Al mismo tiempo, muchas otras deciden seguir trabajando bastante después de la edad "normal" de jubilación, ya sea en el mismo empleo 0 en otra carrera.

Los jubilados tienen hoy, en general, mejor salud y mayor esperanza de vida. En el Reino U nido, el grupo de los mayores de 80 años es el de más rápido crecimiento en la población y cada vez más gente pasa de los noventa. La presencia de la mujer en la población activa ha implicado la presencia de un número creciente de jubiladas, muchas de ellas solteras o viudas debido a su mayor esperanza de vida con respecto a sus parejas masculinas.

La mayor parte de los jubilados conservan durante un tiempo, dos décadas o más en algunos casos, la movilidad, el vigor y las capacidades funcionales perfeccionadas por la experiencia, y este período sigue ampliándose gracias a los mayores niveles de vida y las mejoras en la asistencia sanitaria. La vida de muchas personas se prolonga más allá del tiempo para el que están diseñadas sus estructuras biológicas (así, por ejemplo, algunas de sus funciones corporales dejan de funcionar, mientras que el resto se resiste a caer), dando lugar a una dependencia médica y social creciente, que se ve cada vez menos compensada por otras formas de disfrutar de la vida. El objetivo de la planificación de la jubilación es mejorar y prolongar el disfrute del período de bienestar y garantizar, en la medida de lo posible, los recursos y los sistemas de apoyo necesarios en el momento del declive final. Va, pues, más allá de la planificación del patrimonio y la 
disposición de los bienes y activos, aunque éstos sean a menudo aspectos importantes.

La jubilación puede ofrecer hoy incontables compensaciones y ventajas. Las personas que se jubilen con buena salud pueden tener la esperanza de vivir otros 20030 años, disfrutando de una actividad potencialmente plena durante al menos dos tercios de este período: demasiado tiempo para abandonarse a la inactividad o dejarse enmohecer en alguna soleada "Costa Geriátrica". También están engrosando estas filas las personas que se acogen a la jubilación anticipada por voluntad propia 0 , desgraciadamente, por despido, y las mujeres, que se jubilan en mayor número con pensiones suficientes y con el propósito de permanecer plenamente activas y no vivir a cargo de otras personas.

Hace cincuenta años, las pensiones eran insuficientes y el sostenimiento económico significaba una lucha por la supervivencia para la mayoría de las personas de edad avanzada. $\mathrm{H}$ oy, las pensiones de empresa y las prestaciones asistenciales públicas, pese a ser aún insuficientes en muchos casos, permiten llevar una vida no demasiado mala. Las posibilidades de encontrar un trabajo a tiempo parcial están mejorando también para estas personas, gracias a la disminución de personal especializado en muchos sectores y al reconocimiento por la empresa de que los trabajadores de mayor edad son empleados productivos y, a menudo, de mayor confianza.

Los jubilados representan alrededor de un tercio de la población. Son personas sanas física y mentalmente, que constituyen un segmento importante y potencialmente contributivo de la sociedad y que podrán, a medida que tomen conciencia de su importancia y su potencial, organizarse para desempeñar un papel más importante. Un ejemplo en los Estados U nidos es la American Association of Retired Persons (AARP), que ofrece a sus 33 millones de miembros (no todos jubilados, ya que se permite la incorporación de cualquier persona de 50 o más años de edad) una amplia gama de ventajas y ejerce una influencia política considerable. Lord $\mathrm{H}$ oughton, presidente de la Pre-R etirement Association (PRA) del Reino Unido y miembro del Gobierno, dijo en la primera junta general anual, celebrada en 1964, que "si los pensionistas actuaran unidos, podrían dar la vuelta a unas elecciones". Esto no ha ocurrido aún, y no ocurrirá probablemente nunca en estos términos, pero hoy se reconoce ya en la mayoría de los países desarrollados la existencia de una "tercera edad" que representa un tercio de la población y que tiene expectativas y necesidades propias, a la vez que un enorme potencial para contribuir al beneficio de sus miembros y de la comunidad en su conjunto.

Junto con este reconocimiento, se ha tomado conciencia de la necesidad, vital para la estabilidad social, de dotar de servicios y oportunidades a este grupo. En las últimas décadas, los políticos y los gobiernos han comenzado a reaccionar, ampliando y mejorando la gama de programas de seguridad social y de bienestar, si bien limitados por exigencias fiscales y rigideces burocráticas.

O tro obstáculo importante ha sido la actitud de los propios pensionistas. En demasiados casos han aceptado la imagen personal y social estereotipada de la jubilación como el fin de la consideración de miembro útil de la sociedad, o incluso digno de atención, y la expectativa de ser relegado a un rincón y convenientemente olvidado. La superación de esta imagen negativa ha sido, y en buena medida sigue siendo, el principal objetivo de la preparación para la jubilación.

Al aumentar el número de jubilados que han realizado esta transformación y han tratado de satisfacer sus nuevas necesidades, se han hecho conscientes ellos mismos de las insuficiencias de los programas públicos y han empezado a dirigirse a las empresas para cubrir este vacío. Gracias a los ahorros acumulados y a los planes de pensiones, muchos de ellos configurados mediante convenios colectivos, han sacado a la luz recursos financieros, a menudo importantes. Para reforzar el valor de sus planes de pensiones privados, las empresas y los sindicatos han empezado a gestionar, e incluso a ofrecer, programas de asesoramiento y a prestar apoyo a su realización.

En el Reino Unido, el mérito de este logro se debe principalmente a la Pre-Retirement Association, que, con el apoyo del Estado, a través del Departamento de Educación (inicialmente, los Departamentos de Sanidad, Empleo y Educación se estuvieron pasando la pelota con este programa), va siendo aceptado como la vía principal de preparación para la jubilación.

Con el crecimiento de esta demanda de orientación y apoyo ha surgido un importante sector de organizaciones voluntarias y mercantiles. Algunas operan de modo principalmente altruista, mientras que otras se mueven por propio interés. Entre éstas se incluyen las compañías de seguros, que buscan vender rentas vitalicias y otros seguros; las sociedades de inversión, que gestionan los ahorros acumulados y los ingresos por pensiones; los agentes inmobiliarios, que ofrecen residencias para jubilados; los gestores de comunidades de jubilación, que buscan la incorporación de nuevos miembros; las entidades benéficas, que prestan asesoramiento sobre las ventajas fiscales de legados y donaciones, etc. Como complemento, un ejército de editoriales ofrecen libros, revistas y cintas de audio y vídeo del tipo "A prenda a ...", mientras que las universidades y entidades de educación para adultos imparten seminarios y cursos sobre temas de interés.

M uchas de estas entidades prestadoras de servicios se centran prioritariamente en los problemas financieros, sociales y familiares, pero la percepción de que el bienestar y la vida productiva dependen de la salud ha llevado a un incremento de los programas de educación sanitaria y de promoción de la salud, dirigidos a evitar, retrasar o minimizar la enfermedad y la incapacidad. Así ocurre especialmente en los Estados U nidos, donde los compromisos financieros de las empresas se han convertido, debido a los crecientes costes de la asistencia sanitaria a los jubilados y las personas a cargo de éstos, no sólo en una carga muy pesada, sino en un pasivo que debe reflejarse en el balance incluido en las cuentas anuales de la empresa.

A lgunas de las organizaciones sanitarias voluntarias por especialidades, como, por ejemplo, las del corazón, cáncer, diabetes 0 artritis, elaboran material educativo diseñado específicamente para los trabajadores que se acercan a la edad de jubilación.

En resumen, ha llegado la tercera edad. Los programas de jubilación y prejubilación permiten maximizar el rendimiento y el bienestar social, personal y proporcionan la información, la preparación y el apoyo necesarios.

\section{El papel de la empresa}

Aunque están lejos aún de ser universales, el apoyo y la financiación de los programas de prejubilación han procedido principalmente de las empresas, así como de la administración central y local y de las fuerzas armadas. En el R eino U nido, han sido decisivos los esfuerzos de la PRA, que desde tiempo atrás ha favorecido la incorporación de empresas ofreciéndoles apoyo, asesoramiento y cursos a domicilio. No ha sido difícil en la práctica convencer al sector privado de que su responsabilidad va mucho más allá de la mera prestación de pensiones. Además, la progresiva complicación de los planes de pensiones y de sus implicaciones fiscales ha dado mayor importancia a las explicaciones en detalle y al asesoramiento personalizado.

El lugar de trabajo ofrece un público muy localizado que favorece la eficacia y la reducción de los costes de presentación de los programas, a la vez que la mutua presencia de los compañeros estimula la participación de los trabajadores. De ello se derivan claras ventajas para los trabajadores y las personas a su 
cargo. Para la empresa, las ventajas son también sustanciales, aunque más sutiles: mejora del estado de ánimo, reforzamiento de la imagen de la empresa como patrón apetecible, estímulo para conservar a trabajadores de mayor edad que poseen una valiosa experiencia y mantenimiento de la participación de los jubilados en el fondo de comercio de la empresa, muchos de los cuales son también accionistas gracias a la participación en beneficios y a los planes de inversión patrocinados por ésta. Cuando la empresa necesita reducir la plantilla, sus programas de prejubilación le permiten realzar el atractivo de la gratificación por fin de servicios, un conjunto de incentivos para los que aceptan la jubilación anticipada.

Los sindicatos obtienen ventajas similares cuando ofrecen estos programas como complemento de sus planes de pensiones, haciendo más atractiva la afiliación sindical y reforzando la buena voluntad y la conciencia de grupo entre sus afiliados. Debe resaltarse que, en el Reino Unido, los sindicatos apenas han empezado a interesarse por estos programas, especialmente los pequeños sindicatos profesionales, como los de pilotos de compañías aéreas.

Las empresas pueden contratar un programa completo preconfigurado o sólo alguna de las prestaciones puntuales contenidas en la lista que ofrecen organizaciones como la PRA, las diversas instituciones de educación para adultos y las numerosas compañías de seguros, de pensiones o de inversión que ofertan como actividad mercantil cursos de preparación para la jubilación. En cuanto a estas últimas, aunque prestan por lo general servicios de calidad, deben ser supervisadas para garantizar que la información que ofrecen sea leal y objetiva, y no se limite a promocionar sus propios productos y servicios.

En la empresa, los departamentos de personal, de pensiones y de educación (cuando lo hay) deben participar en la configuración y la presentación del programa, que puede prestarse en sus propias instalaciones 0 en algún local adecuado. Algunas empresas lo ofrecen durante la jornada de trabajo, pero lo más habitual es que tengan lugar en el descanso del almuerzo 0 al final del día, siendo esto último lo más frecuente, porque minimiza las interferencias con los planes de trabajo y permite la asistencia de los cónyuges.

Algunas empresas cubren la totalidad de los costes de participación, mientras que otras los comparten con el trabajador o se los reembolsan a éste total o parcialmente si completa con éxito el programa. Sin perjuicio de la debida competencia de los prestadores del servicio, en el caso de consultas personales individualizadas se suele remitir a los participantes al consejo de especialistas. Por lo general, los participantes se hacen cargo de este coste, si bien, en algunos casos, estos especialistas están adscritos a los programas y la empresa puede negociar con ellos tarifas reducidas.

\section{El curso de prejubilación}

\section{Planteamiento del curso}

La separación del trabajo es una experiencia desgarradora para muchas personas, especialmente para los "adictos al trabajo". EI trabajo nos proporciona status, identidad y relaciones con otras personas. En muchas culturas tendemos a identificarnos socialmente, y a identificar a los demás, en función de nuestro trabajo respectivo. El contexto laboral en que nos movemos domina nuestra vida, especialmente a medida que nos hacemos mayores, y determina qué hacemos, dónde vamos y, sobre todo para los profesionales, nuestras prioridades cotidianas. La separación de los compañeros de trabajo y el grado de preocupación, a veces insano, por asuntos familiares y domésticos menores ponen de manifiesto la necesidad de desarrollar una nueva pauta de referencia social.

Llegada la jubilación, el bienestar y la supervivencia dependen de la comprensión de estos cambios y de la disposición a aprovechar el mayor número posible de las oportunidades que conllevan. Para esta comprensión es esencial el concepto de mantenimiento de la salud en su sentido más amplio, tal como lo define la Organización Mundial de la Salud, y un enfoque global más moderno de los problemas médicos. La adopción de una forma de vida saludable debe complementarse con una gestión adecuada de las finanzas, la vivienda, las actividades y las relaciones sociales. Conservar recursos económicos para el momento en que una discapacidad cada vez más acusada exija atenciones y ayudas especializadas que pueden aumentar el coste de la vida suele ser más importante que planificar el patrimonio.

La piedra angular de la preparación para la prejubilación la constituyen los cursos organizados de información y orientación, cuyos responsables deberán tener en cuenta que su finalidad no es dar todas las respuestas, sino perfilar las áreas potencialmente problemáticas y apuntar las soluciones ideales para cada persona.

\section{Areas temáticas}

Los programas de prejubilación pueden comprender diversos aspectos. A continuación se describen brevemente los fundamentales, que deben tenerse siempre presentes en el desarrollo de cualquier programa:

Estadísticas vitales y demografía. Esperanza de vida en las edades consideradas - las mujeres viven más que los hombres- y tendencias en la composición de la familia, con sus implicaciones.

Comprensión de la jubilación. Cambios en la forma de vida, la motivación y las oportunidades que habrán de emprenderse en los próximos 20 ó 30 años.

Mantenimiento de la salud. Comprensión de los aspectos físicos y mentales del envejecimiento y de los factores del estilo de vida que favorecen un bienestar y una capacidad funcional óptimas (por ejemplo: la actividad física, la dieta y el control del peso, la adaptación a la pérdida progresiva de la vista y el oído, la acentuación de la sensibilidad al clima frío y cálido y el consumo de tabaco, alcohol y otras drogas). $\mathrm{H}$ ay que hacer referencia a los médicos y al sistema de asistencia sanitaria, a las revisiones médicas periódicas, a las medidas preventivas y a las actitudes ante la enfermedad y la incapacidad.

Planificación financiera. Comprensión del plan de pensiones de la empresa, así como de las potenciales ventajas de la seguridad social y las políticas de bienestar público; gestión de inversiones, para conservar los recursos y maximizar los ingresos, incluyendo la inversión de cantidades percibidas a tanto alzado; gestión de la propiedad de la vivienda y otros bienes, de las hipotecas, etc.; prolongación de los seguros médicos, sean patrocinados por la empresa, los sindicatos u otros, incluyendo el estudio de los seguros de asistencia a largo plazo, si los hay; elección de asesor financiero.

Planificación doméstica. Planificación inmobiliaria y elaboración del testamento; otorgamiento de testamento vital (por ejemplo: establecimiento de directrices médicas o designación de un representante para la asistencia sanitaria) para consignar los deseos personales con relación los tratamientos médicos que deban o no ser administrados en caso de incapacidad para participar en la decisión ante una enfermedad terminal; las relaciones 
con el cónyuge, los hijos y nietos; adaptación a la disminución de las relaciones sociales; inversión de papeles en los casos en que la mujer continúa desarrollando su carrera o sus actividades externas, asumiendo el hombre mayores tareas domésticas.

Vivienda. La casa y el jardín resultan demasiado grandes, laboriosos y costosos a medida que decaen las fuerzas físicas y los recursos económicos, o bien se quedan pequeños para el jubilado que instala una oficina o un puesto de trabajo en casa; cuando los dos cónyuges viven en casa, es aconsejable organizar el espacio de manera que cada uno disponga de su propio territorio privado donde realizar sus actividades o reflexionar; decisión de trasladarse a otra zona o país, o a una residencia de jubilados; disponibilidad de transporte público cuando no se puede, 0 es imprudente, conducir el vehículo propio; preparación para una posible mengua de la salud; asistencia doméstica en las tareas del hogar y en las relaciones sociales para los que viven solos.

Posibles actividades. Cómo encontrar oportunidades y formación para nuevos trabajos, aficiones y actividades de voluntariado; educación (por ejemplo: terminación de un curso o carrera interrumpida); viajes (en los Estados U nidos, una organización de voluntarios llamada Elderhostel ofrece un amplio catálogo de cursos anuales, semanales y bisemanales para adultos, impartidos en universidades y centros de vacaciones dentro y fuera del país).

Organización del tiempa Elaboración de un plan de actividades que permitan dar sentido, disfrutar y equilibrar la participación individual y conjunta; aunque las nuevas oportunidades de vida en común constituyen una ventaja de la jubilación, es importante ser consciente del valor de las actividades independientes y evitar interferir en la vida del otro; actividades de grupo, entre ellas las de clubs, agrupaciones religiosas y organizaciones vecinales; reconocimiento del valor motivacional de la dedicación a tareas remuneradas o de voluntariado.

\section{Organización del curso}

El patrocinador determina normalmente el tipo de curso, su contenido y duración a partir de los recursos disponibles y los costes previstos, así como del grado de dedicación y de los intereses de los trabajadores participantes. Serán pocos los cursos que puedan abarcar en detalle todas las áreas temáticas anteriormente mencionadas, pero deberán, en todo caso, incluir algún análisis de la mayoría de ellas (y, preferiblemente, de todas).

El curso ideal, en opinión de los educadores, es el del tipo "día liberado" (los trabajadores asisten al curso en horas de trabajo), con unas diez sesiones, en las que los participantes pueden llegar a conocerse y los instructores están en condiciones de analizar las necesidades e intereses individuales. E ste lujo está al alcance de pocas empresas, pero las asociaciones dedicadas a la prejubilación (que en el Reino U nido están organizadas en una red) y los centros de educación para adultos los llevan a cabo con éxito. Si el curso se concentra en el tiempo, por ejemplo en dos días, permite más participación y deja tiempo para la orientación de actividades, mientras que los cursos de un solo día, por su condensación, exigen una presentación más didáctica que participativa, o se limitan a unas sesiones más 0 menos breves.

\section{¿Quién asiste a los cursos?}

Es conveniente que los cursos estén abiertos a los cónyuges y compañeros de los participantes, lo que puede condicionar el tiempo y lugar de su celebración.

Todos los trabajadores camino de la jubilación deben tener la oportunidad de asistir. No obstante, hay una dificultad derivada de la mezcla de distintos tipos de personas: los altos directivos tienen actitudes, aspiraciones, experiencias y recursos muy diferentes a los de los directivos intermedios y el personal de línea; la asistencia de personas con un entorno cultural y social muy distinto puede restar espontaneidad y fluidez a las relaciones entre los participantes, cuando éste es un aspecto muy valioso de los cursos, especialmente en lo que respecta a las finanzas y las actividades postjubilación; la organización en grupos muy numerosos impone un enfoque más didáctico, mientras que los grupos de diez a veinte per sonas favorecen intercambios productivos de intereses y experiencias.

L os trabajadores de grandes empresas que acentúan su identidad corporativa, como IBM en los Estados U nidos y M arks \& Spencer en el Reino Unido, tienen a menudo dificultades para encontrar su sitio en el mundo fuera del entorno del "hermano mayor". Así se advierte, sobre todo, en los distintos servicios de las fuerzas armadas, al menos en el Reino Unido y en los Estados U nidos. Al mismo tiempo, en estos grupos tan cerrados los trabajadores tienen a veces dificultades para expresar intereses que pueden ser interpretados como deslealtad hacia la empresa, lo que no será muy problemático en el caso de cursos impartidos fuera de sus locales o dirigidos a trabajadores de varias empresas, como siempre ocurre con las organizaciones más pequeñas. Estos grupos "mixtos" suelen ser menos formales y más productivos.

\section{¿Quién imparte los cursos?}

Es esencial que el instructor posea los conocimientos y la capacidad de comunicación necesaria para hacer del curso una experiencia útil y agradable. Pueden participar los departamentos médico, de personal y de educación de la empresa, pero a menudo se considera que los consultores especializados o los expertos externos son más objetivos. En algunos casos, pueden incorporarse instructores cualificados de entre los jubilados de la empresa, que combinan la mayor objetividad con el conocimiento del entorno y la cultura de aquélla. La configuración ideal suele ser la de un director de curso apoyado por varios especialistas, ya que es poco frecuente que una sola persona sea experta en todos los aspectos a tratar.

\section{Los materiales complementarios}

Las sesiones del curso se complementan habitualmente con manuales prácticos, cintas de vídeo y otras publicaciones. M uchos programas incluyen la suscripción a libros, periódicos y circulares de interés, que resultan más eficaces cuando se remiten al domicilio, donde pueden compartirse con el cónyuge y los demás miembros de la familia. La pertenencia a organizaciones de ámbito nacional, como PRA y AARP, o a sus ramas locales, permite acceder a reuniones y publicaciones interesantes.

\section{¿Cuándo se imparte el curso?}

Los programas de prejubilación se inician generalmente unos cinco años antes de la fecha prevista de jubilación (recuérdese que se permite la incorporación a AAR P a los cincuenta años). En algunas empresas, el curso se repite todos los años o cada dos años, invitándose a los trabajadores a participar tantas veces como deseen, mientras que en otras el programa se divide en segmentos, que se imparten en años sucesivos al mismo grupo de participantes, variando el contenido a medida que se aproxima la fecha de jubilación.

\section{Evaluación del curso}

Los mejores indicadores de la utilidad del curso son el número de candidatos que se incorporan y la tasa de abandonos. Para que sirva de base a posibles modificaciones, debe introducirse algún mecanismo que permita a los participantes retroalimentar sus 
impresiones acerca de los contenidos del curso y la calidad de los instructores.

\section{Algunas advertencias}

Es improbable que un curso cargado de materiales irrelevantes llegue a tener éxito. Por este motivo, algunas empresas utilizan encuestas o grupos de prueba para garantizar que el curso tenga interés para los participantes potenciales.

Un aspecto importante en el proceso de toma de decisiones es el relativo al estado de las relaciones entre la empresa y el trabajador. Cuando hay una hostilidad abierta o subyacente, es probable que los trabajadores no concedan gran valor a ninguna oferta procedente de la empresa, especialmente si se presenta como algo a realizar "por su propio bien". En cambio, puede favorecerse la aceptación de los trabajadores permitiendo la participación de delegados de personal o representantes sindicales en el diseño y planificación del programa.

Por último, a medida que la jubilación se aproxima y se convierte en una forma de vida, las circunstancias cambian y surgen nuevos problemas, lo que aconseja repetir periódicamente el curso, tanto para los que desean asistir de nuevo como para los que comienzan a aproximarse a la "tercera edad".

\section{Actividades posteriores a la jubilación}

M uchas empresas siguen en contacto con sus jubilados durante toda la vida de éstos, incluidos también sus cónyuges viudos, especialmente cuando se mantiene un seguro de enfermedad. La empresa proporciona revisiones médicas periódicas, programas de promoción y educación sanitaria diseñados para las personas de edad y, si es necesario, consultas individuales en temas sanitarios, financieros, domésticos y sociales. $\mathrm{H}$ ay un número creciente de grandes empresas que subvencionan clubs de pensionistas dotados de mayor o menor autonomía en su programación.

Algunas empresas dan mucha importancia a la contratación de jubilados, temporalmente 0 a tiempo parcial, en los momentos en que se necesita personal complementario. 0 tras, como la Equitable Life A ssurance Society of the U nited States, de N ueva York, fomentan la participación voluntaria de los jubilados en organizaciones sin ánimo de lucro de la comunidad y en instituciones educativas, pagándoles una pequeña remuneración para compensar los gastos. EI National Executive Service Corps gestiona la aportación de la experiencia acumulada por los directivos jubilados a empresas y organismos públicos de todo el mundo. La International Ladies Garment Workers Union (ILGWU) ha instituido el "programa de visitas de amistad", que prepara a los jubilados para prestar compañía y servicios de interés a aquellos de sus miembros afectados por problemas de la edad. L os clubs de pensionistas del R eino U nido patrocinan actividades similares.

La mayor parte de los programas de posjubilación, con excepción de los clubs de pensionistas de patrocinio sindical y empresarial, son ejecutados por las organizaciones de educación para adultos mediante su oferta de cursos formales. En el Reino Unido hay varios grupos de pensionistas de ámbito nacional, como PROBUS, que celebra reuniones locales periódicas para prestar información y relaciones sociales a sus miembros, y la PRA, que está abierta a la incorporación de personas y empresas que deseen información, cursos, tutoría y asesoría general.

M uchas empresas y sindicatos ofrecen información y asesoría a través de sus publicaciones internas ordinarias y de materiales específicamente dirigidos a los jubilados, ilustrados a menudo con anécdotas relativas a sus actividades y experiencias. La mayoría de los países desarrollados tienen al menos una o dos revistas de circulación general dirigidas a los jubilados: la francesa Notre Temps tiene gran difusión entre las personas de la tercera edad; en los Estados U nidos, M odern M aturity, perteneciente a AARP, se distribuye a sus más de 33 millones de miembros. En el Reino U nido hay dos publicaciones mensuales para jubilados: Choice y SAGA M agazine. La Comisión Europea patrocina en la actualidad un manual práctico para la jubilación, en varias lenguas, titulado $M$ aking the $M$ ost of Your R etirement.

\section{Cuidado de personas de edad avanzada}

En muchos países desarrollados, las empresas son cada vez más conscientes de la transcendencia de los problemas a que se enfrentan los trabajadores que tienen padres, suegros y abuelos ancianos 0 incapacitados. Algunos de éstos quizás sean pensionistas de otras empresas, pero su necesidad de ayuda, atención y servicios directos puede suponer una pesada carga para los trabajadores, que han de hacer frente además de a su propio trabajo, a sus asuntos personales. Para aligerar esta carga y reducir la fatiga, el absentismo y la pérdida de productividad resultantes, las empresas ofrecen a estos últimos "programas sobre el cuidado de personas de edad" (Barr, Johnson y Warshaw 1992; US General Accounting Office 1994), que combinan diversos aspectos de educación, información y consulta con otras medidas, como la modificación de los horarios de trabajo, los descansos, el apoyo social y la ayuda financiera.

\section{Conclusión}

Las tendencias demográficas y sociales de la población activa en los países desarrollados están dando lugar de manera inequívoca a una progresiva conciencia de la necesidad de información, preparación y asesoramiento acerca de toda la gama de problemas de la tercera edad. Las empresas y sindicatos, y asimismo los políticos, participan de esta toma de conciencia, que se está plasmando en los programas de prejubilación y las actividades posjubilación y que ofrecen grandes ventajas potenciales a las personas de edad, sus empresas y sindicatos, y a la sociedad en su conjunto.

\section{RECOLOCACION}

Saul G. Gruner y Leon J. Warshaw

La recolocación (outplacement) es un servicio profesional de consultoría que ayuda a las organizaciones a planificar y efectuar despidos aislados o reducciones de plantilla disminuyendo al máximo las interrupciones y evitando responsabilidades jurídicas, y que asesora a los trabajadores que han sido despedidos a fin de minimizar el trauma de la separación orientándoles, al mismo tiempo, hacia la búsqueda de empleos alternativos o de carreras nuevas.

La recesión económica que comenzó durante el decenio de 1980 y prosigue en el de 1990 se ha caracterizado por una auténtica pandemia de despidos como consecuencia del cierre de servicios, fábricas y empresas obsoletos o improductivos, la eliminación de excedentes originados por fusiones, absorciones, consolidaciones y reorganizaciones, y el recorte de personal excedentario destinado a reducir los costes de explotación y a obtener una plantilla escasa pero suficiente. Aunque menos notable que en el sector privado, gracias a la protección de la normativa sobre la función pública y a las presiones políticas, se ha podido apreciar un fenómeno similar en las organizaciones públicas que luchan por reducir su déficit presupuestario y por una filosofía de "adelgazamiento" de la A dministración pública.

Para los trabajadores que han quedado sin empleo, esta pérdida constituye un factor importante de estrés y ocasiona 
traumas, especialmente si el despido se ha producido de forma súbita y brutal; genera ira, angustia y depresión, e incluso puede descompensar a quienes se encuentran en los límites de una enfermedad mental crónica. En casos aislados, la ira se expresa en forma de sabotaje o violencia hacia los supervisores y los directores responsables del despido. 0 tras veces esa violencia se encauza hacia el propio cónyuge y otros miembros de la familia.

El trauma de la pérdida del empleo también se ha relacionado con dolencias físicas que van desde dolores de cabeza, trastornos gastrointestinales y otras molestias hasta enfermedades relacionadas con el estrés, como ataques cardíacos, úlceras pépticas sangrantes y colitis.

Además del efecto financiero derivado de la falta de ingresos $y$, en Estados Unidos, de la pérdida del seguro de enfermedad patrocinado por la empresa, el desempleo altera la salud y el bienestar familiar.

Por lo demás, la situación afecta también a los trabajadores que conservan su puesto de trabajo. Por más que la empresa les dé seguridades, es normal que se preocupen por la posibilidad de nuevos despidos (está comprobado que el riesgo de perder el empleo es un factor de estrés incluso más fuerte que la pérdida en sí), a lo cual hay que sumar el estrés que origina la adaptación a las nuevas tareas y funciones, como consecuencia de los cambios en las relaciones con los compañeros. La reducción de plantilla puede resultar traumática incluso para la empresa, ya que a veces requiere tiempo y effuerzo resolver los desajustes organizativos y alcanzar la eficiencia productiva deseada. Puede ocurrir que abandonen la empresa algunos empleados valiosos, cuyo despido no estaba previsto, en busca de puestos de trabajo más seguros y empresas mejor organizadas. También existe la posibilidad de que surjan responsabilidades jurídicas, cuando los trabajadores despedidos alegan incumplimiento de contrato 0 discriminación ilegal.

\section{Recolocación: Un método preventivo}

La recolocación es un servicio profesional destinado a prevenir 0 , por lo menos, a minimizar el trauma de la reducción de personal para los trabajadores despedidos, para los que conservan su empleo y para la empresa.

Ciertamente, no todos los trabajadores que pierden su empleo necesitan asistencia. En el caso de algunos, el despido les brinda de repente la oportunidad de buscar otro trabajo, tras librarse de un puesto frustrante que les ofrecía pocas esperanzas de promoción. Para la gran mayoría, no obstante, el asesoramiento profesional para superar la ira y la desilusión casi inevitables entre los trabajadores despedidos, además del apoyo en la búsqueda de un nuevo puesto de trabajo, facilitan la recuperación del bienestar y la confianza en sí mismos. Incluso los que aceptan la tentación del despido con indemnización (paquete que incluye la cesación de empleo y unas prestaciones de jubilación ventajosas) y dejan de trabajar voluntariamente pueden beneficiarse de esa asistencia mientras realizan los reajustes necesarios.

Por lo general, se considera que los servicios de recolocación resultan más económicos cuando son ofrecidos por el personal de la misma empresa. Sin embargo, incluso en grandes organizaciones que dispongan de personal competente y eficaz, es posible que éste no haya tenido mucha experiencia en la delicada labor del acoplamiento y esté demasiado ocupado planificando la reestructuración de la empresa después del éxodo para ocuparse de los detalles. H asta los ejecutivos más agresivos se suelen sentir incómodos cuando tienen que tratar con sus antiguos compañeros. Asimismo, es probable que los trabajadores que dejan la empresa se fíen más de los consejos procedentes de alguien "neutral".
Por lo tanto, resulta más práctico para la mayoría de las organizaciones contratar un consultor o una empresa de consultoría. A fin de destacar esta neutralidad, todos los contactos posibles tienen lugar fuera del edificio de la organización, en las oficinas de los consultores, aunque éstos sólo las ocupen transitoriamente.

\section{El proceso de recolocación}

Es necesario individualizar el proceso de recolocación en función de la actitud, la capacidad y las circunstancias de cada uno de los empleados despedidos y las características del mercado laboral tanto a nivel local como en otras regiones. Para trabajadores de producción no exentos y mandos intermedios, esta tarea suele ser sencilla, aunque a veces las circunstancias externas la complican bastante. Consiste en confeccionar una lista de las cualificaciones de cada trabajador y, si existe un mercado para ellas, ayudarle a colocarse. A falta de puestos de trabajo del mismo tipo, hay que evaluar las posibilidades de reconversión profesional, remitirle a ésta y colaborar en la "venta" de las nuevas cualificaciones. Surge una complicación desafortunada y difícil de superar cuando la escala retributiva de los nuevos puestos de trabajo disponibles no está a la altura de los ingresos del empleo anterior.

En el caso de personas que ocupaban puestos directivos y "creativos", el proceso abarca por lo general una serie de fases que se suelen solapar y que se describen a continuación.

Abandono de la empresa. El objetivo es ayudar al candidato a superar las etapas de reacción para llegar al conocimiento y la aceptación de su situación. En ocasiones hace falta la intervención de un profesional experto en salud mental.

Para ello, a veces conviene llevar a cabo un análisis del despido. A fin de ganarse la confianza del candidato y establecer una relación adecuada, por lo general el consultor examina las circunstancias del despido y comprueba si el candidato las comprende $y$, además, si ha recibido todas las prestaciones monetarias o de otro tipo que le correspondan.

Esta fase concluye cuando el candidato es capaz de abordar de forma constructiva sus problemas y responsabilidades inmediatos y está dispuesto a prepararse para el futuro adoptando una actitud positiva. Es conveniente establecer algún tipo de reconciliación con la antigua empresa y conseguir que el candidato no tenga reparos en aceptar el apoyo que ésta le ofrezca, por ejemplo en forma de permiso de uso transitorio de un despacho con un domicilio comercial y una línea telefónica, además de los servicios de una secretaria que colabore en tareas de mecanografía y en hacer fotocopias, recibir mensajes y confirmar entrevistas. La mayoría de los candidatos trabajan con mayor eficacia desde un entorno cuasi-empresarial que en su propio domicilio. Además el consultor colabora en la formulación de un motivo del despido y en la preparación de las respuestas a las solicitudes de referencia de las posibles empresas contratantes de forma satisfactoria y aceptable para ambas partes.

Preparación para un nuevo emplea. El objetivo de esta fase es establecer el enfoque y la estructura de un modo nuevo de pensar y de actuar. Implica la recuperación de la autoconfianza (que prosigue a lo largo de todo el proceso) mediante la elaboración de una base de datos personal que incluya las cualificaciones, capacidades, conocimientos y experiencia del candidato, y el aprendizaje del modo de comunicar toda esta información en términos claros y funcionales. Al mismo tiempo, el candidato debe empezar a reconocer y confirmar objetivos laborales adecuados y a considerar el tipo de empleo para el cual sus antecedentes podrían resultar más adecuados. Durante todo este 
proceso, aprende a reunir y organizar la información que mejor destaque la magnitud de su experiencia y su nivel de aptitud.

Currículum vitae EI candidato aprende a elaborar un "instrumento" flexible para presentar sus objetivos, cualificaciones y antecedentes, llamar la atención de las posibles empresas contratantes, ayudarle a conseguir entrevistas y servirle de ayuda durante éstas. El currículum no tiene un formato fijo, sino que ha de ser lo bastante variado para presentar cualificaciones y experiencias en un solo "paquete" de modo que resulten lo más atractivas posible para cada oportunidad de empleo.

Evaluación de las oportunidades laborales. EI consultor orienta al candidato para que evalúe la oferta de trabajo considerando distintos sectores, así como el mercado laboral en distintas localidades, las oportunidades de mejora y progreso y la probable capacidad de obtención de ingresos. La experiencia demuestra que un $80 \%$ de las oportunidades laborales están "ocultas", es decir que no se encuentran de inmediato a partir de una designación ocupacional o de la denominación de un puesto. Cuando corresponde, la evaluación también incluye la valoración de la posibilidad del trabajo autónomo.

Campaña de búsqueda de emplea. Esta fase comprende la identificación y exploración de oportunidades reales y potenciales a través del trato directo con las posibles empresas contratantes y el desarrollo y aprovechamiento de los contactos e intermediarios. Con este fin se utilizan los métodos adecuados para conseguir entrevistas con las personas "indicadas" y se recurre a la correspondencia tanto para obtener las entrevistas como a modo de recordatorio.

En el marco de esta campaña de búsqueda de empleo, el consultor también ayuda al candidato a mejorar su redacción y su comportamiento durante las entrevistas. La práctica en la escritura de cartas pretende mejorar una destreza comunicativa que sirve como ninguna otra para definir las oportunidades laborales, identificando a las personas "indicadas" o estableciendo contactos con ellas, consiguiendo entrevistas y haciendo un seguimiento de estas reuniones. Asimismo se adiestra al candidato en la realización de entrevistas, mediante la técnica de interpretación de papeles o la observación crítica de cintas de vídeo que contienen entrevistas simuladas, a fin de aprovechar al máximo su eficacia para presentar la personalidad, la experiencia y los deseos del candidato. De este modo aumentan las probabilidades de que el candidato salga de una entrevista por lo menos con una cita para la siguiente, o incluso con una oferta laboral concreta.

Negociación de la remuneración. El consultor ayuda al candidato a superar el desagrado o incluso el temor que le inspira el hecho de hablar de la remuneración durante la negociación de un posible puesto de trabajo, a fin de obtener el mejor paquete de remuneración posible, teniendo en cuenta las circunstancias, evitando de este modo la posibilidad de "venderse" demasiado caro o demasiado barato, o de provocar un enfrentamiento con el entrevistador.

Control. Dentro de los límites del contrato de consultoría, se mantiene un contacto regular con el candidato hasta que éste obtiene un nuevo puesto de trabajo estable, lo cual implica reunir y organizar información para saber cómo avanza la campaña y para asegurar un óptimo aprovechamiento del tiempo y el esfuerzo. Con ello se evitan errores de omisión y se ayuda a corregir los errores de comisión.

Complementa Cuando el candidato obtiene un nuevo puesto de trabajo, lo notifica al consultor y a su antigua empresa, así como a las demás empresas con las que haya estado negociando.

Seguimiento. Siempre dentro de los límites del contrato, el consultor mantiene contactos con el candidato para colaborar con él durante su adaptación al nuevo puesto, a fin de ayudarle a superar los factores adversos y animarle a continuar con el crecimiento y desarrollo de su carrera profesional. Por último, al finalizar el programa, el consultor presenta a la empresa un informe donde se sintetizan los resultados. (La información individual es confidencial).

\section{La organización}

No es habitual que el consultor de recolocación participe en la designación de los trabajadores que van a ser despedidos y los que van a conservar su empleo; por lo general, esta decisión corresponde a la alta dirección, que suele consultar a los jefes de departamento y los supervisores teniendo en cuenta, además, la nueva estructura prevista. Sin embargo, el consultor orienta sobre la planificación, el calendario y la división en etapas del proceso de reducción de plantilla, aś como sobre las comunicaciones tanto con el personal despedido como con el que permanece. Como siempre corren rumores, es imprescindible que estas comunicaciones sean oportunas, completas y precisas. U na comunicación adecuada sirve asimismo para los casos en los que se alega discriminación. El consultor suele colaborar asimismo en las relaciones públicas con el sector, con los clientes y con la comunidad.

\section{Advertencias}

En la última década se han producido tal cantidad de redimensionamientos, por lo menos en Estados U nidos, que ha aparecido un auténtico sector de consultorías de recolocación. Numerosas empresas que antes se dedicaban a buscar candidatos para cubrir puestos de trabajo han adoptado la recolocación como actividad secundaria, y diversos semiprofesionales, entre ellos antiguos directores de personal, trabajan ahora como consultores sobre este tema.

H asta fechas recientes no se había adoptado formalmente ningún código profesional ni unas normas éticas que rigieran la actividad de los consultores de recolocación. No obstante, en 1992, la Asociación Internacional de Profesionales de la Recolocación (AIPR) patrocinó la creación del Instituto de Recolocación, para pertenecer al cual hay que cumplir una serie de requisitos relacionados con la formación y la experiencia personales, demostrar la participación constante en programas de desarrollo personal y profesional, y comprometerse a defender y observar las normas éticas publicadas por la AIPO.

\section{Conclusión}

La reducción del tamaño de la plantilla es, en el mejor de los casos, una experiencia angustiosa para los trabajadores que han sido despedidos u obligados a jubilarse, así como para los que permanecen en la organización y para ésta misma. Resulta siempre traumática. La recolocación es un servicio profesional de consultoría que pretende evitar o reducir al mínimo los posibles efectos adversos y promover la salud y el bienestar de todas las personas que participan en tal proceso. 


\section{Referencias}

Adami, H G , JA Baron, KJ R othman. 1994. Ethics of a prostate cancer screening trial. Lancet (343):958-960.

Akabas, SH, M H anson. 1991. Workplace drug and alcohol programmes in the United States Documento de trabajo presentado en el Simposio tripartito de Washington sobre los programas de ayuda y prevención del alcoholismo y las toxicomanías en el lugar de trabajo. Ginebra: OIT.

American College of $\mathrm{O}$ bstetricians and $\mathrm{G}$ ynecologists (ACOG). 1994. Exercise during Pregnancy and the Postpartum Period. Vol. 189. Technical Bulletin. Washington, $D C: D C L$.

American Dietetic Association (ADA) y O ffice of Disease Prevention and $\mathrm{H}$ ealth Promotion. 1994. W orksite N utrition: A Guide to Planning, Implementation, and $E$ valuation. Chicago: ADA.

American Lung Association. 1992. Survey of the public's attitudes toward smoking. Preparado para la Gallup Organization por la American Lung Association.

Anderson, DR, MP O'D onnell. 1994. Toward a health promotion research agenda: "State of the Science" reviews. Am J H ealth Promot (8):482-495.

Anderson, JJB. 1992. The role of nutrition in the functioning of skeletal tissue. Nutr R ev (50):388-394.

Artículo 13-E de la Ley de Salud Pública del Estado de Nueva Y ork.

Baile, WF, M Gilbertini, F U Ischak, S Snow-Antle, D $\mathrm{H}$ ann. 1991. Impact of a hospital smoking ban: $C$ hanges in tobacco use and employee attitudes. Addict B ehav 16(6):419-426.

Banco Mundial. 1993. W orld Development Report: Investing in H ealth. Nueva Y ork: 1993.

Bargal, D. 1993. An international perspective on the development of social work in the workplace. En $W$ ork and W ell-Being, the Occupational Social Work Advantage, dirigido por P K urzman y SH Akabas. Washington, DC: NASW Press.

Barr, JK, KW Johnson, LJ Warshaw. 1992. Supporting the elderly: Workplace programs for employed caregivers. M ilbank Q (70):509-533.

Barr, JK, JM Waring, LJ Warshaw. 1991. Employees' sources of AIDS information: The workplace as a promising educational setting. I O ccup $M$ ed (33):143-147.

Barr, JK, LJ Warshaw. 1993. Stress among W orking W omen: R eport of a National Survey. N ueva Y ork: $\mathrm{N} \mathrm{ew}$ $Y$ ork Business $\mathrm{G}$ roup on $\mathrm{H}$ ealth

Beery, W, VJ Schoenbach, EH Wagner y cols. 1986. $H$ ealth Risk Appraisal: M ethods and Programs, with Annotated Bibliography. Rockville, Maryland: $\mathrm{N}$ ational $\mathrm{C}$ enter for $\mathrm{H}$ ealth Services R esearch and $\mathrm{H}$ ealth Care T echnology Assessment.

Bertera, RL. 1991. The effects of behavioral risks on absenteeism and healthcare costs in the workplace. I 0 ccup M ed (33):1119-1124.

Bray, GA. 1989. Classification and evaluation of the obesities. M ed Clin N orth Am 73(1):161-192.

Brigham, J, J Gross, ML Stitzer, LJ Felch. 1994. Effects of a restricted worksite smoking policy on employees who smoke. Am I Public $\mathrm{H}$ ealth 84(5):773-778.

Bungay, GT, MP Vessey, CK M cPherson. 1980 Study of symptoms of middle life with special reference to the menopause. B rit M ed J 308(1):79.

Bureau of N ational Affairs (BNA). 1986. W here There's Smoke: Problems and Policies Concerning Smoking in the W orkplace. R ockville, M aryland: BN A

-. 1989. Workplace smoking, corporate practices and developments. BNA's E mployee R elations W eekly 7(42): 5-38.
-. 1991. Smoking in the workplace, SHRM-BNA Survey N o. 55. BNA Bulletin to M anagement.

Burton, WN, DJ Conti. 1991. V alue-managed mental health benefits. J 0 ccup M ed (33):311-313.

Burton, WN, D Erickson, J Briones. 1991. Women's health programs at the workplace. I O ccup M ed (33):349-350.

Burton, WN, DA Hoy. 1991. A computer-assisted health care cost management system. J O ccup M ed (33):268-271.

Burton, W N, DA H oy, RL Bonin, L G ladstone. 1989. $Q$ uality and cost effective management of mental health care. J 0 ccup M ed (31):363-367.

Caliber Associates. 1989. Cost-B enefit Study of the Navy's Level III Alcohol Rehabilitation Programme Phase T wo: Rehabilitation vs R eplacement Costs. Fairfax, V irginia: Caliber Associates

Charafin, FB. 1994. US sets standards for mammography. B rit M ed J (218):181-183.

Children of Alcoholics Foundation. 1990. Children of Alcoholics in the Medical System: Hidden Problems, $\mathrm{H}$ idden Costs. NuevaY ork: Children of Alcoholics Foundation.

Ciudad de Nueva York. Título 17, capítulo 5 del Código de Administración de la Ciudad de Nueva York.

Coalition on Smoking and $\mathrm{H}$ ealth. 1992. State L egislated Actions On T obacco I ssues. Washington, DC: C oalition on Smoking and $\mathrm{H}$ ealth.

Corporate Health Policies Group. 1993. Issues of Environmental Tobacco Smoke in the Workplace. Washington, DC: N ational Advisory Committee of the Interagency Committee on Smoking and $\mathrm{H}$ ealth.

Cowell, JWF. 1986. Guidelines for fitness-to-work examinations. CM AJ 135 (1 de noviembre): 985-987.

Daniel, WW. 1987. W orkplace Industrial Relations and T echnical Change. Londres: Policy Studies Institute.

Davis, RM. 1987. Current trends in cigarette advertising and marketing. New Engl J Med 316:725-732.

DeC resce, R, A M azura, M Lifshitz, J Tilson. 1989. $D$ rug T esting in the W orkplace. Chicago: ASCP Press.

DeFriese $\mathrm{GH}$, JE Fielding 1990. Health risk appraisal in the 1990s: O pportunities, challenges, and expectations. Annual Revue of Public $\mathrm{H}$ ealth (11):401-418.

Dishman, RH. 1988. Exercise Adherence: Its I mpact On Public $\mathrm{H}$ ealth. Champaign, Illinois: $\mathrm{K}$ inetics Books.

Duncan, MM, JK Barr, LJ Warshaw. 1992. Employer-Sponsored Prenatal Education Programs: A Survey Conducted By the New York Business Group On $H$ ealth. M ontvale, Nueva Jersey: Business and $\mathrm{H}$ ealth Publishers.

Elixhauser, A. 1990. The costs of smoking and the effectiveness of smoking-cessation programs. J Publ $H$ ealth Policy (11): 218-235.

Ewing, JA. 1984. Detecting alcoholism: The CAGE questionnaire. J AM A 252(14):1905-1907.

Fielding, JE. 1989. Frequency of health risk assessment activities at US worksites. Am | Pre $M$ ed 5:73-81.

Fielding, JE, PV Piserchia. 1989. Frequency of worksite health promotion activities. Am I P rev M ed 79:16-20

Fielding, JE, KK Knight, RZ Goetzel, M Laouri. 1991. Utilization of preventive health services by an employed population. J O ccup M ed 33:985-990.

Fiorino, F. 1994. Airline outlook. Aviat week space technol (1 de agosto):19.

Fishbeck, W. 1979. Internal Report and Letter. M idland, Michigan: Dow Chemical Company, Corporate M edical Dept.
Forrest, P. 1987. B reast Cancer Screening 1987. Report to the $\mathrm{H}$ ealth $\mathrm{M}$ inisters of $\mathrm{England}, \mathrm{W}$ ales, Scotland, and reland. Londres: H M SO

Freis, JF, CE K oop, PP Cooper, MJ England, RF Greaves, If Sokolov, D Wright, $\mathrm{H}$ ealth Project Consortium. 1993. Reducing health care costs by reducing the need and demand for health services. $\mathrm{N}$ ew Engl J M ed 329:321-325.

Fundación Europea para la Mejora de las Condiciones de Vida y de Trabajo.1991. O verview of innovative action for workplace health in the UK. Documento de trabajo núm. WP/ 91/ 03/EN.

Glanz, K, RN Mullis. 1988. Environmental interventions to promote healthy eating: A review of models, programs, and evidence. $\mathrm{H}$ ealth $\mathrm{E}$ duc $\mathrm{O}$ 15:395-415.

Glanz, K, T Rogers. 1994. Worksite nutrition programs in health promotion in the workplace. En $\mathrm{H}$ ealth Promotion in the Workplace, dirigido por M P O 'D onnell y J H arris. Albany, N ueva Y ork: Delmar.

Glied, S, S K ofman. 1995. W omen and M ental H ealth: Issues for $\mathrm{H}$ ealth Reform. Nueva York: The Commonwealth Fund.

Googins, B, B Davidson. 1993. The organization as client: Broadening the concept of employee assistance programs. Social W ork 28:477-484.

Guidotti, TL, JWF Cowell, GG Jamieson. 1989. O ccupational H ealth Services: A Practical Approach. Chicago: American M edical Association.

H ammer, L. 1994. Equity and gender issues in health care provision: T he 1993 W orld Bank D evelopment R eport and its implications for health service recipients. Working Paper Series, No.172. La Haya: Instituto de Estudios Sociales.

H arris, L y cols. 1993. The $H$ ealth of American W omen. N ueva Y ork: The Commonwealth Fund.

Haselhurst, J. 1986. M ammographic screening. En Complications in the $M$ anagement of $B$ reast $D$ isease, dirigido por RW Blamey. Londres: Balliere Tindall.

Henderson, BE, RK R oss, M C Pike. 1991. Toward the primary prevention of cancer. Science 254:1131-1138.

H utchison, J, A T ucker. 1984. Breast screening results from a healthy, working population. Clin Oncol 10:123-128.

Institute for Health Policy. O ctubre, 1993. Substance Abuse: The Nation's Number One $\mathrm{H}$ ealth Problem. Princeton: R obert W ood Johnson Foundation.

K aplan, GD, VL Brinkman-K aplan. 1994. Worksite weight management in health promotion in the workplace. En $\mathrm{H}$ ealth Promotion in the Workplace, dirigido por MP O'D onnell y J Harris. Albany, Nueva Y ork: D elmar.

K arpilow, C. 1991. O ccupational M edicine in the Industrial W orkplace Florence, K entucky: Van Nostrand $R$ einhold.

K ohler, S, J Kamp. 1992. American W orkers under Pressure: T echnical Report. St. Paul, M innesotta: St. Paul Fire and $M$ arine Insurance Company.

$\mathrm{K}$ ristein, M. 1983. H ow much can business expect to profit from smoking cessation? Prevent $M$ ed 12:358-381.

Lesieur, HR, SB Blume. 1987. The South Oaks Gambling Screen (SOGS): A new instrument for the identification of pathological gamblers. Am J Psychiatr 144(9):1184-1188.

Lesieur, HR, SB Blume, RM Zoppa. 1986. Alcoholism, drug abuse and gambling. Alcohol, $\mathrm{Clin}$ Exp Res 10(1):33-38.

Lesmes, G. 1993. Getting employees to say no to smoking. Bus $\mathrm{H}$ ealth (marzo):42-46. 
Lew, EA, L Garfinkel. 1979. Variations in mortality by weight among 750,000 men and women. Chron D is 32:563-576.

Lewin, K. [1951] 1975. Field Theory in Social Science Selected Theoretical Papers by Kurt L ewin, dirigido por D Cartwright. W estport: G reenwood Press.

M alcolm, AI. 1971. T he Pursuit of Intoxication. Toronto: ARF Books.

M andelker, J. 1994. A wellness program or a bitter pill. B us H ealth (marzo):36-39.

March of Dimes Birth Defects Foundation. 1992. $L$ essons L earned from the B abies and Y ou Program. White Plains, Nueva Y ork: M arch of Dimes Birth D efects Foundation.

- . 1994. H ealthy Babies, H ealthy Business: An E mployer's Guidebook on Improving $M$ aternal and Infant $\mathrm{H}$ ealth. White Plains, Nueva Y ork: $M$ arch of Dimes Birth D efects Foundation.

M argolin, A, SK A vants, P C hang, T R K osten. 1993. Acupuncture for the treatment of cocaine dependence in methadone-maintained patients. Am J Addict 2(3):194-201.

Maskin, A, A Connelly, EA Noonan. 1993. Environmental tobacco smoke: Implications for the workplace. Occ Saf H ealth R ep (2 de febrero).

Meek, DC. 1992. The impaired physician programme of the M edical Society of the District of Columbia. M aryland M ed J 41(4):321-323.

Morse, RM, DK Flavin. 1992. The definition of alcoholism. J AM A 268(8):1012-1014.

M uchnick-Baku, S, S O rrick. 1992. W orking for Good $H$ ealth: $H$ ealth Promotion and Small Business. Washington, DC: Washington Business G roup on $\mathrm{H}$ ealth.

National Advisory Council for Human Genome Research. 1994. Statement on use of DNA testing for presymptomatic identification of cancer risk. J AM A 271:785.

National Council on Compensation Insurance (N CCI ). 1985. E motional Stress in the W orkplace- N ew L egal Rights in the E ighties. N ueva Y ork: NCCI.

$\mathrm{N}$ ational Institute for $\mathrm{O}$ ccupational Safety and $\mathrm{H}$ ealth (NIOSH). 1991. Current Intelligence Bulletin 54. Bethesda, M aryland: NIO SH

National Institutes of $\mathrm{H}$ ealth (NIH). 1993a. National $\mathrm{H}$ igh B lood Pressure E ducation Program W orking Group $R$ eport on Primary Prevention of $H$ ypertension. National $\mathrm{H}$ igh B lood Pressure $\mathrm{E}$ ducation Program, National $\mathrm{H}$ eart, Lung, and Blood Institute. NIH Publication No. 93-2669. Bethesda, M aryland: NIH .

-. 1993b. Second Report of the Expert Panel on D etection Evaluation, and $T$ reatment of $\mathrm{H}$ igh $\mathrm{B}$ lood Cholesterol in Adults (AT P II). National Cholesterol E ducation Program, $\mathrm{N}$ ational Institutes of $\mathrm{H}$ ealth, National $\mathrm{H}$ eart, L ung, and Blood Institute NIH Publication no. 93-3095. Bethesda, M aryland: NIH.

National Research Council. 1989. Diet and $\mathrm{H}$ ealth Implications for Reducing Chronic Disease Risk Washington, DC: N ational Academy Press.

$\mathrm{N}$ ew Y ork Academy of M edicine. 1989. Drugs in the workplace: Proceedings of a symposium. B NY Acad $M$ ed 65(2).

N oah, T. 1993. EPA declares passive smoke a human carcinogen. W all Street J , 6 de enero.

O rganización Mundial de la Salud (OMS). 1988 $\mathrm{H}$ ealth promotion for working populations: Report of a W H O expert committee. Technical Report Series, N 0.765. Ginebra: O M S.

-. 1992. W orld NO-T obacco Day Advisory Kit 1992 Ginebra: O M S.

- 1993. W omen and Substance Abuse: 1993 Country Assessment Report. Documento núm. WH O/ PSA/ 93.13. Ginebra: O M S.

—. 1994. A Guide On Safe F ood for T ravellers. Ginebra: OMS.
Organización de las Naciones Unidas para la Agricultura y la Alimentación (FAO) y O rganización M undial de la Salud (O M S). 1992. International Conference on Nutrition: M ajor I ssues for Nutrition Strategies. Ginebra: O M S.

Ornish, D, SE Brown, LW Scherwitz, JH Billings, WT Armstrong, TA Ports, SM M CLanahan, RL Kirkeeide, RJ Brand, KL Gould. 1990. Can lifestyle changes reverse coronary heart disease? The lifestyle heart trial. L ancet 336:129-133.

Parodi vs. Veterans Administration. 1982. $540 \mathrm{~F}$. Supl. 85 WD. Washington, DC.

Patnick, J. 1995. NHS B reast Screening Programmes: R eview 1995. Sheffield: Clear Communications.

Pelletier, K R. 1991. A review and analysis of the cost effective outcome studies of comprehensive health promotion and disease prevention programs. Am J $H$ ealth Promot 5:311-315.

-. 1993. A review and analysis of the health and cost-effective outcome studies of comprehensive health promotion and disease prevention programs. Am J H ealth Promot 8:50-62.

—. 1994. Getting your money's worth: The strategic planning programme of the Stanford Corporate Health Programme. Am I $\mathrm{H}$ ealth Promot 8:323-7,376

Penner, M, S Penner. 1990. Excess insured health costs from tobacco-using employees in a large group plan. J O ccup M ed 32:521-523.

Preventive Services T ask Force. 1989. Guide to Clinical Preventive Services: An Assessment of the E ffectiveness of 169 Interventions. Baltimore: Williams \& Wilkins.

Richardson, G. 1994. A W elcome for Every Child: $\mathrm{H}$ ow $F$ rance $P$ rotects $M$ aternal and $C$ hild $H$ ealth- $A$ N ew F rame of $R$ eference for the $U$ nited States. Arlington, $V$ irginia: $\mathrm{N}$ ational Center for Education in $\mathrm{M}$ aternal and Child $\mathrm{H}$ ealth.

Richmond, K. 1986. Introducing heart healthy foods in a company cafeteria. J Nutr E duc 18:S63-S65.

R obbins, LC, JH H all. 1970. H ow to Practice Prospective M edicine Indianapolis, Indiana: M ethodist H ospital of Indiana.

Rodale, R, ST Belden, T Dybdahl, M Schwartz. 1989. The Promotion Index: A Report Card on the Nation's H ealth. Emmaus, Pensilvania: Rodale Press.

R yan, AS, GA M artinez. 1989. Breastfeeding and the working mother: A profile. Pediatrics 82:524-531.

Saunders, JB, OG Aasland, A Amundsen, M Grant 1993. Alcohol consumption and related problems among primary health care patients: WHO collaborative project on early detection of persons with harmful alcohol consumption-I. Addiction 88:349-362.

Schneider, WJ, SC Stewart, MA Haughey. 1989. $H$ ealth promotion in a scheduled cyclical format. J o ccup M ed 31:482-485.

Schoenbach, VJ. 1987. Appraising health risk appraisal. Am J Public H ealth 77:409-411.

Seidell, JC. 1992. Regional obesity and health. Int J 0 besity 16:S31-S34

Selzer, ML. 1971. The Michigan alcoholism screening test: The quest for a new diagnostic instrument. Am J Psychiatr 127(12):89-94.

Serdula, MK, DE Williamson, RF Anda, A Levy, A H eaton, $T$ Byers. 1994. W eight control practices in adults: R esults of a multistate survey. Am J Publ $H$ ealth 81:1821-24.

Shapiro, S. 1977. Evidence of screening for breast cancer from a randomised trial. C ancer:2772-2792.

Skinner, HA. 1982. The drug abuse screening test (DAST ). Addict B ehav 7:363-371.

Smith-Schneider, LM, MJ Sigman-Grant, PM K ris-Etherton. 1992. Dietary fat reduction strategies. J Am D iet Assoc 92:34-38.
Sorensen, G, H Lando, TF Pechacek. 1993. Promoting smoking cessation at the workplace. I O ccup M ed 35(2):121-126.

Sorensen, G, N Rigotti, A R osen, I Pinney, R Prible. 1991. Effects of a worksite smoking policy: Evidence for increased cessation. Am J Public $\mathrm{H}$ ealth 81(2):202-204

Stave, GM, GW Jackson. 1991. Effect of total work-site smoking ban on employee smoking and attitudes. J O ccup M ed 33(8):884-890.

Thériault, G. 1994. Cancer risks associated with occupational exposure to magnetic fields among electric utility workers in O ntario and Quebec Canada, and France. Am I Epidemiol 139(6):550-572.

Tramm, M L, LJ Warshaw. 1989. Screening for Alcohol Problems: A Guide for $\mathrm{H}$ ospitals, Clinics, and Other $\mathrm{H}$ ealth Care Facilities. Nueva York: New York Business $\mathrm{G}$ roup on $\mathrm{H}$ ealth.

US Department of Agriculture: Human Nutrition Information Service. 1990. Report of the Dietary Guidelines Advisory Committee On Dietary Guidelines for Americans. Publication No. 261-495/20/24. $H$ yattsville, M aryland: US Government Printing O ffice.

US Department of $\mathrm{H}$ ealth, Education and Welfare 1964. Smoking and $\mathrm{H}$ ealth Report of the Advisory Committee to the Surgeon General of the Public $\mathrm{H}$ ealth Service. PHS Publication No. 1103. Rockville, $M$ aryland: US Department of $\mathrm{H}$ ealth, Education, and Welfare.

US Department of $\mathrm{H}$ ealth and $\mathrm{H}$ uman Services (U SD H H S). 1989. Reducing the $\mathrm{H}$ ealth $\mathrm{C}$ onsequences of Smoking: 25 Years of Progress. A Report of the Surgeon General. USDHHS Publication No.10 89-8411.Washington, DC: US Government Printing 0 ffice.

-. 1990. E conomic Costs of Alcohol and D rug Abuse and M ental I Iness. DHHS Publication No. (ADM) 90-1694. Washington, DC: Alcohol, Drug Abuse, and $\mathrm{M}$ ental $\mathrm{H}$ ealth $\mathrm{Administration}$.

- 1991. Environmental Tobacco Smoke in the W orkplace: Lung Cancer and 0 ther E ffects. USDHHS (NIOSH) Publication No. 91-108. Washington, DC: USDHHS.

US Food and Drug Administration (FDA). 1995. $M$ ammography quality deadline. FDA M ed Bull 23: 3-4.

US G eneral Accounting O ffice. 1994. L ong-T erm Care: Support for Elder Care Could Benefit the Government W orkplace and the Elderly. GAO/HEHS-94-64. W ashington, DC: US G eneral Accounting 0 ffice.

US Office of Disease Prevention and $\mathrm{H}$ ealth Promotion. 1992. 1992 National Survey of W orksite $\mathrm{H}$ ealth Promotion Activities: Summary Report. Washington, DC: Department of $\mathrm{H}$ ealth and $\mathrm{H}$ uman Services, Public H ealth Service.

US Public H ealth Service. 1991. H ealthy People 2000: $\mathrm{National} H$ ealth Promotion and Disease Prevention Objectives- Full Report W ith Commentary. DHHS Publication No. (PHS) 91-50212. Washington, DC: US Department of $\mathrm{H}$ ealth and $\mathrm{H}$ uman Services.

Voelker, R. 1995. Preparing patients for menopause AM A 273:278.

Wagner, EH, WL Beery, VJ Schoenbach, RM Graham. 1982. An assessment of health hazard/ health risk appraisal. Am J Public $\mathrm{H}$ ealth 72:347-352.

Walsh, DC, RW Hingson, DM Merrigan, SM Levenson, LA Cupples, T H eeren, GA Coffman, CA Becker, TA Barker, SK Hamilton, TG M cGuire, CA K elly. 1991. A randomized trial of treatment options for alcohol-abusing workers. New Engl J M ed 325(11):775-782. 
Warshaw, LJ. 1989. Stress, Anxiety, and D epression in the W orkplace: R eport of the NYGBH / Gallup Survey. Nueva Y ork: The $\mathrm{N} \mathrm{ew}$ Y ork Business $\mathrm{G}$ roup on $\mathrm{H}$ ealth.

Weisman, CS. 1995. National Survey of W omen's $\mathrm{H}$ ealth Centers: Preliminary Report for Respondents. Nueva York: The Commonwealth Fund.

Wilber, CS. 1983. The Johnson and Johnson Program. Prevent M ed 12:672-681.

Woodruff, TJ, B Rosbrook, I Pierce, SA Glantz. 1993. Lower levels of cigarette consumption found in smoke-free workplaces in California. Arch Int M ed 153(12):1485-1493.

W oodside, M. 1992. Children of Alcoholics At W ork: The $\mathrm{N}$ eed to Know M ore. NuevaY ork: Children of Alcoholics Foundation.

Yen, LT, DW Edington, P Witting. 1991. Prediction of prospective medical claims and absenteeism for 1,285 hourly workers from a manufacturing company, 1992. J O ccup M ed 34:428-435.

\section{0 tras lecturas recomendadas}

A kabas, SH, PA K urzman. 1982. W ork, W orkers and W ork Organizations: A View from Social W ork. Englewood Cliffs, Nueva Jersey: Prentice $\mathrm{H}$ all.

American College of Sports M edicine. 1992. ACSM Fitness B ook. Champaign, Illinois: L eisure Press.

American Heart Association, NYCA. 1993. Annotated Bibliography of $E$ ducational $M$ aterials Related to Cardiovascular $\mathrm{H}$ ealth for Patients and Families. Nueva York: American Heart Association, New York City Affiliate.

Ashton, D. 1994. Exercise: $H$ ealth benefits and risks. European Occupational Health Series, No. 7. Copenhague: O ficina Regional de la OMS para Europa.

Barlow, DH. 1994. Advisory Group On Osteoporosis $\mathrm{R}$ eport. R eino U nido: D epartment of $\mathrm{H}$ ealth.

Blum, A. 1983. Curtailing the tobacco pandemic. En Cancer: Principles and Practice of Oncology, dirigido por VTJ DeVita, S Hellman y SA Rosenberg Filadelfia: JB Lippincott.

Bowden, KM, MA M CDiarmid. 1994 O ccupationally acquired tuberculosis: What's known. J 0 ccup M ed 36(3):320-325.

Bureau of National Affairs (BNA). 1988. Cost of Cesarean Deliveries. Washington, DC: Benefits Today.

Buring, JE, CH Hennekens. 1993. Retinoids and carotenoids. En Cancer: Principles and Practice of Oncology, dirigido por VTJ DeVita, S Hellman, y SA R osenberg. Filadelfia: JB Lippincott.

Center for Corporate Public Involvement. 1994. 1994 Social Report. Washington, DC: American Counci of Life Insurance and $\mathrm{H}$ ealth Insurance Association of America.

Centers for Disease Control (CDC). 1990. Public health burden of vaccine-preventable diseases among adults: Standards for adult immunization practice. M orb M ortal W eekly R ep 39:725-729.

- . 1991. Successful strategies in adult immunization. M orb M ortal W eckly R ep 40:700-3;709.

CIGNA Corporation. 1992. Infant $\mathrm{H}$ ealth in America: E verybody's B usiness (a R eport). Columbia, M aryland: The $C$ enter for $\mathrm{R}$ isk $\mathrm{M}$ anagement and Insurance R esearch, G eorgia State U niv. y C enter for $\mathrm{H}$ ealth Policy Studies.

Committee on Diet and $\mathrm{H}$ ealth Food and $\mathrm{N}$ utrition Board, C of LS, N ational Research C ouncil. 1989. Diet and $\mathrm{H}$ ealth: Implications for Reducing Chronic Disease R isk. Washington, DC: N ational Academy Press.

Consult America, I. 1989. O utplacement Consulting in the U nited States: I ssues, M arketing and T rends. M aynard $M$ assachussetts: Consult America.

Cooper, CL, R Payne. 1988. Causes, Coping, and Consequences of Stress At W ork. N ueva Y ork: Wiley.
Dejoy, DM, MG Wilson. 1994. Critical Issues in W orksite $\mathrm{H}$ ealth Promotion. Needham Heights, M assachussetts: Allyn \& Bacon.

Denning, J. 1984. W omen's W ork and $\mathrm{H}$ ealth $\mathrm{H}$ azards. Londres: Department of $\mathrm{O}$ ccupational $\mathrm{H}$ ealth School of $\mathrm{H}$ ygiene and $\mathrm{T}$ ropical $\mathrm{M}$ edicine.

Eckenrode, J, S Gore. 1990. Stress B etween W ork and Family. N ueva Y ork: Plenum Press.

Fauske, S. 1995. M odel Programmes for D rug and Alcohol Abuse Prevention Among Workers and Ther Families. Ginebra: OIT.

Fielding, JE. 1989. Work site stress management: National survey results. J 0 ccup M ed 31:990-995.

-. 1990. Worksite health promotion in the US: Progress, lessons and challenges. $H$ ealth Promot Int 5:75-84.

-. 1991. Occupational health physicians and prevention. J 0 ccup M ed 33:314-326.

Fowinkle, FJ. 1987. H ealthier People Atlanta: The C arter C enter of Emory U niv.

Fulwood, R, S Abraham, E Johnson. 1981. Height and weight of adults ages 18-74 years by socioeconomic and geographic variables, U nited States. Vital $\mathrm{H}$ ealth Stat 11(224).

Googins, B, J Godfrey. 1987. O ccupational Social W ork. Englewood Cliffs, N ueva Jersey: Prentice $\mathrm{H}$ all.

Gould, GM, ML Smith. 1988. Social W ork in the W orkplace. Nueva Y ork: Springer Press.

Greenwald, P. 1993. Dietary fiber and cancer. En Cancer: Principles and Practice of 0 ncology, dirigido por VTJ DeVita, S Hellman y SA Rosenberg. Filadelfia: JB Lippincott.

Greenwald, P, C Clifford. 1993. Dietary fat and cancer. En Cancer: Principles and Practice of Oncology, dirigido por VTJ DeVita, S Hellman y SA R osenberg. Filadelfia: JB L ippincott.

Guerrant, RL, DA Bobak. 1991. Bacterial and protozoal gastroenteritis. N ew Engl J M ed 325(5):327-340.

Guthrie, H A, M F Picciano. 1995. H uman Nutrition. St Louis: M osby.

Henderson, BE, L Bernstein, R R oss. 1993. $\mathrm{H}$ ormones. En Cancer: Principles and Practice of Oncology, dirigido por VTJ DeV ita, S Hellman y SA R osenberg. Filadelfia: JB Lippincott.

H ouse, J. 1981. W ork Stress and Social Support. R eading $M$ assachussetts: Addison-W esley.

H udson Institute. 1987. Workforce 2000: Work and workers for the twenty-first century. Exec Summ junio 1987:85.

Jamison, DT, WH Mosely, AR Measham, JL Bobadilla. 1993. Disease Control Priorities in D eveloping Countries. Washington, DC: Oxford Univ. Press (Banco Internacional para la Reconstrucción y el Desarrollo/ Banco M undial.)

Kammerman, S, A Kahn. 1987. The Responsive W orkplace. Nueva Y ork: Columbia U niv. Press.

K eita, GP, SL Sauter. 1992. W ork and W ell-Being: An Agenda for the 1990's. Washington, DC: American Psychological Association.

K urzman, PA, SH Akabas. 1993. W ork and W ell-B eing: The 0 ccupational Social W ork Advantage Washington, DC: N ational Association of Social W orkers Press.

Lalonde, M . 1975. A new perspective on the health of C anadians: A working document. Inform Canada.

Lechner, V M , M A Creedon. 1994. M anaging W ork and F amily L ife. Nueva Y ork: Springer.

Levi, L. 1981. Preventing W ork Stress. Reading $M$ assachussetts: Addison-W esley.

MCLean, AA. 1979. W ork Stress. Reading, $M$ assachussetts: Addison-W esley.

McPherson, A. 1993. W omen's Problems in General Practice. Washington, D C: 0 xford U niv. Press.
M inor, AF. 1991. Source B ook of $H$ ealth Insurance $D$ ata. Unpublished Tabulations. Washington, DC: $\mathrm{H}$ ealth Insurance Association of A merica.

Muchnick-Baku, S. 1994. Conference Board Report. Washington, DC: Washington Business Group on $\mathrm{H}$ ealth.

National Coordinating Committee on Worksite Health Promotion. 1993. H ealth Promotion Goes to W ork: Programs W ith an Impact. Washington, DC: US G overnment Printing O ffice.

New York Business Group on Health. 1990 Risk- $R$ ated $H$ ealth Insurance: Incentives for $\mathrm{H}$ ealthy Lifestyles. Discussion paper, vol. 10(1). N ew Y ork Business $\mathrm{G}$ roup on $\mathrm{H}$ ealth.

$\mathrm{N}$ ichol, K L, A K ind, KL M argolis y cols. 1995. The effectiveness of vaccination against influenza in healthy, working adults. New Engl J M ed 333:889-893.

Nutrition recommendations and principles for people with diabetes mellitus. 1994. J Am Diet Assoc 94:504-506.

O 'D onnell, M P , JS H arris. 1994. H ealth Promotion in the W orkplace. Nueva Y ork: D elmar.

Paton, E. 1993. European Alcohol Action Plan. Copenhague: Unidad de Alcohol, Drogas y T abaco, D epartamento de Estilos de V ida y Salud, O ficina R egional de la O M S para Europa.

Pecina, M M , I Bojanic. 1993. Overuse Injuries of the M usculoskeletal System. Boca R atón: CR C Press.

Peterson, K W, SB H illes. 1992. Directory of $\mathrm{H}$ ealth R isk Appraisals. Indianapolis: Society for Prospective M edicine.

Ramanathan, CS. 1991. O ccupational social work and multinational corporations. J Sociol Soc W elfare X VII(3):135-147.

Ramirez, S. 1994. H ealth Promotion for All: Strategies for Reaching D iverse Populations in the W orkplace. O maha, N ebraska: Wellness C ouncils of A merica.

Reynolds, B. 1951. Social W ork and Social Living. Nueva Y ork: Citadel.

Schneider, WJ. 1989. AIDS in the Workplace. I 0 ccup $M$ ed 31:839-841.

Scofield, ME. 1990. Worksite Health Promotion. 0 ccup M ed: State Art R ev 5(4) (octubre-diciembre).

Silverman, B, B Simon, R Woodrow. 1991. Workers in job jeapordy. $\mathrm{En} H$ andbook of Social Practice in Vulnerable Populations, dirigido por A Gitterman. N ueva Y ork: Columbia U niv. Press.

Sloan, R P, JC Gruman, JP Allegrante. 1987. Investing in $\mathrm{E}$ mployee $\mathrm{H}$ ealth: $\mathrm{A}$ G uide to $\mathrm{E}$ ffective $\mathrm{H}$ ealth Promotion in the W orkplace. San Francisco: Jossey-Bass.

Society for Nutrition Education. 1986. Nutrition at the worksite. J Nutr E duc 18(2).

Society for Prospective M edicine. 1981. Guidelines for $\mathrm{H}$ ealth Risk Appraisal/ Reduction Systems. Bethesda, $M$ aryland: Society for Prospective M edicine.

Swaim, M, R Swaim. 1988. Out the Organization. N ueva Y ork: M aster M edia.

Tabar, L, G Fagergberg. 1985. Reduction in mortality from breast cancer after mass screening with mammography. Lancet 1:829-832.

Task Force on Adult Immunization. 1994. Guide for Adult Immunization. Filadelfia: The American College of Physicians.

US Centers for Disease Control (CDC). 1993 International Infant M ortality D atabase. A tlanta: CDC

US Department of Agriculture. 1990. Cross-Cultural Counselling. A Guide for Nutrition and $\mathrm{H}$ ealth Counselors. Washington, DC: U nited States Department of $\mathrm{H}$ ealth and $\mathrm{H}$ uman Services.

US Department of Commerce, B of C. 1992. Employment Status of $M$ others By Single $Y$ ear Age of Youngest Child. Washington, DC: US Department of Commerce. 
US Office of Disease Prevention and $\mathrm{Health}$ Promotion. 1994. Put P revention into Practice E ducation and Action Kit (Includes Clinician's $\mathrm{H}$ andbook of Clinica Preventive Services As W ell As Personal H ealth Guide). Washington, DC: US Government Printing 0 ffice.

- 1991. Federal E mployee W orksite H ealth Promotion Case Study Project: Summary Report. Washington, DC: Office of Labor Relations and Workforce Performance, $\mathrm{O}$ ffice of Personnel $\mathrm{M}$ anagement.

US Department of Labor Statistics. 1993. Employment and Earnings. Vol. 40, núm. 1, tabla 3. W ashington, DC: US Department of Labor Statistics.
-. 1992. Employment status of mothers by single year of age of youngest child. In Current Population Survey. Washington, D C: U S D epartment of Labor Statistics

US Public Health Service. 1988. USDHHS: The Surgeon General's Report On Nutrition and $\mathrm{H}$ ealth. Summary and Recommendations. Washington, DC: US G overnment Printing $O$ ffice.

US Small Business Administration. 1993. The State of Small Business. Washington, DC: US Government Printing 0 ffice.
Vanchieri, C. 1988. Breast cancer screening, the evidence of benefit for women 40-49. J Natl Cancer Inst 80:1090-1092.

Wark, TEE. 1987. Shopping for health risk appraisals. $H$ ealth Act $M$ anage 10 oct:1,6-9.

Warshaw, LJ. 1979. M anaging Stress. Reading, $M$ assachussetts: Addison-W esley.

Williams, WW, M A H ickson, M A K ane, y cols. 1988. Immunization policies and vaccine coverage among adults. The risk for missed opportunities. Ann Intern M ed 108:616-625. 



\section{SERVICIOS DE SALUD EN EL TRABAJO}

Directores del capítulo

I gor A. F edotov, M arianne Saux

yJ orma Rantanem

\section{Sumario}

N ormas, principios y enfoques de los servicios de salud en el trabajo

J orma R antanen el gor A. Fedotov.

Los servicios de la salud en el trabajo y la práctica

Georges H. Coppée

Inspección médica del trabajo en Francia

$M$ arianne Saux

Los servicios de salud en el trabajo en la pequeña empresa

J orma R antanen y L eon J. W arshaw

El seguro de accidentes y los servicios de salud en el trabajo en Alemania

W ilfried Coenen y E dith Perlebach.

Los servicios de salud en el trabajo en Estados U nidos: introducción Sharon L. M orris y Peter O rris

O rganismos públicos de salud en el trabajo en

Estados U nidos

Sharon L. M orris y L inda R osenstock.

Servicios de salud en el trabajo en las empresas de

Estados U nidos: servicios prestados internamente

W illiam B. B unn y R obert J. M cC unney. .

Servicios de salud en el trabajo mediante contrato en Estados U nidos

Penny H iggins.

Actividades sindicales en Estados U nidos

Lamont Byrd.

Servicios académicos de salud en el trabajo en

Estados U nidos

D ean B. B aker.

Los servicios de salud en el trabajo en Japón

Ken Takahashi.

La protección de los trabajadores en la Federacion Rusa: legislación y prácticas

Nikolai F. I zmerov el gor A. F edotov.

La práctica de los servicios de salud en el trabajo en la República Popular China

Zhi Su

Salud y seguridad en el trabajo en la R epublica $\mathrm{C}$ heca

Vladimír B encko y D aniela Peldová.

La práctica de la salud en el trabajo en la India

T. K. Joshi . . . 


\section{- NORMAS, PRINCIPIOS Y ENFOQUES DE LOS SERVICIOS DE SALUD EN EL TRABAJO}

Jorma Rantanen e Igor A. Fedotov

Este artículo se basa en las normas, principios y enfoques contenidos en el Convenio de la OIT sobre los servicios de salud en el trabajo, 1985 ( $n$ - 161) y su Recomendación de acompañamiento (no 171); el Convenio de la OIT sobre seguridad y salud de los trabajadores y medio ambiente de trabajo, 1981 (no 155) y su Recomendación de acompañamiento (no 164); y el Documento de trabajo de la Décimo segunda reunión del Comité M ixto OIT/OMS sobre Medicina del Trabajo, celebrada los días 5-7 de abril de 1995.

El Convenio de la OIT sobre los servicios de salud en el trabajo (no 161) define los "servicios de salud en el trabajo" como servicios investidos de funciones esencialmente preventivas y encargados de asesorar al empleador, y a los trabajadores y sus representantes acerca de los requisitos necesarios para establecer y conservar un medio ambiente de trabajo seguro y saludable que favorezca una salud física y mental óptima en relación con el trabajo y de la adaptación de éste a las capacidades de los trabajadores, habida cuenta de su estado de salud física y mental.

La prestación de servicios de salud en el trabajo implica realizar actividades en el lugar de trabajo con el fin de proteger y promover la seguridad, la salud y el bienestar de los trabajadores, así como mejorar las condiciones y el medio ambiente de trabajo. Estos servicios se prestan por profesionales de la salud en el trabajo que actúan individualmente o integrados en servicios especiales de la empresa o en servicios externos.

El campo de la salud en el trabajo es más amplio y no abarca sólo las actividades realizadas por el servicio de salud en el trabajo. Es una actividad interdisciplinaria e intersectorial en la que participan, además de los profesionales de la salud y la seguridad en el trabajo, otros especialistas tanto de la empresa como no pertenecientes a ella, así como las autoridades competentes, las empresas y los trabajadores y sus representantes. Este tipo de participación hace necesario un sistema bien desarrollado y coordinado en el lugar de trabajo. La infraestructura necesaria debería comprender todos los sistemas administrativos, organizativos y operativos necesarios para realizar con éxito las tareas de salud en el trabajo y garantizar su desarrollo sistemático y su mejora continua.

La infraestructura más elaborada para las actividades de salud en el trabajo se describe en el Convenio de la OIT sobre seguridad y salud de los trabajadores y medio ambiente de trabajo, 1981 ( $n$ - 155) y en el Convenio sobre los servicios de salud en el trabajo, 1985 ( $n$ ㅇ 161).

El establecimiento de servicios de salud en el trabajo según los modelos recomendados por el Convenio no 161 y su Recomendación de acompañamiento no 171 es una de las opciones. En todo caso, aunque es evidente que los servicios de salud en el trabajo más avanzados son los acordes a los instrumentos de la OIT, pueden emplearse también otros tipos de infraestructuras. La medicina del trabajo, la higiene del trabajo y la seguridad en el trabajo pueden practicarse separada o conjuntamente en el ámbito de un mismo servicio de salud en el trabajo.

El servicio de salud en el trabajo puede ser una entidad integrada única o una combinación de varios servicios de salud y seguridad unidos por una preocupación común por la salud y el bienestar de los trabajadores.

\section{Disponibilidad de servicios de salud en el trabajo}

Los servicios de salud en el trabajo están desigualmente distribuidos en el mundo (O M S 1995b). En la Región Europea, en torno a la mitad de la población activa carece aún de una cobertura aceptable de servicios de salud en el trabajo, aunque la variación entre países es muy grande, oscilando entre el $5 \%$ y el $90 \%$. L os países de Europa Central y 0 riental, actualmente en transición, están encontrando dificultades para prestar estos servicios debido a la reorganización de sus actividades económicas y a la descomposición de las grandes industrias centralizadas en unidades más pequeñas.

En otros continentes se registran cifras de cobertura inferiores. Sólo unos pocos países (Estados Unidos, Canadá, Japón, Australia, I srael) muestran cifras comparables a las de Europa 0 ccidental. En las típicas regiones en vías de desarrollo, la cobertura de los servicios de salud por empleado oscila, en el mejor de los casos, entre el $5 \%$ y el $10 \%$, encontrándose principalmente los servicios en las empresas manufactureras y quedando algunos sectores industriales, agrícolas, autónomos y de pequeñas empresas y el sector informal completamente faltos de cobertura. Incluso en los países con altas tasas de cobertura hay desfases, con prestaciones insuficientes para las pequeñas empresas, ciertos trabajadores móviles, la construcción, la agricultura y los trabajadores autónomos.

$\mathrm{H}$ ay, por tanto, una necesidad universal de aumentar la cobertura de trabajadores mediante servicios de salud en el trabajo. En varios países, los programas de intervención para aumentar la cobertura han demostrado que es posible mejorar sustancialmente la disponibilidad de estos servicios en un período relativamente corto y a un coste razonable. Estas intervenciones han mostrado mejorar tanto el acceso de los trabajadores a los servicios como la eficacia en función del coste de los servicios prestados.

\section{Impacto de la política de instrumentos internacionales}

La denominada reforma del medio ambiente de trabajo que tuvo lugar en la mayor parte de los países industrializados en los decenios de 1970 y 1980 dio lugar a la aprobación de importantes instrumentos y directrices internacionales, que reflejaban las reacciones de las políticas de salud en el trabajo ante las nuevas necesidades de la vida laboral y la consecución de un consenso internacional sobre el desarrollo de la salud y la seguridad en el trabajo.

La O IT puso en práctica en 1976 el Programa Internacional para el M ejoramiento de las Condiciones y del M edio Ambiente de Trabajo (PIACT) (EI M ejoramiento de las Condiciones y del Medio Ambiente de Trabajo: un Programa Internacional (PIACT), 1984; Septuagésima primera reunión de la Conferencia Internacional del Trabajo, 1985). EI Convenio de la O IT sobre seguridad y salud de los trabajadores y medio ambiente de trabajo, 1981 (n- 155), con su Recomendación de acompañamiento ( $n$ - 164) y el Convenio de la OIT sobre los servicios de salud en el trabajo, 1985 (no 161) y su Recomendación de apoyo ( $n$ - 171) ampliaron la influencia de la O IT en el desarrollo de la seguridad y la salud en el trabajo. El 31 de mayo de 1995 se habían registrado ya 40 ratificaciones de estos $C$ onvenios, pero sus efectos prácticos fueron muy superiores al número de ratificaciones, ya que muchos países pusieron en práctica los principios contenidos en estos instrumentos pese a no poder ratificarlos.

Simultáneamente, la Estrategia G lobal de la O M S Salud para Todos para el Año 2000 (H ealth for All by the Year 2000, H FA) (1981), introducida por primera vez en 1979, fue seguida en el decenio de 1980 por la introducción y puesta en práctica de 
estrategias regionales y nacionales de HFA, en las que la salud de los trabajadores constituía un elemento esencial. En 1987, la OMS introdujo un Programa de Acción para la Salud de los Trabajadores y en 1994 los Centros Colaboradores de la O M S para la Salud en el Trabajo desarrollaron la Estrategia M undial para la Salud en el Trabajo para Todos (1995), avalada por el Consejo Ejecutivo de la O M S (EB97.R 6) y unánimemente aprobada por la A samblea M undial de la Salud en mayo de 1996 (AMS 49.12).

Las principales características del consenso internacional sobre la seguridad y la salud en el trabajo son:

- un enfoque en salud y seguridad en el trabajo para todos los trabajadores, independientemente del sector económico, tipo de trabajo, (asalariado o autónomo), tamaño de la empresa 0 sociedad (industria, sector público, servicios, agricultura, etc.);

- la responsabilidad de los gobiernos para el establecimiento de infraestructuras adecuadas para la práctica de la salud en el trabajo mediante la legislación, los convenios colectivos y cualquier otro mecanismo aceptable, previa consulta con las organizaciones representativas de los trabajadores y de las empresas;

- la responsabilidad de los gobiernos con respecto al desarrollo y puesta en práctica de una política de seguridad y salud en el trabajo en colaboración tripartita con las organizaciones de trabajadores y de empresas;

- la responsabilidad primaria del empleador con respecto a la prestación de servicios de salud en el trabajo a nivel de empresa, con profesionales competentes en la materia para la aplicación de lo dispuesto en la legislación nacional o en los convenios colectivos

- la prevención de los accidentes de trabajo y las enfermedades profesionales y el control de los peligros del lugar de trabajo, así como el desarrollo de un medio ambiente de trabajo y un trabajo que favorezcan la salud de los trabajadores, son el objetivo principal de los servicios de salud en el trabajo.

La C umbre de las $\mathrm{N}$ aciones U nidas sobre M edio A mbiente y Desarrollo celebrada en Río de Janeiro en 1993 abordó varios aspectos del medio ambiente humano con relevancia para la salud en el trabajo (OMS, 1993). Su Agenda 21 contiene elementos sobre la prestación de servicios para los trabajadores insuficientemente atendidos y la garantía de la seguridad química en el lugar de trabajo. La D eclaración de R ío recalca el derecho de las personas a vivir una "vida sana y productiva en armonía con la naturaleza", lo que exige que el trabajo y el medio ambiente laboral cumplan ciertos niveles mínimos de seguridad y salud.

Estos instrumentos y programas internacionales han estimulado, directa o indirectamente, la inclusión de la prestación de servicios de salud en el trabajo en los programas nacionales Salud para Todos para el Año 2000 y en otros programas de ámbito nacional. Así, los instrumentos internacionales han servido de directriz para el desarrollo de programas y legislaciones nacionales.

Un papel significativo en el desarrollo mundial de la salud en el trabajo ha sido el desempeñado por el Comité Mixto OIT/OMS sobre Salud en el Trabajo, el cual, en sus doce reuniones celebradas desde 1950, ha realizado importantes aportaciones para la definición de conceptos y su plasmación en prácticas nacionales y locales.

\section{Estructuras legislativas para la práctica de la salud en el trabajo}

La mayoría de los países han adoptado normas reguladoras sobre la prestación de servicios de salud en el trabajo, pero la estructura legal, contenidos y cobertura de los trabajadores en estas disposiciones varían considerablemente (Rantanen 1990; O M S 1989c). L as normas más tradicionales consideran los servicios de salud en el trabajo como un grupo de actividades especializadas independientes, tales como la asistencia sanitaria en el trabajo, los servicios de seguridad e higiene en el trabajo, los programas de promoción de la salud en el lugar de trabajo, etc.

En muchos países, en lugar de establecer lo que podríamos considerar programas, la legislación determina el deber de la empresa de realizar evaluaciones de riesgo para la salud, reconocimientos médicos de trabajadores y otras actividades individuales relacionadas con la salud y seguridad de los trabajadores.

Normas más recientes que reflejan las directrices internacionales, tales como las contenidas en el Convenio de la OIT sobre los servicios de salud en el trabajo (n- 161), consideran este servicio como un equipo integrado, global e interdisciplinar que contiene todos los elementos necesarios para la mejora de la salud en el trabajo, el medio ambiente de trabajo, la salud de los trabajadores y el desarrollo global de todos los aspectos estructurales y de gestión en el lugar de trabajo necesarios para la salud y la seguridad.

La legislación suele delegar el establecimiento, aplicación y control de los servicios de salud en el trabajo en ministerios u organismos como los de Trabajo, Sanidad o Seguridad Social (O M S 1990).

$\mathrm{H}$ ay dos tipos principales de disposiciones reguladoras de los servicios de salud en el trabajo:

Las del primer tipo contemplan el servicio de salud en el trabajo como una infraestructura de servicio integral interdisciplinar y establecen los objetivos, actividades, obligaciones y derechos de los distintos participantes, las condiciones de funcionamiento y las cualificaciones del personal. Son ejemplos la Directiva M arco de la Unión Europea no 89/391/CEE sobre seguridad y salud en el trabajo (CEC 1989; N eal y Wright 1992), la ley AR BO holandesa (K roon y O vereynder 1991) y la Ley sobre Servicios de Salud en el Trabajo finlandesa (transposición de la Ley de A sistencia Sanitaria en el Trabajo y del Decreto del Consejo del Estado no 1.009 1979).

Existen pocos ejemplos de la organización de sistemas de servicios de salud en el trabajo en el mundo industrializado que sean acordes con este tipo de disposiciones, pero se espera que aumenten con la progresiva implantación de la mencionada Directiva M arco de la U nión Europea (89/391/ CEE).

El otro tipo de disposiciones se encuentran en la mayoría de los países industrializados y son más fragmentarias. En lugar de una ley única en la que se establezca el servicio de salud en el trabajo como una entidad global, se adoptan un conjunto de normas que simplemente obligan a las empresas a realizar ciertas actividades, ya sea determinándolas de forma muy específica o bien de modo general, dejando abierto lo relativo a su organización y condiciones de funcionamiento (O MS 1989c). En muchos países en vías de desarrollo, esta normativa sólo es aplicable a los principales sectores industriales, quedando sin cobertura otros muchos, como la agricultura, las pequeñas y medianas empresas y el sector informal.

Durante el decenio de 1980, y especialmente en los países industrializados, ciertos aspectos de la evolución social y demográfica, tales como el envejecimiento de la población activa, el aumento de las pensiones por discapacidad y del absentismo por enfermedad y la dificultad de controlar los presupuestos nacionales de seguridad social dieron lugar a algunas reformas interesantes de los sistemas nacionales de salud en el trabajo, centradas en la prevención de las discapacidades a corto y a largo plazo, la conservación de la capacidad de trabajo, especialmente entre los trabajadores de más edad, y la reducción de las jubilaciones anticipadas. 
Por ejemplo, la modificación de la Ley ARBO holandesa ( $K$ roon y O vereynder 1991) junto con otras tres leyes sociales dirigidas a la prevención de la discapacidad a corto y a largo plazo, establecieron requisitos importantes para los servicios de salud y seguridad en el trabajo a nivel de fábrica, entre los que se incluyen:

- requisitos mínimos para los procedimientos, guías e instalaciones;

- requisitos mínimos en cuanto al número, composición y competencia de los equipos, que han de incluir especialistas tales como médicos competentes en la materia, expertos superiores en seguridad, higienistas del trabajo y consultores de gestión;

- requisitos relativos a la especificación de la organización de los servicios y sus actividades;

- exigencia de sistemas de aseguramiento de la calidad, incluyendo auditorías adecuadas;

- exigencia de que los especialistas que trabajen en el servicio estén acreditados por las autoridades competentes y que el propio servicio esté también acreditado mediante una auditoría externa.

Este nuevo sistema se pondrá en práctica paso a paso y debería estar concluido antes de finales del decenio de 1990.

Las modificaciones de la Ley sobre Servicios de Salud en el Trabajo finlandesa de 1991 y 1994 introdujeron el principio de mantenimiento de la capacidad de trabajo, especialmente de los trabajadores de más edad, como un nuevo elemento de las actividades preventivas de origen legislativo de estos servicios. Puesto en práctica mediante la estrecha colaboración de todos los actores del lugar de trabajo (dirección, trabajadores, servicios de salud y seguridad), supone la mejora y adaptación del trabajo, el medio ambiente de trabajo y el equipo del trabajador, mejorando y manteniendo su capacidad física y mental de trabajo y haciendo la organización del trabajo más favorable al mantenimiento de dicha capacidad. En la actualidad, se están tratando de desarrollar y evaluar métodos prácticos para alcanzar estos objetivos.

La aprobación, en 1987, del Acta Unica Europea dio un nuevo impulso a las medidas de seguridad y salud en el trabajo adoptadas por las Comunidades Europeas. La salud y seguridad en el trabajo se incluía por primera vez en el Tratado CEE de 1957, y se hacía mediante el nuevo artículo 118a. Para el nivel de protección tiene una importancia significativa el que las directivas aprobadas por los Estados miembros en virtud del artículo 118a establezcan requisitos mínimos relativos a esta materia. Según este principio, los Estados miembros han de elevar su nivel de protección si se encuentra por debajo de los requisitos mínimos establecidos por las directivas. Por encima de esto, se les anima y faculta para mantener e introducir medidas protectoras más intensas.

En junio de 1989 se aprobó la primera y probablemente más importante directiva, que establecía requisitos mínimos en la materia al amparo del artículo 118a: la Directiva $\mathrm{M}$ arco 89/391/ CEE relativa a la aplicación de medidas para promover la mejora de la seguridad y de la salud de los trabajadores en el lugar de trabajo. Es la estrategia central de salud y seguridad en el trabajo, sobre la que se asentarán todas las directivas futuras, que será complementada por directivas específicas sobre áreas determinadas y que establece también el marco general para futuras directivas conexas.

La Directiva M arco 89/391/ CEE contiene muchos aspectos de los Convenios OIT no 155 y 161, que los 15 países de la Unión Europea aplicarán en sus leyes y prácticas nacionales.
Entre las principales disposiciones de esta Directiva en materia de salud y seguridad en el trabajo se encuentran:

- el desarrollo de una política global coherente de prevención a nivel de la empresa, que integre el medio ambiente de trabajo, la tecnología, la organización del trabajo, las condiciones de trabajo y las relaciones sociales;

- el deber de la empresa de garantizar la seguridad y la salud de los trabajadores en todos los aspectos relacionados con el trabajo, incluida la prevención de los peligros del trabajo, la aportación de información y formación, así como la necesaria organización del trabajo, las medidas de control y los medios para realizar las actividades de salud en el trabajo en colaboración entre la empresa y los trabajadores;

- la indicación de que los trabajadores deben disfrutar de vigilancia sanitaria adecuada a los riesgos para la salud que soportan en el trabajo;

- el derecho de los trabajadores a recibir toda la información necesaria sobre los riesgos para la salud y la seguridad, así como la adopción de medidas preventivas con respecto tanto a la empresa en general como a cada tipo de puesto de trabajo y de tarea;

- la necesidad de que la planificación y la introducción de nuevas tecnologías esté sujeta a la consulta con los trabajadores y sus representantes con respecto a la elección de los equipos, las condiciones de trabajo y el medio ambiente de trabajo para la seguridad y la salud de los trabajadores;

- la exigencia de que los principios generales de prevención incluyan los objetivos de evitar los riesgos; evaluar los riesgos que no se pueden evitar; combatir los riesgos en su origen; adaptar el trabajo a la persona, en particular en lo que respecta al diseño de los puestos, la elección del equipo y los métodos de trabajo y de producción; tener en cuenta la evolución de la técnica; sustituir lo peligroso por lo que entraña poco o ningún peligro; adoptar medidas que antepongan la protección colectiva a la individual y dar las debidas instrucciones a los trabajadores.

Durante los últimos años se han adoptado numerosas disposiciones en la U nión Europea, entre ellas una serie de directivas basadas en los principios formulados en la Directiva $\mathrm{M}$ arco, algunas complementarias a las sujetas a medidas de armonización técnica en preparación y otras relativas a riesgos específicos en sectores de alto riesgo. Entre los ejemplos del primer grupo se encuentran las directivas relativas a los requisitos mínimos de salud y seguridad en el lugar de trabajo, al uso de equipos de trabajo por parte de los trabajadores, al uso de equipos de protección personal, al manejo manual de cargas, al trabajo con equipos de pantallas de visualización de datos, al establecimiento de señalización de seguridad y salud en el trabajo y a la puesta en práctica de las exigencias mínimas de seguridad y salud en lugares de construcción móviles o temporales. EI segundo grupo incluye directivas tales como las relativas a la protección de los trabajadores frente a los riesgos relativos a la exposición al cloruro de vinilo monómero, el plomo metálico y sus compuestos iónicos, el amianto, las sustancias cancerígenas y agentes biológicos, y a la protección de los trabajadores mediante la prohibición de determinados agentes y tareas, entre otras (N eal y Wright 1992; CE 1994).

Se ha propuesto recientemente la adopción de otras directivas (en concreto, sobre agentes físicos y químicos, actividades de transporte y lugares de trabajo, y equipo de trabajo) para consolidar algunas de las que ya están en vigor y racionalizar el planteamiento global de la seguridad y la salud de los trabajadores en estos campos (CE 1994).

Muchos nuevos elementos de las disposiciones y prácticas nacionales son una respuesta a los problemas de la vida laboral 
que surgen actualmente y contienen normas de desarrollo futuro de las infraestructuras de salud en el trabajo. Se refieren especialmente a la programación, a escala nacional y de empresa, de actividades más exhaustivas con respecto a los aspectos psicosociales, de organización y de capacidad de trabajo, prestándose una atención especial al principio de participación. También se establece la aplicación de ciertos sistemas de gestión de calidad, auditoría y certificación de la competencia de los expertos y los servicios con respecto a los requisitos de la legislación sobre la materia. Así, estas disposiciones nacionales, al absorber el contenido sustantivo de los instrumentos de la OIT, con independencia de que éstos hayan sido ratificados o no, llevan a la paulatina aplicación de los objetivos y principios contenidos en los Convenios O IT no 155 y 161 y del conjunto de la Estrategia HFA de la OMS.

\section{Objetivos de la práctica de salud en el trabajo}

L os objetivos de la práctica de la salud en el trabajo inicialmente definidos en 1950 por el Comité M ixto O IT / O M S sobre M edicina del Trabajo establecían que:

La Medicina del Trabajo persigue la promoción y el mantenimiento del más alto grado de bienestar físico, mental y social de los trabajadores en todas las profesiones; la prevención de pérdida de la salud derivada de las condiciones de trabajo; la protección de los trabajadores en su empleo contra los riesgos derivados de factores adversos para la salud; la colocación y el mantenimiento del trabajador en un ambiente de trabajo adaptado a sus capacidades fisiológicas y psicológicas. En resumen: la adaptación del trabajo al hombre y de cada hombre a su trabajo.

En 1959, a partir de los análisis del comité tripartito especial de la OIT (con representación de los gobiernos, las empresas y los trabajadores), la Cuadragésima segunda reunión de la Conferencia Internacional del Trabajo aprobó la Recomendación no 112 (O IT 1959), que definía el servicio de medicina en el trabajo como un servicio organizado en los lugares de trabajo 0 en sus inmediaciones, destinado:

- a asegurar la protección de los trabajadores contra todo riesgo que perjudique a su salud y que pueda resultar de su trabajo 0 de las condiciones en que éste se efectúa;

- a contribuir a la adaptación física y mental de los trabajadores, en particular por la adecuación del trabajo a los trabajadores y por su colocación en puestos de trabajo correspondientes a sus aptitudes;

- a contribuir al establecimiento y mantenimiento del nivel más elevado posible de bienestar físico y mental de los trabajadores.

En 1985, la O IT aprobó nuevos instrumentos internacionales [el Convenio sobre los servicios de salud en el trabajo ( $n$ - 161) y su Recomendación de acompañamiento (no 171) (OIT 1985A, 1985B)] que definían los servicios de salud en el trabajo como titulares de funciones básicamente preventivas y encargados del asesoramiento al empleador, a los trabajadores y a sus representantes en la empresa acerca de los requisitos necesarios para establecer y conservar un medio ambiente de trabajo seguro y sano que favorezca una salud física y mental óptima en relación con el trabajo, así como la adaptación del trabajo a las capacidades de los trabajadores, habida cuenta de su estado de salud física y mental.

En 1980, el Grupo de Trabajo O M S/ Europa para la Evaluación de los Servicios de Salud en el Trabajo e H igiene Industrial (OMS 1982) definió el fin último de estos servicios como "la promoción de las condiciones de trabajo que garanticen el máximo grado de calidad dela vida laboral mediantela protección de la salud de los trabajadores, potenciando su bienestar físico, mental y social y previniendo la pérdida de la salud y los accidentes."

El amplio estudio sobre los servicios de salud en el trabajo en los 32 países de la Región Europea realizado en 1985 por la O ficina Regional para Europa de la OMS (Rantanen 1990) señaló como objetivos los siguientes principios:

- proteger la salud de los trabajadores frente a los peligros en el trabajo (principio de protección y prevención);

- adaptar el trabajo y su medio ambiente a las capacidades de los trabajadores (principio de adaptación);

- potenciar el bienestar físico, mental y social de los trabajadores (principio de promoción de la salud);

- minimizar las consecuencias de los peligros, accidentes y lesiones profesionales, así como de las enfermedades profesionales y las relacionadas con el trabajo (principio de curación y rehabilitación);

- prestar servicios de asistencia sanitaria general a los trabajadores y sus familias, tanto curativos como preventivos, ya sea en el lugar de trabajo o desde instalaciones cercanas (principio de asistencia sanitaria primaria general).

Estos principios pueden considerarse aún relevantes con respecto a la evolución de las políticas y disposiciones de los países. Por otra parte, la formulación de objetivos de práctica de la salud en el trabajo como los recientemente aparecidos en leyes nacionales y el desarrollo de nuevas necesidades para la vida laboral parece recalcar las siguientes tendencias (O M S 1995a, 1995b; R antanen, Lehtinen y M ikheev 1994):

- El ámbito de la salud en el trabajo se está ampliando para cubrir no sólo la salud y la seguridad, sino también el bienestar psicológico y social y la capacidad de llevar una vida social y económicamente productiva.

- La gama completa de objetivos va más allá del ámbito de las cuestiones tradicionales de salud y seguridad en el trabajo.

- Los nuevos principios van más allá de la mera prevención y control de los efectos perjudiciales para la salud y la seguridad de los trabajadores, para abarcar la promoción activa de la salud y la mejora del medio ambiente y la organización del trabajo.

En consecuencia, existe realmente una tendencia a la expansión del ámbito de los objetivos de la práctica de la salud en el trabajo hacia nuevos tipos de cuestiones con consecuencias sociales y económicas para los trabajadores.

\section{Funciones y actividades de los servicios de salud en el trabajo}

Para proteger y promover la salud de los trabajadores, un servicio de salud en el trabajo ha de atender las especiales necesidades de la empresa a la que presta sus servicios y de los trabajadores empleados en ella. Dada la amplísima gama y ámbito de las actividades económicas industriales, de fabricación, comerciales, agrícolas y demás, no es posible establecer un programa detallado de actividad o un patrón de organización y unas condiciones de funcionamiento del servicio de salud en el trabajo que sean adecuadas para todas las empresas y situaciones. Según el Convenio de la O IT sobre seguridad y salud de los trabajadores y medio ambiente de trabajo ( $\mathrm{n}$ - 155) y el Convenio OIT sobre los servicios de salud en el trabajo (no 161), la responsabilidad primaria respecto a la salud y la seguridad de los trabajadores reside en la empresa. Las funciones del servicio de salud en el trabajo son proteger y promover la salud de los trabajadores, mejorar las condiciones y el medio ambiente de trabajo y mantener la salud en la empresa en su conjunto mediante la prestación de servicios de salud en el trabajo a los trabajadores y asesoramiento especializado a la empresa acerca de cómo 
conseguir el máximo nivel de salud y seguridad en beneficio de la comunidad laboral de la que forma parte.

EI Convenio de la O IT no 161 y su Recomendación de acompañamiento no 171 consideran que los servicios de salud en el trabajo tienen un carácter interdisciplinar, integral y que, aunque con tareas fundamentalmente preventivas, puede realizar también actividades curativas. Los documentos de la O M S que reclaman servicios para las pequeñas empresas y los trabajadores autónomos y agrícolas recomiendan la prestación de servicios por parte de las unidades de asistencia sanitaria primaria (Rantanen, Lehtinen y M ikheev 1994). Estos documentos, así como las legislaciones y programas nacionales, recomiendan una aplicación paulatina, de modo que las actividades puedan adaptarse a las necesidades nacionales y locales y a las circunstancias existentes.

En teoría, el servicio de salud en el trabajo debería establecerse y actuar con arreglo a un programa de actividades adaptado a las necesidades de la empresa en la que opera. Sus funciones deberían ser adecuadas a los peligros profesionales y a los riesgos para la salud de la empresa, con especial atención a los problemas específicos de la rama de actividad en cuestión. A continuación se exponen las funciones básicas y más habituales de un servicio de salud en el trabajo.

\section{Orientación preliminar a la empresa}

Si los servicios de salud en el trabajo no se han establecido con anterioridad o se contrata nuevo personal, es necesaria una orientación preliminar a la situación de la seguridad y la salud en el trabajo en la empresa, lo que implica los siguientes pasos:

- El análisis del tipo de producción indicará los tipos de peligros típicos de esa actividad, tarea o profesión, que podrán por tanto esperarse en la empresa y pueden ayudar a determinar los que requieren especial atención.

- La revisión de los problemas detectados por los profesionales de la salud en el trabajo, la dirección de la empresa, los trabajadores y otros especialistas, así como las medidas anteriormente adoptadas en el lugar de trabajo, indicarán la percepción de los problemas por parte de la empresa. Esto debería incluir el estudio de los informes de las actividades de salud y seguridad en el trabajo, las medidas de higiene industrial, los datos de control biológico, etc.

- La revisión de las características de la plantilla (es decir: datos de edades, sexos, antecedentes étnicos, relaciones familiares, clasificaciones profesionales, historiales laborales y, si es posible, cuestiones sanitarias relacionadas) ayudará a detectar los grupos vulnerables y a quienes tengan necesidades especiales.

- Deben estudiarse los datos disponibles sobre enfermedades, accidentes y absentismo por enfermedad en el trabajo, agrupados, si es posible, por departamentos, profesiones y tipo de trabajo, factores desencadenantes y tipos de lesiones 0 enfermedades.

- Los datos sobre métodos de trabajo, sustancias químicas manejadas, últimas medidas de exposición y número de trabajadores expuestos a peligros especiales son necesarios para determinar los problemas prioritarios.

- Debe analizarse el conocimiento de los problemas sanitarios por parte de los trabajadores, su grado de formación sobre las medidas de emergencia y primeros auxilios y las previsiones para un comité de salud y seguridad en el trabajo eficaz.

- Por último, deben estudiarse los planes de cambios en los sistemas de producción, establecimiento de nuevas instalaciones, maquinarias y equipos, introducción de nuevos materiales y cambios en la organización del trabajo como punto de partida para el cambio de la práctica futura de salud en el trabajo.

\section{Vigilancia del medio ambiente de trabajo}

La calidad del medio ambiente de trabajo, derivada del cumplimiento de los estándares de salud y seguridad en el trabajo, ha de garantizarse mediante la vigilancia en el lugar de trabajo. Según el Convenio O IT no 161, ésta es una de las tareas fundamentales de los servicios de salud en el trabajo.

A partir de la información obtenida mediante la orientación preliminar de la empresa se realiza un estudio directo del lugar de trabajo, preferiblemente a cargo de un equipo interdisciplinar de salud en el trabajo complementado por representantes de los trabajadores y de la empresa. Este estudio debe incluir entrevistas con los directivos, encargados y trabajadores. En caso necesario, pueden realizarse revisiones especiales de seguridad, higiene, ergonómicas o psicológicas.

Existen listas de control y directrices especiales recomendables para estos estudios. Las observaciones pueden mostrar la necesidad de adoptar medidas o controles específicos de especialistas en higiene, ergonomía, toxicología, ingeniería de seguridad o psicología del trabajo, pertenecientes o no al equipo de salud en el trabajo. Estas mediciones o revisiones especiales pueden exceder de los recursos de las pequeñas empresas, las cuales tendrán que basarse en las observaciones realizadas durante el estudio, complementadas con datos cualitativos 0 , en el mejor de los casos, semicualitativos.

C omo lista básica de control, puede recomendarse la Lista de Enfermedades Profesionales (enmendada en 1980) anexa al Convenio de la OIT relativo a las prestaciones en caso de accidentes del trabajo y enfermedades profesionales, 1964 ( $n$ - 121), en el que se enumeran las principales causas conocidas de enfermedades profesionales y que, pese a tener como objetivo principal dar pautas para la indemnización por enfermedades profesionales, puede servir también para su prevención. L os peligros no mencionados en esta lista pueden añadirse en función de las circunstancias locales o nacionales.

El ámbito de vigilancia del medio ambiente de trabajo, en los términos definidos por la Recomendación de la OIT sobre Servicios de Salud en el Trabajo ( $n$ - 171), abarca lo siguiente:

- la identificación y evaluación de los factores del medio ambiente de trabajo que pueden afectar a la salud de los trabajadores;

- la evaluación de las condiciones de higiene en el trabajo y de los factores de la organización del trabajo que puedan engendrar riesgos para la salud de los trabajadores;

- la evaluación de los medios de protección colectiva e individual;

- la evaluación, cuando sea apropiado, de la exposición de los trabajadores a los agentes nocivos, mediante métodos de control válidos y generalmente aceptados;

- la verificación de los sistemas de control destinados a eliminar o reducir la exposición.

Con los resultados del estudio directo debe elaborarse un inventario de riesgos, señalando todos los que sean propios de la empresa, necesario para calcular la potencial exposición y proponer medidas de control. A efectos de este inventario y para facilitar el diseño, puesta en práctica y evaluación de los controles, los peligros deben correlacionarse con los riesgos que suponen de resultados agudos o crónicos para la salud de los trabajadores y en función del tipo de peligro (por ejemplo, químico, físico, biológico, psicológico o ergonómico).

El siguiente paso es la valoración cuantitativa de la exposición, necesaria para un evaluación más precisa de los peligros para la salud, que consiste en medir la intensidad o concentración, la variación en el tiempo y la duración total de la exposición, así como el número total de trabajadores expuestos. La medición y evaluación de la exposición suelen ser realizadas por 
especialistas en control de lesiones, ergónomos e higienistas del trabajo, y se basan en los principios del control medioambiental, debiendo incluir, cuando sea necesario, el control del medio ambiente para recoger datos de exposición en un determinado medio ambiente de trabajo, así como el control de la exposición personal de un determinado trabajador o grupo de trabajadores (por ejemplo, expuestos a peligros específicos). La medición de la exposición es necesaria cuando los peligros son esperados o razonablemente previsibles, y debe basarse en el inventario completo de peligros, combinado con una evaluación de las prácticas de trabajo. Para establecer prioridades de intervención debe utilizarse el conocimiento de los efectos potenciales de cada peligro.

La evaluación de los peligros para la salud en el lugar de trabajo debe realizarse teniendo en cuenta la totalidad de las exposiciones en comparación con los estándares establecidos, que se expresan en términos de niveles permisibles y límites de exposición y son fruto de numerosos estudios científicos sobre la correlación entre exposición y efectos en la salud. Algunos de ellos se han convertido en estándares nacionales y son jurídicamente obligatorios según la legislación y la práctica del país, tales como las $C$ oncentraciones $M$ áximas Permisibles (M AK, en Alemania, M AC, en los países de Europa O riental), y los Límites de Exposición Permisible (PEL, en Estados Unidos). H ay PEL para unas 600 sustancias químicas habituales en los lugares de trabajo. También hay límites de exposición media ponderada en el tiempo, límites de exposición a corto plazo (STEL), topes y límites para algunas condiciones duras que pueden dar lugar a absorción cutánea.

L a vigilancia del medio ambiente de trabajo incluye el control tanto de las exposiciones peligrosas como de los efectos para la salud. Si la exposición a los peligros es excesiva, debe controlarse con independencia de los efectos y evaluarse la salud de los trabajadores expuestos. La exposición se considera excesiva si se acerca o sobrepasa los límites establecidos, tales como los anteriormente mencionados

Esta vigilancia proporciona información sobre las necesidades de salud profesional de la empresa y muestra las prioridades de acción preventiva y de control. La mayoría de los instrumentos que marcan las pautas de los servicios de salud en el trabajo recalcan la necesidad de realizar la vigilancia antes de poner en marcha los servicios, periódicamente durante las actividades y siempre que se produzcan cambios sustanciales en el trabajo o el medio ambiente de trabajo.

Los resultados obtenidos aportan los datos necesarios para calcular si las medidas preventivas adoptadas son efectivas y si los trabajadores ocupan puestos adecuados a sus capacidades. L os servicios de salud en el trabajo emplean también estos datos para garantizar que se mantenga una protección fiable contra las exposiciones y para formular recomendaciones sobre el modo de poner en práctica controles para mejorar el medio ambiente de trabajo. Además, la información acumulada se emplea para la realización de estudios epidemiológicos, para la revisión de los niveles permisibles de exposición y para la evaluación de la eficacia de las medidas de ingeniería de control y demás métodos de diversos programas preventivos.

\footnotetext{
Información a la empresa, la dirección y los trabajadores sobre los peligros para la salud en el trabajo

Una vez obtenida la información sobre peligros sanitarios potenciales en el lugar de trabajo, debe comunicarse a los responsables de adoptar medidas preventivas y de control, así como a los trabajadores expuestos a los mismos. La información ha de ser tan precisa y cuantitativa como sea posible, y debe describir las medidas preventivas adoptadas y explicar lo que deben hacer los trabajadores para garantizar su eficacia.
}

La Recomendación de la O IT sobre Servicios de Salud en el Trabajo ( $n$ - 171) establece que, de conformidad con la legislación y la práctica nacionales, los datos resultantes de la vigilancia del lugar de trabajo deberían consignarse en forma adecuada y mantenerse a disposición del empleador, de los trabajadores y de sus representantes en la empresa o del comité de salud y seguridad e higiene, cuando existen. Tales datos deberían utilizarse respetando su carácter confidencial y solamente para orientar y dar asesoramiento acerca de las medidas destinadas a mejorar el medio ambiente de trabajo y la salud y seguridad de los trabajadores. La autoridad competente debería tener acceso a estos datos, los cuales sólo debería comunicar el servicio de salud en el trabajo a terceros previo acuerdo del empleador y de los trabajadores. Los trabajadores afectados deben ser informados de forma adecuada sobre los resultados de la vigilancia y ha de reconocérseles el derecho a solicitar el control del medio ambiente de trabajo.

\section{Evaluación de los riegos para la salud}

Para evaluar los riesgos para la salud en el trabajo se combina la información procedente de la vigilancia del medio ambiente de trabajo con datos de otras fuentes, tales como estudios epidemiológicos sobre profesiones y exposiciones determinadas y valores de referencia tales como límites de exposición profesional y estadísticas disponibles. Los datos cualitativos (por ejemplo, si la sustancia es cancerígena) y, en la medida de lo posible, cuantitativos (por ejemplo, cuál es el grado de exposición) pueden mostrar que los trabajadores están expuestos a peligros sanitarios y señalar la necesidad de adoptar medidas preventivas y de control.

Entre los pasos para la evaluación de riesgos para la salud en el trabajo se encuentran:

- la identificación de los peligros para la salud en el trabajo (fruto de los resultados de la vigilancia sobre el medio ambiente de trabajo);

- el análisis del modo en que el peligro puede afectar al trabajador (vías de entrada y tipo de exposición, valores límite umbral, relaciones dosis-efecto, efectos adversos potenciales para la salud, etc.);

- la identificación de los trabajadores o grupos de trabajadores expuestos a peligros específicos;

- la identificación de personas y grupos con puntos vulnerables especiales;

- la evaluación de las medidas actuales de prevención y control de peligros;

- la formulación de conclusiones y documentación de las conclusiones de la evaluación;

- la revisión periódica y, en caso necesario, reevaluación.

\section{Vigilancia de la salud de los trabajadores}

D ebido a las limitaciones tecnológicas y económicas, a menudo no es posible eliminar todos los peligros para la salud en el lugar de trabajo. En estos casos, la vigilancia de la salud de los trabajadores pasa a ocupar un lugar primordial. Esta vigilancia comprende varias formas de evaluación médica de los efectos sanitarios de la exposición de los trabajadores a los peligros del lugar de trabajo.

Los objetivos principales de los reconocimientos médicos son evaluar la adecuación del trabajador para determinados trabajos, evaluar cualquier deficiencia sanitaria potencialmente relacionada con la exposición a agentes nocivos inherentes al proceso de trabajo e identificar los casos de enfermedad profesional con arreglo a la legislación nacional.

Los reconocimientos médicos no protegen a los trabajadores frente a los peligros para la salud ni sustituyen a las medidas de control adecuadas, que tienen carácter prioritario en la jerarquía 
de acciones, pero pueden ayudar a detectar circunstancias que hagan a un trabajador más vulnerable a los efectos de agentes peligrosos o signos de deficiencias sanitarias causadas por dichos agentes. L os reconocimientos deben realizarse en paralelo con la investigación del medio ambiente de trabajo, que proporciona información sobre exposición potencial en el lugar de trabajo y se emplea por los profesionales de la salud en el trabajo para evaluar los resultados obtenidos mediante la vigilancia sanitaria de los trabajadores expuestos.

\section{La vigilancia de la salud de los trabajadores puede ser pasiva y activa}

En el caso de la vigilancia pasiva, se pide a los trabajadores enfermos 0 afectados que consulten a los profesionales de la salud en el trabajo. Este tipo de vigilancia sólo suele detectar enfermedades sintomáticas y requiere que los profesionales sanitarios sean capaces de diferenciar los efectos de la exposición en el trabajo de otros efectos similares de exposiciones no profesionales.

En el caso de la vigilancia activa, los profesionales de la salud en el trabajo seleccionan y examinan a los trabajadores que padecen alto riesgo de sufrir enfermedades o lesiones relacionadas con el trabajo. Puede llevarse a cabo de diversas formas, incluidos los reconocimientos médicos periódicos de todos los trabajadores, los de trabajadores expuestos a peligros específicos y la exploración selectiva y supervisión de grupos seleccionados de trabajadores. Las formas específicas de vigilancia sanitaria dependen en gran medida de los efectos potenciales sobre la salud de una determinada exposición profesional. La vigilancia activa es más apropiada para los trabajadores con un historial de múltiples exposiciones y para los que soportan mayores riesgos de enfermedad o lesión.

L os detalles sobre la vigilancia de la salud se encuentran en el Convenio de la OIT no 161 y la Recomendación no 171, que especifican que la vigilancia debe incluir, en los casos y condiciones establecidos por las autoridades competentes, todas las evaluaciones necesarias para proteger la salud de los trabajadores, entre las que pueden encontrarse:

- la evaluación de la salud de los trabajadores antes de que se les asignen tareas específicas que puedan entrañar un peligro para su salud o para la de los demás;

- evaluaciones de la salud a intervalos periódicos durante todo empleo que implique una exposición a riesgos particulares para la salud;

- una evaluación de la salud de los trabajadores que reanudan el trabajo tras una ausencia prolongada por motivos de salud, con la finalidad de descubrir sus eventuales orígenes profesionales, de recomendar una acción apropiada para proteger a los trabajadores y de adaptabilidad de los trabajadores a sus tareas y la necesidad de una reclasificación y de una readaptación;

- evaluaciones de la salud al terminar y después de terminar asignaciones a puestos de trabajo que entrañen riesgos susceptibles de provocar juicios ulteriores para su salud o de contribuir a tales perjuicios.

La evaluación de la situación sanitaria de los trabajadores es de primordial importancia cuando se inicia la práctica de la salud en el trabajo, se contrata a nuevos trabajadores, se introducen nuevas prácticas de trabajo o tecnologías, cuando se detectan exposiciones especiales y cuando determinados trabajadores tienen características sanitarias que hagan necesario un seguimiento. Varios países han adoptado reglamentaciones 0 directrices en las que se especifica cuándo y cómo deben realizarse los reconocimientos médicos. Los reconocimientos deben controlarse y desarrollarse continuamente para detectar efectos sanitarios relacionados con el trabajo en sus primeras fases de desarrollo.

\section{Reconocimientos médicos previos a la asignación (previos al empleo)}

Este tipo de evaluación de la salud se realiza antes de la colocación de los trabajadores o de su asignación a una determinada tarea que pueda suponer un peligro para su salud o la de otras personas. El objetivo es determinar si la persona se ajusta física y psicológicamente al puesto específico y asegurarse de que su colocación no supondrá un peligro para su salud o la de otros trabajadores. En la mayoría de los casos, la revisión del historial médico, el reconocimiento médico general y las pruebas habituales de laboratorio (por ejemplo, análisis de sangre y de orina) serán suficientes, pero en algunos casos, la existencia de un problema sanitario o las especiales exigencias de un determinado puesto pueden exigir reconocimientos funcionales 0 pruebas diagnósticas.

$\mathrm{H}$ ay varios problemas sanitarios que pueden hacer que un trabajo sea peligroso para el trabajador o para otros trabajadores 0 terceras personas. Por estos motivos, puede resultar necesario, por ejemplo, excluir a trabajadores con hipertensión incontrolada 0 diabetes inestable de ciertos trabajos peligrosos (tales como los de piloto aéreo o marítimo, conductor de vehículos de servicio público o de grandes transportes, operador de grúas, etc.). El daltonismo puede justificar la exclusión de trabajos que requieran discernir los colores por razones de seguridad (por ejemplo, en las señales de tráfico). Para los trabajos que requieran un alto nivel de forma física general, tales como el buceo en profundidad, los servicios de bomberos y de policía o el pilotaje de aviones, sólo serán aceptables los trabajadores que cumplan los requisitos de rendimiento. La posibilidad de que las enfermedades crónicas se vean agravadas por las exposiciones inherentes a un determinado trabajo debe tenerse también en cuenta. Es esencial, por tanto, que quien practica el reconocimiento conozca a fondo el puesto y el medio ambiente de trabajo y sea consciente de que las descripciones estandarizadas de los puestos de trabajo pueden ser excesivamente superficiales e incluso equívocas.

U na vez terminada la evaluación de la salud prescrita, el médico del trabajo debe comunicar los resultados por escrito tanto al trabajador como a la empresa. Las conclusiones transmitidas a la empresa no deben contener información alguna de carácter médico, sino una conclusión relativa a la adecuación de la persona reconocida para el puesto actual o propuesto y una especificación del tipo de trabajos y condiciones de trabajo médicamente contraindicadas para la persona, sea temporal 0 permanentemente.

El reconocimiento médico previo al empleo es importante para el historial profesional posterior del trabajador, ya que proporciona la información clínica y los datos de laboratorio necesarios sobre su situación sanitaria en el momento de ocupar su puesto. También supone un punto de partida indispensable para posteriores evaluaciones de cualquier cambio potencial en su situación sanitaria.

\section{Reconocimientos médicos periódicos}

Se realizan a intervalos periódicos durante los empleos que supongan una exposición a peligros potenciales que no puedan eliminarse completamente mediante acciones de control preventivo. El objetivo es controlar la salud del trabajador durante su empleo, verificando su ajuste al puesto y detectando tan pronto 
como sea posible cualquier síntoma de falta de salud que pueda deberse al trabajo. Suelen complementarse con otros reconocimientos según el tipo de peligros detectados.

Entre sus objetivos están:

- detectar lo antes posible cualquier efecto adverso para la salud causado por prácticas de trabajo o exposición a peligros potenciales;

- detectar la posible aparición de una enfermedad profesional;

- verificar si la salud de un trabajador especialmente vulnerable o enfermo crónico se está viendo adversamente afectada por el trabajo o el medio ambiente de trabajo;

- controlar la exposición personal con la ayuda de controles biológicos;

- comprobar la eficacia de las medidas preventivas y de control;

- identificar posibles efectos sanitarios de los cambios en las prácticas de trabajo, las tecnologías o las sustancias utilizadas en la empresa.

Estos objetivos determinarán la frecuencia, contenidos y métodos de los reconocimientos médicos periódicos, que podrán llegar a realizarse con una frecuencia de uno o tres meses, o bien cada ciertos años, dependiendo de la naturaleza de la exposición, la reacción biológica esperada, las oportunidades de adoptar medidas preventivas y la viabilidad del método de reconocimiento. Pueden ser globales o limitarse a unas pocas pruebas. En varios países existen directrices especiales sobre los objetivos, frecuencia, contenidos y metodología para la realización de estos reconocimientos.

\section{Reconocimientos médicos en la reincorporación al trabajo}

Este tipo de evaluación de la salud es necesario para autorizar la reanudación del trabajo tras una larga ausencia por motivos de salud y determina la adecuación del trabajador para el puesto, recomendando acciones apropiadas para protegerle de futuras exposiciones e identificando si existe alguna necesidad de reclasificación o de readaptación.

De modo similar, cuando un trabajador cambia de puesto, el médico del trabajo debe certificar que se adecúa a las nuevas tareas. El objetivo del reconocimiento, su necesidad y el destino de los resultados determinarán su contenido y sus métodos y contexto de realización.

\section{Reconocimientos médicos generales}

En muchas empresas, los reconocimientos médicos generales corren a cargo del servicio de salud en el trabajo. Suelen ser voluntarios y están a disposición de todo el personal o sólo de ciertos grupos caracterizados por la edad, la duración del empleo, el nivel jerárquico, etc. Pueden ser exhaustivos o estar limitados a la exploración selectiva de ciertas enfermedades o peligros para la salud. Sus objetivos determinan su frecuencia, contenidos y métodos empleados.

\section{Reconocimientos médicos al término del servicio}

Este tipo de evaluación de la salud se realiza a la terminación de una asignación que suponga peligros que puedan causar o contribuir a la aparición de perjuicios para la salud. El objetivo es realizar una evaluación final de la salud del trabajador, compararla con los reconocimientos médicos previos y evaluar cómo han afectado a la salud las asignaciones de puestos anteriores.

\section{Observaciones generales}

L as observaciones generales resumidas a continuación se aplican a todos los tipos de reconocimientos médicos.

Los reconocimientos médicos de los trabajadores deben realizarse por profesionales cualificados formados en salud en el trabajo, familiarizados con las exposiciones, las exigencias físicas y demás condiciones de trabajo en la empresa y con experiencia en el uso de técnicas e instrumentos de reconocimiento médico adecuados, así como en la gestión de impresos de registro apropiados.

El reconocimiento médico no es un sustitutivo de las acciones de prevención o control de exposiciones peligrosas en el medio ambiente laboral. Si la prevención tiene éxito, se necesitarán pocos reconocimientos.

Todos los datos reunidos con respecto a los reconocimientos médicos son confidenciales y deben quedar registrados por el servicio de salud en el trabajo en archivos confidenciales de salud. Los datos personales relativos a la evaluación de la salud sólo pueden comunicarse a otras personas con el consentimiento consciente del trabajador afectado. Si éste desea que los datos se remitan a un médico particular, debe prestar un consentimiento formal.

Las conclusiones relativas a la adecuación del trabajador a un determinado puesto o a los efectos sobre la salud de dicho puesto deben comunicarse a la empresa de forma que no se infrinja el principio de confidencialidad de los datos sanitarios personales.

El uso de los reconocimientos médicos y sus resultados para cualquier tipo de discriminación contra los trabajadores no puede tolerarse y debe quedar estrictamente prohibido.

\section{Iniciativas sobre medidas preventivas y de control}

Los servicios de salud en el trabajo no sólo son responsables de la detección y evaluación de riesgos potenciales para la salud de los trabajadores, sino también de la prestación de asesoramiento sobre medidas preventivas y de control que ayuden a evitarlos.

Tras analizar los resultados de la vigilancia del medio ambiente de trabajo, incluido, en caso de ser necesario, el control de la exposición personal de los trabajadores, y los resultados de la vigilancia de la salud de los trabajadores, incluidos también en caso necesario los resultados del control biológico, los servicios de salud en el trabajo deben estar en condiciones de evaluar posibles conexiones entre la exposición a los peligros profesionales y los perjuicios para la salud resultantes y de proponer medidas adecuadas de control para la protección de ésta. Tales medidas se recomiendan conjuntamente con otros servicios técnicos de la empresa tras consultar a la dirección, la empresa, los trabajadores y sus representantes.

Las medidas de control han de ser apropiadas para prevenir exposiciones innecesarias durante las condiciones normales de funcionamiento y durante los accidentes y emergencias. Deben tenerse también en cuenta, las modificaciones de los procesos de trabajo planeadas y las recomendaciones han de ser adaptables a las necesidades futuras.

Las medidas de control de los peligros para la salud se emplean para eliminar la exposición en el trabajo, minimizarla 0 , en todo caso, reducirla a límites permisibles. Incluyen en primer lugar la tecnología, los controles técnicos en el medio ambiente de trabajo, los cambios en las tecnologías, sustancias y materiales $y$, como medidas preventivas secundarias, los controles del comportamiento humano, los equipos de protección personal, el control integrado y otros.

La formulación de recomendaciones sobre medidas de control es un proceso complicado que incluye el análisis de la información relativa a los riesgos sanitarios actuales en la empresa y la toma en consideración de las necesidades y exigencias de seguridad y salud en el trabajo. Para los análisis de viabilidad y de costes/ beneficios, debe tenerse en cuenta que las inversiones realizadas en materia de seguridad y salud pueden dar frutos durante largos períodos en el futuro, pero no necesariamente de forma inmediata. 
Los instrumentos de la OIT incluyen la exigencia de que las empresas, los trabajadores y sus representantes colaboren y participen en la puesta en práctica de tales recomendaciones. Suelen analizarse en los comités de seguridad y salud de las grandes empresas, y por los representantes de la empresa y los trabajadores en las pequeñas.

Es importante documentar las recomendaciones propuestas, de modo que sea posible hacer un seguimiento de su aplicación. Esta documentación debe recalcar la responsabilidad de la dirección con respecto a las medidas preventivas y de control.

\section{Función de asesoramiento}

Los servicios de salud en el trabajo tienen a su cargo una importante tarea de prestación de asesoramiento a la dirección, la empresa, los trabajadores y los comités de salud y seguridad tanto de forma personal como en cuanto colectivos. Esto debe tenerse en cuenta y aplicarse en los procesos de toma de decisión, ya que suele ocurrir que las profesionales de la salud en el trabajo no participen directamente en ellos.

EI Convenio de la OIT sobre los servicios de salud en el trabajo ( $n$ - 161) y la Recomendación correspondiente ( $n$ ㅇ11) promueven la función asesora en la empresa de los profesionales de la salud en el trabajo.

Para promover la adaptación del trabajo a los trabajadores y mejorar las condiciones y el medio ambiente de trabajo, estos servicios deben actuar como asesores en materia de salud, higiene, ergonomía, equipos de seguridad individuales y colectivos para la empresa, los trabajadores y sus representantes en la empresa, y el comité de seguridad y salud, así como colaborar con otros servicios que ya ejercen esta función. Deben asesorar acerca de la planificación y organización del trabajo, el diseño de los lugares de trabajo, la elección, mantenimiento y estado de la maquinaria y demás equipos, así como sobre las sustancias y materiales empleados en la empresa.

También deben participar en el desarrollo de programas para la mejora de las prácticas de trabajo, así como en la realización de pruebas y en la evaluación de aspectos sanitarios de los nuevos equipos.

Los servicios de salud en el trabajo deben prestar asesoramiento personal a los trabajadores sobre su salud con respecto al trabajo.

0 tra importante tarea es prestar asesoramiento e información sobre la integración de trabajadores víctimas de accidentes 0 enfermedades de trabajo para ayudarles a conseguir una rehabilitación rápida, proteger su capacidad de trabajo, reducir el absentismo y reinstaurar un buen ambiente psicosocial en la empresa.

Las actividades educativas y de formación están estrechamente vinculadas a la tarea de asesoramiento que prestan estos profesionales con respecto a la empresa y los trabajadores. Tienen especial importancia cuando se prevé modificar las instalaciones 0 introducir nuevos equipos, o cuando puede haber cambios en la disposición del lugar de trabajo, los puestos de trabajo y la organización del trabajo.

Estas actividades aportan una ventaja cuando se emprenden en el momento adecuado, ya que permiten una mayor consideración de los factores humanos y los principios ergonómicos para la mejora de las condiciones y el medio ambiente de trabajo.

Los servicios de asesoramiento técnico en el lugar de trabajo constituyen una importante función preventiva de los servicios de salud en el trabajo. Deben dar prioridad a la sensibilización respecto a los peligros profesionales y a la participación de los trabajadores y la empresa en el control de dichos peligros y en la mejora del medio ambiente de trabajo.
Servicios de primeros auxilios y preparación para urgencias La organización de tratamientos de urgencia y primeros auxilios es una responsabilidad tradicional de los servicios de salud en el trabajo. El Convenio de la OIT no 161 y la Recomendación no 171 establecen que estos servicios deben realizar estas tareas en casos de accidente o indisposición de trabajadores en el lugar de trabajo y colaborar en la organización de la administración de primeros auxilios

Esta función implica la preparación frente a los accidentes y afecciones graves de trabajadores individuales, así como la capacidad de reacción en colaboración con otros servicios de urgencias en caso de accidentes graves que afecten a la totalidad de la empresa. La formación en primeros auxilios es un deber primordial de los servicios de salud en el trabajo y su personal debe estar entre los primeros en reaccionar.

El servicio de salud en el trabajo debe mantener acuerdos preliminares con los servicios de ambulancias y los bomberos, la policía, los servicios de salvamento y los hospitales de la comunidad, con el fin de evitar demoras y confusiones que puedan poner en peligro la supervivencia de trabajadores gravemente heridos o enfermos. Estos acuerdos, complementados si es posible con los procedimientos correspondientes, son especialmente importantes en la preparación frente a grandes urgencias, tales como incendios, explosiones, emisiones tóxicas y otras catástrofes que pueden afectar a muchas personas de la empresa y del vecindario y producir varias víctimas.

\section{Servicios de asistencia sanitaria en el trabajo y servicios sanitarios generales preventivos y curativos}

Los servicios de salud en el trabajo pueden participar en el diagnóstico, tratamiento y rehabilitación de las lesiones y enfermedades profesionales. El conocimiento de éstas, unido al del trabajo, el medio ambiente y las exposiciones del trabajo permiten a estos profesionales desempeñar un papel clave en la gestión de los problemas sanitarios relacionados con el trabajo.

Según el ámbito de actividades y las exigencias de la legislación nacional, o en función de la práctica del país, los servicios de salud en el trabajo comprenden tres categorías principales según desempeñen:

- funciones esencialmente preventivas, incluyendo principalmente visitas en el lugar de trabajo, reconocimientos médicos y prestación de primeros auxilios;

- funciones preventivas complementadas con servicios de asistencia sanitaria general y curativa selectiva,

- funciones en una amplia gama de actividades, incluidas tanto las preventivas como las curativas integrales y las de rehabilitación.

La Recomendación de la OIT sobre los servicios de salud en el trabajo (no 171) promueve la prestación de servicios de asistencia sanitaria curativa y general como funciones propias de los servicios de salud en el trabajo cuando resulten adecuados. Habida cuenta de la legislación y la práctica nacionales, los servicios de salud en el trabajo podrán asumir o participar en una o más de las siguientes funciones curativas en relación con las enfermedades profesionales:

- el tratamiento de los trabajadores que no hayan interrumpido su trabajo o que se hayan reintegrado al mismo tras una ausencia;

- el tratamiento de las enfermedades profesionales y de las afecciones agravadas por el trabajo;

- el tratamiento de víctimas de accidentes del trabajo;

- los aspectos médicos de la reeducación y readaptación profesionales. 
La prestación de servicios de asistencia sanitaria preventivos y curativos generales incluye la prevención y tratamiento de enfermedades no profesionales y otros importantes servicios de asistencia sanitaria primaria. Normalmente, los servicios de asistencia sanitaria preventiva general incluyen vacunaciones, la asistencia por maternidad y puericultura, y servicios generales de higiene y sanitarios, en tanto que los servicios de asistencia sanitaria curativa general incluyen la actividad propia del médico general. A este respecto, la Recomendación $\mathrm{n} 0171$ de la OIT establece que el servicio de salud en el trabajo, habida cuenta de la organización de la medicina preventiva a nivel nacional, podría desempeñar las siguientes funciones:

- proceder a inmunizaciones en relación con los riesgos biológicos que se presentan en el lugar de trabajo;

- participar en campañas de protección de la salud;

- colaborar con las autoridades sanitarias en el marco de programas de salud pública.

Los servicios de salud en el trabajo establecidos en las grandes empresas, así como los que operan en áreas alejadas o médicamente subatendidas, pueden asumir la prestación de la asistencia sanitaria no profesional no sólo para los trabajadores, sino también para sus familias. El alcance de estos servicios dependerá de la infraestructura de los servicios sanitarios de la comunidad y de la capacidad de la empresa. Cuando las empresas industriales se establecen en áreas poco desarrolladas, puede ser incluso conveniente prestar tales servicios junto con la asistencia sanitaria en el trabajo.

En algunos países, los servicios de salud en el trabajo prestan en horas de trabajo el tratamiento ambulatorio normalmente a cargo del médico general. Suele limitarse a tratamientos senciIlos, pero puede suponer una asistencia médica más completa si la empresa tiene un acuerdo con la seguridad social u otra entidad de seguros en el que se establezca el reembolso de los costes del tratamiento de los trabajadores.

\section{Rehabilitación}

La participación de los servicios de salud en el trabajo es especialmente decisiva en la orientación de la rehabilitación de los trabajadores y su reincorporación al trabajo, función cada vez más importante debido al gran número de accidentes profesionales de los países en vías de desarrollo y al envejecimiento de la población activa en los países desarrollados. L os servicios de rehabilitación suelen ser prestados por unidades externas, ya sean autónomas 0 integradas en un hospital, dotadas de especialistas en rehabilitación, terapeutas del trabajo, especialistas en asesoramiento profesional, etc.

$\mathrm{H}$ ay algunas cuestiones importantes relativas a la participación de los servicios de salud en el trabajo en la rehabilitación de trabajadores lesionados.

En primer lugar, este servicio puede ayudar decisivamente a que el trabajador que se recupera de una lesión o enfermedad le sea enviado sin dilación. Es mucho mejor que el trabajador regrese a su lugar de trabajo original, si es posible, y el servicio de salud en el trabajo tiene como importante función mantener el contacto durante el período de incapacidad con los responsables del tratamiento en las fases agudas para conocer cuándo podrá producirse esa reincorporación.

En segundo lugar, el servicio de salud en el trabajo puede facilitar el pronto regreso al trabajo colaborando en la planificación con el servicio de rehabilitación. Su conocimiento del trabajo y el medio ambiente de trabajo será útil para estudiar las posibilidades de modificar el trabajo original (por ejemplo: cambios en la asignación de tareas, limitación de jornada, períodos de descanso, equipos especiales, etc.) o de disponer una sustitución alternativa temporal.
Por último, el seguimiento de los progresos del trabajador permite al servicio de salud en el trabajo mantener informada a la dirección acerca de la probable duración de la ausencia o la limitación de capacidad, o sobre el grado de una posible discapacidad residual, de modo que puedan tomarse las medidas necesarias para una dotación alternativa de personal con una repercusión mínima sobre los planes de producción. Por otra parte, el servicio mantiene contacto con los trabajadores y a menudo también con sus familias, facilitando y preparando mejor su reincorporación al trabajo.

\section{Adaptación del trabajo a los trabajadores}

Para facilitar la adaptación del trabajo a los trabajadores y mejorar las condiciones y el medio ambiente de trabajo, los servicios de salud en el trabajo deben asesorar a la empresa, a los trabajadores y al comité de seguridad y salud sobre las cuestiones de salud, higiene y ergonomía en el trabajo. Pueden formular recomendaciones sobre modificaciones del trabajo, de los equipos y del medio ambiente de trabajo encaminadas a permitir al trabajador actuar de forma segura y eficaz. En este sentido quizá sea necesario reducir la carga física de trabajo para el trabajador de más edad, proporcionar equipos especiales a los trabajadores con deficiencias sensoriales o locomotrices, o adaptar los equipos - las prácticas de trabajo a las dimensiones antropométricas. Las adaptaciones pueden ser temporales en el caso de trabajadores en fase de recuperación de una lesión o enfermedad. Varios países tienen disposiciones legales que exigen adaptaciones en el lugar de trabajo.

\section{Protección de grupos vulnerables}

EI servicio de salud en el trabajo es responsable de formular recomendaciones para la protección de los grupos vulnerables de trabajadores, tales como los que presentan hipersensibilidades, enfermedades crónicas o determinadas discapacidades. Las recomendaciones pueden aludir a la búsqueda de un puesto que minimice los efectos adversos, a la entrega de equipos especiales 0 dispositivos de protección, a la prescripción de bajas por enfermedad, etc. D eben ser viables en función de las circunstancias del lugar concreto de trabajo, y pueden incluir la petición a los trabajadores de que reciban formación especializada sobre prácticas de trabajo adecuadas y uso de equipos de protección personal.

\section{Información, educación y formación}

Los servicios de salud en el trabajo deben desempeñar un papel activo en el suministro de información y en la organización de la educación y formación relevantes para el trabajo.

EI Convenio de la OIT sobre los servicios de salud en el trabajo (no 161) y la correspondiente Recomendación (no 171) establecen la participación de los servicios de salud en el trabajo en el diseño y ejecución de los programas de información, educación y formación en materia de seguridad y salud profesionales para el personal de la empresa. Estos servicios deberían participar en la formación gradual y continuada de todo el personal de la empresa que contribuya a la seguridad y a la salud en el trabajo.

Los profesionales de la salud en el trabajo pueden ayudar a incrementar la sensibilización de los trabajadores respecto a los peligros profesionales a los que están expuestos, analizar con ellos los riesgos sanitarios existentes y asesorarles sobre la protección de su salud, incluidas las medidas protectoras y el uso adecuado del equipo personal de protección. Todos los contactos con los trabajadores ofrecen una oportunidad de suministrar información útil y fomentar comportamientos saludables en el trabajo.

Los servicios de salud en el trabajo deben aportar toda la información relativa a los riesgos profesionales existentes en el 
lugar de trabajo, así como sobre los baremos de salud y seguridad correspondientes a la situación actual. Esta información debe redactarse en un lenguaje comprensible para los trabajadores y ofrecerse de forma periódica, especialmente cuando se introducen nuevas sustancias o equipos o cuando se realizan cambios en el medio ambiente de trabajo.

La educación y la formación pueden desempeñar un papel importante en la mejora de las condiciones y el medio ambiente de trabajo. Los intentos de mejorar la seguridad, la salud y el bienestar profesionales se ven a menudo sustancialmente limitados por falta de concienciación, conocimientos técnicos y know-how. La educación y formación en áreas estratégicas de la seguridad y salud en el trabajo y del medio ambiente de trabajo pueden facilitar tanto el diagnóstico de problemas como la ejecución de soluciones, contribuyendo por tanto a superar tales limitaciones.

Los Convenios de la OIT no 155 y 161 y sus Recomendaciones de acompañamiento subrayan el papel clave de la educación y la formación en la empresa. La formación es esencial para el cumplimiento de las obligaciones tanto de la empresa como de los trabajadores. La empresa es responsable de la organización de la formación interna sobre seguridad y salud en el trabajo, y los trabajadores y sus representantes en la empresa debe colaborar plenamente al respecto.

La formación sobre salud y seguridad en el trabajo debe organizarse como parte integral de la tarea global de mejora de las condiciones y el medio ambiente de trabajo, y los servicios de salud en el trabajo deben desempeñar un papel destacado al respecto. La formación debe orientarse a la resolución de diversos problemas relativos al bienestar físico y mental de los trabajadores y ha de tratar los temas de la adaptación de la tecnología y los equipos, la mejora de las condiciones de trabajo, la ergonomía, la jornada, la organización y contenidos del trabajo y el bienestar de los trabajadores.

\section{Actividades de promoción de la salud}

$\mathrm{H}$ ay una tendencia, especialmente en N orteamérica, a realizar las actividades de promoción del bienestar en forma de programas de salud en el trabajo. No obstante, estos programas son básicamente de promoción general de la salud, y pueden incluir elementos de educación sanitaria, gestión del estrés y evaluación de riesgos personales. Suelen ir encaminados al cambio de las prácticas personales de salud, tales como el abuso de alcohol y drogas, el consumo de tabaco, la dieta y el ejercicio físico, con vistas a mejorar el estado general de salud y reducir el absentismo. Aunque se supone que estos programas deben mejorar la productividad y reducir los costes de asistencia sanitaria, no se han evaluado adecuadamente hasta el momento. Diseñados como programas de promoción de la salud, pese a su valor, no suelen ser habitualmente considerados como programas de salud en el trabajo, sino como servicios sanitarios públicos prestados en el lugar de trabajo, pues su atención y sus recursos se centran en los hábitos personales de salud, más que en la protección de los trabajadores frente a los peligros profesionales.

$\mathrm{H}$ ay que reconocer que la ejecución de los programas de promoción de la salud es un factor importante de la mejora de la salud de los trabajadores en la empresa. En algunos países, la "promoción de la salud en el lugar de trabajo" se considera una disciplina autónoma ejercida por grupos completamente independientes de especialistas de la salud, distintos a los de la salud profesional. En este caso, sus actividades deberían coordinarse con las de este último servicio, cuyo personal puede garantizar su idoneidad, viabilidad y el carácter duradero de sus efectos. La participación de estos servicios en la realización de los programas de promoción de la salud no debe limitar la realización de sus funciones principales como servicios sanitarios especializados creados para proteger a los trabajadores frente a las exposiciones peligrosas y las condiciones no saludables de trabajo.

Un avance muy reciente en algunos países (por ejemplo, en los Países Bajos y en Finlandia) es el establecimiento de actividades de promoción de la salud profesional dentro de los servicios de salud en el trabajo, orientando la promoción y mantenimiento de la capacidad de trabajo de los trabajadores mediante acciones de prevención anticipada y promoción a los trabajadores y su salud, al medio ambiente de trabajo y a la organización del trabajo. Los resultados están siendo muy positivos.

\section{Recopilación de datos y mantenimiento de registros}

Es importante que todos los contactos, evaluaciones, valoraciones y encuestas médicos sean adecuadamente documentados y que se almacenen de forma segura los registros, de modo que, en caso de necesidad, puedan ser recuperados años o incluso décadas después para reconocimientos médicos de seguimiento o para fines jurídicos o de investigación.

La Recomendación de la O IT sobre los servicios de salud en el trabajo (no 171) establece que estos servicios deberían consignar los datos relativos a la salud de los trabajadores en expedientes de salud personales y confidenciales. Dichos expedientes deberían también contener informaciones acerca de las tareas que hayan realizado los trabajadores, de su exposición a los riesgos profesionales inherentes a su trabajo y de los resultados de toda evaluación de dicha exposición. Los datos personales relativos a la evaluación del estado de salud sólo deberían comunicarse a terceros previo consentimiento del trabajador debidamente informado.

Las condiciones y el período de conservación, comunicación o transferencia de estos expedientes, así como las medidas necesarias para preservar su carácter confidencial, en particular cuando estén informatizados, deberían establecerse en las disposiciones legales y reglamentarias o dictarse por las autoridades competentes, rigiéndose por pautas de ética reconocidas.

\section{Investigación}

Según la Recomendación de la O IT sobre los servicios de salud en el trabajo (no 171), estos servicios, en consulta con los representantes de los empleadores y de los trabajadores, deberían contribuir a la investigación, en la medida de sus recursos, participando en estudios o encuestas efectuados a nivel de la empresa 0 de la rama de actividad económica (por ejemplo, con objeto de reunir información epidemiológica o participar en programas nacionales de investigación). Los médicos del trabajo participantes en la ejecución de proyectos de investigación estarán vinculados, por tanto, por las consideraciones éticas aplicables a los mismos según la A sociación M édica M undial (World M edical Association, WM A) y el Consejo de O rganizaciones Internacionales de las Ciencias M édicas (COICM ). La investigación en el medio ambiente de trabajo puede contar con "voluntarios" sanos, que deben ser plenamente informados por el servicio de salud en el trabajo de la finalidad y carácter de la investigación. Todos los participantes deben dar su consentimiento personal a la participación, sin que sea suficiente la prestación de consentimiento colectivo por el sindicato de la empresa. Los trabajadores deben sentirse libres de abandonar en cualquier momento la investigación, y el servicio de salud en el trabajo debe encargarse de que no sufran presiones indebidas para permanecer en el proyecto contra su voluntad.

\section{Coordinación y comunicaciones}

Un servicio de salud en el trabajo eficaz ha de desarrollar necesariamente varios tipos de comunicación. 


\section{Colaboración interna}

El servicio de salud en el trabajo forma parte integrante del aparato productivo de la empresa, y debe coordinar estrechamente sus actividades con los servicios de higiene, seguridad, educación sanitaria, promoción de la salud en el trabajo y otros cuando estos servicios actúan separadamente. Además, debe colaborar con todos los servicios en el funcionamiento de la empresa: administración de personal, finanzas, relaciones con los trabajadores, planificación y diseño, ingeniería de producción, mantenimiento de las instalaciones, etc. No debe haber obstáculos para acceder a cualquier departamento de la empresa cuando se trate de cuestiones de salud y seguridad de los trabajadores. Al mismo tiempo, el servicio de salud en el trabajo debe tener en cuenta las necesidades y restricciones de los restantes departamentos. Y, si no depende de un alto directivo, debe tener el privilegio del acceso directo a la alta dirección en los casos en que no se preste la debida consideración a recomendaciones importantes sobre la salud de los trabajadores.

Para funcionar eficazmente, el servicio de salud en el trabajo necesita el apoyo de la empresa, la dirección, los trabajadores y sus representantes. Los instrumentos de la OIT (OIT 1981a, $1981 b, 1985 a$ y 1985b) exigen a la empresa y a los trabajadores que cooperen y participen en la ejecución de las medidas organizativas y de otra índole relativas a los servicios de salud en el trabajo de forma igualitaria. La empresa debe colaborar con el servicio de salud en el trabajo para conseguir sus objetivos, especialmente de las siguientes formas:

- proporcionando información general sobre la salud y la seguridad profesional en la empresa;

- proporcionando información sobre cualquier factor que afecte a la salud de los trabajadores, bien sea conocido o se sospeche su existencia;

- proporcionar a los servicios de salud en el trabajo los recursos adecuados en cuanto a instalaciones, equipos y suministros, así comopersonalcualificado;

- dotar al servicio de salud en el trabajo de la autoridad necesaria para realizar sus funciones:

- permitir el libre acceso a todas las dependencias e instalaciones de la empresa (incluidas fábricas separadas y servicios de campo) y proporcionar información sobre los planes de cambios en los equipos y suministros de producción, así como en los procesos y la organización del trabajo, de modo que puedan adoptarse medidas preventivas antes de que los trabajadores se vean expuestos a peligros potenciales;

- atender sin dilación cualquier recomendación formulada por el servicio de salud en el trabajo para el control de los peligros profesionales y la protección de la salud de los trabajadores, así como garantizar su aplicación;

- salvaguardar la independencia profesional de los profesionales de la salud en el trabajo, fomentando y, cuando sea posible, financiando su educación y formación continuadas.

Si se requiere un programa especial a escala de fábrica para las actividades de salud en el trabajo, es crucial la colaboración para la preparación del mismo y la elaboración del informe de actividades

Los servicios de salud en el trabajo tienen como fin proteger y promover la salud de los trabajadores mediante la evitación de las lesiones del trabajo y las enfermedades profesionales. M uchas funciones de los servicios de salud en el trabajo no pueden ser realizadas sin la colaboración de los trabajadores. Según los instrumentos de la OIT, los trabajadores y sus organizaciones deben colaborar con los servicios de salud en el trabajo y apoyarlos en la ejecución de sus tareas (OIT, 1981a, 1981b, 1985a, 1985b). Esta colaboración se concreta especialmente en:
- informar al servicio de salud en el trabajo de cualquier factor del trabajo o el medio ambiente de trabajo del que se sepa que tiene o se sospeche que puede tener efectos adversos sobre su salud;

- ayudar al personal de salud en el trabajo a realizar sus tareas en el lugar de trabajo;

- participar en los reconocimientos médicos, encuestas y demás actividades realizadas por el servicio de salud en el trabajo;

- observar las normas y reglamentos de salud y seguridad;

- disponer de equipos de seguridad y dispositivos personales de protección, así como materiales de primeros auxilios y equipos de emergencia y aprender a utilizarlos adecuadamente;

- participar en los ejercicios de educación sanitaria y formación de seguridad en el lugar de trabajo;

- informar sobre la eficacia de las medidas de salud y seguridad adoptadas,

- participar en la organización, planificación, ejecución y evaluación de las actividades de los servicios de salud en el trabajo.

Los instrumentos de la OIT recomiendan la colaboración entre la empresa y los trabajadores en materia de salud y seguridad en el trabajo (OIT 1981a, 1981b, 1985a, 1985b). Esta colaboración se realiza en el seno del comité de salud y seguridad de la empresa, que consta de representantes de ambas partes y constituye un foro para el análisis de cuestiones relativas a esta materia. La creación de este comité puede venir impuesta por la legislación nacional o por los convenios colectivos en empresas de 50 o más trabajadores. En empresas más pequeñas, sus funciones se realizan mediante reuniones menos formales entre delegados de seguridad de los trabajadores y la empresa.

El comité tiene una amplia gama de funciones (OIT 1981b), entre las que se incluyen:

- participar en las decisiones relativas a la creación, organización, dotación de personal y funcionamiento del servicio de salud en el trabajo;

- participar en la elaboración del programa de salud y seguridad en el trabajo de la empresa;

- prestar apoyo al servicio de salud en el trabajo en la realización de sus funciones;

- participar en la evaluación de las actividades del servicio de salud en el trabajo y en la elaboración de los informes que remite a los organismos financiadores, a la dirección de la empresa y a las autoridades públicas;

- facilitar la transmisión de información sobre el tema entre los distintos servicios de la empresa;

- ofrecer un foro de debate y decisión sobre acciones de colaboración en la materia;

- evaluar el estado global de la salud y seguridad en el trabajo en la empresa.

El principio de la participación de los trabajadores en las decisiones relativas a su propia salud y seguridad, a los cambios en los puestos de trabajo y en el medio ambiente de trabajo y a las actividades de salud y seguridad queda recalcado en recientes directrices sobre la práctica de la salud en el trabajo. También es necesario que los trabajadores tengan acceso a la información sobre las actividades de la empresa en este campo y sobre cualquier peligro potencial para la salud en el lugar de trabajo. Del mismo modo, las legislaciones de varios países han reforzado el principio del "derecho a saber" y el de transparencia.

\section{Colaboración externa}

Los servicios de salud en el trabajo deben establecer estrechas relaciones con instituciones y servicios externos. 0 cupan un lugar primordial las relaciones con el sistema sanitario público del país en su conjunto y con las instituciones e instalaciones de las 
comunidades locales. Las relaciones comienzan en el nivel de los servicios de asistencia primaria y se amplían al nivel de los servicios hospitalarios especializados, algunos de los cuales pueden prestar también servicios de salud en el trabajo. Estas relaciones son importantes cuando se necesita remitir a un trabajador a servicios sanitarios especializados para una adecuada evaluación y tratamiento de lesiones y enfermedades profesionales, y también ofrece la oportunidad de atenuar los posibles efectos adversos de problemas sanitarios no profesionales sobre la asistencia y el rendimiento en el trabajo. La colaboración con los servicios de salud pública y medioambiental es asimismo importante. Invitar a los médicos generales y a otros profesionales de la salud a visitar el servicio de salud en el trabajo y familiarizarse con las exigencias impuestas a sus pacientes por sus tareas o por los peligros a que están expuestos no sólo ayuda a establecer relaciones amistosas, sino que ofrece también una oportunidad de sensibilizarles frente a las cuestiones específicas de salud en el trabajo a las que normalmente no prestarían atención en su tratamiento a los trabajadores en el marco de los servicios de asistencia sanitaria general.

Los institutos de rehabilitación suelen ser colaboradores importantes, especialmente en el caso de trabajadores con discapacidades crónicas que requieran esfuerzos especiales de intensificación y mantenimiento de su capacidad de trabajo. Esta colaboración es especialmente importante para la recomendación de modificaciones temporales del trabajo que aceleren y faciliten la reincorporación de las personas en fase de recuperación de lesiones o enfermedades graves con etiología tanto profesional como no profesional.

Las organizaciones de asistencia de urgencia y primeros auxilios, tales como los servicios de ambulancias, las consultas de urgencia y externas del hospital, los centros toxicológicos, los servicios de policía y bomberos y las organizaciones cívicas de asistencia pueden permitir el tratamiento rápido de lesiones y enfermedades agudas y ayudar a planificar y ejecutar las reacciones ante las urgencias. Los contactos adecuados con la seguridad social y las instituciones de seguros sanitarios pueden facilitar la administración de prestaciones y el funcionamiento del sistema de remuneración de los trabajadores.

Las autoridades competentes en materia de salud y seguridad y de inspección laboral son colaboradores clave de los servicios de salud en el trabajo. Además de facilitar las inspecciones formales, unas buenas relaciones pueden prestar apoyo a las actividades internas de salud y seguridad y ofrecer oportunidades de participar en la elaboración de las reglamentaciones y sus métodos de aplicación.

La participación en asociaciones profesionales y actividades de institutos de educación y formación y de universidades es útil para proporcionar educación continuada al personal profesional. En teoría, el tiempo y los gastos deben correr de cuenta de la empresa. Además, los contactos colegiales con profesionales de la salud en el trabajo de otras empresas puede proporcionar conocimientos e información estratégica y dar lugar a colaboraciones estables para la recopilación de datos y la investigación.

Los tipos de colaboración descritos deben emprenderse desde el inicio de las actividades del servicio de salud en el trabajo, y continuar y ampliarse convenientemente. No sólo pueden facilitar el logro de los objetivos del servicio, sino también contribuir a la buena marcha de las actividades de relaciones públicas y comunitarias de la empresa.

\section{Infraestructuras de los servicios de salud en el trabajo}

Las infraestructuras para la prestación de los servicios de salud en el trabajo están insuficientemente desarrolladas en la mayor parte del mundo, incluidos los países desarrollados y en vías de desarrollo. La necesidad de dotarse de estos servicios es especialmente acuciante en los países en vías de desarrollo y en los recién industrializados, que representan ocho de cada diez trabajadores del mundo. Si estuvieran adecuada y eficazmente organizados, estos servicios contribuirían significativamente no sólo a la salud de los trabajadores, sino también al desarrollo socioeconómico global, la productividad, la salud medioambiental y el bienestar de los países, las comunidades y las familias (O M S 1995b; Jeyaratnam y C hia 1994). U nos servicios de salud en el trabajo eficaces no sólo reducirían el absentismo por enfermedad evitable y las discapacidades profesionales, sino que ayudarían también a controlar los costes de la asistencia sanitaria y la seguridad social. Por tanto, el desarrollo de unos servicios de salud en el trabajo que cubran a todos los trabajadores está plenamente justificado tanto desde el punto de vista de la salud de éstos como desde el de la economía.

Las infraestructuras para la prestación de los servicios de salud en el trabajo deben permitir una ejecución efectiva de las actividades necesarias para alcanzar los objetivos del servicio (O IT 1985a, 1985b; R antanen, L ehtinen y M ikheev 1994; O M S 1989b). Para permitir la necesaria flexibilidad, el artículo 7 del Convenio de la OIT no 161 establece que los servicios de salud en el trabajo pueden organizarse como servicios para una sola empresa o como servicios comunes a varias empresas. 0 bien, de conformidad con las condiciones y las prácticas nacionales, ser organizados por las empresas o los grupos de empresas interesadas, los poderes públicos o servicios oficiales, las instituciones de seguridad social, cualquier otro organismo habilitado por la autoridad competente, o una combinación de cualquiera de las fórmulas anteriores.

Algunos países regulan la organización de los servicios de salud en el trabajo en función del tamaño de la empresa. Por ejemplo, las empresas más grandes tienen que establecer su propio servicio interno, en tanto que las medianas y pequeñas deben participar en servicios conjuntos. Por lo general, la legislación es flexible en cuanto a la elección de los modelos estructurales de los servicios de salud en el trabajo para ajustarse a las circunstancias y prácticas locales.

\section{Modelos de servicios de salud en el trabajo}

Se han desarrollado varios modelos de servicios de salud en el trabajo para dar respuesta a las necesidades de las empresas en este campo, las cuales varían ampliamente en función del sector, tamaño, tipo de actividad, estructura, etc. (R antanen, Lehtinen y M ikheev 1994; O M S 1989). En los países en vías de desarrollo y en los recién industrializados, por ejemplo, donde la asistencia sanitaria del conjunto de la población puede ser insuficiente, el servicio de salud en el trabajo puede prestar asistencia sanitaria no profesional a los trabajadores y a sus familias. Esto se ha hecho ya también con éxito en Finlandia, Suecia e Italia (R antanen 1990; O M S 1990). Por otra parte, el alto nivel de cobertura de trabajadores en Finlandia ha sido posible debido a la organización de centros sanitarios municipales (servicios PHC) que prestan servicios de salud en el trabajo a los trabajadores de pequeñas empresas, los autónomos e incluso a los pequeños lugares de trabajo gestionados por grandes empresas y dispersos por todo el país.

\section{M odelo interno (en la empresa)}

Muchas grandes empresas, industriales o no, tanto del sector público como privado, tienen un servicio de salud en el trabajo integrado y global en sus instalaciones que no sólo presta una gama completa de servicios de salud en el trabajo, sino también servicios sanitarios no profesionales a los trabajadores y a sus familias y, en ocasiones, practica la investigación. Estos servicios suelen tener un personal interdisciplinario que puede incluir no 
sólo profesionales de la enfermería y médicos del trabajo, sino también higienistas del trabajo, técnicos de laboratorio y de rayos $X$, y probablemente fisioterapeutas, asistentes sociales, educadores sanitarios, consejeros y psicólogos industriales. Los servicios de seguridad e higiene industrial pueden ser prestados por el personal del servicio de salud en el trabajo o por otros servicios autónomos de la empresa. Normalmente, sólo las grandes empresas (multinacionales, a menudo) puede permitirse estos servicios interdisciplinarios, cuya calidad y efectos sobre la salud y la seguridad son muy convincentes.

Las empresas de menor tamaño suelen tener un servicio interno integrado por uno o más profesionales de enfermería del trabajo y, a tiempo parcial, un médico del trabajo que acude varias horas al día o varias veces a la semana. U na variante es el servicio integrado por uno o más profesionales de enfermería del trabajo más un médico "localizado" que sólo acude cuando se le requiere y presta normalmente servicios de carácter reglamentario, autorizándose a los profesionales de la enfermería a realizar determinadas prácticas o administrar determinados medicamentos, funciones habitualmente reservadas a médicos titulados. En algunos casos, en Estados U nidos e Inglaterra, un contratista externo, tal como un hospital local o una organización empresarial privada, gestiona y controla estos servicios.

Por varias razones, el personal de salud en el trabajo puede verse en ocasiones progresivamente separado de la estructura operativa central de la empresa y, en consecuencia, la gama de servicios que presta tiende a restringirse a los primeros auxilios y el tratamiento de enfermedades y lesiones profesionales agudas y a la realización de reconocimientos médicos periódicos. Los médicos a tiempo parcial, y especialmente los "localizados", no suelen llegar a conocer lo suficiente las especificidades de las distintas tareas realizadas y del medio ambiente de trabajo, y muchos de ellos no tienen suficiente contacto con la dirección y con el comité de seguridad para recomendar eficazmente la adopción de medidas preventivas adecuadas.

En el marco de las reducciones de plantilla propias de las épocas de recesión económica, algunas grandes empresas están reduciendo sus servicios de salud en el trabajo y, en algunos casos, eliminándolos por completo. Es posible que ocurra esto último cuando una empresa que carece de servicio de salud en el trabajo compra otra con uno ya establecido. En tales casos, la empresa quizá contrate servicios externos que gestionen las instalaciones internas y emplee consultores de forma ocasional para prestar servicios especializados tales como los de higiene en el trabajo, toxicología e ingeniería de seguridad. Algunas empresas optan por mantener un especialista en salud en el trabajo y el medio ambiente, como director o gerente médico interno encargado de coordinar los servicios de los prestadores externos, controlar su trabajo y asesorar a la alta dirección en cuestiones relativas a la salud y seguridad de los trabajadores y al medio ambiente.

\section{M odelo colectivo o interempresas}

Compartir los servicios de salud en el trabajo entre un grupo de pequeñas o medianas empresas es una práctica muy extendida en países industrializados como Suecia, N oruega, Finlandia, Dinamarca, los Países Bajos, Francia y Bélgica, que permite a las empresas demasiado pequeñas para mantener servicios propios disfrutar las ventajas de un servicio global bien dotado de personal y de equipamientos. EI Plan Slough, organizado hace algunas décadas en una comunidad industrial de Inglaterra, aplicó por primera vez este tipo de sistema. En el decenio de 1980 se realizaron interesantes experiencias en Suecia, que resultaron viables y especialmente útiles para empresas medianas, y algunos países, tales como Dinamarca, han tratado de aumentar el tamaño de estos servicios compartidos para permitir que presten una gama más amplia de servicios, en lugar de dividirlos en pequeñas unidades monodisciplinarias.

Un frecuente inconveniente del modelo colectivo en comparación con el de servicios internos propio de las empresas de mayor tamaño es la distancia entre el lugar de trabajo y el de ubicación del servicio de salud en el trabajo, lo que resulta importante no sólo en casos de primeros auxilios para las lesiones más graves (a veces resulta más conveniente enviar directamente a los afectados a un hospital local, prescindiendo del servicio de salud), sino también porque se suele perder más tiempo cuando el trabajador tiene que acudir al servicio en horas de trabajo. O tro problema surge cuando las empresas participantes no son capaces de aportar fondos suficientes para mantener el servicio, que se ve abocado al cierre al desaparecer las subvenciones públicas o de fundaciones privadas que apoyan en ocasiones su establecimiento.

\section{M odelo de especialización sectorial (por ramas de actividad)}

Una variante del modelo colectivo es el uso conjunto de un servicio de salud en el trabajo por parte de varias empresas del mismo sector o rama de actividad. La construcción, la alimentación, la agricultura, la banca o los seguros son ejemplos de sectores que han adoptado este planteamiento en Europa, en concreto en Suecia, los Países Bajos y Francia. La ventaja de este modelo es la posibilidad de que el servicio de salud en el trabajo se concentre en ese sector en particular, para especializarse en la resolución de sus problemas propios. En el sector de la construcción de Suecia, este modelo presta servicios interdisciplinarios avanzados de alta calidad a todo el país y ha permitido realizar programas de investigación y desarrollo relativos a problemas específicos del sector.

\section{Consultas exter nas del hospital}

Las consultas externas del hospital y el servicio de urgencias prestan tradicionalmente sus servicios a los trabajadores lesionados 0 enfermos que los solicitan. U n notable inconveniente es la falta de conocimientos especializados sobre las enfermedades profesionales por parte del personal regular y los médicos de servicio. En algunos casos, como se ha señalado anteriormente, los servicios de salud en el trabajo han alcanzado acuerdos con los hospitales locales para la prestación de determinados servicios especializados con el fin de salvar la brecha mediante la colaboración en la asistencia o la formación del personal del hospital en el tipo de casos que les pueden ser remitidos.

$M$ ás recientemente, los hospitales han comenzado a gestionar servicios o consultas específicas de salud en el trabajo, que comparten las ventajas de los grandes servicios internos o colectivos anteriormente descritos. Estas consultas están integradas por médicos especializados en salud en el trabajo, quienes en ocasiones realizan también investigaciones relativas a los problemas que detectan.

En Suecia, por ejemplo, hay ocho consultas regionales de medicina del trabajo, varias de las cuales están asociadas a facultades de medicina, que prestan sus servicios a empresas de diversas comunidades. Varias de ellas tienen una unidad especial para atender a pequeñas empresas.

U na diferencia significativa entre los servicios colectivos y los de base hospitalaria es que, en el caso de aquéllos, las empresas participantes suelen compartir su propiedad y ostentan el poder de decisión sobre su funcionamiento, mientras que estos últimos funcionan como policlínicas públicas o privadas, manteniendo una relación de tipo prestador-cliente con sus empresas clientes. Esto limita, por ejemplo, el grado de influencia de la participación y colaboración entre empresas y trabajadores sobre la gestión del servicio. 


\section{Centros sanitarios privados}

En el modelo de centros sanitarios privados, existe un servicio normalmente organizado por un grupo de médicos (puede ser una empresa privada que contrata a los médicos) para prestar diversos tipos de servicios sanitarios ambulatorios y en ocasiones hospitalarios. Los centros más grandes suelen tener personal interdisciplinario y en ocasiones ofrecen servicios de fisioterapia e higiene industrial, mientras que los más pequeños suelen limitarse a prestar servicios médicos.

Al igual que en el modelo de la consulta hospitalaria, la relación prestador-cliente con las empresas participantes puede obstaculizar la aplicación del principio de participación de la empresa y el trabajador en la formulación de las políticas y procedimientos.

En algunos países se ha criticado a los centros sanitarios privados por orientarse en exceso a los servicios clínicos curativos prestados por los médicos, crítica justificada en el caso de los centros más pequeños, donde los servicios son prestados por médicos generales en lugar de profesionales sanitarios especializados en la práctica de la salud en el trabajo.

\section{Servicios de asistencia sanitaria primaria}

Los servicios de asistencia sanitaria primaria suelen ser creados por autoridades municipales $u$ otro tipo de autoridades locales 0 bien por el servicio nacional de salud y suelen prestar tanto servicios preventivos como asistencia sanitaria primaria. Se trata de un modelo decididamente recomendado por la OMS para la prestación de servicios a pequeñas empresas y especialmente a empresas agrícolas, al sector informal y a los trabajadores autónomos. $D$ ado que las enfermeras y los médicos generales suelen carecer de experiencia y conocimientos especializados en materia de salud en el trabajo, el éxito depende crucialmente de la cantidad de formación que pueda proporcionárseles.

U na ventaja de este modelo es la buena cobertura del país y su ubicación en las comunidades en las que viven y trabajan las personas a las que prestan sus servicios. Este aspecto resulta especialmente conveniente en la prestación de servicios a los trabajadores agrícolas y autónomos.

Un inconveniente es su concentración en los servicios sanitarios curativos generales y en la atención a urgencias, con la consiguiente limitación de la capacidad para realizar la vigilancia del medio ambiente de trabajo y de establecer las medidas preventivas necesarias en el lugar de trabajo. La experiencia de Finlandia, en donde los grandes servicios de asistencia sanitaria primaria emplean equipos de especialistas para prestar servicios de salud en el trabajo, es, no obstante, muy positiva. En China se han ensayado nuevos e interesantes modelos de prestación de servicios de salud en el trabajo por parte de los servicios de asistencia sanitaria primaria el área de Shanghai.

\section{M odelo de seguridad social}

En Israel, M éxico, España y algunos países africanos, por ejemplo, la prestación de servicios de salud en el trabajo corre a cargo de servicios especializados creados y gestionados por el sistema de seguridad social.

En I srael, este modelo es básicamente similar en su estructura y funcionamiento al modelo colectivo, mientras que en el resto de los casos está más orientado a la asistencia sanitaria curativa. Su característica básica es que está gestionado por la organización responsable de la indemnización a los trabajadores en caso de lesión o enfermedad profesional. Aunque se prestan servicios curativos y de rehabilitación, el énfasis en el control de los costes de seguridad social ha llevado a dar prioridad a los servicios preventivos.

\section{Elección de un modelo de servicio de salud en el trabajo}

La decisión primaria de establecer o no un servicio de salud en el trabajo puede venir determinada por la ley, por el contrato entre la dirección y los trabajadores o por la preocupación de la dirección por la salud y la seguridad de éstos. Aunque la conciencia del valor que tiene un servicio de salud en el trabajo para el mantenimiento del aparato productivo induce a muchas empresas a la prestación de estos servicios, otras veces influyen consideraciones económicas, tales como el control del coste de las prestaciones indemnizatorias a los trabajadores, la evitación del absentismo por enfermedad y la discapacidad, la jubilación anticipada por causas sanitarias, las multas reglamentarias, las reclamaciones judiciales, etc.

El modelo de prestación de servicios de salud en el trabajo puede venir prescrito por normas legales o reglamentarias, ya sean de carácter general o exclusivamente aplicables a determinados sectores. Este suele ser el caso del modelo de seguridad social, en el que las empresas clientes no tienen otras opciones.

En la mayoría de los casos, el modelo elegido viene determinado por factores tales como el tamaño de la mano de obra y sus características demográficas, el tipo de trabajo que realizan y los peligros del lugar de trabajo a que se enfrentan, la ubicación del lugar de trabajo, el tipo y calidad de los servicios sanitarios disponibles en la comunidad y, tal vez lo más importante, la holgura económica de la empresa y su capacidad para prestar el apoyo económico necesario.

En algunos casos la empresa crea un servicio mínimo que va ampliándose y multiplicando sus actividades a medidas que demuestra su valía y consigue la aceptación de los trabajadores. Son pocos los estudios comparativos realizados hasta el momento sobre el funcionamiento de los diversos modelos de servicios de salud en el trabajo en diversas circunstancias.

\section{Servicios de higiene industrial}

Las directrices e instrumentos internacionales recomiendan decididamente la inclusión de servicios de higiene industrial en el servicio interdisciplinario de salud en el trabajo.

En algunos países, no obstante, estos servicios se prestan habitualmente como actividad separada e independiente. En tales circunstancias, es necesaria la colaboración con otros servicios implicados en las actividades de salud y seguridad en el trabajo.

\section{Ser vicios de seguridad}

Los servicios de seguridad suelen prestarse como actividad separada, ya sea a cargo de agentes de seguridad 0 de ingenieros de seguridad contratados por la empresa (OIT 1981a; Bird y Germain 1990) o a través de algún sistema de consultoría. En el servicio interno, el agente de seguridad suele ser también el máximo responsable de la seguridad en la empresa y representa a la misma en tales cuestiones.

De nuevo, existe actualmente una tendencia a integrar la seguridad con la higiene y la salud en el trabajo y con otros servicios relacionados con las actividades de salud en el trabajo, con el fin de formar una entidad interdisciplinaria.

Cuando las actividades de seguridad se realizan paralelamente a las de salud e higiene en el trabajo, la colaboración es especialmente necesaria con respecto a la identificación de los peligros de accidentes, la evaluación de riesgos, la planificación y puesta en práctica de medidas preventivas y de control, la educación y formación de directivos, supervisores y trabajadores, la recopilación, mantenimiento y registro de accidentes y el funcionamiento de las medidas de control establecidas. 


\section{Dotación de personal para el servicio de salud en el trabajo}

Tradicionalmente, el servicio de salud en el trabajo está integrado exclusivamente por un médico especializado en la materia o bien por un médico y una enfermera, quienes, tal vez junto con un higienista industrial, son designados como personal "básico". Las disposiciones más recientes, no obstante, exigen que siempre que sea posible el personal de salud en el trabajo tenga una composición interdisciplinaria.

EI personal puede ampliarse hasta constituir un equipo interdisciplinario completo, dependiendo del modelo de servicio, la naturaleza del sector y los tipos de trabajo en cuestión, la disponibilidad de los diversos especialistas o de los programas para su formación y la cantidad de recursos económicos disponibles. Cuando no se incluyen en la plantilla, los puestos complementarios se cubren en ocasiones mediante servicios externos de apoyo (O M S 1989a, 1989b). Puede tratarse de ingenieros de seguridad, fisiólogos del trabajo, ergonomistas, fisioterapeutas, toxicólogos, epidemiólogos y educadores sanitarios. La mayoría de ellos no suelen formar parte del personal a tiempo completo del servicio de salud en el trabajo y participan a tiempo parcial o "según necesidad" (R antanen 1990).

Dado que las necesidades cuantitativas de personal de un servicio de salud en el trabajo varían ampliamente dependiendo de la empresa, del modelo organizativo y de los servicios prestados, así como de la disponibilidad de servicios paralelos y de apoyo, esta variable no puede establecerse de forma categórica (Rantanen 1990; Rantanen, Lehtinen y M ikheev 1994). Por ejemplo, 3.000 trabajadores de una gran empresa necesitan un personal más reducido que el que se precisaría para prestar la misma gama de servicios a 300 lugares de trabajo con 10 trabajadores cada uno. Se ha señalado, no obstante, que la proporción habitual actual en Europa es de un médico y dos enfermeras para atender a entre 2.000 y 3.000 trabajadores. L as cifras varían mucho, entre 1 por cada 500 y 1 por cada 5.000 trabajadores. En algunos países, la empresa adopta las decisiones de dotación de personal en función de los tipos y volúmenes de servicios prestados, mientras que en varios otros países están legalmente establecidos el número y composición del personal. Por ejemplo, una reciente norma de los Países Bajos exige que el equipo de salud en el trabajo conste de al menos un médico, un higienista, un ingeniero de seguridad y un especialista en relaciones laborales (O rden M inisterial de 1993 sobre Certificación de Servicios SH W y Requisitos de Especialización de los Servicios SH W )

M uchos países han elaborado criterios oficiales o semioficiales de competencia para los enfermeros y médicos del trabajo, aunque no para las restantes disciplinas. Los nuevos principios de la Unión Europea exigen la confirmación de la competencia de todos los especialistas de la salud en el trabajo y algunos países han establecido sistemas de certificación para los mismos (CCE 1989; Orden M inisterial de 1993 sobre Certificación de Servicios SH W y Requisitos de Especialización de los Servicios SHW).

Aún no hay planes de estudios completamente desarrollados para los especialistas de la salud en el trabajo, aparte de los aplicables a los médicos, las enfermeras y, en algunos países, los higienistas ( $R$ antanen 1990). Se recomienda el establecimiento de un plan de estudios a todos los niveles para todas las categorías de especialistas, incluyendo programas de educación básica, de postgrado y continuada. También se considera conveniente incluir aspectos de formación sobre salud en el trabajo en la educación básica, no sólo en las facultades de medicina sino también en otras instituciones, como las escuelas técnicas, las facultades de ciencias, etc. A demás de la formación en ciencias y las cualificaciones prácticas necesarias para la práctica de la salud en el trabajo, la formación debe incluir el desarrollo de actitudes adecuadas ante la protección de la salud de los trabajadores. La formación en colaboración con especialistas de otras disciplinas permitiría un enfoque interdisciplinario. También se considera necesaria la formación en colaboración con las autoridades competentes y la empresa.

La identidad profesional de los especialistas en salud en el trabajo debe apoyarse igualmente en las distintas disciplinas. R eforzar la independencia profesional es crucial para la realización eficiente de sus tareas y puede aumentar el interés de otros profesionales de la salud hacia la dedicación profesional definitiva al área de la salud en el trabajo. Es importante reorganizar el plan de estudios en tanto los países desarrollan nuevos criterios de competencia y de certificación para estos especialistas.

\section{Infraestructuras para servicios de apoyo}

La mayoría de las empresas no puede permitirse disponer del servicio global interdisciplinario de salud en el trabajo necesario para desarrollar sus programas de salud y seguridad profesionales. Además de los servicios básicos prestados por la empresa, el propio servicio de salud en el trabajo puede necesitar de especialistas técnicos en áreas tales como las siguientes ( $\mathrm{K}$ roon y $O$ vereynder 1991; CEC 1989; Rantanen, Lehtinen y M ikheev 1994):

- higiene industrial (medición y análisis);

- ergonomía;

- información y asesoramiento sobre nuevos problemas y los planteamientos para su solución;

- desarrollo organizativo;

- gestión del estrés y psicología;

- últimos avances en equipos y medidas de control;

- apoyo a la investigación.

L os distintos países han aplicado diferentes planteamientos a la organización de estos servicios. Por ejemplo, Finlandia dispone de un Instituto de Salud en el Trabajo con seis institutos regionales para la prestación de apoyo especializado a los servicios de primera línea. La mayoría de los países industrializados tienen este tipo de institutos nacionales o algún organismo similar cuyas funciones principales son la prestación de servicios de investigación, formación, información y consultoría. Estas entidades son frecuentes, sin embargo, en los países en vías de desarrollo. Cuando no existe tal tipo de organización, estos servicios pueden ser prestados por grupos de investigación universitaria, instituciones de seguridad social, servicios nacionales de salud, autoridades públicas de salud y seguridad en el trabajo o consultores privados.

L a experiencia de los países desarrollados demuestra la conveniencia de crear en todos los países en vías de desarrollo y en los recién desarrollados un centro especial de investigación y desarrollo en materia de salud en el trabajo capaz de:

- prestar apoyo al desarrollo, evaluación y control de las políticas;

- prestar apoyo científico continuado para el establecimiento de normas y límites de exposición en el trabajo;

- desarrollar y aplicar criterios de evaluación de competencia en las diversas disciplinas de salud en el trabajo;

- aportar y promover la creación de programas de educación y formación para aumentar el número y la capacidad de los especialistas en este campo:

- prestar información y asesoramiento en cuestiones de salud en el trabajo no sólo a las personas dedicadas a este campo, sino también a los directivos de empresas, los sindicatos, los organismos públicos y la población general; 
- realizar o encomendar a terceros la realización de las necesarias investigaciones en materia de salud y seguridad en el trabajo.

Cuando no hay una institución individual capaz de prestar todos los servicios necesarios, puede ser imprescindible organizar una red que enlace a los distintos prestadores, tales como universidades, instituciones de investigación y otras entidades.

\section{Financiación de los servicios de salud en el trabajo}

Según los instrumentos de la O IT, la responsabilidad primaria de la financiación de los servicios de salud y seguridad en el trabajo recae en la empresa, sin cargo alguno para los trabajadores. En algunos países, no obstante, existen variantes al respecto. Por ejemplo, los costes de la prestación de estos servicios pueden estar subvencionados en gran parte por la organización de la seguridad social. Un ejemplo es el de Finlandia, donde la responsabilidad económica primaria recae en la empresa pero el $50 \%$ de los costes son reembolsados por la seguridad social siempre que se acredite haber cumplido las disposiciones de salud y seguridad en el trabajo y que el comité de salud y seguridad de la empresa confirme que los servicios se han prestado correctamente.

En la mayoría de los países existen sistemas nacionales de reembolso de este tipo. En el modelo de centro sanitario comunitario, la comunidad se hace cargo de los gastos de establecimiento de las instalaciones, equipos y personal, mientras que los gastos de funcionamiento se cubren mediante el cobro de tarifas a las empresas y a los trabajadores autónomos.

Los sistemas de reembolso o subvención tienen por finalidad fomentar la disponibilidad de servicios para las empresas con restricciones económicas y especialmente para las pequeñas empresas, que no suelen disponer de los recursos necesarios. La eficacia de estos sistemas queda puesta de manifiesto por la experiencia sueca del decenio de 1980, en la que la asignación de importantes cantidades de fondos públicos a subvencionar servicios de salud en el trabajo para las empresas en general y para las pequeñas empresas en especial permitió aumentar la proporción de trabajadores cubiertos del $60 \%$ a más del $80 \%$.

\section{Sistemas de calidad y evaluación de los servicios de salud en el trabajo}

El servicio de salud en el trabajo debe autoevaluar continuamente sus objetivos, actividades y resultados en términos de protección de la salud de los trabajadores y mejora del medio ambiente de trabajo. M uchas empresas tienen sistemas de auditorías periódicas independientes realizadas por consultores externos. En algunos países hay mecanismos públicos o privados de renovación de certificaciones mediante protocolos formales de auditoría. En algunas empresas, las encuestas periódicas de trabajadores proporcionan indicadores útiles de la consideración que prestan a estos servicios y de su grado de satisfacción con respecto a los mismos. Para que estas encuestas sean verdaderamente útiles debe proporcionarse información sobre los resultados a los trabajadores participantes y acreditar que se adoptan las medidas adecuadas para resolver cualquier problema que se ponga de manifiesto.

M uchos de los países industrializados (por ejemplo, los Países Bajos y Finlandia) han comenzado a utilizar las normas de la serie ISO 9000 para el desarrollo de sistemas de calidad para los servicios sanitarios en general, incluidos los de salud en el trabajo. Se trata de una actitud especialmente adecuada, pues muchas empresas clientes aplican estas normas a su proceso de producción. Algunas empresas han incluido sus servicios de salud en el trabajo en el ámbito de aplicación de la G estión de calidad total (Total Q uality M anagement, también conocida como
M ejora continua de la calidad o C ontinuous Q uality I mprovement) en toda la organización y han indicado que la experiencia ha resultado positiva en cuanto a la mejora de la calidad y el funcionamiento más eficiente de los servicios.

En la práctica, la aplicación de un programa de mejora continua de la calidad significa que cada departamento o unidad de la empresa analiza sus funciones y sus resultados y adopta los cambios necesarios para alcanzar un nivel óptimo de calidad. EI servicio de salud en el trabajo debe no sólo estar dispuesto a participar en esta tarea, sino también ofrecer su aportación para que no se descuide lo relativo a la salud y la seguridad de los trabajadores en este proceso.

La evaluación de la calidad de los servicios de salud en el trabajo no sólo favorece a los intereses de la empresa, los trabajadores y las autoridades competentes, sino también a los de los prestadores de los servicios. En varios países se han desarrollado diversos programas de evaluación. A efectos prácticos, la autoevaluación por el personal del propio servicio puede ser el sistema más apropiado, especialmente cuando hay un comité de salud y seguridad que valore los resultados de la evaluación.

$\mathrm{H}$ ay un interés creciente por el estudio de los aspectos económicos de los servicios de salud y seguridad en el trabajo y por la confirmación de su eficacia en términos de coste, pero aún disponemos de pocos estudios conocidos.

\section{Desarrollo progresivo de los servicios de salud en el trabajo}

EI Convenio de la O IT sobre los servicios de salud en el trabajo, 1985 (no 161) y su Recomendación de acompañamiento (no 171) alientan a los países a establecer progresivamente servicios de salud para todos los trabajadores, incluidos los del sector privado y los miembros de las cooperativas de producción, en todas las ramas de actividad económica y en todas las empresas. Algunos países ya han desarrollado servicios bien organizados a partir de lo dispuesto en sus legislaciones.

Partiendo de los servicios establecidos, hay tres estrategias de desarrollo futuro: ampliar toda la gama de actividades para cubrir más empresas y más trabajadores; ampliar el contenido de los servicios ofreciendo sólo servicios básicos, o ampliar progresivamente tanto el contenido como la cobertura.

Se ha discutido cuáles son las actividades mínimas que deben prestarse. Algunos países se limitan a reconocimientos médicos por médicos especialistas autorizados. En 1989, la Consulta OMS/ Europa sobre Servicios de Salud en el Trabajo (OMS 1989b) recomendó las siguientes actividades mínimas:

- evaluación de las necesidades de salud en el trabajo;

- medidas preventivas y de control dirigidas al medio ambiente de trabajo;

- actividades preventivas dirigidas al trabajador;

- actividades curativas limitadas a los primeros auxilios, el diagnóstico de enfermedades profesionales y la rehabilitación para la reincorporación al trabajo;

- seguimiento y evaluación de estadísticas sobre lesiones y enfermedades profesionales.

En la práctica, hay muchos lugares de trabajo en el mundo que no prestan aún servicio alguno a sus trabajadores. Por tanto, el primer paso de un programa nacional puede limitarse al mero establecimiento de estos servicios y a la prestación de actividades básicas para los más necesitados.

\section{Perspectivas futuras de desarrollo de los servicios de salud en el trabajo}

El desarrollo futuro de los servicios de salud en el trabajo depende de varios factores del mundo laboral, así como de la economía y la política nacional. Entre los factores más 
importantes en los países industrializados hay que mencionar el envejecimiento de la población, el aumento de las pautas irregulares de empleo y de horario de trabajo, el trabajo a distancia (teletrabajo), los lugares de trabajo móviles y el gradual aumento de las pequeñas empresas y los trabajadores autónomos. Se introducen nuevas tecnologías, se emplean nuevas sustancias y materiales y aparecen nuevas formas de organizar el trabajo. $\mathrm{H}$ ay presiones en favor del aumento simultáneo de la productividad y la calidad, que obligan a mantener una fuerte motivación para el trabajo en el marco de un ritmo creciente de cambio, y la necesidad de aprender nuevas prácticas y métodos de trabajo crece también a ritmo acelerado.

Aunque las medidas tradicionalmente aplicadas para hacer frente a los peligros profesionales han tenido éxito, especialmente en los países industrializados, no es probable que estos peligros desaparezcan en un futuro próximo, por lo que seguirán constituyendo un riesgo, si bien para un número menor de trabajadores. Los problemas psicológicos y psicosociales están convirtiéndose en peligros profesionales generalizados. La mundialización de la economía, la regionalización y el crecimiento de las economías y empresas multinacionales están creando una población activa internacionalmente móvil y dan lugar a la exportación de peligros profesionales a áreas en las que no existen reglamentaciones protectoras y las restricciones son débiles o inexistentes.

En respuesta a estas tendencias, la Segunda Reunión de Centros Colaboradores de la O M S para la Salud en el Trabajo (la Red de 52 Institutos N acionales de Salud en el Trabajo) celebrada en octubre de 1994 desarrolló la Estrategia G lobal de Salud en el Trabajo para Todos, con especial atención al desarrollo futuro de la práctica de la salud en el trabajo. A este respecto, en el futuro será necesario hacer frente a las siguientes cuestiones:

- desarrollo universal de la salud en el trabajo para todos con el fin de igualar las condiciones de trabajo y salud en todas las partes del mundo;

- desarrollar mejores métodos de predicción para evaluar anticipadamente los riesgos sanitarios de las exposiciones y proporcionar criterios de salud y seguridad a los ingenieros, diseñadores y planificadores industriales;

- mejorar la integración de los servicios de salud en el trabajo con los demás servicios de al empresa;

- desarrollar sistemas mejorados de prestación de servicios de salud en el trabajo a las pequeñas empresas, los trabajadores agrícolas y los autónomos;

- acelerar y mejorar la evaluación de los peligros potenciales introducidos por las nuevas tecnologías, materiales y sustancias;

- reforzar las estrategias y metodologías aplicables para tratar con los aspectos psicosociales del trabajo, con especial atención al control de los peligros y la prevención de sus efectos adversos;

- mejorar la capacidad de prevenir y controlar trastornos musculoesqueléticos, lesiones de tensión acumulativa y estrés profesional;

- aumentar la atención prestada a las necesidades de los trabajadores de mayor edad y mejorar los métodos aplicados para su adaptación al trabajo y para el mantenimiento de su capacidad de trabajo;

- desarrollar y mejorar los programas de mantenimiento de la capacidad de trabajo de los desempleados y de favorecimiento de su recolocación,

- aumentar el número y la competencia de los profesionales de las diversas disciplinas implicadas en la salud y la seguridad en el trabajo y reconocer la necesidad de incluir otras disciplinas nuevas, tales como la ciencia de la organización del trabajo, la gestión de calidad y la economía sanitaria.

En resumen, durante la próxima década y en lo sucesivo los servicios de salud en el trabajo deberán hacer frente a retos formidables, aparte de las presiones económicas, políticas y sociales inherentes al cambio de las circunstancias nacionales e industriales. Entre ellos se encuentran los problemas asociados a las nuevas tecnologías de la información y a la automatización, las nuevas sustancias químicas y formas de energía física, los peligros de las nuevas biotecnologías, la reubicación y transferencia internacional de tecnologías peligrosas, el envejecimiento de la población activa, los problemas sociales de grupos vulnerables tales como los enfermos crónicos y los discapacitados, así como el desempleo y las recolocaciones impuestos por la búsqueda de trabajo y la aparición de enfermedades hasta ahora desconocidas que pueden afectar a la población activa.

\section{Conclusiones}

L as infraestructuras de salud en el trabajo están insuficientemente desarrolladas para atender las necesidades de los trabajadores de todas las partes del mundo. La necesidad de disponer de servicios efectivos no está disminuyendo, sino aumentando. Los instrumentos de la OIT sobre servicios de salud en el trabajo y las estrategias paralelas de la OMS constituyen una base útil para conseguir un importante desarrollo de dichos servicios, y deben ser utilizados por los países al establecer objetivos de la política para salvaguardar la salud y la seguridad profesionales de los trabajadores del país.

Los países en vías de desarrollo y los recién industrializados representan unos 8 de cada 10 trabajadores mundiales, de los cuales no más de un $5 \%$ a un $10 \%$ tienen acceso a servicios de salud en el trabajo adecuados. Si pudieran organizarse estos servicios y prestarse a todos los trabajadores, no sólo saldría ganando su salud, sino también el bienestar y el nivel socioeconómico de los países, sus comunidades y la totalidad de su población. También se ayudaría a controlar los costes de la parte evitable del absentismo por enfermedad y la discapacidad y se contendría la escalada de los costes de la asistencia sanitaria y la seguridad social.

Existen directrices internacionales para conseguir unas políticas y programas de salud en el trabajo eficaces, pero se no se aplican suficientemente en los ámbitos local y nacional. Debe fomentarse la colaboración entre los países y las organizaciones internacionales, así como entre los propios países, a fin de conseguir el apoyo económico, técnico y profesional necesario para aumentar el acceso a los servicios de salud en el trabajo.

La gama y cantidad de servicios de salud en el trabajo necesarios en una empresa varían ampliamente en función de las circunstancias del país y de la comunidad, de la naturaleza del sector y los procesos y materiales empleados, y de las características de la fuerza de trabajo. D ebe darse la máxima prioridad a los servicios preventivos y conseguirse un nivel aceptable de calidad.

$\mathrm{H}$ ay diversos modelos disponibles para la organización de servicios de salud en el trabajo y la creación de las correspondientes infraestructuras. La elección debe venir determinada por las características de la empresa, la disponibilidad de recursos en términos de finanzas, instalaciones y personal cualificado, los tipos de problemas previstos y los recursos disponibles en la comunidad. Es necesaria una mayor investigación sobre la adecuación de los diversos modelos a las distintas situaciones.

La prestación de servicios de salud en el trabajo de alta calidad suele requerir la intervención de una amplia gama de disciplinas de salud y seguridad, sanidad general y psicosociología. El servicio ideal contaría con un equipo interdisciplinario 
en el que estuvieran representadas varias de estas disciplinas. No obstante, incluso este tipo de servicio necesita recurrir a fuentes externas cuando se requieren especialistas poco habituales. Pare hacer frente a la necesidad creciente de especialistas debe contratarse a un número suficiente de ellos, formarles y proporcionarles la especialización en este campo necesaria para una eficacia óptima en el mundo laboral. D ebe fomentarse la colaboración internacional para la recolección de la información disponible, el diseño de su aplicación en distintas circunstancias y su difusión a través de redes ya establecidas muy promocionadas.

Las actividades de investigación en la materia han estado tradicionalmente centradas en áreas como la toxicología, la epidemiología y el diagnóstico y tratamiento de los problemas de salud. Se necesitan más investigaciones sobre la eficacia de los diversos modelos y mecanismos de prestación de servicios de salud en el trabajo, su eficiencia en términos de coste y su adaptabilidad a las diferentes situaciones.

Los servicios de salud en el trabajo tienen diversas metas y objetivos, algunos de los cuales pueden requerir una reconsideración, dado el constante cambio del mundo laboral, por parte de los organismos internacionales más autorizados y a la luz de los nuevos problemas en este campo y los nuevos modos de promover y proteger la salud de los trabajadores.

Los Convenios y Recomendaciones de la OIT sobre salud y seguridad en el trabajo, los planteamientos y normas que en ellos se establecen, las estrategias y resoluciones de la O M S y los programas internacionales de ambas organizaciones constituyen una sólida base para el trabajo en el ámbito nacional y para mejorar la cooperación internacional con el fin de desarrollar y perfeccionar los servicios y la práctica de la salud en el trabajo. Estos instrumentos y su correcta aplicación son especialmente necesarios en todo el mundo en la fase actual de rápido cambio de la vida de trabajo, de aplicación de nuevas tecnologías y de existencia de un riesgo creciente de establecer objetivos materiales y económicos a corto plazo con carácter prioritario sobre los valores de la salud y la seguridad.

\section{- Los SERVICIOS DE LA SALUd EN EL TRABAJO Y LA PRACTICA}

Georges H. Coppée

\section{Infraestructuras, práctica y enfoques de la salud en el trabajo}

Aunque desde el decenio de 1980 se ha avanzado mucho hacia un enfoque integral de la salud en el trabajo, en el que se persiga la protección y la promoción de la salud de los trabajadores junto con el mantenimiento de su capacidad de trabajo y se haga especial hincapié en el establecimiento y mantenimiento de un medio ambiente de trabajo sano y seguro para todos, es mucho lo que aún queda por debatir con respecto a la forma en que se aplica en la actualidad. Actualmente se designa con la expresión práctica de la salud en el trabajo el conjunto de actividades realizadas por la empresa, los trabajadores y sus organizaciones, los diseñadores y arquitectos, los fabricantes y suministradores, los legisladores y parlamentarios, los inspectores laborales y sanitarios, los analistas y especialistas en organización del trabajo, las organizaciones de normalización, las universidades e instituciones investigadoras, dirigidas a proteger la salud y promover la salud y la seguridad en el trabajo.

Entre esas actividades se incluyen sin limitarse a ellas, las realizadas por los profesionales de la salud en el trabajo.
A menudo se producen confusiones debido al uso de la expresión servicios de salud en el trabajo para designar, indistintamente:

- la prestación de servicios de salud en el trabajo (es decir, la contribución de los profesionales de la salud a la salud y la seguridad en el trabajo);

- Ios mecanismos establecidos para la prestación de dichos servicios (es decir, los servicios de salud en el trabajo como parte de la infraestructura de protección y promoción de la salud de los trabajadores).

Con el fin de superar este problema y otras muchas causas habituales de malentendidos, el segundo punto del orden del día de la Décimo segunda reunión del Comité M ixto OIT/OMS sobre M edicina del Trabajo estaba redactado así: "Infraestructuras para la práctica de la salud en el trabajo: opciones y modelos nacionales para las políticas, enfoques de asistencia sanitaria primaria, estrategias, programas y funciones de los servicios de salud en el trabajo" (1995b), con las siguientes acepciones:

- Práctica de la salud en el trabajo: conjunto de actividades de todos los que contribuyen a la protección de la salud de los trabajadores y a la mejora de las condiciones y el medio ambiente de trabajo; este término no debe entenderse limitado a la práctica de los profesionales de la salud en el trabajo.

- Enfoques de la salud en el trabajo: principios y enfoques orientadores de las medidas a adoptar, tales como el principio general de asistencia sanitaria primaria defendido por la O M S y el de la mejora de las condiciones y el medio ambiente de trabajo, defendido por la OIT.

- Infraestructuras para la práctica de la salud en el trabajo: mecanismos establecidos para poner en práctica las políticas nacionales y tomar medidas en el ámbito de la empresa; las infraestructuras pueden revestir la forma de servicios "institucionalizados" e incluir otros muchos organismos, tales como institutos nacionales de salud y seguridad en el trabajo

El uso de los términos infraestructuras, práctica y enfoques permite diferenciar las funciones de los diversos protagonistas y participantes en la prevención en sus respectivas áreas de competencia, sin perjuicio de su actuación conjunta.

Los servicios de salud en el empleo contribuyen a la práctica de la salud en el trabajo, que es intrínsecamente interdisciplinaria e intersectorial e incluye a otros especialistas, tanto de la empresa como externos, además de los profesionales del ramo, así como las correspondientes autoridades públicas, las empresas, los trabajadores y sus representantes.

Existen muchos modelos de servicios de salud en el trabajo. U no de ellos disfruta de gran consenso a escala internacional: es el modelo propuesto por el Convenio de la OIT sobre los servicios de salud en el trabajo ( $n$ ㅇ 161) y la Recomendación ( $n$ ํ 171) promulgados por la Conferencia Internacional del Trabajo en 1985. L os países deben considerar este modelo como un objetivo hacia el cual avanzar, teniendo en cuenta, por supuesto, las particularidades locales y la disponibilidad de personal especializado y recursos económicos.

D eben adoptarse políticas nacionales para desarrollar progresivamente servicios de salud en el trabajo para todos los trabajadores, tomando en consideración los riegos específicos de las empresas. Estas políticas han de formularse, ponerse en práctica y revisarse periódicamente a la vista de las condiciones y prácticas nacionales y en consulta con las organizaciones de empresas y de trabajadores más representativas. D eben establecerse planes que señalen los pasos a dar cuando no puedan establecerse servicios de salud en el trabajo de forma inmediata en todas las empresas. 


\section{Definición de la salud en el trabajo adoptada} por el Comité Conjunto OIT/ OMS

\section{sobre Medicina del Trabajo (1950)}

La salud en el trabajo debe orientarse hacia la promoción y mantenimiento del más alto grado posible de bienestar físico, mental y social de los trabajadores de todas las profesiones; la prevención de la pérdida de la salud de los trabajadores por causa de sus condiciones de trabajo; la protección de los trabajadores frente a los riesgos derivados de factores nocivos para la salud en su puesto de trabajo; la colocación y mantenimiento de los trabajadores en un medio ambiente de trabajo adaptado a sus capacidades físicas y psicológicas y, en resumen, la adaptación del trabajo al hombre y del hombre a su trabajo.

La salud en el trabajo se centra principalmente en tres objetivos diferenciados: (i) el mantenimiento y la promoción de la salud y la capacidad de trabajo de los trabajadores; (ii) la mejora del trabajo y el medio ambiente de trabajo para que favorezcan la salud y la seguridad de los trabajadores y (iii) el desarrollo de formas organizativas y culturas de trabajo favorecedoras de la salud y la seguridad en el trabajo y, en consecuencia, que promuevan un clima social positivo y un funcionamiento eficiente y mejoren la productividad de la empresa. El concepto de cultura de trabajo alude, en este contexto, al reflejo de los sistemas de valores fundamentales adoptados por la empresa en cuestión, que se plasma en la práctica en sus sistemas de gestión, políticas de personal, principios de participación, políticas de formación y gestión de la calidad.

\section{Cooperación interdisciplinaria y colaboración intersectorial: perspectiva global}

La OIT y la OMS tienen una definición común de salud en el trabajo (ver cuadro), adoptada por el Comité M ixto O IT / O M S sobre Medicina del Trabajo en su primera reunión (1950) y revisada en la décimosegunda (1995).

Los estados, en colaboración con las organizaciones de empresas, de trabajadores y de profesionales implicados, deben diseñar políticas, programas y planes de acción adecuados para el desarrollo de la salud en el trabajo con un contenido interdisciplinario y una cobertura integral. En cada país, el ámbito y contenido de los programas debe adaptarse a las necesidades nacionales, teniendo en cuenta las condiciones locales, e incorporarse a los planes nacionales de desarrollo. El Comité M ixto O IT / O M S recalcó que los principios contenidos en los Convenios de la OIT n 155 y no 161 y en sus Recomendaciones de acompañamiento, así como en las resoluciones, directrices y enfoques de la O M S relativos a la salud en el trabajo constituyen una guía universalmente aceptada para el diseño de dichas políticas y programas (Comité M ixto OIT/OMS sobre Medicina del Trabajo, 1992).

$\mathrm{H}$ ay rasgos similares entre la estrategia de la OIT para la mejora de las condiciones y el medio ambiente de trabajo y el principio general de asistencia sanitaria primaria de la OMS, pues ambos se basan en consideraciones técnicas, éticas y sociales similares y:

- se dirigen a todos los afectados, trabajadores y población en general;

- definen políticas, estrategias y medios de acción;

- subrayan la responsabilidad de la empresa con respecto a la salud y seguridad de los trabajadores en sus empleos;

- hacen hincapié en la prevención primaria y el control de riesgos en la fuente;
- dan especial importancia a la información, la educación sanitaria y la formación;

- señalan la necesidad de desarrollar una práctica de la salud en el trabajo que sea fácilmente accesible para todos y esté disponible en el lugar de trabajo;

- reconocen el papel esencial de la participación, la participación comunitaria en los programas de salud, la participación intersectorial y la de los trabajadores en la mejora de las condiciones y el medio ambiente de trabajo;

- resaltan las interacciones entre salud, medio ambiente y desarrollo, así como entre seguridad y salud en el trabajo y empleo productivo.

La actividad de la OIT se ha centrado principalmente en la aportación de directrices internacionales y de un marco jurídico para el desarrollo de políticas e infraestructuras de salud en el trabajo de carácter tripartito (que incluye a los estados, las empresas y los trabajadores) y en el apoyo práctico a las medidas de mejora del lugar de trabajo, en tanto que la OMS se ha centrado en prestar respaldo científico, metodológico, apoyo técnico y en la formación de personal sanitario y de ámbitos conexos para la salud en el trabajo (Comité M ixto OIT/OMS sobre M edicina del Trabajo, 1992).

\section{Cooperación interdisciplinaria}

Para la OMS, la salud en el trabajo incluye la seguridad en el mismo. La higiene se considera orientada a la prevención de las enfermedades, en tanto que la seguridad se contempla como la disciplina relativa a la prevención de las lesiones físicas por accidente. Para la OIT, la salud y seguridad en el trabajo es una disciplina orientada a la prevención de lesiones profesionales (tanto enfermedades como accidentes) y a la mejora de las condiciones y del medio ambiente de trabajo. Se utilizan los términos seguridad en el trabajo, salud en el trabajo, medicina del trabajo, higiene del trabajo y asistencia de enfermería en el trabajo para reconocer la participación de diversos profesionales (por ejemplo, ingenieros, médicos, enfermeras, higienistas) y el hecho de que la organización de la salud y seguridad en el trabajo a escala de la empresa suele comprender diversos servicios y comités de salud y seguridad profesional.

En cierta medida, la seguridad en el trabajo y la prevención primaria están más directamente vinculadas a la tecnología empleada, al proceso de producción y a la gestión diaria que la salud en el trabajo, más centrada en las relaciones entre trabajo y salud, en particular en la vigilancia del medio ambiente de trabajo y la salud de los trabajadores (prevención secundaria), así como en los factores humanos y los aspectos ergonómicos. Además, en el ámbito de la empresa, los ingenieros son una parte necesaria e integrada en la línea de gestión (ingenieros de producción, técnicos de mantenimiento, etc.), mientras que la salud e higiene en el trabajo requiere la intervención de especialistas del ámbito sanitario que no son necesarios para el funcionamiento de la empresa, sino que pueden ser consultores 0 pertenecer a un servicio de salud en el trabajo externo.

Sean cuales sean los mecanismos de organización y la terminología empleados, lo más importante es que los profesionales de la salud y la seguridad en el trabajo actúen en equipo. No han de pertenecer necesariamente a la misma unidad o servicio, aunque esto pueda ser deseable en su caso. No debe prestarse atención a la estructura de los servicios, sino a la correcta ejecución de sus funciones en el ámbito de la empresa (desde un punto de vista científico, técnico y ético). Debe acentuarse la cooperación y coordinación en la elaboración y aplicación de un programa de acción, así como en el desarrollo de conceptos unificadores, tales como los de "culturas de trabajo" (cultura de seguridad, de protección del trabajador, corporativa) que 
Tabla 16.1 - Seis principios y tres niveles para una buena práctica de la salud en el trabajo.

\begin{tabular}{|c|c|c|c|c|c|}
\hline \multirow[b]{2}{*}{ Niveles } & \multicolumn{5}{|c|}{ Principios } \\
\hline & Prevención & Protección & Adaptación & Promoción & Atenuación \\
\hline Personas ( diversidad) & $\begin{array}{l}\text { Prevención de accidentes } \\
\text { Higiene industrial } \\
\text { Decenio de } 1920\end{array}$ & $\begin{array}{l}\text { Medicina industrial } \\
\text { Equipos de } \\
\text { protección personal } \\
\text { Decenio de } 1930\end{array}$ & $\begin{array}{l}\text { Organización científica } \\
\text { del trabajo } \\
\text { Análisis de puestos de } \\
\text { trabajo } \\
\text { Decenio de } 1950\end{array}$ & $\begin{array}{l}\text { Programas de } \\
\text { ayuda al trabajador } \\
\text { Decenio de } 1950\end{array}$ & $\begin{array}{l}\text { Indemnización } \\
\text { por tratamiento } \\
\text { Decenio de } 1910\end{array}$ \\
\hline $\begin{array}{l}\text { Grupos } \\
\text { (grupos expuestos, necesidades } \\
\text { específicas) }\end{array}$ & $\begin{array}{l}\text { Medio ambiente de } \\
\text { trabajo sano y seguro } \\
\text { Seguridad incorporada } \\
\text { Decenio de } 1970\end{array}$ & $\begin{array}{l}\text { Medicina del trabajo } \\
\text { Protección de máquinas } \\
\text { Decenio de } 1940\end{array}$ & $\begin{array}{l}\text { Ergonomía incluido } \\
\text { el diseño } \\
\text { Decenio de } 1950\end{array}$ & $\begin{array}{l}\text { Programas de promoción } \\
\text { de la salud de los } \\
\text { trabajadores } \\
\text { Decenio de } 1980\end{array}$ & $\begin{array}{l}\text { Planificación y } \\
\text { preparación de } \\
\text { urgencia } \\
\text { Decenio de } 1950\end{array}$ \\
\hline $\begin{array}{l}\text { La sociedad y el conjunto de los } \\
\text { trabajadores } \\
\text { (principio general de asistencia } \\
\text { sanitaria primaria) }\end{array}$ & $\begin{array}{l}\text { Tecnologías de control } \\
\text { Gestión de la salud } \\
\text { medioambiental } \\
\text { Decenio de } 1970\end{array}$ & $\begin{array}{l}\text { Salud medioambiental } \\
\text { Epidemiología } \\
\text { Asistencia sanitaria } \\
\text { preventiva } \\
\text { Decenio de } 1960\end{array}$ & $\begin{array}{l}\text { Tecnologías adecuadas } \\
\text { Protección del consumidor } \\
\text { Decenio de } 1970\end{array}$ & $\begin{array}{l}\text { Programas de educación y } \\
\text { promoción de la salud } \\
\text { Decenio de } 1970\end{array}$ & $\begin{array}{l}\text { Asistencia sanitaria } \\
\text { curativa } \\
\text { Rehabilitación } \\
\text { Decenio de } 1920\end{array}$ \\
\hline
\end{tabular}

Nota: Las fechas $(1910,1920$, etc.) son arbitrarias y se ofrecen con la mera intención de dar una idea del curso temporal del desarrollo progresivo de un enfoque integral de la salud en el trabajo. Los datos varían entre los diversos países y pueden indicar tanto el inicio como el pleno desarrollo de una determinada disciplina o la aparición de nuevos términos o enfoques de una práctica anteriormente realizada durante muchos años. Esta Tabla no pretende exponer de forma exacta las disciplinas implicadas en el proceso, sino mostrar sucintamente las relaciones existentes en el marco de un enfoque interdisciplinario y de cooperación intersectorial orientado hacia la consecución de un medio ambiente de trabajo sano y seguro para todos, con un enfoque participativo y con el objetivo de lograr nuevas formas de desarrollo, que habrán de ser equitativas para poder ser sostenibles.

generen salud y seguridad en el trabajo y el de "mejora continua de la calidad" de las condiciones y el medio ambiente de trabajo.

En 1992, el Comité M ixto O IT / O M S señaló que el ámbito de la salud en el trabajo es muy amplio (como puede verse en la Tabla 16.1), pues comprende disciplinas tales como la medicina del trabajo, la asistencia de enfermería en el trabajo, la higiene industrial, la seguridad en el trabajo, la ergonomía, la ingeniería, la toxicología, la higiene medioambiental, la psicología del trabajo y la gestión de personal. La colaboración y la participación de las empresas y los trabajadores en los programas de salud en el trabajo es un requisito esencial para el éxito de la práctica de la salud en el trabajo.

La definición de un objetivo común es una de las soluciones para evitar quedar atrapados en una excesiva compartimentación de disciplinas, aunque en ciertos casos ésta pueda suponer una ventaja al permitir un análisis especializado en profundidad de los problemas. A menudo puede constituir un factor negativo, pues impide el desarrollo de un enfoque interdisciplinario. Es necesario unificar conceptos que abran terrenos de cooperación. La nueva definición de la salud en el trabajo adoptada por el Comité M ixto en 1995 tiene este objetivo.

En ocasiones se han mantenido vivos debates sobre si la salud en el trabajo constituye en sí misma una disciplina o si forma parte de la protección del trabajo, la salud medioambiental o la salud pública. Cuando la cuestión no es puramente académica e implica decisiones tales como qué organización o ministerio es competente en determinadas áreas, el resultado puede tener consecuencias importantes para la asignación de fondos o la distribución de recursos disponibles en forma de especialización y equipos.

U na de las soluciones al problema consiste en fomentar enfoques convergentes basados en los mismos valores con un objetivo común. EI enfoque de la O M S sobre la asistencia primaria y el de la OIT sobre la mejora de las condiciones y el medio ambiente de trabajo pueden servir a este fin. Con la mente puesta en los valores comunes de la equidad, la solidaridad, la salud y la justicia social, estos enfoques pueden plasmarse en estrategias (la estrategia de la OMS sobre salud en el trabajo para todos) y programas (el Programa Internacional de la OIT para el $\mathrm{M}$ ejoramiento de las Condiciones y del M edio Ambiente de Trabajo), así como en planes de acción y actividades realizadas a escala empresarial, nacional o internacional por todos los participantes en la prevención, la protección y la promoción de la salud de los trabajadores, ya sea independiente 0 conjuntamente.

$\mathrm{H}$ ay otras posibilidades. La Asociación Internacional de la Seguridad Social (AISS) propone el "concepto de prevención" como vía ideal para que la seguridad social permita alcanzar la "seguridad en todo el mundo" en el trabajo y en el hogar, en la carretera y en el tiempo de ocio. La Comisión Internacional de M edicina del Trabajo (CIM T) está desarrollando un enfoque de ética en la salud del trabajo y catalizando el nuevo enfoque y la interacción enriquecedora entre la salud en el trabajo y la salud medioambiental. Puede observarse una tendencia similar en varios países en los que, por ejemplo, las asociaciones profesionales acogen ahora a especialistas en ambas disciplinas.

\section{Colaboración intersectorial}

En 1984, la Conferencia Internacional del Trabajo anual de la OIT promulgó una resolución relativa a la mejora de las condiciones y del medio ambiente de trabajo que incorporaba el concepto de su carácter esencial para la promoción de la justicia social. Se puso de manifiestoo que la mejora de las condiciones y del medio ambiente de trabajo constituyen una contribución positiva al desarrollo nacional y una medida del éxito de cualquier política social y económica, señalándose tres principios fundamentales:

- El trabajo debe realizarse en un medio ambiente sano y seguro. 
- Las condiciones de trabajo deben ser adecuadas para el bienestar de los trabajadores y coherentes con la dignidad de la persona.

- El trabajo debe ofrecer oportunidades reales de logros personales, autorrealizacion y servicio a la sociedad.

Durante el decenio de 1980 se sustituyó el concepto de desarrollo por el de "desarrollo sostenible", que incluye "el derecho a una vida sana y productiva en armonía con la naturaleza", como indicaba el primer principio de la Declaración de Río (Conferencia de las $\mathrm{N}$ aciones U nidas sobre M edio A mbiente y Desarrollo, UNCED 1992). EI objetivo de un medio ambiente sano y seguro se ha convertido así en parte integrante del concepto de desarrollo sostenible, que también implica equilibrar la protección del medio ambiente con la generación de oportunidades de empleo y la mejora de los medios de vida y la salud para todos. Tanto la salud medioambiental como la del trabajo contribuyen a que el desarrollo sea sostenible, equitativo y sólido, no sólo desde un punto de vista económico, sino también humano, social y ético. Este cambio de paradigma se muestra en la Figura 16.1.

El objetivo de esta Figura es ilustrar la interacción existente entre salud del trabajo y salud medioambiental y el reforzamiento mutuo de su contribución al desarrollo sostenible. Se identifica un área que representa la integración de los objetivos económicos y sociales que pueden alcanzarse teniendo en cuenta, al mismo tiempo, el medio ambiente, el empleo y la salud.

La Comisión de Salud y M edio A mbiente de la O M S ha reconocido, además, que "el tipo de desarrollo necesario para salvaguardar la salud y el bienestar dependerá de varias condiciones, entre ellas el respeto al medio ambiente, mientras que el desarrollo sin consideración al medio ambiente conducirá inevitablemente al deterioro de la salud de las personas" (O M S 1992). En el mismo sentido, la salud en el trabajo debe considerarse un "valor añadido", es decir, una contribución positiva al desarrollo nacional y una condición necesaria para su sostenibilidad.

Revisten especial importancia para el trabajo de la OIT y la O M S la Declaración y el Programa de Acción adoptados por la Cumbre Mundial para el Desarrollo Social celebrada en

Figura 16.1 - Enfoque multidisciplinar para un desarrollo sostenible y equitativo.

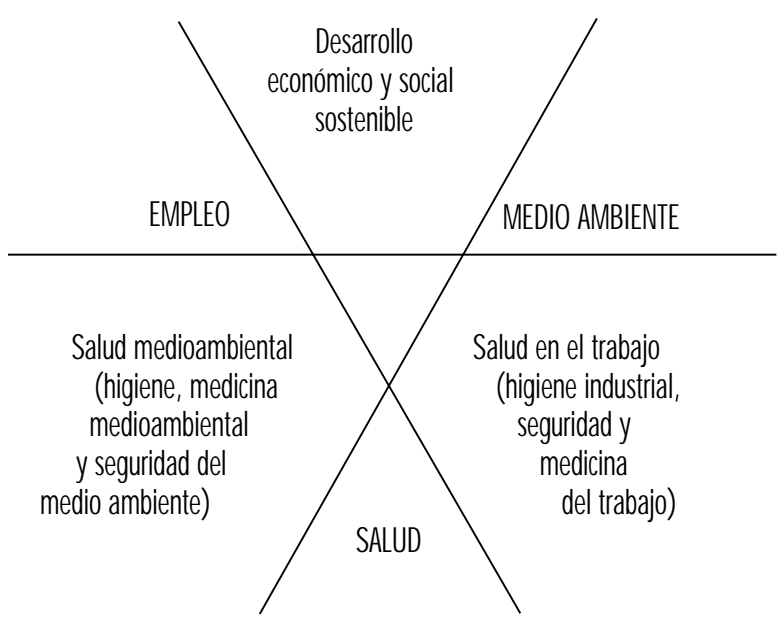

Copenhague en 1995. La Declaración compromete a las naciones del mundo a perseguir el objetivo del pleno empleo productivo y libremente elegido como prioridad básica de sus políticas sociales y económicas. La Cumbre señaló claramente que el objetivo no debe ser la creación de cualquier tipo de trabajo, sino de empleos de calidad que salvaguarden los derechos e intereses básicos de los trabajadores, y que debe incluir la adopción de medidas dirigidas a conseguir un medio ambiente de trabajo sano y seguro, eliminar los peligros sanitarios del medio ambiente de trabajo y generar salud y seguridad en el trabajo. Es un indicador de que en el futuro la salud en el trabajo puede tener una participación importante en la conciliación de empleo, salud y medio ambiente orientada a un desarrollo equitativo y sostenible.

El enfoque de la asistencia sanitaria primaria pone el acento en la equidad social, la disponibilidad económica y la accesibilidad, la participación y la implicación comunitaria, como señaló el Comité M ixto O IT / O M S sobre M edicina del Trabajo en 1995. A mbas organizaciones comparten valores morales y éticos básicos. El enfoque de la asistencia sanitaria primaria es innovador porque aplica valores sociales a la asistencia sanitaria preventiva y curativa. Esta complementariedad no siempre ha sido bien entendida, debiéndose en ocasiones la confusión a la interpretación de palabras comunes, lo que ha producido ciertos malentendidos en el debate sobre las funciones y actividades que realmente corresponden a la OIT y la OMS, que son complementarias y se apoyan mutuamente.

La asistencia sanitaria primaria puede considerarse basada en principios de equidad social, autodependencia y desarrollo comunitario. También puede considerarse una estrategia de reorientación de los sistemas sanitarios para promover la participación individual y comunitaria y la colaboración entre todos los sectores implicados en la salud. Un principio general debería ser el de que la asistencia sanitaria primaria incluya un componente de salud en el trabajo y que los servicios especializados de salud en el trabajo apliquen el principio general de la asistencia sanitaria primaria con independencia del modelo estructural adoptado.

Son muchos los participantes en la prevención que comparten los planteamientos tanto de la OIT como de la OMS, y que deben hacer las aportaciones necesarias para desarrollar una buena práctica de salud en el trabajo. El Comité Mixto OIT/OMS ha indicado que ambas organizaciones debe promover un enfoque global de la salud en el trabajo en sus países miembros. Si se empleara tal enfoque, la salud en el trabajo podría contemplarse como una materia interdisciplinaria e integrada. Las actividades de las distintas organizaciones y ministerios no serían competitivas o contradictorias sino complementarias y de apoyo mutuo, orientadas al desarrollo equitativo y sostenible. Debe ponerse el acento en los objetivos comunes, los conceptos unificados y los valores básicos.

Como señaló el Comité M ixto O IT / O M S en 1995, es necesario desarrollar indicadores de salud en el trabajo para la promoción y control del avance hacia la salud y el desarrollo sostenible. Las formas de desarrollo que pongan en peligro la salud no pueden defenderse alegando su carácter equitativo 0 sostenible. Los indicadores de "sostenibilidad" deben incluir necesariamente indicadores de salud, ya que la CNUMAD señala que el compromiso de "proteger y promover la salud de las personas" es un principio fundamental del desarrollo sostenible (Agenda 21, capítulo 6). La O M S ha asumido un papel de liderazgo tanto en el desarrollo del concepto como del uso de los indicadores de salud medioambiental, algunos de los cuales afectan a la salud y al medio ambiente de trabajo.

Se espera que tanto la OIT como la OMS desarrollen indicadores de salud en el trabajo que sirvan de ayuda a los 
países para la evaluación retrospectiva y prospectiva de su práctica en este campo y para el control de los avances hacia los objetivos establecidos por las políticas nacionales de seguridad y salud en el trabajo y de medio ambiente de trabajo. EI desarrollo de estos indicadores centrados en las interacciones entre trabajo y salud podría ser también de ayuda a los servicios de salud en el trabajo para la evaluación de sus programas y actividades y para orientarlos a la mejora de las condiciones y el medio ambiente de trabajo (es decir, controlar su eficiencia y la forma en que realizan sus funciones).

\section{Normas y orientación}

Los Convenios y Recomendaciones de la O IT sobre salud y seguridad en el trabajo definen los derechos de los trabajadores y asignan deberes y responsabilidades en esta materia a las autoridades correspondientes, las empresas y los trabajadores. Estos instrumentos, adoptados por la Conferencia Internacional del Trabajo, constituyen, en conjunto, el Código Internacional del Trabajo, que define normas mínimas en el ámbito laboral.

L a política de la OIT en esta materia está básicamente contenida en dos Convenios internacionales, con sus correspondientes Recomendaciones de apoyo. EI C onvenio sobre salud y seguridad de los trabajadores y medio ambiente de trabajo ( $n$ - 155) y su Recomendación (no 164), de 1981, prevén la adopción de una política nacional de salud y seguridad en el trabajo y describen las medidas que es necesario adoptar en el ámbito nacional y empresarial para promoverlas y para mejorar el medio ambiente de trabajo. El Convenio sobre los servicios de salud en el trabajo ( $n$ 161) y su Recomendación ( $n$ ㅇ 171), de 1985, prevén el establecimiento de servicios de salud en el trabajo que contribuyan a la puesta en práctica de la política en la materia y realicen estas funciones en el ámbito de la empresa.

Estos instrumentos prevén un enfoque integral de la salud en el trabajo que incluye la prevención primaria, secundaria y terciaria y es coherente con los principios generales de la asistencia sanitaria primaria. En ellos se indica la forma ideal en que debe prestarse a los trabajadores la asistencia sanitaria en el trabajo y se propone un modelo que canaliza hacia el lugar de trabajo actividades organizadas que requieren un personal especializado para catalizar la interacción entre diversas disciplinas con el fin de promover la cooperación entre todos los participantes en la prevención. Estos instrumentos proporcionan también un marco organizativo en el que los profesionales de la salud en el trabajo pueden prestar eficientemente servicios de calidad para conseguir la protección y promoción de la salud de los trabajadores y contribuir a la salud de la empresa.

\section{Funciones}

El Convenio no 161 define los servicios de salud en el trabajo como servicios investidos de funciones básicamente preventivas y encargados de asesorar al empleador, a los trabajadores y a sus representantes en la empresa acerca de los requisitos necesarios para establecer y de conservar un medio ambiente laboral sano y seguro que favorezca una salud física y mental óptima en relación con el trabajo y acerca de la adaptación del trabajo a las capacidades de los trabajadores, habida cuenta de su estado de salud física y mental.

El Convenio especifica que los servicios deben incluir, entre las siguientes funciones, las que resulten adecuadas para los riesgos de la empresa para la salud en el trabajo:

- identificación de los riesgos que puedan afectar a la salud en el lugar de trabajo;

- vigilancia de los factores del medio ambiente de trabajo y de las prácticas de trabajo que puedan afectar a la salud de los trabajadores, incluidos las instalaciones sanitarias, comedores y alojamientos en los casos, cuando estas facilidades sean ofrecidas por el empleador;

- asesoramiento sobre la planificación y la organización del trabajo, incluido el diseño de los lugares de trabajo, sobre la selección, el mantenimiento y el estado de la maquinaria y de los equipos y sobre las sustancias utilizadas en el trabajo;

- participación en el desarrollo de programas para el mejoramiento de las prácticas de trabajo, así como en las pruebas y la evaluación de nuevos equipos, en relación con la salud;

- asesoramiento en materia de salud, de seguridad y de higiene en el trabajo y de ergonomía, así como en materia de equipos de protección individual y colectiva;

- vigilancia de la salud de los trabajadores en relación con el trabajo;

- fomento de la adaptación del trabajo a los trabajadores;

- asistencia en pro de la adopción de medidas de rehabilitación profesional:

- colaboración en la difusión de informaciones, en la formación y educación en materia de salud e higiene en el trabajo y de ergonomía;

- organización de los primeros auxilios y de la atención de urgencia;

- participación en el análisis de los accidentes de trabajo y de las enfermedades profesionales.

EI Convenio y la Recomendación de la OIT son muy flexibles con respecto a las formas de organizar los servicios de salud en el trabajo. El establecimiento de estos servicios puede venir exigido por normas legales o reglamentarias o por convenios colectivos, 0 bien ser aprobado de cualquier otro modo por la autoridad competente tras consultar a las organizaciones representativas de las empresas y trabajadores afectados. Pueden organizarse para una sola empresa o con carácter común para varias. En la medida de lo posible, deben estar ubicados cerca del lugar de trabajo u organizarse de forma que se garantice su correcto funcionamiento en éste. Pueden ser organizados por la propia empresa afectada, los poderes públicos o servicios oficiales, las instituciones de seguridad social o cualquier otro organismo autorizado, o bien por una combinación de cualquiera de los anteriores, lo que permite un alto grado de flexibilidad. Incluso en un mismo país pueden emplearse varios de estos métodos según las condiciones y prácticas locales.

La flexibilidad del Convenio demuestra que el espíritu de los instrumentos de la OIT en la materia es acentuar los objetivos más que las reglas administrativas para lograrlos. Es importante asegurar la salud en el trabajo de todos los trabajadores, 0 al menos avanzar hacia este objetivo. Este progreso sólo puede realizarse habitualmente de forma gradual, pero es necesario hacer algunos avances hacia estos objetivos y emplear los recursos de la forma más eficiente para este fin.

$H$ ay varios métodos de financiación de los servicios de salud en el trabajo. En muchos países, la obligación de crear y mantener estos servicios corresponde a las empresas, mientras que en otros forman parte de los programas sanitariosnacionaleso de los servicios sanitarios públicos. EI Convenio no detalla los aspectos de la dotación de personal, la financiación y la formación del personal, dejándolo al enfoque nacional de cada país.

$\mathrm{H}$ ay diversos ejemplos de servicios de salud en el trabajo creados por instituciones de seguridad social o financiados por programas de seguro especiales de los trabajadores. En algunos casos la financiación se rige por un acuerdo entre el M inisterio de Trabajo y el de Sanidad o entre las instituciones de la seguridad social. En determinados países, los sindicatos gestionan este tipo de servicios. También hay mecanismos 
especiales en virtud de los cuales una institución central u organismo tripartito recauda fondos entre los empleados y luego paga por la prestación de estos servicios o distribuye los fondos para financiar el funcionamiento de los servicios.

Las fuentes de financiación también pueden variar en función de las actividades de los servicios. Por ejemplo, si realizan actividades curativas, la seguridad contribuye en algunos casos a financiarlos. Si participan en programas sanitarios públicos y en actividades de promoción de la salud o de investigación, pueden encontrarse otras fuentes de financiación. La financiación no depende sólo del modelo estructural elegido, sino también del valor que la sociedad asigna a la protección y promoción de la salud y de su disponibilidad a invertir en la salud en el trabajo y la prevención de los peligros profesionales.

\section{Condiciones de funcionamiento}

Se hace hincapié en las condiciones de funcionamiento de los servicios de salud en el trabajo. No sólo es necesario que realicen un cierto número de tareas, sino también que éstas se realicen de forma adecuada, tomando en consideración los aspectos técnicos y éticos.

EI Convenio de la OIT sobre los servicios de salud en el trabajo y especialmente su Recomendación de acompañamiento señalan algunos requisitos básicos:

- El personal debe estar cualificado y disfrutar de plena independencia profesional.

- Debe garantizarse la confidencialidad.

- Debe informarse a los trabajadores de las actividades de los servicios y de los resultados de sus evaluaciones de salud.

- Las empresas, los trabajadores y sus representantes deben participar en el funcionamiento de los servicios y en el diseño de sus programas.

Los aspectos éticos de la salud en el trabajo se tienen cada vez más en cuenta, poniéndose el énfasis en la necesidad tanto de calidad como de evaluación permanente de los servicios. N o sólo es necesario determinar qué debe hacerse, sino también con qué finalidad y en qué condiciones. La Recomendación de la OIT sobre los servicios de salud en el trabajo (no 171) establece un conjunto de principios a este respecto. El Código Etico Internacional para los Profesionales de la Salud en el Trabajo adoptado por la Comisión Internacional de M edicina del Trabajo (CIM T 1992) aporta directrices adicionales.

En 1995, el Comité Mixto OIT/OMS sobre Salud en el Trabajo señaló que "la garantía de calidad de los servicios debe formar parte integral del desarrollo de los servicios de salud en el trabajo. No es éticamente admisible prestar servicios de mala calidad." EI Código Etico del CIM T prescribe que "Ios profesionales de la salud en el trabajo deben establecer un programa de auditoría profesional de sus propias actividades para garantizar que se han establecido normas adecuadas, que éstos se están cumpliendo y que las deficiencias, si las hubiera, se están detectando y corrigiendo".

\section{Objetivos y valores comunes}

El papel de los servicios de salud en el trabajo institucionalizados debe contemplarse en el marco más amplio de las políticas e infraestructuras sanitarias y sociales, pues contribuyen a la puesta en práctica de las políticas nacionales de seguridad en el trabajo, salud en el trabajo y medio ambiente de trabajo recomendadas por el Convenio de la O IT sobre seguridad y salud de los trabajadores y medio ambiente de trabajo (no 155) y su Recomendación (no 164), de 1981. Los servicios de salud en el trabajo contribuyen también a la consecución de los objetivos contenidos en la estrategia "Salud para todos" defendida por la O M S como política para la equidad, la solidaridad y la salud.

$\mathrm{H}$ ay signos de una tendencia cada vez más acusada a poner en juego la experiencia y los recursos en el marco de una conexión en red de los distintos mecanismos. A escala internacional, éste es ya el caso de la seguridad química, para la que existe un mecanismo interorganizativo: el Programa Interorganizativo para una C orrecta G estión de las Sustancias Q uímicas (I O M C). $\mathrm{H}$ ay otros muchos campos, tales como la protección contra la radiación y la seguridad biológica, en los que están apareciendo o podrían desarrollarse formas flexibles de cooperación internacional entre países y organizaciones internacionales.

Los mecanismos de conexión en red abren nuevos campos de cooperación que pueden adaptarse de forma flexible al tema de que se trate, ya sea el estrés en el trabajo, la coordinación de la investigación o la actualización de esta Enciclopedia. Se pone el acento en la interacción y ya no en la compartimentación vertical de las disciplinas. El concepto de liderazgo da paso a la participación activa. La conexión internacional en redes está desarrollándose rápidamente y podría hacerlo aún más interconectando las estructuras actuales. EI papel de la OIT y la OMS podría consistir en la puesta en marcha de redes internacionales para atender las necesidades y exigencias de sus participantes y alcanzar el objetivo común de proteger a las personas en el trabajo.

Los valores éticos y sociales acordados por la comunidad internacional están incorporados a los Convenios y R ecomendaciones de la O IT, así como a la política de "Salud para todos" de la O M S. D esde el decenio de 1980 se ha implantado progresivamente el concepto de desarrollo sostenible, que tras la Conferencia de Río y la Cumbre Social de Copenhague tiene ya en cuenta las interrelaciones entre empleo, salud y medio ambiente. El objetivo común de lograr un medio ambiente de trabajo sano y seguro para todos reforzará la decisión de todos los implicados en la materia de prestar un mejor servicio a la salud de los trabajadores y contribuir a un desarrollo sostenible y equitativo para todos. Uno de los principales retos de la salud en el trabajo podría ser el de resolver el conflicto existente entre valores como el derecho a la salud y el derecho al trabajo de la persona y del conjunto de los trabajadores, con el fin de proteger la salud y hacer posible el empleo.

\section{IN SPECCION MEDICA DEL TRABAJO EN FRANCIA}

M arianne Saux

\section{Historia}

En el decenio de 1930, la aplicación en Francia de ciertas disposiciones del código laboral relativas a la higiene en el trabajo demostró la utilidad de dar a los inspectores de trabajo acceso a médicos consultores.

Las leyes de 17 de julio de 1937 y de 10 de mayo de 1946 (artículos L 611-7 y R 611-4) autorizaron al Departamento de Inspección del Trabajo a ordenar intervenciones médicas temporales. Con el tiempo, estas intervenciones, inicialmente concebidas con carácter intermitente, evolucionaron hasta convertirse en actividades permanentes complementarias de la inspección de trabajo y realizadas simultáneamente a ésta.

Tras la promulgación de la Ley de 11 de octubre de 1946 sobre medicina del trabajo se estableció un marco técnico permanente para la inspección médica del trabajo. El Decreto de 16 de enero de 1947 estableció el contexto, escalas de remuneración, nivel y funciones de los inspectores médicos. 
Desde 1947, no obstante, el desarrollo técnico en este campo ha sido irregular y esporádico, y el número de inspectores médicos ha sido en ocasiones insuficiente para las tareas de inspección, como también lo ha sido el de inspecciones de los lugares de trabajo. Así, aunque los departamentos médicos creados en virtud de la Ley de 11 de octubre de 1946 aumentaron en número e importancia, el número de inspectores médicos se redujo gradualmente desde los 44 inicialmente designados en 1947 a 21. Estas tendencias contradictorias explican en parte algunas de las críticas a que ha debido hacer frente el sistema de medicina del trabajo.

No obstante, desde 1970 y especialmente desde 1975 se ha hecho un esfuerzo serio para crear un Departamento de Inspección M édica del Trabajo capaz de dar respuesta a las necesidades de los aproximadamente 6.000 médicos responsables de más 12 millones de trabajadores. En 1980 se asignaron 39 puestos remunerados a los servicios de inspección, de los cuales se cubrieron 36. En 1995 había 43 puestos disponibles. EI Plan Prioritario de Acción número 12 del VII Plan establece 45 inspectores médicos, lo que elevará la cifra de personal a los niveles inicialmente previstos en 1947.

Al mismo tiempo que los funcionarios franceses caían en la cuenta de la necesidad de establecer un departamento especializado de inspección responsable de la aplicación de las directrices legislativas y reglamentarias relativas a la higiene y la medicina en el trabajo, en otros países se alcanzaban estas mismas conclusiones. A nte este consenso creciente, la O IT, en colaboración con la O M S, convocó en 1963 en G inebra un simposio internacional sobre inspección médica de los lugares de trabajo. Entre los resultados dignos de mención se encuentran la definición de las responsabilidades, deberes y requisitos de conocimientos y formación de los inspectores médicos, así como las técnicas y métodos de inspección.

\section{Organización general}

La oficina central del Departamento de Inspección M édica del Trabajo y de los Trabajadores está integrada en el D epartamento de Relaciones Industriales y depende directamente del Director Regional de Relaciones Industriales e Inspección M édica. EI Director Regional, por su parte, forma parte del Consejo Regional de Trabajo y Empleo y depende directamente del Director Regional de Trabajo y Empleo. En 1995, el número de profesionales y trabajadores de Francia era:

- 12,5 millones de trabajadores con cobertura general,

- 6.337 médicos, de los cuales 2.500 a tiempo completo,

- 4.000 enfermeras

- 1.500 departamentos médicos

- el $90 \%$ de los trabajadores tiene seguimiento por parte de departamentos médicos sectoriales.

EI número de inspectores médicos de cada región depende del de puestos remunerados de medicina en el trabajo existente en la misma. En general, cada inspector médico regional debe tener a su cargo en torno a 300.000 trabajadores. N o obstante, esta regla general está sujeta a posibles modificaciones en ambos sentidos, dependiendo del tamaño y las características geográficas de cada región.

\section{Misión}

Aunque muchas de sus disposiciones han dejado de ser aplicables o han prescrito, no deja de ser útil repasar las responsabilidades de los inspectores médicos establecidas en el Decreto citado de 16 de enero de 1947.

El médico encargado del departamento es responsable, entre otras cosas, de la coordinación de todos los problemas médicos de los diversos departamentos del M inisterio de Trabajo y Seguridad Social. Sus funciones pueden ampliarse por decreto.

EI Inspector M édico del Trabajo y debe:

1. M antener, junto con los Comités T écnicos de las U niones de Crédito de la Seguridad Social, contacto directo y permanente con el Departamento de Inspección del Trabajo y garantizar la aplicación de la legislación relativa a la salud en el trabajo y la protección de la salud de los trabajadores.

2. Realizar permanentemente las actividades destinadas a proteger la salud de los trabajadores en el lugar de trabajo, las cuales incluirán, entre otras, la supervisión de los Departamentos de M edicina del Trabajo establecidos por la Ley de 11 de octubre de 1946.

3. Supervisar, en estrecha colaboración con los departamentos psicotécnicos, reconocimientos médicos dirigidos a determinar la adecuación del trabajador para el trabajo y a reclasificar y remitir a los centros de rehabilitación a los trabajadores que se encuentren temporalmente en situación no apta para el trabajo o físicamente discapacitados.

4. Ssupervisar, en colaboración con los Comités T écnicos de las U niones de Crédito de la Seguridad Social, la preparación, compilación y utilización de estadísticas relativas a las características psicopatológicas de la población activa.

El Inspector M édico del Trabajo comunicará la información que posea sobre riesgos de enfermedades y accidentes profesionales en diversas empresas a los Comités Técnicos de las Uniones de Crédito de la Seguridad Social. La N ota de 15 de septiembre sobre organización de los D epartamentos de Relaciones Industriales asigna al Departamento de Inspección M édica del Trabajo las siguientes responsabilidades:

- la investigación de los aspectos técnicos de la patología y la medicina del trabajo, la ergonomía y la psicología del trabajo;

- la investigación de las cuestiones relativas a la protección de la salud de los trabajadores y las condiciones de trabajo;

- la investigación de los aspectos médicos del trabajo:

- el control de los avances en la medicina, la psicología y la ergonomía,

- la coordinación de la recopilación de información regional.

La dirección de los inspectores médicos implica:

- la coordinación de los inspectores médicos regionales;

- el desarrollo y la aplicación de los informes, investigaciones y estudios técnicos realizados en el ámbito regional o transrregional y, en último término, de los grupos especializados de trabajo;

- la organización de reuniones que ofrezcan a los miembros del Departamento de Inspección M édica del Trabajo la oportunidad de comparar experiencias y definir enfoques coherentes de los nuevos problemas;

- la preparación de los procedimientos de contratación y formación de inspectores médicos del lugar de trabajo y de los trabajadores;

- la educación continua de todos los inspectores médicos regionales.

Además de estas actividades básicas, el Departamento de Inspección M édica del Trabajo colabora también con los departamentos de relaciones industriales y de recursos humanos en todos los casos en que intervienen aspectos médicos del trabajo (especialmente los que afectan a los trabajadores discapacitados, los candidatos a la educación continuada y los solicitantes de trabajo) y es responsable de la dirección, coordinación y formación de los inspectores médicos regionales y de su educación técnica continuada. Por último, la oficina central del 
D epartamento realiza también actividades de consultoría y es la representante oficial del Estado en cuestiones relativas a la medicina del trabajo.

Los D epartamentos de Inspección M édica del Trabajo central o regionales del Departamento de Trabajo pueden ser requeridos para intervenir cuando otros servicios gubernamentales que carecen de servicios de inspección médica propios (principalmente el Departamento de Sanidad y Seguridad Social) tienen problemas relativos a la prevención o corrección de peligros para la salud en el trabajo. Estos servicios del Departamento de Trabajo pueden ayudar también a constituir departamentos de prevención médica. Excepto en los casos en que la parte solicitante es otro servicio público de inspección de trabajo, el papel del Departamento suele estar limitado al asesoramiento.

Entre el 7 y el 10 de junio de 1994, casi 1.500 personas asistieron a las XIII J ournées nationales de médecine du travail (23a Jornadas nacionales de medicina del trabajo) organizadas por la Société et I'I nstitut de médecine du travail et d'ergonomie de $F$ ranche C omté (Sociedad e Instituto de M edicina del Trabajo y de Ergonomía del Franco C ondado). Se debatieron los siguientes temas:

- la neurotoxicidad de la exposición a disolventes de bajo nivel;

- la salud y la precariedad de la salud en el trabajo;

- el estrés y la tensión en el trabajo actual - papel del médico del trabajo.

EI Departamento es el representante del gobierno, ante los organismos o instituciones médicosociales, científicas y profesionales en el campo de la medicina del trabajo, entre los que se encuentran el Conseil $\mathrm{N}$ ational de l'O rdre des $\mathrm{M}$ édecins (el Consejo $\mathrm{N}$ acional de Colegios $\mathrm{M}$ édicos), le $\mathrm{H}$ aut Comité d'É tudes et d'I nformation contre l'alcoolisme (el Alto Comité de Estudios y de Información contra el Alcoholismo) y diversas instituciones universitarias y científicas. Además, suele encomendarse al Departamento central de Inspección M édica del Trabajo la representación de la postura del Gobierno francés en cuestiones médicas ante la Comunidad Económica Europea, la O M S y la O IT. Los departamentos regionales tienen responsabilidades similares, con arreglo a la Circular DRT no 18-79, de 6 de julio de 1979, sobre el papel de la cooperación entre inspectores del trabajo e inspectores médicos del trabajo en la prevención de peligros profesionales. La circular enumera actividades de orientación, información, supervisión, gestión e intervención a realizar, en caso necesario, en colaboración con los departamentos de inspección del lugar de trabajo regionales, departamentales 0 locales.

Aunque tanto los inspectores del trabajo como los inspectores médicos comparten objetivos comunes (la prevención de los peligros para la salud en el trabajo) sus actuaciones concretas pueden ser diversas, dependiendo de la especialización técnica necesaria. Por otra parte, las circunstancias pueden hacer necesaria la colaboración entre unos y otros.

\section{Propuesta de nueva circular}

La nueva circular, en fase de elaboración, reitera y actualiza las cláusulas de la de 6 de julio de 1979. Debe señalarse que el 1 de enero de 1995 los Departamentos de Formación Profesional asumieron las responsabilidades de los $D$ epartamentos regionales de Trabajo y Empleo, por lo que debe revisarse la función, papel y misión de los inspectores médicos del lugar de trabajo.

En resumen, podemos decir que en 1980 los departamentos de inspección médica habían recuperado, a todos los efectos, el papel y las funciones inicialmente previstos para ellos en el período 1946-47. El siguiente paso de la inspección médica será, con la mayor probabilidad, aumentar la importancia de la promoción, gestión e investigación del lugar de trabajo. H ay que señalar que esta evolución es paralela a la de la propia medicina del trabajo. Tras un largo período de desarrollo y puesta en práctica que hoy puede considerarse ya prácticamente terminado, la medicina del trabajo ha de entrar en una nueva era de mejora cualitativa y avance científico.

\section{LOS SERVICIOS DE SALUD EN EL TRABAJO EN LA PEQUEÑA EMPRESA}

Jorma Rantanen y Leon J. Warshaw

La cobertura de los trabajadores de la pequeña empresa $(P E)$ es tal vez el reto más acuciante para los sistemas de prestación de servicios de salud en el trabajo. En la mayor parte de los países, las PE representan la gran mayoría de las organizaciones comerciales e industriales (llegando al $90 \%$ en algunos países en vías de desarrollo o recién industrializados) y están presentes en todos los sectores económicos. Estas empresas dan empleo a casi el $40 \%$ de la población activa en los países industrializados pertenecientes a la Organización para la Cooperación y el Desarrollo Económico y hasta el $60 \%$ de la de los países en vías de desarrollo o recién industrializados. Aunque sus trabajadores están probablemente expuestos a una gama más amplia de peligros que sus compañeros de las grandes empresas (Reverente 1992; $\mathrm{H}$ asle y cols. 1986), suelen tener escaso o nulo acceso a los modernos servicios de salud y seguridad en el trabajo.

\section{Definición de pequeña empresa}

L as empresas se clasifican como PE en función de características tales como la cuantía de su inversión de capital, la cifra de ingresos anuales o el número de empleados. Según el contexto, esta última cifra oscila entre 1 y 500 empleados. En este artículo, aplicaremos el término PE a las empresas de cincuenta o menos empleados, que es la definición más generalmente aceptada (OIT 1986).

Las PE están adquiriendo importancia creciente en las economías nacionales. Son intensivas en empleo, son flexibles para adaptarse a las circunstancias rápidamente cambiantes del mercado y ofrecen oportunidades de trabajo para muchas personas que de otro modo se verían abocadas al desempleo. Sus necesidades de capital suelen ser bajas y pueden producir bienes y servicios cerca del cliente.

También tienen inconvenientes. Su ciclo de vida suele ser corto, lo que hace difícil controlar sus actividades, y con frecuencia obtienen márgenes de beneficio muy cortos a costa de sus trabajadores (que suelen ser también los propietarios), que los pagan en términos de horas e intensidad de trabajo y de exposición a riegos para la salud en el trabajo.

\section{La plantilla de las PE}

La plantilla de las PE se caracteriza por su diversidad. En muchos casos comprende el director y varios miembros de su familia. Las PE ofrecen una vía de acceso al trabajo para los jóvenes y actividades de interés para las personas de mayor edad y los trabajadores despedidos de las grandes empresas. En consecuencia, suelen exponer a grupos especialmente vulnerables, tales como los niños, las mujeres embarazadas y las personas de mayor edad, a riesgos para la salud en el trabajo. Además, dado que muchas $P E$ operan en el hogar 0 en sus proximidades, suelen exponer a los miembros de la familia y a los vecinos a los peligros físicos y químicos del lugar de trabajo y crear problemas de salud pública por la contaminación del aire, el agua o los alimentos cultivados cerca de sus instalaciones. 
EI nivel educativo y socioeconómico de los trabajadores de las PE varía ampliamente, pero suele ser inferior al de la media de la población activa. Es especialmente importante el hecho de que sus propietarios-directores tienen menor formación en gestión y dirección y aún menos en la detección, prevención y control de los riesgos sanitarios del trabajo. Aunque se pongan a su disposición los recursos educativos necesarios, no suelen tener tiempo, energías y recursos financieros suficientes para aprovecharlos.

\section{Los peligros profesionales en las PE y el estado de salud de sus trabajadores}

Como todos los demás aspectos de las PE, las condiciones de trabajo varían ampliamente, dependiendo de la naturaleza de la empresa, el tipo de producción, su propiedad y su ubicación. En general, los peligros para la seguridad y la salud en el trabajo son muy parecidos a los de la grandes empresas, pero, como ya se ha señalado, la exposición a los mismos suele ser muy superior. En algunos casos, no obstante, las condiciones de trabajo pueden ser mucho mejores que las de grandes empresas con tipos similares de producción (Paoli 1992).

Aunque se han hecho públicos pocos estudios, no resulta sorprendente que las encuestas sobre la salud de los trabajadores en las PE de países industrializados tales como Finlandia (H uuskonen y Rantala 1985) y A lemania (H auss 1992) hayan revelado una incidencia relativamente alta de problemas sanitarios, muchos de los cuales estaban asociados a una capacidad reducida de trabajo o a la propia naturaleza del trabajo. En las PE de los países en vías de desarrollo se ha descrito una prevalencia aún superior de enfermedades profesionales y problemas sanitarios relacionados con el trabajo (Reverente 1992).

\section{Barreras para los servicios de salud en el trabajo en las PE}

La prestación de servicios de salud en el trabajo en las PE se enfrenta a enormes barreras estructurales, económicas y psicológicas, entre las que se encuentran las siguientes:

1. Tradicionalmente, la legislación de salud y seguridad en el empleo de la mayoría de los países ha dejado fuera a las PE y se aplica con carácter general tan sólo al sector de la fabricación. El "sector informal" (término que incluye aquí a los trabajadores autónomos) y la agricultura no quedaban cubiertos. Incluso en los casos en los que la legislación tenía un ámbito de aplicación más amplio, no era aplicable a las empresas con pocos empleados (el límite inferior solía ser de 500 empleados). R ecientemente, algunos países (por ejemplo, Francia, Bélgica y los países nórdicos) han promulgado normativas que exigen la prestación de servicios de salud en el trabajo en todas las empresas con independencia de su tamaño y del sector económico (R antanen 1990).

2. Las PE, en los términos definidos a efectos del presente artículo, son demasiado pequeñas para justificar un servicio interno de salud en el trabajo. Su gran diversidad en cuanto a tipo de industria y métodos de producción, así como en cuanto a estilo de organización y funcionamiento, junto con su dispersión geográfica, hace difícil organizar servicios de salud en el trabajo que se ajusten a sus necesidades.

3. Las barreras económicas son muy importantes. M uchas PE están en equilibrio al borde de la supervivencia y no pueden permitirse en modo alguno aumentar sus costes de funcionamiento aunque sea con la promesa de importantes ahorros futuros. Además, pueden no estar en condiciones de permitirse la educación y formación en detección, prevención y control de peligros para los propios propietarios-directores y mucho menos aún para los empleados. Algunos países han resuelto este problema concediendo subvenciones a través de organismos públicos o instituciones de la seguridad social (R antanen 1994) o han incluido los servicios de salud en el trabajo en los programas de promoción del desarrollo económico y social general de las PE (Kogi, Phoon y Thurman 1988).

4. Aun cuando las restricciones económicas no son definitivas, suele haber una reticencia por parte de los propietarios-directores de las PE a dedicar el tiempo y las energías necesarias para adquirir los conocimientos básicos necesarios sobre las relaciones entre trabajo y salud. Una vez adquiridos, no obstante, las PE pueden aplicar de forma muy eficaz esta información y capacidades en sus lugares de trabajo ( $\mathrm{N}$ iemi y Notkola 1991; N iemi y cols. 1991).

5. Las empresas del sector informal y las pequeñas empresas agrícolas no suelen estar registradas y sus conexiones formales con los organismos oficiales pueden ser débiles o completamente inexistentes. Las actividades realizadas como negocio resultan muy difíciles de deslindar de las relativas al ámbito privado del hogar y la familia, lo que puede dar lugar a recelos sobre la intimidad y a resistencias a la intervención de "extraños". Las PE suelen resistirse a participar en asociaciones empresariales y en organizaciones comunitarias $y$, tal vez en la mayoría de los casos, sus empleados no están afiliados a sindicatos. Para superar estas barreras, algunos países han utilizado organizaciones de extensión para la distribución de información, han creado oportunidades especiales de formación para las PE por parte de organismos oficiales de salud y seguridad en el trabajo y han adoptado el modelo de asistencia primaria para la prestación de estos servicios (Jeyaratnam 1992).

6. Muchas PE están ubicadas en comunidades con acceso directo a servicios de urgencias y de asistencia primaria. No obstante, la falta de conocimientos y experiencia de los médicos y enfermeras en el campo de los peligros profesionales y sus efectos suele dar lugar, a menudo, a la no detección de enfermedades profesionales y, lo que es probablemente más importante, a la pérdida de oportunidades de establecer las necesarias medidas de prevención y control.

\section{Instrumentos internacionales aplicables a los servicios de salud y seguridad}

En algunos países, las actividades de salud y seguridad en el trabajo son competencia del ministerio de trabajo y están regulados por un órgano específico competente en materia de salud y seguridad; en otros, los ministerios de trabajo, de sanidad y de asuntos sociales comparten esta responsabilidad. En algunos países, como I talia, las disposiciones aplicables a los servicios de salud y seguridad en el trabajo están incorporadas a la legislación sanitaria 0, como en el caso de Finlandia, a una ley especial. En Estados U nidos y en Inglaterra, la prestación de estos servicios es voluntaria, mientras que en Suecia, entre otros países, se reguló en alguna ocasión mediante convenio colectivo.

EI C onvenio de la O IT sobre seguridad y salud de los trabajadores y medio ambiente de trabajo ( $n$ - 155) (OIT 1981a) exige que los estados establezcan una política de salud y seguridad en el trabajo aplicable a todas las empresas de todos los sectores y puesta en práctica por una autoridad competente. El Convenio establece la responsabilidad de las autoridades, las empresas y los trabajadores y, complementado por su correspondiente R ecomendación no 164 , define las actividades básicas de todos los principales participantes en la materia tanto en el ámbito nacional como local.

La O IT complementó estos instrumentos en 1985 mediante el Convenio Internacional no 161 y la Recomendación no 171 sobre los servicios de salud en el trabajo, en los que se establecen 
disposiciones sobre diseño de políticas, administración, inspección y colaboración de los servicios de salud en el trabajo, actividades de los equipos de salud y seguridad en el trabajo y condiciones de funcionamiento y responsabilidades de la empresa y de los trabajadores, además de ofrecer directrices para organizar estos servicios en el ámbito de la empresa. Aunque no se cita específicamente a las PE, éstas fueron tenidas en cuenta para la elaboración de estos instrumentos, ya que no se establecen límites de tamaño para los servicios de salud en el trabajo y se recalca su necesaria flexibilidad organizativa.

D esgraciadamente, la ratificación de estos instrumentos ha sido limitada, especialmente entre los países en vías de desarrollo. A partir de la experiencia de los países industrializados, es probable que sin medidas especiales y apoyo por parte de las autoridades públicas los principios de la O IT no lleguen a aplicarse en las PE.

La O M S ha promovido activamente el desarrollo de los servicios de salud en el trabajo. En una consulta del año 1989 (O M S 1989a) se realizó un estudio de las exigencias legales, y se ha publicado una serie de unos 20 documentos técnicos sobre diversos aspectos del tema. En 1985 y de nuevo en 1992, la O ficina Regional para Europa de la OMS realizó y dio a conocer encuestas sobre los servicios de salud en el trabajo en esta región, mientras que la O rganización Panamericana de la Salud designó 1992 como año especial de la salud en el trabajo mediante la promoción de las actividades de este campo en general y la realización de un programa especial en América Central y del Sur.

La U nión Europea ha promulgado 16 directivas relativas a la salud y la seguridad en el trabajo, la más importante de las cuales es la Directiva 391/1989, denominada "Directiva M arco" (CCE 1989). Contienen disposiciones relativas a medidas específicas, tales como la exigencia a las empresas de la organización de evaluaciones de riesgos profesionales de diversas instalaciones técnicas 0 el ofrecimiento de reconocimientos médicos a los trabajadores expuestos a peligros especiales. También se regula la protección de los trabajadores frente a los peligros físicos, químicos y biológicos, incluyendo la manipulación de grandes pesos y el trabajo con pantallas de vídeo.

Aunque todos estos instrumentos y esfuerzos internacionales se desarrollaron teniendo en cuenta a las PE, el hecho es que la mayoría de sus disposiciones sólo resultan prácticas para empresas más grandes. Están aún por desarrollar modelos eficaces de organización de un nivel similar de servicios de salud en el trabajo para las PE.

\section{Organización de los servicios de salud en el trabajo para las $\mathrm{PE}$}

Como se ha señalado anteriormente, las reducidas dimensiones de las PE, su dispersión geográfica y su gran variedad de tipos y condiciones de trabajo, unidas a sus grandes limitaciones de recursos económicos y humanos hacen muy difícil organizar eficazmente servicios de salud en el trabajo para estas empresas. Sólo unos pocos de los diversos modelos de prestación de estos servicios descritos en detalle en este capítulo son adaptables a este tipo de empresas.

Tal vez la única excepción la constituyan las PE que son unidades operativas dispersas de grandes empresas y están regidas por políticas establecidas para el conjunto de la organización, participan en las actividades de educación y formación de toda la empresa y tienen acceso a un equipo interdisciplinario de especialistas en salud en el trabajo ubicado en un servicio central de salud normalmente situado en la sede central de la empresa. Un factor muy importante del éxito de este modelo es que todos los costes estén cubiertos por dicho servicio central 0 por el presupuesto corporativo. Cuando, como sucede cada vez con mayor frecuencia, los costes se asignan al presupuesto de explotación de la PE, puede haber dificultades para conseguir la plena cooperación del director local, cuyos resultados pueden ser enjuiciados en función de la rentabilidad de esa determinada empresa.

Se han implantado con éxito en varios países europeos (Finlandia, Suecia, Noruega, Dinamarca, los Países Bajos y Francia), servicios colectivos organizados conjuntamente por varias empresas pequeñas o medianas. $\mathrm{En}$ otros casos se han realizado experiencias con la ayuda de subvenciones del Estado 0 de fundaciones privadas, que no han sobrevivido a la finalización de las ayudas.

U na variante interesante del modelo de servicios colectivos es el servicio orientado a la rama de actividad, que presta servicios a un gran número de empresas del mismo tipo de industria, tales como las de la construcción, la explotación forestal, la agricultura, la industria alimentaria, etc. Este modelo permite que los servicios se especialicen en los problemas típicos de esa rama de actividad y acumulen así gran competencia en el sector al que atienden. U n ejemplo famoso es el Bygghälsan sueco, que presta servicios a las empresas de la construcción.

U na notable excepción es el mecanismo creado por un sindicato cuyos miembros trabajan en PE muy dispersas de una misma industria (por ejemplo, personal sanitario, carniceros, administrativos y trabajadores de la confección). C reados habitualmente en virtud de un convenio colectivo, se financian mediante las contribuciones de la empresa, pero suelen estar dirigidos por un comité integrado por representantes de la empresa y de los trabajadores. Algunos de ellos gestionan centros sanitarios locales que prestan una amplia gama de servicios primarios y de asistencia clínica especializada no sólo para los trabajadores, sino también para las personas a su cargo.

En algunos casos, los servicios de salud en el trabajo se prestan en las consultas externas de los hospitales, en centros sanitarios privados 0 en centros comunitarios de asistencia primaria, todos los cuales tienden a ocuparse sobre todo del tratamiento de lesiones y enfermedades agudas relacionadas con el trabajo y , exceptuando tal vez los reconocimientos médicos periódicos, no aportan gran cosa en cuanto a servicios preventivos. Su personal suele estar poco especializado en este campo y el hecho de que se les pague habitualmente por servicio prestado no supone un gran incentivo a su implicación en la vigilancia, prevención y control de los riesgos del lugar de trabajo.

Un inconveniente específico de estos sistemas de "servicios externos" es que la relación de cliente con los usuarios suele impedir la participación y colaboración de las empresas y los trabajadores en la planificación y control de estos servicios que prevén los Convenios de la OIT y los restantes instrumentos internacionales elaborados para orientarlos.

O tra variante es el "modelo de seguridad social", en el que los servicios de salud en el trabajo son prestados por la misma organización que se hace cargo del coste de la indemnización por accidentes y enfermedades profesionales. Esto facilita la disponibilidad de recursos para financiar los servicios, en los que, aunque se ofrecen servicios curativos y de rehabilitación, se suele dar prioridad a los de tipo preventivo.

Un estudio exhaustivo realizado en Finlandia (K alimo y cols. 1989), uno de los muy escasos intentos de evaluar los servicios de salud en el trabajo, mostró que los centros sanitarios municipales y los de carácter privado eran los principales prestadores de estos servicios a las PE, seguidos por los de tipo colectivo o compartido. Cuanto más pequeña es la empresa, más probable es que recurra al centro municipal: hasta un $70 \%$ de las PE con cinco trabajadores 0 menos. Entre las conclusiones relevantes del estudio se encuentra la verificación de la importancia de las 
visitas del personal del centro sanitario al centro de trabajo de las PE para conocer: a) las condiciones de trabajo y los problemas sanitarios específicos de las empresas clientes y b) la necesidad de prestarles formación especializada en salud y seguridad en el trabajo antes de que emprendan la prestación de estos servicios.

\section{Tipos de actividades de los servicios de salud en el trabajo para las PE}

Los servicios de salud en el trabajo destinados a las PE varían ampliamente según las disposiciones y prácticas nacionales, el tipo de trabajo y de medio ambiente de trabajo, las características del estado de salud de los trabajadores y la disponibilidad de recursos (tanto en términos de capacidad de las PE para financiar los servicios como de disponibilidad de instalaciones personal en la localidad). A partir de los instrumentos internacionales anteriormente citados y de los seminarios y consultas regionales, se ha elaborado una lista de actividades para los servicios integrales de salud en el trabajo (R antanen 1989; OMS 1989a, 1989b). En estos informes se exponen varias actividades clave que siempre deben estar presentes en todo programa de servicios de salud en el trabajo y que son de aplicación a las PE, como por ejemplo:

\section{Evaluación de las necesidades de la empresa en materia de salud en el trabajo}

- estudio previo de las actividades de la empresa e identificación de los riesgos para la salud y la seguridad comunes a los lugares de trabajo;

- inspección y vigilancia del lugar de trabajo para identificar y cuantificar los riesgos realmente existentes en la empresa en cuestión;

- evaluación del nivel de riesgo que representan y clasificación de los mismos en función de su urgencia y prioridad,

- repetición de la evaluación de riesgos siempre que se produzcan cambios en los equipos, materiales y métodos de producción.

\section{Actividades de prevención y control en el lugar de trabajo}

- comunicación de los resultados de las evaluaciones a los propietarios-directores y a los representantes de los trabajadores;

- identificación de las medidas de prevención y control necesarias y disponibles, y asignación de prioridad relativa en función de su urgencia y viabilidad;

- supervisión de su instalación y puesta en práctica;

- control de su eficacia permanente.

\section{Actividades preventivas orientadas a los trabajadores}

- evaluación y vigilancia del estado de salud de los trabajadores mediante reconocimientos previos a la colocación, chequeos y reconocimientos periódicos que pueden ser tanto generales como centrados en los efectos biológicos de riesgos determinados a los que hayan estado expuestos los trabajadores;

- adaptación del trabajo, el puesto de trabajo y el medio ambiente del lugar de trabajo para promover la salud y seguridad permanentes de los trabajadores, con especial atención a grupos vulnerables como los más jóvenes, los de mayor edad y los que padezcan discapacidades y enfermedades adquiridas;

- suministro a los trabajadores de educación y formación sanitaria sobre las prácticas adecuadas de trabajo;

- suministro a los propietarios-directores y a los supervisores de una educación y formación que les haga conscientes de las necesidades sanitarias de los trabajadores y les inculque la motivación para adoptar medidas de prevención y control adecuadas.

\section{Actividades curativas}

- prestación de servicios adecuados de diagnóstico, terapéuticos y de rehabilitación por enfermedad y lesión profesionales;

- prestación de servicios de rehabilitación precoz para eliminar discapacidades evitables y fomentar y supervisar ajustes en el trabajo que permitan una rápida reincorporación;

- suministro de educación y formación (y actualización periódica) sobre procedimientos de primeros auxilios y de urgencia;

- elaboración de procedimientos y realización de simulacros de actuación en caso de emergencias tales como vertidos, fuego, explosión, etc.;

- fomento de la participación de los trabajadores en programas de promoción del bienestar y la salud generales.

\section{M antenimiento de registros y evaluación}

- elaboración y conservación de registros adecuados sobre accidentes, lesiones y enfermedades profesionales, y si es posible sobre exposición; a partir de estos datos, evaluación del estado de salud y de seguridad global de la empresa;

- control de la eficacia de las medidas de control y prevención de peligros.

En la anterior lista de actividades básicas está implícita la adecuada disponibilidad de asesoramiento y consulta en especialidades de salud y seguridad en el trabajo tales como higiene industrial, ergonomía, psicología del trabajo, ingeniería de seguridad, psiquiatría y psicología del trabajo, etc. Estos especialistas no suelen formar parte del personal de las instalaciones que prestan los servicios de salud en el trabajo a las PE, pero en caso de necesidad son aportados, generalmente por organismos públicos, universidades y consultas privadas.

D ebido a su falta de especialización y de tiempo, los propietarios-directivos de las PE están obligados a depender en mayor medida de los proveedores de equipos de seguridad en cuanto a la eficacia y fiabilidad de sus productos y de los suministradores de productos químicos y otros materiales de producción en cuanto a la disponibilidad de una información clara y completa (por ejemplo, hojas de datos) sobre los peligros que pueden suponer y sobre el modo de prevenirlos o controlarlos. Es importante, por ello, que existan normas legales y reglamentarias nacionales relativas al adecuado etiquetado, la calidad y fiabilidad de los productos y la entrega de información fácilmente comprensible (en el idioma local) sobre el uso y mantenimiento de los equipos y sobre el uso y almacenamiento de los productos. Como respaldo, las organizaciones empresariales y comunitarias a las que las PE suelen pertenecer deben ofrecer en sus circulares y comunicaciones de otro tipo información sobre la prevención y el control de exposiciones potencialmente peligrosas.

\section{Conclusiones}

A pesar de su importancia para la economía nacional y de su papel como empresas en las que trabaja la mayoría de la población activa de los países, las PE, los trabajadores autónomos y el sector agrícola suelen estar insuficientemente atendidos por los servicios de salud en el trabajo. El Convenio no 161 y la Recomendación no 171 de la O IT ofrecen directrices importantes para el desarrollo de estos servicios para las PE y deben ser ratificados y aplicados por todos los países. Los gobiernos nacionales deben desarrollar los mecanismos legales, administrativos y financieros necesarios para ofrecer a todos los lugares de trabajo servicios de salud y seguridad en el trabajo que identifiquen, prevengan y controlen eficazmente la exposición a peligros potenciales y 
promuevan la mejora y la conservación de niveles óptimos de salud, bienestar y capacidad productiva en todos los trabajadores. Debe fomentarse la colaboración en los ámbitos internacional, regional y subregional, como la ofrecida por la OIT y la OMS, para estimular el intercambio de información y experiencias, el desarrollo de normas y directrices adecuadas y la realización de importantes programas de formación e investigación.

Las PE pueden mostrarse, en muchos casos, reticentes a buscar activamente estos servicios pese a ser sus beneficiarios últimos potenciales. A la vista de esto, algunos gobiernos e instituciones, especialmente en los países nórdicos, han adoptado una nueva estrategia basada en las intervenciones a gran escala para el establecimiento o el desarrollo de los servicios. Por ejemplo, el Instituto Finlandés de Salud en el Trabajo está aplicando actualmente un Programa de Acción para 600 PE que emplean a 16.000 trabajadores, dirigido al desarrollo de servicios de salud en el trabajo, el mantenimiento de la capacidad de trabajo, la prevención de los peligros del medio ambiente en el vecindario y la mejora de la competencia de las PE en materia de salud y seguridad en el trabajo.

\section{- EL SEGURO DE ACCIDENTES Y LOS SERVICIOS DE SALUD EN EL TRABAJO En ALEmania}

\section{Wilfried Coenen y E dith Perlebach}

Todas las empresas están contractualmente obligadas a tomar precauciones para garantizar la seguridad de sus empleados. Las normas y reglamentos relacionados con el trabajo a las que hay que prestar atención son imperativas, como también lo son los peligros existentes en el lugar de trabajo. Por este motivo, la Ley de Seguridad en el Trabajo (ASiG) de la República Federal de Alemania incluye entre las obligaciones de la empresa la de consultar a profesionales especializados en materia de seguridad en el trabajo, lo que significa que ésta debe designar no sólo personal especializado (especialmente para resolver cuestiones técnicas), sino también médicos de empresa para los aspectos médicos de la seguridad en el trabajo.

La Ley de Seguridad en el Trabajo entró en vigor en diciembre de 1973. En ese momento había en Alemania unos 500 médicos formados en lo que se llamaba medicina del trabajo. El seguro obligatorio de accidentes ha desempeñado un papel decisivo en el desarrollo y establecimiento del sistema actual, gracias al cual la medicina del trabajo ha logrado implantarse en las organizaciones empresariales a través de la figura del médico de empresa.

\section{El sistema dual de salud y seguridad en el trabajo de la República Federal de Alemania}

U no de los cinco ramos de la seguridad social, el seguro obligatorio de accidentes, tiene asignada la tarea prioritaria de adoptar todas las medidas necesarias para lograr la prevención de los accidentes de trabajo y enfermedades profesionales mediante la detección y eliminación de los riesgos para la salud relacionados con el trabajo. Para dar cumplimiento a este mandato legal, los legisladores han concedido un amplio poder a un sistema autogestionado de seguro de accidentes que puede dictar sus propias normas y reglamentos para especificar y configurar las medidas preventivas necesarias. Por este motivo, el sistema de seguro obligatorio de accidentes ha asumido (dentro de los límites marcados por la legislación actual) la función de determinar cuándo se exige a una empresa contratar a un médico de empresa, qué cualificaciones profesionales en medicina del trabajo pueden exigirse a estos médicos y cuánto tiempo pude calcular la empresa que necesitará el médico para atender a sus empleados.

La primera redacción de esta normativa sobre prevención de accidentes data de 1978. En ese momento, el número de médicos con especialización en medicina del trabajo disponibles no parecía suficiente para garantizar la asistencia a todas las empresas, por lo que se decidió establecer unas determinadas condiciones para las empresas de mayor dimensión. De hecho, las grandes empresas industriales ya se habían dotado de mecanismos propios para disponer de médicos de empresa, los cuales ya cumplían e incluso superaban las exigencias legales de la normativa de prevención de accidentes.

\section{Contratación de un médico de empresa}

Las horas dedicadas a la empresa para la asistencia a los empleados (denominadas tiempos de asignación) son establecidas por el seguro obligatorio de accidentes. Los conocimientos de los aseguradores sobre los riesgos para la salud existentes en las distintas ramas constituyen la base para el cálculo de los tiempos de asignación. La clasificación de las empresas con respecto a los aseguradores concretos y la evaluación de sus posibles riesgos para la salud son, por tanto, la base para la asignación de un médico de empresa.

D ado que la asistencia prestada por los médicos de empresa es una medida de seguridad en el trabajo, la empresa debe hacerse cargo de sus costes de asignación. El número de empleados en cada una de las áreas de riesgo, multiplicado por el tiempo asignado para la asistencia, determina el importe de los gastos. El resultado es una gama de distintos tipos de asistencia, ya que la empresa puede pagar (dependiendo de su tamaño) por un médico 0 médicos contratados a tiempo completo 0 bien a tiempo parcial, por horas. Esta variedad de necesidades ha llevado a una variedad de formas organizativas de prestación de los servicios de medicina del trabajo.

\section{Obligaciones del médico de empresa}

En primer lugar, es necesario distinguir, por razones jurídicas, entre las medidas adoptadas por una empresa para prestar asistencia a los empleados y el trabajo realizado por los médicos del sistema sanitario público responsable de la asistencia médica general a la población.

Con el fin de diferenciar claramente qué servicios de medicina del trabajo son responsabilidad de la empresa, los cuales se exponen en la Figura 16.2, la Ley de M edicina del Trabajo ha establecido legislativamente un catálogo de obligaciones de los médicos de empresa. Estas no están sujetas a las órdenes de las empresas en el cumplimiento de estas obligaciones, aunque hasta el momento presente han venido luchando contra la imagen de médicos "de la empresa".

Una de las obligaciones esenciales del médico de empresa es el reconocimiento médico de los trabajadores en los aspectos de la salud relacionados con el trabajo. Este reconocimiento puede ser necesario según las características específicas de una determinada empresa, en especial si existen condiciones de trabajo que lleven al médico a ofrecer, por iniciativa propia, un reconocimiento a los trabajadores afectados. De todas formas, el médico no puede obligar a un empleado a someterse a un reconocimiento, de modo que ha de convencerle ganándose su confianza.

\section{Chequeos preventivos especiales en la medicina del trabajo}

Además de este tipo de reconocimiento, existe un chequeo preventivo especial, para el cual la empresa cuenta con la participación de los trabajadores por imperativo legal. Terminado el 
Figura 16.2 - O bligaciones de los médicos del trabajo en las empresas de Alemania.

A. Los médicos de empresa tienen la obligación de apoyar a ésta en todas las cuestiones de protección de la salud en materia de seguridad y prevención de accidentes del trabajo. En particular, deben:

1. Asesorar a la empresa y a todas las personas con responsabilidades en materia de seguridad y prevención de accidentes del trabajo, en especial con respecto a:

- la planificación, puesta en marcha y mantenimiento de las fábricas y de mecanismos sociales y sanitarios

- la dotación de medios técnicos de trabajo y el establecimiento de procedimientos y materiales de trabajo

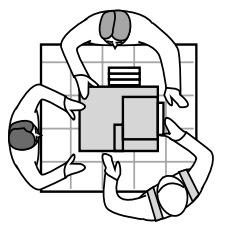

- la elección y ensayo de medios de protección corporal

- aspectos fisiológicos, psicológicos y otros ergonómicos e higiénicas del trabajo, en particular ritmos, horarios y descansos del trabajo, configuración de los puestos de trabajo, el desarrollo del trabajo y el medio ambiente de trabajo

- organización de primeros auxilios en la fábrica

- cuestiones relativas a cambios del lugar de trabajo, aś como incorporación y reincorporación de personas

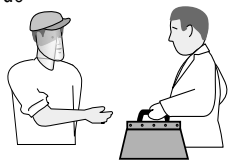
discapacitadas en el proceso de trabajo.

2. Realizar exploraciones, evaluar y asesorar a los trabajadores con arreglo a las normas de la medicina del trabajo, aś como registrar y evaluar los resultados de las exploraciones.

3. Supenvisar la puesta en práctica de las medidas de seguridad y prevención de accidentes, en particular:

- visitar el lugar de trabajo de forma periódica e informar de las carencias al empleador y a las personas con responsabilidades en materia de seguridad y prevención de accidentes en el trabajo, proponer medidas para cubrir estas carencias y colaborar en su puesta en práctica

- prestar atención al uso de medios de protección corporal

- investigar las causas de las enfermedades relacionadas con el trabajo, registrar y evaluar los resultados de la investigación y proponer medidas preventivas.

4. Fomentar activamente entre todos los trabajadores de la empresa un comportamiento adecuado a las exigencias de la seguridad y la prevención de accidentes de trabajo y, en particular, educarlos en materia de los peligros de accidente y los riesgos para la salud derivados de su trabajo y en materia de los mecanismos y precauciones a adoptar para evitarlos, así como ayudar a la planificación de la asignación y la formación del personal de asistencia de primeros auxilios y el personal médico auxiliar.

B. No es obligación de los médicos de la empresa verificar la notificación de las enfermedades realizada por los trabajadores a efectos de su justificación.

C. A solicitud de la empresa, el médico de la empresa debe informar de los resultados de las investigaciones en materia de medicina del trabajo.

chequeo, se emite un certificado médico en el que el médico que lo ha realizado certifica que a partir de la revisión practicada no formula ninguna objeción a la incorporación del trabajador al lugar de trabajo en cuestión. La empresa sólo puede asignar al trabajador una vez por cada certificado médico emitido.

Los chequeos preventivos especiales de medicina del trabajo son jurídicamente obligatorios si el lugar de trabajo implica la exposición a determinados materiales peligrosos o si la práctica del trabajo obliga a realizar determinadas actividades peligrosas y no pueden evitarse los riesgos para la salud mediante las correspondientes precauciones de seguridad en el trabajo. Sólo en circunstancias excepcionales (tales como los chequeos de protección contra la radiación) la exigencia legal de que se realice un reconocimiento se complementa con una reglamentación relativa a las cuestiones a las que el médico ha de prestar atención, los métodos que debe utilizar, los criterios que ha de emplear para interpretar los resultados del reconocimiento y los que debe utilizar para enjuiciar el estado de salud con respecto a la asignación de tareas.

Este es el motivo por el que en 1972 las Berufsgenossenschaften, mutuas que gestionan el seguro de accidentes para la industria y el comercio, encomendaron a un comité de expertos que elaborara unas recomendaciones adecuadas para los médicos dedicados a la medicina del trabajo. Las Directrices para los Chequeos Preventivos Especiales de las Berufsgenossenschaften, recogidas en la Figura 16.3, incluyen actualmente un total de 43 procedimientos de reconocimiento en función de los distintos riesgos para la salud que pueden combatirse, habida cuenta de los conocimientos actuales, con medidas preventivas médicas adecuadas para evitar la aparición de enfermedades.

Las B erufsgenossenschaften deducen el deber de ofrecer estas recomendaciones a partir de su obligación de adoptar todas las medidas necesarias para evitar la aparición de enfermedades profesionales. En todo caso, estas Directrices son modélicas en el campo de la medicina del trabajo. Son aplicables en todos los ámbitos de actividad, no sólo en las empresas del comercio y la industria.

En relación con el ofrecimiento de estas recomendaciones de medicina del trabajo, las B erufsgenossenschaften tomaron también pronto medidas para conseguir que se exigiera a las empresas carentes de su propio médico de empresa la realización de estos chequeos preventivos. Con sujeción a ciertos requisitos básicos, relacionadosprincipalmente con los conocimientos especializados del médico pero también con las instalaciones disponibles para su trabajo, incluso los médicos sin experiencia en este campo pueden adquirir la competencia necesaria para ofrecer a las empresas sus servicios de realización de chequeos preventivos recogidos en la póliza gestionada por lasB erufsgenossenschaften. Sobre esta base se ha alcanzado la cifra actual de 13.000 médicos autorizados de Alemania, que realizan los 3,8 millones de chequeos preventivos anuales.

La existencia de un número suficiente de médicos ha permitido también exigir legalmente a las empresas la realización de estos chequeos preventivos, con absoluta independencia de que tengan o no contratado un médico a tal efecto. Así, el seguro obligatorio de accidentes ha podido aplicarse para garantizar el cumplimiento de ciertas medidas de protección de la salud en el trabajo, incluso en las pequeñas empresas. Las disposiciones legales correspondientes figuran en la O rdenanza sobre Sustancias Peligrosas y, de forma global, en la normativa sobre prevención de accidentes, que regula los derechos y obligaciones de la empresa y del trabajador examinado y la función del médico autorizado.

\section{Asistencia prestada por los médicos de empresa}

Las estadísticas que da a conocer anualmente el Colegio Federal de M édicos (B undesärztekammer) indican que, en el año 1994, más de 11.500 médicos cumplían los requisitos establecidos, en términos de conocimientos especializados de medicina del trabajo, para actuar como médicos de empresa (véase la Tabla 16.2). En la República Federal de Alemania, la Standesvertre tung, que representa a la profesión médica, regula de forma autónoma las cualificaciones se exigen, desde el punto de vista de los estudios y de la competencia, para trabajar como médicos en una determinada especialidad. 
Figura 16.3 - Sumario de servicios externos de las Berufgenossenschaften del sector.

Guía de riesgos para la salud

G1.1 polvo silicótico

G1.2 polvo con amianto

$\mathrm{G} 2$ plomo y sus componentes (excepto alquilos de plomo)

$G 3$ alquilos de plomo

$G 4$ cáncer de piel

$G 5$ nitroglicerina o nitroglicol

$G 6$ disulfuro de carbono

$G 7$ monóxido de carbono

$G 8$ benceno

$G 9$ mercurio 0 sus compuestos

$G 10$ metanol

G11 sulfuro de hidrógeno

$\mathrm{G} 12$ fósforo (blanco)

G13 tetradlorometano (tetraclonuro de carbono)

$G 14$ tricloruro de etileno

G 15 compuestos de cromo-VI
$\mathrm{G} 16$ arsénico y sus compuestos

$\mathrm{G} 17$ tetracloroetileno y pentacloruro de etano

$G 18$ tetracloetano y pentaetano

[ G19 radiaciones láser (explicación de la retirada de esta lista)]

$G 20$ ruido

$\mathrm{G} 21$ trabajo en condiciones de baja temperatura

G 22 deterioro de los dientes por ácido

G 23 enfermedades obstructivas del tracto respiratorio

G 24 enfermedades de la piel (excluido cáncer de piel)

G 25 conducción o manejo de vehículos y actividades de vigilancia

G 26 dispositivos respiratorios de protección

G 27 isocianato

$G 28$ monoclorometano (cloruro de metilo)

G 29 homólogos del benceno (tolueno, xileno)
$\mathrm{G} 30$ trabajo en condiciones de alta temperatura

G 31 presión excesiva

$G 32$ cadmio y sus compuestos

$G 33$ nitro 0 aminocompuestos aromáticos

$G 34$ flúor y sus compuestos inorgánicos

G 35 estancias de trabajo en países extranjeros

G 36 cloruro de vinilo

G 37 unidades de visualización de datos

$G 38$ níquel y sus componentes

$G 39$ humo de soldadura

$G 40$ materiales cancerígenos peligrosos, en general

$G 41$ trabajo en situaciones de riesgo de caídas

$G 42$ enfermedades infecciosas

1 ạ parte: agentes patógenos tuberculosos

2ª parte: virus de la hepatitis A (VHA)

3 a parte: virus de la hepatitis B (VHB)

$G 43$ biotecnología

$\mathrm{G} 44$ polvo de madera de haya 0 de roble
En el caso de los médicos de empresa, se requiere tener la especialidad de "medicina del trabajo" o la adicional de "medicina de empresa" [es decir, cuatro años de estudios adicionales tras obtener la licencia de ejercicio, si se quiere trabajar como médico de empresa, o tres años de estudios adicionales, si se quiere trabajar como médico de empresa exclusivamente en conexión con otra especialidad que ya se posea (por ejemplo, medicina interna)]. Los médicos suelen preferir esta segunda alternativa. En cualquier caso, son ellos quienes ponen el acento en su trabajo profesional como médicos de una especialidad distinta de la medicina del trabajo.

La medicina del trabajo constituye para ellos una fuente adicional de ingresos, lo que explica porqué el reconocimiento sigue siendo la práctica dominante en la profesión de médico de empresa, aunque la legislación y el seguro obligatorio de accidentes subrayan la importancia de la inspección de empresas y del asesoramiento médico a las empresas y a los trabajadores.

Además, existe un grupo de médicos que, teniendo conocimientos especializados en medicina del trabajo, no reúne otros requisitos que se exigieron en su día. Es especialmente notable el caso de los requisitos que se exigían a los médicos de la antigua República D emocrática Alemana para ejercer como médicos de empresa.

\section{Organización de la asistencia prestada por los médicos de empresa}

En principio, se deja a la empresa la libertad de elegir un médico entre los que ofrezcan servicios de medicina del trabajo. $D$ ado que no había una oferta de este tipo cuando seestablecieron a principios

Tabla 16.2 - Médicos con conocimientos especializados en medicina del trabajo.

\begin{tabular}{|c|c|c|}
\hline & Número & Porcentaje \\
\hline Designación del campo "medicina del trabajo" & 3.776 & 31,4 \\
\hline Designación adicional "medicina corporativa" & 5.732 & 47,6 \\
\hline $\begin{array}{l}\text { Conocimientos especializados en medicina del trabajo } \\
\text { con arreglo a otras cualificaciones }\end{array}$ & 2.526 & 21,0 \\
\hline Total & 12.034 & 100 \\
\hline
\end{tabular}

del decenio de 1970, los correspondientes requisitos legales, el seguro obligatorio de accidentes tomó la iniciativa de regular la ofertaylademandadel mercado.

Las B erufsgenossenschaften del sector de la construcción establecieron sus propios servicios de medicina del trabajo, contratando para ello médicos con conocimientos especializados en sus estatutos, establecieron la obligación de cada una de las empresas de recibir la asistencia de su propio servicio de medicina del trabajo. Los costes se repartirían luego entre todas ellas mediante formas adecuadas de financiación. EI resumen de los datos relativos a los servicios externos de medicina del trabajo de las B erufsgenossenschaften del sector de la construcción se ofrece en la Tabla 16.3.

Las Berufsgenossenschaften del sector marítimo y del transporte nacional también crearon sus propios servicios de medicina del trabajo para sus empresas. La idiosincrasia del sector (empresas no estacionarias, con requisitos profesionales especiales) fue

Tabla 16.3 • Distribución por sectores de la afiliación sindical.

\begin{tabular}{|c|c|c|c|c|}
\hline & $\begin{array}{l}\text { Médicos que } \\
\text { prestan asis- } \\
\text { tencia como } \\
\text { actividad } \\
\text { principal }\end{array}$ & $\begin{array}{l}\text { Médicos que } \\
\text { prestan asis- } \\
\text { tencia como } \\
\text { actividad } \\
\text { secundaria }\end{array}$ & Centros & $\begin{array}{l}\text { Trabajadores } \\
\text { atendidos }\end{array}$ \\
\hline ARGE Baul ${ }^{1}$ & 221 & & $\begin{array}{l}83 \\
\text { móviles: } 46\end{array}$ & \\
\hline$B A D^{2}$ & 485 & 72 & $\begin{array}{l}175 \\
\text { móviles: } 7\end{array}$ & 1,64 millones \\
\hline $\mathrm{IAS}^{3}$ & 183 & & 58 & 500.000 \\
\hline TÜV4 & & & 72 & \\
\hline $\begin{array}{l}\text { AMD } \\
\text { Würzburg }\end{array}$ & $60-70$ & & $30-35$ & \\
\hline
\end{tabular}

${ }^{1}$ ARGE Bau = Comunidad de Trabajadores de las Berufgenossenschaften de las Asociaciones de la Industria de la Construcción. 2 BAD = Servicio de Medicina del Trabajo de las Berufgenossenschaften. ${ }^{3}$ IAS = Instituto de Medicina Social y del Trabajo. ${ }^{4}$ TUUV = Asociación de Control Técnico, ${ }^{5}$ AMD Würzburg = Servicio Médico del Trabajo de las Berufgenossenschaften. 
decisiva para convencer a éstas de la necesidad de dotarse de médicos de empresa.

Consideraciones similares llevaron a las restantes Berufsge nossenschaften a unirse en una confederación y a crear el Servicio de M edicina del Trabajo de las B erufsgenossenschaften (BAD). La creación de esta organización, que ofrece servicios a todas las empresas del mercado, fue posible en un principio gracias a la garantía económica prestada por las B erufsgenossenschaften respecto a la cobertura de todo el territorio de la República Federal de Alemania. Con ello se garantizaba que incluso las empresas ubicadas en estados federados con una actividad económica relativamente pobre tuvieran acceso a un médico de empresa en su zona. Este principio se ha mantenido hasta la actualidad. EI BAD es actualmente el mayor prestador de servicios de medicina del trabajo, si bien el sistema de mercado le obliga a hacer frente a la competencia de otros prestadores, especialmente en los grandes núcleos urbanos, mediante el mantenimiento de un alto nivel de calidad.

Los servicios de medicina del trabajo de la Asociación de Inspecciones T écnicas (T Ü V) y del Instituto de M edicina Social y del Trabajo (IAS) son el segundo y el tercer prestador interregionales, respectivamente. $\mathrm{H}$ ay muchas otras organizaciones más pequeñas de ámbito regional en todos los estados federados de Alemania.

\section{Cooperación con otros prestadores de servicios de salud y seguridad en el trabajo}

La Ley de Seguridad en el Trabajo, que constituye la base jurídica de la asistencia prestada por los médicos de empresa, establece también la supervisión profesional de la seguridad en el trabajo, especialmente para garantizar la intervención de personas informadas del seguimiento de las precauciones técnicas. L as exigencias de la práctica industrial han cambiado de tal modo que los conocimientos técnicos relativos a las cuestiones de seguridad en el trabajo deben complementarse hoy cada vez más con el conocimiento de la toxicidad de los materiales empleados. Además, las cuestiones de la organización ergonómica de las condiciones de trabajo y los efectos fisiológicos de los agentes biológicos desempeñan un papel cada vez mayor en la evaluación de las tensiones en el lugar de trabajo.

Los conocimientos necesarios sólo pueden reunirse mediante la cooperación interdisciplinaria de expertos en el campo de la salud y la seguridad en el trabajo. Por este motivo, el seguro obligatorio de accidentes apoya especialmente el desarrollo de formas de organización que tengan en cuenta este tipo de cooperación y establece dentro de su propia estructura los requisitos precisos mediante el adecuado diseño de sus servicios administrativos. Lo que en un tiempo se llamaba Servicio de Inspección Técnica del seguro obligatorio de accidentes se ha convertido en un órgano de prevención, en el que colaboran en la búsqueda de soluciones a los problemas de seguridad en el trabajo no sólo ingenieros, sino también químicos, biólogos y, cada vez más, médicos.

Esteesuno de los requisitos previos para la creación de una base parael tipo deorganización decooperación interdisciplinaria(entre lasempresasy entrelasorganizacionesdeservicios detecnología de seguridad y los médicos de empresa) necesaria para solucionar eficazmente los problemas inmediatos de salud y seguridad en el trabajo.

Además, debe desarrollarse en todas las empresas la supervisión de la tecnología de seguridad, del mismo modo que la supervisión por parte de los médicos de empresa. Las empresas deben contratar especialistas en seguridad por aplicación de la misma base jurídica (la Ley de Seguridad en el Trabajo) 0 formar adecuadamente a personal del sector. Al igual que en el caso de la supervisión realizada por los médicos de empresa, el Reglamento sobre Especialistas de Seguridad en el Trabajo (VBG 122) establece los requisitos para la contratación de estos profesionales. Con ello se sientan las bases para su incorporación a los 2,6 millones de empresas que actualmente integran el sector privado, así como a las del sector público.

U nos dos millones de ellas tienen menos de 20 empleados y están clasificadas como pequeñas empresas. Con la plena supervisión de todas las empresas, incluidas las más pequeñas, el seguro obligatorio de accidentes constituye en sí mismo una plataforma para la implantación de la salud y la seguridad en el trabajo en todas las áreas.

\section{LOS SERVICIOS DE SALUD EN EL TRABAJO EN ESTADOS UNIDOS: INTRODUCCION}

\section{Sharon L. M or ris y Peter Orris}

\section{Historia}

Los servicios de salud en el trabajo en Estados U nidos siempre han estado divididos entre el funcionamiento y el control. El grado en que la administración pública debe, en cualquier nivel, dictar normas relativas a las condiciones de trabajo ha sido objeto de permanente controversia. Además, ha habido una incómoda tensión entre los gobiernos estatales y federal acerca de quién debe asumir la competencia primaria sobre los servicios preventivos, basados principalmente en normas de salud y seguridad en el trabajo.

La indemnización económica por las lesiones y enfermedades profesionales ha sido básicamente responsabilidad de las aseguradoras privadas, y la educación en materia de salud y seguridad en el trabajo, sin cambios hasta hace pocos años, se ha dejado esencialmente a los sindicatos y a las grandes empresas.

El primer intento público de regular las condiciones de trabajo se produjo en el ámbito estatal. En el decenio de 1800, cuando el aumento de la producción industrial dio lugar a altas tasas de accidentes, los estados comenzaron a promulgar disposiciones sobre salud y seguridad en el trabajo. Pennsylvania adoptó la primera ley de inspección de minas de carbón en 1869 y Massachusetts fue el primer estado en aprobar una ley de inspección de fábricas en 1877.

En 1900, los estados más industrializados disponían de normas reguladoras de determinados peligros en el trabajo. A principios del siglo $X X$, Nueva York y Wisconsin tenían los programas de salud y seguridad en el trabajo más amplios del país.

Entre 1919 y 1920 la mayoría de los estados promulgaron normas sobre indemnizaciones a los trabajadores en las que se obligaba a contratar seguros privados. Algunos, como el de Washington, establecieron un sistema de gestión pública que permitía la recopilación de datos y la consecución de objetivos de investigación. Las normas de indemnización variaban ampliamente entre los distintos estados, no solían aplicarse debidamente y dejaban sin cobertura a muchos trabajadores, tales como los agrícolas. Sólo los trabajadores del ferrocarril, los estibadores y los trabajadores portuarios, así como los funcionarios federales, tenían sistemas nacionales de indemnización.

En las primeras décadas del siglo XX, la función básica de la administración federal en materia de salud y seguridad en el trabajo era la de investigación y consulta. En 1910, el Departamento de Interior estableció el Federal Bureau of M ines para investigar accidentes, tramitar consultas en el sector, realizar investigación de seguridad y de producción y suministrar 
formación sobre prevención de accidentes, primeros auxilios y salvamento en las minas. En 1914 se creó la O ffice of Industrial $\mathrm{H}$ ygiene and Sanitation en el Public Health Service para realizar investigaciones y ayudar a los estados en la resolución de problemas de salud y seguridad en el trabajo. Estaba ubicada en Pittsburgh por su estrecha vinculación con la Bureau of M ines y su especialización eran las lesiones y enfermedades de la minería y la siderurgia.

En 1913 se creó un Departamento de Trabajo. En 1934 se establecieron la Bureau of Labor Standards y el Interdepartmental Safety Council. En 1936, el Departamento de Trabajo comenzó a asumir competencias reguladoras en virtud de la L ey Walsh-H ealey de Contratos Públicos, que exigía a determinados contratistas federales el cumplimiento de unos baremos mínimos de salud y seguridad. La aplicación de estos baremos por parte de los estados solía hacerse con distintos grados de eficacia, en virtud de acuerdos cooperativos con el Departamento de Trabajo. M uchos consideraban que esta mezcla de normas federales y estatales no resultaba eficaz para la prevención de las enfermedades y lesiones del trabajo.

\section{La época moderna}

L as primeras leyes federales globales sobre salud y seguridad en el trabajo se aprobaron en 1969 y 1970. En noviembre de 1968, una explosión en Farmington, Virginia 0 ccidental, mató a 78 mineros del carbón y dio un impulso a las exigencias de los mineros en favor de una legislación federal más rigurosa. En 1969 se aprobó la Ley Federal de Salud y Seguridad en la M inería del Carbón, que establecía normas obligatorias para la explotación subterránea. La Ley Federal de Salud y Seguridad Minera de 1977 ampliaba y combinaba la anterior ley con otras previas del sector minero y creaba la $\mathrm{M}$ ine Safety and $\mathrm{H}$ ealth $\mathrm{A}$ dministration (M SH A), encargada de elaborar y aplicar baremos sobre salud y seguridad en todas las minas del país.

La promulgación de la Ley de Salud y Seguridad en el Trabajo de 1979 se vio favorecida no ya por un desastre aislado, sino por un aumento sostenido de las tasas de lesiones durante el decenio de 1960. La naciente sensibilización medioambiental y una década de legislación progresista hicieron posible esta nueva ley, que se aplica a la mayoría de los lugares de trabajo de Estados U nidos. En ella se creó la O ccupational Safety and H ealth Administration (OSH A), dependiente del Departamento de Trabajo, con la función de elaborar y aplicar estándares federales sobre salud y seguridad en el trabajo. La ley no suponía una ruptura completa con el pasado, pues contenía un mecanismo que permitía a los estados gestionar sus propios programas O SH A. Creó también el $\mathrm{N}$ ational Institute for $\mathrm{O}$ ccupational Safety and $\mathrm{H}$ ealth (NIOSH), dependiente de lo que hoy es el Departamento de Sanidad y Servicios Humanos, para realizar investigaciones, formar profesionales en salud y seguridad, elaborar estándares sobre salud y seguridad en el trabajo.

En la actualidad, las competencias de los servicios de salud y seguridad en Estados U nidos están repartidas entre varios sectores. En las grandes empresas, los servicios de tratamiento, prevención y educación corren principalmente a cargo de sus propios departamentos médicos. En las más pequeñas, estos servicios suelen ser prestados por hospitales, clínicas o consultas privadas.

Las evaluaciones médicas independientes y toxicológicas son prestadas por médicos individuales, así como por centros hospitalarios del sector público y universitarios. Por último, las instituciones gubernamentales se encargan de la aplicación, la financiación de la investigación, la educación y el establecimiento de normas sobre salud y seguridad en el trabajo.

Este complejo sistema se describe en los artículos siguientes. Los Dres. Bunn y M cC unney, de M obil O il Corporation y del
$M$ assachusetts Institute of Technology, respectivamente, exponen lo relativo a los servicios de empresa. Penny $\mathrm{H}$ iggins, $\mathrm{RN}, \mathrm{BS}$, de $\mathrm{N}$ orthwest Community $\mathrm{H}$ ealthcare en Arlington $\mathrm{H}$ eights, Illinois, perfila los programas hospitalarios. Dean Baker, M D, M PH, director del Irvine's Centre for O ccupational and Environmental $\mathrm{H}$ ealth de la Universidad de California, revisa las actividades de los centros hospitalarios académicos. $L a$ Dra. Linda Rosenstock, directora del $\mathrm{N}$ ational Institute for O ccupational Safety and H ealth, y Sharon L. M orris, presidenta adjunta de Prestaciones Sociales Comunitarias del Departamento de Salud Medioambiental de la Universidad de Washington, resumen las actividades gubernamentales en los niveles federal, estatal y local. LaM ont Byrd, director de Salud y Seguridad del International Brotherhood of Teamsters, de la AFL-CIO, describe los diversos servicios que presta su servicio a los miembros de este sindicato internacional.

Esta división de responsabilidades en materia de salud en el trabajo suele dar lugar a solapamientos y, en el caso de la indemnización a los trabajadores, a incoherencias en los requisitos y servicios. Este enfoque pluralista es al mismo tiempo el punto fuerte y débil del sistema de Estados U nidos, que promueve múltiples enfoques de los problemas pero puede inducir a confusión a cuantos no sean absolutamente expertos en la materia. Es un sistema que oscila con frecuencia, según el equilibrio de poder se desplace hacia un lado u otro entre los protagonistas fundamentales: el sector privado, los sindicatos y los gobiernos estatales y federal.

\section{O RGANISMOS PUBLICOS DE SALUD EN EL TRABAJO EN ESTADOS UNIDOS}

\author{
Sharon L. M orris y Linda Rosenstock
}

\section{La Occupational Safety and Health Administration (OSHA)}

\section{Objetivos y organización}

La O ccupational Safety and Health Administration (O SHA) se creó para promover entre las empresas y los trabajadores la reducción de los peligros del lugar de trabajo y para poner en práctica programas eficaces de salud y seguridad. Para alcanzar estos objetivos tiene encomendado elaborar y aplicar normas, controlar los resultados de sus OSHA en el ámbito estatal, solicitar a las empresas que mantengan registros de lesiones y enfermedades relacionadas con el trabajo, prestar formación sobre salud y seguridad a las empresas y a los trabajadores, e investigar las reclamaciones de los trabajadores que aleguen discriminación por haber informado de la existencia de riesgos para la salud o la seguridad.

La OSHA está dirigida por un Secretario Adjunto para la Salud y la Seguridad en el Trabajo, dependiente del Secretario de Trabajo, y tiene su sede en Washington, DC; cuenta con diez oficinas regionales y unas 85 oficinas de área. Alrededor de la mitad de los estados gestionan sus propios programas de salud y seguridad, quedando esta tarea a cargo de la O SHA federal en los estados que no los han aprobado. La Ley de Salud y Seguridad en el Trabajo exige también que cada agencia del gobierno federal disponga de un programa de salud y seguridad coherente con las normas de la OSH A.

\section{Programa y servicios}

L as normas son la base del programa de aplicación de la O SH A, pues establecen los requisitos que han de cumplir las empresas. Las normas propuestas se publican en el Registro Federal para 
que sean comentadas y debatidas públicamente. Las normas definitivas se publican también en el Registro Federal y pueden ser impugnadas en los tribunales de apelación de EE.UU.

En los ámbitos en las que la OSHA no haya elaborado normas, las empresas están obligadas a atenerse a la cláusula general de la Ley de Salud y Seguridad en el Trabajo que obliga a todas ellas a disponer de "lugares de trabajo libres de peligros conocidos que causen o puedan con probabilidad causar la muerte o perjuicios físicos graves a sus trabajadores."

La OSH A está facultada para entrar en los lugares de trabajo con el fin de determinar si la empresa cumple las exigencias de la ley. En sus actividades concede la máxima prioridad a la investigación de las situaciones de peligro inminente, catástrofes y accidentes mortales, quejas de los empleados e inspecciones programadas en industrias de alto riesgo.

Si la empresa deniega la entrada a la OSHA, el inspector debe obtener de un juez de distrito un mandamiento de inspección. Los representantes tanto de los trabajadores como de la empresa tienen derecho a acompañar a los inspectores de la OSHA durante sus visitas. El inspector emite citaciones y propuestas de sanción por las infracciones observadas durante la inspección, fijando un plazo para su corrección.

La empresa puede impugnar la citación ante la 0 ccupational Safety and $\mathrm{H}$ ealth R eview Commission, un organismo independiente establecido para resolver las impugnaciones de las citaciones y propuestas de sanción de la O SH A. Si la resolución de este organismo es desfavorable, la empresa puede apelarla ante los tribunales federales.

Las empresas que se comprometen a corregir los peligros graves detectados por el consultor pueden recibir gratuitamente su asistencia de consultoría tanto para desarrollar programas de salud y seguridad como para formar a los empleados. Este servicio, orientado a las empresas más pequeñas, está financiado en su mayor parte por la OSHA y es prestada por organismos públicos estatales o universidades.

La OSHA tiene un programa voluntario de protección (VPP) que exime a los lugares de trabajo de las inspecciones programadas si éstos observan ciertos criterios y se comprometen a desarrollar sus propios programas globales de salud y seguridad. En todo caso, se les exige tener una tasa de accidentes inferior a la media, disponer de programas de seguridad redactados por escrito, poner a disposición de la O SH A los registros de lesiones y de exposición, y hacer saber sus derechos a los trabajadores.

\section{Recursos}

En 1995, el presupuesto de la OSHA fue de 312 millones de dólares y su plantilla, de unos 2.300 empleados. Con estos recursos da cobertura a más de 90 millones de trabajadores de Estados U nidos.

\section{Programas OSHA estatales}

\section{Objetivos y organización}

La Ley de Salud y Seguridad en el Trabajo concede a los gobiernos de los estados la opción de regular la salud y la seguridad en el trabajo.

A tal fin, los estados preparan sus propios programas de elaboración y aplicación de normas sobre salud y seguridad, y remiten un plan a la O SH A para su aprobación. El plan expone en detalle la forma en que el estado se propone establecer y aplicar las normas, que han de ser "al menos igual de efectivas" que las de dicho organismo, y asumir la jurisdicción sobre los empleados públicos estatales, locales y federales no amparados de otro modo por la propia OSHA. En estas condiciones, el gobierno federal delega la competencia reglamentaria directa, aportando al mismo tiempo financiación parcial para los programas estatales y controlando la adecuación de sus actividades a las normas nacionales.

\section{Programa y servicios}

A proximadamente la mitad de los estados han optado por gestionar sus propios programas. 0 tros dos estados, N ueva York y Connecticut, se han inclinado por mantener sus territorios bajo jurisdicción federal, si bien añadiendo un sistema de salud y seguridad en el lugar de trabajo de ámbito estatal para los empleados públicos.

Los programas O SH A gestionados por los estados permiten a éstos adecuar sus recursos y dirigir sus actividades de reglamentación hacia sus necesidades específicas. Por ejemplo, la tala de madera se realiza de modo diferente en los estados del Este y del $O$ este. Carolina del Norte, que aplica su propio programa O SH A, ha orientado sus disposiciones sobre concesión de prestaciones sociales, formación y programas de cumplimiento a las necesidades de salud y seguridad de los trabajadores de dicho sector en ese estado.

El estado de Washington, con una amplia base económica agrícola, aplica normas sobre seguridad agrícola más restrictivas que los mínimos nacionales y ha traducido al español la información de seguridad para atender a las necesidades de los trabajadores agrícolas de habla española.

A demás de preparar programas para hacer frente a sus necesidades específicas, los estados pueden elaborar programas y adoptar disposiciones que no cuenten con suficiente apoyo a escala federal. California, Utah, Vermont y Washington han establecido restricciones a la exposición al humo de tabaco en el medio ambiente del lugar de trabajo; en los estados de Washington y 0 regon se exige a las empresas elaborar planes específicos de prevención de lesiones y enfermedades en cada lugar de trabajo; las normas de U tah en materia de perforación petrolífera y de gas y de fabricación de explosivos son superiores a las normas O SH A de ámbito federal.

Los programas estatales pueden incluir actividades de asistencia gratuita a las empresas que deseen detectar y corregir los peligros del lugar de trabajo. Las consultas correspondientes, que se realizan exclusivamente a solicitud de las empresas, se mantienen al margen de los programas de verificación del cumplimiento.

\section{Recursos}

En 1993, los programas gestionados por los estados contaban con 1.170 trabajadores encargados de la verificación del cumplimiento, según la Occupational Safety and Health State Plan Association. Además, había 300 consultores de salud y seguridad y casi 60 coordinadores de educación y formación. La mayoría de estos programas son gestionados por los departamentos estatales de trabajo.

\section{Mine Safety and Health Administration (MSHA)}

\section{Objetivos y organización}

La M ine Safety and Health Administration (M SH A) elabora y aplica normas dirigidas a la reducción de lesiones, enfermedades y fallecimientos en las minas y en las actividades de procesamiento de minerales, con independencia del tamaño y el número de trabajadores de la explotación y de los métodos de extracción.

A demás de los programas de verificación del cumplimiento, la Ley de Salud y Seguridad en la M inería exige a este organismo la elaboración de disposiciones sobre formación en salud y seguridad para los mineros, la mejora y reforzamiento de las normas de salud y seguridad en la minería, y el fomento de la participación de los mineros y de sus representantes en las actividades de 
seguridad. La MSH A colabora también con las explotaciones mineras en la resolución de problemas de salud y seguridad mediante programas de educación y formación y a través del desarrollo de controles de ingeniería para reducir las lesiones.

Al igual que la OSHA, la M SH A está dirigida por un Secretario Adjunto de Trabajo. Las actividades de salud y seguridad en el trabajo de la minería del carbón se gestionan en diez oficinas de distrito de las regiones de la minería de carbón, y las de la minería del metal y la no metálica, en seis oficinas de distrito de las áreas mineras del país.

$H$ ay varias oficinas que ayudan a gestionar las tareas de este organismo en la sede de Arlington, Virginia. Entre ellas se encuentran la $\mathrm{O}$ ffice of Standards, Regulations and Variances; la O ffice of Assessments; el Technical Support Directorate y la O ffice of Program Policy. Además, la Educational Policy and D evelopment $O$ ffice supervisa el programa de formación de este organismo en la National M ine H ealth and Safety A cademy en Beckley, Virginia O ccidental, que es la mayor institución del mundo exclusivamente dedicada a la formación en salud y seguridad en la minería.

\section{Programa y servicios}

Las muertes y lesiones en la minería se han reducido notablemente en los últimos cien años. Entre 1880 y 1910 fallecieron miles de mineros del carbón, registrándose 3.242 muertes tan sólo en el año 1907. Había asimismo un elevado número de fallecimientos en otros tipos de minas. En la actualidad, la media de muertes en la minería se ha reducido hasta menos de 100 anuales.

La MSHA vigila el cumplimiento de las disposiciones de la Ley de minas que exigen a las empresas la disponibilidad de un plan de formación aprobado sobre salud y seguridad en el que se prevean 40 horas de formación básica para nuevos trabajadores subterráneos, 24 horas para los de superficie y 8 horas anuales de actualización para todos los mineros, así como la formación en tareas relacionadas con la seguridad para los asignados a nuevos puestos. La National M ine $\mathrm{H}$ ealth and Safety Academy ofrece una amplia variedad de cursos de salud y seguridad. La MSH A ofrece programas especiales de formación para directivos y trabajadores de pequeñas explotaciones mineras, y sus materiales de formación, incluidas cintas de vídeo, películas, publicaciones y materiales técnicos, están disponibles en la Academia y en varias oficinas.

\section{Recursos}

En 1995, la M SH A tenía un presupuesto de unos 200 millones de dólares y contaba con unos 2.500 trabajadores. Con estos recursos, debía velar por la salud y la seguridad de unos 113.000 mineros del carbón y 197.000 mineros de la minería del metal y la no metálica.

\section{El National Institute for Occupational Safety and Health (NIOSH)}

\section{Objetivos y organización}

EI National Institute for O ccupational Safety and Health (N IO SH ) es el organismo federal encargado de realizar las investigaciones sobre lesiones y enfermedades del trabajo y de transmitir a la OSHA propuestas de normas. Financia programas educativos para profesionales de la salud y la seguridad en el trabajo a través de los Educational Resource Centres (ERC), y asimismo proyectos de formación en universidades de la totalidad de Estados U nidos. En virtud de la Ley Federal de Salud y Seguridad en la M inería de 1977, el NIOSH realiza también investigaciones y evaluaciones de riesgos para la salud, y presenta propuestas de normas sobre salud en la minería a la M ine Safety and $\mathrm{H}$ ealth $\mathrm{Administration.}$

El director del NIOSH depende del director de los Centers for Disease Control and Prevention del Departamento de Salud y Servicios H umanos. La sede del NIOSH está en Washington, DC, y cuenta con oficinas administrativas en A tlanta, G eorgia, y laboratorios en Cincinnati, O hio, y Morgantown, Virginia o ccidental.

\section{Programa y servicios}

EI NIO SH realiza tanto investigaciones de campo como de laboratorio. L os programas de vigilancia detectan las lesiones y enfermedades relacionadas con el trabajo ocurridas y recopilan datos objetivos sobre varias de ellas, tales como los niveles altos de plomo en la sangre de los adultos o las lesiones de los trabajadores adolescentes. EI NIOSH también compila los datos reunidos por los estados y por otros organismos federales para propiciar la obtención de una imagen de ámbito nacional de los efectos de los peligros profesionales.

Las investigaciones de campo se realizan en los lugares de trabajo de todo el país. A través de ellas se pueden detectar peligros, evaluar los grados de exposición y determinar la eficacia de las medidas preventivas. El Instituto tiene reconocido, a este efecto el derecho a entrar en los lugares de trabajo. Las investigaciones de campo realizadas se plasman en artículos científicos, así como en recomendaciones para la prevención de peligros en determinados lugares de trabajo.

En colaboración con los departamentos de salud estatales, el NIOSH investiga los fallecimientos en el trabajo por causas específicas, tales como electrocución, caídas, incidentes con máquinas y accidentes por entrada en espacios confinados. Dispone además de un programa especial para ayudar a las pequeñas empresas mediante el desarrollo de tecnologías baratas y eficaces de control de exposiciones peligrosas en origen.

EI NIOSH realiza asimismo investigaciones de laboratorio para estudiar los peligros del lugar de trabajo en situaciones controladas. Estos estudios le permiten determinar las causas y mecanismos de las enfermedades y lesiones del trabajo, desarrollar herramientas para la medición y control de las exposiciones, y desarrollar y evaluar tecnologías de control y equipos de protección personal.

En torno al $17 \%$ del presupuesto del NIOSH está dedicado a financiar actividades de servicios, muchas de ellas también basadas en la investigación, tales como el programa de evaluación de riesgos para la salud. EI organismo realiza centenares de evaluaciones anuales de riesgos para la salud a solicitud de las empresas, los trabajadores o los organismos federales o estatales. U na vez evaluado el lugar de trabajo, facilita a los trabajadores y empresas recomendaciones para reducir las exposiciones.

EI NIOSH también responde a solicitudes telefónicas de información sobre salud y seguridad a través de un teléfono gratuito, por el cual se puede solicitar también una evaluación de riesgos o conseguir alguna publicación. La Home Page del $\mathrm{NIOSH}$ en la World Wide Web es otra buena fuente de información.

EI NIOSH tiene varias bases de datos, como NIOSHTIC, una base bibliográfica en materia de salud y seguridad en el trabajo, y el Registry of Toxic Effects of Chemical Substances (RTECS), un compendio de datos toxicológicos extraídos de la literatura científica que da cumplimiento a su mandato de "clasificar todas las sustancias tóxicas conocidas y las concentraciones a las que se sabe que se produce la toxicidad".

EI NIOSH también realiza pruebas con respiradores y certifica que se ajustan a las normas nacionales establecidas, 
ayudando así a las empresas y trabajadores a elegir el modelo más adecuado para determinados medio ambientes peligrosos.

EI NIOSH financia programas de formación para médicos de empresa, profesionales de enfermería en el trabajo, higienistas industriales y profesionales de la seguridad en universidades de todo el país, así como programas para introducir la salud y la seguridad en las escuelas de negocios, de economía y de formación profesional. Estos programas, que pueden ser tanto interdisciplinarios como unidisciplinarios, han supuesto una contribución significativa al desarrollo de la salud en el trabajo como disciplina y a la cobertura de la necesidad de profesionales cualificados en el campo de la salud y la seguridad.

\section{Recursos}

En 1993, el NIOSH tenía unos 900 trabajadores y un presupuesto de 133 millones de dólares. Es el único organismo federal con competencias legalmente reconocidas en materia de formación profesional e investigación sobre la salud y seguridad en el trabajo.

\section{El futuro de los programas de salud y seguridad en el trabajo}

El futuro de estos programas federales en EE.UU. es bastante incierto, dado el ambiente desregulador del decenio de 1990. EI Congreso sigue elaborando importantes propuestas que, de ser aprobadas, transformarían radicalmente el funcionamiento de estos programas.

U na de estas propuestas exige a los organismos reguladores que se centren más en la educación y la consulta y menos en la elaboración de normas y la verificación de su cumplimiento; otra impone la realización de complejos análisis de coste/ beneficio como requisito previo a la elaboración de normas; el NIO SH se enfrenta a la amenaza de supresión o de fusión con la O SH A, y todos estos organismos se han convertido en puntos de mira de la reducción de costes.

Si llegaran a ser aprobadas, estas propuestas reducirían en gran medida el papel de la administración federal en la realización de investigaciones y en la elaboración y la verificación del cumplimiento de normas sobre salud y seguridad en el trabajo uniformes para Estados U nidos.

\section{- Servicios de salud en el trabajo EN LAS EMPRESAS DE ESTADOS UNIDOS: SERVICIOS PRESTADOS INTERN AMENTE}

\section{William B. Bunn y Robert J. M cCunney}

Los programas de medicina del trabajo varían tanto en su contenido como en su estructura. Existe la convicción generalizada de que sólo se dan programas de este tipo en las grandes empresas y de que son lo suficientemente amplios para evaluar todos los posibles efectos negativos para la totalidad de los trabajadores. Sin embargo, los programas puestos en práctica en los distintos sectores de actividad se caracterizan por su ámbito muy variado. Algunos ofrecen tan sólo exploraciones selectivas previas a la colocación, mientras que otros ofrecen vigilancia médica total, servicios de promoción de la salud y otros servicios especiales. Además, su estructura es variada, como también lo son los miembros de los equipos de salud y seguridad. Algunos programas cuentan con un médico externo contratado para la prestación de los servicios médicos, en tanto que otros disponen de un servicio interno de salud, con médicos y personal de enfermería respaldado por una plantilla de epidemiólogos, ingenieros, toxicólogos e higienistas del trabajo. Las obligaciones y responsabilidades de estos miembros del equipo de salud y seguridad varían dependiendo del sector de actividad y del riesgo existente.

\section{Motivos para adoptar programas de medicina del trabajo}

El control médico de los trabajadores surge de múltiples factores. En primer lugar, la preocupación por la salud y seguridad en general del trabajador. En segundo lugar, el beneficio económico derivado de las actividades de vigilancia a través del aumento de la productividad del trabajador y la reducción de los costes de la asistencia médica. En tercer lugar, el cumplimiento de lo previsto en la Ley de Salud y Seguridad en el Trabajo (O ccupational Safety and $\mathrm{H}$ ealth Act, O SH A), de las exigencias de la igualdad de oportunidades de empleo (equal employment opportunity, EEO), de lo establecido en la L ey de norteamericanos con discapacidades (Americans with Disabilities Act, ADA) y otras normas legales de carácter imperativo. Por último, la amenaza de las reclamaciones judiciales en el orden civil y penal si no se establecen los correspondientes programas o éstos no son adecuados (M cC unney 1995; Bunn 1985).

\section{Tipos de servicios y programas de salud en el trabajo}

Los servicios de salud en el trabajo se establecen previa evaluación de las necesidades. Entre los factores que determinan qué tipo de servicio deberá utilizarse figuran los riesgos potenciales de las actividades normales, las variables demográficas de la plantilla y el interés de la dirección por la salud en el trabajo. También influyen el tipo de industria, los riesgos físicos, químicos o biológicos existentes y los métodos empleados para evitar la exposición, así como las normas, normas y reglamentos fijados por el sector público y por el privado.

Entre las tareas más importantes de los servicios generales de salud se encuentran las siguientes:

- evaluación de la capacidad de los trabajadores para realizar las tareas asignadas de forma segura (evaluaciones previas a la colocación);

- detección de síntomas y señales precoces de efectos para la salud relacionados con el trabajo e intervención adecuada (las exploraciones médicas de vigilancia pueden poner de manifiesto estos signos);

- ofrecimiento de tratamiento y rehabilitación para las lesiones y enfermedades del trabajo y los trastornos no profesionales que afecten al rendimiento en el trabajo (lesiones relacionadas con el trabajo):

- promoción y mantenimiento de la salud de los trabajadores (bienestar);

- evaluación de la capacidad de la persona para trabajar a la vista de un trastorno médico crónico (en este caso es necesaria una exploración médica independiente);

- supervisión de las políticas y programas relacionados con la salud y la seguridad en el trabajo.

\section{Ubicación de las instalaciones de los servicios de salud}

\section{Instalaciones in situ}

La prestación de servicios de salud en el trabajo se realiza cada vez más a través de centros médicos locales y mediante la subcontratación. Sin embargo, el enfoque tradicional era el de los servicios in situ constituidos por las propias empresas. En los centros con un número sustancial de trabajadores o con determinados riesgos para la salud, los servicios in situ resultan eficaces en 
términos de coste y prestan servicios de alta calidad. Su ámbito varía considerablemente, oscilando entre el apoyo de enfermería a tiempo parcial y las instalaciones médicas con plena dotación de personal y médicos a tiempo completo.

La necesidad de servicios in situ suele venir determinada por la naturaleza de las actividades de la empresa y por los riegos para la salud en el lugar de trabajo. Por ejemplo, una empresa que utilice benceno como materia prima o como ingrediente de sus procesos de fabricación necesitará probablemente un programa de vigilancia médica. Además, es posible que otras muchas sustancias químicas manipuladas o producidas en la misma fábrica sean tóxicas. En estas situaciones, puede resultar económicamente viable y médicamente recomendable prestar servicios médicos in situ. Algunos de estos servicios ofrecen apoyo de enfermería en el trabajo durante las horas de trabajo diurno y en ocasiones también durante el segundo y tercer turno 0 en fin de semana.

Los servicios in situ deben prestarse en zonas de la fábrica compatibles con el ejercicio de la medicina. Las instalaciones deben estar situadas en un lugar céntrico, para que resulten accesibles a todos los trabajadores. $\mathrm{H}$ an de tenerse en cuenta las necesidades de calefacción y acondicionamiento de aire, para hacer posible la utilización más económica de las instalaciones. Como regla práctica se fija a los servicios médicos internos un espacio equivalente a $0,09 \mathrm{~m}^{2}$ cuando hay hasta 1.000 trabajadores, con un mínimo de $27 \mathrm{~m}^{2}$. Los especialistas han descrito los costes del espacio y varios aspectos importantes de diseño (M cC unney 1995; Felton 1976).

En algunas instalaciones de fabricación ubicadas en zonas rurales o remotas pueden prestarse eficazmente los servicios mediante una furgoneta móvil. En caso de que se disponga de este tipo de elemento, han de tenerse en cuenta las siguientes recomendaciones:

- Debe prestarse asistencia a las empresas cuyos servicios médicos internos no estén plenamente equipados para hacer frente a los programas de vigilancia médica que requieran la utilización de equipos especiales, tales como audiómetros, espirómetros o aparatos de rayos $X$.

- Deben aplicarse programas de vigilancia médica en las zonas geográficas remotas, especialmente para garantizar la uniformidad de los datos recogidos con fines epidemiológicos. Por ejemplo, para mejorar la precisión científica de un estudio de los trastornos pulmonares del trabajo debería utilizarse un espirómetro similar y la preparación de las placas torácicas habría de ajustarse a normas internacionales adecuadas, tales como los de la O rganización Internacional del Trabajo (O IT ).

- Deben coordinarse los datos de diferentes centros para su incorporación a un programa informático.

Las empresas que dependan de una furgoneta móvil seguirán necesitando, en todo caso, un médico que realice exploraciones previas a la colocación y garantice la calidad de los servicios prestados por la empresa que gestione la furgoneta.

\section{Servicios más habitualmente prestados} en las instalaciones internas

La evaluación in situ es imprescindible para determinar el tipo de servicios de salud adecuados para una determinada instalación. Los servicios más habituales prestados en los centros de salud en el trabajo son las evaluaciones previas a la colocación, la evaluación de lesiones o enfermedades relacionadas con el trabajo y las exploraciones médicas de vigilancia.

\section{Evaluaciones previas a la colocación}

La exploración previa a la colocación se realiza cuando el sujeto recibe una oferta condicional de empleo. La ADA utiliza el término previa al empleo para poner de manifiesto que la contratación de la persona en cuestión dependerá de que supere la exploración médica.

La exploración previa a la colocación debe realizarse con atención a las obligaciones del puesto, incluidas las exigencias físicas y cognitivas (por sensibilidad a la seguridad) y la exposición potencial a materiales peligrosos. El contenido de la exploración depende de la evaluación del lugar de trabajo y del puesto. Por ejemplo, un puesto que requiera el uso de un equipo de protección personal, tal como un respirador, suele incluir un estudio pulmonar (prueba de respiración). L as personas que participan en las actividades del D epartamento de Transportes (D epartment of Transportation, DOT) de EE.UU. suelen requerir pruebas de orina para la detección de drogas. Para evitar errores tanto en el contenido como en el contexto de la exploración, es recomendable desarrollar protocolos estandarizados convenidos entre la empresay el médico examinador.

Tras la exploración, el médico emite un dictamen escrito sobre la adecuación de la persona a la realización del trabajo sin riesgo para su salud o la de terceros. En circunstancias normales, este dictamen no puede contener datos médicos, sino tan sólo expresar la adecuación o no para la tarea. En ocasiones se emplea un impreso estandarizado que se incluye a continuación en el expediente del trabajador. L os registros médicos especiales, no obstante, quedan en las instalaciones sanitarias, a cargo del médico 0 la enfermera.

\section{Lesiones y enfermedades relacionadas con el trabajo}

U na asistencia médica rápida y de calidad es esencial en caso de lesión relacionada con el trabajo o de enfermedad profesional. Es el servicio médico, o el médico contratado, el que debe tratar al trabajador. El servicio médico de la empresa desempeña un importante papel en la gestión de los costes por indemnización de los trabajadores, especialmente mediante la realización de las evaluaciones de reincorporación al trabajo tras la baja por enfermedad o lesión. U na de las principales funciones del profesional médico es la coordinación de los servicios de rehabilitación para los trabajadores en baja con el fin de asegurar una reincorporación sin problemas. Los programas de rehabilitación más eficaces preven la modificación de las asignaciones de tareas o el ofrecimiento de alternativas.

Una tarea importante del asesor médico de la empresa es determinar la relación existente entre la exposición a agentes peligrosos y la enfermedad, lesión o discapacidad. En algunos estados, el empleado puede elegir su propio médico, mientras que en otros la empresa impone 0 al menos sugiere la evaluación por un determinado médico o centro de asistencia sanitaria. La empresa suele tener la facultad de determinar qué médico realizará otra exploración para aportar una "segunda opinión", especialmente en caso de recuperación prolongada o de trastorno médico grave.

La enfermera o el médico asesoran a la dirección acerca de la declaración de las lesiones y enfermedades del trabajo con arreglo a las exigencias de la O SH A y deben conocer las directrices de ésta y de la Bureau of Labor Statistics (BLS). La dirección debe asegurarse de que el prestador de la asistencia sanitaria conoce a fondo estas directrices.

\section{Exploraciones médicas de vigilancia}

Algunas normas de la O SH A requieren la realización de exploraciones médicas de vigilancia respecto a la exposición a algunas sustancias (amianto, plomo, etc.) y se recomiendan como buena práctica médica en relación con otras como los disolventes, 
metales y polvos como el de sílice. Las empresas deben realizar estas exploraciones, siempre que lo exijan las normas de la OSH A, sin cargo para el trabajador. Este podrá negarse a ellas, si bien la empresa podrá imponerlas como condición previa para la contratación.

El objetivo de la vigilancia médica es evitar las enfermedades relacionadas con el trabajo mediante la detección precoz de los problemas, evidenciados, por ejemplo, por unos resultados anormales de laboratorio quizás asociados a fases precoces de la enfermedad. En este caso se reevalúa al trabajador a intervalos periódicos. El seguimiento sistemático de las anomalías detectadas durante las exploraciones médicas de vigilancia es esencial. Aunque la dirección debe ser informada de cualquier trastorno médico relacionado con el trabajo, las enfermedades que no hayan surgido en el lugar de trabajo deben mantenerse de forma confidencial y ser tratadas por el médico de familia. En todo caso, la empresa debe ser informada de los resultados (M cC unney 1995; Bunn 1985, 1995; Felton 1976).

\section{Consultas de la dirección}

Aunque el médico y la enfermera de salud en el trabajo son fácilmente reconocidos por sus cualificaciones para el ejercicio médico directo, también pueden prestar asesoramiento médico de interés a cualquier empresa. Los profesionales de la salud pueden desarrollar procedimientos y prácticas para programas médicos, incluida la promoción de la salud, la detección del abuso de drogas y la formación al respecto y el mantenimiento de registros médicos.

En las instalaciones que disponen de un programa médico interno es necesaria una política de la dirección sobre tratamiento de residuos médicos y actividades conexas, con arreglo a la norma de la O SH A sobre agentes patógenos en la sangre. La formación sobre determinadas normas de la OSHA, como la referente a la comunicación de peligros o la relativa al acceso a los registros médicos y de exposición, y las exigencias de mantenimiento de los registros de este organismo son esenciales en un programa bien gestionado.

En todas las instalaciones en las que exista un riesgo superior de catástrofe natural 0 en las que se procesen, utilicen o fabriquen materiales potencialmente peligrosos deben desarrollarse procedimientos de gestión de las urgencias, con arreglo a la Superfund Act Reauthorization Amendment (SARA). L os principios de gestión de las urgencias médicas y de las catástrofes deben, con la asistencia del médico de la empresa, incorporarse a cualquier plan de urgencia del centro de trabajo. Puesto que los procedimientos diferirán en función del peligro, el médico y la enfermera deberán estar preparados para hacerse cargo tanto de los peligros físicos, tales como los que se producen en un accidente radiactivo, como de los químicos.

\section{Promoción de la salud}

Los programas de promoción de la salud y del bienestar dirigidas a la educación de las personas sobre los efectos adversos de ciertas formas de vida (tales como el consumo de cigarrillos, la mala dieta y la falta de ejercicio físico) son cada vez más comunes. Aunque no son esenciales para el programa de salud en el trabajo, pueden ser valiosos para los empleados.

La incorporación de los planes de promoción de la salud y del bienestar al programa médico es recomendable siempre que sea posible. El objetivo de este tipo de programas es configurar una plantilla productiva y consciente de su salud. Las medidas de promoción de la salud pueden permitir reducir los costes de la asistencia sanitaria
Programas de detección de abuso de sustancias. En los últimos años, especialmente desde la aprobación de la Resolución sobre pruebas para la detección del consumo de drogas (1988) por el Departamento de Transportes (DOT) de EE.UU., muchas empresas han desarrollado programas de ese tipo. En la industria química, entre otras de fabricación, el tipo más común de prueba de orina es el que se realiza en la evaluación previa a la colocación. La Resolución del DOT aplicable al transporte interestatal por camión, a las actividades de transporte de gases (oleoductos) y a los sectores ferroviario, de guardacostas y de aviación es considerablemente más rigurosa e incluye la realización de pruebas periódicas "con causa", es decir, en los casos en que hay sospecha de abuso de drogas. Los médicos participan en estos programas mediante la revisión de los resultados para excluir otros factores en los casos en positivos. D eben garantizar además la integridad del proceso y confirmar cualquier prueba positiva con el trabajador antes de revelar los resultados a la dirección. Son esenciales un programa de asistencia al empleado y una política uniforme de la empresa.

\section{Registros médicos}

Los registros médicos son documentos confidenciales que el médico 0 la enfermera del trabajo deben mantener de forma que se proteja esa confidencialidad. Algunos, tales como la carta en la que se indique que la persona es apta para el uso de un respirador, deben mantenerse in situ en previsión de una auditoría reglamentaria. En cambio, deben examinarse los resultados de pruebas médicas específicas. El acceso a estos registros debe estar limitado al profesional de la salud, el trabajador y otras personas designadas por éste. En algunos casos, tales como el de interposición de una reclamación de indemnización de un trabajador, se renuncia a la confidencialidad. La norma de la OSHA sobre acceso a los registros de exposición y a los registros médicos (20 CFR 1910.120) exige que se informe anualmente a los trabajadores de su derecho a acceder a sus registros médicos y de la localización de éstos.

La confidencialidad de los registros médicos debe preservarse con arreglo a las directrices legales, éticas y reglamentarias. LoS trabajadores deben ser informados cuando la dirección vaya a revelar información médica. Lo ideal sería que se les pidiera que firmasen un impreso médico en el que autoricen la revelación de determinados datos médicos, incluidas las pruebas de laboratorio o los materiales de diagnóstico.

El primer punto del Código de Ética del American College of $O$ ccupational and Environmental M edicine establece que "los médicos deben dar la máxima prioridad a la salud y la seguridad de las personas tanto en el lugar de trabajo como en el medio ambiente". En la práctica de la medicina del trabajo, tanto la empresa como el trabajador se benefician si los médicos actúan de modo imparcial y objetivo, aplicando principios médicos, científicos y humanitarios sólidos.

\section{Programas internacionales}

En la medicina internacional del trabajo y del medio ambiente, los médicos que trabajan en el sector privado en EE.UU. no sólo tienen las responsabilidades tradicionales propias de su cargo, sino también importantes tareas de gestión clínica. La responsabilidad del departamento médico incluye la asistencia clínica a los trabajadores y normalmente también a su cónyuge e hijos. En ocasiones, se incluyen asimismo los trabajadores del servicio doméstico, el conjunto de la familia y la comunidad. Además, el médico del trabajo debe ocuparse de los programas relativos a los peligros y riesgos del lugar de trabajo. Los programas de vigilancia médica, así como las exploraciones previas a la colocación y las periódicas, son en este curso elementos cruciales. 
O tra responsabilidad importante es el diseño de programas adecuados de prevención y promoción de la salud. En el ámbito internacional, estos programas incluyen cuestiones adicionales a las de la forma de vida habitualmente consideradas en Estados U nidos 0 en Europa 0 ccidental. Las enfermedades infecciosas requieren un enfoque sistemático de la vacunación y la quimioprofilaxis necesarias. Los programas educativos de prevención deben prestar atención a los agentes patógenos transmitidos por los alimentos, el agua y la sangre y a la higiene en general. Los programas de prevención de accidentes deben contemplarse a la luz del alto riesgo de fallecimientos relacionados con el tráfico en muchos países en vías de desarrollo. Las cuestiones especiales, tales como la evacuación y la asistencia de urgencia, deben analizarse detalladamente y ser objeto de programas adecuados. La exposición medioambiental a los peligros químicos, biológicos y físicos suele ser mayor en los países en vías de desarrollo. Los programas de prevención medioambiental se basan en planes de educación divididos en varias etapas caracterizadas por las correspondientes pruebas biológicas. Los programas clínicos a desarrollar internacionalmente pueden incluir la gestión de la asistencia hospitalaria, ambulatoria, de urgencia e intensiva a los expatriados y a los trabajadores nacionales.

Un aspecto complementario de los médicos internacionales del trabajo es el relativo a los viajes. La seguridad de los residentes extranjeros y de los viajeros requiere conocimientos especiales sobre las vacunaciones adecuadas y otras medidas preventivas a escala mundial. Además de las vacunaciones recomendadas, es imprescindible conocer los requisitos médicos para la obtención de los visados. M uchos países exigen la realización de pruebas serológicas o de radiografías torácicas, y algunos tienen en cuenta una determinada enfermedad al decidir sobre la concesión de un visado de trabajo o de residencia.

Los servicios de asistencia a trabajadores y los de la armada y la aviación suelen incluirse también entre las responsabilidades de los médicos internacionales del trabajo. La planificación de los servicios de urgencia y la administración de medicinas adecuadas y de formación sobre su uso son retos importantes para buques y aeronaves. El apoyo psicológico tanto a los expatriados como a los trabajadores nacionales suele ser conveniente $y$, en ocasiones, necesario. Los programas de asistencia a los trabajadores pueden extenderse a los expatriados, prestando especial apoyo a los familiares. Los programas sobre las drogas y el alcohol deben contemplarse en el contexto social del país en cuestión (Bunn 1995).

\section{Conclusión}

En conclusión, el ámbito y la organización de los programas de salud en el trabajo de las empresas pueden variar ampliamente. No obstante, si se analizan y aplican adecuadamente, estos programas resultan eficaces en términos de coste, protegen a la empresa frente a posibles responsabilidades jurídicas y promueven la salud profesional y general de la plantilla.

\section{- SeRVicios de SALUd En El trabajo MEDIANTE CONTRATO EN ESTADOS UNIDOS}

Penny Higgins

\section{Contexto}

En Estados U nidos, las empresas han prestado desde hace mucho tiempo asistencia médica a sus trabajadores lesionados a través de agentes privados, ya sean médicos, centros hospitalarios, instalaciones de asistencia inmediata o servicios hospitalarios de urgencias. Esta asistencia ha sido, en su mayor parte, de carácter puntual y escasamente coordinada, pues sólo las mayores empresas podían disponer de servicios internos de salud en el trabajo.

U na reciente encuesta sobre 22.457 empresas con menos de 5.000 trabajadores de un área suburbana de Chicago mostró que el $93 \%$ tenían menos de 250 trabajadores. De este grupo, un $52 \%$ utilizaban un prestador específico para las lesiones del trabajo, un $24 \%$ no utilizaban un prestador específico y otro $24 \%$ permitían al trabajador elegir su propio prestador. Sólo el $1 \%$ contaban con un director médico. Estas empresas representaban el $99 \%$ de todas las del área estudiada y más de 524.000 trabajadores (N ational H ealth Systems 1992).

Desde la aprobación de la ley de creación de la 0 ccupational Safety and Health Administration, en 1970, y los correspondientes cambios en la financiación de la asistencia sanitaria, los planteamientos y las prioridades han cambiado. Los costes del seguro de indemnización a los trabajadores y de la asistencia sanitaria colectiva aumentaron entre un $14 \%$ y un $26 \%$ anual entre 1988 y 1991 (BNA 1991). En 1990, los costes de asistencia sanitaria representaban el mayor componente de los 53.000 millones de dólares gastados en EE.UU. por prestaciones de indemnización a los trabajadores, y se espera que en 1995 las prestaciones médicas alcancen el $50 \%$ de un importe total de 100.000 millones de dólares de costes de indemnización a los trabajadores (R esnick 1992).

L os costes por primas varían entre los distintos estados debido a las diferentes reglamentaciones de indemnización a los trabajadores. La Kiplinger W ashington L etter de 9 de septiembre de 1994 declaraba que "en M ontana, los contratistas pagan una media de 35,29 dólares de seguro de indemnización por cada 100 dólares de nómina; en Florida, 21,99; en Illinois, 19,48. La misma cobertura cuesta 5,55 dólares en Indiana y 9,55 en C arolina del Sur". Al evolucionar la necesidad de indemnizar económicamente la asistencia a los trabajadores, las empresas demandan mayor ayuda por parte de sus prestadores de asistencia sanitaria.

En esencia, esta asistencia médica es prestada por centros médicos independientes. L as empresas pueden contratar la asistencia, desarrollar una relación con un prestador o recurrir a la asistencia cuando se necesite. La mayor parte de la asistencia se presta según el modelo de pago por servicio, surgiendo en la segunda mitad del decenio de 1990 los sistemas de capitación (reparto) y de contratación directa.

\section{Tipos de servicios}

L as empresas exigen universalmente que los servicios de salud en el trabajo incluyan el tratamiento de lesiones y enfermedades agudas tales como esguinces, torceduras, lesiones oculares y de espalda y laceraciones, las cuales constituyen la mayoría de los casos agudos presentes en los programas de salud en el trabajo.

A menudo, las exploraciones se solicitan con carácter previo a la colocación o tras una oferta de trabajo, con el fin de determinar la capacidad de los trabajadores potenciales para realizar la tarea requerida sin perjuicio para sí o para terceros. Estas exploraciones deben evaluarse con arreglo a la normativa contenida en la Ley de norteamericanos con discapacidades, que prohíbe la discriminación en la contratación por una discapacidad que no impida a la persona realizar las funciones esenciales del puesto. La empresa está obligada, además, a realizar una "acomodación razonable" del trabajador discapacitado (EEOC y Department of Justice 1991).

Aunque la ley sólo lo exige para determinadas clases de trabajos, las pruebas para detectar el consumo de drogas 0 alcohol son habituales en el $98 \%$ de las 200 empresas de 
Fortune. Implican la realización de análisis de orina, y de sangre y la práctica de pruebas de función pulmonar para determinar los niveles de drogas ilegales o de alcohol (BNA 1994).

Además, una empresa puede necesitar servicios especiales, tales como las pruebas médicas de vigilancia exigidas por la OSHA, por ejemplo, exploraciones de aptitud para el uso del respirador, basadas en la capacidad del trabajador para llevar un respirador con seguridad; exploraciones en relación con el amianto y otras pruebas de exposición química, destinadas a evaluar el estado de salud de la persona ante posibles exposiciones y efectos a largo plazo de un determinado agente sobre su salud global.

Con el fin de valorar el estado de salud de los trabajadores clave, algunas empresas contratan la realización de exploraciones físicas a sus directivos, las cuales suelen ser de carácter preventivo y permiten una evaluación integral de la salud, para lo cual se llevan a cabo pruebas de laboratorio, radiografías, determinaciones de presión arterial, exploraciones selectivas para el cáncer y actividades de asesoramiento sobre formas de vida. La frecuencia de estas exploraciones suele basarse en la edad, más que en el tipo de trabajo.

Los municipios suelen contratar exploraciones periódicas de la capacidad física para el trabajo con el fin de evaluar el estado de salud de los funcionarios de policía y de bomberos, a quienes se suele someter a pruebas para medir su capacidad física para soportar situaciones físicamente estresantes y determinar si se han producido exposiciones en el lugar de trabajo.

Las empresas contratan también servicios de rehabilitación, incluidos los de fisioterapia, evaluación ergonómica del lugar de trabajo y terapia ocupacional.

M ás recientemente, como prestación a los trabajadores y en un intento de reducir los costes de la asistencia sanitaria, las empresas han empezado a contratar programas de bienestar. Estos programas educativos y exploraciones selectivas basados en la prevención tratan de evaluar la salud a fin de poder ofrecer medidas adecuadas para modificar las formas de vida que contribuyan a generar enfermedades, tales como las exploraciones de colesterol, las evaluaciones de riesgo sanitario, los programas de abandono del tabaco, los de control del estrés y la educación nutricional.

$\mathrm{H}$ ay programas en todas las áreas de la asi stencia sanitaria para satisfacer las necesidades de los trabajadores. Entre ellos destacan los de asistencia a los trabajadores (Employee Assistance Programs, EAP), recientemente desarrollados para prestar servicios de asesoramiento y de reconducción a los trabajadores afectados por el abuso de sustancias o por problemas afectivos, familiares o económicos, en los casos en que la empresa ha llegado a la conclusión de que afectan a su capacidad de trabajo.

0 tro servicio novedoso en el campo de la salud en el trabajo es el de gestión de casos. N ormalmente prestado por enfermeras o por personal administrativo supervisado por éstas, ha reducido efectivamente los costes ofreciendo al mismo tiempo una asistencia adecuada y de calidad a los trabajadores afectados. Las compañías de seguros cubren desde hace tiempo los costes de la gestión de reclamaciones cuando el trabajador afectado ha estado ausente del trabajo un determinado período de tiempo o cuando se alcanza una determinada cantidad de dinero. La gestión de casos es un proceso más activo, que puede aplicarse desde el primer día de la lesión. Aquí, los gestores de casos dirigen al paciente al nivel adecuado de asistencia, tratan con el médico para determinar qué tipos de trabajos puede realizar aquél desde el punto de vista médico y colaboran con la empresa para conseguirle un trabajo que no agrave su lesión. El objetivo del gestor de casos trata así de reincorporar al trabajador con la mínima modificación de su trabajo y lo más rápidamente posible, así como encontrar médicos de buena calidad cuya intervención favorezca en mayor medida al paciente.

\section{Los prestadores}

Los servicios pueden obtenerse de diversos prestadores con distintos grados de especialización. La consulta del médico privado puede administrar pruebas de detección de abuso de sustancias y realizar exploraciones previas a la colocación, así como el seguimiento de las lesiones graves. Suele ser necesario pedir cita dentro del horario establecido. Si el médico privado está capacitado, puede ofrecer también exploraciones a directivos o remitir a éstos a un hospital cercano para realizar las pruebas de laboratorio, radiografías y pruebas de estrés.

L os centros hospitalarios suelen ofrecer asistencia por lesiones agudas (incluido el seguimiento), pruebas de detección de abuso de sustancias y exploraciones previas a la colocación. Suelen disponer de rayos $X$ y de laboratorio y a veces tienen médicos expertos en evaluación del lugar de trabajo. Sus horarios suelen estar también limitados a las horas de trabajo, de modo que las empresas con segundos y terceros turnos de trabajo quizá tengan que recurrir a un servicio de urgencias en las horas del final de la tarde y del fin de semana. Estos centros hospitalarios no suelen atender a pacientes privados y suelen ser considerados como "los médicos de la empresa", ya que suelen pactarse sistemas de facturación directa a la empresa o a la compañía aseguradora de ésta.

Los centros de asistencia inmediata son otra alternativa para la prestación de servicios de asistencia médica general sin necesidad de cita. Suelen estar equipados con rayos $X$ y laboratorio y atendidas por médicos especializados en medicina de urgencias, medicina interna o asistencia familiar. El tipo de cliente varía desde los pacientes pediátricos hasta los adultos con dolor de garganta. A demás de la asistencia por lesiones graves y el seguimiento menor de los trabajadores lesionados, pueden realizar pruebas de detección de abuso de sustancias y exploraciones físicas previas a la colocación. Los centros que se han especializado en medicina del trabajo suelen realizar exploraciones periódicas y exploraciones selectivas exigidas por la OSH A, y en ocasiones mantienen relaciones contractuales con prestadores adicionales de otros servicios que ellos no atienden por sí mismos.

El servicio de urgencias de los hospitales suele ser el lugar elegido para el tratamiento de las lesiones graves y no suele estar en condiciones de prestar otros tipos de servicios a efectos de la salud en el trabajo, pese a que los hospitales disponen de los recursos necesarios para cubrir la mayoría de los servicios necesarios excepto los correspondientes a los médicos especialistas en medicina del trabajo. De todas formas, el servicio de urgencias carece de capacidad en materia de gestión de la asistencia y de reincorporación al trabajo, hoy demandadas por el sector privado.

\section{Programas hospitalarios}

L os gestores hospitalarios han caído en la cuenta de que no sólo disponen de los recursos y la tecnología necesarios, sino que la indemnización a los trabajadores es uno de los últimos regímenes de "seguro" que paga tarifas por servicio, y que les ofrece la oportunidad de aumentar unos ingresos que se han visto afectados por los descuentos acordados con las compañías de seguro de asistencia gestionada, tales como las H M O y las PPO. Estas últimas compañías, así como los programas Medicare y Medicaid de financiación estatal y federal para la asistencia sanitaria general, han demandado estancias más cortas o han impuesto un sistema de pago basado en la "agrupación por diagnósticos" (diagnosisrelated grouping, DRG). Tales mecanismos han obligado a los hospitales a reducir costes a través de la mejora de la 
coordinación de la asistencia y la oferta de nuevos productos generadores de ingresos. Se ha llegado a temer incluso que los costes pasaran de la asistencia gestionada colectiva a la indemnización a los trabajadores, temores bien fundados en algunos casos en que los costes del tratamiento de una lesión de espalda por la vía de la indemnización al trabajador duplicaban o triplicaban los de los planes de asistencia colectiva. Un estudio del Departamento de Trabajo e Industria de M innesota realizado en 1990 mostró que los costes del tratamiento de los esguinces y torceduras era 1,95 veces superior y el de las lesiones de espalda 2,3 veces superior por la vía de la indemnización al trabajador que a través de los regímenes de seguro sanitario colectivo (Zaldman 1990).

Se han desarrollado varios modelos de prestación hospitalaria, como la consulta propia del hospital (en el propio recinto 0 fuera de el), el servicio de urgencias, el servicio de "asistencia rápida" (para urgencias no agudas) y los servicios de salud en el trabajo gestionados administrativamente. La A merican H ospital Association ha expuesto lo siguiente, según un estudio realizado por Ryan Associates and O ccupational Health Research sobre 119 programas de salud en el trabajo de Estados Unidos (N ewkirk 1993):

- el 25,2 \% son servicios hospitalarios de urgencias;

- el $24,4 \%$ son servicios hospitalarios no de urgencias;

- el $28,6 \%$ son consultas hospitalarias;

- el $10,9 \%$ son consultas independientes;

- el $10,9 \%$ corresponde a otros tipos de programas.

Todos estos programas evalúan los costes por el sistema de tarifa por servicio y ofrecen diversos servicios, entre los que se incluyen, además del tratamiento de los trabajadores con lesiones agudas, exploraciones previas a la colocación, pruebas de detección de consumo de drogas y alcohol, rehabilitación, asesoramiento sobre el lugar de trabajo, vigilancias médicas exigidas por la OSHA, pruebas físicas para directivos y programas de bienestar. Además, algunos ofrecen programas de asistencia a los trabajadores, servicios de enfermería in situ, primeros auxilios y gestión de casos.

En la actualidad, lo más frecuente es que los programas de salud en el trabajo incluyan un modelo de enfermería de gestión de casos. Con este tipo de modelo, que incorpora una gestión médica integral, pueden reducirse en un $50 \%$ los costes totales de indemnización a los trabajadores, lo que supone un importante incentivo para que la empresa utilice prestadores que ofrezcan este servicio (Tweed 1994). Estas reducciones de costes son el resultado de una atención rigurosa al objetivo de una rápida reincorporación al trabajo y a la consultoría sobre programas de trabajo modificado. Las enfermeras colaboran con los especialistas para ayudar a definir un trabajo médicamente aceptable que el trabajador lesionado pueda realizar sin riesgos ni restricciones.

En la mayoría de los estados, los trabajadores reciben dos terceras partes de su sueldo mientras perciben la indemnización temporal por incapacidad total. Al reincorporarse a un trabajo modificado, continúan prestando un servicio a sus empresas y manteniendo su autoestima gracias al trabajo. Los trabajadores que han estado ausentes del trabajo seis semanas 0 más no suelen reincorporarse a su trabajo completo, sino que suelen verse obligados a realizar tareas de menor cualificación y peor pagadas.

El objetivo último de los programas hospitalarios de salud en el trabajo es dar a los pacientes acceso al hospital para el tratamiento de lesiones del trabajo y permitirles que sigan acudiendo al hospital como su prestador primario de todos los servicios de asistencia sanitaria. A medida que se evoluciona en el país hacia un sistema de asistencia sanitaria por capitación, el número de personas cubiertas por un hospital se convierte en la primera señal de éxito.

En este modelo de financiación de la asistencia sanitaria por capitación, los trabajadores pagan una tasa por cabeza a los prestadores por todos los servicios de asistencia sanitaria que puedan necesitar para sí o para las personas a su cargo. Si las personas cubiertas por un plan de este tipo se mantienen sanas, el prestador puede obtener beneficios. Si las personas cubiertas utilizan mucho los servicios, el prestador puede no reunir ingresos suficientes por primas para cubrir los costes de la asistencia, de modo que perderá dinero. Varios estados del país han adoptado el modelo de capitación en los seguros médicos y unos pocos están ensayando la cobertura de 24 horas para toda la asistencia sanitaria, incluidas las prestaciones médicas de indemnización a los trabajadores. En lo sucesivo, los hospitales no juzgarán el éxito por su censo de pacientes, sino por la relación entre las personas cubiertas y los costes.

Los programas hospitalarios integrales de salud en el trabajo están destinados a satisfacer la necesidad de programas integrales de alta calidad de medicina del trabajo para el colectivo profesional y empresarial. Su diseño se basa en la premisa de que, aunque la asistencia por lesiones y las exploraciones físicas previas a la colocación son importantes, no constituyen por sí solas un programa de medicina del trabajo. Un hospital que atienda a varias empresas puede permitirse disponer de un médico del trabajo que supervise los servicios médicos y, por tanto, puede abordar una vertiente más amplia de medicina del trabajo que incluya consultas toxicológicas, evaluaciones del lugar de trabajo y exploraciones exigidas por la OSHA para detectar contaminantes como el amianto o el plomo, así como equipos tales como respiradores, además de los servicios habituales de tratamiento de las lesiones del trabajo, las exploraciones físicas y la exploración selectiva para detectar el consumo de drogas. Los hospitales pueden disponer también de los recursos necesarios para dotarse de una base de datos informatizada y un sistema de gestión de casos.

Al ofrecer a la empresa un centro único de servicios plenos para atender las necesidades de asistencia sanitaria de sus trabajadores, el programa de salud en el trabajo puede garantizar en mayor medida la recepción, por parte de éstos, de una asistencia de calidad en las instalaciones más adecuadas, reduciendo al mismo tiempo los costes para la empresa. Los prestadores de servicios de salud en el trabajo pueden controlar las tendencias de una empresa o de un sector y formular recomendaciones para reducir los accidentes en el lugar de trabajo y mejorar la seguridad.

Los programas hospitalarios globales de salud en el trabajo permiten a las pequeñas empresas compartir los servicios de un departamento médico. Estetipo de programasofrecen servicios de prevención y de bienestar, así como asistencia en casos agudos, y permiten centrarse en mayor medida en la promoción de la salud de los trabajadores y sus familias.

\section{ACTIVIDADES SIN DICALES EN ESTADOS UNIDOS}

Lamont Byrd

En 1995, la O ficina de Estadísticas de Trabajo del Departamento de Trabajo de EE.UU. publicó un informe en el que se indicaba que 18,8 millones de trabajadores, esto es, un $16 \%$ de la población activa del país, están afiliados a sindicatos 0 , sin estarlo, están cubiertos por un convenio sindical (US Department of 
Tabla 16.4 • Distribución por sectores de la afiliación sindical de la población activa en los EE.UU. en 1994.

\begin{tabular}{|c|c|c|c|c|c|}
\hline \multirow[t]{2}{*}{$\begin{array}{l}\text { Profesión } \\
\text { o sector }\end{array}$} & \multirow{2}{*}{$\begin{array}{l}\text { Trabaja- } \\
\text { dores } \\
\text { totales }\end{array}$} & \multicolumn{2}{|l|}{$\begin{array}{l}\text { Afiliados a } \\
\text { sindicatos }\end{array}$} & \multicolumn{2}{|c|}{$\begin{array}{l}\text { Representados por } \\
\text { sindicatos }{ }^{2}\end{array}$} \\
\hline & & Trabajadores & $\begin{array}{l}\text { Total } \\
(\%)\end{array}$ & Trabajadores & $\begin{array}{l}\text { Total } \\
(\%)\end{array}$ \\
\hline $\begin{array}{l}\text { Trabajadores agrícolas } \\
\text { a sueldo y salario }\end{array}$ & 1.487 & 34 & 2,3 & 42 & 2,8 \\
\hline $\begin{array}{l}\text { Trabajadores privados } \\
\text { no agrícolas a sueldo } \\
\text { y salario }\end{array}$ & 88.163 & 9.620 & 10,9 & 10.612 & 12 \\
\hline Minería & 652 & 102 & 15,7 & 111 & 17,1 \\
\hline Construcción & 4.866 & 916 & 18,8 & 966 & 19,9 \\
\hline Fabricación & 19.267 & 3.514 & 18,2 & 3.787 & 19,7 \\
\hline Bienes duraderos & 11.285 & 2.153 & 19,1 & 2.327 & 20,6 \\
\hline Bienes perecederos & 7.983 & 1.361 & 17 & 1.460 & 18,3 \\
\hline $\begin{array}{l}\text { Transporte y servicios } \\
\text { públicos }\end{array}$ & 6.512 & 1.848 & 28,4 & 1.997 & 30,7 \\
\hline Transporte & 3,925 & 1.090 & 27,8 & 1.152 & 29,3 \\
\hline $\begin{array}{l}\text { Comunicaciones y } \\
\text { servicios públicos }\end{array}$ & 2.587 & 758 & 29,3 & 846 & 32,7 \\
\hline $\begin{array}{l}\text { Comercio mayorista y } \\
\text { minorista }\end{array}$ & 22.319 & 1.379 & 6,2 & 1.524 & 6,8 \\
\hline Comercio mayorista & 3.991 & 260 & 6,5 & 289 & 7,2 \\
\hline Comercio minorista & 18.328 & 1.120 & 6,1 & 1.236 & 6,7 \\
\hline $\begin{array}{l}\text { Finanzas, seguros e } \\
\text { inmobiliarias }\end{array}$ & 6.897 & 156 & 2,3 & 215 & 3,1 \\
\hline Servicios & 27.649 & 1.704 & 6,2 & 2.012 & 7,3 \\
\hline Empleados públicos & 18.339 & 7.094 & 38,7 & 8.195 & 44,7 \\
\hline
\end{tabular}

1 Datos relativos a afiliados a sindicatos 0 asociaciones similares de trabajadores. 2 Datos relativos a asociados a sindicatos 0 asociaciones similares de trabajadores, así como a trabajadores que no indican afiliación pero cuyos puestos están cubiertos por un convenio sindical o de asociación de trabajadores. Nota: Datos relativos al trabajo exclusivo o principal de trabajadores a tiempo completo 0 a tiempo parcial. No se incluyen los trabajadores autónomos cuyos negocios tienen forma societaria aunque técnicamente reúnan las características de los trabajadores a sueldo y salario. Los datos de 1994 no son directamente comparables con los de 1993 y años anteriores. Puede obtenerse más información en "Revisions in the current population survey effective January 1994", en el número de febrero de Employment and Earning

Labor 1995). La Tabla 16.4 parte de este informe para mostrar la población empleada sindicada por sectores. La mayoría de estos trabajadores están representados por la American Federation of Labour and Congress of Industrial O rganizations (AFL-CIO), que reúne a 86 sindicatos nacionales e internacionales (Statistical Abstract of the U nited States 1994). Los sindicatos suelen estar organizados en centrales nacionales 0 internacionales, oficinas regionales y de distrito y sindicatos locales.

L os sindicatos ofrecen servicios globales de salud y seguridad a los trabajadores afiliados. A través de los convenios colectivos y mediante la prestación de servicios técnicos y similares, atienden las necesidades e intereses de sus miembros.

En los ámbitos nacional e internacional, los cargos sindicales y los miembros del personal (profesionales de salud y seguridad, abogados, especialistas en lobbies, etc.) influyen sobre los dirigentes electos para la adopción de normas legales y reglamentarias de salud y seguridad que protejan a los trabajadores. LoS representantes sindicales también desarrollan y negocian con las empresas convenios colectivos, que contienen estipulaciones de salud y seguridad jurídicamente vinculantes.
Los sindicatos garantizan a los trabajadores un medio ambiente de trabajo seguro y sano a través de los convenios colectivos. Lo ideal es que éstos ofrezcan también a los trabajadores un medio de resolver los problemas o controversias de salud y seguridad que puedan surgir en el lugar de trabajo.

\section{Asistencia técnica}

En las oficinas centrales, los sindicatos suelen contratar a higienistas industriales, ergonomistas, médicos del trabajo, ingenieros y otros profesionales de la salud y la seguridad para prestar asistencia técnica a los trabajadores mediante la investigación de reclamaciones, la realización de evaluaciones de salud y seguridad in situ y la interpretación y traducción de datos de control medioambiental, resultados médicos y otros datos técnicos a un lenguaje comprensible para el trabajador medio.

La investigación de las reclamaciones de salud y seguridad suele correr a cargo de consultores o de personal profesional de los sindicatos. Trabajando en colaboración con los representantes de los trabajadores designados pertenecientes al sindicato local afectado, estos profesionales resuelven cuestiones tales como la exposición del trabajador a peligros físicos o químicos, las lesiones y enfermedades musculoesqueléticas y el incumplimiento de reglamentaciones vigentes en materia de salud y seguridad.

A demás, los sindicatos participan en la investigación de accidentes cuando los trabajadores afectados no están conformes con los resultados de la investigación realizada por la empresa.

Los representantes sindicales pueden utilizar la información obtenida durante estas investigaciones para resolver quejas en materia de salud y seguridad colaborando con la empresa en el proceso de negociación colectiva. Se sirven del procedimiento de reclamación 0 de las estipulaciones sobre salud y seguridad contenidas en el convenio para proteger a los trabajadores. También, pueden optar por recurrir a un organismo regulador federal o estatal si la empresa no cumple las normas legales 0 reglamentarias vigentes.

Los profesionales sindicales de la salud y la seguridad y los representantes sindicales designados en el lugar de trabajo (por ejemplo, miembros del comité local de salud y seguridad o delegados sindicales) realizan encuestas in situ para evaluar los peligros existentes en el medio ambiente de trabajo.

Durante las encuestas se evalúan los procesos de fabricación y demás actividades realizadas en el lugar de trabajo. L os registros de salud y seguridad (por ejemplo, los formularios O SH A 200, los partes de accidentes del Departamento de Transportes (DOT), los resultados del control medioambiental y los programas escritos) se revisan para determinar el cumplimiento de lo pactado en el convenio colectivo y en las normas y reglamentaciones públicas. Los resultados de las encuestas se documentan y cualquier problema se resuelve mediante la negociación colectiva o el recurso a un organismo regulador público.

Los propios trabajadores suelen solicitar información e informes técnicos o reglamentarios, tales como hojas de datos químicos, resultados del control medioambiental o biológico, y reglamentaciones federales o estatales de salud y seguridad. D ebido al carácter técnico de estos datos, es posible que precisen ayuda para comprender el tema y su repercusión sobre su lugar de trabajo. El personal sindical de salud y seguridad puede brindarles esta asistencia de la forma más adecuada a sus necesidades.

Los sindicatos actúan también como centro de servicios para la asistencia médica especializada o para la ayuda a los trabajadores en los procedimientos de indemnización. A tal fin, suelen tener listas con los nombres y direcciones de médicos 
independientes de prestigio a los que, en caso de necesidad, pueden remitir al trabajador.

\section{Actividades legales y reglamentarias}

La participación activa en las actividades reglamentarias públicas en materia de salud y seguridad es de gran interés para los sindicatos, que animan a sus afiliados a participar en ellas en distintos ámbitos.

Los sindicatos tratan de influir sobre los políticos proponiendo normas adecuadas de salud y seguridad en el lugar de trabajo, respondiendo a las propuestas de los organismos reguladores, influyendo en la forma en que estos organismos verifican el cumplimiento de las reglamentaciones y apoyándoles cuando se ven afectados por reducciones presupuestarias o cambios operativos por parte del Congreso de EE.UU.

Los responsables sindicales, los profesionales técnicos, los encargados de la investigación y el personal jurídico son los principalmente implicados en estas actividades, encargándose de la recopilación, análisis y sistematización de los datos necesarios para determinar la postura a adoptar por el sindicato con respecto a las actividades legislativas o reglamentarias y de establecer los contactos necesarios con organismos y personas para conseguir que esa postura se presente ante los cargos electos.

Si los responsables de salud y seguridad del sindicato se encuentran ante un problema de salud y seguridad que afecte a los trabajadores pero no está regulado por un organismo público, pueden elaborar comentarios escritos o un testimonio oral para presentarlo durante los procedimientos públicos con el fin de instruir a los cargos competentes e incitarles a aprobar una normativa que lo resuelva.

Los organismos encargados de velar por el cumplimiento de las disposiciones de salud y seguridad son, en ocasiones, víctimas de las reducciones presupuestarias. Estos recortes presupuestarios suelen considerarse perjudiciales para la protección de la salud y la seguridad de los trabajadores en el puesto de trabajo, por lo que los sindicatos diseñan y ponen en práctica estrategias para evitarlos, ya sea colaborando con los expertos sindicales para instruir a los legisladores y otros cargos sobre los efectos negativos de los recortes, ya sea emprendiendo acciones "de base" tales como organizar y movilizar a los trabajadores para que escriban cartas a sus cargos electos mostrando su oposición a tales medidas.

Además, los sindicatos participan muy intensamente en la elaboración y presentación de comentarios escritos y testimonios orales en respuesta a proposiciones de normas reglamentarias de los organismos reguladores federales y estatales en materia de salud y seguridad. Para los trabajadores es vital tener la oportunidad de participar verdaderamente en el proceso de elaboración de las normas, lo cual consiguen por medio de los sindicatos.

\section{Convenios colectivos}

Los convenios colectivos son la primera herramienta empleada por los sindicatos para implementar servicios para sus miembros. Los sindicatos utilizan la especialización técnica de sus higienistas industriales, ergonomistas, ingenieros, médicos del trabajo y otros profesionales de la salud y la seguridad para reunir y analizar datos sobre salud y seguridad con el fin de preparar a los representantes sindicales encargados de negociar los convenios colectivos

Los sindicatos utilizan los convenios colectivos como documentos jurídicamente vinculantes para la protección de la salud y la seguridad de los trabajadores. El objetivo primordial es proteger a los trabajadores no cubiertos por las normas y reglamentaciones federales o estatales y ampliar la protección por encima de estos mínimos.
Para preparar la negociación, los sindicatos recopilan información sobre las cuestiones de salud y seguridad que afectan a sus afiliados, lo que puede hacerse mediante encuestas entre éstos, colaborando con personal técnico y consultores para detectar los peligros del lugar de trabajo y revisando datos sobre reclamaciones o investigaciones anteriores y sobre indemnizaciones a los trabajadores, encuestas de control medioambiental y archivos de lesiones y enfermedades.

En las últimas fases de la preparación, el comité negociador ordena por prioridades las diversas cuestiones y estudia sus posibles soluciones.

\section{Educación y formación de los trabajadores}

Los sindicatos desempeñan un papel muy importante al impartir a sus miembros formación y educación en materia de salud y seguridad.

El tipo de formación va desde la exposición de los derechos básicos de seguridad en el lugar de trabajo (por ejemplo, comunicación de peligros) hasta la formación integral específica sobre el sector en cuestión, tal como la que se imparte a los trabajadores que participan en proyectos peligrosos de reciclaje de residuos. Esta formación es vital para quienes trabajan en un medio ambiente de trabajo rápidamente cambiante.

La formación de los trabajadores impartida por los sindicatos suele financiarse mediante cuotas de los afiliados, subvenciones federales y estatales y fondos constituidos por las empresas según lo negociado en los convenios colectivos. Los cursos son elaborados por personal profesional y consultores, con amplia participación de los trabajadores. A menudo se ofrecen cursos de "formación para formadores" con el fin de formar a compañeros del mismo nivel.

\section{Actividades de investigación}

L os sindicatos colaboran con instituciones tales como las universidades y organismos públicos en la realización de investigaciones específicas en materia de salud y seguridad en el trabajo. Las actividades de investigación suelen estar financiadas por el sindicato, por las empresas o por una entidad federal o estatal.

Los sindicatos utilizan los resultados de los estudios en el proceso de elaboración de normas de salud y seguridad para negociar las estipulaciones del convenio, con el fin de eliminar 0 reducir significativamente los peligros del lugar de trabajo 0 , alternativamente, tomar medidas para eliminar 0 reducir significativamente los riesgos de los afiliados (por ejemplo, ofreciendo cursos de abandono del tabaco para los trabajadores expuestos al amianto). Además, los resultados de las investigaciones pueden emplearse para crear 0 modificar los equipos utilizados en el trabajo.

Los servicios de salud y seguridad en el trabajo prestados por los sindicatos son de carácter esencialmente preventivo y requieren el trabajo combinado de profesionales técnicos, médicos del trabajo, abogados, especialistas en lobbies y sindicalistas. Estos servicios permiten a los sindicatos asegurar eficazmente la salud y la seguridad de sus afiliados y de otros trabajadores presentes en el lugar de trabajo.

\section{SERVICIOS ACADEMICOS DE SALUd EN EL TRABAJO EN ESTADOS UNIDOS}

Dean B. Baker

Durante los decenios de 1980 y 1990, los centros hospitalarios académicos de medicina del trabajo y del medio ambiente se han 
convertido en una pequeña pero importante fuente de servicios de salud en el trabajo en Estados U nidos. Estos centros hospitalarios están asociados a centros médicos académicos, facultades de medicina o escuelas de salud pública. El personal médico está compuesto principalmente por profesores participantes en los programas académicos dedicados esencialmente a la enseñanza y la investigación en el campo de la medicina del trabajo. La principal actividad de estos centros hospitalarios es realizar evaluaciones médicas diagnósticas de enfermedades potenciales del trabajo y el medio ambiente. Desempeñan así un papel importante en la salud en el trabajo de Estados U nidos como fuente independiente de dictámenes periciales médicos en materia de enfermedades del trabajo, así como en calidad de importantes centros de formación de especialistas en la materia y, últimamente, de médicos de asistencia primaria.

\section{Contexto}

En materia de enfermedades del trabajo se necesitan fuentes independientes de peritaje médico porque las empresas sólo están jurídicamente obligadas a prestar asistencia médica y abonar los salarios perdidos si se demuestra que la lesión o enfermedad en cuestión está relacionada con el trabajo. Como ya se ha señalado en artículos anteriores de este capítulo, la mayor parte de la asistencia médica de los trabajadores lesionados es prestada por las empresas ya sea directa o indirectamente mediante la formalización de contratos con médicos, centros hospitalarios, servicios de asistencia inmediata y programas hospitalarios, todos ellos de carácter privado. Este sistema es bastante adecuado para trabajadores con lesiones o enfermedades agudas, porque en estos casos está clara la conexión entre el trabajo y la enfermedad y a la empresa le conviene proporcionar al trabajador un tratamiento médico rápido y efectivo para que se reincorpore lo más rápidamente posible. Sin embargo, los sistemas de indemnización a los trabajadores de Estados U nidos no funcionan adecuadamente para quienes padecen lesiones crónicas y enfermedades del trabajo, porque las empresas no están obligadas a pagar la asistencia médica a menos que se demuestre que la enfermedad es de carácter profesional. Si la empresa se opone a la reclamación de indemnización, sus representantes y los del trabajador deben encontrar una evaluación independiente que determine si la enfermedad es o no de origen profesional. Los centros hospitalarios académicos actúan como peritos a este respecto.

L os centros hospitalarios académicos de medicina del trabajo han podido conservar esta independencia porque no suelen depender de contratos con empresas u otro tipo de intereses económicos similares que puedan dar lugar a conflictos de intereses al evaluar las enfermedades de los trabajadores. Suelen actuar como entidades no lucrativas que absorben una parte del coste de las evaluaciones médicas en el marco de su función educativa y de servicio, dado que las evaluaciones diagnósticas complejas no suelen ser casi nunca actividades eficaces en términos de coste sin el apoyo de la empresa.

La expansión de los centros hospitalarios académicos de medicina del trabajo y el medio ambiente ha sido también consecuencia del aumento del número de programas de esta misma materia en las facultades de medicina y en los centros médicos académicos. Hasta hace poco, en EE.UU. tan sólo había un pequeño número de programas de salud en el trabajo, prácticamente todos ellos ubicados en escuelas de salud pública, en los que se ponía el acento en disciplinas tales como la higiene industrial, la toxicología y la epidemiología. El número de programas de medicina del trabajo y el medio ambiente en las facultades de medicina aumentó sustancialmente durante los decenios de 1980 y 1990.
Este aumento tuvo diversas causas. La Ley de Salud y Seguridad en el Trabajo, aprobada en 1970, creó el National Institute for $\mathrm{O}$ ccupational Safety and $\mathrm{H}$ ealth (NIO SH), que puso en práctica un programa de subvenciones para apoyar la formación como residente en medicina del trabajo. Las facultades de medicina desarrollaron numerosos programas para impartir tal formación con la ayuda estas subvenciones. Por otro lado, la organización de acreditación profesional de la medicina del trabajo en Estados U nidos trató de aumentar la importancia de esta materia mediante la elaboración de un programa formal de formación (en lugar de la mera experiencia de trabajo en ese campo) como requisito para la acreditación como especialista en medicina del trabajo. Se establecieron asimismo programas como reacción ante los informes de prestigiosas organizaciones profesionales, tales como el Institute of M edicine (IOM), en las que se exponía la grave carencia de médicos cualificados en el campo de la medicina del trabajo y el medio ambiente (IOM 1993). M uchos de los nuevos programas de residencia recurrieron a los centros hospitalarios para la formación. U na gran parte de los futuros especialistas de EE.UU. recibirá su formación clínica en los centros hospitalarios académicos de medicina del trabajo y el medio ambiente.

\section{Apoyo organizativo para los centros hospitalarios}

Los centros hospitalarios académicos no suelen prestar servicios periódicos rentables de salud de los trabajadores como los que realizan los prestadores contractuales, por lo que el apoyo institucional es fundamental para mantener estos programas. Varios organismos públicos han desempeñado un papel importante. Como ya se ha señalado, el NIOSH ha prestado apoyo a los programas de residencia de medicina del trabajo a través de los consorcios de formación del Educational Resource C entre y posteriormente a través de subvenciones a la formación. EI N ational Institute for Environmental H ealth Sciences (N IEHS) ha prestado apoyo de investigación y formación a los programas académicos de medicina del trabajo. Muchos de los centros hospitalarios más importantes están asociados da los centros de investigación sobre salud medioambiental apoyados por el NIEHS. LOS centros hospitalarios apoyan a estos centros identificando las poblaciones para las investigaciones clínicas y epidemiológicas. EI NIEHS estableció también a finales del decenio de 1980 el programa de subvenciones Environmental and Occupational Medicine Academic Award, para prestar apoyo a las facultades de medicina en la formación del profesorado en este campo, apoyo que han recibido una parte sustancial de las facultades que actualmente cuentan con centros hospitalarios. La Agency for Toxic Substances and Disease Registry (ATSDR), creada por la Ley de Reacción, Indemnización y Responsabilidad Medioambiental (conocida como "Superfund") de 1980, que regula las evaluaciones de salud medioambiental y la mejora de la formación de los profesionales en la evaluación de sustancias peligrosas, ha prestado un apoyo esencial al desarrollo de programas y a las actividades conexas de formación de profesionales a medida que muchos centros hospitalarios han comenzado a tratar cuestiones de salud medioambiental y profesional.

Varios estados tienen programas de apoyo a servicios sanitarios ocasionales. El mayor de ellos es el denominado University of California Centres for 0 ccupational and Environmental $\mathrm{H}$ ealth, en virtud del cual se establecieron centros de este tipo en cinco campus universitarios que incluyen programas interdisciplinarios de investigación, formación y servicios clínicos. Varios estados más (por ejemplo, los de $\mathrm{N}$ ew Jersey, O regon, M ichigan y Washington) apoyan también estos programas a través de las facultades estatales de medicina o las 
escuelas de salud pública. EI Estado de Nueva York ha creado una red estatal de centros hospitalarios de salud profesional y medioambiental que permite evaluar a las personas con problemas médicos profesionales o medioambientales potenciales aun en el caso de que no puedan pagar los servicios. Estos centros han desarrollado un sistema de bases de datos comunes para que la red opere como sistema de vigilancia de enfermedades profesionales en el estado.

Las asociaciones profesionales también han prestado un apoyo decisivo al aumento de los centros hospitalarios académicos. L os miembros de la American Public H ealth Association (APHA) prestaron un atención temprana a la comunicación entre los nuevos centros hospitalarios y su apoyo fortaleció la orientación de estos centros hacia la prevención y la salud pública. En 1987, los miembros del comité de centros hospitalarios de medicina del trabajo de la APHA constituyeron una nueva organización, la Association of O ccupational and Environmental Clinics (AOEC), como "red de instalaciones hospitalarias dedicadas a la investigación y la formación, así como a la prevención y tratamiento de enfermedades profesionales y medioambientales" (AOEC 1995). La AOEC se ha convertido en una red nacional de más de 50 centros hospitalarios, la mayoría de ellos de base académica, a la que pertenece la mayor parte de los principales centros hospitalarios académicos. La Asociación mejora la comunicación entre los centros hospitalarios, establece directrices para la asistencia de calidad y los derechos de los pacientes, busca financiación para las actividades profesionales y educativas, y está desarrollando una base de datos que permite reunir y analizar sistemáticamente los datos de los centros hospitalarios.

\section{Características de los programas}

Como ya se ha señalado, la principal actividad de los centros hospitalarios consiste en detectar enfermedades relacionadas con el trabajo y medioambientales, más que prestar servicios periódicos de salud a los trabajadores. Esta orientación distingue sus programas de los que prestan los servicios contratados por las empresas (Rosenstock 1982). Los profesionales de estos centros hospitalarios tienen como clientes principales a los trabajadores potencialmente afectados y a los miembros de la comunidad, no a las empresas. Los médicos participan en los aspectos médicos, sociales, económicos y jurídicos de los problemas de los pacientes. EI cociente paciente/ prestador es bajo: Ios centros hospitalarios, centrados en casos médicos relativamente poco frecuentes pero complejos, requieren visitas más largas y minuciosas fuera de las horas de funcionamiento normal.

Debido a las actividades de investigación y enseñanza, los centros médicos académicos suelen operar a tiempo parcial, ofreciendo un cierto número de sesiones semanales. Según un directorio de los 41 centros hospitalarios miembros de la AO EC, había entre 1 y 13 médicos por centro, con un $85 \%$ de centros que tenían entre dos y seis médicos (AO EC 1985). O tra característica es que los centros utilizan equipos interdisciplinarios de profesionales para mejorar la evaluación de la exposición y la toxicidad y para prestar servicios de prevención y educación. Por ejemplo, de los 41 centros del directorio, la mayoría disponían de higienistas industriales (32), mientras que aproximadamente la mitad tenían toxicólogos (22), trabajadores sociales (19), educadores sanitarios (19) y epidemiólogos (24) entre su per sonal profesional (AOEC 1995)

Los centros hospitalarios ponen el acento en la orientación del servicio a la comunidad. La mayoría de ellos establecen programas de prestaciones sociales, tanto para constituir una red de remisión para la identificación de pacientes como para impartir educación a los profesionales de la salud, los trabajadores y los residentes en la comunidad. Muchas clínicas establecen comités asesores para los trabajadores y la comunidad con el fin de ofrecerles una panorámica de las actividades de los centros hospitalarios.

M uchos centros hospitalarios tienen bases de datos informáticas que permiten obtener y analizar datos relativos a sus experiencias. Estas bases incluyen la fuente de remisión del paciente, el código del puesto y de la industria de todos los trabajos (0, al menos, los más actuales o importantes), el nombre de la empresa, las exposiciones, las enfermedades relacionadas con el trabajo, la evaluación de las conexiones entre las exposiciones y el diagnóstico, y datos demográficos (Rosenstock, Daniell y Barnhart 1992). H asta el momento, los datos reunidos por los centros hospitalarios no han estado bien coordinados, pero la AOEC ha desarrollado un sistema de bases de datos comunes que permitirá reunirlos de forma más sistemática en el futuro.

\section{Servicios}

Los tipos de pacientes de los centros hospitalarios varían según los riesgos comunitarios y de las empresas de la región, aun en mayor medida que entre los servicios contractuales, los cuales tienden a centrarse en las necesidades de la empresa. Estos centros suelen ofrecer servicios de diagnóstico especializado, dependiendo de sus líneas de investigación y de especialización. L os pacientes acuden a ellos por los conocimientos especializados y la reputación del programa académico. Suelen presentar una enfermedad ya en curso, y desean saber si ésta tiene su causa en el trabajo o en un factor medioambiental, o bien acuden con un caso de exposición potencialmente tóxica que les lleva a desear conocer si pueden producirse consecuencias adversas.

Los diagnósticos de medicina del trabajo más habituales en los centros hospitalarios son, según un reciente directorio de la AO EC (AO EC 1995) los siguientes: asma, enfermedades pulmonares relacionadas con el amianto y otras; síndrome del túnel carpiano; esguinces recidivantes; patologías musculoesqueléticas y enfermedades dermatológicas. U nos pocos centros mencionan como diagnósticos habituales los problemas neurológicos y muy pocos han tratado a pacientes con lesiones agudas. LoS problemas de exposición en el trabajo más habitualmente mencionados son los relativos al amianto, el plomo y otros metales pesados, las sustancias químicas y los disolventes.

La distribución de los diagnósticos medioambientales habituales es diferente a la de los problemas profesionales, apareciendo como diagnósticos más comunes el síndrome de sensibilidad química múltiple y el "síndrome del edificio enfermo", o síntomas debidos a problemas con el aire en el interior del inmueble. Los problemas de exposición medioambiental más comúnmente mencionados se refieren a los plaguicidas, el plomo, las sustancias químicas y los residuos peligrosos en las comunidades.

Los pacientes acuden remitidos por diversas fuentes (por iniciativa propia o enviados por las empresas, sindicatos, organismos de salud pública, médicos, abogados y por los sistemas de indemnización. En algunos casos, lo que buscan es una evaluación médica independiente y de alta calidad. En muchos casos, la remisión va dirigida a determinados médicos (a menudo profesores de las facultades) de reconocida cualificación, en ocasiones localizados tras una búsqueda de ámbito nacional o incluso internacional.

Los centros hospitalarios académicos ofrecen otros servicios además de la evaluación de enfermedades profesionales y medioambientales. Muchos de ellos realizan exploraciones médicas selectivas de trabajadores a instancia de las empresas, sindicatos 0 grupos de trabajadores preocupados por determinadas exposiciones, tales como las de amianto o plomo. También realizan las exploraciones médicas de vigilancia impuestas por la OSH A o por las normas estatales. La mayoría 
actúan como centros regionales, atendiendo consultas clínicas de trabajadores, residentes de la comunidad y médicos, normalmente por teléfono.

Además de los servicios clínicos, su personal interdisciplinario realiza evaluaciones de riesgos en el lugar de trabajo y en la comunidad, que en ocasiones incluyen el control de exposiciones. Prácticamente todos los centros ofrecen formación de prevención y educación sanitaria para personas físicas, comunidades y profesionales de la salud.

\section{El futuro}

El futuro de los centros hospitalarios académicos de Estados Unidos puede verse afectado por los cambios globales de los sistemas de indemnización y asistencia médica a los trabajadores. Las evaluaciones médicas independientes de los problemas profesionales y medioambientales seguirán siendo necesarias, pero muchos estados han puesto en práctica o están estudiando la adopción de cambios en las normas de indemnización a los trabajadores para restringir su libertad de opción con respecto a la evaluación médica. También existe una tendencia a integrar la asistencia médica de las enfermedades profesionales y no profesionales en un único prestador. Los centros hospitalarios tendrán que reaccionar ante el aumento de la asistencia gestionada en el campo de la salud en el trabajo, pues su planteamiento independiente puede verse mayoritariamente excluido de un sistema de indemnización a los trabajadores más gestionado.

Para reaccionar ante estos cambios en el sistema de asistencia médica, algunos centros hospitalarios académicos están estableciendo relaciones con entidades contratadas por las empresas para actuar como institutos de remisión especializada, en tanto que aquéllas se hacen cargo de los casos periódicos y del tratamiento médico. Posiblemente tengan que establecer relaciones con centros médicos prestadores de asistencia primaria, de asistencia de urgencias, de servicios de rehabilitación y de otras especialidades con el fin de dar un carácter más integral a los servicios globalmente prestados por la asistencia sanitaria del trabajo y otros servicios de asistencia médica. Este enfoque permitirá aumentar la estabilidad financiera mediante el establecimiento de contratos, además de cobrar por cada servicio, e impartir formación práctica a los médicos, muchos de los cuales ejercerán en estas instalaciones.

Los centros hospitalarios académicos se enfrentan con el reto de mantener su orientación independiente al pasar a funcionar como sistema integral de asistencia gestionada financiada por las empresas. La opción de las consultas independientes se mantendrá en cierta medida debido a las pautas regionales y nacionales de remisión basadas en la reputación de un determinado centro hospitalario. Los médicos clínicos continuarán también atendiendo a consultas de personas individuales y abogados en el ámbito de la responsabilidad civil, que está evolucionando en EE.UU., si bien más lentamente que el sistema de asistencia médica. N o obstante, y pese a estas fuentes de apoyo, estos centros seguirán necesitando apoyo de los organismos públicos y las organizaciones profesionales para continuar desempeñando su papel de consultores, investigadores y formadores médicos independientes. El futuro de muchos de ellos dependerá de que los gobiernos federal y estatal continúen apoyando estos programas.

\section{- LOS SERVICIOS DE SALUD EN EL TRABAJO EN JAPON}

Ken Takahashi

\section{Políticas y legislación}

En Japón, el único organismo administrativo en materia de salud en el trabajo es el M inisterio de Trabajo y la norma básica es la Ley de Seguridad y Salud Industrial, promulgada en 1972 (que denominaremos "Ley de Salud" a efectos de este artículo). La Ley de Salud y sus reglamentos de ejecución establecen la obligación de la empresa de prestar servicios de salud y seguridad en el trabajo, incluida la designación de un médico de salud en el trabajo (M ST), dependiendo del tamaño del lugar de trabajo. Se obliga a todos lugares de trabajo con 50 o más trabajadores a designar un MST (que deberá ser a tiempo completo en los lugares de trabajo con más de 1.000 trabajadores). Además, todos los lugares de trabajo, con independencia de su tamaño, están obligados a ofrecer exploraciones médicas a sus trabajadores, tanto previas a la colocación como periódicas de carácter general para los contratados a tiempo completo, así como específicas para aquéllos de estos últimos que realizan "tareas de riesgo". EI nivel de cumplimiento de estos requisitos suele ser bueno, aunque la tasa de cumplimiento tiene cierta correlación con el tamaño del lugar de trabajo.

\section{Modelos de organización y de prestación de servicios}

Los modelos de organización y de prestación de servicios varían considerablemente según el tamaño del lugar de trabajo. Los de gran escala suelen disponer de servicios de salud plenos en sus instalaciones, tales como un departamento de administración de salud, un departamento de promoción de la salud o un centro hospitalario. Estas unidades funcionales pueden revestir la forma de instituciones independientes, especialmente si se centran en actividades curativas, pero en muchos casos están subordinadas a otros departamentos, como el de trabajo o el de asuntos generales. En algunos casos, el servicio de salud en el trabajo es gestionado por una asociación de seguros médicos. EI M ST a tiempo completo suele ocupar un puesto directivo, en ocasiones nominalmente equivalente a los de ejecutivo. EI personal no facultativo puede estar integrado por enfermeras generales, enfermeras del trabajo y técnicos médicos y de radiología.

En contraposición, muchos lugares de trabajo de pequeñas dimensiones carecen de los recur sos humanos y materiales necesarios para realizar funciones de salud en el trabajo. En este sector se contrata a M ST a tiempo parcial entre médicos generales privados, médicos de hospitales o universidades y médicos de salud en el trabajo, independientes o no. Los M ST a tiempo parcial realizan una variada gama de actividades de salud en el trabajo, dependiendo de las necesidades del lugar de trabajo y de su propia cualificación. Las organizaciones de salud en el trabajo (OST), que prestan servicios de salud en el trabajo con ánimo de lucro, han desempeñado un papel esencial en la prestación de estos servicios a los pequeños lugares de trabajo. LoS servicios que pueden adquirirse de estas organizaciones cubren la realización y seguimiento de diversas exploraciones sanitarias, la realización de mediciones medioambientales e incluso el envío de MST y enfermeras. Muchos pequeños lugares de trabajo designan un MST a tiempo parcial y contratan una OST para atender necesidades específicas que puedan surgir.

\section{Actividades y contenido}

La Fundación para la Promoción de la Salud en el Trabajo, una organización sin ánimo de lucro dependiente del M inisterio de Trabajo, viene realizando encuestas de ámbito nacional mediante cuestionarios centrados en las actividades de los M ST a tiempo completo y a tiempo parcial. Según la encuesta de 1991, a la que 
contestaron 620 MST a tiempo completo, el tiempo medio de asignación más largo correspondía a las actividades curativas (495 horas/ año), seguidas por las exploraciones sanitarias periódicas (136) y las consultas de salud (107). El tiempo asignado a la vigilancia del lugar de trabajo fue de una media de 26,5 horas/ año. Los 340 MST a tiempo parcial que respondieron también a la encuesta indicaron un tiempo medio asignado proporcionalmente menor al de los M ST a tiempo completo. No obstante, una observación detallada muestra que las actividades de los M ST a tiempo parcial varían ampliamente en cantidad y calidad dependiendo de varios factores interrelacionados:

1. El tamaño y características del lugar de trabajo

2. El trabajo principal y otros compromisos del médico

3. La dedicación al trabajo.

\section{Recursos de personal}

No hay disposiciones legales acerca de las cualificaciones de los M ST: simplemente, pueden designarse (sean a tiempo parcial 0 completo) "entre los médicos" (según la Ley de Salud). En el año 1995, se calcula que el número total de médicos era de 225.000, con un incremento anual de unos 5.000 (es decir, un aumento de 7.000 licenciados en las 80 facultades de medicina del Japón y una disminución de 2.000 médicos por fallecimiento). Se calcula que en 1991 había 34.000 M ST (2.000 a tiempo completo y 32.000 a tiempo parcial), lo que equivalía a un $16,6 \%$ del número total de médicos (205.000). Además, varios miles de enfermeras de todo el país desempeñan un papel activo en el campo de la salud en el trabajo, aunque no existe una definición jurídica de esta figura. De entre los trabajadores se selecciona un supervisor de salud, que según la Ley de la Salud es la persona encargada de las cuestiones técnicas relativas a la salud. EI M ST se relaciona estrechamente con el supervisor de salud, a quien, según la ley, puede "dar orientaciones o consejos".

\section{Administración}

Dentro del M inisterio de Trabajo, la salud en el trabajo está directamente gestionada por el Departamento de Seguridad y Salud Industrial, dependiente de la Oficina de Normas de Trabajo. Entre las unidades funcionales de la O ficina a escala local se incluyen las $\mathrm{O}$ ficinas de $\mathrm{N}$ ormas de Trabajo de las prefecturas (existen 47) y las 0 ficinas de Inspección de $\mathrm{N}$ ormas de Trabajo (existen 347) distribuidas por todo el país y con una plantilla total de en torno a 3.200 "inspectores", 390 "funcionarios especializados en seguridad industrial" y 300 "funcionarios especializados en salud industrial".

EI M inisterio de Trabajo ha puesto en práctica planes quinquenales consecutivos de prevención de accidentes de trabajo, de los cuales el más reciente (el octavo) se vinculó al lema "conseguir una vida de trabajo más sana y segura tanto en su dimensión física como mental". En consecuencia, el M inisterio está elaborando un plan de Promoción Total de la Salud (PT S), según el cual el MST prescribe un menú de ejercicios para cada trabajador a partir de los datos de medición de la salud. El gobierno organiza programas de formación con representantes de la empresa para desarrollar las cualificaciones necesarias. EI gobierno reconoce también los méritos de los OST capaces de prestar servicios relativos a la puesta en práctica de la PT S.

\section{Sistemas de financiación}

Cuando los servicios de salud en el trabajo se prestan en las instalaciones de la empresa, como en el caso de los grandes lugares de trabajo, suelen revestir la forma de un departamento interno que, en consecuencia, queda sujeto a las restricciones financieras de la empresa. 0 tra variante es la existencia de un servicio adscrito pero autosuficiente (centro hospitalario u OST) que emplea personal de salud en el trabajo. En algunos casos, este servicio está gestionado por una asociación corporativa de seguros de salud. M uchos lugares de trabajo pequeños, que carecen de los recursos humanos, económicos y materiales necesarios pero están obligados a designar un M ST a tiempo parcial, suelen contratar médicos generales, médicos de hospitales o de universidades, u otros. Como ya se ha señalado, el M ST a tiempo parcial desempeña una gama variable de actividades de salud en el trabajo, dependiendo de las necesidades del lugar y de su cualificación profesional. Las obligaciones del lugar de trabajo, tales como la realización de exploraciones sanitarias periódicas a todos los trabajadores, suelen exceder del tiempo disponible del médico contratado y de su disposición, lo que produce un desfase entre la oferta y la demanda que suele ser cubierto por los O ST.

\section{Investigación}

La Sociedad Japonesa de Salud en el Trabajo (Japan Society for O ccupational Health, JOSH) es una asociación académica compuesta por M ST, investigadores y enfermeras de salud en el trabajo, que actualmente supera los 6.000 miembros y está creciendo a un ritmo rápido. Celebra reuniones científicas anuales a escala nacional y regional, y recientemente ha comenzado a publicar un periódico científico en lengua inglesa titulado J ournal of $\mathrm{O}$ ccupational $\mathrm{H}$ ealth. Algunos institutos básicos de investigación son el Instituto Nacional de Salud Industrial (publicación periódica: Industrial $\mathrm{H}$ ealth, bianual, en lengua inglesa), el Instituto de Ciencias del Trabajo (publicación periódica: J ournal of Science of $L$ abour, mensual, en japonés e inglés), la A sociación Japonesa de Seguridad y Salud Industrial (publicaciones: Industrial Safety Yearbook y otras) y el Instituto de Ciencias E cológicas Industriales de la U niversidad de Salud Profesional y M edioambiental (publicación periódica: J ournal of U OEH , bimensual, en japonés e inglés).

\section{Evolución futura}

EI M inisterio de Trabajo acaba de emprender un plan global dirigido a la prevención de la enfermedad y la promoción de la salud de los trabajadores del país, que prevé establecer centros de salud en el trabajo (CST) financiados por el estado a escala de prefecturas y regiones de todo el país en un plazo de ocho años. $\mathrm{H}$ ay 47 prefecturas, en cada una de las cuales habrá un centro con una plantilla de 15 personas, incluido un médico a tiempo completo administrativo y tres o cuatro médicos a tiempo parcial. La función básica de los centros será proporcionar formación y difundir información a los M ST que trabajen en el entorno. Se prevén 347 centros regionales para el conjunto del país, asociados a las divisiones locales de la A sociación M édica Japonesa (Japan M edical Association, JM A). Estos centros estarán orientados a la prestación de servicios de salud en el trabajo al sector insuficientemente atendido, es decir, los trabajadores de las pequeñas empresas. El presupuesto inicial para el ejercicio fiscal de 1993 fue de 2.300 millones de yenes ( 20 millones de dólares) por el establecimiento de seis CST de prefectura y 50 regionales. Ambos tipos de CST operarán interrelacionados entre sí y también con la administración, la JM A, los hospitales de trabajadores, etc. La colaboración entre estas diversas instituciones será la clave del éxito de este plan.

\section{LA PROTECCION DE LOS TRABAJADORES EN LA FEDERACION RUSA: LEGISLACION Y PRACTICAS}

ENCICLOPEDIA DE SALUDY SEGURIDAD EN EL TRABAJO 


\section{Nikolai F. Izmerov e Igor A. Fedotov}

La organización de la protección de los trabajadores heredada de los tiempos anteriores por la Federación Rusa constituye una estructura jerárquica construida en el seno de la anterior sociedad y que opera mediante rigurosos controles administrativos junto con la planificación y la asignación de recursos. Los recientes cambios en los sistemas económicos y sociales del país producidos por la transición a una economía de mercado han hecho necesaria la revisión de la legislación de trabajo vigente y la reorganización de todo el sistema de protección de los trabajadores, especialmente en lo relativo a la prestación de servicios de salud en el trabajo a la población activa.

\section{Legislación de trabajo}

La protección de los trabajadores en Rusia es un sistema complejo dirigido a garantizar unas condiciones de trabajo sanas y seguras, lo que incluye medidas jurídicas, socioeconómicas, organizativas, preventivas, de seguridad, de higiene, técnicas y de otros órdenes.

La legislación de trabajo de la Federación Rusa comprende ciertas disposiciones de la Constitución Rusa, el Código Laboral, la Ley Básica de Protección de los Trabajadores y legislación de habilitación constituida por actos jurídicos, reglamentos y directivas, así como directrices, ordenanzas, normas estatales y otras normas aprobadas por las autoridades competentes de la Federación Rusa y de las repúblicas que la integran.

El artículo 37 de la Constitución de la Federación Rusa establece que todos los ciudadanos tienen derecho al trabajo en un medio ambiente que cumpla los requisitos de salud y seguridad, a una remuneración no discriminatoria y no inferior al mínimo establecido por el Gobierno Federal y a la protección frente al desempleo.

La Ley Básica de Protección de los Trabajadores, promulgada en agosto de 1993, contiene disposiciones que garantizan el derecho de los trabajadores a la protección de su salud. También regula las relaciones laborales entre la empresa y los trabajadores en todas las ramas de la economía, con independencia del tipo de propiedad. Según su artículo 4, los trabajadores tienen derecho a:

- unas condiciones de trabajo sanas y seguras;

- unos lugares de trabajo protegidos frente a los peligros de trabajo que puedan causar accidentes o enfermedades profesionales o reducir la capacidad de trabajo;

- recibir una indemnización por las lesiones del trabajo y las enfermedades profesionales;

- recibir información sobre los peligros del trabajo y los riesgos sanitarios existentes, así como sobre las medidas adoptadas por la empresa para controlarlos;

- recibir equipos personales de protección a cargo de la empresa.

El artículo 9 de la Ley Básica de Protección de los Trabajadores obliga a la empresa a establecer unas condiciones de trabajo sanas y seguras, mientras que el artículo 16 establece sanciones económicas en caso de incumplimiento de esta obligación o de deterioro de la salud del trabajador por causa de exposiciones, lesiones o enfermedades del trabajo.

El C apítulo 10 del Código de Trabajo de la Federación Rusa se refiere a la salud y la seguridad en el trabajo. El artículo 139 establece la responsabilidad de la dirección por el establecimiento de condiciones de trabajo sanas y seguras mediante la utilización de medidas de prevención de accidentes y procedimientos de seguridad actualizados que garanticen el adecuado control de los peligros y la prevención de los accidentes y las enfermedades del trabajo.
El artículo 143 de esta misma norma exige a la dirección de la empresa dotar a los lugares de trabajo de maquinaria y equipos seguros y establecer unas condiciones de trabajo adecuadas a las normas técnicas e higiénicas, así como a las reglamentaciones intersectoriales y sectoriales de salud y seguridad en el trabajo desarrolladas y aprobadas con arreglo a la vigente legislación de trabajo.

L as reglamentaciones intersectoriales de salud y seguridad en el trabajo, que cubren todas las ramas de la economía, imponen exigencias jurídicas aplicables a todas las empresas, con independencia del tipo de actividad económica (por ejemplo, las normas de higiene SN 245-71 para el diseño de empresas industriales). Estas reglamentaciones son aprobadas por el Consejo de Ministros de la Federación Rusa o por otras autoridades competentes a solicitud de éste.

Las reglamentaciones sectoriales de salud y seguridad en el trabajo establecen requisitos para diversos procesos económicos, tipos de trabajos y equipos de ramas determinadas de la economía (por ejemplo, normas de seguridad para las actividades de soldadura en la construcción o para el manejo de grúas de carga en los muelles). Estas reglas tienen en cuenta las características específicas de cada rama de actividad y son adoptadas por los ministerios correspondientes, los comités estatales, los organismos estatales de supervisión y otras autoridades competentes.

Los ministerios también promulgan directrices, ordenanzas y normas técnicas de salud y seguridad en el trabajo en sus respectivas áreas de actividad económica. O tras ordenanzas, tales como las que obligan a la empresa a impartir formación interna sobre salud y seguridad en el trabajo o a cumplir los requisitos de seguridad, están sujetas a consulta con las organizaciones de empresas y de trabajadores.

Las empresas están obligadas a proporcionar a los trabajadores ropas o uniformes adecuados y equipos de protección personal, en los términos establecidos en las reglamentaciones. También deben realizar exploraciones sanitarias periódicas para ciertas categorías de trabajadores, tales como los que realizan trabajos pesados o peligrosos y los trabajadores del transporte, entre otros.

Junto con las obligaciones y responsabilidades de la empresa (cuando es propiedad del Estado, es la dirección la que representa a la empresa), la legislación de trabajo impone a los trabajadores la obligación de cumplir las exigencias de salud y seguridad establecidas en los correspondientes reglamentos y ordenanzas. Por ejemplo, deben participar en la formación sobre salud y seguridad, mantener y utilizar adecuadamente los equipos de protección personal, recibir formación en prevención de incendios, realizar el mantenimiento de la maquinaria y los equipos que utilicen y mantener limpio su lugar de trabajo.

A nivel de la empresa, la supervisión cotidiana de las normas y requisitos de salud y seguridad es responsabilidad de la oficina de salud y seguridad, unidad integrada en la empresa y que disfruta de estatuto independiente. Entre sus principales funciones se encuentran la evaluación de los peligros del trabajo, la valoración de riesgos, la recomendación de medidas de seguridad y control, la prevención de accidentes laborales, el análisis de las causas de los accidentes en el trabajo, la cooperación con otras unidades de la empresa para la prevención de accidentes y lesiones del trabajo, el control de la maquinaria y equipos y la puesta en práctica de programas de seguridad. La oficina tiene autoridad para detener una determinada maquinaria, proceso 0 tarea que pueda poner en peligro la vida o la salud de los trabajadores.

Las pequeñas empresas no suelen estar en condiciones de establecer una oficina de salud y seguridad en el trabajo (ver "Servicios de salud en el trabajo en la pequeña empresa"). EI 
artículo 8 de la Ley Básica de Protección de los Trabajadores otorga a estas empresas el derecho a consultar a especialistas externos en la materia y a recurrir a sus servicios mediante contrato mercantil.

Con el fin de dotar de mayor eficacia a las reglamentaciones que regulan la protección de los trabajadores en la Federación Rusa, existe un sistema de establecimiento de normas estatales de salud y seguridad en el trabajo (GOST). Estas normas son jurídicamente obligatorias y las autoridades estatales competentes velan por su cumplimiento.

En conjunto, hoy existen más de 2.000 reglamentos, directivas, ordenanzas, normas de higiene y normas estatales sobre salud y seguridad, elaborados en su mayoría por los distintos ministerios, comités estatales y otras autoridades de la antigua URSS. Estas normas siguen en vigor, aunque 700 de ellas son anteriores a 1981 y tenían un período de vigencia previsto de tan sólo cinco años. La mayoría de ellas necesitan ser reconsideradas y reformadas a la luz de la nueva situación económica.

En el marco de la reorganización del sistema de protección de los trabajadores de Rusia, el Decreto Presidencial de 4 de mayo de 1994 creó la Inspección Federal de Trabajo (R ostrudinspekcija), dependiente del $\mathrm{M}$ inisterio de Trabajo y encargada de velar por el cumplimiento de la legislación de trabajo en todos los territorios de la Federación Rusa. Así se estableció el sistema de control y supervisión estatal en el ámbito de la protección de los trabajadores (anteriormente, el control del cumplimiento de la legislación de trabajo era responsabilidad de los inspectores sindicales). En todas las regiones que integran la Federación se designarán Inspectores Regionales, con una estructura de red, hasta completar la estructura organizativa de la Inspección Federal de Trabajo.

\section{Legislación sanitaria}

La legislación sanitaria de la Federación Rusa es un instrumento para la ejecución de la política estatal de salud pública y bienestar epidemiológico. EI Servicio Higiénico y Epidemiológico Federal de la Federación Rusa realiza sus actividades con arreglo a la legislación sanitaria y desempeña un importante papel en las actividades de promoción de la salud y la seguridad en el trabajo y la salud pública en general.

La legislación sanitaria está integrada por la Ley de Bienestar H igiénico y Epidemiológico de la Población, promulgada el 13 de abril de 1992 por el Consejo Supremo de la Federación, y por las correspondientes directivas y reglamentos promulgados por las autoridades competentes en virtud de esta L ey.

El artículo 1 de la Ley define el término bienestar higiénico y epidemiológico como "un estado de salud pública y de medio ambiente en el que no existan influencias peligrosas de factores medioambientales sobre la salud de la población y sí condiciones favorables a la realización de actividades creativas".

La legislación sanitaria establece normas higiénicas para las empresas, nuevos tipos de maquinaria y equipos y nuevos procesos tecnológicos y materiales. También impone el cumplimiento de las normas y normas vigentes.

La supervisión higiénica del estado tiene dos vertientes:

- La supervisión higiénica preventiva incluye el cumplimiento de las normas higiénicas en el diseño, construcción y reconstrucción de empresas, la introducción de nuevas tecnologías, la fabricación de maquinaria y equipos y el control del medio ambiente.

- La supervisión higiénica periódica comprende la vigilancia sistemática del medio ambiente de trabajo de la empresa empleando métodos higiénicos de control de la exposición, toma de muestras y análisis. También incluye el control de la aplicación de normas higiénicas en la manipulación de maquinaria y equipos y el mantenimiento de la empresa en general.

El artículo 9 de la Ley obliga a las empresas a cumplir la legislación sanitaria sujetándose a las normas higiénicas vigentes y controlando el medio ambiente laboral, así como a evitar la polución del medio ambiente y a desarrollar y poner en práctica programas de salud y seguridad dirigidos a la mejora del medio ambiente de trabajo y a la prevención de accidentes y lesiones de trabajo.

El capítulo 4 de la Ley distingue varios grados de responsabilidad por infracción de la legislación sanitaria rusa. L as personas responsables del incumplimiento están sujetas a responsabilidades civiles y penales (artículo 27).

El capítulo 5 establece las funciones de la supervisión higiénica y epidemiológica estatal, entre las que se encuentran:

- la evaluación y pronóstico de la salud medioambiental de la población;

- la detección de las enfermedades contagiosas, las enfermedades e intoxicaciones no contagiosas pero generalizadas, así como sus causas;

- la elaboración de medidas obligatorias que garanticen el bienestar higiénico y epidemiológico de la población;

- la supervisión del cumplimiento de la legislación sanitaria y las normas higiénicas por parte de las empresas;

- la persecución de las organizaciones y personas que incumplan la legislación sanitaria y las normas higiénicas;

- la recopilación de estadísticas sobre enfermedades contagiosas, enfermedades profesionales y enfermedades e intoxicaciones no contagiosas pero generalizadas derivadas de factores medioambientales adversos.

Consecuencia de los cambios estructurales en las pautas de empleo, la Ley obliga, por primera vez, a cumplir lo relativo a la legislación sanitaria, las normas higiénicas, la calidad higiénica de los productos y la prevención de la polución medioambiental no sólo a la dirección de la empresa y a sus trabajadores, sino también a los trabajadores autónomos a tiempo completo (artículo 34).

Según el artículo 32 de la Ley, al Servicio Higiénico y Epidemiológico Federal de la Federación Rusa le corresponde la responsabilidad de velar por el cumplimiento de la legislación sanitaria. Además, el Consejo de M inistros aprobó la Directiva no 375, que reorganiza las antiguas estaciones higiénicas y epidemiológicas en Centros de Supervisión H igiénica y Epidemiológica Estatal (CSHES), presentes en todo el territorio de la Federación.

La nueva legislación sanitaria es un avance crucial en la regulación jurídica del bienestar higiénico y epidemiológico de la población, como lo es también la drástica reestructuración del Servicio para su aplicación. Se ha asignado recientemente al Servicio el carácter de Servicio Federal, de modo que ahora forma parte de los organismos federales de control estatal. En consecuencia, se ha creado el Comité Federal de la Federación Rusa para la Supervisión Higiénica y Epidemiológica para supervisar globalmente este Servicio.

El Servicio Higiénico y Epidemiológico Federal está compuesto por los siguientes organismos:

- el Comité Federal de la Federación Rusa para la Supervisión H igiénica y Epidemiológica;

- los Centros de Supervisión H igiénica y E pidemiológica Estatal (CSHES) en los ámbitos republicano, regional, municipal, de distrito y local;

- Ios CSHES lineales para el transporte aéreo, marítimo y fluvial;

- el Centro de Información y Análisis de la Federación Rusa 
- Ios institutos médicos y centros de formación especializada para educación y formación de expertos destinados a los CSHES;

- Ios institutos de investigación especializados en higiene y epidemiología del trabajo;

- los centros médicos especializados en la elaboración de vacunas;

- los centros de desinfección.

Según la Directiva no 375, entre las principales funciones del Servicio H igiénico y Epidemiológico Federal se encuentran:

- velar por el cumplimiento de la legislación sanitaria;

- elaborar estándares y normas higiénicas;

- elaborar programas federales, republicanos, regionales y locales de protección y promoción de la salud;

- suministrar información técnica a las autoridades, empresas, organizaciones de empresas y de trabajadores y demás instituciones implicadas en las actividades de salud y seguridad en el trabajo, incluida la información sobre trastornos higiénicos y epidemiológicos en el país, estadísticas sobre morbilidad de la población e interpretación de documentos jurídicos relativos a la legislación sanitaria;

- coordinación de las actividades de empresas, organizaciones de empresas y de trabajadores, asociaciones científicas y otras instituciones y organizaciones con respecto al desarrollo y la puesta en práctica de normas higiénicas.

Los especialistas de los CSH ES pueden visitar e inspeccionar las empresas para velar por el cumplimiento de la legislación sanitaria. E stos especialistas investigan las causas de las enfermedades del trabajo y detectan peligros profesionales y medioambientales potenciales que puedan causar enfermedades, lesiones e intoxicacioanes relacionadas con el trabajo. El supuesto ideal es el de colaboración con los médicos y enfermeras del trabajo de los servicios de salud en el trabajo.

La financiación de los CSHES proviene directamente del presupuesto federal de la Federación Rusa. Además, los CSH ES pueden prestar servicios y asesoramiento especializados mediante contrato a las empresas y a otros agentes que puedan necesitar de sus conocimientos especializados. EI Comité Federal de Supervisión H igiénica y Epidemiológica aprueba anualmente la lista de servicios especializados a prestar por los CSHES.

La legislación sanitaria se impone mediante la aplicación de directivas, reglamentos, ordenanzas, estándares y requisitos, entre los que se incluyen los siguientes:

- reglamentos, estándares y requisitos higiénicos dirigidos a establecer condiciones de trabajo sanas y seguras, proteger el medio ambiente y promover la salud pública en general;

- normas de higiene que establecen límites de exposición en el trabajo y niveles máximos permisibles de peligros potenciales en los lugares de trabajo y el medio ambiente;

- normas de higiene que establecen criterios para factores específicos que puedan afectar a la salud de las generaciones futuras;

- reglamentaciones de higiene uniformes que combinen distintas normas.

\section{La protección de la salud de los trabajadores}

El artículo 41 de la Constitución de la Federación Rusa establece que todos los ciudadanos tienen derecho a la protección de la salud y la asistencia médica. Las nuevas leyes prevén el establecimiento de sistemas municipales y privados de asistencia sanitaria para complementar al sistema estatal. La asistencia sanitaria en los centros estatales y municipales es gratuita, financiada con cargo a fondos presupuestarios federales y locales, fondos de seguros sanitarios y otras fuentes.
La Ley de Bienestar Higiénico y Epidemiológico de la población incluye las siguientes disposiciones dirigidas a la protección de la salud de los trabajadores:

- Los trabajadores de las empresas deben pasar una exploración sanitaria previa a la colocación y exploraciones sanitarias periódicas.

- Las exploraciones sanitarias previas a la colocación y periódicas son obligatorias para todos los trabajadores expuestos a determinados peligros y trabajos de riesgo incluidos en una lista aprobada por el Comité Federal de Supervisión H igiénica y Epidemiológica y el M inisterio de Salud de la Federación Rusa, en consulta con las organizaciones representativas de las empresas y los trabajadores.

- Las empresas deben adoptar todas las medidas necesarias para realizar exploraciones sanitarias de todos los trabajadores.

U na característica del sistema de asistencia sanitaria del país es la introducción, en 1991, del seguro sanitario obligatorio, modificado en 1993. La Ley de Seguro Sanitario de los Ciudadanos de la Federación Rusa establece un nuevo modelo de seguro en virtud del cual las empresas aportan cuotas del 3,6 \% de la nómina total a las administraciones locales para cubrir las necesidades de seguro sanitario. En 1996, unos 40 millones de trabajadores estaban cubiertos por el Fondo Federal de Seguro Sanitario O bligatorio de la Federación Rusa. El objetivo principal del establecimiento de este seguro obligatorio era garantizar la financiación de la asistencia sanitaria en el sistema económico postsoviético basado en los principios de seguro, usando fondos aportados mediante contribuciones voluntarias y obligatorias. El seguro sanitario obligatorio estableció dos nuevos tipos de relaciones públicas en el sistema de asistencia sanitaria: la participación de los aseguradores, representados por las autoridades locales responsables de que el seguro sanitario cubra a los empleados públicos y a los desempleados, y la participación de los aseguradores industriales, representados por las empresas responsables de la cobertura de los trabajadores. Según el artículo 23 de la Ley de Salud y Bienestar Epidemiológico de la Población, las exploraciones de los trabajadores están incluidas en la lista de servicios cubiertos por el seguro sanitario obligatorio.

Con arreglo a la Ley Básica de Protección de la Salud de los Ciudadanos de la Federación Rusa, promulgada por el Consejo Supremo de la Federación el 22 de julio de 1993, los principios básicos de la protección de la salud son:

- respeto a los derechos humanos en el campo de la protección de la salud, que quedan garantizados por el gobierno;

- prioridad de la prevención;

- acceso universal a la asistencia social y sanitaria;

- protección social de los trabajadores en caso de discapacidad;

- responsabilidad del Estado, las autoridades competentes, las empresas, con independencia de su propiedad, y la dirección de las instituciones y organizaciones con respecto a la protección y promoción de la salud de los trabajadores.

La Ley Básica perfila las relaciones entre la población activa y las autoridades competentes, las empresas del estado, las del sector privado y los centros de asistencia sanitaria de titularidad estatal, municipal y privada en materia de protección y promoción de la salud.

En la práctica, los servicios de salud en el trabajo se prestan a los trabajadores en los centros públicos (hospitales y policlínicas) ubicados cerca de su residencia y en los servicios especializados en salud en el trabajo ubicados en su mayor parte en las grandes empresas. El objetivo de este modelo es acercar lo más posible los servicios de asistencia sanitaria cualificada a los trabajadores y a sus lugares de trabajo. 
Los servicios de salud en el trabajo suelen crearse en las grandes empresas con más de 4.000 trabajadores y en las del sector químico, petroquímico, minero y de canteras con más de 2.000 trabajadores. Todas las empresas con más de 800 empleados están obligadas a dotarse de un servicio interno con un médico y una enfermera del trabajo; las que tienen entre 300 y 800 están obligadas a disponer de una enfermera del trabajo; en el caso de las empresas químicas, petroquímicas, mineras y de canteras, el número mínimo es de 200 empleados. Estos servicios internos forman parte del sistema público de asistencia sanitaria.

Las pequeñas empresas dependen de los hospitales y las policlínicas del sistema público de asistencia sanitaria, que han de proporcionar un médico del trabajo para realizar las exploraciones sanitarias de los trabajadores.

El servicio de salud en el trabajo de las empresas más grandes suele incluir un hospital con servicios de hospitalización, una policlínica con servicios ambulatorios, servicios de enfermería del trabajo y un dispensario. Sus servicios pueden ser "cerrados" (es decir, limitados a las personas que trabajan en la empresa) 0 "abiertos" (es decir, también a disposición de las familias de los trabajadores y, en ocasiones, de las personas que viven en el barrio).

\section{Conclusiones}

Las importantes transformaciones de los sistemas sociales y económicos de Rusia son reflejo de su transición a una economía de mercado, la aparición de diversas formas de propiedad, la concesión de libertad económica a las empresas y la abolición del control administrativo del Estado, todo lo cual ha generado múltiples cambios en la sociedad.

El sistema de protección de los trabajadores anteriormente descrito está sufriendo una profunda reorganización, pese a mantener sus características generales, con el fin de adaptarlo a las nuevas realidades y dotarlo de capacidad de reacción frente a los nuevos retos. Aunque se ha emprendido ya el camino, el proceso no ha hecho más que empezar.

La prestación de servicios de salud en el trabajo a la población activa requiere una especial atención debido a la parcial desintegración de la antigua red de servicios consecuencia de problemas económicos bien conocidos y también a innovaciones tales como la aparición de un sector privado, la introducción de un seguro sanitario obligatorio y la integración de los centros médicos privados en el sistema de asistencia sanitaria del país.

Aunque se han hecho algunos avances en la reducción del número de accidentes de trabajo y de la incidencia de lesiones y enfermedades del trabajo, las tasas siguen siendo inadmisiblemente altas, lo que puede tener graves consecuencias en términos de deterioro de la salud de los trabajadores, con su consiguiente efecto negativo sobre la economía. La mejora de las condiciones y del medio ambiente de trabajo y la protección y promoción de la salud de los trabajadores suponen, por tanto, una destacada prioridad en la revisión de la política social del Estado, para lo cual resulta crucial la participación activa de los profesionales expertos en la materia.

Entre los requisitos previos para la mejora del sistema de protección de los trabajadores en Rusia se encuentran los siguientes:

- crear estímulos económicos para la mejora de las condiciones y del medio ambiente de trabajo;

- formular una política nacional coherente en la materia;

- revisar la legislación de trabajo vigente y establecer bases legislativas sólidas para la práctica de la salud y la seguridad en el trabajo;

- hacer cumplir efectivamente la legislación de trabajo;
- lograr una mayor cooperación de las empresas y los trabajadores en las cuestiones relacionadas con la salud y la seguridad en el trabajo;

- autorizar a los organismos estatales de control a cerrar empresas con condiciones de trabajo insanas o inseguras, así como las que polucionen el medio ambiente;

- hacer hincapié en la mejora de las condiciones de trabajo, junto con la protección del medio ambiente general;

- analizar y pronosticar detalladamente los posibles efectos del diseño y construcción de nuevas empresas sobre la salud de los trabajadores y sobre el medio ambiente;

- ofrecer más opciones a los trabajadores para obtener servicios de salud en el trabajo y conceder más independencia a los profesionales de este campo;

- dar a todos los trabajadores acceso a un lote "estándar" de servicios de salud en el trabajo;

- establecer servicios integrales e interdisciplinarios de salud en el trabajo en las grandes empresas, capaces de prestar una gama completa de servicios, incluido el tratamiento y la rehabilitación, a los trabajadores y sus familias;

- elevar la categoría de las instalaciones técnicas de los servicios de salud en el trabajo y los CSHES, y mejorar el nivel de especialización de su personal;

- organizar y establecer centros sanitarios que presten servicios de salud en el trabajo a las pequeñas empresas;

- practicar los tipos recomendados de exploraciones sanitarias a todos los trabajadores, incluidos los de la agricultura y los del sector informal, mediante el uso más eficiente de los diversos recursos médicos;

- mejorar la educación y formación de los profesionales de la salud en el trabajo;

- prestar atención especial a la educación y formación de los trabajadores en materia de salud y seguridad en el trabajo.

\section{LA PRACTICA DE LOS SERVICIOS DE SALUD EN EL TRABAJO EN LA Republica Popular ChINA}

Zhi Su

China, el mayor país del mundo en vías de desarrollo, está luchando por conseguir una modernización sin precedentes. La política de "apertura" a los intereses extranjeros y la reforma económica en vigor desde 1979 han traído profundos cambios a la economía china y a todos los aspectos de su sociedad. EI PNB aumentó desde 358.800 millones de yuanes R M B en 1978 a 2,4 billones en 1992, un aumento de más del triple en dinero constante. La tasa anual media de crecimiento del PNB fue del $9,0 \%$. El valor del producto industrial bruto fue de 3,7 billones en 1992, un crecimiento anual medio del 13,2 \% entre 1979 y 1992 (O ficina Nacional de Estadísticas, 1993). China es crecientemente considerada como un "centro potencial de actividad económica" y ha atraído el $40 \%$ de la inversión extranjera directa del mundo en vías de desarrollo. A finales de 1993 se habían aprobado 174.000 proyectos con financiación extranjera, que aportaron 63.900 millones de dólares al país, y la entrada total acumulada de fondos extranjeros era de 224.000 millones de dólares (C hina D aily 1994a, 1994b).

Con el fin de avanzar en las actuales reformas de forma integral y armónica en todos los sectores económicos se ha decidido emprender una reforma en profundidad. El objetivo de esta reforma de la estructura económica es establecer una economía socialista de mercado que libere y amplíe aún más las fuerzas productivas chinas. La economía de planificación central 
promovida durante 40 años se está transformando en un sistema de mercado. Todo lo que pueda ser gestionado por el propio mercado, debe dejarse a su control, correspondiendo al gobierno guiar su crecimiento mediante políticas, reglamentaciones y planificación económicas, así como a través de los medios administrativos necesarios.

Durante el período de rápido cambio social e industrialización, especialmente en el curso de la transición desde un sistema económico de planificación central hacia una economía orientada al mercado, el servicio tradicional chino de salud en el trabajo había de verse sometido a grandes retos. Al mismo tiempo, surgen continuamente muchos nuevos problemas de salud en el trabajo sin que se hayan resuelto aún los más antiguos.

Al repasar la historia de más de 40 años de desarrollo de la salud en el trabajo en China se detectan grandes logros y muchas iniciativas de éxito, pero sigue existiendo un gran desfase entre la creciente necesidad de recursos de salud en el trabajo y los limitados recursos actualmente disponibles. Como muchos otros aspectos de la vida china, el servicio de salud en el trabajo está sufriendo una profunda reforma.

\section{Revisión histórica}

El servicio de salud en el trabajo se creó a principios del decenio de 1950 como un subsistema de los servicios públicos chinos de salud. Al fundarse, en 1949, la República Popular China, el estado de salud de los chinos era malo, con una esperanza de vida de 35 años. La situación de la salud y la seguridad de los trabajadores era aún peor: la prevalencia de las enfermedades profesionales, las enfermedades contagiosas y las lesiones era alta, y los trabajadores solían abandonar prematuramente sus puestos de trabajo. Para hacer frente a las peligrosas condiciones de trabajo y a la deficiente higiene de las fábricas de la "vieja China", el nuevo gobierno adoptó tres medidas (Zhu 1990): a) crear unas instituciones de servicio de salud en las grandes empresas industriales; b) realizar una investigación exhaustiva de salud e higiene

Tabla 16.5 - Requisitos mínimos de las instalaciones sanitarias internas.

\begin{tabular}{|c|c|c|c|}
\hline $\begin{array}{l}\text { Tamaño de } \\
\text { la empresa } \\
\text { (trabajadores) }\end{array}$ & $\begin{array}{l}\text { Instala- } \\
\text { ciones } \\
\text { sanitarias } \\
\text { internas }\end{array}$ & $\begin{array}{l}\text { Espacio } \\
\text { en planta } \\
\left(\mathrm{m}^{2}\right)\end{array}$ & $\begin{array}{l}\text { Requisitos } \\
\text { mínimos }\end{array}$ \\
\hline$>5.000$ & Hospital ${ }^{1}$ & $\begin{array}{l}\text { Según el estándar } \\
\text { de constucción } \\
\text { para Hospitales } \\
\text { Integrales }\end{array}$ & \\
\hline $3.501-5.000$ & Consulta & $140-190$ & $\begin{array}{l}\text { Sala de espera, consul- } \\
\text { torio, sala de trata- } \\
\text { miento, laboratorio } \\
\text { clínico e inmunohemato- } \\
\text { lógico, radiología y } \\
\text { farmacia }\end{array}$ \\
\hline $2.001-3.500$ & Consulta & $110-150$ & (igual que el anterior) \\
\hline $1.001-2.000$ & Consulta & $70-110$ & $\begin{array}{l}\text { No es obligatorio } \\
\text { disponer de rayos-X }\end{array}$ \\
\hline $300-1.000$ & Consulta & $30-0$ & $\begin{array}{l}\text { No es obligatorio } \\
\text { disponer de laboratorio ni } \\
\text { de rayos-X }\end{array}$ \\
\hline
\end{tabular}

1 Las empresas industriales con más de 3.000 trabajadores pueden establecer hospitales internos $s$ tienen procesos productivos de alto riesgo o están ubicadas a gran distancia de una ciudad 0 en zonas montañosas mal comunicadas. en las fábricas y c) mejorar las condiciones sanitarias de los lugares de trabajo y de las viviendas de los trabajadores.

Los datos estadísticos sobre las explotaciones industriales más antiguas de China muestran que en 1952 se habían creado 28 hospitales de fábrica, 795 centros hospitalarios y 30 sanatorios en China oriental; en la región septentrional, el nivel de servicios médicos y sanitarios en las empresas industriales aumentó un $27,6 \%$, el número de trabajadores sanitarios un $53,2 \%$ y el número de camas hospitalarias el $12 \%$, todo ello en el período de tres años comprendido entre 1950 y 1952. La mayor parte de las condiciones de trabajo gravemente inseguras encontradas las revisiones gubernamentales de las empresas estatales se mejoraron mediante iniciativas conjuntas con la participación del gobierno y los trabajadores. El gobierno proporcionó también apoyo financiero para la construcción de viviendas e instalaciones sanitarias. En 1952, las viviendas de los trabajadores habían aumentado diez veces con respecto a las cifras de 1950, el número de instalaciones de sanitarios higiénicos había aumentado un $216 \%$, los cuartos de baño en un $844 \%$ y los clubes de trabajadores en un 207 \% (según las estadísticas de la región septentrional). Desde 1950 se proporcionaban subsidios para alimentación a los trabajadores expuestos a peligros profesionales. Estos avances favorecieron en gran medida la recuperación de la producción industrial en aquel momento.

Desde 1954, siguiendo la llamada de $\mathrm{M}$ ao Tse Tung a "avanzar paso a paso hacia una nación socialista industrializada", China aceleró su desarrollo económico. Las prioridades del gobierno con respecto a la salud de los trabajadores comenzaron a desplazarse de la higiene sanitaria a la salud en el trabajo y la salud medioambiental, concentrándose en la prevención y el control de las enfermedades y lesiones profesionales graves. La primera Constitución de la R epública Popular China establece que los trabajadores deben disfrutar del derecho a la protección del gobierno y que debe mejorarse su salud y su bienestar.

El gobierno central (el Consejo de Estado) ha prestado mucha atención a los graves problemas de la salud en el trabajo. En 1954, tan sólo cuatro años después de la fundación de la República Popular C hina, tuvo lugar en Pekín la Primera Conferencia $\mathrm{N}$ acional sobre Control de Polvo de Sílice en el M edio Ambiente de Trabajo, convocada conjuntamente por los M inisterios de Salud Pública (M SP) y de Trabajo (M T) y la Federación China de Sindicatos (FChS). La Segunda Conferencia se celebró cinco años después con los mismos convocantes, a los que se unieron otros sectores de la administración industrial, tales como el M inisterio de la Industria del Carbón y el M inisterio de Fabricación de $M$ ateriales de $C$ onstrucción.

Al mismo tiempo, el estrés por calor, las intoxicaciones en el trabajo, las lesiones por ruido y otras enfermedades producidas por factores físicos, así como la intoxicación por pesticidas en la agricultura, pasaron a formar parte de la agenda de la salud en el trabajo. Fruto de las recomendaciones activas dirigidas al Consejo de Estado a través de las iniciativas conjuntas del M SP, el MT, la FChS y el M inisterio de Administración Industrial (MAI), el Consejo adoptó una serie de decisiones, políticas y estrategias para fortalecer el programa de salud en el trabajo, tales como las relativas al seguro de trabajo, los requisitos de salud y seguridad en el medio ambiente de trabajo, la asistencia médica por enfermedad profesional, las exploraciones sanitarias de los trabajadores dedicados a tareas peligrosas, la creación de sistemas de "inspección sanitaria" y también el importante apoyo financiero necesario para mejorar las condiciones de trabajo. 
Figura 16.4 • Red nacional de servicios de salud en el trabajo.

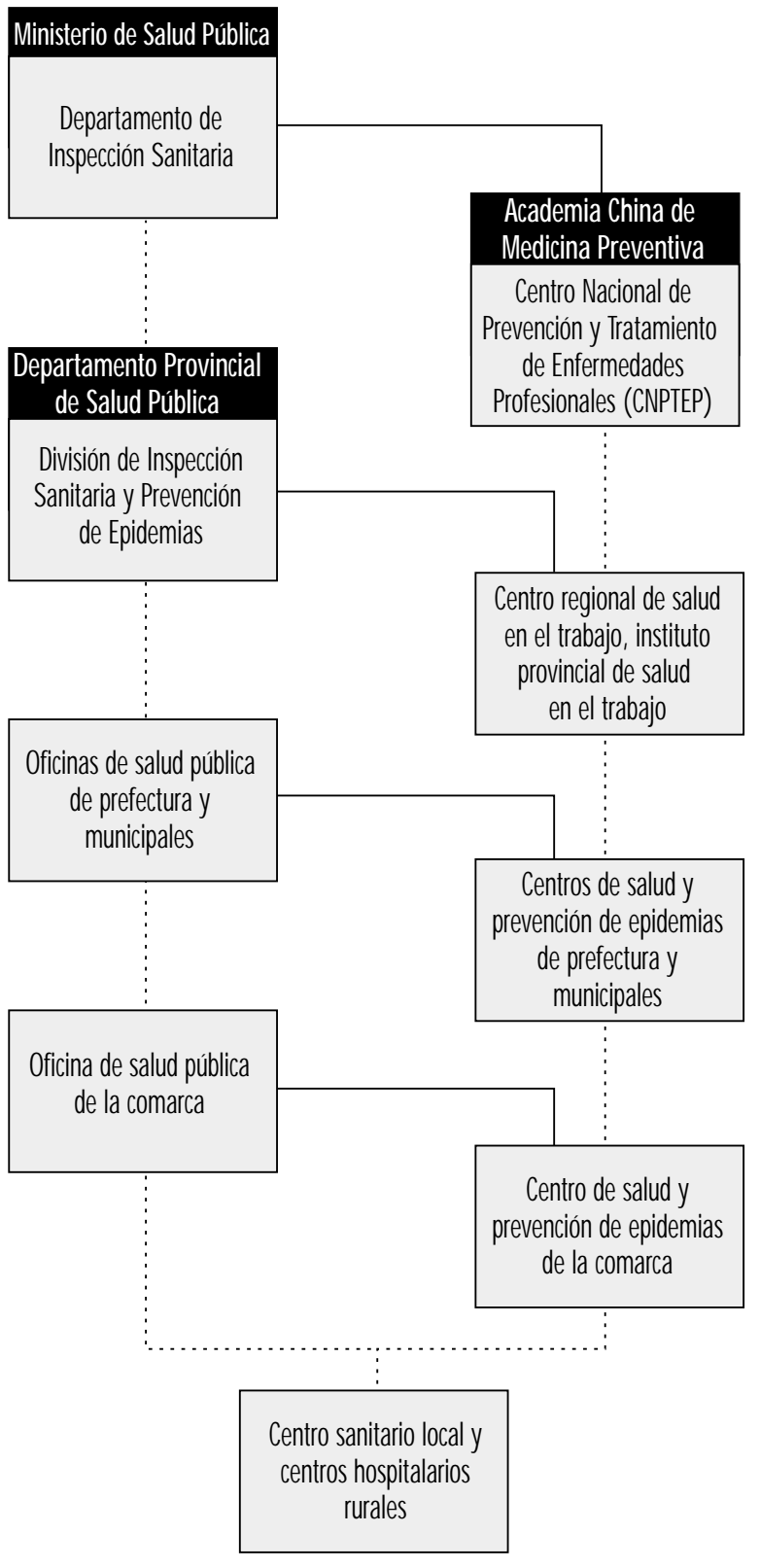

\section{Estructura organizativa de la prestación de servicios de salud en el trabajo}

La red china del servicio de salud en el trabajo se creó en el decenio de 1950 y se ha configurado gradualmente a lo largo de cuarenta años. Pueden distinguirse varios niveles:

\section{Servicio interno}

Ya en 1957, el M SP (1957) publicó una Recomendación para el Establecimiento y la Dotación de Personal de las Instituciones M édicas y Sanitarias en las Empresas I ndustriales. L os principios del documento se adoptaron como normas nacionales en las $\mathrm{N}$ ormas H igiénicas para e D iseño de Instalaciones Industriales (M O PH 1979) (véase la Tabla 16.5). Debe haber un servicio de salud o de salud y seguridad en el nivel de dirección de la empresa, que ha de estar también bajo la supervisión de las autoridades sanitarias públicas locales del gobierno. Un hospital para los trabajadores vinculado a dicho servicio opera como centro médico-sanitario que presta servicios preventivos y curativos, incluida la vigilancia sanitaria de los trabajadores a efectos de salud y seguridad, la evaluación de la capacidad de trabajo desde el punto de vista médico y la aprobación de las bajas por enfermedad de los trabajadores. $\mathrm{H}$ ay centros de asistencia sanitaria cerca de los talleres, los cuales, bajo la dirección del hospital de los trabajadores y con su apoyo técnico, desempeñan un papel importante en los primeros auxilios, la educación de los trabajadores en materia de salud en el trabajo, la recolección de datos sanitarios de los trabajadores en los lugares de trabajo y la supervisión de la salud y la seguridad conjuntamente con los sindicatos y los departamentos de ingeniería de seguridad.

\section{Prestación de servicios de salud en el trabajo basados en la} división ter ritorial administrativa

La prestación de servicios de salud es una de las responsabilidades de un gobierno. A principios del decenio de 1950, y con el fin de mejorar la salud medioambiental, se crearon Centros de Salud y Prevención de Epidemias (CSPE) en todas las demarcaciones administrativas del país, desde las provincias hasta las

Figura 16.5 • Gestión de la elaboración de estándares sanitarios.

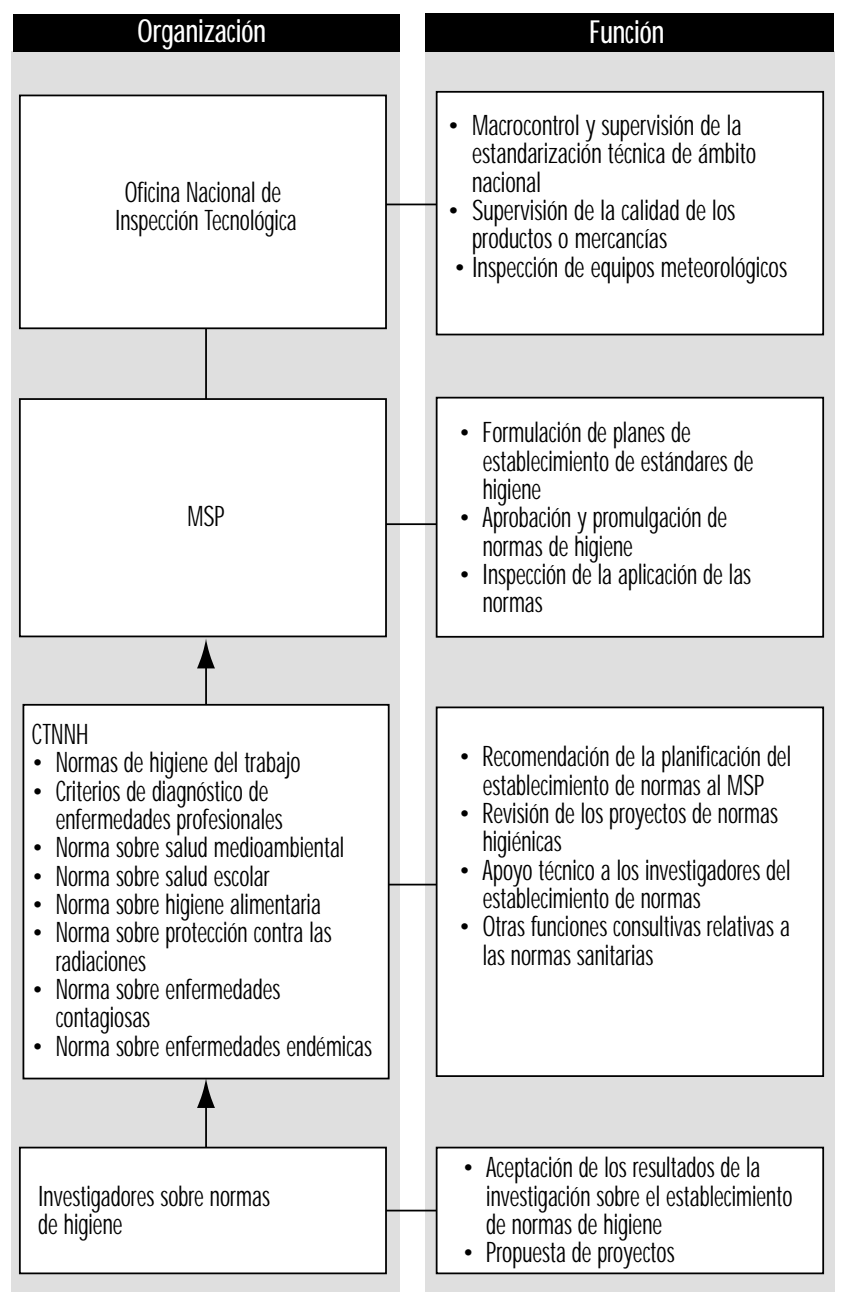


comarcas. Las funciones de los C SPE se ampliaron, al hilo de las necesidades crecientes de desarrollo social y económico, para incluir servicios de control preventivo que cubrían la salud en el trabajo, la salud medioambiental, la higiene alimentaria, la salud escolar, la protección contra la radiación y el control de las enfermedades contagiosas y de algunas no contagiosas. Se autorizó a los CSPE a velar por el cumplimiento de las reglamentaciones y normas sanitarias públicas promulgadas por el estado o los gobiernos locales, así como a llevar a cabo la inspección. Los CSPE, especialmente los de ámbito provincial, prestan también asistencia técnica y servicios de salud pública a la comunidad y participan en la formación interna y en la investigación científica.

El impulso industrializador de la China del decenio de 1950 y de principios del decenio de 1960 aceleró notablemente el desarrollo del programa del servicio de salud en el trabajo, que se convirtió en uno de los mayores departamentos del sistema CSPE. La mayoría de las pequeñas y medianas empresas industriales, incapaces de mantener servicios internos de salud en el trabajo e higiene industrial, podrían recibir la cobertura de los servicios de salud en el trabajo de los CSPE, gratuitos en su mayor parte.

Durante la "Revolución Cultural", entre 1966 y 1976, la red del servicio de salud en el trabajo y sus actividades se vieron gravemente deterioradas. Ésta es una de las importantes razones por la que algunas enfermedades del trabajo siguen siendo gravemente prevalentes en China. La reconstrucción del programa de salud en el trabajo comenzó a finales del decenio de 1970, cuando C hina comenzó a caer de nuevo en la cuenta de la importancia del desarrollo económico. Desde el inicio del decenio de 1980, se han creado en la mayor parte de las provincias y en algunos sectores administrativos, bajo la política favorable del gobierno, hospitales para la prevención y tratamiento de las enfermedades del trabajo y los institutos de salud en el trabajo, denominados instituciones de salud en el trabajo (IST). Las IST se basaban fundamentalmente en la utilización del personal de salud en el trabajo de los CSPE junto con médicos del trabajo de hospitales. Durante el período 1983-1991, los gobiernos central y locales invirtieron un total de 33,8 millones de yuanes R M B para apoyar la construcción de IST. En el ámbito de las provincias y las prefecturas se crearon 138 IST con laboratorios o equipos clínicos adecuados. En la actualidad, el número de IST ha llegado a 204, de las cuales 60 han sido creadas por el sector industrial. O tros 110 millones de yuanes RM B se han invertido en el equipamiento de los 1.789 centros de salud y prevención de epidemias de ámbito comarcal (He 1993). Los programas de salud en el trabajo de los CSPE comarcal fueron uno de los primeros elementos importantes del proyecto en recibir equipamiento. Para reforzar la capacidad nacional de investigación, formación y coordinación del servicio de salud en el trabajo se creó el C entro $\mathrm{N}$ acional para la Prevención y Tratamiento de las Enfermedades del Trabajo (CNPTET), dependiente del Insituto de Medicina del Trabajo de la Academia China de M edicina Preventiva, así como siete centros regionales de salud en el trabajo ubicados en Pekín, Shangai, Shenyang, Lanzhou, Chengdu, Changsa and Guangzhou. La red nacional actual de servicios de salud en el trabajo se muestra en la Figura 16.4 .

$\mathrm{H}$ asta el momento se han creado 34 escuelas o departamentos de salud pública en las facultades de medicina, que constituyen las principales fuentes de personal especializado en la materia. En 1983 se crearon seis centros nacionales de formación interna en salud en el trabajo. En 1992, el total de profesionales de la salud en el trabajo, incluidos médicos, higienistas industriales, técnicos de laboratorio y otros trabajadores de la salud implicados en programas de salud en el trabajo alcanzó la cifra de 30.000 .

\section{Normas y legislación de salud en el trabajo.}

Para fomentar la investigación y adopción de normas higiénicas se creó en 1981 el Comité T écnico Nacional de N ormas H igiénicas (CT NNH ) como organismo consultivo y de revisión técnica del M SP para el establecimiento de normas. En la actualidad, el CTNNH tiene ocho subcomités, responsables de salud en el trabajo, salud medioambiental, higiene escolar, higiene alimentaria, protección contra la radiación, diagnóstico de enfermedades del trabajo, prevención de enfermedades endémicas y enfermedades contagiosas (Figura 16.5). Los miembros del CT NNH son especialistas procedentes de universidades, institutos de investigación, organismos gubernamentales y sindicatos. Las Normas H igiénicas para el Diseño de Instalaciones I ndustriales se formularon por primera vez en el decenio de 1950, revisándose y promulgándose de nuevo en 1979, de modo que en la actualidad contienen una lista de límites de exposición en el trabajo en términos de concentraciones máximas permisibles (maximum allowable concentrations, M AC) de 120 polvos y agentes tóxicos, junto con otros requisitos relativos a medidas de control de peligros en los lugares de trabajo, instalaciones higiénicas y sanitarias en las fábricas, etc. También hay 50 normas de higiene en el trabajo referentes a agentes físicos y químicos peligrosos en el lugar de trabajo, promulgadas por el M inisterio de Salud Pública. 0 tras 127 normas higiénicas del trabajo están siendo objeto de revisión. EI M inisterio de Salud Pública ha emitido criterios diagnósticos para las 50 enfermedades del trabajo indemnizables.

Como es bien sabido, $\mathrm{C}$ hina ha tenido un sistema económico de planificación central y ha estado controlada por un gobierno central unificado durante más de 40 años. En consecuencia, la mayor parte de los requisitos reglamentarios en materia de salud y seguridad estaban establecidos en forma de documentos de "Tí́tulo R ojo" del gobierno central. Estos documentos tenían el máximo rango jurídico y constituían el marco normativo básico de la salud en el trabajo. Son más de 20 los documentos de este tipo promulgados por el Consejo de Estado o por sus ministerios. Las principales diferencias entre estos documentos y la legislación ordinaria es que aquéllos no establecen sanciones, su efecto vinculante no es tan fuerte como el de las leyes y la vigilancia de su cumplimiento es menor.

La reforma económica ha favorecido un sistema orientado al mercado, siguiendo la política de apertura, por lo que la legislación nacional ha recibido también un notable énfasis. La gestión de la salud en el trabajo se está transformando también desde los enfoques administrativos tradicionales hacia enfoques de base reglamentaria. U no de los documentos jurídicos más importantes es el Reglamento de Prevención y Control de Neumoconiosis, promulgada por el Consejo de Estado en 1987. O tro hito en la protección de los derechos de los trabajadores es la promulgación de la Ley de Trabajo por el Congreso Popular $\mathrm{N}$ acional, con fecha de entrada en vigor anticipada al 1 de enero de 1995, que establece como uno de sus objetivos principales la salud y la seguridad de los trabajadores. Para poner en práctica esta ley a efectos del control de las enfermedades, el $M$ inisterio de Salud Pública remitió a la O ficina de Legislación del Consejo de Estado un proyecto de ley de prevención y control de enfermedades del trabajo, en el que se recoge la mayor parte de las experiencias y políticas de salud en el trabajo básicas para las instituciones competentes tanto en C hina como en el extranjero. EI proyecto debe ser objeto de una revisión adicional antes de ser remitido al Comité Permanente del Congreso Popular Nacional.

\section{El sistema de inspección sanitaria}

El gobierno ha insistido en el lema "La prevención es lo primero", que se ha convertido en un importante principio de la salud pública básica nacional. Ya en 1954, cuando apenas había 
comenzado la industrialización, el gobierno central tomó la decisión de establecer un sistema de inspección sanitaria para velar por el cumplimiento de las reglamentaciones y políticas sanitarias nacionales de higiene industrial. Se autorizó a los CSPE a realizar la inspección sanitaria en nombre de las autoridades sanitarias gubernamentales. Entre las tareas principales de la inspección sanitaria de empresas se encuentran las siguientes:

- inspeccionar la empresa para el control de los peligros del lugar de trabajo, de modo que sus concentraciones o intensidades se ajusten a las normas nacionales de higiene industrial;

- comprobar si se han realizado con arreglo a las reglamentaciones nacionales y a los requisitos locales las exploraciones previas a la colocación y periódicas de los trabajadores expuestos;

- asegurarse de que los trabajadores que padezcan enfermedades profesionales sean adecuadamente tratados, se les permita recuperarse, sean trasladados a otros puestos o se les ofrezcan otras opciones adecuadas con arreglo a las reglamentaciones aplicables;

- realizar evaluaciones de higiene y supervisar las medidas de control de peligros en el lugar de trabajo;

- supervisar como se llevan a cabo los registros de salud en el trabajo, la notificación de las enfermedades profesionales y el control medioambiental en la empresa.

Estas actividades forman parte de la "inspección sanitaria normal" y se consideran tareas rutinarias que deben realizarse periódicamente. Junto a ellas, las restantes tareas de la inspección sanitaria son:

- inspección sanitaria preventiva de los proyectos de construcción industrial (antes de toda nueva construcción industrial o reconstrucción o ampliación de viejas empresas industriales, todos los diseños de ingeniería, instalaciones de control de peligros e instalaciones médico sanitarias y de acomodación de trabajadores deben superar una inspección inicial de salud en el trabajo):

- evaluación toxicológica de nuevas sustancias químicas industriales.

Diversas leyes y reglamentos de salud pública han establecido la inspección sanitaria, especialmente la de carácter preventivo, como principio fundamental de las medidas de intervención en materia de salud pública. Desde el decenio de 1970, a medida que se ha prestado mayor atención al control de la polución medioambiental, la inspección sanitaria se ha ampliado a inspección de todo el proceso. El principio de que "las instalaciones de control de peligros deben diseñarse, construirse y utilizarse simultáneamente a la parte principal del proyecto" fue uno de los importantes requisitos establecidos en el Reglamento de Prevención y Control de la Neumoconiosis y en la Ley de Protección M edioambiental.

\section{Estrategia integral de prevención de enfermedades profesionales}

Junto con el control de la neumoconiosis y la contaminación grave por polvos en el entorno de trabajo, se ha subrayado la prevención integral, sintetizada en ocho caracteres de la escritura china que se traducen del siguiente modo:

- innovación: mejora tecnológica, tal como utilizar materiales seguros o de bajo riesgo y procesos más productivos, y sustitución de métodos productivos desfasados mediante técnicas avanzadas adecuadas;

- mantenimiento de la humedad: mantener húmedos los lugares de trabajo polvorientos para reducir la concentración de polvo,
Tabla 16.6 • Exploraciones periódicas obligatorias para los trabajadores expuestos al polvo.

Clase de polvo Intervalo de exploración (años) Trabajadores en servicio Trabajadores retirados

Contenido de sílice libre (\%)

80

40

$0,5-1$

$1-2$

$2-3$

10

$<10$

3-5

Amianto

$0,5-1$

Otras clases de polvo

3- 5

1

2

3

5

1

5

especialmente en las actividades de perforación y de triturado de la industria minera;

- separación: separar a los trabajadores, los equipos y las áreas medioambientales para evitar los escapes de polvo y la consiguiente contaminación de los trabajadores;

- ventilación: mejorar la ventilación natural y mecánica;

- protección: proporcionar protección personal a los trabajadores expuestos;

- supervisión: establecer reglas y normas de funcionamiento seguras, y supervisar su cumplimiento por parte de los trabajadores;

- educación: poner en práctica programas de educación en materia de salud y seguridad para promover la participación de los trabajadores y mejorar su concienciación con respecto a su protección personal;

- comprobación: inspeccionar el medio ambiente de trabajo para verificar el cumplimiento de las normas nacionales y explorar periódicamente la salud de los trabajadores a la luz de los requisitos nacionales.

Se ha demostrado en las prácticas de muchas empresas que la estrategia de los "ocho caracteres" es importante y eficaz para la mejora de las condiciones de trabajo.

\section{Supervisión medioambiental en el lugar de trabajo}

Las empresas que tienen un medio ambiente de trabajo peligroso deben supervisar periódicamente las concentraciones o intensidades de los peligros y adoptar medidas (por ejemplo, con respecto a los valores de MAC). Si la empresa no es capaz de realizar por sí misma esta supervisión medioambiental, pueden recurrir a los servicios de las IST y C SPE locales.

Para controlar la calidad de la supervisión del lugar de trabajo realizado por la empresa, las IST y CSPE deben practicar inspecciones regularmente y siempre que sea necesario. $E L$ CNPTET es responsable del control de calidad, en el ámbito nacional, sobre la supervisión de los riesgos en el lugar de trabajo. La vigilancia del aire en el lugar de trabajo ha sido objeto de varias reglamentaciones técnicas del M SP y publicaciones del CNPTET (por ejemplo, M ethods for Airborne Dust $M$ easurement in the Workplace (G B 5748-85) (M OPH 1985) y $M$ ethods for $M$ onitoring and Analysis of Chemical $\mathrm{H}$ azards in $\mathrm{A}$ ir of W orkplace (Instituto de M edicina del Trabajo 1987).

Para un mayor control de la calidad de la supervisión del medio ambiente en el lugar de trabajo se ha remitido al M SP, para su revisión y aprobación, un conjunto de normas de garantía de calidad en la medición de sustancias peligrosas. Las cualificaciones de las instituciones encargadas de la supervisión 
del lugar de trabajo se revisarán y sujetarán a licencia, exigiéndose:

- capacidad profesional de las personas que tomen las muestras o realicen funciones analíticas;

- equipos necesarios para la toma y análisis de muestras, así como para su adecuada calibración;

- soluciones patrón y reactivos;

- garantías de calidad en la toma de muestras ambientales y biológicas;

- garantías de calidad en el laboratorio y comprobaciones similares.

En la actualidad se está realizando un estudio piloto sobre la evaluación de los laboratorios en 200 instituciones y laboratorios, lo que supone un primer paso en la puesta en práctica de la Norma de Garantía de Calidad.

\section{La exploración de salud de los trabajadores}

Los trabajadores expuestos a peligros profesionales en el lugar de trabajo deben disponer de exploraciones de salud al efecto. Este principio se impuso por primera vez para los trabajadores expuestos al polvo en el decenio de 1950 y se extendió rápidamente hasta cubrir a todos los trabajadores expuestos a productos químicos tóxicos y a peligros físicos.

Las exploraciones sanitarias incluyen una exploración previa al empleo o de capacidad física para el trabajo y exploraciones periódicas, todas las cuales deben ser realizadas por las IST 0 instituciones médico-sanitarias competentes con licencia de las administraciones sanitarias públicas gubernamentales.

\section{La exploración previa al empleo}

La exploración previa al empleo es obligatoria para los trabajadores nuevos o trasladados por primera vez a lugares de trabajo peligrosos. Esta prueba se centra en la evaluación de la salud del trabajador con respecto a las condiciones del lugar de trabajo para garantizar que el trabajo específico que va a realizar no perjudicará su salud y para excluir a quienes no tengan la capacidad física para realizarlo. L os criterios sanitarios utilizados para determinar las contraindicaciones de distintos trabajos peligrosos están establecidos en detalle en the $\mathrm{N}$ ational Diagnostic C riteria and Principles of $M$ anagement of $O$ ccupational $D$ iseases ( $H$ ealth Standards O ffice 1993) y Guideline of O ccupational $H$ ealth Service and Inspection promulgado por el M SP (1991b).

\section{Las exploraciones periódicas}

Los trabajadores expuestos a distintos peligros tienen diferentes intervalos de realización de las exploraciones médicas. EI de los trabajadores expuestos al polvo, por ejemplo, aparece en la

Tabla 16.7 • Exploraciones físicas para los trabajadores expuestos a peligros profesionales.

\begin{tabular}{ccccc} 
Año & $\begin{array}{l}\text { Número de } \\
\text { trabajadores } \\
\text { (miles) }\end{array}$ & $\begin{array}{l}\text { Proporción de } \\
\text { trabajadores } \\
\text { expuestos (\%) }\end{array}$ & $\begin{array}{l}\text { Tasa de explo- } \\
\text { ración de } \\
\text { trabajadores } \\
\text { expuestos (\%) }\end{array}$ & $\begin{array}{l}\text { Tasa de enfer- } \\
\text { medades profe- } \\
\text { sionales } \\
\text { detectadas (\%) }\end{array}$ \\
1988 & 62.680 & 29,36 & 18,60 & 0,90 \\
1989 & 62.791 & 29,92 & 20,67 & 0,57 \\
1990 & 65.414 & 29,55 & 20,47 & 0,50 \\
1991 & 66.039 & 30,30 & 21,03 & 0,57 \\
1992 & 64.222 & 30,63 & 20,96 & 0,40 \\
1993 & 64.345 & 31,28 & 17,97 & 0,46 \\
& & & & \\
\hline
\end{tabular}

Figura 16.6 • Gestión del diagnóstico de enfermedades profesionales en China.

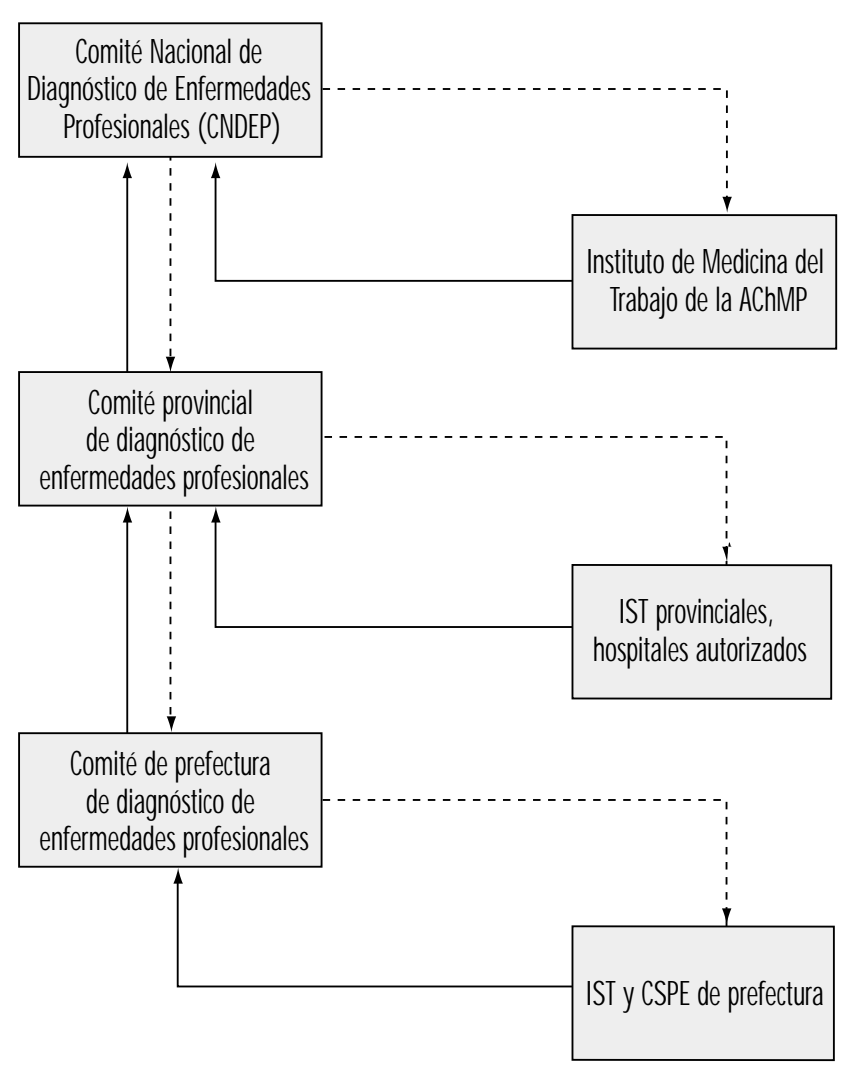

Tabla 16.6. Los que padecen neumoconiosis deben someterse a exploraciones físicas anuales.

Todos los registros médicos deben garantizarse tanto en las empresas como en las IST locales y notificarse anualmente a la autoridad pública sanitaria gubernamental y luego al CNPTET $y$ al MSP.

Los trabajadores trasladados a una empresa procedentes de una fábrica en la que existen riesgos de exposición peligrosa deben someterse a una exploración sanitaria a cargo de una IST local para determinar si su salud se ha visto perjudicada por dicha exposición, y los registros sanitarios deben enviarse a la nueva empresa junto con el trabajador (M O PH 1987).

La Tabla 16.7 muestra las estadísticas de las exploraciones sanitarias a los trabajadores en el período 1988-1993. Un total de 64 millones de trabajadores estaban cubiertos por la red del servicio de salud en el trabajo, que incluía empresas estatales y otras propiedad colectiva de las ciudades y parte de las industrias rurales en el ámbito de las pequeñas ciudades. L os trabajadores expuestos a peligros del trabajo constituían un $30 \%$ del total. Casi 4 millones de trabajadores expuestos, en torno al $20 \%$ del total, tenían exploraciones médicas anuales. En 1993, por ejemplo, la población industrial total era de 64.345.193 trabajadores, según el informe del C entro $\mathrm{N}$ acional de Informes de Salud en el Trabajo (CNIST) (faltaban, no obstante, datos de Neimeng, el Tibet y Taiwan). La proporción de trabajadores expuestos a peligros del trabajo era del 31,28 \% (20.126.929), de los cuales 3.982.940 tuvieron exploraciones, lo que representa 
un $19,79 \%$. L a tasa total de enfermedades profesionales indemnizables detectadas fue del $0,46 \%$ en 1993 (M O PH 1994).

\section{La gestión de las enfermedades profesionales}

\section{Enfermedades profesionales indemnizables}

En términos generales, cualquier enfermedad causada por la exposición a factores peligrosos presentes en el lugar de trabajo 0 derivada de los procesos de producción se considera enfermedad profesional. No obstante, a efectos de indemnización el M SP, M T, el M inisterio de $\mathrm{H}$ acienda y la FChS han elaborado una lista de enfermedades profesionales (M OPH 1987). La lista cubre nueve categorías, incluida la neumoconiosis; las intoxicaciones agudas y crónicas en el trabajo; las enfermedades inducidas por factores físicos; las enfermedades contagiosas del trabajo; las dermatosis del trabajo; los deterioros visuales del trabajo; las enfermedades otorrinolaringológicas del trabajo y los tumores del trabajo, hasta un total de 99 enfermedades. Si los gobiernos locales o los sectores del gobierno proponen cualquier otra enfermedad para complementar la lista, deben remitir la propuesta al M SP para su aprobación.

\section{E I diagnóstico de enfermedades profesionales indemniza bles}

Según lo establecido en el Reglamento sobre diagnóstico de enfermedades profesionales promulgado por el MSP, en los niveles provinciales y de prefectura las enfermedades profesionales indemnizables deben ser diagnosticadas por IST o instituciones médico-sanitarias con licencia concedida al efecto por el departamento de salud pública del gobierno local. Con el fin de controlar la calidad del diagnóstico y de prestar asistencia técnica para la confirmación de casos complicados y la resolución controversias en el diagnóstico, se han creado comités de diagnóstico de enfermedades profesionales en los niveles nacional, provincial y municipal o de prefectura (Figura 16.6) (M OPH 1984).

El Comité Nacional de Diagnóstico de Enfermedades Profesionales (CNDEP) consta de cinco subcomités encargados de las intoxicaciones en el trabajo, la neumoconiosis, las enfermedades profesionales inducidas por factores físicos, la enfermedades causadas por la radiación y la patología de neumoconiosis,

Tabla 16.8 - Resultados del control medioambiental de los peligros del lugar de trabajo.

\begin{tabular}{|c|c|c|c|c|}
\hline \multirow[t]{2}{*}{ Año ${ }^{1}$} & \multicolumn{2}{|c|}{ Empresas de propiedad estatal } & \multicolumn{2}{|c|}{ Empresas rurales + } \\
\hline & $\begin{array}{l}\text { Núm. de } \\
\text { locales } \\
\text { medioambien- } \\
\text { tales } \\
\text { controlados }\end{array}$ & $\begin{array}{l}\text { Proporción } \\
\text { de locales que } \\
\text { cumplen los } \\
\text { estándares } \\
(\%)\end{array}$ & $\begin{array}{l}\text { Núm. de locales } \\
\text { medioambien- } \\
\text { tales } \\
\text { controlados }\end{array}$ & $\begin{array}{l}\text { Proporción } \\
\text { de locales que } \\
\text { cumplen los } \\
\text { estándares (\%) }\end{array}$ \\
\hline 1986 & 417.395 & 51,40 & 53.798 & 42,50 \\
\hline 1987 & 458.898 & 57,20 & 50.348 & 42,60 \\
\hline 1988 & 566.465 & 55,40 & 68.739 & 38,50 \\
\hline 1989 & 614.428 & 63,10 & 74.989 & 53,50 \\
\hline 1990 & 606.519 & 66,40 & 75.398 & 50,30 \\
\hline 1991 & 668.373 & 68,45 & 68.344 & 54,00 \\
\hline 1992 & 646.452 & 69,50 & 89.462 & 54,90 \\
\hline 1993 & 611.049 & 67,50 & 104.035 & 54,80 \\
\hline
\end{tabular}

respectivamente. La central del Comité se encuentra en el Departamento de Inspección del M SP. Su dirección ejecutiva está en el IOM/CAPM. Todos los miembros del Comité son designados por el M SP.

Los criterios de diagnóstico de enfermedades profesionales se dictan por el M SP. En este momento hay criterios para 66 enfermedades profesionales en vigor. Para otras enfermedades profesionales indemnizables sin criterios nacionales de diagnóstico, los departamentos provinciales de salud pública pueden formular criterios provisionales de aplicación en sus propias provincias previa remisión al M SP a efectos de registro.

Según los Criterios de Diagnóstico, éste debe basarse en los siguientes tipos de evidencias: historia de exposiciones, síntomas y signos clínicos, resultados de laboratorio y de la supervisión medioambiental en el lugar de trabajo y exclusión fundada de otras enfermedades. U na vez formulado el diagnóstico, la IST debe emitir una Certificación de Enfermedad Profesional (CEP) en tres copias: una para enviar al trabajador, otra a la empresa a los efectos de los correspondientes mecanismos de indemnización y otra para conservarla para futuros tratamientos médicos y evaluaciones de la capacidad de trabajo.

\section{La gestión de pacientes con enfermedades profesionales}

$L a$ indemnizaciones y otras prestaciones a los pacientes afectados por enfermedades del trabajo son a cuenta de la empresa, según las Reglamentaciones del Seguro de Trabajo. La dirección de la empresa, el sindicato y el comité de evaluación de la capacidad de trabajo de la empresa deben participar conjuntamente en el estudio y elección del tratamiento y la indemnización adecuados para los pacientes con arreglo a las CEP y al grado de pérdida de capacidad de trabajo. Para quienes se acredite la incapacidad de ejecutar su trabajo original tras la realización del adecuado tratamiento médico, la empresa debe trasladarlos a otros lugares de trabajo 0 adoptar las medidas adecuadas de empleo con arreglo a su estado de salud en el plazo de dos meses 0 , en casos especiales, de seis meses. Cuando un trabajador afectado por una enfermedad profesional se traslada a otra empresa, las prestaciones por enfermedad deben seguir siendo a cuenta de la empresa inicial o bien compartirse por ambas, si alcanzan un acuerdo. Todos los registros sanitarios, las CEP y otros datos relativos a la asistencia sanitaria del trabajador deben trasladarse también a la nueva empresa, debiendo una y otra informar del traslado a sus IST locales a efectos de llevanza de registros y de seguimiento.

$\mathrm{Si}$ el diagnóstico de enfermedad profesional se alcanza después de que el trabajador se haya trasladado a otra empresa, la indemnización y las prestaciones serán de cuenta de ésta, con independencia de que la enfermedad esté relacionada o no con sus condiciones laborales actuales. En el caso de los trabajadores sin contrato laboral o contratados de forma temporal, si la enfermedad profesional se diagnostica durante el período de

\begin{tabular}{ccc}
\hline Tabla 16.9 & $\begin{array}{c}\text { Exposición al polvo y prevalencia de la } \\
\text { silicosis en la mina de tungsteno Yiao G ang } \\
\text { Xian. }\end{array}$ \\
Año & $\begin{array}{c}\text { Concentraciones de polvo } \\
\left(\mathrm{mg} / \mathrm{m}^{3}\right)\end{array}$ & $\begin{array}{c}\text { Tasas de silicosis detectadas } \\
(\%)\end{array}$ \\
1956 & 66 & 25,8 \\
1960 & 3,5 & 18,6 \\
1965 & 2,7 & 2,6 \\
1970 & 5,1 & 0,3 \\
1975 & 1,6 & 1,2 \\
1980 & 0,7 & 2,1 \\
\hline
\end{tabular}


Tabla 16.10 - Tasa de detección de silicosis en la acería Anshan.

$\begin{array}{lcrcc}\text { Decenios } & \begin{array}{l}\text { Núm. de } \\ \text { exploraciones }\end{array} & \text { Casos } & \text { Tasa (\%) } & \begin{array}{c}\text { Tasa de cumplimiento } \\ \text { de polvo (\%) }\end{array} \\ 1950 & 6.980 & 1.269 & 18,21 & 23,60 \\ 1960 & 48.929 & 1.454 & 2,97 & 29,70 \\ 1970 & 79.422 & 863 & 1,08 & 28,70 \\ 1980 & 33.786 & 420 & 1,24 & 64,10\end{array}$

desempleo y hay pruebas de la exposición a un medio ambiente de trabajo peligroso en el tiempo en que estuvo contratado por una determinada empresa, la asistencia sanitaria y la indemnización serán de cuenta de ésta (M O PH 1987).

\section{Logros en la prevención y control de las enfermedades profesionales}

La mejora de las condiciones de trabajo

La concentración 0 intensidad de los peligros del trabajo en el lugar de trabajo se ha reducido notablemente. Las estadísticas de supervisión del medio ambiente de trabajo suministradas por el CNIST muestran que la proporción de lugares de trabajo que cumplen las normas nacionales se ha incrementado un $15 \%$ entre 1986 y 1996 (N CO HR 1994). Esto es especialmente cierto en las empresas industriales de propiedad estatal o de propiedad colectiva urbana, de las cuales casi un $70 \%$ tenía un medio ambiente de trabajo ajustado a las normas nacionales. La situación en las empresas industriales rurales también está cambiando. La tasa de cumplimiento en materia de peligros profesionales ha aumentado desde el 42,5\% al 54,8 \% en 1993 (Tabla 16.8). Es importante señalar que los cálculos de tasas de cumplimiento en las industrias de pequeñas ciudades pueden ser superior a lo indicado, pues este informe periódico sólo puede cubrir un $15 \%$ de las industrias rurales anualmente y la mayor parte de ellas están ubicadas cerca de ciudades con instalaciones de servicios sanitarios bien desarrollados.

\section{Prevalencia de algunas enfermedades profesionales graves y puesta en práctica de medidas preventivas integrales}

Los datos del informe nacional de salud en el trabajo indican que la prevalencia de las enfermedades profesionales indemnizables se ha mantenido en una tasa de entre $0,4 \% \%$ y $0,6 \%$, aunque las industrias se han desarrollado muy rápidamente en los últimos años. La silicosis, por ejemplo, lleva años bajo control en algunas grandes empresas industriales o mineras del estado. Las Tablas 16.9 y 16.10 muestran el éxito de la mina de tungsteno Y iao Gang X ian y de la acería Anshan en el control de la silicosis (Zhu 1990).

La encuesta epidemiológica nacional de neumoconiosis en el período 1987-90 mostró también que el tiempo medio de trabajo de los pacientes entre su primera exposición al polvo de sílice y la aparición de signos de neumoconiosis se había prolongado notablemente, pasando de 9,54 años en el decenio de 1950 a 26,25 en el decenio de 1980 para los trabajadores con silicosis y de 16,24 años 24,72 años para los trabajadores del carbón afectados por neumoconiosis en el mismo período de tiempo. La edad media de los pacientes de silicosis en el momento de su muerte aumentó también de 36,64 a 60,64 años, así como la de los pacientes de silicosis, que pasó de 44,80 a 61,43 años (M O PH 1992). Estas mejoras pueden atribuirse en parte al éxito de las políticas e intervenciones gubernamentales en materia de
Figura 16.7 - Estrategia del estudio piloto de servicios de salud en el trabajo en empresas de pequeñas ciudades.

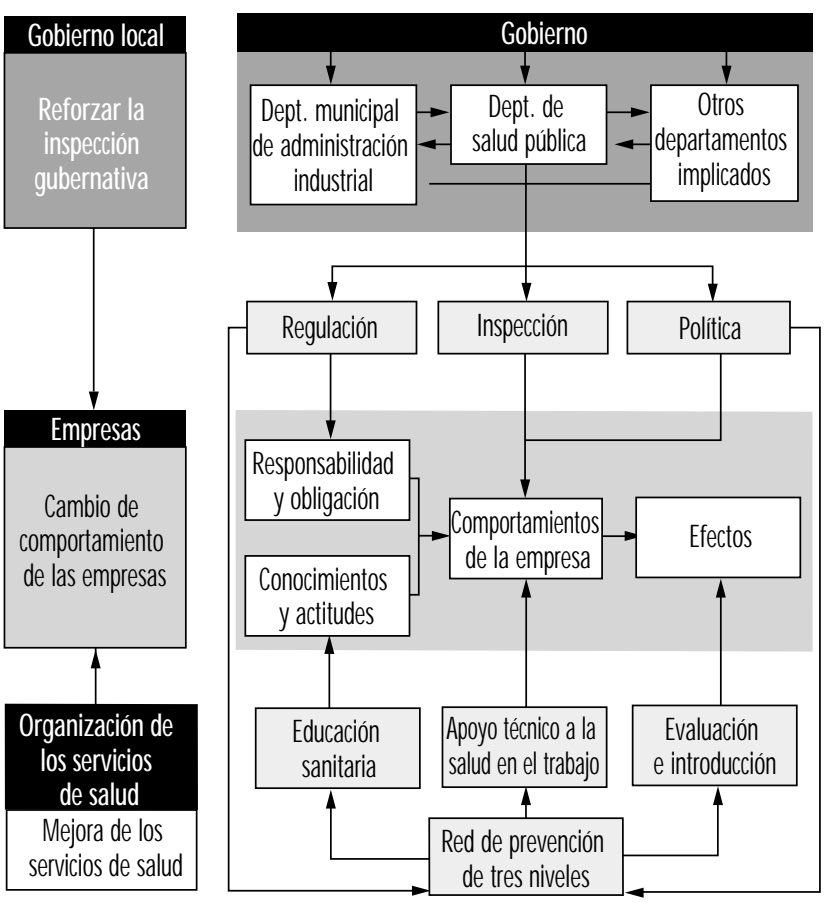

salud en el trabajo, así como a los grandes esfuerzos de los profesionales de este campo.

\section{La promoción de los programas de salud en el trabajo en las pequeñas empresas}

Ante el rápido y continuo desarrollo de las pequeñas empresas, especialmente en la industria de las pequeñas ciudades, y el creciente desfase entre los servicios de salud en el trabajo y las necesidades reales, el M inisterio de Salud Pública decidió realizar un estudio de campo más completo sobre intervención en esta área. Este estudio es importante no sólo para ayudar a resolver problemas de salud en el trabajo en las industrias rurales, sino también para explorar enfoques para la reforma del sistema del servicio de salud en el trabajo en las empresas propiedad del estado para adaptarse a las cambiantes exigencias del sistema económico de mercado que se está estableciendo. Por tanto, en diciembre de 1992 se creó en el seno del Departamento de Inspección Sanitaria del M inisterio de Salud Pública el Grupo de Expertos para el Estudio de C ampo sobre Políticas de Servicio de Salud en el Trabajo para las Pequeñas Empresas. EI Grupo se creó para ayudar a las provincias a desarrollar programas y enfoques de salud en el trabajo para una intervención eficaz en las situaciones de peligro. Como primer paso, el Grupo redactó un "Programa Recomendado para el Estudio de Campo Nacional" para los gobiernos provinciales, aprobado y promulgado por el MSP en 1992. La estrategia prioritaria del programa es la siguiente:

La empresa, el prestador de salud en el trabajo y el gobierno local son los tres componentes claves del programa. El programa se centra en el reajuste de las relaciones entre estos tres componentes para establecer un nuevo modelo de desarrollo. L os objetivos básicos del programa son reforzar el control reglamentario 
del gobierno, cambiar las actitudes con respecto a la salud y el comportamiento de los departamentos productivos y operativos de las empresas y aumentar la cobertura del servicio mínimo de salud en el trabajo, al tiempo que se mejoran las condiciones de trabajo mediante medidas tecnológicas adecuadas (Figura 16.7). EI MSP ha seleccionado cuatro comarcas (o distritos) como áreas nacionales de prueba previa a la puesta en práctica del programa en la totalidad del país, entre las que se encuentran el distrito de Zhangdian, en el municipio de Zibo, provincia de Shandong; el distrito de Baoshan, en el municipio de Shanghai; la comarca de Jinhua, en la provincia de Zhejiang; y el distrito de Yuhong, en el municipio de Shenyang, provincia de Liaoning.

El programa destaca siete ámbitos de intervención de política:

- fortalecimiento de la supervisión y la inspección de la salud en el trabajo en las pequeñas empresas por parte de los gobiernos locales;

- estudio de la forma de conciliar los servicios de salud en el trabajo de las empresas rurales con el objetivo "Salud para todos en el año 2000" en China;

- mejora de las redes organizativas sanitarias de base para la prestación de servicios de salud en el trabajo, su gestión y la supervisión de las empresas;

- estudio de enfoques prácticos para llevar a la práctica el servicio y la inspección de salud en el trabajo en las empresas de pequeñas ciudades;

- búsqueda y recomendación de tecnología adecuada para el control de peligros y la protección personal para las empresas de pequeñas ciudades;

- puesta en práctica de los programas de educación de salud en el trabajo en las empresas de pequeñas ciudades;

- desarrollo de personal de salud en el trabajo y mejora de las condiciones de trabajo del servicio de salud en el trabajo para reforzar su red, especialmente en los ámbitos de las pequeñas ciudades y de los condados.

Se han obtenido algunos resultados preliminares en las cuatro áreas de prueba y las ideas básicas del programa se están introduciendo en otras áreas de C hina, estando prevista la evaluación final para el año 1996.

El autor agradece la ayuda del Prof. F. S. H e en la revisión de este artículo.

\section{SALUD Y SEGURIDAD EN EL TRABAJO EN LA REPUBLICA CHECA}

\section{Vladimír Bencko y Daniela Pelclová}

\section{Marco geopolítico}

El predominio de la industria pesada (industria del hierro y acero, altos hornos y refinerías), la metalurgia y la fabricación de maquinaria, así como el énfasis en la producción de energía han predeterminado notablemente la estructura económica de los países de Europa Central y Oriental en las cuatro últimas décadas. Esta situación ha dado lugar a exposiciones relativamente altas a ciertos tipos de peligros profesionales en el lugar de trabajo. Los intentos actuales de transformar las economías de estos países con arreglo al modelo de mercado y de mejorar la seguridad y la salud en el trabajo han tenido un éxito considerable en este corto período de tiempo.

$\mathrm{H}$ asta hace muy poco, la prevención de los efectos adversos de las sustancias químicas presentes en los lugares de trabajo y en el medio ambiente, en el agua potable y en la cesta de la compra de alimentos de la población se lograba mediante el cumplimiento obligatorio de las normas higiénicas y sanitarias y los límites de exposición en el trabajo, tales como las Concentraciones $M$ áximas Permisibles ( $M$ aximum Allowable Concentrations, MAC), los Valores Límite de Umbral (Threshold Limit Values, TLV) y la Dosis Diaria Aceptable (Acceptable Daily Intake, ADI). Los principios de comprobación de la toxicidad y evaluación de la exposición recomendados por diversas organizaciones internacionales, incluidas las normas aplicadas en los países de la U nión E uropea, serán cada vez más compatibles con los utilizados en los países de Europa Central y Oriental a medida que éstos se interrelacionan progresivamente con las restantes economías europeas.

Durante el decenio de 1980 se reconoció progresivamente la necesidad de armonizar las metodologías y enfoques científicos en el campo de la toxicología y la estandarización higiénica aplicados en los países de la O CDE con los empleados en los países miembros del Consejo de Asistencia Económica Mutua (COMECON). Esto se debió principalmente al aumento de la producción y el comercio, incluyendo los productos químicos industriales y agrícolas. Un factor que reforzó la urgencia con que se contemplaba esta necesidad fue el problema creciente de la contaminación aérea y fluvial a través de las fronteras de Europa (Bencko y U ngváry 1994).

El modelo económico de Europa Central y O riental estaba basado en una política económica de planificación central orientada al desarrollo de la industria básica del metal y el sector energético. En 1994, la economías de la Federación Rusa, U crania, Bielorrusia, Polonia y las repúblicas checa y eslovaca conservaban aún, exceptuados cambios menores, sus viejas estructuras (Pokrovsky 1993).

La minería del carbón es un sector muy desarrollado en la R epública Checa. Al mismo tiempo, la minería del carbón negro (por ejemplo, en la región septentrional de M oravia) es la causa del $67 \%$ de todos los nuevos casos de neumoconiosis del país. El carbón marrón se extrae en minas a cielo abierto del norte de Bohemia, el sur de Silesia y zonas vecinas de Alemania. Las centrales térmicas de producción eléctrica, las plantas químicas y la minería del carbón marrón son factores decisivos de la contaminación medioambiental de la región, que constituye el Ilamado "triángulo sucio" o "negro" de Europa. El uso incontrolado de pesticidas y fertilizantes en la agricultura no era algo excepcional (República Federal Checa y E slovaca 1991b).

La población activa de la República Checa asciende a unos 5 millones de trabajadores. En torno a 405.500 de ellos (es decir, el $8,1 \%$ ) realizan actividades peligrosas (M inisterio de Sanidad de la República Checa 1992). La Figura 16.8 muestra los datos relativos al número de trabajadores expuestos a distintos peligros profesionales y la proporción de mujeres entre ellos.

\section{Necesidades cambiantes}

EI sistema de salud en el trabajo de la República Checa ha atravesado tres etapas consecutivas en su desarrollo y se ha visto influido por los cambios políticos y económicos experimentados por el país (Pelclová, Weinstein y Vejlupková 1994).

1a E tapa: 1932-48. Este período viene marcado por la fundación del primer Departamento de Medicina del Trabajo por parte del Profesor J. Teisinger en la universidad más antigua de Europa Central (Universidad Carlos, fundada en 1348). M ás tarde, en 1953, este departamento se convirtió en el Centro H ospitalario de Medicina del Trabajo, con 27 camas. El Profesor Teisinger fundó también el Instituto de Investigación sobre Salud en el Trabajo y, en 1962, el Centro de Información sobre Venenos, en el seno del Centro $\mathrm{H}$ ospitalario. Teisinger recibió varios premios internacionales, entre ellos uno de la American Association of Industrial Hygienists en 1972 por su aportación personal al desarrollo de la salud en el trabajo. 
Figura 16.8 - N úmero de trabajadores expuestos a los riesgos profesionales más graves en la República Checa.

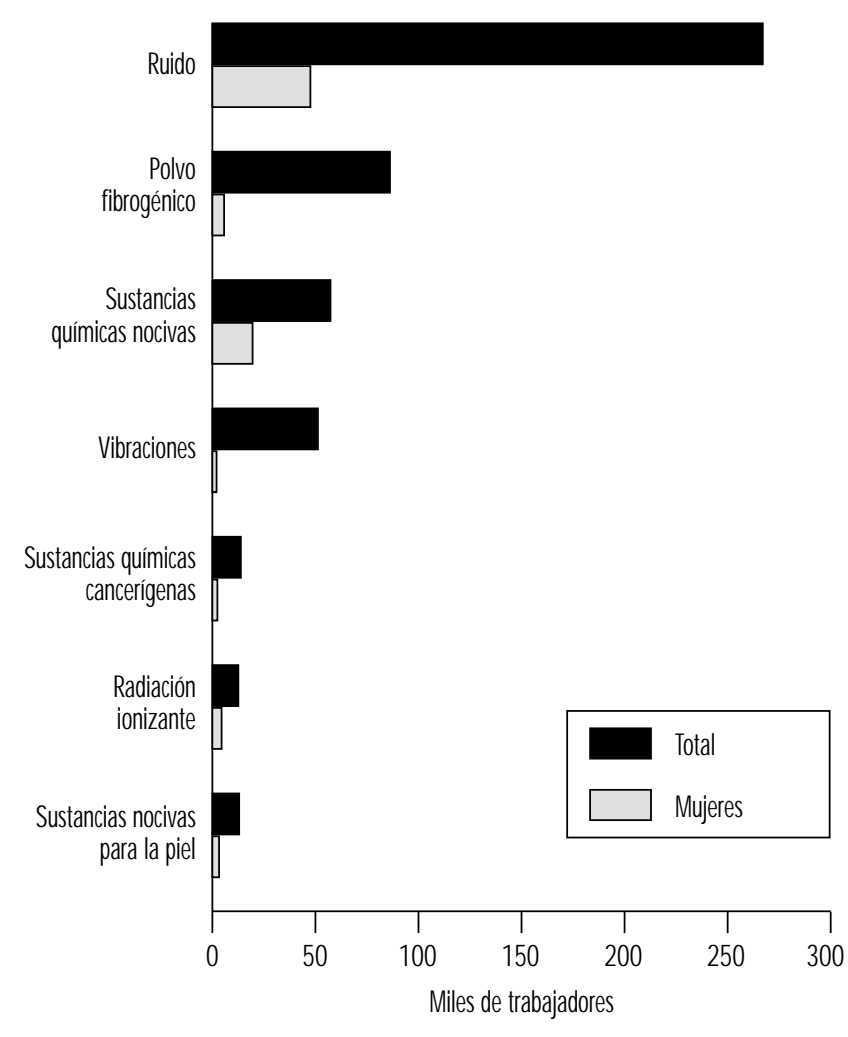

2a E tapa: 1949-88. Este período muestra muchas incoherencias, caracterizándose en algunos aspectos por notables deficiencias y en otros por indudables progresos. En esta etapa se reconoció la necesidad de reorganizar el sistema vigente de salud en el trabajo, pese a su fiabilidad y buen desarrollo en algunos aspectos. La asistencia sanitaria se consideraba un derecho civil fundamental garantizado por la Constitución. Los seis principios básicos del sistema sanitario eran (C zech and Slovak Federal Republic 1991a):

- integración planificada de la asistencia sanitaria en la sociedad;

- promoción de una forma de vida sana;

- desarrollo científico y técnico;

- prevención de las enfermedades físicas y mentales;

- acceso gratuito y universal a los servicios de asistencia sanitaria;

- intervención del estado en favor de un medio ambiente saludable.

Pese a los avances realizados en algunos aspectos, ninguno de estos objetivos se alcanzó plenamente. La esperanza de vida (67 años para los hombres y 76 para las mujeres) es la más corta de los países industrializados. $\mathrm{H}$ ay una alta tasa de mortalidad por enfermedades cardiovasculares y cáncer. En torno al $26 \%$ de los adultos son obesos y el $44 \%$ de ellos tienen niveles de colesterol superiores a $250 \mathrm{mg} / \mathrm{dl}$. La dieta contiene mucha grasa animal y pocas frutas y verduras frescas. El consumo de alcohol es relativamente alto y alrededor del $45 \%$ de los adultos fuma, lo que causa la muerte de en torno a 23.000 personas al año.

La asistencia médica y dental, así como las medicinas, se entregaban gratuitamente y el número de médicos $(36,6$ por cada 10.000 habitantes) y de enfermeras (68,2 por cada 10.000$)$ estaba entre los más altos del mundo, pero con el tiempo el estado se vio incapaz de cubrir los importantes gastos continuamente crecientes de la salud pública. $\mathrm{Ha}$ habido carencias temporales de algunos fármacos y equipos, así como dificultades en la prestación de servicios de asistencia sanitaria y rehabilitación. La estructura actual, que no permitía al paciente elegir a su médico de cabecera, creaba muchos problemas. EI personal médico de los hospitales estatales recibía salarios bajos y fijos, sin incentivos para la prestación de más servicios. No existía un sistema privado de asistencia sanitaria. En los hospitales, el principal criterio de buen funcionamiento era el "número de camas ocupadas" y no la calidad de la asistencia prestada.

No obstante, el sistema estatal centralizado de salud en el trabajo tenía algunos aspectos positivos, entre ellos un registro prácticamente completo de lugares de trabajo peligrosos y un sistema bien organizado de control higiénico por parte del Servicio H igiénico. Los servicios internos de salud en el trabajo de las grandes empresas facilitaban la prestación de servicios integrales de asistencia sanitaria, incluidas las exploraciones médicas periódicas y el tratamiento de los trabajadores. N o existían pequeñas empresas privadas, que suelen constituir un grave problema para los programas de salud en el trabajo.

En la agricultura, la situación era similar, sin pequeñas explotaciones privadas sino grandes cooperativas, de modo que el médico del trabajo que operaba en el centro de salud e una fábrica o granja cooperativa prestaba los servicios de salud en el trabajo a los trabajadores.

El rigor en el cumplimiento de la normativa de salud y seguridad en el trabajo era en ocasiones contradictorio. Si tras la inspección de un lugar de trabajo peligroso por parte de un higienista industrial 0 un inspector de fábrica éste exigía la reducción del nivel de exposición en el trabajo y el cumplimiento de las normas de salud y seguridad, en lugar de corregir estos riesgos se entregaba a los trabajadores una indemnización económica. Aparte del hecho de que con frecuencia las empresas no tomaban medida alguna para mejorar las condiciones de trabajo, los propios trabajadores no estaban interesados en hacerlo y preferían, en su lugar, seguir recibiendo

Figura 16.9 • Enfermedades profesionales en la República Checa en el período 1981-1992.

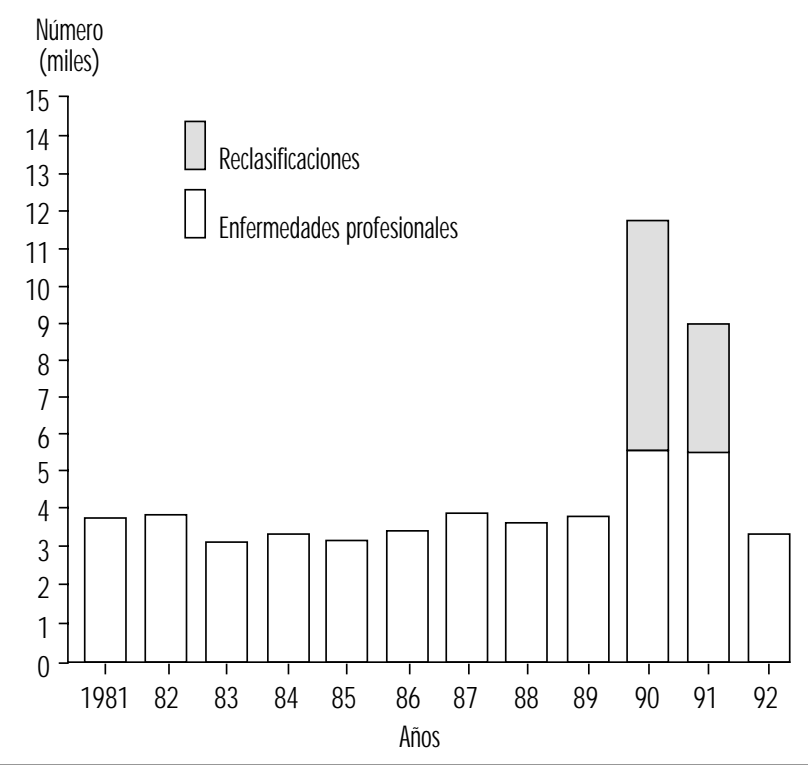


Figura 16.10 • Enfermedades profesionales en la República Checa en 1992.

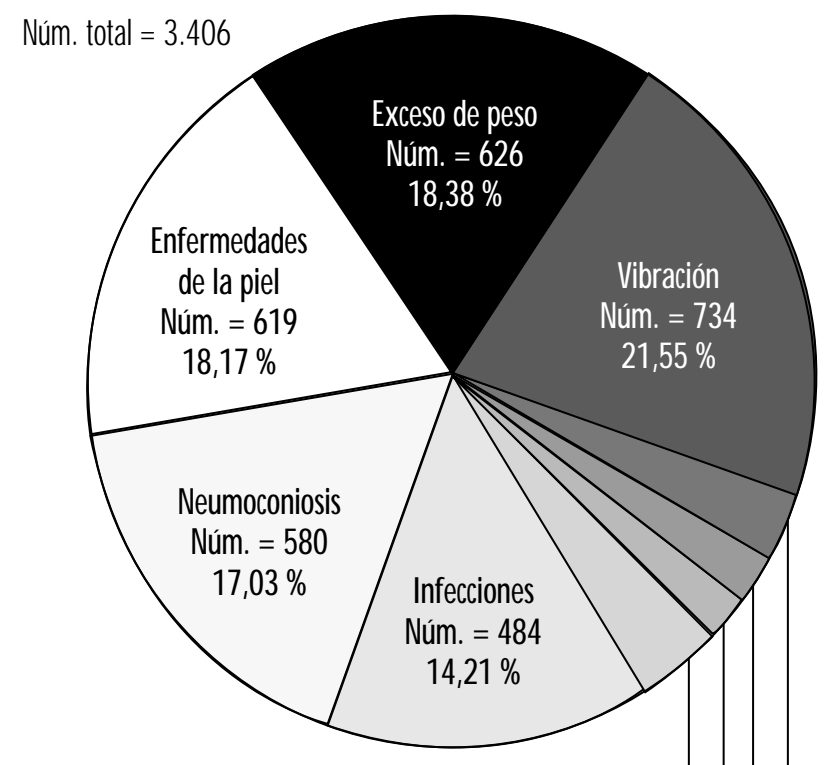

Pérdida de audición; Núm. $=127-3,73 \%$

Cáncer de pulmón; Núm. $=71-2,08 \%$

Intoxicaciones; Núm. $=64-1,88 \%$

Otras; Núm. $=101-2,97 \%$

primas. Además, el trabajador que contraía una enfermedad profesional recibía una indemnización económica importante dependiendo de la gravedad de la enfermedad y de su nivel salarial previo. Este tipo de situación provocaba conflictos de intereses entre los higienistas industriales, los médicos del trabajo, los sindicatos y las empresas. Como muchas prestaciones eran de cargo del estado y no de la empresa, a ésta le resultaba con frecuencia más barato no mejorar la salud y la seguridad en el lugar de trabajo.

Por extraño que pueda parecer, algunas normas higiénicas, incluidas los niveles permitidos de ruido y los límites de exposición en el trabajo, eran más rigurosas que los de Estados U nidos - Europa 0 ccidental. En consecuencia, a veces resultaba imposible no excederlos al utilizar maquinaria o equipos anticuados. Los lugares de trabajo que excedían los límites se clasificaban como de "4a categoría" 0 más peligrosos, pero por razones económicas no se interrumpía la producción y, en su lugar, se ofrecían indemnizaciones a los trabajadores.

3a E tapa: 1989- la actualidad. La "revolución de terciopelo" de 1989 hizo posible un cambio inevitable en el sistema de salud pública. La reorganización ha sido bastante compleja y en algunos casos difícil de conseguir: téngase en cuenta, por ejemplo, que el sistema de asistencia sanitaria tiene más camas hospitalarias y médicos por cada 10.000 habitantes que cualquier país industrializado, al tiempo que destina una cantidad desproporcionadamente menor de recursos económicos.

\section{Estado actual de la salud y la seguridad en el trabajo}

El peligro profesional más frecuente en la República $C$ heca es el ruido: en torno al $65,8 \%$ de los trabajadores de riesgo están expuestos a este peligro (Figura 16.8). El segundo peligro principal relacionado con el trabajo es el polvo fibrogénico, que representa un peligro para alrededor del $21,3 \%$ de los trabajadores de riesgo. A proximadamente el $14,3 \%$ de los trabajadores están expuestos a sustancias químicas tóxicas. $M$ ás de mil de ellos están expuestos a tolueno, monóxido de carbono, plomo, gasolina, benceno, xileno, compuestos organofosforados, cadmio, mercurio, manganeso, tricloroetileno, estireno, tetracloroetileno, anilina y nitrobenceno. 0 tro peligro físico (la vibración localizada en manos y brazos) afecta al $10,5 \%$ de los trabajadores de riesgo. 0 tros trabajadores están expuestos a sustancias químicas cancerígenas, radiaciones ionizantes y sustancias peligrosas que causan lesiones dermatológicas.

El número de casos reconocidos de enfermedades del trabajo en la R epública Checa en 1981-92 se muestra en la Figura 16.9.

El aumento de la morbilidad derivada de enfermedades del trabajo en el período $1990-91$ se debe al proceso de reclasificación de enfermedades profesionales solicitado por los mineros y trabajadores de otras actividades, así como por sus sindicatos, que pedían el cambio de la calificación como "riesgo de padecer una enfermedad del trabajo" empleada para las formas menos evidentes de deterioro profesional con baja indemnización por la de enfermedad plenamente indemnizable. EI M inisterio de Sanidad reconsideró en 1990 esta calificación de "en situación de riesgo" para las siguientes patologías del trabajo:

- formas leves de neumoconiosis;

- formas leves de trastornos musculoesqueléticos crónicos por exceso de peso y vibraciones;

- formas leves de pérdida de audición en el trabajo.

La reclasificación se aplicó a todos los casos producidos antes de 1990, amparó a 6,272 casos en ese año y a 3,222 en 1991 (Figura 16.9). Posteriormente se suprimió la categoría de "en situación de riesgo". La Figura 16.10 muestra datos relativos a 3,406 nuevos casos de enfermedades del trabajo por categorías diagnosticados en la República Checa en 1992, de los cuales 1.022 corresponden a mujeres (Urban, Hamsova y N ěmeček 1993).

Algunas carencias en el suministro de equipos de medición para la toma de muestras y el análisis de sustancias tóxicas hacen difícil realizar evaluaciones de higiene en el mismo lugar de trabajo. Por otra parte, en el caso de varias sustancias se emplean biomarcadores en las pruebas de exposición para el control de trabajadores en actividades peligrosas, con arreglo a las reglamentaciones del país. También se han establecido legalmente pruebas similares en Hungría, Eslovaquia, Eslovenia, Croacia, Polonia y algunos otros países de Europa Central y O riental. El uso de las pruebas de exposición ha resultado ser una herramienta muy eficaz para el control de la exposición del personal, permitiendo la detección precoz y la prevención de algunas enfermedades y reduciendo así los costes de indemnización.

La transición a la economía de mercado y los crecientes costes de los servicios de salud en el trabajo en la República Checa han influido en los servicios de salud en el trabajo. En el pasado, el servicio o centro interno de salud en el trabajo prestaba tanto vigilancia como tratamiento sanitarios a los trabajadores. En la actualidad, estas actividades están sujetas a ciertas restricciones, lo que ha dado lugar a una reducción de la vigilancia sanitaria y el control de riesgos y a un aumento de enfermedades y accidentes en el trabajo. Los trabajadores de las pequeñas empresas, que están proliferando rápidamente y que suelen utilizar 
maquinaria y equipos poco fiables, están en la práctica fuera del alcance de los profesionales de la salud en el trabajo.

\section{Proyectos de futuro}

Se espera que el nuevo sistema de salud pública de la República Checa incorpore los siguientes principios:

- prevención y promoción de la salud;

- acceso global a la asistencia sanitaria "estándar";

- política descentralizada de prestación de los servicios;

- integración de los servicios sanitarios en una red territorial;

- mayor autonomía para los profesionales de la asistencia sanitaria;

- importancia de la asistencia ambulatoria;

- seguro de salud obligatorio;

- participación de la comunidad;

- más opciones para los pacientes;

- nueva forma de participación pública y privada para prestar una asistencia sanitaria "superior al estándar", que ya no prestará el sector público.

EI establecimiento del sistema de seguro de salud obligatorio y la creación de la O ficina General del Seguro de Salud, que comenzó a operar en enero de 1993, y de pequeñas compañías de seguro sanitario han marcado el inicio de la reforma en el sector de la salud pública. Estos cambios han planteado ciertos problemas a los servicios de salud en el trabajo, dado su carácter preventivo y el alto coste del tratamiento hospitalario, de modo que el papel de los centros médicos ambulatorios para el tratamiento de pacientes con enfermedades tanto profesionales como convencionales está creciendo permanentemente en importancia.

\section{Efectos potenciales de los continuos cambios en la salud y la seguridad en el trabajo}

El avance de la reforma en el sector de la salud pública ha generado la necesidad de un cambio para los médicos del trabajo, higienistas industriales y centros médicos de asistencia hospitalaria, así como a un énfasis en la prevención. La capacidad de centrarse en la prevención y en formas leves de enfermedades se explica en parte por los resultados positivos previos y por el relativamente buen funcionamiento del anterior sistema de salud en el trabajo, que ha eliminado eficazmente la mayor parte de las enfermedades graves. Estos cambios implican un giro de la atención desde las formas graves de patologías del trabajo, que requerían tratamiento urgente (tales como la intoxicación industrial y la neumoconiosis con fallo cardíaco y respiratorio), hacia formas leves de enfermedad. El cambio en las actividades de los servicios de salud en el trabajo desde una orientación curativa hacia el diagnóstico precoz afecta hoy a enfermedades tales como formas leves de neumoconiosis, afecciones hepáticas crónicas y trastornos musculoesqueléticos crónicos por exceso de peso o vibraciones. Deben tomarse también medidas preventivas en las fases precoces de las enfermedades del trabajo.

Las actividades de higiene industrial no están cubiertas por el sistema de seguro sanitario y los higienistas industriales de los centros de higiene siguen estando remunerados por el estado. Se espera una reorganización y una reducción del número de estos centros.

0 tro cambio en el sistema de asistencia sanitaria es la privatización de algunos servicios. Ya ha comenzado la privatización de los pequeños centros médicos de asistencia ambulatoria. Los hospitales (incluidos los universitarios) no participan por el momento en este proceso y aún es necesario clarificar los detalles de su privatización. L a nueva normativa relativa a las obligaciones de las empresas, los trabajadores y los servicios de salud en el trabajo está promulgándose gradualmente.

\section{La encrucijada de la salud en el trabajo}

Gracias al avanzado sistema de salud en el trabajo fundado por el Profesor Teisinger en 1932, la República Checa no padece hoy problemas graves de educación universitaria en este campo, pese a que en algunos otros países de Europa Central y Oriental la tasa de enfermedades profesionales reconocidas es hasta cinco veces menor. La Lista de Enfermedades Profesionales checa no varía en gran medida de la que figura como apéndice al Convenio de la OIT sobre las prestaciones en caso de accidentes del trabajo y enfermedades profesionales ( $n$ - 121) (OIT 1964). La proporción de enfermedades importantes del trabajo no reconocidas es pequeña.

El sistema de salud en el trabajo de la República Checa se encuentra hoy en una encrucijada y la necesidad de una reorganización es manifiesta, pero al mismo tiempo es necesario mantener los aspectos positivos adquiridos de la experiencia con el sistema anterior, concretamente:

- el registro de las enfermedades profesionales en el lugar de trabajo;

- el mantenimiento de un amplio sistema de exploraciones médicas periódicas de los trabajadores;

- la prestación de servicios de asistencia sanitaria curativa en las grandes empresas;

- la oferta de un sistema de vacunación y control de enfermedades contagiosas;

- el mantenimiento del sistema por el que los servicios de salud en el trabajo admiten a pacientes con diversas enfermedades profesionales, un sistema en el que los hospitales universitarios participan en el tratamiento de los pacientes y la educación y formación de los estudiantes y licenciados en medicina.

\section{LA PRACTICA DE LA SALUD EN EL TRABAJO EN LA INDIA}

\section{T. K. Joshi}

D esde hace casi medio siglo, los médicos de la India se han interesado por la salud de los trabajadores. En 1940 se fundó en la ciudad de Jamshedpur, en la que se encuentra la planta siderúrgica más antigua y conocida del país, la A sociación de Salud en el Trabajo de la India. No obstante, la práctica interdisciplinaria de la salud en el trabajo se desarrolló en los decenios de 1970 y 1980, cuando la O IT envió un equipo que ayudó a crear un centro modelo de salud en el trabajo. La industria y los lugares de trabajo solían prestar asistencia sanitaria bajo el rótulo de Centros de Primeros Auxilios/Servicios M édicos de Fábrica. Estas instalaciones resolvían los problemas sanitarios y lesiones menores en el lugar de trabajo. Algunas empresas han establecido recientemente servicios de salud en el trabajo, y es de esperar que otras más sigan este camino. No obstante, los hospitales universitarios han ignorado hasta el momento esta especialidad.

La práctica de la salud y la seguridad en el trabajo comenzó con la notificación y la prevención de las lesiones y accidentes. Se cree, no infundadamente, que siguen sin notificarse todos los que se producen. Las tasas más altas de incidencia de lesiones del período 1990-91 corresponden a los sectores eléctrico $(0,47$ de cada 1.000 trabajadores), de metalurgia básica $(0,45)$, químico $(0,32)$ y no metálico $(0,27)$, con cifras algo inferiores en las industrias maderera y de pasta de madera $(0,08)$ y de maquinaria y equipos $(0,09)$. La industria textil, con más trabajadores (1,2 millones en 1991), tiene una tasa de incidencia de 0,11 por cada 1.000 trabajadores. Con respecto a las lesiones mortales, las tasas de incidencia en 1989 fueron de 0,32 por cada 1.000 trabajadores en las minas de carbón y de 0,23 en las minas no 
de carbón. En 1992 se produjeron en los puertos un total de 20 accidentes mortales y 753 no mortales.

$\mathrm{N}$ o se dispone de cifras de peligros profesionales y del número de trabajadores expuestos a peligros específicos, pues las estadísticas publicadas por la $\mathrm{O}$ ficina de Trabajo no ofrecen estos datos. No se ha elaborado aún un sistema de encuestas de salud en el trabajo. EI número de enfermedades notificado en 1978 fue de sólo 19, que ascendieron a 84 en 1982 . No hay pautas o tendencias manifiestas en las enfermedades notificadas, siendo las más frecuentes la intoxicación por benceno, la intoxicación por halógenos (derivados halogenados), la silicosis y la neumoconiosis, la bisinosis, la ulceración por cromo, la intoxicación por plomo, la pérdida de audición y la ictericia tóxica.

No existe una normativa integral de salud en el trabajo. Las tres leyes principales son la Ley de Fábricas, de 1948; la Ley de M inas, de 1952, y la Ley de Seguridad, Salud y Bienestar de los Trabajadores Portuarios, de 1986. Está en proyecto una ley de seguridad para los trabajadores de la construcción. La Ley de Fábricas, promulgada inicialmente en 1881 , sigue cubriendo tan sólo a los trabajadores de las fábricas registradas, de modo que un gran número de trabajadores manuales y no manuales siguen sin reunir los requisitos necesarios para beneficiarse de las prestaciones de salud y seguridad previstas en cualquiera de las leyes. La inadecuación de la normativa y la reducida firmeza en su aplicación son la causa del nivel escasamente satiffactorio de salud en el trabajo del país.

La mayor parte de los servicios de salud en el trabajo en la industria están gestionados por médicos 0 enfermeras, y son pocos los de carácter interdisciplinario, que están limitados a las grandes empresas. L as grandes fábricas de los sectores público y privado ubicadas en zonas remotas tienen sus propios municipios y hospitales.

La medicina del trabajo y ocasionalmente la higiene industrial son dos disciplinas comunes en la mayoría de los servicios de salud en el trabajo. Algunos servicios han comenzado también a contratar a un ergonomista. El control biológico y de la exposición no reciben aún la atención necesaria. La base académica de la medicina del trabajo y la higiene industrial no está aún bien desarrollada, con un acceso restringido a los cursos avanzados de higiene industrial y los de postgrado en práctica de salud en el trabajo.

Cuando Delhi se convirtió en un estado, en 1993, el M inisterio de Sanidad pasó a estar encabezado por un profesional de la salud que subrayó su dedicación a la mejora de la asistencia sanitaria pública y preventiva. Un comité creado para estudiar la cuestión de la salud del trabajo y del medio ambiente recomendó crear un centro hospitalario al efecto en el seno de un hospital académico de prestigio de la ciudad.

La gestión de los complejos problemas derivados de los peligros del trabajo y la contaminación medioambiental requiere una participación más activa de la comunidad médica. El hospital de la universidad recibe cientos de pacientes al día, muchos de los cuales han sufrido exposición a materiales peligrosos en el trabajo y a un medio ambiente urbano insano. La detección de los trastornos sanitarios inducidos por el trabajo y por el medio ambiente requiere aportaciones de muchos especialistas clínicos, servicios de imagen (radiología), laboratorios, etc. D ebido al estado avanzado de la enfermedad, es necesario cierto tratamiento de apoyo y asistencia médica. Este tipo de centro hospitalario cuenta con la especialización de un hospital académico, y tras la detección del trastorno sanitario puede permitir un tratamiento o rehabilitación de la víctima o una propuesta de intervención para la protección de terceros que resulten más eficaces gracias a la mayor competencia y prestigio de la institución.
El centro hospitalario tiene competencia especializada en el campo de la medicina del trabajo y se propone colaborar con el departamento de trabajo, que tiene un laboratorio de higiene industrial desarrollado con generosas ayudas bajo un programa de la OIT para reforzar la salud y la seguridad en la India, lo cual facilitará la tarea de identificación y evaluación de peligros. Se asesorará a los médicos en materia de evaluación de la salud de grupos expuestos en el momento del ingreso y periódicamente, así como sobre la llevanza de registros. El centro hospitalario ofrecerá a las empresas y los trabajadores sus conocimientos especializados sobre educación de la salud y prácticas seguras en el uso y manipulación de materiales peligrosos en el lugar de trabajo. Esto debe contribuir a hacer más factible la prevención primaria y fortalecerá la vigilancia de la salud en el trabajo, según lo previsto en el Convenio de la OIT sobre los servicios de salud en el trabajo ( $n$ ㅇ 161) (OIT 1985a).

El centro hospitalario se está desarrollando en dos fases. La primera se centra en la identificación de los peligros y la creación de una base de datos, así como en la sensibilización y el desarrollo de estrategias de prestaciones sociales con respecto a los casos de medio ambiente de trabajo peligroso. La segunda fase se centrará en el reforzamiento del control de la exposición, la evaluación médica toxicológica y los factores ergonómicos. El centro se propone popularizar la enseñanza de la salud en el trabajo entre los estudiantes de medicina aún no licenciados. Para los estudiantes de postgrado que preparan la tesis, se fomenta la elección de temas del área de la medicina medioambiental y del trabajo. Uno de estos estudiantes ha concluido recientemente con éxito un proyecto sobre el contagio de infecciones por vía sanguínea entre los trabajadores de la asistencia sanitaria en los hospitales.

La clínica se propone también abordar cuestiones medioambientales, concretamente los efectos nocivos del ruido y la contaminación acústica creciente, así como los de la exposición de los niños al plomo. A largo plazo, se prevé también la educación de prestadores de asistencia sanitaria y grupos comunitarios. El otro objetivo es crear registros de enfermedades profesionales prevalentes. La participación de varios especialistas clínicos en medicina medioambiental y del trabajo permitirá, asimismo, crear un núcleo académico para un momento futuro en el que pueda emprenderse en el país una mayor cualificación de postgrado, hoy inasequible.

El centro hospitalario ha conseguido atraer la atención de los organismos reguladores y de supervisión del cumplimiento hacia los graves riesgos sanitarios a que estuvieron expuestos los bomberos de la ciudad que participaron en la extinción de un incendio de cloruro polivinilo, cuando los medios de comunicación y los medioambientalistas sólo la estaban prestando a los riesgos para la comunidad. Se espera que, en el futuro, todas las principales ciudades cuenten con este tipo de centros hospitalarios, pues es la única forma de lograr la participación de los especialistas médicos en la práctica de la medicina medioambiental y del trabajo.

\section{Conclusión}

La India necesita urgentemente una L ey de Salud y Seguridad en el Trabajo al estilo de las de muchos países industrializados, que debería venir unida a la creación de una autoridad competente para la supervisión de su aplicación y cumplimiento. Esto sería de gran ayuda para alcanzar una norma uniforme de asistencia sanitaria en el trabajo en todos los estados del país. En la actualidad, no hay conexión entre los distintos centros de salud en el trabajo. 0 tras prioridades son proporcionar una formación de calidad en materia de higiene industrial, toxicología médica y epidemiología del trabajo. Se necesitan buenos laboratorios de análisis, a los que 


\section{Referencias}

Asociación Internacional de la Seguridad Social (AISS). 1995. Prevention Concept "Safety W orldwide". Ginebra: OIT.

Association of Occupational and Environmental Clinics (AOEC). 1995. M embership Directory. Washington, DC: AOEC.

Bencko, V, G Ungváry. 1994. Risk assessment and environmental concerns of industrialization: A central European experience. En Occupational $\mathrm{H}$ ealth and National Development, dirigido por Jeyaratnam y K S Chia. Singapur: W orld Science.

Bird, FE, GL Germain. 1990. Practical Loss Control L eadership. G eorgia: Institute Publishing Division of the International Loss C ontrol Institute.

Bunn, WB. 1985. Industrial M edical Survellance Programmes. Atlanta: Centers for Disease Control (CDC).

-. 1995. The scope of international occupational medical practice. 0 ccup M ed. En imprenta.

Bureau of National Affairs (BNA). 1991. W orkers' Compensation Report. Vol. 2. Washington, DC: BNA.

- 1994. Workers' Compensation Report. Vol. 5. Washington, DC: BNA.

Centro Nacional de Información sobre la Salud en el Trabajo. 1994. Informes anuales sobre la situación sanitaria en el trabajo en 1987-1994. Pekín, China: Centro Nacional de Información sobre la Salud en el Trabajo.

Código del Trabajo de la Federación Rusa. 1993. Zakon, Supl. de Izvestija (M oscú), junio: 5-41.

Comisión Europea. 1994. E urope for Safety and $\mathrm{H}$ ealth At W ork. Luxemburgo: Comisión Europea.

Comisión Internacional de Salud en el Trabajo $(\mathrm{ICOH})$. 1992. International Code of Ethics for 0 ccupational $\mathrm{H}$ ealth Professionals. G inebra: $\mathrm{ICOH}$.

Comité Mixto OIT/OMS sobre Medicina del Trabajo. 1950. R eport of the F irst M eeting, 28 August-2 September 1950. Ginebra: OIT

- . 1992. Eleventh Session, D ocument N O. GB.254/11/ 11. Ginebra: OIT.

-. 1995a. Definition of Occupational $H$ ealth. Ginebra: OIT.

-. 1995b. T welfth Session, Document No. GB.264/ ST M / 11. Ginebra: OIT.

Conferencia de las Naciones U nidas sobre Medio Ambiente y Desarrollo (UNCED). 1992. Río de Janeiro.

Consejo de la Comunidad Europea (CCE). 1989. Directiva del Consejo sobre la adopción de medidas para promover mejoras en la seguridad y la salud de los trabajadores en el lugar de trabajo. Bruselas: Consejo de la Comunidad Europea.

Constitución de la Federación Rusa. 1993. Izvestija (M oscú), N o. 215, 10 de noviembre.

Cumbre Mundial de Desarrollo Social. 1995. Declaración y Programa de Acción. Copenhague: Cumbre M undial de Desarrollo Social.

China D aily. 1994a. N ew sectors opened to lure foreign investment. 18 de mayo.

-. 1994b. Foreign investors reap advantages of policy changes. 18 de mayo.

Equal Employment Opportunity Commission (EEO C), Department of Justice. 1991. Americans with D isabilities Act H andbook. EEO C-BK -19, P.1. 1, 2, octubre.

Felton, JS. 1976. 200 years of occupational medicine in the US. J O ccup M ed 18:800.

Goelzer, B. 1993. Guidelines on control of chemical and physical hazards in small industries Documento de trabajo para el Task Group
Interregional de protección y promoción de la salud de los trabajadores en las pequeñas empresas, 1-3 de noviembre, Bangkok, T ailandia. Bangkok: OIT.

H asle, P, S Samathakorn, C V eeradejkriengkrai, C Chavalitnitikul, and J Takala. 1986. Survey of working conditions and environment in small-scale enterprises in T hailand, NICE project. Informe técnico núm. 12. Bangkok: NICE/UNDP/OIT.

Hauss, F. 1992. Health promotion for the crafts. D ortmund: Forschung FB 656

$\mathrm{He}$ IS. 1993. Documento de trabajo sobre la situación nacional de la salud en el trabajo. Ponencia en la Conferencia Nacional de M edicina del Trabajo. Pekín, China: Ministerio de Salud Pública.

H uuskonen, M, K R antala. 1985. W ork Environment in Small Enterprises in 1981. Helsinki: K ansaneläkelaitos.

Improving working conditions and environment: An International Programme (PIACT). The evaluation of the International Programme for the Improvement of Working Conditions and Environment (PIACT). 1984. Informe presentado en la $70^{\text {a }}$ sesión de la Conferencia Internacional del T rabajo. G inebra: OIT

Institute of Medicine (IOM). 1993. Environmental $M$ edicine and the M edical School Curriculum. Washington, DC: N ational Academy Press.

Instituto de M edicina del T rabajo. 1979. T raducción al inglés de la Ley de servicios de salud en el trabajo y del Decreto núm. 1009 del Consejo de Estado, Finlandia. Finlandia: Instituto de M edicina del Trabajo.

Instituto de M edicina del Trabajo.1987. M étodos para el control y el análisis de peligros químicos en la atmósfera del lugar de trabajo. Pekín, China: Centro Nacional de Publicaciones M édicas.

Jeyaratnam, J. 1992. O ccupational health services and developing nations. En Occupational $\mathrm{H}$ ealth in Developing Countries, dirigido por J Jeyaratnam. Oxford: OUP.

-. y K S Chia (dirs.). 1994. Occupational Health and National D evelopment. Singapur: World Science.

Kalimo, E, A K aristo, T K laukkla, R Lehtonen, K Nyman, R Raitasalo. 1989. O ccupational $H$ ealth Services in Finland in the Mid-1980s. Helsinki: $\mathrm{K}$ ansaneläkelaitos

Kogi, K, WO Phoon, JE Thurman. 1988. Low Cost W ays of Improving W orking Conditions: 100 Examples from A sia. Ginebra: O IT.

K roon, PJ, M A O vereynder. 1991. O ccupational H ealth Services in Six M ember States of the EC. Amsterdam: Studiecentrum Arbeid \& Gezonheid, Univ. de Amsterdam.

Ley básica sobre protección de los trabajadores. 1993. R ossijskaja Gazeta (M oscú), 1 de septiembre.

M cC unney, RJ. 1994. O ccupational medical services. En A Practical Guide to 0 ccupational and Environmental M edicine, dirigido por RJ McCunney. Boston: Little, Brown \& Co.

-. 1995. A M anager's Guide to Occupational $\mathrm{H}$ ealth Services. Boston: OEM Press and American College of $O$ ccupational and Environmental M edicine.

Ministerio de Asuntos Sociales y Empleo. 1994. M edidas para reducir las bajas por enfermedad y mejorar las condiciones de trabajo. La Haya, Países Bajos: M inisterio de Asuntos Sociales y Empleo.

M inisterio de Salud Pública. 1957. Recomendación sobre la creación y dotación de personal de centros médicos y sanitarios en empresas industriales. Pekín, China: $\mathrm{M}$ inisterio de Salud Pública.

- 1979. Comité E statal de Construcción, Comité E statal de Planificación, Comité E statal de E conomía, M inisterio de
T rabajo, Normas de higiene para el diseño de instalaciones industriales. Pekín, China: M inisterio de Salud Pública.

- 1984. Normas para el diagnóstico de enfermedades profesionales. Documento núm. 16. Pekín, China: M inisterio de Salud Pública.

-. 1985. M étodos para la medición del polvo atmosférico en el lugar de trabajo. Documento núm. GB5748-85. Pekín, China: M inisterio de Salud Pública.

—. 1987. M inisterio de Salud Pública, M inisterio de T rabajo, M inisterio de Finanzas, Federación China de Sindicatos: Normas para la elaboración de la lista de enfermedades profesionales y la atención a los enfermos. Documento núm. I60. Pekín, China: M inisterio de Salud Pública.

- 1991a. Normas para elaborar las estadísticas de inspección sanitaria. Documento núm. 25. Pekín, China: M inisterio de Salud Pública.

— . 1991b. Guía del servicio y la inspección de la salud en el trabajo. Pekín, China: M inisterio de Salud Pública.

- . 1992. Procedimientos utilizados en la Encuesta Nacional sobre la Neumoconiosis. Pekín, China: Centro U niversitario de Publicaciones M édicas de Pekín.

-. 1994 Informes estadísticos anuales de la inspección sanitaria en 1988-1994. Pekín, China: Departamento de Inspección Sanitaria, M inisterio de Salud Pública.

M inisterio de Sanidad de la R epública Checa. 1992. Programa Nacional de Rehabilitación y Promoción de la Salud en la República Checa. Praga: Centro N acional para la Promoción de la Salud.

National Health Systems. 1992. M arket and Feasibility Study. Oak Brook, Illinois: National Health Systems.

Neal, AC, FB W right. 1992. The E uropean Communities' $\mathrm{H}$ ealth and Safety Legislation. Londres: Chapman \& $\mathrm{H}$ all.

Newkirk, WL. 1993. Occupational H ealth Services. Chicago: American $\mathrm{H}$ ospital Publishing.

Niemi, J, J H eikkonen, V N otkola, K H usman. 1991. An intervention programme to promote improvements of the work environment in small enterprises: Functional adequacy and effectiveness of the intervention model. T yö ja inminen 5:361-379.

Niemi, J, V Notkola. 1991. O ccupational health and safety in small enterprises: Attitudes, knowledge and behaviour of the entrepreneurs. T yö ja inminen 5:345-360.

O ficina de N ormas Sanitarias.1993. Criterios nacionales de diagnóstico y principios de la gestión de enfermedades profesionales. Pekín, China: Centro Nacional de Publicación de $\mathrm{N}$ ormas.

O ficina Nacional de Estadística. 1993. Anuario de estadísticas nacionales de la República Popular de China. Pekín, China: $O$ ficina $\mathrm{N}$ acional de Estadística.

Organización Internacional del Trabajo (OIT). Recomendación núm. 112 (1959): Servicios de medicina del trabajo. Ginebra: O IT.

— . 1964. Convenio núm. 121 (1964): Prestaciones en caso de accidentes del trabajo y enfermedades profesionales. Ginebra: O IT

—. 1981a. Convenio núm. 155 (1981): Seguridad y salud de los trabajadores. Ginebra: O IT

- 1981b. Recomendación núm. 164 (1981): Seguridad y salud de los trabajadores. Ginebra: 0 IT

- 1984. Resolución sobre la mejora de las condiciones y el medio ambiente de trabajo. Ginebra: OIT

—. 1985a. Convenio núm. 161 (1985): Servicios de salud en el trabajo. Ginebra: OIT.

- 1985b. Recomendación núm. 171 (1985): Servicios de salud en el trabajo. Ginebra: OIT. 
-. 1986. The Promotion of Small and M edium-Sized Enterprises. Conferencia Internacional del Trabajo, 72a sesión. Informe VI. G inebra: OIT.

Organización Mundial de la Salud (OMS). 1981. Global Strategy for $\mathrm{H}$ ealth for All by $\mathrm{Y}$ ear 2000 . H ealth for All, N o. 3. G inebra: O M S

-. 1982. Evaluation of O ccupational $\mathrm{H}$ ealth and Industrial $H$ ygiene Services. Informe del Grupo de Trabajo. EURO Reports and Studies N o. 56. Copenhague: O ficina R egional de la O M S para Europa.

-. 1987. Eighth General Programme of W ork Covering the Period 1990-1995. Health for All, N o.10. Ginebra: OMS.

- 1989a. Consultation On O ccupational H ealth Services, H elsinki, 22-24 M ay 1989. Ginebra: O M S.

- 1989b. Final Report of Consultation On O ccupational $\mathrm{H}$ ealth Services, Helsinki 22-24 M ay 1989 Publicación núm. ICP/OCH 134. Copenhague: O ficina R egional de la O M S para Europa.

-. 1989c. Report of the W H O Planning M eeting On the D evelopment of Supporting M odel Legislation for Primary $\mathrm{H}$ ealth Care in the W orkplace 70 ctober 1989, $\mathrm{H}$ elsinki, Finland. G inebra: O M S

-. 1990. Occupational $\mathrm{H}$ ealth Services. Country reports. EUR/HFA target 25. Copenhague: O ficina R egional de la OM S para Europa.

—. 1992. O ur Planet: O ur H ealth. Ginebra: O M S.

-. 1993. WHO Global Strategy for $\mathrm{H}$ ealth and Environment. Ginebra: O M S.

- . 1995a. Concern for Europe's tomorrow. Capítulo 15 en $O$ ccupational $H$ ealth. Copenhague: $O$ ficina R egional de la OM S para Europa.

-. 1995b. Global Strategy On O ccupational H ealth for All. $T$ he $W$ ay to $\mathrm{H}$ ealth At W ork: Recommendation of the Second $\mathrm{M}$ eeting of the WHO Collaborating Centres in O ccupational $\mathrm{H}$ ealth, 11-14 October 1994 Beijing, China. Ginebra: OMS.

- . 1995C. R eviewing the $H$ ealth- $F$ or-All Strategy. Ginebra: OMS.

Paoli, P. First E uropean Survey On the W ork Environment, 1991-1992. Dublín: Fundación Europea para la M ejora de las C ondiciones de V ida y de T rabajo.

Pelclová, D, CH Weinstein, I Vejlupková. 1994 $\mathrm{O}$ ccupational $\mathrm{H}$ ealth in the Czech R epublic: Old and $\mathrm{New}$ Solutions.

Pokrovsky, VI. 1993. The environment, occupational conditions and their effect on the health of the population of Russia. Presentado en la Conferencia Internacional de Salud Humana y M edio Ambiente en Europa Oriental y Central, abril de 1993, Praga.

Rantanen, J. 1989. Guidelines on organization and operation of occupation health services. Artículo presentando en el seminario subregional asiático de la OIT sobre la organización de los servicios de salud en el trabajo, 2-5 de mayo, M anila.
-. 1990. O ccupational H ealth Services. European Series, No. 26. Copenhague: Publicaciones R egionales de la OMS.

-. 1991. Guidelines on the organization and operation of occupational health services in the light of the ILO Occupational $\mathrm{H}$ ealth Services Convention No, 161 and Recommendation No. 171. Artículo presentando en el seminario subregional africano sobre los servicios de salud en el trabajo, 23-26 de abril, M ombasa.

-. 1992. How to organize plant-level collaboration for workplace actions. Afr $\mathrm{News}$ lttr $\mathrm{O}$ ccup $\mathrm{H}$ ealth Safety 2 Supl. 2:80-87.

-. 1994. $H$ ealth Protection and $H$ ealth Promotion in Small-Scale Enterprises. H elsinki: Instituto Finlandés de M edicina del Trabajo.

_ , S Lehtinen, M M ikheev. 1994. H ealth Promotion and $\mathrm{H}$ ealth Protection in Small-Scale Enterprises. Ginebra: OMS.

- - R Kalimo, H Nordman, E Vainio, Viikari-Juntura. 1994. N ew epidemics in occupational health. People and Work. Research reports N o. I. Helsinki: Instituto Finlandés de Medicina del Trabajo.

República Federal Checa y Eslovaca 1991a. The health sector: Issues and priorities. División de Recursos Humanos. Departamento de Europa Central y Oriental. Región de Europa, Oriente $M$ edio y N orte de Africa, Banco M undial.

- . 1991b. Joint environmental study.

Resnick, R. 1992. M anaged care comes to Workers' Compensation. B us $\mathrm{H}$ ealth (septiembre): 34

Reverente, BR. 1992. O ccupational health services for small-scale industries. En O ccupational $H$ ealth in Developing Countries, dirigido por J Jeyaratnam. Oxford: OUP

Rosenstock, L, W Daniell, S Barnhart. 1992. The 10-year experience of an academically affiliated occupational and environmental medicine clinic. W estern J M ed 157:425-429.

- . and N Heyer. 1982. Emergence of occupational medical services outside the workplace. Am J Ind M ed 3:217-223.

Statistical Abstract of the U nited States. 1994. 114a edición:438.

Tweed, V. 1994. M oving toward 24-hour care. Bus $H$ ealth (septiembre):55.

U rban, P, L H amsová, R. Nemecek. 1993. Estudio de las enfermedades profesionales declaradas en la R epública Checa en el año 1992. Praga: Instituto Nacional de Salud Pública.

US Department of Labor. 1995. Employment and E arnings. 42(1):214.

Zaldman, B. 1990. Industrial strength medicine. I W orker Comp :21.

Zhu, G. 1990. Experiencias históricas en el ejercicio de la medicina preventiva en la Nueva China. Pekín, China: Centro $\mathrm{N}$ acional de Publicaciones $\mathrm{M}$ édicas.

\section{0 tras lecturas recomendadas}

Chen, YB. 1993. Desarrollo y perspectivas de las empresas municipales en China. Pekín, China: Consejo Chino para la Promoción del Comercio Internacional.

China Daily, 1993. City planned to take up surplus rural workforce. 25 de noviembre.

- 1993. Discrimination against women still prevalent. 26 de noviembre.

-. 1993. M apping new road to rural reforms. 7 de diciembre.

Felton, JS. 1989. Occupational M edicine M anagement. Boston: Little, Brown \& C 0 .

Guidotti, TL, JWF Cowell, GG Jamleson. 1989. Occupational $H$ ealth Services. A Practical Approach. Chicago: American M edical Association.

Higashi, T, T M izoue, T M uto. 1994. Present conditions of occupational health services for small-scale enterprises in Japan and their administrative support. J U niv $\mathrm{O}$ ccup $\mathrm{E}$ nviron $\mathrm{H}$ ealth 16(4):309-320.

Hospital para la prevención y el tratamiento de enfermedades profesionales de la provincia de Guangdong. 1992. Informe de la intoxicación aguda sufrida por los trabajadores de dos fábricas extranjeras de juguetes en la zona económica especial de Zhuhai.

Levy, B, D Wegman. 1988. Occupational H ealth: Recognizing and Preventing Work-Related Disease. Boston: Little, Brown \& Co.

M inisterio de Salud Pública y M inisterio de Trabajo. 1986. Informe de las responsabilidades y la coordinación entre el M inisterio de Salud Pública y el M inisterio de T rabajo en la Inspección Sanitaria en el T rabajo. Pekín, China: M inisterio de Salud Pública.

M inisterio de Salud Pública. 1992. Departamento de Inspección Sanitaria, M inisterio de Salud Pública: Informe general sobre las necesidades de servicios de salud en el trabajo y contramedidas para las industrias municipales. En E studios de las necesidades de servicios de salud en el trabajo y contramedidas, dirigido por XG Kan. Pekín, China: Departamento de Inspección Sanitaria: M inisterio de Salud Pública.

M oser, R. 1992. E ffective $M$ anagement of $O$ ccupational and Environmental $H$ ealth and Safety Programmes. Boston: EOM Press.

$\mathrm{N}$ ational Institute for $\mathrm{O}$ ccupational Safety and $\mathrm{H}$ ealth (NIOSH). 1977. Occupational Diseases: A Guide to Their Recognition. Washington, DC: US G overnment Printing $O$ ffice.

O rganización Mundial de la Salud (OMS). 1989. Occupational Health Services. Helsinki: O ficina R egional de la O M S para Europa.

Scope of occupational and environmental health programmes and practice. 1992. J O ccup M ed 34:436.

Takahashi, K T O kubo. 1994. Current status of occupational health in Japan. 0 ccup M ed 44:66-69.

Zenz, C, OB Dickerson, E Horvath. 1994. $O$ ccupational Medicine: Principles and Practical Applications. St. Louis: M osby. debe exigirse algún tipo de certificación que garantice la calidad de su trabajo. La India se está industrializando rápidamente y seguirá haciéndolo en el próximo siglo. Si no se resuelven estas cuestiones, se producirá un nivel incalculablemente alto de morbilidad y absentismo por problemas sanitarios relacionados con el trabajo, lo que debilitará la productividad y la competitividad de su economía y afectará gravemente a la determinación del país de acabar con la pobreza. 
Directores del capítulo

W illi M omm y

Robert R ansom

\section{Sumario}

Discapacidad: conceptos y definiciones

W illi M omm y 0 tto $G$ eiecker . . . . . . . . . . . . . . . . . 17.2

Estudio de caso: clasificación legal de las personas

discapacitadas en Francia

$M$ arie L ouise C ros-Courtial y M arc Vericel

Política social y derechos humanos: conceptos

de la discapacidad

Carl Raskin ....

N ormas laborales internacionales y legislación nacional

de empleo en favor de las personas discapacitadas

W illi M omm y M asaaki luchi . .......................

Servicios de rehabilitación profesional y de apoyo a los trabajadores

E rwin Seyfried.

Gestión de la discapacidad en el lugar de trabajo: visión de conjunto y tendencias futuras

D onald E. Shrey

Rehabilitación y pérdida auditiva inducida por el ruido Raymond $H$ étu . . . . . . . . . . . . . . . . . . . . . . . . . 17.29

Derechos y obligaciones: el punto de vista de la empresa Susan Scott-Parker . . . . . . . . . . . . . . . . . . . . 17.36

Derechos y obligaciones: el punto de vista de los

trabajadores

Angela Traiforos y D ebra A. Perry. 


\section{- DISCAPACIDAD: CONCEPTOS Y DEFINICIONES}

\section{Willi M omm y 0 tto G eiecker}

\section{Consideraciones preliminares}

La mayoría de la gente parece saber lo que es una persona discapacitada y está segura de que podría reconocer a un individuo como discapacitado, bien porque la discapacidad es visible, bien porque se sabe que determinado estado de salud se presta a ser denominado discapacidad. Sin embargo, no es tan fácil establecer qué significa exactamente el término discapacidad. U na opinión común es que tener una discapacidad determina que un individuo sea menos capaz de realizar una serie de actividades. De hecho, el término discapacidad se utiliza en general para indicar una disminución o una desviación respecto de la norma, una insuficiencia de un individuo que la sociedad debe asumir. En casi todas las lenguas, los términos equivalentes al de discapacidad contienen las nociones de menor valor, menor capacidad, estado de limitación, privación o desviación. Son este tipo de conceptos los que llevan a considerar la discapacidad como un problema exclusivo del individuo afectado y los problemas asociados con la presencia de una discapacidad como algo más 0 menos común a todas las situaciones.

Es cierto que un estado de discapacidad puede afectar en diferentes medidas a la vida personal de un individuo y a sus relaciones con la familia y la comunidad. D e hecho, el individuo que tiene una discapacidad puede experimentarla como algo que le sitúa aparte de los otros y que tiene un efecto negativo en el modo en que está organizada la vida.

Sin embargo, el significado y las repercusiones de la discapacidad varían sustancialmente en función de si el entorno y las actitudes del público se adaptan o no a ella. Por ejemplo, la persona que utiliza una silla de ruedas se encuentra en un estado de completa dependencia en un contexto determinado, mientras que en otro es tan autónoma y operativa como cualquiera.

En consecuencia, el efecto de una supuesta disfunción es relativo al entorno, y la discapacidad es por consiguiente un concepto social y no exclusivamente el atributo de un individuo. Es además un concepto muy heterogéneo, que determina que la búsqueda de una definición homogénea sea una tarea prácticamente imposible.

A pesar de los muchos intentos de definir la discapacidad en términos generales, persiste el problema de qué hace que un individuo sea discapacitado y a quién se debe incluir en este grupo. Por ejemplo, si se define la discapacidad como la disfunción de un individuo, ¿cómo clasificar a una persona que a pesar de una deficiencia grave es completamente funcional? ¿Es el especialista en informática ciego, que tiene un empleo remunerado y ha logrado resolver sus problemas de transporte, conseguir una vivienda adecuada y formar una familia, una persona discapacitada? ¿D ebe contarse entre los desempleados discapacitados al panadero que ya no puede ejercer su profesión debido a una alergia a la harina? En tal caso, ¿cuál es el significado real de discapacidad?

Para comprender mejor este término, hay que empezar por distinguirlo de otros conceptos relacionados que a menudo se confunden con el de discapacidad. El malentendido más frecuente consiste en equiparar discapacidad con enfermedad. Es frecuente describir a las personas discapacitadas por oposición a las personas sanas y, en consecuencia, como necesitadas de la ayuda de la profesión sanitaria. Sin embargo, las personas discapacitadas, como todas las demás, sólo necesitan ayuda médica en situaciones de enfermedad o patología grave. Aun en los casos en que la discapacidad es el resultado de una enfermedad prolongada o crónica, como la diabetes o una cardiopatía, no es la enfermedad como tal, sino sus consecuencias sociales lo que aquí importa.

La otra confusión más frecuente consiste en equiparar discapacidad con el estado de salud que es una de sus causas. Por ejemplo, se han elaborado listas en las que se clasifica a las personas discapacitadas por tipos de "discapacidad", categoría en la que se incluyen, por ejemplo, la ceguera, las malformaciones físicas, la sordera o la paraplejia. Estas listas son importantes para determinar a quién se debe considerar discapacitado, con la salvedad de que el uso del término discapacidad es inexacto, porque se confunde con deficiencia.

$M$ ás recientemente, se ha intentado describir la discapacidad como la dificultad para llevar a cabo determinados tipos de funciones. En consecuencia, una persona discapacitada sería alguien cuya capacidad para actuar en una o varias áreas clave - como la comunicación, la movilidad, la destreza y la velocidad - está afectada. U na vez más, el problema es que se establece un vínculo directo entre la deficiencia y la pérdida funcional resultante, sin tener en cuenta los factores del entorno, como la disponibilidad de tecnología adecuada para compensar la pérdida funcional hasta hacer que ésta sea insignificante. Entender la discapacidad como el efecto funcional de una deficiencia, prescindiendo de la dimensión del entorno, implica echar toda la culpa del problema al individuo discapacitado. Esta definición perpetúa la tradición de considerar la discapacidad como una desviación respecto de la norma y hace caso omiso de los demás factores individuales y sociales que juntos constituyen el fenómeno de la discapacidad.

¿Puede censarse a las personas discapacitadas? Desde luego, sí, dentro de un sistema que aplique criterios precisos respecto a quién presenta un nivel de deficiencia suficiente para ser censado como discapacitado. La dificultad estriba en hacer comparaciones entre sistemas o países que aplican criterios diferentes. En todo caso, ¿a quién habría que incluir? Estrictamente hablando, los censos y las encuestas encaminadas a obtener datos sobre la discapacidad sólo pueden censar a las personas que informan personalmente de que tienen una deficiencia 0 una limitación funcional por razón de una deficiencia, o de que creen que están en una situación de desventaja debido a una deficiencia. A diferencia del sexo o la edad, la discapacidad no es una variable estadística claramente definible, sino un término contextual expuesto a interpretación. Por consiguiente, los datos sobre discapacidad son necesariamente aproximados y deben tratarse con sumo cuidado.

Por las razones indicadas, el presente artículo no constituye un intento más de proponer una definición universal de discapacidad, o de tratar ésta como un atributo de un individuo o de un grupo. Por el contrario, trata de crear una sensibilización respecto a la relatividad y la heterogeneidad del término y de comprender los factores históricos y culturales que han configurado la legislación y las medidas positivas adoptadas en favor de las personas reconocidas como discapacitadas. Tal sensibilización es un requisito imprescindible para la integración satisfactoria de las personas discapacitadas en el lugar de trabajo. Permite comprender mejor las circunstancias que deben darse para que el trabajador discapacitado sea un miembro válido de la plantilla, en lugar de excluirle del empleo o jubilarle. L a discapacidad se presenta aquí como algo que puede ser gestionado. Para ello, se parte del supuesto de que las necesidades del individuo, como la mejora de las destrezas o la prestación de ayuda técnica, deben abordarse y asumirse mediante la adaptación del lugar de trabajo.

Existe actualmente un intenso debate internacional, cuya punta de lanza son las organizaciones de discapacitados, en 
torno a una definición no discriminatoria de discapacidad. En este contexto, está ganando terreno la opinión de que la discapacidad debe identificarse con la existencia o la previsión de una desventaja social o funcional concreta vinculada a una deficiencia. La cuestión es cómo demostrar que la desventaja no es el resultado natural, sino evitable, de la deficiencia, causado por el hecho de que la sociedad no ha previsto adecuadamente la eliminación de barreras físicas. A parte de que este debate refleja principalmente la opinión de las personas discapacitadas con movilidad reducida, la posible consecuencia no deseada de esta posición es que el Estado podría reducir el gasto destinado a la discapacidad, por ejemplo el correspondiente a prestaciones 0 a medidas especiales por discapacidad, en favor del destinado a mejorar el entorno.

En todo caso, este debate aún vigente ha puesto de relieve la necesidad de encontrar una definición de discapacidad que refleje la dimensión social, sin sacrificar el carácter específico de la desventaja basada en una insuficiencia y sin que la definición pierda su calidad operativa. La definición que se ofrece seguidamente intenta reflejar esta necesidad. Según ella, la discapacidad puede describirse como el efecto, determinado por el entorno, de una deficiencia que, al interactuar con otros factores en un contexto social específico, puede hacer que un individuo experimente una desventaja indebida en su vida personal, social 0 profesional. La expresión "determinado por el entorno" significa que diversos factores, como las medidas de prevención, corrección e indemnización y las soluciones tecnológicas y de adaptación, influyen en el efecto de la deficiencia.

Esta definición reconoce que en un entorno diferente, que levante menos barreras, la misma deficiencia puede carecer de consecuencias significativas y, por consiguiente, no dar lugar a una discapacidad. Destaca aquí la dimensión correctora, por encima de un concepto de la discapacidad como hecho inevitable que se limita a intentar mejorar las condiciones de vida de las personas afectadas. Al mismo tiempo, se mantiene la base que justifica la adopción de medidas compensatorias, como prestaciones económicas, porque, a pesar del reconocimiento de otros factores, la desventaja sigue estando vinculada específicamente a la deficiencia, independientemente de que ésta sea el resultado de una disfunción del individuo o de una actitud negativa de la comunidad.

A hora bien, muchas personas discapacitadas pueden experimentar limitaciones sustanciales incluso en un entorno ideal y comprensivo. En tales casos, la discapacidad está basada principalmente en la deficiencia y no en el entorno. La mejora de las condiciones del entorno puede reducir sustancialmente la dependencia y las limitaciones, pero no altera la verdad fundamental de que para muchas de estas personas gravemente discapacitadas (lo cual es diferente de gravemente deficientes) la participación en la vida social y profesional seguirá estando limitada. Es para estos grupos, en especial, para quienes la protección social y las disposiciones de mejora seguirán desempeñando una función más importante que el objetivo de la integración plena en el lugar de trabajo, que con frecuencia responde a razones sociales más que económicas.

Por supuesto, esto no quiere decir que las personas así definidas como gravemente discapacitadas deban vivir una vida aparte ni que sus limitaciones deban ser motivo de segregación y exclusión de la vida de la comunidad. Una de las principales razones que aconsejan proceder con cautela al emplear las definiciones de discapacidad es la práctica extendida de hacer de una persona así reconocida y etiquetada el objeto de medidas administrativas discriminatorias.

Todo esto, en cualquier caso, indica una ambigüedad en el concepto de discapacidad, que genera mucha confusión y que puede ser una de las principales razones de la exclusión social de las personas discapacitadas. En efecto, por un lado, muchos hacen campaña con el eslogan de que discapacidad no significa incapacidad; por otro lado, todos los sistemas de protección existentes se basan en la premisa de que discapacidad significa incapacidad para ganarse la vida por uno mismo. La reticencia de muchos empresarios a contratar personas discapacitadas puede tener su fundamento en esta contradicción básica. La respuesta a tal tipo de razonamientos es un recordatorio de que las personas discapacitadas no constituyen un grupo homogéneo, y de que cada caso debe juzgarse por separado y sin prejuicios. A hora bien, es cierto que discapacidad puede significar ambas cosas: incapacidad para actuar según la norma o capacidad para actuar tan bien como los demás o incluso mejor si se dispone de la oportunidad y del apoyo adecuado.

Es obvio que un concepto de discapacidad como el descrito pide un nuevo fundamento para las políticas de discapacidad: fuentes de inspiración sobre cómo modernizar las políticas y los programas en favor de las personas discapacitadas pueden encontrarse, por ejemplo, en el Convenio sobre la readaptación profesional y el empleo de personas inválidas, 1983 (no 159) (OIT 1983) y en las Normas de las Naciones U nidas sobre la I gualdad de O portunidades para las Personas con Discapacidades (N aciones U nidas 1993).

En los apartados siguientes se analizan y describen empíricamente las distintas dimensiones del concepto de discapacidad por lo que respecta a la legislación y las prácticas actuales. Se ofrecen datos sobre la diversidad de definiciones de discapacidad en uso, reflejo de los diferentes legados políticos y culturales de todo el mundo, en lugar de fomentar la esperanza de hallar una sola definición universal que todos entiendan del mismo modo.

\section{Discapacidad y normalidad}

Como se ha señalado, casi todos los intentos normativos de definir la discapacidad han caído de un modo u otro en la tentación de describirla como un concepto principalmente negativo 0 de desviación. El ser humano afectado por una discapacidad se ve como un problema y se convierte en un "caso social". Se supone que una persona discapacitada es incapaz de realizar actividades normales. Se trata de una persona con la que no todo marcha bien. Abundan las publicaciones científicas que describen al discapacitado como una persona con un problema de comportamiento y, en muchos países, la "defectología" era y sigue siendo una ciencia reconocida que se ocupa de medir el grado de desviación.

En general, las personas que tienen una discapacidad se defienden contra esa caracterización. 0 tras se resignan al papel que se les ha asignado. Clasificar a las personas como discapacitadas es olvidar que lo que éstas tienen en común con los no discapacitados suele superar con creces a lo que les diferencia. Por otra parte, el concepto subyacente de que la discapacidad es una desviación respecto de la norma es un juicio de valor cuestionable. Tales consideraciones han llevado a muchas personas a preferir el término de personas con discapacidades al de personas discapacitadas, en la medida en que podría entenderse que este último hace de la discapacidad la característica principal de un individuo.

Es perfectamente concebible definir la realidad humana y social de tal manera que la discapacidad se considere como coherente con la normalidad y no como una desviación con respecto a ella. De hecho, en la Declaración adoptada en 1995 por los Jefes de Estado y de Gobierno en la C umbre M undial de la ONU sobre Desarrollo Social, celebrada en Copenhague, se describe la discapacidad como una forma de diversidad social. Esta definición requiere un concepto de sociedad entendida como sociedad "para todos". Por consiguiente, los anteriores intentos de definir la discapacidad negativamente, como desviación 
respecto de la norma o como deficiencia, ya no son válidos. U na sociedad que se adapta a la discapacidad de un modo inclusivo puede superar en buena medida los efectos de la discapacidad que, de lo contrario, se experimentan como excesivamente restrictivos.

\section{Discapacidad como identidad}

A pesar del peligro de que esta etiqueta implique segregación y discriminación, hay razones válidas para atenerse al uso del término discapacidad y agrupar a ciertas personas en esa categoría. Desde un punto de vista empírico, no se puede negar que muchos individuos con discapacidades comparten experiencias similares, casi siempre negativas, de discriminación, exclusión y dependencia económica o social.

Existe una clasificación objetiva de los seres humanos como discapacitados, porque hay pautas específicas de comportamiento social negativo o censurable que parecen estar basadas en la discapacidad. A la inversa, cuando se adoptan medidas para luchar contra la discriminación por razón de discapacidad, también resulta necesario establecer quién debe tener el derecho a disfrutar de protección conforme a ellas.

El hecho de que muchos individuos que han experimentado algún tipo de discriminación por razón de su discapacidad se agrupen es una reacción al trato que la sociedad da a las personas con discapacidades. Lo hacen en parte porque se sienten más cómodos entre quienes comparten su experiencia, y en parte porque desean defender unos intereses comunes. En consecuencia, aceptan el papel de discapacitados, si bien por motivos muy diferentes: algunos porque quieren inducir a la sociedad a considerar la discapacidad, no como un atributo de individuos aislados, sino como el resultado de la acción y la negligencia de la comunidad que cercena indebidamente sus derechos y oportunidades, y otros porque reconocen su discapacidad y reivindican su derecho a ser aceptados y respetados en su diferencia, lo cual incluye su derecho a luchar por la igualdad de trato.

Sin embargo, la mayoría de los individuos que tienen algún tipo de limitación funcional debido a una deficiencia no parecen considerarse a sí mismos discapacitados. Esto crea un problema que no deben subestimar los responsables de la formulación de políticas al respecto. Por ejemplo, ¿debe censarse entre las personas discapacitadas a quienes no se identifican a sí mismos como discapacitados, o sólo a quienes están registrados como tales?

\section{Reconocimiento jurídico de los discapacitados}

En muchas circunscripciones, las definiciones de discapacidad están vinculadas al acto administrativo de su reconocimiento. Este reconocimiento de una persona como discapacitada se convierte en el requisito para que pueda reivindicar apoyo por una limitación física o mental o litigar al amparo de una legislación antidiscriminatoria. Tal apoyo puede incluir medidas de rehabilitación, actividades de educación especial o de formación de reconversión, privilegios para obtener y conservar un puesto de trabajo, garantías de subsistencia a través de la renta, pagos compensatorios, ayudas a la movilidad, etc.

En todos los casos en los que se aplica una disposición legal para compensar por las desventajas o para prevenirlas, se plantea la necesidad de aclarar quién puede acogerse a ella, ya se trate de prestaciones, servicios o medidas de protección. De lo anterior se deduce que la definición de discapacidad está condicionada por el tipo de servicio o de normativa que se ofrece. De este modo, prácticamente todas las definiciones de discapacidad existentes reflejan un ordenamiento jurídico del que extraen su significado. Ser reconocido como discapacitado significa cumplir las condiciones establecidas para beneficiarse de las posibilidades que ofrece tal sistema. Esas condiciones, sin embargo, pueden variar según los ámbitos y programas y, en consecuencia, es posible que coexistan muchas definiciones diferentes en un solo país.

Los países en los que, como Alemania y Francia, se ha establecido un régimen que prevé cuotas o la imposición de multas para garantizar el acceso de las personas discapacitadas a las oportunidades de empleo ofrecen pruebas adicionales de que la realidad jurídica de cada nación determina la definición de discapacidad. Puede demostrarse que con este tipo de normativa aumenta radicalmente el número de trabajadores "discapacitados". Tal aumento sólo puede explicarse por el hecho de que algunos trabajadores - a menudo por recomendación de los empresarios - que en ausencia de este tipo de legislación nunca se habrían considerado a sí mismos discapacitados, se registran como tales. Por supuesto, tampoco habían sido registrados nunca estadísticamente como discapacitados.

0 tra diferencia jurídica entre los países es la referente al tratamiento de la discapacidad como estado temporal o como estado permanente. En algunos países que ofrecen a las personas discapacitadas ventajas 0 privilegios específicos, éstos se limitan al período de duración de una desventaja reconocida. Si la desventaja se subsana mediante acciones correctoras, se pierden los privilegios, independientemente de que subsistan o no los hechos médicos (p. ej., la pérdida de un ojo o un miembro). A sí, un individuo que ha completado con éxito un proceso de rehabilitación tras el cual ha podido recuperar capacidades funcionales perdidas puede quedar privado de sus derechos a prestaciones por discapacidad 0, incluso, excluido del plan de prestaciones.

En otros países, se ofrecen privilegios duraderos para compensar desventajas reales o hipotéticas. Esta práctica ha dado lugar al desarrollo de una categoría de discapacidad legalmente reconocida que implica elementos de "discriminación positiva". Tales privilegios suelen aplicarse incluso a quienes ya no los necesitan realmente porque están social y económicamente bien integrados.

\section{El problema del registro estadístico}

Es imposible lograr una definición de discapacidad que pueda aplicarse universalmente, ya que todos los países, y prácticamente todos los organismos administrativos, trabajan con diferentes conceptos de discapacidad. Todo intento de medir estadísticamente la discapacidad debe tener en cuenta que ésta es un concepto dependiente del sistema y, por consiguiente, relativo.

De este modo, la mayoría de las estadísticas regulares contienen información únicamente sobre los beneficiarios de medidas estatales 0 públicas específicas aplicadas de conformidad con las definiciones legales. L as personas que no se consideran discapacitadas y se enfrentan solas a la discapacidad no suelen incluirse en las estadísticas oficiales. D e hecho, en muchos países, como el Reino U nido, muchas personas discapacitadas evitan su registro estadístico. El derecho al no registro como discapacitado emana de los principios de la dignidad humana.

Por esta razón, periódicamente se hacen esfuerzos para determinar mediante encuestas y censos el total de personas discapacitadas. Como se ha señalado, estos instrumentos tropiezan con límites conceptuales objetivos que impiden en la práctica las comparaciones entre países.

La cuestión más polémica es qué es exactamente lo que esos estudios pretenden demostrar, en especial considerando que no existe un concepto sostenible de discapacidad como conjunto objetivo de conclusiones que se apliquen y comprendan por igual en todos los países. De este modo, el reducido número de personas con discapacidad registradas estadísticamente en algunos países no refleja necesariamente una realidad objetiva, sino, con mayor probabilidad, el hecho de que los países en 
cuestión ofrecen menos servicios y disposiciones legales en favor de las personas discapacitadas. A la inversa, es probable que los países que disponen de un amplio sistema de protección social y rehabilitación muestren un elevado porcentaje de individuos discapacitados.

\section{Contradicciones en el uso del concepto de personas discapacitadas}

Por todo lo expuesto, no deben esperarse resultados objetivos en el plano de la comparación cuantitativa. Ahora bien, tampoco hay uniformidad de interpretación desde un punto de vista cualitativo. U na vez más, el contexto y la intención de cada legislador determinan la definición de discapacidad. Por ejemplo, el esfuerzo por garantizar la protección social a las personas discapacitadas obliga a definir la discapacidad como la incapacidad de una persona para ganarse la vida. En cambio, una política social cuyo objetivo sea la integración profesional procura describir la discapacidad como un estado que, con la ayuda de medidas apropiadas, no tiene por qué tener efectos perjudiciales en el nivel de rendimiento.

\section{Definiciones internacionales de discapacidad}

\section{El concepto de discapacidad según el Convenio no 159 de la Organización Internacional del Trabajo}

Las consideraciones anteriores sustentan también la definición marco utilizada en el Convenio sobre la readaptación profesional y el empleo de personas inválidas, 1983 ( $n$ - 159) (O IT 1983). EI apartado 1 del artículo I contiene la siguiente enunciación: "A los efectos del presente Convenio, se entiende por 'persona inválida' toda persona cuyas posibilidades de obtener y conservar un empleo adecuado y de progresar en el mismo queden substancialmente reducidas a causa de una deficiencia de carácter físico o mental debidamente reconocida".

$L$ a definición contiene los siguientes elementos: la referencia a una deficiencia mental o física como causa original de la discapacidad; la necesidad de un procedimiento de reconocimiento del Estado que - de conformidad con cada realidad nacional- determine a quién se debe considerar discapacitado; la especificación de que la discapacidad no está constituida por la propia deficiencia, sino por las consecuencias sociales reales y posibles de ésta (en este caso, una situación más difícil en el mercado de trabajo), y el derecho establecido a medidas que ayuden a garantizar la igualdad de trato en el mercado de trabajo (véase el apartado 2 del artículo I). Esta definición evita conscientemente toda asociación con conceptos como el de incapacidad y deja un margen para interpretar que la discapacidad también puede estar condicionada por las opiniones erróneas de una empresa, que pueden dar lugar a discriminación consciente 0 inconsciente. Por otro lado, no descarta la posibilidad de que, en caso de discapacidad, el rendimiento se vea objetivamente limitado, y deja abierta la eventualidad de si el principio de igualdad de trato del Convenio se aplicaría o no en ese caso.

EI Convenio de la OIT no pretende ofrecer una definición global y universalmente aplicable de discapacidad. Su único objetivo es ofrecer una aclaración de qué puede significar discapacidad en el contexto del empleo y las medidas laborales.

\section{El concepto de discapacidad según la definición de la Organización Mundial dela Salud}

La Clasificación Internacional de D eficiencias, D iscapacidades y M inusvalías (CIDDM) de la O rganización M undial de la salud (OMS 1980) distingue, en el área de la política sanitaria, entre deficiencia, discapacidad y minusvalía:
- "Dentro de la experiencia de la salud, una deficiencia es toda pérdida o anormalidad de una estructura o función psicológica, fisiológica o anatómica".

- "D entro de la experiencia de la salud, una discapacidad es toda restricción o ausencia (debida a una deficiencia) de la capacidad de realizar una actividad en la forma o dentro del margen que se considera normal para un ser humano".

- "D entro de la experiencia de la salud, una minusvalía es una situación desventajosa para un individuo determinado, consecuencia de una deficiencia o de una discapacidad, que limita 0 impide el desempeño de un rol que es normal en su caso (en función de la edad, sexo y factores sociales y culturales)".

Los aspectos innovadores y distintivos de esta diferenciación conceptual no radican en su enfoque epidemiológico tradicional y en su estructura de clasificación, sino más bien en la introducción del concepto de minusvalía, que exige que los responsables de las políticas sanitarias reflexionen sobre las consecuencias sociales que determinadas deficiencias pueden tener para la persona afectada y consideren el proceso de tratamiento como parte de un concepto de vida global.

La aclaración de la O M S era especialmente necesaria porque las palabras deficiencia y discapacidad solían equipararse con conceptos como los de lisiado, retrasado mental y similares, que transmiten una imagen exclusivamente negativa de la discapacidad. U na categorización de este tipo no se ajusta en realidad a una definición exacta de la situación concreta de un individuo discapacitado en la sociedad. D esde la formulación de esta definición, la terminología de la OMS se ha convertido en referencia para el debate sobre el concepto de discapacidad a escala nacional e internacional. Por lo tanto, es conveniente explicar un poco más estos conceptos.

D eficiencia. Con este concepto, los profesionales de la salud suelen designar una lesión existente o en proceso de desarrollo de las funciones corporales o los procesos vitales de una persona concreta, que afectan a una o más partes del organismo 0 indican un defecto en el funcionamiento psíquico, mental 0 emocional, como resultado de una enfermedad, un accidente 0 una enfermedad congénita o hereditaria. La deficiencia puede ser temporal o permanente. Las influencias del contexto profesional o social o del entorno en su conjunto no se tienen en cuenta en esta categoría. En este caso, lo único que cuenta es la evaluación que hace el médico de la situación de salud o la deficiencia de una persona, al margen de las consecuencias que esta deficiencia pueda tener para ella.

Discapacidad. Esa deficiencia o pérdida puede dar lugar a una limitación sustancial de la vida activa de las personas afectadas. E sta consecuencia de la deficiencia se denomina discapacidad. L os trastornos funcionales del organismo, como los trastornos psíquicos y las crisis mentales, pueden conducir a discapacidades más o menos graves o a efectos negativos en la ejecución de actividades y deberes específicos de la vida cotidiana. Estos efectos pueden ser temporales o permanentes, reversibles o irreversibles, constantes, progresivos o fáciles de controlar mediante un tratamiento. El concepto médico de discapacidad designa, por consiguiente, limitaciones funcionales que surgen en la vida de personas concretas como resultado directo o indirecto de una deficiencia física, psicosocial o mental. Por encima de todo, discapacidad refleja la situación personal del individuo que tiene una deficiencia. Sin embargo, puesto que las consecuencias personales de una discapacidad dependen de la edad, el sexo, la posición social y la profesión, entre otros factores, los mismos o similares trastornos funcionales pueden tener consecuencias personales radicalmente diferentes para diferentes individuos.

M inusvalía. En cuanto una persona con deficiencias físicas o mentales entra en su contexto social, profesional o privado, 
pueden plantearse dificultades que la lleven a una situación de desventaja o de minusvalía en relación con otros.

En la versión original de la CIDDM, la definición de minusvalía significa una desventaja que aparece como resultado de una deficiencia o una discapacidad, y que limita a un individuo en el desempeño de lo que se considera una función "normal". Esta definición de minusvalía, que basa el problema exclusivamente en la situación personal del individuo afectado, ha sido objeto de críticas, en el sentido de que no tiene suficientemente en cuenta el papel del entorno y la actitud de la sociedad en la aparición de la situación de desventaja. Una definición que tenga en cuenta estas objeciones debe asumir la relación entre el individuo discapacitado y las múltiples barreras ambientales, culturales, físicas o sociales que tiende a erigir una sociedad que refleja las actitudes de sus miembros no discapacitados. En consecuencia, toda desventaja en la vida de una persona concreta que no sea tanto el resultado de una deficiencia o una discapacidad como de actitudes negativas o poco propicias en el sentido más amplio debe denominarse "minusvalía". A demás, cualquier medida que se tome para mejorar la situación de los individuos discapacitados, incluidos los que les ayudan a participar plenamente en la vida y en la sociedad, puede contribuir a prevenir la "minusvalía". Por consiguiente, una minusvalía no es el resultado directo de una deficiencia o discapacidad existente, sino el resultado de la interacción entre un individuo con una discapacidad, el contexto social y el entorno inmediato.

No se puede suponer de entrada, por consiguiente, que una persona con una deficiencia o una discapacidad deba automáticamente tener también una minusvalía. M uchas personas discapacitadas consiguen, a pesar de las limitaciones causadas por su discapacidad, desempeñar con éxito una profesión. Por otro lado, no todas las minusvalías pueden atribuirse a una discapacidad. También pueden deberse a una falta de educación, vinculada o no a una discapacidad.

E ste sistema jerárquico de clasificación - deficiencia, discapacidad, minusvalía - puede compararse con las distintas fases de la rehabilitación; por ejemplo, cuando el tratamiento puramente curativo se complementa con una rehabilitación de limitaciones funcionales y psicosociales y se completa con un proceso de readaptación o formación profesional que permita llevar una vida autónoma.

Por esta razón, la evaluación objetiva del grado de una discapacidad por lo que respecta a sus consecuencias sociales (minusvalía) no puede basarse únicamente en criterios médicos, sino que debe tener en cuenta los contextos profesional, social y personal, y en especial la actitud de la población no discapacitada. Este estado de cosas hace que sea bastante difícil medir y establecer inequívocamente un "estado de discapacidad".

\section{Definiciones utilizadas en distintos países}

\section{La discapacidad como categoría jurídica para la fundamentación de derechos}

Por regla general, la situación de discapacidad está determinada por la autoridad nacional competente a partir de las conclusiones alcanzadas tras un examen de casos individuales. Por consiguiente, el fin para el cual se trate de reconocer la situación de discapacidad desempeña una función decisiva; es lo que ocurre, por ejemplo, cuando puede servir de base para hacer valer derechos personales específicos o para solicitar prestaciones legales. Por tanto, el principal interés de una definición legalmente válida de discapacidad no responde a razones médicas, de rehabilitación o estadísticas, sino más bien a razones jurídicas.

En muchos países, las personas cuya discapacidad se reconoce pueden reivindicar su derecho a beneficiarse de distintos servicios y medidas normativas en áreas específicas de las políticas sanitaria y social. En principio, el objetivo de tales normas o prestaciones es mejorar su situación personal y apoyarles para que superen las dificultades. La base que garantiza tales prestaciones es, por consiguiente, un acto de reconocimiento oficial de la discapacidad de un individuo fundamentado en las disposiciones legales en vigor.

\section{Ejemplos de definiciones extraídas de la práctica legislativa}

Estas definiciones varían mucho entre diferentes Estados. Baste con citar aquí unos cuantos ejemplos actuales, que sirven para ilustrar la variedad y el carácter discutible de muchas definiciones. Puesto que no se trata de debatir modelos jurídicos específicos, no se facilitan las fuentes de las citas ni se evalúa qué definiciones parecen más adecuadas. Ejemplos de definiciones nacionales de personas discapacitadas:

- Las que están afectadas por una deficiencia funcional no estrictamente temporal, debida a una situación física, mental o psicológica irregular, o amenazadas por tal discapacidad. Si el grado de discapacidad es de al menos el $50 \%$, se considera que la discapacidad es grave.

- Todas aquellas cuya capacidad de trabajo esté disminuida en al menos un 30 \% (en caso de discapacidad física) o al menos un $20 \%$ (en caso de discapacidad mental).

- Todas aquellas cuyas posibilidades de obtener y conservar un empleo estén restringidas por una carencia o una limitación de sus capacidades físicas o mentales.

- Todas aquellas a quienes una deficiencia o invalidez les dificulte 0 impida desempeñar actividades normales. La deficiencia puede referirse tanto a funciones mentales como corporales.

- Todas aquellas cuya capacidad para trabajar está permanentemente restringida debido a un defecto físico, psíquico o sensorial.

- Todas aquellas que necesitan cuidados o un tratamiento especial para garantizar el mantenimiento, desarrollo y restablecimiento de sus capacidades profesionales. Se incluyen en este concepto discapacidades físicas, mentales, psíquicas y sociales.

- Todas aquellas que, debido a una limitación permanente de sus capacidades físicas, mentales o sensoriales - con independencia de que sea hereditaria 0 adquirida - ven limitadas sus oportunidades de seguir una educación y de participar en la vida profesional y social.

- Las víctimas de accidentes de trabajo, los inválidos de guerra y las personas que sufren una deficiencia física, mental o psíquica. La reducción de la capacidad de trabajo debe ser al menos del $30 \%$.

- Todas aquellas que, debido a una deficiencia, patología 0 enfermedad hereditaria, tienen sustancialmente reducidas sus posibilidades de obtener y conservar un empleo apropiado para su edad, experiencia y cualificaciones.

- Las personas con una deficiencia física o mental que restrinja en una medida significativa una parte importante de su actividad vital, 0 aquéllas de las que se suponga que sufren esa deficiencia o de las que se tengan historiales anteriores al respecto.

- Las personas afectadas por un trastorno o una enfermedad funcional que lleve a: a) una pérdida total o parcial de funciones físicas o mentales; b) una enfermedad causada, o previsiblemente causada, por la presencia de microorganismos en el cuerpo; c) la pérdida de una función normal debido a una deformación de partes del cuerpo; d) la aparición de dificultades de aprendizaje no presentes en individuos sin trastornos 0 limitaciones funcionales, y e) una deficiencia del comportamiento, el proceso cognitivo, el juicio o la vida emocional. 
- Las personas que, debido a una deficiencia física o mental resultante de un defecto de nacimiento, una enfermedad o un accidente, se suponga que son incapaces de ganarse la vida, ya sea permanentemente o durante un período prolongado.

- Las personas que, como resultado de una enfermedad, una lesión o una debilidad mental o física, no están en condiciones, durante un período de al menos seis meses, de ganar, con un trabajo que se corresponda con sus capacidades potenciales y su nivel cultural, una fracción determinada $(1 / 3,1 / 2,2 / 3)$ de la renta que recibiría un individuo en buenas condiciones en la misma profesión y con el mismo nivel cultural.

- El término discapacidad significa, respecto de un individuo: a) una deficiencia física o mental que limita sustancialmente una o más de las principales actividades vitales de ese individuo; b) el registro de esa deficiencia, o c) la consideración del individuo como persona afectada por esa deficiencia.

La diversidad de definiciones legales que se complementan y excluyen parcialmente unas a otras da a entender que sirven, sobre todo, para fines burocráticos y administrativos. De las arriba enumeradas, ni una sola puede considerarse plenamente satisfactoria, y todas plantean más interrogantes que respuestas. A parte de unas cuantas excepciones, la mayoría tratan de identificar deficiencias de un individuo, y no de abordar la correlación entre éste y su entorno. Lo que en realidad es el reflejo de una relatividad compleja se reduce, en un contexto administrativo, a una cantidad aparentemente neta y estable. Tales definiciones excesivamente simplificadas tienden entonces a cobrar vida propia y con frecuencia obligan a los individuos a aceptar una situación que es acorde con la ley, pero no necesariamente con sus posibilidades y aspiraciones.

\section{La discapacidad como ámbito de acción sociopolítica}

Los individuos reconocidos como discapacitados tienen, en principio, derecho a ser destinatarios de medidas, por ejemplo, de rehabilitación médica o profesional o a beneficiarse de ayudas financieras específicas. En algunos países, el conjunto de medidas sociopolíticas previstas incluye también determinados privilegios y apoyos, así como medidas de protección especiales. He aquí algunos principios y derechos aplicados: el principio consagrado legalmente de igualdad de oportunidades en la integración profesional y social; el derecho establecido legalmente a recibir la asistencia necesaria para la realización de la igualdad de oportunidades; el derecho constitucional a la educación y la integración profesional, la promoción de la formación profesional y la colocación laboral, y la garantía constitucional de recibir un mayor apoyo en caso de necesitar ayuda especial del Estado. Algunos Estados basan su actuación en la absoluta igualdad de todos los ciudadanos en todas las áreas de la vida y han hecho de la realización de esa igualdad su objetivo, sin ver una razón para tratar los problemas especiales de las personas discapacitadas en leyes promulgadas específicamente al efecto. Por lo común, esos Estados se abstienen de definir la discapacidad.

\section{La discapacidad en el contexto de la rehabilitación profesional}

A diferencia de lo que ocurre respecto al reconocimiento de pensiones o privilegios, la definición de discapacidad en el área de la integración profesional trata de subrayar los efectos evitables y corregibles de la misma. De hecho, se pretende eliminar, a través de medidas de rehabilitación y políticas de mercado de trabajo activas, las desventajas profesionales relacionadas con la discapacidad. La integración profesional de las personas discapacitadas se fomenta mediante la concesión de ayuda económica, la realización de medidas de acompañamiento en el área de la formación profesional y la adaptación del lugar de trabajo a las necesidades especiales de dichas personas. U na vez más, las prácticas varían enormemente de unos países a otros. La serie de prestaciones previstas abarca desde ayudas económicas relativamente bajas y de corta duración hasta medidas de rehabilitación profesional a más largo plazo.

La mayoría de los Estados conceden un valor relativamente elevado a la formación profesional de las personas discapacitadas. Esta formación puede impartirse en centros ordinarios 0 especiales, dirigidos por organismos públicos 0 entidades privadas, así como en las propias empresas. La preferencia por una opción u otra varía según los países. En ocasiones, la formación profesional se lleva a cabo en un taller protegido, o se ofrece como formación en el puesto de trabajo reservada para un trabajador discapacitado.

Teniendo en cuenta que las implicaciones económicas de estas medidas pueden ser considerables para el contribuyente, el acto de reconocimiento de una discapacidad tiene una amplia repercusión. Con frecuencia, sin embargo, el registro es llevado a cabo por un órgano diferente del que administra el programa de rehabilitación profesional y cubre sus costes.

\section{La discapacidad como desventaja permanente}

Aunque el objetivo de la rehabilitación profesional es superar los posibles efectos negativos de la discapacidad, existe un amplio acuerdo en que, en ocasiones, se requieren de medidas complementarias de protección social para garantizar la integración profesional y social. También se reconoce generalmente que la discapacidad entraña el riesgo continuo de exclusión social, independientemente de la existencia efectiva de un trastorno funcional. En reconocimiento de esta amenaza permanente, los legisladores ofrecen una serie de medidas de protección y de apoyo.

En muchos países, por ejemplo, las empresas que emplean a personas discapacitadas se benefician de bonificaciones en materia de salarios y de cotizaciones a la seguridad por dichos trabajadores, con importe y duración variables. En general, se procura que los trabajadores discapacitados reciban los mismos ingresos que los no discapacitados. En ocasiones, cuando aquéllos perciben un salario inferior de sus empresas se les abona la diferencia, por aplicación de medidas previstas en el régimen de protección social.

Incluso la creación de pequeñas empresas por parte de los individuos discapacitados puede contar con el apoyo de distintas medidas, como préstamos y garantías de préstamo, intereses subvencionados y ayudas para los alquileres.

La protección de los individuos discapacitados frente al despido y la protección de su derecho a la reincorporación al empleo se abordan de formas diferentes. En muchos Estados no se aplica una normativa legal especial respecto a su despido; en algunos, existe una comisión o institución especial que decide sobre la justificación y la legitimidad de tal despido; en otros, se aplican disposiciones especiales previstas para las víctimas de accidentes de trabajo, para los trabajadores con invalidez grave y para los trabajadores en situación de larga enfermedad. La situación jurídica en lo que respecta a la reincorporación al empleo es similar. Aquí también, hay países en los que se reconoce la obligación general de la empresa de mantener empleado al trabajador después de una lesión o de readmitirlo una vez concluidas las medidas de readaptación. En otros países, no existe tal obligación. En algunos casos, el régimen aplicable es el previsto en distintas recomendaciones y convenios, y en ciertos 
países se garantiza la recolocación o readmisión del trabajador que ha sufrido incapacidad laboral.

\section{Diferencias de trato por razón de discapacidad}

Lo expuesto hasta aquí revela que las leyes conceden diferentes tipos de derechos que tienen claras consecuencias para los respectivos conceptos nacionales de discapacidad. También a la inversa es cierto: en los países que no prevén tales derechos, no existe la necesidad de definir la discapacidad en términos jurídicamente claros y vinculantes. En tales casos, se tiende a reconocer como discapacitados únicamente a quienes lo son visible y marcadamente en un sentido médico, es decir, a quienes presentan deficiencias físicas, ceguera, sordera o minusvalía mental.

En la legislación moderna sobre discapacidades aunque menos en el terreno de las disposiciones de seguridad socialtiene cada vez más arraigo el principio de finalidad. Este principio significa que no es la causa de una discapacidad, sino exclusivamente las necesidades asociadas con ella y el resultado final de las medidas, lo que debe interesar a los legisladores. No obstante, la situación social y los derechos de los individuos discapacitados a menudo dependen de la causa de su discapacidad.

Por lo que respecta a esta causa de la discapacidad, las definiciones difieren no sólo en su significado, sino también en sus consecuencias en términos de prestaciones y ayuda potenciales. Las distinciones más importantes se establecen entre: discapacidades debidas a defectos o deficiencias físicos, mentales o psicológicos hereditarios o congénitas; discapacidades causadas por enfermedades; discapacidades causadas por accidentes domésticos, de trabajo, de deporte o de tráfico; discapacidades provocadas por factores profesionales o medioambientales, y discapacidades resultantes de una contienda civil o un conflicto armado.

La preferencia relativa de trato por algunos grupos de discapacitados a menudo se debe a que están mejor cubiertos en el sistema de seguridad social. Puede reflejar también la actitud de una comunidad _por ejemplo, en el caso de los excombatientes 0 de o las víctimas de un accidente- que se siente corresponsable del incidente causante de la discapacidad, mientras que la discapacidad hereditaria suele considerarse un problema exclusivamente de la familia. Tales actitudes sociales ante la discapacidad a menudo tienen consecuencias más significativas que la política oficial y pueden ejercer una influencia decisiva, negativa o positiva, en el proceso de reintegración social.

\section{Resumen y perspectivas}

Debido a la diversidad de situaciones históricas, jurídicas y culturales, es prácticamente imposible acuñar un concepto unitario de discapacidad, igualmente aplicable a todos los países y situaciones. Al no haber una definición común y objetiva de discapacidad, las estadísticas oficiales son con frecuencia una forma de mantener un registro de clientes y de interpretar el resultado de las medidas aplicadas, lo cual determina que la comparación internacional sea muy difícil, ya que los regímenes y condiciones varían notablemente de unos países a otros. Incluso cuando se dispone de estadísticas fiables, persiste el riesgo de que estén incluidos en ellas individuos que ya no sean discapacitados o que, tras un proceso satisfactorio de rehabilitación, ya no tiendan a considerarse a sí mismos discapacitados.

En la mayoría de los países industrializados, la definición de discapacidad está vinculada, sobre todo, al derecho a beneficiarse de medidas médicas, sociales y profesionales, a recibir protección frente a la discriminación o a percibir prestaciones en efectivo. En consecuencia, la mayoría de las definiciones en uso reflejan prácticas y requisitos legales que varían de unos países a otros. En muchos casos, están vinculadas a un acto de reconocimiento oficial de la situación de discapacidad.

Por efecto de factores tan variados como la reciente legislación sobre derechos humanos o los avances tecnológicos, los conceptos tradicionales de discapacidad que dieron lugar a situaciones de exclusión y segregación protegidas están perdiendo terreno. El concepto moderno de discapacidad sitúa la cuestión en la intersección entre las políticas sociales y las de empleo. La discapacidad es, por tanto, un término de relevancia social y profesional, más que médica. Requiere medidas correctoras y positivas que garanticen la igualdad de acceso y de participación, más que medidas pasivas de apoyo a la renta.

Es en cierto modo paradójico entender la discapacidad, por un lado, como algo que puede superarse con medidas positivas, $y$, por otro, como algo duradero que requiere medidas permanentes de protección y mejora. U na contradicción similar se plantea entre la idea de discapacidad como limitación funcional o del rendimiento personal, y como causa injustificada de exclusión y discriminación social.

O ptar por una definición que pretenda abarcar todos los casos puede tener graves consecuencias sociales para personas concretas. Si se declarase que todas las personas discapacitadas pueden trabajar, muchas quedarían privadas de su derecho a pensión y a protección social. Si se juzgara que todas las personas discapacitadas presentan una productividad 0 un rendimiento reducidos, sería difícil que un individuo discapacitado pudiera obtener un empleo. En consecuencia, debe buscarse un enfoque pragmático que acepte la heterogeneidad de la realidad implícita en un término ambiguo como el de discapacidad. El nuevo concepto de discapacidad tiene en cuenta la situación y las necesidades específicas de los individuos discapacitados, así como la viabilidad económica y social de la eliminación de las barreras a la integración.

El objetivo de prevenir la desventaja indebida posiblemente vinculada a una discapacidad se logrará mejor aplicando una definición flexible de esta última que tenga en cuenta las circunstancias personales y sociales individuales y que evite los supuestos estereotipados. M ientras haya legislaciones nacionales que concedan diferentes derechos, sobre todo por lo que respecta a la igualdad de oportunidades de formación y empleo, seguirá siendo preciso un enfoque caso por caso para reconocer la discapacidad.

No obstante, aún se utilizan definiciones de discapacidad que evocan connotaciones negativas y contradicen los conceptos integradores al hacer excesivo hincapié en los efectos limitadores de la deficiencia. $\mathrm{H}$ ay que renovar la interpretación del tema. EI aspecto central debe ser el reconocimiento de los individuos discapacitados como ciudadanos dotados de derechos y capacidades, y su habilitación para que se hagan cargo de su destino como adultos que quieren participar en la vida social y económica normal.

Por otra parte, es preciso seguir inculcando a la comunidad un sentido de la solidaridad que descarte un concepto imperfecto de discapacidad como fundamento para la exclusión irreflexiva de otros ciudadanos. Entre el cuidado excesivo y la negligencia debe existir un concepto equilibrado de discapacidad que no mistifique ni subestime sus consecuencias. La 
discapacidad puede ser, pero no necesariamente, motivo para que se adopten medidas específicas, y en ningún caso debe justificar la discriminación y la exclusión social.

\section{- ESTUDIO DE CASO: CLASIFICACION LEGAL DE LAS PERSONAS DISCAPACITADAS EN FRANCIA}

\section{M arie-L ouise Cros-Courtial y $M$ arc Vericel}

L a heterogeneidad de las discapacidades tiene su reflejo en la diversidad de las disposiciones legales promulgadas y de las prestaciones establecidas en la mayoría de los países en los últimos cien años. Se ha tomado a F rancia como ejemplo debido a que este país posee, posiblemente, uno de los marcos reguladores más desarrollados por lo que respecta a la clasificación de las discapacidades. Si bien es posible que el sistema francés no sea representativo de los vigentes en muchos otros países, posee, por lo que respecta al objeto del presente capítulo, todos los elementos característicos de una clasificación que ha tenido un desarrollo histórico. Por tanto, en este estudio de caso se ponen de manifiesto las cuestiones básicas que se deben abordar en cualquier sistema en $\mathrm{d}$ que se reconozca a las personas discapacitadas unos derechos sometidos a recursos legales.

El vigésimo aniversario de la L ey de 30 de junio de 1975, aplicable a las personas discapacitadas, suscitó en Francia un interés renovado por la situación de los discapacitados. El número de franceses discapacitados se estima entre 1,5 y 6 millones de personas, que constituyen el $10 \%$ de la población, si bien estas estimaciones se basan en una definición imprecisa de la discapacidad. Esta población se encuentra, en gran medida, marginada por la sociedad y, a pesar de los progresos realizados en los dos últimos decenios, su situación plantea todavía un grave problema social, con dolorosas repercusiones humanas, éticas y emocionales que trascienden los sentimientos colectivos de solidaridad nacional.

Según la legislación francesa, los discapacitados disfrutan de los mismos derechos y libertades que el resto de los ciudadanos, y tienen garantizada la igualdad de trato y de oportunidades. N o obstante, a menos que se adopten medidas específicas de apoyo, esta igualdad resulta meramente teórica. Por ejemplo, es posible que los discapacitados necesiten que la planificación urbana y el transporte se adapten a su discapacidad para poder circular con la misma libertad que los demás ciudadanos. Este tipo de medidas, diseñadas para hacer efectiva la igualdad de trato a las personas discapacitadas, no tienen la finalidad de establecer privilegios, sino de eliminar las desventajas que la discapacidad lleva aparejadas. Se trata de medidas legislativas y de otras iniciativas estatales diseñadas para garantizar la igualdad de trato en la educación, la formación, el empleo y la vivienda. Esta igualdad de trato, junto con la reducción de la discapacidad, constituyen el objetivo fundamental de la política social orientada a los discapacitados.

N o obstante, en la mayoría de los casos, las diversas medidas (generalmente denominadas medidas políticas discriminatorias) previstas en la legislación francesa no benefician a todas las personas afectadas de una determinada discapacidad, sino, más bien, a determinadas subcategorías. Por ejemplo, un determinado subsidio o un programa específicamente diseñado para facilitar la reincorporación al trabajo se ofrece únicamente a una categoría concreta de personas discapacitadas. La diversidad de discapacidades y la multiplicidad de contextos en los que se produce la discapacidad ha inducido el desarrollo de unos sistemas de clasificación basados tanto en la situación oficial de la persona como en su grado de incapacidad.

\section{Diversidad de discapacidades y determinación de la situación legal}

En Francia, la clasificación de las discapacidades es, básicamente, una función del contexto en el que se aquéllas se producen. Por supuesto, las clasificaciones fundadas en la naturaleza (física, mental 0 sensorial) y en el grado de discapacidad influyen también en el tratamiento de las personas discapacitadas, por lo que se deben tomar en consideración. Estos otros sistemas de clasificación son particularmente importantes para determinar si la asistencia sanitaria o la terapia ocupacional es la elección adecuada, y si resulta aconsejable adoptar medidas de custodia (las personas afectadas de discapacidades mentales pueden ser sometidas a la tutela del Estado). No obstante, la naturaleza de la discapacidad constituye el principal criterio aplicable en la determinación de la situación legal de las personas discapacitadas y de su derecho a recibir prestaciones.

El examen de las disposiciones legales francesas aplicables a los discapacitados pone de manifiesto la multiplicidad y la complejidad de los sistemas de apoyo. Esta prolijidad normativa, explicable por causas históricas, ha sobrevivido hasta nuestros días y es fuente de complicaciones.

\section{Desarrollo del concepto de "situación legal"}

$\mathrm{H}$ asta finales del siglo XIX, la asistencia a los discapacitados consistía, esencialmente, en una labor de "beneficencia" que solía realizarse en los hospicios. Sólo en los primeros años del siglo XX aparecieron los conceptos de rehabilitación y de "sustitución de ingresos", en el contexto de una nueva actitud social y cultural ante la discapacidad. En este nuevo contexto, los discapacitados se veían como personas disminuidas que necesitaban ser rehabilitadas, si no hasta recuperar su estado anterior, al menos hasta alcanzar una situación equivalente. Este cambio de mentalidad se debió tanto al desarrollo de la mecanización y de su corolario, los accidentes de trabajo, como al enorme número de combatientes en la primera Guerra M undial que quedaron discapacitados de forma permanente.

La ley de 8 de abril de 1898 introdujo una mejora en el sistema de indemnización por accidentes de trabajo, al prescindir de la carga de la prueba de la responsabilidad de la empresa e introducir un sistema de pago de una indemnización a tanto alzado. En 1946, la gestión del riesgo derivado de los accidentes de trabajo se transfirió al sistema de seguridad social.

En un esfuerzo por mitigar los perjuicios experimentados por los combatientes heridos o discapacitados en la primera Guerra $M$ undial, se promulgaron las leyes siguientes:

- Ley de 1915, por la que se creaba un sistema de readaptación profesional;

- Ley de 1916 (desarrollada por otra de 1923), por la que se concedía prioridad a los inválidos de guerra en el acceso al empleo público;

- Ley de 31 de marzo de 1918, por la que se reconocía el dere cho a percibir una pensión fija en función del grado de discapacidad;

- Ley de 26 de abril de 1924, por la que se obligaba a las empresas del sector privado a emplear un determinado porcentaje de inválidos de guerra.

En el período de entreguerras se crearon las primeras grandes asociaciones de civiles discapacitados, entre las que destacan la Fédération des mutilés du travail (1921), la Ligue pour l'adaptación des diminués physiques au travail (LADAPT) (1929) y la Association des Paralysés de F rance (APF) (1933). G racias a la presión ejercida por estas asociaciones y por los sindicatos, inicialmente las víctimas 
de accidentes de trabajo y, finalmente, todos los civiles discapacitados se incorporaron gradualmente a unos sistemas de apoyo inspirados en los que se crearon en un principio para los inválidos de guerra.

En 1930 se creó un sistema de seguro de incapacidad laboral de los trabajadores, que fue posteriormente desarrollado en el Decreto de 1945, por el que se creó el sistema de seguridad social. En este sistema, los trabajadores tienen derecho a una pensión si su capacidad para trabajar o para ganarse la vida se ve sensiblemente mermada por causa de un accidente 0 una enfermedad. En una ley de 1930 se reconocía el derecho de las víctimas de accidentes de trabajo a la readaptación profesional. En 1945 se estableció un sistema de readaptación profesional de los ciegos, cuya cobertura se amplió en 1949 a todas las personas afectadas de serias discapacidades. En 1955, la obligación legal de emplear un porcentaje mínimo de inválidos de guerra se amplió a otras personas discapacitadas.

La evolución del concepto de integración profesional condujo a la promulgación de tres leyes por las que se perfeccionaban y se fortalecían los sistemas de apoyo vigentes: la Ley de 27 de noviembre de 1957, sobre reclasificación profesional de los trabajadores con incapacidad laboral; la Ley de 30 de junio de 1975, sobre las personas discapacitadas (primera disposición legal en la que abordaron con un criterio global los problemas que afectan a los discapacitados, especialmente el de la reinserción social); y la ley de 10 de julio de 1987, de promoción del empleo de los trabajadores con incapacidad laboral. Sin embargo, en estas leyes no se derogaban las disposiciones específicamente aplicables a los inválidos de guerra y a las víctimas de accidentes de trabajo.

\section{Multiplicidad y diversidad de los sistemas de apoyo a los discapacitados}

Existen en la actualidad tres sistemas diferenciados que prestan apoyo a los discapacitados: uno está dedicado a los inválidos de guerra, el otro ampara a las víctimas de accidentes de trabajo, y el tercer sistema, de derecho común, presta cobertura a todos los demás discapacitados.

A priori, la coexistencia de varios sistemas en los que se selecciona a los usuarios sobre la base del origen de su discapacidad no parece ser una solución satisfactoria, especialmente porque todos los sistemas prestan el mismo tipo de apoyo, consistente en unos programas de integración y apoyo generalmente orientados a la reinserción profesional, combinados con uno o más tipos de subsidios. Por consiguiente, se han realizado esfuerzos concertados para armonizar los sistemas de apoyo al empleo. Por ejemplo, los programas de formación profesional y de rehabilitación médica existentes en todos los sistemas se orientan, tanto a la socialización de los costes como al pago de prestaciones económicas a los discapacitados; además, la formación especializada y los centros de rehabilitación médica, incluidos los centros gestionados por Office des anciens combattants (O NAC) están a disposición de todos los discapacitados, y la reserva de plazas en el sector público a los inválidos de guerra se amplió a los civiles discapacitados en virtud del Decreto de 16 de diciembre de 1965.

Por último, en la Ley de 10 de julio de 1987 se unificaron las disposiciones garantes del empleo mínimo en los sectores público y privado. Por una parte, las condiciones de estos programas resultaban ser extremadamente complejas en la práctica y, por otra, su aplicación dependía de que el discapacitado fuese un civil (en cuyo caso se aplicaba el derecho común) 0 un inválido de guerra. La entrada en vigor de esta ley ha supuesto el reconocimiento de las siguientes categorías de beneficiarios de los programas de empleo mínimo: trabajadores con incapacidad laboral reconocidos por la Commission technique d'orientation à la réinsertion professionnelle (COTOREP), víctimas de accidentes de trabajo y enfermedades profesionales que reciben una pensión y sufren una invalidez permanente no menor del $10 \%$, civiles perceptores de subsidios por discapacidad, antiguos miembros de las Fuerzas Armadas y demás perceptores de subsidios militares por discapacidad. Según el sistema de derecho común, corresponde a la COTOREP declarar la situación de incapacidad.

Por otra parte, existen sensibles diferencias entre los subsidios que conceden los distintos sistemas. En efecto, los discapacitados acogidos al sistema de derecho común reciben del sistema de seguridad social una prestación básicamente asimilable a una pensión de incapacidad, y un subsidio complementario destinado a equiparar el importe global de la prestación al de la pensión correspondiente a un adulto discapacitado, que, al 1 de julio de 1995, se situaba en 3.322 francos mensuales. El importe de la pensión estatal que reciben los inválidos de guerra depende del grado de invalidez. Por último, la prestación mensual (o el pago único, si el grado de invalidez permanente fuese inferior al $10 \%$ ) que el sistema de seguridad social abona a las víctimas de accidentes de trabajo y enfermedades profesionales está en función del grado de incapacidad del beneficiario y de su salario anterior.

Tanto los criterios aplicables a la concesión de las prestaciones como la cuantía de las mismas varían sustancialmente de uno a otro sistema, lo que produce divergencias significativas en el tratamiento conferido a las personas cuyas discapacidades afectan a distintos sistemas orgánicos, además de generar estados de ansiedad que, a veces, dificultan la rehabilitación y la integración social (Bing y Levy 1978).

A tendiendo a las numerosas voces que exigían la armonización, si no la unificación, de los distintos subsidios por discapacidad (Bing y Levy, 1978), en 1985 el Gobierno creó un grupo de trabajo encargado de estudiar posibles soluciones al problema. Sin embargo, hasta ahora no se han propuesto soluciones, debido, en parte, a que la divergencia de los objetivos de los distintos subsidios dificulta su unificación. Los subsidios regulados en el derecho común son prestaciones de subsistencia cuya finalidad es permitir que los beneficiarios conserven un nivel de vida decoroso. En cambio, las pensiones de los inválidos de guerra constituyen una indemnización por las discapacidades sufridas en el servicio de las armas, y los subsidios de las víctimas de accidentes de trabajo y enfermedades profesionales sirven para indemnizar a los pacientes por la incapacidad derivada de la actividad laboral. Por consiguiente, las dos clases de subsidios últimamente citados suelen ser sensiblemente superiores, para un determinado nivel de discapacidad, a los que reciben las personas afectadas por discapacidades congénitas o producidas al margen del servicio militar 0 de los accidentes y enfermedades relacionados con el trabajo.

\section{Efectos de la situación legal en la evaluación del grado de discapacidad}

Se han desarrollado históricamente diversos sistemas de indemnización por discapacidad. Esta diversidad se refleja, no sólo en los distintos subsidios que en cada sistema se abonan a los discapacitados, sino también en los criterios de concesión aplicados en cada uno y en los métodos de evaluación del grado de discapacidad.

En todos los casos, la determinación de los criterios de concesión y la evaluación del grado de discapacidad se confía a un comité ad hoc. Para la declaración de discapacidad, no basta con una simple manifestación del solicitante, que debe declarar ante la comisión si desea verse reconocida la situación legal de discapacidad y recibir las prestaciones correspondientes. Para algunas personas, este procedimiento es deshumanizado y 
contrario al objetivo de la integración, ya que las personas reacias a que sus diferencias se "oficialicen" y que, por ejemplo, se niegan a acudir a la COTOREP, no pueden acceder a la situación legal de discapacitados y, por tanto, no tienen derecho a participar en los programas de reinserción profesional.

\section{Criterios para la declaración de la discapacidad}

En cada uno de los tres sistemas se aplican diversos criterios para determinar si una persona tiene derecho a las prestaciones por discapacidad.

\section{Régimen de derecho común}

En el régimen de derecho común se abona a las personas discapacitadas unos subsidios de subsistencia (en los que se incluyen el subsidio por incapacidad de los adultos, un subsidio de indemnización y el subsidio escolar, que se destina a los menores discapacitados) que les permiten seguir viviendo independientemente. Sólo los solicitantes afectados de una grave invalidez permanente - que, en la mayoría de los casos, debe ser del $80 \%$ - tienen derecho a estos subsidios, si bien se exige un grado menor de discapacidad (del orden del $50 \%$ al $80 \%$ ) en el caso de los niños que asisten a una institución especializada o que reciben educación especial o asistencia a domicilio. En todos los casos, el grado de discapacidad se evalúa con referencia a la escala oficial contenida en el A nexo 4 al Decreto de 4 de noviembre de 1993, sobre el pago de diversos subsidios a los discapacitados.

La concesión de los subsidios por discapacidad que, como ocurre con el régimen de prestaciones de derecho común, tienen un componente de pensión de subsistencia, obedece a criterios de adjudicación diversos. En efecto, los solicitantes de esta prestación deben estar percibiendo la pensión de la seguridad social y sufrir una discapacidad que merme su capacidad para generar ingresos, como mínimo, en las dos terceras partes, esto es, que les impida devengar, en el ejercicio de una profesión, un salario superior a la tercera parte del que fuesen capaces de percibir antes de quedar discapacitados. Este salario se calcula sobre la base del salario devengado en la misma región por los trabajadores de características similares.

No existen criterios oficiales para la concesión de los subsidios, que se basa en la situación global del interesado. En la ley de seguridad social se establece que "el grado de discapacidad se evaluará sobre la base de la capacidad física residual para el trabajo, el estado general, las facultades físicas y mentales, la aptitud y la formación profesional".

Como se deduce claramente de esta definición, la discapacidad se asimila a la incapacidad general para ganarse la vida y no se circunscribe a la discapacidad física ni a la incapacidad para ejercer una determinada profesión, y se evalúa en función de los factores que pueden influir en la reorientación profesional de la persona. Estos factores son los siguientes:

- naturaleza y gravedad de la discapacidad, así como edad del solicitante, facultades físicas y mentales, aptitudes, formación profesional y profesión anterior

- capacidad física residual para el trabajo respecto a la de la población activa de la región de residencia

Para poder optar por un determinado programa de reinserción profesional, los adultos discapacitados deben satisfacer los criterios legales siguientes: "trabajador con incapacidad laboral es toda persona cuya capacidad para conseguir o conservar un trabajo ha disminuido, de hecho, como consecuencia de una reducción o insuficiencia de su capacidad física o mental".

Esta definición responde en gran medida al criterio de la Recomendación sobre la adaptación y readaptación profesionales de los inválidos, 1955 (no 99) (OIT 1955), en la que se define el discapacitado como una persona "cuyas posibilidades de obtener y conservar un empleo adecuado se hallan realmente reducidas debido a una reducción de su capacidad física 0 mental".

No obstante, este criterio pragmático deja un margen a la interpretación: ¿Q ué significa "de hecho"? Q ué criterios se aplican para determinar si la capacidad física para el trabajo se encuentra "reducida" o es "insuficiente"? La falta de unas directrices claras al respecto ha permitido que distintas comisiones evalúen de forma muy diversa la incapacidad laboral.

\section{Sistemas específicos}

Para el cumplimiento de su objetivo básico de indemnización y resarcimiento, estos sistemas abonan los subsidios y pensiones siguientes:

- Las pensiones por invalidez de guerra se basan en el grado de discapacidad meramente física determinado por los expertos. Se exige, como mínimo, una discapacidad del $10 \%$ en las lesiones y del $30 \%$ en los casos de enfermedad. El grado de discapacidad se determina utilizando la escala oficial.

- En los sistemas de accidentes de trabajo, las víctimas de estos accidentes 0 de enfermedades profesionales que experimentan una incapacidad permanente reciben, bien un pago único, bien un subsidio.

El grado de discapacidad permanente se determina de acuerdo con una escala oficial en la que se toman en consideración la naturaleza de la discapacidad, el estado general del solicitante, las facultades físicas y mentales, las aptitudes y la cualificación profesional.

\section{Escalas de evaluación de la discapacidad}

Si bien en todos los sistemas la concesión de las prestaciones depende de una decisión administrativa, la evaluación médica de la discapacidad, realizada mediante exploración o consulta, conserva toda su importancia.

Existen dos criterios de evaluación médica de la discapacidad. El primero descansa en el cálculo de la indemnización en función del grado de discapacidad parcial permanente; el segundo, en la disminución de la capacidad física para el trabajo.

El primer criterio se aplica en el sistema de prestaciones por invalidez de guerra, mientras que en el sistema de accidentes de trabajo y en el régimen de derecho común se exige que el solicitante sea examinado por la COTOREP.

El grado de discapacidad parcial permanente de los inválidos de guerra se establece según los baremos de la escala oficial aplicable a los casos previstos en el Code des pensions militaires d'invalidité et victimes de guerre (actualizado el 1 de agosto de 1977, con la inclusión de las escalas de 1915 y 1919). En los casos de accidente de trabajo, se aplica una escala establecida en 1939 y revisada en 1995.

Los sistemas de clasificación aplicados en ambos supuestos obedecen a criterios específicamente orgánicos y funcionales (como la ceguera, la insuficiencia renal y cardíaca) y en los mismos se define un nivel de discapacidad parcial permanente para cada tipo de discapacidad. Aunque se han recomendado varios sistemas de clasificación de las discapacidades mentales, todos son insuficientemente precisos para estos fines. Es de subrayar que, aparte de sus otras insuficiencias, en estos sistemas se pueden evaluar distintos niveles de discapacidad parcial permanente para una determinada discapacidad. Así, una reducción del $30 \%$ de la agudeza visual bilateral se considera una discapacidad parcial permanente del $3 \%$ en el sistema de accidentes de trabajo, y del 19,5\% en el sistema de invalidez de guerra; en cambio, una reducción del 50 \% constituye, en uno u 
otro sistema, una discapacidad parcial permanente del $10 \%$ y del $32,5 \%$, respectivamente.

H asta hace poco, la COTOREP utilizaba la escala de discapacidades establecida en el Code des pensions militaires d'invalidité et victimes de guerre para conceder indemnizaciones y prestaciones como las cartillas de discapacidad, los subsidios a los adultos discapacitados y los subsidios de indemnización a terceros. Esta escala, creada para garantizar una indemnización adecuada a los inválidos de guerra, se adapta mal a otras aplicaciones, especialmente a la tasa de natalidad. La falta de un referente común ha sido causa de que en distintas reuniones de la COTOREP se hayan adoptado, respecto al grado de discapacidad, conclusiones divergentes que han producido serias injusticias en el trato dado a los discapacitados.

Para remediar esta situación, el 1 de diciembre de 1993 se promulgó una nueva escala de defectos y discapacidades que responde a un nuevo concepto de la discapacidad (A nexo al Decreto no 93-1216, de 4 de noviembre de 1993, Journal O fficiel de 6 de noviembre de 1993). La guía metodológica, basada en conceptos desarrollados por la O M S, específicamente los de deficiencia, minusvalía y discapacidad, se aplica fundamentalmente a evaluar la discapacidad en la vida familiar, escolar y patrimonial, con independencia del diagnóstico médico concreto. Si bien éste es de importancia fundamental en la predicción de la evolución del problema y constituye el enfoque más eficaz del tratamiento de los casos, tiene una utilidad limitada en la determinación del grado de discapacidad.

E stas escalas son meramente indicativas, con una única excepción: su aplicación es preceptiva en la evaluación de la discapacidad parcial permanente de los perceptores de pensiones militares que han sufrido la amputación o la resección de un órgano. Varios otros factores influyen en la evaluación del grado de discapacidad. Por ejemplo, en la determinación del grado de discapacidad parcial permanente de las víctimas de accidentes de trabajo se deben tomar en consideración tanto los aspectos médicos (estado general, naturaleza de la discapacidad, edad, facultades físicas y mentales) como los factores sociales (aptitudes y cualificación profesional). La inclusión de otros criterios permite a los médicos adecuar la evaluación del grado de discapacidad parcial permanente a los progresos de la terapéutica y a la capacidad de rehabilitación, así como contrarrestar la rigidez de las escalas, que raras veces se actualizan o se revisan.

El segundo sistema, basado en la pérdida de capacidad laboral, suscita otras cuestiones. La evaluación de la disminución de la capacidad laboral puede ser necesaria con diversos fines: determinación de la pérdida de capacidad laboral a efectos del seguro, declaración de la pérdida de capacidad de trabajo por la COTOREP, evaluación de un déficit de capacidad laboral con el objeto de declarar la discapacidad de un trabajador 0 de incorporarlo a un programa especial.

No existen normas de evaluación de la pérdida de capacidad laboral, puesto que el "trabajador medio" es una construcción teórica. En realidad, el concepto mismo de la capacidad laboral se encuentra mal definido, ya que es una función, no sólo de las aptitudes intrínsecas a la persona, sino también de las necesidades y la idoneidad del entorno profesional. Esta dicotomía pone de relieve la diferencia entre capacidad en el trabajo y capacidad para el trabajo. En síntesis, se pueden producir dos situaciones.

En el primer supuesto, es preciso determinar objetivamente el grado de pérdida de capacidad de trabajo respecto a la reciente situación profesional específica del solicitante.

En el segundo caso, hay que evaluar la pérdida de capacidad de trabajo de las personas que 0 , bien no forman actualmente parte de la población activa (por ejemplo, los pacientes de enfermedades crónicas que llevan mucho tiempo sin trabajar), o bien nunca han formado parte de ella. Esta última situación, que se produce frecuentemente cuando se calculan las pensiones de discapacidad de los adultos, es claramente ilustrativa de las dificultades que el médico responsable de cuantificar la pérdida de capacidad de trabajo debe afrontar. En estas circunstancias, los médicos, consciente 0 inconscientemente, suelen tomar como referentes los grados de discapacidad parcial permanente para evaluar la capacidad de trabajo.

No obstante las evidentes imperfecciones de este sistema de evaluación de la discapacidad y de las irregularidades médicoadministrativas a que a veces obliga, en la mayoría de los casos permite fijar el nivel de indemnización por discapacidad.

Es evidente que el sistema francés, que descansa sobre una clasificación oficial de los discapacitados en función del origen de la discapacidad, resulta, en el mejor de los casos, problemático en diversos aspectos. La situación de las personas que sufren discapacidades de origen diverso y a las que, por este motivo, se les asignan distintas situaciones legales, es todavía más complejo. Considérese, por ejemplo, la situación de una persona afectada de una discapacidad motriz compleja que sufre un accidente de trabajo: no es difícil imaginar los problemas que la superación de esta situación lleva aparejados.

Las raíces históricas de las diversas situaciones legales convierten en problemática la perspectiva de que alguna vez Ileguen a unificarse totalmente. Sin embargo, la armonización gradual de los distintos sistemas, sobre todo por lo que respecta a los respectivos métodos de evaluación de la incapacidad a los fines de concesión de indemnizaciones económicas, resulta muy deseable.

\section{POLITICA SOCIAL Y DERECHOS HUMANOS: CONCEPTOS DE LA DISCAPACIDAD}

Carl Raskin

Aunque la mayoría de los discapacitados en edad laboral quieren y pueden trabajar, a menudo deben afrontar serios obstáculos en su esfuerzo por acceder al trabajo en condiciones de igualdad. En el presente artículo se examinan los aspectos principales que rodean la incorporación de los discapacitados al mundo del trabajo, en relación con los conceptos de política social y de derechos humanos.

Primeramente, se ofrece una visión global de la magnitud y las consecuencias de la discapacidad, así como de la medida en que los discapacitados han estado tradicionalmente excluidos de la plena participación en la vida social y económica. A continuación, se expone el concepto de los derechos humanos como un proceso de superación de las dificultades que los discapacitados afrontan para acceder a un empleo justo. Estas barreras a la plena participación en el lugar de trabajo y en la vida nacional responden, en la mayoría de los casos, más a unas actitudes y prácticas discriminatorias que a causas asociadas a la discapacidad de las personas. La consecuencia última de todo ello es que los discapacitados suelen ser objeto de una discriminación que se produce, bien deliberadamente, bien como resultado de la existencia de barreras intrínsecas o estructurales en el entorno.

Por último, el análisis de la discriminación conduce a la descripción de las vías de superación de esta situación mediante un trato equitativo, la acomodación del lugar de trabajo y la accesibilidad.

\section{Alcance y consecuencias de la discapacidad}

El examen de los conceptos de política social y de derechos humanos en el contexto de la discapacidad se debe iniciar con 
una exposición general de la situación global que los discapacitados afrontan.

El alcance exacto del concepto de discapacidad es susceptible de muy diversas interpretaciones en función de la definición empleada. El informe del Disability Statistics Compendium, de las Naciones Unidas (1990), denominado también Compendio DISTAT, es el resultado de 63 encuestas sobre la discapacidad realizadas en 55 países. En él se pone de relieve que el porcentaje de discapacitados oscila entre el $0,2 \%$ en Perú y el 20,9\% en Austria. En el decenio de 1980, un $80 \%$ de los discapacitados vivían en los países en vías de desarrollo, en los que, por causa de la desnutrición y de las enfermedades, aproximadamente el $20 \%$ de la población sufre alguna discapacidad. EI empleo de definiciones divergentes hace que los porcentajes de población discapacitada que aparecen en las diversas encuestas nacionales no sean comparables entre sí. Desde la perspectiva global, aunque limitada, aportada por el Compendio DISTAT, cabe observar que el concepto de discapacidad es, en gran medida, una función de la edad; que su incidencia es mayor en las zonas rurales y que la misma se asocia a una mayor prevalencia de la pobreza y de unos niveles económicos y educativos bajos. Además, las estadísticas reflejan sistemáticamente una menor frecuencia de la discapacidad entre la población empleada que en el conjunto de la población.

Por lo que respecta al empleo, Cart, miembro del Consejo de Administración de la O IT y ex presidente de Canadian Labour Force, ha brindado una descripción gráfica de la situación que afrontan las personas discapacitadas. D urante un foro parlamentario sobre la discapacidad celebrado en Canadá en 1992, Shirley Cart observó que los discapacitados tropiezan con un "techo de hormigón" y que hay tres prefijos que golpean a las personas discapacitadas: desempleo, subempleo e infrautilización. Lamentablemente, la situación de los discapacitados no es en ningún lugar mejor que en Canadá y, en la mayoría de los casos, es mucho peor.

\section{Discapacidad y exclusión social}

Por diversas causas, muchos discapacitados se han visto tradicionalmente sujetos al aislamiento socioeconómico. Sin embargo, desde el final de la segunda Guerra M undial se ha producido una disminución, lenta pero constante, de la política de segregación de los discapacitados, y de la creencia de que éstos precisan cuidados, conmiseración y caridad. Los discapacitados reclaman con insistencia creciente su derecho a no ser excluidos de los lugares de trabajo y a ser tratados con un espíritu de integración y en plano de igualdad con las personas no discapacitadas, así como su derecho a participar activamente en la vida económica del país.

Los discapacitados deben integrarse plenamente en el empleo, ya que resulta económicamente rentable para ellos que, en lugar de depender de la asistencia social, se les permita dedicarse a una actividad remunerada en la máxima medida de sus posibilidades. Pero, sobre todo y en primer lugar, los discapacitados deben incorporarse plenamente al mundo del trabajo $y$, por tanto, al conjunto de la vida nacional, porque esto es lo éticamente correcto. En este sentido, es preciso tener presentes las observaciones de Leandro Despouy, Relator Especial de la ONU, quien, en su informe al Consejo Económico y Social de las Naciones U nidas (1991), manifestaba que "el trato conferido a los discapacitados revela la naturaleza más profunda de una sociedad y pone de relieve los valores culturales que la sustentan". Y a continuación exponía algo que, lamentablemente, resulta menos evidente:

(...) los discapacitados son seres humanos, tanto o más humanos que los demás. Su esfuerzo cotidiano por superar las barreras y el trato discriminatorio del que suelen ser objeto imprime en ellos unos rasgos especiales de personalidad, entre los que destacan la integridad, la perseverancia y una profunda actitud de comprensión ante la incomprensión y la intolerancia. No obstante, esta última consideración no debe hacer olvidar la circunstancia de que, como sujetos de derechos, los discapacitados disfrutan plenamente de la capacidad legal inherente a la condición de persona humana. En resumen, los discapacitados son personas como nosotros, que tienen derecho a vivir con y como nosotros.

\section{Discapacidad y actitudes sociales}

Las cuestiones suscitadas por el Relator Especial de la ONU apuntan a la existencia de unas actitudes sociales negativas y de unos estereotipos que constituyen una importante barrera al logro de un trato más equitativo en el lugar de trabajo para las personas discapacitadas. Entre estas actitudes figura el temor de que el coste de acomodación de los lugares de trabajo a los discapacitados resulte demasiado elevado, de que éstos no sean productivos o de que los clientes y las demás personas que reciben formación profesional se sientan incómodos en su presencia. Existen, además, otras reticencias asociadas a la presunta debilidad o enfermedad de los discapacitados y de sus posibles efectos sobre la aptitud que demuestran para seguir un programa de formación profesional o para conservar un puesto de trabajo. El denominador común de todos estos argumentos consiste en que se basan en presunciones derivadas de una única característica de estas personas: su condición de discapacitados. Como ha puesto de manifiesto el Consejo A sesor para D iscapacitados de la provincia canadiense de 0 ntario (1990):

Las presunciones relativas a las necesidades de los discapacitados se suelen basar en determinadas ideas respecto a lo que una persona no puede hacer. Así, la discapacidad se convierte en seña de identidad del conjunto de la persona, en lugar de un aspecto de la misma. La discapacidad se percibe como un estado generalizado y suele asociarse a la idea de incompetencia.

\section{Discapacidad y habilitación: el derecho a elegir}

La idea de que es preciso habilitar a los discapacitados para decidir libremente sobre su formación profesional y la elección de una profesión es inherente al reconocimiento de su derecho a incorporarse plenamente al núcleo de la vida económica y social del país.

Este derecho fundamental se reconoce en el Convenio sobre el desarrollo de los recursos humanos, 1975 (no 142) (O IT 1975), en el que se estipula que los programas y políticas de formación profesional deben "alentar y ayudar a todas las personas, en un pie de igualdad y sin discriminación alguna, a desarrollar y utilizar sus aptitudes para el trabajo en su propio interés y de acuerdo con sus aspiraciones".

A prender a elegir es parte inseparable del desarrollo personal. Sin embargo, a muchos discapacitados se les ha denegado la posibilidad de optar efectivamente en materia de formación profesional y colocación. M uchas personas afectadas de graves discapacidades carecen de las destrezas precisas para reconocer las preferencias personales y elegir eficazmente entre una serie de opciones. Sin embargo, esta falta de autonomía y de capacidad decisoria, lejos de responder a las limitaciones o a las deficiencias de la persona, obedece con frecuencia a unas actitudes y prácticas negativas. No es infrecuente que se ofrezcan a los discapacitados opciones sesgadamente restringidas o trucadas. Por ejemplo, a veces se les presiona para que participen en cualquier curso de formación profesional que interese ofertar, sin 
tomar seriamente en consideración sus opciones personales. 0 tras veces, las "opciones" tienden, sencillamente, a la evitación de situaciones indeseables, como cuando se accede a convivir en grupo o a compartir habitación con desconocidos, para evitar situaciones todavía más desagradables, como tener que vivir en una institución. Lamentablemente para muchos discapacitados, las posibilidades de manifestar los intereses profesionales personales, de elegir determinadas posibilidades de formación profesional 0 de buscar un determinado puesto de trabajo suelen estar limitadas tanto por el marchamo de discapacidad unido a su persona como por las presunciones de terceros respecto a su capacidad. La falta de posibilidades de elección proviene también de una actitud arraigada de que, en cuanto beneficiarios involuntarios del sistema de bienestar social, "Ios pedigüeños no pueden elegir".

Esta cuestión es sumamente preocupante. Las investigaciones realizadas han revelado que el grado de influencia que las personas ejercen sobre las decisiones que afectan a su vida laboral influyen decisivamente en su satisfacción en el puesto de trabajo y, por ende, en el éxito de las estrategias de integración. Toda persona, independientemente de la gravedad de su discapacidad, tiene el derecho y la capacidad de comunicarse con otros, de expresar sus preferencias habituales y de determinar, al menos, en alguna medida, su vida cotidiana. Consustancial con la libertad es el derecho a la libre elección de profesión, a la necesaria formación basada en la tecnología disponible y al respeto y los incentivos al trabajo. Para los afectados de cualquier grado de discapacidad y con cualquier nivel de destrezas, incluidos los que sufren discapacidades intelectuales y psicosociales, la elección es fundamental para la afirmación de la identidad y la personalidad propias. No hay que olvidar tampoco que errar y aprender de los errores es parte de la experiencia humana.

$\mathrm{H}$ emos de resaltar de nuevo que las personas discapacitadas son seres humanos. Es una cuestión de respeto elemental a la dignidad humana ofrecer a esas personas las oportunidades para tomar en la vida aquellas decisiones que las personas que no tienen discapacidades hacen de forma rutinaria.

\section{Discapacidad y justicia social: la cuestión de la discriminación}

¿Por qué hemos desarrollado unos estereotipos negativos y qué relación tienen éstos con la discriminación? H ahn (1984) subrayó la contradicción aparente entre la profunda simpatía que los discapacitados suscitan y la circunstancia de que, colectivamente, sean objeto de unas actitudes discriminatorias más acentuadas que ninguna otra minoría reconocida como tal. Esto obedece a que suelen poseer características físicas y patrones de comportamiento que los segregan del resto de la población:

Si no fuese por estas diferencias físicas identificables, los discapacitados no serían objeto de los mismos estereotipos, estigmas, sesgos, prejuicios, discriminaciones y segregaciones que sufren todos los grupos minoritarios. Por otra parte, cuando estos rasgos van acompañados de un marchamo social negativo, los efectos de la discriminación se magnifican.

$\mathrm{H}$ ahn asegura igualmente que existe una relación directa entre el grado de discriminación que una persona experimenta y la visibilidad de su discapacidad.

Por consiguiente, la clave para que los discapacitados reciban un trato equitativo en el trabajo y en la sociedad consiste en reducir y eliminar las actitudes negativas y los estereotipos que generan los comportamientos discriminatorios, así como en aplicar unos programas y prácticas que se ajusten a las necesidades personales específicas de los discapacitados. En el resto del presente artículo se desarrollan estas ideas.

\section{¿Qué se entiende por discriminación?}

En el transcurso de nuestra vida ejercemos cotidianamente la "discriminación". Continuamente optamos entre ir al cine 0 al ballet, y entre comprar una prenda de vestir de mayor o menor precio. Este tipo de discriminación no es problemático. En cambio, la discriminación comienza a ser perturbadora cuando se establecen distinciones negativas sobre la base de características inmutables de las personas o grupos de personas.

La Conferencia Internacional del Trabajo adoptó una definición de la discriminación que se ha recogido en el Convenio relativo a la discriminación en materia de empleo y ocupación, 1958 (no 111).

Según este convenio, se entiende por "discriminación":

(a) cualquier distinción, exclusión o preferencia basada en motivos de raza, color, sexo, religión, opinión política, ascendencia nacional u origen social, que tenga por efecto alterar la igualdad de oportunidades o de trato en el empleo y la ocupación;

(b) cualquier otra distinción, exclusión o preferencia que tenga por efecto anular o alterar la igualdad de oportunidades 0 de trato en el empleo u ocupación, que podrá ser especificada por el M iembro interesado previa consulta con las organizaciones representativas de empleadores y de trabajadores, cuando dichas organizaciones existan, y con otros organismos apropiados.

\section{Tres formas de discriminación}

La anterior definición se comprende mejor a la luz de las tres formas de discriminación que se han producido desde el final de la segunda Guerra Mundial. Las tres categorías siguientes, conceptualizadas inicialmente en Estados U nidos, han sido objeto de una aceptación generalizada en muchos países.

\section{Animus hostil}

En un principio, se entendía que había discriminación cuando existía un trato inspirado en prejuicios, esto es, actos lesivos motivados por antipatía personal por el grupo al que pertenecía la persona discriminada. Estos actos consistían en la denegación deliberada de oportunidades de empleo. Por tanto, se exigía la prueba, no sólo de esta denegación, sino también de que la misma obedecía a un prejuicio. Dicho de otro modo, la definición se basaba en la existencia de un animus hostil, esto es, de una actitud mental. U n ejemplo de esta forma de discriminación es la del empleador que dice al discapacitado que no le contrata por temor a la reacción negativa de los clientes.

\section{Trato diferencial}

En el decenio de 1950 y a mediados del siguiente, desde la promulgación la Ley de derechos civiles, los organismos administrativos de Estados U nidos aplicaron un concepto de la discriminación basado en la noción de "protección equitativa". En su virtud, se entendía por discriminación la producción de un perjuicio económico "al tratar a los miembros de una minoría de forma menos favorable que a los miembros del grupo mayoritario que disfrutan de una situación análoga" (Pentney 1990). Según este concepto del trato diferencial, se deben aplicar idénticas normas a todos los empleados y solicitantes, sin necesidad de acreditar la actitud discriminatoria. En este contexto, se incluye entre las prácticas discriminatorias la exigencia de que los trabajadores discapacitados se sometan a una exploración médica antes de poder optar a las prestaciones de un seguro de enfermedad colectivo, si estas exploraciones no se exigen para el resto de los empleados. 


\section{Discriminación indirecta o de efectos adversos}

Si bien el concepto de discriminación basado en la noción de trato diferencial exigía que las políticas y prácticas de empleo se aplicasen a todos de modo equitativo, en la práctica se imponían requisitos aparentemente inocuos, como los relativos al nivel de estudios o los referentes a la superación de determinadas pruebas de nivel, que, repercutían negativamente en diversos grupos. En 1971, el Tribunal Supremo de Estados U nidos abordó esta cuestión al añadir, en la sentencia dictada en la famosa causa Giggs contra Duke Power, una tercera definición de la discriminación en el empleo. Con anterioridad a la promulgación de la Ley de derechos civiles, D uke Power discriminaba a los negros al restringirlos al departamento de mano de obra donde estaban peor remunerados. Tras la promulgación de la Ley, se exigió para el traslado a otros departamentos que los solicitantes hubiesen finalizado la enseñanza secundaria y aprobasen unas pruebas de aptitud. En la zona de captación de solicitantes, sólo el $12 \%$ de los negros poseían el nivel de estudios exigido, frente al $34 \%$ de los blancos. Además, mientras que el $58 \%$ de los blancos superaron la prueba, sólo lo lograron el $6 \%$ de los negros. Estos requisitos se implantaron a pesar de la evidencia de que los trabajadores contratados con anterioridad a la modificación de la política de empleo que carecían de las cualificaciones exigidas continuaban rindiendo satisfactoriamente. EI Tribunal Supremo revocó las exigencias de posesión de un cierto nivel de estudios y de aprobación de las pruebas, aduciendo que surtían el efecto de excluir a los negros y carecían de toda relación con las necesidades de los puestos de trabajo. No hubo pronunciamiento sobre la intención de la empresa: lo relevante era el efecto de la política o práctica en cuestión. U n ejemplo de esta forma de discriminación sería la exigencia de aprobar un examen oral, que perjudicaría a los sordos y a los demás solicitantes afectados de alguna discapacidad para la expresión verbal.

\section{Igualdad de trato o trato equitativo}

El modelo de discriminación indirecta o de efectos adversos es el más problemático para los discapacitados. En efecto, si las personas discapacitadas reciben el mismo tratamiento que las demás, ¿cómo se puede hablar de discriminación? Este modelo se basa, por el contrario, en el criterio de que tratar a todos por igual constituye, en ocasiones, una forma de discriminación. Abella ha expuesto este principio de forma sumamente descriptiva en su informe (C anada R oyal Commission 1984), al observar lo siguiente:

Antiguamente se pensaba que la igualdad implicaba tan sólo mismidad y que tratar a todas las personas como iguales implicaba otorgarles el mismo trato. Ahora sabemos que tratar a todos de la misma forma puede ser atentatorio a la noción de igualdad. No es justo aprovechar las diferencias entre las personas para impedirles arbitrariamente que participen en plano de igualdad. La igualdad es un concepto vacío si no se interpreta en el sentido de que todos tenemos el mismo valor, con independencia de las diferencias de sexo, raza o etnia, o de la existencia de una discapacidad. En efecto, no es admisible que los tópicos, mitos y elucubraciones en torno a tales diferencias sirvan para impedir la plena participación.

Para subrayar este concepto, la expresión trato equitativo tiende a reemplazar progresivamente a la de igualdad de trato.

\section{Discapacidad y medio ambiente: accesibilidad y adaptación del lugar de trabajo}

De los conceptos de discriminación indirecta 0 de efectos adversos y de trato equitativo se deriva la idea de que, para no dar un trato discriminatorio a los discapacitados, es preciso velar por que tanto el lugar de trabajo como el entorno, sean accesibles; y de que se precisa un effuerzo por acomodar razonablemente el lugar de trabajo a las necesidades de los discapacitados.

\section{Accesibilidad}

La accesibilidad no consiste únicamente en construir una rampa a la entrada de los edificios para permitir el acceso de las personas que utilizan sillas de ruedas; supone igualmente poner a disposición de los discapacitados medios de transporte accesibles para trasladarse al trabajo o a la escuela; rebajar la altura del bordillo de las aceras; colocar avisos en el sistema braille en ascensores y edificios; facilitar el acceso a los cuartos de baño de las personas que van en silla de ruedas; retirar las alfombras y moquetas que dificultan el desplazamiento de las sillas de ruedas; $y$, entre otras medidas, facilitar a las personas con deficiencias visuales ayudas técnicas tales como manuales impresos en grandes caracteres y cintas de audio, y colocar señales ópticas a disposición de las personas con deficiencias auditivas.

\section{Acomodación razonable del lugar de trabajo}

EI trato equitativo supone igualmente la acomodación razonable de las condiciones de los lugares de trabajo a las necesidades personales de los discapacitados. Por acomodación razonable cabe entender la eliminación de las barreras que impiden a los discapacitados disfrutar de igualdad de oportunidades ante la formación profesional y el empleo. Para Lepofsky (1992), la acomodación consiste en lo siguiente:

(...) ajustar las normas, prácticas, condiciones o exigencias del trabajo a las necesidades concretas de un grupo o de una persona... La acomodación puede traducirse en la adopción de medidas tales como eximir a un trabajador de someterse a determinados requisitos o exigencias aplicables a los demás... L a regla de oro para saber si una determinada medida de acomodación es razonable consiste en determinar si resulta necesaria para que el trabajador pueda participar plenamente y en plano de igualdad en el lugar de trabajo.

Ciertamente, la relación de las posibles medidas de acomodación es infinita, dado que cada discapacitado tiene sus necesidades específicas. Además, es posible que las necesidades de acomodación de dos personas afectadas de las mismas o similares discapacidades sean muy diversas. Lo importante es recordar que la acomodación es una función de las necesidades de la persona que la necesita y que es preciso consultarla.

Con todo, es preciso reconocer que, en algunos casos, a pesar de las buenas intenciones, no resulta razonablemente posible acomodar a los discapacitados. Se puede afirmar que la acomodación no resulta razonable o que presenta dificultades excesivas en los casos siguientes:

- si una persona no está en condiciones de llevar a cabo los elementos esenciales de un puesto de trabajo o no puede completar los elementos esenciales o nucleares de un programa de formación

- si la acomodación del lugar de trabajo a las necesidades de la persona lleva aparejado un riesgo para la salud o la seguridad del propio interesado o de terceros que exceda de los beneficios inherentes a la situación de mayor igualdad para los discapacitados.

Al determinar los riesgos para la salud o la seguridad, es preciso tomar en consideración la disposición del discapacitado a afrontar el riesgo que la acomodación del lugar de trabajo pueda llevar aparejado. Por ejemplo, quizás no sea posible que 
un discapacitado que utilice una prótesis ortopédica se calce unas botas de seguridad en el marco de un programa de formación. Si no existe otro tipo de calzado de seguridad, se debe eximir a esa persona de la obligación de usar las botas, siempre que se muestre dispuesta a asumir el riesgo, sobre la base de una decisión informada. Es lo que se conoce como doctrina de la dignidad del riesgo.

La determinación de si la acomodación plantea graves riesgos a personas distintas del discapacitado debe tomarse sobre la base de los niveles de riesgo socialmente aceptados.

La evaluación del nivel de riesgo se debe realizar en función de criterios objetivos, tales como los datos disponibles, el dictamen de los expertos e información pormenorizada sobre la actividad laboral o de formación que se pretenda llevar a cabo. No son admisibles las impresiones ni las apreciaciones subjetivas.

Se considera igualmente que la acomodación plantea dificultades excesivas si los costes han de repercutir de forma gravemente adversa en la viabilidad de la empresa o del centro de formación. No obstante, en muchos países se conceden ayudas y subsidios para financiar las modificaciones precisas para facilitar la integración de los discapacitados.

\section{Discapacidad y política social: obtención de la opinión de las organizaciones de discapacitados}

Como se ha indicado anteriormente, se debe reconocer a los discapacitados el derecho de elección en todos los aspectos de la vida, incluidos la formación profesional y el empleo. Esto supone consultarles, a nivel individual, sobre sus deseos

Análogamente, cuando los interlocutores sociales (sindicatos, organizaciones empresariales y administración pública) toman decisiones, se debe escuchar a las organizaciones representativas de los intereses de los discapacitados.

Dicho de otro modo, al estudiar la adopción de políticas de empleo y de formación profesional, los discapacitados, considerados individual y colectivamente, conocen mejor que nadie sus necesidades y el modo de satisfacerlas.

Además, es preciso tener en cuenta que, aunque los términos discapacidad y discapacitados se suelen utilizar de forma genérica, las necesidades de acomodación y de formación profesional de quienes presentan deficiencias físicas o motrices son distintas de las que tienen quienes presentan deficiencias intelectuales 0 sensoriales. Por ejemplo, si bien la construcción de rampas en las aceras puede ser de gran utilidad para quienes se desplazan en sillas de ruedas, puede suponer un riesgo formidable para los ciegos, quizá incapaces de discernir que su integridad corre peligro al abandonar la acera.

Por tanto, siempre que se estudie la modificación de políticas o programas, es preciso conocer los puntos de vista de las organizaciones representativas de los afectados de diversos tipos de discapacidad.

\section{Directrices complementarias en materia de política social y discapacidad}

Varios importantes documentos internacionales aportan directrices útiles respecto a los conceptos y medidas para conseguir la igualdad de oportunidades para las personas discapacitadas. Entre estos documentos figuran el Programa mundial de acción de las $\mathrm{N}$ aciones U nidas sobre personas discapacitadas (Naciones U nidas 1982), el Convenio sobre la readaptación profesional y el empleo de personas inválidas, 1983 (no 159) (OIT 1983) y las R eglas uniformes de las $N$ aciones $U$ nidas sobre la igualdad de oportunidades para las personas con discapacidades (N aciones U nidas 1993).

\section{NORMAS LABORALES INTERNACIONALES Y LEGISLACION NACIONAL DE EMPLEO EN FAVOR DE LAS PER SO NAS DISCAPACITADAS}

\author{
Willi Momm y Masaaki luchi
}

EI Convenio sobre la readaptación profesional y el empleo de personas inválidas, 1983 (no 159) y la Recomendación sobre la readaptación profesional y el empleo de personas inválidas, 1983 (no 168), por los que se desarrolla y se actualiza la Recomendación sobre la adaptación y la readaptación profesionales de los inválidos, 1955 (no 99), constituyen los principales documentos de referencia de una política social en materia de discapacidad. Existen, no obstante, otros documentos de la OIT en los que se hace mención explícita o implícita de la discapacidad. Son el Convenio relativo a la discriminación en materia de empleo y ocupación, 1958 (no 111), la Recomendación sobre la discriminación en materia de empleo y ocupación, 1958 (no 111), el Convenio sobre la orientación profesional y la formación profesional en el desarrollo de los recursos humanos, 1975 (no 142) y la Recomendación sobre la orientación profesional y la formación profesional en el desarrollo de los recursos humanos, 1975 ( $n$ - 150).

A demás, existen importantes referencias a cuestiones relacionadas con la discapacidad en varios otros documentos importantes de la OIT, como el Convenio relativo a la organización del servicio de empleo, 1948 ( $n$ - 88), el Convenio relativo a la norma mínima de la seguridad social, 1952 (no 102), el Convenio relativo a las prestaciones en caso de accidentes del trabajo y enfermedades profesionales, 1964 (121), el Convenio sobre promoción del empleo y protección contra el desempleo, 1986 (no 168), la Recomendación sobre la organización del servicio de empleo, 1948 (no 83), la Recomendación sobre la administración del trabajo: cometido, funciones y organización, 1978 ( $n-158$ ) y la Recomendación sobre política de empleo (disposiciones adicionales), 1984 (no 169).

En las normas laborales internacionales, las discapacidades se abordan, fundamentalmente, en dos grandes capítulos: las medidas pasivas de transferencia de renta y de protección social, y las medidas positivas de formación y promoción del empleo.

U no de los objetivos iniciales de la OIT consistía en reivindicar que los trabajadores recibiesen una indemnización económica suficiente en caso de quedar discapacitados, en especial si la discapacidad se producía en el trabajo o en el servicio de las armas. Los objetivos subyacentes han sido lograr que las lesiones se indemnicen suficientemente, que se reconozca la responsabilidad de la empresa por los accidentes y por la existencia de unas condiciones de trabajo poco seguras; y que, en el mejor interés de las relaciones laborales, se conceda un trato justo a los trabajadores. Una remuneración adecuada es un elemento fundamental de la justicia social.

El objetivo de la protección social se distingue nítidamente del obje tivo de la indemnización. En las normas de la O IT que abordan los problemas de la seguridad social, la discapacidad se trata, en gran medida, como una "contingencia" que se debe prever en la regulación legal de la seguridad social, sobre la base del principio de que la discapacidad puede ocasionar una merma de la capacidad de generación de ingresos y, por tanto, puede ser una causa legítima para garantizar aquéllos mediante una transferencia de renta. El objetivo principal consiste en establecer un seguro contra la pérdida de ingresos y, por tanto, garantizar unas condiciones de vida decorosas para las personas privadas de los medios de ganarse el sustento por causa de una deficiencia. 
De modo similar, las políticas que persiguen un objetivo de protección social se orientan, por regla general, a prestar asistencia pública a los discapacitados no amparados por la seguridad social. También en estas políticas subyace la presunción tácita de que discapacidad es sinónimo de incapacidad para generar unos ingresos suficientes con el trabajo y de que, por tanto, los discapacitados constituyen una carga pública. Por consiguiente, la aplicación de las políticas relativas a las discapacidades, que son, por regla general, políticas pasivas de ayuda económica, corresponde principalmente a los organismos de bienestar social.

Sin embargo, en las normas de la O IT expresamente referidas a los discapacitados (como los convenios números 142 y 159 y las recomendaciones números 99,150 y 168) se trata a éstos como trabajadores y, en claro contraste con los principios de indemnización y de protección social, se sitúa la discapacidad en el contexto de las políticas del mercado de trabajo, cuyo objetivo es garantizar la igualdad de trato y de oportunidades en la formación y el empleo, y en las que se incluye a los discapacitados en la población económicamente activa. En estas normas, la discapacidad se entiende, básicamente, como una situación de desventaja laboral que se puede y se debe superar por medio de una serie de medidas, regulaciones, programas y servicios.

La Recomendación no 99 de la OIT (1955), en la que, por primera vez, se instaba a los Estados miembros a reemplazar los objetivos de bienestar o de protección social de la política sobre discapacidad por un objetivo de integración laboral, ejerció una notable influencia en la legislación promulgada en los decenios de 1950 y 1960. No obstante, la verdadera revolución se produjo en 1983, cuando la Conferencia Internacional del Trabajo aprobó dos nuevos documentos: el Convenio no 159 y la Recomendación no 168 de la OIT. En marzo de 1996, 57 de los 169 Estados miembros habían ratificado este Convenio.

M uchos otros países han modificado su legislación nacional para armonizarla con el Convenio, aunque no lo hayan ratificado todavía. L o que distingue a estos nuevos documentos de los precedentes es el reconocimiento por parte de la comunidad internacional y de las organizaciones sindicales y empresariales del derecho de los discapacitados a la igualdad de trato y de oportunidades en la formación y el empleo.

Los tres documentos forman ahora una normativa destinada a garantizar la participación activa de los discapacitados en el mercado de trabajo y plantear así un reto a la validez exclusiva tanto de las medidas de protección pasiva como de las políticas que tratan la discapacidad como un problema de salud.

Las normas laborales internacionales que se han promulgado para alcanzar este objetivo tienen como finalidad eliminar los obstáculos a la plena participación e integración de los discapacitados en el centro de la vida social, y crear los medios necesarios para promover eficazmente la independencia económica y la autonomía social de los mismos. Van a contracorriente de la práctica de tratar a los discapacitados como personas situadas al margen de la normalidad y de excluirlos de la actividad plena. Se oponen a la política de tomar la discapacidad como excusa para la marginación social de los discapacitados y para negarles, precisamente por causa de su discapacidad, los derechos civiles y laborales que las demás personas disfrutan como algo normal.

Por razones de claridad, podemos agrupar en dos categorías las disposiciones de las normas laborales internacionales que sustentan el derecho de los discapacitados a participar activamente en la formación y el empleo: las que responden al principio de la igualdad de oportunidades y las que responden al principio de igualdad de trato.

I gualdad de oportunidades: el objetivo de política que subyace en este concepto es asegurar a los grupos de población desfavorecidos idénticas oportunidades de acceso al empleo y a la actividad remunerada que al resto de la población.
Para hacer efectiva la igualdad de oportunidades para los discapacitados, en las normas laborales internacionales se establecen reglas y se propone la adopción de medidas orientadas a tres clases de actuaciones:

- Actuaciones dirigidas a habilitar a los discapacitados para alcanzar el nivel de cualificaciones y destrezas necesario para aprovechar las oportunidades de empleo, así como a facilitarles los medios técnicos y asistenciales precisos para que puedan realizar las tareas propias de un puesto de trabajo. Este tipo de actuaciones constituyen la parte esencial del proceso de readaptación profesional.

- Actuaciones encaminadas a adecuar el entorno a las necesidades específicas de los discapacitados, como pueden ser la adaptación del lugar y el puesto de trabajo, la maquinaria y las herramientas, así como la adopción de medidas legales y de promoción que permitan superar las actitudes negativas y discriminatorias que son causa de exclusión.

- Actuaciones que ofrecen a los discapacitados oportunidades de empleo fectivas. Se trata de medidas políticas y legislativas que favorecen el acceso al trabajo remunerado, más que de medidas pasivas de apoyo a la renta, así como de medidas que animen a las empresas a contratar o conservar a los trabajadores discapacitados.

- Actuaciones por las que se fijan objetivos de empleo o se establecen cupos o tasas (multas) en el marco de programas de actuación positivos. Entre éstas se incluyen igualmente los servicios que los organismos de empleo y otras organizaciones ofrecen a los discapacitados para ayudarles a conseguir un puesto de trabajo y promocionarse profesionalmente.

Por consiguiente, estas normas, promulgadas para garantizar la igualdad de oportunidades, llevan aparejada la adopción de unas medidas positivas específicas que ayudan a los discapacitados a incorporarse a la vida activa o que evitan una recaída innecesaria e injustificada en una existencia dependiente de las medidas pasivas de apoyo al ingreso. Por consiguiente, las políticas orientadas a garantizar la igualdad de oportunidades se suelen centrar en el establecimiento de sistemas de apoyo y en la adopción de medidas específicas de promoción de la igualdad efectiva de oportunidades, que se justifican por la necesidad de compensar las desventajas reales o presuntas de la discapacidad. Expresado en el lenguaje jurídico de la O IT: "Las medidas positivas especiales encaminadas a lograr la igualdad efectiva de oportunidades...entre los trabajadores inválidos y los demás trabajadores no deberán considerarse discriminatorias respecto a estos últimos" (Convenio oㅡ 159, artículo 4).

I gualdad de trato: EI principio de la igualdad de trato tiene un objetivo diferente, aunque asociado al anterior. En este caso, se trata de una cuestión de derechos humanos y las normas que los Estados miembros de la OIT se han comprometido a observar revisten una relevancia jurídica precisa, su aplicación está sometida a supervisión y su eventual infracción puede llevar aparejado el ejercicio de acciones legales o la apertura de procesos arbitrales.

En el Convenio no 159 de la OIT se define la igualdad de trato como un derecho garantizado. Se especifica, además, que la igualdad debe ser "efectiva". Esto supone crear unas condiciones que garanticen que la igualdad no sea algo meramente formal, sino real, y que el trato otorgado al discapacitado le coloque en un plano "equitativo", esto es, en una posición que, por sus resultados, y no únicamente en virtud de las medidas mismas, se corresponda con la situación de las personas no discapacitadas. Por ejemplo, asignar a un trabajador discapacitado el mismo trabajo que a un trabajador no aquejado de discapacidad no constituye un trato equitativo si el lugar de 
trabajo no es de fácil acceso o si el puesto de trabajo no se adapta a la discapacidad padecida.

\section{Legislación vigente en materia de rehabilitación profesional y empleo de los discapacitados}

Cada país tiene un historial distinto de rehabilitación profesional y de empleo de los discapacitados. La legislación vigente en los distintos Estados miembros varía en función de factores tales como sus respectivos estadios de desarrollo industrial y su situación económica. Por ejemplo, en algunos países se había legislado en favor de los discapacitados con anterioridad a la segunda Guerra M undial, en virtud de las medidas adoptadas a principios de siglo en beneficio de los excombatientes o de los pobres afectados de discapacidades. Otros países comenzaron a adoptar medidas concretas de apoyo a los discapacitados y a promulgar normas legislativas en el campo de la rehabilitación profesional con posterioridad a la segunda Guerra M undial. El alcance de estas medidas se amplió en muchos casos tras la aprobación de la Recomendación sobre la adaptación y readaptación profesionales de los inválidos, 1955 (no 99) (OIT 1955). En otros países, en cambio, sólo recientemente se han empezado a tomar medidas de apoyo a los discapacitados, como consecuencia de la sensibilización auspiciada de la convocatoria de 1981 como Año Internacional de los Discapacitados, la adopción en 1983 del Convenio no 159 y de la Recomendación no 168 de la OIT, y la celebración del Decenio de los Discapacitados (1983-1992) por las Naciones U nidas.

La legislación vigente en materia de rehabilitación profesional y empleo de los discapacitados se divide en cuatro categorías, en función de los distintos antecedentes históricos y de las respectivas políticas (Figura 17.1)

Es preciso ser conscientes de que no existe una distinción nítida entre las cuatro categorías, que, a veces, se solapan entre sí. Es posible que la legislación vigente en un determinado país, lejos de subsumirse en un único grupo, se enmarque en varios de ellos. Por ejemplo, en la legislación vigente en muchos países se combinan características de dos o más tipos de normas. Parece ser que la legislación del tipo A se promulga en los estadios iniciales de la implantación de políticas aplicables a los discapacitados, mientras que la legislación del tipo $B$ corresponde a un estadio posterior. La legislación del tipo $D$, en la que se establece la prohibición de la discriminación por razón de discapacidad, se ha desarrollado en estos últimos años, como complemento de la prohibición de la discriminación basada en el sexo, la raza, la religión, las opiniones políticas, etc. L a amplitud de la legislación de los tipos C y D permite su empleo como modelos a imitar por los países en vías de desarrollo que todavía no han promulgado una legislación específica en materia de discapacidad.

\section{Algunas medidas subsumibles en cada tipo}

En los apartados siguientes se ilustra la estructura de la legislación promulgada y de las medidas adoptadas con varios ejemplos de cada tipo. Dado que las políticas de rehabilitación profesional y empleo de los discapacitados son bastante parecidas en todos los países, independientemente del tipo de legislación en que dichas políticas se desarrollen, se produce un cierto solapamiento.

Tipo A: Medidas de promoción de la rehabilitación profesional y el empleo de los discapacitados incluidas en la legislación laboral general, como las leyes de promoción del empleo y las leyes sobre rehabilitación profesional. La legislación laboral general incluye a veces medidas destinadas a los discapacitados.

Es característico de este tipo de legislación la inclusión de medidas destinadas a los discapacitados en las leyes promulgadas para el conjunto de los trabajadores - incluidos aquéllos - y para la totalidad de las empresas. Como las medidas sobre promoción y seguridad en el empleo de los discapacitados se suelen incluir en la legislación de ámbito general destinada al conjunto de los trabajadores, en la política nacional se otorga prioridad a los esfuerzos internos de rehabilitación realizados por las empresas, así como a las medidas de prevención y de actuación oportuna sobre el medio ambiente de trabajo. Para ello, es frecuente crear en las empresas comités dedicados a los problemas del medio ambiente de trabajo, integrados por representantes de la empresa, de los trabajadores y del personal de salud y seguridad. Las políticas plasmadas en las leyes se suelen desarrollar en los reglamentos y normas dictados para su aplicación.

Por ejemplo, la Ley noruega sobre el medio ambiente de trabajo se aplica a la totalidad de los trabajadores empleados en la mayoría de las empresas del país. En ella se prevé la adopción de diversas medidas previstas especialmente para los minusválidos. 1) Siempre que sea posible, los servicios sanitarios, pasillos, instalaciones y equipo tecnológico se deben diseñar y construir de modo que se facilite el trabajo de los minusválidos en la empresa. 2) Si un trabajador ha adquirido una minusvalía de resultas de un accidente 0 una enfermedad, la empresa, siempre que sea posible, debe adoptar las medidas precisas para que aquél pueda acceder a un empleo adecuado o mantenerse en el mismo. A ser posible, se le ofrecerá la posibilidad de continuar realizando su trabajo anterior mediante la adopción de medidas como la adaptación de la actividad laboral, la modificación de las instalaciones técnicas, la rehabilitación, la formación, etcétera. L os siguientes ejemplos ilustran las medidas que la empresa puede tomar:

- adquisición o modificación del equipo utilizado por el trabajador, como maquinaria, herramientas, etcétera.

- adecuación del lugar de trabajo, que puede consistir en la modificación del mobiliario y equipo, la adaptación de los accesos y entradas, la instalación de ascensores, la construcción de rampas para las sillas de ruedas, el desplazamiento del pomo de las puertas y de los conmutadores de luz, etcétera.

- organización del trabajo. En estas medidas se pueden incluir la modificación de los métodos de trabajo, la alteración de los horarios de trabajo, la colaboración de otros trabajadores. Un ejemplo de estas modificaciones sería la grabación y transcripción desde un dictáfono.

- medidas de formación y readaptación profesional.

A demás de estas medidas, existe un programa de concesión de subsidios a las empresas que emplean minusválidos, con el objeto de financiar el coste de adaptación del lugar de trabajo al trabajador y viceversa.

Tipo B: M edidas destinadas a los discapacitados incluidas en leyes especiales y que se contraen exclusivamente a la rehabilitación profesional y al empleo de los mismos.

En este tipo de legislación suelen figurar disposiciones específicas sobre rehabilitación profesional y empleo, que prevén diversas medidas, al tiempo que en otro tipo de leyes figuran otras medidas aplicables a los discapacitados.

Por ejemplo, en la Ley alemana sobre personas con discapacidades graves se establecen las siguientes medidas especiales de ayuda a los discapacitados para mejorar sus posibilidades de empleo, además de la prestación de servicios de orientación profesional y colocación:

- formación profesional en empresas o centros de formación, 0 en instituciones especializadas en rehabilitación profesional;

- prestaciones especiales a los discapacitados y sus empresas, que comprenden el pago de los costes de solicitud y traslado, subsidios de transición, adaptación técnica de los lugares de trabajo, 
Figura 17.1 - Cuatro tipos de legislación sobre derechos de los discapacitados.

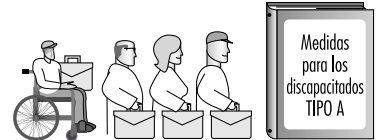
laboral general, como las leyes de promoción del empleo y las leyes sobre rehabilitación profesional. La legislación laboral general incluye a veces medidas destinadas a los discapacitados.

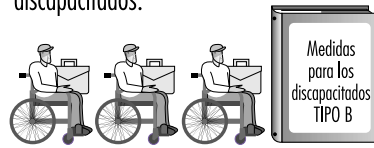

Medidas destinadas a los discapacitados incluidas en leyes especiales y que se contraen exclusivamente a la rehabilitación profesional y al empleo de los mismos.

EJEMPLOS

- Noruega: Ley de 27 de junio de 1947, de medidas de promoción del empleo; Ley de 4 de febrero de 1977, de protección de los trabajadores y medio ambiente de trabajo; Ley del Seguro Nacional, de 17 de junio de 1966.

- Suecia: Ley de promoción del empleo (1974); Ley de seguridad en el empleo (1982); Ley del medio ambiente de trabajo (1977)

- Francia: Ley n 87-517, de promoción del empleo de los discapacitados (1987)

- Alemania: Ley de personas con discapacidades graves (1974)

- Japón: Ley de promoción, etc. del empleo de los discapacitados (1960)

- Países Bajos: Ley de empleo de trabajadores minusválidos (1986); Ley de empleo protegido (1967)

- Polonia: Ley de empleo y rehabilitación profesional de los discapacitados (1991)

- Tailandia: Ley de rehabilitación de minusválidos (1991)

- Reino Unido: Ley (de empleo) de discapacitados (1944)

- Estados Unidos: Ley de rehabilitación (1973)

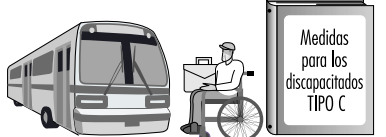

aplicables a los discapacitados y que se asocian a la adopción de medidas para prestación de otros servicios, como los de salud, accesibilidad, accesos y transporte.
- Australia: Ley de servicios a los discapacitados (1986)

- China: Ley de la República Popular China de protección de los discapacitados (1990)

- Islandia: Ley de asuntos de los discapacitados (1992)

- Filipinas: Carta Magna de los discapacitados (1992)

- España: Ley 13 de 1982, de integración social de los discapacitados

- Zimbabwe: Ley de personas con discapacidades (1992)

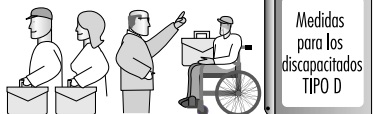

Medidas de prohibición de la discriminación en el empleo por razón de discapacidad incluidas en leves especiales contra la
- Australia: Ley sobre discriminación de los discapacitados (1992)

- Estados Unidos: Ley de norteamericanos con discapacidades (1990)

discriminación de ámbito general, junto con medidas excluyentes de la discriminación en áreas como el transporte los alojamientos públicos y las telecomunicaciones.

Los países que aparecen en cursiva y negrilla han ratificado el Convenio no 159 de la $01 \mathrm{~T}$

costes de alojamiento, ayuda para la adquisición de un vehículo adaptado o del equipo especial complementario, o para la obtención del permiso de conducir;

- obligación de las empresas públicas y privadas de reservar el $6 \%$ de los puestos de trabajo a las personas de discapacidades graves. Las empresas deben abonar una indemnización por los puestos que no se cubran según esta norma;

- protección especial contra el despido, efectiva al cabo de seis meses, a todas las personas con discapacidades graves;

- delegación de la representación de las personas con discapacidades graves en un asesor de personal;

- pago de prestaciones complementarias a las personas con discapacidades graves para facilitar su integración en el empleo;

- talleres dedicados a los discapacitados que no pueden integrarse en el mercado de trabajo general por causa de la gravedad de su impedimento;

- pago de subsidios a las empresas, por un máximo del $80 \%$ del salario abonado a los discapacitados durante un período de dos años, así como abono de los costes de adaptación de los lugares de trabajo y de la aplicación de períodos de prueba especiales.

Tipo C: M edidas de rehabilitación profesional y empleo de los discapacitados incluidas en leyes especiales de ámbito general aplicables a los discapacitados y que se asocian a la adopción de medidas para la prestación de otros servicios, como los de salud, accesibilidad y transporte.

Este tipo de leyes suelen constar de un primer capítulo referido al objeto, la formulación de políticas, la cobertura y la definición de los términos y expresiones utilizados, mientras que en los capítulos siguientes se prevén diversos servicios en materia de empleo o rehabilitación profesional, salud, accesibilidad, transporte y telecomunicaciones, servicios sociales complementarios, etc.

Por ejemplo, en la Carta magna de los discapacitados de Filipinas se consagra el principio de igualdad de oportunidades en el empleo. En el capítulo dedicado al empleo figuran las medidas siguientes:

- reserva los discapacitados del $5 \%$ de los puestos de trabajo en los ministerios y organismos oficiales;

- concesión a las empresas de incentivos como la reducción de su base tributable en el equivalente a un determinado porcentaje de los salarios abonados a los discapacitados o de los costes de modificación o adaptación de las instalaciones;

- medidas de rehabilitación profesional orientadas a desarrollar las posibilidades y destrezas de los discapacitados y a permitirles optar en condiciones favorables a las oportunidades de empleo remunerado y productivo, en concordancia con el principio de igualdad de oportunidades para los trabajadores discapacitados en general;

- servicios de rehabilitación profesional y subsistencia de los discapacitados de las zonas rurales;

- servicios de orientación, asesoramiento y formación profesional que permitan a los discapacitados conseguir, conservar y promocionarse en el empleo, así como la contratación y formación de asesores y personal cualificado en general para la prestación de estos servicios;

- creación, en todas las provincias, de escuelas públicas técnicas y profesionales, que impartan una formación técnica y profesional específica a los discapacitados; 
- talleres protegidos para los discapacitados que no pueden encontrar un empleo adecuado en el mercado de trabajo libre;

- aprendizaje

Además, se incluyen disposiciones sobre prohibición de la discriminación de los discapacitados en el empleo.

Tipo D: M edidas de prohibición de la discriminación en el empleo por razón de discapacidad incluidas en leyes especiales contra la discriminación de ámbito general, junto con medidas excluyentes de la discriminación en áreas como el transporte, los alojamientos públicos y las telecomunicaciones.

El rasgo distintivo de este tipo de legislación es la prohibición de la discriminación por causa de incapacidad en el empleo, el transporte público, el alojamiento, las telecomunicaciones y otros ámbitos. Los servicios de rehabilitación profesional y promoción del empleo de los discapacitados se suelen regular en otro tipo de leyes y reglamentos.

Por ejemplo, en la Ley sobre los norteamericanos con discapacidades se prohibe la discriminación en ámbitos tan importantes como el empleo, el acceso a los alojamientos públicos, las telecomunicaciones, el transporte, el sufragio, los servicios públicos, la educación, la vivienda y el ocio. Por lo que respecta, específicamente, al empleo, se prohibe la discriminación de "las personas cualificadas con discapacidad" que, con o sin una "acomodación razonable", sean capaces de realizar las tareas básicas del puesto de trabajo, a menos que la acomodación sea "indebidamente gravosa" para la actividad de la empresa. En la Ley se prohibe la discriminación en todas las facetas del empleo, como los sistemas de selección de personal, la contratación, el despido, la promoción, la remuneración, la formación y otros derechos laborales y condiciones de empleo. La Ley se aplica a la publicidad, contratación, prestación, despido, permisos, prestaciones extrasalariales y otros conceptos vinculados al empleo.

El objeto de la Ley australiana sobre discriminación por discapacidad es brindar mayores oportunidades a los discapacitados y ayudarles a superar los obstáculos a su participación en el mercado de trabajo y otros aspectos de la vida. En la Ley se prohibe la discriminación de los discapacitados en el empleo, el alojamiento, los espectáculos y el ocio. El nuevo texto legal ha venido a complementar la anterior legislación en la materia, por la que se prohibe la discriminación por razón de sexo o de raza.

\section{¿Leyes de cupos o tasas o leyes contra la discriminación?}

La naturaleza de la legislación nacional sobre empleo y rehabilitación profesional de los discapacitados varía en alguna medida de un país a otro, por lo que resulta difícil establecer qué tipo de leyes es el mejor. No obstante, dos clases de leyes: las de cupos o tasas, y las leyes antidiscriminatorias, parecen constituir los modelos legislativos más válidos.

Si bien algunos países europeos, entre otros, poseen sistemas de cupos que se suelen plasmar en normas legislativas del tipo $B$, estos sistemas varían sensiblemente en algunos aspectos, como la clase de discapacitados amparados, la clase de empresas sometidas a la obligación de contratación (en función, por ejemplo, de su dimensión o de su pertenencia al sector público) y el número de puestos de trabajo reservados (3\%, $6 \%$, etc.). En la mayoría de los países, el sistema de cupos se combina con un sistema de tasas o de subsidios. El sistema de cupos aparece también en la legislación de países no industrializados tan dispares como Angola, Mauricio, Tanzania y Polonia. En China se estudia igualmente la posibilidad de implantar un sistema de este tipo.

Es obvio que un sistema de cupos obligatorios puede contribuir en gran medida a elevar el nivel de contratación de los discapacitados en el mercado de trabajo libre. Por otra parte, el sistema de tasas y subsidios contribuye a aminorar los desequilibrios económicos que se producen entre las empresas que contratan trabajadores discapacitados y las otras, pues las tasas generan importantes recursos aplicables a la financiación de la rehabilitación profesional y al pago de incentivos a las empresas

Por otra parte, una de las dificultades que este sistema plantea es que en él se exige una definición inequívoca de la incapacidad que permita su reconocimiento, así como unos procedimientos y normas estrictos para su declaración, lo que puede contribuir a estigmatizar a los discapacitados. Existe igualmente el problema de la posible incomodidad de los discapacitados que trabajan en una empresa que no los quiere y que únicamente los admite para evitar la imposición de sanciones legales. A demás, para que el sistema de cupos sea eficaz, se precisa un procedimiento ejecutorio eficaz y la voluntad real de aplicarlo.

La legislación antidiscriminatoria, esto es, la del tipo $D$, parece adecuarse mejor al principio de normalización, al garantizar a los discapacitados el disfrute de la igualdad de oportunidades en la vida social, ya que fomenta las iniciativas empresariales y la conciencia social a través de la mejora del medio ambiente, no mediante los cupos obligatorios.

Por otra parte, la aplicación de este tipo de legislación resulta dificultosa en algunos países. Por ejemplo, en algunos lugares sólo pueden adoptarse medidas sancionadoras a instancia de la víctima y, en ciertos casos, las prácticas discriminatorias son difíciles de probar. Por otra parte, la sustanciación de las quejas suele ser muy lenta, ya que, tanto los tribunales como las comisiones de igualdad de derechos reciben una cantidad ingente de denuncias. En general, se acepta que está por demostrar la eficacia de la legislación antidiscriminatoria para facilitar el acceso y conservación de un puesto de trabajo para un considerable número de discapacitados.

\section{Tendencias futuras}

Aunque es difícil prever la evolución futura de la legislación, existe la impresión de que tanto los países industrializados como las naciones en vías de desarrollo estudiarán la posibilidad de decantarse por las leyes antidiscriminatorias (las del tipo D).

Es probable que los países industrializados en los que existe una tradición de cupos evalúen la experiencia de naciones como Estados U nidos y Australia antes de emprender la modificación de sus respectivos ordenamientos jurídicos. Lo más probable es que en países como los europeos, en los que dominan los principios de justicia redistributiva, el actual ordenamiento jurídico se mantenga, complementado o reforzado con la introducción de disposiciones antidiscriminatorias en la legislación de nueva planta.

Es posible que en países como Estados Unidos, Australia y Canadá, se planteen dificultades políticas al establecimiento de un sistema de cupos para los discapacitados sin que existan igualmente cupos aplicables a otros grupos de población que se encuentran en situación desventajosa en los mercados de trabajo, como las mujeres y las minorías étnicas y raciales amparadas actualmente por la legislación sobre derechos humanos y equidad en el empleo. Si bien el sistema de cupos aporta algunas ventajas a los discapacitados, el aparato administrativo que se requeriría para un sistema tan heterogéneo sería enorme.

Existe la impresión de que los países en vías de desarrollo que carecen de legislación sobre discapacitados podrían decantarse por la normativa del tipo $C$, reforzada por algunas disposiciones prohibitivas de la discriminación, dado que éste sistema es el más amplio. Por otra parte, en este sistema existe el riesgo de que una legislación de ámbito general, que atañe a las competencias de varios ministerios, quede sometida a un único departamento, por regla general el de bienestar social. Esto puede resultar contraproducente, al reforzar la segregación y reducir la 
capacidad del gobierno para hacer cumplir las leyes. La experiencia nos enseña que las leyes de ámbito general, aunque positivas en el papel, raras veces se aplican.

\section{- SERVICIOS DE REHABILITACION PROFESIONAL Y DE APOYO ALOS TRABAJADORES}

\section{Erwin Seyfried}

Por regla general, la información disponible corrobora que los discapacitados tienen menos posibilidades de integración profesional que el resto de la población. N o obstante, en muchos países se han producido iniciativas políticas destinadas a mejorar esta situación. Por ejemplo, se han dictado medidas legislativas por las que se obliga a las empresas a emplear un determinado porcentaje de discapacitados y - a veces, como complemento de las medidas anteriores - se les incentiva para que contraten más personas con estas características. A demás, en años recientes se han creado en numerosos países servicios de apoyo y asistencia a los discapacitados que intentan incorporarse al mundo del trabajo. En el texto que sigue se describen estos servicios y sus funciones específicas en el contexto de la rehabilitación profesional y la incorporación de los discapacitados al empleo.

Se describen los servicios que prestan apoyo y asesoramiento a los discapacitados durante la fase de rehabilitación, esto es, la fase previa a la incorporación ala vida activa. Aunque, en otro tiempo, los servicios de apoyo se limitaban casi exclusivamente a este área, la persistencia general de dificultades para el empleo de los discapacitados ha inducido a los modernos servicios de empleo a prestar mayor atención a las fases de colocación e integración en la empresa.

EI mayor peso que han alcanzado estos servicios en la promoción de la integración profesional se ha debido, en no escasa medida, al incremento de la actividad de los servicios de rehabilitación de ámbito comunitario y, desde la perspectiva meramente práctica, al número creciente de esfuerzos, cada vez más fructíferos, de integración social de los discapacitados. La tendencia sostenida a la apertura de nuevos centros de cuidados y a la superación de la concepción de esos centros como meros lugares de internamiento de los discapacitados ha sido la causa de que las necesidades de este segmento de población sean realmente conocidas por vez primera. Nos encontramos así con una gama creciente de estos servicios de apoyo, dado que la demanda cada vez mayor de integración social de todos los discapacitados lleva aparejado un incremento de las actividades conexas.

\section{Rehabilitación e integración}

El objetivo real de la rehabilitación sólo se alcanza cuando se produce la integración social del discapacitado. Por consiguiente, el objetivo último de los programas de rehabilitación profesional sigue siendo el de encontrar un empleo y, por ende, lograr la plena participación en el mercado de trabajo local.

Por regla general, las medidas de rehabilitación médica y profesional establecen las bases de la incorporación o la reincorporación de los discapacitados a la vida laboral. El objetivo es permitir que los discapacitados desarrollen sus posibilidades hasta el punto de hacer posible la vida en la sociedad con un mínimo de limitaciones. Los servicios que intervienen en esta etapa y asisten al discapacitado durante el proceso se denominan servicios de apoyo a la rehabilitación. Si bien en otro tiempo podía presumirse fundadamente que una rehabilitación médica completa y una rehabilitación profesional rigurosa constituían, si no la garantía, al menos un elemento clave de la integración profesional, estas exigencias elementales han dejado de ser suficientes en vista de la rápida evolución de la situación del mercado de trabajo y de las complejas exigencias del lugar de trabajo. Por supuesto, la base de la integración en el trabajo sigue siendo una sólida formación profesional; sin embargo, en la situación actual, muchos discapacitados precisan una asistencia complementaria para conseguir empleo e integrarse en el lugar de trabajo. Los servicios que intervienen en esta etapa se pueden definir, globalmente, como servicios de apoyo al empleo.

Si bien el discapacitado es, en sí mismo, el punto de partida de las medidas de rehabilitación médica y profesional, con las que se pretende desarrollar su capacidad funcional y su cualificación profesional, los servicios de apoyo al empleo hacen especial hincapié en el medio ambiente de trabajo y, por tanto, en la adaptación del mismo a las necesidades del discapacitado.

\section{Perspectivas globales de la integración profesional}

A pesar de la importancia de los servicios de apoyo, no hay que perder de vista que la rehabilitación no puede ser, en ninguna de sus etapas, una mera forma pasiva de tratamiento, sino más bien un proceso efectivamente dirigido por el propio discapacitado. EI diagnóstico, el asesoramiento, la terapia y otras formas de apoyo pueden, a lo sumo, constituir una ayuda al esfuerzo por lograr unos objetivos que se definen por sí mismos. Teóricamente, la labor de estos servicios sigue consistiendo en proponer varias vías de actuación, entre las que los discapacitados optan en la medida de lo posible.

O tro y no menos importante parámetro de la integración profesional es su carácter omnicomprensivo, que debe ser una de las señas de identidad del proceso. Esto significa que la rehabilitación debe ser global y no circunscribirse al tratamiento de la deficiencia. $\mathrm{H}$ a de abarcar la totalidad de la persona y apoyar a éste en el esfuerzo por encontrar una nueva identidad o por afrontar las consecuencias de la discapacidad. En muchos casos, la rehabilitación del discapacitado es mucho más que un proceso de estabilización física y de ampliación de las destrezas: si se quiere que se desarrolle satisfactoriamente, debe ser, igualmente, un proceso de estabilización psicosocial, de forja de una identidad y de integración en las relaciones sociales cotidianas.

Una de las principales áreas de actividad de los servicios de apoyo, lamentablemente poco conocida, es la prevención de las discapacidades graves. Es particularmente importante para la vida laboral que los servicios de rehabilitación y empleo se ofrezcan no sólo a los discapacitados, sino también a las personas amenazadas por la discapacidad. C uanto antes se reaccione ante una discapacidad incipiente, antes se puede iniciar la readaptación profesional y más fácil resulta prevenir las discapacidades graves.

Estos objetivos globales de la rehabilitación profesional configuran, igualmente, un perfil de los parámetros y las tareas esenciales de los servicios de apoyo. A demás, es preciso subrayar que las complejas tareas que se describen aquí se realizan con más eficacia a través de la colaboración multidisciplinaria de especialistas en diversas materias. Por tanto, podemos valorar el concepto actual de la rehabilitación como una labor de cooperación entre el discapacitado y un equipo integrado no sólo por instructores profesionales, sino también por médicos, técnicos, psicólogos y educadores cualificados.

\section{Rehabilitación médica}

La labor de rehabilitación médica se suele desarrollar en hospitales y otros centros especiales. El trabajo de los servicios de apoyo en esta fase consiste en dar los primeros pasos para el 
abordaje psicológico de la discapacidad. Sin embargo, también la (re)orientación profesional debe iniciarse tan pronto como sea posible, por así decirlo, junto al lecho del paciente, puesto que la construcción de una nueva perspectiva profesional suele contribuir a establecer un fundamento de motivación que, a su vez, puede facilitar la rehabilitación médica. 0 tras medidas, como las de formación motriz y sensorial, psicoterapia, terapia ocupacional o logoterapia, pueden ayudar asimismo en esta etapa a acelerar el proceso natural de regeneración y a reducir o evitar la creación de dependencias.

La decisión relativa a las perspectiva profesionales no debería ser adoptada en ningún caso por un facultativo ni desde una perspectiva exclusivamente médica, como por desgracia sigue ocurriendo en la práctica. La decisión sobre el futuro profesional de un discapacitado no se debe basar únicamente en una serie de carencias médicamente diagnosticables, sino, más bien, en las destrezas y posibilidades residuales. Por tanto, los servicios de apoyo a la rehabilitación deben realizar, en colaboración con el discapacitado, una revisión en profundidad del historial profesional del cliente y hacer balance de sus intereses actuales y sus posibilidades. Sobre esta base, se puede elaborar un plan de rehabilitación en el que se tomen en consideración tanto los intereses, posibilidades y necesidades del discapacitado como las posibilidades del entorno social.

O tro campo de actuación de los servicios de apoyo a la rehabilitación en esta fase es el del asesoramiento al discapacitado en relación con la asistencia técnica, el equipo, las sillas de ruedas, las prótesis, etc. A veces, se produce un rechazo inicial de la oferta de asistencia técnica. Si el discapacitado no recibe la ayuda y la instrucción necesarias en esta primera fase, es posible que el rechazo inicial se transforme en una fobia que, posteriormente, dificulte el aprovechamiento completo del aparato en cuestión. Dada la gran variedad de medios de asistencia técnica actualmente disponibles, la elección del equipo debe hacerse con sumo cuidado, adaptándolo en la medida de lo posible a las necesidades del discapacitado.

\section{Rehabilitación profesional}

En el Convenio de la O IT "sobre la readaptación profesional y el empleo de las personas inválidas", 1983 (159), se establece que el objeto de la rehabilitación profesional consiste en "permitir que la persona inválida obtenga y conserve un empleo adecuado y progrese en el mismo, y que se promueva así la integración o la reintegración de dicha persona en la sociedad".

Los servicios de rehabilitación profesional de los discapacitados han experimentado un rápido desarrollo en los últimos treinta años. Entre ellos deben citarse la evaluación profesional orientada a obtener un perfil válido del potencial de la persona, los cursos de orientación dirigidos a restituir a la persona su autoestima, la orientación profesional necesaria para adquirir una (nueva) perspectiva y elegir una determinada profesión, las oportunidades de formación y readaptación profesional en el área de actividad elegida, y los servicios de empleo destinados a ayudar al discapacitado a encontrar un empleo adecuado.

La (re)incorporación del discapacitado al empleo suele efectuarse a través de programas de rehabilitación profesional individual o de grupo, que pueden desarrollarse en distintos centros. La tarea de los servicios de apoyo a la rehabilitación consiste en analizar con el discapacitado si el programa de rehabilitación profesional se debe impartir en una institución de formación profesional o en un centro especializado, si el discapacitado debe acudir a instalaciones públicas o realizar el programa en su propio lugar de trabajo. Esta última posibilidad es la más aconsejable si el puesto de trabajo se encuentra todavía vacante y la dirección de la empresa se ha mostrado, en principio, dispuesta a readmitir a su antiguo trabajador. No obstante, también en otros casos puede ser aconsejable cooperar con un centro de trabajo convencional durante la formación profesional, dado que la experiencia ha demostrado que esta cooperación contribuye igualmente a ampliar las posibilidades de que el participante sea después contratado por la empresa. Resulta, evidente, por tanto, que, si la formación profesional se imparte en un centro de rehabilitación profesional, los servicios de apoyo deben ayudar al discapacitado a explorar las posibilidades de recibir una formación práctica en el puesto de trabajo.

Evidentemente, estas posibilidades de desarrollo de los programas de rehabilitación profesional no se pueden valorar por separado de determinados parámetros y requisitos, que varían de un país a otro. Además, la decisión última sobre el lugar en que la rehabilitación se debe impartir está asimismo en función tanto del tipo de discapacidad y de la clase de trabajo prevista como del entorno social del discapacitado y del grado de apoyo que se puede esperar del mismo.

Con independencia del escenario de la rehabilitación profesional, los servicios de apoyo a la rehabilitación deben seguir de cerca el proceso, examinar con el discapacitado los progresos realizados y enriquecer el plan, adaptándolo a las nuevas circunstancias en la medida de lo posible.

\section{Servicios de apoyo al empleo}

$M$ ientras que en muchos países los servicios de rehabilitación médica y profesional pueden apoyarse en una red institucional más o menos extensa, en algunos, incluso entre los más industrializados, no existe aún una estructura similar que se ocupe de promover la integración de los discapacitados en el empleo. Además, así como en algunos países existen modelos sumamente válidos que, en ciertos casos, llevan años funcionando, los servicios de empleo de la mayoría de los países, con algunas excepciones localizadas en Australia, Estados U nidos, Nueva Zelanda y Alemania, no se han incorporado todavía a los respectivos sistemas nacionales de asistencia a los discapacitados.

Aunque, en muchos países, la colocación de los discapacitados forma parte, preceptivamente, de la política general de empleo, el aumento del nivel de desempleo suele impedir a la administración pública el cumplimiento de esta obligación suya. Tal situación se recrudece en muchos casos por la falta de personal debidamente cualificado, capaz de armonizar los deseos y posibilidades de los discapacitados con las exigencias del mundo del trabajo. La creación de servicios de apoyo al empleo constituye, por otra parte, una reacción al creciente fracaso del concepto tradicional de "formar para colocar", inherente a la rehabilitación profesional institucionalizada. A pesar de los programas rigurosos y, a veces, eficaces de rehabilitación médica y profesional, la incorporación al trabajo sin una asistencia complementaria es cada día más difícil.

A quí es donde se manifiesta la necesidad de contar con servicios especializados de apoyo al empleo. Allí donde se han creado este tipo de servicios, se ha producido una ingente demanda por parte de los discapacitados y sus familias. Se trata de servicios particularmente necesarios y útiles como vínculos institucionales entre los centros de trabajo y las escuelas, los centros de rehabilitación, los talleres protegidos y otras instalaciones destinadas a la rehabilitación de los discapacitados. Por lo demás, su nacimiento está vinculado a la experiencia de que son muchos los discapacitados que precisan apoyo y asistencia no sólo en la fase de acceso al empleo, sino también durante la etapa de integración en el lugar de trabajo. Algunas grandes empresas cuentan con servicios propios de asistencia interna que se responsabilizan de la integración de los trabajadores recién contratados y de la permanencia en su puesto de trabajo de los antiguos trabajadores discapacitados. 


\section{Tareas de los servicios de apoyo al empleo}

La atención de los servicios de apoyo al empleo se centra en el momento crítico del inicio de la vida laboral. Su labor consiste, en términos generales, en vincular al trabajador discapacitado con su empresa, esto es, con su superior inmediato y sus futuros compañeros de trabajo.

Los servicios de apoyo al empleo se responsabilizan, en primer lugar, de ayudar al discapacitado a encontrar trabajo. Este cometido se desempeña, en parte, fomentando la autoestima mediante la formación (asistida por medios audiovisuales) para la realización de entrevistas de selección y la asistencia en la redacción de cartas de solicitud de empleo, así como, muy especialmente, impartiendo formación práctica en el puesto de trabajo. La experiencia acumulada indica claramente que esta última modalidad constituye la mejor vía de entrada en la empresa. En caso necesario, el personal correspondiente acompaña al discapacitado a la entrevista de selección, le ayuda a tramitar la documentación precisa y le presta asistencia en la fase inicial de adaptación al lugar de trabajo. La carencia de medios impide a la mayoría de los servicios de apoyo al empleo proyectar ese apoyo más allá de los confines del lugar de trabajo. En todo caso, al menos en la teoría, tal tipo de apoyo no resulta deseable. Si se precisa continuar prestando en la esfera privada alguna asistencia de índole psicológica, médica o relacionada con las destrezas vitales, lo habitual es remitir al discapacitado a centros e instituciones especializados.

Por otra parte, por lo que respecta a las empresas, la más importante responsabilidad inicial de los servicios de apoyo consiste en inducirlas a contratar a discapacitados. Aunque muchas empresas son extremadamente reticentes a tales prácticas, no es imposible encontrar algunas dispuestas a colaborar permanentemente con los centros de rehabilitación profesional y los servicios de empleo. U na vez establecida la buena disposición inicial a cooperar, el paso siguiente consiste en encontrar puestos de trabajo adecuados. 0 bviamente, antes de la contratación, es preciso contrastar las exigencias del puesto de trabajo concreto con las destrezas del discapacitado. No obstante, el tiempo y la energía que a veces se invierten en ciertos proyectos piloto, en los que se aplican procedimientos presuntamente "objetivos" para contrastar diversos perfiles de destreza y exigencia con el objeto de hallar el puesto de trabajo "óptimo" para un determinado discapacitado, no suelen guardar relación con las posibilidades reales de éxito ni con las dificultades que la búsqueda de un puesto de trabajo supone efectivamente. Lo más importante es que los discapacitados se conviertan en actores de su propio desarrollo profesional, puesto que el valor psicológico de su participación en la conformación de su futuro profesional es incalculable.

En los métodos de colocación contrastados se parte de un análisis en profundidad de la estructura organizativa y de los procesos productivos, para luego recomendar a la empresa la reestructuración de determinadas áreas de trabajo con el fin de conceder oportunidades de empleo a los discapacitados. Entre estas recomendaciones pueden figurar la reducción de determinadas exigencias productivas, la implantación del trabajo a tiempo parcial y de los horarios flexibles, o la reducción de los niveles de ruido y de estrés en el lugar de trabajo.

Los servicios de apoyo al empleo ofrecen igualmente ayuda a las empresas para conseguir subvenciones públicas, como las bonificaciones salariales, o para agilizar la tramitación administrativa de las solicitudes de las ayudas estatales destinadas a la financiación de las adaptaciones técnicas impuestas por las limitaciones asociadas a la discapacidad. Sin embargo, no todo el apoyo prestado a los discapacitados en el lugar de trabajo tiene por qué ser necesariamente de naturaleza técnica. Por ejemplo, es posible que los trabajadores con deficiencias visuales precisen no sólo un teclado de ordenador en braille y una impresora adecuada, sino también que alguien les lea en voz alta; asimismo, se puede ayudar a las personas con deficiencias auditivas poniendo a su disposición un intérprete especializado en el lenguaje de los signos. En ocasiones, se precisa apoyo para la adquisición de la cualificación que el puesto de trabajo requiere o para la integración social en la empresa. Estas y otras tareas similares se suelen encomendar a un trabajador de los servicios de apoyo conocido como "instructor de trabajo". El apoyo personalizado que éste presta tiende a reducirse en el tiempo.

Las personas con discapacidades psíquicas o mentales suelen precisar una integración gradual, caracterizada por un incremento progresivo de las exigencias del puesto, de las horas de trabajo y de la integración social, que debe ser coordinado por los servicios de apoyo con la empresa y con el discapacitado.

Todas las modalidades de apoyo deben adaptarse a las circunstancias personales del discapacitado y adecuarse, además, a los recursos de la empresa.

\section{El ejemplo de empleo asistido}

En el sistema de empleo asistido de los discapacitados, se combinan las bonificaciones salariales en favor de las empresas participantes y los servicios de apoyo personalizado a los discapacitados para alcanzar el objetivo de la plena integración en la vida laboral. Se trata de un sistema especialmente extendido en Australia y Nueva Zelanda, además de Estados U nidos y otros países europeos. H asta ahora, se ha utilizado principalmente en la integración de los discapacitados psíquicos y mentales.

Los servicios de apoyo al empleo se responsabilizan de colocar a los discapacitados en las empresas; gestionar la asistencia técnica, financiera y organizativa que éstas precisan; y poner a disposición de las mismas un instructor de trabajo que asista en la integración laboral y social de los discapacitados.

Con ella la empresa se libera de los problemas habitualmente asociados a la contratación de los discapacitados. En la medida de lo posible y de lo necesario, los servicios de apoyo al empleo se responsabilizan igualmente de efectuar las adaptaciones precisas en el lugar de trabajo y en el entorno laboral inmediato del discapacitado. Aunque a veces es preciso impartir al solicitante una formación complementaria fuera de la empresa, lo habitual es que el instructor de trabajo realice su tarea en el puesto de trabajo. Corresponde, asimismo, al instructor de trabajo instruir a los compañeros y superiores del discapacitado respecto al apoyo técnico y humano que éste precisa, dado el objetivo de reducir el nivel de asistencia profesional prestado por el servicio de apoyo al empleo.

En todo caso, es absolutamente necesario recordar que, si se producen problemas serios, se debe recurrir al servicio de apoyo al empleo para que preste la asistencia precisa. Esto implica personalizar el apoyo y adaptarlo a las necesidades específicas tanto de los compañeros y superiores como de la propia empresa.

Los análisis coste-beneficio de este sistema que se han realizado en Estados Unidos indican que, si bien la fase inicial de integración es sumamente intensiva en apoyo y, por tanto, en costes, cuanto más tiempo permanezca el discapacitado en el empleo, más se justifica la inversión, incluso desde la perspectiva financiera, no sólo para él, sino también para la empresa y para el presupuesto público.

La colocación de los discapacitados a través de los servicios de apoyo al empleo es más frecuente en relación con los puestos de trabajo relativamente poco cualificados, que son los que se suprimen con más frecuencia.

El futuro del sistema de apoyo al empleo depende no tanto de la evolución del mercado de trabajo como del desarrollo del sistema mismo. 


\section{Escollos en el futuro de los servicios de apoyo al empleo}

En las secciones siguientes se examinan algunos aspectos críticos cuya importancia para el futuro desarrollo de los principios y de la labor cotidiana de los servicios de apoyo al empleo no es posible subestimar.

\section{Creación de redes con los centros de formación profesional y las empresas}

Si los servicios de apoyo al empleo no quieren perder de vista las necesidades reales, una de sus tareas principales consistirá en crear vínculos estructurales con los centros de formación profesional. La experiencia demuestra que los servicios de integración de discapacitados que carecen de vínculos con los centros de rehabilitación corren el riesgo de funcionar más como cauces de selección que como auténticos servicios de integración profesional.

Ahora bien, no basta a los servicios de apoyo con la creación de redes de colaboración con los centros de formación profesional; precisan también, y muy especialmente, adoptar una postura inequívoca respecto de la cooperación con las empresas. Los servicios de apoyo al empleo no deben, bajo ningún concepto, limitar su actividad al asesoramiento de los discapacitados y sus familias; deben seguir esforzándose por buscar empleo y colocar a sus clientes. La proximidad al mercado de trabajo es la clave del acceso a las empresas y, en última instancia, de las oportunidades de empleo de los discapacitados. Si se desea ampliar las vías de acceso a las empresas de estos servicios, es imperativo que se sitúen lo más cerca posible del escenario de la actividad económica.

\section{Relación entre cualificación, colocación y empleo} Parte importante de todos los esfuerzos de integración profesional $y$, por tanto, un serio reto para los servicios de apoyo al empleo es la coordinación del esfuerzo de preparación y cualificación profesional con las exigencias del lugar de trabajo, aspecto que aún se suele pasar por alto. Por muy justificada que esté la crítica al modelo tradicional de "formar para colocar", la política de colocar primero para luego impartir formación en las destrezas precisas resulta igualmente insuficiente. Trabajar en las condiciones actuales no sólo implica practicar las denominadas virtudes laborales secundarias, esto es, puntualidad, concentración y velocidad, sino también poseer unas destrezas técnicas que siempre son necesarias y que el aspirante debe dominar antes de acceder al empleo. Pedir más sería exigir demasiado, no sólo a los aspirantes al puesto, sino también a las empresas dispuestas a contratarles.

\section{Movilización del apoyo natural}

Las oportunidades de integración efectiva de los discapacitados en el mercado laboral se incrementan con la posibilidad de prestarles ayuda y apoyo, bien paralelamente al desarrollo de los procesos productivos, bien directamente en el lugar de trabajo. Sobre todo en la fase inicial de ajuste, es preciso no sólo ayudar al discapacitado a afrontar las exigencias del trabajo, sino también apoyar a todos los que integran el medio ambiente de trabajo. Son los servicios de apoyo al empleo los que suelen responsabilizarse de esta asistencia directa. A hora bien, a largo plazo, la integración de un discapacitado será más efectiva cuanto más pueda reemplazarse este tipo de asistencia profesional por una movilización del apoyo natural que los compañeros y superiores pueden brindar dentro de la empresa. En un programa recientemente desarrollado en Alemania para la movilización del apoyo natural existente en el lugar de trabajo por parte de los denominados animadores laborales, en un plazo de 24 meses se logró integrar efectivamente a 42 discapacitados en más de 100 empresas que accedieron a participar. En el programa se puso de relieve que pocas empresas poseían el nivel de conocimientos y de experiencia precisos para tratar con discapacitados. Se evidenciaba, por tanto, la necesidad de que los servicios de empleo elaborasen un esquema conceptual para la sustitución del apoyo profesional por el apoyo natural en el centro de trabajo. Por ejemplo, en el Reino Unido, los trabajadores dispuestos a colaborar como animadores laborales reciben una pequeña recompensa económica.

\section{Orientación al éxito y control por parte del usuario}

Por último, los servicios de apoyo al empleo deben incentivar a su propio personal para que acuda a empresas y colabore en la colocación de los discapacitados, por cuanto es aquí donde deben centrarse sus esfuerzos. Claro está, por otra parte, que tales esfuerzos sólo pueden ser eficaces a largo plazo si la dotación financiera de los propios servicios de apoyo al empleo y de su personal se vincula en alguna medida al éxito de la gestión. ¿Como se puede motivar permanentemente al personal de estos servicios para que abandone su centro de trabajo y arrostre la frustración del rechazo de las empresas? La colocación de los discapacitados es una actividad compleja. ¿D ónde hay que buscar la energía necesaria para luchar encarnizadamente contra los prejuicios? En toda organización se crean unos intereses corporativos que no coinciden necesariamente con los intereses de sus clientes, y en todas las instituciones financiadas con fondos públicos existe el riesgo de un alejamiento de los intereses de los clientes. Esto hace que sea aconsejable una rectificación en el sentido de ofrecer incentivos globales, no sólo a los servicios de apoyo al empleo, sino también a otros servicios sociales, que los induzca a trabajar en el sentido deseado.

O tra reforma necesaria del método de trabajo de los servicios financiados con fondos públicos consistiría en escuchar a sus miembros en las cuestiones que les atañen. Esta cultura de participación se debe reflejar igualmente en los principios que informan su labor. En este sentido, los servicios de apoyo, como las demás instituciones financiadas con fondos públicos, se deben someter al control y evaluación de los usuarios -esto es, los discapacitados y sus familias- y, por último, aunque no lo menos importante, de las empresas que colaboran con ellos.

\section{Comentarios finales}

La determinación de quiénes y cómo se pueden incorporar finalmente al mercado de trabajo gracias a la rehabilitación profesional y al esfuerzo de los servicios de apoyo al empleo no puede hacerse en abstracto. La experiencia demuestra que ni el grado de discapacidad ni la situación del mercado de trabajo se pueden considerar límites absolutos. En la práctica, los resultados están en función tanto de factores como los modos de trabajo de los servicios de apoyo y la situación del mercado laboral, como de la dinámica que se genera dentro de los servicios e instituciones de asistencia a los discapacitados, una vez que estas oportunidades de empleo se convierten en una posibilidad real. En todo caso, la experiencia acumulada en varios países muestra que la cooperación entre los servicios de apoyo al empleo y los centros protegidos tiene una considerable influencia en el funcionamiento interno de estos últimos.

Las personas necesitan perspectivas, y la motivación y el impulso sólo se generan cuando hay perspectivas o se crean éstas a partir de nuevas oportunidades ofrecidas. Si las cifras absolutas de colocaciones conseguidas por los servicios de apoyo al empleo son importantes, no menos importancia reviste la creación de oportunidades para el desarrollo personal de los discapacitados debido a la existencia misma de dichos servicios. 


\section{GESTION DE LA DISCAPACIDAD EN EL LUGAR DE TRABAJO: VISION DE CONJUNTO Y TENDENCIAS FUTURAS*}

Donald E. Shrey

Las empresas se ven sometidas a una presión social y legislativa cada vez mayor para que acepten e integren en su organización a los discapacitados. Por otra parte, los crecientes costes de asistencia sanitaria y de indemnización por accidentes de trabajo amenazan su supervivencia y consumen recursos que normalmente se dedicarían a financiar el desarrollo económico. Sin embargo, existen indicios de que las empresas pueden afrontar eficazmente los problemas planteados por las lesiones y discapacidades. De hecho, se conocen modelos sumamente válidos de programas de gestión de la discapacidad aplicados por empresas que asumen el control y afrontan la responsabilidad de la prevención de las lesiones, la intervención precoz, la reincorporación de los trabajadores lesionados y la acomodación de los lugares de trabajo. La política de gestión de la discapacidad actualmente aplicada por las empresas industriales refleja un sensible desplazamiento de los servicios prestados en la comunidad a la actuación en el propio lugar de trabajo.

En el presente artículo se ofrece una definición funcional de la gestión de la discapacidad. Se presenta un modelo ilustrativo de los elementos estructurales de un programa óptimo en este campo. Además, se esbozan diversas estrategias y actuaciones efectivas en el mismo, incluidos los principios de organización fundamentales para mejorar la prestación de los servicios y optimizar los resultados. Se examinan la colaboración de los trabajadores con la empresa y la utilización de servicios interdisciplinarios, que muchos consideran imprescindibles para la ejecución de unos programas óptimos de gestión de la discapacidad en la industria, inspirados en la promoción de la dignidad y el respeto entre los discapacitados y los profesionales prestadores de servicios.

\section{Definición de la gestión de la discapacidad}

La gestión de la discapacidad se define, desde una perspectiva operativa, como un proceso dinámico de aminoración de los efectos de cualquier afectación (producida por una lesión o enfermedad) de la capacidad de una persona para participar competitivamente en el mercado de trabajo (Shrey y Lacerte 1995). He aquí los principios básicos que la informan:

- Se trata de un proceso proactivo;

- Es un proceso que permite a los trabajadores y a la empresa asumir conjuntamente la responsabilidad de actuar proactivamente en la toma de decisiones, la planificación y la coordinación de los servicios y actuaciones que se desarrollan en el lugar de trabajo;

- Fomenta la adopción de medidas de prevención, la elaboración de los principios informativos de la rehabilitación, y la aplicación de programas de reincorporación segura al trabajo, diseñados para limitar los costes personales y económicos de las lesiones y discapacidades producidos en el lugar de trabajo.

El éxito de la gestión de las secuelas de las lesiones y las enfermedades agudas o crónicas de los trabajadores descansa en los presupuestos siguientes:

* Este artículo es, en parte, una adaptación de los trabajos de Shrey y Lacerte (1995) y de Shrey (1995).
- un conocimiento cabal de los tipos de lesiones y enfermedades que pueden producirse

- una oportuna respuesta de la empresa a las enfermedades y lesiones

- unos principios y procedimientos de gestión claramente definidos

- una utilización eficaz de los servicios de rehabilitación y asistencia sanitaria

Los métodos de gestión de la discapacidad responden a una concepción empresarial amplia, coherente y avanzada de la atención de las complejas necesidades de los discapacitados en un determinado contexto laboral y socioeconómico. A pesar del crecimiento en espiral de los costes de tratamiento de las lesiones y discapacidades, existen técnicas de rehabilitación y se dispone de medios de gestión de la discapacidad que permiten a las empresas y a la industria en general realizar ahorros a medio y más largo plazo. Si se integran correctamente en la estructura de la empresa, los principios, procedimientos y estrategias de gestión de la discapacidad aportan el marco necesario para esta gestión y para el mantenimiento de la competencia en el mercado global.

No resulta fácil controlar el coste de la discapacidad en las empresas y en la industria, ni sus efectos últimos sobre la productividad de los trabajadores. Existe una interacción compleja entre los objetivos, los recursos y las expectativas de las empresas; las necesidades y los intereses privativos de trabajadores, proveedores de asistencia sanitaria, sindicatos y abogados; y los servicios disponibles en la comunidad. La capacidad de la empresa para participar de forma dinámica y eficaz en esta relación contribuye tanto al control de los costes como a la garantía del empleo permanente y productivo del trabajador.

\section{Objetivos de la gestión de la discapacidad}

Tanto los procedimientos y políticas como las estrategias y actuaciones de gestión de la discapacidad aplicados en las empresas se deben diseñar en función de objetivos realistas y posibles. LoS sistemas de gestión de la discapacidad en el lugar de trabajo deben permitir a la empresa:

- agilizar el control de los problemas de discapacidad;

- mejorar su competitividad;

- reducir las interrupciones del trabajo y las pérdidas de tiempo inadmisibles:

- reducir la incidencia de los accidentes y la magnitud de la discapacidad;

- reducir la duración (y los costes) de enfermedades y discapacidades;

- promover la actuación precoz y la adopción de medidas preventivas;

- optimizar el empleo de los recursos internos (de la empresa);

- mejorar la coordinación con los proveedores externos de servicios y la responsabilidad de los mismos;

- reducir el coste humano de la discapacidad;

- fomentar el estado de ánimo del trabajador valorando su variedad física y cultural;

- tutelar el derecho del trabajador al empleo;

- velar por el cumplimiento de la legislación (como la Ley de norteamericanos con discapacidades, de 1990) que garantiza la reincorporación y la equidad en el empleo;

- reducir el carácter contencioso y litigioso de la discapacidad;

- mejorar las relaciones laborales;

- mejorar la colaboración de los trabajadores con la empresa;

- facilitar la participación directa de los trabajadores en la planificación 


\section{Conceptos y estrategias básicos de la gestión de la discapacidad}

Empresas y sindicatos están corporativamente interesados en tutelar la capacidad de los trabajadores para acceder al empleo, así como en controlar los costes que lesiones y discapacidades producen a la industria. Los sindicatos defienden el acceso de los trabajadores al empleo, y las empresas están interesadas en evitar los elevados costes de rotación del personal, al tiempo que conservan los trabajadores más productivos, fiables y experimentados. Los estudios realizados subrayan la importancia de los conceptos y estrategias siguientes para la formulación y aplicación en el centro de trabajo de unos programas eficaces de gestión de la discapacidad.

\section{Participación de trabajadores y empresas}

La gestión de la discapacidad se basa en la participación, el apoyo y la responsabilidad de trabajadores y empresas. L os dos interlocutores sociales son elementos clave del proceso de gestión de la discapacidad y participan intensamente en la toma de decisiones, la planificación y la coordinación de los servicios y actuaciones Es preciso que ambos evalúen sus posibilidades de actuación conjunta frente a las lesiones y la discapacidad. Este proceso exige a veces un análisis inicial de los puntos fuertes y débiles conjuntos, así como una evaluación de los recursos disponibles para gestionar adecuadamente los esfuerzos de integración y de reincorporación al trabajo de los trabajadores discapacitados. M uchas empresas que cuentan con presencia sindical han desarrollado y aplicado eficazmente sus programas de gestión de la discapacidad bajo la dirección y los auspicios de comités paritarios (Bruyere y Shrey 1991).

\section{Cultura empresarial}

Las estructuras de organización, la actitud de los trabajadores, los deseos de la dirección y la historia contribuyen a configurar la cultura empresarial. Antes de elaborar un programa de gestión de la discapacidad, es preciso conocer la cultura empresarial, incluidos los intereses privativos y las motivaciones de los trabajadores y las empresas en materias como la prevención de accidentes, la acomodación del lugar de trabajo y la rehabilitación de los accidentados.

\section{Características de las lesiones y discapacidades}

Es preciso adaptar los programas de gestión de la discapacidad en la industria a las características específicas de las lesiones y discapacidades entre los trabajadores, incluidos los tipos de deficiencias, la edad de aquéllos, las estadísticas de horas perdidas y de accidentes y los costes generados por las indemnizaciones por discapacidad.

\section{Equipo interdisciplinario de gestión de la discapacidad}

La gestión de la discapacidad precisa el concurso de un equipo interdisciplinario, compuesto por representantes de la empresa (como jefes de seguridad, enfermeras de empresa, directores de gestión de riesgos, personal del departamento de recursos humanos y directores de línea) y de los sindicatos, el médico que se ocupe del tratamiento, un director de rehabilitación, un fisioterapeuta o terapeuta ocupacional y el propio discapacitado.

\section{Actuación precoz}

Quizás el concepto más importante de la gestión de la discapacidad sea el de actuación precoz. Tanto en los principios como en las medidas de rehabilitación aplicados por la mayoría de los sistemas de prestaciones por discapacidad se reconoce el valor de la actuación precoz, a la luz de los resultados de los estudios sobre gestión de la incapacidad realizados en los diez últimos años. Las empresas han logrado reducir sustancialmente los costes de dicha gestión promoviendo la aplicación de sistemas de actuación precoz, incluida la supervisión sistemática de los trabajadores con limitaciones de trabajo. Los programas y estrategias de actuación precoz orientados a la pronta reincorporación al trabajo permiten reducir las horas perdidas, incrementar la productividad de las empresas y reducir los costes de gestión de la discapacidad y de indemnización por accidentes de trabajo. Con independencia de que la discapacidad esté o no relacionada con el trabajo, la actuación precoz se considera el factor determinante de la posterior rehabilitación médica, psicosocial y profesional (Lucas 1987, Pati 1985, Scheer 1990, Wright 1980). No obstante, el éxito de la gestión de la discapacidad depende igualmente de la posibilidad de una pronta reincorporación al trabajo, de la acomodación del lugar de trabajo y de los apoyos (Shrey y O lshesky 1992, Habeck y cols. 1991). Por regla general, los programas de reincorporación precoz al trabajo en la industria implican una combinación de medidas de gestión de la discapacidad, promovidas por un equipo multidisciplinario de la propia empresa y coordinadas por un director de rehabilitación cualificado.

\section{Actuaciones proactivas en los planos individual y del medio ambiente de trabajo}

L as medidas de gestión de la discapacidad deben orientarse tanto a las personas como al medio ambiente de trabajo. En los métodos tradicionales de rehabilitación no se suele tener en cuenta que la discapacidad profesional puede ser la consecuencia, no sólo de circunstancias personales del trabajador, sino también de barreras ambientales. La insatisfacción del trabajador con su trabajo, los conflictos con los superiores y la deficiente configuración del puesto de trabajo ocupan un lugar destacado entre las numerosas barreras ambientales a la gestión de la discapacidad. En resumen, para optimizar los resultados de la rehabilitación de los trabajadores lesionados es preciso distribuir equilibradamente el esfuerzo entre los factores personales y los ambientales. La acomodación de los puestos de trabajo, prevista tanto en la Ley de norteamericanos con discapacidades como en otras disposiciones de protección de la equidad en el empleo, ha permitido ampliar el abanico de posibilidades en la búsqueda de un trabajo de transición para el trabajador lesionado. La rectificación de las herramientas, el diseño de los puestos de trabajo con arreglo a criterios ergonómicos, el uso de dispositivos adaptados y la modificación de los horarios de trabajo constituyen otros tantos métodos eficaces de gestión de la discapacidad que permiten al trabajador realizar las tareas básicas (G ross 1988). Estas actuaciones se pueden desarrollar igualmente de forma proactiva con el objeto de conocer y modificar los puestos de trabajo susceptibles de producir más lesiones.

\section{Diseño del plan de prestaciones}

Los planes de prestaciones suelen inducir a los trabajadores a prolongar su situación de discapacidad. U no de los factores que más contribuyen a producir efectos negativos, materializados en una pérdida inaceptable de horas de trabajo y en los correlativos costes, es la falta de incentivos económicos. En lugar de desincentivar la vuelta al trabajo, los planes de prestaciones deben recompensar a los trabajadores discapacitados que se reincorporan al empleo y cuidan su salud y su productividad.

\section{Programas de reincorporación al trabajo}

Existen, básicamente, dos formas de reducir los costes de discapacidad en la industria: (1) evitar los accidentes y las lesiones, y (2) reducir la pérdida innecesaria de horas de trabajo. Los programas de reducción del esfuerzo aplicados tradicionalmente en la industria no han resultado plenamente efectivos en la 
reincorporación de los trabajadores discapacitados al empleo. Las empresas recurren con frecuencia cada vez mayor a esquemas flexibles y creativos de transición a la reincorporación al trabajo y al sistema de acomodación razonable de los lugares de trabajo a las limitaciones de los trabajadores. Este esquema de transición permite que el trabajador discapacitado se reincorpore al trabajo antes de haberse recuperado plenamente de las lesiones. EI trabajo de transición implica normalmente la combinación de una modificación temporal de las tareas, un acondicionamiento físico del lugar de trabajo, la adopción de prácticas seguras de trabajo, la aplicación de medidas de educación y la introducción de ajustes en el trabajo. La reducción de la pérdidas de horas de trabajo que la transición permite se traduce en una disminución de los costes. El trabajador lesionado asume temporalmente la realización de otras tareas productivas mientras se reincorpora gradualmente a su puesto anterior.

\section{Promoción de unas relaciones laborales positivas}

$L$ a relación entre el trabajador y el medio ambiente de trabajo es de naturaleza dinámica y compleja. U nas relaciones armónicas suelen propiciar la satisfacción con el puesto de trabajo, el incremento de la productividad y unas relaciones laborales positivas, que resultan igualmente satisfactorios para el trabajador y para su empresa. Por el contrario, unas relaciones caracterizadas por la acumulación de conflictos no resueltos pueden desembocar en consecuencias funestas para trabajadores y empresa por igual. Un primer paso importante para la solución de las reclamaciones por lesiones y discapacidades consiste en conocer la dinámica de la relación entre el individuo y el medio ambiente. Una empresa responsable fomenta unas relaciones laborales positivas y promueve la satisfacción en el puesto de trabajo y la participación de los trabajadores en la toma de decisiones.

\section{Aspectos psicológicos y sociales de la discapacidad}

L as empresas deben ser conscientes de las consecuencias psicológicas y sociales de las lesiones y discapacidades, y de los efectos globales de la interrupción del trabajo en la familia del trabajador. Los problemas psicosociales derivados de la lesión física inicial suelen traducirse en un aumento de la pérdida de horas de trabajo. Las relaciones de familia se deterioran rápidamente por causa del abuso de la bebida y de la conciencia de desvalimiento. Ahora bien, si otros familiares se ven afectados por las lesiones del trabajador, las relaciones familiares adquieren un perfil patológico. El trabajador discapacitado experimenta un cambio de funciones, y sus familiares reaccionan ante ello. Q uien era anteriormente un trabajador independiente y autosuficiente asume ahora una situación de dependencia pasiva. La hostilidad se recrudece si la vida familiar se quiebra por la presencia de una persona autoritaria, exigente, colérica a veces y, a menudo, depresiva. Este es el resultado habitual de unos problemas laborales no resueltos, alimentados por el estrés y desencadenados por la iniciación de litigios que tienen un desarrollo frustrante. Aunque las relaciones entre estos factores a veces se comprendan mal, el daño suele ser profundo.

\section{Programas de prevención de accidentes y de ergonomía en el trabajo}

Numerosas empresas han logrado reducir sensiblemente la frecuencia de los accidentes mediante la creación de comités permanentes de seguridad y ergonomía. Estos comités se suelen responsabilizar tanto del control de la seguridad y la supervisión de factores de riesgo del tipo de la exposición a vapores y productos químicos peligrosos como de la implantación de controles diseñados para reducir la frecuencia y magnitud de los accidentes. Con mayor frecuencia, abordan problemas como las lesiones producidas por los movimientos repetitivos y los trastornos causados por los traumatismos acumulativos, como el síndrome del túnel carpiano. La ergonomía consiste en la aplicación de la tecnología para ayudar al factor humano en el trabajo manual. Su objetivo global es la adaptación de las tareas a los seres humanos para mejorar su eficacia en el lugar de trabajo. Esto quiere decir que la ergonomía se orienta a los siguientes aspectos:

- prevención o reducción de la frecuencia de lesiones, luxaciones y dislocaciones;

- reducción de la fatiga y de los esfuerzos excesivos;

- reducción del absentismo y de la rotación del personal;

- mejora de la calidad y cantidad de la producción;

- reducción de la pérdida de horas de trabajo y de los costes producidos por accidentes y lesiones;

- aumento de la seguridad, la eficiencia, la comodidad y la productividad.

Las actuaciones ergonómicas son tanto preventivas, como rehabilitadoras. D esde la perspectiva de la prevención, es preciso realizar un análisis ergonómico de los trabajos que provocan lesiones e introducir modificaciones que eviten su repetición. Desde el punto de vista de la rehabilitación, se pueden aplicar conceptos ergonómicos al proceso de adecuación del lugar de trabajo en beneficio de los trabajadores afectados de limitaciones. Esto puede llevar aparejada, bien la imposición de controles administrativos con fines ergonómicos (como pausas en el trabajo, rotación en las tareas y reducción del horario), bien la reformulación de las tareas con arreglo a criterios ergonómicos, con el objeto de eliminar los factores de riesgo de producción de nuevas lesiones (como variar la altura de la mesa, incrementar la iluminación o cambiar los embalajes para reducir los pesos que deben izarse).

\section{Responsabilidad y habilitación dela empresa}

La habilitación de la empresa es un principio fundamental de la gestión de la discapacidad. D espués del trabajador discapacitado, la empresa es el elemento central de este proceso de gestión. Es ella la que asume la iniciativa al adoptar medidas de actuación precoz después de producirse un accidente de trabajo con lesiones. En cuanto conocedora de los procesos productivos en profundidad, es la más indicada para aplicar programas eficaces de seguridad y prevención de accidentes. De modo similar, está en situación óptima para facilitar la reincorporación al trabajo de las víctimas de lesiones que han supuesto una pérdida de horas de trabajo. Lamentablemente, la experiencia indica que muchas empresas han delegado su responsabilidad respecto a la gestión de la discapacidad en entidades ajenas al medio ambiente de trabajo. Así, la toma de decisiones y la solución de los problemas relacionados con la discapacidad laboral se han delegado en entidades aseguradoras, gestores de siniestros, organismos gestores de la indemnización por accidente de trabajo, médicos, terapeutas, profesionales de la rehabilitación e incluso abogados. La escalada de la pérdida de horas de trabajo y de los costes derivados de las lesiones relacionadas con el trabajo sólo se puede invertir si se confía a la empresa la gestión de la discapacidad. D esde luego, el reconocimiento del control de la empresa sobre los costes de la discapacidad no es un capricho. Al igual que ocurre con los discapacitados, suele asumir estas competencias cuando se reconocen sus recursos y sus posibilidades internas. Muchas empresas precisan sensibilización, confianza y orientación para vencer la dinámica implacable de causas y efectos de la discapacidad laboral. 


\section{Gestión de casos y coordinación de la reincorporación al trabajo}

Los servicios de gestión de casos coadyuvan a la formulación y aplicación de los planes de gestión de la discapacidad y de los programas de reincorporación al trabajo de los trabajadores discapacitados. El gestor de casos es un elemento fundamental del equipo de gestión de la discapacidad que actúa como enlace entre la empresa, los representantes de los trabajadores, los trabajadores lesionados, los proveedores de asistencia sanitaria comunitaria y otros agentes. Puede cooperar en la elaboración, aplicación y evaluación de un programa de trabajo de transición o de retención del trabajador en el lugar de trabajo, que ayude a: (1) evitar la interrupción del trabajo de los empleados con deficiencias que perjudiquen la realización del trabajo; y (2) promover la reincorporación puntual y segura al trabajo de los trabajadores discapacitados en situación de baja por enfermedad, que perciban indemnización por accidentes de trabajo o que se encuentren en situación de incapacidad de larga duración. En la administración de los programas de trabajo de transición en el lugar de trabajo, el gestor de casos puede asumir la responsabilidad directa de: (1) la evaluación objetiva del trabajador, (2) la catalogación de las exigencias físicas del trabajo, (3) la vigilancia y supervisión médica, y (4) la planificación del empleo estable en unos puestos convenientemente modificados.

\section{Principios y procedimientos de gestión de la discapacidad: generación de expectativas entre los supervisores, los representantes de los trabajadores y estos últimos}

Es importante que en las empresas se mantenga un equilibrio entre las expectativas de sindicatos y trabajadores y los objetivos de los directivos y supervisores. Este equilibrio se basa en la colaboración de los trabajadores y la dirección en la formulación de políticas y procedimientos formales de gestión de la discapacidad. Los programas contrastados de gestión de la discapacidad descansan sobre unos manuales escritos de principios y procedimientos, en los que figura una delimitación de funciones que refleja los intereses y responsabilidades de la dirección y de los trabajadores. Normalmente, en los manuales se definen las funciones y misiones de los miembros del comité de gestión interna de la discapacidad, y se describe pormenorizadamente su actuación, desde la producción de la lesión hasta la reincorporación puntual y segura al trabajo. En las políticas de gestión de la discapacidad se suelen describir las relaciones entre la empresa, los proveedores de asistencia sanitaria y los servicios de rehabilitación de ámbito comunitario. Los manuales de métodos y políticas constituyen un medio eficaz de comunicación entre los diversos actores: médicos, entidades aseguradoras, sindicatos, directivos, empleados y prestadores de servicios.

\section{Intensificación de la sensibilización de los médicos respecto a los puestos y al medio ambiente de trabajo}

U no de los problemas crónicos que aquejan a la gestión de las lesiones profesionales es la falta de influencia de la empresa sobre el alta médica para reincorporarse al trabajo. Los médicos que se ocupan del tratamiento suelen mostrarse reacios a autorizar la reincorporación del trabajador lesionado antes de su total recuperación. Con frecuencia se ven obligados a decidir sobre el alta laboral sin un conocimiento adecuado de las exigencias del trabajo. L os programas de gestión de la discapacidad han servido para transmitir a los médicos la disposición de la empresa a acomodar a los trabajadores con limitaciones mediante la aplicación de programas de trabajo de transición y su asignación temporal a tareas diferentes. A este respecto es preciso que las empresas elaboren una descripción funcional de sus puestos de trabajo en la que se cuantifique el esfuerzo exigido por cada tarea. De este modo, los médicos podrán juzgar la compatibilidad del estado físico del trabajador con las exigencias funcionales del puesto. Muchas empresas invitan a los médicos a visitar los centros de producción y sus lugares de trabajo con objeto de que se familiaricen con las exigencias de cada puesto y con el medio ambiente de trabajo.

\section{Selección, utilización y evaluación de los servicios de la comunidad}

Muchas empresas han realizado ahorros sustanciales y han logrado mejorar la efectividad del proceso de reincorporación al trabajo mediante la selección, el uso y la evaluación de los servicios médicos y de rehabilitación comunitarios más eficaces. L OS trabajadores que sufren lesiones o enfermedades suelen escuchar sugerencias relativas a la selección de un proveedor de asistencia $y$, si son mal aconsejados, corren el riesgo de que recibir un tratamiento inadecuado o excesivamente prolongado, de incurrir en gastos de asistencia médica excesivos y de que los resultados no sean óptimos. En los sistemas eficaces de gestión de la discapacidad, la empresa participa activamente en la selección de unos servicios de calidad adecuados a las necesidades de los trabajadores discapacitados. Si la empresa "interioriza" estas fuentes externas, las mismas se integran en la estructura general de gestión de la discapacidad. Este proceso permite remitir a los trabajadores discapacitados a unos prestadores de servicios responsables, que asumen los objetivos comunes de la reincorporación al trabajo.

\section{Utilización de evaluadores médicos independientes}

En ocasiones, en los informes médicos sobre los trabajadores discapacitados se echa en falta una descripción objetiva de la deficiencia advertida y de las limitaciones médicas. Con frecuencia, las empresas se sienten rehenes de los diagnósticos del médico encargado del tratamiento, en especial si las razones que han inducido a éste a establecer restricciones a la prestación laboral del trabajador no aparecen documentadas con análisis médicos objetivos y pruebas cuantificables. No cabe duda de que están en su derecho a solicitar pruebas médicas y evaluaciones de la capacidad física de fuentes independientes cuando se trata de valorar reclamaciones por discapacidad discutibles. En este sistema, a ellas les corresponde seleccionar fuentes objetivas y cualificadas de evaluación médica y rehabilitación en el ámbito comunitario.

\section{Elementos básicos de un sistema óptimo de} gestión de la discapacidad

Un sistema óptimo de gestión de la discapacidad en la empresa se compone de tres elementos básicos (Shrey 1995, 1996). En primer lugar, unos recursos humanos. Un aspecto esencial de este elemento es la creación de un equipo interno de gestión de la discapacidad. Se prefieren los equipos paritarios, normalmente integrados por representantes de los sindicatos y de las divisiones de gestión de riesgos, salud y seguridad en el trabajo, operaciones y gestión financiera. He aquí algunos criterios básicos aplicables a la selección de los miembros de ese equipo:

- capacidad: conocimiento de las operaciones de la empresa, de las relaciones laborales, de los recursos internos y externos y de la cultura empresarial

- influencia: capacidad para inducir modificaciones en el proceso de toma de decisiones de la dirección;

- liderazgo: capacidad para ganarse el respeto de los trabajadores, supervisores y altos directivos;

- creatividad: capacidad para adoptar iniciativas proactivas que funcionen a pesar de las dificultades;

- compromiso: criterios profesionales congruentes con la misión y los principios de la gestión de la discapacidad;

- motivación: capacidad para motivarse y para motivar a otros a identificarse con los objetivos del programa. 
Suelen producirse disfunciones en la asignación y delegación de funciones para la solución de los problemas de discapacidad. Las nuevas tareas se deben asignar con criterios que aseguren la adecuada coordinación del proceso, desde la producción de la lesión hasta la reincorporación al trabajo. Este elemento relativo a los recursos humanos implica la posesión de conocimientos y destrezas o de una formación que permitan a los directivos y supervisores desempeñar las funciones asignadas. La responsabilidad es un concepto esencial que se ha de incorporar a la estructura de organización del programa de gestión de la discapacidad de la empresa.

El segundo elemento de un sistema óptimo de gestión de la discapacidad son las operaciones. Se incluyen en este concepto ciertos servicios, actividades y actuaciones que se producen antes, durante y después de la ocurrencia de la lesión. Entre los elementos anteriores a la lesión figuran unos programas eficaces de seguridad, la prestación de servicios ergonómicos, los métodos de selección previa a la colocación, los programas de prevención de siniestros y los comités paritarios. Todos ellos son de carácter preventivo y pueden incluir servicios de promoción de la salud y el bienestar, como los programas para la pérdida de peso, los grupos para estimular el abandono del tabaco y las clases de aerobic

Entre los elementos coetáneos con la producción de la lesión hay que mencionar las políticas de actuación precoz, los servicios de gestión de casos, los programas formales de trabajo de transición, la acomodación de los lugares de trabajo, los programas de asistencia a los empleados y otros servicios de salud. El objetivo de estas actividades es solucionar los problemas de discapacidad que no han podido prevenirse antes de la lesión.

Los elementos que se desarrollan con posterioridad a la lesión en los programas óptimos de gestión de la discapacidad conciernen a los servicios de retención de los trabajadores, creados para facilitar la adaptación de éstos a las exigencias de los puestos, dentro de sus limitaciones físicas o mentales y en el marco de las condiciones ambientales. Esta fase de la actividad debe comprender igualmente la evaluación de los programas, la gestión financiera para lograr la eficacia en función del coste y la mejora de los programas.

EI tercer elemento integrante de un sistema óptimo de gestión de la discapacidad son las comunicaciones, incluidas, tanto las interiores como las exteriores. En el ámbito interno, los aspectos operativos del programa de gestión de la discapacidad en la empresa se deben difundir de forma precisa y sistemática entre los trabajadores, supervisores, directivos y representantes de los trabajadores. Los documentos, procedimientos y políticas rectores de la actividad de reincorporación al trabajo se deben difundir en comunicaciones elaboradas por la dirección y la representación de los trabajadores.

Las comunicaciones externas permiten estrechar las relaciones de la empresa con los médicos ocupados del tratamiento, los gestores de siniestros, los prestadores de servicios de rehabilitación y los administradores de los sistemas de indemnización por accidentes de trabajo. La empresa puede contribuir a una pronta reincorporación al trabajo facilitando a los médicos una descripción funcional de los puestos de trabajo, de las medidas de seguridad en el trabajo y de las posibles opciones de trabajo de transición para los trabajadores lesionados.

\section{Conclusiones}

Los programas de gestión de la discapacidad y de trabajo de transición constituyen un nuevo paradigma en las actividades de rehabilitación de los trabajadores afectados por enfermedades 0 lesiones. Se aprecia un desplazamiento del esfuerzo de rehabilitación desde las instituciones sanitarias hacia el lugar de trabajo. Proliferan las iniciativas conjuntas de empresas y trabajadores en el campo de la gestión de la discapacidad, que han abierto nuevas vías y posibilidades de actuación a sindicatos, empresas y profesionales de la rehabilitación de la comunidad.

Los miembros del equipo interdisciplinario de gestión de la discapacidad están aprendiendo a dominar los recursos y tecnologías existentes en el medio ambiente de trabajo. Las exigencias que se dirigen a la empresa conciernen fundamentalmente a su creatividad, imaginación y flexibilidad para adaptar la actividad de gestión de la discapacidad al medio ambiente de trabajo. La acomodación del trabajo y las posibilidades de realizar tareas de transición han venido a mejorar las posibilidades alternativas de reincorporación gradual al trabajo de los trabajadores con limitaciones. La modificación de las herramientas, el diseño ergonómico de los lugares de trabajo, el empleo de dispositivos adaptados y la modificación del horario de trabajo constituyen otros tantos sistemas eficaces de gestión de la discapacidad que capacitan al trabajador para ejecutar tareas fundamentales. Estas mismas técnicas se pueden aplicar de forma preventiva para determinar y modificar los trabajos susceptibles de provocar lesiones.

La tutela de los derechos de los trabajadores discapacitados constituye un elemento importante de la gestión de la discapacidad. Todos los años, miles de trabajadores sufren discapacidades de resultas de accidentes de trabajo y enfermedades profesionales. Si no existiesen el trabajo de transición y las posibilidades de acomodación de los lugares de trabajo, afrontarían un riesgo de sufrir discriminación idéntico al que sufren otros discapacitados. Por consiguiente, la gestión de la discapacidad constituye un eficaz medio de defensa que protege tanto a la empresa como al trabajador discapacitado. Las políticas de gestión de la discapacidad tutelan por igual el acceso del trabajador al empleo y los intereses económicos de la empresa.

En el decenio próximo, los efectos de la escalada de los costes de la indemnización por accidentes de trabajo se hará sentir profundamente en la comunidad empresarial e industrial de todo el mundo. Sin embargo, ante el reto que esta crisis plantea a la industria, las medidas de gestión de la discapacidad en la industria y los programas de trabajo de transición ofrecen una posible solución. En un contexto caracterizado por la reducción de la fuerza de trabajo, el envejecimiento de la población activa y la creciente mundialización de la competencia, las empresas de los países industrializados deben aprovechar las oportunidades de controlar los costes económicos y humanos de las lesiones y discapacidades. Su éxito será una función de la medida en que logren generar actitudes positivas en los directivos y los representantes de los trabajadores, al tiempo que crean una infraestructura capaz de sustentar los sistemas de gestión de la discapacidad.

\section{REH ABILITACION Y PERDIDA AUDITIVA INDUCIDA POR EL RUIDO*}

Raymond H étu

Aunque el presente artículo se ocupa de la discapacidad producida por la exposición al ruido, se ha reproducido aquí porque en él se enuncian conceptos importantes aplicables a la rehabilitación relacionada con discapacidades causadas por la exposición a otros riesgos.

\section{Aspectos psicosociales de la pérdida auditiva de origen profesional}

Como toda experiencia humana, la pérdida auditiva causada por la exposición al ruido en el lugar de trabajo recibe su significación -esto es, se valora y experimenta cualitativamente- de los

* El malogrado Dr. Hétu escribió este artículo poco antes de su fallecimiento. Para sus colegas y amigos, el trabajo es un homenaje a su memoria. 
afectados y del grupo social al que pertenece. Sin embargo, esta significación puede constituir un obstáculo formidable a la rehabilitación de las personas aquejadas de pérdida auditiva de origen profesional (H étu y G etty 1991b). Como se expone más adelante, esto se debe, principalmente, a que las personas que sufren pérdida auditiva experimentan problemas de percepción asociados a los signos y los efectos de su deficiencia, y a que la manifestación de síntomas inequívocos de pérdida auditiva tiene efectos sumamente estigmatizantes.

\section{Problemas de comunicación originados por la percepción distorsionada de los problemas de audición}

Los problemas de audición y comunicación producidos por la pérdida auditiva de origen profesional se suelen atribuir a otras causas, como las pobreza de facultades de audición y comunicación, el desinterés o la falta de concentración. Esta imputación errónea se produce tanto por parte de la persona afectada como de quienes se relacionan con ella, y obedece a causas múltiples, aunque concatenadas.

1. Las lesiones del oído interno no son visibles, por lo que los pacientes no se consideran físicamente afectados por el ruido

2. La evolución de la pérdida auditiva en sí es muy insidiosa. La fatiga auditiva virtualmente cotidiana que sufren los trabajadores expuestos a ruidos en el lugar de trabajo hace que la detección precoz de los trastornos irreversibles de la función auditiva sea extremadamente difícil. Las personas expuestas al ruido jamás perciben el deterioro palpable de su capacidad auditiva. De hecho, para la mayoría de los trabajadores expuestos cotidianamente a unos niveles de ruido nocivos, el incremento del umbral auditivo es del orden de un decibelio por año de exposición (H étu, Tran Q uoc y Duguay 1990). Si la pérdida auditiva es simétrica y gradual, el paciente carece de un referente propio que le permita evaluar la merma auditiva inducida. Por causa de esta evolución insidiosa de la pérdida auditiva, los afectados modifican sus hábitos de forma sumamente gradual y evitan las situaciones desventajosas para ellas, aunque sin llegar a asociar expresamente este cambio de hábitos con la pérdida de audición.

3. Los síntomas de pérdida auditiva son sumamente ambiguos y suelen consistir en una pérdida de capacidad de discriminación de frecuencias, esto es, en una reducción de la capacidad para distinguir entre dos o más señales acústicas simultáneas, debido a que la señal más intensa enmascara las otras. Específicamente, esta incapacidad causa diversos grados de dificultad para seguir una conversación que produce un eco considerable o que se entremezcla con ruidos de fondo producidos por otras conversaciones, televisores, ventiladores, vehículos de motor, etc. En otras palabras, la capacidad auditiva de las personas cuya capacidad de discriminación de frecuencias se encuentra disminuida es una función directa de las condiciones ambientales reinantes en un momento dado. Las personas que tratan cotidianamente a los afectados perciben estas oscilaciones de la capacidad auditiva como un comportamiento incoherente del afectado y se lo recriminan con expresiones como: "Sólo entiendes lo que te conviene". Por su parte, el afectado atribuye su discapacidad auditiva y de comunicación a los ruidos de fondo, a la deficiente expresión de sus interlocutores 0 a una distracción propia. Esto impide que el síntoma más característico de la pérdida auditiva se reconozca como tal.

4. Los efectos de la pérdida auditiva se suelen manifestar fuera del lugar de trabajo, en el ámbito de la vida familiar. Esto hace que los problemas no se asocien a la exposición al ruido en el trabajo y no se comenten con los compañeros que los sufren también.

5. El reconocimiento de los problemas auditivos suele producirse como consecuencia de las recriminaciones del círculo familiar y social del afectado (H étu, Jones y G etty 1993). Las personas afectadas vulneran determinadas convenciones sociales, al hablar demasiado alto, pedir continuamente a sus interlocutores que repitan las cosas y sintonizar la radio y la televisión con un volumen excesivamente elevado. Este comportamiento suscita en los demás la típica, y despreciativa, reacción de preguntar: "¿Estas sordo?". La reacción defensiva que la pregunta suscita no favorece, precisamente, el reconocimiento de la sordera parcial.

La concatenación de estos cinco factores impide que las personas afectadas por una pérdida auditiva de origen profesional reconozcan los efectos del padecimiento en su vida cotidiana mientras la sordera no es demasiado pronunciada. Esto suele producirse cuando los afectados son conscientes de que deben pedir continuamente a sus interlocutores que repitan las cosas (H étu, Lalonde y G etty 1987). Sin embargo, incluso en este estadio, se muestran sumamente reticentes a reconocer la merma de audición, por causa del estigma producido por la sordera.

\section{Estigmatización de los síntomas desordera}

Las reacciones hostiles suscitadas por los síntomas de pérdida auditiva son un reflejo de la valoración extremadamente negativa que suele acompañar a la sordera. Los trabajadores que manifiestan síntomas de sordera están expuestos a que se les considere anormales, incapaces, prematuramente envejecidos o minusválidos; esto es, a verse marginados socialmente en el lugar de trabajo (H étu, G etty y Waridel 1994). De este modo, la imagen negativa que proyectan se intensifica a medida que la pérdida auditiva progresa. O bviamente, los afectados se niegan a asumir esta imagen y, con ello, a aceptar los síntomas de la pérdida de audición. Tal actitud les induce a atribuir sus dificultades de audición y sus problemas de comunicación a otras causas y a adoptar una actitud pasiva frente a estas causas.

En la Figura 17.2. se ilustran los efectos combinados de la sordera y de la percepción distorsionada de los síntomas y efectos de la pérdida auditiva sobre la rehabilitación.

Si los problemas de audición progresan hasta el punto de que resulta imposible negarlos o restarles importancia, el afectado trata de ocultarlos, lo que conduce invariablemente a la autoexclusión social del trabajador y a su marginación por parte de su grupo social, que atribuye el aislamiento del afectado más a una falta de interés por comunicar con los demás que a la pérdida auditiva. El resultado de ambas reacciones es que el paciente no recibe ayuda ni información sobre las posibilidades de superar el problema. Puede llegar a disimular su angustia en una medida tal que acaso sus familiares y compañeros no sean conscientes del daño que le causan las bromas que los síntomas de la sordera provocan. Esta dinámica no hace sino exacerbar el proceso de estigmatización y sus consiguientes efectos negativos. Como se ilustra en la Figura 17.2., la percepción distorsionada de los síntomas y efectos de la pérdida auditiva y la estigmatización resultante de tal distorsión constituyen otros tantos obstáculos a la superación de los problemas de audición. Como los afectados ya son víctimas del estigma, se niegan, en un principio, al uso de audífonos, que, al delatar inconfundiblemente la sordera, impulsan el proceso de estigmatización.

El modelo que se ilustra en la Figura 17.2 explica el hecho de que los afectados de una pérdida auditiva de origen profesional no consulten a un otorrino, se abstengan de pedir la adaptación de su puesto de trabajo y no conciertan técnicas de mitigación 
Figura 17.2 - Marco conceptual de los efectos de la discapacidad.

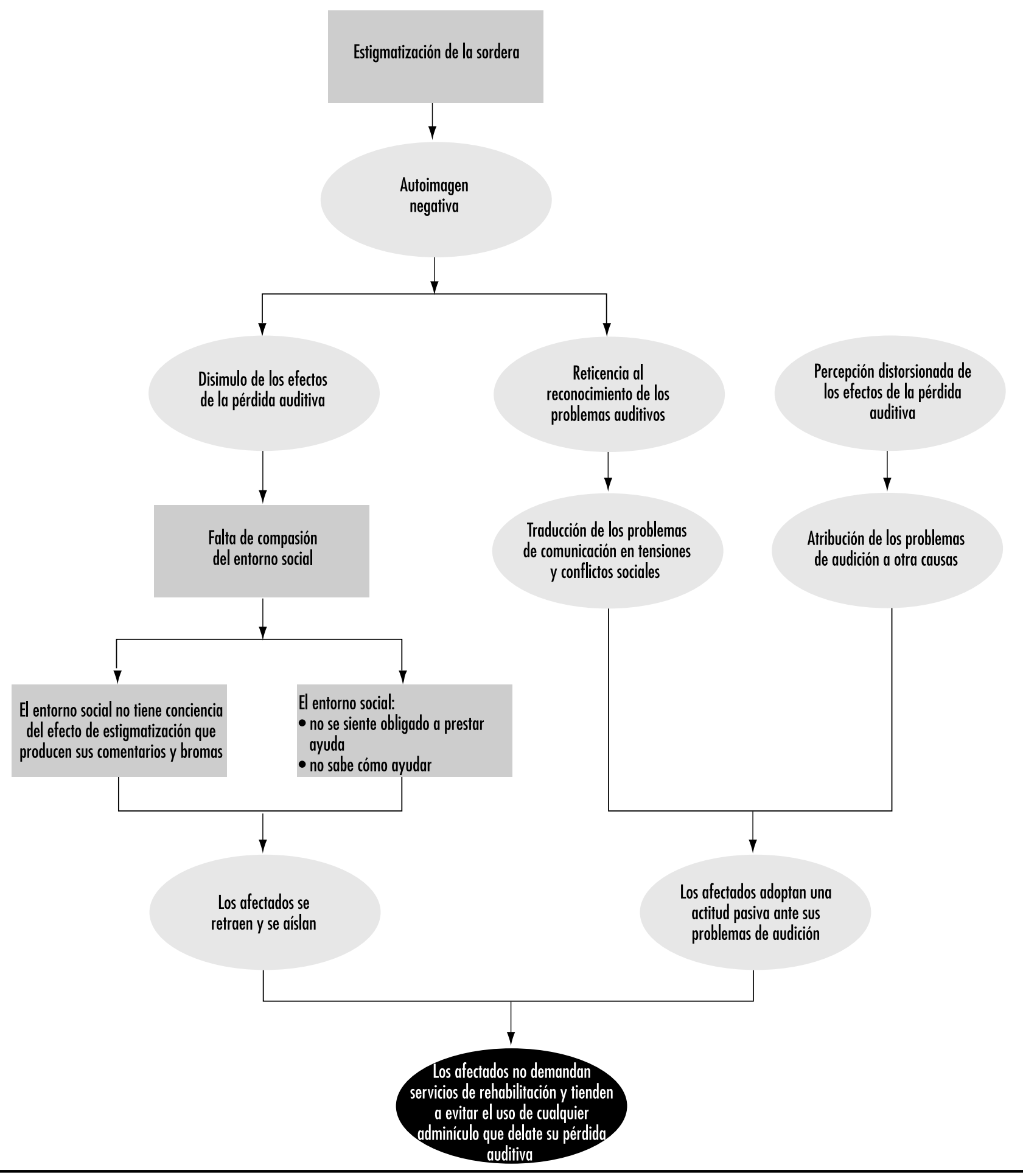

con su familia y su entorno social. Esto es, soportan pasivamente sus dificultades y evitan las situaciones que pongan de manifiesto su deficiencia auditiva.

\section{Marco conceptual de la rehabilitación}

Para ser eficaz, la rehabilitación debe superar las barreras precedentemente indicadas. Por tanto, lejos de limitarse al restablecimiento de la capacidad auditiva, en la labor de rehabilitación se deben abordar igualmente las cuestiones asociadas a la percepción de las dificultades auditivas por los afectados y por su entorno. La estigmatización de la sordera es el mayor obstáculo a la rehabilitación (H étu y Getty 1991b; H étu, Getty y Waridel 1994) y debe ser el objetivo central de todo el proceso. Por consiguiente, para ser eficaz, la actuación debe dirigirse tanto a los 
trabajadores estigmatizados por la sordera como a su entorno familiar y de amigos y compañeros, y a las demás personas que se relacionan con el afectado, pues son ellos quienes producen el estigma y quienes, por ignorancia, someten a la persona a unas exigencias imposibles. Específicamente, es preciso crear un entorno que permita al afectado salir de su círculo vicioso de pasividad y aislamiento, así como formular soluciones efectivas a sus dificultades de audición. Estas medidas deben ir acompañadas de la sensibilización del entorno a las necesidades concretas de los damnificados. Este proceso se fundamenta en el enfoque ecológico de la incapacidad y la minusvalía que se ilustra en la Figura 17.3.

Según el modelo ecológico, la pérdida auditiva se define como una disparidad entre la capacidad residual de una persona y las exigencias físicas y sociales del entorno. Por ejemplo, los trabajadores afectados por una pérdida de la capacidad de discriminación de frecuencias resultante de una dificultad auditiva inducida por el ruido tienen dificultad para percibir las alarmas acústicas instaladas en los lugares de trabajo con altos niveles de ruido. Si esas señales acústicas de alarma no se gradúan en un nivel sensiblemente superior al necesario para las personas con una capacidad auditiva normal, quedan en una situación desventajosa (H étu 1994b), al verse privados de un medio de protección. Sin embargo, el simple hecho de reconocer la pérdida auditiva entraña para el trabajador el riesgo de ser considerado "anormal" por sus compañeros y, si se le coloca la etiqueta de discapacitado, experimenta el temor de que aquéllos y sus superiores le tachen de incompetente. En cualquier caso, el trabajador procura enmascarar su minusvalía o, sencillamente, se niega a reconocer el problema, con lo que se coloca en una situación desventajosa en el trabajo.

Como se aprecia en la Figura 17.3, la discapacidad es una situación compleja, caracterizada por varias limitaciones imbricadas entre sí. En este contexto de factores interdependientes, la prevención o la reducción de las desventajas o de los factores que limitan la actividad precisa una actuación simultánea en diversos frentes. Por ejemplo, si bien el uso de audífonos permite recuperar parcialmente la capacidad auditiva (elemento no 2), no evita la aparición de una imagen personal negativa, ni la estigmatización del trabajador por parte del entorno (elementos no 5 y no 6), que se encuentran en el origen del aislamiento y de la falta de comunicación (elemento no 7). Por otra parte, las prótesis auditivas no permiten recuperar plenamente la capacidad de audición, en especial por lo que respecta a la discriminación de frecuencias. En efecto, si bien la amplificación del sonido incrementa la capacidad de percepción de las alarmas acústicas, no mejora la posibilidad de distinción de señales simultáneas que se precisa para identificar las alarmas acústicas que suenen en presencia de un considerable nivel de ruido de fondo. Por consiguiente, la prevención de las limitaciones relacionadas con el trabajo obliga a modificar las exigencias físicas y sociales en el lugar de trabajo (elemento n-3). Es obvio que, si bien las medidas dirigidas a modificar las percepciones (dementos n- 5 y no 6 ) son imprescindibles y sirven, efectivamente, para prevenir la discapacidad, no mitigan los efectos inmediatos de estas situaciones.

\section{Individualización de la rehabilitación}

La aplicación del modelo de la Figura 17.3 varía en función de las circunstancias de cada caso. Según diversos estudios cualitativos y encuestas realizados (H étu y G etty 1991b; H étu, Jones y Getty 1993; H étu, Lalonde y G etty 1987; H étu, G etty y Waridel 1994; H étu 1994b), las consecuencias de la discapacidad sufrida por los afectados de una pérdida auditiva de origen profesional se hacen sentir especialmente: (1) en el lugar de trabajo, (2) en el ámbito de la actividad social, (3) en el círculo familiar. Se han propuesto diversos criterios de actuación para cada una de estas tres situaciones.

\section{El lugar de trabajo}

En los centros de trabajo industriales se pueden distinguir las cuatro limitaciones o desventajas siguientes, que demandan actuaciones específicas:

1. Riesgos de accidentes vinculados a la no percepción de señales de alarma.

2. Esfuerzo, estrés y ansiedad producidos por problemas de audición y comunicación.

3. O bstáculos a la integración social.

4. O bstáculos a la promoción profesional.

\section{Riesgos de accidente}

Las alarmas acústicas son de uso frecuente en los lugares de trabajo industriales. La pérdida de audición de origen profesional puede mermar considerablemente la capacidad del trabajador para detectar, localizar o identificar dichas alarmas, especialmente en los lugares de trabajo con elevados niveles de eco. La merma de la capacidad de discriminación de frecuencias que inevitablemente acompaña a la pérdida de audición puede ser, ciertamente, $\tan$ pronunciada que obligue a que la alarma suene entre 30 y 40 decibelios más alta que los ruidos de fondo para que los trabajadores afectados la escuchen y distingan (H étu 1994b); para las personas con una capacidad auditiva normal, este valor es de entre 12 y 15 decibelios. Actualmente, es infrecuente graduar la potencia de las alarmas para contrarrestar los niveles de ruido de fondo, la merma de capacidad auditiva de los trabajadores o el uso de equipo de protección de la audición. Esto coloca a los trabajadores afectados en una situación de seria desventaja, en especial por lo que respecta a su seguridad.

En vista de las limitaciones citadas, la rehabilitación debe basarse en un análisis riguroso de la compatibilidad de la agudeza de percepción auditiva exigida con la capacidad auditiva residual de los trabajadores afectados. Existen técnicas de determinación clínica de la capacidad de las personas para percibir señales acústicas en presencia de ruidos de fondo, como

Figura 17.3 - Modelo de limitaciones producidas por la pérdida auditiva.

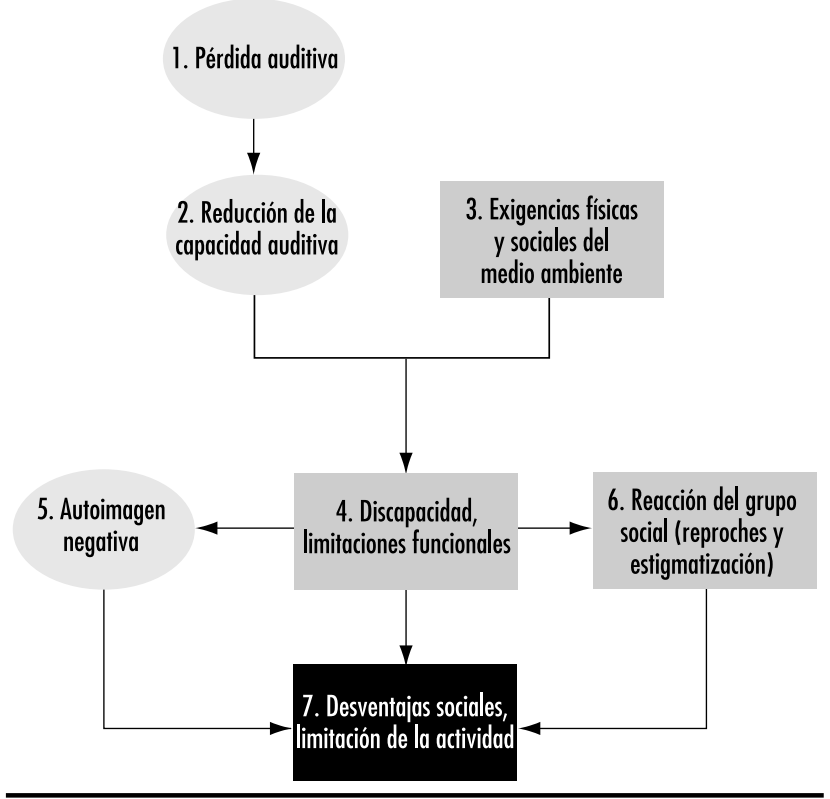


el paquete de software Detectsound ${ }^{\mathrm{TM}}$ (Tran Quoc, Hétu y Laroche 1992). Estos sistemas permiten simular la percepción auditiva, tanto normal como deficiente, tomando en consideración las características del ruido producido en los lugares de trabajo y los efectos del equipo de protección auditiva. Evidentemente, toda medida orientada a reducir el nivel de ruidos facilita la percepción de las alarmas acústicas; no obstante, es preciso adaptar los niveles acústicos de las alarmas a la capacidad auditiva residual de los trabajadores afectados.

En algunos casos de pérdida auditiva relativamente intensa, puede ser preciso, bien recurrir a otros tipos de alarmas, bien complementar la capacidad auditiva. Por ejemplo, es posible transmitir señales de alarma en anchuras de banda de frecuencia modulada, y recibirlas en una unidad portátil conectada directamente a un audífono. Este sistema es sumamente efectivo, siempre que: (1) la clavija del audífono se ajuste perfectamente (con el fin de atenuar el ruido de fondo), y (2) la curva de respuesta del audífono se ajuste en la medida precisa para compensar el efecto de enmascaramiento del ruido de fondo, atenuado por la clavija del audífono y por la capacidad auditiva del trabajador (H étu, Q uoc y Tougas 1993). Es posible ajustar el audífono hasta el punto de integrar los efectos de todo el espectro de los ruidos de fondo, la atenuación producida por la clavija del audífono y el umbral auditivo del trabajador. La cuantificación de la capacidad de determinación de frecuencias del trabajador permite optimizar los resultados. También es posible utilizar el receptor de frecuencia modulada del audífono para facilitar la comunicación oral con los compañeros de trabajo, si esto resulta imprescindible para la seguridad del trabajador.

En ciertos casos, es preciso modificar el diseño del propio puesto de trabajo para garantizar la seguridad del trabajador.

\section{Audición y problemas de comunicación}

Se suelen utilizar señales acústicas para informar a los trabajadores de la situación de los procesos productivos y como medio de comunicación entre ellos. En los lugares de trabajo en que se emplean estos sistemas, las personas afectadas de pérdida auditiva deben recurrir a otras fuentes de información para realizar su trabajo. Estas soluciones alternativas pueden consistir en una supervisión visual rigurosa y en la discreta colaboración de los compañeros. La comunicación oral, por teléfono o en reuniones celebradas con los superiores en talleres con fuertes ruidos de fondo, impone un considerable effuerzo a los afectados y plantea serios problemas a estos discapacitados que trabajan en centros industriales. Como estas personas se sienten inclinadas a ocultar sus problemas de audición, se encuentran atenazadas por el temor de no poder afrontar las situaciones o de cometer graves errores. Tal situación puede ser causa de profunda ansiedad (H étu y G etty 1993).

En estas circunstancias, la rehabilitación se debe orientar inicialmente a lograr que la empresa y sus representantes sean conscientes de que algunos de sus trabajadores experimentan problemas de audición provocados por la exposición al ruido. La aceptación de estas dificultades ayuda a los afectados a reconocerlas y a servirse de los medios precisos para mitigarlas. Sin embargo, es preciso que existan tales medios. A este respecto, sorprende extraordinariamente comprobar que, por regla general, el receptor de los teléfonos instalados en los lugares de trabajo carece de amplificadores adaptados a los trabajadores aquejados de pérdida auditiva, y que en las salas de reuniones se echan de menos sistemas adecuados (por ejemplo, transmisores y receptores de frecuencia modulada o de infrarrojos). Por último, se precisa una política de divulgación de las necesidades de los afectados de pérdida auditiva. El estrés causado por los problemas de comunicación se reduciría considerablemente si las medidas que facilitan la comunicación con los afectados se conociesen mejor. Estas medidas se aplican en la secuencia siguiente:

- acercarse a la persona afectada y hablarle cara a cara;

- articular el lenguaje sin exageración;

- repetir las frases que no se hayan entendido perfectamente, empleando un vocabulario distinto;

- mantenerse lo más lejos posible de los focos de ruido.

Es evidente que cualquier medida que contribuya a reducir la intensidad del eco y los niveles de ruido en el lugar de trabajo facilita igualmente la comunicación con las personas afectadas de pérdida auditiva.

\section{Obstáculos a la integración social}

El eco y los ruidos presentes en el lugar de trabajo dificultan la comunicación en tal medida que, a menudo, ésta debe limitarse al mínimo imprescindible para realizar las distintas tareas. Se produce así un grave deterioro de la comunicación informal, que constituye uno de los factores definitorios de la calidad de la vida laboral (H étu 1994a). La situación se hace especialmente difícil para los afectados de una pérdida auditiva. En efecto, los trabajadores que sufren de pérdida auditiva de origen profesional se ven aislados de sus compañeros, no sólo en el puesto de trabajo, sino también durante las pausas y comidas, en una típica manifestación de la combinación de unas exigencias laborales excesivas y el temor al ridículo que ellos mismos sienten.

La solución de este problema pasa por la aplicación de las medidas indicadas anteriormente, como la reducción de los niveles globales de ruido - sobre todo en las áreas de descanso - y la sensibilización de los compañeros de trabajo hacia los problemas de los afectados. Asimismo, el reconocimiento de las necesidades específicas de los afectados por parte de la empresa constituye, en sí mismo, una forma de apoyo psicológico y social, capaz de mitigar el estigma normalmente asociado a los problemas de audición.

\section{Obstáculos a la promoción profesional}

U na de las causas de que los afectados por una pérdida auditiva de origen profesional realicen tales esfuerzos por ocultar su problema es el temor real a verse en una situación de desventaja profesional (H etu y G etty 1993); algunos temen, incluso, por su puesto de trabajo si se descubre su pérdida de audición. L a consecuencia directa de esta reacción es una autolimitación de la carrera profesional, que puede implicar la renuncia a optar por el puesto de supervisor, supervisor de turnos o capataz. Lo mismo ocurre en el ámbito de la movilidad profesional fuera de la empresa, puesto que muchos trabajadores experimentados desaprovechan sus cualificaciones por temor a que las pruebas audiométricas bloqueen su acceso a mejores puestos de trabajo. Esta autolimitación no constituye el único obstáculo que la pérdida auditiva supone para la promoción profesional. De hecho, algunos trabajadores han denunciado las prácticas discriminatorias de la empresa cuando se trata de cubrir puestos de trabajo que precisan una comunicación oral fluida.

Al igual que ocurre con otros aspectos de la discapacidad anteriormente reseñados, el reconocimiento por parte de la empresa de las necesidades específicas del trabajador contribuye en gran medida a eliminar las barreras a la promoción profesional. Desde la perspectiva de los derechos humanos (H étu y $G$ etty 1993), los afectados tienen igual derecho a disfrutar de las opciones de promoción que el resto de los trabajadores, y una adaptación adecuada de los lugares de trabajo puede facilitar su acceso a los puestos superiores.

En resumen, la prevención de la discapacidad en el lugar de trabajo pasa por la sensibilización de la empresa y de los 
compañeros de trabajo hacia las necesidades específicas de los afectados por una pérdida auditiva de origen profesional. Esta política de sensibilización se puede complementar con una campaña informativa sobre los síntomas y efectos de la pérdida auditiva inducida por el ruido, dirigida a disipar la idea errónea de que se trata de un fenómeno improbable de escasa relevancia. El empleo de audífonos y otros medios sólo es posible si su utilidad está reconocida por los compañeros y superiores del afectado, y por el propio trabajador.

\section{Actividades sociales}

Las personas afectadas por una pérdida auditiva de origen profesional se encuentran en situación desventajosa en los lugares con acústica deficiente, por ejemplo, en presencia de un eco o de ruidos de fondo, en las situaciones que requieren la comunicación a distancia y en las conversaciones telefónicas. En la práctica, esta situación limita en medida considerable su vida social, al dificultar su acceso a los servicios públicos y a las actividades culturales, con el consiguiente menoscabo de su integración social (H étu y G etty).

\section{Acceso a los servicios públicos y a las actividades culturales}

Según el modelo de la Figura 17.3, en la limitación del acceso a las actividades culturales se pueden distinguir cuatro elementos (elementos 2, 3, 5 y 6), para cuya eliminación se precisan múltiples intervenciones. Por ejemplo, se puede facilitar el acceso de los afectados por una pérdida auditiva a los templos, auditorios y salas de concierto dotando a éstos de medios de audición adecuados, como los sistemas de frecuencia modulada o de transmisión por infrarrojos (elemento 3 ) e informando a sus responsables de las necesidades de aquéllos (elemento 6). No obstante, los afectados sólo solicitan la instalación de equipo de audición si conocen su existencia, saben cómo utilizarlo (emento 2) y han recibido la ayuda psicosocial necesaria para reconocer y transmitir su necesidad de disponer del equipo (elemento 5).

En el contexto de un programa experimental de rehabilitación (G etty y H étu 1991, H étu y G etty 1991a), se han desarrollado diversas técnicas eficaces de comunicación, formación y apoyo psicosocial de los trabajadores con deficiencia auditiva, que se examinan posteriormente, en "Vida familiar".

El acceso de las personas con deficiencias auditivas a lugares y servicios públicos como bancos, grandes almacenes y servicios oficiales y de salud se dificulta, principalmente, por el desconocimiento de estas instituciones. Por ejemplo, en algunos bancos, los clientes se encuentran separados por mamparas de vidrio del personal de ventanilla que, a veces, se dedica a informatizar datos 0 a rellenar impresos mientras habla con ellos. Los efectos acumulados de la falta de comunicación directa, de unas condiciones acústicas desfavorables y de una comunicación en la que cualquier malentendido puede tener consecuencias desastrosas hacen que esta situación sea extremadamente difícil para los afectados. En los centros de salud, los pacientes esperan en salas relativamente ruidosas a que les nombre un empleado situado a una distancia considerable o a través de un sistema de megafonía que en ocasiones es difícilmente audible. A pesar de que los pacientes con pérdida auditiva experimentan una gran ansiedad ante la posibilidad de no acudir a la llamada, no suelen informar al personal de sus problemas de audición. Este tipo de comportamiento es relativamente frecuente.

Por regla general, resulta posible superar estas situaciones desventajosas informando al personal sobre los síntomas y efectos de la sordera parcial y de los medios para facilitar la comunicación con los afectados. Algunos servicios públicos ya han adoptado medidas para facilitar la comunicación con los afectados por la pérdida auditiva de origen profesional (H étu,
Getty y Bédard 1994), con los resultados que se indican a continuación. El empleo de medios gráficos y audiovisuales permite transmitir la información necesaria en menos de 30 minutos y conseguir que los conocimientos adquiridos se conserven seis meses después de las reuniones informativas. Este sistema facilita en gran medida la comunicación con el personal de los servicios afectados. Se obtienen sustanciales beneficios de su aplicación, no sólo para los clientes afectados por la pérdida auditiva, sino también para el propio personal, cuyas tareas se han simplificado con la prevención de situaciones de este tipo.

\section{Integración social}

U na de las secuelas más negativas de la pérdida auditiva de origen profesional es la tendencia a evitar las conversaciones en grupo, que imponen un considerable esfuerzo a los afectados. En tales situaciones, éstos deben tratar de adaptarse a los demás, ya que suele resultar sumamente difícil que el ritmo de la conversación y la forma de expresión del grupo se ajuste a sus circunstancias. L os afectados pueden afrontar esta situación de tres formas:

- interpretando la expresión facial;

- empleando técnicas de comunicación especiales;

- empleando un audífono.

Evidentemente, la interpretación de la expresión facial y la lectura labial pueden facilitar la comprensión de las conversaciones; sin embargo, estas técnicas exigen un grado considerable de atención y concentración, imposible de mantener durante mucho tiempo. En todo caso, el sistema puede ser de utilidad si, además, se pide a los interlocutores que repitan o resuman sus palabras. Ahora bien, las conversaciones suelen discurrir con una velocidad tal que el recurso a esta estrategia no suele resultar fácil. Por último, si bien el uso de un audífono suele mejorar la capacidad para seguir las conversaciones, los dispositivos de amplificación actualmente en uso no restauran la capacidad de discriminación de frecuencias; esto es, se amplifican tanto la señal como el ruido, lo cual contribuye a empeorar, antes que mejorar, la situación de las personas que experimentan una seria discapacidad de la discriminación de frecuencias.

El empleo de los audífonos y la petición de la colaboración de los interlocutores para que se adapten a las circunstancias del discapacitado presupone que éste no se sienta acomplejado al reconocer su problema. Esto significa que, como se expone posteriormente, las medidas de fortalecimiento de la autoestima constituyen una condición previa a los esfuerzos por incrementar la capacidad auditiva.

\section{Vida familiar}

La familia es el escenario principal de la expresión de los problemas producidos por la pérdida auditiva de origen profesional (H étu, Jones y Getty 1993). La aparición de una autoimagen negativa es el principal resultado de la pérdida auditiva, por lo que los afectados procuran enmascarar su problema en sus relaciones sociales agudizando la atención o esquivando las situaciones especialmente difíciles. Estos esfuerzos y la ansiedad que producen crean la necesidad de desahogarse en el ámbito familiar, en el que la necesidad de ocultar la situación personal es menos acuciante. Por esto, los afectados suelen trasladar sus problemas a los familiares y tienden a coaccionarles para que se adapten a sus problemas de audición. Con ello se impone un pesado gravamen al cónyuge y al resto de la familia, que se resienten al tener que repetir las cosas, oír la televisión a todo volumen y "tener que ponerse siempre al teléfono". El cónyuge se ve sometido, además, a serias limitaciones en la vida social de la pareja y a otras importantes restricciones en la vida familiar. La pérdida de audición empobrece la convivencia y la intimidad, 
genera tensiones, malentendidos y conflictos, además de perturbar las relaciones con los hijos.

L as dificultades auditivas y los problemas de comunicación no solamente perjudican la intimidad, sino que, además, su percepción por parte de los afectados y de su entorno familiar (elementos 5 y 6 de la Figura 17.3) genera frustración, enfado y resentimiento ( $H$ étu, Jones y $G$ etty 1993). Los afectados suelen negarse a reconocer su deficiencia y no atribuyen sus problemas de comunicación a un déficit auditivo. Esto les lleva a trasladar sus dificultades a los familiares, en vez de procurar una adaptación mutuamente satisfactoria. Por su parte, el cónyuge suele percibir el problema como una negativa a comunicarse y como una modificación del carácter de la persona afectada. La situación puede desembocar en reproches y acusaciones mutuos y, finalmente, al aislamiento, la soledad y la tristeza, sobre todo para el cónyuge que no padece la insuficiencia.

La solución de esta crisis de relación precisa el esfuerzo de ambos miembros de la pareja, que necesitan:

- información sobre el origen auditivo del problema;

- apoyo psicosocial;

- aprendizaje del empleo de medios complementarios de comunicación.

Sobre la base de estos datos, se ha elaborado un programa de rehabilitación destinado a los pacientes y a sus cónyuges (G etty y Hétu 1991, Hétu y Getty 1991a). Su objetivo es fomentar la investigación de la solución de los problemas provocados por la pérdida auditiva, teniendo en cuenta la pasividad y la marginación social característicos de los aquejados por la misma.

Puesto que el estigma que la sordera produce es la causa principal de este tipo de comportamientos, era imprescindible crear un entorno propicio para la recuperación de la autoestima, que indujese a las personas afectadas a buscar decididamente soluciones a sus problemas de audición.

El estigma de la sordera sólo se puede borrar si se convence a los demás de que se es una persona normal a pesar del déficit auditivo. Los trabajadores consultados sobre la ayuda más efectiva que se puede prestar a los compañeros con deficiencias auditivas han sugerido que el medio más eficaz para alcanzar este objetivo consiste en conocer a otras personas con idénticos problemas. Sin embargo, es preciso que estos contactos tengan lugar fuera del lugar de trabajo, precisamente para evitar el riesgo de que el estigma se acentúe (H étu, G etty y Waridel 1994).

Esta realidad se ha tenido en cuenta en el desarrollo del programa de rehabilitación anteriormente mencionado, y las reuniones con los afectados tuvieron lugar en un servicio de salud comunitario (G etty y H étu 1991). La selección de los participantes constituía uno de los elementos fundamentales del programa, dadas la pasividad y la automarginación de la población destinataria del programa. Por tanto, varias enfermeras de empresa se reunieron inicialmente con los aquejados por la pérdida auditiva y con sus cónyuges en el domicilio de éstos. Al término de la conversación, centrada en los problemas de audición y sus efectos, se invitó a las parejas a participar en una serie de cuatro reuniones semanales vespertinas de dos horas de duración. Las reuniones se desarrollaron según un calendario rígido, centrado en los objetivos de información, apoyo y formación establecidos en el programa. L os participantes fueron posteriormente objeto de un seguimiento dirigido a facilitar su acceso a los servicios audiológicos y a las prótesis auditivas. Tres meses después de la última reunión semanal, tuvo lugar otro encuentro con los participantes.

Los resultados del programa, recogidos al final de la fase experimental, pusieron de relieve que los participantes y sus cónyuges eran más conscientes de su problema auditivo y se mostraban más confiados en poder superarlos. En efecto, los trabajadores habían adoptado algunas medidas, incluido el uso de audífonos, que revelaban su padecimiento auditivo a su círculo social y su necesidad de ayuda para tratar de mejorar la comunicación.

Un estudio de seguimiento realizado con el mismo grupo de personas al cabo de cinco años de su participación en el programa demostró que éste había servido, efectivamente, para inducir a los participantes a buscar soluciones. El estudio puso igualmente de relieve que la rehabilitación es un proceso complejo, que requiere varios años de esfuerzo antes de que los afectados estén en condiciones de valerse de todos los medios disponibles para reintegrarse en la sociedad. En la mayoría de los casos, este proceso de rehabilitación precisa unos seguimientos periódicos.

\section{Conclusión}

Como se ilustra en la Figura 17.3, la percepción que tanto las personas afectadas por una pérdida auditiva de origen profesional como sus allegados tienen de su situación constituye un factor clave en los casos de minusvalía. En los métodos de rehabilitación que se describen en el presente estudio se ha tenido muy en cuenta dicho factor.

No obstante, la aplicación concreta de estos métodos es una función del contexto sociocultural específico, dado que la percepción de estos fenómenos puede variar de uno a otro. Incluso en el contexto sociocultural en que se desarrollaron las técnicas anteriormente descritas puede ser preciso introducir modificaciones significativas. Por ejemplo, el programa destinado a las personas afectadas por una pérdida auditiva de origen profesional y a sus cónyuges (Getty y Hétu 1991) se ensayó con una población de varones afectados.

Probablemente se precisarían estrategias diferentes en el caso de una población de mujeres afectadas, sobre todo si se toman en consideración las distintas funciones que varones y mujeres desempeñan en las relaciones conyugales y paternofiliales (H étu, Jones y G etty 1993).

Sería igualmente preciso introducir modificaciones ad hoc en otros contextos culturales distintos del norteamericano, en el que se desarrollaron los métodos. Con todo, el esquema conceptual propuesto (Figura 17.2) puede servir para orientar eficazmente cualquier medida de rehabilitación de las personas afectadas por una pérdida auditiva de origen profesional.

Por otra parte, si este tipo de medidas se aplican en gran escala, contribuyen en gran medida a prevenir la propia pérdida auditiva. D e hecho, los aspectos psicosociales de la pérdida auditiva de origen profesional dificultan tanto la rehabilitación (Figura 17.3) como la prevención.

Además de que la percepción distorsionada de los problemas de audición demora su reconocimiento, la ocultación del problema por parte de los individuos seriamente afectados refuerza la impresión generalizada de que se trata de un fenómeno infrecuente y relativamente inocuo, incluso en los lugares de trabajo más ruidosos. Esto impide que tanto las empresas como los trabajadores expuestos al riesgo perciban la pérdida auditiva producida por el ruido como un grave problema de salud; y es la causa de que no exista una conciencia real de la necesidad de adoptar medidas de protección en los lugares de trabajo más ruidosos.

Por otra parte, las personas que ya padecen una discapacidad auditiva y que reconocen el problema son ejemplos ilustrativos de la gravedad de la situación. Por tanto, la rehabilitación debe constituir el primer paso de una política de prevención. 


\section{- DERECHOS Y OBLIGACIONES: EL PUNTO DE VISTA DE LA EMPRESA}

\section{Susan Scott-Parker}

Ante el escaso éxito del método tradicionalmente aplicado para facilitar la incorporación al trabajo de los discapacitados, es evidente que se precisa un cambio radical. Por ejemplo, las tasas oficiales de desempleo de los discapacitados son, invariablemente, el doble de las correspondientes a los no discapacitados, cuando no mayores. El porcentaje de discapacitados que no trabajan se suele acercar al 70 por ciento (Estados U nidos, Reino U nido y Canadá). A demás, hay muchos más discapacitados en situación de pobreza que no discapacitados; por ejemplo, dos tercios de los 6,2 millones de discapacitados del Reino U nido no tienen otros ingresos que las prestaciones estatales.

Estos problemas se complican debido a la incapacidad que habitualmente experimentan los servicios de rehabilitación para satisfacer la demanda de las empresas de personal cualificado.

En muchos países, la discapacidad no se suele definir en términos jurídicos ni de igualdad de oportunidades, por lo que resulta difícil promover una ética empresarial en la que la discapacidad se equipare al sexo y a la raza en la política de igualdad de oportunidades o de prioridad de la diversidad. Tanto la proliferación de las cuotas como la falta absoluta de legislación específica refuerzan la presunción de las empresas de que la discapacidad es, básicamente, un problema médico 0 de beneficencia.

Las frustraciones generadas por la insuficiencia de los sistemas actuales tienen su reflejo en la demanda creciente de los propios discapacitados de una legislación basada en los derechos civiles, en el derecho al trabajo o en ambas cosas, del tipo de la existente en Estados U nidos, Australia y, desde 1996, también en el Reino U nido. La incapacidad del sistema de rehabilitación para satisfacer las necesidades y expectativas de las empresas más avanzadas ha sido lo que ha impulsado a la comunidad empresarial británica a crear el Employers' Forum on Disability.

L amentablemente, las actitudes de las empresas son un reflejo de la postura del conjunto de la sociedad, si bien los profesionales de la rehabilitación suelen pasar por alto esta circunstancia. En efecto, los empresarios comparten con otros sectores sociales ciertos errores generalizados respecto a cuestiones como las siguientes:

- ¿Q ue es la discapacidad? ¿Q uién es discapacitado y quién no?

- ¿Quién me puede asesorar y prestar los servicios necesarios para contratar y emplear a personas discapacitadas?

- ¿Cómo puedo modificar la cultura de mi organización y mis sistemas de trabajo?

- ¿Que beneficios pueden generar los mejores sistemas de gestión de la discapacidad a mi empresa y al conjunto de la economía?

Esta incapacidad para satisfacer las expectativas de información y de servicios de la comunidad empresarial constituye un serio obstáculo para los discapacitados que desean trabajar; sin embargo, el problema no suele ser abordado correctamente por los profesionales de la rehabilitación ni por los responsables de la formulación de políticas públicas.

\section{Mitos arraigados que colocan a los discapacitados en una situación desventajosa en el mercado de trabajo}

Las organizaciones no gubernamentales (O NG), las administraciones públicas $\mathrm{y}$, sin duda, todos cuantos participan en la rehabilitación médica y profesional de los discapacitados, suelen compartir una serie de presunciones arraigadas, a menudo no reconocidas, que no hacen sino acentuar la situación desventajosa de los discapacitados a quienes pretenden ayudar:

- "La empresa es el problema; a menudo, incluso, el enemigo". Se suele culpar a las empresas de las dificultades que los discapacitados experimentan para encontrar trabajo, a pesar de la evidencia de que muchos otros factores pueden ser igualmente importantes.

- "Las empresas no son consideradas clientes ni usuarios". En efecto, los servicios de rehabilitación no miden el éxito de su gestión por la medida en que hacen posible que las empresas contraten y empleen a personas discapacitadas. En consecuencia, las dificultades injustificadamente creadas por los prestadores de servicios de rehabilitación hacen difícil que las empresas más avanzadas y mejor intencionadas encuentren justificación al coste y los esfuerzos necesarios para materializar el cambio. Por su parte, las empresas peor informadas encuentran una coartada perfecta para su reticencia a cambiar en la falta de cooperación de los servicios de rehabilitación.

- "Los discapacitados no pueden competir efectivamente sobre la base de los méritos". M uchos prestadores de servicios depositan escasas expectativas en el potencial de los discapacitados para el trabajo. Les resulta difícil convencer a las empresas, porque ellos mismos dudan de que el empleo de discapacitados produzca auténticos beneficios mutuos. Por el contrario, el tono y los principios subyacentes en su relación con las empresas hacen hincapié en la obligación moral y jurídica (laboral) en una forma que sólo contribuye a recrudecer el estigma que acompaña a los discapacitados.

- "La discapacidad no constituye un problema económico importante. Lo mejor es confiarla a los expertos, médicos, prestadores de servicios de rehabilitación y entidades benéficas". La circunstancia de que los medios de comunicación y las campañas de recaudación de fondos proyecten la imagen de la discapacidad como un problema de beneficencia, y de que se presente a los discapacitados como receptores pasivos de ayuda, constituye un obstáculo formidable al empleo de éstos y genera tensiones en unas organizaciones que, por una parte, procuran colocar a las personas $y$, por otra, recurren a imágenes que despiertan las fibras más sensibles de la gente.

Estas presunciones tienen dos consecuencia:

- Las empresas y los discapacitados se encuentran todavía separados por un laberinto de servicios prestados con las mejores intenciones, pero generalmente fragmentarios y mal coordinados, en los que el éxito raras veces se mide por el grado de satisfacción de las empresas.

- Los discapacitados y las empresas se encuentran igualmente privados de toda influencia efectiva sobre la elaboración de las políticas, pues es muy raro que se les pida que evalúen los servicios desde su perspectiva particular y que propongan soluciones.

A sistimos al nacimiento de una tendencia de ámbito internacional - caracterizada por el desarrollo de los servicios de "entrenamiento para el trabajo" - al reconocimiento de que el éxito de la rehabilitación de los discapacitados es una función de la calidad de los servicios y del apoyo prestado a la empresa.

Es seguro que el principio de que "mejores servicios para las empresas suponen mejores servicios a los discapacitados" será objeto de mayor aceptación a medida que aumenta la presión económica sobre las empresas en virtud de la política de reestructuración y ahorro aplicada por las administraciones públicas. No obstante, resulta sumamente significativo que, en un reciente informe de Helios (1994), en el que se resumen las 
competencias que precisan los especialistas en rehabilitación profesional, no se haga mención alguna de la necesidad de adquirir cualificaciones asociadas al tratamiento de las empresas como clientes.

Si bien se observa una conciencia cada vez mayor de la necesidad de trabajar en asociación con las empresas, nuestra experiencia demuestra la dificultad de establecer y mantener esta asociación hasta tanto los profesionales de la rehabilitación no satisfagan inicialmente las exigencias de las empresas como clientes y comiencen a valorar tal relación con éstas "en calidad de clientes".

\section{Funciones de las empresas}

En diversas ocasiones y en diferentes coyunturas, el funcionamiento de los sistemas y servicios induce a las empresas a desempeñar una o más de las funciones siguientes, que, no obstante, no se suelen estructurar.

- el problema: "se precisa esclarecimiento";

- el objetivo: "se precisan educación, información y sensibi- lización";

- el cliente: "inducir a la empresa a utilizar nuestros servicios para contratar y emplear a personas discapacitadas";

- la asociación: inducir a la empresa a "establecer una relación duradera y mutuamente satisfactoria".

Además, mientras dure la relación, es posible - en realidad, es lo más probable - que se recabe de la empresa que asuma funciones filantrópicas o de financiación.

La clave del éxito consiste en tratar a la empresa como "cliente". De hecho, los sistemas en que se valora únicamente a la empresa como "el problema" o "el objetivo" están abocados a un círculo vicioso de disfunciones.

\section{Factores independientes de la voluntad de la empresa}

La identificación de las actitudes negativas manifestadas por las empresas como la causa principal de que los discapacitados sufran elevadas tasas de desempleo contribuye sistemáticamente a desviar la atención de otros problemas importantes que se deben abordar para lograr un cambio efectivo.

Por ejemplo:

- Una encuesta recientemente realizada en el Reino Unido reveló que el $80 \%$ de las empresas no eran conscientes de haber recibido jamás una sola solicitud de empleo de un discapacitado.

- Los sistemas de bienestar social y de prestaciones suelen desincentivar la incorporación al trabajo de los discapacitados.

- Tanto las redes de transporte como las áreas de vivienda son notoriamente inaccesibles, y las personas sólo pueden confiar en encontrar trabajo cuando han satisfecho sus necesidades básicas de vivienda, transporte y subsistencia.

- Según una encuesta reciente del Reino U nido, el 59 \% de los demandantes de empleo discapacitados carecían de cualificación, en contraste con un $23 \%$ de trabajadores no cualificados entre los demás demandantes. Por regla general, los discapacitados se ven, sencillamente, imposibilitados de competir en el mercado de trabajo a menos que posean un nivel de cualificación competitivo.

- Los profesionales de la medicina suelen subestimar el potencial de los discapacitados para rendir en el trabajo y, por tanto, se muestran incapaces de recomendar los ajustes y adaptaciones precisos para que éstos puedan acceder al empleo.

- Es improbable que los discapacitados reciban orientaciones válidas para su promoción profesional, y sus posibilidades son sistemáticamente subestimadas por profesores y asesores.
- Las cuotas y otras iniciativas legislativas poco felices erosionan sistemáticamente el mensaje de que la discapacidad es un problema de igualdad de oportunidades.

Un ordenamiento jurídico que genere un marco de relaciones contencioso o litigioso reduce las perspectivas de empleo de los discapacitados, debido a que su contratación podría entrañar un riesgo para la empresa.

L os profesionales de la rehabilitación suelen tener dificultades para conseguir una formación y titulación especializadas, y pocas veces cuentan con la financiación necesaria para suministrar a las empresas los productos y servicios idóneos.

\section{Implicaciones para la política}

Es imprescindible que los prestadores de servicios de rehabilitación sean conscientes de que, antes de que la empresa pueda llevar a cabo cambios en la organización y en su cultura, ellos mismos deben protagonizar cambios similares. Los que valoran a las empresas como clientes deben comprender que la atenta consideración de sus demandas genera, de forma casi inevitable, la necesidad de modificar el diseño y la prestación de los servicios.

Por ejemplo, se suele recabar de los prestadores de servicios que faciliten a la empresa las tareas siguientes:

- encontrar solicitantes cualificados;

- conseguir servicios de asesoramiento y de otro tipo orientados a la empresa y de elevada calidad;

- dirige a los discapacitados en calidad de solicitantes y de compañeros;

- entender, no sólo la necesidad de un cambio de política, sino también la forma de producir este cambio;

- promover un cambio de actitudes en el conjunto de la organización;

- comprender las razones, tanto económicas como sociales, para emplear a los discapacitados.

Los esfuerzos por reformar en profundidad la política social aplicada a los discapacitados se resienten del desconocimiento de las necesidades, las expectativas y las exigencias legítimas de los agentes de los que depende en buena medida el éxito del intento, esto es, de las empresas. Por ejemplo, en los esfuerzos por lograr que las personas que actualmente trabajan en talleres protegidos se incorporen al trabajo regular se suele pasar por alto la circunstancia de que únicamente las empresas están en condiciones de ofrecer ese trabajo. A sí se limitan las perspectivas de éxito, no sólo porque se entorpece innecesariamente la capacidad de la empresa para crear oportunidades de empleo, sino también por la pérdida de las sinergias que resultarían de la colaboración dinámica entre la empresa y los responsables de la formulación de políticas.

\section{Posibilidades de participación de las empresas}

Es posible inducir a las empresas a que contribuyan de varias formas a una evolución gradual del empleo protegido al empleo libre 0 apoyado. A tal fin, las empresas pueden:

- Prestar asesoramiento en la formulación de políticas, esto es, respecto a lo que hay que hacer para lograr que las empresas ofrezcan trabajo a los discapacitados;

- Prestar asesoramiento sobre las cualificaciones que los discapacitados necesitan para encontrar trabajo;

- Prestar asesoramiento sobre las cualificaciones que los prestadores de servicios precisan para satisfacer las exigencias de las empresas de un servicio de calidad;

- Evaluar los talleres protegidos y ofrecerles asesoramiento práctico sobre el modo de gestionar un servicio orientado a facilitar la incorporación de las personas al trabajo regular; 


\section{Ejemplos de buenas prácticas}

\section{SABRE Employment (Reino Unido)}

\section{Declaración de intenciones}

Difundir los propósitos globales y empresariales, que no se limitan a la prestación de un servicio de calidad a los solicitantes, sino que, además, reflejan claramente la voluntad de brindar a las empresas un servicio de selección eficaz que les permita mejorar sus posibilidades de contratación de discapacitados. Se debe hacer hincapié en el objetivo fundamental de la satisfacción del cliente. "Toda la actividad de Sabre comienza con el cliente. $\mathrm{N}$ uestro objetivo consiste en ofrecer soluciones para la selección del personal mediante una adaptación efectiva al perfil del puesto de trabajo y un servicio adecuado de apoyo y formación, gracias a nuestra experiencia en la selección y contratación de personas discapacitadas."

Recientemente se celebró una feria del trabajo que sirvió de foro para que las personas se familiarizaran con las empresas y los distintos puestos de trabajo. MacDonald Restaurants Ltd. organizó un seminario sobre la técnicas de entrevista y patrocinó la feria en colaboración con Shell y Pizza Hut. Las empresas organizaron muestras que sirvieron de marco a la celebración de contactos informales con empleados potenciales con dificultades de aprendizaje.

\section{Programa de bolsas de Coverdale (Reino Unido)}

Coverdale, pequeña empresa británica de consultoría de gestión (70 empleados), lleva cinco años ofreciendo bolsas de formación de 10.000 libras por persona a los discapacitados que desean recibir formación de gestión de alto nivel. A continuación, estas personas se incorporan a entidades como Barclays Bank, Correos y M idland Bank, para proseguir su formación en un proceso que, a largo plazo, propicia un cambio de actitud por parte de las entidades participantes. El programa, que actualmente se encuentra en vías de expansión, ha sido adaptado por The Canadian Council for Rehabilitation and W ork.

\section{Brook Street y FYD (Reino Unido)}

La empresa privada de selección Brook Street lleva varios años colaborando con Friends for the Young Deaf (FYD), entidad no lucrativa que se ocupa de los jóvenes invidentes. Brook Street ofrece experiencia de trabajo y servicios de evaluación de los jóvenes invidentes licenciados que cursan el programa FYD de formación de mandos. Por último, coloca a los aspirantes mejor cualificados, por los que factura los mismos honorarios que por los demás aspirantes.

\section{Employers' Forum on Disability (Reino Unido)}

Las empresas participantes en el Employers's Forum on Disability, sociedad financiada por la comunidad empresarial y dedicada a promover la integración de los discapacitados en el mercado de trabajo y a prestar servicios de asesoramiento a las empresas interesadas, ayudó al empresario discapacitado Stephen Duckworth a crear su propia empresa, Disability Matters, que actualmente ofrece servicios de consultoría de alto nivel y de difusión del conocimiento de los problemas de los discapacitados en el Reino Unido. Los principios de la empresa se resumen en los aspectos siguientes:

- conocer y definir las razones empresariales para contratar a los discapacitados

- actuar como portavoz autorizado de las empresas en cuestiones de la discapacidad
- prestar servicios de formación y empleo más orientados al mercado;

- investigar nuevas formas de a traer a los solicitantes discapacitados y de mantener en la empresa a los trabajadores con discapacidades;

La clave para influir en las empresas e inducirlas a participar es construir un entramado que:

- promueva la idea mediante la comunicación de empresa a empresa;

- promueva los contactos personales entre los discapacitados y las empresas;

- haga posible que la empresa asuma la cuestión como propia y fomente entre los prestadores de servicios de rehabilitación la convicción de que se le debe tratar como un agente social, un cliente y un posible asociado;

- sitúe la discapacidad en el marco del debate más general sobre la regeneración económica y social, el desempleo de larga dura. ción, la pobreza y las políticas micro y macroeconómica.

\section{Otros ejemplos británicos: la Employers Agenda on Disability}

Varias importantes empresas británicas han elaborado un impor tante documento marco de política, titulado "Employers Agenda on Disability: a Ten Point Plan". El plan, lanzado por el Primer M inistro, ha merecido el refrendo público de más de cien grandes empresas y se ha convertido en un importante motor del cambio, ya que ha sido elaborado por las propias empresas en coordina ción con expertos en discapacidad. En la actualidad, el documento constituye una ayuda inestimable para las empresas en el cumplimiento de la legislación contra la discriminación.

Los patrocinadores de la Agenda se han comprometido públicamente a configurar su política social en materia de discapacidad sobre la base de un decálogo en el que se abordan las cuestiones siguientes: declaración sobre principios y procedimientos de igualdad de oportunidades; formación del personal y sensibilización respecto a la discapacidad; el medio ambiente de trabajo; contratación; promoción profesional; retención, readaptación profesional y asignación de nuevas tareas; formación y experiencia de trabajo; los discapacitados en el conjunto de la sociedad; participación de los discapacitados, y control del rendimiento.

El Employers' Forum on Disability ha elaborado el manual Action File on Disability, en el que se ofrece información práctica sobre la aplicación del plan precedentemente expuesto.

\section{Contratación de licenciados}

Un total de más de veinte empresas han creado un consorcio que colabora con "W orkable", entidad que media en el ofrecimiento sistemático y organizado de oportunidades de realizar prácticas de trabajo a los estudiantes discapacitados.

Veinticinco empresas financian conjuntamente un programa de organización de ferias anuales de oportunidades profesionales para los estudiantes, a las que tienen acceso los alumnos discapacitados. Actualmente es posible acceder al recinto ferial en silla de ruedas; además, se ofrecen servicios de interpretación a los sordomudos, se distribuyen folletos impresos en grandes caracteres y se brindan otras ayudas. Las empresas han experimentado tales dificultades con los métodos tradicionales para atraer a los licenciados discapacitados que han optado por experimentar nuevos sistemas de captación directamente dirigidos a los estudiantes discapacitados. 


\section{HIRED (Estados Unidos)}

El proyecto HIRED, que se desarrolla en San Francisco, refleja esta nueva orientación de las empresas. HIRED es la sigla de Helping Industry Recruit Employees with Disabilities y en el material impreso que edita se ponen de relieve los servicios que ofrecen a los trabajadores.

"El Proyecto HIRED es una organización privada sin ánimo de lucro que desarrolla su actividad en la región de la bahía de San Francisco. N uestra misión consiste en ayudar a los discapacitados a conseguir un puesto de trabajo adecuado a sus cualificaciones y aspiraciones profesionales. 0 frecemos a las empresas los servicios siguientes:

- remisión gratuita de candidatos cualificados, previamente seleccionados, adecuados a los puestos de trabajo ofrecidos

- servicios de empleo temporal de calidad a precios competitivos

- seminarios, ajustados a las necesida des del cliente e impartidos en sus locales, sobre los aspectos técnicos, jurídicos y de relaciones personales de la discapacidad en el lugar de trabajo

- asesoramiento sobre materias relacionadas con la discapacidad en el lugar de trabajo.

Además de otros sistemas más informales de colaboración con las empresas, el Proyecto HIRED ha puesto en marcha un programa de asociación de empresas del que forman parte unas cincuenta compañías del área de la bahía de San Francisco. Las empresas asociadas tienen derecho a recibir asesoramiento gratuito y a beneficiarse de un descuento en la cuota de participación en seminarios. Actualmente se estudia la posibilidad de ofrecer nuevos servicios, como una filmoteca de producciones de vídeo, que contribuyan al éxito de los esfuerzos de las empresas asociadas por incorporar a los discapacitados a su plantilla."

\section{ASPHI (Italia)}

Los orígenes de ASPHI (Associazione per lo Sviluppo di Progetti Informatici per gli Handicappati) se remontan a los últimos años del decenio de 1970, cuando IBM Italia organizó unos cursos de programación informática para las personas afectadas por deficiencias visuales. Varias empresas, que posteriormente habían empleado a los alumnos, en colaboración con diversas organizaciones no lucrativas asociadas al proyecto, fundaron ASPHI para servir a las personas físicamente discapacitadas y a los afectados por deficiencias mentales 0 por la pérdida auditiva. La asociación está constituida por más de 40 empresas que, aparte de financiar el proyecto, aportan la colaboración de su personal y de colabo. radores voluntarios, además de facilitar asesoramiento y oportunidades de empleo a los diplomados de ASPHI. El objetivo de ASPHI es desarrollar tecnologías informáticas que permitan la integración social y profesional de los minusválidos. Sus actividades consisten en la formación profesional, la investigación y desarrollo de nuevos productos (especialmente software) que permitan el desarrollo de sistemas diferenciados de comunicación, el ejercicio de la autonomía personal y la rehabilitación; y asimismo de la educación social, contribuyendo así a la desaparición de los prejuicios y actitudes discriminatorias de los discapacitados. ASPHI forma unos sesenta jóvenes todos los años, de los que un $8,5 \%$ consiguen un puesto de trabajo fijo. El éxito de ASPHI la ha hecho acreedora del reconocimiento nacional e internacional.

\section{Una iniciativa de la Federación de Empresarios Suecos} El proyecto de la Federación de Empresarios Suecos denominado "Los discapacitados en la empresa" ha colocado la cuestión de la discapacidad en el centro del debate sobre el mercado de trabajo sueco y ha proyectado el mensaje de que la discapacidad es importante para las empresas afiliadas a la Confederación de Empresarios Suecos. Para esta Confederación: "Es preciso allanar el camino de los discapacitados hacia el empleo". ¿Condiciones para el logro de este objetivo?:

- una información exacta a las empresas de los costes y obligaciones;

- contrapartidas financieras de los costes extraordinarios en que eventua Imente incurran la emp resas que contratan discapacitados;

- un mayor conocimiento de las discapacidades y del potencial de los discapacitados para modificar actitudes y valores;

- mayor cooperación entre empresas, autoridades y personas en la creación de un mercado de trabajo dinámico y flexible".
- Ofrecer a los profesionales de la rehabilitación la experiencia laboral que precisan para familiarizarse con un sector y así mejorar el nivel de formación impartido a los discapacitados;

- Ofrecer a los discapacitados evaluación y formación en el puesto de trabajo;

- Realizar entrevistas simuladas y orientar a los discapacitados que buscan empleo;

- Destinar a su personal a trabajar en el sistema o en las instituciones que lo integran;

- Colaborar en la promoción de los servicios de las agencias de rehabilitación, recomendar políticas y organizaciones a otras empresas, y remitirles a los discapacitados que buscan empleo;

- Ofrecer una formación personalizada, participando directamente en la adquisición de destrezas profesionales por parte de los discapacitados;

- Bien participar en los órganos rectores de las agencias de rehabilitación, bien prestar informalmente servicios de asesoramiento a los proveedores y a los responsables nacionales de la formulación de políticas;

- Presionar, junto con los discapacitados y los prestadores de servicios de rehabilitación, en favor de una mejora de los programas y políticas públicos;

- Facilitar especificaciones sobre los servicios y productos que precisan, con objeto de mejorar su calidad.

\section{La empresa como cliente}

Es imposible que los profesionales de la rehabilitación se asocien estrechamente con las empresas si no son conscientes de la necesidad de prestar unos servicios de calidad.

Los servicios se deben inspirar en el principio del beneficio mutuo. Es muy improbable que quienes no estén profundamente convencidos de que sus clientes discapacitados tienen un beneficio tangible que ofrecer a la empresa puedan ejercer una influencia real en el mundo empresarial.

La mejora de la calidad de los servicios prestados a las empresas se traduce rápida e inevitablemente en un mejor servicio a los discapacitados que buscan empleo. A continuación se ofrece una lista de comprobación de utilidad para las entidades interesadas en mejorar la calidad de los servicios prestados a las empresas.

¿Se ofrece a las empresas:

\section{Información y asesoramiento respecto:}

- a las ventajas comerciales derivadas del empleo de los discapacitados?

- a los posibles solicitantes?

- al acceso a los servicios y a la índole de los servicios ofrecidos?

- a los modelos de procedimientos y políticas cuya eficacia ha sido contrastada por otras empresas?

- a las obligaciones legales? 
2. unos servicios de contratación en los que se incluya el acceso:

- a los solicitantes más idóneos?

- a los instructores de trabajo?

3. una preselección de los solicitantes de acuerdo con las expectativas de las empresas?

4. servicios profesionales de análisis y de adaptación de los puestos de trabajo, capaces de asesorar sobre la remodelación de los puestos de trabajo y respecto al uso de medios auxiliares y de adaptaciones tecnológicas?

5. programas de asistencia financiera adecuadamente comercializados, adecuados a las necesidades de las empresas, de fácil acceso y aplicados eficazmente?

6. la información y la asistencia material precisas para que las empresas puedan facilitar el acceso físico al lugar de trabajo?

7. educación de las empresas y los trabajadores sobre los beneficios que produce el empleo, tanto de los discapacitados en general como de determinadas personas?

8. servicios de formación en el puesto de trabajo que aporten a la empresas un apoyo sustancial?

9. servicios de habituación al trabajo o de orientación de los trabajadores, en los que intervengan instructores de trabajo y que comprendan unos sistemas de trabajo compartido?

10. apoyo paralelo al empleo, incluidos el asesoramiento sobre los sistemas más eficaces de prevención del absentismo y de acomodación de las deficiencias de origen laboral?

11. asesoramiento de las empresas sobre la promoción profesional de los trabajadores discapacitados y sobre la satisfacción de las necesidades de los trabajadores discapacitados subempleados?

\section{Medidas prácticas: facilitar la labor de la empresa}

Sin duda, todo sistema de prestación de servicios a los discapacitados que se proponga facilitar su acceso a la formación y al trabajo logrará mejores resultados si satisface plenamente las necesidades y expectativas de la empresa. (O bservación: Es difícil elegir un término que defina correctamente el conjunto de agencias y organizaciones - estatales, ONG y sin ánimo de lucrodedicadas a la formulación de políticas y la prestación de servicios a los discapacitados que buscan empleo. Para resumir, se aplicarán los términos entidad de servicio y prestador de servicio al conjunto de los agentes de este complejo sistema.

U na comunicación fluida y continua con las empresas constituye una vía eficaz para elaborar recomendaciones del tipo de las siguientes:

Se necesitan unos códigos de conducta en los que se definan los elevados niveles de calidad de los servicios que las agencias de servicios relacionados con el empleo deben prestar a las empresas. En estos códigos, que deben elaborarse en colaboración con las empresas, se deben establecer normas relativas tanto a la efectividad de los servicios actuales como a la índole de los nuevos servicios ofertados. Es preciso realizar un seguimiento de estos códigos mediante la realización de encuestas periódicas del grado de satisfacción de las empresas.

La formación y titulación específicas de los profesionales de la rehabilitación para satisfacer las necesidades de las empresas deben recibir la máxima prioridad.

Las entidades de servicios deben contratar personal con experiencia directa en el mundo del comercio y la industria, y capacidad para solucionar los problemas de comunicación entre el mundo empresarial y el de las actividades no lucrativas.

Las entidades de servicios deben empezar por contratar una cantidad sustancialmente mayor de discapacitados, con lo que se lograría reducir el número de intermediarios no discapacitados que tratan con las empresas. Su misión es proyectar, desde diversos ángulos, una imagen positiva de los discapacitados en el mundo de la empresa.

Las entidades de servicios deben esforzarse por reducir la fragmentación de sus esfuerzos de educación, comercialización y promoción. Resulta especialmente contraproducente utilizar carteles, anuncios y mensajes publicitarios para proyectar un perfil que refuerce la imagen médica de la discapacidad y el estigma que acompaña a determinadas deficiencias, en vez de subrayar la capacidad laboral de las personas y la necesidad de que las empresas reaccionen con una política y unas actuaciones adecuadas.

Las entidades de servicios deben colaborar para facilitar el acceso a los servicios y apoyos tanto de las empresas como de los discapacitados. Es preciso analizar con especial atención la jornada del cliente (considerando clientes a la empresa y al discapacitado por igual), de forma que se reduzcan las evaluaciones y se promueva la incorporación del cliente al empleo de forma rápida, aunque gradual. Las entidades de servicios deben acudir a las técnicas de promoción probadas para conseguir que se otorgue prioridad a los discapacitados.

Las entidades de servicios se deben reunir periódicamente para recabar su opinión cualificada respecto a los medios de mejorar la calidad, tanto de los servicios, como de los aspirantes.

\section{Conclusiones}

En muchos países, los servicios orientados a facilitar el acceso al trabajo de los discapacitados son complejos, engorrosos y resistentes al cambio, a pesar de la evidencia acumulada decenio tras decenio de que el cambio se impone.

Un modo renovado de tratar con las empresas tendría enormes posibilidades de transformar profundamente la situación, al modificar radicalmente la posición de un protagonista clave: la empresa.

Se asiste a un debate de alcance entre la administración pública y la comunidad empresarial sobre el sentido de los cambios que los agentes sociales deben inevitablemente emprender en los próximos veinte años. Por ejemplo, las empresas Ianzan la Iniciativa Empresarial Europea contra la Exclusión Social, varias grandes empresas del Reino U nido se asocian en Tomorrow's Company para replantearse sus relaciones con la sociedad británica, y el Employers Forum on Disability se convierte en una más de las diversas iniciativas de las empresas británicas dedicadas a resolver los problemas de igualdad y diversidad.

Las empresas tienen una gran tarea por delante para que la cuestión de la discapacidad ocupe el lugar que le corresponde por imperativo ético y empresarial; a su vez, los servicios de rehabilitación necesitan una nueva filosofía en la que se replanteen sus relaciones de trabajo con todos los agentes sociales, con el objeto de facilitar a las empresas la tarea de materializar la igualdad de oportunidades.

\section{DERECHOS Y OBLIGACIONES: EL PUNTO DE VISTA DE LOS TRABAJADORES}

Angela Traiforos y Debra A. Perry

H istóricamente, las personas discapacitadas han experimentado tremendos obstáculos para incorporarse a la población activa, y las víctimas de accidentes de trabajo afectadas por alguna una discapacidad se han visto abocadas al desempleo, con sus secuelas 
negativas de orden sociológico, social y financiero. Aún hoy, los discapacitados no están proporcionalmente representados en la población activa, ni aún en los países que disfrutan de la legislación más progresista en materia de derechos civiles y fomento del empleo, a pesar de los esfuerzos que se realizan en el ámbito internacional para mejorar su situación.

Existe ahora una mayor conciencia de los derechos y necesidades de los trabajadores discapacitados, y se tiene una idea más clara de la gestión de la discapacidad. Los sistemas de indemnización de los trabajadores y de seguridad social diseñados para la protección de las rentas son ahora comunes en los países industrializados. EI mayor coste producido por la administración de esos programas ha permitido establecer la base económica para la promoción del empleo de los discapacitados y la rehabilitación de los trabajadores lesionados. Al mismo tiempo, los discapacitados se han asociado para reivindicar sus derechos y la integración en todos los aspectos de la vida social, incluida la población activa.

Los sindicatos de numerosos países han prestado un decidido apoyo a estos esfuerzos. Las empresas mejor informadas reconocen la necesidad de conceder a los discapacitados un trato equitativo y han adquirido conciencia de la necesidad de proteger la salud en el lugar de trabajo. Se han desarrollado el concepto de gestión de la discapacidad y la política de abordaje de los problemas relacionados con la discapacidad en el lugar de trabajo. Los sindicatos, a los que corresponde parte del mérito de la aparición de estos conceptos, continúan desempeñando una función importante.

Según la Recomendación de la OIT sobre la readaptación profesional y el empleo de personas inválidas (no 168), "Ias organizaciones de trabajadores deberían adoptar una política destinada a promover la formación y del empleo adecuados de las personas inválidas, en un pie de igualdad con los otros trabajadores". Se propugna igualmente que las organizaciones de trabajadores participen en la formulación de políticas nacionales, cooperen con los profesionales y las organizaciones especializados en la rehabilitación y promuevan la integración y la rehabilitación profesional de los trabajadores discapacitados.

En el presente artículo se examina el problema de la discapacidad en el lugar de trabajo desde la perspectiva de los derechos y obligaciones de los trabajadores y se describen las funciones específicas que los sindicatos desempeñan en la promoción de la integración de los discapacitados en el trabajo.

En un medio ambiente de trabajo saludable, la empresa y los trabajadores velan por igual por la calidad del trabajo, la salud y la seguridad, y por el trato justo a todos los trabajadores. Los trabajadores se contratan con arreglo a su capacidad. Trabajadores y empresas colaboran en el mantenimiento de la salud y la seguridad y, si se produce una lesión o una discapacidad, tienen el derecho - y la obligación- de tratar de reducir los efectos sobre las personas y sobre en el lugar de trabajo. Aunque empresas y trabajadores tengan puntos de vista distintos, la asociación les permite alcanzar el objetivo de proteger la salud, la seguridad y la equidad en el trabajo.

El término derechos se suele confundir con el de derechos legales. En muchos países europeos, además de Japón y otras naciones, se han establecido sistemas de cuotas por los que se obliga a emplear determinados porcentajes de personas discapacitadas y se imponen multas a las empresas que no las aplican. En Estados U nidos, la Ley de norteamericanos con discapacidades (LAD) prohibe discriminar a los discapacitados en el trabajo y en la vida social. En la mayoría de los países existen leyes de salud y seguridad destinadas a preservar a los trabajadores de los métodos y condiciones de trabajo inseguros. Se han establecido diversos sistemas de seguridad social y de indemnización por accidentes de trabajo que ofrecen servicios médicos, sociales y, en ocasiones, también de rehabilitación profesional. Los derechos específicos de los trabajadores se pueden reconocer en los convenios colectivos y, de este modo, adquieren fuerza de ley.

L os derechos (y obligaciones) de los trabajadores en el ámbito del trabajo y la discapacidad están en función de la complejidad del ordenamiento jurídico, que varía de uno a otro país. A los fines del presente artículo, entendemos por derechos de los trabajadores, sencillamente, los derechos legales o morales que redundan en su interés en relación con el desarrollo de una actividad productiva en un medio ambiente de trabajo seguro y no discriminatorio. Las obligaciones se identifican con los deberes que los trabajadores tienen consigo mismos, con sus compañeros y con la empresa de contribuir eficazmente a la productividad y la seguridad en el lugar de trabajo.

En el presente artículo, los derechos y obligaciones de los trabajadores se insertan en el contexto de cuatro cuestiones relacionadas con la discapacidad: 1) selección y contratación; 2) salud, seguridad y prevención de la discapacidad; 3) recuperación del trabajador discapacitado, incluidas la rehabilitación y la reincorporación al trabajo después de la lesión; 4) integración plena del trabajador en el lugar de trabajo y en la sociedad. La actividad sindical en estos campos comprende la organización y la defensa de los derechos de los trabajadores discapacitados, bien propugnando la promulgación de leyes de ámbito nacional, bien por otras vías; la reivindicación y protección de los derechos de dichos trabajadores mediante su inclusión en los convenios colectivos; la educación de los afiliados y de las empresas sobre los problemas de la discapacidad y sobre los derechos y obligaciones derivados de la gestión de la discapacidad; la cooperación con la dirección en la difusión de los derechos y obligaciones asociados a la gestión de la discapacidad; la prestación a los trabajadores discapacitados de los servicios necesarios para incorporarse o integrarse en mayor medida en la población activa; y, si todos los demás esfuerzos fracasan, bien la iniciación de una solución amistosa o contenciosa de los conflictos, bien la promoción de la adopción de medidas legislativas de protección de los derechos.

\section{Cuestión I: sistemas de selección, contratación y empleo}

A pesar de que las obligaciones legales de los sindicatos se contraen específicamente a sus afiliados, estas organizaciones poseen una tradición, tan antigua como los sindicatos mismos, de lucha por la mejora de las condiciones de vida de los trabajadores, incluidos los discapacitados. No obstante, la aplicación de los principios de equidad en la selección, contratación y empleo adquiere especial relieve cuando se trata de trabajadores discapacitados. Tanto los estereotipos negativos de la discapacidad como

Figura 17.4 - Derechos y obligaciones: prácticas de selección, contratación y empleo.

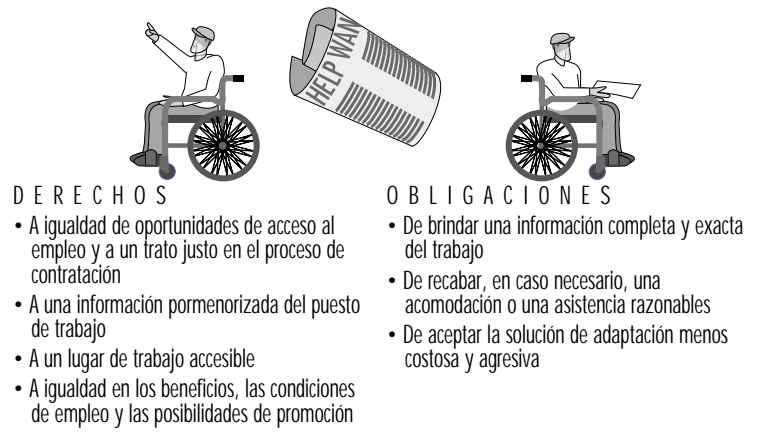


las barreras arquitectónicas, de comunicación y de otro tipo son causa de que los discapacitados se vean a menudo privados de sus derechos o de que sean objeto de prácticas discriminatorias.

Las listas básicas de derechos que figuran más adelante (Figuras 17.4 a 17.7), aunque de una formulación sencilla, tienen profundas implicaciones para la igualdad de acceso al empleo de los trabajadores discapacitados. Estos, a su vez, tienen, como todos los trabajadores, determinadas obligaciones, como la de presentarse y plantear sus intereses, habilidades y destrezas, y sus expectativas en el centro de trabajo, de forma abierta e inequívoca.

En el proceso de selección, se debe evaluar a los solicitantes sobre la base de sus respectivas cualificaciones y destrezas (Figura 17.4). D eben conocer perfectamente el puesto de trabajo para determinar su interés por el trabajo y su capacidad para realizarlo. A simismo, una vez contratados, los trabajadores se deben juzgar y evaluar sobre la base de su rendimiento en el trabajo, al margen de cualquier sesgo producido por consideraciones ajenas al trabajo. Los discapacitados deben disfrutar de igualdad de acceso a los beneficios del empleo y de idénticas posibilidades de promoción. En caso necesario, se deben realizar las adaptaciones razonablemente necesarias para que el discapacitado pueda desarrollar las tareas propias del puesto. Estas adaptaciones pueden consistir, simplemente, en aumentar la altura de una mesa de trabajo, colocar una silla o añadir un pedal.

En Estados U nidos, en la L ey de norteamericanos con discapacidades, no sólo se prohibe la discriminación de los trabajadores cualificados (esto es, los que poseen las cualificaciones y destrezas precisos para realizar las tareas básicas de un puesto de trabajo) por razones de discapacidad, sino que, además, se exige que las empresas realicen las acomodaciones razonablemente necesarias, que pueden consistir en la instalación de un determinado equipo, en la modificación de las tareas no esenciales para el puesto de trabajo 0 en la realización de cualquier otra modificación que no resulte injustificadamente onerosa para la empresa, con objeto de facilitar al discapacitado la realización de las tareas básicas del puesto. El objetivo de estas disposiciones es tanto tutelar los derechos de los trabajadores como "proteger" a los peticionarios de adaptaciones. Según la experiencia norteamericana, el coste de la mayoría de las acomodaciones es relativamente bajo (menos de 50 dólares de Estados U nidos).

Derechos y obligaciones van de la mano. Los trabajadores tienen la obligación de poner en conocimiento de la empresa toda circunstancia que pueda afectar su capacidad de realizar el trabajo 0 atentar contra su seguridad o la de otras personas. Están obligados a exponer su situación y sus cualificaciones con honradez. En caso necesario, deben solicitar una acomodación razonable y aceptar la más adecuada a la situación, la más eficaz en función del coste y la menos agresiva para el lugar de trabajo, siempre que satisfaga sus necesidades.

Estos mismos derechos y obligaciones, y las implicaciones de los mismos, se abordan tanto en el Convenio de la O IT sobre la readaptación profesional y el empleo de las personas inválidas (no 159) como en la Recomendación no 168. En el Convenio no 159 se establece que, en ocasiones, puede ser necesario adoptar medidas positivas especiales encaminadas a lograr la igualdad efectiva de oportunidades y de trato entre los trabajadores inválidos y los demás trabajadores". Se añade que tales medidas "no deberán considerarse discriminatorias respecto de estos últimos".

\section{Qué pueden hacer los sindicatos}

Los dirigentes sindicales suelen estar profundamente arraigados en la sociedad en que actúan y pueden ser asociados valiosos en la promoción de la selección, contratación y empleo continuado de los discapacitados. U na de las primeras cosas que pueden hacer es elaborar una declaración de política sobre los derechos de los discapacitados al empleo. El paso siguiente consistiría en la educación de los afiliados y la elaboración de un plan de actuación en apoyo de la política adoptada. Los sindicatos pueden reivindicar los derechos de los trabajadores discapacitados en un ámbito más amplio mediante la promoción, el seguimiento y el apoyo de las medidas legislativas pertinentes. En el lugar de trabajo, deben instar a la dirección a elaborar políticas e iniciar actuaciones orientadas a eliminar las barreras al empleo de los discapacitados. Pueden, además, colaborar en las acomodaciones precisas de los puestos de trabajo y, a través de los convenios laborales, tutelar y defender los derechos de los trabajadores discapacitados en todos los aspectos del empleo.

Los sindicatos pueden asociarse con empresas, ministerios, organizaciones no gubernamentales y asociaciones con objeto de aplicar programas destinados a fomentar la selección, contratación y trato equitativo en el empleo de las personas discapacitadas. Los delegados sindicales pueden acceder a los órganos rectores y ofrecer sus conocimientos a las organizaciones de ámbito comunitario que trabajan con los discapacitados. Pueden, igualmente, fomentar la conciencia de los afiliados y, cuando, a su vez, contratan personal, pueden dar ejemplo de conducta justa y equitativa.

\section{Ejemplos de lo que hacen los sindicatos}

En Inglaterra, el Trades U nion Congress (T U C) ha participado intensamente en la defensa de la igualdad de derechos en el empleo para los discapacitados, tanto mediante la elaboración de declaraciones de política, como a través de la actividad directa. Para esta organización, el empleo de los discapacitados es una cuestión de igualdad de oportunidades, dado que las experiencias de los discapacitados no se diferencian de las de otros grupos sociales que han sido objeto de discriminación o de exclusión. EI T U C apoya los actuales sistemas de cuotas legales y propugna la imposición de tasas (multas) a las empresas que incumplan las leyes.

Esta organización sindical ha publicado una serie de guías destinadas a educar a sus afiliados y apoyar sus actividades, como T U C Guidance, Trade U nions and D isabled M embers, E mployment of D isabled People, D isability L eave y D eaf People and T heir R ights. En Trades $U$ nion and $D$ isabled $M$ embers se ofrecen orientaciones respecto a los puntos básicos que los sindicatos deben tomar en consideración al negociar por cuenta de sus afiliados discapacitados. La central sindical I rish Congress of Trade U nions ha elaborado una guía con idéntico objetivo: $D$ isability and $D$ iscrimination in the W orkplace: Guidelines for N egotiators. En la guía se ofrecen orientaciones prácticas sobre la lucha contra la discriminación en el lugar de trabajo y la promoción de la igualdad y el acceso al empleo a través de los convenios colectivos.

La Federación de Sindicatos A lemanes también ha elaborado un amplio documento de principios en el que se definen su política de integración en el empleo, su posición contraria a la discriminación y su determinación a utilizar su influencia para hacer valer sus puntos de vista. La Federación propugna unos amplios esquemas de formación profesional y de acceso al aprendizaje de los discapacitados, y aboga por la adopción de políticas sindicales de apoyo al acceso al transporte público y de integración en todos los aspectos de la vida social.

En Estados U nidos, el Screen Actors Guild cuenta con unos 500 afiliados discapacitados. En los convenios colectivos firmados por esta organización sindical se incluye una disposición de no discriminación y prioridad de derechos. En colaboración con la American Federation of Televisión and Radio Artists, se ha concertado con los grupos de activistas nacionales para formular políticas de incremento de la presencia de los discapacitados en sus respectivos sectores. La International 
Union of United Automobile, Aerospace and Agricultural Implement Workers of America es otro de los sindicatos que incluye en sus convenios colectivos disposiciones excluyentes de la discriminación de los discapacitados. Propugna igualmente la adaptación razonable del lugar de trabajo para sus afiliados, a los que ofrece regularmente programas de formación sobre los problemas de la discapacidad en el trabajo. Por su parte, U nited Steel Workers of America lleva años estipulando en sus convenios colectivos cláusulas de prohibición de la discriminación, y somete las denuncias de discriminación por causa de incapacidad a través de un procedimiento de conciliación y por otras vías.

Los sindicatos norteamericanos apoyaron la promulgación y promueven la aplicación de la Ley de norteamericanos con discapacidades. Antes, incluso, de la aprobación de la Ley, numerosos sindicatos afiliados a la central AFL-CIO desarrollaban una intensa actividad de formación de sus militantes en la defensa de los derechos de los discapacitados (AFL-CIO 1994). L os representantes de A FL-CIO y de otras organizaciones sindicales realizan un seguimiento minucioso de la aplicación de la Ley, incluidas las actuaciones judiciales y las vías alternativas de solución de los conflictos, en su esfuerzo por apoyar a los trabajadores discapacitados en el marco de la Ley y de velar por el respecto de los derechos de todos los trabajadores.

Desde la promulgación de la Ley de norteamericanos con discapacidades, los sindicatos han producido un considerable volumen de literatura y de material audiovisual y han impartido un gran número de seminarios y de cursos de formación destinados a la educación continua de sus afiliados. Así, el Departamento de Derechos Civiles de AFL -CIO ha editado folletos y ha organizado seminarios para los sindicatos afiliados a la central. La International Association of $\mathrm{M}$ achinists and Aerospace Workers Center for Administering R ehabilitation and Education Services (IAM CARES), con ayuda de la administración federal, ha producido dos vídeos y diez folletos destinados a informar a las empresas, las personas discapacitadas y los sindicatos sobre los derechos y obligaciones que asumen en virtud de la Ley de norteamericanos con discapacidades. Por su parte, la A merican Federation of State, County and Municipal Employees (AFSCM E) posee una larga tradición de defensa de los derechos de los trabajadores discapacitados. D espués de la promulgación de la Ley, ha actualizado sus publicaciones y sus programas de formación de millares de afiliados y empleados de la organización sindical aquejados de discapacidades.

Aunque en Japón existe un sistema de cuotas y tasas, un sindicato japonés ha reconocido que los afectados por discapacidades mentales suelen tener una tasa más baja de representación en las plantillas de las empresas, especialmente de las grandes. Se han adoptado medidas para superar esta situación. En efecto, el Consejo Regional de K anagawa del Sindicato Japonés de Electricidad, Electrónica e Informática colabora con la ciudad de Yokohama en el desarrollo de un centro de apoyo al empleo, destinado a la formación de personas afectadas por discapacidades mentales y a la prestación de servicios de empleo de estas personas y de otras categorías de discapacitados. Además, proyecta crear un centro de formación destinado a informar de los problemas de la discapacidad y a enseñar el lenguaje por señas a los afiliados al sindicato, personal directivo, supervisores de producción y otras personas. El objetivo es aprovechar el contexto favorable de las buenas relaciones laborales e interesar a los miembros del mundo empresarial en la gestión y las actividades del centro. El proyecto iniciado por el sindicato promete convertirse en un paradigma de cooperación entre sindicatos, empresas y gobierno.

Los sindicatos de Estados U nidos y Canadá han venido colaborando de forma creativa con el gobierno y las empresas con el objeto de promover el empleo de los discapacitados a través del programa Projects with Industry (PWI). U niendo los recursos de los sindicatos con la financiación del gobierno, IAM CARES y el Human Resoures Development Institute (HRDI) de la AFL-CIO han venido administrando programas de formación y colocación de los discapacitados, independientemente de su afiliación sindical. En 1968, el HRDI comenzó a funcionar como servicio de empleo y formación de A FL-CIO, mediante la prestación de asistencia a distintos grupos étnicos, mujeres y personas discapacitadas. En 1972, el HRDI puso en práctica un programa especialmente dirigido a la colocación de los discapacitados en empresas que habían suscrito convenios colectivos con los sindicatos nacionales e internacionales. D esde 1995, este programa ha hecho posible la colocación de más de 5.000 personas discapacitadas. Gracias al programa IAM CARES, que se desarrolla en los mercados de trabajo de Estados U nidos y Canadá, más de 14.000 personas la mayoría de ellas afectadas de graves discapacidades, han encontrado trabajo. En ambos programas se ofrece asesoramiento y asistencia profesional y ayuda para la colocación, gracias a las relaciones establecidas con las empresas y a la colaboración del gobierno y de los sindicatos.

Además de asistir directamente a los trabajadores discapacitados, estos programas PWI sirven de marco a la realización de actividades de difusión pública de los problemas de los discapacitados, de promoción de la acción conjunta de empresas y sindicatos para fomentar el acceso y la conservación del empleo, y de prestación de servicios de formación y asesoramiento a sindicatos y empresas locales.

Los anteriores son simplemente algunos ejemplos del cúmulo de actividades que los sindicatos desarrollan para promover la igualdad ante el empleo de los trabajadores discapacitados y que se enmarcan en su objetivo de promover la solidaridad de los trabajadores y poner fin a todo tipo de discriminación.

\section{Cuestión 2: prevención de la discapacidad; salud y seguridad}

Si bien la exigencia de unas condiciones seguras de trabajo constituye una de las prioridades de la actividad sindical en numerosos países, la responsabilidad del mantenimiento de la salud y la seguridad en el lugar de trabajo ha sido tradicionalmente competencia de la empresa. N ormalmente, la dirección se responsabiliza del diseño de los puestos de trabajo, de la elección de las herramientas, de la configuración de los procesos y del medio ambiente de trabajo, que influyen en la seguridad y la productividad.

Afortunadamente, las empresas más avanzadas reconocen la importancia de la retroinformación generada por los trabajadores, especialmente ahora que la estructura organizativa del lugar de trabajo se está modificando para incrementar la autonomía de los trabajadores. Las investigaciones realizadas en materia de seguridad y prevención también avalan la necesidad de que los trabajadores participen en el diseño de los puestos de trabajo, la formulación de políticas y la aplicación de los programas de salud seguridad y prevención de la discapacidad.

Otra tendencia observada, consistente en el sensible incremento experimentado por los costes de indemnización por accidentes de trabajo y otros costes derivados de las lesiones y discapacidades profesionales, ha inducido a las empresas a valorar la prevención como un elemento clave de la función de gestión de la incapacidad. Los programas de prevención deben centrarse en todo el abanico de factores de estrés, incluidos los de naturaleza psicológica, sensorial, química o física, así como en las lesiones, accidentes y exposiciones a peligros evidentes. A veces, la discapacidad no se proviene de un suceso único, sino de la exposición reiterada a unos agentes o factores de estrés 
débiles. Por ejemplo, algunos agentes pueden producir o activar el asma; el ruido fuerte 0 reiterado puede causar pérdida auditiva; las presiones generadas por el proceso productivo, por ejemplo, en el sistema de trabajo a destajo, pueden producir síntomas de estrés psicológico, y los movimientos repetitivos producen problemas de estrés acumulado, como el síndrome del túnel carpiano. La exposición a estos factores de estrés pueden agudizar las discapacidades existentes y producir un mayor debilitamiento.

Desde el punto de vista del trabajador, la indemnización no debe eclipsar nunca las ventajas de la prevención. En la Figura 17.5 se relacionan algunos de los derechos y obligaciones de los trabajadores en el marco de la prevención de la discapacidad en el lugar de trabajo.

Los trabajadores tienen derecho a disfrutar del medio ambiente de trabajo más seguro posible y a ser informados exhaustivamente de los riesgos y las condiciones de trabajo. Esta información es particularmente importante para los trabajadores discapacitados, que quizás necesiten conocer la existencia de determinadas condiciones para decidir si pueden realizar las tareas de su puesto de trabajo sin comprometer su salud y seguridad o las de otros.

M uchos trabajos entrañan riesgos o peligros que no se pueden eliminar totalmente. Por ejemplo, el trabajo en la construcción y otros trabajos en los que se produce una exposición a sustancias tóxicas llevan aparejados riesgos evidentes. O tros trabajos aparentemente inocuos, como la introducción de datos en un sistema informático y la utilización de una máquina de coser, imponen, sin embargo, una serie de movimientos reiterados o de posturas corporales inadecuadas. Tales riesgos también se pueden reducir.

Todos los trabajadores deben recibir el equipo de protección necesario y la información relativa a los procesos y métodos productivos que precisen para reducir el riesgo de sufrir lesiones 0 de contraer enfermedades de resultas de la exposición a situaciones de peligro, a movimientos repetitivos o a otros factores de estrés. Los trabajadores deben sentirse libres para presentar quejas sobre los sistemas de seguridad y para formular recomendaciones orientadas a mejorar las condiciones de trabajo, sin temor a perder el empleo. Es preciso animarles para que comuniquen cualquier enfermedad o discapacidad, especialmente si ésta puede empeorar por causa de las tareas realizadas o de la exposición al medio ambiente de trabajo.

Por lo que respecta a las obligaciones, los trabajadores han de aplicar medidas de seguridad que reduzcan el nivel de riesgo tanto para sí mismos como para los demás. Estas obligaciones pueden consistir en denunciar las condiciones de trabajo inseguras, propugnar la adopción de medidas de salud y seguridad, y responsabilizarse de su propia salud. Por ejemplo, si una enfermedad o una discapacidad entraña un riesgo para el trabajador o para otras personas, el trabajador afectado está obligado a eliminar el riesgo.

La ergonomía se desarrolla y aporta métodos eficaces de prevención de las discapacidades resultantes del modo de organización y ejecución del trabajo. Consiste, básicamente, en el estudio del trabajo y de la forma de adaptar un trabajo o una tarea al trabajador, en vez de hacer lo contrario (AFL-CIO 1992). Sus aplicaciones han permitido prevenir la discapacidad en campos tan diversos como la agricultura y la informática. Entre esas aplicaciones posibles figura la adaptabilidad de los medios de trabajo para ajustarlos a la estatura y demás características físicas del trabajador (por ejemplo, las sillas de despacho adaptables, las herramientas provistas de mangos ajustables y las modificaciones ligeras de los sistemas de trabajo que permiten reducir los movimientos repetitivos y el estrés de algunas partes del cuerpo).
Figura 17.5 - Derechos y obligaciones: salud y seguridad.
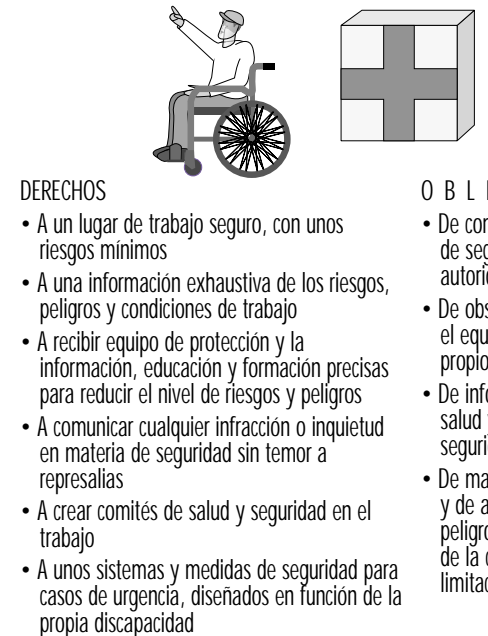

OB LIGACIONES

- De comunicar las infracciones de las normas de seguridad a la empresa 0 a las autoridades competentes

- De observar las normas de seguridad y utilizar el equipo necesario para reducir los riesgos propios y de terceros

- De informarse sobre las leyes y normas de salud y seguridad y de promover la salud y la seguridad propias y de terceros

- De mantenerse en un estado de salud óptimo y de abstenerse de poner indebidamente en peligro la salud propia o la de otros por causa de la conducta, las discapacidades o las

limitaciones personales

Sindicatos y empresas adquieren una conciencia cada vez mayor de la importancia de proyectar los programas de salud y seguridad más allá del lugar de trabajo. Aun cuando la causa de una lesión o enfermedad no esté relacionada con el trabajo, la empresa corre con los costes del absentismo, del seguro de enfermedad y, quizás, también de la nueva contratación y readaptación profesional. Además, algunas patologías, como el alcoholismo, la drogadicción y los trastornos psíquicos, pueden quebrantar la productividad del trabajador o aumentar su vulnerabilidad a los accidentes de trabajo y al estrés. Por éste y otros motivos, muchas empresas informadas realizan actividades de educación en la salud, la seguridad y la prevención de la discapacidad, dentro y fuera del lugar de trabajo. Sindicatos y empresas, independientemente o en un esfuerzo conjunto en el que puede participar el gobierno, desarrollan diversos programas de bienestar en los que se abordan cuestiones como la reducción del estrés, la nutrición, el abandono del tabaco y la prevención del SIDA.

Algunas empresas desarrollan programas de bienestar y de asistencia a los empleados (asesoramiento y remisión) dirigidos a la solución de tales problemas. Todos estos programas de prevención y salud redundan en beneficio del trabajador y de la empresa por igual. Por ejemplo, el coeficiente del ahorro respecto de la inversión de los programas de protección de la salud y de asistencia a los empleados suele dar valores entre 3:1 y 15:1.

\section{¿Qué pueden hacer los sindicatos?}

Los sindicatos disfrutan de una posición envidiable para aprovechar su influencia como representantes de los trabajadores para promover la aplicación de programas de promoción de la salud, la seguridad, la prevención de la discapacidad y la ergonomía en el lugar de trabajo. La mayoría de los expertos en ergonomía y prevención coinciden en que la participación de los trabajadores en la formulación de las medidas y políticas de prevención mejora las posibilidades de aplicación y efectividad de las mismas (LaBar 1995; Westlander y cols. 1995; AFL-CIO 1992). Los sindicatos pueden asumir un protagonismo especial en los comités de salud y seguridad y de ergonomía. Estas organizaciones pueden propugnar la promulgación de medidas legislativas en materia de seguridad en el puesto de trabajo y colaborar con 
la dirección en la creación de comités paritarios de seguridad que pueden contribuir a reducir sustancialmente los accidentes de trabajo (Fletcher y cols. 1992).

Los sindicatos deben informar a sus afiliados de sus derechos y de los sistemas y normas de seguridad en el trabajo y de prevención de la discapacidad, dentro y fuera del lugar de trabajo. Estos programas pueden recogerse en los convenios colectivos e informar la labor de los comités sindicales de salud y seguridad.

Además, los sindicatos pueden utilizar los documentos de política, los convenios colectivos y los demás cauces de que disponen para negociar la aplicación de medidas de prevención de la discapacidad y de condiciones especiales para los discapacitados. Si un trabajador queda discapacitado, especialmente si su discapacidad está relacionada con el trabajo, el sindicato debe reivindicar el derecho de ese trabajador a la acomodación, a la dotación de nuevas herramientas 0 a la asignación de nuevas tareas, con objeto de evitar su exposición a situaciones de estrés o de peligro capaces de aumentar sus limitaciones. Por ejemplo, es preciso evitar que los afectados por una pérdida auditiva de origen profesional continúen exponiéndose a ciertos tipos de ruido.

\section{Algunos ejemplos de lo que los sindicatos pueden hacer}

En el documento de política de la Federación de Sindicatos Alemanes sobre los discapacitados se subraya la necesidad de evitar riesgos para la salud de los trabajadores discapacitados y de adoptar medidas preventivas de posteriores lesiones.

En el marco del convenio colectivo suscrito por Boeing Aircraft Corporation y la International Association of $\mathrm{M}$ achinists and Aerospace Workers (IAM AW ), el IAM / Boeing H ealth and Safety Institute aporta financiación, desarrolla distintos programas piloto, recomienda la adopción de medidas de protección de la salud y seguridad de los trabajadores y gestiona la reincorporación al trabajo de los trabajadores aquejados de deficiencias de origen profesional. El I nstituto, creado en 1989, se financia con una aportación de cuatro centavos por hora del fondo fiduciario de salud y seguridad. EI C onsejo de A dministración del fondo está integrado a partes iguales por representantes de la empresa y del sindicato.

La D isabled Forestry Workers Foundation of C anada es otro ejemplo de colaboración entre empresas y sindicatos. $L a$ entidad tuvo su origen en una iniciativa de 26 empresas, sindicatos y organizaciones diversas que se asociaron para producir un vídeo (Every Twelve Seconds) en el que se llamaba la atención sobre la elevada tasa de accidentes registrada entre los trabajadores del sector forestal en Canadá. En la actualidad, la fundación centra su esfuerzo en las medidas de salud y seguridad, prevención de accidentes y política de reincorporación al trabajo.

IAM CARES lleva a cabo una intensa actividad de educación de sus afiliados en cuestiones de la seguridad, especialmente en los puestos de trabajo considerados peligrosos y de alto riesgo de la industria química, la construcción y el sector siderúrgico. La organización imparte formación tanto a los representantes sindicales, como a los militantes de base, además de promover la creación de comités de salud y seguridad gestionados por el sindicato e independientes de las empresas.

Gracias a una subvención del Departamento de Trabajo de Estados U nidos, el George M eany Center, de la AFL-CIO, se dedica a producir material educativo sobre el abuso de sustancias, diseñado para ayudar a los afiliados del sindicato y a sus familiares a afrontar los problemas del alcoholismo y la drogadicción.

La Association of Flight Attendants (AFA) ha llevado a cabo una importante tarea en el campo del SIDA y de su prevención. Los voluntarios de esta organización han creado el AIDS C ritical and Terminal Illness Awareness Project para educar a sus afiliados en la prevención del SIDA y otras enfermedades que amenazan la vida. La organización ha impartido educación sobre el SIDA en treinta y tres de sus locales a unos 10.000 afiliados. Asimismo, se ha creado una fundación que administra las ayudas económicas a los afiliados que sufren enfermedades que amenazan la vida.

\section{Cuestión 3: recuperación del trabajador discapacitado: apoyo, rehabilitación e indemnización}

L os sindicatos de numerosos países han reivindicado el reconocimiento de la indemnización por accidentes de trabajo, la prestación de incapacidad y otras prestaciones relacionadas con las lesiones en el trabajo. Dado que uno de los objetivos de los programas de gestión de la discapacidad consiste en reducir los costes de estas prestaciones, es de presumir que los sindicatos no estén en favor de dichos programas. Los sindicatos reivindican los derechos a la protección en el trabajo, la actuación precoz, la prestación de servicios de rehabilitación y algunos aspectos de la gestión de la discapacidad. Se valoran particularmente los sistemas de gestión de la discapacidad orientados a disminuir los padecimientos de los trabajadores, a superar los problemas de la pérdida de tiempo de trabajo, incluidas sus secuelas financieras, y a prevenir la discapacidad de corta y larga duración. Estos programas deben posibilitar la reincorporación al trabajo, siempre que sea posible, y la realización de las adaptaciones precisas. Cuando esto no sea posible, se deben ofrecer otras soluciones, como la formación de reconversión y la asignación a nuevas tareas. Como solución extrema, es preciso reconocer el derecho a la indemnización por discapacidad de larga duración y a las prestaciones sustitutorias del salario.

Afortunadamente, los datos disponibles demuestran que es posible configurar los sistemas de gestión de la discapacidad de

Figura 17.6 - Derechos y obligaciones: apoyo, rehabilitación e indemnización.

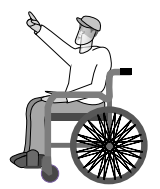

DERECHOS

- A una política oficial coherente de gestión de la discapacidad

- A una asistencia médica rápida y eficaz

- A la protección en el trabajo

- A un salario sustitutorio durante la recuperación

- A la participación efectiva, con capacidad de elección, en todos los aspectos de la rehabilitación médica y profesional

- A la prestación rápida y efectiva de senvicios de rehabilitacion (actuacion temprana)

- A reincorporarse, siempre que sea posible, a su anterior puesto de trabajo

- A una adaptación razonable del lugar de trabajo, siempre que sea necesaria y posible

- A la formación de reconversión y la asignación de nuevas tareas, en caso necesario

- En caso necesario, a recibir indemnización por incapacidad de larga duración o permanente
O B LI G A C I O NES

- De comunicar sin demora cualquier lesión 0 enfermedad

- De seguir un tratamiento médico adecuado para reducir los efectos de las lesiones 0 enfermedades

- De cooperar de buena fe con los profesionales de la rehabilitación y con la empresa en relación con la reincorporación al trabajo

- De comunicar a la empresa las necesidades de adaptación del lugar de trabajo

- De aceptar el sistema de adaptación menos costoso y agresivo que produzca los resultados apetecidos 
modo que se respeten los derechos y se satisfagan las necesidades de los trabajadores sin menoscabo del objetivo empresarial de eficacia en función del coste. El crecimiento exponencial experimentado por los costes de las indemnizaciones por accidente de trabajo en los países industrializado ha inducido a desarrollar sistemas eficaces, en los que se incluyen los servicios de rehabilitación, que actualmente son objeto de evaluación. Los sindicatos pueden ser protagonistas importantes del desarrollo de estos programas. Deben reivindicar y proteger los derechos de los trabajadores que se ilustran en la Figura 17.6 y educar a éstos en el cumplimiento de sus obligaciones.

La mayor parte de los derechos de los trabajadores incluidos en la relación se enmarcan en los servicios habituales de reincorporación al trabajo de los trabajadores lesionados, en los que se utilizan las técnicas de rehabilitación más avanzadas (Perlman y $\mathrm{H}$ anson 1993). Los trabajadores tienen derecho a recibir una rápida atención médica y a la garantía del salario y del puesto de trabajo. Se ha establecido que la actuación precoz y la prontitud de la atención permiten reducir el tiempo de baja laboral. $L$ a reticencia al pago de las prestaciones puede inducir al desinterés del trabajador por la rehabilitación y la reincorporación al trabajo, y producir resentimientos y un espíritu de confrontación con la empresa y el sistema. Los trabajadores deben ser conscientes de las consecuencias de sufrir una lesión o una discapacidad, y conocer en profundidad la política de la empresa y las garantías legales. Lamentablemente, algunos sistemas de prevención, rehabilitación e indemnización por accidente de trabajo se han caracterizado por su fragmentación y por la comisión de abusos que han desconcertado a los usuarios en unos momentos delicados para ellos.

La mayoría de los sindicalistas están de acuerdo en que los trabajadores que quedan discapacitados tienen poco que ganar si pierden su puesto y su capacidad de trabajo. La rehabilitación es una respuesta voluntaria a una lesión o una discapacidad, que debe abarcar la actuación precoz, la evaluación global y la planificación individual, con la participación y posibilidad de decisión del propio trabajador. En los programas de reincorporación al trabajo se deben prever la reanudación gradual de las tareas, la readaptación, la jornada de trabajo reducida o la asignación a otras tareas, hasta tanto el trabajador no se encuentre en condiciones de recuperar su pleno rendimiento.

No obstante, esta política de acomodación puede colisionar con los derechos reconocidos al conjunto de los trabajadores, incluidos los derechos de antigüedad. Si bien los sindicalistas reivindican y defienden el derecho de los trabajadores discapacitados a reincorporarse al empleo, buscan soluciones que no vulneren las estipulaciones de los convenios colectivos en materia de antigüedad ni obliguen a reestructurar los puestos de trabajo de forma que otros trabajadores se vean obligados a realizar tareas o asumir responsabilidades que no les correspondan o que no les sean remuneradas. La colaboración y la participación de los sindicatos son imprescindibles para solucionar los problemas que se produzcan. Todas estas cuestiones ponen de relieve la necesidad de que los sindicatos participen en la elaboración y aplicación de las medidas legislativas, la gestión de la discapacidad y la formulación de programas y medidas de rehabilitación.

\section{Lo que los sindicatos pueden hacer}

Los sindicatos deben participar en las comisiones nacionales de debate de medidas legislativas relativas a la discapacidad y en los grupos de trabajo que se ocupan de esas cuestiones. En el lugar de trabajo y en los órganos de la empresa, deben contribuir a crear comités paritarios que elaboren planes de gestión de la discapacidad en el ámbito de la empresa, y supervisar los resultados concretos. Pueden facilitar la reincorporación al trabajo recomendando la adopción de medidas de acomodación, asegurando la colaboración de los compañeros y prestando asistencia a los trabajadores lesionados.

Los sindicatos pueden colaborar con las empresas en el desarrollo de programas de gestión de la discapacidad que beneficien a los trabajadores y permitan lograr el objetivo de limitar los costes. Pueden llevar a cabo proyectos de investigación de las necesidades de los trabajadores, elaborar códigos de conducta y realizar otras actividades de averiguación y defensa de los derechos de los trabajadores. Los derechos y obligaciones de educación de los trabajadores son igualmente esenciales para dar una respuesta adecuada a las lesiones y discapacidades.

\section{Algunos ejemplos de lo que los sindicatos han hecho} Algunos sindicatos han ayudado a sus gobiernos a superar las disfunciones de sus respectivos sistemas de gestión de las lesiones profesionales y de indemnización por accidentes de trabajo. En Australia, en respuesta a la presión de los costes derivados de las indemnizaciones por accidentes de trabajo y a la preocupación de los sindicatos por la falta de un sistema efectivo de rehabilitación, se promulgó en 1988 la Ley federal de indemnización y rehabilitación, en la que se establecía un nuevo sistema de coordinación de la prevención y la gestión de las lesiones y enfermedades profesionales de los trabajadores de la administración federal. El nuevo sistema se basa en el principio de que la rehabilitación efectiva y la reincorporación al trabajo, en su caso, constituyen el escenario más favorable tanto para el trabajador como para la empresa. La ley incorpora al sistema las políticas de prevención, rehabilitación e indemnización. Se garantizan al discapacitado tanto el empleo como la percepción de las prestaciones. El sistema de indemnización comprende el salario sustitutorio, los gastos de asistencia médica y similares $y$, en ciertos casos, un pago de pequeñas sumas globales. Si los afectados no pueden regresar al trabajo, reciben una prestación adecuada. Las cifras iniciales reflejan una tasa de reincorporación al trabajo del $87 \%$. Se ha atribuido el éxito del nuevo sistema a diversos factores, entre los que se incluye la colaboración de los agentes sociales, como los sindicatos.

El ya mencionado IAM / Boeing $\mathrm{H}$ ealth and Safety Institute es un ejemplo de colaboración entre sindicatos y dirección en el marco de la empresa. El programa de reincorporación al trabajo fue una de las primeras iniciativas del instituto, en respuesta a la deficiente atención que las necesidades de las víctimas de accidentes de trabajo recibían de unos sistemas fragmentarios de prestación de servicios que gestionaban las administraciones federal, estatal y local, junto a diversas entidades y organizaciones privadas de rehabilitación. Después de un análisis de los datos y de realizar una serie de entrevistas, el sindicato y la empresa produjeron un programa piloto que se juzga adecuado a los intereses de ambas partes. En él se reconocen algunos de los derechos anteriormente citados: actuación precoz, agilidad en la prestación de los servicios y en el pago de las indemnizaciones eventualmente exigibles, y evaluación periódica de los resultados del programa y de la satisfacción de los trabajadores.

Los últimos estudios de la satisfacción de los trabajadores indican que tanto la dirección como los trabajadores afectados estiman que el programa de reincorporación al trabajo nacido de la iniciativa conjunta del sindicato y la empresa han permitido mejorar el nivel de los servicios. Se espera que este programa, aplicado después en otras cuatro plantas de Boeing, se extienda al conjunto de la empresa. Hasta hoy, más de 100.000 trabajadores lesionados han recibido servicios de rehabilitación en el marco del programa.

EI programa HRDI de AFL-CIO ofrece igualmente servicios de rehabilitación para la reincorporación al trabajo de los trabajadores víctimas de accidentes de trabajo en las empresas con 
presencia sindical. El programa se asoció al Workplace Center de la Universidad de Columbia para gestionar el denominado Programa de Actuación Precoz, con objeto de determinar si la actuación precoz puede acelerar la reincorporación al trabajo de los trabajadores en situación de baja por una incapacidad de corta duración. La aplicación del programa permitió reincorporar al trabajo al $65 \%$ de los participantes, así como identificar diversos factores básicos del éxito. D os hallazgos revisten particular importancia en este análisis: (1) la práctica totalidad de los trabajadores sufren angustia derivada de las preocupaciones económicas, y (2) el apoyo del sindicado permitió reducir la hostilidad y las suspicacias hacia el programa.

La Disabled Forestry Workers Foundation of Canada desarrolló el programa denominado Modelo de Gestión de Casos para la Integración en el Lugar de Trabajo. El programa, que responde igualmente a una iniciativa conjunta del sindicato y la empresa, permite rehabilitar y reintegrar al trabajo a los trabajadores discapacitados. En el marco del programa se ha editado Industrial D isability M anagement: An E ffective E conomic and $H$ uman Resource Strategy, para contribuir a la aplicación de un modelo basado en la colaboración entre sindicatos, empresas, gobierno y consumidores. Asimismo, en el mismo marco se ha creado el $N$ ational Institute of $O$ ccupational Disability and Research, en el que colaboran sindicatos, empresas, educadores y profesionales de la rehabilitación. El instituto imparte diversos programas de formación de personal de recursos humanos y representantes sindicales que deben propiciar la difusión del modelo.

\section{Cuestión 4: Incorporación e integración en la comunidad y en el lugar de trabajo}

Antes de que los discapacitados puedan integrarse plenamente en el lugar de trabajo, es preciso que consigan la igualdad de acceso a los medios comunitarios que impelen a las personas a trabajar, les apoyan en el trabajo (oportunidades de recibir educación y formación, servicios sociales, etc.) y facilitan su acceso al medio ambiente de trabajo (vivienda, medios de transporte y de comunicación, etc. accesibles). M uchos sindicatos han comprendido que los discapacitados no se pueden integrar en el lugar de trabajo si se les excluye de la plena participación en la vida social. Además, una vez empleados, es posible que los discapacitados precisen unos servicios y adaptaciones específicos para integrarse plenamente o para mantener su rendimiento en el trabajo. La igualdad en la vida social son los precursores de la equidad en el empleo; por tanto, para afrontar adecuadamente los problemas del empleo y la discapacidad, es preciso abordar la cuestión, más amplia, de los derechos humanos.

Los sindicatos son igualmente sabedores de que, para garantizar la equidad en el empleo, puede ser precisa la prestación de determinados servicios o la realización de algunas adaptaciones y, movidos por el espíritu de solidaridad, optan, bien por prestar por sí mismo tales servicios a sus afiliados, bien por reivindicar la prestación de los servicios y la realización de las adaptaciones que se precisen. En la Figura 17.7 se relacionan los derechos y obligaciones en que se traduce la necesidad de disfrutar de pleno acceso a la vida social.

\section{Lo que los sindicatos pueden hacer}

Los sindicatos pueden convertirse en motores del cambio en las comunidades en que desarrollan su actividad mediante la promoción de la plena integración de los discapacitados en el lugar de trabajo y en el conjunto de la sociedad. Los sindicatos pueden acercarse a los trabajadores discapacitados y a las organizaciones que los representan y concertar con ellos la adopción de medidas efectivas. En el presente artículo se han puesto de relieve las

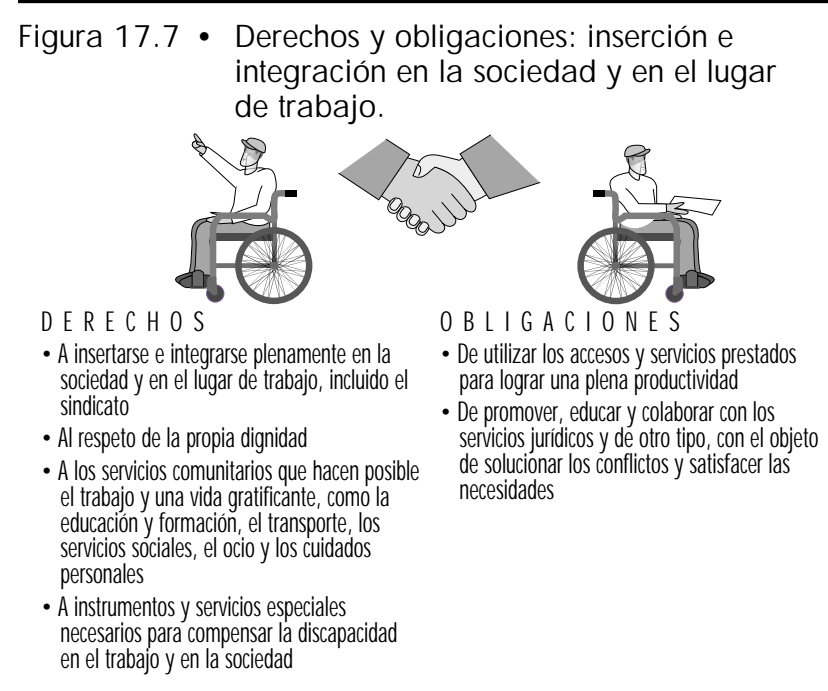

posibilidades de ejercer presiones políticas e influir en las reformas legislativas, dentro del espíritu de la Recomendación no 168 y del Convenio no 159 de la OIT. En ambos documentos se subrayan tanto la responsabilidad de las empresas y organizaciones empresariales en la elaboración de la política de rehabilitación profesional como su función en la aplicación de esa política y en la prestación de servicios.

Los sindicatos tienen la obligación de representar las necesidades de los trabajadores. Deben fijar unos modelos de prestación de servicios, de desarrollo de programas y de representatividad dentro de la estructura sindical, que comprendan la incorporación e integración de los discapacitados en todos niveles de la organización. Como se ilustra en algunos de los ejemplos siguientes, los sindicatos han utilizado a sus bases en la recaudación de fondos, la formación de un voluntariado o la prestación de servicios directos en el lugar de trabajo y en la sociedad, con objeto de lograr la plena integración de los discapacitados en la vida social y laboral.

\section{Lo que los sindicatos han hecho}

En Alemania existe un mandato legal de representatividad. Según la Ley de personas con discapacidades graves, en el comité de empresa de toda entidad, incluidos los sindicatos, que tenga cinco o más trabajadores fijos debe haber un representante de los trabajadores discapacitados, con la misión de velar por el respeto de los derechos e intereses de los representados. La dirección de la empresa está obligada a consultar a este representante sobre el sistema de contratación y la política general. Esta ley ha impulsado el compromiso de los sindicatos con las cuestiones de la discapacidad.

El I rish C ongress of Trade U nions (ICT U ) ha editado y distribuido Charter of Rights of People with Disabilities (1990), una relación de dieciocho derechos fundamentales para la plena equiparación de los discapacitados tanto en el lugar de trabajo como en el conjunto de la sociedad. Entre ellos se incluyen el derecho a un medio ambiente libre de obstáculos, a la vivienda, a una asistencia sanitaria de calidad, a la educación y formación, al empleo y a un medio ambiente accesible.

En 1946, la IAM AW inició su labor de asistencia a los discapacitados mediante la creación de International Guiding Eyes. En el marco de este programa, se facilitan perros guía y se educa a los ciegos y personas con deficiencia visual sobre el modo de utilizarlos para disfrutar de una vida más independiente y 
gratificante. U nas 3.000 personas de muchos países se han beneficiado de estas ayudas. U na parte de los costes de aplicación del programa se financian con las aportaciones de los afiliados al sindicato.

Anteriormente se ha comentado la labor que un sindicato japonés viene realizando y que tuvo su origen en los esfuerzos que la Asamblea de Sindicatos inició en el decenio de 1970, cuando uno de los afiliados, que tenía un hijo autista, recabó ayuda del sindicato para los niños discapacitados. La central sindical estableció una fundación financiada con el producto de la venta, inicialmente, de cerillas y, más tarde, de servilletas de papel, realizada por los afiliados al sindicato. La fundación estableció una línea telefónica de urgencia para aconsejar a los padres y ayudarles a afrontar la difícil tarea de educar a un hijo discapacitado en una sociedad segregacionista. Fruto de este esfuerzo, los padres se organizaron para exigir a la administración pública la eliminación de las barreras (se presionó a los ferrocarriles para que facilitaran el acceso, y la campaña prosigue aún). En verano, la fundación patrocinaba la celebración de festivales y otras actividades de ocio, además de visitas de ámbito nacional e internacional con objeto de dar a conocer los problemas de los discapacitados.

Veinte años más tarde, los niños han crecido y sus necesidades de ocio y educación se han transformado en demandas de acceso a la cualificación y al empleo. Se elaboró un programa de aprendizaje profesional destinado a los jóvenes discapacitados, que han estado disfrutando de la experiencia durante varios años. L os sindicatos recabaron de las empresas que facilitasen el aprendizaje laboral de los alumnos de segundo año de bachillerato aquejados de discapacidades. La experiencia de este programa evidenció la necesidad de fundar el Centro de A poyo al Empleo, aludido anteriormente, en la Cuestión I.

M uchos sindicatos prestan a los discapacitados una asistencia complementaria en el lugar de trabajo para ayudarles a conservar el empleo. Los sindicatos japoneses recurren al voluntariado para ejecutar programas de educación en el puesto de trabajo de los jóvenes empleados en las empresas con representación sindical. En Estados U nidos y Canadá, IAM CARES aplica un sistema de hermanamiento de los nuevos empleados discapacitados con militantes sindicales que actúan como tutores de aquéllos. Además, IAM CARES ha patrocinado la aplicación de programas de empleo protegido de los trabajadores discapacitados en Boeing y otras empresas. En los programas de empleo protegido, los trabajadores con discapacidades más graves cuentan con el apoyo de animadores laborales que les asisten en el aprendizaje del trabajo y colaboran en el mantenimiento de un nivel de rendimiento rentable.

Algunos sindicatos han creado subcomités o grupos de trabajo integrados por trabajadores discapacitados, con la misión de velar por el reconocimiento de los derechos e intereses de los afiliados discapacitados dentro de la estructura sindical. La American Postal Workers U nion es un magnífico exponente del funcionamiento de estos grupos de trabajo y de los resultados que se pueden obtener. En el decenio de 1970 se eligió al primer sordo para el cargo de delegado sindical. A partir de 1985 se han celebrado varias conferencias dedicadas exclusivamente a los afiliados afectados por la pérdida auditiva. Estos afiliados forman igualmente parte de los equipos negociadores que abordan las cuestiones de adaptación del lugar de trabajo y gestión de la discapacidad. En 1990, este equipo de trabajo colaboró con el servicio de correos en el diseño de un sello oficial cuyo motivo consistía en una mano que, por señas, decía: "Te quiero".

\section{Conclusiones}

Los sindicatos son, en su dimensión más elemental, organizaciones concebidas para las personas y sus necesidades. Desde su nacimiento, han hecho algo más que luchar por unos salarios justos y unas mejores condiciones de trabajo. En efecto, han procurado mejorar la calidad de vida y ampliar los horizontes de todos los trabajadores, incluidos los discapacitados.

Aunque donde más se siente su fuerza es en los lugares de trabajo, su influencia no se limita al ámbito de las empresas regidas por convenios colectivos. Como ilustran muchos de los ejemplos citados en el presente trabajo, los sindicatos también pueden influir en el entorno social general, a través de una serie de actividades e iniciativas dirigidas a eliminar la discriminación y la desigualdad que sufren los discapacitados.

Aun cuando sindicatos, empresas, organismos públicos, profesionales de la rehabilitación profesional y discapacitados poseen, a veces, perspectivas diversas, deben compartir la exigencia de un puesto trabajo saludable y productivo. Los sindicatos disfrutan de una posición de privilegio para unir estos grupos tan disímiles en torno a unos valores compartidos y asumir así una función central en el esfuerzo por enriquecer la vida de los discapacitados.

\section{Referencias}

Advisory C ouncil for Disabled Persons. 1990. Fulfilling the Potential of People with Disabilities. Toronto, O ntario.

AFL-CIO Department of Civil Rights. 1994. U nions and the Americans with Disabilities Act. Washington, DC: AFL-CIO

AFL-CIO Workplace $\mathrm{H}$ ealth Fund. 1992. Ergonomic T raining Program. W ashington, DC: AFL-CIO.

Bing, J, M Levy. 1978. Harmonisation et unification des législation de réparation du handicap. D roit Soc 64

Bruyere, S, D Shrey. 1991. Disability management in industry: A joint labour-management process R ehab Counsel Bull 34(3):227-242.

Canada Royal Commission on Equality in Employment, RS Abella. 1984. Report of the Commission on Equality in Employment/ Rosalie Silberman Abella, Commissioner. O ttawa, Canadá: $M$ inister of Supply and Services.
D egener, T, Y K oster-D reese. 1995. H uman Rights and D isabled Persons. D ordrecht: $M$ artinus N ijhoff.

Despouy, L. 1991. Human Rights and Disability. Ginebra: U NESCO

Fletcher, GF, JD Banja, BB Jann, SL Wolf. 1992 Rehabilitation M edicine Contemporary Clinical Perspectives. Filadelfia: Lea \& Febiger.

Getty, L, R H étu. 1991. The development of a rehabilitation program for people affected by occupational hearing loss. II: R esults from group intervention with 48 workers and their spouses. Audiology 30:317-329.

Gross, C. 1988. Ergonomic workplace assessments are the first step in injury treatment. Occ Saf $\mathrm{H}$ ealth R ep (16-19 M ay):84.

Habeck, R, M Leahy, H H unt, F Chan, E Welch 1991. Employer factors related to workers' compensation claims and disability management. R ehab Counsel Bull 34(3):210-226.

$\mathrm{H}$ ahn, H. 1984. The issue of equality: European perceptions of employment for disabled persons.
En International Exchange of Experts and Information in Rehabilitation. Nueva York: Fondo Mundial de Rehabilitación.

Helios, II. 1994. Economic integration of disabled people, exchange and information activities. En The Vocational Counsellor.

Hétu, R, H Tran Quoc, P Duguay, 1990. The likelihood of detecting a significant hearing threshold shift among noise-exposed workers subjected to annual audiometric testing. Ann 0 ccup $H$ yg 34(4):361-370.

Hétu, R, H Tran Quoc, Y Tougas. 1993. The hearing aid as warning signal receiver in noisy workplaces. Canadian A coustics/A coustique Canadienne 21(3):27-28

Hétu, R, L Getty, M C Bédard. 1994. R aising awareness about hearing impairment in public services: The nature of the benefits. XXII Congreso internacional de audiología, $\mathrm{Halifax}$ (julio 1994), Mesa redonda sobre la audiología desde la perspectiva de la salud pública. 
H étu, R, L G etty, S W aridel. 1994. Attitudes towards co-workers affected by occupational hearing loss. II: Focus group interviews. $\mathrm{Br} /$ Audiology. Pendiente de publicación.

Hétu, R, L Getty. 1991a. The development of rehabilitation programs for people affected by occupational hearing loss. 1: A new paradigm. Audiology 30:305-316.

-. 1991b. The nature of the handicap associated with occupational hearing loss: Obstacles to prevention. En Occupational $\mathrm{N}$ oise Induced $\mathrm{H}$ earing Loss- Prevention and Rehabilitation, dirigido por W Noble. Sidney, Australia: National O ccupational $\mathrm{H}$ ealth and Safety Commission. Arndale: U niversidad de N ueva Inglaterra.

Hétu, R, L G etty. 1993. O vercoming difficulties experienced in the work place by employees with occupational hearing loss. Volta R ev 95:301-402.

Hétu, R, L Jones, L Getty. 1993. The impact of acquired hearing loss on intimate relationships: Implications for rehabilitation. Audiology 32:363-381.

Hétu, R, M Lalonde, L G etty. 1987. Psychosocial disadvantages due to occupational hearing loss as experienced in the family. Audiology 26:141-152.

Hétu, R. 1994a. M ismatches between auditory demands and capacities in the industrial work environment. Audiology 33:1-14.

-. 1994b. Psychoacoustic performance in workers with NIHL. En Proceedings of the Vth International Symposium on the Effects of $\mathrm{N}$ oise on $\mathrm{H}$ earing Gothenburg, 12-14 de mayo, 1994

LaBar, G. 1995. Ergonomic help for material handling. 0 ccup $\mathrm{H}$ azards ( $\mathrm{an}$.):137-138.

Lepofsky, MD. 1992. The duty to accommodate: a purposive approach. Can Law J I(1, 2) (primavera/ verano).

Lucas, S. 1987. Putting a lid on disability costs. $M$ anage Solns (abril):16-19.

N aciones U nidas. 1982. Programa de A cción M undial para las Personas con D iscapacidad. Nueva Y ork: NU

—. 1990. D isability Statistics Compendium. N ueva Y ork: $\mathrm{NU}$

- 1983-1992. Decenio de las Naciones U nidas para las Personas con D iscapacidad. Nueva Y ork: NU.

- . 1993. N ormas uniformes de las $N$ aciones U nidas para la igualdad de oportunidades de las personas con discapacidad. N uevaY ork: NU.

Noble, W, R H étu. 1994. An ecological approach to disability and handicap in relation to impaired hearing. Audiology 33:117-126.

O rganización Internacional del Trabajo (O IT). 1948. Convenio núm. 88 (1948): Servicio del empleo. Ginebra: OIT.

—. 1948. Recomendación núm. 83 (1948): Servicio del empleo. Ginebra: OIT

-. 1952. Convenio núm. 102 (1952): Seguridad social (norma mínima). Ginebra: OIT.

- 1955. Recomendación núm. 99 (1955): Adaptación y readaptación profesional de los inválidos. G inebra: O IT

—. 1958. Convenio núm. 111 (1958): Discriminación (empleo y ocupación). Ginebra: O IT

- . 1964. Convenio núm. 121 (1964): Prestaciones en caso de accidentes del trabajo y enfermedades profesionales. Ginebra: OIT.

- 1975. Recomendación núm. 150 (1975): Desarrollo de los recursos humanos. Ginebra: OIT.

- 1978. Recomendación núm. 158 (1978) Administración del trabajo. Ginebra (OIT).
—. 1983. Convenio núm. 159 (1983): Readaptación profesional y empleo de personas inválidas. Ginebra: OIT

1983. Recomendación núm. 168 (1983): Readaptación profesional y empleo de personas inválidas. Ginebra: O IT .

—. 1984. Recomendación núm. 169 (1984): Política del empleo (disposiciones complementarias). Ginebra: OIT.

- Convenio núm. 108 (1988): Promoción de empleo y protección contra el desempleo. Ginebra: OIT

Organización M undial de la Salud (OMS). 1980. Clasificación internacional de deficiencias, discapacidades y minusvalías. Ginebra: O M S.

Pati, G. 1985. Economics of rehabilitation in the workplace. J Rehabil (oct., nov., dic.):22-30.

Perlman, LG, CE Hanson. 1993. Private Sector Rehabilitation: Insurance Trends and I ssues for the 21st Century. Informe sobre el 170 Seminario en memoria de Mary E. Switzer. Alejandría, $\checkmark$ irginia: N ational R ehabilitation Association.

Scheer, S. 1990. M ultidisciplinary Perspectives in Vocationa Assessment of Impaired W orkers. R ockville, M aryland: Aspen.

Shrey, D, J O Isheski. 1992. Disability management and industry-based work return transition programs. En Physical M edicine and Rehabilitation: State of the Art Review, dirigido por $\mathrm{C}$ Gordon y PE $K$ aplan. Filadelfia: $\mathrm{H}$ anley \& Belfus.

Shrey, D, M Lacerte. 1995. Principles and Practices of Disability $M$ anagement in Industry. Winter Park, Fla. GR Press.

Shrey, D. 1995. Employer empowerment through disability management. Work Injury $M$ anage $4(2): 7-9,14-15$

- . 1996. Disability management in industry: the new paradigm in injured worker rehabilitation. Disab Rehab, Int J . (en imprenta).

Tran Quoc, H, R Hétu, C Laroche. 1992. Computerized assessment and prediction of the audibility of sound warning signals for normal and hearing impaired individuals. En Computer Application in Ergonomics. Occupational $\mathrm{H}$ ealth and Safety, dirigido por $M$ Mattlis y W K arwowski. Amsterdam: Elsevier.

Westlander, G, E Viitasara, A Johansson, H Shahnavaz. 1995. Evaluation of an ergonomics intervention programme in VDT workplaces. Appl E rgon 26(2):83-92.

Wright, D. 1980. T otal Rehabilitation. Nueva York: Little Brown \& Co.

\section{0 tras lecturas recomendadas}

Akabas, SH, LB Gates. 1991. Disability M anagement: Labor $M$ anagement Initiatives in Early Intervention. Nueva York: Centre for Social Policy in the Workplace, School of Social Work, U niversidad de Columbia.

Carson, R. 1994. Stand by your job. O ccup H ealth Saf 63(4):38,40-42.

Daniels, SM. 1985. Attitudinal influences on affirmative action implementation. En Complete Guide to Employing Persons with Disabilities, dirigido por H M cC arthy. Albertson, N ueva Y ork: H uman R esources Centre.

Dickinson, DE. 1995. Proposed manual handling international and European standards. Appl Ergon 26(4):265-270.

Disabled Forestry Workers Foundation of Canada. 1991. E ffective Reintegration Strategies for the ' $90 \mathrm{~s}$ : T he Role of E mployers, U nions, Governmental and Consumers in Partnership. Vancouver: Disabled Forestry W orkers Foundation of $\mathrm{C}$ anada.

- 1992. Industrial Disability M anagement: An Effective E conomic and $H$ uman Resource Strategy. V ancouver: Disabled Forestry W orkers Foundation of Canada.

Doyle, B. 1995. Disability, Discrimination and Equal Opportunities: A Comparative Study of the Employment Rights of D isabled Persons. Londres: $M$ ansell.

Driedger, D. 1989. The Last Civil Rights M ovement; D isabled Peoples' International. L ondres: H urst \& C 0 .

Eklund, JAE. 1995. Relationships between ergonomics and quality in assembly work. Appl E rgon 26(5):15-20.

Erekson, T, A Rotatori. 1986. Accessibility to Employment Training for the Physically $\mathrm{H}$ andicapped. Springfield, Illinois: Charles C. Thomas Publishing.

H unt, H A, M Berkowitz. 1992. New T echnologies and the E mployment of D isabled Persons. Ginebra: OIT.

Konig, A, RL Schalock. 1991. Supported employment: Equal opportunities for severely disabled men and women. Int Labour Rev 130(1):21-37.

LaBar, G. 1995. Ergonomics: Lost in the mail? 0 ccup $H$ azards (octubre):142-147.

— . 1995. What makes ergonomic teams work? 0 ccup $\mathrm{H}$ azards (Feb.):83,85.

Lunt, N, P Thornton. 1993. Employment Policies for Disabled People. A Review of Legislation and Services in Fifteen Countries. Londres: Department of Employment.

M inistro Federal de Trabajo y Asuntos Sociales (Alemania). 1987. Integración profesional de los discapacitados - Guía para el procedimiento de las empresas. Bonn: Instituto Federal de Empleo.

Momm, W, A K onig. 1989. Community integration for disabled people. A new approach to their vocational training and employment. Int $\mathrm{L}$ abour $\mathrm{Rev}$ 128(4):497-509.

Organización de Cooperación y Desarrollo Económico (O CDE). 1992. Employment Policies for People W ith Disabilities, Report By an E valuation Panel. París: OCDE

O verman, S. 1995. Cutting the high costs of piecework. 0 ccup H ealth Saf 64(10):113-4,116.

Pentney, W. 1990. Discrimination and the Law. T oronto: Richard DeBoo.

Rainbird, G, D O 'N eill. 1995. O ccupational disorders affecting agricultural workers in tropical developing countries. Appl E rgon 26(3):189-193.

Schwartz, GE, SD Watson, DE Galvin, E Lipoff. 1989. The Disability M anagement Sourcebook. Washington, DC: Washington Business G roup on $\mathrm{H}$ ealth/Institute for Rehabilitation and Disability $M$ anagement.

Seyfried, E. 1991. Preconditions for the Successful Integration of the $\mathrm{H}$ andicapped into $W$ orking Life Summary R eport of a Study in B elgium, G ermany, F rance the Netherlands and the U nited Kingdom. Documento del CEDEFOP Luxemburgo: O ficina de Publicaciones $\mathrm{O}$ ficiales de la Comunidad Europea.

Smith, RB. 1995. Protected workers breathe easier. $O$ ccup $H$ ealth Saf 64(5):71-77.

Versloot, JM, A Rozeman, M Van Son, PF Van Akkerveeken. 1992. The cost-effectiveness of a back school program in industry: A longitudinal controlled field study. Spine 7(1):22-27.

Whaley, KE. 1994. Foam products plant institutes policies for reducing repetitive motion illnesses. 0 ccup H ealth Saf 63(5):68,70-71.

Williams, K. 1992. D oing business with carpal tunnel syndrome. W ork J Prev Assess R ehab 2(4):2-7. 

Director del capítulo Stew en $\mathrm{H}$ ecker

\section{Sumario}

Introducción y visión general

Steven $\mathrm{H}$ ecker

Principios de formación

Gordon Atherley y D ilys R obertson.

Educación y formación de los trabajadores

Robin B aker y $\mathrm{N}$ ina W allerstein .

\section{ESTUDIOSDE CASO}

Evaluación de la formación sobre salud y seguridad: esudio de caso de la educación de los trabajadores de residuos peligrosos del Sindicato Internacional de Trabajadores Q uímicos

T.H . M CQ uiston, P. Coleman, N.B. W allerstein, A.C. M arcus,

J.S. M orawetz, D.W. Ortieb y sincerely. H ecker.

Educación y formación ambiental: situación de la educación de los trabajadores que manejan materiales peligrosos en Estados U nidos

Glenn paulson, M ichelle M adelien, Susan Sink y Steven $\mathrm{H}$ ecker

La educación de los trabajadores y la mejora ambiental

E dward Cohen-R osenthal . . . . . . . . . . . . . . . . . . 18.17

Formación sobre salud y seguridad de los directivos J ohn Rudge. ...

Formación de los profesionales en materia de salud y seguridad

Wai-On Phoon

Un nuevo enfoque del aprendizaje y la formación: estudio de caso del Proyecto Africano de Salud y Seguridad de la O IT-FINNIDA Antero Vahapasi y $M$ erri W eigner. 


\section{- INTRODUCCION Y VISION GENERAL}

\section{Steven H ecker}

Un estudio de 1981 sobre la formación en seguridad y salud de los trabajadores en los países industrializados comenzaba con la siguiente cita del escritor francés V íctor H ugo: "N inguna causa puede triunfar sin hacer primero de la educación su aliado". (H eath 1981). Esta observación es válida para la salud y la seguridad en el trabajo aún a finales del siglo $X X$, y resulta apropiada para el personal de las organizaciones a todos los niveles.

A medida que el lugar de trabajo se hace cada vez más complejo, surgen nuevas exigencias de una mejor comprensión de las causas y medios de prevención de los accidentes, lesiones y enfermedades. Funcionarios públicos, estudiosos, empresas y sindicatos tienen un importante papel que desempeñar en el desarrollo de las investigaciones encaminadas a esa comprensión. El siguiente e importante paso es la transmisión eficaz de esa información a los trabajadores, supervisores, directivos, inspectores de la Administración y profesionales de la salud y la seguridad. Aunque los cursos para los médicos y especialistas en higiene del trabajo difieren en muchos aspectos de los de formación para trabajadores en el centro de trabajo, existen también unos principios comunes aplicables a todos ellos.

Es obvio que las políticas y prácticas nacionales de educación y formación varían, en función de las condiciones económicas, políticas, sociales, culturales y tecnológicas de cada país. En general, las naciones industrializadas disponen proporcionalmente de más profesionales especializados en la seguridad y la salud en el trabajo que los países en vías de desarrollo y estos trabajadores formados cuentan, además, con unos programas de educación y formación más avanzados. Las naciones menos industrializadas y más rurales tienden a confiar más en "trabajadores de atención primaria" que pueden ser representantes de los trabajadores en las fábricas o los campos o miembros del personal sanitario de los centros locales de salud. Es evidente que las necesidades de formación y los recursos disponibles varían mucho en estas situaciones. No obstante, todas tienen en común la necesidad de profesionales formados.

En el presente artículo se ofrece una visión general de las cuestiones más importantes relativas a la educación y formación, incluidos el análisis de los destinatarios y sus necesidades, el formato y contenido de una formación eficaz y las tendencias actuales importantes en este ámbito.

\section{Los destinatarios}

En 1981, el Comité Conjunto OIT / O M S sobre M edicina del Trabajo definió estos tres niveles educativos necesarios en el ámbito de la ergonomía, la salud y la seguridad en el trabajo: (1) concienciación, (2) formación para necesidades específicas y (3) especialización. Tales niveles no son independientes, sino que, más bien, forman parte de un continuo; cualquier persona puede solicitar información sobre uno y otro de ellos. Los principales grupos de destinatarios de la sensibilización básica son los legisladores, los responsables de la formulación de políticas, los directivos y los trabajadores. Dentro de estas categorías, muchas personas necesitan formación adicional sobre tareas más concretas. Por ejemplo, aunque todos los directivos deben tener un conocimiento básico de los problemas de salud y seguridad en sus áreas de responsabilidad y han de saber dónde buscar ayuda especializada, es posible que los responsables específicos de la salud y la seguridad y del cumplimiento de la normativa necesiten una formación más intensiva. A nálogamente, los trabajadores que actúan como delegados de prevención o pertenecen a los comités de seguridad y salud no pueden limitarse a una mera concienciación, como tampoco los funcionarios públicos que participan en la inspección de fábricas y desempeñan funciones de salud pública relacionadas con el lugar de trabajo.

Los médicos, enfermeras y (sobre todo en las áreas rurales y en desarrollo) el personal no médico de atención primaria cuya formación o práctica principal no incluye la medicina del trabajo necesitarán ampliar esa formación para prestar servicios a los trabajadores y poder reconocer, por ejemplo, las enfermedades profesionales. Por último, ciertos titulados (por ejemplo, ingenieros, químicos, arquitectos y diseñadores), cuya labor influye de modo considerable en la salud y la seguridad de los trabajadores, requieren una educación y una formación mucho más específica en estas áreas de la que reciben normalmente.

Los especialistas necesitan la educación y la formación más intensivas, sobre todo del tipo que se imparte en los programas de grado y postgrado. M édicos, enfermeras, higienistas industriales, ingenieros especialistas en seguridad y, más recientemente, expertos en ergonomía pertenecen a esta categoría. D ebido a la rápida evolución actual de todos estos campos, la educación continua y la experiencia en el puesto de trabajo constituyen una parte esencial de la formación de dichos profesionales

Es necesario subrayar que la especialización cada vez mayor en el ámbito de la seguridad y la higiene industrial ha tenido lugar sin que se preste una atención proporcional a los aspectos interdisciplinarios de esta materia. Es probable que la enfermera o el médico que sospeche la relación de una enfermedad con el trabajo requiera la ayuda de un higienista industrial para identificar, por ejemplo, la exposición tóxica en el lugar de trabajo que provoca el problema de salud. Dada la limitación de recursos, muchas empresas y administraciones públicas suelen emplear a un especialista en seguridad y no a un higienista, exigiéndole a aquél que se haga cargo tanto de las cuestiones de salud como de las de seguridad. La interdependencia de ambos ámbitos debe abordarse ofreciendo una formación y una educación interdisciplinarias a los profesionales especializados en salud y seguridad.

\section{¿Por qué formación y educación?}

La tecnología, la aplicación y la formación (lo que los ingleses denominan "la triple E: engineering, enforcement y education") son las principales herramientas necesarias para alcanzar los objetivos de reducción del número de lesiones y enfermedades profesionales y de fomento de la seguridad y la salud en el trabajo. Las tres son interdependientes y alcanzan diferentes niveles de importancia en el marco de los distintos sistemas nacionales. El objetivo global de la formación y la educación es mejorar la sensibilización respecto de los peligros para la salud y la seguridad, aumentar el conocimiento de las causas de las enfermedades y lesiones profesionales, y fomentar la aplicación de medidas preventivas eficaces. No obstante, el fin específico y el fomento de la formación variarán en función de los destinatarios.

\section{Directivos intermedios y altos directivos}

C ada vez se reconoce con mayor claridad la necesidad de que los directivos conozcan los aspectos de seguridad y salud de las operaciones de las que son responsables. Las empresas son conscientes de los cuantiosos costes directos e indirectos que generan los accidentes graves y los casos de responsabilidad civil y, en algunos ordenamientos, penal que tanto ellas como sus integrantes pueden verse obligados a afrontar. Aunque sigue aceptándose el enfoque del "trabajador descuidado" para explicar los accidentes y lesiones, cada vez se admite más la posibilidad de atribuir éstos a los "descuidos de los directivos" debido a una inadecuada gestión de las condiciones bajo su control. Por último, las empresas también se dan cuenta de unos resultados deficientes 
en materia de seguridad se traducen en una mala imagen pública; grandes desastres como el de la fábrica de Union Carbide en Bhopal (India) pueden echar abajo años de esfuerzo dedicados a una buena reputación.

La mayoría de los directivos han estudiado economía, ciencias empresariales o ingeniería y han recibido una formación escasa o nula en cuestiones de salud y seguridad en el trabajo. No obstante, sus decisiones diarias tienen una influencia decisiva en este ámbito, tanto directa como indirectamente. Para remediar tal situación, han empezado a considerarse las cuestiones de salud y seguridad en los planes de estudios de dirección de empresas e ingeniería y en los programas de formación continua de muchos países. O bviamente, es necesario dedicar más esfuerzos a la mejora de la difusión de información sobre salud y seguridad.

\section{Supervisores}

L os estudios llevados a cabo han puesto de manifiesto el importante papel que desempeñan los supervisores en los accidentes producidos en las empresas de construcción (Samelson 1977). Q ue los supervisores estén informados de los peligros para la salud y la seguridad de sus actividades, que impartan una formación eficaz a los miembros de sus equipos (sobre todo a los trabajadores nuevos) y que sean considerados responsables de la actuación de sus equipos es fundamental para que la situación mejore. Constituyen el vínculo más importante entre los trabajadores y las políticas de salud y seguridad de la empresa.

\section{Trabajadores}

La legislación, la costumbre y las tendencias actuales en los lugares de trabajo contribuyen a difundir la formación y la educación de los trabajadores. Cada vez son más las disposiciones públicas que contemplan su formación en materia de salud y seguridad. En algunas se hace referencia a la práctica general, mientras que en otras se considera la formación en sectores, ocupaciones o peligros concretos. A pesar de la sorprendente escasez de datos de evaluación válidos sobre la eficacia de la formación como medida para contrarrestar las enfermedades y lesiones relacionadas con el trabajo, (Vojtecky y Berkanovic 1984-85), la aceptación de ésta y de la educación para mejorar la actuación en materia de salud y seguridad en muchas áreas de trabajo es cada vez mayor en numerosos países y empresas.

El aumento de los programas de participación de los trabajadores en los equipos de trabajo autogestionados y la responsabilidad de tomar decisiones por parte de los trabajadores ha afectado asimismo al modo de considerar la salud y la seguridad. La educación y la formación suelen utilizarse para mejorar los conocimientos y las cualificaciones de los trabajadores de línea, considerados esenciales en la actualidad para la eficacia de estas nuevas tendencias en organización del trabajo. U na medida beneficiosa que las empresas pueden adoptar consiste en implicar pronto a los trabajadores (por ejemplo, en las etapas de planificación y diseño cuando se vayan a incorporar nuevas tecnologías en el lugar de trabajo) para anticiparse a los efectos adversos sobre el medio ambiente de trabajo y, en su caso, minimizarlos

Los sindicatos han actuado como una fuerza motriz en la defensa de una mejor y más amplia formación de los trabajadores y en el desarrollo y presentación de programas de estudio y materiales pedagógicos para sus afiliados. En muchos países, los miembros de los comités de seguridad, los delegados de prevención y los representantes de los comités de empresa han asumido un papel cada vez mayor tanto en la resolución de situaciones de peligro en el lugar de trabajo como en la inspección y la defensa jurídica. Las personas que ocupan estos puestos requieren una formación más completa y avanzada que la que se imparte a un trabajador que realiza una tarea específica.

\section{Profesionales de la salud y la seguridad}

Las obligaciones del personal de salud y seguridad comprenden una amplia gama de actividades que difieren en gran medida de un país a otro e incluso en una misma profesión. En este grupo se incluyen médicos, enfermeras, higienistas e ingenieros de seguridad, ya actúen por cuenta propia o por cuenta ajena en lugares de trabajo, grandes empresas, servicios de inspección de salud 0 de trabajo 0 instituciones académicas. $L a$ demanda de profesionales formados en el área de salud y seguridad en el trabajo ha crecido rápidamente desde el decenio de 1970 con la proliferación de leyes y reglamentos paralela al desarrollo de departamentos de salud y seguridad en las empresas y de la investigación académica en este campo.

\section{Alcance y objetivos de la formación y la educación}

Esta enciclopedia de la OIT presenta los numerosos peligros y cuestiones que deben abordarse y la variedad del personal necesario para desarrollar un programa exhaustivo de seguridad e higiene. En términos generales, los objetivos de formación y educación en materia de salud y seguridad pueden considerarse de diversas formas. En 1981 el Comité Conjunto OIT/OMS sobre M edicina del Trabajo facilitó las siguientes categorías de objetivos pedagógicos, que se aplican en alguna medida a todos los grupos mencionados: (1) cognitivos (conocimiento), (2) psicomotores (cualificaciones profesionales), y (3) afectivos (actitudes y valores). En otro marco se describe el continuo "informacióneducación-formación", que responde aproximadamente al "qué", el "por qué" y el "cómo" de los peligros y su control. En el modelo de "educación capacitante", analizado más adelante, se hace hincapié en la distinción entre formación (enseñanza de habilidades basadas en la competencia con resultados previsibles en el comportamiento) y educación (desarrollo de un pensamiento crítico independiente y de las cualificaciones para la toma de decisiones que den lugar a una actuación colectiva efectiva) (Wallerstein y Weinger 1992).

Los trabajadores necesitan comprender y utilizar procedimientos de seguridad, herramientas adecuadas y equipo de protección para llevar a cabo determinadas tareas como parte de la formación para adquirir las cualificaciones propias de su puesto. Asimismo, requieren formación sobre el modo de corregir los peligros que observen y familiarizarse con los procedimientos internos de la empresa, conforme a las leyes y reglamentos sobre salud y seguridad aplicables a su área de trabajo. A nálogamente, los supervisores y los directivos deben ser conscientes de los peligros físicos, químicos y psicosociales presentes en sus lugares de trabajo y de los factores sociales, organizativos y de relaciones laborales acaso relacionados con la creación y corrección de dichos peligros. Así, la mejora de los conocimientos y cualificaciones técnicas, organizativas, de comunicación y de resolución de problemas constituye un objetivo necesario de la educación y la formación.

En los últimos años, los avances en la teoría de la educación y, sobre todo, en las teorías sobre aprendizaje de adultos han influido en la educación sobre salud y seguridad. Tales avances se concretan en aspectos como la educación de capacitación, el aprendizaje cooperativo y el aprendizaje participativo. Todos ellos comparten el principio según el cual los adultos aprenden mejor cuando participan activamente en ejercicios de resolución de problemas. Además de la transmisión de conocimientos y cualificaciones específicas, una educación eficaz requiere el desarrollo de un pensamiento crítico y la comprensión del contexto de los comportamientos y de las formas de relacionar lo aprendido en clase con la realidad del lugar de trabajo. Estos principios parecen ser especialmente adecuados para la salud y la seguridad en el lugar de trabajo, donde las causas de lesiones 
y enfermedades, y de las condiciones peligrosas suelen consistir en una combinación de los factores físicos y ambientales, el comportamiento humano y el contexto social.

Al trasladar dichos principios a un programa de educación, deben considerarse cuatro categorías de objetivos:

O bjetivos de información: el conocimiento específico que los trabajadores en período de formación adquirirán; por ejemplo, el relativo a los efectos de los disolventes orgánicos sobre la piel y el sistema nervioso central.

O bjetivos de comportamiento: las aptitudes y cualificaciones que los trabajadores lograrán; por ejemplo, la capacidad de interpretar fichas de datos químicos o de alzar un objeto pesado de forma segura.

0 bjetivos de actitud: deben abordarse las creencias que interfieran con la actuación segura o con la respuesta a la formación. Creer que los accidentes no pueden evitarse o que "los disolventes no pueden hacerme daño porque llevo años trabajando con ellos y estoy perfectamente" son algunos ejemplos.

O bjetivos de acción social: la capacidad para analizar un problema concreto, identificar sus causas, proponer soluciones, planear y adoptar las medidas necesarias para resolverlo. Por ejemplo, la tarea de analizar un trabajo específico en el que varias personas han sufrido lesiones de espalda, y de proponer modificaciones ergonómicas, exige una acción social consistente en el cambio de la organización del trabajo mediante la cooperación entre la empresa y los sindicatos.

\section{Cambio tecnológico y demográfico}

O bviamente, la formación centrada en la concienciación y la gestión de peligros específicos para la salud y la seguridad depende del tipo de lugar de trabajo. Aunque algunos peligros permanecen relativamente constantes, los cambios de las características de los puestos de trabajo y de las tecnologías requieren una continua actualización de las necesidades de formación. Las caídas desde altura, la caída de objetos y el ruido, por ejemplo, han sido y seguirán siendo peligros importantes en el sector de la construcción, pero la introducción de muchos nuevos tipos de materiales sintéticos de construcción exige una sensibilización y unos conocimientos adicionales en cuanto a su capacidad para producir efectos perjudiciales para la salud. Asimismo, correas, filos y otros puntos peligrosos sin protección en la maquinaria siguen constituyendo amenazas corrientes para la seguridad, pero también la introducción de robots industriales y otros dispositivos controlados por ordenador requiere formación en este nuevo género de peligros técnicos.

Debido a la rápida integración económica mundial y a la movilidad de las empresas multinacionales, los viejos y los nuevos peligros relacionados con el trabajo coexisten en los países industrializados y en los países en vías de desarrollo. En estos últimos, pueden encontrarse centros de producción de electrónica avanzada junto a fundiciones de metal que siguen dependiendo de tecnologías primarias y que hacen un uso extensivo de mano de obra. Por otra parte, en los países industrializados conviven talleres de confección caracterizados por unas condiciones de salud y seguridad ínfimas y actividades de reciclaje del plomo de las baterías (pese a la amenaza que representa la toxicidad de este material) con empresas modernas altamente automatizadas.

La necesidad de una actualización continua de la información afecta tanto a trabajadores y directivos, como a los profesionales de la salud en el trabajo. Las insuficiencias en la formación, incluso de estos últimos, se ponen de manifiesto al comprobar que la mayoría de los higienistas industriales que realizaron sus estudios en el decenio de 1970 recibieron escasa formación en ergonomía; y aunque fueron ampliamente instruidos en el control de la calidad del aire, estos conocimientos se aplicaban casi exclusivamente a los lugares de trabajo industriales. En cualquier caso, la mayor innovación tecnológica, que ha afectado a millones de trabajadores desde entonces, es el uso generalizado de terminales de ordenador con pantallas de visualización de datos (PVD). La evaluación ergonómica y la intervención para evitar problemas musculosqueléticos o de visión entre los usuarios de dichas pantallas eran medidas desconocidas en el decenio de 1970; a mediados del decenio de 1990, los peligros para estos usuarios se han convertido en una cuestión principal en el campo de la higiene industrial. Asimismo, la aplicación de los principios de la higiene industrial a los problemas de calidad del aire en interiores (por ejemplo, para remediar el "síndrome del edificio enfermo/hermético") ha exigido la formación continua de los higienistas habituados únicamente a la evaluación de fábricas. Los factores psicosociales, en buena medida no reconocidos como peligros para la salud en el trabajo antes del decenio de 1980, desempeñan un papel importante en el tratamiento de los peligros relacionados con el uso de PVD, el aire interior y otros. Todos los que investigan estos problemas para la salud necesitan educación y formación para poder comprender las complejas interacciones entre el medio ambiente, los individuos y la organización social en este marco.

El cambio de la composición demográfica de la población activa también debe tenerse en cuenta al diseñar la formación sobre salud y seguridad. L as mujeres constituyen una proporción de la población activa cada vez mayor, tanto en los países desarrollados como en los países en vías de desarrollo y sus necesidades sanitarias dentro y fuera del lugar de trabajo deben ser satiffechas. La participación de trabajadores inmigrantes plantea nuevas cuestiones de formación, incluidas las relacionadas con el idioma, aunque, obviamente, los problemas de idioma y de alfabetización no se circunscriben a este grupo de población: los distintos niveles de alfabetización de los trabajadores nacionales también deben considerarse al diseñar e impartir formación. L os trabajadores de edad avanzada constituyen otro grupo cuyas necesidades deben estudiarse e incorporarse a los programas de educación ya que su número crece respecto al total de la población activa de muchos países.

\section{Lugares y proveedores de la formación}

El lugar elegido para impartir programas de educación y formación depende de los destinatarios, el propósito, el contenido y la duración del programa, sin olvidar, siendo realistas, los recursos disponibles en el país o la región. Los destinatarios de la educación sobre salud y seguridad son los escolares, alumnos en formación y aprendices, además de trabajadores, supervisores, directivos y profesionales de la seguridad y la salud.

\section{Formación en las escuelas}

La incorporación de la educación sobre salud y seguridad a la enseñanza primaria y secundaria y, sobre todo, a los centros de formación profesional y técnica es una tendencia positiva y cada vez más habitual. La enseñanza de la identificación y el control del peligro como parte ordinaria de la capacitación para profesiones u oficios concretos es mucho más eficaz que cualquier intento de impartir estos conocimientos más tarde, cuando el trabajador ha desarrollado su actividad durante varios años y ha adquirido ciertas prácticas y comportamientos. Sin duda, tales programas exigen que los profesores de dichos centros también hayan sido formados para identificar peligros y aplicar medidas preventivas.

\section{Formación en el puesto de trabajo}

La formación en el puesto de trabajo es apropiada para trabajadores y supervisores que se enfrentan a peligros concretos. Si tiene una duración significativa, se recomienda encarecidamente 
la instalación de aulas cómodas en el mismo centro de trabajo. En los casos en que estas actividades puedan intimidar a los trabajadores o desalentar su plena participación en las clases, será preferible utilizar instalaciones externas. Es posible que los trabajadores se sientan más cómodos en un local sindical cuando el sindicato desempeña un papel principal en el diseño y puesta en práctica del programa. No obstante, las visitas sobre el terreno a centros de trabajo reales que ilustren los peligros en cuestión son siempre un complemento positivo.

Formación de miembros de comités y delegados de prevención La formación de mayor duración y complejidad recomendada para los representantes de los comités y los delegados de seguridad suele impartirse en centros de formación especializados, universidades 0 instalaciones de empresas. Cada vez se emprenden más iniciativas para establecer normas que regulen la formación y certificación de los trabajadores que deben actuar en áreas peligrosas, como la retirada del amianto o el manejo de residuos peligrosos. Estos cursos suelen incluir clases teóricas y prácticas, en las que se simula la acción real, y requieren instalaciones y equipos especiales.

Las entidades responsables de impartir los programas dentro y fuera del lugar de trabajo a los trabajadores y los representantes de los comités de seguridad son los organismos públicos, las organizaciones tripartitas como la OIT u órganos análogos nacionales o subnacionales, las asociaciones empresariales y sindicatos, las universidades, asociaciones profesionales y consultores de formación privados. M uchos gobiernos destinan fondos al desarrollo de programas de formación y educación sobre salud y seguridad dirigidos a sectores o peligros concretos.

\section{Formación académica y profesional}

La formación de los profesionales de la salud y seguridad difiere de un país a otro en función de las necesidades de la población activa y de los recursos y estructuras en cada caso. La formación de los profesionales se centra en programas universitarios para licenciados y no licenciados, pero su disponibilidad varía en las distintas partes del mundo. Pueden ofrecerse programas de licenciatura para especialistas en medicina y enfermería del trabajo; y puede incorporarse la salud laboral a la formación de los médicos dedicados a la medicina general y de las enfermeras que trabajan en la asistencia primaria o en la sanidad pública. El número de programas de licenciatura para higienistas industriales ha registrado un aumento espectacular. Con todo, sigue existiendo una fuerte demanda de cursos breves y de formación menos general para técnicos en higiene, muchos de los cuales han recibido su formación básica en su puesto de trabajo en determinadas empresas.

$\mathrm{H}$ ay una gran demanda de personal especializado en salud y seguridad en los países en vías de desarrollo. A pesar de la favorable acogida que sin duda recibirán los médicos, enfermeras e higienistas acreditados que acudan a ellos, es previsible que muchos servicios de salud sigan siendo prestados por trabajadores de la atención sanitaria primaria. E stas per sonas necesitan formación sobre la relación entre trabajo y salud, la identificación de los principales riesgos para la salud y seguridad asociados al tipo de trabajo habitual en su región, las técnicas básicas de encuesta y muestreo, la utilización de las redes de referencia disponibles en su región para presuntos casos de enfermedades relacionadas con el trabajo y la educación sanitaria y las técnicas de comunicación de riesgos (O M S 1988).

Las alternativas a los programas de licenciatura universitaria son muy importantes para la formación profesional en los países en vías de desarrollo y en los industrializados y, entre otras opciones, deben incluir la educación continua y a distancia, la formación en el puesto de trabajo y la autoformación.

\section{Conclusión}

La educación y la formación no pueden solucionar todos los problemas de salud y seguridad en el trabajo, y ha de procurarse que las técnicas aprendidas en tales programas sean, de hecho, aplicadas eficazmente a las necesidades detectadas. No obstante, constituyen componentes primordiales de los programas de salud y seguridad eficaces desarrollados en este ámbito cuando se emplean combinadas con soluciones técnicas y de ingeniería. Una formación acumulativa, interactiva y continua, es esencial para adaptar la rápida evolución de nuestros entornos de trabajo a las demandas de los trabajadores, sobre todo en lo que se refiere a la prevención de enfermedades o lesiones. Tanto quienes desarrollan su labor en el lugar de trabajo, como quienes prestan su apoyo externamente requieren la información más actual disponible y las cualificaciones que permiten utilizarla para la protección y el fomento de la salud y la seguridad de los trabajadores.

\section{PRINCIPIOS DE FORMACION}

\section{G ordon Atherley y Dilys R obertson}

La formación puede producir y producirá resultados positivos siempre que se base en necesidades claramente definidas y específicas del lugar de trabajo y se imparta prestando atención tanto a éstas como al modo de aprendizaje de los adultos. O bviamente, esta afirmación también es aplicable a la formación sobre salud y seguridad. Sus principios no difieren de los que se aplican a cualquier otro tipo de formación empresarial. D e hecho, existen argumentos convincentes a favor de la integración de la formación sobre seguridad y la formación de cualificaciones siempre que sea posible. La formación sobre salud y seguridad que no genera resultados positivos porque no está basada en análisis solventes es, en el mejor de los casos, una pérdida de tiempo y de dinero. En el peor, puede dar lugar a una engañosa sensación de confianza, aumentando así el riesgo de accidentes.

\section{Evaluación de las necesidades}

El primer paso en el diseño de la formación sobre salud y seguridad es la identificación de los problemas que deben abordarse. Esta medida puede aplicarse a toda una organización, a un centro 0 a un trabajo concreto. O tra solución consistiría en centrar el análisis de las necesidades de formación en una cuestión específica, como el cumplimiento de la legislación sobre salud y seguridad o la actuación del comité de seguridad y salud. No obstante, no todos los problemas pueden resolverse a través de la formación; en algunos casos hay que emprender acciones suplementarias. Un ejemplo sencillo de esta situación hace referencia al problema del bajo nivel de cumplimiento de la norma que obliga a los trabajadores a utilizar los equipos de protección personal. Aunque el problema puede deberse parcialmente a la incomprensión por parte de los empleados de la necesidad de dicho equipo y del modo de utilizarlo correctamente, también es posible que esté causado, en todo o en parte, por continuas deficiencias en la reposición del equipo dañado o perdido.

L os problemas pueden traducirse en altas tasas de accidentes, en situaciones de negativa a trabajar por parte de los empleados 0 en citaciones o requerimientos de los inspectores de la Administración. Con todo, son los problemas que subyacen a estos signos externos de dificultad los que han de especificarse. Se define como evaluación de las necesidades de formación el proceso de identificación de problemas que, caracterizados por incumplimientos de normas o de requisitos externos, pueden ser resueltos, total o parcialmente, mediante la formación. Un enfoque sistemático del análisis de las necesidades de formación 
abarca varios pasos lógicos: identificación de problemas, análisis, identificación de las necesidades de formación, ordenación de dichas necesidades según su urgencia y determinación de los objetivos de formación.

\section{Identificación de los problemas}

Los problemas susceptibles de solución a través de la formación pueden clasificarse como sigue:

Problemas que se identifican una vez que se ha producido un accidente. En este caso, los problemas pueden detectarse revisando las estadísticas de accidentes o los informes de investigación de accidentes 0 , más en general, analizando los niveles de incumplimiento de los objetivos empresariales sobre salud y seguridad.

Problemas que pueden preverse. Es posible identificar los peligros antes de que se produzca un daño real; por ejemplo, puede preverse el peligro implícito en la introducción de nuevas sustancias, procedimientos o maquinaria en el lugar de trabajo, en la utilización de procesos que nunca han sido analizados con detalle 0 en la práctica habitual contraria a los procedimientos de seguridad reconocidos.

Existencia de requisitos externos. El ejemplo típico es el de las nuevas disposiciones legales que imponen obligaciones concretas en materia de salud y seguridad, y que por tanto aluden a la necesidad de formación. 0 tro ejemplo es el de elaboración de nuevos códigos de prácticas empresariales y de normas nacionales 0 internacionales relativos a la salud y la seguridad.

\section{Análisis de los problemas}

EI paso siguiente consiste en el análisis de los problemas para establecer cuál es la formación necesaria. Este análisis exige la recogida de información sobre el problema para determinar sus causas, así como la determinación de una norma adecuada que deba seguirse. Si el problema identificado tiene que ver, por ejemplo, con una falta de eficacia del comité de seguridad y salud, con ese análisis se tratará de responder a varias preguntas. En primer lugar, ¿qué se supone que hace el comité? En segundo lugar, ¿en qué medida lleva a cabo satisfactoriamente cada una de sus tareas asignadas? (Esta cuestión exigirá del analista la determinación de los criterios de actuación adecuados que deben aplicarse.) En tercer lugar, ¿por qué no realiza ciertas tareas de forma eficaz?

\section{Determinación de soluciones}

Una vez analizado el problema, el siguiente paso consiste en determinar las soluciones idóneas. Si la formación es la solución 0 forma parte de ella, deben establecerse las necesidades específicas pertinentes. ¿Q ué combinación de cualificaciones y conocimientos se requiere y por quién?

Un elemento esencial de la investigación de las necesidades de formación es la evaluación de las personas interesadas. Su objetivo es triple: en primer lugar, es más probable que las personas refuercen su compromiso con la formación ( $y$, por tanto, más probable que aprendan) si han participado en la identificación de sus propias necesidades; en segundo lugar, suele ser necesario evaluar en cada momento el nivel de habilidades y conocimientos requeridos en el grupo de empleados destinatarios (por ejemplo, podría investigarse si los miembros del comité de seguridad y salud conocen realmente sus obligaciones); en tercer lugar, deben conocerse los niveles educativos básicos y la destreza en el uso del lenguaje, la lectura y la escritura, a fin de aplicar métodos didácticos adecuados. Las encuestas son útiles para evaluar algunas de estas variables. En tal caso, deberá garantizarse la confidencialidad individual.
E stablecimiento de prioridades y objetivos

Una vez que las necesidades de formación han sido claramente identificadas, el siguiente paso consiste en establecer prioridades y objetivos. Debe considerarse la urgencia relativa de las distintas necesidades de formación, teniendo en cuenta factores como la gravedad relativa de las consecuencias en caso de accidente, la frecuencia con la que probablemente se produzcan los problemas, el número de personas afectadas y el cumplimiento de la legislación.

Los objetivos de la formación deben ser concretos, ya que, en caso contrario, resultará difícil evaluar si ésta ha tenido éxito. Unos objetivos específicamente definidos ayudan también a determinar el contenido y el modo de impartir la formación más adecuados. A través de los objetivos se establecen los resultados que deben conseguirse. $\mathrm{He}$ aquí algunos ejemplos de objetivos de formación específicos: a) conseguir que los directivos y los supervisores conozcan y comprendan los derechos y deberes en materia de salud y seguridad que son jurídicamente aplicables tanto a ellos como a los demás trabajadores; b) conseguir que los soldadores conozcan y entiendan los peligros de su actividad y los procedimientos de control establecidos; c) proporcionar a los operarios de carretillas elevadoras la cualificación necesaria para manejar sus vehículos con seguridad de acuerdo con los procedimientos establecidos.

\section{Métodos de evaluación de las necesidades}

Los métodos de evaluación de las necesidades de formación dependen del alcance de dicha evaluación y de los recursos disponibles. Pueden utilizarse algunos o la totalidad de los métodos siguientes:

- E studio de documentación. Para establecer su relación con las necesidades de formación pueden examinarse, por ejemplo, informes escritos sobre prácticas de trabajo seguras, requisitos legales, procedimientos y políticas empresariales, estadísticas de accidentes o informes de inspección en centros de trabajo.

- Análisis específico. Por su especial pertinencia para el problema en cuestión, pueden examinarse estadísticas de accidentes, actas del comité conjunto o informes de investigación sobre accidentes y peligros del trabajo o el tipo de tarea.

- Entrevistas y observación. Pueden utilizarse entrevistas con muestras representativas de supervisores, trabajadores y otros para evaluar actitudes y áreas de problemas percibidos; pueden observarse trabajos representativos para evaluar el cumplimiento de las prácticas de trabajo seguras.

- Encuestas. Pueden realizarse encuestas con grupos relativamente grandes para recoger información sobre los niveles de cualificaciones y de conocimientos en cada momento y sobre las necesidades de formación y las áreas de problemas percibidas.

\section{Elección de métodos didácticos adecuados}

Entre los métodos didácticos hay que mencionar técnicas como las conferencias, los ejercicios de resolución de problemas, los debates en pequeños grupos y la interpretación de papeles (roleplaying). Los métodos que se elijan deben adecuarse a lo que se esté aprendiendo (ya sean conocimientos, destrezas o conceptos) y a los objetivos de la formación. Por ejemplo, si el objetivo de formación es impartir conocimientos sobre las reglas de seguridad básicas en el lugar de trabajo, una breve conferencia puede resultar apropiada. No obstante, existen distintos niveles en el aprendizaje de adultos. En el nivel inferior, la actividad se reduce a la recepción de la información; el nivel siguiente consiste en la adquisición de conocimientos; el tercero, en el desarrollo de la capacidad de comprensión; y, finalmente, el nivel más alto, en la adquisición de la capacidad para aplicar lo aprendido a distintas situaciones. En la mayoría de las situaciones de formación, los 
participantes deberán aprender a más de un nivel y, por tanto, será necesario utilizar varias técnicas didácticas. Asimismo, los métodos didácticos deben basarse en sólidos principios sobre el modo en que los adultos aprenden mejor.

\section{Principios del aprendizaje de adultos}

La forma en que aprenden los adultos difiere de la que es habitual entre los niños en varios aspectos importantes, debido a que afrontan esta tarea contando con una experiencia vital y un desarrollado concepto de sí mismos. El proceso de aprendizaje constituye una experiencia individual que tiene lugar dentro del alumno y que depende de su disposición a aprender, de su capacidad para relacionar sus propias experiencias con lo que está aprendiendo y de su percepción del valor de lo aprendido. En muchos casos, los adultos escogen libremente su acceso al aprendizaje y por ello, a diferencia de los niños, participan de forma voluntaria. No obstante, cuando se imparte formación sobre salud y seguridad en el lugar de trabajo, puede ser conveniente exigir a trabajadores y directivos su asistencia a sesiones de formación sin dejar otra opción. En tal caso, es necesario prestar especial atención a los participantes tanto en el proceso de identificación de las necesidades de formación, como en el diseño del programa en sí. El estudio de las necesidades de formación percibidas por los trabajadores puede ser tan importante como la identificación de necesidades en otras áreas. La formación de adultos exige, sobre todo, cambios. Su aceptación depende, como en cualquier cambio, de que el alumno crea que tiene algún control sobre el mismo y de que éste no se perciba como una amenaza.

La investigación ha permitido identificar varios factores que facilitan el aprendizaje de adultos:

- M otivación. Puesto que el aprendizaje es una experiencia individual, los adultos deben querer aprender y darse cuenta de la importancia de lo que aprenden para sus intereses personales.

- Ver y escuchar. Los adultos tienden a aprender mejor cuando, además de oír, pueden ver lo que se está enseñando. Así, en las conferencias debe utilizarse material visual de apoyo, como transparencias o diapositivas.

- Práctica. La oportunidad de practicar lo que se enseña facilita el aprendizaje. Cuando se explica una determinada técnica (por ejemplo, la colocación correcta de un respirador autónomo), debe permitirse a los alumnos practicar por sí mismos. Si el objetivo consiste en aplicar los conocimientos, pueden utilizarse ejercicios de resolución de problemas. Los ejercicios prácticos que permiten a los alumnos experimentar realmente la aplicación de conceptos abstractos como el trabajo en equipo constituyen valiosas herramientas didácticas.

- Relación con la experiencia práctica. El aprendizaje resulta más sencillo cuando el material pedagógico puede relacionarse fácilmente con la experiencia práctica de los alumnos. En este sentido, los ejemplos utilizados deben estar relacionados, en la medida de lo posible, con procesos de trabajo conocidos para los alumnos.

- Participación en el proceso de aprendizaje. Los adultos deben saber desde el principio cuáles son los objetivos del aprendizaje y tener la oportunidad de comparar el contenido de las lecciones con dichos objetivos.

- Retroinformación. Los adultos necesitan disponer de retroinformación sobre sus propios resultados (sobre la bondad de su actuación), además de un apoyo positivo.

- Probar ideas. La oportunidad de probar y desarrollar ideas forma parte del proceso individual de interiorización de nueva información y de su aplicación. Este proceso puede facilitarse a través del debate en pequeños grupos de colegas.

- Entorno físico. Las instalaciones y los equipos utilizados para la formación deben adaptarse a las necesidades de los alumnos, de forma que puedan acceder al material visual y trabajar eficazmente en pequeños grupos.

\section{Ejecución de la formación}

D ebe prestarse especial atención a la selección de los formadores, la planificación de la formación y las pruebas piloto. Al elegir los formadores, deben considerarse dos aptitudes igualmente importantes: el conocimiento de la materia y la capacidad docente. No todos los que han adquirido los conocimientos requeridos sobre salud y seguridad tienen necesariamente tal capacidad. En general, es más fácil cumplir la primera condición que la segunda. En la mayoría de los centros de trabajo, hay personas a todos los niveles que poseen una capacidad docente natural y tienen la ventaja de conocer el lugar de trabajo y de comprender los ejemplos prácticos. En el caso del aprendizaje en pequeños grupos un "facilitador" puede ocupar el lugar del formador. EI facilitador aprende al mismo tiempo que el resto del grupo, pero comparte responsabilidades respecto al proceso de aprendizaje.

Deben considerarse varias cuestiones importantes relacionadas con la planificación de la formación. Por ejemplo, ésta debe impartirse en un horario conveniente para los trabajadores, en el que las interrupciones sean mínimas. Asimismo, puede concentrarse en módulos autónomos que permitan espaciarla en el tiempo (así, podría programarse un módulo de tres horas una vez a la semana). Este enfoque no sólo interfiere menos en la producción, sino que también permite a los alumnos disponer de un período entre las distintas sesiones para tratar de aplicar lo aprendido.

Todo programa de formación debe someterse a una prueba piloto antes de su aplicación. Esta medida permite su contraste respecto a los objetivos perseguidos. En las pruebas piloto deben participar no sólo los formadores, sino también una muestra representativa de los futuros alumnos.

\section{Evaluación de la formación}

EI fin de la evaluación de la formación es bastante simple; consiste en establecer si se han alcanzado sus objetivos, y, en tal caso, si se ha resuelto así el problema considerado al fijarlos. Es necesario comenzar a preparar la evaluación de la formación ya en la etapa de diseño. Es decir, el problema que va a abordarse mediante la formación debe estar claro, sus objetivos han de ser concretos y debe conocerse la situación previa al inicio de la formación. Así, si el problema afrontado consiste en un cumplimiento deficiente de las prácticas de trabajo seguras en las operaciones de manipulación de materiales, y se ha diseñado la formación para abordar parte de este problema suministrando información y proporcionando cualificación, por ejemplo, a los operarios de carretillas elevadoras, un resultado positivo en este caso consistirá en conseguir un alto grado de cumplimiento de las prácticas de trabajo seguras y apropiadas.

La evaluación de la formación puede llevarse a cabo a varios niveles. En un primer nivel, se estudian las reacciones de los alumnos al programa de formación. ¿Les ha gustado el programa, el monitor, el material del curso?; ¿se han aburrido?; ¿consideran que han aprendido algo? Este enfoque puede ser útil al evaluar la percepción de los alumnos respecto al valor del programa. La mejor forma de realizar estas evaluaciones consiste en administrar una encuesta de actitudes, aunque no por el monitor del curso. Es improbable que los participantes 
respondiesen de forma sincera en ese momento aunque los cuestionarios fueran anónimos. Como ayuda para este tipo de evaluación, puede permitirse a los alumnos someterse a prueba respecto al contenido de la formación.

En el siguiente nivel de la evaluación se trata de estudiar si se han alcanzado los objetivos del aprendizaje. Estos se relacionan con el contenido de la formación y definen lo que el alumno debe ser capaz de hacer o de saber cuando ésta haya finalizado. Suelen fijarse para cada parte del curso y se comunican a los alumnos para que sepan lo que van a aprender. La evaluación a este nivel trata de averiguar si los alumnos han aprendido lo especificado en los objetivos de formación. Con este fin, puede sometérseles a una prueba al final del curso. Los conocimientos, conceptos y cualificaciones de tipo abstracto pueden evaluarse mediante pruebas escritas, mientras que las de tipo práctico pueden valorarse a través de la observación directa de los alumnos en una demostración de las mismas. Al utilizar este nivel de evaluación, es absolutamente necesario saber cuáles son los conocimientos y cualificaciones de los alumnos antes de comenzar su formación.

El tercer nivel de evaluación consiste en averiguar si los conocimientos y cualificaciones adquiridos durante la formación se aplican realmente en el trabajo. En este sentido, puede utilizarse la observación directa durante intervalos concretos. La evaluación hecha nada más finalizar la formación puede dar un resultado muy diferente del que se obtendría si se realiza tres meses más tarde. Por lo demás, conviene tener en cuenta que, si pone de manifiesto una falta de aplicación transcurridos tres meses, hay que contar con la posibilidad de que no sea deficiente en sí la formación, sino que exista una falta de apoyo a la misma en el lugar de trabajo.

Finalmente, en el nivel superior de evaluación se trata de determinar si el problema abordado a través de la formación ha sido resuelto. Si el problema era una alta tasa de lesiones musculosqueléticas en el área de carga y descarga, ¿existen pruebas de que se haya podido reducir? De nuevo, la elección del momento adecuado es importante. En este caso, puede pasar algún tiempo hasta que la formación resulte eficaz. Es posible que la tasa no disminuya en varios meses debido al carácter frecuentemente acumulativo de tales lesiones y que, por tanto, refleje durante algún tiempo las condiciones anteriores a la formación. A demás, acaso ésta genere una mayor sensibilización respecto al problema, con el consiguiente aumento de los partes de lesiones poco después de finalizada la misma.

Lo deseable es que se consideren los cuatro niveles de evaluación de la formación al diseñarla y ejecutarla. En los casos en que sólo se aplique un nivel, sus limitaciones deben ser claramente comprendidas por todos los interesados.

Cuando es una entidad externa la que diseña e imparte la formación, la empresa puede y, en cualquier caso, debe evaluar su utilidad potencial aplicando criterios basados en los principios aquí esbozados.

\section{Apoyo a la formación}

Independientemente de la eficacia de la formación para alcanzar los objetivos previstos, su efecto disminuirá con el tiempo si no se le presta un apoyo regular y coherente en el lugar de trabajo. Tal apoyo debe ser una tarea habitual de los supervisores, directivos y los comités conjuntos de salud y seguridad. Puede prestarse mediante la realización de controles regulares de la actuación en el puesto de trabajo, el reconocimiento de la actuación correcta o la utilización rutinaria de reuniones breves, anuncios y carteles para recordar lo aprendido.

\section{EDUCACION Y FORMACION DE LOS TRABAJADORES}

\author{
Robin Baker y Nina Wallerstein
}

La formación de los trabajadores en salud y seguridad en el trabajo puede obedecer a propósitos muy diversos. Con excesiva frecuencia, se considera únicamente un modo de cumplir los reglamentos administrativos o de reducir los costes de seguros a través del cumplimiento estricto de las normas de seguridad en el trabajo. En realidad, la educación de los trabajadores obedece a un fin mucho más amplio, ya que trata de capacitar a los trabajadores para que sean parte activa en la seguridad del lugar de trabajo, en vez de estimular simplemente el cumplimiento de las normas de seguridad de la dirección.

En las dos últimas décadas se ha extendido en muchos países el movimiento en favor de una amplia participación de los trabajadores en el ámbito de la salud y la seguridad. Las nuevas disposiciones se basan menos que antes en el posible efecto estimulante de las inspecciones a cargo de la administración. Cada vez se alienta más a los sindicatos y a las empresas a que colaboren para promover la salud y la seguridad a través de comités conjuntos o de otros mecanismos. Este enfoque exige la disponibilidad de una mano de obra cualificada y bien informada que pueda interactuar directamente con la empresa.

Por fortuna, existen muchos modelos internacionales para formar a los trabajadores en todas las destrezas necesarias para participar de lleno en los esfuerzos a favor de la salud y la seguridad en el lugar de trabajo. Estos modelos se han desarrollado a través de la actuación combinada de los sindicatos, los programas de educación laboral de las universidades y las organizaciones no gubernamentales. M uchos programas innovadores de formación de los trabajadores se han elaborado con la ayuda financiera del Estado o de los sindicatos o con aportaciones de las empresas a los fondos de salud y seguridad negociados colectivamente.

Estos programas participativos, diseñados en distintos entornos nacionales para diversas poblaciones de trabajadores, comparten el mismo enfoque general: un enfoque basado en sólidos principios de la educación de adultos e inspirados en la filosofía de capacitación de la "educación popular". En este artículo se describe ese enfoque educativo y sus consecuencias para el diseño eficaz de la formación de los trabajadores.

\section{Enfoque educativo}

Dos disciplinas han influido en el desarrollo de los programas de educación para la salud y la seguridad dirigidos a los trabajadores: la denominada educación obrera y, más recientemente, la educación "popular" o de capacitación.

La educación obrera comenzó en la misma época que el movimiento sindical, a principios del siglo $X I X$. Sus objetivos iniciales se orientaban hacia el cambio social, es decir, al fomento de la fortaleza de los sindicatos y de la integración de los trabajadores en organizaciones políticas y sindicales. La educación obrera se definió como una "rama especializada de la educación de adultos que trata de satisfacer las necesidades e intereses educativos derivados de la participación de los trabajadores en el movimiento sindical". D esde entonces se ha desarrollado de acuerdo con principios bien conocidos de la teoría del aprendizaje adulto, entre los que pueden mencionarse los siguientes: 
- Los adultos se automotivan, sobre todo cuando la información que reciben tiene una aplicación inmediata a su vida y a su trabajo. Por ejemplo, esperan obtener herramientas prácticas que les ayuden a solucionar problemas en su lugar de trabajo.

- Los adultos aprenden mejor cuando construyen sobre lo que ya saben, de manera que puedan incorporar ideas nuevas a su repertorio de conocimientos. Desean que se respete la experiencia adquirida en la vida. En consecuencia, los métodos más eficaces se basan en sus propios conocimientos y estimulan la reflexión sobre los conocimientos de base.

- Los adultos aprenden de formas diferentes. Cada uno tiene su propio estilo de aprendizaje. U na sesión educativa se desarrollará mejor si los participantes tienen ocasión de experimentar diversas modalidades de aprendizaje: escuchar, observar medios visuales, hacer preguntas, simular situaciones, leer, escribir, practicar con equipos y discutir cuestiones críticas. La variedad no sólo garantiza el acercamiento a cada estilo cognitivo, sino que favorece también la repetición para reforzar el aprendizaje y, por supuesto, combate el aburrimiento.

- Los adultos aprenden mejor cuando participan activamente, cuando "aprenden haciendo". Son más receptivos a los métodos activos y participativos que a las medidas pasivas. Las clases magistrales y los materiales escritos tienen su sitio en un repertorio completo de métodos, pero es más probable que los estudios de casos, los juegos de roles, las simulaciones y otras actividades en pequeños grupos que permiten participar a cada individuo promuevan mejor la retención y la aplicación de los nuevos aprendizajes. I dealmente, cada sesión supone la interacción entre los participantes e incluye ocasiones para aprender nueva información, para aplicar nuevas destrezas y para comentar causas de problemas y obstáculos para su resolución. Los métodos participativos requieren más tiempo, grupos más pequeños y, quizá, destrezas instructivas diferentes de las que suelen poseer muchos formadores, pero, para aumentar el impacto de la educación, es esencial la participación activa.

Desde el principio de la década de 1980, la perspectiva de la educación "popular" o "de capacitación" ha influido también en la formación de los trabajadores en la salud y la seguridad. De hecho, la educación popular empezó a desarrollarse ya en el decenio de 1960, en gran medida a partir de la filosofía del educador brasileño Paulo Freire. Se trata de un enfoque participativo del aprendizaje, basado en la realidad de las experiencias de los estudiantes o trabajadores en sus lugares de trabajo. Favorece el diálogo entre educadores y trabajadores; analiza críticamente los obstáculos que se oponen al cambio, como las causas organizativas 0 estructurales de los problemas, y tiene como objetivos la acción y la capacitación del trabajador. Estos principios acogen las premisas básicas de la educación de adultos, aunque hacen hincapié en la acción del trabajador en el proceso educativo, tanto como meta para mejorar las condiciones del lugar de trabajo como en cuanto mecanismo para el aprendizaje.

La educación participativa en un contexto de capacitación es algo más que la realización de actividades en pequeños grupos que involucren a los estudiantes-trabajadores en el aprendizaje activo en el aula. Significa que los estudiantes-trabajadores tienen oportunidad de adquirir destrezas de pensamiento analíticas y críticas, destrezas prácticas de acción social y la confianza suficiente para elaborar estrategias que mejoren el ambiente de trabajo mucho después de finalizar las sesiones educativas.

\section{Diseño de programas educativos}

Conviene tener en cuenta que la educación es un proceso continuado y no un hecho aislado. Es un proceso que requiere una planificación cuidadosa y hábil, al menos de cada etapa importante. Para llevar a la práctica un proceso educativo participativo basado en principios bien fundados de la educación de adultos y que capacite a los trabajadores, deben observarse determinadas fases en la planificación y aplicación de la educación participativa de los trabajadores, similares a las que se utilizan en otros programas de formación (véase "Principios de formación"), aunque hace falta prestar especial atención al objetivo de la capacitación de los trabajadores:

\section{Primera fase: evaluación de las necesidades}

La evaluación de las necesidades constituye el fundamento de todo el proceso de planificación. U na evaluación completa de las necesidades que implica la formación de los trabajadores incluye tres componentes: una evaluación de los peligros, un perfil de la población a la que se dirige la formación y una información previa sobre el contexto social de la formación. La evaluación de los peligros pretende identificar los problemas prioritarios que hay que abordar. EI perfil de la población trata de responder un amplio conjunto de cuestiones sobre los trabajadores: ¿quién sacará más provecho de la formación? ¿Q ué formación ha recibido ya la población objetivo? ¿Q ué conocimientos y experiencia aportan al proceso los participantes? ¿Cuál es la composición étnica y de sexos de los trabajadores? ¿Q ué nivel de alfabetización tienen los trabajadores y qué idiomas hablan? ¿A quién respetan y de quién desconfían? Por último, la obtención de información sobre el contexto social de la formación permite al formador maximizar el impacto de la misma teniendo en cuenta las fuerzas que pueden respaldar las condiciones mejoradas de salud y seguridad (como una fuerte protección sindical que permita hablar con libertad a los trabajadores sobre los peligros) y las que pueden plantear obstáculos (como las presiones a favor de una productividad mayor o la inseguridad del puesto de trabajo).

La evaluación de las necesidades puede basarse en cuestionarios, en la revisión de documentos, en observaciones efectuadas en el centro de trabajo o en entrevistas con los trabajadores, sus representantes sindicales y otras personas. EI enfoque de la educación popular emplea un proceso de "escucha" sobre la marcha para obtener información acerca del contexto social de la formación, incluidas las preocupaciones de las personas y los obstáculos que pudieran impedir el cambio.

\section{Segunda fase: obtención de apoyos}

El éxito de los programas de educación de los trabajadores se funda en la identificación y la participación de los actores clave. La población objetivo debe participar en el proceso de planificación; es difícil ganar su confianza sin haber pedido su opinión. En un modelo de educación popular, el educador trata de crear un equipo de planificación participativo, a partir del sindicato 0 comité de empresa, que pueda aportar sobre la marcha consejo y apoyo, establecer una red de contactos y comprobar la validez de los resultados de la evaluación de las necesidades.

Tanto los sindicatos y las empresas como distintos grupos de la comunidad pueden facilitar la educación de los trabajadores en relación con la salud y la seguridad. Aunque no patrocinen directamente la formación, pueden desempeñar un papel clave respaldando el trabajo educativo. El sindicato puede facilitar el acceso a los trabajadores y respaldar las iniciativas de cambio determinadas por la formación. Los activistas sindicales, respetados por sus conocimientos o su compromiso, pueden ayudar a ampliar el alcance de la formación y a asegurar el resultado satisfactorio de la misma. La empresa puede conceder a los trabajadores permiso pagado para ausentarse del puesto de trabajo y asistir a las sesiones de formación y apoyar activamente los esfuerzos para mejorar la salud y la seguridad 
derivados del proceso de formación que ha "comprado". Algunas empresas comprenden la importancia y la eficacia en función del coste de la formación global de los trabajadores en el ámbito de la salud y la seguridad, mientras que otras no participan si no existen normas obligatorias al respecto 0 acuerdos pactados en convenio colectivo que recojan el derecho a un permiso pagado para la asistencia a sesiones educativas de formación en salud y seguridad.

Las organizaciones no públicas pueden prestar recursos, apoyo 0 actividades de seguimiento. Para los trabajadores no sindicados, que pueden ser especialmente vulnerables a represalias por defender la salud y la seguridad en el trabajo, resulta especialmente importante descubrir los recursos de apoyo de la comunidad (grupos religiosos, organizaciones ecologistas, grupos de apoyo a los trabajadores discapacitados o proyectos relativos a los derechos de los trabajadores pertenecientes a grupos minoritarios). Cualquier persona que tenga algún papel significativo que desempeñar debe participar en el proceso a través del copatrocinio, la participación en comités asesores, los contactos personales o por cualquier otro medio.

\section{Tercera fase: establecimiento de los objetivos educativos y de los contenidos}

U tilizando la información obtenida en la evaluación de las necesidades, el equipo de planificación puede identificar unos objetivos específicos de aprendizaje. Es frecuente el error de considerar que el objetivo de los seminarios consiste, simplemente, en presentar información. Importa menos lo que se presenta que lo que recibe la población destinataria. Los objetivos deben formularse en términos de lo que los trabajadores sabrán, creerán y serán capaces de hacer o cumplir como consecuencia de la formación. La mayoría de los programas tradicionales de formación se centran en objetivos que pretenden modificar los conocimientos o el comportamiento de los individuos. La meta de la educación popular de los trabajadores es la formación de una mano de obra activista que defienda eficazmente un ambiente de trabajo más sano. Entre sus objetivos pueden figurar ciertamente el aprendizaje de información y destrezas nuevas, el cambio de actitudes y la adopción de comportamientos seguros. Sin embargo, la meta última no es el cambio individual, sino la capacitación colectiva y la modificación del lugar de trabajo. L os objetivos que conducen a esta meta son los siguientes:

- Objetivos informativos: remiten a los conocimientos específicos que recibirá el aprendiz; por ejemplo, información sobre los peligros de los disolventes para la salud.

- Objetivos de destrezas: tratan de garantizar que los participantes puedan realizar tareas específicas al regresar a su trabajo, utilizando desde destrezas técnicas individuales (por ejemplo, cómo levantar pesos de forma adecuada) hasta destrezas de acción de grupo (por ejemplo, cómo defender el rediseño ergonómico del lugar de trabajo). La educación orientada hacia la capacitación enfatiza más las destrezas de acción social que el dominio de las tareas individuales.

- O bjetivos de actitudes: tratan de influir en las ideas preconcebidas de los trabajadores. Son importantes para que las personas superen sus propios impedimentos al cambio y sean capaces de utilizar realmente sus conocimientos recién adquiridos. Entre los ejemplos de actitudes cuya modificación puede procurarse se encuentran la creencia de que los accidentes son provocados por el trabajador descuidado, al prejuicio de que los trabajadores son apáticos y no se preocupan por la salud y la seguridad o el convencimiento de que las cosas no cambian nunca y nada puede hacerse al respecto.

- Objetivos de comportamientos individuales: no sólo tratan de influir en lo que el trabajador puede hacer, sino en lo que éste hace
Figura 18.1 • Jerarquía de los objetivos de formación.

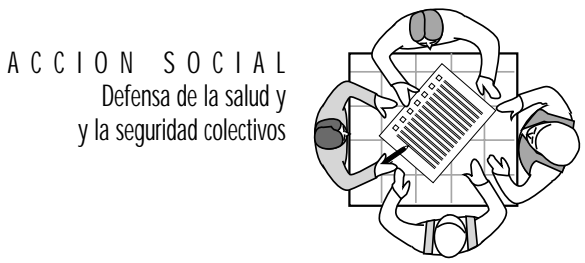

COMPORTAMIENTOS I N D I V I DUALES

Adopción de prácticas seguras en el trabajo
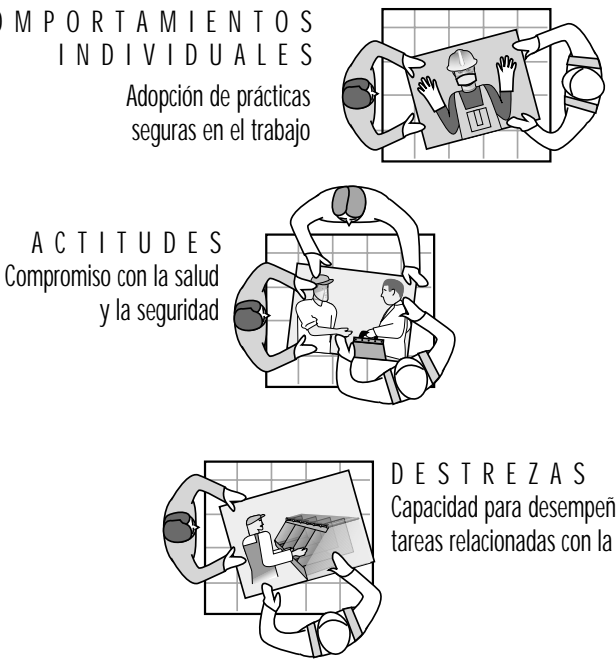

DESTREZAS

Capacidad para desempeñar tareas relacionadas con la seguridad

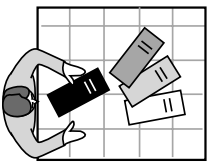

CONOCIMIENTOS

Obtención de información

sobre la salud y la seguridad

realmente en el trabajo como consecuencia de la formación. Por ejemplo, un programa de formación con objetivos comportamentales procurará influir positivamente en la forma de utilizar un respirador en el trabajo y no sólo transmitir información en el aula sobre el empleo adecuado del respirador. El problema del cambio individual del comportamiento en cuanto objetivo es que las mejoras de la salud y la seguridad en el trabajo no suelen llevarse a cabo de forma individual. Sólo puede utilizarse adecuadamente un respirador si éste es adecuado y se dispone del tiempo para adoptar todas las precauciones necesarias, con independencia de la presiones relativas a la producción.

- Objetivos de acción social: también pretenden producir un efecto cuando el trabajador regrese a su puesto, pero se orientan a la meta de la acción colectiva para la modificación del ambiente de trabajo, no al cambio del comportamiento individual. Las acciones que se derivan de esta formación abarcan desde pequeños pasos, como investigar un peligro concreto, hasta el establecimiento de un comité activo de salud y seguridad o el lanzamiento de una campaña para rediseñar un proceso de trabajo peligroso.

Estos objetivos se ordenan jerárquicamente (Figura 18.1). En términos comparativos, los objetivos informativos son los más fáciles de alcanzar (lo cual no significa que sean fáciles de lograr en sentido absoluto); los objetivos de destrezas requieren mayor formación práctica para garantizar su dominio; los objetivos de actitudes resultan más difíciles porque pueden oponerse a convicciones profundas de los individuos; los objetivos 
comportamentales individuales sólo pueden alcanzarse si se tratan los obstáculos constituidos por las actitudes y si la actuación, la práctica y el seguimiento en el trabajo se entroncan en la formación; los objetivos de acción social son los que suponen el reto mayor, porque la formación debe preparar a los participantes para una acción colectiva, con el fin de conseguir más de lo que cada uno podría hacer solo.

Por ejemplo, comunicar los riesgos que implica el amianto es una tarea relativamente sencilla. El paso siguiente consiste en garantizar que los trabajadores tengan las destrezas técnicas necesarias para seguir todos los procedimientos de seguridad en el trabajo. M ás difícil aún es cambiar lo que creen personalmente ( $p$. ej., convencerles de que ellos y sus compañeros están en situación de riesgo y que puede y debe hacerse algo al respecto). Aun en el caso de que posean las destrezas y actitudes correctas, puede resultar difícil que sigan procedimientos de trabajo seguros, sobre todo si carecen del equipo adecuado o del apoyo de la empresa. EI reto final consiste en promover la acción social, de manera que adquieran las destrezas, la confianza y la disposición para insistir en la utilización de materiales menos peligrosos o pedir que se utilicen todos los controles ambientales necesarios cuando se trabaje con amianto.

La educación obrera orientada hacia la capacitación pretende siempre influir en la acción social desarrollada en el nivel más elevado. Para ello se requiere que los trabajadores desarrollen el pensamiento crítico y las destrezas de planificación estratégica que les permitan fijar metas a su alcance, respondiendo constantemente a los obstáculos que puedan surgir y modificando los planes sobre la marcha. Son destrezas complejas que requieren un enfoque de la formación lo más práctico e intensivo posible, así como un apoyo fuerte y continuo.

El contenido específico de los programas educativos dependerá de la evaluación de las necesidades, de lo establecido en los reglamentos y de cuestiones de tiempo. Los bloques temáticos que suelen tratarse son:

- peligros para la salud derivados de exposiciones importantes (como ruido, productos químicos, vibraciones, calor, estrés, enfermedades infecciosas y peligros relacionados con la seguridad);

- métodos de identificación de los peligros, incluidos los medios de obtención e interpretación de los datos en relación con las condiciones del lugar de trabajo;

- tecnologías de control de procesos, incluidos los cambios técnicos y organizativos, así como las prácticas de trabajo seguras y los equipos de protección personal;

- derechos legales, incluidos los relativos a las estructuras reguladoras, el derecho del trabajador a conocer los peligros que encierra su trabajo, el derecho a exponer sus quejas y el derecho a indemnización por accidente;

- disposiciones sindicales sobre salud y seguridad, incluidos los acuerdos recogidos en convenios colectivos que otorgan a los participantes el derecho a un ambiente seguro, el derecho a la información y el derecho a negarse a desarrollar un trabajo en condiciones peligrosas;

- recursos sindicales, de la empresa, del Estado y de la sociedad;

- funciones y competencias de los miembros del comité de salud y seguridad;

- clasificación jerárquica de los peligros y desarrollo de estrategias para mejorar el lugar de trabajo, incluidos el análisis de posibles obstáculos estructurales u organizativos y el diseño de planes de acción.

\section{Cuarta fase: selección de los métodos educativos}

Es importante seleccionar los métodos adecuados a los objetivos escogidos. En general, cuanto más ambiciosos sean los objetivos, más intensivos deben ser los métodos. Con independencia de los métodos que se seleccionen, hay que tener en cuenta el perfil de los trabajadores. Por ejemplo, es preciso ponerse a la altura del nivel lingüístico y de alfabetización de éstos. Si su nivel de alfabetización es bajo, el formador debería utilizar métodos orales y gráficos abundantes. Si hablan distintos idiomas, el formador deberá emplear un enfoque plurilingüe.

A causa de las limitaciones de tiempo, quizá no sea posible presentar toda la información relevante. Es más importante ofrecer una buena combinación de métodos que permita a los trabajadores adquirir destrezas de investigación y desarrollar estrategias de acción social, de manera que ellos mismos puedan procurarse los conocimientos necesarios, que tratar de condensar demasiada información en poco tiempo.

El gráfico de métodos de enseñanza (véase Tabla 18.1) presenta un resumen de distintos métodos y de los objetivos que éstos pueden satisfacer. Algunos métodos, como las clases magistrales o las películas informativas, satisfacen sobre todo objetivos cognitivos. Las fichas de trabajo y los ejercicios de brainstorming pueden servir para los objetivos de información y de actitudes. 0 tros métodos más globales, como los estudios de casos, los juegos de rol o los vídeos cortos, que suscitan la discusión, pueden relacionarse con los objetivos de acción social, aunque también contienen información nueva y pueden dar ocasión para explorar las actitudes.

\section{Quinta fase: realización de una sesión educativa}

En realidad, la realización de una sesión educativa bien diseñada constituye la parte más fácil del proceso; el educador se dedica a llevar a cabo el plan. De hecho, actúa como un mediador que conduce a los alumnos a través de una serie de actividades diseñadas para: (a) aprender y explorar nuevas ideas 0 destrezas; (b) poner en común los pensamientos y habilidades, y (c) combinar ambos aspectos.

En los programas de educación popular, basados en la participación activa y en la puesta en común de las propias experiencias de los trabajadores, es fundamental que en los seminarios se establezca un ambiente de confianza, de seguridad en las discusiones y de facilidad de comunicación. $\mathrm{H}$ ay que planear con minuciosidad el entorno físico y social para fomentar la máxima interacción, la dinámica de los grupos de trabajo y la confianza en que el grupo comparte la norma de escuchar y estar dispuesto a participar. Este papel de mediación en el aprendizaje puede exigir de algunos educadores cierta "reconversión profesional". Es un papel que se basa menos en la capacidad para hablar en público - elemento fundamental tradicional de las destrezas de formación- que en la destreza para fomentar el aprendizaje cooperativo.

Va popularizándose la participación como formadores de los compañeros de trabajo. Su actuación presenta dos ventajas principales: (1) poseen el suficiente conocimiento práctico del lugar de trabajo para dar relevancia a la formación, y (2) permanecen en el lugar de trabajo, lo que facilita las consultas sobre la marcha en relación con la salud y la seguridad. El éxito de los programas en que intervienen trabajadores formadores depende de que éstos adquieran unas bases sólidas a través de programas globales de "formación de formadores" y de que tengan acceso a expertos técnicos cuando lo crean necesario.

\section{Sexta fase: evaluación y seguimiento}

Aunque en la educación de los trabajadores se pase por alto con frecuencia, la evaluación es esencial y cumple distintos fines. Permite al alumno juzgar su progreso en relación con nuevos conocimientos, destrezas, actitudes o acciones, y al educador juzgar la eficacia de la formación y dilucidar lo que se ha conseguido, así como documentar el éxito de la formación para justificar futuros 
Tabla 18.1 - Gráfico de métodos de enseñanza.

\begin{tabular}{|c|c|}
\hline Métodos de enseñanza & Puntos fuertes \\
\hline Clase magistral & $\begin{array}{l}\text { Presenta material concreto de forma directa y lógica. } \\
\text { Contiene experiencias que inspiran. } \\
\text { Estimula a pensar para iniciar una discusión. } \\
\text { Método indicado para grupos numerosos. }\end{array}$ \\
\hline $\begin{array}{r}\text { Fichas de trabajo } \\
\text { y cuestionarios }\end{array}$ & $\begin{array}{l}\text { Permite que cada persona piense por sí misma sin la } \\
\text { influencia de otros en la discusión. } \\
\text { Después, los pensamientos individuales de cada uno pueden } \\
\text { intercambiarse en grupos pequeños o grandes. }\end{array}$ \\
\hline Brainstorming & $\begin{array}{l}\text { Ejercicio de escucha que permite la acción del } \\
\text { pensamiento creador de ideas nuevas. } \\
\text { Estimula la plena participación, porque se recogen } \\
\text { todas las ideas. }\end{array}$ \\
\hline Tablero de planificación & $\begin{array}{l}\text { Puede utilizarse para catalogar información rápidamente. } \\
\text { Permite a los alumnos aprender un procedimiento } \\
\text { ordenando sus partes. } \\
\text { Experiencia de planificación en grupo. }\end{array}$ \\
\hline Mapa de riesgos & $\begin{array}{l}\text { El grupo puede crear un mapa visual de peligros, } \\
\text { controles y planes de acción. } \\
\text { Útil como herramienta de seguimiento. }\end{array}$ \\
\hline $\begin{array}{l}\text { Materiales audiovisuales } \\
\text { (películas, presentación de } \\
\text { diapositivas, etc.) }\end{array}$ & $\begin{array}{l}\text { Forma entretenida de enseñar contenidos y suscitar } \\
\text { cuestiones. } \\
\text { Mantiene la atención de los asistentes. } \\
\text { Eficaz en grupos grandes. }\end{array}$ \\
\hline $\begin{array}{l}\text { Audiovisuales como } \\
\text { elementos provocadores }\end{array}$ & $\begin{array}{l}\text { Desarrollan las destrezas analíticas. } \\
\text { Permiten el estudio de soluciones. }\end{array}$ \\
\hline $\begin{array}{l}\text { Estudios de casos como } \\
\text { elementos provocadores }\end{array}$ & $\begin{array}{l}\text { Desarrollan las destrezas analíticas y de resolución de } \\
\text { problemas. } \\
\text { Permiten el estudio de soluciones. } \\
\text { Permiten a los alumnos aplicar nuevos conocimientos } \\
\text { y destrezas. }\end{array}$ \\
\hline $\begin{array}{l}\text { Juegos de roles (Role- } \\
\text { playing) (provocación) }\end{array}$ & $\begin{array}{l}\text { Introducen en forma dramatizada situaciones problemáticas. } \\
\text { Desarrollan las destrezas analíticas. } \\
\text { Facilitan el ponerse en el lugar del otro. } \\
\text { Permiten el estudio de soluciones. }\end{array}$ \\
\hline Sesiones de revisión & $\begin{array}{l}\text { Permiten la discusión en grandes grupos de los juegos } \\
\text { de roles, los estudios de casos y los ejercicios en } \\
\text { pequeños grupos. } \\
\text { Son una oportunidad para reflexionar sobre las propias } \\
\text { experiencias. }\end{array}$ \\
\hline $\begin{array}{l}\text { Clasificación de prioridades } \\
\text { y planificación de la } \\
\text { actividad. }\end{array}$ & $\begin{array}{l}\text { Asegura la participación de los alumnos. } \\
\text { Proporciona experiencias de análisis y de clasificación } \\
\text { de problemas según su importancia. } \\
\text { Permite la discusión y el debate activos. }\end{array}$ \\
\hline Práctica directa & $\begin{array}{l}\text { Facilita la práctica en el aula del comportamiento } \\
\text { aprendido. }\end{array}$ \\
\hline
\end{tabular}

Limitaciones

Los expertos no siempre son buenos profesores.

Los asistentes adoptan una postura pasiva.

Dificultad para calibrar el aprendizaje.

Precisa una introducción y un resumen claros.

Sólo puede utilizarse en períodos cortos de tiempo.

Requiere un tiempo de preparación para recabar la información.

Requiere unos conocimientos básicos

Puede diluirse la atención.

Debe limitarse a 10 ó 15 minutos.

Requiere planear y crear múltiples tableros de planificación.

Requiere trabajadores del mismo centro de trabajo u otro semejante.

Puede requerir investigación externa.

Con frecuencia, se presentan demasiadas cuestiones a la vez para centrar la discusión.

Demasiado pasivo si no se combina con la discusión

Es posible que en la discusión no participen todos.

Las personas pueden considerar que no son relevantes para su propia situación.

Para ser eficaces, los casos y las tareas tienen que estar definidos con claridad para los grupos pequeños.

Es posible que las personas sean demasiado tímidas.

No es adecuado para grupos grandes.

Pueden resultar repetitivas si todos los pequeños grupos dicen 10 mismo.

Los formadores deben preparar preguntas para centrar la discusión y evitar las reiteraciones.

Requiere una pared 0 tablero grande para poner los carteles.

Los carteles deben ponerse con rapidez para que sean eficaces.

Requiere tiempo suficiente, un espacio físico adecuado y equipo.
Objetivos alcanzados

Conocimiento.

Conocimiento.

Actitudes/ emociones.

Conocimiento.

Actitudes/ emociones.

Conocimiento.

Conocimiento

Destrezas de acción social.

Conocimiento.

Destrezas de acción social.

Actitudes/ emociones. Destrezas de acción social.

Actitudes/ emociones.

Destrezas de acción social.

Actitudes/ emociones.

Destrezas de acción social.

Conocimiento.

Destrezas de acción social.

Destrezas comportamentales

Adaptado por: Wallerstein y Rubenstein 1993. Con autorización

gastos en recursos. Los protocolos de evaluación deben establecerse de acuerdo con los objetivos de la educación. La evaluación pone de manifiesto si se han conseguido o no esos objetivos.

$\mathrm{H}$ asta la fecha, la mayoría de las evaluaciones valoran los efectos inmediatos, como los conocimientos adquiridos 0 el grado de satisfacción con el seminario. En las evaluaciones específicas del comportamiento se emplean las observaciones en el lugar de trabajo.
Las evaluaciones referidas a los resultados en el lugar de trabajo, sobre todo las que versan sobre la tasa de incidencia de lesiones y enfermedades, pueden ser engañosas. Por ejemplo, los esfuerzos de la empresa para promover la seguridad implican, a menudo, el ofrecimiento de incentivos para mantener baja la tasa de accidentes ( $p$. ej., un premio al equipo que tenga menos accidentes en el año). Estos effuerzos pueden llevar a mantener en secreto algunos accidentes $y$, con frecuencia, a que no se 
conozcan las condiciones reales de salud y seguridad en el trabajo. En cambio, la formación orientada a la capacitación estimula a los trabajadores a que reconozcan e informen de los problemas de salud y seguridad. Aun cuando, al principio, puede ocurrir que aumente el número de partes de lesiones y enfermedades, en realidad están mejorando las condiciones de salud y seguridad.

Desde no hace mucho, una vez que los programas de formación en salud y seguridad han empezado a adoptar las metas y los métodos de la capacitación y la educación popular, se han ampliado los protocolos de evaluación para incluir la valoración de la actuación de los trabajadores de vuelta a sus puestos, así como los cambios habidos en los lugares de trabajo. Los objetivos de acción social requieren una evaluación a largo plazo que tenga en cuenta los cambios a escala individual, ambiental y organizativa, así como la interacción entre los cambios individuales y ambientales. En esta evaluación a largo plazo, el seguimiento es fundamental. L as llamadas telefónicas de seguimiento, las encuestas e, incluso, nuevas sesiones pueden ser útiles no sólo para evaluar el cambio, sino también para apoyar a los alumnos-trabajadores en la aplicación de sus nuevos conocimientos, destrezas, iniciativas o acciones sociales emprendidas como resultado de la formación.

Se ha señalado la importancia de diversos elementos programáticos para promover cambios reales comportamentales y en los lugares de trabajo: tales elementos son las estructuras sindicales de apoyo, la participación paritaria de sindicatos y empresa, el pleno acceso a la formación, a la información y a los expertos por parte de los trabajadores y de sus sindicatos, el desarrollo de la formación en el contexto de una estructura que permita cambios globales, el desarrollo de programas basado en la evaluación de las necesidades de los trabajadores y de los lugares de trabajo, y la integración de los métodos interactivos en grupos pequeños con las metas de la capacitación de los trabajadores y la acción social.

\section{Conclusión}

En este artículo se ha expuesto la necesidad cada vez mayor de preparar a los trabajadores para que participen en los esfuerzos de prevención de las lesiones y las enfermedades que se producen en los lugares de trabajo, así como el papel decisivo que desempeñan como defensores de la salud y la seguridad. Se ha examinado el papel de la formación de capacitación en respuesta a las
Figura 18.2 - El aprendizaje es un proceso de tres direcciones.

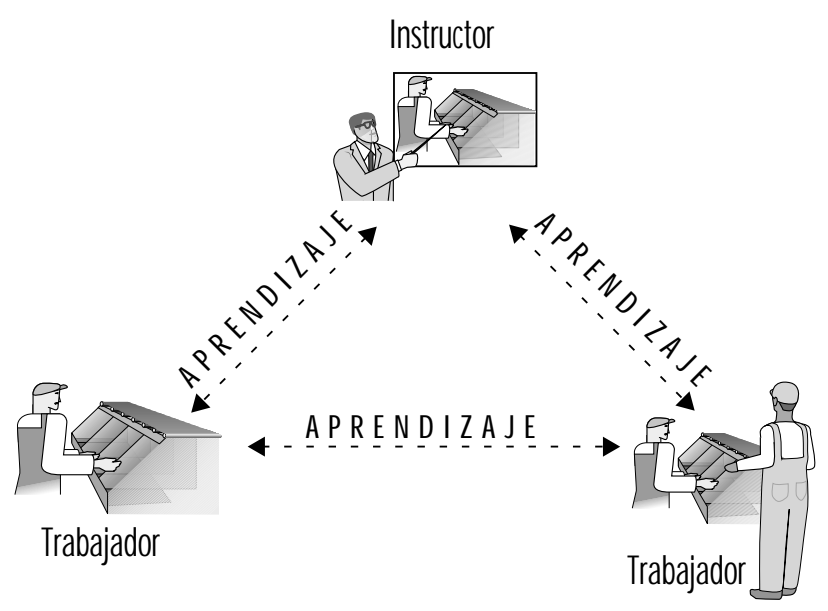

necesidades, y los principios y tradiciones educativas que contribuyen a este enfoque. Por último, se ha descrito paso a paso el proceso educativo necesario para alcanzar los objetivos de la participación y la capacitación de los trabajadores.

Este enfoque de la educación centrado en el alumno supone una nueva relación entre los profesionales de la salud y la seguridad en el trabajo y los trabajadores. El aprendizaje no puede seguir siendo una vía unidireccional, en la que el "experto" imparte el saber a los "alumnos"; el proceso educativo constituye una asociación. Es un proceso dinámico de comunicación que utiliza las destrezas y conocimientos de los trabajadores. El aprendizaje se produce en todas direcciones: los trabajadores aprenden de los formadores; éstos aprenden de aquéllos, y unos aprenden de otros (véase la Figura 18.2).

Para que la asociación tenga éxito, los trabajadores deben participar en las distintas fases del proceso educativo y no sólo en el aula. $\mathrm{H}$ an de participar en el quién, qué, dónde, cuándo y cómo de la formación: ¿quién diseñará e impartirá la formación?, ¿qué se enseñará?, ¿quién la pagará?, ¿quién podrá acceder a ella?, ¿dónde y cuándo tendrá lugar?, ¿qué necesidades satisfará y cómo se medirán sus resultados?

\section{ESTUDIOS DE CASO}

\section{Evaluacion de la Formacion SO BRE SALUD Y SEGURIDAD: ESTUDIO DE CASO DE LAEDUCACION DE LOS TRABAJADORES DE RESIDUOS PELIGROSOS DEL SINDICATO INTERNACIONAL DE TRABAJADORES QUIMICOS}

T.H. M cQuiston, P. Coleman, N.B. Wallerstein, A.C. M arcus, J.S. M orawet, D.W. Ortieb y S. H ecker

H asta hace muy poco, la eficacia de la formación y la educación para el control de la salud y la seguridad en el trabajo era más bien una cuestión de fe que de evaluación sistemática (Vojtecky y
Berkanovic 1984-85; Wallerstein y Weinger 1992).C on la rápida expansión, durante la pasada década, de los programas en este ámbito, financiados con fondos federales en los Estados U nidos, esta situación ha empezado a cambiar. Los educadores e investigadores aplican actualmente enfoques más rigurosos para evaluar el impacto real de la formación y educación del trabajador sobre las variables finales, como los accidentes, las enfermedades y las lesiones, y sobre las variables intermedias, como la destreza para descubrir, manejar y resolver los peligros que surjan en los lugares de trabajo. El programa que combina la formación en materia de emergencias químicas con la formación sobre residuos peligrosos del Centro para la Educación de los Trabajadores en la Salud y la Seguridad, del Sindicato Internacional de Trabajadores $Q$ uímicos, es un ejemplo de programa bien diseñado con un eficaz sistema de evaluación.

EI Centro se estableció en Cincinnati (O hio), en 1988, gracias a una ayuda concedida al Sindicato Internacional de Trabajadores Químicos por el National Institute for Environmental 
$\mathrm{H}$ ealth Sciences con el fin de formar a los trabajadores en relación con los residuos peligrosos y las emergencias. Formado conjuntamente por seis sindicatos, un centro local de salud en el trabajo y un departamento universitario de salud ambiental, el Centro adopta ante la formación un enfoque educativo de capacitación y, en sentido amplio, define su cometido como:

(...) promover las destrezas de los trabajadores para resolver problemas y desarrollar estrategias de tipo sindical para mejorar las condiciones de salud y seguridad en el trabajo (M cQ uiston y cols. 1994).

Para evaluar la eficacia de su programa en relación con este cometido, el Centro ha llevado a cabo estudios de seguimiento a largo plazo de los trabajadores participantes. Esta evaluación global es más amplia que la que suele realizarse inmediatamente después del período de formación y que se limita a medir la retención de la información por el sujeto a corto plazo y la satisfacción del mismo (o su reacción) con respecto a la educación recibida.

\section{Programa y asistentes}

El curso sometido a evaluación es un programa de formación sobre residuos peligrosos y emergencias químicas, con una duración de cuatro o cinco días. Se imparte a trabajadores de seis sindicatos y a un número más reducido de directivos de algunas de las fábricas representadas por los sindicatos, eligiéndose como candidatos a los que están expuestos a liberaciones importantes de sustancias tóxicas o trabajan con residuos peligrosos. Cada clase tiene un máximo de 24 alumnos, con el fin de promover el diálogo. El C entro alienta a los sindicatos locales para que envíen al curso a tres o cuatro trabajadores de cada centro, ya que es más probable que la actuación de un grupo sea más eficaz que la de una persona sola en la reducción de los peligros, una vez de vuelta al centro de trabajo.

El programa ha establecido unos objetivos interrelacionados a largo y a corto plazo:

A largo plazo: convertir a los trabajadores en participantes activos en la determinación y el perfeccionamiento de las condiciones de salud y seguridad.

Con carácter inmediato: ofrecer a los alumnos las herramientas pertinentes, las destrezas de resolución de problemas y la confianza necesaria para utilizar dichas herramientas (M cQ uiston y cols. 1994).

Al establecer estos objetivos, en vez de centrarse en la memorización de la información, el programa adopta un enfoque formativo inspirado en el "proceso", de modo que "se establezca la autoconfianza necesaria para saber cuándo hace falta información adicional, dónde encontrarla y cómo interpretarla y utilizarla" (M cQ uiston y cols. 1994).

La formación es teórica y práctica. Los métodos didácticos favorecen las actividades de resolución de problemas en pequeño grupos, con participación activa de los trabajadores. Durante el curso se desarrolla además un proceso participativo en el que actúan expertos en salud y seguridad, personal del programa y consultores, los cuales evalúan el curso y recomiendan, en su caso, modificaciones del programa, de los materiales y de los métodos, basándose en amplias conversaciones mantenidas con los alumnos. Esta evaluación formativa constituye un aspecto importante en el proceso de evaluación que tiene lugar durante el programa y no al final del mismo.

Durante el curso se entrega a los participantes un conjunto de documentos de consulta sobre materiales peligrosos. LOS alumnos elaboran además un "gráfico de riesgos" para utilizarlo durante el curso al evaluar los peligros y los programas de salud y seguridad de sus fábricas. Estos gráficos constituyen la base de los planes de acción que sirven para enlazar lo aprendido en el curso con lo que se considera necesario al volver al lugar de trabajo.

\section{Metodología de la evaluación}

EI Centro administra a los participantes diversas pruebas anónimas antes y después de la formación para determinar el aumento del nivel de conocimientos. Adicionalmente, para conocer la eficacia del programa a largo plazo, el Centro mantiene entrevistas tel efónicas de seguimiento a los 12 meses del final, y se entrevista además a uno de los participantes de cada sindicato local y a todos los directivos asistentes. La encuesta mide los resultados en cinco áreas importantes:

1. U tilización de los recursos y materiales de consulta recibidos durante la formación.

2. Cantidad de formación secundaria, es decir, la impartida por los participantes a sus compañeros cuando regresan a sus respectivos centros de trabajo tras su asistencia al curso.

3. Iniciativas y logros de los alumnos en cuanto a los cambios efectuados en el centro de trabajo respecto a los programas de respuesta ante emergencias o los programas, procedimientos o equipo para el manejo adecuado de residuos tóxicos.

4. M ejoras posteriores a la formación en el modo de manejar las fugas en el centro de trabajo.

5. O piniones de los alumnos acerca de la eficacia del programa de formación.

L os últimos resultados de esta evaluación publicados se basan en 481 entrevistas con sindicalistas, cada uno de los cuales representa un centro de trabajo diferente, y 50 con directivos. La proporción de respuestas fue del $91,9 \%$ entre los sindicalistas y del $61,7 \%$ entre los directivos.

\section{Resultados y consecuencias}

\section{Utilización de recursos materiales}

Al menos el $60 \%$ de los alumnos del programa, tanto sindicalistas como directivos, utilizaron los seis principales recursos materiales presentados en el curso, salvo el gráfico de riesgos. El más utilizado fue el manual de formación del C entro, la NIOSH Pocket Guide to $\mathrm{C}$ hemical $\mathrm{H}$ azards.

\section{Formación de los compañeros de trabajo}

C asi el $80 \%$ de los sindicalistas y el $72 \%$ de los directivos participantes llevaron a cabo actividades de formación de sus compañeros al regresar a su centro de trabajo. Es digno de mencionar el número de compañeros que recibieron formación al respecto (70) y el promedio de horas dedicadas ( 9,7 horas). EI hecho de que más de la mitad de los sindicalistas participantes impartiera formación a los directivos de los centros de trabajo reviste una significación especial. La formación secundaria abarcó gran cantidad de temas, entre los que destacan la identificación de sustancias químicas, la selección y uso de equipos de protección individual, los efectos sobre la salud, la respuesta ante las emergencias y el empleo de los materiales de consulta.

\section{Consecución de mejoras en los centros de trabajo}

En las entrevistas se hacían una serie de preguntas relacionadas con los intentos de mejorar los programas, prácticas y equipos de las empresas en 11 áreas distintas como las siguientes:

- formación sobre los efectos en la salud,

- disponibilidad de fichas técnicas de seguridad, 
- etiquetado de productos químicos,

- formación, pruebas y disponibilidad de respiradores,

- guantes y trajes protectores,

- respuesta ante emergencias,

- métodos de descontaminación.

L as preguntas determinaban si los entrevistados consideraban necesario efectuar cambios y, en su caso, si se habían realizado mejoras.

En general, los sindicalistas entrevistados señalaron una mayor necesidad de introducir modificaciones que los directivos, aunque con grados de diferencia variables. En todo caso, los porcentajes de entrevistados, tanto sindicalistas como directivos, que informaron haber tratado de conseguir mejoras en la mayoría de las áreas fueron bastante altos. La proporción de éxitos respecto a las once áreas oscilaba entre el 44 y el $90 \%$ entre los sindicalistas y del 76 al $100 \%$ entre los directivos.

\section{Respuesta ante fugas}

Las preguntas relativas a las fugas y liberaciones de sustancias tóxicas procuraban esclarecer si la asistencia al curso había conseguido modificar el comportamiento al respecto. Tanto los trabajadores como los directivos informaron de un total de 342 fugas graves durante el año siguiente a su formación. Un $60 \%$ manifestaron que se había actuado de forma diferente gracias a la formación recibida. Para recabar más datos cualitativos y cuantitativos, se añadieron posteriormente otras preguntas más detalladas. El estudio de evaluación presenta diversos comentarios de los trabajadores sobre fugas concretas y sobre la función desempeñada por la formación en la respuesta adoptada ante las mismas. A continuación se dan dos ejemplos:

Tras la formación, se facilitó el equipo adecuado. Todo se hizo según los libros. Hemos avanzado mucho desde que formamos un equipo. La formación ha merecido la pena. No nos preocupa lo que diga la empresa: ahora podemos juzgar qué hace falta por nuestros propios medios.

La formación sirvió para informar al comité de seguridad sobre las necesidades prioritarias. Estamos mejor preparados y ha mejorado la coordinación entre todos los departamentos.

\section{Preparación}

La inmensa mayoría de los entrevistados, fuesen sindicalistas 0 directivos, apreciaron que estaban "mucho mejor" o "algo mejor" preparados para manejar productos químicos peligrosos y para hacer frente a las emergencias debido a la formación recibida.

\section{Conclusión}

Este caso ilustra muchos de los aspectos fundamentales del diseño y evaluación de los programas de formación y educación. Las metas y objetivos del programa se han enumerado explícitamente. D estacan en especial los objetivos de acción social en relación con la capacidad de los trabajadores para pensar y actuar por sí mismos y para defender tanto cambios globales como más concretos, en relación con los conocimientos y con el comportamiento. Los métodos de formación se han elegido teniendo presentes estos objetivos. Los métodos de evaluación miden el cumplimiento de estos objetivos poniendo de manifiesto cómo aplican los alumnos el material del curso en sus centros de trabajo a largo plazo. M iden los efectos de la formación sobre resultados concretos, como la respuesta ante las fugas, y sobre variables intermedias, como la medida en que se transmite la formación a otros trabajadores y la forma de utilizar los recursos materiales recibidos durante el curso.

\section{EDUCACION Y FORMACION AMBIENTAL: SITUACION DE LA EDUCACION DE LOS TRABAJADORES QUE MANEJAN MATERIALES PELIGROSOS EN ESTADOS UNIDOS}

\author{
G lenn Paulson, M ichelle M adelien, Susan \\ Sink y Steven H ecker
}

Cuando se relaciona la expresión educación ambiental con los empleados, directivos y centros de trabajo, hace referencia a un conjunto potencialmente muy amplio de problemas y actividades:

- Educación para la sensibilización general con respecto a los problemas ambientales.

- Educación y formación para la modificación de las prácticas, procesos y materiales de trabajo, a fin de reducir el impacto ambiental de los procesos industriales sobre las comunidades locales.

- Educación profesional para ingenieros y demás titulados relacionados con las cuestiones ambientales.

- Educación y formación de los trabajadores que desempeñan su labor en el campo de la supresión de riesgos ambientales, que incluye la eliminación de residuos peligrosos, la respuesta a emergencias provocadas por fugas, liberaciones y otros accidentes, y las reparaciones con amianto y pinturas con plomo.

Este artículo se centra sobre la situación, en Estados U nidos, de la formación y educación de los trabajadores que desempeñan su labor en el campo de la recuperación ambiental, disciplina que cada día está más en auge. No se trata de un tratamiento exhaustivo de la educación ambiental, sino de una ilustración de la relación entre la salud y seguridad en el trabajo y el medio ambiente, y del carácter variable del trabajo en el que el saber técnico y científico ha llegado a ser cada vez más importante en labores tradicionalmente "manuales", como la construcción. En este contexto, "formación" se refiere a los programas a corto plazo, organizados e impartidos tanto por instituciones académicas como no académicas. "Educación" alude a programas de estudio formal en instituciones acreditadas, de dos o cuatro años de duración. En la actualidad, no existe una carrera específica que puedan cursar las personas interesadas por estos temas. La meta que pretende conseguir el $\mathrm{N}$ ational Environmental Education and Training Center, Inc. (NEETC), de la Indiana University de Pennsylvania, consiste precisamente en el desarrollo de una carrera más específica en relación con este campo. Por el momento, existe una amplia oferta de programas de educación y formación de distintos niveles, impartidos por un conjunto de instituciones universitarias y no universitarias. El material con el que se redactó el informe original a partir del cual se escribió este artículo es un estudio de dichas instituciones (M adelien y Paulson 1995).

\section{Programas de formación}

Un estudio realizado en 1990 por la Wayne State University (Powitz y cols. 1990) reveló la existencia de 675 cursillos diferentes y no reglados de formación para trabajadores sobre el manejo de residuos peligrosos, en centros de enseñanza superior. C ada año se impartían más de 2.000 cursos en toda la nación. Sin embargo, este estudio no tiene en cuenta algunas de las principales entidades que se hacen cargo de este tipo de formación: programas de los community colleges (instituciones comunitarias de formación profesional), programas de formación de la 0 ccupational Safety and $\mathrm{H}$ ealth Administration de Estados U nidos, y de 
empresas o grupos independientes contratados al efecto. Por tanto, es probable que haya que duplicar o triplicar el número de programas que da el estudio de la Wayne U niversity para estimar la oferta de cursos no reglados que existe actualmente en Estados Unidos.

El principal programa de formación en recuperación ambiental financiado por la administración pública es el del National Institute for Environmental H ealth Sciences (NIEH S). Establecido al amparo de la legislación de superfinanciación de 1987, facilita ayudas a organizaciones sin ánimo de lucro que tengan acceso a las poblaciones de trabajadores adecuadas. Entre los beneficiarios se encuentran los sindicatos; programas universitarios de educación laboral y estudios sobre el trabajo, salud pública, ciencias de la salud e ingeniería; community colleges y grupos de salud y seguridad sin ánimo de lucro, conocidos como grupos COSH (Committees on O ccupational Safety and $\mathrm{H}$ ealth). M uchas organizaciones de este tipo operan en consorcios regionales. EI público al que se dirigen está constituido por:

- T rabajadores de la construcción que participan en la limpieza de residuos peligrosos.

- Personal dedicado a actuar ante emergencias, de los servicios de bomberos y de entidades de servicios de urgencia y de fábricas.

- Trabajadores de transportes que trasladan materiales peligrosos.

- Trabajadores en instalaciones de tratamiento, almacenamiento y destrucción de residuos peligrosos.

- Trabajadores del tratamiento de aguas residuales.

EI programa NIEH S ha dado como resultado un amplio desarrollo curricular y de materiales, así como numerosas innovaciones, caracterizadas por una considerable comunicación y sinergía entre los becarios. El programa financia un centro de documentación que mantiene una biblioteca y un fondo curricular y publica una revista mensual.

O tros programas financiados por la administración pública ofrecen cursillos dirigidos a titulados de la industria de residuos peligrosos, no a trabajadores de primera línea. Muchos de ellos se desarrollan en los centros de recursos educativos de universidades, financiados por el $\mathrm{N}$ ational Institute for $\mathrm{O}$ ccupational Safety and $\mathrm{H}$ ealth (NIOSH).

\section{Programas de educación}

\section{Community colleges}

El cambio de mayor fuste que se ha producido en los últimos años en el panorama de la educación y la formación sobre residuos peligrosos ha sido el desarrollo espectacular de los programas y consorcios de los community colleges. Desde la década de 1980, éstos centros han protagonizado el desarrollo curricular más organizado y amplio de la educación secundaria.

EI Departamento de Energía de los Estados U nidos financia programas de ámbito nacional para disponer de personal allí donde las necesidades de técnicos nucleares han sido sustituidas por las de trabajadores de limpieza de residuos peligrosos. Esta formación se imparte con el máximo rigor en los community colleges, muchos de los cuales han solucionado las necesidades de personal de determinados organismos de dicho Departamento. Estos programas han dado lugar también a las principales actividades de desarrollo curricular y de establecimiento de consorcios para compartir información. Tratan de establecer unos niveles de formación más coherentes y elevados y de favorecer la movilidad de la mano de obra, permitiendo que una persona formada para trabajar en un lugar pueda trasladarse a otro con unas mínimas necesidades de formación adicional.
Varios consorcios de community colleges ofrecen currículos en este campo. La Partnership for Environmental Technology Education (PETE) actúa en seis regiones. Trabaja con la U niversidad de Northern lowa para crear una red de programas ambientales de community colleges relacionados con centros de enseñanza media, a fin de informar y preparar a los estudiantes para que puedan acceder a estos programas bianuales de nivel universitario. Sus objetivos son el desarrollo de: 1) modelos curriculares de validez nacional, 2) programas de desarrollo profesional global y 3) una agencia de distribución nacional dedicada a la educación ambiental.

El $\mathrm{H}$ azardous $\mathrm{M}$ aterials Training and Research Institute (H M T RI) atiende las necesidades de desarrollo curricular, desarrollo profesional y comunicaciones impresas y electrónicas de 350 colleges que imparten programas reglados de dos años de duración sobre tecnologías ambientales. D esarrolla y distribuye los currículos y materiales e imparte programas educativos en su propio Centro de Formación Ambiental del K irkwood Community College de lowa, que dispone de amplias instalaciones de aulas, laboratorios y para estudios simulados de campo.

EI Center for O ccupational Research and Development (CORD) desempeña un papel de liderazgo nacional en relación con la iniciativa Tech Prep/ Associate D egree del Departamento de Educación de los Estados U nidos. Este programa de preparación técnica exige la coordinación de instituciones de enseñanza media y superior para que los alumnos adquieran una base sólida que les permita cursar una carrera e introducirse en el mundo laboral. Tal actividad ha llevado a la elaboración de diversos textos de carácter práctico y experimental sobre ciencias básicas y matemáticas, diseñados para que los alumnos aprendan conceptos nuevos en relación con los conocimientos y la experiencia que ya poseen.

EI CORD ha desempeñado también un papel significativo en la iniciativa nacional de la Administración de Clinton: "Goals 2000: Educate America". Ante la necesidad de formar a personal cualificado, esta iniciativa facilita el desarrollo de los niveles de cualificación para el trabajo (esto es, los conocimientos, destrezas, actitudes y nivel de habilidad necesarios para desenvolverse satiffactoriamente en cometidos específicos). Entre los 22 proyectos de desarrollo de dichos niveles está el de técnicos en gestión de materiales peligrosos.

Articulación entre los programas profesionales y los académicos $L$ a falta de vínculos entre las instituciones de dos y de cuatro años ha sido un problema constante, al impedir el ingreso en los programas de ingeniería a los alumnos que lo deseaban y que habían terminado los estudios del grado de associate (dos años) en gestión de residuos peligrosos y radiactivos. N o obstante, hay una serie de consorcios de community colleges que han empezado a ocuparse de este problema.

Environmental Technology (ET) es una red de community colleges de California que han firmado acuerdos con cuatro centros de estudios superiores de cuatro años de duración. La instauración de una nueva categoría laboral, "técnico ambiental", por la California Environmental Protection Agency constituye un incentivo añadido para que los graduados del programa ET prosigan sus estudios. El certificado ET constituye el requisito para el ingreso en la carrera de técnico ambiental. La obtención del grado de associate faculta para acceder al nivel laboral inmediato superior. Los estudios complementarios y la experiencia laboral permiten al trabajador progresar en la carrera profesional.

Es posible que el Waste-management Education and Research Consortium (WERC), un consorcio de escuelas de Nuevo $M$ éxico, sea el modelo más avanzado de enlace entre la educación profesional y la tradicional de cuatro años. Está constituido 
por la Universidad de Nuevo M éxico, el New M exico Institute of $M$ ining and Technology, la U niversidad del Estado de N uevo M éxico, el Navajo Community College, Sandia Laboratory y Los Alamos Laboratories y utiliza un programa de televisión interactiva de aprendizaje a distancia que aprovecha las diversas cualidades de las instituciones participantes.

Los alumnos matriculados en el programa ambiental deben cursar un total de 6 horas en asignaturas de las otras instituciones, bien a distancia o durante un semestre fuera de su centro. El programa es claramente interdisciplinario y combina un mínimo de materias relativas a la gestión de residuos y materiales peligrosos con un máximo de materias de otro departamento (ciencias políticas, economía, introducción al derecho, ingeniería o cualquiera de las ciencias). El planteamiento es "a la vez, amplio y restringido", en la medida en que reconoce la necesidad de que los estudiantes adquieran unos conocimientos básicos amplios en su propio campo y cierta formación específica sobre la gestión de residuos y materiales peligrosos. Además compagina la participación del alumno en una investigación aplicada con un desarrollo curricular de carácter industrial. Los cursos correspondientes al mínimo de formación sobre gestión de residuos y materiales peligrosos aprovechan las especialidades peculiares de cada escuela, pero todos los programas, incluido el de grado de associate, tienen un núcleo común de asignaturas de humanidades y ciencias sociales.

0 tra característica exclusiva es que las escuelas de cuatro años ofrecen grados de associate de dos años en tecnología de materiales radiactivos y peligrosos. El programa para la obtención del grado de associate en ciencias ambientales que ofrece el $\mathrm{N}$ avajo Community College incluye asignaturas sobre la historia de los navajos y asignaturas importantes de comunicaciones y ciencias empresariales, así como de carácter técnico. En el campus del $\mathrm{N}$ avajo Community College se ha establecido también un laboratorio, característica poco habitual en un community college, que pone de manifiesto el compromiso del consorcio con el aprendizaje en laboratorio, la investigación aplicada y el desarrollo de la tecnología. Las instituciones que forman parte del WERC ofrecen asimismo un programa certificado "no reglado" de estudios de gestión de residuos, que parece ir mucho más allá que los cursillos de 24 y 40 horas que ofrecen otros centros. Está pensado para titulados universitarios que deseen aprovechar los seminarios y cursos especializados de las universidades.

\section{Conclusiones}

En los últimos años, la orientación de la educación y la formación relacionadas con la industria de los residuos peligrosos ha experimentado diversos cambios significativos, a lo que debe añadirse la proliferación de seminarios de formación y de los tradicionales programas de ingeniería. En general, parece que el Departamento de Energía ha centrado la educación en el nivel del community college, dirigiéndola a la formación adicional de la mano de obra ya preparada, sobre todo a través de la Partnership for Environmental Technology Education (PETE), el Waste-management Education and Research Consortium (WERC), y otros consorcios parecidos

En el terreno del medio ambiente, hay una distancia importante entre la formación profesional y la educación tradicional. Por ello, los trabajadores que manejan residuos peligrosos carecen de una vía de desarrollo normal a través de una carrera y les resulta difícil progresar en el sector privado o en la administración pública sin las titulaciones técnicas clásicas. Aunque las opciones interdepartamentales para la educación en materia de gestión están bien establecidas por los departamentos de economía, derecho y medicina, que reconocen la amplitud de la industria ambiental, sigue tratándose de titulaciones profesionales con una marcada base académica que no es frecuente entre la mano de obra con experiencia de que se dispone actualmente.

A medida que progresa la industria de la limpieza ambiental, se irá esclareciendo el camino hacia una formación y educación más equilibradas y hacia una carrera bien desarrollada de acuerdo con las necesidades de la mano de obra a largo plazo. El gran número de trabajadores despedidos de las instalaciones militares clausuradas refuerza las presiones sobre el mercado de trabajo en el sector del medio ambiente, así como las demandas de formación y colocación dirigidas a los sindicatos (y procedentes tanto del personal militar licenciado como del personal civil despedido). Se necesitan programas educativos que satisfagan tanto las necesidades del personal que ingresa en la industria como las de ésta misma para disponer de una mano de obra más equilibrada y mejor formada.

Puesto que los miembros de los sindicatos son uno de los principales grupos preparados para entrar en el campo de la eliminación de residuos peligrosos y la protección del medio ambiente, parece que es a los departamentos de estudios y relaciones laborales a los que corresponde lógicamente instaurar programas reglados que incluyan un currículo ambiental y de residuos peligrosos en el desarrollo de las cualificaciones laborales y de gestión.

\section{LAEDUCACION DE LOS TRABAJADORES Y LA MEJORA AMBIENTAL}

\section{Edward Cohen-Rosenthal}

Los artículos de este capítulo se han centrado hasta ahora en la formación y en la educación en relación con los peligros presentes en el lugar de trabajo. La educación ambiental sirve a múltiples finalidades y es un complemento útil de la formación sobre salud y seguridad en el trabajo. La educación de los trabajadores es un aspecto fundamental, que a menudo se pasa por alto, de una estrategia completa y eficaz de protección del medio ambiente. Las cuestiones ambientales se consideran con frecuencia una materia de carácter estrictamente tecnológico 0 científico que queda fuera del alcance de los trabajadores, cuyo conocimiento, sin embargo, es decisivo para la eficacia de todas las soluciones ambientales. A los trabajadores les interesan las cuestiones medioambientales tanto en su trabajo como por su condición de ciudadanos, ya que el medio ambiente configura su vida y repercute en su comunidad y en su familia. Incluso la introducción de soluciones tecnológicas que requieren el uso de nuevos equipos y programas informáticos, o un nuevo enfoque de los procesos, precisa de trabajadores comprometidos y competentes, tanto en los sectores y profesiones directamente relacionados con el medio ambiente como en otros puestos de trabajo y actividades.

La educación de los trabajadores puede ofrecer, además, una base conceptual para fomentar su participación en la mejora ambiental, así como en la mejora de las condiciones de salud y seguridad y organizativas. En el UNEP Industry and Environment Programme se observa que "muchas empresas han llegado a la conclusión de que la participación de los trabajadores en la mejora ambiental puede reportar beneficios importantes" (UNEP 1993). En el marco de la Iniciativa para el Trabajo y el M edio A mbiente (Work and Environment I niciative, WEI) de la U niversidad de Cornell se realizó un estudio de empresas estadounidenses, cuya conclusión fue que una participación intensa 
de los trabajadores reduce a una tercera parte la necesidad de recurrir a soluciones externas y técnicas, además de potenciar los resultados de otros enfoques tecnológicos (Bunge y cols. 1995).

La educación ambiental de los trabajadores adopta diferentes formas: la concienciación y la educación en el marco de los sindicatos, la formación y la orientación profesional, la incorporación de los aspectos medioambientales en los programas de salud y seguridad en el trabajo y la concienciación general de los trabajadores como ciudadanos son las más destacadas. Se imparte en marcos diversos, como lugares de trabajo, locales de los sindicatos, aulas y círculos de estudio, utilizando tanto sistemas tradicionales como otros más innovadores de base informática. Es justo decir que la educación ambiental de los trabajadores es un campo subdesarrollado, especialmente si se compara con la formación técnica y de gestión y con la educación ambiental que se imparte en el ámbito académico. A escala internacional, la educación de los trabajadores de primera línea suele mencionarse de pasada y suele pasarse por alto cuando se trata de hacerla efectiva. La Fundación Europea para la M ejora de las $C$ ondiciones de $V$ ida y de Trabajo ha encargado una serie de estudios sobre la dimensión educativa de la protección del medio ambiente, y en su próximo programa de trabajo se ocupará directamente de los trabajadores de talleres y fábricas y sus necesidades de educación ambiental. A continuación se exponen varios ejemplos recopilados en el contexto de la iniciativa WEI de la U niversidad de Cornell, que ilustran casos prácticos y posibilidades de educación ambiental de los trabajadores. La iniciativa WEI es una red de directivos, sindicalistas, especialistas en medio ambiente y funcionarios públicos de 48 países de todo el mundo, cuyo objetivo es encontrar formas en que los trabajadores y el lugar de trabajo pueden contribuir a la conservación y la mejora del medio ambiente. Para ello, se interesa por un amplio conjunto de sectores, desde la extracción primaria hasta la producción, los servicios y las empresas públicas, y propone un tipo de acción y educación ambiental basado en reforzar los conocimientos en los ámbitos laboral y académico, a fin de lograr unos lugares de trabajo más limpios y más productivos y una mejor conexión entre el medio ambiente interior y el exterior.

\section{Australia: módulos de cualificaciones ecológicas} La agrupación sindical Australian Council of Trade Unions (ACTU) ha desarrollado un nuevo enfoque de la educación ambiental de los trabajadores que incluye la concienciación social general y competencias laborales específicas, dirigido especialmente a los trabajadores más jóvenes.

La ACTU ha organizado una empresa de formación sobre medio ambiente (Environment Training Company), cuyas amplias atribuciones le permiten abordar diversos sectores, si bien su prioridad inicial han sido las cuestiones relacionadas con la gestión de la tierra. En este contexto se encuadra la enseñanza sobre formas eficaces y seguras de llevar a cabo la recuperación de tierras, garantizando la compatibilidad con los pueblos indígenas y el medio ambiente natural. Con la participación de sindicalistas, expertos en medio ambiente y empresas, la empresa de formación desarrolló una serie de módulos de "cualificaciones ecológicas" para impartir unos conocimientos medioambientales básicos a trabajadores de diversos sectores. Estos conocimientos se complementan con una serie de competencias prácticas de carácter técnico, social y de seguridad.

Los módulos 1 y 2 de cualificaciones ecológicas contienen una base amplia de información medioambiental, y su enseñanza se combina con la de otros programas de formación de nivel introductorio. Los niveles 3 y superiores están dirigidos a personas especializadas en trabajos de reducción de los impactos medioambientales. Los dos primeros módulos de ecocualificaciones se componen de dos ciclos de cuarenta horas. Los trabajadores en período de formación adquieren sus cualificaciones a través de clases magistrales, sesiones de resolución de problemas en grupo y técnicas prácticas. Se les evalúa mediante exposiciones escritas y orales, trabajo en grupo y juegos de rol.

En las sesiones se tratan temas como los siguientes: introducción a los principios de un desarrollo ecológicamente sostenible; uso eficiente de los recursos y producción más limpia, y sistemas de gestión del medio ambiente. Al terminar el módulo 1, los trabajadores deben ser capaces de:

- identificar las consecuencias de determinada forma de vida para la sostenibilidad a largo plazo, haciendo especial hincapié en la forma de vida presente y futura del alumno

- identificar formas de reducir el impacto medioambiental de las actividades humanas

- describir estrategias para reducir los impactos medioambientales en un sector determinado (agricultura, silvicultura, manufactura, turismo, tiempo libre, minería)

- describir las principales características de un Sistema de Gestión M edioambiental

- identificar la función de las partes interesadas en la reducción de la contaminación medioambiental y el agotamiento de los recursos.

El módulo 2 amplía estos objetivos iniciales y prepara a los trabajadores para empezar a aplicar métodos de prevención de la contaminación y conservación de los recursos.

Existen sectores industriales interesados en conectar, a todos los niveles, los conocimientos sobre impacto ambiental con las normas aplicadas en el desarrollo de su actividad. La concienciación con respecto a las cuestiones ambientales debe reflejarse en el trabajo diario de todos los trabajadores industriales, sea cual sea su nivel de cualificación. EI hecho de que las tablas salariales se establezcan en función de las normas de cada sector constituye un incentivo para los trabajadores. El experimento australiano es aún muy reciente, pero es un claro intento de trabajar con todas las partes para crear actividades basadas en una serie de competencias capaces de generar empleo y de fomentar la seguridad en el trabajo, mejorando al tiempo la calidad del medio ambiente y difundiendo la concienciación respecto a su importancia.

\section{Salud y seguridad en relación con la formación ambiental}

Uno de los sindicatos más activos de Estados U nidos en materia de formación ambiental es el Laborers International U nion of North America (LIU NA). Existe una norma pública que obliga a ofrecer un período mínimo de 40 horas de formación sobre reducción de riesgos. El sindicato, junto con los contratistas participantes, ha desarrollado un curso intensivo de 80 horas, cuyo objeto es fomentar en los trabajadores que manejan residuos potencialmente peligrosos la concienciación con respecto a la seguridad en el trabajo. En 1995, más de 15.000 trabajadores recibieron formación sobre la eliminación de plomo, amianto y de otros residuos peligrosos, así como sobre otras actividades de conservación del medio ambiente. El programa Laborers-Associated General Contractors ha preparado 14 cursos de conservación del medio ambiente y otros programas de formación de formadores, para contribuir a los effuerzos que, a escala nacional, se están llevando a cabo en favor de una conservación segura y adecuada. Los cursos se impartieron en 32 centros de formación y en cuatro unidades móviles. 
A demás de ofrecer formación sobre temas técnicos y de seguridad, se anima a los participantes a reflexionar sobre problemas medioambientales más amplios. Entre otras tareas, los alumnos recogen material publicado por la prensa local sobre temas de medio ambiente, que utilizan como punto de partida para analizar problemas más generales del medio ambiente. Una plantilla de 19 trabajadores, equivalente a tiempo completo, trabaja en formación ambiental en la oficina central de esta asociación de sindicatos y empresas, cuya financiación es de más de 10 millones de dólares. Los materiales y los métodos de formación cumplen exigentes normas de calidad, con un uso extensivo de medios audiovisuales y otros materiales de formación, atención a competencias específicas, y compromiso de calidad y evaluación incorporados al plan de estudios. Existe un vídeo para "aprender en casa", en el que se exponen ciertas cuestiones de naturaleza básica y se relacionan conocimientos de tipo general y medioambientales. Para aquellos que lo deseen, seis de los cursos son convalidables por créditos universitarios. EI programa trabaja activamente con grupos minoritarios, de los que proceden más de la mitad de sus participantes. Además, se están desarrollando otros programas, en colaboración con instituciones de grupos minoritarios, con proyectos de viviendas sociales y con otros centros de enseñanza.

EI sindicato afirma que una gran parte de sus futuros miembros se dedicarán a actividades relacionadas con el medio ambiente y considera que los programas de educación de los trabajadores fortalecen las bases de ese crecimiento. No sólo la seguridad es mejor en los puestos ocupados por trabajadores formados, sino que también mejora la productividad. Sin embargo, el sindicato se fija también en consecuencias de mayor alcance:

"El efecto más interesante que ha tenido la formación ambiental sobre quienes la han seguido es que ha aumentado su respeto hacia los productos químicos y las sustancias nocivas que se encuentran en el lugar de trabajo y en el hogar... También ha aumentado la preocupación por las consecuencias de la contaminación continua y por los costes que representa la limpieza del medio ambiente... El verdadero impacto va mucho más allá de la preparación de las personas para el trabajo" (LIU NA 1995).

En Estados U nidos, este tipo de formación sobre materiales peligrosos también se imparte en agrupaciones sindicales de mecánicos, pintores, carpinteros, trabajadores del petróleo y de las industrias químicas y nucleares, trabajadores químicos, maquinistas, camioneros y trabajadores del acero.

EI LIUNA trabaja también a escala internacional con la Confederación de Trabajadores M ejicanos (CT M), y colabora con otras iniciativas de formación públicas y privadas, así como con grupos de empresas, con objeto de desarrollar metodologías de enseñanza. Se presta especial atención a la formación de trabajadores mejicanos en materia de conservación del medio ambiente y en cualificaciones de construcción. La Interamerican Partnership for Environmental Education and Training (IPEET) organizó su primer curso de formación para trabajadores mejicanos durante el verano de 1994 en Ciudad de M éjico. Asistió al curso un grupo de líderes laborales y de trabajadores de las empresas locales, entre otras, de fabricación de pinturas y de tratamiento de metales; las clases duraron una semana y versaron sobre la seguridad y salud ambientales. Se están estableciendo otros grupos del LIUNA en Canadá; los materiales, cuyo contenido ha sido objeto de una adaptación a este país, serán editados en francés. También se han establecido acuerdos con el Instituto Europeo de Educación y Formación Ambiental, para impartir este tipo de formación en países de Europa O riental y de la CEI.

\section{Zambia: manual de enseñanza sobre salud y seguridad en el trabajo}

En Zambia, la salud y la seguridad en el trabajo sólo suelen tomarse en serio cuando hay un incidente que acarrea lesiones o daños para la propiedad de la empresa. La industria también hace caso omiso de las cuestiones ambientales. EI M anual sobre salud y seguridad en el trabajo se escribió para educar a los trabajadores y las empresas sobre la importancia de las cuestiones de salud y seguridad en el trabajo.

El primer capítulo del Manual subraya la importancia de la educación en todos los niveles de la empresa. Se espera que los supervisores comprendan el papel que les corresponde en la creación de unas condiciones de trabajo seguras y sanas. A los trabajadores se les enseña que, si mantienen una actitud positiva y cooperante, redundará en favor de su propia seguridad y del medio ambiente de trabajo.

EI M anual se refiere de forma concreta a los temas ambientales, resaltando que todas las grandes ciudades de Zambia se enfrentan a:

“(...) la amenaza de daños ambientales cada vez mayores. En concreto, la ZCT U indicó que la industria minera estaba poniendo en peligro el medio ambiente, debido a sus explotaciones a cielo abierto y a la contaminación del aire y del agua derivada de unas prácticas de mala calidad. Muchas fábricas están contaminando el aire y el agua, al verter sus residuos directamente en las corrientes y ríos más próximos, y al permitir la liberación incontrolada de humos y vapores a la atmósfera". (ZCTU 1994).

Aunque muchos sindicatos africanos están interesados en fomentar la educación ambiental, se encuentran con la importante barrera de la falta de fondos suficientes para la formación de los trabajadores y la necesidad de información sobre la relación entre los peligros del medio ambiente y los correspondientes al ámbito local y al lugar de trabajo.

\section{Educación y formación ambiental de los trabajadores en la empresa}

Las empresas, en especial las grandes, disponen de un buen número de actividades de educación ambiental. En muchas ocasiones, se trata de actividades de formación de carácter obligatorio, ligadas a determinados requisitos de seguridad en el trabajo o de seguridad ambiental. Sin embargo, cada vez es mayor el número de empresas que se dan cuenta de la importancia de que sus trabajadores tengan una formación amplia, más allá de la estrictamente ajustada al cumplimiento de unas normas. El grupo de empresas Royal Dutch/Shell ha integrado los temas de salud, seguridad y medio ambiente (SSM A) en su programa general de formación; además, el medio ambiente forma parte integrante de todas las decisiones de la dirección (Bright y van Lamsweerde 1995). Se trata de una práctica general y obligatoria. U no de sus objetivos es definir las competencias en materia de SSMA necesarias para determinados puestos de trabajo. La competencia de los trabajadores se desarrolla mediante el refuerzo de la concienciación, los conocimientos y las cualificaciones; una formación adecuada aumenta los dos primeros, mientras que las cualificaciones se van desarrollando al aplicar los nuevos conocimientos. Un amplio conjunto de técnicas de comunicación y aprendizaje ayuda a difundir y reforzar el mensaje medioambiental.

En Estados Unidos, la empresa Duquesne Light ofreció formación, con buenos resultados, a sus 3.900 trabajadores; el tema era "cómo la empresa y sus trabajadores afectan al medio ambiente". William DeLeo, vicepresidente para asuntos medioambientales, comentó: 


\begin{abstract}
"Para desarrollar un programa de formación que nos permitiera cumplir nuestros objetivos estratégicos, llegamos a la conclusión de que nuestros trabajadores debían tener una concienciación general respecto a la importancia de la protección del medio ambiente, así como una formación técnica específica para las tareas correspondientes a su puesto de trabajo. Estas dos cuestiones se convirtieron en la estrategia por la que se guía nuestro programa de educación ambiental" (Cavanaugh 1994).
\end{abstract}

\section{Programas de educación ambiental por iniciativa de los trabajadores o de los sindicatos}

EI Servicio de Educación de los Trabajadores de la OIT ha preparado un juego de seis folletos sobre temas generales, para estimular el debate entre sindicalistas y otras partes interesadas en cuestiones como las siguientes: el medio ambiente en relación con los trabajadores, con el lugar de trabajo y con la comunidad; cuestiones ambientales de trascendencia mundial; el nuevo programa de negociación colectiva, una guía de recursos y un glosario de términos. Ofrecen una reflexión amplia y de fácil lectura y pueden utilizarse para analizar temas importantes para los trabajadores, tanto en los países industrializados como en los países en vías de desarrollo. Están basados en proyectos concretos de Asia, el Caribe y Africa meridional. Se pueden usar todos juntos, como un texto unitario, o se pueden distribuir en un círculo de estudios, para promover el diálogo general.

La OIT, en una revisión de las necesidades de formación, señala:

"Los sindicalistas deben estar más concienciados ante los temas ambientales en general y ante el impacto de sus empresas sobre el medio ambiente, lo cual incluye la seguridad y salud de sus propios trabajadores. Los sindicatos y sus miembros deben entender las cuestiones ambientales y las consecuencias que los correspondientes peligros tienen para sus miembros y para la comunidad en general, y tienen que ser capaces de desarrollar soluciones sostenibles en sus negociaciones con la dirección de la empresa y con las organizaciones patronales" (OIT 1991).

Por su parte, la Fundación Europea para la M ejora de las Condiciones de Vida y de Trabajo ha destacado:

“Los sindicatos de ámbito local y otros representantes de los trabajadores se encuentran en una situación particularmente difícil. Tendrán el conocimiento pertinente de la situación local y del lugar de trabajo, pero, en la mayoría de los casos, no estarán suficientemente especializados en complejas cuestiones estratégicas y ambientales.

Por lo tanto, no serán capaces de ejercer sus funciones, a menos que reciban una formación complementaria y especializada" (Fundación E uropea para la M ejora de las Condiciones de Vida y de Trabajo 1993).

Algunos sindicatos de ámbito nacional han pedido un incremento de la educación de los trabajadores en temas ambientales. Entre ellos figura el LO de Suecia, cuyo Programa Ambiental para el año 1991 pedía una ampliación de la educación y de las actividades en el lugar de trabajo, así como más materiales para el estudio en grupo sobre el medio ambiente, a fin de promover la concienciación y el aprendizaje. EI M anufacturing Workers Union de Australia ha preparado un curso de formación y un conjunto de materiales previstos para ofrecer orientación en materia de medio ambiente, en los que se trata, entre otros objetivos, de abordar este tipo de cuestiones en la negociación colectiva.

\section{Resumen}

Si los trabajadores tienen una buena formación en materia de medio ambiente, dispondrán de los conceptos y de los conocimientos técnicos necesarios para ampliar su concienciación ante estas cuestiones y para aprender formas concretas de modificar determinadas prácticas de trabajo perjudiciales para el medio ambiente. Al mismo tiempo, también los programas pueden aprender de los propios trabajadores, e incorporar sus inquietudes, sus reflexiones y sus puntos de vista sobre las cuestiones prácticas relativas al medio ambiente en el lugar de trabajo.

La mejor forma de llevar a cabo la educación ambiental en el lugar de trabajo es relacionarla con los retos ambientales que se plantean a escala local y global, de forma que los trabajadores tengan una idea clara sobre el modo en que su trabajo está integrado en un medio ambiente general y aprendan cómo contribuir a lograr un lugar de trabajo y un ecosistema global más limpios.

\section{FORMACION SOBRE SALUD Y SEGURIDAD DE LOS DIRECTIVOS}

John Rudge

Tras una breve revisión de las aportaciones de la educación a la salud y la seguridad de los trabajadores y de los primeros fundamentos de la educación de los directivos, este artículo se ocupa del desarrollo curricular. En relación con las necesidades educativas de los futuros altos directivos, es importante tener en cuenta las dos vías de acceso a estos puestos. En primer lugar, se establecen los contenidos curriculares relativos a los problemas de gestión; a continuación, se examinan las cuestiones pertinentes para comprender las causas de las lesiones.

La educación sobre la salud y la seguridad en el trabajo se ha dirigido, primordialmente, a los directivos responsables de la seguridad y a los médicos de empresa $y$, desde hace menos tiempo, a los enfermeros de salud en el trabajo, a los ergónomos y a los higienistas, es decir, personas llamadas a ocupar puestos de especialistas en las organizaciones.

La función de estos especialistas, en cuanto asesores, abarca tareas tales como las exploraciones médicas previas a la contratación, las revisiones médicas, la supervisión de la exposición de los empleados a una serie de peligros y las inspecciones ambientales. Entre otras actividades, son responsables de planificar los puestos de trabajo y las diversas tareas de tal modo que se ajusten a los controles técnicos y administrativos, minimizando, si no eliminando, por ejemplo, los efectos lesivos de las exigencias posturales o de la exposición a sustancias tóxicas.

Por regla general, este enfoque educativo centrado en los especialistas ha pasado por alto el problema fundamental de la creación de lugares de trabajo sanos y seguros, es decir, la extraordinaria diversidad de los conocimientos operativos necesarios para convertir esta necesidad en realidad. $\mathrm{H}$ ay que tener en cuenta que los directivos tienen la responsabilidad de planificar, organizar y controlar las actividades laborales de empresas públicas y privadas en todos los sectores de la economía.

\section{Antecedentes}

Durante el decenio de 1970 surgieron muchas iniciativas para ofrecer programas de estudios de tercer ciclo que aportaran una educación profesional con formación práctica, dirigidos a los ingenieros, científicos y trabajadores sanitarios que se introdujeran en el campo de la salud y la seguridad en el trabajo.

En el decenio de 1980 se hizo patente que las personas más directamente preocupadas por la salud y la seguridad en el 
Figura 18.3 - Contenidos curriculares de los módulos. G uía de recursos del proyecto Minerva.

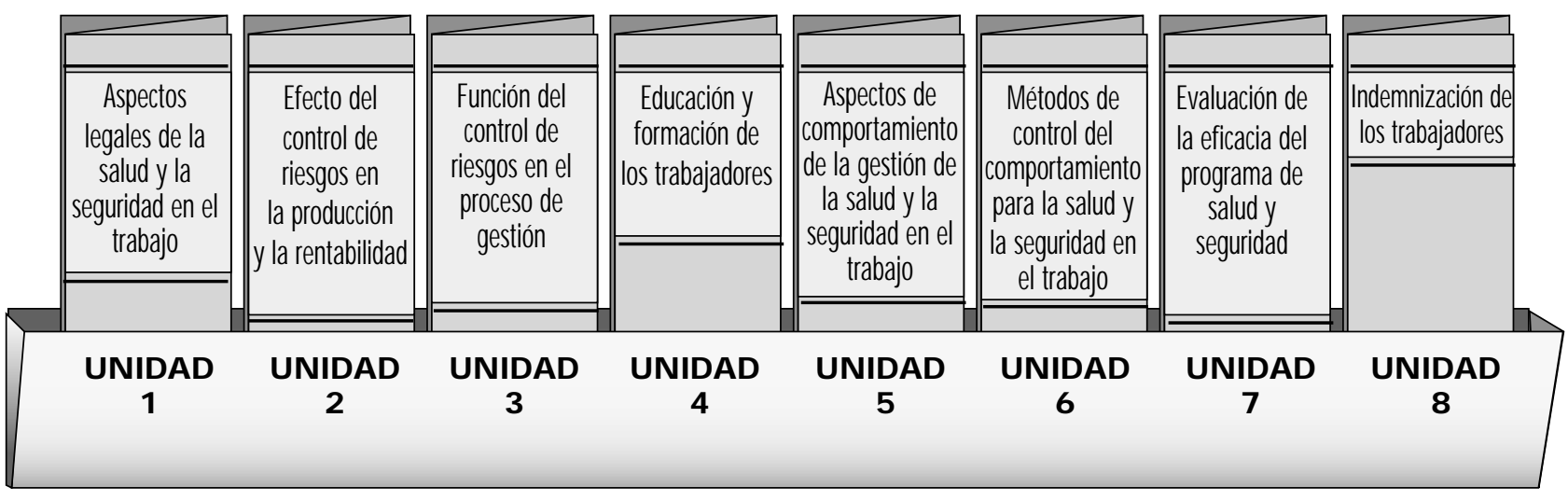

trabajo - los directivos, los propios trabajadores y sus asociaciones - eran las grupos más influyentes en la reducción de las lesiones y de las enfermedades. Los responsables de la toma de decisiones empezaron a contemplar la necesidad de ofrecer una educación a los trabajadores que formaran parte de los comités de seguridad y a los representantes elegidos de salud y seguridad. Estos cambios pusieron de manifiesto por primera vez las escasas posibilidades de educación y formación para directivos.

\section{Una primera iniciativa para ocuparse de la educación de los directivos}

Para solucionar este problema, se aportaron diversas medidas. Una de las iniciativas que más éxito tuvo es el Proyecto M inerva del National Institute of $\mathrm{O}$ ccupational Safety and Health (N IO SH ), que supuso un primer intento de agrupar las destrezas específicas de gestión necesarias para garantizar la seguridad de los lugares de trabajo y que, "en términos generales, va más allá de lo que se ofrece en el currículo tradicional de los estudios empresariales" (N IO SH 1985). Las facultades de ciencias empresariales recibieron materiales de enseñanza del Proyecto $M$ inerva para abordar las cuestiones más urgentes relativas a la salud y la seguridad. La guía de recursos incluía módulos didácticos, estudios de casos y una antología de textos especializados. En la Figura 18.3 se recogen los temas de los módulos.

La Canadian Society of Safety Engineers recomendó esta estructura para las facultades de ciencias empresariales, en su intento de incorporar a sus currículos los materiales relativos a la salud y la seguridad.

\section{Fundamentos de la gestión: más necesidades generales que específicas}

Cualquier trabajo de responsabilidad supone la adquisición de los conocimientos pertinentes y de las destrezas adecuadas para llevarlo a cabo. La dirección de la salud y la seguridad en el trabajo dentro de una organización compete cada vez más a los directivos de los distintos niveles jerárquicos. Se trata de una competencia que requiere la adecuada asunción de responsabilidades y la autoridad suficiente para ordenar los recursos necesarios. Los conocimientos y destrezas para hacerse cargo de estas competencias configuran el currículo de la educación de directivos en materia de salud y seguridad en el trabajo.

A primera vista, parece que un currículo de este tipo debería satisfacer todas las demandas concretas del conjunto de funciones directivas propias de una serie de puestos, como jefe de departamento, enfermero jefe, director de operaciones, responsable de suministros y compras, coordinador de flota e, incluso, capitán de barco. Por otra parte, los currículos tendrían que reflejar también todo el conjunto de industrias y trabajos en los que aparezcan dichos puestos. Sin embargo, la experiencia indica que no es así. En realidad, las destrezas y conocimientos necesarios son comunes a todas las funciones directivas y son más importantes que los conocimientos especializados. Estos conocimientos comunes constituyen la base de cualquier cargo de gestión. No obstante, no todos los directivos acceden a los puestos de responsabilidad por las mismas vías.

\section{Carreras profesionales de los directivos}

Las vías típicas de acceso a un cargo directivo son la realización de funciones de supervisión, o el desarrollo de funciones especializadas. En el primer caso, la promoción profesional depende de la experiencia laboral y de los conocimientos de la tarea; en el segundo, son frecuentes la educación universitaria y la formación postgrado, como la de ingeniero o jefe de enfermería. Por cualquiera de las dos vías, hace falta adquirir una cualificación en salud y seguridad en el trabajo. En el segundo caso, suele conseguirse en una escuela de postgrado.

En la actualidad, es habitual que los directivos estén en posesión de un título de M aster of Business Administration (MBA). Por eso, el Proyecto M inerva dirigió su atención a las más de 600 escuelas de dirección de empresas para postgraduados existentes en Estados U nidos. Al incorporar estos aspectos de la salud y la seguridad en el trabajo al currículo del M BA por considerarlos imprescindibles para realizar una buena gestión, se pensó que este material acabaría integrándose en los estudios formales de gestión de nivel medio.

Ante la enorme proliferación de invenciones tecnológicas y descubrimientos científicos, las carreras universitarias, particularmente las ingenierías y las disciplinas científicas, tienen pocas oportunidades para integrar una teoría y una práctica amplias de la seguridad dentro de los estudios relacionados con proyectos, procesos y operaciones.

Puesto que quienes han recibido una educación especializada tienen que empezar a desempeñar funciones directivas poco después de su titulación, es necesario proporcionarles los conocimientos y destrezas de los directivos, especialistas y generalistas en cuestiones de salud y seguridad.

Es importante que el resto del personal con responsabilidades de este tipo conozca el contenido del currículo dedicado a los objetivos de salud y seguridad en el trabajo para los directivos. Por tanto, la formación de los empleados clave, en cuanto representantes de salud y seguridad, debe diseñarse de manera que estén al tanto de esos desarrollos curriculares. 


\section{El currículo para gestionar la salud y la seguridad en el trabajo}

$\mathrm{H}$ ay dos grandes clases de conocimientos en los que cabe la disciplina de la salud y seguridad en el trabajo. U na es la que abarca las funciones y principios de la dirección, y la otra trata de la naturaleza y el control proactivo de los peligros. El modelo de desarrollo curricular que se expone a continuación observa esta división. Tanto la vía de acceso a la dirección que se desarrolla a través de las tareas de inspección como la especializada requieren una forma específica de abordar ambas clases de conocimientos

La cuestión del nivel de complejidad y detalle tecnológico que hay que transmitir a los alumnos puede determinarse de acuerdo con el objetivo del curso, su duración y la intención de quienes lo imparten en relación con la educación y el desarrollo de destrezas posteriores. Trataremos estas cuestiones en una sección posterior.

En concreto, los currículos deben ocuparse de la seguridad de la maquinaria y la instalación, el ruido, la radiación, el polvo, los materiales tóxicos, el fuego, los procedimientos de emergencia, los planes médicos y de primeros auxilios, la supervisión del lugar de trabajo y de los empleados, la ergonomía, la higiene ambiental, el diseño y mantenimiento del lugar de trabajo y, más importante aún, el desarrollo de procedimientos operativos estándar y la formación correspondiente. Este último aspecto es un componente esencial de los conocimientos de los directivos. No sólo deben incluirse las tareas y los procesos en la formación de los operarios, el perfeccionamiento continuo de las personas y los procesos son aspectos imprescindibles de la formación y el reciclaje para mejorar la calidad. Es preciso aplicar la teoría y la práctica del aprendizaje adulto al desarrollo de los materiales curriculares que guíen este proceso de formación continua.

\section{Funciones y principios de la dirección}

Los objetivos fundamentales de la dirección abarcan la planificación, la organización y el control de las actividades que se desarrollan en el centro de trabajo. Asimismo, se incluye la incorporación de prácticas que maximicen las oportunidades de participación de los trabajadores en el establecimiento de objetivos, el funcionamiento de equipos y la mejora de la calidad. M ás aún, para que la dirección tenga éxito ha de integrar la salud y seguridad en el trabajo en todas las actividades de la organización.

A parte de las escuelas de estudios empresariales, es raro que los programas universitarios incluyan estos conocimientos. Sin embargo, son esenciales en la práctica diaria de los especialistas en este campo.

\section{Marco de organización}

Los directivos deben comprender que la formulación de la misión, el plan estratégico y la estructura establecida para orientar y facilitar el cumplimiento de los objetivos de la organización es la base de sus actividades individuales. Cada división de la organización, ya se trate de un hospital, una empresa de camiones de transporte 0 una mina de carbón, tendrá sus propios objetivos y su propia estructura, pero será necesario que haya una meta común para toda la organización en su conjunto.

\section{Políticas y procedimientos}

La primera materialización de los objetivos de una organización está representada por los documentos normativos y las orientaciones para los empleados en relación con temas específicos (en algunas zonas, la legislación impone la publicación de una política general de la organización). Estos documentos deben incluir referencias al conjunto de programas de salud y seguridad en el trabajo diseñados en relación con las actividades y procesos que ocupan la jornada laboral de los empleados. Normalmente se abordan temas como la evacuación de emergencia, las normas contra incendios, los procedimientos de compra, los partes de lesiones y la investigación de accidentes e incidencias. Por otra parte, los peligros específicos requieren sus propios materiales normativos sobre procesos específicos, por ejemplo, en relación con el manejo de sustancias peligrosas, las intervenciones ergonómicas o la entrada a espacios restringidos.

Tras el establecimiento de una política reguladora, actividad que debe llevarse a cabo preferentemente con la participación de representantes de los trabajadores y la intervención de los sindicatos, deben fijarse procedimientos detallados para ponerla en práctica. De nuevo, las prácticas participativas contribuyen a la aceptación sin reservas de los procedimientos por parte de los trabajadores como una valiosa aportación a su salud y seguridad.

La Figura 18.4 ilustra esquemáticamente un sistema de gestión de salud y seguridad.

\section{E structuras de organización que definen las funciones clave}

La fase siguiente del proceso de gestión consiste en la definición de una estructura organizativa que caracterice las funciones desempeñadas por las personas clave -por ejemplo, el director ejecutivo- y los asesores profesionales, como los asesores de seguridad, los higienistas del trabajo, los enfermeros de salud en el trabajo, el médico y el ergónomo. Para facilitar el desempeño de sus funciones, las relaciones de estas personas, de los representantes elegidos de salud y seguridad (obligatorios en algunas jurisdicciones) y de los trabajadores miembros de los comités de seguridad con la estructura de la organización deben ser explícitas.

Las funciones directivas de planificación y organización introducirán en las actividades operativas de la empresa: estructuras, políticas y procedimientos.

Figura 18.4 • Un sistema de gestión de salud y seguridad.

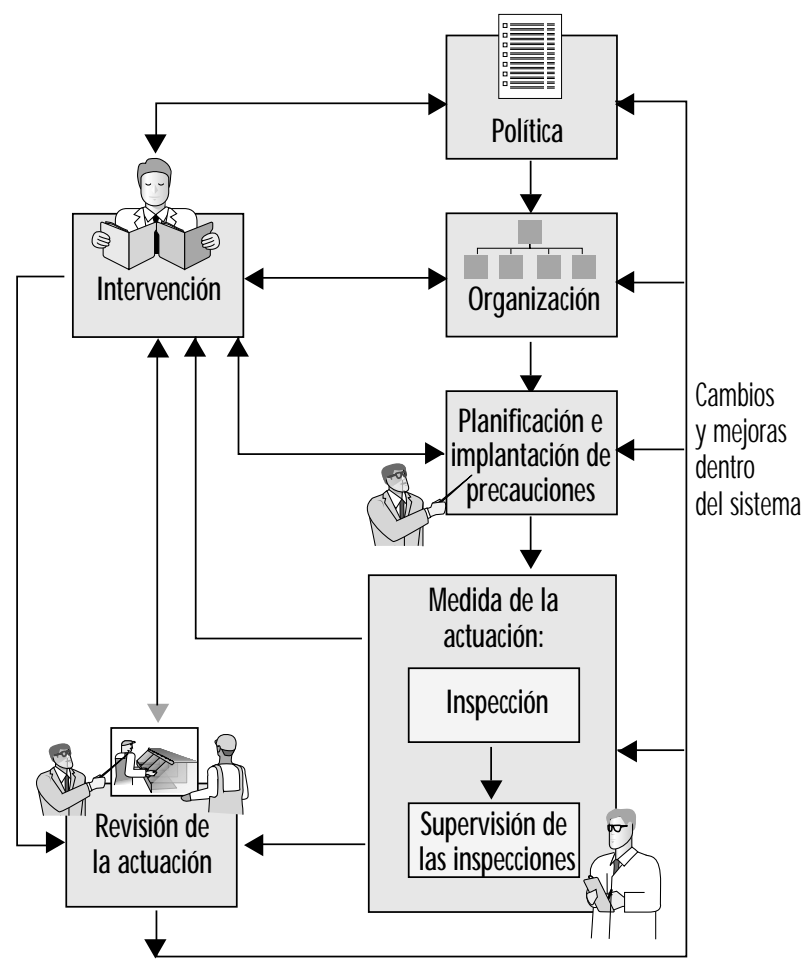


Figura 18.5 - El proceso error-lesión.

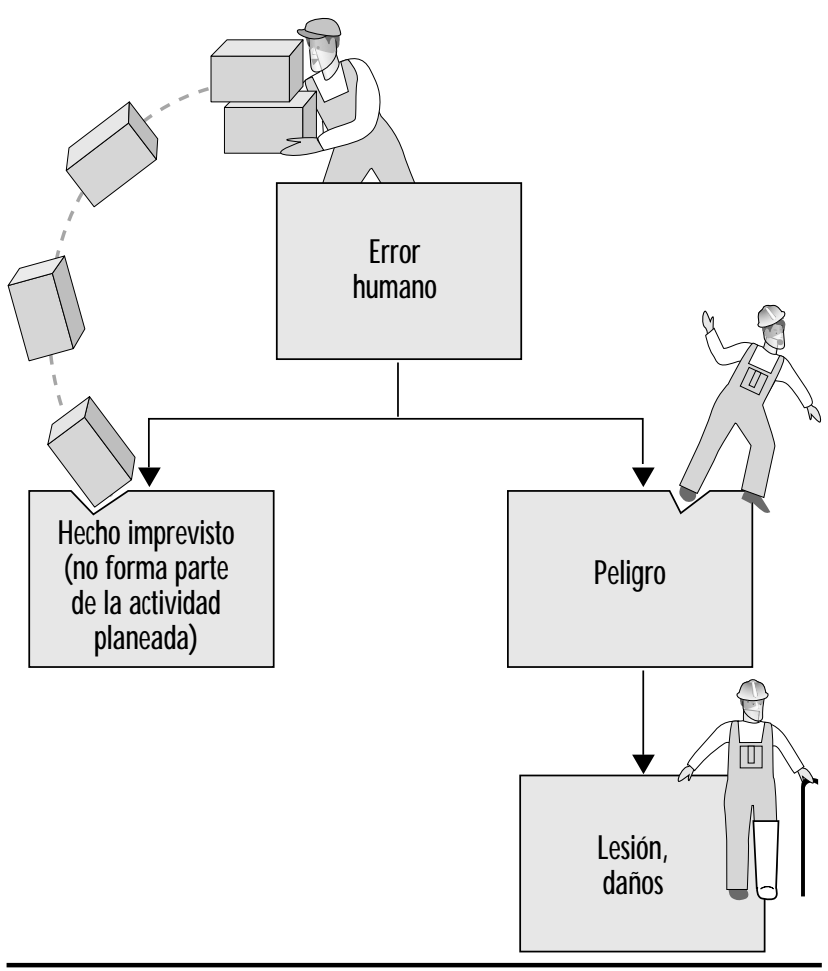

\section{Control}

Las actividades de control -establecimiento de procesos y objetivos, determinación de niveles de logro aceptables y medida de la actuación en relación con dichos niveles- son las fases operativas que llevan a la realización de las intenciones del plan estratégico. También han de establecerse mediante la codeterminación. Las herramientas de control son las inspecciones del lugar de trabajo, que pueden ser continuas, frecuentes, aleatorias o formales.

El conocimiento de estas actividades constituye un componente importante de los programas de educación para directivos, y deben desarrollarse las destrezas necesarias para llevarlas a cabo. Esas destrezas son tan esenciales para el éxito de un plan integrado de salud y seguridad como para separarlas de cualquier otra función directiva, sea la de compras o la de operaciones de la flota.

\section{Desarrollo de la organización y currículo}

Puesto que la introducción de nuevas estructuras de organización, nuevos equipos y nuevos materiales se produce a un ritmo muy rápido, hay que prestar especial atención a los procesos de cambio. Los empleados a quienes afecten estos cambios pueden tener una influencia decisiva sobre su eficacia y sobre la eficiencia del grupo de trabajo. Deben adquirirse los conocimientos adecuados de los factores psicosociales que influyen en las actividades de la organización y desarrollar las destrezas para utilizar estos conocimientos en la consecución de los objetivos de la organización. Es especialmente importante que el directivo delegue su autoridad y parte de sus competencias en que funcionen como equipos autónomos o semiautónomos. El currículo de la educación para directivos debe poner a disposición de los alumnos las herramientas necesarias para cumplir con su obligación de garantizar no sólo la mejora del proceso y de la calidad, sino también el desarrollo de múltiples destrezas y la adecuada sensibilización del personal, aspectos directamente relacionados con la cuestión de la seguridad.

$\mathrm{H}$ ay que examinar otros dos componentes del currículo para directivos. U no de ellos es la actividad de investigación de accidentes; y el otro, sobre el que descansa toda esta actividad, es la comprensión del fenómeno del accidente.

\section{El fenómeno del accidente}

El trabajo de Derek Viner (1991) sobre la importancia de las fuentes de energía como peligros potenciales en todos los lugares de trabajo significó la definición de la mitad de la ecuación de los accidentes. En conjunción con el trabajo de Viner, la aportación del Dr. Eric Wigglesworth (1972) al identificar el error humano, elemento crucial de la gestión de las actividades de seguridad en los centros de trabajo, completa su definición. Benner (1985) demostró, estudiando los métodos de investigación de accidentes, que el enfoque más productivo de la gestión de la salud y seguridad de los trabajadores consiste en prestar la máxima atención al proceso de cada episodio lesivo.

La Figura 18.5 muestra la sucesión de hechos que acaba en lesiones, daños y pérdidas, tal como la expone Wigglesworth. Realza el papel del error humano no culpable, aś como el elemento esencial de la pérdida de contención de energía y el potencial de lesiones cuando ocurre esto.

Las consecuencias del modelo de gestión se hacen patentes cuando se tienen en cuenta, en la planificación de los procesos de trabajo, las actuaciones comportamentales que influyen en esos procesos, sobre todo cuando se otorga al diseño un lugar destacado como mecanismo iniciador para el desarrollo del equipo y de los procesos. Cuando la planificación tiene en cuenta tanto el diseño de la instalación y del equipo como los factores humanos que influyen en la actividad, pueden implantarse mecanismos de coordinación y control que aseguren la contención de los peligros identificados.

Puede utilizarse un modelo para ilustrar la importancia de la interacción entre el trabajador, el equipo, las herramientas y máquinas empleadas para llevar a cabo los objetivos de la tarea

\section{Figura 18.6 • Representación de los elementos del lugar de trabajo relevantes para las causas y el control de lesiones.}

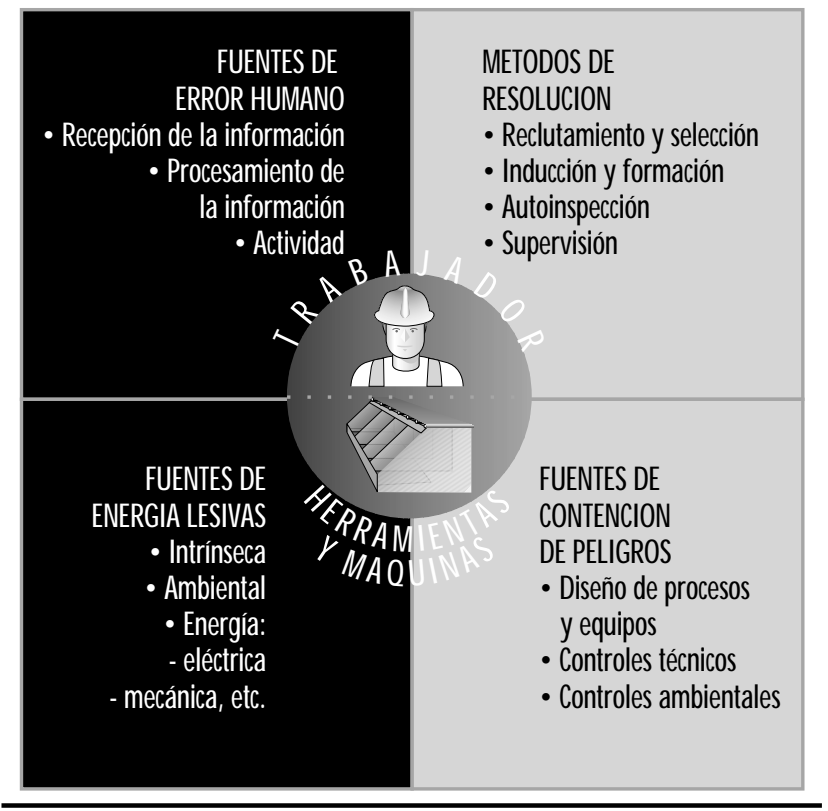


y el ambiente en el que tiene lugar la actividad. El modelo pone de relieve la necesidad de prestar atención a los factores de los tres elementos que pueden contribuir a que se produzcan hechos perjudiciales. En el ambiente del lugar de trabajo, que engloba, entre otros, los componentes térmico, acústico y lumínico, el trabajador interactúa con las herramientas y el equipo necesario para realizar el trabajo (véase la Figura 18.6).

\section{Investigación y análisis de accidentes}

La investigación de los accidentes cumple una serie de funciones importantes. En primer lugar, puede ser un proceso proactivo, utilizándose en situaciones en las que se produce una incidencia sin resultados de daños o lesiones, aunque hubiera podido haberlos. El estudio de la sucesión de hechos puede descubrir características del proceso de trabajo que podrían haber tenido consecuencias más graves. En segundo lugar, podemos comprender mejor el proceso de desarrollo de los hechos, identificando las carencias e insuficiencias de diseño, formación, supervisión o controles de las fuentes de energía en el proceso o tarea. En tercer lugar, muchas jurisdicciones exigen por ley la investigación de ciertos tipos de accidentes, por ejemplo, la caída de andamios y los desprendimientos de tierra en zanjas, las electrocuciones y los fallos de equipos elevadores. El trabajo de Benner (1985) ilustra muy bien la importancia de adquirir una clara comprensión del fenómeno del accidente y de disponer de un protocolo eficaz para investigar las lesiones y los daños.

\section{La naturaleza y el control de los peligros}

Todas las lesiones son el resultado de alguna forma de intercambio de energía. La liberación incontrolada de energía física, química, biológica, térmica o en cualquier otra forma constituye una fuente de daños potenciales para diversas clases de trabajadores. La contención por medio de mecanismos adecuados técnicos o administrativos es un aspecto esencial de un control adecuado. U na condición previa al control es la identificación y la evaluación de estas energías.

En consecuencia, el currículo de la educación de los directivos debe contener temas que abarquen un conjunto de actividades, como el establecimiento de objetivos, la planificación del trabajo, la elaboración de normas y procedimientos, el desarrollo de cambios en la organización y la instalación de controles

Figura 18.7 - Programa de estudios de salud y seguridad en el trabajo.

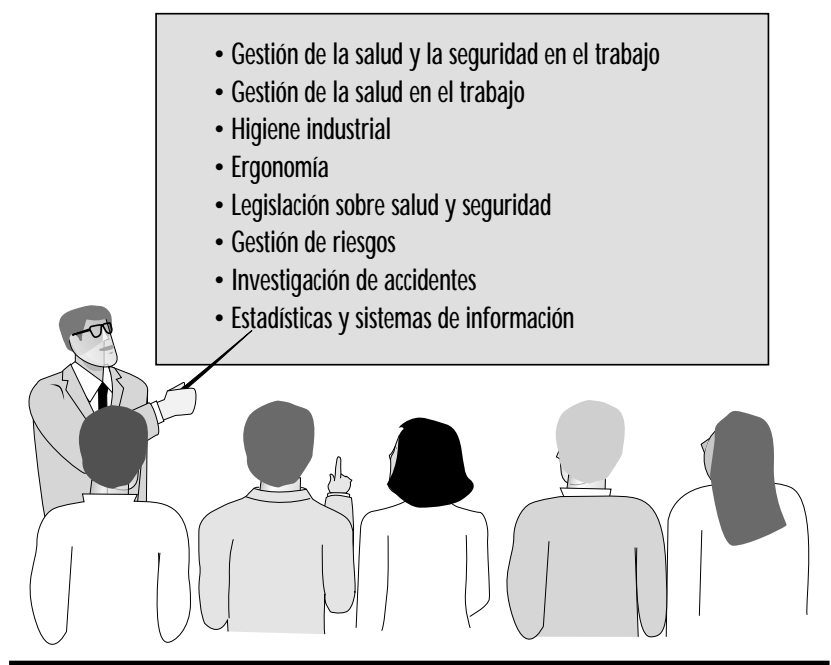

Figura 18.8 - Programas cortos de estudios de salud y seguridad en el trabajo.

GESTION DE LA SALUD Y LA SEGURIDAD EN EL TRABAJO - Planificación, organización, coordinación y control

- Desarrollo de políticas

- Causas de las lesiones

- Modificación y desarrollo de la organización

- Formación y procedimientos normalizados

- Integración de la calidad y la seguridad en las actividades de gestión

- Modelos de diagnóstico, intervención estratégica y procedimientos de consulta GESTION DE LA SALUD EN EL TRABAJO

- Anatomía y fisiología básicas, toxicología

- Vigilancia de los trabajadores y del lugar de trabajo - Enfermedades profesionales e industriales - Problemas de salud de grupos especificos de la plantilla (migrantes, mujeres, trabajadores de más edad)

- Función de los profesionales y los senvicios de salud en el trabajo

- Rehabilitación de los trabajadores lesionados y evaluación de la incapacidad

- Indemnización de los trabajadores y su efecto en las actividades de prevención HIGIENE INDUSTRIAL

- Amenazas ambientales y laborales para la salud y la seguridad - Procedimientos de reconocimiento de los peligros - Medición ambiental del lugar de trabajo - Interpretación de los datos de muestreo - Actividades de control de los contaminantes Normas de higiene

- Encuestas en el lugar de trabajo

- Equipo de protección personal

- Requisitos legislativos

- Manipulación, almacenamiento y transporte de sustancias peligrosas

- Radiación, incendios y explosiones

ERGONOMIA

- Características de la actuación humana

- Características del sistema trabajador/ máquina

- Principios ergonómicos del diseño y la remodelación de los puestos de trabajo y como estrategias preventivas en las actividades del lugar de trabaio

- Ruido, vibración

- Características de las máquinas, el equipo y las herramientas - Mantenimiento y deterioro

- Satisfacción laboral, rendimiento laboral y estrés

LEGISLACION SOBRE SALUD Y SEGURIDAD

- Leyes, reglamentos y códigos profesionales (internacionales, nacionales y regionales) sobre:

- Salud, seguridad y bienestar en el trabajo - Indemnización y rehabilitación de los trabajadores - Regulación de las relaciones laborales

GESTION DE RIESGOS

- Identificación de los riesgos

- Clases de peligros

- Evaluación de la probabilidad, frecuencia y gravedad - Medidas de control adecuadas a cada exposición

- Fallos potenciales de las medidas de control INVESTIGACION Y ANALISIS DE ACCIDENTES

- Conceptos sobre las causas

- Función del intercambio de energía en las lesiones humanas y en los daños y pérdidas materiales

- El proceso de los hechos imprevistos

- Marco conceptual y principios de la investigación de incidentes concretos, p. ej., momentos críticos, como cuando se pierde el control sobre un peligro

- Aplicación del análisis del árbol causal, análisis del peligro y la operabilidad y análisis del árbol secuencial

ESTADISTICAS Y SISTEMAS DE INFORMACION

- Recopilación de información práctica sobre procesos, equipos, mantenimiento, materiales, fiabilidad, uso y evacuación de residuos

- Características de los trabajadores: asistencia,

lesiones y problemas de salud y control sanitario

- Evaluación y manipulación estadística de estos datos

para facilitar información útil para la toma de decisiones sobre producción, y salud y seguridad 
sobre los procesos de trabajo (y, concretamente, sobre las fuentes de energía utilizadas para llevar a cabo el trabajo), orientadas a la prevención de lesiones. M ientras que los currículos diseñados para las áreas técnicas de operaciones sólo tienen que ocuparse de principios fundamentales, las organizaciones que utilizan materiales o procesos muy peligrosos deben contar con un directivo de categoría superior, con suficiente formación respecto a las formas específicas de manipular, almacenar y transportar esa tecnología para garantizar la seguridad y la salud de los trabajadores y de los miembros de la comunidad.

\section{G randes y pequeñas empresas}

Los directivos que trabajan en organizaciones grandes, que emplean, por ejemplo, a cien o más personas, suelen tener solamente algunas responsabilidades funcionales y rinden cuentas ante un alto directivo o un consejo. T ienen la responsabilidad de la salud y la seguridad en el trabajo de sus subordinados y actúan de acuerdo con las orientaciones normativas establecidas. Sus necesidades educativas pueden satisfacerse mediante los programas formales que ofrecen las escuelas de empresariales en los niveles de diplomatura o licenciatura.

Por otra parte, los directores únicos o socios de pequeñas empresas no suelen tener una formación universitaria y, si la tienen, es más probable que sea de tipo técnico que empresarial, por lo que resulta más difícil satisfacer sus necesidades con respecto a la gestión de la salud y la seguridad en el trabajo.

\section{Necesidades de las pequeñas empresas}

La oferta de programas de formación para estos directivos, que trabajan durante muchas horas, plantea una dificultad constante. Aunque una serie de jurisdicciones legislativas han producido folletos orientativos fijando unos mínimos, los enfoques más prometedores corresponden a las asociaciones industriales, como la O ntario Industrial Accident Prevention Associations, financiada mediante las cuotas que el Workers' Compensation Board recauda de todas las empresas del correspondiente sector industrial.

\section{Contenidos del programa}

La Figura 18.7 resume, por temas, el conjunto de conocimientos y destrezas necesarios para los mandos del nivel de supervisores de primera línea, los mandos intermedios y los altos ejecutivos. La Figura 18.8 presenta programas cortos extraídos de una serie de planes de estudios universitarios de licenciatura.

Las necesidades de los supervisores de primera línea pueden satisfacerse mediante la adquisición de los conocimientos y destrezas correspondientes a los temas relacionados con las exigencias operativas. La formación de los altos ejecutivos se centrará en temas como la planificación estratégica, la gestión de riesgos y las cuestiones relativas al cumplimiento de normas, así como a la iniciación de propuestas de políticas. Las horas asignadas a cada curso deben adaptarse a las necesidades de los alumnos.

\section{Resumen}

La educación de directivos en relación con la salud y la seguridad en el trabajo requiere un enfoque ecléctico de un amplio conjunto de problemas. Comparte con la calidad la necesidad de integrarse en todas las actividades de los directivos y de los trabajadores, en cada descripción del trabajo de cada empleado, y debe formar parte de la evaluación de la actuación de todos.

\section{FORMACION DE LOS PROFESIONALES EN MATERIA DE SALUD Y SEGURIDAD}

Wai-On Phoon

\section{Grupos de profesionales de la salud y seguridad en el trabajo que necesitan formación y educación}

La prestación de servicios de salud y seguridad en el trabajo (SST) requiere equipos interdisciplinarios con un alto nivel de preparación. En algunos países poco desarrollados no existen estos equipos, pero en la mayoría al menos se suele disponer de expertos en diferentes aspectos de la SST, aunque no siempre en cantidad suficiente.

La cuestión de quiénes pertenecen a las categorías de profesionales de la SST es fuente de controversias. N ormalmente no se duda de que los médicos del trabajo, las enfermeras de empresa, los especialistas en higiene del trabajo y los profesionales en materia de seguridad (a los que a veces se incluye en la medicina preventiva) trabajan en el ámbito de la SST. Sin embargo, otras muchas disciplinas podrían con razón reclamar su inclusión en la lista; ése sería el caso de los ergónomos, toxicólogos, psicólogos y otros, si se especializan en la rama laboral de sus respectivas disciplinas. EI presente artículo, sin embargo, no entrará a analizar la formación de estos últimos, ya que con frecuencia la materia central de sus estudios no es la SST.

\section{Perspectiva histórica}

En la mayoría de los países la formación específica en SST es bastante reciente. Hasta la segunda Guerra M undial, la mayor parte de los profesionales con vocación por la SST recibían una escasa o nula preparación formal en estos temas. Eran pocas las escuelas de salud pública y las universidades que ofrecían cursos formales de SST, aunque algunas instituciones incluían la SST como un tema más, dentro de cursos de contenido más amplio, normalmente sobre salud pública. Algunas cuestiones de la SST se enseñaban en los estudios de postgrado, dentro de los programas de materias como la dermatología o la medicina del aparato respiratorio. También se enseñaban en las escuelas técnicas ciertas partes de la ingeniería relacionadas con la seguridad, como la protección de la maquinaria. En la mayor parte de los países, era difícil encontrar cursos sobre elementos específicos de la higiene en el trabajo antes de la segunda Guerra M undial. L a creación de los estudios de enfermería de empresa es aún más reciente.

La formación en SST recibió un gran impulso en los países desarrollados, durante la segunda Guerra Mundial, al mismo tiempo que se multiplicaban los servicios correspondientes. La movilización masiva de naciones enteras a causa de la guerra hizo que se diera mucha importancia a la protección de la salud de los trabajadores (y, por tanto, a su capacidad para combatir 0 para producir munición, aviones militares, tanques y buques de guerra). Al mismo tiempo, sin embargo, las condiciones de la guerra y la incorporación de profesores y estudiantes de la universidad a las fuerzas armadas dificultó la creación de cursos formales en los que impartir la enseñanza de la SST. Pero cuando terminó la guerra, se establecieron muchos de esos cursos, algunos de ellos con la generosa ayuda de becas de estudios ofrecidas por el gobierno a los militares desmovilizados.

Tras la segunda Guerra M undial, la mayoría de las colonias de los imperios europeos alcanzaron la independencia y emprendieron el camino de la industrialización, que en mayor 0 menor grado constituía el medio para conseguir el desarrollo nacional. No pasó mucho tiempo sin que estos países en vías de desarrollo se vieran a sí mismos padeciendo todos los males que 
había tenido la revolución industrial en la Europa del siglo XIX, pero a un ritmo acelerado y a una escala sin precedentes. Los accidentes y las enfermedades profesionales se extendieron por todas partes, y lo mismo ocurrió con la contaminación ambiental. Esto motivó el desarrollo de la formación en SST, aunque incluso en la actualidad estas enseñanzas registran grandes diferencias en los distintos países.

\section{Relación de programas internacionales actuales}

\section{Organización Internacional del Trabajo (OIT)}

$\mathrm{H}$ a habido varias iniciativas de la O IT en los últimos años relativas a la formación en SST. M uchas de ellas están dedicadas a la formación práctica sobre medidas de intervención en los lugares de trabajo. Algunas otras se desarrollan en colaboración con los gobiernos de las naciones (Rantanen y Lehtinen 1991).

Desde el decenio de 1970, la OIT ha llevado a cabo otras actividades en países en vías de desarrollo de todo el mundo. Algunas de ellas, por ejemplo, se dedicaron a mejorar los conocimientos de los inspectores de las fábricas, en países como Indonesia, Filipinas, K enya, Tailandia, Tanzania o Zimbabwe.

$\mathrm{La}$ O IT, en colaboración con organizaciones de las $\mathrm{N}$ aciones U nidas (como el Programa de las N aciones U nidas para el D esarrollo), también ha ayudado a establecer o mejorar institutos nacionales de SST, que destacan por la alta prioridad de la labor docente.

La OIT también ha publicado diversas monografías de tipo práctico, muy útiles como material de enseñanza en los cursos de SST (K ogi, Phoon y T hurman 1989).

\section{Organización M undial de la Salud (OMS)}

La OMS ha organizado en los últimos años un número importante de congresos y seminarios internacionales y regionales sobre la formación en SST. En 1981 se celebró un congreso con el título de "La Formación del Personal de la Salud en el Trabajo", bajo los auspicios de la O ficina Regional de la O M S para Europa. Ese mismo año, la OMS y la OIT crearon un Comité Conjunto OIT/OM S sobre M edicina del Trabajo, que se centró en "la educación y la formación en materia de salud y seguridad en el trabajo, y de ergonomía laboral" (O M S 1981). En las reuniones se analizaron las necesidades de educación a diferentes niveles, se diseñaron políticas y se hicieron sugerencias sobre metodologías y programas (O M S 1988).

En 1988, un Grupo de estudio de la O M S publicó un informe titulado $L a$ Formación y la E ducación en materia de Salud en el Trabajo, que trata principalmente de las nuevas políticas sobre las estrategias en atención sanitaria primaria adoptadas por los Estados miembros de la OMS, las nuevas necesidades provocadas por el desarrollo tecnológico, y los nuevos enfoques para promover la salud en el trabajo (O M S 1988).

\section{Comisión Internacional de M edicina del Trabajo (CIM T)}

Esta Comisión estableció en 1985 un Comité Científico sobre Educación y Formación en materia de Salud en el Trabajo. EI Comité organizó cuatro jornadas internacionales y algunos pequeños simposios sobre la materia, todo ello encuadrado en los Congresos Internacionales sobre Salud en el Trabajo (CIMT 1987). Una de las conclusiones de las segundas jornadas, que establecía la necesidad de desarrollar estrategias y métodos de formación, fue objeto de mención especial en la lista de temas prioritarios (CIM T 1989).

U no de los temas principales de las terceras jornadas fue la metodología en la formación SST, que incluye aspectos del tipo de la enseñanza participativa, el aprendizaje por resolución de problemas, y la evaluación de los cursos, de los profesores y de los alumnos (CIM T 1991).

\section{Iniciativas regionales}

En diferentes partes del mundo, las organizaciones regionales han creado actividades de formación en SST. Por ejemplo, la Asian Association of O ccupational Health, creada en 1954, cuenta con un Comité Técnico de Educación en materia de Salud en el Trabajo, que realiza investigaciones sobre la formación de los estudiantes de medicina, y sobre otros temas similares.

\section{Tipos de programas profesionales}

\section{Programas de estudios sancionados por un título}

El ejemplo típico de estos programas es el de los cursos que organizan las escuelas de salud pública y otras instituciones similares. La enseñanza superior en salud pública es de creación relativamente reciente. En Estados U nidos, la primera escuela dedicada a este fin se fundó en 1916 en la U niversidad Johns H opkins, y se denominó Institute of $\mathrm{H}$ ygiene. En aquella época, la máxima preocupación en materia de salud pública eran las enfermedades contagiosas. Con el paso del tiempo, la educación sobre prevención y control de los peligros creados por el hombre, junto con la salud en el trabajo, fueron ganando un mayor protagonismo en los programas de formación de las escuelas de salud pública (Sheps 1976).

Las escuelas de salud pública dan cursos de SST para la obtención de un diploma de postgrado, o para el $M$ áster en Salud Pública, especializados en asignaturas de salud en el trabajo. N ormalmente, uno de los requisitos para matricularse es poseer una cualificación de enseñanza de postgrado. Algunas escuelas le dan también mucha importancia a la experiencia profesional previa en temas de SST. La duración de los cursos a tiempo completo suele ser de un año para el diploma y dos para el Máster.

A lgunas escuelas forman a todo el personal de SST en cursos comunes, con una posterior especialización en áreas específicas (por ejemplo, medicina del trabajo, higiene, enfermería de empresa). La formación conjunta es probablemente una gran ventaja, ya que permite a los alumnos de las diferentes disciplinas de la SST comprender las funciones de los demás y adquirir una experiencia del trabajo en equipo.

Las escuelas de medicina, de enfermería y de ingeniería ofrecen, sobre todo en los últimos años, cursos muy similares a los que se imparten en las escuelas de salud pública.

En algunas universidades, aunque no en muchas, se incluyen asignaturas de SST en el plan de estudios básicos. Al contrario de lo que ocurre en los cursos tradicionales de postgrado, en los que la admisión suele estar condicionada a la posesión de un título anterior, estas universidades admiten a alumnos que no tengan más que el bachillerato. Esta nueva modalidad todavía genera muchas controversias. Sus defensores argumentan que con ella se forman profesionales de la SST en más cantidad, en menos tiempo y a un coste menor. Sus adversarios responden que los profesionales de la SST serían más eficaces si su formación en esta materia se fundara en unos amplios conocimientos básicos sobre los que realizar la práctica de la SST, como pudieran ser la medicina o la enfermería del trabajo. EI conocimiento de las ciencias básicas puede adquirirse en una especialización posterior, si no se aprendió en su día como parte de la formación universitaria regular.

L os cursos sobre SST para médicos varían unos de otros en lo que se refiere a su componente clínico. En el congreso mencionado anteriormente sobre la formación de los profesionales de la salud en el trabajo, organizado por la O ficina Regional de la O M S para Europa, se llegó a la conclusión de que "la medicina del trabajo es fundamentalmente una disciplina clínica, y quienes la practiquen deben tener competencia plena en medicina clínica". También debe resaltarse el hecho de que el 
diagnóstico de una intoxicación por un producto químico en un trabajador es de naturaleza básicamente clínica, como también lo es la diferenciación entre las "enfermedades profesionales" y otras que pueden ser objeto de un tratamiento diferente (Phoon 1986). En consecuencia, se ha instaurado en todo el mundo la tendencia a realizar prácticas en las clínicas como parte de la formación en medicina del trabajo. En Estados U nidos y en Canadá, por ejemplo, los alumnos realizan un programa de cuatro años como internos y dedican una parte importante de su tiempo a asignaturas como dermatología y medicina del aparato respiratorio, además de otros contenidos exigidos por el currículo del M áster en Salud Pública o su equivalente.

La enseñanza formal de la enfermería de empresa varía en las distintas partes del mundo probablemente más que la de los médicos. Estas diferencias vienen motivadas por las variaciones en las competencias y funciones de los enfermeros de empresa. En algunos países se define esta profesión como "la aplicación de los principios de la enfermería a la conservación de la salud de los trabajadores de todo tipo de oficios. Incluye la prevención, el reconocimiento y el tratamiento de las enfermedades y lesiones, y requiere ciertas capacidades y conocimientos especiales en materias como la asesoría y la formación sanitarias, la salud ambiental, la rehabilitación y las relaciones humanas" (K ono y N ishida 1991). En otros países se entiende que un enfermero laboral es el que trabaja en un equipo interdisciplinario dedicado a la salud en el trabajo, y de quien se espera una completa participación en la gestión sanitaria general, en la prestación de servicios de salud, en el control del medio ambiente, en hacer que se trabaje de una forma sana y segura, y en impartir formación en materias de SST. Sin embargo, una encuesta realizada en Japón demostró que no todos los titulados pertenecientes a una unidad de enfermería laboral desempeñaban todas estas funciones. Tal vez la causa era la falta de comprensión del papel de un enfermero en los temas de SST, además de una formación poco adecuada en ciertas materias (K ono y Nishida 1991).

Según la American Industrial H ygiene Association, la higiene industrial es la "ciencia y arte que se dedica a reconocer, evaluar y controlar los factores ambientales del lugar de trabajo que puedan causar enfermedades, empeorar la salud o el bienestar 0 crear de forma apreciable molestias o ineficiencias entre los trabajadores o entre los ciudadanos de una comunidad." También en el campo general de la higiene industrial se está extendiendo la formación especializada; en ella se incluye la química, la ingeniería, el estudio del ruido, la radiación, la contaminación atmosférica y la toxicología.

\section{Programa de estudios para la formación de personal dedicado a la salud y seguridad en el trabajo}

Se expone en las páginas siguientes el contenido detallado del currículo para formar en estas cuestiones a médicos, enfermeros, higienistas y personal de seguridad, tal y como lo recomendó en 1981 el Comité Conjunto OIT/OMS sobre Medicina del Trabajo mencionado anteriormente. En lo que respecta a las materias principales, el Comité recomienda las siguientes:

- Organización de los servicios de salud y seguridad en el trabajo: actividades, legislación y reglamentos

- M edicina del trabajo

- Higiene industrial

- Seguridad en el trabajo

- Fisiología del trabajo y ergonomía, con atención especial a la adaptación del trabajo al hombre, pero también a la adaptación laboral de los discapacitados.

- Psicología de empresa, sociología y educación sanitaria.
Figura 18.9 - Programa de formación de postgrado para médicos y enfermeros.

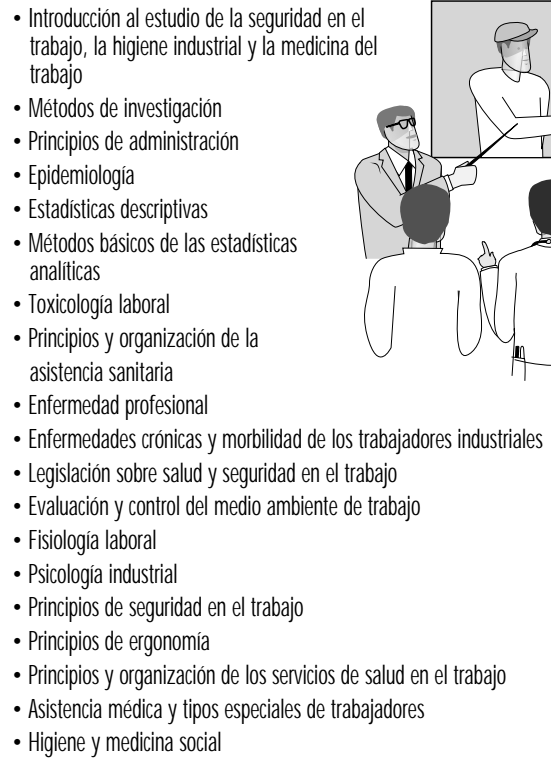

Según el perfil de los alumnos, los programas educativos podrán profundizar más o menos en las diferentes materias para satisfacer las demandas de las correspondientes profesiones, tal y como se expone más adelante para las diferentes categorías.

Es difícil exponer detalladamente los contenidos que deberían incluirse en los cursos de SST. U na opinión generalizada es que deberían tener un temario sobre ciencias del comportamiento bastante mayor del que se imparte en la actualidad, aunque siempre teniendo en cuenta la situación sociocultural del país o región para el que se diseñara el curso. Además, no se debe enseñar la SST de forma independiente de los servicios sanitarios generales ni de la situación social en esta cuestión dentro de cada país o región. También deben incluirse en el currículo sobre SST los fundamentos de la gestión empresarial, para mejorar la comprensión de las estructuras y prácticas de las organizaciones empresariales, así como para reforzar las capacidades administrativas de los profesionales de la SST. Asimismo, es recomendable la inclusión en todos los currículos sobre SST de técnicas de comunicación y metodología de la ciencia para realizar investigaciones sobre los problemas de SST y elaborar las soluciones (Phoon 1985b).

\section{M édicos y enfermeros}

Todos los estudiantes de medicina deberían recibir formación sobre la salud en el trabajo. En algunos países, existen asignaturas independientes, pero en otros se tratan estos temas dentro de las asignaturas de fisiología, farmacología, toxicología, salud pública, medicina social o medicina interna. No obstante, no es frecuente que los estudiantes de medicina tengan los conocimientos y la preparación suficiente para practicar de forma independiente estas funciones, por lo que se hace necesario algún tipo de formación de postgrado en el campo de la salud y seguridad en el trabajo. Debe haber programas de formación de postgrado para quienes deseen seguir alguna especialidad en esta materia, por ejemplo, en enfermedades profesionales o en campos aún más definidos, como la neurología o la dermatología profesionales. 
También habría que organizar cursos dirigidos a los enfermeros de los servicios de salud en el trabajo; estos cursos podrían ser de corta 0 de larga duración, según la diversidad de actividades de los alumnos.

En la Figura 18.9 se relacionan las materias que podrían incluirse en los programas de formación de postgrado y en los cursos dirigidos a la especialización de médicos y enfermeros.

\section{Técnicos en salud y seguridad y agentes de seguridad}

La seguridad en el trabajo, en su vertiente más práctica, se dedica a cuestiones del tipo de fallos de los materiales, máquinas, procesos y estructuras, que puedan dar lugar a situaciones peligrosas, incluidas las liberaciones de sustancias contaminantes. $L a$ educación en este terreno tiene como finalidad capacitar a los alumnos para prever los peligros, tanto en la fase de planificación de los proyectos como en su realización práctica, cuantificar los riesgos y diseñar medidas para combatirlos. La formación en seguridad del trabajo incluye el estudio de algunas cuestiones fundamentales de ciertas materias de ingeniería y ciencias de los materiales, sobre todo de la ingeniería mecánica, civil, química, eléctrica y de las estructuras.

D ebería haber módulos temáticos diferentes, dedicados, por ejemplo, a estructuras y resistencia de materiales, en la ingeniería mecánica; a las fuerzas en las estructuras, en ingeniería civil; al manejo y transporte de productos químicos, en la ingeniería química; a las normas de diseño, a los equipos de protección y a la teoría del mantenimiento preventivo, en la ingeniería eléctrica; y al comportamiento de los estratos, en la ingeniería de minas.

Los técnicos en seguridad, además de sus conocimientos básicos, deberían realizar un curso de especialización. Las recomendaciones formuladas por el Comité Conjunto OIT/OMS en 1981 para un curso de especialización técnica en salud y seguridad en el trabajo se indican en la Figura 18.10.

L os cursos pueden ser a tiempo completo, a tiempo parcial o "cursos mixtos"; en este último caso, los períodos de estudio se entremezclan con períodos de prácticas. La elección de los cursos depende básicamente de las circunstancias o preferencias individuales. Esto es especialmente cierto si se tiene en cuenta que muchos profesionales de la seguridad tienen amplios conocimientos adquiridos gracias a su experiencia laboral en sectores concretos. En todo caso, dentro de una comunidad grande 0 un país, es preferible que haya un gran número de opciones para atender las diferentes necesidades.

Los recientes y enormes avances en el ámbito de las tecnologías de la comunicación deben ampliar las posibilidades de utilizar los cursos de aprendizaje a distancia, que de este modo podrían llegar a zonas alejadas e incluso atravesar las fronteras nacionales. Lamentablemente, esa tecnología es aún bastante cara, y es muy probable que la mayoría de los países o zonas que necesitan esos recursos de aprendizaje a distancia sean precisamente los que menos se los pueden permitir.

\section{Profesionales de la atención médica primaria}

Existe un déficit muy importante de profesionales de la SST en los países en vías de desarrollo. Además, tanto los que se dedican a la atención primaria en particular, como los profesionales de la salud, en general, tienden a concentrar su actividad principal en la prestación de servicios curativos. Sería conveniente compensar esta tendencia por medio de una formación adecuada que centrara la atención en el establecimiento de medidas preventivas en el lugar de trabajo, para lo que se podría contar con la ayuda de otras partes interesadas, como los trabajadores y los directivos. De este modo, se podrían subsanar, en cierta medida, los problemas de falta de personal especializado en SST, en los países en vías de desarrollo (Pupo-N oguiera y R adford 1989).
Figura 18.10 - Programa de especialización técnica en seguridad en el trabajo.

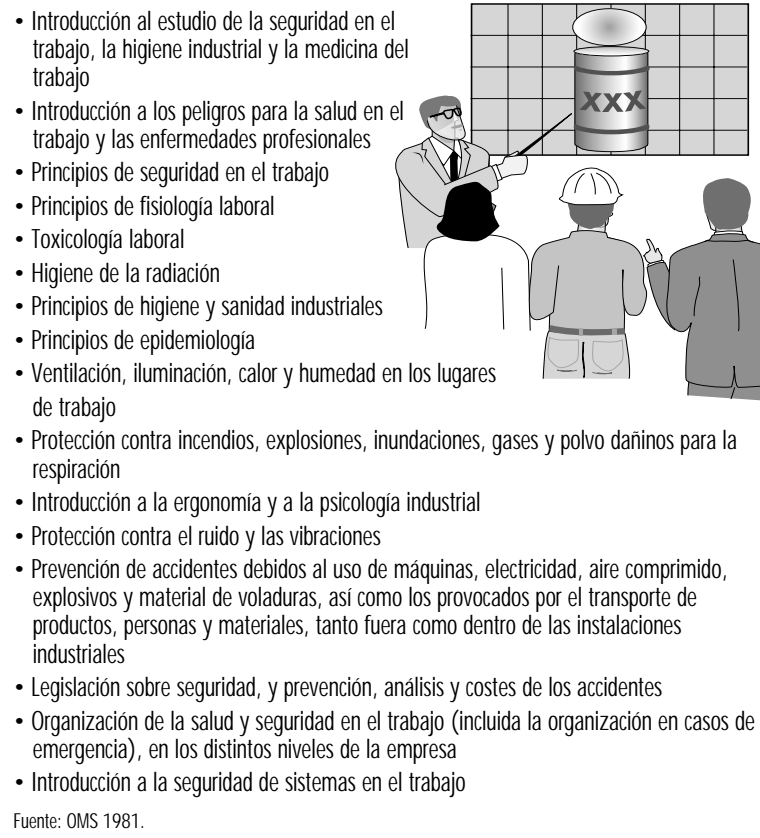

- Legislación sobre seguridad, y prevención, análisis y costes de los accidentes

- Organización de la salud y seguridad en el trabajo (incluida la organización en casos de emergencia), en los distintos niveles de la empresa

- Introducción a la seguridad de sistemas en el trabajo

Fuente: OMS 1981

Algunos de estos países han puesto en marcha recientemente cursos cortos de formación sobre SST, dirigidos a los profesionales de atención primaria y salud pública. El abanico de organizaciones en las que se han emprendido estos cursos es muy amplio; entre ellas podemos citar comités nacionales de productividad (Phoon 1985), asociaciones de agricultores, consejos nacionales de seguridad, institutos nacionales de salud y colegios profesionales como las asociaciones de médicos y de enfermeros (Cordes y R ea 1989).

La escasez de profesionales especializados en SST no sólo afecta a los países en vías de desarrollo sino también a muchos países desarrollados. En Estados U nidos se intentó hacer frente a este problema por medio de un informe conjunto realizado por un grupo de especialistas en medicina preventiva y médicos generales; este grupo recomendó que los programas de estudios en medicina general concedieran una importancia mayor al control de los peligros en el lugar de trabajo y en el medio ambiente, ya que la mayoría de los pacientes que acuden a las consultas son trabajadores. A demás tanto la A merican Academy of Family Physicians como la American Medical Association han publicado varias monografías sobre la salud en el trabajo, dirigidas a los médicos de familia. En un estudio del American Institute of Medicine se volvió a confirmar la función de los médicos de atención primaria respecto a la salud en el trabajo, se expusieron las cualificaciones básicas necesarias y se subrayó la importancia de estos aspectos en la formación básica y en los programas de educación continua (Ellington y Lowis 1991). No obstante, en todos los países, desarrollados o no, sigue siendo insuficiente el número de programas de formación en materia de SST, dirigidos a los profesionales de atención primaria, así como la cantidad de personal cualificado.

\section{Formación interdisciplinaria}

La formación en SST, que es de naturaleza interdisciplinaria, puede verse favorecida si se asegura que todos los que la imparten están completamente familiarizados con las funciones, actividades 
y áreas de actuación de los demás profesionales de la SST. Por ejemplo, en un curso que se imparte en Escocia, participan en las clases miembros de las diferentes profesiones relacionadas con la salud y seguridad en el trabajo. Los alumnos reciben material de estudio que les aporta un conocimiento detallado e interno de las distintas áreas profesionales de la SST. En este curso se hace también plena utilización de las técnicas de aprendizaje experimental, como los juegos de roles y los estudios de caso participativos. Por ejemplo, se pide a cada alumno que rellene una lista de comprobación indicando la forma en que cada una de las áreas de la salud en el trabajo podría influir en su propia actuación profesional, y cómo cree que podría cooperar de manera efectiva con los demás profesionales de la salud en el trabajo.

Cuando se dirige un curso interdisciplinario sobre SST, uno de los elementos clave es la combinación de alumnos con formaciones profesionales diferentes en una misma aula. El material del curso, por ejemplo, los ejercicios y ensayos conjuntos, deberá seleccionarse con mucho cuidado para no dar preferencia a ninguna disciplina en concreto. Asimismo, los profesores deberán estar preparados para plantear preguntas y problemas de carácter multidisciplinar (D'Auria, H awkins y K enny 1991).

\section{Educación continua}

En la formación especializada de cualquier tipo, cada vez está más extendida la opinión en favor de una educación continua. En el campo concreto de la SST, los nuevos datos sobre peligros ya conocidos, y los nuevos problemas derivados de los cambios tecnológicos se desarrollan a tal velocidad que cualquier profesional que pretenda estar al día deberá realizar un esfuerzo sistemático y constante.

La educación continua en SST puede ser formal o informal, voluntaria u obligatoria (por ejemplo para conservar una titulación). Es esencial para quien trabaje en SST leer de forma permanente las publicaciones especializadas más importantes, al menos las de su área de trabajo. Cuando aparece un peligro nuevo, resulta muy útil realizar una búsqueda de la literatura existente sobre esa materia en una biblioteca. Si no se tiene acceso a ninguna, se puede consultar con el Centro Internacional de Información sobre Seguridad y Salud en el Trabajo (CIS) de la OIT. Por otra parte, es esencial tener un acceso continuo y directo a algunos textos actualizados sobre SST.

0 tras modalidades más formales de la educación continua podrían ser los congresos, los talleres, las conferencias, las presentaciones de publicaciones especializadas o los seminarios. Las instituciones de enseñanza superior y las organizaciones profesionales suelen organizar este tipo de programas. Siempre que sea posible, deberían celebrarse reuniones anuales para intercambiar puntos de vista y experiencias prácticas de diversas zonas geográficas. Los congresos y seminarios regionales o internacionales constituyen una oportunidad muy valiosa para los participantes, que pueden beneficiarse no sólo de los temas que se traten formalmente, sino también de la información que intercambien con otros profesionales e investigadores fuera de las sesiones formales.

C ada vez es mayor el número de organizaciones profesionales de SST que exigen a sus miembros un mínimo de asistencia a cursos de educación continua para mantener el carné de socios. $\mathrm{N}$ ormalmente no se exige más que la asistencia a las clases correspondientes, pero la asistencia por sí sola no garantiza, como es lógico, que el participante haya obtenido algún resultado del curso. Existen otras alternativas, como la de someter a los profesionales de la SST a exámenes periódicos, pero también plantean problemas. Dentro de cada una de las disciplinas de SST, es tan amplia la variedad de funciones diferentes incluso dentro de un mismo país que resultaría extremadamente difícil diseñar un examen que fuera justo para todos los profesionales.

\section{El aprendizaje independiente}

En todo curso de formación sobre SST debe darse mucha importancia a la necesidad de que los alumnos estudien por su cuenta y de forma continuada. Para ello, resulta indispensable enseñar a obtener información de los trabajos que se vayan publicando y a analizarlos con sentido crítico. También puede ser beneficiosa la formación en el uso de ordenadores, para obtener datos de los excelentes centros de información sobre SST que existen en todo el mundo. En los últimos años se han creado diversos cursos para promover el aprendizaje independiente y la gestión de la información a través de ordenadores personales (Koh, Aw y Lun 1992).

\section{Desarrollo de los planes de estudios}

Cada día es mayor la demanda de evaluación y mejora de los planes de estudios por parte del alumnado y de la sociedad en general. En la actualidad muchos de estos planes se basan en la formación previa. Así, se define en primer lugar la competencia profesional que requiere para acceder a los estudios. Puesto que dicha definición puede responder a diversos puntos de vista, se deberá consultar al respecto con profesores de universidad y profesionales en materia de SST (Pochyly 1973). Asimismo, será necesario consultar con los "clientes" (es decir, alumnos, trabajadores y empresas), establecer un programa de evaluación y fijar unos objetivos didácticos bien definidos pero flexibles (Phoon 1988). Para realizar estas consultas, puede ser útil crear comités asesores sobre los planes de estudio o las técnicas de enseñanza, con representantes de los alumnos y de los profesores, aunque también puede incluirse a otros miembros de la comunidad.

\section{Desarrollo de medios}

C uando se analiza la formación y la enseñanza en temas de SST, suelen pasarse por alto las cuestiones relacionadas con la infraestructura. Sin embargo, los elementos auxiliares y los recursos, como pueden ser los ordenadores, las bibliotecas, un personal administrativo y unos procedimientos de trabajo eficientes, y un acceso físico cómodo y seguro son medios muchas veces vitales para el éxito de los cursos de formación. El adecuado seguimiento de los progresos que van haciendo los alumnos, el asesoramiento y la ayuda que se les pueda prestar en sus problemas, la atención médica para ellos y para sus familias (cuando sea necesaria), un servicio de guardería para sus hijos, los comedores, las instalaciones de recreo, las taquillas y armarios para sus prendas personales, etc. son detalles importantes a los que se debe prestar atención.

\section{Contratación y preparación del profesorado}

La calidad y el prestigio de un programa de formación suelen ser los aspectos más importantes a la hora de determinar las características del personal que deberá ocupar los puestos vacantes. Como es natural, existen otros factores también importantes, tales como unas condiciones de trabajo satisfactorias y la posibilidad de hacer carrera 0 de tener un adecuado desarrollo intelectual.

Es necesario considerar con mucho cuidado las condiciones y requisitos de cada puesto de trabajo. Los profesores deben tener las cualificaciones necesarias en SST, aunque debe actuarse con flexibilidad, de forma que se pueda contratar a personas procedentes de disciplinas ajenas a la SST, pero que puedan hacer una aportación especial a la enseñanza, o a solicitantes con cualidades prometedoras, aunque no cumplan todos los requisitos de titulación o experiencia exigidos para el puesto. Siempre que sea posible, los profesores deben tener experiencia práctica en SST.

Tras la contratación, la dirección y los responsables de la escuela 0 de sus departamentos deben encargarse de que los 
nuevos profesores reciban todo el apoyo y cuenten con todas las oportunidades de ampliación de conocimientos que sea posible. Los recién llegados deben asumir la cultura interna de la organización, pero también tienen que sentirse animados a expresarse con libertad y a participar en los procesos de toma de decisiones que puedan afectar a los programas de enseñanza e investigación. A simismo, se les informará de todo lo referente a su actuación como profesores de una forma cuidadosa y positiva; si es necesario, se les ofrecerá apoyo para poner remedio a alguna limitación concreta que puedan tener. En muchos departamentos se ha visto que puede ser extraordinariamente útil mantener reuniones periódicas del personal para tratar temas de enseñanza y de evaluación. 0 tras medidas importantes para el perfeccionamiento de los profesores son los intercambios con las empresas y los permisos sabáticos. También puede ayudar a darle a la enseñanza académica un carácter más práctico la realización de algún tipo de trabajo de consultoría, que puede ser en una clínica, en una empresa o en un laboratorio, según la asignatura y las áreas de actividad de cada uno de los profesores.

\section{Instalaciones}

Las aulas deben estar diseñadas y amuebladas con criterios ergonómicos y contar con equipos audiovisuales. La iluminación y la acústica deben ser satisfactorias. Conviene que el acceso al aula permita entrar y salir sin molestar al resto de la clase.

Los laboratorios tendrán que diseñarse y construirse atendiendo a los principios de SST que le sean de aplicación. Determinados equipos de higiene y seguridad como duchas, lavabos, botiquines, equipos de primeros auxilios y campanas extractoras de humos deben ubicarse en los lugares donde sean necesarios, ya sea de una forma fija o portátil. Los laboratorios deben ser luminosos, ventilados y carentes de olores.

L os centros donde se realicen las visitas prácticas se seleccionarán de forma que se les muestre a los alumnos un repertorio amplio de cuestiones relacionadas con la SST. Es preferible siempre y cuando se pueda, elegir lugares de trabajo con diferentes niveles de normas sobre SST. En todo caso, de ninguna manera debe ponerse en riesgo la seguridad o la salud de los alumnos.

La selección de los centros en los que desarrollar el trabajo de tipo clínico dependerá en gran medida de la naturaleza y del nivel del curso que se esté realizando. En algunas circunstancias puede estar indicada la enseñanza en las propias salas de hospitalización, para mostrar la forma adecuada de hacer la recogida de datos sobre historiales clínicos; en otras, podrán obtenerse los mismos resultados por medio de la presentación de casos, con o sin pacientes.

\section{Los exámenes y las evaluaciones}

Actualmente se tiende a buscar alternativas al examen sumativo final, realizado al terminar el curso. En algunos cursos se han suprimido los exámenes formales, y han sido sustituidos por trabajos o evaluaciones periódicas; en otros se realiza una combinación de trabajos, evaluaciones y exámenes, ya sea con libros 0 sin ellos. H oy en día cada vez está más asentada la convicción de que los exámenes y las evaluaciones no sólo miden la calidad de los alumnos, sino también la del curso y la de los profesores.

Las opiniones de los alumnos sobre el conjunto de los estudios o sobre sus distintos componentes, obtenida por medio de cuestionarios o reuniones, es de un inmenso valor para el perfeccionamiento del curso. Los cursos deben ser evaluados de forma constante, en la medida de lo posible, al menos una vez al año, y modificados siempre que resulte necesario.

En lo que se refiere a las modalidades de examen, la que consiste en desarrollar un tema puede servir para medir la organización, la capacidad para integrar cuestiones o la destreza en la escritura. Sin embargo, la precisión y validez de este tipo de exámenes de desarrollo de temas parecen ser escasas. Los exámenes tipo test con varias respuestas entre las que se debe elegir una son menos subjetivos, pero son difíciles de preparar para que sean buenos; además, no permiten apreciar ciertos conocimientos prácticos. 0 tra forma de examinar es por medio de preguntas cortas que se diferencian de los métodos anteriores en que el alumno va recibiendo de forma progresiva la información sobre un problema; se le pide al alumno que vaya dando respuestas cortas, con lo que no se le dan pistas ni se le presenta un conjunto de alternativas entre las que debe escoger la más adecuada. L os exámenes orales pueden medir la capacidad para resolver problemas, el buen criterio profesional, la capacidad de comunicación y la habilidad para mantener la compostura en situaciones de tensión. La principal dificultad de los exámenes orales radica en que puede dar lugar a la llamada "falta de objetividad". Los exámenes orales pueden ser más fiables si se les ajusta a una estructura determinada (Verma, Sass-K ortsak y Gaylor 1991). Tal vez la mejor de todas las alternativas sea la de usar una mezcla de todos estos diferentes tipos de exámenes, en vez de confiar sólo en uno o dos de ellos.

\section{Certificación y acreditación}

El término certificación se aplica normalmente al hecho por el que se confiere a un profesional la autorización para practicar su profesión. La certificación puede ser hecha por un consejo nacional, por una universidad o por una institución de profesionales de una disciplina de SST. Las certificaciones en SST suelen concederse únicamente tras un período de formación prefijado, en el que se hayan seguido unos cursos u ocupados ciertos puestos; además, se requiere superar un examen. Esta "certificación general" suele ser vitalicia, a menos que se demuestre negligencia profesional o una conducta impropia. Sin embargo, existen algunas formas de acreditación que requieren renovación periódica; en algunos países, por ejemplo, es obligatoria esta renovación para poder realizar ciertos tipos especiales de exámenes médicos legales o para hacer informes médicos sobre las radiografías de personas que han estado expuestas al amianto.

La acreditación, por otra parte, es el reconocimiento de los cursos sobre SST, sancionado por un consejo nacional, por una organización profesional o por un organismo de concesión de becas. Las acreditaciones deben someterse a una evaluación periódica para garantizar que los cursos se mantienen al día y cuentan con el adecuado nivel de efectividad.

\section{UN NUEVO ENFOQUE DEL APRENDIZAJE Y LA FORMACION: ESTUDIO DE CASO DEL PROYECTO AFRICANO DE SALUd y SEgURIDAD DE LA O IT-FIN NIDA}

Antero Vahapassi y Merri Weinger

Abuya: ¿Q ué te pasa? Pareces agotado.

M wangi: Estoy agotado de verdad, y muy enfadado. M e he pasado media noche preparando la conferencia que acabo de presentar, y creo que no ha salido muy bien. No he conseguido interesarles en el tema; no han hecho una sola pregunta, no se han entusiasmado. Se diría que no han comprendido ni una palabra de lo que les he explicado. 
Kariuki: Ya sé a qué te refieres. Hace unos días pasé un mal rato intentando explicar en suajili la seguridad en la industria química.

A buya: No creo que sea un problema del idioma. Seguramente el tema se les escapaba. ¿C rees de verdad que estos trabajadores necesitan muchos conocimientos técnicos?

Kariuki: N ecesitan los conocimientos suficientes para proteger su seguridad. Si no conseguimos que comprendan esto, perdemos el tiempo. M wangi, ¿por qué no probaste a preguntarles algo o contarles alguna historia?

M wangi: No sabía qué hacer. Ya sé que tiene que haber una forma mejor de hacerlo, pero a mí tampoco me han enseñado cómo dar estas charlas correctamente.

Abuya: Dejémoslo; ¿Para qué vamos a preocuparnos? Con todas las inspecciones que hemos de hacer, ¿quién tiene tiempo para ocuparse de la formación?

Esta conversación entre inspectores de una fábrica africana, que podría haber tenido lugar en cualquier otra parte del mundo, pone de manifiesto un auténtico problema: cómo transmitir un mensaje en una sesión de formación. U tilizar un caso real como punto de partida o desencadenante del análisis es una técnica excelente para identificar los obstáculos potenciales en el proceso de formación, sus causas y sus posibles soluciones. Esta conversación, por ejemplo, la hemos utilizado en Kenya y Etiopía como "juego de rol" ("role-playing") en nuestro taller de Formación de Formadores.

EI Proyecto A fricano de Salud y Seguridad de la OIT-FIN NIDA forma parte de las actividades de cooperación técnica de la OIT, dirigidas a mejorar la formación y los servicios de información en materia de salud y seguridad en el trabajo en 21 países africanos de habla inglesa. Está patrocinado por FINNIDA, la Finnish International Development Agency. Este proyecto se realizó entre 1991 y 1994, con un presupuesto de 5 millones de dólares. U no de sus objetivos principales era determinar el enfoque más apropiado de la formación para favorecer un aprendizaje de alta calidad. En el estudio de caso que presentamos a continuación describiremos la puesta en práctica de nuestro nuevo enfoque en el curso "La formación de los formadores" (FDF) (Weinger 1993).

\section{El desarrollo de un nuevo enfoque de la formación}

H asta ahora, el enfoque de la formación en la mayor parte de los inspectores de fábricas africanos, así como en muchos proyectos de cooperación técnica de la OIT, ha estado basado en temas aislados sobre salud y seguridad en el trabajo (SST) seleccionados aleatoriamente y presentados principalmente mediante métodos de conferencia. El Proyecto Africano de Salud y Seguridad impartió su primer curso piloto de FDF en 1992, para 16 países participantes. El curso se organizó en dos partes: la primera trataba de los principios básicos de la educación para adultos (cómo aprenden las personas, cómo establecer objetivos didácticos y seleccionar contenidos, cómo diseñar el currículo y seleccionar métodos de instrucción y actividades educativas, y cómo mejorar las aptitudes personales para la enseñanza) y la segunda se ocupaba de la formación práctica en SST, a partir de tareas individuales confiadas a cada participante durante un período de cuatro meses, a continuación de la primera parte del curso.

Las principales características de este nuevo enfoque son la participación y la orientación activa. Nuestra formación no sigue el modelo tradicional de aprendizaje en clase, en el que los participantes son receptores pasivos de información y la conferencia es el método educativo dominante. Además, se apoya en las más recientes investigaciones sobre la moderna educación para adultos y en un enfoque cognitivo y teórico-activo del aprendizaje y la enseñanza (Engeström 1994).
Sobre la base de la experiencia adquirida durante el curso piloto, que tuvo un gran éxito, se elaboró un conjunto muy detallado de $M$ ateriales para la formación de formadores, que consta de dos partes: un manual para el formador y una serie de notas para repartir entre los participantes. Estos materiales sirvieron de pauta para las sesiones de planificación, a las que asistieron durante diez días entre 20 y 25 inspectores de fábricas, dirigidas a establecer cursos nacionales de FDF en dos países africanos: K enya y Etiopía.

\section{El aprendizaje de alta calidad}

EI aprendizaje de alta calidad tiene cuatro componentes clave:

La motivación para el aprendizaje. Hay motivación cuando los participantes perciben el "valor de uso" de lo que están aprendiendo. Para que surja el estímulo, deben ser capaces de advertir la distancia que separa lo que conocen y lo que necesitan conocer para resolver un problema.

La organización del tema. Con demasiada frecuencia se piensa que el objeto del aprendizaje es el almacenamiento de datos aislados en el cerebro, al modo en que guardamos las cosas distribuyéndolas en cajas sobre una estantería. La realidad es que las personas, al aprender, elaboran modelos o imágenes mentales del mundo. Por eso, cuando para mejorar el aprendizaje los enseñantes promueven el enfoque cognitivo, tratan de organizar los hechos en forma de modelos e introducen principios o conceptos explicativos (el "pero, por qué" que subyace en un hecho o una cualificación).

El avance por etapas en el proceso de aprendizaje. En el proceso de aprendizaje, el participante se asemeja a un investigador que persigue un modelo para comprender el tema estudiado. Con la ayuda del profesor, elabora este modelo, practica su utilización y evalúa su utilidad. Este proceso se puede descomponer en las seis etapas siguientes:

- motivación,

- orientación,

- integración de nuevos conocimientos (interiorización),

- aplicación,

- crítica del programa,

- evaluación por los participantes.

La interacción social. La interacción social entre los participantes de una sesión de formación es un elemento esencial del aprendizaje. Mediante las actividades en grupo, los participantes aprenden unos de otros.

\section{La planificación de la formación para el aprendizaje de alta calidad}

Se denomina formación a un tipo de educación centrada en técnicas y habilidades específicas y dirigida a facilitar un aprendizaje de alta calidad, mediante un proceso que se desarrolla en una serie de etapas, todas ellas igualmente importantes, y que requiere una planificación cuidadosa de cada etapa. Aunque el proceso de aprendizaje puede descomponerse para su análisis de distintas maneras, desde el punto de vista de la concepción cognitiva la planificación de un curso de formación se articula en seis etapas:

Etapa 1: haga una evaluación de las necesidades (conozca a su audiencia);

Etapa 2: formule los objetivos de aprendizaje;

Etapa 3: desarrolle una base orientativa o "mapa de carreteras" del curso;

Etapa 4: desarrolle el currículo, estableciendo sus contenidos y sus correspondientes métodos de formación, y utilizando un diagrama para perfilar su propio plan del curso;

Etapa 5: imparta el curso; 
Etapa 6: evalúe el curso y desarrolle el seguimiento a partir de esta evaluación.

\section{La ejecución práctica de los cursos de FDF de ámbito nacional}

Sobre la base del enfoque de la formación y de la experiencia del primer curso piloto anteriormente mencionados, se pusieron en práctica dos cursos de FDF de ámbito nacional, uno en Kenya, en 1993, y otro en Etiopía, en 1994.

L as necesidades de formación se habían advertido a la luz del trabajo de los inspectores de fábricas y se concretaron mediante un cuestionario previo y un debate con los participantes en el curso acerca de su trabajo cotidiano y del tipo de cualificaciones y habilidades necesarias para llevarlo a cabo (véase la Figura 18.11). Se trata, por lo tanto, de un curso diseñado en principio para inspectores de fábricas (en nuestros cursos de FDF de ámbito nacional participaron normalmente entre 20 y 25 inspectores), pero que podría aplicarse a otro tipo de personal que requiera formación de salud y seguridad en el trabajo, como enlaces sindicales, encargados o funcionarios de los servicios de salud y seguridad.

A continuación presentamos una recopilación de los objetivos de estos cursos, elaborada paso a paso con la colaboración de los participantes.

\section{L os objetivos de los cursos de FDF de ámbito nacional} Los objetivos del curso de formación de formadores son:

- Aumentar la comprensión, por parte de los inspectores de fábricas, de sus cambiantes funciones y tareas, que van desde la supervisión inmediata hasta el asesoramiento a largo plazo, incluyendo la formación y consulta;

Figura 18.11 - Base orientativa para la actividad labora del inspector de fábricas.

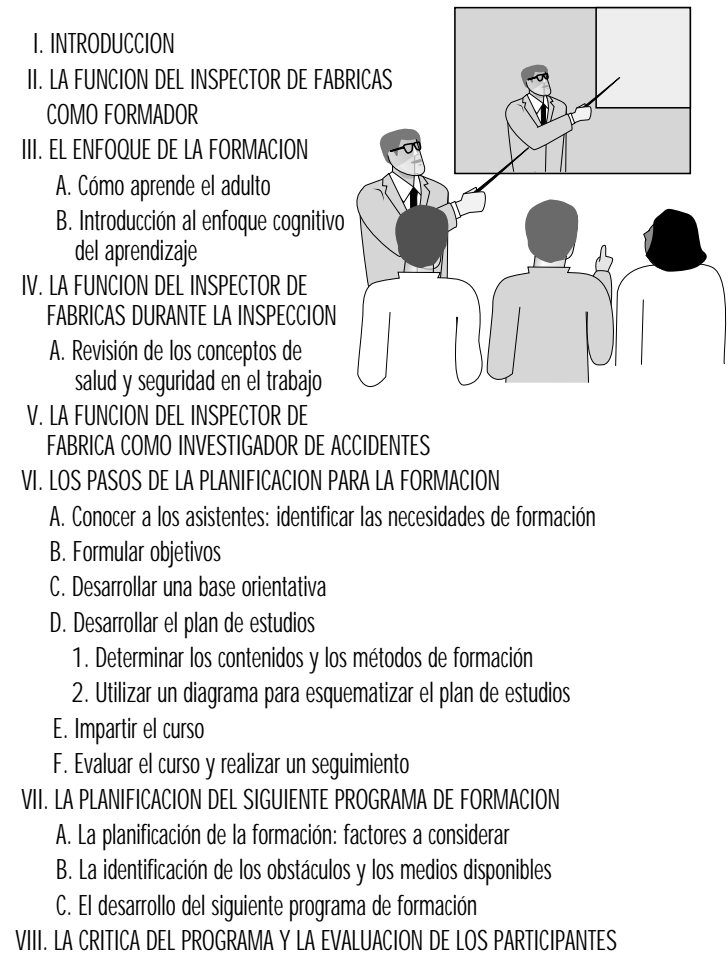

- M ejorar el conocimiento de los principios básicos del aprendizaje y la enseñanza de alta calidad;

- Aumentar la comprensión de las diversas cualificaciones aplicables a los programas de planificación de la formación: la identificación de las necesidades de formación, la formulación de los objetivos de aprendizaje, el desarrollo del plan de estudios y de los materiales didácticos, la selección de los métodos de enseñanza adecuados, la presentación efectiva del curso y la evaluación del programa;

- Reforzar la cualificación de los participantes para la comunicación efectiva, con vistas a su aplicación durante las inspecciones, consultas y sesiones oficiales de formación,

- Facilitar el desarrollo de planes de formación a corto y largo plazo, en los que se pongan en práctica las nuevas técnicas de enseñanza.

\section{L os contenidos del curso}

L as áreas temáticas 0 unidades curriculares clave que sirvieron de pauta para la puesta en práctica del curso de FDF en Etiopía están perfiladas en la Figura 18.12, que puede servir de orientación básica para la totalidad del curso.

\section{La determinación de los métodos de formación}

La configuración externa del método de enseñanza se percibe de inmediato en cuanto se entra en el aula: conferencia, debate 0 trabajo individual o en grupo. Lo que no se percibe es el aspecto más esencial, la configuración interna: la clase de actividad mental que realiza el estudiante.

Los métodos de enseñanza pueden clasificarse en tres grupos principales:

- La exposición didáctica: exposiciones por los participantes, conferencias, demostraciones, exposiciones audiovisuales.

- Las tareas independientes: exámenes o tests, actividades en pequeños grupos, lecturas recomendadas, utilización de materiales autodidácticos, juegos de rol.

- La instrucción cooperativa: debates con el formador, sesiones de respuesta a preguntas y de "brainstorming", prácticas y otros ejercicios conjuntos.

La mayor parte de estos métodos se han utilizado en nuestros cursos de FDF. La elección de uno u otro depende de los objetivos de aprendizaje perseguidos. Todo método debe reunir

Figura 18.12 - Areas temáticas clave del curso de FDF.

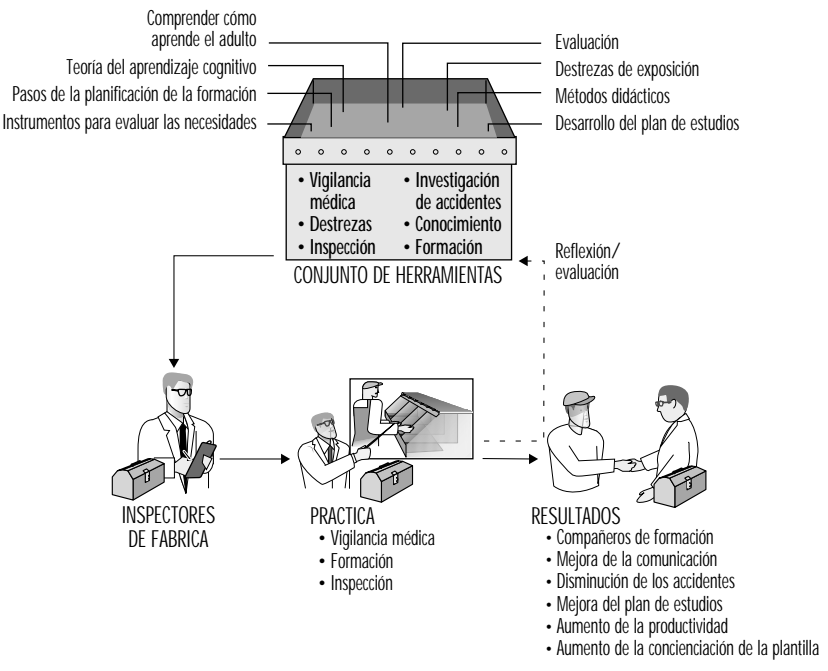


ciertas funciones instructivas, que son las actividades del profesor. Estas funciones se corresponden con los pasos del proceso de aprendizaje anteriormente descritos y pueden servir de orientación para la selección de métodos. Presentamos a continuación una lista de las nueve funciones instructivas:

1. Preparación

2. M otivación

3. O rientación

4. Transmisión de nuevos conocimientos

5. Consolidación de lo enseñado

6. Práctica (plasmación de los conocimientos en técnicas)

7. Aplicación (resolución de nuevos problemas con la ayuda de los conocimientos adquiridos)

8. Crítica del programa

9. Evaluación de los participantes

\section{La planificación del currículo: elaboración de un diagrama del curso}

U na de las funciones del currículo o plan del curso es ayudar a la orientación y supervisión del proceso de enseñanza y aprendizaje. El currículo puede dividirse en dos partes, la general y la específica.

EI currículo general ofrece una imagen de conjunto del curso: sus objetivos a corto y largo plazo, sus contenidos, los participantes y las directrices para su selección, el enfoque pedagógico (cómo se impartirá el curso) y las disposiciones organizativas, tales como las tareas requeridas antes del curso. Este currículo general sirve, en principio, como descripción del curso y proyecto de programa o lista de temas.

Un currículo específico ofrece información detallada sobre lo que se va a impartir y la forma de hacerlo. Si se elabora por escrito en forma de diagrama, servirá para perfilar el diseño de un currículo suficientemente específico para orientar la ejecución del curso. Este diagrama debe incluir las siguientes categorías:

E I tiempo: la estimación del tiempo necesario para cada actividad de aprendizaje;

L as unidades curriculares: las áreas temáticas principales;

L os temas: los temas comprendidos en cada unidad curricular;

Las funciones instructivas: la función de cada actividad como ayuda a la consecución de los objetivos de aprendizaje;

L as actividades: los pasos a seguir en cada actividad

Los materiales: los medios y materiales necesarios para cada actividad

E I formador: el enseñante responsable de cada actividad (cuando hay varios).

A continuación se indican los pasos a seguir para diseñar el currículo utilizando el formato de diagrama [este proceso se ilustra en la obra de Weinger (1993)]:

1. Especificación de las áreas temáticas principales del curso (las unidades curriculares), basadas en los objetivos del formador y sus orientaciones de partida.

2. Listado de los temas a tratar en cada una de estas áreas

3. Elaboración de un plan que incluya en cada área temática tantas funciones instructivas como sea posible, con vistas a seguir todos los pasos del proceso de aprendizaje.

4. Elección de aquellos métodos que satisfagan cada función y estimación del tiempo requerido. El tiempo, el tema y la función deben consignarse en el diagrama.

5. Señalamiento de pautas para el desarrollo de las actividades por el formador, que deben consignarse en el diagrama, en su columna de actividades, pudiendo incluirse también los puntos principales a tratar en esta sesión. Esta columna debe ofrecer una imagen clara y exacta de todo lo que tendrá lugar en este período del curso.
6. Listado de los materiales didácticos necesarios para cada actividad, tales como hojas de trabajo, notas a repartir o equipos.

7. Previsión de descansos adecuados, que deben incluirse siempre en el diseño de cualquier ciclo de actividades.

\section{La evaluación y el seguimiento del curso}

El último paso en el proceso de formación es la evaluación y seguimiento, demasiado a menudo olvidado o ignorado $y$, a veces, evitado. La evaluación, elemento esencial de la formación, es la determinación del grado de cumplimiento de los objetivos del curso, que debe incluir la crítica del programa (por los administradores del curso) y la evaluación de los participantes.

Los participantes deben tener la oportunidad de evaluar los factores externos de la enseñanza recibida: la cualificación del formador para la exposición, las técnicas utilizadas, las instalaciones y la organización del curso. Las herramientas de evaluación más utilizadas son los cuestionarios posteriores a la terminación del curso y los tests previos y posteriores.

El seguimiento es una actividad de apoyo esencial en el proceso de formación, que debe orientarse a ayudar a los participantes a aplicar y trasladar lo aprendido a su trabajo. Como ejemplos de actividades de seguimiento utilizadas en nuestros cursos de FDF pueden citarse:

- los planes y proyectos de acción;

- las sesiones o talleres formales de seguimiento;

- las consultas individuales y de grupo.

\section{La selección de los formadores}

Se seleccionaron formadores familiarizados con el enfoque cognitivo del aprendizaje, que tuvieran buenas habilidades de comunicación. En el curso piloto realizado en 1992 utilizamos expertos internacionales que habían participado en el desarrollo de este enfoque didáctico en Finlandia en el decenio de 1980. En los cursos de ámbito nacional contamos con varios expertos: un experto internacional, uno o dos expertos regionales, que habían participado en el primer curso piloto, y dos o tres organizadores locales con responsabilidades de formación en sus propios países, o que hubieran participado con anterioridad en este enfoque de la formación. Siempre que fue posible, se contó también con personal del proyecto.

\section{Análisis y resumen}

\section{La necesidad de evaluación de la formación en fábricas}

L a visita a la fábrica, y la enseñanza práctica consiguiente, es un elemento muy importante del curso y se utilizó para evaluar las necesidades de la formación en el lugar de trabajo (unidad curricular VI A, en Figura 18.11). Es recomendable completar la formación teórica y de métodos con anterioridad a la visita. En Etiopía, programamos la visita antes de abordar el tema de los métodos de enseñanza, y visitamos dos fábricas, cuando hubiéramos podido ampliar el tiempo dedicado a la evaluación de las necesidades eliminando una de las visitas. Por este motivo, las visitas deben limitarse y concentrarse sólo en la fábrica en la que se está llevando a cabo la formación.

La parte del seminario relativa a la elaboración de mapas de riesgo (que forma parte también de la unidad curricular VI A) tuvo aún más éxito en Etiopía que en Kenya. Los mapas de riesgo se introdujeron en las prácticas en fábricas y aportaron una importante motivación para los trabajadores. Para futuros seminarios, hay que subrayar que los peligros de carácter específico deben ser objeto de especial atención dondequiera que se presenten, en vez de usar, por ejemplo, un símbolo de color verde para representar una variedad de peligros físicos, de modo 
que se ponga más claramente de manifiesto la magnitud de un peligro concreto.

\section{Los métodos de formación}

Los métodos didácticos se centraron en las técnicas audiovisuales y en la utilización de temas de debate, ambos con buenos resultados. Como útil complemento de las sesiones con transparencias, se pidió a los participantes que trabajaran en grupos para elaborar sus propias transparencias sobre el tema asignado.

Los cuadernos de láminas sobre caballetes (se elaboró uno especialmente para el seminario) y el brainstorming fueron una novedad para los participantes. A demás de un excelente apoyo a la formación, los cuadernos de láminas y las pizarras para rotuladores ("pizarras mágicas") son un recurso muy barato y un sustitutivo práctico del retroproyector, fuera del alcance de la mayoría de los inspectores en los países en vías de desarrollo.

\section{La microenseñanza con cintas de vídeo}

La "microenseñanza", o formación en el aula centrada en problemas locales particulares, se llevó a cabo mediante la grabación en cintas de vídeo y crítica posterior de los participantes y organizadores, y tuvo mucho éxito. Además de reforzar los métodos didácticos externos, permitió debatir sobre áreas a mejorar en los contenidos antes de la enseñanza en la fábrica.

Un error muy común fue la incapacidad para poner en relación los temas de debate y las actividades de brainstorming con el contenido o mensaje de una actividad, aplicando el método mecánicamente e ignorando sus efectos. 0 tros errores también comunes fueron el uso de una terminología excesivamente técnica y la falta de adecuación de la formación a las necesidades de la audiencia mediante ejemplos específicos del lugar de trabajo. N o obstante, las presentaciones posteriores en la fábrica se diseñaron para que reflejaran con claridad las críticas de los participantes en el día previo.

\section{Las prácticas en la fábrica}

En su evaluación de las sesiones de prácticas en la fábrica, los participantes se mostraron muy impresionados por la utilización de una variedad de métodos didácticos, como los medios audiovisuales, pósters elaborados por ellos mismos, cuadernos de láminas, brainstorming, juegos de rol, grupos de debate, etc. La mayoría de los grupos utilizaron también un cuestionario de evaluación, una novedad para ellos. Hicieron hincapié en cómo habían conseguido despertar con éxito el interés de su audiencia, después de haberse limitado en el pasado al método de dictar conferencias. Por lo general, la gestión del tiempo y el uso de términos y explicaciones demasiado científicas fueron aspectos a mejorar. En el futuro, los organizadores deberán tratar de garantizar que todos los grupos incluyan en el proceso de aprendizaje los pasos relativos a la aplicación y la evaluación.

\section{La planificación del curso como experiencia formativa} Durante estos dos cursos se pudieron observar cambios significativos en la comprensión de los seis pasos del aprendizaje de alta calidad por parte de los participantes.

En el último curso, se añadió al programa una sección sobre la plasmación escrita de objetivos, en la que cada participante redactó una serie de objetivos de formación, algo que la mayoría de ellos nunca había hecho y que resultó de gran utilidad.

En cuanto a la utilización del diagrama curricular para la planificación, percibimos claros progresos en todos los participantes, y una gran destreza en algunos, y parece que debería, sin duda, dedicarse más tiempo a esta área. Para futuros seminarios, añadiríamos alguna actividad en la que los participantes utilizasen el diagrama para seguir un tema a lo largo del proceso, haciendo uso de todas las funciones instructivas. $\mathrm{H}$ ay todavía una tendencia a englobar la formación y los contenidos materiales (los temas) y a intercalar, sin la debida consideración de su relevancia, las distintas funciones instructivas dentro de una serie de temas. También es necesario que los formadores, dentro del proceso de aprendizaje, hagan hincapié en las actividades correspondientes a la etapa de aplicación y adquieran más experiencia en el desarrollo de las tareas del alumno. La aplicación es un concepto nuevo para la mayoría, y difícil de incorporar al proceso formativo.

La utilización del término unidad curricular, por último, resultó complicada y, en algunos casos, indujo a confusión. U na buena manera de abordarla es la simple identificación y ordenación de las áreas temáticas relevantes. También hubo claras dificultades con muchos conceptos propios del enfoque cognitivo del aprendizaje, como los de bases de orientación, factores internos y externos del aprendizaje y la enseñanza, funciones instructivas y algunos otros.

En resumen, consideramos que debe dedicarse más tiempo a las secciones de teoría y desarrollo curricular, como se ha indicado anteriormente, y a la planificación del currículo futuro, lo que permite observar la capacidad de cada participante para la aplicación de la teoría.

\section{Conclusión}

EI Proyecto Africano de Salud y Seguridad de la O IT-FIN NIDA ha asumido una tarea particularmente complicada y exigente: cambiar nuestros viejos conceptos y prácticas con respecto al aprendizaje y la formación. El problema de la reflexión sobre el aprendizaje es que este concepto ha perdido, en su uso actual, su significado central, identificándose con el de asimilación de información, que sólo guarda una lejana relación con el auténtico aprendizaje, mediante el cual nos reformamos y adquirimos la capacidad de hacer algo que con anterioridad no podíamos hacer (Senge 1990). Este es el mensaje del nuevo enfoque de nuestro proyecto con respecto al aprendizaje y la formación. 


\section{Referencias}

Benner, L. 1985. Rating accident models and investigation methodologies. J Saf Res 16(3):105-126.

Bright, P, C V an Lamsweerde. 1995. Environmental education and training in the Royal Dutch/Shell Group of Companies. En Employee Participation in Pollution Reduction, dirigido por $E$ Cohen-R osenthal y A R uiz-Q uintinalla. Preliminary analysis of the Toxic Release Inventory, CAHRS Research Report. Ithaca, NY: U NEP Industry.

Bunge, J, E Cohen-Rosenthal, A Ruiz-Q uintinalla (dirs.). 1995. Employee Participation in Pollution Reduction. Premiliminary analysis of the Toxic Release Inventory, CAHRS Research Report Ithaca, NY:

Cavanaugh, HA. 1994. M anaging the Environment: Duquesne Light 'green' plan trains employees for full compliance. E lectr W orld (N ovember):86.

Comité Mixto OIT/OMS sobre Medicina de Trabajo. 1981. Education and training in occupational health, safety and ergonomics. Technical R eport Series No. 663. Ginebra: Organización Mundial de la Salud (OM S).

Cordes, DH, DF Rea. 1989. Education in occupational medicine for primary-health care providers in the U nited States: A growing need. En Proceedings of the Second International Conference on $\mathrm{E}$ ducation and $\mathrm{T}$ raining in $\mathrm{O}$ ccupational. $\mathrm{H}$ ealth. Espoo, Finlandia: ICOH.

D'Auria, D, L H awkins, P K enny. 1991. J U niv 0 ccup E nvir $H$ ealth I4 Suppl.:485-499.

Ellington, H, A Lowis. 1991. Inter-disciplinary education in occupational health. J U niv Occup E nvir $H$ ealth 14 Suppl.:447-455

Engeström, Y. 1994. T raining for Change: N ew Approach to Instruction and Learning in W orking Life Ginebra: O ficina Internacional del T rabajo (OIT).

Fundación Europea sobre la mejora de las condiciones de Vida y de Trabajo 1993. Environmental Education and Training R equirements in Industry. Working document. 6 de abril.

Heath, E. 1981. W orker T raining and Education in $O$ ccupational Safety and $\mathrm{H}$ ealth: A R eport on Practice in Six Industrialized W estern Nations. Washington, DC US Department of Labor, O ccupational Safety and $\mathrm{H}$ ealth $\mathrm{Administration}$

International Commission on $\mathrm{O}$ ccupational $\mathrm{H}$ ealth $(\mathrm{COH})$. 1987. Proceedings of First Conference On Education and $T$ raining in $O$ ccupational $H$ ealth. $\mathrm{H}$ amilton, $\mathrm{O}$ ntario, Canadá: ICO H .

- . 1989. Proceedings of Second International Conference On $\mathrm{E}$ ducation and $\mathrm{T}$ raining in $\mathrm{O}$ ccupational $\mathrm{H}$ ealth. Espoo, Finlandia: ICOH.

-. 1991. Proceedings of T hird International C onference On Education and $\mathrm{T}$ raining in $\mathrm{O}$ ccupational $\mathrm{H}$ ealth $\mathrm{K}$ itakyushu, Japón: ICOH.

Kogi, H, WO Phoon, I Thurman 1989. Low-Cost W ays of Improving W orking Conditions: 100 Examples from Asia. Ginebra: OIT.

Koh, D, TC Aw, KC Lun. 1992. Microcomputer education for occupational physicians. En Actas de la 3 a Conferencia internacional sobre educación y formación en salud en el trabajo. K itakyushu, Japón: ICO H.

K ono, K, K Nishida. 1991. Survey for O ccupational $\mathrm{H}$ ealth Nursing Activities of the Graduates of the specialized courses for $O$ ccupational $H$ ealth
Nursing. En Actas de la 3 a Conferencia internacional sobre educación y formación en salud en el trabajo. K itakyushu, Japón: ICOH.

Laborers International Union of North America (LIUNA). 1995. Environmental training teaches more than just job skills. Laborer (M ay-J une):BR 2.

M adelien, M , G Paulson. 1995. T he State of $H$ azardous $M$ aterials T raining, Education and Research. Indiana, PA: National Environmental Education and Training Center.

M cQ uiston, TH, P Coleman, NB Wallerstein, AC Marcus, IS M orawetz, DW O rtlieb. 1994 $\mathrm{H}$ azardous waste worker education: Long-term effects. J 0 ccup M ed 36(12):1310-1323.

$\mathrm{N}$ ational Institute for $\mathrm{O}$ ccupational Safety and $\mathrm{H}$ ealth (N IO SH ). 1978. T he N ew Nurse in Industry: A Guide for the Newly Employed Occupational $\mathrm{H}$ ealth Nurse Cincinnati, O hio: US Department of $\mathrm{H}$ ealth, Education and Welfare

-. 1985. Project M inerva, Supplemental Business Curriculum Guide. Cincinnati, O hio: US NIOSH .

O rganización Internacional del Trabajo (OIT). 1991. Training, the Environment and the IL O. Ginebra: OIT.

Organización Mundial de la Salud (OMS). 1981. T raining of occupational health personnel. Euro R eports and Studies, No. 58. Copenhague: O ficina Regional de la O M para Europa.

-. 1988. Training and education in occupational health. T echnical R eport Series, N o. 762. G inebra: O M S

Phoon, WO . 1985a. The designated factory doctors' course in Singapore. Actas de la $10^{\mathrm{a}}$ Conferencia asiática sobre salud en el trabajo, M anila.

-. 1985b. Education and training in occupational health: formal programmes. En 0 ccupational $\mathrm{H}$ ealth in Developing Countries in Asia, dirigido por WO Phoon y CN Ong. Tokyo: Southeast Asian $M$ edical Information Center.

-. 1986. M atching Precept and Practice in 0 ccupational H ealth. Lucas Lectures, No. 8. London: Royal College of Physicians Faculty of Occupational $M$ edicine.

-.1988 . Steps in the development of a curriculum in occupational health and safety. En B ook of Abstracts. Bombay: $12^{a}$ Conferencia asiática sobre salud en el trabajo.

Pochyly, DF. 1973. Educational programme planning. En Development of Educational Programmes for the $\mathrm{H}$ ealth P rofessions. Ginebra: O M S.

Powitz, RW. 1990. Evaluating $\mathrm{H}$ azardous W aste Education and Training. Washington, DC: US D epartment of $\mathrm{H}$ ealth and $\mathrm{H}$ uman Services, junto con la Wayne State U niv.

Programa de las Naciones Unidas para el Medio Ambiente (PNU M A). 1993. E ducation for Sustainable Industry. Industry and Environment Programme. Nairobi: PNUMA

Pupo-N ogueira, D， J R adford. 1989. Report of workshop on primary health care. En Actas de la 2 Conferencia internacional sobre educación y formación en salud en el trabajo. Espoo, Finlandia: ICOH.

Rantanen, J. S Lehtinen. 1991. ILO/FINNIDA project on training and information for African countries on occupational safety and health. East Afr Newslett on Occup Safety and $\mathrm{H}$ ealth Suppl.:117-118.

Samelson, N M . 1977. T he E ffect of F oremen On Safety in Construction. Technical Report No. 219. Stanford,
California: Stanford U niv. Department of Civil Engineering.

Senge, P. 1990. T he F ifth D iscipline- T he Art and Practice of the L earning O rganization. N ueva Y ork: D oubleday.

Sheps, CG. 1976. Higher education for public health. T he M ilbank M emorial Fund Report.

Successful Health and Safety M anagement. 1991. L ondres: $\mathrm{H}$ er M ajesty's Stationary O ffice.

Verma, KK, A Sass-K ortsak, DH Gaylor. 1991. Evaluation of professional competency in occupational hygiene in Canada. En Actas de la $3^{3}$ Conferencia internacional sobre educación y formación en salud en el trabajo, Japón: ICOH

Viner, D. 1991. Accident Analysis and Risk Control. Carlton South,V ic:: VRJ Delphi.

Vojtecky, MA， E Berkanovic. 1984-85. The evaluation of health and safety training. Int 0 Community $\mathrm{H}$ ealth $\mathrm{E}$ duc 5(4):277-286.

Wallerstein, N, H R ubenstein. 1993. T eaching about J ob $\mathrm{H}$ azards: $\mathrm{A}$ Guide for Workers and Their $\mathrm{H}$ ealth Providers. Washington, DC: American Public $\mathrm{H}$ ealth Association.

Wallerstein, N, M W einger. 1992. H ealth and safety education for worker empowerment. Am I Ind M ed 11(5)

Weinger, M . 1993. T raining of T rainer's Package, Part 1: Trainer's M anual, Part 2: Participants' $\mathrm{H}$ andout. African Safety and Health Project, R eport 9a/ 93 and $9 \mathrm{~b} / 93$. Ginebra: O ficina Internacional del Trabajo (OIT).

Wigglesworth, EC. 1972. A teaching model of injury causation and a guide for selecting countermeasures. 0 ccup P sychol 46:69-78.

Zambia Congress of Trade Unions (ZCTU). 1994. $\mathrm{M}$ anual on $\mathrm{O}$ ccupational $\mathrm{H}$ ealth and Safety. (julio):21.

\section{0 tras lecturas recomendadas}

Colligan, MJ. 1994. Training in occupational safety and health. 0 ccup M ed: State Art R ev 9(2).

Heath, E, T Ferry. 1990. T raining in the W orkplace: Strategies for I mproved Safety and Performance. Goshen, NY: Aloray.

Heath, ED. 1981. Worker training and education in occupational safety and health: a report on practice in six industrialized western nations. Am J Ind M ed 2:379-403.

Hudock, S. April-June 1994. The application of educational technology to occupational safety and health training. 0 ccup M ed: State Art R ev 9(2).

Kauppi, A. 1993. Evolution of Planning for Adult Education. African Safety and $\mathrm{H}$ ealth Project, Report 8/93. Ginebra: O ficina Internacional del Trabajo (OIT).

Labour Occupational Health Program. 1993. The Right to U nderstand: Linking Literacy to $\mathrm{H}$ ealth and Safety T raining. Berkeley: Labour O ccupational $\mathrm{H}$ ealth Program, U niv. of California at Berkeley.

Trades U nion Congress. 1986. H ealth and Safety At W ork: W orkbook. L ondres: T rades U nion Congress.

Vojtecky, MA， E Berkanovic. 1984-1985. The evaluation of health and safety training. Int $Q$ Community $\mathrm{H}$ ealth $\mathrm{E}$ duc 5(4):277-286.

Wallerstein, NB, M Weinger. 1992a. Empowerment approaches to worker health and safety education. Am J Ind M ed 22(5).

-. 1992b. Health and safety education for worker empowerment. Am J Ind M ed 22:619-635. 

Director del capítulo

G eorges H. C oppée

\section{Sumario}

\section{Códigos y directrices}

Colin L. Soskolne. . . . . . . . . . . . . . . . . . . . 19.2

Ciencia y responsabilidad: normas éticas y conducta moral en la medicina del trabajo

Richard A. Lemen y Phillip W. Strine. . . . . . . . . . . . . . . . . . . 19.5

Aspectos éticos de la investigación sobre la salud y la seguridad en el trabajo

Paul W. B randt-R auf y Sherry I. B randt-R auf. . . . . . . . . . . . 19.8

La ética en el lugar de trabajo: marco para el juicio moral

Sheldon W. Samuds ......................... 19.10

Vigilancia del medio ambiente de trabajo

Law rence D. Kornreich.

Aspectos éticos de la información y la confidencialidad

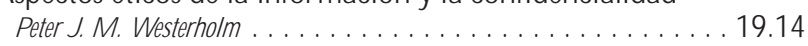

Etica en la protección y promoción de la salud

D. W ayne Corneil y Annalee Yassi . . . . . . . . . . . . . . . . . . . 19.20

Estudio de caso: consideraciones éticas sobre el

consumo de drogas y alcohol en el lugar de trabajo

B ehrouz Shahandeh y R obert $H$ usbands . . . . . . . . . . . . 19.25

Código deontológico internacional para los profesionales de la salud en el trabajo

Comisión I nternacional de M edicina del Trabajo. 


\section{- CODIGOS Y DIRECTRICES}

Colin L. Soskolne

\section{Finalidad de los códigos}

L os códigos deontológicos profesionales sirven para numerosos fines. En el ámbito de una profesión, los códigos establecen las normas de acuerdo con las cuales la profesión puede considerarse responsable de la conducta de sus miembros. Además, al delegar la sociedad el control de muchas de las profesiones en las propias asociaciones profesionales, éstas han desarrollado códigos que constituyen la base de su autorregulación (Soskolne 1989). Para un profesional en particular, los códigos pueden servir como una guía práctica cuando se enfrenta a dilemas morales o éticos en lo que se refiere a su conducta profesional en determinadas circunstancias. Cuando un profesional se ve sometido a tensiones morales o éticas, es evidente que los códigos pueden servir para asesorarle.

La existencia de un código constituye la base para organizar un programa de actividades de ética profesional dirigido a divulgar normas éticas entre los miembros de una determinada profesión (G ellermann, Frankel y Ladenson 1990; H all 1993). EI código puede revisarse mediante las aportaciones de los miembros de la profesión en reuniones, seminarios y congresos. Este constante debate sobre problemas y asuntos de interés constituye un proceso de revisión que garantiza que los códigos reflejen en todo momento los valores sociales, que están sometidos a un continuo proceso de cambio. De esta manera, las profesiones cuya supervivencia depende de los fondos públicos pueden seguir siendo útiles y responsables ante la sociedad (Glick y Shamoo 1993).

Los códigos también pueden servir de ayuda a los profesionales acusados de negligencia profesional o incluso demandados ante los tribunales. El hecho de que se demuestre que un profesional ha respetado el código de la profesión probablemente se considerará indicativo del cumplimiento de unas normas prácticas coherentes con las normas profesionales. Si esas prácticas producen algún daño, será menor la probabilidad de que el profesional que haya respetado el código sea declarado culpable y responsable de su error. No obstante, según el principio de la confianza (Pellegrino, Veatch y L angan 1991), la sociedad espera que se aplique el mejor juicio profesional posible para garantizar el interés general. C uando se trata de la relación entre médico y paciente, el paciente tiene derecho a esperar que sus intereses se protejan de la mejor forma posible. Sin embargo, los intereses particulares de un paciente pueden estar en conflicto con el interés general. En esos casos, el interés general debe anteponerse a los intereses particulares. A pesar ello, los códigos no pueden eximir a nadie de las responsabilidades por conductas incorrectas que se contemplan en las leyes promulgadas por el gobierno para proteger el interés general (C ohen 1982).

\section{La importancia y la finalidad de los códigos}

Es cierto que los códigos se asocian al concepto de la fuerza de la ley, lo que supone que pueden aplicarse a través de algún tipo de acción disciplinaria. En efecto, los conceptos de responsabilidad y autorregulación antes citados implican algún tipo de control (como mínimo, la opinión de los compañeros de profesión y, como máximo, la prohibición de ejercer esa profesión) que ejerce la propia asociación profesional sobre sus miembros. Por ello, algunas asociaciones profesionales han preferido evitar estas connotaciones asociadas a los códigos y han optado por "directrices". Estas últimas son de carácter orientativo y tienen menos implicaciones en lo que se refiere a su cumplimiento. Otros grupos han preferido evitar todas las connotaciones asociadas a los códigos y directrices y han recurrido a las "declaraciones de ética profesional" dirigidas a sus miembros (Jowell 1986). En este capítulo, el término código tendrá el significado de "conjunto de directrices".

Es evidente que los códigos (y las directrices) no tienen fuerza de ley. En esencia, los códigos y las directrices tienen el propósito de orientar a los profesionales, ya sea colectiva o individualmente, en las relaciones con sus clientes (incluidos sus pacientes o los que participan en sus investigaciones), sus colegas y colaboradores (incluidos sus alumnos) y la sociedad en general (incluidas las partes con intereses concretos). Los códigos pretenden asimismo mejorar la calidad del trabajo profesional y, por consiguiente, la talla de la profesión. En general, los códigos referentes a la relación entre médico y paciente exigen que los intereses del paciente se antepongan a cualquier otro, correspondiéndole al médico el papel de "defensor del paciente". Las enfermedades infecciosas constituyen una excepción, ya que en este caso los derechos del paciente pueden quedar supeditados al bienestar general. Por el contrario, los códigos referentes a las investigaciones científicas deben anteponer el interés general a cualquier interés particular o de otro tipo. U na excepción sería el caso de un investigador que descubre que uno de los participantes en su estudio ha sido objeto de abusos sexuales; en este caso, el investigador tiene la obligación de informar a las autoridades competentes.

\section{Desarrollo, análisis y revisión de los códigos}

EI proceso por el cual se desarrollan los códigos tiene consecuencias para su aplicación. El hecho de permitir la participación de los miembros y estudiantes de una profesión en el desarrollo de los códigos, así como en su análisis y revisión, aumenta la probabilidad de que dichos códigos sean aceptados y respetados por un mayor número de personas.

\section{Contenido y estructura de los códigos}

EI contenido de un código debe ser sencillo para lograr su máxima utilidad, aunque su longitud varía. Algunos son reducidos; otros tienen una extensión considerable. Cuanto más extensos, más específicos podrán ser. La facilidad de manejo de un código depende de su estructura y su contenido. Por ejemplo, puede empezar con un resumen de los principios en los que se basa y proseguir con descripciones más detalladas de las aspiraciones o preceptos que constituyen el código en sí mismo, posiblemente acompañadas de un comentario que explique cada una de ellas y con mención a circunstancias especiales en forma de estudios de casos que sirvan de ejemplos útiles. Sin embargo, los principios y su interpretación dependen en gran medida de los valores que se consideren inherentes a las aspiraciones de una determinada profesión. Aunque estos valores sean universales, sus interpretaciones, así como su aplicación a escala local y regional, pueden variar. Por lo tanto, aunque la exposición de los valores esenciales de una profesión sirva como fundamento para establecer sus principios éticos y deba aparecer siempre como prólogo a las directrices (G ellermann, Frankel y Ladenson 1990), sólo los comentarios más detallados y los estudios de casos pueden reflejar la diversidad regional.

Estos comentarios deben incorporar, ir seguidos de, o complementarse con estudios de casos extraídos de situaciones reales que plantean dilemas o conflictos éticos. Los estudios de casos pueden ser anónimos o hacer referencia a los nombres de las partes implicadas (por supuesto, sólo con su permiso) (Soskolne 1991). El objetivo de los estudios de casos no es conseguir una retribución a cambio, sino ofrecer ejemplos con fines didácticos. El aprendizaje resulta más sencillo cuando se plantean situaciones de la vida real. 
U na profesión sólo puede desarrollar un código de conducta más detallado basándose en la interpretación de su código deontológico. El código de conducta hace referencia a actividades más específicas relacionadas con la práctica profesional, desde las relaciones interpersonales hasta la manera de llevar a cabo una investigación y la manera de presentar los resultados. EI código de conducta de una profesión podría incluirse en un compendio de ética; al reflejar el conjunto de competencias de cada profesión, añade consideraciones particulares que van más allá de la exposición de sus principios éticos.

\section{Ambito de aplicación de los códigos}

El desarrollo de un código profesional casi siempre está motivado por cuestiones que tienen relación directa con esa profesión. Por consiguiente, los códigos suelen centrarse en los problemas que más preocupan a cada profesión. Sin embargo, los códigos también deben tener en cuenta cuestiones sociales más amplias (Fawcett 1993). De hecho, en un análisis reciente de varios códigos, Summers y cols. (1995) observaron que los códigos actuales casi nunca incluyen directrices sobre cuestiones sociales específicas, como, por ejemplo, efectos ambientales o solución de conflictos. Teniendo en cuenta la considerable influencia que tienen los colectivos profesionales, si sus códigos abordaran cuestiones sociales más amplias podrían concentrarse los esfuerzos para eliminar las conductas que están en contra del interés general de la sociedad. Esta presión ayudaría a reducir los peligros para el bienestar de la humanidad, como el militarismo o la destrucción ecológica.

\section{Formación ética}

$\mathrm{H}$ ay que tener en cuenta que existen dos escuelas de pensamiento para la formación ética: una de ellas se basa en un enfoque inspirado en principios; la otra se basa en casos y se llama también casuística. El autor de este artículo opina que el equilibrio entre estas dos escuelas es esencial para el éxito de la formación ética profesional, aunque esta opinión todavía no se ha contrastado (Soskolne 1991/92). No obstante, se sabe que la aplicación del estudio de casos a la ética tiene un papel muy importante en el proceso educativo. Los casos proporcionan el contexto para la aplicación de los principios.

Puesto que la enseñanza universitaria de la ética profesional se considera cada vez más importante para que los estudiantes adquieran consciencia de los valores, los principios éticos y el código de conducta de una profesión, lo ideal sería que el código de dicha profesión incluyera un plan de estudios; de esta forma, se facilitaría la formación de los alumnos que desean ejercer dicha profesión. Esta necesidad se puso de manifiesto en una reciente encuesta que identificó irregularidades y limitaciones en los aspectos éticos de los planes de estudios universitarios en E stados U nidos (Swazey, A nderson y Seashore 1993).

\section{Historia reciente de los códigos en algunas profesiones}

En las culturas occidentales, los debates sobre ética médica se remontan a Sócrates (470-399 a.c.), Platón (427-347 a.c.) y A ristóteles (384-322 a.c.) (Johnson 1965). Desde entonces, se han desarrollado numerosos códigos que se someten a revisiones periódicas para responder a los nuevos problemas que van surgiendo como resultado de, por ejemplo, cambios en las escalas de valores 0 , más recientemente, los avances tecnológicos (D eclaración de Helsinki 1975; Comité Especial sobre Etica M édica 1984; Russel y Westrin 1992). Desde el decenio de 1960, muchas otras profesiones han desarrollado códigos para sus asociaciones profesionales. De hecho, la elaboración de códigos profesionales se ha convertido en una práctica común desde el decenio de 1980. La American Association for the Advancement of Science (AAAS) ha sido la principal promotora de este movimiento. Bajo los auspicios de su Comité para la Libertad y la Responsabilidad Científica, la AAAS inició un proyecto de ética profesional para estudiar las características y las actividades asociadas con los códigos en las profesiones relacionadas con la ciencia y la ingeniería. El informe resultante de este estudio renovó el interés por los debates sobre el desarrollo y la revisión de los códigos en muchas profesiones (C halk, Frankel y Chafer 1980).

D esde hace mucho tiempo, las profesiones sanitarias y asistenciales han mantenido debates sobre los conflictos éticos originados por la naturaleza de sus aspiraciones profesionales. Sin embargo, los códigos resultantes se han centrado principalmente en la relación entre médico y paciente y en los problemas de la confidencialidad. En los últimos tiempos y probablemente como consecuencia de los avances en el campo de la investigación médica aplicada, los códigos han ampliado su ámbito para abarcar temas como las relaciones entre el investigador y el paciente. $L a$ investigación basada en la población ha motivado la incorporación de códigos que abordan los problemas de relación entre investigador y población con la ayuda de otras disciplinas como la sociología, la antropología y la estadística.

M uchas de las profesiones relacionadas con la salud en el trabajo han participado en estos debates sobre ética profesional, entre ellas las siguientes: higiene industrial (Yoder 1982; LaD ou 1986); epidemiología (Beauchamp y cols. 1991; Seminario sobre ética, política sanitaria y epidemiología de la AIE 1990; Grupo de Trabajo de Epidemiología de la Chemical M anufacturers Association 1991; Consejo de O rganizaciones Internacionales de Ciencias M édicas 1991, 1993); medicina y sus numerosas especialidades, incluida la salud en el trabajo (Coye 1982; American O ccupational Medical Associación 1986; Comisión Internacional de Medicina del Trabajo 1992; Comité Permanente de Médicos de la CEE 1980); enfermería; toxicología; estadística (Instituto Internacional de Estadística 1986); psicología, ingeniería y análisis de riesgos.

En las áreas específicamente relacionadas con la medicina del trabajo de los servicios de salud (G uidotti y cols. 1989), la medicina (Samuels 1992), la salud y la seguridad (LaD ou 1986) y la salud en el trabajo y ambiental (Rest 1995), se aplican las partes relevantes de los respectivos códigos profesionales, aunque los debates deberán proseguir en estas áreas a fin de revisar los códigos existentes.

La importancia de integrar la ética en las actividades cotidianas de los profesionales se pone de manifiesto en estos textos recientes, que contienen secciones detalladas sobre ética. E sta es una manera de recordar a los profesionales que, en todos los aspectos del ejercicio de la profesión, sus decisiones y recomendaciones tienen siempre implicaciones éticas.

Los últimos trabajos sobre el tema de las conductas poco éticas en la ciencia deberán incorporarse a los nuevos textos (D ale 1993; Grandjean y Andersen 1993; O ficina del Subsecretario de Salud 1992; Price 1993; Reed 1989; Sharphorn 1993; Soskolne 1993a; Soskolne 1993b; Soskolne y M acfarlane, 1995; Teich y Frankel 1992). Puesto que uno de los objetivos fundamentales de la ciencia es la búsqueda de la verdad a través de la objetividad, el plagio y la manipulación o falsificación de los datos son prácticas contrarias a la ética científica. A medida que las iniciativas científicas se amplían para incluir a un número cada vez mayor de científicos, las conductas científicas poco éticas están empezando a atraer la atención de la opinión pública cada vez con más frecuencia. N o obstante, se cree que a pesar de la creciente competencia y de los posibles conflictos de intereses, la gran mayoría de los científicos respetan los 
principios de la verdad y la objetividad, aunque todavía resulta difícil evaluar la frecuencia de las prácticas incorrectas (Goldberg y Greenberg 1993; Greenberg y Martell 1992; Frankel 1992).

El posible daño que pueden infligir a las actividades científicas las conductas poco éticas es motivo de preocupación. También preocupa la pérdida de confianza de la sociedad en los científicos, con la consiguiente reducción del apoyo a las investigaciones científicas. Esto último podría tener consecuencias tan desastrosas para la ciencia y la sociedad que hace necesario que todos los científicos, y especialmente los estudiantes de ciencias, reciban una formación permanente en ética científica y se les recuerde estos principios cada cierto tiempo.

Existen varios casos que sirven como ejemplo de lo que constituye una conducta poco ética (Broad y Wade 1982; O ficina de Integridad en la Investigación 1993; Price 1993; N eedleman, Geiger y Frank 1985; Soskolne y M acfarlane 1995; Swazey, Anderson y Seashore 1993; Soskolne 1991). Son muchos los factores que determinan los dilemas éticos, pero una encuesta realizada a los analistas de riesgos en Nueva Jersey (G oldberg y G reenberg 1993) sugiere que las dos causas más importantes son la "tensión en el trabajo" y la "tensión originada por las repercusiones económicas del resultado". Los autores del presente estudio observaron que entre las posibles causas de una conducta poco ética figuran "los conflictos de intereses, la competencia con competidores no regulados y sin escrúpulos y la ausencia general de una ética personal y social". Aunque algunos códigos hacen referencia a la necesidad de honestidad y objetividad en la ciencia, las intensas presiones que existen en la actualidad para obtener resultados en presencia de una clara decadencia de la conciencia ética de la sociedad, implican la necesidad de que la ética, los valores y la filosofía se incluyan en todos los niveles de enseñanza. EI Servicio de Salud Pública de Estados Unidos exige a todas las universidades que solicitan becas de investigación que dispongan de procedimientos para hacer frente y notificar todos los casos de conducta científica poco ética (R eed 1989). A demás, los planes de estudios universitarios en las disciplinas relacionadas con la salud deben incluir obligatoriamente la formación ética para poder recibir financiación federal (O ficina del Subsecretario de Salud 1992).

\section{Carácter normativo de los códigos}

Los códigos de conducta profesional suelen consistir en una descripción detallada de un conjunto de prácticas normativas. Estas prácticas se ajustan a las normas morales y éticas de un colectivo, ya sea una organización profesional, una asociación 0 la sociedad, que posee un conjunto común de destrezas al servicio de los demás.

Los códigos profesionales se basan en la regla de oro de que toda persona debe tratar a los demás como le gustaría que le tratasen a ella, debe hacer todo lo que esté en su mano y debe informar a los demás sobre cualquier conducta poco ética.

\section{Diferentes enfoques para la aplicación de los códigos}

La mayoría de las asociaciones profesionales han elaborado sus códigos aplicando un enfoque "descendente", de manera que los niveles jerárquicos superiores han sido los responsables de esta tarea. N o obstante, como ya se ha dicho antes (véase "D esarrollo, análisis y revisión de los códigos"), es probable que el enfoque "ascendente" lograra un mayor consenso con respecto a los códigos, ya que la participación en el proceso produce un sentimiento de propiedad que facilita la aceptación. La credibilidad de un código es menor cuando los que más poder tienen dentro de una profesión ejercen una influencia considerable a la hora de definir lo que se considera una conducta profesional adecuada. Cuanto más refleje el código "final" las normas de la comunidad, mayor será la probabilidad de que sea repetado.

Los códigos desarrollados por organizaciones internacionales pueden conseguir que los grupos regionales consideren los problemas y declaraciones que se incluyen en los códigos internacionales. De esta forma, algunos grupos regionales que no se hubieran planteado todavía la posibilidad de elaborar un código podrían decidirse a hacerlo. Siempre y cuando los códigos internacionales se limiten a proporcionar este tipo de estímulo, la interacción continua podría servir para modificar y actualizar periódicamente los códigos internacionales de manera que reflejen fielmente los problemas transnacionales. Es importante que los códigos internacionales respeten las normas culturales regionales que no entran en conflicto, por ejemplo, con D eclaraciones U niversales de Derechos Humanos. Por lo tanto, los responsables de la elaboración de los códigos deben tener siempre en cuenta estas diferencias culturales, sin permitir que su trabajo sirva para unificar la conducta humana, sino para fomentar la diversidad cultural.

\section{Mecanismos de aplicación}

Como ya se ha mencionado antes, los códigos implican cierto grado de autorregulación, sobre todo si pretenden servir de base a la asunción de responsabilidades. Esto sugiere la necesidad de que haya procedimientos para investigar denuncias de todo tipo de conductas o prácticas poco éticas y para corregir conductas que se consideran profesionalmente inaceptables (Price 1993; Dale 1993; Grandjean y Andersen 1993). Además, se deben prever los procedimentos necesarios para remediar los daños y perjuicios ocasionados por una conducta profesional poco ética.

Los procedimientos utilizados para investigar las denuncias de conductas o prácticas poco éticas deben especificarse de antemano. El principio de la "presunción de inocencia" debe aplicarse siempre. No obstante, puesto que la confianza de la sociedad depende de la autorregulación profesional, las investigaciones deben llevarse a cabo con la mayor eficiencia posible y respetando los trámites procesales en todo momento (Sharphorn 1993; Soskolne 1993a, b).

U no de los instrumentos más eficaces para lograr el máximo nivel de cumplimiento de un código por parte de los miembros de una asociación profesional es la retirada de la licencia profesional. Sin embargo, muchas profesiones no cuentan con este instrumento, ya que sus miembros son personas con diferentes niveles de titulación que se limitan a pagar unos derechos y que no están obligados por ley a obtener una licencia para poder ejercer su profesión. Por lo tanto, en muchas profesionales la prohibición de ejercer la profesión no es un instrumento que pueda utilizarse para sancionar conductas poco éticas. En estos casos, el único recurso posible es la presión que puedan ejercer los compañeros de profesión.

\section{Problemática actual de los profesionales de la salud en el trabajo}

En el presente artículo no se pretende desarrollar un código completo, sino describir el proceso mediante el cual se desarrollan los códigos. Con ello se pretende estimular un debate continuo sobre los códigos (como componentes de un programa de ética profesional de mayor envergadura) y llamar la atención del lector sobre los problemas actuales que todavía tienen que ser debatidos para su posible inclusión en los códigos revisados.

G uidotti y cols. (1989) observaron que los códigos que existían en aquel entonces no abordaban algunos aspectos importantes, como el derecho de libre acceso a información precisa y la protección de los trabajadores cuando existen evidencias, no 
demostradas pero fundadas, de la existencia de riesgos en el lugar de trabajo. Los conceptos de "información precisa" y de "verdad implícita" se asocian a otros aspectos relacionados con la integridad científica (como se denomina en Norteamérica) o el fraude científico (como se denomina en D inamarca) (Andersen y cols. 1992; Grandjean y Andersen 1993). Es evidente que la búsqueda de la verdad como meta principal de las actividades científicas debe reforzarse por todos los medios posibles, entre ellos mediante su plena integración en los códigos, en los estudios de casos y en los programas de ética en general (H all 1993).

Gracias a los avances tecnológicos, los parámetros biológicos pueden ahora medirse con mayor precisión. Por ejemplo, los biomarcadores pueden dar lugar a un sinfín de problemas y conflictos éticos que todavía no se contemplan en los códigos. Ashford (1986) y Grandjean (1991) han identificado algunos problemas de este tipo. Puesto que los códigos que existen en la actualidad se desarrollaron antes de que esta tecnología estuviera disponible en el mercado, deberían actualizarse para orientar a los profesionales de la salud en el trabajo con respecto a ciertos problemas. Pero antes tendrán que celebrarse seminarios y congresos para debatir a fondo cuestiones tan delicadas como el derecho de una persona a seguir trabajando cuando los biomarcadores han identificado su elevada sensibilidad a los riesgos presentes en el lugar de trabajo. Los estudios de casos pueden ayudar en este terreno. L as ramificaciones de los estudios con biomarcadores son tan profundas, que sus implicaciones, al igual que las de otros posibles avances tecnológicos, deben abordarse mediante una constante revisión de los códigos profesionales.

A nte la dificultad de resolver determinados problemas, como los relacionados con los biomarcadores, convendría que los profesionales que se ocupan de estos temas aunaran sus esfuerzos y establecieran mecanismos de intercambio de información que ayudaran a resolver problemas éticos complejos. En particular, deberían existir comités permanentes de ética en las distintas profesiones relacionadas con la salud y seguridad en el trabajo que decidiesen cuál es el momento más adecuado de introducir procedimientos de alta tecnología cuyas implicaciones éticas todavía no se han determinado. En estos debates deberían participar otros grupos interesados e incluso los representantes de la comunidad en cuyo seno se realizaran estos estudios.

Es necesario reconocer que el entusiasmo de los investigadores por la aplicación de nuevas tecnológicas en estudios cuyas repercusiones no se conocen todavía (convencidos de obtener resultados positivos) puede llegar a ocasionar más daño que beneficio a los participantes en esos estudios (por ejemplo, la pérdida del puesto de trabajo en el presente puede causar más daño que la posibilidad de una muerte prematura en el futuro). Por lo tanto, la aplicación de estas tecnologías debe hacerse con una gran precaución y considerarse sólo después de haber sido objeto de debate entre los colectivos profesionales interesados en dichas tecnologías y todos los demás grupos afectados.

0 tro asunto de interés que cada cierto tipo es objeto de debate público es el de la confidencialidad de la información. En la era de los ordenadores, se pueden cruzar archivos que se han creado con fines distintos. Los defensores de la confidencialidad de la información han expresado su preocupación ante la posibilidad de que este tipo de práctica perjudique a los intereses particulares. Aunque los derechos fundamentales a la intimidad deben recibir prioridad sobre las necesidades de investigación de la sociedad, estos defensores de la confidencialidad deben recordar que los estudios de poblaciones no están interesados en datos a escala individual y que el interés general de la sociedad se verá favorecido si se permite que investigadores debidamente cualificados y expertos en procesamiento y confidencialidad de la información tengan acceso a datos individuales para los fines de la investigación basada en poblaciones.

Ya se ha comentado antes (véase "H istoria reciente de los códigos en algunas profesiones") la preocupación por la medida en que los principios aplicados en el contexto de la relación entre médico y paciente se extrapolan a los estudios de poblaciones. Vineis y Soskolne (1993) observaron que los principios establecidos de autonomía, beneficiencia, no maleficencia y justicia distributiva no se aplican con facilidad a la sociedad en general. Por ejemplo, la información disponible sobre la seguridad de las exposiciones es muchas veces insuficiente para permitir la autonomía de decisión; la beneficiencia se considera desde el punto de vista social más que individual, y con frecuencia se producen injusticias. A la hora de definir lo que es aceptable para la sociedad, la ética debe recibir una especial atención; las simples fórmulas matemáticas utilizadas para evaluar los riesgos y beneficios no pueden aplicarse directamente a los individuos. Todas estas ideas tendrán que desarrollarse e integrarse en el futuro.

En resumen, los códigos desempeñan un papel fundamental para las profesiones. También podrían desempeñar la importante función de proteger el interés común si tuvieran en cuenta otras cuestiones sociales más amplias. En su desarrollo deben participar todos los grupos interesados, como parte de un programa ético general apoyado por cada profesión. Los códigos, junto con los valores esenciales de la profesión, los comentarios que acompañan a los códigos y los estudios de casos, tienen que someterse a un proceso periódico de análisis y revisión. A hora más que nunca, los códigos son necesarios, no sólo para los fines de la responsabilidad y la autorregulación profesional, sino también para ayudar a los profesionales a afrontar los retos morales y éticos planteados por los avances tecnológicos que repercuten en los derechos y deberes de todas las personas afectadas y todos los grupos interesados. Tenemos ante nosotros un gran reto.

\section{CIENCIA Y RESPONSABILIDAD: NORMAS ETICAS Y CONDUCTA MORAL EN LA MEDICINA DEL TRABAJO}

\author{
Richard A. Lemen y Phillip W. Strine
}

Para empezar, queremos dejar claro que nosotros no somos expertos en ética, ni nos presentamos como tales. Somos científicos, igual que ustedes, y nuestro trabajo científico tiene como finalidad la búsqueda de la verdad. En ese campo, nos enfrentamos a los mismos problemas que ustedes: la diferencia entre el bien y el mal, lo correcto y lo incorrecto, la objetividad y la subjetividad. Como investigadores, nos esforzamos en resolver cuestiones complejas referentes a los métodos y los resultados. L os que llegamos a desempeñar un trabajo administrativo nos preocupamos por los mismos problemas, especialmente cuando tenemos que tomar decisiones políticas para establecer unas normas laborales adecuadas que protejan a los trabajadores.

En el proceso de preparación de este artículo, hemos revisado una serie de libros y documentos en busca de respuestas simples a problemas complejos. Hemos consultado, no sólo trabajos escritos por los profesionales de la salud y la seguridad en el trabajo, sino también algunos libros de texto clásicos sobre ética.

En el aspecto profesional, hemos leído varios artículos y códigos deontológicos de distintos grupos de investigación. Todos ellos contienen aspectos relacionados con la investigación 
de la salud en el trabajo. No obstante, cada uno de ellos adopta un enfoque diferente, dependiendo del tipo de investigación realizada por cada autor. Algunos se extienden mucho sobre lo que hay que hacer y lo que no hay que hacer. 0 tros tienen un contenido más general.

En lo que respecta a los libros de texto, abundan las teorías éticas desarrolladas desde los tiempos de Sócrates hasta nuestros días. Se han publicado numerosos artículos sobre ética, códigos de conducta y análisis por escrito de las normas éticas. Al menos en Estados Unidos, la mayoría de las facultades de medicina cuentan con expertos en ética médica y en casi todas las universidades con un departamento de filosofía existe un experto en ética como parte del profesorado. Se trata de una disciplina a la que algunos dedican toda su vida, lo que confirma la complejidad del tema.

Antes de proseguir, es importante que intentemos aclarar de qué estamos hablando. ¿Q ué significa el término ética? En inglés, los términos ética y moral se usan indistintamente. Puesto que este artículo está dirigido a un grupo muy diverso de personas, pensamos que sería interesante realizar una encuesta a los profesionales de los Centros para el Control y Prevención de las Enfermedades (Centers for Disease Control and Prevention, $C D C$ ) cuya lengua materna no era el inglés. U na mujer cuyas lenguas maternas eran el eslavo, el alemán y el ruso respondió que en las tres lenguas existen palabras equivalentes a ética y moral. Sin embargo, nos explicó que, en la lengua eslava, ni ética ni moral se utilizan solas, como en inglés. Nos explicó que en lugar de decirse que una persona no tiene moral, se dice que su conducta no es moral. Tampoco se dice que una persona carece de ética, sino que carece de principios éticos. U n chino nos contó que ambos términos, moral y ética, tienen traducción en chino, aunque se utilizan indistintamente. Las personas que hablaban español, francés y alemán nos explicaron que ambos conceptos tienen traducción en sus respectivas lenguas y que también se utilizan como sinónimos.

Sin embargo, en los libros de texto que revisamos, los expertos en ética distinguen entre la ética y la moral, y nosotros decidimos aceptar esta distinción en aras de una mayor claridad. Tanto M elden (1955) como M othershead (1955) sugieren que el término ética se refiere a un conjunto de principios o normas de conducta, mientras que el término moral se refiere a la conducta de una persona o grupo de personas, es decir, a su comportamiento. Este uso es consecuente con las respuestas de los profesionales de los CDC).

El profesor M elden escribe en su libro: "Todos conocemos estas reglas de conducta. Todas las sociedades, religiones, colectivos profesionales o comunidades poseen unos principios, unas normas de conducta. Las personas que deseamos tener una conducta responsable recurrimos habitualmente a un conjunto de principios que guían nuestra conducta". A nuestro alrededor podemos encontrar numerosos ejemplos de estos principios. En la comunidad judeocristiana existen, como mínimo, los Diez $M$ andamientos. Todas las sociedades promulgan leyes de ámbito local, nacional e internacional que describen y dictan lo que ha de considerarse como una conducta aceptable o inaceptable. También existe el método científico, como por ejemplo el Código internacional de ética para los profesionales de la salud en el trabajo o la Guía de ética para los médicos de empresa, por citar algunos ejemplos, aunque existen muchos otros. Lo que queremos decir es que estamos supeditados a una serie de normas de conducta o ética, en el sentido en que utilizamos el término. Por lo tanto, consideramos que ha llegado el momento de establecer algunas normas para nosotros mismos.

¿Por qué los profesionales sanitarios necesitamos normas en nuestro trabajo? Como dice el profesor $\mathrm{M}$ elden, somos personas que intentamos ser responsables. Si pretendemos ser buenos científicos, debemos asumir el máximo de responsabilidad, lo que supone promover la seguridad y la salud. Por otra parte, por muy buenas que sean las intenciones del investigador, cuando la ciencia se ve comprometida pueden producirse muertes, enfermedades, discapacidades o lesiones graves en lugar de proteger a los trabajadores. En estos casos, siempre son los trabajadores los perjudicados.

¿Por qué la ciencia puede verse comprometida? D esde nuestro punto de vista existen varias razones.

En algunas ocasiones, la ciencia se ve comprometida por que no sabemos hacer mejor las cosas. Tomemos como ejemplo tres causas de daños graves en el trabajo: amianto, benceno y sílice. En un principio, no se sabía que estas sustancias fueran peligrosas. Con los avances tecnológicos, el desarrollo de la epidemiología y la creciente sofisticación de la medicina, se demostró lo obvio. En estos tres ejemplos, los problemas existían, pero los científicos no poseían o no aplicaban los instrumentos necesarios para descubrir su causa.

0 tras veces la ciencia se ve comprometida por unas prácticas científicas incorrectas. Seguro que todos ustedes han sido testigos de este tipo de prácticas o han leído sobre el tema en las revistas científicas. Son prácticas incorrectas porque no tienen nada de ciencia. Son opiniones expresadas de tal manera que parecen científicas y por lo tanto objetivas. Esta situación puede remediarse fácilmente con un riguroso proceso de revisión mutua.

En algunos casos, la ciencia se ve comprometida porque el investigador actúa precipitadamente al verse apremiado por unos plazos poco realistas, la escasez de recursos o influencias que no tienen nada que ver con el análisis puramente científico. Un ejemplo de este tipo de situación es el de un estudio toxicológico sobre el cáncer en el que se puso fin a la vida de los animales de laboratorio antes de que hubiera transcurrido un tercio de su período de vida normal, reduciendo así el período de latencia necesario para que pudieran desarrollar cáncer como consecuencia de la exposición. De esta forma, se perjudicó el rigor del trabajo y las conclusiones se extrajeron considerando sólo una parte de la situación estudiada.

El peor caso de todos es probablemente cuando la ciencia se ve comprometida por el ánimo de lucro del investigador o por su deseo de conseguir éxitos académicos que justifiquen su ascenso. Todos hemos visto pruebas de ello en la prensa y en las revistas profesionales. En algunos casos, el investigador busca más el prestigio académico que el beneficio económico. En otros, el beneficio económico, a corto o medio plazo, influye en los resultados. Como ejemplo del primero de estos casos, recordemos que algunos investigadores con intereses económicos relacionados con el amianto no publicaron los resultados positivos de sus estudios hasta muchos años más tarde, cuando miles de trabajadores ya habían sufrido o fallecido por enfermedades relacionadas con la exposición incontrolada al amianto (Lemen y Bingham 1994). En algunas ocasiones, hemos podido ver cómo los que financian una investigación pueden influir en el resultado final.

Estos son sólo algunos ejemplos en los que un código deontológico podría desempeñar un papel importante, aunque ningún código, por perfecto que sea, podrá detener a los que no tienen escrúpulos.

La medicina del trabajo es una disciplina compleja en la que resulta difícil impedir conductas poco éticas. Incluso cuando descubrimos métodos para la prevención de enfermedades y lesiones profesionales, la solución al problema se considera con frecuencia una amenaza para los beneficios, o se oculta el problema para evitar el gasto que supondría la adopción de medidas correctoras. El interés por los beneficios y la complejidad de estos problemas pueden dar lugar tanto a abusos como 
a limitaciones en el sistema. ¿Cuáles son algunas de la principales dificultades?

Muchas enfermedades profesionales tienen períodos de latencia increíblemente largos, dando lugar a variables desconcertantes. Por el contrario, los estudios de enfermedades infecciosas son más sencillos y producen resultados en poco tiempo. Un ejemplo de ello sería una campaña bien gestionada de vacunación ante un brote de sarampión. En este caso, el período de latencia es corto, la tasa de infección se aproxima al $100 \%$ de las personas susceptibles, la vacuna tiene un porcentaje de eficacia del 95 al $98 \%$ y el brote se puede erradicar en tan sólo unos días. El caso de la asbestosis o el síndrome del túnel carpiano es muy diferente, ya que afecta a algunas personas pero no a otras y la discapacidad suele tardar meses o años en manifestarse.

Los problemas de la salud en el trabajo deben abordarse adoptando un enfoque interdisciplinario. Cuando un químico trabaja con otros químicos, todos ellos hablan el mismo idioma, todos tienen un mismo interés y pueden compartir el trabajo. Pero la salud en el trabajo es interdisciplinaria y suele implicar a químicos, físicos, higienistas industriales, epidemiólogos, ingenieros, microbiólogos, médicos, psicólogos, estadísticos y otros. En el triángulo epidemiológico (receptor, agente, medio ambiente), el receptor es imprevisible, los agentes son numerosos y el medio ambiente es complejo. Por ello es vital la cooperación entre distintas disciplinas. Un equipo de profesionales, con conocimientos y destrezas totalmente diferentes, se reúnen para abordar un problema. El único punto que tienen en común es su deseo de proteger a los trabajadores. Este aspecto complica aun más la revisión mutua, ya que cada especialidad utiliza nomenclaturas, equipos y métodos distintos para resolver el problema.

Como consecuencia del largo período de latencia de muchas enfermedades y lesiones profesionales y de la rotación de los trabajadores, los profesionales de la salud en el trabajo suelen verse obligados a rellenar algunas lagunas en los datos cuando no pueden localizar a muchos de los trabajadores expuestos o en situación de riesgo. Esto les obliga a recurrir a modelos y cálculos estadísticos que pueden comprometer las conclusiones del estudio. La probabilidad de error es elevada, ya que no siempre se pueden llenar todas esas lagunas.

A veces resulta difícil relacionar una enfermedad con el medio ambiente de trabajo 0 , lo que es peor, identificar la causa. En las enfermedades infecciosas, el triángulo epidemiológico suele ser menos complejo. En el decenio de 1990, el personal de los CDC investigó el brote de una enfermedad en un crucero. EI receptor pudo definirse y localizarse fácilmente, el agente también se identificó sin problemas, la forma de transmisión era obvia y la acción correctora, evidente. Sin embargo, en las enfermedades y lesiones profesionales, el receptor se puede definir, pero a menudo es difícil de encontrar. En el medio ambiente de trabajo, existen agentes que suelen actuar de manera sinérgica, así como otros factores que no están directamente implicados en el problema de salud pero que desempeñan un papel importante en su solución. Estos otros factores incluyen aspectos tales como los intereses y las preocupaciones de los trabajadores, la dirección o los organismos públicos implicados en el tema.

Pero volvamos al tema que nos ocupa: elaborar un código deontológico, un conjunto de principios o normas de conducta que podamos utilizar para guiar nuestra conducta, nuestro comportamiento, en este entorno tan complejo.

Como escribe con tanta claridad el profesor M elden (1955): "No podemos depender totalmente de estos principios para guiar nuestra conducta, simplemente porque es imposible establecer un conjunto de normas suficientemente completas para prever todas las situaciones que plantean un dilema moral". Y prosigue: "Un conjunto de principios éticos que abarquen todas las posibilidades morales es tan imposible como un conjunto de leyes tan completo que haga innecesaria cualquier otra legislación". K enneth W. Goodman (1994b) declara por su parte: "Aunque es importante que admitamos el estrecho o incluso inseparable vínculo que existe entre ciencia y ética, no existe razón alguna para suponer que un código deontológico formal será la solución de todas o la mayoría de las discrepancias sobre la naturaleza de los datos, su selección, su gestión, etc." . Citemos al Profesor M eden una vez más: "Para que sean útiles, los principios éticos deben ser de carácter general; pero si son generales, su utilidad se ve inevitablemente limitada".

Teniendo en cuenta todas estas advertencias, proponemos que el código deontológico para los profesionales de la salud en el trabajo incluya los siguientes requisitos:

- Que, como mínimo, se requiera una revisión mutua que incluya una revisión tripartita en la que participen los representantes de los trabajadores, la industria y el gobierno, y una revisión por parte de los académicos. Este proceso es difícil porque requiere tiempo: tiempo para identificar a revisores con conocimientos adecuados en cada uno de las tres partes, tiempo para que se reúnan y debatan y tiempo para analizar todos los problemas que les preocupan. En el Instituto $\mathrm{N}$ acional para la Salud y la Seguridad en el Trabajo ( $N$ ational Institute for O ccupational Safety and Health, NIOSH) de Estados U nidos, este proceso se exige para todas las publicaciones. No presumimos de tener todas las respuestas, ni siquiera disponemos de todos los datos. Es mucho lo que podemos aprender de los trabajadores y de la industria sobre las situaciones que se producen en el lugar de trabajo y sobre la resolución de problemas. La revisión tripartita es la única manera que conocemos de reducir al mínimo la influencia de grupos con intereses especiales.

- Que se eviten hasta los compromisos percibidos. En algunos casos, la ciencia pierde credibilidad por culpa de compromisos percibidos. Algunos ejemplos de compromisos son la fuente de financiación del estudio, la selección de un grupo interesado para revisar el estudio y sesgos conocidos de los revisores. En estos casos se requiere el buen criterio del investigador, pero aunque su criterio y su decisión posterior sean los adecuados, la credibilidad del estudio puede verse afectada por un compromiso percibido.

- Que los protocolos de todos los estudios sean revisados por otros científicos antes de iniciarse el estudio. Incluso el investigador con las mejores intenciones puede incorporar un sesgo al protocolo, que sólo se pondrá de manifiesto con una minuciosa revisión del mismo.

- Q ue desde el principio se siga el método científico: a) elaborar una hipótesis, b) realizar una búsqueda de documentación, c) recopilar datos, d) cotejar los datos, e) poner a prueba la hipótesis y f) divulgar los resultados.

- Que cuando la ciencia se utilice para elaborar normas sobre la salud y la seguridad en el trabajo, todas las partes implicadas en la decisión declaren sus afiliaciones, sus intereses económicos y sus conflictos potenciales con el sector industrial o el objeto de la regulación, exponiendo claramente todo ello en la documentación final. La percepción tiene la máxima importancia para cualquier norma o recomendación. Si se cree que la norma está basada en una interpretación sesgada, carecerá de credibilidad. Las normas basadas exclusivamente en la interpretación de la ciencia por personas que tienen intereses en el sector en cuestión se verán perjudicadas por esa interpretación o, peor aún, no ofrecerán una protección adecuada a los 
trabajadores. La incorporación de factores de control como los que se han descrito durante el proceso de elaboración de una nueva norma puede garantizar que esto no ocurra.

H emos intentado abordar un asunto complejo y delicado para el que no existen soluciones sencillas. Sin embargo, nuestro esfuerzo es noble y justo, porque el objetivo de proteger al trabajador en su lugar de trabajo también lo es. No podemos abordar esta tarea por nuestra cuenta, ni de forma aislada, porque los problemas que nos ocupan no están aislados. Nos necesitamos unos a otros para controlar los instintos naturales que nos llevan a buscar el beneficio y la gloria personal y para descubrir los sesgos que incorporamos a nuestros estudios. U n esfuerzo así nos permitirá contribuir a los conocimientos y al bienestar de la humanidad.

\section{- ASPECTOS ETICOS DE LA INVESTIGACION SOBRE LA SALUD Y LA SEGURIDAD EN EL TRABAJO}

Paul W. Brandt-Rauf y Sherry I. Brandt-Rauf

En los últimos decenios, se ha realizado un gran esfuerzo por definir y abordar los problemas éticos que se plantean en el contexto de la experimentación biomédica. Los principales problemas éticos que se han identificado en ese tipo de investigaciones se refieren a la relación entre riesgo y beneficio y al consentimiento previo voluntario e informado de los participantes del estudio. En general, se ha recurrido a un organismo independiente, como un Consejo Institucional de Revisión, para asegurar que estos problemas reciban la debida atención mediante una revisión de los protocolos de los estudios. En Estados U nidos, por ejemplo, las instituciones que realizan investigaciones biomédicas y que reciben fondos del Servicio de Salud Pública están obligadas a seguir estrictamente las directrices del gobierno federal, entre ellas el requisito de que un Consejo Institucional de Revisión revise todos los protocolos de investigación, analice los riesgos y beneficios y se ocupe de obtener el consentimiento informado de los participantes del estudio. En gran medida, este modelo ha llegado a aplicarse a las investigaciones científicas con seres humanos que se realizan en las sociedades democráticas de todo el mundo (Brieger y cols. 1978).

Aunque las limitaciones de este enfoque han sido objeto de debate - por ejemplo, en un reciente H uman R esearch Report, M aloney (1994) afirma que algunos comités institucionales de revisión no actúan correctamente en cuanto al consentimiento informado-, son muchos los que se muestran partidarios de su aplicación en los protocolos formales de investigación con seres humanos. Sin embargo, las deficiencias del planteamiento se manifiestan cuando no existen protocolos formales o cuando los estudios presentan un parecido superficial con la experimentación humana, pero no están dentro de los límites de la investigación académica. El lugar de trabajo es un ejemplo evidente de este tipo de situación. Naturalmente, han existido protocolos formales de investigación sobre trabajadores que satisfacen los requisitos del análisis de riesgos y beneficios y del consentimiento informado. No obstante, cuando las fronteras de la investigación formal se confunden con observaciones menos formales sobre la salud de los trabajadores y con la conducta cotidiana de las empresas, es fácil que las consideraciones éticas relacionadas con el análisis de riesgos y beneficios y el consentimiento queden relegadas a un segundo plano.
Pongamos como ejemplo el "estudio" de la empresa Dan R iver sobre la exposición de los trabajadores al polvo de algodón en su fábrica de Danville, Virginia. Cuando entró en vigor la norma sobre el polvo de algodón de la Administración para la Salud y la Seguridad en el Trabajo de Estados U nidos (O ccupational Safety and $\mathrm{H}$ ealth Administration, OSHA) después de la investigación realizada por el Tribunal Supremo en 1981, D an R iver solicitó al estado de Virginia que le eximiera de aplicar dicha norma hasta que la empresa hubiera realizado un estudio. El propósito de dicho estudio era demostrar la hipótesis de que la bisinosis estaba causada por unos microorganismos que contaminaban el algodón y no por la exposición al polvo de algodón en sí misma. Doscientos trabajadores de la fábrica de Danville se verían expuestos a diferentes concentraciones de microorganismos y a unos niveles de polvo de algodón que superaban los límites establecidos por la norma. La empresa Dan R iver solicitó a la O SH A que financiara su proyecto (técnicamente considerado como una desviación de la norma y no como una investigación en seres humanos), pero el proyecto nunca llegó a someterse a una revisión formal en función de consideraciones éticas, ya que la OSH A carecía de un comité institucional de revisión. La revisión técnica realizada por un toxicólogo de la O SH A planteó serias dudas sobre el valor científico del proyecto, lo que ya de por sí planteaba problemas éticos, ya que la exposición de los trabajadores a riesgos en un estudio defectuoso es inaceptable. Sin embargo, aunque el estudio hubiera sido técnicamente válido, probablemente no habría sido aprobado por ningún comité institucional de revisión, puesto que "vulneraba todos los criterios básicos para la protección del bienestar de los participantes" (Levine 1984). Era evidente que los participantes del estudio, en este caso los trabajadores, se verían expuestos a riesgos sin obtener ningún beneficio a cambio, ya que el principal beneficio habría correspondido a la empresa, mientras que el beneficio para la sociedad en su conjunto resultaba vago y dudoso. Por lo tanto, se incumplía el requisito de un equilibrio entre riesgos y beneficios. EI sindicato local fue informado sobre el estudio y no protestó, lo que podría interpretarse como consentimiento tácito. No obstante, aunque hubiera dado su consentimiento, éste nunca habría sido voluntario, debido a la relación desigual y fundamentalmente coactiva que siempre existe entre una empresa y sus trabajadores. Al ser Dan River una de las empresas con mayor número de trabajadores de la zona, el delegado sindical reconoció que los trabajadores no habían protestado por miedo a que se cerrase la fábrica y perdieran su puesto de trabajo. Por consiguiente, también se vulneró el requisito del consentimiento voluntario.

A fortunadamente, el estudio propuesto por Dan River fue rechazado. Sin embargo, las cuestiones que planteó este estudio siguen vigentes y van mucho más allá de los límites de la investigación formal. ¿Cómo podemos lograr un equilibrio entre beneficios y riesgos a medida que ampliamos nuestros conocimientos sobre los peligros para la salud de los trabajadores? ¿Cómo podemos garantizar un consentimiento voluntario e informado en este contexto? En la medida en que el lugar de trabajo puede ser objeto de un experimento humano informal y no controlado, ¿cómo se pueden abordar estas cuestiones éticas? Se ha apuntado muchas veces que los trabajadores podrían ser utilizados como "conejillos de indias" para el resto de la sociedad. En un día normal, en algunos lugares de trabajo, los trabajadores pueden estar expuestos a sustancias potencialmente tóxicas. La sociedad sólo inicia una investigación sobre la toxicidad de una sustancia cuando ya se han manifestado sus efectos negativos, lo que significa, de hecho, que utilizamos antes a los trabajadores como "sujetos experimentales" para determinar el efecto de sustancias químicas antes desconocido en el ser humano. 
A lgunos comentaristas han sugerido que la estructura económica del empleo ya tiene en cuenta algunas consideraciones relacionadas con el equilibrio entre riesgos y beneficios y con el consentimiento. En cuanto al equilibrio entre riesgos y beneficios, se podría decir que la sociedad compensa el trabajo peligroso con una "prima por riesgo" que aumenta directamente la retribución de los trabajadores que asumen el riesgo. Además, en la medida en que los riesgos son conocidos, los mecanismos del derecho a información permiten el consentimiento informado del trabajador. Cuando el trabajador conoce los beneficios que puede esperar y los riesgos que debe asumir, puede decidir "voluntariamente" si asume o no esos riesgos. Sin embargo, la capacidad de actuar voluntariamente requiere algo más que información y la posibilidad de pronunciar la palabra no. También requiere la ausencia de coacciones e influencias indebidas. En efecto, un consejo institucional de revisión observaría con escepticismo un estudio en el que los participantes recibieran una compensación económica significativa como "prima por riesgo". La preocupación del comité estaría motivada por el hecho de que los incentivos económicos reducen al mínimo la posibilidad de que el consentimiento sea realmente voluntario. Como en el caso de la empresa Dan River y como declaró la $O$ ffice of Technology Assessment de Estados U nidos:

(...) estos incentivos pueden plantear problemas especialmente en el lugar de trabajo, si los trabajadores piensan que la seguridad de su empleo o sus posibilidades de promoción se verán afectadas por su decisión de participar o no en una investigación (O ffice of Technology A ssessment 1983).

En un caso así, ¿no podría el trabajador simplemente escoger un trabajo menos peligroso? Se ha dicho que una de las principales características de una sociedad democrática es el derecho de la persona a elegir su trabajo. Pero también se ha dicho que esta libre elección puede ser una mera ficción, ya que todas las sociedades, democráticas o no:

(...) disponen de mecanismos de ingeniería social para encontrar trabajadores que ocupen los puestos de trabajo libres. Los regímenes totalitarios lo consiguen a la fuerza; las sociedades democráticas, a través de un proceso hegemónico llamado libertad de elección (G raebner 1984).

Por eso, es poco probable que muchas de las situaciones que se dan en el lugar de trabajo cumplieran los requisitos de un comité institucional de revisión. Puesto que nuestra sociedad ha decidido aparentemente que todos aquellos que contribuyen al progreso biomédico, como los que participan en las investigaciones humanas, merecen un alto nivel de protección y un profundo control de los aspectos éticos, habrá que meditar mucho antes de privar de este mismo nivel de protección a los que favorecen nuestro progreso económico: los trabajadores.

$\mathrm{H}$ ay quien dice también que, considerando que el lugar de trabajo puede ser objeto de un experimento humano no controlado, todas las partes implicadas, y los trabajadores en particular, deberían comprometerse a estudiar sistemáticamente estos problemas e intentar resolverlos. ¿Tenemos la obligación de ampliar nuestros conocimientos sobre los peligros en el trabajo mediante investigaciones formales e informales? Evidentemente, sin este tipo de investigación, el derecho de los trabajadores a la información no tiene sentido. La afirmación de que los trabajadores tienen la obligación de aceptar la exposición es más problemática porque parece violar el principio ético de que las personas no deben usarse como instrumento para que otros se beneficien. Por ejemplo, excepto cuando el riesgo sea muy pequeño, un comité de revisión institucional no tendrá probablemente en cuenta el beneficio que pueda obtener un tercero a la hora de evaluar el riesgo para los sujetos de la investigación.
Sin embargo, las demandas de reciprocidad, es decir, los beneficios que pueden obtener todos los trabajadores afectados, han impuesto a los trabajadores la obligación moral de participar en las investigaciones. Por ello se ha sugerido "la necesidad de crear un contexto para la investigación en el que los trabajadores - por su sentido de obligación recíproca- actuarán de manera consecuente con la obligación moral de colaborar en un trabajo cuyo objetivo es reducir la carga de morbilidad y mortalidad"(M urray y Bayer 1984).

Independientemente de que se acepte 0 no la idea de que la participación de los trabajadores debe ser voluntaria, la creación de un entorno adecuado para la investigación en el terreno de la salud en el trabajo exige que se preste particular atención a otros problemas que preocupan a los trabajadores participantes en una investigación. U no de ellos es el posible uso indebido de los datos en perjuicio de trabajadores concretos, por ejemplo, a través de la discriminación en el empleo o en la contratación de una póliza de seguro. Por lo tanto, para que la autonomía, la justicia y la intimidad de los trabajadores que participan en una investigación se respeten como es debido, la confidencialidad de los datos debe recibir la máxima atención. Otro problema es hasta qué punto se debe informar a los trabajadores de los resultados de una investigación en la que han participado. En situaciones normales de experimentación, los participantes siempre son informados de los resultados. Sin embargo, muchos estudios que se realizan en el lugar de trabajo son de naturaleza epidemiológica, por ejemplo, los estudios retrospectivos de cohortes, que nunca han necesitado el consentimiento informado de los participantes o la notificación de los resultados. No obstante, si existe la posibilidad de una intervención eficaz, informar a los trabajadores con un elevado riesgo de enfermedad por exposiciones profesionales en el pasado podría ser importante para la prevención. Si no existe esa posibilidad, ¿se debe informar a los trabajadores de los resultados? ¿Se les debe informar si no existen implicaciones clínicas conocidas? La necesidad y los aspectos prácticos de la notificación y la vigilancia siguen siendo cuestiones importantes que todavía no han encontrado una respuesta en las investigaciones de la salud en el trabajo (Fayerweather, H igginson y Beauchamp 1991).

En razón de la complejidad de todas estas consideraciones éticas, el papel del profesional de la salud en el trabajo adquiere una gran importancia en la investigación del lugar de trabajo. EI médico de empresa tiene en el lugar de trabajo las mismas obligaciones que cualquier otro profesional de la asistencia sanitaria, según establece la Comisión Internacional de M edicina del Trabajo:

Los profesionales de la salud en el trabajo deben proteger la salud y el bienestar de los trabajadores, tanto individual como colectivamente. Las obligaciones de los profesionales de la salud en el trabajo incluyen la protección de la vida y la salud de los trabajadores, el respeto a la dignidad humana y la promoción de los principios éticos más elevados en los programas y las políticas de salud en el trabajo.

Por otra parte, la participación del médico de empresa en las investigaciones se considera una obligación moral. Por ejemplo, el código deontológico del American College of O ccupational and Environment M edicine especifica que: "Ios médicos deben participar en las investigaciones éticas en la medida en que sea adecuado" (1994). Sin embargo, al igual que otros profesionales sanitarios, el médico de empresa actúa como un "agente doble" que debe asumir responsabilidades potencialmente conflictivas por el hecho de prestar asistencia a los trabajadores y trabajar él mismo para la empresa. Este problema del "agente doble" no es desconocido para el profesional de la salud en el trabajo, ya que el ejercicio de su profesión les exige con frecuencia dividir sus 
lealtades, responsabilidades y obligaciones entre los trabajadores, las empresas y otras partes afectadas. No obstante, los profesionales de la salud en el trabajo deben prestar una atención especial a estos posibles conflictos porque, como ya se ha dicho antes, no existe un mecanismo de revisión formal independiente 0 un comité institucional de revisión para proteger a los trabajadores de las exposiciones en el lugar de trabajo. Por lo tanto, el profesional de la salud en el trabajo será en gran medida el responsable de asegurar que las consideraciones éticas, entre ellas el equilibrio entre riesgo y beneficio y el consentimiento voluntario informado, reciban una atención adecuada.

\section{- La etica en el lugar de trabajo: MARCO PARA EL JUICIO MORAL}

Sheldon W. Samuels

\section{El marco}

Desde el punto de vista ético, no puede existir ningún diálogo serio sobre cuestiones morales sin establecer el marco de las herramientas - supuestos- para la toma de decisiones críticas de los participantes. Diferentes herramientas tienen como resultado diferentes decisiones.

Los supuestos críticos más importantes en cuanto a las relaciones laborales son aquellos que sirven de base para asignar obligaciones 0 deberes ante las distintas alternativas, a menudo en conflicto, para proteger los "derechos" de los trabajadores y de las empresas.

¿Cómo decidimos atender las necesidades diferentes, y a menudo contrapuestas de los colectivos naturales (como el individuo, la familia, el entorno sociocultural, la comunidad) y los artificiales (partidos políticos, sindicatos, empresas, nación), que pueden contener muchos colectivos naturales diversos?

¿Cómo decidimos quién tiene la responsabilidad de prestar asistencia sanitaria a las familias o crear herramientas "seguras" para diseñar un puesto de trabajo? ¿Cómo establecemos el nivel de riesgo al que puede exponerse una persona?

¿Cómo asignamos la responsabilidad moral y distribuimos la carga de riesgo?

\section{La "escala de justicia social"}

Para asignar responsabilidades, podemos utilizar una "escala de justicia social". Según esta escala, los más capacitados para actuar están obligados por lógica a asumir el mayor nivel de responsabilidad y a ser los primeros en actuar para conseguir un objetivo moral. Están obligados a actuar antes que otros porque son los únicos o los que están más capacitados para actuar. Esto no significa que sólo ellos deban actuar. Cuando los que tienen obligaciones especiales no actúan, o necesitan ayuda, la obligación recae en los que ocupan el siguiente peldaño.

Entendemos que acción racional no es únicamente la que sigue lógicamente a otra, sino también las acciones que se realizan para evitar el dolor, la discapacidad, la muerte y la disminución del placer (G ert 1993).

La Ley de salud y seguridad en el trabajo aprobada en Estados U nidos en 1970 es un ejemplo de la aplicación de la escala de justicia social. Según esta ley "las empresas y los trabajadores tienen derechos y obligaciones diferentes pero dependientes en lo que respecta al logro de unas condiciones de trabajo seguras y saludables".

Un trabajador tiene $\mathrm{d}$ deber de cumplir las normas únicamente "aplicables a sus acciones y a su conducta". La empresa tiene deberes que se basan en su capacidad única de velar por el cumplimiento de las normas aplicables al lugar de trabajo en su conjunto. EI gobierno tiene un deber diferente, que se basa en su capacidad exclusiva para, por ejemplo, imponer normas cuando la persuasión fracasa.

Existen otros supuestos que configuran el marco común de cualquier sistema de valores éticos en cualquier cultura. En nuestro caso, debemos hacer hincapié en los supuestos relacionados con la naturaleza de nuestra sociedad, el significado de "derechos", el método de los axiomas morales, la verdad o el bien, la asignación de riesgos, los ideales y la realidad, así como la necesidad ética de que los trabajadores participen.

Desde una perspectiva ecológica, los seres humanos existen como una comunidad global. En nuestro entorno, los colectivos naturales (como familias o entorno sociocultural) son más importantes que los colectivos artificiales (como empresas o partidos políticos). En esta comunidad, compartimos las obligaciones necesarias para proteger y ayudar a todo el mundo a actuar de forma racional de acuerdo con sus derechos, en la misma medida en que debemos proteger nuestro propios derechos, independientemente de las costumbres y los valores culturales. Estas obligaciones, cuando tienen como resultado la protección de los trabajadores por encima de las fronteras nacionales, no constituyen una imposición de los valores establecidos por una nación sobre otro colectivo artificial de personas, sino que reflejan el reconocimiento formal de unos valores morales naturales, eternos y universales.

L os derechos humanos fundamentales, los derechos genéricos a la libertad y a la vida (o al bienestar), se derivan de unas necesidades que, cuando se ven satisfechas, nos permiten vivir como seres humanos (Gerwirth 1986). No han sido impuestos por ningún gobierno ni empresa. Siempre los hemos tenido, por lógica y filogenética. Las leyes que regulan el medio ambiente de trabajo y las normas consecuentes con los derechos que intentan proteger no son actos benévolos, sino expresiones de moral.

Los derechos fundamentales, tales como el derecho a la intimidad y el "derecho" a saber y a actuar para evitar riesgos en el trabajo, aunque se expresen de forma diferente en distintas culturas, son básicamente los mismos en todos los países.

Si nos guiamos por las declaraciones de nuestros derechos, podemos encontrar conflictos entre los derechos que protegen al individuo, como el derecho a la confidencialidad de las historias clínicas, y los que hacen referencia a los deberes de la empresa, como el deber de obtener información de las historias médicas para proteger otras vidas mediante la identificación y eliminación de peligros para la salud.

Estos conflictos pueden resolverse, no encomendándose a la capacidad de un médico en solitario o de una asociación profesional para enfrentarse a problemas con los tribunales o las empresas, sino seleccionando axiomas de conducta moral que sean racionales para todo el mundo colectivamente en el lugar de trabajo. Por consiguiente, los conflictos podrían resolverse con medidas de carácter global, como sería la decisión de que una entidad "neutral" con representantes de los trabajadores y de la empresa y supervisada por el gobierno se hiciera cargo de las historias clínicas individuales (como la Berufgenossenschaften en Alemania).

U n supuesto crítico que constituye el fundamento de este marco de juicio moral es la creencia de que sólo existe un mundo real y que los derechos genéricos se aplican a todo el mundo, no como ideales a los que aspiramos, sino como condiciones genéricas de la existencia misma. Si no pueden aplicarse, es porque no hemos aprendido a enfrentarnos al hecho de que nuestro conocimiento de ese mundo y de la forma más racional de comportarnos en él nunca es perfecto. D eberíamos aprender a utilizar los postulados y axiomas, no sólo en el campo de la 
ética, sino también para describir el mundo y guiar nuestra conducta en ausencia de un conocimiento perfecto.

La naturaleza de los axiomas morales se ilumina con la observación de Bertrand Russell de que "toda la conducta racional de la vida se basa en el método del frívolo juego histórico en el que discutimos cómo sería el mundo si la nariz de Cleopatra hubiera sido medio centímetro más larga" (Russell 1903).

El juego del "como si" nos permite actuar frente a la eterna incertidumbre moral y científica. Ahora bien, los axiomas no deben confundirse con la "verdad definitiva" (Woodger 1937). Se mantienen y utilizan sólo si sirven para aplicar los principios básicos de la ética. Cuando dejan de ser útiles, se abandonan y sustituyen por otro conjunto de convenciones.

Los axiomas morales trasladan el marco del juicio moral al nivel de la práctica, al "taller". Un ejemplo es la práctica habitual de desarrollar códigos deontológicos para médicos de empresa y otros profesionales. Estos códigos se elaboran para proteger derechos genéricos y sus especificaciones, salvando las lagunas en los conocimientos, a fin de organizar la experiencia y permitirnos actuar por delante del conocimiento moral o científicamente certero.

Como todos los axiomas, éstos no son ni correctos ni incorrectos, ni verdaderos ni falsos. M uchas veces nos comportamos como si fueran verdaderos o correctos (de hecho podrían serlo) y los mantenemos sólo mientras que nos ayudan a actuar de forma racional. Su utilidad varía con el tiempo y según la cultura porque, al contrario que los principios éticos genéricos, las normas culturales reflejan valores relativos.

En las culturas orientales, existen importantes sanciones sociales y legales para los que incumplen las conductas profesionales, que se basan en la creencia budista de que existen ocho caminos para la rectitud, el quinto de los cuales es ganarse la vida honradamente, 0 en las tradiciones confucianas de la responsabilidad profesional. En estos contextos, los códigos deontológicos profesionales pueden ser una potente herramienta para la protección del paciente o los participantes de una investigación, así como para los médicos o científicos.

En las culturas occidentales, al menos por el momento y a pesar de la fuerte tradición hipocrática en la medicina, los códigos son menos eficaces aunque todavía conservan un valor limitado. Esto no sólo se debe a que las sanciones legales y sociales son menores, sino también a que algunos supuestos no encajan con la realidad actual de las culturas occidentales.

Es evidente, por ejemplo, que la incorporación a los códigos deontológicos de la doctrina generalizada - un axioma - que requiere el consentimiento "informado" y "voluntario" previo a cualquier procedimiento que pueda invadir la intimidad (como las pruebas genéticas) es irracional. El consentimiento pocas veces es realmente voluntario o informado. La información transmitida rara vez es exacta o completa (ni siquiera en la mente del científico o el médico). El consentimiento suele obtenerse bajo coacción social (o económica). El investigador no siempre cumple sus promesas de proteger la intimidad y la confidencialidad. El profesional puede estar social y jurídicamente protegido por los códigos que incorporan esta doctrina, pero el trabajador se convierte con facilidad en la víctima de un cruel engaño que tiene como resultado el estigma social y dificultades económicas originadas por su discriminación en el trabajo y en la contratación de pólizas de seguro.

Por consiguiente, la incorporación de la doctrina del consentimiento a los códigos de conducta profesional, así como para la protección del trabajador contra los peligros de las pruebas genéticas, no es ética porque se crea una fachada que no encaja en el contexto moderno de una cultura occidentalizada y universal gracias a los bancos de datos internacionales conectados a través del teléfono y el ordenador. Esta práctica debe ser abandonada y sustituida por códigos basados en unos supuestos que encajen con el mundo real, junto con protecciones que puedan ser social y legalmente aplicadas.

\section{Asignación del riesgo}

Es irracional (y, por consiguiente, inmoral) distribuir o asignar los riesgos por categorías, es decir, asignar distintos niveles de riesgo a diferentes grupos de personas según su genotipo, edad, situación socioeconómica, situación geográfica dentro de la comunidad, pertenencia étnica o profesión. La asignación del riesgo por categorías supone que existen seres humanos cuyos derechos fundamentales son diferentes a los de los demás. $L$ as necesidades básicas del ser humano son iguales; por lo tanto, los derechos fundamentales son también iguales para todos.

El concepto de "riesgo aceptable," que se utiliza con frecuencia, cuando no universalmente, para establecer las normas, es una forma de asignación del riesgo por categorías. D epende de la asignación de un diferencial de riesgo que se basa en el cálculo de los riesgos profesionales en el pasado o la exposición actual a sustancias tóxicas o peligros en el lugar de trabajo. Esta práctica común acepta y fomenta los riesgos innecesarios, asignando de forma arbitraria, por ejemplo, un riesgo relativo "aceptable" de una muerte por cada mil personas a la hora de establecer un límite de exposición permisible para los trabajadores, frente a una muerte por un millón de personas para otros miembros de la misma comunidad.

O tros ejemplos de asignación irracional (inmoral) del riesgo son la aceptación de diferenciales de riesgo dentro de una misma categoría, como sería entre los adultos y los niños más vulnerables (estableciendo una única norma para ambos cuando los niños necesitan una mayor protección), entre el medio ambiente de trabajo y la comunidad, entre los trabajadores de "fuera" (u otros con menor influencia) y los trabajadores nativos, así como los riesgos (mayores de los que hemos establecidos para nosotros mismos) impuestos a los trabajadores menos protegidos de los países en desarrollo por la gran demanda de sus productos en los mercados de los países desarrollados.

Los riesgos innecesarios no son nunca aceptables desde un punto de vista moral. U n riesgo es éticamente "aceptable" sólo si es necesario para proteger la vida (o el bienestar) y la libertad, o 1) está culturalmente aceptado y es muy difícil de eliminar 0 controlar en un plazo corto de tiempo y 2) su control recibe una menor prioridad en un programa racional de protección que otro peligro de tipo biológico.

\section{Participación de los trabajadores}

Los derechos fundamentales a la vida y a la libertad exigen que los trabajadores estén facultados para actuar en defensa de esos derechos. Esto se consigue mediante el acceso a información, las oportunidades de educación para entender dicha información (y no simplemente reaccionar a ella) y la capacidad de actuar libremente y sin coacciones basándose en esos conocimientos para evitar o asumir riesgos.

Es posible que la educación que facilita esos conocimientos no se consiga con una clase típica de "formación en materia de seguridad", ya que la formación tiene como finalidad conseguir una reacción condicionada a una serie de señales o acontecimientos previsibles y no proporciona unos conocimientos profundos. Sin embargo, no todos los factores causales que provocan accidentes, entre ellos los acontecimientos que están bajo el control de los trabajadores o de los directivos, pueden preverse.

Los accidentes verdaderos se definen como "episodios fortuitos" (Webster's T hird International Dictionary 1986). Por 
tanto, no se producen de forma natural. Todos los acontecimientos tienen una causa (Planck 1933; Einstein 1949). El concepto de la casualidad es un axioma utilizado cuando no se conoce o comprende la causa, y no debe confundirse con la realidad invariable. $\mathrm{Ni}$ siquiera cuando una lesión o enfermedad está claramente relacionada con el trabajo se conocen 0 comprenden todos los factores causales de los acontecimientos dentro y fuera del lugar de trabajo (Susser 1973). Por consiguiente, aunque dispusiéramos de unos recursos ilimitados en términos de tiempo, dinero y formación, sería imposible formar a un trabajador para que supiera reaccionar a todas las posibles señales de todos los posibles acontecimientos.

Para reducir eficazmente el riesgo de "accidentes", el hecho de que el trabajador entienda un proceso químico o una práctica para la manipulación de un material le permite afrontar los acontecimientos imprevistos. La formación del trabajador y del colectivo natural al que pertenece, como la familia o el entorno sociocultural, amplía sus conocimientos y aumenta su capacidad de actuación para prevenir o reducir riesgos. Por lo tanto, forma parte de las especificaciones de sus derechos fundamentales.

Existe otro aspecto ético relacionado con el entorno natural del trabajador. La elección de un lugar adecuado para que el trabajador decida asumir o no un riesgo es un factor crucial para garantizar un resultado ético. M uchas decisiones (como la aceptación de una prima por riesgo), si han de ser verdaderamente "voluntarias", deben tomarse fuera de un entorno artificial como es el lugar de trabajo (o a veces el sindicato). La familia, el entorno sociocultural y otros entornos naturales pueden representar alternativas menos coactivas. Los incentivos económicos para la aceptación de un riesgo innecesario conocido para el trabajador, la empresa o el gobierno - incluso aunque sea el resultado de un contrato justamente negociadoson siempre inmorales. Sólo debe compensarse a la familia de un trabajador cuando el riesgo esté justificado y cuando el trabajador tenga acceso a otros puestos de trabajo similares sin ser objeto de un estigma. Para que esta elección sea ética, el entorno debe ser lo más neutral o menos coactivo posible.

Si no existe un entorno así, la decisión debe tomarse en el lugar más neutral posible asociado al colectivo artificial más neutral posible o a un organismo que pueda proteger la capacidad de decisión del trabajador o su entorno natural. La importancia para el bienestar de un trabajador de los valores culturales y éticos que prevalecen en su familia, su entorno sociocultural y la comunidad subraya la importancia de proteger su participación y educación como elementos éticos de su capacidad para tomar decisiones informadas.

\section{Confusión de los axiomas con la realidad en la comunicación}

La mayoría de nosotros, ya seamos médicos, científicos o ingenieros, hemos aprendido los métodos axiomáticos en la escuela primaria. De lo contrario, no podríamos entender ni aritmética ni geometría. Sin embargo, son muchos los que confunden conscientemente las hipótesis con los hechos (que pueden ser lo mismo, pero no lo son siempre) en un intento de imponer sus propios valores sociales en un curso específico de acción u omisión. Esto se hace evidente en la manera de presentar, seleccionar, organizar e interpretar la información.

El uso de palabras como accidentes y seguro son buenos ejemplos de ello. Hemos definido los accidentes como acontecimientos que no ocurren de forma natural. La seguridad es un concepto similar. La mayoría de las personas creen que esta palabra significa "libre de daños, lesiones o riesgos" (Webster's T hird International Dictionary 1986). Los riesgos siempre existen, aunque los expertos suelen hablar de "ausencia de riesgo" refiriéndose a un proceso o sustancia química para dar la impresión de que no existe riesgo, cuando en realidad están suponiendo o pensando en otro significado, como es su creencia de que el riesgo es relativamente bajo o "aceptable", del que no informan al público. Si se trata de un simple error inconsciente, se llama falacia semilógica. Si se trata de un error consciente, como ocurre demasiado a menudo, se trata simplemente de una mentira.

La confusión de los axiomas, los modelos científicos o la evaluación de datos con la realidad inmutable parece agravarse cuando se trata de establecer normas. Los conceptos y métodos axiomáticos utilizados para este fin, cuya validez se supone y confunde muchas veces con la realidad incontrovertible, son entre otros los siguientes:

- umbrales de efectos tóxicos en poblaciones (nunca se encuentran);

- niveles de efectos observados (dependen del método);

- factores de fiabilidad estadística (arbitrarios por definición);

- extrapolaciones exactas de riesgos (raramente coinciden con los datos);

- tolerancias a riesgo cero (existen sólo con exposición cero);

- márgenes de "seguridad" (siempre especulativos);

- viabilidad de los controles (depende de los valores);

- métodos de medición (elección de instrumentos);

- normas fisiológicas (abstracciones de las medias);

- variables de valoración biológicas (estimación de un efecto);

- homogeneidad de estilos de vida y genética (nunca existe).

Estos axiomas se debaten habitualmente como si fueran la verdad. No son más que hipótesis descartables sobre individuos, riesgos y su control, que se basan (en el mejor de los casos) en una información limitada.

L os valores sociales y económicos implícitos en la selección y el uso de estos axiomas guían los juicios políticos de los que gobiernan, gestionan y controlan. Estos valores, y no sólo los datos científicos, determinan las normas medioambientales y biológicas en la comunidad y en el lugar de trabajo. En consecuencia, estos valores, los juicios que se basan en ellos y los axiomas seleccionados también deben juzgarse por su racionalidad, es decir, por su éxito a la hora de evitar el riesgo de dolor, muerte y discapacidad.

\section{Leyes y contratos: sistemas de axiomas morales}

Incluso el más amplio sistema de axiomas morales debe entenderse como un experimento en la aplicación de principios morales al medio ambiente de trabajo, especialmente los sistemas de leyes y contratos que regulan el lugar de trabajo.

Las leyes del Estado, los reglamentos de sus ministerios e incluso los procedimientos adoptados informalmente (como los modelos de valoración del riesgo) pueden tratarse - y modificarse- como cualquier otro sistema de axiomas. Considerando nuestro marco de principios morales, tratados como axiomas morales, las leyes y normas sobre la seguridad y la salud en el trabajo pueden integrarse plenamente con los sistemas axiomáticos que atienden otras necesidades sanitarias de la comunidad. Pueden constituir una parte diferenciada (pero no degradada) del conjunto de la estructura social.

Los programas de asistencia médica, educación, rehabilitación e indemnización de los trabajadores, seguridad social, protección de los discapacitados y otros programas de salud pública y protección del medio ambiente suelen coordinarse mediante decisiones legislativas con los programas de seguridad y salud en el trabajo. En este proceso, deben tomarse precauciones para no imponer o crear y perpetuar sin pretenderlo un sistema de castas.

¿Cómo deben tomarse estas precauciones? La participación de los trabajadores, los representantes de los sindicatos libremente organizados en el lugar de trabajo y los organismos 
públicos constituye una garantía que debe formar parte del experimento. La participación es otra especificación de los derechos humanos. Las barreras eficaces contra la creación de sistemas de castas en el lugar de trabajo son los comités de trabajadores (garantizados en las constituciones de algunos países), los comités de empresa, los comités ministeriales responsables de la formulación de políticas y prácticas, y del establecimiento y la aplicación de normas, y la educación (tanto profesional como básica) y otras estructuras participativas.

El ejercicio de los "derechos" de participación de los trabajadores en la determinación de sus propios riesgos es un medio éticamente obligado de defensa contra la aparición de castas de trabajadores en función de su nivel de cualificación. Es el primer paso para la asignación ética de responsabilidades y la distribución de la carga de riesgo en el lugar de trabajo. Sin embargo, el ejercicio de estos derechos puede entrar en conflicto con los derechos de la dirección y de la sociedad en su conjunto.

La resolución del conflicto pasa por entender que estos derechos son especificaciones de derechos genéricos, cuyo imperativo es absoluto y que, en última instancia, deben prevalecer mediante el reconocimiento de los derechos de participación de los trabajadores, la dirección y el público en general en las decisiones que afectan a la vida y la libertad de la comunidad a la que pertenecen.

\section{- VigilanCIA DEL MEDIO AMBIENTE DE TRABAJO}

\section{Lawrence D. Kornreich}

Desde que Ramazzini publicó el texto básico sobre la salud en el trabajo (R amazzini 1713), hemos aprendido que algunos trabajos pueden causar enfermedades específicas. Al principio, sólo disponíamos de instrumentos de observación para estudiar el medio ambiente de trabajo. Los avances tecnológicos nos permitieron realizar mediciones en los entornos en los que los trabajadores ejercían sus oficios. D e esta manera pudimos, por ejemplo, identificar las fuentes del estrés en el lugar de trabajo. Sin embargo, este mayor conocimiento trajo consigo la necesidad de establecer límites de exposición para proteger la salud de los trabajadores. De hecho, hemos descubierto formas de detectar la presencia de sustancias tóxicas, incluso en concentraciones bajas, antes de que puedan crear problemas para la salud. En la actualidad, con frecuencia podemos predecir los resultados de las exposiciones sin esperar a que aparezcan sus efectos, lo que nos permite prevenir enfermedades y lesiones irreversibles. U n buen estado de salud en el trabajo no es algo que se consiga por casualidad, sino que requiere la vigilancia de los trabajadores y de su entorno.

\section{Límites de exposición en el lugar de trabajo}

Los primeros límites de exposición en el lugar de trabajo se establecieron para prevenir enfermedades graves y muertes. H oy en día, disponemos de mucha más información e intentamos respetar límites mucho más bajos para prevenir enfermedades crónicas y efectos subclínicos en la salud. EI intento sistemático que más éxito ha tenido para establecer límites de exposición profesional fue el realizado por el Comité de Límites U mbral creado por la Conferencia A mericana de Higienistas Industriales del Gobierno (American Conference of G overnmental Industrial H ygienists, ACGIH) en 1943. (La ACGIH es una organización estadounidense sin relación formal con ningún organismo normativo público). El éxito de este esfuerzo se demuestra por el hecho de que muchos países en todo el mundo han adoptado los valores límite umbral (TLV) publicados por la ACGIH, cuyo número asciende hoy a más de 600 , como normas sobre la exposición en el lugar de trabajo. El uso extendido de estos límites como normas aplicables ha motivado el estudio crítico de los TLV y del proceso a través del cual se han establecido. A pesar de su utilidad, Ios TLV han recibido críticas de tres sectores que intervienen en el proceso de toma de decisiones: el científico, el político y el ético. A continuación se resumen algunas de las críticas formuladas.

L os científicos han criticado el hecho de que los T LV basados en un volumen considerable de información no se diferencien de los T LV basados en muchos menos datos.

L os T LV nunca pretendieron ser niveles "seguros" de exposición para todos los trabajadores. EI Comité T LV reconoció que, debido a las variaciones biológicas entre los trabajadores y a otros factores que no podían estimarse, era imposible fijar límites que garantizasen la seguridad de todos los trabajadores en todos los entornos. La decisión de adoptar los T LV como normas de obligado cumplimiento plantea un problema político, porque no protegen a una parte de la población trabajadora. La única garantía total de protección es el nivel cero de exposición, pero la exposición cero y el riesgo cero no son alternativas que se den en la práctica.

M uchos de los datos que manejó el Comité T LV procedían de estudios realizados y financiados por la industria, que no se habían publicado. Las personas protegidas por estos límites sostienen que deberían tener acceso a los datos que han servido para establecer dichos límites. Son muchos los que opinan que el intento de la industria de restringir el acceso a estos datos, por la razón que sea, es una postura poco ética y que beneficia sólo a la industria.

Todavía hoy se siguen respetando los TLV como directrices sobre la exposición de los trabajadores al estrés ambiental, para que sean utilizados por profesionales que puedan interpretarlos correctamente.

\section{Límites de exposición en la comunidad}

Existe una relación entre las exposiciones en el trabajo y en el medio ambiente. Cualquier efecto perjudicial para la salud en los trabajadores es resultado de su exposición total a los contaminantes ambientales. La dosis total es importante a la hora de seleccionar unos límites de exposición adecuados. Esto ya se considera necesario en el caso de las sustancias tóxicas que se acumulan en el organismo, como son el plomo y las sustancias radioactivas.

Los actuales límites de exposición son diferentes para los trabajadores y para la comunidad, en parte porque las exposiciones de los trabajadores tienen carácter intermitente. L os T LV se establecieron para semanas laborales de cinco días y jornadas de ocho horas, la norma en Estados U nidos. L os T LV reflejan la actuación de los mecanismos de reparación del organismo humano. Sin embargo, muchos piensan que los límites de exposición en el trabajo y en la comunidad no deberían ser diferentes.

Cuando no se dispone de información específica sobre los efectos sinérgicos 0 antagonistas, los límites de exposición, tanto para los trabajadores como para la comunidad, reflejan sólo la adición de las interacciones de distintos contaminantes ambientales. A la hora de establecer los límites para una sustancia determinada, es imposible evaluar todas las posibles interacciones entre los contaminantes ambientales. En su lugar, podemos realizar los siguientes supuestos para simplificar el proceso: 1) la mezcla básica de sustancias químicas en nuestro medio ambiente no ha cambiado sustancialmente, y 2) la información epidemiológica y los criterios ambientales utilizados para establecer las normas reflejan nuestra exposición a esa mezcla de sustancias químicas. Si aceptamos estos supuestos, 
podemos pasar por alto las interacciones al fijar los límites de exposición en la comunidad a una sustancia en particular. Aunque sería útil aplicar el mismo razonamiento para establecer los límites de exposición en el lugar de trabajo, esta lógica es discutible, ya que la mezcla de sustancias en distintos lugares de trabajo no es uniforme, si se compara con la existente en nuestras comunidades.

U na parte del debate político se centra en si deben adoptarse normas internacionales de exposición. ¿D ebe un país establecer sus propias prioridades, reflejadas en sus límites de exposición, 0 deben adoptarse normas internacionales basadas en los mejores datos disponibles? M uchos gobiernos de países en desarrollo han adoptado la posición de que los países desarrollados deberían establecer límites de exposición ambiental más estrictos, ya que la contaminación procedente de la industria y la agricultura de estos países ha creado un medio ambiente menos saludable.

\section{Criterios de salud basados en el tipo de riesgo}

En la actualidad, los ensayos de toxicidad en animales sirven con frecuencia para establecer los límites de exposición en el hombre. L a tecnología avanzada que existe hoy en día nos brinda la posibilidad de determinar el grado y el tipo de toxicidad que sufrirá un organismo después de estar expuesto a una sustancia. Podemos medir la capacidad de una sustancia para producir cáncer, lesiones congénitas o incluso tumores benignos. También medimos el grado en que esa sustancia puede afectar a los sistemas somáticos. Muchos científicos suponen que existe un nivel seguro de exposición, habiéndose validado este supuesto mediante las observaciones de las primeras enfermedades que acosaron a la humanidad. Sin embargo, es posible que ese supuesto ya no esté justificado, especialmente en el caso del cáncer. Los expertos siguen sin ponerse de acuerdo sobre la existencia o ausencia de un efecto "nulo" o un nivel "seguro" de exposición.

C oexistimos con sustancias naturales cancerígenas en nuestro medio ambiente. Para poder enfrentarnos a ellas, debemos calcular el riesgo asociado a la exposición a estas sustancias y utilizar la mejor tecnología disponible para reducir el riesgo a un nivel aceptable. Creer que podemos conseguir un nivel cero de riesgo es una idea errónea que posiblemente nos llevaría por el camino equivocado. El elevado coste y la complejidad de los ensayos en animales nos obligan a utilizar modelos matemáticos para predecir los riesgos de exposición a pequeñas dosis de una sustancia. Lo más que podemos conseguir son predicciones estadísticamente fiables de lo que posiblemente son niveles seguros de exposición a factores de estrés ambiental, suponiendo un nivel de riesgo que la comunidad acepte.

\section{Control del medio ambiente de trabajo}

El control del medio ambiente de trabajo es la especialidad de los higienistas del trabajo (llamados higienistas industriales en Norteamérica). Estos profesionales practican la técnica y la ciencia de identificar, evaluar y controlar los factores de estrés profesional. Dominan las técnicas utilizadas para evaluar el medio ambiente en el que trabajan las personas. Al tener la obligación de proteger la salud y el bienestar de los trabajadores y de la comunidad, los higienistas industriales están muy interesados en las cuestiones éticas. Como resultado, las principales asociaciones de higienistas industriales de Estados U nidos han finalizado recientemente la revisión de su código deontológico, que fue redactado por primera vez en 1978 (véase el recuadro "Cánones de conducta ética y directrices para su interpretación").

\section{Problemas de confidencialidad}

Los datos obtenidos del control del medio ambiente de trabajo son cruciales para mejorar los límites de exposición, tanto para los trabajadores como para la comunidad. Si se pretende que los límites sean los más adecuados para equilibrar el riesgo, el coste y la viabilidad técnica, los profesionales responsables de establecer dichos límites deben tener acceso a todos los datos de la industria, los trabajadores y el gobierno. Este planteamiento consensuado está cada vez más aceptado en una serie de países y puede llegar a ser el procedimiento de elección para establecer las normas internacionales.

Por lo que se refiere a los secretos comerciales y a otras informaciones de carácter confidencial, el nuevo código deontológico contiene directrices al respecto para los higienistas industriales. Como profesionales, están obligados a asegurar que todas las partes que necesitan información sobre los riesgos para la salud y las exposiciones tengan acceso a ella. Sin embargo, los higienistas deben mantener en secreto la información comercial más importante, salvo cuando por cuestiones de salud y seguridad se vean obligados a revelarla.

\section{ASPECTOSETICOS DE LA INFORMACION Y LA CONFIDENCIALIDAD}

Peter J. M. Westerholm

Este artículo trata sobre los aspectos éticos de las actividades relacionadas con la salud en el trabajo, entre ellas la investigación, con respecto al tratamiento de la información de trabajadores individuales, no tanto en términos prácticos o de eficacia, sino por referencia a lo que puede considerarse correcto o incorrecto. Aquí no se ofrece una fórmula universal para decidir si las prácticas relacionadas con el tratamiento de la información o las cuestiones de confidencialidad pueden ser éticamente justificadas 0 defendidas. En este artículo se describen los principios éticos básicos de autonomía, beneficencia, ausencia de maleficencia y equidad, así como sus implicaciones para estos aspectos de los derechos humanos.

Los principios básicos utilizados en los análisis éticos pueden aplicarse también al análisis de las implicaciones éticas en la producción, la comunicación y la utilización de otro tipo de información como, por ejemplo, los resultados de las investigaciones sobre la salud en el trabajo. Puesto que este artículo sólo pretende ser un resumen, no se describirán con detalle aplicaciones específicas.

\section{Escenario}

En el mercado de trabajo, en una empresa o en un lugar de trabajo, las cuestiones relacionadas con la salud afectan fundamentalmente a personas independientes y económicamente activas. Pueden ser personas sanas o personas con problemas de salud, cuyas causas, manifestaciones y consecuencias estén en mayor o menor medida relacionadas con su trabajo y con las condiciones del lugar de trabajo. Además, una amplia gama de profesionales y personas con distintas funciones y responsabilidades pueden verse implicadas en problemas de salud que afecten a individuos o grupos en el lugar de trabajo, como por ejemplo:

- empresas y sus representantes;

- sindicatos y sus representantes;

- profesionales sanitarios;

- administradores de seguros y seguridad social;

- investigadores;

- representantes de los medios de comunicación. 


\section{CANONES DE CONDUCTA ETICA Y DIRECTRICES PARA SU INTERPRETACION}

\section{OBJETVO}

Estos cánones establecen las normas de conducta ética que deben aplicar los higienistas industriales en el ejercicio de su profesión y de su principal misión: proteger la salud y el bienestar de los trabajadores y de la sociedad en general contra los peligros químicos, microbiológicos y físicos para la salud presentes u originados en el lugar de trabajo.

\section{CANONES DE CONDUCTA ETICA}

El higienista industrial debe

- Ejercer su profesión de acuerdo con los principios científicos establecidos, sabiendo que la vida, la salud y el bienestar de las personas pueden depender de su juicio profesional y que está obligado a proteger la salud y el bienestar de las personas.

- Asesorara las partes afectadas con respecto a los riesgos potenciales para la salud y las precauciones que deben adoptarse para evitar efectos nocivos en la salud.

- Mantener la confidencialidad de la información personal y empresarial que obtenga durante el desarrollo de las actividades de higiene industrial, excepto cuando la ley u otras consideraciones sobre la salud y la seguridad dicten lo contrario.

- Evitar circunstancias en las que pueda verse comprometido su juicio profesional o puedan surgir conflictos de intereses.

- Prestar servicios exclusivamente en su ámbito de competencia.

- Actuar de manera responsable para contribuir a la integridad de la profesión.

\section{CANON 1}

Ejercer su profesión de acuerdo con los principios científicos establecidos, sabiendo que la vida, la salud y el bienestar de las personas pueden depender de su juicio profesional y que está obligado a proteger la salud y el bienestar de las personas.

\section{DIRECTRICES PARA SU INTERPRETACION}

- El higienista industrial debe basar sus opiniones, juicios e interpretaciones profesiona les de resultados y recomenda ciones en principios y prácticas científicos reconocidos que preserven y protejan la salud y el bienestar de las personas.

- El higienista industrial no debe distorsionar, alterar u ocultar hechos cuando presente sus opiniones o recomendaciones profesionales.

- El higienista industrial no debe realizar declaraciones a sabiendas de que está tergiversando u omitiendo hechos.

\section{CANON 2}

Asesorar a las partes afectadas con respecto a los riesgos potenciales para la salud y las precauciones que deben adoptarse para evitar efectos nocivos en la salud.

\section{DIRECTRICES PARA SU INTERPRETACION}

- El higienista industrial debe obtener de fuentes fiables la información sobre los riesgos potenciales para la salud.

- El higienista industrial debe a na lizar la informa ción pertinente y disponible para informar de los hechos a las partes afectadas.

- El higienista industrial debe adoptar las medidas oportunas para comprobar que las partes a fectadas son informadas de los riesgos para la salud.

- Las partes a fectadas pueden ser la dirección, los clientes, los trabajadores, los trabajadores de un contratista y otras partes dependiendo de las circunstancias en ese momento.

\section{CANON 3}

Mantener la confidencialidad de la información personal y empresarial que obtenga durante el desarrollo de las actividades de higiene industrial, excepto cuando la ley u otras consideraciones sobre la salud y la seguridad dicten lo contrario.

\section{DIRECTRICES PARA SU INTERPRETACION}

- El higienista industrial debe notifica ry divulgar la información que sea necesaria para proteger la salud y la seguridad de los trabajadores y de la sociedad en general.
- Si se hace caso omiso de su juicio profesional en circunstancias en las que la salud o la vida de las personas pueden verse en peligro, el higienista industrial debe informar a la empresa, al cliente 0 a cualquier otra autoridad, según considere oportuno.

- El higienista industrial debe revelar información personal o empresarial de carácter confidencial sólo con la expresa autorización del propietario de la información, excepto cuando esté obligado por ley a desvelar esa información.

\section{CANON 4}

Evitar circunstancias en las que pueda verse comprometido su juicio profesional o puedan surgir conflictos de intereses.

\section{DIRECTRICES PARA SU INTERPRETACION}

- El higienista industrial debe informar puntualmente de cualquier conflicto de intereses potencial o conocido a las partes que pueden verse afectadas.

- El higienista industrial no debe solicitar ni aceptar, directa o indirectamente, retribuciones monetarias o de otra índole que tengan como finalidad influir en su juicio profesional.

- El higienista industrial no debe ofrecer ningún regalo de valor considerable ni ninguna otra retribución de valor para conseguir ese trabajo.

- El higienista industrial debe asesorar a sus clientes o empresas cuando crea inicialmente que un proyecto para mejorar las condiciones de higiene industrial no tendrá éxito.

- El higienista industrial no debe aceptar trabajos que limiten su capacidad para cumplir con otros compromisos que ya haya aceptado.

- En el caso de que este código deontológico esté aparentemente en conflicto con otro código profesional que los higienistas industriales están obligados a acatar, el conflicto se resolverá de una manera que proteja la salud de las partes afectadas.

\section{CANON 5}

Prestar servicios exclusivamente en su ámbito de competencia.

\section{DIRECTRICES PARA SU INTERPRETACION}

- El higienista industrial debe ofrecer sólo aquellos servicios para los que esté cualificado por su educación, formación o experiencia en los campos técnicos implicados, salvo que reciba suficiente asistencia de socios, consultores o trabajadores cualificados.

- El higienista industrial debe obtener los certifica dos, los registros y/ o las licencias que exijan las administra ciones públicas antes de prestar servicios de higiene industrial, cuando este tipo de credenciales sean necesarias.

- El higienista industrial debe imprimir o autorizar el uso de su sello, tampón o firma cuando el documento sea preparado por él mismo 0 por otra persona bajo su dirección y control.

\section{CANON 6}

Actuar de manera responsable para contribuir a la integridad de la profesión.

\section{DIRECTRICES PARA SU INTERPRETACION}

- El higienista industrial debe evitar conductas o prácticas que probablemente desacreditarán la profesión o decepcionarán al público.

- El higienista industrial no debe permitir el uso de su nombre o el de su empresa por parte de ninguna persona o empresa cuando tenga razones para sospechar que sus prácticas de higiene industrial son fraudulentas o deshonestas.

- El higienista industrial no debe hacer publicidad de sus conocimientos de experto o de sus servicios con declaraciones que tergiversen los hechos ni omisión de la información necesaria para evitar que dichas declaraciones se interpreten de manera incorrecta.

- El higienista industrial no debe permitir deliberadamente que las personas que trabajan para él, la sempresas para las que él trabaja y otras personas presenten su experiencia profesional, sus conocimientos de experto 0 sus servicios de una manera que resulte engañosa.

- El higienista industrial no debe engañar en lo que se refiere a su formación académica, su experiencia o sus credenciales.

Facilitado por el American Board of Industrial Hygiene (1995). 
La información que se obtiene de la práctica o la ciencia de la medicina del trabajo y las cuestiones relacionadas con el derecho a la información afectan a todos estos grupos y a la relación que mantienen entre sí. Esto significa que las cuestiones del libre acceso o la confidencialidad de la información con respecto a los derechos humanos, los derechos de los trabajadores y las necesidades de las empresas 0 de la sociedad en general, tienen un gran alcance y pueden presentar también una gran complejidad. De hecho se trata de un área de importancia decisiva en la ética de la medicina del trabajo.

\section{Consideraciones básicas}

Este artículo parte del supuesto de que las personas tienen la necesidad y el derecho prima facie a la intimidad, lo que significa que tienen la necesidad y el derecho de ocultar o revelar, de conocer o ignorar distintos aspectos de la vida en sociedad y de su relación con el mundo exterior. De igual forma, un colectivo o una sociedad necesitan saber ciertas cosas sobre los ciudadanos. Es posible que esta necesidad no exista en otros terrenos. En el lugar de trabajo 0 en una empresa, las cuestiones relacionadas con la productividad y la salud afectan a empresarios y trabajadores, como colectivo y como individuos. En algunas situaciones, entran también en juego los intereses públicos, representados por organismos públicos u otras instituciones que reclaman el legítimo derecho a saber.

La cuestión que inmediatamente se plantea es la manera de conciliar estas necesidades y las condiciones que deben darse para que la necesidad de información de una empresa o de la sociedad permita legítimamente inmiscuirse en el derecho a la intimidad de una persona. En este proceso de conciliación se producen conflictos éticos que han de resolverse. Si la necesidad de información de una empresa o de la sociedad no es compatible con la necesidad de protección de la intimidad de los trabajadores, tendrá que decidirse qué necesidad o derecho a la información debe prevalecer. El conflicto ético se origina como consecuencia de la responsabilidad de la empresa de adoptar las medidas preventivas necesarias contra los peligros para la salud en el lugar de trabajo. Para poder asumir esta responsabilidad, la empresa necesita información tanto sobre las condiciones de trabajo como sobre la salud de los trabajadores. Es posible que los trabajadores deseen que cierto tipo de información sobre sí mismos se mantenga confidencial o en secreto, aun cuando reconozcan la necesidad de medidas preventivas.

\section{Perspectivas morales}

L as cuestiones y los conflictos éticos en el campo de la medicina del trabajo pueden enfocarse utilizando los dos paradigmas éticos clásicos: ética consecuencialista o ética deontológica. La ética consecuencialista se centra en lo que es bueno o malo, perjudicial o útil en función de sus consecuencias. Por ejemplo, la ambición social expresada como el principio de maximizar los beneficios para el mayor número de miembros de una comunidad es un reflejo de la ética consecuencialista. La característica distintiva de la ética deontológica es que considera obligatorias determinadas acciones o conductas humanas como, por ejemplo, decir siempre la verdad - el principio de la veracidad-con independencia de sus consecuencias. El deontólogo considera que los principios morales son absolutos y nos imponen el deber absoluto de respetarlos. Estos dos paradigmas de la filosofía moral básica pueden utilizarse, por separado o conjuntamente, para valorar las actividades o conductas humanas desde un punto de vista ético.

\section{Derechos humanos}

Cuando se debaten los aspectos éticos de la medicina del trabajo, la influencia de los principios éticos en las relaciones humanas y las cuestiones relativas a la necesidad de información en el lugar de trabajo, es imprescindible exponer con claridad los principios básicos más importantes. Estos principios pueden encontrarse en las declaraciones internacionales de derechos humanos y en las recomendaciones y directrices que se derivan de las decisiones adoptadas por las organizaciones internacionales. También se reflejan en los códigos de ética y de conducta de los profesionales.

Los derechos humanos tanto individuales como sociales desempeñan un papel importante en la asistencia sanitaria. LoS más relacionados con esta actividad son el derecho a la vida, el derecho a la integridad física y el derecho a la intimidad. Estos derechos se contemplan en:

- La Declaración U niversal de Derechos H umanos adoptada en 1941 por la O rganización de las N aciones U nidas.

- El Convenio Europeo para la Protección de los Derechos Humanos y de las Libertades Fundamentales (Consejo de Europa, 1950).

- El Pacto Internacional de Derechos Civiles y Políticos, de 1966, de la O rganización de las N aciones U nidas.

Los códigos profesionales formulados y adoptados por la Asociación M undial de M édicos tienen especial importancia para el personal de los servicios de medicina del trabajo. Estos códigos son:

- Código internacional de ética médica (1949-1968) y Declaración de Ginebra (1948-1968).

- Declaración de Helsinki: Recomendaciones para los doctores en medicina que realizan investigaciones biomédicas en seres humanos (1964-1975-1983).

Los derechos humanos individuales no tienen, en principio, relación alguna con las condiciones económicas. Se basan en el derecho a la autodeterminación, que requiere tanto la autonomía como la libertad del ser humano.

\section{Principios éticos}

El principio de autonomía se centra en el derecho que tiene toda persona a la autodeterminación. Según este principio, todos los seres humanos tienen la obligación moral de respetar el derecho humano a la autodeterminación, siempre y cuando no se usurpe el derecho de los demás a decidir su forma de actuar en asuntos que tan sólo les conciernen a ellos. U na consecuencia importante de este principio para el ejercicio de la medicina del trabajo es el deber moral de considerar confidencial cierto tipo de información sobre las personas.

El segundo principio, el principio de la asistencia, combina dos principios éticos: la ausencia de maleficencia y la beneficencia. El primero establece la obligación moral de todo ser humano de no causar sufrimiento a otros. El segundo establece el deber de hacer el bien. Según este principio, todos los seres humanos tienen la obligación moral de prevenir y eliminar el sufrimiento o el daño y, también en cierta medida, de promover el bienestar. Una consecuencia práctica para el ejercicio de la medicina del trabajo es la obligación de tratar de identificar de forma sistemática los riesgos de enfermedad en el lugar de trabajo o las condiciones del mismo que pueden poner en peligro la salud o la calidad de vida de los trabajadores, así como la obligación de adoptar medidas preventivas o correctoras siempre que se descubran esos riesgos o factores de riesgo. EI principio de beneficencia puede aplicarse también a la investigación de la salud en el trabajo.

El principio de equidad implica la obligación moral que tiene todo ser humano de respetar los derechos de los demás, siempre de forma imparcial, y de contribuir al reparto de las cargas y beneficios, de tal manera que los miembros o colectivos menos privilegiados de la comunidad reciban una atención especial. En la práctica, las consecuencias más importantes de este principio 
se concretan en la obligación de respetar el derecho de los demás a la autodeterminación y de dar prioridad a las personas o los grupos más vulnerables o más expuestos a riesgos para la salud en el lugar de trabajo.

Cuando se consideran estos tres principios, conviene recordar que, en los servicios de salud, el principio de autonomía ha reemplazado al principio de la beneficiencia como principio básico de la ética médica. Esto constituye, de hecho, una de las reorientaciones más radicales en la larga historia de la tradición hipocrática. La aparición de la autonomía como concepto sociopolítico, jurídico y moral ha influido profundamente en la ética médica. $\mathrm{H}$ a desplazado el centro de la toma de decisiones del médico al paciente y, como resultado, ha cambiado la relación entre médico y paciente de forma revolucionaria. Esta tendencia tiene consecuencias obvias en el campo de la medicina del trabajo. En los servicios de salud y en las investigaciones biomédicas, esta tendencia se relaciona con una serie de factores que influyen en el mercado de trabajo y en las relaciones laborales. Entre estos factores cabe mencionar la atención que están recibiendo los enfoques participativos que implican a los trabajadores en los procesos de decisión, la expansión y mejora de la enseñanza pública, la aparición de distintos movimientos en defensa de los derechos humanos y los vertiginosos cambios tecnológicos en las técnicas de producción y organización del trabajo.

Estas tendencias han contribuido al surgimiento del concepto de integridad como un valor importante íntimamente relacionado con el de la autonomía. La integridad, en su sentido ético, significa el valor moral del todo, considerando a todos los seres humanos como personas y fines en sí mismos, independientes en todas las funciones y acreedores de respeto por su dignidad y valor moral.

L os conceptos de autonomía e integridad están vinculados en el sentido de que la integridad expresa un valor fundamental equivalente a la dignidad de la persona. El concepto de autonomía expresa más bien el principio de libertad de acción dirigido a la protección y la promoción de esa integridad. Existe una importante diferencia entre estos dos conceptos y es que el valor de la integridad no admite grados. 0 se mantiene intacta 0 se quebranta o incluso pierde. La autonomía admite distintos grados y es variable. En ese sentido, la autonomía puede restringirse más o menos 0 , por el contrario, ampliarse.

\section{Intimidad y confidencialidad}

EI respeto a la intimidad y a la confidencialidad de las personas es consecuencia del principio de la autonomía. La intimidad puede ser invadida y la confidencialidad violada cuando se revela o publica información que puede utilizarse para identificar 0 exponer a una persona a reacciones 0 respuestas no deseadas, 0 incluso hostiles, de otros. Esto significa que existe la necesidad de proteger dicha información para que no se divulgue. Por otro lado, cuando la información es esencial para descubrir o prevenir riesgos para la salud en el lugar de trabajo, existe la necesidad de proteger la salud de ciertos trabajadores 0 , incluso a veces, de un colectivo más grande de trabajadores que están expuestos a los mismos riesgos en el lugar de trabajo.

Es importante determinar si la necesidad de proteger la información sobre los individuos y la necesidad de proteger la salud del colectivo de trabajadores y mejorar las condiciones de trabajo son compatibles. Se trata de sopesar las necesidades del individuo frente a los beneficios para el colectivo. Es posible que surjan conflictos con los principios de autonomía y beneficencia, respectivamente. En este tipo de decisiones, habrá que analizar las cuestiones de quién debe estar autorizado a saber y con qué fin.
Es muy importante analizar estos dos aspectos. Si la información sobre los trabajadores individuales se puede utilizar para mejorar las condiciones de trabajo en beneficio de todo el colectivo, existen razones éticas de peso para examinar el caso en profundidad.

Siempre deben existir procedimientos para impedir el acceso a la información a personas no autorizadas y su utilización para fines distintos a los establecidos o acordados con anterioridad.

\section{Análisis ético}

En un análisis ético es esencial proceder paso a paso en la identificación, clarificación y resolución de los conflictos éticos. Como ya hemos comentado, los distintos intereses creados y las diferentes partes presentes en el lugar de trabajo o en el mercado laboral, pueden presentarse como intereses éticos. EI primer paso consiste, por tanto, en identificar las partes principales que participan en el proceso, describir sus intereses racionales y localizar los conflictos de intereses evidentes y potenciales. Es esencial que esos conflictos de intereses entre las diferentes partes interesadas se pongan de manifiesto y se expliquen en vez de ser ignorados. Es también importante aceptar el hecho de que este tipo de conflictos son bastante comunes. En todos los conflictos éticos existen uno 0 más agentes y una 0 más personas a las que conciernen las acciones emprendidas por el agente 0 los agentes.

El segundo paso consiste en identificar los principios éticos de autonomía, beneficencia, ausencia de maleficencia y equidad. El tercer paso consiste en identificar las ventajas y beneficios éticos, así como las desventajas y los costes para aquellas personas u organismos implicados o afectados por el problema de salud en el trabajo. Las expresiones beneficio ético o coste ético adquieren en este contexto un significado bastante amplio. Todo aquello que razonablemente pueda juzgarse beneficioso o con un efecto positivo desde el punto de vista ético es un beneficio. Todo aquello que pueda afectar al grupo de forma negativa es, de forma análoga, un coste ético.

Estos principios éticos fundamentales (autonomía, beneficencia y equidad) y las etapas del análisis asociadas a ellos se aplican tanto al tratamiento de la información en la práctica cotidiana de la medicina del trabajo como al tratamiento y divulgación de la información científica. Considerada desde esta perspectiva, la confidencialidad de las historias médicas o de los resultados de los estudios de la salud en el trabajo puede analizarse aplicando los principios antes expuestos.

Este tipo de información puede referirse, por ejemplo, a peligros potenciales o sospechados para la salud en el lugar de trabajo, y su calidad y utilidad práctica varía en cada caso. Es evidente que el uso que se haga de este tipo de información plantea una serie de cuestiones éticas.

$\mathrm{H}$ ay que recalcar que este modelo de análisis ético está destinado principalmente a estructurar las complejas relaciones que existen entre un trabajador individual, el colectivo de trabajadores de una empresa y los intereses creados en el lugar de trabajo y en la comunidad en general. En el contexto actual se trata fundamentalmente de un ejercicio pedagógico basado sobre todo en el supuesto, considerado controvertido por la filosofía moral, de que la solución objetiva y correcta a un conflicto ético simplemente no existe. Bertrand Russell escribió:

"N osotros mismos somos los árbitros definitivos e irrefutables de los valores y, en el mundo de los valores, la naturaleza es tan sólo una parte. Por ello, en este mundo somos superiores a la Naturaleza. En el mundo de los valores, la naturaleza es en sí misma neutra; no es ni buena ni mala, por lo que no merece admiración ni tampoco censura. Nosotros somos quienes creamos valores y nuestros deseos son los que les confieren valor. En ese reino somos los reyes y si nos doblegamos a la Naturaleza, nos degradamos.

ENCICLOPEDIA DE SALUDYSEGURIDAD EN EL TRABAJO 
Nosotros somos los que tenemos que decidir lo que es bueno, no la N aturaleza, ni siquiera la naturaleza personificada en Dios (Russell 1979).

Esta es otra manera de decir que la autoridad de los principios éticos, como ya se mencionó antes, está determinada por las personas o los grupos de personas, que pueden o no estar de acuerdo sobre lo que es intelectual o emocionalmente aceptable.

Por consiguiente, a la hora de resolver los conflictos y problemas éticos, el diálogo entre las diferentes partes implicadas adquiere una especial relevancia. Es muy importante que todos los interesados tengan la posibilidad de intercambiar sus puntos de vista con los demás en un clima de respeto mutuo. Aunque se acepta como un hecho que los conflictos éticos no tienen soluciones objetivamente correctas, no se puede deducir de eso que la definición del posicionamiento ético se base en ideas subjetivas y carentes de principios. Es importante tener siempre presente que las cuestiones de la confidencialidad y la integridad pueden ser planteadas por diversos grupos o personas partiendo de normas y valores muy diferentes. Por tanto, uno de los pasos importantes en un análisis ético consiste en diseñar el procedimiento para establecer contacto con y entre las personas y los intereses colectivos afectados, así como los pasos que deben seguirse para iniciar el proceso que terminará en un acuerdo 0 desacuerdo sobre el tratamiento o divulgación de información confidencial.

Por último, se insiste en que el análisis ético se puede utilizar como herramienta para examinar las prácticas y estrategias alternativas de actuación. Este análisis no nos dará respuestas sobre lo que es correcto o incorrecto, o lo que se considera aceptable o inaceptable desde el punto de vista ético, pero crea un marco para la toma de decisiones cuando entran en juego los principios éticos fundamentales de la autonomía, la beneficencia, la maleficencia y la equidad.

\section{Etica e información en la medicina del trabajo}

Las cuestiones y dilemas éticos que surgen en la práctica y en la ciencia de la medicina del trabajo se derivan de la recogida, almacenamiento, análisis y utilización de información sobre personas concretas. Estos procesos pueden llevarse a cabo de una manera sistemática, o bien para un fin concreto, para mejorar la salud y la calidad de vida de los trabajadores o las condiciones de trabajo. Son motivos en sí mismos que tienen siempre una importancia fundamental para la salud en el trabajo. Sin embargo, esta información puede utilizarse también para prácticas selectivas que pueden llegar a ser discriminatorias si se aplican, por ejemplo, a la selección de personal 0 al reparto de tareas. La información obtenida de las historias clínicas o de los archivos personales plantea, en principio, la posibilidad de que se utilice en contra del individuo de una manera inaceptable o que viole los principios éticos fundamentales.

La información puede estar compuesta de datos y observaciones registrados en exploraciones médicas previas a la contratación o en programas rutinarios de vigilancia de la salud o de exploración selectiva. Este tipo de programas o rutinas suelen ser introducidos por las propias empresas o motivados por requisitos legales. La información puede incluir también los datos recogidos en las consultas médicas a las que acuden las personas afectadas. U na fuente de información que tiene un interés especial en el campo de la medicina del trabajo es el control biológico de las exposiciones en el lugar de trabajo.

En el ejercicio de la medicina del trabajo, así como en las investigaciones que se realizan en este campo, se recogen y documentan diferentes tipos de observaciones que a la larga se utilizan en mayor o menor medida. La información puede referirse a estados de salud en el pasado o a comportamientos relacionados con la salud, como el absentismo por enfermedad. También puede contener observaciones sobre síntomas y resultados de reconocimientos médicos y pruebas de laboratorio. Este último tipo de información puede referirse a la capacidad funcional, la fuerza muscular, la resistencia física o las destrezas cognitivas o intelectuales del trabajador y puede contener también evaluaciones de diferentes aspectos del rendimiento. La información puede contener también, en el extremo opuesto del espectro de la salud, datos sobre problemas de salud, minusvalías, estilos de vida extremos, consumo de alcohol, drogas y otros productos tóxicos, etc. Aunque muchos de estos datos resultan relativamente triviales o inocuos por separado, cuando se combinan y se recopilan con carácter continuo a lo largo del tiempo pueden llegar a proporcionar una descripción muy detallada y extensa de las características de una persona.

La información se puede registrar y almacenar utilizando diferentes métodos. En el caso de los archivos que contienen información individual sobre las personas, el método más habitual consiste en rellenar a mano las fichas. También se pueden utilizar bases de datos informatizadas, empleando cintas magnéticas o disquetes para guardar la información. Puesto que la capacidad de memoria de estos archivos informatizados es enorme, las bases de datos constituyen en sí mismas una posible amenaza para la integridad personal. La información que se almacena en estos bancos de datos, registros y ficheros, si cae en manos de personas sin escrúpulos, puede convertirse en un instrumento de poder y utilizarse en perjuicio de la persona en cuestión.

La definición del tipo de información que debe tener o no carácter confidencial queda fuera del ámbito de este artículo. Tampoco es nuestra intención dar aquí una definición funcional del concepto de la integridad personal o proponer un esquema detallado para juzgar qué información ha de considerarse más o menos confidencial con respecto a los principios éticos fundamentales. Eso sería sencillamente imposible. La sensibilidad de la información en este sentido depende del contexto y de muchos otros factores. Lo que sí es importante es aplicar los principios éticos fundamentales a la hora de tratar cuestiones sobre cómo, por quién y en qué circunstancias se tratan estos datos y ese tipo de información.

\section{Análisis de riesgos y resultados de las investigaciones}

H emos abordado la explicación de los principios del análisis ético desde el punto de vista de la información sobre la salud o relacionada con ella contenida en registros individuales, como son las historias clínicas o los archivos personales. Sin embargo, tanto en la práctica como en la ciencia de la medicina del trabajo, existen otros tipos de información cuya obtención, procesamiento y utilización pueden plantear problemas éticos o incluso conflictos con los principios éticos. No obstante, este tipo de información suele analizarse tomando como referencia los principios éticos de autonomía, beneficencia y equidad. Es el caso de la evaluación de los peligros y el análisis de los riesgos. En una situación en la que, por ejemplo, la información sobre un peligro para la salud en el trabajo se oculta deliberadamente a los trabajadores, cabe esperar que el análisis ético demuestre claramente que se han violado los tres principios éticos fundamentales. Esto se cumple con independencia de que alguna de las partes interesadas considere que la información es confidencial. La dificultad surge cuando la información es incierta, insuficiente o incluso inexacta. También es fácil que existan opiniones muy diferentes sobre la validez de las pruebas, lo cual no altera la estructura fundamental de las cuestiones éticas que se plantean.

En las investigaciones de la salud en el trabajo, es frecuente que los trabajadores tengan que recibir información sobre los 
proyectos de investigación pasados, presentes o futuros. Si la investigación se realiza sin explicar a los trabajadores participantes ni el motivo de la misma ni todas las implicaciones del proyecto, y sin solicitar el consentimiento informado de todos los participantes, el análisis ético demostrará que se han violado los principios éticos fundamentales de autonomía, beneficencia y equidad.

Es evidente que la naturaleza técnica y compleja de este tema pueda causar dificultades prácticas en la comunicación entre los investigadores y otras partes interesadas. Este hecho en sí mismo no altera la estructura del análisis ni las cuestiones éticas que se plantean.

\section{Garantías}

Existen una serie de garantías administrativas que pueden aplicarse para proteger la información confidencial. Los métodos más comunes son los siguientes:

1. D iscreción y confidencialidad. EI contenido de las historias clínicas y otros materiales clasificados como información médica puede considerarse confidencial o secreto desde el punto de vista jurídico. Hay que decir, sin embargo, que no toda la información contenida en estos documentos es necesariamente de naturaleza confidencial. T ambién contienen información que puede comunicarse libremente sin causar daño a nadie.

0 tro aspecto es la obligación que tienen algunos profesionales de guardar en secreto la información que les ha sido facilitada en confianza. Es el caso de las relaciones fiduciarias que se establecen en las consultas y la obligación de confidencialidad se aplica a la información médica o de cualquier otra índole que se trata en la relación entre médico y paciente. Este tipo de información puede estar protegida por la legislación, los convenios colectivos o los códigos profesionales.

No obstante, debe tenerse en cuenta que el concepto de "información sobre la salud" no tiene una definición práctica, como tampoco la tiene el concepto de salud, razón por la cual el término puede ser objeto de diferentes interpretaciones.

2. Autorización de acceso a la información. Este requisito puede, por ejemplo, aplicarse a los investigadores que buscan información en las historias clínicas o en los archivos personales de la seguridad social.

3. Consentimiento informado, como condición para la recogida de datos y acceso a los archivos con información personal. El principio del consentimiento informado, que implica el derecho a que la persona afectada participe en la decisión, es una práctica establecida por ley en muchos países para todas las cuestiones relacionadas con la recogida y el acceso a información personal.

El principio del consentimiento informado se considera cada vez más importante para el tratamiento de la información personal. Este principio implica que la persona en cuestión tiene el derecho prima facie a decidir qué información puede recogerse, con qué fin, por quién, con qué métodos, en qué condiciones y qué garantías administrativas o técnicas deben existir para evitar el acceso de personas no autorizadas a dicha información.

4. Garantías técnicas para la protección de la información almacenada en ordenadores. Estas garantías pueden consistir, por ejemplo, en la introducción de procedimientos codificados o en clave para evitar el acceso no autorizado a los archivos que contienen información personal 0 , si el acceso es legítimo, evitar que las personas puedan ser identificadas en la base de datos (protección del anonimato). Sin embargo, debe decirse que el anonimato, que significa codificar o encubrir el nombre y otros datos de la identidad de una persona, como es su número de la seguridad social, no siempre garantiza una protección fiable contra la identificación. El resto de la información que contienen los archivos personales puede ser suficiente para identificar a una persona.

5. R equisitos legales, entre ellos la prohibición, la autorización y el control para establecer y manejar fuentes informatizadas de datos que contienen expedientes 0 archivos personales.

6. Códigos deontológicos profesionales. Las asociaciones y organizaciones profesionales pueden adoptar principios éticos para la práctica de su profesión en forma de códigos deontológicos profesionales. Este tipo de documentos existen en muchos países y también en el ámbito internacional. El lector que desee más información sobre este tema puede remitirse a los siguientes documentos internacionales:

- Código internacional de ética para los profesionales de la salud en el trabajo, adoptado por la Comisión Internacional de Medicina del Trabajo en 1992

- Directrices éticas adoptadas por la Asociación Internacional de E pidemiología

- Directrices internacionales para el análisis ético de los estudios epidemiológicos, adoptadas por el Consejo de O rganizaciones Internacionales de las $\mathrm{C}$ iencias $\mathrm{M}$ édicas.

Antes de terminar esta sección, debemos insistir en que un principio elemental en la planificación y establecimiento de prácticas para la recogida de datos consiste en evitar hacerlo sin antes haber considerado con detenimiento los móviles y la importancia de la recogida de datos para la salud en el trabajo. Los riesgos éticos inherentes a la recogida de información que no se utiliza en beneficio del trabajador o de la persona afectada son evidentes. En principio, las alternativas y estrategias para planificar la recogida y el tratamiento de información sobre los trabajadores pueden ser sometidas a un análisis ético en términos de autonomía, beneficencia y equidad.

\section{Archivos personales informatizados}

Gracias a los avances en la tecnología informática, las empresas tienen ahora la posibilidad de recoger, almacenar y procesar información de los trabajadores sobre diferentes aspectos referentes a su conducta y su rendimiento en el trabajo. El uso de esos sistemas informáticos avanzados ha aumentado considerablemente en los últimos años y ha suscitado el temor a los riesgos de intrusión en la integridad individual. Es razonable predecir que estos riesgos serán aún mayores en el futuro, como también lo será la necesidad de proteger los datos y adoptar diferentes medidas contra las violaciones de la integridad.

Al mismo tiempo, es evidente que la nueva tecnología proporciona importantes beneficios para la producción en una empresa 0 en el sector público y ofrece medios para mejorar la organización del trabajo o eliminar problemas, como las tareas de ciclos cortos y monótonas. La cuestión fundamental es alcanzar un equilibrio razonable entre los beneficios que pueden obtenerse con la utilización de las técnicas informáticas y la necesidad y el derecho legítimo de los trabajadores a estar protegidos contra las intrusiones en su integridad personal.

El Consejo de Europa adoptó en 1981 una Recomendación (núm. R 81-1) sobre las bases de datos médicas y una convención sobre la Protección de los individuos contra el procesamiento automático de datos. El Consejo de la U nión Europa ha tratado estos temas en la Directiva (95/ 46/ CE), sobre la Protección de los individuos contra el procesamiento de datos personales y la libre circulación de dichos datos. D ebe recordarse que la aplicación de esta normativa 
a los datos personales informatizados se considera en muchos países en el contexto de las relaciones laborales.

\section{Conclusión}

En la práctica, el tratamiento de la información sobre la salud en el trabajo requiere el juicio de los profesionales de ésta y de otras disciplinas. Los profesionales de la salud en el trabajo tienen que decidir lo que es correcto o incorrecto, o más o menos aceptable, en muchos contextos y circunstancias culturales. EI análisis ético es un instrumento que proporciona la base para emitir juicios y tomar decisiones basadas en principios éticos y conjuntos de valores que nos ayudan a evaluar y elegir entre diferentes líneas de actuación.

\section{- ETICA EN LA PROTECCION Y PROMOCION DE LASALUD}

\section{Wayne Corneil y Annalee Yassi}

Aunque los servicios de medicina del trabajo están cada vez más extendidos en todo el mundo, los recursos para desarrollar y financiar estas actividades no han aumentado al mismo ritmo que las demandas. M ientras tanto, los límites entre lo que es la vida privada y profesional han cambiado, planteando la cuestión de cuáles pueden o deben ser las competencias legítimas de la medicina del trabajo. Los programas aplicados en el lugar de trabajo para detectar el consumo de drogas o la seropositividad al V IH , 0 los servicios de asesoramiento para problemas personales, son un reflejo evidente de la frontera cada vez menos nítida entre lo que es la vida privada y profesional.

Desde el punto de vista de la salud pública, existen suficientes argumentos para no intentar separar los factores relacionados con el estilo de vida, el lugar de trabajo y el medio ambiente en general. Aunque objetivos como la lucha contra el consumo de drogas y otros hábitos nocivos para la salud sean muy loables, la manera de abordar estos problemas en el lugar de trabajo plantea problemas éticos. También debe evitarse que las medidas que se adopten para combatir esos hábitos no sustituyan a otras medidas de protección de la salud. L a finalidad de este artículo es analizar específicamente los aspectos éticos de la protección y la promoción de la salud en el lugar de trabajo.

\section{Protección de la salud}

\section{Protección individual y colectiva de los trabajadores}

Aunque la conducta ética es fundamental en todos los aspectos de la asistencia sanitaria, la definición y promoción de dicha conducta suele ser más compleja en el contexto de la medicina del trabajo. Los médicos de atención primaria deben dar prioridad a las necesidades de sus pacientes, mientras que los profesionales de la salud pública deben dar prioridad a las necesidades sanitarias de la colectividad. El profesional de la salud en el trabajo, por su parte, tiene que atender las necesidades tanto del paciente como de la colectividad: el trabajador, la plantilla y el público en general. A veces estas obligaciones múltiples dan lugar a responsabilidades que entran en conflicto.

En la mayoría de los países, los trabajadores tienen el derecho innegable a recibir protección contra accidentes en el lugar de trabajo y los programas de salud en el trabajo deben estar precisamente orientados a velar por este derecho. Los problemas éticos que plantea la protección de los trabajadores contra condiciones de trabajo poco seguras suelen deberse al hecho de que los intereses económicos de la empresa, ya sean reales 0 percibidos, actúan muchas veces en contra de la adopción de las medidas necesarias para proteger la salud de los trabajadores. Sin embargo, la postura ética que deben adoptar los profesionales de la salud en el trabajo está clara. Como se establece en el Código deontológico internacional para los profesionales de la salud en el trabajo: "Los profesionales de la salud en el trabajo deben actuar siempre, de forma prioritaria, en beneficio de la salud y seguridad de los trabajadores".

El profesional de la salud en el trabajo, ya forme parte de la plantilla de la empresa o actúe en calidad de asesor, se siente muchas veces presionado para ignorar sus planteamientos éticos en la protección de la salud de los trabajadores. Puede incluso ocurrir que un trabajador le pida que declare en su defensa y en contra de la empresa cuando se emprende algún tipo de acción legal o cuando el trabajador o el propio profesional creen que no se están adoptando las medidas necesarias para la protección de la salud.

Los conflictos pueden reducirse en la vida real estableciendo expectativas sociales, incentivos de mercado y mecanismos de infraestructura que contrarresten las desventajas económicas reales 0 percibidas por la empresa de las medidas para proteger la salud de los trabajadores. Estos mecanismos pueden consistir en unos reglamentos claros que exijan una prácticas seguras y que impongan unas sanciones elevadas por el incumplimiento de las normas, lo cual requiere una infraestructura adecuada para vigilar su cumplimiento y aplicación. También se puede recurrir a un sistema de bonificación de los trabajadores que promueva las medidas preventivas. Sólo si los factores sociales, las normas, las expectativas y la legislación reflejan la importancia de la protección de la salud en el trabajo podrá realmente prosperar la práctica ética.

\section{El derecho a ser protegido de condiciones y actuaciones peligrosas originadas por otras}

En ocasiones se plantea otra cuestión ética relativa a la protección de la salud: se trata de la situación en la que el propio trabajador representa un peligro en el lugar de trabajo. Entre las numerosas responsabilidades del profesional de la salud en el trabajo, siempre debe considerarse el derecho de los miembros del colectivo (la plantilla y el público en general) a recibir protección contra las actuaciones de otros. En muchas jurisdicciones, "la aptitud para un trabajo" se define, no sólo en términos de la capacidad del trabajador para realizar un trabajo, sino también para realizarlo sin que ello suponga un riesgo para sus compañeros o el público en general. No es ético negar el trabajo a alguien (es decir, declarar a un trabajador no apto para un trabajo) por el solo hecho de que sufra determinado problema de salud, si no existen evidencias científicas que demuestren que ese problema impide al trabajador realizar el trabajo de forma segura. Sin embargo, en algunos casos el médico puede opinar que el trabajador representa un peligro para los demás, aun cuando pueda aportar escasa o ninguna documentación para respaldar su opinión. Por ejemplo, la decisión de permitir que un trabajador que sufre mareos de causa desconocida maneje una grúa puede tener consecuencias muy graves. D e hecho, puede ser poco ético permitir que una persona asuma responsabilidades especiales en esos casos.

La necesidad de mantener un equilibrio entre los derechos individuales y colectivos no es exclusiva de la medicina del trabajo. En muchas jurisdicciones, el médico está obligado por ley a informar a las autoridades sanitarias públicas sobre determinados trastornos médicos, como las enfermedades de transmisión sexual, la tuberculosis o el abuso de menores, aunque ello suponga romper la promesa de confidencialidad hecha a las personas afectadas. Aunque no siempre existen directrices concretas que ayuden al profesional de la salud en el trabajo a tomar este tipo de decisiones, los principios éticos exigen que 
realice una revisión exhaustiva de la documentación científica y emita el juicio profesional que considere más oportuno. Por consiguiente, las consideraciones sobre salud pública y seguridad deben combinarse con las consideraciones sobre el trabajador en cuestión cuando se realizan reconocimientos médicos y otros tipos de exámenes para seleccionar a los candidatos a puestos de trabajo con responsabilidades especiales. De hecho, la exploración selectiva para la detección del consumo de drogas y alcohol, si tiene que justificarse como una actividad legítima de los profesionales de la salud en el trabajo, sólo puede justificarse desde este punto de vista. El Código internacional para los profesionales de la salud en el trabajo establece:

Cuando el estado de salud de un trabajador y la naturaleza de su trabajo sean tales que pueda llegar a poner en peligro la seguridad de otros, se debe informar claramente al trabajador de la situación. En el caso de una situación especialmente peligrosa, la dirección y, cuando así lo exija la legislación nacional, la autoridad competente, también deberán ser informadas sobre las medidas necesarias para proteger a otras personas.

Cuando la atención del profesional se centra excesivamente en el individuo, tiende a pasar por alto e incluso a ignorar su obligación de proteger el bien general de la sociedad 0 de algunos colectivos específicos. Por ejemplo, cuando la conducta de una persona se convierte en un peligro para ella misma o para otros, ¿cuándo debe actuar el profesional en beneficio del colectivo y dejar a un lado los derechos del individuo? Estas decisiones tienen importantes consecuencias para el personal de los programas de asistencia a los trabajadores que trabajan con personas discapacitadas. Deben tener muy clara su obligación de advertir a los compañeros o los clientes que pueden utilizar los servicios de la persona discapacitada, frente a su obligación de proteger la confidencialidad de la persona. EI profesional no puede limitarse a proteger la confidencialidad y los derechos del individuo, como ya hemos comentado antes.

\section{Programas de promoción de la salud}

\section{Los supuestos y el debate}

Los supuestos en los que se basan generalmente las actividades desarrolladas en el lugar de trabajo para promover cambios en el estilo de vida de los trabajadores son:

(1) que las decisiones que toman los trabajadores en el día a día sobre su estilo de vida en cuanto al ejercicio físico, la alimentación, el tabaco y el control del estrés tienen un efecto directo en su estado de salud presente y futuro, su calidad de vida y su rendimiento en el trabajo, y (2) un programa patrocinado por la empresa para promover cambios positivos en el estilo de vida, administrado por personal a tiempo completo, pero voluntario y abierto a todos los trabajadores, alentará a estos últimos a introducir cambios positivos en su estilo de vida suficientes para mejorar tanto su estado de salud como su calidad de vida (Nathan 1985).

$\mathrm{H}$ asta donde puede llegar la empresa en su intento de modificar una conducta, como el consumo de drogas fuera del horario de trabajo, o una condición como el exceso de peso, que no afecta directamente a los demás ni al rendimiento del propio trabajador? En las actividades de promoción de la salud, las empresas se comprometen a reformar aquellos aspectos del estilo de vida de los trabajadores que son o se perciben como perjudiciales para su salud. En otras palabras, la empresa puede convertirse en un agente del cambio social. Puede incluso convertirse en el inspector sanitario con respecto a aquellos procesos que se consideran favorables o perjudiciales para la salud y aplicar medidas disciplinarias con el fin de mantener a los trabajadores en un buen estado de salud. Algunas empresas imponen restricciones específicas que prohíben a los trabajadores rebasar ciertos límites de peso. Pueden introducir incentivos especiales, como la reducción de las primas del seguro u otras prestaciones para los trabajadores que cuiden su salud, especialmente a través del ejercicio. Pueden formular políticas para animar a algunos grupos de trabajadores, como los fumadores, a abandonar hábitos perjudiciales para su salud.

Muchas empresas afirman que no tienen la intención de inmiscuirse en la vida privada de sus trabajadores, sino que tan solo intentan influir en ellos para que se comporten de forma razonable. Sin embargo, se plantea la cuestión de si las empresas deben intervenir en un área que pertenece al ámbito de la conducta privada. Q uienes se oponen a esta idea piensan que estas actividades constituyen un abuso de poder por parte de la empresa, y rechazan no tanto la legitimidad de las propuestas como la motivación paternalista y elitista que se esconde tras ellas. Los programas de promoción de la salud pueden calificarse también de hipócritas cuando la empresa no introduce cambios en factores relacionados con la organización que afectan a la salud de los trabajadores y su motivación principal es la reducción de gastos.

\section{Reducción de gastos como principal motivación}

Una característica importante del contexto de los servicios de medicina del trabajo es que la actividad "principal" de la empresa no consiste en prestar asistencia médica a los trabajadores, aunque este tipo de servicios pueden contribuir de manera importante al logro de los objetivos de la organización si consiguen, por ejemplo, aumentar la eficiencia de las operaciones 0 reducir los gastos. En la mayoría de los casos, las actividades de promoción de la salud de los programas de asistencia a los trabajadores y los servicios de rehabilitación son desarrolladas por las empresas con la finalidad de lograr los objetivos de su organización, como una plantilla más productiva o la reducción del coste de los seguros o de las indemnizaciones a los trabajadores. Aunque la retórica empresarial ha insistido en el carácter humanitario de los programas de asistencia a los trabajadores, la razón fundamental de los mismos es el interés de las empresas por reducir los gastos, el absentismo y la pérdida de productividad asociados a los problemas de salud mental y consumo de drogas y alcohol. Estos objetivos son sustancialmente diferentes de los objetivos tradicionales de los profesionales sanitarios, ya que estos últimos tienen en cuenta tanto los intereses de la empresa como las necesidades del paciente.

Cuando las empresas financian directamente los servicios y éstos se prestan en el lugar de trabajo, los profesionales tienen necesariamente que considerar los objetivos de la empresa y la cultura que predomina en el lugar de trabajo. Los programas pueden estructurarse para que tengan un efecto en la rentabilidad y es posible que tenga que llegarse a un compromiso sobre los objetivos de los servicios de salud ante la necesidad real de reducir los gastos. Las acciones recomendadas por el profesional pueden verse influidas por estas consideraciones, y puede plantearse un dilema ético sobre la manera de alcanzar un equilibrio entre lo que sería mejor para un trabajador y lo que sería más rentable para la empresa. Cuando la principal responsabilidad del profesional es la asistencia gestionada con el objetivo de reducir los gastos, los conflictos pueden agravarse. Por este motivo, los programas de asistencia gestionada deben abordarse con precaución, para que los objetivos de la asistencia sanitaria no se vean comprometidos por el esfuerzo de limitar o reducir los gastos. 
¿Q ué trabajadores tienen derecho a los servicios de asistencia a los trabajadores? ¿Q ué tipo de problemas deben considerarse? ¿D ebe ampliarse el programa a los familiares de los trabajadores 0 a los jubilados? M uchas de estas decisiones parecen basarse no tanto en la intención expresa de mejorar el estado de salud de los trabajadores como en el límite de cobertura de las prestaciones. El personal a tiempo parcial sin derecho a prestaciones extrasalariales no suele tener acceso a los programas de asistencia a los trabajadores y, de este modo, la empresa se ahorra ese gasto adicional. Sin embargo, el personal a tiempo parcial también puede tener problemas que afecten a su rendimiento y productividad.

En el equilibrio entre una asistencia de calidad y la reducción de gastos, ¿quién debe decidir el nivel de calidad necesario y a qué precio: el paciente que utiliza los servicios pero que no paga por ellos o el profesional responsable del programa de asistencia de los trabajadores que no paga la factura pero cuyo trabajo puede depender del éxito del tratamiento? ¿Q uién debe tomar la decisión: el prestador del servicio o el asegurador, que es al final quien lo paga?

I gualmente, ¿quién debe decidir cuándo se puede prescindir de un trabajador? Y si los costes de seguro y tratamiento dictan esa decisión, ¿cuándo es más rentable despedir a un trabajador que, por ejemplo, padece una enfermedad mental, y contratar y formar a uno nuevo? Desde luego, la función de los profesionales de la salud en el trabajo en este tipo de decisiones tiene que ser analizada más a fondo.

\section{¿Acción voluntaria o coacción?}

L os problemas éticos planteados por una lealtad poco clara hacia el cliente se hacen evidentes de inmediato en los programas de asistencia a los trabajadores. La mayoría de los profesionales que participan en estos programas han aprendido que el centro legítimo de los mismos es el individuo cuyos intereses defienden. Este concepto depende de la noción de voluntarismo. Es decir, el cliente solicita ayuda voluntariamente y consiente en establecer la relación, que se mantiene sólo con su participación activa. Incluso cuando el cliente es remitido por un supervisor o director, se sigue considerando que la participación es fundamentalmente voluntaria. Los mismos argumentos pueden aplicarse a las actividades de promoción de la salud.

Esta opinión de los profesionales de los programas de asistencia a los trabajadores de que los clientes actúan por voluntad propia no siempre se corresponde con la realidad. La idea de una participación plenamente voluntaria es una ilusión. La posibilidad de elección del cliente es algunas veces mucho menor que la proclamada y la remisión de trabajadores por parte de sus supervisores puede fácilmente basarse en el enfrentamiento o la coacción. Lo mismo ocurre con la mayoría de las llamadas autorremisiones que se producen cuando un trabajador recibe una clara sugerencia por parte de su superior. Aunque se hable de libertad de elección, es evidente que las alternativas son muy limitadas y sólo existe una manera correcta de proceder.

C uando los costes de la asistencia sanitaria corren a cargo de la empresa o de un seguro suscrito por la misma, las fronteras entre lo que es vida pública y vida privada se hacen menos nítidos y aumenta todavía más la posibilidad de coacción. En la actualidad, este tipo de programas tienen carácter voluntario, aunque ¿puede alguna actividad ser completamente voluntaria en el entorno laboral?

L as burocracias no son democracias y cualquier conducta considerada voluntaria en el entorno laboral probablemente puede ponerse en tela de juicio. A diferencia del entorno comunitario, la empresa establece una relación contractual a largo plazo con la mayoría de los trabajadores, que en muchos casos es dinámica, con la posibilidad de aumentos de sueldo, ascensos así como traslados a puestos de inferior categoría. Esta situación puede dar la impresión, deliberada o inadvertida, de que la participación en un programa activo de prevención es obligatoria y lo que se espera de los trabajadores (R oman 1981).

También es preciso tener cuidado con las declaraciones sobre el carácter voluntario de la educación sanitaria que no tienen en cuenta las fuerzas sutiles y poderosas que determinan las conductas en el lugar de trabajo. EI hecho de que las actividades de promoción de la salud reciban una publicidad positiva considerable y de que sean gratuitas puede dar la impresión de que la dirección, no sólo es partidaria de que los trabajadores participen en estas actividades, sino que consideran dicha participación altamente deseable. Los trabajadores pueden también crearse expectativas de obtener otros beneficios además de los relacionados con la salud o considerar necesaria su participación para conseguir un ascenso 0 , al menos, para mantener su trayectoria dentro de la empresa.

La dirección puede sentirse defraudada cuando desarrolla actividades de promoción de la salud obedeciendo a su sincero interés por el bienestar de los trabajadores y dejando a un lado sus objetivos de reducción de gastos. Los incentivos directos, como el aumento de las primas de los seguros de los fumadores 0 los trabajadores con exceso de peso, pueden aumentar la participación, pero también constituyen un tipo de coacción.

\section{Factores de riesgo individual y colectivo}

Las actividades de promoción de la salud en el lugar de trabajo suelen centrarse en el estilo de vida individual como unidad de intervención, distorsionando así la complejidad de las conductas sociales. Los programas que se centran exclusivamente en el cambio de hábitos personales descuidan otros factores sociales, como la discriminación por motivos de raza, sexo o clase social. Este tipo de enfoque sitúa la conducta fuera de contexto y supone "que los hábitos personales son distintos y pueden modificarse de manera independiente; las personas pueden decidir voluntariamente cambiar esa conducta" (C oriel, Levin y Jaco 1986).

Teniendo en cuenta la influencia de los factores sociales, ¿qué grado de control ejercen realmente las personas para modificar los riesgos para la salud? Desde luego que existen factores de riesgo relacionados con la conducta, pero también deben tenerse en cuenta los efectos de la estructura social, el medio ambiente, la herencia y la simple casualidad. U na persona no es la única responsable de la aparición de una enfermedad, aunque eso es precisamente lo que se supone en muchas actividades de promoción de la salud que se desarrollan en el lugar de trabajo.

Un programa de promoción de la salud que sobrestime la responsabilidad individual tendrá un tono moralizante.

Aunque la responsabilidad personal es un factor indiscutible, por ejemplo, en el consumo de tabaco, otros factores sociales, como la clase social, el estrés, la educación y la publicidad influyen también. Siempre resulta más fácil culpar a la víctima cuando se cree que los factores individuales son los únicos responsables. A los trabajadores que fuman, presentan exceso de peso, hipertensión, etc. se les considera culpables de su estado, aunque sea de forma implícita. Así, la empresa y la sociedad se ven eximidas de toda responsabilidad en el problema y pueden culpar a los trabajadores tanto de su problema de salud como de no hacer nada al respecto.

Esta tendencia a considerar responsable únicamente a la persona no tiene en cuenta un gran volumen de datos científicos que existen en la actualidad. Las evidencias sugieren que las secuelas psicológicas del trabajo pueden tener un efecto en la salud que persiste una vez finalizada la jornada laboral. Se ha 
demostrado claramente que existe una relación entre los factores relacionados con la organización (como participación en la toma de decisiones, interacción y apoyo social, ritmo de trabajo, sobrecarga de trabajo, etc.) y las consecuencias para la salud, sobre todo en lo que se refiere a las enfermedades cardiovasculares. Esto sugiere claramente la necesidad de modificar, no sólo la conducta de los trabajadores, sino también la organización de las empresas. No obstante, la mayoría de los programas de promoción de salud tienen como único objetivo modificar la conducta individual y rara vez tienen en cuenta otros factores relacionados con la organización de las empresas.

El enfoque centrado en el individuo sorprende menos si se tiene en cuenta que la mayoría de los profesionales que participan en los programas de promoción de la salud, bienestar social y asistencia a los trabajadores son médicos que no tienen experiencia en el campo de la salud en el trabajo. Incluso cuando los médicos identifican factores de interés en el lugar de trabajo, rara vez están capacitados para recomendar o llevar a cabo intervenciones orientadas a la organización.

\section{Actividades con otros fines distintos a la protección de la salud}

M uy pocas veces los programas de bienestar han propuesto intervenciones para modificar la cultura de empresa o la organización del trabajo y evitar así estilos de gestión estresantes, tareas aburridas o niveles elevados de ruido. Si se descuida la contribución del medio ambiente de trabajo a los efectos en la salud, programas incluso tan populares como el control del estrés pueden tener consecuencias negativas para la salud. Por ejemplo, si el único objetivo es reducir el estrés a escala individual en lugar de modificar los factores de estrés en el trabajo, las actividades de promoción de la salud en el lugar de trabajo pueden, de hecho, contribuir a que los trabajadores se adapten a un medio ambiente poco saludable y producir un aumento de la morbilidad a largo plazo. Es más, las investigaciones realizadas hasta la fecha no han apoyado los enfoques clínicos. Por ejemplo, en un estudio se demostró que los programas de control del estrés individual tenían un efecto menor en la producción de catecolamina que la modificación de los sistemas salariales (G anster y cols. 1982).

Por su parte, Pearlin y Schooler (1978) observaron que, aunque existían distintas respuestas eficaces para resolver 0 enfrentarse a problemas en la vida personal y familiar, esas mismas respuestas no eran eficaces para enfrentarse a los factores de estrés relacionados con el trabajo. 0 tros estudios han sugerido también que algunas conductas útiles para enfrentarse a problemas personales aumentan de hecho la angustia cuando se aplican en el lugar de trabajo (Parasuramen y Cleek 1984).

Los partidarios de los programas de bienestar suelen ignorar los problemas tradicionales de la salud en el trabajo y, ya sea 0 no de manera consciente, hacen caso omiso de los peligros en el lugar de trabajo. Como los programas de bienestar no suelen tener en cuenta el riesgo de enfermedades profesionales o los peligros en el lugar de trabajo, los partidarios de la protección de la salud temen que si se individualiza el problema de la salud de los trabajadores, las empresas prescindan de los costosos cambios necesarios para reducir los riesgos en la estructura y el contenido de los lugares o puestos de trabajo.

\section{Confidencialidad}

Algunas empresas se creen con derecho a acceder a la información médica sobre los trabajadores que reciben servicios del profesional. Sin embargo, el profesional está obligado, por ética profesional y por necesidades prácticas, a mantener la confianza del trabajador. Este problema se agrava especialmente cuando se interponen procesos legales o cuando conlleva una gran carga emocional, como es el caso de la discapacidad por SIDA.
L os profesionales pueden verse también implicados en asuntos confidenciales relacionados con las prácticas y actividades de la empresa. Si existe una gran competencia en el sector industrial en cuestión, es posible que la empresa desee mantener en secreto información relacionada con sus planes de organización, reorganización o reducción de plantilla. Cuando existe la posibilidad de que las prácticas empresariales influyan en la salud de los trabajadores, ¿cómo puede el profesional evitar esos efectos nocivos sin desvelar información secreta o confidencial de la empresa?

Según Roman y Blum (1987), la confidencialidad sirve para proteger al profesional de un control exhaustivo. Citando el derecho a la confidencialidad del cliente, muchos se oponen a las revisiones de calidad o a las revisiones mutuas que pueden poner de manifiesto que el profesional ha rebasado los límites de su formación o competencia profesional. Esto es una consideración ética importante por el poder que tiene el profesional de influir en la salud y el bienestar de sus clientes. La cuestión está en explicar claramente al cliente la naturaleza de la intervención, en términos de lo que puede o no puede hacer.

La confidencialidad de la información recopilada por los programas que se centran en el individuo más que en los sistemas de trabajo puede ser perjudicial para la seguridad de los trabajadores. La información obtenida en los programas de promoción de la salud puede utilizarse incorrectamente para influir en la situación del trabajador con respecto al seguro médico u otros aspectos de su vida personal. Cuando se dispone de datos agregados, puede resultar difícil evitar que se utilicen para identificar a trabajadores concretos, especialmente en empresas de pequeño tamaño.

Cuando la información recopilada en los programas de asistencia a los trabajadores se centra en una unidad o en un lugar de trabajo concretos, los profesionales suelen mostrarse reacios a facilitar esa información a la dirección. En algunas ocasiones, la confidencialidad se utiliza en realidad para enmascarar la incapacidad de recomendar intervenciones razonables, por temor del profesional a que la dirección de la empresa no acepte una crítica negativa sobre su comportamiento u organización. D esafortunadamente, los médicos carecen a veces de las cualificaciones científicas y epidemiológicas necesarias para presentar datos sólidos que respalden sus observaciones.

O tros problemas están relacionados con el uso incorrecto de la información por parte de diferentes grupos de intereses. Las entidades aseguradoras, las empresas, los sindicatos, los grupos de clientes y los profesionales de la salud pueden hacer un uso incorrecto tanto de la información colectiva como de la individual que se recopila durante las actividades de promoción de la salud.

Algunos pueden utilizar estos datos para denegar un servicio o cobertura a los trabajadores 0 a sus herederos en procedimientos legales o administrativos relativos a reclamaciones de indemnización o de otras prestaciones al amparo de un seguro. Los participantes en los programas pueden creer que la "garantía de confidencialidad" que ofrecen éstos es inviolable. Por ello, se debe advertir claramente a los trabajadores que, en determinadas circunstancias (es decir, en investigaciones legales o administrativas), la información personal recogida por el programa puede ponerse a disposición de otras partes.

Los datos agregados pueden usarse indebidamente para trasladar la responsabilidad de una parte interesada a otra. El acceso a este tipo de información puede no ser equitativo si el acceso a la información colectiva se permite sólo a los representantes de la empresa pero no a los particulares que reclaman una prestación. Aunque las empresas pueden revelar datos personales de los trabajadores sobre los estilos de vida que contribuyen a una enfermedad, pueden restringir el acceso a 
información sobre las prácticas empresariales que contribuyen a ese mismo problema.

Los datos epidemiológicos sobre la frecuencia de las enfermedades o la presencia de otros factores relacionados con el trabajo no deben recopilarse de tal manera que se facilite su explotación por parte de la empresa, la entidad aseguradora, el sistema de indemnizaciones o los clientes.

\section{Conflictos con las normas de otras profesiones 0 servicios}

Las normas y los valores profesionales pueden entrar en conflicto con las prácticas de una determinada organización. L os métodos de confrontación que se utilizan en los programas contra el alcoholismo en el lugar de trabajo pueden resultar poco productivos o entrar en conflicto con los valores profesionales cuando se aplican a otros trastornos o discapacidades, aunque el profesional que trabaja en este contexto puede recibir presiones para utilizar este tipo de métodos.

Las relaciones éticas con proveedores externos también deben considerarse. Aunque los programas de asistencia a los trabajadores han establecido claramente la necesidad de que los médicos eviten la remisión de pacientes a servicios terapéuticos con los que están estrechamente afiliados, los prestadores de servicios de promoción de la salud no han definido con la misma claridad sus relaciones con los prestadores externos de servicios que pueden ser atractivos para los trabajadores que desean asesoramiento sobre su estilo de vida personal. Cuando los acuerdos entre los programas de asistencia a los trabajadores y otros proveedores externos para la remisión de pacientes que necesitan recibir tratamiento tienen más en cuenta las ventajas económicas de los proveedores que las necesidades clínicas de los clientes, se plantea un conflicto evidente de intereses.

Existe también la tentación de contratar a personas no cualificadas para las actividades de promoción de la salud. M uchos de los profesionales que trabajan en los programas de asistencia a los trabajadores no han recibido formación suficiente en técnicas de educación sanitaria, fisiología o determinación de la capacidad física para el trabajo, que les cualifique para llevar a cabo estas actividades. Cuando los programas son administrados por la dirección y su preocupación principal es el coste, el incentivo para contratar a los profesionales más capacitados y competentes es menor, ya que los resultados en términos de coste y beneficio cambiarán.

Cuando estos servicios son prestados por los propios compañeros de trabajo, se plantea otra serie de problemas. Se ha demostrado que el apoyo social de los compañeros de trabajo puede amortiguar el efecto de ciertos factores de estrés en la salud. M uchos programas han sacado provecho de la influencia positiva del apoyo social haciendo que sean los propios compañeros de trabajo quienes presten los servicios de asesoramiento o creando grupos de ayuda mutua. Sin embargo, aunque los compañeros de trabajo puedan utilizarse hasta cierto punto como complemento, sigue existiendo la necesidad de contratar profesionales sanitarios cualificados. Los compañeros de trabajo necesitan un extenso programa de orientación para conocer las prácticas éticas y no sobrepasar sus límites o competencias personales, ya sea explícitamente o por una interpretación incorrecta.

\section{Exploración selectiva y pruebas para detectar el consumo de} drogas

Las pruebas para la detección del consumo de drogas se han convertido en el aspecto más conflictivo de los reglamentos e interpretaciones legales y no ha podido demostrarse que constituyan una vía eficaz para el tratamiento o la prevención de dicho consumo. El reciente informe del National Research Institute
(O 'Brien 1993) ha concluido que las pruebas para la detección del consumo de drogas no son medidas disuasorias para evitar el abuso de alcohol y drogas. 0 tras evidencias sugieren que tampoco tienen un efecto significativo en el rendimiento laboral.

Un resultado positivo en una de estas pruebas puede revelar mucho sobre el estilo de vida de un trabajador, pero nada sobre su nivel de aptitud o inaptitud para desempeñar su trabajo.

Las pruebas para la detección del consumo de drogas se han considerado el filo del arma que las empresas pueden utilizar para deshacerse de todos los trabajadores menos los más invulnerables, los más resistentes. EI problema radica en decidir hasta dónde puede llegar la empresa. ¿Puede someter a sus trabajadores a pruebas para detectar conductas compulsivas como ludopatía u otros trastornos mentales, como la depresión?

Existe también el temor a que las empresas puedan utilizar la exploración selectiva para identificar rasgos poco deseables (como predisposición a enfermedades cardiovasculares o lesiones de espalda) y tomar decisiones sobre el personal basándose en dicha información. En la actualidad, esta práctica parece limitarse a la cobertura de seguro médico, pero, ¿cuánto tiempo podrán resistir esta tentación las empresas que intentan reducir sus gastos?

La práctica promovida por el gobierno de realizar una exploración selectiva a los trabajadores para detectar el consumo de drogas, y la futura posibilidad de que se intenten detectar genes defectuosos y categorías enteras de trabajadores queden excluidos de la cobertura del seguro médico resucitan el antiguo supuesto de que las características de los trabajadores, y no las del trabajo, explican las discapacidades y disfunciones, justificando así que los trabajadores tengan que soportar los costes sociales y económicos. Esto nos vuelve a situar en una perspectiva en la que los factores basados en el individuo, y no en el trabajo, se convierten en el centro de atención de las actividades de promoción de la salud.

\section{Explotación por el cliente}

En algunas ocasiones, el profesional puede ver claramente que los trabajadores están intentando aprovecharse indebidamente de los servicios prestados por una empresa, por la entidad aseguradora o por el sistema de indemnizaciones. Es posible que se encuentre con problemas como demandas de rehabilitación poco realistas o simulación de una enfermedad para obtener prestaciones económicas. L os métodos para enfrentarse a comportamientos de ese tipo y adoptar las medidas oportunas deben sopesarse frente a las realidades clínicas como, por ejemplo, las reacciones psicológicas ante la discapacidad.

\section{Promoción de actividades de eficacia cuestionable}

A pesar de los numerosos partidarios de la promoción de la salud en el lugar de trabajo, los datos científicos que existen para evaluar estas intervenciones son limitados. La profesión en su conjunto no se ha planteado todavía los aspectos éticos de las actividades de promoción que carecen de un sólido respaldo científico o de las decisiones de prestar los servicios que producen más beneficios en lugar de los que tienen un efecto demostrado.

I rónicamente, los programas actuales se basan en evidencias poco fundadas sobre el aumento de la productividad o la reducción de los costes, el absentismo, los gastos de asistencia sanitaria y la rotación de los trabajadores. Los estudios están mal diseñados y rara vez incluyen grupos de referencia o un seguimiento a largo plazo. Los pocos que cumplen las normas del rigor científico han aportado escasas evidencias de una rentabilidad positiva de la inversión en estos programas. 
Algunas evidencias sugieren que las personas que participan en las actividades de promoción de la salud en el lugar de trabajo suelen ser relativamente más sanas:

En conjunto, los participantes fuman menos, están más preocupados por su salud, se sienten en un mejor estado de salud y practican más ejercicio físico, especialmente ejercicio aeróbico, que los que no participan. Existen también algunas evidencias de que los participantes utilizan menos los servicios de salud y son algo más jóvenes que los que no participan (C onrad 1987).

Puede ocurrir que las personas que están en mayor situación de riesgo no utilicen los servicios de salud.

Incluso cuando existen evidencias que apoyan determinadas actividades y todos los profesionales están de acuerdo en la necesidad de esos servicios como seguimiento, en la práctica no siempre se prestan. En general, los programas de asistencia a los trabajadores se centran en la detección de nuevos casos y dedican poco tiempo a la prevención en el lugar de trabajo. Los servicios de seguimiento no existen o se limitan a una o dos visitas tras la reincorporación al trabajo. Considerando la posibilidad que existe siempre de una recaída en los casos de abuso de alcohol y drogas, no parece que los programas de asistencia a los trabajadores dediquen energía suficiente a la asistencia continuada, cuyo coste es muy elevado, sino que más bien se centran en actividades que pueden generar nuevos ingresos.

\section{Reconocimientos médicos para los fines del seguro y la determinación de prestaciones}

De la misma forma que la frontera entre los factores de la vida privada y profesional que influyen en la salud es cada vez más difusa, también lo es la distinción entre la capacidad o incapacidad física para el trabajo o entre la salud y la enfermedad. Por ello, los reconocimientos médicos que se realizan para los fines del seguro o para recibir una prestación no se centran en si el trabajador está o no enfermo o discapacitado y, por consiguiente, "merece" recibir una prestación; por el contrario, cada vez está más claro que con determinados cambios en el lugar de trabajo y con las actividades de promoción de la salud, el trabajador podría ocupar algún puesto de trabajo a pesar de su enfermedad o discapacidad. Efectivamente, el Convenio de la O IT sobre los servicios de salud en el trabajo, 1985 (no 161) hace referencia a la "la adaptación del trabajo a las capacidades de los trabajadores, habida cuenta de su estado de salud física y mental".

La conexión entre las medidas de protección de la salud y las actividades de promoción de la salud no son tan importantes en ningún otro campo como en la asistencia a los trabajadores con necesidades especiales. De la misma forma que un paciente concreto puede reflejar la patología de un grupo, un trabajador con necesidades especiales puede reflejar las de toda la plantilla. La modificación del lugar de trabajo para acomodar a este tipo de trabajadores tiene muchas veces como resultado la introducción de mejoras en el lugar de trabajo que benefician a todos los trabajadores. Los servicios de tratamiento y promoción de la salud para los trabajadores con necesidades especiales pueden reducir los gastos de la organización al reducir las primas de seguro y las prestaciones por indemnización; pero, lo principal es que se trata de la manera más ética de actuar.

Reconociendo que la rehabilitación y la acomodación de los trabajadores lesionados es un "buen negocio", muchas empresas han incorporado a sus programas nuevas actividades de intervención precoz, rehabilitación y reincorporación al trabajo. Algunos de estos programas se ofrecen a través de los comités de indemnización de los trabajadores, que han entendido que tanto la empresa como los trabajadores se ven perjudicados cuando el sistema de prestaciones incentiva que se siga adoptando el "papel de enfermo" en lugar de incentivar la rehabilitación física, mental y profesional.

\section{Conclusión}

EI Código deontológico internacional para los profesionales de la salud en el trabajo (que se reproduce en este capítulo) proporciona directrices para asegurar que las actividades de promoción de la salud no desvíen su atención de las medidas de protección de la salud y para fomentar la práctica ética en dichas actividades. El Código establece lo siguiente:

Los profesionales de la salud en el trabajo pueden contribuir a la salud pública de muchas maneras, en particular a través de sus actividades de educación sanitaria, promoción de la salud y exploración selectiva. Los profesionales de la salud en el trabajo deben exigir la participación... tanto de las empresas como de los trabajadores en el diseño y aplicación de estos programas. Asimismo, deben proteger la confidencialidad de los datos personales sobre la salud de los trabajadores.

Finalmente, debemos reiterar que la práctica ética de la medicina del trabajo podría promoverse mejor considerando la infraestructura del lugar de trabajo y de la sociedad que debe existir para proteger los intereses individuales y colectivos. Por consiguiente, los programas de control del estrés, promoción de la salud y asistencia a los trabajadores, que hasta ahora se centraban casi exclusivamente en el individuo, deben tener en cuenta otros factores institucionales del trabajo. También será necesario garantizar que estas actividades no desplacen a las medidas de protección de la salud.

\section{ESTUDIO DE CASO : CONSIDERACIONES ETICAS SOBRE EL CONSUMO DE DROGAS Y ALCOHOL EN EL LUGAR DE TRABAJO}

Behrouz Shahandeh y Robert H usbands

\section{Introducción}

Los problemas de drogas y alcohol en el lugar de trabajo pueden plantear dilemas éticos a una empresa. Antes de tomar una decisión, deben sopesarse las consideraciones sobre las personas con problemas de abuso de drogas y alcohol, y la obligación de administrar correctamente los recursos financieros de los accionistas y proteger la seguridad de otros trabajadores.

Pese a que, en algunos casos, tanto las medidas preventivas como correctoras pueden ser útiles para los trabajadores y la empresa, en otras situaciones lo que la empresa cree que es bueno para la salud y el bienestar de los trabajadores es considerado por éstos como una importante restricción de su libertad. A simismo, las medidas que adopte una empresa para enfrentarse a problemas de seguridad y productividad pueden ser consideradas innecesarias, ineficaces y una intromisión en la vida privada.

\section{El derecho a la intimidad en el trabajo}

Los trabajadores consideran que la intimidad es un derecho fundamental. En algunos países es un derecho reconocido por la ley, pero que se interpreta de manera flexible de acuerdo con las necesidades de la empresa para garantizar, entre otras cosas, una mano de obra segura, sana y productiva y unos productos o servicios que no sean peligrosos para los consumidores ni para el público en general. 
El consumo de alcohol y drogas suele tener lugar durante el tiempo libre y fuera del lugar de trabajo. El consumo de alcohol puede producirse también en el lugar de trabajo cuando así lo permite la legislación local. Cualquier intromisión en la vida privada del trabajador por parte de la empresa con respecto al consumo de drogas o alcohol debe justificarse con razonamientos convincentes y aplicando el método que implique menos entrometimiento a igualdad de costes.

Las empresas utilizan dos tipos de prácticas muy controvertidas para identificar a los consumidores de drogas y alcohol entre los candidatos a un puesto de trabajo y los trabajadores: pruebas para la detección de alcohol y drogas en el organismo (aire exhalado, sangre, orina) y encuestas orales o escritas sobre el consumo pasado y presente de alcohol y drogas. Otros métodos de identificación que también suscitan polémica son la observación y la vigilancia, así como las pruebas de rendimiento realizadas por ordenador.

\section{Pruebas para detectar sustancias en el organismo}

Estas pruebas constituyen probablemente el método de identificación más polémico. En el caso del alcohol, se utilizan alcoholímetros o se analizan muestras de sangre. En el caso de las drogas, la práctica más extendida es el análisis de orina.

Las empresas alegan que estas pruebas son útiles para promover la seguridad y prevenir accidentes, determinar la capacidad física para el trabajo, aumentar la productividad, reducir el absentismo y la falta de puntualidad, controlar los costes sanitarios, aumentar la confianza del público en la seguridad de sus productos o servicios, evitar que se deteriore la imagen de la empresa, identificar y rehabilitar a los trabajadores, evitar delitos de robo y disuadir conductas ilegales 0 socialmente inaceptables en los trabajadores.

Los trabajadores alegan por su parte que estas pruebas son censurables ya que la toma de muestras de sustancias corporales constituye una grave intromisión en la vida privada; que los procedimientos de muestreo pueden ser humillantes y degradantes, sobre todo en el caso de los análisis de orina realizados bajo supervisión para evitar falsificaciones; que estas pruebas no son una manera eficaz de promover la seguridad o la salud y que la forma más eficiente de promover la salud y la seguridad es mediante unas actividades de prevención más eficaces, una supervisión más estrecha y los programas de asistencia a los trabajadores.

O tros argumentos en contra de la exploración selectiva son que las pruebas para detectar el consumo de drogas (al contrario que las del alcohol) no reflejan el deterioro actual del estado de salud, sino tan solo el consumo previo y, por lo tanto, no son indicativas de la capacidad actual para el trabajo; que las pruebas, sobre todo las que se utilizan para detectar el consumo de drogas, requieren procedimientos complicados; que, en caso de no respetar esos procedimientos, podría obtenerse un resultado erróneo de consecuencias graves e injustas y que este tipo de pruebas pueden crear problemas morales entre la dirección y los trabajadores, así como un ambiente de desconfianza.

0 tros afirman que las pruebas se utilizan para identificar conductas moralmente inaceptables para la empresa; que en muchos lugares de trabajo no existe una base empírica convincente de que existan problemas de alcohol o drogas que justifiquen la exploración selectiva previa a la contratación, aleatoria o periódica, y que este tipo de control constituye una grave intromisión en la vida privada del trabajador, porque las pruebas se efectúan aunque no existan sospechas fundadas. También se ha dicho que las pruebas para la detección del consumo de drogas ilegales equivalen a que la empresa asuma la función de hacer aplicar la ley, que no le corresponde a ella.

En algunos países europeos, como Suecia, N oruega, Países Bajos y Reino U nido, estas pruebas están permitidas, aunque normalmente en circunstancias muy específicas. Por ejemplo, en muchos países europeos existen leyes que permiten a la policía realizar estas pruebas a personas que trabajan en el sector del transporte por carretera, ferrocarril, aéreo y marítimo, cuando tienen sospechas fundadas de que el consumo se ha producido durante las horas de trabajo. Este tipo de pruebas también se realizan en el sector privado, aunque generalmente sólo cuando existen sospechas fundadas a raíz de un accidente 0 incidente grave. En el contexto de los puestos de trabajo con necesidades especiales de seguridad, se ha informado de la realización de pruebas previas a la contratación y, en casos muy limitados, pruebas periódicas o aleatorias. Sin embargo, las pruebas aleatorias son poco frecuentes en los países europeos.

En Estados U nidos, se aplican diferentes normas según las pruebas sobre el consumo de alcohol y drogas sean efectuadas por personal del sector privado o público. Las pruebas realizadas por el gobierno o por las empresas en aplicación de la normativa vigente deben cumplir los requisitos constitucionales que amparen este tipo de decisiones. Este ha sido el motivo de que los tribunales permitan estas pruebas sólo en el caso de puestos de trabajo con necesidades especiales de seguridad, aunque permiten casi todo tipo de pruebas, entre ellas las previas a la contratación, las que se realizan cuando existe una sospecha fundada, las pruebas periódicas, las pruebas realizadas después de un accidente 0 incidente y las pruebas aleatorias. Para realizar las pruebas, no existe la obligación de demostrar la existencia de sospechas razonables sobre el abuso de abuso de drogas en una empresa, en alguna de sus divisiones o por parte de alguna persona. Algunos observadores han denunciado la falta de ética de este planteamiento, al no existir la obligación ni siquiera de demostrar la existencia de una sospecha razonable de un problema en la empresa o en algún trabajador antes de realizar este tipo de pruebas, entre ellas la exploración selectiva aleatoria.

En el sector privado, la legislación federal no impone restricciones a la realización de pruebas, aunque algunos Estados norteamericanos han impuesto restricciones procesales y jurídicas a las pruebas para detectar el consumo de drogas. No obstante, en la mayoría de esos estados existen pocas restricciones, o ninguna, sobre las pruebas realizadas por las empresas privadas para detectar abuso de drogas y alcohol. Estas pruebas se realizan a una escala mucho mayor que en Europa, donde las empresas privadas las realizan principalmente por razones de seguridad.

\section{Encuestas o cuestionarios}

Aunque menos invasivos que los análisis, las encuestas y los cuestionarios que intentan obtener información sobre el consumo pasado o presente de alcohol y drogas constituyen una intromisión en la vida privada del trabajador y son innecesarios para cumplir los requisitos de la mayoría de los puestos de trabajo. En Australia, C anadá, algunos países europeos y Estados Unidos, existen leyes sobre el derecho a la intimidad, aplicables tanto al sector público como al privado, que exigen que las encuestas y cuestionarios sean directamente pertinentes para el puesto de trabajo en cuestión. En la mayoría de los casos, estas leyes no imponen restricciones específicas a las encuestas sobre el consumo de drogas y alcohol, aunque en Dinamarca, por ejemplo, está prohibido recoger y guardar información sobre su consumo. En N oruega y Suecia, los datos sobre el consumo de alcohol y drogas se consideran datos confidenciales que, en 
principio, no se pueden conservar en un registro salvo que sea necesario por razones específicas y la autoridad correspondiente en materia de inspección de datos haya dado su consentimiento.

En A lemania, las empresas sólo pueden hacer preguntas para juzgar las destrezas y competencias de un candidato que estén relacionadas con el puesto de trabajo al que éste aspira. El candidato puede dar una respuesta falsa a las preguntas de carácter personal que no sean pertinentes. Por ejemplo, una sentencia judicial ha establecido que una mujer puede legalmente responder que no está embarazada aunque sí lo esté. Estos asuntos íntimos se deciden en los tribunales caso por caso; por lo tanto, el derecho de mentir a las preguntas sobre el consumo de alcohol y drogas en el pasado o en el presente depende probablemente de que este tipo de preguntas sean razonablemente necesarias para determinar la capacidad de ocupar el puesto de trabajo en cuestión.

\section{Observación y vigilancia}

La observación y la vigilancia son los métodos tradicionales para detectar problemas de alcohol y drogas en el lugar de trabajo. En términos sencillos, si un trabajador muestra claras señales de intoxicación o de sus efectos posteriores, su supervisor puede identificarle por su comportamiento. El método de la supervisión para detectar problemas de alcohol y drogas es el más extendido, el menos polémico y el preferido por los representantes de los trabajadores. Sin embargo, la doctrina que mantiene que el tratamiento de los problemas de drogas y alcohol tiene más posibilidades de éxito si se basa en una intervención precoz, plantea un problema ético. Si este enfoque se aplica a la observación y la vigilancia, los supervisores pueden verse tentados a identificar signos de conducta ambigua o menor rendimiento en el trabajo y especular sobre el consumo privado de alcohol o drogas por parte de un trabajador. La observación minuciosa, combinada con un cierto grado de especulación, puede tacharse de poco ética. Por lo tanto, los supervisores deben limitarse a los casos en los que el trabajador está claramente bajo la influencia del alcohol o las drogas y por ello no sea capaz de conseguir un nivel aceptable de rendimiento en el trabajo.

L a otra cuestión que se plantea es lo que debe hacer un supervisor cuando el trabajador muestra claras señales de intoxicación. Algunos comentaristas pensaban antes que el supervisor debía enfrentarse al trabajador y desempeñar un papel directo a la hora de ayudarle. Sin embargo, en la actualidad predomina la opinión de que un enfrentamiento así puede ser contraproducente y de que posiblemente agravará el problema. Por el contrario, el trabajador debe ser remitido a un servicio de salud adecuado que evalúe su problema y, en caso necesario, le ofrezca asesoramiento, tratamiento y rehabilitación.

\section{Pruebas de rendimiento por ordenador}

Algunos comentaristas han sugerido las pruebas de rendimiento por ordenador como método alternativo para detectar a los trabajadores que están bajo la influencia del alcohol y las drogas. Se ha dicho que estas pruebas son más eficaces que otras alternativas de identificación porque determinan la incapacidad actual y no el consumo previo, son más dignas, constituyen una menor intromisión en la vida privada, y la incapacidad laboral puede atribuirse a distintas razones, como falta de sueño, enfermedad 0 intoxicación por alcohol o drogas. La principal objeción a estas pruebas es que, desde el punto de vista técnico, no siempre miden con exactitud las destrezas para el trabajo que pretenden medir, no siempre detectan niveles bajos de alcohol y drogas que también pueden afectar al rendimiento, y las pruebas más sensibles y exactas son a la vez las que resultan más costosas y difíciles de administrar.

\section{Aspectos éticos de la elección entre disciplina y tratamiento}

U na de las decisiones más difíciles para una empresa es cuándo debe adoptar medidas disciplinarias como respuesta a un incidente relacionado con el consumo de alcohol o drogas en el trabajo; cuándo la respuesta correcta es ofrecer asesoramiento, tratamiento y rehabilitación; y en qué circunstancias debe emprender simultáneamente ambas acciones (tanto disciplina como tratamiento). Este tema plantea la pregunta de si el consumo de alcohol y drogas es por su naturaleza una conducta 0 una enfermedad. Nuestra opinión es que el consumo de alcohol y drogas es esencialmente una conducta, pero que el consumo prolongado de cantidades excesivas de estas sustancias produce una dependencia que puede considerarse una enfermedad.

Desde el punto de vista de la empresa, lo verdaderamente importante es la conducta del trabajador; es decir, su rendimiento en el trabajo. Una empresa tiene derecho a imponer sanciones disciplinarias y ese derecho se convierte en una obligación cuando un comportamiento inadecuado de un trabajador puede repercutir en la seguridad, la salud y el bienestar económico de los demás. Trabajar bajo la influencia del alcohol o las drogas puede definirse como un comportamiento inadecuado y si la persona ocupa un puesto que requiere unas condiciones especiales de seguridad, esta situación puede definirse como una falta grave de conducta. Sin embargo, una persona que tiene problemas en el trabajo por el consumo de alcohol y drogas puede tener también un problema de salud.

En el caso de una conducta inadecuada provocada por el alcohol y las drogas, la empresa debe ofrecer ayuda al trabajador para determinar si se trata de un problema de salud. Si el trabajador rechaza esa oferta de ayuda, la empresa debe aplicar la sanción disciplinaria correspondiente. La decisión de rechazar una oferta de ayuda puede ser una decisión legítima del trabajador porque prefiera que la empresa no conozca sus problemas de salud 0 porque en realidad no sufra ningún problema de salud. Dependiendo de las circunstancias, la empresa puede imponer también una sanción disciplinaria.

O tra cosa sería la reacción de una empresa ante una falta grave de conducta relacionada con el consumo de alcohol o drogas cuando el puesto de trabajo que ocupa ese trabajador requiere unas condiciones especiales por motivos de seguridad. En este caso, la empresa tiene, por un lado, el deber moral de proteger la seguridad de los demás trabajadores y del público en general y, por otro, la obligación moral de ser justa con el trabajador en cuestión. En una situación así, la preocupación ética primordial de la empresa sería proteger la seguridad del público y retirar inmediatamente al trabajador de su puesto de trabajo. Incluso en el caso de despido por falta grave, la empresa debe ayudar al trabajador para que reciba la asistencia sanitaria adecuada.

\section{Aspectos éticos de los servicios de asesoramiento, tratamiento y rehabilitación}

También pueden plantearse cuestiones éticas relacionadas con la ayuda que se ofrece a los trabajadores. EI problema inicial que puede surgir es el de la evaluación y la remisión. Este tipo de servicios pueden ser prestados por el servicio de medicina de trabajo de la empresa, un profesional sanitario que trabaje en un programa de asistencia a los empleados o por el médico personal del trabajador. Si no existe ninguna de estas posibilidades, la empresa tendrá que encontrar a otros profesionales especializados en el asesoramiento, tratamiento y rehabilitación de los problemas derivados del consumo de alcohol y drogas y sugerir al trabajador que se ponga en contacto con alguno de ellos para que evalúe su estado $\mathrm{y}$, en su caso, lo remita al especialista adecuado. 
La empresa debe también intentar ayudar al trabajador durante todo el tiempo que esté de baja laboral para recibir tratamiento. En la medida de lo posible, la empresa debe poner a disposición del trabajador la posibilidad de una baja laboral remunerada y otro tipo de excedencias cuando su tratamiento exija hospitalización. Si el tratamiento ambulatorio del trabajador requiere la adaptación de su horario de trabajo o la reducción de su jornada, la empresa debe responder favorablemente a estas peticiones y realizar los ajustes necesarios, sobre todo porque el hecho de que la persona siga trabajando en la empresa se considera un factor positivo para su recuperación. L a empresa debe también ofrecer apoyo y vigilar el rendimiento del trabajador. Si el medio ambiente de trabajo puede haber contribuido inicialmente al problema de alcohol o drogas, la empresa debe introducir los cambios necesarios en el lugar de trabajo. Si esto no es posible ni práctico, debe considerarse la posibilidad de transferir al trabajador a otro puesto de trabajo una vez realizada la readaptación profesional razonable y necesaria.

U na cuestión ética complicada es hasta qué punto la empresa debe seguir ayudando a un trabajador que se encuentra de baja por problemas de salud relacionados con el alcohol y las drogas y en qué momento debe despedirle por razones de salud. En principio, la empresa debe considerarlo como cualquier otro tipo de baja laboral por enfermedad y las mismas consideraciones que aplique a los otros despidos por motivos de salud deberá aplicarlas a los despidos causado por problemas relacionados con el alcohol y las drogas. Por otra parte, las empresas no deben olvidar que puede producirse una recaída y que, de hecho, ésta forma parte del proceso hacia una recuperación completa.

\section{Aspectos éticos de la relación con consumidores de drogas ilegales}

La empresa se enfrentará a decisiones éticas difíciles en su relación con un trabajador que consume, 0 ha consumido en el pasado, drogas ilegales. Por ejemplo, se ha planteado la cuestión de si una empresa debe despedir a un trabajador que está detenido 0 acusado de un delito relacionado con drogas ilegales. Si el delito es tan grave que la persona deba ingresar en prisión, es evidente que no podrá trabajar. Sin embargo, en muchos casos, los consumidores y pequeños traficantes, que venden sólo lo necesario para financiarse su propio hábito, obtienen libertad condicional o se les sanciona con una multa. En tal caso, la empresa no debería considerar otras sanciones disciplinarias o el despido del trabajador por su conducta fuera de las horas y los locales de trabajo. En algunos países, si la persona ha cumplido su condena o ha pagado la multa correspondiente, puede existir una barrera jurídica real contra la discriminación laboral de esa persona.

0 tra cuestión que se plantea a veces es si un consumidor de drogas ilegales en el pasado o en el presente debe ser objeto de discriminación laboral por parte de las empresas. Se dice que la respuesta ética debe ser que los consumidores de drogas ilegales en el pasado o en el presente no sean objeto de discriminación si el consumo tiene lugar fuera de las horas de trabajo y fuera del lugar de trabajo. En este sentido, la empresa debe estar dispuesta a realizar los ajustes necesarios para adaptar el trabajo al consumidor actual de drogas ilegales que está de baja para recibir asesoramiento, tratamiento o rehabilitación. Esta postura se recoge en la ley federal canadiense sobre los derechos humanos, que prohibe la discriminación laboral por motivos de discapacidad y califica como tal la dependencia del alcohol y las drogas. También la legislación laboral francesa prohibe la discriminación laboral por motivos de salud o discapacidad, a no ser que el médico determine que la persona está incapacitada para trabajar. En cambio, la legislación de Estados U nidos protege de la discriminación a los que han consumido drogas en el pasado, pero no a los que las consumen en el presente.

En principio, si una empresa observa que un candidato a un puesto de trabajo o un trabajador consume, o se sospecha que consume, drogas fuera de las horas de trabajo y del lugar de trabajo, y el consumo no afecta materialmente al funcionamiento de la empresa, no tiene la obligación de informar a las autoridades encargadas de hacer cumplir la ley. Según las disposiciones legales estadounidenses que exigen a los organismos públicos que realicen pruebas para detectar el consumo de drogas, los candidatos a un puesto de trabajo y los trabajadores que obtengan resultados positivos en dichas pruebas no deben ser denunciados a las autoridades encargadas de hacer cumplir la ley.

$\mathrm{Si}$, por otro lado, un trabajador realiza actividades relacionadas con drogas ilegales dentro del horario y lugar de trabajo, la empresa tiene la obligación moral de aplicar sanciones disciplinarias, denunciar el caso a las autoridades encargadas de hacer cumplir la ley o ambas cosas.

U na consideración importante que la empresa debe tener presente es la confidencialidad. La empresa puede enterarse de que un aspirante a un puesto de trabajo o un trabajador consume drogas ilegales porque la persona en cuestión decida revelar esa información por razones de salud, por ejemplo, para facilitar ajustes en su trabajo durante el proceso de asesoramiento, tratamiento y rehabilitación. L a empresa tiene una clara obligación moral, y a menudo jurídica, de mantener cualquier información de esa naturaleza estrictamente confidencial. Dicha información no debe ser revelada ni a las autoridades encargadas de hacer cumplir la ley ni a nadie más sin el expreso consentimiento de la persona afectada.

En muchos casos, la empresa puede no ser consciente de que el trabajador consume drogas ilegales, pero el servicio de salud de la empresa puede saberlo por los reconocimientos que realiza al trabajador para determinar su capacidad física para el trabajo. El profesional de la salud tiene el deber moral de mantener la confidencialidad de la información sobre la salud de su paciente. En una situación así, el servicio de salud en el trabajo sólo tiene que informar a la empresa de si el trabajador está o no capacitado desde el punto de vista médico, para realizar su trabajo (o lo está con ciertas reservas), pero no está obligado a revelar la naturaleza del problema a la empresa 0 a un tercero, por ejemplo, a las autoridades judiciales.

\section{Otras cuestiones éticas}

\section{Sensibilidad hacia el medio ambiente de trabajo}

Normalmente, las empresas están obligadas por ley a proporcionar un medio ambiente de trabajo seguro y saludable. La propia empresa es la que decide la manera de aplicar este requisito al contexto del alcohol y las drogas. Los representantes de los trabajadores alegan que muchos de los problemas relacionados con el alcohol y las drogas se producen principalmente como consecuencia de factores relacionados con el trabajo, por ejemplo, largas jornadas de trabajo, trabajo aislado, trabajo nocturno, trabajo monótono o sin contenido, malas relaciones en el trabajo (con jefes o compañeros), inseguridad laboral, trabajo mal retribuido, tareas sometidas a una gran presión y de poca importancia y otras circunstancias que provocan estrés. 0 tros factores, como el fácil acceso al alcohol y a las drogas y ciertos hábitos culturales que fomentan al consumo de alcohol dentro y fuera del trabajo, también pueden dar lugar a problemas de abuso de sustancias. Las empresas deben tener en cuenta todos estos factoresy adoptar las medidas oportunas. 


\section{Restricciones al consumo de alcohol y drogas en el lugar de trabajo}

Existe un amplio consenso en el sentido de que el alcohol y las drogas no deben consumirse durante las horas de trabajo, sea cual sea la profesión. N o obstante, la cuestión más delicada es si una empresa debe prohibir o restringir la disponibilidad de bebidas alcohólicas, por ejemplo, en su cafetería o comedor. Los puristas dirían que la manera correcta de actuar sería la prohibición absoluta, que la disponibilidad de bebidas alcohólicas dentro de la empresa puede fomentar el consumo de alcohol en trabajadores que normalmente no lo beberían y que incluso el consumo de pequeñas cantidades de alcohol puede tener efectos negativos sobre la salud. Los liberales dirían que ese tipo de restricciones sobre una actividad legal son injustificables; que durante los descansos para comer, los trabajadores tienen derecho a relajarse y a consumir bebidas alcohólicas con moderación, si así lo desean.

Sin embargo, la respuesta ética adecuada se encuentra entre estos dos extremos y depende mucho de los factores sociales y culturales y también de las circunstancias laborales. En algunas culturas, beber forma parte de la vida social y profesional hasta tal punto que las empresas han observado que es mejor permitir el consumo de ciertas bebidas alcohólicas durante la hora de las comidas que prohibirlo. La prohibición puede hacer que los trabajadores abandonen las instalaciones de la empresa para acudir a bares o "pubs", lugares en donde probablemente consumirán más cantidad de alcohol. El resultado puede ser un mayor consumo de alcohol, o el consumo de licores en lugar de cerveza 0 vino. En otras culturas en las que el consumo de bebidas alcohólicas no constituye una característica tan integrada en la vida social o profesional, la prohibición de consumir cualquier tipo de bebida alcohólica en las instalaciones de la empresa podría aceptarse sin problemas, sin tener resultados contraproducentes en términos del consumo fuera del lugar de trabajo.

\section{Prevención a través de programas de información, educación y formación}

La prevención es probablemente el componente más importante de cualquier política sobre el consumo de alcohol y drogas en el lugar de trabajo. Aunque las personas con este tipo de problemas merecen desde luego una especial atención y tratamiento, la mayoría de los trabajadores beben con moderación y consumen drogas legales, como tranquilizantes, para superar sus problemas. Puesto que estos últimos representan la mayoría, un cambio en su conducta, aunque pequeño, puede tener una gran repercusión en el número de accidentes laborales, la productividad, el absentismo y la impuntualidad.

Algunos ponen en duda que el lugar de trabajo sea el sitio más adecuado para desarrollar actividades preventivas mediante programas de información, educación y formación, ya que las actividades preventivas enfocan los riesgos para la salud relacionados con el consumo de alcohol y drogas principalmente desde la perspectiva de la salud pública y están dirigidas a un público de trabajadores que dependen económicamente de su empresa. La respuesta a estas dudas es que estos programas facilitan también información valiosa y útil sobre los peligros y consecuencias del consumo de alcohol y drogas en el lugar de trabajo; que el lugar de trabajo es quizás la parte más estructurada del entorno cotidiano de una persona y, por tanto, puede ser el foro adecuado para facilitar información sobre la salud, y que las campañas de salud pública no suelen resultar ofensivas para los trabajadores, sobre todo cuando recurren a la persuasión y no a la coacción para modificar conductas o estilos de vida.

Aunque las empresas deben reconocer que estos programas de salud pública tienen una orientación más persuasiva que coactiva, la decisión ética adecuada consiste en introducir y respaldar estos programas no solamente por los beneficios económicos que puede obtener la empresa al reducirse los problemas de alcohol y drogas, sino también por el bienestar general de los trabajadores.

También habría que señalar que los trabajadores tienen responsabilidades éticas con respecto al consumo de alcohol y drogas en el lugar de trabajo, entre ellas la obligación de mantenerse en condiciones de trabajar y abstenerse del consumo de drogas y alcohol inmediatamente antes o durante el trabajo, así como la obligación de evitar el consumo de ciertas sustancias cuando el trabajo que se realiza requiere unas condiciones especiales por motivos de seguridad. 0 tros preceptos éticos serían la obligación de ayudar a los compañeros con problemas de alcohol y drogas y de crear un ambiente de trabajo que ofrezca apoyo y amistad a los que están intentando superar ese problema. Los trabajadores deben apoyar las medidas razonables que adopte la empresa para promover la seguridad y la salud en el lugar de trabajo. Sin embargo, los trabajadores no están obligados a aceptar una intromisión en su vida privada cuando no exista una clara justificación relacionada con el trabajo o cuando las medidas adoptadas por la empresa sean desproporcionadas para el fin que pretende conseguir.

En 1995, una reunión internacional de expertos de la OIT, constituida por 21 expertos procedentes de gobiernos, grupos de empresarios y organizaciones de trabajadores, adoptaron un código de conducta para el tratamiento de problemas relacionados con el consumo de alcohol y drogas en el lugar de trabajo. En este código se plantean muchas de las consideraciones éticas que deben analizarse cuando se plantean este tipo de problemas. El código es especialmente útil como referencia porque también ofrece recomendaciones prácticas sobre el tratamiento de los posibles problemas relacionados con el alcohol y las drogas que pueden surgir en el contexto laboral.

\section{CODIGO DEONTOLOGICO INTERNACIONAL PARA LOS PROFESIONALES DE LA SALUD EN EL TRABAJO}

\section{Comisión Internacional de Medicina del Trabajo}

\section{Introducción}

Algunos países han adoptado en los últimos diez años códigos deontológicos para los profesionales de la salud en el trabajo, además de los códigos deontológicos para los médicos. Existen varias razones de este creciente interés por la ética en la medicina del trabajo, tanto a escala nacional como internacional.

U na de ellas es que cada vez se reconocen más las responsabilidades complejas y a menudo contrapuestas de los profesionales de la seguridad y la salud en el trabajo hacia los trabajadores, las empresas, la sociedad, las autoridades competentes y otros organismos (autoridades sanitarias, laborales, judiciales y de seguridad social). 0 tra de las razones es el aumento del número de profesionales de la seguridad y la salud en el trabajo, como resultado de la creación, obligatoria o voluntaria, de los servicios de medicina del trabajo. Un tercer factor es la adopción de un enfoque interdisciplinario e intersectorial de la salud en el trabajo, que implica la creciente participación de especialistas de diversas profesiones en los servicios de medicina del trabajo.

A los efectos de este código, el término "profesionales de la salud en el trabajo" engloba a todas aquellas personas que, por su profesión, desarrollan actividades relacionadas con la seguridad y la salud en el trabajo, prestan servicios de medicina del 
trabajo o están implicadas en el ejercicio de la medicina del trabajo aunque sólo sea de manera ocasional. Existen numerosas disciplinas relacionadas con la salud en el trabajo, ya que ésta constituye un plano de contacto entre la tecnología y la salud que engloba aspectos técnicos, médicos, sociales y jurídicos. Entre los profesionales de la salud en el trabajo figuran médicos y personal de enfermería, inspectores de fábricas, higienistas industriales, psicólogos del trabajo y especialistas en ergonomía, prevención de accidentes, mejora del medio ambiente de trabajo e investigación sobre la seguridad y la salud en el trabajo. La tendencia consiste en utilizar las competencias de estos profesionales de la salud en el trabajo en el marco de un enfoque interdisciplinario que algunas veces puede adoptar la forma de un equipo interdisciplinario.

M uchos otros profesionales de disciplinas como la química, la toxicología, la ingeniería, la protección frente a las radiaciones, la epidemiología, la salud ambiental, la sociología aplicada y la educación sanitaria pueden también participar de una forma u otra en las actividades relacionadas con la salud en el trabajo. También los funcionarios de los organismos públicos competentes, las empresas, los trabajadores y sus representantes y el personal de primeros auxilios desempeñan una función esencial e incluso pueden ser directamente responsables de la aplicación de las políticas y programas de salud en el trabajo, aunque por su profesión no sean especialistas en este campo. Finalmente, muchos otros profesionales, como abogados, arquitectos, fabricantes, ingenieros, expertos en cuestiones laborales, especialistas en la organización del trabajo, profesores de escuelas técnicas, universidades y otras instituciones, así como profesionales de los medios de comunicación, pueden desempeñar una función importante para mejorar el medio ambiente y las condiciones de trabajo.

El objetivo de la medicina del trabajo es proteger la salud de los trabajadores y promover la creación y el mantenimiento de un medio ambiente de trabajo seguro y saludable, así como promover la adaptación del trabajo a las capacidades de los trabajadores teniendo en cuenta su estado de salud. Los grupos más vulnerables y las poblaciones activas más desfavorecidas deben recibir una clara prioridad. La medicina del trabajo es esencialmente preventiva y debe ayudar a los trabajadores, individual y colectivamente, a proteger su salud en el trabajo. Por consiguiente, debe también ayudar a las empresas a garantizar unas condiciones y un medio ambiente de trabajo seguros y saludables, aspectos que constituyen los criterios de una gestión eficiente y que deben encontrarse siempre en las empresas correctamente gestionadas.

El campo de la medicina del trabajo es extenso y abarca la prevención de todos los problemas de salud que se originan en el trabajo, lesiones y enfermedades relacionadas con el trabajo, entre ellas las enfermedades profesionales, así como todos los aspectos referentes a las interacciones entre trabajo y salud. Los profesionales de la salud en el trabajo deben participar, siempre que sea posible, en el diseño de equipos, métodos y procedimientos para garantizar la seguridad y la salud en el trabajo, así como promover la participación de los trabajadores en estas actividades. Los profesionales de la salud en el trabajo tienen que desempeñar un papel importante en la promoción de la salud de los trabajadores y deben ayudarles a obtener y mantener su empleo a pesar de los problemas de salud o discapacidades que puedan sufrir. El término "trabajadores" se utiliza aquí en el sentido amplio de la palabra y abarca a todos los trabajadores, entre ellos los directivos y los trabajadores autónomos.

El enfoque de la medicina del trabajo es interdisciplinario e interprofesional. Estos profesionales tienen que asumir numerosas obligaciones y establecer relaciones complejas. Por lo tanto, es importante definir la función que llevan a cabo los profesionales de la salud en el trabajo y su relación con otros profesionales y con los interlocutores sociales en la esfera de la política y el desarrollo económico, social y sanitario. Para ello, es necesario establecer con claridad los principios éticos para los profesionales de la salud en el trabajo y las normas de su conducta profesional.

En general, las disposiciones legales definen los deberes y las obligaciones de estos profesionales. Las empresas son responsables de la salud y la seguridad de sus trabajadores. Cada profesión tiene sus responsabilidades que están relacionadas con la naturaleza de sus obligaciones. Cuando se adopta un enfoque interdisciplinario en el que especialistas de distintas profesiones trabajan juntos, es importante que todos ellos se basen en unos principios éticos comunes y que conozcan las obligaciones, las responsabilidades y las normas profesionales de los demás. L oS aspectos éticos requieren una atención especial, sobre todo cuando existan derechos que entran en conflicto, como el derecho a la protección del empleo y el derecho a la protección de la salud, el derecho a la información y el derecho a la confidencialidad o los derechos individuales y los colectivos.

Las disposiciones legales definen algunos de los requisitos que deben cumplir los profesionales de la salud en el trabajo y los servicios de medicina del trabajo. U no de los requisitos básicos para una buena práctica de la medicina del trabajo es la plena independencia profesional, lo que quiere decir que los profesionales de la salud en el trabajo deben disfrutar de independencia en el ejercicio de sus funciones para poder emitir juicios y dar consejos sobre la protección de la seguridad y la salud de los trabajadores de acuerdo con sus conocimientos y su experiencia.

Existen unos requisitos básicos para una práctica aceptable de la medicina del trabajo. Algunas de estas normas de conducta se establecen en la legislación nacional e incluyen, en particular, el libre acceso al lugar de trabajo, la posibilidad de tomar muestras y evaluar el medio ambiente de trabajo, realizar análisis de los puestos de trabajo y participar en las investigaciones después de un accidente, así como la posibilidad de consultar a las autoridades competentes sobre la aplicación de las normas de seguridad y salud en el trabajo. Los profesionales de la salud en el trabajo deben tener asignado un presupuesto que les permita desempeñar sus funciones de acuerdo con unas prácticas correctas y el máximo nivel de profesionalidad. Estos recursos deben consistir en personal adecuado, formación y readaptación profesional, apoyo y acceso a información relevante y al nivel jerárquico adecuado.

Este código establece los principios éticos para el ejercicio de la medicina del trabajo. Los códigos deontológicos nacionales 0 las directrices para profesiones específicas pueden facilitar información más detallada sobre una serie de aspectos concretos. Al final de este documento se citan varios documentos sobre la ética en la medicina del trabajo. Las disposiciones de este código pretenden servir de orientación a todos aquellos que realizan actividades relacionadas con la salud en el trabajo y que colaboran para mejorar el medio ambiente y las condiciones de trabajo. Su propósito es contribuir, en lo que respecta a la ética y la conducta profesional, al establecimiento de unas normas comunes para el trabajo en equipo y el enfoque interdisciplinario de la medicina del trabajo.

La decisión de elaborar este código deontológico se adoptó en el Consejo de la CIMT celebrado en Sydney en 1987. LoS miembros del Consejo recibieron un borrador en $\mathrm{M}$ ontreal y a finales de 1990 y principios de 1991 se llevó a cabo un proceso de consultas. El Código deontológico para los profesionales de la salud en el trabajo de la CIMT fue aprobado por el Consejo el 29 de noviembre de 1991. Este documento será sometido a revisiones periódicas. Cualquier comentario que desee realizarse 
para mejorar su contenido puede remitirse al Secretario G eneral de la Comisión Internacional de M edicina del Trabajo.

\section{Principios básicos}

Los tres apartados siguientes resumen los principios éticos en los que se basa el Código deontológico internacional para los profesionales de salud en el trabajo, elaborado por la Comisión Internacional de M edicina del Trabajo (CIM T):

E I ejercicio de la medicina del trabajo debe ajustarse a las normas profesionales y los principios éticos más estrictos. Los profesionales de salud en el trabajo deben contribuir a mantener la salud y el bienestar social de los trabajadores, individual y colectivamente. Asimismo, deben contribuir a proteger la salud del medio ambiente y de la sociedad en general.

Los profesionales de la salud en el trabajo tienen la obligación de proteger la vida y la salud de los trabajadores, respetando la dignidad humana y fomentando los principios éticos más elevados en las políticas y los programas para promover la salud en el trabajo. La integridad en la conducta profesional, la imparcialidad y la protección de la confidencialidad de los datos médicos y de la intimidad de los trabajadores forman parte de estas obligaciones.

Los profesionales de la salud en el trabajo son expertos que deben disfrutar de plena independencia profesional en el ejercicio de sus funciones. Deben adquirir y mantener las competencias necesarias para asumir sus obligaciones y exigir las condiciones que les permitan llevar a cabo sus tareas de acuerdo con la buena práctica y la ética profesional.

\section{Deberes y obligaciones de los profesionales de la salud en el trabajo}

1. El objetivo principal de la medicina del trabajo es proteger la salud de los trabajadores y promover un medio ambiente de trabajo seguro y saludable. Para alcanzar este objetivo, los profesionales de la salud en el trabajo deben utilizar métodos válidos para evaluar los riesgos, proponer medidas preventivas eficaces y vigilar su cumplimiento. Deben también asesorar a las empresas sobre el cumplimiento de sus responsabilidades en el campo de la seguridad y la salud en el trabajo y deben aconsejar con sinceridad a los trabajadores sobre la protección y la mejora de su salud en el trabajo. Los profesionales de la salud en el trabajo deben mantenerse en contacto directo con los comités de seguridad y salud, cuando existan.

2. L os profesionales de la salud en el trabajo deben esforzarse en todo momento por conocer a fondo el trabajo y el medio ambiente de trabajo, así como por mejorar sus competencias y permanecer bien informados sobre los conocimientos técnicos y científicos, los riesgos laborales y los medios más eficaces para eliminar o reducir los riesgos existentes. Siempre que sea posible, deben realizar visitas periódicas y rutinarias a los lugares de trabajo y consultar a los trabajadores, los técnicos y la dirección sobre el trabajo que se realiza.

3. Los profesionales de la salud en el trabajo deben aconsejar a la dirección y a los trabajadores sobre los factores que pueden afectar a la salud de los trabajadores. La evaluación de los riesgos profesionales debe servir para formular una política de seguridad y salud en el trabajo y un programa de prevención adaptado a las necesidades de la empresa. Los profesionales de la salud en el trabajo deben proponer esa política basándose en los conocimientos científicos y tecnológicos disponibles, así como en su conocimiento del medio ambiente de trabajo. Deben asesorar también sobre un programa de prevención adaptado a los riesgos presentes en el lugar de trabajo que incluya, en su caso, medidas para controlar y vigilar los peligros para la seguridad y la salud en el trabajo, así como para reducir sus consecuencias en caso de producirse un accidente.

4. Los profesionales de la salud en el trabajo deben centrarse en la rápida aplicación de medidas preventivas que sean sencillas, rentables, técnicamente adecuadas y de fácil aplicación. M ediante investigaciones posteriores, deberán comprobar la eficacia de estas medidas $y$, en caso necesario, recomendar una solución más adecuada. Si tienen dudas sobre la gravedad de un peligro profesional, deben adoptar inmediatamente medidas de precaución.

5. Si una empresa rechaza o no está dispuesta a adoptar las medidas adecuadas para eliminar un riesgo inaceptable 0 para poner remedio a una situación que representa un peligro para la salud o la seguridad, los profesionales de la salud en el trabajo deben dirigirse al directivo adecuado, a la mayor brevedad posible, para expresarle su preocupación e insistir en la necesidad de tener en cuenta los conocimientos científicos y de aplicar las normas vigentes para la protección de la salud, entre ellas los límites de exposición. Al mismo tiempo, deben recordar a la empresa su obligación de aplicar las leyes y reglamentos vigentes, así como de proteger la salud de sus trabajadores. Siempre que sea necesario, deben informar a los trabajadores afectados y a sus representantes y establecer contacto con las autoridades competentes.

6. Los profesionales de la salud en el trabajo deben informar a los trabajadores sobre los peligros a los que pueden estar expuestos en el trabajo, con objetividad y prudencia, sin ocultar ningún dato y haciendo hincapié en las medidas preventivas. Deben colaborar con la empresa y ayudarle a asumir su responsabilidad de proporcionar a los directivos y a los trabajadores formación e información adecuada en materia de salud y seguridad y del nivel conocido de certidumbre con relación a los peligros cuya existencia se sospecha en el lugar de trabajo.

7. Los profesionales de la salud en el trabajo no deben revelar secretos industriales o comerciales que puedan llegar a conocer durante el ejercicio de sus funciones. Sin embargo, no deben ocultar la información necesaria para proteger la seguridad y la salud de los trabajadores o de la sociedad en general. Cuando sea necesario, deberán consultar a las autoridades competentes encargadas de vigilar la correcta aplicación de la legislación vigente.

8. Los profesionales de la salud deben definir claramente los objetivos y los procedimientos para la vigilancia de la salud, informando de ello a los trabajadores. Los profesionales designados por las autoridades competentes deben evaluar la validez de la vigilancia, que siempre se llevará a cabo con el consentimiento de los trabajadores. Las posibles consecuencias positivas o negativas de la participación en los programas de exploración selectiva o de vigilancia de la salud deben analizarse con los trabajadores a los que conciernan.

9. Los resultados de las exploraciones realizadas en el marco de la vigilancia de la salud deben ser notificados al trabajador al que se refieran. La determinación de la capacidad física para el trabajo debe basarse en la evaluación de la salud del trabajador y en un profundo conocimiento de las exigencias del puesto y del lugar de trabajo. Los trabajadores deben ser informados de la posibilidad de expresar su desacuerdo con las conclusiones acerca de su capacidad física para el trabajo si piensan que están en contra de sus intereses, para lo cual debe existir un procedimiento de apelación.

10. La dirección sólo debe ser informada de los resultados de las exploraciones impuesta por leyes o reglamentos nacionales en lo que se refiere a la capacidad física para realizar el trabajo asignado o las limitaciones necesarias desde el punto de vista médico en la asignación de las tareas o la exposición a 
peligros profesionales. Siempre que se obtenga el consentimiento del trabajador en cuestión, se podrá facilitar información general sobre su capacidad física para el trabajo, su estado de salud o los efectos posibles o probables de los riesgos profesionales.

11. Cuando el estado de salud del trabajador y la naturaleza de las tareas que realiza sean tales que puedan poner en peligro la seguridad de los demás, el trabajador debe ser claramente informado de la situación. En el caso de una situación especialmente peligrosa, la dirección y, cuando así lo exija la legislación nacional, las autoridades competentes, deberán ser informadas sobre las medidas necesarias para proteger a otras personas.

12. Las pruebas biológicas y otras investigaciones deben seleccionarse en función de su validez para proteger la salud del trabajador en cuestión, teniendo en cuenta su sensibilidad, su especificidad y su valor predictivo. Los profesionales de la salud en el trabajo no deben utilizar pruebas de cribaje 0 investigaciones que no sean fiables o que no tengan suficiente valor predictivo del cumplimiento de los requisitos del puesto de trabajo. Cuando existe la posibilidad de elegir entre varias alternativas, siempre debe darse prioridad a los métodos y exploraciones que no sean invasivos y que no representen ningún peligro para la salud del trabajador en cuestión. U na investigación invasiva o una exploración que suponga un riesgo para la salud del trabajador sólo podrá recomendarse una vez sopesados sus beneficios y riesgos y en ningún caso podrá justificarse para reclamar las prestaciones de un seguro. Este tipo de investigaciones exigen el consentimiento informado del trabajador y deben realizarse cumpliendo las normas profesionales más estrictas.

13. Los profesionales de la salud en el trabajo pueden contribuir a la salud pública de distintas formas, en particular a través de su participación en la formación, la promoción y la vigilancia de la salud. Deben intentar que las empresas y los trabajadores participen en el diseño y la aplicación de estos programas. Deben también proteger la confidencialidad de los datos personales sobre la salud de los trabajadores.

14. Los profesionales de la salud en el trabajo deben ser conscientes de la importancia de la labor que desarrollan para proteger a la comunidad y al medio ambiente. Deben iniciar y participar, según sea conveniente, en la identificación, la evaluación, y el asesoramiento sobre la prevención de peligros ambientales originados por las operaciones 0 los procesos que se realizan en la empresa.

15. Los profesionales de la salud en el trabajo deben informar con objetividad a la comunidad científica de los peligros nuevos o sospechados en el trabajo y de los correspondientes métodos preventivos. Cuando participen en investigaciones, deberán diseñar y desarrollar sus actividades sobre una base científica sólida, con plena independencia profesional y respetando los principios éticos del trabajo de investigación y de la investigación médica, entre ellos la necesidad de una evaluación por parte de un comité de ética independiente.

\section{Requisitos para el ejercicio de las funciones de los profesionales de la salud en el trabajo}

1. Los profesionales de la salud en el trabajo deben actuar siempre, como cuestión prioritaria, en beneficio de la seguridad y la salud de los trabajadores. Deben basar sus decisiones en sus conocimientos científicos y sus competencias técnicas, solicitando consejo a expertos especialistas cuando lo consideren necesario. Deben evitar cualquier juicio, consejo o actividad que pueda dañar la confianza en su integridad e imparcialidad.
2. Los profesionales de la salud en el trabajo deben mantener su plena independencia y respetar las normas de confidencialidad en el ejercicio de sus funciones. No deben permitir, bajo ninguna circunstancia, que sus juicios y declaraciones se vean influidos por conflictos de intereses, especialmente cuando asesoren a la empresa, a los trabajadores 0 a sus representantes sobre los riesgos y situaciones en el trabajo que puedan representar un peligro evidente para la seguridad y la salud.

3. Los profesionales de la salud en el trabajo deben establecer una relación de confianza y equidad con las personas a las que prestan sus servicios. Todos los trabajadores deben ser tratados de manera equitativa, sin ningún tipo de discriminación por razón de edad, sexo, posición social, raza, opiniones ideológicas o religiosas, naturaleza de la enfermedad o razón que haya motivado la consulta. Se debe establecer y mantener un canal fluido de comunicación entre los profesionales de la salud en el trabajo y el consejo de administración de la empresa o los altos cargos responsables de las decisiones al más alto nivel sobre las condiciones y la organización del trabajo y del medio ambiente de trabajo.

4. Los profesionales de la salud en el trabajo deben solicitar, en la medida de lo posible, que se incorpore una cláusula sobre la ética en su contrato de trabajo. Esta cláusula debe contemplar el derecho de los especialistas de la salud en el trabajo a aplicar las normas y los principios éticos de su profesión. No deben aceptar condiciones que les impidan desempeñar sus funciones de acuerdo con las normas profesionales y los principios éticos establecidos. En particular, los contratos de trabajo deben indicar la posición contractual jurídica y ética en materia de conflictos, acceso a registros y confidencialidad y no deben contener disposiciones que puedan restringir su independencia profesional. En caso de duda, deberá recurrirse a las autoridades competentes para analizar las condiciones del contrato.

5. Los profesionales de la salud en el trabajo deben mantener registros exactos y confidenciales que les permitan identificar los problemas de salud en el trabajo en la empresa. Estos registros incluyen datos sobre la vigilancia del medio ambiente de trabajo, datos personales, como experiencia laboral previa, y datos relacionados con la salud, como historia de exposiciones en el pasado, resultados de la vigilancia personal de la exposición a peligros profesionales y certificados de capacidad física para el trabajo. Los trabajadores deben tener acceso a sus propios expedientes.

6. Los datos médicos de los trabajadores y los resultados de las investigaciones médicas deben archivarse en registros médicos confidenciales y conservarse en un lugar seguro bajo la responsabilidad del médico de empresa o del profesional de la enfermería del trabajo. El acceso a las historias clínicas, su transmisión y la publicación o uso de la información que contienen están sujetos a las leyes y reglamentos nacionales y a los códigos deontológicos nacionales de medicina.

7. Siempre que la identificación individual no sea posible, se podrán facilitar los datos agregados de grupos de trabajadores a la dirección, a los representantes de los trabajadores 0 a los comités de seguridad y salud, cuando existan, para ayudarles a cumplir sus obligaciones en materia de protección de la salud y la seguridad de los grupos de trabajadores expuestos. Las autoridades competentes deberán ser informadas sobre las lesiones y enfermedades profesionales según exijan las leyes y reglamentos nacionales.

8. Los profesionales de la salud en el trabajo no deben solicitar información personal que no sea pertinente para la protección de la salud de los trabajadores en el trabajo. Sin embargo, el médico de empresa puede solicitar información o datos médicos adicionales al médico personal del trabajador 
o al personal médico de un hospital, con el consentimiento informado del trabajador, a fin de proteger su salud. Cuando lo haga, deberá informar al médico personal del trabajador 0 al personal médico del hospital de las razones por las que solicita dicha información. Con el consentimiento del trabajador, el medico de empresa o el profesional de la enfermería del trabajo pueden, en caso de que sea necesario, facilitar al médico personal del trabajador datos médicos relevantes, así como informarle de los peligros, las exposiciones profesionales y los requisitos del trabajo que constituyen un riesgo especial en vista del estado de salud del trabajador.

9. Los profesionales de la salud en el trabajo deben colaborar con otros profesionales sanitarios para proteger la confidencialidad de los datos médicos y sobre la salud de los trabajadores. Cuando existan problemas de especial importancia, deberán informar a las autoridades competentes de los procedimientos y prácticas vigentes que, en su opinión, incumplen los principios éticos. Esto afecta sobre todo a la confidencialidad de los datos médicos, incluidos los comentarios verbales, la conservación de archivos y la protección de la confidencialidad durante el registro y el uso de la información almacenada en ordenador.

10. Los profesionales de la salud en el trabajo deben procurar que las empresas, los trabajadores y sus representantes sean conscientes de su necesidad de plena independencia profesional y deben evitar cualquier interferencia con la confidencialidad médica para respetar la dignidad humana y ejercer con mayor eficacia su profesión.

11. Los profesionales de la salud en el trabajo deben buscar el apoyo de las empresas, los trabajadores y sus organizaciones, así como de las autoridades competentes, para aplicar las normas éticas más estrictas en el ejercicio de la medicina del trabajo. Deben aplicar un programa de auditoría profesional de sus propias actividades, con objeto de garantizar que se han establecido las normas adecuadas, que éstas se cumplen y que las deficiencias, en caso de existir, se detectan y corrigen.

\section{Referencias}

Ad hoc Committee on Medical Ethics ( $A C$ of $P$ ). 1984. Position paper. American College of Physicians ethics manual. Part I. History of medical ethics, the physician and the patient, the physician's relationship to other physicians, the physician and society. Ann Intern M ed 101:129-137.

American College of $\mathrm{O}$ ccupational and Environmental M edicine. 1994. Code of ethical conduct. I OCcup M ed 29:28.

American 0 ccupational Medical Association (AOM A). 1986. Drug screening in the workplace: Ethical guidelines. J 0 ccup M ed 28(12):1240-1241.

Andersen, D, L Attrup, N Axelsen, P Riis, 1992. Scientific dishonesty and good scientific practice. $D$ anish M ed Res Counc : 126 .

Ashford, NA. 1986. Medical screening in the workplace: Legal and ethical considerations. Sem 0 ccup M ed 1:67-79.

Beauchamp, TL, RR Cook, WE Fayerweather, GK Raabe, WE Thar, SR Cowles, GH Spivey. 1991. Ethical guidelines for epidemiologists. J Clin E pidemiol 44 Supl. 1:151S-169S.

Brieger, GH, AM Capron, C Fried, MS Frankel. 1978. Human experimentation. En Encyclopedia of B ioethics, dirigido por WT R eich. Nueva Y ork: Free Press.

Broad, W, N Wade. 1982. B etrayers of the Truth: Fraud and $\mathrm{D}$ eceit in the $\mathrm{H}$ alls of Science. Nueva Y ork: Simon $\&$ Schuster.

Chalk, R, MS Frankel, SB Chafer. 1980. AAAS Professional E thics Project: Professional E thics Activities in the Scientific and Enginering Societies. AAAS Publication 80-R -4. Washington, DC: American Association for the Advancement of Science, Committee on Scientific Freedom and R esponsibility.

Chemical M anufacturers Association's Epidemiology Task Group. 1991. Guidelines for good epidemiology practices for occupational and environmental epidemiologic research. I 0 ccup $M$ ed 33(12):1221-1229.

Código Internacional de Etica M édica. 1983. Aprobado por la 3a Asamblea General de la Asociación M édica M undial, Londres, 1949, modificado por la 22a A samblea M édica M undial, Sidney, 1968 y la 35a A samblea M édica M undial, $\checkmark$ enecia, 1983

Cohen, KS. 1982. Professional liability in occupational health: Criminal and civil. En Legal and $\mathrm{E}$ thical Dilemmas in $\mathrm{O}$ ccupational $\mathrm{H}$ ealth, dirigido por JS Lee y WN Rom. Ann Arbor, M ichigan Ann Arbor Science Publishers.

Comité Permanente de M édicos de la CEE. 1980. Carta sobre la salud en el trabajo. Documento núm. CP80/182. A probado en Bruselas, 1969, revisado en Copenhague, 1979, y en Dublín, 1980.

Conrad, P. 1987. Wellness in the work place: Potentials and pitfalls of work-site health promotion. M ilbank 0 65(2):255-275.

Consejo de Organizaciones Internacionales de Ciencias Médicas (CIOMS). 1991. International Guidelines for Ethical Review of E pidemiological Studies. Ginebra: CIOM S

—. 1993. International Ethical Guidelines for Biomedical Research I nvolving H uman Subjects. Ginebra: CIO M S.

Coriel, P, JS Levin, EG Jaco. 1986. Lifestyle: An emergent concept in the social sciences. Cult M ed Psychiatry 9:423-437.

Coye, MJ. 1982. Ethical issues of occupational medicine research. En Legal and E thical Dilemmas in $O$ ccupational $H$ ealth, dirigido por JS Lee y WN Rom. Ann Arbor, Michigan: Ann Arbor Science Publishers.

Dale, ML. 1993. Integrity in science: M isconduct investigations in a US University. I Expos Anal Environ E pidemiol 3 Supl. 1:283-295.

Declaración de Helsinki: R ecomendaciones orientativas para los médicos que realicen investigación biomédica con sujetos humanos. 1975. A probada por la 18a Asamblea M édica M undial, Finlandia, 1964 y revisada por la 29a A samblea M édica M undial, T okio, Japón, 1975.

Einstein, A. 1949. Reply to criticisms. En Albert E instein: Philosopher-Scientist, dirigido por Schlipp. La Salle: 0 pen C ourt.

Fawcett, E. 1993. Working group on ethical considerations in science and scholarship. Account Res 3:69-72.

Fayerweather, WE, J Higginson, TC Beauchamp. 1991. Industrial epidemiology forum's conference on ethics in epidemiology. J Clin E pidemiol 44 Supl. 1:1-169.

Frankel, M S. 1992. In the societies. Professional ethics report. N ewslett Am Assoc Adv Sci 1:2-3.

Ganster, D, B Mayes, W Sime, G Tharp. 1982. $M$ anaging organizational stress: A field experiment. J Appl Psychol 67:533-542.

Gellermann, W, MS Frankel, RF Ladenson. 1990. Values and $\mathrm{E}$ thics in Organization and $\mathrm{H}$ uman Systems D evelopment: Responding to D ilemmas in Professional Life. San Francisco: Josey-Bass.
Gert, B. 1993. D efending irrationality and lists. E thics 103(2):329-336.

Gewirth, A. 1986. Human rights and the workplace. En The Environment of the Workplace and Human Values, dirigido por SW Samuels. Nueva York: Liss.

Glick, IL, AE Shamood. 1993. A call for the development of "Good R esearch Practices" (GRP) guidelines. Account Res 2(3):231-235.

Goldberg, LA, M R Greenberg. 1993. Ethical issues for industrial hygienists: Survey results and suggestions. Am Ind H yg Assoc f 54(3):127-134.

Goodman, K W. 1994a. Case Presentation on Ethical Topics in Epidemiology. American College of Epidemiology (marzo)

- . 1994b. Review and Analysis of Key D ocuments on $E$ thics and Epidemiology. American College of Epidemiology (marzo)

Graebner, W. 1984. Doing the world's unhealthy work: The fiction of free choice. $H$ astings $C$ enter $R$ ep 14:28-37.

Grandjean, P, D Andersen. 1993. Scientific dishonesty: A Danish proposal for evaluation and prevention. J Expos Anal Environ Epidemiol 3 Supl. 1:265-270.

Grandjean, P. 1991. Ethical aspects of genetic predisposition to disease. Capítulo 16 en E cogenetics: $G$ enetic Predisposition to Toxic Effects of Chemicals, dirigido por P Grandjean. Londres: Shapman \& $\mathrm{H}$ all.

Greenberg, M R, J M artell. 1992. Ethical dilemmas and solutions for risk assessment scientists. J Expos Anal Environ E pidemiol 2(4):381-389.

Guidotti, TL, JWF Cowell, GG Jamieson, AL Engelberg. 1989. Ethics in occupational medicine. Capítulo 4 en 0 ccupational $\mathrm{H}$ ealth Services. A Practical Approach. Chicago: American M edical Association.

Hall, WD. 1993. M aking the Right Decision: Ethics for $M$ anagers. T oronto: John Wiley \& Sons.

Instituto Internacional de Estadística. 1986. Declaration on professional ethics. Int Stat Rev 54:227-242.

Johnson, OA. 1965. E thics: Selections from Classical and Contemporary W riters. N ueva Y ork: H olt, R inehart \& Winston.

J owell, R. 1986. The codification of statistical ethics. 0 fficial Stat 2(3):217-253.

LaDou, J. 1986. Introduction to Occupational $\mathrm{H}$ ealth and Safety. Chicago: N ational Safety Council. 
Lemen, RA, E Bingham. 1994. A case study in avoiding a deadly legacy in developing countries. T oxicol Ind $\mathrm{H}$ ealth 10(1/2):59-87.

Levine, CA. 1984. A cotton dust study unmasked. $H$ astings $C$ enter $R$ ep 14:17.

M aloney, DM . 1994. H uman Research Report. O maha, N ebraska: D eem Corp.

Melden, Al. 1955. Ethical Theories. NuevaY ork Prentice $\mathrm{H}$ all.

M othershead, JL Jr. 1955. Ethics, M odern Conceptions of the Principles of Right. N ueva $\mathrm{Y}$ ork: $\mathrm{H}$ olt.

Murray, TH, R Bayer. 1984. Ethical issues in occupational health. En Biomedical Ethics Reviews, dirigido por JM Humber y RF Almeder. Clifton, Nueva J ersey: H umana Press.

Nathan, PE. 1985. Johnson and Johnson's Live for Life: a comprehensive positive lifestyle change program. En B ehavioral $\mathrm{H}$ ealth: A $\mathrm{H}$ andbook of $\mathrm{H}$ ealth Enhancement and $D$ isease Prevention, dirigido por JD M atarazzo, NE Miller, JA Herd y SM Weiss. Nueva Y ork: Wiley.

Needleman, HL, SK Geiger, R Frank. 1985. Lead and IQ scores: A reanalysis. Science 227:701-704.

O 'Brien, C. 1993. Under the Influence? D rugs and the American W ork Force Washington, DC: National Research Council.

O ffice of R esearch Integrity (O RI). 1993. Findings of scientific misconduct. F ed Reg 58:117:33831.

O ffice of Technology Assessment. 1983. The R ole of $G$ enetic T esting in the Prevention of $O$ ccupational $D$ isease Washington, DC: US Government Printing O ffice.

O ffice of the Assistant Secretary for Health. 1992. Guidelines for the Conduct of Research within the Public $\mathrm{H}$ ealth Service Washington, DC: Department of $\mathrm{H}$ ealth and H uman Services, PH S

O rganización Internacional del T rabajo (OIT). 1996 $M$ anagement of Alcohol and Drug-related Issues in the W orkplace G inebra: OIT

Parasuramen, S, M A Cleek. 1984. Coping behaviours and managers' affective reactions to role stressors. I Vocat B ehav 24:179-183.

Pearlin, LI, C Schooler. 1978. The structure of coping. J $H$ ealth Soc B ehav (19):2-21.

Pellegrino, ED, RM V eatch, JP Langan. 1991. E thics, Trust, and the Professions: Philosophical and Cultural Aspects. W ashington, DC: G eorgetown U niv. Press.

Planck, M. 1933. W here is science going? W oodbridge: Oxbow.

Price, AR. 1993. The U nited States Government scientific misconduct regulations and the handling of issues related to research integrity. J Expos Anal E nviron E pidemiol 3 Supl. 1:253-264.

Ramazzini, B. 1713. De M orbis Artificum (D iseases of W orkers). N ueva Y ork: $\mathrm{H}$ afner

Reed, RR. 1989. Responsibilities of awardee and applicant institutions for dealing with and reporting misconduct in science. $F$ ed $R$ eg 54(151):32446-32451.

Rest, KM. 1995. Ethics in occupational and environmental health. Capítulo 12 en 0 ccupational $\mathrm{H}$ ealth - Recognizing and Preventing W ork-R elated Disease, dirigido por BS Levy y DH Wegman. Boston: Little Brown \& Co

Roman, P. 1981. Prevention and $\mathrm{H}$ ealth Promotion Programming in W ork Organizations. DeK alb, Illinois: U niv. del Norte de Illinois.

Roman, PM, TC Blum. 1987. Ethics in worksite health programming: Who is served? H ealth $E$ duc $Q$ 14(1):57-70.

Royal College of Physicians of London. 1993a Guidance on $\mathrm{E}$ thics for $\mathrm{O}$ ccupational Physicians. Londres: R oyal C ollege of Physicians.

- 1993b. Guidance on E thics for O ccupational Physicians. L ondres: R oyal College of Physicians.
Russel, E, C-G Westrin 1992 Ethical issues in epidemiological research: Guidelines containing the minimum common standards of practice recommended for use by project leaders and participants in the operation of future concerted actions. En Commission of the E uropean Communities $M$ edicine and $\mathrm{H}$ ealth: COM AC E pidemiology, dirigido por M Hallen y Vuylsteek. Luxemburgo: COMAC.

Russell, B. 1903. The Principles of M athematics. Nueva Y ork: O xford U niversity Press

R ussell, B. 1979. What I believe. Capítulo 3 en W hy I Am not a Christian - and other Essays on Religion and Related Subjects, dirigido por P Edwards. Londres: U nwin Paperbacks.

Samuels, SW. 1992. Principles for ethical practice of environmental and occupational medicine Capítulo 124 en Environmental and Occupational M edicine, dirigido por WN Rom. Boston: Little, Brown \& Co.

Seminario de la IEA sobre ética, política sanitaria y epidemiología. 1990. Proposed ethics guidelines for epidemiologists (R evised). Am Publ H ealth Assoc $\mathrm{N}$ ewslett (E pidemiol Sect) (Invierno):4-6.

Sharphorn, DH. 1993. Integrity in science: Administrative, civil and criminal law in the USA. J Expos Anal E nviron E pidemiol 3 Supl. 1:271-281.

Soskolne, CL, DK M acfarlane. 1995. Scientific misconduct in epidemiologic research. En Ethics and Epi-demiology, dirigido por S Coughlin y T Beauchamp. NuevaY ork: O xford U niv. Press.

Soskolne, CL. 1985. Epidemiological research, interest groups, and the review process. I Publ H ealth Policy 6(2):173-184.

- . 1989. Epidemiology: Q uestions of science, ethics morality and law. Am J E pidemiol 129(1):1-18.

—. 1991. Ethical decision-making in epidemiology: The case-study approach. J Clin E pidemiol 44 Supl. 1:125S-130S

- 1991/92. Rationalizing professional conduct Ethics in disease control. Publ $\mathrm{H}$ ealth $\mathrm{Re}$ 19:311-321.

- . 1993a. Introduction to misconduct in science and scientific duties. J Expos Anal Environ Epidemiol 3 Supl. 1:245-251.

- . 1993b. Q uestions from the delegates and answers by the panelists concerning "Ethics and Law in Environmental Epidemiology". I Expos Anal Environ E pidemiol 3 Supl. 1:297-319.

Summers, C, CL Soskolne, C Gotlieb, E Fawcett, P M cClusky. 1995. Do scientific and scholarly codes of ethics take social issues into account? Account $R$ es 4:1-12.

Susser, M . 1973. Causal Thinking in the $H$ ealth Sciences: Concepts and Strategies of E pidemiology. Nueva Y ork: Oxford U niversity Press.

Swazey, JP, MS Anderson, LK Seashore. 1993. Encounters with ethical problems in graduate education: $\mathrm{H}$ ighlights from national surveys of doctoral students and faculty. Publ Am Assoc Adv Sc Scientific F ree R esp L aw Prog V I (4 O toño):1,7.

Teich, AH, MS Frankel. 1992. Good Science and Responsible Scientists: $M$ eeting the $C$ hallenge of $F$ raud and $M$ isconduct in Science Washington, DC. : American Association for the Advancement of Science.

V ineis, P, CL Soskolne. 1993. Cancer risk assessment and management: An ethical perspective. I 0 ccup M ed 35(9):902-908

Woodger, JH. 1937. The Axiomatic M ethod in Biology. Cambridge: Cambridge U niversity Press.

Yoder, JD. 1982. Ethical issues in industrial hygiene in the 1980s. En Legal and Ethical Dilemmas in O ccupational $\mathrm{H}$ ealth, dirigido por JS Lee y W N R om. Ann Arbor, Michigan: Ann Arbor Science Publishers.

\section{0 tras lecturas recomendadas}

AAOH N Executive Committee. 1977. Code of E thics. American Association of $\mathrm{O}$ ccupational $\mathrm{H}$ ealth $\mathrm{Nurses}$ Atlanta, Georgia: AAO H N

American O ccupational Medical Association. 1976 Code of ethical conduct for physicians providing occupational medical services. Am O ccup M ed Assoc (23 de julio): 1

American Society of Safety Engineers (ASSE). 1974 Code of Ethics for the Safety Profession. Des Plaines, Illinois: ASSE.

Arnold, T. 1994. Women boycott $U$ of $C$ survey on breast implants: Funds come from manufacturer Edmonton J ournal, 19 de marzo, B4.

A sociación M édica M undial. 1983. International Code of M edical Ethics. Ferney-V oltaire, Francia: A sociación $M$ édica $M$ undial.

Australian College of O ccupational M edicine. 1987. Ethics for occupational health physcians. M elbourne.

Baram, M S. 1984. Charting the future course for corporate management of health risks. Am 」 Public $H$ ealth 74:1163-1166.

Barrell, J. 1988. Code of professional conduct Institute for $\mathrm{O}$ ccupational Safety and $\mathrm{H}$ ealth (IOSH ). Saf Practitioner :31-32.

Begley, S. 1992. Lead, lies and data tape. Newsweek, 16 de marzo, 62

Bernier, R. 1994. NIH actions against breast cancer researcher raise issues for epidemiologists. N ew E pidemiol $M$ on 15(4):1-2.

Calabrese, EJ. 1978. M ethodological A pproaches to D eriving Environmental and 0 ccupational $H$ ealth Standards. N uevaY ork: Wiley-Interscience.

Canadian Medical Association. 1988. Provision of O ccupational Health Services: A Guide for Physicians. O ttawa: Canadian M edical Association.

Castleman, BI, GE Ziem. 1988. Corporate influence on threshold limit values. Am I Ind $M$ ed 13(5): 531-559.

Committee on Government O perations 1990. Are scientific misconduct and conflicts of interest hazardous to our health? N oveno informe, 101 Congr., $2^{\mathrm{a}}$ Ses., H. Rept. 101-688

Conseil national de l'Ordre des Médecins. 1979 Code de déontologie médicale. Décret no. 79-506 du 28 juin 1979 portant Code de déontologie médicale (1.0. du 30 juin 1979) remplacant le décret no. 55-1591 du 28 novembre 1955 modifié par le décret no. 77-638 du 21 juin 1977.

Corbett, TH. 1982. Ethics and environmental health. $\mathrm{En} \mathrm{L}$ egal and $\mathrm{E}$ thical Dilemmas in $\mathrm{O}$ ccupational $\mathrm{H}$ ealth, dirigido por JS Lee y WN Rom. Ann Arbor, $M$ ichigan: Ann Arbor Science Publishers.

Dawson, NJ. 1987. Ensuring scientific integrity (C arta). N ature 327 (18 de junio):550.

Doll, R. 1985. O ccupational cancer: A hazard for epidemiologists. Int ] E pidemiol 14:22-31.

Feinstein, AR. 1988. Fraud, distortion, delusion, and consensus: the problems of human and natural deception in epidemiologic science. Am 」 $\mathrm{M} \mathrm{ed}$ 84:475-478

G lazer, M . 1989. T he W histleblowers: E xposing Corruption in Government and Industry. Nueva Y ork: Basic Books.

Hammond, E, IJ Selikoff. 1979. Public control of environmental health hazards. Ann NY Acad Sci 329

Lord, M W. 1982. K eynote address: corporate ethics and environmental pollution. En Legal and Ethical Dilemmas in $\mathrm{O}$ ccupational $\mathrm{H}$ ealth, dirigido por JS Lee y WN Rom. Ann Arbor, Michigan: Ann Arbor Science Publishers.

Lowrance, WW. 1976. Of Acceptable Risk. Los Altos, California: William K aufmann. 
Lowy, FH, EM Meslin. 1993. Fraud in medical research. Capítulo 24 en T extbook of Ethics in Pediatric R esearch, dirigido por $G$ K oren. M alabar, Florida: $\mathrm{K}$ reiger.

Mason, JO. 1992. Opportunity for a hearing on $O$ ffice of R esearch Integrity scientific misconduct findings. F ederal R eg 57(216):53125-53126.

M cC utchen, CW. 1991. Peer review: T reacherous servant, disastrous master. Tech Rev (octubre):28-40

Pellegrino, ED. 1992. Character and the ethical conduct of research. A ccount $R$ es 2(1):1-11.

R eece, RD, H A Siegel. 1986. Studying People- A P rime in the Ethics of Social Research. Macon, Georgia: M ercer U niv. Press.

R oyal C ollege of N ursing. 1991. Professional practice and ethics for occupational health nurses. En A Guide to an $O$ ccupational $H$ ealth Service: A $H$ andbook for E mployers and N urses. Londres: Scutari Projects.
R oyal C ollege of Physicians. 1986. Guidance on E thics for $O$ ccupational Physicians. Londres: R oyal College of Physicians.

Shamoo, A, Z Annau. 1987. Ensuring scientific integrity (C arta). N ature 327 (18 de junio):550.

Shamoo, AE, Z Annau. 1989. Data audit-H istorical perspective Capítulo 1 en Principles of R esearch $D$ at Audit, dirigido por AE Shamoo. Newark, Nueva Jersey: Gordon \& Breach.

Shamoo, AE. 1991. Policies and quality assurance in the pharmaceutical industry. Account Res 1:273-284.

Shapiro, IM. 1992. Speaking out: Petition for a colleague. Almanac (17 de marzo):3.

Social Sciences and H umanities R esearch Council of Canada. 1994. Integrity in Research and Scholarship: A Tri-Council Policy Statement. $O$ ttawa: M edical R esearch C ouncil of $C$ anada.

Spice, B. 1991. Pitt to review charges against lead researcher. Pittsburgh P ost $G$ az ette, 30 de diciembre, 4.
Thilly, F. 1957. A H istory of Philosophy. R evisado por $L$ Wood. Nueva Y ork: $\mathrm{H}$ olt.

T wedt, S. 1991. Pitt expert on toxic lead has research challenged. The Pittsburgh Press, 29 de diciembre, A1.

Weiss, T. 1991. To0 many scientists who 'blow the whistle' end up losing their jobs and careers. Chron $\mathrm{H}$ igh $\mathrm{E}$ duc (junio):A 36.

Westman, DP. 1991. W histleblowing: The Law of Retaliatory Discharge Rockville, MD: Bureau of $N$ ational Affairs.

Wohleber, C. 1992. OSI asks for internal inquiry. Needleman challenged again on landmark 1979 study of low-lead exposure's effects. U niv Times, 9 de enero, 4.

Worksafe Australia. 1992. Guidelines on ethical aspects of OHS workplace research. W SA N ewslttr (junio):7. 



\section{DESARROUO, TECNOLOGIA Y COMERCIO}

Director del capítulo

J erry J eyaratnam

\section{Sumario}

Tendencias de la salud en el trabajo en el ámbito

de los países en desarrollo

J erry J eyaratnam . . . . . . . . . . . . . . . . . . . . . . . . 20.2

Países industrializados y salud y seguridad en el trabajo

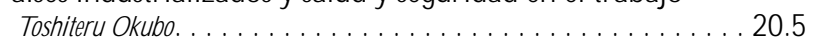

Estudios de caso sobre cambio tecnológico

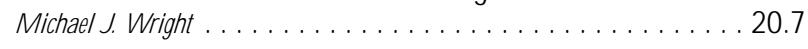

Pequeñas empresas y salud y seguridad en el trabajo

Bill Glass ............................ 20.8

Transferencia de tecnología y elección tecnológica

J oseph LaD ou . . . . . . . . . . . . . . . . . . . . . . . 20.11

Acuerdos de libre comercio

H oward F rumkin . . . . . . . . . . . . . . . . . . . . . . . 20.14

Responsabilidad respecto a los productos y traslado de riesgos industriales

Barry Castleman ......................... 20.16

Aspectos económicos de la salud y la seguridad en el trabajo

Alan M aynard. . . . . . . . . . . . . . . . . . . . . 20.23

Estudio de caso: industrialización y problemas de salud en el trabajo en China

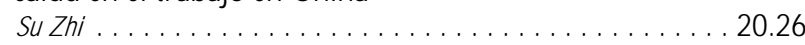




\section{TENDENCIAS DE LA SALUD EN EL TRABAJO EN EL AMBITO DE LOS PAISES EN DESARROLLO}

\section{Jerry Jeyaratnam}

En el presente artículo se analizan algunas cuestiones específicas relativas a la salud en el trabajo que actualmente despiertan interés en los países en desarrollo y otras áreas del mundo. Los aspectos técnicos generales comunes a estos países y a los desarrollados (p. ej., plomo y pesticidas) no se tratan aquí, puesto que ya han sido abordados en otras secciones de la Enciclopedia. Además de las cuestiones relacionadas con los países en desarrollo, se examinan en este capítulo otras de reciente planteamiento que afectan a los países de la Europa oriental.

Se estima que, para el año 2000, ocho de cada diez trabajadores de la población activa mundial procederán de los países en desarrollo, lo que muestra la prioridad que debe otorgárseles para satisfacer sus necesidades fundamentales en materia de salud en el trabajo. La prioridad en este caso consiste en dotar a su población activa de un sistema de prestación de asistencia sanitaria. Esta necesidad es coherente con la definición de salud en el trabajo de la O rganización M undial de la Salud (O M S), en la que se consigna el interés por la salud total del trabajador y no simplemente por las enfermedades profesionales. Como se señala en la Figura 20.1, el trabajador puede verse afectado por las enfermedades generales de la comunidad, como la malaria, así como por otras multifactoriales relacionadas con el trabajo, en las que el trabajo puede contribuir al desarrollo del proceso 0 agravarlo. Son ejemplos de este caso las enfermedades

Figura 20.1 - Categorías de enfermedades que afectan a los trabajadores.

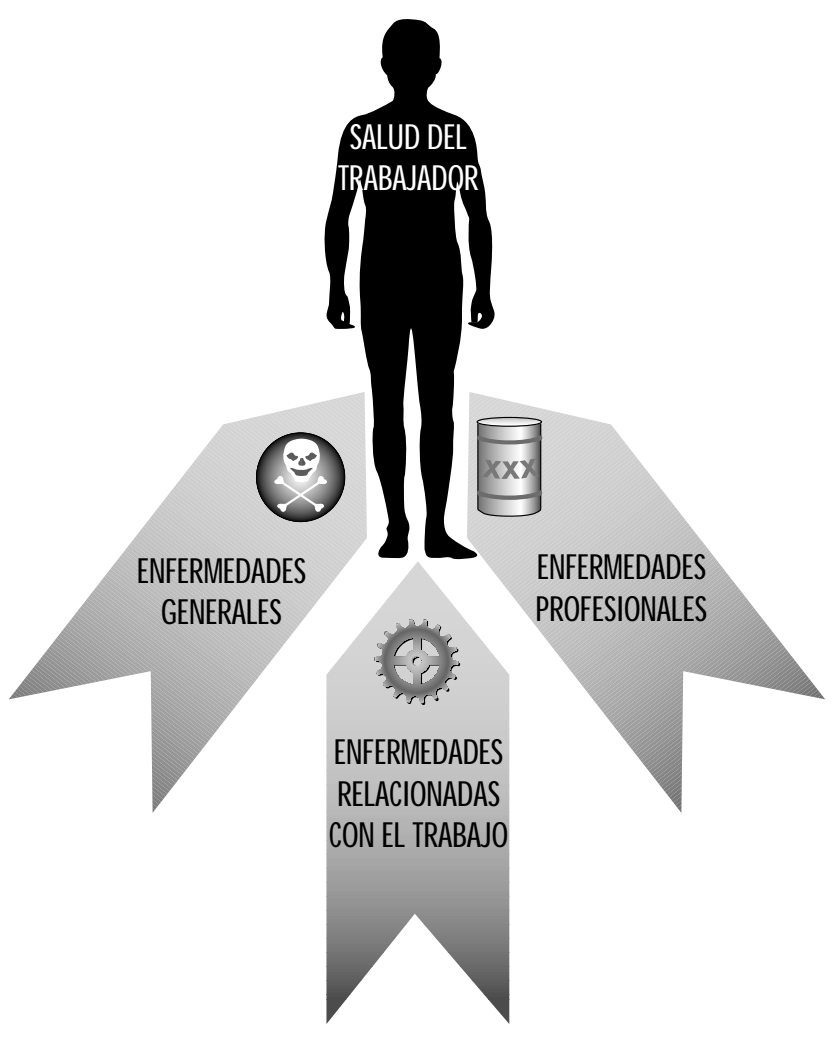

cardiovasculares, las psicosomáticas y el cáncer. Por último, hay enfermedades profesionales cuya causa esencial es la exposición en el lugar de trabajo, como la intoxicación por plomo, la silicosis y la sordera provocada por el ruido.

La OMS reconoce la existencia de una relación biunívoca entre trabajo y salud, como se expresa gráficamente en la Figura 20.2). El primero puede tener un efecto perjudicial 0 beneficioso sobre la segunda, mientras que el estado de salud de los trabajadores repercute en el trabajo y la productividad.

U n trabajador sano contribuye positivamente a mejorar la productividad y la calidad de los productos, así como la motivación y la satisfacción en el puesto de trabajo; de este modo, contribuye a la optimización general de la calidad de vida de las personas y de la sociedad, lo que convierte a la salud en el trabajo en un objetivo importante de las políticas de desarrollo nacional. Para alcanzar esta meta, la O M S ha propuesto recientemente una Estrategia global sobre salud en el trabajo para todos (O M S 1995), en la que se definen los diez objetivos prioritarios siguientes:

- consolidación de las políticas nacionales e internacionales relativas a la salud en el trabajo y desarrollo de los instrumentos políticos necesarios;

- desarrollo de un medio ambiente de trabajo saludable;

- desarrollo de prácticas de trabajo saludables y promoción de la salud en el trabajo;

- consolidación de los servicios de salud en el trabajo.

- creación de servicios de apoyo a la salud en el trabajo;

- elaboración de normas sobre salud en el trabajo basadas en una evaluación de riesgos científica;

- desarrollo de recursos humanos para la salud en el trabajo;

- establecimiento de sistemas de datos y registro, desarrollo de servicios de información para expertos, transmisión de datos eficaz y fomento de la sensibilización de la población mediante la información pública;

- promoción de la investigación;

- desarrollo de la colaboración en materia de salud en el trabajo con otras actividades y servicios.

Figura 20.2 - Relación biunívoca entre trabajo y salud.

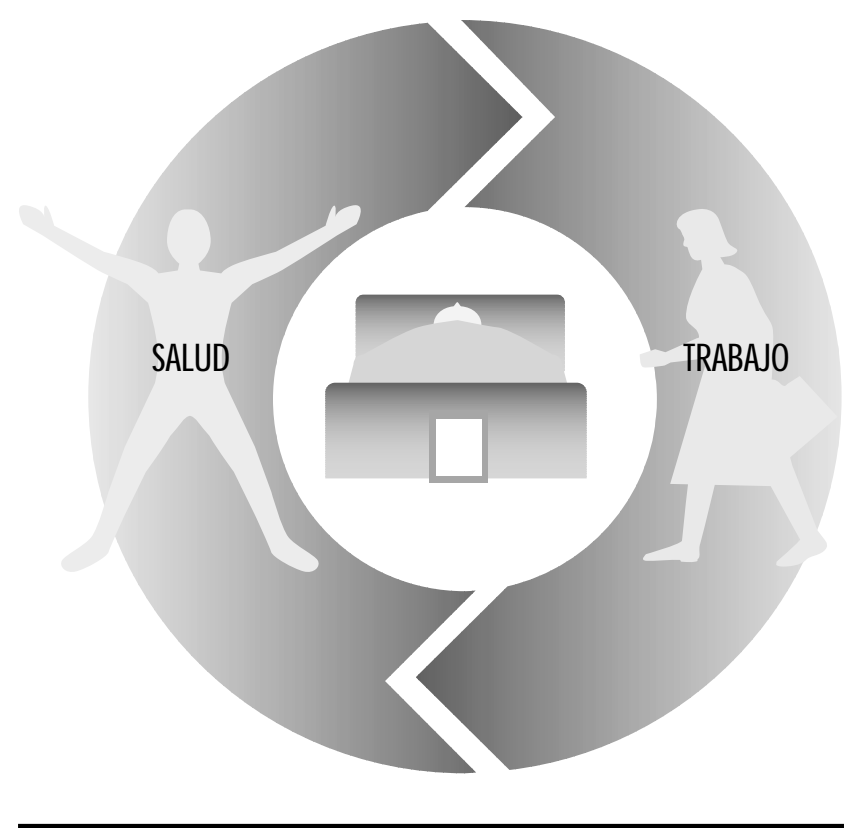




\section{Salud en el trabajo y desarrollo nacional}

Es útil considerar la salud en el trabajo en el contexto del desarrollo nacional, puesto que ambos conceptos están íntimamente relacionados. Todas las naciones desean alcanzar un estado de desarrollo avanzado, pero son los países en desarrollo los que con más ansiedad (casi con exigencia) desean lograr este objetivo. La mayoría de las veces, las ventajas económicas que reporta su consecución son las más buscadas. N o obstante, se acepta comúnmente que el auténtico desarrollo tiene un significado más amplio y engloba el proceso de mejora de la calidad de la vida humana, lo que incluye a su vez aspectos de progreso económico, mejora de la autoestima y aumento de la libertad de elección de las personas. A continuación se analiza la repercusión de este desarrollo en la salud de la población activa, es decir, la relación entre desarrollo y salud en el trabajo.

Aunque el producto interior bruto (PIB) apenas ha variado en el mundo en el período de 1965-1989, en los países en desarrollo se ha registrado un aumento casi diez veces mayor. Ahora bien, este rápido crecimiento económico debe contemplarse en un contexto de pobreza generalizada. En estos países habita un $75 \%$ de la población mundial, pero sólo se genera un $15 \%$ del producto interior mundial. En Asia, como ejemplo característico, todos los países menos Japón se clasifican como parte del mundo en desarrollo. Sin embargo, debe reconocerse que su desarrollo no es uniforme, ni siquiera en el caso de los países asiáticos. Por ejemplo, Estados como Singapur, República de Corea, H ong, K ong y Taiwan (C hina) se agrupan actualmente bajo la denominación de países de reciente industrialización (NICS). A pesar de su arbitrariedad, esta clasificación refleja el paso por una etapa de transición de la condición de país en desarrollo a la de país industrializado. En cualquier caso, hay que admitir que no existen criterios inequívocos para definir un NIC. Algunas de sus características comunes más destacadas son la obtención de tasas de crecimiento elevadas y sostenidas, la reducción de las desigualdades de renta, el desempeño de un papel activo por parte de la Administración, una presión fiscal moderada, un Estado del bienestar subdesarrollado, una alta tasa de ahorro y la orientación de la economía a la exportación.

\section{Salud y desarrollo}

Existe una estrecha relación entre salud, desarrollo y medio ambiente. Puede considerarse que, en ciertas circunstancias, la adopción de medidas de desarrollo incontroladas y agresivas encaminadas únicamente a fomentar la expansión económica afecta negativamente a la salud. Sin embargo, suele existir una relación positiva sólida entre la situación económica de un país y el estado de salud de su población, indicado por la esperanza de vida.

A pesar de esta vinculación positiva entre desarrollo y salud, aún no se ha reconocido convenientemente que la salud es una fuerza generadora de desarrollo. D ebe admitirse que la salud es algo más que un producto de consumo. La inversión en este campo mejora el capital humano de la sociedad. A diferencia de las carreteras y los puentes, cuyos valores de inversión disminuyen con el tiempo debido al deterioro, el rendimiento de los fondos dedicados a la salud pueden reportar amplios beneficios sociales durante la vida de las personas beneficiarias y la de sus descendientes. $\mathrm{H}$ ay que asumir que los daños para la salud que sufra un trabajador tendrán probablemente un efecto adverso sobre su rendimiento laboral, lo que resulta de especial interés para los Estados inmersos en procesos de rápido desarrollo. Por ejemplo, se estima que las deficiencias de la salud en el trabajo y la reducción de la capacidad laboral de los trabajadores puede provocar pérdidas económicas de entre el 10 y el $20 \%$ del producto nacional bruto (PNB). Por otra parte, el Banco $M$ undial estima que dos tercios de los años de vida modificados por una discapacidad determinada por el trabajo (DALYS) podrían evitarse mediante la aplicación de programas de salud y seguridad en el trabajo. En este sentido, la prestación de un servicio de salud en el trabajo no debe considerarse un gasto nacional que ha de evitarse, sino una inversión necesaria para el desarrollo y la economía del país. Se ha observado que un nivel de salud en el trabajo alto está relacionado positivamente con un PNB por habitante elevado (O M S 1995). Los países que más invierten en salud y seguridad en el trabajo registran los mayores niveles de productividad y presentan las economías más sólidas, mientras que una inversión deficiente en este campo se asocia a la situación contraria. A escala mundial, se dice que cada trabajador contribuye con 9.160 dólares al producto interior anual. O bviamente, el trabajador constituye el motor de las economías nacionales y debe mantenerse en perfectas condiciones de salud.

El desarrollo da lugar a numerosos cambios en el tejido social, incluidos los sistemas de empleo y la transformación de los sectores productivos. En una primera etapa, la agricultura contribuye ampliamente al aumento de la riqueza nacional y absorbe la mayor proporción de la población activa. Posteriormente, la función del sector primario comienza a declinar y prevalece la aportación de la industria. Por último, se llega a una situación en la que el sector de servicios se convierte en la principal fuente de renta, como ocurre en las economías avanzadas de los países industrializados. Esta evolución se comprueba fácilmente comparando el grupo de NIC y el conjunto de Estados que integran la Asociación del Sudeste Asiático (ASEAN). Estos últimos pueden clasificarse como países en desarrollo de renta intermedia, mientras que los NIC se encuentran a medio camino entre el mundo en desarrollo y el industrializado. Singapur, miembro de la ASEAN, es también un NIC. Aunque una cuarta parte del PIB de los Estados de esta asociación procede de la agricultura, casi la mitad es aportado por los sectores industrial y manufacturero. Los NIC, por una parte, sobre todo en el caso de $\mathrm{H}$ ong $\mathrm{K}$ ong y Singapur, obtienen dos tercios de su PIB del sector de servicios, mientras que la contribución de la agricultura es mínima o nula. Es importante tener en cuenta este cambio de pautas para que los servicios de salud en el trabajo puedan atender las necesidades de la población activa de cada país en función de su fase de desarrollo (Jeyaratnam y C hia 1994).

Con el desarrollo, además de esta transición en el lugar de trabajo, se produce otra en las pautas de enfermedad. Este cambio se asocia a una aumento de la esperanza de vida, consecuencia del crecimiento del PIB. Se ha observado que el desarrollo en general, o esta mejora de la esperanza de vida en particular, da lugar a una importante reducción de las muertes provocadas por enfermedades infecciosas, mientras que aumenta el número de defunciones por enfermedades cardiovasculares y cáncer.

\section{Cuestiones de salud en el trabajo y desarrollo}

La salud de la población activa es un factor fundamental del desarrollo de un país. Al mismo tiempo, hay que reconocer y prevenir adecuadamente las dificultades y peligros potenciales que conlleva el desarrollo. No deben ignorarse los efectos dañinos que éste puede tener para la salud humana y el medio ambiente. La planificación puede constituir un instrumento de prevención de esos aspectos negativos.

\section{Falta de una estructura jurídica e institucional adecuada}

Los países desarrollados perfeccionaron su estructura jurídica y administrativa para adaptarse a los avances tecnológicos y económicos. En cambio, los países en desarrollo pueden acceder a las tecnologías avanzadas de los primeros sin haber consolidado aún una infraestructura jurídica 0 de gestión que les permita 
controlar las consecuencias adversas de éstas para la población activa y el medio ambiente, lo que provoca un desequilibrio entre el progreso tecnológico y el desarrollo social y administrativo.

Por otra parte, se omite imprudentemente la aplicación de mecanismos de control por razones económicas y políticas (p. ej., el desastre químico de Bophal, donde se hizo caso omiso del consejo de un directivo por motivos políticos y otras razones). A menudo, los países en desarrollo tienen la intención de adoptar las normas y la legislación de los países desarrollados, pero les falta personal formado para administrarlas y aplicarlas. Además, dichas normas suelen ser inapropiadas y, al formularlas, no se tienen en cuenta las diferencias en cuanto a estado nutricional, predisposición genética, niveles de exposición y horarios de trabajo.

En el área de la gestión de residuos, la mayoría de los países en desarrollo carecen de un sistema adecuado o una entidad reguladora que garantice una evacuación eficaz. Aunque la cantidad total de residuos generados puede ser reducida en comparación con la producida por los países desarrollados, la mayoría se evacua por medios líquidos. La contaminación de cursos y fuentes de agua es grave. Los residuos sólidos se depositan en emplazamientos carentes de las medidas de protección adecuadas. Además, los países en desarrollo suelen ser los receptores de residuos peligrosos procedentes de los países desarrollados.

Si no se establecen las garantías necesarias para su evacuación, los efectos de la contaminación medioambiental afectarán a varias generaciones. Se sabe, por ejemplo, que las fuentes de agua de la India, Tailandia y China están contaminadas por plomo, mercurio y cadmio.

\section{Falta de una planificación adecuada al elegir el emplaza- miento de las industrias y las áreas residenciales}

En la mayoría de los países, la planificación del emplazamiento de industrias y áreas residenciales es competencia de la Administración. Si no se establecen las disposiciones adecuadas, estas áreas tenderían a congregarse en torno a las zonas industriales, que constituyen una fuente de empleo para la población local. Así ocurrió en el caso de Bophal, India, antes mencionado, y en el complejo industrial de U Isan/ O nsan en la República de Corea. La concentración de inversión en este complejo dió lugar a un rápido aflujo de población a U Isan C ity. En 1962, la ciudad tenía unos 100.000 habitantes; al cabo de 30 años, la cifra había aumentado hasta los 600.000. En 1962, eran 500 los hogares situados dentro de los límites del complejo industrial; en 1992, había 6.000. Los habitantes de la zona declararon padecer diversos problemas de salud atribuibles a la contaminación industrial (O M S 1992).

Como resultado de las elevadas densidades de población en los complejos industriales y sus alrededores, el riesgo de contaminación, residuos peligrosos, incendios y accidentes se multiplica exponencialmente. Además, la salud y el futuro de los niños que viven en torno a estas áreas se encuentran en una situación de auténtico peligro.

\section{Falta de sensibilización de trabajadores y directivos respecto a la seguridad}

Los trabajadores de los países en desarrollo suelen recibir una formación inadecuada para adaptarse a las nuevas tecnologías y procesos industriales. M uchos proceden del ámbito agrario rural, donde el ritmo de trabajo y los riesgos profesionales que deben afrontar son completamente distintos. A menudo, su nivel educativo es muy deficiente en comparación con el habitual en los países desarrollados. Todos estos factores contribuyen a perpetuar un estado general de ignorancia respecto de los riesgos para la salud y las prácticas seguras en el lugar de trabajo. El incendio de la fábrica de juguetes de Bangkok, Tailandia, que se analiza en el capítulo Incendios, es un ejemplo de ello. En este siniestro, no se habían mantenido las precauciones adecuadas en materia de seguridad contra incendios. Las salidas de emergencia estaban bloqueadas. El almacenamiento de las sustancias inflamables era deficiente e impedía la huida por las salidas disponibles. EI resultado final fue el peor incendio en una fábrica de la historia, con un total de 187 fallecidos y 80 desaparecidos (Jeyaratnam y C hia 1994).

A menudo, los accidentes se deben a una falta de compromiso de los directivos con la salud y la seguridad de los trabajadores. Esta situación se explica en parte por la falta de personal cualificado para el mantenimiento y la prestación de servicios relacionados con los equipos industriales. A simismo, en estos países no abundan las divisas y los controles a la importación impuestos por los gobiernos dificultan la obtención de los repuestos adecuados. A demás, el elevado índice de rotación de las plantillas y el gran número de trabajadores disponibles de inmediato hacen que la inversión en formación y educación del personal sea una opción poco rentable para la dirección.

\section{Traslado de industrias peligrosas}

Las industrias peligrosas y las tecnologías inadecuadas de los países desarrollados se trasladan con frecuencia a los países en desarrollo. Resulta más barato transferir toda la producción a un país en el que la normativa medioambiental y sanitaria sea más fácil de cumplir y menos costosa. Por ejemplo, las empresas situadas en el complejo industrial U Isan/O nsan, República de Corea, aplicaban medidas de control de emisiones conformes a la legislación local coreana, menos estricta que la vigente en su país de origen. EI resultado es que se trasladan las industrias potencialmente contaminantes al país en desarrollo.

\section{Elevada proporción de pequeñas empresas}

En comparación con los países desarrollados, la proporción de pequeñas empresas y de trabajadores miembros de sus plantillas es superior en los países en desarrollo. Así, resulta más difícil en estas áreas mantener y hacer cumplir las disposiciones sobre salud y seguridad en el trabajo.

\section{Deficiente estado de salud y calidad de la asistencia sanitaria}

EI desarrollo económico e industrial plantea nuevos riesgos para la salud en un contexto de deficiencia del estado de salud de la población y carencia de un sistema de asistencia sanitaria primaria adecuado. Estos riesgos ejercen una presión aún mayor sobre los limitados recursos de la asistencia sanitaria.

El estado de salud de los trabajadores de los países en desarrollo suele ser inferior al de los trabajadores de los países desarrollados. Son habituales las deficiencias nutricionales y el padecimiento de enfermedades parasitarias e infecciosas de otro tipo. Estos trastornos pueden aumentar la propensión del trabajador a desarrollar enfermedades profesionales. O tra cuestión importante es el efecto combinado de los factores relacionados y no relacionados con el lugar de trabajo sobre la salud de los trabajadores. Los que padecen anemias nutricionales suelen ser muy sensibles a la exposición a concentraciones de plomo inorgánico muy reducidas. A menudo se detectan anemias significativas con niveles de plomo en la sangre en torno a $20 \mu \mathrm{g} / \mathrm{dl}$. 0 tro ejemplo es el de los trabajadores con anemias congénitas, como la talasemia, registrándose en algunos países tasas de portadores elevadas. Se ha observado que estos últimos son muy sensibles al plomo inorgánico, y el tiempo requerido para que la hemoglobina alcance niveles normales es superior al necesario en el caso de los no portadores.

Esta situación pone de manifiesto la existencia de una estrecha línea divisoria entre las enfermedades profesionales 
tradicionales, las enfermedades relacionadas con el trabajo y las enfermedades generales habituales en la comunidad. EI interés de los países en desarrollo debe centrarse en la salud general de todos los trabajadores. Para lograr este objetivo, el sector sanitario de cada país debe aceptar la responsabilidad de organizar un programa de trabajo para la prestación de servicios de asistencia sanitaria a la población activa.

Tampoco debe pasarse por alto el importante papel que ha de desempeñar el sector laboral garantizando la seguridad del medio ambiente de trabajo. C on este fin, es necesario revisar la legislación de forma que en ésta se consideren todos los lugares de trabajo. La normativa no debe limitarse a las instalaciones industriales. La legislación, además de garantizar la seguridad y la estabilidad en el lugar de trabajo, debe prever la prestación de servicios de salud ordinarios a los trabajadores.

A sí pues, dos sectores importantes, como el laboral y el sanitario, deben desempeñar un papel destacado en el ámbito de la salud profesional. Este reconocimiento de la intersectorialidad es un elemento fundamental para el éxito de los programas aplicados en este campo. Debe crearse un organismo intersectorial para asegurar la coordinación entre los dos sectores.

En definitiva, la promulgación de una legislación que garantice la prestación de servicios de salud laboral y la seguridad en el lugar de trabajo resulta esencial. Numerosos países asiáticos han reconocido esta necesidad y disponen ya de dicha legislación, aunque su aplicación sea incompleta.

\section{Conclusiones}

En los países en desarrollo, la industrialización es un rasgo necesario del crecimiento económico y el desarrollo. Aunque este proceso puede tener efectos perjudiciales para la salud, el progreso económico asociado puede compensarlos. El objetivo es reducir al mínimo los problemas sanitarios y medioambientales y optimizar las ventajas de la industrialización. En los países desarrollados, la experiencia de los efectos adversos provocados por la Revolución Industrial dio lugar a una regulación del ritmo de desarrollo. En general, estos países han reaccionado adecuadamente y han dispuesto del tiempo necesario para establecer toda la infraestructura necesaria para controlar los dos tipos de problemas indicados.

El reto a que se enfrentan actualmente los países en desarrollo que, debido a la competencia internacional, no pueden permitirse el lujo de regular su ritmo de industrialización, consiste en aprender de los errores y las soluciones de los países desarroIlados. A su vez, el reto para estos últimos estriba en ayudar a los primeros. L os países desarrollados no deben aprovecharse de los trabajadores de las áreas en desarrollo ni de su falta de capacidad financiera y de mecanismos de regulación, pues, a escala mundial, la contaminación medioambiental y los problemas de salud no respetan fronteras políticas ni geográficas.

\section{- PaISE S IN DU ST RIALIZADO S Y SALUd Y SEGURIDAD EN EL TRABAJO}

Toshiteru O kubo

\section{Visión general}

La actividad económica, expresada en términos del producto nacional bruto por habitante $(\mathrm{PNB})$, difiere considerablemente entre los países en desarrollo y los industrializados. De acuerdo con la clasificación del Banco M undial, el PNB del país que encabeza la lista es unas cincuenta veces superior al del que ocupa la última posición. La proporción del PNB total mundial generada por los Estados miembros de la O rganización para la Cooperación y el Desarrollo Económico (OCDE) es casi del $20 \%$.

L os países de la OCDE consumen casi la mitad de la energía mundial. Las emisiones de dióxido de carbono de los tres primeros representan un $50 \%$ del total producido en el planeta; estos países son responsables de los principales problemas de contaminación mundial. No obstante, desde las dos crisis del petróleo de 1973 y 1978, han emprendido iniciativas de ahorro energético basadas en la sustitución de procesos anticuados por otros de mayor eficacia. Simultáneamente, las industrias pesadas, que consumen una gran cantidad de energía y requieren la realización de tareas arduas y la exposición a trabajos arriesgados 0 peligrosos, se han trasladado a países menos industrializados. En consecuencia, el consumo de energía en estos países aumentará en la próxima década y se agravarán los problemas relacionados con la contaminación medioambiental y la salud y la seguridad en el trabajo.

En el transcurso del proceso de industrialización, muchos países experimentaron un envejecimiento de la población. En los principales Estados industrializados, las personas de 65 o más años representan entre el 10 y el $15 \%$ de la población total. Esta proporción es significativamente superior a la que se registra en los países en desarrollo.

Tal disparidad refleja la existencia de tasas de reproducción y mortalidad inferiores en los países industrializados. Por ejemplo, la tasa de reproducción en estos países es inferior al $2 \%$, mientras que en áreas de Africa y 0 riente Próximo se registran tasas superiores al $5 \%$ y en un gran número de países en desarrollo son habituales las iguales o superiores al $3 \%$. El aumento de la proporción de trabajadoras, que ha pasado del 35 al $50 \%$ de la población activa en los países industrializados (suele ser inferior al $30 \%$ en los Estados menos industrializados) puede estar relacionado con el descenso del número de hijos.

La mejora del acceso a la educación superior está asociada con un aumento del porcentaje de profesionales liberales. Esta característica es otra de las disparidades significativas entre países industrializados y en desarrollo. En estos últimos, la proporción de este tipo de trabajadores nunca ha excedido del $5 \%$, lo que contrasta fuertemente con las cifras de los países nórdicos, donde se sitúa entre el 20 y el $30 \%$. El resto de los países europeos y norteamericanos están a medio camino entre ambos extremos, con una proporción de profesionales superior al $10 \%$ de la población activa. La industrialización depende fundamentalmente de la investigación y el desarrollo, tareas vinculadas más con un exceso de estrés y tensiones que con los riesgos físicos característicos de gran parte de los trabajos realizado en los países en desarrollo.

\section{Situación actual de la salud y la seguridad en el trabajo}

El crecimiento económico y los cambios en la estructura de las principales industrias de numerosos países desarrollados se han asociado con una disminución de la exposición a los productos químicos peligrosos, tanto en lo que se refiere al nivel de exposición, como al número de trabajadores expuestos. En consecuencia, los casos de intoxicación aguda, así como la incidencia de las enfermedades profesionales típicas, se reducen. Con todo, siguen observándose efectos aplazados o crónicos debidos a la exposición mantenida durante años (p. ej., la pneumoconiosis y el cáncer de origen profesional), incluso en los países más industrializados.

Al mismo tiempo, las innovaciones técnicas han introducido la utilización de sustancias químicas de reciente creación en los procesos industriales. En diciembre de 1982, para garantizar la protección respecto de estas nuevas sustancias, la O CDE adoptó 
una recomendación internacional sobre un Conjunto de Datos de Seguridad M ínimos Previos a la Comercialización.

Entretanto, ha seguido aumentando el nivel de estrés vinculado a la vida en el lugar de trabajo y en otros ámbitos. La proporción de trabajadores aquejados de problemas relacionados con el abuso del alcohol y las drogas y el absentismo han crecido en muchos países industrializados.

Las lesiones profesionales se han reducido en muchos países desarrollados debido en gran parte a la mejora de las medidas de seguridad en el trabajo y a la introducción generalizada de equipos y procesos automatizados. 0 tro factor importante que ha contribuido a este descenso es la reducción del número absoluto de trabajadores dedicados a tareas peligrosas como resultado del cambio en la estructura industrial, caracterizado por el aumento de industrias ligeras y la disminución de las pesadas. EI número de trabajadores muertos en accidente de trabajo en Japón pasó de 3.725 en 1975 a 2.348 en 1995. No obstante, el análisis de esta tendencia en el tiempo indica que el ritmo de descenso ha aminorado en los últimos diez años. La incidencia de las lesiones profesionales en Japón (incluidos los casos de fallecimiento) pasó de 4,77 por millón de horas de trabajo en 1975 a 1,88 en 1995, mientras que en el período de 1989 a 1995 la reducción fue más lenta. Esta aminoración de la tendencia a la reducción de los accidentes industriales también se ha detectado en otros países industrializados; por ejemplo, la frecuencia de lesiones profesionales en Estados U nidos no ha mejorado en más de 40 años. Este dato refleja en parte la sustitución de los accidentes de trabajo clásicos, que pueden prevenirse mediante la adopción de diversas medidas de seguridad, por nuevos tipos de accidente provocados por la introducción de maquinaria automatizada.

El Convenio no 161 de la OIT, adoptado en 1985, constituye una norma de referencia importante para los servicios de salud en el trabajo. Aunque se refiere a países en desarrollo y desarrollados, sus conceptos fundamentales se basan en la experiencia y en los programas existentes en estos últimos.

El marco básico de un sistema de servicios de salud en el trabajo suele venir definido por la legislación. $\mathrm{H}$ ay dos tipos principales. El primero es el característico de Estados U nidos y el Reino Unido, en los que la legislación sólo establece las normas que deben cumplirse. La consecución de los objetivos se deja a las empresas, y la Administración ofrece información y asistencia técnica previa solicitud. La comprobación del cumplimiento de la normativa es una competencia administrativa fundamental.

El segundo tipo está representado por la legislación francesa, en la que no sólo se establecen los objetivos, sino que también se detallan los procedimientos para alcanzarlos. Se exige a las empresas que proporcionen a sus plantillas servicios de salud en el trabajo especializados y que recurran a médicos especialistas oficialmente reconocidos, y a las instituciones de servicio que cumplan con los mismos requisitos. Se especifica el número de trabajadores que deben ser atendidos por cada médico del trabajo designado: en los centros de trabajo cuyo medio ambiente no sea peligroso, un único médico puede tratar a más de 3.000 trabajadores; esta cifra se reduce en caso de exposición a riesgos definidos.

L os especialistas dedicados a la salud en el trabajo se ocupan de un campo de actuación cada vez más amplio en los países industrializados. La especialización de los médicos en prevención y gestión de la salud es cada vez mayor. Además, los profesionales de la enfermería del trabajo, los higienistas industriales, los fisioterapeutas y los psicólogos desempeñan un papel importante en los países desarrollados. Los higienistas industriales tienen una presencia destacada en Estados U nidos, mientras que en Japón son mucho más habituales los especialistas en la medición del medio ambiente. Los fisioterapeutas del trabajo son bastante característicos de los países nórdicos. En definitiva, existen algunas diferencias de tipo y distribución entre los especialistas comunes en cada región.

Los centros con millares de trabajadores en plantilla suelen contar con su propia organización independiente de servicios de salud en el trabajo. El empleo de especialistas distintos de los médicos del trabajo y el establecimiento de las instalaciones mínimas necesarias para la prestación completa de este tipo de servicios sólo suele ser viable con plantillas de esa magnitud. La oferta de servicios de salud en el trabajo en centros de menores dimensiones, sobre todo cuando el número de trabajadores es reducido, se plantea de forma muy diferente. $\mathrm{Ni}$ siquiera en muchos países industrializados las organizaciones que prestan este tipo de servicios en pequeñas empresas se han establecido de forma sistemática. Francia y otros países europeos disponen de una legislación que establece los requisitos mínimos que deben cumplir las instalaciones y los servicios ofrecidos por dichas organizaciones, y las empresas que carecen de un servicio propio deben contratarlo con éstas.

En algunos países industrializados, el contenido del programa de salud en el trabajo se centra más en los servicios de prevención que en los de curación, si bien esta prioridad suele ser objeto de debate. En general, los países que disponen de un sistema de servicios de salud comunitaria global tienden a limitar el ámbito de dicho programa y consideran el tratamiento como una disciplina de la medicina comunitaria.

La necesidad de que todos los trabajadores sean sometidos a reconocimientos médicos periódicos es otro tema de debate. Si bien hay quien considera que no se ha demostrado que los reconocimientos que exigen una exploración selectiva general resulten beneficiosos, Japón es uno de los muchos países en que se exige a las empresas que realicen este tipo de pruebas a los miembros de su plantilla. En este tipo de programas se recomienda encarecidamente la aplicación de un seguimiento exhaustivo y la oferta continua de educación sanitaria y promoción de la salud; además, el registro de historiales individuales se considera indispensable para la consecución de los objetivos. La evaluación de estos programas requiere un seguimiento a largo plazo.

Los sistemas de seguro que cubren la asistencia médica y la indemnización por lesiones o enfermedades relacionadas con el trabajo se utilizan en casi todos los países industrializados. No obstante, hay una gran diversidad en cuanto a su gestión, cobertura, pago de primas, tipo de prestaciones, magnitud del compromiso con la prevención y disponibilidad de apoyo técnico. En Estados U nidos, el sistema es independiente en cada Estado y las compañías de seguros privadas desempeñan un papel destacado, mientras que en Francia, el sistema es gestionado en su totalidad por el sector público y está incorporado en gran medida en la administración de la salud en el trabajo. Los especialistas que trabajan para el sistema de seguros a menudo desempeñan una función importante de ayuda técnica para la prevención de los accidentes de trabajo y las enfermedades profesionales.

M uchos países disponen de un sistema educativo de posgrado y de cursos de formación en régimen de residencia sobre salud en el trabajo. El doctorado suele ser el grado académico superior en esta materia, pero existen también sistemas de cualificación especializada.

Las escuelas de salud pública desempeñan un papel importante en la educación y la formación de expertos en salud en el trabajo en Estados U nidos. De las 24 escuelas acreditadas, 22 impartieron programas de salud en el trabajo en 1992: 13 ofrecieron programas de medicina del trabajo y 19 de higiene industrial. Los cursos de salud en el trabajo impartidos por estas 
escuelas no dan lugar necesariamente a la obtención de un título académico, pero están estrechamente relacionados con la acreditación de especialistas, en cuanto que forman parte de las cualificaciones necesarias para acceder a los exámenes que deben aprobarse para ser miembro de uno de los consejos de especialistas en salud en el trabajo.
El Programa de Recursos Educativos (E ducational Resource Program, ERC), financiado por el $N$ ational Institute for $O$ ccupational Safety and H ealth (NIOSH) ha apoyado la puesta en práctica de programas en régimen de residencia en estas escuelas. El ERC ha designado 15 de éstas como centros regionales para la formación de profesionales de la salud en el trabajo.

\section{Estudios de casos sobre cambio tecnológico}

Los cambios en las tecnologías industriales, las presiones de la producción y la necesidad de formar continuamente a los trabajadores son elementos fundamentales para un medio ambiente seguro y saludable. A continuación se exponen tres casos acaecidos en Estados Unidos. El cambio tecnológico concierne a todos los trabajadores del mundo.

\section{Producción frente a seguridad}

Las presiones de la producción pueden comprometer gravemente la salud y la seguridad si los directivos no analizan con cuidado las posibles consecuencias de las decisiones adoptadas para aumentar la productividad. Un ejemplo es el accidente ocurrido en 1994 en una pequeña fábrica siderúrgica de Estados Unidos.

Aproximadamente a las 4 de la mañana, varios trabajadores se preparaban para verter acero fundido de un horno de arco eléctrico. El mercado del acero se encontraba en una situación favorable y la empresa vendía todo lo que podía producir. Los trabajadores realizaban muchas horas extraordinarias y la fábrica funcionaba a pleno rendimiento. Se había previsto cerrar el horno con el fin de sustituir su revestimiento refractario, que se había desgastado hasta quedar sus paredes peligrosamente finas.

Al comenzar el vertido, el revestimiento del recipiente comenzó a arder. El acero y la escoria se derramaron a través de la rotura y se fundieron rápidamente a través de un conducto de agua del sistema de refrigeración del horno. El agua estalló en forma de vapor con una fuerza tremenda. Dos trabajadores se encontraban en su trayectoria. Ambos sufrieron quemaduras graves. Uno de ellos murió tres días más tarde.

Una causa obvia del accidente fue la utilización del horno con posterioridad al final de la vida útil de su revestimiento refractario. Además, los hornos eléctricos suelen diseñarse de forma que los principales conductos de refrigeración se mantengan siempre por encima de la altura del acero y la escoria fundidos, con el fin de evitar precisamente este tipo de accidente. Sin embargo, el horno había sido modificado pocos días antes para elevar su capacidad mediante el aumento del nivel de material fundido y los ingenieros pasaron por alto el problema de la conducción de agua. Un simple derrame de acero y escoria fundidos habría sido grave, pero sin la presencia del conducto de agua no se habría producido una explosión de vapor y las lesiones habrían sido más leves. Ambos factores se debieron a la exigencia de elevar la productividad sin prestar la atención suficiente a la seguridad.

\section{Formación}

La formación de los trabajadores debe incluir algo más que un conjunto de normas de seguridad específicas. La mejor formación en materia de seguridad exige una comprensión global del proceso, el equipo y los riesgos potenciales. Es importante que los trabajadores entiendan la razón de ser de las normas y puedan responder a situaciones imprevistas que no se recogen en éstas.

La importancia de una formación global se demuestra al analizar el accidente sucedido en 1986 en una acería norteamericana. Dos trabajadores entraron en el recipiente de un horno para desmontar el andamio que se había utilizado para revestirlo con ladrillos refractarios nuevos. Los trabajadores siguieron un "análisis de seguridad de la operación" detallado en el que se describían todas sus fases. Pero este análisis era deficiente. El recipiente había sido reparado dos años antes con un sistema de inyección de gas argón a través del metal fundido para mezclarlo con mayor eficacia, y el análisis no se había actualizado con este dato sobre el nuevo sistema basado en el argón.

0 tro equipo de trabajo volvió a conectar ese sistema poco antes de que los dos trabajadores entraran en el recipiente. Las válvulas tenían fugas y los conductos no habían sido bloqueados. La prueba atmosférica exigida para el acceso a un espacio cerrado no se llevó a cabo convenientemente y los trabajadores no se encontraban presentes en el momento de su realización.

Los dos trabajadores murieron por falta de oxígeno. Un tercer trabajador entró en el recipiente en un intento por rescatarles, pero también resultó afectado. Le salvó la vida un cuarto compañero que cortó el extremo de una manguera de aire comprimido y arrojó ésta al recipiente, suministrando así oxígeno a la víctima inconsciente.

La causa evidente del accidente fue la no actualización del análisis de seguridad de la operación por parte de la empresa. $\mathrm{N}$ o obstante, una formación global sobre el proceso, el equipo y los riesgos inherentes podría haber permitido a los trabajadores determinar las deficiencias del análisis y adoptar medidas para garantizar un acceso seguro al recipiente.

\section{Cambio tecnológico}

La importancia de analizar la tecnología nueva o modificada se pone de manifiesto al examinar el accidente ocurrido en 1978 en una fábrica química de Estados Unidos. La empresa llevaba a cabo reacciones de tolueno y otras sustancias químicas orgánicas en un recipiente cerrado. La reacción era inducida mediante calor, suministrado al recipiente a través de un serpentín de caldeo con agua caliente en circulación. El departamento de ingeniería de la fábrica decidió sustituir el agua por nitrato de sodio fundido para acelerar el proceso. Sin embargo, el serpentín había sido reparado con materiales con una temperatura de fusión inferior a la del nitrato de sodio. Como consecuencia, esta sustancia comenzó a filtrarse y acceder al interior del recipiente, donde reaccionó con los compuestos orgánicos para formar nitratos orgánicos inestables.

La explosión subsiguiente hirió a varios trabajadores, destruyó el recipiente del reactor y dañó el edificio. Con todo, las consecuencias podrían haber sido mucho peores. El accidente se produjo entrada la noche, cuando ningún trabajador se encontraba cerca. Además, metralla caliente entró en una unidad de proceso próxima que contenía una gran cantidad de dietil éter. Afortunadamente, ninguno de los recipientes ni de las conducciones resultaron alcanzados. Una explosión durante el turno de mañana 0 una que hubiese generado una nube de vapor de dietil éter habría provocado numerosas víctimas mortales.

Michael J. Wright 
A menudo resulta difícil organizar la educación y la formación sobre salud en el trabajo destinadas a los médicos y otros profesionales de la salud que ya forman parte de los servicios de asistencia sanitaria primaria de la comunidad. Se han desarrollado diversos métodos de aprendizaje a distancia en algunos países, como un curso por correspondencia en el R eino U nido y otro basado en la comunicación telefónica en Nueva Zelanda, que han recibido una valoración positiva.

\section{Factores que influyen en la salud y la seguridad en el trabajo}

La prevención a escala primaria, secundaria y terciaria debe constituir un objetivo básico del programa de salud y seguridad en el trabajo. La prevención primaria basada en la higiene industrial ha obtenido un éxito considerable en la reducción del riesgo de enfermedades profesionales. N o obstante, cuando se llega a un nivel bastante inferior al admisible, este enfoque pierde eficacia, sobre todo si se tienen en cuenta los costes y beneficios.

El paso siguiente en el ámbito de la prevención primaria consiste en el control biológico, haciendo hincapié en las diferencias en materia de exposición individual. La sensibilidad de cada persona es importante en esta fase. La determinación de la idoneidad para el trabajo y la asignación de un número razonable de trabajadores a tareas específicas son objeto de una atención cada vez mayor. La ergonomía y diversas técnicas de salud mental diseñadas para reducir el estrés en el trabajo son otros de los elementos indispensables en esta etapa.

El objetivo de prevenir las exposiciones a riesgos en el lugar de trabajo ha ido perdiendo importancia en favor de la promoción de la salud. El objetivo final es lograr la autogestión de la salud. La educación sanitaria orientada a la consecución de este objetivo se considera una de las áreas principales a las que deben dedicar sus esfuerzos los especialistas. El gobierno japonés ha propuesto un programa de promoción de la salud denominado "Plan de Promoción de la Salud Total", en el que la formación de especialistas y la ayuda financiera al programa de cada centro de trabajo son componentes fundamentales.

En la mayoría de los países industrializados, los sindicatos desempeñan un papel importante en el desarrollo de iniciativas de salud y seguridad en el trabajo en todos los ámbitos, desde el central hasta el periférico. En muchos países europeos los representantes sindicales son invitados oficialmente a formar parte de los comités encargados de decidir la orientación administrativa básica del programa. En Japón y Estados U nidos, la participación de los trabajadores es indirecta y los ministerios o departamentos de trabajo conservan las competencias administrativas.

Parte de la población activa de numerosos países industrializados procede del extranjero, ya sea oficial o extraoficialmente. Estos trabajadores inmigrantes plantean diversos problemas, como los relativos a la lengua, las barreras étnicas y culturales, el nivel educativo y las deficiencias de salud.

Las empresas que aportan servicios profesionales en el campo de la salud en el trabajo cumplen una función importante en lo que se refiere a la ayuda a la formación y la educación y la información. Algunas sociedades académicas expiden certificaciones especializadas. Estas organizaciones contribuyen asimismo a la cooperación internacional.

\section{Previsiones de futuro}

La cobertura de los trabajadores por parte de los servicios de salud en el trabajo especializados sigue siendo poco satisfactoria, salvo en algunos países europeos. M ientras que la prestación de este servicio siga siendo voluntaria, habrá muchos trabajadores privados de ella, sobre todo en las pequeñas empresas. En países con un alto nivel de cobertura, como Francia y algunos Estados nórdicos, los sistemas de seguro contribuyen en gran medida a la disponibilidad de ayuda financiera y asistencia técnica. Para garantizar el servicio en centros de menor tamaño puede ser necesario cierto nivel de compromiso por parte de la seguridad social.

Los servicios de salud en el trabajo suelen actuar con mayor celeridad que la sanidad general. Así ocurre especialmente en las grandes empresas. EI resultado es un desfase entre los servicios prestados en cada uno de los dos ámbitos. L os trabajadores que reciben un mejor servicio sanitario a lo largo de su vida laboral frecuentemente experimentan problemas de salud después de la jubilación. En ocasiones, la disparidad entre grandes y pequeñas empresas no puede ignorarse, por ejemplo, en Japón, donde muchos trabajadores de edad avanzada se mantienen activos en las pequeñas empresas tras su jubilación obligatoria en las grandes. La continuidad de los servicios en estos entornos diferentes es una cuestión que deberá abordarse inevitablemente en un futuro próximo.

A medida que aumenta la complejidad del sistema industrial, el control de la contaminación ambiental resulta más difícil. U na actividad anticontaminación intensiva en una fábrica puede dar lugar, sencillamente, al traslado de la fuente de contaminación a otra industria 0 a otra instalación productiva. A simismo, puede provocar la exportación de la fábrica, con su problema medioambiental asociado, a un país en desarrollo. La integración entre salud en el trabajo y salud medioambiental es cada vez más necesaria.

\section{PEQ UEÑ AS EMPRESAS Y SALUd Y SEGURIDAD EN EL TRABAJO}

Bill Glass

La pequeña empresa es un modo de producción característico desde tiempos remotos. Industrias artesanales en que los miembros de una familia desarrollan su actividad en función de una determinada división del trabajo siguen existiendo actualmente en los medios rural y urbano. De hecho, la mayoría de los trabajadores de todos los países, remunerados o no, prestan sus servicios en empresas que pueden calificarse de pequeñas.

Antes de determinar sus problemas de salud, es necesario definir qué es una pequeña empresa. Se admite comúnmente que son aquellas empresas en las que trabajan plantillas de 500 menos miembros. Pueden localizarse en el propio domicilio, en una explotación agraria, en una pequeña oficina, en una fábrica, en una mina o cantera, en una explotación silvícola, en un jardín o en un barco de pesca. La definición se basa en el número de trabajadores, no en lo que hacen ni en si se les remunera o no. El propio domicilio constituye sin lugar a dudas una pequeña empresa.

\section{Características comunes de las pequeñas empresas}

Las características comunes de las pequeñas empresas son las siguientes (véase la Tabla 20.1):

- Es probable que su capitalización sea insuficiente.

- La presencia de los sindicatos suele ser nula (sobre todo en los domicilios y en las explotaciones agrarias) o escasa (oficinas, fábricas, establecimientos de alimentación, etc.).

- La probabilidad de que sean inspeccionadas por organismos públicos es menor. De hecho, en un estudio realizado hace algunos años se indicaba que la existencia de un gran número de pequeñas empresas era desconocida para el departamento gubernamental responsable de las mismas (D epartamento de Salud Comunitaria 1980). 
Tabla 20.1 • Características de las pequeñas empresas y sus consecuencias.

Falta de capital

- condiciones ambientales deficientes

- materias primas más baratas

- mantenimiento de equipos inferior

- protección personal inadecuada

Implantación sindical nula o escasa

- bajos niveles retribuidos

- jornadas de trabajo más largas

- incumplimiento de las condiciones de indemnización

- explotación del trabajo infantil

\section{Servicios de inspección inferiores}

- condiciones ambientales precarias

- nivel de riesgo superior

- mayores tasas de accidentes y enfermedades

En consecuencia, las condiciones ambientales en estos pequeños lugares de trabajo, que suelen ser el reflejo del capital disponible, son inevitablemente inferiores a las habituales en las grandes empresas: se adquieren materias primas de menor coste, se reduce el mantenimiento de la maquinaria y se dispone de menos equipos de protección personal.

La sindicación escasa o nula da lugar a una remuneración inferior, a la realización de jornadas de trabajo de mayor duración y al incumplimiento de las condiciones de trabajo legales. El trabajo suele ser más intensivo y hay más probabilidades de explotación de niños y personas de edad avanzada.

Unos servicios de inspección de menor eficacia provocan el empeoramiento del medio ambiente de trabajo, el aumento de los riesgos en el lugar de trabajo y el incremento de las tasas de accidentes y enfermedades profesionales.

Estas características de las pequeñas empresas las sitúan en el límite de las condiciones de supervivencia económica. La creación y el desmantelamiento de este tipo de unidades es frecuente.

Para compensar estas significativas desventajas, las pequeñas empresas tratan de asegurar la flexibilidad de sus sistemas productivos. Pueden responder con rapidez a los cambios y aplican con frecuencia soluciones imaginativas y fáciles de adaptar a los requisitos del reto tecnológico. En el plano social, el propietario suele ocupar el puesto de director ejecutivo y mantiene una relación más personal con la plantilla.

$\mathrm{H}$ ay datos que avalan estas afirmaciones. Por ejemplo, en un estudio realizado en Estados U nidos se observó que los trabajadores de chapisterías de barrio estaban en contacto habitualmente con disolventes, pigmentos metálicos, pintura, vapores de plásticos de poliéster y polvo, y soportaban ruidos y vibraciones (Jaycock y Levin 1984). 0 tro estudio realizado en ese mismo país puso de manifiesto que la existencia de múltiples exposiciones de corta duración a sustancias químicas era una característica de las pequeñas industrias (K endrick, D ischer y H oladay 1968).

En un estudio de Finlandia en el que se investigaban este tipo de casos en 100 lugares de trabajo, se llegó a la conclusión de que las exposiciones a sustancias químicas durante períodos breves eran habituales en las pequeñas empresas y que la duración de la exposición aumentaba con el crecimiento de la unidad de producción (Vihina y Nurminen 1983). Esta tendencia se asociaba a la multiplicidad de exposiciones a sustancias químicas diferentes y a una frecuencia de exposición que alcanzaba niveles máximos. El estudio concluía que la exposición química en las pequeñas empresas es de naturaleza compleja.

Q uizás, el ejemplo más patente de la repercusión del tamaño en el riesgo para la salud en el trabajo se presentó en el Segundo Seminario Internacional sobre el Benceno, celebrado en Viena en 1980. La mayoría de los delegados procedentes de la industria del petróleo afirmaron que el benceno planteaba escasos riesgos para la salud en sus lugares de trabajo, ya que en ellos se empleaban avanzadas técnicas médicas, de higiene y de ingeniería con el fin de controlar y eliminar la posibilidad de exposición. En cambio, un delegado de Turquía, al referirse a la industria de fabricación de botas, que es en gran medida una actividad artesanal realizada en el domicilio del trabajador, indicó que hombres, mujeres y niños estaban expuestos a una concentración elevada de "un disolvente no etiquetado", el benceno, que daba lugar a casos de anemia y leucemia (A ksoy y cols. 1974). La diferencia de exposición en ambas situaciones era una consecuencia directa del tamaño del lugar de trabajo y de un contacto más estrecho de los trabajadores en la fabricación artesanal de botas respecto a los que se producen en las grandes empresas petroleras.

Dos investigadores canadienses han descrito las principales dificultades a que se enfrentan las pequeñas empresas: falta de sensibilización de los directivos respecto de los riesgos para la salud, coste por trabajador superior para reducir estos riesgos y entorno competitivo inestable, que reduce la probabilidad de que estas empresas puedan permitirse aplicar las normas y regulaciones vigentes en materia de seguridad (L ees y Zajac 1981).

Así, gran parte de la experiencia y los datos registrados indican que los trabajadores de las pequeñas empresas constituyen un grupo de población que recibe menos prestaciones desde el punto de vista de la salud y la seguridad. Rantanan (1993) acometió un estudio crítico de las fuentes disponibles para el Grupo de Trabajo Interregional de la OM S sobre Protección y Promoción de la Salud de los Trabajadores de Pequeñas Empresas, y llegó a la conclusión de que, por desgracia, los datos cuantitativos sobre las enfermedades y lesiones de estos trabajadores son escasos.

A pesar de la falta de datos cuantitativos fiables, la experiencia ha demostrado que las pequeñas empresas, por sus características, se asocian con una mayor probabilidad de lesiones musculosqueléticas, laceraciones, quemaduras, heridas por pinchazos, amputaciones y fracturas, intoxicaciones por inhalación de disolventes y otros productos químicos y, en el sector rural, por pesticidas.

\section{Satisfacción de las necesidades en materia de salud de los trabajadores de pequeñas empresas}

$L$ a dificultad para atender las necesidades en materia de salud y seguridad de los trabajadores en las pequeñas empresas se debe a Ios factores siguientes:

- Las empresas rurales suelen estar aisladas, debido a su localización alejada de los centros principales y a las deficiencias de carreteras y otras vías de comunicación.

- El acceso de los trabajadores de buques de pesca y empresas silvícolas de pequeño tamaño a los servicios de salud y seguridad también es limitado.

- El propio domicilio, donde se ubican la mayoría de las industrias artesanales y las "tareas domésticas" no remuneradas, suele ser ignorado en la legislación sobre salud y seguridad. 
- El nivel educativo de los trabajadores de las pequeñas empresas suele ser inferior, debido a un abandono más temprano de los centros docentes o a la falta de acceso a éstos. Esta tendencia se acentúa por el empleo de niños y trabajadores migrantes (legales e ilegales) con dificultades culturales y lingüísticas.

- Aunque es evidente que las pequeñas empresas contribuyen de forma significativa al producto interior bruto, la fragilidad de las economías de los países en desarrollo dificulta la provisión de fondos para satisfacer las necesidades de salud y seguridad de sus trabajadores.

- El gran número de pequeñas empresas y su variabilidad complica la organización eficaz de sus servicios de salud y seguridad.

En resumen, los trabajadores de las pequeñas empresas presentan ciertas características que les hacen vulnerables a los problemas de salud y dificultan la prestación de asistencia sanitaria. Son las siguientes:

- Inaccesibilidad a los servicios de salud disponibles por razones geográficas o económicas y disposición a tolerar condiciones de inseguridad e insalubridad en el trabajo, sobre todo por pobreza e ignorancia.

- Privaciones debidas a las deficiencias de educación, vivienda, transporte y ocio.

- Incapacidad para influir en la formulación de políticas.

\section{¿Cuáles son las soluciones?}

Pueden plantearse a varias escalas: internacional, nacional, regional, local y en el lugar de trabajo. Su aplicación abarca formulación de políticas, educación, práctica y financiación.

En la reunión de Colombo (D eclaración de Colombo 1986) se desarrolló un enfoque conceptual, centrado fundamentalmente en los países en desarrollo. A continuación se reformulan los principios de dicho enfoque para su aplicación a las pequeñas empresas, con independencia de su localización:

1. D eben formularse políticas nacionales para mejorar la salud y la seguridad de los trabajadores de las pequeñas empresas, haciendo especial hincapié en la educación y la formación de los directivos, los supervisores y los trabajadores y en los medios para garantizar una información adecuada con el fin de proteger la salud y la seguridad de todos los trabajadores.

2. Los servicios de salud en el trabajo de las pequeñas empresas deben integrarse en los sistemas sanitarios existentes de asistencia primaria.

3. Es necesario impartir una formación adecuada al personal de salud en el trabajo, adaptada al tipo de actividad desempeñada y que atienda las necesidades de formación concretas de los especialistas y los trabajadores de la asistencia sanitaria primaria, así como de los inspectores de salud pública y el personal de enfermería.

4. Es necesario establecer sistemas de comunicación adecuados, que permitan un flujo libre de información sobre salud y seguridad en el trabajo entre directivos, trabajadores y el personal de este campo a todas las escalas.

5. Debe ofrecerse asistencia sanitaria en el trabajo a colectivos reducidos y aislados mediante la contribución del personal de asistencia sanitaria primaria (PASP) u otros profesionales equivalentes. En las áreas rurales, es probable que estas personas presten asistencia sanitaria general a tiempo parcial y pueden asignárseles tareas relacionadas con la salud en el trabajo. En los pequeños lugares de trabajo urbanos, esta solución es menos factible. Será necesario contar con miembros de las plantillas seleccionados por sus compañeros de trabajo.

6. Este PASP rural y urbano, que necesitará una formación y una supervisión inicial y continua, debe estar conectado con los servicios de salud existentes. El "trabajador sanitario de enlace" debe ser un profesional de la salud que trabaje a tiempo completo y tenga un mínimo de tres años de formación. Este profesional constituye el vínculo esencial para un funcionamiento eficaz del servicio (véase la Figura 20.3).

7. La higiene industrial, que comprende la medición, la evaluación y el control de los riesgos ambientales, es una parte esencial de la asistencia de salud en el trabajo. Los servicios y las cualificaciones de higiene industrial deben introducirse en el servicio de salud, tanto a escala central como periférica.

A pesar de la formulación de estos principios, los avances logrados son escasos, debido, casi con toda certeza, a la baja prioridad concedida a los pequeños lugares de trabajo y al personal que desarrolla su actividad en ellos en la planificación de los servicios de salud de la mayoría de los países. Las razones de esta situación son las siguientes:

- estos trabajadores no influyen en la formulación de políticas;

- es difícil atender las necesidades de salud por factores ya mencionados como el aislamiento, los niveles educativos y el tradicionalismo inherente;

- carencia de un sistema de asistencia sanitaria primaria eficaz;

Para la solución de este problema se plantean enfoques a escala internacional, nacional y local.

\section{A escala internacional}

Un elemento problemático de la economía mundial son los aspectos negativos asociados a la transferencia de tecnología, y de los correspondientes procesos peligrosos, desde los países desarrollados a los países en desarrollo. O tro problema reside en el "dumping social": con el fin de competir en el mercado mundial, se reducen los salarios, se hace caso omiso de las normas de seguridad, se amplían las jornadas de trabajo, se rebaja la edad mínima de acceso al empleo y se instituye una forma moderna de esclavitud. Es urgente que la O IT y la OM S desarrollen nuevos instrumentos (convenios y recomendaciones) que prohíban esas prácticas.

\section{A escala nacional}

Es necesario promulgar una legislación general sobre salud y seguridad en el trabajo, respaldada por la voluntad de aplicarla y velar por su cumplimiento. Esta medida debe contar con el apoyo de una promoción de la salud positiva y generalizada.

\section{A escala local}

$\mathrm{H}$ ay varios modelos organizativos de los servicios de salud y seguridad en el trabajo que han resultado eficaces y que, con las modificaciones pertinentes, pueden adaptarse a la mayoría de las situaciones locales. Son los siguientes:

- Puede crearse un centro de salud en el trabajo en las localidades que posean una elevada densidad de pequeños lugares de trabajo, con el fin de ofrecer tratamiento en caso de accidente u otras urgencias y desempeñar funciones educativas y de intervención. Estos centros suelen financiarse con fondos públicos, pero también puede recurrirse al reparto de costes entre varias pequeñas empresas locales, normalmente en función del número de trabajadores. 
Figura 20.3 - Modelos de asistencia sanitaria para los trabajadores en fábricas pequeñas.

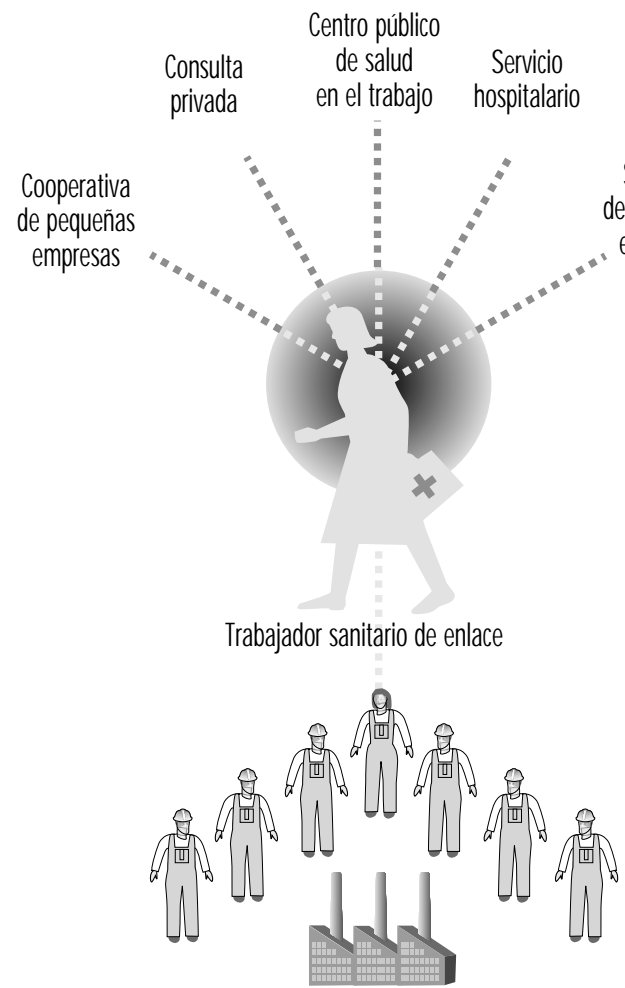

Trabajadores de fábricas pequeñas/ Trabajador atendido por la asistencia sanitaria primaria

- El servicio de salud en el trabajo de una gran compañía puede prestar dicho servicio a las pequeñas empresas próximas a ésta.

- Un servicio de salud en el trabajo situado en un hospital, que ya cubra el tratamiento de accidentes y otras urgencias, puede completar esta prestación con un servicio de asistencia de salud a domicilio que se concentre en la educación y la intervención.

- Un médico general puede prestar servicios de tratamiento en una clínica y recurrir a personal de enfermería del trabajo para que realice labores de educación e intervención en el lugar de trabajo.

- Puede crearse un servicio especializado de salud en el trabajo, integrado por un equipo interdisciplinario compuesto por médicos del trabajo, médicos generales, personal de enfermería del trabajo, fisioterapeutas y especialistas en radiografía, patología, etc.

- Con independencia del modelo empleado, el servicio debe conectarse con el lugar de trabajo a través del "trabajador sanitario de enlace", un profesional de la salud capacitado y multicualificado en los aspectos clínicos y de higiene de este medio. (V éase la Figura 20.3).

Cualquiera que sea la forma organizativa utilizada, las funciones esenciales deben ser las siguientes (G lass 1982):

- un centro para la formación de personal de primeros auxilios entre los trabajadores de las pequeñas empresas circundantes;

- un centro para el tratamiento de daños de poca importancia y otros problemas de salud relacionados con el trabajo;

- un centro para la prestación de un servicio de control biológico básico, incluida la realización de exploraciones selectivas del oído, la función pulmonar, la vista, la presión sanguínea, etc., así como de los primeros síntomas de los efectos tóxicos provocados por la exposición a riesgos laborales

- un centro para la realización de investigaciones medioambientales básicas que se integren con el control biológico

- un centro que ofrezca educación en salud y seguridad, dirigido o al menos coordinado por consultores en materia de seguridad que conozcan los lugares de trabajo a los que se va a prestar servicio

- un centro en el que puedan planificarse y ofrecerse programas de rehabilitación y coordinar éstos con la reincorporación al trabajo.

\section{Conclusión}

Las pequeñas empresas constituyen una forma de producción fundamental y generalizada. No obstante, los trabajadores que componen sus plantillas suelen carecer de servicios de salud y seguridad en el trabajo adecuados y son ignorados con frecuencia por la legislación y las normas que los rigen. En consecuencia, debido a las peculiares características de las pequeñas empresas, su personal sufre una mayor exposición a los riesgos laborales.

Las tendencias actuales de la economía mundial dan lugar a un agravamiento de la explotación de los trabajadores de las pequeñas empresas $y$, por tanto, a un aumento del riesgo de exposición a sustancias químicas peligrosas. A escala internacional, nacional y local, se han señalado medidas apropiadas para reducir dichos riesgos y mejorar la salud y el bienestar del personal en estos centros de trabajo.

\section{TRANSFERENCIA DE TECNOLOGIA Y ELECCION TECNOLOGICA}

Joseph LaD ou

\section{El período reciente de transición rápida}

EI traslado de empresas de los países desarrollados a los países en desarrollo se suele explicar por el menor coste de la mano de obra en estos últimos. Las empresas también establecen centros en el extranjero para reducir los costes de transporte acercando la producción a los mercados de destino, para superar barreras comerciales y para evitar las fluctuaciones de los mercados de divisas. No obstante, algunas empresas se trasladan a países en desarrollo con la intención de eludir las normativas sobre trabajo y medio ambiente de aplicación en su país de procedencia. Para muchos Estados, este tipo de inversión constituye la fuente principal de creación de empleo.

En la última década, las empresas y los inversores extranjeros han generado más del $60 \%$ de la inversión industrial en los países en desarrollo. En los años 80 comenzó a emerger un mercado financiero mundial. En un período de diez años, los préstamos bancarios internacionales concedidos por los principales países desarrollados pasaron de un 4 a un $44 \%$ del PIB. Entre 1986 y 1990, la inversión exterior realizada por Estados Unidos, Japón, Alemania O ccidental, Francia y Reino U nido creció a una tasa anual del $27 \%$. La inversión transfronteriza global se cifra actualmente en 1.700 .000 millones de dólares ( $L$ aD ou y Levy 1995). Existen unas 35.000 empresas transnacionales, con 147.000 filiales en el extranjero. Gran parte de la inversión en los países en desarrollo procede de estas empresas. $L$ as ventas anuales totales de las 350 mayores sociedades transnacionales equivalen a un tercio de los productos interiores brutos combinados de los países industrializados y superan con mucho el PIB de los países en desarrollo. 
La mayoría de las inversiones en los países en desarrollo se destinan a Asia. Entre 1986 y 1990, las regiones del este y el sudeste asiático recibieron 14.000 millones de dólares, América Latina 9.000, y Africa 3.000. En la actualidad, Europa central compite abiertamente por una porción de la inversión mundial. L a India, V ietnam, E gipto, N icaragua y U zbekistán han liberalizado recientemente sus normativas en materia de propiedad para aumentar su atractivo ante los inversores.

Pueden encontrarse empresas e inversiones japonesas en casi todos los países del mundo. Debido a sus limitaciones de superficie y su gran densidad de población, Japón tiene una necesidad acuciante de exportar sus industrias generadoras de residuos. Los Estados europeos han trasladado sus fábricas peligrosas y anticuadas desde el punto de vista medioambiental a Africa y O riente Próximo y comienzan a exportarlas a Europa central. L as empresas de Europa occidental son las principales inversoras en Bangladesh, la I ndia, Pakistán, Singapur y Sri Lanka.

China y la India, con el mayor número de habitantes del planeta, han experimentado cambios políticos radicales que han abierto el acceso al país a empresas de muchos países. Las de Estados Unidos predominan en China , Indonesia, Filipinas, Tailandia, H ong K ong y Taiwan (China) y se preveía que invirtieran 1.000 millones de dólares en Singapur en 1995, lo que representa un aumento del 31 \% respecto de 1994.

\section{La motivación de los países industrializados}

En los países desarrollados, las empresas ofrecen empleo, pagan impuestos con los que se financian los servicios comunitarios y se someten a la legislación vigente en materia de medio ambiente y salud en el trabajo. A medida que los Estados industrializados promulgan leyes con el fin de limitar los riesgos medioambientales asociados a muchas operaciones industriales, los costes de producción aumentan y socavan las ventajas competitivas. Para superar este problema, los fabricantes trasladan muchos de sus centros de producción peligrosos a países de reciente industrialización. Allí son acogidos favorablemente, ya que la creación de infraestructuras en muchos de estos NIC depende de la expansión industrial de las empresas extranjeras.

Cuando la industria se traslada a los países en desarrollo, las empresas no sólo aprovechan el menor coste salarial, sino también los bajos tipos impositivos habituales en comunidades que no dedican grandes fondos a servicios como sistemas de alcantarillado, plantas de tratamiento de agua, centros educativos y medios de transporte públicos. C uando las empresas establecen fábricas en países en desarrollo, la carga fiscal que soportan es una proporción mínima de la que tendrían que soportar en los países más desarrollados.

\section{Datos anecdóticos que apoyan la transición}

La U niversidad de California, la U niversidad John H opkins y la Universidad de $M$ assachusetts han analizado recientemente la salud de los trabajadores de la industria de semiconductores de Estados U nidos. Los estudios realizados ponen de manifiesto un importante aumento del riesgo de aborto en las mujeres que trabajan en este subsector. L os autores subrayan que las empresas despiden al personal y cierran fábricas con tanta rapidez que, probablemente, estos estudios sean los últimos efectuados en Estados U nidos sobre una muestra de tamaño suficiente para que los resultados sean fiables.

\section{Predicciones de reducción de los estudios sobre salud en el trabajo}

El traslado de las empresas de semiconductores de Estados U nidos y Japón al sudeste asiático es manifiesto en un país de reciente industrialización como Malasia. Desde mediados de los años 70, este país se ha convertido en el tercer fabricante y el mayor exportador de semiconductores del mundo. Es muy poco probable que las empresas extranjeras sigan financiando la investigación en materia de salud en el trabajo y medio ambiente en un país lejano en el que emplean a trabajadores extranjeros. EI ahorro obtenido por estos fabricantes de semiconductores aumentará gracias a la posibilidad de desatender los aspectos relativos a la salud y la seguridad, siguiendo la orientación de sus competidores internacionales. Los gobiernos y las empresas de los países de reciente industrialización harán caso omiso de la tasa de abortos de las trabajadoras de la industria de los semiconductores. La mayoría de los trabajadores no reconocerán la asociación entre trabajo y aborto.

\section{El empeoramiento de la salud ambiental y laboral en los países en desarrollo}

M uy pocos países en desarrollo tienen una normativa aplicable en materia de trabajo y medio ambiente. Deben ocuparse de problemas más acuciantes, como el desempleo, la desnutrición y las enfermedades infecciosas, lo que a menudo les lleva a pasar por alto los riesgos ambientales. Los países de reciente industrialización están ansiosos por obtener los beneficios financieros que las empresas y los inversores extranjeros les reportan. No obstante, estos beneficios llevan aparejados problemas sociales y ecológicos.

Los positivos resultados económicos y sociales de la actividad industrial en los países en desarrollo van acompañados de una grave degradación medioambiental. Las ciudades principales de estos Estados comienzan a acusar las consecuencias de la contaminación atmosférica, la ausencia de tratamiento y depuración de las aguas residuales y el aumento de las cantidades de residuos peligrosos enterrados, depositados sobre el terreno 0 vertidos en ríos y océanos. M uchos países del mundo carecen de una normativa sobre medio ambiente y, cuando existe, su aplicación es escasa o nula.

La población activa de los países en desarrollo está acostumbrada a trabajar en pequeñas empresas. En general, cuanto más pequeñas, mayor es la tasa de accidentes y enfermedades profesionales. Estas unidades de producción se caracterizan por la inseguridad de los edificios y otras estructuras, la antigüedad de la maquinaria utilizada, las deficiencias de ventilación, el ruido, el bajo nivel de educación, cualificación y formación de los trabajadores y la escasez de recursos financieros. $R$ ara vez disponen de prendas de protección, equipos respiratorios, guantes, protectores auditivos y gafas de seguridad. Las empresas suelen resultar inaccesibles a las inspecciones de los organismos públicos competentes en materia de salud y seguridad. En muchos casos, funcionan como una "industria sumergida" formada por empresas que ni siquiera están registradas por la Administración a efectos tributarios.

La opinión pública basa su idea de las empresas en el extranjero en las grandes multinacionales. Sin embargo, mucho más habituales que estos gigantes industriales son los miles de pequeñas empresas propiedad de extranjeros y gestionadas 0 supervisadas por directivos locales. La capacidad de la mayoría de los gobiernos extranjeros para regular estas empresas 0 incluso controlar el transporte de productos y materiales es extremadamente limitada. En general, las empresas trasladadas se adaptan al cumplimiento de las normas en materia de medio ambiente y de salud y seguridad en el trabajo vigentes en el país de acogida. En consecuencia, las tasas de fallecimiento de trabajadores en los países de reciente industrialización son muy superiores a las de los países desarrollados y sus tasas de accidentes en el lugar de trabajo son semejantes a las registradas en estos últimos en los primeros años de la R evolución Industrial. En este sentido, puede decirse que la Revolución Industrial está 
produciéndose de nuevo, pero el número de trabajadores y países que participan en ella es mucho mayor.

C asi todo el crecimiento de la población mundial se concentra en los países en desarrollo. Actualmente, la población activa en estos países asciende a unos 1.760 millones de personas, pero llegará a 3.100 millones en el 2025, lo que conlleva la necesidad de crear de 38 a 40 millones de nuevos puestos de trabajo por año (K ennedy 1993). En esta situación, no es muy probable que los trabajadores demanden una mejora de las condiciones de trabajo.

\section{Migración de las enfermedades y daños profesionales a los países en desarrollo}

La incidencia de las enfermedades profesionales ha alcanzado un nivel sin precedentes. La O rganización de las Naciones U nidas estima que se producen 6 millones de casos cada año en el mundo. Las enfermedades profesionales por trabajador expuesto se dan con mayor frecuencia en los países en desarrollo y, lo que es más importante, su gravedad ha aumentado. En algunos de estos países, el amianto es la principal causa de enfermedad y discapacidad de los trabajadores de la minería, la construcción y la producción de este mineral y, de acuerdo con algunas estimaciones, también de muerte. L os riesgos profesionales y medioambientales que plantean los productos a base de amianto no disuaden a las empresas que los fabrican de promoverlos en los países en desarrollo, donde la demanda de materiales de construcción de bajo coste prevalece sobre la preocupación por la salud.

Las operaciones de fundido y refinado del plomo están trasladándose de los países desarrollados a los países en desarrollo. A sí ocurre también con el reciclado de productos de plomo, que tiende a desplazarse a las naciones menos favorecidas, a menudo poco preparadas para afrontar los riesgos medioambientales y profesionales que genera. Actualmente, el número de fundiciones de plomo en los países industrializados es escaso, ya que esta actividad se ha trasladado a los países de reciente industrialización. M uchos de los procesos relacionados con esta actividad se llevan a cabo en países con tecnologías inalteradas desde hace un siglo. Aunque los países desarrollados presuman de los logros alcanzados en el reciclado del plomo, en casi todos los casos este proceso se realiza en países en desarrollo y el plomo reciclado regresa a aquéllos como producto acabado.

En los Estados en desarrollo, los gobiernos y las empresas aceptan los materiales peligrosos sabiendo que es imposible que se legislen 0 apliquen unos niveles de exposición razonables. La gasolina, las pinturas, la tinta y los tintes, las pilas y muchos otros productos que contienen plomo son producidos en dichos países por empresas que suelen ser propiedad de extranjeros y que posteriormente los venden en el mercado internacional.

En los países en desarrollo, donde la mayoría de los trabajadores se dedican a la agricultura, los pesticidas se aplican manualmente. En el sudeste de Asia se registran cada año tres millones de casos de intoxicación por pesticidas (Jeyaratnam 1992). La mayor parte de la fabricación de estas sustancias en dichos países corresponde a empresas de propiedad extranjera o empresas locales con participación de capital extranjero. La utilización de pesticidas en estos países aumenta con rapidez, a medida que la población conoce las ventajas que ofrecen a la industria agraria y mejora la capacidad de producción en el propio país. Pesticidas como el DDT y el dibromocloropropano (DBCP), prohibidos en la mayoría de los Estados desarrollados, se venden y utilizan con profusión y sin restricciones en los países en desarrollo. Cuando los riesgos para la salud ocasionan la retirada de un pesticida del mercado de un país desarrollado, suele encontrarse un modo para que el producto en cuestión acceda a los mercados desregulados de los países en desarrollo.

El químico es uno de los sectores industriales de más rápido crecimiento en la economía mundial emergente. Las empresas químicas de los países desarrollados se han extendido por todo el mundo. Muchas de las de menor tamaño se trasladan a los países en desarrollo y convierten a esta industria en uno de los principales factores de contaminación medioambiental. Con el crecimiento de la población y la industrialización en las regiones más desfavorecidas de la tierra, aumenta la demanda de pesticidas, fertilizantes químicos y otras sustancias químicas industriales. Además, para agravar este problema, las sustancias químicas prohibidas en los países desarrollados se fabrican en cantidades cada vez mayores en los países de reciente industrialización. EI DDT es un ejemplo evidente. Su producción alcanza niveles sin precedentes, a pesar de que su producción y utilización son ilegales en la mayoría de los países desarrollados desde los años 70.

\section{Traslado de costes a los países en desarrollo}

L a experiencia de los países industrializados respecto a los costes de los programas de medio ambiente y seguridad en el trabajo es que una parte considerable de la carga financiera está trasladándose a países de reciente industrialización. El coste de posibles accidentes, como el de Bophal, la atenuación de los daños al medio ambiente y los efectos sobre la salud pública no suelen analizarse abiertamente en los países en desarrollo. Las consecuencias de la mundialización de la industria pueden ser el origen de conflictos internacionales generalizados cuando se hagan más evidentes las repercusiones económicas a largo plazo del desplazamiento de empresas.

\section{El enigma de los países en desarrollo}

Los países en desarrollo no suelen apoyar la adopción de las normas sobre medio ambiente de los países desarrollados. En algunos casos, sus detractores señalan que la soberanía nacional permite a cada nación elaborar sus propias normas. En otros, existe un arraigado resentimiento hacia cualquier influencia exterior, sobre todo cuando ésta procede de países que han aumentado su nivel de vida gracias a las actividades industriales que ahora se trata de regular. Los países en desarrollo adoptan una postura según la cual ya formularán políticas de regulación más estrictas cuando hayan alcanzado el nivel de vida de los países desarrollados. Si se pide a éstos que trasladen a aquéllos industrias con tecnologías respetuosas con el medio ambiente, el interés del traslado de empresas disminuye drásticamente.

\section{Necesidad de una intervención internacional}

Las organizaciones internacionales deben asumir un mayor protagonismo en la aprobación y coordinación de la transferencia de tecnología. Es preciso poner fin a la práctica vergonzosa de exportar tecnologías peligrosas y obsoletas a los países en desarrollo cuando sus procesos dejan de satisfacer las normas sobre medio ambiente en los países desarrollados. Los acuerdos internacionales deben anular los incentivos perversos que amenazan el medio ambiente del planeta.

Se han emprendido numerosas iniciativas para controlar el comportamiento de la industria. Las Directrices para las empresas multinacionales de la $O$ rganización para la Cooperación y el D esarrollo E conómico $(O C D E$ ), el Código de conducta para empresas transnacionales de las Naciones U nidas y la Declaración tripartita de principios relativos a las empresas multinacionales y la política social de la Organización Internacional del Trabajo (OIT) ofrecen un marco de comportamiento ético. En marzo de 1994 se adoptó el Convenio de Basilea sobre el control de los movimientos 
transfronterizos de residuos peligrosos y su evacuación. Aunque prohíbe el traslado transfronterizo de los residuos más peligrosos, permite institucionalizar un comercio de residuos reciclables, reflejo de la falta de compromiso político en el momento de su adopción.

Algunas instituciones de crédito internacionales realizan en la actualidad evaluaciones de impacto medioambiental (EIM) cuando el país receptor no está en condiciones de abordar esta tarea. La evaluación del posible impacto local de, al menos, deter minados emplazamientos industriales peligrosos debería ser obligatoria y debería completarse con la aplicación de normas sobre salud y seguridad en el trabajo.

La O rganización Internacional de Normalización (ISO) ha iniciado el desarrollo de la serie ISO 14000, de carácter voluntario, que probablemente se convertirá en la norma internacional para la gestión del medio ambiente. Estas normas abarcan los sistemas de gestión medioambiental, las auditorías medioambientales, las etiquetas ecológicas, las evaluaciones de actuación medioambiental, las evaluaciones del ciclo vital y los aspectos medioambientales de las normas sobre productos (C asto y Ellison 1996).

M uchos países desarrollados han definido niveles de exposición recomendados para los trabajadores, que no pueden superarse sin una acción normativa o jurídica previa. En cambio, en los países en desarrollo, no suelen existir normas sobre exposición, o bien no se aplican o son demasiado laxas. Pueden y deben desarrollarse normas internacionales. Podría concederse a los países en desarrollo, y en especial a las empresas extranjeras que fabrican en ellos, un período razonable para que cumplan las normas vigentes en la mayoría de los Estados desarrollados. Si no se adopta esta medida, algunos trabajadores de esos países pagarán una parte excesiva del coste de la industrialización.

\section{Conclusiones}

Como norma internacional más adecuada en materia de salud y seguridad en el trabajo debería desarrollarse un sistema internacional de seguro de indemnización para los trabajadores. Los trabajadores de todos los países tienen derecho a beneficiarse de las prestaciones básicas recogidas en la legislación sobre indemnizaciones. Las empresas deben sentirse de tal modo incentivadas para garantizar un lugar de trabajo seguro y saludable de acuerdo con lo establecido en los seguros de indemnización, que resulten beneficiados los trabajadores de todos los países, con independencia de la propiedad de la empresa.

$\mathrm{Ha}$ de establecerse un sistema jurídico internacional que permita abordar las cuestiones relativas al medio ambiente y un mecanismo de ejecución suficientemente capaz para desalentar al más criminal de los responsables de la contaminación. En 1972, los Estados miembros de la OCDE acordaron basar sus políticas medioambientales en el principio de que "el que contamina, paga" (O CDE 1987). Se pretendía animar a las empresas a asumir internamente los costes medioambientales y trasladarlos a los precios de los productos. Basándose en este principio, podrían desarrollarse disposiciones sobre responsabilidad estricta en las legislaciones de todos los países, respecto a los daños a la propiedad y a terceros. De este modo, los generadores de residuos serían considerados responsables, mediante la aplicación de un sistema internacional de responsabilidad estricta, de la gestión de los residuos desde su producción hasta su evacuación.

Los países en desarrollo carecen de grupos de defensa del medio ambiente amplios y bien financiados, como los que operan en los países desarrollados. El cumplimiento de la legislación requerirá la formación de personal y la prestación de apoyo por parte de los gobiernos, que, hasta hace poco, hacían tanto hincapié en la expansión industrial que la cuestión de la protección del medio ambiente ni siquiera se tenía en cuenta.

\section{ACUERDOS DE LIBRE COMERCIO}

\section{H oward Frumkin}

Durante mucho tiempo, los economistas consideraron el libre comercio un ideal. En 1821, D avid R icardo afirmó que cada país debía exportar los bienes que era capaz de producir en condiciones de ventaja comparativa. Aunque Ricardo sólo tuvo en cuenta un único factor de producción, el trabajo, teóricos posteriores de las proporciones relativas de los factores ampliaron este marco al capital, los recursos naturales y otros. La mayoría de los economistas actuales creen que las restricciones al comercio (aranceles proteccionistas, subvenciones a la exportación y cuotas a la importación) generan ineficiencias económicas, distorsionan los incentivos de productores y consumidores y cuestan dinero a los países. Señalan que, en mercados nacionales restringidos, proliferan las pequeñas empresas que sirven a mercados limitados, lo que reduce la obtención de economías de escala, y se atenúan los incentivos para que los productores innoven y compitan. Los defensores del libre comercio creen que los argumentos a favor de las restricciones comerciales, aunque suelen basarse en el "interés nacional", son en definitiva reivindicaciones encubiertas de intereses específicos.

Con todo, hay varios argumentos económicos en contra del libre comercio. Uno de ellos se refiere a los fallos de los mercados nacionales. Si un mercado interno como el del trabajo no funciona adecuadamente, la suspensión del libre comercio puede ayudar a mejorarlo o generar beneficios compensatorios en otros sectores de la economía nacional. El segundo argumento consiste en que un supuesto fundamental de la teoría del libre comercio, la inmovilidad del capital, ha dejado de ser cierto, de modo que la libertad de intercambio puede perjudicar a algunos países. D aly y C obb (1994) señalan lo siguiente:

El libre flujo de capital y bienes (en lugar de sólo bienes) significa que la inversión se rige por la rentabilidad absoluta y no por la ventaja comparativa. La ausencia de un flujo libre de mano de obra reduce las oportunidades de empleo de los trabajadores del país en que no se invierte. Esta visión del mundo en que vivimos es más exacta que la asociada al principio de la ventaja comparativa, a pesar de su aplicabilidad en la época de R icardo.

Dentro de una zona de libre comercio, los precios de los bienes que se comercializan tienden a igualarse. De acuerdo con el teorema de la igualación del precio de los factores, esta tendencia también es válida para los factores de producción, incluidos los salarios, los costes del cumplimiento de la legislación y, quizás, factores externos como la contaminación atmosférica. Esta teoría suscita un tercer argumento contrario al libre comercio: éste puede ejercer una presión a la baja sobre los salarios, la salud, la seguridad y las prácticas ecológicas, y sobre otros factores de producción, hacia los niveles más bajos de todos los países que comercian, lo que plantea una seria preocupación respecto de la salud y la seguridad en el trabajo.

D esde la segunda G uerra M undial, la industria ha adquirido un carácter cada vez más internacional. Las comunicaciones y el transporte han avanzado con rapidez. La movilidad de la información y el capital es cada vez mayor. La importancia del papel desempeñado por las empresas multinacionales en la economía 
mundial aumenta. En este proceso, los modelos de producción se transforman, las fábricas cambian de localización y el empleo se desestabiliza. A diferencia del capital, el trabajo es relativamente inmóvil, tanto desde el punto de vista geográfico como en lo tocante a la cualificación. Por tanto, la reubicación industrial ha generado tensiones considerables para los trabajadores.

En este contexto, el libre comercio se ha ido ampliando de forma constante. Desde 1946, se han celebrado ocho rondas de negociaciones sobre comercio multilateral bajo los auspicios del Acuerdo General sobre Aranceles Aduaneros y Comercio (GATT). La más reciente, la Ronda de U ruguay, concluyó en 1994 con la constitución de la Organización Mundial del Comercio (O M C). Los Estados miembros del GAT T (y ahora de la OMC) aceptan tres principios generales: se abstienen de conceder subvenciones a la exportación (salvo en la agricultura); se abstienen de imponer cuotas unilaterales a la importación (excepto cuando las importaciones amenacen con "distorsionar el mercado"); y, si imponen nuevos aranceles o aumentan los existentes, deben reducir otros para compensar a los socios comerciales. La O M C no suprime los aranceles, pero los limita y regula. M ás de $130 \mathrm{E}$ stados, muchos de ellos en desarrollo o "en transición", son miembros de esta organización. Se prevé que el número total de miembros supere los 150

Desde el decenio de 1980, se han emprendido nuevas iniciativas en favor del libre comercio a escala regional basadas en los acuerdos de comercio preferencial. En virtud de esos acuerdos, los países vinculados suprimen los aranceles comerciales aplicables entre sí y los mantienen respecto al resto del mundo. Estos convenios se conocen con el nombre de uniones aduaneras, mercados comunes o áreas de libre comercio y son ejemplos de esta práctica la U nión Europea y los tres países de América del $\mathrm{N}$ orte. $\mathrm{O}$ tras alianzas económicas, si bien, con un menor nivel de compromiso, como la Cooperación Económica del Asia y el Pacífico (APEC), la A sociación de $\mathrm{N}$ aciones de Asia Sudoriental (ASEAN) y el M ercado Común del Sur (MERCO SUR ) también fomentan el comercio entre sus miembros.

\section{Salud y seguridad en el trabajo en los acuerdos de libre comercio}

El objetivo de los acuerdos de libre comercio es promover el comercio y el desarrollo económico y, en su mayoría, abordan aspectos sociales como la salud y la seguridad de los trabajadores únicamente de forma indirecta, en el mejor de los casos. No obstante, en el marco de estos acuerdos puede plantearse una amplia gama de cuestiones relacionadas con dichos aspectos.

\section{Desplazamiento, desempleo y migración de trabajadores}

Los acuerdos de libre comercio se celebran en un contexto de tendencias económicas y sociales más generales con las que interactúan. Consideremos el libre comercio entre dos países con diferentes niveles de desarrollo, escalas salariales y oportunidades de empleo. En esta situación, las empresas cambian de ubicación, desplazando a los trabajadores de sus puestos de trabajo y generando desempleo en el país de origen. Los nuevos trabajadores desempleados pueden trasladarse a zonas donde haya más posibilidades de encontrar trabajo, sobre todo si, como en Europa, las barreras a la emigración también se han suprimido. El desempleo, el temor a sufrirlo, la migración y sus consecuencias como el estrés y la desorganización social que generan, repercuten gravemente en la salud de los trabajadores y sus familias. Algunos gobiernos han intentado atenuar estos efectos mediante la aplicación de programas sociales, que comprenden la formación para la reconversión profesional, la asistencia por reubicación y ayudas similares, con éxito desigual.

\section{Normas de salud y seguridad en el trabajo}

Los Estados miembros de un acuerdo de libre comercio pueden presentar diferencias en lo que se refiere a las normas sobre salud y seguridad en el trabajo. Esto significa que en los países que aplican normas menos exigentes su repercusión en los costes de producción son inferiores, lo que supone una ventaja comercial importante. Un resultado probable de esas diferencias es que se ejerzan presiones políticas para que se moderen las normas en los países más protectores y para que no se amplíen en los que garantizan una protección menor, con el fin de conservar las ventajas comerciales. L os defensores de la salud y la seguridad en el trabajo señalan esta reacción como una de las principales consecuencias negativas del libre comercio.

0 tro de los resultados probables es igualmente preocupante. Un país puede optar por bloquear la importación de ciertos materiales o equipos peligrosos, con objeto de mejorar en materia de salud en el trabajo. Sus socios comerciales pueden acusarle de llevar a cabo prácticas desleales al considerar este tipo de política una barrera comercial encubierta. En 1989, en virtud del Acuerdo de Libre comercio entre Estados U nidos y Canadá, este país acusó a aquél de comercio desleal, cuando Estados U nidos decidió suprimir las importaciones de amianto. Estos conflictos pueden socavar las normas de salud y seguridad de un país cuyas exigencias legislativas son mayores.

Por otra parte, el libre comercio también puede ofrecer la posibilidad de mejorar las normas mediante la colaboración en su definición, la puesta en común de la información técnica en que se basan y la armonización de disparidades tomando como referencia los niveles más altos. Esta mejora es posible tanto en el caso de las normas sobre salud y seguridad en el trabajo como en el de otras normas laborales afines, como las relativas al trabajo infantil, el salario mínimo y la negociación colectiva. Un obstáculo fundamental para la armonización ha sido la cuestión de la soberanía nacional: muchos países se han mostrado reacios a negociar la pérdida de control sobre su legislación laboral.

\section{Prácticas de aplicación de las normas}

Las mismas reflexiones se plantean en lo tocante a la aplicación de las disposiciones recogidas en los documentos oficiales. Aunque dos socios comerciales dispongan de normas sobre salud y seguridad en el trabajo semejantes, uno de ellos puede aplicarlas con menos rigor que el otro, reduciendo así los costes de producción y mejorando sus ventajas competitivas. Entre las soluciones a este problema figura la puesta en marcha de un proceso de resolución de conflictos que permita a los países recurrir cuando se les impute una presunta práctica de comercio desleal, y la adopción de medidas de colaboración para armonizar las prácticas de aplicación.

\section{Información sobre los riesgos}

La información sobre los riesgos engloba una amplia gama de prácticas: formación de los trabajadores, suministro de material escrito sobre riesgos y medidas de protección, etiquetado de los contenedores y acceso de los trabajadores a los historiales médicos y los registros de exposición. Estas prácticas se consideran elementos fundamentales de la eficacia de los programas de salud y seguridad en el trabajo. El libre comercio en particular y el comercio internacional en general repercuten sobre la información, al menos, de dos formas.

En primer lugar, cuando se transportan sustancias químicas o procesos peligrosos atravesando fronteras internacionales, los trabajadores del país receptor pueden encontrarse en una situación de riesgo. Es posible que dicho país carezca de la capacidad necesaria para informar adecuadamente de los riesgos existentes. Como parte del proceso de importación y exportación, es necesario que se faciliten documentos informativos, material 
pedagógico y etiquetas de advertencia redactados en la lengua del país receptor y que los trabajadores expuestos puedan comprender con facilidad.

En segundo lugar, la disparidad de los requisitos en materia de información sobre los riesgos supone un inconveniente para las empresas que operan en más de un país. Las medidas de armonización, como la adopción de un formato único para los documentos de información sobre productos químicos, contribuyen a resolver este problema y pueden fomentarse en el contexto del libre comercio.

\section{Formación y desar rollo de los recursos humanos}

Cuando los socios comerciales difieren en sus niveles de desarrollo económico, es probable que también sean dispares en cuanto a recursos humanos. Los países menos favorecidos deben afrontar la falta de higienistas industriales, ingenieros de seguridad, médicos y enfermeros del trabajo, educadores laborales cualificados y otros profesionales imprescindibles. Aun cuando dos países tengan niveles de desarrollo semejantes, pueden diferir en sus enfoques tecnológicos respecto de la salud y la seguridad en el trabajo. Los acuerdos de libre comercio brindan la oportunidad de conciliar esas disparidades. M ediante el establecimiento de estructuras paralelas, los profesionales de la salud y la seguridad en el trabajo de los países que comercian entre sí pueden reunirse, comparar sus prácticas y acordar la adopción de procedimientos comunes cuando proceda. Del mismo modo, si un país tiene pocos profesionales de determinada área en comparación con uno o varios de sus socios comerciales, todos ellos pueden cooperar en la oferta de formación reglada, cursillos y otros medios de desarrollar los recursos humanos. Estas iniciativas constituyen un elemento necesario para una armonización eficaz de la práctica de la salud en el trabajo.

\section{Recogida de información}

Un aspecto importante de las actividades coordinadas de protección de la salud y la seguridad de los trabajadores es la recogida de información. En el marco de un acuerdo de libre comercio, hay distintos tipos de datos relacionados con esta cuestión. En primer lugar, hay que obtener información sobre las prácticas de salud en el trabajo de cada país, sobre todo en lo relativo a la aplicación de las normas en el lugar de trabajo. Este tipo de información contribuye a realizar un seguimiento de los avances logrados en materia de armonización y permite detectar infracciones que puedan considerarse una práctica comercial desleal. Deben recogerse datos sobre las exposiciones en el lugar de trabajo, no sólo por estas razones, sino también como parte de la práctica rutinaria de la salud en el trabajo. Los datos sobre exposiciones deben recopilarse utilizando unas buenas prácticas de higiene industrial; si los Estados miembros utilizan procedimientos de medición coherentes, la comparación es posible. Igualmente, los datos sobre morbilidad y mortalidad son elementos esenciales para la eficacia de los programas de salud y seguridad en el trabajo. Si los países que han firmado un acuerdo de libre comercio emplean métodos coherentes para recoger este tipo de información, pueden cotejar sus efectos sanitarios, determinar las áreas problemáticas y las intervenciones prioritarias. U na coordinación como ésta puede resultar difícil de lograr, ya que muchos países recopilan los datos sobre salud y seguridad basándose en las estadísticas de indemnización de los trabajadores, y los regímenes de indemnización son muy dispares.

\section{Prevención}

Por último, el libre comercio ofrece la posibilidad de armonizar los enfoques preventivos, intercambiar asistencia técnica entre los Estados miembros y compartir soluciones. Estas posibilidades pueden ser útiles en el sector privado, ya que una empresa que opere en varios países puede aplicar las mismas prácticas o tecnologías de prevención en varios de ellos. Por su parte, las empresas especializadas en servicios de salud en el trabajo pueden operar a escala internacional incentivadas por un acuerdo de libre comercio y difundir prácticas preventivas en sus Estados miembros. Los sindicatos nacionales también pueden colaborar en el marco de un acuerdo de libre comercio. Por ejemplo, la O ficina T écnica Sindical Europea para la Salud y la Seguridad, con sede en Bruselas, fue creada por el Parlamento Europeo con el apoyo de los principales sindicatos. Estas iniciativas pueden animar a los Estados miembros a avanzar en la armonización de las actividades preventivas. La armonización también puede producirse a nivel de las administraciones, mediante la colaboración para el desarrollo tecnológico, la formación y otras actividades. En definitiva, el efecto más positivo del libre comercio sobre la salud y la seguridad en el trabajo es la mejora de la prevención en cada uno de los Estados miembros.

\section{Conclusión}

Los acuerdos de libre comercio se diseñan fundamentalmente para reducir las barreras al comercio y, en su mayoría, no abordan cuestiones como la salud y la seguridad de los trabajadores (véase el recuadro). En Europa, el libre comercio ha evolucionado a lo largo de varias décadas hasta convertirse en un proceso en el que se otorga a los aspectos sociales una importancia inusual. Las organizaciones europeas responsables de la salud y la seguridad en el trabajo reciben una financiación adecuada, cuentan con la representación de todos los sectores y pueden aprobar directivas vinculantes para sus Estados miembros; obviamente, esta situación es la más avanzada en materia de salud de los trabajadores de todos los acuerdos de libre comercio del mundo. En América del Norte, el T LC contempla un proceso detallado de resolución de conflictos aplicable también a las cuestiones de salud y seguridad en el trabajo, pero pocas iniciativas más para mejorar las condiciones de trabajo en los tres Estados miembros. O tros pactos comerciales regionales no han incorporado ninguna iniciativa de este tipo.

La integración económica de los países del mundo progresa impulsada por los rápidos avances de las comunicaciones, el transporte y las estrategias de inversión de capital. Los acuerdos de libre comercio rigen una parte, pero no todo el comercio creciente entre países. Los cambios en las pautas comerciales y la expansión del comercio internacional tienen consecuencias fundamentales para la salud y la seguridad de los trabajadores. Es esencial vincular las cuestiones comerciales con las de salud y seguridad en el trabajo utilizando los acuerdos de libre comercio y otros instrumentos, a fin de garantizar que los avances en el comercio se acompañen de una mejora en la protección de los trabajadores.

\section{RESPONSABILIDAD RESPECTO A LOS PRODUCTOSY TRASLADO DE RIESGOS INDUST RIALES}

Barry Castleman

Las empresas multinacionales (EMN) dominan la fabricación y comercialización de sustancias químicas y otros productos que presentan riesgos para la salud y la seguridad en el trabajo. Estas empresas tienen una experiencia prolongada pero variable en el control de dichos riesgos y algunas han formado amplias plantillas 


\section{Estudios de caso}

\section{Organización Mundial del Comercio}

La O rganización Mundial del Comercio (O MC), creada en 1995 como resultado de la Ronda de Uruguay de negociaciones sobre comercio multilateral, es la entidad sucesora del Acuerdo $G$ eneral sobre Aranceles Aduaneros y Comercio (GATT), que data de finales de los años 40. La OMC constituye la base jurídica e institucional del sistema de intercambio comercial multilateral en el mundo. Su objetivo es promover el libre comercio internacional, no sólo de mercancías (como en el caso del GATT), sino también de servicios y de la propiedad intelectual. Asimismo, esta entidad se propone explícitamente contribuir al avance del desarrollo, sobre todo en los países donde éste es menor.

La OMC se ha diseñado para fomentar el comercio y cuestiones afines como la salud y la seguridad en el trabajo sólo se abordan en la medida en que pueden perjudicar al librecambio. Hay dos Acuerdos relacionados con este tema. El Acuerdo sobre la Aplicación de Medidas Sanitarias y Fitosanitarias, que comprende disposiciones relativas a la seguridad de los alimentos y a la salud animal y vegetal, permite a los países promulgar este tipo de disposiciones, pero exige que tengan una base científica, que se apliquen únicamente en la medida necesaria para proteger la salud y la vida humana, animal y vegetal, y que no den lugar a una discriminación arbitraria entre Estados miembros. Aunque se anima a éstos a basar sus disposiciones en las normas internacionales, se les autoriza a establecer otras más estrictas si análisis científicos y evaluaciones de riesgos así lo justifican.

El Acuerdo sobre Barreras Técnicas al Comercio refuerza estos preceptos. Su objetivo es evitar que las normas y disposiciones técnicas planteen obstáculos innecesarios al comercio. Con este fin, se ha establecido un código de buenas prácticas relativo a la promulgación de normas y se exige que éstas sean aplicadas equitativamente a productos nacionales e importados.

Aunque los dos Acuerdos anteriores aluden fundamentalmente a las normas sobre medio ambiente, calidad de los alimentos y cuestiones farmacéuticas, es posible aplicarlos a la regulación de la salud y la seguridad en el trabajo. En la declaración sumaria de la asamblea de la OMC celebrada en Marrakech en 1995 se prevé la constitución de un equipo dedicado al análisis de las $\mathrm{N}$ ormas Internacionales del Trabajo. N o obstante, la OMC ha evitado hasta el momento abordar cuestiones de salud y seguridad en el trabajo y varios gobiernos miembros, sobre todo de los países en desarrollo, han defendido que la salud de los trabajadores siga siendo una prerrogativa nacional desvinculada de consideraciones de comercio internacional. Por tanto, la OMC no ha contribuido hasta la fecha al progreso de la salud y la seguridad en el trabajo.

\section{Europa}

La integración económica de Europa se caracteriza por sus tempranos orígenes, que se remontan al Tratado de Roma de 1957, y por la prioridad concedida a los aspectos sociales y políticos junto a las consideraciones económicas. De hecho, la integración europea va más allá de la reducción de las barreras comerciales; comprende asimismo la libre circulación de trabajadores (y pronto la de personas en general), la promulgación de leyes y reglamentos transnacionales vinculantes y la creación de una burocracia internacional con un apoyo financiero notable. Como resultado, la salud en el trabajo ha sido objeto de una atención considerable.
La Comunidad Económica Europea (CEE), o M ercado Común, fue creada en virtud del Tratado de Roma de 1957. Este acuerdo marcó el inicio de la supresión de barreras comerciales entre Estados miembros y estableció la estructura organizativa de la CEE. La Comisión de las Comunidades Europeas se convirtió en funcionariado y el órgano administrativo de la Comunidad, dividido en 23 Direcciones $G$ enerales (incluida la DG V, responsable de empleo, relaciones laborales y asuntos sociales). El Consejo de $M$ inistros se ocupa de la formulación de las políticas principales, mientras que el Parlamento Europeo desempeña una función de codecisión. El Tribunal de Justicia resuelve los conflictos planteados en relación con los Tratados. El Comité Consultivo sobre Seguridad, Higiene y Protección de la Salud en el Trabajo (ACSH), creado en 1974 por el Consejo para asesorar a la Comisión, está constituido por representantes de los trabajadores, los empresarios y los gobiernos de cada Estado miembro y cuenta con el apoyo del personal de la Dirección de Salud y Seguridad de la DG V. EI ACSH revisa las propuestas legislativas relacionadas con la salud en el trabajo, desarrolla actividades sobre riesgos específicos y coordina las iniciativas conjuntas. El Comité Económico y Social desempeña una función consultiva.

En 1978, la Comisión presentó el primer Programa de acción sobre salud y seguridad, con la colaboración del ACSH. En él se abordaban cuestiones como el tratamiento de las sustancias peligrosas, la prevención de riesgos tecnológicos, el control y las inspecciones, y la mejora de las actitudes respecto a la salud y la seguridad. Desde entonces, se han desarrollado nuevos programas de acción centrados en diversas cuestiones relativas a la salud y la seguridad en el trabajo, como la ergonomía, las estadísticas, la asistencia a las pequeñas empresas y la formación. Estas iniciativas han fomentado la adopción en todos los Estados miembros de medidas de salud en el trabajo consistentes en la provisión de formación, asesoramiento técnico y material escrito. Por ejemplo, en 1982, la Comisión convocó un grupo informal de inspectores de trabajo en puestos de responsabilidad para promover el intercambio de personal e información entre los doce Estados miembros y la comparación y mejora de las prácticas de cada uno de ellos. Estas iniciativas ponen de manifiesto cómo la integración de las economías nacionales puede tener efectos positivos sobre la práctica de la salud y la seguridad en el trabajo.

El Acta Unica Europea (AUE) de 1987 constituyó un paso adelante fundamental en la integración europea y en el desarrollo del Espacio Económico Europeo. Se fijó 1992 como fecha para la creación del mercado único y se fomentaron las actividades relacionadas con diversas cuestiones sociales, incluida la salud y la seguridad en el trabajo. Dejó de exigirse la unanimidad entre Estados miembros como requisito para formular políticas; en su lugar, comenzó a aplicarse la "mayoría cualificada". Dos de los artículos del Acta están especialmente relacionados con la salud en el trabajo. En el artículo 100 (a) se trata de armonizar las normas sobre productos en los Estados miembros, un proceso que tiene repercusiones importantes para la seguridad. En este artículo se establece que las normas deben dar lugar a la consecución de un "nivel de protección elevado". En el artículo 118 (a) se aborda directamente la salud y la seguridad en el trabajo y se estipula que los Estados miembros "procurarán promover la mejora, en particular, del medio de trabajo, para proteger la seguridad y la salud de los trabajadores, y se fijarán como objetivo la armonización, dentro del progreso, de las condiciones existentes en ese ámbito". 
En 1989, dos acontecimientos importantes consolidaron el papel de la salud en el trabajo en el proceso de integración europea. 0 nce de los doce Estados miembros de la época adoptaron la Carta Social, que incluía una cláusula en la que se subrayaba la necesidad de la formación, información, consulta y participación equilibrada de los trabajadores sobre los riesgos a los que se enfrentan y las medidas adoptadas para erradicarlos 0 reducirlos.

También en 1989, el Consejo adoptó la Directiva Marco, la principal iniciativa política emprendida de acuerdo con el AUE. En ella se definía el enfoque de la CE [actualmente Unión Europea (UE)] respecto a la salud y la seguridad de los trabajadores tanto de empresas privadas como empresas 0 entes públicos de todos los Estados miembros. A las empresas se les asignó "la obligación [general] de garantizar la salud y la seguridad de los trabajadores en todos los aspectos relacionados con su actividad laboral" y las obligaciones específicas de:

- evaluar los riesgos en el lugar de trabajo:

- integrar medidas preventivas en todos los aspectos de la producción;

- informar a los trabajadores y sus representantes de los riesgos existentes y las medidas preventivas adoptadas;

- consultar con los trabajadores y sus representantes respecto de todas las cuestiones de salud y seguridad;

- impartir formación sobre salud y seguridad a todos los trabajadores;

- designar trabajadores con responsabilidades específicas en materia de salud y seguridad;

- establecer un sistema de vigilancia de la salud adecuado

- proteger a los grupos sensibles a determinados riesgos;

- llevar registros de accidentes y enfermedades.

En la Directiva Marco se adopta una visión amplia de los factores del lugar de trabajo que afectan a la salud en el trabajo, incluidas cuestiones relacionadas con el diseño de los lugares, equipos, etc., las tareas rutinarias y el trabajo a destajo. Se insta a los trabajadores a participar activamente en los programas de salud y seguridad, a celebrar reuniones con los inspectores del gobierno y a negarse a trabajar en caso de "peligro grave, inminente 0 inevitable" (sin perjuicio de las legislaciones nacionales). En varias de las denominadas directivas "derivadas" aprobadas con posterioridad a la Directiva Marco se aborda la utilización de equipos de trabajo, de equipos de protección personal, el transporte manual de cargas, el trabajo con terminales de ordenador, la protección frente a agentes cancerígenos, biológicos y otras cuestiones.

¿Se traducirá la Directiva Marco en una política nacional efectiva? Aquí subyace el compromiso explícito de la UE con el principio de subsidiaridad, según el cual todas las políticas deben ser aplicadas por los Estados miembros y no por la UE, salvo que "por el alcance de los efectos de la acción propuesta" resulte más adecuado llevarla a cabo a escala central. La aplicación de este principio generará tensiones entre las obligaciones impuestas por estas directivas y las acciones soberanas de los Estados miembros.

Los Estados miembros están obligados a transponer la Directiva Marco (como el resto de directivas) a la legislación nacional, a aplicar las políticas pertinentes de acuerdo con ella y a llevarlas a la práctica. Este proceso deja a los países un cierto margen de maniobra y puede dar lugar a cierto grado de incumplimiento. En todo caso, la UE no dispone de los medios necesarios para comprobar si los Estados miembros cumplen las directivas comunitarias sobre salud y seguridad en el trabajo. Será necesario un seguimiento más estricto de las prácticas nacionales y la voluntad política de utilizar las acciones disponibles en caso de incumplimiento (incluido el recurso al Tribunal de Justicia) si se quiere materializar todo el potencial de la UE en materia de promoción de la salud en el trabajo.

Esto está relacionado con la cuestión de saber qué suerte correrán las políticas de aquellos Estados miembros de carácter más protector que las de la UE. Puesto que en el artículo 118 (a) se exige únicamente un nivel común mínimo de protección en el lugar de trabajo, puede tenderse a una armonización a la baja debido a las presiones económicas.

En 1994, el Consejo, en respuesta a una propuesta de tres años de antigüedad presentada por la Comisión, creó la Agencia Europea de salud y seguridad en el trabajo, con sede en Bilbao, España. El objetivo de la Agencia es ofrecer a los organismos de la Comunidad, los Estados miembros y las partes interesadas la información técnica, científica y económica útil en el campo de la salud y la seguridad en el trabajo. Se centrará en la consulta y asesoramiento técnico y científico a la Comisión, el intercambio de información, la formación, la recogida de datos pertinentes y el fomento de la investigación.

En 1995, la Comisión publicó su programa de acción para el período 1996-2000. Un aspecto importante es la constante atención prestada a las iniciativas legislativas, lo que garantiza que las directivas comunitarias sean trasladadas adecuadamente a las legislaciones nacionales, y la promulgación de nuevas directivas sobre agentes físicos y químicos, transporte y equipos de trabajo. Se formalizó la constitución de un Comité de Inspectores de Trabajo, que llevaba varios años funcionando, con el fin de armonizar los métodos de inspección del lugar de trabajo y controlar la aplicación de las legislaciones laborales nacionales. No obstante, se hizo especial hincapié en las medidas no legislativas, en particular en la información y la sensibilización. Se anunció una nueva iniciativa, SAFE (Acciones sobre Seguridad para Europa), adoptada para abordar los problemas de salud y seguridad que se plantean en las pequeñas y medianas empresas. El planteamiento previsto consiste en identificar las iniciativas eficaces en determinadas empresas tipo y utilizarlas en otras empresas.

En resumen, la integración económica y el librecambio en Europa han evolucionado como parte de un programa más amplio de integración social y política. Este proceso ha exigido un análisis pormenorizado de las cuestiones sociales, incluida la salud y la seguridad en el trabajo. Una administración compleja engloba diversas instituciones que se ocupan de esta cuestión. El punto de referencia para la UE es la legislación comunitaria y las legislaciones nacionales, a diferencia del resto de acuerdos de librecambio. Este sistema constituye el ejemplo más avanzado en el mundo de promoción de la salud y la seguridad en el trabajo como componentes de la libertad de comercio. No afectará únicamente a los Estados miembros de la UE; las consideraciones relativas a la salud y la seguridad en el trabajo formarán parte de toda asociación o acuerdo de cooperación entre la UE y los países de Europa central y oriental, lo que facilitará la difusión de esta tradición progresista. Los problemas pendientes (la conciliación de la soberanía nacional con el progreso coordinado, el seguimiento del grado de cumplimiento de las directivas comunitarias, la supresión de diferencias entre los países más y menos progresistas y la puesta en común de los escasos conocimientos técnicos y recursos disponibles) seguirán planteando retos a la integración europea en los próximos años.

\section{América del Norte}

Los tres países de América del $\mathrm{N}$ orte han sido socios comerciales durante muchas décadas. El primer paso hacia la celebración de un acuerdo de comercio regional fue el Tratado de Libre Comercio establecido entre Estados Unidos y Canadá en 1987 , 
en virtud del cual se redujeron los aranceles y otras restricciones al comercio de esos dos Estados. A principios de los años 90 , como paso previo a la celebración de un acuerdo de comercio de todo el continente, los responsables en materia laboral de Estados Unidos y México emprendieron varias iniciativas de cooperación, como la formación de inspectores de trabajo. En 1993, M éxico, Canadá y Estados Unidos ratificaron el Tratado de Libre Comercio de América del $\mathrm{N}$ orte (TLC), que entró en vigor en 1994 para su plena aplicación durante una década. El TLC se diseñó para erradicar la mayoría de las restricciones comerciales existentes entre los tres países.

El proceso que dio lugar a la celebración del TLC difirió de la experiencia europea en diversos aspectos. El TLC tenía una historia más breve y se negoció con rapidez. No había una tradición de incorporar cuestiones sociales en el proceso. Las cuestiones medioambientales y laborales se recogieron en última instancia en dos acuerdos accesorios adoptados junto con el TLC propiamente dicho. Los grupos ecologistas desempeñaron un papel activo en el debate previo a la firma del TLC y consiguieron que se incluyeran ciertas garantías medioambientales en el correspondiente acuerdo accesorio, pero los colectivos de trabajadores adoptaron un enfoque diferente. Los sindicatos y sus aliados, especialmente en Estados Unidos y Canadá, se opusieron firmemente al Tratado y realizaron campañas más orientadas a su bloqueo general que a la inclusión de disposiciones específicas favorables a los trabajadores. Además, ninguno de los tres $\mathrm{G}$ obiernos estaba dispuesto a ceder parte de su soberanía en materia de legislación laboral. En consecuencia, el Acuerdo sobre trabajo incluido en el TLC es relativamente limitado si se le compara con el acuerdo sobre medio ambiente 0 con la experiencia europea.

En el Acuerdo sobre trabajo, en un anexo, se definen "principios rectores que las Partes se comprometen a promover, sin perjuicio de la legislación nacional de cada parte, pero no se establecen normas comunes mínimas". Estos principios incluyen la prevención de los accidentes y las enfermedades profesionales, la indemnización cuando éstas se produzcan, la protección de los trabajadores migrantes y los niños, otros derechos más tradicionales como la libertad de asociación, de organización, de negociación colectiva y de huelga y la prohibición del trabajo forzado. Los objetivos declarados del acuerdo accesorio son mejorar las condiciones de trabajo, fomentar el intercambio de información, la recogida de datos y la colaboración en los estudios, así como promover el cumplimiento de las legislaciones laborales de cada país.

En los primeros artículos del Acuerdo sobre trabajo se insta a los países a difundir su propia legislación laboral a escala nacional y a aplicarla con justicia, equidad y transparencia. Además, se prevé la formación de una Comisión para la cooperación en materia de trabajo. Consta de un Consejo formado por los tres ministros de trabajo o sus representantes, encargado de la formulación de políticas y la promoción de actividades de cooperación, y una Secretaría a cargo de un director ejecutivo que elaborará los informes de referencia y otros estudios y prestará ayuda al Consejo. Además, se indica a las partes que creen una 0 ficina administrativa nacional que funcione como vínculo con la Comisión y facilite el trabajo de ésta. Se establecen varios procedimientos generales, como el relativo a la obtención de conocimientos expertos mediante la cooperación con la O IT. No obstante, el Tratado define pocos procedimientos específicos que respalden la consecución de estos objetivos.

El interés prestado al acuerdo accesorio se basaba en buena medida en la posibilidad de que un Estado miembro, presuntamente $M$ éxico, podría obtener una ventaja comercial desleal mediante la aplicación de prácticas laborales menos exigentes; esta actitud expondría a los trabajadores mexicanos a la recepción de salarios reducidos y al sometimiento a condiciones de trabajo insalubres y provocaría la pérdida de puestos de trabajo en Estados Unidos y Canadá. Por tanto, gran parte del acuerdo accesorio se dedica a los procedimientos de gestión de quejas y reclamaciones. En su caso, el primer paso consistiría en la consulta a escala ministerial entre los gobiernos afectados. A continuación, la Comisión crearía un Comité de Expertos de Evaluación (CEE), compuesto por tres personas cualificadas "elegidas estrictamente en función de su objetividad, fiabilidad y capacidad de juicio", con el fin de considerar la cuestión, siempre que esté relacionada con el comercio y "se recoja en legislaciones laborales mutuamente reconocidas". EI CEE puede basarse en información ofrecida por la Comisión, los Estados miembros, organizaciones, personas con conocimientos especializados 0 el público en general. Los informes del CEE se ponen a disposición de todos los Estados miembros.

Si el CEE llega a la conclusión de que un país ha dejado de aplicar sus normas de trabajo, puede iniciarse un proceso formal de resolución de conflictos. Es significativo que sólo pueda recurrirse a este proceso si el conflicto tiene que ver con la salud y la seguridad en el trabajo, el trabajo infantil o el pago del salario mínimo. En primer lugar, los países implicados tratan de negociar un acuerdo. Si éste no prospera, se convoca un grupo de árbitros elegidos de una lista de expertos elaborada y actualizada por el Consejo. El grupo presenta sus resultados, su conclusión respecto al incumplimiento y sus recomendaciones para la adopción de acciones correctoras. Si el país en cuestión no las cumple, puede volver a convocarse el grupo e imponerse multas. Si el país se niega a pagar la multa, su castigo definitivo sería la suspensión de los beneficios derivados del TLC, normalmente mediante la imposición de aranceles en el sector en que se cometió la infracción con el fin de recuperar la cuantía de la multa.

En general, el acuerdo accesorio sobre trabajo, como marco para la salud y la seguridad en el seno del TLC, es menos amplio que los acuerdos europeos correspondientes. En el TLC, se centra la atención en la resolución de los conflictos y no en la investigación conjunta, el intercambio de información, la formación, el desarrollo de tecnologías y otras iniciativas afines. El proceso de resolución de conflictos, para los defensores de los trabajadores, es pesado, relativamente ineficaz y requiere mucho tiempo y, 10 que es más importante, el acuerdo accesorio no expresa un compromiso compartido con los derechos fundamentales de los trabajadores. En él se respetan las legislaciones nacionales de cada país y no figuran disposiciones relativas a la mejora o la armonización de las que son deficientes. Su alcance es limitado $y$, aunque la experiencia acumulada hasta la fecha es escasa, es probable que el planteamiento general europeo respecto a la salud en el trabajo, incluida la consideración de cuestiones como el trabajo por turnos y el estrés, no se reproducirá en América del $\mathrm{N}$ orte.

\section{Asia y América Latina}

Aunque Asia es la región económica de crecimiento económico más rápido, las negociaciones sobre librecambio no han avanzado significativamente en esta zona. $\mathrm{N}$ i la ASEAN ni la APEC han abordado la salud y la seguridad en el trabajo en sus negociaciones comerciales. Del mismo modo, los acuerdos de librecambio cada vez más numerosos en América Latina, como MERCOSUR y el Pacto Andino, no contemplan la adopción de iniciativas al respecto. 
y desarrollado numerosos procedimientos con este fin. Dada la tendencia al aumento de los acuerdos de libre comercio, se prevé que el dominio de las EM N se amplíe y, por tanto, se reduzca el número de empresas de propiedad pública y privada. Resulta oportuno, por tanto, considerar el papel desempeñado por las EMN en el marco de su expansión actual en todo el mundo, sobre todo en los países que, hasta la fecha, han dedicado escasos recursos a la protección del trabajador y del medio ambiente.

EI Consejo de la Industria Q uímica Europea (CEFIC), en sus D irectrices sobre transferencia de tecnología (Aspectos de seguridad, salud y medio ambiente) señala que la tecnología transferida debe satisfacer unos requisitos de seguridad y protección de la salud y del medio ambiente iguales a los del proveedor y equivalentes a los exigidos en las instalaciones de su sede (CEFIC 1991). Esta medida parece especialmente aplicable a las filiales de las EM N repartidas por el mundo.

\section{Dobles normas}

Muchas EMN no han sido tan rigurosas en el control de los riesgos industriales en los países en desarrollo como en sus países de origen. L os casos más numerosos de esta duplicidad de criterios se refieren al amianto y otros materiales extremadamente peligrosos y en situaciones en las que un control eficaz de los peligros constituiría una parte importante de los costes generales de producción y reduciría las ventas por otras razones. Los casos descritos en los años 70 y principios de los 80 corresponden a empresas con sede en Alemania occidental, Estados U nidos, Reino Unido, Suiza, Italia, Austria y Japón (Castleman y Navarro 1987).

El caso de "doble rasero" mejor analizado es el de la fábrica de pesticidas que causó millares de muertes y daños permanentes para la salud a decenas de miles de personas en Bhopal, la India, en 1984. La comparación entre la fábrica de Bhopal y otra similar instalada en Estados U nidos puso de manifiesto hasta qué punto se había aplicado un criterio diferente en cuanto al diseño y el funcionamiento de los centros, las auditorías de seguridad, la formación de los trabajadores, el personal empleado en las tareas peligrosas, el mantenimiento de las instalaciones y la responsabilidad de la dirección. O tros factores importantes fueron las carencias relativas en materia de normativa pública y responsabilidad civil en la India respecto de Estados U nidos (C astleman y Purkayastha 1985).

El desastre de Bhopal atrajo la atención mundial sobre las políticas y las prácticas de las EMN en lo que respecta a la protección de la salud y la seguridad de los trabajadores y del medio ambiente. M uchas empresas manufactureras de grandes dimensiones se dieron cuenta de repente de que corrían un riesgo excesivo, que podían reducir, y comenzaron a rebajar las cantidades de gases comprimidos altamente tóxicos que almacenaban y transportaban. Por ejemplo, el traslado de grandes cilindros de gas fosgeno pasó de ser una práctica habitual en Estados Unidos a evitarse por sistema. Estos cambios se debieron en buena medida a la práctica desaparición de los seguros de protección contra las consecuencias de los vertidos químicos en las comunidades. A hora bien, dejando a un lado las consideraciones puramente económicas, la ética y la moralidad de la conducta de las empresas multinacionales fue puesta en tela de juicio como no lo había sido antes.

O bviamente, la relajación de las normas sobre protección de los trabajadores y el medio ambiente puede proporcionar a los propietarios de las fábricas cierto ahorro, al menos a corto plazo. La tentación de aumentar los beneficios mediante el recorte de los costes resulta especialmente atractiva cuando las disposiciones de la Administración, la sensibilización del público en general, la presión sindical y la asunción de responsabilidades por los daños son casi inexistentes en caso de accidente. EI caso de Bhopal demostró que, cuando los niveles de beneficio son bajos, los directivos están sometidos a una mayor presión para reducir los costes de explotación mediante la aplicación de métodos cuyos costes inmediatos son moderados, pero que implican riesgos a largo plazo que pueden resultar catastróficos. Además, la estructura de las EM N parecía idónea, al no obligar a los altos directivos a asumir responsabilidades personales por las consecuencias del cumplimiento de las normas locales en todo el mundo.

En la investigación de la OIT, Safety and $\mathrm{H}$ ealth Practices of M ultinational Enterprises, se llegó a la conclusión de que "al comparar el rendimiento en materia de salud y seguridad de las EMN con sede en su país de origen y el de sus filiales, puede afirmarse que, en general, el funcionamiento en las instalaciones centrales es mejor que el de las filiales en los países en desarrollo" (OIT 1984). En un informe del Centro de las Naciones Unidas sobre las Empresas Transnacionales (UNCTC) se instaba a analizar las políticas de las EMN con respecto a "la salud y la seguridad en el trabajo en sus filiales de todo el mundo". En el informe se afirmaba la existencia de "numerosos ejemplos de 'doble rasero', en los que las medidas de protección del trabajador y de la salud de la comunidad adoptadas por las EM N son muy inferiores en los países en desarrollo que en los países de origen". Esta tendencia pudo comprobarse en las industrias productoras de cloruro de vinilo, pesticidas, cromatos, acero, cloro y amianto (U NCTC).

La respuesta de las mayores EMN químicas con sede en Estados U nidos y el R eino U nido fue negar que la política de la empresa consistiera en aplicar criterios diferentes en países diferentes para proteger a las personas contra los mismos peligros industriales. No obstante, estas opiniones se han expresado con diversos matices, y en algunos casos se ha asumido un mayor compromiso que en otros. Además, muchos consideran con escepticismo que sigue existiendo una amplia brecha entre las declaraciones de política empresarial y la realidad del doble rasero en la conducta de las empresas.

\section{Responsabilidad sobre los productos}

$L$ a responsabilidad sobre los productos es la que tiene el vendedor con objeto de evitar que los productos que vende resulten dañinos a lo largo de su ciclo vital de utilización y eliminación. Incluye la responsabilidad de garantizar que la empresa que compra el producto químico al vendedor no lo utilice de forma peligrosa; al menos una empresa de Estados U nidos, D ow Chemical, aplica desde hace tiempo la política de evitar la venta de sus productos a clientes inadecuados. En 1992, las empresas integrantes de la Chemical $M$ anufacturers Association de Estados U nidos adoptaron un código que contempla la suspensión de las ventas a clientes que no corrijan "prácticas inadecuadas" al utilizar las sustancias químicas que venden.

M uchos ejemplos avalan la necesidad de que los fabricantes de pesticidas asuman su responsabilidad sobre el producto. EI reenvasado de pesticidas en recipientes de alimentos y la utilización de bidones de pesticidas para almacenar agua son causa de un gran número de muertes y enfermedades. La utilización y el almacenamiento de pesticidas y sus recipientes por parte de pequeños agricultores refleja una falta generalizada de formación que los fabricantes podrían impartir.

En el valle de Costanza de la República D ominicana, la defoliación provocada por el uso excesivo de pesticidas ha hecho que Ilamen a la zona el "Valle de la M uerte". Al aumentar la atención prestada a este caso por los medios de comunicación, Ciba-Geigy, una importante EM N del sector químico, puso en marcha un programa de formación para pequeños agricultores 
en el que se impartían nociones de agronomía, gestión integrada de plagas y seguridad, y se admitía que la utilización de pesticidas en el valle debía reducirse. La prensa económica indicó que la respuesta de la comunidad local al esfuerzo de C iba para "demostrar los beneficios económicos y sociales de un mercado sostenible" era alentadora. Esta empresa aplica programas semejantes para pequeños agricultores en Colombia, Filipinas, Indonesia, Pakistán, M ali, M ozambique y Nigeria. La Pesticide Action N etwork se muestra escéptica hacia la interpretación que hacen las empresas de una "gestión integrada de las plagas", pues subrayan la "mejor combinación" de pesticidas en lugar de formar a las personas en técnicas basadas en el empleo de estas sustancias sólo como último recurso.

Un aspecto importante de la responsabilidad sobre el producto es la educación de los trabajadores y del público en general mediante la difusión de etiquetas de advertencia, folletos y programas de formación de los usuarios. En el caso de ciertos productos y recipientes peligrosos, dicha responsabilidad conlleva la recuperación de materiales que, de otro modo, podrían ser utilizados inadecuadamente por los clientes o eliminados como residuos peligrosos.

En los tribunales de Estados U nidos, la responsabilidad sobre el producto se asume con un grado de compromiso muy elevado debido a que se exigen responsabilidades por los daños que puedan causar los productos peligrosos y por la contaminación. Personas perjudicadas por productos cuyos peligros no siempre se especificaban en las advertencias de los fabricantes han recibido indemnizaciones considerables por pérdidas económicas, lesiones y daños morales y, en algunos casos, daños punitivos adicionales. Los fabricantes han preferido retirar del mercado de Estados Unidos productos que podían causar anomalías de la función reproductora, comprobado en los experimentos realizados con animales, a arriesgarse a pagar cifras astronómicas en pleitos interpuestos por defectos de nacimiento en los hijos de los trabajadores en contacto con el agente tóxico. En ocasiones, las mismas empresas comercializaron esos mismos productos en otros países en los que la responsabilidad sobre el producto no es importante.

Por tanto, la responsabilidad y la regulación han obligado a los fabricantes de algunos países a desarrollar procesos y productos menos tóxicos. Ahora bien, en ausencia de esos factores y de una sensibilización del público en general, existe la posibilidad de que las tecnologías más peligrosas y atrasadas sigan siendo económicamente competitivas, e incluso es posible mantener un mercado de tecnologías anticuadas que pueden explotarse en numerosos países. Así, a pesar de los avances obtenidos por las EM N en el desarrollo de "tecnologías limpias", no es previsible que éstas se difundan en breve a Africa, Asia, América Latina y Europa central y oriental. Es muy posible que algunas de las industrias de reciente creación en estas regiones recurran a equipos usados de importación. Esta transferencia plantea un desafío ético a las EM N propietarias de equipos que están sustituyéndose en Europa y América del $\mathrm{N}$ orte.

\section{Avances en materia de salud pública}

Varios avances logrados en los últimos años contribuirán sin duda a la protección de la salud pública y del medio ambiente en los lugares en que se consoliden. Los químicos especializados en investigación industrial, cuyo objetivo ha sido tradicionalmente optimizar el rendimiento de los productos, sin preocuparse demasiado por la toxicidad de éstos o de sus derivados, analizan en la actualidad la evolución de la tecnología menos tóxica en simposios sobre "química ecológica" o "ecología industrial" (Illman 1994). A continuación se ofrecen algunos ejemplos de los avances alcanzados:
- sustitución de éteres de glicol, disolventes tratados con cloro y disolventes de clorofluorocarbonos como agentes limpiadores en los procesos microelectrónicos;

- sustitución de los disolventes orgánicos por otros basados en agua, en adhesivos y selladores;

- reducción de los disolventes orgánicos volátiles de muchas pinturas en favor de las pinturas a base de agua, la tecnología de pintura por pulverización basada en la utilización de una concentración supercrítica de dióxido de carbono y recubrimientos de material pulverizado;

- sustitución del cadmio y el plomo en los pigmentos;

- eliminación de la contaminación atmosférica por óxido nitroso al fabricar ácido adípico (utilizado para fabricar nylon, poliéster y poliuretano);

- sustitución de la acrilamida en los compuestos de lechada de cemento;

- sustitución del blanqueado con cloro en la fabricación de papel;

- sustitución del fósgeno, el hidrógeno de arsénico y otros gases tóxicos por productos intermedios menos tóxicos que pueden utilizarse en su lugar en los procesos industriales, evitando así el almacenamiento y el transporte de grandes cantidades de gases comprimidos altamente tóxicos;

- sustitución del proceso basado en el fósgeno para la fabricación de policarbonatos por un proceso basado en el carbonato de dimetilo;

- síntesis de los isocianatos alifáticos a partir de aminos y dióxido de carbono en lugar de los procesos en los que se utiliza fósgeno;

- sustitución del ácido fluorhídrico por ácido sulfúrico o, mejor, por catalizadores sólidos en las unidades de alquilación de gasolina de las refinerías de petróleo;

- utilización de catalizadores de zeolita en la producción de cumeno en sustitución del ácido fosfórico o de catalizadores de cloruro de aluminio, lo que elimina los problemas de evacuación de residuos ácidos y de tratamiento de materiales corrosivos.

La promoción a escala mundial de tecnologías menos tóxicas puede ser emprendida tanto por las EMN a título individual como por organismos colectivos. La Industry Cooperative for $O$ zone Layer Protection es uno de los medios que han utilizado las principales empresas para fomentar las tecnologías más respetuosas con el medio ambiente. A través de esta organización, con el apoyo adicional del Banco M undial, IBM ha intentado ayudar a las empresas de A sia y América L atina a adoptar métodos de limpieza y secado de circuitos impresos y componentes de discos basados en la aplicación de agua.

\section{Funciones de la Administración}

En muchos países está teniendo lugar una expansión industrial y, al considerar las solicitudes para desarrollar nuevos proyectos industriales, los gobiernos tienen la oportunidad y la responsabilidad de evaluar los riesgos para la salud y la seguridad de la tecnología importada. El país receptor debe garantizar que las nuevas empresas cumplan estrictas normas de funcionamiento. Los solicitantes deben comprometerse a respetar unos niveles específicos de emisión de agentes contaminantes que no sean superados durante la actividad de sus fábricas y a establecer unos límites de exposición de los trabajadores a las sustancias tóxicas. Asimismo, han de estar dispuestos a pagar a la Administración para obtener el equipo de control necesario para garantizar la observación efectiva de dichos límites y permitir el acceso inmediato en cualquier momento de los inspectores públicos.

En especial, los solicitantes deberán aportar información sobre su experiencia en el pasado con la tecnología que se va a 
Tabla 20.2 • Información solicitada a los inversores extranjeros para la realización de análisis medioambientales.

A. El inversor extranjero realizará un análisis de impacto medioambiental del proyecto propuesto que incluya:

(1) una lista de las materias primas, productos intermedios, productos finales y residuos (incluyendo un diagrama de flujo)

(2) una lista de todas las normas sobre salud y seguridad en el trabajo y sobre medio ambiente (vertidos de aguas residuales, tasas de emisión atmosférica de todos los agentes contaminantes del aire, descripción detallada y tasa de generación de residuos sólidos o de otro tipo que deben eliminarse sobre el terreno o mediante incineración)

(3) plan para controlar todos los peligros para la salud y la seguridad en el trabajo de las fábricas, el almacenamiento y el transporte de materias primas, productos y residuos potencialmente peligrosos

(4) un ejemplar de las directrices empresariales del inversor extranjero para la realización de análisis de impacto medioambiental y de salud y seguridad en el trabajo correspondientes a nuevos proyectos

(5) fichas técnicas de seguridad del fabricante de todas las sustancias utilizadas.

B. El inversor extranjero deberá ofrecer una información completa sobre la ubicación, la antigüedad y el rendimiento de las fábricas existentes y de las cerradas en los últimos cinco años, que sean propiedad total o parcial del inversor extranjero y en las que se utilicen procesos y productos semejantes, e incluirá:

(1) una relación de todas las normas sobre medio ambiente y salud y seguridad en el trabajo, incluidos los requisitos jurídicos (normas, leyes, regulaciones) y normas voluntarias de la empresa y prácticas empleadas para el control de toda clase de riesgos medioambientales y agrupacionales.

(2) descripción de todos los casos de incapacidad permanente yl o total sufridos real o presuntamente por trabajadores, incluidas sus reclamaciones de indemnización

(3) explicación de las multas, sanciones, citaciones, infracciones, acuerdos regulatorios y reclamaciones de indemnización por daños y perjuicios civiles relativas a cuestiones de salud y seguridad en el trabajo, así como a los riesgos y daños atribuidos a la comercialización y el transporte de los productos de la empresa de que se trate

(4) descripción del porcentaje de propiedad y participación tecnológica del inversor extranjero en cada fábrica y una información similar relativa a otros socios de capital y proveedores de tecnología

(5) nombres y direcciones de las autoridades públicas que regulan o controlan las cuestiones medioambientales y de salud y seguridad en el trabajo en cada fábrica

(6) explicación de los casos en los que el impacto medioambiental de una fábrica ha sido objeto de polémica con la comunidad local o con las autoridades normativas, incluida la descripción de las prácticas criticadas y el modo en que dichas críticas se resolvieron en cada caso

(7) copias, con resumen, de todas las auditorías e informes de inspección sobre medio ambiente y salud y seguridad en el trabajo de cada sede de la empresa, incluidas las auditorías y los informes elaborados por consultores

(8) copias de los informes de seguridad y los informes de evaluación y análisis de riesgos llevados a cabo con tecnología similar por el inversor extranjero y sus consultores

(9) ejemplares de los formularios de emisiones tóxicas que hayan sido presentados a los organismos públicos (p. ej., la US Environmental Protection Agency y entidades semejantes en otros países) en los últimos cinco años con relación a todos los emplazamientos de fábricas

(10) la información que el inversor extranjero considere pertinente

C. El inversor extranjero presentará una declaración de política empresarial sobre salud, seguridad y rendimiento medioambiental de sus empresas en todo el mundo. En dicha declaración se referirá a la política empresarial relativa a leyes, reglamentos, normas, directrices y prácticas en lo que respecta a nuevos proyectos industriales e instalaciones de producción. El inversor extranjero explicará el modo en que se aplica su política mundial mediante: la descripción del personal encargado de llevarla a la práctica, sus competencias y responsabilidades y su situación en la estructura empresarial del inversor. Asimismo, en estas descripciones se incluirán el nombre, la dirección y el número de teléfono de los altos directivos de la empresa a cargo de esta función del personal. El inversor extranjero declarará si en todo el mundo se atiene a las mismas normas sobre protección de los trabajadores y del medio ambiente en todos los nuevos proyectos y, en caso contrario, explicará por qué no.

D. El inversor extranjero facilitará al país en desarrollo un acceso inmediato a la instalación industrial propuesta, en cualquier momento de su funcionamiento, con el fin de que puedan realizarse inspecciones controlar la exposición de los trabajadores a los riesgos y tomar muestras de las emisiones de agentes contaminantes.

E. El inversor extranjero aceptará formar completamente a todos los trabajadores expuestos a riesgos profesionales potenciales, incluida formación sobre los posibles efectos para la salud de todas las exposiciones y las medidas de control más eficaces.

F. El inversor extranjero suministrará al país en desarrollo el equipo para analizar las exposiciones en el lugar de trabajo y la generación de contaminantes, incluidas las mediciones indicadas en $\mathrm{A}(2)$ (aunque pueden ser más), mientras dure el proyecto propuesto. El inversor extranjero aceptará que el proyecto propuesto pague al gobierno del país en desarrollo el coste de todos los seguimientos médicos y de exposiciones mientras dure el proyecto propuesto.

G. El inversor extranjero aceptará que el proyecto propuesto indemnice plenamente a toda persona cuya salud, capacidad para obtener ingresos o propiedades queden dañadas como consecuencia de los riesgos profesionales y del impacto medioambiental del proyecto, de acuerdo con lo que determine el gobiemo del país en desarrollo.

H. El inversor extranjero se impondrá garantías de comercialización tan restrictivas como las que se aplican en cualquier otro lugar del mundo para asegurarse de que los trabajadores y la población en general no resulten dañados como resultado de la utilización de sus productos.

1. Si el inversor extraniero tiene noticia de un riesgo considerable de daño para la salud o periuicio para el medio ambiente derivado de una sustancia que fabrica 0 vende en un país en desarrollo, un riesgo desconocido y descubierto en el momento de presentar la solicitud, lo notificará de inmediato al organismo de protección ambiental del gobierno del país en desarrollo. (Esta exigencia es similar a los requisitos previstos en la sección 8e de la Ley de control de sustancias tóxicas de Estados Unidos).

1. El inversor extranjero facilitará los nombres, cargos, direcciones, teléfonos y números de fax de sus altos directivos encargados de la aplicación de las políticas medioambientales y de salud y seguridad en el trabajo, incluido el diseño y el funcionamiento de las fábricas, las inspecciones empresariales, las revisiones del rendimiento de los centros de producción y la responsabilidad sobre los productos.

Fuente: Bruno 1994 
utilizar y sus riesgos. La Administración del país de acogida tiene pleno derecho a conocer qué riesgos existen en el lugar de trabajo y qué niveles de contaminación presentan otras fábricas similares gestionadas por los solicitantes del proyecto. I gualmente, es importante saber conforme a qué leyes, reglamentos y normas sobre la protección de la salud pública actúan los solicitantes para instalaciones similares de otros países.

EI proceso de aprobación de solicitudes por parte de la administración del país de acogida debe incluir una evaluación crítica de las mismas en función de las necesidades reales. En caso de aceptación, deberá llevarse a cabo un análisis de seguimiento para garantizar que la tecnología empleada hace los procesos menos peligrosos y proporciona productos que satisfacen las necesidades que se pretenden cubrir. Este procedimiento es coherente con las políticas declaradas por las principales EM N. El cumplimiento de las obligaciones éticas por parte de las administraciones y las empresas puede permitir una rápida expansión mundial de los avances relacionados con la salud pública en el campo de la tecnología.

Los grandes proyectos presentados en los países en desarrollo suelen exigir la participación de EM N extranjeras como inversoras. Las directrices incluidas en la Tabla 20.2 han sido publicadas por Greenpeace y Third World Network (M alaisia), y en ellas se detalla la información que las administraciones pueden solicitar a los inversores extranjeros (Bruno 1994). Cuando éstos no presenten datos sobre la tecnología y sus peligros, las administraciones pueden y deben adoptar las medidas oportunas para obtener información al respecto de forma independiente.

Los riesgos industriales no son la única razón para realizar estudios de impacto medioambiental y los proyectos industriales no son los únicos que deben someterse a este tipo de análisis. La importación y la utilización generalizada de tecnología ineficaz desde el punto de vista energético para la fabricación de refrigeradores, motores eléctricos y aparatos de iluminación han causado considerables problemas. En muchos países, la generación de energía eléctrica difícilmente podría satisfacer la demanda aun cuando la eficiencia energética se considerase un criterio para la evaluación de las nuevas tecnologías y el diseño de edificios comerciales. La ineficiencia energética plantea graves dificultades para el desarrollo, entre ellas los costes de construcción y mantenimiento de una capacidad de generación de electricidad excesiva, la contaminación y los desincentivos a la expansión provocados por un suministro de energía poco fiable y las averías. La eficiencia energética puede liberar unos recursos importantísimos para satisfacer las necesidades básicas, en lugar de construir y poner en marcha centrales eléctricas innecesarias.

\section{Conclusión}

Las empresas multinacionales se encuentran en una posición privilegiada para determinar los tipos de tecnología que deben transferirse a los países de A sia, Africa, América L atina y Europa central y oriental. L as grandes empresas tienen la obligación ética y moral de aplicar con prontitud políticas globales encaminadas a eliminar la duplicidad de criterio en materia de salud pública y medio ambiente. La vida de las generaciones presentes y futuras se verá afectada radicalmente por la medida en que se transfieran tecnologías mejoradas y menos peligrosas en todo el mundo.

Por otra parte, los gobiernos tienen el deber moral de evaluar de una manera independiente y crítica los proyectos industriales y comerciales. El cumplimiento de esta función mejora con la realización de análisis basados en la investigación de las tecnologías y las empresas que las utilizan. La credibilidad y la eficacia del proceso de evaluación dependerá en gran medida de su transparencia y de la participación del público en él.
Las citas de fuentes empresariales se basan en informes publicados en revistas del sector químico y en comunicaciones remitidas al autor.

\section{ASPECTOS ECONOMICOS DE LA SALUD Y LA SEGURIDAD EN EL TRABAJO}

\section{Alan Maynard}

L as pérdidas que infringen a la sociedad los accidentes y las enfermedades relacionados con el trabajo son graves, pero ninguna sociedad puede permitirse prevenir todas estas pérdidas. Debido a la escasez de recursos, las inversiones, de cuantía limitada, deben asignarse con cuidado para obtener la máxima rentabilidad. La sola determinación de los costes de las enfermedades profesionales no facilita la orientación de la inversión. Una evaluación económica adecuada puede resultar útil si está bien diseñada y se lleva a cabo correctamente. Sus resultados pueden emplearse una vez realizada una valoración crítica de la práctica de la evaluación, para definir las opciones de inversión. La evaluación económica no puede ni debe determinar las decisiones al respecto. Estas serán resultado de la consideración de valores económicos, políticos y sociales. C omo señala Fuchs (1974):

En la mayoría de nuestros principales problemas sanitarios subyacen juicios de valor. ¿Qué tipo de personas somos? ¿Q ué tipo de vida queremos llevar? ¿Q ué clase de sociedad queremos construir para nuestros hijos y nietos? ¿Q ué importancia queremos conceder a la libertad individual? ¿Y a la igualdad? ¿Y al progreso material? ¿Y al ámbito del espíritu? ¿Q ué importancia otorgamos a nuestra propia salud? ¿Y a la de nuestro vecino? Las respuestas a estas preguntas, así como la orientación que podemos obtener de la ciencia económica, pueden y deben determinar la política de asistencia sanitaria.

La decisión de regular la minería para que disminuya el número de trabajadores fallecidos y lesionados en el trabajo, si tiene éxito, genera beneficios para la salud de la población activa. A hora bien, esos beneficios llevan unidos unos costes. En la vida real, el aumento de los costes para mejorar la seguridad elevará los precios, reducirá las ventas en los mercados mundiales competitivos y puede inducir a las empresas a incumplir las regulaciones. A su vez, los sindicatos y sus afiliados pueden admitir este incumplimiento por preferir una aplicación imperfecta de la legislación sobre salud y seguridad si así mejoran los ingresos y las perspectivas de empleo.

El objetivo del análisis económico en el contexto de la salud en el trabajo es facilitar la determinación de qué nivel de inversión en seguridad es eficiente. La eficiencia significa que el coste de hacer un poco más (coste marginal) para mejorar la seguridad igualará al beneficio (el beneficio marginal en lo que se refiere a la mejora de la salud y la seguridad deriva de la reducción de riesgos). Los aspectos económicos de la salud y la seguridad en el trabajo son fundamentales para la toma de decisiones a todas las escalas: en el centro de trabajo, en la empresa, en el sector y en la sociedad. Comportarse como si todos los riesgos para la salud de los trabajadores pudieran erradicarse puede resultar ineficiente. Los riesgos pueden eliminarse cuando su supresión es eficaz en relación con el coste. Algunos riesgos son poco frecuentes y su erradicación resulta demasiado cara: han de ser tolerados y, si finalmente se materializan dañando el bienestar del trabajador, deben aceptarse como sucesos desafortunados, pero eficientes. $\mathrm{H}$ ay un nivel óptimo de riesgo profesional por encima del cual, los costes de reducir los riesgos superan los beneficios. La inversión en seguridad más 
Tabla 20.3 - Costes para la economía del Reino Unido de los accidentes de trabajo y la salud relacionada con la actividad laboral (1990 fm).

Coste para las víctimas y sus familias

Pérdida de renta

Lesión

Enfermedad
Coste para las empresas

(fm) Costes de producción adicionales

376 Lesión

579 Enfermedad

Daños y pérdidas en accidentes

Lesión

No lesión

Seguro

\section{Administración/ contratación}

Lesión

Enfermedad

No lesión

$\begin{array}{ll}1.907 & \text { Responsabilidad de la empresa } \\ 2.398 & \text { Seguro } \\ 5,260 & \text { Total }\end{array}$

Pérdida de bienestar

Lesión

Enfermedad

Total

Menos: indemnización del seguro de responsabilidad empresarial
Coste para la sociedad en su conjunto

(fm) Pérdida de producción

336 Lesión

1.365

230 Enfermedad

1.908

Costes financieros: daños en accidentes

15-140 Lesión

2.152-6.499 No lesión

505 Asegurado

$15-140$

$2.152-6.499$

Tratamiento médico

Lesión

$58-244$

Enfermedad

$58-219$

Administración, etc.

58-69 Lesión

79-212 Enfermedad

132-143

$163-296$

382.787

Pérdida de bienestar

Lesión

1.907

2.398

4.432-9.453 Total

Fuente: Davies y Teasdale 1994.

allá de este punto generará unos beneficios en materia de seguridad que sólo deben perseguirse si la sociedad está dispuesta a actuar en condiciones de ineficiencia económica. Esta es una decisión de política social.

\section{Tipos de análisis económicos}

\section{Análisis de costes}

El análisis de costes exige la determinación, medición y valoración de las consecuencias para los recursos, de los accidentes y las enfermedades profesionales. Estas descripciones permiten definir la magnitud del problema, pero no informan a los responsables de la toma de decisiones sobre cuál de las distintas intervenciones posibles en materia de regulación del medio ambiente de trabajo es la más eficiente.

Un buen ejemplo de esta situación lo ofrece un estudio realizado en el R eino U nido sobre los costes económicos de los accidentes y las enfermedades relacionados con el trabajo (D avies y Teasdale 1994). En 1990, se registraron 1,6 millones de accidentes laborales y 2,2 millones de personas sufrieron enfermedades causadas 0 agravadas por el medio ambiente de trabajo. Como resultado, 20.000 personas sufrieron incapacidad para trabajar y se perdieron 30 millones de jornadas laborales. La pérdida de ingresos y bienestar de las víctimas y sus familias se cifró en 5.200 millones de libras. Las pérdidas de las empresas oscilaron entre los 4.400 y los 9.400 millones de libras. Las pérdidas para la sociedad en su conjunto se situaron entre 10.900 y 16.300 millones de libras (véase la Tabla 20.3). Los autores del informe sobre el R eino U nido señalaban que, si bien el número de accidentes y enfermedades profesionales había descendido, los costes estimados eran superiores.
Los costes eran superiores a los de estudios previos debido a la revisión de las técnicas de estimación de pérdida de bienestar y a la mejora de las fuentes de información. Los datos fundamentales en este tipo de determinación de costes son los relativos a la epidemiología de los accidentes y las enfermedades relacionados con el trabajo. Como en las demás áreas de análisis de los costes sociales, (p. ej., los generados por el alcohol; véase M cD onnell y M aynard 1985), la medición del volumen de casos suele ser deficiente. Algunos accidentes (¿cuántos?) no son comunicados. La vinculación entre la enfermedad y el lugar de trabajo puede ser obvia en algunos casos ( $p$. ej., las enfermedades relacionadas con el amianto) e incierta en otros (p. ej., las cardiopatías y los factores de riesgo profesional). Por tanto, es difícil determinar el número de casos relacionados con el trabajo.

La determinación del coste de estos casos también resulta problemática. Si el estrés en el trabajo degenera en alcoholismo y en despido del empleo, ¿cómo deben valorarse los efectos de estos acontecimientos en la vida familiar? Si un accidente en el trabajo causa daños crónicos icómo deben evaluarse? M uchos costes pueden identificarse, algunos pueden medirse, pero, a menudo, una proporción considerable de los que son medidos e incluso cuantificados no pueden valorarse.

A ntes de dedicar un gran esfuerzo a la evaluación de los costes de estos casos, es esencial tener claro el objetivo de esta actividad y el valor de una gran precisión. El cálculo de los costes de los accidentes y las enfermedades relacionadas con el trabajo no facilita la adopción de decisiones sobre las inversiones para prevenir dichos casos, pues no mejora el conocimiento de los directivos sobre los costes y los beneficios de ampliar o reducir un poco una determinada actividad de prevención. La determinación del coste de los casos relacionados con las enfermedades 
Tabla 20.4 - Tipos de evaluación económica.

\begin{tabular}{|c|c|c|c|}
\hline & $\begin{array}{l}\text { Medición } \\
\text { de costes }\end{array}$ & $\begin{array}{l}\text { Medición del } \\
\text { resultado } \\
\text { ¿Cuál? }\end{array}$ & $\begin{array}{l}\text { Medición del } \\
\text { resultado } \\
\text { ¿Cómo se valora? }\end{array}$ \\
\hline $\begin{array}{l}\text { Análisis de minimi- } \\
\text { zación de costes }\end{array}$ & $f$ & Se supone idéntico & No hay unidades \\
\hline $\begin{array}{l}\text { Análisis } \\
\text { coste-beneficio }\end{array}$ & $f$ & $\begin{array}{l}\text { Todos los efectos } \\
\text { producidos por la } \\
\text { alternativa }\end{array}$ & Libras \\
\hline $\begin{array}{l}\text { Análisis de la } \\
\text { eficacia en función } \\
\text { del coste }\end{array}$ & n & $\begin{array}{l}\text { Una variable específica } \\
\text { común obtenida en } \\
\text { distintas medidas }\end{array}$ & $\begin{array}{l}\text { Unidades comunes } \\
\text { (por ejemplo, años } \\
\text { de vida) }\end{array}$ \\
\hline $\begin{array}{l}\text { Análisis de } \\
\text { coste-utilidad }\end{array}$ & $f$ & $\begin{array}{l}\text { Efectos de los } \\
\text { tratamientos } \\
\text { alternativos obtenidos } \\
\text { en diferentes niveles }\end{array}$ & QALY o DALY \\
\hline
\end{tabular}

profesionales permite identificar pérdidas parciales (personales, familiares y empresariales) y de la sociedad. Sin embargo, esta tarea no sirve como base para la actividad de prevención. La información adecuada para la toma de decisiones en este ámbito sólo puede obtenerse de la evaluación económica.

\section{Principios de la evaluación económica}

H ay cuatro tipos de evaluación económica: análisis de minimización de costes, análisis coste-beneficio, análisis de eficacia en función del coste y análisis de coste-utilidad. Las características de estos planteamientos se esbozan en la Tabla 20.4

En los análisis de minimización de costes (AM C) se supone que el efecto final es el mismo en cada una de las alternativas comparadas. Así, pueden plantearse dos intervenciones para reducir los efectos cancerígenos de un proceso productivo, y los datos de ingeniería y de otro tipo indican que los efectos son idénticos en cuanto a exposición y reducción del número de cánceres. EI AM C puede utilizarse para determinar el coste de las estrategias alternativas y saber así cuál es la más barata.

O bviamente, el supuesto de que los efectos sean idénticos es extremo y no es probable que se pueda aplicar en la mayoría de los casos de inversión; por ejemplo, los efectos de estrategias de seguridad alternativas sobre la duración y la calidad de vida de los trabajadores serán desiguales. En este caso, deberán utilizarse otros métodos de evaluación.

El más ambicioso de ellos es el análisis coste-beneficio (ACB). Exige que el analista identifique, mida y valore los costes y los beneficios de estrategias de prevención alternativas en función de una medida monetaria común. La valoración de los costes de tales inversiones puede ser difícil. N o obstante, estas dificultades se quedan pequeñas en comparación con la problemática de la valoración monetaria de los beneficios: ¿cuánto vale una lesión evitada o una vida salvada? Por estas dificultades, el ACB no ha sido muy utilizado en el ámbito de los accidentes y la salud.

Una forma más restringida de evaluación económica, el análisis de la eficacia en función del coste (AEFC), se ha empleado mucho en el campo de la salud. EI AEFC fue desarrollado por los militares de Estados U nidos, cuyos analistas adoptaron la célebre medida del efecto denominada "recuento de cuerpos" y trataron de averiguar cuál era el método más barato de lograr un determinado número de víctimas en el enemigo (es decir, cuáles eran los costes relativos de los bombardeos de artillería, de las bombas de napalm, de las cargas de infantería, de los movimientos de tanques y otras "inversiones" para lograr el efecto de mortalidad deseado en el enemigo).
Por tanto, el AEFC suele conllevar una medición sencilla del efecto específico en un área, lo que permite calcular los costes para lograr diversos niveles de reducción, por ejemplo, de los episodios o de la mortalidad en el lugar de trabajo.

La limitación del AEFC consiste en que las mediciones de los efectos pueden no ser generalizables, es decir, que una medida utilizada en un área ( $p$. ej., reducción de la exposición al amianto) puede no ser utilizable en otra (p. ej., la reducción de las tasas de accidentes en el sector de suministro eléctrico). Por consiguiente, el AEFC puede facilitar la toma de decisiones en un área determinada, pero no ofrece una información de evaluación que permita determinar los costes y los efectos de las opciones de inversión de una amplia gama de estrategias de prevención.

EI análisis de coste utilidad (ACU) fue ideado para superar este problema utilizando una medida de efecto genérica, como el año de vida ajustado en función de la calidad (QALY) y el año de vida ajustado en función de la discapacidad (DALY) (véase, por ejemplo, Williams 1974 y el World Bank Report on Health 1993). Las técnicas basadas en el ACU pueden aplicarse para determinar los efectos sobre el coste/ Q ALY de estrategias alternativas y esta información puede servir de base para las estrategias de inversión en prevención de un modo más general.

La utilización de técnicas de evaluación económica en el campo de la asistencia sanitaria está consolidada, aunque su aplicación en la medicina del trabajo es más limitada. Estas técnicas, teniendo en cuenta las dificultades de medir y valorar los costes y beneficios ( $p$. ej., en QALY), resultan útiles, cuando no esenciales, como base para la toma de decisiones sobre la inversión en prevención. Es sorprendente que se apliquen en tan pocas ocasiones y que, en consecuencia, la inversión se determine "mediante suposiciones y conjeturas" y no sobre la base de una medición pormenorizada en un marco analítico acreditado.

\section{La práctica de la evaluación económica}

Como en las demás áreas del conocimiento científico, hay una diferencia entre los principios de la evaluación económica y su práctica. Por tanto, al utilizar estudios sobre los aspectos económicos de las enfermedades y los accidentes profesionales, es esencial analizar las evaluaciones con cuidado. Los criterios para determinar su idoneidad fueron establecidos hace tiempo (p. ej., D rummond, Stoddart y Torrance 1987 y M aynard 1990). Alan Williams, pionero en esta tarea, elaboró hace más de dos décadas la siguiente relación de aspectos necesarios (Williams 1974):

- ¿Cuál es la pregunta concreta a la que se intentaba responder con el estudio?

- ¿Cuál es la pregunta a la que se ha respondido en realidad?

- ¿Cuáles son los objetivos supuestos de la actividad estudiada?

- ¿M ediante qué medidas se representan éstos?

- ¿Cómo están ponderadas?

- ¿N os permiten establecer si los objetivos se están alcanzando?

- ¿Q ué gama de opciones se consideraron?

- ¿Q ué otras opciones podrían haberse considerado?

- ¿Se rechazaron o ignoraron justificadamente?

- Su consideración, ¿habría cambiado probablemente los resultados?

- ¿Es probable que alguien que no ha sido considerado en el análisis se vea afectado?

- En tal caso, ¿por qué fue excluido?

- El concepto de coste, ¿es más amplio y profundo que el gasto del organismo de que se trate? 
- En caso contrario, ¿queda claro que dicho gasto engloba todos los recursos utilizados y representa con exactitud su valor si éstos se dedicaran a otros usos?

- En caso afirmativo, ise realizan las distinciones necesarias para incluir a todos los posibles beneficiarios y perjudicados, y se determina el coste de los recursos en función de su valor en su mejor uso alternativo?

- ¿Se tienen adecuadamente en cuenta las diferencias de calendario en las partidas de los flujos de costes y beneficios (p. ej., mediante el descuento) y, en tal caso, en qué proporción?

- En caso de incertidumbre o cuando existen márgenes de error conocidos, ¿se precisa el grado de sensibilidad del resultado con respecto a estos elementos?

- En líneas generales, ¿son los resultados lo suficientemente buenos para el trabajo en cuestión?

- ¿H ay alguien que lo haya hecho mejor?

H ay varias áreas de la evaluación económica en las que la práctica suele ser defectuosa. Por ejemplo, con relación a los dolores de espalda, que ocasionan grandes pérdidas a la sociedad por enfermedad relacionada con el trabajo, se discute sobre los diversos tratamientos disponibles y sus efectos. EI tratamiento "anticuado" de esta dolencia consiste en guardar reposo en la cama, mientras que el preferido en la actualidad se basa en la actividad y el ejercicio para eliminar la tensión muscular que genera el dolor (K laber M offett y cols. 1995). Las evaluaciones económicas deben basarse en el conocimiento clínico, y éste suele ser incierto. Por tanto, sin una estimación cuidadosa de la eficacia de los conocimientos de base, la realización de modelos sobre los efectos económicos de intervenciones alternativas puede resultar sesgada y confusa para los responsables de la toma de decisiones, como ocurre en el ámbito de la asistencia sanitaria (Freemantle y M aynard 1994).

$\mathrm{H}$ ay pocas evaluaciones económicas de alta calidad sobre inversiones en prevención encaminadas a reducir las enfermedades y los accidentes relacionados con el trabajo. Como sucede en el ámbito de la asistencia sanitaria en general, los estudios disponibles suelen ser de poca calidad ( $M$ ason y Drummond 1995). Por tanto, los usuarios deben mantenerse alerta. Las evaluaciones económicas son esenciales, pero las deficiencias en la práctica ordinaria son tales que los usuarios de esta ciencia deben ser capaces de evaluar críticamente la base de conocimientos disponible antes de comprometer los escasos recursos de la sociedad.

\section{ESTUDIO DE CASO:} INDUSTRIALIZACION Y PROBLEMAS DE SALUD EN EL TRABAJO EN CHINA

Su Zhi

Los agricultores chinos han logrado éxitos considerables en la industrialización rural y el desarrollo de empresas locales (Tabla 20.5). De hecho, para la población rural, estos procesos han constituido la oportunidad más importante de escapar de la pobreza con rapidez. Desde el decenio de 1970, más de 100 millones de agricultores han comenzado a trabajar en empresas locales, lo que representa una cifra de trabajadores superior a la de las plantillas de las empresas de propiedad estatal y propiedad colectiva municipal de entonces. Actualmente, uno de cada cinco trabajadores rurales desarrolla su actividad en una empresa local. De un 30 a un $60 \%$ de la renta neta personal media de la población rural procede de la riqueza generada por estas unidades. En 1992, el valor de su producción ascendía al $30,8 \%$ de la producción industrial nacional total. Se prevé que, en el año 2000, más de 140 millones de trabajadores agrarios excedentes (un $30 \%$ de la población activa rural estimada) trabajen en las empresas locales (Chen 1993; C hina D aily, 5 de enero de 1993).

Este rápido paso de la población activa agrícola al trabajo no agrario en las áreas rurales ha ejercido una fuerte presión sobre los recursos de los servicios de salud en el trabajo. La "Encuesta sobre necesidades del servicio de salud en el trabajo y contramedidas en las empresas locales" (ENSSTCEL), realizada en 30 distritos elegidos aleatoriamente de 13 provincias y 2 municipios

Tabla 20.5 - Desarrollo de las empresas locales en China.

$\begin{array}{lcc} & 1978 & 1991 \\ \text { Número de empresas (en millones) } & 1,52 & 19 \\ \text { Número de trabajadores (en millones) } & 28 & 96 \\ \text { Activos fijos (miles de millones de yuans) } & 22,96 & 338,56 \\ \text { Valor total de la producción (en miles de } & 49,5 & 1.162,1\end{array}$
millones de yuans)

Tabla 20.6 - La cobertura de los SST prestados a las empresas locales por las ESPE de distrito.

$\begin{array}{lrrr}\text { Temas } & \text { Empresas } & \begin{array}{l}\text { Empresas } \\ \text { cubiertas por } \\ \text { el SST }\end{array} & \% \\ & 7.716 & 106 & 1,37 \\ \begin{array}{l}\text { Inspección preventiva de salud y } \\ \text { seguridad en el trabajo }\end{array} & 55.461 & 19.767 & 35,64 \\ \begin{array}{l}\text { Revisión general de higiene industrial } \\ \text { Control de riesgos en el lugar de }\end{array} & 55.461 & 2.164 & 3,90 \\ \text { trabajo } & & & \\ \text { Exploración física de los trabajadores } & 55.461 & 1.494 & 2,69 \\ \text { Ayuda para establecer registros de } & 55.461 & 16.050 & 28,94\end{array}$

Tabla 20.7 - Tasas de conformidad relativas a seis riesgos planteados en los lugares de trabajo.

$\begin{array}{lrrrr}\text { Riesgos }^{1} & \text { Empresas } & \begin{array}{l}\text { Lugares de } \\ \text { trabajo } \\ \text { controlados }\end{array} & \begin{array}{l}\text { Lugares de } \\ \text { trabajo } \\ \text { satisfactorios }\end{array} & \begin{array}{l}\text { Tasa de } \\ \text { conformidad } \\ (\%)^{2}\end{array} \\ \text { Plomo } & 177 & 250 & 184 & 73,60 \\ \text { Derivados del benceno } & 542 & 793 & 677 & 85,37 \\ \text { Cromo } & 56 & 64 & 61 & 95,31 \\ \text { Polvo de sílice } & 589 & 1.338 & 98 & 7,31 \\ \text { Polvo de carbón } & 68 & 140 & 40 & 28,57 \\ \text { Polvo de amianto } & 6 & 12 & 0 & 0,00 \\ \text { Total } & 1.438 & 2.597 & 1.060 & 40.82\end{array}$

${ }^{1}$ No se encontró mercurio en las áreas seleccionadas para la muestra. 2 La tasa de conformidad en cuanto al ruido fue de $32.96 \%$; para mas informacion, vease el texto. 
Tabla 20.8 - Tasas detectables de enfermedades profesionales.

\begin{tabular}{|c|c|c|c|c|c|c|c|}
\hline \multirow[t]{2}{*}{ Enfermedades profesionales } & \multirow{2}{*}{$\begin{array}{l}\text { Personas } \\
\text { reconocidas } \\
\quad \text { № }\end{array}$} & \multicolumn{2}{|c|}{ Sin enfermedad } & \multicolumn{2}{|c|}{ Con enfermedad } & \multicolumn{2}{|c|}{ Presunta enfermedad } \\
\hline & & № & $\%$ & № & $\%$ & № & $\%$ \\
\hline Silicosis & 6.268 & 6.010 & 95,88 & 75 & 1,20 & 183 & 2,92 \\
\hline Neumoconiosis de los trabajadores del carbón & 1.653 & 1.582 & 95,70 & 18 & 1,09 & 53 & 3,21 \\
\hline Asbestosis & 87 & 66 & 75,86 & 3 & 3,45 & 18 & 20,69 \\
\hline Intoxicación crónica por plomo & 1.085 & 800 & 73,73 & 45 & 4,15 & 240 & 22,12 \\
\hline Intoxicación por benceno ${ }^{1}$ y derivados & 3.071 & 2.916 & 94,95 & 16 & 0,52 & 139 & 4,53 \\
\hline Intoxicación crónica por cromo & 330 & 293 & 88,79 & 37 & 11,21 & - & - \\
\hline Pérdida de audición inducida por el ruido & 6.453 & 4.289 & 66,47 & $633^{2}$ & 9,81 & $1.531^{3}$ & 23,73 \\
\hline Total & 18.947 & 15.956 & 84,21 & 827 & 4,36 & 2.164 & 11,42 \\
\hline
\end{tabular}

y organizada conjuntamente por el M inisterio de Salud Pública (MSP) y el M inisterio de Agricultura (MA) en 1990, puso de relieve que la mayoría de las empresas locales no habían prestado los servicios de salud en el trabajo básicos (M SP 1992). La cobertura de las cinco actividades ordinarias del servicio de salud en el trabajo realizadas por las instituciones de salud en el trabajo (IST) y las estaciones de salud y prevención de epidemias (ESPE) para dichas empresas era muy escasa, sólo entre el 1,37 y el 35,64 \% (Tabla 20.6). L os servicios que requerían la aplicación de técnicas complejas o la participación de profesionales de salud del trabajo capacitados eran especialmente limitados. Por ejemplo, la inspección preventiva de la salud en el trabajo, el reconocimiento físico de los trabajadores expuestos a riesgos y el control en el lugar de trabajo eran sin duda insuficientes.

A demás, existe una tendencia al agravamiento de los problemas de salud en el trabajo en las empresas rurales. Así, la encuesta reveló que un $82,7 \%$ de las empresas industriales rurales registraban al menos un tipo de riesgo profesional en el lugar de trabajo. Un 33,9 \% de los trabajadores manuales estaban expuestos, como mínimo, a una forma de riesgo. Las tomas de muestras de plomo, benceno y derivados, del cromo, polvo de sílice y polvo de amianto en el aire realizadas en 2.597 lugares de trabajo de 1.438 empresas indicaron que la tasa total de cumplimiento era del $40,82 \%$ (Tabla 20.7). Las tasas de conformidad con respecto a los niveles de polvo eran muy bajas: 7,31 \% en el caso de la sílice, $28,57 \%$ en el del carbón y $0,00 \%$ en el del amianto. La tasa total de conformidad en cuanto al ruido analizada en 1.155 empresas era del 32,96\%. Se realizaron reconocimientos físicos de los trabajadores expuestos a más de siete tipos de riesgos (Tabla 20.8).

L a frecuencia total de enfermedades profesionales causadas por la exposición a estos siete tipos era del 4,36 \%, un porcentaje muy superior a la frecuencia de todas las enfermedades profesionales indemnizables registradas en las empresas públicas. De un $11,42 \%$ de los trabajadores expuestos se sospechaba que podían padecer también estas enfermedades. Posteriormente, las industrias peligrosas han seguido trasladándose de las áreas urbanas a las rurales y de las empresas públicas a las locales. La mayoría de los trabajadores que desarrollan su actividad en estas industrias fueron agricultores antes de ingresar en sus plantillas y carecen de formación. Incluso los propietarios y los directivos tienen un nivel de educación muy limitado.

En un estudio sobre 29.000 empresas locales se observó que el $78 \%$ de los empresarios y directivos sólo habían realizado estudios de enseñanza secundaria o primaria y que algunos de ellos eran sencillamente analfabetos (Tabla 20.9). Un $60 \%$ de los empresarios y directivos desconocen los requisitos de salud en el trabajo impuestos por la Administración. En el estudio se preveía que la frecuencia de las enfermedades profesionales en las empresas rurales aumentaría y alcanzaría un nivel máximo en el año 2000.

Tabla 20.9 - Distribución de actividades laborales peligrosas y educación de los directivos.

\begin{tabular}{|c|c|c|c|c|c|c|}
\hline $\begin{array}{l}\text { Educación de los } \\
\text { directivos }\end{array}$ & $\begin{array}{l}\text { № total de } \\
\text { empresas } \\
\text { (1) }\end{array}$ & $\begin{array}{l}\text { Empresas con } \\
\text { actividades peligrosas } \\
\text { (2) }\end{array}$ & $\begin{array}{l}\text { Trabajadores } \\
\text { manuales } \\
\text { (3) }\end{array}$ & $\begin{array}{l}\text { Trabajadores } \\
\text { expuestos } \\
\text { (4) }\end{array}$ & $\begin{array}{l}\text { Empresas } \\
\text { peligrosas (\%) } \\
(2) /(1)\end{array}$ & $\begin{array}{l}\text { Trabajadores } \\
\text { expuestos }(\%) \\
\text { (4)/(3) }\end{array}$ \\
\hline Analfabetismo & 239 & 214 & 8.660 & 3.626 & 89,54 & 41,87 \\
\hline Enseñanza primaria & 6.211 & 5.159 & 266.814 & 106.076 & 83,06 & 39,76 \\
\hline Enseñanza presecundaria & 16.392 & 13.456 & 978.638 & 338.450 & 82,09 & 34,58 \\
\hline Enseñanza técnica secundaria & 582 & 486 & 58.849 & 18.107 & 83,51 & 30,77 \\
\hline Enseñanza postsecundaria & 5.180 & 4.324 & 405.194 & 119.823 & 83,47 & 29,57 \\
\hline Universidad & 642 & 544 & 74.750 & 21.840 & 84,74 & 29,22 \\
\hline Total & 29.246 & 24.183 & 1.792 .905 & 607.922 & 82,69 & 33,91 \\
\hline
\end{tabular}




\section{El reto de la migración generalizada de la población activa}

En 1992, la población activa en China estaba constituida por 594,32 millones de personas, de los que un $73,7 \%$ eran clasificados como trabajadores rurales (O ficina Nacional de Estadística 1993). Un tercio de los 440 millones de trabajadores rurales del país se encuentran actualmente en situación de desempleo (C hina Daily, 7 de diciembre de 1993). El enorme excedente de mano de obra, que ha superado con creces la demanda de empleo disponible en las empresas locales, se desplaza a las áreas urbanas. EI desplazamiento masivo de agricultores a las ciudades en los últimos años, especialmente acusado desde el comienzo del decenio de 1990, constituye el gran reto a que se enfrentan las administraciones central y locales. Por ejemplo, en el primer semestre de 1991, sólo 200.000 agricultores abandonaron sus localidades de procedencia en Jiangxi, mientras que en 1993, fueron más de 3 millones los que emigraron, lo que representa una quinta parte de los trabajadores rurales de esta provincia (China D aily, 25 de noviembre de 1993). A demás, unos 20 millones de jóvenes alcanzan cada año la edad legal para trabajar en el país (O ficina N acional de E stadística 1993) D ebido a la urbanización generalizada y la amplia apertura al mundo exterior, que atrae la inversión extranjera, se han creado más oportunidades para los trabajadores rurales migrantes. Estas personas desarrollan un gran número de actividades en las ciudades en los sectores industrial, obras públicas, el transporte, el comercio, los servicios y la mayoría de tareas de alto riesgo o peligrosas que la población urbana rechaza. Estos trabajadores tienen el mismo contexto personal que los que integran las plantillas de las empresas rurales locales y se enfrentan a problemas de salud en el trabajo semejantes. A demás, por su movilidad, es difícil hacerles un seguimiento y las empresas pueden obviar con facilidad el cumplimiento de sus responsabilidades respecto de la salud de su personal. Por otra parte, estos trabajadores a menudo se dedican a varias actividades en las que el riesgo para la salud debido a exposiciones peligrosas puede ser elevado y es difícil facilitarles el acceso a los servicios de salud en el trabajo. Estas condiciones agravan la situación.

\section{Los problemas de salud en el trabajo en las empresas financiadas con capital extranjero}

Actualmente, hay más de 10 millones de trabajadores nacionales empleados en más de 70.000 empresas financiadas con capital extranjero. Las políticas preferenciales encaminadas a fomentar la inversión exterior, la abundancia de recursos naturales y el bajo coste de la mano de obra atraen a un número de inversores cada vez mayor. La Comisión de Planificación Estatal del Consejo de Estado ha decidido reducir el número de exámenes administrativos impuestos a los solicitantes. Se ha facultado a las administraciones locales para aprobar proyectos de inversión. La decisión relativa a los que requieren una financiación inferior a 30 millones de dólares puede ser adoptada por las autoridades locales, previo registro en la Comisión de Planificación Estatal, y se anima a las empresas extranjeras a licitar por estos proyectos (China D aily, 18 de mayo de 1994). O bviamente, las empresas de financiación extranjera también resultan muy atractivas para muchos trabajadores chinos, sobre todo por la posibilidad de obtener salarios superiores.

Con el fomento de la inversión extranjera, se han instalado en el país empresas peligrosas. El M inisterio de Salud Pública y otros organismos afines han mostrado su preocupación por la salud laboral de los trabajadores en estos sectores. Algunos estudios locales han puesto de manifiesto la magnitud del problema, que se concreta en un elevado nivel de exposición a riesgos laborales, largas jornadas de trabajo, condiciones de trabajo deficientes, dificultades especiales para las trabajadoras, falta de medios de protección personal adecuados, carencia de reconocimientos médicos y de formación, inexistencia de seguros de enfermedad, despido del personal afectado por enfermedades profesionales, etc.

La incidencia de accidentes por intoxicación con sustancias químicas ha aumentado en los últimos años. De acuerdo con los datos del Instituto Provincial de G uangdong para la Prevención y el Tratamiento de las Enfermedades Profesionales, en 1992 se registraron simultáneamente dos accidentes de intoxicación por disolventes en dos fábricas de juguetes financiadas con capital extranjero en la zona económica especial de Zhuhai, que afectaron a 23 trabajadores. De éstos, 4 personas resultaron intoxicadas por 1,2-dicloroetano, de las que 3 fallecieron, y 19 fueron expuestas a benceno y derivados (xileno y tolueno). Estos trabajadores llevaban en las fábricas menos de un año, y algunos sólo 20 días (H ospital Provincial de Guandong para la Prevención y el Tratamiento de las Enfermedades Profesionales 1992). En ese mismo año, se registraron dos accidentes por intoxicación en Dalian City, provincia de Liaoning, que afectaron, respectivamente, a 42 y 1.053 trabajadores (Instituto de Prevención y Tratamiento de las Enfermedades Profesionales de $D$ alian) en la Tabla 20.10 se muestran algunos datos relativos a la salud en el trabajo en tres zonas económicas especiales (ZEE) de Guangdong y en el Area de Desarrollo Económico y Tecnológico de Dalian analizadas por IST y ESPE locales (Instituto de Prevención y Tratamiento de las Enfermedades Profesionales de Dalian 1992b).

Los propietarios de las empresas de financiación extranjera, y en especial los de los pequeños centros de producción industrial, hacen caso omiso de la normativa pública relativa a los derechos y a la salud y la seguridad de los trabajadores. Sólo una

Tabla 20.10 - Datos generales sobre la salud en el trabajo en las empresas de financiación extranjera.

\begin{tabular}{|c|c|c|c|c|c|c|c|}
\hline \multirow[t]{2}{*}{ Area } & \multirow[t]{2}{*}{$\begin{array}{l}\text { № de } \\
\text { empresas }\end{array}$} & \multirow[t]{2}{*}{$\begin{array}{l}\text { №de } \\
\text { trabajadores }\end{array}$} & \multirow[t]{2}{*}{$\begin{array}{l}\text { Empresas con } \\
\text { peligros en } \\
\text { el trabajo (\%) }\end{array}$} & \multirow[t]{2}{*}{$\begin{array}{l}\text { Trabajadores } \\
\text { expuestos } \\
(\%)\end{array}$} & \multirow[t]{2}{*}{$\begin{array}{l}\text { Empresas que } \\
\text { disponen de una } \\
\text { OSST }^{1}(\%)\end{array}$} & \multicolumn{2}{|c|}{$\begin{array}{l}\text { Empresas que realizan exploraciones } \\
\text { de salud }(\%)\end{array}$} \\
\hline & & & & & & Periódicas & Previas a la contratación \\
\hline Guangdong $^{2}$ & 657 & 69.996 & 86,9 & 17,9 & 29,3 & 19,6 & 31,2 \\
\hline Dalian 3 & 72 & 16.895 & 84,7 & 26,9 & 19,4 & 0,0 & 0,0 \\
\hline
\end{tabular}

1 Cualquier forma de organización de salud y seguridad en el trabajo planificada; por ejemplo, consultas, comité de SST, etc. 2 El estudio de 1992 fue realizado en tres zonas económicas especiales (ZEE): Shenzhen, Zhuhai y Shantou. ${ }^{3}$ La encuesta de 1991 se llevó a cabo en el Area de Desarrollo Económico y Tecnológico de Dalian. 
proporción de trabajadores que oscila entre el 19,2 y el $31,2 \%$ de los trabajadores en las tres ZEE de Guangdong pueden someterse a reconocimientos médicos (véase la Tabla 20.10). U n 49,2 \% de las empresas no suministra equipos de protección personal a los trabajadores expuestos y sólo el $45,4 \%$ ofrece subsidios por exposición a riesgos en el trabajo (China D aily, 26 de noviembre de 1993). En Dalian, la situación es aún peor. En otro estudio realizado por el Sindicato Provincial de Guangdong en 1993, se indica que más del $61 \%$ de los trabajadores realizan jornadas semanales de más de seis días (C hina D aily, 26 de noviembre de 1993).

Las trabajadoras padecen condiciones de trabajo aún más deficientes, según un informe publicado en junio por la Confederación de Sindicatos de China (ACFT U). U na encuesta realizada bajo la dirección de esta entidad en 1991 y 1992 en 914 empresas de financiación extranjera, puso de manifiesto que un $50,4 \%$ de los 160.000 trabajadores que componían las plantillas eran mujeres. Esta proporción es superior en algunas zonas en los últimos años. M uchas empresas extranjeras no habían celebrado contratos con sus trabajadores y algunas fábricas admitían y despedían trabajadoras a voluntad. Ciertos inversores exteriores sólo daban trabajo a solteras con edades comprendidas entre 18 y 25 años, a las que despedían si se casaban o quedaban embarazadas. Además, muchas mujeres fueron obligadas con frecuencia a trabajar horas extraordinarias sin recibir remuneración adicional a cambio. En una fábrica de juguetes de Guangzhou, capital de la provincia Guangdong, los trabajadores, en su mayoría mujeres, tenían que realizar jornadas de 15 horas diarias. $\mathrm{N}$ i siquiera se les concedían los domingos libres o vacaciones anuales (China D aily, 6 de julio de 1994). No se trata de un caso aislado. Aún no se han difundido datos pormenorizados sobre el estado de salud de los trabajadores de las empresas de financiación extranjera. No obstante, de lo referido anteriormente se deduce la gravedad del problema.

\section{N uevos problemas en las empresas públicas}

Para cumplir los requisitos de una economía de mercado, las empresas públicas, y en especial las grandes y medianas, deben transformar su funcionamiento tradicional y establecer un sistema empresarial moderno, que permita definir con claridad los derechos de propiedad y los derechos y responsabilidades de las empresas y que impulse el acceso de las empresas públicas al mercado, con el fin de aumentar su vitalidad y eficiencia. A lgunas pequeñas empresas públicas pueden ser arrendadas o vendidas a colectivos y personas. Las reformas deben alcanzar a todos los aspectos de la actividad, incluidos los programas de salud en el trabajo.

A ctualmente, las pérdidas constituyen un problema grave al que se enfrentan muchas empresas públicas. Cerca de un tercio de éstas se encuentran en situación deficitaria. Las razones son diversas. En primer lugar, deben soportar una carga fiscal y financiera elevada para hacerse cargo de un enorme contingente de jubilados y ofrecer prestaciones sociales a los trabajadores en activo. En segundo lugar, el gran excedente de personal, del 20 al $30 \%$ como media en cada empresa, no puede integrarse en el sistema de seguridad social existente, caracterizado por su fragilidad. En tercer lugar, el sistema de gestión, anticuado, se diseñó para funcionar en la economía planificada tradicional. Por último, las empresas públicas carecen de ventajas competitivas derivadas de la formulación de políticas respecto a las empresas de financiación extranjera (China D aily, 7 de abril de 1994).

En estas circunstancias, la salud en el trabajo en las empresas públicas tiende a debilitarse inevitablemente. En primer lugar, el apoyo económico a los programas de salud se ha reducido en algunas empresas, y las instituciones médicas o sanitarias
Tabla 20.11 - Instrumentos ordinarios en materia de salud en el trabajo en las ESPE de 28 distritos chinos en 1990.

$\begin{array}{lccc}\text { Instrumentos } & \begin{array}{l}\text { Número de } \\ \text { instrumentos }\end{array} & \begin{array}{l}\text { Número de } \\ \text { instrumentos } \\ \text { exigidos por } \\ \text { norma }\end{array} \\ \text { Porcentaje } \\ \text { Aparato de muestreo de aire } & 80 & 140 & 57,14 \\ \text { Aparato de muestreo en personas } & 45 & 1.120 & 4,02 \\ \text { Aparato de muestreo de polvo } & 87 & 224 & 38,84 \\ \text { Detector de ruido } & 38 & 28 & 135,71 \\ \text { Detector de vibraciones } & 2 & 56 & 3,57 \\ \text { Detector de radiación térmica } & 31 & 28 & 110,71 \\ \text { Espectrofotómetro (Tipo 721) } & 38 & 28 & 135,71 \\ \text { Espectrofotómetro (Tipo 751) } & 10 & 28 & 35,71 \\ \text { Detector de mercurio } & 20 & 28 & 71,43 \\ \text { Cromatógrafo de gases } & 22 & 28 & 78,57 \\ \text { Báscula (1/ 10,000 g) } & 31 & 28 & 110,71 \\ \text { Electrocardiógrafo } & 25 & 28 & 89,29 \\ \text { Prueba de la función pulmonar } & 7 & 28 & 25,00 \\ \text { Total } & 436 & 1.820 & 23,96\end{array}$

integradas en las empresas, que solían ofrecer asistencia sanitaria únicamente a las plantillas de éstas, comienzan a ser accesibles a la comunidad en general. En segundo lugar, algunos servicios de salud integrados empiezan a desvincularse de las empresas en el marco de un esfuerzo por reducir los costes soportados por las empresas públicas. Antes de que se adoptara el nuevo sistema de seguridad social, despertaba cierta inquietud también la posibilidad de que la financiación de los programas internos de salud en el trabajo se viese afectada. En tercer lugar, gran parte de la tecnología y los equipos anticuados funcionan desde hace décadas, habitualmente con niveles elevados de emisiones peligrosas, y no pueden mejorarse o sustituirse en un período de tiempo breve. M ás del $30 \%$ de los lugares de trabajo de las empresas públicas estatales o municipales no cumplen con las normas nacionales de higiene (MAC O MAI). En cuarto lugar, la aplicación de la normativa sobre salud en el trabajo se ha debilitado en los últimos años; obviamente, una de las razones de esta situación es la incompatibilidad entre el antiguo sistema de gestión en esta materia, característico de la época de la planificación central, y la nueva situación de reforma empresarial. En quinto lugar, con el fin de reducir el coste de la mano de obra y ofrecer un mayor número de oportunidades de empleo, la contratación de trabajadores estacionales o temporales, en su mayoría emigrantes de las áreas rurales, asignados a tareas peligrosas en empresas públicas se ha convertido en un fenómeno habitual. M uchos de ellos ni siquiera pueden obtener el equipo de protección personal más simple, ni reciben de sus empresas formación alguna en materia de seguridad. Esta situación sigue constituyendo una amenaza potencial para la salud de la población activa de C hina.

\section{Problemas del Sistema de Servicios de Salud en el Trabajo}

L a cobertura de los servicios de salud en el trabajo no es suficientemente amplia. Como ya se ha mencionado, sólo el $20 \%$ de los trabajadores (en su mayoría pertenecientes a empresas públicas) 
expuestos a riesgos pueden someterse a reconocimientos médicos periódicos. Las razones que explican esta deficiencia son las siguientes:

En primer lugar, la falta de recursos de los servicios de salud en el trabajo constituye uno de los factores principales. Así ocurre especialmente en las industrias rurales, que carecen de capacidad para prestar tales servicios por sí solas. L os datos de la ENSSTCEL han puesto de manifiesto la existencia de 235 profesionales de la salud en el trabajo en las ESPE en los 30 distritos elegidos aleatoriamente para la encuesta. Estos tienen que prestar sus servicios a 170.163 empresas con 3.204 .576 trabajadores (M SP 1992). Así, a cada uno de estos profesionales a tiempo completo le corresponde una media de 1.115 empresas y 20.945 trabajadores. De la encuesta de 1989 también se deduce que los gastos sanitarios de las 30 administraciones locales representaban únicamente un 3,06 \% de los gastos totales. $L$ as cantidades dedicadas a las inspecciones sanitarias y la prevención de la salud sólo absorbían un 8,36 \% de los gastos sanitarios totales de estas administraciones. La proporción asignada específicamente a los servicios de salud en el trabajo era aún más reducida. La falta de equipos básicos para la prestación de estos servicios es un problema fundamental en los distritos analizados. La disponibilidad media de 13 categorías de equipos en 28 de los 30 distritos sólo alcanzaba el $24 \%$ de la cifra establecida en la normativa nacional (T abla 20.11).

En segundo lugar, la limitada utilización de los servicios de salud en el trabajo existentes es otro de los factores que deben considerarse. La escasez de recursos, por una parte, y el uso insuficiente, por otra, constituyen los problemas esenciales del servicio de salud en el trabajo de China en la actualidad. Incluso a escalas superiores, por ejemplo, en las IST provinciales, los equipos siguen sin funcionar a pleno rendimiento. Las razones de esta situación son complejas. Tradicionalmente, los servicios de salud en el trabajo y otros de carácter médico preventivo eran financiados y mantenidos por la Administración, incluidos los salarios de los trabajadores sanitarios, los equipos y edificios, los gastos generales, etc.. Todos los servicios de salud en el trabajo prestados por las IST públicas eran gratuitos. Con la rápida industrialización y la reforma económica iniciadas en 1979, las necesidades de la sociedad respecto de esos servicios han aumentado y el coste de su prestación también ha crecido vertiginosamente, lo que refleja una subida en el índice de precios. No obstante, los presupuestos de las IST, financiados por la Administración, no han aumentado para adaptarse a sus nuevas demandas. Cuantos más servicios prestan las IST, más financiación requieren. Con el fin de promover el desarrollo de los servicios de salud pública y satisfacer unas necesidades sociales cada vez mayores, la Administración central ha instituido la política de permitir que el sector de la salud pública subvencione pagos por servicios, y se han adoptado disposiciones con el fin de controlar el precio de los servicios de salud. Debido a la debilidad de la legislación sobre prestación de servicios de salud en el trabajo en las empresas, las IST se enfrentan con dificultades para mantenerse mediante el cobro de servicios.

\section{0 tras consideraciones relativas a la formulación de políticas y tendencias en los servicios de salud en el trabajo}

Sin lugar a dudas, el servicio de salud en el trabajo es una de las cuestiones más importantes en un país en desarrollo como China, inmerso en un proceso de rápida modernización y con un enorme número de trabajadores. Además de afrontar estos retos, el país acoge favorablemente las grandes oportunidades que surgen de las reformas sociales actuales. Muchas experiencias de éxito recopiladas en el ámbito internacional pueden utilizarse como referencia. Con su amplia apertura al exterior, China demuestra en la actualidad su disposición activa a adoptar tecnologías e ideas avanzadas en materia de gestión de la salud en el trabajo procedentes del resto del mundo.

\section{Referencias}

Aksoy, M, S Erdem, G Dincol. 1974. Leukaemia in shoe-workers chronically exposed to benzene. Blood 44:837.

Banco M undial. 1993. W orld D evelopment Report 1993: Investing in $\mathrm{H}$ ealth. O xford: O U P.

Bruno, K. 1994. Guidelines for environmental review of industrial projects evaluated by developing countries. En Screening Foreign Investments, dirigido por K Bruno. Penang, M alasia: Greenpeace, R ed del T ercer $M$ undo.

Castleman, B, V Navarro. 1987. International mobility of hazardous products, industries and wastes. Ann R ev Publ H ealth 8:1-19.

Castleman, BL, P Purkayastha. 1985. The Bhopal disaster as a case-study in double standards. A péndice en The Export of $\mathrm{H}$ azard, dirigido por $\mathrm{JH}$ Ives. Boston: R outledge \& K egan Paul.

Casto, KM, EP Ellison. 1996. ISO 14000: Origin, structure, and potential barriers to implementation. Int J Occup Environ $\mathrm{H}$ ealth 2 (2):99-124.

Centro de las Naciones U nidas sobre las Empresas Transnacionales (UNCTC). 1985. Environmental Aspects of the Activities of $T$ ransnational Corporations: A Survey. N ueva Y ork: N aciones U nidas.

Chen, Y B. 1993. D esarrollo y perspectivas de las empresas municipales en China. Recopilación de ponencias de Congreso Mundial de Pequeñas y Medianas Empresas. Pekín: Consejo Chino para la Promoción del Comercio Internacional.
China Daily. 1993. Rural industrial output breaks one trillion yuan mark. 5 de enero.

- .1993. City planned to take up surplus rural workplace. 25 de noviembre.

-.1993 . Discrimination against women still prevalent. 26 de noviembre.

- .1993. M apping new road to rural reforms. 7 de diciembre.

-.1994 . Tips to rejuvenate state enterprises. 7 de abril.

-.1994 . Foreign investors reap advantages of policy charges. 18 de mayo.

- .1994. The ripple effect of rural migration. 21 de mayo.

- .1994. U nion urges more women to close ranks. 6 de julio.

Colombo statement on occupational health in developing countries. 1986. J O ccup Safety, Austr NZ 2 (6):437-441.

Comisión M undial de M edio Ambiente y Desarrollo (WCED). 1987. O ur Common F uture. O xford: O U P.

Comisión de Salud y Medio Ambiente de la O rganización M undial de la Salud. 1992. Report of the Panel On Industry. G inebra: O M S.

Consejo Europeo de la Industria Química (CEFIC). 1991. CEFIC Guidelines On Transfer of T echnology (Safety, H ealth and Environmental Aspects). Bruselas: CEFIC.

Daly, HE, JB Cobb. 1994. For the Common Good: Redirecting the Economy Towards Community, the
Environment, and a Sustainable Future. 2- ed. Boston: Beacon Press.

Davies, NV, P T easdale. 1994. The Costs to the B ritish $\mathrm{E}$ conomy of W ork R elated III-H ealth. Londres: $\mathrm{H}$ ealth and Safety Executive, Her Majesty's Stationery O ffice.

Department of Community $\mathrm{H}$ ealth. 1980. Survey of health services available to light industry in the Newmarket area. A fifth-year medical student project. Auckland: Auckland School of M edicine.

Departamento de Inspección Sanitaria del M inisterio de Salud Pública 1992. Ministerio de Salud Pública: Informe general sobre las necesidades de servicios de medicina del trabajo y contramedidas para las industrias municipales. En R esultados de los estudios de las necesidades de servicios de medicina de trabajo y contramedidas, dirigido por X G K an. Pekín: Departamento de Educación de Inspección Sanitaria, M inisterio de Salud Pública.

Drummond, M F, GL Stoddart, GW T orrance. 1987. $M$ ethods for the $E$ conomic $E$ valuation of $H$ ealth Care Programmes. O xford: OUP.

Freemantle, N, A M aynard. 1994. Something rotten in the state of clinical and economic evaluations? $H$ ealth $E$ con 3:63-67.

Fuchs, V. 1974. Who Shall Live? Nueva York: Basic Books.

Glass, WI. 1982. O ccupational health in developing countries. Lessons for $\mathrm{New}$ Zealand. $\mathrm{N}$ ew Z ealand $H$ ealth R ev 2 (1):5-6. 
H ospital provincial de G uangdong para la prevención y tratamiento de enfermedades profesionales. 1992. Informe sobre la intoxicación profesional aguda en dos fábricas extranjeras en la zona económica especial de Zhuhai. Provincia de Guangdong, China: Instituto de Prevención y Tratamiento de Enfermedades Profesionales de la Provincia de Guangdong.

Hunter, WJ. 1992. EEC legislation in safety and health at work. Ann 0 ccup H yg 36:337-47.

Illman, DL. 1994. Environmentally benign chemistry aims for processes that don't pollute. Chem Eng N ews (5 de septiembre: 22-27.

Instituto de Prevención y Tratamiento de Enfermedades Profesionales de la Ciudad de Dalian. 1992a. Informe sobre la salud en el trabajo en la zona de desarrollo económico y tecnológico de Dalian. Ciudad de Dalian, Provincia de Liaoning, China: Instituto de Prevención y Tratamiento de Enfermedades Profesionales de la Ciudad de Dalian

-. 1992b. Informe sobre la incidencia de enfermedades de causa desconocida en los trabajadores de una empresa extranjera. Ciudad de Dalian, Provincia de Liaoning, China: Instituto de Prevención y Tratamiento de Enfermedades Profesionales de la Ciudad de Dalian.

Jaycock, MA, L Levin. 1984. Health hazards in a small automotive body repair shop. Am $\mathrm{O}$ ccup $\mathrm{H}$ yg 28 (1):19-29.

Jeyaratnam, J. 1992. Occupational $H$ ealth in Developing Countries. Oxford: OUP.

Jeyaratnam, J, KS Chia. 1994. O ccupational $\mathrm{H}$ ealth in National Development. Singapur: World Scientific Publishing.

K endrick, M , D Discher, D H oladay. 1968. Industrial hygiene survery of metropolitan Denver. Publ $H$ ealth R ep 38:317-322.

K ennedy, P. 1993. Preparing for the T wenty- $F$ irst $C$ entury. N ueva Y ork: R andom H ouse.

K laber M offett, 」, G Richardson, TA Sheldon, A M aynard. 1995. Back Pain: Its M anagement and Cost to Society. Discussion Paper, N o. 129. York, Reino Unido: Centre for $\mathrm{H}$ ealth Economics, Univ. de York

LaDou, J, BS Levy (dirs.). 1995. Special Issue: International issues in occupational health. Int J $\mathrm{O}$ ccup E nviron $\mathrm{H}$ ealth 1 (2).
Lees, REM, LP Zajac. 1981. O ccupational health and safety for small businesses. $\mathrm{O}$ ccup $\mathrm{H}$ ealth $\mathrm{O}$ ntario 23:138-145

Mason, I. M Drummond. 1995. The DH Register of Cost-E ffectiveness Studies: A R eview of Study Content and $Q$ uality. Discussion Paper, No. 128. Y ork, Reino Unido: Centre for $\mathrm{H}$ ealth Economics, Univ. de York

M aynard, A. 1990. The design of future cost-benefit studies. Am H eart ] 3 (2):761-765.

M CDonnell, R, A M aynard. 1985. The costs of alcohol misuse. Brit J Addict 80 (1):27-35.

O ficina Nacional de Estadística. 1993. Anuario de estadísticas nacionales de la República Popular de China. Pekín, China: $O$ ficina Nacional de Estadística.

O rganización Internacional del T rabajo (OIT). 1984. Safety and $\mathrm{H}$ ealth Practices of $\mathrm{M}$ ultinational Enterprises. Ginebra: OIT

Organización Mundial de la Salud (OMS). 1995. Global Strategy on $\mathrm{O}$ ccupational $\mathrm{H}$ ealth for All. Ginebra: OMS.

R antanan, J. 1993. Health protection and promotion of workers in small-scale enterprises. Borrador de documento de trabajo, Task Force Interregional de la OM S para la Protección y Promoción de la Salud de los Trabajadores en las Pequeñas Empresas.

Vihina, T, M Nurminen. 1983. Occurrence of chemical exposure in small industry in Southern Finland 1976. Publ H ealth R ep 27 (3):283-289.

Williams, A. 1974. The cost benefit approach. Brit $M$ ed Bull 30 (3):252-256.

W orld economy. 1992. E conomist 324 (7777):19-25.

\section{O tras lecturas recomendadas}

Barnet, RJ, J Cavanagh. 1994. Global D reams: Imperial Corporations and the New W orld Order. Nueva Y ork: Simon \& Schuster.

Cavanagh, J, J Gershman, K Baker, G H elmke. 1992. Trading F reedom: $H$ ow $F$ ree $T$ rade Affects O ur Lives, W ork and Environment. San Francisco: Institute for Food and Development Policy.

Centro de las $\mathrm{N}$ aciones U nidas sobre las Empresas T ansnacionales (UNCTC). 1988. T ransnational Corporations in W orld D evelopment: T rends and Prospects. $\mathrm{N}$ ueva $\mathrm{Y}$ ork: $\mathrm{N}$ aciones $U$ nidas.

Drache, D, H Galsbeek. 1992. T he Changing W orkplace. T oronto: James L orimer \& Co.
Fondo Internacional para la Educación y la Investigación sobre los Derechos de los T rabajadores (ILREF). 1988. Trade's H idden Costs: W orker Rights in a Changing W orld E conomy. Washington, DC: ILREF.

Grunwald, J, K Flamm. 1985. The Global Factory: F oreign A ssembly international T rade. Washington, DC: Brookings Institution.

Hecker, S. 1993a. Occupational health and safety policy in the European Community: A case-study of economic integration and social policy. Part 2 -The framework directive: Whither harmonization? N ew Directions (Fall):57-67.

-. 1993b. O ccupational health and safety policy in the European Community: A case-study of economic integration and social policy. Part I -Early initiatives through the Single European Act. $N$ ew D irections (verano):59-69.

Hecker, S, M Hallock. 1991. Labour in a Global E conomy. Eugene: Univ. of O regon Books.

H uman D evelopment R eport. 1991. O xford: O UP.

Hunter, WJ. 1992. EEC legislation in health and safety at work. Ann 0 ccup $\mathrm{H}$ yg 36:337-347.

K arasek, RA, T Theorell. 1990. H ealthy W ork, Stress, Productivity and the Reconstruction of W orking Life. Nueva Y ork: Basic Books.

K rugman, PR, M Obstfeld. 1991. International E conomics: Theory and Practice. Nueva Y ork: $\mathrm{H}$ arper Collins.

M archak, P. 1991. T he Integrated Circus: T he N ew Right and the Restructuring of Global M arkets. Montreal: M cG ill Q ueen's U niv. Press.

Occupational Health Services for Small-Scale Industries. Informe remitido por la Oficina R egional de la O rganización M undial de la Salud para el Pacífico O ccidental, M anila, Filipinas.

Schoepfle, GK, KA Swinnerton. 1994. International Labor Standards and Global Economic Integration: Proceedings of a Symposium. Washington: US Department of Labor, Bureau of International Labor Affairs.

Schor, J. 1992. T he O verw orked American: T he U nexpected $D$ ecline of $L$ essure. N ueva $Y$ ork: Basic Books.

van Liemt, G. 1992. Industry On the M ove: Causes and Consequences of International Relocation in the $M$ anufacturing Industry. Ginebra: O IT

Williams, A. 1985. Economics of coronary artery bypass grafting. BrM ed J 249:326-329. 



\section{RELACIONES LABORALES Y GESTION DE RECURSOS HUMANOS}

Directora del capítulo

Anne T rebilcock

\section{Sumario}

Relaciones laborales y gestión de recursos humanos:

visión general

Anne Trebilcock

Derechos de asociación y representación

$B$ reen C reighton ..

Negociación colectiva y salud y seguridad

M ichae J. W right .

Cooperación tripartita y bipartita a escala nacional en materia de salud y seguridad en el trabajo

R obert $H$ usbands .

Formas de participación de los trabajadores

$M$ uneto O zaki y Anne Trebilcock.

Consulta e información sobre salud y seguridad

$M$ arco Biagi

Aspectos de la formación vinculados a las relaciones laborales

$M$ e Doyle.

Aspectos de la inspección de trabajo vinculados a las relaciones laborales

M aría L uz Vega Ruiz . .

Conflictos colectivos por cuestiones de salud y seguridad

Shauna L. OIney . . . . . . . . . . . . . . . . . . . . . 21.34

Conflictos individuales por cuestiones de salud

y seguridad

Anne Trebilcock 


\section{- RELACIONES LABO RALES Y GESTION DE RECURSOS HUMANOS: VISION GENERAL}

\section{Anne Trebilcock}

\section{Relaciones laborales o industriales}

El término relaciones laborales (también se utiliza relaciones industriales), hace referencia al sistema en el que las empresas, los trabajadores y sus representantes y, directa o indirectamente, la Administración, interactúan con el fin de establecer las normas básicas que rigen las relaciones de trabajo. Asimismo, alude al campo de estudio dedicado al análisis de dichas relaciones. Su aparición es consecuencia de la revolución industrial, cuyos excesos dieron lugar a la creación de los sindicatos como medio de representación de los trabajadores y al desarrollo de las relaciones laborales colectivas. U n sistema de relaciones laborales 0 industriales refleja la interacción entre los principales actores que lo componen: el Estado, la empresa (empresas o asociaciones de empresas), los sindicatos y los trabajadores (que pueden participar o no en los sindicatos y otras entidades encargadas de su representación). Los términos "relaciones laborales" y "relaciones industriales" se emplean asimismo en relación con diversas formas de participación de los trabajadores; además, pueden referirse a las relaciones de empleo específicas establecidas entre una empresa y un trabajador en virtud de un contrato de trabajo escrito o implícito, si bien éstas suelen denominarse "relaciones de empleo". La variación en la utilización de los términos es considerable, lo que refleja en parte la evolución de este campo de estudio en el tiempo y en el espacio. No obstante, existe un acuerdo generalizado respecto a la consideración en el mismo de la negociación colectiva, las diversas formas de participación de los trabajadores (como los comités de empresa, y los comités conjuntos de salud y seguridad) y los mecanismos de resolución de conflictos colectivos e individuales. La amplia gama de sistemas de relaciones laborales existentes en el mundo ha dado lugar a la necesidad de matizar los estudios comparativos y de la identificación de tipos debida a las limitaciones del exceso de generalización y las analogías erróneas. Tradicionalmente, se han descrito cuatro tipos diferenciados de gestión del lugar de trabajo: dictatorial, paternalista, institucional y participativo. En este capítulo se analizan fundamentalmente los dos últimos.

En un sistema de relaciones laborales se ponen en juego simultáneamente intereses públicos y privados. EI Estado también participa y su papel puede ser pasivo o activo según el país en cuestión. El carácter de las relaciones entre los trabajadores organizados, las empresas y la Administración en lo que respecta a la salud y la seguridad es indicativo de la situación general de las relaciones laborales en un país o en un sector y viceversa. Los sistemas de relaciones laborales poco desarrollados suelen ser autoritarios y sus normas son dictadas por las empresas sin que el trabajador participe directa 0 indirectamente, salvo en lo que se refiere a la aceptación del empleo en las condiciones ofrecidas.

En un sistema de relaciones laborales se incorporan valores sociales (p. ej., libertad de asociación, sentido de la solidaridad de grupo, búsqueda de la optimización de beneficios) y técnicas (p. ej., métodos de negociación, organización del trabajo, consulta y resolución de conflictos). H istóricamente, los sistemas de relaciones laborales se han clasificado de acuerdo con categorías nacionales, pero la validez de este procedimiento es cada vez menor debido a la creciente diversidad de las prácticas de cada país y el auge de una economía de naturaleza más global impulsada por la competencia internacional. Algunos países se han caracterizado por el mantenimiento de modelos basados en la cooperación (p. ej., Alemania, Bélgica), mientras que otros son conocidos por su tendencia al conflicto (p. ej., Bangladesh, C anadá, Estados U nidos). A simismo, los diversos sistemas se han clasificado en función de su utilización de mecanismos de negociación colectiva centralizada (p. ej., los países nórdicos, aunque tienden actualmente a abandonar estos procedimientos, como sucede en el caso de Suecia), negociación a escala sectorial o industrial (como en Alemania), o negociación a escala de empresa o centro de trabajo (p. ej., Japón, Estados U nidos). En los países que han pasado de una economía de planificación a otra de libre mercado, dichos sistemas se encuentran en transición. Por otra parte, aumenta el número de estudios sobre las tipologías de las relaciones de empleo individuales como indicadores de los tipos de sistemas de relaciones laborales.

$\mathrm{Ni}$ aún las descripciones más clásicas de tales sistemas consisten en caracterizaciones estáticas, puesto que éstos cambian para adaptarse a las nuevas circunstancias económicas y políticas. La globalización de la economía de mercado, el debilitamiento del Estado como fuerza efectiva y el declive del poder sindical en numerosos países industrializados plantean desafíos importantes a los sistemas de relaciones laborales tradicionales. El desarrollo tecnológico ha provocado cambios en el contenido y la organización del trabajo que tienen una repercusión fundamental en la posibilidad de desarrollo de las relaciones laborales colectivas y en la dirección que adoptan éstas. La jornada de trabajo convencional y el lugar de trabajo común han ido cediendo el paso a la utilización de horarios más variados y a la realización de las tareas en diversos emplazamientos, incluido el domicilio propio, con una supervisión menos directa por parte de la empresa. Lo que se había denominado relaciones de empleo "atípicas" lo son cada vez menos a medida que la población activa afectada sigue ampliándose. Esta tendencia, a su vez, ejerce presión sobre los sistemas de relaciones laborales establecidos.

Las formas más recientes de representación y participación de los trabajadores crean una nueva orientación en la situación de las relaciones laborales en varios países. Un sistema de relaciones laborales establece las normas básicas formales e informales que determinan la naturaleza de las relaciones industriales colectivas, así como el marco de las relaciones de empleo individuales entre el trabajador y su empresa. La situación en el lado de la gestión se complica por la intervención de actores como las agencias de trabajo temporal y los contratistas de mano de obra y puestos de trabajo, que pueden tener responsabilidades respecto a los trabajadores sin tener el control del entorno físico en el que éstos desarrollan su actividad, ni la oportunidad de impartir formación sobre seguridad. Por otra parte, los trabajadores de los sectores público y privado se rigen por legislaciones específicas en la mayoría de los países, por lo que los derechos y las medidas de protección en cada sector suelen diferir significativamente. Además, el sector privado está influido por las fuerzas de la competencia internacional, que no afectan directamente a las relaciones laborales en el sector público.

Por último, la ideología neoliberal, que favorece la celebración de contratos de trabajo individualizados en detrimento de los acuerdos basados en la negociación colectiva, representa una amenaza adicional para los sistemas de relaciones laborales tradicionales. Estos se desarrollaron como resultado de la aparición de la representación colectiva de los trabajadores, debida a la experiencia acumulada de que el poder individual de un trabajador es débil comparado con el de la empresa. El abandono de toda forma de representación colectiva podría dar lugar a una vuelta al concepto propio del siglo XIX según el cual, la aceptación de un trabajo peligroso se consideraba en gran medida como una cuestión de libre elección personal. La 
globalización de la economía, el ritmo acelerado de cambio tecnológico y la consiguiente llamada a favor de una mayor flexibilidad por parte de las instituciones implicadas en las relaciones industriales plantean nuevos retos para su supervivencia y prosperidad. En función de las tradiciones y las instituciones existentes, las partes que intervienen en un sistema de relaciones laborales pueden reaccionar de modo diferente a las mismas presiones: por ejemplo, los directivos pueden optar por una estrategia basada en los costes o bien, otra relacionada con el valor añadido, al enfrentarse a un aumento de la competencia (L ocke, K ochan y Piore, 1995). Sin lugar a duda, la medida en la que la participación de los trabajadores y la negociación colectiva constituyan elementos ordinarios de los sistemas de relaciones laborales repercutirá en el modo en que el personal directivo aborda los problemas de salud y seguridad.

Por otra parte, hay una constante: la dependencia económica del trabajador respecto a la empresa sigue siendo el factor que subyace a su relación y tiene consecuencias importantes en lo que se refiere a la salud y la seguridad. Se considera que la empresa tiene el deber general de ofrecer un lugar de trabajo seguro y saludable y de formar y equipar a los trabajadores para que lleven a cabo su labor sin riesgos. EI trabajador tiene el deber recíproco de seguir las instrucciones de salud y seguridad y evitar dañarse a sí mismo o a los demás en el trabajo. El incumplimiento de estas u otras obligaciones puede generar conflictos que dependen del sistema de relaciones laborales para su resolución. Entre los mecanismos que facilitan ésta figuran las normas que rigen no sólo las interrupciones de la actividad (huelgas, en general, de celo o de trabajo lento) y los cierres patronales, sino también la disciplina y el despido de los trabajadores. Además, en muchos países se exige a las empresas que participen en diversas instituciones relacionadas con la salud y la seguridad, realicen un control de estas condiciones, informen de los accidentes de trabajo y las enfermedades profesionales e, indirectamente, indemnicen a los trabajadores que los padecen.

\section{Gestión de recursos humanos}

La gestión de recursos humanos se ha definido como "la ciencia y la práctica que se ocupan de la naturaleza de las relaciones de empleo y del conjunto de decisiones, acciones y cuestiones vinculadas a dichas relaciones" (Ferris, Rosen y Barnum 1995; véase la Figura 21.1). Aborda las políticas y las prácticas empresariales que consideran la utilización y la gestión de los trabajadores como un recurso de la actividad en el contexto de la estrategia general de la empresa encaminada a mejorar la productividad y la competitividad. Se trata de un término que suele describir el enfoque empresarial de la administración de personal basado en la prioridad concedida a la participación de los trabajadores, normalmente, aunque no siempre, en centros de trabajo sin presencia sindical, con el fin de motivarles para que aumenten su productividad. Esta área de estudio se formó sobre la base de la fusión de diversas teorías de la gestión científica, del trabajo social y de la psicología industrial en la época de la primera Guerra Mundial y ha experimentado una evolución considerable desde entonces. Actualmente, se centra en las técnicas de organización del trabajo, la contratación y la selección, la evaluación del rendimiento, la formación, la mejora de las cualificaciones y el desarrollo de la carrera profesional, así como la participación directa de los trabajadores y la comunicación. La gestión de recursos humanos se ha propuesto como alternativa al "fordismo", el tipo de producción tradicional basada en la cadena de montaje, en el que los ingenieros se ocupan de la organización del trabajo y las tareas asignadas al personal se dividen y circunscriben específicamente. Las formas habituales de participación de los trabajadores están representadas por los sistemas de planteamiento de sugerencias, las encuestas sobre actitud, los planes de enriquecimiento del puesto de trabajo, el trabajo en equipo y otros mecanismos de capacitación, la optimización de los programas relativos a la vida laboral y la creación de círculos de calidad y grupos de acción. 0 tra característica de la gestión de recursos humanos consiste en la vinculación de la remuneración, individual o colectiva, con el rendimiento. Cabe destacar que el Comité M ixto OIT/OM S sobre M edicina del Trabajo ha definido uno de los tres objetivos en materia de salud en el trabajo como "el desarrollo de las organizaciones y las culturas del trabajo en una dirección que favorezca la salud y la seguridad en este ámbito y, de este modo, fomente un clima social positivo y facilite el funcionamiento adecuado y la productividad de las empresas..." (OIT 1995b). Este objetivo representa el intento de desarrollar una "cultura de la seguridad".

El ejemplo de un programa de gestión del rendimiento en materia de seguridad ilustra algunas teorías sobre gestión de recursos humanos en el contexto de la salud y la seguridad en el trabajo. Como señalan Reber, Wallin y Duhon (1993), este enfoque ha tenido un éxito considerable al reducir el tiempo perdido a causa de los accidentes. Se basa en la especificación de comportamientos seguros e inseguros, la enseñanza a los trabajadores del modo de reconocerlos y la motivación del personal para que se atenga a las normas de seguridad mediante la fijación de objetivos y la retroinformación. Este tipo de programas se fundamentan en técnicas de formación consistentes en enseñar a los trabajadores métodos correctos y seguros mediante el vídeo o la escenificación en vivo. A continuación, se les brinda la oportunidad de practicar nuevos comportamientos y se les suministra con frecuencia retroinformación sobre su rendimiento. Además, algunas empresas ofrecen premios y otras compensaciones materiales por seguir un comportamiento seguro (y no simplemente por tener menos accidentes). La consulta con los trabajadores es otra de las características importantes de estos programas.

Las repercusiones de la gestión de recursos humanos en las prácticas de las relaciones industriales siguen constituyendo una fuente de polémica. Así ocurre especialmente en el caso de ciertas formas de participación de los trabajadores considerados por los sindicatos como una amenaza. En algunos casos, las estrategias de gestión de recursos humanos se establecen paralelamente a la negociación colectiva; en otros, se trata de sustituir 0 evitar con aquéllas las actividades de las organizaciones independientes de trabajadores que defienden sus intereses. Los partidarios de la gestión de recursos humanos señalan que, desde el decenio de 1970, la gestión de personal, uno de los campos de esta actividad, ha pasado de ser una función de mantenimiento, supeditada a la de las relaciones industriales, a adquirir una importancia fundamental para la eficacia de una organización (Ferris, Rosen y Barnum 1995). Puesto que la gestión de recursos humanos es una herramienta de la que disponen los directivos para aplicarla como parte de su política de personal y no un elemento de la relación entre una empresa y los representantes elegidos por los trabajadores, no es objeto de estudio en el presente capítulo.

En los artículos siguientes se describen las partes principales que intervienen en un sistema de relaciones laborales y los principios básicos que subyacen a su interacción: los derechos a la libertad de asociación y representación. Un corolario natural de esta primera libertad es el derecho a la negociación colectiva, un fenómeno que debe distinguirse de los sistemas consultivos y de participación de los trabajadores no sindicados. La negociación colectiva se establece entre los representantes elegidos por los trabajadores y los que actúan en nombre de la empresa y da lugar a la celebración de un acuerdo vinculante y mutuamente aceptado que puede cubrir una amplia gama de materias. 0 tras 


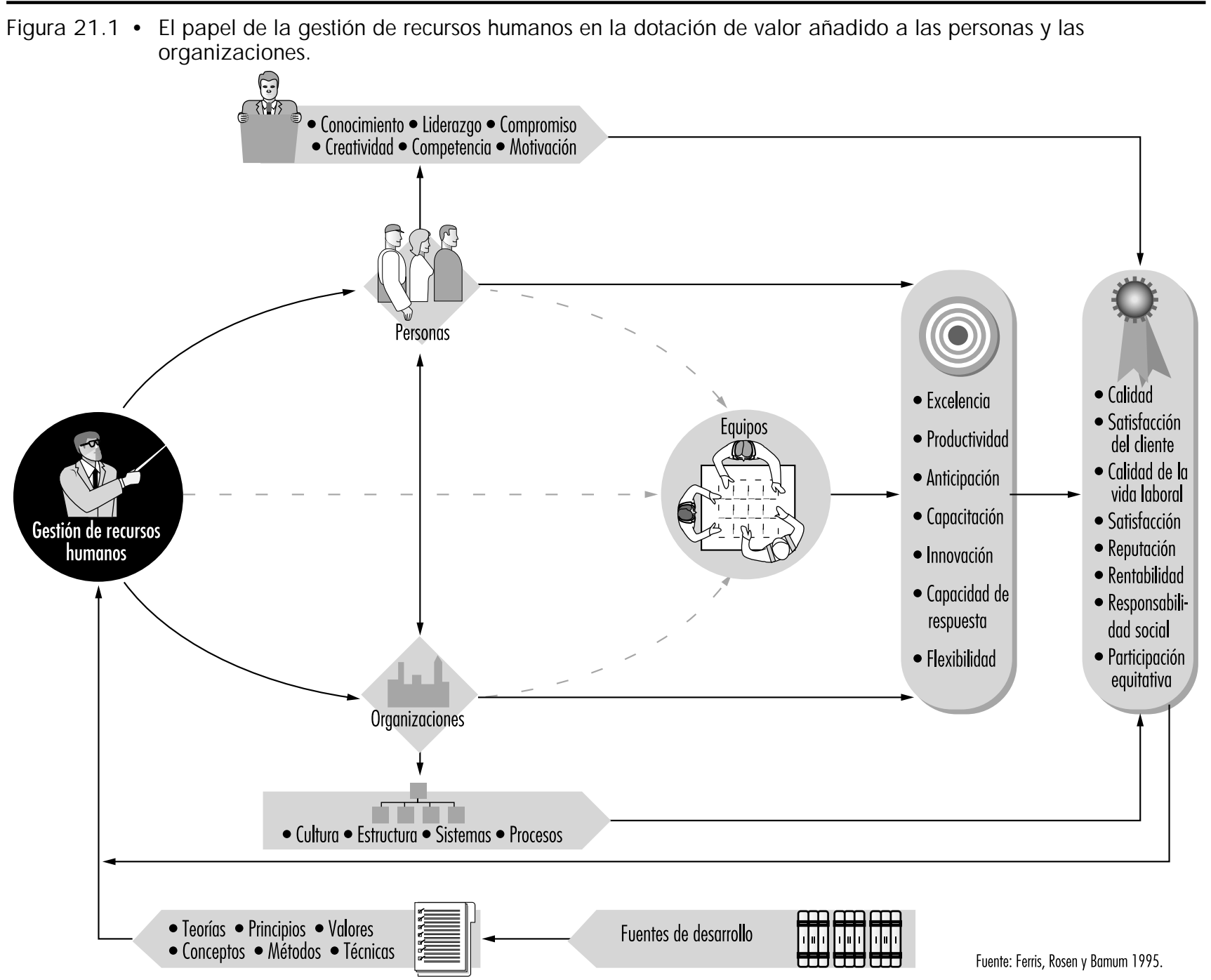

formas de participación de los trabajadores, los órganos consultivos a escala nacional, los comités de empresa y la representación de salud y seguridad en la empresa, constituyen asimismo elementos importantes de algunos sistemas de relaciones laborales y, por tanto, son analizados en el presente capítulo. La consulta puede adoptar diversas formas y realizarse a distintas escalas, en el marco de sistemas nacionales, regionales, sectoriales o de empresa. Los representantes de los trabajadores en los órganos consultivos pueden ser seleccionados por éstos, aunque no necesariamente, y el Estado y las empresas no están obligados a seguir sus indicaciones ni a atenerse a los resultados del proceso de consulta. En ciertos países, la negociación colectiva y los sistemas consultivos coexisten y, para funcionar adecuadamente, deben engranarse con cuidado. Para ambos, los derechos a la información sobre la salud y la seguridad y a la formación resultan esenciales. Por último, en el presente capítulo se tiene en cuenta que en cualquier sistema de relaciones laborales se plantean conflictos, ya sean individuales o colectivos. Las cuestiones de salud y seguridad pueden provocar disensiones en el ámbito laboral y, por tanto, suspensiones de la actividad. El capítulo concluye con un análisis del papel desempeñado por la inspección de trabajo en el ámbito de las relaciones laborales y la descripción de las formas de resolución de conflictos en dicho ámbito, como el arbitraje, la mediación o el recurso a los tribunales ordinarios o de trabajo
Protagonistas del sistema de relaciones laborales Tradicionalmente, se han definido tres partes integrantes del sistema de relaciones laborales: el Estado, las empresas y los representantes de los trabajadores. En este contexto deben incluirse otras fuerzas que trascienden a estas categorías: los sistemas de integración económica regionales y multilaterales a otra escala, establecidos entre $\mathrm{E}$ stados y empresas multinacionales como empleadores que carecen de identidad nacional, pero que pueden considerarse instituciones del mercado de trabajo. Puesto que la repercusión de estos fenómenos en las relaciones laborales sigue siendo poco claro en muchos aspectos, el análisis se centrará en los actores más clásicos, a pesar de la restricción que supone limitar el estudio en una comunidad cada vez más global. Además, es necesario prestar especial atención a la consideración del papel que desempeña la relación de empleo individual en el ámbito de los sistemas de relaciones laborales generales y el impacto de las nuevas formas de trabajo alternativas.

\section{El Estado}

EI Estado siempre ejerce un efecto al menos indirecto en las relaciones laborales. C omo fuente de legislación, constituye un factor inevitable en la aparición y el desarrollo de los sistemas que rigen aquéllas. Las leyes pueden dificultar o fomentar, directa o indirectamente, la creación de organizaciones representativas de los trabajadores y las empresas. Asimismo, establecen un nivel 
mínimo de protección de los trabajadores y estipulan "las reglas del juego". Por ejemplo, puede garantizarse una mayor o menor protección a los trabajadores que se niegan a llevar a cabo tareas que, razonablemente, consideran peligrosas en exceso, 0 a aquellos trabajadores que actúan como representantes en materia de salud y seguridad.

Mediante el desarrollo de una administración laboral, el Estado influye asimismo en el modo en que funcionan los sistemas de relaciones laborales. Si se asegura la aplicación efectiva de la legislación mediante la intervención de la inspección de trabajo, puede recurrirse a la negociación colectiva en los campos en los que la ley no se pronuncia. Si, por el contrario, la infraestructura del Estado, dedicada a la protección de los derechos y la ayuda a la resolución de conflictos entre empresas y trabajadores es débil, éstos actores tendrán que arreglárselas para desarrollar sus propias instituciones y mecanismos alternativos.

A simismo, la medida en que el Estado haya establecido unos tribunales eficaces u otros sistemas de resolución de conflictos, puede afectar al desarrollo de las relaciones laborales. La facilidad con la que trabajadores, empresas y sus respectivas organizaciones puedan ejercer sus derechos jurídicos puede ser tan importante como los propios derechos. Así, la decisión adoptada por un Gobierno de establecer órganos administrativos o tribunales especiales para abordar los conflictos laborales y los desacuerdos relativos a problemas de empleo individuales puede indicar la prioridad concedida a estas cuestiones en la sociedad.

En muchos países, el Estado desempeña un papel directo en las relaciones laborales. En aquellos en que no se respetan los principios de la libertad de asociación, esta intervención puede consistir en un control directo de las organizaciones de empresarios y trabajadores y la interferencia en sus actividades. EI Estado puede tratar de invalidar los acuerdos alcanzados por la vía de la negociación colectiva que considere contrarios a sus objetivos de política económica. No obstante, en general, el papel del Estado en los países industrializados ha consistido en el fomento de las relaciones industriales ordenadas, mediante el establecimiento del marco legislativo necesario, del que forman parte la fijación de niveles mínimos de protección al trabajador, la oferta de información a las partes, el asesoramiento y la prestación de servicios para la resolución de conflictos.

En algunos países, el Estado es un participante activo más en el sistema de relaciones industriales e interviene en las negociaciones nacionales tripartitas. Por ejemplo, en Bélgica durante décadas y, más recientemente en Irlanda, los representantes de la Administración se han reunido con los de las empresas y los sindicatos para concluir acuerdos o pactos nacionales sobre una amplia gama de cuestiones laborales y sociales. EI mecanismo tripartito de determinación de los salarios mínimos ha formado parte tradicionalmente del sistema de relaciones laborales en Argentina y M éxico. El interés del Estado en esta participación deriva de su deseo de lograr que la economía nacional evolucione en una dirección concreta y de mantener la paz social durante la vigencia de los pactos; estos acuerdos bipartitos y tripartitos crean lo que se ha denominado el "diálogo social", como en los casos de Australia (hasta 1994), Austria, Bélgica, I rlanda y Países Bajos, por ejemplo. Las ventajas y los inconvenientes de los enfoques "corporativistas" o "neocorporativistas" respecto a las relaciones laborales se han debatido ampliamente durante años. Con su estructura tripartita, la Organización Internacional del Trabajo ha defendido tradicionalmente una cooperación sólida a esa escala, en la que los "interlocutores sociales" desempeñen un papel significativo en la configuración de la política de la Administración pública relativa a numerosas cuestiones.

\section{Organizaciones internacionales de empresas}

Con sede en G inebra, Suiza, la 0 rganización Internacional de Empleadores (O IE) agrupaba en 1996 a 118 organizaciones nacionales de empresarios de 116 países. La forma exacta de las organizaciones miembro puede diferir de un país a otro, pero para poder optar al aceso a la 0 IE deben cumplir ciertas condiciones: han de ser la organización de empresas más representativa (exclusivamente de empresas) del país, ser voluntarias e independientes, estar libres de la injerencia extena y representar y defender los principios de la libre empresa. Entre los miembros figuran federaciones y confederaciones de empresas, cámaras de comercio e industria, consejos y asociaciones. Las organizaciones regionales o sectoriales no pueden ser miembros, ni las empresas, con independencia de su tamaño o importancia, pueden afiliarse directamente a la $0 \mathrm{IE}$, restricción que le ha permitido garantizar que sus opiniones sean representativas de la comunidad empresarial en general y no respondan a los intereses particulares de empresas o sectores específicos.

$\mathrm{N} 0$ obstante, la actividad principal de la $\mathrm{O} \mathrm{IE}$ consiste en organizar a las empresas siempre que tengan que abordar cuestiones sociales y laborales a escala global. En la práctica, la mayor parte de esta acción tiene lugar en la 0 IT, que es responsable de tales cuestiones en el sistema de las $\mathrm{N}$ aciones Unidas. Asimismo, la O IE ocupa una posición consultiva de categoría I en el Consejo Económico y Social de las $\mathrm{N}$ aciones Unidas, en el que interviene cuando se plantean asuntos de interés que afectan a las empresas.

La O IE es una de las dos únicas organizaciones que la comunidad empresarial ha establecido para representar sus intereses a escala mundial. La otra es la Camara de Comercio Internacional, con sede principal en París, que se ocupa fundamentalmente de cuestiones económicas. Aunque su estructura es bastante diferente, las dos organizaciones se complementan entre sí. Cooperan en función de un acuerdo que define sus áreas de responsabilidad, de las buenas relaciones personales que mantienen sus representantes $y$, en cierta medida, de una base de afiliados común. O bviamente, muchas cuestiones son objeto simultáneamente de sus mandatos, pero se abordan de manera pragmática evitando las fricciones. En ciertos aspectos, como el de las empresas multinacionales, las dos organizaciones incluso actúan al unísono.

\section{por la directora del capítulo} (extraído de: OIT 1994)

En algunos países, como Alemania y Estados U nidos, la idea misma de que el Estado participe en la negociación del sector privado es inconcebible. En este tipo de sistema, el papel que desempeña el Estado, aparte de su función legislativa, está por lo general restringido a proporcionar ayuda para que las partes lleguen a un acuerdo, como proporcionar servicios voluntarios de mediación. Pasivo o activo, el Estado es en cualquier sistema de relaciones laborales un socio permanente. Además, cuando el mismo Estado es la empresa, o cuando la empresa es propiedad pública, participa directamente en las relaciones laborales con los empresarios y sus representantes. En tales circunstancias, el Estado cumple su papel de proveedor de servicios públicos y/ 0 de protagonista económico.

Para finalizar, el impacto de los acuerdos de integración económica regionales en la política estatal también hace que se resienta el ámbito de las relaciones laborales. En la U nión Europea, la práctica en los Estados miembros ha variado para reflejar las directivas relativas a la consulta con los trabajadores 
y sus representantes, incluidos los que se ocupan en concreto de la salud y la seguridad. Los acuerdos comerciales multilaterales, como el acuerdo laboral incluido en el Tratado de Libre Comercio de América del Norte (Canadá, Estados U nidos y M éxico) o los constitutivos del mercado común de M ercosur (A rgentina, Brasil, C hile, Paraguay; se prevé la incorporación en breve de Bolivia y Chile) también contienen en ocasiones mecanismos y disposiciones relativas a los derechos de los trabajadores que pueden tener con el tiempo una repercusión indirecta en los sistemas de relaciones laborales de los países miembros.

\section{Empresas}

Las empresas (es decir, los oferentes de trabajo) suelen diferenciarse en los sistemas de relaciones laborales en función de su pertenencia a los sectores público o privado. H istóricamente, el sindicalismo y la negociación colectiva se desarrollaron primero en el sector privado, pero en los últimos años, este fenómeno se ha extendido también a muchos centros de trabajo del sector público. La posición de las empresas de propiedad estatal (cuyo número, en cualquier caso, se reduce en todo el mundo) como oferentes de empleo varía en función del país. (Siguen desempeñando un papel fundamental en China, La India, Vietnam y muchos países africanos.) En Europa central y oriental, uno de los mayores retos de la era postcomunista ha consistido en la creación de organizaciones independientes de empresas.

En el sector privado, la situación puede resumirse como sigue:

Las empresas tienen intereses comunes que defender y causas precisas que propugnar. Al organizarse, persiguen varios objetivos que, a su vez, determinan el carácter de sus organizaciones. Estas pueden adoptar la forma de cámaras de comercios, federaciones económicas y organizaciones empresariales (para las cuestiones sociales y laborales)... Cuando los aspectos abordados pertenecen esencialmente al ámbito social y de las relaciones industriales, incluida la negociación colectiva, la salud y la seguridad en el trabajo, el derecho laboral y los salarios, el deseo de coordinar las acciones ha dado lugar a la creación de organizaciones de empresarios, que siempre son de carácter voluntario... (OIT 1994a).

Algunas organizaciones de empresarios se establecieron inicialmente en respuesta a la presión ejercida por los sindicatos para negociar, mientras que otras tienen su origen en los gremios medievales $u$ otros grupos fundados para defender intereses de mercado particulares. Estas organizaciones se han definido como grupos formales de empresas creados para defender, representar y asesorar a sus afiliados y consolidar su posición en la sociedad en general respecto a las cuestiones laborales, distintas de las económicas... A diferencia de los sindicatos, compuestos por personas, estas entidades están constituidas por empresas (O echslin 1995).

De acuerdo con 0 echslin, tres funciones principales suelen ser comunes a todas las organizaciones de empresarios: la defensa y la promoción de los intereses de sus miembros, la representación en la estructura política y la prestación de servicios a sus afiliados. La primera función se refleja en gran medida en el ejercicio de presiones sobre la Administración para que ésta adopte políticas favorables a los intereses de las empresas y en la influencia sobre la opinión pública, sobre todo mediante campañas en los medios de comunicación. La función representativa puede desempeñarse en la estructura política o en las instituciones que rigen las relaciones industriales. La representación política se ejerce en los sistemas en los que la consulta de los grupos económicos interesados está prevista por la legislación (p. ej., en Suiza), en los países en que los comités económicos y sociales contemplan la representación de las empresas (p. ej., en Francia, países africanos francófonos y Países Bajos) y en las instancias donde existe participación en foros tripartitos, como la Conferencia Internacional del Trabajo y otros aspectos de la actividad de la O IT. A demás, estas organizaciones pueden ejercer una influencia considerable a escala regional (especialmente en la U nión E uropea).

El modo en que se concreta la función representativa en el sistema de relaciones laborales depende en gran medida de la escala a la que tiene lugar la negociación colectiva en cada país. Asimismo, este factor determina en buena parte la estructura de las organizaciones de empresas. Si la negociación se centraliza a escala nacional, la estructura interna y el funcionamiento de las organizaciones reflejarán esta circunstancia (banco central de datos estadísticos y económicos, creación de mutuas de seguros de huelga, sentido estricto de la disciplina de los miembros, etc.) Incluso en los países en que la negociación se produce en el ámbito empresarial (como Japón y Estados U nidos) las organizaciones de empresas pueden ofrecer a sus miembros información, orientación y asesoramiento. O bviamente, la negociación a escala sectorial (como en Alemania, donde, sin embargo, algunas empresas se han desvinculado de sus organizaciones) o a múltiples escalas (como en Francia e I talia) también influye en la estructura de las organizaciones.

En cuanto a la tercera función, 0 eschlin señala que "no siempre es fácil trazar una línea divisoria entre las actividades que apoyan las funciones descritas anteriormente y las realizadas por los miembros en su propio interés" (p. 42). La investigación es un ejemplo característico, ya que puede utilizarse con diversos fines. La salud y la seguridad es un área en la que los datos y la información pueden ser compartidos por empresas de varios sectores. A menudo, nuevos conceptos 0 reacciones a recientes avances en el ámbito del trabajo han sido el resultado de una amplia reflexión acometida en el seno de las organizaciones de empresas. Asimismo, estos grupos imparten formación a sus miembros sobre diversas cuestiones relacionadas con la gestión y emprenden acciones en la esfera social, como el desarrollo de viviendas para trabajadores o el apoyo a las actividades comunitarias. En algunos países, las organizaciones de empresas prestan asistencia jurídica a sus miembros en los tribunales de trabajo.

La estructura de estas organizaciones no depende únicamente de la escala a la que se desarrolla la negociación, sino también del tamaño, el sistema político y, en ocasiones, las tradiciones religiosas de cada nación. En los países en desarrollo, el reto principal ha consistido en la integración de miembros muy heterogéneos, como las pequeñas y medianas empresas, las empresas públicas y las filiales de las empresas multinacionales. La fuerza de una organización de empresas se refleja en los recursos que sus miembros están dispuestos a dedicarle, ya sea en forma de cuotas y aportaciones o de conocimientos técnicos y tiempo.

EI tamaño de una empresa es un determinante fundamental en su planteamiento respecto a las relaciones laborales: es más probable que aquéllas con una plantilla reducida se basen en medios informales para abordar la relación con sus trabajadores. Las pequeñas y medianas empresas, cuya definición es variable, se encuentran en ocasiones en el umbral de los regímenes de participación de los trabajadores impuestos por la legislación. Si la negociación colectiva se produce a escala empresarial, es mucho más probable que se dé en las grandes empresas; si tiene lugar a escala sectorial o nacional, es más probable que afecte a áreas en las que las grandes empresas han dominado históricamente el mercado del sector privado.

Como instituciones que defienden intereses, las organizaciones de empresas (al igual que los sindicatos) tienen problemas en lo que se refiere a la dirección, la toma de decisiones interna 
y la participación de los miembros. No obstante, puesto que las empresas tienden a ser individualistas, el reto de imponer disciplina entre los afiliados es superior en el caso de estas organizaciones. Como señala Van Waarden (1995), "las asociaciones empresariales tienen, en general, coeficientes de densidad elevados... No obstante, las empresas consideran que cumplir con las decisiones y las normas de sus asociaciones constituye un gran sacrificio, ya que éstas reducen la libertad de empresa que les es tan querida". L as tendencias en la estructura de estas organizaciones refleja en gran medida la del mercado de trabajo: a favor 0 en contra de la centralización y la regulación de la competencia. Van Waarden añade: "Aunque se mantenga la presión a favor de la flexibilización en la era "posfordista", las asociaciones empresariales no dejarán necesariamente de ser válidas ni perderán influencia (...) seguirán desempeñando un papel importante como foros para la coordinación de las políticas de mercado de trabajo entre bastidores y como asesores de empresas y asociaciones filiales que participen en la negociación colectiva" (ibíd., p. 104). A simismo, pueden cumplir una función solidaria; a través de estas organizaciones, las pequeñas empresas pueden acceder a servicios jurídicos o de asesoramiento que, de otra forma, no podrían permitirse.

Las empresas públicas han comenzado a verse a sí mismas como tales en fecha relativamente reciente. En un principio, las Administraciones consideraban que la participación de los trabajadores en la actividad sindical era incompatible con el servicio al Estado soberano. Después, hicieron caso omiso de las llamadas a participar en la negociación colectiva con el argumento de que el poder legislativo, y no la Administración pública, es la entidad encargada de los pagos y que, por tanto, es imposible que ésta sea parte en un acuerdo al respecto. No obstante, este razonamiento no impidió las huelgas (a menudo ilícitas) del sector público en muchos países y ha acabado abandonándose. En 1978, la Conferencia Internacional del Trabajo adoptó el Convenio sobre la protección del derecho de sindicación y los procedimientos para determinar las condiciones de empleo en la Administración pública ( $n$ - 151) y la Recomendación sobre los procedimientos para determinar las condiciones de empleo en la Administración pública (no 159). La negociación colectiva en el sector público ha pasado a ser habitual en muchos países desarrollados (p. ej., Australia, Francia, Reino U nido) y en algunos países en desarrollo (p. ej., numerosos países del A frica francófona y de A mérica Latina).

EI nivel de representación de las empresas en el sector público depende en gran medida del sistema político del país. En algunos, se trata de una función centralizada (Francia), mientras que, en otros, refleja las divisiones de la Administración (como en Estados Unidos, donde la negociación puede tener lugar a escala federal, estatal y municipal). A lemania constituye un caso interesante, ya que miles de comunidades locales se han agrupado para que un único agente se encargue de la negociación colectiva con los sindicatos en el sector público de todo el país.

Puesto que las empresas públicas forman parte del Estado, no son objeto de las leyes que exigen el registro de las organizaciones empresariales. La designación del agente negociador varía considerablemente de un país a otro; puede ser la Comisión de Servicio Público, el M inisterio de Trabajo, el de Economía u otra entidad. Las posiciones adoptadas por las empresas públicas al negociar con los trabajadores de este sector tienden a seguir la orientación política del partido político en el poder. Esta puede oscilar entre la toma de una postura específica en la negociación y la negación absoluta del derecho de los funcionarios a organizarse sindicalmente. No obstante, aunque el número de empresas públicas se reduce en muchos países, su disposición a participar en las negociaciones y las consultas con los representantes de los trabajadores es cada vez mayor.

\section{Sindicatos}

Según la definición clásica, un sindicato es "una asociación continua de asalariados cuyo objetivo es mantener y mejorar las condiciones de su empleo" (Webb y Webb 1920). L os orígenes de los sindicatos se remontan a los primeros intentos de organizar la acción colectiva al comienzo de la Revolución Industrial. N o obstante, en su concepción moderna, los sindicatos surgieron en la última parte del siglo XIX, cuando los Gobiernos comenzaron a concederles el derecho jurídico a constituirse (anteriormente, se habían considerado asociaciones ilícitas, perjudiciales para la libertad de comercio o como grupos políticos al margen de la ley). Los sindicatos son resultado de la convicción de que sólo aunando esfuerzos los trabajadores pueden mejorar su situación. Los derechos sindicales se obtuvieron gracias a la lucha económica y política basada en la consideración del sacrificio individual a corto plazo por causa del beneficio colectivo a largo plazo. Los sindicatos han desempeñado con frecuencia un papel importante en la política de los países y han influido en la evolución del ámbito laboral a escala regional e internacional. N o obstante, en los últimos años, tras haber registrado una caída en el número de afiliados en varios países (A mérica del $\mathrm{N}$ orte y ciertas áreas de E uropa), su función se ha puesto en tela de juicio en numerosas instancias (véase la Figura 21.2). Esta tendencia se combina con ciertas áreas de crecimiento de la afiliación en el servicio público de muchos países y la aparición de nuevos sindicatos en lugares donde no existían o actuaban limitados por restricciones graves (p. ej., Corea, Filipinas, algunos países de Europa central y oriental). EI progreso de las instituciones democráticas coincide con el ejercicio de las libertades sindicales, como ocurrió en los casos de Chile y Polonia en los decenios de 1980 y 1990. Asimismo, puede observarse en el ámbito sindical de muchos países el inicio de un proceso de reforma interna y reorientación para atraer un mayor número de afiliados de diversa procedencia, especialmente mujeres. El tiempo dirá si éstos y otros factores serán suficientes para invertir las tendencias a la "descolectivización", también denominada "atomización" de las relaciones laborales, que ha acompañado al auge de la globalización económica y el individualismo ideológico.

Básicamente, las funciones desempeñadas por los sindicatos en los sistemas de relaciones laborales contemporáneos son semejantes a las que cumplen las organizaciones empresariales: defensa y promoción de los intereses de los afiliados, representación política, y prestación de servicios. La función que les diferencia es la de control: su legitimidad depende en parte de su capacidad para imponer disciplina a sus afiliados, por ejemplo, al convocar o desconvocar una huelga. EI reto constante de los sindicatos consiste en aumentar su densidad, es decir, el número de afiliados como porcentaje de los trabajadores del sector formal. Los afiliados a los sindicatos son personas físicas; sus cuotas, denominadas cotizaciones en algunos sistemas, financian las actividades de la organización. (Los sindicatos financiados por empresas, llamados "sindicatos de empresa", o por la Administración, como los de los antiguos países comunistas no se consideran aquí, ya que sólo las organizaciones independientes de trabajadores son verdaderos sindicatos.) En general, la afiliación depende de la decisión voluntaria individual, si bien algunos sindicatos que han celebrado acuerdos de sindicación obligatoria se consideran los representantes de todos los trabajadores cubiertos por un convenio colectivo determinado (en los países en los que los sindicatos son reconocidos como representantes de los trabajadores en una unidad de negociación determinada). Los sindicatos pueden afiliarse a organizaciones generales que operan a escala sectorial, nacional, regional e internacional.

Los sindicatos se estructuran de acuerdo con diversas categorías: por oficio o profesión, por rama de la industria, por 
Figura 21.2 - Tasas de afiliación a sindicatos, 1980-1990.

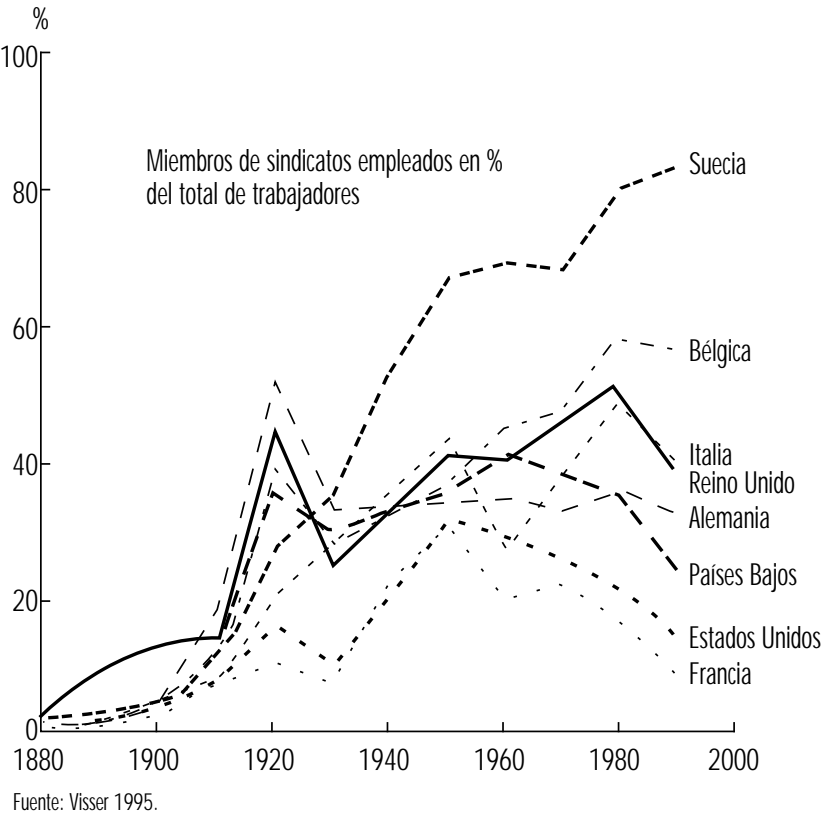

desempeño de actividades manuales o no manuales $y$, en ocasiones, incluso por empresa. Asimismo, hay sindicatos generales, a los que se afilian trabajadores de diversas profesiones y sectores. Incluso en los países en los que las fusiones de sindicatos sectoriales y generales constituyen la tendencia, la situación de los trabajadores agrarios o rurales ha favorecido con frecuencia el desarrollo de estructuras especiales para este sector. A parte de esta división, existe otra territorial caracterizada por la existencia de unidades regionales $y$, en ocasiones, locales dentro del sindicato. En ciertos países, se ha asistido a la fragmentación del movimiento sindical siguiendo líneas ideológicas (política de partidos) e incluso religiosas, que se ven reflejadas en la estructura y la afiliación de los sindicatos. Los funcionarios suelen estar representados por sindicatos ajenos a los representantes de los trabajadores del sector privado, aunque también existen excepciones.

La situación jurídica de un sindicato puede ser la de cualquier otra asociación o bien puede someterse a normas especiales. Un gran número de países exigen a los sindicatos que se registren y ofrezcan ciertos datos básicos a las autoridades (nombre, dirección, identidad de los gestores, etc.). En algunos casos, esta exigencia trasciende al mero registro y llega al intervencionismo y, en los más extremos, caracterizados por la desconsideración de los principios de libertad de asociación, los sindicatos necesitan de la autorización de la Administración para funcionar. Como representantes de los trabajadores, los sindicatos están capacitados para asumir compromisos en su nombre. Ciertos países (como Estados Unidos) exigen el reconocimiento del sindicato por parte de la empresa como requisito previo para participar en la negociación colectiva.

La densidad sindical varía en gran medida a escala inter e intranacional. Por ejemplo, en algunos países de Europa occidental, es muy elevada en el sector público, pero tiende a ser limitada en el privado, en especial entre los trabajadores no manuales. Las cifras correspondientes a los trabajadores manuales en esta región son dispares y oscilan de unos valores elevados en Austria y Suecia a otros bajos en Francia, donde, sin embargo, el poder político de los sindicatos excede con mucho al

\section{Federaciones internacionales de sindicatos}

El movimiento sindical internacional a escala mundial, a diferencia de los niveles regional o nacional, esta integrado por asociaciones internacionales de federaciones internacionales de sindicatos. Actualmente existen tres organizaciones internacionales de este tipo que siguen diferentes tendencias ideológicas: la Confederación Internacional de 0 rganizaciones Sindicales Libres (CIO SL), la Federación Sindical Mundial (FSM) y el Congreso Mundial del Trabajo, de dimensión relativamente menor y origen cristiano (CMT). La CIOSL es la mayor, con 174 sindicatos afiliados en 1995 procedentes de 124 países, lo que representa un número total de 116 millones de miembros de sindicatos. Estos órganos ejercen presiones sobre las organizaciones intergubernamentales en materia de formulación de políticas económicas y sociales generales y a favor de la protección mundial de los derechos sindicales básicos. Puede considerárseles la fuerza política que subyace al movimiento sindical internacional.

La fuerza sectorial del movimiento sindical internacional radica en las asociaciones internacionales de sindicatos específicos, normalmente centradas en una actividad comercial, industrial 0 del sector económico. Conocidas como Secretarías Profesionales Internacionales (SPI) u 0 rganizaciones Internacionales de Sindicatos (O IS), pueden ser independientes 0 estar afiliadas o controladas por los organismos internacionales. Tradicionalmente, la cobertura se ha basado en la clasificación por sector, aunque en a lgunos casos también se han utilizado las categorías de trabajadores (como la de trabajadores no manuales) o de empresas (públicas o privadas). Por ejemplo, en 1995 existáan 13 SPI asociadas a la CIOSL y distribuidas de la forma siguiente: construcción y carpintería, industrias químicas y minería, energía, comercio, administrativos, profesionales liberales y técnicos, educación, industria del ocio, alimentación, agricultura, restauración y abastecimiento, artes gráficas, periodismo, metal, servicio postal y telecomunicaciones, servicio público, industria textil, confección e industria del cuero, y transporte. Las SPI se ocupan fundamentalmente de cuestiones específicas de cada sector, como los conflictos laborales y las tasas de remuneración, pero también de la aplicación de las disposiciones en materia de salud y seguridad en un sector concreto. O frecen información, educación, formación y otros servicios a los sindicatos afiliados. Asimismo, ayudan a coordinar la solidaridad interna. cional entre los sindicatos de los diferentes países y representan los intereses de los trabajadores en diversos foros regionales e internacionales.

Como ejemplo de esta acción puede citarse la respuesta sindical internacional al accidente de Bhopal en La India, causado por la emisión de isocianato de metilo, que provocó miles de víctimas en diciembre de 1984 . A petición de sus sindicatos nacionales afiliados de este país, la C IO SL y la Federación Internacional de Sindicatos $\mathrm{G}$ enerales y de los Sectores $\mathrm{Q}$ uímico, Energético y $M$ inero (IC EM) envió una misión a Bhopal para estudiar las causas y los efectos de la fuga de gas. En el informe se formularon recomendaciones para la prevención de desastres semejantes y se ofrecía una relación de principios de seguridad: este documento ha sido utilizado por los sindicalistas de los países en desarrollo e industrializados como base para el desarrollo de programas de mejora de la salud y la seguridad en el trabajo

Fuente: Rice 1995.

que podría deducirse del número de afiliados. Existe cierta correlación positiva entre la centralización de la negociación y la densidad sindical, pero se observan asimismo algunas excepciones. 
Como asociaciones voluntarias, los sindicatos establecen sus propias normas, habitualmente recogidas en unos estatutos y reglamentos. En las estructuras sindicales democráticas, los miembros eligen a sus gestores mediante el voto directo 0 a través de delegados asistentes a las asambleas generales. Es probable que la gestión interna en un sindicato pequeño y altamente descentralizado de trabajadores de un determinado colectivo profesional difiera de forma significativa con la de los grandes sindicatos generales o sectoriales centralizados. Las tareas se asignan entre los gestores y los representantes remunerados y no remunerados del sindicato y deben llevarse a cabo labores de coordinación. Asimismo, los recursos financieros disponibles varían en función de su tamaño y de su facilidad para recaudar las cuotas. La institución de un sistema de retención en nómina de la cotización sindical (en virtud del cual, las cuotas se deducen del salario del trabajador y se abonan directamente al sindicato) simplifica esta tarea en gran medida. En la mayoría de los países de E uropa central y oriental, los sindicatos que eran dominados y financiados por el Estado están siendo transformados 0 incorporados por las nuevas organizaciones independientes; todos luchan por encontrar su lugar y desarrollar su actividad con éxito en la nueva estructura económica. Los salarios extremadamente bajos (y, por tanto, las cuotas) en esta región y en los países en desarrollo, junto con la existencia de sindicatos financiados por la Administración, dificultan la creación de un movimiento sindical independiente y sólido.

A demás de la participación en la negociación colectiva, una de las principales actividades de los sindicatos en muchos países es su labor política. Esta puede adoptar la forma de la representación directa, basada en la asignación de escaños en ciertos parlamentos (p. ej., Senegal) y en la intervención en órganos tripartitos que participan en la formulación de la política económica y social nacional (p. ej., Austria, Francia, Países Bajos), o que desempeñan un papel consultivo en los ámbitos del trabajo y los asuntos sociales (p. ej., muchos países de América Latina y algunos de Africa y A sia). En la U nión Europea, las federaciones sindicales han tenido un efecto importante en la formulación de la política social. Habitualmente, los sindicatos influyen mediante el ejercicio del poder (respaldado por la amenaza de huelga) y de presiones sobre los responsables de la toma de decisiones políticas a escala nacional. No cabe duda de que han tenido éxito en su lucha por lograr una mayor protección legislativa para los trabajadores en todo el mundo; sin embargo, algunos creen que ésta ha sido una victoria agridulce, ya que, a largo plazo, socava la justificación de su existencia. A menudo, los objetivos y los problemas abordados mediante la acción política sindical han trascendido con mucho otros intereses más limitados. U n ejemplo fundamental de esta tendencia consiste en la lucha contra el apartheid en Sudáfrica y la solidaridad internacional expresada por los sindicatos de todo el mundo mediante las palabras y los hechos ( $p$. ej., el boicot de los trabajadores portuarios al carbón importado de Sudáfrica). O bviamente, la actitud, al ataque 0 a la defensiva, de la actividad política sindical dependerá en gran medida de que el Gobierno en el poder sea favorable o contrario a la actuación de los sindicatos. A simismo, dependerá de la relación de los sindicatos con los partidos políticos; algunos, sobre todo en Africa, participaron en la lucha de su país para lograr la independencia y mantienen una vinculación muy estrecha con los partidos políticos en el poder. En ciertos países, existe una interdependencia tradicional entre el movimiento sindical y un partido político (p. ej., Australia, Reino U nido), mientras que en otros, las alianzas pueden modificarse con el tiempo. En cualquier caso, el poder de los sindicatos suele exceder a lo que podría esperarse de su fuerza numérica, sobre todo cuando representan a los trabajadores de la función pública o de sectores económicos clave como el transporte o la minería.
A parte de los sindicatos, han surgido otras formas de participación de los trabajadores para garantizar su representación directa 0 indirecta. En algunos casos, coexisten junto a los sindicatos; en otros, constituyen la única vía de participación disponible. Las funciones y facultades de los representantes de los trabajadores que actúan en virtud de estos nuevos sistemas se describen en el artículo "Formas de participación de los trabajadores".

El tercer tipo de función de los sindicatos, que consiste en la prestación de servicio a sus miembros, se centra prioritariamente en el lugar de trabajo. La misión de un delegado sindical activo, a escala empresarial, es garantizar que los derechos de los trabajadores recogidos en el convenio colectivo y en la legislación sean respetados y, en caso contrario, adoptar las medidas pertinentes. $L$ a tarea del gestor sindical consiste en defender los intereses de los trabajadores ante la dirección, legitimando así su propio papel representativo. Esta función puede exigir la presentación de una reclamación individual por causas disciplinarias 0 por despido, o cooperar con la dirección en un comité mixto de salud y seguridad. Fuera del lugar de trabajo, muchos sindicatos ofrecen otro tipo de prestaciones, como el acceso preferencial al crédito y la participación en programas sociales. Además, las sedes sindicales pueden utilizarse para el desarrollo de actividades culturales e incluso grandes celebraciones familiares. La gama de servicios que un sindicato puede ofrecer a sus miembros es amplia y refleja su creatividad y sus recursos, así como el entorno cultural en el que desempeña su labor.

Como señala $\mathrm{V}$ isser:

El poder de los sindicatos depende de diversos factores externos e internos. Puede distinguirse entre el poder organizativo (¿cuántas fuentes de poder internas pueden movilizar los sindicatos?), el institucional (¿de qué fuentes de apoyo externas pueden depender los sindicatos?) y el económico (¿qué fuerzas de mercado actúan teniendo en cuenta el interés de los sindicatos?) (Visser en van Ruysseveldt y cols. 1995).

Entre los factores que señala para lograr una estructura sindical sólida, figura la movilización de un número elevado y estable de afiliados cualificados que paguen sus cuotas (podría añadirse que la composición del conjunto de afiliados debe reflejar la del mercado de trabajo), la evitación de la fragmentación organizativa y de las escisiones políticas e ideológicas, y el desarrollo de una estructura organizativa que favorezca la presencia en cada unidad empresarial y permita al mismo tiempo mantener un control central de los fondos y de la toma de decisiones. La capacidad de este modelo, que hasta la fecha ha tenido un carácter nacional, para actuar con éxito y evolucionar en el contexto de una economía cada vez más internacionalizada, constituye el gran reto actual de los sindicatos.

\section{DERECHOS DE ASOCIACION Y REPRESENTACION}

Breen Creighton

\section{Relación entre los derechos de asociación y representación y la salud y la seguridad en el trabajo}

La consulta y la participación conjuntas sólo pueden ser eficaces en un entorno en el que se reconozcan adecuadamente y se respeten los derechos de las empresas y los trabajadores a asociarse libremente y el de sus organizaciones a representar sus intereses de modo efectivo. Por tanto, en un sentido plenamente realista, el respeto al derecho a organizarse puede considerarse una condición previa esencial de una estrategia de salud y 
seguridad en el trabajo, eficaz a escala nacional e internacional y en el lugar de trabajo. Así, es necesario y pertinente analizar con mayor detenimiento las normas de la OIT relativas a la libertad de asociación, teniendo en cuenta su aplicación en el contexto de la prevención de las lesiones y las enfermedades profesionales y la indemnización y la rehabilitación de los que las han sufrido. Dichas normas exigen un reconocimiento adecuado en la legislación y en la práctica del derecho de los trabajadores y las empresas a constituir organizaciones y a incorporarse a las de su elección, así como del derecho de éstas, una vez establecidas, a formular y aplicar sus programas libremente.

Asimismo, los derechos de asociación y representación sostienen la cooperación tripartita (Administración, empresas y trabajadores) en el campo de la salud y la seguridad en el trabajo. Esta forma de cooperación se promueve en el contexto de la determinación de normas de la O IT, por ejemplo:

- exigiendo a los Gobiernos que consulten con las organizaciones representativas de empresarios y trabajadores en relación con la formulación y la aplicación de la política de salud y seguridad en el trabajo a escala nacional y regional (p. ej., Convenio sobre la utilización del asbesto en condiciones de seguridad, 1986 (no 162), artículo 4, y Convenio sobre seguridad y salud de los trabajadores y medio ambiente de trabajo, 1981 (no 155), artículos 1 y 8);

- fomentando la consulta y la cooperación conjuntas en materia de salud y seguridad en el lugar de trabajo [p. ej., Convenio sobre la prevención de accidentes industriales graves, 1993 (no 174), artículo 9 (f) y (g)];

- exigiendo la participación conjunta de las empresas y los trabajadores en la formulación y la aplicación de la política de salud y seguridad en el lugar de trabajo (véase especialmente el Convenio sobre seguridad y salud de los trabajadores y medio ambiente de trabajo, 1981 (nำ155), artículos 19 y 20, y la R ecomendación sobre seguridad y salud de los trabajadores y medio ambiente de trabajo, 1981 [( $n$ - 164), apartado 12].

\section{La OIT y los derechos de asociación y representación}

El "derecho legal de asociación a todos los efectos para los trabajadores y las empresas" era uno de los métodos y principios establecidos en el artículo 41 de la Constitución original de la OIT. Este principio es objeto actualmente de un reconocimiento expreso en el Preámbulo a la Constitución como una de las condiciones previas esenciales para la materialización de la justicia social, que a su vez se considera un requisito inicial básico para lograr una paz universal y duradera. Junto con el principio del tripartismo, también es reconocido explícitamente en el artículo I de la Declaración de Filadelfia, que se incluyó como apéndice a la Constitución de 1946. Esta consideración en la Constitución de la importancia del respeto a los principios de libertad de asociación ayuda a establecer una de las bases jurídicas de la capacidad de la Comisión de Investigación y de Conciliación en M ateria de Libertad Sindical y del Comité de Libertad Sindical del Consejo de Administración para investigar las presuntas contravenciones de dichos principios.

Ya en 1921, la Conferencia Internacional del Trabajo adoptó el Convenio sobre el derecho de asociación (agricultura), 1921 (no 11), que exige la ratificación de los Estados para "asegurar a todos las personas dedicadas a la agricultura los mismos derechos de asociación y organización que a los trabajadores industriales". No obstante, no se mencionan los derechos que deben concederse a éstos para situarse en las mismas condiciones que los trabajadores agrarios. Los intentos de adoptar un instrumento más general relativo a la libertad de asociación en el decenio de 1920 fracasaron debido a la insistencia de empresas y
Gobiernos en la necesidad de que el derecho a constituir y afiliarse a sindicatos se acompañase del derecho correspondiente a no afiliarse. Se volvió sobre esta cuestión en el período inmediatamente posterior a la segunda $\mathrm{G}$ uerra $\mathrm{M}$ undial. Estas iniciativas dieron lugar a la adopción del Convenio relativo al derecho de asociación y a la solución de los conflictos de trabajo en los territorios no metropolitanos, 1947 ( $n$ - 84), el Convenio relativo a la libertad sindical y a la protección del derecho de sindicación, 1948 (n- 87) y el Convenio relativo a la aplicación de los principios del derecho de sindicación y de negociación colectiva, 1949 (no 98).

Los Convenios no 87 y no 98 se encuentran entre los más importantes y más ampliamente ratificados de los de la O IT: el 31 de diciembre de 1996, el primero de ellos había sido ratificado por 119 países, y el segundo por 133. Recogen los que pueden considerarse propiamente como los cuatro elementos principales de la noción de libertad de asociación. Se les cataloga como el punto de referencia fundamental relativo a la protección internacional de la libertad de asociación a efectos sindicales, como reflejan, por ejemplo, el artículo 8 del Pacto Internacional de Derechos E conómicos, Sociales y Culturales y el artículo 22 del Pacto Internacional de Derechos C iviles y Políticos. Dentro de la estructura de la OIT, constituyen la base de los principios de libertad de asociación desarrollados y aplicados por el Comité de Libertad Sindical del Consejo de Administración y la Comisión de Investigación y de Conciliación en $M$ ateria de Libertad Sindical, aunque, desde un punto de vista técnico, estos órganos reciben sus competencias de la Constitución de la $\mathrm{O}$ rganización y no de los $\mathrm{C}$ onvenios. Asimismo, constituyen una referencia esencial para las deliberaciones del Comité de Expertos para la A plicación de los Convenios y R ecomendaciones y de la Comisión de la Conferencia para la A plicación de los Convenios y Recomendaciones.

A pesar del papel esencial desempeñado por los Convenios n- 87 y no 98, debe tenerse en cuenta que éstos no son de ningún modo los únicos instrumentos formales para la determinación de normas que han sido adoptados bajo los auspicios de la O IT en el campo de la libertad de asociación. Por el contrario, desde 1970, la Conferencia ha aprobado otros cuatro convenios y cuatro recomendaciones que abordan con mayor detalle diversos aspectos de los principios de libertad de asociación y su aplicación en ciertos contextos específicos:

- Convenio relativo a la protección y facilidades que deben otorgarse a los representantes de los trabajadores en la empresa, 1971 ( $n$ - 135) y R ecomendación, 1971 (no 143).

- Convenio sobre las organizaciones de trabajadores rurales y su función en el desarrollo económico y social, 1975 (no 141) y Recomendación, 1975 ( $n$ - 149).

- Convenio sobre la protección del derecho de sindicación y los procedimientos para determinar las condiciones de empleo en la Administración Pública, 1978 (no 151) y Recomendación, 1978 (no 158).

- Convenio sobre el fomento de la negociación colectiva, 1981 (no 154) y R ecomendación, 1981 (no 163).

\section{Principios de libertad de asociación}

\section{E lementos esenciales}

Los elementos esenciales de los principios de libertad de asociación recogidos en los C onvenios no 87 y no 98 son:

- "Los trabajadores y empleadores, sin ninguna distinción y sin autorización previa, tienen el derecho de constituir las organizaciones que estimen convenientes, así como el de afiliarse a 
estas organizaciones, con la sola condición de observar los estatutos de las mismas" (artículo 2 del Convenio no 87).

- "Las organizaciones de trabajadores y de empleadores tienen el derecho de redactar sus estatutos y reglamentos administrativos, el de elegir libremente sus representantes, el de organizar su administración y sus actividades y el de formular su programa de acción" [artículo 3(1) del Convenio no 87]. A demás, "las autoridades públicas deberán abstenerse de toda intervención que tienda a limitar este derecho o entorpecer su ejercicio legal" [artículo 3(2)].

- "Los trabajadores deberán gozar de adecuada protección contra todo acto de discriminación tendente a menoscabar la libertad sindical en relación con su empleo" [artículo 1(1) del Convenio no 98].

- “Deberán adoptarse medidas adecuadas a las condiciones nacionales, cuando ello sea necesario, para estimular y fomentar entre los empleadores y las organizaciones de empleadores, por una parte, y las organizaciones de trabajadores, por otra, el pleno desarrollo y uso de procedimientos de negociación voluntaria, con objeto de reglamentar, por medio de convenios colectivos, las condiciones de empleo" (artículo 4 del Convenio $\mathrm{n}$-98).

Todas las garantías contempladas en el Convenio no 87 se someten a la condición establecida en el artículo 8(1): "Al ejercer los derechos que se les reconocen en el presente Convenio, los trabajadores, los empleadores y sus organizaciones respectivas están obligados... a respetar la legalidad". Esta obligación se somete a su vez a la estipulación siguiente: "La legislación nacional no menoscabará ni será aplicada de suerte que menoscabe las garantías previstas por el presente Convenio".

A simismo, debe señalarse que, en virtud del artículo 9(1) del Convenio no 87, es permisible, pero no necesario, restringir la aplicación de las garantías previstas en el mismo respecto a los miembros de la policía y las fuerzas armadas. El artículo 5(1) del Convenio no 98 recoge la misma condición, mientras que en el artículo 6 de este instrumento se estipula que el Convenio "no trata de la situación de los funcionarios públicos al servicio del Estado y no deberá interpretarse, en modo alguno, en menoscabo de sus derechos o de su estatuto."

\section{EI derecho de afiliación}

El derecho de los trabajadores y las empresas a constituir organizaciones y a afiliarse a las de su elección es el elemento esencial de todas las garantías previstas por los Convenios no 87 y $n 098$ y por los principios de libertad de asociación. Sólo está sujeto a la condición establecida en el artículo 9(1) del primer Convenio. Así, no es permisible denegar a ningún grupo de trabajadores distintos de los miembros de la policía y las fuerzas armadas el derecho a constituir sindicatos y a afiliarse a los de su elección. Por tanto, la denegación o la restricción del derecho de los funcionarios públicos, los agricultores, los profesores u otros colectivos a crear organizaciones e incorporarse a las de su elección no sería coherente con los requisitos establecidos en el artículo 2.

No obstante, es permisible que las normas de un sindicato 0 una organización empresarial restrinjan las categorías de trabajadores o de empresas que pueden afiliarse. Se trata de que esta restricción sea el resultado de la libre elección de los miembros de la organización y no sea impuesta desde el exterior.

EI derecho de afiliación recogido en el artículo 2 no se acompaña del derecho correlativo a no afiliarse. Debe recordarse que los primeros intentos de adoptar un convenio general sobre libertad de asociación fracasaron debido a la insistencia de los delegados de las empresas y de algunos $\mathrm{G}$ obiernos respecto a la necesidad de que el derecho positivo de afiliación conllevase un derecho negativo a la no afiliación. Esta cuestión volvió a plantearse en el contexto de los debates sobre los Convenios n87 y no 98. Con todo, en esta ocasión se alcanzó un compromiso en virtud del cual la Conferencia adoptó una resolución en la que se establecía que los instrumentos de seguridad sindical (como los sistemas de sindicación obligatoria y de retención en nómina de la cotización sindical) eran admisibles. En otras palabras, los Convenios no sancionan ni condenan la sindicación obligatoria y otros instrumentos de seguridad sindical, aunque estas medidas no se consideran aceptables si se imponen legalmente y no se adoptan mediante el acuerdo de las partes (O IT 1994b; O IT 1995a).

Quizás la cuestión más difícil planteada en relación con el artículo 2 sea la medida en la que avala la noción de pluralismo sindical. Es decir, ies coherente con el artículo 2 que la legislación limite, directa o indirectamente, el derecho de los trabajadores (o las empresas) a constituir una organización o afiliarse a la de su elección mediante la aplicación de criterios administrativos o legislativos?

En este contexto hay dos conjuntos de intereses en conflicto. Por una parte, el artículo prevé claramente la protección del derecho de los trabajadores y de las empresas a elegir la organización a la que deseen pertenecer y optar por no afiliarse a aquéllas con las que no simpatizan por razones políticas, religiosas o de otro tipo. Por la otra, las Administraciones (e incluso los sindicatos) pueden argümentar que una proliferación excesiva de sindicatos y organizaciones empresariales, como posible consecuencia de la libertad de elección ilimitada, no facilita el desarrollo de organizaciones libres y eficaces ni la creación y el mantenimiento de procesos de relaciones industriales ordenados. Esta cuestión suscitó dificultades especiales en la etapa de la Guerra Fría, cuando los Gobiernos trataban de restringir la gama de sindicatos a los que podían afiliarse los trabajadores por causas ideológicas. Sigue siendo una cuestión muy sensible en muchos países en desarrollo cuyos Gobiernos, fundada 0 infundadamente, desean evitar lo que consideran una proliferación excesiva de sindicatos mediante la imposición de restricciones en cuanto al número y al tamaño de los que pueden actuar en un lugar de trabajo o en un sector de la economía determinados. Los órganos de supervisión de la OIT han tendido a adoptar un enfoque restrictivo respecto a esta cuestión, permitiendo la formación de monopolios sindicales cuando éstos son el resultado de la libre elección de los trabajadores y la adopción de criterios de registro "razonables", pero haciendo excepciones en el caso de los monopolios impuestos legalmente y de los criterios de registro "no razonables". Debido a esta actitud, han sido objeto de numerosas críticas, expresadas sobre todo por los Gobiernos de los países en desarrollo, que los acusan de adoptar un planteamiento eurocéntrico respecto a la aplicación del Convenio y de no tener en cuenta que el interés típicamente europeo en los derechos del individuo se opone a las tradiciones colectivistas de muchas culturas no europeas.

\section{Autonomía organizativa y derecho de huelga}

Si el artículo 2 del Convenio no 87 protege el derecho fundamental de las empresas y los trabajadores a constituir organizaciones y a afiliarse a las de su elección, el artículo 3 puede considerarse como su corolario lógico, al proteger la autonomía organizativa de dichas entidades una vez establecidas.

Como se indica claramente en el artículo 3(1), la autonomía organizativa incluye la redacción, la adopción y la aplicación de los estatutos y reglamentos administrativos y la realización de elecciones. No obstante, los órganos de supervisión han aceptado que las autoridades públicas impongan unas condiciones mínimas sobre el contenido y la administración de las normas con el fin de "garantizar una administración adecuada y evitar complicaciones jurídicas debidas a una elaboración de estatutos 
y reglamentos insuficientemente detallada" (OIT 1994b). En cualquier caso, si tales condiciones son excesivamente detalladas o de aplicación onerosa, es probable que sean declaradas disconformes con los requisitos del artículo 3.

Con el tiempo, los órganos de supervisión han adoptado firmemente una visión según la cual, "el derecho de huelga constituye un corolario intrínseco del derecho a organizarse contemplado en el Convenio $n=87$.

La Comisión [de Expertos] considera que el derecho de huelga es uno de los medios esenciales de los que disponen los trabajadores y sus organizaciones para proteger sus intereses económicos y sociales. Estos no sólo tienen que ver con la obtención de condiciones de trabajo mejores y el planteamiento de demandas colectivas de carácter profesional, sino también con la búsqueda de soluciones a las cuestiones relacionadas con la formulación de políticas económicas y sociales y con los problemas laborales de todo tipo que afectan directamente a los trabajadores.

Este es uno de los aspectos más controvertidos de la jurisprudencia relativa a la libertad de asociación y, sobre todo en los últimos años, ha sido objeto de fuertes críticas por parte de los miembros representantes de las empresas y la Administración en la Comisión de la Conferencia para la A plicación de los Convenios y Recomendaciones. [V éase, por ejemplo, Conferencia Internacional del Trabajo, 80a Sesión (1993), A ctas de las deliberaciones, $25 / 10-12$ y $25 / 58-64$ y Conferencia Internacional del Trabajo, 81a Sesión (1994), Actas de las deliberaciones, $25 / 92-94$ y $25 / 179-180$.] No obstante, constituye un elemento firmemente arraigado en la jurisprudencia sobre la libertad de asociación. Se reconoce con claridad en el artículo 8(1) (d) del Pacto Internacional de D erechos Económicos, Sociales y Culturales y fue avalado por la Comisión de Expertos en su Encuesta general sobre la libertad de asociación y la negociación colectiva de 1994 (OIT 1994b).

N o obstante, es importante subrayar que el derecho de huelga reconocido por los órganos de supervisión no es ilimitado. En primer lugar, no es aplicable a los grupos de trabajadores respecto a los que pueden atenuarse las garantías establecidas en el Convenio no 87, es decir, los miembros de la policía y las fuerzas armadas. Además, se ha determinado que el derecho de huelga puede denegarse legítimamente a "funcionarios públicos que actúen como agentes de la autoridad pública" y a los trabajadores que prestan servicios esenciales "cuya interrupción podría poner en peligro la vida, la seguridad personal o la salud de toda o de parte de la población." En cualquier caso, las restricciones del derecho a la huelga de los trabajadores en estas categorías deben compensarse mediante garantías como "Ios procedimientos de conciliación y mediación tendentes, en el caso de llegar a un punto muerto, a la aplicación de un mecanismo de arbitraje considerado fiable por las partes implicadas. Es esencial que éstas puedan participar en la determinación y la puesta en práctica del procedimiento, que, además, debe ofrecer suficientes garantías de imparcialidad y rapidez: los laudos arbitrales serán vinculantes para ambas partes y, una vez emitidos, deben ser aplicados con rapidez y en su totalidad" (O IT 1994b).

Asimismo, es admisible imponer restricciones temporales respecto al derecho de huelga en períodos de "emergencia nacional grave". En general, pueden exigirse condiciones previas como el planteamiento de requisitos de voto, el agotamiento de los procedimientos de conciliación y otros, al ejercicio del derecho de huelga. Con todo, estas restricciones deben "ser razonables y... de tal naturaleza que no constituyan una limitación considerable de los medios de acción de que disponen las organizaciones sindicales".
El derecho de huelga suele describirse como el último recurso en el contexto de la negociación colectiva. Si se interpreta que el artículo 3 protege su utilización, parece razonable suponer que también debe proteger el proceso de negociación colectiva en sí misma. De hecho, los órganos de supervisión han adoptado esta postura en varias ocasiones, pero, en general, han preferido basar su jurisprudencia sobre negociación colectiva en el artículo 4 del Convenio $n$ ㅇ 98. (Para un análisis más pormenorizado de la jurisprudencia de la OIT sobre derecho de huelga, véase $\mathrm{H}$ odges-A eberhard y $O$ dero de D ios 1987; Ben-I srael 1988).

La autonomía de las organizaciones de empresas y trabajadores se aborda asimismo en los artículos 4 a 7 del Convenio no 87 y en el artículo 2 del Convenio no 98. En el artículo 4 se establece que tales organizaciones no están "sujetas a disolución o suspensión por vía administrativa". Esto no significa que los sindicatos o las organizaciones empresariales no puedan ser excluidas del registro o disueltas, por ejemplo, en el caso de mala conducta grave en el ámbito laboral o de una gestión no acorde a las normas establecidas, pero sí que este tipo de sanciones deben ser impuestas por un tribunal debidamente constituido y otro órgano pertinente y no mediante una resolución administrativa.

El artículo 5 protege los derechos de las organizaciones a constituir federaciones y confederaciones y a afiliarse a las mismas, así como el derecho de estas entidades a incorporarse a organizaciones internacionales de empresas y de trabajadores. Por otra parte, de acuerdo con el artículo 6, las garantías previstas en los artículos 2, 3 y 4 se aplican a las federaciones y confederaciones del mismo modo que a las organizaciones de base, mientras que en el artículo 7 se estipula que la adquisición de personalidad jurídica por las organizaciones de empresarios y de trabajadores no puede estar sujeta a "condiciones cuya naturaleza limite la aplicación de las disposiciones de los artículos 2 , 3 y 4 de este Convenio".

Por último, en el artículo 2(1) del Convenio no 98 se exige que las organizaciones de empresarios y de trabajadores gocen de "adecuada protección contra todo acto de injerencia de unas respecto de las otras, ya se realice directamente o por medio de sus agentes o miembros, en su constitución, funcionamiento 0 administración". En la práctica, parece poco probable que los sindicatos interfieran o puedan interferir realmente en el funcionamiento interno de las organizaciones empresariales. Sin embargo, es factible que, en ciertas circunstancias, las empresas o sus organizaciones traten de injerirse en los asuntos internos de las organizaciones de trabajadores, por ejemplo, financiándolas parcial o totalmente. Esta posibilidad se recoge expresamente en el artículo 2(2):

Se consideran actos de injerencia, en el sentido del presente artículo, principalmente, las medidas que tiendan a fomentar la constitución de organizaciones de trabajadores dominadas por un empleador o una organización de empleadores, 0 a sostener económicamente, 0 en otra forma, organizaciones de trabajadores, con objeto de colocar estas organizaciones bajo el control de un empleador o de una organización de empleadores.

\section{Protección frente a las represalias}

O bviamente, para que las garantías previstas en los Convenios no 87 y no 98 cobren pleno sentido en la práctica, es necesario que las personas que ejercen su derecho a constituir 0 afiliarse a organizaciones de trabajadores sean protegidos frente a las represalias tomadas por su acción. Este principio lógico es reconocido en el artículo 1(1) del Convenio no 98, que, como se ha indicado, estipula que "Ios trabajadores deberán gozar de adecuada protección contra todo acto de discriminación tendente a menoscabar 
la libertad sindical en relación con su empleo". En el artículo 1(2) se amplía la consideración de esta cuestión:

Dicha protección deberá ejercerse especialmente contra todo acto que tenga por objeto

(a) condicionar el empleo de un trabajador a la situación de que no se afilie a un sindicato 0 a la de dejar de ser miembro de un sindicato:

(b) despedir a un trabajador o perjudicarle en cualquier otra forma a causa de su afiliación sindical o de su participación en actividades sindicales fuera de las horas de trabajo 0 , con el consentimiento del empleador, durante las horas de trabajo.

La discriminación tendente a menoscabar la libertad sindical incluirá, a estos efectos, la negativa a contratar, el despido y otras medidas como "el traslado, la reubicación, la reducción de categoría y otras privaciones y restricciones de todo tipo (remuneración, prestaciones sociales, formación profesional)" que puedan causar graves perjuicios al trabajador en cuestión [véase asimismo el Convenio sobre la terminación de la relación de trabajo por iniciativa del empleador, 1982 (no 158), artículos 5(a), (b) y (c), así como O IT 1994b, párrafo 212].

No sólo debe garantizarse una protección generalizada respecto a la discriminación contra la libertad sindical, sino que, en virtud del artículo 3 del Convenio no 98, debe disponerse de medios eficaces para aplicarla:

L as normas jurídicas son inadecuadas si no se acompañan de procedimientos eficaces y expeditivos y de sanciones penales con el suficiente poder de disuasión para asegurar su aplicación... La responsabilidad asignada a las empresas para que prueben que presuntas medidas de discriminación contra la libertad sindical están relacionadas en realidad con cuestiones ajenas a los sindicatos, y los supuestos establecidos a favor de los trabajadores, constituyen vías adicionales para garantizar una protección efectiva del derecho a organizarse garantizado por el Convenio. La legislación que permite a una empresa, en la práctica, terminar la relación de empleo con un trabajador a condición de pagar la indemnización prevista por la ley en caso de despido injustificado... es inadecuada de acuerdo con las disposiciones del artículo 1 del Convenio. Asimismo, la legislación debe ofrecer medios eficaces para aplicar los mecanismos de indemnización, que constituyen la solución jurídica más apropiada en los casos de discriminación contra la libertad sindical.

\section{Negociación colectiva}

La garantía establecida en el artículo 4 del Convenio no 98 ha sido interpretada como una medida de protección tanto del derecho a participar en la negociación colectiva como de la autonomía del proceso de negociación. En otras palabras, no es coherente con el artículo 4 que a las empresas y a los trabajadores les sea negado el derecho a participar en la negociación colectiva si desean intervenir en ésta, teniendo en cuenta que no es contrario al Convenio negar estos derechos a los miembros de la policía y las fuerzas armadas y que "el Convenio no trata de la situación de los funcionarios públicos al servicio del Estado". L as partes no sólo deben ser libres para participar en la negociación colectiva si así lo desean, sino que debe permitírseles alcanzar acuerdos propios sujetos a sus propias condiciones sin injerencias de las autoridades públicas, sin perjuicio de ciertas limitaciones por "razones apremiantes de interés económico nacional" (OIT 1994) y a los requisitos razonables que se impongan en cuanto a forma, registro, etc.

Por el contrario, no se ha interpretado que el artículo 4 proteja el derecho de reconocimiento a efectos de la negociación colectiva. Los órganos de supervisión han subrayado repetidamente la conveniencia de dicho reconocimiento, pero no han podido avanzar un paso más en la determinación de que la negativa a reconocer y la ausencia de un mecanismo mediante el cual las empresas puedan ser obligadas a reconocer a los sindicatos a los que pertenecen sus trabajadores, constituye un incumplimiento del artículo 4 (O IT 1994b, OIT 1995a). Han justificado esta interpretación basándose en que el reconocimiento obligatorio privaría a la negociación colectiva de su carácter voluntario, contemplado en dicho artículo (O IT 1995a). En contra de este razonamiento, puede argumentarse que el pretendido derecho a participar en la negociación colectiva se verá inevitablemente comprometido si las empresas son libres para negarse a ejercerlo, a pesar de tener derecho a intervenir en dicha negociación, si lo desean. Por otra parte, permitir a las empresas negarse a reconocer a los sindicatos, en los que sus trabajadores están afiliados, parece poco coherente con el deber de "promover" la negociación colectiva, que, aparentemente, constituye el principal objetivo del artículo 4 (Creighton 1994).

\section{Aplicación de los principios de libertad de asociación en el contexto de la salud y la seguridad en el trabajo}

Antes se indicó que las normas de la O IT relativas a la salud y la seguridad en el trabajo avalan el concepto de la participación bipartita y tripartita en tres contextos principales: (1) la formulación y la aplicación de la política a escala nacional y regional; (2) la consulta entre empresas y trabajadores en el lugar de trabajo y (3) la participación conjunta de empresas y trabajadores en la formulación y la aplicación de la política en el lugar de trabajo. Debe quedar claro de lo anterior que la intervención efectiva de las empresas y (sobre todo) de los trabajadores en estos tres contextos depende, esencialmente, de un reconocimiento adecuado de sus derechos de asociación y representación. 0 bviamente, el respeto al derecho a constituir organizaciones y a afiliarse a ellas es una condición previa fundamental de las tres formas de participación conjunta. La consulta y la participación a escala gubernamental sólo es factible cuando existen organizaciones sólidas y eficaces capaces de representar los intereses de sus miembros. Esta condición es necesaria para facilitar la comunicación y conseguir que la Administración se sienta obligada a considerar seriamente las opiniones expresadas por los representantes de empresarios y trabajadores. Indudablemente, la consulta y la participación en el lugar de trabajo es una propuesta realista sólo si los trabajadores pueden constituir y afiliarse a organizaciones capaces de representar sus intereses en las conversaciones con las empresas y sus organizaciones, ofrecer recursos de apoyo a los representantes del personal, facilitar la relación con la inspección pública, etc. En teoría, los representantes de los trabajadores pueden ejercer su función en el lugar de trabajo sin tener que estar vinculados con una organización de base más amplia, pero la realidad de las relaciones de poder en la mayoría de los lugares de trabajo es tal que, probablemente, les impide cumplir su cometido eficazmente sin el apoyo de una organización sindical. Como mínimo, los trabajadores deben gozar del derecho a este forma de defensa de sus intereses si así lo eligen.

La autonomía organizativa de las organizaciones de empresas y de trabajadores es otra condición previa esencial de una participación efectiva a todos los niveles. Por ejemplo, es necesario que las organizaciones de trabajadores tengan derecho a formular y aplicar sus políticas en materia de salud y seguridad en el trabajo sin injerencias externas, con el fin de garantizar su consulta con la Administración en relación con: (1) cuestiones como la regulación jurídica de sustancias y procesos peligrosos y (2) la formulación de la política legislativa relativa a la 


\section{El Acuerdo Laboral entre la Corporación del Acero de Belén y la Unión de Trabajadores de la Industria del Acero de Estados Unidos}

El acuerdo entre la Corporación del Acero de Belén y la Unión de Trabajadores del Acero de EE UU es característico del tipo de acuerdos realizados entre grandes empresas estadounidenses donde el sindicalismo cuenta con mucho poder. Los acuerdos laborales de la industria del acero llevan más de 50 años incluyendo artículos sobre salud y seguridad. Muchas de las cuestiones que se negociaron en el pasado supusieron derechos para los trabajadores y los sindicatos, que posteriormente quedarían protegidos por la ley. A pesar de esa redundancia, las provisiones figuran todavía en el contrato como una barrera contra los cambios en la ley, y permiten al sindicato la posibilidad de llevar los casos de violación de sus derechos ante árbitros imparciales en lugar de ante los tribunales.

El acuerdo de Belén abarca desde el 1 de agosto de 1993 hasta el 1 de agosto de 1999. Hay 17.000 trabajadores de seis plantas acogidos a dicho acuerdo, que ocupa en su totalidad 275 páginas, de las cuales 17 están dedicadas a la salud y la seguridad.

La Sección 1 del artículo sobre seguridad y salud exhorta a la empresa y al sindicato a que cooperen en el empeño de acabar con los peligros para la salud y los accidentes. O bliga a la empresa a proporcionar lugares de trabajo seguros y saludables, a obedecer las leyes estatales y federales, a proporcionar a los empleados los equipos protectores que necesiten de manera gratuita, a dar al sindicato información sobre seguridad química y a informar a los trabajadores de los peligros y los controles para sustancias tóxicas. Concede al departamento de salud y seguridad de la central sindical el derecho a tener acceso a cualquier información en posesión de la empresa que sea "relevante y esencial" para la comprensión de los peligros potenciales. Exige a la empresa la realización de pruebas de muestreo de aire e investigaciones ambientales si así lo solicita el copresidente del sindicato del comité de seguridad y salud de la planta.

La Sección 2 establece comités conjuntos de empresa y sindicatos sobre salud y seguridad en la planta y a nivel nacional; prescribe las normas a las que están sujetos; ordena que los miembros del comité reciban formación; para facilitar la labor de éstos, les permite el acceso a cualquier parte de la planta y especifica los costes que implica la labor de los miembros del comite. Esta sección especifica también el modo de resolver los litigios sobre los equipos de protección, ordena a la empresa que notifique al sindicato cualquier accidente potencial que pueda dar

indemnización por lesiones profesionales y la rehabilitación de los trabajadores afectados. Esta autonomía es aún más importante en el lugar de trabajo, donde dichas organizaciones necesitan desarrollar y mantener la capacidad de representar los intereses de sus miembros en materia de salud y seguridad en el trabajo en el diálogo con las empresas. Dicha capacidad puede exigir que los gestores sindicales y los especialistas en salud y seguridad tengan derecho de acceso al lugar de trabajo, que pueda solicitarse la ayuda de las autoridades públicas en relación con situaciones peligrosas $y$, en ciertas circunstancias, que se organicen acciones sindicales con el fin de proteger la salud y la seguridad de los afiliados.

Asimismo, para que la autonomía organizativa sea efectiva, debe garantizarse a los gestores sindicales y los afiliados una protección adecuada frente a las represalias tomadas a causa de su afiliación o sus actividades o por haber iniciado o participado en procedimientos judiciales relacionados con cuestiones de salud y seguridad en el trabajo. En otras palabras, las garantías lugar a discapacidades, establece un sistema de investigación conjunta de accidentes, obliga a la empresa a recopilar y ofrecer al sindicato determinados datos estadísticos sobre salud y seguridad, y contempla un amplio programa para todos los empleados sobre salud y seguridad.

La Sección 3 recoge el derecho de los trabajadores a negarse a realizar trabajos que supongan peligros que trasciendan aquellos "propios de la operación" y proporciona un mecanismo de arbitrio por el cual pueden resolverse los pleitos sobre esa negativa a realizar un trabajo. Ateniéndose a esto, un trabajador no puede ser sancionado por actuar de buena fe y basándose siempre en pruebas objetivas, aun en el caso de que una investigación posterior demuestre que el peligro no existió realmente.

La Sección 4 especifica que el papel del comité es de asesoría y que los miembros del comité y los directivos del sindicato, mientras desempeñan sus funciones oficiales, no son responsables de las lesiones ni de las enfermedades.

La Sección 5 afirma que el alcoholismo y el abuso de drogas son susceptibles de tratamiento, estableciendo para ello un programa de rehabilitación.

La Sección 6 establece un amplio programa para el control del monóxido de carbono, un grave peligro en la producción primaria del acero.

La Sección 7 proporciona a los trabajadores folletos para la compra de zapatos de seguridad.

La Sección 8 exige que la empresa lleve fichas médicas individuales, confidenciales a excepción de determinadas circunstancias. No obstante, los trabajadores tienen acceso a su propio historial médico y pueden llevarlo al sindicato 0 a un médico privado. Además, los médicos de empresa han de notificar a los trabajadores de los resultados médicos adversos.

La Sección 9 establece un programa de vigilancia médica.

La Sección 10 establece un programa para investigar y controlar los riesgos de los terminales de vídeo.

La Sección 11 establece que debe haber permanentemente en cada planta representantes de seguridad, elegidos por el sindicato aunque remunerados por la empresa.

Además, un apéndice al acuerdo insta a la empresa y al sindicato para que revisen el programa de seguridad de cada planta, en especial todos los equipos móviles que funcionen por carriles (los equipos sobre carriles fijos son la causa principal de muertes por lesiones traumáticas en la industria del acero en Estados Unidos).

contra la discriminación previstas en el artículo 1 del Convenio no 98 son tan pertinentes para la actividad sindical relativa a la salud y la seguridad en el trabajo como para cualquier otra, incluida la negociación colectiva, la incorporación de afiliados, etc.

El derecho a participar en una negociación colectiva autónoma constituye otro elemento esencial para la consecución de una participación efectiva de los trabajadores en relación con la salud y la seguridad en el trabajo. Las garantías previstas en el artículo 4 del Convenio no 98 son importantes en este contexto. No obstante, como ya se ha indicado, estas garantías no comprenden el derecho a ser reconocido a efectos de la negociación. Por otra parte, puede considerarse que disposiciones como las incluidas en el artículo 19 del Convenio sobre seguridad y salud de los trabajadores y medio ambiente de trabajo, 1981 ( $n$ - 155) se acercan en gran medida a la exigencia del reconocimiento de los sindicatos en el contexto de la salud y la seguridad en el trabajo: 
D eberán adoptarse disposiciones a nivel de empresa en virtud de las cuales:

- los representantes de los trabajadores en la empresa reciban información adecuada acerca de las medidas tomadas por el empleador para garantizar la seguridad y la salud y puedan consultar a sus organizaciones representativas acerca de esta información, a condición de no divulgar secretos comerciales;

- los trabajadores y sus representantes en la empresa reciban una formación apropiada en el ámbito de la seguridad y salud en el trabajo;

- Ios trabajadores o sus representantes y, llegado el caso, sus organizaciones representativas en la empresa estén habilitados, de conformidad con la legislación y la práctica nacionales, para examinar todos los aspectos de la seguridad y la salud relacionados con su trabajo.

En la práctica, resultaría muy difícil aplicar estas disposiciones sin conceder algún tipo de reconocimiento formal al papel desempeñado por las organizaciones de trabajadores. Esta necesidad permite, a su vez, subrayar de nuevo la importancia de un reconocimiento adecuado de los derechos de asociación y representación como condición previa para el desarrollo y la aplicación de estrategias eficaces de salud y seguridad en el trabajo a escala nacional y empresarial.

\section{- NEGOCIACION COLECTIVA Y SALUd Y SEGURIDAD}

\section{Michael J. Wright}

La negociación colectiva es el proceso que permite a los trabajadores negociar, como colectivo, con su empresa, y puede desarrollarse a varias escalas (empresarial, sectorial, nacional). Tradicionalmente, los temas de la negociación son los salarios, las prestaciones, las condiciones de trabajo y un trato equitativo. No obstante, pueden abordarse también cuestiones que no afecten directamente a los trabajadores contratados por la empresa, como el aumento de las pensiones de vejez de los ya jubilados. Con menor frecuencia, se consideran aspectos que trascienden con mucho al lugar de trabajo, como la protección del medio ambiente exterior.

En las empresas muy pequeñas, los trabajadores pueden tratar como un solo grupo con su empleador. Este tipo de negociación colectiva se ha mantenido durante siglos. Por el contrario, en la actualidad, de la negociación se encargan las organizaciones de trabajadores, o sindicatos.

La definición utilizada en el artículo 2 del Convenio sobre el fomento de la negociación colectiva, 1981 (no 154), es amplia:

(...) la expresión... comprende todas las negociaciones que tienen lugar entre un empleador, un grupo de empleadores 0 una organización o varias organizaciones de empleadores, por una parte, y una organización o varias organizaciones de trabajadores, por otra, con el fin de:

(a) fijar las condiciones de trabajo y empleo, 0

(b) regular las relaciones entre empleadores y trabajadores; 0

(c) regular las relaciones entre empleadores o sus organizaciones y una organización 0 varias organizaciones de trabajadores.

La negociación colectiva es una herramienta importante para elevar el nivel de vida y mejorar las condiciones de trabajo. Aunque la salud y la seguridad se abordan en la legislación nacional de casi todos los países, la negociación colectiva suele constituir el mecanismo mediante el cual dicha legislación se aplica en el lugar de trabajo. Por ejemplo, la ley puede ordenar la creación de comités conjuntos de salud y seguridad o comités de empresa, pero deja que los detalles sean negociados entre las organizaciones de empresarios y las de trabajadores.

Por desgracia, la negociación colectiva es atacada por empresas autoritarias y G obiernos represivos, tanto en los países en desarrollo como en los desarrollados. R aramente se lleva a cabo en el sector informal o en las pequeñas empresas tradicionales. En consecuencia, la mayoría de los trabajadores del mundo no disfrutan aún de las ventajas de este mecanismo en el marco de los derechos de los trabajadores garantizados por la legislación.

\section{Historia de la acción sindical en materia de salud y seguridad}

Las acciones colectivas adoptadas por las organizaciones de trabajadores en materia de salud y seguridad tienen una larga tradición. En 1775, Percival Pott, un médico inglés, elaboró el primer informe conocido sobre cáncer profesional: el cáncer de piel de los deshollinadores de Londres (L ehman 1977). Dos años más tarde, el Gremio de Deshollinadores de Dinamarca, en lo que constituye la primera respuesta conocida a la amenaza del cáncer profesional, ordenó que los aprendices recibieran los medios necesarios para someterse a un baño diario.

No obstante, la salud y seguridad no solía constituir una cuestión explícitamente abordada en los primeros conflictos laborales. Los trabajadores empleados en puestos peligrosos debían ocuparse de problemas más acuciantes, como el bajo nivel salarial, el excesivo número de horas de trabajo o el poder arbitrario de los propietarios de fábricas y minas. Los riesgos para la seguridad se reflejaban en las cifras diarias de lesiones y fallecimientos, pero la salud en el trabajo no era bien comprendida. L as organizaciones de trabajadores eran débiles y estaban sometidas al acoso continuo de propietarios y Gobiernos. Su objetivo primordial era garantizar la mera supervivencia. Como resultado, en las reclamaciones de los trabajadores del siglo XIX rara vez se defendía la consecución de condiciones de mayor seguridad (C orn 1978).

Con todo, la salud y la seguridad se sumaron a otras cuestiones abordadas en las primeras luchas sindicales. A finales del decenio de 1820, los trabajadores de la industrial textil en Estados U nidos comenzaron a movilizarse a favor de la reducción de la jornada de trabajo. Muchos de los trabajadores eran mujeres, al igual que las dirigentes de frágiles sindicatos como las asociaciones para la reforma del trabajo de las mujeres de N ueva Inglaterra. La propuesta de una jornada de diez horas se consideraba mayoritariamente como una cuestión de bienestar general. Sin embargo, al declarar ante la asamblea legislativa de $M$ assachusetts, los trabajadores también criticaron los efectos de 12 y 14 horas de trabajo diarias en fábricas mal ventiladas y describieron una "enfermedad debilitante" que atribuyeron al polvo de algodón y a la mala ventilación y que actualmente se admite como una de las primeras referencias a la bisinosis. Su éxito en cuanto al reconocimiento por parte de los propietarios de las fábricas y a la adopción de medidas por parte de la asamblea fue escaso (Foner 1977).

En otras acciones sindicales se abordaron más los efectos de los riesgos profesionales que su prevención. M uchos sindicatos del siglo XIX adoptaron programas sociales para sus afiliados, como la concesión de pensiones de discapacidad a los lesionados y de prestaciones a los supervivientes. Los sindicatos mineros de Estados U nidos y Canadá avanzaron un paso más y crearon hospitales, consultas e incluso cementerios para sus afiliados (D erickson 1988). Aunque los sindicatos intentaron mejorar la negociación de las condiciones de trabajo con las empresas, la mayoría de las movilizaciones por razones de salud y seguridad 
en América del Norte se produjeron en las minas y se dirigieron a los órganos legislativos estatales y provinciales (Fox 1990).

En Europa, la situación comenzó a cambiar en torno al final del siglo, con la consolidación de las organizaciones de trabajadores. En 1903, los sindicatos de pintores de Francia y Alemania iniciaron una campaña contra los riesgos de la pintura a base de plomo. El Sindicato de Trabajadores Industriales de Alemania adoptó un programa activo de higiene industrial en 1911, publicó textos pedagógicos sobre riesgos químicos y emprendió una campaña para la consecución de garantías respecto al cáncer de pulmón inducido por el cromo, que dio lugar finalmente a un cambio del método de producción. Los sindicatos del Reino U nido representaban a sus afiliados en los casos de indemnización de trabajadores y propugnaron una mejora de las leyes y reglamentos. Su labor reflejaba la interacción entre la negociación colectiva en materia de salud y seguridad y el sistema de inspección industrial. En 1905, por ejemplo, los sindicatos presentaron 268 quejas ante la inspección industrial del Reino U nido (Teleky 1948). En 1942, la Confederación Empresarial de Suecia y la Confederación Sueca de Sindicatos celebraron un acuerdo nacional sobre medio ambiente de trabajo relativo a los servicios locales de salud y seguridad. El acuerdo ha sido revisado y ampliado en varias ocasiones; en 1976 se sumó a las partes iniciales la Federación de Trabajadores Asalariados (Joint Industrial Safety Council of Sweden 1988).

América del N orte sufría un retraso en comparación con estas iniciativas. Fueron adoptados programas formales de seguridad por algunas grandes empresas en torno al cambio de siglo [para una descripción de dichos programas en la industria del acero, véase Brody (1960) o el Year Book of the American Iron and Steel Institute for 1914 (AISI 1915) de autofelicitación]. Los programas tenían un carácter muy paternalista, confiaban más en la disciplina que en la educación y solían basarse en la premisa de que los propios trabajadores eran culpables en gran medida de los accidentes de trabajo. G randes desastres como el incendio de Triangle Shirtwaist en 1911 en N ueva York, en el que murieron 146 trabajadores, dieron lugar al lanzamiento de campañas sindicales a favor de la adopción de mejoras y optimizaron en última instancia la legislación en materia de seguridad contra incendios. No obstante, la consideración de la salud y la seguridad como una cuestión laboral generalizada sólo se planteó con el auge de los sindicatos en los decenios de 1930 y 1940. En 1942, por ejemplo, los estatutos de la U nión de Trabajadores de la Industria del Acero de Estados U nidos exigían que todos los sindicatos locales establecieran comités de salud y seguridad. A mediados del decenio de 1950, los trabajadores y las empresas habían creado este tipo de comités en la mayoría de las minas y centros de fabricación con presencia sindical y en otros muchos lugares de trabajo del sector de la construcción y de los servicios; además, la mayoría de los contratos sindicales incluían una sección sobre salud y seguridad.

\section{Proceso de negociación colectiva}

Suele concebirse la negociación colectiva como un proceso formal que se desarrolla a intervalos de tiempo regulares y que da lugar a la celebración de un acuerdo por escrito entre las organizaciones de trabajadores y la empresa o empresas. Este tipo de negociación conlleva una sucesión de demandas o propuestas, contrapropuestas y amplias deliberaciones. El proceso puede generar diversos resultados: un convenio colectivo, cartas de entendimiento, declaraciones conjuntas o códigos de práctica convenidos.

No obstante, la negociación colectiva puede entenderse asimismo como un proceso continuo de resolución de los problemas surgidos en cada momento. Este tipo de actividad se realiza cada vez que un delegado sindical se reúne con un supervisor de área para solucionar un conflicto o atender una reclamación, cada vez que un comité mixto de salud y seguridad se reúne para analizar los problemas del centro de trabajo o cada vez que un equipo constituido por los sindicatos y la dirección considera un nuevo programa empresarial.

Esta flexibilidad de la negociación colectiva ayuda a garantizar su viabilidad continua. En cualquier caso, existe una condición previa para emprender una negociación formal o informal: para que tenga éxito, los representantes de ambas partes deben estar facultados para negociar y llegar a un acuerdo que ha de ser respetado.

En ocasiones, la negociación colectiva se considera como una prueba de fuerza, en la que una ganancia para una parte supone una pérdida para la otra. Por ejemplo, un aumento salarial se observa como una amenaza para la obtención de beneficios. Un acuerdo que impide los despidos se ve como un factor limitante de la flexibilidad de la dirección. Si la negociación se considera una competición, el determinante más importante del resultado final será el poder relativo de cada una de las partes. Para las organizaciones de trabajadores, esto equivale a la capacidad de interrumpir la producción mediante una huelga, organizar un boicot del producto o el servicio de la empresa o ejercer otro tipo de presión, manteniendo la lealtad de los afiliados a la organización. Para las empresas, el poder significa la capacidad para resistir estas presiones, sustituir a los trabajadores en huelga en los países donde esta práctica se permite 0 aguantar hasta que las dificultades económicas les obliguen a retornar a sus puestos de trabajo de acuerdo con las condiciones de la dirección.

O bviamente, la gran mayoría de las negociaciones laborales acaban con éxito y sin que se interrumpa la actividad. En cualquier caso, son las amenazas de una de las partes las que llevan a ambas a buscar un acuerdo. Este tipo de negociación recibe en ocasiones el calificativo de posicional, ya que comienza con la adopción de una posición y continúa con su defensa por cada una de las partes hasta que se alcanza un compromiso basado en su fuerza relativa.

De acuerdo con un segundo modelo, la negociación colectiva consiste en la búsqueda mutua de una solución óptima (Fisher y Ury 1981). En este caso, se supone que un acuerdo adecuado puede reportar ventajas para ambas partes. Por ejemplo, un aumento de salarios puede compensarse con una mayor productividad. Un acuerdo que impide los despidos puede animar a los trabajadores a mejorar su eficacia, ya que sus puestos de trabajo no se verán amenazados como resultado de su actividad. En ocasiones, esta forma de negociación se denomina de "ventajas mutuas", de "ganancias compartidas" o de "suma positiva". Lo que es más importante es la capacidad de cada parte para comprender los intereses de la otra y encontrar soluciones que permitan optimizar ambos. La salud y la seguridad en el trabajo suele considerarse como una cuestión ideal para la negociación de ventajas mutuas, ya que las dos partes están interesadas en evitar la existencia de accidentes de trabajo y enfermedades profesionales.

En la práctica, estos modelos de negociación no se excluyen entre sí y ambos son importantes. Los negociadores cualificados tratan en todo caso de comprender a sus interlocutores y de situarse en áreas donde las partes puedan beneficiarse de un acuerdo prudente. No obstante, es poco probable que una parte sin poder logre sus objetivos. Siempre existirán ámbitos en los que las partes consideren sus intereses dispares. La negociación basada en la buena fe funciona mejor si las partes se temen entre sí.

El poder es importante, incluso en las negociaciones sobre salud y seguridad. Una empresa puede estar menos interesada 
en reducir la tasa de accidentes si puede repercutir externamente su coste. Si los trabajadores lesionados pueden ser sustituidos con facilidad y a bajo precio, sin necesidad de conceder una indemnización considerable, la dirección puede sentirse tentada de evitar la realización de mejoras en la seguridad si supone un coste elevado. A sí ocurre especialmente en el caso de las enfermedades profesionales con períodos de latencia prolongados, ya que el coste de los controles se asume cuando éstos son instalados, pero pueden pasar muchos años hasta que se observen los beneficios. En consecuencia, es más probable que una organización de trabajadores alcance sus metas si éstos tienen el poder para detener la producción o solicitar la intervención de un inspector de la Administración en caso de que las partes no acuerden una solución.

\section{Marco jurídico}

En los Convenios de la OIT sobre libertad de asociación, protección de los derechos de organización y participación en la negociación colectiva, y en los Convenios y las Recomendaciones de esta institución sobre la salud y la seguridad en el trabajo, se reconoce el papel desempeñado por las organizaciones de trabajadores. Aunque estos instrumentos constituyen el marco internacional, los derechos de los trabajadores sólo pueden garantizarse mediante la legislación y las normas nacionales.

Es obvio que la base jurídica de la negociación colectiva, la escala a la que ésta tiene lugar e incluso el proceso de negociación varía de un país a otro. La legislación de la mayoría de los países industrializados contempla la aplicación de un sistema de regulación de dicho proceso. También en Europa, el grado de regulación puede diferir ampliamente, desde el planteamiento mínimo de Alemania a otro mucho más desarrollado de Francia. Asimismo, el efecto jurídico de un convenio colectivo es variable. En la mayor parte de los países, los convenios son aplicables legalmente; sin embargo, en el Reino U nido, éstos se consideran informales y deben ponerse en práctica de acuerdo con la buena fe de las partes y respaldados por la amenaza de la interrupción de la actividad laboral. Se prevé que esta variabilidad disminuya en Europa como resultado del avance en el proceso de unificación.

La escala de negociación también varía. En Estados U nidos, Japón y la mayoría de los países de América Latina, ésta tiene lugar a escala de la empresa individual, aunque los sindicatos suelen intentar negociar convenios "de referencia" con las principales empresas de cada sector. En el otro extremo, Austria, Bélgica y los países nórdicos tienden a adoptar regímenes de negociación centralizados en los que la mayoría de los lugares de trabajo se someten a acuerdos marco negociados entre las federaciones nacionales representantes de empresas y sindicatos. L oS convenios sectoriales relativos a industrias y profesiones específicas son habituales en países como A lemania y Francia.

Los países del Africa francófona suelen seguir el ejemplo de Francia y optan por la negociación sectorial. Algunos países en desarrollo anglófonos adoptan también este régimen. En otros, varios sindicatos negocian en nombre de diferentes grupos de trabajadores en cada empresa. La escala de la negociación determina la cobertura de los convenios colectivos. Por ejemplo, en Francia y Alemania, éstos suelen ser válidos para todos los trabajadores que inician su actividad en la profesión o en el sector al que se aplica el convenio. Por otra parte, en Estados Unidos y otros países en los que se negocia a escala de la empresa, los convenios colectivos cubren únicamente los lugares de trabajo en los que el sindicato en cuestión haya sido reconocido como agente negociador.

Un factor aún más importante al determinar la cobertura de la negociación colectiva es el hecho de que la legislación nacional facilite o impida ésta y la sindicación. Por ejemplo, en algunos países no se permite a los funcionarios negociar colectivamente. En otros, los sindicatos del sector público se expanden con rapidez, Como resultado de estos factores, el porcentaje de trabajadores amparados por convenios colectivos oscila entre un máximo de casi el $90 \%$ en Alemania y los países nórdicos y menos del $10 \%$ en numerosos países en desarrollo.

Asimismo, el marco jurídico afecta al modo en que la negociación colectiva se aplica a la salud y la seguridad en el trabajo. Por ejemplo, la L ey de salud y seguridad en el trabajo de Estados U nidos reconoce a las organizaciones de trabajadores el derecho a la información sobre sustancias químicas peligrosas y otros riesgos del centro de trabajo, el derecho a acompañar a un inspector en el lugar de trabajo y un derecho limitado a intervenir en los procesos jurídicos iniciados por la Administración contra una empresa por incumplimiento de las normas establecidas

M uchos países van más allá en sus medidas. La mayoría de los países industrializados exigen a la mayor parte de las empresas que establezcan comités conjuntos de salud y seguridad. La provincia canadiense de Ontario estipula que los trabajadores de gran parte de los lugares de trabajo elijan representantes acreditados en materia de salud y seguridad, y que se imparta a éstos un curso normalizado de formación a costa de la empresa. La Ley de medio ambiente de trabajo de Suecia exige la designación de delegados de seguridad por parte de las organizaciones sindicales locales. Estos delegados gozan de amplios derechos de información y consulta. Lo que es más importante, tienen la facultad de suspender las actividades peligrosas hasta que sean sometidas al examen de la Inspección de trabajo de Suecia.

Estas leyes refuerzan el proceso de negociación colectiva en materia de salud y seguridad. Los comités de seguridad conjuntos impuestos por la legislación constituyen un mecanismo rutinario para facilitar la negociación. La formación permite a los representantes sindicales adquirir los conocimientos necesarios para participar en el proceso eficazmente. EI derecho a suspender las actividades peligrosas ayuda a las partes a centrarse en la eliminación de la fuente de riesgo.

\section{Aplicación de contratos y legislación laboral}

O bviamente, los convenios colectivos tienen un valor limitado si no se acompañan de un mecanismo de aplicación. La huelga es uno de los métodos de que disponen las organizaciones de trabajadores para responder a un presunto incumplimiento por parte de la empresa; ésta, por su parte, puede llevar a cabo un cierre patronal y negar el empleo a los miembros de dichas organizaciones hasta que se resuelva el conflicto. N o obstante, la mayoría de los convenios colectivos en los países desarrollados se basan en métodos de aplicación menos perjudiciales. D e hecho, en muchos de los acuerdos se prohiben las huelgas y los cierres patronales durante su vigencia (cláusulas de no declaración de huelga y compromisos de paz). En algunos se restringen a un número limitado de circunstancias; por ejemplo, los contratos negociados en Estados U nidos entre la U nión de Trabajadores de la Automoción y las principales empresas de este sector permiten la convocatoria de huelgas debidas a la existencia de condiciones de trabajo inseguras, pero no las relacionadas con salarios o prestaciones en el período de vigencia del acuerdo.

Un mecanismo de aplicación habitual en los países desarrollados consiste en un sistema de arbitraje, en el que la resolución de conflictos se deja en manos de un árbitro imparcial elegido conjuntamente por la empresa y la organización de trabajadores. En algunos casos, los conflictos pueden resolverse mediante el recurso al sistema judicial, ya sea en los tribunales ordinarios o en magistraturas de trabajo específicas. En Estados U nidos, por ejemplo, los conflictos relativos a la interpretación 
de un contrato suelen resolverse mediante arbitraje. No obstante, si la parte a la que no se da la razón decide negarse a acatar la decisión arbitral, la otra parte puede acudir a los tribunales para que apliquen la decisión. El Consejo $\mathrm{N}$ acional de Relaciones Laborales, un órgano cuasijudicial de Estados U nidos, atiende las reclamaciones relativas a las prácticas laborales injustas, como la que consiste en que una de las partes no negocie de buena fe. En muchos otros países, los tribunales de trabajo cumplen esta función.

\section{La negociación colectiva en la actualidad}

La negociación colectiva es un proceso dinámico en todos los sistemas de relaciones laborales en que se practica. La situación en Europa cambia con rapidez. Los países nórdicos se caracterizan por la adopción de acuerdos generales sobre el medio ambiente de trabajo negociados a escala de todo el país e integrados en una legislación nacional muy desarrollada. La sindicación es elevada; en los convenios colectivos y en la legislación se prevé el establecimiento de comités conjuntos y representantes de los trabajadores en materia de seguridad en la mayoría de los lugares de trabajo. Los mecanismos de negociación colectiva relativos a la salud y la seguridad y las tasas de sindicación son más modestas en otros países europeos. Los Estados miembros de la U nión Europea se enfrentan a la tarea de armonizar las legislaciones nacionales de acuerdo con el Acta Unica Europea y la Directiva "marco" sobre salud y seguridad (Hecker 1993). Los sindicatos europeos tratan de coordinar sus iniciativas, sobre todo mediante la Confederación Europea de Sindicatos. Se aprecian ciertos signos de que la negociación colectiva será sustituida, o más probablemente, complementada en última instancia por la celebración de acuerdos a escala europea, aunque la resistencia de las empresas a esta medida es elevada. EI primer ejemplo de esta negociación paneuropea alude a la determinación del permiso de paternidad. En el área de la salud y la seguridad, el sindicato GMB del Reino Unido ha propuesto un ambicioso Fondo Europeo sobre el M edio Ambiente de Trabajo, basado en entidades similares existentes en los países nórdicos.

La E uropa central y oriental y los países de la antigua U nión Soviética cambian con una rapidez aún mayor. Las normas sobre salud y seguridad eran exhaustivas en la época comunista, pero rara vez se aplicaban. Los sindicatos existían, pero sólo bajo el control del Partido Comunista. En las empresas, los sindicatos funcionaban como departamentos de relaciones laborales en el lugar de trabajo y se sometían a la supervisión de la dirección, sin que se llevase a cabo ningún tipo de negociación bipartita. Los sindicatos independientes de nuevo cuño ayudaron a precipitar la caída del comunismo; en ocasiones, sus reivindicaciones se centraban en las condiciones de trabajo 0 en medidas sanitarias básicas como la disposición de jabón en los lavaderos de las minas de carbón. A ctualmente, los antiguos sindicatos han desaparecido o luchan por reconstituirse. Los nuevos sindicatos independientes intentan dejar de ser organizaciones políticas opuestas al G obierno y transformarse en instituciones dedicadas al fomento de la negociación colectiva y la representación de sus afiliados en el lugar de trabajo. Las condiciones de trabajo inadecuadas y, a menudo, en proceso de deterioro seguirán constituyendo uno de los objetivos importantes.

El sistema japonés de participación de los trabajadores, mejora continua y formación amplia fomenta en la práctica la salud y la seguridad, pero sólo en las empresas en las que éstas constituyen un objetivo explícito. La mayoría de los sindicatos japoneses existen únicamente a escala empresarial; las negociaciones tienen lugar mediante un sistema de consulta conjunta continua (Inohara 1990). L os comités conjuntos de salud y seguridad se establecen de conformidad con la Ley de seguridad e higiene en el trabajo, modificada.

\section{Acción sindical en Zimbabwe}

El Congreso de Sindicatos de Zimbabwe (CSZ) ha iniciado una Campaña $\mathrm{N}$ acional para la Defensa de los Derechos de los Trabajadores Accidentados, en la que se combina la acción a escala nacional y la emprendida en los centros de trabajo con el fin de modificar la legislación y mejorar los convenios colectivos.

Desde 1990, la legislación de Zimbabwe prevé la creación de comités de seguridad y la elección de representantes y supervisores de salud y seguridad en todos los centros de trabajo. EI CSZ ha insistido en que dichos representantes sean elegidos por los trabajadores: En su Campaña $\mathrm{N}$ acional se efectúan las demandas siguientes:

1. Trabajo seguro. Esto exige la determinación de los riesgos del lugar de trabajo mediante la realización de estudios y la investigación de los accidentes, así como la negociación de la mejora de las condiciones.

2. Participación de los trabajadores y los sindicatos en las cuestiones de salud que les competen. Aquí se incluyen los derechos de los trabajadores a elegir sus propios representantes en materia de salud y seguridad, a obtener información como los datos sobre seguridad y los informes de los inspectores industriales y a investigar conjuntamente y comunicar los accidentes y los daños (como en Suecia).

3. Indemnización adecuada y asistencia para los trabajadores lesionados. Se incluye una revisión de los niveles de indemnización.

4. Seguridad en el puesto de trabajo para los trabajadores accidentados. Los representantes sindicales han negociado la concesión del derecho a regresar al trabajo y recibir ayuda en el nuevo puesto.

Para el CSZ, su programa de formación para fomentar la participación eficaz de los trabajadores en el tratamiento de la salud y la seguridad en el lugar de trabajo ha sido una medida fundamental en la prevención de accidentes. La formación de los representantes de los trabajadores ha consistido en la realización de visitas de inspección en el lugar de trabajo y en la presentación de informes sobre los riesgos detectados, en primer lugar, a los trabajadores y, después, a la dirección para su análisis. Una vez en acción, los representantes sindicales en materia de salud y seguridad han participado en inspecciones y han contribuido a garantizar que los daños se comunican. Este factor es especialmente importante en sectores que, de otra modo, resultarían inaccesibles, como la agricultura.

Asimismo, el CSZ ha exigido un aumento de las sanciones que pueden imponerse a las empresas declaradas culpables de incumplimiento de la legislación sobre salud y seguridad.

\section{por la directora del capítulo} (extraído de Loewenson 1992).

L os convenios colectivos en E stados U nidos contienen disposiciones sobre salud y seguridad relativamente amplias por dos razones. En primer lugar, esta cuestión es considerada importante por los sindicatos del país, como lo es para las organizaciones de trabajadores de todos los países industrializados. $\mathrm{N}$ o obstante, la legislación en Estados U nidos no incluye muchas de las disposiciones contempladas en otros países, lo que obliga a los sindicatos a negociar derechos y medidas de protección garantizadas en otros casos por la ley. Por ejemplo, los comités conjuntos de salud y seguridad se consideran en general como un mecanismo importante para la cooperación y la negociación ordinaria entre los trabajadores y las empresas. Sin embargo, la Ley de salud y seguridad en el trabajo de Estados U nidos no 
exige la constitución de los mismos. En consecuencia, los sindicatos deben negociar para conseguirlos. Puesto que la tasa de sindicación en el país es reducida, la mayoría de los trabajadores no tienen acceso a dichos comités.

La legislación canadiense varía de una provincia a otra, aunque en general es más exhaustiva que en Estados U nidos. Por ejemplo, los sindicatos no necesitan negociar la existencia de comités de salud y seguridad, aunque pueden tratar de constituir otros más amplios y con más competencias. La legislación mexicana también estipula la creación de estos comités.

La situación en los países en desarrollo es diversa. Las organizaciones de trabajadores en países como la India, Brasil y Zimbabwe hacen cada vez más hincapié en la salud y la seguridad mediante la negociación colectiva y la movilización a favor de la mejora de la legislación. Por ejemplo, el Congreso de Sindicatos de Zimbabwe ha propugnado la ampliación del código de trabajo nacional, incluidas sus disposiciones en materia de salud y seguridad, a las zonas francas industriales (véase el recuadro). Sin embargo, los sindicatos se ven sometidos a restricciones graves 0 son suprimidos en muchas partes del mundo y la gran mayoría de trabajadores de los países en desarrollo no pertenecen a organizaciones de trabajadores ni se benefician de la negociación colectiva.

\section{El futuro de la negociación colectiva}

Las organizaciones de trabajadores y la negociación colectiva afrontan retos difíciles en los años venideros. Casi todos los procesos de negociación colectiva tienen lugar a escala empresarial, sectorial o nacional. Por otra parte, la economía se globaliza cada vez más. No obstante, con la excepción de Europa, las organizaciones de trabajadores aún tienen que desarrollar mecanismos eficaces de negociación transnacional. Este objetivo es prioritario para las federaciones internacionales de sindicatos. $L a$ mejor vía para alcanzarlo consiste en la consecución de estructuras sindicales internacionales más sólidas y capaces, la inclusión de cláusulas sociales amplias en los acuerdos comerciales mundiales y la adopción de instrumentos apropiados como los que ofrece la Organización Internacional del Trabajo. Por ejemplo, la Declaración Tripartita de la OIT sobre Empresas M ultinacionales alude específicamente a la negociación colectiva y a la salud y la seguridad en el trabajo. M uchos sindicatos desarrollan en la actualidad vínculos directos con las organizaciones de trabajadores de otros países, con el fin de coordinar su estrategia de negociación y prestarse ayuda mutua.

Los rápidos cambios experimentados en los ámbitos de la tecnología y la organización del trabajo pueden convertir los convenios colectivos existentes en instrumentos obsoletos. Las organizaciones de trabajadores intentan desarrollar una forma de negociación continua que responda a la evolución del lugar de trabajo. Hace tiempo que reconocen la vinculación entre el medio ambiente de trabajo y el medio ambiente exterior. Algunos sindicatos han comenzado a abordar cuestiones relacionadas con éste último en sus convenios colectivos. U n ejemplo de esta actitud es el Acuerdo de Referencia sobre Medio Ambiente propuesto por la $\mathrm{M}$ anufacturing-Science-Finance (M SF) U nion del Reino U nido.

Un objetivo fundamental de los sindicatos es mantener los derechos humanos y el bienestar social al margen de la competencia económica, con el fin de evitar que las empresas o países busquen la consecución de ventajas competitivas mediante el empobrecimiento de sus trabajadores y les obliguen a trabajar en condiciones peligrosas. L a negociación colectiva es esencial para la salud y la seguridad en el trabajo. No obstante, las organizaciones de trabajadores ejercen un papel fundamental en este proceso y son acosadas en numerosos países en desarrollo y desarrollados. La supervivencia y el progreso de estas organizaciones determinará en gran medida que los trabajadores disfruten de un aumento en el nivel de vida y de la mejora de las condiciones de trabajo 0 , por el contrario, se enfrenten a un círculo vicioso de pobreza, lesiones y enfermedad.

\section{COOPERACION TRIPARTITAY BIPARTITA A ESCALA NACIONAL EN MATERIA DE SALUD Y SEGURIDAD EN EL TRABAJO}

\section{Robert H usbands}

La cooperación entre los trabajadores, las empresas y la Administración en la elaboración y la aplicación de las medidas relativas a la salud y la seguridad en el trabajo a escala nacional o regional es habitual en un número significativo de países. A simismo, no es infrecuente la participación de grupos de interés y expertos técnicos en este proceso. Esta forma de cooperación se caracteriza por un desarrollo elevado y ha sido institucionalizada en varios países mediante el establecimiento de organizaciones consultivas y de colaboración. En general, éstas han sido objeto de una amplia aceptación por todos los participantes en el mercado de trabajo, ya que parece existir un consenso generalizado en cuanto a la consideración de la salud y la seguridad como cuestiones de interés general respecto a las que el diálogo entre los interlocutores sociales, la Administración y otras partes interesadas resulta extremadamente importante.

L as instituciones que se han establecido para facilitar este tipo de cooperación varían significativamente en cuanto a la forma. U n planteamiento consiste en crear organizaciones consultivas ad hoc o permanentes para asesorar a la Administración en cuestiones relativas a la política de salud y seguridad en el trabajo. Esta no suele estar obligada a seguir las recomendaciones propuestas, pero, en la práctica, resulta difícil ignorarlas y a menudo se tienen en cuenta en la formulación de la política gubernamental.

El otro planteamiento consiste en lograr que los interlocutores sociales y otras partes interesadas cooperen activamente con la Administración en las instituciones públicas establecidas para aplicar la política de salud y seguridad en el trabajo. La participación de los actores privados en las instituciones públicas con competencias en esta materia suele basarse en la representación de las organizaciones de empresarios y trabajadores y, en algunos casos, otras representaciones en los consejos de administración de dichas instituciones, aunque en ocasiones la participación se extiende a la gestión e incluso a la elaboración de proyectos. Estas personas suelen ser designadas por la administración previa recomendación de las partes representadas, aunque, en ciertos casos, las organizaciones de empresas y de trabajadores tienen derecho a elegir directamente sus representantes en estas instituciones de colaboración. Normalmente, los organismos constituidos a escala nacional (o regional, estatal o provincial) son completados por la dotación de estructuras 0 sistemas a escala sectorial, empresarial y de centro de trabajo.

\section{Asesoramiento sobre formulación de políticas y regulación}

Probablemente, la forma más común de cooperación consiste en la creación de organizaciones consultivas para que asesoren sobre formulación de políticas y regulación. Los ejemplos de esta práctica pueden ir desde un enfoque modesto, en el que se emplean relativamente pocos recursos, hasta otros más institucionalizados, caracterizados por una movilización de recursos significativa. 
En Estados U nidos se ha optado por el primer enfoque. A escala federal, el National Advisory Committee on $O$ ccupational Safety and $\mathrm{H}$ ealth, establecido en virtud de la Ley de seguridad y salud en el trabajo de 1970, es el principal comité consultivo permanente. De acuerdo con la Ley, debe estar compuesto por representantes de las empresas, los sindicatos, los profesionales de la salud y la seguridad en el trabajo y el público en general, actuando un representante de éste como presidente. EI Comité formula recomendaciones al Secretario de Trabajo y al Secretario de Salud. N o obstante, en la práctica, sus reuniones no han sido frecuentes. Sus miembros no son remunerados y el Secretario de Trabajo ha facilitado una secretaría ejecutiva y otros servicios auxiliares necesarios con cargo a su presupuesto. Por tanto, los costes de mantenimiento del Comité son muy limitados, aunque las restricciones presupuestarias actuales ponen en tela de juicio la continuidad incluso de este reducido apoyo. En julio de 1971, de conformidad con la O rden Ejecutiva 11612, se creó el Federal Advisory C ouncil on $\mathrm{O}$ ccupational Safety and $\mathrm{H}$ ealth, un comité permanente de carácter similar con la misión de asesorar al Secretario de Trabajo sobre cuestiones relativas a la salud y la seguridad de los trabajadores federales.

La Ley de seguridad y salud en el trabajo de 1970 prevé asimismo la creación de comités asesores ad hoc para facilitar el desempeño de las funciones de regulación. Estos comités son designados por el Secretario de Trabajo y deben estar formados por un máximo de 15 miembros, incluidas una o varias personas elegidas por el Secretario de Salud. Cada comité de regulación ha de estar compuesto por el mismo número de representantes de las organizaciones de trabajadores y de empresas. Asimismo, el Secretario de Trabajo puede designar uno o varios representantes de las agencias estatales de salud y seguridad, así como expertos técnicos que pueden ser, por ejemplo, representantes de las organizaciones de técnicos o profesionales especializados en salud y seguridad en el trabajo o de organizaciones reguladoras reconocidas a escala nacional. Estos comités de regulación han sido objeto de una utilización intensiva y, en ocasiones, se han mantenido en funcionamiento varios años hasta la finalización de la tarea que se les había encomendado. $L$ as reuniones pueden ser frecuentes, dependiendo de la naturaleza de las tareas que deben llevarse a cabo. Aunque los miembros de estos comités no suelen ser remunerados, se les abonan una dietas razonables por desplazamiento y, en el pasado, los servicios de apoyo han sido financiados por el Departamento de Trabajo. El objetivo de los comités es formular recomendaciones sobre las normas aplicables a la agricultura, el amianto, las sustancias cancerígenas, las emisiones de los hornos de "coque", los riesgos para la piel, el etiquetado de sustancias y preparados peligrosos, el estrés por calor, las instalaciones portuarias, el ruido, la salud y la seguridad de las actividades costeras, las normas de empleo en astilleros, las normas de la industria del acero, etc.

Se establecieron otros comités consultivos ad hoc de naturaleza semejante, que persiguen una legislación similar y que son competencia del Secretario de Trabajo. Por ejemplo, se crearon varios comités de normalización a tenor de lo dispuesto en la Ley federal de seguridad y salud en la minería, de 1977. Estos comités se caracterizan por la escasa cuantía de los recursos dedicados a su establecimiento y de los costes de administración, la infraestructura limitada, la participación voluntaria de partes externas sin remuneración y su disolución tras la realización de sus tareas.

En cambio, en otros países se adoptan formas de consulta institucionalizadas más elaboradas. En los Países Bajos, por ejemplo, la organización preeminente es el Consejo de Medio Ambiente de Trabajo, creado en virtud de la Ley del consejo de medio ambiente de trabajo de 1990. Este organismo emite dictámenes para el M inisterio de Asuntos Sociales y Empleo, previa solicitud 0 a iniciativa propia, y formula comentarios sobre propuestas de leyes y decretos, y puede presentar sus propias propuestas para la formulación de políticas o la promulgación de legislación. Asimismo, expresa su opinión respecto a la conveniencia de otorgar subvenciones a la investigación sobre cuestiones relativas al medio ambiente de trabajo, la concesión de exenciones, la formulación de directrices para la A dministración y la política de la Inspección de trabajo. Está compuesto por ocho representantes de las organizaciones empresariales centrales, otros ocho de las de trabajadores y siete de los órganos gubernamentales. No obstante, sólo los representantes de las organizaciones de empresarios y trabajadores tienen derecho al voto y el presidente del Consejo es independiente. Las reuniones son mensuales. Por otra parte, el Consejo dispone de unos 15 comités de trabajo dedicados a cuestiones específicas y, además, grupos de trabajo ad hoc establecidos para la consideración pormenorizada de ciertos aspectos, cuando su naturaleza así lo justifica. Los expertos externos desempeñan un papel importante en los comités y grupos de trabajo, que elaboran informes y documentos analizados en las reuniones del Consejo que suelen constituir la base de las posturas adoptadas posteriormente. Las recomendaciones de este organismo tienen un alcance general y son publicadas. Aunque, normalmente, las partes tratan de adoptar una postura consensuada, pueden remitirse dictámenes independientes al Ministerio de Asuntos Sociales y Empleo cuando los representantes de empresas y de trabajadores no consiguen ponerse de acuerdo. Más de 100 personas participan en el trabajo del Consejo y sus organizaciones subsidiarias y, por tanto, éste debe contar con el apoyo de recursos económicos y administrativos considerables.

En los Países Bajos existen otras organizaciones consultivas menos importantes centradas en cuestiones más específicas de salud y seguridad en el trabajo. Se trata de la Fundación para el M edio Ambiente de Trabajo en el Sector de la Construcción, la Fundación para la Asistencia Sanitaria en la Agricultura, la Comisión para la Prevención de Desastres provocados por Sustancias Peligrosas y la Comisión de Inspección de Trabajo y Política de A plicación.

A continuación se enumeran ejemplos de otros países de las organizaciones consultivas bipartitas, tripartitas o multipartitas que formulan recomendaciones sobre la política y las normas de salud y seguridad en el trabajo: en Canadá, comités ad hoc de reforma legislativa y normalización a escala federal (en Alberta, el Foro para la Acción en Materia de Salud y Seguridad en el Trabajo; en Ontario, el Comité Director Conjunto sobre Sustancias Peligrosas en el Lugar de Trabajo; en Terranova, el Comité Consultivo para la Prevención de las Lesiones de Espalda; en la Isla del Príncipe Eduardo, el Consejo de Salud y Seguridad en el Trabajo; en M anitoba, el Consejo Consultivo de Seguridad y Salud en el Lugar de Trabajo; en Saskatchewan, el Consejo de Salud y Seguridad en el Trabajo; y en la Columbia Británica, el Foro para la Seguridad de la Explotación Forestal); en Dinamarca, el Consejo del M edio A mbiente de Trabajo; en Francia, el Consejo Central para la Prevención de los R iesgos Profesionales y la Comisión Nacional de Salud y Seguridad en el Trabajo en la Agricultura; en Italia, la Comisión Consultiva Permanente para la Prevención de Accidentes de Trabajo y Salud Laboral; en Alemania, el Consejo A sesor del Instituto Federal de Salud y Seguridad en el Trabajo; y en España, la Comisión $\mathrm{N}$ acional de Seguridad y Salud en el trabajo.

\section{Aplicación de políticas}

Varios países disponen de organizaciones bipartitas, tripartitas y multipartitas que también participan en la aplicación de políticas. Estas entidades colaboradoras suelen ser instituciones públicas compuestas por representantes de las organizaciones de empresas y de trabajadores y, en algunos casos, otras personas y grupos 
interesados tanto en la formulación como en la aplicación de políticas. Normalmente de una dimensión muy superior a los comités, las comisiones y los consejos consultivos, estas organizaciones colaboradoras se encargan de aplicar la política gubernamental, suelen gestionar recursos presupuestarios abundantes y, a menudo, cuentan con una nutrida plantilla.

Un ejemplo de este tipo de organizaciones es la $\mathrm{H}$ ealth and Safety Commission del Reino Unido. Creada a tenor de lo dispuesto en la Ley de salud y seguridad de 1974, debe velar por la adopción de las medidas pertinentes para garantizar la salud, la seguridad y el bienestar de los trabajadores, proteger a las personas frente a los riesgos para la salud y la seguridad surgidos fuera del trabajo, controlar el almacenamiento y la utilización de explosivos, materiales altamente inflamables y otras sustancias peligrosas, y supervisar la emisión de sustancias nocivas o perjudiciales en el lugar de trabajo. Depende de la Secretaría de Estado de Educación y Empleo y de otras secretarías de Estado, como las de Comercio e Industria, Transporte, M edio Ambiente y Agricultura. La Comisión está compuesta por nueve personas, designadas por la Secretaría de Estado de Educación y Empleo. Una de ellas actúa como presidente, tres miembros son nombrados previa consulta con las principales organizaciones empresariales centrales, otros tres previa consulta con las de trabajadores y dos previa consulta con asociaciones de la Administración local.

La Comisión cuenta con la ayuda de varias organizaciones auxiliares (Figura 21.3). La más importante es el $\mathrm{H}$ ealth and Safety Executive, un órgano establecido por la ley y compuesto por un consejo rector de tres personas designadas por la Comisión, con la aprobación del Secretario de E stado de Educación y Empleo. El Health and Safety Executive lleva a cabo el trabajo esencial de la Comisión, incluida la aplicación de las normas de salud y seguridad contempladas en la Ley de salud y seguridad de 1974, y desempeña otras funciones delegadas por aquélla. La Administración local también desempeña funciones de aplicación respecto a la legislación en materia de salud y seguridad. Además, la Comisión, para desarrollar su trabajo, recibe la ayuda de varios comités consultivos de carácter bipartito, tripartito o multipartito. Estas entidades se organizan por sectores y en función de los aspectos que abordan. Existe un comité consultivo para cada una de las cuestiones siguientes: sustancias tóxicas, patógenos peligrosos, sustancias peligrosas, modificaciones genéticas, salud en el trabajo, emisiones medioambientales, instalaciones nucleares y radiaciones-ionizantes. A simismo, se dispone de comités consultivos activos en los sectores siguientes: agricultura, cerámica, construcción, educación,

Figura 21.3 - Salud y seguridad en el Reino Unido: instituciones principales.

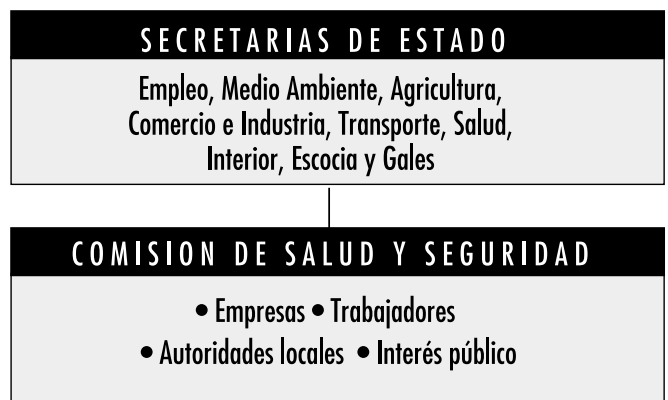

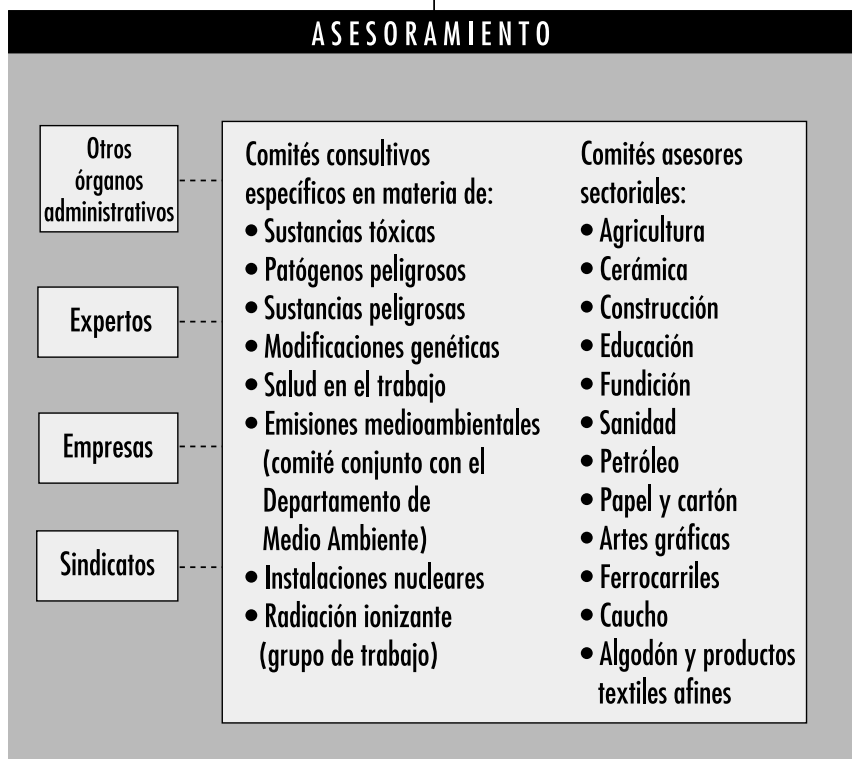

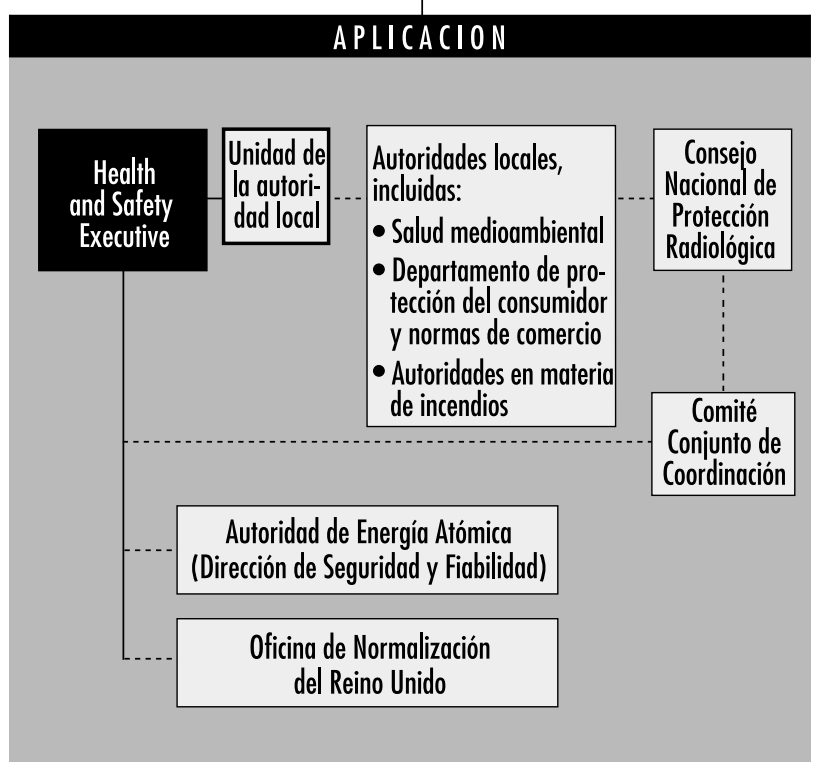

Fuente: Comisión de Salud y Seguridad, 1992. 
fundición, sanidad, petróleo, papel y cartón, artes gráficas, ferrocarriles, caucho, algodón y textiles. Los primeros suelen estar compuestos por un número de miembros que oscila entre los 12 y los 18, más un presidente y tienen un carácter multipartito, ya que suelen incluir expertos técnicos, así como representantes de las organizaciones centrales de trabajadores y de empresas, de la Administración y de otros grupos de interés. Los comités sectoriales, por su parte, suelen ser bipartitos y están compuestos por 12 miembros que representan a partes iguales a las organizaciones de trabajadores y de empresas y presididos por una persona designada por la Administración. Los recursos de que dispone la Comisión y el $\mathrm{H}$ ealth and Safety Executive son considerables. Por ejemplo, en 1993 contaban con una plantilla conjunta de 4.538 personas y un presupuesto de 211,8 millones de libras.

0 tros ejemplos de organizaciones colaboradoras en este ámbito son las que actúan en Canadá. A escala federal, el Centro Canadiense para la Salud y la Seguridad en el Trabajo es la principal institución del país para obtener información sobre esta materia. EI Centro fomenta asimismo la salud y la seguridad en el lugar de trabajo, facilita el establecimiento de normas exigentes al respecto y contribuye al desarrollo de programas y políticas de reducción y erradicación de los riesgos profesionales. AI Centro, creado en virtud de una ley del parlamento de 1978, se le asignó un órgano directivo para garantizar su imparcialidad en las cuestiones relativas a la salud y la seguridad y la inexistencia de sesgos en su función de fuente de información. Su consejo directivo está compuesto por un presidente y 12 consejeros: cuatro representan a las A dministraciones federal, provincial y territorial, cuatro a los sindicatos y cuatro a las empresas. EI C entro gestiona una cantidad de recursos económicos y humanos considerable y sus gastos totales en 1993 ascendieron a unos 8,3 millones de dólares canadienses.

En algunas provincias también existe organizaciones colaboradoras. En Q uebec, dos de las más importantes son la Comisión de Salud y Seguridad en el Trabajo y el Instituto de Investigación en M ateria de Salud y Seguridad en el Trabajo. La Comisión cumple dos funciones. En primer lugar, formula y aplica la política de salud y seguridad en el trabajo, incluida la determinación de normas y su puesta en práctica; presta su apoyo a la aplicación de los programas de prevención, los mecanismos de participación y los servicios de salud y ofrece formación, información y servicios de investigación. En segundo lugar, se encarga de remunerar a los trabajadores accidentados en su trabajo y gestiona un fondo de seguros con este fin, al que las empresas deben contribuir. La Comisión, creada por ley en 1981 y sucesora de la Comisión de Accidentes de Trabajo fundada en 1931, está dirigida por un consejo de administración bipartito compuesto por siete representantes de los trabajadores, siete de las empresas y un presidente. Estos representantes son elegidos entre las personas incluidas en las listas ofrecidas por las principales organizaciones de empresas y de trabajadores. La Comisión disponen de recursos humanos y económicos abundantes; a finales de 1992, registró un gasto de 2.151.700 de dólares canadienses y contaba con una plantilla de 3.013 trabajadores permanentes y 652 eventuales.

EI mandato del Instituto de I nvestigación en M ateria de Salud y Seguridad en el Trabajo de Q uebec, fundado en 1980, consiste en contribuir, mediante la investigación científica, a la determinación y la eliminación de las fuentes de riesgo en el lugar de trabajo, así como a la readaptación de los trabajadores que han sufrido daños. Su consejo de administración está constituido por las mismas personas que el de la Comisión de Salud y Seguridad en el Trabajo, a pesar de que se trata de una institución independiente. Asimismo, el Instituto cuenta con un consejo científico que desempeña funciones de asesoramiento y está compuesto por cuatro representantes de las organizaciones de trabajadores, cuatro de las de empresas, seis de la comunidad científica y técnica y el Director General del Instituto. En 1992, los gastos de esta entidad ascendieron a 17,9 millones de dólares canadienses y su plantilla estaba compuesta por unos 126 trabajadores.

La Agencia de Salud y Seguridad en el Lugar de Trabajo de O ntario, creada en 1990 en virtud de la modificación de la Ley de salud y seguridad en el trabajo, también se ocupa de la formulación y la aplicación de políticas y la gestión de los programas en esta materia. Su consejo directivo tiene un carácter bipartito y está compuesto por 18 personas, que representan en igual número a las organizaciones de trabajadores y de empresas. U n representante de cada una de las partes actúa como primer ejecutivo conjunto de la entidad. Los recursos que gestiona son cuantiosos y sus gastos totales ascendieron a 64,9 millones de dólares canadienses en 1992.

Suecia, país con una larga tradición de organizaciones colaboradoras en el campo de la salud y la seguridad en el trabajo, decidió abandonar esta forma de organización en 1992 y, en consecuencia, ha comenzado a utilizar en su lugar organizaciones consultivas. Cabe señalar que esta decisión no se limitó al ámbito de la salud y al seguridad, sino que afectó a las entidades de todo tipo en las que los representantes de las organizaciones de trabajadores y de empresas desempeñaban un papel en la toma de decisiones a escala nacional. El impulso para adoptar estos cambios partió de la principal organización empresarial, que optó unilateralmente por dejar de participar en las instituciones públicas colaboradoras. Para justificar tal decisión, argumentó que los grupos de interés no deben ejercer responsabilidades políticas en la gestión de las instituciones públicas y que esta función le corresponde al Gobierno y al Parlamento, que el papel de una organización empresarial consiste en representar los intereses de sus afiliados, que esta actividad puede ser incompatible con el deber de atender a los intereses de las instituciones públicas si las organizaciones empresariales participan en los consejos de administración de aquéllas y que tal participación debilita la democracia y el desarrollo de las instituciones públicas. A unque las organizaciones de trabajadores no se mostraron de acuerdo con esta postura, el G obierno llegó a la conclusión de que los órganos colaboradores sin representación de las principales organizaciones empresariales carecen de utilidad y decidió limitar la representación de estas organizaciones y de las de trabajadores, así como la de otros grupos de interés, únicamente a los órganos consultivos.

Aunque en la mayoría de los países las organizaciones colaboradoras son menos habituales que las consultivas, cuya difusión es considerable, el caso del rechazo de Suecia a las primeras, al menos en el ámbito de la salud y la seguridad, parece ser aislado. A pesar de que algunas instituciones colaboradoras, dedicadas sobre todo al tratamiento de cuestiones de política económica, formación y empleo, fueron desmanteladas en el Reino Unido en los decenios de 1980 y 1990 por los sucesivos Gobiernos conservadores, la $\mathrm{H}$ ealth and Safety Commission no se vio afectada. Para algunos, esta excepción se debe a la consideración de la salud y la seguridad en el trabajo como una cuestión de interés común, tanto para las organizaciones de trabajadores y de empresas, como para la Administración y otras partes afectadas y, por tanto, a la existencia de un gran interés de todas ellas por alcanzar un consenso relativo a la formulación y la aplicación de políticas. Asimismo, en Canadá, estas instituciones colaboradoras se crearon a escala federal y en algunas provincias, precisamente, porque se consideraba que un enfoque basado en la colaboración era más útil en la búsqueda de consenso entre los agentes del mercado de trabajo y porque la administración de la legislación sobre salud y seguridad en el 
trabajo resultaría más imparcial y justa con los sometidos a la misma.

En todo caso, a una escala más general, hay dos órganos consultivos nacionales que también se ocupan de la salud y la seguridad en el trabajo dentro de sus competencias más generales en relación con todas las cuestiones económicas y sociales importantes en el ámbito nacional. En los Países Bajos, la Fundación para el Trabajo, creada en mayo de 1945, es una organización bipartita gestionada conjuntamente por el mismo número de representantes de las principales organizaciones de empresas y de trabajadores (incluidos los agricultores), que desempeña un papel significativo como órgano consultivo del Gobierno. Aunque históricamente su función fundamental se ha relacionado con las cuestiones de política salarial, expresa asimismo sus opiniones acerca de otras condiciones de trabajo. El otro órgano consultivo de importancia es el Consejo Económico y Social, establecido en 1950 de conformidad con la Ley de asociaciones sectoriales. T iene carácter tripartito y está constituido por 15 representantes de las organizaciones empresariales centrales, otros 15 representantes de las de trabajadores y 15 expertos independientes. Los representantes de empresas y de trabajadores son elegidos por sus organizaciones y los expertos por la Administración. En sus designaciones, ésta intenta mantener un equilibrio entre los distintos partidos políticos. El Consejo es independiente del Gobierno y se financia mediante un impuesto obligatorio exigido a las empresas. Dispone de un presupuesto de varios millones de dólares y de su propia Secretaría. Suele reunirse una vez al mes y cuenta con la ayuda de diversos comités ad hoc y permanentes, que se constituyen a menudo con un carácter tripartito. La Administración está obligada por ley a remitir todas las propuestas de legislación económica y social al Consejo para que éste preste su asesoramiento al respecto y toda la legislación sobre trabajo (incluidas las propuestas relativas a la salud y la seguridad en el trabajo) se presenta también a este organismo.

Cabe añadir que varios países exigen que los comités de salud y seguridad en el trabajo deban o puedan establecerse en empresas cuyas plantillas superan un cierto número de trabajadores. Estos comités son bipartitos y están compuestos por representantes de las empresas y los trabajadores. Su función suele consistir en investigar y proponer vías y medios para contribuir activamente a la materialización de las medidas adoptadas a fin de garantizar las mejores condiciones posibles en materia de salud y seguridad en los centros de trabajo, y puede incluir la promoción y el seguimiento de estas condiciones en la empresa con el fin de velar, entre otras cosas, por el cumplimiento de la legislación y las normas pertinentes. Por ejemplo, la legislación exige la constitución de este tipo de comités en Alemania, Bélgica, C anadá, España, Francia y Países Bajos.

\section{- Formas DE PARTICIPACION DE LOS TRABAJADORES}

\section{M uneto Ozaki y Anne T rebilcock}

La expresión participación de los trabajadores se utiliza de manera imprecisa para hacer referencia a las diversas formas de participación de los trabajadores en los procesos de toma de decisiones, normalmente a escala empresarial. Estas formas son un complemento de otras que pueda haber a escala sectorial 0 nacional, como los órganos de cooperación tripartita. Existen grandes diferencias en las funciones y facultades de estos sistemas, que van desde los programas informales de presentación de propuestas por parte de los trabajadores hasta la determinación conjunta de ciertas cuestiones por los representantes suyos y el personal directivo. Los mecanismos utilizados para fomentar la participación de los trabajadores presentan una variabilidad tan grande que resulta imposible analizarlos aquí con detalle. Las modalidades principales que han sido objeto de interés en fecha reciente, sobre todo en el campo de la organización del trabajo, se estudian más adelante; a ellas puede añadirse el ejemplo histórico de la autogestión de los trabajadores en la antigua Yugoslavia. Por su especial importancia en la actualidad, los comités conjuntos de salud y seguridad se analizan como una forma especial de participación de los trabajadores en el contexto más amplio de las relaciones laborales.

La idea de la participación de los trabajadores surgió en Europa, donde la negociación colectiva se ha desarrollado habitualmente a escala sectorial, lo que, con frecuencia, ha dejado un hueco sin cubrir en lo que se refiere a la representación en las empresas y los centros de trabajo, que ha sido llenado por órganos como los comités de empresa, los consejos de trabajadores y otros. También muchos países en desarrollo han emprendido iniciativas legislativas encaminadas a establecer comités de empresas y estructuras similares ( $p$. ej., Pakistán, Tailandia, Zimbabwe) como medio para fomentar la cooperación entre trabajadores y directivos. La relación de estos órganos con los sindicatos y la negociación colectiva ha sido objeto de numerosas iniciativas legislativas y de negociaciones. Esta actividad se refleja en una disposición del Convenio relativo a la protección y facilidades que deben otorgarse a los representantes de los trabajadores en la empresa, 1971 (no 135) de la O IT, en la que se establece que, cuando existan simultáneamente representantes sindicales y representantes elegidos en la misma empresa, se adoptarán las medidas oportunas para garantizar que dicha coincidencia no se utilice para menoscabar la posición de los sindicatos (artículo 5).

\section{Participación directa}

Los trabajadores pueden participar en la toma de decisiones de una manera directa o indirecta a través de sus representantes, ya sean sindicales o elegidos por ellos mismos. Desde el decenio de 1980 se ha ampliado la participación directa, si el término participación se entiende como el ejercicio de algún tipo de influencia en su trabajo o en el modo en que se lleva a cabo. Por tanto, los trabajadores "participan" en las decisiones relacionadas con el trabajo, no sólo cuando existen instituciones como los círculos de calidad en el lugar de trabajo. Un sencillo ejercicio de enriquecimiento de tareas puede constituir una forma de promoción de la participación directa.

Esta puede tener un carácter individual, como ocurre con los programas de presentación de propuestas. Asimismo, puede practicarse colectivamente, como en los círculos de calidad o en actividades semejantes organizadas en grupos reducidos similares. El trabajo en equipo constituye en sí mismo una forma de participación directa de grupo. Este tipo de participación puede integrarse en las decisiones sobre el trabajo diario o tener lugar fuera del horario habitual, como en el caso de los círculos de calidad voluntarios diferenciados de las estructuras colectivas que suelen utilizarse. Además, la participación directa puede ser "consultiva" o "deliberante"; en los estudios realizados por la Fundación Europea para el M ejoramiento de las Condiciones de Vida y de Trabajo se ha analizado con detalle este aspecto concreto (Regalia y Gill 1996). En el caso de la participación consultiva, se anima y capacita a los trabajadores, individualmente o como miembros de un grupo, a manifestar sus opiniones, pero la aceptación o el rechazo de sus propuestas depende de la dirección. En la participación deliberante, por el contrario, se asigna a los trabajadores parte de las responsabilidades tradicionales en materia de gestión, como sucede en el 
trabajo en equipo o en los grupos de trabajo semiautónomos, en los que se delegan algunas competencias en los componentes de la plantilla.

\section{Comités de empresa y estructuras similares; cogestión}

El término comités de empresa agrupa las organizaciones creadas para la representación de los trabajadores, habitualmente en los centros de trabajo, aunque también a escalas superiores (empresa, grupo de empresas, sector, U nión Europea). La relación con los sindicatos suele estar determinada por la legislación o especificada en los convenios colectivos, pero, en ocasiones, siguen caracterizándose por las tensiones. La utilización generalizada de los comités de empresa, a veces denominados comités de trabajadores o de cooperación, se encuentra consolidada en varios países europeos como Alemania, Bélgica, Dinamarca, Francia y Países Bajos y, debido al impulso transmitido por la Directiva no 94/ 45/ CE de 1994 sobre comités de empresa europeos, puede preverse su difusión en las grandes empresas de esta región. Varios países de Europa central y oriental, como Hungría y Polonia, han dictado normas con el fin de fomentar el establecimiento de estos órganos. Se prevén asimismo en algunos países de Africa, Asia y América Latina; por ejemplo, la reforma de la legislación laboral posterior al "apartheid" en Sudáfrica comprende la creación de un tipo de comités de empresa paralelos a las estructuras sindicales.

Las posibles competencias de los comités de empresa pueden analizarse mejor observando el ejemplo de Alemania, aunque, en cierto modo, éste es un caso único. Weiss (1992) describe el comité de empresa en dicho país como la forma de representación institucionalizada de los intereses de los trabajadores en el centro de trabajo. El comité de empresa dispone de ciertos derechos de información, consulta (como en todos los países) y cogestión (mucho menos habitual). Como forma de participación de mayor alcance, la cogestión implica la intervención en los programas de salud y seguridad en el trabajo y la adopción formal de un sistema de conciliación de intereses y un "plan social" en caso de alteración sustancial del centro, como ocurre cuando se proyecta su cierre. La cogestión se extiende también al establecimiento de directrices para la selección y la evaluación del personal, la formación en el puesto y las medidas que afectan específicamente a los trabajadores, como la clasificación en categorías, los traslados y los despidos. Los comités de empresa alemanes tienen capacidad para celebrar convenios laborales a escala empresarial y presentar reclamaciones cuando consideran que el convenio no está siendo respetado. Son áreas de cogestión obligatoria la prevención de accidentes y la protección de la salud, las normas de trabajo, la jornada de trabajo, la determinación de las tasas de remuneración en relación con el rendimiento, la forma de pago, los principios generales que rigen la administración de las vacaciones, etc. En estas cuestiones, la empresa no puede adoptar acciones sin el consentimiento del comité de empresa. Asimismo, éste tiene derecho a tomar la iniciativa y puede remitir un asunto a un comité de arbitraje del centro para su resolución. Como señala Weiss (1992), el papel del comité de empresa es el de "participar en el 'cómo' concretar una medida cuando la empresa ha adoptado la decisión de adoptarla". El derecho de consulta brinda a los comités de empresa la posibilidad de intervenir en las decisiones tomadas por la empresa, pero la falta de consulta no invalida la decisión tomada en su caso. Las cuestiones que exigen una consulta previa son la protección contra el despido, la prevención de los riesgos laborales, la formación y la elaboración de planes sociales.

Los comités de empresa deben atenerse a los principios de cooperación con la empresa y respetar la "obligación de paz" (evitar las interrupciones del trabajo); asimismo, han de colaborar con los sindicatos existentes en el lugar de trabajo y con la organización empresarial pertinente. Están obligados a llevar a cabo su actividad con imparcialidad, sin tener en cuenta la raza, la religión o el credo, la nacionalidad, el origen, la actividad política o sindical, el sexo o la edad de los trabajadores. Las empresas ponen a su disposición fondos e instalaciones y son responsables por sus acciones.

En Alemania se eligen comités de empresa específicos para trabajadores manuales y no manuales. Se celebran elecciones especiales a unos y otros y, aunque no existe una vinculación jurídica entre estos representantes y los dirigentes sindicales, en la práctica los puestos son ocupados a menudo por las mismas personas. En Austria y Alemania se garantiza la representación especial de los trabajadores discapacitados, los jóvenes y el personal en período de formación. Los miembros de los comités no reciben ninguna remuneración por su actividad en los mismos, aunque se les reembolsan los gastos justificables efectuados. A demás, se les garantiza el mantenimiento de su nivel de retribución y su categoría laboral una vez que su mandato haya concluido y gozan de una protección especial contra el despido. Tienen derecho a abandonar el puesto de trabajo para realizar las tareas relativas al comité de empresa y recibir formación. Estas medidas de protección son coherentes con lo estipulado en el Convenio relativo a la protección y facilidades que deben otorgarse a los representantes de los trabajadores en la empresa, 1971 (no 135), en el que se establece que los representantes de los trabajadores en una empresa deben ser objeto de una protección efectiva contra los actos que les perjudiquen, incluido el despido, por razón de su situación o sus actividades de representación (artículo 1).

En muchos países se admiten regímenes de comités de empresa menos ambiciosos en los que se reconocen los derechos de información y consulta. Especialmente en los casos en que los sindicatos tienen una presencia menor en los centros de trabajo, existe un interés considerable en establecer comités de empresa o de trabajadores como medio para dotarles de voz en este ámbito.

\section{Círculos de calidad y Gestión de la Calidad Total}

Los círculos de calidad y actividades colectivas semejantes comenzaron a establecerse con rapidez en un gran número de empresas de algunos países de Europa occidental (p. ej., Reino U nido y Francia) a comienzos del decenio de 1980 y en Estados Unidos con cierta anterioridad. Se basan en los programas de "Calidad de la Vida Laboral" (CVL) o "Humanización del Trabajo" que comenzaron a desarrollarse a principio del decenio de 1970. Su difusión fue bastante posterior en otros países occidentales (como Alemania) y aún parece muy limitada en países donde los grupos responsables de proyecto conjuntos constituyen el medio principal de abordar la organización del trabajo, como Suecia. Cobraron impulso debido a la creencia en que la capacidad de Japón para obtener productos innovadores de alta calidad a bajo coste tenía algo que ver con el modo en que se administraban los recursos humanos en este país: los círculos de calidad representaban la característica más visible y fácilmente transferible de la gestión de estos recursos en Japón. En general, se espera de los círculos de calidad que generen dos tipos de efectos: la mejora de la calidad y la productividad por un lado, y el fomento entre los trabajadores de un sentido de la participación en las decisiones relacionadas con su actividad, que dé lugar al aumento de la satisfacción en el empleo y la optimización de las relaciones laborales. En Japón se ha hecho hincapié en el primer efecto y, en Europa y América del Norte, en el segundo. Asimismo, existen diferencias estructurales: mientras que, normalmente, los líderes de los círculos son designados por la 
dirección en Japón, en Alemania, suelen ser elegidos. Actualmente, se concede más prioridad en los programas de CVL a la maximización de la productividad y la competitividad (O zaki 1996).

En algunos de los países en los que los círculos de calidad se experimentaron con profusión en el decenio de 1980, como Francia y el R eino U nido, se ha observado un cierto desencanto debido a su relativa ineficacia para la generación de los resultados previstos. Muchos círculos desaparecieron pocos años después de su creación y otros existen sobre el papel, pero en la práctica no son operativos. Este fracaso se ha atribuido a numerosos factores, como su tendencia a provocar confusión en las líneas de mando habituales, el control de sus miembros al margen de la dirección, la determinación por parte de los círculos de su propia agenda sin tener en cuenta las prioridades de la dirección, la falta de entusiasmo o la hostilidad de los mandos intermedios, la ausencia de un compromiso duradero de la alta dirección y la restricción de su alcance a las cuestiones laborales menores.

La concreción de estas carencias dio lugar a la elaboración de la teoría de la "G estión de la Calidad Total" (GCT). Algunos de sus principios afectan a la participación de los trabajadores: todos los miembros de la plantilla deben intervenir en el proceso de mejora de la actividad de la empresa y la responsabilidad respecto a la calidad debe asignarse a las personas que la controlan en la práctica al llevar a cabo su labor. Así, la GCT fomenta la ampliación y el enriquecimiento de tareas tendente a la creación de grupos de trabajo semiautónomos. Además, promueve la coordinación horizontal en la empresa mediante la utilización, por ejemplo, de equipos de proyectos ad hoc, multifuncionales 0 interdepartamentales.

\section{Grupos responsables de proyectos conjuntos}

La práctica de establecer grupos responsables de proyectos conjuntos para estudiar las mejores vías de introducción de los cambios tecnológicos y organizativos, basada en la colaboración de directivos y trabajadores, es una característica tradicional de algunos países como Suecia. Un grupo de este tipo suele estar compuesto por directivos, representantes de los sindicatos presentes en el lugar de trabajo y trabajadores, y a menudo cuenta con la ayuda de expertos externos. Con frecuencia, la dirección y los sindicatos establecen grupos responsables de proyecto conjuntos dedicados específicamente a la consideración de alguno de los aspectos siguientes: nuevas tecnologías, organización del trabajo, formación y medio ambiente de trabajo. EI modelo sueco al respecto constituye un ejemplo notable de participación directa de los trabajadores en un marco de relaciones laborales colectivas establecidas. Este tipo de sistemas también funciona en otros países, como Alemania y Japón.

\section{Trabajo en grupos semiautónomos y trabajo en equipo}

El trabajo en grupos semiautónomos y el trabajo en equipo son dos formas de participación directa de los trabajadores de un centro en las decisiones relacionadas con su actividad, a diferencia del trabajo que desempeñan los grupos responsables de proyectos conjuntos, cuya participación se configura fuera de la línea jerárquica. La diferencia principal entre estas dos modalidades radica en el grado de autonomía de que disponen los miembros del equipo o del grupo al organizar su labor. Se ha hecho una utilización intensiva de los grupos semiautónomos en Escandinavia, aunque recientemente se ha vuelto a un planteamiento más tradicional. En otras partes de Europa también se ha experimentado el sistema.
M ientras que el número de experimentos basados en el trabajo de los grupos semiautónomos es cada vez menor, el trabajo en equipo se extiende con rapidez en todos los países occidentales. El grado de autonomía asignado a un equipo varía enormemente de una empresa a otra. Su estructura también difiere. En muchos países, los jefes de equipo suelen ser designados por la dirección, pero en algunos (p. ej., Alemania) son elegidos a menudo por sus compañeros de trabajo. Es frecuente que la creación de equipos coincida con cambios significativos en el papel desempeñado por los supervisores de primera línea; éstos tienden a asumir una mayor responsabilidad en cuanto al asesoramiento de los miembros de los equipos y en el ámbito de la comunicación vertical y horizontal, pero dejan de ejercer su función de control. Las empresas han puesto de manifiesto un interés cada vez mayor por el trabajo en equipo, ya que suele facilitar la mejora de las cualificaciones de los trabajadores y amplía la gama de tareas que realizan, permitiendo así una mayor flexibilidad en los procesos productivos. No obstante, este sistema recibe en ocasiones la crítica de los trabajadores por considerarlo un medio de inducirles a trabajar más "voluntariamente", al sustituir el control de la dirección por la presión ejercida por los compañeros.

\section{Representación de los trabajadores en los órganos de supervisión; propiedad de acciones por parte de los trabajadores}

Algunos observadores consideran las formas de copropiedad de los trabajadores y de representación de éstos en los órganos empresariales como expresiones de su participación. En Alemania y los países escandinavos, entre otros, los trabajadores tienen una participación indirecta a nivel empresarial mediante la inclusión de sus representantes en los órganos de supervisión. Para ello se incorporan representantes de la plantilla a la estructura tradicional de gestión, en la que se encuentran en minoría (aunque, en ocasiones, amplia, como en el caso de Alemania). No existe necesariamente una participación en la gestión activa de la empresa, y los representantes de los trabajadores tienen la misma consideración que otros miembros de los órganos de dirección. Esto significa que deben velar, en primer lugar, por los intereses empresariales y que están vinculados por el mismo deber de confidencialidad que los demás miembros. No obstante, su participación en los órganos de dirección puede facilitar el acceso a información adicional y varios sindicatos han solicitado la concesión del derecho a incluir sus representantes en los mismos. Este fenómeno se observa actualmente en Europa oriental y occidental y en América del $\mathrm{N}$ orte, pero sigue siendo infrecuente en el resto del mundo.

O tra forma de participación de los trabajadores se basa en la posesión de acciones en las empresas. En ocasiones, consiguen reunir el capital suficiente para adquirir empresas que, de otra forma, desaparecerían del mercado. La explicación de este tipo de situaciones consiste en que un trabajador que se identifica económicamente con su empresa trabajará más para contribuir a su éxito. Este sistema presenta variaciones importantes, debidas a la forma de participación (derechos a obtener el rendimiento del capital invertido o derechos de control), al grado de ésta (cuantía y periodificación de los beneficios) y a las razones que subyacen a la participación financiera. En cualquier caso, estas prácticas se concentran mayoritariamente en Europa y A mérica del Norte. Ahora bien, si las cooperativas se consideran una forma más de participación, la noción de los trabajadores como accionistas interesados en la eficacia de su trabajo está mucho más generalizada en todo el mundo. Sería interesante analizar en qué medida la propiedad de una empresa o de 


\section{Dinamarca: participación de los trabajadores en la salud y la seguridad}

Las relaciones laborales en Dinamarca constituyen un ejemplo de un país con varias instituciones que desempeñan un papel en relación con la salud y la seguridad. Las principales características son:

NEG OCIACION COLECTIVA: N egociación de los acuerdos en virtud de los cuales, los sindicatos y las empresas determinan los salarios, las condiciones de trabajo, etc. Los aspectos más destacados son:

Los delegados sindicales, que son elegidos por los trabajadores de acuerdo con el convenio colectivo, están protegidos por ley contra el despido y actúan como nexo entre los trabajadores y la dirección en lo que respecta a las condiciones de trabajo.

En el Convenio Colectivo sobre Cooperación y Comités de Cooperación se establece la obligación de ofrecer información a las personas y a los grupos de trabajadores por anticipado, de forma que puedan expresar sus opiniones antes de que se adopte una decisión, y de crear comités de cooperación.

Deben establecerse comités de cooperación en todas las empresas con más de 35 trabajadores $(25$ en la función pública). Los comités conjuntos de fomento de la cooperación en las actividades ordinarias deben ser consultados sobre la introducción de nuevas tecnologías y la organización de la producción; en algunos casos, disfrutan de derechos de codeterminación en materia de condiciones de trabajo, formación y datos personales.

En el convenio colectivo nacional sobre conflictos industriales (de 1910) se concede a los trabajadores el derecho (rara vez ejercido) a suspender el trabajo si por razones de "vida, bienestar u honor" esta medida es absolutamente necesaria. En otros convenios colectivos figuran disposiciones sobre formación y los sindicatos también la imparten.

LFY MARC 0: La ley sobre medio ambiente de trabajo crea "la base sobre la cual las empresas podrán resolver las cuestiones relativas a la salud y la seguridad bajo las directrices y la supervisión del Servicio de Inspección de Trabajo" [Sec. 1(b)]. La Ley establece un sistema completo, desde la escala del centro de trabajo a la nacional, para permitir la participación de los trabajadores:

Los representantes de seguridad son representantes elegidos obligatoriamente en las empresas con al menos diez trabajadores; gozan de la misma protección frente al despido y a represalias que los delegados sindicales y tienen derecho al reembolso de los gastos originados en el desempeño de su función.

Grupos de seguridad: El representante de seguridad y el supervisor de departamento componen el grupo de seguridad.

Sus funciones son las siguientes:

- supervisar las condiciones de trabajo.

- inspeccionar los equipos, las herramientas y los materiales;

- informar de los riesgos que no pueden evitarse de forma inmediata;

- detener la producción en caso necesario para evitar un peligro grave e inminente

- garantizar que el trabajo se realiza en condiciones de seguridad y que se dan las instrucciones adecuadas;

acciones de la misma por parte de los trabajadores afecta al nivel de salud y seguridad en el lugar de trabajo.

\section{Representantes y comités de salud y seguridad}

El establecimiento de comités y representantes en materia de salud y seguridad se considera como una forma especializada de participación de los trabajadores (para más información sobre la
- investigar los accidentes industriales y las enfermedades profesionales;

- participar en las actividades preventivas;

- cooperar con el servicio de salud en el trabajo;

- actuar como vínculo entre los trabajadores y el comité de seguridad;

Los miembros del grupo de seguridad tienen derecho a recibir la formación y la información necesaria.

Los comités de seguridad son obligatorios en las empresas con al menos 20 trabajadores. En las empresas que disponen de más de dos grupos de seguridad, los comités de seguridad están integrados por trabajadores elegidos entre los representantes de seguridad, dos miembros supervisores y un representante de la empresa.

Sus funciones son las siguientes:

- planificar, dirigir y coordinar las actividades de salud y seguridad; - ser consultado sobre estas cuestiones:

- cooperar con otras empresas que participan en las actividades desarrolladas en el mismo lugar de trabajo

- colaborar con el servicio de salud en el trabajo de la empresa

- supervisar la actividad de los grupos de seguridad:

- formular recomendaciones sobre la prevención de accidentes y enfermedades.

En el CONSEJO DE MEDIO AM BIEN TE DE TRABAJO participan organizaciones de empresas y trabajadores en la definición y la aplicación de políticas preventivas a escala nacional. Está compuesto por 11 representantes de las organizaciones de trabajadores, un profesional de la medicina del trabajo, un experto técnico y representantes gubernamentales sin derecho a voto. Funciones:

- es consultado sobre la elaboración de legislación y disposiciones;

- puede ocuparse, por iniciativa propia, de una cuestión relativa a la salud y la seguridad;

- remite anualmente sus recomendaciones sobre la política de medio ambiente de trabajo;

- coordina las actividades de los Consejos Sectoriales de Seguridad;

- supervisa la actividad del Fondo para el Medio Ambiente de Trabajo.

EI FO N DO PARA ELM EDIO AM BIEN TE DE TRABAJO es gestionado por un consejo tripartito. Desempeña fundamentalmente tareas de información y formación, pero también financia programas de investigación.

CON SEJO S SEC TO RIALES DE SEG URIDAD: Doce Consejos Sectoriales de Seguridad analizan los problemas de su sector 0 industria y asesoran a las empresas. Asimismo, son consultados respecto a la elaboración de legislación. Cuentan con una representación equitativa de las organizaciones de empresas y supervisores por un lado, y de las de trabajadores por el otro.

ORGAN OS ADM IN ISTRATIVOS: Por otra parte, el Ministerio de Trabajo, el Servicio de Inspección de Trabajo y, dentro de éste, el Instituto Danés de Medio Ambiente de Trabajo, prestan diversos tipos de servicio y asesoramiento en el campo de la salud y la seguridad en el trabajo. Los conflictos colectivos son resueltos por la Magistratura de Trabajo.

\section{por la directora del capítulo} (extraído de Vogel 1994).

participación de los trabajadores en Dinamarca, véase el Recuadro). La legislación de varios países prevé la creación de tales comités y la elección de representantes (p. ej., Bélgica, algunas provincias de C anadá, Dinamarca, Francia, Países Bajos, Suecia y España). Las pequeñas empresas, con independencia de su definición, suelen quedar excluidas de la aplicación de estas medidas obligatorias, pero, como otras unidades de mayor 
tamaño, constituyen a menudo los comités a iniciativa propia. Además, muchos convenios colectivos han dado lugar a la creación de estos órganos y la designación de representantes de salud y seguridad (p. ej., C anadá y Estados U nidos).

L os convenios colectivos suelen ampliar las competencias asignadas a estos representantes y reconocidas en la legislación. Los comités y los representantes varían en cuanto a su relación con los sindicatos y los comités de empresa, su forma de elección o designación, sus deberes y funciones y su repercusión. Como manifestación de la participación de los trabajadores en la esfera especializada de la salud y la seguridad, estos comités y representantes pueden contribuir a la mejora de las condiciones de trabajo y el clima de relaciones laborales. R esultan sumamente eficaces cuando constituyen una parte integrante del programa de salud y seguridad de la dirección, tienen acceso a la información adecuada, fomentan la intervención de los trabajadores en sus actividades para ayudar a garantizar la continuidad y están respaldados por una inspección de trabajo pública eficaz. En los casos en que las empresas prestan servicios de salud en el trabajo o disponen de expertos en seguridad, una relación fructífera con éstos puede asimismo facilitar el éxito de los comités conjuntos de salud y seguridad. Por ejemplo, en un estudio reciente sobre los lugares de trabajo realizado en el Reino U nido, se observó que "los comités consultivos conjuntos, en los que todos los representantes de los trabajadores son designados por los sindicatos, consiguieron reducir los daños profesionales en un número significativamente superior al registrado en los centros donde la dirección determina unilateralmente los programas de salud y seguridad" (Reilly, Paci y H oll 1995). A simismo, estos autores señalan el importante papel desempeñado por los comités consultivos conjuntos en los casos en los que los representantes de los trabajadores se eligen de otro modo. No obstante, algunos estudios también indican que este tipo de comités no cumplen con las expectativas que se les asignan inicialmente. $L$ as razones de esta carencia difieren: apoyo insuficiente de la dirección, participantes inadecuadamente informados 0 formados, representación de los trabajadores ineficaz, etc.

Los representantes de los trabajadores en materia de salud y seguridad en el trabajo pueden ser designados por la dirección (como en muchos lugares de trabajo sin presencia sindical) o por los sindicatos (como en el Reino U nido), o elegidos directamente por los trabajadores a escala empresarial u otra superior (como en Dinamarca). Se utiliza un sistema paralelo en el caso de los representantes de los trabajadores en los comités conjuntos de salud y seguridad que, a pesar de su carácter bipartito, no siempre cuentan con una representación equitativa de ambas partes. Las instituciones generales de representación de los trabajadores suelen acompañarse de estructuras representativas especiales dedicadas a cuestiones de salud y seguridad (como en España). El mecanismo elegido suele reflejar la existencia de otras instituciones relacionadas con las relaciones laborales en un país: en Francia, por ejemplo, los miembros que actúan en nombre de los trabajadores en los comités conjuntos de salud, seguridad y condiciones de trabajo son designados por un delegado elegido entre los componentes del comité de empresa y los representantes del personal; en Alemania, los comités de empresa designan miembros que presten sus servicios en un comité mixto de salud y seguridad. Los comités de empresa en Ios Países Bajos pueden delegar sus competencias en la materia en un comité de seguridad, salud y bienestar. Suele considerarse conveniente la existencia de un vínculo sólido entre los representantes sindicales y los representantes de salud y seguridad, cuando no el desempeño de estas funciones por las mismas personas [Q uebec (C anadá), Irlanda, N oruega y Suecia, España], pero si la densidad sindical es baja se corre el riesgo de privar a un gran número de trabajadores de los derechos de representación en esta materia. Se ha observado que la hipótesis según la cual los comités conjuntos de salud y seguridad pueden dar lugar a la ampliación de la participación de los trabajadores en otros ámbitos carece en gran medida de fundamento.

Normalmente, los representantes de los trabajadores en materia de salud y seguridad tienen los derechos siguientes: acceder a la información al respecto y sobre la introducción de nuevas tecnologías, ser consultados acerca de las cuestiones que les competen, participar en el control de las condiciones en el lugar de trabajo, acompañar a los inspectores (el denominado "derecho a la ronda de supervisión"), intervenir en las investigaciones de los accidentes y formular recomendaciones a la dirección sobre la mejora de las condiciones de trabajo. En algunos países, sus competencias van más allá de las enumeradas e incluyen el derecho a tomar parte en la toma de decisiones conjunta, iniciar inspecciones e investigaciones de accidentes y revisar los informes de la dirección remitidos a la Administración. Lo que es más importante, algunos de los representantes de los trabajadores en materia de salud y seguridad están capacitados para ordenar el cierre de un centro que representa un peligro inminente (el denominado "etiquetado en rojo", por las etiquetas colocadas en el lugar de peligro) en países como Dinamarca, Finlandia, N oruega y Suecia. En ciertos casos, como en Francia y algunas provincias de Canadá, intervienen directamente en la aplicación de la normativa sobre salud y seguridad. En ocasiones, la empresa debe consultar previamente con el comité mixto para poder realizar cambios significativos en las condiciones de salud, seguridad o trabajo (en Francia, España y los Países Bajos). En Bélgica, los servicios sanitarios interempresariales se someten al control de un comité mixto. En Italia, el papel del comité comprende el fomento de la prevención y, en Grecia, los comités, con el permiso de la empresa, pueden solicitar el dictamen de un experto sobre las cuestiones que les atañen.

L os representantes de los trabajadores en materia de salud y seguridad disfrutan necesariamente de protección frente a la discriminación o la adopción de represalias a causa del ejercicio de sus funciones. Tienen derecho a disponer de un período mínimo de permiso remunerado y de los medios necesarios (cuya definición suele ser objeto de debate) para llevar a cabo su actividad. A demás, durante su permanencia en el cargo, reciben garantías especiales respecto a las reducciones de plantilla por causas económicas y los despidos (como en Bélgica). Con frecuencia, gozan del derecho a recibir formación especializada (Dinamarca, E spaña).

Obviamente, el posible efecto de los representantes y los comités conjuntos de salud y seguridad no sólo dependerá de los derechos y los deberes establecidos en la legislación o en un convenio colectivo, sino del modo en que éstos se ejerzan en la práctica. A demás, deberá tenerse en cuenta la influencia de los factores que afectan a la participación de los trabajadores en general. Estos representantes y comités no sustituyen a la aplicación efectiva de las normas de salud y seguridad por parte de la Administración ni a los posibles logros alcanzados mediante la negociación colectiva. No obstante, "la mayoría de los observadores consideran que los comités [conjuntos de salud y seguridad obligatorios] ofrecen un régimen de regulación más eficaz en esta materia que los sistemas de inspección o de responsabilidad civil" (K aufman y K leiner 1993). En cualquier caso, no cabe duda de la tendencia a ampliar la participación de los trabajadores en el tratamiento de las cuestiones de salud y seguridad, al menos en lo que respecta a los convenios colectivos de las grandes empresas y a la legislación. C uando funcionan como instituciones eficaces, los comités conjuntos de salud y seguridad pueden constituir una herramienta valiosa en la detección de 
problemas y el aumento de la sensibilización respecto a los riesgos, contribuyendo así a la reducción de la incidencia de lesiones, enfermedades y muertes en el trabajo. Con todo, su nivel de eficacia depende de un gran número de variables existentes en cada sistema de relaciones laborales y relacionadas con el planteamiento estratégico adoptado respecto a la salud y la seguridad en el lugar de trabajo.

\section{Evaluación}

Schregle (1994) afirma:

En la práctica, ninguno de estos regímenes de participación de los trabajadores ha dado los resultados previstos. $\mathrm{H}$ ay muchas razones que explican esta carencia. En primer lugar, los sindicatos y las empresas, en general, no tienen el mismo punto de vista sobre la participación. M ientras que los trabajadores desean ejercer una influencia tangible y concreta sobre las decisiones empresariales que les permita compartir las competencias, las empresas insisten en mantener sus derechos y prerrogativas, derivados de la propiedad privada, para gestionar de acuerdo con sus propios criterios y su poder de toma de decisiones, concediendo a los trabajadores, a lo sumo, el derecho a expresar sus opiniones y posturas sin carácter vinculante para la dirección. El resultado de esta situación es la confusión existente en lo que se refiere a aspectos como la consulta, la participación de los trabajadores, la intervención de éstos en la gestión, la codeterminación, la gestión compartida, etc.

En definitiva, en la mayoría de los lugares de trabajo de todo el mundo, la participación real de los trabajadores es escasa a escala empresarial. El primer nivel de participación y, de hecho, un pre-requisito de la misma, es la información, seguida de la consulta. En Europa, los estudios realizados indican una amplia variabilidad en la extensión de la aplicación de la Directiva marco sobre salud y seguridad de 1989, en lo que respecta a la participación de los trabajadores. La consideración de esta cuestión puede adquirir un nuevo impulso con la promulgación de la Directiva sobre comités de empresa europeos de 1995. O tras regiones se caracterizan asimismo por el limitado nivel de participación. No obstante, siguen abrigándose esperanzas de que se consoliden los mecanismos de intervención de los trabajadores a escala empresarial.

El planteamiento tradicional respecto a la participación de los trabajadores, considerada como un incentivo a una mayor cooperación entre éstos y el personal directivo, no resulta satisfactorio en relación con las cuestiones de salud y seguridad, ya que la clasificación de las relaciones laborales como conflictivas o cooperativas no constituye un avance significativo del debate. Como señala Vogel (1994):

(...) obviamente, el problema de la participación de los trabajadores no se limita a las formas institucionalizadas al respecto dentro o fuera de la empresa. La base de la participación radica en el reconocimiento de que se encuentran en juego intereses diferenciados, lo que da lugar a la adopción de razonamientos específicos... La legitimidad esencial de la participación deben encontrarse al margen de la empresa, en un requisito democrático en el que se rechaza la asunción de que la autodeterminación de las personas debe circunscribirse a las normas de la representación política, y en una visión de la salud como un proceso social útil mediante el cual, las personas y las comunidades desarrollan estrategias de autorrealización y defensa.

En definitiva, las diferentes funciones de las diversas formas de participación de los trabajadores hacen difícil evaluar comparativamente su repercusión. No obstante, puesto que la cobertura de la negociación colectiva se reduce, puede preverse un aumento en la utilización de los sistemas de participación de los trabajadores.

\section{CONSULTAE INFORMACION SOBRE SALUD Y SEGURIDAD}

\section{Marco Biagi}

\section{Participación de los trabajadores en las cuestiones de salud y seguridad}

La participación de los trabajadores en la organización de la seguridad en los centros de trabajo puede enfocarse de muchos modos, dependiendo de la legislación y la práctica nacionales. En el presente artículo sólo se hace referencia a los sistemas de información y consulta y no a las formas afines de intervención de los trabajadores. Además, se analizan aspectos específicos relacionados en cierta medida con la consulta y la información (p. ej., la intervención o la convocatoria de inspecciones, la participación en actividades de formación).

La idea de la colaboración de empresas y trabajadores encaminada a mejorar la salud y la seguridad en el trabajo se basa en varios principios:

1. Los trabajadores pueden contribuir a la prevención de los accidentes en el trabajo identificando y avisando de los riesgos potenciales y notificando los peligros inminentes.

2. El fomento de la participación de los trabajadores les forma y les anima a cooperar en la promoción de la seguridad.

3. Las ideas y las experiencias de los trabajadores se consideran una contribución útil a la mejora de la seguridad.

4. Las personas tienen derecho a intervenir en la toma de decisiones que afectan a su vida laboral, en general y a su salud y su bienestar, en particular.

5. La cooperación entre los interlocutores sociales, esencial para mejorar las condiciones de trabajo, debe basarse en una participación equitativa.

Estos principios constan en el Convenio sobre seguridad y salud de los trabajadores y medio ambiente de trabajo, 1981 (no 155). En el artículo 20, se establece que "la cooperación entre los empleadores y los trabajadores o sus representantes en la empresa, deberá ser un elemento esencial de las medidas de organización y de otro tipo" que se adopten en el área de la salud y la seguridad en el trabajo. A simismo, en el párrafo 2(1) de la Recomendación sobre las comunicaciones entre la dirección y los trabajadores dentro de la empresa, 1967 (no 129) se subraya que:

(...) tanto los empleadores y sus organizaciones como los trabajadores y sus organizaciones deberían, en su interés común, reconocer la importancia que tiene, dentro de la empresa, un clima de comprensión y confianza mutuas favorable tanto para la eficacia de la empresa como para las aspiraciones de los trabajadores.

El razonamiento que subyace es que las empresas y los trabajadores tienen un interés común en la aplicación de un sistema de autorregulación de la prevención de accidentes profesionales; en realidad, están más interesados en la seguridad que en la salud en el trabajo, ya que el origen laboral de los accidentes es más sencillo de establecer y, por tanto, éstos se indemnizan con mayor facilidad. También por esta razón, los representantes en materia de seguridad de muchos países fueron históricamente los primeros que tuvieron derechos y deberes en el lugar de trabajo establecidos en la legislación o los convenios colectivos. 
Actualmente, es probable que no exista una cuestión en el campo de las relaciones laborales y la gestión de recursos humanos, respecto a la cual los interlocutores sociales estén tan dispuestos a colaborar como la concerniente a la salud y la seguridad. No obstante, en ciertos contextos nacionales, los sindicatos no han dedicado recursos suficientes a las iniciativas en esta materia para que ocupen un puesto destacado en los temarios de las negociaciones y la administración de contratos.

\section{Derechos de información y consulta recogidos en la legislación de la OIT y la Unión Europea}

La obligación general de las empresas de ofrecer información sobre salud y seguridad a los trabajadores y sus representantes y tener en cuenta sus opiniones a través de los sistemas de consulta, se establece en el artículo 20 del Convenio sobre la prevención de los accidentes industriales graves, 1993 ( $n$ 174). En esta norma se prescribe que "Ios trabajadores y sus representantes en instalaciones que represente un riesgo grave serán consultados a través de los mecanismos de cooperación pertinentes, con el fin de garantizar un sistema de trabajo seguro". En concreto, los trabajadores y sus representantes tienen derecho a:

(a) ser informados adecuada y convenientemente de los riesgos asociados a dichas instalaciones y sus probables consecuencias; (b) ser informados de las órdenes, instrucciones o recomendaciones efectuadas por la autoridad competente; (c) ser consultados sobre la elaboración de los documentos siguientes: (i) informes de seguridad, (ii) planes y procedimientos de emergencia, (iii) informes de accidentes y tener acceso a los mismos.

Como consecuencia de estos derechos de información y consulta, los trabajadores tienen derecho asimismo a "debatir con la empresa los riesgos potenciales que consideren capaces de generar un accidente grave" [artículo 20 (f)].

Desde un punto de vista más general, en el Convenio de la O IT $\mathrm{n}$ ㅇ 155 se establecen las normas relativas a la salud y la seguridad en el medio ambiente de trabajo y se prevé la adopción de disposiciones a nivel de empresa en virtud de las cuales: “(c) los representantes de los trabajadores... reciban información adecuada acerca de las medidas tomadas por el empleador para garantizar la seguridad y la salud y puedan consultar a sus organizaciones representativas acerca de esta información, a condición de no divulgar secretos comerciales" (artículo 19). En el mismo Convenio se estipula que, en virtud de estas disposiciones, los trabajadores o sus representantes "estén habilitados... para examinar todos los aspectos de la seguridad y la salud relacionados con su trabajo, y sean consultados a este respecto por el empleador; con tal objeto, y de común acuerdo, podrá recurrirse a consejeros técnicos ajenos a la empresa".

En el párrafo 12 de la R ecomendación de la O IT no 164, que completa el Convenio no 155, se dispone que deben concederse derechos de información y consulta sobre cuestiones de salud y seguridad a diversas instituciones participativas: delegados de seguridad de los trabajadores, comités de trabajadores de seguridad y salud, comités conjuntos de seguridad y salud, y otras representaciones de los trabajadores. Asimismo, se establecen principios importantes que afectan a la naturaleza y el contenido de la información y la consulta. En primer lugar, estas prácticas deben capacitar a las instituciones de representación mencionadas para "contribuir al proceso de toma de decisiones a nivel de la empresa, en lo que concierne a las cuestiones de seguridad y de salud" [artículo 12(e)].

$\mathrm{N}$ o se trata simplemente de derechos que deben conocerse y escucharse: los trabajadores y sus representantes deben: “(a) recibir información suficiente sobre las cuestiones de seguridad y salud, tener la posibilidad de examinar los factores que afectan a la salud y la seguridad de los trabajadores y ser alentados a proponer medidas en este campo". Asimismo, deben "(b) ser consultados cuando se prevean - y antes de que se ejecuten- nuevas medidas importantes de seguridad y salud, y procurar por su parte conseguir la adhesión de los trabajadores a tales medidas" y "(c) ... cuando se prevean cambios en las operaciones y procesos de trabajo y en el contenido o en la organización del trabajo, que puedan tener repercusiones en la seguridad o la salud de los trabajadores".

El principio según el cual "el empleador debería informar y consultar previamente a los representantes de los trabajadores de la empresa sobre los proyectos, medidas o decisiones que puedan tener consecuencias nocivas para la salud de los trabajadores, en relación con la contaminación del aire, el ruido y las vibraciones en el lugar de trabajo" (Recomendación de la OIT sobre la protección de los trabajadores contra los riesgos profesionales debidos a la contaminación del aire, el ruido y las vibraciones en el lugar de trabajo, 1977 (no 156), párrafo 21) refleja la idea de una "política eficaz de comunicaciones" establecida en términos generales en el párrafo 8 de la Recomendación de la OIT (no 129), que debería asegurar que se difundan "informaciones y que se efectúen consultas entre las partes interesadas... antes de que la dirección adopte decisiones sobre asuntos de mayor interés". Para que estas prácticas sean eficaces, "deberían adoptarse medidas para dar a los interesados una formación sobre la utilización de métodos de comunicación" (párrafo 6).

El enfoque participativo en las relaciones laborales en el área de la salud y la seguridad queda confirmado por otros textos jurídicos internacionales. U n ejemplo significativo al respecto es la Directiva marco $89 / 391 /$ CEE relativa a la aplicación de medidas para promover la mejora de la seguridad y de la salud de los trabajadores en el trabajo en los países de la U nión Europea. En el artículo 10 se establece que el empresario adoptará las medidas adecuadas para que los trabajadores y/ o sus representantes reciban, de conformidad con las legislaciones y/ 0 los usos nacionales, todas las informaciones necesarias correspondientes a los riesgos para la seguridad y la salud, las medidas y actividades de protección o de prevención (y a los primeros auxilios, la lucha contra incendios, la evacuación de los trabajadores y los casos de riesgo inminente y grave). Esta información debe "ofrecerse de forma adecuada a los trabajadores temporales y contratados presentes en el centro de trabajo o en la empresa". A demás, "Ios trabajadores que desempeñen una función específica en la protección de la seguridad y de la salud de los trabajadores, o los representantes de los trabajadores que tengan una función específica en materia de protección de la seguridad y de la salud de los trabajadores" deben tener acceso a la evaluación de los riesgos y a las medidas de protección, a los informes sobre accidentes y enfermedades profesionales sufridos por los trabajadores y a la información procedente de todas las actividades de protección y de prevención, así como de los servicios de inspección y organismos competentes para la seguridad y la salud.

En el artículo 11 de la Directiva de la CE se vincula la consulta y la participación. De hecho, los empresarios "consultarán a los trabajadores y/ o sus representantes y permitirán su participación en el marco de todas las cuestiones que afecten a la seguridad y la salud en el trabajo". Ello implica "la consulta de los trabajadores, el derecho de los trabajadores y/ o de sus representantes a formular propuestas, la participación equilibrada de conformidad con las legislaciones y/ o los usos nacionales". En el mismo texto se establece que:

(...) los trabajadores o los representantes de los trabajadores que tengan una función específica en materia de protección de la seguridad y de la salud de los trabajadores, participarán de forma equilibrada, de conformidad con las 
legislaciones y/ o los usos nacionales, o serán consultados previamente y a su debido tiempo por el empresario...

El objetivo de estos derechos es cubrir todas las medidas que puedan afectar sustancialmente a la salud y la seguridad, incluida la designación de trabajadores exigida para aplicar ciertas medidas (primeros auxilios, lucha contra incendios y evacuación de los trabajadores) y la planificación y la organización de una formación adecuada en materia de salud y seguridad a lo largo de la relación de trabajo (sobre contratación, traslado de puesto de trabajo, introducción de nuevos equipos de trabajo, adopción de nuevas tecnologías).

La opción es clara: no al conflicto, sí a la participación en los aspectos de la salud y la seguridad de las relaciones laborales. Este es el significado de la Directiva marco de la CE, que va más allá de la simple lógica del derecho a la información. EI sistema se basa en una forma de consulta genuina, ya que debe producirse "previamente y a su debido tiempo"; en otras palabras, no sólo con anterioridad a la adopción de las decisiones por parte del empresario, sino también con la suficiente antelación para que los trabajadores puedan realizar comentarios y propuestas respecto a dichas decisiones.

Asimismo, en la Directiva se utiliza la expresión ambigua "participación equilibrada", abierta a diversas interpretaciones La noción es más amplia (o, al menos diferente) a la de la consulta, pero no hasta el punto de constituir una forma de toma de decisiones conjunta, que pueda evitar que las empresas adopten medidas no aprobadas previamente por los trabajadores o sus representantes. Parece claramente una forma de participación que va más allá de la mera consulta (de otro modo, titular el artículo "consulta y participación" carecería de sentido), pero no necesariamente hasta llegar a la toma de decisiones conjunta. En cierta medida, el concepto es vago: comprende diversas formas de participación de los trabajadores que pueden variar considerablemente entre los Estados miembros de la U nión Europea. Además, en cualquier caso, la D irectiva no establece la obligación de ofrecer una forma específica de participación equilibrada.

Tanto en los textos de la OIT como de la CE, la información parece concebirse como el suministro de datos, por escrito o en una reunión, por parte de la dirección a los órganos de representación de los trabajadores. La consulta significa el establecimiento normalmente de comités conjuntos, en los que los representantes de los trabajadores no sólo son informados por la dirección, sino también pueden realizar comentarios y esperar una justificación de la misma en el caso en que las opiniones difieran. 0 bviamente, estos conceptos se apartan del de negociación (en la que se obtiene un resultado contractualmente vinculante en comités conjuntos, que operan a escala empresarial o interempresarial) y el de cogestión (en la que el trabajador tiene derecho a vetar y la adopción de decisiones requiere el acuerdo de ambas partes). En cuanto a las empresas y los grupos de empresas comunitarios, la Directiva del Consejo no 94/ 45/ CE de 22 de septiembre de 1994 prevé la creación de comités de empresa europeos o procedimientos de información y consulta. La información está relacionada "en particular con las cuestiones transnacionales que afectan significativamente a los trabajadores" [artículo 6(3)]. El tiempo dirá si se utiliza para fines relativos a la salud y la seguridad.

\section{Función de los representantes de los trabajadores en la evaluación de riesgos y en la mejora del medio ambiente de trabajo: registros} El carácter activo de la consulta también se subraya en el artículo $11(3)$ de la Directiva marco de la CE, en el que se establece que los representantes de los trabajadores que tengan una función específica en materia de protección de la seguridad y de la salud de los trabajadores "tendrán derecho a solicitar del empresario que tome las medidas adecuadas y a presentarle propuestas en ese sentido para paliar cualquier riesgo para los trabajadores $\mathrm{y} / 0$ eliminar las fuentes de riesgo"

La Directiva marco, con sus disposiciones sobre gestión de riesgos, aunque asigna claramente la responsabilidad a las empresas, favorece asimismo una mayor participación de los trabajadores y sus representantes en las consultas sobre estrategias de gestión de la salud y la seguridad. Los empresarios deben evaluar los riesgos y presentar sus sistemas de control de riesgos mediante un plan u otro tipo de declaración. En todos los casos, se espera de ellos que consulten con los trabajadores y sus representantes y cuenten con su participación en el diseño, la aplicación y la supervisión de estos sistemas. No obstante, es innegable que esta Directiva, al conferir derechos de participación importantes a los trabajadores, ha adoptado simultáneamente un enfoque de "autoevaluación". O tras directivas de la CE exigen, entre otras cosas, el registro de los resultados de las mediciones y los análisis y estipulan los derechos de acceso de los trabajadores a estos registros.

Por otra parte, en el párrafo 15(2) de la R ecomendación de la O IT $\mathrm{n}$ 0 164 se establece que:

(...) debería exigirse a los empleadores que registren los datos sobre seguridad y salud de los trabajadores y medio ambiente de trabajo que la autoridad o autoridades competentes consideren indispensables, entre los que podrían incluirse datos sobre todos los accidentes de trabajo producidos y todos los casos de daños para la salud que sobrevengan durante el trabajo o en relación con éste, y que se hallen sujetos a declaración; autorizaciones y exenciones en virtud de las leyes o los reglamentos en la materia, así como las condiciones a que estén sujetas tales autorizaciones y exenciones; certificados relativos al control de la salud de los trabajadores en la empresa, y datos sobre exposición a sustancias y agentes determinados.

En todo el mundo se aplica el principio general según el cual, las empresas están obligadas a llevar registros, por ejemplo, de accidentes y enfermedades profesionales, o sobre la utilización 0 la existencia de controles biológicos y medioambientales.

\section{Legislación y usos nacionales}

Por comparación, hay sistemas de relaciones laborales (p. ej., en I talia) en los que la legislación no confiere derechos de información y consulta en materia de salud y seguridad en el trabajo a los representantes de los trabajadores, aunque tales derechos suelan contemplarse en los convenios colectivos. La legislación italiana otorga a los propios trabajadores el derecho a controlar la aplicación de las normas relativas a la prevención de accidentes y enfermedades profesionales, así como el derecho a elaborar estudios y adoptar las medidas adecuadas encaminadas a salvaguardar la salud y la seguridad en el trabajo. En otros sistemas (p. ej., en el Reino U nido), para lograr la divulgación de la información sobre esta materia prevista en la legislación es necesario primero haber designado representantes de seguridad, y esto sólo es posible si existe un sindicato reconocido en la empresa. En situaciones en las que ésta no reconoce a un sindicato o suspende el reconocimiento necesario, los derechos de información y consulta no pueden ejercerse. Estas experiencias nacionales plantean una cuestión: ¿en qué medida es eficaz la participación de los trabajadores en la salud y la seguridad condicionada por la adopción de disposiciones previstas en la ley? No cabe duda de que un cierto respaldo jurídico puede resultar útil, siendo el alcance óptimo de la legislación probablemente aquél que establece la elección de 
representantes de los trabajadores con derechos suficientemente consolidados que les permitan actuar con independencia de la dirección, y, al mismo tiempo, prevé la existencia de diversos sistemas organizativos de participación en los diferentes sectores y empresas.

En general, en los sistemas de relaciones laborales se establece legalmente que los representantes de los trabajadores sean informados y consultados en cuestiones de salud y seguridad. A los comités conjuntos compuestos por representantes de los trabajadores y la dirección se les asignan competencias considerables. En Francia, por ejemplo, los comités de salud, seguridad y condiciones de trabajo pueden proponer medidas preventivas: la empresa que no las acepte debe justificar detalladamente su decisión. No obstante, las pruebas empíricas demuestran que, en ocasiones, los representantes en materia de seguridad resultan más eficaces que los comités, ya que dependen en menor medida de la existencia de una relación de cooperación.

M ediante diversas formas de participación basada en la representación, los trabajadores en general disfrutan de derechos reconocidos en los Convenios y las R ecomendaciones de la O IT (además, en su caso, de las directivas de la CE) antes mencionados, con referencia especial a las economías industrializadas de libre mercado. Los representantes de seguridad y los miembros de los comités de empresa tienen derecho a ser informados y consultados por la empresa respecto a todas las cuestiones relativas a su actividad y la mejora de las condiciones de trabajo, incluidas las de salud y seguridad. Tienen derecho a revisar todos los documentos pertinentes que la empresa está obligada a registrar en virtud de la legislación, las declaraciones al respecto y los resultados de las investigaciones efectuadas. Asimismo, pueden solicitar copias de estos documentos en caso necesario.

\section{Eficacia de los derechos de información y de consulta}

A parte de ciertos aspectos específicos (como la utilización de expertos, la participación o la convocatoria de inspecciones o la protección contra las represalias) que afectan enormemente a la eficacia de los derechos de información y de consulta en materia de salud y seguridad, hay otros factores generales que deben tenerse en cuenta al respecto. En primer lugar, el tamaño de la empresa: la eficacia de los controles se reduce en las unidades pequeñas, donde los sindicatos y otras formas de representación de los trabajadores son casi inexistentes. Además, es menos probable que estos centros apliquen lo previsto en la legislación.

En segundo lugar, si los representantes en materia de seguridad están integrados en la organización sindical formal presente en el centro en cuestión, es más probable que logren las mejoras previstas en el medio ambiente de trabajo. En tercer lugar, los regímenes de información y consulta relativos a la salud y la seguridad reflejan el carácter más basado en el conflicto (p. ej., Reino Unido, Italia) o en la cooperación (p. ej., A lemania, países escandinavos, Japón) del sistema de relaciones laborales en los que se aplican. Además, en general, la colaboración entre la dirección y los trabajadores favorece la difusión de la información y la consulta.

En cuarto lugar, no debe subestimarse el papel de la iniciativa de la dirección. Más que por la existencia de derechos reconocidos por la ley, la consulta y la información son eficaces cuando hay una cultura empresarial que las respalda. Las empresas, mediante su actitud respecto a la formación, su compromiso con la divulgación de información y su celeridad al responder las consultas, pueden crear un clima de conflicto o de cooperación. El apoyo jurídico es esencial para garantizar la plena independencia de los representantes de los trabajadores que actúan en este campo, pero, posteriormente, el éxito de los regímenes de información y consulta depende en gran medida de la opción voluntaria de ambas partes.

Por último, cabe señalar que una condición previa para una representación de los trabajadores eficaz en materia de salud y seguridad en el lugar de trabajo, es la sensibilización de la población trabajadora. Para el éxito de esta forma especializada de representación de los trabajadores, es fundamental que tal necesidad sea percibida y valorada por éstos. Se dispone de pruebas empíricas que ponen de manifiesto la consideración por parte de los trabajadores de la salud y la seguridad como una de las cuestiones más significativas en su vida laboral.

\section{Garantías relativas a la utilización de información}

La experiencia comparada demuestra que, en general, se considera que los representantes de los trabajadores infringen su compromiso de confidencialidad si revelan datos relativos a los procesos productivos empresariales y otros secretos profesionales. Además, están obligados a actuar con discreción en lo que se refiere a la información suministrada y que la empresa califica de confidencial. En el Convenio de la O IT no 155 se reconoce esta obligación al establecer que los representantes en la empresa pueden consultar con sus organizaciones representativas acerca de la información sobre salud y seguridad en el trabajo "a condición de no divulgar secretos comerciales" [artículo 19 (c)].

En algunos sistemas (p. ej., G recia), los representantes de los trabajadores en los comités de empresa están obligados a no comunicar a terceros la información obtenida que sea de importancia fundamental para la empresa y que, si se divulga, menoscabaría su competitividad. Se espera de los representantes de los trabajadores y de la empresa que decidan conjuntamente qué información debe divulgarse. En otros sistemas (p. ej., Luxemburgo), si los representantes de los trabajadores no están de acuerdo con la clasificación de unos determinados datos como confidenciales, pueden remitir la cuestión a la inspección para que adopte una decisión al respecto.

En algunos países, el deber de confidencialidad sólo es implícito (p. ej., Italia). Asimismo, cuando no se impone específicamente en este sentido (p. ej., R eino U nido), los representantes de los trabajadores no pueden recibir de la empresa información relativa a la salud de las personas (salvo que éstas otorguen su consentimiento), datos que perjudicarían la seguridad nacional 0 informaciones dañinas para la empresa. Por último (p. ej., en Suecia), es posible que dicho deber no evite que los representantes en materia de seguridad comuniquen ciertas informaciones recibidas al consejo ejecutivo de su sindicato, que quedará obligado asimismo a respetar la confidencialidad.

\section{ASPECTOS DE LAFORMACION VINCULADOS A LAS RELACIONES LABORALES}

Mel Doyle

Puede incluirse en la política o el programa general de desarrollo de los recursos humanos un sistema de formación, a escala empresarial, sectorial o nacional. Su aplicación en la práctica será mucho más fácil si se reconoce el permiso educativo remunerado (véase el recuadro). Si su concesión no está reconocida por la legislación nacional (a diferencia de lo que ocurre en Francia y en España, por ejemplo, donde sí se contempla), el permiso para 


\section{Aspectos destacados del Convenio de la OIT relativo a la licencia pagada de estudios, 1974 (no 140)}

O bjetivo de la norma

Promover la educación y la formación durante la jornada de trabajo con derecho a contraprestación económica.

\section{O bligaciones}

Los Estados que ratifiquen el Convenio deben formular y aplicar una política encaminada a promover la concesión de licencias pagadas de estudio para la formación a todos los niveles: educación general, social y cívica; educación sindical.

Al formular esta política, debe tenerse en cuenta la fase de desarrollo y las necesidades específicas de cada país, y debe coordinarse con otras políticas relativas al empleo, la educación y la formación y la jornada de trabajo.

La licencia pagada de estudios no será denegada a un trabajador por razón de su raza, color, sexo, religión, opinión política, procedencia nacional u origen social.

La financiación será regular y adecuada.

El período de licencia pagada de estudios tendrá la misma consideración que el período de servicio real, a efectos de la solicitud de prestaciones sociales y otros derechos derivados de la relación de trabajo.

\section{por la directora del capítulo} (extraído del Convenio de la OIT, 1974 (no 140).

asistir a la formación adecuada en materia de salud y seguridad en el trabajo debe ser tratado por los representantes de las empresas y los trabajadores en el marco del proceso de negociación colectiva.

En los sistemas de formación negociados se determinan las materias que deben impartirse, así como otros aspectos administrativos, financieros y organizativos. En la formación sobre salud y seguridad en el trabajo deben abordarse las cuestiones siguientes:

- legislación sobre salud y seguridad y medios de aplicación;

- actitudes de las empresas respecto a la salud y la seguridad;

- actitudes de los trabajadores respecto a la salud y la seguridad;

- problemas de salud y seguridad y medios para mejorar las prácticas en esta materia.

Los dos elementos fundamentales en todo planteamiento respecto a la formación son el contenido y el proceso. Ambos están determinados por los objetivos de la actividad pedagógica y las aspiraciones de los participantes y los formadores. El fin último en este caso consiste en contribuir a la mejora de la salud y la seguridad en el lugar de trabajo, por lo que el contenido se basará en la determinación de los medios prácticos para lograrla. Este tipo de enfoque exige una evaluación de los problemas existentes en este campo a los que se enfrentan los trabajadores. En líneas generales, son los siguientes:

- riesgos para la seguridad, como el levantamiento de cargas, el transporte, maquinaria, caídas, las escaleras, etc.;

- problemas y riesgos para la salud, como la tensión ocular, las sustancias químicas, el ruido, el polvo, los dolores musculares, etc.;

- cuestiones de bienestar, como las instalaciones higiénicas, los primeros auxilios, la vivienda.
Este enfoque metodológico facilita el tratamiento sistemático de cuestiones mediante la descripción del problema y el análisis del modo en que se conoció, quien se vio implicado, qué medidas se adoptaron y su resultado.

U na consecuencia importante de este planteamiento es la determinación de prácticas "buenas" y "malas" en materia de salud y seguridad en el trabajo, que, al menos teóricamente, pueden constituir la base para la acción común de empresas y trabajadores. Para aplicar esta metodología, es necesario satisfacer exigencias informativas importantes. Se incluyen entre ellas la obtención de documentación acerca de legislación sobre salud y seguridad, normas e información técnica, y la identificación de otros datos necesarios para eliminar el riesgo o el problema, como los relativos a las políticas o los acuerdos elaborados por otros sindicatos y empresas, soluciones alternativas y estrategias.

U na actividad pedagógica eficaz requiere la utilización de métodos de aprendizaje activo, que se desarrollan sobre la base de la experiencia, las cualificaciones, el conocimiento, las actitudes y los objetivos de los participantes. La experiencia y los conocimientos se revisan, las actitudes se analizan y las cualificaciones se desarrollan y mejoran mediante el trabajo colectivo. Como parte del proceso, se anima a los participantes a aplicar los resultados de su actividad pedagógica en su medio ambiente de trabajo. De esta forma, se hace hincapié en los resultados prácticos y en su contenido relevante.

Las preguntas que el formador y los alumnos deben plantearse respecto al proceso y el contenido son: ¿qué logramos que pueda ser aplicado a nuestro medio ambiente de trabajo? ¿mejora la formación nuestras cualificaciones y conocimientos? ¿nos ayuda a actuar con mayor eficacia en nuestro medio ambiente de trabajo?

El formador debe abordar estas cuestiones en las fases de planificación, aplicación y evaluación del programa de formación y el proceso metodológico anima a los participantes a plantearse las mismas preguntas en el proceso de la actividad pedagógica.

Este método, al que suele denominarse "aprendizaje activo", se basa en gran medida en las experiencias, las actitudes, las cualificaciones y los conocimientos de los participantes; por tanto, las actividades de formación deben integrarlo. En los programas de salud y seguridad en el trabajo, pueden incluirse las actividades esbozadas en la Tabla 21.1.

La formación en materia de salud y seguridad en el trabajo puede desarrollar la sensibilización de los trabajadores y las empresas respecto a las distintas cuestiones y ofrecer una base para la acción común y el acuerdo sobre el modo de superar los problemas. En la práctica, las buenas prácticas en dicha materia no sólo facilitan la mejora del medio ambiente de trabajo y posibles aumentos de productividad, sino que también fomentan una actitud más positiva de los interlocutores sociales respecto a las relaciones laborales.

\section{ASPECTOS DE LA INSPECCION DE TRABAJO VINCULADOS A LAS RELACIONES LABORALES}

M aría L uz Vega Ruiz

El papel fundamental desempeñado por la inspección de trabajo en el desarrollo de las relaciones laborales es indiscutible; de hecho, la historia de la legislación laboral es la historia del sistema de inspección de trabajo. Antes de la creación de los primeros 
Tabla 21.1 - Actividades prácticas - formación en materia de salud y seguridad.

$\begin{array}{ll}\text { Actividad } & \text { Cualificaciones afines } \\ \text { Determinación de riesaos } & \text { Análisis crítico } \\ & \text { Puesta en común de la información } \\ & \text { Análisis de la información } \\ \text { Resolución de problemas } & \text { Análisis crítico } \\ & \text { Puesta en común de la información } \\ & \text { Colaboración } \\ & \text { Desarrollo de estrateaias } \\ \text { Búsaueda de información } & \text { Utilización de recursos } \\ & \text { Capacidad investiaadora } \\ & \text { Reciclado de la información } \\ & \text { Análisis crítico } \\ \text { Formación de actitudes } & \text { Reevaluación de actitudes } \\ & \text { Argumentación y debate eficaces }\end{array}$

cuerpos de inspección de trabajo, las leyes laborales eran meras declaraciones de objetivos cuyo incumplimiento no daba lugar a la sanción. El verdadero derecho del trabajo surge cuando se encarga a un órgano específico que garantice el cumplimiento de las normas, dando vigencia a la ley mediante la imposición de sanciones jurídicas.

Los primeros intentos nacionales de establecimiento de un sistema de inspección de trabajo se basaron en la creación de órganos voluntarios que actuaban gratuitamente para proteger a las mujeres y los niños empleados en la industria y que constituyeron una respuesta a la naturaleza peculiar del liberalismo económico. La experiencia pronto impuso la necesidad de crear un órgano de carácter coercitivo que fuera realmente capaz de proteger a la población activa en su conjunto. La primera ley en la que se previó la creación de un cuerpo oficial de inspectores de trabajo se promulgó en el Reino U nido en 1878, debido a que los requisitos relativos a la designación de personal responsable no se habían cumplido fielmente y, por tanto, las medidas de protección no se habían aplicado. La ley confería a los inspectores las competencias básicas siguientes: acceso ilimitado a las fábricas, libertad para interrogar a trabajadores y empresarios, y capacidad para exigir la presentación de documentos, resolver conflictos y determinar las infracciones de la legislación.

En los años posteriores, la evolución de los diversos reglamentos dio lugar a la consolidación de la autoridad de los inspectores de trabajo como funcionarios administrativos, excluyendo y suprimiendo gradualmente su función como jueces. Comenzó a arraigar la idea del inspector como un funcionario remunerado, pero también como un participante en el sistema de relaciones laborales, responsable de garantizar que la Administración muestre su lado humano mediante su actuación directa en el lugar de trabajo. Con este objetivo en mente, la inspección de trabajo se transformó en un órgano básico para el desarrollo y la aplicación de la legislación; se convirtió, de hecho, en un pilar fundamental de la reforma social.

Este concepto dual de sus actividades (control estricto y observación activa de los hechos) revela los orígenes de la actividad de inspección en las instituciones jurídicas. Por una parte, la inspección de trabajo basa su actividad en textos jurídicos claros y específicos que deben aplicarse; por la otra, la correcta articulación y ejercicio de sus funciones le lleva a interpretar la letra de la ley por medio de la acción directa. El inspector debe conocer no sólo la letra, sino también el espíritu de la ley y, por tanto, ha de ser sensible a la situación laboral y poseer un conocimiento exhaustivo, no sólo de las normas, sino también de los procedimientos técnicos y productivos. Así, la inspección de trabajo constituye un órgano de la política de trabajo, pero también una institución creativa de progreso, progreso que resulta fundamental para la propia evolución del derecho del trabajo y las relaciones laborales.

La evolución del mundo del trabajo ha seguido arraigando y reforzando el papel de la inspección como un órgano de control independiente, situado en pleno ámbito de las relaciones laborales. De modo paralelo, la modificación y el cambio de este mundo generan nuevos objetivos y formas de relación interna en el complejo microcosmos que representa el lugar de trabajo. El concepto original de un tipo de relación paternalista entre el inspector y los sometidos a la inspección dió paso pronto a una acción más participativa de los representantes de las empresas y los trabajadores y al fomento, por parte de los inspectores, de la intervención de los interlocutores interesados en sus actividades. Por consiguiente, desde un principio se asignó a los inspectores de trabajo el papel de conciliadores en los conflictos colectivos en la legislación de muchos países.

Junto a la consolidación del papel del inspector público, los avances logrados en el movimiento sindical y en las organizaciones profesionales suscitaron un mayor interés por parte de los propios trabajadores en la participación activa en la inspección. D espués de varios intentos de éstos para incorporarse a la acción de inspección directa (p. ej., designación de trabajadores inspectores como los que existían en los países comunistas), acabó favoreciéndose el estatuto independiente y objetivo de la inspección y su transformación definitiva en un órgano público. Con todo, la actitud participativa de los representantes de los trabajadores y de las empresas no se perdió en sus contactos con la nueva institución: la inspección, además de una entidad independiente, se convirtió en un interlocutor que ocupa un puesto especial en el diálogo entre dichos representantes.

D esde este punto de vista, la inspección se desarrolló progresiva y paralelamente a la evolución económica y social. Por ejemplo, la tendencia proteccionista del Estado en el primer tercio del siglo XX dio lugar a la adopción de modificaciones sustanciales en la legislación laboral, añadiéndose un número considerable de licenciados a los profesionales previamente registrados como inspectores. Una consecuencia inmediata de estos acontecimientos fue la creación de una verdadera administración laboral. I gualmente, es obvio que la aparición de nuevas formas de organización del trabajo y la presión ejercida por las fuerzas de mercado sobre el servicio público al final del presente siglo, han repercutido en la inspección de trabajo de muchos países.

La inspección, concebida inicialmente como un órgano constituido por controladores jurídicos, ha modificado su actividad con el tiempo y se ha convertido en un mecanismo útil e integrado que responde a las necesidades tecnológicas de las nuevas formas de trabajo. De este modo, la legislación laboral también se ha ampliado, adaptándose a las nuevas exigencias de la producción y los servicios e incorporando normas de carácter técnico. A esta razón obedece la intervención de ciencias afines: la sociología del trabajo, la ergonomía, la salud y la seguridad en el trabajo, la economía del trabajo, etc. Con las nuevas prioridades y perspectivas, que transcienden al ámbito jurídico, el inspector se ha transformado en un elemento activo dedicado a una auténtica aplicación de las normas en los lugares de trabajo, no sólo en virtud de la imposición de sanciones, sino también como asesor de los representantes de las empresas y los trabajadores. 


\section{Generalistas frente a especialistas}

En las legislaciones nacionales se han adoptado dos planteamientos organizativos diferentes respecto a la inspección: la inspección generalista (surgida en la Europa continental) y la especializada (originada en el Reino Unido). Sin entrar en los argumentos relativos a las ventajas de uno u otro sistema, la terminología utilizada en su denominación revela la adopción de dos perspectivas completamente dispares. Por una parte, en el enfoque generalista (también denominado unitario), la acción de inspección es realizada por una sola persona asistida por diversas instituciones técnicas, en el supuesto de que la evaluación general de un único inspector puede ofrecer una base más lógica y coherente para la solución de los problemas laborales. El inspector generalista es un árbitro (en el sentido de la palabra utilizada en la antigua Roma) que, previa consulta a los órganos especializados pertinentes, intenta responder a las dificultades y los problemas planteados por un lugar de trabajo concreto. Aborda directamente los conflictos vinculados a las relaciones laborales. En cambio, en el enfoque especializado, se emprenden acciones directas mediante la utilización de un inspector eminentemente técnico, que debe resolver problemas específicos con una perspectiva más limitada. Por otra parte, las cuestiones puramente vinculadas a las relaciones laborales son tratadas por mecanismos bipartitos y, en ocasiones, tripartitos (empresas, sindicatos y otros organismos públicos) que intentan resolver los conflictos por medio del diálogo.

A pesar de las diferencias entre estas dos tendencias, el punto de convergencia radica en que el inspector sigue siendo una expresión viva de la ley. En el sistema de inspección generalista, la posición central de quien la ejerce le permite a éste reconocer las necesidades inmediatas y realizar las modificaciones pertinentes. La situación en Italia es particularmente ilustrativa de este enfoque: la legislación capacita al inspector para adoptar decisiones ejecutivas que complementen las disposiciones generales y a sustituir otras disposiciones más específicas. En el caso de la inspección especializada, el conocimiento exhaustivo del inspector acerca del problema y de las normas técnicas, le permiten evaluar la posibilidad de incumplimiento de los requisitos jurídicos y la prevención de riesgos, y proponer soluciones alternativas para su aplicación inmediata.

\section{La función actual de la inspección}

El papel esencial desempeñado por el inspector significa que, además de su función de supervisión, éste se convierte con frecuencia en un pilar de apoyo para las instituciones sociales existentes en el ámbito laboral. A parte de la función de control general de los requisitos jurídicos relativos a las condiciones de trabajo y la protección de los trabajadores, la inspección de numerosos países supervisa el cumplimiento de otros requisitos vinculados con los servicios sociales, el empleo de trabajadores extranjeros, la formación profesional, la seguridad social, etc. Para ser eficaz, la inspección de trabajo debe tener las características enunciadas en el Convenio sobre la inspección de trabajo de la OIT, 1947 (no 81): dotación de personal suficiente, independencia, formación y recursos adecuados y las competencias necesarias para llevar a cabo inspecciones y obtener soluciones a los problemas planteados.

En muchos países, a los servicios de inspección también se les asignan competencias en materia de resolución de conflictos laborales, participación en la negociación de convenios colectivos a solicitud de las partes, actividades relativas a la recogida y evaluación de datos socioeconómicos, redacción de memorias, asesoramiento técnico especializado en su ámbito de actuación a la Administración laboral y otras funciones de carácter estrictamente administrativo. Esta amplitud y multiplicidad de tareas se deben a la asunción del concepto de inspector como experto en relaciones laborales dotado de conocimientos técnicos específicos. Asimismo, refleja una visión especial de un marco de funcionamiento de las empresas en el que la inspección constituye la institución ideal para evaluar y resolver las dificultades relacionadas con el trabajo. No obstante, este carácter multidisciplinario da lugar en algunos casos al planteamiento de un problema básico: la dispersión. Puede cuestionarse si los inspectores de trabajo, obligados a asumir varias responsabilidades, no corren el riesgo de tener que favorecer las actividades de naturaleza económica o de otro tipo en detrimento de las que deberían constituir la esencia de su misión.

La principal controversia respecto a la determinación de las funciones típicas y prioritarias de la inspección, se centra en la función de conciliación de los conflictos laborales. Aunque las labores de seguimiento y supervisión forman parte sin duda de la actividad diaria del inspector, no es menos cierto que el lugar de trabajo es el centro de conflicto laboral, ya sea individual o colectivo. Por tanto, se plantea la cuestión de si la actividad de control y evaluación de la inspección no implica en cierta medida la adopción de acciones "paliativas" aplicadas a los conflictos. Analicemos un ejemplo: el inspector que sugiere la aplicación de ciertos requisitos legales relativos al ruido responde en muchos casos a las quejas planteadas por los representantes de los trabajadores, que consideran que un nivel de decibelios elevado afecta al rendimiento en el trabajo. Al asesorar a la empresa, el inspector propone una medida para resolver un conflicto específico generado en las relaciones de trabajo ordinarias. La solución puede o no ser adoptada por la empresa, sin perjuicio del posterior inicio de acciones legales en el caso de incumplimiento. De modo similar, una visita de un inspector a un lugar de trabajo para analizar si se ha producido un acto de discriminación antisindical tiene como objetivo el diagnóstico y, si es posible, la eliminación de las diferencias internas que hayan surgido en este sentido.

¿En qué medida difiere la prevención y la solución de conflictos de la actividad diaria del inspector? La respuesta no es clara. La estrecha interrelación de todas las esferas que forman parte del ámbito laboral da lugar a que la inspección no sea únicamente una expresión viva de la ley, sino también una institución fundamental en el sistema de relaciones laborales. Un órgano de inspección que analice el mundo laboral en su conjunto podrá contribuir a la consecución de condiciones de trabajo mejores, un medio ambiente de trabajo seguro y, como resultado, la optimización de las relaciones laborales.

\section{CONFLICTOS COLECTIVOS POR CUESTIONES DE SALUD Y SEGURIDAD}

Shauna L. OIney

En los últimos años, en la legislación, en los instrumentos internacionales y en la bibliografía en general se ha subrayado la importancia de la información, la consulta y la cooperación entre trabajadores y empresas. Se ha hecho hincapié en la prevención de los conflictos más que en su resolución. Para algunos, en el área de la salud y la seguridad en el trabajo, los intereses de trabajadores y empresas convergen y, por tanto, los conflictos pueden eludirse con mayor facilidad. No obstante, se plantean conflictos de todos modos.

La relación de empleo es objeto de intereses y prioridades divergentes y cambiantes, incluidos los aspectos relativos a la salud y la seguridad. Por tanto, existe la posibilidad de desacuerdo o discrepancia que puede desembocar en un conflicto laboral. Aunque puede haber consenso respecto a la 
importancia de las cuestiones de salud y seguridad en general, puede surgir la desavenencia acerca de la necesidad de adoptar medidas específicas o de su aplicación, sobre todo cuando éstas exigen la dedicación de tiempo o dinero adicionales o la producción puede reducirse. Al abordar la salud y la seguridad, hay pocos conceptos absolutos: qué constituye un riesgo "aceptable", por ejemplo, es relativo. Se debate dónde trazar los límites de ciertas cuestiones, especialmente debido a la posibilidad de que situaciones complejas tengan que abordarse con una asistencia técnica limitada y una falta de pruebas científicas concluyentes. Asimismo, la percepción en este campo cambia continuamente como resultado de la utilización de nuevas tecnologías, la investigación médica y científica, la modificación de las actitudes sociales, etc. En consecuencia, la probabilidad de divergencia de opiniones y conflicto en este ámbito es elevada.

En todas las áreas de las relaciones laborales, pero quizá especialmente en lo que se refiere a la salud y la seguridad, la resolución equitativa y eficaz de los conflictos es esencial. Estos pueden superarse en una fase temprana, como resultado de la sensibilización de una de las partes respecto a factores importantes propiciada por la otra. Esta solución puede adoptarse formal o informalmente. A simismo, los conflictos pueden abordarse mediante el recurso a procedimientos internos de presentación de reclamaciones en los que, normalmente, participa personal directivo cada vez de superior categoría. La conciliación o la mediación puede ser necesaria para facilitar la resolución del conflicto o es posible que se adopte una solución impuesta por un tribunal o un árbitro. En el área de la salud y la seguridad, la inspección de trabajo también puede desempeñar un papel importante en la resolución de conflictos. Algunos de éstos pueden dar lugar a la interrupción del trabajo, que, en el caso de la salud y la seguridad, puede o no ser considerada jurídicamente como huelga.

\section{Categorías de conflicto}

En la esfera de la salud y la seguridad, pueden plantearse varios tipos de conflictos. Aunque las categorías no siempre son obvias, asignar al conflicto una determinación específica suele ser importante para determinar los mecanismos de resolución que deben aplicarse. En general, los conflictos pueden clasificarse en individuales y colectivos, en función de quién los inicia o tiene la competencia para iniciarlos. En general, un conflicto individual afecta a un trabajador en concreto, y uno colectivo afecta a un grupo de trabajadores, normalmente representados por un sindicato. A menudo se hace otra distinción entre los conflictos de derechos y los conflictos de intereses. En el primer caso (también denominados conflictos jurídicos) está en juego la aplicación o la interpretación de derechos recogidos en la legislación o en las disposiciones de un contrato de empleo o un convenio colectivo. En un conflicto de intereses, se debate la creación de derechos u obligaciones o la modificación de los ya vigentes. Estos surgen fundamentalmente en relación con la negociación colectiva.

En ocasiones, la definición de un conflicto como colectivo o individual determina la elección de los procedimientos de resolución; no obstante, la importancia suele radicar en la interrelación entre categorías: conflictos colectivos de derechos, conflictos colectivos de intereses y conflictos individuales de derechos reciben habitualmente un tratamiento distinto. En este artículo sólo se analizan las dos primeras categorías, pero debe tenerse en cuenta que algunas fases del proceso de conflicto colectivo coinciden con las correspondientes a los conflictos individuales.

El carácter colectivo o individual puede depender de que la legislación permita a los sindicatos plantear un conflicto sobre la cuestión objeto de debate. En varios países, con el fin de obtener la autorización necesaria para negociar sobre salud y seguridad y otros aspectos, los sindicatos deben registrarse ante la
Administración pública o ser reconocidos como representantes de un determinado porcentaje de los trabajadores afectados. En algunos países, estos requisitos previos se aplican asimismo a la autorización para plantear conflictos de derechos. En otros, la empresa debe acceder voluntariamente a tratar con el sindicato antes de que éste pueda actuar en nombre de los trabajadores.

Un sindicato puede iniciar procedimientos para resolver un conflicto colectivo de derechos en el que están en juego las obligaciones en materia de salud y seguridad que afectan al lugar de trabajo en su conjunto: por ejemplo, si existe una disposición en el convenio colectivo o en la legislación en la que se establece que los niveles de ruido no pueden exceder de un límite determinado y la empresa no la cumple, deben tomarse precauciones especiales respecto a la maquinaria, o suministrarse equipos de protección personal. También pueden plantearse conflictos colectivos de derechos, por ejemplo, cuando la empresa no consulta con los representantes o los comités de salud y seguridad, ni les informan de acuerdo con lo establecido en la legislación o el convenio colectivo. En algunos países, una presunta infracción del convenio colectivo, dada su naturaleza, puede ser considerado un conflicto colectivo, sobre todo si afecta a la puesta en práctica de disposiciones de aplicabilidad general como las relativas a la salud y la seguridad, incluso aunque, en realidad, sólo un trabajador resulte perjudicado de forma inmediata y directa por la contravención de la empresa. El incumplimiento de las disposiciones jurídicas puede considerarse colectivo si el sindicato, en caso de que esté facultado, actúa en nombre de todos los trabajadores afectados.

L os conflictos colectivos de intereses sobre cuestiones de salud y seguridad también pueden adoptar muchas formas. Suelen plantearse a consecuencia de las negociaciones entre los sindicatos y la empresa sobre la constitución o las competencias de un comité de salud y seguridad, la introducción de nuevas tecnologías, las medidas específicas para el tratamiento de los materiales peligrosos, el control medioambiental, etc. Las negociaciones pueden centrarse en la adopción de declaraciones generales de principios relativas a la salud y la seguridad, la obtención de mejoras específicas o la fijación de límites. Cuando las partes llegan a un atolladero en las negociaciones, el tratamiento del conflicto se considera una extensión de la libertad de negociar colectivamente. En el Convenio sobre el fomento de la negociación colectiva, 1981 ( $n$ ㅇ 154), la O IT destaca la importancia de establecer órganos y procedimientos para la resolución de los conflictos laborales como parte del proceso de fomento de la negociación colectiva [artículo 5(2) (e)].

\section{Procedimientos de reclamación}

El término procedimiento de reclamación suele utilizarse para hacer referencia a los procedimientos internos establecidos en el convenio colectivo para resolver los conflictos relativos a su aplicación o interpretación (conflictos de derechos). No obstante, suelen adoptarse procedimientos semejantes incluso en caso de ausencia de un sindicato o un convenio colectivo, con el fin de abordar los problemas quejas de los trabajadores, ya que se consideran un medio más justo y menos costoso de resolución de conflictos que el litigio (M cC abe 1994). Normalmente, los convenios colectivos prevén el tratamiento de las reclamaciones a través de un procedimiento de varias fases en el que participan jerarquías de la organización cada vez más elevadas. Por ejemplo, un conflicto sobre salud y seguridad puede dirigirse en primer lugar al supervisor inmediato. Si no se resuelve en esta fase inicial, el supervisor y el representante de salud y seguridad pueden emprender una investigación, cuyos resultados se remiten a un directivo 0 , quizá, al comité competente en la materia. Si el conflicto sigue sin resolverse, puede intervenir una escala directiva superior. Es posible que existan varias fases que deban 
superarse antes de poner en marcha procedimientos externos. EI convenio puede establecer la intervención de terceros en calidad de agentes de inspección, conciliación y arbitraje, aspectos que se analizarán más adelante.

En la Recomendación sobre el examen de reclamaciones dentro de la empresa con vistas a su solución, (no 130), adoptada en 1967 por la OIT, se subraya la importancia de los procedimientos de reclamación en los conflictos de derechos, ya sean individuales o colectivos. Se afirma que las organizaciones o los representantes de los trabajadores en la empresa deben asociarse con las empresas en la creación y la aplicación de procedimientos de reclamación en el centro de trabajo. Se insta a la adopción de procedimientos rápidos y sencillos. Cuando se agotan los procedimientos en la empresa, sin alcanzar una solución aceptable por ambas partes, la Recomendación prevé la aplicación de otros encaminados a la consecución de una solución definitiva, que incluyen el análisis conjunto del caso por parte de las organizaciones de empresarios y de trabajadores, la conciliación 0 el arbitraje y el recurso a la magistratura de trabajo u otras instancias judiciales.

\section{Conciliación y mediación}

Los convenios colectivos o la legislación pueden exigir la remisión de los conflictos colectivos a sistemas de conciliación o mediación antes de aplicar otros procedimientos de resolución. Incluso en el caso de que no se imponga esta obligación, las partes pueden solicitar voluntariamente un conciliador o mediador, un tercero imparcial, que les ayude a reducir sus diferencias y, en última instancia, a llegar a un acuerdo. En algunos sistemas de relaciones laborales, se distingue, al menos en teoría, entre conciliación y mediación, aunque en la práctica el límite es difícil de determinar. EI papel de los conciliadores consiste en reabrir las líneas de comunicación, si han quedado cortadas, para ayudar a las partes a encontrar una base común que les permita alcanzar un consenso y, quizá, adoptar una decisión sobre la cuestión de hecho. No obstante, el conciliador no presenta propuestas formales para resolver el conflicto (aunque en la realidad, rara vez se adopta una actitud tan pasiva). De un mediador, por su parte, se espera que proponga las condiciones del acuerdo, aunque las partes siguen siendo libres para aceptarlas 0 rechazarlas. En muchos países no se establece una distinción real entre conciliación y mediación y tanto conciliadores como mediadores tratan de ayudar a las partes a encontrar una solución a su conflicto, utilizando la táctica más adecuada en cada momento, unas veces basada en la pasividad y otras en la presentación de propuestas de resolución.

La conciliación es uno de los procedimientos de utilización más difundida y se considera uno de los más eficaces para la resolución de conflictos de intereses. En el proceso de negociación colectiva, puede valorarse como la continuación de las negociaciones con la ayuda de una parte neutral. En un número cada vez mayor de países, la conciliación también se utiliza en las fases iniciales de la resolución de conflictos de derechos. La Administración puede poner a disposición servicios de conciliación o establecer un órgano independiente que los preste. En algunos países, los inspectores de trabajo participan en el proceso de conciliación.

La OIT, a través de la adopción de la Recomendación sobre la conciliación y el arbitraje voluntarios, 1951 ( $n$ - 92) defiende la conveniencia de establecer organismos de conciliación voluntaria, gratuitos y expeditivos, "con objeto de contribuir a la prevención y solución de los conflictos de trabajo entre empleadores y trabajadores" (párrafos 1 y 3). EI papel de la conciliación para garantizar el ejercicio eficaz del derecho a la negociación colectiva se recoge en la C arta Social Europea [10 de octubre de 1961, artículo 6(3)].

\section{Arbitraje}

El arbitraje exige la intervención de un tercero neutral que, a pesar de no ser miembro de la judicatura, está autorizado para imponer decisiones. En varios países, casi todos los conflictos de derechos derivados de la aplicación o la interpretación de los convenios colectivos se abordan mediante el arbitraje vinculante, en ocasiones a continuación de una fase obligatoria de conciliación que se ha mostrado ineficaz. El arbitraje se ofrece en muchos países como procedimiento voluntario, mientras que en otros es obligatorio. En los casos en que se impone como método de resolución de conflictos de intereses, suele limitarse a la función pública o a los servicios esenciales. Con todo, en algunos países, sobre todo en los que se encuentran en desarrollo, el arbitraje de los conflictos de intereses se aplica con más generalidad.

El arbitraje se aborda en la Recomendación sobre la conciliación y el arbitraje voluntarios, 1951 (no 92). Como en el caso de la conciliación, en la Recomendación se alude a los conflictos remitidos voluntariamente al proceso de arbitraje y se establece que, en estos casos, las partes deben abstenerse de convocar huelgas o efectuar cierres durante el procedimiento y aceptar el laudo arbitral correspondiente. El carácter voluntario de la remisión al arbitraje también se destaca en la Carta Social Europea (ibíd.) Si una de las partes o la Administración pueden iniciar el procedimiento de arbitraje, éste se considera obligatorio. El Comité de Expertos de la OIT sobre la A plicación de los Convenios y las Recomendaciones ha declarado que, en el caso de los conflictos de intereses, el arbitraje obligatorio es, en general, contrario a los principios del Convenio relativo a la aplicación de los principios del derecho de sindicación y de negociación colectiva, 1949 ( $n$ - 98), ya que invalida la autonomía de las partes negociadoras (O IT 1994b). U n laudo definitivo que vincula a las partes interesadas, si éstas no han remitido voluntariamente el conflicto al procedimiento de arbitraje, puede asimismo considerarse como una limitación injustificada del derecho de huelga. El Comité de Expertos ha declarado que "tal prohibición limita gravemente los medios de que disponen los sindicatos para fomentar y defender los intereses de sus miembros, así como su derecho a organizar sus actividades y formular sus programas, y no es compatible con el artículo 3 del Convenio $\mathrm{n} 087$ [Convenio relativo a la libertad sindical y a la protección del derecho de sindicación, 1948 (no 87)]." (ibíd., párrafo 153).

\section{Autoridades de la administración de trabajo}

En la mayoría de los países, la administración de trabajo tiene diversas competencias y una de las más importantes consiste en la inspección de los centros para garantizar el cumplimiento de la legislación sobre empleo, en particular la referida a la salud y la seguridad. Los inspectores no necesitan un conflicto laboral para intervenir. No obstante, cuando en un conflicto se declara una infracción de la legislación o de un convenio, estos funcionarios pueden desempeñar un papel importante en su solución.

En la resolución de conflictos, las autoridades de la administración de trabajo suelen cumplir un papel más activo respecto a la salud y la seguridad que en otras áreas. EI papel del inspector en los conflictos puede definirse en los convenios colectivos o en la legislación sobre salud y seguridad, sobre derecho del trabajo en general, sobre indemnización de los trabajadores o sobre aspectos específicos. En algunos países, el representante 0 el comité de salud y seguridad tiene derecho a remitir sus reclamaciones contra la empresa al inspector de trabajo u otro funcionario público competente en materia de trabajo o salud y seguridad. Puede solicitarse al inspector que intervenga en los casos en que, presuntamente, no se cumplen las disposiciones relativas a salud y seguridad. Asimismo, puede pedirse a las autoridades de la administración de trabajo que intervengan en 
virtud de su competencia en los regímenes públicos de indemnización de los trabajadores.

Los inspectores pueden estar autorizados para dictar órdenes de mejora, prohibición o detención del trabajo, imponer multas e incluso, iniciar procesamientos. Pueden emprenderse procesamientos civiles o penales en función del carácter de la infracción, la gravedad de sus consecuencias, el conocimiento previo de la probable repercusión y su reiteración. N ormalmente, la decisión de un inspector puede ser revisada en recurso de apelación a una instancia pública superior o un órgano o tribunal especializado en trabajo o salud y seguridad. En ciertos sectores pueden coexistir mecanismos administrativos y de apelación independientes (p. ej., la minería).

En la Recomendación sobre la inspección de trabajo, 1947 (no 81) de la OIT, se fomenta la colaboración entre los altos funcionarios de la inspección de trabajo y los representantes de las empresas y los trabajadores. La Directiva $M$ arco de la U nión Europea no 89/391/ CEE sobre salud y seguridad adoptada en 1989 establece que los trabajadores y sus representantes tengan derecho a recurrir a la autoridad competente en materia de salud y seguridad en el trabajo si consideran que las medidas adoptadas por el empresario no son suficientes para garantizar la salud y la seguridad en el trabajo. De acuerdo con la Directiva, los representantes de los trabajadores deben tener la posibilidad de presentar sus observaciones durante las visitas de inspección efectuadas por la autoridad competente [artículo 11(6)].

\section{Tribunales ordinarios y tribunales de trabajo}

Puesto que en los conflictos de derechos se ponen en juego derechos y obligaciones preexistentes, el principio general que subyace a su resolución es que deben ser solventados en última instancia por tribunales 0 árbitros y no mediante acciones de reivindicación, como una huelga. En algunos países se establece que los tribunales ordinarios resuelvan judicialmente los conflictos de derechos, sin tener en cuenta su vinculación a las relaciones laborales. No obstante, en muchos otros, el Tribunal de trabajo (también denominado "Juzgado de lo social") o tribunales especializados se encargan de esta clase de conflictos. Pueden ocuparse de los conflictos de derechos en general o sólo de ciertos tipos, como las denuncias de disciplina injustificada o de despido improcedente. La razón principal para disponer de estos órganos judiciales especializados es la necesidad de aplicar procedimientos rápidos, baratos e informales y contar con un servicio centrado específicamente en las cuestiones laborales. Los retrasos y los gastos que genera el sistema judicial ordinario no se consideran aceptables para tratar aspectos del empleo, que constituye un área de crucial importancia para la vida de una persona y que conlleva la existencia de una relación que debe mantenerse incluso después de la resolución del conflicto. La jurisdicción sobre conflictos colectivos de derechos puede dividirse entre los tribunales ordinarios y los tribunales de trabajo: por ejemplo, en algunos países, los únicos conflictos colectivos que se someten a la competencia del Tribunal de trabajo son los que derivan de un presunto incumplimiento del convenio colectivo, dejando la resolución de las infracciones de las disposiciones jurídicas a los tribunales ordinarios.

A menudo, los representantes de los trabajadores y de las empresas, así como un juez independiente, son miembros de los tribunales de trabajo. Asimismo, existen tribunales compuestos exclusivamente por los representantes de los trabajadores y de las empresas. Con esta composición bipartita o tripartita se pretende garantizar que los miembros tengan conocimientos técnicos en materia de relaciones laborales y, por tanto, que las cuestiones pertinentes sean analizadas y abordadas a la luz de realidades prácticas. Además, esta composición ayuda a dar credibilidad y capacidad de persuasión a las decisiones adoptadas. Los representantes de las empresas y los trabajadores pueden asumir las mismas competencias en la determinación del resultado del conflicto o sólo tener derecho a actuar en calidad de asesores. En otros países, los jueces neutrales respecto a ambas partes de las relaciones laborales resuelven los conflictos colectivos de derechos.

En algunos países, los tribunales de trabajo se ocupan tanto de los conflictos colectivos de derechos como de los conflictos de intereses. Como ya se ha mencionado respecto al arbitraje, cuando los fallos son vinculantes en materia de conflictos de intereses, se menoscaba el carácter voluntario de la negociación colectiva.

\section{Suspensiones del trabajo}

Una suspensión del trabajo concertada puede tener lugar por diversas razones. $\mathrm{H}$ abitualmente, se considera como una forma de presión sobre la empresa para que acepte ciertas condiciones una vez que se ha alcanzado un atolladero en el proceso de negociación colectiva. En la mayoría de los países, esta acción recibe la denominación de huelga y se valora como un medio legítimo a disposición de los trabajadores y sus organizaciones para promover y proteger sus intereses.

El derecho de huelga se reconoce expresamente como derecho general en el Pacto Internacional de Derechos Económicos, Sociales y Culturales [16 de diciembre de 1996, artículo 8(1) (d)]. En la Carta Social Europea (supra, artículo 6 (4)) se vincula el derecho de huelga con el derecho a la negociación colectiva y se declara que los trabajadores y las empresas deben gozar del derecho a la acción colectiva en los casos de conflictos de interés, sin perjuicio de las obligaciones que se deriven del convenio colectivo. La Carta de la O rganización de Estados Americanos [30 de abril de 1948, artículo 43 c)] define el derecho de huelga como un elemento integral de la libertad de asociación, junto con el derecho de negociación colectiva. El Comité de Expertos de la OIT sobre la Aplicación de los Convenios y Recomendaciones y el Comité de Libertad Sindical del Consejo de Administración, han reconocido el derecho de huelga como originado en los principios de libertad de asociación establecidos en el Convenio relativo a la libertad sindical y a la protección del derecho de sindicación, 1948 (no 87), aunque este derecho no se menciona específicamente en el texto del Convenio. El Comité de Expertos ha declarado que "una prohibición general de la huelga constituye una restricción considerable de las oportunidades de que disponen los sindicatos para promover y defender los intereses de sus afiliados... y del derecho de estas entidades a organizar sus actividades" (OIT 1994b, párrafo 147).

En algunos países, el derecho de huelga corresponde a los sindicatos y, por tanto, las que no son organizadas o autorizadas por estas instituciones se consideran "informales" o ilícitas. En otros, por el contrario, el derecho de huelga es individual, aunque suela ejercerlo un grupo, en cuyo caso la distinción entre huelgas "oficiales" e "informales" no tiene mucho sentido.

Incluso cuando el derecho de huelga es reconocido en principio, ciertas categorías de trabajadores pueden quedar excluidos de su disfrute, como los miembros de la policía y las fuerzas armadas o los altos funcionarios públicos. A simismo, este derecho puede estar sujeto a ciertas limitaciones de procedimiento, como la exigencia de una notificación previa o la celebración de una votación para comprobar el apoyo a la huelga. En varios países, las partes están obligadas a abstenerse de convocar una huelga o realizar un cierre, plenamente 0 en lo que se refiere a ciertas cuestiones reguladas en un convenio colectivo en vigor. Esta "obligación de paz" suele estipularse específicamente en la legislación o en los convenios colectivos, 0 
puede deducirse de la interpretación judicial. El derecho de huelga en muchos países se encuentra gravemente restringido e incluso prohibido, en los servicios esenciales

Esta restricción es conforme con los principios de la OIT si los servicios a los que se aplica son sólo aquéllos cuya suspensión puede poner en peligro la vida, la seguridad personal o la salud del conjunto o de una parte de la población. (OIT 1994b, párrafo 159).

En cuanto a los conflictos en materia de salud y seguridad debe distinguirse entre los relativos a la negociación de ciertos derechos (por ejemplo, la determinación de las funciones precisas de un representante de seguridad en la aplicación de una política general de salud y seguridad) y los que tienen que ver con situaciones de riesgo inminente. Cuando existe una situación peligrosa, o se cree que existe, la legislación y los convenios colectivos prevén en general la concesión a los trabajadores del derecho a suspender la actividad. Esta interrupción suele considerarse como un derecho individual del trabajador 0 los trabajadores que están afectados directamente por un riesgo. Existen varias fórmulas para justificar la suspensión del trabajo. La creencia sincera en la existencia de peligro puede bastar o es posible que haya que demostrar la existencia de un peligro objetivo. Respecto a quien está en peligro, los trabajadores puede dejar de trabajar si están sometidos a una amenaza inmediata, si bien el derecho puede ser más amplio e incluir la posibilidad de que se provoque peligro para los demás. En general, las suspensiones colectivas del trabajo por solidaridad (huelgas de apoyo) no se prevén en las disposiciones ( $y$, por tanto, pueden considerarse ilícitas), pero, de hecho, sí se convocan. La facultad de suspender el trabajo también puede asignarse a los representantes en materia de salud y seguridad en el lugar de trabajo. EI trabajo puede ser interrumpido pendiente de una decisión definitiva adoptada por las autoridades administrativas.

En el Convenio sobre seguridad y salud de los trabajadores y medio ambiente de trabajo, 1981 ( $n$ - 155) se establece que los trabajadores no sufrirán consecuencias injustificadas por haber interrumpido una situación de trabajo por creer que ésta entraña un peligro inminente y grave para su vida o su salud (artículo 13). U na disposición similar puede encontrarse en el artículo 8(4) de la Directiva marco de la Unión Europea de 1989 , en la que se hace referencia a un "peligro grave, inminente y que no pueda evitarse". A menudo, se contempla en la legislación sobre salud y seguridad el derecho a suspender el trabajo debido a un peligro inminente. En algunos países, este derecho se reconoce en la legislación laboral y se concibe como una interrupción del trabajo que no constituye una huelga; por tanto, los requisitos de procedimiento aplicables en este caso no deben satisfacerse y la obligación de paz no se incumple. Del mismo modo, cuando la empresa cierra el lugar de trabajo en cumplimiento de una orden de suspensión del trabajo 0 debido a una creencia razonable en la existencia de una situación peligrosa, no suele considerarse un cierre patronal.

\section{- CONFLICTOS INDIVIDUALES POR CUESTIONES DE SALUD Y SEGURIDAD}

Anne Trebilcock

\section{Tipos de conflictos}

Se plantea un conflicto individual cuando existe un desacuerdo entre un trabajador y su empresa respecto a un determinado aspecto de su relación de empleo. Se trata de un ejemplo de "conflicto de derechos", es decir, el relativo a la aplicación de las condiciones de la legislación o del acuerdo vigente, ya sea un convenio colectivo o un contrato de trabajo individual por escrito 0 verbal. Por tanto, los conflictos pueden deberse a la desavenencia respecto a la cuantía de los salarios abonados, o la manera de pago, los sistemas y las condiciones de trabajo, el derecho a permisos, etc. En el ámbito de la salud y la seguridad, el conflicto puede surgir en relación con la utilización del equipo de protección personal, la remuneración extraordinaria por la realización de tareas peligrosas (plus de peligrosidad: una práctica que ha dejado de verse con buenos ojos, ya que en la actualidad se opta más bien por favorecer la eliminación de los riesgos), el rechazo a llevar a cabo trabajos que representan un peligro inminente y el cumplimiento de las normas de salud y seguridad.

El conflicto individual puede iniciarse por la reclamación de un trabajador que reivindica lo que considera su derecho o que reacciona a las acciones disciplinarias impuestas por la empresa 0 al despido. Si un conflicto de este tipo da lugar a la presentación de reclamaciones semejantes en nombre de trabajadores individuales o está relacionado con una cuestión de principios importante para un sindicato, el conflicto individual puede desembocar asimismo en una acción colectiva y, en caso de que se pretenda la concesión de nuevos derechos, a un conflicto de intereses. Por ejemplo, un trabajador que se niega a realizar tareas que, en su opinión, son demasiado peligrosas puede ser sancionado e incluso despedido por la empresa; si el sindicato considera que estas tareas suponen un peligro permanente para otros trabajadores, puede abordar la cuestión mediante la acción colectiva, incluida la suspensión de la actividad (es decir, la convocatoria de una huelga legal, o salvaje). De este modo, un conflicto individual puede dar lugar y convertirse en otro colectivo. I gualmente, el sindicato puede considerar una cuestión de principio que, si no se reconoce, le llevará a realizar nuevas demandas, planteando así un conflicto de intereses en futuras negociaciones.

La resolución de un conflicto individual dependerá en gran medida de tres factores: (1) el alcance de la protección jurídica concedida a los trabajadores en cada país; (2) el sometimiento 0 no del trabajador a las condiciones del convenio colectivo; y (3) la facilidad con la que los trabajadores puedan lograr la aplicación de sus derechos, con independencia de que se reconozcan en la legislación o en el convenio colectivo.

\section{Conflictos sobre represalias y despidos}

No obstante, en la mayoría de los países, ciertos derechos de los trabajadores permanecen inalterados con independencia de la duración de su compromiso con la empresa o el tamaño de ésta. Suele tratarse de los derechos a la protección contra las represalias adoptadas por el ejercicio de la actividad sindical o por la comunicación a las autoridades de una presunta infracción de la legislación por parte de la empresa, denominada protección “del denunciante". También en la mayor parte de los países, la legislación prevé la protección de todos los trabajadores contra la discriminación por razón de la raza, el sexo (incluido el estado de embarazo) y, en muchos casos, la religión, la opinión política, la procedencia nacional o el origen social, el estado civil y las responsabilidades familiares. Todos estos factores se enumeran en la relación de motivos, que no justifican un despido, establecida en el Convenio de la OIT sobre la terminación de la relación de trabajo por iniciativa del empleador, 1982 ( $n-158$ ), a los que se añaden: la afiliación a un sindicato y la participación en actividades sindicales, ser candidato a representante de los trabajadores 0 actuar o haber actuado en esa calidad, presentar una queja 0 participar en un procedimiento entablado contra un empresario por supuestas infracciones de leyes o reglamentos y recurrir ante las autoridades administrativas competentes. 
O bviamente, estos tres últimos motivos tienen una importancia especial para la protección de los derechos de los trabajadores en el campo de la salud y la seguridad. El Comité de Expertos de la OIT sobre la Aplicación de los Convenios y Recomendaciones subrayó recientemente la gravedad de las medidas de represalia, sobre todo las que conducen a la terminación de la relación de trabajo, adoptadas contra los trabajadores que informan del incumplimiento de la empresa en la aplicación de las normas de salud y seguridad en el trabajo mientras la integridad física, la salud e incluso las vidas de los trabajadores pueden haber estado en peligro. Cuando se ponen en juego los derechos fundamentales o la integridad física de los trabajadores, sería conveniente que las condiciones de prueba (inversión de la carga de la prueba) y las medidas de reparación (readmisión) fueran tales que permitieran al trabajador informar de las prácticas ilícitas sin temor a las represalias (O IT 1995c).

No obstante, en lo que se refiere al mantenimiento del puesto de trabajo en la práctica, existen dos factores determinantes de los derechos de empleo de una persona: el mecanismo de aplicación disponible para reivindicar estos derechos y el tipo de contrato de trabajo en virtud del cual ha sido contratada en la empresa. En general, cuanto mayor sea el período de contratación, más sólida será la protección. Así, un trabajador en período de prueba (en la mayoría de los países, de unos pocos meses de duración) estará poco o nada protegido frente al despido. A sí ocurre también en el caso de los trabajadores eventuales (es decir, las personas contratadas por días) y estacionales (es decir, los contratados por un período limitado cada año). Un trabajador con un contrato de empleo con un plazo de terminación fijo disfrutará de protección durante la vigencia del mismo, pero, normalmente, no tendrá derecho a su renovación. El personal con contratos indefinidos gozan de la situación más segura, pero pueden seguir siendo despedidos por razones específicas 0 , más en general, por lo que suele denominarse "conducta indebida grave". Asimismo, sus puestos de trabajo pueden resultar eliminados a causa de una reestructuración empresarial. D ebido a las presiones cada vez mayores a favor de una mayor flexibilidad en el mercado de trabajo, la tendencia reciente en la legislación que rige los contratos de empleo consiste en facilitar a las empresas los "recortes de plantilla" en los procesos de reestructuración. Además, han surgido nuevas formas de relación de trabajo ajenas a la tradicional de empresa/ trabajador. Si carece del reconocimiento de trabajador, es posible que éste deba conformarse con una protección jurídica limitada.

\section{Conflictos por la negativa del trabajador a realizar tareas peligrosas}

Suelen plantearse conflictos individuales debidos a la negativa de un trabajador a realizar tareas que, en su opinión, constituyen un riesgo inminente, siempre que esta opinión sea expresada por una persona razonable y se mantenga de buena fe. En Estados U nidos, esta creencia razonable debe basarse en que la ejecución de una tarea constituye un peligro inminente de muerte o lesión física grave. En algunos países, este derecho se considera en la negociación colectiva, en otros, existe en virtud de la legislación y las interpretaciones de los tribunales. Por desgracia, este importante derecho no ha sido objeto aún de un reconocimiento universal, a pesar de su inclusión como principio básico en el artículo 13 del Convenio sobre seguridad y salud de los trabajadores y medio ambiente de trabajo, 1981 (no 155). Incluso, cuando este derecho se contempla en la legislación, es posible que los trabajadores teman la aplicación de represalias o la pérdida del empleo por ejercerlo, sobre todo si no cuentan con el respaldo de un sindicato o de una inspección de trabajo eficaz
El derecho a rechazar la realización de un trabajo suele acompañarse del deber de informar inmediatamente de la situación a la empresa; en ocasiones, el comité mixto de seguridad también ha de ser informado. $\mathrm{Ni}$ al trabajador que rechaza, ni a otro en su lugar, debe asignárseles la tarea rechazada hasta que se haya resuelto el problema. Si se le asigna pese a todo y el trabajador resulta lesionado, la legislación puede (como en Francia y Venezuela) imponer a la empresa sanciones civiles y penales graves. En Canadá, tanto el trabajador que rechazó la tarea como el representante de salud y seguridad tienen derecho a asistir a la investigación sobre el terreno que lleve a cabo la empresa. Si el trabajador sigue negándose a realizarla después de que la empresa haya adoptado medidas correctivas, puede iniciarse una inspección pública urgente y, hasta que se tome una decisión, la empresa no podrá exigir al trabajador que lleve a cabo la tarea en cuestión y debe asignarle un trabajo alternativo para evitar la pérdida de ingresos. Al trabajador designado para sustituir al que rechazó la tarea debe comunicársele la negativa de su compañero.

El reconocimiento del derecho a rechazar un trabajo peligroso constituye una excepción importante a la norma general según la cual, la empresa asigna las tareas y el trabajador no debe abandonar su puesto ni negarse a cumplir las instrucciones que se le imponen. Su justificación conceptual radica en la urgencia de la situación y en la intervención de intereses de orden público para salvar una vida (Bousiges 1991; Renaud y St. Jacques 1986).

\section{Participación en una huelga}

0 tra causa que puede provocar un conflicto individual relacionado con la salud y la seguridad es la participación de un trabajador en una huelga para protestar por la existencia de condiciones de trabajo inseguras. Las consecuencias dependerán de que la suspensión de la actividad fuese lícita o ilícita y de la medida en que se garantice el derecho de huelga en esas circunstancias concretas. En este caso, se tiene en cuenta no sólo su consideración como derecho colectivo, sino también el modo en que el sistema jurídico valora la interrupción de la actividad por parte del trabajador. En muchos países, la participación en una huelga constituye un incumplimiento del contrato de trabajo por parte del trabajador y el perdón o no de esta infracción dependerá en buena medida del poder de su sindicato en relación con la empresa y, posiblemente, la A dministración. U n trabajador que goza de un derecho de huelga teórico sólido, pero que puede ser sustituido de manera temporal o permanente, se mostrará reacio a ejercerlo por temor a la pérdida del empleo. En otros países, participar en una huelga lícita se especifica como una de las razones por las que no puede terminarse una relación de trabajo (Finlandia, Francia).

\section{Medios de resolución de conflictos}

En general, las vías para resolver un conflicto individual son las mismas que las utilizadas en el caso de los conflictos colectivos. No obstante, en los diversos sistemas de relaciones laborales se adoptan diferentes enfoques. En algunos países (p. ej., Alemania, Israel, Lesotho y Namibia) existen tribunales de trabajo encargados de la resolución de conflictos individuales y colectivos. LoS tribunales de trabajo de Dinamarca y Noruega sólo conocen de los conflictos colectivos y las reclamaciones de los trabajadores a título individual deben dirigirse a los tribunales civiles ordinarios. En otros países, como Francia y el Reino U nido, se aplican mecanismos especiales a los conflictos entre un trabajador y su empresa. En Estados U nidos, los trabajadores tienen derecho a iniciar acciones de denuncia por discriminación ilícita en el empleo ante órganos distintos de los que conocen de las reclamaciones por prácticas laborales injustas. No obstante, en 
situaciones sin intervención sindical, el arbitraje impuesto por la empresa para la resolución del conflicto individual goza de popularidad a pesar de las críticas de los profesionales de las relaciones laborales. Si un trabajador se acoge a un convenio colectivo, su reclamación puede ser tramitada por un sindicato en virtud de dicho convenio, que suele remitir los conflictos al arbitraje voluntario. La capacidad de un trabajador para sacar adelante su reclamación suele depender de su acceso a procedimientos equitativos, asequibles y rápidos y del apoyo de un sindicato o una inspección de trabajo eficaz.

\section{Referencias}

American Iron and Steel Institute (AISI). 1915. Year Book of the American I ron and Sted Institute for 1914. Nueva Y ork: AISI.

Ben-Israel, R. 1988. International Labour Standards: T he Case of $F$ reedom to Strike. Deventer: $K$ luwer.

Bousiges, A. 1991. Le droit des salariés de se retirer d'une situation dangereuse pour leur integrité physique. D roit Soc (4) (abril):279-291.

Brody, D. 1960. Stedworkers in America: The Nonunion Era. Cambridge, M assachussetts: H arvard U niv. Press.

Consejo Mixto de Seguridad Industrial de Suecia. 1988. W orking Environment Agreement. Estocolmo: Consejo M ixto de Seguridad Industrial de Suecia.

Corn, J. 1978. H istorical aspects of industrial hygiene: Changing attitudes toward occupational health. Am Ind H yg Assoc ] 39:695-699.

Creighton, WB. 1994. The ILO and protection of freedom of association in the $U$ nited $K$ ingdom. $E n$ $H$ uman Rights and Labour Law, dirigido por KD Ewing, CA Gearty y BA Hepple. Londres: $M$ ansell.

Derickson, A. 1988. W orkers' H ealth, W orkers' D emocracy: The W estern M iners' Struggle, 1891-1925. Ithaca, N ueva Y ork: Cornell U niv. Press.

Ferris, GR, SD Rosen, DT Barnum. 1995. H andbook of $H$ uman Resources. Cambridge, $M$ assachussetts: Blackwell.

Fisher, R, W U ry. 1981. Getting to Yes. Nueva Y ork: $\mathrm{H}$ oughton $\mathrm{M}$ ifflin.

Foner, PS. 1977. The Factory Girls. U rbana, Illinois: U niv. of Illinois Press.

Fox, M B. 1990. U nited W e Stand. Washington, DC: $U$ nited $M$ ine $W$ orkers of A merica.

$\mathrm{H}$ ealth and Safety Commission. The H ealth and Safety System in G reat B ritain. Londres: H M SO .

Hecker, S. 1993. O ccupational health and safety policy in the European community. New Solution III-4,IV -1:59-69,57-67.

Hodges-A eberhard, J, A O dero de Dios. 1987. Principles of the Committee on Freedom of Association concerning strikes. Int Labour Rev 126:543.

Inohara, H. 1990. H uman Resource Development in J apanese Companies. Tokio: O rganización Asiática para la Productividad.

K aufman, BE, M M K leiner (dirs.). 1993. Employee Representation: Alternatives and Future Directions. M adison, Wisconsin: Industrial Relations R esearch Association.

Lehman, P. 1977. Cancer and the W orker. Nueva Y ork: $\mathrm{N}$ ew $\mathrm{Y}$ ork A cademy of Sciences.

Locke, R, TA Kochan, M Piore. 1995. Employment Relations in a Changing W orld E conomy. Cambridge, M assachussetts: M IT Press.

Loewenson, R. 1992. Trade union accident programmes in Zimbabwe. Afr Newslett on 0 ccup $H$ ealth and Safety (H elsinki) 2(2):36-38.

M cC abe, D. 1994. Non-union grievance procedures: A strategic analysis of organizational due process in "Employee rights and industrial justice". B Comp Labour R elat 28:101-113.
Oechslin, JJ. 1995. Employers' organizations. En European $L$ abour $L$ aw, dirigido por $R$ Blanpain y $C$ Engels. Deventer: K luwer L aw and T axation.

O rganización Internacional del T rabajo (O IT ). 1983. Conciliation Services: Structures, Functions and T echniques. Labour-M anagement Relations Series, No.62. Ginebra: OIT.

— . 1994a. Employers' organizations. En W orld Labour Report. Ginebra: OIT

- . 1994b. F reedom of Association and Collective B argaining: General Survey by the Committee of Experts on the Application of Conventions and Recommendations. Ginebra: OIT.

-. 1995a. F reedom of Association: Digest of Decisions and Principles of the $F$ reedom of Association Committee of the Governing B ody of the IL O. G inebra: OIT.

-. 1995b: Documento de la Junta Directiva GB.264/ ST M / 4, Apéndice, sección I.

-. 1995c. Protection Against U njustified Dismissal. Ginebra: OIT.

Ozaki, M. 1996. Labour relations and work organization in industrialized countries. Int Labour Rev 135(1):37-58.

Reber, R, J Wallin, D Duhon. 1993. Preventing occupational injuries through performance management. Publ Pers M anage 22(2):301-311.

Regalia, I, C Gill (dirs.). 1995. The Position of the Social Partners in Europe on Direct Participation. Country Studies: Vol. I. Dublín: Fundación Europea para la M ejora de las C ondiciones de V ida y de T rabajo.

—. 1996. The Position of the Social Partners in Europe on Direct Participation. Country Studies: Vol. II. Dublín: Fundación Europea para la Mejora de las Condiciones de Vida y de T rabajo.

Reilly, B, P Paci, P Holl. 1995. Unions, safety committees and workplace injuries. B rit J Ind Relat 33(2):275.

Renaud, M, C St.-Jacques. 1986. Le droit de refus, cinq ans après: l'évolution d'un nouveau mode d'expression des risques. Sociol Société M ontréal 18(2):99-112.

Rice, A. 1995. International Labor Federation. 0 ccup Environ $\mathrm{H}$ ealth 1 (2):215-222.

Schregle, J. 1994. O ccupational safety and health and the working environment: The role of workers' participation. B Labour Res 4:18.

T eleky, L. 1948. T he H istory of F actory and $\mathrm{M}$ ine $\mathrm{H}$ ygiene. N ueva Y ork: Columbia U niv. Press.

US Department of Labor and M exican Secretariat of Labor and Social Welfare. 1992. A Comparison of $\mathrm{O}$ ccupational Safety and $\mathrm{H}$ ealth Programs in the U nited States and M exico: An O verview. Washington, DC: US G overnment Printing 0 ffice.

van R uysseveldt, J, R H uiskamp, J van $\mathrm{H}$ oof. (dirs.). 1995. Comparative Industrial and Employment Relations. Londres: Sage.

van Waarden. 1995. En Comparative Industrial and E mployment R elations, dirigido por J van R uysseveldt, R H uiskamp y J van H oof. Londres: Sage.

Visser, J. 1995. Interest organizations and industrial relations in a changing Europe. En Comparative Industrial and $\mathrm{E}$ mployment $\mathrm{R}$ elations, dirigido por I van R uysseveldt, R H uiskamp y J van Hoof. Londres: Sage.
Vogel, L. 1994. Prevention at the W orkplace. Bruselas: Oficina Sindical Europea para la Salud y la Seguridad.

W ebb, S, B W ebb. 1920. T he H istory of T rade U nionism. Londres: L ongman $\mathrm{G}$ reen.

Weiss, M. 1992. Germany. En European E mployment and Industrial Relations G lossary. Londres: Sweet and M axwell.

Zinn, S. 1995. Labor solidarity in the New World Order. Labor Res R ev 23:35-43.

\section{0 tras lecturas recomendadas}

Adams, R. 1993. Regulating unions and collective bargaining: A global, historical analysis of determinants and consequences. Comp Labor L aw J 14(3) (Spring):272-291.

- 1995. Industrial Relations U nder Liberal Democracy: $\mathrm{N}$ orth America in Comparative Perspective Columbia, SC: U niv. of South Carolina Press.

Bamber, G, R Lansbury. 1993. International and Comparative Industrial Relations. St. Leonards, Australia: Allen \& U nwin.

Bean, R. 1994. Comparative Industrial Relations: An Introduction to Cross-National Perspectives. Londres: R outledge.

Beaumont, PB. 1993. Safety at W ork and the U nions. Londres.

Bellace, J. 1993. The state and industrial relations: A strategic choice model. Comp Labor Law 」 14(3): 249-271.

Benner, A, D Jones. 1995. Employee participation, ownership and productivity: A theoretical framework. Ind Relat I 34(4):532-554.

Biagi, M. 1990. From conflict to participation in safety: Industrial relations and the working environment in Europe 1992. Int J Comp Labour L aw Ind Re 6(2):67 79.

Blanpain, R (dir.). 1993. Comparative Labour Law and Industrial Relations in Industrialized M arket E conomies, 5a ed. Deventer: $K$ luwer.

Blanpain, R, C Engels. 1995. European Labour Law. D eventer: $K$ luwer $L$ aw and $T$ axation.

Bokat, SA, HA Thompson. 1988. O ccupational Safety and $H$ ealth Law. Washington, DC: Bureau of $N$ ational Affairs.

Brewster, C, S T yson. 1992. International Comparisons in $H$ uman R esource $M$ anagement. Londres: Pitman.

Bronstein, A. 1995. Societal change and industrial relations in Latin America: T rends and prospects. Int L abour Rev 134(2):163-186.

Clerc, J. 1982. Training as an instrument of a strategy for the improvement of working conditions and environment. Int Labour Rev 121(5):565-576

Creighton, WB. 1993. Freedom of association. En Comparative $L$ abour $L$ aw and Industrial Relations in Industrialised $M$ arket $\mathrm{E}$ conomies, dirigido por $\mathrm{R}$ Blanpain y C Engels. D eventer: K luwer.

Crouch, C. 1993. Industrial Relations and European State T raditions. O xford: 0 xford U niv. Press.

Dawson, S, P Pointer, D Stevens. 1984. R esolving the health and safety conflict. M anagement Today (abril):33-36.

Deery, S, R M itchell. 1993. Labour Law and Industrial Relations in Asia. M elbourne: Longman Cheshire. 
de Givry, J. 1989. D roits de l'H omme, T ravail et Syndicats. París: Editions U niv.

de R oo, A, R Jagtenberg. 1994. Settling Labour Disputes in $E$ urope. Deventer: K luwer.

Dunlop, J. 1993. Industrial Relations Systems, 2a ed. Cambridge, M assachussetts: $H$ arvard Business School Press.

Dunning, H. 1991. Negotiating and W riting a Collective A greement. G inebra: OIT.

E mployment relations in the growing Asian economies. 1995. Londres: R outledge.

Ermida U riarte, O . 1993. Intervención y Autonomía en las Relaciones Colectivas de Trabajo. Montevideo: Fundación de Cultura U niv.

Fashoyin, T. 1992. Industrial Relations and African D evelopment. Nueva D elhi: South A sian Publishers.

Frenkel, S, J H arrod. 1995. Industrialization and Labour Relations: Contemporary Research in Seven Countries. Ithaca, Nueva Y ork: ILR Press.

Gladstone, A. 1984. Voluntary Arbitration of Interest Disputes: A Practical Guide. G inebra: O IT .

-. 1993. Settlement of disputes over rights, comparative labour law and industrial relations in industrialized market economies. En Comparative Labour Law and Industrial Relations in Industrialized $\mathrm{M}$ arket $\mathrm{E}$ conomies, $5^{\mathrm{a}}$ ed., dirigido por $\mathrm{R}$ Blanpain. D eventer: K luwer.

Goldman, A. 1993. Settlement of disputes over interests. En Comparative Labour Law and Industrial Relations in Industrialized $M$ arket $E$ conomies, 5a ed. dirigido por R Blanpain. Deventer: K luwer.

Gordon, BR. 1994. Employee involvement in the enforcement of the occupational safety and health laws of $C$ anada and the U nited States. Comp Labor Law J 15(4):527-560.

Goss, D. 1994. Principles of H uman R esource M anagement. Londres: R outledge.

International $\mathrm{H}$ andbook on Contract of $\mathrm{E}$ mployment. 1995. La H aya: K luwer.

Jacoby, SM . 1995. W orkers of Nations: Industrial R elations in a Global Economy. Nueva Y ork: Oxford Univ. Press.

Jenks, CW. 1957. The International Protection of T rade U nion F reedom. Londres: Stevens.

Kochan, TA, L Dyer, DB Lipsky. 1977. The Effectiveness of $U$ nion $\mathrm{H}$ ealth and Safety Committees.
K alamazoo, Michigan: WE U pjohn Institute for Employment R esearch.

K ochan, TA, HC K atz, RB M CK ersie. 1986. The T ransformation of American Industrial Relations. Nueva Y ork: Basic Books.

K orostoff, J, L Yimmermann, C Ryan. 1991. Rethinking the OSHA approach to workplace safety: A look at worker participation in the enforcement of safety regulations in Sweden, France and Great Britain. Comp Labour Law J . 13 (1) (O toño): 45-95

K rieger, H. 1990-1991. Participation of employees' representatives in the protection of the health and safety of workers. Int J Comp Labour L aw Ind Rel 6(4) (Invierno):217-218.

Lewin, D, O Mitchell, P Sherer. 1992. Research F rontiers in Industrial Relations and $\mathrm{H}$ uman Resources. Madison, Wisconsin: Industrial Relations Research Association.

Luttringer, J-M , B Pasquier. 1980. Paid educational leave in five European countries. Int Labour Rev 119(4):407-424.

M artens, M H , S M itter. 1994. W omen In T rade U nions. Ginebra: OIT.

M itchell, D, D Lewin. 1994. International Perspectives and Challenges in $H$ uman Resource $M$ anagement. LoS Angeles: International Perspectives and Challenges in $\mathrm{H}$ uman $\mathrm{R}$ esource $\mathrm{M}$ anagement.

Niland, J, R Lansbury, C Verevis. 1994. The Future of Industrial R elations. Beverly H ills, California: Sage.

Nyman, T. 1981. A Guide to the Teaching of Collective B argaining. G inebra: OIT.

Organización Internacional del Trabajo (OIT) 1981. Education and $T$ raining Policies in 0 ccupational Safety and $H$ ealth and E rgonomics. $O$ ccupational Safety and $H$ ealth Series, N 0.47. Ginebra: OIT

-. 1983. Salud Ocupacional y Seguridad en Programas de Formación Profesional. CINTER FOR. M ontevideo: OIT.

- 1986. Collective Bargaining: A W orkers' Education $M$ anual. Ginebra: OIT.

- 1989. Grievance Arbitration: A Practical Guide Ginebra: OIT

-. 1990. Structure and Functions of Rural W orkers Organisations. Ginebra: OIT

-. 1991. W orkers' Education in Action: Selected Articles from L abour E ducation. Ginebra: OIT.
- . 1992. International Standards and Guiding Principles On Labour Law and Labour Relations. Labour$M$ anagement Relations Series, No.74. Ginebra: OIT.

R ebitzer, JB. 1995. Job safety and contract workers in the petrochemical industry. Ind R el 34 (1):40-57.

Rogers, J, W Streeck. 1995. W orks Councils. Chicago: Univ. of Chicago Press.

Simard, M, C Lévesque, D Bouteiller. 1986. Services spécialisés et comités paritaires de santé-sécurité au travail. Sociétés 18(2):77-86.

Taylor, TA, L Dyer, DB Lipsky, 1977. The Effectiveness of U nion $H$ ealth and Safety Committees. Kalamazoo, Michigan: U pjohn Institute for Employment R esearch.

Thirkell, J, R Scase, S Vicerstaff. 1995. Labour Relations and Political Change in Eastern Europe: $A$ Comparative Perspective. L ondres: U CL Press.

Trebilcock, A. 1994. T owards Social D ialogue: T ripartite Cooperation in National Economic and Social Policy-M aking. Ginebra: O IT.

Treu, T. 1987. Public Service Labour Relations: Recent $T$ rends and $F$ uture Prospects. Ginebra: 0 IT

- . 1992. Participation in Public Policy-M aking, The Role of T rade $U$ nions and $E$ mployers' Associations. Berlín: de Gruyter.

Valticos, N, K Sampson. 1993. International labour law. En Comparative Labour Law and Industrial Relations in Industrialised $M$ arket $E$ conomies, dirigido por R Blanpain y C Engels. Deventer: K luwer.

Valticos, N, G van Potolsky. 1995. International Labour Law. D eventer: K luwer.

Verma, A, TA Kochan, RD Lansbury. 1995. Employment $R$ elations in the Growing Asian $E$ conomies. Londres: R outlegde.

Vogel, L. 1992. Evolution of Preventive Services in the W orkplace and the Implementation of the Community's F ramew ork Directive 89/391 Comparative Study in the EEC and EFTA Countries. Bruselas.

Walters, D, A Dalton, D Gee. 1993. W orker Representation on $\mathrm{H}$ ealth and Safety in E urope. Bruselas: O ficina Sindical Europea para la Salud y Seguridad.

Windmuller, JP, A Gladstone. 1984. Employers' Associations and Industrial R elations. O xford: Clarendon.

Wokutch, R. 1990. Cooperation and Conflict in $\mathrm{O}$ ccupational Safety and $\mathrm{H}$ ealth: A M ultination Study of the Automotive I ndustry. N ueva Y ork: Praeger. 



\section{RECURSOS: INFORMACION Y SALUD Y SEGURIDAD EN EL TRABAJO}

Director del capítulo

J ukka T akala

\section{Sumario}

La información: una condición previa para la acción

J ukka Takala ................................ 22.2

Acceso a la información

P.K. A beytunga, E mmert Clevenstine, Vivian M organ y Sheila Pantry. . . . . 22.5

Gestión de la información

Gordon Atherley .

Estudio de caso: servicio de información de $M$ alaisia

sobre toxicidad de pesticidas

D.A. Razak, A.A. Latiff, M .I. A. M ajid y R. Awang

Estudio de caso: una experiencia de gestión de

información eficaz en Tailandia

Chaiyuth Chavalitnitikul. 


\section{- LA INFORMACION: UNA CONDICION PREVIA PARA LA ACCION}

Jukka Takala

La producción comprende diversas actividades humanas cuyo resultado es la generación de materiales, energía, información u otros productos que son de utilidad tanto en el ámbito individual como para la sociedad en general; su desarrollo depende de la recogida, el tratamiento, la divulgación y la utilización de la información. El trabajo se puede definir como una actividad humana encaminada a la conservación de unos objetivos preestablecidos en el proceso de producción, en la que se utilizan herramientas y equipos como instrumentos materiales. No obstante, debe tenerse en cuenta que en el proceso de trabajo, la información que se recibe y organiza continuamente afecta y orienta el proceso.

El proceso de trabajo en sí contiene información en forma de la experiencia acumulada por el trabajador (como conocimientos y destrezas); e incorporada en cierto sentido en las herramientas, los equipos, la maquinaria y, en particular, en sistemas tecnológicos complejos; y materializada explícitamente mediante los equipos de tratamiento de la información. El proceso de trabajo constituye una forma concreta y dinámica de utilizar la información para alcanzar determinados objetivos. Los componentes de seguridad de esta información se distribuyen equitativamente entre los diversos elementos del trabajo: y son compartidos por el trabajador, las herramientas y el equipo, el medio ambiente de trabajo, y los objetivos de la producción; de hecho en teoría, la información sobre seguridad ha de formar parte de la información necesaria para la producción: en lugar de "cómo producir algo" debería plantearse "cómo producir algo con seguridad (con menor riesgo)". Varios experimentos han demostrado que la información, que vincula la seguridad a la producción no sólo es necesaria, sino que también va percibiéndose cada vez más.

La producción supone no sólo la creación técnica de nuevos productos a partir de materias primas o de materiales y mercancías preexistentes fabricadas por el hombre, sino también la modificación y la reorganización de la información relativa al proceso de producción de materiales y al propio ciclo de información. El alcance de la información en un proceso de producción en desarrollo aumenta con rapidez. Siguiendo la práctica habitual de dividir el proceso productivo en tres partes; concretamente, producción de energía, producción de materiales y producción de información, es posible asimismo clasificar sus productos en categorías similares. N o obstante, éstas, en general, no son independientes. La energía, suele ser conducida por materiales, y la información se asocia a éstos (material impreso, por ejemplo) o a la energía, como la carga eléctrica o los impulsos electrónicos u ópticos conducidos por cables de fibra óptica. No obstante, a diferencia de los productos materiales, la información no pierde necesariamente su valor cuando se somete a procesos reproductivos. Es un producto que puede ser reproducido masivamente $y$, manteniendo las copias el mismo valor que el original.

\section{Información sobre seguridad y su utilización en los sistemas productivos}

La información sobre la seguridad abarca una amplia gama de cuestiones, y por tanto puede adoptar, una gran variedad de formas. Puede ser clasificada de acuerdo con su contenido en cifras estadísticas, datos descriptivos, datos de referencia, textos originales, o materiales cuantitativos o cualitativos. Puede consistir en una tabla estadística en la que figuren un conjunto de datos cuantitativos referentes a la incidencia de accidentes, o una hoja de datos de seguridad sobre sustancias químicas. Puede tratarse de una base de datos informatizada, materiales listos para su utilización (incluidos ilustraciones y gráficos), legislación y normas, o los resultados de la investigación sobre un problema de seguridad concreto. H istóricamente, la mayoría de las necesidades de información se han cubierto mediante el recurso de métodos de comunicación convencionales, orales y escritos, hasta la llegada, relativamente reciente, de la fotografía, la radio, el cine, la televisión y las producciones de vídeo. Los métodos de los medios de comunicación podían facilitar la reproducción electrónica, pero carecían de capacidad de selección. Sencillamente les faltaba selectividad. No todas las personas necesitan o tienen interés en el mismo tipo de información sobre seguridad. Las bibliotecas, y en particular, los centros especializados en documentación sobre seguridad ofrecen una amplia selección de documentos, en los que cada usuario podrá encontrar los datos específicos que se requiere, pero no se encuentran disponibles como material impreso. Los métodos recientes de obtención, almacenamiento, y recuperación de la información sí han solventado este problema. La información tratada electrónicamente puede contener la misma o mayor cantidad de datos que una amplia biblioteca especializada, y puede ser duplicada con facilidad y rapidez.

Los profesionales de la seguridad, como inspectores, higienistas, ingenieros de seguridad, representantes de seguridad, directivos, supervisores, investigadores, y también los trabajadores harán uso de la información en la medida de lo deseable sólo si pueden disponer de ella fácilmente. Todo lo que necesitan debe ser accesible en su propia mesa de trabajo 0 en sus estanterías. La documentación existente debería presentarse en formato electrónico y organizarse de tal manera que su recuperación fuera fácil y fiable. Esta labor ya se lleva a cabo, y representa un enorme esfuerzo. En primer lugar, la selección es esencial. La información debería ser recopilada y facilitada en función de las prioridades, y el proceso de recuperación debe ser cómodo y fiable. Estos objetivos exigen una mejor organización de las bases de datos y un software y un hardware más inteligentes.

\section{Información cuantitativa sobre seguridad}

La información cuantitativa sobre hechos, se expresa, esencialmente, en forma numérica. Las medidas cuantitativas pueden registrar valores nominales, tales como un número de accidentes determinado; valores ordinales que definen prioridades; o coeficientes, que pueden describir la frecuencia de accidentes en relación con su gravedad. El problema principal es definir los criterios necesarios para garantizar la eficacia de las prácticas de seguridad y encontrar el mejor modo de evaluarlas (Tarrants, 1980). O tro problema es diseñar formas de información que sean eficaces al representar el carácter (y la necesidad) las medidas de seguridad y, al mismo tiempo, comprensibles para las personas interesadas, como los trabajadores o los usuarios de sustancias y material químico. Se ha observado que la información sobre seguridad influye en la conducta, pero que su modificación está influida, a su vez, no sólo por el contenido de la información, sino también por la forma en que se presenta, por ejemplo, por su atractivo e inteligibilidad. Si los riesgos no se presentan eficazmente ni se comprenden y reconocen correctamente, no puede esperarse un comportamiento racional y seguro por parte de los trabajadores, los directivos, los diseñadores, los proveedores y otras personas relacionadas con la seguridad.

En general los datos cuantitativos sobre riesgos no son bien entendidos. Existe una gran confusión acerca de cuáles son los mayores y menores riesgos, porque no se dispone de una medida uniforme para evaluarlos. Una de las razones de esta situación es que los medios de comunicación no hacen hincapié en los 
problemas que se plantean, ni siquiera de los más graves, y tienden a destacar las noticias más curiosas y "sorprendentes".

0 tro factor que limita la eficacia de la educación sobre seguridad alude a la posibilidad de que el tratamiento de la información cuantitativa compleja exceda la capacidad cognitiva de las personas, hasta el extremo de que éstas llegan a confiar en la heurística, recurriendo a las lecciones de la experiencia, de forma no sistemática, para facilitar la gestión de las tareas relacionadas con la seguridad. En general, se sobrestiman los riesgos menores y se subestiman los mayores (V icusi 1987). Este sesgo puede entenderse si se considera que, sin información, todos los riesgos se considerarían iguales. Toda información obtenida a través de la experiencia provocará que se perciba el riesgo enormemente, y se preste más atención a los incidentes más frecuentes, pero menos perjudiciales (y evitados con mayor cautela) que a los menos frecuentes pero más peligrosos.

\section{Información cualitativa sobre seguridad}

Aunque la información cuantitativa sobre seguridad, especialmente centrada en riesgos concretos, es fundamental para concentrar nuestros esfuerzos en problemas de seguridad esenciales, necesitamos una información cualitativa, con su fondo de conocimientos técnicos pertinentes, para encontrar soluciones prácticas (Takala, 1992). Debido a su naturaleza, esta clase de información no puede ser precisa y cuantitativa sino heterogénea y descriptiva. Procede de diversas fuentes, como la jurídica, los materiales de formación, los productos audiovisuales, las etiquetas, los signos y símbolos, las fichas de seguridad de datos químicos y técnicos, las normas, los códigos de prácticas, los libros de texto, artículos científicos en prensa, las tesis, pósters, boletines, e incluso folletos. Esta variedad de materiales dificulta su clasificación y, por consiguiente, su recuperación cuando se necesiten. No obstante esto puede hacerse, y de hecho se ha realizado satisfactoriamente: la elaboración de perfiles de riesgo en el ámbito de una empresa, una rama industrial, industria, e incluso a escala nacional representa un ejemplo práctico de oferta de información cualitativa en una forma sistemática en la que, al mismo tiempo, aporta medidas cuantitativas en función de la importancia relativa de los problemas en cuestión.

0 tra cuestión fundamental es la de la inteligibilidad. La información ha de presentarse de forma comprensible para el usuario. La utilización inadecuada del lenguaje, tanto el coloquial como la terminología técnica especializada (incluida la jerga), puede constituir quizás la mayor barrera a la difusión global de la información sobre seguridad. Los textos deben estructurarse de forma consciente y deliberada para atraer al público al que van dirigidos.

Sería deseable establecer una amplia base de conocimientos compuesta por toda la información acumulada sobre salud y seguridad a la que puedan acceder los usuarios a través de "interfaces" preparadas especialmente para cada grupo. Estos "interfaces" deben aportar los elementos deseados de esta información, sin redundancia, en un formato comprensible para el usuario, ya sea mediante la utilización de un lenguaje natural, una terminología específica (o la ausencia de ésta), imágenes, ilustraciones, gráficos o con sonido, y adaptarlo a las necesidades y las capacidades del usuario.

\section{Repercusión, presentación y tipos de información sobre seguridad}

\section{Información sobre seguridad en la empresa y ciclo de información}

L os estudios sobre los sistemas de información sobre seguridad en las empresas indican que el flujo de la información en éstas sigue un patrón cíclico: recogida de datos $\rightarrow$

análisis y almacenamiento de datos $\rightarrow$

distribución de información sobre seguridad $\rightarrow$

desarrollo de medidas preventivas $\rightarrow$

producción de bienes y materiales (riesgos y accidentes) $\rightarrow$ recogida de datos, etc.

L os métodos principales utilizados en la recogida de datos son las investigaciones sobre accidentes, las inspecciones de seguridad efectuadas por el personal de la empresa y los informes sobre peligro de accidente. Estos métodos se concentran en los problemas de seguridad, y no prestan mucha atención a los de salud e higiene industrial. Tampoco ofrecen información sobre la experiencia acumulada fuera de la empresa. Es esencial compartir la experiencia procedente de varios lugares, ya que los incidentes son acontecimientos poco frecuentes y no es probable que un número suficiente de accidentes similares, sobre todo si son graves, (como los desastres de Bhopal, Flixborough, Seveso y la Ciudad de M éxico) ocurra en una sola empresa, 0 incluso en un mismo país, y sirvan como base para establecer medidas preventivas eficaces. No obstante, los accidentes pueden repetirse en otros lugares del mundo (O IT 1988).

Las actividades relacionadas con la seguridad a disposición de las empresas pueden adoptar diferentes formas. L as campañas de información dirigidas a mejorar la difusión de la información sobre seguridad pueden incluir la utilización de frases de reclamo, el desarrollo de un índice de actividad doméstica, y la aplicación de programas de consolidación positivos y de formación para los trabajadores (Saarela 1991). En algunos países se han establecido servicios de salud en el trabajo para que el personal sanitario participe en el trabajo de la empresa en materia de prevención de accidentes. Estos servicios deben ser capaces de recoger información en el lugar de trabajo (por ejemplo, para llevar a cabo análisis sobre carga de trabajo y riesgos) para desarrollar sus actividades diarias. A demás, muchas empresas han establecido sistemas informatizados para el registro y la presentación de informes sobre accidentes. En varios países se han creado sistemas similares adaptados para registrar los accidentes en los lugares de trabajo de acuerdo con el formato normalizado, exigido por los órganos de las entidades de indemnización de los trabajadores.

Información sobre seguridad a escala nacional y mundial y ciclo de información

Así como existe un ciclo de información sobre seguridad en las empresas, también hay un ciclo semejante a escala nacional e internacional. El flujo de datos sobre seguridad de una nación a otra puede entenderse como un ciclo que representa diversas fases en el movimiento de la información, donde la información sobre seguridad puede ser necesitada, procesada o difundida.

Para evaluar las ventajas selectivas de los distintos sistemas de información, es conveniente analizar la difusión de ésta en función del "ciclo de información". El flujo de datos sobre seguridad a escala internacional se representa esquemáticamente en la Figura 22.1, basada en el modelo de Robert (Robert 1983; Takala 1993). Como primer paso, la información sobre seguridad, es identificada o descrita por el autor del documento en el que la palabra "documento" es utilizada en su más amplio sentido, y puede referirse a un artículo científico, un libro de texto, un informe estadístico, una parte de la legislación, materiales audiovisuales pedagógicos, una ficha de seguridad química, 0 incluso un disquete 0 una base de datos completa. Así pues, con independencia de su tipo, la información puede entrar en el ciclo, en soporte electrónico o impreso. 
Figura 22.1 - El ciclo de la información.

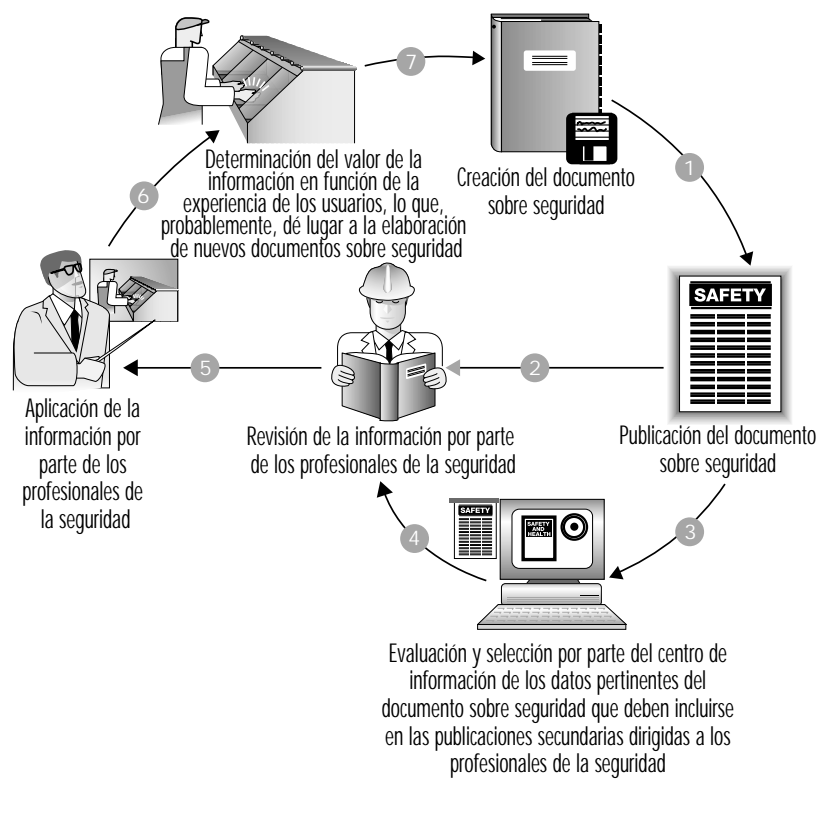

1. La información se envía al editor o al corrector, que evaluará su validez para ser publicada.

2. La publicación de un documento es un factor importante de su utilidad y accesibilidad general, sencillamente porque los materiales no publicados son difíciles de localizar.

3. Los documentos publicados pueden ser utilizados directamente por un profesional de la seguridad o dirigirse a un usuario no profesional, como el trabajador en su lugar de trabajo (por ejemplo, fichas de datos sobre seguridad química). Posteriormente el documento puede enviarse a un centro de información. En el caso de documentos que recogen información primaria (por ejemplo, los resultados de una investigación inicial), el centro recogerá, analizará y seleccionará sistemáticamente cualquier tipo de información útil que pueda contener, llevando a cabo así la primera lectura no exhaustiva de un gran volumen de documentos.

4. Una publicación secundaria, difundida y actualizada regularmente, como una revista, un periódico o una base de datos, constituida por resúmenes y artículos, puede ser publicada 0 puesta a disposición por el centro de información. Esto atraerá la atención de forma continua respecto a los nuevos avances importantes en materia de salud y seguridad en el trabajo. Estas publicaciones secundarias o bases de datos se dirigen fundamentalmente a los profesionales de la seguridad. Algunos ejemplos son la base de datos CISDOC y el boletín Salud y Seguridad en el Trabajo, de la O rganización Internacional del Trabajo y la base de datos NIOSHTIC del $\mathrm{N}$ ational Institute for $\mathrm{O}$ ccupational Safety and $\mathrm{Health}$ (NIOSH) de Estados Unidos. El vehículo de intercambio entre una entidad institucional concreta (por ejemplo, una empresa) y el ciclo de la información mundial o nacional es, en todos los casos, el usuario. Este no es necesariamente un profesional ya que puede ser también el sistema de gestión de la seguridad de la institución. Un usuario de material publicado puede transmitir retroinformación directamente al autor 0 a la editorial; ésta es una práctica habitual en las publicaciones científicas.

5. En este punto del ciclo de información, el documento publicado puede ser modificado como resultado de la "prueba de la realidad", la fase en la que el profesional de seguridad utiliza información realmente, con el fin de reducir el número de accidentes 0 enfermedades profesionales o para resolver otros problemas en el trabajo.

6. La experiencia contribuye a mejorar la previsión de los riesgos para la salud y los accidentes.

7. La experiencia puede traducirse en nuevos resultados de investigación materializados en informes y documentos enviados al editor; de esta forma, el ciclo se completa.

Figura 22.2 - Posibles aplicaciones de la información informatizada.

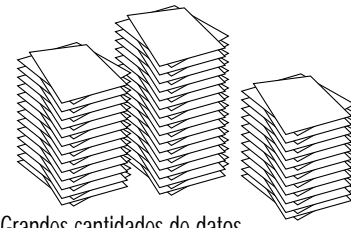

Grandes cantidades de datos

- Estadísticas sobre accidentes (pueden existir centenares de miles o millones de registros)

- Informes de investigación de accidentes (el número de registros es menor, pero la información es más detallada); principales incidentes causantes de

situaciones de riesgo

- Productos y sustancias químicas

- Resultados de las investigaciones

- Servicios bibliográficos y de documentación, centros de información

- Personal de seguridad (miembros del servicio de salud en el trabajo, responsables de seguridad,

representantes

en materia de seguridad)

- Registros sanitarios de los trabajadores

- Datos de encuestas y mediciones de higiene industrial - Otras bases de datos

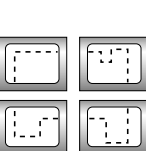

\section{Control de}

procesos

técnicos y maquinaria

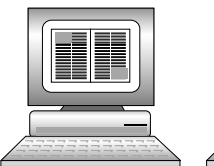

Diseño gráfico

- Diseño asistido

por ordenador

- Tablas de gráficos

- Autoedición

- Tratamiento de

la imagen

- Hipertexto

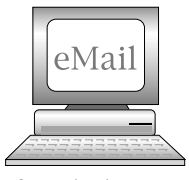

Comunicación con otros ordenadores

- Servicios en línea

- World-Wide Web

- Transferencia de archivos

- Tablones de anuncios

- Senvidores de listados

- Redes de área local

- Internet
- Correo electrónico

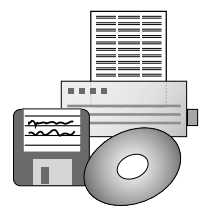

Impresión descentralizada; sustitución de los soportes en papel por soportes electrónicos; envíos en disquetes, discos compactos

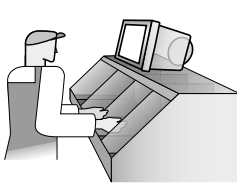

Formación basada en la utilización de medios informáticos

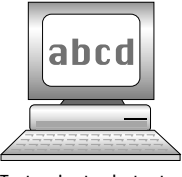

Tratamiento de texto - Reconocimiento de caracteres ópticos
Cálculos complejos Análisis y cálculo (1) numero de variables

Traducción automática

- Inteligencia artificial

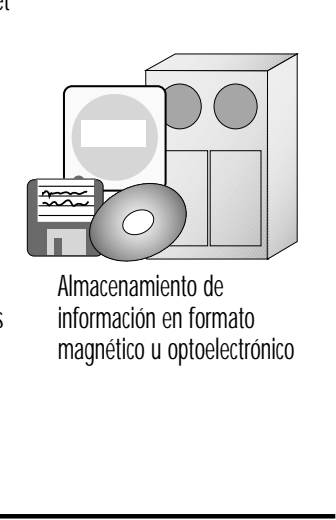




\section{Aplicaciones de la información sobre seguridad}

La información puede ser utilizada con diversos fines: formación dentro y fuera de la empresa; diseño de maquinaria, procesos, materiales y métodos; operaciones de inspección y control. EI carácter diverso de tales usos indica que la información debe elaborarse de forma adecuada para cada tipo de usuario. Los propios usuarios modifican y reelaboran los datos transformándola en nuevos productos de información. Por ejemplo, un servicio de inspección puede redactar nuevas normas y reglamentos, los productores de maquinaria pueden establecer nuevas directrices, a la luz de su participación en las actividades de normalización en materia de seguridad, los fabricantes de productos químicos pueden recopilar sus propias etiquetas y fichas de datos sobre seguridad de materiales, y los formadores pueden elaborar manuales, material audiovisual y folletos. Algunos tipos de información pueden ser específicos, listos para ser utilizados y ofrecer soluciones directas a los problemas individuales de salud y seguridad, mientras que otros pueden mejorar los procesos de producción, por ejemplo, aumentando tanto la seguridad de un método, una maquinaria o un material. A pesar de su variedad, el elemento común de todos estos tipos de información consiste en la necesidad de que garantizan su utilidad, que sean empleados por el sistema de gestión de seguridad de una empresa. Los recursos relacionados con los procesos, los materiales, y los métodos deben ser seleccionados, adquiridos, transportados e instalados, las personas que los utilizan han de ser seleccionadas y formadas, deben realizarse tareas de seguimiento y supervisión y los resultados deben ser distribuidos prestando una atención constante a la gran variedad de necesidades de información.

\section{Sistemas informatizados de información sobre seguridad}

L os ordenadores constituyen el último eslabón en el proceso de desarrollo que abarca todos los medios de información, desde el lenguaje hablado y escrito, hasta los sistemas electrónicos contemporáneos. De hecho, pueden llevar a cabo las mismas tareas que todos los tipos de gestión de información anteriores. Los ordenadores son particularmente apropiados para este fin debido a su capacidad para efectuar tareas específicas en las que se manejan grandes volúmenes de información. En el campo de la información sobre seguridad, los ordenadores pueden ser especialmente útiles para satiffacer las necesidades enumeradas en la Figura 22.2

\section{- ACCESO A LA INFORMACION}

\section{P.K. Abeytunga, E mmert Clevenstine, Vivian M organ y Sheila Pantry}

A medida que el fondo de conocimientos acumulado sobre seguridad e higiene aumenta y se hace público en los medios de comunicación generales y especializados, los problemas relacionados con la salud en general, los riesgos del medio ambiente y la salud y la seguridad en el trabajo reciben una atención cada vez mayor. Sobre todo en lo que se refiere al lugar de trabajo, cada vez se reconoce y aplica más el principio de que tanto los trabajadores como las empresas tienen la necesidad y el derecho de recibir información adecuada sobre salud y seguridad.

\section{Necesidad de información}

La información fiable, global e inteligible es esencial para conseguir los objetivos de salud y seguridad en el trabajo (SST). Esta información debe ser accesible, actualizada, y directamente aplicable a las circunstancias específicas del usuario. N o obstante, la gran variedad de centros de trabajo y el enorme volumen y la diversidad de la información sobre SST, ya sea relacionada con la toxicología, la bioquímica, las ciencias de la conducta o la ingeniería, representa un desafío para sus proveedores en cuanto a la satisfacción de necesidades como son las siguientes:

- información académica o teórica, requerida por investigadores o especialistas técnicos o científicos

- información práctica, solicitada por entidades reguladoras, empresas y trabajadores

- información legislativa, necesaria para formular y aplicar políticas, la formación de empresas y trabajadores, el desarrollo y aplicación de programas de SST y el cumplimento de los requisitos que plantea esta disciplina. Las responsabilidades de los profesionales de la seguridad y de los representantes y los miembros de comités asignados a tareas relacionadas con la misma suelen incluir la oferta de información a otras personas. Además, en muchos países, la legislación en materia de salud y seguridad exige que la información (a) sea facilitada a los trabajadores por parte de las Administraciones, las empresas, los proveedores de sustancias químicas y otros agentes y (b) sea generada por organizaciones como las empresas a las que se aplica la legislación.

La información sobre salud y seguridad en el trabajo es necesaria para:

- Adoptar decisiones fundadas. La información sobre SST permite a las entidades reguladoras, los legisladores, los profesionales de salud y seguridad en el trabajo, las organizaciones industriales y sindicales, las empresas y los trabajadores tomar las decisiones más acertadas, para conseguir un medio ambiente de trabajo sano y seguro. Estas decisiones pueden incluir la formulación y la aplicación de políticas de salud y seguridad en el trabajo, requisitos reglamentarios y programas de salud y seguridad adecuados al lugar de trabajo.

- D esempeñar las tareas de forma segura. L os trabajadores necesitan información sobre salud y seguridad en el trabajo, para poder adoptar decisiones diarias relativas al desempeño seguro y eficaz de sus tareas. Las empresas la solicitan para formar a sus trabajadores en la adopción de este tipo de decisiones.

- Cumplir los requisitos legislativos y normativos. Sin una información completa y exacta sobre salud y seguridad en el trabajo, los trabajadores, las empresas, las organizaciones sindicales y los profesionales de la SST no podrían cumplir tales requisitos.

- Ejercer derechos. A un número cada vez mayor de trabajadores se les ha concedido el derecho a conocer los riesgos de las tareas que llevan a cabo y a participar en el proceso de toma de decisiones sobre su medio ambiente de trabajo. En algunos países, tienen el derecho a rechazar trabajos peligrosos.

\section{Difusión eficaz de la información}

Para garantizar que un programa de difusión de información sobre SST sea eficaz, es necesario abordar las cuestiones siguientes.

1. La información debe presentarse de forma adecuada a las necesidades, las circunstancias y los antecedentes del usuario final. Por ejemplo, los documentos que contienen información técnica pueden resultar más útiles a los profesionales de la salud y la seguridad en el trabajo que a los trabajadores y las empresas, que suelen estar menos familiarizados con el lenguaje técnico. No obstante, siempre debe considerarse la conversión de éste a un registro más general con el fin de aplicar un programa global de información sobre SST. Para 
que sea eficaz, este tipo de información ha de ser útil y comprensible.

2. Deben tenerse en cuenta la diversidad de públicos a los que va dirigida la información. Por ejemplo, un artículo sobre los riesgos de los restaurantes comerciales puede ser de interés para los colegios, las prisiones y otras instituciones con servicios de alimentación.

3. La información debe llegar a las personas que la necesitan y ha de desarrollarse una estrategia global para garantizar su difusión. Entre los métodos disponibles figuran el envío postal directo mediante la utilización de una lista de correo elaborada 0 adquirida, los simposios, los cursos de formación, las presentaciones en seminarios, conferencias profesionales y reuniones de trabajadores y pequeñas empresas y la publicidad en publicaciones periódicas comerciales y profesionales.

4. Con frecuencia, pueden utilizarse transmisores secundarios para ampliar la estrategia de difusión. Estas iniciativas de cooperación fomentan la coherencia, reducen la duplicación y se benefician de las ventajas de dichos transmisores. Por ejemplo, después de prestar servicio como revisor de documentos, un representante de una asociación sectorial puede estar interesado en poner a disposición de los afiliados una publicación relacionada con los trabajadores 0 , al menos, en comunicarles la disponibilidad del documento original. Asimismo, es posible que los transmisores secundarios reduzcan costes, ya que pueden estar dispuestos a reimprimir el material en cuestión para aquéllos que lo necesiten, sobre todo si se les presta la copia de cámara o los negativos.

\section{[V. Morgan]}

\section{Usuarios}

La salud y la seguridad en el trabajo afecta a la totalidad de las actividades laborales y a las profesiones. La información sobre la salud y la seguridad en estas actividades es necesaria para las personas que, de acuerdo con la legislación, tienen la responsabilidad de garantizar la seguridad y la salubridad del medio ambiente de trabajo o para aquéllos que pueden verse afectados negativamente por los riesgos debidos, incluso de una forma remota, a las actividades laborales. Se trata de personas en contacto directo con los riesgos del trabajo, o que, por su profesión, se dedican a la SST; miembros de organizaciones que prestan servicios en el lugar de trabajo y las comunidades y el público en general, que pueden estar expuestos, quizás en mayor grado, a los efectos perjudiciales de los procesos de trabajo. En consecuencia, los usuarios de información sobre salud y seguridad son de tipo muy diverso.

En primer lugar cabe citar al responsable de la toma de decisiones. En cada centro existen diversas categorías de personas que ocupan puestos fundamentales para la toma de decisiones que afectan directamente (y con frecuencia indirectamente) a la salud y al bienestar de las personas vinculadas a un lugar de trabajo específico, de las que habitan las comunidades más próximas, y de otras sobre las que puede repercutir las prácticas del centro de trabajo. Puede tratarse de empresarios, altos directivos de línea, miembros de los comités conjuntos de salud y seguridad, representantes de salud y seguridad, o personal especializado responsable de la SST, las compras, la formación o la gestión de la información. El personal de todas estas categorías precisa la información adecuada para llevar a cabo de forma eficaz sus funciones relacionadas con la seguridad, y adoptar decisiones fundadas en lo que se refiere a los problemas de SST y el modo de abordarlos.

Los propios empresarios no están exentos de la necesidad de adquirir información sobre SST y actuar en función de ésta. Todos los empresarios, ya sean autónomos o presten sus servicios en el sector privado 0 en las instituciones públicas, con independencia del país, la localización, el sector o la función, tienen una responsabilidad en materia de salud y seguridad asociada a su trabajo y que requiere una información de acuerdo con sus circunstancias específicas. Todos necesitan ser conscientes de los riesgos potenciales o reales que les afectan y conocer las posibles soluciones y las medidas preventivas, sus derechos y responsabilidades y los recursos a su alcance que pueden ayudarles a cumplir sus obligaciones a este respecto.

En el campo de la salud y la seguridad, los trabajadores que se ocupan específicamente de esta materia en el lugar de trabajo, los médicos especializados en SST y ámbitos afines (personal de enfermería y médicos, ya sean internos o externos), los educadores en materia de seguridad, los inspectores de seguridad, y otros profesionales cuyos conocimientos técnicos se centran en la seguridad, la salud y la higiene en el lugar de trabajo tienen una necesidad constante de información sobre diversas cuestiones de SST para llevar a cabo sus tareas diarias.

Aunque un gran número de personas y organizaciones están en contacto con los lugares de trabajo sólo a través de los servicios que prestan, debe tenerse en cuenta que pueden verse afectados por las condiciones de seguridad en que se encuentren estos lugares y el ambiente en ellos. Los proveedores de equipos, materiales y sustancias químicas a consumidores como fábricas y oficinas, asociaciones industriales, sindicatos, servicios de transporte, servicios de inspección, o servicios de salud de los trabajadores deben preocuparse por analizar si la relación que mantienen con los lugares de trabajo puede originar problemas de seguridad no previstos y, para ello, necesitan información sobre las circunstancias específicas asociadas con la prestación de sus servicios en estos emplazamientos.

Los estudiosos y los investigadores dedicados a temas relacionados con la salud y la seguridad en el trabajo son grandes consumidores de la información al respecto, generalmente estudios e informes de trabajos de investigación antiguos y actuales. Asimismo, la información técnica y científica es necesaria para los profesionales de la ingeniería, la química, la medicina, y la propia gestión de información. Además, para presentar informes de acontecimientos o cuestiones específicas, los profesionales de los medios de comunicación deben obtener información de referencia sobre temas de SST que les permitan, a su vez, informar al público en general.

0 tra categoría de usuarios de información sobre salud y seguridad son las A dministraciones a todas las escalas; local, regional y nacional. Los responsables de la formulación de políticas y los legisladores, así como las entidades de regulación, los planificadores y otros funcionarios, también se ocupan de cuestiones de salud y seguridad relacionadas con sus funciones específicas.

En lo que respecta a la difusión, quizá sea la sociedad la que necesita y utiliza la información a mayor escala. La preocupación por el medio ambiente y la salud, un mayor reconocimiento de los derechos de los ciudadanos y la repercusión de los medios de comunicación actuales, han aumentado la sensibilización de la sociedad respecto a las cuestiones de salud y seguridad y han creado una amplia demanda de información, de forma que la sociedad en conjunto exige un volumen cada vez mayor de información sobre varios aspectos de la SST. L os consumidores, comunidades próximas a los lugares de trabajo y el público en general están interesados en las actividades que se realizan en estos emplazamientos y en los productos que se fabrican, y desean conocer su repercusión en la salud y la seguridad. En concreto, los grupos de ciudadanos y de presión preocupados por la salud y la seguridad de las comunidades demandan información sobre todos los aspectos de los riesgos relacionados con las actividades del lugar de trabajo, como la producción, las emisiones al medio ambiente, el transporte y la eliminación de residuos, vinculados con su causa. 
Existen grandes dificultades para informar a esta amplia gama de usuarios de información, puesto que poseen distintos antecedentes, niveles de formación, culturas, lenguas y grado de conocimiento de la salud y la seguridad en el trabajo (por no mencionar el medio ambiente de trabajo). Para ser eficaces, el contenido, la presentación y la accesibilidad de la información deben satisfacer las necesidades específicas de cada categoría de usuarios.

\section{[V. Morgan y P.K. Abeytunga]}

\section{Naturaleza de la información sobre salud y seguridad}

\section{Calidad de la información}

La información sobre SST debe ser de fuentes autorizadas y, lo que es más importante, habrá de ser validada por expertos. La información autorizada procede de fuentes $u$ organizaciones oficiales y reconocidas, pero hay que tener presente el aumento en la oferta de información de otras fuentes que no parece haber sido verificada. Algunos ejemplos de errores debidos a la falta de validación son:

- Las medidas no se comprueban y se indican mediante abreviaturas incorrectas (por ejemplo, " $\mathrm{m}$ " de metros, en lugar de "mm" milímetros).

- La coma de los decimales aparece en un lugar incorrecto cuando se especifica un límite de exposición.

- Se utilizan nombres de productos químicos erróneos.

- En las ilustraciones se muestran prácticas de salud y seguridad incorrectas.

\section{Problemas relacionados con la información sobre salud y seguridad en el trabajo}

Aunque la cantidad de información sobre salud y seguridad en el trabajo es desbordante, hay áreas en las que los datos son escasos o no se han recogido en un formato accesible. La información necesaria aparece fragmentada entre varias áreas temáticas y fuentes, (algunas de ellas sesgadas), y con frecuencia no se encuentra disponible 0 , al menos, no en el formato que puedan utilizar las personas que la necesitan. Para ahorrar tiempo, el buscador de información debe tener en cuenta las cuestiones siguientes.

Legislación: Se dispone de toda la legislación sobre salud y seguridad en el trabajo, pero todavía no existe una base de datos central que recoja la de todos los países. La sede central del C entro Internacional de Información sobre Seguridad y Salud en el Trabajo (CIS), con sede en la 0 ficina I nternacional del Trabajo (O IT ) ha emprendido algunas iniciativas, pero CISDO C, la base de datos del CIS, no es muy completa. En el Reino U nido, la U nidad de L egislación Europea sobre Salud y Seguridad en el Trabajo de la U niversidad de Salford posee el conjunto completo y actualizado de textos de la legislación sobre salud y seguridad en el trabajo de los Estados miembros de la U nión Europea, incluidas las directivas europeas en vigor en cada país. Esta base de datos se encuentra en fase de ampliación para incluir a los países escandinavos y, en última instancia, al resto del mundo. La sede central del Safety and $\mathrm{H}$ ealth Executive Information Service del Reino Unido en Sheffield también dispone del conjunto de textos completos de la legislación de los Estados miembros de la U nión Europea, pero sólo está actualizado hasta 1991. Existe un determinado número de bases de datos disponibles que ofrecen referencias a la legislación de diferentes países, así como algunos servicios de actualización impresa en diversos Estados.
E stadísticas: La mayoría de los países no disponen de un sistema uniforme y coherente de recopilación de datos. Por tanto, no es de prever que dos países utilicen la misma metodología; en consecuencia, los datos obtenidos en diferentes países no se pueden utilizar con facilidad para realizar estudios comparativos.

E rgonomía: Aunque muchas bases de datos ofrecen información sobre ergonomía, no hay ninguna que recoja la información de todas las fuentes mundiales. Ergonomics Abstracts, es una publicación impresa de gran utilidad disponible en formato CD-RO M que ofrece resúmenes relacionados con esta materia.

Investigación: No existe una fuente global de información sobre la investigación a escala internacional en materia de salud y seguridad en el trabajo, pero sí se dispone de varias publicaciones y bases de datos que ofrecen los resultados de ésta y de los programas de investigación. EI Institut $N$ ational de Recherche et de Securité pour la Prevention des Accidents du travail et des $M$ aladies Professionnels (IN R S) de Francia dispone de una base de datos, pero ésta no contiene todos los estudios sobre salud y seguridad en el trabajo conocidos.

Películas y vídeos: Las películas y los vídeos sobre salud y seguridad en el trabajo sirven para transmitir la información de forma sencilla y comprensible, pero no existe una base de datos global que los contenga en su totalidad, aunque aparecen nuevos títulos constantemente. EI CIS ha intentado recoger información sobre el material disponible en las bases de datos del CISDOC, así como los Safety and $\mathrm{H}$ ealth Executive Information Services del Reino Unido en la base de datos HSELINE. Algunos países como el Reino U nido, Estados U nidos y Francia elaboran catálogos anuales que contienen los nuevos títulos publicados el año anterior.

Otras consideraciones: Debido a estos problemas y las lagunas de información, la persona que busque datos sobre SST no encontrará una sola fuente completa que responda a todas sus preguntas. $\mathrm{H}$ ay determinadas materias y disciplinas que deben ser consultadas para obtener una imagen completa de las cuestiones de salud y seguridad en el trabajo.

El usuario de información debe tener en cuenta la posibilidad de que exista una falta de conocimiento sobre una cuestión concreta 0 , incluso, de que existan opiniones en conflicto 0 sesgadas, y sea preciso consultar a especialistas antes de llegar a determinadas conclusiones. En el mundo actual, parte de la información puede transferirse con facilidad y rapidez, pero deben tenerse en cuenta las condiciones locales, así como los requisitos jurídicos de cada país.

\section{Coste de la información}

Aunque existen grandes organizaciones de carácter público y dispuestas a compartir la información con un coste nulo o muy reducido, el buscador de información sobre salud y seguridad en el trabajo ha de ser consciente de que el coste de unos datos adecuados y validados aumenta constantemente, ya que los derechos de autor y los costes de producción, impresión y distribución del material impreso y de los productos electrónicos siguen creciendo.

Por tanto, un servicio de información eficaz en función del coste que disponga no sólo de datos actualizados, sino también de profesionales de la información de alta calidad, formados y cualificados, es cada vez menos frecuente. Entidades como la O rganización Internacional del Trabajo $(0 \mathrm{IT})$, con un número de países miembros cada vez mayor, fomentan la creación de centros de información focales o de instalaciones en las que el buscador de información puede utilizar y acceder a otros centros mundiales. La mejora de las telecomunicaciones directas debe elevar la capacidad de apoyo a los centros regionales. 
Puesto que los precios fluctúan constantemente, no parece adecuado incluirlos en la sección siguiente. No obstante, los costes relativos de los documentos dependerán siempre de la cantidad de esfuerzo necesario para recopilar su contenido, del número de copias que se impriman y de la medida en que el coste de adquirir un documento quede compensado por el beneficio de aplicar sus contenidos, aunque el precio de las publicaciones de gran calidad puede reducirse mediante la subvención pública.

[S. Pantry]

\section{Tipos de información sobre salud y seguridad y dónde obtenerla}

Los tipos de usuarios antes descritos definen la gama de documentos que constituyen la "información sobre salud y seguridad en el trabajo". Resulta útil distinguir entre los documentos que tratan exclusivamente de cuestiones de salud y seguridad en el trabajo ("publicaciones fundamentales"), y las ("otras) que contienen información útil, pero con un enfoque diferente. El número de publicaciones que figura en la Tabla 22.1 se ha limitado debido al espacio disponible. Las revistas se han elegido en función de la frecuencia con que han sido citados en otras publicaciones 0 en bases de datos bibliográficas. (La mención de una fuente no debe considerarse como un aval por parte de la OIT en perjuicio de una publicación o de una serie que no se cite).

\section{Fuentes tradicionales en papel}

El papel es el vehículo de información más común, en forma de libros y de otro tipo de publicaciones. Estas se editan regularmente, y los libros tienen redes de distribución amplias y consolidadas. La bibliografía básica es el conjunto de publicaciones en las que los autores informan de sus nuevas observaciones, descubrimientos e invenciones. Los análisis de actualidad también

Tabla 22.1 - Ejemplos de publicaciones destacadas en el campo de la salud y seguridad en el trabajo.

$\begin{array}{lll}\text { Lengua } & \text { Nombre } & \text { Tema } \\ \text { Inglés } & \text { American Industrial Hygiene } & \text { Higiene industrial } \\ & \text { Association Journal } & \\ & \text { American Journal of Industrial } & \text { Salud en el trabajo } \\ & \text { Medicine } & \\ & \text { Applied Ergonomics } & \text { Ergonomía } \\ & \text { Applied Industrial Hygiene } & \text { Higiene industrial } \\ & \text { Occupational and Environmental } & \text { Salud en el trabajo } \\ & \text { Medicine (antes BJIM) } & \\ & \text { Ergonomics } & \text { Ergonomía } \\ & \text { Journal of Hazardous Materials } & \text { Seguridad química } \\ & \text { Safety Science } & \text { Ciencia de la seguridad } \\ & \text { Scandinavian Journal of Work, } & \text { Salud y seguridad en el trabajo } \\ & \text { Environment and Health } & \\ \text { Francés } & \text { Travail et sécurité } & \text { Ciencia de la seguridad } \\ \text { Italiano } & \text { Medicina del Lavoro } & \text { Salud en el trabajo } \\ \text { Japonés } & \text { Japanese Journal of Industrial } & \text { Salud en el trabajo } \\ & \text { Health } & \\ \text { Ruso } & \text { Gigiena truda i professional'nye } & \text { Higiene industrial } \\ & \text { zabolevanija } & \\ \text { Español } & \text { Salud y Trabajo } & \text { Salud y seguridad en el trabajo }\end{array}$

aparecen en este tipo de publicación. Para que un artículo sea admitido en una publicación básica ha de ser revisado por varios expertos en ese campo y garantizan que se atenga a las buenas prácticas y que sus conclusiones corresponden a los hechos presentados. EI proceso se denomina revisado y aceptación.

Son publicaciones típicas de la categoría de "otras" el I ournal of the International Institute of $\mathrm{N}$ oise C ontrol E ngenering y el J ournal of the American M edical Association (J AM A). En muchos países, los organismos gubernamentales editan estadísticas, catalogadas como bibliografía básica, aunque no se les aplica el proceso de revisión y aceptación. EI M orbidity and M ortality W eekly Report publicado en Estados Unidos por los Centers for Desease Control and Prevention es un ejemplo típico. Las publicaciones básicas pueden encontrarse de las instituciones pertinentes (por ejemplo, el JAM A en la facultad de medicina y en las bibliotecas de los hospitales).

Existen algunas revistas fundamentales de gran tirada que no se someten a revisión y aceptación, pero que sí ofrecen información básica en forma de noticias sobre acontecimientos recientes o próximos, además de artículos de fácil lectura sobre cuestiones de actualidad. Suelen incluir anuncios sobre productos y servicios de salud y seguridad en el trabajo que constituyen una información útil sobre novedades. Pueden ser publicados por las Administraciones, como Australian N ewsletter y B ezopasnost' truda v promyshlennosti (Rusia), por consejos de seguridad privados sin ánimo de lucro (A ustralian Safety N ews, Safety and $\mathrm{H}$ ealth [Estados Unidos], Promosafe [Bélgica], Safety M anagement [Reino U nido], Arbetsmiljö [Suecia], SNOP [Italia], o por empresas privadas, como Occupational Safety and $\mathrm{H}$ ealth Letter [Estados Unidos]). Asimismo, existen muchas publicaciones sobre otras especialidades que ofrecen información útil e interesante (Chemical W œk, Plant E ngineer, Fire Prevention).

La dificultad para encontrar la información sobre un tema en concreto en el conjunto de la bibliografía básica ha impulsado al desarrollo de fuentes secundarias. Se trata de guías bibliográficas 0 sobre los últimos acontecimientos, como juicios, cuyas actas oficiales aparecen también en otras publicaciones. En estas guías se indica dónde se publica un determinado documento sobre un asunto específico y suele incluirse un breve resumen de su contenido. Asimismo existen índices de referencias bibliográficas que enumeran las publicaciones que citan un documento concreto, lo que permiten encontrar las publicaciones pertinentes, una vez identificada la referencia clave (desafortunadamente, no existe ninguno dedicado en exclusiva a la salud y la seguridad en el trabajo). Debido a la necesidad de actualización, en las fuentes secundarias se utiliza la tecnología electrónica más avanzada para acelerar su publicación.

Para optimizar el acceso, particularmente a áreas con un número de ordenadores limitado, algunas bases de datos se ofrecen en formato impreso. El boletín Safety and $H$ ealth at Work de la OIT/CIS es una versión impresa del CISDOC que se publica seis veces al año e incluye índices anuales y quinquenales. I gualmente, Excerpta $M$ edica se encuentra disponible en formato de periódico. Algunas bases de datos secundarias también se pueden conseguir en microfichas, como en el caso de RTECS, aunque es más habitual que la información bibliográfica en papel se presente en microfichas en el texto completo. En estos casos, la base de datos se divide en dos partes: referencias bibliográficas y resúmenes en papel (o en formato electrónico) y el texto completo en microfichas.

$\mathrm{O}$ tros títulos de fuentes secundarias son: $\mathrm{O}$ ccupational $\mathrm{H}$ ealth and Industrial M edicine, y CA Selects "Occupational Safety and H ealth", Science Citation Index, Social Science Citation Index, Chemical Abstracts, y BIOSIS. Debido al número de personal altamente cualificado que participa en su elaboración, las fuentes secundarias suelen ser caras. 
Algunos boletines constituyen fuentes secundarias de gran valor, ya que citan publicaciones recientes, leyes o resoluciones jurídicas importantes. Son ejemplos de este tipo de publicación: OSH A Compliance Advisor (Estados U nidos), Chemicals in Progress Bulletin (Estados Unidos EPA). M ientras que muchas de estas publicaciones gubernamentales son gratuitas, los boletines cuya información ha sido recopilada e investigada por organizaciones privadas, tienden a ser caras. Son difíciles de encontrar en bibliotecas, por lo que para los interesados puede resultar más útil suscribirse.

Un tercer tipo de fuentes de información son los libros de texto, las enciclopedias y los compendios. M ientras que los análisis que se pueden encontrar en la bibliografía básica se refieren a un campo de conocimiento en el momento de su elaboración, los que se incluyen en las fuentes terciarias se refieren a su evolución en un contexto más amplio. Los compendios de datos reúnen valores evaluados y comunicados en diferentes ocasiones a lo largo de varios años.

Las publicaciones básicas en esta "categoría terciaria" son: Patty's Industrial H ygiene and Toxicology (Patty 1978), Reactive Chemical $\mathrm{H}$ azards (Bretherick 1979), Dangerous Properties of Industrial $M$ ate rials (Sax 1989), H andbuch der gefährlichen Güter (Hommel 1987), $T$ he Diseases of $O$ ccupations (H unter 1978) y la presente Enciclopedia. Los ejemplos de publicaciones terciarias en la categoría de "otras" son las enciclopedias de un solo volumen de M cG raw-H ill, que cubren diversas áreas de la ciencia y la tecnología, y la cuarta edición de 27 volúmenes (se han publicado del 1 al 5) de la Kirkt- 0 thmer Concise Encyclopedia of Chemical Technology (Grayson y Eckroth 1985). L os lectores no deben pasar por alto la gran cantidad de información sobre SST que puede encontrarse en las grandes enciclopedias generales: B ritannica, U niversalis, B rockhaus, etc.

\section{Literatura gris}

Existen muchos libros y revistas que no disponen del mismo sistema de publicaciones y distribución altamente organizado que la bibliografía tradicional en papel, como informes, hojas de datos y catálogos; a estos documentos se les denomina literatura gris porque resultan difíciles de encontrar. La bibliografía básica en la categoría "gris" incluye informes de agencias gubernamentales (informes de investigaciones, estadísticas, investigaciones de accidentes, etc.), tesis e informes de institutos de investigación universitarios y privados (como el State Research Institute de Finlandia, o el European Chemical Industry Ecology-Toxicology Research Centre (ECETOC) en Bélgica). Una buena fuente de información sobre salud y seguridad en el trabajo en los países en desarrollo puede encontrarse en los informes de organismos públicos y privados. L os catálogos de fabricantes pueden ofrecer una gran cantidad de información. M uchos de ellos se han publicado en más de una lengua, por lo que, en conjunto, sirven de referencia para un tipo de terminología común que no suele aparecer en los diccionarios.

Para ayudar a los profesionales de la salud y la seguridad a conseguir estos documentos de publicación irregular, se han creado varias fuentes secundarias, entre las que pueden citarse los informes gubernamentales, los anuncios, los índices de publicaciones y los resúmenes de tesis. Los editores pueden incluir ocasionalmente en la serie de informes un catálogo de documentos publicados anteriormente en la misma. Las fuentes secundarias no pertenecen a la literatura gris: se publican regularmente y son fáciles de encontrar en las bibliotecas.

U na gran parte de la literatura gris es terciaria: hojas de datos sobre seguridad de materiales (MSDS) y los documentos orientativos. (Algunas hojas de datos son de publicación periódica; una de ellas es la Industrial Safety Data File, que se publica mensualmente por Wilmington Publishers en el Reino
U nido). Las fuentes básicas son: Administraciones nacionales (N IO SH, Arbetsmiljöinstitutet), programas internacionales, como el Programa Internacional de Seguridad de las Sustancias Q uímicas (IPCS), y productos de fabricantes (M SDS).

\section{Legislación, normas y patentes impresas}

La mayoría de los países y agrupaciones regionales (por ejemplo, la U nión Europea) tienen como fuente básica un boletín oficial, donde se publican las nuevas leyes, reglamentos derivados y patentes. Las separatas de leyes concretas, patentes, etc. también son publicadas por agencias de la Administración. Las normas constituyen un caso más complicado. Las de carácter técnico suelen ser desarrolladas por asociaciones voluntarias oficialmente reconocidas como la American Society for Testing and $M$ aterials (AST M ) 0 institutos independientes autorizados por la Administración como el Deutsche Industrie Normen (DIN); estos organismos financian sus costes de explotación mediante la venta de copias de sus normas. L as relativas a la salud y el bienestar (como los límites de la jornada de trabajo o a la exposición a ciertas sustancias) suelen ser impuestas por organismos públicos, por lo que los textos aparecen en las publicaciones oficiales.

La American Association of Law Libraries ha comenzado a publicar Foreign Law: C urrent Sources of Codes and L egislation in I urisdictions of the World. Dos de los tres volúmenes previstos ya han aparecido ( $T$ he Western $H$ emisphere 1989, y Western and Eastern E urope and the European Communities 1991). Los volúmenes, con hojas sueltas, son actualizados anualmente. En esta obra se describen los sistemas jurídicos de todos los Estados miembros de las $\mathrm{N}$ aciones U nidas y de las dependencias que tienen sus propios regímenes jurídicos. Se indican los textos pertinentes clasificados en diversos apartados por temas (los textos sobre salud y seguridad en el trabajo aparecen en los apartados de "trabajo" y en los correspondientes a los sectores industriales). Los directores de la publicación destacan otras fuentes secundarias e incluyen una relación de proveedores de publicaciones jurídicas extranjeras.

El compendio es la herramienta habitual para trabajar con leyes y reglamentos derivados; el lapso temporal entre la publicación de una nueva ley en un boletín oficial y su inclusión en compendios suele ser muy breve y puede que el texto sólo tenga significado en el contexto de otros reglamentos. En el caso de las normas también suele suceder que una en concreto como, por ejemplo, la International Electrochemical Standard (IEC) 3352-28 sobre máquinas de coser no estipule todos los requisitos aplicables, sino que cite una norma "superior" en la misma serie que establece requisitos universales (IEC 335-1, Safety of household and similar electrical appliances). Muchos países disponen de ediciones consolidadas de sus códigos de trabajo, en las que puede encontrarse la legislación más importante sobre salud y seguridad en el trabajo. D el mismo modo, la O IT y la O rganización Internacional de Normalización (ISO) publican recopilaciones de normas y el Archivo Jurídico del Registro internacional de productos químicos potencialmente tóxicos (IR PT C ) contiene información de trece países.

\section{La información en formato electrónico}

El estudio de la salud y la seguridad en el trabajo y las disciplinas en que se apoya creció vigorosamente de 1950 a 1990. La organización y la clasificación del conjunto de publicaciones resultante fue una de las primeras aplicaciones de los ordenadores.

\section{Bases de datos}

En 1996, sólo existían algunas bases de datos con textos completos dedicadas en exclusiva a la SST, pero su número aumenta con rapidez. No obstante, la información mejor puede encontrarse en otras, como las bases de datos en línea de los 
American Chemical Society Journals Online, el Dow-Jones y otros servicios. Por otra parte, hay numerosas fuentes secundarias en materia de salud y seguridad disponibles en línea: CISDOC, NIOSHTIC, HSELINE, INRS, CSNB y partes de HEALSAFE. $O$ tras fuentes son el servicio ERIC (E ducational R esources Information C enter) de Estados U nidos; M ED LINE, que ofrece resúmenes de la bibliografía médica mundial elaborados por la U nited States National Library of M edicine; NTIS, que ofrece un índice de "literatura gris" de Estados U nidos; y SIGLE, que realiza la misma actividad en Europa.

A continuación se refieren los distintos tipos de bases de datos sobre salud y seguridad en el trabajo:

- Bases de datos bibliográficas. Se trata de bases de datos concretos de documentos previamente publicados, donde una entrada (registro) puede incluir datos (campos), como el nombre del autor, el título del documento, nombre del editor o la fuente, la localización del documento y su resumen. Los registros suelen incluir indicadores de clasificación, que son descriptores primarios o secundarios, o palabras clave, que describen el documento. Las palabras clave proceden habitualmente de un vocabulario controlado o tesauro. El documento en sí no se almacena en la base de datos.

- B ases de datos de textos completos. A diferencia de la base de datos bibliográfica, que contiene sólo información bibliográfica y quizá un resumen, en este tipo de bases se incluye todo el texto que se requiere (el texto completo) del documento. También se utilizan clasificadores y descriptores para facilitar la localización. Las bases de datos sobre fichas de datos de seguridad química, que comprenden de una a diez páginas, e incluso enciclopedias completas y otros grandes documentos, pueden mantenerse en este formato. Las bases de datos de textos completos corresponden a las fuentes primarias y terciarias de información impresa (son recopilaciones y conjuntos completos de datos), mientras que las bases de datos bibliográficas son fuentes secundarias que describen o se refieren a otros documentos. Al igual que las fuentes secundarias impresas, pueden incluir resúmenes de la información citada.

- Bases de datos de valores puntuales. Contienen medidas o valores numéricos tales como los límites umbral de sustancias químicas.

- B ases de datos multimedia. Contienen fotografías, dibujos, gráficos, ilustraciones, sonido y vídeo (o referencias y relaciones con los mismos), así como el texto del documento. (A beytunga y de Jonge, 1992).

- Bases de datos combinadas. Están compuestas por elementos de las bases de datos descritas anteriormente.

Estas bases de datos permiten a las personas que deben efectuar una consulta acceder a la información electrónica buscada a través de dos vías: mediante la utilización de líneas telefónicas conectadas a un ordenador donde la información está almacenada, o la adquisición de un disquete o un compact disc con dicha información y su instalación en un ordenador personal.

\section{Servicios en línea}

Las bases de datos sobre seguridad amplias a las que puede accederse a través de grandes ordenadores y se mantienen accesibles siempre que éstos estén conectados a las mismas se denominan en línea. Las organizaciones que gestionan sistemas en línea se conocen como "servidores" (Takala y cols. 1992). H asta fecha reciente, las bases de datos en línea han constituido el único medio viable para almacenar y difundir la información mediante medios magnéticos que permiten la utilización de ordenadores y software de búsqueda, especialmente diseñado para la recuperación y la carga de datos (Wood, Philipp, y Colley 1988). Casi todas las personas que tiene acceso a un terminal de vídeo (o microordenador) y a una línea de telecomunicación (datos 0 teléfono) puede hacer uso de una base de datos en línea.

Debido a la proliferación de los servicios comerciales disponibles en línea desde principios del decenio de 1970, ha mejorado la accesibilidad a la información. Se ha estimado que en 1997 había en el mundo más de 6.000 bases de datos disponibles para la recuperación de información que cubren una amplia gama de campos y contienen más de 100 millones de referencias. Además, existen más de 2.300 fuentes en CD-RO M , incluido un número cada vez mayor de CD-ROM de textos completos.

Los servicios en línea, que comenzaron con las bases de datos bibliográficas, dependen de enormes ordenadores centrales con costes de instalación y mantenimiento elevados. A medida que aumenta el volumen de información y el número de usuarios, simplemente la actualización del sistema exige una inversión elevada.

Los sistemas abiertos, que permiten a los ordenadores comunicarse entre sí en cualquier lugar del mundo constituyen cada vez más una característica habitual del medio ambiente de trabajo, eliminando la necesidad de mantener toda los datos sobre seguridad necesarios en un ordenador "interno".

Los problemas de telecomunicación y el número limitado de terminales disponibles en los países en desarrollo limitan estos servicios fundamentalmente al mundo industrializado. EI nivel de infraestructura existente; las cuestiones políticas como la seguridad, la confidencialidad y la centralización; y las peculiaridades culturales pueden restringir gravemente el uso de los servicios en línea. Además, la complejidad del acceso y los sistemas de búsqueda limita aún mas el número de usuarios. Es muy probable que las personas interesadas sólo esporádicamente en la información carezcan de las cualificaciones suficientes en las técnicas necesarias o puedan haber olvidado por completo los procedimientos correctos de utilización. En consecuencia, son los especialistas en información cualificados los que utilizan con mayor frecuencia, los sistemas informatizados. L os profesionales de la seguridad, especialmente en el ámbito de la fábrica, casi no los utilizan. Las bases de datos en línea no se aplican en gran medida a la formación en materia de seguridad, debido al elevado coste de la conexión por minuto y usuario. No obstante, estas bases de datos son insustituibles, cuando su tamaño es tal que un CD-ROM , o incluso varios de ellos, no pueden contener todos los datos deseados.

\section{Guías de búsqueda en línea}

Existen varias guías publicadas de gran utilidad para la búsqueda en línea y el empleo de las bases de datos que las personas interesadas en la información sobre SST pueden desear consultar. Estas guías pueden conseguirse en bibliotecas o servicios de información universitarios o públicos, o bien adquirirse en la editorial.

Los grandes servidores mantienen cientos de bases de datos diferentes disponibles 24 horas al día. Al realizar una búsqueda en línea, pueden seguirse varias estrategias en las que se combinan diversos requisitos técnicos. U tilizando técnicas de búsqueda especiales, como las basadas en la aplicación de descriptores o palabras claves, es posible acceder a una gran cantidad de materiales disponibles y consultar la información más adecuada a las propias necesidades. A demás de la búsqueda mediante palabras clave, la búsqueda de forma libre, se realiza mediante palabras específicas que se encuentran en casi todos los campos del texto de la base de datos, y que puede asimismo ampliar la información. Casi no existen limitaciones en cuanto al tamaño de las bases de datos, ya que pueden combinarse varias de ellas para formar una unidad de información (cluster). Es posible utilizar un cluster como si fuera una base de datos individual, lo que permite aplicar una estrategia de búsqueda en todas 0 en una determinada selección de bases de datos 
simultáneamente. Este modelo de bases de datos "All Safety" está siendo instalado por uno de los mayores servidores, el Sistema de Recuperación de Información de la European Space Agency (ESA-IRS). El objetivo de esta agrupación, de varios gigabytes de tamaño y con capacidad para almacenar miles de millones de caracteres, es combinar un gran número de grandes bases de datos. O bviamente, este tipo de agrupación depende totalmente del ordenador.

Las listas completas de las bases de datos en línea disponibles pueden solicitarse a los principales servidores internacionales, como ESA-IRS, DIALOG, ORBIT, STN, CCINFO line $y$ Q uestel. Los servidores sólo identifican sus propias bases de datos; para encontrar listados más exhaustivos, es necesario consultar directorios como Gale R esearch's Directory of Databases (incluye CD-ROM y disquetes), disponible en línea en ORBIT y Q uestel, así como en versión impresa.

Pueden consultarse bases de datos sobre salud y seguridad en el trabajo en algunos discos compactos, como el CD-ROM de la O SH A (U nited States O ccupational Safety and H ealth Administration), los discos C CINFO del Canadian Centre for O ccupational H ealth and Safety (CCOHS) en inglés y francés (C COHS 1996), los discos de texto completo OSH-CD y OSH OFFSHORE del $\mathrm{H}$ ealth and Safety Executive Information Service del Reino U nido, editados por SilverPlatter que publica asimismo muchos otros CD-ROM relacionados con la salud y la seguridad en el trabajo, como CHEMBANK, EINECS, TOXLINE, y EXCERPTA MEDICA. Por su parte, SpringerVerlag publica GEFAHRGUT, un CD-ROM en alemán. EI texto completo de los Convenios y las Recomendaciones de la OIT sobre salud y seguridad en el trabajo puede encontrarse en ILOLEX, un CD-ROM publicado por Kluwer. Asimismo, puede consultarse información secundaria en los discos CCINFO y en el OSH-ROM de SilverPlatter. MEDLINE y PESTBANK son otros dosCD-ROM de interés.

M uchos tipos de fuentes de información útiles pueden obtenerse de esta forma en disquete: en GLOVES se enumeran las propiedades de los materiales usados para fabricar guantes de protección, con el fin de ayudar a los usuarios a elegir los más resistentes para un determinado trabajo. B retherick's Reactive Chemical $\mathrm{H}$ azards se encuentra disponible en disquete, así como CHENDATA, una recopilación de datos de la OIT sobre la normativa relativa a los productos químicos utilizados en el lugar de trabajo, los límites de exposición en 13 países, las frases sobre riesgo y seguridad que deben Figurar en las etiquetas y las citas de publicaciones que apoyan el tema.

$O$ tras fuentes en disquete son UN-E arth, que incluye datos sobre las oficinas, los programas y las áreas de competencia de las $\mathrm{N}$ aciones U nidas. A simismo, existen guías secundarias para obtener datos. U na fuente esencial es FACTS, que contiene resúmenes de informes de accidentes industriales propiedad del Dutch National Technical Institute (T NO). 0 tros programas de ayuda al profesional son: ACCUSAFE (un sistema de auditoría de la seguridad del U nited States National Safety Council); EBE, un sistema de gestión de la información desarrollado para Asia por el CIS Regional Technical Co-operation Project; CHEMDATA.

\section{Especialistas en la materia}

Solucionar los problemas de salud y seguridad en el trabajo no es simplemente una cuestión de acumular datos; alguien debe utilizarlos para encontrar soluciones. Todos los especialistas de salud y seguridad en el trabajo son expertos en determinadas materias, y cuando un problema escapa a la competencia de una persona, es el momento de solicitar ayuda. Los sectores principales suelen disponer de entidades dedicadas a la salud y la seguridad, como el Centro para la Seguridad de los Procesos Químicos del American Institute of Chemical Engineers. Los centros locales de control de tóxicos ayudan a la identificación de productos, así como en las situaciones de emergencia en el lugar de trabajo. Las sociedades profesionales (por ejemplo, The American Society for Testing and $M$ aterials) pueden publicar registros de expertos reconocidos. Las publicaciones especializadas incluyen anuncios de utilidad (por ejemplo Fire Prevention). Asimismo, en muchos países, los organismos nacionales ofrecen servicios de consultoría.

Todas las bibliotecas del mundo son centros de información donde pueden encontrarse datos relacionados con la salud y seguridad en el trabajo. No obstante, una sola biblioteca no puede dar respuesta a todas las preguntas. Generalmente, los especialistas en información y los bibliotecarios conocen las fuentes especializadas en sus regiones y pueden aconsejar adecuadamente a sus clientes. Existen guías impresas como el $G$ ale R esearch Inc's D irectory of Special L ibraries and I nformation Centres (16a edición, 1993). Las instituciones de cada país que actúan como Centros Nacionales y en Colaboración con el CIS forman una red que puede dirigir las solicitudes de información a la fuente de conocimientos prácticos más apropiada.

\section{Información sobre seguridad en el lugar de trabajo}

Estas "publicaciones" (carteles, señales, folletos, etc.), puesto que consisten más en imágenes que en palabras y números, no han sido susceptibles de almacenamiento y recuperación por medios electrónicos en el pasado. Actualmente, esta dificultad está subsanándose, pero, probablemente, el especialista en SST que trate de repartir folletos adecuados en un curso de media jornada sobre seguridad en caso de incendio deba recurrir al departamento de bomberos local antes de encender su ordenador. De las principales bases de datos sobre SST, sólo CISDO C incluye sistemáticamente referencias a materiales pedagógicos y su recopilación es más indicativa que exhaustiva.

Puesto que las bibliotecas no suelen almacenar catálogos, las personas interesadas debe elaborar una recopilación propia mediante el contacto con los proveedores. Entre éstos Figuran las empresas comerciales ( $p$. ej., Lab Safety Supply International) y los organismos nacionales o privados reconocidos por la Administración (aseguradoras, sindicatos). Puede reunirse un conjunto inicial de direcciones mediante la consulta de la información sobre fuentes de CISD O C.

[E. Clevenstine]

\section{Etapas de acceso a la información}

\section{Estrategias de búsqueda}

La búsqueda de información puede ser frustrante. A continuación se ofrecen consejos dirigidos especialmente a las personas que no disfrutan de las ventajas de un servicio de información 0 una biblioteca plenamente desarrollados.

\section{Cómo obtener un préstamo o una fotocopia de un artículo, un libro o un informe}

Pueden utilizarse bibliotecas públicas locales, universitarias, politécnicas $u$ hospitalarias. $M$ uchas de ellas ofrecen únicamente material de referencia, pero disponen de máquinas fotocopiadoras en sus instalaciones, de forma que pueden reproducirse los documentos solicitados (respetando los derechos de autor). En primer lugar, deben consultarse los índices o los catálogos de la biblioteca; si el documento buscado no está disponible, el especialista en información o el bibliotecario indicará otro establecimiento que pueda ser de ayuda. Asimismo, es posible recurrir al especialista en seguridad del sindicato, la asociación profesional, 0 
la empresa del solicitante de información. L as peticiones se elaborarán del modo más inequívoco posible, prestando atención a las necesidades del especialista o el bibliotecario respecto a los datos siguientes:

- título y autor o autores del artículo, del libro o del informe;

- editor:

- año de publicación;

- edición;

- International Standard Book Number (ISBN) (número internacional uniforme para los libros) es un identificador único asignado a todos los documentos que se publican;

- nombre de la publicación periódica o el diario;

- fecha de la publicación periódica o el diario y volumen, número de laparte a que pertencen y páginas solicitadas;

- nombre de la base de datos.

La atención de la solicitud puede llevar tres o más semanas si el documento ha de pedirse prestado a otra fuente, pero la búsqueda puede agilizarse mediante el pago de una "prima" por el servicio.

¿Cómo buscar información sobre una cuestión en particular? Una vez más deben utilizarse los servicios y los contactos locales. Los especialistas en información o los bibliotecarios asistirán al solicitante de información en la utilización de los diversos resúmenes e índices tradicionales. La información adicional incluida en el presente capítulo puede ser de utilidad para cualquier búsqueda, y es posible consultar diferentes bibliografías, anuarios, guías, otras enciclopedias, diccionarios y otras obras, o dirigirse por escrito a las organizaciones pertinentes para obtener más datos. La utilización de las redes establecidas resulta eficaz. Los especialistas en información y las bibliotecas locales deben ser capaces de llevar a cabo búsquedas en línea o en CD-ROM de una 0 varias de las bases de datos informatizadas enumeradas en este capítulo.

\section{Técnicas de búsqueda}

La información buscada debe especificarse con claridad; por ejemplo, el término "lesiones" es demasiado amplio para buscar datos sobre el tema "problemas de lumbago del personal de enfermería". Los aspectos concretos de una cuestión deben definirse con precisión, mencionando las palabras clave, los términos relacionados, los sinónimos, las denominaciones de productos químicos, los números de registro de los resúmenes químicos, etc., de que pueda disponer el solicitante de la información. Puede consultarse el nombre de un autor conocido como experto en el área de interés para encontrar otras publicaciones más recientes. $\mathrm{H}$ ay que decidir la cantidad de información necesaria: sólo algunas referencias o una búsqueda exhaustiva. No debe pasarse por alto la información publicada en otras lenguas; el British Library Document Supply Centre (BLDSC) recopila traducciones de todas las materias. NIOSH en Estados Unidos, CCOHS en Canadá y el Health and Safety Executive (HSE) en el Reino Unido disponen de programas de traducción exhaustivos. EI HSE registra más de 700 traducciones en el BLDSC cada año.

Resulta útil aplicar un formato de búsqueda normalizado (véase la Tabla 22.2) para asegurar que las consultas se llevan a cabo de un modo sistemático y coherente.

El organigrama de la Figura 22.3 ilustra un itinerario típico para localizar información.

\section{Avance de la tecnología}

La tecnología sigue avanzando con rapidez y ofrece mejoras como la transmisión a alta velocidad en todo el mundo a través de las llamadas autopistas de la información y con costes cada vez
Tabla 22.2 • Formato de búsqueda normalizado.

\section{BUSQUEDA DE}

Palabras clave

Sinónimos

Número de registro de sustancias químicas

Autor 0 autores conocidos

¿A qué fecha hay que remontarse en la búsqueda?

¿Cuántas referencias se solicitan?

Dónde buscar ( $p$. ej., índices, bibliotecas)

Diarios/ publicaciones periódicas acreditadas

Libros/ informes acreditados

Bases de datos/CD- ROM acreditados

Términos utilizados en la búsqueda

Número de referencias encontradas

Fecha

más reducidos. Asimismo, la utilización del correo electrónico facilita el acceso a la información y simplifica la búsqueda de asesoramiento y orientación de los especialistas de todos los países. La difusión y la utilización de la transmisión de datos facsímil ha constituido una contribución valiosa, también con un gasto limitado. El potencial de estas nuevas tecnologías de la información es enorme. Sus prestaciones de acceso a datos a un coste en constante descenso pueden ayudar cada vez más a reducir las disparidades existentes en cuanto a disponibilidad de información entre países y regiones. A medida que las redes de transmisión de información se expanden y se crean otras aplicaciones innovadoras mediante la utilización de estas tecnologías beneficiosas, aumenta el número de personas que podrán aprovecharlas, lo que permitirá materializar la función de la información como medio para llevar a cabo los cambios deseados en el lugar de trabajo.

\section{Coste-beneficio de la tecnología}

Las nuevas tecnologías también benefician a los países en desarrollo. Es bien sabido que el conocimiento y la información son esenciales para mejorar la calidad de vida y del medio ambiente. Las tecnologías de la información constituyen uno de los medios más eficaces en función del coste para que estos países sigan el ritmo de los progresos en los diversos campos de actividad. Las tecnologías electrónicas pueden elevar sustancialmente la capacidad del mundo en desarrollo para aprovechar las ventajas que ofrece una difusión de la información optimizada y rentable.

L os sistemas centrales y en línea, aunque no son obsoletos en absoluto, resultan caros para muchas instituciones. Costes como los que genera la producción de datos y las telecomunicaciones son elevados y a menudo prohibitivos. Las tecnologías actuales, como el CD-ROM e Internet constituyen las mejores vías para que estos países reciban información y se mantengan al día del estado del conocimiento actual en muchas áreas, sobre todo las más importantes en relación con la salud. Son innegables las ventajas que ofrecen al presentar grandes recopilaciones de datos dirigidas directamente a los usuarios que satisfacen con celeridad y precisión sus diversas necesidades.

Los costes de una estación de trabajo completa (ordenador personal, lector de CD-ROM y aplicaciones) se reducen con rapidez. El precio asequible de la información basada en la utilización de ordenadores personales y las cualificaciones locales relativas a las tecnologías necesarias para su tratamiento brindan 
Figura 22.3 • Vías sencillas hacia la información.

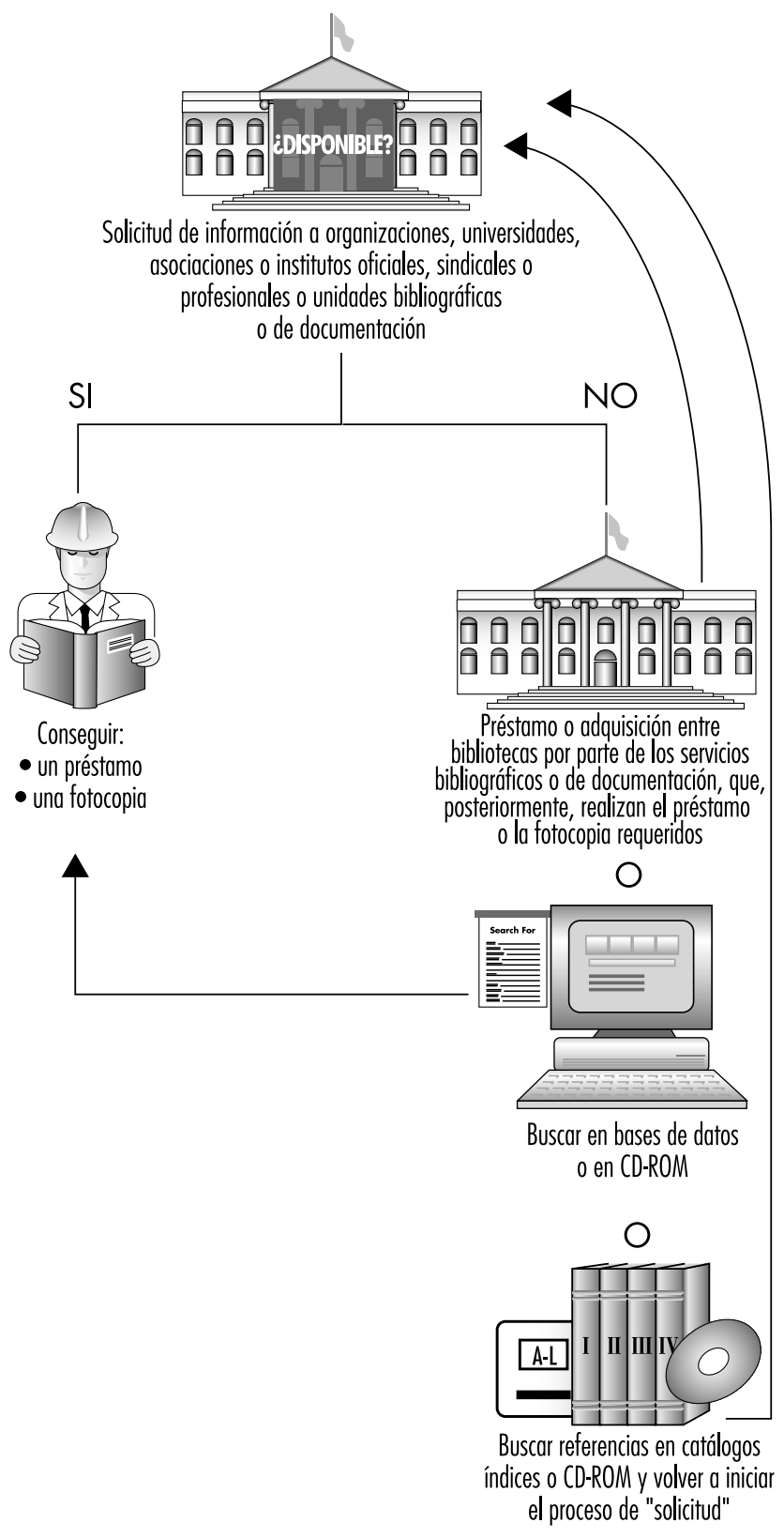

a los países en desarrollo la oportunidad de realizar actividades en relación con la información fundamental a la misma escala que los países desarrollados.

[S. Pantry y P.K. Abeytunga]

\section{- GESTION DE LA INFORMACION}

G ordon Atherley

U na información fiable, exhaustiva e inteligible es esencial para la salud y la seguridad en el trabajo. Sus usuarios son directivos, trabajadores, profesionales de la SST, representantes de salud y seguridad y miembros de los comités competentes en esta materia. Las responsabilidades de los profesionales, los representantes y los miembros de los comités suelen incluir en la oferta de información a otras personas. La legislación sobre SST de muchos países exige que la Administración, las empresas, los proveedores de productos químicos y otros agentes suministren información, a los trabajadores y que ésta sea generada por organizaciones tales como las propias empresas, sometidas a la misma.

\section{Información en el ámbito de la empresa}

Desde el punto de vista de una organización, hay dos tipos básicos de información necesaria en materia de salud y seguridad en el trabajo:

Información procedente de fuentes externas. se utiliza para cubrir necesidades específicas y solucionar problemas. Esta información es diversa y extensa y procede de numerosas fuentes (véase la Tabla 22.3. Para que alcance el grado deseado de fiabilidad, comprensión e inteligibilidad, es necesario gestionarla. La gestión de la información comprende tres procesos continuos:

1. A nálisis de las necesidades de información de sus usuarios.

2. Determinación y obtención de la información requerida.

3. O ferta de la información que necesitan los usuarios.

Información procedente de fuentes internas. Se utiliza para ayudar a identificar los problemas de salud y seguridad en el trabajo, controlar el rendimiento y cumplir con los requisitos jurídicos.

La recogida, clasificación y almacenamiento de la información procedente de las investigaciones de accidentes puede ayudar a identificar los accidentes más usuales y a averiguar sus causas. Por ejemplo, los datos sobre exposición de los trabajadores a determinadas sustancias químicas, pueden ser importantes años más tarde si se plantean problemas relativos a enfermedades profesionales.

La información procede del análisis de los datos. Para que éste permita obtener conclusiones fidedignas, los datos deben ser generales y fiables. La fiabilidad depende de una recogida y una compilación acorde a los principios científicos. Por ejemplo, es necesario definir previamente y con claridad la cuestión o el problema que se ha de tratar, para que se recojan los datos pertinentes y

- se definan estrictamente los tipos de datos que deben incluirse en la recopilación;

- la recogida de datos se lleve a cabo de un modo coherente que permita la comprobación de su validez y fiabilidad;

- se comprendan y establezcan las limitaciones de la recogida de datos

La gestión de la información comprende los procesos de recogida de datos, almacenamiento, recuperación y análisis.

\section{Organización de la gestión de la información}

Las tareas de la gestión de la información, suelen ser organizadas y realizadas por un servicio de información. Las funciones de este servicio son:

1. A segurar que la información sea esencial y actual y que los usuarios no se vean abrumados por una excesiva o recargada información.

2. Garantizar la utilidad de la información para los usuarios. Para ello, suele ser necesario un conocimiento detallado de sus demandas y de la información que buscan.

3. Ayudar a los usuarios a encontrar la información por sí mismos.

4. Difundir activamente la información. EI acceso a la información sobre salud y seguridad en el trabajo es un derecho general y no un privilegio de un grupo selecto. La 
Tabla 22.3 • Información necesaria en el ámbito de la salud y la seguridad en el trabajo.

\begin{tabular}{|c|c|c|c|c|c|c|}
\hline & $\begin{array}{c}\text { Conocimientos } \\
\text { técnicos } \\
\text { individuales }\end{array}$ & Informes & Publicaciones & $\begin{array}{c}\text { Información } \\
\text { accesible } \\
\text { a traves del } \\
\text { ordenador }\end{array}$ & $\begin{array}{c}\text { Documen- } \\
\text { tación } \\
\text { registrada } \\
\end{array}$ & $\begin{array}{l}\text { Medios } \\
\text { audio- } \\
\text { visuales }\end{array}$ \\
\hline $\begin{array}{l}\text { Libros y revistas cientificos y } \\
\text { médicos disponibles en las } \\
\text { bibliotecas }\end{array}$ & & & & & & \\
\hline $\begin{array}{l}\text { Información técnica y cientifica } \\
\text { no suele encontrarse en bibliote } \\
\text { como las hojas de datos técnico } \\
\text { de seguridad de materiales y ot } \\
\text { fichas técnicas }\end{array}$ & & & & & & \\
\hline $\begin{array}{l}\text { Información estadística y } \\
\text { demográfica sobre las } \\
\text { enfermedades y las lesiones } \\
\text { profesionales, los accidentes } \\
\text { importantes, los registros de } \\
\text { exposición, etc, elaborada por } \\
\text { organizaciones intemacionales } \\
\text { nacionales }\end{array}$ & & & & & & \\
\hline $\begin{array}{l}\text { Leyes, reglamentos, políticas, } \\
\text { procedimientos }\end{array}$ & & & & & & \\
\hline $\begin{array}{l}\text { Informes especiales sobre } \\
\text { cuestiones especiales, como el } \\
\text { amianto o las lesiones producid } \\
\text { por esfuerzos repetitivos }\end{array}$ & & & & & & \\
\hline $\begin{array}{l}\text { Fotografías, gráficos por ordena } \\
\text { películas y videos, grabaciones } \\
\text { sonoras de conferencias }\end{array}$ & & & & & & \\
\hline $\begin{array}{l}\text { Experiencia y conocimientos } \\
\text { practicos de personas y } \\
\text { organizaciones }\end{array}$ & & & & & & \\
\hline $\begin{array}{l}\text { Colecciones especiales de } \\
\text { documentos gráficos, por ejemp } \\
\text { de equipos de seguridad y de } \\
\text { componentes mecánicos } \\
\text { defectuosos }\end{array}$ & & & & & & \\
\hline $\begin{array}{l}\text { Informes de consultores; inform } \\
\text { empresariales acerca de los } \\
\text { sistemas de información sobre } \\
\text { seguridad, como los registros d } \\
\text { accidentes y los de situaciones } \\
\text { peligro de accidente }\end{array}$ & & & & & & \\
\hline Programas informáticos & & & & & & \\
\hline $\begin{array}{l}\text { Bases de datos sobre la } \\
\text { investigación de los accidentes } \\
\text { graves }\end{array}$ & & & & & & \\
\hline $\begin{array}{l}\text { Estudios epidemiológicos, } \\
\text { encuestas y otros informes de } \\
\text { investigacion }\end{array}$ & & & & & & \\
\hline $\begin{array}{l}\text { Bases de datos y sistemas de } \\
\text { registro de inspecciones }\end{array}$ & & & & & & \\
\hline $\begin{array}{l}\text { Listas, datos y direcciones de } \\
\text { expertos }\end{array}$ & & & & & & \\
\hline $\begin{array}{l}\text { Bases de datos de registros } \\
\text { médicos }\end{array}$ & & & & & & \\
\hline
\end{tabular}

publicación por medios informáticos ha reducido los costes de producción de folletos, boletines y otros materiales de distribución generalizada.

5. R ecoger y ofrecer información de modo eficaz y económico. $\mathrm{N}$ ingún servicio de información dispone de un presupuesto ilimitado.

6. Estar al día en lo que respecta a las responsabilidades jurídicas en materia de recogida y oferta de información.
7. O frecer y coordinar los recursos y los conocimientos prácticos necesarios para producir y analizar la información procedente de fuentes internas. Son los siguientes:

- Sistemas empresariales de información sobre seguridad (registros de accidentes, informes sobre hechos que estuvieron a punto de causar accidentes).

- Estadísticas de accidentes y enfermedades, datos de exposición (véase asimismo el capítulo Sistemas de registro y vigilancia).

- Bases de datos de estudios sobre accidentes graves (véase asimismo el artículo Auditorías, inspecciones einvestigaciones).

- Estudios específicos sobre recogida de datos (véase asimismo el capítulo E pidemiología y E stadística).

- Sistemas y bases de datos de registros de inspección.

- Listas y datos de expertos, direcciones.

- Bases de datos de registros médicos (véase asimismo los capítulos Servicios de Salud en el Trabajo y A suntos E ticos).

- Facilitar los estudios y la investigación. Estos métodos proceden con frecuencia de disciplinas científicas como la epidemiología y la estadística. El servicio de información puede ayudar a los investigadores a conseguir la información básica que necesitan, ofrecer programas informáticos para almacenar datos y difundir los resultados de investigación en los sectores relacionados con la salud y la seguridad en el trabajo. En algunos estudios, el servicio de información puede participar también en la recogida de datos.

Para que un servicio de información cumpla todas estas funciones con eficacia, debe resolver diversas cuestiones. Un problema muy común consiste en la elevada tasa de crecimiento de la cantidad de información relacionada con la SST, que ya es considerable. Las numerosas actualizaciones y revisiones que se realizan en la información ya existente agravan este problema. Una dificultad adicional es que el aparente exceso de información encubre una falta de material multidisciplinario. Por ejemplo, gran parte de la información procedente de la investigación en medicina e ingeniería se comunica a los especialistas. Puede ser ininteligible para las demás personas. Por tanto, los nuevos conocimientos no pueden transmitirse a algunos usuarios, para los que podría ser de gran importancia. U na de las funciones de un servicio de información es fomentar la producción de documentación multidisciplinaria.

O tros problemas se deben a los obstáculos con que se enfrentan los usuarios potenciales para acceder o utilizar la información. Por ejemplo:

- Lenguaje humano. G ran parte de la información disponible sobre salud y seguridad en el trabajo está redactada en un lenguaje total o parcialmente incomprensible para gran parte de los usuarios. Un servicio de información debe ser capaz de traducir ésta al lenguaje ordinario del usuario, sin reducir su calidad. L os ordenadores pueden ayudar a superar las barreras del lenguaje. Facilitan la traducción de un idioma a otro y pueden generar automáticamente el texto en un tipo de lenguaje, mientras que el usuario introduce la información en otro. M ediante la generación estructurada de textos, los ordenadores pueden redactar varios informes de forma automática.

- Capacidad de comprensión. Puede plantearse otro obstáculo a la comunicación eficaz relacionado con el lenguaje debido a la insuficiencia de la capacidad de comprensión para entender la información sobre SST de carácter más técnico. Los ordenadores pueden ayudar a superar este obstáculo, mediante las técnicas que analizan automáticamente el nivel de complejidad de la documentación escrita y permiten así evaluar su idoneidad para cada usuario. 
- Restricciones de distribución y disponibilidad. Parte de la información de gran importancia en materia de salud y seguridad en el trabajo puede considerarse confidencial (datos médicos, secretos comerciales, algunos documentos gubernamentales). Asimismo, la legislación sobre derechos de autor impide la duplicación de información de diversos tipos. En algunos casos, mantener la confidencialidad de la información es una responsabilidad tan importante como difundirla. Tal condición ha de ser considerada por las personas y organizaciones que generan información. La gestión de ésta exige la disposición de conocimientos prácticos para evitar problemas de confidencialidad, por ejemplo, utilizando datos de conjunto, y no individuales y conociendo con exactitud las disposiciones legales para proteger la privacidad.

- Instrumentos de acceso a la información (ayudas de búsqueda) utilizados en bibliotecas para buscar información. No todos los usuarios saben cómo utilizar las herramientas avanzadas de acceso a la información, como los catálogos informatizados (véase más adelante), y no toda la información se encuentra disponible a través de los instrumentos de acceso En la mayoría de los casos, su utilización requiere experiencia y cualificación, así como un buen conocimiento del inglés. Los sistemas de menú constituyen un intento de simplificar la tarea de la persona que busca información, pero la simplificación puede dar lugar también a su ocultación. Estos problemas pueden minimizarse si los profesionales de la información asumen la función de asesores.

- El teclado del ordenador. Para algunas personas, el teclado del ordenador constituye un obstáculo porque no se les ha formado para utilizarlo. Las personas con discapacidades como las lesiones por tensión repetitiva no pueden usarlo durante períodos de tiempo prolongados o incluso nunca. Los programas de reconocimiento de voz constituyen un método alternativo de comunicación con el ordenador.

- El coste económico (y medioambiental) de la información y la difusión de documentos. El papel es un medio de distribución de información caro. Aunque, en teoría, permiten ahorrar papel, en la práctica pueden desperdiciarlo en grandes cantidades. Los sistemas de información informatizados bien gestionados constituyen la vía más eficaz en función del coste (y menos gravosa medioambientalmente) de distribución y almacenamiento de información).

\section{Servicios de información y bibliotecas}

Los servicios de información y las bibliotecas trabajan en colaboración. Las grandes bibliotecas comunitarias y las especializadas, como las dedicadas al derecho o la medicina, suelen disponer de servicios de información. Los especializados (incluidas las bibliotecas) dedicados a la salud y la seguridad en el trabajo, suelen ubicarse en organizaciones como instituciones de SST, empresas, universidades y departamentos gubernamentales.

El servicio de información se ocupa de responder a las preguntas formuladas por los usuarios y de mantenerles al corriente de cuestiones importantes. Requiere la utilización de técnicas y recursos de biblioteconomía para buscar y obtener información y abordar algunas cuestiones relacionadas con los derechos de autor. El sistema de información analiza ésta en función de las necesidades de los solicitantes. 0 frece respuestas que suelen exigir la consulta de información procedente de fuentes fuera del ámbito de una biblioteca pública (véase la Tabla 22.3)

A lgunos expertos en información y en salud y seguridad en el trabajo diferencian entre las bibliotecas comunitarias y los servicios de información. D efienden la necesidad de evitar la duplicación de esfuerzos por razones de coste y de otro tipo. U na regla de oro, producto de la experiencia, es que los materiales de una biblioteca comunitaria susceptibles de préstamo a los que pueden acceder los usuarios de un servicio de información no deben encontrarse disponibles para el préstamo en dicho servicio. Por la misma razón, el servicio de información debería especializarse en la documentación sobre salud y seguridad en el trabajo que, normalmente, no puede conseguirse en las bibliotecas comunitarias. $\mathrm{H}$ a de centrarse en los grupos y personas con unas necesidades específicas en materia de salud y seguridad en el trabajo. Asimismo, puede ayudar a una organización en el cumplimiento de sus obligaciones jurídicas relativas a la oferta y la generación de información, tarea cuyo desempeño no puede esperarse de una biblioteca comunitaria.

Las bibliotecas dependen de sistemas informáticos altamente desarrollados para la adquisición y la catalogación de materiales, así como para el control y el seguimiento de su circulación. Los servicios de información acceden a estos sistemas por medio del trabajo en equipo con personal especializado de las bibliotecas. Estas y los servicios de información necesitan cooperar estrechamente en la organización del material de referencia (no disponible para el préstamo), los préstamos entre bibliotecas, los sistemas en línea y el material audiovisual. Normalmente, el sistema de información dispone de un conjunto esencial de material de referencia, como la Enciclopedia de Salud y Seguridad en el Trabajo de la OIT.

La difusión selectiva de información (DSI) es un aspecto de los servicios de información, en el que la cooperación entre éstos y las bibliotecas comunitarias es especialmente importante. Para poner en marcha un servicio de DSI, el proveedor de información almacena un perfil de búsqueda personal, según las necesidades del usuario. Por ejemplo, un grupo de perfiles para investigadores se utiliza para consultar los títulos de artículos científicos según se publican. Los que se ajustan a determinados perfiles se notifican a las personas interesadas. Aunque el SDI puede ser un servicio importante, es posible que resulte difícil organizarlo eficazmente cuando las necesidades de información de los usuarios varían considerablemente con el tiempo, como ocurre a menudo en el caso de la salud y la seguridad en el trabajo.

\section{Formación para acceder a la información}

L os trabajadores y los directivos necesitan saber de quién y dónde pueden obtener información. Por ejemplo, en el ámbito de la salud y la seguridad, las fichas de seguridad de materiales constituyen una importante fuente de información sobre los productos químicos usados en el lugar de trabajo. Los trabajadores y los directores necesitar recibir formación relativa a la búsqueda y la utilización de este tipo de información. Puesto que, posiblemente, ningún programa de formación sobre salud y seguridad en el trabajo puede abarcar todos los problemas potenciales, saber dónde buscar la información es vital tanto para los trabajadores como para la dirección. En todos los programas de formación sobre SST debería incluirse un apartado sobre fuentes y servicios de información.

La formación sobre las formas de acceso a la información es una parte esencial de la educación de profesionales, representantes y miembros de comités.

Al formular los programas de formación, se supone que estas personas conocen bien el campo de la salud y la seguridad en el trabajo, pero necesitan formación básica en cualificaciones de gestión de la información. Estas incluyen la búsqueda en recursos de información en línea y la utilización eficaz de un servicio de información. La formación debe incluir la experiencia práctica del trabajo en equipo con bibliotecarios y personal especializado en información.

Estos profesionales son las personas con un mayor nivel de educación y formación en el campo de la información. No obstante, durante su período de formación, pueden haber 
tenido un contacto escaso con las cuestiones de salud y la seguridad en el trabajo. Es necesario potenciar estos contenidos y, quizá, desarrollar una formación universitaria especializada para este grupo.

\section{El ordenador en la gestión de la información}

En todos los procesos de gestión de la información se utilizan cada vez más los ordenadores. Aunque gran parte de la información a escala mundial sigue difundiéndose en papel y es probable que esta tendencia no varíe durante algunos años, el trabajo realizado por los ordenadores se amplía en todas las áreas. Son cada vez más baratos y más pequeños y, al mismo tiempo, aumenta su capacidad. Los microordenadores asequibles, denominados asimismo ordenadores personales (PC) pueden llevar a cabo el mismo trabajo de gestión de información que hace sólo algunos años habría exigido un ordenador central de coste elevado. $\mathrm{H}$ ay tres conceptos informáticos que son especialmente importantes para la gestión de la información: bases de datos, sistemas de gestión de bases de datos y comunicación informática.

\section{Bases de datos}

Una guía telefónica constituye un ejemplo sencillo de base de datos. La compañía telefónica posee una lista principal de nombres y números de teléfono en un ordenador. Esta lista es una base de datos informática. Puede ser modificada con rapidez, lo que garantiza su actualización permanente. Asimismo, se utiliza para imprimir la versión en papel de la guía telefónica, que constituye una base de datos de acceso público. Las personas y las organizaciones suelen disponer de sus propias listas con los números de teléfono más utilizados. Estas representan bases de datos privadas o personales.

La versión en papel de la guía telefónica es un modelo de la forma esencial de una base de datos. La información está clasificada por apellidos en orden alfabético. Las iniciales y las direcciones distinguen a los abonados con el mismo apellido. Por cada combinación única de apellido, iniciales y dirección existe al menos un número de teléfono. En la terminología de las bases de datos, cada línea (apellido número de teléfono) es un registro. Los nombres, iniciales, direcciones y números de teléfono se denominan campos.

La versión en papel de una gran base de datos, como la guía telefónica, tiene grandes limitaciones. Si con lo único que cuenta una persona es con un número de teléfono, encontrar el nombre al que corresponde éste en la guía de una gran ciudad es, como mínimo, difícil. N o obstante, esta tarea es fácil para el ordenador de la compañía telefónica, esta labor es muy fácil. Simplemente reordena todos los registros de números de teléfono por orden numérico. La facilidad con la que pueden ser reordenados los registros es una de las características más útiles de una base de datos informatizada.

L os catálogos de las bibliotecas son bases de datos disponibles en versión electrónica y en papel. Cada registro corresponde a un libro 0 a un artículo en concreto. Los campos identifican la fecha y lugar de publicación y especifican dónde se encuentra una copia de los mismos. En las bibliotecas existen bases de datos sobre muchas materias, incluidas algunas de importancia para la salud y la seguridad en el trabajo. EI CISDOC de la OIT es un ejemplo de estas bases de datos bibliográficos.

Además de los nombres de los autores y de los datos de referencia (como el título y fecha de publicación y el nombre de la revista), una base de datos bibliográfica suele incluir también un resumen. En éste el usuario obtiene información del contenido del artículo que le permite decidir si desea consultar su versión integra o no.
En las bases de datos no sólo pueden almacenarse resúmenes, sino también el texto completo de los artículos e imágenes (gráficos) como fotografías y diagramas. Los sistemas multimedia constituyen una potente aplicación de la tecnología de bases de datos para combinar sonido, texto e imágenes estáticas y en movimiento.

Los avances en los medios de almacenamiento óptico y magnético han reducido los costes del almacenamiento de alta capacidad. Como resultado, bases de datos cada vez más grandes y complejas se almacenan en ordenadores personales 0 son accesibles a través de éstos.

\section{Sistemas de gestión de bases de datos}

Los sistemas de gestión de bases de datos (SGBD) ordenan los registros de una base de datos y desempeñan otras muchas funciones importantes de gestión de información, como la búsqueda de determinados registros. Un SG BD es un programa que permite al usuario trabajar con la información almacenada en la base de datos. Por tanto, constituye un elemento esencial en la gestión de la información. U na versión especial de programa DBM S es el gestor de información personal, utilizado en el caso de los directorios telefónicos personales, listas de tareas, agendas de reuniones y otros datos personales.

El concepto de filtro es apropiado para explicar cómo el DBM S estructura una búsqueda. Cada búsqueda puede considerarse como un filtro que sólo permite el paso de los registros que corresponden a un perfil específico. Por ejemplo, el usuario puede solicitar todos los registros publicados sobre asbestos en 1985. La orden de búsqueda será interpretada por el ordenador como una instrucción para filtrar todos los registros que contengan la palabra clave "asbestos" en el título y que fueron publicados en 1985. U na instrucción típica podría ser:

palabra clave en el título $=$ asbestos $Y$ fecha de publicación $=1985$

El término $Y$ se conoce como operador B ool eano, llamado así en honor al matemático inglés George Boole, que inventó un sistema de lógica algebraica en el siglo XIX conocido como al gebra booleana. 0 tros operadores booleanos utilizados habitualmente son 0 y NO. Al usarlos, los filtros de búsqueda pueden conseguir una elevada precisión.

\section{Comunicaciones informáticas}

L as comunicaciones informáticas han dado lugar a la creación de numerosas redes formales e informales que permiten el intercambio de información. Estas redes suelen cubrir grandes distancias. Muchas operan a través de la red telefónica normal vía módem. 0 tras utilizan la comunicación por satélite.

En una red típica, las bases de datos se almacenan en un ordenador (el ordenador de destino), y el ordenador personal (el ordenador de origen) hace la solicitud de búsqueda. La respuesta del ordenador del destino es enviar los datos obtenidos en la búsqueda. Se han desarrollado normas internacionales para garantizar que esta comunicación entre ordenadores se lleve a cabo adecuadamente. Un ejemplo son las normas ISO 10162 y 10163-1 (de 1993), relativas a la búsqueda y recuperación de información.

En el pasado, las comunicaciones por ordenador requerían equipos grandes y caros. La potencia y la capacidad de los ordenadores personales actuales son tan grandes que incluso una única persona puede organizar redes desde su oficina o su casa.

La red que permite la conexión de las personas con el mundo de la información es la Internet. En 1996, este servicio se ha convertido en el sistema de comunicación de más rápido crecimiento en toda la historia, y se prevé que existan mil millones de usuarios a finales de siglo. U n instrumento de este crecimiento es 
la World Wide Web. Este conjunto de herramientas de software simplifican la complejidad de Internet. Gracias a la Web, el usuario no necesita conocer los lenguajes ni los comandos informáticos. Tampoco tiene que depender de los servicios de un profesional de la información, como sucedía en el pasado. La herramienta fundamental para el usuario es el navegador, un programa informático que le permite explorar la red. M ediante su utilización, millones de documentos Web (los recursos de información de la red) son accesibles. Los recursos de la red no sólo están constituidos por texto, sino que también integran presentaciones multimedia completas que incluyen sonido y animación.

La capacidad multimedia convierte a la red en un medio de formación importante. En 1996, comenzaron a aparecer en Internet programas de formación sobre salud y seguridad en el trabajo. De las páginas Web de mayor tamaño pueden sacarse programas informáticos para su utilización en este campo. En lo que respecta a otros recursos de información en la red, aumenta el número de páginas de bibliotecas relacionadas con la salud y la seguridad en el trabajo va en aumento. Dado el crecimiento continuo de Internet, es posible que, en el transcurso de la elaboración de esta edición de la E nciclopedia de la O IT, se asista al desarrollo de una "universidad virtual" mundial de SST.

Internet ofrece un sistema de correo electrónico global que permite el envío de mensajes privados entre las personas. Asimismo, la red se utiliza cada vez más para la prestación de servicios de correo de voz y videoconferencia.

La mensajería electrónica difiere del correo electrónico. M ediante la primera, todos los miembros de un grupo pueden leer y responder a un mensaje. La mensajería se utiliza en las conferencias por ordenador, en las que muchas personas participan en un debate sobre una determinada cuestión. Es una forma barata de crear una red, por ejemplo, de profesionales de la salud y la seguridad en el trabajo que tengan un interés común en un tipo concreto de riesgo profesional.

La transferencia de archivos es un proceso informático básico. En la terminología informática, un archivo es la unidad básica de almacenamiento que permite a un ordenador distinguir un paquete de información de otro. Un archivo puede ser un programa de ordenador, un documento de un procesador de texto, una base de datos completa 0 un conjunto de registros filtrados obtenido mediante una búsqueda en una base de datos. La transferencia de archivos es el medio que permite a los ordenadores compartir información. Varios protocolos de transferencia de archivos (FTP) garantizan que los datos no sean modificados durante el proceso. La transferencia de archivos es especialmente importante en la gestión de información sobre salud y seguridad en el trabajo, ya que un servicio de información que cuente únicamente con un modesto ordenador personal puede recibir todo tipo de información de cualquier lugar del mundo. La transferencia de archivos y los servicios afines suelen constituir el método más eficaz en función del coste para el traslado de información. A medida que mejoran las prestaciones de los ordenadores, aumenta la cantidad y el alcance de la información que puede ser transferida.

Un ejemplo de proceso de transacción en línea consiste en solicitar una determinada publicación a través de un ordenador personal. 0 tro ejemplo es enviar a un ordenador situado en una ciudad lejana un dato relacionado con un proyecto de investigación que cubre varias regiones geográficas.

0 tras formas de comunicación informática que desempeñan un papel cada vez más importante en el campo de la salud y la seguridad en el trabajo son los servicios de solicitud de fax a través de ordenador. El usuario telefonea al ordenador para pedir información específica. A continuación, el ordenador envía la información al fax del usuario.
En general, puede afirmarse que el ordenador no sólo constituye el principal instrumento de la gestión de información, sino que también es el gran inductor de la revolución de la información que sigue cobrando impulso en el ámbito de la salud y la seguridad en el trabajo, al igual que en otras áreas importantes de la actividad humana.

\section{ESTUDIO DE CASO: SERVICIO DE INFORMACION DE MALAISIA SOBRE TOXICIDAD DE PESTICIDAS}

\author{
D.A. Razak, A.A. Latiff, M.I. A. M ajid y
}

R. Awang

\section{Introducción}

$M$ ientras que los riesgos de los pesticidas que más preocupan a los países industrializados son, entre otros, la exposición crónica a los mismos en el trabajo y la contaminación medio ambiental, el mayor peligro de estas sustancias, en muchos países en desarrollo, es la intoxicación aguda que pueden causar. La cifra anual de casos de intoxicaciones graves por pesticidas estimada por la O rganización M undial de la Salud (OM S) es de 3 millones, con el resultado de 220.000 muertes. O tro tema preocupante es asimismo, según un informe sobre envenenamientos leves declaradas por los propios afectados en cuatro países de Asia, cada año, 25 millones de trabajadores del sector agrario en los países en desarrollo están expuestos a riesgos de intoxicación aguda por pesticidas (J eyaratnam 1990)

En M alaisia, un país eminentemente agrario, el uso de pesticidas es relativamente frecuente. Sólo en la zona peninsular de $M$ alaisia, unos 1,5 millones de hectáreas se destinan al cultivo del caucho, y 0,6 millones de hectáreas al del aceite de palma. Casi 4,3 millones de personas se dedican a la agricultura. En M alaisia, la legislación principal relativa al control de pesticidas es la Ley de pesticidas de 1974. Su objetivo fundamental es controlar la fabricación y la importación de pesticidas mediante el registro. 0 tras medidas de control consisten en la concesión de licencias a establecimientos que venden pesticidas y los almacenan para su venta, el etiquetado adecuado de los pesticidas y el control de la importación de pesticidas no registrados que se utilizan en el campo de la investigación y enseñanza (Tan y col. 1992).

Los estudios realizados por la industria agroquímica local, indican que, en 1987, la mayoría de los 715.000 pequeños propietarios que se dedicaban al cultivo del caucho y el aceite de palma usaban paraquat (Shariff 1993). En el período comprendido entre 1979 y 1988, los pesticidas causaron el 40,3\% de los 5.152 casos de intoxicación humana en Malaisia. El paraquat fue responsable del $27,8 \%$ de los casos, otros herbicidas del $1,7 \%$, el malatión del $4,7 \%$, otros organofosforados del $2,1 \%$, los compuestos organoclorados del 2,6\% y otros pesticidas del $1,4 \%$. Anualmente, se gastan 230 millones de ringgits (M Y R) sólo en herbicidas (Tara y col. 1989). Se estima que un $73 \%$ de las intoxicaciones por paraquat son en realidad casos de suicidio, mientras que el $14 \%$ se deben a accidentes y el $1 \%$ son exposiciones profesionales (Jeyaratnam 1990).

L os casos de intoxicación debidos a la utilización de pesticidas no han sido bien documentados. No obstante, de acuerdo con ciertos, estos incidentes ocurren. Un estudio demostró que se habían dado casos de intoxicación en el 14,5\% de los 4.531 agricultores que cultivan hortalizas, flores y frutas en las Cameron $\mathrm{H}$ ighlands. El 32,1\% de los ingresos en los hospitales eran debidos a intoxicación accidental por pesticidas y el 67,9\% 
a casos de suicidio. En Tanjung $\mathrm{K}$ arang, una zona dedicada al cultivo de arroz, el $72 \%$ de los agricultores experimentaron síntomas de intoxicación al utilizar pesticidas, y rara vez utilizaban la ropa, las gafas, el calzado y las máscaras de protección respiratoria adecuados. En 1989, 448 trabajadores en contacto con pesticidas recibieron tratamiento médico en los hospitales estatales (L ee 1991).

Según otro estudio (Awang y cols. 1991) realizado en una zona predominantemente agraria, el $12,2 \%$ de los 264 casos de intoxicación tratados en un hospital universitario, se debieron a pesticidas. En otro estudio reciente (M ajid y cols. 1991), se registraron niveles de pseudocolinesterasa en suero, sustancia que es utilizada como indicador de la exposición a los organofosforados, y se encontró que era significativamente menor en los agricultores que cultivaban hortalizas: su nivel en sangre disminuye dependiendo del tiempo de exposición a estas sustancias.

El uso de pesticidas en M alaisia ha causado una gran preocupación. En un informe reciente elaborado por el Departamento de Industria y M aquinaria de M alaisia, un organismo que vela por el cumplimiento de la Ley de salud y seguridad en el Trabajo, se puso de relieve que la tasa de accidentes debidos a un uso inapropiado de pesticidas, es cuatro veces superior a la de otros sectores y asciende a 93 casos por cada 1.000 trabajadores, frente a la media nacional de 23 por 1.000 (Rengam 1991). Este nivel parece indicar que existe una carencia de material educativo y de información sobre seguridad, así como una obvia falta de cuidado en el manejo de pesticidas. En un informe de 1994 también se hace hincapié en las muertes de unas 70 reses, presuntamente causadas por una intoxicación por paraquat, como consecuencia de la entrada de las reses en una zona pulverizada con este pesticida ( $\mathrm{N}$ ew Straits T imes 1994).

O bviamente, hay una necesidad urgente, no sólo de recoger datos, sino también de educar a las personas que utilizan

Figura 22.4 - Flujo de información y acceso relacional en el sistema de información sobre pesticidas.

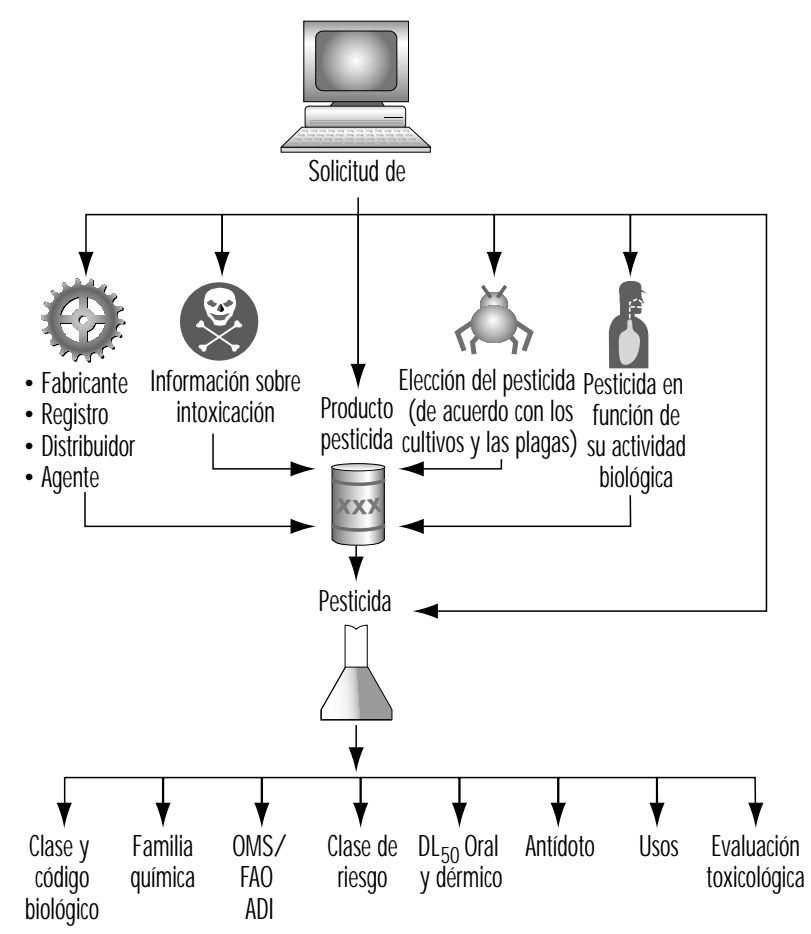

pesticidas. Por esta razón se creó un servicio de información sobre pesticidas y en 1989 comenzó a aplicarse un sistema de información piloto en todo el país. Este sistema forma parte del Servicio de Información Integral sobre Fármacos y T óxicos (IDPIS), con sede en la U niversidad de Sains M alaisia (USM ), en Penang.

EI objetivo principal del IDPIS es difundir información sobre cuestiones relacionadas con la salud, especialmente sobre el uso de fármacos y el control de tóxicos, a los profesionales de la salud y al público en general (R azak y cols. 1991).

El servicio de información sobre pesticidas, que comenzó a aplicarse a través del sistema videotex, ha tenido un efecto secundario beneficioso ya que ha brindado nuevas posibilidades a otras bases de datos importantes en materia de salud. Las bases de datos del IDPIS se utilizaron como guía para el desarrollo de otras dedicadas a la gestión de la información relacionada con pesticidas, productos químicos industriales o de uso doméstico y complementos nutritivos. El sistema Pestinfo fue uno de ellos; fue puesto en práctica por el IDIPS en colaboración con la Comisión de Pesticidas (el órgano regulador de estas sustancias en $M$ alaisia) y el Proyecto sobre Pesticidas M alayo-Germano. Esta iniciativa ha tenido un gran éxito en lo que respecta a la validación de información y a la evaluación de las necesidades de ésta teniendo en cuenta las tendencias en la utilización de pesticidas a escala nacional.

Este sistema se centra en los pesticidas registrados en Malaisia, pero también puede ofrecer información sobre los registrados en la región de Asia y el Pacífico. $\mathrm{H}$ asta la fecha, en el sistema de información sobre pesticidas se han incorporado datos sobre más de 500 sustancias bioquímicamente activas y se han catalogado los perfiles de aproximadamente unos 3.000 productos disponibles en el mercado y sus características. A este sistema se puede acceder por dos vías, por medio del sistema videotex, 0 a través de una red informática, basado en la utilización de ordenadores personales. El primer modo de acceso se denomina Pestinfo, y el segundo es el Sistema de Información sobre Pesticidas (véase la Figura 22.4).

\section{Pestinfo}

El sistema Pestinfo es el primero disponible en el región y funciona a través de TELITA, el Sistema Nacional de Videotex de $M$ alaisia. A través de la Compañía de Telecomunicaciones de $M$ alaisia, TELITA facilita un acceso a escala nacional rápido y barato. Se puede acceder a TELITA mediante una televisión y un decodificador, o de un sistema informático equipado con un módem conectado a la red telefónica (Siraj 1990). Este servicio resulta económico, ya que cada conexión cuesta sólo 0,13 M YR (menos de 0,05 dólares) y el precio por minuto es de sólo 0,08 MYR. El enfoque del servicio es único a escala internacional, ya que pueden acceder a él tanto profesionales como el público en general. La información en Pestinfo se combina con la de otras dos bases en línea estrechamente interrelacionadas (D rugline y Poisonline) para maximizar la oferta de información afín al usuario final.

A Pestinfo pueden acceder, tanto profesionales como el público en general, incluidos los trabajadores del sector agrario, tanto los trabajadores de pequeñas como de grandes extensiones. Todas las bases de datos están bien integradas y al mismo tiempo son independientes, lo que permite un acceso fácil a los datos pertinentes. Por está razón, el servicio Pestinfo se ha estructurado secuencialmente en un mínimo de 15 sub-categorías.

Los proveedores de asistencia sanitaria también pueden acceder directamente a Poisonline, una base en la que pueden consultarse datos más especializados sobre el tratamiento de pacientes en casos de intoxicación. 
De hecho, Poisonline es un módulo de información exhaustivo sobre distintos tipos de tóxicos, incluidos los productos farmacéuticos, las sustancias químicas de uso industrial y doméstico, los alimentos y los cosméticos. Facilita información sobre signos y síntomas de intoxicación de acuerdo con sistemas anatómicos, modalidades de tratamiento y control y aspectos de prevención de la intoxicación. Asimismo, ofrece detallada información sobre antídotos y procedimientos para tratamientos de urgencia.

EI Sistema de Comunicación de Intoxicaciones en línea es un servicio incorporado a Pestinfo y a Poisonline. Permite que el usuario final informe directa y electrónicamente, por medio de un formato especial, de los casos de intoxicación detectados. No sólo permite una documentación automática de todos los casos registrados, sino que también actúa simultáneamente como un sistema de referencia instantáneo, que facilita un seguimiento sistemático. A demás, gracias al sistema de comunicación, puede iniciarse un mecanismo de respuesta inmediata al usuario para ayudarle en el tratamiento de los casos de intoxicación. Los datos obtenidos a través del Sistema de Comunicación de Intoxicaciones son almacenados automáticamente en una red informática de ordenadores personales que permite informes estadísticos.

Por otra parte los usuarios de Pestinfo pueden acceder a varias bases de datos, de fácil uso, sobre enseñanza pública, en las que se presta especial atención a la salud, sobre todo en áreas de carácter farmacéutico. El objetivo de estas bases de datos es educar al público en general sobre el uso apropiado de medicamentos y productos químicos, y el mantenimiento de un buen estado de salud. La principal base de datos diseñada con este fin se denomina Public Infoline.

U na característica atractiva para la educación de los ciudadanos es el sistema "Pregunte a su farmacéutico", que consiste en un servicio de correo electrónico de preguntas y respuestas sobre cualquier asunto relacionado con la salud. Es gratuito para todos los usuarios.

\section{Sistema de Información sobre Pesticidas}

La experiencia inicial con Pestinfo ha dado lugar al desarrollo del Sistema de Información sobre Pesticidas, que brinda nuevas posibilidades de procesamiento de información para identificar casos de intoxicación, y puede servir como medio de referencia para los trabajadores agrarios y como mecanismo de recopilación de casos de intoxicación que podrían facilitar la toma de decisiones al formular políticas y la planificación de centros de salud. D ado que el sistema videotex no estaba suficientemente equipado para cubrir estas necesidades, se desarrolló una aplicación que ofrece varias funciones de búsqueda flexible utilizando un ordenador personal.

Como ya se ha mencionado, el Sistema de Información sobre Pesticidas se ha complementado con un sistema informático de red de fácil uso, conectado a la red, que puede utilizarse en

Figura 22.5 • Red del Sistema de Información Integrado sobre Medicamentos y Sustancias Tóxicas (IDPIS).

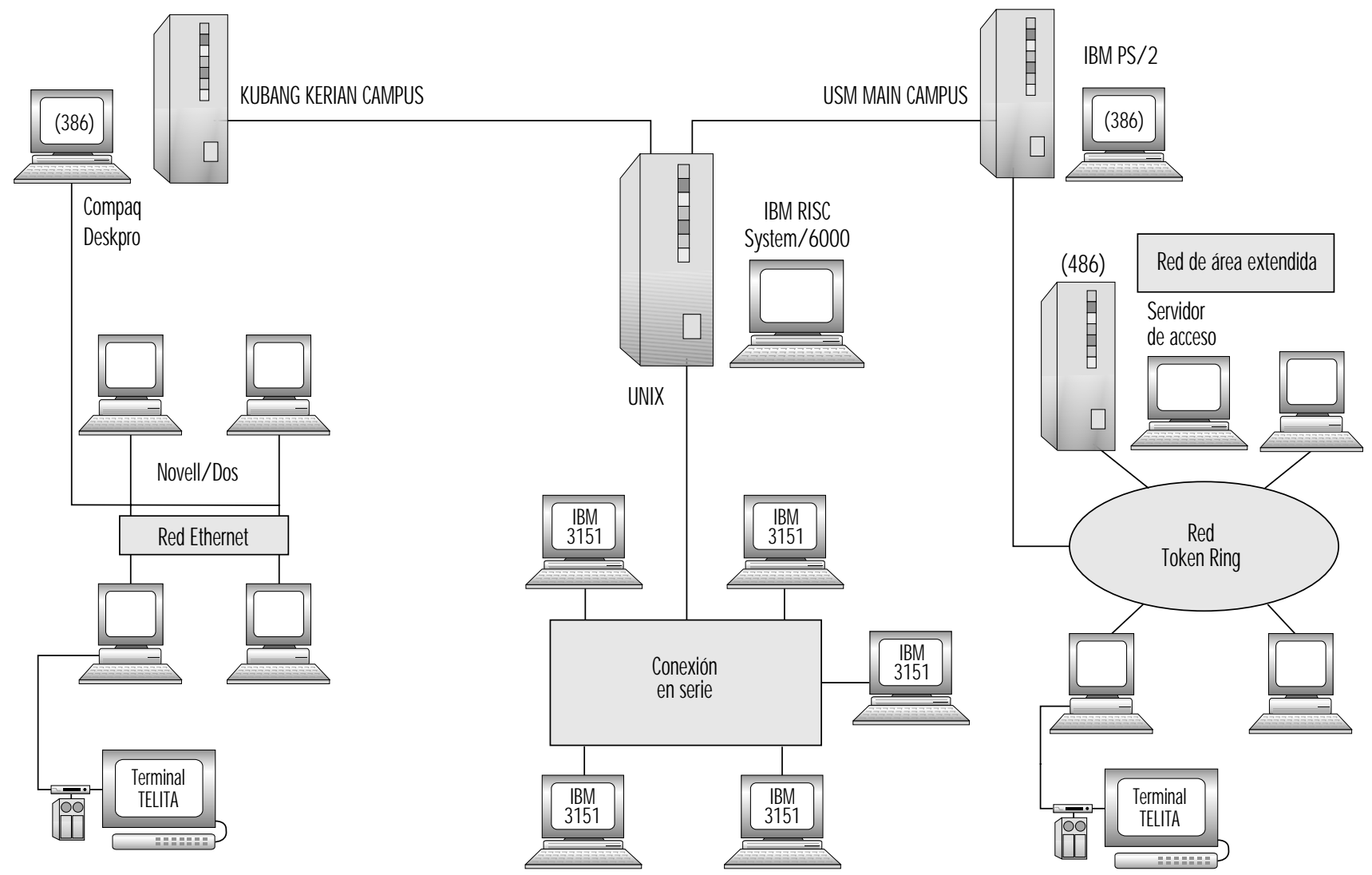


ordenadores personales compatibles IBM. El nombre de esta aplicación es Sistema de Información sobre Pesticidas Versión 2.3 y ha sido diseñada especialmente para actualizar de forma continua la información del sistema y para procesar los datos sobre intoxicaciones, recibidos electrónicamente o por otra vía. Puede adaptarse asimismo para la elaboración de informes estadísticos básicos, y cubrir otras demandas de gestión de datos estipulados en el software. Por tanto, es más flexible a la hora de recuperar información, dada la mayor capacidad interactiva y de procesamiento en cada ordenador personal. Fue diseñado usando dB ase3 Plus y recopilado con el Clipper Summer 5.0.

EI Sistema de Información sobre Pesticidas contiene información adicional importante, a la cual puede accederse rápidamente escribiendo el nombre del pesticida, su composición, su número de registro o el nombre del fabricante o propietario del registro de los productos declarados en el país. EI menú principal del sistema se describe en la Figura 22.4. El sistema esta especialmente indicado para su utilización por profesionales de la salud y por personal agrario, ya que puede cargarse en un ordenador portátil.

H asta la fecha, más del $50 \%$ de los casos de envenenamiento recibidos en línea están relacionados con pesticidas ( $L$ atieff y cols. 1991). No cabe duda de que la combinación de los dos modos de operación descritos ha mejorado la utilización del Sistema de Información sobre Pesticidas y ha facilitado la oferta de una respuesta aún más rápida a una amplia gama de consultas.

\section{Perspectivas para el futuro}

La tarea de recopilación y difusión de la información sobre pesticidas a los usuarios ha tenido mucho éxito, aunque se ha llevado a cabo de forma no oficial. EI IDPIS también ha adoptado una nueva orientación a la luz de los avances en informática y tecnología de las comunicaciones. Por ejemplo, los usuarios a escala nacional también podrán tener acceso a aplicaciones en la red, gracias a la colaboración de una empresa de comunicaciones que facilita conexiones de comunicación a todo el país. Esta prestación facilitará el intercambio de información sobre salud, ya que brinda soluciones asequibles tanto al usuario, como al IDPIS, como proveedor de información.

Actualmente, el IDPIS opera en dos redes, llamadas Token Ring y E thernet, con el fin de realizar trabajos de investigación y desarrollo en sistemas de información (Figura 22.5). La primera está instalada en el Hospital U niversitario. Ambas redes están conectadas con un IBM RISC 6000 para que la información y los recursos de los dos servidores puedan ser compartidos y coordinados para prestar servicios en materia de educación, formación e investigación. Las redes se diseñarán para incorporar un instrumento de vigilancia en las áreas de farmacoepidemiología y toxicovigilancia.

En 1996 IDPIS estableció su propio Homepage en Internet como M alaysian D rug and Poison N et, en http:/ / prn.usm.my.

\section{- EST UDIO DE CASO: UNA EXPERIENCIA DE GESTION DE INFORMACION EFICAZ EN TAILANDIA}

\section{Chaiyuth Chavalitnitikul}

\section{Antecedentes}

Tailandia cuenta con una población de 59 millones de habitantes y una superficie de 514.000 kilómetros cuadrados. El crecimiento de la población es del 1,7 \% anual. La población activa en 1995 ascendía a 34 millones de personas; 33 millones empleados y 1 millón desempleado. En el sector agrario trabajan unos 17 millones de personas, y unos 14 en el no agrario.

En el pasado, la economía de Tailandia era agraria y basada en una exportación conjunta de arroz y tapioca superior a la de cualquier otro país, pero en el período de 30 años comprendido entre 1960 y 1990, ha experimentado enormes cambios estructurales. El sector industrial ha pasado a ocupar el primer puesto en la contribución al PIB. Estas modificaciones han convertido a Tailandia en una de las economías de más rápido crecimiento en la región, caracterizada por una expansión acelerada del sector manufacturero que genera textiles, ropa, artículos eléctricos y electrónicos, joyas y otros productos dirigidos a los mercados mundiales y locales.

La Administración thailandesa considera con preocupación el bienestar de los trabajadores en los sectores industrial y agrario del país. Este interés ha dado lugar a la celebración de seminarios en los que se subrayó la necesidad de adoptar medidas eficaces que mejoren las condiciones de trabajo y el medio ambiente de los trabajadores en los diversos sectores y situaciones laborales. Teniendo en cuenta estas consideraciones, se creó el Instituto $\mathrm{N}$ acional para la $\mathrm{M}$ ejora de las Condiciones y el $M$ edio Ambiente de Trabajo (NICE) basado en los mecanismos de colaboración establecidos entre la Administración thailandesa y las Naciones U nidas. EI NICE se convirtió en una división del Departamento de Protección y Bienestar de los Trabajadores (DLPW), que se ocupa fundamentalmente de la protección de los trabajadores en Tailandia y trata de alcanzar sus objetivos mediante la consolidación de los procedimientos de los sistemas institucionales existentes y de sus prestaciones técnicas.

EI objetivo del NICE es mejorar la protección de los trabajadores frente a los accidentes y las enfermedades profesionales y las condiciones de trabajo poco satisfactorias. Sus actividades principales son las siguientes:

1. El desarrollo y la aplicación de programas de formación sobre salud y seguridad en el trabajo y condiciones de trabajo.

2. El desarrollo y la puesta en funcionamiento del sistema de información para la gestión (SIG) con el fin de centralizar toda la información recogida y ofrecer una base para la formulación de programas y políticas de planificación, evaluación y coordinación encaminadas a mejorar las condiciones y el medio ambiente de trabajo.

3. El desarrollo de un punto focal visible para el intercambio a escala nacional de información y conocimientos prácticos sobre las condiciones y el medio ambiente de trabajo.

4. La prestación de apoyo técnico para mejorar la capacidad del personal de inspección que se ocupa de las condiciones y el medio ambiente de trabajo.

5. La prestación de servicios de laboratorio en materia de higiene industrial, fisiología del trabajo y ergonomía y la comprobación de los equipos de seguridad.

6. La oferta de ayuda mediante la prestación de servicios de investigación y asesoramiento técnico, por ejemplo para la ampliación de la protección a las pequeñas empresas.

EI NICE dispone de una plantilla de 50 profesionales y está dividido en las secciones siguientes: Administración General, Medio Ambiente de Trabajo, Ergonomía y Fisiología del Trabajo, Tecnología de Seguridad, Formación y Promoción de la Seguridad, Centro de Información sobre Salud y Seguridad, $M$ edios Audiovisuales y 12 centros regionales en las áreas industriales de todo el país. 


\section{Centro Nacional de Información sobre Salud y Seguridad en el Trabajo de Tailandia}

Con el fin de mejorar la capacidad del NICE para satisfacer su objetivo con mayor eficacia, el Instituto, en colaboración con el Centro Internacional de Información sobre Seguridad y Salud en el Trabajo, creó el Centro $\mathrm{N}$ acional de Información sobre Salud y Seguridad en el Trabajo de Tailandia. El C entro se ocupa principalmente de la recogida de datos sobre salud y seguridad en el trabajo y condiciones de trabajo de Tailandia y de otros países, el tratamiento y el almacenamiento de esta información y su difusión a las empresas, los trabajadores, sus respectivas organizaciones y los órganos afines que la necesitan. El Centro de Información está compuesto por una biblioteca de consulta, una unidad de documentación, un servicio de consultas y una unidad informática.

\section{La biblioteca}

Cuando se inauguró, sólo disponía de algunos cientos de libros; actualmente, su colección comprende unos 3.000 títulos de libros y unos 20.000 de microfichas sobre diversas cuestiones relativas a la SST, como las enfermedades profesionales, la ingeniería de la salud y seguridad y las condiciones de trabajo. Por otra parte, desde 1983, la biblioteca está suscrita a 24 publicaciones en lengua inglesa y diez diarios thailandeses. D ispone además de 30 títulos en vídeo y carteles. La importancia de esta institución para los profesionales de la salud y la seguridad aumenta continuamente.

\section{La unidad de documentación}

La obligación de esta unidad consiste en elaborar un boletín sobre salud y seguridad en el trabajo, directrices, un manual y un código de prácticas, un folleto y fichas de información.

1. Boletín de salud y seguridad. Se elaboran anualmente cuatro boletines en el que se ofrecen actualizaciones, noticias sobre investigación, entrevistas, estadísticas, etc. Se editan 6.000 ejemplares de cada número.

2. Fichas de información. En ellas se abordan cuestiones divididas en cuatro grupos:

- Salud y seguridad en general, por ejemplo, construcción en condiciones de seguridad, prevención de incendios y ventilación del lugar de trabajo.

- U tilización práctica de la seguridad, por ejemplo, en el uso seguro de las herramientas manuales 0 de los equipos eléctricos

- Datos sobre sustancias químicas como pueden ser los relacionados con el hidróxido de sodio o el amoniaco.

- L egislación sobre seguridad, como la relativa a la seguridad del medio ambiente de trabajo, etc.

3. R ecientemente, la unidad de documentación editó 109 títulos de fichas informativas e imprimió 10.000 ejemplares de cada una, lo que representa en total más de un millón de ejemplares.
4. Directrices, manuales y códigos de prácticas. A mediados del decenio de 1990 se habían editado 15 títulos de esta publicación; por ejemplo, uno de ellos incluía directrices para el manejo seguro de pesticidas y un manual de primeros auxilios en el sector. De cada publicación se imprimen 3.000 ejemplares.

5. Folletos. Se han editado diez títulos, por ejemplo, sobre la utilización de tapones para los oídos en el trabajo. De cada título se imprimen 5.000 ejemplares, lo que representa un total de 50.000 copias.

\section{EI servicio de consultas}

Se creó con el fin de buscar respuestas a las preguntas sobre salud y seguridad en el trabajo planteadas por las personas interesadas en esta materia: inspectores de trabajo, funcionarios competentes en cuestiones de seguridad, empresas, trabajadores, estudiantes y otros agentes. Las consultas pueden dirigirse al Centro por correo, teléfono o fax. Antes de remitir una respuesta, el personal técnico del NICE comprueba la exactitud de la información.

Cada año se hacen unas 600 consultas al $C$ entro.

\section{La unidad informática}

Como punto focal para la recogida y el intercambio de información, conocimientos prácticos y experiencias en el área de la salud y la seguridad en el trabajo, el NICE ha creado varias bases de datos: sobre centros industriales, informes de investigación de accidentes, informes de la inspección de trabajo, funcionarios expertos en materia de seguridad, instalaciones para control de riesgos, informes de inspección de calderas, informes de la inspección de medio ambiente de trabajo e informes sobre exploración selectiva de la salud de los trabajadores. Para mejorar la capacidad de esta unidad, el NICE ha desarrollado un sistema informático centralizado que actuará como base central de datos sobre salud y seguridad en el trabajo. Esta tarea ha sido llevada a cabo con la ayuda del C entro Internacional de Investigación para el Desarrollo (IDRC) y la Organización Internacional del Trabajo. Por otra parte, se ha establecido una red de área local (LAN) entre el NICE y el resto de Centros Regionales de Salud y Seguridad en el Trabajo. Este vínculo facilitará el acceso del personal de estos $C$ entros a la información de las bases de datos del NICE y de varias bases de datos en CD-ROM en la unidad informática del Instituto.

Con el fin de fomentar como objetivo directo la mejora de las condiciones de trabajo y la SST de los trabajadores thailandeses, los servicios del NICE son gratuitos y el Instituto financia en la actualidad a todos los inspectores de trabajo, unos 5.000 funcionarios competentes en materia de seguridad, unos 650 sindicatos organizados de medianas y grandes empresas y a empresarios y trabajadores de todo el país. Por tanto, el NICE sigue avanzando en el desarrollo y la consolidación de su capacidad para proteger a los trabajadores respecto al rendimiento poco satisfactorio y las lesiones debidas a la inseguridad de las condiciones laborales y a los riesgos del medio ambiente de trabajo. 


\section{Referencias}

A beytunga, PK, HC de Jonge. 1992. Repetitive motion injuries: An interactive training package En Computer Applications in Ergonomics, Occupational Safety and Health-Proceedings of the CAES ' 92 Symposium, dirigido por M M attila y W K arwowski. Amsterdam: Elsevier Science.

Awang, R, NA Samah, DS Razak, AA Latiff, MB Bahari, MIA M ajid, R Ariffin, P Ibrahim.1991. $M$ onitoring of poisoning cases involving natural toxins in a teaching hospital in Kelantan. Presentado en el 10 Congreso mundial sobre toxinas animales, vegetales y microbianas; 3-8 de noviembre.

Bretherick, L. 1979. H andbook of Reactive Chemical $\mathrm{H}$ azards. Londres: Butterworth.

$\mathrm{C}$ anadian $\mathrm{C}$ entre for $\mathrm{O}$ ccupational $\mathrm{H}$ ealth and Safety (CCOHS). 1996. CCINFO disc Series A, B, and C. $\mathrm{H}$ amilton, $\mathrm{O}$ ntario: $\mathrm{CCOHS}$

Grayson, M, D Eckroth. 1985. Kirk-0thmer Concise Encyclopedia of Chemical Technology. Nueva Y ork: Wiley.

Hommel, G. 1987. H andbuch der gefährlichen Güter. Berlín: Springer V erlag.

H unter, D. 1978. The Diseases of O ccupations. Londres: H odder y Stoughton.

Jeyaratnam, J. 1990. Acute pesticide poisoning: A major global health problem. W orld $\mathrm{H}$ ealth Stat Q 43:139-144.

K jellén, U. 1993. Analysis and D evelopment of Corporate Practices for Accident Control. Estocolmo: The Royal Institute of T echnology.

Latiff, AA, DA Razak, R Awang, MIA M ajid, ABA $M$ ajeed, AH Hussin, SH H ussain. 1991. Malaysian Integrated Drug and Poison Information Service: A ten years experience. Presentado en el Seminario sobre esperiencias globales de los Centros de información toxicológica; 9 de noviembre.

Lee, SA. 1991. M inimising occupational exposure to pesticides. Presentado en el Seminario sobre gestión del riesgo de los pesticidas agrícolas. K uala Lumpur, 13 de agosto.

Majid, MIA, DA Razak, AA Latiff, R Awang, MB Bahari, ABA Majeed, SH Hussain, AH Hussin. 1991. Exposure of organophosphates among vegetable farmers in Penang. Presentado en la Conferencia internacional sobre toxicología ambiental e industrial: investigación y aplicaciones. Bangkok, 21-25 de julio.

$\mathrm{New}$ Straits Times. 1994. Cattle died of paraquat poisoning. 5 de enero.
O rganización Internacional de Normalización (ISO). 1993a. ISO Standard 10162. O pen Systems Interconnection - Search and Retrieve Application Service D efinition. Ginebra: ISO

-. 1993b. ISO Standard 10163-1. O pen Systems Interconnection - Search and R etrieve Application Protocol Specification-Part 1: Protocol Specification. Ginebra: ISO.

O rganización Internacional del Trabajo (OIT). 1988. $\mathrm{M}$ ajor $\mathrm{H}$ azard Control- A Practical M anual. G inebra: ILO.

Patty's Industrial H ygiene and Toxicology, dirigido por LJ Cralley, LV Cralley, y JS Bus. 1978. Nueva Y ork: Wiley.

Razak, DA, AA L atiff, R A wang, MIA M ajid, ABA $M$ ajeed, AH Hussin, SH Hussain. 1991. Poison control and information: Their implications in poison prevention and treatment. Presentado en el Seminario sobre gestión del riesgo de los pesticidas agrícolas. K uala L umpur, 13 de agosto.

Rengam, S. 1991. Poisoned harvest: Pesticide problems in Asia. Presentado en Mujeres y pesticidas: seminario de formación. Kuala Lumpur, 3-8 de junio.

Robert, M. 1983. Information and documentation. En Enciclopedia de salud y seguridad en el trabajo, dirigida por L Parmeggianni. Ginebra: OIT.

Saarela, K L. 1991. Promoting Safety in Industry: Focus on Informative Campaigns and Participative Programs. $H$ elsinki: H elsinki U niv. of T echnology.

Sax, NI, RJ Lewis Sr. 1989. Dangerous Properties of Industrial M aterials. Nueva Y ork: Van Nostrand Reinhold.

Shariff, N. 1993. Precaution vital when using paraquat. N ew Straits T imes. 20 de diciembre.

Siraj, M F. 1990. T elita: M alaysia's N ational V ideotex Service. ST M J 2(1):50-55

Takala, J. 1992. Safety and health information systems: Analysis of local, national and global methods. T esis doctoral, T ampere U niversity of T echnology, T ampere, Finlandia.

-. 1993. CD-ROMS and databases as vehicles for chemical safety information. Am Ind $\mathrm{H}$ yg Assoc 5(11):683-696.

Takala, J, E Clevenstine, I Fedotov, M Nahmias, I O badia, G Sándi. 1992. Sources of information in occupational health practice. En Occupational $\mathrm{H}$ ealth in Developing Countries, dirigido por J Jeyaratnam. O xford: O UP.

Tan, SH, HF Yeoh, Z K arim, M Yusof. 1992. Pesticide use and control in M alaysia. Presentado en el Seminario sobre impacto ambiental de los pesticidas en la agricultura y el ecosistema. K uala Lumpur, 27-28 de noviembre.
Tara, HS, ET Chang, KP Tham, M Jusoh, PW Ng. 1989. Toxicological analytical facilities in Malaysia. Presentado en la 1ạ Reunión internacional malayo/ asiática sobre prevención y gestión de las intoxicaciones. Kuala Lumpur, 27-28 de noviembre.

Tarrants, WE. 1980. The M easurement of Safety Performance. Nueva Y ork: G arland ST PM Press.

Viscusi, WK. 1987. Learning About Risk. Cambridge, $M$ ass: $H$ arvard U niv. Press.

Wood, N, R Philipp, J Colley. 1988. O n-line medical database searching. J Soc 0 ccup M ed 38(3):73-76.

\section{0 tras lecturas recomendadas*}

Atherley, G. 1990. CCINFO social setting, description, performance, policy, strategy and future. En Conferencia para especialistas en información sobre salud y seguridad e higiene en el trabajo. Luxemburgo, 26-28 junio 1989 - Actas. Bruselas: CCE.

Atherton, P. 1977. H andbook for Information Systems and Services. París: U NESCO.

Date, CJ. 1985. An Introduction to D atabase Systems. V ol. I. R eading, M ass: Addison-W esley.

Guinchat, C, M M enou. 1983. General Introduction to the T echniques of Information and Documentation W ork. París: UNESCO

Institute of Occupational Health (IOH). 1987. Successful Accident Prevention: R ecommendations and I deas Field Tested in the Nordic Countries, Reviews 12. $\mathrm{H}$ elsinki: $\mathrm{IOH}$.

Jackaman, P. 1985. B asic R eference and Information W ork. $H$ untingdon, RU : ELM

Järvenpää, $A E$. 1990. H acia una tecnología segura (en finés). $\mathrm{O}$ tatieto $\mathrm{O}$ y, Finlandia: $\mathrm{H}$ ämeenlinna.

Leakey, RE, R Lewin. 1978. Origins. Nueva York: Dutton.

McAfee, RB, AR Winn. 1989. The use of incentives/ feedback to enhance work place safety: A critique of the literature. J Saf Res 20(1):7-19.

Naciones Unidas. 1985. Modern M anagement and Information Systems for Public Administration in D eveloping C ountries. N ueva Y ork: N aciones U nidas.

Petersen, D. 1989. Safe B ehavior Reinforcement. Nueva Y ork: Aloray.

SilverPlatter. N.d. Directory of CD-ROM. Londres: SilverPlatter.

Stanton, J, RP Wells, S Rochowansky, M M ellin. 1985. Apple Software 1985. Los Angeles: The Book Company.

* Estas lecturas no pretenden ser una lista actualizada de referencias y recursos electrónicos. 


\section{RECURSOS INSTITUCIONALES, ESTRUCTURALES Y JURIDICOS}

Directores del capítulo

Rachael F. T aylor y

Simon Pickvance

\section{Sumario}

0 rígenes, medios institucionales, estructurales y jurídicos: introducción

Simon Pickvance.

Inspección de trabajo

W olfgang von Richthofen.

Responsabilidad civil y penal en el campo de la

salud y seguridad en el trabajo

Felice M orgenstern (Adaptación) . . . . . . . . . . . . . . . . 23.16

La salud en el trabajo como derecho humano

Ilise L evy Feitshans ${ }^{*} \ldots \ldots \ldots \ldots \ldots \ldots \ldots \ldots \ldots \ldots \ldots .23 .24$

AMBITO COMUNITARIO

O rganizaciones de ámbito comunitario

Simon Pickvance. . . . . . . . . . . . . . . . . . . . . . . . . . . . . . . 23.32

Derecho de saber: función de las organizaciones

de ámbito comunitario

Carolyn N eedleman

El movimiento $\mathrm{COSH}$ y el derecho a conocer

J oel Shufro....

EJEMPLOSDE AMBITO REGIONAL YNACIONAL

Salud y seguridad en el trabajo: la U nión Europea

Frank B. W right

L egislación tutelar de los derechos de los trabajadores en China

SuZhi ............................. 23.40

Estudio de caso: normas de exposición rusas

Nikolai F. Izmerov
ORGANIZACIONESINTERNACIONALES

GUBERNAMENTALES Y NO GUBERNAMENTALES

Cooperación internacional en la salud laboral:

función de las organizaciones internacionales

G eorges H. Coppée . . . . . . . . . . . . . . . . . . . . . . . . . . . . 23.42

L as N aciones U nidas y sus agencias especializadas. . . . . . . 23.48

O rganización Internacional del Trabajo

Georg R. Kliesch ............................ 23.53

Convenios de la OIT: procedimiento ejecutivo

Anne Trebilcock ......................... 23.58

O rganización Internacional de N ormalización (ISO )

Lawrence D. E icher. . . . . . . . . . . . . . . . . . . . . . . . . . . . . 23.60

A sociación Internacional de la Seguridad Social (AISS)

Dick J. M ertens ............................ 23.63

Comisión Internacional de M edicina del

Trabajo (CIM T)

J erry J eyaratnam . . . . . . . . . . . . . . . . . . 23.67

Asociación Internacional de Inspectores

de Trabajo (IALI)

D avid Snowball . 


\section{O ORIGENES, MEDIOS INSTITU CIONALES, ESTRUCTURALES Y JURIDICOS: INTRODUCCION}

\section{Simon Pickvance}

Las estructuras nacionales e internacionales relacionadas con la salud y seguridad en el lugar de trabajo se han desarrollado rápidamente en los últimos 25 años, en respuesta a una preocupación creciente por la salud de los trabajadores. Este proceso se ha producido en el marco de unos cambios económicos, políticos y sociales.

Entre las causas económicas están la pérdida de poder de los trabajadores en favor de las empresas multinacionales y los órganos legislativos supranacionales, la modificación de la competitividad relativa de los distintos estados en el contexto de la economía mundial y los cambios tecnológicos introducidos en el proceso productivo. Entre las causas sociales destacan los progresos de la medicina y la consiguiente elevación de las expectativas sanitarias, y la creciente aprehensión respecto a los efectos de los avances científicos y tecnológicos sobre el medio ambiente, dentro y fuera del lugar de trabajo. Entre los factores políticos pueden citarse la demanda de una mayor participación en la vida política que se observa en muchos países desde el decenio de 1960, la crisis del sistema de bienestar social en algunas de las naciones desarrolladas más maduras y una mayor sensibilidad hacia las prácticas de las multinacionales en los países en vías de desarrollo.

Los sindicatos han contratado los servicios de expertos en salud y seguridad para que asesoren a los afiliados y negocien en representación de las organizaciones sindicales en los ámbitos local y nacional. En los últimos diez años se ha producido una rápida proliferación de las asociaciones de víctimas de enfermedades profesionales, que puede considerarse como una reacción a las dificultades específicas que estas personas afrontan allí donde la prestación de servicios sociales es inadecuada. Ambos procesos se han reflejado en el ámbito internacional por la creciente importancia que las confederaciones sindicales internacionales y las conferencias internacionales de los trabajadores de determinados sectores industriales vienen concediendo a la salud y la seguridad. En varios capítulos de esta Enciclopedia se analizan las cuestiones jurídicas y estructurales relacionadas con las organizaciones de trabajadores, las asociaciones de empresarios y las relaciones laborales.

L os cambios experimentados por las organizaciones empresariales y los organismos públicos en estos últimos años tienen un carácter, en parte pasivo, y en parte de mayor impulso. Las leyes promulgadas en los últimos 25 años han constituido, en cierta medida, una respuesta a las preocupaciones que los trabajadores han venido expresando desde finales del decenio de 1960 y, en parte, un esfuerzo por regular el rápido desarrollo experimentado por las nuevas tecnologías de producción durante el período de posguerra. L as estructuras organizativas establecidas en las diversas normativas legales constituyen, ciertamente, un reflejo de los respectivos ordenamientos jurídicos y culturas nacionales, en los que existen elementos comunes. Entre estos destaca la mayor importancia atribuida a los servicios de prevención y a la formación de los trabajadores, directivos y especialistas en salud y seguridad; la creación de estructuras de participación y consulta, tanto en el lugar de trabajo, como en el ámbito nacional; y la reestructuración de las inspecciones de trabajo y de otros cuerpos del estado relacionados con el cumplimiento de la normativa. En diferentes estados se han establecido sistemas de cobertura por seguros a los trabajadores víctimas de accidentes de trabajo o de enfermedades profesionales, así como de vinculación de las organizaciones implicadas en la salud y seguridad a otros entes públicos orientados al empleo y al medio ambiente.

L os cambios estructurales de este tipo generan nuevas necesidades de formación de los profesionales afectados: inspectores, técnicos de seguridad, higienistas industriales, ergónomos, psicólogos y médicos del trabajo, y profesionales de la enfermería del trabajo. Las asociaciones y organizaciones profesionales abordan los problemas de la formación en los planos nacional e internacional, y las principales profesiones se reúnen en congresos internacionales para establecer normas generales y códigos de prácticas.

La investigación es una parte esencial de los programas de prevención estructurada y correctora. Los distintos gobiernos son la mayor fuente de financiación de la investigación, que se dirige principalmente a los programas nacionales de investigación. En el ámbito internacional existen, además de la O rganización Internacional del Trabajo (OIT) y la Organización M undial de la Salud (OMS), diversas instituciones dedicadas a la investigación, como el Instituto Europeo de Seguridad Conjunta y la Agencia Internacional de Investigación sobre el Cáncer, dedicados a desarrollar programas internacionales de investigación de la salud y seguridad en el trabajo.

Si bien la OIT, la OMS y otras organizaciones de la ONU han incorporado a su normativa su preocupación por la salud y la seguridad en el trabajo desde la Segunda Guerra M undial o, incluso, antes, muchos organismos internacionales vinculados a la salud laboral no han cumplido 25 años. La salud y seguridad son actualmente un asunto de especial preocupación para los organismos de comercio mundial y las organizaciones regionales de libre comercio, por lo que los efectos sociales de los acuerdos de libre comercio se suelen abordar en las respectivas negociaciones. La O rganización para la Cooperación y el Desarrollo E conómico $(O C D E)$, evalúa las políticas de salud y seguridad aplicadas en los distintos países, además de las magnitudes puramente económicas. EI prolongado debate en torno a la inclusión de una cláusula social en las negociaciones del GATT ha puesto nuevamente de relieve esta vinculación.

Es preciso que se reconozca la autoridad de las organizaciones nacionales e internacionales para que funcionen con eficacia. La autoridad de los órganos legislativos y ejecutivos dimana de las leyes, y la autoridad de las instituciones dedicadas a la investigación se basa en la aplicación de los métodos científicos aceptados. Sin embargo, el desplazamiento del poder legislativo y de la capacidad negociadora de acuerdos sobre salud y seguridad en el trabajo hacia las organizaciones internacionales plantea problemas a la autoridad y legitimidad de otras entidades, como las asociaciones de empresarios y las organizaciones de trabajadores.

La autoridad de la empresa dimana de la utilidad social de los productos y servicios que suministra, al tiempo que las organizaciones de trabajadores deben su posición negociadora a unas estructuras democráticas que les permiten reflejar los puntos de vista de los afiliados. Estos criterios de legitimidad son más difíciles de implantar en las organizaciones internacionales. Es probable que la creciente globalización de la economía traiga una política de coordinación cada vez mayor entre todas las facetas de la salud y seguridad en el trabajo, con especial atención a unas normas generalmente aceptadas sobre prevención, indemnización, formación profesional y supervisión. El problema de las organizaciones que se desarrollen en respuesta a estas necesidades consistirá en mantener su autoridad mediante una relación dinámica e interactiva con los trabajadores y el lugar de trabajo. 


\section{- INSPECCION DE TRABAJO}

\section{Wolfgang von Richthofen}

El Convenio sobre la Administración del Trabajo, 1978 (no 150) de la O IT y la correlativa Recomendación no 158 han sentado las bases del desarrollo y funcionamiento de los modernos sistemas de administración del trabajo. Ambos documentos internacionales aportan valiosas directrices y una referencia a las diversas administraciones nacionales del trabajo para la valoración, la función, la orientación, la estructura y las competencias, así como el actual cumplimiento de su gestión.

El objeto de la administración del trabajo es la gestión de los asuntos públicos en el campo del trabajo, lo que, en su sentido tradicional, puede abarcar la totalidad de los asuntos que afectan al conjunto de la población económicamente activa en cualquier sector. Esta interpretación, aunque genérica, se apoya en el texto del citado Convenio no 150, en el que la administración del trabajo se define como "las actividades de la administración pública en materia de política nacional del trabajo". Entre estas actividades se suelen incluir las siguiente:

- formulación de políticas, incluida la elaboración de directrices para las nuevas iniciativas;

- elaboración de proyectos de nuevas leyes que, con sus reglamentos, den una formulación positiva a las políticas de trabajo;

- elaboración de proyectos y programas, y planificación de actividades que sirvan de apoyo a la aplicación de las políticas;

- configuración de políticas, incluida la formulación y discusión de nuevas iniciativas;

- aplicación de políticas, incluidas la aplicación de la legislación laboral y la prestación de asesoramiento sobre su observancia;

- supervisión y evaluación de la aplicación de las políticas;

- información y difusión del conocimiento de las cuestiones de política y legislación laboral.

De esta definición genérica se deduce que la administración del trabajo puede exceder del ámbito de las competencias y funciones típicas de los ministerios de trabajo (empleo, asuntos sociales, etcétera), dado que "el ámbito de la política de trabajo puede afectar a varios ministerios, departamentos, entes públicos y otras funciones públicas ajenas al campo del trabajo".

Es preciso, por tanto, pensar desde la perspectiva de un sistema de administración del trabajo compuesto de diversos elementos que se relacionan y se condicionan mutuamente para formar una unidad sinergética. El componente básico que aglutina los demás es la política laboral, en la que se incluyen todas las actividades que se realizan en su marco. Si bien éste varía de un sistema nacional a otro por causas históricas, políticas, económicas, sociales 0 de otro tipo, suele comprender las relaciones laborales, la inspección de trabajo, la seguridad en el trabajo, la salud laboral, la indemnización por accidente de trabajo, los servicios de empleo, el fomento del empleo, la formación, orientación y asesoramiento profesionales, la evaluación y certificación profesional, la planificación de los recursos humanos, la información laboral y del empleo, los trabajadores extranjeros y permisos de trabajo, los grupos vulnerables y desfavorecidos, la estadística laboral y, ciertamente, otras cuestiones.

De lo anterior se infiere que los sistemas de administración del trabajo suelen ser complejos, que se deben coordinar en todos los niveles para alcanzar su objetivo, y que son sistemas dinámicos en el sentido de que, según el Convenio no 150 de la O IT, comprenden "todos los órganos de la administración pública" y "toda estructura institucional" asociada a la política nacional de trabajo. Finalmente, se infiere de esta normativa internacional que la inspección de trabajo debe ser parte integrante de la administración del trabajo, y que, en el ámbito de la protección del trabajador (que comprende, aunque no únicamente, la salud y seguridad en el trabajo) la inspección de trabajo es la herramienta operativa que todo sistema de administración del trabajo utiliza para garantizar el cumplimiento de la política y la legislación laboral de ámbito nacional. En palabras de un antiguo Director $G$ eneral de la OIT: "La legislación laboral sin inspección es, más un tratado de ética, que una normativa socialmente vinculante".

\section{Dos niveles de la inspección de trabajo}

La inspección de trabajo, como parte integrante de la administración del trabajo, se suele estructurar en dos niveles: las inspecciones de trabajo, dedicadas principalmente a la actividad de campo, y la autoridad central, dedicada a la formulación y supervisión de la aplicación de las políticas y a la elaboración y gestión de los programas. Es evidente que los servicios de inspección y la autoridad central deben colaborar estrechamente.

\section{Servicios de campo}

La inspección de trabajo desempeña sus funciones de inspección y asesoramiento por medio de unos servicios de inspección que constituyen su fundamento y que le confieren, respecto a otros servicios, la ventaja de su contacto directo con el mundo del trabajo en el ámbito de la empresa, esto es, con los directivos y trabajadores, que constituyen la población activa de un país.

Recíprocamente, la supervisión de las empresas permite a la inspección facilitar a la administración central una información pormenorizada, que sólo puede conseguirse en las visitas y reuniones con los agentes sociales, sobre el clima social, las condiciones y el medio ambiente de trabajo y las eventuales dificultades para aplicar la legislación, que pueden obedecer a una insuficiencia de la función disuasoria de los tribunales de justicia, a problemas con las autoridades regionales, a la presión ejercida por algunas empresas que se prevalen de su posición económica, y a la falta de coordinación en la actuación de los diversos servicios públicos. Los servicios de inspección se encuentran igualmente en una situación única para poner de manifiesto, como exige la normativa internacional, posibles fallos y abusos no previstos en las disposiciones legales.

Según el artículo 2 ( $M$ inería y transporte) del Convenio sobre la inspección del trabajo en la industria y el comercio, 1947 (no 81) de la OIT, los inspectores de los servicios locales están obligados "a presentar a la autoridad central (...) informes periódicos sobre los resultados de sus actividades". Esta disposición, recogida igualmente en el Convenio relativo a la inspección del trabajo en la agricultura, 1969 (no 169) confiere a los Estados una amplia autonomía para determinar la forma, el contenido y la frecuencia de los informes. Sin embargo, se trata de una disposición clave, tanto para la continuidad de los contactos entre los inspectores y el organismo central, como para informar a éste de la situación económica y social de las regiones y hacer posible que el mismo formule y aplique su política nacional de inspección, así como para la elaboración de un informe anual sobre la actividad de los servicios de inspección, destinado a ser distribuido nacionalmente, de conformidad con las obligaciones internacionales contraídas.

\section{La autoridad central}

La administración central dirige la inspección de trabajo (o bien, en el caso de muchos sistemas federales, las inspecciones estatales) y afirma su posición en la organización de la estructura del ministerio responsable de la gestión de la política laboral y de la administración del Estado. Ciertamente, la realización de las tareas de inspección no depende únicamente de la iniciativa personal de los inspectores, si bien ésta es de capital importancia. L os inspectores de trabajo no actúan aisladamente; son parte de una 
administración y aplican una serie de directrices administrativas nacionales.

La primera medida de toda gestión consiste en elaborar un presupuesto, aprobarlo y administrarlo. El presupuesto es un reflejo de las opciones sociales del Gobierno, y sus magnitudes traducen el montante de los recursos concedidos a los distintos servicios. En este sentido, pueden ser de utilidad las consultas con las organizaciones sindicales, que están interesadas en la eficacia de la inspección.

Dirigir significa también formular una política de protección de los trabajadores, enunciar los principios inspiradores de la inspección de trabajo, establecer un orden de prioridades en función de las características de las diversas ramas de actividad y del tipo de empresas y los resultados que generan, racionalizar la actividad (política de aplicación), perfeccionar los métodos y programas, promover y coordinar los distintos servicios, evaluar los resultados y formular recomendaciones para mejorar el funcionamiento de la inspección.

Corresponde a la autoridad central brindar a los servicios periféricos unas instrucciones lo suficientemente claras para garantizar la interpretación coherente y congruente de las disposiciones legales en el conjunto del país. Esto se suele lograr mediante una política global de aplicación de ámbito nacional, elaborada, por regla general (y a ser posible) previa consulta con las organizaciones más representativas de los agentes sociales. Por último, la autoridad central debe gestionar sus recursos humanos, impartirle formación profesional y de reconversión (política de formación), garantizar su independencia y la observancia de la ética profesional, y evaluar periódicamente el trabajo de los funcionarios.

De conformidad con las disposiciones de los Convenios no 81 y 129 de la O IT, la autoridad central debe elaborar un informe anual cuyos elementos esenciales se citan en los artículos 20 y 21, relativos al trabajo de los servicios de inspección. La publicación de estos informes dentro de los doce meses siguientes al final del año al que se contraen permite que los trabajadores, empresas y organismos interesados conozcan la labor de la inspección. Estos informes, que se comunican a la O ficina Internacional del Trabajo dentro de los tres meses siguientes a su publicación, sirven de base a un estudio extremadamente útil de los sistemas vigentes y los resultados obtenidos en los Estados miembros y, en su caso, hace posible que los servicios de la OIT recuerden sus obligaciones a los Estados miembros. L amentablemente, esta comunicación, obligatoria para todos los Estados miembros que han ratificado el Convenio, se suele incumplir con demasiada frecuencia.

Corresponde, finalmente, a la autoridad central transmitir la información recibida de los servicios de inspección, tanto a los órganos de asesoramiento que funcionan en el ministerio (por ejemplo, el comité nacional de salud y seguridad y la mesa de seguimiento de los convenios colectivos), como a los demás ministerios afectados y a los agentes sociales. A simismo, la autoridad central utiliza esta información para adoptar las iniciativas precisas, tanto en la labor de inspección, como en la elaboración de proyectos de leyes y reglamentos. En resumen, estas publicaciones constituyen una ayuda inestimable para que la inspección de trabajo documente su actividad y los resultados conseguidos en los ámbitos nacional e internacional.

\section{Colaboración técnica}

En los Convenios no 81 y no 129 de la OIT se expone la necesidad de adoptar medidas de promoción de la cooperación entre los servicios de inspección de trabajo y otros servicios prestados por organismos estatales o por instituciones públicas o privadas dedicadas a realizar actividades similares.

\section{Colaboración con otros servicios de la administración del} trabajo

La primera medida consiste en establecer relaciones de cooperación con los demás servicios de administración del trabajo, tanto centrales, como locales. L as distintas competencias de la administración del trabajo - condiciones de trabajo, salud y seguridad, salarios, empleo, relaciones laborales, seguridad social y estadística- suelen estar íntimamente asociadas y se deben abordar como un todo.

La autoridad central debe compartir su información y colaborar en la elaboración de una política y unas directrices comunes, para su aprobación por el ministerio o ministerios competentes o por el organismo central de planificación. En el plano local, la inspección de trabajo debe mantener unos contactos regulares, principalmente con los servicios de empleo, con los organismos que atienden a los trabajadores extranjeros y con los servicios vinculados a las relaciones laborales (siempre que éstas sean competencia de los servicios especializados).

En los países en que funcionan varios servicios de inspección de trabajo, bien adscritos a un mismo ministerio (como en Bélgica), bien dependientes de distintos departamentos estatales, se impone el establecimiento de unas relaciones estrechas de colaboración para el intercambio de información, la formulación de métodos y sistemas de actuación y la elaboración de unos programas conjuntos de actividad. La efectividad del trabajo realizado por los diversos servicios es una función directa de la calidad de la cooperación entre los mismos; sin embargo, la experiencia demuestra que, en la práctica, esta cooperación resulta sumamente difícil de establecer y que, en el mejor de los casos, es sumamente costosa, tanto desde el punto de vista del tiempo, como de los recursos utilizados. Esto hace que, por regla general, la cooperación no disfrute de prioridad. O tra consecuencia de este problema es la dificultad de aplicar el imprescindible enfoque global de la prevención como objetivo primario de la inspección de trabajo.

\section{Colaboración con la administración de la seguridad social}

En muchos países, una parte de los servicios de la seguridad social, concretamente, los responsables del seguro de indemnización por accidente de trabajo y enfermedad profesional, se ocupan también de la prevención de los riesgos profesionales. 0 tros peritos oficiales realizan verificaciones en las empresas para determinar las medidas que deben aplicarse. En algunos países, como Nueva Gales del Sur (Australia) y Zimbabwe, la inspección de trabajo depende del sistema de la seguridad social. En otros, como Francia y Alemania, funciona un cuerpo de inspectores paralelo e independiente. En un tercer grupo de países, como Suiza, se remunera a la inspección de trabajo en proporción a la actividad de inspección orientada a la prevención de problemas de salud y seguridad en las empresas. Si bien la actividad de los empleados de la seguridad social no se deriva directamente de la autoridad del Estado, excepto en los casos en que ostenten la calidad de funcionarios públicos, como en Nueva Gales del Sur y en Zimbabwe, sus actuaciones pueden Ilevar aparejadas consecuencias financieras, que pueden consistir en un incremento de las cotizaciones de las empresas con una tasa de siniestralidad elevada que no apliquen las recomendaciones recibidas. En cambio, las empresas que realizan un esfuerzo efectivo de prevención pueden beneficiarse de una reducción de las cotizaciones sociales o de préstamos concedidos en condiciones especialmente ventajosas para continuar su trabajo. Evidentemente, este sistema de castigos y recompensas (primas y sanciones) constituye un método eficaz de presión.

La colaboración entre el servicio de seguridad social y el de inspección de trabajo es esencial, aunque no siempre fácil de 
lograr, a pesar de que ambos servicios dependen generalmente (aunque no siempre) de un mismo ministerio. Este problema depende en gran medida de la actitud de unas administraciones que gozan de mayor o menor autonomía y que defienden celosamente su independencia. No obstante, si la instancia superior es lo bastante eficaz para establecer la coordinación, los resultados pueden ser notables, en especial en el campo de la prevención.

La colaboración con la autoridad central se debe traducir en el intercambio de información, la utilización de datos y la formulación conjunta de programas de prevención. En el ámbito local, la colaboración puede consistir en la realización de pesquisas conjuntas (por ejemplo, en caso de accidente), el intercambio de información y la posibilidad de utilizar los medios de los servicios de seguridad social (que suelen estar mucho mejor dotados financieramente) en la inspección de trabajo.

\section{Colaboración con los expertos y con los organismos técnicos y de investigación}

La inspección de trabajo no puede aislarse del entorno; es preciso que se mantenga en estrecho contacto con los centros de investigación y las universidades, con el objeto de incorporarse a la corriente del cambio tecnológico y del progreso de las ciencias humanas y sociales, y así obtener la información específica necesaria para incorporarse a las nuevas tendencias. La colaboración no puede ser unilateral; ciertamente, la inspección de trabajo puede prestar una importante ayuda a los centros de investigación, encomendándole el estudio de determinadas materias y colaborando en la verificación de campo de los resultados. Los inspectores de trabajo reciben invitaciones a participar en seminarios y coloquios sobre problemas sociales y a impartir formación especializada. En algunos países, como la República Federal de Alemania, la Federación Rusa y el Reino Unido, se atribuye gran importancia a esta colaboración, que, a veces, se desarrolla de forma sistemática.

En el plano de la salud y seguridad en el trabajo, la inspección de trabajo debe autorizar o colaborar con los organismos competentes para realizar la verificación técnica de algunos tipos de instalaciones y equipo (aparatos que funcionan a presión, mecanismos de elevación de cargas e instalaciones eléctricas) allí donde estén instalados. En otros países, como Sudáfrica, esta función corresponde todavía en gran medida a la propia inspección de trabajo. Estos contactos regulares con organismos externos permiten a la inspección recabar informes técnicos y observar los efectos de las cuantificaciones recomendadas.

Los problemas que la inspección de trabajo afronta en la actualidad, especialmente en los aspectos técnicos y jurídicos, son de tal complejidad que dichos servicios se verían imposibilitados de realizar inspecciones rigurosas de las empresas sin una asistencia especializada. En el Convenio no 81 se insta a los Estados miembros a adoptar las medidas necesarias "para garantizar la colaboración de peritos y técnicos (...), entre los que figurarán especialistas en medicina, ingeniería, electricidad y química, en el servicio de inspección (...) a fin de velar por el cumplimiento de las disposiciones legales relativas a la protección de la salud y seguridad (...) e investigar los efectos de los procedimientos empleados, de los materiales utilizados y de los métodos de trabajo". En el Convenio no 129 figura una disposición similar.

Es innegable que los diversos aspectos de las condiciones de trabajo se encuentran íntimamente imbricados, como demuestran los estudios recientemente realizados, y que las inspecciones de trabajo deben ser capaces de abordarlos como un todo. Esto pone especialmente de relieve las posibilidades del sistema multidisciplinario, que permite combinar las ventajas de la especialización y la versatilidad, siempre que se disponga de los medios financieros adecuados.

\section{Autoridades regionales y o de departamento}

La mayoría de los países se dividen en un número de circunscripciones que reciben diferentes nombres (cantones, provincias, regiones, departamentos, etc.), que, a su vez, se pueden subdividir en unidades menores, en las que las competencias de la administración central se delegan en unos altos funcionarios que pueden denominarse gobernadores, prefectos, etc. El personal de los servicios periféricos de los diversos ministerios suele estar subordinado a esos altos funcionarios por lo que respecta al estatuto del funcionariado y a la comunicación de la política aplicable, además de que los gobernadores, prefectos, etc., suelen dar posesión de sus cargos a los inspectores de trabajo designados. A su vez, los inspectores (o, en su caso, los directores de trabajo de cada departamento, provincia o región) informan a los altos funcionarios citados de las cuestiones de su competencia. A simismo, los inspectores deben cooperar con dichas autoridades facilitándoles, directamente o por los cauces reglamentarios, toda la información que precisen. No obstante, los inspectores han de ser responsables, en todo caso, ante el ministro del ramo (por regla general, el de trabajo), a través de su superior jerárquico (el director provincial, regional, etc.), respecto al contenido de su trabajo, la forma de realizarlo y la información de los resultados.

Estas circunstancias pueden poner a los inspectores de trabajo en una situación delicada, ya que los funcionarios que representan a la autoridad central suelen estar mal informados de las funciones de la inspección de trabajo y pueden sentir la tentación, especialmente cuando se suscitan determinados conflictos, de basar sus decisiones en consideraciones de orden público o de paz social. Los inspectores de trabajo deben subrayar la importancia de la aplicación general de la legislación laboral, siempre que la misma se cuestione y, si se suscitan problemas, deben trasladar la cuestión a sus superiores.

\section{Autoridades judiciales}

Los inspectores de trabajo suelen tener una relación funcional estructurada con las autoridades judiciales, cuya colaboración es esencial para prevenir infracciones. En la mayoría de los países, los inspectores no pueden instar actuaciones judiciales por sí mismos, pues esta prerrogativa corresponde a la fiscalía, dependiente del ministerio de justicia. Si los inspectores descubren una infracción que estiman sancionable, remiten un informe al respecto al ministerio público. En este informe, que reviste gran importancia para el buen fin de las actuaciones legales, se deben relatar los hechos observados por el inspector y se han de indicar claramente las disposiciones violadas. Por regla general, la fiscalía disfruta de la facultad discrecional para decidir sobre la institución de acciones legales sobre la base del informe o, en su caso, el archivo del informe.

De lo anterior se deduce, no sólo la importancia de la elaboración del informe sobre las irregularidades observadas, sino también la conveniencia de que los inspectores y los funcionarios de la fiscalía tengan, al menos, un contacto personal. Normalmente, antes de denunciar las infracciones descubiertas, el inspector de trabajo utiliza la persuasión como medio de hacer respetar las normas legales. $\mathrm{Ni}$ los fiscales ni los jueces tienen siempre un conocimiento suficiente de esta circunstancia, y este desconocimiento de los métodos de trabajo de los inspectores los induce con frecuencia a sobreseer las actuaciones o a imponer sanciones insignificantes. Esto pone de relieve la importancia de celebrar reuniones interministeriales en el más alto nivel.

Existen otros motivos por los que los inspectores de trabajo tengan contacto con los jueces: por ejemplo, si se les requiere 
para que aporten alguna información en las diligencias preliminares de una causa o se les cita a testificar en el proceso. Es importante que se facilite a la inspección de trabajo el texto íntegro de las sentencias (incluidos los fundamentos invocados en la misma) tan pronto como las mismas se publiquen. Esto facilita la denuncia de la eventual reincidencia en la infracción, en el caso de que las anomalías no se subsanen, y, si se estima que la sanción impuesta es insuficiente, hace posible que la inspección inste de la fiscalía la presentación de un recurso. Por último, la comunicación de la sentencia es tanto más útil si en la misma se sienta jurisprudencia.

\section{Otras a utoridades}

Los inspectores de trabajo pueden mantener contactos regulares o esporádicos con otras autoridades públicas. En efecto, a veces se les invita a colaborar con los servicios de planificación del desarrollo. En tales casos, su función consiste en subrayar la importancia de determinados factores sociales y las consecuencias de algunas decisiones económicas. Por lo que respecta a la clase política, si alguna personalidad pública (alcalde, diputado, dirigente de un partido político, etc.) solicita información a un inspector de trabajo, éste debe extremar la prudencia y proceder con la imparcialidad que debe informar su conducta en todo momento. Es igualmente preciso regular las relaciones con la policía, por ejemplo, para la supervisión del horario de trabajo en el transporte público por carretera (sólo la policía puede ordenar la detención de un vehículo) o para la verificación de la posible presencia de trabajadores inmigrantes ilegales. Es igualmente preciso (aunque, en la práctica, infrecuente) prever la posibilidad de que los inspectores de trabajo entren en los centros de trabajo, en caso necesario, con ayuda de la policía.

\section{Relaciones con las asociaciones de empresarios y las organizaciones de trabajadores}

O bviamente, los servicios de inspección de trabajo mantienen una relación estrecha y estable con las empresas, los trabajadores y las organizaciones que respectivamente los representan. En este sentido, en los Convenios $n=81$ y $n-129$ se insta a las autoridades competentes a tomar las medidas necesarias para favorecer esta colaboración.

Inicialmente, los inspectores de trabajo mantienen contactos con los trabajadores y las empresas en los lugares de trabajo, bien en el curso de las visitas de inspección, bien en las reuniones que celebran órganos como los comités de salud y seguridad y los comités de empresa, así como en los actos de conciliación dedicados a prevenir o zanjar disputas. L os inspectores también mantienen frecuentes contactos con empresarios y trabajadores fuera de la empresa. En efecto, suelen reunirse con los agentes sociales en las inspecciones para expresarles sus puntos de vista y brindarles asesoramiento e información. A veces, incluso, presiden las reuniones de los comités paritarios para negociar convenios colectivos o resolver disputas. En ocasiones, también imparten cursos sobre temas laborales a sindicalistas y directores de empresas.

\section{La inspección del trabajo y los trabajadores}

Puesto que la principal responsabilidad cotidiana de la inspección de trabajo es la protección de los trabajadores, es imprescindible que inspectores y trabajadores mantengan una relación sumamente estrecha. En primer lugar, todo trabajador puede acudir personalmente al inspector para plantearle sus problemas o solicitar ayuda. No obstante, lo habitual es establecer los contactos a través de los sindicatos, los delegados sindicales o los representantes de los trabajadores. Puesto que el objetivo de los sindicatos es representar y defender los intereses de los trabajadores, su presencia suele ser fundamental.
Este entramado de relaciones, cuya forma varía de un país a otro y en función de los problemas planteados, se analiza en el capítulo titulado R elaciones laborales y gestión de los recursos humanos. Es de subrayarse que en el ordenamiento internacional - Convenios no 81 y no 129, y el Protocolo de 1995 al Convenio no 81- se establece el principio de colaboración con las empresas y con los propios trabajadores, al disponerse que la autoridad competente "deberá adoptar las medidas pertinentes para fomentar (...) la colaboración de los funcionarios de la inspección con los empleadores y trabajadores o sus organizaciones". Es de subrayarse igualmente que las relaciones de la inspección de trabajo con los trabajadores y las empresas no se pueden segregar del conjunto de las relaciones laborales, y que aquéllas están inevitablemente condicionadas por el hecho de que la inspección de trabajo se inserta en un sistema socioeconómico que varía de un país a otro.

\section{Colaboración}

La colaboración se puede estructurar de diversas formas, específicamente, mediante los contactos directos 0 en los órganos de representación o de participación en la empresa. En algunos países se practican otras modalidades de colaboración en el ámbito regional o por departamentos, de conformidad con diversos procedimientos.

\section{Relaciones directas}

Una de las funciones básicas de la inspección de trabajo mencionadas en el artículo 3 del Convenio no 81 de la OIT consiste en informar y asesorar a empresas y trabajadores, que pueden recabar la opinión y solicitar la intervención de los inspectores en las cuestiones de su competencia. A través del sindicato, los trabajadores pueden formular quejas o recabar la opinión o la intervención de la inspección (por ejemplo, visitando un lugar de trabajo). Si bien los inspectores ostentan la facultad discrecional de actuar o abstenerse de actuar en la forma que estimen pertinente, las organizaciones de trabajadores tienen una cierta capacidad de iniciativa en materia de inspección.

\section{Relaciones de la inspección de trabajo con los órganos de} representación y participación en la empresa

E sta es, probablemente, la forma más sobresaliente y sistemática de colaboración. Por su experiencia y su conocimiento del trabajo, los trabajadores se encuentran en una situación especialmente ventajosa para descubrir las anomalías que se producen en las condiciones de trabajo - especialmente en lo relativo a la salud y seguridad- y para proponer soluciones. Es, pues, normal que se les consulte y se les incorpore al estudio y la solución de los problemas y a la toma de las decisiones que les afectan. Estas consideraciones, que inducen al diálogo y a la colaboración en la empresa, impulsan, con la misma lógica inapelable, el intercambio de información y la colaboración con la inspección de trabajo.

U no de los órganos de participación más comunes en las empresas es el comité de salud y seguridad. Este comité, integrado por representantes de la empresa y de los trabajadores, desarrolla, en el marco de sus competencias, la labor de la inspección. Los representantes de los trabajadores suelen ser mayoritarios en estos órganos. La dirección de estos comités suele recaer en los jefes de las empresas o en los delegados de aquéllos, que se responsabilizan de traducir en actuaciones los acuerdos del comité. En la medida de lo posible, el comité recaba la colaboración de expertos, como médicos del trabajo y especialistas en seguridad. Para las reuniones especialmente importantes, el comité puede invitar al inspector de trabajo y al ingeniero de los servicios de seguridad social. Los miembros del comité de salud y seguridad pueden, y deben, realizar frecuentes 
trabajo en la que se basa cualquier sistema de "autoinspección". Muchas organizaciones sindicales se mueven, precisamente, en esta dirección. En diversas reuniones internacionales celebradas recientemente se ha puesto de manifiesto la determinación de los sindicatos, independientemente de su orientación política, a participar en el estudio y aplicación de medidas diseñadas para humanizar las condiciones y el medio ambiente de trabajo.

Reviste particular importancia la elección de delegados de seguridad que representen al conjunto de los trabajadores de la empresa en todo lo relativo a la protección de la salud y la seguridad. Estos delegados, que deben recibir una formación adecuada por cuenta de la empresa y disfrutar del tiempo libre necesario para realizar inspecciones, deben estar facultados para interrumpir cualquier trabajo que estimen peligroso, hasta tanto las autoridades competentes (en principio, la inspección de trabajo) no verifique las sospechas.

La participación de los sindicatos en la fijación de los criterios de utilización de productos y sustancias peligrosos es otro de los principios básicos. Los representantes de los trabajadores deben participar efectivamente en el proceso de toma de las decisiones relativas al uso de sustancias peligrosas, la elección de los materiales, la elaboración de los procesos productivos y la protección del medio ambiente. En términos generales, se debe reconocer a los sindicatos y representantes de los trabajadores el derecho a participar, tanto en el lugar de trabajo como en el ámbito nacional, en la protección de la salud y seguridad de sus afiliados y compañeros.

EI Convenio y la R ecomendación de la O IT sobre seguridad y salud de los trabajadores, 1981 (n 155 y nํ 164, respectivamente), van en la misma línea. En el Convenio se afirma que la salud y la seguridad en el trabajo deben ser objeto de "una política nacional coherente", formulada, aplicada y periódicamente revisada "en consulta con las organizaciones más representativas de empleadores y de trabajadores". En ambos acuerdos internacionales, en los que se formulan los principios de esta política y se postulan las medidas que se deben adoptar en la empresa y en el ámbito nacional, se insta a los Estados a garantizar la observancia de las leyes y los reglamentos aplicables a la salud y seguridad en el trabajo y a la protección del medio ambiente de trabajo mediante el establecimiento de un sistema adecuado de inspección, a proporcionar orientación a empresas y trabajadores, y a sancionar a los infractores.

Las disposiciones que revisten mayor interés para la inspección de trabajo y los dirigentes sindicales locales son las que atañen a la empresa. En el Convenio figura el pasaje siguiente:

(1) los trabajadores (...) cooperen al cumplimiento de las obligaciones que incumben al empleador;

(2) los representantes de los trabajadores en la empresa cooperen con el empleador en el ámbito de la seguridad e higiene en el trabajo;

(3) los representantes de los trabajadores en la empresa reciban información adecuada acerca de las medidas tomadas por el empleador para garantizar la seguridad y la salud y puedan consultar a sus organizaciones representativas acerca de esta información, a condición de no divulgar secretos comerciales;

(4) Ios trabajadores y sus representantes en la empresa reciban una formación apropiada en el ámbito de la seguridad e higiene en el trabajo;

(5) Ios trabajadores o sus representantes y, llegado el caso, sus organizaciones representativas en la empresa ... estén habilitados, de conformidad con la legislación y las prácticas nacionales, para examinar todos los aspectos de la seguridad y la salud relacionados con su trabajo y sean consultados a este respecto por el empleador; con tal objeto y de común acuerdo, podrá recurrirse a consejeros técnicos ajenos a la empresa;

(6) el trabajador informará de inmediato (...) cualquier situación de trabajo que, a su juicio, entrañe, por motivos razonables, un peligro inmediato y grave para su vida o su salud; mientras el empleador no haya tomado medidas correctivas, si fuere necesario, no podrá exigir de los trabajadores que reanuden una situación de trabajo (...).

$N$ aturalmente, en la Recomendación ( $n$ - 164), que desarrolla el Convenio, figuran disposiciones mucho más específicas y detalladas en relación con la cuestión global de las condiciones y el medio ambiente de trabajo. En dicho documento se establece, entre otras cosas, lo que se debe facilitar a los representantes de los trabajadores para que puedan realizar su tarea: formación, información, tiempo disponible durante las horas de trabajo, participación en las negociaciones y la toma de decisiones, acceso a todas las dependencias del lugar de trabajo, posibilidad de comunicar con los trabajadores y libertad para establecer contactos con los inspectores de trabajo y para consultar con expertos. Los representantes de los trabajadores deben "estar protegidos contra el despido y otras medidas perjudiciales cuando cumplan sus funciones en la esfera de la seguridad e higiene del trabajo".

El contenido global del Convenio y de la Recomendación, que ha sido objeto de un consenso general por parte de los gobiernos y los agentes sociales en el plano internacional, apunta a la dirección en que se mueven, no sólo la acción sindical en lo relativo a las condiciones y al medio ambiente de trabajo en las empresas, sino también la labor de la inspección de trabajo.

Es evidente que la cooperación entre los directivos de las empresas y los trabajadores o sus representantes se desarrollará simultáneamente con el reforzamiento de la participación de los trabajadores en la supervisión de sus condiciones de trabajo. Entonces, la función de la inspección de trabajo consistirá, fundamentalmente, en prestar asesoramiento en el marco de un sistema en que los agentes sociales participan intensamente. 0 tra de las tareas de la inspección de trabajo consistirá en supervisar el normal funcionamiento de los sistemas de cooperación en la empresa, sin renunciar a su función de inspección en el caso de que las circunstancias justifiquen su presencia en el lugar de trabajo, que, si bien será, evidentemente, cada vez menos necesaria, será todavía frecuente durante un cierto tiempo (en especial, en la pequeña y mediana empresa) allí donde la cooperación no se encuentre aún firmemente arraigada. La función independiente de la inspección de trabajo continuará siendo indispensable, incluso en los países en que el diálogo social tiene una mayor raigambre y la conciencia de los peligros profesionales se encuentra más arraigada. La inspección de trabajo continuará siendo la herramienta principal en el esfuerzo por garantizar la protección efectiva de los trabajadores.

\section{Objetivos de la inspección}

Existen a lo largo y ancho del mundo muchos y muy diversos sistemas de inspección de trabajo. No obstante, más allá de sus diferencias, todos persiguen unos mismos objetivos básicos que determinan las funciones genéricas de la inspección. ¿Cuáles son estos objetivos? En el artículo 3 del Convenio no 81 de la OIT, que ha alcanzado una dimensión prácticamente universal, al haber sido ratificado por cerca de 120 Estados miembros, dichos objetivos se definen en la forma siguiente:

Las funciones del sistema de inspección de trabajo serán:

(1) garantizar la aplicación de las disposiciones legales relativas a las condiciones de trabajo y a la protección de los 
trabajadores durante la realización de sus tareas, como son las disposiciones relativas a horarios, salarios, salud, seguridad y bienestar, al empleo de niños y jóvenes, y a otras cuestiones afines, siempre que la inspección de trabajo pueda exigir la observancia de dichas disposiciones;

(2) proporcionar a empresas y trabajadores información y asesoramiento técnico respecto al modo más eficaz de aplicar las disposiciones legales;

(3) poner en conocimiento de la autoridad competente cualquier fallo o irregularidad no previsto expresamente en las disposiciones legales vigentes.

El anterior texto, rotundo y flexible al mismo tiempo, abre un enorme campo a la actuación de la inspección de trabajo. En efecto, se hace responsable a la inspección de trabajo de "garantizar la aplicación de las disposiciones legales". El lenguaje ha sido seleccionado cuidadosamente por los redactores del Convenio, que evitaron deliberadamente hablar de "supervisar" 0 de "promover" la aplicación de las disposiciones legales, y optaron por estipular claramente la obligación de los servicios de inspección de garantizar una aplicación efectiva.

¿Q ué disposiciones son estas? Según el texto del Convenio, aparte de las leyes y los reglamentos, el término comprende los laudos arbitrales y los convenios colectivos que tienen fuerza de ley para los interesados y son ejecutorios por los inspectores de trabajo. Estas disposiciones constituyen la base amplia de la labor de todos los inspectores de trabajo de un país y la garantía de empresas y trabajadores por igual contra la arbitrariedad, la desigualdad y la injusticia. La función del inspector no consiste en hacer valer sus ideas personales, por válidas que sean, sino velar por el cumplimiento de la legislación vigente (esto es, actuar como instrumento fiel y efectivo de la autoridad nacional competente - el legislador - en el campo de la protección de los trabajadores).

Podría pensarse que la alusión a las disposiciones legales limita la función de los inspectores en el sentido de que no pueden imponer la adopción de todas las mejoras de las condiciones de trabajo que consideren aconsejables. En realidad, una de las tareas de la inspección consiste en "poner en conocimiento de la autoridad competente cualquier fallo o irregularidad no previsto expresamente en las disposiciones legales vigentes". Esta tarea disfruta de idéntico grado de prioridad que la de hacer cumplir la legislación y convierte a la inspección de trabajo en un motor del desarrollo social al reconocerle la prerrogativa de adoptar iniciativas en la esfera de la protección del trabajo.

El ámbito de la inspección de trabajo varía de un país a otro, como función del desarrollo y la naturaleza de la legislación vigente, de los poderes reconocidos por el Estado al cuerpo de inspectores y de la extensión del sistema. En algunos casos, los inspectores disfrutan de amplios poderes para hacer observar toda la legislación aplicable a las condiciones y al medio ambiente de trabajo; en otros, su función se circunscribe a cuestiones concretas, como los salarios o la salud y la seguridad. Por otra parte, la inspección puede limitarse a unos sectores determinados 0 aplicarse a toda la actividad económica; y es posible que cubra la totalidad del territorio nacional o únicamente una parte del mismo. En el Convenio no 81 se prevén todas estas posibilidades, de modo que los servicios de inspección pueden tener un ámbito sumamente restringido o abarcar un campo francamente extenso y, a pesar de todo, estar incluido en la definición internacional de los objetivos de la inspección.

Entre las normas internacionales, las relativas a la inspección de trabajo se presentan como indispensables para formulación, la aplicación y el perfeccionamiento de la legislación laboral. La inspección de trabajo es uno de los motores del progreso social, al garantizar la aplicación de unas normas sociales coercitivas (por supuesto, siempre que tenga la capacidad de hacerlo así) y pone de relieve las mejoras que pueden introducirse.

\section{Función de la inspección}

Se ha visto anteriormente que la misión de la inspección de trabajo se traduce en tres tareas principales: la aplicación de las leyes, principalmente mediante la supervisión; el asesoramiento e información a trabajadores y empresas; y la información a la autoridad competente.

\section{Inspección}

La inspección se realiza, básicamente, mediante visitas a los lugares de trabajo sujetos a la inspección de trabajo, y se propone (mediante la observación y el diálogo), inicialmente, definir la situación y, a continuación (por los métodos que se expondrán posteriormente), promover y garantizar efectivamente el cumplimiento de la legislación aplicable a la prevención.

La inspección no debe orientarse a la represión sistemática de los fallos, pues su objetivo consiste en lograr que la legislación se cumpla, no en cazar a los infractores. No obstante, es imprescindible que los inspectores puedan, en caso necesario, recurrir a medidas coercitivas, consistentes en levantar actas que sirvan de base a la imposición de unas sanciones lo suficientemente severas para que surtan un efecto disuasorio. Si no se imponen sanciones, o si éstas no producen los resultados deseados dentro de un plazo razonable, los inspectores de trabajo pierden toda su credibilidad y su labor resulta ineficaz. Esto ocurre especialmente si la inspección de trabajo tiene que acudir a los tribunales civiles para hacer cumplir sus resoluciones y lograr la imposición de sanciones.

Resulta evidente que el objetivo de la inspección es la protección de los trabajadores mediante la eliminación de los factores de peligro y de las situaciones irregulares. En el campo de la salud y la seguridad, la inspección funciona en tres etapas. Por ejemplo, antes de levantarse una fábrica, equiparse una planta industrial o producirse una máquina, la inspección garantiza, desde la fase de planificación, la observancia de la legislación aplicable. Esta verificación preliminar se complementa con las visitas rutinarias de inspección de los lugares de trabajo. Por último, en caso de accidente, la supervisión se traduce en una investigación dirigida, principalmente, a prevenir la repetición del siniestro.

La inspección puede adoptar diversas formas, en función del método de inspección aplicado en el país en cuestión y de su objetivo específico. En el campo de la salud y seguridad en el trabajo, la inspección se realiza principalmente mediante la visita a talleres y otros lugares de trabajo. En el ámbito de los salarios, el trabajo infantil y las horas de trabajo, la inspección puede reclamar los libros y registros que las empresas deben llevar obligatoriamente, con el objeto de verificar su veracidad. En la función de tutela de la libertad de asociación, los inspectores deben verificar, en cumplimiento de las disposiciones legales, si los procesos electorales convocados se desarrollan correctamente y si los sindicatos pueden desarrollar libremente su actividad sin que se discrimine a sus afiliados.

Para el desarrollo de su actividad, los sindicatos pueden recabar diversos tipos de ayuda (véase la sección anterior, dedicada a la colaboración), bien para profundizar en el conocimiento de la situación (organismos supervisores; expertos independientes; servicios de prevención de las mutualidades de la seguridad social; órganos internos de la empresa, como el comité de salud y seguridad; etc.), bien para proyectar su labor (los delegados de personal, los servicios de prevención anteriormente mencionados, las organizaciones de trabajadores y asociaciones de empresarios, etc.). La actividad de la inspección 
es discontinua, por lo que precisa de un complemento permanente dentro de la empresa.

\section{Información y asesoramiento a empresas y trabajadores}

El texto del Convenio no 81 confiere a la función de información y asesoramiento de empresas y trabajadores un objeto muy concreto: mostrarles "la manera más efectiva de cumplir las disposiciones legales". Esta función, como la de inspección, contribuye a garantizar la observancia de la legislación. La función de información y asesoramiento es complementaria de la inspección, ya que, como se ha indicado anteriormente, la labor del inspector de trabajo no tiene un carácter exclusivamente coercitivo.

Por consiguiente, las actuaciones de la inspección, inevitablemente breves, pueden surtir efectos perdurables en el lugar de trabajo. Por consiguiente, la actividad de información y asesoramiento de los inspectores se proyecta hacia el futuro. La inspección no puede limitarse a una especie de supervisión retrospectiva dirigida a determinar si todo está en orden. En efecto, los inspectores deben aconsejar la adopción de las medidas precisas para garantizar la protección de los trabajadores, explicar la normativa legal aplicable al pago de salarios, informar del lugar en que deben realizarse las exploraciones médicas y el contenido de las mismas, hacer ver la necesidad de limitar las horas de trabajo y analizar los problemas actuales 0 potenciales con las empresas. Las opiniones más autorizadas aseguran que los inspectores más eficaces son los que dedican el mayor esfuerzo a realizar una labor de educación en el lugar de trabajo entre el personal de dirección y los representantes de los trabajadores. Así ocurre normalmente en países como la República Federal de Alemania, el Reino U nido, los países escandinavos y muchos otros.

Debido a su contenido educativo, los efectos de la labor de información y asesoramiento pueden trascender el problema en cuestión y contribuir a la prevención; ciertamente, dichos efectos pueden hacerse sentir en otros casos similares 0 , incluso, diferentes, y coadyuvar a que las mejoras vayan más allá del cumplimiento de las disposiciones legales.

\section{Información y asesoramiento durante las visitas a los lugares de trabajo}

Como se ha observado reiteradamente, es casi inevitable que la labor de inspección, que se realiza principalmente durante las visitas a los lugares de trabajo, lleve aparejado el ofrecimiento de información y asesoramiento. Los inspectores de trabajo deben responder a las preguntas que formulen los directivos y los representantes de los trabajadores, y resulta igualmente normal que expresen sus opiniones y brinden explicaciones. Ciertamente, la información y el asesoramiento están tan profundamente imbricados con la inspección que resulta difícil distinguirlos. Sin embargo, el equilibrio exacto entre asesoramiento y supervisión es un tema de considerable debate en los foros nacionales e internacionales. Esta cuestión suele constituir el núcleo de todo documento amplio y coherente de formulación de políticas nacionales de actuación.

\section{Información y asesoramiento en las inspecciones de trabajo}

Los inspectores de trabajo deben ser fácilmente abordables y las puertas de la inspección deben estar abiertas de par en par a cualquiera que desee consultar algo, plantear un problema 0 presentar una queja sobre determinadas circunstancias. Su conducta debe consistir, invariablemente, en fomentar la plena y consciente observancia de las disposiciones legales.

Es preciso establecer un nexo entre esta actividad y el tratamiento de las disputas puntuales. En efecto, éstas conciernen, por regla general, a la aplicación de leyes y reglamentos y, en algunos países, consumen buena parte del tiempo del personal empleado en la inspección, incluidos los propios inspectores. EI problema planteado por este tipo de actividad se ha zanjado en los Convenios $n=81$ y $n=129$, en los que se admite esta actividad únicamente si la misma no entorpece el desempeño efectivo de las funciones básicas de los inspectores ni menoscaba su autoridad o imparcialidad. En algunos países se estima que el problema consiste en disponer del personal adecuado y que la organización debe tener la dimensión suficiente para hacer posible que los inspectores desempeñen sus demás funciones con igual competencia.

\section{Actividades educativas}

La información y el asesoramiento son tareas educativas, por cuanto no se facilitan con el objeto exclusivo de que se apliquen al pie de la letra en un contexto determinado, sino para que, además, se comprendan y se asimilen, que produzcan convicción $y$, en resumen, que surtan efectos amplios y perdurables. La información y el asesoramiento se pueden proporcionar igualmente mediante cursos, charlas y conferencias, como se propugna, por otra parte, en la Recomendación no 81 . Estos canales permiten llegar a un público más extenso, explicar, tanto la letra, como el espíritu de la legislación laboral y lograr una mejor comprensión, una mayor aceptación y, por ende, una aplicación más eficaz de aquélla. Por ejemplo, en N oruega existe un comité nacional de formación, integrado por representantes de la inspección de trabajo, de las empresas y de los trabajadores.

\section{Difusión de la información}

EI desconocimiento de la legislación social y la ignorancia de su utilidad y de los objetivos que la informan figuran entre los mayores obstáculos que la inspección de trabajo afronta, principalmente en los países en vías de desarrollo. Resulta evidente la enorme utilidad de toda medida que contribuya a la difusión de información sobre la legislación laboral. No hay que omitir detalle alguno en este campo, en el que las asociaciones de empresarios y las organizaciones de trabajadores pueden desempeñar igualmente una importante función. Mención aparte merece en este punto la labor de los servicios de información del $\mathrm{H}$ ealth and Safety Executive británico, que recopila y difunde un gran volumen de información (disponen de biblioteca y de servicios de documentación y traducción, producen programas de radio y televisión, preparan exposiciones, etc.).

\section{Información a la autoridad competente}

Esta función se suele infravalorar o pasar por alto. No obstante, en los Convenios no 81 y 129 de la OIT hay una alusión expresa a la misma. En efecto, la inspección de trabajo está obligada a "poner en conocimiento de la autoridad competente las deficiencias y los abusos que no estén específicamente cubiertos por las disposiciones legales existentes". Esta obligación, impuesta a la inspección de trabajo en su conjunto, desde los inspectores de menor rango hasta las altas instancias de la jerarquía, complementa la normativa que convierte a la inspección en un importante agente de cambio social. El conocimiento que los inspectores de trabajo poseen de los problemas laborales y de la situación de los trabajadores, especialmente por lo que respecta a la protección que la legislación social y sus reglamentos otorgan a los trabajadores, sitúa a la inspección en una posición privilegiada para informar a las autoridades.

\section{Otras funciones}

En muchos países, la inspección de trabajo desempeña, además, otras funciones. Si bien en los convenios no 81 y no 129 se admite esta posibilidad, se añade que "ninguna otra función que se encomiende a los inspectores del trabajo deberá entorpecer el 
cumplimiento efectivo de sus funciones principales o perjudicar (...) la autoridad e imparcialidad que los inspectores necesitan en sus relaciones con los empleadores y los trabajadores".

\section{La esfera económica}

L as cuestiones sociales están íntimamente vinculadas a las económicas. Gracias a los contactos que mantiene con el mundo del trabajo y a la información que recoge durante el desempeño de sus tareas, el servicio de inspección de trabajo posee un gran volumen de datos de naturaleza social (salud y seguridad en el trabajo, situación de la mujer trabajadora y de los trabajadores jóvenes, estado de las relaciones laborales, negociación y firma de convenios colectivos, etc.) o económica (número de empresas, dimensión de las plantillas, horas de trabajo realizadas, salario medio en cada sector económico, distribución de la demanda de trabajadores cualificados, por sectores o por áreas geográficas, etcétera).

N o resulta, pues, sorprendente que las autoridades de muchos países hayan decidido aprovechar una fuente tan valiosa de información, principalmente en la elaboración de sus planes de desarrollo. Ciertamente, la inspección de trabajo, objetiva y rigurosa por su propia naturaleza, es capaz de suministrar la información necesaria y así contribuir al desarrollo y la administración del país.

\section{Relaciones laborales: conciliación y arbitraje}

En los convenios internacionales no se atribuyen a la inspección de trabajo competencias expresas en materia de conciliación y arbitraje. No obstante, en la Recomendación sobre la inspección de trabajo, 1947 ( $n$ - 81) se excluyen expresamente ambas competencias, ya que, si se atribuyesen a los inspectores de trabajo, peligraría su independencia y su imparcialidad. Por consiguiente, el arbitraje y la conciliación no se abordan en el presente estudio. No obstante, en muchos países, alguna de estas funciones, especialmente la de conciliación, se ha atribuido a los servicios de inspección de trabajo. Desde la adopción, en 1947, de la Recomendación no 81, esta cuestión ha sido siempre objeto de debate. Por otra parte, la R ecomendación sobre la inspección de trabajo (agricultura), 1969 ( $n$ ㅇ133), es menos explícita que la Recomendación no 81, pues en aquélla se admite, como medida transitoria, la participación de los inspectores de trabajo en la solución de los conflictos laborales, allí donde no existan organismos especializados en la conciliación.

\section{Protección de los representantes de los trabajadores}

En el Convenio sobre Representantes de los Trabajadores, 1971 ( $n$ - 135), complementado por la Recomendación no 143, de ese mismo año, se establece lo siguiente:

Los representantes de los trabajadores en la empresa deberán gozar de protección eficaz contra todo acto que pueda perjudicarlos, incluido el despido por razón de su condición de representantes de los trabajadores, de sus actividades como tales, de su afiliación al sindicato, o de su participación en la actividad sindical, siempre que dichos representantes actúen conforme a las leyes, convenios colectivos $u$ otros acuerdos comunes en vigor.

En algunos países se obliga a las empresas a recabar el acuerdo de los sindicatos 0 a obtener una autorización judicial antes de despedir a un representante de los trabajadores. En otros, como Francia y los países adheridos a la tradición administrativa francesa, el despido de un delegado sindical o de un representante elegido por los trabajadores se subordina a la aprobación de la inspección de trabajo (a menos que el comité de empresa haya dado su acuerdo, circunstancia ésta que, como es de suponer, resulta extremadamente infrecuente). Antes de dictar una resolución, los inspectores de trabajo deben tratar de verificar si las faltas que la empresa imputa al representante de los trabajadores está o no relacionada con la actividad sindical del mismo, tal como la misma se defina en las leyes y la doctrina legal vigentes. En este último caso, la inspección de trabajo deniega la autorización y, en el primer supuesto, la concede (por supuesto, siempre que los cargos aducidos contra la persona en cuestión sean lo suficientemente graves).

\section{La supervisión en el ámbito del empleo}

En muchos países, principalmente en los adheridos a la tradición administrativa francesa, la inspección de trabajo desempeña una función importante en el campo del empleo, especialmente en el aspecto de la resolución de la relación laboral. Cuando en Francia se insta un expediente de reducción de plantilla, corresponde a los inspectores de trabajo verificar la observancia del procedimiento de autorización previa, la legalidad de las causas aducidas para la regulación de empleo y la procedencia de las medidas de indemnización y reconversión adoptadas. Examinada la situación financiera de la empresa o la coyuntura del mercado de trabajo, el inspector de trabajo puede desestimar la pretensión de la empresa; en la práctica, sin embargo, esto sólo ocurre en alrededor del cinco por ciento de los casos.

En este mismo campo del empleo, suele corresponder a la inspección de trabajo la misión de garantizar el cumplimiento del principio de exclusión de la discriminación, tanto en la contratación como en la extinción de la relación laboral. Este principio consiste en la exclusión de toda discriminación por motivos de raza, sexo, religión, opiniones políticas, nacionalidad o situación familiar. Los inspectores supervisan la actividad de las agencias de empleo temporal con el objeto de prevenir las posibles consecuencias negativas para los asalariados del desarrollo de diversas modalidades de empleo precario, en particular, del empleo temporal. Las dificultades económicas y el elevado desempleo presentes en algunos países indujeron a un reforzamiento de la supervisión en el marco de la lucha contra el trabajo clandestino y de la regulación, entre otras cuestiones, de la contratación de trabajadores extranjeros y de las horas extraordinarias.

\section{0 tras funciones}

En ocasiones, se encomienda a la inspección de trabajo el desempeño de otras funciones, como la supervisión de la protección del medio ambiente contra la contaminación producida por las empresas y la prevención de incendios. Estas funciones, que, a veces, sólo pueden ser desempeñadas por los servicios de inspección de trabajo, no se enmarcan exactamente en el ámbito funcional de la inspección de trabajo y no deben entorpecer la realización de las tareas fundamentales de protección de los trabajadores en el lugar de trabajo.

\section{Distintos sistemas de inspección}

Aunque los servicios de inspección de trabajo difieren de un país a otro, es posible distinguir dos sistemas generales: los servicios que abarcan la totalidad de los sectores económicos y los que dedican un departamento a cada sector (minería, agricultura, industria, transporte, etcétera). Los objetivos de la inspección pueden igualmente variar de uno a otro servicio: salud y seguridad, condiciones de trabajo, salarios y relaciones laborales. También se puede distinguir entre los servicios cuyos inspectores aplican las disposiciones legales vigentes en todos los campos sobre los que la inspección ostenta competencias, y los servicios que cuentan con secciones especializadas en cada tipo de inspección. En algunos países, determinadas funciones de inspección se delegan en las administraciones locales, al tiempo que en los 
países en que existe una industria minera funciona un sistema específico en este sector.

\section{Estructura de los sistemas}

\section{Competencias por sectores de actividad}

En algunos países existe un único sistema de inspección para todos los sectores de la economía. Si se deja al margen la minería, que en la inmensa mayoría de los países depende del ministerio del ramo (aunque hay excepciones, como M éxico), este sistema se aplica en países europeos, como Luxemburgo, España y Suiza, además de en numerosos países africanos y asiáticos. En los países francófonos de Africa, por ejemplo, existen sistemas de inspección dependientes del ministerio de trabajo que comprenden todos los sectores de la actividad.

La ventaja de este sistema es que confiere a la inspección y, especialmente, al ministerio de trabajo, una visión global de los distintos sectores, puesto que los problemas de la protección de los asalariados suelen ser similares. A demás, en los países pobres, el sistema permite reducir el número de visitas necesario para supervisar distintas actividades. En otros países, en cambio, existen varios servicios de inspección especializados en los diversos sectores de la economía y dependientes de los ministerios correspondientes.

A finales del siglo XIX, en la mayor parte de los países europeos existía un organismo competente en materia de legislación laboral, por lo general, adscrito al ministerio del interior 0 al de comercio e industria. En la primera preguerra mundial surgieron ministerios de trabajo autónomos, en los que se delegó la función de aplicar la legislación laboral con ayuda de un cuerpo de funcionarios especializados. Esta es la causa de que, en determinados sectores económicos, la supervisión del cumplimiento de la legislación protectora de los trabajadores haya seguido correspondiendo al ministerio competente inicialmente.

Entre los dos extremos - un único sistema de inspección adscrito a un solo ministerio que ostenta competencias sobre todos los sectores de actividad, o diversos servicios especializados sectorialmente y dependientes de varios ministerios- existen soluciones intermedias en las que, un determinado servicio de inspección tiene asignados varios sectores, o varios servicios de inspección están adscritos a un sólo sector y a un mismo ministerio.

En años recientes, se ha venido observando la tendencia a consolidar los servicios de inspección bajo la autoridad de un mismo organismo, por regla general, el ministerio de trabajo, debido, tanto a que los problemas que se suscitan en los distintos sectores suelen ser similares, si no idénticos, como a la circunstancia de que esta consolidación incrementa la eficacia y reduce los costes de la administración. U n sistema unificado e integrado aumenta las perspectivas de la prevención de los peligros profesionales y de la protección jurídica de los trabajadores.

En 1975 se unificaron los principales servicios de inspección franceses, y el órgano interministerial surgido de la unificación quedó sometido a un mismo reglamento de servicio y a la autoridad del Ministerio de Trabajo. Ese mismo, año, el Reino Unido decidió igualmente unificar, bajo la autoridad de la Comisión Ejecutiva de Salud y Seguridad, los siete servicios de inspección de la salud y seguridad en el trabajo que hasta entonces habían estado adscritos a cinco ministerios diferentes. Con la creación de la Comisión, tanto la Inspección Industrial, como los demás servicios de inspección (y, posteriormente, incluso, los servicios de inspección de las explotaciones de gas y petróleo en la plataforma marina y del transporte público), el Servicio de Asesoramiento de M edicina del Trabajo y los demás organismos oficiales dedicados a la prevención, se integraron en un único servicio, dependiente de un solo ministerio: el de
Empleo. Sin embargo, este ministerio se suprimió en 1995, y la inspección de trabajo depende actualmente del M inisterio del Medio Ambiente, tendencia ésta que también se observa en otros países, como Alemania). El deseo de coordinar el esfuerzo de prevención y de mejora de las condiciones de trabajo en el contexto de una normativa legal crecientemente compleja ha inducido a otros países a centralizar la supervisión del cumplimiento de las normas de protección de los trabajadores en un único órgano, normalmente dependiente del ministerio de trabajo.

\section{Competencias según el objeto de la inspección}

Los servicios de inspección de trabajo supervisan el cumplimiento de las disposiciones legales aplicables en muchos y muy diversos campos, como la salud y seguridad, las condiciones de trabajo, los salarios y las relaciones laborales.

En algunos países, como Bélgica, Italia y el Reino U nido, los sistemas de inspección de trabajo cuentan con diversos servicios especializados en los diferentes tipos de inspección. En Bélgica existe una inspección técnica dedicada a la prevención y la seguridad en las empresas, una inspección médica responsable de la salud e higiene, una inspección especializada en la legislación social reguladora de las condiciones de empleo (salarios, horas de trabajo, etcétera) y una inspección que verifica el pago de las cotizaciones sociales, aparte de un cuerpo de funcionarios especializados en las relaciones laborales. En este tipo de sistemas, si bien cada servicio se especializa en un campo determinado, sus competencias abarcan, por lo general, la totalidad de los sectores económicos.

La especialización de los inspectores de trabajo ha venido impuesta por la creciente complejidad de la función inspectora. Los defensores de la especialización aducen que un inspector no puede poseer todos los conocimientos necesarios para abordar la totalidad de los problemas que la protección de los trabajadores plantea. En algunos países, la especialización ha llegado a un extremo tal que las condiciones de trabajo, entendidas en el sentido más amplio de la expresión, pueden estar sometidas a cuatro o cinco tipos de inspección en una misma empresa.

En otros países, por contra, existe un sistema único y un sólo cuerpo de funcionarios competentes en todas las cuestiones relacionadas con la inspección de trabajo. Este es el caso de Austria, Alemania y los países francófonos de Africa, por ejemplo. Por razones obvias, estos últimos países no han podido asumir el considerable gasto de organizar varios cuerpos especializados y se han conformado con crear una inspección única adscrita al ministerio de trabajo. En estos casos, la inspección se responsabiliza de la totalidad de las tareas que se desarrollan en las empresas y el inspector o supervisor es el único representante del ministerio en la empresa.

Este sistema posee la ventaja de proporcionar a los inspectores una visión global de los problemas laborales, a menudo relacionados entre sí, además de evitar la proliferación de inspecciones y las consiguientes disfunciones; sin embargo, cabe preguntarse hasta qué punto los inspectores son capaces de cumplir un programa tan extenso, en vista de la creciente complejidad de las cuestiones jurídicas y técnicas.

Existe una solución intermedia, consistente en un sistema en el que los inspectores, además de ejercer competencias en numerosos campos, poseen los conocimientos técnicos necesarios para descubrir las posibles situaciones de riesgo y recabar la asistencia de especialistas en medicina, química e ingeniería, de conformidad con lo previsto en el Convenio no 81. Esto es lo que ocurre en Francia. 0 tro ejemplo es el del Reino U nido, donde los inspectores generales de salud y seguridad recaban la ayuda de inspectores especializados en las materias más técnicas (electricidad, química, energía nuclear, etc.) cuando se producen 
problemas específicos. Esto ha producido en la inspección de trabajo una cierta tendencia a convertirse en una actividad multidisciplinaria, condición que ya posee en los Países Bajos y en Dinamarca, y en otros países nórdicos, en los que existen equipos de inspección de distrito compuestos, además de por los inspectores (que han recibido una formación técnica), por un número de ingenieros, médicos, psicólogos, abogados y ergónomos. La presencia de estos equipos multidisciplinarios confiere a los coordinadores una visión global de los diversos aspectos de las condiciones de trabajo y les permite basar sus decisiones en una síntesis de las opiniones conocidas. Aunque sumamente costoso, el sistema resulta sumamente eficaz, siempre que exista una coordinación efectiva del trabajo de los diversos especialistas.

El proceso de unificación 0 , al menos, de coordinación de los servicios de inspección, que se ha venido desarrollando en cierto número de países, se explica en virtud de las estrechas relaciones existentes entre los distintos aspectos de las condiciones de trabajo. Dicho proceso satisface las expectativas, tanto de los funcionarios responsables de la supervisión, como de los trabajadores y sus sindicatos. Los trabajadores con problemas no comprenden por qué tienen que recurrir a un funcionario distinto para abordar cada aspecto del problema y exponer nuevamente la situación en cada entrevista, quizás con una perdida considerable de tiempo. El interés del sindicato consiste en mejorar la eficacia de la inspección de trabajo y facilitar los contactos entre ésta y los afiliados.

\section{Funciones de las comunidades locales}

Algunos Estados aún recaban la colaboración de las administraciones locales con los servicios de inspección de trabajo o, incluso delegan en las mismas la realización de determinadas tareas de inspección en lugar de los servicios estatales.

En Suecia, por ejemplo, en la Ley del medio ambiente de trabajo, de 19 de diciembre de 1997, se confiaba la aplicación de sus disposiciones y de los reglamentos dictados para su desarrollo al Consejo de Protección de los Trabajadores y al servicio de la inspección de trabajo, adscrito al Consejo y sometido a la supervisión del mismo. Según la ley, cada municipio, previa consulta con el servicio de inspección de trabajo, debe nombrar uno 0 más supervisores que colaboren en la realización de las tareas del servicio de la inspección de trabajo. Por regla general, esta labor consiste en supervisar las empresas con menos de diez trabajadores que no emplean maquinaria. Todos los municipios están obligados a presentar al servicio de inspección de trabajo una memoria anual de la actividad de supervisión desarrollada.

En Italia, concretamente, se promulgó la Ley de 23 de diciembre de 1978, de reforma del sistema sanitario, por la que se delegaban las responsabilidades por la sanidad pública, incluida la salud laboral y la seguridad, en las autoridades sanitarias regionales y locales. L as unidades locales de salud, creadas por las autoridades municipales, se ocupan de todo lo relativo a la salud pública: administración de los hospitales, gestión de los servicios de salud locales, salud y seguridad en las empresas, etcétera. Por tanto, la reforma legislativa ha privado a la inspección de trabajo, organismo dependiente del Ministerio de Trabajo, de la función para la que se creó inicialmente.

La transferencia de las funciones de supervisión de la salud y seguridad, anteriormente desempeñadas por la inspección de trabajo, a las unidades locales de salud, ha resultado en la coexistencia de dos servicios de inspección de trabajo: uno, adscrito al M inisterio de Trabajo, que continúa supervisando la aplicación de la legislación laboral (salarios, horas de trabajo, permisos retribuidos, etc.) y desempeñando algunas funciones relativas a la salud y seguridad (medición de las radiaciones ionizantes, inspección de los ferrocarriles en colaboración con el personal de ferrocarriles, etcétera), y otro, integrado en el Instituto $\mathrm{N}$ acional de la Salud, que tiene competencias en la mayoría de las cuestiones de salud y seguridad y está constituido por los servicios locales denominados unidades locales de salud.

En U ganda se ha realizado un importante esfuerzo de descentralización que ha colocado la inspección de trabajo - aunque no la inspección industrial- bajo la dependencia directa de las autoridades locales (de distrito). N o obstante, los ejemplos anteriormente citados constituyen excepciones y no la regla. A demás, estos casos suscitan serias dudas respecto a su compatibilidad con algunas de las disposiciones más importantes de los Convenios de la OIT, específicamente, el artículo 4 del C onvenio $n$ o 81), según las cuales la inspección de trabajo debe depender de una autoridad central.

\section{La inspección de trabajo en las minas}

En la práctica totalidad de los países en los que existe un sector minero funciona un servicio de inspección del sector basado en el sistema que ha estado funcionando durante varias generaciones en las antiguas naciones mineras de Europa, como Bélgica, Francia, la República Federal de Alemania y el Reino U nido.

L os sistemas actuales poseen dos importantes rasgos comunes. Mientras que la supervisión de las condiciones de trabajo reinantes en la superficie corresponde a la inspección de trabajo, la preservación de la salud y seguridad en las instalaciones subterráneas está encomendada, excepto en algunos países, como $M$ éxico, a los ingenieros de minas, que constituyen un cuerpo especializado. A demás, en todos estos sistemas, los delegados de los mineros colaboran en el lugar de trabajo - en mayor 0 menor medida y con facultades variables - con la inspección de trabajo.

\section{Poderes y obligaciones de los inspectores de trabajo}

\section{Poderes}

\section{Libertad de entrada e inspección}

El primer derecho de los inspectores, sin el cual no podría existir la inspección, es el de poder visitar las empresas. Las disposiciones del C onvenio no 81 (recogidas en el Convenio no 129, relativo a la agricultura) en las que se regula este derecho son las siguientes:

Los inspectores de trabajo que acrediten debidamente su identidad estarán autorizados:

(1) para entrar libremente y sin previa notificación, a cualquier hora del día o de la noche, en todo establecimiento sujeto a inspección;

(2) para entrar de día en cualquier lugar, cuando tengan un motivo razonable para suponer que está sujeto a inspección

Durante la elaboración de estas normas internacionales, se produjo una considerable oposición al reconocimiento del derecho de entrada en los lugares de trabajo. Tampoco la consagración de este derecho en las distintas legislaciones nacionales ha estado ausente de dificultades. Se aducía, específicamente, que este proceder constituía una violación flagrante del derecho de propiedad. La autorización para acceder a los lugares de trabajo a cualquier hora suscitó una resistencia especialmente intensa; sin embargo, es evidente que los inspectores sólo pueden verificar el posible empleo ilegal de trabajadores realizando inspecciones en horas inusuales. En la práctica, el derecho de entrada en los establecimientos es una costumbre generalizada en todos los países que cuentan con servicios de inspección. 
Esta y otras cuestiones relacionadas con los poderes de inspección fueron nuevamente objeto de un intenso debate durante el período de sesiones de 1995 de la Conferencia Internacional del Trabajo, en la que se abordó el problema de la inspección de trabajo en el sector de los servicios no comerciales. En la Conferencia se aprobó un "Protocolo de aplicación del Convenio no 81" a este sector y se confirmaron esencialmente los poderes de los inspectores, aunque admitiendo algunas posibles excepciones y limitaciones, por ejemplo, por motivos de seguridad nacional 0 en razón de determinadas exigencias operativas, respecto a los lugares de trabajo adscritos a las fuerzas armadas, al cuerpo de policía, al servicio de prisiones, a los cuerpos de bomberos y de salvamento o a otros cuerpos similares (véase, en O IT 1996, los artículos 2 a 4 del Protocolo de 1995).

Según los Convenios no 81 y no 129 , se debe autorizar a los inspectores a "proceder a cualquier prueba, investigación o examen que consideren necesario para cerciorarse de que las disposiciones legales se observan estrictamente", lo que lleva aparejado, de conformidad con ambas normas internacionales, el derecho a interrogar, a solas 0 en presencia de testigos, al empresario o a su personal; el derecho a exigir la presentación de libros, registros y demás documentos que deben llevarse por imperativo legal o reglamentario; y el derecho a tomar muestras con fines de análisis. Estos derechos se encuentran ampliamente reconocidos, si bien en algunos países se limita el acceso a la documentación financiera.

Se tiene, pues, la impresión de que, con raras excepciones, la facultad supervisora de los inspectores ha sido aceptada y ha dejado de suscitar una oposición abierta. Sin duda, el derecho a recabar el auxilio de la fuerza pública, reconocido en la mayoría de las legislaciones, es un elemento disuasorio de peso, siempre que los ministerios competentes hayan acordado un procedimiento eficaz.

Evidentemente, estos poderes se encuentran sometidos a idénticas limitaciones como cualquier otra potestad legal, pues, si se ejercen indiscriminadamente, pueden producir, en última instancia, unos efectos opuestos a los deseados. Estas facultades se confieren a los inspectores para que las desempeñen prudentemente y, como la experiencia ha demostrado, su capacidad para cumplir esta función depende en gran medida de la calidad de su formación.

\section{Poderes de jurisdicción}

En el Convenio no 81 se establece que "Ios inspectores de trabajo estarán facultados para tomar medidas a fin de eliminar los defectos observados en la instalación, en el montaje o en los métodos de trabajo que, según ellos, constituyan razonablemente un peligro para la salud o seguridad de los trabajadores". Esta disposición se recoge, casi literalmente, en el Convenio no 129 , igualmente aplicable al uso de sustancias peligrosas, debido, evidentemente, al uso generalizado de productos químicos en la agricultura.

Si la inspección de trabajo careciese de medios para subsanar las situaciones irregulares descubiertas en las empresas, su eficacia se vería, evidentemente, disminuida. Ciertamente, la eficacia de un servicio de inspección únicamente se puede medir por el alcance real de sus poderes, por el modo en que éstos se ejercen y por los resultados de las advertencias que los inspectores formulan y de las órdenes que dictan.

Aunque en los dos Convenios y el Protocolo mencionados se subraya la importancia que, en principio, revisten los poderes de jurisdicción, en los tres documentos se deja a los gobiernos una cierta libertad de acción. En efecto, después de establecer que los inspectores "estarán facultados (...) a ordenar o hacer ordenar" la adopción de las medidas necesarias, las modificaciones en la instalación, dentro de un plazo determinado, o la adopción de medidas de aplicación inmediata, se concede que, si este sistema no fuese compatible con la práctica administrativa o judicial del Estado miembro en cuestión, los inspectores podrán "dirigirse a la autoridad competente para que se dicten órdenes - se adopten medidas de aplicación inmediata". Se imponía tomar en consideración la imposibilidad, de acuerdo con el ordenamiento constitucional de algunos Estados miembros, de conferir tales poderes a un organismo administrativo. Por consiguiente, los poderes reconocidos a los inspectores de trabajo suelen diferir de un país a otro, incluso entre los E stados que han ratificado el Convenio n- 81 de la OIT.

Con el objeto de "eliminar los defectos observados", el inspector puede, bien dictar una orden por la que se conceda a la empresa un plazo determinado para subsanar los defectos, bien requerir la adopción de medidas de aplicación inmediata, en caso de peligro inminente. Esta última facultad se ha venido reconociendo a los inspectores de trabajo en un número creciente de países, entre los que merecen citarse Bélgica, la República Federal de Alemania, Japón, el Reino U nido, las naciones escandinavas, Sudáfrica y muchos otros países que emprendieron procesos de reforma de sus respectivas legislaciones sobre salud y seguridad en el trabajo en el decenio de 1980 y principios del siguiente. En otros países, la competencia para dictar este tipo de medidas sigue correspondiendo en exclusiva a los tribunales ordinarios; sin embargo, el tiempo que un tribunal tarda en dictar un fallo y el tiempo que lleva la ejecución de ese fallo suponen una demora durante la cual se puede producir un accidente. Por otra parte, los jueces de la jurisdicción ordinaria no suelen conocer en profundidad las cuestiones de la protección de los trabajadores, por lo que no es infrecuente que se muestren escasamente sensibles a las infracciones. Ciertamente, se suelen imponer multas muy pequeñas, lo cual, junto con otras circunstancias que contribuyen a minar la autoridad de los inspectores de trabajo, han acentuado la tendencia a reemplazar el encausamiento judicial, incluso, de las infracciones menores que se substanciaban por la vía penal, por una tramitación administrativa sobre la que la inspección de trabajo puede ejercer un mayor control. Con el objeto de reducir estas demoras, en algunos países se ha implantado un procedimiento de urgencia, según el cual los inspectores de trabajo pueden recurrir al Juez competente, incluso en horas inhábiles, en demanda de un mandamiento ejecutivo de efectos inmediatos.

\section{Derecho de apelación}

Lógicamente, las decisiones de obligado cumplimiento dictadas por los inspectores suelen ser apelables por parte de la empresa, pues es preciso que exista una vía de prevención y subsanación de posibles abusos. Por regla general, las decisiones ejecutorias dentro de un plazo son apelables en ambos efectos, al tiempo que las órdenes de ejecución inmediata no son apelables, dado el peligro inminente que pretenden evitar.

\section{Adopción de medidas en caso de infracción}

"Las personas que violen las disposiciones legales por cuyo cumplimiento velen los inspectores del trabajo, o aquéllas que muestren negligencia en la observación de las mismas, deberán ser sometidas inmediatamente, sin aviso previo, a un procedimiento judicial." Este mandato estricto, formulado en el Convenio no 81 y recogido en el Convenio no 129, queda, no obstante, moderado por otras dos disposiciones. La primera de ellas reza así: "Sin embargo, la legislación nacional podrá establecer excepciones, para los casos en que deba darse un aviso previo, a fin de remediar la situación o tomar disposiciones preventivas". La segunda de dichas disposiciones es del tenor siguiente: "Los inspectores de trabajo tendrán la facultad 
discrecional de advertir y aconsejar, en vez de iniciar o recomendar un procedimiento".

En la segunda de las disposiciones citadas se concede a los inspectores de trabajo una discrecionalidad absoluta. En cada situación, los inspectores deben decidir el medio más adecuado para garantizar el cumplimiento de la ley. La elección se ajustará a un plan que la inspección habrá adecuado a las características de la empresa, así como a una escala de objetivos ordenados por orden de importancia.

Si los inspectores optan por la vía judicial, pueden, bien ejercitar por sí mismos las acciones legales pertinentes (como ocurre en los países adscritos a la tradición administrativa británica), bien instar al ministerio fiscal 0 a la autoridad judicial competente la incoación de actuaciones, que es el caso más frecuente. En este último caso, los inspectores de trabajo elaboran un informe que se considera fehaciente a menos que sea desestimado o (en algunos países) hasta tanto su validez no se impugne judicialmente.

En los Convenios no 81 y no 129 se dispone que "la legislación nacional deberá prescribir sanciones penales adecuadas, que habrán de ser efectivamente aplicadas, en los casos de violación de las disposiciones legales por cuyo cumplimiento velen los inspectores de trabajo". Si bien en todas las legislaciones nacionales se prevé la imposición de sanciones a los infractores, no es frecuente que aquéllas sean "adecuadas". Las multas, cuyo montante se suele fijar en las normas legales a la promulgación de las mismas y no se suele modificar durante años, son tan leves que sus efectos disuasorios son casi nulos. Si el tribunal impone una pena de privación de libertad, su ejecución suele quedar en suspenso hasta tanto no se produzca la reincidencia del condenado. Los tribunales disfrutan en todos los casos de una discrecionalidad absoluta. Es preciso reconocer a este respecto que la voluntad de un gobierno de hacer cumplir la legislación protectora de los trabajadores se puede medir en función de la severidad de las sanciones prescritas en la ley y de la aplicación que los tribunales hacen de la misma.

En las legislaciones nacionales se suelen sancionar severamente todo acto de resistencia al desempeño de las funciones de la inspección de trabajo y toda contestación de la autoridad del Estado, previéndose, además, la posibilidad de recabar el auxilio de la fuerza pública. En realidad, no es frecuente que los directores de empresas utilicen tácticas obstrucionistas.

\section{Obligaciones}

\section{Imparcialidad}

Según los Convenios no 81 y no 129, "se prohibirá que los inspectores de trabajo tengan cualquier interés directo o indirecto en las empresas que estén bajo su vigilancia". En la mayoría de los países, esta prohibición figura, tanto en el reglamento de la función pública, como en disposiciones especiales.

\section{Secreto profesional}

Los inspectores de trabajo "estarán obligados, so pena de sufrir sanciones o medidas disciplinarias apropiadas, a no revelar, aún después de haber dejado el servicio, los secretos comerciales o de fabricación o los métodos de producción de que puedan haber tenido conocimiento en el desempeño de sus funciones". El estatuto jurídico de la función pública obliga con carácter general a todos los funcionarios y, por ende, a los inspectores, a guardar el secreto profesional. Por regla general, esta obligación consta en el acta de nombramiento del inspector o se asume al prestar juramento en la toma de posesión. Los inspectores prometen entonces guardar secreto, no sólo mientras permanezcan en el cargo, sino de por vida.

\section{Reserva respecto al origen de las quejas}

Los inspectores de trabajo "deberán considerar absolutamente confidencial el origen de cualquier queja (...) y no manifestarán al empleador 0 a su representante que la visita de inspección se ha efectuado por haberse recibido dicha queja". Esta obligación, absolutamente vinculante, persigue el doble objeto de proteger a los trabajadores que formulan quejas y de aumentar la eficacia de la labor del inspector. Al igual que las obligaciones anteriormente citadas, ésta suele figurar en alguna disposición legal o en el reglamento del funcionariado, y se suele asumir en el juramento que se presta al tomar posesión del cargo.

\section{Independencia de los inspectores}

La independencia entraña para los inspectores una obligación y una garantía. Tanto en el Convenio no 81, como en el $n \circ 0129$ se establece que "el personal de inspección deberá estar compuesto por funcionarios públicos cuya situación jurídica y cuyas condiciones de servicio les garanticen la estabilidad en su empleo y les independicen de los cambios de gobierno y de cualquier influencia exterior indebida", como las que algunos directores de empresa poco escrupulosos y determinados medios políticos podrían tratar de ejercer.

\section{Inspección de trabajo preventiva}

En las postrimerías del siglo $X X$, muchas instituciones dedicadas a las tareas de la política social y laboral, que nacieron en el siglo XIX con una vocación y una preocupación muy marcadas por la prevención, están inmersas en un proceso de cambios rápidos y profundos. Estos cambios, que obedecen a una serie de factores, tanto internos, como externos, de orden político, social, económico, administrativo y tecnológico, repercutirán profundamente en el ámbito de actuación, la importancia y las funciones de estas instituciones, así como en sus relaciones entre sí y con sus principales clientes, a medida que dichas instituciones traspasan el umbral del siglo XXI. Es preciso analizar y comprender la naturaleza de estos cambios, sus efectos sobre el comportamiento, la capacidad, los efectos y las relaciones entre los principales agentes del cambio, y el contexto social en el que se producen.

En numerosos documentos internacionales, como en los Convenios números $81,129,155,174$ y otros de la 0 IT, figuran referencias a la prevención como parte de la protección de los trabajadores, así como a la función de la inspección de trabajo a este respecto. Sin embargo, si bien en los documentos dedicados a la inspección de trabajo (Convenios números 81 y 129, y R ecomendaciones números 81,82 y 133) se promueven y se alientan de forma genérica los principios de la prevención, sólo se aborda directamente esta cuestión en la fase previa al empleo (véanse los párrafos 1 a 3 de la Recomendación no 81, y el párrafo 11 de la Recomendación no 133).

Desde la aprobación de estos documentos normativos de la inspección de trabajo (de los cuales, concretamente, el Convenio no 81, sobre la inspección de trabajo en el comercio y la industria, ha adquirido una dimensión universal al haber sido ratificado por 120 Estados miembros de la OIT), el concepto de prevención ha variado sustancialmente. El término "prevención" alude, ante todo, a un esfuerzo denodado de evitación de accidentes, incidentes, disputas, conflictos, etc. Sin embargo, es mucho más fácil documentar, cuantificar y valorar los sucesos producidos que han sido objeto de actuaciones o sanciones que los riesgos evitados. ¿Cómo se cuantifican el número y los efectos de los accidentes que no se han producido? ¿Y cómo se acreditan la efectividad y la eficiencia de la prevención a modo de resultado y como evidencia del éxito?

Actualmente, la prevención constituye un paradigma de política social y laboral orientada al objetivo global de lograr que las personas tengan una vida productiva más larga y saludable, 
contribuyendo con ello a moderar el crecimiento geométrico de los costes que la seguridad social produce a las empresas, a las personas y a la sociedad en su conjunto. Por otra parte, en el mundo del trabajo, la prevención se valora en medida creciente, no sólo como una función de sus beneficios inmediatos, sino también por su contribución al mantenimiento y sustentación de la capacidad de trabajo, la productividad y la calidad, la seguridad en el empleo y otros resultados, por lo que igualmente se valora en mayor medida cada vez como condición indispensable para que las personas lleven una vida digna en sociedad. La prevención se configura así como una concepto "abierto", universal y pluralista, orientado a la evitación de múltiples riegos sociales, técnicos, médicos, psicológicos y de otro tipo, y cuya efectividad depende en medida creciente de la identificación, el análisis y la interpretación de una serie de indicadores precoces.

El enorme bagaje de experiencia acumulado en los últimos diez años por la OIT en colaboración con sus afiliados de todo el mundo demuestra que la evolución desde una concepción relativamente rígida de actuación correctiva hacia una política de prevención conduce invariablemente a un desarrollo sustancial de la administración del trabajo y a unos mejores resultados. Sin embargo, esta experiencia también demuestra la dificultad inherente a este cambio de rumbo y a su mantenimiento frente a una pluralidad de factores que lo obstaculizan.

Asimismo, para que una política de prevención sea eficaz, se precisa la participación de todas las personas directamente interesadas. Por consiguiente, se suele requerir inicialmente la adhesión e identificación de las organizaciones representativas de los interlocutores sociales con todas las iniciativas. Asimismo, los objetivos de prevención fijados se deben integrar plenamente en el conjunto de objetivos de las empresas afectadas. A su vez, este requisito exige, más que una participación intensa, el protagonismo de la dirección empresarial. Empero, estos requisitos están aún lejos de haberse alcanzado en el ámbito mundial, ni aún en los más desarrollados entre los países de economía de mercado.

Aparte de las consideraciones anteriores, las restricciones presupuestarias a que se ven sometidos los gobiernos de todo el mundo (tanto de los países industrializados como de las naciones en vías de desarrollo) y, por consiguiente, los servicios operativos de la administración del trabajo y de la inspección de trabajo (restricciones que, en el caso de estos servicios, suelen ser francamente desproporcionadas) ponen en peligro la continuidad 0 , cuando menos, la entidad, de cualquier orientación o reorientación de la política en el sentido anteriormente indicado, dado que estos procesos son, al menos en un principio, laboriosos y altamente costosos, además de difíciles de cuantificar y, por lo tanto, de justificar.

No obstante, en todos los países industrializados, los costes económicos y sociales de la no prevención están creciendo desproporcionadamente, hasta situarse en unos niveles económica y políticamente inaceptables. A estas consideraciones se debe añadir el reconocimiento creciente de la insuficiencia global de la actuación correctiva, todo lo cual ha producido la convicción de que es absolutamente imprescindible reforzar los aspectos preventivos de todo sistema de protección social y laboral. Esto ha suscitado en los foros nacionales e internacionales un amplio debate en torno a la necesidad de formular unos fundamentos válidos y efectivos para la inspección de trabajo preventiva.

El ritmo acelerado del cambio y la innovación en todos los aspectos de la vida laboral - relaciones laborales, organización del trabajo, tecnología de producción, condiciones de trabajo, informática, nuevos riesgos, etcétera- plantea a la inspección de trabajo un desafío creciente. L os inspectores no están, simplemente, obligados a mantenerse al tanto de la evolución de una pluralidad de áreas disímiles, crecientemente complejas y cada vez más especializadas, que deben dominar para realizar su labor; de hecho, deben, además, prever los nuevos fenómenos y tendencias, y comprender y anticiparse a sus efectos sobre la protección de los trabajadores, con el objeto de diseñar y poner en práctica nuevas políticas de prevención.

En el mundo laboral, la inspección de trabajo es uno de los principales (si no el principal) cauce de la presencia e intervención del Estado, orientada a forjar, estimular y contribuir al desarrollo de una cultura de la prevención en todas las áreas sujetas a su competencia: relaciones laborales, condiciones generales de trabajo, salud y seguridad en el trabajo, seguridad social. Para alcanzar plenamente este objetivo básico, las inspecciones de trabajo deben replantearse sus políticas y orientar la reforma de la legislación, los sistemas, las relaciones laborales, etcétera, hacia el desarrollo de los medios de prevención, tanto internos como externos. Esto atañe, no sólo a los sistemas y políticas que las autoridades competentes deben aplicar, sino también a los métodos de inspección utilizados por los inspectores en los lugares de trabajo.

Las presiones y exigencias que convergen sobre las inspecciones de trabajo desde perspectivas económicas, políticas y administrativas constituyen elementos clave en este contexto. Estos factores se definen normalmente utilizando términos como desregulación, privatización, ajustes estructurales y liberalización. En la práctica, estas políticas dificultan y complican la labor de la inspección de trabajo, si bien, a veces, se convierten en la fuerza motriz del cambio. Sin embargo, lo que suelen hacer es acentuar una escasez de recursos que, ya de por sí, suele ser crónica. Por lo tanto, la inspección de trabajo debe explorar otras posibles fuentes de desarrollo de su contribución específica a la prevención.

El objetivo último consiste en forjar, en el lugar de trabajo y en la sociedad una "cultura de la prevención" amplia y coherente, en la que se tome en consideración la dinámica creada por la evolución de las relaciones laborales en la empresa, la contestación a los principios de autoridad y legitimidad inducida por los cambios producidos en las actitudes, en la organización del trabajo, etc., los niveles de educación y formación generalmente superiores (y en ascenso) de empresarios y trabajadores por igual, las nuevas formas de participación que forjan un entorno propicio, etcétera. Todos estos cambios promueven nuevas formas de cooperación de la inspección de trabajo con los trabajadores, las empresas y las instituciones, no sólo en relación con la aplicación de las normas de protección de los trabajadores, sino, además, en el interés de lograr el cumplimiento global de los objetivos fijados en materia de prevención en las nuevas leyes y políticas laborales y sociales adoptadas en el campo de la prevención.

\section{RESPONSABILIDAD CIVIL Y PENAL EN EL CAMPO DE LA SALUD Y SEGURIDAD EN EL TRABAJO}

Felice M orgenstern*

\section{Obligaciones en materia de salud y seguridad}

En el campo del derecho, el concepto de responsabilidad tiene dos dimensiones: una es la obligación de hacer o no hacer algo; la otra es el deber de responder de lo hecho. El examen de las

* El presente artículo es una adaptación de Deterrence and Compensation, de Felice M orgenstern (O IT 1982) 
responsabilidades legales que diferentes categorías de personas asumen en el ámbito nacional por las causas de los accidentes de trabajo y las enfermedades profesionales debe ir precedida de un resumen de las obligaciones que esas personas asumen en el esfuerzo de prevención de tales accidentes y enfermedades. Estas obligaciones se pueden regular expresamente en los acuerdos internacionales 0 en la legislación nacional, aunque también pueden tener su origen en la jurisprudencia. Se ha cuestionado la utilidad de determinar, en un proceso civil posterior a la producción de la lesión, cuál habría sido el comportamiento exigible a las personas interesadas antes de la lesión. Sin embargo, no es menos evidente que algunas de las sentencias dictadas, y la publicidad que han suscitado, han servido de incentivo al esfuerzo en el campo de la prevención.

\section{Organismos públicos}

Los organismos públicos (departamentos ministeriales, autoridades competentes en materia de salud y seguridad, y otros entes públicos) contribuyen en considerable medida a fijar el marco de determinación de la responsabilidad, tanto mediante la adopción de normas (de ámbito general o especial) reguladoras de las obligaciones de diversos grupos de personas, como a través de su contribución a la aplicación de las mismas.

Tanto las normas de aplicación general a la salud y seguridad en el trabajo, como las normas de protección de la salud y la seguridad en sectores concretos o frente a determinados peligros, pueden figurar en leyes y reglamentos, códigos de conducta y especificaciones técnicas aprobadas por los organismos públicos. En algunos convenios internacionales de trabajo se exige la normalización oficial de la totalidad de las cuestiones regulada en el documento en cuestión, al tiempo que en otros convenios se establece la obligación de dictar prohibiciones específicas o de fijar normativamente los límites de ciertas exposiciones. En la legislación nacional, tanto en los códigos del trabajo, como en la regulación legal específica de la salud y seguridad, se suele establecer la obligatoriedad de que los organismos públicos dicten reglamentos o normas pormenorizados, bien con carácter coercitivo, bien en forma de directrices autorizadas; por regla general, los organismos públicos competentes gozan de una amplia discrecionalidad, tanto respecto a las materias reguladas en su normativa, como en relación a su contenido. En el contexto del presente trabajo, puede ser preciso especificar en esas normas los organismos o personas en los que recae la obligación de hacer cumplir el contenido de las mismas. En varios Convenios internacionales, como el Convenio de la OIT sobre el cáncer profesional, 1974 (no 139) se establece este criterio.

El incumplimiento de las normas no coercitivas, como los códigos de práctica, no constituye, por sí sólo, base jurídica alguna para la institución de actuaciones civiles o penales. Sin embargo, tal incumplimiento es aducible en el curso de los procedimientos judiciales que se sustancien por la infracción de otras normas generales de naturaleza coercitiva, ya que aquél puede constituir un indicio de que no se ha procedido con la diligencia debida en el cumplimiento de las normas imperativas.

$\mathrm{Ni}$ la ausencia de una normativa ni el desfase de las normas vigentes respecto de las exigencias de la tecnología más avanzada eximen automáticamente a las empresas - industriales 0 de otro tipo- de sus responsabilidades legales; ciertamente, algunos tribunales han sentado la doctrina de que las empresas no pueden escudarse tras la inercia de los organismos públicos. Así, en 1971, el Tribunal Superior de Justicia de Inglaterra, al fallar una demanda de resarcimiento de daños y perjuicios por una forma grave de embolia aérea (necrosis ósea), estimó que, cuando la lesión se produjo, era de conocimiento general entre las personas avezadas en el funcionamiento de los túneles aerodinámicos que la tabla oficial de descomprensión era inadecuada; en efecto, el Tribunal resolvió que la empresa estaba obligada a mantenerse al tanto de los avances técnicos (R ansom contra Sir Robert M CAlpine and Sons Ltd. 1971). En algunos países, la inspección de trabajo está expresamente facultada para conminar a las empresas a que subsanen situaciones de peligro no previstas en las normas de obligado cumplimiento.

\section{Fabricantes, proveedores, etcétera}

En la mayoría de los países se han dictado normas legales, directrices, etc., en las que se regulan las obligaciones de los fabricantes, proveedores, etc., en relación con la salud y seguridad en el trabajo. Por regla general, esta normativa atañe, en unos casos, a la maquinaria y equipo, y, en otros, a las sustancias peligrosas. Las exigencias de salud y seguridad que la maquinaria y equipo deben satisfacer antes de su instalación en el lugar de trabajo son de tres clases: su diseño y construcción deben ser tan seguros como sea posible; se deben someter a ensayos que establezcan efectivamente su seguridad; y sólo se pueden comercializar (a través de los canales de compraventa, alquiler, importación o exportación) una vez contrastada su seguridad. La responsabilidad principal a este respecto puede ser imputable al fabricante, al vendedor 0 a toda la cadena de distribución.

Aunque los requisitos generales exigidos a las sustancias utilizadas en el lugar de trabajo sean similares a los aplicables a la maquinaria y equipo, los efectos de una determinada sustancia sobre la salud suelen ser mucho más difíciles de determinar. Por consiguiente, mientras que en algunos ordenamientos jurídicos nacionales se regula la responsabilidad por el uso de sustancias en pie de igualdad con las obligaciones derivadas del empleo de maquinaria y equipo, en otros países se afronta directamente esta dificultad. Por ejemplo, en el Código de Trabajo francés, modificado en 1976, se exige que, antes de iniciar la comercialización de una sustancia que entrañe algún peligro para los trabajadores, "cualquier persona dedicada a su producción, importación o venta", facilite a las instituciones homologadas la información necesaria para la evaluación de los riesgos (artículo L. 231-7); además, se puede requerir que la persona en cuestión participe en la evaluación del riesgo. En numerosos países, se incluyen en este tipo de obligaciones la de etiquetado de las sustancias peligrosas y la de informar de los medios seguros de manipular las sustancias. Estas obligaciones no se limitan necesariamente al período de comercialización inicial del producto; en efecto, en el Reino Unido existe, en principio, la obligación de hacer lo necesario a la luz de las circunstancias en presencia para mantenerse al tanto del progreso técnico, así como de actuar con la diligencia exigible en virtud de la naturaleza de la información suministrada. Las medidas exigibles son una función, tanto de la gravedad potencial del riesgo, como de las consecuencias previsibles de la retirada del producto (causa W right contra D unlop Rubber C 0 . y otro 1971). Son de subrayar el interés y el esfuerzo crecientes que se observan en el plano internacional por la armonización de las etiquetas de las sustancias peligrosas. Por ejemplo, en los Convenios 170 y 174 de la OIT se establecen algunos requisitos de información en la exportación de sustancias.

\section{Exigencia coercitiva de las obligaciones relativas a la salud y seguridad}

Existen dos formas de exigir responsabilidades por el incumplimiento de una obligación: una es la responsabilidad objetiva por la infracción misma, independientemente de que se produzcan o no resultados; la otra modalidad es la responsabilidad por las consecuencias de la infracción. 


\section{Organismos públicos}

En la mayoría de los países resulta extremadamente difícil obligar, mediante el ejercicio de acciones legales, a los organismos públicos a ejercitar sus competencias reguladoras, como la obligación contenida en algunos convenios internacionales de trabajo y en diversas legislaciones nacionales de dictar normas sobre la salud y seguridad en el trabajo. Si bien en algunos países de derecho consuetudinario existe la institución del mandamus, mandamiento judicial que se dicta a requerimiento de parte directamente autorizada y por el que se obliga a los funcionarios públicos a cumplir las obligaciones impuestas a los mismos en el derecho consuetudinario o en las leyes escritas, el recurso a esta vía legal parece ser sumamente infrecuente en las circunstancias presentes. En todo caso, la utilización de este medio se dificulta enormemente en los casos (mayoritarios) en que la legislación aplicable confiere a los organismos públicos amplios poderes discrecionales respecto a las áreas, los medios y los plazos de actuación. Los medios más eficaces de promover la intervención de las autoridades son extrajudiciales, por ejemplo, mediante la presión de los sindicatos, las organizaciones de consumidores y otros grupos influyentes en la opinión pública. Sin embargo, éstos no son métodos ejecutivos en el sentido estricto del término.

Es más frecuente que las medidas adoptadas por los poderes públicos sean revocadas sobre la base de su ilegalidad o de que rebasan los poderes conferidos por las leyes (desviación de poder) 0 , como sucede más frecuentemente, de que tales medidas son inadecuadas o poco razonables. No se trata en este caso de hacer cumplir una obligación, sino, más bien, de fijar sus límites.

\section{Fabricantes y proveedores}

Además de atribuir obligaciones específicas a los fabricantes y proveedores, en la legislación aplicable a la salud y seguridad en el trabajo se suele prever igualmente la imposición de sanciones a los infractores. Esto es lo que ocurre, por ejemplo, el Francia, el Reino Unido, Dinamarca y Suecia. En algunos países, las sanciones consisten en multas. Esta es la situación imperante en el Reino U nido, excepto en los casos de incumplimiento de una prohibición expresa. En otros países, como Francia y Venezuela, los reincidentes en la infracción pueden ser condenados a penas privativas de libertad. Existe un tercer grupo de países en los que los infractores primarios pueden ser condenados indistintamente al pago de multas o a penas de prisión. Esta posibilidad se prevé en el artículo 1 del capítulo 8 de la Ley sueca del medio ambiente de trabajo, de 1978.

La prevención de la distribución de maquinaria o de sustancias que no satisfagan las normas de salud y seguridad debe constituir uno de los objetivos centrales de la política ejecutiva dirigida a los fabricantes y proveedores. Esta filosofía ha quedado reflejada en algunas normas legales, como el Código de Trabajo francés, en el que se prevé la posibilidad de recurrir a un procedimiento de urgencia para paralizar la comercialización de sustancias peligrosas o el uso de maquinaria poco segura. En dicho cuerpo legal se prevé, incluso, la posibilidad de rescindir las transacciones de compraventa 0 de arrendamiento de que haya sido objeto algún equipo inseguro.

\section{Empresas}

En todos los convenios internacionales de trabajo recientemente suscritos en el campo de la salud y seguridad en el trabajo se confía la supervisión de su aplicación a unos servicios de inspección adecuados. En la sección dedicada a la "Inspección de trabajo" en este mismo artículo se aborda esta cuestión en mayor profundidad. No obstante, la cuestión de si los inspectores de trabajo pueden iniciar actuaciones legales por sí mismos, si han de acudir a sus superiores jerárquicos o si deben trasladar la cuestión a otra instancia, como el ministerio público, reviste particular importancia en este sentido. Diversas estadísticas indican que el número de actuaciones incoadas es muy bajo en relación con la frecuencia de las infracciones.

\section{Trabajadores}

Allí donde las empresas pueden delegar sus responsabilidades en el campo de la salud y seguridad en el trabajo, y en los casos en que la legislación vigente responsabiliza directamente al personal técnico 0 de supervisión, las obligaciones de dichas personas suelen hacerse efectivas de forma similar a las de la empresa. En algunos ordenamientos legales, como el sueco y el británico, se establece explícitamente que la inspección de trabajo puede dictar órdenes y prohibiciones directamente a esas personas. Asimismo, las personas responsables están sujetas a las mismas disposiciones legislativas de orden penal que las empresas. Además, contra esas personas se pueden adoptar medidas que son imposibles de aplicar a las empresas.

Los regímenes disciplinarios aplicables a las obligaciones relativas a la salud y seguridad en el trabajo difieren de un país a otro. La escala de sanciones aplicables a las faltas leves oscila entre la amonestación verbal y la retención del salario de un día; respecto a las faltas graves, las sanciones pueden oscilar desde la amonestación pública o el traslado y la suspensión de empleo durante algunos días, hasta la exclusión de la promoción durante un máximo de un año; y en el caso de las faltas muy graves, la sanción puede ir desde la retención del sueldo entre 7 y 15 días y la suspensión por un máximo de dos meses, hasta la exclusión de la promoción durante dos años o el despido.

El incumplimiento de las obligaciones impuestas a los trabajadores en relación con la salud y seguridad en el trabajo puede también dar lugar a la exigencia de responsabilidades penales. En algunos países, como España, este tipo de responsabilidades sólo se exigen en los casos de delitos graves; en otros, la responsabilidad criminal se produce únicamente por el incumplimiento de determinados deberes. Por ejemplo, en la sección L 263-2 del Código de Trabajo francés, modificado en 1976, sólo se exige responsabilidad penal a los trabajadores subalternos si introducen bebidas alcohólicas en el lugar de trabajo. En otros países, como el Reino U nido, Dinamarca y Suecia, esta responsabilidad tiene un alcance más general, si bien en algunos lugares las sanciones previstas suelen ser leves, como ocurre en M éxico, que se limita al salario de una semana. Existe, además, un grupo de países en cuyo ordenamiento jurídico no se prevé la exigencia de responsabilidad penal a los trabajadores que no ejercen funciones de supervisión. Este es el sistema adoptado en la legislación laboral vigente en algunos países de la Europa del este. En Estados Unidos existe una situación muy similar desde la promulgación de la Ley de salud y seguridad en el trabajo 1970, en la que únicamente se exigen responsabilidades civiles a las empresas por el incumplimiento de las normas de salud y seguridad.

\section{Consecuencias de los accidentes de trabajo y las enfermedades profesionales}

\section{Seguridad social}

U na de las prioridades que se plantean a raíz de un accidente de trabajo o una enfermedad profesional es garantizar la subsistencia de la víctima y de su familia, y el medio más importante para este fin es la indemnización por accidente de trabajo. Aunque el examen de los sistemas de prestaciones por accidente de trabajo y enfermedad profesional excedería del ámbito del presente trabajo, algunos aspectos de la cuestión merecen especial consideración.

La primera consideración es que, en un gran número de países, las prestaciones por accidentes de trabajo se enmarcan en 
unos sistemas basados en el principio de responsabilidad individual de la empresa. En algunos países, esta responsabilidad es objeto de un seguro obligatorio y, en muchos otros, la empresa es libre de contratar o no un seguro de responsabilidad e, incluso en el primer supuesto, a veces pueden permanecer de forma conjunta con la entidad aseguradora. Existe otro grupo de naciones en las que la cobertura del seguro estatal obligatorio no alcanza aún a la totalidad de los trabajadores y los que se encuentran excluidos del sistema público están acogidos a un esquema de responsabilidad de la empresa. Este sistema de responsabilidad objetiva de la empresa se basa en el riesgo, no en la culpabilidad; dicho de otro modo, dentro de unos límites establecidos y en unas condiciones determinadas, la empresa ha de afrontar las consecuencias de todo accidente 0 enfermedad que revista una relación causal con el empleo. En ocasiones, existen también disposiciones especiales en la que se establecen determinadas prestaciones complementarias en caso de "culpa grave" de la empresa.

En segundo lugar, en la financiación del seguro de enfermedades profesionales y accidentes de trabajo, es preciso tomar en consideración el comportamiento histórico de los accidentes de trabajo y las enfermedades profesionales en determinados sectores y empresas. Como principio general de financiación, esta norma se aplica únicamente allí donde la cobertura de los accidentes de trabajo y las enfermedades profesionales es independiente del régimen general de la seguridad social e, incluso en estos casos, su aplicación no es universal. En efecto, la clasificación, sectorial o individual, del riesgo que se realiza en muchos países sirve para graduar los tipos de las contribuciones en función de los costes previstos; aunque también existen sistemas de clasificación individual diseñados para calcular los costes reales correspondientes al período de referencia (como en Francia y Estados U nidos), y sistemas basados en un tipo base de contribución que se incrementa o se reduce para las distintas empresas sobre la base, bien del gasto real por accidentes de trabajo y enfermedades profesionales, bien de la eficacia de las medidas de prevención aplicadas (como ocurre en Canadá, Italia, Japón y Alemania). Con independencia del criterio de financiación que se adopte, se suelen imponer sanciones al margen del tipo de contribución acordado a las empresas que no adopten las medidas de prevención prescritas y, además, en el sistema de seguridad social vigente en muchos países - también en este caso, independientemente del criterio de financiación aplicado- se prevé la imposición de sanciones económicas en caso de producirse accidentes por causa de un incumplimiento grave o de una seria negligencia de la empresa; en algunas naciones, se condena a la empresa en tales casos al reembolso íntegro de los gastos irrogados a la entidad aseguradora. Existen puntos de vista divergentes respecto a la eficacia relativa de uno y otro de los distintos sistemas. Todos ellos precisan, aunque en distinta medida, una infraestructura administrativa que los convierte en sumamente costosos y que dificulta su adopción en las naciones en vías de desarrollo. Además, resulta problemático intentar una clasificación individual basada en el comportamiento histórico, especialmente en las empresas pequeñas.

En tercer lugar, los sistemas de seguridad social de muchos países desempeñan una función importante en la protección de la salud y seguridad en el trabajo. En algunos países, esta función comprende, no sólo la adopción, sino también la aplicación de normas de seguridad, incluyéndose en esta última facultad la de imponer sanciones. Esta política se ha seguido, específicamente, en Canadá, Chile, Francia, Alemania y Luxemburgo.

Por último, las posibilidades de que el trabajador o sus herederos exijan responsabilidades civiles a la empresa o a los compañeros de trabajo suelen ser limitadas en virtud de la existencia de un sistema de seguridad social. Se pueden distinguir tres vías principales.

En primer lugar, en algunos países que cuentan con un sistema de prestaciones por accidente de trabajo y enfermedad profesional basado en la responsabilidad individual de la empresa, el trabajador puede optar entre acogerse a los beneficios del sistema legal de indemnización objetiva por accidentes de trabajo o reclamar judicialmente daños y perjuicios al amparo de las normas de responsabilidad civil, en principio, por conducta negligente. No es posible desistir de una vía en favor de la otra una vez que ha comenzado una reclamación o ha iniciado actuaciones judiciales. Por consiguiente, el trabajador que opta por las prestaciones, en principio mayores, de las acciones de responsabilidad civil se arriesga a no recibir nada si su pretensión es desestimada.

La segunda solución - aplicada en numerosos países de la Europa occidental, el Africa francófona, Canadá, M éxico y Pakistán- consiste en denegar la acción civil contra la empresa o los compañeros de trabajo en los casos ordinarios amparados por el sistema de prestaciones por accidente de trabajo y enfermedad profesional. La posibilidad de ejercitar acciones de responsabilidad civil continúa abierta - quizás, más en la teoría que en la práctica - si es posible demostrar la conducta dolosa de la empresa 0 , en su caso, del compañero de trabajo. En otro grupo de países, la vía judicial también es practicable en los casos en que se ha producido una condena en la vía penal (Italia), negligencia temeraria (Noruega) o falta grave, mientras que, en otros lugares, como en Francia y muchos países del Africa francófona, España y M éxico, la negligencia "inexcusable" o el incumplimiento grave de la empresa lleva aparejado el incremento de las prestaciones de la seguridad social por cuenta de la empresa. El concepto de negligencia grave o inexcusable ha sido definido en la legislación o en la doctrina jurisprudencial de los países citados. La gravedad de la falta se gradúa en función, bien del grado de desprecio por las consecuencias previsibles de una acción u omisión, bien de la inacción ante los peligros que se han puesto de manifiesto a la empresa de resultas de accidentes anteriores o por otros motivos. En algunos de los países adheridos a este sistema, la vía de la acción de responsabilidad civil continúa abierta respecto a determinados supuestos indemnizables, como los sufrimientos psíquicos y morales, excluidos de la cobertura del sistema público (Austria, Bélgica y Suiza).

El tercer sistema consiste en admitir el acceso ilimitado a las acciones legales de responsabilidad civil, con el objeto de complementar las prestaciones por accidente de trabajo o enfermedad profesional abonables por la seguridad social. En algunos países, como Estados U nidos, G recia, Japón y Suecia, es posible exigir por esta vía, tanto la responsabilidad por actos culposos, como - allí donde existe- la responsabilidad objetiva. Por contra, en otros países, como Colombia, Chile y Perú, la vía judicial sólo es asequible para reclamar daños y perjuicios resultantes de actos culposos. Este sistema rige igualmente en los Países Bajos y en varias naciones de la Europa O riental, en las que los accidentes de trabajo y las enfermedades profesionales no se enmarcan en un régimen especial de la seguridad social.

Es de subrayarse que, si bien los sistemas de prestaciones por accidente de trabajo y enfermedad profesional amparan normalmente todo accidente relacionado con el trabajo, la cobertura raras veces alcanza a la totalidad de las enfermedades profesionales. En efecto, la relación causal puede ser más difícil de establecer en las enfermedades profesionales y, además, la demostración de la responsabilidad se puede complicar aún más respecto a las enfermedades que tienen un período de incubación prolongado y cuyos síntomas sólo se manifiestan algún tiempo después de la finalización de la relación laboral. En el caso de las enfermedades no amparadas por el sistema 
- debido, por ejemplo, a que el mismo se basa en una relación taxativa de enfermedades indemnizables- se aplican las reglas de la responsabilidad civil ordinaria.

\section{Responsabilidad civil}

La posibilidad de recurrir acciones civiles en los casos de accidente de trabajo o enfermedad profesional no está, ni mucho menos, generalizada. En los casos en que se excluye o se limita sustancialmente la posibilidad de demandar a la empresa 0 a los compañeros de trabajo, subsiste la posibilidad de proceder contra el fabricante o el proveedor, aunque esta vía sólo es utilizable respecto a las consecuencias de los defectos de la maquinaria y equipo o las sustancias utilizadas. Por otra parte, en algunos de los países en que las acciones civiles son libremente ejercitables, tanto el número de reclamaciones que se formulan, como el porcentaje de aquéllas que llegan a los tribunales son relativamente pequeños, tanto en los casos de accidente o enfermedad de origen profesional, como respecto a las conductas discriminatorias.

La acción civil se puede basar en diversas causas. En efecto, es posible fundarla en el incumplimiento de una obligación contractual (contraída en un contrato de trabajo, de servicios 0 , incluso, de suministro). Sin embargo, lo más frecuente es acogerse a las reglas de responsabilidad culposa, o de violación de una obligación establecida por ley. A su vez, tales acciones se pueden fundamentar, bien en la violación de obligaciones consagradas en el derecho consuetudinario o de las disposiciones generales del código civil o de la legislación de trabajo, bien en el incumplimiento de obligaciones establecidas en la regulación legal específica de la salud y seguridad en el trabajo. Por último, la acción por ilícito civil se puede fundar, tanto en actos culposos, como en la responsabilidad "objetiva" o de resultado de riesgo, esto es, sin intervención de culpa alguna.

\section{El demandante}

Si en el ordenamiento legal de la indemnización por accidente de trabajo no excluye el recurso a las acciones civiles, éstas son ejercitables por las víctimas de lesiones resultantes del incumplimiento de una obligación, bien por un acto culposo, bien por la producción de un riesgo. Estas acciones son ejercitables, primordialmente, por los trabajadores víctimas de una lesión de origen profesional. En caso de fallecimiento del trabajador, las acciones suelen ser ejercitables por sus causahabientes, si bien, mientras en algunos ordenamientos legales se tiene por tales a las personas efectivamente dependientes del fallecido, en otros, el concepto se hace extensivo a todas las personas que el trabajador tuviese la obligación legal de mantener. En algunos fallos judiciales (dictados en países como Francia e I talia) se ha reconocido que, en determinadas circunstancias, los sindicatos están legitimados para ejercitar por sí mismos acciones civiles. En otros países no existen precedentes de que los sindicatos hayan intentado ejercitar acciones civiles en defensa de sus intereses específicos en la materia, siendo lo más frecuente que los sindicatos brinden apoyo financiero 0 de otro tipo a las reclamaciones formuladas por las personas directamente afectadas. En algunos países, tanto los organismos competentes de la seguridad social como las personas directamente interesadas están legitimados, a tenor de la legislación de la seguridad social, para reclamar judicialmente el incremento de las prestaciones en caso de negligencia inexcusable de la empresa. Además, los organismos de la seguridad social que han abonado alguna prestación pueden demandar para recuperarla a las personas civilmente responsables de una lesión de origen profesional.

\section{El demandado}

Las acciones civiles se pueden ejercitar contra una pluralidad de personas físicas o jurídicas con responsabilidades en el campo de la salud y seguridad. En la práctica, allí donde el ordenamiento legal de la seguridad social no excluye la posibilidad de tales acciones, la inmensa mayoría de las demandas civiles se dirigen contra la empresa. En la práctica totalidad de los países, las empresas están igualmente obligadas a resarcir las lesiones producidas por las acciones u omisiones culposas de sus empleados, con independencia del nivel de sus responsabilidades respectivas, si bien el fundamento de tal responsabilidad varía de un lugar a otro. Así, en algunos países de derecho consuetudinario existe la institución de la "responsabilidad subsidiaria", al tiempo que, en algunos países de derecho escrito, la responsabilidad se basa en el principio de que la empresa es el mandante (esto es, la que ha dispuesto la realización del acto). Ambos conceptos presentan concomitancias con el mandato y sus efectos prácticos son similares a los de éste. En otros lugares, la responsabilidad de la empresa se deriva de su negligencia en la selección o la supervisión de los trabajadores. L o normal es que la exigencia de responsabilidades a la empresa no excluya el ejercicio paralelo de acciones legales contra el trabajador causante del daño, si bien lo habitual es que el perjudicado prefiera demandar a la empresa.

El alcance de la obligación de la empresa de reparar las lesiones producidas por las acciones $u$ omisiones culposas de personas no empleadas en la misma es difícil de determinar. La legislación o la jurisprudencia de algunos países ha establecido, en determinadas circunstancias, la responsabilidad de las empresas por el cumplimiento, tanto de las obligaciones de protección de la salud y seguridad en los lugares de trabajo sometidos a su supervisión - incluso si los riesgos en cuestión han sido producidos por terceros, como los subcontratistascomo de los deberes de sus trabajadores destinados fuera de la empresa, incluso si el lugar de trabajo de aquéllos estuviese bajo el control de otra empresa. A menos que las disposiciones legales sean de mayor alcance, la responsabilidad exigible en estos casos se basa en el incumplimiento de la responsabilidad genérica de la empresa por el cumplimiento de sus obligaciones, de la que no puede eximirse en virtud de una relación contractual o de otro tipo contraída con terceros; si la empresa ha actuado con la diligencia razonablemente exigible a la misma, no se genera responsabilidad alguna.

Se plantea igualmente la cuestión de recurrir. En ocasiones, varias personas concurren como responsables de los hechos causantes de la lesión profesional: fabricante y empresa, empresa y contratista, etc. Es, asimismo, posible que la empresa sea tenida como responsable de los actos de terceros. En el supuesto de que, voluntariamente o por imperativo legal, el trabajador proceda judicialmente, bien contra uno solo de varios "corresponsables culposos", bien contra la empresa, con exclusión de las personas de cuyos actos sea responsable la empresa, se suele reconocer al demandado el derecho a recurrir contra los demás responsables.

\section{Relación causal y carga de la prueba}

En el procedimiento civil, la carga de la prueba corresponde al demandante, que tiene que probar los motivos de su pretensión. En primer lugar, el demandante debe acreditar que en el demandado concurre la legitimación pasiva de la demanda. Si la reclamación se dirige contra la empresa, esto no suele plantear demasiadas dificultades. En cambio, puede resultar mucho más complicado - especialmente en el caso de las enfermedades cuyo período de incubación es prolongado- identificar al proveedor de la maquinaria o las sustancias pretendidamente peligrosas. La tendencia que parece consolidarse actualmente en determinadas cuestiones relacionadas con las lesiones profesionales, como la producción de amianto, es la de demandar conjuntamente a todos los principales fabricantes en el caso de que la responsabilidad no se pueda atribuir en un principio a una determinada empresa. 
El segundo paso para el demandante consiste en fundar la reclamación contra el demandado. Si la demanda se basa en la responsabilidad objetiva del mismo, independientemente de que se trate de lesiones profesionales indistintas 0 de lesiones causadas por determinadas clases de elementos peligrosos, sólo es preciso demostrar que la lesión ha sido efectivamente causada por el trabajo o por el riesgo en cuestión. Si la lesión se funda en la violación de una obligación específicamente establecida en una disposición legal en la que no se conceda discrecionalidad alguna en cuanto a la forma de extinguirla, se impone demostrar que la obligación no se ha cumplido en la forma debida. Como se trata de acreditar hechos, la prueba no debe plantear demasiados problemas. En cambio, si en la legislación se confiere discrecionalidad para el cumplimiento de una obligación - por ejemplo, mediante el uso de expresiones como "razonablemente posible" - o si la demanda se basa en el incumplimiento de un deber genérico de diligencia (independientemente de que ese deber dimane del derecho común o escrito, o de la legislación laboral), no siempre resulta fácil probar el incumplimiento del deber. Esto ha llevado a los tribunales a plantearse la cuestión de si se debe trasladar del trabajador a la empresa u otro demandado en alguna medida la carga de la prueba de si se ha producido o no violación de una obligación.

Si bien alguna praxis nacional, como la anteriormente descrita, releva al demandante de la necesidad de probar que una conducta diligente por parte de la empresa habría evitado el accidente 0 enfermedad, esto no significa necesariamente que la pretensión prospere. En muchas ocasiones, el demandado puede probar que ha procedido con la máxima diligencia exigible en las circunstancias en presencia (esto es, que no ha existido negligencia por su parte). Esto es especialmente así en los casos en que es preciso acreditar la existencia de un determinado grado de culpa para que la demanda prospere, como sucede cuando se pide una prestación complementaria de la seguridad social por causa de una "falta inexcusable" de la empresa.

Tanto si la acción civil se basa en una conducta culposa como si responde a una situación de riesgo, es preciso demostrar la existencia de una relación causal, esto es, que la lesión producida es el resultado de la culpa o del riesgo en cuestión. Por regla general, no se exige la prueba de que la culpa o, en su caso, el riesgo, es la causa única o eficiente del resultado, pero sí de que es una causa directa de la lesión.

La prueba de la relación causal es especialmente complicada si se trata de enfermedades cuyo origen no se ha establecido incontestablemente, si bien los tribunales han interpretado a veces la ley en el sentido de otorgar al trabajador el beneficio de la duda. El problema puede provenir de circunstancias como la exposición del trabajador a nuevas tecnologías o sustancias cuyos efectos no se conozcan perfectamente. En otros casos, la enfermedad puede tener un período prolongado de incubación o el trabajador puede haber estado expuesto a diversos agentes. Incluso si la lesión ha sido causada por un accidente, no siempre es posible demostrar "más allá de toda duda razonable" (el nivel probatorio exigido en los procedimientos civiles) que la lesión ha sido causada por un incumplimiento demostrado. Se producen, asimismo, casos en los que la relación causal entre el incumplimiento demostrado y la lesión se rompe por la conducta culpable de una persona de cuyos actos no es responsable el demandado, si bien este tipo de intervenciones no rompe necesariamente la relación causal.

\section{Medios de defensa}

Incluso si se han podido demostrar la existencia de un riesgo o una conducta culposa y su relación causal con la lesión producida, la responsabilidad del demandado se puede reducir 0 , incluso, inhibir, en virtud de diversas circunstancias.
En primer lugar, está la culpa del trabajador lesionado, que puede traducirse en el incumplimiento de las normas de seguridad, en una negligencia que exceda del simple descuido, en una conducta "frívola" (esto es, un comportamiento en el lugar de trabajo incompatible con la realización habitual del trabajo), la desobediencia o el alcoholismo. En algunos ordenamientos jurídicos se ha adoptado un criterio de determinación de la indemnización basado en la compensación del alcance de esta culpa con el grado de culpa del demandado.

O tra excepción legal aplicada en algunos países responde al principio de que volenti non fit injuria (esto es, en la aceptación voluntaria por parte del trabajador del riesgo causante de la lesión). D ada la situación de desigualdad existente entre el trabajador y su empresa, los tribunales se han mostrado reticentes a admitir este medio de defensa en los casos en que el trabajador se ha limitado, con o sin protestas, a realizar un trabajo del que es consciente que entraña un riesgo superior al normalmente inherente a su trabajo. Si bien en otro tiempo era práctica habitual en el mundo laboral abonar una "prima de riesgo" a los trabajadores que accedían a puestos especialmente peligrosos a modo de contraprestación contractual por la asunción del riesgo, se duda de la validez de los contratos en los que el trabajador se obliga, incluso por una contraprestación, a asumir riesgos de los que la empresa es, en principio, responsable; incluso, en algunos lugares, estas estipulaciones contractuales se encuentran expresamente prohibidas. Por otra parte, las leyes se muestran especialmente benignas con los trabajadores que asumen voluntaria y conscientemente algún riesgo para salvar a otras personas. Se observa igualmente una creciente protección legal de los trabajadores que se sustraen a las situaciones que implican un riesgo inminente y que "hacen sonar la alarma" cuando se producen violaciones de las leyes de salud y seguridad en el trabajo.

A veces, los demandados han intentado valerse del argumento de que el proceso industrial peligroso que ha producido un accidente es de uso generalizado en el sector. N o se conoce ningún caso en que este argumento haya servido para reducir la responsabilidad de la parte demandada. En cambio, el uso generalizado en una industria de determinadas prácticas probadamente seguras se ha admitido como prueba de la conducta culposa de un demandado que no había adoptado tales prácticas.

\section{Plazos para reclamar}

En la mayoría de los ordenamientos jurídicos se fijan unos plazos más o menos breves para la interposición de reclamaciones a partir de la fecha de producción de la causa para reclamar. Aunque, en algún caso, el plazo puede ser de sólo doce meses, su duración normal es de dos a tres años. Dado que las demoras prolongadas dificultan la prueba de los hechos, la preclusión de los plazos redunda en interés de todos los interesados.

Sin embargo, con la aparición de enfermedades profesionales que sólo presentan síntomas muchos años después de la exposición a los agentes y sustancias causantes - específicamente, aunque no exclusivamente, los diversos tipos de cáncer de origen profesional- se evidenció que, en algunos casos, se imponía fijar como inicio del plazo de presentación de la reclamación el momento en que el trabajador afectado tiene conocimiento de que le asiste una causa para reclamar. En la actualidad, esta circunstancia es objeto de amplio reconocimiento, tanto en la legislación especial aplicable, como en las disposiciones especiales de las leyes generales de limitación de la responsabilidad. Esta tendencia no elimina automáticamente todas las dificultades, ya que no siempre resulta fácil determinar el punto en el tiempo en que el actor ha estado o ha debido estar en posesión de todos los elementos de juicio necesarios para deducir su demanda. Esto se facilita un tanto si la patología en cuestión figura en una relación o clasificación de enfermedades. 


\section{Clases de indemnización}

La indemnización que se puede obtener mediante el ejercicio de acciones civiles se enmarca en tres clases distintas, aunque no todas ellas están universalmente reconocidas: (a) reembolso de todos los gastos de asistencia médica y de rehabilitación no cubiertos por la seguridad social; (b) compensación por la pérdida de ingresos, que en la mayoría de los países se concede en la medida en que no se encuentre prevista en la seguridad social, (c) resarcimiento de daños morales, desfiguración y pérdida de disfrute 0 de las expectativas de vida. El principio que subyace en el resarcimiento de los daños culposos es el de la reparación, esto es, la restitución del demandante a una situación, como mínimo, igual a la que habría disfrutado si el acto culposo no se hubiese cometido.

La pérdida de ingresos se compensa en algunos casos mediante pagos periódicos complementarios de las prestaciones abonadas por la seguridad social y de los ingresos que el trabajador pueda devengar con posterioridad a la lesión, de modo que el ingreso total se sitúe en el nivel anterior. Por regla general, la compensación se realiza mediante un pago único. En los casos de fallecimiento o incapacidad permanente, la necesaria estimación de los ingresos futuros tiene un carácter necesariamente especulativo, tanto por lo que respecta al nivel de ingresos, como en relación con la esperanza de vida. Si se concede una prestación a los derechohabientes, la estimación recae, no solo sobre los futuros ingresos previsibles, sino también sobre las expectativas de sustento futuro. Si bien se procura tomar en consideración la inflación y la presión fiscal, resulta extraordinariamente difícil realizar una estimación realista de estos factores en el cálculo de un pago único. Por lo tanto, no es sorprendente que el montante de los pagos únicos abonados para compensar la pérdida de ingresos varíe sensiblemente y que a veces se prefieran los subsidios abonables mediante pagos periódicos, en los que resulta más fácil tomar en consideración los efectos de la inflación y de la presión fiscal.

La indemnización por pérdidas no pecuniarias del tipo de los daños morales sólo puede basarse en una estimación razonable. También en este caso se registran variaciones en el montante de las indemnizaciones. En algunos ordenamientos jurídicos, los tribunales están facultados para adjudicar indemnizaciones de castigo, cuyo montante puede resultar muy elevado.

\section{Conflictos de leyes}

Se impone en este punto una mención del funcionamiento de la responsabilidad civil en los casos en que la lesión profesional se produce en circunstancias susceptibles de subsumirse en varios ordenamientos legales. En la actualidad, resulta frecuente que ciertas actividades peligrosas, como la construcción o las prospecciones petrolíferas, se lleven a cabo en un país por empresas de otro país que emplean trabajadores de terceros países. Si, en tales circunstancias, sobreviene una lesión o enfermedad, se produce un conflicto de leyes y se aplican las normas del derecho internacional privado. Su carácter internacional no consiste en que se trate de normas de aceptación universal o general en todos los ordenamientos jurídicos, sino, más bien, de una rama propia y privativa de cada sistema de derecho privado; sin embargo, las divergencias son mínimas en lo que respecta a la regulación de diversas materias y algunas de las áreas de divergencia subsistentes se encuentran en vías de armonización, principalmente a través de los convenios internacionales. Siempre que en un ordenamiento jurídico aparece una referencia a las reglas del derecho internacional privado, se trata únicamente de elucidar tres cuestiones previas. En primer lugar, está la cuestión de si los tribunales del país son o no competentes para conocer la materia. Si la cuestión de competencia se resuelve afirmativamente, el tribunal debe decidir a continuación si aplica su propia legislación nacional $u$ otro ordenamiento legal aplicable en principio. Por último, el tribunal ha de decidir sobre el reconocimiento de la doctrina jurisprudencial establecida en un país extranjero o sobre la estimación o denegación de la ejecutoriedad de una sentencia extranjera en la que se reconozcan derechos a una de las partes. El concurso de distintas legislaciones nacionales en un una misma reclamación por daños puede conducir al "oportunismo jurisdiccional", esto es, al intento de presentar la demanda en el país en el que parezca poder obtenerse una indemnización más elevada.

\section{Responsabilidad penal}

La responsabilidad penal resultante de una lesión profesional, considerada en su sentido más lato de incurrir en una sanción, se puede producir por cuatro causas distintas.

En primer lugar, el acaecimiento de un accidente de trabajo o la aparición de una enfermedad profesional debe ser subsumible en las disposiciones legales ejecutorias de las leyes y los reglamentos aplicables a la salud y seguridad en el trabajo. Por una parte, la inspección de trabajo de la mayoría de los países está demasiado infradotada de personal para ejercer una supervisión continua de todos los posibles riesgos. Por otra parte, cuando se tiene conocimiento de la producción de un accidente o de una enfermedad, normalmente, mediante su comunicación obligatoria, se pueden realizar visitas de inspección que, en su caso, tienen su continuación en el ejercicio de acciones penales.

En segundo lugar, en algunas normas legales aplicables a la salud y seguridad en el trabajo figuran disposiciones relativas a las sanciones imponibles en caso de producirse accidentes 0 lesiones, especialmente si son graves. Existen disposiciones equivalentes a éstas en los sistemas de indemnización por accidente de trabajo, consistentes en un incremento de las cotizaciones de las empresas que muestran un pobre historial en materia de salud y seguridad.

En tercer lugar, las lesiones profesionales, en especial si son graves o fatales, pueden ser subsumibles en determinados tipos penales no asociados directamente a la salud y seguridad en el trabajo, como son los de homicidio, incendio, daños, estragos, etc. En algunas naciones, como Italia y los Países Bajos, las sanciones aplicables a estos delitos se agravan en algunos casos si los hechos se producen en un lugar de trabajo.

Por último, en algunos códigos penales existen disposiciones especiales aplicables a las lesiones provocadas por la violación de las normas de salud y seguridad en el trabajo.

En algunas legislaciones se estipula expresamente que el ejercicio de acciones legales basadas en una de las cuatro causas anteriores no excluye la posibilidad de ejercitar acciones paralelas fundadas en otra de dichas causas. En otros países ocurre, exactamente, lo contrario, Por ejemplo, en Suecia, el ejercicio por parte de la inspección de trabajo de su facultad de dictar prohibiciones u órdenes de subsanación de incumplimientos so pena de imposición de multas excluye la institución de actuaciones en los juzgados de lo penal. En algunos casos - aunque no siempre- la elección de entre un abanico de posibles sanciones está en función de la naturaleza - civil, administrativa o penal- de las sanciones específicamente concebidas como medio de ejecución. Aunque no existen estadísticas oficiales que lo acrediten, parece de todo punto evidente que la mayor parte del escaso número de acciones criminales que se ejercitan de resultas de la violación de las normas de salud y seguridad en el trabajo se contrae a casos en que la violación ha producido lesiones. Tampoco existe información estadística relativa al uso de la vía penal en relación con las lesiones profesionales. Parece ser, no obstante, que se registran más variaciones a este respecto de un país a otro que en relación con otros aspectos de la aplicación de la ley. 


\section{Elementos del tipo delictivo}

Existe un consenso generalizado en torno al principio de que no hay delito ni pena sin una ley anterior. En efecto, si bien en los tribunales civiles resulta posible afirmar la existencia de una obligación no definida expresamente en las leyes, esto no suele ser posible en la jurisdicción penal. Sí resulta, en cambio, factible que los tribunales penales fijen el alcance de una obligación previamente establecida en las leyes, por lo que, en la práctica, la diferencia entre la responsabilidad civil y la penal puede ser meramente de grado. Por otra parte, en algunos ordenamientos jurídicos sólo se admite la responsabilidad penal por los actos dolosos 0 - en algunos sistemas legales- por los resultados de una negligencia criminal, a menos que en las leyes se disponga lo contrario.

En algunos códigos penales y en las disposiciones ejecutorias de distintas leyes de salud y seguridad en el trabajo se tipifica como delito el incumplimiento de las obligaciones legales al respecto, con independencia de que la conducta punible sea dolosa o producto de una negligencia inexcusable. Esta política penal ha sido consagrada por la doctrina jurisprudencial. Por ejemplo, en una sentencia de 28 de febrero de 1979, el Tribunal Supremo de España falló que el incumplimiento de las normas de seguridad aplicables en el sector de la construcción llevaba aparejada la imposición de las penas previstas en la normativa sancionadora correspondiente. En algunos casos, esta responsabilidad objetiva se traduce en meras sanciones civiles 0 administrativas. En varios países, las diferencias entre la doctrina de la responsabilidad objetiva y la exigencia de voluntariedad no siempre son tan acusadas como aparentan a primera vista. Se observan, en efecto, divergencias entre los diversos ordenamientos jurídicos en relación con el grado de negligencia 0 imprudencia necesario para que la misma pueda calificarse de culpable y llevar aparejada la imposición de sanciones.

\section{Iniciación del procedimiento penal}

En principio, todas las actuaciones judiciales se deben instar ante la autoridad competente, ya que el ordenamiento penal es un derecho público cuyas sanciones tienen por objeto tutelar los intereses de la colectividad, no de las personas. No obstante, en algunos países (como Suiza, Austria, Inglaterra, Finlandia y Francia) se admite, en ciertos casos, la posibilidad de que los particulares ejerciten acciones penales. Si bien, en ocasiones, los inspectores de trabajo pueden instar procesos, lo más frecuente es delegar esta función en la fiscalía general o de distrito, la abogacía del Estado u otros órganos similares. Aunque estos servicios actúan sobre la base de la información que reciben de la inspección de trabajo, de los organismos de la seguridad social o de los propios lesionados, la decisión final sobre la vía de actuación a seguir es enteramente suya. En principio, si consideran que existen indicios racionales de delito, tienen la obligación de actuar.

Cabe añadir aquí dos comentarios. En primer lugar, por lo que respecta a los plazos de prescripción de la acción penal, los términos legalmente establecidos no parecen haber planteado dificultades excesivas, posiblemente, porque los términos de prescripción establecidos en los procedimientos penales suelen ser muy largos. En segundo lugar, la ley penal es de ámbito territorial, esto es, su aplicación se contrae al territorio en el que rige la ley aplicable. En los desplazamientos internacionales de los trabajadores, este ámbito territorial de la legislación penal puede plantear dudas respecto al país competente para controlar la salud y seguridad.

\section{Personas responsables}

Las actuaciones penales, como las civiles, se pueden ejercitar, en principio, contra toda persona que ostente responsabilidades en el campo de la salud y seguridad. Esto suscita el problema de la responsabilidad de las personas jurídicas (esto es, de las sociedades mercantiles que asumen obligaciones, tanto en calidad de fabricantes, como respecto a sus trabajadores). Según uno de los principios fundamentales del derecho penal, únicamente las personas físicas pueden ser criminalmente responsables; en unos casos, éste es un principio absoluto; en otros, se aplica únicamente a determinados delitos. En efecto, en algunos países se admite la posibilidad de incriminar a las sociedades mercantiles por los delitos relacionados con la salud y seguridad en el trabajo. L a aplicación de los principios generales del derecho penal limita en ciertos países (como Bélgica, E spaña y algunas naciones escandinavas) la responsabilidad de las empresas a las sanciones impuestas por las inspecciones de trabajo y a otras penas civiles y administrativas; en otros países (como Inglaterra y Estados U nidos) no se establece esta distinción. En ocasiones se establece expresamente que la responsabilidad de las sociedades mercantiles se contrae al pago de multas. En Inglaterra, al revés de lo que ocurre en muchos países, la legitimación pasiva de las empresas en relación con las acciones judiciales es prioritaria respecto a la de las personas empleadas en la sociedad, sobre la base del principio de que en la empresa ostenta un poder de control mucho mayor.

Las personas físicas - con independencia de que se trate de empresarios individuales o de consejeros o directores de sociedades- pueden ser consideradas responsables por el incumplimiento de las obligaciones de la empresa, ya que los consejeros y directores son subsidiaria o complementariamente responsables de los actos de la sociedad. Para que se aprecie esta responsabilidad, es preciso que exista culpabilidad individual. Teniendo en cuenta el carácter general de las obligaciones exigidas a la empresa, no resulta difícil a los tribunales descubrir alguna omisión. No obstante, se han producido algunas absoluciones sobre la base de ausencia de culpabilidad del empresario individual o del director imputado. En algunos casos, la empresa delega determinadas funciones (y la correlativa responsabilidad penal) en materia de salud y seguridad en los directivos de línea; y es igualmente posible que la responsabilidad en estas cuestiones recaiga directamente sobre los técnicos y supervisores. $L a$ jurisprudencia muestra que la imputación de responsabilidad penal a estas personas no es una cuestión meramente teórica. Así, el 22 de enero de 1981, el tribunal de lo penal de Béthune, Francia, declaró culpable de homicidio involuntario al ingeniero jefe de una mina por una explosión de grisú ocurrida en 1974, que costó 40 vidas humanas. El tribunal apreció una imprudencia grave en la conducta del ingeniero, al no haber instalado un detector de gases. En Italia, en una causa substanciada en 1977 por el uso de benceno en una fábrica de tintes, el director general, el director técnico y el médico de la empresa, junto con los propietarios y el director gerente, fueron declarados culpables de homicidio involuntario. En un estudio sobre la imputación de responsabilidades penales en la praxis judicial que se realizó en Finlandia en 1979, se puso de manifiesto que el $19 \%$ de los procesamientos y el $15 \%$ de las sentencias condenatorias recayeron sobre los directivos, al tiempo que los porcentajes respectivos para los ejecutivos era del $36 \%$ por ciento en ambos casos; y, en relación con los supervisores, del $35 \%$ y el $38 \%$, respectivamente. Si bien en cierto número de países es posible exigir responsabilidades penales a los trabajadores que no ejercen funciones técnicas ni de supervisión, esta práctica no está universalmente consagrada; los ejemplos parecen ser relativamente escasos y, en todo caso, se exige una culpabilidad individual sumamente alta.

Medios de defensa

Por regla general, en el procedimiento penal no se acepta como excusa la ignorancia de la ley. Por el contrario, se suele subrayar 
la obligación de la empresa y del personal técnico y de supervisión de poseer los conocimientos necesarios.

Contrariamente a lo que sucede en las causas civiles, la circunstancia de que la negligencia o imprudencia de la víctima haya constituido una causa del accidente no se suele admitir como excusa. Por ejemplo, un tribunal suizo condenó en 1972 a un empresario por la electrocución de un trabajador que se encontraba cargando objetos metálicos en un camión situado debajo de una conducción eléctrica activada. El tribunal resolvió que, si bien el trabajador habría podido adoptar la precaución elemental de desconectar la corriente, correspondía al supervisor (en el caso de autos, a la empresa) la responsabilidad de garantizar la seguridad del trabajador realizando dicha operación.

Por otra parte, pueden existir diversas circunstancias atenuantes (como, por ejemplo, una hoja de servicios impecable) que los tribunales toman en consideración al graduar la sanción. Así, en un fallo dictado en Suiza en la causa seguida por un accidente causado por el insuficiente apuntalamiento de una zanja de desagüe, la circunstancia de que la empresa había querido ahorrar las horas de trabajo a los obreros retribuidos a destajo, aunque no fue admitida en la sentencia como eximente, sí lo fue como atenuante.

\section{Sanciones}

En esta misma sección dedicada a las medidas ejecutorias, se han visto varios ejemplos de las sanciones imponibles en el marco de la legislación sobre salud y seguridad en el trabajo. En algunos casos, los topes de las sanciones pecuniarias previstas son más altos que los establecidos en los códigos y leyes penales de ámbito más general.

Por otra parte, el abanico de posibles penas de privación de libertad suele ser mucho más amplio en los códigos y leyes penales generales.

En ciertos casos, se pueden imponer otros castigos, como la interdicción especial para el ejercicio de la profesión en la que se haya producido una muerte violenta. Asimismo, según el artículo L 263-3-1 del Código de Trabajo francés, modificado en 1976 , en caso de producirse un accidente en una empresa en la que se hayan registrado violaciones graves o reiteradas de las normas de salud y seguridad, el tribunal puede requerir de la empresa la sumisión de un plan de normalización de las condiciones de trabajo; si la empresa incumple este requerimiento, el tribunal puede obligarla a poner en práctica cualquier otro plan aprobado por aquél.

Al igual que ocurre en otras áreas del derecho penal, existe la impresión de que las sanciones impuestas raras veces agotan todas las posibilidades ni alcanzan el valor máximo posible. Se dictan condenas de privación de libertad, aunque escasas, y se imponen multas que, sin embargo, pocas veces alcanzan el límite máximo permitido.

Debido, en gran medida, tanto a la escasa disponibilidad de información estadística sistematizada al respecto, como a la circunstancia de que, aparentemente, muy pocas reclamaciones relativas a cuestiones de salud y seguridad llegan a los tribunales, resulta extraordinariamente difícil evaluar, tanto desde una perspectiva global, como en términos comparativos, el efecto disuasorio de la responsabilidad civil y penal. Resulta igualmente difícil determinar la importancia de las responsabilidades legales en la política de prevención, tanto voluntaria, como inspirada por la seguridad social. Sin embargo, esta circunstancia no priva a las acciones civiles y penales de su capacidad disuasoria.

*EI presente trabajo se basa en una conferencia dictada el 13 de febrero de 1995 en el marco de los Seminarios de Trabajo y Empleo de la U niversidad de Columbia, patrocinados por el Centro de Estudios de los Derechos H umanos de dicha universidad.

\section{LA SALUD EN EL TRABAJO COMO DERECHO HUMANO}

\author{
Ilise Levy Fei tshans*
}

"El disfrute del máximo nivel de salud posible es uno de los derechos fundamentales de todo ser humano... Los logros de cualquier Estado en la promoción y protección de la salud es importante para todos." P reámbulo de la Constitución de la Organización M undial de la Salud (OM S).

La universalidad es un principio fundamental del derecho internacional. Las cuestiones planteadas en el ámbito de la salud y seguridad corroboran este concepto, ya que ningún trabajo está libre de los riesgos profesionales. De los estudios dedicados a los riesgos para la salud y seguridad derivados de distintos tipos de trabajo merecen citarse los de Corn 1992 y 1985; Faden 1985; Feitshans 1993; Nightingale 1990; Rothstein 1984; Stellman y Daum 1973; Weeks, Levy y Wagner 1991.

La amenaza universal que las condiciones de trabajo insalubres suponen para unos derechos humanos fundamentales como la vida y la seguridad ha sido reconocida, tanto en los convenios de la OIT, como en diversos documentos internacionales dedicados a los derechos humanos. Así, según el artículo 3 de la Declaración Universal de Derechos Humanos, adoptada en 1948 (A samblea General de las Naciones U nidas 1994): “Todo individuo tiene derecho a la vida, a la libertad y a la seguridad de su persona". En el preámbulo de la Constitución de la OIT se proclama que "la protección del trabajador contra las enfermedades y lesiones sufridas en el empleo" constituyen condiciones necesarias para "U na paz universal y duradera". Esto significa que, para la O IT, la mejora de las condiciones de vida y de trabajo constituyen un elemento fundamental de los derechos universales.

C omo se ha evidenciado en una muestra recientemente realizada en la Secretaría de las N aciones U nidas en N ueva York, los trabajadores de la organización han sido secuestrados, torturados, privados de libertad e incluso, asesinados por los terroristas. En la Resolución 1990/ 31 de la Comisión de Derechos $\mathrm{H}$ umanos de las $\mathrm{N}$ aciones $\mathrm{U}$ nidas se ponen de relieve estos peligros y se hace hincapié en la necesidad de aplicar los actuales mecanismos de protección de los derechos humanos a la salud y seguridad en el trabajo. Para estos profesionales, su función de servir de canales de comunicación para la protección de vidas humanas, y su dedicación a la tarea fundamental de la organización que los emplea, los expone a unos riesgos comparables, si no mayores que los demás trabajadores, sin la contrapartida de que los problemas de salud y seguridad se tomasen en consideración en la elaboración de sus programas de trabajo.

En los documentos internacionales de derechos humanos se proclama el derecho de todos los trabajadores a unas condiciones de trabajo seguras y saludables, tanto en la oficina, en el trabajo de campo y en otros lugares de trabajo, como en los desplazamientos hacia y desde el trabajo. Este principio, que informa los acuerdos internacionales sobre los derechos humanos en el marco de la salud y seguridad en el trabajo, ha sido recogido en la Carta de las Naciones Unidas de 1945 (Naciones U nidas 1994) y en la D eclaración U niversal de Derechos Humanos, desarrollado en los acuerdos internacionales sobre derechos humanos (como el Pacto Internacional de Derechos E conómicos, Sociales y Culturales) y consagrado en los más importantes tratados relativos a los derechos humanos, como la Convención sobre la Eliminación de Todas las Formas de D iscriminación contra la M ujer, adoptada en 1979 e incorporada, tanto a los principios de la OIT y de la OMS, como a diversos acuerdos regionales (véase posteriormente). 
No es sencillo formular una definición de la salud laboral que refleje el alcance de las responsabilidades que gobiernos y empresas asumen en el marco del derecho internacional. La mejor formulación se ofrece en el Preámbulo de la Constitución de la O M S: "L a salud es un estado de bienestar físico, mental y social pleno y no únicamente la ausencia de enfermedad". EI término "bienestar" es enormemente significativo, ya que se utiliza sistemáticamente, tanto en los documentos sobre derechos humanos, como en los acuerdos internacionales relativos a la salud. I gual importancia reviste la interpretación de la definición misma; en efecto, la definición constituye, en sus propios términos, el reconocimiento de que la salud es la resultante del juego de una serie de factores interactivos: el bienestar físico, mental y social, cuyos componentes se valoran en función de un baremo idóneo del bienestar que es algo más que la "simple ausencia de enfermedad". Aunque, por su naturaleza misma, este término no se asocia a unos baremos específicos de salud, es susceptible de interpretarse y materializarse en un contexto flexible de aplicación.

Por consiguiente, el fundamento jurídico de la aplicación de los derechos humanos internacionalmente reconocidos a la protección de la salud laboral en el lugar de trabajo desde la perspectiva de la seguridad personal, en el contexto de la protección del derecho humano a la salud, constituye un importante conjunto de normas laborales internacionales. Permanece en pie, por lo tanto, la cuestión de determinar si el derecho de las personas a la salud y seguridad en el trabajo se inserta en el marco de los derechos humanos internacionales y, en caso afirmativo, qué medios pueden utilizarse para lograr un nivel adecuado de salud y seguridad. Por otra parte, el desarrollo de nuevas formas de solucionar los problemas del cumplimiento constituirá el núcleo del esfuerzo por garantizar la protección de los derechos humanos en el siglo próximo.

\section{Perspectiva global del derecho internacional a la protección de la salud y la seguridad en el trabajo}

\section{La legislación sobre derechos humanos y la Carta de las Naciones Unidas}

La protección del derecho a la salud es uno de los principios constitucionales reconocidos en numerosos países. A demás, existe un consenso internacional respecto a la necesidad de ofrecer un empleo saludable y seguro, que se refleja en numerosos documentos internacionales sobre derechos humanos, en respuesta a los principios legales vigentes en numerosos países, incluidas las normas constitucionales sobre protección de la salud y la normativa legal de ámbito nacional o local. Se crearon servicios oficiales de inspección para la prevención de accidentes de trabajo en Bélgica, en 1810; en Francia, en 1841; y en Alemania, en 1839 (seguidos de la implantación de las exploraciones médicas obligatorias en 1845). La cuestión del "derecho" a la protección de la salud y a la asistencia sanitaria se suscitó en torno al examen de la posibilidad de que Estados Unidos ratificase el Pacto Internacional de Derechos Económicos, Sociales y Culturales (por ejemplo, Grad y Feitshans 1992). La cuestión del derecho humano a la protección de la salud se ha abordado desde perspectivas más globales - aunque no siempre se han dado respuestas plenamente satisfactorias- en la Carta de las Naciones Unidas, en la Declaración U niversal de Derechos Humanos, en los artículos 7 y 12 del Pacto Internacional de Derechos Económicos, Sociales y Culturales, y en las normas adoptadas posteriormente por la O IT, la O M S y otras organizaciones internacionales vinculadas a las $\mathrm{N}$ aciones $\mathrm{U}$ nidas.
En la $\mathrm{C}$ arta de las $\mathrm{N}$ aciones $\mathrm{U}$ nidas, los estados contratantes manifiestan su propósito de "fomentar" el progreso económico y social, y unos "niveles de vida más elevados", incluida, según el artículo 13 de la Carta, la protección de los derechos humanos. En un lenguaje que recuerda el de la carta constitucional de la O IT, promulgada en el Tratado de Versalles, en el artículo 55 de la Carta de la ONU se subraya expresamente la vinculación entre la "creación de unas condiciones de estabilidad y bienestar" para la paz y unos "niveles de vida más elevados", y "el respeto y observancia universales de los derechos humanos y las libertades fundamentales". EI debate en torno a la interpretación de estos conceptos y a la cuestión de si los mismos comprendían la totalidad o una parte únicamente de los derechos constitucionales reconocidos de los Estados miembros de la $\mathrm{ONU}$, fue objeto de una politización excesiva durante la era de la guerra fría.

No obstante, este grupo de documentos fundamentales adolece de una laguna, consistente en que sólo ofrecen un enunciado vagoroso de la protección de la vida, la seguridad de las personas y los derechos económicos al empleo, sin que aparezca una mención explícita de la salud y seguridad en el trabajo. Aunque en todos estos documentos se alude retóricamente a la garantía de un nivel de salud "adecuado" y a los correspondientes derechos humanos a la salud, resulta difícil obtener un consenso en torno a la calidad de la asistencia y a los "niveles de vida más elevados" para hacer efectiva la protección.

\section{La protección de la salud y seguridad en el trabajo en la} Declaración Universal de Derechos H umanos

\section{La seguridad de la persona en el artículo 3 de la Declaración Universal de Derechos Humanos}

Aunque no existe una doctrina jurisprudencial que fije el alcance de este término, en el artículo 3 de la Declaración U niversal de Derechos Humanos se asegura el derecho a la vida de toda persona. Esto influye en los riesgos profesionales y a los efectos de los accidentes de trabajo y de las enfermedades profesionales.

\section{Los derechos de los trabajadores en los artículos 23, 24 y 25} de la Declaración Universal de Derechos Humanos

En la Declaración U niversal de Derechos Humanos figura una relación breve, pero significativa, de derechos al empleo y a "unas condiciones equitativas y satiffactorias de trabajo". L os principios consagrados en tres artículos consecutivos de la Declaración son el fruto de una evolución histórica que ha tenido su reflejo en antiguas leyes. Se plantea un problema desde la perspectiva del estudio de la salud laboral. En efecto, si bien la Declaración Universal de Derechos Humanos es un documento muy importante que goza de la aceptación general, en el mismo no se abordan expresamente las cuestiones de la salud y seguridad en el trabajo. Más bien, la alusión a cuestiones relacionadas con la seguridad personal, la calidad de las condiciones de trabajo y la calidad de vida permite inferir que la protección de la salud y seguridad en el trabajo se inserta en el marco de la Declaración U niversal. Por ejemplo, si bien no figura una definición expresa de las "condiciones equitativas y satisfactorias de trabajo", es indudable que los riesgos profesionales influyen en el logro de ese objetivo social. Asimismo, en la Declaración U niversal se exige que la protección de los derechos humanos en el lugar de trabajo pase por el respeto a la "dignidad humana", que repercute, no sólo en la calidad de vida, sino también en la aplicación de programas y medidas destinados a prevenir la degradación de las condiciones de trabajo. Por consiguiente, la Declaración U niversal de Derechos $\mathrm{H}$ umanos constituye una referencia vaga, pero válida, de la promoción internacional de los derechos humanos en el campo de la salud y seguridad en el trabajo. 
Pacto Internacional de Derechos Económicos, Sociales y Culturales

El contenido y aplicación de los derechos anteriormente citados se desarrollan en los principios consagrados en el Pacto Internacional de Derechos Económicos, Sociales y Culturales. Así, en los artículos 6 y $7 \mathrm{~b}$ de la Parte III se reconoce a todos los trabajadores el derecho a "la seguridad y la higiene en el trabajo". En el artículo 7 se precisa el contenido del derecho a unas condiciones de trabajo equitativas y satisfactorias. En el concepto de las condiciones satisfactorias de trabajo se incluyen los salarios y las horas de trabajo (artículo 7.1 del Pacto), así como "la seguridad y la higiene en el trabajo" (Summers 1992). Por lo tanto, el uso de esta expresión en el marco conceptual de las condiciones satiffactorias de trabajo precisa el alcance de la protección concedida en la Declaración U niversal de Derechos H umanos y pone de manifiesto la vinculación - desarrollada en el artículo 12 del Pacto Internacional de Derechos E conómicos, Sociales y Culturalesentre otros enunciados de los derechos humanos y la protección de la salud y seguridad en el trabajo.

\section{Promoción de la salud laboral en el marco del artículo 12 de Pacto Internacional de Derechos Económicos, Sociales y Culturales}

De todas las disposiciones contenidas en los documentos internacionales sobre los derechos humanos adoptados en el marco de las Naciones Unidas, el artículo 12 del Pacto Internacional de Derechos Económicos, Sociales y Culturales es el que aborda de forma más clara y decidida la cuestión de la salud, al mencionar expresamente el derecho a la protección de la salud, a través de la "salud laboral", y a la protección contra las "enfermedades profesionales". Por otra parte, la alusión a la mejora de la salud laboral es congruente a tenor del artículo 7(b) del Pacto Internacional de Derechos Económicos, Sociales y Culturales en relación con la seguridad e higiene en el trabajo. No obstante, incluso con esta garantía expresa de la protección de la seguridad e higiene en el trabajo falta una exposición detallada del significado de estos derechos, y falta, asimismo, toda alusión a las posibles vías para alcanzar los objetivos del Pacto. En la línea de los principios expresados en muchos otros acuerdos internacionales sobre derechos humanos, el lenguaje utilizado en el artículo 12 se asemeja deliberadamente al empleado por la OMS para enunciar los conceptos fundamentales de la salud. Es evidente que en el artículo 12 subyace la idea de que la salud y seguridad en el trabajo está presente en la preocupación por la salud y la atención al bienestar individual. Según el mencionado artículo 12:

Los Estados Partes en el presente Pacto reconocen el derecho de toda persona al disfrute del más alto nivel posible de salud física y mental (...). Entre las medidas que deberán adoptar los Estados Partes en el Pacto a fin de asegurar la plena efectividad de este derecho, figurarán las necesarias para:

(b) El mejoramiento de todos los aspectos de la higiene del trabajo y del medio ambiente.

(c) La prevención y el tratamiento de todas las enfermedades epidémicas, endémicas, profesionales y de otra índole, y la lucha contra ellas.

Resulta significativo que en el artículo 12 figure también una alusión directa a las consecuencias de las enfermedades profesionales sobre la salud, lo que equivale a un reconocimiento del principio - un tanto controvertido- de que la medicina del trabajo disfruta de la tutela de los derechos humanos. En el artículo 12 del Pacto, los Estados partes del mismo reconocen el derecho a la salud física y mental, indirectamente proclamado en el artículo 25 de la Declaración U niversal de Derechos
Humanos, en la Convención Americana, en la Carta Social Europea y en la Carta revisada de la O rganización de Estados Americanos (OEA) (véase posteriormente). Además, en el párrafo 2 del artículo 12, esos Estados se comprometen a la adopción de un mínimo de cuatro "medidas" con el objeto de asegurar la "plena efectividad" de este derecho.

Es de subrayarse que, en lugar de ofrecer una definición de la "salud", el artículo 12 se adhiere a la definición del documento constitutivo de la OMS. Sin embargo, según Grad y Feitshans (1992), en el párrafo 1 del borrador del Pacto, auspiciado por la Comisión de Derechos Humanos, sí figuraba una definición de la salud en los mismos términos de la definición recogida en el instrumento constitutivo de la OMS: "Un estado de bienestar físico, mental y social completo, y no simplemente la ausencia de enfermedad". Al igual que la O IT en relación con los artículos 6 a 11 del Pacto Internacional de Derechos Económicos, Sociales y Culturales, la O M S aportó ayuda técnica en la redacción del artículo 12. EI Tercer Comité declinó la propuesta de la OM S de incluir una definición, aduciendo que esta casuística estaba fuera de lugar en un texto legal, que en el resto del articulado no figuraba definición alguna y que la definición propuesta era incompleta.

En la documentación de trabajo aparece la expresión "higiene ambiental e industrial", sin remisión a ninguna documentación interpretativa. Citando otros acuerdos adoptados en la Asamblea Mundial de la Salud de 1979, en el informe se expresa, asimismo, la preocupación por "la aplicación incontrolada de algunos procesos industriales y agrícolas que producen peligros físicos, químicos, biológicos y psicosociales" y se subraya que la Asamblea había, además, instado a los Estados miembros a "desarrollar y fortalecer las instituciones dedicadas a la salud laboral, y adoptar medidas de prevención de los peligros en los lugares de trabajo (Grad y Feitshans 1992). Se añade, reiterando un concepto recogido en numerosos documentos internacionales anteriores dedicados a los derechos humanos, que "el derecho de toda persona a disfrutar del más alto nivel posible de salud física y mental" constituye un objetivo compartido sin reservas por los trabajadores, empresas y gobiernos de muchas naciones". Lamentablemente, se trata de un objetivo tan universalmente aceptado como complicado de alcanzar.

\section{Convención Internacional sobre la Eliminación de Todas las Formas de Discriminación contra la M ujer}

En el artículo 11(a) de la Parte III de la Convención Internacional sobre la Eliminación de Todas las Formas de Discriminación contra la M ujer (1979) se afirma que "el derecho al trabajo es un derecho inalienable de todos los seres humanos", y en el artículo 11 (f) de la misma convención se establece "el derecho a la protección de la salud y a unas condiciones de trabajo seguras, incluida la protección de la función reproductora".

En el artículo 11.2(a) se prohíben "el despido y la imposición de sanciones con motivo de la ausencia por maternidad", cuestión ésta que, tanto históricamente, como en la actualidad, ha sido objeto de considerable controversia y de violaciones de los derechos humanos reconocidos internacionalmente. Bajo muchos sistemas legales de los Estados miembros de las $\mathrm{N}$ aciones $\mathrm{U}$ nidas para las mujeres embarazadas y otros trabajadores, estas importantes cuestiones no han sido resueltas por la doctrina jurisprudencial relativa al embarazo. Por tanto, el artículo 11.2 se dirige claramente a superar el lastre de generaciones de discriminación institucionalmente enraizada y legalmente consagrada, nacida de unas creencias erróneas sobre las posibilidades de la mujer durante el embarazo y el período de crianza de los hijos. En la jurisprudencia sobre el embarazo se observa una dicotomía entre el proteccionismo y el paternalismo, que se 
ha manifestado en la praxis judicial a lo largo del siglo XX. Así, la jurisprudencia del Tribunal Supremo de Estados U nidos ha oscilado entre la preocupación por limitar las horas de trabajo de la mujer debido a su necesidad de cuidar de los hijos en el hogar, como se observa en la sentencia del caso M uller contra el E stado de 0 regón, 208 U.S.412 (1908); y la prohibición de la esterilización forzosa de las mujeres expuestas a riesgos para la salud en la reproducción en el lugar de trabajo, entre otras cosas, contenida en el fallo dictado en la causa UAW contra Johnson Controls, 499 U.S. 187 (1991) (Feitshans 1994). Si bien los efectos de esta dicotomía en la filosofía que informa esta convención se manifiestan en el artículo 11.2(d) de la misma, tal dicotomía no se ha superado totalmente, puesto que los efectos positivos de la "protección especial" que suele ser necesaria para prevenir los efectos enormemente nocivos de agentes inherentes a las condiciones de trabajo se suelen valorar exageradamente.

En el artículo 11.2(d) de esta Convención figura el mandato de "proporcionar una protección especial a las mujeres embarazadas que realizan trabajos demostradamente nocivos para ellas". Existen muchos puntos oscuros en esta disposición, como, por ejemplo, lo que se entiende por protección especial, si la misma se limita a prevenir los posibles daños a la embarazada y, en el caso contrario, cuáles son los efectos sobre la protección del feto. Por otra parte, en esta convención no se define el grado de verificación preciso para que una determinada "protección especial" se considere necesaria o aceptable, ni se define tampoco el alcance de los mecanismos de protección considerados aceptables.

En el artículo 11.3 se limita el alcance del concepto de "protección especial", al disponerse expresamente que las medidas de protección de la salud y seguridad en el trabajo se deben basar en criterios científicos y no en valores sociales. En efecto, según el mencionado artículo 11.3: “La tutela legislativa de las materias reguladas en el presente artículo serán revisados periódicamente a la luz de los avances científicos y tecnológicos, y se debe modificar, ampliar o suprimir en la medida de lo necesario." Es igualmente preciso elaborar unos sistemas de supervisión y evaluación correcta de los riesgos, con el fin de asegurar la tipificación de las prácticas inaceptablemente excluyentes - como la exigencia de someterse a la esterilización para conseguir o conservar un trabajo- como violaciones graves de los derechos humanos internacionalmente reconocidos y, por consiguiente, de garantizar la exclusión de tales medidas del ámbito de esta Convención. Estas cuestiones espinosas han suscitado litigios judiciales y continuarán planteando controversias cada vez más complejas en torno a la aplicación y observancia de los postulados de la Convención, a medida que la epidemiología industrial descubre nuevos peligros para la salud en la reproducción y pone de relieve la necesidad de adoptar medidas de protección eficaces.

Además, los redactores de la Convención se adhirieron a los criterios fijados por la OIT al propugnar un sistema de información pormenorizada de la supervisión y observancia del documento, consistente en la presentación obligatoria de informes periódicos a la Comisión de Derechos Humanos de la Convención. De conformidad con el procedimiento establecido en el artículo 18 de la Convención, los Estados miembros se comprometen a "informar de las medidas legislativas, judiciales, administrativas y de otro tipo, adoptadas para aplicar (estas) disposiciones", dentro del término de un año y con una periodicidad mínima cuadrienal, debiendo comunicarse igualmente los eventuales obstáculos a la aplicación de esas medidas. Este mecanismo de intercambio de información significativa sobre la aplicación de la normativa puede servir de cauce a la fijación de los criterios necesariamente aplicables a las medidas de prevención de los peligros para la salud del sistema reproductor presentes en el lugar de trabajo.

\section{Tratados regionales y declaraciones sobre los derechos humanos}

\section{Convención Americana sobre Derechos Humanos}

En el Preámbulo a la Convención A mericana figura una alusión a los derechos económicos y sociales, en los que se incluye, según el artículo 3, el derecho a la vida. No obstante, en el texto de la Convención no se incluyen la salud ni las condiciones de trabajo entre los derechos fundamentales tutelados en otros tratados. Sin embargo, una característica importante de la Convención Americana para la protección de los derechos humanos internacionalmente reconocidos es que en la misma se fija la composición de un tribunal y una comisión de derechos humanos, mediante la creación de una Comisión Interamericana de Derechos $\mathrm{H}$ umanos. Entre los poderes de la Comisión que se regulan en la convención figura el de recabar información incriminatoria de los gobiernos acusados de cometer violaciones de los derechos humanos. En la convención no se abordan directamente las cuestiones de salud y seguridad en el trabajo que afectan a las personas que trabajan en el sistema interamericano.

\section{Carta Africana (Banjul) de Derechos Humanos y de los Pueblos} $\mathrm{L}$ a $\mathrm{C}$ arta Africana de Derechos H umanos y de los Pueblos, adoptada el 27 de junio de 1981, aporta una nueva perspectiva de los conceptos aceptados en relación con los derechos humanos proclamados en los acuerdos dedicados a los mismos. Según el análisis realizado por Alston (1984) desde una perspectiva meramente teórica, ajena a toda referencia específica a la C arta Africana, este documento constituyó un verdadero hito en el esfuerzo por ampliar el ámbito de la protección internacional de los derechos humanos y por ofrecer esa protección a todas las personas en un marco flexible. D entro de un enfoque general, en la Carta Africana se proclaman derechos a un medio ambiente limpio, derechos políticos y derechos a un desarrollo sostenido. Es de subrayarse que, en contraste con la Carta Social Europea, en la Carta Africana no se aborda la protección de las condiciones de trabajo ni la salud y seguridad en el trabajo. De forma que recuerda a la protección acordada en la Declaración U niversal de Derechos Humanos, en el artículo 4 de la Carta Africana se prohíben las violaciones de los derechos humanos que "atenten contra la vida y la integridad de las personas". También en la misma línea de la Declaración de D erechos Humanos, en el artículo 6 de la Carta Africana se garantiza la seguridad de las personas.

Adoptando, en parte, el lenguaje de la carta constitucional de la OMS, que constituyó el punto de partida de la protección internacional de los derechos humanos a la salud, en el artículo 16 se insta a las partes contratantes a proteger el "derecho a disfrutar del máximo nivel posible de salud física y mental". Las partes signatarias se comprometen a "tomar las medidas necesarias para proteger la salud de sus pueblos y para asegurar que reciban atención médica cuando se enfermen".

Al igual que en muchos otros documentos internacionales dedicados a los derechos humanos, en la Carta Africana se establece un mecanismo de supervisión y aplicación, consistente en una Comisión de Derechos Humanos. Los Estados pueden investigar la violación de los derechos humanos cometidas por otros Estados, siempre que se satisfaga el requisito del agotamiento previo de las vías legales. Este procedimiento se describe detalladamente en los artículos 30 a 59. 


\section{La Carta Social Europea}

En el apartado (2) de la Parte I de la Carta Social Europea, promulgada en 1965, se indica expresamente que "todos los trabajadores tienen derecho a unas condiciones de trabajo equitativas", y en la parte I (3) se afirma que "todos los trabajadores tienen derecho a la seguridad y a la higiene en el trabajo". Estos derechos se desarrollan en el artículo 3 de la Parte II, en el que se ofrece un análisis pormenorizado del derecho a condiciones de trabajo, seguridad y salud, con el objeto de garantizar el disfrute de unas condiciones de trabajo seguras e higiénicas. No obstante, a diferencia de otros acuerdos internacionales sobre derechos humanos, en la Carta Social Europea se alude también a la conveniencia de crear unos mecanismos ejecutivos y a otras cuestiones suscitadas en torno a la aplicación y observancia de las normas de derecho internacional relativas a los derechos humanos, en el marco literal del documento. En el artículo 3.2 se insta a las Partes Contratantes a "tomar las medidas precisas para controlar la aplicación de tales reglamentos", al tiempo que en el artículo 3.3 se les anima a "consultar, cuando proceda, a las organizaciones de empleadores y trabajadores sobre las medidas encaminadas a mejorar la seguridad e higiene del trabajo". La trascendencia de esta rotunda disposición se refuerza en las estipulaciones relativas a los procedimientos de comunicación contenidas en los artículos 21 y 22 de la Parte IV, en los que se prevé la supervisión periódica internacional de la aplicación de la normativa.

Es de subrayarse que, aparte de esta admirable perspectiva global de la tutela de los derechos humanos en el plano internacional, especialmente por lo que respecta a la salud y seguridad en el trabajo, en la Carta Social E uropea se sientan clara y decididamente las bases de las futuras tareas de aplicación de sus disposiciones. Por ejemplo, la mención de las facultades reglamentarias y de control que aparece en el artículo 3 es congruente con el sistema internacional de supervisión y aplicación por parte de los Estados signatarios y de las O NG, tanto en el marco del sistema europeo como de los respectivos ordenamientos nacionales. El concepto de consultar a empresas y trabajadores que figura en el artículo 3.3 va más allá del esquema tripartito de la OIT, como reflejo de la creciente aceptación de los comités paritarios de seguridad como cauces del respecto de los derechos humanos internacionalmente reconocidos en el ámbito del empleo.

\section{Normas de la OIT}

Como se indica en la carta constitucional de la OIT, la "protección del trabajador contra las enfermedades y lesiones producidas por el trabajo" es una condición necesaria para una "paz universal y duradera". Por consiguiente, la mejora de las condiciones de vida y de trabajo es uno de los objetivos inspiradores de los convenios y recomendaciones de la OIT. Johnston (1970) escribió que "el principio subyacente es que determinadas necesidades humanas básicas se deben sustraer del ámbito de la competencia internacional, con el objeto de garantizar unos niveles mínimos de solidez y de dignidad humana". Si bien la OIT carece de una "autoridad universal (...) para excluir a las empresas infractoras del mercado de trabajo legal", Friedman (1969) avizora una función más relevante para la OIT: "Es posible prever que, algún día, las leyes y directrices de la OIT lograrán esta fuerza, y que el estigma de su incumplimiento producirá la exclusión del mercado de trabajo internacional".

La OIT ha promovido también la adopción de normas sistemáticas aplicables a los problemas de seguridad que no pueden regularse en los convenios de la organización sin invadir las competencias jurisdiccionales de los Estados soberanos. Por ejemplo, los códigos de conducta promulgados por la OIT en relación con las normas de seguridad han inspirado cierto número de leyes y reglamentos aplicables en áreas como el trabajo portuario, la transferencia de tecnología a las naciones en vías de desarrollo, el sector de la construcción y la industria pesada. Estos modelos de conducta, que a veces se incorporan, con ligeras modificaciones, a los proyectos legislativos, reflejan los principios que informan diversos Convenios de la O IT relativos a la salud y seguridad en el trabajo, como el Convenio sobre la protección de los cargadores de muelle contra los accidentes (revisado), 1932 ( $n$ - 32), el Convenio sobre las prescripciones de seguridad (edificación), 1937 (no 62), el Convenio sobre el examen médico de los menores (industria), 1946 (no 77), y el Convenio sobre el examen médico de los menores (trabajos no industriales), 1946 ( $n$ - 78), el Convenio sobre la protección de la maquinaria, 1963 ( $n$ - 119), el Convenio sobre la higiene (comercio y oficinas), 1964 ( $n$ - 120), el Convenio sobre la seguridad y salud (trabajos portuarios), 1979 ( $n$ ㅇ 152), y el Convenio sobre la seguridad y salud laboral, 1981 (no 155). Este último convenio será posteriormente objeto de un examen en profundidad.

\section{El Convenio 155 de la OIT: Convenio sobre la seguridad y salud} de laboral y medio ambiente de trabajo 1981; sus antecedentes D esde su creación, la O IT ha propugnado la mejora de las condiciones de trabajo. Inicialmente, el esfuerzo de la organización se centró en los accidentes y en las vías legales de reclamación de indemnizaciones por accidentes de trabajo. Esta tendencia se refleja en los primeros convenios de la O IT, como el Convenio sobre la protección de los cargadores de muelle contra los accidentes (revisado), 1932 (no 32), el Convenio sobre las prescripciones de seguridad (edificación), 1937 (no 62), y los Convenios sobre el examen médico de los trabajadores y sobre la protección de la maquinaria. Las normas específicas de prevención de accidentes promulgadas en estos convenios han servido de modelo a las normas de actuación incorporadas a los reglamentos de seguridad en el trabajo que actualmente rigen en muchos países. En todos estos convenios subyace el principio de que la protección contra los accidentes de trabajo es un derecho de todos los trabajadores.

En la línea de esta tradición, en el artículo 3(e) del Convenio no 155 se afirma que el término salud, "en relación con el trabajo, comprende, no solamente la ausencia de afecciones o de enfermedad, sino también los elementos físicos y mentales que afectan a la salud y están directamente relacionados con la seguridad e higiene en el trabajo." Esta definición es, al mismo tiempo, amplia y engañosamente sencilla; en efecto, la misma revela la compleja interconexión existente entre la exposición a factores de riesgo en el lugar de trabajo, la forma de vida individual y los factores ambientales que influyen en los efectos de las condiciones de trabajo (Mausner y K ramer 1985). Por otra parte, éste es un concepto multidimensional, ya que, en el interés por abarcar los aspectos, tanto físicos, como mentales, de la salud y el bienestar, se reconocen implícitamente los efectos del estrés en el trabajo y otros problemas mentales.

Sin embargo, el meollo del Convenio no 155 implica a la creación de unos mecanismos eficaces de aplicación y observancia de las demás normas de la OIT, tanto en los lugares de trabajo, como en los ámbitos regional y nacional. En efecto, en el Convenio no 155, adoptado en la sexagésima séptima reunión de la Conferencia Internacional del Trabajo, celebrada en 1981, se propugna la creación, aplicación y evaluación periódica de normas de salud y seguridad en el trabajo por parte de los Estados miembros de la O IT. Por ejemplo, en el artículo 4.1 de este convenio se establece el objetivo de promover el desarrollo de una "política nacional coherente" en materia de seguridad y salud de los trabajadores. A este fin, los Estados miembros que 
han ratificado el Convenio se obligan a promover la investigación, la evaluación estadística de la exposición a los peligros (del tipo de las medidas de supervisión médica) y la educación y formación de los trabajadores. En este Convenio se emplea un lenguaje genérico para el establecimiento de un marco regulador. Se exige la celebración de consultas con las empresas y organizaciones representativas antes de la concesión de exenciones; además, de conformidad con el artículo 2.3, para excluir determinadas categorías de trabajadores de la aplicación del convenio se exige la aportación de información "sobre los progresos realizados hacia una aplicación más amplia." En el Convenio no 155 se propugna igualmente la educación de las "organizaciones representativas" y la participación de los trabajadores en la elaboración y aplicación de las normas de salud y seguridad en el trabajo, tanto en el ámbito interno, como en los planos regional, nacional e internacional.

\section{Convenios de la OIT en los que se instituye la indemnización a los trabajadores}

La OIT ha elaborado y adoptado diversos Convenios relativos a la indemnización a los trabajadores (O IT 1996a).

Entre estos documentos figuran el Convenio no 12 sobre la indemnización a trabajadores (agricultura), 1921 (no 12); el Convenio sobre la indemnización por accidentes del trabajo, 1925 ( $n$ - 17); el Convenio sobre las enfermedades profesionales, 1925 ( $n$ - 18); el Convenio sobre el seguro de enfermedad (industria), 1927 (no 24); el Convenio sobre el seguro de enfermedad (agricultura), 1927 ( $n$ - 25); y el Convenio sobre asistencia médica y prestaciones económicas por enfermedad, 1969 (no 130). La regulación legal de la indemnización por accidente de trabajo, bastante generalizada entre los Estados miembros de la OIT, responde a unos criterios económicos más que a un compromiso con los derechos humanos: se trata de proporcionar asistencia a los trabajadores lesionados y de superar las incertidumbres inherentes a un proceso judicial mediante un sistema de prestaciones prefijadas que se conceden por causas objetivas y en cuyo sistema se fija un límite monetario a las prestaciones acordadas a las víctimas de accidentes de trabajo o de enfermedades profesionales. Un ejemplo de esta tendencia legislativa es la Ley (comentada) de indemnización por accidente de trabajo promulgada en 1982 en Virginia, Estados U nidos, según la cual todo acto exigible en virtud del contrato de trabajo puede causar el derecho a recibir una indemnización. La reclamación de asistencia médica al amparo de estos sistemas independientes suele originar demoras, infravaloraciones, prestaciones deficitarias y litigios judiciales. A pesar de estas limitaciones objetivas de su eficacia, la "universalidad" de estos sistemas de protección, tanto en la legislación norteamericana, como en el derecho internacional, refleja una voluntad colectiva de desincentivar financieramente los trabajos peligrosos y de prestar apoyo económico a los trabajadores lesionados.

\section{Mecanismos de investigación y comunicación en la OIT}

Para Alstom, la OIT constituye un modelo internacional de garantías procesales que "legitima la promulgación de nuevas normas" (1984). EI procedimiento aplicado por la OIT consiste en la realización de una investigación preliminar de la legislación aplicable en los Estados miembros, seguida de un acuerdo del Consejo de Administración de la O IT respecto a la inclusión de la cuestión en el orden del día de la Conferencia Internacional del Trabajo anual, y de un cuestionario que la Secretaría de la OIT remite a los Estados miembros participantes. Una vez examinado por una comisión técnica, el borrador del documento se distribuye entre los Estados miembros y entre las organizaciones representativas de trabajadores y empresas; a continuación, se elabora una versión revisada del documento, que se somete al examen de la comisión técnica y a debate por parte de la comisión de plenos y proyectos, antes de votarse y aprobarse en la Conferencia Internacional del Trabajo. Este procedimiento facilita al máximo el intercambio de ideas y el debate entre las organizaciones destinatarias de los convenios y sus órganos rectores. Posteriormente, en este mismo capítulo, en la sección dedicada a la O rganización Internacional del Trabajo, figura un examen pormenorizado del procedimiento de información aplicado por la OIT.

Este procedimiento, establecido en 1926, al constituirse la Comisión de Expertos sobre la A plicación de Convenios y R ecomendaciones, no ha dejado de proyectarse sobre el sistema internacional. Por ejemplo, el paradigma de la OIT informa la contemporánea Convención sobre la Eliminación de Todas las Formas de Discriminación contra la Mujer, en cuyo artículo 18 se establece, con carácter preceptivo, un procedimiento de aportación de informes a una Comisión internacional que igualmente se regula en el articulado del convenio. Asimismo, la Comisión debe examinar la totalidad de los informes exigibles en relación con las medidas de aplicación y ejecución, al final del primer año siguiente a la ratificación y, a partir de entonces, con una frecuencia mínima de una vez cada cuatro años. 0 tros sistemas de comunicación utilizados en la supervisión de la aplicación de los convenios de la O IT son las misiones de contacto directo (véase en Samson 1984 una excelente exposición de las tareas de mediación y conciliación realizadas por las misiones de contacto directo de la OIT); las comisiones de encuesta, que investigan casos concretos de violación flagrante de los convenios y de la carta constitucional de la OIT; y la supervisión periódica realizada mediante la presentación de informes a la Conferencia, al Consejo de Administración y al Tribunal Administrativo. Estos procedimientos informativos, aunque lentos, son de un valor incalculable y constituyen un elemento clave de un esfuerzo de mucha mayor envergadura por fomentar en la opinión pública mundial una actitud positiva hacia los problemas del trabajo.

Ruda (1994) observa que el Convenio sobre la libertad de asociación y protección del derecho de sindicación, 1948 (no 87) y el Convenio sobre el derecho de sindicación y de negociación colectiva, 1949 (no 98), ambos de la O IT, escritas dentro de los acuerdos de Gdansk, suscritos entre el gobierno polaco y el sindicato Solidaridad. "Ni la Comisión de Expertos ni la Comisión de la Conferencia para la A plicación de las $\mathrm{N}$ ormas pueden imponer sanciones de orden alguno, si bien sus resoluciones se asumen en ocasiones como sanciones morales o políticas." Esta situación ha sido un factor permanente de frustración a lo largo de la historia de la Comisión, si bien la misma se enorgullece de su capacidad para influir en algunos gobiernos en determinadas circunstancias.

\section{Organización M undial de la Salud}

\section{La Declaración de Alma Ata de la OMS sobre la asistencia primaria}

En la denominada Declaración de Alma Ata (Organización M undial de la Salud 1978), adoptada en la Conferencia Internacional sobre Asistencia Sanitaria Primaria celebrada por la OM S y UNICEF en Alma Ata, URSS, entre el 6 y el 12 de septiembre de 1978, la O M S lanzó una campaña internacional conocida por el lema "Salud para todos 2000", que refleja un esfuerzo concertado en el plano internacional por mejorar el nivel sanitario y la prestación de los servicios de salud, en especial los de asistencia primaria, aunque sin excluir la salud y seguridad en el trabajo, en todo el mundo. Si bien en el lenguaje sencillo de la Declaración no se alude a la salud y seguridad en el trabajo, ésta se ha incorporado a la planificación estratégica; así, se ha promovido la 
aplicación de los principios básicos de la protección de la salud mediante la difusión de información y el desarrollo de programas estratégicos orientados a lograr los objetivos de "Salud para todos 2000" en el marco de la D eclaración.

En consonancia con el espíritu y la letra de la Constitución de la OMS, anteriormente comentada, en la Declaración de Alma-A ta se insta "la adopción de medidas urgentes por parte de todos los gobiernos, de todos cuantos trabajan en la salud y el desarrollo, y de la comunidad internacional, con el objeto de promover la salud de la población mundial". Específicamente, en el artículo 1 del documento se proclama abiertamente que "la salud ... es un derecho humano fundamental y que el logro de los mayores niveles posibles de salud constituye un objetivo social de la máxima importancia en el plano mundial ..." En el artículo 3 se dice lo siguiente: "La promoción y protección de la salud humana es esencial para un crecimiento económico sostenido y contribuye a mejorar la calidad de vida y a la paz mundial". Además, en la conferencia se sentaron las bases para el desarrollo de unas estrategias de actuación específicamente orientadas al logro de estos objetivos. Entre las medidas de aplicación práctica de los acuerdos de Alma-Ata en el ámbito de la salud y seguridad en el trabajo se incluye el desarrollo de los servicios de salud laboral en el marco de las estrategias nacionales e internacionales. La O rganización Panamericana de la Salud (OPS) es una iniciativa regional que ha asumido el Plan de Actuación de la O M S denominado "Salud para Todos 2000: Estrategias" (O rganización Panamericana de la Salud 1990), en el que se incorporan las cuestiones de salud y seguridad en el trabajo en los planes de desarrollo de los centros de formación y en la formulación de los programas de protección de la salud.

\section{Declaración de Pekín de la OMS sobre Salud Laboral para Todos, 1994}

En octubre de 1994, la Segunda Reunión de Centros Colaboradores de la OMS en cuestiones de salud laboral aprobó y suscribió la Declaración sobre la Salud Laboral para Todos. La Declaración de Pekín se inserta decididamente en la filosofía de la Declaración de Alma-Ata sobre la Asistencia Primaria y de numerosos documentos de la OIT dedicados a la salud y seguridad en el trabajo. Después de recordar que 100 millones de trabajadores se lesionan y 200.000 fallecen todos los años de resultas de accidentes de trabajo, y que entre 68 y 157 millones de nuevos casos de enfermedad profesional se atribuyen a la exposición a agentes peligrosos o a las cargas de trabajo, en la Declaración de Pekín se aboga por la aplicación de "nuevos programas y estrategias a la salud laboral en todo el mundo" y se afirma que los programas de salud laboral "no constituyen una carga, sino que producen unos efectos positivos en la productividad de las empresas y de la economía nacional" y, por lo tanto, se asocian a la idea del desarrollo sostenible. En la D eclaración se propugna igualmente el desarrollo de las infraestructuras, incluidos los servicios de salud laboral, con vigilancia médica y la promoción de la salud; así como una mayor vinculación de los programas de salud laboral con otras actividades de promoción de la salud laboral con los programas y actividades patrocinados por la OMS.

\section{Comité Conjunto OIT/OMS sobre Salud y Seguridad en el Trabajo}

La OM S coopera con la O IT en el marco del Comité Conjunto OIT / O M S sobre Salud y Seguridad en el Trabajo, fundado en 1946. U no de los proyectos iniciales del Comité consistió en la creación de la Comisión Internacional del $\mathrm{R}$ in contra las Enfermedades de Transmisión Sexual. En el decenio de 1950, a petición de Egipto e Irán, los expertos consultores de la O IT y de la
O MS prestaron asistencia técnica en la realización de extensos estudios de salud laboral.

El Comité ha definido la salud y seguridad en el trabajo como "el logro y mantenimiento del mayor nivel de bienestar físico, mental y social de los trabajadores de todas las profesiones, la prevención de la pérdida de la salud de los trabajadores causada por las condiciones de trabajo, la protección de los trabajadores en el lugar de trabajo contra los riesgos producidos por los agentes nocivos para la salud, la colocación y el mantenimiento de los trabajadores en un medio ambiente de trabajo adaptado a sus características fisiológicas y psicológicas y, en resumen, la adaptación del trabajo al hombre y de cada hombre a su trabajo".

\section{Resumen de doctrinas y disposiciones legales relativas a los derechos humanos a la protección de la salud en el lugar de trabajo}

De la ausencia de unos mecanismos legales específicamente orientados a la tutela de los derechos a la salud y seguridad en el trabajo se puede inferir la inexistencia de una doctrina legal de la protección de la vida y la salud humanas en el lugar de trabajo, salvo por las raras interpretaciones jurisprudenciales de los principales documentos que sobre los derechos humanos. Por ejemplo, en el artículo 3 de la Declaración Universal de Derechos $\mathrm{H}$ umanos de las $\mathrm{N}$ aciones U nidas se alude expresamente a la necesidad de proteger el derecho a la vida, la libertad y la seguridad de la persona, sin mencionarse el entorno ambiental o de trabajo en que dicha protección se debe materializar. Por otra parte, la ausencia, tanto de un sistema de sanciones penales a las violaciones de los derechos humanos en general (excepto por las violaciones más graves de esos derechos, como la esclavitud, el genocidio, la segregación racial y los crímenes de guerra), como de una normativa internacional punitiva de los atentados contra la seguridad personal causados por la exposición a riesgos para la salud y seguridad en el trabajo, plantea la necesidad de estudiar posibles alternativas al sistema tradicional de tutela de los derechos, si se quiere que la protección de la salud y seguridad en el trabajo sea una realidad.

Como se ha indicado anteriormente, en numerosos documentos internacionales sobre los derechos humanos se asume el principio de que la salud y seguridad en el trabajo constituye uno de los derechos fundamentales del hombre, en especial por lo que respecta al derecho individual de la persona humana a la vida, al bienestar y a la seguridad personal. Estos derechos se han plasmado igualmente en diversos documentos internacionales no orientados específicamente a la tutela de los derechos humanos. Por lo tanto, se puede postular que, en términos globales, el derecho humano a un lugar de trabajo saludable es una norma aceptada de derecho internacional. Al mismo tiempo, empero, el ordenamiento jurídico interno de los Estados miembros adolece de idéntica contradicción que la normativa internacional, esto es, que la insuficiente protección de las condiciones generales de trabajo, en general, y de la salud del lugar de trabajo, en particular, suscita una serie de complicaciones derivadas de la contradicción entre, de una parte, unas políticas de prevención orientadas a grandes segmentos de una determinada población y diseñadas para reducir la propagación de la enfermedad o los efectos de la exposición a determinados peligros y, de otra parte, el sentimiento popular, que se resiste a la pérdida temporal de determinados derechos individuales a desplazarse, a realizar determinadas actividades 0 a dedicarse al comercio, con el objeto de proteger el derecho de las personas a la salud en el trabajo. Por lo tanto, persiste la duda respecto a la posibilidad de una aplicación coercitiva de los derechos a la salud y seguridad en el trabajo, tanto en el ámbito internacional como en cada Estado, que permita mejorar la calidad de las condiciones de 
trabajo de las personas. ¿Es posible alcanzar el objetivo de tutelar estos derechos humanos en el marco del nuevo lugar de trabajo y de las normas escritas de derecho internacional?

Por consiguiente, la plasmación en normas positivas del concepto doctrinal de la tutela de la salud y la seguridad se inscribe en el marco de los derechos humanos. Por lo tanto, la revisión y aplicación de esta normativa protectora constituirá el primero de los objetivos de la protección de los derechos humanos en el próximo siglo. Como aportación al logro de este objetivo, posteriormente se examinan nuevos enfoques posibles de la solución de estos problemas.

\section{Panorámica de los problemas de aplicación y observancia en el contexto del ordenamiento internacional}

D esde la promulgación de la Carta de las Naciones U nidas, los más escépticos han cuestionado la posibilidad de aplicar coercitivamente el derecho público internacional, en especial, por lo que respecta a las violaciones más graves de los derechos humanos. La prevención de tales hechos en el marco del ordenamiento internacional constituye, en el mejor de los casos, un proceso en dos fases que requiere (1) la promulgación de una normativa escrita, y (2) la adopción de medidas eficaces de aplicación y cumplimiento. Por regla general, las teorías al uso parten del supuesto de una sociedad estructurada y dotada de instituciones jurídicas y procedimientos ejecutorios tradicionales, que sirven de cauce a la imposición de sanciones y a la disuasión de los "malos agentes" que se niegan a aceptar los valores sociales y los objetivos plasmados en el ordenamiento. La aplicación y observancia de los derechos humanos en general, y de los lugares de trabajo en particular, es una tarea difícil y compleja. Cincuenta años después de la firma de la $\mathrm{C}$ arta de las $\mathrm{N}$ aciones U nidas, existe un sistema internacional efectivo que manifiesta un cierto grado de eficacia en el establecimiento de políticas en normas escritas; en cambio, se echa en falta un marco jurídico positivo para el desarrollo de unos procedimientos de aplicación y observancia. Se impone, por consiguiente, examinar las cuestiones fundamentales que se plantean. ¿Existen otros modelos de aplicación no coercitivos que permitan reforzar la protección efectiva de la seguridad y salud en el trabajo? ¿Como se pueden generar nuevos incentivos estrajurídicos para la protección de los derechos humanos internacionalmente consagrados a la salud y seguridad en el trabajo?

Las limitaciones intrínsecas del ordenamiento internacional impiden la adopción de un sistema de principios y normas de protección de la salud y seguridad en el trabajo mientras el derecho internacional no se apoye en algún mecanismo de aplicación 0 en unos incentivos para la observancia de las normas. Sin embargo, la aplicación de unos criterios cuantitativos no constituye la regla en la praxis internacional de la salud y seguridad en el trabajo, como se observa, por ejemplo, en el Convenio de la OIT sobre la utilización del asbesto en condiciones de seguridad, 1986 (no 162). En efecto, en el artículo 11.1 del Convenio se proscribe expresamente el uso de crocidolita. Empero, en el artículo 11.2 se invierte el criterio y no se establece un mecanismo formal de inspección que permita la eliminación de los peligros, más allá de las posibilidades limitadas ofrecidas a los informes institucionales. A demás, la norma reguladora de las exposiciones máximas al asbesto no se ha transcrito en el Convenio $n 0162$, que delega en las autoridades competentes de cada país la promulgación de las normas pertinentes. Por otra parte, la propia naturaleza del sistema de información sin unos mecanismos coercitivos de aplicación y sin unos incentivos positivos a la observancia de la normativa por parte de los distintos países o de las empresas limita, en la práctica, la aplicación de los principios y normas legales relativos a los derechos humanos (H enkin 1990). Como observa este autor, "el derecho internacional pide continuas disculpas (...) para justificar su existencia" porque carece de gobierno y de instituciones rectoras.

A pesar de la capacidad contrastada del sistema internacional para reducir las agresiones entre los estados, que se traduce en las relaciones diplomáticas y otras modalidades de acuerdo, son contados los casos en que el sistema internacional puede aplicar sanciones y castigos a los "malos agentes" del tipo de los que se imponen en el marco del derecho interno. En estas circunstancias, en los pasillos de las sedes de las $\mathrm{N}$ aciones $\mathrm{U}$ nidas y de las conferencias internacionales en que participan organizaciones no gubernamentales han resonado súplicas vehementes en favor de la implantación de un sistema de protección internacional de los derechos humanos. A falta de un cuadro de medidas coercitivas - consistentes en multas u otras sanciones- que surtan efectos, tanto punitivos, como disuasorios, se experimenta la necesidad acuciante de implantar unos dispositivos eficaces de aplicación y observancia de las normas internacionales de protección de la seguridad y salud en el trabajo. Esto hace que los modelos "interactivos" de observancia sean ideales para llenar este vacío, siempre que se apliquen en conjunción con unas políticas prácticas de aplicación de incentivos positivos a la mejora de las condiciones de trabajo en el conjunto del sistema internacional (Feitshan 1993). Se produce, por lo tanto, una necesidad inequívoca de contar con unos mecanismos de aplicación y observancia que, en palabras de K.T. Samson, ex director del área de A plicación de Normas de la O IT, confieran al lábil e infravalorado sistema de información, "una dimensión que trascienda del diálogo".

Ahora que el sistema internacional ha desplazado la necesidad de codificación de las normas universales de protección de los derechos humanos del primer plano de la actividad internacional, muchos piensan que ha llegado el momento de dirigir la atención internacional hacia la aplicación y observancia de esas normas. Los principales exégetas (como Sigler y M urphy 1988) parten de la hipótesis de trabajo, escasamente estructurada, pero importante, de que la competencia entre organizaciones - independientemente de que se trate de las empresas o de los Estados miembros de la ONU - puede coadyuvar al logro de una protección eficaz de la salud y seguridad en el trabajo, siempre que se fomente esa competencia mediante la aplicación de incentivos positivos en vez de los tradicionales modelos de castigo y disuasión. Según Joseph M urphy, abogado y redactor de Corporate Conduct $Q$ uarterly, boletín especializado en los temas de la observancia, "tendemos más a inducir a las organizaciones a que se controlen y se supervisen a sí mismas".

\section{Conclusiones}

El primer medio siglo de vida de las $\mathrm{N}$ aciones U nidas ha dado como fruto la plasmación de las normas internacionales de protección de los derechos humanos en el campo de la salud en el lugar de trabajo en un número de importantes instrumentos clave internacionales en derechos humanos. Sin embargo, la efectividad de estos instrumentos internacionales es intrínsecamente limitada, en virtud de la ausencia - excepto por la supervisión administrativa- de unos mecanismos de ejecución y disuasión que garanticen su aplicación. Se ha producido un profundo sentimiento de frustración por causa de esta limitación de la efectividad del sistema internacional, a pesar de la acumulación de un volumen ingente de documentos e informes internacionales en numerosos organismos de la O NU, debido a que toda esta labor se traduce en escasas posibilidades de supervisión y control que excedan de la presentación de informes. Los tratados y convenios mencionados en el presente trabajo, orientados a la protección o 
la aplicación de los derechos a la salud, reflejan esta frustración, a pesar de los importantes avances logrados mediante la utilización oportuna de los cauces para la elaboración de informes.

L os principales conceptos que informan los documentos internacionales consagrados a los derechos humanos responden a la filosofía de que las enfermedades relacionadas con el trabajo constituyen un resultado evitable de la industrialización, a la vez que reflejan un sentimiento internacional, escasamente estructurado, de que las personas no deben matarse ni enfermarse gravemente en el trabajo. Estos documentos - y los principios que los informan- han sido concebidos para tutelar el derecho humano a la seguridad en el lugar de trabajo y no como modelos de perfección. Aunque en estos acuerdos se consagran los derechos humanos internacionales a la salud y seguridad en el trabajo, no se deben interpretar por ello, ni como el límite del esfuerzo por mejorar la calidad de vida de los trabajadores, ni como el mejor resultado posible desde la perspectiva de las mejoras que pueden lograrse fomentando la competencia por los incentivos positivos. Por el contrario, estas normas constituyen los niveles "máximos" de protección internacional de los derechos humanos en el lugar de trabajo y se han concebido para mejorar la calidad de vida de todos los trabajadores.

\section{AMBITO COMUNITARIO}

\section{- ORganizaCIONES DE AMBITO COMUNITARIO}

\section{Simon Pickvance}

El protagonismo de los grupos comunitarios y del voluntariado en el campo de la salud y seguridad en el trabajo se ha incrementado sensiblemente en los últimos veinte años. Centenares de estos grupos, diseminados en más de treinta países, promueven los intereses de los trabajadores y de las personas afectadas de enfermedades profesionales, con especial atención a los individuos cuyas necesidades no se encuentran cubiertas en el lugar de trabajo por parte de los sindicatos o de los servicios estatales. La salud y seguridad en el trabajo es una de las áreas de interés de muchas otras organizaciones que defienden los derechos de los trabajadores desde unas perspectivas muchos más amplias de actuación en los campos de la salud o de la defensa de la igualdad de sexos.

A veces, estas organizaciones tienen una vida fugaz, debido, en parte, a que, de resultas de su labor, otras organizaciones mejor estructuradas hacen suyos los objetivos de aquéllas. No obstante, muchas organizaciones comunitarias y del sector voluntario llevan 10 o 20 años funcionando y adaptando sus métodos y escalas de prioridades a las necesidades cambiantes de sus usuarios y del mundo del trabajo.

Este tipo de organizaciones no constituye una novedad. U na de las más antiguas fue la Asociación de Asistencia Sanitaria de la Unión de Trabajadores de Berlín, integrada por médicos y trabajadores y dedicada a prestar asistencia médica a 10.000 trabajadores berlineses a mediados del siglo XIX. Antes del surgimiento de los sindicatos de trabajadores en ese siglo, muchas organizaciones voluntarias lucharon por reducir las horas de trabajo y por los derechos de los jóvenes trabajadores. La ausencia de indemnización por determinadas enfermedades profesionales fomentó, a mediados del decenio de 1960, la creación de organizaciones de trabajadores y familiares.

Sin embargo, la actual proliferación de grupos comunitarios y voluntarios tuvo su origen en los cambios políticos ocurridos a finales del decenio de 1960 y en el decenio siguiente. En esos años, los conflictos entre trabajadores y empresas se centraron, tanto en las condiciones de trabajo, como en la remuneración.

La nueva regulación legal de la salud y seguridad en el trabajo nació en los países industrializados por mor del creciente interés de los trabajadores y sindicatos por las cuestiones de la salud y seguridad en el lugar de trabajo y, a su vez, la promulgación de esta legislación redundó en un incremento de la conciencia pública. Si bien la promulgación de esta normativa ha hecho posible en la mayoría de los países que la salud y la seguridad sean objeto de negociación directa entre sindicatos, empresas y gobiernos, los trabajadores y otras personas aquejadas de lesiones y enfermedades profesionales han optado con frecuencia por ejercer presión en escenarios externos a este marco de negociación tripartita, guiados por el convencimiento de que un derecho humano tan fundamental como el de la salud y la seguridad en el trabajo no es negociable.

M uchos de los grupos voluntarios creados desde entonces se han beneficiado igualmente de la evolución de los patrones culturales determinantes de la función social de la ciencia, caracterizados por la conciencia creciente de los científicos de la necesidad de que la ciencia satisfaga las necesidades sociales y de los trabajadores, y por un aumento de la cualificación científica de éstos. EI nombre de algunas organizaciones refleja esta convergencia de intereses; este es el caso de la sociedad danesa Acción de Investigadores y Trabajadores (AAA), y de la Sociedad para la Investigación Participativa en Asia, con sede en India.

\section{Puntos fuertes y débiles}

Para el sector voluntario, su fuerza radica en la inmediatez de su respuesta a los problemas que se suscitan en torno a la salud y seguridad en el trabajo, en su estructura organizativa abierta, en la incorporación de los trabajadores y otras personas marginadas que sufren enfermedades y lesiones profesionales, y en la ausencia de constreñimientos institucionales a su libertad de palabra y de acción. L os problemas del sector voluntario estriban en la precariedad de sus ingresos, en la dificultad para coordinar los estilos de trabajo del personal voluntario y remunerado, y la imposibilidad de atender a las innumerables necesidades insatisfechas de los trabajadores y otras personas aquejadas de enfermedades profesionales.

Se ha mencionado anteriormente la fugacidad de muchas de estas organizaciones; en efecto, de dieciséis organizaciones de este tipo que había en el Reino U nidos en 1985, diez años más tarde sólo quedaban siete. En ese mismo período de tiempo se habían creado veinticinco organizaciones, en un proceso característico de todas las organizaciones voluntarias. Su estructura interna suele ser horizontal y nutrirse de delegados y afiliados de los sindicatos y otras organizaciones, con el concurso de las personas afectadas de problemas de salud relacionados con el trabajo. Si bien las relaciones con los sindicatos, partidos políticos y organismos estatales son vitales para el éxito de su esfuerzo de transformación de las condiciones de trabajo, la mayoría de estas organizaciones han optado por una relación indirecta con esas entidades y por un esquema de financiación plural que, por regla general, se alimenta de fondos procedentes de subvenciones públicas, de los sindicatos y de organizaciones mercantiles y de beneficencia. $\mathrm{H}$ ay muchas más organizaciones de carácter enteramente voluntario o que distribuyen alguna 
publicación entre los suscriptores, cuyas cuotas cubren exclusivamente los costes de impresión y distribución.

\section{Actividades}

Un rasgo común a las organizaciones del sector voluntario es que centran su actividad en peligros concretos (identificables con determinadas enfermedades, empresas multinacionales, sectores de empleo, grupos étnicos o sexos), centros de asesoramiento, servicios de salud en el trabajo, publicación de revistas y boletines, centros de formación e investigación, y redes supranacionales.

Algunas de las organizaciones más antiguas defienden los intereses de los pacientes de las enfermedades profesionales que se relacionan a continuación y que resumen los objetivos principales de los grupos comunitarios de todo el mundo: hipersensibilidad múltiple a los productos químicos, asbestosis, antracosis, silicosis, karoshi (muerte repentina causada por el exceso de trabajo), lesión por esfuerzo repetitivo, víctimas de accidentes, hipersensibilidad a la electricidad, salud laboral de la mujer, salud laboral de los negros y minorías étnicas, asbestosis (amianto), pesticidas, fibras minerales artificiales, microondas, equipos de visualización, peligros profesionales en el arte, trabajo en la construcción, Bayer, U nion Carbide, Río Tinto Zinc.

Esta concentración del esfuerzo puede ser sumamente eficaz; en efecto, las publicaciones del Center for Art $\mathrm{H}$ azards, de la ciudad de Nueva York, fueron modelos en su clase, y tanto en E stados U nidos, como en Japón, el R eino U nido y otros países se han desarrollado con éxito diversas campañas para llamar la atención hacia las necesidades específicas de los trabajadores migratorios pertenecientes a minorías étnicas.

Una docena de organizaciones de todo el mundo se esfuerzan por resolver los problemas sanitarios de los trabajadores pertenecientes a minorías étnicas: latinoamericanos en Estados U nidos; paquistaníes, yemeníes y bengalíes en Inglaterra; marroquíes en Francia; y trabajadores del sudeste asiático en Japón, entre otras minorías. Dada la gravedad de las lesiones y enfermedades que suelen sufrir estos trabajadores, la reivindicación inicial consiste en obtener una indemnización suficiente, lo que suele llevar aparejado el reconocimiento de su situación legal. No obstante, la reivindicación principal consiste en abrogar las prácticas discriminatorias en el empleo de los trabajadores pertenecientes a grupos étnicos minoritarios, que trabajan en unas condiciones que los miembros de la mayoría no aceptan. Es mucho lo que estos grupos han conseguido, en parte, gracias a la difusión, en sus respectivos idiomas, de mejor información relativa a la salud y seguridad y a sus derechos laborales.

Particularmente notable ha sido el éxito logrado por la organización Pesticides Action N etwork y sus asociaciones hermanas, especialmente en su campaña por lograr la proscripción de determinados pesticidas (la campaña contra la "docena de (productos) nocivos"). Estos problemas y la degradación sistemática del medio ambiente de trabajo y general por parte de algunas empresas multinacionales constituyen problemas espinosos, por lo que las organizaciones dedicadas a resolverlos, después de lograr numerosas victorias parciales, se han fijado nuevos objetivos.

\section{Centros de asesoramiento}

La complejidad del mundo del trabajo, la debilidad de los sindicatos en muchos países y la insuficiencia del asesoramiento formal en materia de salud y seguridad en el trabajo, han inducido la creación de centros de asesoramiento en numerosos países. Las principales redes existentes en los países anglófonos atienden decenas de miles de consultas todos los años. El funcionamiento de estas redes está, en gran medida, en función de las necesidades expresadas por los usuarios. La tendencia contrastada en la estructura económica de las sociedades avanzadas hacia la reducción del tamaño de los lugares de trabajo, la precariedad del empleo y el incremento del trabajo no estructurado y a tiempo parcial (circunstancias que dificultan la regulación de las condiciones de trabajo) han facilitado la financiación de los centros de asesoramiento por parte de las administraciones locales y estatales. La Red Europea sobre los Riesgos en el Trabajo, integrada por trabajadores y asesores de salud y seguridad en el trabajo, ha recibido recientemente fondos de la U nión Europea. Por su parte, la red de centros de asesoramiento de Sudáfrica se ha beneficiado de los fondos para el desarrollo de la U nión Europea, mientras que los comités de salud y seguridad en el trabajo de ámbito comunitario existentes en Estados Unidos han recibido fondos del programa de $\mathrm{N}$ uevas Directrices de la Administración para la Salud y Seguridad en el Trabajo de Estados U nidos

\section{Servicios de salud laboral}

Algunos de los esfuerzos más notables del voluntariado se han centrado en la mejora de la calidad de los servicios de salud laboral. Las organizaciones integradas por personal médico y por especialistas técnicos y trabajadores han demostrado la necesidad de tales servicios y han puesto en práctica nuevos métodos de prestación de asistencia sanitaria en el trabajo. Los servicios sectoriales de salud laboral que se han creado en Dinamarca a lo largo de los últimos 15 años han recibido el apoyo decidido de la AAA, en especial por lo que respecta a la participación de los representantes de los trabajadores en la gestión de los servicios. 0 tros ejemplos de esta tendencia son el desarrollo de los servicios de asistencia sanitaria primaria en el Reino U nido, así como la creación, en Australia, de servicios específicamente destinados a los pacientes con trastornos en los miembros superiores relacionados con el trabajo, de resultas de la experiencia acumulada por los centros de medicina del trabajo.

\section{Investigación}

Los progresos científicos de los decenios de 1960 y 1970 han impulsado la experimentación con nuevos métodos de investigación denominados de investigación activa, investigación participativa 0 epidemiología informal. La concreción de las necesidades de investigación de los trabajadores y sus sindicatos ha posibilitado que un número de centros se especialicen en realizar investigaciones para aquéllos. Algunos de los centros más antiguos son la red de Centros Científicos de los Países Bajos, DIESAT, el centro de medios de salud y seguridad de los sindicatos brasileños, SPRIA (Society for Participatory Research in Asia) en India y la red de centros de la República de Sudáfrica. Las investigaciones realizadas por estas instituciones marcan la pauta de la incorporación de las aspiraciones de los trabajadores en el ámbito de la salud y sus peligros a la corriente dominante de la medicina del trabajo.

\section{Publicaciones}

Muchos grupos del sector voluntario editan diversas publicaciones, las más importantes de las cuales imprimen hasta veinte números anuales que alcanzan tiradas de millares de ejemplares y gozan de amplia difusión, no sólo entre los grupos de trabajadores a los que están dirigidas, sino también en medios oficiales y sindicales. Estas publicaciones (como el boletín $\mathrm{H}$ azards, en el Reino Unido, y Arbeit und Ökologie - Trabajo y ecología- en Alemania) constituyen unas redes eficaces de comunicación en sus respectivos países. Si bien la escala de prioridades que estas publicaciones propugnan suele reflejar, en un principio, sus diferencias culturales con otras organizaciones, los sindicatos y partidos políticos asumen frecuentemente sus planteamientos. EI 
endurecimiento de las sanciones aplicables a los infractores de la normativa legal de salud y seguridad con resultados de lesiones 0 de muerte de trabajadores es una constante de la línea editorial de estas publicaciones.

\section{Redes internacionales}

La rápida mundialización de la economía ha inducido a los sindicatos a conferir mayor importancia a las secretarías sectoriales internacionales, a constituir organizaciones sindicales de ámbito regional, como la O rganización para la U nidad de los Sindicatos Africanos, y a promover reuniones de los trabajadores de determinados sectores. Estas organizaciones suelen asumir los problemas de salud y seguridad, como se refleja en la Carta de Salud y Seguridad en el Trabajo promulgada por la mencionada O rganización para la U nidad de los Sindicatos A fricanos. En el sector voluntario, se han establecido vínculos formales entre los grupos interesados en la actividad de determinadas empresas multinacionales (con el objeto de contrastar, bien las normas de seguridad y el comportamiento en materia de salud y seguridad de las empresas estudiadas en varias partes del mundo, bien los antecedentes en materia de salud y seguridad de diversos sectores, como la producción de cacao o la fabricación de neumáticos), que han creado redes en las principales áreas de libre comercio: TLC, UE, MERCOSUR y Asia Oriental. Estas redes internacionales persiguen la armonización de las normas de protección de los trabajadores, el reconocimiento e indemnización de las lesiones y enfermedades profesionales, y la participación de los trabajadores en los sistemas de salud y seguridad en el trabajo. U na reivindicación permanente de estos grupos es la armonización de la normativa según los criterios más avanzados.

M uchas de estas redes internacionales se han desarrollado en un contexto político distinto del que albergó a las organizaciones nacidas en el decenio de 1970 y enfocan de modo diferente la asociación entre el medio ambiente de trabajo y el entorno externo al lugar de trabajo. Estas redes propugnan unos niveles superiores de protección del medio ambiente y promueven la asociación de los trabajadores de algunas empresas con las personas afectadas por la actividad de aquéllas: consumidores, poblaciones indígenas asentadas en la proximidad de las explotaciones mineras y otros residentes. El clamor internacional suscitado por el desastre de Bhopal se ha encauzado a través del Tribunal Popular Permanente para los Peligros de 0 rigen Industrial y los D erechos $\mathrm{H}$ umanos, que ha formulado diversas exigencias de que se regule la actividad de las empresas multinacionales.

Existen varios criterios para evaluar la eficacia de las organizaciones voluntarias: desde la perspectiva de los servicios que prestan a los trabajadores y grupos de trabajadores o como función de su capacidad para impulsar la modificación de los métodos de trabajo y de la legislación. La formulación de políticas es un proceso múltiple, por lo que las propuestas raras veces dimanan de una sola persona u organización. N o obstante, el sector voluntario ha mostrado una gran constancia en la defensa de unas reivindicaciones que se han considerado irrealizables hasta que se han convertido en aceptables.

Las siguientes son algunas de las reivindicaciones constantes de las organizaciones voluntarias y los grupos comunitarios:

- un código de ética para las empresas multinacionales;

- sanciones más severas para los daños producidos por las empresas;

- participación de los trabajadores en la prestación de servicios de salud laboral;

- reconocimiento de nuevas enfermedades profesionales, por ejemplo, para la percepción de indemnizaciones;

- prohibición del uso de pesticidas, amianto, fibras minerales artificiales, resinas epoxídicas y disolventes.
El sector voluntario está presente en la salud y seguridad en el trabajo debido al elevado coste del mantenimiento de un medio ambiente de trabajo saludable y de la oferta de unos servicios y una indemnización adecuados a las víctimas de unas condiciones de trabajo deficientes. Incluso los sistemas que ofrecen una cobertura más amplia, como los existentes en Escandinavia, adolecen de deficiencias que el voluntariado procura subsanar. Las crecientes presiones en favor de la desregulación de las materias de salud y seguridad que se ejercen en los países de larga tradición industrial en respuesta a la presión competitiva de los productores multinacionales ha originado una nueva reivindicación en favor del mantenimiento de unos niveles elevados de protección y de armonización al alza de las medidas incorporadas en las distintas legislaciones nacionales.

A pesar de que, indiscutiblemente, participan de forma significativa en las iniciativas legislativas y de regulación, estas organizaciones experimentan una justificada impaciencia por el tiempo que sus propuestas tardan en aceptarse. Su importancia seguirá creciendo allí donde los trabajadores sientan que los servicios oficiales no satisfacen sus necesidades.

\section{DERECHO A SABER: FUNCION DE LAS ORGANIZACIONES DE AMBITO COMUNITARIO}

Carolyn Needleman

En el marco de la salud y seguridad en el trabajo, la expresión "derecho a conocer" hace referencia, por regla general, a los reglamentos, leyes y normas que obligan a informar a los trabajadores sobre los riesgos para la salud relacionados con su trabajo. De acuerdo con el principio del "derecho a conocer", los trabajadores que manipulan sustancias químicas potencialmente nocivas no deben permanecer ajenos a los posibles riesgos. La empresa está legalmente obligada a informarles de las características químicas de la sustancia y del daño que la misma puede ocasionar a su salud. En algunos casos, en la información se deben incluir unas instrucciones sobre el modo de evitar la exposición y sobre el tratamiento aplicable en el caso de que la exposición se produzca. E sta política contrasta profundamente con la situación imperante anteriormente y que, lamentablemente, aún prevalece en muchos lugares de trabajo, en los que los trabajadores sólo conocen los productos químicos que utilizan por el nombre comercial 0 mediante un código convencional, como "limpiador no 9" y no tienen modo de saber si existe un riesgo para su salud.

Según el principio del "derecho a conocer", se advierte de los riesgos por el sistema de fijar avisos en el equipo y en los contenedores situados en el lugar de trabajo, complementado por un programa de formación en la salud y seguridad. En Estados U nidos, el cauce principal del ejercicio del "derecho a conocer" de los trabajadores es la Norma sobre comunicación de riesgos de la Administración de Salud y Seguridad en el Trabajo, promulgada en 1986. Esta norma federal obliga a etiquetar los productos químicos peligrosos en todos los lugares de trabajo del sector privado. Además, se obliga a las empresas a poner a disposición de los trabajadores un "cuadro de especificaciones de seguridad de los materiales" (MSDS) de cada producto químico etiquetado, así como a formar a los trabajadores en la correcta manipulación de los productos químicos. En la Figura 23.1 se reproduce una típica etiqueta de advertencia derecho a conocer de las utilizadas en Estados U nidos.

Es de observar que, como filosofía, la comunicación de los riesgos difiere sensiblemente del control legal directo del riesgo 
Figura 23.1 - Etiqueta de advertencia sobre sustancias químicas inspirada en el derecho a conocer.

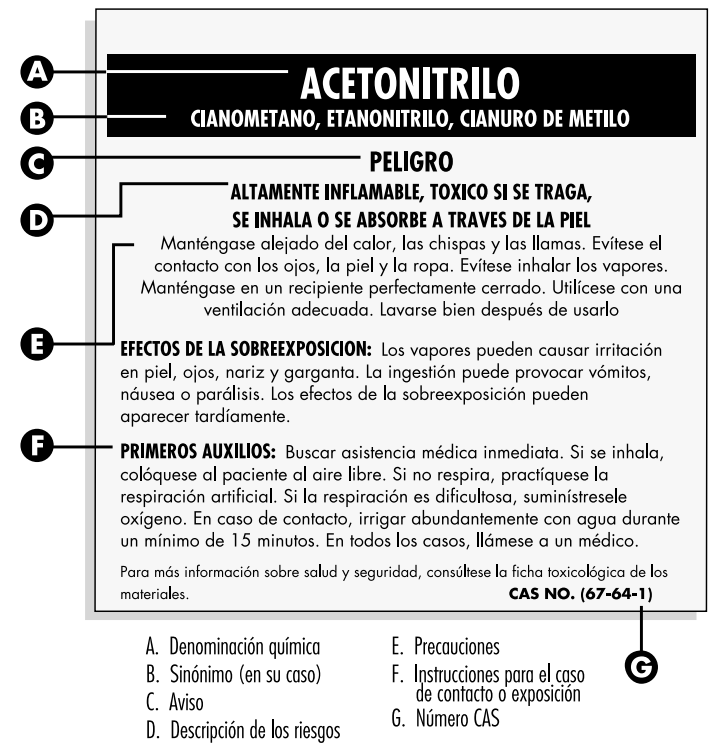

mismo. El método del etiquetado dimana de una filosofía de confianza en la responsabilidad individual, en la elección informada y en el libre juego de las fuerzas del mercado. Se supone que el trabajador informado hace lo que mejor le conviene $y$, bien exige unas condiciones de trabajo seguras, bien, en caso necesario, busca otro puesto de trabajo. Por el contrario, en el control legal directo de los riesgos profesionales se presume la necesidad de una intervención más directa del Estado con el objeto de compensar el desequilibrio de poder existente en la sociedad, que impide que algunos trabajadores utilicen eficazmente por sí mismos la información relativa al riesgo. Como el sistema de etiquetado implica que el trabajador informado es, en última instancia, el responsable de su propia seguridad en el trabajo, la filosofía del "derecho a conocer" es objeto de una valoración política un tanto ambigua. Por una parte, los defensores del mundo del trabajo ensalzan el concepto como una victoria que permite que los trabajadores se protejan más eficazmente. Por otra parte, este sistema puede lesionar los intereses de los trabajadores si se permite que el etiquetado reemplace 0 debilite la aplicación de otras normas de salud y seguridad en el trabajo. Como aseguran vivamente los activistas, el "derecho a conocer" es un punto de partida que debe complementarse con el "derecho a comprender" y el "derecho de actuar", además de con un esfuerzo permanente de prevención directa de los peligros en el trabajo.

Las organizaciones locales prestan una colaboración múltiple y valiosa al proceso de aplicación práctica de los reglamentos y leyes inspirados en el "derecho a conocer". En primer lugar, la promulgación misma de estas normas responde con frecuencia a la presión de determinados grupos de intereses, muchos de los cuales son de ámbito comunitario. Por ejemplo, los Comités de Salud y Seguridad en el Trabajo (COSH), de gran arraigo social, desempeñaron un papel destacado en el largo proceso regulador y contencioso que condujo a la promulgación de la $\mathrm{N}$ orma sobre información de riesgos en $\mathrm{E}$ stados U nidos. V éase en el recuadro una descripción detallada de la actividad de los Comités de Salud y Seguridad en el Trabajo (COSH).

Las organizaciones de ámbito comunitario local realizan también otra labor importante, consistente en ayudar a los trabajadores a ejercer efectivamente su derecho a recibir información

\section{El movimiento COSH y el derecho a conocer}

Los comités de salud y seguridad en el trabajo, surgidos de la Ley norteamericana de salud y seguridad en el trabajo de 1970, se han configurado como agrupaciones locales integradas por defensores de la salud pública, profesionales en la materia y simples activistas, que se reúnen para abordar los problemas suscitados por la presencia de sustancias tóxicas en el lugar de trabajo. Los primeros grupos COSH iniciaron su andadura en Chicago, Boston, Filadelfia y $\mathrm{N}$ ueva York. En el Sur, su desarrollo ha sido paralelo al de organizaciones como la denominada Carolina Bisinosis (pulmón oscuro), que agrupa a los trabajadores textiles afectados de la enfermedad bisinosis. Actualmente existen en todo el país 25 de estos comités en diversos estadios de desarrollo y financiados por diferentes vías. $N$ umerosos $\mathrm{COSH}$ han tomado la decisión estratégica de trabajar con el movimiento sindical y a través del mismo, conscientes de que los trabajadores respaldados por los sindicatos son los mejor situados para promover la mejora de las condiciones de trabajo.

En los comités de salud y seguridad en el trabajo se integra un amplio espectro de organizaciones y personas procedentes de los sindicatos, del mundo de la sanidad pública y de los grupos interesados en el medio ambiente, entre los que se incluyen simples activistas de la salud y la seguridad, investigadores, abogados, médicos, profesionales de la salud pública, trabajadores sociales y otros. Los comités constituyen un foro de intercambio de puntos de vista sobre los problemas de seguridad y salud en el trabajo entre grupos de intereses que habitualmente no coordinan su actividad. En los COSH, los trabajadores tienen la posibilidad de analizar los problemas de salud y seguridad que afrontan en el taller con investigadores y médicos especialistas. Este debate permite traducir los hallazgos de la investigación médica y académica en información útil para los trabajadores.

Estos comités han desarrollado una intensa actividad política, tanto a través de los cauces tradicionales (por ejemplo, mediante campañas públicas concebidas como medios de presión), como recurriendo a métodos más pintorescos (como el de formar piquetes y desfilar portando ataúdes frente al domicilio de los dirigentes políticos contrarios al movimiento sindical. Asimismo, los comités de salud y seguridad en el trabajo han participado activamente en la lucha en favor de la promulgación de leyes locales y estatales basadas en el derecho a conocer, organizando frentes amplios integrados por organizaciones sindicales y grupos interesados por el medio ambiente y los problemas comunitarios, y movilizándolos en favor de la causa. Por ejemplo, el comité del área de Filadelfia (PHILAPOSH) organizó una campaña que coadyuvó a la promulgación del primer reglamento municipal tutelar del derecho a conocer de todo el país. En el punto culminante de la campaña, los miembros de PHILAPOSH realizaron una demostración práctica de la necesidad de información sobre riesgos abriendo un bote presurizado desprovisto de marca durante una sesión de información pública y forzando así a los ediles a refugiarse literalmente debajo de la mesa como reacción al escape de gas (oxígeno).

Las campañas locales de defensa del derecho a conocer resultaron finalmente en la promulgación de 23 leyes de protección de este derecho en el ámbito local y estatal. La normativa era tan diversa que las empresas químicas terminaron exigiendo la promulgación de una norma nacional, con el objeto de no tener que atenerse a una variedad tal de reglamentos locales. La experiencia de los comités de salud y seguridad en el trabajo constituye un ejemplo ilustrativo de cómo el esfuerzo de las organizaciones sindicales y de los grupos comunitarios se pueden coordinar en el ámbito local para influir decisivamente en la política de salud y seguridad en el trabajo.

Joel Shufro 
sobre los riesgos. Por ejemplo, los Comités de Salud y Seguridad en el Trabajo (COSH) asesoran y ayudan a los trabajadores temerosos de sufrir represalias si recaban información sobre riesgos, promueven la lectura y observancia de las etiquetas de advertencia, y denuncian las violaciones por parte de las empresas de la normativa basada en el derecho a conocer. Esta ayuda es de especial importancia para los trabajadores reticentes a ejercitar sus derechos por causa de su bajo nivel de educación, la precariedad en el empleo o la ausencia de un sindicato que los respalde. L os C omités también ayudan a los trabajadores a interpretar la información contenida en las etiquetas y en los cuadros de especificaciones de seguridad de los materiales. Para los trabajadores con escaso nivel cultural, este tipo de ayuda es de importancia vital. La asistencia permite igualmente a los trabajadores con un nivel de educación aceptable, aunque carentes de formación técnica, comprender las especificaciones de seguridad de los materiales, generalmente redactadas en un lenguaje técnico difícil de comprender para un lector no avezado.

El "derecho a conocer" de los trabajadores no se circunscribe a la transmisión de información, sino que posee, además, una dimensión emocional. El sistema hace posible que los trabajadores descubran que sus puestos de trabajo los exponen a unos peligros de los que antes no eran conscientes. Este descubrimiento puede suscitar sentimientos, a veces, muy intensos, de desengaño, temor, indignación e impotencia. Esto ha inducido a las organizaciones de ámbito comunitario a asumir una tercera función esencial en el campo del derecho a conocer de los trabajadores, consistente en prestarles el apoyo moral necesario para afrontar las implicaciones personales de la información del riesgo. Los grupos que fomentan la autoayuda ofrecen a los trabajadores reconocimiento, la posibilidad de exteriorizar sus sentimientos, la sensación de apoyo colectivo y asesoramiento práctico. Además de los Comités de Salud y Seguridad en el Trabajo, existen en Estados Unidos otras organizaciones de autoayuda, como Injured Workers, red nacional de grupos de apoyo que edita un boletín y organiza sesiones de apoyo de ámbito local para quienes tramitan o se proponen reclamar indemnizaciones por accidente de trabajo; el National Center for Environmental H ealth Strategies, organización radicada en Nueva Jersey y dedicada a prestar ayuda a los trabajadores expuestos 0 afectados de hipersensibilidad múltiple a las sustancias químicas; y A sbestos Victims of America, red nacional con sede en San Francisco, que ofrece información, asesoramiento y apoyo a los trabajadores expuestos al amianto.

Un aspecto especial de la normativa basada en el derecho a conocer es la ubicación de los trabajadores que en el pasado han estado notoriamente expuestos a riesgos profesionales, y la información del grave riesgo para su salud. En Estados U nidos, este tipo de actuación se conoce como "información a los trabajadores de alto riesgo". Numerosos organismos federales y estatales de ese país, además de algunos sindicatos y grandes empresas, han elaborado programas de información de riesgos a los trabajadores. Actualmente, el organismo federal más activo en el proceso de información a los trabajadores es el Instituto Nacional para la Salud y la Seguridad en el Trabajo (NIOSH). Este organismo llevó a cabo una serie de ambiciosos programas piloto de información a los trabajadores a principios del decenio de 1980 y actualmente ha incorporado esta actividad a todas sus investigaciones epidemiológicas.

La experiencia acumulada por el NIOSH en esta actividad informativa resulta ilustrativa. En el contexto de sus programas piloto, el NIOSH elaboraba unos listados de acuerdo a un programa a trabajadores presuntamente expuestos a sustancias químicas peligrosas en una determinada planta; remitía a todos los trabajadores incluidos en las listas cartas personalizadas en las que les informaba del posible riesgo para la salud y, si era posible y aconsejable, los inducía a someterse a controles médicos. Pronto se evindenció, no obstante, que esta actividad de comunicación no concernía exclusivamente al organismo y al trabajador afectado. En efecto, la actuación de las instituciones locales y las organizaciones de ámbito comunitario se hacía sentir en toda la actividad del organismo.

La intervención más controvertida del NIOSH tuvo lugar a principios del decenio de 1980 en Augusta, Georgia, cuando se remitieron comunicaciones a 1.385 trabajadores del sector químico que habían estado expuestos a un potente cancerígeno: la $\beta$-naftilamina. Los trabajadores afectados, en su mayoría varones afroamericanos, carecían de representación sindical, de recursos y de instrucción. Según uno de los activistas del programa, el clima social de la localidad se encontraba "sumamente crispado por la discriminación racial, la pobreza y un desconocimiento profundo de los peligros derivados de las sustancias tóxicas". EI NIOSH contribuyó a la creación de un grupo de asesoramiento de ámbito comunitario, con el objeto de fomentar la participación de la sociedad local. El grupo cobró autonomía a medida de que nuevas organizaciones militantes con arraigo social y algunos activistas del mundo del trabajo se sumaron a la causa. Las demandas judiciales presentadas por algunos trabajadores contra la empresa contribuyeron a crispar aún más el entorno del programa. Algunas organizaciones locales, como la Cámara de Comercio y el Colegio M édico del condado, también se involucraron en la polémica. M uchos años más tarde, aún no se han apagado los rescoldos de los conflictos suscitados entre las organizaciones locales implicadas en aquella comunicación. Al final, el programa sirvió para informar eficazmente a los trabajadores expuestos del riesgo permanente de desarrollar cáncer de vejiga, curable en un porcentaje muy elevado de casos si se detecta a tiempo. M ás de 500 trabajadores fueron sometidos a controles clínicos, seguidos, en algunos casos, de intervenciones médicas posiblemente salvadoras.

U n aspecto insólito del conflicto de Augusta ha sido la labor destacada desempeñada por los medios de comunicación social. En efecto, los medios informativos locales dieron profusa cobertura a la aplicación del programa, que fue el tema de más de 50 artículos aparecidos en los periódicos y de un documental ("Lethal Labour") que se proyectó en la televisión local. Estas informaciones llegaron a un público muy extenso y afectaron profundamente, tanto a los trabajadores notificados, como al conjunto de la colectividad, suscitando en el director de proyectos del NIOSH el comentario de que "actualmente, los medios de comunicación son los que realmente notifican". En algunos casos, conviene considerar a los periodistas locales parte integrante del concepto del derecho a conocer y asignarles una función definida en el proceso de comunicación, con el objeto de lograr una cobertura informativa más rigurosa y constructiva.

Si bien los casos mencionados en este artículo se han producido en Estados U nidos, estas mismas cuestiones se suscitan en todo el mundo. El acceso de los trabajadores a la información sobre los riesgos constituye un paso adelante en la protección de los derechos humanos fundamentales y se ha convertido en un objetivo prioritario de las organizaciones de ámbito comunitario dedicadas a promover los derechos de los trabajadores en muchos países. En las naciones que otorgan escasa protección legal a sus trabajadores o que carecen de un movimiento sindical potente, gana en importancia la labor de las organizaciones de ámbito comunitario en las cuestiones estudiadas en este artículo: propugnar la promulgación de mejores leyes basadas en el derecho a conocer (y en el derecho de actuar), ayudar a los trabajadores a utilizar mejor la información basada en el derecho a conocer, y prestar apoyo social y moral a las personas que adquieren conciencia de haber estado expuestas a riesgos profesionales. 


\section{SALUd Y SEgURIDAD En EL TRABAJO: LA UNION EUROPEA}

\section{Frank B. Wright}

La U nión Europea ejerce actualmente una gran influencia en la legislación y las políticas aplicables en todo el mundo en materia de salud y seguridad en el trabajo. En 1995, eran miembros de la U nión Europea Austria, Alemania, Bélgica, Dinamarca, España, Finlandia, Francia, Grecia, I rlanda, Italia, Luxemburgo, Países Bajos, Portugal, el Reino U nido y Suecia. Está prevista la ampliación de la U nión en los años venideros.

La Comunidad Europea, antecesora de la U nión, se creó en el decenio de 1950 en virtud de tres tratados: el Tratado de la Comunidad Europea del Carbón y del Acero (CECA), firmado en París en 1951; y los tratados de la Comunidad Económica Europea (CEE), y de la Comunidad Europea de la Energía Atómica (CEEA), suscritos en Roma en 1957. La Unión Europea se constituyó con la entrada en vigor, el 1 de enero de 1992, del Tratado de M aastricht, celebrado en 1989.

La U nión está compuesta por cuatro órganos: la Comisión, el Consejo, el Parlamento y el Tribunal Europeo de Justicia. LoS poderes de estas instituciones dimanan de los tratados.

\section{Estructuras}

\section{La Comisión}

La Comisión es el órgano ejecutivo de la U nión, responsable de iniciar, proponer y hacer cumplir la política comunitaria. Asimismo, si un Estado miembro vulnera las obligaciones asumidas en virtud de los tratados, la Comisión puede instar actuaciones en contra del mismo ante el Tribunal Europeo de Justicia.

La Comisión está compuesta por diecisiete personas nombradas por los gobiernos de los Estados miembros para un mandato, renovable, de cuatro años. Cada Comisario desempeña una cartera y tiene a su cargo una o más Direcciones G enerales, una de las cuales, la DG V, es competente en materia de empleo, relaciones laborales y asuntos sociales. Las políticas de salud pública y de salud y seguridad en el trabajo se diseñan y proponen, precisamente, en esta Dirección General (DG V/F). El Comité A sesor de Seguridad, Higiene y Protección de la Salud en el Trabajo, y la Fundación Europea para la M ejora de las Condiciones de Vida y de Trabajo colaboran con la Comisión en las labores legislativas y de formulación de políticas de salud y seguridad.

\section{El Comité Consultivo de Seguridad, Higiene y Protección de la Salud en el Trabajo}

El Comité Consultivo, creado en 1974, está presidido por el Comisario responsable de la Dirección G eneral de Empleo, Relaciones Laborales y Asuntos Sociales. Componen el Comité 96 miembros permanentes, en representación del gobierno, los sindicatos y las organizaciones empresariales de cada Estado miembro, cada uno de cuyos estamentos elige dos representantes.

La función del Comité Consultivo consiste en "prestar asistencia a la Comisión en la preparación y realización de actividades en el campo de la seguridad, la higiene y la protección de la salud en el trabajo". Gracias a su estructura y a la representatividad de sus miembros, el Comité Consultivo es mucho más importante y activo de lo que su nombre indica, y ha ido adquiriendo con los años una influencia considerable en la formulación de la política estratégica, en colaboración con el Parlamento Europeo y con el Comité E conómico y Social. Específicamente, el Comité realiza las funciones siguientes dentro del marco global de sus competencias:

- intercambiar experiencias y puntos de vista en relación con la normativa vigente o prevista;

- contribuir a la formulación de unos criterios compartidos respecto a los problemas existentes en el campo de la seguridad, la higiene y la protección de la salud en el trabajo; así como a la determinación de las prioridades de la U nión y a la adopción de las medidas necesarias para hacerlas efectivas;

- llamar la atención de la Comisión respecto de las áreas evidentemente necesitadas de la aportación de nuevos conocimientos y de la ejecución de unos proyectos adecuados de investigación y educación;

- establecer, dentro del marco de los programas de actuación de la U nión y en colaboración con la Comisión de Salud y Seguridad en las $M$ inas, (i) los criterios y objetivos de la campaña contra el riesgo de accidentes de trabajo y los riesgos para la salud en el lugar de trabajo; y (ii) unos medios que permitan a las empresas y sus empleados evaluar y mejorar el nivel de protección;

- colaborar en la labor de informar a las administraciones nacionales, los sindicatos y las organizaciones empresariales sobre las medidas adoptadas por la U nión, con el objeto de recabar su cooperación y de impulsar la participación de dichas entidades en el intercambio de experiencias y en la promulgación de códigos de conducta;

- emitir dictámenes sobre las propuestas de directivas y respecto a todas las medidas que la Comisión proponga en el ámbito de la salud y la seguridad en el trabajo.

Al margen de estas funciones, el Comité elabora una memoria anual que la Comisión distribuye en su momento entre el Consejo, el Parlamento y el Comité E conómico y Social.

\section{La Fundación de Dublín}

La Fundación Europea para la M ejora de las Condiciones de Vida y de Trabajo, con sede en Dublín, se creó en 1975 como un ente autónomo especializado de la C omunidad. La Fundación se dedica fundamentalmente a la investigación aplicada en las áreas de la política social, la aplicación de nuevas tecnologías y la protección y mejora del medio ambiente, con el objeto de identificar, abordar y prevenir la aparición de problemas en el medio ambiente de trabajo.

\section{Agencia Europea para la Salud y la Seguridad en el Lugar de Trabajo}

El Consejo de Europa ha creado recientemente la Agencia Europea para la Salud y Seguridad en el Lugar de Trabajo, que tiene su sede en Bilbao, España, y por objeto la recopilación y difusión de información en su campo de actividad. Además, la Agencia impartirá cursos de formación, proporcionará asistencia técnica y científica a la Comisión, y establecerá contactos estrechos con las entidades especializadas de ámbito nacional. La Agencia creará, asimismo, un sistema de redes destinado al intercambio de información y experiencias entre los Estados miembros

\section{EI Parlamento E uropeo}

EI Parlamento Europeo realiza una función consultiva de importancia creciente en el proceso legislativo de la U nión, gestiona, junto con el Consejo, una parte del presupuesto comunitario y 
ratifica, tanto los acuerdos de asociación de la U nión Europea con los países no incorporados a la misma, como los tratados de adhesión de los nuevos Estados miembros. Además, el Parlamento Europeo es el órgano supervisor de la U nión.

\section{El Comité Económico y Social}

El Comité Económico y Social es un órgano consultivo que tiene como objetivo prestar asesoramiento en diversas materias de orden social y laboral, incluida la salud y seguridad en el trabajo. Los miembros del Comité representan tres grupos: las organizaciones empresariales, la de trabajadores, y un grupo independiente, que comprende un amplio espectro de intereses profesionales, económicos y agrarios, además del movimiento de cooperativistas y de las organizaciones de consumidores.

\section{Instrumentos jurídicos}

El legislador comunitario apoya su labor en cuatro grandes instrumentos. En el artículo 189, modificado, del Tratado de la CEE se establece que "para la realización de sus tareas de conformidad con las disposiciones del presente Tratado, el Parlamento Europeo, en coordinación con el Consejo y la Comisión, promulgará reglamentos y adoptará directivas, tomará decisiones, formulará recomendaciones o emitirá dictámenes".

\section{Reglamentos}

Se establece que "los reglamentos serán de aplicación general. Serán vinculantes en su totalidad y directamente aplicables en todos los Estados miembros". Los reglamentos son directamente ejecutorios en los Estados miembros, sin necesidad de desarrollarlos en el ordenamiento interno. De hecho, los órganos legislativos no tienen competencias al respecto. Los escasos reglamentos promulgados en el campo de la salud y seguridad en el trabajo son de naturaleza administrativa.

\section{Directivas y decisiones}

Se establece que "las directivas serán vinculantes, por lo que respecta al objeto perseguido, para todos los Estados miembros a los que se dirige, si bien la elección de los métodos y modalidades será facultad discrecional de las autoridades nacionales". Las directivas son instrucciones que se cursan a los Estados miembros de que promulguen leyes orientadas al logro de un objetivo. En la práctica, las directivas se utilizan principalmente para armonizar o aproximar las legislaciones nacionales, de conformidad con el artículo 100. Esto hace que sean los medios más adecuados y utilizados en materia de salud y seguridad en el trabajo. Por lo que respecta a las decisiones, se establece que "serán vinculantes en su totalidad para los destinatarios de las mismas".

\section{Dictámenes y recomendaciones}

Aunque los dictámenes y recomendaciones carecen de fuerza vinculante, son el reflejo de unos determinados criterios políticos.

\section{Política}

A mediados del decenio de 1980, las Comunidades Europeas adoptaron la decisión de impulsar decididamente el proceso de armonización de la normativa de salud y seguridad. De las razones aducidas para explicar la creciente importancia de esta actividad, hay cuatro que destacan especialmente.

En primer lugar, se afirma que la armonización de la normativa de salud y seguridad contribuye a la integración económica, dado que las mercancías no pueden circular libremente dentro del territorio comunitario si los precios de productos similares difieren entre los Estados miembros por causa de los costes variables de salud y seguridad impuestos a las empresas. En segundo lugar, 10 millones de personas sufren todos los años accidentes de trabajo de los que fallecen unas 8.000 personas al año (de una población activa que en 1994 ascendía a 138 millones de personas). Esta sombría estadística se salda todos los años con una factura anual de 26.000 millones de ecus abonados en indemnización por accidentes de trabajo y enfermedades profesionales. Solo en el Reino Unido, según el Report E nforcing $\mathrm{H}$ ealth and Safety in the Workplace, editado por el National Audit O ffice, se estima que el coste anual de los accidentes para las empresas y contribuyentes asciende a 10.000 millones de libras. Se aduce que la reducción de los costes humanos, sociales y económicos de los accidentes y enfermedades profesionales que afectan a esta fuerza de trabajo, no sólo produciría un enorme ahorro de recursos financieros, sino que, además, contribuiría sustancialmente a mejorar la calidad de la vida de los ciudadanos del conjunto de la U nión. En tercer lugar, se afirma que la implantación de unos métodos de trabajo más eficientes contribuiría a mejorar la productividad, a reducir los costes de explotación y a mejorar las relaciones laborales.

Por último, se postula la conveniencia de una armonización de ámbito supranacional de las medidas de protección contra determinados riesgos, como los derivados de potentes explosiones, que basándose en el gran volumen de recursos (argumento que recuerda al primeramente mencionado antes), $y$, en parte, a que toda divergencia en el contenido y aplicación de esta normativa distorsionaría la competencia y repercutiría en los precios de los productos. Esta campaña se dirigió a la totalidad de la población trabajadora de la Comunidad, en especial a los sectores de alto riesgo y a la pequeña y mediana empresa.

Gran parte del impulso recibido por este programa provino de la campaña patrocinada por la Comisión, en colaboración con los doce Estados miembros por entonces de la Comunidad, en el marco del Año Europeo de la Salud y Seguridad, que se inició el 1 de marzo de 1992.

En todos los tratados fundacionales se han sentado las bases de una nueva legislación de salud y seguridad. Por ejemplo, en el Tratado de la Comunidad Económica Europea existen dos artículos (el 117 y el 118), dedicados, al menos, en parte, a promover la salud y seguridad.

\section{La Carta comunitaria de los derechos sociales fundamentales de los trabajadores}

En respuesta a este reto, la Comisión elaboró en 1987 un amplio paquete de medidas, que fueron adoptadas por el Consejo el año siguiente. En este programa figuraban diversas medidas de salud y seguridad, agrupadas en los apartados de seguridad y ergonomía, salud e higiene, información y formación, iniciativas dirigidas a la pequeña y mediana empresa, y diálogo social. Esta serie de medidas se desarrollaron en la Carta comunitaria de los derechos sociales fundamentales de los trabajadores, aprobada en Estrasburgo en diciembre de 1989 por once de los doce Estados miembros (con la abstención del Reino U nido).

En la Carta Social, adoptada en diciembre de 1989, figuran doce categorías de "derechos sociales fundamentales", varios de los cuales revisten especial importancia en este contexto:

- M ejora de las condiciones de vida y de trabajo. Es preciso mejorar las condiciones de trabajo, particularmente por lo que respecta a la limitación de las horas de trabajo, con especial atención a los trabajadores eventuales, a los contratados a tiempo parcial, etcétera.

- Protección social. Los trabajadores, incluidos los desempleados, tienen derecho a una protección social adecuada y a las prestaciones de la seguridad social.

- Información, consulta y participación de los trabajadores. Estos derechos son especialmente aplicables en las empresas multinacionales, 
en particular, en los procesos de reestructuración, reducción de plantillas e implantación de nuevas tecnologías.

- Protección de la salud y seguridad en el lugar de trabajo.

- Protección de los niños y adolescentes. La edad mínima de admisión al trabajo no debe ser inferior a la edad de finalización de la enseñanza obligatoria, y en ningún caso ha de ser inferior a 15 años. Asimismo, se debe limitar la jornada laboral de los menores de 18 años, que, como norma, no deben realizar trabajo nocturno.

- Personas mayores. Se debe garantizar a los trabajadores unos ingresos que les permitan disfrutar de un nivel de vida decoroso a la jubilación. Los demás han de disfrutar de unos medios suficientes y de una asistencia médica y social adecuada.

- Discapacitados. Se debe prestar a los discapacitados una ayuda complementaria que permita su integración social y profesional.

Se reconoce a los Estados miembros, en el marco de su ordenamiento interno, las competencias necesarias para garantizar los derechos reconocidos en la C arta y para adoptar las medidas precisas al efecto; asimismo, se recaba de la Comisión que formule propuestas en las áreas de su competencia.

Desde 1989, se ha puesto de relieve que la Carta Social cuenta con un extenso apoyo dentro de la Comunidad. Es indudable que los Estados miembros tienen interés en demostrar que los trabajadores, los niños y los jubilados pueden beneficiarse de la Comunidad tanto como los directivos y accionistas de las empresas.

\section{La directiva marco de 1989}

Los principios que informan el programa de salud y seguridad de la Comisión se plasmaron en otra "Directiva $M$ arco" (89/391 CEE) sobre la introducción de medidas de mejora de la salud y seguridad en el trabajo. El nuevo texto constituye un paso adelante respecto de los criterios sustentados en una "Directiva M arco" anterior, de 1980. En concreto, en la Directiva de 1989, al tiempo que se recoge y se reafirma el concepto de la "autoevaluación", se establece una serie de obligaciones básicas, en especial para las empresas. Además, en el articulado de la Directiva de 1989 se incorpora expresamente el mandato de promover el "diálogo social" en el ámbito de la salud y seguridad en el trabajo, y se establecen importantes obligaciones de información, consulta y participación de los trabajadores y sus representantes en el lugar de trabajo. En la Directiva de 1989 se fijaba el 31 de diciembre de 1992 como fecha límite para su aplicación.

En esta Directiva se reafirman diversos principios generales relativos, en particular, a la prevención de los riesgos profesionales, la protección de la salud y seguridad, y la información, consulta y formación de los trabajadores y sus representantes; así como los principios informativos de la aplicación de esas medidas. Este documento constituyó un primer paso en el desarrollo global de las directivas de armonización técnica concebidas para culminar el mercado interior. Asimismo, en la Directiva de 1989 se recogieron las disposiciones de la Directiva $\mathrm{M}$ arco de 1980 sobre los riesgos derivados del uso de agentes químicos, físicos y biológicos en el trabajo. La Directiva es concomitante con el Convenio de la OIT sobre seguridad laboral y salud, 1981 ( $n$ - 155) y con la correlativa Recomendación (no 161).

Los objetivos globales de la Directiva de 1989 se pueden resumir como sigue:

- humanización del medio ambiente de trabajo;

- prevención de accidentes y protección de la salud en el lugar de trabajo:
- promoción de la información, el diálogo y la participación equilibrada en la salud y seguridad, mediante la aplicación de procedimientos e instrumentos;

- promoción, en todo el ámbito de la Comunidad, del desarrollo armónico de la actividad económica, de un crecimiento continuo y equilibrado y de la elevación acelerada de los niveles de vida;

- promoción de la colaboración creciente de los trabajadores y la dirección en las iniciativas y toma de decisiones;

- implantación de idéntico nivel de protección de la salud de los trabajadores de todas las empresas, incluida la pequeña y mediana empresa; y cumplimiento de las obligaciones contenidas en el Acta Unica Europea en relación con el mercado único;

- reemplazo gradual de la legislación nacional por la comunitaria.

En esta norma se imponen a las empresas obligaciones generales de vigilancia; de adopción de medidas directamente encaminadas a garantizar la salud y seguridad; de planificación estratégica de la prevención de riesgos para la salud y seguridad; de formación y orientación de la plantilla; de información, consulta y participación de los trabajadores; y de registro e información.

En la Directiva se establecen garantías análogas para la pequeña y mediana empresa. A sí, se dispone que se debe tomar en consideración la dimensión de un establecimiento o empresa en la determinación del volumen de recursos destinables al sistema de prevención y protección. Esta circunstancia se debe tener igualmente en cuenta en la imposición de obligaciones en materia de primeros auxilios, lucha contra incendios y evacuación de los trabajadores. A demás, en la Directiva se autoriza la aplicación de unos criterios variables en función de la dimensión de la empresa por lo que respecta a la documentación exigible. Por último, en relación con el deber de información, se dice que en las normas nacionales "se pueden tomar en consideración, entre otras circunstancias, la dimensión del establecimiento o de la empresa".

Se han promulgado diversas directivas específicas en el marco de la Directiva de 1989. En estas directivas "hijas" se regulan, especialmente, los niveles mínimos de salud y seguridad en el lugar de trabajo, el uso de las herramientas de trabajo y del equipo de protección personal de los trabajadores, la manipulación de cargas y el trabajo con equipo de pantallas de visualización.

Se han adoptado igualmente las D irectivas siguientes:

- Directiva 93/103/CEE del Consejo, de 20 de diciembre de 1993, relativa a las disposiciones mínimas de seguridad y salud en el trabajo a bordo de los buques de pesca.

- Directiva 93/ 88/ CEE del Consejo, de 12 de octubre de 1993, por la que se modifica la Directiva 90/679/ CEE sobre la protección de los trabajadores contra los riesgos relacionados con la exposición a agentes biológicos durante el trabajo.

- Directiva 92/104/CEE del Consejo, de 3 de diciembre de 1992, relativa a las disposiciones mínimas destinadas a mejorar la protección en materia de seguridad y de salud de los trabajadores de las industrias extractivas a cielo abierto o subterráneas.

- Directiva 92/91/CEE del Consejo, de 3 de noviembre de 1992, relativa a las disposiciones mínimas destinadas a mejorar la protección en materia de seguridad y de salud de los trabajadores de las industrias extractivas por sondeos.

- Directiva 92/ 85/ CEE del Consejo, de 19 de octubre de 1992, relativa a la aplicación de medidas para promover la mejora de la seguridad y de la salud en el trabajo de la trabajadora embarazada que haya dado a luz o en período de lactancia. 
- Directiva 92/58/CEE del Consejo, de 24 de junio de 1992, relativa a las disposiciones mínimas en materia de señalización de seguridad y de la salud en el trabajo.

- Directiva 92/57/CEE del Consejo, de 24 de junio de 1992, relativa a las disposiciones mínimas de seguridad y de salud que deben aplicarse en las obras de construcción temporales o móviles.

- Directiva 92/ 29/ CEE del Consejo, de 31 de marzo de 1992, relativa a las disposiciones mínimas de seguridad y de salud para promover una mejor asistencia médica a bordo de los buques.

- Directiva 90/219/ CEE del Consejo, de 23 de abril de 1990, relativa a la utilización confinada de microorganismos modificados

Desde la firma del Tratado de $\mathrm{M}$ aastricht se han promulgado diversas normas, concretamente, una recomendación relativa a un protocolo europeo de enfermedades profesionales, una directiva relativa al amianto, una directiva relativa a las señalizaciones de salud y seguridad en el trabajo, una directiva sobre la asistencia médica a bordo de los buques, directivas relativas a la protección de la salud y seguridad en las industrias extractivas, y una directiva relativa a la mejora de las condiciones de desplazamiento de los trabajadores afectados de discapacidades motrices.

\section{EI Mercado Unico}

El artículo 100 del Tratado de la U nión Europea ha recibido una nueva redacción. En el nuevo texto se establece la obligación de consultar al Parlamento Europeo y al Comité E conómico y Social en todos los casos y no únicamente cuando la aplicación de una directiva implique la modificación de la normativa legal vigente en uno o más Estados miembros.

\section{- LEgISLACION TUTELAR DE LOS DERECH OS DE LOS TRABAJADORES EN CHINA}

Su Zhi

La seguridad y salud en el trabajo constituye uno de los aspectos más relevantes de las disposiciones contenidas en la Ley de Trabajo, promulgada en julio de 1994. En el marco del esfuerzo por promover la incorporación de las empresas al sistema de mercado, sin descuidar la protección de los derechos de los trabajadores, se ha otorgado prioridad en el programa de gobierno a la reforma en profundidad del sistema de contratos de trabajo, de las escalas salariales y del régimen de la seguridad social. L a aportación de una cobertura de bienestar común a todos los trabajadores, independientemente del régimen de propiedad de la empresa, es uno de los objetivos perseguidos, que comprenden igualmente la cobertura del desempleo, los sistemas de pensiones de jubilación, y el seguro de indemnización por enfermedades y lesiones profesionales. En la mencionada Ley de Trabajo se establece la obligación de las empresas de abonar contribuciones a la seguridad social para sus trabajadores. Algunas de las medidas legislativos previstas en el marco de la Ley de Trabajo, como la Ley de prevención y control de las enfermedades profesionales, han sido objeto de una atención especial, en un esfuerzo por regular la actividad y definir las responsabilidades de las empresas en la prevención de los riesgos profesionales, al tiempo que se reconocen a los trabajadores nuevos derechos en la protección de su salud.

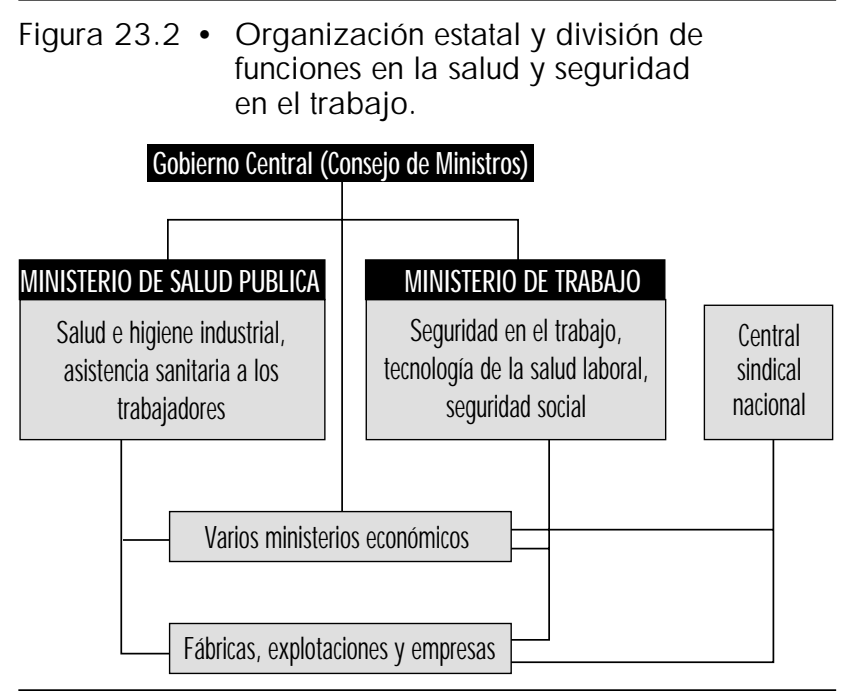

C ooperación de los organismos oficiales con la Federación de Sindicatos de China en la formulación de políticas y la aplicación de las leyes

Los ministerios de Salud Pública y de Trabajo han venido colaborando durante largo tiempo con la Federación de Sindicatos de China en la formulación de políticas y en la realización de actividades importantes, resultado de juntar sus esfuerzos.

La actual división de funciones entre el M inisterio de Salud Pública y el de Trabajo en materia de salud y seguridad en el trabajo es la siguiente:

- Desde la perspectiva de la prevención médica, el M inisterio de Salud Pública es competente en materia de higiene industrial y salud laboral, ejerciendo estas competencias mediante un sistema nacional de inspección sanitaria.

- Las funciones del M inisterio de T rabajo consisten en la planificación del control de los riesgos profesionales y en la organización del trabajo, así como en la supervisión de la salud y seguridad en el trabajo y en la gestión de la inspección nacional de trabajo (Figura 23.2) (M inisterio de Salud Pública y M inisterio de T rabajo).

Es difícil trazar una línea divisoria entre las competencias de los ministerios de Salud Pública y de Trabajo. Se espera que, en el futuro, la cooperación se centre en mejorar la aplicación de las normas de salud y seguridad en el trabajo.

La Federación de Sindicatos de C hina se ha venido implicado de forma creciente en la defensa de los derechos de los trabajadores. U na de las principales tareas de la central sindical es la creación de secciones sindicales en las empresas de capital extranjero. En la actualidad, sólo el $12 \%$ de estas empresas cuenta con presencia sindical.

\section{ESTUDIO DE CASO : NORMAS DE EXPOSICION RUSAS}

Nikolai F. Izmerov

\section{Comparación entre los Criterios Básicos de las Concentraciones Máximas Admisibles (MAC) y los Valores Límite Umbral (TLVs)}

EI rápido desarrollo de la química y el uso generalizado de los productos químicos han impulsado la realización de estudios toxicológicos y de evaluación de riesgos en relación con los efectos 
combinados y a largo plazo de las sustancias químicas. Los higienistas industriales de muchos países del mundo trabajan en la elaboración de normas aplicables al uso de productos químicos en el medio ambiente de trabajo. Diversas organizaciones internacionales y regionales, como la O rganización Internacional del Trabajo, la Organización M undial de la Salud, el Programa de las Naciones U nidas para el M edio Ambiente, la O rganización para la Agricultura y la Alimentación, y la U nión Europea.

Es mucho lo que los científicos rusos y norteamericanos han logrado en este campo. En 1922, se realizó en Rusia un estudio destinado a la elaboración de normas sobre la presencia de agentes químicos en la atmósfera de lugares de trabajo cerrados, a partir del cual se fijó el valor de la concentración máxima admisible (M AC) de gases conteniendo azufre. En 1930, sólo se habían fijado 12 valores MAC, cifra que en 1960 se había elevado a 181.

La Conferencia Americana de Higienistas Industriales del Gobierno (ACGIH) inició su andadura en 1938, y en 1946 publicó la primera lista de los Valores Límite U mbral (T LVs) correspondientes a 144 sustancias. Los TLV s solamente son interpretados y utilizados por especialistas en este campo. Si un TLV ha sido incluido en las normas de seguridad (las llamadas normas de consenso nacional), las normas federales lo hacen legal.

H asta el momento, se han establecido en Rusia los valores de 1.500 concentraciones tolerables máximas. Por su parte, en Estados U nidos se han adoptado más de 550 T LV s de sustancias químicas.

Los análisis de las normas de salud laboral realizados entre 1980 y 1981 permitieron detectar diferencias en 220 sustancias químicas relacionadas en la lista de concentraciones máximas admisibles, MAC (Rusia) y en la relación de TLVs (Estados Unidos). En efecto, se detectaron entre dos y cinco tipos de diferencias en 48 sustancias ( $22 \%$ ), en otras 42 sustancias se descubrieron de cinco a diez clases de diferencias, y en otras 69 sustancias (31\%) se observaron más de diez tipos de diferencias. Además, el diez por ciento de los T LV s recomendados tenían unos valores cincuenta veces más elevados que las concentraciones tolerables máximas fijadas para las mismas sustancias. A su vez, las concentraciones tolerables máximas de 16 sustancias eran mayores que los correlativos T LV s.

Las mayores divergencias entre ambas normas se produjeron entre los hidrocarburos clorados. EI análisis de la lista de T LV S aprobada en el período 1989-1990 reveló la existencia de una tendencia hacia la reducción de los T LV s inicialmente recomendados en comparación con las concentraciones tolerables máximas de hidrocarburos clorados y algunos disolventes. En cambio, las divergencias entre los TLVs y las MAC de la mayoría de los aerosoles metálicos, y de los metaloides y sus compuestos, eran insignificantes. I gualmente menores eran las diferencias en cuanto a los gases irritantes. L os T LV s correspondientes al plomo, manganeso y el teluro se distanciaban 15, 16 y 10 veces, respectivamente, de los correlativos valores de las M AC. Las mayores divergencias se registraron en los respectivos valores del aldehído acético y el formaldehído: 36 y 6 veces, respectivamente. En términos generales, los valores de las M AC en Rusia son inferiores a los T LV s vigentes en E stados U nidos.

Estas divergencias son una función, tanto de los principios aplicados en el desarrollo de las normas de salud laboral en ambos países, como del modo de aplicación de estas normas a la protección de la salud de los trabajadores.

Un MAC es la medida de salud laboral utilizada en Rusia para indicar una concentración de una sustancia nociva en la atmósfera de un lugar de trabajo que no provoca, durante una jornada de trabajo de ocho horas diarias (o de cualquier otra duración que no exceda de 41 horas a la semana) durante la vida laboral de una persona, ninguna enfermedad o alteración de su estado de salud detectable aplicando los métodos conocidos, bien durante la vida laboral, bien durante la vida posterior, de la generación actual y de la siguiente. Por tanto, en la definición de la concentración máxima admisible (MAC) se excluye cualquier efecto adverso en el trabajador 0 en su progenie. La concentración tolerable máxima constituye una concentración segura.

Un TLV es el nivel de concentración (en aire) de una sustancia al que la mayoría de los trabajadores pueden exponerse diariamente sin sufrir efectos nocivos. La ACGIH establece y revisa anualmente estos valores, que constituyen concentraciones ponderadas en el tiempo, sobre la base de una jornada laboral de siete a ocho horas y de una semana laboral de 40 horas. El valor fijado para la mayoría de los materiales se puede rebasar dentro de unos ciertos límites, siempre que, durante la jornada laboral (o, en algunos casos, durante la semana laboral), se establezcan unos períodos compensatorios en los que la exposición sea inferior al valor fijado. Respecto a determinados materiales (principalmente, los que provocan una reacción rápida), el límite constituye una concentración máxima (esto es, una concentración tolerable máxima) que no se debe rebasar. Según la ACGIH, los TLV deben utilizarse como pautas en el control de los riesgos para la salud y no se pueden interpretar, ni como unas líneas sutiles de separación entre las concentraciones seguras y las peligrosas, ni como un índice ponderado de toxicidad.

Aunque en la definición del TLV subyace también el principio de la inadmisibilidad de los efectos nocivos, esta exclusión no abarca la totalidad de la población trabajadora, aceptándose que un pequeño porcentaje de trabajadores pueden experimentar problemas de salud 0 , incluso, contraer patologías profesionales. Por tanto, los T LV s no constituyen unos valores seguros para todos los trabajadores.

Según los expertos de la O IT y de la O M S, estas divergencias son una función de la distinta valoración científica de cierto número de factores correlacionados, entre los que se incluye la definición de los efectos adversos sobre la salud. Por consiguiente, la divergencia inicial entre los sistemas de control de los riesgos de origen químico conduce a la adopción de unos conceptos metodológicos distintos, cuyos aspectos básicos se exponen posteriormente.

\section{Tabla 23.1 - Comparación de algunos de los fundamentos conceptuales de las normas rusas y norteamericanas.}

Rusia (Concentración

máxima admisible)

Estados Unidos

(Valor límite umbral)

Fijación de umbrales para toda clase de efectos adversos. Se valora la variación de los factores específicos e inespecíficos relativos a los criterios de determinación de la nocividad de los efectos.

Prioridad de los criterios médicos y biológicos sobre los factores tecnológicos y económicos.

Evaluación toxicológica e interpretación de las normas a largo plazo, previas a la comercialización de los productos químicos.
No se fija un umbral para los mutágenos ni para algunos cancerígenos. Se evalúa la variación de los factores específicos y no específicos en función de las relaciones "dosisefecto" y "dosis-respuesta".

Prevalecen los criterios tecnológicos y biológicos.

Fijación de normas con criterios retrospectivos 
En la Tabla 23.1 se contrastan los principios básicos que inspiran la fijación de las normas de salud laboral en Rusia con los aplicados en Estados U nidos. Especial importancia reviste el concepto teórico del valor umbral, en el que reside la principal discrepancia entre los especialistas rusos y norteamericanos y que explica la adopción de criterios diferentes en la fijación de las normas. En Rusia se acepta la existencia de un umbral respecto a todo tipo de efectos peligrosos de las sustancias químicas.

Sin embargo, la aceptación de un umbral respecto a determinados efectos supone distinguir entre los efectos lesivos y no lesivos de las sustancias químicas. Por consiguiente, el umbral establecido en Rusia respecto de los efectos nocivos es la concentración (dosis) mínima de una sustancia química que produce unos cambios en exceso de los límites de las reacciones de adaptación fisiológica o que provoca patologías latentes (temporalmente compensadas). Además, se aplican diversos criterios estadísticos, metabólicos y tóxico-cinéticos a los efectos adversos de las sustancias químicas, con el objeto de distinguir entre los procesos de adaptación fisiológica y los de compensación patológica. En Estados Unidos se ha recomendado el uso de los cambios patomorfológicos y de los síntomas narcóticos de deficiencias antiguas, con el objeto de distinguir entre los efectos lesivos y los otros. Esto significa que en Rusia se han adoptado unos métodos de evaluación de la toxicidad más sensibles que en Estados U nidos, lo que explica que los niveles de las concentraciones tolerables máximas sean, en general, inferiores a los TLVs. Cuando los métodos de detección de los efectos lesivos son parecidos o prácticamente coincidentes, como en el caso de los gases irritantes, las normas no difieren sensiblemente entre sí.

La evolución de la toxicología ha impulsado la aplicación de nuevos métodos de detección de los cambios menores producidos en los tejidos, consistentes en la inducción de enzimas en el tejido hepático reticular endoplástico liso y la hipertrofia reversible del hígado. Estos cambios pueden aparecer después de la exposición a bajas concentraciones de muchas sustancias químicas. Para algunos investigadores, se trata de reacciones de adaptación, mientras que otros las interpretan como deficiencias incipientes. U na de las operaciones más difíciles de la toxicología actual es la obtención de datos que permitan establecer si las perturbaciones enzimáticas, los desórdenes del sistema nervioso y las modificaciones de los comportamientos reactivos son el resultado del deterioro de las funciones fisiológicas. Esto posibilitaría la predicción de las deficiencias más graves o irreversibles en los casos de exposición de larga duración a sustancias peligrosas.

Se hace especial hincapié en las diferencias entre los métodos de sensibilidad aplicados en la determinación de las M AC y los
TLVs. Se ha podido determinar que los métodos sumamente sensibles, basados en los reflejos condicionados, que se aplican en Rusia al estudio del sistema nervioso constituyen la causa principal de las diferencias existentes entre las M AC y los T LV S. Sin embargo, no es obligatorio aplicar este método en el proceso de normalización de la salud laboral. En efecto, en la elaboración de una norma de higiene se suelen utilizar numerosos métodos de distintos niveles de sensibilidad.

$\mathrm{G}$ ran parte de los estudios que se realizan en Estados U nidos en relación con la fijación de límites de exposición tienen por finalidad el examen de la transformación de los compuestos de origen industrial en el organismo humano (vías de exposición, circulación, metabolismo, eliminación, etc.). Los métodos de análisis clínico utilizados para determinar los valores de TLV s y las MAC provocan igualmente divergencias por causa de los diferentes grados de selectividad, precisión y sensibilidad. Un factor importante que la Administración de Salud y Seguridad en el Trabajo (por OSHA) suele tomar en consideración en el proceso de normalización en Estados U nidos es la "asequibilidad técnica" de una norma en un determinado sector. Por consiguiente, algunas normas se adoptan sobre la base de las concentraciones mínimas actualmente existentes.

En Rusia, los niveles de concentración tolerable máxima se adoptan en función de las características médicas y biológicas prevalentes, al tiempo que la viabilidad tecnológica prácticamente no se toma en consideración. Esta es, en parte, la causa de que el valor de la concentración tolerable máxima sea inferior respecto de algunas sustancias químicas.

En Rusia se realizan estudios toxicológicos para determinar los valores de las concentraciones tolerables máximas antes de autorizarse el uso industrial de una sustancia. Durante la síntesis química de una sustancia se establece un límite provisional de la exposición tolerable. El valor de la concentración tolerable máxima se determina experimentando con animales en la fase de diseño del proceso industrial. Este valor se corrige después de evaluadas las condiciones de trabajo y el estado de salud de los trabajadores una vez que la sustancia se ha utilizado en la industria. En Rusia, la mayoría de los niveles seguros de exposición se recomiendan después de experimentar con animales.

En Estados Unidos, la norma definitiva se establece con posterioridad a la introducción de una sustancia química en la industria. debido a que los niveles admisibles de exposición se basan en la evaluación del estado de salud. M ientras subsistan las diferencias de criterio entre los TLV s y las concentraciones tolerables máximas, no es previsible que estas normas se aproximen en un futuro cercano. Sin embargo, la tendencia observada a la reducción de algunos T LV s permite concluir que esta convergencia no es tan improbable como parece.

\section{ORGANIZACIONES INTERNACIONALES GUBERNAMENTALES Y NO GUBERNAMENTALES}

\section{- COOPERACION INTERNACIONAL EN LA SALUD LABORAL: FUNCION DE LAS ORGANIZACIONES INTERNACIONALES}

\section{G eorges H. Coppée}

La función de las organizaciones internacionales consiste, fundamentalmente, en servir de marco estructurado a la cooperación internacional. A lo largo de la historia, los hombres han intercambiado información y experiencia de muchas formas. La cooperación entre naciones, científicos y estamentos profesionales se ha desarrollado gradualmente en el tiempo $y$, a principios del siglo XX, era evidente que algunas cuestiones sólo podían abordarse colectivamente.

Por regla general, se suele distinguir entre las organizaciones internacionales "intergubernamentales" y las "no gubernamentales". Entre las organizaciones intergubernamentales $(0 I G)$ se cuentan las $\mathrm{N}$ aciones U nidas y sus agencias especializadas, además de muchas otras organizaciones, como la O rganización para la Cooperación y el Desarrollo Económico (OCDE), la O rganización de la U nidad Africana (O UA), la O rganización de Estados A mericanos (OEA) y de los entes regionales del tipo de la Unión Europea (antes, Comunidades Europeas), M ERCO SUR 
(M ercado Común de Sur), la Comunidad del Caribe (CARICO M), la Asociación Europea de Libre Comercio (AELC) y el Tratado de Libre Comercio de América del Norte (TLC), concertado entre $C$ anadá, $\mathrm{E}$ stadosU nidosy $\mathrm{M}$ éxico.

Algunas organizaciones internacionales no gubernamentales, como la Comisión Internacional de Medicina del Trabajo (CIMT) y la Asociación Internacional de la Seguridad Social (AISS), se ocupan de todas las facetas de la salud y seguridad en el trabajo. Muchas otras organizaciones internacionales no gubernamentales abordan las cuestiones de salud y seguridad en el trabajo en el marco de su actividad global. Este es el caso de las organizaciones empresariales y sindicales, y de varias asociaciones profesionales internacionales. Algunas organizaciones no gubernamentales, como la Organización Internacional de Normalización (ISO), realizan funciones de normalización, y muchas otras organizaciones no gubernamentales centran su labor en áreas específicas o en determinados sectores de la actividad económica.

M uchas organizaciones intergubernamentales y no gubernamentales se interesan por los aspectos técnicos, médicos, sociales y jurídicos de la salud y seguridad en el trabajo, en los que intervienen diversas profesiones y disciplinas y participan distintos grupos sociales. Existe una vasta red de organizaciones cuyos medios y conocimientos se pueden utilizar para promover el intercambio de información y experiencias entre las naciones.

\section{Objetivos de las organizaciones intergubernamentales}

Una de las principales funciones de las organizaciones internacionales es traducir los valores generalmente aceptados en derechos y obligaciones. La Carta de las Naciones Unidas ( $N$ aciones U nidas 1994) constituye un ejemplo ilustrativo de cuál debe ser la función de una organización internacional en el sistema de la ONU, que no es otra que "realizar la cooperación internacional en la solución de problemas internacionales de carácter económico, social, cultural o humanitario, y estimular el respeto a los derechos humanos y a las libertades fundamentales de todos, sin hacer distinción por motivos de raza, sexo, idioma o religión". En el Pacto Internacional de Derechos Económicos, Sociales y Culturales se reiteran los principios proclamados en la Carta de las $\mathrm{N}$ aciones Unidas y se reconoce el derecho de todos a unas condiciones de trabajo saludables y seguras.

L os objetivos de las organizaciones internacionales se plasman en su carta fundacional, estatutos, constitución o sus textos fundamentales. Por ejemplo, en la constitución de la O rganización M undial de la Salud (1978) se proclama que el objetivo de la organización es que "todos logren el máximo nivel posible de salud". Según el Preámbulo de la constitución de la O IT (véanse posteriormente y OIT 1992), una de las tareas asignadas a la organización es la protección de los trabajadores contra las lesiones y enfermedades de origen profesional. En la Declaración de O bjetivos de la O rganización Internacional del Trabajo, adoptada en la vigésima sexta reunión de la Conferencia Internacional del Trabajo, celebrada en Filadelfia en 1944, se proclama la obligación de la OIT de promover entre las naciones del mundo la ejecución de programas que hagan efectiva una "protección adecuada de la vida y la salud de los trabajadores de todas las profesiones".

La comunidad internacional reconoce la interdependencia de las naciones en algunas cuestiones, y una de las funciones principales de las organizaciones intergubernamentales consiste en abordar esas cuestiones. En el Preámbulo de la Constitución de la O IT, adoptada en 1919, se reconoce que "la negativa de cualquier nación a implantar unas condiciones de trabajo humanas constituye un obstáculo para otras naciones deseosas de mejorar las condiciones propias" y se afirma que "una paz universal y duradera sólo es posible si se basa en la justicia social". En la Declaración de Filadelfia de la O IT se asegura que "la pobreza en cualquier parte es un peligro para la prosperidad en todas partes". Por su parte, en la Constitución de la O M S se establece que "un desarrollo desigual entre las naciones en la promoción de la salud y el control de las enfermedades, en especial de las contagiosas, constituye un peligro para todos" y que "los logros de cualquier Estado en la promoción y protección de la salud son importantes para todos". La función de las organizaciones internacionales consiste en garantizar la continuidad y lograr la estabilidad en el tiempo con vistas a esos objetivos de política a largo plazo, al tiempo que en el ámbito nacional suele prevalecer la planificación a corto y medio plazo, por causa de las condiciones socioeconómicas y de las circunstancias políticas.

Toda organización internacional tiene un mandato conferido por sus miembros, y aborda sus objetivos específicos en materias como la salud y seguridad en el trabajo en el marco de ese mandato. Las organizaciones intergubernamentales tienen como rasgos comunes la función de fijar pautas, formular recomendaciones y elaborar normas. Los instrumentos internacionales forjados en el marco de las $\mathrm{N}$ aciones $\mathrm{U}$ nidas que se pueden aplicar en el ámbito nacional se pueden dividir en dos categorías. D e una parte, están los instrumentos no vinculantes, consistentes en recomendaciones y resoluciones que pueden servir de base a la normativa legal interna. L os instrumentos vinculantes, por su parte, obligan a adaptar el ordenamiento legal interno y su praxis a los acuerdos adoptados en el ámbito internacional. La mayoría de los intrumentos vinculantes consisten en convenios internacionales, que precisan de un acto de ratificación, aprobación o adhesión, en virtud del cual cada Estado conviene en obligarse por las disposiciones del convenio.

Las organizaciones internacionales son un foro para la discusión y adopción de políticas y estrategias comunes en una gran variedad de campos, incluido el de la salud y seguridad en el trabajo. L os países utilizan estos foros para contrastar principios y criterios e intercambiar información y experiencias, debatir y proponer soluciones, y acordar las modalidades de cooperación en el esfuerzo por alcanzar unos objetivos, con el objeto de concertar acuerdos, tratados y convenios internacionales en los que se plasme el consenso entre las partes respecto a lo que se debe y no se debe hacer.

U na de las ventajas de las organizaciones internacionales es que aportan a los contactos internacionales un foro estructurado que se rige por unos procedimientos y reglas fijados por los miembros y que permite, simultáneamente, una multitud de contactos, tanto diplomáticos, como informales, de un ámbito mucho mayor del que se puede alcanzar en el marco de un solo país. Este foro permite a diversos estamentos y países que tienen problemas comunes unificar criterios y mejorar sus estrategias. Desde una perspectiva internacional, se facilita la adopción de unos criterios objetivos respecto a problemas específicos vinculados a los sistemas institucionales nacionales o a unas condiciones históricas concretas. En estos foros, los agentes sociales que, quizás sean incapaces de dialogar en el escenario nacional, se sientan a la misma mesa. Así se renueva el diálogo y pueden surgir posibilidades de alcanzar acuerdos que habrían resultado imposibles en el ámbito nacional. Los grupos de presión pueden actuar como catalizadores del proceso de consenso sin necesidad de utilizar tácticas agresivas. En las conferencias internacionales, no sólo se intercambia información y experiencias, sino que se facilita a diversos grupos la oportunidad de explorar el nivel de aceptabilidad mundial de sus principios, ideas y políticas.

En la práctica, las organizaciones internacionales realizan una extensa gama de actividades de intercambio de información; transmisión de conocimientos; unificación de conceptos y terminología; negociación de acuerdos; códigos de práctica y de 
conducta; y promoción y coordinación de la investigación. La mayoría de las organizaciones internacionales llevan a cabo un gran número de actividades y programas diseñados para ayudar a los Estados miembros a lograr los objetivos previstos en su carta constitucional, incluida la cooperación técnica. Estas organizaciones se valen de una serie de medios de actuación, como informes y estudios, reuniones de expertos, seminarios, cursillos, simposios, conferencias, servicios de asesoramiento técnico, intercambio de información; y actúan como centros de distribución de la información. Con el tiempo, los objetivos básicos de las organizaciones internacionales se han ampliado y se han hecho más específicos en virtud de los programas y acuerdos adoptados por los miembros en las asambleas generales, como la Conferencia Internacional del Trabajo de la OIT y la A samblea M undial de la Salud, de la O M S.

\section{Las Naciones Unidas y sus agencias especializadas}

En el sistema de las Naciones U nidas existen dos agencias especializadas que tienen un interés directo en la seguridad e higiene en el trabajo globalmente consideradas: la O rganización Internacional del Trabajo (OIT) y la O rganización M undial de la Salud (O M S). Entre las agencias especializadas de las $\mathrm{N}$ aciones U nidas destaca la O rganización Internacional del Trabajo por su estructura tripartita, ya que está constituida por representantes de los gobiernos y de las organizaciones sindicales y de empresarios. 0 tro rasgo distintivo de la O IT es su función de promulgación de normas, puesto que la $\mathrm{O}$ rganización $\mathrm{M}$ undial del Trabajo adopta Convenios y Recomendaciones internacionales. Como el medio ambiente de trabajo se considera parte integrante del entorno humano (O rganización Internacional del Trabajo/ Programa de las Naciones U nidas para el M edio Ambiente/ O rganización M undial de la Salud 1978), el Programa de las N aciones U nidas para el Medio Ambiente (PNUMA) también se ocupa de la materia, especialmente por lo que respecta a los productos químicos. En efecto, el Registro internacional de productos químicos potencialmente tóxicos (RIPQPT), dependiente del PNUM A, colabora estrechamente con la OIT y con la OMS en el marco del Programa Internacional de Seguridad de las Sustancias Q uímicas (IPCS).

Además de sus estructuras centrales, las organizaciones internacionales cuentan con servicios de campo y con órganos e instituciones especializados, como la Agencia Internacional para la Investigación sobre el Cáncer (IARC), de la OMS, y el Centro Panamericano para la Ecología y la Salud H umanas (ECO ), que colabora en la aplicación del Programa Regional de Salud Laboral de la Organización Panamericana de la Salud (OPS). Asimismo, el Centro de Formación Internacional de la OIT en Turín, I talia, realiza actividades de formación en el campo de la salud y seguridad en el trabajo, y elabora materiales de formación para diversos grupos profesionales; y el Instituto Internacional de Estudios Laborales (IEL) aborda ocasionalmente los problemas de la salud y seguridad en el trabajo. Tanto la O M S como la O IT cuentan con oficinas regionales y de área, y tienen corresponsales nacionales. Periódicamente se celebran conferencias regionales de la OIT y de la OMS. La OPS, fundada en 1902, es la O ficina R egional de la O M S en el continente americano. En 1990, la Conferencia Sanitaria Panamericana adoptó un acuerdo en materia de salud laboral (O PS 1990), en el que se fijaban pautas para el programa de la O PS y se designaba 1992 como el "Año de la Salud Laboral en América".

La sede central y los servicios de campo de la OIT canalizan los esfuerzos y actividades de los Estados miembros en el área de la salud y seguridad en el trabajo en el marco de su Programa Internacional para la M ejora de las Condiciones y el M edio Ambiente de Trabajo (PIACT) (OIT 1984). Este programa gestiona una extensa gama de servicios de asesoramiento y cooperación técnica en todo el mundo. Recientemente, la OIT ha adoptado un documento de política de participación activa (PPA) con el objetivo de acercar la organización a sus participantes en los Estados miembros mediante el fortalecimiento de sus servicios de campo, principalmente mediante la creación de equipos multidisciplinarios (M DTs).

Varias otras agencias especializadas de la ONU realizan una función importante en aspectos concretos de la salud y seguridad en el trabajo; este es el caso del O rganismo Internacional de Energía A tómica (O IEA), ocupado en la seguridad nuclear, la protección de los trabajadores contra las radiaciones y el control de los focos de radiación. La O rganización de las Naciones Unidas para el Desarrollo Industrial (O NUDI) se ocupa de la salud y seguridad en el trabajo en sectores industriales específicos y, en colaboración con el Banco Mundial y el PNUMA, elabora normas de control y prevención de la contaminación industrial que abarcan igualmente los problemas de salud y seguridad en el trabajo. Por su parte, la O rganización de las $\mathrm{N}$ aciones Unidas para la Agricultura y la Alimentación (FAO), que promueve la seguridad en el empleo de pesticidas (FAO 1985) y la salud y seguridad en el trabajo forestal, ha suscrito diversos convenios de cooperación con la OIT y con la Comisión Económica para E uropa de las $\mathrm{N}$ aciones $\mathrm{U}$ nidas.

El Comité de Expertos en el Transporte de M ercancías Peligrosas del Consejo E conómico y Social de las Naciones U nidas ha elaborado diversas recomendaciones sobre el transporte de mercancías peligrosas, que sirven de pautas a las diversas legislaciones nacionales y al esfuerzo por uniformar en alguna medida los distintos modos de transporte en todo el mundo. La O rganización de Aviación Civil Internacional $(\mathrm{OACI})$ ha adoptado normas internacionales de explotación de aeronaves y ha editado un manual de medicina de la aviación civil en el que se tratan diversos aspectos de la salud laboral del personal de vuelo. Por su parte, la O rganización Marítima Internacional $(\mathrm{OMI})$ ha adoptado un Convenio Internacional para la Seguridad de la Vida H umana en el M ar (SOLAS). La OMS y la OIT, en colaboración con la OMI, han elaborado una Guía $M$ édica Internacional para buques, dividida en unidades diferenciadas, en la que se indica lo que se debe incluir en el botiquín de un barco y se reproduce la sección médica del Código Internacional de Señales. Asimismo, la OM I, en cooperación con la O M S y la O IT, ha elaborado una guía de primeros auxilios utilizable en los accidentes en que intervengan sustancias peligrosas.

Las organizaciones financieras, como el Programa de las $\mathrm{N}$ aciones Unidas para el Desarrollo (PNUD) han venido prestando apoyo económico en estos últimos 25 años a un gran número de proyectos de salud y seguridad en el trabajo desarrollados en muchos países, entre los que se incluye la creación de institutos nacionales de salud y seguridad en el trabajo. La O IT y la OMS han canalizado la ejecución de tales proyectos, conjunta 0 individualmente. En sus proyectos de desarrollo económico, el Banco Mundial toma en consideración los aspectos ambientales, sanitarios y de ecología humana (Banco M undial 1974), incluidas las cuestiones de salud y seguridad en el trabajo. En 1987, el Banco M undial inició un ingente esfuerzo por incorporar las inquietudes ambientales a todas las facetas de su actividad. Este esfuerzo comprende un mayor hincapié en el desarrollo de la capacidad institucional de gestión del medio ambiente en el ámbito nacional, una mayor conciencia de la necesidad de incorporar las preocupaciones por el medio ambiente al trabajo sectorial, y un énfasis creciente en los aspectos sociales del desarrollo sustentable por el medio ambiente (Banco M undial 1993a). Además, en el informe Investing in $\mathrm{H}$ ealth se analiza la correlación existente entre la salud 
humana, la política sanitaria y el desarrollo económico (Banco M undial 1993b).

\section{Otras organizaciones intergubernamentales}

La actividad de la O rganización para la Cooperación y el D esarrollo Económico $(O C D E)$ reviste particular importancia en relación con las cuestiones de salud ambiental, seguridad en el empleo de sustancias químicas, métodos de evaluación de los riesgos químicos y protección contra las radiaciones. EI Consejo de Europa ha adoptado diversas resoluciones sobre la salud y seguridad en el trabajo, en relación, entre otros aspectos, con los servicios de seguridad en la empresa. En la Carta Social Europea, adoptada por el Consejo de Europa en 1961, se reconoce el derecho de los trabajadores a unas condiciones de trabajo sanas y seguras. EI Consejo de Estados N órdicos se interesa por la salud y seguridad en el trabajo y los problemas del medio ambiente, y formula recomendaciones relativas a las sustancias tóxicas y peligrosas, la seguridad nuclear y la protección contra las radiaciones, además de elaborar programas de actuación sobre el medio ambiente de trabajo. La 0 rganización Arabe del Trabajo, fundada en 1965 como agencia especializada en el marco de la Liga Arabe, realiza estudios e investigaciones sobre la seguridad en el trabajo y la salud laboral. Por su parte, los países del MERCO SUR han creado una comisión especial para la armonización de las leyes de salud y seguridad en el trabajo.

La U nión Europea promulga directivas que se deben transponer en el ordenamiento interno de los Estados miembros y son vinculantes para ellos. Las directivas europeas abarcan todo el espectro de la salud y seguridad en el trabajo y sirven para armonizar las normativas nacionales, sobre la base del principio de subsidiariedad. Existen tres órdenes de directivas (TUTB 1991): las directivas marco, del tipo de la Directiva Relativa a la A plicación de M edidas para Promover la M ejora de la Seguridad y de la Salud de los Trabajadores en el Trabajo (89/391/ CEE); las directivas relativas a los riesgos a que se exponen los trabajadores (plomo, amianto, ruido, radiación ionizante, etcétera); y directivas reguladoras del diseño del equipo de trabajo. EI Comité Europeo de Normalización (CEN) se ocupa de la elaboración de normas técnicas. La Comisión de la U nión Europea (antiguamente, Comisión de las Comunidades Europeas) elabora las directivas y gestiona un importante programa de salud y seguridad en el trabajo (Comisión de las Comunidades Europeas 1990). La Fundación Europea para la M ejora de las Condiciones de Vida y de Trabajo, con sede en Dublín, realiza diversas actividades en el campo de la salud y seguridad en el trabajo, entre las que se incluyen las de un equipo de trabajo dedicado a las estrategias de salud laboral en Europa. EI Año Europeo de la Protección de la Seguridad, la Higiene y la Salud en el Trabajo", celebrado en 1992, sirvió de marco para la promoción de diversos proyectos de salud y seguridad en el trabajo desarrollados en varios países de la U nión europea. En Bilbao se ha creado la A gencia Europea para la Salud y Seguridad en el Trabajo, como organismo especializado de la U nión Europea.

\section{Organizaciones internacionales no gubernamentales}

Diversos estamentos científicos, profesionales y de otro tipo, han experimentado igualmente la necesidad de desarrollar la cooperación internacional y de constituir organizaciones internacionales no gubernamentales, que pueden estar integradas por expertos, instituciones 0 asociaciones nacionales de expertos. En otro artículo de este mismo capítulo se analiza la Comisión Internacional de Medicina del Trabajo (CIM T), constituida en 1906 con el nombre de Comisión Permanente para las Enfermedades Profesionales.

La A sociación Internacional de la Seguridad Social (AISS) es una organización internacional integrada por organismos públicos responsables de la gestión de la seguridad social y desde 1954 viene aplicando un programa de prevención de los riesgos profesionales. Esta organización se analiza igualmente en profundidad en otra parte del presente capítulo.

M ientras que el CIM T y la AISS se interesan por la salud y seguridad en el trabajo en su conjunto, diversas organizaciones no gubernamentales centran sus esfuerzos, bien en segmentos concretos de la actividad económica, como la agricultura, bien en áreas tan diversas como la tecnología, la toxicología, la organización del trabajo, la seguridad de los procesos, la ingeniería humana, la epidemiología, la medicina social, el equipo de izado, la manipulación de cargas, los contenedores presurizados, el transporte de contenedores y materiales peligrosos, la señalización de seguridad, la seguridad vial y la seguridad nuclear. Entre las numerosas organizaciones internacionales no gubernamentales que se interesan por el medio ambiente y la protección del consumidor destacan la U nión M undial para la Naturaleza (UICN) y la Organización Internacional de Asociaciones de C onsumidores (IOCU). Estas organizaciones se interesan fundamentalmente en la salud ambiental $y$, en cierta medida, en la salud laboral, especialmente en relación con los pesticidas y las sustancias químicas.

En el campo de la protección de los trabajadores, los pacientes y el público contra los efectos adversos de la radiación ionizante, destaca en todo el mundo la labor de la Comisión Internacional de Protección Radiológica (CIPR), que inspira las recomendaciones de alcance internacional formuladas por las organizaciones intergubernamentales. La A sociación Internacional de Protección Radiológica (IR PA) ha creado una Comisión Internacional de Protección de la R adiación no Ionizante (ICNIR P), que fija los valores límites de la exposición y colabora con las publicaciones de la OIT y la OMS dedicadas a la radiación no ionizante. $\mathrm{H}$ ay muchas otras organizaciones y asociaciones internacionales no gubernamentales que se interesan por la salud y seguridad en el trabajo o por aspectos concretos de la misma. M erecen citarse la A sociación E rgonómica Internacional (IEA); la Sociedad de Ergonomía de los Países Francófonos (SELF); el Consejo Internacional de Enfermeras (ICN); el Consejo Interamericano de Seguridad (IASC); la A sociación Internacional de Inspección de Trabajo (IALA); la A sociación Internacional para la Salud laboral (AOHA); la Asociación Internacional de M edicina Agrícola y Salud Rural (IAAM R H ); la Asociación Internacional de Salud Pública y Rural (ALASEHT); la Asociación Latinoamericana de Seguridad e Salud laboral, la Federación Internacional de Asociaciones de Especialistas en Seguridad en el Trabajo e Salud laboral; la A sociación Europea de Escuelas de M edicina del Trabajo; la Federación M undial de Asociaciones de Centros de Toxicología Clínica y Control de Venenos; y el Consejo de Seguridad Internacional, filial mundial del Consejo de Seguridad Nacional de Estados U nidos.

$\mathrm{H}$ ay otro grupo de organizaciones no gubernamentales especializadas en las labores de normalización, como la O rganización Internacional de Normalización (ISO) y la Comisión Electrotécnica Internacional (CEI). La ISO se analiza en un artículo posterior de este mismo capítulo.

L as organizaciones empresariales y sindicales de ámbito internacional realizan una importante labor de formulación de prioridades y políticas de salud y seguridad en el trabajo de dimensión internacional. La participación de estas organizaciones es necesaria, debido que en la legislación laboral interna se responsabiliza a las empresas de la protección del trabajador contra los peligros profesionales, y a que los principales

C ENCICLOPEDIA DE SALUDY SEGURIDADENEL TRABAJO 
interesados son los propios trabajadores, puesto que su salud y su seguridad están en juego. Entre las organizaciones internacionales de empresarios y de trabajadores que se ocupan globalmente de la salud y seguridad en el trabajo destaca la O rganización Internacional de Empleadores (OIE), la U nión de Confederaciones de la Industria y de O rganizaciones Empresariales de Europa (UNICE), la Confederación Internacional de $O$ rganizaciones Sindicales Libres (CIOSL), la Confederación M undial del Trabajo (CMT) y la Federación Sindical M undial (FSM ). Existen, además, numerosas organizaciones sindicales internacionales de carácter sectorial que se ocupan de cuestiones concretas, como la Confederación Internacional de Sindicatos de la Q uímica, la Energía, la M inería y G eneral; la Federación Internacional de Trabajadores de las Industrias $M$ etalúrgicas (FITIM ); la Federación M undial de Trabajadores de la Construcción y de la Madera; la Federación Internacional de los Trabajadores de las Plantaciones, Agrícolas y Similares (FITPAS); y la Federación Internacional de Empleados, T écnicos y Similares (FIET). Existen también organizaciones regionales, como la O rganización para la U nidad Sindical Africana y la Confederación Europea de Sindicatos (CES), que ha creado una O ficina T écnica Sindical Europea para la Salud y la Seguridad en el Trabajo (T UTB). Estas organizaciones realizan una extensa gama de actividades, especialmente de difusión de información, asesoramiento técnico y formación para la salud y seguridad en el trabajo.

También los productores, fabricantes y operadores se muestran activos en el campo de la salud y seguridad en el trabajo, bien a través de sus propias organizaciones, bien por medio de los organismos e instituciones especializados, como el Consejo Internacional de Asociaciones de la Química, el Consejo Europeo de Federaciones de Industriales de la Química, el Grupo Internacional de Asociaciones Nacionales de Industrias Agroquímicas, la Asociación de Transporte Aéreo Internacional (IATA), la Asociación Mundial de Operadores de Plantas Nucleares, la Sociedad de Ingeniería de Luminotecnia, la Asociación Internacional del Amianto, el Grupo Internacional de Seguridad de las Fibras y el Consejo de Prevención de la Hepatitis V írica, dedicado a la prevención de la hepatitis B como enfermedad profesional. Además, diversos organismos internacionales y otras instituciones creadas por los productores, fabricantes y organizaciones sectoriales, realizan labores de protección del medio ambiente y de la salud ambiental, que pueden aplicarse en alguna medida a la salud laboral. Entre estos organismos merecen citarse el Centro Internacional de la Industria y el Medio Ambiente, el Consejo Internacional del Metal y el Medio Ambiente, el Instituto Internacional de Aluminio Primario, y el Grupo Internacional de Estudios de las Compañías Petroleras para la Conservación de la Pureza del Aire y del Agua.

Por último, los científicos, asociaciones profesionales y otros grupos de intereses científicos, profesionales o económicos afines han creado numerosas organizaciones internacionales no gubernamentales que, si bien no se ocupan directamente de los problemas de la salud y seguridad en el trabajo, se interesan por cuestiones científicas, médicas, técnicas y sociales que se relacionan con la salud y seguridad en el trabajo. Entre estas organizaciones se cuentan la A sociación $M$ édica $M$ undial, el Consejo de $O$ rganizaciones Internacionales de las Ciencias $M$ édicas (COICM ), la U nión Internacional de Q uímica Pura y A plicada (IUPAC), el Consejo Internacional de Estudios y Documentación de Investigación en la Construcción, la Asociación Epidemiológica Internacional, la Sociedad Internacional de Derecho del Trabajo y Seguridad Social, y la O ficina Internacional para la Epilepsia (IBE), que ha elaborado un Código de conducta para la contratación de personas con epilepsia.

\section{Programas conjuntos de cooperación internacional}

Resulta interesante examinar la forma en que las organizaciones internacionales se complementan y movilizan sus respectivos medios de actuación en la lucha contra determinados peligros profesionales. Por ejemplo, por lo que respecta al ruido y la vibración, la CEI dicta normas aplicables a los dispositivos de medición, la ISO establece los métodos de medición, la O M S fija los criterios sanitarios, y la O IT recomienda unos límites a la exposición en su Código de Práctica sobre el ruido y la vibración, además de formular un enfoque y una estrategia globales en su Convenio sobre el medio ambiente de trabajo (contaminación del aire, ruido y vibraciones), 1977 (no 148) y en la Recomendación no 156.

La labor de las organizaciones internacionales se caracteriza por la cooperación creciente en el marco de los programas internacionales y las empresas conjuntas orientados a unos objetivos específicos que afectan a las naciones y a las organizaciones intergubernamentales y no gubernamentales. La cooperación internacional en la protección contra la radiación ionizante y en la promoción de la seguridad en la manipulación de sustancias químicas ilustra este tipo de actividad.

En el campo de la protección contra la radiación ionizante, la Comisión Internacional de Protección R adiológica (CIPR) y el Comité Científico de las Naciones U nidas para el Estudio de los E fectos de las $R$ adiaciones A tómicas (U N SC EAR ) se responsabilizan de los aspectos científicos. En 1960, la OIT adoptó el Convenio sobre la protección contra las radiaciones ( $n$ 일 115) y la Recomendación (no 114), en los que se alude específicamente a las directrices del CIPR. También se emiten directrices en diversos códigos de práctica elaborados por el OIEA y patrocinados conjuntamente, en algunos casos, por la O IT y la O M S, así como en el Código de práctica de protección contra la radiación (ionizante) de la OIT, de 1987. Estas normas se complementan con los manuales, guías, materiales de formación y documentación técnica editados, principalmente, por el OIEA y por la Agencia de Energía Nuclear de la OCDE. La cooperación técnica en este campo corresponde, fundamentalmente, al O IEA, con la participación puntual de otras organizaciones.

En 1990 se produjo un importante hito en el proceso de armonización internacional del control de las radiaciones con la creación del Comité Interagencias de Seguridad de la Radiación, a modo de foro de consulta y cooperación en el control de la radiación entre las organizaciones internacionales. Se creó una secretaría común con el objeto de revisar la edición de 1982 de las N ormas Básicas de Seguridad para la Protección contra la Radiación de OIEA/OIT/OMS/AEN-OCDE. Seis organizaciones internacionales, la FAO, la OIEA, la OIT, la Agencia de Energía Nuclear de la OCDE, la OMS y la OPS, aunaron sus esfuerzos en la elaboración de normas internacionales que inspirasen el trabajo legislativo de los Estados miembros. Bajo la inspiración de la OIEA, se desarrolló un ingente proceso de consultas con los distintos países y diversas organizaciones intergubernamentales y no gubernamentales, incluidas las organizaciones empresariales y sindicales, que culminó en la elaboración de sendas normas internacionales de Protección contra la R adiación Ionizante y de Seguridad de las fuentes de radiación (OIEA 1994). Estas normas internacionales constituyen una normativa unificada en el marco del sistema de la O NU.

La cooperación internacional en la promoción de la seguridad de las sustancias químicas es ilustrativa del modo en que las organizaciones internacionales coordinan sus esfuerzos por dar una respuesta a las demandas de la población mundial recogidas por la comunidad internacional, y de cómo las declaraciones generales de principios proclamadas en las conferencias internacionales se traducen en programas de actuación y en actividades 
prácticas basadas en conocimientos científicos. Existe un consenso en el sentido de que en el tratamiento de las sustancias químicas se deben tomar en consideración los aspectos relativos a las exposiciones profesionales y a la protección del público y del medio ambiente. La evaluación de los riesgos en un marco internacional permite concretar los conocimientos y recursos necesarios. Con esta finalidad, en 1980 se inició el Programa Internacional de Seguridad de las Sustancias Q uímicas (IPC S), patrocinado por la OMS, el Programa de las Naciones Unidas para el Medio Ambiente (PNUMA) y la OIT. La voluntad de estas organizaciones asistenciales de cooperar en el IPCS se plasmó en un acuerdo suscrito en 1988, en el que se establecían los objetivos del Programa. Las funciones técnicas del IPCS corresponden a un grupo de instituciones nacionales e internacionales que participan en las actividades y se responsabilizan de tareas concretas. EI Programa mantiene unas relaciones funcionales íntimas y eficaces con otras organizaciones, asociaciones y corporaciones profesionales, tanto intergubernamentales, como no gubernamentales, que realizan labores importantes en el campo de la seguridad de las sustancias químicas.

En la Conferencia de las Naciones U nidas sobre el Medio Ambiente y el Desarrollo (CNUMAD), celebrada en Río de Janeiro en 1992 se reconoció la necesidad de asegurar una gestión ambientalmente segura de las sustancias tóxicas y se concretaron seis áreas de interés para la cooperación internacional:

1. R eforzamiento y agilización de la evaluación internacional de los riesgos químicos.

2. Armonización de la clasificación y el etiquetado de las sustancias químicas.

3. Intercambio de información relativa a las sustancias tóxicas y a los riesgos químicos.

4. Desarrollo de programas de reducción de riesgos.

5. R eforzamiento de los medios y posibilidades de manipulación de las sustancias químicas en el ámbito nacional.

6. Prevención del tráfico internacional ilegal de productos tóxicos y peligrosos.

Este reconocimiento fue seguido, en 1994, de una Conferencia Internacional de Seguridad de las Sustancias Q uímicas (C onferencia de Estocolmo 1994), en la que se creó el Foro Intergubernamental de Seguridad de las Sustancias Q uímicas, se estableció un orden de prioridades de actuación y se invitó a las organizaciones intergubernamentales a participar en un programa común de seguridad de las sustancias químicas. Se puso en marcha un Programa Interorganizaciones para la Gestión Segura de las Sustancias Q uímicas, con la participación de la OMS, la OIT, el PNUMA, la FAO, la ONUDI y la OCDE. En el marco del Programa, funciona un Comité de Coordinación Interorganizaciones, que coordina las labores de control de las sustancias químicas que las organizaciones participantes llevan a cabo conjunta o individualmente, y realiza un seguimiento de la aplicación de las recomendaciones de la CNU M AD.

Se observa una clara tendencia a una mayor utilización de recursos y conocimientos en el marco de la actividad conjunta. Así ocurre, por ejemplo, en el campo de la formación y el intercambio de información sobre la salud y seguridad en el trabajo. En el campo de la seguridad biológica, se ha desarrollado la cooperación entre la ONUDI, el PNUMA, la OMS y la FAO, que han canalizado determinadas actividades a través del IPCS. Se ha encomendado a la ONUDI el seguimiento de la aplicación del capítulo 6 de la Agenda 21 (sobre la gestión ambientalmente segura de la biotecnología) de la Conferencia de Río, la coordinación de los programas y actividades conjuntos, y el desarrollo de unas políticas comunes en materia de biotecnología en el marco del sistema de la O NU. La OCDE cuenta con un programa relativo a los aspectos ambientales de la biotecnología. En 1990 se adoptó una Directiva Europea (90/ 679/ CEE), modificada en 1993 (93/88/CEE), sobre la protección de los trabajadores contra los riesgos relacionados con la exposición a agentes biológicos durante el trabajo. También en 1993, la Conferencia Internacional del Trabajo de la Organización Internacional del Trabajo adoptó una resolución relativa a la seguridad y la exposición a los agentes biológicos en el trabajo, en la que se reconoce la necesidad de estudiar la cuestión e incluso, de promulgar nuevos instrumentos internacionales (convenios, recomendaciones, o ambos) que permitan reducir los riesgos para los trabajadores, el público y el medio ambiente.

Pueden citarse otros dos casos, que se refieren a la protección de los trabajadores contra la radiación no ionizante y a la armonización de los sistemas de clasificación y etiquetado de las sustancias químicas. La O M S, el PNU M A y la Comisión Internacional de Protección contra la Radiación no Ionizante han elaborado algunos documentos que definen los criterios de salud ambiental relativos a la radiación no ionizante. En la actualidad se desarrolla una cooperación más vasta en materia de protección contra la radiación no ionizante, incluida la exposición profesional, en la que participan la OIT, la Comisión de la U nión E uropea, la Comisión Electrotécnica I nternacional (CEI), la Agencia Internacional para la Investigación sobre el Cáncer (IARC), y el Comité Científico sobre R adiación y Trabajo de la CIM T. En el campo de la armonización de los sistemas de clasificación y etiquetado de las sustancias químicas se desarrolla una intensa campaña de cooperación, promovida por la OIT, entre los países, las organizaciones intergubernamentales (como la OCDE y la U nión Europea) y no gubernamentales (como las organizaciones sindicales y empresariales, y las organizaciones internacionales de consumidores y de protección del medio ambiente) el Comité de Expertos en el Transporte de M ercancías Peligrosas de la ONU, la FAO, el PNUMA, la OMS, la $\mathrm{OMI}$ y la $\mathrm{OACl}$.

$\mathrm{H}$ ay muchos otros campos en los que empiezan a producirse 0 podrían promoverse nuevas y más flexibles modalidades de cooperación entre las naciones y las organizaciones internacionales, como el de la lucha contra el estrés en el trabajo y las enfermedades pulmonares de origen profesional, en especial, la silicosis. La colaboración internacional en el campo de la salud y seguridad en el trabajo experimenta un desarrollo creciente en torno a objetivos como la coordinación de la investigación. Resultaría ventajoso desarrollar una red internacional de salud y seguridad en el trabajo sobre la base de las estructuras actuales de las organizaciones internacionales, que podrían interconectarse, como los Centros Colaboradores de la O M S, los C omités Científicos de la CIM T, las secciones internacionales de la AISS, los corresponsales nacionales del RIPQPT, los puntos de contacto del Procedimiento Complementario de Información de la O CDE, las I nstituciones Participantes en el IPCS, los C entros Nacionales y de Colaboración del Centro Internacional de Información sobre Seguridad y Salud en el Trabajo (CIS) de la OIT y los órganos competentes del Sistema Internacional de Alarma sobre R iesgos para la Salud y Seguridad en el Trabajo de la OIT.

\section{Objetivos comunes y enfoques complementarios en salud laboral}

L os objetivos estratégicos de la O M S y la O IT en el campo de la salud y seguridad en el trabajo son idénticos y consisten en proteger y promover la salud y seguridad de los trabajadores de todas las profesiones. Las directrices políticas se dictan en los convenios y recomendaciones internacionales de la O IT relativas a la salud y seguridad en el trabajo, y en las resoluciones acordadas por la Asamblea Mundial de la Salud de la OMS en 
relación con la salud de los trabajadores y con la asistencia sanitaria primaria que la organización propugna.

Desde la Conferencia de Asistencia Sanitaria Primaria celebrada en Alma-Ata en 1978, la O M S ha procurado ampliar la cobertura de sus actividades de promoción y protección de la salud para abarcar a la totalidad de los trabajadores, con especial atención a la población trabajadora menos protegida y más vulnerable. En la cuadragésima Asamblea M undial de la Salud se instó al Director G eneral de la O M S:

1. A promover la aplicación del programa de salud de los trabajadores, en el marco de un sistema nacional de sanidad basado en la asistencia sanitaria primaria, en estrecha colaboración con otros programas y organizaciones no gubernamentales competentes y con la totalidad de las agencias de las $\mathrm{N}$ aciones $\mathrm{U}$ nidas.

2. A elaborar directrices para la prestación de asistencia sanitaria primaria en el lugar de trabajo, dirigidas principalmente a la población trabajadora más desasistida, con inclusión de los materiales didácticos precisos en diferentes niveles.

3. A elaborar pautas de promoción de la salud en el lugar de trabajo, en cooperación con los centros colaboradores de la OMS.

4. A impulsar, en su caso, la realización de actividades de promoción de la salud de los trabajadores.

En octubre de 1994, la Segunda Reunión de la Red de Centros Colaboradores en Salud Laboral (compuesta por 52 instituciones especializadas y de investigación distribuidas en 35 países del mundo) adoptó una "Estrategia Global sobre Salud Laboral para Todos" y recomendó que este documento se sometiese a la consideración de la O M S y, eventualmente, se convirtiese en la "estrategia global de salud laboral para todos" de la organización. El objetivo se logró en mayo de 1996, con el apoyo de la OIT.

En los convenios y recomendaciones de la O IT sobre la salud y seguridad en el trabajo se establecen los derechos de los trabajadores y se definen las respectivas responsabilidades en la materia de los trabajadores, las empresas y las autoridades competentes. G lobalmente considerados, los convenios y recomendaciones adoptados en la Conferencia Internacional del Trabajo de la OIT constituyen un código internacional del trabajo en el que se establecen unas normas mínimas en el ámbito laboral. La filosofía de la OIT en el materia de salud y seguridad en el trabajo se ha plasmado, principalmente, en dos convenios internacionales y sus respectivas recomendaciones. En el Convenio sobre seguridad y salud de los trabajadores, 1981 (no 155) y la correlativa Recomendación ( $n$ - 164) se propugna la adopción de una política nacional de salud y seguridad en el trabajo y se especifican las medidas necesarias, tanto en el ámbito nacional, como en las empresas, para promover la salud y seguridad en el trabajo y mejorar el medio ambiente de trabajo. En el Convenio sobre los servicios de salud en el trabajo, 1985 ( $n$ 161) y la correspondiente Recomendación ( $n$ o 171) se propugna la creación de unos servicios de salud laboral que contribuirán a la aplicación de la política de salud y seguridad en el trabajo y que funcionarán en el ámbito de la empresa.

En 1984, la Conferencia Internacional del Trabajo aprobó una resolución relativa a la mejora de las condiciones y del medio ambiente de trabajo, en la que se subrayaba que dicha mejora era un aspecto esencial de la promoción de la justicia social. Se hacía hincapié en que la mejora de las condiciones y del medio ambiente de trabajo contribuyen efectivamente al desarrollo nacional y constituyen una medida del éxito de toda política económica y social. En la resolución se definían tres principios fundamentales:
- el trabajo se debe realizar en un ambiente sano y seguro

- las condiciones de trabajo deben ser compatibles con el bienestar y la dignidad humana de los trabajadores

- el trabajo debe ofrecer posibilidades reales de promoción y realización personales, y de servicio a la sociedad.

Existen muchas coincidencias entre la estrategia de la OIT para la mejora de las condiciones y del medio ambiente de trabajo y la política de asistencia sanitaria primaria de la O M S. Ambas filosofías se inspiran en unos principios similares y ambas:

1. Se dirigen a todos los interesados: trabajadores y público en general.

2. Definen políticas, estrategias y medios de actuación.

3. Subrayan la responsabilidad de cada empresa por la salud y seguridad de sus trabajadores.

4. Hacen hincapié en la prevención primaria, en el control de los riesgos en el origen y en la educación sanitaria.

5. Conceden especial importancia a la formación y la información.

6. Reconocen la necesidad de promover unas medidas de salud laboral de fácil acceso para todos y aplicables en el lugar de trabajo.

7. Conceden una importancia primordial a la participación: participación de la comunidad en los programas sanitarios y participación de los trabajadores en la mejora del medio ambiente y de las condiciones de trabajo.

8. Ponen de relieve la correlación, tanto entre el entorno sanitario y el desarrollo, como entre la salud y seguridad en el trabajo y el empleo productivo.

El actual proceso de globalización de la economía internacional y de integración regional ha incrementado la interdependencia y la necesidad de cooperación entre las naciones. En el presente análisis se ha puesto de relieve la existencia de objetivos, políticas y enfoques comunes en materia de salud y seguridad en el trabajo. Existe, además, una estructura sobre la que se puede erigir una cooperación de ámbito mundial. Este es el objetivo del Programa M undial de la Salud, la Seguridad y el M edio A mbiente, que la O IT pondrá en marcha en 1998.

\section{LAS NACIONES UNIDAS Y SUS AGENCIAS ESPECIALIZADAS*}

\section{Origen de las Naciones Unidas}

En 1992, las Naciones U nidas estaban integradas por 179 naciones legalmente comprometidas a colaborar en la defensa de los principios y objetivos consagrados en la Carta de la organización. Estos consisten en erradicar la guerra, promover los derechos humanos, fomentar el respeto a la justicia y al derecho internacional, promover el progreso social y las relaciones de amistad entre las naciones, y utilizar la organización como foro de la coordinación de los esfuerzos dirigidos al logro de esos fines.

La C arta de las $\mathrm{N}$ aciones U nidas fue acordada en los días siguientes de la Segunda Guerra M undial por los gobiernos de cincuenta países, reunidos en la Conferencia de las $\mathrm{N}$ aciones Unidas sobre O rganización Internacional, celebrada en 1945. La Carta se redactó sobre la base de las propuestas elaboradas por los representantes de C hina, Francia, la U nión Soviética, el Reino U nido y Estados U nidos. Su aprobación y firma tuvo lugar el 26 de junio de 1945.

*EI presente artículo es una adaptación de B asic Facts A bout the $U$ nited $N$ ations (Naciones U nidas 1992) 
Las Naciones U nidas han proporcionado abrigo y ayuda a millones de perseguidos y refugiados de guerra, La organización ha servido de catalizador de la transición protagonizada por 100 millones de personas desde la administración colonial hacia la independencia y la soberanía. Asimismo, la ONU ha realizado numerosas operaciones de mantenimiento de la paz, dirigidas a poner fin a las hostilidades y a colaborar en la resolución de los conflictos. La ONU ha contribuido igualmente al desarrollo y codificación del derecho internacional y a la erradicación de la viruela de la faz del planeta. En sus cinco decenios de existencia, la organización ha promulgado unos 70 instrumentos legales diseñados para promover o imponer el respeto a los derechos humanos, coadyuvando de este modo al vuelco histórico de las expectativas de libertad de los pueblos del mundo.

\section{Miembros}

En la Carta se indica que podrán ser $\mathrm{M}$ iembros de las $\mathrm{N}$ aciones U nidas todos los Estados amantes de la paz que acepten las obligaciones consignadas en el documento y que, a juicio de la 0 rganización, estén capacitados para cumplir dichas obligaciones y se hallen dispuestos a hacerlo. La A samblea General, a propuesta del Consejo de Seguridad, resuelve sobre la admisión de nuevos Estados como M iembros de la O rganización. La C arta también dispone la suspensión o expulsión de los miembros por violación de los principios de la Carta, pero tales acciones no han tenido lugar.

\section{Idiomas oficiales}

De acuerdo con la Carta de las Naciones U nidas, los idiomas oficiales de la O rganización son el español, el inglés, el francés, el ruso y el chino. Posteriormente se ha incluido el árabe entre las lenguas oficiales del Consejo de Seguridad, la Asamblea General y el Consejo E conómico y Social.

\section{Estructura}

L as $\mathrm{N}$ aciones U nidas poseen una estructura compleja, compuesta por seis órganos centrales y un gran número de programas, agencias, comisiones y otros órganos subsidiarios. Si bien los órganos subsidiarios tienen un estatuto jurídico (algunos son autónomos, otros dependen directamente de la ONU, etcétera) y unos objetivos y esferas de competencia diferentes, el sistema se caracteriza por un nivel elevado de cooperación. En la Figura 23.3 se ilustran esquemáticamente la estructura del sistema y algunos de los vínculos existentes entre los distintos órganos. V éase más información en Basic Facts A bout the U nited N ations (1992).

\section{La Corte Internacional de Justicia}

La Corte Internacional de Justicia es el principal órgano judicial de la O NU. Todos los Estados de la O NU son, de pleno derecho, partes en el Estatuto de la Corte Internacional de Justicia. Los demás Estados pueden ser parte en dicho Estatuto en las condiciones que la Asamblea General determine a propuesta del Consejo de Seguridad. Además, el Consejo de Seguridad puede proponer que un determinado litigio se someta a la consideración de la Corte. U nicamente los Estados pueden ser parte en los litigios que se substancian en la Corte Internacional de Justicia, lo que priva a las personas físicas de legitimidad procesal. Asimismo, tanto el Consejo de Seguridad como la Asamblea General pueden solicitar de la Corte Internacional de Justicia que emita una opinión consultiva sobre cualquier cuestión jurídica. Además, tanto los otros órganos de la O NU, como sus agencias especializadas, previo acuerdo de la A samblea General, pueden solicitar la emisión de opiniones consultivas sobre cuestiones jurídicas subsumibles en sus respectivos ámbitos de competencias; así, por ejemplo, la Organización Internacional del Trabajo puede recabar estas opiniones consultivas en relación con las normas laborales internacionales.

Las competencias de la Corte Internacional de Justicia comprenden la totalidad de las materias indicadas en la Carta de la ONU y en los tratados y convenios vigentes, así como el resto de las cuestiones que los Estados sometan a su consideración. En la resolución de los litigios, la C orte no está constreñida a basarse estrictamente en los principios jurídicos consagrados en los tratados y convenios, pudiendo, por el contrario, recurrir a la totalidad del ordenamiento jurídico internacional, incluido el derecho consuetudinario.

\section{La Asamblea G eneral}

La A samblea G eneral es el principal órgano de deliberación de la ONU y está integrada por los representantes de todos los Estados miembros, cada uno de los cuales dispone de un voto. Las decisiones de la A samblea G eneral en cuestiones importantes - como las relativas al mantenimiento de la paz y la seguridad internacionales, la admisión de nuevos M iembros en las N aciones U nidas y las cuestiones presupuestarias- se adoptan por una mayoría de dos tercios de los votos emitidos. En las demás cuestiones, las resoluciones se adoptan por mayoría simple de los votos emitidos.

Entre los poderes de la Asamblea General figura el de estudio y formulación de recomendaciones relativas a los principios de cooperación en el mantenimiento de la paz y la seguridad internacionales, incluidos el desarme y la regulación de los armamentos. Asimismo, la Asamblea General auspicia estudios y formula recomendaciones orientados a fomentar la cooperación internacional en el plano político, el desarrollo y codificación del derecho internacional; la efectividad de los derechos humanos y de las libertades fundamentales de todos: y la cooperación internacional en materias de carácter económico, social, cultural, educativo y sanitario. Además, la Asamblea General recibe y delibera sobre los informes elaborados por el Consejo de Seguridad y otros órganos de la O NU; examina y aprueba el presupuesto de la O rganización, y distribuye los gastos de la misma entre los Estados miembros; y elige a los miembros no permanentes del Consejo de Seguridad, a los miembros del Consejo E conómico y Social, y a los miembros electivos del Consejo de Administración Fiduciaria. Asimismo, la Asamblea General, conjuntamente con el Consejo de Seguridad, elige a los Jueces integrantes de la Corte Internacional de Justicia y, a propuesta del C onsejo de Seguridad, nombra al Secretario General.

Al iniciarse cada período anual de sesiones ordinarias, la Asamblea General celebra un debate general en el que los Estados miembros expresan sus puntos de vista sobre una gran variedad de cuestiones de interés internacional. Debido al elevado número de asuntos que la Asamblea General debe examinar (por ejemplo, el orden del día del período de sesiones de 1992 constaba de 150 puntos), la Asamblea distribuye la mayor parte de los asuntos entre los siete comités principales siguientes:

- Primer Comité (desarme y cuestiones afines de seguridad internacional).

- Comité Político Especial.

- Segundo C omité (asuntos económicos y financieros).

- Tercer Comité (asuntos sociales, humanitarios y culturales).

- Cuarto Comité (descolonización).

- Q uinto C omité (asuntos administrativos y presupuestarios)

- Sexto Comité (asuntos jurídicos).

\section{Consejo E conómico y Social (ECOSOC)}

EI Consejo Económico y Social se creó en la Carta de las $\mathrm{N}$ aciones U nidas como órgano principal de la $\mathrm{O}$ rganización para la coordinación de la labor económica y social de la 
Figura 23.3 - En la Carta de las N aciones Unidas se crean seis órganos principales.

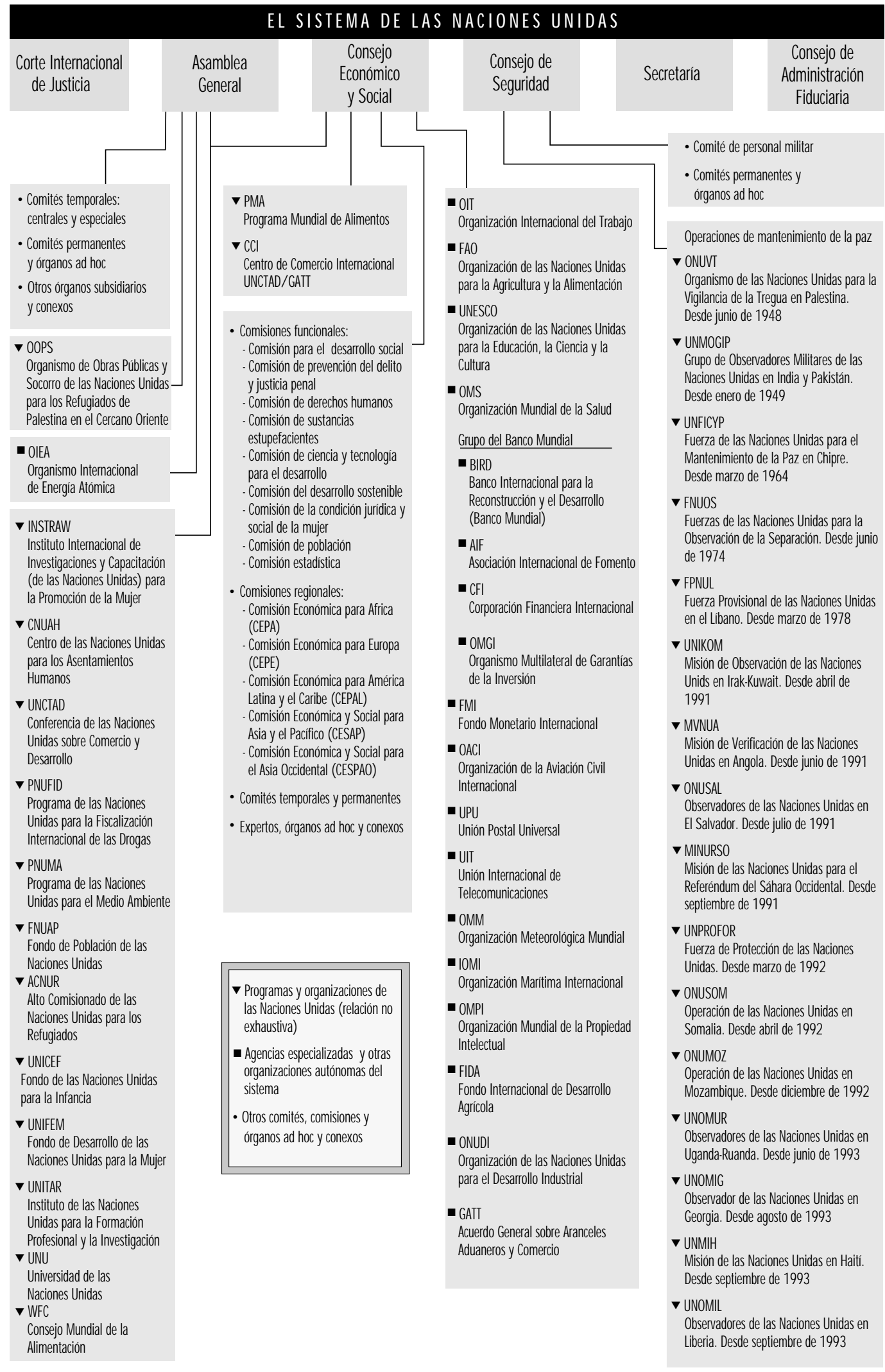




\section{Medios de contacto con las organizaciones de las Naciones Unidas}

Sede de la OMS:

150, cours Albert Thomas,

F-69372 Lyon Cedex 08, Francia

Tfno.: $+33-72738485$

Fax: $+33-72738575$

Télex: 380023

Sede: 20 avenue Appia,

211 G eneva 27, Switzerland

Tfno.: +41-22-7912111

Fax: $+41-22-7910746$

Télex: 845415416

Cable: UN ISAN TE G EN EVE

Sede de IARC:

150, cours Albert Thomas,

F-69372 Lyon C edex 08, Francia

Tfno.: +33-7 2738485

Fax: $+33-72738575$

Télex: 380023

Sede del PN UMA:

P.O. Box 30552 ,

$\mathrm{N}$ airobi, Kenya

Tfno.: 2-230800

Fax: $2-226831$

Télex: 22068 KN EPKE

C able: UN ITERRA N AIRO BI

Sede de la 0 IEA

Viena International C entre,

W agramerstrasse 5 ,

P.O. Box 100

A-1 400 Vienna, Austria

Tfno.: +43-1-23 60

Fax: +43-1-23 45 64

Télex: 112645 ATO M A

Cable: IN ATO M VIEN N A
Sede del

UN DP:

1 United $\mathrm{N}$ ations Plaza,

$\mathrm{N}$ ew York,

NY 10017

Estados Unidos

Tfno.: +1-212-9065000

Fax: $+1-212-9065778$

Sede de la

FAO :

Viale delle Terme de Caracalla,

$1-00100$ Roma, Italia

Tfno.: +39-6-52251

Fax: +39-6-522 53152

Télex: $610181 \mathrm{FAO}$ ।

Cable: FO O DAG RI RO ME

Sede de la

$O \mathrm{M} \mathrm{I}$ :

4 Albert Embankment,

Londres SE1 7SR,

United Kingdom

Tfno.: +44-171-7357611

Fax: +44-171-5873210

Télex: 23588

Sede de la

UN CTAD:

Palais des $\mathrm{N}$ ations,

$\mathrm{CH} 1211$

G inebra 10

Suiza

Tfno.: +41-22-97 1234

Fax: +41-22-907 0057

C able: UN ATIO N S G EN EVE
O rganización y de sus agencias e instituciones especializadas. El Consejo Económico y Social es el principal foro, tanto del debate de las cuestiones económicas y sociales de naturaleza global 0 multidisciplinaria, como de la formulación de propuestas políticas en esas materias; asimismo, el Consejo se effuerza por promover el respeto de los derechos humanos y las libertades fundamentales de todos. El Consejo Económico y Social puede auspiciar estudios, elaborar informes y formular recomendaciones sobre cuestiones internacionales de naturaleza económica, social, cultural, educativa, sanitaria y similares; organizar conferencias internacionales y elevar propuestas de convenios a la A samblea G eneral. Corresponden igualmente al Consejo Económico y Social la negociación de acuerdos con las agencias especializadas en los que se definen sus relaciones con la ONU y la coordinación de sus actividades, así como la celebración de consultas con las O NG sobre las materias de interés para el Consejo.

\section{Organos subsidiarios}

La estructura funcional del Consejo está constituida por diversas comisiones ejecutivas y regionales, seis comités permanentes (como el Comité para las O rganizaciones no Gubernamentales y el Comité para las Sociedades Transnacionales) y diversos grupos permanentes de expertos en cuestiones como el control y prevención de la delincuencia, la planificación del desarrollo y el transporte de mercancías peligrosas.

\section{Relaciones con las organizaciones no gubernamentales}

M ás de 900 O N G prestan servicios de asesoramiento al Consejo, con diversos niveles de participación. Estas ONG pueden enviar observadores a las reuniones públicas del consejo y sus órganos subsidiarios, y elaborar informes escritos sobre la labor de tales órganos. Las O NG también celebran consultas con la Secretaría de la O NU sobre cuestiones de interés común.

\section{El Consejo de Seguridad}

Según la C arta de la O NU, corresponde al Consejo de Seguridad la responsabilidad primordial de mantener la paz y la seguridad internacionales. M ientras que los demás órganos de la ONU formulan recomendaciones a los gobiernos, el Consejo de Seguridad ostenta la facultad exclusiva de adoptar acuerdos que, de conformidad con la Carta de la ONU, son de obligado cumplimiento para los Estados miembros.

\section{Secretaría}

La Secretaría está constituida por un cuerpo internacional de funcionarios que prestan sus servicios, tanto en la sede de la organización, como en diversas comisiones de servicio. Este personal 
presta servicios a otros órganos de la ONU y gestiona los programas y aplica las políticas formulados por aquéllos. EI Secretario General, que dirige la Secretaría, es elegido para un mandato de cinco años por la Asamblea General a propuesta del Consejo de Seguridad.

\section{Consejo de Administración Fiduciaria}

En la Carta de las Naciones U nidas se crea un sistema de administración fiduciaria internacional y se constituye el Consejo de Administración Fiduciaria como uno de los órganos principales de la 0 rganización, investido de la función de supervisar la administración de los territorios fideicomitidos en el marco del sistema de la administración fiduciaria. Los objetivos principales del sistema consisten en promover el progreso de los habitantes de los territorios sujetos a fideicomiso y su transición gradual hacia la autonomía o la independencia.

\section{La función del sistema de las Naciones Unidas en la salud y seguridad en el trabajo}

Si bien la mejora de las condiciones de trabajo y del medio ambiente se suele enmarcar en la política nacional de promoción del desarrollo económico y el progreso social, de conformidad con los objetivos y prioridades nacionales, se precisa un cierto grado de armonización internacional que asegure en todas partes un medio ambiente de trabajo compatible con la salud y el bienestar de los trabajadores; y es preciso ayudar a los Estados miembros a lograr este objetivo. Esta es, fundamentalmente, la función de la O NU en este campo.

N umerosas agencias y organizaciones del sistema de la O NU contribuyen a mejorar el medio ambiente y las condiciones de trabajo. La O rganización Internacional del Trabajo (0IT) está investida del mandato constitucional de mejorar el medio ambiente y las condiciones de trabajo para humanizarlo. La estructura tripartita de esta organización, que garantiza que las normas internacionales se reflejen directamente en la legislación, la política y la praxis nacional, se examina en profundidad en otro artículo del presente capítulo.

La O rganización M undial de la Salud (OMS) se interesa por la salud laboral por mandato de su documento constitucional, en el que se define a la OMS como el "órgano rector y coordinador de la labor sanitaria internacional" y se establece que las funciones de la OMS comprenden la "promoción de...económico y las condiciones de trabajo y otros aspectos de la higiene ambiental". Diversos acuerdos de la Asamblea M undial de la Salud y del Consejo Ejecutivo de la OMS han impuesto a la organización nuevos objetivos. El programa de salud laboral de la OMS se orienta a promover el conocimiento y el control de los problemas de salud de los trabajadores, incluidas las enfermedades profesionales y las relacionadas con el trabajo, y a colaborar con las naciones en el desarrollo de programas de asistencia sanitaria a los trabajadores, especialmente a los más desasistidos. La OMS, en colaboración con la OIT, el PNUMA y otras organizaciones, ofrece cooperación técnica a los Estados miembros, dicta pautas, realiza estudios de campo, imparte formación profesional y promueve la capacitación del personal. La OMS ha establecido la Red Global de Epidemiología Ambiental - GEENET - integrada por personas e instituciones de todo el mundo profesionalmente dedicadas a la investigación y formación en el campo de la epidemiología ambiental y del trabajo. Se ha creado la Agencia Internacional para la Investigación sobre el Cáncer (IARC), como centro independiente de investigación que, sin embargo, se enmarca en el sistema de la O M S. En los estatutos de la Agencia se le asigna la misión de "planificar, promover y desarrollar la investigación de todos los aspectos de la producción, el tratamiento y la prevención del cáncer". D esde el inicio de su actividad, la Agencia se ha dedicado a estudiar los factores cancerígenos presentes en el medio ambiente humano, en la creencia de que la detección de un agente cancerígeno constituye, necesariamente, el primer paso en la eliminación o la reducción de la presencia en el medio ambiente del agente causal, con el objeto de prevenir el cáncer que aquél podría haber provocado. Los trabajos de investigación de la A gencia se pueden clasificar en dos grandes categorías: la investigación epidemiológica y la de laboratorio, si bien existe una considerable concomitancia entre ambas categorías en los proyectos de investigación que se llevan a cabo.

A demás de las dos organizaciones citadas, que centran su actividad en el mundo del trabajo y en la salud, respectivamente, varias agencias de la ONU incluyen las cuestiones de salud y seguridad en su ámbito de actividad especializada o sectorial.

El Programa de las Naciones U nidas para el M edio Ambiente (PNUMA) tiene como objetivo la conservación y mejora del medio ambiente - incluido el medio ambiente de trabajo- en beneficio de la generación actual y de las futuras. El Programa realiza, esencialmente, una labor de coordinación y canalización en el marco de la ONU. El organismo desempeña estas funciones mediante la coordinación de programas y el apoyo que el Fondo del Medio Ambiente presta a las actividades. Además de este mandato general, las funciones específicas del PNUMA en relación con el medio ambiente dimanan de las Recomendaciones números 81 y 83 de la Conferencia de las $\mathrm{N}$ aciones Unidas sobre el M edio Ambiente Humano y de los acuerdos del Consejo de Administración del PNUMA por los que se requiere al Director Ejecutivo que integre plenamente los principios y objetivos relativos a la mejora del medio ambiente de trabajo en el contexto del programa ambiental. EI PNUMA está igualmente comprometido a colaborar con las organizaciones empresariales y sindicales pertinentes en el desarrollo de un programa de actuación en escala del sistema sobre el medio ambiente vital y de trabajo de los trabajadores, en cooperación con las agencias correspondientes de la O NU. Por ejemplo, el PNUM A colabora con la OM S y la OIT en el Programa Internacional de Seguridad de las Sustancias Q uímicas.

EI PNUM A administra el Registro internacional de productos químicos potencialmente tóxicos (RIPQ PT ), que se esfuerza por hacer llegar el patrimonio mundial de conocimientos químicos a quienes necesitan conocerlos. $L$ a serie de acuerdos suscritos por el PNUMA en materia ambiental goza, asimismo, de un predicamento y una influencia internacional crecientes (que se han hecho sentir, por ejemplo, en el histórico Convenio de Viena y en el Protocolo de Montreal sobre la protección de la capa de ozono).

EI O rganismo I nternacional de E nergía A tómica (O IEA) se ocupa de los peligros derivados de la radiación ionizante producida durante el ciclo de la combustión nuclear. EI OIEA impulsa y orienta el desarrollo de las aplicaciones pacíficas de la energía atómica, dicta normas de seguridad nuclear y protección del medio ambiente, brinda cooperación técnica a los países miembros y promueve el intercambio de información técnica y científica relativa a la energía nuclear. La actividad del 0 rganismo en el área de la protección de los trabajadores contra la radiación consiste en la elaboración de las normas mencionadas; en la preparación de guías, códigos y manuales de seguridad; en la celebración de actividades científicas destinadas al intercambio de información o a la preparación de manuales o de guías técnicas; en la organización de cursos de formación, seminarios de campo y viajes de estudio; en la difusión de los conocimientos técnicos entre los Estados miembros en vías de desarrollo mediante la concesión de becas y contratos de investigación; y en la prestación de ayuda a los Estados miembros en vías de desarrollo para la ejecución de programas de protección contra la radiación, mediante la oferta de asistencia técnica y de los 
servicios de especialistas, el envío de equipos de expertos y el asesoramiento en materia de derecho nuclear.

EI P rograma de las $N$ aciones U nidas para el D esarrollo (PNUD) y el Banco M undial han incluido en diversos acuerdos de ayuda al desarrollo disposiciones relativas a la seguridad en el trabajo. EI PNUD participa en un gran número de proyectos concebidos para ayudar a los países en vías de desarrollo a consolidar sus economías emergentes y elevar sus niveles de vida. Un equipo internacional integrado por varios miles de expertos trabaja permanentemente en los proyectos. Varios de estos proyectos se orientan a mejorar las normas de salud y seguridad en el trabajo en la industria y otros sectores económicos, cuya aplicación está encomendada a la O IT y la O M S. EI alcance de estos proyectos de campo varía desde el asesoramiento puntual hasta la ejecución de importantes programas plurianuales de asistencia destinados a la creación de institutos de salud y seguridad en el trabajo perfectamente dotados para impartir formación, realizar investigación de campo y prestar asistencia directa a los servicios de empleo.

La Organización M arítima Internacional (OMI) se ocupa de la seguridad de los trabajadores embarcados. La O M I constituye para los gobiernos y organizaciones interesados un foro de intercambio de información y de cooperación en la solución de los problemas técnicos, jurídicos y generales de la navegación marítima y la prevención de la contaminación marina causada por las embarcaciones. La O M I ha elaborado diversos convenios y recomendaciones que los gobiernos han adoptado y aplicado. Entre estos documentos figuran varios convenios internacionales sobre la seguridad de la vida humana en el mar, la prevención de la contaminación marina causada por las embarcaciones, la formación y certificación de los marinos, la prevención de colisiones en el mar, diversos intrumentos sobre responsabilidades e indemnizaciones, y muchos otros. La OM I ha adoptado igualmente varios cientos de recomendaciones sobre materias como el transporte marítimo de mercancías peligrosas, la señalización marítima, la seguridad de los pescadores y los barcos pesqueros, y la seguridad de los barcos mercantes de propulsión nuclear.

La Organización de las Naciones U nidas para la Agricultura y la Alimentación (FAO) se interesa por la protección de los trabajadores agrícolas contra los peligros derivados del uso de pesticidas y de herramienta y maquinaria agrícola. Diversas actividades de la FAO se relacionan directa 0 indirectamente con la salud y seguridad en el trabajo y con la ergonomía en el trabajo en la agricultura, la pesca y la silvicultura. En el sector pesquero existe una colaboración, en el nivel de secretarías, entre la FAO, la OIT y la OMI, en el marco del Subcomité de Seguridad en las E mbarcaciones Pesqueras de la O M I; además, la FAO participa intensamente en la labor del Subcomité de Normas de Formación y Supervisión de la O M I. Asimismo, la FAO colabora con la OIT en relación con las condiciones de trabajo imperantes en el sector pesquero. En la silvicultura, el Comité de FAO / OIT / ECE de Técnicas de Trabajo Forestal y Formación de los Trabajadores Forestales coordina el trabajo de las organizaciones en el ámbito de la salud y la seguridad. Tanto el trabajo de campo como las publicaciones dedicadas a estas cuestiones se ocupan de aspectos como la seguridad en la tala y en la industria, y el estrés por calor en el trabajo forestal.

En el ámbito de la agricultura, algunas enfermedades del ganado que tienen graves repercusiones económicas constituyen, además, un peligro para las personas que trabajan con el ganado y manipulan productos de origen animal. Ejemplos de estas patologías son la brucelosis, la tuberculosis, la leptospirosis, el ántrax y la rabia). Las actividades de la FAO relacionadas con estas enfermedades se coordinan estrechamente con la O M S a través de diversos comités conjuntos. La FAO se ocupa igualmente de la armonización de los requisitos para el registro de los pesticidas y de la evaluación de sus residuos en los alimentos y en el medio ambiente. Por lo que respecta al uso de la energía atómica en los productos alimenticios y en la agricultura, se desarrollan diversos programas en coordinación con el OIEA para ayudar a los científicos de los países en vías de desarrollo a utilizar de forma segura y eficaz las técnicas de aplicación de isótopos (como el empleo de sustratos enzimáticos marcados en la detección de la exposición profesional a los insecticidas).

La O rganización de las Naciones U nidas para el D esarrollo Industrial (ONUDI) se esfuerza por acelerar el crecimiento industrial de los países en vías de desarrollo. El organismo se ocupa de los riesgos para la salud y seguridad en el trabajo, del medio ambiente y de la gestión de los residuos peligrosos en el contexto del proceso de industrialización.

Las Comisiones Económicas regionales de la ONU contribuyen a la eficacia y la armonización de las actividades que se realizan en sus respectivos ámbitos geográficos. .

$\mathrm{La}$ Conferencia de las Naciones U nidas sobre Comercio y Desarrollo (UNCTAD) se ocupa de los aspectos profesionales de la transferencia internacional de bienes, servicios y tecnologías.

\section{O RGANIZACION INTERNACIONAL DEL TRABAJO}

Georg R. Kliesch La OIT es uno de los organismos especializados de las $N$ aciones U nidas y es la más antigua de las organizaciones internacionales que integran el sistema de la O NU. La organización se fundó en 1919, en el marco de la Conferencia de Paz de Versalles, a raíz de la Primera Guerra M undial.

\section{Fundación de la OIT}

La OIT es un producto del pensamiento social del siglo $X I X$. Economistas y sociólogos adquirieron una conciencia creciente de la situación intolerable de los trabajadores al comienzo de la revolución industrial. Los reformadores sociales pensaban que cualquier nación o industria que adoptase medidas para mejorar las condiciones de trabajo sufriría un aumento de los costes de mano de obra que la colocarían en una situación desventajosa respecto a otros países o sectores. Esto les impulsó a realizar una labor paciente de persuasión de las potencias europeas para que concluyesen acuerdos internacionales para la mejora de las condiciones de trabajo y la reducción de las horas de trabajo. A partir de 1890, se celebraron tres conferencias internacionales sobre estas cuestiones. La primera se reunió ese año en Berlín, en respuesta a la convocatoria conjunta del Emperador de Alemania y del Papa; la segunda conferencia tuvo lugar en Bruselas, en 1897, bajo los auspicios de las autoridades belgas. En la tercera de dichas conferencias, celebrada en la ciudad suiza de Berna en 1906, se adoptaron por primera vez dos acuerdos internacionales relativos, respectivamente, al uso de fósforo blanco en la fabricación de cerillas y a la prohibición del trabajo nocturno de la mujer. Como la Primera Guerra M undial había interrumpido el proceso de codificación internacional de las condiciones de trabajo, la Conferencia de Paz de Versalles, movida por la voluntad de erradicar las causas de futuras guerras, asumió los objetivos que habían inspirado los esfuerzos de la preguerra y estableció una Comisión de Legislación Laboral Internacional. La propuesta formulada por esta Comisión para la creación de una normativa internacional de protección de los trabajadores se convirtió en la Parte X III del Tratado de Versalles y ha sido hasta nuestros días la carta constitucional de la O IT.

C ENCICLOPEDIA DE SALUDY SEGURIDADENEL TRABAJO 
La primera Conferencia Internacional del Trabajo se celebró en Washington DC en octubre de 1919, y la Secretaría Permanente de la O rganización, la O ficina Internacional del Trabajo, estableció su sede en la ciudad suiza de G inebra.

\section{Constitución de la Organización I nternacional del Trabajo}

La paz mundial permanente, la justicia y la humanidad, eran $-y$ son- los objetivos que alientan a la O rganización Internacional del Trabajo y que se recogen en el Preámbulo a la Constitución de la organización, que es del tenor siguiente:

Por cuanto, una paz universal y duradera sólo es posible si

se basa en la justicia social;

$Y$, por cuanto, existen condiciones de trabajo que suponen una situación tal de injusticia, de privación y de penuria para un gran número de personas que produce un desasosiego tal, que hace peligrar la paz y la armonía en el mundo; y se necesita urgentemente mejorar esas condiciones, por ejemplo, mediante:

- la regulación de las horas de trabajo, incluida la fijación de una jornada y una semana laboral máxima,

- la regulación de la oferta de mano de obra,

- la prevención del desempleo,

- el pago de un salario de subsistencia adecuado,

- la protección del trabajador contra las enfermedades y lesiones relacionadas con el trabajo,

- la protección de los niños, los jóvenes y las mujeres,

- las prestaciones de vejez y por accidente,

- la protección de los trabajadores empleados en países extranjeros,

- el reconocimiento del principio de igualdad de remuneración por el mismo trabajo,

- el reconocimiento del principio de libertad de asociación,

- la organización de la formación técnica y profesional y la adopción de otras medidas.

Por cuanto, asimismo, la ausencia de unas condiciones de trabajo humanas en cualquier país constituye un impedimento para otras naciones deseosas de mejorar sus propias condiciones

Las Altas Partes Contratantes, movidas por un sentimiento de justicia y de humanidad, y por el deseo de lograr una paz permanente en el mundo, y con el fin de lograr los objetivos formulados en el presente Preámbulo, acuerdan la siguiente Constitución de la O rganización Internacional del Trabajo ..."

Los propósitos y objetivos de la O rganización Internacional del Trabajo, en su versión moderna, se han plasmado en la Declaración de Filadelfia, adoptada en la Conferencia Internacional del Trabajo celebrada en esa ciudad norteamericana en 1944. En la Declaración, que se ha convertido en un Anexo a la Constitución de la OIT, se proclama el derecho de todo ser humano "a perseguir, tanto su bienestar material, como su desarrollo espiritual, en unas condiciones de libertad y dignidad, de seguridad económica y de igualdad de oportunidades". En el documento se afirma igualmente que "la pobreza en cualquier lugar constituye un peligro para la prosperidad en todas partes".

La función de la OIT, proclamada en el artículo 1 de la Constitución de la O rganización, consiste en promover los objetivos enunciados en su Preámbulo y en la D eclaración de Filadelfia.

\section{Estructura de la Organización Internacional del Trabajo}

La O rganización Internacional del Trabajo está integrada por 173 Estados. Todo Estado miembro de las Naciones Unidas puede acceder a la OIT por el procedimiento de comunicar al Director $G$ eneral de esta organización su aceptación formal de las obligaciones contenidas en la Constitución. Los Estados no pertenecientes a la ONU pueden, no obstante, incorporarse a la OIT mediante acuerdo tomado por mayoría de votos en la Conferencia Internacional del Trabajo. Por ejemplo, Suiza, que no pertenece a la ONU, es miembro de la O IT (artículo 1 de la Constitución). La estructura de la representación de los Estados miembros de la OIT no tiene paralelo en el resto del sistema de la ONU. En efecto, tanto en la propia O NU como en sus organismos especializados, la representación de los Estados corresponde a miembros del gobierno, como los ministros, sus delegados y otros representantes autorizados. En cambio, en la 0 IT, los agentes sociales interesados forman parte de la representación de los Estados miembros. Esta representación está compuesta por delegados de los gobiernos y de los empresarios y trabajadores de cada uno de los miembros (artículo 3 de la Constitución). Este es, fundamentalmente, el esquema tripartito de la OIT.

La composición de la O rganización Internacional del Trabajo es la siguiente:

- la Conferencia Internacional del Trabajo, que se celebra anualmente con la participación de representantes de todos los miembros

- el Consejo de Administración, compuesto por 28 representantes de los gobiernos y por otros 28 representantes, por partes iguales, de los empresarios y los trabajadores

- La Oficina Internacional del Trabajo, que es la secretaría permanente de la OIT y depende de su Consejo de Administración.

La Conferencia Internacional del Trabajo - conocida también como Parlamento $M$ undial del Trabajo- se celebra regularmente en junio de cada año, con la participación de unos 2.000 delegados y asesores. En el orden del día de la Conferencia se incluyen la adopción de acuerdos internacionales (los Convenios y Recomendaciones de la OIT), el estudio de problemas laborales específicos, con el objeto de diseñar las futuras políticas; la adopción de R esoluciones inspiradoras de la actuación de los Estados miembros y la formulación de instrucciones al Director G eneral de la O rganización para su ejecución por parte de la Oficina; un debate general e intercambio de información; y, cada dos años, la aprobación de un programa bienal y del presupuesto de la 0 ficina I nternacional del Trabajo.

El Consejo de Administración es el nexo de unión entre la Conferencia Internacional del Trabajo, en la que participan todos los Estados miembros, y la O ficina Internacional del Trabajo. En sus tres reuniones anuales, el Consejo de Administración ejerce el control de la O ficina Internacional del Trabajo mediante el examen de la labor realizada, la formulación de instrucciones al Director $\mathrm{G}$ eneral de la $\mathrm{O}$ ficina, la aprobación de los documentos creados por la O ficina, como los Códigos de Práctica, la supervisión y dirección de los asuntos financieros, y la elaboración del orden del día de las futuras Conferencias Internacionales del Trabajo. Los miembros del Consejo de Administración son elegidos para un mandato de tres años por los representantes de los tres estamentos que componen la C onferencia: gobiernos, empresas y trabajadores. Diez representantes de los gobiernos de los países más industrializados son miembros permanentes del Consejo de Administración.

\section{Estructura tripartita}

Los mecanismos de toma de decisiones de la OIT poseen una estructura única. En efecto, todas las decisiones de la representación de los Estados miembros son adoptadas por los delegados de 
los tres grupos representados, concretamente, de los gobiernos, de las empresas y de los trabajadores de cada Estado miembro. Las decisiones relativas a los aspectos sustantivos de la labor de los Comités de la Conferencia respecto a los Convenios y Recomendaciones Internacionales, de la Reunión de Expertos en materia de Códigos de Práctica, y de los Comités A sesores respecto a los criterios relativos a las futuras condiciones de trabajo, son adoptadas por los miembros de los respectivos Comités, compuestos, por partes iguales, por los representantes de los gobiernos, las empresas y los trabajadores.

Todas las decisiones de naturaleza política, financiera y estructural, se adoptan en la Conferencia Internacional del Trabajo o en el Consejo de Administración, en los que los representantes de los gobiernos (dos por cada Estado miembro de la Conferencia) ostentan el $50 \%$ de los votos, los representantes de las empresas emiten el $25 \%$ de los sufragios, y los representantes de los trabajadores (uno por cada grupo perteneciente a cada Estado miembro de la Conferencia) cuenta con el $25 \%$ restante. Unicamente los gobiernos contribuyen financieramente a la O rganización, y los dos estamentos no gubernamentales no aportan contribuciones. Por esta razón, el Comité Financiero está integrado exclusivamente por los gobiernos.

\section{Convenios}

Entre 1919 y 1995, la Conferencia Internacional del Trabajo ha adoptado 176 convenios y 183 recomendaciones.

En setenta y cuatro convenios se regulan las condiciones de trabajo; de ellos, 47 se refieren a las condiciones generales de trabajo, y 27 a la salud y la seguridad en su sentido estricto.

En los convenios relativos a las condiciones generales de trabajo se regulan materias como las horas de trabajo, la edad laboral mínima (trabajo infantil), el trabajo nocturno, la exploración médica de los trabajadores, la protección de la maternidad, el trabajo y las obligaciones familiares, y el trabajo a tiempo parcial. También interesan a la salud y seguridad en el trabajo los convenios de la OIT relativos a la erradicación de la discriminación de los trabajadores por diversas causas (raza, sexo, discapacidad, etc.), mediante la protección contra el despido improcedente y la concesión de indemnizaciones en caso de lesión o enfermedad profesional.

De los 27 convenios relativos a la salud y seguridad, dieciocho se han adoptado con posterioridad a 1960 (cuando el proceso de descolonización dió lugar a un gran incremento de los miembros de la O IT ) y únicamente nueve se aprobaron entre 1919 y 1959. EI más difundido de este último grupo de instrumentos es el Convenio sobre la inspección del trabajo, 1947 ( $n$ - 81), que ha sido ratificado por más de 100 Estados miembros de la 0 IT. Un convenio similar, aplicable a la agricultura, ha sido ratificado por 33 países.

La ratificación de un documento por un elevado número de países puede denotar la determinación de mejorar las condiciones de trabajo. Por ejemplo, Finlandia, Noruega y Suecia, con un meritorio historial en materia de salud y seguridad en el trabajo y que constituyen el referente obligado en la materia, han ratificado casi todos los convenios adoptados en este campo a partir de 1960 .

Los convenios sobre la inspección de trabajo se han visto posteriormente complementados por otras dos normas internacionales fundamentales: el Convenio sobre seguridad y salud de los trabajadores, 1981 ( $n$ ㅇ 155) y el Convenio sobre los servicios de salud en el trabajo, 1985 ( $n$ - 161).

En el C onvenio sobre seguridad y salud laboral se establece el esquema de un sistema nacional de salud y seguridad que debe servir de modelo a las legislaciones nacionales en la materia. A sí, la directiva marco de la Unión Europea sobre la salud y seguridad se inspira en la estructura y el contenido del convenio de la OIT. Los quince Estados miembros de la Unión Europea deben incorporar la directiva marco de la UE a su legislación interna.

En el Convenio sobre los servicios de salud en el trabajo se aborda el sistema operativo de aplicación dentro de la empresa de la legislación de salud y seguridad en el trabajo.

Se han adoptado varios convenios relativos a diferentes áreas de actividad económica y a las sustancias peligrosas. M erecen citarse el Convenio sobre seguridad y salud en las minas, 1995 ( $n$ - 176); el Convenio sobre seguridad y salud en la construcción, 1988 (no 167); el Convenio sobre seguridad laboral (trabajos portuarios), 1979 ( $n$ - 152); el Convenio sobre la cerusa (pintura), 1921 (no 13); el Convenio sobre el benceno, 1971 (136); el Convenio sobre asbestos, 1986 (no 162); el Convenio sobre productos químicos, 1990 (no 170); y el Convenio sobre la prevención de los accidentes de trabajo mayores, 1993 (no 1974).

Se asocian a los convenios anteriormente citados el Convenio sobre el medio ambiente de trabajo (protección de los trabajadores frente a los riesgos laborales en el ambiente de trabajo debido a la contaminación del aire, ruido y vibraciones), 1977 ( $n$ - 148); el Convenio sobre el Cáncer profesional, 1974 ( $n$ - 139) y la relación de enfermedades profesionales que forma parte del Convenio sobre las prestaciones por decisiones en el trabajo, 1964 (no 121). La relación, que se actualizó por última vez en la Conferencia de 1980, es objeto de examen en el capítulo titulado Aspectos de la indemnización de los trabajadores.

O tros convenios relativos a cuestiones de salud y seguridad son el Convenio sobre el transporte de cargas, 1929 ( $n$ - 27); el Convenio sobre el peso máximo, 1967 (no 127); el Convenio sobre la protección frente a radiaciones, 1960 (no 115); el Convenio sobre la protección de maquinaria, 1963 (no 119); y el Convenio sobre la higiene (comercio y oficinas), 1964 ( $n \div$ 120).

En un principio, la OIT promulgaba recomendaciones en lugar de convenios, destacando las relativas a la prevención del ántrax y del envenenamiento por plomo y por fósforo blanco. En cambio, en tiempos recientes, las recomendaciones se han adoptado a modo de complementos de los convenios, en los que se regula detalladamente la aplicación de éstos.

\section{Contenido de los Convenios sobre salud y seguridad}

Tanto el contenido como la estructura de los convenios sobre salud y seguridad se ajustan a un modelo común:

\section{- ámbito y definiciones;}

- obligaciones de los gobiernos;

- consultas con las organizaciones sindicales y empresariales;

- obligaciones de las empresas;

- obligaciones de los trabajadores;

- derechos de los trabajadores;

- inspección;

- sanciones;

- disposiciones finales (sobre las condiciones de entrada en vigor, registro, ratificación y denuncia).

En todo convenio se definen las competencias de los gobiernos en la regulación de la materia, se subrayan las obligaciones de las empresas, se especifican la función y los derechos y obligaciones de los trabajadores y de sus organizaciones representativas $\mathrm{y}$, finalmente se adoptan disposiciones relativas a la inspección y a la adopción de medidas contra los infractores de la ley. O bviamente, en el convenio se debe estipular, asimismo, su ámbito de aplicación, incluidas las posibles exenciones y exclusiones. 


\section{Diseño de los Convenios relativos a la salud y seguridad en el trabajo}

\section{Preámbulo}

Cada convenio está encabezado por un preámbulo alusivo a las fechas y al punto del orden del día de la Conferencia Internacional del Trabajo; a otros convenios e instrumentos aplicables en la materia; a los problemas existentes en el área que hayan inducido a la adopción del convenio; a las causas subyacentes en dichos problemas; a la cooperación con otras organizaciones internacionales, como la O MS y el PNU M A; a la configuración del acuerdo internacional en cuestión como convenio o recomendación; y la fecha de adopción e identificación del convenio.

\section{Ambito}

La definición del ámbito del convenio responde a una voluntad de flexibilidad en su aplicación. El principio general es que el convenio ha de aplicarse a todos los trabajadores y sectores económicos. No obstante, para facilitar la ratificación del convenio por la totalidad de los Estados miembros, este principio general suele flexibilizarse en el sentido de admitir su no aplicación total o parcial en diversas áreas de actividad. Los Estados miembros pueden eximir del cumplimiento del convenio a determinados sectores de actividad o a empresas concretas, en el caso de que la aplicación de determinadas disposiciones del documento 0 de la totalidad del mismo pueda plantear problemas específicos de importancia. A veces, se admite también la posibilidad de una aplicación gradual de las disposiciones, en consideración a las condiciones prevalentes en cada país. Estas exclusiones son igualmente una función de los medios disponibles en cada país para la promulgación de nuevas leyes de salud y seguridad en el trabajo. Las exclusiones se subordinan, en general, a la condición de que se apliquen otros procedimientos para asegurar la salud y seguridad en el trabajo y de que la exclusión se consulte con los trabajadores y empresas. En el ámbito del convenio se incluye igualmente la definición de los términos y expresiones utilizados en el texto del mismo, como sectores económicos, trabajadores, lugar de trabajo, empresa, reglamento, representantes de los trabajadores, salud, sustancia química peligrosa, instalación sumamente peligrosa, informe de seguridad, etcétera.

\section{Obligaciones de los gobiernos}

En los convenios sobre salud y seguridad se establece, en primer lugar, la misión de los gobiernos de formular, aplicar y actualizar una política nacional ajustada a los términos del convenio. Las organizaciones empresariales y de trabajadores deben participar en la elaboración de la política y en la definición de sus objetivos. El segundo bloque de disposiciones concierne a la promulgación de leyes y reglamentos de aplicación del articulado del convenio y a la aplicación de los mismos, con la ayuda, incluso, de personal cualificado, así como a la prestación de apoyo al personal de los servicios de inspección y asesoramiento. Según los artículos 19 y 22 de la Constitución de la O IT, los gobiernos están igualmente obligados a informar a la Oficina Internacional del Trabajo, periódicamente y a requerimiento de la misma, sobre la actividad de aplicación del convenio y su recomendación. Estas obligaciones constituyen la base del procedimiento de supervisión establecido por la OIT.

\section{Consulta con las organizaciones empresariales y de trabajadores}

Resulta evidente la importancia de la participación de las personas directamente afectadas por la aplicación de las normas y que sufren las consecuencias de los accidentes. El éxito de la política de salud y seguridad pasa por recabar la opinión y ganar la buena voluntad de los interesados. Por consiguiente, en los convenios se dispone que las autoridades deben consultar con los trabajadores y empresas antes de excluir determinadas instalaciones de la aplicación de las normas legales, respecto a la aplicación gradual de las disposiciones y en la formulación de una política nacional en la materia regulada en el convenio.

\section{Obligaciones de las empresas}

La responsabilidad por la observancia de las normas legales en la empresa recae en los propietarios o en sus representantes. EI derecho de participación legalmente reconocido a los trabajadores no modifica la responsabilidad fundamental de la empresa. Entre las obligaciones que se imponen a las empresas en los convenios figuran las de utilizar unos métodos de trabajo saludables y seguros, la adquisición de maquinaria y equipo seguros, el empleo de sustancias no peligrosas en los procesos productivos, el control y medición de las concentraciones de sustancias químicas en suspensión en la atmósfera de los lugares de trabajo, el control sanitario de los trabajadores y la prestación de primeros auxilios, la comunicación a las autoridades competentes de los accidentes y enfermedades que se produzcan, la formación de los trabajadores, la información sobre los peligros asociados al trabajo y su prevención y la cooperación con los trabajadores y sus representantes en el ejercicio de sus responsabilidades.

\section{Obligaciones de los trabajadores}

En los convenios adoptados a partir del decenio de 1980 se establece la obligación de los trabajadores de cooperar con sus empresas en la aplicación de las normas de salud y seguridad, así como de observar los sistemas y medidas de seguridad vigentes. Entre las obligaciones de los trabajadores se incluye la de poner en conocimiento de sus superiores, tanto las situaciones que entrañen un riesgo específico, como el eventual abandono del lugar de trabajo por el trabajador en caso de peligro grave e inminente para su vida o su salud.

\section{Derechos de los trabajadores}

En los convenios de la O IT sobre salud y seguridad se han consagrado diversos derechos de los trabajadores. Por regla general, se reconoce al trabajador el derecho a ser informado de los peligros inherentes a sus condiciones de trabajo, de la naturaleza de las sustancias químicas utilizadas en el trabajo y del contenido de las especificaciones de seguridad de las sustancias químicas; el derecho a recibir formación en los métodos de seguridad en el trabajo; el derecho a ser consultado por su empresa en todas las cuestiones de salud y seguridad relacionadas con su trabajo; y el derecho a someterse a controles médicos, gratuitamente y sin pérdida de ingresos. En algunos de estos convenios se reconocen igualmente los derechos de los representantes de los trabajadores, especialmente en materia de consulta e información. Estos derechos se confirman en otros convenios de la OIT relativos a la libertad de asociación, la negociación colectiva, la representación de los trabajadores y la protección contra el despido.

Diversos artículos de los convenios adoptados a partir de 1981 se contraen al derecho de los trabajadores a sustraerse a los peligros presentes en el lugar de trabajo. En el Convenio sobre la prevención de los accidentes industriales graves, 1993 (no 174) se reconoce el derecho de los trabajadores a denunciar a la autoridad competente la presencia de peligros potenciales capaces de provocar accidentes graves.

\section{Inspección}

En los convenios sobre salud y seguridad se indica la necesidad de que los gobiernos cuenten con unos servicios adecuados de inspección que supervisen la observancia de las medidas adoptadas en aplicación del convenio. La obligación de inspeccionar 
se complementa con la de dotar a los servicios de inspección de los medios necesarios para realizar su labor.

\section{Sanciones}

En los convenios sobre salud y seguridad se suele propugnar la adopción de normas internas sancionadoras de las violaciones de las disposiciones legales. Así, en el artículo 9 (2) del Convenio marco sobre seguridad y salud de los trabajadores, 1981 ( $n$ - 155) se indica que "el sistema de control deberá prever sanciones adecuadas en caso de infracción de las leyes o de los reglamentos". Estas sanciones pueden ser de orden administrativo, civil o penal.

\section{Convenio sobre la inspección del trabajo, 1947 ( $n$ 0 81)}

En el Convenio relativo a la inspección del trabajo, 1947 (no 81) se recaba de los Estados que establezcan un sistema de inspección de trabajo en los lugares de trabajo industrial. En su texto se definen las obligaciones de los gobiernos en relación con la inspección y se concretan los derechos, funciones y obligaciones de los inspectores. Complementan este convenio dos Recomendaciones (no 81 y no 82) y el Protocolo de 1995, por el que se amplía el ámbito de aplicación del convenio al sector de los servicios no comerciales (como los servicios públicos y las empresas de propiedad estatal). Las disposiciones, relativas al sector agrario, del Convenio sobre la inspección del trabajo (agricultura), 1969 (n- 129) son muy similares a las del Convenio no 81. A simismo, en los convenios y recomendaciones marítimos de la O IT se regula la inspección de las condiciones de vida y de trabajo de los marinos.

El gobierno debe crear un cuerpo, independiente y suficientemente dotado, de inspectores de trabajo cualificados. La inspección debe contar con los medios necesarios para prestar un servicio de calidad. Asimismo, los gobiernos están obligados a dictar disposiciones legales sancionadoras de las violaciones de las normas de salud y seguridad. Por su parte, los inspectores tienen la obligación de hacer cumplir las disposiciones legales y de ofrecer información y asesoramiento técnico a empresas y trabajadores sobre los medios más efectivos de cumplir las disposiciones legales.

Los inspectores deben comunicar a las autoridades competentes las eventuales deficiencias de la normativa y elaborar informes anuales de su trabajo. Se responsabiliza a los gobiernos de la elaboración de informes anuales con estadísticas de las inspecciones efectuadas.

Se estipulan los derechos y facultades de los inspectores, como el derecho a entrar en los locales y lugares de trabajo, a efectuar pruebas y exámenes, a tomar medidas correctoras, y a disponer la modificación de las instalaciones y la adopción de medidas de aplicación inmediata. En caso de infracción de las obligaciones de la empresa, los inspectores pueden efectuar apercibimientos e iniciar actuaciones legales al respecto.

En el convenio se dictan normas de conducta aplicables los inspectores, como la prohibición de poseer intereses en las empresas sujetas a su supervisión y de revelar los secretos comerciales e industriales de esas empresas, y - muy especialmentela obligación de guardar reserva absoluta respecto de las quejas formuladas por los trabajadores, lo que implica ocultar a la empresa todo indicio de la identidad del denunciante.

\section{Los convenios como instrumento de promoción del desarrollo gradual}

Se pretende que el contenido de los convenios refleje la legislación y la praxis de los Estados miembros de la O rganización. No obstante, en ocasiones se incorporan elementos que previamente no han sido objeto de un reconocimiento generalizado en las legislaciones nacionales. La iniciativa puede provenir de los delegados participantes en la discusión de una norma en un Comité de la Conferencia. Si la Oficina Internacional del Trabajo lo estima pertinente, puede incorporar la propuesta al borrador inicial del documento. Conviene examinar dos ejemplos:

(1) El derecho del trabajador a interrumpir un trabajo que entrañe un peligro grave e inminente para su vida o su salud.

Normalmente, las personas entienden que tienen un derecho natural a retirarse de un lugar de trabajo si existe un peligro para su vida. Sin embargo, este proceder puede ocasionar daños a la maquinaria o a los materiales y productos y, en ocasiones, resultar excesivamente costoso. A medida que aumenta el coste y la complejidad de las instalaciones, es mayor la probabilidad de que se culpe al trabajador de haberse retirado injustificadamente y hacerle responsable del daño. Cuando se debatía en un Comité de la Conferencia el Convenio sobre seguridad y salud de los trabajadores, se formuló la propuesta de proteger a los trabajadores contra la adopción de represalias en tales casos. Al cabo de un debate que se prolongó durante varias horas, el Comité de la Conferencia acordó finalmente una disposición de protección de los trabajadores aceptable para la mayoría de los miembros.

Por consiguiente, el texto del artículo 13 del Convenio no 155 sobre ello es el siguiente: "D e conformidad con la práctica y las condiciones nacionales, deberá protegerse de consecuencias injustificadas a todo trabajador que juzgue necesario interrumpir una situación de trabajo por creer, por motivos razonables, que ésta entraña un peligro inminente y grave para su vida o su salud".

O bviamente, entre las "consecuencias injustificadas" se incluyen, tanto el despido y las medidas disciplinarias, como la exigencia de responsabilidad legal. Varios años más tarde, la situación se replanteó en un nuevo contexto. M ientras el Convenio sobre seguridad y salud en la construcción se debatía en la Conferencia, en el período 1987-1988, los representantes de los trabajadores propusieron una enmienda en el sentido de reconocer el derecho del trabajador a retirarse en caso de peligro grave e inminente. La propuesta fue finalmente aceptada por la mayoría de los miembros del Comité, a condición de que se vinculase a la obligación del trabajador de comunicar el suceso inmediatamente a su superior.

Esta disposición se ha incorporado igualmente al Convenio sobre la seguridad en la utilización de los productos químicos en el trabajo, 1990 (no 170) y, con una redacción similar, al Convenio sobre la salud y la seguridad en las minas, 1995 (no 176). Por consiguiente, los países que han ratificado el Convenio sobre seguridad y salud de los trabajadores o los convenios sobre seguridad y salud en la construcción, seguridad química o seguridad en las minas deben estipular en su legislación interna el derecho de los trabajadores a separarse de los riesgos para protegerse de las "consecuencias injustificadas". Probablemente, esta tendencia conducirá, tarde o temprano, al reconocimiento de igual derecho a los trabajadores de todos los sectores económicos. $\mathrm{M}$ ientras, este derecho recientemente reconocido a los trabajadores se ha incorporado a la fundamental Directiva de la UE sobre la aplicación de medidas para promover la mejora de la seguridad y de la salud de los trabajadores en el trabajo. Todos los Estados de la U nión Europea habrían de reconocer este derecho en su legislación interna para finales de 1992.

(2) El derecho del trabajador a una exploración médica, en lugar de la obligatoriedad de la exploración

Durante mucho años, en la legislación nacional se ha exigido la exploración médica de los trabajadores de determinadas 


\section{Convenios de la OIT: procedimiento ejecutivo}

Todo país que ratifica un convenio de la O IT se compromete a "tomar las medidas que sean necesarias para hacer efectivas sus disposiciones" (artículo 19(5) de la Constitución de la O IT). Tanto las organizaciones de empresarios y de trabajadores como los terceros países (pero no las personas físicas) disponen de diversas vías para inducir a un gobierno a cumplir las obligaciones asumidas. Las organizaciones sólo tienen que remitir una carta con suficiente información al Director $\mathrm{G}$ eneral de la 0 ficina Internacional del Trabajo, en 4 route des Morillons, 1211 Ginebra 22. Suiza (no de fax 41-22-798-8685). Las reglas de procedimiento que se examinan aquí se complementan con la labor de la O IT para promover la aplicación de las normas internacionales de trabajo en seminarios y cursillos que imparten los asesores regionales.

Normas de procedimiento del artículo 22. Los gobiernos deben informar a la 0 ficina Internacional del Trabajo de la aplicación de los convenios ratificados por aquéllos. Asimismo, los gobiernos están obligados a facilitar copias de los informes a las organizaciones de empresarios y trabajadores más representativas en el país (artículo 23). Estas organizaciones pueden comentar los informes y aportar información complementaria sobre la aplicación de un convenio. Un organismo independiente, el Comité de Expertos en la Aplicación de Convenios y Recomendaciones (CEARC) examina cada informe y los eventuales comentarios y, en su caso, formula sus comentarios a los gobiernos afectados, en el sentido, bien de recomendar la introducción de cambios en las leyes y en los sistemas aplicados, o de reconocer los progresos realizados. El Comité de Expertos, a su vez, eleva un informe anual a la tripartita Conferencia Internacional del Trabajo. La Conferencia establece entonces un Comité de Peticiones, que examina una selección de casos para informar al plenario. La Conferencia encarece entonces a los gobiernos a respetar las obligaciones asumidas al ratificar los convenios de la O IT y, en ocasiones, les insta a acoger a las misiones de "contacto directo", con el objeto de buscar soluciones en consulta con el gobierno y con las organizaciones de empresarios y trabajadores del país.

$N$ ormas de procedimiento del artículo 24. Según este artículo de la Constitución de la O IT, toda "asociación profesional de empresarios o de trabajadores" puede formular alegaciones en el sentido de que un Estado miembro de la organización ha incumplido un determinado convenio de la O IT ratificado por aquél. Para ser admisibles, las alegaciones deben provenir de una de las organizaciones anteriormente citadas, que debe formular sus cargos mediante escrito, en el que se hará mención expresa del artículo 24 de la Constitución de la 0 IT y se detallará el incumplimiento del convenio ratificado (identificado por su nombre y número) por parte del Estado miembro en cuestión. A continuación, el Consejo de Administración de la 0 IT puede encargar a un comité que examine las alegaciones, las ponga en conocimiento del gobierno interesado y recabe sus observaciones, y elabore un informe, que podrá ser publicado por el Consejo de Administración. En ocasiones, este procedimiento puede originar el envío de una misión de contacto directo. Si un gobierno no atiende a las alegaciones formuladas al amparo del artículo 24, el Consejo de Administración puede incoar el procedimiento de queja previsto en el artículo 26 de la Constitución de la 0 IT.

$N$ ormas de procedimiento del artículo 26 . En este artículo de la Constitución de la O IT se prevé la posibilidad de elevar a la O ficina Internacional del Trabajo quejas contra un Estado Miembro que pretendidamente haya omitido la aplicación de algún convenio ratificado por el mismo. Las quejas también pueden ser formuladas por otro Estado miembro adherido al mismo convenio, por un delegado (de un gobierno o una organización de empresarios o de trabajadores) a la Conferencia Internacional del Trabajo, o por el propio Consejo de Administración de la $\mathrm{O}$ IT. El Consejo puede encargar a una Comisión de Investigación el estudio de la queja y la presentación de un informe al órgano citado. En ese caso, se publican, tanto los hechos considerados probados por la Comisión de Investigación, como sus recomendaciones. En caso de discrepancia con las recomendaciones de la Comisión de Investigación, la cuestión se puede someter a la Corte Internacional de Justicia, cuyos fallos son firmes.

Procedimiento de tutela de la libertad de asociación. La libertad de asociación y el derecho a la negociación colectiva, que ocupa un lugar destacado en la escala de valores de los miembros de la O IT, han inspirado un procedimiento especial de sustanciación de las quejas por presuntas violaciones de esos derechos. El Comité de libertad de Asociación del Consejo de Administración examina las quejas formuladas por las organizaciones nacionales 0 internacionales de empresarios o de trabajadores contra cualquier Estado miembro de la $0 \mathrm{IT}$, incluso en el caso de que el mismo no haya ratificado los dos convenios básicos de la O IT sobre libertad de asociación y negociación colectiva. Este Comite también puede recomendar que un gobierno acepte una misión de contacto directo que colabore con el mismo en la aplicación de ambos principios fundamentales.

Efectos. Si bien la O IT carece de una fuerza de policía y de una inspección de trabajo competentes para imponer la aplicación de medidas de seguridad en un lugar de trabajo, los gobiernos se muestran sensibles a las demandas de que observen las obligaciones que asumen al ratificar los convenios de la 0 IT. En numerosos casos, la presión pública desencadenada por la aplicación de las normas de procedimiento de la 0 IT ha inducido la modificación de leyes y sistemas en el sentido de contribuir a la mejora de las condiciones de trabajo.

Anne Trebilcock

profesiones, como condición previa a su incorporación al trabajo o a su continuidad en el mismo. A lo largo de los años se había ido engrosando la lista de exploraciones médicas obligatorias, tanto previas al acceso al empleo como periódicas. Sin embargo, estas exigencias bien intencionadas se han ido convirtiendo en una carga, ya que, a veces, una misma persona ha de someterse a un número excesivo de exploraciones médicas. Si los resultados de las exploraciones se consignan en la cartilla sanitaria del trabajador como testimonio vitalicio de su mala salud, como es preceptivo en algunos países, la exploración médica puede convertirse, en última instancia, en una herramienta de selección para el acceso al desempleo. En efecto, un joven trabajador que se haya sometido a lo largo de su vida laboral a múltiples exploraciones médicas motivadas por su exposición a sustancias peligrosas, podría tener dificultades para encontrar una empresa dispuesta a contratarlo. Se puede suscitar una 
sospecha excesivamente seria de que, más tarde o más temprano, el trabajador podría faltar al trabajo con excesiva frecuencia por causa de enfermedad.

0 tra circunstancia tomada en consideración ha sido que toda exploración médica constituye una intromisión en la privacidad del individuo y que, por tanto, corresponde al trabajador decidir sobre las intervenciones médicas.

Esto indujo a la O ficina Internacional del Trabajo a proponer el reconocimiento, en el Convenio sobre el trabajo nocturno, 1989 (no 171) del derecho del trabajador a una exploración médica, en lugar de prescribir la obligatoriedad de la exploración. La idea recibió un amplio apoyo y terminó por incorporarse al artículo 4 del Convenio sobre el trabajo nocturno adoptado por la Conferencia Internacional del Trabajo en 1990, cuyo texto es el siguiente:

1. A requerimiento suyo, los trabajadores tendrán derecho a someterse a un control médico sin coste alguno, y a ser asesorados sobre el modo de evitar o disminuir los problemas de salud relacionados con el trabajo: (a) antes de acceder a un puesto de trabajo nocturno; (b) a intervalos regulares, durante el desempeño de ese puesto de trabajo; (c) si, durante el desempeño de dicho puesto, experimentan problemas de salud que no tengan por causa factores distintos de la realización de ese trabajo.

2. Excepto en el caso de que se detecte una condición que inhabilite para el desempeño de ese puesto, el resultado de dicho control no se comunicará a terceros sin el consentimiento del trabajador ni se utilizará en perjuicio del mismo.

Resulta difícil para muchos profesionales de la salud adaptarse a este nuevo sistema. Sin embargo, deben comprender que el derecho de una persona a decidir si se somete o no a una exploración médica se enmarca en la concepción actual de los derechos humanos. Esta disposición ha sido recogida, por ejemplo, en Alemania, en la Ley sobre la jornada laboral, de 1994, en la que se menciona el convenio citado. Más importante aún, la Directiva M arco de la U nión Europea relativa a la aplicación de medidas para promover la mejora de la seguridad y de la salud de los trabajadores en el lugar de trabajo, responde a este modelo y sus provisiones sobre vigilancia de la salud.

\section{Funciones de la Oficina Internacional del Trabajo}

Entre las funciones de la O ficina Internacional del Trabajo, enunciadas en el artículo 10 de la Constitución de la OIT, se incluye la recogida y difusión de información sobre todas las cuestiones relacionadas con la regulación internacional de las condiciones de vida profesional y de trabajo, con especial atención a las futuras normas laborales internacionales; a la elaboración de documentación relativa a los diversos puntos del orden del día de las reuniones de la Conferencia Internacional del Trabajo (especialmente a la labor de preparación del contenido y del texto de los convenios y recomendaciones); a la prestación de servicios de asesoramiento a los gobiernos y a las organizaciones sindicales y empresariales de los Estados miembros en relación con la legislación laboral y los sistemas administrativos, incluidos los sistemas de inspección; y a la edición y difusión de publicaciones de ámbito internacional en las que se aborden los problemas del empleo y la industria.

Como cualquier ministerio de trabajo, la O ficina Internacional del Trabajo está estructurada en oficinas, departamentos y secciones que se ocupan de diversos ámbitos de la política laboral. Se han creado dos organismos destinados a prestar apoyo a la Oficina y a los Estados miembros: el Instituto
Internacional de Estudios Laborales, que funciona en la sede de la OIT, y el Centro Internacional de Formación de la OIT, situado en Turín, I talia.

Un Director General, elegido por el Consejo de Administración para un mandato de cinco años, y tres Directores $G$ enerales A djuntos nombrados por el Director G eneral dirigen en 199613 departamentos y 11 oficinas en Ginebra, Suiza; dos oficinas de enlace con las organizaciones internacionales; cinco departamentos regionales distribuidos por $A$ frica, ambas A méricas, $A$ sia y el Pacífico, los Estados árabes y Europa; además de 35 oficinas de área y de división y 13 equipos multidisciplinarios (compuestos por un grupo de profesionales de diversas disciplinas que asesoran a los Estados miembros de una subregión).

El Departamento de Condiciones de Trabajo y Medio A mbiente realiza el grueso de la labor en el área de la salud y la seguridad. Trabajan en este departamento unas 70 personas de 25 nacionalidades, entre profesionales y personal de servicio, incluidos los expertos de los equipos multidisciplinarios. En 1996, el departamento se componía de dos Divisiones: la División de Condiciones de Trabajo y Servicios de Bienestar (CONDI/T), y la División de Salud y Seguridad en el Trabajo (SEC/HYG).

La Sección de Servicios de Información sobre Salud y Seguridad en el Trabajo de SEC / HYG gestiona el Centro Internacional de Información sobre Seguridad y Salud en el Trabajo (CIS) y la Sección de Sistemas de A poyo a la Información sobre Seguridad y Salud en el Trabajo. La Sección de Sistemas de A poyo alberga el resultado de la labor realizada en la presente edición de la Enciclopedia.

En 1991 se creó una unidad especializada dentro del departamento: el Programa Internacional para la Erradicación del Trabajo Infantil (IPEC). Este nuevo programa, en colaboración con los Estados miembros, desarrolla en todo el mundo programas nacionales de erradicación del trabajo infantil. El programa se financia con las aportaciones de varios Estados miembros, como Alemania, España, Australia, Bélgica, Estados U nidos, Francia y N oruega.

Además, en el contexto de la revisión del programa central de salud y seguridad de la O IT iniciado en el decenio de 1970: el Programa Internacional para la M ejora de las Condiciones y el Medio Ambiente de Trabajo, conocido por su sigla francesa: PIACT, la Conferencia Internacional del Trabajo adoptó en 1984 la Resolución PIACT, que, en principio, constituye el marco de la actividad de la OIT y de sus Estados miembros en el campo de la salud y seguridad y que consiste en los puntos siguientes:

- El trabajo debe desarrollarse en un medio ambiente seguro y saludable.

- Las condiciones de trabajo deben ser compatibles con el bienestar y la dignidad humana de los trabajadores.

- El trabajo debe ofrecer posibilidades efectivas de promoción personal, de realización individual y de servicio a la sociedad.

Dentro de la Serie Salud y Seguridad en el Trabajo se editan varias publicaciones sobre salud laboral, como 0 ccupational Exposure Limits for Airborne Toxic Substances, que constituye una relación de los límites nacionales a la exposición vigentes en 15 Estados miembros; como International Directory of Occupational Safety and $H$ ealth Services and Institutions, que constituye una guía de las organizaciones dedicadas a la salud y seguridad en los Estados miembros; como Protection of Workers from Power Frequency Electric and $M$ agnetic $F$ ields, que es una guía informativa práctica de los posibles efectos de los campos eléctricos y magnéticos sobre la salud humana y de los sistemas que ofrecen un mayor nivel de seguridad. 
Un exponente típico de la labor de la OIT en materia de salud y seguridad en el trabajo son los códigos de práctica, que constituyen prototipos de reglamentación de la salud y seguridad en muchos trabajos industriales. Estos códigos se suelen elaborar con la finalidad de facilitar la ratificación y aplicación de los convenios de la OIT. Por ejemplo, el Código de práctica sobre la prevención de accidentes de trabajo graves, que pretende servir de pauta para la puesta a punto de un sistema técnico, administrativo y jurídico de control de las instalaciones más peligrosas, con el objeto de evitar graves desastres. C on el Código de Práctica en el R egistro y Comunicación de Accidentes de Trabajo y E nfermedades P rofesionales se pretende armonizar los métodos de recogida de datos y elaboración de estadísticas de accidentes, enfermedades y actividades similares, con el objeto de promover las actuaciones preventivas y de facilitar la comparación entre los Estados miembros (se trata, únicamente, de dos ejemplos extraídos de una extensa relación). En el ámbito del intercambio de información, la División de Salud y Seguridad de la OIT organiza dos importantes eventos internacionales: el Congreso $M$ undial de Salud y Seguridad en el Trabajo y la Conferencia Internacional de la OIT sobre la Neumoconiosis (denominada actualmente Conferencia Internacional sobre las Enfermedades Profesionales de las V ías R espiratorias).

El Congreso M undial, que se celebra cada tres o cuatro años, se organiza conjuntamente con la A sociación Internacional de la Seguridad Social (AISS) y con la organización nacional de salud y seguridad del Estado miembro de la OIT que sea sede del Congreso. Estos congresos mundiales vienen celebrándose desde el decenio de 1950. Entre 2.000 y 3.000 expertos de más de 100 países asisten a estos congresos para intercambiar información sobre los sistemas contrastados de protección de la salud y seguridad y sobre las últimas tendencias, así como para relacionarse con los compañeros de otros países y regiones del mundo.

La O IT viene celebrando las conferencias sobre la neumoconiosis desde el decenio de 1930, y la próxima debía celebrarse en K yoto, Japón, en 1997. U no de los resultados más valiosos de esta conferencia es la Clasificación Internacional de Radiografías de $\mathrm{N}$ eumoconiosis.

La cooperación técnica de la O IT en el campo de la salud y la seguridad tiene una dimensión múltiple. En efecto, varios proyectos han servido para ayudar a los Estados miembros a preparar nuevas medidas legislativas en el ámbito de la salud y seguridad y para mejorar los servicios de inspección. En otros países se ha colaborado en la creación de institutos de salud y seguridad destinados a impulsar la investigación y a diseñar distintos programas y actividades. Así, se han diseñado y realizado diversos proyectos relativos a la seguridad en las minas y la seguridad de las sustancias químicas, entre los que se incluye el desarrollo de importantes sistemas de control de riesgos. Estos proyectos pueden estar dirigidos a un solo Estado miembro o a un grupo de países de una misma región. Las funciones de la oficina principal de la OIT consisten en la evaluación de necesidades, el diseño y desarrollo de proyectos, la captación de apoyos financieros de los fondos internacionales y los programas nacionales de ayuda, la selección y prestación de asistencia técnica especializada, la aportación de equipo y servicios de planificación, la organización de viajes de estudio y la gestión de programas de becas para investigación.

Las herramientas operativas de la O IT son la normalización, la recogida y difusión de información y la cooperación técnica. Estas actividades, desarrolladas en íntima colaboración con los tres estamentos que integran la OIT, impulsan la lucha por conseguir el objetivo de la justicia social y la paz mundial.
Este esfuerzo valió a la Organización Internacional del Trabajo en 1969, en el quincuagésimo aniversario de su fundación, que le otorgarán el Premio N obel de la Paz.

\section{ORGANIZACION INTERNACIONAL DE NORMALIZACION (ISO)}

Lawrence D. Eicher

La O rganización Internacional de N ormalización es una federación internacional de organismos nacionales de normalización que en 1996 estaba integrada por organizaciones de 120 países. EI objeto del ISO es impulsar el proceso de normalización en todo el mundo, con el objeto de facilitar el intercambio internacional de bienes y servicios y de promover la cooperación en los ámbitos intelectual, científico, tecnológico y económico. LoS resultados del trabajo de la OIT en el plano tecnológico se plasman en normas internacionales.

Lejos de limitarse a un determinado sector, el campo de actividad del ISO se extiende a todos los ámbitos de la normalización, con la excepción de la ingeniería eléctrica y electrónica, cuya normalización corresponde a la Comisión Electrotécnica Internacional (CEI).

La ISO concilia los intereses de productores, usuarios (incluidos los consumidores), gobiernos y científicos en la preparación de las normas internacionales.

EI trabajo de la ISO se realiza a través de unos 2.800 organismos técnicos. M ás de 100.000 especialistas de todo el mundo colaboran en una labor que, hasta la fecha, se ha traducido en la publicación de más de 10.000 normas internacionales, que ocupan unas 188.000 páginas de información condensada de consulta en inglés y francés.

\section{Origen y miembros}

El proceso de normalización internacional se inició en el campo de la electrotécnica hace unos 90 años. Aunque durante el decenio de 1930 se produjeron algunos intentos de normalización internacional en otras esferas técnicas, hasta la creación de la ISO no existió una organización internacional dedicada a la normalización en general.

A raíz de una reunión celebrada en Londres en 1946, los delegados de 25 países decidieron crear una nueva organización internacional "que tenga por objeto impulsar la coordinación y unificación internacionales de las normas industriales". La nueva organización, denominada ISO, inició su andadura oficial el 23 de febrero de 1947.

Es organismo miembro de la ISO el organismo nacional "más representativo de la normalización en cada país". Se deduce de lo anterior que únicamente se admite en la ISO a un organismo normalizador por cada país. Los organismos miembros pueden participar, con plenos derechos de sufragio, en todos los comités técnicos de la ISO, son elegibles para el Consejo y ocupan un escaño en la A samblea General. En septiembre de 1995, pertenecían a la ISO 83 organismos. M ás del $70 \%$ de los organismos miembros son instituciones oficiales o entidades de derecho público, y los demás se encuentran íntimamente vinculados a las administraciones públicas de sus países respectivos.

Los miembros corresponsales suelen ser organizaciones de los países en vías de desarrollo que aún no cuentan con un organismo nacional de normalización. Si bien los miembros corresponsales no participan activamente en los trabajos técnicos, se 
les mantiene plenamente informados del mismo. Por regla general, los miembros corresponsales - que actualmente son, en su práctica totalidad, instituciones oficiales- se convierten en organismos miembros al cabo de algunos años. En septiembre de 1995 había 24 miembros corresponsales.

Se ha creado una tercera categoría, la de los miembros subscriptores, en beneficio de los países con economías más modestas. Estos subscriptores abonan unas tasas reducidas, que, no obstante, les permiten mantenerse en contacto con el proceso internacional de normalización. En septiembre de 1995 había un total de ocho miembros subscriptores.

La información básica sobre cada uno de los organismos miembros de la ISO aparece en la publicación titulada ISO M embership.

\section{Trabajo técnico}

La labor técnica de la ISO se realiza a través de unos comités técnicos (TC). La decisión de crear un nuevo comité técnico corresponde al Consejo de Dirección Técnica, que define también las funciones de cada comité. Cada comité elabora su programa de trabajo en el marco de sus competencias.

A su vez, los comités técnicos pueden crear subcomités y grupos de trabajo, en los que delegan distintas tareas. Cada comité y subcomité técnico cuenta con una secretaría, que se asigna a un organismo miembro de la ISO. A finales de 1995 funcionaban 185 comités técnicos, 611 subcomités y 2.022 grupos de trabajo.

Aunque las propuestas de incorporar un nuevo campo de actividad al programa de trabajo de la ISO suelen provenir de los organismos miembros, a veces se originan en otras organizaciones internacionales. La limitación de los recursos impone la fijación de prioridades. Por consiguiente, los organismos miembros de la ISO formulan las propuestas y, si se aceptan, el nuevo proyecto se asigna a uno de los comités técnicos existentes o se crea un nuevo comité.

Todo organismo miembro interesado en una materia incluida en las competencias de un comité tiene derecho a estar representado en el mismo. En ISO/ IEC D irectives se establece un procedimiento detallado al respecto.

\section{Normas internacionales}

Toda norma internacional es el resultado de un acuerdo entre los organismos miembros de la ISO y, bien se aplica directamente, bien se incorpora a la normativa interna de los diferentes países.

El primer e importante paso en la adopción de una norma internacional es la elaboración de un borrador del comité correspondiente, cuyo documento se distribuye para su estudio entre los miembros del comité técnico. El borrador pasa por diversas fases antes de su adopción como norma internacional, con el objeto de garantizar la aceptación del resultado final en el mayor número posible de países. U na vez alcanzado el consenso dentro del comité técnico, el borrador se remite a la secretaría central para su registro como borrador de norma internacional, el cual se somete entonces a votación entre todos los organismos miembros. En muchos países, el borrador de norma internacional (DIS) se somete a información pública, con el objeto de suscitar el mayor número posible de comentarios. Si el $75 \%$ de los votos emitidos lo son a favor del borrador de norma internacional, se le tiene por aprobado como borrador definitivo de norma internacional (FDIS). A continuación, el mismo se distribuye entre todos los organismos miembros para su adopción formal por la ISO. También en esta fase se precisa el $75 \%$ de los votos favorables para la publicación del texto como norma internacional. Por regla general, las cuestiones técnicas fundamentales se resuelven en el comité técnico. No obstante, en el procedimiento electoral existen garantías de que ninguna objeción importante se pasa por alto.

La mayor parte de los contactos se realizan por correspondencia y únicamente se convocan reuniones cuando es absolutamente necesario. Todos los años circulan unos 10.000 documentos de trabajo. La mayoría de las normas se revisan periódicamente. Las normas pueden desfasarse por diversas causas, como el progreso tecnológico, la aparición de nuevos métodos y materiales, y la implantación de nuevas normas de seguridad y de calidad. Para afrontar esta situación, la ISO ha adoptado la política general de revisar sus normas cada cinco años, aunque algunas normas deben revisarse con una frecuencia mayor.

En ISO Catalogue se publica una relación completa de las normas de la ISO.

\section{Labor de la ISO en el campo de la seguridad en el trabajo}

Todas las normas internacionales de la ISO reflejan una preocupación por la seguridad que está presente en todo el trabajo de la O rganización.

Las más de 10.000 normas internacionales publicadas hasta ahora por la ISO abarcan un amplio espectro que comprende desde las industrias aeroespacial y aeronáutica, hasta la agricultura y la construcción, las pruebas pirométricas, los contenedores, el equipo médico y de minería, el lenguaje máquina, el medio ambiente, la seguridad personal, la ergonomía, los pesticidas, la energía nuclear, etcétera.

M uchas de las normas internacionales de la ISO son fácilmente identificables como importantes para la prevención de los riesgos profesionales, como la principal señal identificativa de la presencia de radiación ionizante o de materiales radiactivos (ISO 361); los colores y señales de seguridad (ISO 3864); y el casco de seguridad en la industria (ISO 3873), indicado como medio de protección ligero en la minería, la excavación, la construcción naval, la ingeniería civil, la silvicultura, etcétera. 0 tras normas internacionales, cuyos efectos directos no son tan fáciles de reconocer, tienen también una influencia considerable en la prevención de accidentes de trabajo y enfermedades profesionales. Una de estas normas es la de Evaluación de la exposición humana a la vibración de la totalidad del cuerpo (ISO 263), que se ha publicado en tres partes y en la que se gradúan la "frontera de la reducción del confort", la "frontera de la destreza disminuida por la fatiga" y el "límite de la exposición", en función de diferentes niveles de frecuencia de la vibración, de la magnitud de la aceleración y del tiempo de exposición; y en función de la dirección de la vibración respecto a los ejes establecidos del cuerpo humano. Esta norma, como las demás, se actualiza continuamente en función de la investigación y de la experiencia, y se asocia a vehículos de transporte del tipo de los tractores, volquetes, excavadoras y muchos otros vehículos y sitios de trabajo.

LoS comités técnicos de la ISO que se relacionan en la Tabla 23.2 se cuentan entre los más importantes en el campo de la seguridad y la prevención de enfermedades y accidentes.

Estos y otros comités técnicos han elaborado o se encuentran en vías de elaborar diversas normas internacionales sobre los riesgos profesionales en áreas como las obras de construcción, las fábricas, el trabajo portuario, la agricultura y la silvicultura, las instalaciones nucleares, la manipulación de materiales y el equipo y las prendas de protección personal.

El sector de la construcción es un claro ejemplo de la intensa preocupación por la prevención de los accidentes y enfermedades en la labor de la ISO. M ás de cincuenta comités técnicos de la ISO se ocupan de diversos aspectos de la construcción y 
Tabla 23.2 - Comités técnicos de la ISO más estrechamente relacionados con la prevención de los accidentes de trabajo y enfermedades profesionales.
№ Título 10 Dibujo técnico, definición del producto y
documentación anexa
Ejemplo típico de norma ISO
21 Equipo de protección y lucha contra incendios
ISO/ DIS Documentación técnica de productos: especificaciones para el equipo y los materiales
11604 de dibujo
1503941 Clasificación de los incendios
23 Tractores y maquinaria agrícola y forestal
ISO 3776 Tractores agrícolas: anclajes para cinturones de seguridad
35 Pinturas y barnices
ISO 3679 Pinturas, barnices, petróleo yproductos afines- Determinación del punto de ignición- Método rápido en el equilibrio
43 Acústica
ISO 4872 Acústica - Medida del ruido ambiental emitido por máquinas y equipos de construcción para uso en exteriores- Método para determinar el cumplimiento de los límites de ruido
44 Soldadura y procesos afines
59 Construcción de edificios
ISO/ DIS Salud y seguridad en la soldadura y procesos afines- Muestreo de partículas y gases en
10882-2 suspensión en el aire en el campo respiratorio del operario- Parte 2: Muestreo de gases
ISO/ TR 9527 Construcción de edificios- Necesidades de los discapacitados en los edificios- Pautas de diseño 67 Materiales, equipo y estructuras para industrias
de explotación de petróleo y de gas natural
ISO 10418 Industria del petróleo y gas natural- Plataformas de extracción submarina- Análisis, diseño,
82 Minería
ISO 3155 Cables de alambre trenzado para extracción en minas- Componentes de fibra- Características y verificaciones
85 Energía nuclear
IS0 1709 Energía nuclear- Materiales de fisión- Principios de criticidad, seguridad en el almacena- miento, manipulación y tratamiento
86 Refrigeración
ISO 5149 Sistemas mecánicos de refrigeración utilizados en la refrigeración y calefacción. Normas de seguridad
92 Protección contra incendios
ISO 1716 Materiales de construcción- Determinación de la potencia caloríica
94 Seguridad personal: ropa y equipos protectores
ISO 2801 Ropa protectora contra el calor y el fuego- Recomendaciones generales a los usuarios y a sus supervisores
96 Grúas
98 Bases para el diseño de estructuras
ISO 10245-1 Grúas- Dispositivos indicadores y limitadores- Parte 1: General
ISO 2394 Principios generales de fiabilidad para estructuras
101 Equipo de manipulación mecánica continua
ISO 1819 Aparatos de manutención continua- Código de seguridad-Reglas generales
108 Vibración e impacto mecánico
110 Vehículos industriales
ISO 2631-1 Evaluación de la exposición humana a la vibración de todo el cuerpo- Parte 1: Reglas generales
ISO 1074 Carretillas de horquilla elevadora- Pruebas de estabilidad
118 Compresores, herramientas y máquinas neumáticas
ISO 5388 Compresores de aire fijos- Normas de seguridad y código de práctica
146 Calidad del aire
ISO 8518 La atmósfera en el lugar de trabajo- Determinación de la presencia de macropartículas de plomo y sus compuestos- Método espectométrico de absorción atómica de llama
159 Ergonomía
ISO 7243 Medio ambiente calórico - Estimación del estrés por calor del trabajador, basándose en el índice WBGT ( temperatura del globo ocular húmedo)
199 Seguridad de la maquinaria
ISO/ TR Seguridad de la maquinaria- Conceptos básicos, principios generales para diseño.
12100-1 Parte l: terminología, metodología

sus materiales y diez de ellos se interesan por los problemas del medio ambiente de trabajo. Entre los factores físicos presentes en el campo de la construcción figuran aspectos como la seguridad personal, la vibración y el impacto, el ruido, las instalaciones y equipos, las máquinas excavadoras, los montacargas y grúas, y los temas ergonómicos. Los factores químicos son la calidad del aire, los barnices y pinturas, la protección de los soldadores y el equipo y prendas de protección.

La Sección ISO TC 127 (M aquinaria de movimiento de tierras) ha creado un subcomité dedicado específicamente a los problemas de la seguridad y a los factores humanos asociados a todos los actuales tipos básicos de maquinaria de movimiento de tierras, como tractores, excavadoras, volquetes, escarbadoras y niveladoras. Existen actualmente normas de seguridad en el acceso a las cabinas tractoras mediante peldaños, escaleras, plataformas y pasarelas; y se han definido las dimensiones de las cabinas para los operadores de gran y pequeña estatura, sentados o de pie, con o sin ropa impermeable.

Se han dedicado diversas normas internacionales para las posiciones estando sentados y a las formas y dimensiones de los asientos para diferentes tipos de operadores. Actualmente, las posiciones sedentes se asocian a diversos aspectos del confort y al acceso a los mandos manuales y a los pedales. Además, se han elaborado diversas normas para definir el campo visual de los operadores de maquinaria de movimiento de tierra, sobre la base de la determinación de la configuración, la dimensión y la posición de las áreas sin visibilidad resultantes de las partes de la máquina que entorpecen la visión.

Con el objeto de evitar que las máquinas aplasten al operador en caso de vuelco accidental, se han diseñado y normalizado 
estructuras de protección contra vuelcos. La caída de árboles, rocas y cascotes de construcción durante los trabajos de demolición pueden entrañar peligros, por lo que se han diseñado diversos medios de protección contra caída de objetos (FOPS), con el objeto de reducir la posibilidad de que los operadores resulten lesionados.

En la norma ISO 7000, Símbolos gráficos utilizables en el equipo, se resumen varios centenares de símbolos gráficos internacionalmente aceptados, utilizables en todo tipo de equipo y piezas para indicar a sus operarios el funcionamiento y utilización de los mismos.

La labor de la ISO en el campo de la construcción es tan intensa y extensa como en las demás áreas de actuación de la ISO, que abarcan la mayor parte de la actividad agrícola, industrial y marítima, con las únicas excepciones del sector electrónico - competencia de la Comisión Electrónica I nternacionaly de los productos farmacéuticos, de los que se ocupa la O rganización M undial de la Salud.

L as normas internacionales adquieren especial relevancia en las fábricas, debido a que muchas personas que buscan empleo emigran a otros países para trabajar, a veces, en lugares en los que no pueden entender ni leer el idioma. El uso de unos símbolos gráficos de operación de la maquinaria que se ajusten a las normas internacionales es imprescindible, tanto aquí, como en la construcción; tanto como lo es la estandarización de la posición de los pedales y controles manuales y la observancia de las normas internacionales aplicables a las estructuras protectoras de las piezas móviles.

Un código ISO de seguridad de los compresores abarca una extensa gama de factores ambientales y de seguridad, como la prevención de la inhalación de gases del petróleo y el control de los inhibidores de los gases de petróleo tóxicos, la prevención de la ignición del coque de petróleo y de la explosión del cárter, y el uso de válvulas de descompresión y de seguridad.

Existen cerca de cuarenta normas internacionales dedicadas a la seguridad del equipo de manipulación mecánica continua, que abarcan aspectos como la seguridad y los códigos de seguridad para diversas clases de equipo, como los transportadores de banda, los alimentadores vibratorios, los transportadores aéreos de cadena, los transportadores hidráulicos, el equipo neumático de manipulación y los transportadores sin fin y de rodillos.

En el campo de la agricultura y la silvicultura, la ISO ha desarrollado importantes normas internacionales de protección de los trabajadores. U na de las más conocidas es la relativa a los puntos de anclaje de los cinturones de seguridad de los tractores agrícolas; a medida que su aplicación se generaliza, se facilita la exportación e importación, pues la norma ha venido a reemplazar una plétora de reglamentos y normas nacionales en la materia. En las normas ISO se aborda, incluso, la redacción de los manuales operativos y de las publicaciones técnicas sobre tractores y maquinaria agrícola, con el objeto de facilitar su lectura y comprensión.

Los trabajadores portuarios se encuentran protegidos por diversas normas internacionales en las que se define la estabilidad de las grúas fijas y móviles en funcionamiento y se establecen los efectos de distintas intensidades del viento en la estructura de las grúas. 0 tras normas se refieren a los indicadores y dispositivos de seguridad que se ponen en funcionamiento en caso de error de apreciación del operador. Existe un tercer grupo de normas dedicadas al uso de indicadores, como los anemómetros; los indicadores de sobretensión; los indicadores de masa, de declive y de rotación; y los dispositivos de "corte automático", como los topes del desplazamiento de las grúas móviles, los limitadores de la capacidad de elevación de cargas y los limitadores de cuerdas flojas. El objetivo de las normas producidas y en preparación no se limita a la protección de los operadores en el trabajo, sino que se orienta también a mejorar el medio ambiente de trabajo, al fomentar la confianza del personal que se desplaza debajo de las grúas y en su entorno. 0 tra norma internacional asociada a las anteriores, en la que se establecen criterios de eliminación en función del desgaste, la corrosión, la deformación y la rotura de filamentos, tiene por objeto servir de pauta al personal de mantenimiento y supervisión de grúas y equipo de elevación de cargas. En otras normas que actualmente se encuentran en proceso de desarrollo se regulan distintos aspectos del mantenimiento, los dispositivos de anclaje fuera de servicio, la supervisión del estado del equipo, la seguridad en el uso y las señales de seguridad.

La seguridad de los trabajadores y demás personas que aceden a las instalaciones nucleares 0 a sus cercanías es objeto de diversas normas internacionales, con cuya adopción no ha concluido la labor que se realiza en este campo. En dichas normas se abordan cuestiones como los métodos de verificación de los dosímetros y medidores de exposición, un método de verificación de fugas de contenidos y de fugas radiactivas, y las directrices generales para el muestreo de los materiales radiactivos en suspensión en el aire.

$L$ a responsabilidad por las normas internacionales relativas al uso de equipo y prendas protectoras corresponde a ISO TC 94. Además de la norma relativa a los cascos de seguridad en la industria, esta división ha elaborado un vocabulario estandarizado relativo a los protectores oculares personales, ha fijado las reglas de utilización y transmisión de los filtros de infrarrojos para los protectores oculares, y ha formulado recomendaciones generales destinadas a los usuarios - y a sus responsables- de las prendas protectoras contra el fuego y el calor.

Indudablemente, la elaboración y aplicación de las normas internacionales de la ISO del tipo de las mencionadas anteriormente, gestadas en un proceso de colaboración internacional, han contribuido a mejorar la calidad de vida en el lugar de trabajo.

\section{ASO CIACION INTERNACIONAL DE LA SEGURIDAD SO CIAL (AISS)}

Dick J. M eertens

\section{Razón de ser y perspectiva histórica}

EI objetivo de la AISS consiste en cooperar, en el ámbito internacional, en el desarrollo, defensa y promoción de la sociedad social en todo el mundo, fundamentalmente, mediante la elevación de su calidad técnica y administrativa. A ctualmente, la prevención de los riesgos sociales se considera parte del sistema de la seguridad social.

La AISS tuvo un lejano predecesor: el Comité Internacional Permanente de la Seguridad Social (CPIAS), que, en un principio, se limitaba a los riesgos de accidente y que, a partir de 1891, amplió su campo de actuación al conjunto de la seguridad social. En la tercera reunión de la Conferencia Internacional del Trabajo, celebrada en 1927, se adoptaron el Convenio sobre el seguro de enfermedad (industria) (no 24) y el Convenio sobre el seguro de enfermedad (agricultura) ( $n$-25). La AISS se fundó entonces, a iniciativa de la O ficina Internacional del Trabajo, con el objeto de recabar el apoyo de los expertos de varios países europeos a la ratificación de estos convenios. Hasta 1947, la organización se denominó Conferencia Internacional de Fondos del Seguro de Enfermedad y Sociedades M utualistas (C IM AS).

El concepto de prevención existía ya en las mentes rectoras de la organización últimamente citada (CIMAS), cuando 
incluyeron la idea en los principios fundamentales de política adoptados por la Asamblea Constituyente. Sin embargo, no fue hasta 1954 que la A sociación se comprometió seriamente con la actividad de salud y seguridad en el trabajo, mediante la creación de su Comité Permanente para la Prevención de los Riesgos Profesionales. Es de observar que, en este campo, la función de la AISS es complementaria de la labor de la O IT. En efecto, los expertos de la AISS, no sólo colaboran en el desarrollo de los convenios y recomendaciones de la OIT, sino que también participan en su aplicación.

Si bien los programas de prevención predominan, lógicamente, en el campo de la salud y seguridad en el trabajo, en los dos últimos decenios, la importancia de la prevención se ha incrementado igualmente en otras ramas de la seguridad social, especialmente en el ámbito del seguro de enfermedad y, más recientemente, del seguro de desempleo, como se pone de relieve en la actividad de los Comités Permanentes de la AISS. A lo largo del pasado decenio, los esfuerzos de prevención de los accidentes de trabajo y las enfermedades profesionales han sufrido una profunda transformación en las modernas sociedades industrializadas, que se analiza en mayor profundidad posteriormente, en el apartado dedicado al "concepto de prevención" de la Asociación.

\section{Estructura y miembros}

La AISS es un complejo internacional de servicios, instituciones y organismos gestores de una o varias ramas de la seguridad social o de las mutualidades Las oficinas de la organización están situadas en la sede de la OIT en Ginebra.

La Asociación tiene dos clases de miembros. Son miembros afiliados los ministerios, organismos centrales y federaciones nacionales de las instituciones gestoras de la seguridad social 0 de alguna de sus ramas en el ámbito nacional. Pueden ser miembros asociados las instituciones nacionales sin ánimo de lucro, como las dedicadas a la investigación y a la salud y seguridad, cuyos objetivos sean compatibles con los de la Asociación, aunque no estén cualificados para llegar a ser miembros afiliados.

En 1995, había más de 240 organizaciones afiliadas a la AISS, distribuidas en 117 países, además de 95 instituciones asociadas en 35 países, para un total de 338 organizaciones pertenecientes a la Asociación en 127 países de todo el mundo. M ás de 200 instituciones miembros participan directamente en el seguro de accidentes de trabajo y enfermedades profesionales o en la prevención de accidentes y la promoción de la salud y la seguridad, o en ambas actividades.

Como se observa en el organigrama de la Figura 23.4, toda la actividad del AISS está orientada por la A samblea General, integrada por delegados de las organizaciones miembros y conocida también como el parlamento mundial de la seguridad social. EI Consejo de la AISS, compuesto por un delegado de cada uno de los países que cuentan con instituciones afiliadas, se reúne regularmente con ocasión de las reuniones trienales de la Asamblea General. La O ficina, responsable, con el Consejo, de la ejecución de los acuerdos adoptados en la A samblea $\mathrm{G}$ eneral, se reúne dos veces al año y está integrada por 30 miembros elegidos y por los presidentes de los Comités Permanentes.

\section{Actividad}

La A sociación realiza tres clases de actividades básicas:

1. Actividades regionales. Se dirigen a satisfacer las necesidades específicas de las organizaciones miembros de diversas partes del mundo. Con este fin, la AISS ha creado oficinas regionales en Africa, ambas Américas, Asia y Pacífico, y Europa, situadas, respectivamente, en A bidján, Buenos Aires, M anila y París.
Figura 23.4 • Estructura de la A sociación Internacional de la Seguridad Social (AISS).

\section{ASAMBLEA GENERAL}

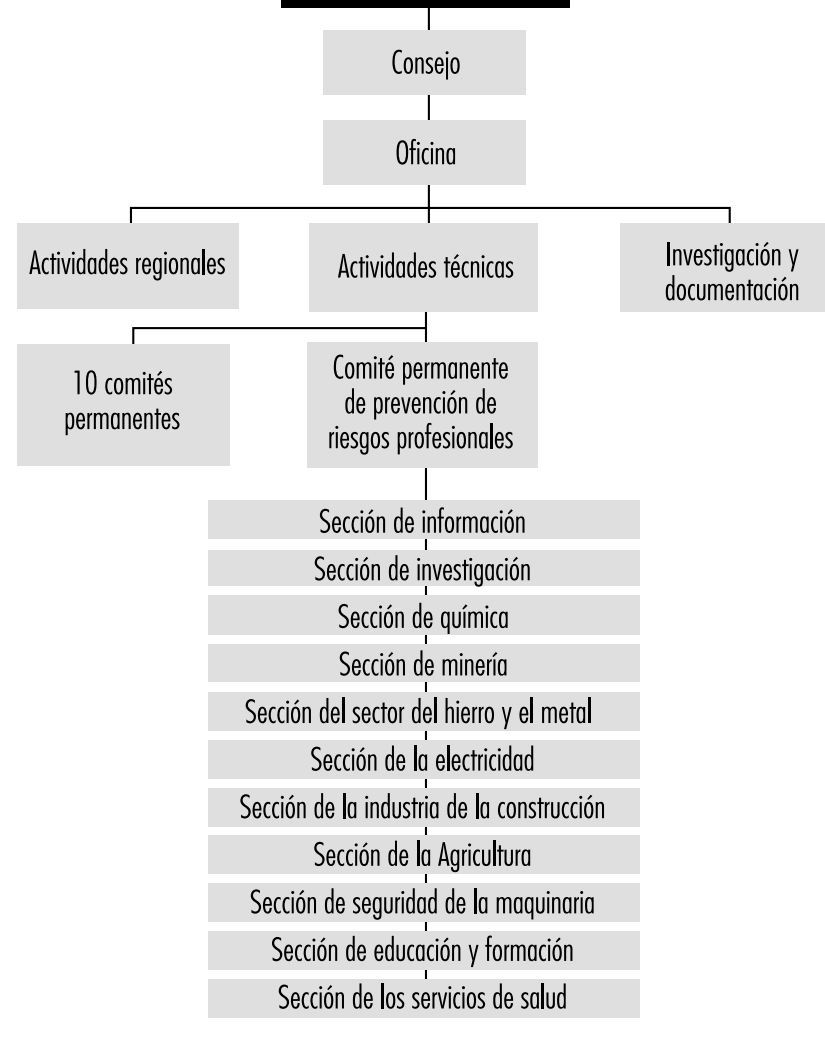

2. Investigación y documentación. $L$ as tendencias y novedades de la seguridad social en todo el mundo son objeto de un seguimiento y análisis realizados desde la perspectiva de la investigación de ámbito nacional e internacional con la colaboración de una red de corresponsales. L a A sociación, que gestiona la mayor biblioteca del mundo especializada en la seguridad social, coopera con el Departamento de Seguridad Social de la O IT en la difusión puntual de información sobre la materia.

3. Actividades técnicas. Cada uno de los diez Comités Permanentes y el Grupo de Estudios se dedica a una rama específica de la seguridad social. Su investigación se centra en los problemas específicos de un sector, como los relacionados con el seguro de enfermedad, el sistema de pensiones, el seguro de desempleo, la protección de la familia, la rehabilitación, la organización y metodología y las cuestiones actuariales y estadísticas.

Los comités permanentes del Seguro de Accidentes de Trabajo y Enfermedades Profesionales, y de Prevención de R iesgos Profesionales, con sus 11 Secciones Internacionales de Prevención de Accidentes, realizan una labor especialmente relevante en la promoción de la salud y seguridad.

\section{Comité Permanente de Prevención de Riesgos Profesionales}

Dos elementos distintos, aunque complementarios (esto es, la promoción de la prevención y las actividades técnicas), se enmarcan en el ámbito competencial de este Comité, que, en colaboración con el Consejo Asesor, realiza un seguimiento de los acontecimientos que se producen en todo el mundo, además de llevar a cabo estudios y encuestas globales de las cuestiones problemáticas. 


\section{Direcciones de las Secciones Internacionales de la AISS}

Sección Internacional de la AISS para la Investigación Secretaría de la Sección:

c/ o Institut $N$ ational de Recherche et de Sécurité (IN RS)

30 rue 0 livier $N$ oyer, F-75680 Paris C edex 14

Tfno. +33-1 40443000 ; Fax +33-140443099

Sección Internacional de la AISS para la Información

Secretaría de la Sección:

c/ o Association nationale pour la prévention des accidents du travail (AN PAT)

88 rue $\mathrm{G}$ achard, Boîte $4, \mathrm{~B}-1050$ Bruselas

Tfno. +32-2 64803 37; Fax +32-26486867

Sección Internacional de la AISS para la Minería

Secretaría de la Sección:

Vẽdeckovýzkumný Uhelný ústav

(Instituto de Investigación Científica de la M inería del Carbón)

Pikartská ul. 7

C S-7 16070 strava Radvanice

República $\mathrm{C}$ heca

Tfno. +42-6962320 48; Fax +42-696232176

Sección Internacional de la AISS para la Industria Q uímica

Secretaría de la Sección:

c/ o Berufsgenossenschaft der chemischen Industrie

Kurfürsten-A nlage 62

D-69115 Heidelberg

Tfno. +49-6221523498; Fax +49-6221523323

Sección Internacional de la AISS para la Industria del Hierro y el M etal

Secretaría de la Sección:

c/ o Allgemeine Unfallversicherungsanstalt

Adalbert-Stifter-Straße 65, A-1200 Viena

Tel. +43-1 33 111558 ; Fax +43-133111469

Sección Internacional de la AISS para la Electricidad

Secretaría de la Sección:

c/ o Berufsgenossenschaft der Feinmechanik und Elektrotechnik

G ustav-Heinemann-Ufer 130, D-50968 Colonia

Tfno. +49-22137781; Fax +49-2213778134 actividades de prevención de los riesgos profesionales:

- intercambio de información y experiencia;

- organización de reuniones internacionales y congresos mundiales;

- realización de encuestas y fomento de la investigación en el campo de la prevención de los riesgos profesionales;

- coordinación de la actividad de las Secciones Internacionales de la AISS para la Prevención de los R iesgos Profesionales;

- cooperación con la OIT y con otras organizaciones dedicadas a la prevención de riesgos profesionales;

- otras actividades de interés para las actividades del C omité.

\section{Congresos Mundiales}

Desde 1955, la OIT y la AISS han venido organizando cada tres años los Congresos M undiales de Salud y Seguridad en el Trabajo, en colaboración con las instituciones miembros de la AISS y con los pertinentes organismos del país anfitrión representados en la OIT. No resulta fácil evaluar la medida en que los Congresos $\mathrm{M}$ undiales han marchado al ritmo marcado por las
Sección Internacional de la AISS para la Industria

de la Construcción

Secretaría de la Sección:

c/ o 0 rganisme professionnel de prévention

du bâtiment et des travaux publics (O PPBTP)

Tour Amboise, 204 Rond-Point du Pont-de-Sèvres

F-92516 Boulogne-Billancourt

Tfno. +33-1 460926 54: Fax +33-146092740

Sección Internacional de la AISS para la Agricultura

Secretaría de la Sección:

c/ o Bundesverband der landwirtschaftlichen

Berufsgenossenschaften

W eissensteinstraße 72

D-34131 Kassel-W ilhelmshöhe,

Tfno. +49-5619359401; Fax +49-5619359414

Sección Internacional de la AISS para la Seguridad de las M áquinas

Secretaría de la Sección:

c/ o Berufsgenossenschaft $\mathrm{N}$ ahrungsmittel und $\mathrm{G}$ aststätten

Dynamostraße $7-9$

D-68165 Mannheim

Tfno. +49-62144562213; Fax +49-62144562125

Sección Internacional de la AISS para la Educación

y la Formación

Secretaría de la Sección:

c/ o C aisse régionale d'assurance maladie

(C RAM - lle-de-France)

17-19 place de l'Argonne

F-75019 París

Tfno. +33-1 $40053802 ;$ Fax +33-1 40053884

Secretaría Internacional de la AISS para los Servicios de Salud

Secretaría de la Sección:

c/ o Berufsgenossenschaft für $\mathrm{G}$ esundheitsdienst

und $\mathrm{W}$ ohlfahrtspflege

Pappelallee $35-37$

D-22089 Hamburgo

Tfno. +49-40202070; Fax +49-4020207525 distintas etapas del desarrollo de la prevención de los riesgos profesionales en concordancia con el progreso económico, social e industrial de estos últimos 25 años, ni la medida en que dichos Congresos han marcado la pauta o promovido ese desarrollo. En cambio, resulta indudable que el consiguiente intercambio de ideas e información sobre las investigaciones recientes y su aplicación práctica en diferentes países, tanto en el ámbito nacional, como dentro de la industria, ha hecho posible que numerosos participantes en los $C$ ongresos se familiaricen con los numerosos cambios que se van produciendo. Esto, a su vez, ha permitido que dichos participantes enriquezcan su aportación en su esfera de actividad específica.

L os cuatro últimos $\mathrm{C}$ ongresos $\mathrm{M}$ undiales han tenido lugar en O ttawa-H ull (1983), Estocolmo (1987), H amburgo (1990), N ueva D elhi (1993) y M adrid (1996).

\section{Secciones Internacionales de la AISS dedicadas a la prevención}

Desde finales del decenio de 1960, a propuesta del Comité Permanente de Prevención de Riesgos Profesionales y de su 
Consejo A sesor, la O ficina de la AISS ha creado once Secciones Internacionales de Prevención de R iesgos Profesionales. 0 cho de esas secciones se ocupan de la prevención de accidentes en distintos sectores de la industria y la agricultura, y las otras tres se dedican, respectivamente, a los medios de información, la investigación en el campo de la salud y seguridad, y la educación y formación para la prevención de accidentes.

Cada Sección Internacional de la AISS está representada por su Presidente y su Secretario General en el Consejo A sesor del Comité Permanente, que asesora a la 0 ficina en los aspectos fundamentales de la actividad del Comité y de sus Secciones Internacionales. Un ejemplo concreto de esta labor es el concepto de la prevención, que posteriormente será objeto de un examen independiente.

Las Secciones Internacionales son financieramente autónomas y poseen una estructura descentralizada y una composición independiente, consistente en miembros de pleno derecho, miembros asociados y miembros corresponsales. Pueden ser miembros de pleno derecho las instituciones pertenecientes a la AISS y otras organizaciones sin ánimo de lucro. Las entidades con fines lucrativos cuya actividad se inserte en el marco competencial de una Sección pueden ser admitidas como miembros asociados, y los expertos pueden solicitar su incorporación como miembros corresponsales. En varios países, las distintas Secretarías de las Secciones se confieren a las instituciones miembros de la AISS especializadas en los campos respectivos.

Cada Sección funciona como centro de difusión de la información generada en su propia esfera de competencias. Todas las Secciones organizan simposios internacionales, coloquios y reuniones de expertos, cuyos informes y actas se reproducen en la serie Prevención 1000, de la AISS. En la actualidad, las Secciones cuentan con unos 45 grupos de trabajo que tienen una composición internacional y que se ocupan de diversas materias, que pueden oscilar desde el asesoramiento sobre cuestiones de seguridad a los trabajadores migrantes de la construcción, confección o sobre una lista de especificaciones para la clasificación de la maquinaria sobre la base de criterios ergonómicos, hasta la seguridad en el trabajo con agentes biológicos. Los hallazgos de estos grupos de trabajo se editan en forma de folletos técnicos como parte de la serie Prevención 2.000 de la AISS. Si bien la mayor parte de los títulos se editan en inglés, francés y alemán, existen algunos en español y otros idiomas. Los folletos se pueden pedir directamente a la Secretaría de la Sección correspondiente.

Revisten especial interés los festivales internacionales cinematográfico y de vídeo, que coinciden con los Congresos $M$ undiales y respecto a los cuales uno de los Grupos de Trabajo de la Sección de la Electricidad funciona como centro de difusión de información. Todas las producciones que se exhiben en ambos festivales se relacionan en un catálogo que se edita en cuatro idiomas y que la Sección mencionada facilita gratuitamente. A continuación se describen brevemente las Secciones Internacionales de la AISS.

\section{Sección Internacional de la AISS para la Investigación.}

Esta sección ofrece información actualizada sobre los proyectos de investigación presentes y futuros en todo el mundo. Dos bancos de datos permiten el acceso rápido y eficaz a esta información. El Grupo de Trabajo denominado "Conceptos de Investigación" aporta la base teórica que garantiza que, en mayor medida que en el pasado, la investigación contribuye a mejorar su campo y la aplicación práctica de los resultados.

\section{Sección Internacional de la AISS para la Información.}

La Sección de Información suministra datos sobre las técnicas de información más eficaces. El Grupo de Trabajo denominado
"Publicaciones sobre Salud y Seguridad" asesora a los expertos en seguridad sobre la forma más efectiva de llegar a su público. Esta Sección brinda asesoramiento especializado sobre la "publicidad para la seguridad".

Sección Internacional de la AISS para la Industria Minera. Esta Sección se interesa por los riesgos típicos del trabajo subterráneo en las minas de carbón (oscuridad, polvo calor, gases, explosiones, hundimientos, etc.) y se ocupa de la formación de los equipos de rescate en las minas.

\section{Sección Internacional de la AISS para la Industria} Química. Si bien la aparición de nuevas sustancias produce unos riesgos nuevos, la industria química ha logrado unos niveles elevados de seguridad que se han revelado ejemplares. La Sección Química trabaja para garantizar que estos niveles de seguridad trasciendan las fronteras en una medida igual, si no mayor, que los riesgos.

Sección Internacional de la AISS para el Hierro y la Metalurgia. Es preciso reducir la elevada tasa de accidentes que se produce en este importante sector. Se desarrollan sistemas de seguridad contra los peligros y causas de accidentes más frecuentes. L os G rupos de Trabajo de esta Sección se interesan fundamentalmente por las nuevas tecnologías y los sustitutos de las sustancias más peligrosas presentes en el trabajo.

\section{Sección Internacional de la AISS para la Electricidad.}

E sta energía "invisible" genera numerosos riesgos invisibles. Esta sección formula recomendaciones prácticas para la prevención de accidentes y establece las bases para el control legal de los sistemas y aparatos eléctricos, apoyado por unos métodos eficaces de prestación de primeros auxilios en caso de accidente eléctrico. La Sección cuenta con un centro de distribución de filmes y vídeos dedicados a la salud y seguridad y al medio ambiente.

Sección Internacional de la AISS para la Industria de la Construcción. La elevadísima tasa de accidentes que se registra en la industria de la construcción impone la adopción de una estrategia de seguridad capaz de adaptarse al cambio continuo que se produce en el medio ambiente del trabajo de la construcción. Lejos de limitarse a la solución de problemas concretos, el objetivo de esta Sección consiste en mejorar la seguridad y el sistema de prevención de accidentes en el conjunto de la industria de la construcción, especialmente mediante una mayor cooperación entre los diferentes ocupaciones que confluyen en un mismo puesto de trabajo.

Sección Internacional de la AISS para la Agricultura. La mecanización y el empleo de productos químicos en la agricultura son causa de problemas en todo el mundo. Esta Sección propugna una rápida evolución social y tecnológica que se desarrolle en el contexto de la revolución técnica y que, al mismo tiempo, garantice que la producción de alimentos no suponga un peligro para la vida humana.

Sección Internacional de la AISS para la Seguridad de la Maquinaria. Esta Sección se ocupa de la seguridad de los sistemas y de la prevención de accidentes en los aparatos, máquinas, dispositivos y sistemas. La labor de los Grupos de Trabajo de esta Sección se centra en la estandarización de los dispositivos de seguridad, los aspectos ergonómicos, la reducción del ruido, los conmutadores de seguridad y la prevención de las explosiones de polvo. 
Sección Internacional de la AISS para la Educación y la Formación. El creciente progreso tecnológico que se produce en todas las esferas de la vida trae consigo nuevos peligros. La causa principal de los accidentes es la falta de educación y formación en el campo de la seguridad. La seguridad se debe incorporar al comportamiento humano en todos los aspectos de la existencia. Esta Sección se ocupa de todos los aspectos pedagógicos de la educación y formación para la prevención y propugna una concepción global de la prevención, basada en aplicar la experiencia generada por la prevención en el lugar de trabajo a la seguridad en todas las esferas de la vida.

Sección Internacional de la AISS para los Servicios de Salud. Esta Sección acude a la cooperación internacional en el esfuerzo por superar los déficits de seguridad existentes en el sector sanitario. Los riesgos profesionales típicos del sector de la salud difieren sensiblemente en algunos aspectos de los riesgos característicos de otras actividades. Ejemplos de esta especificidad son la exposición directa al contagio y los riesgos inherentes a la manipulación de medicamentos - especialmente los anestésicos gaseosos- los desinfectantes y los residuos infecciosos.

\section{El concepto de prevención de la AISS “seguridad mundial"}

En octubre de 1994, la O ficina de la AISS adoptó en 1994 el denominado "Concepto de prevención de la AISS de seguridad mundial": La senda dorada hacia la política social".

Sólo siete de cada cien accidentes mortales se producen en el trabajo, y el resto son accidentes de circulación o domésticos, o bien ocurren en la escuela o con ocasión de la práctica de deportes. Por consiguiente, el objetivo de este concepto consiste en aplicar eficazmente en otros campos la experiencia obtenida en el ámbito de la prevención en el mundo del trabajo.

Partiendo del criterio de que el mantenimiento de la salud es un propósito fundamental de la humanidad y, por lo tanto, un objetivo primordial de la seguridad social, el concepto aboga por la correlación de la prevención, la rehabilitación y la indemnización, así como por la preservación de un medio ambiente intacto. Se pondrá énfasis en la importancia del factor humano en las fases de planificación, organización y aplicación, así como en la necesidad de iniciar la formación en la prevención en la primera infancia. Se hará un esfuerzo por llegar a todos cuantos, en razón de su actividad, están en condiciones de mejorar la protección de las personas contra los distintos riesgos. Estas personas son los legisladores y los responsables de la normalización; los agentes sociales; los responsables del desarrollo, planificación, diseño y producción de bienes y servicios; los profesores y responsables del desarrollo de los planes de estudio; los especialistas en información dedicados a la información pública, los profesionales de la salud en el trabajo; los organismos consultores y supervisores; los directivos responsables de los esquemas de seguro públicos y privados; los responsables de la toma de decisiones y los directores de programas de las organizaciones internacionales y, por último, aunque no lo menos importante, los padres e hijos.

El impulso general a la salud y seguridad en el trabajo y en otros campos se basa en tres clases de medidas: técnicas, organizativas y de modificación del comportamiento. Con este objeto, en el concepto de prevención de la AISS se establecen tres niveles de actuación:

1. Informar al público en general y fomentar la conciencia de los problemas de salud y seguridad, a través de los medios de comunicación social, periódicos y folletos, carteles, etcétera.

2. Alcanzar una proyección amplia y profunda al mismo tiempo, procurando influir en los comportamientos y actitudes por medios dotados de efectos multiplicadores, empleando para ello unos métodos y técnicas enfocados a grupos específicos, como películas y materiales didácticos.

3. Perseguir un impacto profundo en los grupos de riesgo directo, empleando medios específicos como el asesoramiento y los folletos monográficos.

El primer paso en la aplicación del concepto consistirá en hacer inventario de las actividades de prevención, con la finalidad de conocer las necesidades y deficiencias regionales. También se hará inventario de los actuales materiales e instalaciones de apoyo. Además, la AISS impulsará sus actividades de información e investigación y su programa de reuniones, incrementará su cooperación con las organizaciones internacionales en el campo de la prevención e incorporará los proyectos de aquéllas a sus actividades.

En resumen, la única vía segura hacia el éxito pasa por la cooperación entre los sistemas de prevención, de rehabilitación y de indemnización; por la transposición a los ámbitos no laborales de la experiencia positiva generada en las empresas en materia de prevención; y por la concesión de un mayor peso al factor humano.

\section{Publicaciones}

La AISS edita una gran variedad de estudios, encuestas, publicaciones y boletines periódicos y esporádicos. Para mayor información sobre estas publicaciones, puede consultarse el Catálogo de Publicaciones de la AISS, que se puede pedir gratuitamente a la dirección siguiente: ISSA, Case postale 1, CH -1211, G inebra 22, Suiza.

Además de las actas de los Congresos M undiales de Salud y Seguridad en el Trabajo, editadas por el Comité O rganizador del país anfitrión, las publicaciones de las distintas Secciones Internacionales se relacionan en las series 1.000 y 2.000 de Prevención AISS, y se pueden solicitar en la dirección anteriormente indicada.

\section{COMISION INTERNACIONAL DE MEDICINA DEL TRABAJO (CIMT)}

Jerry Jeyaratnam

\section{Perspectiva histórica y objetivos}

La Comisión Internacional de M edicina del Trabajo (CIMT) es una organización profesional no gubernamental de ámbito internacional que tiene por objeto la promoción del progreso científico, el conocimiento y el desarrollo de la salud y seguridad en el trabajo en todas sus facetas. La organización se fundó en M ilán, en 1906, con el nombre de Comisión Permanente de M edicina del Trabajo. En nuestros días, la CIM T es la principal asociación científica internacional dedicada a la medicina del trabajo y está integrada por 2.000 profesionales de 91 países. La CIM T ha sido reconocida por las Naciones U nidas y mantiene estrechos lazos de cooperación con la OIT, la OMS, el PNUMA, la AISS y la $C E E$. Sus idiomas oficiales son el inglés y el francés.

En el momento de su fundación, la Comisión tenía 18 miembros en representación de 12 países. U no de sus objetivos principales consistía en organizar cada tres años congresos internacionales que sirviesen de marco al intercambio de ideas y experiencias entre los más importantes especialistas en la medicina del trabajo, y esta tradición ha continuado hasta nuestros días, que han sido testigos del vigésimo quinto congreso celebrado en Estocolmo en 1996. 
Tabla 23.3 - Sedes de los congresos trienales desde 1906.

\begin{tabular}{llll} 
Sede & Año & Sede & Año \\
Milán & 1906 & Madrid & 1963 \\
Bruselas & 1910 & Vienna & 1966 \\
Viena (aplazado) & 1924 & Tokio & 1969 \\
Amsterdam & 1925 & Buenos Aires & 1972 \\
Budapest & 1928 & Brighton & 1975 \\
Ginebra & 1931 & Dubrovnik & 1978 \\
Bruselas & 1935 & El Cairo & 1981 \\
Francfort & 1938 & Dublín & 1984 \\
Londres & 1948 & Sydney & 1987 \\
Lisboa & 1951 & Montreal & 1990 \\
Nápoles & 1954 & Niza & 1993 \\
Helsinki & 1957 & Estocolmo & 1996 \\
Nueva York & 1960 & Singapur & 2000 \\
& & & \\
\hline
\end{tabular}

El Congreso celebrado en Londres en 1948 tuvo una gran repercusión internacional e impulsó la internacionalización de la Comisión. Se modificó su constitución y el nombre se cambió por el de Comisión Permanente y A sociación Internacional, en un proceso que concluyó en 1957. El proceso de internacionalización y democratización de la comisión se fue acrecentando, hasta que en 1984 adoptó la denominación actual.

La CIMT constituye un foro de intercambio científico y profesional. Para ello, la CIM T:

- organiza congresos y reuniones internacionales sobre la medicina del trabajo;

- crea comités científicos en diversas áreas de la medicina del trabajo y afines;

- difunde información sobre la actividad en el campo de la medicina del trabajo;

- establece directrices y elabora informes sobre la medicina del trabajo y áreas afines;

- colabora con los organismos nacionales e internacionales competentes en materia de salud laboral y ambiental;

- realiza otras actividades incluidas en el marco de la medicina del trabajo;

- recaba y administra las aportaciones económicas precisas para el desarrollo de su actividad.

\section{Estructura y miembros}

La gestión de la CIM T corresponde a un equipo de directivos y a un consejo. Aquél está integrado por el Presidente, dos Vicepresidentes y el Secretario G eneral; al tiempo que el consejo está integrado por el anterior presidente y otros 16 consejeros elegidos entre los miembros de la organización. Además, en caso necesario, el Presidente puede cooptar otros dos miembros del consejo en representación de las áreas geográficas o funcionales insuficientemente representadas.

Entre los miembros de la CIM T hay personas físicas y jurídicas. Las organizaciones, sociedades, industrias y empresas pueden convertirse en miembros patrocinadores de la CIMT. Las organizaciones profesionales o científicas pueden ser miembros afiliados.

L os miembros patrocinadores pueden designar a un representante que reúna los requisitos exigibles para ser miembro titular
Tabla 23.4 • Relación de comités científicos y grupos de trabajo de la CIMT (1966).

\section{Comités científicos}

Prevención de accidentes

Envejecimiento y trabajo

Agricultura

Cardiología

Sector químico (Medichem)

La informática en la salud laboral y medioambiental

La industria de la construcción

Países en vías de desarrollo

Educación y formación

La epidemiología en la higiene industrial

Fibras

Trabajadores de la sanidad

Investiaación v evaluación de los servicios de salud Higiene industrial

Trastornos musculoesqueléticos

Neurotoxicología y psicofisiología

Enfermería de empresa

Toxicología industrial

Polvo de origen orgánico

Pesticidas

Radiación y trabajo

Los servicios de salud laboral en la pequeña empresa

Trabajo por turnos

Toxicología de los metales

Trastornos respiratorios relacionados con el trabajo

Vibración y ruido

Grupos de trabajo científico

Dermatosis profesional y de origen ambiental

Minusvalía y trabajo

Riesgos para la función reproductora en el lugar de trabajo

Factores térmicos

y que disfrutará de los privilegios concedidos a los miembros personales. Por su parte, los miembros afiliados pueden designar un representante que reúna los requisitos exigibles para ser miembro titular y que disfrutará de idénticos derechos que los titulares. L os miembros individuales de la CIM T representan un amplio espectro de intereses profesionales, como médicos, higienistas industriales, profesionales de la enfermería, técnicos en seguridad, psicólogos, químicos, físicos, ergónomos, estadísticos, epidemiólogos, sociólogos y fisioterapeutas. Estos profesionales trabajan en universidades, institutos de medicina del trabajo, administraciones públicas e industrias. A finales de 1993, las naciones más representadas eran Francia, Estados U nidos. Finlandia, Japón, R eino U nido y Suecia, cada una de las cuales contaba con más de 100 miembros. Los miembros patrocinadores y afiliados pueden acceder a la Asamblea General y 
participar en el trabajo de los comités científicos. Asimismo, estos miembros pueden remitir artículos para su publicación en el boletín, que los mantiene informados de las actividades presentes y previstas.

\section{Actividades}

La actividad más destacada de la CIMT son los Congresos M undiales de Medicina del Trabajo, que se celebran cada tres años con unos 3.000 participantes. El Congreso de 1990 se celebró en Montreal, Canadá, y el de 1993 en Niza, correspondiendo a Estocolmo la organización del Congreso de 1996. Está previsto que el del 2000 se celebre en Singapur. En la Tabla 23.3 se relacionan las sedes de todos los congresos que han tenido lugar desde 1906.

En la actualidad, la CIM T alberga veintiséis comités científicos y cuatro grupos de trabajo (Tabla 23.4. La mayor parte de los comités organizan regularmente simposios, publican monografías y aprueban los resúmenes que se presentan a los congresos internacionales. L a CIM T edita un boletín trimestral, que se distribuye gratuitamente entre los miembros. En este boletín bilingüe se publican informes de los congresos, reseñas de publicaciones, el calendario de los próximos eventos e información sobre cuestiones de educación e información, además de anuncios que interesan a los miembros. Algunos de los comités científicos publican también monografías y las actas de sus reuniones respectiva. La CIMT Ileva un archivo informatizado de sus miembros, del que se realizan periódicamente impresiones que se distribuyen entre los socios. Además, la CIM T edita el diario científico International Journal of O ccupational and Environmental Health (IJOEH). Esta publicación se distribuye entre los miembros de la organización mediante el pago de una módica cuota de suscripción.

\section{- ASOCIACION INTERNACIONAL DE INSPECTORES DE TRABAJO (IALI)}

David Snowball

\section{Perspectiva histórica y objetivos}

La Asociación Internacional de Inspectores de Trabajo (IALI) se constituyó en 1972 como foro internacional para el intercambio de información y experiencias profesionales entre los inspectores de trabajo. Su objetivo es estrechar la cooperación y promover entre las diversas inspecciones, autoridades e instituciones interesadas el conocimiento de la función, la realidad y los problemas de la inspección de trabajo. En los estatutos de la Asociación se prohibe toda actividad política, sindical o religiosa y se excluyen los juicios de valor respecto a la legislación laboral y los sistemas de inspección vigentes en cada Estado. Esta organización no gubernamental (O NG) ha sido reconocida por la OIT.

\section{Estructura y miembros}

En 1996, la A samblea G eneral (que se reúne cada tres años, coincidiendo con los $C$ ongresos trienales) eligió un Comité Ejecutivo integrado por siete personas. EI Comité Ejecutivo, a su vez, eligió un Presidente (alemán) y designó un Secretario H onorario (británico) y un Tesorero H onorario (suizo). Las cuatro Vicepresidencias recayeron, respectivamente, en un español, un danés, un tunecino y un húngaro. El Comité Ejecutivo se reúne siempre que lo requieren los intereses de la Asociación, que tiene su domicilio social en 23, rue Ferdinand-H odler CP3874/ 1211, Ginebra 3. Suiza. La Secretaría radica en Hessisches M inisterium für
Frauen, Arbeit und Socialordnung, Dostojewskistrasse 4, 65187 Wiesbaden, Alemania (teléfono +49-611-8173316; fax: +49-611-86837).

Pueden pertenecer a la Asociación Internacional de Inspectores de Trabajo:

- Ios departamentos de trabajo nacionales y regionales (inspecciones de trabajo, departamentos de seguridad e higiene, etcétera);

- las organizaciones nacionales de inspectores de trabajo (asociaciones, sindicatos, etc.).

Existe una cuota anual de afiliación cuya cuantía es una función de la dimensión de la organización solicitante y que se aplica para sufragar los costes de organización de las diversas actividades. En septiembre de 1995, había 65 miembros de la A sociación en 50 países. A ctualmente, la mayoría de los miembros son departamentos e inspecciones de trabajo.

\section{Actividades}

La Asociación se dedica a recoger y resumir información y documentación relativas a determinados aspectos de la función de la inspección de trabajo, así como a realizar estudios comparativos de la labor de sus miembros, con el objeto de fomentar entre los profesionales el conocimiento de las distintas facetas de la inspección de trabajo y de servir de cauce al intercambio de puntos de vista y experiencias entre los mismos. Los simposios técnicos que se organizan conjuntamente con los países miembros y los congresos trienales son otros tantos foros para que los inspectores de trabajo establezcan relaciones personales, intercambien información sobre los problemas y sus soluciones y sobre las nuevas tendencias, y enriquezcan sus conocimientos. Estas reuniones sirven también a la finalidad práctica de centrar el interés de los profesionales en un abanico extenso, aunque cuidadosamente seleccionado, de problemas de la inspección de trabajo, con lo que se procura una mayor coherencia en el funcionamiento de las inspecciones de trabajo de diferentes países. Se publican las actas de las reuniones, además de un boletín periódico que se distribuye entre los miembros.

L os programas de la Asociación Internacional de Inspectores de Trabajo se canalizan exclusivamente hacia la difusión de la información aportada por los informes elaborados y los cuestionarios cumplimentados por los simposios internacionales y regionales. Cada tres años, se celebra en G inebra un congreso internacional, organizado gracias a la generosa ayuda técnica brindada por la OIT con ocasión de su conferencia internacional anual. La O IT colabora igualmente en la organización de muchos de los simposios. A partir de 1974, los programas de la A sociación se han orientado al estudio de una extensa gama de políticas de salud y seguridad y al medio ambiente de trabajo. 0 bjeto de estos estudios han sido los sistemas de registro estadístico de locales y accidentes, los métodos de inspección de las empresas más pequeñas, los problemas de las grandes obras de construcción y el empleo de ordenadores por parte de los inspectores. La A sociación ha analizado las causas de los accidentes y otros problemas asociados al empleo de robots y otros sistemas electrónicos programables. M ás recientemente, en el orden del día de los congresos y simposios de la organización se han incluido cuestiones tan diversas como los factores humanos, la formación de los inspectores, la inspección de los servicios públicos, el trabajo infantil, la agricultura, la evaluación de riesgos y la salud laboral.

\section{El cambiante mundo del trabajo}

La necesidad de lograr un intercambio de información y experiencia más eficaz se ha visto estimulada por una serie de 
acontecimientos significativos en el campo de la inspección de trabajo, entre los que destacan los siguientes:

- la complejidad y cobertura crecientes de la legislación de trabajo;

- la introducción de nuevos conceptos de supervisión, como la evaluación y la gestión de riesgos;

- la magnitud y amplitud de la innovación tecnológica, que se manifiesta, por ejemplo, en el uso de nuevos compuestos y sustancias químicas, en la creciente presencia de los sistemas electrónicos programables, de la manipulación genética, de las nuevas aplicaciones de la radiación ionizante y, en general, en el uso creciente de la tecnología informática;

- los cambios estructurales que se producen en la industria de los países de economía de mercado establecida, en las naciones en período de transición hacia la economía de mercado y en los países en vías de desarrollo;

- el incremento - debido, en parte, a la evolución anteriormente descrita - del número de pequeñas y medianas empresas;

- el declive de la militancia e influencia de los sindicatos, especialmente en muchas economías de mercado desarrolladas;

- la presión que los gobiernos ejercen sobre las inspecciones de trabajo mediante las restricciones presupuestarias y la exigencia de que aquéllas justifiquen su existencia acreditando ( $y$, a ser posible mejorando) la eficiencia y eficacia de su labor.

\section{Desafíos para la inspección de trabajo}

La importancia creciente del factor humano contribuye a modelar todas estas cuestiones. L os inspectores de trabajo deben analizar, comprender y utilizar sus conocimientos con un espíritu constructivo para inducir a trabajadores y empresarios a tomar en consideración esta cuestión primordial en el desarrollo de una estrategia preventiva en el campo de la salud y la seguridad. Además, en muchos países existe una conciencia y una preocupación crecientes por los riesgos del trabajo y sus métodos. En las medidas legislativas con mayor proyección futura, este sentimiento se ha traducido en el reconocimiento de que nadie debe sufrir daños por causa de la necesidad de trabajar. Este mismo sentimiento se manifiesta igualmente en la preocupación por los efectos de la actividad industrial y comercial en el medio ambiente y en la calidad de la vida.

Los inspectores de trabajo no pueden permitirse ignorar estas realidades; han de asumir la iniciativa y utilizar los medios de comunicación social para explicar su función y dar a conocer su trabajo de asesoramiento, con el objeto de fomentar la confianza en la labor constructiva que realizan. L os inspectores de todo el mundo han tenido que replantearse su escala de prioridades, sus métodos de trabajo y el modo de realizar sus inspecciones, con el objeto de poder dedicar más tiempo y un porcentaje mayor de sus limitados recursos a la actividad productiva.

El intercambio de información y de experiencias en todos estos campos es del máximo interés para los inspectores. En efecto, a pesar de que las diversas inspecciones se desenvuelven en unos contextos políticos, económicos y jurídicos diferentes, la experiencia demuestra que tienen muchos intereses reales en común y que pueden beneficiarse de forma sumamente positiva de la experiencia, los diversos puntos de vista, las ideas y los éxitos y fracasos de sus compañeros de otros países.

\section{Referencias}

Agencia Internacional de Energía Atómica (IAEA). 1994. International Standards for Protection against I onizing Radiation and the Safety of Radiation Sources. $\checkmark$ iena: IAEA.

Alston, P. 1984. Conjuring up new human rights: A proposal for quality control. Am J Int Law 78:607-621.

Asamblea General de las Naciones Unidas. 1994 Declaración Universal de Derechos Humanos, Resolución 217A (II) de la A samblea General de las $\mathrm{N}$ aciones U nidas adoptada el 10 de diciembre de 1948. En T wenty-Five H uman Rights Documents. Nueva Y ork: U niv. de Columbia. Center for Study of H uman R ights.

Banco M undial. 1974. Environmental, $H$ ealth and $H$ uman $E$ cologic C onsiderations in $E$ conomic $D$ evelopment Projects.

-. 1993a. The W orld Bank and the Environment, Fiscal 1993. Banco M undial: O xford U niversity Press.

—. 1993b. W orld Development Report 1993, Investing in $H$ ealth. Banco M undial: $O$ xford U niversity Press.

Carta Africana [Banjul] de Derechos H umanos y de los Pueblos. 1982. Documento núm. 21 ILM 59. A probada el 27 de junio de 1981.

Carta Social Europea. 1994. Firmada por el Consejo Europeo el 18 de octubre de 1961. Entró en vigor el 26 de febrero de 1965. En T wenty-Five $H$ uman Rights D ocuments. N ueva Y ork: U niv. de Columbia, C entre for Study of $\mathrm{H}$ uman R ights.

Comisión Europea. 1990. Health and safety at work in the European Community, Social Europe.

Corn, JK . 1992. Response to O ccupational $\mathrm{H}$ ealth $\mathrm{H}$ azards: A H istorical Perspective. NuevaY ork: Van Nostrand R einhold.

Corn, M. 1985. Preventing Injury and IIIness in the W orkplace Washington, DC: US Government Printing 0 ffice.
Departamento de Información Pública de las N aciones U nidas. 1992. Basic F acts A bout the U nited Nations. Nueva Y ork: NU.

Faden, R. 1985. Reproductive $\mathrm{H}$ ealth $\mathrm{H}$ azards in the W orkplace. Washington, DC: US Government Printing 0 ffice.

Feitshans, IL. 1993. Designing an Effective OSHA Compliance Program. Deerfield, Illinois: Boardman Callaghan.

—. 1994. Job security for pregnant employees: The model employment termination act. Ann Am Acad Polit SS 119 (noviembre).

Friedman, W. 1969. International Law: Cases and $M$ aterials. N ueva Y ork: American Casebook Series.

Grad, FP, IL Feitshans. 1992. Article 12: Right to health. En US Ratification of the International Covenants On $\mathrm{H}$ uman Rights, dirigido por $\mathrm{H} \mathrm{H}$ annum y D Fischer. Washington, DC: American Society of International Law.

H enkin, L, JL H argrove (dirs.). 1992. H uman R ights: An Agenda for the Next Century. American Society of International Law.

Henkin, L. 1990. International law: Politics, values and functions. General course on public international law. En Academy of International Law Offprint of Collected Courses. Vol. 216. Dordrecht: $M$ artinus Nijhoff.

Johnston, A. 1970. The International Labour O rganization: Its W ork for Social and Economic Progress. Londres: Europa Publications.

Ley de indemnización de los trabajadores del Estado de Virginia con comentarios. 1982. Sec. 65. 1-7. Charlottesville, Virginia: M ichie.

M ausner, JS, S K ramer. 1985. Epidemiology: An Introductory T ext. Filadelfia: WB Saunders.

M orgenstern, F. 1982. D eterrence and Compensation: L egal Liability in $\mathrm{O}$ ccupational Safety and $\mathrm{H}$ ealth. Ginebra: OIT
Naciones Unidas. 1994. Carta de las Naciones U nidas, firmada el 26 de junio de 1945 y en vigor desde el 24 de octubre de 1945. En T wenty-Five $H$ uman Rights Documents. Nueva York: Univ. de Columbia, Center for Study of $\mathrm{H}$ uman R ights.

Nightingale, E. 1990. Genetic M onitoring and Screening in the W orkplace. Ginebra: OIT

O rganización de las Naciones Unidas para la Agricultura y la Alimentacion (FAO). 1985 Código internacional de conducta sobre la distribución y el uso de plaguicidas.

O rganización Internacional del Trabajo (OIT). 1984. Improving W orking Conditions and Environment: An International Programme (PIACT). Ginebra: OIT.

- . 1990. International Directory of O ccupational Safety and $\mathrm{H}$ ealth Services and Institutions. O ccupational Safety and $\mathrm{H}$ ealth Series, N 0. 66. G inebra: OIT

- 1991. Prevention of M ajor Industrial Accidents. An IL O code of practice. Ginebra: O IT

-. 1991. Occupational Exposure Limits for Airborne T oxic Substances. O ccupational Safety and Health Series, N o. 37. Ginebra: OIT.

1992. Constitution of the International Labour Organization and Standing Orders of the International $L$ abour Conference. Ginebra: OIT.

- .1993. P rotection of $W$ orkers from P ow er $F$ requency E lectric and $M$ agnetic Fields. Occupational Safety and $H$ ealth Series, N 0. 69. Ginebra: O IT.

- . 1996a. Convenios y R ecomendaciones de la Organización Internacional del Trabajo, 1919-1951 (vol. 1), 1952-1976 (vol. 2), 1977-1995 (vol. 3). Ginebra: OIT .

-. 1996b. Recording and Notification of Occupational Accidents and Diseases. An ILO code of practice. Ginebra: OIT

-. 1996. Accident Prevention on B oard Ship at Sea and in Port. An IL O code of practice. Ginebra: O IT. 
-. 1996c. M anagement of Alcohol and D rug-related Issues in the W orkplace. An IL O code of practice. G inebra: O IT

O rganización Mundial de la Salud (OMS). 1978. Constitución de la Organización Mundial de la Salud. En B asic D ocuments. G inebra: O M S.

- 1978. Declaración de Alma-Ata. Conferencia internacional sobre asistencia sanitaria primaria 6-12 de septiembre de 1978, Alma-A ta, UR SS.

O rganización Panamericana de la Salud (O PS). 1980. Documento oficial núm. 173. Washington, DC: OPS.

—. 1990. R esolución XIV sobre la salud de los trabajadores, 23a Conferencia Sanitaria Panamericana.

Pacto Internacional de Derechos Económicos, Sociales y Culturales. 1994. En T wenty-Five $H$ uman Rights D ocuments. N ueva Y ork: U niv. de Columbia, Centre for Study of $\mathrm{H}$ uman Rights.

Pacto internacional para la eliminación de toda discriminación contra la mujer. 1979. D ocumentos no ILM. 33, 12 y 28 ILM 1446, Arts. 6 y 27 A probado el 18 de diciembre de 1979.

Parmeggiani, L (dir.). 1983. Enciclopedia de salud y seguridad en el trabajo. Ginebra: OIT

Ransom V. Sir Robert M cAlpine and Sons Ltd. 1971. Q ueen's Bench Division, 12 de marzo de 1971.

Rothstein, M. 1984. M edical Screening of W orkers. Washington, DC: Bureau of $N$ ational Affairs (BNA).

Ruda, JM. 1994. Those who turn principles into reality. W orld W ork M ag IL 0 (10) (diciembre).

Samsom, K T. 1984. The changing pattern of ILO supervision. Int L abour R ev 569.

Sigler, JA, JE Murphy. 1988. Interactive Corporate Compliance: An Alternative to Regulatory Compulsion. N ueva Y ork: Q uorum Books.

Stellman, J, S Daum. 1973. W ork Is D angerous to Your $\mathrm{H}$ ealth. Nueva Y ork: Pantheon Books.

Summers, C. 1992. Artículo 7. En U S Ratification of the International Covenants 0 n H uman Rights, dirigido por $\mathrm{H}$ Hannum y D Fischer. Washington, DC: A merican Society of International Law.

TUTB. 1991. R esumen de la Directiva europea sobre salud y seguridad.

Weeks, JL, BS Levy, GR Wagner. 1991. Preventing $O$ ccupational Disease and Injury. Washington, DC: American Public H ealth Association (APH A).

W right v. D unlop Rubber C 0 . and another. 1971. Q ueen's Bench Division, 21 de abril de 1971.

\section{O tras lecturas recomendadas}

A shford, NA, CC Caldart. 1985. The right to know: Toxic information transfer in the workplace. Ann $\mathrm{R}$ ev Publ $\mathrm{H}$ ealth 6:383-401.

Bayer, R . 1987. N otifying workers at risk: The politics of the right-to-know. Am । Public $\mathrm{H}$ ealth 76:1352-1356.

Bingham, E. 1983. The "R ight-to-K now" movement Am J Public $\mathrm{H}$ ealth 73:1302.

Carpentier, J, P C azamian. 1977. Night W ork: Its E ffects $O n$ the $\mathrm{H}$ ealth and W elfare of the W orker. Ginebra: OIT

Cowdonan, J, W Von Richthofen. 1996. Labor inspection in transition economies. Ginebra: O IT.

Elling RH. 1989. The political economy of workers' health and safety. Soc. Sci. M ed. 28.11: 1171-1182.

Hadden, SG. 1989. A citizen's right to know: Risk communication and public policy. Boulder, Colorado: Westview Press.

—. 1986. Read the label: Reducing risk by providing information. Boulder, Colorado: Westview Press

Levenstein, C, LI Boden, DH Wegman. 1984. $\mathrm{COSH}$ : A grass-roots public health movement. Am J Public H ealth 74:964-965.
M CG arity, T O. 1984. The new OSHA rules and the workers' right to know. Hastings Centre Rep 14:38-45.

M illar, JD. 1990. The right to know in the workplace: The moral dimension. En $O$ ccupational $\mathrm{H}$ ealth in the 1990s: Developing a Platform for Disease Prevention, dirigido por PJ Landrigan y IJ Selikoff. Nueva Y ork: N ew Y ork A cademy of Sciences.

Needleman, C. 1990. H igh-risk W orker Notification: A Literature Review. Cincinnati, O hio: National Institute for O ccupational Safety and $\mathrm{Health}$ (NIO SH).

-. 1990. High-risk notification: A voiding adverse effects for workers. N ew Solutions 1(2):25-31.

O'N eill R, S Pickvance, (dirs.). 1996. International Directory of W orkers' Occupational $\mathrm{H}$ ealth Contacts. Sheffield, R eino U nido: WHIN.

O rganización Internacional del Trabajo (OIT). 1983. Accident Prevention: A W orkers' Education M anual. Ginebra: OIT .

- 1985. Labour Inspection: $G$ eneral survey by the C ommittee of Experts. Ginebra: OIT.

- . 1986. Labour Inspection: A W orker's E ducation M anual. Ginebra: OIT .

- . 1987. Labour Inspection in Socialist Countries of $E$ urope División de Administración del Trabajo. Ginebra: OIT

- 1987. The Role and Organization of Employment Services. Actas del simposio internacional celebrado el 14-17 de octubre de 1986. División de Administración del Trabajo. Ginebra: OIT.

—. 1987. U se of Computers in Labour Inspection. División de Administración del Trabajo. G inebra: OIT

-. 1988. Computer Applications in the Public E mployment Services of $E$ ight C ountries ( $C$ anada, Côte d'I voire, F ederal Republic of G ermany, H ungary, The N etherlands, U nited Kingdom, U nited States). División de Administración del Trabajo. Ginebra: OIT

-. 1988. Curso subregional sobre a inspeccao do trabalho para africanos de lingua portuguesa e esponhola. M aputo de 28 de setembro a 2 de outubro de 1987 Relaterio Final. División de Administración del T rabajo. Ginebra: OIT

-. 1988. Factory Inspection in the Caribbean. Informe sobre el seminario sobre la inspección eficaz sobre el terreno de las condiciones y el medio ambiente de trabajo celebrado en Jamaica los días 12-16 de diciembre de 1988. División de Administración de Trabajo. Ginebra: OIT

-. 1988. Labour Inspection in the Construction Industry. División de Administración del Trabajo. Ginebra: OIT

—. 1988. L'efficacité de l'inspection du travail. R apport sur un atelier tripartite interregional, Casablanca, 21-25 de septiembre de 1987. División de Administración del Trabajo. Ginebra: OIT .

- 1988. L'informatisation de l'inspection du travail. Ginebra: OIT

- 1989. A M anual for Labour Administration T rainers. División de Administración del Trabajo. Ginebra: OIT

-. 1989. Improvement of Labour Inspection Services in the Caribbean. Informe sobre el seminario celebrado en Barbados los días 12-16 de octubre de 1987 Ginebra: OIT

- 1989. Inspeccao de trabalho na agricultura para los paises africanos de expresao oficial portuguesa e esponhola. Relatorio final do Seminario subregional, Bissau, 21 de Novembro a 2 de Dezembro de 1988 División de Administración del Trabajo. Ginebra: OIT

- 1989. La inspeccion del trabajo en la agricultura para paises de America central y Panama. División de Administración del Trabajo. Ginebra: OIT.
- 1989. Labour Administration in a Changing W orld. División de Administración del Trabajo. Ginebra: OIT

-. 1989. Staff T raining and Development U nits in Labour M inistries. División de Administración del T rabajo. Ginebra: OIT

- 1989. The U se of Computer T echnology in E mployment Services. Actas del simposio internacional celebrado en Estocolmo los días 10-13 de mayo de 1988 División de Administración del Trabajo. Ginebra: OIT

- 1990. La administracion del trabajo en America Latina. División de Administración del Trabajo. Ginebra: OIT

-. 1990. L'inspection du travail, la santé et la sécurité des travailleurs: Guide de formation de formateurs. División de Administración del Trabajo. Ginebra: OIT.

-. 1990. Reunion subregional sobre inspeccion del trabajo. División de Administración del Trabajo. Ginebra: OIT.

- . 1990. The R ole of Public E mployment in the M anpower Redeployment Process: T he Case of Six Countries: France J apan, H ungary, M ali, Sweden, U nited Kingdom. División de Administración del Trabajo. Ginebra: OIT.

1990. U se of Computers in Labour Inspection. Informe del simposio celebrado en Viena los días 29 de agosto y 1 de septiembre de 1989. División de Administración del Trabajo. Ginebra: OIT.

- 1991. E mployment Services in the Caribbean. Informe del seminario sobre servicios de empleo en la promoción del empleo celebrado en Barbados los días 7-11 de mayo de 1990. División de Administración del Trabajo. Ginebra: OIT.

—. 1991. L'inspection du travail et les risques chimiques: analyse spectrale des systèmes d'inspection du travail. División de Administración del Trabajo. Ginebra: OIT.

- 1991. L'intervention de l'inspection du travail dans le construction en Afrique. División de Administración del Trabajo. Ginebra: OIT

- 1991. Labour Inspection in the N on-Commercial Services Sector: A Study Illustrated by Procedures and Practices in Certain Developed and Developing $M$ arket Economy Countries. División de Administración del Trabajo. Ginebra: OIT

-. 1991. The Intervention of Private Firms in the Functioning of Labour $M$ arkets in the Twelve EEC Countries. Ginebra: OIT

—. 1991. Vocational Guidance in Self-employment Promotion. División de Administración del Trabajo. Ginebra: OIT

- 1991. The Role of Employment Services in Human Resources Development. Registros de las actas de simposio internacional celebrado en Ottawa en mayo de 1990. División de Administración del Trabajo. Ginebra: OIT

- 1991. Relatorio 3 Seminario subregional sobre a inspeccao do trabalho, para os paises africanos de lingua portuguesa esponhola. Praia, 26 a 30 de Nobembro de 1990. División de Administración del Trabajo. Ginebra: OIT

- 1992. Labour Inspection and Chemical Hazards: A Spectral Analysis of Labour Inspection Systems. División de Administración del Trabajo. Ginebra: OIT.

— . 1992. Labour Inspection and Child Labour. División de Administración del Trabajo. G inebra: OIT.

- 1992. Labour Inspection in the Oil Refining and Largescale Petrochemical Industries. División de Administración del Trabajo. Ginebra: OIT.

1992. Labour Inspection: Purposes and Practice Ginebra: OIT

- 1992. Relatorio final co Seminario subreginal sobre inspecçao do trabalho na agricultura e agro-industrias para os paises africanos de lingua portuguesa e espanhola. 
Luanda, Angola, 4 a 8 de Maio de 1992. División de Administración del Trabajo. Ginebra: OIT.

-. 1992. Situation et besoins de l'administration du travail dans les pays arabes. División de Administración de Trabajo. Ginebra: OIT.

—. 1993. Labour Inspection in the Public Sector. División de Administración del T rabajo. G inebra: O IT

—. 1993. Labour Inspection Systems and Labour Inspectors: Training Policies. División de Administración de Trabajo. Ginebra: OIT.

—. 1993. Productivity in Labour Administration. División de Administración del Trabajo. Ginebra: OIT.

-. 1994. Development of $L$ abour Administration in Africa. Informe de un simposio tripartito de alto nive celebrado en Swakopomund, Namibia, los días 16-18 de marzo de 1994. División de Administración del Trabajo. Ginebra: OIT.

-. 1994. Employment Counselling Career Guidance and O ccupational Information Provided through an E mployment Service. División de Administración del Trabajo. Ginebra: OIT.

- . 1994. Employment Policy and Labour M arket Policy. División de Administración del Trabajo. Ginebra: OIT.

—. 1994. Informatisation des services de l'emploi. División de Administración del T rabajo. G inebra: O IT

- . 1994. Inspection du travail et l'élaboration d'une politique relative au travail des enfants: L'enfant au travail, approche psychologique División de Administración del Trabajo. Ginebra: O IT.

-. 1994. Inspection du travail et le travail précaire dans I'agriculture et les industries agro-alimentaires en Amérique latine. División de Administración del Trabajo. Ginebra: OIT.

- . 1994. Labour Inspection and the Adoption of a Policy on Child Labour: Training Guide División de Administración del Trabajo. Ginebra: OIT.

-. 1994. Labour Inspection and the Protection of the Environment. División de Administración de Trabajo. G inebra: OIT.

-. 1994. Labour Inspection in the Petroleum Producing Industry. División de Administración del Trabajo. Ginebra: OIT.

—. 1994. L'inspection du travail dans le secteur des services non commerciaux: Pratiques et procédures dans divers pays développés et pays en dévelopement pratiquant une économie de marché. División de Administración del Trabajo. Ginebra: OIT.

— . 1994. L'inspection du travail dans l'industrie du raffinage du pétrole et dans les grandes industries pétrochimques División de Administración del Trabajo. Ginebra: OIT.

- 1994. Public Employment Services and Labour M arke and L abour $M$ arket Information. División de Administración del Trabajo. Ginebra: OIT.

- 1995. Extension of the Labour Inspection Convention 1947 (N 0. 81), to Activities in the Non-commercial
Services Sector. Conferencia Internacional del Trabajo. Informe VI. G inebra: OIT.

- 1995. Guide pratique opérationnel à l'usage des services de l'emploi d'Afrique francophone et lusophone. División de Administración del Trabajo. Ginebra: OIT.

- 1995. Relatoria final: 50 seminario subregional sobre a inspeccao do trabalho e a seguranca e higiene no sector da construcao civil para os paises africanos de lingua protugusa e esponhola. S. Tomè e Principe, de 2 a 6 de $\mathrm{M}$ aio de 1994. División de Administración del Trabajo. Ginebra: OIT.

Pearse, W, C Refshauge. 1987. Workers' health and safety in Australia: an overview. Intl. J. Health Services 17.4: 635-49.

Samuels, SW. 1980. Workers at high risk. En $M$ axcy- $R$ oseneau Public $H$ ealth and Preventive M edicine, dirigido por JM Last. Nueva York: Appleton Century $C$ rofts.

Schulte, PA, K R ingen. 1984. N otification of workers at high risk: An emerging public health problem. Am J Public $\mathrm{H}$ ealth 74:485-491.

Szudy, E, M G Arroyo. 1994. The right to understand: Linking literacy to health and safety training. Berkeley, California: Univ. de California, Labour O ccupational $\mathrm{H}$ ealth Program.

Von Richthofen, W. 1985. Labour inspection. En W orld L abour R eport 2. G inebra: OIT .

—. 1993. Labour inspection in central and eastern Europe. EnEUROECHO 


\section{TRABAJO Y TRABAJADORES}

Directores del capítulo

I eanne M ager Stellman y

L eon J. W arshaw

\section{Sumario}

Trabajo y trabajadores

F reda L. Paltie.

Cambio de paradigmas y políticas

Freda L. Paltiel. . . . . . . . . . . . . . . . . . . 24.2

Salud, seguridad e igualdad en el lugar de trabajo

J oan B ertin.

Empleo precario y trabajo infantil

$L$ eon $J$. W arshaw. . . . . . . . . . . . . . . . . . . . . . . . 24.10

Transformación del mercado y del trabajo

Pat Armstrong................................ 24.17

Tecnologías globalizadoras y transformación del trabajo

$H$ eather $M$ enzies .......................... 24.20 


\section{TRABAJO Y TRABAJADORES}

Freda L. Paltiel

De acuerdo con el concepto de "Salud para todos" de la O rganización M undial de la Salud, el estado de la salud debe ser tal que permita a las personas llevar una vida productiva desde el punto de vista económico y social. Este concepto se opone al principio rector individualista del "hombre económico" que sólo busca satisfacer o mejorar su bienestar material. Por otra parte, al replantear la concepción del mundo del trabajo, es oportuno reconsiderar la noción de "recursos humanos" o "capital humano", según la cual, las personas constituyen instrumentos económicos prescindibles, lo que reduce su humanidad esencial y trascendental. Además, ¿qué validez tiene el concepto de "coeficiente de dependencia", de acuerdo con el cual los jóvenes y las personas de edad avanzada se consideran individuos dependientes no productivos? En definitiva, nuestros preceptos y prácticas actuales subordinan la idea de sociedad a la de economía. Los defensores del desarrollo humano subrayan la necesidad de tener economías sólidas que favorezcan la satisfacción de las necesidades sociales mediante la producción, la distribución y el disfrute equitativo de bienes y servicios.

Cuando se hace hincapié indebidamente en la economía, la familia se considera únicamente como la unidad de producción, mantenimiento y recuperación de la fuerza de trabajo; desde este punto de vista, la familia debe acomodarse a las demandas laborales, mientras que el lugar de trabajo no precisa adaptarse para armonizar el trabajo y la vida familiar. El Convenio de la OIT sobre los trabajadores con responsabilidades familiares, 1981 ( $n$ - 156) ha sido ratificado sólo por 19 Estados, a diferencia de la Convención de las $\mathrm{N}$ aciones U nidas sobre la Eliminación de todas las Formas de Discriminación contra la M ujer, que ha sido ratificada por casi todos sus miembros. La OIT señala que muy pocos países han emprendido la adopción y aplicación de políticas nacionales explícitas en materia de trabajadores y trabajadoras con responsabilidades familiares, de acuerdo con el Convenio.

Actualmente, los proyectos de desarrollo humano del Banco M undial representan únicamente un $17 \%$ de los préstamos. En sus últimos informes, esta institución ha reconocido la importancia de las inversiones en salud y educación y ha admitido que un número significativo de los grandes proyectos de desarrollo han fracasado debido a la escasa participación de los supuestos beneficiarios. En una declaración de intenciones para el futuro, el presidente del Banco ha indicado que se prestará mayor atención a los efectos sobre el medio ambiente y al desarrollo humano para apoyar la educación, la alimentación, la planificación familiar y la mejora de la situación de la mujer.

Con todo, sigue existiendo un desfase conceptual. N os acercamos al siglo XXI guiados anacrónicamente por los principios y las teorías del $X I X$. Sigmund Freud (a pesar de que cedió el testigo a su hija) creía que las mujeres, dada la inestabilidad de su superego, son moral y biológicamente deficientes; Adam Smith nos enseñó que las sirvientas, a diferencia de los obreros, no son productivas desde el punto de vista económico, mientras que Charles Darwin defendía la "supervivencia de los más aptos".

En este capítulo se incluyen ensayos sobre la transformación del trabajo, las nuevas tecnologías y sus efectos en el bienestar de los trabajadores y las diversas formas de explotación de éstos. Se estudian además las necesidades de las trabajadoras y los retos que se presentan para optimizar el potencial humano.

El mundo se encuentra en una encrucijada. Puede seguir el camino de la economía neoclásica y el "darwinismo social", caracterizado por un desarrollo desigual y poco equitativo y el derroche y menosprecio de las capacidades humanas. Por otro lado, puede optar por una política pública saludable a escala nacional e internacional, una política que pretenda reducir las desigualdades, crear entornos propicios y sostenibles y mejorar el control y la capacidad de las personas para afrontar sus problemas. Para alcanzar estos objetivos, hacen falta instituciones democráticas transparentes, sensibles, responsables y verdaderamente representativas.

\section{CAMBIO DE PARADIGMAS Y POLITICAS}

Freda L. Paltiel

Si bien este artículo se presta gran atención a las mujeres, en realidad se dedica a las personas y a éstas como trabajadores. Todas las personas necesitan desafíos y seguridad; los lugares de trabajo saludables facilitan ambos requisitos. Cuando resulta imposible lograr el éxito aunque se haga todo lo posible (objetivos imposibles sin medios adecuados) o cuando no hay desafios (rutina, tareas monótonas) se cumplen las condiciones para que se dé la "incapacidad adquirida". Aunque hay individuos excepcionales capaces de triunfar pese a la adversidad en ambientes hostiles, la mayoría de las personas requieren ambientes propicios, enriquecedores y facilitadores para desarrollar y ejercer sus capacidades. La conveniencia de la estimulación, no sólo en la infancia, sino a lo largo de toda la vida, se apoya en la investigación neurocientífica, que indica que un aumento de la estimulación y la aportación de información puede favorecer el crecimiento cerebral y ampliar la capacidad mental. Estos alentadores resultados tienen consecuencias para la mejora del entorno psicosocial en el trabajo, la prevención de determinados trastornos cerebrales y la obtención de beneficios mediante la rehabilitación después de un traumatismo o una enfermedad.

$\mathrm{L}$ as deslumbrantes proezas intelectuales de Stephen $\mathrm{H}$ awking o los resultados igualmente brillantes de los deportistas paralímpicos con discapacidades físicas o mentales graves prueban la importancia de la motivación personal, reforzada por entornos propicios con estructuras de oportunidades favorables y la aplicación de las tecnologías modernas adecuadas.

El lugar de trabajo se compone de trabajadores con características diversas. EI Convenio de la OIT no 111, 1958 sobre la discriminación en materia de empleo y ocupación, señala en su artículo 5 (2):

Todo M iembro puede... definir como no discriminatorias cualesquiera otras medidas especiales... destinadas a satisfacer las necesidades particulares de las personas a las que, por razones tales como el sexo, la edad, la invalidez, las cargas de familia o el nivel social o cultural, generalmente se les reconozca la necesidad de protección o asistencia especial.

La O rganización para la Cooperación y el Desarrollo Económico ha señalado que los instrumentos legislativos europeos sobre salud y seguridad en el ambiente de trabajo requieren adaptaciones en lo que se refiere al diseño del lugar de trabajo, la elección de equipos y los métodos de producción (por ejemplo, eliminación de las tareas monótonas y repetitivas) para satiffacer las necesidades individuales de los trabajadores y reducir los efectos nocivos para la salud (OCDE, 1993). Algunas normas establecen políticas que regulan la tecnología, la organización y las condiciones de trabajo, las relaciones sociales y otros aspectos del ambiente de trabajo. La reducción del absentismo, de la rotación laboral y de los costes del tratamiento, la rehabilitación, la readaptación profesional y la formación se consideran 
ventajas que obtienen las empresas gracias a la introducción de un medio ambiente y unas condiciones de trabajo saludables.

Los empresarios norteamericanos, en general como respuesta al aumento de los requisitos jurídicos relativos a los derechos humanos en el lugar de trabajo, elaboran actualmente políticas y estrategias positivas para la gestión de plantillas hetereogéneas. Estados U nidos ha desarrollado la legislación probablemente más exhaustiva en relación con sus ciudadanos discapacitados, en virtud de la cual se regulan sus derechos en materia de educación, empleo y demás ámbitos de la vida. A lgunas adaptaciones razonables se refieren a cambios relativos al medio ambiente de trabajo, las responsabilidades laborales o las condiciones de trabajo, que ofrecen a los trabajadores con necesidades especiales la oportunidad de llevar a cabo funciones esenciales. U na adaptación razonable puede satisfacer las necesidades especiales, por ejemplo, de las personas con discapacidades; las mujeres; los trabajadores con enfermedades crónicas o recurrentes, como los afectados por el SIDA; las personas con dificultades lingüísticas; las personas que deben compatibilizar el trabajo con las responsabilidades familiares; las mujeres embarazadas o lactantes, y las minorías religiosas o étnicas. La adaptación puede consistir en la utilización de instrumentos de asistencia técnica; la ropa de trabajo, el equipo de protección personal, o la modificación de los procesos, la ubicación o la programación temporal de tareas esenciales. Con el fin de lograr la igualdad y la justicia para todos los trabajadores, estas adaptaciones deben desarrollarse a través de comités conjuntos integrados por la dirección y los trabajadores, y de la adopción de convenios colectivos.

$\mathrm{H}$ an de aplicarse políticas y tecnologías adecuadas, eficaces en función del coste, para que los beneficios de una adaptación razonable reviertan en los trabajadores de todo el mundo y no sólo en algunos de las sociedades económicamente avanzadas. La mundialización puede contribuir a la consecución de este objetivo mediante la acción de los organismos multilaterales existentes y de la O rganización M undial del Comercio.

\section{Trabajadoras}

¿Por qué se incluye a las mujeres entre los grupos de trabajadores con necesidades especiales? Al analizar las necesidades, los riesgos y las tareas de este colectivo, deben considerarse los factores siguientes:

- discriminación por razón del sexo;

- pobreza o amenaza de sufrirla (la mayor parte de los pobres del mundo son mujeres y sus hijos, sobre todo las madres de familias monoparentales, que representan entre el 20 y el $30 \%$ de los hogares; el $75 \%$ de los 18 millones de refugiados que hay en el mundo son mujeres y niños);

- funciones reproductivas del embarazo, el parto y la lactancia;

- violencia por razón del sexo, actualmente reconocida a escala internacional como una violación de los derechos humanos;

- acoso sexual;

- diferencia entre los sexos en cuanto a la prestación de apoyo, ya que las mujeres desempeñan la mayoría de las funciones asistenciales (un estudio social realizado en Canadá ha puesto de manifiesto que sólo un $10 \%$ de los varones en las familias con dos perceptores de ingresos comparten las tareas domésticas en condiciones de igualdad);

- longevidad, un factor que afecta a largo plazo a su seguridad social y sus necesidades sanitarias.

Todos estos riesgos y necesidades pueden tenerse en cuenta o abordarse en cierta medida en el lugar de trabajo. Además, hay que tener presente que las mujeres constituyen el $50 \%$ de otras categorías de trabajadores con necesidades especiales, lo que las sitúa en una posición de doble riesgo potencial y hace que las consideraciones relativas a las diferencias entre los sexos sean un factor esencial al evaluar sus capacidades y derechos.

El sexismo es la creencia de que las mujeres necesitan, merecen y valen menos que los hombres. La Década Internacional de la M ujer organizada por la O NU, de 1975 a 1985, en torno a los temas de la igualdad, el desarrollo y la paz puso de manifiesto que las mujeres de todo el mundo trabajan en exceso y están infravaloradas. Sobre la base de la revisión de antiguos estudios y la realización de nuevas investigaciones, se llegó a la conclusión de que el trabajo de las mujeres está infravalorado porque ellas mismas lo están, y no porque haya deficiencias inherentes a su labor.

Durante el decenio de 1960 se realizaron un gran número de estudios para determinar qué mujeres trabajaban y por qué lo hacían, como si el trabajo constituyese una aberración para ellas. De hecho, las mujeres eran despedidas sistemáticamente al contraer matrimonio o quedar embarazadas. A finales del citado decenio, los países europeos con una gran demanda de mano de obra prefirieron contratar a trabajadores extranjeros que recurrir a su población activa femenina. Mientras que el trabajo confería dignidad a los varones de la familia perceptores de ingresos, la actividad remunerada de las mujeres casadas se consideraba degradante; sin embargo el trabajo comunitario no remunerado se consideraba ennoblecedor, especialmente porque mejoraba la posición social de sus maridos.

La presencia permanente de las mujeres en el lugar de trabajo a lo largo del ciclo de la vida laboral comenzó en el decenio de 1970 y se consolidó a mediados del de 1980. La maternidad ha dejado de repercutir negativamente en las tasas de participación de las mujeres; de hecho, la necesidad de atender las necesidades de los hijos actúa como acicate para la consecución de un puesto de trabajo. Según los datos de la OIT, las mujeres constituyen actualmente el $41 \%$ de la población activa registrada en todo el mundo (OIT, 1993a). En los países nórdicos, su tasa de participación es casi igual a la de los hombres, aunque en Suecia, el número de mujeres que trabajan a tiempo parcial, si bien está disminuyendo, sigue siendo elevado. En los países industrializados de la OCDE, donde la esperanza de vida general de las mujeres es actualmente de 79 años, se subraya la importancia de obtener trabajo como fuente de seguridad en la percepción de ingresos a lo largo de la vida adulta.

La OCDE reconoce que el marcado aumento de la participación de las mujeres en el mercado de trabajo no ha generado una mayor convergencia en la distribución general del empleo de hombres y mujeres. La segregación de la población activa en función del sexo se mantiene en sentido horizontal y vertical. Comparadas con los hombres, las mujeres trabajan en sectores y profesiones diferentes, y en industrias $u$ organizaciones de menor tamaño, llevan a cabo tareas distintas dentro de una misma profesión, desempeñan con más frecuencia trabajos irregulares y desregulados, tienen menos oportunidades para controlar su labor y se enfrentan a las exigencias psicológicas del trabajo de atención al público o programado en función de ritmos mecánicos.

En buena parte de la bibliografía se sigue culpando a las mujeres de elegir trabajos menos competitivos, que se complementan con las responsabilidades familiares. No obstante, los últimos estudios han puesto de manifiesto que los trabajadores no sólo eligen, sino que resultan elegidos para desempeñar un trabajo. Cuanto mayores son la remuneración y la categoría, más restrictivo es el proceso de selección y, si no hay estructuras y políticas públicas que promuevan la igualdad, más probable es que los encargados de la selección elijan a candidatos con características más similares a las propias en lo que respecta a sexo, raza, situación socioeconómica y rasgos físicos. Los prejuicios 
estereotipados afectan a una amplia gama de capacidades, incluída la de desarrollar el pensamiento abstracto.

Las mujeres no sólo se concentran en profesiones caracterizadas por una remuneración y un reconocimiento bajos y una movilidad física y laboral limitada: la OCDE señala asimismo que las ocupaciones de las mujeres suelen clasificarse en categorías amplias que comprenden tareas muy diferentes, mientras que, en el caso de los hombres, se ha desarrollado una clasificación más precisa que influye en la evaluación del trabajo, la remuneración, la movilidad y la detección de los riesgos para la salud y la seguridad en el ambiente de trabajo.

El sector sanitario es probablemente el mejor ejemplo de persistencia de la discriminación por razón de sexo y de subordinación de las capacidades y el rendimiento a las consideraciones referentes a los sexos. En todo el mundo, las mujeres ocupan un lugar protagonista en el sistema de asistencia sanitaria, en calidad de prestadoras, cuidadoras, intermediarias y, debido a sus necesidades reproductivas y a su longevidad, usuarias. Sin embargo, no dirigen el sistema. En la antigua U nión Soviética, donde la proporción de mujeres dedicadas a la actividad médica era mayoritaria, el reconocimiento de esta profesión era relativamente escaso. En Canadá, donde el $80 \%$ de los trabajadores sanitarios son mujeres, éstas ganan un $58 \%$ de lo ingresado por los hombres que desarrollan su actividad en el mismo sector, un porcentaje inferior al $66 \%$ habitual en otros sectores. Se han adoptado medidas de igualdad salarial a escala federal y provincial para intentar subsanar estas diferencias. En muchos países, a los hombres y las mujeres que realizan trabajos equiparables se les clasifica en categorías profesionales diferentes y, si no hay disposiciones legislativas y prácticas que promuevan la igualdad de remuneración para trabajos de igual valor, las desigualdades se mantienen y las trabajadoras sanitarias, sobre todo las enfermeras, asumen responsabilidades importantes que no se ven reflejadas en su autoridad, su reconocimiento y su retribución. Es interesante señalar que la inclusión de las actividades sanitarias en la categoría de trabajo penoso por parte de la OIT es reciente.

A pesar de la presencia de un "techo de cristal", que confinaba a las mujeres al desempeño de puestos directivos intermedios y a los puestos más bajos de la escala profesional, el crecimiento del empleo público tanto en los países industrializados como en los países en desarrollo resultó muy beneficioso para las mujeres, en especial para aquéllas con un nivel educativo superior. El estancamiento y la reducción del sector público ha tenido graves efectos negativos en las perspectivas profesionales iniciales de las mujeres. Se trataba de puestos que ofrecían una mayor seguridad social, más oportunidades de movilidad, condiciones de trabajo de calidad y prácticas de empleo más justas. Asimismo, los recortes han dado lugar a un aumento de las cargas de trabajo, falta de seguridad y deterioro de las condiciones de trabajo, sobre todo en el sector sanitario, pero también en los trabajos manuales y en los trabajos sujetos a ritmo mecánico, habitualmente desempeñados por mujeres.

\section{"Envenenamiento" del lugar de trabajo}

Faludi (1991) define "contragolpe" como un golpe sin sentido que impide a las mujeres alcanzar su meta. El "contragolpe" adopta numerosas formas y una de las más insidiosas consiste en burlarse de la "corrección política" para desacreditar la aceptación social de la igualdad en el empleo para los grupos desfavorecidos. U tilizado por las autoridades, las minorías intelectuales o personalidades de los medios de comunicación, tiene un efecto intimidador y pretende conseguir un lavado de cerebro.

Para entender el "contragolpe" es necesario comprender el carácter de la amenaza percibida. Aunque las aspiraciones y los esfuerzos del movimiento de las mujeres en favor de la igualdad entre sexos no han culminado en ningún lugar, quienes lideran este "contragolpe" son conscientes de que lo sucedido en las dos últimas décadas no es un mero incremento cuantitativo, sino el comienzo de una transformación cultural que afecta a todas las esferas de la sociedad. EI acceso al reparto de poder sigue siendo minoritario, como demuestra el hecho de que las mujeres ocupan apenas el $10 \%$ de los escaños legislativos en todo el mundo. En cualquier caso, el objetivo del contragolpe es detener, anular y deslegitimizar los avances alcanzados a través de la igualdad en el empleo o de acciones positivas para controlar la discriminación. Combinado con una carencia de práctica y escasas oportunidades de empleo, el "contragolpe" puede tener un efecto perjudicial en el lugar de trabajo, al generar confusión entre injusticias y derechos.

Moghadam (1994), de la O rganización de las Naciones Unidas para la Educación, la Ciencia y la Cultura (UNESCO) se refiere al "contragolpe" cultural, utilizado por los grupos fundamentalistas, que juega con los sentimientos de miedo y vergüenza para limitar la presencia pública de las mujeres y el control sobre sus vidas y confinarlas al ámbito doméstico.

La aplicación sistemática de la Convención de las Naciones U nidas sobre la Eliminación de Todas las Formas de Discriminación contra la M ujer, que ha sido ratificada por casi todos los Estados miembros de las $\mathrm{N}$ aciones U nidas, pretende manifestar y promover la voluntad política de acabar con la discriminación por razón de sexo, especialmente en el empleo, la salud y la educación, así como con la discriminación ejercida contra otros grupos "no reconocidos".

El acoso, que puede dificultar gravemente el ejercicio de las capacidades, sólo recientemente ha llegado a considerarse una cuestión de derechos humanos y salud en el trabajo. Los insultos racistas, las pintadas, las referencias despectivas a personas discapacitadas 0 de minorías visibles, se han trivializado a menudo como "parte del trabajo". La inseguridad en el empleo, el miedo a represalias, el rechazo y la falta de reconocimiento por el propio entorno social o las autoridades y la falta de sensibilización respecto a la naturaleza sistemática de estas actitudes, unido a la escasez de recursos, han promovido la complicidad y la tolerancia.

El acoso sexual, aunque se experimenta en todos los niveles profesionales, está más generalizado en los inferiores, donde se concentran más mujeres y éstas son más vulnerables. (EI porcentaje de varones víctimas de este tipo de acoso es muy limitado). Este problema comenzó a abordarse únicamente cuando un gran número de mujeres profesionales liberales y ejecutivas se enfrentaron en el decenio de 1970 con todo tipo de trabas a medida que accedían a nuevos ámbitos profesionales, lo que les hacía sentir como intrusas en sus nuevos lugares de trabajo. LoS efectos sobre la salud del trabajador son numerosos, llegando en casos extremos a intentos de suicidio. Asimismo, contribuye a la ruptura familiar. Los sindicatos, que no se encuentran en la vanguardia de la lucha contra el acoso sexual, lo consideran en la actualidad como una injusticia tanto laboral, como desde el punto de vista de los derechos humanos, por lo que han desarrollado políticas y mecanismos de compensación. Por el momento, apenas hay servicios dedicados a la curación y el tratamiento de las víctimas de esta actitud.

En un proceso de 1989, el Tribunal Supremo de Canadá definió el acoso sexual como "una conducta no deseada de naturaleza sexual que afecta perjudicialmente al ambiente de trabajo...". El Tribunal Supremo resolvió que la legislación canadiense en materia de derechos humanos impone a las empresas el deber de ofrecer un ambiente de trabajo seguro y saludable, libre de acoso sexual, y que las empresas pueden ser consideradas responsables de las acciones de sus trabajadores, y 
en especial de sus supervisores (H uman Resources D evelopment Canada 1994).

La violencia es un riesgo del lugar de trabajo. Así se pone de manifiesto en un estudio del Departamento de Justicia de Estados U nidos, según el cual, una sexta parte de los delitos violentos, que afectan a casi 1 millón de víctimas anualmente, se producen en el trabajo: un $16 \%$ de las agresiones, un $8 \%$ de las violaciones y un $7 \%$ de los robos, con una pérdida de 1,8 millones de jornadas de trabajo. M enos de la mitad de estos delitos se denuncian a la policía.

Las agresiones y los abusos constituyen una amenaza importante para la salud mental y física de las niñas y mujeres de todas las edades y culturas, pero especialmente para las jóvenes y las de edad avanzada. La Pan-American Health O rganization (PAHO) ha llegado a la conclusión de que en América, las muertes violentas (accidentes, suicidios y homicidios) representan más del $25 \%$ de las muertes de niñas con edades comprendidas entre los 10 y 14 años y el $30 \%$ en el grupo de edad de 15 a 19 años (PAH O 1993).

La violencia en ambos sexos incluye los abusos físicos, sexuales y psicológicos y la apropiación indebida de fondos, así como el acoso sexual, la pornografía, las agresiones sexuales y el incesto. A escala mundial pueden añadirse la selección en función del sexo, el aborto de fetos femeninos, la desnutrición intencionada, la mutilación ritual, la muerte por causa de la dote y la venta de hijas para la prostitución o el matrimonio. Se acepta comúnmente que la violencia contra las mujeres trastorna sus vidas, limita sus opciones y bloquea intencionadamente sus aspiraciones. Tanto por su intención como por sus consecuencias, significa un comportamiento delictivo. No obstante, la violencia contra las mujeres por parte de agresores conocidos en el hogar, en el trabajo o en la calle se ha considerado habitualmente un asunto privado. La matanza de 27 mujeres estudiantes perpetrada en 1989 en una escuela politécnica de $\mathrm{M}$ ontreal, precisamente porque se trataba de mujeres estudiantes de ingeniería en una escuela politécnica, constituye una prueba brutal de la violencia por razón de sexo practicada con el objetivo de frustrar las aspiraciones profesionales.

La prevención y el control de la violencia son cuestiones a considerar en el lugar de trabajo, que pueden abordarse mediante la ejecución de programas de asistencia a los empleados y la constitución de comités de salud y seguridad, en colaboración con los organismos encargados de hacer cumplir la ley y otras entidades sociales, como las organizaciones feministas de todo el mundo, que han conseguido que esta cuestión se incluya entre los temas de interés público y han intentado, sin grandes medios, acabar con la falta de tolerancia de estas actitudes y ayudar a las víctimas.

\section{Evolución del mundo del trabajo}

De 1970 a 1990, los países más poderosos económicamente, miembros del G-7, (excepto Japón y Alemania) experimentaron un proceso de desindustrialización, caracterizado por una disminución del empleo en las actividades manufactureras y la implantación de una economía de servicios postindustrial. Asimismo, este período coincidió con el auge del estado del bienestar. Al final del mismo, los servicios en general (incluidos los relacionados con las manufacturas) absorbían de dos tercios a tres cuartos del empleo total. Salvo en Japón e I talia, el empleo en los servicios sociales representaba entre un cuarto y un tercio del empleo total. Estas dos tendencias generaron una demanda sin precedentes de trabajadoras, que se habían beneficiado de la mejora de las oportunidades educativas. El signo de los tiempos, favorable a la defensa de los derechos humanos y la igualdad de oportunidades, contribuyó también al inicio de la integración de otros trabajadores "no favorecidos" (por ejemplo, personas con discapacidades, minorías) (C astells y 0 ayama 1994).

Actualmente, el mundo del trabajo experimenta una transformación radical caracterizada por la mundialización, las absorciones y fusiones, la creación de empresas conjuntas, la reubicación, la desregulación, la privatización, la informatización, la proliferación de tecnologías, los ajustes estructurales, el redimensionamiento, la subcontratación externa y el cambio de las economías planificadas por economías de mercado. Estas transformaciones y una reingeniería global han alterado la escala, la naturaleza, la localización, los medios y los procesos de producción y comunicación, así como la organización y las relaciones sociales en los lugares de trabajo. A principios del decenio de 1990, la revolución tecnológica del tratamiento de la información y las comunicaciones, la biotecnología y la automatización del procesamiento de materiales se había generalizado, modificando, ampliando o reduciendo el esfuerzo humano y generando un crecimiento "eficiente" sin aumento de empleo. En 1990, había al menos 35.000 empresas multinacionales con 150.000 filiales en el extranjero. U nos 7 millones de personas de los 22 a los que dan empleo trabajan en los países en desarrollo. En la actualidad, estas empresas absorben el $60 \%$ del comercio mundial (se trata en gran parte de un comercio interno con las filiales).

En un documento de trabajo de la O rganización M undial de la Salud elaborado para la Comisión M undial sobre la Salud de la M ujer (1994) se afirma lo siguiente:

La lucha por el acceso a los mercados conlleva un aumento de los riesgos para la salud de millones de productores. En un contexto altamente competitivo en el que se concede prioridad a la producción de bienes baratos y comercializables, las empresas tratan de reducir al mínimo sus costes aumentando las jornadas de trabajo y suprimiendo normas de seguridad que resultan onerosas. En muchos casos, las empresas tienen la oportunidad de reubicar sus unidades de producción en países en desarrollo donde los controles pueden resultar menos estrictos. Las mujeres suelen formar parte de los grupos de trabajadores peor remunerados. Las consecuencias más extremas para la salud pueden comprobarse en las tragedias en las que decenas de trabajadores pierden la vida en incendios en fábricas, debido a las inadecuadas normas de seguridad y a las condiciones de trabajo deficientes.

Además, unos 70 millones de personas, en su mayoría de los países en desarrollo, son trabajadores migrantes privados del apoyo familiar. EI valor de las remesas en efectivo de estos trabajadores ascendió en 1989 a 66.000 millones de dólares, una cantidad muy superior a la dedicada a la ayuda internacional para el desarrollo (46 millones de dólares) y superada sólo por el petróleo en cuanto a valor comercial mundial. Entre las prósperas provincias costeras de China, se estima que, sólo en la de Guangdong viven más de 10 millones de inmigrantes. En toda A sia, la proporción de mujeres es mayoritaria en los lugares de trabajo no regulados y carentes de presencia sindical. En la India, (que, al parecer, ha recibido de las instituciones financieras internacionales más de 40.000 millones de dólares en préstamos para el desarrollo), el $94 \%$ de las trabajadoras desempeñan su actividad en el sector informal.

Detrás del milagro del crecimiento económico exponencial del sureste de Asia, se encuentra el trabajo en el sector de la exportación de mujeres jóvenes, dóciles y capaces, que ganan de 1,50 a 2,50 dólares al día, en torno a una tercera parte del salario base. En algunos países, hay operadoras de ordenadores que tienen formación universitaria y ganan 150 dólares al mes. En Asia y América Latina, el flujo de personas a los centros 
urbanos ha dado lugar a la formación de grandes barrios de chabolas, en los que millones de niños sin escolarizar viven y trabajan en condiciones precarias. Actualmente, más de 90 países en desarrollo tratan de moderar el ritmo de esta concentración urbana. Tailandia, en un intento de frenar 0 invertir el proceso, ha puesto en marcha una iniciativa de desarrollo rural para que los jóvenes se queden o vuelvan a sus comunidades, en algunos casos para trabajar en fábricas cooperativas cuyo trabajo beneficia a esos jóvenes y a toda la comunidad.

El Fondo de Población de las Naciones U nidas (FNUAP) ha señalado que las estrategias de modernización han destruido en muchos casos las bases económicas que permitían a las mujeres el desarrollo de actividades comerciales, artesanales y agrarias, sin alterar el contexto sociocultural (por ejemplo, el acceso al crédito) que les impide aprovechar otras oportunidades (FNUAP 1993). En América Latina y el Caribe, la crisis económica y las políticas de ajuste estructural del decenio de 1980 dieron lugar a recortes importantes en los servicios sociales y en el sector sanitario, que atendían y daban empleo a las mujeres, así como a la reducción de las subvenciones para alimentación básica, y al cobro a los usuarios por muchos servicios prestados anteriormente por el sector público, como parte del desarrollo y la satisfacción de las necesidades humanas básicas. A finales del decenio de 1980, el $31 \%$ del total del empleo no agrario se encontraba en el sector informal precario.

En Africa, el decenio de 1980 se han calificado de década pérdida. La renta por habitante descendió una media anual del $2,4 \%$ en la región subsahariana. Casi el $50 \%$ de la población urbana y el $80 \%$ de la rural viven en condiciones de pobreza. EI sector informal actúa como una esponja que absorbe el "exceso" de población activa de las ciudades. En esa misma región, en la que las mujeres producen hasta el $80 \%$ de los alimentos para el consumo local, sólo el $8 \%$ de ellas son propietarias de la tierra que trabajan (OIT 1991).

La reestructuración económica, la privatización y la democratización han afectado gravemente al empleo de las mujeres en Europa oriental. A pesar de que desempeñaban trabajos penosos con menos remuneración que los hombres y tenían que asumir responsabilidades familiares no compartidas por sus cónyuges y sufrir la limitación de libertad política, las mujeres tenían un empleo seguro y prestaciones públicas de seguridad social, permiso de maternidad y servicios de atención a los hijos. EI encubierto avance actual de la discriminación por razón del sexo, junto con los argumentos de mercado en contra del gasto social, han convertido a las mujeres en trabajadores reemplazables y menos solicitados. De forma paralela a la reducción de los ámbitos de trabajo social y sanitario, donde la presencia de mujeres es mayoritaria, muchas profesionales competentes pierden su empleo.

EI desempleo es un factor importante de desorganización en la vida de los trabajadores, que no amenaza sólo su sustento, sino también sus relaciones sociales, su autoestima y su salud mental. Estudios recientes han puesto de manifiesto que no sólo la salud mental sino también la física pueden estar amenazadas, ya que el desempleo puede tener efectos inmunodepresores que aumentan el riesgo de enfermedad.

$\mathrm{N}$ os acercamos al siglo XXI inmersos en una crisis de valores, en la que se concede prioridad al interés individual sobre el público. ¿Vamos a crear un mundo basado en una competencia sin freno, donde sólo importa ganar y cuyo único criterio es el resultado? ¿Un mundo en el que la limpieza étnica triunfe? 0 , por el contrario, ¿vamos a crear un mundo de interdependencia, cuyos objetivos sean el crecimiento, la justicia distributiva y el respeto de la dignidad humana? En las conferencias mundiales de las $\mathrm{N}$ aciones U nidas celebradas en el decenio de
1990, el mundo contrajo compromisos clave para la protección y la renovación del medio ambiente, sobre políticas demográficas éticas y equitativas, para la protección y la alimentación de todos los niños, para la asignación al desarrollo social del $20 \%$ de los fondos internacionales de desarrollo y el $20 \%$ de los presupuestos de los países en desarrollo, para la ampliación y la aplicación de los derechos humanos, la igualdad entre ambos sexos y la eliminación de la amenaza de catástrofe nuclear. Estos convenios constituyen una orientación moral. La inquietante cuestión que queda por resolver es si existe la voluntad política necesaria para alcanzar estos objetivos.

\section{SALUD, SEGURIDAD E IGUALDAD EN EL LUGAR DE TRABAJO}

Joan Bertin

Las políticas de salud en el trabajo suelen coexistir con otras encaminadas a garantizar la igualdad en el lugar de trabajo. L eyes, reglamentos y normas adoptados o ratificados en muchos países prohíben diversas formas de discriminación en el lugar de trabajo y exigen el cumplimiento de objetivos de salud y seguridad, de forma que no se vulneren otros derechos e intereses de los trabajadores. Las disposiciones jurídicas obligan a las empresas en algunas jurisdicciones a aplicar prácticas que aseguren la igualdad en el lugar de trabajo; aunque la legislación no las imponga, las políticas pueden fomentar prácticas similares, por las razones expuestas por Freda Paltiel al comienzo del presente capítulo.

Desde un punto de vista práctico, la aceptación de los programas de salud y seguridad por parte de los trabajadores puede verse afectada por la forma en que incorporen y reflejen principios de igualdad. La probabilidad de que los trabajadores rechacen estos programas es mayor si se ejecutan a costa de otros intereses importantes, como el de la autodeterminación y la seguridad económica. Hay otras razones para poner en práctica programas de salud y seguridad sin descuidar la igualdad en el lugar de trabajo. La aplicación en este ámbito de normas racionales y justas mejora la satisfacción laboral, la productividad y el bienestar emocional de los trabajadores y reduce el estrés laboral. U n enfoque individualizado de las necesidades y las capacidades de los trabajadores, parte esencial de la salud y la seguridad en el trabajo y de la igualdad en el lugar de trabajo, aumenta el conjunto de trabajadores cualificados y permite aprovechar al máximo sus destrezas y aptitudes.

$\mathrm{H}$ ay determinadas áreas en las que los principios de igualdad, por un lado, y la salud y la seguridad en el trabajo, por otro, parecen estar en conflicto, generalmente suele tratarse de situaciones en las que algunos trabajadores tienen necesidades singulares o especiales. L as trabajadoras embarazadas, los trabajadores de edad avanzada y los discapacitados pertenecen a esta categoría. En muchos casos, un análisis más exhaustivo pone de manifiesto que las necesidades de estos grupos no distan mucho de las de los trabajadores en general, y que pueden adaptarse políticas y prácticas aceptadas en el lugar de trabajo para crear programas que garanticen simultáneamente tanto la salud y la seguridad como la igualdad. El principio rector ha de ser la flexibilidad para realizar evaluaciones y ajustes individuales, lo que constituye un hecho habitual en la mayoría de los centros de trabajo, ya que las enfermedades, la discapacidad temporal y las restricciones laborales suelen requerir flexibilidad y adaptación. En algún momento de su vida laboral, casi todos los trabajadores tienen necesidades en materia de salud en el trabajo relacionadas con "la edad, la situación fisiológica, los aspectos 
sociales, las barreras de comunicación u otros factores semejantes [que] deben atenderse a escala individual" (O IT 1992).

\section{Principios generales}

La igualdad en el lugar de trabajo implica justicia en materia de asignación de puestos de trabajo, tareas, ascensos, prestaciones y otras condiciones de trabajo. Las distinciones existentes en el trabajo por razones de raza, sexo, procedencia o religión, en concreto, han sido reconocidas como formas ominosas de desigualdad y prejuicio social y han sido condenadas en casi todo el mundo. En fechas más recientes, las distinciones realizadas en función de la edad y la discapacidad, han comenzado a ser clasificadas igualmente como poco equitativas. En general, estas características no influyen en el deseo de trabajar y en la necesidad económica de empleo de una persona, ni en su capacidad para llevar a cabo una tarea. El hecho de no integrar a todas las personas capaces y dispuestas en la actividad productiva no sólo entorpece el desarrollo del potencial humano, sino que perjudica también la satisfacción de las necesidades sociales al reducir la población de personas autosuficientes.

Los principios de igualdad se basan en la premisa de que los trabajadores deben ser juzgados en función de una evaluación objetiva de sus cualificaciones, capacidades y características y no de las suposiciones respecto al grupo al que pertenezcan. A sí, el rechazo de los estereotipos y las generalizaciones al juzgar a las personas constituye una parte esencial del concepto de igualdad en el lugar de trabajo, ya que incluso las generalizaciones más exactas suelen describir erróneamente un gran número de casos. Por ejemplo, aunque es cierto que, por término medio, los hombres son más fuertes que las mujeres, hay excepciones. Al contratar a trabajadores para desempeñar una tarea que requiere fuerza, no sería justo excluir a todas las mujeres, incluidas aquéllas con la capacidad suficiente, en función de una generalización respecto a los sexos. En cambio, una evaluación equitativa de las capacidades individuales pondría de manifiesto qué mujeres y qué hombres tienen la fuerza y la capacidad necesarias para realizar adecuadamente el trabajo.

Algunos tipos de pruebas selectivas excluyen desproporcionadamente a miembros de determinados grupos. Las pruebas escritas pueden situar en desventaja a las personas cuya lengua materna es diferente o han tenido menor acceso a las oportunidades educativas. Estas pruebas son justificables si miden realmente las capacidades necesarias para desempeñar la tarea en cuestión. En caso contrario, actúan como barreras impuestas a las personas cualificadas y reducen el conjunto de trabajadores que pueden optar al puesto. La confianza en determinados instrumentos de selección refleja, asimismo, la aceptación de estereotipos en cuanto a las personas que deben realizar determinados tipos de trabajo. Por ejemplo, al imponer requisitos en cuanto a la altura a los funcionarios de orden público se presupone que esta característica física está directamente relacionada con un rendimiento adecuado en el puesto de trabajo. La supresión de estos requisitos ha demostrado que la altura en sí misma no es una condición necesaria para velar con eficacia por el cumplimiento de la ley y ha abierto este sector a más mujeres y miembros de ciertos grupos étnicos.

Entre las barreras clásicas a la igualdad en el lugar de trabajo figuran los requisitos físicos, como la altura y el peso, las pruebas escritas y las exigencias educativas o de titulación. En ocasiones, los sistemas basados en la antigüedad excluyen a miembros de grupos desfavorecidos y las preferencias de los veteranos suelen perjudicar a las mujeres trabajadoras, a las que habitualmente no se exige ni se permite realizar el servicio militar. L os estereotipos, las tradiciones y las suposiciones sobre las destrezas y las características asociadas con la raza, el sexo y el origen étnico también actúan, a menudo de modo subconsciente, para perpetuar la distribución tradicional de las oportunidades de empleo, al igual que otros factores, como la elección preferente de amigos y familiares. La presencia de estas barreras suele ponerse de manifiesto por la existencia de un ambiente de trabajo que no refleja adecuadamente la composición del conjunto de trabajadores cualificados y que se caracteriza por la presencia de miembros de grupos concretos en puestos deseados en una proporción superior a la que podría esperarse por su representación en el sector o en la plantilla. En estos casos, una evaluación pormenorizada de las prácticas de selección de los trabajadores suele revelar la utilización de prácticas que eliminan injustamente a ciertos candidatos cualificados, o la influencia de un sesgo inconsciente, de estereotipos o de una actitud de favoritismo.

A pesar de la adhesión casi universal a los principios de igualdad en el trabajo y del deseo de aplicar prácticas equitativas, estos objetivos quedan frustrados en ocasiones, irónicamente, al considerarse que entran en conflicto con los fines de salud y seguridad en el trabajo. Este tipo de razonamientos son especialmente manifiestos en relación con las mujeres en edad fértil, las embarazadas y las nuevas madres. A diferencia de otros trabajadores, que por lo común disfrutan del derecho a desempeñar el trabajo para el que están cualificados, las mujeres suelen verse sometidas a restricciones involuntarias en nombre de la protección de su salud o la de sus hijos. U nas veces, estas disposiciones garantizan la obtención de prestaciones imprescindibles, otras, imponen un alto precio en lo que se refiere al acceso a la independencia económica y la autonomía personal.

M uchos principios relacionados con la consideración de los derechos y las necesidades de las trabajadoras, son aplicables también a los trabajadores discapacitados o de edad avanzada. Aún más importante es la noción de que los trabajadores deben ser juzgados en función de sus propias habilidades y capacidades, y no de generalizaciones y estereotipos. Este principio ha llevado a reconocer que las personas discapacitadas pueden ser trabajadores altamente productivos y valiosos. Puede que sea necesario hacer una inversión para atender las necesidades de un trabajador discapacitado, pero el acuerdo respecto a la rentabilidad de estas inversiones es cada vez mayor, sobre todo si se tienen en cuenta las consecuencias de obviarlas.

\section{Discriminación por razón de sexo, embarazo y parto}

M uchos convenios y recomendaciones internacionales, como la Convención Internacional sobre la Eliminación de Todas las Formas de Discriminación contra la M ujer (1979), el Pacto Internacional de Derechos Civiles y Políticos (1976) y la Directiva sobre igualdad de trato (76/207/ CEE), defienden la erradicación de la discriminación por razón de sexo en el trabajo. El concepto de igualdad de remuneración para hombres y mujeres que realizan un mismo trabajo fue adoptado por la OIT en el Convenio sobre igualdad de remuneración entre la mano de obra masculina y la mano de obra femenina por un mismo trabajo, 1951 (no 100). En la Recomendación sobre la igualdad de remuneración entre la mano de obra masculina y la mano de obra femenina por un mismo trabajo, 1951 ( $n$ - 90), complementaria del Convenio anterior, se insta asimismo a promover "la igualdad entre la mano de obra masculina y femenina en cuanto al acceso a las diversas profesiones y funciones". En junio de 1958 se adoptó una declaración más general del principio de no discriminación en el Convenio relativo a la discriminación en materia de empleo y ocupación (no 111) y la Recomendación sobre la discriminación en materia de empleo y ocupación (n- 111).

La Directiva de la Comunidad Europea 76/ 207/ CEE sobre igualdad de trato entre hombres y mujeres respecto al acceso al empleo es coherente con estas disposiciones. Por tanto, hay un 
acuerdo generalizado en torno al principio de que las mujeres y los hombres deben disfrutar del mismo acceso a las oportunidades de empleo y de idénticas condiciones en el mismo. Por ejemplo, Austria ha modificado la Ley de igualdad de oportunidades para adaptar su legislación a la de la Comunidad Europea. En estas modificaciones se estipula que no se discriminará por razón de sexo en materia de empleo. Con ello se amplía la prohibición de la discriminación a todos los aspectos de esta relación.

M ucho antes de que los organismos internacionales y las legislaciones nacionales condenaran la discriminación por razón de sexo, muchas personas reconocían la necesidad de proteger la maternidad. El C onvenio sobre Protección de la M aternidad fue el primero que se adoptó, en 1919, y en virtud del mismo se concedía a las mujeres embarazadas, previa obtención de un certificado médico, el derecho a un permiso de seis semanas antes de la fecha prevista para el parto y se prohibía el trabajo "durante las seis semanas posteriores al alumbramiento". Se dispuso que las embarazadas disfrutaran de descansos durante la jornada laboral (O IT 1994). A simismo, el C onvenio reconocía el derecho de las trabajadoras a obtener asistencia médica gratuita y prestaciones económicas. El despido de una mujer durante el permiso de maternidad o durante una enfermedad derivada del embarazo o el parto se declaró "ilegítimo". En el Convenio revisado sobre protección de la maternidad, 1952 (no.103) se estableció la prolongación del permiso de maternidad a 14 semanas, cuando fuera necesario para la salud de la madre, se ampliaron las disposiciones relativas a las madres lactantes y se prohibieron el trabajo nocturno y las horas extraordinarias para las embarazadas y las madres lactantes. Asimismo, se declaró la necesidad de prohibir el trabajo que pudiese perjudicar la salud de las embarazadas o las madres lactantes, como los trabajos penosos o que exijan un equilibrio especial. Además, se permitió a los Estados miembros que establecieran excepciones relativas a las mujeres incluidas en determinadas categorías profesionales, como los sectores no industriales, el trabajo doméstico en casas particulares y las tareas que conllevaran el transporte de mercancías o pasajeros por mar.

De forma coherente con los convenios de la OIT sobre protección de la maternidad, la Comunidad Europea adoptó la Directiva del Consejo 92/85/CEE, de 19 de octubre de 1992, relativa a la aplicación de medidas para promover la mejora de la salud y la seguridad en el trabajo de la trabajadora embarazada, que haya dado a luz o en período de lactancia. En esta Directiva se establece la obligatoriedad de realizar una evaluación para cualquier actividad que pueda presentar un riesgo específico para las mujeres embarazadas o lactantes, la prohibición del trabajo nocturno cuando resulte necesario por motivos de salud y seguridad, el derecho al permiso de maternidad y la garantía de los derechos inherentes al contrato de trabajo durante el embarazo y el parto. Aunque estos convenios y directivas incluyen disposiciones que aumentan los recursos de las mujeres para trabajar y tener hijos con mayor seguridad, se ha criticado que no garantizan la consecución de los resultados que persiguen. Por ejemplo, los estudios realizados por el gobierno de la India han puesto de manifiesto que son pocas las mujeres que reciben prestaciones por maternidad, debido a una aplicación deficiente de la normativa al respecto y a la exclusión de las trabajadoras estacionales y temporales, de las que desarrollan su actividad en pequeñas empresas y de las trabajadoras domésticas (Vaidya 1993). A demás de las prestaciones por maternidad, en algunos países se exige que las mujeres se beneficien de descansos, puestos específicos, servicios sanitarios y otras facilidades.

Por el contrario, otras medidas adoptadas para proteger la salud de las trabajadoras incluyen la limitación de su trabajo.
E stas medidas consisten en prohibir la realización de tareas peligrosas o penosas, restringir el acceso a los puestos considerados fuente de riesgo moral, imponer restricciones durante la menstruación, prohibición de jornadas máximas de trabajo y de horas extraordinarias, etc. (O IT 1989). A diferencia de las disposiciones sobre prestaciones por maternidad, estas acciones tienen un carácter restrictivo, es decir, limitan el acceso de las mujeres a determinados tipos de trabajo. U n ejemplo es la prohibición del trabajo nocturno, que fue una de las primeras cuestiones abordadas en la Conferencia Internacional del Trabajo de 1919. En cuatro documentos de la O IT se amplía el análisis de este tema (OIT 1919a; 1921; 1934; 1948). (Es interesante señalar que no existe una definición normalizada de la palabra nocturno.) LoS antecedentes sobre las actitudes ante las restricciones del trabajo nocturno constituye un ejemplo instructivo de la relación entre los objetivos de salud y seguridad y la igualdad en el trabajo.

Con la prohibición del trabajo nocturno se pretendía salvaguardar la vida familiar y proteger a los trabajadores de la carga física especialmente ardua que representa este tipo de trabajo. En la práctica, el objetivo de los convenios de la O IT es prohibir el trabajo nocturno manual realizado por mujeres en la industria, pero no las tareas no manuales y de gestión o el trabajo en el sector de los servicios. N o obstante, las restricciones impuestas al trabajo nocturno impidieron el acceso de las mujeres a ciertas oportunidades laborales. En nombre de la salud y la moralidad, se les negó la posibilidad de ocupar determinados puestos y se limitó su capacidad para progresar en otros trabajos. La legislación sobre limitación al trabajo nocturno se introdujo como respuesta a la explotación de trabajadores de los dos sexos, a los que se exigía que permanecieran en su puesto un número excesivo de horas. Sin embargo, en Estados U nidos, por ejemplo, estas restricciones impidieron que las mujeres obtuvieran puestos de trabajo lucrativos como conductoras de tranvías, pero no impidieron que trabajaran como bailarinas en clubes nocturnos (K essler-H arris 1982).

Este tipo de incoherencias, junto con la desventaja económica experimentada por las trabajadoras, provocaron las críticas contra las restricciones del trabajo nocturno de las mujeres, que en Estados U nidos fueron sustituidas finalmente por garantías jurídicas frente a la explotación de los trabajadores de ambos sexos. La L ey sobre la igualdad en el trabajo de Estados U nidos, asegura el establecimiento de normas que regulan el empleo.

0 tros países han rechazado igualmente un planteamiento específico por sexos en relación con la protección de las trabajadoras, como respuesta a una sensibilización cada vez mayor respecto a la penalización económica que este enfoque representa y a otros aspectos de la discriminación por razón de sexo. En 1991, el Tribunal de Justicia de la CEE estableció que, de acuerdo con la Directiva 76/207/ CEE, los Estados miembros no pueden prohibir mediante ley el trabajo nocturno de las mujeres. La Comisión Europea solicitó a los Estados miembros de la OIT que habían ratificado el Convenio que prohíbe este tipo de actividad a las mujeres que renunciaran a él, y muchos de ellos han accedido. En 1992, el Tribunal Constitucional de Alemania declaró anticonstitucional la prohibición del trabajo nocturno de las mujeres. En los últimos diez años, leyes que prohíben esta actividad a las mujeres han sido derogadas en Barbados, Canadá, España, Guyana, Irlanda, Israel, Nueva Zelanda y Surinam. Actualmente, 20 países no incluyen en su legislación ninguna restricción del trabajo nocturno de las mujeres. La OIT ha publicado un resumen de las acciones de derogación de las leyes protectoras anteriores a 1989 (1989b).

Esta tendencia es especialmente acusada en los países desarroIlados, en los que las mujeres disfrutan de derechos exigibles por ley que protegen su situación legal, y los derechos en materia de salud y seguridad en el trabajo están reconocidos. Por el 
contrario, en los países donde las condiciones de las mujeres son "deplorables" y mucho peores que las de los hombres, se argumenta en ocasiones que "se necesita más protección, y no menos" (OIT 1989b). Por ejemplo, la semana laboral media de las mujeres de Kenya, de 50,9 horas, excede con mucho a las 33,2 horas por semana que trabajan los hombres (Waga 1992). A pesar de estas advertencias, proteger a las trabajadoras limitando sus posibilidades de trabajo presenta, en términos generales, claras desventajas. En junio de 1990, la OIT aprobó el Convenio sobre trabajo nocturno ( $n-171$ ), en el que se declara que todas las personas que trabajan por la noche, no sólo las mujeres, necesitan protección (O IT 1990). Este enfoque es coherente con la postura general de la OIT, según la cual todo tipo de "trabajo debe desarrollarse en un medio ambiente seguro y saludable" (OIT 1989) y concede la misma consideración a la protección de la salud y a la igualdad en el trabajo.

La evolución de los esfuerzos para proteger a las mujeres de los efectos de los lugares de trabajo peligrosos y de las sustancias tóxicas en el trabajo, coinciden en parte con los observados en el análisis del trabajo nocturno. A principios del siglo XX, la O IT y un gran número de países impidieron la presencia de las mujeres en lugares de trabajo peligrosos, como demuestran los convenios que prohíben la exposición de mujeres y niños al plomo (OIT 1919b). Por costumbre y en virtud de la legislación, no se permitía el acceso de las mujeres a muchos tipos de actividad, desde el servicio en bares hasta la minería. Estas restricciones perjudicaban las posibilidades de empleo y la situación económica de las mujeres y se aplicaban de forma incongruente, al impedir su acceso a puestos lucrativos ocupados exclusivamente por hombres, mientras se permitía el desempeño de trabajos igualmente peligrosos, pero peor remunerados, realizados con frecuencia por mujeres. L os críticos señalan que todos los trabajadores necesitan protección frente a los productos químicos tóxicos.

En Estados Unidos, las iniciativas para excluir a las mujeres de los trabajos peligrosos recibieron el nombre de políticas de "protección fetal". Sus defensores afirmaban que el feto es más sensible a determinados riesgos en el trabajo y que, por tanto, era razonable evitar la presencia en estos ambientes de trabajo de las mujeres que están o pueden estar embarazadas. EI Tribunal Supremo de Estados U nidos rechazó esta postura y sostuvo que las prácticas de salud y seguridad en el trabajo deben cubrir las necesidades de hombres y mujeres. En la resolución del Tribunal se defiende firmemente el derecho de las mujeres al trabajo y se reconoce el derecho a la protección de la salud, concediéndole la misma importancia. En un plano teórico, esta resolución otorga el mismo peso y respeto a los objetivos y las obligaciones relativas a la igualdad y a la salud y la seguridad. En la práctica, algunos sectores han expresado su preocupación ante la posibilidad de que la ausencia de mecanismos adecuados que garanticen el cumplimiento de la legislación sobre salud y seguridad en el trabajo sitúe a hombres y mujeres en una situación de vulnerabilidad frente a las enfermedades del sistema reproductor y de otro tipo (International Union 1991).

0 tros países han buscado una solución diferente. Por ejemplo, la Ley sobre el permiso especial de maternidad de Finlandia, que entró en vigor en julio de 1991, permite a las mujeres expuestas a agentes considerados nocivos para el embarazo o el hijo solicitar, desde el inicio de su estado, un traslado a otro puesto de trabajo exento de riesgos. Si tal puesto no se encuentra disponible, pueden optar a un permiso y a prestaciones especiales por maternidad (Taskinen 1993). Del mismo modo, en la Directiva relativa a las trabajadoras embarazadas (92/85/CEE) se contemplan diversas medidas en favor de las mujeres que necesitan una protección adicional en períodos de embarazo o de lactancia, incluida la modificación del medio ambiente o las condiciones de trabajo, el traslado temporal y la concesión de permisos.

Este enfoque, como el analizado anteriormente, permite resolver algunos problemas, pero no todos: el diferente nivel de prestaciones concedidas a las mujeres puede convertirlas en trabajadoras menos solicitadas y más caras, y fomentar la discriminación por razón de sexo; además, el hecho de no garantizar la protección de los trabajadores varones respecto a los riesgos para la reproducción, puede dar lugar a enfermedades y lesiones en el futuro.

Las disposiciones que otorgan a las mujeres el derecho a solicitar traslados, modificación de las condiciones de trabajo y otras adaptaciones, ponen de relieve la importancia del modo en que se asignan los derechos y las obligaciones entre trabajadores y empresas: el derecho de los primeros a solicitar ciertas prestaciones, que las segundas deben conceder, es acorde con los principios de igualdad, mientras que las normas que permiten a las empresas imponer restricciones no deseadas a los trabajadores, aunque sea "por su propio bien", no lo son. Permitir a las empresas que controlen las condiciones de trabajo de las mujeres, a diferencia de las de los hombres, puede privar a éstas, como colectivo, del poder para tomar decisiones y de autonomía personal e iría en contra de los conceptos básicos de igualdad. La idea de que los trabajadores conserven el control sobre las decisiones relacionadas con la salud, aunque se exija a las empresas que observen determinadas normas y ofrezcan ciertas prestaciones, ya ha sido admitida en lo que se refiere al control biológico (OIT 1985), y es igualmente aplicable para satisfacer las necesidades en materia de salud de las mujeres y otros subgrupos de trabajadores.

Como indica el análisis anterior, las iniciativas adoptadas para proteger a las trabajadoras como grupo específico, basadas en la no concesión de prestaciones a otros trabajadores, han obtenido un éxito relativo. No cabe duda de que algunas mujeres se han beneficiado, pero no todas. Una aplicación deficiente, sobre todo en el caso de las leyes sobre prestaciones por maternidad, ha limitado su pretendido efecto positivo. La restricción de las posibilidades de empleo de las trabajadoras, como en el caso del trabajo nocturno, impone penalizaciones económicas y de otros tipos a las mujeres, al reducir sus opciones, oportunidades y cotizaciones.

Simultáneamente, otros factores han obligado a realizar una nueva evaluación de los mejores métodos para satisfacer las necesidades de los trabajadores en materia de protección de la salud. El acceso de un mayor número de mujeres a todo tipo de puestos de trabajo las ha expuesto a numerosos riesgos profesionales que, anteriormente, sólo afectaban a los hombres, mientras que el conocimiento cada vez mayor de la vulnerabilidad de éstos respecto a las lesiones de la función reproductora y otras lesiones relacionadas con la exposición profesional indica la necesidad de llevar a cabo políticas sanitarias globales. 0 tros factores influyen también en la orientación de las políticas relacionadas con el empleo; algunos de ellos son la demanda de igualdad entre ambos sexos y el hecho de que las mujeres trabajan, lo hacen durante más tiempo y en más tipos de trabajo. Como resultado, la tendencia más actual consiste en ofrecer a hombres y mujeres un mayor número de posibilidades relativas a los distintos aspectos de la familia y el empleo: más hombres han elegido participar en el cuidado de los hijos pequeños, más mujeres son las principales perceptoras de ingresos y más trabajadores de ambos sexos solicitan mayor flexibilidad para organizar su vida laboral y familiar. Estos factores refuerzan la tendencia a ofrecer prestaciones tanto a hombres como a mujeres para satisfacer diversas necesidades previsibles asociadas con el bienestar familiar, como las referidas 
a la salud reproductiva, el embarazo, la discapacidad temporal, el parto y la atención a los hijos y las personas de edad avanzada. Por ejemplo, el Convenio sobre los trabajadores con responsabilidades familiares, 1981 ( $n$ - 156), es aplicable por igual a hombres y a mujeres. Además, en Francia, Alemania, Bélgica, Dinamarca y Grecia se conceden diversas modalidades de permiso parental para atender distintas necesidades familiares. No obstante, las prestaciones destinadas a los hombres aún no igualan a las de maternidad (Dumon 1990). En lugar de excluir a los trabajadores considerados sensibles a los efectos de determinados tóxicos, se han prohibido algunos tóxicos que afectan a la reproducción y otros se han regulado estrictamente, para prevenir posibles daños para la reproducción, reduciendo la exposición para ambos sexos. La opción de trasladar a los hombres y las mujeres expuestos a riesgos laborales que amenazan su función reproductora, se ha adoptado en varios países, como en Estados U nidos en el caso de los trabajadores expuestos al plomo. Asimismo, diversos países ofrecen un permiso parental que concede a los padres mayor libertad para cuidar de sus hijos de corta edad.

\section{Conclusión}

Los ejemplos extraídos de experiencias actuales de mujeres trabajadoras, ilustran principios igualmente aplicables a la situación de muchos trabajadores discapacitados y de edad avanzada. Como las mujeres, estos trabajadores han sido protegidos en ocasiones de los riesgos laborales, de tal modo que se les ha privado de autosuficiencia económica y otras recompensas del trabajo. El hecho de limitar las opciones de estos trabajadores, sugiere que son incapaces de llevar a cabo decisiones apropiadas sobre los riesgos y beneficios del trabajo. Los tres grupos mencionados han tenido que soportar la carga de prejuicios negativos respecto a sus capacidades, y a menudo se les ha negado la oportunidad de demostrar sus habilidades. Además, se ha tendido a considerar la adaptación de estos trabajadores como una carga especialmente pesada, aunque se trate de acomodar a un trabajador lesionado en un accidente de tráfico o a un ejecutivo que ha sufrido un ataque cardíaco.

La igualdad es válida cuando se establecen políticas en el lugar de trabajo para satisfacer las necesidades de todos los trabajadores. Este principio resulta esencial para abordar las situaciones en las que los miembros de conocidos grupos raciales 0 étnicos se consideran especialmente sensibles a determinados riesgos laborales. Estas demandas deben ser objeto de un análisis exhaustivo para garantizar su validez; en ocasiones, se han utilizado sin fundamento y para justificar la exclusión de trabajadores concretos, aunque la variación individual en cuanto a sensibilidad suele ser más importante que las diferencias derivadas de la pertenencia a un grupo (Bingham 1986). Sin embargo, aunque sea así, los principios de igualdad aconsejan que el riesgo debería reducirse o evitarse mediante la aplicación de medidas técnicas, la sustitución de productos u otros medios, y no privando a todo un colectivo de las oportunidades de empleo o sometiendo a sus miembros a determinadas condiciones cuando se sabe que éstas implican un riesgo.

En términos ideales, las capacidades y las necesidades de los trabajadores deben evaluarse individualmente, y deben ajustarse, en la medida de lo posible, a las necesidades individuales. Las estimaciones de riesgo-beneficio suelen ser mejor realizadas por las personas más directamente afectadas. La posibilidad de que los trabajadores sacrifiquen su salud a cambio de su bienestar económico puede reducirse si las normas de la Administración se establecen bajo el supuesto de que en el lugar de trabajo desarrolla su actividad una muestra representativa de la población, que incluye a mujeres embarazadas, trabajadores de edad avanzada, discapacitados y miembros de diferentes grupos racistas y étnicos. Algunos acontecimientos de la vida son fácilmente predecibles: la procreación y el envejecimiento afectan a una gran proporción de la población activa, la discapacidad a un número significativo y todos pertenecemos a determinado subgrupo racial o étnico. Las políticas relacionadas con el trabajo en las que estas circunstancias se consideran normales y se prevén, propician la creación de un medio ambiente de trabajo en el que la igualdad, por un lado, y la salud y la seguridad, por otro, pueden coexistir sin problemas.

\section{EMPLEO PRECARIO Y TRABAJO INFANTIL}

Leon J. Warshaw

En todo el mundo, no sólo en los países en desarrollo, sino también en los industrializados, hay muchos millones de trabajadores cuyo empleo puede calificarse de precario desde el punto de vista de sus posibles efectos sobre la salud y el bienestar. Estos trabajadores pueden clasificarse en varias categorías no exclusivas, en función del tipo de actividad que desempeñan y de la relación que mantienen con su puesto de trabajo y su empresa; tales como los siguientes:

- trabajadores infantiles;

- trabajadores de subcontrata y otros contratos "atípicos";

- trabajadores esclavizados y vinculados abusivamente;

- trabajadores del sector informal;

- trabajadores migrantes;

- trabajadores a destajo;

- trabajadores desempleados y subempleados.

Entre los factores comunes a todas las categorías figuran: la pobreza; la falta de educación y formación; la posibilidad de sufrir explotación y abusos; los problemas de salud y la falta de asistencia médica adecuada; la exposición a riesgos para la salud y la seguridad; la falta de protección por parte de los organismos públicos, incluso en los casos en que se han establecido leyes y reglamentos al respecto; la ausencia de prestaciones sociales (por ejemplo, salario mínimo, seguro de desempleo, seguro de enfermedad y pensiones), y la falta de representación eficaz en los movimientos que pueden mejorar su situación. En buena medida, su condición de víctimas se debe a la pobreza y a la falta de educación y formación, que les obligan a aceptar cualquier trabajo disponible. En ciertas áreas y en algunos sectores, la existencia de estas clases de trabajadores se fomenta mediante políticas sociales y económicas explícitas formuladas por la Administración e, incluso en los casos en que están prohibidas por la legislación local o por la ratificación de convenios internacionales, se promueven mediante la desatención deliberada de los organismos normativos públicos. Los costes que soportan estos trabajadores y sus familias en cuanto a problemas de salud, reducción de la esperanza de vida y consecuencias para el bienestar son imponderables; en ocasiones, se mantienen de una generación a la siguiente. Por una razón u otra, se les puede considerar desfavorecidos.

Asimismo, la explotación de la mano de obra constituye un aspecto perjudicial de la economía mundial, en la que el trabajo más precario y peligroso se transfiere de los países ricos a los pobres. Así, el empleo precario puede y debe considerarse

El apartado de este artículo dedicado al trabajo infantil se basa en gran medida en el informe de la Comisión sobre Empleo y Política Social, de la OIT: Child L abour, GB.264/ E SP/ 1, 264th Session, G inebra, noviembre de 1995. 
también desde un punto de vista macroeconómico. Esta cuestión se analiza con mayor detenimiento en otros apartados de la presente E nciclopedia.

En este artículo se resumen brevemente las características de las más importantes de estas categorías de empleo y sus efectos sobre la salud y el bienestar de los trabajadores.

\section{Trabajadores migrantes}

Los trabajadores migrantes constituyen con frecuencia una parte esencial de la mano de obra de un país. En algunos casos, desarrollan habilidades profesionales y capacidades escasas, sobre todo en las áreas de rápido crecimiento industrial. No obstante, estos trabajadores suelen ocupar puestos no cualificados o semicualificados de baja remuneración despreciados por la población autóctona. En este grupo se incluyen los "trabajos que se realizan agachado", como el cultivo y la cosecha, las tareas manuales del sector de la construcción, los servicios domésticos como la limpieza y la retirada de basuras, y tareas repetitivas escasamente remuneradas, como las realizadas en talleres ilegales de confección o en cadenas de montaje de las industrias ligeras.

Algunos trabajadores migrantes encuentran trabajo en su propio país, pero en los últimos tiempos se trata en su mayoría de trabajadores "externos", ya que proceden de otros países, habitualmente menos desarrollados. En consecuencia, realizan una contribución extraordinaria a la economía de dos naciones: por un lado, realizan trabajos necesarios en el país en el que prestan sus servicios y, por el otro, envían dinero en metálico a las familias que dejan atrás en su país de origen.

D urante el siglo XIX, un gran número de trabajadores chinos fueron contratados en Estados U nidos y Canadá, por ejemplo, para trabajar en la construcción de los tramos occidentales de los ferrocarriles transcontinentales. Posteriormente, en la segunda Guerra M undial, mientras los trabajadores norteamericanos prestaban servicio en las fuerzas armadas o en las industrias bélicas, Estados U nidos estableció un acuerdo formal con M éxico conocido como el Programa B racero (1942-1964), gracias al cual el sector agrario, de vital importancia, dispuso de millones de trabajadores mexicanos temporales. En el período de posguerra, trabajadores "invitados" de Europa meridional, Turquía y el norte de Africa ayudaron a reconstruir los países de Europa occidental asolados por la guerra y, en los decenios de 1970 y 1980, Arabia Saudí, K uwait y otros países productores de petróleo de O riente Próximo, de recién estrenada riqueza, reclutaron trabajadores asiáticos para construir sus nuevas ciudades. A principios del decenio de 1980, unos dos tercios de la población activa en los Estados del golfo A rábigo eran trabajadores inmigrantes (el número de trabajadores autóctonos sólo superaba a los foráneos en Bahrein).

Excepto en el caso de los profesores y los trabajadores del sector sanitario, la mayoría de los migrantes han sido varones. No obstante, en la mayor parte de los países y durante los períodos mencionados, a medida que las familias se enriquecían, aumentó la demanda de trabajadores domésticos, en su mayoría mujeres, para llevar a cabo las tareas del hogar y cuidar a los hijos (Anderson 1993). Esta tendencia se ha repetido en los países industrializados, en los que ha aumentado el número de mujeres que se incorporan a la población activa y necesitan ayuda para desempeñar sus tareas domésticas tradicionales.

0 tro ejemplo es el de A frica. Tras la creación de la R epública de Transkei en 1976, como el primero de los diez territorios independientes previstos en la Ley de promoción del autogobierno de Sudáfrica de 1959, la mano de obra migrante se convirtió en su principal activo para la exportación. Situada en el océano Indico en la costa oriental de Sudáfrica, envió unos 370.000 varones xhosa, su grupo étnico dominante, como trabajadores emigrantes a la vecina Sudáfrica, un número que representaba en torno al $17 \%$ de su población total.

Algunos trabajadores emigrantes disponen de visados y permisos de trabajo temporal, pero estos documentos suelen ser controlados por sus empresas. De este modo, no pueden cambiar de trabajo o quejarse de recibir un tratamiento inadecuado, por miedo a que esta actitud dé lugar a la revocación de sus permisos y a la repatriación obligatoria. A menudo, eluden los procedimientos oficiales de inmigración del país anfitrión y se convierten en trabajadores "ilegales" 0 "indocumentados". En algunos casos, estos trabajadores son reclutados por "contratistas" de mano de obra, que les exigen el pago de unas tarifas exorbitantes para introducirles clandestinamente en el país con el fin de atender las necesidades de las empresas locales. El temor a ser arrestados y deportados, junto con el desconocimiento de la lengua, la legislación y las costumbres del país anfitrión, colocan a estos trabajadores en una situación especialmente vulnerable para su explotación y abuso.

Los trabajadores emigrantes suelen trabajar en exceso, se les niega la utilización de las herramientas y el equipo adecuados y, con frecuencia, se les expone deliberadamente a peligros evitables en materia de salud y seguridad. La utilización de viviendas atestadas y deficientes (a menudo carentes de agua potable y servicios sanitarios básicos), la desnutrición y la falta de acceso a la asistencia médica les convierte en un grupo especialmente expuesto a las enfermedades contagiosas, como las infecciones parasitarias, la hepatitis, la tuberculosis y, más recientemente, el SIDA. Suelen estar mal pagados e incluso son objeto de engaño respecto a la cuantía real de su remuneración, sobre todo en los casos en que viven ilegalmente en un país y, por tanto, se les deniegan los derechos jurídicos básicos. Si son detenidos por las autoridades, se penaliza normalmente a los trabajadores migrantes "indocumentados" y no a las empresas y los contratistas que los explotan. A demás, sobre todo en períodos de recesión económica y aumento del desempleo, incluso los documentados pueden ser deportados.

El interés de la O rganización Internacional del Trabajo por los problemas de los trabajadores migrantes viene de tiempo atrás. Abordó por primera vez este tema en su Convenio sobre los trabajadores migrantes, 1949 (no 97) y en la Recomendación asociada $\mathrm{n}-86$, y volvió a considerarlo en el Convenio sobre los trabajadores migrantes (disposiciones complementarias), 1975 ( $n$ - 143) y en la Recomendación correspondiente $\mathrm{n}$ - 151. Estos convenios, que tienen la fuerza de tratados cuando son ratificados por los países, incluyen disposiciones encaminadas a eliminar las condiciones abusivas y garantizar los derechos humanos básicos y la igualdad de trato para los inmigrantes. Las recomendaciones ofrecen directrices no vinculantes que sirven de orientación en la práctica y para las políticas nacionales; la Recomendación no 86, por ejemplo, incluye un modelo de acuerdo bilateral que puede ser utilizado por dos países como base de un convenio operativo sobre la gestión de la mano de obra migrante.

En 1990, la O rganización de las Naciones U nidas adoptó el Convenio Internacional sobre la Protección de los Derechos de los Trabajadores M igrantes y los M iembros de sus Familias, en el que se formulan derechos humanos básicos, como el derecho a no ser objeto de torturas ni de tratos o penas crueles, inhumanos o degradantes; el derecho a ser tratados igual que los trabajadores nacionales en lo que se refiere a las condiciones de trabajo y empleo, y el derecho a afiliarse a sindicatos y solicitar su asistencia. Este convenio de las $\mathrm{N}$ aciones U nidas entrará en vigor cuando haya sido ratificado por 20 Estados; en julio de 1995 sólo cinco habían dado ese paso (Egipto, Colombia, $M$ arruecos, Filipinas y Seychelles), mientras que $C$ hile y $M$ éxico lo habían firmado, pero no lo habían ratificado formalmente. 
D ebe subrayarse que ni la O IT ni la O NU están facultadas para obligar al cumplimiento de los convenios y que sólo pueden recurrir al ejercicio de presiones políticas colectivas y confiar en que los Estados miembros los apliquen.

Se ha observado que, al menos en Asia, el diálogo internacional sobre la cuestión de los trabajadores migrantes se ha visto dificultado por su carácter delicado desde el punto de vista político. Lim y O ishi (1996) señalan que los países que exportan trabajadores temen perder su cuota de mercado en beneficio de terceros, especialmente desde que la reciente recesión económica mundial ha movido a más países a acceder al mercado internacional de mano de obra emigrante para exportar sus trabajadores "baratos y dóciles" a un número limitado de países anfitriones cada vez más exigentes.

\section{Trabajadores a "destajo"}

El trabajo a destajo es un sistema de remuneración en el que se paga a los trabajadores por unidad de producción realizada. La unidad de pago puede basarse en la realización del artículo completo o sólo de una fase de su producción. En general, este sistema se aplica en sectores en los que el método de producción consiste en tareas diferenciadas y repetitivas cuya realización puede asignarse a un trabajador determinado. En consecuencia, los ingresos se asocian directamente a la productividad del trabajador (en algunos lugares de trabajo en los que se fabrican artículos de mayor tamaño o complejidad, como automóviles, los trabajadores se organizan en equipos que se dividen el pago por pieza). Algunas empresas comparten los beneficios de una mayor productividad complementando los pagos por pieza con gratificaciones basadas en la rentabilidad.

En líneas generales, el trabajo a destajo se concentra en las industrias pequeñas y de escasa remuneración, como talleres de confección y pequeños talleres de montaje. Asimismo, es característico de los agentes de ventas, los contratistas autónomos, el personal dedicado a las reparaciones y otros trabajadores considerados habitualmente distintos a los trabajadores de plantilla.

El sistema puede funcionar bien cuando las empresas están informadas e interesadas por la salud y el bienestar de los trabajadores y, especialmente, cuando éstos se organizan en un sindicato para negociar colectivamente las tarifas de pago por unidad, la disposición de herramientas y equipo apropiados y bien mantenidos y un medio ambiente de trabajo en el que se eliminen o controlen los peligros y se suministren equipos de protección personal en caso necesario, así como la concesión de pensiones, seguridad social y otras prestaciones. Para su buen funcionamiento, es útil poder acceder con facilidad a gestores y supervisores, cualificados en el proceso de producción y capaces de formar 0 asistir a los trabajadores que tengan dificultades y de ayudar a mantener un estado de ánimo elevado en el lugar de trabajo, prestando atención a las preocupaciones de los trabajadores.

Con todo, el sistema de trabajo a destajo se presta con facilidad a la explotación de los trabajadores, lo que genera efectos perjudiciales sobre su salud y su bienestar, como se indica a continuación:

- El trabajo a destajo es característico de los conocidos talleres ilegales, por desgracia aún habituales en los sectores de la confección y la electrónica, en los que los trabajadores deben llevar a cabo tareas repetitivas, a menudo en jornadas de 12 horas y siete días a la semana, en lugares de trabajo deficientes y peligrosos.

- Incluso en los casos en los que la empresa manifieste interés por los posibles riesgos en el trabajo (lo cual no ocurre siempre), la presión para mejorar la productividad puede inducir a los trabajadores a no dedicar a la educación en salud y seguridad un tiempo que no sería remunerado. Esta presión puede llevarles a hacer caso omiso de las medidas diseñadas para controlar riesgos potenciales, por ejemplo suprimiendo los dispositivos y resguardos de seguridad. Al mismo tiempo, las empresas han observado que puede reducirse la calidad del trabajo, lo que obliga a mejorar las inspecciones de los productos para evitar que artículos defectuosos lleguen a las manos de los consumidores.

- La remuneración puede ser tan reducida que obtener un salario mínimo para vivir resulte difícil o casi imposible.

- Los trabajadores a destajo pueden ser considerados trabajadores "temporales", y como tales pueden ser declarados no aptos para recibir prestaciones que son obligatorias para la mayoría de los trabajadores.

- En algunos casos, se niega a los trabajadores menos cualificados y más lentos la formación que les permitiría mantener el ritmo de los más rápidos, mientras las empresas pueden establecer cuotas en función de la producción de los mejores trabajadores y despedir a los que no consigan alcanzarlas. (En algunos lugares de trabajo, los trabajadores llegan a acuerdos sobre las cuotas de producción, que obligan a los trabajadores más rápidos a reducir su ritmo o a dejar de producir, de forma que el trabajo disponible y los ingresos se distribuyen con mayor equidad entre todo el grupo de trabajo).

\section{Trabajadores con contrato atípico}

EI contrato atípico es un sistema por el cual un tercero u organización contrata a una empresa para proporcionar los servicios de los trabajadores cuando y donde se les necesita. $\mathrm{H}$ ay tres tipos de trabajadores con contrato atípico:

1. Los trabajadores temporales son contratados por un período de tiempo breve para sustituir a otros ausentes por enfermedad 0 permiso, reforzar la plantilla cuando no es posible asumir un aumento de la carga de trabajo, o cuando se precisa personal especialmente cualificado durante un tiempo limitado.

2. Los trabajadores cedidos (por Empresas de Trabajo T emporal) son contratados de una forma más o menos permanente por empresas que, por diversas razones, no desean aumentar su plantilla. Entre estas razones se incluyen el ahorro del esfuerzo y los costes que genera la gestión de personal y evitar compromisos como el tipo de remuneración y las prestaciones obtenidas por los trabajadores "ordinarios". En algunos casos, se han eliminado puestos de trabajo como parte de un proceso de "redimensionamiento", y las personas que los ocupaban han vuelto a ser contratadas como trabajadores cedidos.

3. Los trabajadores de subcontratas son reclutados por contratistas y transportados, a veces a grandes distancias y a otros países, para cubrir puestos de trabajo que no pueden ser ocupados localmente. Suele tratarse de los trabajos menos solicitados, repetitivos, mal pagados y que exigen un gran esfuerzo físico. A lgunas contratistas reúnen trabajadores que desean mejorar su situación emigrando a un nuevo país y les hacen firmar contratos que les comprometen a prestar servicios a su requerimiento, hasta que hayan pagado sus honorarios y los gastos de manutención y transporte, que suelen ser desorbitados.

Un problema fundamental de los muchos que puede plantear este sistema consiste en determinar si el propietario de la empresa 0 el contratista que suministra los trabajadores es responsable de su seguridad, salud y bienestar. Cada uno suele "escurrir el bulto" traspasando al otro, la responsabilidad respecto a las deficiencias de las condiciones de trabajo ( $y$, cuando se trata de trabajadores migrantes, de las condiciones de vida), mientras que los trabajadores, que en algunos casos 
desconocen la lengua, las leyes y las costumbres locales y son demasiado pobres para recibir ayuda legal, se ven impotentes para corregir tal situación. Los trabajadores subcontratados suelen estar expuestos a riesgos físicos y químicos al tiempo que se les niega la educación y la formación necesarias para identificarlos y poder prevenirlos.

\section{Trabajadores del sector informal}

En el sector informal o "no documentado" prestan sus servicios trabajadores que acuerdan desarrollar su actividad sin ser registrados formalmente o amparados por un contrato entre la empresa y el trabajador. El pago puede realizarse en efectivo 0 en bienes 0 en especie y, puesto que los ingresos no se declaran a las autoridades, no están sometidos a regulación ni a tributación, tanto en el caso del trabajador como en el de la empresa. Por lo general, no se ofrecen prestaciones sociales complementarias.

En muchas ocasiones, el trabajo informal se realiza a tiempo parcial para satisfacer necesidades específicas, a menudo como una forma de pluriempleo durante o después de la jornada de trabajo en otro puesto. Asimismo, es habitual en el caso de las personas encargadas de las tareas domésticas y del cuidado de niños, que pueden ser importadas (a veces, ilegalmente) de otros países en los que resulta difícil encontrar un trabajo remunerado. A muchas de estas personas se les exige que vivan en la casa y se les imponen jornadas de trabajo de muchas horas, con escaso tiempo libre. Puesto que el alojamiento y la manutención pueden considerarse parte de su retribución, sus ingresos en efectivo suelen ser muy limitados. Por último, los malos tratos físicos y el acoso sexual no son problemas raros para estos trabajadores domésticos (A nderson 1993).

La responsabilidad de las empresas respecto a la salud y la seguridad de los trabajadores del sector informal es, en el mejor de los casos, únicamente implícita y a menudo se niega. A simismo, los trabajadores no suelen tener derecho a recibir una indemnización en caso de enfermedad o accidente relacionados con el desarrollo de su actividad laboral y pueden verse obligados a emprender acciones legales cuando la empresa no les presta los servicios de salud necesarios, finalmente una mayor garantía para la mayoría de estos trabajadores no es posible en todas las jurisdicciones.

\section{Esclavitud}

La esclavitud es un sistema en el que una persona se considera propiedad de otra que la explota y domina, puede negarle la libertad de actividad y movimientos y está obligada a suministrarle sólo una cantidad mínima de alimentos, alojamiento y vestido. Los esclavos no pueden casarse y formar una familia sin el permiso de su propietario y pueden ser vendidos o cedidos a voluntad. Puede obligárseles a realizar todo tipo de trabajos sin remuneración y, a excepción del problema que supone deteriorar una posesión valiosa, sin ninguna consideración respecto a su salud y seguridad.

La esclavitud ha existido en todas las culturas, desde el comienzo de la civilización, tal como la conocemos, hasta el presente. Se menciona en los códigos jurídicos sumerios fechados en torno al 4000 a.C. y en el Código de $\mathrm{H}$ ammurabi elaborado en la antigua Babilonia en el siglo X VIII a.C., y sigue existiendo en la actualidad en algunas áreas del mundo, a pesar de que está prohibida en la Declaración de Derechos H umanos, de la O rganización de las Naciones U nidas, de 1945 y de ser atacada y condenada por casi todas las organizaciones internacionales, incluido el Consejo Económico y Social de ONU, la O rganización de las $\mathrm{N}$ aciones $\mathrm{U}$ nidas para la Alimentación y la Agricultura (FAO), la O rganización M undial de la Salud (O M S) y la OIT (Pinney 1993). Los esclavos han sido utilizados en todo tipo de economías y, en algunas sociedades agrarias e industriales, han constituido el sostén principal de la producción. En las sociedades esclavistas de O riente Próximo, Africa y China, los esclavos se dedicaban principalmente a la prestación de servicios personales y domésticos.

Tradicionalmente, los esclavos han sido miembros de grupos raciales, étnicos, políticos o religiosos distintos a los de sus propietarios. Se les solía capturar en guerras o incursiones bélicas, pero, desde la época del antiguo Egipto, los trabajadores en condiciones económicas precarias han podido venderse a sí mismos, a sus esposas o a sus hijos como esclavos para hacer frente a sus deudas (O IT 1993b).

\section{Desempleo y posibilidades de empleo}

En todos los países y tipos de economía hay trabajadores desempleados (definidos como personas capaces y dispuestas a trabajar que buscan empleo). Los períodos de desempleo constituyen una característica habitual de algunos sectores en los que la mano de obra aumenta y disminuye en función de las estaciones (p. ej., la agricultura, la construcción y la industria de la confección) y de sectores cíclicos en los que se despide a trabajadores cuando la actividad decae y se les vuelve a contratar cuando mejora. Asimismo, un cierto grado de rotación es habitual en el mercado de trabajo, ya que algunos trabajadores abandonan su empleo para ocupar otro mejor y los jóvenes se incorporan a la población activa para sustituir a los que se jubilan. Este proceso recibe la denominación de desempleo friccional.

EI desempleo estructural se produce cuando sectores enteros sufren una recesión como resultado del avance tecnológico ( $p$. ej., la minería y la fabricación de acero) o en respuesta a grandes cambios de la economía local. U n ejemplo de estas transformaciones es el traslado de los centros de producción de un área donde los salarios se han encarecido a otra menos desarrollada en la que hay mano de obra más barata.

En las últimas décadas, el desempleo estructural también ha sido provocado por la multitud de fusiones, absorciones y reestructuraciones de grandes empresas, procesos que se han convertido en un fenómeno habitual, sobre todo en Estados U nidos, donde el número de medidas obligatorias de protección sociales y del propio bienestar del trabajador es mucho menor que en otros países industrializados. Estas tendencias han dado lugar al "redimensionamiento" y la reducción de las plantillas, a medida que se han eliminado filiales de fábricas y oficinas y se han vuelto innecesarios muchos puestos de trabajo. Con ello se ha perjudicado no sólo a los que han perdido su empleo, sino también a los que lo han conservado y han perdido seguridad en el puesto y temen ser despedidos.

EI desempleo estructural suele ser un problema irresoluble, ya que muchos trabajadores carecen de la cualificación y la adaptación necesarias para optar a otros puestos similares existentes a escala local y, con frecuencia, no cuentan con recursos para emigrar a otras zonas en las que puede haber trabajo.

En los casos de despidos generalizados, suele producirse un efecto dominó sobre la comunidad. La pérdida de ingresos enfría la economía local y causa el cierre de las tiendas y las empresas de servicios frecuentadas por los desempleados, lo que aumenta a su vez el número de éstos.

El estrés económico y mental que genera el desempleo suele afectar negativamente a la salud de los trabajadores y sus familias. Se ha observado que la pérdida del empleo y, en particular, la amenaza de sufrirla, son los factores de estrés más potentes relacionados con el trabajo y se ha demostrado que provocan enfermedades emocionales (esta cuestión se analiza en otros apartados de la presente Enciclopedia). Con el fin de evitar estos efectos perjudiciales, algunas empresas ofrecen iniciativas de reconversión profesional y ayuda para encontrar un nuevo empleo, así muchos países han adoptado leyes en las que se exige 
específicamente a las empresas la concesión de prestaciones sociales y económicas a los trabajadores afectados.

El grupo de los subempleados está constituido por los trabajadores cuyas capacidades productivas no son plenamente utilizadas. Se incluyen aquí los trabajadores a tiempo parcial que buscan un empleo de jornada completa y los que poseen un nivel de cualificación elevado y sólo encuentran trabajos que exigen una cualificación relativamente baja. Además de la reducción de ingresos, sufren los efectos adversos que provoca el estrés por la insatisfacción en el trabajo.

\section{Trabajo infantil}

En la mayoría de las familias, se espera que los hijos trabajen tan pronto como tengan edad para ello. Esta actividad puede consistir en ayudar en las tareas domésticas, hacer recados 0 atender a los hermanos más pequeños; es decir, contribuir en general al cumplimiento de las tareas tradicionales del hogar. En las familias dedicadas a la actividad agraria 0 a algún tipo de industria familiar, suele esperarse que los niños ayuden en las tareas adecuadas a su edad y capacidad. Estas actividades son casi siempre a tiempo parcial y, con frecuencia, estacionales. Excepto en los casos en que los niños son objeto de malos tratos 0 explotación, este tipo de trabajo se define por el tamaño y los "valores" de la familia en cuestión; no es remunerado y, normalmente, no dificulta el crecimiento, la educación y la formación de los niños. En este artículo no se aborda esta forma de trabajo. Se analiza, en cambio, el caso de los niños menores de 14 años que trabajan fuera del marco familiar en diversos sectores, habitualmente al margen de las leyes y los reglamentos que regulan el trabajo infantil. Aunque los datos disponibles son escasos, la O ficina de estadísticas de la OIT ha estimado que "sólo en los países en desarrollo, hay al menos 120 millones de niños entre 5 y 14 años de edad que trabajan a tiempo completo, y esta cifra aumenta en más del doble (unos 250 millones) si se incluyen aquéllos para los que el trabajo constituye una actividad secundaria" (OIT 1996). Se considera que las cifras obtenidas con anterioridad deben revisarse al alza, como demuestran los datos recogidos en estudios independientes efectuados en varios países en 1993-1994. Por ejemplo, según esos datos, en G hana, India, Indonesia y Senegal, un $25 \%$ de los niños se dedican a alguna forma de actividad económica. Para un tercio de ellos, el trabajo es su ocupación principal.

El trabajo infantil está generalizado, aunque es mucho más habitual en las zonas desfavorecidas y en desarrollo. A fecta de manera desproporcionada a las niñas, que no sólo suelen trabajar un mayor número de horas, sino que, como las mujeres de edad más avanzada, deben realizar además tareas domésticas en una medida muy superior a los hombres en la misma situación. Por término medio, los niños de las áreas rurales tienen el doble de probabilidades de ser económicamente activos; en las familias de trabajadores agrarios migrantes, es casi la norma que todos los hijos trabajen junto a sus padres. No obstante, la proporción de niños urbanos que trabajan aumenta regularmente, sobre todo en el sector informal de la economía. La mayoría de ellos trabajan en los servicios domésticos, aunque muchos están empleados en el sector manufacturero. Si bien la atención pública se ha centrado en algunos sectores exportadores, como el textil, la confección, el calzado y la fabricación de alfombras, la gran mayoría desarrolla su actividad en puestos de trabajo orientados al consumo interno. Con todo, el trabajo infantil sigue siendo, en general, más habitual en el sector agrario que en la industria.

\section{Esclavitud infantil}

Muchos de los niños que trabajan son esclavos. Es decir, la empresa ejerce un derecho de propiedad temporal o permanente sobre los niños, convertidos en "mercancías" que pueden arrendarse o intercambiarse. Tradicionalmente en el sur de Asia, la franja subsahariana de Africa oriental y, de forma más reciente, en varios países sudamericanos, la esclavitud infantil parece desarrollarse en todo el mundo. A pesar de su ilegalidad en la mayoría de los países en que existe y de la ratificación generalizada de los convenios internacionales que la prohíben, la OIT ha estimado (no se dispone de datos exactos) que hay unos diez millones de niños esclavos en el mundo (O IT 1995). Un gran número de ellos trabajan en la agricultura, el servicio doméstico, la industria del sexo, la fabricación de alfombras, el sector textil, la explotación de canteras y la producción de ladrillos.

De acuerdo con el informe de un Comité de Expertos de la OIT (OIT 1990), se cree que más de 30 millones de niños se encuentran en condiciones de esclavitud en varios países. En el informe se citan, entre otros, India, G hana, G aza, Pakistán, Filipinas, República Dominicana, H aití, Brasil, Perú, M auritania, Sudáfrica y Tailandia. Más de 10 millones de estos niños esclavos se concentran en India y Pakistán. Los lugares habituales de empleo son pequeños talleres y plantaciones en las que imperan los trabajos forzados. En el sector informal pueden ser empleados en el tejido de alfombras, las fábricas de cerillas y de cristal, la producción de ladrillos, la limpieza de pescado, la minería y la explotación de canteras. Asimismo, se les utiliza en el servicio doméstico, la prostitución y el tráfico de drogas.

La esclavitud infantil predomina en los sistemas sociales basados en la explotación de la pobreza. Las familias venden a sus hijos al contado o los ceden como esclavos para saldar deudas, obtener recursos para sobrevivir o cumplir obligaciones sociales o religiosas. En muchos casos, el pago se considera un anticipo respecto a los salarios que se prevé que reciban los niños esclavos durante su contrato de aprendizaje. Las guerras y las migraciones forzadas de grandes masas de población, que alteran la estructura familiar normal, llevan a muchos niños y adolescentes a la esclavitud.

\section{Causas del trabajo infantil}

La pobreza es el principal factor responsable del acceso de niños al mercado de trabajo. La supervivencia de la familia, incluida la de los propios niños suele obligar a dar este paso; así ocurre sobre todo en el caso de familias desfavorecidas con muchos hijos. La necesidad de que los hijos trabajen a jornada completa les impide invertir en su educación.

Incluso cuando la enseñanza es gratuita, muchas familias pobres no pueden afrontar los costes asociados a la educación ( $p$. ej., libros y demás material pedagógico, vestido y calzado, transporte, etc.). En algunos lugares, los gastos generados por un niño que asiste a la escuela primaria pueden representar un tercio de los ingresos en efectivo de una típica familia desfavorecida. Esto conduce a trabajar como la única alternativa posible. En algunas familias numerosas, los hijos de mayor edad trabajan con el fin de obtener los recursos necesarios para educar a sus hermanos menores.

En algunas áreas, el problema no es tanto el coste como la falta de escuelas que ofrezcan una educación de calidad aceptable. Algunas comunidades, sencillamente, no disponen de escuelas. En otras, los niños abandonan su escolarización porque los centros educativos a los que asisten los pobres son tan deficientes, que la asistencia no parece compensar el coste y el esfuerzo invertidos. Así, mientras que muchos niños abandonan la escuela porque tienen que trabajar, muchos otros tienen tan pocos incentivos que prefieren trabajar. En consecuencia, muchos no dejan de ser analfabetos totales o funcionales y no logran desarrollar las capacidades necesarias para progresar en el mundo del trabajo y en la sociedad. 
Por último, en numerosos centros urbanos se ha desarrollado una población indígena de niños de la calle huérfanos o separados de sus familias, que subsisten precariamente realizando trabajos eventuales, mendigando, robando y participando en el tráfico ilegal de drogas.

\section{Demanda de trabajo infantil}

En la mayoría de los casos, los niños acceden al trabajo porque constituyen una mano de obra más barata y generan menos problemas que los trabajadores adultos. En G hana, por ejemplo, un estudio promovido por la OIT ha puesto de manifiesto que tres cuartos de los niños que realizan trabajos remunerados perciben menos de un sexto del salario mínimo obligatorio (O IT 1995). En otras áreas, aunque las diferencias entre los salarios de los niños y de los adultos no son tan acusadas, son lo suficientemente importantes para representar una carga muy significativa para las empresas, que suelen estar constituidas por pequeños contratistas de escasos recursos que obtienen un margen de beneficios muy reducido.

En ciertos sectores, como el del tejido de alfombras a mano y el de la fabricación de brazaletes de cristal (ajorcas) en La India, se prefiere a los trabajadores infantiles antes que a los adultos por su menor tamaño o por la idea de que sus "dedos ágiles" les confieren mayor destreza manual. Un estudio de la OIT ha demostrado que los adultos no son menos competentes para realizar este tipo de tareas y que los trabajadores infantiles no son insustituibles (L evison y cols. 1995).

Los padres constituyen una fuente fundamental de demanda de trabajo para sus propios hijos. U n gran número de niños son trabajadores no remunerados en explotaciones agrarias familiares, talleres y tiendas que dependen de la mano de obra familiar para mantener su viabilidad económica. Tradicionalmente, se supone que la probabilidad de que estos niños sean explotados es mucho menor que la de los que prestan sus servicios fuera del seno familiar, pero numerosos datos indican que éste no siempre es el caso.

Por último, en las áreas urbanas de los países desarrollados en las que el acceso al mercado de trabajo es difícil, los adolescentes son a veces los únicos trabajadores disponibles y dispuestos a aceptar el salario mínimo, casi siempre en puestos de trabajo a tiempo parcial, en establecimientos minoristas, como los restaurantes de comida rápida, comercios al por menor y servicios de mensajería. Recientemente, en períodos en los que incluso la disponibilidad de trabajadores jóvenes se ha visto reducida, las empresas han contratado a jubilados de edad avanzada para ocupar estos puestos.

\section{Condiciones de trabajo}

En numerosos establecimientos en los que se emplea mano de obra infantil, las condiciones de trabajo oscilan entre malas y pésimas. Puesto que, en primer lugar, muchas de estas empresas son pobres y marginales $y$, además, suelen funcionar al margen de la legalidad, se presta poca o ninguna atención a las condiciones que deberían exigírseles para dar empleo a estos trabajadores casi esclavos. La falta de servicios sanitarios elementales y los problemas de calidad del aire, agua potable y alimentación suelen unirse al hacinamiento, una disciplina severa, la antigüedad de los equipos, la deficiente calidad de las herramientas y la ausencia de medidas de protección para controlar la exposición a riesgos laborales. Incluso cuando hay algún equipo de protección, pocas veces se adapta a la pequeña talla de los niños, y su mantenimiento suele ser deficiente.

Son demasiados los niños que trabajan un número excesivo de horas. Las jornadas de trabajo que se extienden del amanecer al anochecer no son excepcionales y, en términos generales, se

\section{Prevención de lesiones infantiles}

El trabajo infantil no se limita a los países en desarrollo. La siguiente relación de precauciones está basada en los consejos propuestos por los Centros de Control y Prevención de Enfermedades, de Estados Unidos.

Los riesgos de lesión y enfermedad relacionadas con el trabajo tanto en el caso de los niños, como en el de los trabajadores de todas las edades, pueden reducirse mediante el cumplimiento de precauciones rutinarias como las siguientes: respeto de las prácticas de trabajo doméstico prescritas; formación y seguimiento de los procedimientos de trabajo seguros; utilización de calzado, guantes y ropa de protección adecuados, así como mantenimiento y utilización de los equipos de seguridad. Además, a los trabajadores menores de 18 años no se les debe exigir que levanten pesos de más de $7 \mathrm{~kg}$ más de una vez por minuto ni, en ningún caso, objetos de más de 14 kg; las tareas que requieran un levantamiento de cargas continuo no deben durar más de dos horas. Los menores de 18 años no deben realizar actividades que obliguen a utilizar habitualmente equipos de protección respiratoria para prevenir la inhalación de sustancias peligrosas.

Las empresas deben conocer y cumplir la legislación sobre trabajo infantil. Los asesores escolares y los médicos que firmen permisos de trabajo para niños, han de conocer también dicha legislación y asegurarse de que el trabajo que aprueban no implica la realización de actividades prohibidas.

La mayoría de los niños que comienzan a trabajar antes de los 18 años acceden al lugar de trabajo con una experiencia laboral previa mínima. Los países industriales avanzados no están exentos de los peligros que generan estas situaciones. Por ejemplo, en el verano de 1992 en Estados Unidos, más de la mitad (54\%) de las personas con edades comprendidas entre los 14 y los 16 años, que fueron tratadas en urgencias por lesiones relacionadas con el trabajo, declararon que no habían recibido ningún tipo de formación para prevenir las lesiones que habían sufrido, y sólo en un $20 \%$ de los casos un supervisor se encontraba presente en el momento de producirse la lesión. Las diferencias de madurez y nivel de desarrollo en cuanto al modo de aprendizaje, capacidad de juicio y comportamiento deben tenerse en cuenta al impartir formación a los jóvenes en materia de salud y seguridad en el trabajo.

Centros de Control y Prevención de Enfermedades, 1996

hace caso omiso de la necesidad de períodos de descanso y vacaciones. A demás de la fatiga crónica, que constituye la principal causa de accidentes, el efecto más perjudicial de la larga duración de la jornada de trabajo es que impide que los niños continúen con su educación. Este problema puede plantearse incluso cuando los niños trabajan sólo a tiempo parcial: algunos estudios han demostrado que una semana laboral de más de 20 horas puede perjudicar el proceso educativo (O IT 1995). El analfabetismo funcional y la falta de formación, a su vez, reducen en gran medida las oportunidades de mejorar profesionalmente.

Las niñas se encuentran en una situación de riesgo más acusado. Dado que suelen ser responsables también de las tareas domésticas, trabajan más horas que los niños que, normalmente, se dedican únicamente a las actividades económicas. Como consecuencia, el índice de niñas que asisten a la escuela y completan su escolarización es, generalmente, inferior.

Los niños son inmaduros desde el punto de vista emocional y necesitan un entorno psicológico y social propicio que facilite su socialización en su ámbito cultural y les permita ocupar un lugar 
Tabla 24.1 - Algunas actividades y sectores en los que trabajan niños, y los riesgos asociados.

Actividad/ sector
Mataderos y producción de carne
Agricultura
Producción y venta de alcohol
Tejido de alfombras
Cemento
Construcción y derribos
Grúas/ montacargas/ maquinaria de elevación
Alquitrán, asfalto, betún
Fabricación de cristal y vidrio
Servicio doméstico
Electricidad
Curtidos
Transporte, manejo de vehículos (clubes nocturnos, bares, casinos, circos, casas de
Trabajo bajo el agua (p. ej., pesca de perlas)
Soldadura y fundición de metales, metalistería
Explosivos (fabricación y manejo)
Hospitales y trabajo con riesgo de infección
Metalurgia del plomo y el zinc
Maquinaria en movimiento (funcionamiento, limpieza,
Minería, explotación de canteras, trabadores y cargadores)
Jajo en la calle
Jubterráneo

Riesgos

Lesiones por cortes, quemaduras, caídas, equipos peligrosos; exposición a enfermedades infecciosas; estrés por calor

Maquinaria poco segura; sustancias peligrosas; accidentes; intoxicación por productos químicos; trabajo penoso; animales peligrosos, insectos, reptiles

Intoxicación, adicción; entorno perjudicial para la moral; riesgo de violencia

Inhalación de polvo, iluminación deficiente, malas posturas ( cuclillas); enfermedades respiratorias y musculosqueléticas; tensión ocular; intoxicación por productos químicos

Sustancias químicas nocivas, exposición al polvo; trabajo penoso; enfermedades musculosqueléticas y respiratorias

Exposición al calor, el frío, el polvo; caída de objetos; objetos cortantes; accidentes; enfermedades musculosqueléticas

Accidentes; caída de objetos; enfermedades musculosqueléticas; riesgo de lesionar a otros

Exposición al calor, quemaduras; intoxicación por sustancias químicas; enfermedades respiratorias

Vidrio líquido; golpe de calor; ventilación deficiente; cortes producidos por los vidrios rotos; transporte de vidrios calientes; quemaduras; enfermedades respiratorias; estrés por calor; polvo tóxico

Exceso de horas de trabajo; malos tratos físicos, emocionales y sexuales; desnutrición; descanso insuficiente; aislamiento

Riesgos del trabajo con alto voltaje; riesgo de caídas; nivel elevado de responsabilidad respecto a la seguridad de otros

Jornadas de trabajo largas que acaban a hora avanzada; abuso sexual; explotación; entorno perjudicial para la moral

Riesgo de explosión, incendio, quemaduras, accidentes mortales

Enfermedades infecciosas; responsabilidad respecto al bienestar de otros

Intoxicación acumulativa; daños neurológicos

Peligro derivado de las partes móviles de la máquina; accidentes; cortes, quemaduras, exposición al calor y al ruido; estrés provocado por el ruido; lesiones oculares y auditivas

Accidentes; calor, quemaduras; caídas de altura; levantamiento de pesos, trabajo penoso, enfermedades musculosqueléticas; enfermedades respiratorias

Exposición a polvo, gases, humos, suciedad; enfermedades respiratorias y musculosqueléticas; accidentes; caída de objetos; trabajo penoso; cargas pesadas

Calor, quemaduras, intoxicación por sustancias químicas

Exposición a drogas, violencia, actividades delictivas; cargas pesadas; enfermedades musculosqueléticas; enfermedades venéreas; accidentes

Intoxicación por sustancias químicas; instrumentos cortantes; enfermedades respiratorias

Accidentes; peligro para sí mismo y para los pasajeros

Enfermedades provocadas por la descompresión; peces peligrosos; muerte o lesión

Exposición a altas temperaturas; chispas y objetos de metal calientes; accidentes; lesiones oculares; estrés por calor

Fuente: Sinclairy Trah 1991.

como adultos en la sociedad a la que pertenecen. M uchos niños que trabajan lo hacen en un medio ambiente de trabajo opresivo; en esencia, se les roba su infancia.

\section{Exposición a riesgos laborales}

En general, los riesgos a los que se enfrentan los niños en el lugar de trabajo coinciden con los que encuentran los adultos. No obstante, sus efectos pueden ser mayores debido al tipo de tareas que se les asignan y a las diferencias biológicas entre los primeros y los segundos.
A los niños suelen adjudicárseles tareas de menor importancia, a menudo sin impartirles la instrucción y la formación necesarias para reducir al mínimo la exposición a los riesgos que puedan encontrar y sin garantizar la supervisión adecuada. Puede que se les asignen tareas de limpieza, en las que se utilizan con frecuencia disolventes o fuertes sustancias alcalinas, o de eliminación de residuos peligrosos acumulados en el lugar de trabajo, sin conocer su toxicidad potencial.

Debido a su menor tamaño, es más probable que se asigne a los niños tareas que exigen trabajar en lugares especiales o confinados o pasar un gran número de horas agachado o de rodillas. 
A menudo se les obliga a manejar objetos que incluso los adultos considerarían demasiado voluminosos o pesados.

A causa de su continuo crecimiento y desarrollo, los niños difieren biológicamente de los adultos. Estas diferencias no han sido cuantificadas, pero es razonable suponer que la mayor rapidez en la división celular unida a su proceso de crecimiento les hace más vulnerables a numerosos agentes tóxicos. La exposición en las primeras etapas de la vida a sustancias de este tipo, con largos períodos de latencia, puede generar la aparición de enfermedades profesionales crónicas causantes de discapacidad, como la asbestosis y el cáncer en la juventud, más que en edades avanzadas; además, hay datos que indican que la exposición durante la infancia a productos químicos tóxicos puede alterar la respuesta a futuras exposiciones tóxicas (Weisburger y cols. 1966).

En la Tabla 24.1 se resume información sobre algunos de los agentes peligrosos a los que pueden estar expuestos los niños que trabajan, clasificados en función de las fuentes de exposición y los tipos de consecuencias para la salud. C abe señalar que estas consecuencias pueden agravarse si los niños expuestos sufren desnutrición, anemia o alguna enfermedad crónica. Por último, la falta de asistencia médica primaria, por no mencionar los servicios de salud en el trabajo con algún grado de especialización, reduce la probabilidad de que estas consecuencias sean reconocidas inmediatamente y tratadas con eficacia.

\section{Consecuencias sociales y económicas del trabajo infantil}

Como se ha señalado, el trabajo infantil se debe en gran parte a la pobreza y tiende a perpetuarla. Cuando el trabajo infantil impide o dificulta seriamente la educación, se reducen los ingresos obtenidos a lo largo de la vida y las posibilidades de ascender en la escala social. Al final, el trabajo que obstaculiza el desarrollo físico, mental y social agota los recursos de salud y bienestar de la comunidad y consolida la pobreza, al degradar las reservas de capital humano necesario para lograr el progreso económico y social. Puesto que los costes sociales del trabajo infantil repercuten fundamentalmente en los grupos de población más pobres y menos privilegiados, se menoscaba el acceso a la democracia y la justicia social y se fomenta el malestar en la sociedad.

\section{Tendencias futuras}

Aunque se ha avanzado mucho en la erradicación del trabajo infantil, lo conseguido no es suficiente ni lo bastante eficaz. En primer lugar, es necesario ampliar y mejorar la información sobre la difusión, la dinámica y los efectos de esta forma de trabajo. El siguiente paso consiste en aumentar y optimizar las oportunidades de educación y formación desde la etapa preescolar hasta las universidades y los institutos técnicos y, posteriormente, en proporcionar a los hijos de las personas desfavorecidas los medios necesarios para aprovecharlas (p. ej., viviendas adecuadas, alimentación y asistencia sanitaria preventiva).

L eyes y reglamentos debidamente elaborados, reforzados por iniciativas internacionales como los convenios de la OIT, deben ser constantemente revisados y consolidados a la luz de la evolución del trabajo infantil, y deben aplicarse con mayor eficacia.

El arma definitiva para alcanzar estos objetivos es tal vez elevar la sensibilización y el rechazo de la opinión pública respecto al trabajo infantil, como comienza a suceder en varios países industrializados (en parte a causa del desempleo de los adultos y la competencia de precios, que lleva a los productores de bienes de consumo a emigrar a zonas donde la mano de obra puede resultar más barata). La publicidad resultante daña la imagen de las organizaciones que comercializan productos fabricados con mano de obra infantil, concita las protestas de sus accionistas y, lo que es más importante, provoca el rechazo a comprar estos productos, aunque puedan costar un poco menos.

\section{Conclusiones}

$\mathrm{H}$ ay muchas formas de empleo en las que los trabajadores son vulnerables al empobrecimiento, la explotación y el abuso, y en las que su seguridad, su salud y su bienestar corren un gran riesgo. A pesar de los intentos concretados en leyes y reglamentos y de su condena en los acuerdos, convenios y resoluciones internacionales, es probable que esas condiciones de trabajo se mantengan mientras haya personas pobres, con vivienda deficiente, desnutridas y oprimidas, a las que se les niegue la información, la educación, la formación y los servicios de salud curativos y preventivos necesarios para que puedan liberarse del marasmo social en el que se encuentran. Las personas y los países ricos suelen responder con generosidad en casos de desastre natural, como tormentas, inundaciones, incendios, erupciones volcánicas y terremotos, pero, a pesar de su importancia, los beneficios de estas ayudas son efímeros. Lo que hace falta es un esfuerzo humano a largo plazo, reforzado con recursos que permitan superar las barreras políticas, raciales y religiosas capaces de impedir su avance.

Por último, aunque es perfectamente adecuado y saludable que los niños trabajen como parte de su desarrollo y su vida familiar normal, el trabajo infantil descrito en el presente artículo es una plaga, que no sólo perjudica la salud y el bienestar de los afectados, sino que, a largo plazo, menoscaba también la seguridad económica y social de la población y de las naciones. D ebe combatirse con vigor y persistencia hasta su erradicación.

\section{TRANSFORMACION DEL MERCADO Y DEL TRABAJO}

Pat Armstrong

La reestructuración profunda y generalizada que se observa a escala local, nacional e internacional tiene efectos importantes para la salud de los trabajadores.

En el ámbito internacional, ha surgido una nueva economía mundial caracterizada por una mayor movilidad del capital y el trabajo entre distintos países. Esta nueva economía ha estado marcada por la negociación de acuerdos comerciales que han dado lugar, simultáneamente, a la eliminación de las barreras entre Estados y al establecimiento de sistemas de protección respecto a los países no pertenecientes al mercado único. Estos acuerdos, como el Tratado de Libre Comercio de América del Norte (TLC) y la Unión Europea, cubren aspectos que van mucho más allá de las cuestiones comerciales; de hecho, abarcan todas las funciones de un Estado. Estos acuerdos han estado acompañados de un compromiso de liberalización de los mercados, desregulación del sector privado y privatización de numerosas empresas públicas.

En algunos casos, los acuerdos han dado lugar a la adopción de normas comunes, que elevan el nivel de protección garantizado a los trabajadores en países donde la protección era mínima o nula. En otros casos, los requisitos exigidos para lograr la condición de miembro u optar a ayudas han sido la no sindicación y las actividades alejadas de los servicios sociales, la agricultura y las empresas locales. Por último, en otros casos, los trabajadores sindicados se han resistido con éxito a los intentos de modificar sus condiciones. No obstante, en todos los casos, las fronteras, las economías y los gobiernos nacionales han perdido importancia en lo que se refiere a la estructuración de las relaciones laborales y la situación del trabajo. 
Aunque la nueva economía mundial se caracteriza por la expansión continua de las empresas transnacionales, este proceso no se ha visto acompañado por la creación de establecimientos cada vez más grandes. De hecho, ha sucedido lo contrario. La empresa tipo ha dejado de ser una enorme fábrica de automóviles con miles de trabajadores, que elaboran un producto normalizado siguiendo una línea de producción fija. Por el contrario, un número creciente de empresas recurre a la producción más conveniente para ofrecer bienes y, cada vez más, servicios a la medida. En vez de economías de escala, utilizan economías de alcance, pasando de un producto a otro con la ayuda de la subcontratación y la utilización de equipos que pueden reprogramarse con facilidad.

De hecho, el cambio generalizado hacia los sectores de servicios y el rápido crecimiento de las pequeñas empresas puede explicarse, al menos en parte, por la subcontratación del trabajo llevada a cabo por las empresas transnacionales. En cuanto a las tareas que siguen siendo desempeñadas directamente por la empresa matriz, la gran acumulación de existencias y los "stocks" de regulación son sustituidos con frecuencia por la producción "ajustada en el tiempo", y las empresas se consideran cada vez más orientadas a la atención al cliente. Asimismo, aumenta el número de empresas que demandan una mano de obra flexible, dotada de diferentes cualificaciones y capaz de adaptarse a diversos horarios de trabajo. De este modo, los trabajadores también pueden desempeñar su actividad de forma "ajustada en el tiempo" y en varios centros de trabajo. Este aumento de la subcontratación y de la multiplicidad de tareas, junto con el auge de formas "atípicas" de trabajo como el trabajo a tiempo parcial o durante una parte del año, dificulta a los sindicatos la utilización de los medios tradicionales para organizar los lugares de trabajo.

Tanto el desarrollo de una economía mundial como la reestructuración del trabajo han sido posibles gracias a la nueva tecnología microelectrónica, que permite la producción más conveniente, ya que los nuevos equipos pueden ser alterados con rapidez y a un bajo coste para adaptarse a nuevas líneas de producción. A demás, esta tecnología no sólo facilita una comunicación barata e instantánea a escala mundial, con independencia de diferencias horarias y otras barreras, sino que también permite a las empresas controlar a trabajadores de filiales lejanas, puesto que pueden realizar un seguimiento de su producción desde otros lugares. Así, ofrece la posibilidad de la producción a domicilio, en la que trabajadores empleados en cualquier lugar del mundo prestan sus servicios a cualquier hora del día o de la noche.

Al mismo tiempo, esta tecnología contribuye a transformar el tipo de especialidades exigidas y la organización del trabajo en las empresas. Cada vez más, sus responsables se refieren a la multidisciplinariedad de los trabajadores que controlan y supervisan diversos equipos y deben moverse entre distintos puestos de trabajo. Aumenta el número de trabajadores que analizan y aplican la información generada, procesada, almacenada y recuperada mediante el uso de las nuevas tecnologías. Ambos tipos de trabajadores pueden organizarse en equipos, de forma que puedan colaborar para mejorar continuamente la calidad. En principio, esta mejora continua de la calidad ha de estar centrada en el proceso de trabajo, como medio de eliminar errores y pérdidas. Esta mejora de la calidad se mide en gran parte mediante las nuevas tecnologías, que permiten a las empresas y a los trabajadores realizar un seguimiento continuo del tiempo empleado por cada trabajador, de los recursos utilizados y de la cantidad y la calidad del producto 0 del servicio. Los directivos, sobre todo a escala intermedia, resultan menos necesarios porque hay menos tareas de supervisión. Como consecuencia, el personal jerárquico disminuye y los organigramas de las organizaciones. Se "achatan", disminuyendo las posibilidades de ascenso a puestos de alta dirección. Los directivos que se mantienen en su cargo se ocupan más de aspectos estratégicos que de la supervisión directa.

A simismo, las tecnologías permiten a las empresas demandar una mano de obra flexible, no sólo en cuanto a especialidades, sino también en lo que se refiere a la disponibilidad de tiempo. La tecnología facilita a las empresas la utilización de fórmulas para calcular la cantidad exacta de horas de trabajo necesarias por puesto y el momento en que el trabajo debe llevarse a cabo. Por tanto, las empresas pueden contratar el número exacto de horas de trabajo requeridas. Además, la tecnología contribuye a eliminar los costes tradicionales asociados a la contratación de varios trabajadores por períodos breves, ya que permite determinar cuántos son necesarios, Ilamarles para que acudan al trabajo, estimar su remuneración y hacer sus cheques. Aunque las tecnologías facilitan el seguimiento y el recuento con un grado de detalle increíble, también aumentan la vulnerabilidad de las empresas transnacionales, ya que un fallo en el suministro eléctrico o una avería informática pueden retrasar o arruinar todo el proceso.

Toda esta reestructuración ha estado acompañada por un aumento del desempleo y de las desigualdades entre los ricos y los pobres. A medida que las compañías adoptan estructuras más ajustadas, la demanda de mano de obra disminuye. En la nueva economía mundial, incluso los trabajadores que conservan su puesto tienen menor seguridad en el empleo. Muchas de las personas con empleo trabajan un gran número de horas a la semana, aunque algunos sólo por un período de tiempo breve, ya que aumentan los trabajos con contratos atípicos y a destajo. EI trabajo a turnos y las jornadas laborales atípicas han aumentado significativamente, debido a la dependencia de las empresas respecto a la flexibilidad de las plantillas. En una situación en la que predomina el trabajo informal, disminuye el número de trabajadores que reciben protección laboral frente al desempleo y que están representados por sindicatos fuertes.

Así ocurre sobre todo en el caso de las mujeres, que constituyen en la actualidad la mayoría de la mano de obra eventual y de la no sindicada. Asimismo, los gobiernos tienden a reducir la prestación de servicios sociales para los desempleados. Por otra parte, la combinación de nuevas tecnologías y nuevas formas de organización del trabajo suele dar lugar a un proceso de crecimiento sin empleo, en el que los beneficios y el desempleo aumentan simultáneamente. El desarrollo económico ha dejado de equivaler a un incremento del trabajo remunerado.

Las consecuencias de esta evolución para la salud de los trabajadores son muy importantes, aunque, normalmente, más difíciles de determinar que las observadas en las organizaciones de trabajo industriales tradicionales. L as formas atípicas de trabajo, al igual que el desempleo, pueden incrementar los riesgos para la salud de los trabajadores. Aunque éstos pueden ser bastante productivos en períodos cortos de actividad, el trabajo informal puede tener el efecto contrario a largo plazo, especialmente si los trabajadores no tienen la posibilidad de hacer planes de futuro. Puede dar lugar a un aumento de los niveles de ansiedad y nerviosismo, a irritabilidad y falta de confianza y a una incapacidad para concentrarse. A simismo, puede tener consecuencias físicas, como la elevación de la presión sanguínea y el aumento de la incidencia de enfermedades como la diabetes y la bronquitis. Además, el trabajo informal y los horarios de trabajo atípicos pueden dificultar la organización laboral de las mujeres que asumen la principal responsabilidad del cuidado de los hijos, de las personas de edad avanzada y la realización de tareas domésticas, elevando significativamente sus niveles de estrés. Por otra parte, el trabajo informal suele conllevar la obtención de 
ingresos irregulares y, a menudo, la pérdida de prestaciones relacionadas con el trabajo, como la asistencia dental, las pensiones, los permisos por enfermedad y la asistencia sanitaria. Estos factores contribuyen también a elevar el estrés que soportan por los trabajadores y limitan su capacidad de mantenerse sanos y productivos.

Los nuevos métodos de organización del trabajo pueden incrementar también los riesgos para la salud de quienes disfrutan de una forma de trabajo más regular. Varios estudios indican que una organización y unos planes de trabajo insalubres 0 inapropiados pueden elevar el riesgo de padecer una enfermedad cardíaca o un accidente cerebrovascular, así como otros problemas de salud relacionados con el trabajo, como las lesiones debidas a esfuerzos repetitivos. La mayor fuente de estrés es la producida por los puestos de trabajo que ofrecen a quienes los ocupan escaso control sobre su actividad o su tiempo de trabajo, los que requieren pocas habilidades reconocidas y los que no permiten a los trabajadores elegir los conocimientos prácticos que deben utilizar. Estos niveles de estrés pueden aumentar aún más en el caso de la mayoría de las mujeres, que han de desempeñar una segunda actividad en el hogar.

Aunque las nuevas formas de organización del trabajo basadas en equipos de multidisciplinares prometen ampliar la serie de especializaciones utilizadas por los trabajadores y el control que éstos ejercen sobre su actividad laboral, en un contexto de mejora continua de la calidad, pueden tener el efecto contrario. $L a$ atención suele centrarse en los aumentos de la productividad a corto plazo, fáciles de cuantificar, y no en los resultados a largo plazo ni en la salud general de los trabajadores. Especialmente cuando no se sustituye a los miembros de los equipos en caso de enfermedad, cuando la dirección fija unilateralmente cuotas o los resultados se miden en función de fórmulas detalladas, las estructuras de equipo pueden reducir el control de cada trabajador y la colaboración colectiva para establecer las contribuciones individuales. Además, la multidisciplinariedad puede dar lugar a que se exija a los trabajadores que realicen una amplia gama de tareas en una rápida sucesión. Con la diversidad de especializaciones, se pretende aprovechar cada segundo y eliminar las interrupciones provocadas por la naturaleza del trabajo o el trasvase de tareas de un trabajador a otro. Sobre todo en el contexto de reducción del control individual, el ritmo determinado por este tipo de trabajo puede causar lesiones por esfuerzos repetitivos y otros síntomas relacionados con el estrés.

Del mismo modo, las nuevas tecnologías, que aumentan la producción y facilitan la adopción de horarios de trabajo más flexibles, pueden generar también una pérdida de control para los trabajadores, incrementar el ritmo de trabajo y el trabajo repetitivo. Al permitir el cálculo preciso del tiempo de trabajo y de la producción, las nuevas tecnologías hacen posible una mejora continua de la calidad y la eliminación de las pérdidas de tiempo. No obstante, los ratos de inactividad pueden dedicarse también a la recuperación física y psicológica y, sin ellos, muchos trabajadores experimentan una elevación de la tensión arterial, un aumento de la actividad del sistema nervioso y, en general, mayores tensiones. Al facilitar la medición electrónica de las actividades de los trabajadores, las nuevas tecnologías limitan también el control de los trabajadores, y un menor control equivale a un mayor riesgo de enfermedad. Al eliminar muchos de los aspectos mentales y manuales del trabajo, realizados con anterioridad por una serie de trabajadores, las nuevas tecnologías pueden reducir también la diversidad de puestos de trabajo y convertir éste en una actividad más alienante que exige menos especialización.

La reorganización del trabajo coincide en el tiempo con su reubicación a escala nacional e internacional. Aumenta el trabajo a domicilio. Las nuevas formas de organización del trabajo permiten que una proporción cada vez mayor de la producción se realice en lugares de trabajo pequeños. Además, las nuevas tecnologías hacen posible que un mayor número de trabajadores adquieran sus propios equipos y desarrollen su trabajo en casa. Actualmente, muchas actividades de servicios, como la contabilidad o el archivo, pueden realizarse en el domicilio, e incluso los repuestos de automóviles pueden fabricarse en los hogares. Aunque el trabajo a domicilio puede reducir el tiempo dedicado al transporte, aumentar las opciones en cuanto a horarios, facilitar el acceso de las personas discapacitadas al empleo remunerado y permitir a las mujeres atender a sus hijos 0 a las personas de edad avanzada, también puede ser peligroso para la salud. Los riesgos para la salud que se plantean en el hogar pueden ser aún menos visibles que los existentes en los nuevos lugares de trabajo.

Los riesgos para la salud originados por el equipo o los materiales utilizados en el lugar de trabajo pueden determinar que todo el hogar se encuentre en una situación de riesgo 24 horas al día. Sin la separación entre domicilio y trabajo, es habitual que los trabajadores se sientan presionados a dedicar todo su tiempo a un trabajo que nunca da por terminado. Pueden plantearse conflictos entre las demandas de los hijos, las personas de edad avanzada y las tareas domésticas, que eleven los niveles de estrés de todos los miembros del hogar. El aislamiento respecto a otros trabajadores que realizan una tarea similar puede convertir el trabajo en una actividad menos gratificante y más difícil de proteger mediante la afiliación sindical. Los problemas de carga física y mental se mantienen ocultos en el hogar. Este puede ser el caso de los discapacitados, que tienen menos oportunidades de trabajar con otros a causa de la presión ejercida sobre las empresas para que mejoren el acceso de estas personas a los puestos de trabajo disponibles en el mercado..

Aunque hay personas en numerosos países de todo el mundo que llevan mucho tiempo trabajando en su hogar, la nueva economía mundial genera a menudo un nuevo tipo de trabajo a domicilio. Este da lugar al establecimiento de nuevas relaciones laborales con una empresa lejana, que puede ejercer un control exhaustivo sobre la actividad realizada en el hogar. Así, aunque los trabajadores permanecen en su hogar alejados de sus empresas, esta nueva forma de trabajo a domicilio puede reducir su control sobre la naturaleza y el ritmo de su actividad, sin que mejore su medio ambiente de trabajo.

Los habitantes de muchos de los países meridionales son absorbidos por la economía mundial como trabajadores a domicilio para empresas internacionales. Estos trabajadores a domicilio son aún más vulnerables respecto a los riesgos para la salud que sus colegas del norte y tienen menos probabilidades de controlar su propio trabajo. M uchos están ubicados en zonas de libre comercio, en las que se ha eliminado la protección a los trabajadores, con frecuencia como método para incentivar la inversión.

Al mismo tiempo, tanto en el Norte como en el Sur, los recortes de los servicios públicos dan lugar con frecuencia a la reubicación y la redistribución del trabajo para las mujeres. Con la reducción de los servicios prestados en el sector público, disminuye el número de puestos de trabajo remunerados para las mujeres integradas en la población activa. Se espera de las mujeres que presten más servicios no remunerados en el hogar. Aunque son las mujeres quienes soportan la carga principal, el traslado del trabajo al domicilio eleva la tensión que soportan todos los miembros de la familia y acaba con su intimidad. A simismo, el aumento de la responsabilidad en el hogar puede elevar la presión ejercida sobre las mujeres y sus hijos para que realicen trabajos a domicilio.

En algunos países, el crecimiento simultáneo del trabajo a domicilio y las pequeñas empresas supone que muchas empresas dejen de someterse a la normativa estatal en materia de 
remuneración, ascensos, horario, condiciones y relaciones de trabajo, acoso sexual y despidos arbitrarios. En cualquier caso, la expansión de estos dos tipos de actividad dificulta la aplicación de normas de salud y seguridad en los muchos y diferentes lugares de trabajo donde se desarrollan. Del mismo modo, el crecimiento del trabajo con contrato atípico da lugar, con frecuencia, a la definición del trabajador como autónomo y, por tanto, a la pérdida del derecho a recibir protección de la persona que paga por el trabajo. Comienza a surgir lo que podría denominarse economía sumergida legal, en la que las normas relativas a la salud y la seguridad dejan de aplicarse y la organización de sindicatos resulta más difícil.

O bviamente, sigue habiendo diferencias significativas entre las economías de todo el mundo. Además, no cabe duda de las grandes disparidades existentes entre trabajadores a escala nacional e internacional, en lo que respecta a los tipos de trabajo y la remuneración correspondiente, la protección que reciben y los peligros que afrontan. No obstante, la economía mundial emergente amenaza los niveles de protección que muchos trabajadores han conseguido, y aumenta la presión para que los Estados "armonicen a la baja" y concedan menor prioridad a la protección y los servicios, mientras el libre comercio se convierte en el fin último.

\section{- TECNO LO GIAS GLOBALIZADORAS Y TRANSFORMACION DEL TRABAJO}

\section{H eather M enzies}

Las nuevas tecnologías de la comunicación informática han dejado de ser un conjunto de herramientas y métodos de producción utilizados en un entorno industrial. Como predijo el experto canadiense en comunicación $\mathrm{M}$ arshall $\mathrm{M}$ CL uhan en el decenio de 1960, se han convertido en el entorno en sí, que nos rodea por todas partes. Los sistemas de comunicación de la nueva economía constituyen no sólo las nuevas herramientas de producción, sino también un medio ambiente de trabajo y una actividad económica plenamente programada, que modifica todo, tanto cuantitativamente (en cuanto a puestos de trabajo y cualificaciones exigidas), como cualitativamente (en lo que respecta al control y el dominio). Por su magnitud, es oportuno considerar esta transformación como un cambio de paradigma de la era industrial a la postindustrial.

Este cambio de paradigma comenzó con la informatización y la consiguiente automatización del trabajo en el decenio de 1970 y principios del de 1980. La transformación continuó con la integración de los ordenadores y los sistemas de comunicación, que generó subsistemas de producción en los centros de operaciones y sistemas de información, para la gestión en los centros de decisión del entorno administrativo. Con la mejora de la convergencia, la integración se amplió, y pequeños subsistemas locales dieron paso a grandes unidades nacionales y multinacionales y a una unificación plena de las operaciones de gestión y decisión. Gradualmente, las cuestiones de comunicación fueron adquiriendo mayor prioridad, y el "netware" necesario para la creación de redes se convirtió en algo tan importante como el hardware y el software de uso individual. A principios del decenio de 1990, comenzó a cambiar también la percepción de los sistemas. Las redes corporativas y de otros tipos se consideraban un medio para alcanzar otros fines y las redes se veían como fines en sí mismas. $\mathrm{H}$ a surgido una superautopista mundial de la información, que se ha convertido en la nueva infraestructura postindustrial de creación de redes, y el paradigma ha cambiado por completo. Las redes han pasado a ser el contexto de la nueva economía. Cada vez más, son los lugares en los que se realizan las transacciones económicas y constituyen el medio de distribución no sólo del dinero, sino también de los bienes y los servicios, e incluso del trabajo. Asimismo, las redes son la clave de los procesos de reingeniería y reestructuración que permiten pasar de una economía industrial a otra postindustrial, al menos en el sector de la economía internacional dominado por las empresas transnacionales de carácter monopolístico. Las redes mundiales de información y producción ofrecen a estas empresas una ventaja considerable respecto a los países de reciente desarrollo y en desarrollo en todos los índices de rendimiento corporativo, desde la productividad hasta la escala y la rapidez. La integración en redes puede situar a estas empresas en condiciones de lanzar una nueva ola de "colonización" mundial, si lo desean.

Tres tipos de tecnología, en particular, ponen de relieve la magnitud de la transformación que se está produciendo:

- la superautopista de la información;

- un instrumento de planificación denominado "respuesta rápida";

- una estrategia de organización de la producción denominada "agilidad".

La superautopista representa la convergencia de muchas tecnologías, como la televisión, los videojuegos, la compra interactiva y la edición electrónica, unidas a las tecnologías esenciales de la informática y la comunicación. Estas siguen constituyendo la base tecnológica que permite el funcionamiento y amplía el alcance de todas las demás. Este alcance ha aumentado de manera significativa desde el principio del decenio de 1990, gracias a la cuantiosa inversión pública en las infraestructuras de esta autopista que se ha realizado en numerosos países industrializados. Además, aunque los medios de comunicación, que han difundido el desarrollo de la autopista entre el público en general, han hecho hincapié en sus posibilidades en materia de educación y ocio, su uso esencial desde el principio ha sido empresarial. La precursora del Programa $\mathrm{N}$ acional de Infraestructuras de Información de Estados U nidos, lanzado en 1994, fue la Ley de informática de alto rendimiento, de 1988, del entonces senador Al G ore, dirigida exclusivamente a las grandes empresas. En Canadá, la primera publicación del gobierno federal sobre la autopista de la información, que data de 1994, se refiere a ésta como un instrumento para mejorar la competitividad de las empresas.

$L$ a respuesta rápida $(R R)$ podría haber quedado simplemente como una interesante estrategia de marketing de la cadena italiana de tiendas de ropa Benneton, si no fuera por la importancia adquirida por las redes. La idea inicial consistía sencillamente en crear vínculos de retroinformación en línea entre las tiendas que venden ropa de Benneton y la sede principal de la empresa, donde se subcontrataba la confección de esa ropa en diferentes estilos, colores y tallas a talleres locales. D esde principios del decenio de 1990, la RR se ha convertido en un nuevo patrón de actuación en todos los sectores de la economía.

En el ámbito militar, la respuesta rápida se utilizó para producir sistemas de armamento innovadores durante la Guerra del Golfo. En la industria, se ha utilizado en la producción de pantalones vaqueros y otros artículos de venta al por menor. En el sector de los servicios, se ha aplicado a la prestación de asistencia sanitaria a la comunidad cuando los recortes del gasto público han dado lugar al cierre de hospitales y a la reducción o la eliminación de servicios institucionales. M ediante las técnicas de RR, lo que funcionaba como una serie de fases o actividades independientes desarrolladas en uno 0 dos lugares 
institucionales, se ha convertido en una interacción fluida de fases concurrentes y acciones diferenciadas que se llevan a cabo en un conjunto de lugares distintos. No obstante, todas estas fases y acciones están coordinadas a través de redes electrónicas y sistemas centralizados de gestión de la información. Antes, las personas y los grupos de trabajo se ocupaban de la coordinación y la integración necesarias en los diferentes lugares de trabajo; ahora, el software de sistemas une y gestiona las conexiones.

Agilidad es el término utilizado para describir aquello que presta la fluidez necesaria a las acciones sobre el terreno. La agilidad se considera la fase final de la reingeniería del proceso productivo mediante la utilización de las comunicaciones informáticas. La reestructuración comenzó con la integración de subsistemas automatizados para crear sistemas operativos semicibernéticos de mayor tamaño. Este proceso recibió el nombre de fabricación integrada por ordenador. A medida que los sistemas que intervienen en esta fase fueron ampliándose regularmente para incluir subcontratistas y proveedores en las redes operativas de las empresas, dicho proceso dió paso a la fabricación just in time, que constituye el "eje" del cambio de paradigma y en la que el sistema de producción, sometido a la reingeniería, se ha transformado (o "mutado") en un nuevo concepto del proceso productivo, sensible al tiempo. Con la adopción de la producción ajustada, como también se ha denominado, la prioridad pasó de la integración de maquinaria en este nuevo proceso a la integración de las personas que gestionaban los sistemas. Los círculos de calidad, la gestión de la calidad total y otros programas de "formación cultural" instruyeron a los trabajadores para que se identificaran con los objetivos de productividad y competitividad de la dirección y contribuyeran a un ajuste constante del proceso productivo con el fin de alcanzar esos objetivos. A principio del decenio de 1990, los ajustes se orientaron cada vez más a la armonización de las operaciones conforme a normas y subsistemas normalizados. Asimismo, dejó de concederse prioridad a la flexibilidad y a la capacidad de intercambio en instalaciones de producción locales y se prestó mayor atención a la capacidad de intercambio entre instalaciones integradas en redes a escala mundial. El objetivo de la agilidad, que estaba aún por materializar a mediados del decenio de 1990, consistía en la distribución flexible del trabajo entre un conjunto organizado de lugares de trabajo conectados (y conectables directamente) con la autopista de la información. El objetivo asociado con éste era la creación y utilización de un conjunto mundial de mano de obra situada en todas partes, desde fábricas automatizadas, talleres, clínicas y oficinas hasta hogares particulares, sótanos, garajes y camiones.

Este proceso de reestructuración ha tenido efectos profundos en la cantidad y la naturaleza del empleo, entre los que pueden citarse:

- el aumento de los niveles de desempleo estructural, a medida que las máquinas y la inteligencia artificial asumen actividades reservadas con anterioridad a las personas y a la inteligencia humana

- el aumento de la polarización de la población activa, caracterizada por la separación entre las personas que trabajan un número excesivo de horas en puestos a jornada completa, y los que constituyen una reserva de mano de obra "contingente" cada vez mayor, situados en la periferia, empleados a tiempo parcial, temporalmente o con contratos a corto plazo

- la transformación del proceso de trabajo, sobre todo en el segundo grupo de trabajadores, caracterizada por la inmersión total de éstos en un medio ambiente de trabajo programado, en el que los ordenadores definen las tareas que deben realizarse y controlan y miden el rendimiento.
En esencia, las relaciones de trabajo son cada vez menos las de un sistema abierto en el que interactúan los trabajadores, los bienes de equipo y la dirección y más las de un sistema cibernético cerrado en el que el trabajador constituye una pieza operativa 0 , en el sector de los servicios, una extensión humana de buena presencia. En lugar de trabajar con máquinas y herramientas, cada vez más se trabaja para las máquinas, incluso dentro de ellas, en el sentido de que las personas actúan como voz, dedos o brazos de sistemas de producción y tratamiento de la información completamente programados. Podría tratarse de lo que Donna Haraway denomina la nueva cibernética del trabajo, en la que las relaciones laborales se definen y negocian enteramente en función de las condiciones de funcionamiento de los sistemas (H araway 1991).

El consenso respecto a estas tendencias es escaso. De hecho, existe una polémica considerable, fomentada en parte por la falta de investigación en áreas importantes y por las rigideces del discurso al respecto. Por ejemplo, en el Informe sobre el empleo anual de la O CDE correspondiente a 1994 se rechaza la vinculación entre la reestructuración tecnológica y las altas tasas de desempleo que, por desgracia, persisten en todos los países industrializados y en desarrollo desde el decenio de 1980. En el informe se reconoce que las nuevas tecnologías han tenido algunos efectos de "desplazamiento de la mano de obra"; sin embargo, también se señala que las empresas "pueden crear puestos de trabajo compensatorios, si combinan adecuadamente estos procesos de cambio tecnológico con la innovación de los productos y la formulación de políticas de marketing adecuadas" (OCDE 1994).

La rigidez del discurso sobre el cambio tecnológico ha tenido al menos dos vertientes, cuyos resultados en la actualidad pueden ser una fundamentación errónea e incluso negativa del debate sobre la reestructuración, de una importancia semejante al efecto informativo que se perseguía en un principio. En primer lugar, dicho discurso defiende un modelo de reestructuración económico o "economicista", abstracto y estrecho de miras, y hace caso omiso no sólo de sus dimensiones sociales, sino también de las psicológicas y culturales. En segundo lugar, este modelo economicista presenta deficiencias graves. En él se supone que, puesto que la tecnología aumenta la productividad mediante la automatización, surgirán nuevas actividades económicas innovadoras que compensarán (aunque quizás no con los mismos requisitos en cuanto a cualificaciones) lo perdido en la fase de automatización. No sólo surgen nuevas actividades económicas (y qué nuevos puestos de trabajo generan en realidad) en lugares remotos a escala mundial, sino que gran parte del nuevo crecimiento económico desde finales del decenio de 1980 no se ha visto acompañado de un aumento del empleo. En ocasiones se trata de instalaciones de producción y transformación completamente automatizadas que duplican o triplican su producción anterior sin ampliar la plantilla. 0 tras veces son nuevos servicios plenamente automatizados, como el envío de llamadas en el campo de las telecomunicaciones o el sistema bancario de múltiples sucursales en el de la financiación, "producidos" y "prestados" únicamente por el software. Cada vez más, las tareas semiautomatizadas se transfieren de los trabajadores remunerados a los consumidores, que no son retribuidos. Los consumidores que utilizan teléfonos digitales en la actualidad, se abren paso a través de una sucesión de grabaciones informatizadas para realizar pedidos de bienes y servicios, matricularse en cursos, gestionar servicios públicos y obtener servicios al cliente.

Es importante abordar las rigideces que caracterizan al discurso, ya que, en este caso, la separación de las cuestiones economicistas "de oferta" y las cuestiones "de demanda" 
Figura 24.1 - Variación neta de los puestos de trabajo equivalentes a tiempo completo entre 1981 y 1986, por actividad y nivel salarial (en miles de dólares).

\begin{tabular}{|c|c|c|c|c|c|c|}
\hline $\begin{array}{l}\text { Nivel } \\
\text { Salarial }\end{array}$ & $\begin{array}{l}\text { Prof. liber./ } \\
\text { Técnicos }\end{array}$ & Ventas & $\begin{array}{c}\text { Trabajos } \\
\text { de oficina }\end{array}$ & Industria & Servicios & $\begin{array}{l}\text { Gestión/ } \\
\text { Admón. }\end{array}$ \\
\hline $\begin{array}{c}\text { BAJO } \\
\text { hasta 6,70 } \\
\text { dólares } \\
\text { por hora }\end{array}$ & $+16,7$ & $+63,2$ & $+13,1$ & $+17,5$ & $+135,1$ & $+51,7$ \\
\hline $\begin{array}{l}\text { MEDI0 } \\
\text { de } 6,77 \\
\text { a 11,87 } \\
\text { dólares } \\
\text { por hora }\end{array}$ & $-7,8^{\circ}$ & $+14,9$ & $\because-51,0$ & $\begin{array}{l}-43,2 \\
-63,2\end{array}$ & $\begin{array}{l}\quad-21,4, \cdot- \\
\therefore \quad+12,4\end{array}$ & $\begin{array}{r}+41,7 \\
+38,9\end{array}$ \\
\hline $\begin{array}{c}\text { ALTO } \\
\text { más de } \\
11,88 \\
\text { dólares } \\
\text { por hora }\end{array}$ & $+34,9$ & $+24,7$ & $\begin{array}{l}:-10,0 \\
\vdots \\
:\end{array}$ & $\begin{array}{r}-17,0 \\
\vdots \\
-62,9\end{array}$ & $+2,4$ & $+104,3$ \\
\hline
\end{tabular}

Fuente: Myles, Picot y Wannell 1988.

relacionadas con el mercado de trabajo en el contexto social y cultural, bloquea la recogida de información esencial para lograr un consenso respecto a qué sucede con las nuevas tecnologías. Por ejemplo, Statistics Canada ha llevado a cabo excelentes macroestudios en los que se analiza el aumento de la polarización en la población activa canadiense. Se realizaron tras la aparición en 1988 de un estudio sobre el cambio de los salarios de los jóvenes y la caída del salario medio (M yles, Picot y Wannell 1988). En el estudio se documentaba la desaparición generalizada de los puestos de trabajo intermedios (de acuerdo con la escala de remuneración) en casi todos los sectores industriales y en todas las profesiones principales entre 1981 y 1986. Además, se observó un crecimiento del empleo muy polarizado entre los extremos superior e inferior de la escala salarial (véase la Figura 24.1).

El estudio parece ofrecer una confirmación a escala macro de la informatización del trabajo (y la simplificación y pérdida de las correspondientes especializaciones) que los estudios de casos sobre la reestructuración tecnológica realizados en el mismo período habían identificado en todos los sectores, desde las industrias generadoras de recursos hasta la manufacturera y de servicios (M enzies 1989). Un estudio de seguimiento comienza haciendo referencia a la bibliografía en la que se defiende la existencia de un vínculo entre la ampliación de las diferencias entre salarios y el cambio tecnológico ( $M$ orissette, Myles y Picot 1993). Sin embargo, a continuación sólo se analizan factores estrictamente relacionados con el mercado de trabajo, como la jornada laboral, el sexo, la edad y el nivel educativo. Se concluye que "el aumento de la polarización en las jornadas semanales y anuales trabajadas, explica en gran medida el incremento de la desigualdad de los ingresos en el decenio de 1980". Se evita considerar la posible existencia de un vínculo entre la simplificación informática del trabajo y el crecimiento de una población activa contingente formada por trabajadores a tiempo parcial y temporales, empleados en unas condiciones de trabajo e ingresos semanales muy por debajo de lo establecido. En cambio, se afirma para terminar, con escasa convicción, que "si el cambio de tecnologías y el cambio asociado a la diversidad de cualificaciones necesarias son los principales factores explicativos de la situación, las fuentes de datos existentes no permiten determinarlo".

Las fuentes de datos existentes son los estudios de casos, muchos de ellos realizados por sindicatos y grupos de mujeres. Sus metodologías pueden no ser uniformes. No obstante, sus resultados indican una pauta específica. En todos los casos registrados a finales del decenio de 1980 y principios del de 1990, los sistemas informáticos no se aplicaron para mejorar lo que hacían las personas, sino para sustituirlas o reducir y controlar sus actividades (M enzies 1989). L a informatización a gran escala no sólo dio lugar a despidos, sino que, además, el personal a jornada completa fue sustituido por trabajadores a tiempo parcial o temporales en diversos sectores y profesiones. A juzgar por los datos disponibles, sobre todo los de estudios basados en entrevistas, parece claro que fue la simplificación informática del trabajo (especialmente, en lo que se refiere a la utilización del software para tareas de administración, planificación y gestión), lo que permitió sustituir al personal a jornada completa por trabajadores a tiempo parcial o trasladar la realización de tareas, de los trabajadores de la empresa a los usuarios no remunerados.

El cambio tecnológico ha estado acompañado con frecuencia de una reestructuración de la organización. Este proceso se ha caracterizado por una transformación de los niveles de clasificación de los puestos de trabajo y por la integración de las tareas simplificadas por la aplicación de la informática. A menudo, tales procesos han dado lugar a una racionalización de las tareas en torno a sistemas informáticos, de forma que éstos puedan definir el trabajo en su totalidad, así como controlar y medir los resultados obtenidos. En ocasiones, la consecuencia ha sido la renovación o la mejora de las cualificaciones. Por ejemplo, en los sectores del automóvil, aeroespacial y de la electrónica en Canadá, los informes señalan repetidamente la creación de un nuevo puesto de gran responsabilidad, que requiere la realización de diversas tareas y precisa de múltiples cualificaciones. A veces recibe la denominación de técnico en electrónica, o TE. Su trabajo suele consistir en supervisar el funcionamiento de diversas máquinas y subsistemas automatizados, detectar problemas y desempeñar algunas tareas de planificación y análisis. LOS TE no sólo deben conocer diferentes sistemas operativos, sino que en ocasiones tienen que encargarse de algunas actividades sencillas de programación para unir los diferentes subsistemas.

No obstante, estos puestos suelen exigir también la eliminación progresiva de herramientas y tareas especializadas, ya que la informatización ha traspasado el trabajo creativo a los ingenieros y los programadores asalariados. En todo caso, para los interesados, suele representar una considerable y grata mejora que sirve como estímulo y responsabilidad profesional.

Aunque se dispone de datos que demuestran una cierta renovación de cualificaciones, esta tendencia es minoritaria y concierne generalmente a un núcleo privilegiado de trabajadores del sector industrial a jornada completa y sindicados, en su mayoría hombres. La tendencia predominante supone una reducción de la especialización, e incluso en la degradación del trabajo, a medida que los trabajadores se ven inmersos en entornos gestionados por ordenadores en los que se programa y controla rigurosamente todo lo que hacen. En esencia, las personas trabajan como extensiones humanas del sistema operativo informático, que se encarga de todos los procesos de inteligencia y toma de decisiones fundamentales. Esta nueva forma de trabajo se generaliza cada vez más en un número creciente de tipos de trabajo, y en especial en aquéllos en los que se concentran las mujeres: oficinas, ventas y servicios. 
El término $\mathrm{M} \mathrm{c}$ ob ha llegado a ser un epíteto popular para esta nueva forma de trabajo, en la que el ordenador define y controla la tarea que debe realizarse. En el decenio de 1990 este término se ha aplicado a diversas actividades, como las realizadas en los restaurantes de comida rápida y las cajas de los supermercados, la contabilidad, la tramitación de solicitudes de indemnización por siniestro y otras, e incluso en el ámbito de la asistencia sanitaria. N o obstante, a mediados del decenio surgió otra tendencia basada en la informatización del trabajo, al menos del relativo al tratamiento de la información. Esta tendencia ha recibido la denominación de "teletrabajo". Una vez que el trabajo había sido plenamente definido y controlado por los sistemas informáticos, también podía ser desinstitucionalizado y redistribuido mediante redes electrónicas a centros remotos de tramitación de llamadas o a teletrabajadores empleados en sus domicilios a través de ordenadores y conexiones de módem. El teletrabajo comenzó a plantearse como una cuestión laboral importante a mediados del decenio de 1990, con la proliferación de los centros de atención telefónica para la tramitación de reservas de vuelos y hotel, la gestión bancaria y de seguros a distancia, la mensajería y otros servicios. Asimismo, en el censo de Canadá de 1991 se registró un aumento del $40 \%$ en la población activa que trabajaba "a domicilio", frente a un $16 \%$ de aumento de la población activa en general. Se observa asimismo un elevado porcentaje de participación de las mujeres en este creciente grupo de trabajadores a domicilio. Este tipo de trabajadores se concentraba en los sectores de administración, ventas y servicios. O btenían ingresos inferiores a 20.000 dólares canadienses y, a menudo, a 10.000, cantidades insuficientes para mantener a una persona, y mucho menos a una familia.

Dependiendo de las tendencias y del modo en que esté estructurado y organizado el entorno tecnológico de la actividad laboral y económica, el teletrabajo puede plantearse como un modelo posfordista (es decir, como el sucesor de un sistema de pleno empleo y salarios elevados), en lugar del modelo de alto valor añadido asociado a Toyota y Suzuki y a la "producción ajustada" japonesa. No obstante, los dos modelos pueden coexistir, el primero como un sistema caracterizado por la precariedad y los salarios bajos y vinculado a las mujeres, los jóvenes y otros grupos menos privilegiados, y el segundo más identificado con los hombres que disfrutan de las ventajas adicionales de la afiliación a sindicatos fuertes, la antigüedad y la ocupación de puestos de trabajo a jornada completa en sectores de utilización intensiva del capital, como el del automóvil, el aeroespacial y la electrónica.

El auge del teletrabajo pone de relieve varias cuestiones relacionadas con el trabajo: el peligro de una explotación similar a la ejercida en talleres de economía sumergida, agravado por la aplicación de un sistema de remuneración basado en el rendimiento como complemento o sustituto del salario regular; las condiciones de trabajo deficientes y agotadoras debidas a la instalación improvisada de módems y ordenadores en sótanos 0 en dormitorios de apartamentos de una sola habitación, a menudo haciendo frente personalmente a los costes generales y de mantenimiento; el estancamiento, el aburrimiento y la soledad provocadas por el trabajo en "celdas de silicio" aisladas, sin la camaradería de los compañeros y la protección de una organización colectiva. No obstante, uno de los problemas laborales más acuciantes está relacionado con la nueva cibernética del trabajo y con lo que sucede cuando la vida laboral de las personas queda completamente controlada por sistemas informáticos. Se ha investigado poco sobre estos aspectos cualitativos del trabajo. Q uizás requieran un enfoque más narrativo y cualitativo, y no los métodos objetivadores de investigación de las ciencias sociales. En Canadá, dos películas documentales han contribuido eficazmente al conocimiento de las experiencias personales relacionadas con el trabajo definido y controlado por ordenadores. En una de ellas, "Q uel Numéro/ What N umber?", dirigida por Sophie Bissonette, se describe la situación de las operadoras telefónicas que trabajan en cabinas aisladas. EI ordenador no sólo controla todos los aspectos de su trabajo, sino que además les ofrece la única retroinformación disponible sobre su rendimiento. Les informa del tiempo medio invertido en el tratamiento (TMG) de cada Ilamada. Las mujeres hablan de que llegan a adaptarse tan bien a "funcionar" como parte del sistema definido por el ordenador que "se enganchan" en el intento de batir sus propios resultados de TMG. Se trata de un proceso psicosocial de ajuste en el que el único contexto y significado de una actividad está determinado, en este caso por el sistema informático.

En la otra película, "Working Lean", dirigida por L aura Sky, se describe un efecto similar generado por los programas de formación cultural de gestión de la calidad total (GCT). En este documental, los trabajadores no se encuentran totalmente aislados en una cabina de trabajo programada por ordenador, sino que se trata de trabajadores del sector del automóvil que participan en equipos de GCT. En este caso, la formación les insta a identificarse con los objetivos de productividad establecidos por la dirección e incorporados en los sistemas de producción, mediante la búsqueda de vías para adaptarse a su consecución. [EI prototipo japonés de este programa de gestión define la calidad en función estrictamente del sistema, como "rendimiento ajustado a los requisitos" (Davidow y Malone 1992)]. Algunos representantes sindicales se refieren a este programa como programa de "gestión mediante el estrés". $\mathrm{M}$ ientras tanto, en muchos lugares de trabajo, las lesiones por esfuerzos repetitivos y otras enfermedades relacionadas con el estrés aumentan a medida que los trabajadores deben adaptarse a una tecnología de ritmo rápido y a todo lo que la acompaña.

En un estudio sobre la formación en los lugares de trabajo en Canadá, se observó que al menos el $50 \%$ de la "formación" que imparten las empresas se vincula a áreas asociadas con la GCT: comunicación empresarial, liderazgo y otros tipos de "formación cultural". "L as iniciativas de formación más estrechamente relacionadas con el desarrollo del capital humano se registraron con una frecuencia muy inferior". Por otra parte, en la categoría de la enseñanza de informática, se detectó en el estudio un cambio pronunciado en cuanto a los receptores de este tipo de formación, marcadamente favorable a los gestores, los profesionales liberales y los técnicos, después de 1985 (Betcherman 1994).

Coinciden muchas tendencias contradictorias. Por ejemplo, hay algunos lugares de trabajo, como los hoteles, en los que la cogestión parece estar a la altura del discurso que la justifica. En otros, los trabajadores hacen más con las nuevas tecnologías de lo que podían o se les permitía hacer con las antiguas. En cualquier caso, las tendencias asociadas con la reestructuración en la nueva economía, consisten en la sustitución de personas inteligentes por máquinas inteligentes, y en la utilización de máquinas para reducir y controlar las actividades de otras personas, sobre todo en el trabajo. La cuestión esencial no es la creación de empleo ni la formación en nuevas especializaciones informáticas. La cuestión es el control: las personas comienzan a estar controladas por sistemas informáticos cibernéticos. Este proceso debe invertirse antes de que los derechos democráticos y los derechos humanos fundamentales sean conculcados. 


\section{Referencias}

Anderson, B. 1993. Britains's Secret Slaves: An Investigation into the Plight of $O$ verseas $D$ omestic W orkers in the U nited Kingdom. Londres: Anti-Slavery International and $\mathrm{K}$ alayaan.

Betcherman, G, K M cM ullen, N Leckie, C Caron. 1994. T he Canadian W orkforce in T ransition. K ingston O ntario: Industrial R elations Centre, U niversidad de Q ueens.

Bingham, E. 1986. Hypersusceptibility to occupational hazards. En $\mathrm{H}$ azards: Technology and Fairness, dirigido por AM W einberg. Washington, $\mathrm{DC}: \mathrm{Na}-$ tional A cademy Press.

Castells, M, Y O ayama. 1994. Paths toward the informational society: Employment structure in G-7 countries 1920-90. Int Lab R ev 133(1):5-33.

Centers for Disease Control and Prevention. 1996. W ork-related injuries and illnesses associated with child labour-U nited States. M orb M ortal W eekly $R$ ep 45:464-468.

Davidow, W, M M alone. 1992. T he Virtual Corporation: Structuring and Revitalizing the Corporation for the 21 st Century. N ueva Y ork: $\mathrm{H}$ arper Collins.

Dumon, W. 1990. Family Policy in EEC Countries. Luxemburgo: $O$ ficina de Publicaciones oficiales de la Comunidad Europea.

Faludi, S. 1991. Backlash:T he U ndeclared W ar against A merican W omen. N ueva Y ork: Crown Publishers.

Fondo de Población de las Naciones Unidas (U NFPA). 1993. Population I ssues, B riefing Kit 1993. Nueva Y ork: UNFPA.

Forastieri, V. 1995. Child and adolescent labour. En $\mathrm{H}$ ealth Care of Women and Children in Developing Countries, dirigido por HM Wallace, K Giri y CV Serrano. Oakland: Third Party Publishing Company

Gulati, L. 1993. W omen M igrant W orkers in Asia: A Review. New Delhi: Asian Regional Team for Employment Protection.

H araway, DJ. 1991. Simians, Cyborgs, and W omen: The Renvention of Nature Londres: Free Association Books.

H uman R esources Development Canada. 1994. F rom awareness to action, strategies to stop sexual harassment in the workplace. $\mathrm{O}$ ttawa, Canadá.

K essler-H arris, A. 1982. O ut to W ork: A H istory of W age Earning $W$ omen in the $U$ nited States. Nueva York: Oxford U niversity Press.

Levison, D, R Anker, S A shraf, S Barge. Julio 1995. Is Child Labour R eally Necessary in India's Carpet Industry? Baroda, India: Centro de Formación e Investigación de Operaciones (Documento de trabajo núm. 6)

Lim, LL, N O ishi. 1996. International Labour M igration of Asian W omen: Distinctive Characteristics and Policy Concerns. Ginebra: OIT

Menzies, H. 1989. Fastforward and Out of Control. T oronto: $\mathrm{M}$ acM illan of $\mathrm{C}$ anada.

M oghadam, VM. 1994. Women in societies. Int Soc Sci J (febrero).

Morissette, R, J Myles, G Picot. 1993. What Is $\mathrm{H}$ appening to Earnings Inequality in Canada? $\mathrm{O}$ ttawa: Business and Labour M arket Analysis Group, Analytical Studies Branch, Statistics C anada.
M yles, J, G Picot, T Wannell. 1988. W ages and J obs in the 1980s: Changing Youth $W$ ages and the Declining Middle Ottawa: Social and Economic Studies Division, Statistics Canada.

Organización de Cooperación y Desarrollo Económico (OCDE). 1993. W omen, W ork and $\mathrm{H}$ ealth. París: OCDE.

- . 1994. Annual J obs Study. París: O CDE.

Organización Internacional del Trabajo (OIT). Convenio núm 4 (1919): Trabajo nocturno (mujeres). G inebra: OIT .

-. 1919b. Recomendación núm. 4 (1919): Saturnismo (mujeres y niños). G inebra: O IT .

—. 1921. Recomendación núm. 13 (1921): Trabajo nocturno de las mujeres (agricultura). Ginebra (OIT).

-. 1934. Convenio núm. 41 (revisado) (1934): T rabajo nocturno (mujeres). Ginebra: OIT.

- 1948. Convenio núm. 89 (revisado) (1948): T rabajo nocturno (mujeres). Ginebra: OIT.

—. 1985. Recomendación núm. 171 (1985): Servicios de salud en el trabajo. Ginebra: OIT.

—. 1989a. International L abour Standards. G inebra: OIT .

- . 1989b. T echnical B ackground Paper, M eeting of Experts on Special Protective $M$ easures for $W$ omen and E quality of 0 pportunity and Treatment (G eneva, 10-17 October 1989). Ginebra: OIT

- 1990. Report of the Committee of Experts on the Application of Conventions and Recommendations. Conferencia Internacional del T rabajo, 77a Sesión, 1990. Informe III (parte 4A). General report and observations concerning particular countries. Ginebra: OIT

-. 1991. African employment report, 1990, jobs and skills program for Africa (JASPA). Addis A baba: OIT .

-. 1992. Eleventh Session of the Joint ILO/WHO Committee on $\mathrm{O}$ ccupational $\mathrm{H}$ ealth, Geneva, 27-29 April 1992. G inebra: OIT.

- 1993a. W orkers with family responsibilities. Conferencia Internacional del Trabajo, 80a Sesión. Informe III (parte 4B). Ginebra: OIT

—. 1993b. 1993 W orld L abour R eport. Ginebra: OIT.

-. 1994. Maternity and work. Cond W ork Dig 13. Ginebra: OIT

- 1995. Child labour: Report of the Committee on E mployment and Social Policy. GB264 22-10.E95/ v.2. Ginebra: OIT

- 1996. Child labour: T argeting the intolerable Conferencia Internacional del T rabajo, 86a Sesión 1998. Informe VI (1). Ginebra: OIT.

Organización Mundial de la Salud (OM S). 1994. W omen's $\mathrm{H}$ ealth $\mathrm{T}$ owards a B etter W orld. Informe para la Comisión M undial de la Salud de la M ujer. Ginebra: OMS.

O rganización Panamericana de la Salud (O PS). 1993. Gender, Women, and $\mathrm{H}$ ealth in America. Scientific Publication, N 0.541. Washington, D C: O PS

Pinney, R. 1993. Slavery. En The Academic American Encyclopaedia (Electronic Version). Danbury, Connecticut: Grolier.

Sinclair, V, G Trah. 1991. Child labour: National legislation on the minimum age for admission to employment or work. Cond W ork D ig 10:17-54.
T askinen, H. 1993. Policies concerning the reproductive health of workers. En Organization for E conomic Cooperation and Development (OECD) Panel Group on $\mathrm{W}$ omen, $\mathrm{W}$ ork and $\mathrm{H}$ ealth, dirigido por $\mathrm{K}$ auppinenToropainen. Helsinki: Ministerio de Asuntos Sociales y Sanidad.

Unión Internacional. 1991. UAW v. Johnson Controls, Inc. 1991499 U S 187.

Vaidya, SA. 1993. W omen and Labour Laws. Bombay: $M$ aniben $\mathrm{K}$ ara Institute.

Waga, M A. 1992. Education and E mployment Patterns for W omen in Kenya: A Review of T rends and Perspectives. $N$ airobi: Priv. Print.

Weisburger, JH, RS Y amamoto, J K orzis. 1966. Liver cancer: N eonatal oestrogen enhances induction by carcinogens. Science 154:673-674.

\section{Otras lecturas recomendadas}

Commonwealth M edical Association. N.d. M anual in Reproductive $H$ ealth and Safe M otherhood. Londres: Commonwealth Medical Association. (Project Services N 0. 2).

Derickson, AD. 1992. Making human junk: Child labour as a health issue in the progressive area. Am J Public H ealth 82:1280-1290.

D rache, D, H Galsbeek. 1992. The Changing W orkplace. T oronto: James L orimer and Company.

$\mathrm{H}$ ealth and W elfare Canada. 1992. Actas de la mesa redonda sobre el género y la salud en el lugar de trabajo. 22-23 de junio de 1992. 0 ttawa.

K arasek, R, T Theorell. 1990a. H ealthy W ork. Londres: Basic W orks.

-. 1990b. Healthy W ork, Stress, Productivity and the Reconstruction of $W$ orking Life. Nueva Y ork: Basic Books.

Leigh-D oyle, S. 1991. W omen in N on-T raditional Fields. Artículo de Debate No. 63, División de Política de Formación. Ginebra: OIT.

M archak, P. 1991. The Integrated Circus: T he N ew Right and the Restructuring of Global M arkets. M ontreal: M cGill Q ueen's U niv. Press.

Menzies, H. 1996. Whose Brave New W orld? The Information $\mathrm{H}$ ighway and the $\mathrm{New} \mathrm{E}$ conomy. Toronto: Between the Lines Press.

$\mathrm{N}$ ational Institute for $\mathrm{O}$ ccupational Safety and $\mathrm{H}$ ealth (NIOSH). 1995. Preventing Deaths and Injuries of Adolescent W orkers. DH HS Publication N 0. 95-125. Cincinnati, O hio: NIOSH.

O rganización Internacional del Trabajo (OIT) 1979. Safety and $H$ ealth of M igrant W orkers- International Symposium, $O$ ccupational Safety and $H$ ealth Series. Ginebra: OIT.

- . 1989. Home work. Cond W ork Dig 8(2). Ginebra: OIT.

-. 1991. Child labour: Law and practice. Cond W ork Dig 7 (Núm. 1). G inebra: OIT.

-. 1993. Child labour: Global offensive. W orld W ork M ag IL 0 Núm. 4:4-13.

Programa de las $\mathrm{N}$ aciones U nidas para el D esarrollo. 1993. H uman Development 1993. Nueva York: $\mathrm{N}$ aciones $U$ nidas.

Schneider de Villegas, G. 1990. Home work: A case for social protection. Int Labour R ev 129:423-429.

Schor, J. 1992. T he O verworked A merican: T he U nexpected D ecline of L eisure. Nueva Y ork: Basic Books. 


\section{INDEMNIZACION A LOS TRABAJ ADORES, VISION GENERAL}

Director del capítulo

T erence G. I son

\section{Sumario}

Sistemas de indemnización a los trabajadores por accidentes de trabajo, visión general

Terence G. I son .............................. 25.2

PARTE PRIMERA: INDEMNIZACION A LOS TRABAJADORES

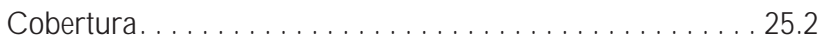

O rganización, administración y adjudicación . . . . . . . . . 25.3

Derecho a las prestaciones. . . . . . . . . . . . . . . . . . . . . . 25.6

Causas múltiples de incapacidad . . . . . . . . . . . . . . . 25.9

Incapacidades so brevenidas. . . . . . . . . . . . . . . . . . . . . . 25.9

Pérdidas indemnizables . . . . . . . . . . . . . . . . . . . . . . 25.10

Incapacidades múltiples. . . . . . . . . . . . . . . . . . . . 25.10

O bjeciones a las reclamaciones . . . . . . . . . . . . . . . . 25.10

Conducta indebida de la empresa . . . . . . . . . . . . . . 25.11

A sistencia médica. . . . . . . . . . . . . . . . . . . . . . . . . . . . 25.11

Pagos en dinero . . . . . . . . . . . . . . . . . . . . . . . . . . . 25.12

Rehabilitación y asistencia. . . . . . . . . . . . . . . . . . . . . 25.19

O bligación de mantener el empleo . . . . . . . . . . . . . 25.20

Financiación. ........................... 25.20

Responsabilidad subsidiaria . . . . . . . . . . . . . . . . . . . . . . 25.22

Salud y seguridad . . . . . . . . . . . . . . . . . . . . . . . . . . . 25.22

Reclamaciones contra terceros. . . . . . . . . . . . . . . . 25.23

PARTE SEGUNDA: OTROS REGIMENES

Seguros sociales y seguridad social. . . . . . . . . . . . . . . . 25.23

Indemnización por accidentes. . . . . . . . . . . . . . . . 25.24

A bono del salario por enfermedad . . . . . . . . . . . . . 25.24

Seguro de invalidez . . . . . . . . . . . . . . . . . . . . . . . . . . . 25.25

Responsabilidad de la empresa . . . . . . . . . . . . . . . . 25.25 


\section{SISTEMAS DE IN DEMNIZACION A LOS TRABAJADORES POR ACCIDENTES DE TRABAJO, VISION GENERAL}

Terence G . Ison

En este capítulo se exponen los sistemas de indemnización por incapacidad (causada por lesión o enfermedad) o muerte prematura a consecuencia del empleo. Su finalidad es explicar las normas reguladoras y la diversidad de las mismas, pero sin describir o especificar los regímenes vigentes en cada país.
La indemnización puede proceder de:

- un régimen de indemnización por accidentes de trabajo;

- un régimen general de seguros sociales o seguridad social;

- un régimen de indemnización por accidentes;

- abono del salario por enfermedad;

- el seguro de invalidez;

- la responsabilidad de la empresa.

La mayoría de los países industrializados utilizan alguna combinación de estos regímenes. La parte I de este capítulo estudia la indemnización por accidentes de trabajo, mientras que en la parte segunda se aborda el estudio de los demás regímenes.

\section{PARTE PRIMERA: INDEMNIZACION A LOS TRABAJADORES}

[N ota sobre "jurisdicción". Esta palabra se utiliza para designar un país o unidad del mismo (p. ej., un estado o una provincia) que gestiona un régimen de indemnización a trabajadores].

Aun cuando ya en civilizaciones anteriores hay rastros de indemnización a los trabajadores, en particular en el Derecho marítimo, los regímenes hoy vigentes se introdujeron en la segunda mitad del siglo XIX o en el siglo actual. En inglés recibieron la denominación de workmen's compensation, que en los últimos 20 años se ha ido sustituyendo por la de workers' compensation).

\section{Cobertura}

\section{Sectores cubiertos}

Normalmente el sistema se aplica obligatoriamente en los sectores establecidos en la correspondiente norma o bien en todos éstos, salvo algunas excepciones. Normalmente están cubiertos los de minería, manufacturas, trabajos forestales, silvicultura, pesca, transporte, construcción, distribución, instituciones de asistencia sanitaria y otros servicios públicos. Ejemplos de sectores excluidos en algunas jurisdicciones son la agricultura, algunos servicios (como las agencias de viajes) y el servicio doméstico. En ellos se aplica a veces la responsabilidad de la empresa (que se expone en la parte II ). Cuando un sector queda fuera de la cobertura obligatoria, algunas jurisdicciones permiten su inclusión previa solicitud de la empresa. En ciertas jurisdicciones se excluyen a las empresas con menos de un determinado número de trabajadores (normalmente entre 3 y 20).

\section{Personas cubiertas}

Todos los trabajadores pertenecientes a una industria con covertura por el sistema se encuentran incluidos dentro de la protección, con independencia de que se trate de trabajadores fijos o eventuales, a tiempo completo o a tiempo parcial, de producción o administrativos. Normalmente quedan acogidos también los trabajadores migrantes, si bien pueden estar excluidos de la cobertura por otros motivos; por ejemplo, pertenecer a un sector no cubierto. No se establecen períodos de carencia para acogerse al sistema. Algunas jurisdicciones incluyen en su ámbito de aplicación a los miembros del Consejo de Administración y demás personal directivo. 0 tras, por el contrario, los excluyen. Las clasificaciones utilizadas en la normativa legal sobre sociedades o relaciones laborales no son generalmente aplicables a la indemnización por accidentes de trabajo. Algunas jurisdicciones excluyen a los miembros de la familia del empresario, y otras a los trabajadores cuyas ganancias exceden de cierto nivel. Es asimismo corriente excluir a las personas que prestan servicios ocasionales o cuando el empresario no contrate la realización de la obra o servicio por razón de su actividad empresarial. C uando un trabajador ha alcanzado la edad que le da derecho a una pensión de jubilación, en la mayoría de las jurisdicciones no por ello queda excluido de la cobertura de la indemnización por accidentes de trabajo, si bien es frecuente la reducción de las prestaciones.

La nacionalidad del trabajador es generalmente irrelevante. En general, se incluyen todas las personas legalmente ocupadas en un sector cubierto, aunque algunas jurisdicciones admiten también a las personas ocupadas ilegalmente. En otras, las prestaciones de indemnización son discrecionales si el trabajador está ocupado en virtud de un contrato ilegal. Algunas jurisdicciones cubren las situaciones de los niños nacidos con una incapacidad que es consecuencia del trabajo desarrollado por alguno de sus progenitores. 0 tras jurisdicciones no prevén nada al respecto.

\section{Conexión territorial}

La cobertura se aplica generalmente a los trabajadores cuyo lugar habitual de empleo está localizado dentro de la jurisdicción pertinente. En los sectores móviles, como el de pesca o el del transporte de mercancías por carretera y por avión, existe normalmente una base o puerto de origen que se considera como el lugar usual de empleo del trabajador. El domicilio social de la empresa es generalmente irrelevante. También lo es el lugar de administración de la nómina, si bien en las ocupaciones móviles sirve a veces para determinar la base o puerto de origen de determinados trabajadores. El lugar de residencia del trabajador 0 persona a su cargo es generalmente irrelevante, aunque en algunas jurisdicciones tiene interés a ciertos efectos.

\section{Acceso opcional}

Algunas jurisdicciones permiten que los empresarios no constituidos en sociedad y los miembros del Consejo de Administración de las sociedades (cuando no están sujetos a cobertura obligatoria) puedan acogerse como trabajadores. En tal caso, disfrutan de las prestaciones y tienen las obligaciones legales de un trabajador asalariado. D e acuerdo con ello, tienen los mismos derechos y obligaciones que un trabajador asalariado, de un lado, y de otro, tienen los mismos derechos y obligaciones que un empresario.

\section{Trabajadores por cuenta propia (trabajadores autónomos)} Esta expresión se utiliza para designar a quienes realizan un trabajo como medio de vida, pero sin ser empresario ni trabajador por cuenta ajena, propiamente dicho.

Los trabajadores por cuenta propia se hallan en una de las situaciones siguientes: 
- están incluidos en la cobertura obligatoria;

- están excluidos de la cobertura obligatoria, pero pueden acceder a ella, previa solicitud;

- están totalmente excluidos.

En algunas jurisdicciones, las personas que se consideran trabajadores por cuenta propia a otros efectos son tratadas como trabajadores asalariados a efectos de la indemnización por accidentes de trabajo. Por ejemplo, algunas jurisdicciones consideran como trabajadores asalariados y afectados por la cobertura a los empresarios dedicados al comercio del pescado, sin perjuicio de que a otros efectos tengan la consideración de trabajadores asalariados.

La distinción entre trabajadores asalariados y autónomos (por cuenta propia) es con frecuencia discutible, dado el interés que el empresario o el trabajador pueden tener para considerar su relación como no laboral. Si se considera que en estos casos no se trata de trabajadores asalariados, ambas partes estarían exentas de contribuir a diferentes fondos públicos y el empresario podría obviar el cumplimiento de determinadas obligaciones empresariales. Por ello es frecuente que una relación que obviamente es laboral en esencia, se formalice documentalmente como no laboral. Dar a esta formalización validez supone contravenir la norma que establece la inclusión obligatoria. El hecho de que una persona preste servicios para otra de forma exclusiva o casi exclusivamente constituye prueba evidente de que la relación es laboral. De igual forma, cuando un contrato se ha firmado con la intención de que la relación no se considere laboral, se está en la mayoría de las ocasiones ante una prueba evidente de que la relación tiene la naturaleza jurídica de laboral.

\section{Ampliaciones}

Algunas jurisdicciones utilizan el régimen de indemnización por accidentes de trabajo para cubrir a personas que no son trabajadores asalariados o para abarcar incapacidades no derivadas del empleo. N ormalmente, se utiliza este mecanismo para incluir a personas sobre las cuales la Administración pública tiene alguna responsabilidad. Entre otros ejemplos, pueden citarse el de los bomberos voluntarios y el de otras personas que realizan un trabajo voluntario de naturaleza gratuita. Son ejemplos menos comunes los de los presos, estudiantes y alumnos en edad escolar. En algunas jurisdicciones, la cobertura se aplica a quienes han sufrido un accidente mientras actuaban en interés público tratando de salvar la vida de alguien en peligro o de prevenir un delito. La cobertura de todos estos grupos, cuando se aplica, se financia generalmente con fondos públicos.

\section{Regímenes especiales}

Algunas jurisdicciones cuentan con un régimen separado para algún sector concreto, como el de la marina mercante, las fuerzas armadas o el servicio público. En los países de estructura federal, el gobierno federal establece a veces un régimen especial para determinados sectores, mientras que las administraciones públicas estatales o provinciales ofrecen el régimen general.

\section{Organización, administración y adjudicación}

\section{E structuras básicas}

La mayoría de los regímenes de indemnización a trabajadores pertenecen a una de tres categorías organizativas básicas.

1. La obligación de facilitar las prestaciones corresponde a las empresas. Se dispone de cobertura del seguro, que en algunas jurisdicciones es obligatoria. Las compañías de seguros están normalmente sujetas a regulación y supervisión por un organismo público. Algunas jurisdicciones limitan el número de compañías de seguros que pueden existir para tales fines. El reconocimiento del derecho se hace en los tribunales ordinarios a través de un procedimiento contradictorio, en un tribunal especial o en otra clase de tribunal.

2. Régimen de seguros sociales y gestionado por un organismo público. Con frecuencia es el M inisterio de Trabajo el organismo que gestiona el sistema, teniendo facultades decisorias. Normalmente existe un sistema de revisión o recursos para resolver los conflictos, y en ocasiones se admiten los recursos ante un órgano exterior.

3. El régimen es de seguros sociales y es gestionado por una A gencia pública, a veces denominada "consejo de indemnización por accidentes de trabajo". Este organismo es (al menos en teoría) independiente del control ministerial y tiene encomendadas la adjudicación y administración, siendo a la vez el asegurador. En algunas jurisdicciones, presta servicios de asistencia médica y rehabilitación, y en otras desempeña las funciones de regulación normativa sobre la salud y seguridad en el trabajo. Los procedimientos pueden ser contradictorios o de investigación, o ambas cosas a la vez. Puede calificarse de régimen de seguros sociales por tratarse de un régimen de seguro obligatorio administrado por la Administración, pero ha de distinguirse de los regímenes generales de seguros sociales que se describen en otro apartado de este artículo.

Algunas jurisdicciones utilizan un sistema combinado de compañías de seguros y fondos públicos. Igualmente, algunas jurisdicciones permiten que los grandes empresarios asuman sus propios riesgos, de tal forma que a las compañías de seguros les compete el papel de "administrador de reclamaciones". I gualmente, en estos casos, las Agencias del Gobierno asumen el papel de órgano que reconoce y gestiona el derecho y solamente el de asegurador como responsable último o avalista, en caso de incumplimiento de dichos empresarios.

En los tres modelos se exige que el trabajador notifique a la empresa, cuando ello sea posible, cualquier lesión o enfermedad que pueda padecer. Normalmente, en la presentación de estas notificaciones y de la consiguiente información hay que cumplir numerosos requisitos. Generalmente, el asegurador recibe informes de la empresa, del solicitante y de los médicos que le atienden. En algunos sistemas de seguros sociales, la empresa que no informa a tiempo es objeto de sanción o de un recargo. A demás, dicha empresa puede ser demandada judicialmente. La falta de cumplimentación debida por el solicitante puede suponer la denegación o suspensión de la prestación. Sin embargo dicha suspensión o denegación puede en muchas ocasiones no aplicarse, aun cuando no haya existido dicha cumplimentación adecuada, de tal forma que las medidas descritas no operan automáticamente. Los requisitos de información exigidos a los médicos que prestan asistencia pueden imponerse suspendiendo el pago de honorarios.

Tradicionalmente, los informes se remiten en papel, y los archivos de los organismos administradores también tienen soporte documental, pero recientemente se han introducido métodos electrónicos de comunicación y almacenamiento de la información.

La mayoría de las jurisdicciones exigen la presentación de la reclamación dentro de un plazo dado, aunque algunas admiten que se inicien los pagos antes de recibir el documento de reclamación. N ormalmente puede ampliarse el plazo de presentación de reclamaciones, pero aun así los plazos establecidos pueden causar graves injusticias en algunos casos de enfermedad.

\section{Decisiones iniciales}

Las decisiones iniciales tomadas en respuesta a una reclamación corresponden a veces a las empresas, pero más corrientemente 
son tomadas por los aseguradores. Cuando el régimen es administrado por compañías de seguros, la decisión inicial puede ser de aceptación o rechazo de la reclamación u oferta hecha por el reclamante, o bien puede consistir en una oferta del asegurador, que a su vez puede ser aceptada o rechazada por el reclamante. Normalmente, el acuerdo se alcanza mediante negociación. En algunas jurisdicciones existen disposiciones para impedir que las compañías de seguros puedan forzar un acuerdo a la baja, reteniendo los pagos periódicos de la prestación. Cuando no hay acuerdo, el caso puede presentarse ante un tribunal u otro órgano de reconocimiento inicial del derecho.

Cuando el régimen es de seguros sociales, el órgano que reconoce el derecho es a la vez el órgano asegurador. En este sistema, y como parte de la filosofía esencial del mismo, no se concibe que el trabajador discapacitado se vea obligado a concluir un acuerdo desde una posición de debilidad. Por ello el sistema prevé un rápido reconocimiento de los derechos establecidos. Si se acepta una reclamación, pero las prestaciones concedidas son menores que las demandadas por el solicitante, deben pagarse aquéllas mientras dure la tramitación del recurso del reclamante.

Las decisiones iniciales suelen basarse en los documentos que obran en el expediente. La gestión y el renococimiento del derecho se hallan fuertemente centralizados en los regímenes administrados por compañías de seguros y en algunos regímenes de seguros sociales. Por su parte, en los sistemas descentralizados de gestión y reconocimiento, el órgano que reconoce las prestaciones recibe los medios de prueba y alegaciones de primera mano, valorando a la vez la veracidad de las mismas. Por este y otros motivos, se han descentralizado algunos regímenes de seguros sociales.

En algunos regímenes de seguros sociales no suele darse audiencia en el reconocimiento inicial aunque ésta esté expresamente prevista por la ley. En otros por el contrario mantiene el trámite de audiencia. Sin embargo, en los regímenes administrados por las compañías de seguros, regidos por el principio contradictorio, es normal el trámite de audiencia cuando el reconocimiento inicial se hace por los Tribunales, a no ser que el empresario, o su asegurador, estén de acuerdo con la solicitud del trabajador, o en caso de desacuerdo, éste se halla resuelto. Algunas jurisdicciones disponen de sistemas de mediación para la solución de estos conflictos. Sin embargo permitir o requerir la mediación previa, cuando una de las partes se ve menoscabada en su poder de negociación por necesitar las prestaciones 0 recursos económicos, puede suponer un perjuicio evidente para los derechos del trabajador. Si un sistema pretende garantizar la continuidad de recursos económicos para el solicitante, sin necesidad de acudir a una asistencia legal profesionalizada, se requiere ineludiblemente que el sistema garantice un reconocimiento inmediato del derecho. Esto es aún más importante cuando el retraso en el reconocimiento de los derechos puede perjudicar la rehabilitación del trabajador.

Un problema frecuente en la toma de decisiones iniciales lo constituyen los sistemas de remisión o referencia. De acuerdo con estos sistemas, la persona que recibe las reclamaciones tiene una capacidad limitada de decisión, por lo que las decisiones de alguna complejidad han de remitirse a alguien que no cuenta con información y argumentos de primera mano. Corrientemente, las decisiones sobre una misma reclamación han de remitirse a personas diferentes, con el consiguiente riesgo de malentendidos, errores e incongruencias. Los sistemas de remisión son una de las principales causas de retrasos, derroche, perjuicios terapéuticos, injusticias y deterioro de las posibilidades de rehabilitación.

\section{Investigaciones, pruebas y prácticas de las mismas}

En las jurisdicciones que se rigen por el principio de contradicción, la responsabilidad sobre la prueba de los hechos y de la aportación de dictámenes médicos incumbe generalmente a las partes. En algunos regímenes de seguros sociales, se prevé que éstas aporten las pruebas de que dispongan y aquellas otras que puedan obtener, pero generalmente corresponde al órgano decisor la responsabilidad de hacer las investigaciones necesarias para obtener cualquier otra prueba. Análogamente, la investigación para comprobar la credibilidad de las pruebas o para otros fines puede corresponder a las partes, al asegurador o al órgano decisor. En los regímenes de seguros sociales, la investigación 0 bien se estructura como una función normal del órgano decisor 0 bien se encomienda a una unidad especial (no obstante, ésta es una estructura menos eficiente).

En los sistemas que se rigen por el principio de contradicción, y en algunos regímenes de seguros sociales que no se rigen por él, corresponde al trabajador la carga de la prueba que sirve de base a una reclamación, salvo en ciertas cuestiones en que dicha carga corresponde a la empresa. En otros regímenes de seguros sociales nadie, excepto el órgano decisor, tiene encomendada la carga de la prueba. A veces, existen presunciones legales aplicables, no en favor 0 en contra del trabajador, sino a determinadas situaciones particulares. La presunción más común es aquella que determina que cuando una lesión resulta de un accidente ocurrido en el curso del trabajo, se presume que es consecuencia del trabajo que se desarrolla, y a la inversa, cuando el accidente es consecuencia del trabajo, se presume que se ha producido durante el curso del mismo. Algunas jurisdicciones disponen que cuando un trabajador es hallado muerto en un lugar de trabajo, se presume que la muerte ha sido consecuencia del empleo, salvo que se demuestre lo contrario.

La valoración de la prueba se basa en el principio de ponderación de las mismas, escogiéndose por tanto la mejor hipótesis posible. Ahora bien, con respecto a la etiología de las enfermedades y a otras cuestiones médicas, los dictámenes médicos no siempre se rigen por los criterios legales pertinentes, por lo que con frecuencia, para ser aceptada una reclamación, se requiere un nivel legalmente exagerado de prueba. Así, por ejemplo, cuando se pide a los médicos un dictamen sobre la etiología suelen mostrarse reacios a presentar un informe que concluya con la frase "No sé", aun cuando así se declare antes expresamente en el mismo informe. Por tanto, una conclusión negativa de un informe médico quizá no refleje otra cosa que una negativa expresada por el médico asesor por carecer de datos positivos. Es, pues, una conclusión legal (a veces, errónea), no una conclusión médica. Algunas jurisdicciones prevén que, cuando las posibilidades debatidas tienen un peso igual, la cuestión debe decidirse en favor del trabajador o de las personas a su cargo, salvo prueba en contrario.

En algunas jurisdicciones no sirve la igualdad de probabilidades para demostrar que la causa es de naturaleza laboral. D ebe denegarse la reclamación a no ser que la respuesta afirmativa tenga un mayor grado de probabilidad que la negativa. Estas cláusulas a veces sólo se aplican a casos de enfermedad. Incluso en estos casos, la igualdad de probabilidades puede seguir siendo la regla para otras cuestiones, como la existencia de una incapacidad.

A lgunos regímenes cuentan con una unidad de investigación de abusos. Esta o bien se limita a investigar los abusos de los reclamantes o también se ocupa de los cometidos por los administradores del régimen, los reclamantes, las empresas, las compañías de seguros y los prestadores de servicios de asistencia sanitaria y rehabilitación. 


\section{D efensa}

La preparación y presentación de reclamaciones es normalmente un asunto sencillo que no requiere grandes capacidades jurídicas, por lo que algunas jurisdicciones prohíben cobrar honorarios por estas funciones. Suele recurrirse a la defensa legal en las reclamaciones impugnadas, tanto más cuanto que los casos llegan a niveles superiores de decisión. Cuando se aplica un sistema de baremos o la misma empresa es el asegurador, tanto el trabajador como la empresa pueden acudir con un letrado. En otro caso, la defensa sólo suele ofrecerse al trabajador.

En los regímenes administrados por compañías de seguros, la defensa en los procesos de reconocimiento de prestaciones suele encomendarse a letrados. En los regímenes de seguros sociales, el defensor puede ser un abogado, un funcionario sindical 0 cualquier otro experto en casos de indemnización por accidentes de trabajo. En algunas jurisdicciones, la Administración o la autoridad de indemnización cuentan con un grupo de letrados al servicio de los trabajadores, y en algunas jurisdicciones existe asimismo un grupo que presta ayuda a las empresas. A veces, se concede al trabajador derecho a la asistencia jurídica en el marco de un plan público de asistencia legal.

\section{Acceso a la documentación}

Cuando un régimen es administrado por las compañías de seguros, los archivos de éstas no suelen estar a disposición del solicitante, si bien, cuando el caso llega a los tribunales, pueden obtenerse ciertos documentos de aquéllos, y además los autos del juicio están a disposición de ambas partes. En los regímenes de seguros sociales, el mismo órgano suele ser a la vez asegurador y decisor. En algunas jurisdicciones los archivos de dicho órgano son accesibles al solicitante. En otras jurisdicciones, y en virtud del principio de equidad, el acceso a los archivos se garantiza al solicitante y a la empresa en algunos casos y con cierta amplitud, lo que en determinadas circunstancias puede perjudicar el principio de confidencialidad de la información médica. Alternativamente, existe un derecho del solicitante a la documentación obrante en el expediente, de acuerdo con la legislación sobre derechos humanos o sobre libertad de información. La empresa, a la que no se le permite de forma absoluta el acceso a la documentación de las reclamaciones por estos motivos, puede, no obstante tener derecho de acceso, por los mismos motivos, a los archivos relacionados con la clasificación y evaluaciones.

Las empresas necesitan a veces información médica a efectos de salud y seguridad en el trabajo o de rehabilitación, pero normalmente hay formas más eficientes de obtenerla que el acceso al archivo de reclamaciones.

\section{Terminación}

La indemnización por accidentes de trabajo difiere de los litigios ordinarios en los tribunales en su terminación. Cuando se presenta ante los tribunales una reclamación por lesión personal según la ley general, la sentencia es normalmente definitiva. En la indemnización por accidentes de trabajo suele haber disposiciones sobre reapertura del juicio en caso de que se produzcan ciertos cambios en las circunstancias. El caso más común se da cuando se ha concedido una pensión por incapacidad parcial permanente y algunos años después la incapacidad se ha agravado (o, raras veces, se ha curado).

Cuanto la indemnización por accidentes de trabajo se enmarca en un régimen de seguros sociales, es normal permitir la reapertura del caso aun cuando no haya habido cambio de circunstancias. Estas disposiciones sobre reapertura (o reconsideración) sirven a una finalidad útil, pero pueden dar lugar a abusos de los administradores del régimen. U na práctica común consiste en desviar toda reclamación o apelación a un proceso de revisión. L as consecuencias negativas son diversas. U na es el retraso en el reconocimiento del derecho, a veces con el consiguiente retraso de la rehabilitación. 0 tra es la que se produce cuando se deniega la primera solicitud por pruebas incompletas o dudosa, reconsiderándola con posterioridad si el solicitante recurre la decisión. En tal caso habría que proceder a una investigación para completar las pruebas. Dicha investigación debería haber sido realizada en la primera instancia. Esta forma de utilizar la "revisión" tiene una influencia negativa en la calidad de las primeras instancias y puede ser causa de injusticia para quienes se conforman en el primer reconocimiento y no recurren.

\section{Cuestiones médicas}

Algunas jurisdicciones exigen que el solicitante o el médico que le atiende presenten un "certificado" médico. 0 tras, que el médico encargado presente un "informe". El "certificado" se considera a veces decisivo, mientras que el "informe" médico suele tener el valor de una prueba más, que se valorará en el conjunto de las pruebas.

L as cuestiones médicas suelen decidirse de la misma manera que otras cuestiones de hecho, pero algunas jurisdicciones han establecido disposiciones especiales al respecto. Las agencias reconocidas cuentan con frecuencia con médicos que asesoran o deciden en este campo. En muchas jurisdicciones, el reclamante ha de someterse a cualquier reconocimiento médico ordenado por la autoridad que concede la indemnización por accidentes de trabajo o por otro asegurador. En unos casos, el reconocimiento se encomienda a un médico nombrado por la empresa, pero tales disposiciones se critican por el riesgo de daños terapéuticos o de pérdida de confidencialidad de la información médica. En casos de muerte, normalmente se utilizan los informes de la autopsia como prueba de la causa del fallecimiento. A veces se utilizan certificados de defunción, pero no suelen ser muy fiables en lo que conciernen a las causas de la muerte.

La interacción entre los aspectos médicos y los jurídicos plantea algunos de los problemas más comunes y difíciles de las decisiones sobre reconocimiento de los derechos. Probablemente, el ejemplo más común sea la presentación de informes elaborados por médicos que no han sido informados sobre las cuestiones legalmente pertinentes sometidas a ellos. En tal caso, el "informe médico" incluye con frecuencia, explícita o implícitamente, supuestos sobre antecedentes (que a veces son erróneos), una opinión sobre la ley (que es comúnmente errónea), así como opiniones médicas. Combatir estos extremos de un informe médico requiere unos conocimientos jurídicos que normalmente no se encuentran en la primera instancia. Para obviar el problema, algunas jurisdicciones exigen que se formule la cuestión médica jurídicamente pertinente antes de pedir el dictamen médico correspondiente.

En regímenes administrados por compañías de seguros, es normal que el asegurador o la empresa participen en la decisión sobre cuestiones médicas y que para ello tengan acceso a información médica. Cuando el régimen es de seguros sociales, una justificación de esa opción es preservar la confidencialidad de la información médica. Puede prohibirse a las empresas tomar parte en la decisión sobre cuestiones médicas o puede carecer de incentivo participar porque la prima a pagar no varía de acuerdo con el coste por reclamaciones. Cuando se utiliza el baremo según experiencia, el sistema se rige por el principio de contradicción y suele comunicarse a la empresa la información médica acerca del trabajador.

A veces, existe un árbitro médico externo o un grupo médico para algunos casos. En algunas jurisdicciones, las conclusiones del panel médico o del árbitro son definitivas y vinculantes. En otras, están sujetas a contradicción mediante nuevas pruebas médicas 0 argumentos en el proceso ordinario de apelación. 
Cuando se dispone de una estructura o procedimiento separado para la solución de una cuestión médica, hay que decidir antes qué cuestiones son "médicas". La responsabilidad de la decisión corresponde normalmente al responsable de decidir sobre la cuestión general. Existe un consenso general sobre lo que es una cuestión "médica", pero hay cierta diferencia de opiniones. Por ejemplo, en casos de incapacidad permanente, cuando se utiliza el método del deterioro físico para fijar la pensión, el establecimiento del grado (porcentaje) de deterioro se considera en algunas jurisdicciones una cuestión médica. En otras se considera como una cuestión general que requiere un dictamen médico.

\section{Recursos}

Es normal que haya un sistema de recursos. Cuando el régimen es de seguros sociales, este sistema puede ser completamente interno o un órgano externo. Generalmente, la decisión última corresponde a dichos órganos aunque en algunas jurisdicciones, éstos actúan en una fase intermedia. En otras, los recursos se presentan ante un tribunal ordinario, 0 ante un tribunal especial. En algunos casos, las comparecencias son automáticas. En otras se producen si se solicitan o si el órgano competente las considera necesarias. En los regímenes de seguros sociales, es normal que este órgano, y en algunas jurisdicciones también las partes, tenga acceso a los documentos que se utilizaron para adoptar la decisión inicial. Así se evita la duplicación de esfuerzos y se permite al órgano ante el que se recurre examinar los errores cometidos, en su caso, en la primera resolución. La información puede complementarse o contradecirse aportando al recurso nuevas pruebas o alegaciones.

EI derecho de recurso suele ser ilimitado en relación con las prestaciones monetarias, pero limitado en relación con la asistencia de rehabilitación. Suelen permitirse recursos en cuestiones de ayuda médica, aunque en muchas jurisdicciones son infrecuentes.

Cuando el fallo del recurso compete a un tribunal ordinario, las causas de interposición son menores que en los casos en que la competencia la tiene un tribunal especial. Además, es menos probable que un tribunal ordinario revise las pruebas sobre las que se entendió en primera instancia o admita nuevas pruebas.

En algunas jurisdicciones se admiten quejas ante el defensor del pueblo, a veces sobre el fondo, pero en otras sólo sobre el procedimiento.

\section{M anuales sobre normativa}

Cuando un régimen es de seguros sociales, suele haber un manual de reconocimiento de derechos que incluye las disposiciones legales que deben aplicar los responsables de la toma de las decisiones sobre reconocimientos. Suele ser una síntesis de las leyes, reglamentos, jurisprudencia y decisiones tomadas por los órganos decisorios o administración en el ejercicio de facultades delegadas. Normalmente lleva el título de "M anual de política", pero tal nombre puede inducir a error. Sólo aquellas partes que se refieren al ejercicio de poderes discrecionales pueden encuadrarse correctamente en el marco de lo que se denomina política. En su mayor parte, el manual es un conjunto normativo que incluye normas vigentes.

D urante decenios, estos manuales han sido tratados casi como documentos secretos. El uso del término "política" en su título ocultaba el hecho de que en esencia se trataba de un conjunto normativo confidencial. En los últimos años así se ha venido reconociendo, exigiéndose, por ello, la publicación de dichos manuales, ya sea por los órganos que gestionan y reconocen el derecho o por previsiones legales.

\section{Derecho a las prestaciones}

\section{Causalidad en casos de lesiones}

Según el principio general, ha de pagarse una indemnización por las lesiones y muertes que sean consecuencia de algún acontecimiento o circunstancia del empleo. En muchas jurisdicciones, la legislación se refiere a una lesión "derivada del empleo y ocurrida durante el mismo". Normalmente, sin embargo, no se exige que haya ocurrido durante el empleo. Lo esencial es que haya sido causada por el empleo. Supongamos que el sujeto A coloca una rata en la fiambrera de $B$ (un compañero de trabajo), quizá maliciosamente 0 quizá en broma. C uando más tarde B abre la fiambrera en su casa, la rata le muerde, causándole una incapacidad significativa. El daño no ha ocurrido durante el empleo, pero no es preciso que haya sido así. Se ha producido durante el empleo (aunque pueda discutirse si con ocasión del mismo). Con todo, algunas jurisdicciones exigen que el "accidente" haya ocurrido durante el empleo.

0 tras jurisdicciones se refieren a una lesión "derivada del empleo u ocurrida durante el mismo", pero parecen ser pocos los casos en que esta diferencia de lenguaje altera el resultado. Algunas jurisdicciones no dan una definición general de la incapacidad con derecho a indemnización, sino que presentan una lista de circunstancias que presentan una conexión con el empleo suficiente para que la incapacidad dé lugar a indemnización.

En la mayoría de los casos y de las jurisdicciones, el lugar de producción de la lesión no es determinante. Es simplemente parte de la prueba para valorar si la causa de la lesión está en el empleo. Tampoco se exige de ordinario que la lesión se haya producido durante la jornada de trabajo. Y también en este caso, su ocurrencia en tales circunstancias puede servir de prueba para decidir si fue consecuencia del empleo. 0 tras jurisdicciones atribuyen mayor importancia a la conexión geográfica o cronológica con el empleo, y en algunas la lesión ha de haber ocurrido en un lugar de trabajo, aunque entendiéndose por tal cualquier lugar en que el trabajador desempeñe su trabajo.

A lgunas jurisdicciones exigen que la incapacidad se produzca dentro de su territorio, pero esta exigencia es incompatible con el principio de cobertura general de las incapacidades resultantes del empleo. N ormalmente basta con que el lugar habitual de trabajo se halle dentro de la jurisdicción en que se presenta la reclamación. A sí, cuando el empleo exige realizar viajes internacionales, la indemnización por accidente de trabajo a causa de una incapacidad sobrevenida en el extranjero es atendida normalmente por el régimen del punto de origen del empleo del trabajador.

Es frecuente el uso de la expresión "relacionada con el trabajo" en la literatura sobre indemnización, pero generalmente es inapropiada y equívoca. En la mayoría de las jurisdicciones, para que una lesión dé lugar a indemnización no se exige que haya sido consecuencia del trabajo (actividad productiva). Algunas exigen que sea consecuencia del trabajo, pero en la mayoría basta con que sea consecuencia del empleo. Por ejemplo, un accidente sufrido al entrar o salir de las instalaciones de la empresa o durante el período de descanso o al recibir la paga da lugar a indemnización en la mayoría de las jurisdicciones.

Algunas especifican que es indemnizable la lesión sufrida durante la reconversión profesional o durante las fases de preparación del trabajo. En otras muchas, tales lesiones están cubiertas por haberse producido a causa del empleo y durante el mismo.

\section{Accidentes}

Uno de los requisitos para tener derecho a indemnización era que la lesión hubiera sido causada por un "accidente". En 
algunas jurisdicciones se ha suprimido esta palabra. En otras es generalmente superflua y equívoca. Independientemente de que se utilice 0 no el término "accidente", la indemnización no se limita en general a las lesiones que se producen en una ocasión particular o a causa de un "incidente específico". Se extiende también a las incapacidades que resulten de la tensión a lo largo del tiempo o de otras causas que tienen una repercusión gradual o acumulativa, incluidas las incapacidades derivadas del trabajo rutinario normal. Cuando en la legislación aparece la palabra "accidente", para lo único que sirve es para causar confusión y costes inútiles de decisión en casos marginales. No obstante, a veces un acontecimiento inusual puede ser una prueba crucial en la etiología. Por ejemplo, en casos de ataque cardíaco, algunas jurisdicciones investigan la posibilidad de una tensión o estrés inusual para determinar si el empleo fue una causa concurrente 0 si el ataque fue resultado exclusivo de la degeneración natural y su aparición durante el empleo fue puramente casual.

\section{Desplazamientos al trabajo y desde el mismo}

M uchas jurisdicciones cubren los daños resultantes de los desplazamientos con ocasión del trabajo (accidentes in itinere), al menos cuando el trabajador viaja por la ruta más directa y sin interrupción alguna para asuntos personales no relacionados con las necesidades del viaje. Suelen fijarse reglas detalladas sobre si la cobertura se aplica en todas las circunstancias, como, por ejemplo, cuando un trabajador viaja por una ruta más larga por motivos de placer personal o se detiene para realizar compras personales. Algunas veces se incluyen también expresamente las lesiones resultantes del viaje entre el trabajo y el lugar de tratamiento médico, si se requiere éste durante las horas de trabajo.

En otras jurisdicciones, las lesiones resultantes de los viajes al trabajo y desde el mismo (accidentes in itinere) no están cubiertas cuando el trabajador viaja entre su casa y un lugar fijo de empleo. Se entiende entonces que, como el trabajador ha elegido dónde vivir y dónde trabajar, es él quien ha elegido el viaje a realizar, por lo cual los riesgos del mismo no se consideran riesgos del empleo. En cambio, si el trabajador no tiene un lugar fijo de empleo, sino que viaja entre la vivienda y diferentes lugares designados por la empresa, esos viajes guardan relación con el empleo y las lesiones resultantes de los mismos son indemnizables. A sí se hace comúnmente en las industrias del transporte y la construcción. A nálogamente, cuando un trabajador trabaja en un centro de trabajo permanente pero es trasladado temporalmente a un lugar distinto, la lesión ocurrida con ocasión de un viaje entre la vivienda y este último es indemnizable. No obstante, en algunas circunstancias los viajes entre la vivienda y el centro de trabajo permanente están cubiertos, por ejemplo, cuando un trabajador que no pertenece a un turno es llamado por la empresa para hacer frente a una emergencia o cuando utiliza un medio de transporte proporcionado por ésta.

\section{Comienzo y terminación de la cobertura}

La cobertura de un trabajador puede extenderse ligeramente más allá de la estricta duración del contrato de trabajo. Así, por ejemplo, si un trabajador sufre una lesión al entrar en las instalaciones de la empresa durante el primer día de trabajo, esa lesión es indemnizable en muchas jurisdicciones, aun cuando no se hayan completado las formalidades del contrato de trabajo. A nálogamente, si un trabajador despedido sufre lesiones antes de abandonar las instalaciones de la empresa, y a veces antes de llegar a su casa, esas lesiones son indemnizables en muchas jurisdicciones, a pesar de haberse extinguido el contrato de trabajo.

\section{Culpabilidad}

Los regímenes de indemnización por accidentes de trabajo han sido diseñados para ofrecer una prestaciones automáticas por la incapacidades laborales y para evitar el coste y los perjuicios terapéuticos de las investigaciones encaminadas a probar quién es el culpable, si alguien lo es. Por tanto, es prácticamente irrelevante si ha habido o no culpa de la empresa, del trabajador o de cualquier otra persona. A continuación se mencionan algunas excepciones a este principio.

\section{Fenómenos naturales}

$\mathrm{H}$ ay opiniones diferentes acerca del derecho a indemnización cuando la incapacidad o muerte es consecuencia de un fenómeno natural. Por ejemplo, si un trabajador muere a causa de un rayo, la muerte es indemnizable en unas jurisdicciones y no en otras. La regla aplicable en algunos casos consiste en averiguar si el empleo expuso al trabajador a un riesgo de ocurrencia de ese accidente mayor que el del público en general. Los fenómenos naturales amparados por esta regla abarcan las lesiones causadas por plantas y animales.

\section{Casos de enfermedad}

Aún es mayor la diversidad entre las jurisdicciones en cuanto al reconocimiento del derecho en casos de enfermedad. Son frecuentes las expresiones "enfermedad laboral" o "enfermedad profesional", pero inducen a error y causan una gran confusión. Suelen implicar que ha de pagarse indemnización, pero que ésta se limita a ciertas categorías de enfermedades conocidas como profesionales. G eneralmente, sin embargo, las cosas no son así.

En algunas jurisdicciones, la cobertura se define estrictamente. Sólo se aplica a enfermedades especificadas en una lista que no incluye todas las enfermedades comúnmente conocidas como enfermedades laborales o profesionales. En otras, la cobertura se define de manera general, por lo que las enfermedades quedan cubiertas con el mismo alcance que las lesiones, incluidas las enfermedades que afectan a la población general y que no reciben el nombre de "profesionales". L o mismo que en los casos de lesiones, en estas jurisdicciones hay que averiguar si la enfermedad en un supuesto determinado ha sido consecuencia del empleo, no si la enfermedad pertenece a aquéllas que normalmente tienen su causa fuera del trabajo. Por ejemplo, una reclamación por tuberculosis de un trabajador sanitario puede tener éxito si se demuestra que ha sido consecuencia del empleo, aunque la enfermedad sea frecuente entre la población en general.

O tras jurisdicciones adoptan una posición intermedia. La cobertura no se limita a listas cerradas de enfermedades, pero tampoco tiene tanto alcance como la de las lesiones. Por ejemplo, se exige que la enfermedad sea "peculiar o característica del empleo" o que sea "debida a la naturaleza" del empleo. Algunas jurisdicciones no prevén prestación económica alguna (sí asistencia sanitaria) en los casos de enfermedad si no se dan a la vez dos requisitos: el deterioro o menoscabo físico y la pérdida de ingresos. Ello ocurre aun cuando dichas jurisdicciones prevean la correspondiente pensión por incapacidad permanente, independientemente de que exista o no pérdida de ingresos. 0 tras jurisdicciones exigen, además, requisitos de notificación o de plazos aplicables exclusivamente a los casos de enfermedad. Algunos de éstos son irreales por guardar relación con períodos de latencia que son comunes a algunas de las enfermedades más graves.

Cuando se alega que una enfermedad ha sido consecuencia de la exposición a algún contaminante, la prueba de que la exposición del trabajador al mismo ha superado los niveles máximos establecidos a efectos reguladores demuestra la causalidad, pero no es concluyente. La prueba de que la exposición se mantuvo siempre por debajo del límite prescrito es normalmente mucho más débil. Se aplica en este caso el principio general según el cual es más difícil probar los hechos negativos 
que los afirmativos. Los registros de exposiciones de años anteriores pueden tener una credibilidad desconocida y guardar relación con el ambiente de trabajo más bien que con la exposición del reclamante, que quizás haya sido mayor que el promedio medioambiental. A demás, dadas las variaciones de la sensibilidad individual y la incertidumbre científica de la mayoría de los límites de exposición, la enfermedad puede haber resultado de la exposición del reclamante aun manteniéndose ésta siempre por debajo del límite prescrito. Por tales motivos, la prueba de que la exposición del trabajador ha estado siempre por debajo del límite prescrito no es muy persuasiva y no implica un rechazo de la reclamación.

Tradicionalmente, han destacado las enfermedades pulmonares de los mineros y otros trabajadores de la industria pesada. En los últimos años ha habido un mayor reconocimiento de las enfermedades de los trabajadores de la industria ligera y de las ocupaciones de oficina, muchas de las cuales son más sutiles en sus efectos en el organismo. Por ejemplo, hoy se reconoce en algunas jurisdicciones que puede tener éxito una reclamación por el síndrome de edificio cerrado herméticamente.

Muchas jurisdicciones tienen catálogos de enfermedades. Estos se presentan en dos columnas. En la primera figura una lista de diagnósticos y, al lado de cada uno de éstos, en la segunda columna, el tipo de industria o proceso de trabajo causante de la enfermedad. La importancia del catálogo varía según las jurisdicciones. Puede ser:

1. Exclusivo y concluyente. Sólo son indemnizables las enfermedades catalogadas. Si en un caso particular se dan las condiciones indicadas en la segunda columna, se acepta la reclamación. En otro caso, se deniega. Las pruebas de etiología son irrelevantes e inadmisibles.

2. Exclusivo y presunto. Sólo son indemnizables las enfermedades catalogadas. Cuando se dan las condiciones indicadas en la segunda columna, se presume que la enfermedad ha sido consecuencia del empleo. No obstante, se admite la prueba contraria y también la prueba de apoyo de la presunción de que fue consecuencia del empleo. Cuando en conjunto la prueba es suficiente para contrapesar la presunción, se deniega la reclamación. En otro caso, se mantiene aquélla y se acepta la reclamación.

3. Presunto, pero no excluyente. Tratándose de enfermedades catalogadas, la posición es la misma que en 2). Tratándose de enfermedades no catalogadas, no hay presunción, pero pueden ser indemnizables. En muchas jurisdicciones, las enfermedades no catalogadas son indemnizables si las pruebas indican que son causadas por el empleo en el caso particular y se han cumplido los requisitos de admisibilidad relativos a las reclamaciones por enfermedad. En otras, una enfermedad no catalogada ha de ser reconocida por el órgano decisorio o administrador como enfermedad profesional para poder ser indemnizable, aun cuando no hay restricción alguna a la gama de enfermedades que pueden ser reconocidas como tales. EI reconocimiento puede ser general o para un caso particular. No se trata de un reconocimiento de que la enfermedad encaje en una categoría preconcebida de enfermedades laborales o profesionales, sino simplemente de que no exista un motivo político superior para que la enfermedad no sea indemnizable. En algunas jurisdicciones las enfermedades no catalogadas solamente son indemnizables si alcanzan un nivel determinado de deterioro.

4. Concluyente, pero no excluyente. Cuando una enfermedad está catalogada y se dan las condiciones de la segunda columna, la reclamación debe aceptarse. La prueba de etiología en los casos particulares es irrelevante e inadmisible. Tratándose de enfermedades no catalogadas, la posición es la misma que en 3).

$\mathrm{H}$ ace tiempo eran frecuentes las posiciones 1 ) y 2 ), pero en los últimos cuarenta años se ha hecho más frecuente la posición 3). La posición 4) es infrecuente. En muchas jurisdicciones, los catálogos son demasiado limitados y anticuados para poder utilizarlos con carácter general en relación con las incapacidades del mundo actual.

U no de los peligros de los catálogos que no pretenden ser excluyentes consiste en que, en la práctica, pueden tender a convertirse en tales. Se parte del principio de que, cuando se presenta una reclamación por una enfermedad no catalogada, han de investigarse las pruebas para determinar si ha sido consecuencia del empleo. El peligro está en que no se proceda así y en la práctica la cobertura tienda a limitarse a las enfermedades catalogadas. Algunas jurisdicciones tratan de evitar este peligro prescindiendo de toda clase de catálogos.

A veces se supone que se requiere un diagnóstico para poder presentar una reclamación por enfermedad, pero esto sólo suele ocurrir en jurisdicciones en las que la indemnización se limita a enfermedades que figuran en listas excluyentes o cerradas. En la mayoría de las restantes jurisdicciones, el diagnóstico no es necesario en la medida de que la etiología o relación con el empleo pueda ser probada sin dicho diagnóstico. Los requisitos de admisibilidad normalmente guardan relación con la etiología, y si esta puede demostrarse, con la igualdad de probabilidades, sin necesidad de diagnóstico, la enfermedad es indemnizable.

\section{Distinción entre lesión y enfer medad}

Como muchas jurisdicciones aplican a las enfermedades criterios distintos que a las lesiones, a veces hay que determinar si una incapacidad debe clasificarse como resultante de una lesión o de una enfermedad. La distinción se ha establecido pragmáticamente, no por referencia a principio alguno. Por tanto, no existe una regla fija para distinguir, aun cuando en la práctica se siguen las que citamos a continuación.

Las incapacidades resultantes de traumatismos se clasifican generalmente como lesiones, y cualquier enfermedad resultante de éstas ( $p$. ej., de la infección de una herida) se asimila a una lesión. Cuando una enfermedad está catalogada, prevista o mencionada expresamente en la legislación, casos como el del ejemplo se incluyen en el concepto de enfermedad. En otro caso, las incapacidades resultantes de un incidente específico suelen clasificarse como lesiones, mientras que las que resultan de la exposición a lo largo del tiempo se clasifican más comúnmente como enfermedades, pero no de manera sistemática, ya que en esta materia no hay una regla fija. Por ejemplo, las torceduras y distensiones suelen clasificarse como lesiones, tanto si resultan de un incidente específico como de la exposición a lo largo del tiempo. Análogamente, la dermatitis suele clasificarse como enfermedad tanto si resulta de un incidente específico como de la exposición a lo largo del tiempo; en cambio, las quemaduras causadas por un solo incidente de exposición química pueden clasificarse como lesiones. La pérdida de audición debida a la exposición al ruido se clasifica como lesión si es consecuencia de una explosión, pero como enfermedad si se debe a la exposición a lo largo del tiempo. La incapacidad causada por la absorción gradual de agentes químicos o biológicos se clasifica como enfermedad. Las reacciones alérgicas suelen clasificarse como enfermedad, tanto si resultan de un solo incidente como de la exposición prolongada.

\section{Trastornos mentales - estrés}

La indemnización por una incapacidad física incluye generalmente todas las dimensiones mentales y consecuencias de la misma. Análogamente, cuando un trastorno mental a consecuencia del empleo causa una incapacidad física, ésta se considera generalmente indemnizable. Las normas legales no suelen circunscribirse a las incapacidades físicas, por lo que en principio no hay motivo para que no se pague indemnización cuando el trastorno mental ha sido consecuencia del empleo sin que se haya 
producido incapacidad física. En muchas jurisdicciones, estos casos están cubiertos por la legislación, pero con frecuencia existe resistencia a reconocer la cobertura en reclamaciones posteriores. En los últimos años ha habido un aumento de reclamaciones por estrés de origen laboral, y en muchas jurisdicciones el estrés queda incluido dentro del concepto de lesión o enfermedad. En las reclamaciones aceptadas por estrés, éste ha sido causado unas veces por condiciones medioambientales, como la temperatura, otras por el comportamiento de los compañeros de trabajo 0 de los jefes, como casos de acoso sexual, e incluso en otras por los sistemas de trabajo, como las reclamaciones por karoshi (muerte por exceso de trabajo). En jurisdicciones en las que la incapacidad resultante de los desplazamientos con ocasión del trabajo es indemnizable, los efectos combinados de éstos y de la situación dentro del trabajo son importantes para decidir si el trabajador ha quedado incapacitado o ha fallecido a consecuencia del estrés laboral.

La evolución política contemporánea, que hace hincapié en la "competitividad" y la "desregulación", incluida la desregulación de las horas extraordinarias, ha suscitado preocupación por la creciente incidencia del estrés laboral. La respuesta de algunas jurisdicciones ha sido una prohibición legal de las reclamaciones por estrés mental.

\section{Dolencias de espalda}

En muchas jurisdicciones, el mayor volumen de reclamaciones impugnadas de indemnización por accidentes de trabajo corresponden a casos de dolencias de espalda. Lo normal es que el trabajador sufra un dolor agudo a consecuencia del levantamiento de un peso o una torcedura durante el trabajo. A veces, le sigue un dolor crónico.

Las reclamaciones por dolencias de espalda suelen tratarse de una de las tres maneras siguientes:

1. Se acepta la reclamación y se paga de la manera ordinaria mientras dura la incapacidad. Este sistema es muy común, ya que la mayoría de las dolencias de espalda se curan en el plazo de un mes.

2. Se deniega la reclamación.

3. Se acepta la reclamación durante un período inicial. Pasado dicho plazo se suprimen las prestaciones por considerar que la continuación de la incapacidad se debe más bien a una enfermedad subyacente que a una enfermedad que tenga su causa en el trabajo. N ormalmente, los informes médicos diagnostican una enfermedad degenerativa de la espina dorsal, frecuente entre la población general.

El dilema primordial en los casos de dolencias de espalda suele consistir en que no hay manera científica alguna de determinar la importancia causal a largo plazo de cualquier hecho sucedido en el trabajo o de la pauta ordinaria de trabajo en comparación con la degeneración natural u otros factores causantes. Los casos de dolencias de espalda ilustran gráficamente las dificultades que plantea la indemnización o no por referencia a la causa de la incapacidad.

\section{M uerte}

En casos de muerte no se exige generalmente que el fallecimiento ocurra dentro de un plazo dado a partir del accidente, lesión o enfermedad; puede dar lugar a indemnización aunque ocurra muchos años después de la terminación del empleo en que se causó. L a muerte a consecuencia de una autolesión no es generalmente indemnizable, pero el suicidio es indemnizable en ciertas circunstancias; por ejemplo, si la lesión indemnizable debida a causas ajenas al paciente da lugar a una grave depresión que conduce al suicidio. Se han aceptado algunas reclamaciones por suicidio tras la negociación con la autoridad que concede la indemnización.

\section{Causas múltiples de incapacidad}

Con frecuencia surgen controversias cuando la incapacidad ha sido consecuencia de los efectos combinados de un acontecimiento o circunstancia del empleo y de un acontecimiento 0 circunstancia que no guarda relación con el empleo. U n ejemplo notable es el cáncer de pulmón debido a los efectos combinados de la contaminación industrial y del consumo de tabaco. En muchas jurisdicciones, el reclamante tiene derecho a indemnización si el empleo ha contribuido significativamente a la incapacidad, a pesar de haber concurrido factores no relacionados con el empleo. Algunas veces exigen que el órgano decisor determine la causa predominante o primaria; pero en tal caso el resultado es arbitrario si la realidad es que la incapacidad no habría ocurrido o no se sabe con seguridad si habría ocurrido en ausencia de una de las causas.

En algunas jurisdicciones existen normas sobre distribución de responsabilidades; en tal caso, el reclamante tiene derecho a indemnización, pero sólo a un nivel reducido de prestaciones. Estas disposiciones dificultan la decisión, principalmente porque de ordinario no hay ningún modo científico de saber en qué proporción debe atribuirse la incapacidad a las diferentes causas. 0 tra dificultad consiste en que las prestaciones resultantes pueden ser inferiores a las que concede la seguridad social, a las que el reclamante tendría derecho de no haber reclamación de indemnización por accidente de trabajo. De ahí que el reclamante, para evitar las molestias de la reclamación de indemnización, quizá opte por solicitar y recibir prestaciones de la seguridad social. En tal caso, el coste de la incapacidad laboral se traslada del sistema de indemnización por accidentes de trabajo a los gastos públicos generales.

Cuando una de las causas concurrentes de una incapacidad es la sensibilidad o una situación previa del reclamante, éstas suelen ser tan irrelevantes para el nivel de indemnización como para la admisibilidad. Tal solución puede parecer justa si la indemnización es igual a lo que el reclamante podía ganar en la situación previa. No obstante, la sensibilidad o la situación previa también pueden ser relevantes para la duración de las prestaciones. Cuando la situación previa se agrava a causa de un acontecimiento o de la exposición durante el empleo, puede haber lugar a una incapacidad indemnizable, pero si el agravamiento es transitorio, el derecho a indemnización termina al concluir éste.

Cuando alguna circunstancia de un empleo contribuye a la producción de una incapacidad, ésta es generalmente indemnizable aun cuando el reclamante ya fuera alérgico a la misma. Cuando alguna circunstancia de un empleo causa una alergia que no padecía antes el trabajador, todos los períodos posteriores de incapacidad causada por reacciones alérgicas suelen ser indemnizables, sin perjuicio de si la reacción alérgica subsiguiente ha sido desencadenada por algo relacionado o no con el empleo. Así, en las jurisdicciones en que la exigencia etiológica crítica es que el empleo haya sido una causa concurrente significativa, basta para la indemnización con que el empleo cause la alergia o desencadene la reacción.

\section{Incapacidades sobrevenidas}

C uando una incapacidad es indemnizable, cualquier otra incapacidad posterior derivada lo es también. Por ejemplo, cuando se infecta una lesión indemnizable, cualquier enfermedad derivada de la infección es indemnizable. Cuando un trabajador sufre una incapacidad indemnizable sometida a tratamiento médico y éste causa otra incapacidad, también ésta es indemnizable. Por ejemplo, si un demandante se cae por la escalera de una clínica 
de rehabilitación mientras recibe tratamiento, cualquier lesión resultante de esa caída se considera generalmente indemnizable. En cambio, cuando la conexión entre las incapacidades originaria y sobrevenida es indirecta, las opiniones se dividen. Por ejemplo, si la segunda lesión es consecuencia de un accidente de tráfico cuando se dirigía a un centro de rehabilitación, es indemnizable en algunas jurisdicciones, pero no en otras.

Cuando la incapacidad consiguiente es muy distante en cuanto al tiempo, el lugar o la conexión causal, quizá se considere demasiado remota para ser indemnizable. Supongamos que un reclamante ha sufrido una amputación indemnizable de una pierna. Diez años después, es arrollado por un vehículo a motor durante las vacaciones. Puede argumentarse que habría evitado el segundo accidente de no haber sido por la prótesis, por lo que la segunda incapacidad es consecuencia de la primera. Aun cuando se establezca la conexión causal, probablemente se concluirá que esta última incapacidad es "demasiado remota" para ser considerada consecuencia indemnizable de la amputación. Asimismo, si la amputación de la pierna da lugar a una pensión medida por el grado de deterioro físico, uno de los factores que se tiene en cuenta al establecer el porcentaje es la limitación del movimiento corporal. Si ésta da lugar a una nueva indemnización por causar una pérdida monetaria reconocida, puede argumentarse que el reclamante estaría recibiendo indemnización dos veces por el mismo motivo.

\section{Pérdidas indemnizables}

L os tipos más comunes de pérdidas indemnizables son las económicas. Así, las prestaciones más comunes son las de asistencia médica e indemnización por pérdida de ingresos o de capacidad de ganancias, pero muchas jurisdicciones pagan también prestaciones por el deterioro físico o mental y por la desfiguración, independientemente de las consecuencias económicas. De ordinario se excluyen los daños a los bienes, pero es frecuente el pago de una indemnización por desperfectos en gafas, dentaduras 0 prótesis. Algunas jurisdicciones indemnizan por daños causados a las prendas de vestir.

\section{Incapacidades múltiples}

Cuando un reclamante padece dos o más incapacidades indemnizables con la misma fecha de comienzo, generalmente se agregan para el cálculo de la indemnización, pero el total a pagar no debe exceder de lo que se pagaría por incapacidad total. Cuando se producen en diferentes ocasiones dos 0 más incapacidades indemnizables, normalmente se tratan como reclamaciones separadas. Las prestaciones se calculan de forma independiente para cada una de ellas, pudiendo tener como referencia diferentes salarios previos. Por tanto, un trabajador puede optar a prestaciones simultáneas por dos o más reclamaciones. Esto es habitual, por ejemplo, cuando, estando recibiendo una pensión por incapacidad permanente parcial, a la vuelta al trabajo, el trabajador sufre otra lesión que le causa una incapacidad total transitoria. Sólo en algunas jurisdicciones hay un máximo aplicable al total combinado de prestaciones que pueden recibirse.

Cuando un reclamante padece dos o más incapacidades, no todas ellas indemnizables, pueden plantearse problemas al decidir qué pérdidas son atribuibles a cada una de ellas. $G$ eneralmente no se plantea problema alguno en este caso cuando la incapacidad indemnizable es la más reciente. Los principios generales suelen exigir el pago de una indemnización por la pérdida de ganancias si antes de la incapacidad indemnizable el reclamante estaba trabajando con una incapacidad no indemnizable. Cuando se supone que la indemnización ha de pagarse por referencia a la pérdida efectiva de ganancias y la incapacidad no indemnizable es la más reciente, puede haber dificultades al decidir sobre si la incapacidad indemnizable es efectivamente causa en relación con cualquier ausencia de trabajo.

\section{Objeciones a las reclamaciones}

L as objeciones más comunes son las relacionadas con el hecho de que el reclamante no haya cumplido uno o más de los requisitos. Aun habiéndolos cumplido todos, puede haber motivos de impugnación. Como los regímenes de indemnización por accidentes de trabajo se han creado en general para evitar la investigación de la prueba de culpabilidad, cualquier alegación de que la incapacidad es consecuencia de la negligencia del reclamante será irrelevante, lo mismo que cualquier alegación de que la causa de la incapacidad estaba fuera del control del empresario.

Las autolesiones no son indemnizables. Generalmente se excluyen de la definición de lesión o accidente indemnizable, pero a veces hay una prohibición explícita. Para que una lesión quede excluida, ha de haber sido causada deliberadamente por el reclamante. No se excluyen las situaciones en que el trabajador se ha colocado deliberadamente en la situación de riesgo que le produjo la lesión.

A lgunas jurisdicciones disponen que la conducta indebida del reclamante es o puede ser un obstáculo a la reclamación, pero en la mayoría de los casos esta alegación sólo es utilizable en casos excepcionales. Para evitar la investigación rutinaria de la prueba de culpabilidad, esta excepción se limita de varias maneras. En algunas jurisdicciones sólo se aplica si la conducta indebida es penal o grave, y en otras, si es seria y deliberada. En ciertas jurisdicciones se dispone la inaplicación de la excepción en caso de muerte 0 cuando la incapacidad es grave o permanente. En otras, para que sea aplicable se exige que la conducta indebida sea la "causa única" de la incapacidad; son muy pocas las lesiones que tienen una causa única.

Cuando la conducta indebida impide la presentación de una reclamación, generalmente impide también las prestaciones, si bien algunas jurisdicciones permiten el pago de prestaciones reducidas aun habiendo una conducta indebida.

U na explicación de la resistencia a permitir las alegaciones de conducta indebida es que, en casos graves o de muerte, pueden sufrir personas inocentes a cargo del trabajador. En casos de lesiones leves, al permitir la alegación de conducta indebida se impediría alcanzar el objetivo de ahorro de costes en la adjudicación, ya que la mayoría de los regímenes no están preparados para realizar investigaciones de pruebas en las decisiones iniciales. Por tanto sería inconveniente permitir alegaciones de conducta indebida si el sistema no está preparado para su valoración adecuada.

A veces se ha paralizado una reclamación por entender que la conducta indebida del trabajador implicaba una situación no producida durante el empleo, pero no parece tratarse de un motivo razonable. De no tomarse muchas precauciones, puede tener el efecto de impedir una reclamación por conducta indebida en circunstancias en las que no son aplicables las limitaciones legales a esa excepción. Este punto puede ilustrarse con casos de lesiones resultantes de peleas amistosas. U n trabajador lesionado en una pelea de este tipo no está en una situación ajena al empleo si no deseaba participar, si no se había desviado sustancialmente de la actividad productiva, si la pelea amistosa era un fenómeno normal del curso ordinario del empleo o si era simplemente una manera más divertida de hacer el trabajo. En cambio, si el trabajador se desvía totalmente de la actividad productiva, si inicia la pelea o participa voluntariamente en ella, puede ser legítimo decidir que la lesión no tiene su causa en el empleo. En otras circunstancias, una reclamación sólo puede impedirse por pelea amistosa si se han cumplido los criterios establecidos sobre conducta indebida. 
En algunas jurisdicciones excluyen la reclamación si la incapacidad tiene su causa en la intoxicación del trabajador con alcohol o drogas. Tal excepción puede no aplicarse a todas las reclamaciones. Por ejemplo, en casos de muerte. En otras jurisdicciones, la intoxicación es generalmente irrelevante, salvo que se considere una conducta indebida, caso en el cual la impugnación está sujeta a las limitaciones aplicables a ésta.

A lgunas jurisdicciones puede impedirse una reclamación si la incapacidad es consecuencia del incumplimiento por el trabajador de las normas sobre salud y seguridad en el trabajo o de las normas sobre seguridad dictadas por la empresa. No obstante, esta excepción puede socavar el incentivo de las empresas a introducir medidas adecuadas de protección de la salud y seguridad en el trabajo. Si una empresa puede establecer reglas, o promover el establecimiento de reglas, que exijan que los trabajadores respeten las medidas de seguridad para protegerse frente a las situaciones de peligro, la inadmisión de una reclamación por incumplimiento del trabajador de las normas de salud y seguridad reduce el incentivo a evitar o minimizar los riesgos mediante una planificación empresarial adecuada. Un problema relacionado es que la conducta de los trabajadores es autónoma hasta cierto punto, pero está condicionada también por las decisiones de la empresa. Es, pues, difícil introducir esta excepción y no tener que realizar investigaciones sobre culpabilidad. Q uizá por estos motivos no se ha generalizado.

En algunas jurisdicciones puede impedirse una reclamación por enfermedad a causa de declaraciones fraudulentas hechas previamente por el trabajador. Estas disposiciones plantean problemas prácticos. En particular, es difícil probar que una declaración ha sido hecha fraudulentamente si el trabajador se ha limitado a firmar un impreso en una ocasión en que no era de esperar que tuviera ese resultado.

A veces se alega que un trabajador es propenso a la incapacidad en que incurre, pero este aspecto es generalmente irrelevante.

En algunas jurisdicciones, los padres de un niño fallecido no pueden optar a indemnización si el trabajo infringía las normas sobre trabajo de menores.

N ormalmente es también irrelevante la percepción de prestaciones de otra fuente. L os regímenes de indemnización por accidentes de trabajo suelen ser los primeros obligados al pago, por lo que el derecho a las prestaciones de otra fuente no opera como una excepción. No obstante, en algunas jurisdicciones hay disposiciones sobre reducción de las correspondientes prestaciones si se perciben algunas de otra fuente.

El impago de las cuotas por la empresa no representa un obstáculo a una reclamación en los regímenes de seguros sociales. En los regímenes administrados por compañías de seguros, el impago de las primas puede extinguir la responsabilidad del asegurador, dejando al reclamante únicamente con un derecho frente a la empresa.

Cuando es válida una objeción a una reclamación, suele tener el carácter de exclusión total del derecho. No obstante, algunas jurisdicciones disponen que ciertas objeciones tengan como efecto la reducción de las prestaciones. Por ejemplo, algunas jurisdicciones disponen que la conducta indebida de un trabajador tenga el efecto de hacerle perder el derecho a las prestaciones monetarias durante un período inicial de una semana o dos.

\section{Conducta indebida de la empresa}

En la mayoría de las jurisdicciones, la conducta indebida de la empresa es irrelevante para la validez de una reclamación, salvo su posible aportación como prueba general de si la incapacidad ha sido consecuencia del empleo. En cambio, en otras se pagan prestaciones adicionales o niveles más elevados de prestaciones en tal caso. Algunas de estas disposiciones son de carácter estricto, refiriéndose únicamente a la conducta criminal, a la negligencia "grave" o a una conducta indebida grave o deliberada. O tras son de carácter más amplio, refiriéndose a negligencia o incumplimiento de las normas sobre salud y seguridad en el trabajo. Todas ellas forman parte del régimen de indemnización por accidentes de trabajo y no tienen relación con la "responsabilidad de la empresa" (que se expone en la parte II). Pueden ser objeto de las mismas objeciones que las relativas a la conducta indebida de los trabajadores, es decir, dar lugar a una investigación en busca de pruebas en un sistema llamado a funcionar en lo posible sin tales investigaciones. Por tal motivo, algunas jurisdicciones limitan el ámbito de esas disposiciones a los casos en que la empresa ha sido condenada por un tribunal penal.

En las jurisdicciones en las que puede impedirse una reclamación por intoxicación del trabajador o por incumplimiento deliberado por éste de las normas de seguridad, se dispone a veces que la excepción no se aplique si puede demostrarse la existencia de culpa de la empresa.

\section{Asistencia médica}

En algunas jurisdicciones, las incapacidades resultantes del empleo son tratadas de la misma manera que las restantes incapacidades en el régimen público de asistencia médica. En otras, el régimen de indemnización por accidentes de trabajo concede ayuda médica específica. Esta puede ser amplia, incluidas la asistencia de personal médico y otros profesionales sanitarios, la asistencia hospitalaria, y asimismo cirugía, prótesis, aparatos, medicamentos, asistencia odontológica, calzado ortopédico y tratamientos necesarios para la rehabilitación. Cuando un reclamante tiene derecho a una prótesis u otro aparato a causa de una incapacidad permanente, se presta el servicio subsiguiente y se le abona la sustitución de los mismos. En general, la ayuda médica se presta de manera totalmente gratuita, aun cuando las prestaciones monetarias vinculadas a las pérdidas económicas sean mayores que las retribuciones dejadas de percibir. De ahí que en algunas jurisdicciones la cobertura de la ayuda médica en la indemnización por accidentes de trabajo sea incluso más amplia que la cobertura del régimen público general. En países que no cuentan con un régimen público de asistencia sanitaria, la ayuda médica prestada en casos de indemnización por accidentes de trabajo puede mostrar un fuerte contraste con aquélla y con la cobertura del seguro médico de que disponen en otro caso los trabajadores. No obstante, en algunas jurisdicciones hay restricciones a la ayuda médica que puede prestarse. Por ejemplo, a veces se excluyen los tratamientos que se consideren "experimentales".

Normalmente se cubren los gastos de viaje y los demás en que incurra el reclamante para recibir asistencia médica, pero en muchos regímenes se limita esa suma a los gastos de utilización del transporte público, salvo que éste no exista o sea inadecuado.

Algunas jurisdicciones disponen de hospitales, clínicas de rehabilitación u otras instalaciones de asistencia sanitaria específicas para la indemnización por accidentes de trabajo. En otro caso, los servicios se prestan en los mismos hospitales y por el mismo personal que los demás casos. La única diferencia, en tal caso, quizá esté en las fuentes de pago. No obstante, a veces hay también diferencias adicionales. Por ejemplo, es posible que un organismo de indemnización por accidentes de trabajo contrate con un hospital general los servicios de este tipo.

Normalmente, para recibir ayuda médica no se exige que el reclamante esté impedido de trabajar o que tenga derecho a prestaciones monetarias. Así, una gran proporción de las reclamaciones de indemnización por accidentes de trabajo 
únicamente se refieren a ayuda médica. En las jurisdicciones que utilizan el baremo según la experiencia, no comunicar las lesiones laborales al organismo encargado de la indemnización por accidentes de trabajo 0 al asegurador da lugar a veces a que la asistencia médica se presta en el marco del régimen general de asistencia sanitaria, y no del régimen específico de accidentes de trabajo.

N ormalmente, la obligación de prestar ayuda médica corresponde al asegurador (sea un organismo público o una compañía de seguros), pero de ordinario esa obligación le incumbe a la empresa en la fase inicial de la lesión, como ocurre con los primeros auxilios y con el transporte en ambulancia a un hospital. En general, los pagos por ayuda médica son efectuados directamente por el asegurador a quien realiza el tratamiento 0 presta el servicio. En la mayoría de las jurisdicciones se considera inapropiado exigir que el reclamante pague y después pida el reembolso. Tal solución podría plantear un problema económico a las personas cuyos ingresos se han reducido precisamente a causa de su incapacidad, así como facilitar la sobrefacturación por la entidad prestadora del servicio, quedando así atrapado el reclamante, que se vería obligado a soportar el exceso de costes.

En los regímenes administrados por las compañías de seguros y aquéllos en que la asistencia médica se regula por las leyes del mercado y no está supeditada a otros controles, se exige en ocasiones a los reclamantes de indemnización por accidente de trabajo que reciban la asistencia en una serie limitada de hospitales u otras instalaciones sanitarias, o se les limita la posibilidad de elegir el médico.

Algunas jurisdicciones establecen que las prestaciones de indemnización pueden 0 deben suspenderse 0 terminarse cuando el reclamante se niega injustificadamente a aceptar el tratamiento médico que se le ofrece; no obstante, tales disposiciones sólo son relevantes en casos muy excepcionales, en los que la negativa equivale a una autolesión. La legislación sobre indemnización por accidentes de trabajo generalmente no pretende suprimir la elección de asistencia sanitaria por el paciente 0 negar el derecho humano básico a la aceptación del tratamiento. Por otra parte, al menos en algunas jurisdicciones, los organismos de indemnización tienen más interés en prevenir el uso excesivo que el uso insuficiente de medicamentos y de la cirugía.

En algunas jurisdicciones existen límites temporales o territoriales a la prestación de ayuda médica. En otras, ésta es prestada según se requiera durante la vida del trabajador, independientemente del cambio del país de residencia. En ellas, este rasgo distingue la ayuda médica concedida por la indemnización por accidentes de trabajo de la cobertura concedida por los regímenes públicos generales de asistencia sanitaria.

\section{Pagos en dinero}

\section{Nivel salarial}

El cálculo de la indemnización monetaria comienza habitualmente por la fijación de un nivel de ganancias o salario de referencia en la reclamación. N ormalmente se trata del salario bruto del trabajador (incluidas las horas extraordinarias) en el momento de la incapacidad, o las retribuciones medias percibidas durante un período precedente que oscila normalmente entre cuatro semanas y tres años. A continuación se fija el nivel de indemnización por referencia a dichos salarios o retribuciones. A veces, el nivel salarial se establece por referencia al salario medio en un sector 0 al promedio nacional, si bien estas normas sólo se aplican en situaciones excepcionales.

A diferencia del proceso de indemnización por daños en las reclamaciones por responsabilidad de la empresa, la fijación del nivel salarial no suele implicar ninguna especulación acerca de los cambios que habrían experimentando las ganancias del trabajador en el futuro de no haber sido por la incapacidad. No obstante, en los casos de incapacidad prolongada y permanente, normalmente se especifica que, cuando el trabajador es un aprendiz o estudiante, el nivel salarial se revaloriza en función de las ganancias básicas de su carrera.

De ordinario, existen reglas detalladas para el cálculo de las ganancias previas; en ellas se regula, por ejemplo, si deben convertirse a ganancias la alimentación y el alojamiento gratuitos proporcionados por la empresa, si deben excluirse 0 modificarse las ganancias concurrentes de otros empleos y del trabajo autónomo, o si deben ajustarse a una media anual las ganancias del empleo estacional.

Algunas enfermedades dan a veces lugar a una erosión gradual de la capacidad de obtención de ganancias, en cuanto que implican el paso del trabajador a un empleo de menor nivel y peor pagado. Si no se presenta una reclamación hasta el cese total del trabajo, la pérdida no se compensa si se utiliza el nivel inmediatamente precedente de ganancias como nivel salarial en la reclamación. Para abordar este problema, algunas jurisdicciones disponen que el nivel salarial se fije por referencia a las ganancias de otros trabajadores de la misma ocupación.

Cuando la cobertura se aplica a un trabajador por cuenta propia, el nivel salarial queda normalmente establecido en el momento en que se concierta la cobertura. En las jurisdicciones en que los trabajadores por cuenta propia sólo quedan cubiertos si aś lo solicitan, puede permitirse a los reclamantes fijar el nivel salarial, dentro de un mínimo y un máximo y con derecho a rechazo de la solicitud si el salario fijado no se ajusta a las ganancias potenciales. EI nivel establecido en el momento de la cobertura se utiliza luego para calcular la prima, así como las prestaciones en caso de incapacidad indemnizable.

En algunas jurisdicciones, el nivel salarial permanece fijo mientras dura la prestación. En otras está sujeto a cambio transcurrido un período especificado. Normalmente, el cambio se justifica en caso de incapacidades prolongadas y permanentes, a fin de que el nivel salarial refleje períodos prolongados de ganancias medias anteriores a la incapacidad. C on ello se facilita la inclusión de ganancias de todas las fuentes, para tener en cuenta las variaciones a lo largo del tiempo y las variaciones estacionales y de otra clase en la continuidad del empleo.

Normalmente, el salario de referencia refleja las ganancias brutas medias del trabajador (excluyendo las cotizaciones de la empresa), pero en algunas jurisdicciones en las que las prestaciones por indemnización no son renta imponible, el nivel salarial se ajusta a unas ganancias "netas" teóricas para después obtener el nivel de la indemnización. El "neto" teórico es la suma bruta menos las sumas pagadas por el impuesto sobre la renta y otros pagos fiscalmente deducibles a fondos públicos.

\section{Nivel de indemnización}

Para pasar del salario de referencia al de indemnización suele utilizarse una fórmula: en general, un porcentaje del salario o de los ingresos "netos" teóricos obtenidos del salario. N ormalmente, la cifra resultante es menor que las ganancias perdidas, considerando que la diferencia representa la contribución del trabajador al coste de la incapacidad laboral. Esta justificación es dudosa si se tiene en cuenta que la prima, o cuota, es hasta cierto punto un coste de oportunidad de la mano de obra. M ás realista es pensar que la diferencia entre el salario y la indemnización representa un incentivo al trabajador lesionado para que retorne al trabajo. A tal fin se considera normalmente suficiente una diferencia del $10 \%$. Tal justificación no es válida en las incapacidades de carácter grave o permanente. 


\section{El tope máximo}

Generalmente se establece un tope máximo tanto para el salario de referencia como para el de indemnización. Como justificación se aduce que los trabajadores con ganancias por encima del tope podrían, si lo desearan, asegurar esas ganancias suscribiendo ellos mismos las pólizas del seguro de accidentes y de enfermedad. No obstante, tal justificación nunca ha estado acorde con la realidad. En el mercado no hay pólizas utilizables por los trabajadores industriales que paguen prestaciones que compensen la pérdida de los niveles más altos de ganancias durante la incapacidad.

Cuando el nivel salarial está sujeto a un tope y un trabajador sufre una incapacidad indemnizable con pérdida de ganancias, pero quedando aún ganancias por encima del tope, puede pensarse que la situación es injusta para el trabajador que sufre una pérdida de salario tras una incapacidad laboral y no está recibiendo indemnización. El problema puede evitarse aplicando el tope al nivel de indemnización o compensando en relación con el grado de deterioro físico independientemente de la pérdida efectiva de ganancias o no imponiendo tope alguno.

0 tro problema que plantea el tope sobre el salario de referencia consiste en que suele utilizarse también para establecer el nivel de ganancias sobre el que han de pagarse las primas 0 cuotas. Por ejemplo, si el tope es de 50.000 unidades monetarias por año, esto significa que el nivel máximo de indemnización será un porcentaje de 50.000 unidades por año. La prima 0 cuota pagada por la empresa será un determinado porcentaje de la nómina, pero con un tope de 50.000 unidades por año. Este puede ser uno de los factores que induzcan a la empresa a requerir la realización regular de horas extraordinarias en lugar de incrementar la plantilla. Por tanto, puede considerarse contraproducente en términos de política social, de estrés laboral y de rehabilitación de los trabajadores incapacitados.

\section{Clasificación de las incapacidades}

Algunas jurisdicciones clasifican las incapacidades indemnizables en totales transitorias, parciales transitorias, totales permanentes y parciales permanentes. La misma incapacidad pasa con frecuencia de uno de esos grupos a otro. $\mathrm{H}$ ay jurisdicciones en las que no se utilizan todas estas categorías, sino una variante de las mismas o principios análogos pero sin una clasificación formal de las incapacidades. En los últimos años, determinadas jurisdicciones que en principio indemnizan por referencia a la pérdida efectiva de ganancias han abandonado en absoluto tales clasificaciones.

\section{Incapacidad total transitoria}

La mayoría de las jurisdicciones pagan prestaciones por la incapacidad total transitoria. Además, en esta categoría se incluye la fase inicial de la mayoría de las incapacidades permanentes. En algunas jurisdicciones existe un límite a las correspondientes prestaciones, pero no suele ser así. La prestación se mantiene hasta que el beneficiario logra una recuperación total o parcial, la incapacidad se clasifica como permanente 0 aquél fallece. $\mathrm{E} n$ algunos casos excepcionales, la prestación puede terminarse por descalificación, como ocurre cuando el beneficiario ha abandonado el tratamiento durante el período en que necesitaba atención médica.

Como la gran mayoría de las incapacidades laborales son leves y transitorias, esta prestación se paga sólo durante algunos días en la mayoría de los casos, tiempo demasiado corto en muchas situaciones para que valga la pena preocuparse por la posibilidad de que el caso deba considerarse como parcial transitorio. En algunas jurisdicciones, el nivel de esta prestación se reduce transcurrido un período especificado o por etapas después de dos o más períodos especificados, como tres meses y seis meses. Estas reducciones no son habituales en los países industrializados avanzados.

La prestación comienza usualmente el día siguiente de la incapacidad para el trabajo, pero en algunas jurisdicciones existe un período de carencia de tres días. En ciertos regímenes, la empresa tiene la obligación de pagar esta prestación durante un breve período inicial, pasando a continuación la obligación al asegurador. Estas normas pueden plantear problemas. Por ejemplo, entrañan el riesgo de retrasar la recogida por el asegurador de las pruebas sobre la causa de la incapacidad.

A parte de la indemnización, algunas jurisdicciones exigen que la empresa continúe pagando las ganancias del trabajador incapacitado durante un brevísimo período inicial, comúnmente durante el día en que se produjo la lesión.

\section{Incapacidad parcial transitoria}

Algunas jurisdicciones no utilizan en absoluto esta categoría. 0 tras la emplean cuando el beneficiario ha conseguido ya cierta recuperación y puede realizar algún trabajo, pero no el de su ocupación regular. En la mayoría de los casos no vale la pena utilizar esta categoría, ya que el beneficiario podrá retornar a la ocupación regular, en cualquier caso, en el plazo de algunos días.

En las jurisdicciones que utilizan la puntuación según la experiencia 0 en las que las empresas tienen por otro motivo algún incentivo financiero para invocar esta categoría, hay dificultades de administración y reconocimiento sustanciales al decidir qué tipo de trabajo se adapta a la condición actual del beneficiario. El miedo al abuso del sistema suscita resistencia a dejar que sea el trabajador el que decida; habría dificultades análogas si se permitiera decidir a la empresa. Al tomar la decisión, se plantea el problema de que acaso los conflictos sobre cuál es el trabajo adecuado para una situación médica particular no puedan resolverse justa y eficientemente sin una investigación. La mayoría de los regímenes no están preparados para realizar una investigación rápida, y algunos no la realizan en absoluto, excepto en caso de recurso. Las decisiones tomadas en estas cuestiones con carácter perentorio son causa de daños terapéuticos, así como de injusticia y derroche. Pueden asimismo provocar en la relación de empleo una tensión que cree impedimentos para la rehabilitación. En parte por estos motivos, algunas jurisdicciones prefieren evitar o minimizar el uso de esta categoría.

En los casos clasificados como de incapacidad parcial transitoria, el nivel de prestaciones suele ser un porcentaje de la diferencia entre las ganancias previas del beneficiario y las ganancias actuales o la suma que se considera que podría estar percibiendo (ganancias "supuestas"). En algunas jurisdicciones es obligatorio calcular ese nivel de prestaciones por referencia al grado de deterioro físico, pero tal método es poco realista. EI período durante el cual puede aplicarse esta categoría es normalmente breve y existe la posibilidad de que la gravedad de la incapacidad cambie con tanta rapidez que resulte inviable este método de cálculo. Algunas jurisdicciones no conceden indemnización por incapacidad parcial transitoria si es pequeña la repercusión en la capacidad de ganancias o en las mismas ganancias.

D eterminadas jurisdicciones exigen que el beneficiario resida en ellas como requisito para seguir disfrutando de las prestaciones transitorias. 0 tras sólo exigen la presencia durante el período en que se necesita tratamiento médico.

\section{Incapacidad total permanente}

En muchas jurisdicciones, la incapacidad grave se clasifica como total independientemente de su repercusión en las ganancias 0 capacidad de ganancias. Por ejemplo, la ceguera total, la paraplejía o la pérdida de dos miembros se clasifican generalmente como incapacidades totales permanentes. Como justificación se 
aduce que debe pagarse indemnización por ellas, independientemente de su alcance económico. Se señala también que suelen dar lugar a costes y, por tanto, a pérdidas económicas, independientemente de su repercusión en las ganancias. Q uizá la justificación más importante es que el pago de una pensión fija sin investigación de la pérdida económica preserva la libertad del individuo, alivia la ansiedad y maximiza el incentivo a la rehabilitación. Algunas jurisdicciones conceden un importe a tanto alzado, además de la pensión.

En otros casos, las prestaciones por incapacidad permanente guardan relación con la pérdida de ganancias, por lo que sólo se pagan cuando se estima que esta última será permanente y total. Sobre todo entre los trabajadores de más edad, se tiene en cuenta el alcance económico de la incapacidad, aun cuando sea bajo el grado de deterioro físico. No obstante, en tales casos es frecuente que haya resistencia a reconocer que la pérdida de ganancias a consecuencia de la incapacidad es probablemente permanente y total.

Una vez que un caso es considerado de incapacidad total permanente, puede pagarse una pensión durante toda la vida 0 hasta la edad normal de jubilación, si bien en algunas jurisdicciones la duración es menor. La fórmula para calcular la pensión es unas veces la misma que en las prestaciones por incapacidad total transitoria, y otras veces es diferente. En particular, puede ajustarse el nivel salarial tal como se indicó en el apartado titulado N ivel salarial (véase más arriba).

En los regímenes administrados por las compañías de seguros, el derecho a percibir cantidades periódicas por una incapacidad permanente se sustituye a veces por el cobro de una cantidad a tanto alzado, aunque en algunas jurisdicciones se conceden anualidades.

\section{Incapacidad parcial permanente}

Esta categoría designa la incapacidad permanente no considerada total. Los mismos métodos (que se exponen más adelante) utilizados para estimar el grado de incapacidad parcial se utilizan también comúnmente para distinguir la incapacidad total de la parcial. La indemnización se paga en forma de cantidad a tanto alzado cuando la incapacidad es poco grave y de prestaciones periódicas cuando es grave. Puede pagarse una pensión vitalicia o hasta la edad normal de jubilación, pero en algunas jurisdicciones su duración es más limitada.

Excepto cuando se trata de incapacidades menores, la pensión fija tiene grandes ventajas en comparación con la cantidad a tanto alzado. M ientras que esta última sirve primordialmente para atender a la pérdida futura de ganancias y a algunos de los costes futuros de la incapacidad, aquélla tiene la gran ventaja de que puede pagarse exactamente por la duración de la pérdida. La cantidad a tanto alzado exige estimar la esperanza de vida, y en casi todos los casos esa estimación es errónea. Además, esa cantidad suele gastarse en un tiempo relativamente breve y en tal caso el beneficiario habría de ser mantenido con cargo a los ingresos públicos generales. La pensión fija ofrece la mejor protección para el presupuesto de la seguridad social.

EI cálculo de las prestaciones por incapacidad parcial permanente ha sido el problema más difícil de la historia de la indemnización por accidentes de trabajo. Básicamente, se utilizan tres métodos.

\section{Método del deterioro físico}

Este método ha sido el tradicional y es el más utilizado en las indemnizaciones por accidentes de trabajo, así como en las pensiones militares. La indemnización se calcula por referencia al grado estimado de deterioro físico y mental resultante de la incapacidad. Suelen utilizarse escalas de puntuación que atribuyen porcentajes a una lista de incapacidades. En algunas jurisdicciones se aplica rígidamente la escala vigente. En otras se utiliza como guía. A veces se permiten o se prescriben variaciones. Así ocurre cuando hay algún factor agravante.

El contenido de las escalas suele criticarse por demasiado rígido. Por ejemplo, suele asignarse a las amputaciones un porcentaje que parece alto a la vista de la perfección de las prótesis modernas. Trastornos más sutiles de las funciones corporales reciben comúnmente puntuaciones bajas en comparación con su repercusión en la vida de los beneficiarios. La American M edical Association publica una lista más amplia que es utilizada por algunas jurisdicciones, bien exclusivamente, bien como referencia cuando su escala propia no incluye alguna incapacidad concreta.

Independientemente de cómo se fije el porcentaje, la pensión se calcula aplicando éste a lo que habría recibido el beneficiario de haber sido clasificado como incapacitado total. En las jurisdicciones que utilizan este método, la escala se utiliza también comúnmente para distinguir la incapacidad total de la parcial. Cuando la incapacidad se puntúa por debajo de cierto porcentaje (normalmente, el $10 \%$ ), en lugar de una pensión suele pagarse una cantidad a tanto alzado, que se calcula utilizando el mismo método y convirtiendo después la pensión resultante a un tanto alzado, o por cualquier otro método. Como la gran mayoría de las incapacidades permanentes son menores, la mayoría de las prestaciones por incapacidad parcial permanente adoptan la forma de una cantidad a tanto alzado. Algunas jurisdicciones disponen que las incapacidades menores no sean indemnizables.

El pago de una cantidad a tanto alzado en lugar de una pensión tiene la ventaja de evitar costes administrativos subsiguientes, pero puede plantear un problema en algunas situaciones, como ocurre cuando un trabajador sufre sucesivas incapacidades menores que, debido a su repercusión, se convierten en acumulativas. $\mathrm{H}$ ay riesgo de que se llegue a una incapacidad importante sin derecho a pensión. Un problema análogo se plantea cuando se ha concedido una cantidad a tanto alzado por una incapacidad menor que posteriormente se agrava. Si el deterioro es gradual, pueden concederse cantidades sucesivas por la misma incapacidad; también en este caso, el resultado final puede ser una incapacidad sustancial sin opción a pensión. Anticipándose a este problema, algunas jurisdicciones insisten en la pensión, no en la cantidad a tanto alzado, aun tratándose de una incapacidad menor, si el estado es inestable o se considera propenso al deterioro.

En cuanto a las incapacidades que no figuran en la escala, la mayoría de las jurisdicciones adoptan una de las cuatro posiciones siguientes.

1. Se establece un porcentaje por extrapolación de la escala, utilizando las cifras de ésta como punto de referencia.

2. Se utiliza alguno de los restantes métodos de cálculo (que se describen más adelante).

3. No se conceden prestaciones fuera de las concedidas por incapacidad transitoria, aun cuando éstas sigan.

4. Se paga la pensión hasta que se cumpla un plazo especificado, aun continuando después la incapacidad y las pérdidas consiguientes.

U na gran ventaja del método del deterioro físico es que maximiza el incentivo a la rehabilitación, a la vez que preserva su voluntariedad y las libertades civiles del beneficiario. En las jurisdicciones que tienen fijado un tope al nivel salarial, este método tiene además la ventaja de que se paga la pensión aunque no haya habido pérdida de ganancias por debajo del tope. 
Como la prueba de pérdida efectiva de ganancias es irrelevante en este método, la pensión se paga aun cuando no haya existido tal pérdida. Se considera que vale la pena pagar este precio para maximizar el incentivo a la rehabilitación y evitar las demás desventajas (más abajo mencionadas) del cálculo de la indemnización por referencia a la pérdida efectiva de ganancias. Además, los casos en que no parece haber pérdida de ganancias suelen ser aquéllos en que el beneficiario continúa trabajando en la misma empresa. La repercusión económica de la incapacidad puede ser más grave si el beneficiario ha de buscar después empleo en el mercado libre. Por otra parte, la pensión concedida por este método es generalmente la única compensación por las pérdidas no monetarias, y su justificación es independiente de cualquier pérdida efectiva de ganancias.

L as pensiones concedidas por este método están sujetas a revisión a solicitud del beneficiario en caso de deterioro de la situación. En algunas jurisdicciones, también pueden revisarse a iniciativa de la Autoridad pagadora, del asegurador o de la empresa cuando se ha curado la incapacidad. Se trata de un caso raro, ya que las incapacidades no se clasifican generalmente como permanentes hasta que deja de haber una perspectiva realista de cura. Con todo, puede suceder que la investigación médica obtenga un remedio desconocido anteriormente.

Este método se abandona a veces en favor del método de la pérdida efectiva de ganancias (más abajo mencionado), pero en ocasiones se vuelve a él cuando se descubren las dificultades e injusticias resultantes en otro caso.

\section{Método de la pérdida prevista de ganancias}

Se trata de otro método para fijar una pensión fija, que se utiliza en algunas jurisdicciones. La pensión se calcula estimando el alcance en que probablemente se reducirán a largo plazo las ganancias del beneficiario a causa de la incapacidad indemnizable. En la mayoría de los casos, el beneficiario habrá retornado al empleo en el momento en que se haga el cálculo, por lo que pueden utilizarse como punto de partida las ganancias actuales. $\mathrm{H}$ ay que considerar si éstas son mayores o menores que las ganancias potenciales a largo plazo. Si el beneficiario no ha retornado al empleo, el cálculo puede ser más difícil; pero como en ese caso sólo hay que hacerlo una vez, puede recurrirse a una investigación probatoria u otro método que pueda resultar más apropiado. Los datos estadísticos no sirven gran cosa. No deben utilizarse exclusivamente o como prueba primaria; si se emplean, pueden dar lugar a un error de hecho.

Al igual que el método del deterioro físico, éste preserva el incentivo a la rehabilitación, su voluntariedad y las libertades civiles del beneficiario. Además, la pensión concedida está sujeta a revisión en caso de deterioro de la situación, aunque no por pérdida efectiva de ganancias. Se evitan, por tanto, la mayoría de los problemas (más abajo mencionados) del método de la pérdida efectiva de ganancias. Como no se tienen en cuenta los gastos ocasionados por la incapacidad ni las pérdidas no monetarias, puede utilizarse en combinación con otras prestaciones.

\section{Método de la pérdida efectiva de ganancias}

Con este método, utilizado en algunas jurisdicciones, no se concede pensión fija alguna. Las prestaciones periódicas se ajustan a la pérdida efectiva estimada de ganancias a consecuencia de la incapacidad. Están sujetas a variación según cambie la pérdida efectiva estimada de ganancias. En algunas jurisdicciones, se revisan cuando hay algún cambio de éstas; en otras, se revisan a intervalos fijos, por ejemplo anualmente.

U no de los problemas que plantea este método es la dificultad de estimar sistemáticamente la repercusión de la incapacidad indemnizable en las ganancias del beneficiario en comparación con la repercusión de otros factores, como las incapacidades posteriores, el envejecimiento natural, el cambio tecnológico o los cambios políticos o económicos que afecten al mercado de trabajo.

0 tro problema importante deriva del riesgo de que un beneficiario gane menos de lo que podría haber ganado. Normalmente se "supone" que cada beneficiario está ganando lo que se considera capaz de ganar. Esta "suposición" es una de las principales causas de injusticia y resentimiento en la historia de la indemnización por accidentes de trabajo. Aun cuando tal suposición se pretenda aplicar sólo a modo de excepción, termina por convertirse en rutinaria cuando se utiliza el método de la pérdida efectiva de ganancias. Se "supone" que los beneficiarios son capaces de ganar en un "puesto de trabajo fantasma", es decir, en un puesto de trabajo que no ocupan. Esa misma "suposición" se aplica cuando el beneficiario se niega a aceptar un puesto de trabajo por motivos sanitarios o morales. En ese momento se terminan las prestaciones de indemnización, aunque continúen la incapacidad y las consiguientes pérdidas económicas. En las jurisdicciones en las que se aplica este método, las prestaciones periódicas son normalmente la única compensación que recibe el beneficiario por las pérdidas económicas resultantes de la incapacidad permanente. La legislación no dispone que sean temporales, pero éste suele ser el resultado práctico de la "suposición".

Este método da lugar a otra injusticia, derivada de la forma en que trata la promoción laboral. Con un régimen de pensión fija, el beneficiario pierde el beneficio de la promoción laboral en la ocupación que tenía antes de la enfermedad, pero retiene el beneficio de cualquier posible promoción en ocupaciones posteriores. Con el método de la pérdida efectiva de ganancias, pierde el beneficio de cualquier promoción laboral, tanto en la ocupación previa a la situación de incapacidad como en cualquier otra ocupación posterior.

La "suposición" presiona asimismo al trabajador para que tome las medidas de rehabilitación recomendadas (o impuestas) por el organismo que concede la indemnización, independientemente de que coincidan con sus aspiraciones de rehabilitación, por lo que se pierde la voluntariedad de la rehabilitación y pueden deteriorarse las libertades civiles del beneficiario. Puede perderse, por ejemplo, incluso el derecho humano básico a trasladarse a otro país. U nicamente por este motivo, el uso del método puede dar lugar a una grave injusticia cuando queda incapacitado un trabajador migrante.

Este método causa asimismo recelo acerca de la rehabilitación y en consecuencia puede ser desincentivador. Si el éxito en curso no garantiza las oportunidades de empleo, los beneficiarios algunas veces temen coger el empleo, por miedo al fracaso. El riesgo está en que la terminación del empleo puede en ese caso atribuirse a motivos distintos de la incapacidad y en que no continúen las prestaciones periódicas.

0 tro problema serio de este método es la imposibilidad, en muchos casos, de tomar las decisiones pertinentes de manera justa sin una investigación de los hechos. Sin embargo, la investigación no suele ser viable dado el volumen de decisiones que han de tomarse cuando las prestaciones periódicas están sujetas a cambios periódicos.

\section{Variantes e híbridos}

Son muchas las variantes de estos métodos; algunas jurisdicciones utilizan una combinación de los mismos, un método híbrido de los tres descritos. Por ejemplo, se concede una pensión por el método de la pérdida prevista de ganancias, pero sometiéndola a revisión en dos ocasiones, por ejemplo, dos años después de la evaluación inicial y de nuevo a los cinco años. Con ello puede corregirse cualquier proyección que resulte errónea, si bien existen serias desventajas. Se prolonga la inseguridad y, si un 
beneficiario es propenso a neurosis de indemnización o a cualquier otra forma de ansiedad, la situación puede agravarse. Se prolongan asimismo los desincentivos al éxito en la rehabilitación laboral. Caben asimismo las demás objeciones ya dirigidas al método de pérdida efectiva de ganancias, como la referente al deterioro del derecho básico a la libre circulación.

\section{Personas a cargo}

Como las prestaciones de indemnización en casos no de muerte tienen normalmente relación con las ganancias, no es común que haya variaciones por las personas a cargo, si bien en algunas jurisdicciones se conceden por este motivo prestaciones complementarias.

En las jurisdicciones en que las prestaciones se consideran renta imponible, la existencia de personas a cargo puede influir en la suma neta recibida, de la misma forma que influiría en la suma neta de salarios recibida. En las jurisdicciones en que las prestaciones no constituyen renta imponible, pero el nivel de indemnización es un porcentaje de las ganancias "netas" estimadas, a veces se cuentan las personas a cargo al estimar el nivel del impuesto sobre la renta que habría que haber pagado por los salarios, influyendo de esta manera en el nivel de indemnización.

\section{Desfiguración}

Muchas jurisdicciones conceden indemnización por desfiguración, en particular de la cara. En algunos casos se trata de un tanto alzado, independientemente de la indemnización por pérdida de ganancias. En otros, la desfiguración es un factor a considerar al calcular el tanto alzado o la pensión por incapacidad parcial permanente.

\section{Dolor y padecimientos}

A diferencia del sistema de responsabilidad de la empresa, los regímenes de indemnización por accidentes de trabajo no suelen conceder indemnización específicamente por el dolor, los padecimientos, la pérdida de esperanza de vida, la pérdida de disfrute de la vida 0 la pérdida de actividad social. Con todo, estas pérdidas se compensan hasta cierto punto. Cuando se utiliza el método del deterioro físico para calcular una pensión por incapacidad permanente, la pensión se paga normalmente con independencia de cualquier pérdida de ganancias. Parece, pues, ser una compensación por las pérdidas tanto no monetarias como monetarias. En las jurisdicciones en que se supone que la indemnización por incapacidad permanente se paga por referencia a la pérdida efectiva de ganancias, hay a veces una prestación independiente por la misma incapacidad, es decir, por las pérdidas no monetarias. Esta prestación adopta normalmente la forma de una cantidad a tanto alzado, pero en algunas jurisdicciones y en casos muy graves puede ser también una pensión.

\section{Pérdidas económicas indirectas}

Generalmente no se paga indemnización por las pérdidas económicas que son consecuencia indirecta de la incapacidad o del accidente. Por ejemplo, si un trabajador ha pagado por anticipado unas vacaciones y luego sufre una lesión indemnizable que le impide disfrutar de ellas, la pérdida correspondiente no es indemnizable.

\section{Gastos y subsidios}

Es normal que el régimen haga frente a los gastos derivados de una incapacidad indemnizable 0 al menos a parte de ellos. Por ejemplo, a los beneficiarios normalmente se les reembolsan los gastos de reconocimiento médico o los procesos entablados para decidir sobre las reclamaciones. Los gastos irregulares suelen reembolsarse por su coste efectivo, y lo mismo ocurre a veces con los gastos corrientes. En otros casos se paga un subsidio para gastos corrientes. El subsidio para asistencia externa es probablemente el más común e importante. Son corrientes también el subsidio para ropa especial de uso obligado debido a la implantación de prótesis, el complemento de pensión para quienes no acuden al ambulatorio y los "subsidios por inconvenientes" para una amplia gama de incapacidades. U n ejemplo más concreto de aplicación local es el subsidio para combustible sin humo.

\section{Compensación}

Cuando a un beneficiario hay que pagarle en virtud de dos o más conceptos legales, sea por la misma reclamación, sea por diferentes reclamaciones, la regla general es que el derecho es acumulativo. No hay compensación, salvo que así lo disponga la ley. No obstante, a veces las prestaciones acumulativas están sujetas a un máximo global. En ocasiones se establece una excepción cuando se pagan prestaciones alternativas por la misma pérdida. Un ejemplo común es el del beneficiario a quien se concede una pensión por incapacidad parcial permanente y que posteriormente sufre una recurrencia que le causa una incapacidad total transitoria derivada de la misma lesión. Si no se aplica un salario de referencia para el cálculo de las prestaciones transitorias, es normal suspender la pensión mientras se pagan las prestaciones por pérdida de salarios durante la incapacidad total transitoria o continuar con la pensión y reducir las prestaciones transitorias por pérdida de salarios por importe de la pensión.

La misma persona puede optar a prestaciones por una incapacidad indemnizable y a prestaciones como cónyuge superviviente a cargo del trabajador fallecido. U nas y otras conceden derechos independientes. Normalmente no se prevé la compensación, ni se aplica máximo alguno al agregado.

Con relación a las prestaciones de otros regímenes, normalmente otros sistemas de seguros, la indemnización por accidentes de trabajo suele ocupar la posición de primer pagador, por lo que no hay compensación o reducción. A veces, el otro régimen deniega o reduce las prestaciones cuando el beneficiario recibe indemnización por accidente de trabajo. No obstante, en algunas jurisdicciones esta última se reduce por las sumas recibidas al amparo de otros regímenes, normalmente de la seguridad social o de los seguros sociales, o por los pagos concedidos por la empresa.

\section{Daños a los bienes}

Por regla general no se paga indemnización por los daños a los bienes del trabajador, si bien hay excepciones. M uchas jurisdicciones compensan los daños causados a la dentadura, las gafas, los audífonos o las prótesis. Algunas jurisdicciones indemnizan también por los daños a la ropa del trabajador. Cuando se paga indemnización por daños a los bienes, los criterios que se aplican son generalmente los mismos que para las lesiones, aun cuando algunas jurisdicciones exigen que haya un "accidente" para poder reclamarlos si no concurre una reclamación por lesiones.

L as disposiciones mencionadas se refieren a daños a los bienes ocurridos durante el empleo. También hay disposiciones relativas a los daños a los bienes derivados de una incapacidad indemnizable. El ejemplo más común es el del subsidio para ropa (véase Gastos y subsidios, más arriba) que se paga para compensar la ropa especial necesaria por usar una prótesis.

\section{Recurrencias}

Cuando un beneficiario que ha recibido prestaciones por incapacidad transitoria retorna al empleo regular, normalmente terminan aquéllas, si bien es posible que siga recibiendo una pensión u otras prestaciones por incapacidad residual. En caso de recurrencia de la incapacidad total transitoria, posiblemente 
tenga derecho a recuperar las prestaciones transitorias, si bien acaso haya conseguido para entonces un nuevo nivel de ganancias. Algunas jurisdicciones aceptan la aplicación de este nuevo nivel, cuando es más favorable al beneficiario. Estas disposiciones son particularmente importantes cuando el nivel de salario reclamado no se revisa de acuerdo con la inflación. Comúnmente, estas disposiciones sólo se aplican después de un número especificado de años desde la incapacidad inicial.

\section{M uerte no indemnizable de un beneficiario de prestaciones de incapacidad}

Este subepígrafe se refiere a los casos en los que una persona que está recibiendo o puede optar a una pensión por incapacidad permanente fallece y la muerte no es indemnizable por no ser consecuencia de la incapacidad o del empleo. La regla general es que las prestaciones terminan a la muerte (o al final del mes en que ocurra ésta). No obstante, a veces se dan las excepciones siguientes.

1. Cuando el beneficiario fallecido estaba recibiendo prestaciones por incapacidad total o muy grave, algunas jurisdicciones conceden por la muerte prestaciones que se abonan como si la incapacidad hubiera sido su causa. (Estas prestaciones se mencionan en el subepígrafe siguiente.)

2. Algunas jurisdicciones conceden que la pensión por incapacidad continúe en favor del cónyuge superviviente a cargo durante un breve período, por ejemplo tres meses, en forma de cantidad que se abona de una sola vez.

3. Cuando se concede una pensión por incapacidad permanente, algunas jurisdicciones disponen que, en ciertas condiciones, el derecho se convirtió en una pensión durante la vida conjunta del beneficiario y del cónyuge; en tal caso, el nivel de pensión es menor.

4. Algunas jurisdicciones conceden una prestación al beneficiario superviviente en forma de pensión o de cantidad a tanto alzado independientemente de la causa de la muerte.

\section{Casos de muerte}

Este subepígrafe se refiere a los casos de indemnización por muerte. Esta puede ser instantánea, estar causada por el empleo o ser resultado de una incapacidad indemnizable. En la mayoría de las jurisdicciones no es preciso que la muerte haya ocurrido en un momento determinado después de la fecha de incapacidad. No obstante, el período transcurrido entre la incapacidad y la muerte sirve a veces de prueba de que ésta fue consecuencia de la incapacidad.

Es corriente conceder una prestación por gastos de entierro. En algunas jurisdicciones se paga una cantidad establecida, independientemente del coste real. En otras se reembolsa este coste, con un máximo. N ormalmente, la legislación no especifica a quién debe pagarse la prestación, por lo que puede ser reclamada por cualquiera que haya pagado los gastos.

Las prestaciones más importantes en casos de muerte son las concedidas a los supervivientes a cargo. Puede tratarse de una cantidad a tanto alzado, un pago periódico o ambas cosas. Algunas jurisdicciones conceden sumas establecidas a pagar por cada persona a cargo; por ejemplo, tanto por mes por el cónyuge superviviente y tanto por mes por cada hijo. En otras jurisdicciones, las sumas varían en relación con las ganancias previas del trabajador fallecido. Así se hace normalmente cuando las pensiones de las personas a cargo se fijan en forma de porcentaje de lo que se habría pagado por incapacidad total al trabajador fallecido. Algunas veces se utiliza una fórmula mixta, que da lugar al pago de una suma establecida y a ciertas diferencias según las ganancias previas del trabajador fallecido.
Cuando las prestaciones son una suma establecida por cada persona a cargo, normalmente no hay un máximo, por lo que el total puede exceder de lo que se habría pagado por incapacidad total al trabajador fallecido. Cuando las prestaciones guardan relación con las ganancias, a veces se fija el máximo en la suma que se habría pagado al fallecido por la incapacidad total o un porcentaje de esa suma; en ocasiones el máximo es menor cuando no hay cónyuge superviviente. En las jurisdicciones en que se utiliza una fórmula mixta, puede haber o no un máximo.

$\mathrm{H}$ istóricamente, se han pagado prestaciones por muerte a la viuda superviviente 0 al viudo incapacitado, y éste sigue siendo el criterio que se aplica en muchas jurisdicciones. En otras, la reciente tendencia a la igualdad entre los sexos ha eliminado la distinción, reduciendo normalmente las prestaciones a pagar a las viudas 0 viudos supervivientes y en otras ocasiones suprimiendo las pensiones. A demás, las pensiones de viudedad solían terminar en caso de nuevo matrimonio, pagándose entonces con frecuencia una cantidad a tanto alzado. En algunas jurisdicciones se han derogado estas disposiciones. Donde continúan vigentes, siguen concediéndose subsidios por hijos. Además, en algunos casos en que se prevé que la pensión de viudedad termine con el nuevo matrimonio, sólo se aplica esta regla cuando no hay hijos. Sólo en algunas jurisdicciones en que la pensión de viudedad termina en caso de nuevo matrimonio está sujeta a revisión en caso de divorcio. En otras, la pensión del cónyuge superviviente también termina si éste abandona loshijos.

En ocasiones, las prestaciones se pagan simplemente por la relación de parentesco. En otros casos es necesario demostrar tanto esa relación como la situación de dependencia. Normalmente, para probar la dependencia basta con que el beneficiario viviera en un hogar común con el trabajador fallecido o que dependiera económicamente del trabajador fallecido. EI beneficiario no suele quedar privado de las prestaciones por ganar dinero, aunque, de no haber un hogar común y pagos significativos de ayuda, esto acaso permita demostrar que no estaba a cargo del trabajador fallecido.

Algunas jurisdicciones reconocen la dependencia parcial, normalmente cuando el beneficiario y el trabajador fallecido no vivían en un hogar común. En tal caso, suelen concederse prestaciones basadas en una proporción de lo que resultaría si el beneficiario hubiera sido considerado totalmente a cargo. 0 tras jurisdicciones no reconocen la dependencia parcial, por lo que ha de tomarse una decisión sencilla sobre si el reclamante era 0 no una persona a cargo del trabajador fallecido.

Las prestaciones por personas a cargo se pagan directamente a éstas mismas (o a las que ejerzan la tutela de los hijos dependientes). En algunas jurisdicciones, estas prestaciones se limitan al cónyuge y a los hijos. En otras se extienden a los hermanos 0 hermanas, padres, abuelos, nietos y otros miembros de la familia. N ormalmente tienen prioridad el cónyuge y los hijos del fallecido, si existen. Con esta condición, pueden pagarse prestaciones a otros miembros de la familia que son, o podrían haber sido en el futuro, personas a cargo del fallecido.

Las pensiones por cónyuge superviviente se pagan normalmente con carácter vitalicio. Sin embargo, en algunas jurisdicciones se reconocen durante un número fijo de años o hasta que llegue la edad normal de jubilación. Los pagos periódicos por hijos terminan cuando éstos cumplen cierta edad. Generalmente se prolongan los pagos algunos años cuando los hijos están cursando estudios a tiempo completo o durante toda su vida si están incapacitados.

Cuando hay hijos supervivientes, pero no cónyuge, ordinariamente el subsidio se paga al tutor. La suma equivale con frecuencia a la cantidad que se habría pagado al cónyuge superviviente a cargo, si bien la duración es diferente: el subsidio termina normalmente cuando el último hijo alcanza cierta edad, 0 antes si termina la tutela. 
Normalmente no se requiere que exista matrimonio para optar a las prestaciones por cónyuge. En ocasiones se entiende que existe matrimonio cuando la pareja cohabitaba en el momento de la muerte y durante un período especificado anteriormente. Ese período es normalmente menor, o no existe período mínimo, si hay algún hijo de la unión.

El cónyuge que esté separado del trabajador en el momento de la muerte de éste pierde las prestaciones en algunas jurisdicciones o tiene derecho sólo a parte de ellas. Cuando el trabajador fallecido tenía a su cargo un cónyuge separado y estaba cohabitando con otra persona, algunas jurisdicciones disponen que las prestaciones en favor del cónyuge se dividan entre ellos, sin aumentar el total a pagar. Al decidir la división, lo normal es que el cónyuge tenga prioridad, aun cuando existe una tendencia en algunas jurisdicciones a lo contrario.

En la mayoría de las jurisdicciones es indiferente que el matrimonio o la cohabitación hubieran comenzado después de la incapacidad causante de la muerte.

\section{Ajustes por inflación}

En algunas jurisdicciones, las prestaciones monetarias no se ajustan automáticamente a la inflación, por lo que sus valores se deterioran con el tiempo, salvo los ajustes ocasionales que se aprueben. En otras, las prestaciones tienen un valor estable, puesto que se revisan de acuerdo con la inflación. Este sistema puede adoptar dos formas. En la primera se revisan los pagos por nuevos derechos, incluido el tope. En la segunda se revisan los pagos habituales que se hacen por derechos anteriores. EI factor de revisión puede aplicarse directamente a las prestaciones 0 al nivel salarial al que se tiene derecho, con los ajustes consiguientes de las prestaciones.

\section{Tributación por las prestaciones}

En algunas jurisdicciones, las prestaciones o algunas de ellas están sujetas al impuesto sobre la renta, que suele deducirse en origen. En otras, no están sujetas a dicho impuesto. En este último caso, el tope en el salario de referencia 0 al de prestaciones garantiza normalmente que el trabajador no salga ganando con la indemnización en comparación con su situación de actividad. Este mismo resultado puede lograrse, sin recurrir al tope, fijando el nivel de indemnización en porcentaje del nivel salarial según una escala regresiva con respecto a los ingresos.

\section{Protección de las prestaciones}

Para garantizar que los trabajadores incapacitados y personas a su cargo dispongan de las prestaciones para su mantenimiento, algunas jurisdicciones prohíben cualquier cesión de las mismas a los acreedores $u$ otras personas, no pudiendo ser embargados judicialmente. Reconociendo este principio legal, algunos organismos de indemnización se niegan asimismo a aceptar cualquier indicación del beneficiario en el sentido de que las prestaciones de indemnización se envíen a la dirección de un letrado.

$\mathrm{H}$ ay varias excepciones. Cuando una empresa ha continuado pagando salarios o ha pagado otras prestaciones a un trabajador que padece una incapacidad indemnizable, algunas jurisdicciones disponen que la autoridad de indemnización reembolse a la empresa la menor de las prestaciones de indemnización a que tenga derecho el trabajador y las sumas pagadas al mismo por ella. Cuando un beneficiario ha estado recibiendo prestaciones de la seguridad social mientras espera el resultado de la reclamación de indemnización por accidente de trabajo, algunas jurisdicciones disponen que el asegurador reembolse esta última a la seguridad social. Cuando un beneficiario con incapacidad indemnizable no atiende a las personas a su cargo, algunas jurisdicciones disponen que una parte de las prestaciones de indemnización se pague directamente a esas per sonas.

\section{Suspensión de las prestaciones}

$\mathrm{H}$ ay varias disposiciones sobre la suspensión de pagos periódicos. Ejemplos corrientes son la ausencia del solicitante de la incapacidad de la jurisdicción durante un período en que se requiere asistencia médica, la negativa injustificada a recibir asistencia médica, la cohabitación de una persona superviviente a su cargo con otra persona y la prisión del beneficiario. El alcance de la suspensión no siempre está claro en la legislación. Cuando se utilizan términos que indican suspensión, sin utilizar a su vez cualquier otro términos que signifique "supresión" o ausencia del derecho, dicha suspensión implica simplemente que se aplazan los pagos, pero permaneciendo intacto el derecho, por lo que los atrasos se pagan al final del período de suspensión. Sin embargo, otras veces se utilizar términos o palabra que implican "supresión" de derechos, o se advierte por otros indicios del contexto que no deben pagarse prestaciones en ningún momento por el período de suspensión.

\section{Pagos indebidos}

La expresión "pagos indebidos" designa aquéllos a los que el beneficiario no tiene derecho o que superan su derecho. Puede darse un exceso de pago por error del asegurador, del beneficiario 0 de un tercero, o deberse a fraude del beneficiario o de un tercero. La obligación del beneficiario de devolver el exceso depende a veces de las circunstancias; en particular, de la culpabilidad del beneficiario. Este puede:

- Haber inducido al pago indebido por actuación fraudulenta, negligente, o incumplimiento de la obligación de suministrar información.

- Haber sido inocente de la causa del pago indebido, pero conocedor de su recepción, y haber dejado de informar deliberada o negligentemente al asegurador.

- Haber sido inocente de cualquier colaboración a la causa del pago indebido y desconocedor del mismo.

A lgunas reglas sobre indemnización por accidentes de trabajo disponen que el asegurador podrá recuperar los pagos indebidos, aunque no necesariamente en todas las circunstancias. Cuando la legislación calla en esta materia, los pagos indebidos pueden recuperarse según los principios legales generales, aunque no en todas las circunstancias. Por ejemplo, en algunas jurisdicciones el exceso de pago no es recuperable si fue consecuencia de un error cometido por el asegurador o si el beneficiario no ha inducido a error.

Cuando el pago indebido es recuperable legalmente, los métodos de recuperación son generalmente los utilizables por cualquier acreedor. Por ejemplo, una acción judicial de reclamación de deuda, ejecutándose la sentencia mediante el embargo de los bienes del beneficiario. Puede no haber derecho o sólo un derecho limitado a recuperar el pago en exceso mediante deducciones de las prestaciones futuras. Teniendo presente que los pagos de indemnizaciones normalmente los gasta el beneficiario según los va recibiendo y que las prestaciones futuras tienen como finalidad atender a necesidades futuras, a veces la legislación sobre indemnizaciones dispone que los pagos futuros vayan haciéndose según vencen, sin descuentos por exceso de pagos anteriores. En tal caso, los pagos en exceso sólo son recuperables por otros métodos de ejecución.

La práctica real varía. Si se descubre que un pago indebido se ha obtenido mediante fraude, es normal buscar la recuperación por todos los métodos legales de ejecución disponibles, incluyendo los procedimientos penales. Cuando el pago indebido es consecuencia de un error, puede ser cancelado, en particular si se recibió sin conocer su carácter. En otro caso, el pago indebido puede recuperarse mediante procedimientos legales ordinarios, y a plazos en las jurisdicciones en las que es legítimo recuperar 
pagos indebidos mediante deducciones de las prestaciones futuras. No obstante, las autoridades de indemnización tratan a veces de evitar las deducciones de futuras prestaciones, aun cuando la ley las permita.

Cuando se hace un pago indebido a un médico $u$ otro prestador de servicios, la situación jurídica es generalmente la misma que cuando se trata de un pago indebido a un trabajador incapacitado, con la salvedad de que el derecho de compensación es más general, por lo que la recuperación puede hacerse mediante deducciones de facturas futuras, y ésta es la práctica común.

Cuando se hace un pago indebido a un trabajador incapacitado que fallece posteriormente, la recuperación puede obtenerse del patrimonio del trabajador fallecido, pero generalmente no se permiten deducciones de las posibles prestaciones a pagar a las personas a su cargo.

\section{Compensaciones (cancelaciones)}

Algunas jurisdicciones permiten la compensación (cancelación) de todo o parte de una pensión por un tanto alzado. Este puede adoptar la forma de:

- Una compensación total de toda la pensión

- Una compensación de las prestaciones de pensión plena durante un plazo de años, de modo que después de ese período se reinicie la pensión

- Una compensación parcial que reduce el nivel de las prestaciones de pensión mientras dura ésta

- Una compensación parcial durante un período de años, de modo que las prestaciones de pensión se reducen durante ese período, después del cual se reinicia el pago de la pensión en su totalidad.

Entre las jurisdicciones que permiten las compensaciones, muchas no permiten todos los tipos, siendo el primero el más común.

Las disposiciones sobre compensación pueden dar lugar a abusos de los administradores del sistema, en particular utilizando para calcular el tanto alzado una fórmula que da un valor mucho menor que el valor real capitalizado de la pensión. La posibilidad de compensación puede asimismo hacer al beneficiario vulnerable a prácticas predatorias de los proveedores de servicios. Puede hacer también que los contribuyentes pierdan la protección que pretende otorgarles la ley impidiendo al beneficiario gastar el tanto alzado recibido y después acogerse a prestaciones procedentes de ingresos públicos generales.

Para evitar estos problemas, algunas jurisdicciones prohíben o no regulan la posibilidad de estas prácticas. 0 tras disponen que la compensación sólo sea aplicable a discreción de la autoridad de indemnización, definiéndose este poder discrecional (por la normativa legal o por la autoridad de indemnización) de modo que se admitan sólo a ciertos efectos. A pesar de ser discrecional la conmutación, algunas jurisdicciones permiten apelar contra su denegación; en tal caso, el coste de administración y reconocimiento que conlleva ese poder discrecional puede ser excesivo en comparación con las sumas en cuestión.

En las jurisdicciones en las que el régimen es administrado por compañías de seguros, el asegurador (o la empresa) o el trabajador, o ambos, pueden tener derecho, después de un período inicial, como 12 meses, a la cancelación de los pagos periódicos futuros por una cantidad a tanto alzado. Si no hay acuerdo, la suma la determinará el tribunal. Estas disposiciones pueden ser objeto de crítica, ya que en la práctica el trabajador recibe sustancialmente menos que el valor pleno capitalizado de los futuros pagos periódicos y las necesidades futuras de renta del beneficiario se convierten en una carga para los fondos públicos.

\section{Rehabilitación y asistencia}

L os servicios de las clínicas de rehabilitación, de los médicos y de otros terapeutas son prestados generalmente bajo el epígrafe de ayuda médica. Las disposiciones sobre rehabilitación contenidas en la normativa sobre indemnización por accidentes de trabajo normalmente guardan relación con otros tipos de asistencia para la rehabilitación. Algunas partidas, como las prótesis, son suministradas bajo el epígrafe de rehabilitación en algunas jurisdicciones y bajo el de ayuda médica (o asistencia sanitaria) en otras.

La asistencia de rehabilitación forma parte de la cobertura en muchos regímenes de indemnización por accidentes de trabajo, por lo que es una asistencia permanente. Alternativamente, los demandantes de indemnización por accidentes de trabajo pueden optar a esa asistencia dentro del régimen general de seguridad social, que cubre a todas las personas incapacitadas. En algunas jurisdicciones el régimen de seguridad social puede excluir los casos de indemnización por accidentes de trabajo, pero en otras no lo hace, por lo que se da cierto solapamiento y la asistencia pueden prestarla ambos.

Generalmente no se fijan objetivos de la prestación de asistencia de rehabilitación. Las definiciones de objetivos presentadas en conferencias internacionales se exponen en la literatura sobre indemnización por accidentes de trabajo, pero raras veces sirven de guía para la práctica cotidiana. En particular, en muchas jurisdicciones hay ambigüedad sobre si el objetivo de un programa de rehabilitación laboral debe ser maximizar 0 mejorar las oportunidades de empleo de los beneficiarios 0 hacer que puedan volver al trabajo.

No obstante, hasta cierto punto los objetivos de la rehabilitación laboral están implícitos en la forma de las prestaciones por incapacidad permanente. U na pensión concedida por el método del deterioro físico es congruente con la idea de que la rehabilitación es voluntaria y que, por tanto, el objetivo global de cualquier programa de rehabilitación debe ser ampliar las oportunidades de los beneficiarios, por lo que los objetivos en cada caso particular han de ser los del beneficiario. U tilizar el método de la pérdida efectiva de ganancias implica que la rehabilitación es obligatoria, que no puede distinguirse del control de la prestación, que el objetivo del programa en cada caso es hacer que el beneficiario retorne al trabajo 0 , alternativamente, proporcionar pruebas que justifiquen la terminación de las prestaciones.

Cuando la asistencia de rehabilitación es prestada dentro del régimen de indemnización por accidentes de trabajo, los servicios suelen ser discrecionales, en particular cuando se ofrece una amplia gama de servicios. En los últimos años ha habido una tendencia a establecer legalmente un "derecho" ostensible a la rehabilitación, pero es difícil definir en este contexto un "derecho" de obligado cumplimiento. El intento de lograrlo ha venido de ordinario acompañado por una reducción de las prestaciones monetarias y de nuevos límites a la asistencia de rehabilitación que puede prestarse.

En cuanto a la rehabilitación laboral, la asistencia ofrecida puede incluir la orientación profesional, formación para entrevistas en busca de trabajo, un servicio de colocación, la ayuda durante un período de búsqueda de empleo, la reconversión profesional, la mejora de la formación y a veces los gastos de recolocación. A demás de rehabilitación laboral, algunas jurisdicciones ofrecen asistencia para rehabilitación social, como equipo para hobbies o deportes, cursos de maquillaje, asistencia para la adaptación social o asistencia para la solución de problemas conyugales. La rehabilitación social puede prestarse como un objetivo independiente 0 en auxilio de la rehabilitación laboral. La asistencia permanente puede consistir en todo tipo de ayuda, incluida la ayuda en casa. Esa asistencia se presta usualmente bajo el epígrafe de "rehabilitación", aunque en muchos casos es realmente asistencia permanente. 
En algunas jurisdicciones, los servicios de rehabilitación alcanzaron un máximo durante el decenio de 1970, pero han perdido importancia en los últimos años. En particular, ha disminuido la prestación de servicios de colocación y se han producido retrasos en la prestación de otros servicios. Cuando todavía se prestan servicios de colocación, se produce cierta erosión del principio tradicional según el cual los trabajadores incapacitados deben ser colocados en empleos de producción. Por ejemplo, hoy se les impone o exige a veces que trabajen en telemarketing (hacer llamadas publicitarias no solicitadas a los hogares), a pesar de las críticas de que éste es una forma de molestia pública y una invasión de la electrónica en la vida privada. Un aspecto de esa erosión consiste en que la prestación de asistencia de rehabilitación se considera hoy generalmente como destinada a trabajadores de oficina no cualificados más bien que a trabajadores de campo cualificados y entrenados profesionalmente.

La idea actual de la rehabilitación se refiere generalmente a una actividad subsiguiente a una incapacidad, pero algunas jurisdicciones ya reconocen el valor de la rehabilitación preventiva, es decir, de la prevención de una incapacidad, aun en casos en que todavía no se ha producido. Por ejemplo, las dolencias de espalda y ciertas enfermedades derivadas de la contaminación industrial son con frecuencia previsibles y a veces es conveniente ayudar al trabajador a obtener otro puesto de trabajo como medida preventiva. No suele prestarse asistencia de rehabilitación con esta finalidad, excepto en algunas jurisdicciones y en ciertas circunstancias. La asistencia de rehabilitación puede ser entonces uno de los remedios utilizables en programas de salud y seguridad en el trabajo. Algunas jurisdicciones cuentan asimismo con medidas de rehabilitación para la protección del feto o de un recién nacido al que todavía alimenta su madre, cuando la exposición del trabajador a la contaminación o a otra situación del empleo puede poner en peligro la salud del feto 0 del niño.

En algunas jurisdicciones el proceso de decisión en materia de rehabilitación es el mismo que en materia de indemnización. En otras es diferente, con un mayor énfasis en el debate y el consenso y un papel menor para la adjudicación y apelación.

En algunas jurisdicciones, los costes de la asistencia de rehabilitación se cargan de la misma forma que las prestaciones. En otras se cargan al fondo general y se distribuyen entre las clases, aun cuando se aplique la puntuación según experiencia para determinar el coste de las prestaciones monetarias. Como los casos en que se necesita asistencia de rehabilitación laboral son usualmente aquellos en los que la empresa donde se produjo el accidente no mantiene el empleo, este método de cargo de los costes permite tomar decisiones de rehabilitación sin que la empresa intervenga como parte. De esta manera se evitan los daños terapéuticos derivados de los procesos regidos por el principio de contradicción. Cuando los costes de la asistencia de rehabilitación se cargan a un fondo general, pueden cargarse de la misma manera los costes de indemnización por lesiones sufridas durante la rehabilitación.

\section{Obligación de mantener el empleo}

En los últimos años, algunas jurisdicciones se han propuesto imponer a la empresa en servicio en la cual quedó incapacitado el trabajador por una lesión o enfermedad indemnizable (la empresa del accidente) la obligación de mantener el empleo de ese trabajador. N ormalmente, la obligación comienza cuando el trabajador ha alcanzado una recuperación suficiente para retornar a algún tipo de trabajo que pueda ofrecer la empresa y continúa durante un período de uno o dos años. La promulgación de estas disposiciones suele ir acompañada o seguida por una reducción de las prestaciones de indemnización por incapacidad permanente.

En jurisdicciones con una economía de mercado fundamentalmente no regulada y donde la mayor parte del empleo no está acogido a la negociación colectiva, esas disposiciones son contraproducentes. Restan fuerza y socavan la prestación de cualquier servicio genuino de rehabilitación. A un trabajador con una incapacidad permanente no le asiste normalmente un "derecho" temporal al empleo. Además, estas disposiciones modifican la imagen del trabajador incapacitado: de ser una persona que normalmente puede esperar continuar trabajando en la misma empresa, pasaría a ser considerado como una carga para ésta. Este cambio de imagen no se limita a los casos que en cualquier caso hubieran planteado un problema de rehabilitación, por lo cual estas disposiciones pueden plantear problemas de rehabilitación.

Dado que el "derecho" ostensible es pertinente sólo cuando la empresa desea dar por terminada la relación de empleo, ese "derecho" es inevitablemente frágil. En la mayoría de las jurisdicciones, una relación de empleo puede terminarse por diversos motivos, que no suelen desaparecer por el "derecho" del trabajador a continuar en el empleo. Aun cuando se termine ilegalmente el empleo, los remedios pueden ser difíciles de aplicar. Por tanto, el "derecho" es frágil, y a pesar de su fragilidad, su ejercicio o la negativa del trabajador a ejercerlo son motivos para la terminación de las prestaciones de indemnización.

Se discute mucho sobre cuál es el empleo adecuado en relación con la incapacidad residual, pero la solución no es fácil sin una investigación probatoria. Aun cuando se haga esa investigación y se tome una decisión razonada, su alcance puede ser limitado, en particular si las circunstancias están cambiando o expira el plazo de la obligación. Cuando una discusión sobre la obligación se resuelve en favor del trabajador, no por eso se logra la continuación del empleo. Generalmente se llega a acuerdo económico. Así pues, aunque el resultado sea "bueno" para el trabajador, consiste en la concesión de una suma monetaria mediante un proceso altamente ineficiente y una causa de daños terapéuticos.

La promulgación de ese "derecho" perjudica asimismo a la prestación de un genuino servicio de rehabilitación. Como el trabajador tiene un "derecho" ostensible a retornar a la misma empresa, esto suele considerarse como la solución normal, por lo que es poco probable que se consideren formas alternativas de rehabilitación. Por todos estos motivos, la legislación destinada a imponer una obligación a la empresa y a conceder una opción al trabajador, en realidad impone una obligación al trabajador y concede una opción a la empresa.

Algunas jurisdicciones exigen la continuación del empleo de un trabajador que ha sufrido una incapacidad, independientemente de la causa. Estas disposiciones solamente son aplicables en el contexto de la negociación colectiva o de un mercado de trabajo altamente regulado.

0 tras jurisdicciones prohíben el despido de un trabajador que no acude al trabajo a causa de una incapacidad indemnizable, pero no el despido de ese mismo trabajador cuando se recupera de la incapacidad.

\section{Financiación}

\section{Distribución de costes}

El coste de la indemnización por accidentes de trabajo se financia generalmente con las primas o cuotas pagadas por las empresas. Por este motivo, se afirma o supone generalmente que las empresas soportan el coste del sistema, pero evidentemente esta afirmación es incorrecta. La carga de cualquier impuesto puede trasladarse del sujeto sobre el que recae inicialmente la obligación 
de contribuir; existe una abundante doctrina económica que explica que el impuesto sobre la nómina es normalmente una reserva económica para las emergencias en el trabajo. Parte del coste de las primas de la indemnización por accidentes de trabajo recae sobre las empresas, pero otra parte se traslada al trabajo en forma de menores salarios y otras prestaciones y quizá también a los consumidores. Además, las prestaciones de indemnización no compensan completamente las pérdidas económicas de los trabajadores incapacitados. En la medida en que estas pérdidas superan la indemnización recibida, son costes de la incapacidad laboral que no figuran como tales en el régimen de indemnización por accidentes de trabajo. Esos costes son soportados en su mayor parte por los trabajadores incapacitados, aun cuando hasta cierto punto pueden ser trasladados a otros, como los miembros de las familias o los acreedores.

\section{E quilibrio de las cuentas}

El primer paso para diseñar un sistema de financiación consiste en establecer un criterio de equilibrio de las cuentas, de modo que los ingresos y gastos agregados sean aproximadamente iguales a lo largo del tiempo. En regímenes gestionados por compañías de seguros se supone que esto se hace mediante el ajuste de las primas, por lo que los ingresos reflejarán la experiencia de costes de las reclamaciones. En regímenes de seguros sociales, la legislación suele exigir que las cuentas se equilibren de la misma manera, pero con frecuencia hay presiones políticas para reducir el nivel de las primas o cotizaciones y después equilibrar los gastos con las cotizaciones aprobadas. A no ser que el gobierno resista esas presiones, el conflicto permanente entre la legislación y las presiones políticas causa una continua fricción en la administración del régimen y las decisiones sobre adjudicación. Puede también hacer que aumente el endeudamiento.

\section{Ingresos y clasificación}

L a mayoría de los regímenes de indemnización por accidentes de trabajo utilizan clasificaciones industriales y establecen primas 0 cotizaciones para cada clase o subclase de actividad industrial. La clasificación puede hacerse por referencia al producto final 0 a las tareas que desempeñan los trabajadores. La clasificación por el producto final es más fácil desde el punto de vista de la administración y adjudicación. La clasificación por referencia a las tareas de los trabajadores puede incrementar la complejidad de la auditoría, en particular cuando algunos trabajadores desempeñan varias tareas.

U na vez establecida la cotización de la empresa, suele adoptar la forma de porcentaje de la nómina. En jurisdicciones en las que hay un tope en el salario de referencia, suele aplicarse ese mismo tope máximo a la cantidad a pagar por trabajador a efectos de cotización. Por ejemplo, puede exigirse a una empresa que pague 2 unidades monetarias por 100 unidades de nómina, hasta un máximo de 50.000 unidades, por trabajador y año. En general, las cotizaciones se revisan anualmente. Aun siendo normal la cotización en forma de porcentaje de la nómina, a veces se utilizan métodos alternativos, como la prima por el valor estimado de los activos o por el precio de los bienes vendidos. Algunos regímenes reciben un subsidio parcial del gobierno.

\section{Puntuación según la experiencia}

En muchos regímenes, la prima a pagar por la empresa difiere de la cotización normal para la clase o subclase a la que pertenece la empresa por tener en cuenta la experiencia en reclamaciones de esa empresa en comparación con otras. Este procedimiento recibe el nombre de "puntuación según la experiencia". Con frecuencia recibe también el nombre de "puntuación según los méritos", pero este último no parece correcto, ya que la diferencia de cotizaciones no guarda relación alguna conocida con ningún tipo de mérito. Generalmente, la fórmula para calcular las diferencias utiliza la experiencia de costes de reclamaciones, pero puede incluir otros factores, como la frecuencia de las reclamaciones. A veces, se supone un coste mínimo en casos de muerte. Las pequeñas empresas suelen ser excluidas de los planes de puntuación según experiencia; y cuando se incluyen, se les aplican variaciones menores de la puntuación.

La puntuación según la experiencia es normal en los regímenes administrados por compañías de seguros. Se utiliza también a veces en regímenes de seguros sociales con indemnización por accidentes de trabajo; su uso en estos regímenes ha ganado terreno en los últimos años, pero sustancialmente es incompatible con la justificación de su creación. Una gran ventaja del régimen de seguros sociales consiste en que en la adjudicación de reclamaciones pueden evitarse los procesos contradictorios, mientras que el uso de la puntuación según la experiencia priva al régimen de esa ventaja.

En los regímenes administrados por compañías de seguros, la puntuación según experiencia suele aplicarse a todos los gastos hechos con motivo de una reclamación. A veces ocurre lo mismo en los regímenes de seguros sociales, pero en algunos de éstos la puntuación según experiencia se limita a las prestaciones monetarias. No se aplica a los gastos de ayuda médica o de rehabilitación. La finalidad es minimizar el uso de procesos contradictorios para llegar a decisiones sobre esos gastos.

La justificación más frecuente de la puntuación según la experiencia es que crea un incentivo a la empresa de reducir la frecuencia y gravedad de las incapacidades laborales, pero esta afirmación no se basa en pruebas creíbles. Los únicos "estudios" que tratan de demostrar que la puntuación según la experiencia tiene algún efecto beneficioso en la salud y seguridad utilizan los datos sobre reclamaciones como medida del efecto. Por varios motivos, no es conveniente utilizarlos para esta finalidad. La puntuación según la experiencia incentiva a las empresas a prevenir o desalentar la presentación de reclamaciones, a retener información positiva, a oponerse a las reclamaciones, a apelar las decisiones favorables a los demandantes, a presionar a éstos para que retornen prematuramente al trabajo, a buscar información médica personal relacionada con los demandantes y a requerir nuevos reconocimientos médicos de los reclamantes. Aun cuando algunas de estas prácticas son generalmente legítimas, su uso generalizado desaconseja la utilización de los datos sobre reclamaciones como medida del "éxito" de la puntuación según experiencia en relación con la salud y seguridad. Además, estas prácticas elevan los costes de administración y adjudicación del régimen; y a causa de los retrasos y daños terapéuticos que pueden causar, probablemente también incrementan los costes de indemnización.

La puntuación según la experiencia puede inducir a la empresa a facilitar en ciertas circunstancias la rehabilitación de un trabajador incapacitado, pero en conjunto probablemente su influencia en la rehabilitación es negativa. Normalmente da lugar a que las lesiones leves sean tratadas con sospecha. Esta actitud puede ser causa de ansiedad y un impedimento a la rehabilitación. Además, puede desanimar a la empresa de contratar personas discapacitadas y mantener el empleo del trabajador incapacitado. Sucede así primordialmente porque los costes de la indemnización de cualquier incapacidad derivada pueden aumentar cuando se potencia su repercusión para la incapacidad previa. Para contrarrestar esta influencia negativa de la puntuación según experiencia, algunas jurisdicciones utilizan un "segundo fondo de lesiones". Parte del coste de la indemnización de la incapacidad subsiguiente puede cargarse a ese fondo y no repercutir en la empresa. Los costes de este fondo se distribuyen entre todas las clases de primas 0 cotizaciones y entre 
todas las empresas. Las reglas de uso del fondo varían, pero el principio general es que, cuando alguna incapacidad o condición previa ha contribuido a causar una incapacidad indemnizable, ha incrementado su gravedad o ha aumentado sus consecuencias en orden a la indemnización, una parte del coste de la indemnización de la incapacidad debe recaer sobre el segundo fondo de lesiones.

Estos fondos no logran su objetivo, lo que se debe en parte a los demás motivos (reales o imaginarios) por los que muchas empresas evitan el empleo de personas discapacitadas y en parte a que la transferencia de costes a un segundo fondo de lesiones depende de la sentencia dictada en casos de reclamaciones una vez sobrevenida la incapacidad derivada. Además, el coste de tramitación de las solicitudes de transferencia de los costes al segundo fondo de lesiones es otro motivo por el que la puntuación según experiencia eleva los costes generales del régimen.

La puntuación según experiencia parece a primera vista mejorar la equidad de la distribución de los costes entre las empresas. Y hasta cierto punto así lo hace, pero a la vez crea nuevas desigualdades. Por ejemplo, las solicitudes de transferencia de costes a un segundo fondo de lesiones 0 a otro fondo general son presentadas con mayor frecuencia por las grandes empresas, que cuentan con personal o consultores externos dedicados a esta tarea. EI resultado de estas transferencias es elevar la cotización normal de la clase o subclase, con el resultado final de ser una subvención de las pequeñas empresas a las grandes.

\section{Capitalización}

En función de su dimensión temporal, la financiación de la indemnización por accidentes de trabajo se organiza de dos maneras básicas.

1. Capitalización. L os ingresos totales necesarios en cualquier año se determinan estimando los costes actuales y futuros de todas las incapacidades indemnizables que se produzcan durante ese año (o de todas las reclamaciones recibidas durante el año).

2. Financiación de los costes corrientes (a veces, denominado sistema de reparto). Los ingresos totales necesarios en cualquier año se determinan estimando los gastos totales a pagar durante ese año en relación con todas las reclamaciones actuales y pasadas.

$\mathrm{H}$ ay variantes de cada una de estas formas, por lo que existe cierto espacio intermedio entre ellas. La capitalización exige la creación de cuantiosas reservas, y su adecuación ha de reestimarse normalmente cada año. Con el sistema de reparto se requiere cierto volumen de reservas de emergencia, pero no cálculos actuariales repetidos.

Cuando el régimen es administrado por compañías de seguros, los principios generales de la ley del seguro imponen la capitalización. El régimen de seguros sociales ocupa una posición diferente, ya que el gobierno puede imponer por ley cotizaciones futuras. En la práctica, algunos regímenes de seguros sociales están obligados a la capitalización plena y otros utilizan el sistema de reparto. O tros adoptan una posición diferente, como la capitalización parcial o la capitalización únicamente de algunas partidas del coste futuro.

La financiación por el sistema de reparto es ligeramente más barata a largo plazo, pero la capitalización es esencial en muchas jurisdicciones, como las pequeñas, y en las que dependen fuertemente de industrias de producción primaria.

\section{Falta de pago de las primas o cotizaciones}

En los regímenes administrados por compañías de seguros puede permitirse al asegurador cancelar la cobertura del seguro si no se paga la prima. La empresa es en tal caso responsable de los pagos de indemnización por futuras reclamaciones, y los demandantes futuros dependen de la continuación de la solvencia de la empresa. Cuando es legalmente obligatorio el seguro de indemnización por accidentes de trabajo y una empresa ha dejado de pagar una prima, generalmente se imponen sanciones, normalmente una multa o prisión, además de la responsabilidad de la empresa por las reclamaciones. A veces, puede procederse al cierre de la empresa.

Cuando un régimen de indemnización por accidentes de trabajo es de seguros sociales, algunas jurisdicciones exigen 0 permiten la cancelación de la cobertura si la empresa no paga las primas. Más comúnmente, el pago de la indemnización no depende del pago de las primas, no permitiéndose la cancelación de la cobertura por cualquier impago. Cada reclamación representa una carga sobre el correspondiente fondo, y en algunas jurisdicciones, sobre todo el fondo.

En caso de impago de primas, pueden utilizarse varios mecanismos de ejecución forzosa. Normalmente son análogos a los mecanismos de ejecución forzosa utilizables en la jurisdicción de otras formas de tributación: embargo de la propiedad de la empresa (incluyendo la tierra y los bienes), embargo de las cuentas bancarias de la empresa y mandatos de cierre de la empresa. En algunas jurisdicciones, el impago de las primas es un delito. $\mathrm{H}$ abrán de cumplirse las penas impuestas y, además, pagar las primas vencidas, pudiendo exigirse a la empresa que reembolse al organismo gestor los gastos por reclamaciones presentadas durante el período de impago. Cuando una empresa no es sociedad, los directivos de la misma pueden incurrir en responsabilidad personal.

\section{Responsabilidad subsidiaria}

Esta expresión abarca las situaciones en las que una persona es responsable de las obligaciones de otra. Cuando se utilizan trabajadores de una empresa ("contratista") para trabajar para otra ("principal"), algunas jurisdicciones disponen que en ciertas circunstancias el principal es en realidad un garante de las obligaciones del contratista en relación con la indemnización por accidentes de trabajo. Esas disposiciones suelen aplicarse al trabajo realizado en lugares de construcción, aun cuando también se aplican a veces a otras situaciones.

\section{Salud y seguridad}

En los regímenes gestionados por compañías de seguros, el papel a representar por el asegurador, si es que tiene alguno, varía según las jurisdicciones y empresas en relación con la salud y seguridad en el trabajo. A veces, el asegurador no juega papel alguno 0 éste es insignificante. A veces, realiza una encuesta de riesgos, pero limitada a una gama establecida de epígrafes. 0 tras veces realiza una encuesta más profesional y sofisticada de riesgos. Así suele hacerse en ciertas industrias en las que el asegurador puede asumir otros tipos de cobertura además de la indemnización por accidentes de trabajo. Cuando se realizan encuestas, pueden repetirse posteriormente, o pueden servir sólo para la fijación inicial de las primas, utilizando el asegurador la experiencia en costes de reclamaciones para ajustes posteriores de las primas.

Cuando la indemnización por accidentes de trabajo funciona dentro de un régimen de seguros sociales, la posición más común es que ese régimen apoye al organismo público que tiene la jurisdicción reguladora en relación con la salud y seguridad en el trabajo. Este apoyo suele consistir en el suministro de información estadística y en la distribución de información sobre sanidad y seguridad entre las empresas, sindicatos y trabajadores. El régimen de indemnización por accidentes de trabajo puede prestar otros servicios de sanidad y seguridad directamente a las empresas, por ejemplo, asesoramiento técnico, o 
puede financiar la prestación de servicios por asociaciones industriales (aun cuando se discuten los méritos de este procedimiento).

En algunas jurisdicciones, el organismo encargado de la indemnización por accidentes de trabajo tiene también poderes reguladores públicos en relación con la salud y seguridad en el trabajo. En ellas, el régimen de indemnización por accidentes de trabajo puede utilizarse, y a veces se utiliza, ampliamente en auxilio de la sanidad y seguridad en el trabajo. Este uso puede incluir la aportación de información sobre salud y seguridad procedente de archivos de inspecciones o de otras fuentes, la aportación de recursos técnicos y profesionales y la prestación de servicios de apoyo. Con gran diferencia, el aspecto más valioso es el uso del ajuste de las primas de indemnización como sanción para imponer el cumplimiento de las disposiciones sobre sanidad y seguridad en el trabajo. La prima a pagar por una empresa puede incrementarse según la situación de riesgo observada en una inspección (no según los datos de archivo). Esta es la única sanción adecuada utilizable para hacer cumplir la normativa sobre salud y seguridad en la mayoría las situaciones en las que son inadecuadas las sanciones penales (p. ej., la permanencia de niveles elevados de contaminación tóxica).

El sistema de indemnizaciones puede utilizarse también de otras maneras para sancionar el incumplimiento de la normativa sobre salud y seguridad en el trabajo. Por ejemplo, cuando de un incumplimiento grave de la normativa de la empresa, o de cualquier otra negligencia grave, ha resultado una incapacidad, se impone a la empresa el pago de todo o parte del coste de la reclamación. Por tanto, aunque la culpabilidad de la empresa es irrelevante como regla general en las indemnizaciones por accidentes de trabajo, en algunas jurisdicciones puede invocarse excepcionalmente en casos extremos como sanción por la violación de la normativa sobre salud y seguridad. La variación de las primas mediante el uso de auditorías de sanidad y seguridad no tiene grandes posibilidades, pero puede hacerse en ciertas circunstancias.

\section{Reclamaciones contra terceros}

E ste epígrafe se refiere a reclamaciones civiles presentadas por un trabajador incapacitado contra las personas, distintas de la empresa, que supuestamente han sido causa de incapacidad. En algunas jurisdicciones la legislación sobre indemnización por accidentes de trabajo prohíbe estas reclamaciones. Cuando no están prohibidas, algunas jurisdicciones permiten al trabajador la presentación de la reclamación, pero el demandado tiene derecho a que se reduzcan los daños por la suma que ha recibido o recibirá el beneficiario dentro del régimen de indemnización por accidentes de trabajo.

O tras jurisdicciones permiten que el asegurador (la autoridad de indemnización, la compañía de seguros o la empresa, según proceda) se subrogue en el derecho a presentar la reclamación contra el tercero. Este procedimiento recibe el nombre de "subrogación". En algunas jurisdicciones el derecho de subrogación es total. El asegurador se hace cargo de toda la reclamación, pero si se recupera una cantidad por encima de la indemnización que se ha pagado o que se ha de pagar, el asegurador debe dar cuenta del exceso al trabajador. En otras jurisdicciones la subrogación es parcial. Por ejemplo, la legislación puede disponer que el asegurador pueda presentar la reclamación por la suma que se paga o ha de pagarse por la indemnización, mientras que el trabajador puede presentar la reclamación por el exceso. 0 puede disponer que el asegurador presente la reclamación de pérdidas monetarias mientras que el trabajador reclame las pérdidas no monetarias.

\section{PARTE SEGUNDA: OTROS REGIMENES}

\section{Seguros sociales y seguridad social}

La expresión "seguros sociales" se refiere usualmente a un régimen de seguros, administrado por el gobierno, con cobertura obligatoria y cotizaciones que han de pagar las empresas, los trabajadores 0 ambos, aun cuando puede haber asimismo una aportación de los ingresos públicos generales. Este régimen normalmente cubre a los trabajadores asalariados, aun cuando también pueden acogerse los trabajadores por cuenta propia, al menos hasta cierto punto. El régimen puede ser específico; por ejemplo, un régimen de indemnizaciones por accidentes de trabajo puede ser de seguros sociales; o puede ser general, con prestaciones que se pagan en caso de desempleo, enfermedad, incapacidad, embarazo, jubilación y fallecimiento. De estos regímenes generales de seguros sociales es de los que nos ocupamos en este epígrafe. Las prestaciones pueden ser lineales o relacionadas con las ganancias. Pueden estar excluidas de la cobertura determinadas industrias o categorías de asalariados, pero las exclusiones suelen ser menos amplias que las de un régimen de indemnización por accidentes de trabajo.

La expresión "seguridad social" tiene varios significados. En su sentido más estricto, suele referirse a un régimen de prestaciones pagadas por el $\mathrm{G}$ obierno con los ingresos públicos generales a personas que pueden optar a ellas por motivo de incapacidad, vejez, desempleo o algún otro. Normalmente se conceden previa comprobación de medios disponibles. EI régimen suele acoger a todas las personas residentes habituales de la jurisdicción. L as prestaciones suelen ser lineales, aunque puede haber variantes en relación con las personas a cargo. La expresión "seguridad social" se utiliza también corrientemente en un sentido mucho más amplio, que incluye estas prestaciones más los seguros sociales, la asistencia médica y los servicios sociales. En este capítulo la utilizaremos en su sentido estricto, es decir referida a las prestaciones monetarias distintas de las de los seguros sociales.

Muchos países no cuentan con un régimen separado de indemnización por accidentes de trabajo. La incapacidad y muerte que resulten del empleo son cubiertas por el régimen general de la seguridad social o de seguros sociales, que incluyen la incapacidad y el fallecimiento por otras causas. La ayuda médica por incapacidades resultantes del empleo se presta usualmente en estos países dentro del mismo régimen público de asistencia médica que se aplica a incapacidades derivadas de otras causas. En algunas jurisdicciones se prestan a veces otros tipos 0 niveles de asistencia médica cuando la incapacidad es consecuencia del empleo, y ciertos servicios o tratamientos pueden ser gratuitos cuando suponen un coste derivado de incapacidades no producidas en el empleo.

En relación con las prestaciones monetarias de corta duración, generalmente las incapacidades y muertes producidas en el empleo pueden ser tratadas de la misma manera que las que son consecuencia de otras causas, pero en muchas jurisdicciones hay una prestación adicional o una tasa más alta de prestación cuando la incapacidad es consecuencia del empleo. Así ocurre con las incapacidades permanentes y a veces también con los casos de muerte. La explicación histórica frecuente es que el régimen general de seguros sociales sustituyó a un régimen 
anterior de indemnización por accidentes de trabajo. Esta estructura puede además servir para cumplir los convenios de la OIT. Algunos regímenes incluyen prestaciones especiales 0 niveles especiales de prestaciones para los que desempeñan determinadas ocupaciones.

La cobertura de los regímenes generales de seguros sociales suele ser universal, es decir, acoge a todos los que viven 0 trabajan en el país, aun cuando suelen darse algunas excepciones con respecto a los nacionales de otros países.

A la financiación del régimen suelen contribuir obligatoriamente los trabajadores y las empresas en relación con sus empleados. La contribución puede consistir en una cuota fija (sistema general si las prestaciones fijas) o guardar relación con las ganancias (sistema general si las prestaciones guardan relación con las ganancias). Suele exigirse un período de carencia para poder acceder a las prestaciones, período que puede ser también pertinente para el nivel de prestaciones. Cuando se pagan prestaciones adicionales o más altas por incapacidades 0 muertes que son consecuencia del empleo, los correspondientes costes suelen ser a cargo de las cotizaciones de las empresas.

C uando las cotizaciones y las prestaciones guardan relación con las ganancias, suele haber un tope para ambas. Así, la cobertura del seguro sólo suele aplicarse a rentas de niveles bajos, que son las que suelen soportar total o parcialmente los costes del régimen. Las prestaciones del régimen general de seguros sociales suelen situarse a niveles más bajos que en los regímenes de indemnización por accidentes de trabajo. No obstante, existen muchas veces complementos varios, por ejemplo, complementos para personas a cargo.

La administración y adjudicación primaria están generalmente encomendadas a un órgano público. Si hay algún conflicto, suele ser entre el reclamante y el departamento. En los regímenes de seguros sociales no suele utilizarse la puntuación según la experiencia. Por esto, la empresa no suele tener interés en el resultado de las reclamaciones ni se considera parte de las mismas, aun cuando a veces se le exija que suministre información. L os recursos pueden recaer en el propio departamento 0 en un tribunal separado. En ocasiones se admiten recursos ante los tribunales ordinarios, pero éstos no suelen estar preparados para atender casos de seguros sociales en un volumen significativo.

En el régimen general de seguros sociales existe con frecuencia un período de carencia de tres días. Se hacen pagos periódicos por incapacidades transitorias y durante la fase inicial de las permanentes. Reciben generalmente el nombre de "prestación por enfermedad", aunque se pagan también en caso de lesiones. La causa de una incapacidad es generalmente irrelevante, pero de ordinario se paga la prestación si la incapacidad es causa de ausencia del trabajo.

Suelen pagarse pensiones por incapacidades totales permanentes. En muchas jurisdicciones también se pagan pensiones por incapacidades parciales permanentes, aun cuando a veces esta prestación se limita a las derivadas del empleo. Las incapacidades parciales que se clasifican como menores pueden ser indemnizadas con un tanto alzado o no compensadas en absoluto. La distinción entre incapacidad total y parcial y el nivel de pensión por incapacidad parcial, dependen en algunas jurisdicciones de la repercusión estimada de la incapacidad en la capacidad de ganancias del beneficiario. En otras puede medirse por el grado de deterioro físico y mental. A veces se utiliza una fórmula mixta en la que se consideran ambos factores. En algunas jurisdicciones, una incapacidad parcial se clasifica como total durante cualquier período de hospitalización para el tratamiento de la misma. Normalmente se conceden prestaciones especiales por necesidades especiales, como asistencia personal.

Las prestaciones de fallecimiento suelen incluir un tanto alzado para gastos de funeral, una pensión para el cónyuge superviviente, que en algunas jurisdicciones sólo se concede a la viuda, y pagos periódicos a los hijos supervivientes.

En los regímenes generales de seguros sociales es frecuente que no se den ciertos rasgos de los de indemnización por accidentes de trabajo. Entre otros, la cobertura opcional, las compensaciones, las clasificaciones industriales, la puntuación según experiencia, la capitalización y el papel en la salud y seguridad en el trabajo.

En algunas jurisdicciones que cuentan con un régimen separado de indemnización por accidentes de trabajo, los demandantes de ese sistema no tienen la posibilidad de recibir prestaciones de incapacidad del régimen general de seguros sociales o del régimen de seguridad social. En otras que tienen un régimen separado de indemnización por accidentes de trabajo, se permite la acumulación total o parcial de prestaciones. En algunas de estas jurisdicciones, el régimen general de seguros sociales ocupa la posición de primer obligado al pago, tanto con respecto a la asistencia médica como a las prestaciones monetarias, acumulándose las prestaciones del régimen de indemnización por accidentes de trabajo, a veces por todas las pérdidas.

G eneralmente, los programas de seguros sociales y seguridad social prestan asistencia de rehabilitación. El alcance de la misma varía, lo mismo que en los regímenes de indemnización por accidentes de trabajo. En algunos países hay tendencia a reducir el ámbito de las pensiones de incapacidad y a incrementar la asistencia para rehabilitación profesional. Esto plantea el problema de que el recorte de las prestaciones monetarias puede ser real, mientras que la sustitución por asistencia para rehabilitación puede ser ilusoria a consecuencia de la evolución económica y financiera, que dificulta la prestación de asistencia para rehabilitación profesional. La viabilidad de los regímenes de seguros sociales está hoy amenazada en algunos países por el debilitamiento del Estado y del empleo organizado y por la expansión de la "economía informal", del trabajo por cuenta propia y de las empresas muy pequeñas.

Estos sistemas se exponen con mayor detalle en tratados sobre seguridad social y seguros sociales.

\section{Indemnización por accidentes}

Algunas jurisdicciones cuentan con un régimen de indemnización por accidentes o seguro de accidentes administrado por el gobierno. Estos regímenes difieren de la indemnización por accidentes de trabajo en que cubren todas las lesiones causadas por un accidente, independientemente de la causa, más alguna categoría de enfermedades profesionales, o todas las enfermedades derivadas del empleo. Sustituyen a la indemnización por accidentes de trabajo y al componente de lesiones personales en los seguros de vehículos a motor, pero cubren asimismo las lesiones producidas en el hogar, durante la práctica del deporte o de otras maneras. Las prestaciones son las típicas de la indemnización por accidentes de trabajo, incluyendo la ayuda médica, la compensación monetaria y la asistencia para rehabilitación. Estos regímenes difieren de los generales de seguros sociales en que no cubren la mayoría de las incapacidades y muertes derivadas de enfermedades que no se demuestre que han sido consecuencia del empleo. Por este motivo, no cubren la mayoría de las incapacidades y muertes.

\section{Abono del salario por enfermedad}

En algunas jurisdicciones, el derecho laboral exige que las empresas, o algunas de ellas, continúen pagando el sueldo o salario, al menos en parte, cuando un trabajador queda incapacitado para trabajar a consecuencia de una enfermedad o lesión. Además, independientemente de cualquier obligación legal, es corriente que muchas empresas continúen pagando el sueldo 0 
salario durante algún tiempo cuando un trabajador queda inútil para el trabajo. Aun cuando este régimen recibe con frecuencia el nombre de "paga por enfermedad", sus disposiciones normalmente se aplican a las ausencias del trabajo causadas por lesiones o por enfermedades. Generalmente son informales, en particular entre las pequeñas empresas. L as grandes empresas suelen tener regímenes contractuales de indemnización por enfermedad, a veces a consecuencia de la negociación colectiva. En algunas jurisdicciones es obligatoria la paga por enfermedad.

El régimen de indemnización por accidentes de trabajo, cuando es aplicable, ocupa la posición de primer obligado al pago, por lo que la paga por enfermedad es inaplicable a casos cubiertos por la indemnización por accidentes de trabajo, o concede ingresos complementarios. Alternativamente, la empresa puede continuar pagando los salarios y recibiendo un reembolso total o parcial del organismo de indemnización por accidentes de trabajo. En algunas jurisdicciones la paga por enfermedad cubre un período inicial para todas las incapacidades, después del cual la indemnización por accidentes de trabajo cubre las prestaciones por la incapacidad, cuando ésta da lugar a prestación.

En las jurisdicciones que no cuentan con un régimen de indemnización por accidentes de trabajo, la paga por enfermedad se aplica generalmente a las incapacidades resultantes del empleo y a las derivadas de otras causas. La paga por enfermedad puede en tal caso conceder la renta total del trabajador 0 complementar una prestación de los seguros sociales.

\section{Seguro de invalidez}

A modo de alternativa a la paga por enfermedad, el seguro de invalidez de corta duración (a veces denominado "seguro de indemnización semanal") lo organizan algunas empresas en algunas jurisdicciones. Es análogo a la paga por enfermedad, excepto que es administrado por compañía de seguros.

El seguro de invalidez de larga duración lo organizan muchas empresas de muchas jurisdicciones mediante una póliza de grupo, concertada con una compañía de seguros. En el sector sindicado, estas pólizas son con frecuencia resultado de la negociación colectiva. En el sector no sindicado, a veces se conciertan pólizas de grupo a iniciativa de la empresa. Las primas las paga comúnmente la empresa, aunque a veces lo hacen en todo o en parte los trabajadores.

En jurisdicciones que cuentan con un régimen de indemnización por accidentes de trabajo, esas pólizas excluyen generalmente las incapacidades cubiertas por éste. En otras, la cobertura de esas pólizas puede incluir incapacidades resultantes del empleo. Las prestaciones adoptan generalmente la forma de pagos periódicos, que pueden conmutarse por un tanto alzado.

Estas pólizas suelen limitarse a casos de incapacidad total, o incluyen ciertos casos de incapacidad parcial, pero sólo durante un plazo limitado. También en otros aspectos la cobertura de esas pólizas es más restringida que la de la indemnización por accidentes de trabajo. Por ejemplo, las prestaciones pueden estar sujetas a terminación después de dos años si el beneficiario es capaz de realizar algún tipo de trabajo, aunque sea a un nivel mucho más bajo de retribución y el beneficiario sólo pueda hacer ese trabajo durante algunas horas por la semana. Es usual cancelar las prestaciones después de un período inicial alegando que el beneficiario es capaz de realizar algún tipo de trabajo, aunque este beneficiario no pueda acceder a él.

\section{Responsabilidad de la empresa}

La mayoría de las jurisdicciones tienen o han tenido una norma legal que en ciertas circunstancias hace responsables a las empresas de las incapacidades causadas a sus trabajadores.
G eneralmente, los criterios de responsabilidad son los siguientes: negligencia de la empresa, del personal directivo o de un compañero de trabajo o incumplimiento de alguna ordenanza o de una norma sobre salud y seguridad en el trabajo. Esta responsabilidad pueden crearla los tribunales mediante la jurisprudencia, una ordenanza laboral o un código civil.

La indemnización adopta la forma de un tanto alzado, conocido por el nombre de "daños y perjuicios". El importe puede incluir una estimación de las pérdidas económicas (usualmente, pérdida de ganancias) y una cantidad estimada por las pérdidas no económicas (dolor y padecimientos, desfiguración, disfunción sexual, deterioro de actividades sociales y pérdida de esperanza de vida). La cantidad a tanto alzado cubre estimaciones de pérdidas futuras y pasadas. En casos de muerte, entre los daños recuperables por personas a cargo pueden citarse la pérdida de su participación en las ganancias futuras del trabajador y, en algunas jurisdicciones, una indemnización a las personas a cargo por pérdidas no económicas. La negligencia del trabajador como causa concurrente es una excepción perentoria en algunas jurisdicciones. En otras se rebaja la cuantía de los daños y perjuicios.

En jurisdicciones que no cuentan con un régimen de indemnización por accidentes de trabajo, la responsabilidad de la empresa tiene normalmente vigencia plena, pero la admisibilidad a las prestaciones del régimen general de seguros sociales 0 de seguridad social puede reducir los daños y perjuicios. En otras tiene vigencia la responsabilidad de la empresa, pero se limita su ámbito. Cuando un trabajador incapacitado de algunas jurisdicciones recibe prestaciones del régimen general de seguros sociales, éste se subroga en la reclamación contra la empresa.

En jurisdicciones que cuentan con un régimen de indemnización por accidentes de trabajo que no cubre todas las industrias o todas las ocupaciones, la responsabilidad de la empresa tiene plena vigencia en general para quienes no están cubiertos por la indemnización por accidentes de trabajo.

Cuando una incapacidad o muerte está cubierta por el régimen de indemnización por accidentes de trabajo, se produce generalmente una de las consecuencias siguientes en relación con la responsabilidad de la empresa.

- La responsabilidad de la empresa sigue vigente, pero el beneficiario ha de elegir entre reclamar las prestaciones de la indemnización por accidentes de trabajo o reclamar contra la empresa. Cuando el trabajador elige la segunda opción, en algunas jurisdicciones se extingue la posibilidad de aplicar la primera. En otras puede reclamarse la indemnización por accidentes de trabajo si fracasa la de responsabilidad de la empresa.

- La responsabilidad de la empresa sigue vigente, pero hay una compensación, de modo que sólo pueden recibirse daños y perjuicios por las pérdidas que superen las prestaciones de la indemnización por accidentes de trabajo.

- La responsabilidad de la empresa sigue vigente, pero se limita a daños y perjuicios por pérdidas no monetarias.

- Se excluyen las reclamaciones por responsabilidad de la empresa para trabajadores cubiertos por la indemnización por accidentes de trabajo, pero con algunas excepciones, como lesiones causadas deliberadamente por la empresa o producidas en carretera. En esos casos pueden aplicarse los subpárrafos 1, 2 ó 3.

- Se excluyen las reclamaciones por responsabilidad de la empresa para trabajadores cubiertos por la indemnización por accidentes de trabajo. En algunas jurisdicciones esta exclusión comprende también las reclamaciones por daños y perjuicios por lesiones personales contra compañeros de trabajo, contra 
cualquier otra empresa acogida al régimen de indemnización por accidentes de trabajo y contra cualquier trabajador de esa otra empresa, siempre que la reclamación se base en conductas del acusado durante el empleo 0 actividad productiva.

En jurisdicciones en las que sigue vigente la responsabilidad de la empresa en casos cubiertos por la indemnización por accidentes de trabajo, las prestaciones de ésta parecen ser más restringidas, y así se espera que sigan.

C uando no se admiten reclamaciones por responsabilidad de la empresa, la prohibición se refiere con frecuencia sólo a las reclamaciones de daños y perjuicios causados por la lesión o enfermedad. En algunas jurisdicciones pueden seguir presentándose reclamaciones por otros motivos. Por ejemplo, puede presentarse una reclamación de daños y perjuicios contra una empresa por impedir la tramitación de una reclamación de indemnización por un trabajador, por ejemplo, incumpliendo la obligación legal de conservar o suministrar datos relativos a la exposición de un trabajador a una contaminación. Además, la prohibición de reclamaciones de responsabilidad de la empresa normalmente sólo se aplica a incapacidades indemnizables en el régimen de indemnización por accidentes de trabajo. Así, si un trabajador queda incapacitado por negligencia de una empresa, pero no puede optar a la indemnización por accidentes de trabajo, se admite una reclamación de daños y perjuicios contra la empresa. Por ejemplo, en algunas jurisdicciones no se paga indemnización por estrés laboral; y tampoco por la incapacidad de un niño a consecuencia de la exposición prenatal o lesión de los padres durante el empleo. En estas situaciones no está en principio excluida por la legislación sobre indemnización por accidentes de trabajo la reclamación de daños y perjuicios contra la empresa.

\section{Lecturas recomendadas}

Gussum, LV. 1994. Les Accidents du T ravail, 3a ed. Bruselas: DeBoeck.
Ison, T G. 1989. W orkers' Compensation in Canada, 2a ed. T oronto: Butterworths.

- . 1994. Compensation Systems for I njury and D isease: The Policy Choices. T oronto: Butterworths.
Larson, A. The Law of W orkmen's Compensation, cuaderno actualizado. NuevaY ork: M atthew Bender.

Lewis, R. 1987. Compensation for Industrial Injury. A bingdon: Professional Books. 


\section{INDEMNIZACION A LOS TRABAJADORES: TEMAS RELACIONADOS}

Directores del capítulo

Paule Rey y

$M$ ichel Lesage

\section{Sumario}

Enfermedades relacionadas con el trabajo y enfermedades profesionales: lista internacional de la O IT

M ichel Lesage. . . . . . . . . . . . . . . . . . . . . . . . . 26.2

Indemnización por accidentes de trabajo: tendencias y perspectivas

Paule Rey.

Prevención, rehabilitación e indemnización en el sistema alemán de seguro de accidentes

D ieter G reiner y Andreas Kranig .

Seguro e indemnización de las lesiones profesionales en Israel

$H$ aim Chayon ......................... 26.22

La indemnización por accidentes de trabajo en Japón Kazutaka Kogi y H aruko Suzuki. . .

Estudio de caso: Suecia

Peter W esterholm 


\section{ENFERMEDADES RELACIONADAS CON EL TRABAJO Y ENFERMEDADES PROFESIONALES: LISTA INTERNACIONAL DE LA O IT}

M ichel Lesage

En 1919, año de su creación, la O rganización Internacional del Trabajo (OIT) definió el ántrax como enfermedad profesional. En 1925 se estableció la primera Lista de enfermedades profesionales de la OIT en virtud del Convenio no 18 , relativo a la indemnización por enfermedades profesionales. En él se incluían tres enfermedades. Poco después fue modificado por el Convenio no 42, de 1934, en el que figuraban diez enfermedades. En 1964 la Conferencia Internacional del Trabajo aprobó un nuevo Convenio ( $n \div 0121)$ sobre las prestaciones en caso de accidentes del trabajo y enfermedades profesionales. Al Convenio se unió como anexo una Lista de enfermedades profesionales, lo que permitía su modificación sin necesidad de adoptar un nuevo convenio (OIT 1964).

\section{Definición de las enfermedades relacionadas con e trabajo y de las enfermedades profesionales}

En la tercera edición de la Enciclopedia de salud y la seguridad en el trabajo se distinguía, respecto a los procesos patológicos susceptibles de afectar a los trabajadores, entre las enfermedades causadas por el trabajo (enfermedades profesionales) y las agravadas por el trabajo o que tienen una mayor incidencia por causa de las condiciones de trabajo (enfermedades relacionadas con el trabajo) separándose ambas de las enfermedades no asociadas a la actividad laboral. No obstante, en algunos países, las enfermedades relacionadas con el trabajo se asimilan a las enfermedades profesionales. Los conceptos de enfermedad profesional y de enfermedad relacionada con el trabajo han sido siempre objeto de debate.

En 1987, un comité de expertos conjunto de la OIT y la O M S sobre salud en el trabajo propuso que el concepto de enfermedades relacionadas con el trabajo se aplicase, no solamente a las enfermedades profesionales reconocidas, sino también a otros trastornos a cuya aparición contribuyen significativamente, como factores causales, el medio ambiente laboral y la realización del trabajo (Comité M ixto OIT/OMS sobre Salud en el Trabajo 1989).

Si resulta evidente la existencia de una relación causal entre un determinado riesgo profesional y una enfermedad específica, ésta se suele clasificar, tanto médica como jurídicamente, como enfermedad profesional, y se puede definir como tal. Sin embargo, no todas las enfermedades relacionadas con el trabajo son susceptibles de una definición tan específica. En efecto, en el número 1 del apartado 6 de la Recomendación no 121 de la OIT de 1964 sobre las prestaciones en caso de accidentes del trabajo y enfermedades profesionales, aparece la definición siguiente: "Todo M iembro debería, en las condiciones establecidas, considerar como enfermedades profesionales las que se sabe provienen de la exposición a sustancias o condiciones peligrosas inherentes a ciertos procesos, oficios u ocupaciones".

N o obstante, no siempre es fácil establecer si una determinada enfermedad está relacionada con el trabajo. De hecho, muchas de ellas están asociadas de un modo u otro con una profesión 0 con las condiciones de trabajo. Por una parte, están las clásicas enfermedades de naturaleza profesional, por lo general vinculadas a un agente causal y relativamente fáciles de identificar; por otra, existen múltiples trastornos que carecen de una relación estrecha o específica con una profesión y pueden obedecer a numerosas causas.

M uchas de estas enfermedades de etiología múltiple pueden estar relacionadas con el trabajo sólo en determinadas circunstancias. Esta cuestión se debatió en un simposio internacional dedicado a las enfermedades relacionadas con el trabajo que la OIT organizó en Linz, Austria, en octubre de 1992 (O IT, 1993). La diversidad de relaciones entre trabajo y enfermedad se tradujo en el reconocimiento de las categorías siguientes:

- enfermedades profesionales, reconocidas como tales y con una relación específica o poderosa con una profesión, debidas, por lo general, a un único agente causal;

- enfermedades relacionadas con el trabajo, de etiología compleja, debidas a múltiples agentes causales, de cuya evolución pueden ser factores coadyuvantes las condiciones del medio ambiente de trabajo, combinadas con otros factores de riesgo;

- enfermedades que aquejan a la población trabajadora, que, si bien carecen de un nexo causal con el trabajo, pueden verse agravadas por los riesgos sanitarios de origen laboral.

\section{Criterios de identificación de las enfermedades profesionales en general}

La definición de las enfermedades profesionales se basa en dos elementos centrales:

- la relación exposición-efecto entre un determinado medio ambiente de trabajo o actividad y una cierta enfermedad;

- el hecho de que la enfermedad tenga entre la población trabajadora una incidencia superior a la morbilidad media del resto de la población.

Resulta evidente que para establecer la relación exposiciónefecto de una determinada enfermedad profesional y la correlativa actividad propia de determinadas profesiones, son indispensables: (a) datos clínicos y patológicos, y (b) un análisis de los antecedentes laborales y del puesto de trabajo, siendo también de interés (c) los datos epidemiológicos.

Por regla general, los síntomas no son lo suficientemente específicos para permitir un diagnóstico de la enfermedad profesional sobre bases distintas de los cambios patológicos generados por los factores físicos, químicos, biológicos y de otro tipo que están presentes en el desarrollo de la actividad profesional. Es normal, por tanto, que, como consecuencia de un mejor conocimiento de la actuación de los factores comentados, del incremento sostenido del número de sustancias utilizadas y de la calidad 0 de la variedad de los agentes utilizados, sea cada vez más posible efectuar un diagnóstico correcto y, al mismo tiempo, ampliar el abanico de estas enfermedades. Paralelamente el auge de la investigación en este campo, el desarrollo y perfeccionamiento de las encuestas epidemiológicas han contribuido en gran medida a enriquecer el conocimiento de la relación entre exposición y efectos, lo que ha facilitado, entre otras cosas, la identificación y definición de diversas enfermedades profesionales. En la práctica, la identificación del origen profesional de una enfermedad es un ejemplo típico de toma de decisiones clínicas o de epidemiología clínica aplicada. La determinación del origen de una enfermedad, lejos de constituir una ciencia exacta, es una cuestión de juicio basado en un análisis crítico de los elementos disponibles, entre los que se deben incluir los siguientes:

- Intensidad de la asociación. Se observa un incremento evidente de la enfermedad profesional en función de la exposición a un riesgo.

- Concordancia. Los resultados de investigaciones suelen presentar resultados y conclusiones similares. 
- Especificidad. La exposición al riesgo se traduce en un patrón claramente definido de la enfermedad o enfermedades y no en un simple incremento de las causas de morbilidad 0 de mortalidad.

- H orizonte temporal adecuado. La enfermedad se produce después de la exposición, dentro de un período determinado.

- Gradiente biológico. A mayor nivel de exposición, mayor gravedad de la enfermedad.

- Plausibilidad biológica. De acuerdo a los datos aportados por las características toxicologicas, químicas, físicas y de otro tipo del riesgo estudiado, es correcto, desde el punto de vista biológico, afirmar que la exposición genera una determinada alteración.

- Coherencia. U na síntesis global de las evidencias (epidemiología humana, estudios en animales, etc.) lleva a la conclusión de que existe una relación causal en sentido amplio y desde la perspectiva del sentido común.

La magnitud del riesgo es otro elemento básico generalmente utilizado en la determinación del origen profesional de una enfermedad. Los criterios cuantitativos y cualitativos desempeñan una función importante en la evaluación del riesgo de contraer una enfermedad profesional. Este riesgo se puede expresar en función, bien de su magnitud (por ejemplo, las cantidades empleadas de una determinada sustancia, el número de trabajadores expuestos, los índices de prevalencia de la enfermedad en diferentes países, etc.), bien de la gravedad del riesgo, evaluada en base a sus efectos sobre la salud del trabajador (es decir, la probabilidad de que produzca cáncer o mutaciones, o que, con el tiempo, sea causa de incapacidad). Es de subrayar que las cifras disponibles sobre los índices de prevalencia y sobre la gravedad de las enfermedades profesionales se deben tomar con cierta reserva, justificada por la existencia de diversos procedimientos de notificación de los casos y de recogida y evaluación de los datos. Esto mismo ocurre en lo que respecta al número de trabajadores expuestos, dado que las cifras son, a veces, aproximaciones.

Por último, en el ámbito internacional, es preciso tomar, asimismo, en consideración un factor sumamente importante: el reconocimiento del carácter profesional de la enfermedad en cierto número de países constituye un importante criterio para su inclusión en la lista internacional. Se puede afirmar que su inclusión en la lista de enfermedades comprendidas en la cobertura de las prestaciones demuestra tanto la considerable importancia socioeconómica de la enfermedad como que sus factores de riesgo son conocidos y han alcanzado una gran difusión.

Resumiendo, los criterios de inclusión de una nueva enfermedad profesional en la lista internacional son: la intensidad de la relación entre exposición y efectos; la aparición de la enfermedad junto con una determinada actividad 0 un medio ambiente de trabajo concreto (que comprende tanto la aparición del cuadro como una naturaleza específica de esta relación); la magnitud del riesgo, medida sobre la base del número de trabajadores expuestos o de la gravedad del riesgo; y la inclusión de la enfermedad en varias listas nacionales.

\section{Criterios de identificación de una enfermedad determinada}

Tanto la relación entre exposición y efectos (esto es, la relación entre la exposición y la gravedad del daño causado al individuo) como la relación entre exposición y respuesta (esto es, la vinculación entre la exposición y el número de individuos afectados) son importantes en la descripción de las enfermedades profesionales, que se ha desarrollado considerablemente en el último decenio gracias a los esfuerzos de investigación y a los estudios epidemiológicos. Estos conocimientos de la relación causal entre enfermedad y exposición en el lugar de trabajo nos han permitido mejorar la definición clínica de las enfermedades profesionales. U nido a ello la definición legal de la enfermedad profesional, que era en otro tiempo un asunto bastante complejo, se asocia ahora cada vez más a las definiciones clínicas. EI ordenamiento jurídico que regula los derechos a la percepción de prestaciones varía de un país a otro. En el artículo 8 del Convenio no 121, sobre las prestaciones en caso de accidente del trabajo o enfermedades profesionales, en el que se relacionan las diversas opciones relativas a la elaboración de las listas de enfermedades profesionales comprendidas en el sistema de prestaciones a los trabajadores, se establece lo siguiente:

Todo M iembro deberá:

a) establecer una lista de enfermedades en la que figuren, por lo menos, las que se enumeran en el cuadro I del presente Convenio y que serán reconocidas como enfermedades profesionales cuando sean contraídas en las condiciones predefinidas;

(b) incluir en su legislación una definición general de enfermedad profesional, que deberá ser suficientemente amplia para que abarque, por lo menos, las enfermedades enumeradas en el cuadro I del presente Convenio;

(c) establecer una lista de enfermedades en cumplimiento del apartado a), añadiendo, además, una definición general de enfermedad profesional o bien otras disposiciones que permitan establecer el origen profesional de las enfermedades que no figuran en la lista o que se manifiestan bajo condiciones diferentes a las predefinidas.

El punto a) es lo que se denomina sistema de listas; el punto b) sistema de definición genérica o de cobertura global, y el punto c) sistema mixto.

Si bien el sistema de lista tiene el inconveniente de que únicamente comprende un determinado número de enfermedades profesionales, presenta la ventaja de relacionar las enfermedades que se presumen de origen profesional. En este sistema suele ser muy difícil, si no imposible, demostrar la relación causal directa entre una enfermedad y la profesión del paciente. En el número 2 del apartado 6 de la Recomendación no 121 se establece que "el origen profesional de estas enfermedades debería presumirse, salvo prueba en contrario" (en las condiciones preestable cidas). Este sistema presenta asimismo la importante ventaja de indicar claramente dónde se debe centrar la prevención.

En teoría, el sistema de la definición genérica abarca la totalidad de las enfermedades profesionales; si bien el ámbito previsto en él, más amplio y flexible, corresponde al afectado demostrar el origen profesional de la enfermedad y no se pone especial acento en la prevención específica.

En vista de la sensible diferencia existente entre una definición genérica y una lista de enfermedades específicas, muchos Estados miembros de la OIT han optado por el sistema mixto, que combina las ventajas de los otros dos y está libre de sus inconvenientes.

\section{Lista de enfermedades profesionales}

\section{Convenio no 121 y Recomendación no 121}

La lista de la O IT desempeña una función clave en la armonización del desarrollo de la política relativa a las enfermedades profesionales y a la promoción de su prevención. De hecho, ha logrado una importancia considerable en el campo de la salud y la seguridad en el trabajo. En ella se especifican claramente los trastornos o enfermedades susceptibles de prevención. En realidad, la lista no incluye la totalidad de las enfermedades profesionales; su objeto es exponer las que tienen mayor 
Tabla 26.1 - Lista de enfermedades profesionales propuesta por la O IT.

1. Enfermedades causadas por agentes

1.1 Enfermedades causadas por agentes químicos

1.1.1 Enfermedades causadas por el berilio 0 sus compuestos tóxicos

1.1.2 Enfermedades causadas por el cadmio 0 sus compuestos tóxicos

1.1.3 Enfermedades causadas por el fósforo 0 sus compuestos tóxicos

1.1.4 Enfermedades causadas por el cromo 0 sus compuestos tóxicos

1.1.5 Enfermedades causadas por el manganeso 0 sus compuestos tóxicos

1.1.6 Enfermedades causadas por el arsénico 0 sus compuestos tóxicos

1.1.7 Enfermedades causadas por el mercurio 0 sus compuestos toxicos

1.1.8 Enfermedades causadas por el plomo 0 sus compuestos tóxicos

1.1.9 Enfermedades causadas por el flúor o sus compuestos tóxicos

1.1.10 Enfermedades causadas por el disulfuro de carbono

1.1.11 Enfermedades causadas por los derivados halogenados tóxicos de los hidrocarburos alifáticos 0 aromáticos

1.1.12 Enfermedades causadas por el benceno 0 sus homólogos tóxicos

1.1.13 Enfermedades causadas por los derivados nitrados y amínicos tóxicos del benceno o de sus homólogos

1.1.14 Enfermedades causadas por la nitroglicerina u otros ésteres del ácido nítrico

1.1.15 Enfermedades causadas por los alcoholes, los glicoles 0 las cetonas

1.1.16 Enfermedades causadas por sustancias asfixiantes: monóxido de carbono, cianuro de hidrógeno o sus derivados tóxicos, sulfuro de hidrógeno

1.1.17 Enfermedades causadas por el acetonitrilo

1.1.18 Enfermedades causadas por los óxidos de nitrógeno

1.1.19 Enfermedades causadas por el vanadio 0 sus compuestos tóxicos

1.1.20 Enfermedades causadas por el antimonio 0 sus compuestos tóxicos

1.1.21 Enfermedades causadas por el hexano

1.1.22 Enfermedades dentales debidas a los ácidos minerales

1.1.23 Enfermedades debidas a los agentes farmacéuticos

1.1.24 Enfermedades debidas al talio 0 sus compuestos

1.1.25 Enfermedades debidas al osmio o sus compuestos.
1.1.26 Enfermedades debidas al selenio o sus compuestos tóxicos

1.1.27 Enfermedades debidas al cobre 0 sus compuestos

1.1.28 Enfermedades debidas al estaño o sus compuestos

1.1.29 Enfermedades debidas al zinc 0 sus compuestos tóxicos

1.1.30 Enfermedades debidas al ozono 0 al fosgeno

1.1.31 Enfermedades debidas a sustancias irritantes: benzoquinona y otras sustancias irritantes de la córnea

1.1.32 Enfermedades causadas por cualquier otra sustancia química no mencionada en los anteriores apartados 1.1 .1 a 1.1.31, siempre que se establezca una relación entre la exposición del trabajador a la sustancia en cuestión y la enfermedad sufrida

1.2 Enfermedades causadas por agentes físicos

1.2.1 Afección auditiva producida por el ruido

1.2.2 Enfermedades causadas por las vibraciones (afecciones de los músculos, de los tendones, de los huesos, de las articulaciones, de los vasos sanguíneos o de los nervios periféricos)

1.2.3 Enfermedades causadas por el trabajo en aire comprimido

1.2.4 Enfermedades causadas por las radiaciones ionizantes

1.2.5 Enfermedades causadas por las radiaciones térmicas

1.2.6 Enfermedades causadas por las radiaciones ultravioletas

1.2.7 Enfermedades debidas a temperaturas extremas (por ejemplo, insolación, congelación)

1.2.8 Enfermedades causadas por cualquier otro agente físico no mencionado en los anteriores apartados 1.2 .1 a 1.2.7, siempre que se establezca una relación directa entre la exposición del trabajador al agente físico en cuestión y la enfermedad sufrida

1.3 Agentes biológicos

1.3.1 Enfermedades infecciosas o parasitarias contraídas en una actividad que implique un riesgo especial de contaminación

2. Enfermedades por sistemas orgánicos afectados

2.1 Enfermedades profesionales de las vías respiratorias

2.1.1 Neumoconiosis causada por polvos minerales esclerógenos (silicosis, antracosilicosis, asbestosis) y silicotuberculosis, siempre que la silicosis sea una causa determinante de incapacidad o muerte

2.1.2 Bronconeumopatías causadas por el polvo de metales duros 
Tabla 26.1 - Lista de enfermedades profesionales propuesta por la O IT. Continuación.

2.1.3 Enfermedades broncopulmonares causadas por el polvo de algodón, de lino, de cáñamo o de sisal (bisinosis)

2.1.4 Asma profesional causada por agentes sensibilizantes 0 irritantes reconocidos como tales e inherentes al tipo de trabajo

2.1.5 Alveolitis alérgicas extrínsecas causadas por la inhalación de polvos orgánicos, según lo prescrito en la legislación nacional

2.1.6 Siderosis

2.1.7 Enfermedades pulmonares obstructivas crónicas

2.1.8 Enfermedades pulmonares debidas al aluminio

2.1.9 Trastornos de las vías respiratorias superiores causados por agentes sensibilizantes 0 irritantes reconocidos como tales e inherentes al tipo de trabajo

2.1.10 Cualquier otra enfermedad de las vías respiratorias no mencionada en los anteriores apartados 2.1.1 a 2.1.9 causada por un agente, siempre que se establezca una relación directa entre la exposición del trabajador a este agente y la enfermedad sufrida

2.2 Enfermedades profesionales de la piel

2.2.1 Enfermedades de la piel no mencionadas anteriormente causadas por agentes físicos, químicos o biológicos

2.2.2 Vitíligo profesional

2.3 Enfermedades profesionales musculosqueléticas

2.3.1 Enfermedades musculosqueléticas causadas por determinadas actividades o medios ambientales de trabajo en que hay factores de riesgo específicos

He aquí algunos ejemplos de estas actividades 0 medios ambientales de trabajo:

(a) Movimientos rápidos o repetitivos

(b) Esfuerzos ímprobos (c) Concentración excesiva de esfuerzos mecánicos

(d) Posturas forzadas o no naturales

(e) Vibraciones

El frío localizado o ambiental puede potenciar el riesgo

2.3.2 Nistagmo del minero

3. Cáncer profesional

3.1 Cáncer causado por los agentes siguientes:

3.1.1 Amianto

3.1.2 Bencidina y sus sales

3.1.3 Éter biclorometílico (EDCM)

3.1.4 Cromo y compuestos de cromo

3.1.5 Alquitranes de hulla y brea de alquitranes de hulla; hollín

3.1.6 Betanaftilamina

3.1.7 Cloruro de vinilo

3.1.8 Benceno o sus homólogos tóxicos

3.1.9 Derivados nitrados y amínicos tóxicos del benceno y sus homólogos

3.1.10 Radiaciones ionizantes

3.1.11 Alquitrán, brea, betún, aceites minerales, antracineno y los compuestos, productos o residuos de estas sustancias

3.1.12 Emisiones de los hornos de coque

3.1.13 Compuestos del níquel

3.1.14 Polvo de madera

3.1.15 Cáncer causado por cualesquiera otros agentes no mencionados en los anteriores apartados 3.1.1 a 3.1 .14 , siempre que se establezca una relación directa entre el agente en cuestión y el cáncer padecido.

En su informe, los expertos indicaron que la lista se debería actualizar periódicamente para facilitar la armonización de la prestaciones de la seguidad social en el ámbito internacional. En el documento se afirmaba rotundamente que no existía ninguna razón ética o moral para recomendar en un país la adopción de niveles inferiores a los de otros países. Otros motivos que aconsejan la revisión frecuente de la lista son: (1) el fomento de la prevención de las enfermedades profesionales mediante el aumento de la sensibilización respecto a los riesgos inherentes al trabajo, (2) el estímulo de la lucha contra el uso de sustancias nocivas, y (3) el mantenimiento de los trabajadores bajo supervisión médica. La prevención de las enfermedades profesionales sigue siendo un objetivo prioritario de todo sistema de seguridad social dirigido a la protección de la salud de los trabajadores.

incidencia en las empresas de muchos países y cuya prevención puede beneficiar en mayor medida la salud de los trabajadores.

Debido al cambio profundo y continuo que experimentan los sistemas de empleo y de riesgos, y a la evolución de los conocimientos aportada por los estudios epidemiológicos y la investigación, es preciso ampliar y actualizar la lista, para que refleje la evolución de los conocimientos, en aras de un trato justo a los afectados

En los países desarrollados, la industria pesada, como la siderurgia y la minería subterránea, ha experimentado una disminución considerable, y las condiciones ambientales han mejorado.
La importancia relativa de los sectores de servicios y de gestión automatizada se han incrementado. Un porcentaje mucho mayor de la población activa está constituido por mujeres que, además, en su mayor parte, realizan las tareas domésticas y cuidan de los hijos. La necesidad de cuidados de los hijos pequeños somete a las mujeres a un estrés creciente. Las jornadas nocturnas y el trabajo en turnos rotatorios se han convertido en prácticas habituales. El estrés, en todas sus manifestaciones, es actualmente un problema importante.

En los países en desarrollo, la industria pesada crece rápidamente para satisfacer las necesidades de los mercados locales y 
de exportación, además de crear empleo para una población que aumenta rápidamente. Los habitantes de las zonas rurales se desplazan a las ciudades en busca de empleo y para huir de la pobreza.

Se conocen los riegos que algunos nuevos productos químicos entrañan para la salud humana, y se concede una importancia especial a los experimentos biológicos a corto plazo y a la exposición prolongada de cobayas a los efectos de esas sustancias, con objeto de evaluar su potencial tóxico y cancerígeno. Es probable que la exposición de la población trabajadora se mantenga en unos niveles bajos en los países desarrollados, pero no existe idéntica seguridad respecto al uso de productos químicos en muchos otros países. Si bien existen pocas dudas de que estos productos contribuyen al incremento de los rendimientos agrícolas a corto plazo, además de permitir un mayor control de las enfermedades transmitidas por vectores, como la malaria, no se sabe exactamente en qué condiciones de control se deben utilizar para que no menoscaben seriamente la salud de los trabajadores agrícolas y de las personas que consumen los alimentos así producidos. A parentemente, en algunos países, su empleo ha producido intoxicaciones a un gran número de trabajadores agrarios. Incluso en los países más desarrollados, la salud de los agricultores plantea problemas muy serios, debido a que su aislamiento y la falta de supervisión los expone a un riesgo real. La persistencia de la producción de ciertos productos químicos en países en los que su uso se encuentra prohibido, para su exportación a otros países en los que no existe tal prohibición, es un tema que debe destacarse.

Especial atención han merecido el proyecto y funcionamiento de los modernos edificios inteligentes y del equipo electrónico de oficina. Los movimientos repetitivos realizados de modo continuo se consideran generalmente causantes de trastornos que debilitan la salud.

Aunque la emisión de humo de tabaco en el lugar de trabajo no se considera, por sí misma, una causa de enfermedad profesional, podría crear problemas en el futuro, puesto que los no fumadores se muestran cada vez más intolerantes al respecto. Es probable que la presión por la venta de productos de tabaco en los países en desarrollo produzca en el futuro cercano una epidemia nunca vista de enfermedades. La exposición de los no fumadores a la contaminación producida por el humo del tabaco será objeto de creciente debate en el futuro y, en algunos países, ya se han dictado medidas legislativas al respecto. Particularmente grave es el peligro que corren los trabajadores del sector sanitario, que están expuestos a una extensa gama de productos químicos, agentes irritantes e infecciones. EI SIDA y la hepatitis son buenos ejemplos.

La incorporación de la mujer al mundo del trabajo en todos los países pone de relieve el problema de los trastornos en la reproducción asociados al lugar de trabajo, como la infertilidad, las disfunciones sexuales y los efectos sobre el feto y el embarazo producidos por la exposición a los agentes químicos y a otros factores presentes en el lugar de trabajo, incluida la fatiga debida a causas ergonómicas. Existen pruebas cada vez más firmes de que los varones pueden verse afectados por estos mismos problemas.

En este contexto de evolución de los patrones demográficos y del riesgo, se impone una revisión de la lista y la adición de las nuevas enfermedades consideradas profesionales. Por consiguiente, es preciso actualizar la lista adjunta al Convenio no 121 e incluir en ella los trastornos generalmente reconocidos como de origen profesional y los que entrañan más peligros para la salud. De hecho, en diciembre de 1991 la OIT celebró en Ginebra una reunión informal al respecto. En el dictamen de los expertos se incluía un proyecto de nueva lista, que se reproduce en la Tabla 26.1.
Se ha propuesto un nuevo formato en el que la lista se desglosa en las tres categorías siguientes:

1. Enfermedades causadas por agentes (químicos, físicos, biológicos).

2. Enfermedades que afectan a varios sistemas orgánicos (respiratorio, cutáneo, musculosquelético);

3. Cáncer de origen profesional.

\section{INDEMNIZACION POR ACCIDENTES DE TRABAJO: TENDENCIASY PERSPECTIVAS}

Paule Rey

Los sistemas de indemnización por accidentes de trabajo se crearon con el fin de sufragar los gastos de asistencia médica y de los servicios de rehabilitación en favor de los trabajadores víctimas de lesiones e incapacidades relacionadas con el trabajo. M ediante ellos se abonan igualmente prestaciones compensatorias a los trabajadores afectados y a las personas a su cargo durante el período de incapacidad. Estos sistemas se han inspirado en los regímenes gestionados por los antiguos gremios y sociedades de socorros mutuos, cuyos afiliados cotizaban a unos fondos que, en su momento, se distribuían entre los miembros que se veían impedidos para trabajar por haber sufrido accidentes de trabajo. U na vez agotadas las reservas, generalmente escasas, de esos fondos, la única posibilidad abierta a sus miembros era recurrir a la beneficencia o demandar a la empresa sobre la base de que la lesión había sido causada por la conducta dolosa o negligente de la misma. Las demandas judiciales raras veces prosperaban, entre otras por las razones siguientes:

- la carencia, por parte del trabajador, de los conocimientos jurídicos necesarios, y la escasez de sus recursos en comparación con los de la empresa

- la dificultad para vencer la estrategia defensiva de la empresa, basada en la pretensión de que el accidente causante de la lesión había sido, bien un caso fortuito, bien el resultado de la ineptitud o la negligencia del trabajador y no de la empresa

- la imposibilidad de que el trabajador aguardase el período de tiempo, generalmente largo, que llevaba la tramitación de las demandas civiles.

Los sistemas de indemnización por accidentes de trabajo se basan en la responsabilidad objetiva y en ellos sólo se exige al trabajador que cumplimente una solicitud en la forma establecida y acredite que la lesión o la incapacidad está "relacionada con el trabajo", de acuerdo con la definición dada a este concepto en la legislación reguladora del sistema en el país en cuestión. Los recursos financieros necesarios se obtienen de fondos constituidos por un organismo oficial. Estos fondos se nutren de impuestos que pagan las empresas, de mecanismos de seguro obligatorio financiados con las cotizaciones abonadas por las mismas, o según otros sistemas en los que se combinan ambos métodos en medida variable. La estructura y el funcionamiento de los sistemas de indemnización por accidentes de trabajo se exponen en profundidad en el capítulo redactado por Ison.

A pesar de algunas lagunas y deficiencias que han justificado diversas modificaciones legislativas y reglamentarias a lo largo del siglo pasado, los sistemas de indemnización por accidentes de trabajo han desempeñado bastante bien su función de cubrir las necesidades de los trabajadores lesionados en el trascurso de 
su trabajo. En un principio, la protección se centraba en los accidentes (esto es, episodios imprevistos ocurridos en el puesto o el lugar de trabajo), que son más fáciles de diagnosticar que las enfermedades profesionales. La inmediatez de la relación causal entre el episodio y la lesión facilita en mayor o menor medida la asociación entre esta última y el lugar de trabajo, en el marco de la normativa legal y reglamentaria aplicable. Por consiguiente, las organizaciones de seguros han tratado de desarrollar, con distinto éxito, una epidemiología de los accidentes en la que se definen las categorías de personas, puestos de trabajo y circunstancias laborales asociados a determinados tipos de lesión. Se ha producido así el desarrollo de una importante industria de la seguridad, dedicada al estudio de diversos tipos de lesiones producidas en el trabajo y al diseño de sistemas de prevención. Se ha obligado a las empresas a implantar estos sistemas de prevención, con la esperanza de ahorrar los gravosos costes producidos por los accidentes evitables. Estos costes están representados por las perturbaciones ocasionadas en los lugares de trabajo, la pérdida temporal o permanente de trabajadores productivos y el incremento en espiral de los impuestos y primas de seguro abonados para financiar los regímenes de indemnización por accidentes de trabajo. O tro factor coadyuvante al proceso ha sido la promulgación, en numerosos países, de normas legislativas sobre salud y seguridad en el trabajo, por las que se obliga a las empresas a tomar medidas efectivas de prevención de accidentes, apoyadas en sistemas de inspección de los centros de trabajo y en la imposición de diversas sanciones a los infractores.

No obstante, tal esquema no ha funcionado excesivamente bien en el campo de las enfermedades profesionales. En estos casos, la relación entre los peligros existentes en el lugar de trabajo y la enfermedad del trabajador suele ser mucho más sutil y compleja, debido tanto al período, a menudo largo, de latencia entre la exposición y los primeros síntomas como a los efectos contradictorios de factores tales como el estilo de vida y los hábitos del trabajador (por ejemplo, el consumo de tabaco), y el desarrollo simultáneo de enfermedades no relacionadas con el trabajo. (Por lo demás, estas últimas pueden verse propiciadas, agravadas e incluso precipitadas por determinadas exposiciones en el lugar de trabajo que, en ciertos casos, justifican su cobertura por parte de los sistemas de indemnización por accidentes de trabajo).

EI presente artículo se centra, inicialmente, en la validez de dos hipótesis vinculadas entre sí:

1. Los sistemas de indemnización por accidentes de trabajo pueden desarrollar programas de prevención basados en evaluaciones del riesgo presente en los lugares de trabajo, a partir del análisis de los datos generados por los accidentes y lesiones por los que se ha abonado una indemnización.

2. Los sistemas de indemnización por accidentes de trabajo pueden ofrecer importantes incentivos financieros (por ejemplo, bonificaciones en las primas o sistemas bonus malus) para inducir a las empresas a implantar sistemas de prevención eficaces (Burger 1989).

Resumiendo, la naturaleza y magnitud del riesgo en el lugar o el puesto de trabajo se pueden inferir del análisis de los datos generados por las indemnizaciones abonadas a los trabajadores empleando ciertas variables, como la presencia de agentes potencialmente nocivos (químicos, físicos biológicos, etc.), las características de los trabajadores expuestos, las circunstancias en el momento de la exposición (por ejemplo, la naturaleza, intensidad y duración de ésta), los efectos fisiopatológicos sobre el trabajador, la gravedad e irreversibilidad de la enfermedad 0 incapacidad resultante, y la distribución de los casos por sectores, puestos de trabajo y lugares de trabajo. La identificación y clasificación de los riesgos potenciales permite el desarrollo de programas destinados a eliminarlos o controlarlos. Con la aplicación de estos programas puede reducirse la incidencia de las enfermedades y lesiones relacionadas con el trabajo, lo cual no sólo redunda en beneficio de los trabajadores, sino que contribuye igualmente a reducir las cargas financieras, directas 0 indirectas que, de otra forma, han de ser soportadas por la empresa.

Trataremos de demostrar que las conexiones entre los casos en que se ha pagado indemnización, la evaluación del riesgo, los esfuerzos en favor de una prevención eficaz y la reducción de las cargas financieras de las empresas no suelen ser tan sencillas como se suele creer. Además, se examinarán diversas propuestas formuladas por médicos del trabajo, abogados y ergónomos con el objeto de enriquecer nuestro conocimiento de los riesgos, aumentar la seguridad en puesto de trabajo y hacer que los sistemas de compensación por accidentes de trabajo sean más justos.

\section{Resultados de los estudios}

\section{Valor de la base de datos de la entidad aseguradora de accidentes de trabajo}

Según Léger y M acon (1990), el valor de una base de datos de accidentes está en función del grado en que permita medir la eficacia del sistema de seguridad, conocer las causas de los accidentes de trabajo y establecer el grado de exposición a los riesgos de los diversos subgrupos en que se divide la población trabajadora. U nas estadísticas de accidentes exactas y efectivas son de gran valor para la elaboración de programas eficaces de previsión de accidentes por parte de las empresas, las organizaciones sindicales y los organismos reguladores oficiales.

\section{¿Qué datos se recopilan?}

Las estadísticas se ciñen a los accidentes y enfermedades definidos en los reglamentos y leyes aplicables y, por tanto, amparados por los sistemas de indemnización por accidentes de trabajo. Existen sensibles diferencias entre los supuestos amparados, tanto en distintos momentos, como en un mismo país o ámbito jurisdiccional y entre diversos países 0 ámbitos jurisdiccionales

En Francia, por ejemplo, las estadísticas recogidas por el Instituto national de recherche et de Sécurité (Instituto N acional de Investigación Científica, INRS), se basa en una lista de enfermedades profesionales cruzada con una lista de sectores de riesgo. En Suiza, la ley del seguro de accidentes contiene una clasificación de las enfermedades profesionales basada en las condiciones predominantes en los lugares de trabajo. Dicha clasificación contempla dos categorías: en la primera figura una lista de agentes nocivos, combinada con una relación de enfermedades; en la segunda se establece una lista de patologías en las que existe una elevada probabilidad de relación causal entre exposición y enfermedad.

La definición de los accidentes de trabajo también puede variar. En Suiza, por ejemplo, los accidentes ocurridos in itinere no se consideran laborales, mientras que los episodios que se producen en el lugar de trabajo, con independencia de que tengan 0 no alguna relación con la actividad laboral (por ejemplo, las quemaduras producidas al calentar la comida), tienen la condición de tales.

Por consiguiente, el número de casos identificados y contabilizados en un determinado país está en función de la definición de accidente de trabajo y de enfermedad profesional en el correspondiente sistema de indemnización. En este sentido, resultan 
ilustrativas la estadísticas suizas relativas a la pérdida de audición debida a causas profesionales, que fue reconocida como enfermedad profesional durante el período 1955-1960. Tras este reconocimiento se produjo un incremento sensible del número de casos comunicados, así como un aumento correlativo del número total de casos de enfermedades laborales imputables a agentes físicos. En años posteriores, la frecuencia de los casos tendió a reducirse. Esto no significa que la incidencia de la pérdida de audición por causas profesionales disminuyese. Puesto que se trata de una enfermedad de desarrollo lento, una vez contabilizado el número total de casos no registrados hasta entonces, el número de nuevos casos reconocidos cada año reflejaba la relación real entre la exposición al ruido y el riesgo de pérdida de audición. En la actualidad asistimos a un nuevo y sensible incremento del número de casos comunicados que son causados por agentes físicos, debido al reciente reconocimiento oficial de los trastornos musculosqueléticos, vulgarmente denominados "trastornos ergonómicos", como la tenosinovitis, la epicondilitis, el síndrome del túnel carpiano y otros.

\section{Comunicación de casos}

Resulta evidente que en todos los países, deliberadamente o por omisión, se dejan de comunicar muchos accidentes y casos de enfermedad relacionados con el trabajo. La obligación de comunicar estos episodios suele corresponder a la empresa. Sin embargo, como han subrayado algunos autores, a veces ésta prefiere no comunicar el hecho, con lo que no sólo se libra de los engorrosos trámites administrativos, sino que, además, mantiene su reputación de lugar de trabajo seguro y evita una eventual acumulación de reclamaciones que podría ocasionar un incremento de los impuestos y primas de financiación de su seguro. Esto ocurre, sobre todo, cuando no se pierden horas de trabajo, así como en los casos atendidos en el propio lugar de trabajo por el servicio de asistencia sanitaria de la empresa (Brody, Letourneau y Poirier 1990).

Corresponde a los médicos identificar y comunicar los casos de lesiones y enfermedades profesionales, y recordar a los pacientes su derecho a ser indemnizados. Sin embargo, algunos casos no se comunican porque no son tratados por médicos especialistas y no se descubre el origen profesional de la patología. El conocimiento de los aspectos jurídicos y profesionales de la asistencia sanitaria debería incorporarse a la formación médica. Las organizaciones internacionales, como la OIT, deben fomentar la inclusión de estas materias en los planes de estudio, tanto de licenciatura, como de posgrado, de todos los profesionales de la salud. Aunque diagnostiquen correctamente el origen de la afección, algunos médicos se muestran reacios a asumir las molestias que implican los trámites burocráticos y arriesgarse a ser citados a testificar en los procedimientos administrativos o en las actuaciones judiciales, en el caso de que se impugne el derecho del trabajador. En algunos países, la circunstancia de que los honorarios legales o estipulados para el tratamiento de los casos amparados por el seguro de enfermedad y lesiones profesionales pueden ser inferiores a los honorarios habitualmente cobrados por el médico puede contribuir a desalentar la comunicación de estos casos.

La comunicación de los casos depende igualmente de la medida en que los trabajadores conozcan sus derechos y el sistema de indemnización por accidentes de trabajo al que están afiliados. Por ejemplo, Walters y $\mathrm{H}$ aines (1988) estudiaron una muestra de 311 trabajadores sindicados y no sindicados de una región industrializada de 0 ntario, C anadá, para evaluar su nivel de utilización y de conocimientos del "sistema de responsabilidad interna". Este sistema había sido establecido con objeto de inducir a las empresas y a sus trabajadores a resolver los problemas de salud y seguridad en el centro de trabajo. A pesar de que el $85 \%$ de los encuestados pensaban que sus condiciones de trabajo podrían perjudicar su salud, sólo el $20 \%$ manifestó haber perdido horas de trabajo por problemas de salud relacionados con su actividad. Por tanto, a pesar de su opinión respecto a los efectos perjudiciales del trabajo sobre su salud, sólo un porcentaje relativamente reducido hacía uso de los derechos y medios previstos en la legislación. En la exposición de sus reticencias hacia el trabajo y en sus quejas sobre los efectos del mismo sobre su salud había escasas referencias al "sistema de responsabilidad interna" legalmente previsto. Incluso aseguraban haber tratado los problemas con su superior jerárquico, en lugar de plantearlos a sus representantes en materia de salud e higiene.

Los investigadores descubrieron que el conocimiento de la normativa legal era mayor entre los trabajadores sindicados y que se solía traducir en la adopción de iniciativas vinculadas a la salud y seguridad en el trabajo (Walters y H aines 1988).

Por otra parte, algunos trabajadores reclaman indemnización aunque la lesión o enfermedad no esté relacionada con su trabajo, o mantienen su reclamación aun cuando ya estén en condiciones de regresar al trabajo. Ciertos estudios han revelado que los sistemas de indemnización más generosos pueden incluso operar como un incentivo al respecto. Según Walsh y Dumitru (1988), "la mejora de las prestaciones puede traducirse en un mayor número de reclamaciones y en una mayor incidencia de lesiones". Utilizando el ejemplo de las lesiones en la espalda (que comprenden el $25 \%$ de las reclamaciones de indemnización que se producen en Estados U nidos), los autores concluyen que "Ios trabajadores son más propensos a pedir la baja laboral si la indemnización es comparable al salario devengado", y añaden que "el sistema de indemnización por incapacidad vigente en Estados Unidos tiende a incrementar la frecuencia de determinados tipos de incapacidad y contribuye a prolongar la recuperación de los problemas de espalda producidos por el trabajo", aparte de que "los factores asociados a la indemnización pueden demorar la recuperación, prolongar los síntomas y reforzar el comportamiento enfermizo".

Judd y Burrows (1986) formularon conclusiones similares sobre la base del análisis de una muestra representativa de trabajadores australianos, de la cual, en el curso de un año, el $59 \%$ "habían estado de baja más de dos meses y el $38 \%$, más de seis meses". L os servicios médicos y jurídicos, señalaron, podrían dar lugar a "esta elevada tasa de invalidez prolongada" y "la recuperación podría ser perjudicial para los intereses del paciente, al menos por lo que respecta al pago de la indemnización".

\section{Admisibilidad de los casos}

Como se ha indicado anteriormente, las estadísticas nacionales reflejan variaciones en la admisibilidad de los distintos tipos de casos. Ejemplos de esta tendencia son la inclusión de una nueva entidad en la lista de enfermedades indemnizables (como ha ocurrido en Suiza con la pérdida de audición) la ampliación de la cobertura a nuevas categorías de trabajadores (como la modificación de los límites de la escala salarial introducida en Sudáfrica), o la extensión de la cobertura a nuevos tipos de actividades.

A diferencia de los accidentes, las enfermedades profesionales no se indemnizan con tanta facilidad. En la Suiza francófona se analizó una extensa muestra de trabajadores que habían estado de baja un mes como mínimo. El estudio puso de relieve que, si bien la mayoría de los accidentes se admitían como laborales y se indemnizaban rápidamente, sólo se aceptaba un porcentaje muy pequeño de las enfermedades (Rey y Bousquet 1995). En algunos casos, es el seguro de enfermedad del paciente, no el sistema de indemnización por enfermedad y accidentes de trabajo, el que abona los gastos médicos. Esto no supone un 
incremento del coste para la empresa (Rey y Bousquet 1995; Burger 1989). Es de subrayar que en países como Estados Unidos, en los que la empresa asume igualmente el seguro general de enfermedad, el coste puede ser incluso superior, dado que los honorarios establecidos en el sistema de indemnización suelen ser inferiores a los que se abonan a los seguros médicos privados.

Yassi (1983) elaboró un informe basado en una conferencia dictada por el profesor Weiler en Toronto. A continuación se reproducen algunas de las observaciones de Weiler, citadas por Yassi:

"La Ley de indemnización por enfermedades profesionales y accidentes de trabajo ha funcionado razonablemente bien respecto a la cobertura de la incapacidad producida por accidentes; sin embargo, no puede afirmarse lo mismo de las enfermedades profesionales. M ientras que, incluso en los casos más complicados de lesiones provocadas por accidentes, el cheque tarda alrededor de un mes en enviarse, la resolución de las reclamaciones por cáncer se demora, por término medio, unos siete meses (igual que en las reclamaciones por enfermedad del sistema respiratorio). Sólo se desestima una pequeña proporción de las reclamaciones por lesiones (en torno al $2 \%$ ); por el contrario, la tasa de desestimación de las reclamaciones por enfermedad grave supera el $50 \% "$.

Particularmente sorprendente es la baja tasa de comunicación del cáncer de origen profesional: "M enos del $15 \%$ de la cifra estimada de casos de cáncer de origen profesional se comunica a la Junta".

La necesidad de demostrar la existencia de una relación causal entre una enfermedad y la actividad laboral (esto es, un agente tóxico reconocido o una enfermedad incluida en la lista oficial) constituye un grave obstáculo para los trabajadores que reclaman indemnización. En la actualidad, en la mayoría de los países industrializados, los sistemas de indemnización por enfermedad profesional y accidente de trabajo compensan menos del $10 \%$ de los casos de enfermedad profesional y, en la mayoría de los casos, se trata de enfermedades relativamente leves, como la dermatitis. Además, en la mayoría de los casos incluidos en el $10 \%$ que finalmente se indemniza, los pagos sólo se realizan una vez establecida por vía contenciosa la procedencia de la reclamación (Burger 1989).

El problema reside, en parte, en que la legislación vigente puede establecer las que se han denominado "barreras artificiales" al pago de la indemnización por enfermedad profesional. Estas barreras pueden consistir, por ejemplo, en la exigencia de que, para ser indemnizable, la enfermedad sea típica de un lugar de trabajo y no una patología surgida "en el curso normal de la vida", que el padecimiento figure en una lista específica de enfermedades, que no se trate de una enfermedad infecciosa, o que la reclamación de indemnización se formule dentro de un plazo perentorio a partir de la exposición y no desde la fecha de diagnóstico (Burger 1989).

0 tro elemento disuasorio ha sido la certeza creciente de que muchas enfermedades profesionales son de origen múltiple. Esto dificulta en ocasiones la identificación de un determinado riesgo laboral como origen de la enfermedad y, viceversa, permite denegar la reclamación sobre la base de la pretensión de que la enfermedad ha sido causada por factores no relacionados con el trabajo. La dificultad para probar una exclusiva relación causal con el lugar de trabajo constituye a menudo una carga probatoria insoportable para el trabajador con incapacidad (Burger 1989).
En su análisis de los aspectos científicos de las barreras artificiales a la indemnización, M allino (1989) comenta lo siguiente:

"La mayoría de estas barreras artificiales tiene escasa o nula relación con la ciencia médica moderna, que ha llegado a la conclusión de que la mayor parte de las enfermedades profesionales se debe a múltiples causas y tiene un período de latencia relativamente prolongado entre la exposición inicial y su manifestación efectiva.

En la mayoría de los casos de fallecimiento o de lesiones traumáticas, la relación causal es evidente: un trabajador pierde una mano en una cizalla, se cae de un andamio 0 pierde la vida en una explosión de un elevador de granos".

En muchas de estas enfermedades, como el cáncer etiológicamente relacionado con el trabajo, suele resultar difícil, si no imposible, establecer una causa específica y luego relacionarla directamente con una exposición o un conjunto de exposiciones asociadas con el lugar de trabajo.

Además, la exposición al riesgo nunca es uniforme, por lo que resulta sumamente problemático estimar el nivel y la naturaleza del riesgo laboral sobre la base exclusiva de los casos indemnizados. La evolución histórica de la indemnización en los distintos sectores del empleo suele constituir la base utilizada por las entidades aseguradoras para clasificar los riesgos laborales y calcular las primas que se fijan a las empresas. Esto contribuye escasamente a fomentar la adopción de programas de prevención, por mucho que algunos sectores, como la minería y la silvicultura, sean reconocidamente peligrosos.

M ás sustancioso es, sin embargo, el concepto, comentado por M orabia (1984), de los "grupos homogéneos". En efecto, el agrupamiento de trabajadores de características similares pertenecientes a distintos sectores demuestra con claridad que el riesgo está más estrechamente asociado al nivel de cualificación que al sector de actividad como tal.

\section{Desigualdades entre los trabajadores que afrontan riesgos profesionales}

Existen diversas variables para medir la desigualdad frente al riesgo.

\section{E fectos del nivel de cualificación}

L as diferencias en el grado de exposición al riesgo entre los trabajadores cualificados y sin cualificar no dependen del tipo de producción de la empresa ni están únicamente en función de las características del centro de trabajo y a la exposición a sustancias tóxicas (Rey y Bousquet 1995). Por ejemplo, en Canadá, Laflamme y Arsenault (1984) descubrieron que la frecuencia de los accidentes entre diferentes categorías de trabajadores industriales no se distribuye de forma aleatoria. Los trabajadores manuales, menos cualificados - minoritarios dentro de la población activa- , experimentan el mayor porcentaje de accidentes.

Tampoco es aleatoria la distribución de las lesiones; los trabajadores no cualificados remunerados a destajo sufren con mayor frecuencia lesiones lumbares que los de otros grupos y que los empleados en otros lugares. En el modelo de organización del trabajo descrito por Laflamme y Arsenault (1984), los trabajadores sin cualificar concentraban sobre sí los factores de riesgo. Las diferencias con otros grupos en cuanto al grado de exposición al riesgo se incrementaban por efecto de una actitud "política" implícita, según la cual las medidas de prevención se centraban en mayor medida en los trabajadores cualificados, en el marco de un sistema organizativo intrínsecamente discriminatorio hacia los trabajadores sin cualificar, que eran los más expuestos al riesgo. 


\section{Efectos de la experiencia la boral}

L os trabajadores más vulnerables son los que tienen menos experiencia en el puesto de trabajo, bien por ser recién contratados, bien por los cambios frecuentes de trabajo. Por ejemplo, los datos facilitados en Francia por el INRS y por el CNAM (Conservatoire national des arts et métiers) muestran que el índice de siniestralidad entre los trabajadores temporales es 2,5 veces mayor que entre los trabajadores fijos. Esta diferencia se atribuye a la falta de formación básica, a la menor experiencia en un puesto de trabajo concreto y a la preparación insuficiente para éste. Ciertamente, los investigadores subrayan que los trabajadores temporales son, en su mayor parte, jóvenes inexpertos que se exponen a elevados riesgos en el lugar de trabajo, sin unas medidas eficaces de prevención.

Por otra parte, los accidentes se producen con mayor frecuencia durante el primer mes en el empleo (François y Liévin 1993). La Armada norteamericana ha descubierto que, entre el personal de tierra, la mayor incidencia de lesiones se produce durante las primeras semanas en el empleo. A proximadamente el $35 \%$ de los ingresos en centros de salud se produce durante el primer mes de trabajo en un nuevo destino; a continuación, este índice se reduce de forma radical y el declive prosigue a medida que aumenta la experiencia en un puesto de trabajo. La tendencia es similar entre el personal embarcado, si bien las tasas de incidencia son inferiores, quizás como reflejo de una permanencia más prolongada en la Armada (H elmkamp y Bone 1987). Al contrastar sus datos con los suministrados en 1979 por la O ficina de Estadísticas del Trabajo del Consejo Nacional de Seguridad, los autores descubrieron que los resultados eran similares. Asimismo, observaron que las realidades descritas experimentan muy escasa variación con la edad. Si bien los trabajadores más jóvenes corren un mayor riesgo de sufrir accidentes por las razones expuestas, la falta de experiencia en el trabajo conserva su importancia en todas las edades.

\section{Efectos del tipo de sistema salarial}

La modalidad de retribución de los trabajadores puede influir en la frecuencia de los accidentes. En su revisión crítica de los trabajos dedicados a los incentivos salariales, Berthelette (1982) observa que el sistema de pago a destajo se corresponde con un mayor riesgo de accidentes. Esto puede explicarse, en parte, por el pago de incentivos para "buscar atajos" y hacer caso omiso de los riesgos derivados del exceso de trabajo y de la fatiga acumulada. Estos efectos negativos del pago de incentivos en el trabajo a destajo han sido igualmente identificados por L aflamme y Arsenault (1984) en la industria del mueble, y por Stonecipher y $\mathrm{H}$ yner (1993) en otros sectores industriales.

\section{El "efecto del trabajador sano" (ETS)}

Existen pruebas convincentes de los efectos beneficiosos del trabajo sobre la salud y de la repercusión negativa del desempleo. Sin embargo, el concepto del ETS no implica que el trabajo sea bueno para la salud. Significa, más bien, que la población trabajadora es más sana que el conjunto de la población. Esto se debe tanto a la dificultad que tienen los enfermos crónicos, los afectados por serias discapacidades y las personas muy mayores para conseguir y conservar un trabajo, como a la circunstancia de que los menos capaces de afrontar los riesgos laborales se ven rápidamente desplazados de sus puestos de trabajo, lo que deja una población activa constituida por los trabajadores más sanos y aptos.

Los epidemiólogos expresan el efecto del trabajador sano como una submortalidad (o una submorbilidad) de los trabajadores en comparación con el conjunto de la población. Para los epidemiólogos que estudian las enfermedades en el ámbito de las empresas, es preciso reducir el peso de este efecto. En su artículo sobre el ETS, Choi (1992) no sólo aborda las causas, sino también los métodos de reducción de este sesgo de selección.

Para los ergónomos deben ser tomados en consideración factores extraprofesionales, como la escasez de medios económicos y los problemas familiares además de los factores asociados al trabajo, como la ausencia de incentivos profesionales y el temor de no reunir los requisitos exigidos por el puesto de trabajo. Si un trabajador abandona voluntariamente su empleo muy pronto - pocos días o semanas después de acceder al mismo- es preciso tomar en consideración la posibilidad de que la edad haya mermado su capacidad para satisfacer las exigencias del puesto de trabajo.

Por ejemplo, la reducción de la incidencia de los dolores lumbares con la edad no significa necesariamente que los trabajadores mayores sean más resistentes a estos padecimientos; más bien significa que los trabajadores más predispuestos a padecer dolores de espalda (por ejemplo, los que padecen malformaciones, musculatura lábil o mal estado físico) han llegado a la conclusión que sus problemas son incompatibles con el levantamiento de grandes pesos y han optado por otros tipos de trabajo (Abenhaim y Suissa 1987).

Los datos utilizados en el estudio de Abenhaim y Suissa proceden de una muestra obtenida por el Workmen's Compensation Board (Instituto de Indemnización de los Trabajadores) de Q uebec de 2.532 trabajadores que habían perdido, como mínimo, un día de trabajo por causa de los padecimientos de espalda. El $74 \%$ de trabajadores indemnizados que habían causado baja laboral durante menos de un mes contabilizaba el $11,1 \%$ de las jornadas de trabajo perdidas, mientras que el $7,4 \%$ de trabajadores que habían dejado de trabajar durante más de seis meses acumulaba el $68,2 \%$ de las mismas. Este último grupo de trabajadores (el $0,1 \%$ de la población activa) había generado el $73,2 \%$ de los costes de asistencia médica y había recibido el $76 \%$ de la suma total pagada en concepto de retribución e indemnización (un total de 125 millones de dólares en 1981). El coste medio generado por cada uno de estos pacientes ascendió a unos 45.000 dólares canadienses. La elevada incidencia registrada entre los varones $(85 \%$ de los casos) podría explicarse por el predominio del sexo masculino entre los trabajadores que realizan las tareas más propensas a producir lesiones de espalda. 0 tras posibles explicaciones, como la mayor vulnerabilidad de los varones o el mayor porcentaje de hombres que reclaman indemnización, son menos plausibles. A benhaim y Suissa afirman lo siguiente:

"El patrón de aumento-disminución de los dolores de espalda obedece, probablemente, al "efecto del trabajador sano". Ciertamente, es más probable que los trabajadores realicen tareas perjudiciales para su espalda antes de cumplir 45 años y que abandonen esos trabajos al sentirse envejecer(...). Los resultados del estudio desmienten la creencia predominante en los países industrializados de que la mayor parte de estos gastos de atención médica obedecen a múltiples períodos "no controlados" de ausencia del trabajo, producidos por dolores de espalda no acompañados de "signos objetivos". Los casos socialmente más relevantes son los que producen una ausencia laboral más prolongada y gastos de asistencia médica más cuantiosos. Esto se debe tomar en consideración en la formulación de las políticas de prevención y de salud y seguridad en el trabajo.

Resumiendo: existen numerosos factores que no se toman en consideración en las estadísticas de las enfermedades y lesiones profesionales y que pueden alterar el significado esencial de los datos y sesgar totalmente las conclusiones a las que llegan los 
responsables del sistema de indemnización de los trabajadores y otros interesados. Este aspecto es particularmente relevante para quienes utilizan los datos para elaborar los programas de control del riesgo o para evaluar la urgencia de su aplicación.

\section{E pisodios vitales y la borales; estrés}

El estrés es uno de los principales factores causantes de lesiones y enfermedades relacionadas con el trabajo. La presencia de estrés en el lugar de trabajo, con independencia de que tenga su origen en el propio trabajo o en la actividad doméstica o social, puede afectar el comportamiento, los procesos mentales, las facultades físicas y la coordinación, y provocar accidentes y lesiones, aparte de los indicios cada vez mayores de posible afectación del sistema inmunológico, con el consiguiente aumento de la vulnerabilidad a las enfermedades. Por otra parte, el estrés influye considerablemente en la capacidad de respuesta al tratamiento de rehabilitación y, por tanto, en el grado y duración de las eventuales incapacidades residuales.

En su esfuerzo por explicar el incremento del índice de siniestralidad durante las semanas siguientes al paso del servicio en tierra a un destino a bordo y viceversa, H elmkamp y Bone (1987) señalan que el estrés generado por la adaptación y por el cambio en el estilo de vida podría explicar parcialmente el fenómeno. A nálogamente, Von Allmen y Ramaciotti (1993) subrayan la influencia de los factores psicosociales, tanto extraprofesionales como relacionados con el trabajo, en la aparición de problemas crónicos de espalda.

Un estudio prospectivo con una duración de 27 meses sobre una muestra de controladores del tráfico aéreo permitió establecer una trágica relación entre el estrés de origen social y la producción de accidentes. El $25 \%$ de los 100 trabajadores de la muestra que reconocieron sufrir niveles elevados de estrés registró una tasa total de morbilidad un $69 \%$ mayor que los que presentaban niveles de estrés más bajos, además de un $80 \%$ más de probabilidades de sufrir lesiones (N iemcryk y cols. 1987).

Por tanto, no resulta sorprendente que, al menos en Estados U nidos, hayan proliferado las reclamaciones de indemnización formuladas por trabajadores que atribuyen su incapacidad al estrés de origen laboral. A pesar de que este tipo de reclamaciones no se admite todavía en muchos países, es posible que su tasa de incremento sólo sea superada por el reciente aluvión de reclamaciones por lesiones causadas por actividades repetitivas, como el síndrome del túnel carpiano y otros trastornos de naturaleza ergonómica.

Las reclamaciones basadas en el estrés aducido son igualmente ilustrativas de las "barreras artificiales" al pago de indemnizaciones que se han mencionado anteriormente. Por ejemplo, en algunos ámbitos jurisdiccionales de E stados U nidos (especialmente en los estados de la U nión) no se admiten las reclamaciones basadas en el estrés; en otros, la reclamación prospera únicamente si el factor estresante es un episodio repentino, singular, traumatizante o que produzca temor; y en varios otros, se exige que el estrés sea "inusual", esto es, que exceda del nivel considerado normal en el trabajo o en la vida cotidiana. En algunos lugares, las reclamaciones por causa de estrés se fallan en consideración a sus méritos, mientras que en otros no existe aún normativa legal ni doctrina jurisprudencial en la materia. A parentemente, por tanto, las probabilidades de que prospere una reclamación de indemnización fundada en el estrés dependen tanto del lugar en el que se presente, como de sus propios méritos (Warshaw 1988).

\section{Percepción del riesgo}

Para que las empresas se decidan a mejorar las condiciones de trabajo y los trabajadores accedan a trabajar con mayor seguridad, es preciso que perciban la existencia de un riesgo evitable. La percepción debe ser personal y el conocimiento teórico no sirve de gran ayuda. Por ejemplo, los trabajadores no sindicados suelen quejarse menos de los posibles riesgos profesionales porque normalmente están peor informados de su existencia (Walters y H ines 1988).

La asunción de riesgos, esto es, la disposición de los trabajadores a afrontar peligros en el lugar de trabajo, depende en gran medida de la cultura de la organización. En algunas se percibe una actitud negligente que alienta esa asunción de riesgos (D ejours 1993), mientras que en otras prevalece un enfoque de mayor prudencia (H elmkamp y Bone 1987).

Si el índice de siniestralidad es bajo y los trabajadores nunca han presenciado un accidente grave, sobre todo si no existe un sindicato que les sensibilice respecto a los peligros latentes, es posible que se llegue al punto de despreciar efectivamente el riesgo. Por otra parte, si los trabajadores son conscientes del peligro de que se produzcan lesiones graves o incluso muertes, es posible que exijan el pago de complementos por riesgo (C ousineau, Lacroix y G irard 1989). EI deseo o la necesidad de cobrar este complemento puede inducir, por tanto, a la asunción de riesgos.

Las actitudes ante la asunción de riesgos en el trabajo suelen corresponderse con la actitud de los trabajadores ante la prevención en la vida privada. Stonecipher y H yner (1993) han observado que los empleados a sueldo participaban en mucha mayor medida en los programas de exploración selectiva de salud y llevaban una vida más saludable que los trabajadores retribuidos por horas, que, por regla general, poseían un nivel inferior de instrucción y percibían una remuneración más baja. Por tanto, los trabajadores asalariados peor pagados y con menor formación, que, como se ha indicado antes, son más propensos a sufrir accidentes y lesiones, manifiestan igualmente una mayor tendencia al abuso del tabaco y del alcohol, poseen hábitos alimenticios peores y utilizan en menor medida los servicios de prevención sanitaria. Estas circunstancias les colocan en una situación de mayor riesgo.

\section{La cultura de la organización y los niveles de riesgo en la empresa}

La naturaleza de la cultura empresarial puede influir en la percepción del riesgo en el lugar de trabajo y, por consiguiente, en las medidas que se adopten para su control, que pueden incluirse en los apartados siguientes:

\section{Dimensión de la empresa}

EI riesgo de sufrir lesiones y accidentes profesionales es inversamente proporcional a la dimensión de la empresa. Por ejemplo, en Suiza, las empresas más pequeñas no pertenecientes a los sectores de alta tecnología (diez trabajadores o menos) contabilizan un porcentaje muy elevado de las enfermedades profesionales registradas por la Caja $\mathrm{N}$ acional Suiza de Seguros en caso de Accidente (Caisse nationale suisse d'assurance en cas d'assurance, CNA). En comparación con las empresas mayores, tienen escasas posibilidades de contratar los trabajadores mejor formados, más experimentados y más resistentes desde el punto de vista sanitario. Además, sus propietarios y directivos suelen tener menos conocimiento de los peligros existentes en el lugar de trabajo, además de menos tiempo y recursos para abordarlos. Las inspecciones son menos frecuentes en esas empresas, que también tienen muchos más problemas que las organizaciones mayores para acceder a la asistencia técnica y los servicios especializados que necesitan (G ressot y Rey 1982). 


\section{Rechazo de la responsabilidad}

En Suiza, la empresa es responsable de la seguridad de los trabajadores, que, a su vez, están obligados a cumplir las normas de seguridad establecidas en el centro de trabajo. Lamentablemente, sin embargo, la ley y la práctica no siempre van de la mano. En un estudio realizado en centros de trabajo suizos con 100 o más trabajadores se puso de manifiesto una cierta tendencia de las partes implicadas a declinar la responsabilidad por el accidente y culpar a la otra parte. En efecto, las empresas apuntaban al alcoholismo 0 al incumplimiento de las normas de seguridad por parte de los trabajadores como causas de los accidentes, mientras que éstos culpaba a las deficiencias existentes en el lugar de trabajo y a la ineficacia de la dirección. A demás, en los sectores considerados más peligrosos por las compañías de seguro se suelen infravalorar los riesgos (R ey y cols. 1984).

\section{La prevención de los episodios indemnizables reduce los costes de la empresa}

En teoría, el sistema de indemnización por accidentes de trabajo ha sido concebido para recompensar a las empresas que implantan sistemas de prevención efectivos que disminuyen la gravedad y frecuencia de las lesiones y enfermedades profesionales mediante una reducción de los impuestos o primas aplicables. Esta hipótesis, no siempre se confirma en la práctica. Es posible que el coste de los programas de prevención excedan del importe de la reducción de la prima, especialmente si éstas se fijan en un porcentaje de la nómina total abonada en un período en el que se han producido importantes incrementos salariales. Además, a veces, la reducción sólo es apreciable en las organizaciones muy grandes, a las que se aplican tarifas a menudo basadas en la experiencia de la empresa en cuestión, en contraste con las tarifas "manuales" de las primas que pagan las empresas menores y que reflejan la experiencia de un grupo de organizaciones pertenecientes a una región geográfica o a un determinado sector. En este último caso, los logros de una empresa pueden verse contrarrestados por la evolución desfavorables de otras del grupo.

Se da, además, la circunstancia de que, si bien es posible reducir el número y gravedad de los accidentes y lesiones, las primas se pueden disparar debido al incremento en espiral de los costes de asistencia médica y al aumento de las prestaciones por incapacidad, especialmente en los países industrializados.

En teoría -y, con frecuencia, también en la práctica- los costes de los programas de prevención se recuperan con creces con las reiteradas "reducciones" de primas que se consiguen a medida que el comportamiento positivo del coste de las indemnizaciones se prolonga, así como por el ahorro de los costes indirectos producidos por las enfermedades y lesiones relacionadas con el trabajo, expresados por el absentismo, la pérdida de producción y los trastornos producidos en el centro de trabajo. Estos costes indirectos pueden exceder de los gastos de indemnización de los trabajadores por enfermedad o accidente.

\section{Actitudes de los directivos y las empresas}

La mayoría de las empresas se preocupan efectivamente por la salud y el bienestar de sus trabajadores y, en muchas grandes organizaciones, esta preocupación se suele traducir en una política explícita, formalmente establecida. No obstante, hay demasiados directivos que únicamente velan por su propio estatuto y por lograr incrementos de sueldos y primas, y por ascender dentro de la organización. La competencia entre diversas áreas de una misma organización por lograr reconocimientos y gratificaciones por reducir la incidencia de lesiones y enfermedades puede conducir a la ocultación de los accidentes y a la desestimación de las reclamaciones de indemnización de los trabajadores.
Un aspecto importante de la cuestión es que, así como los programas de prevención exigen una inversión inicial de dinero y recursos, específicamente, de tiempo y trabajo de la plantilla y de honorarios pagados a los consultores, su rentabilidad se ve con frecuencia demorada o velada por episodios atípicos desvinculados. Esto se convierte en un obstáculo serio si la empresa experimenta problemas financieros y se ve obligada a limitar 0 incluso reducir los gastos. Este retraso en la generación de los resultados puede ser crítico para los directores de producción y los altos directivos cuyo rendimiento se valora en función de los "resultados" al final del ejercicio fiscal o del período contable de referencia. Es muy posible que tales directivos se sientan tentados de dejar la inversión en un programa de seguridad para cuando hayan ascendido en la organización y traspasen el problema a su sucesor.

\section{Colaboración entre los interlocutores sociales}

La colaboración entre los interlocutores sociales es imprescindible para el éxito de los programas de prevención de las lesiones y enfermedades relacionadas con el trabajo. La solución ideal consiste en crear un comité paritario que investigue los problemas, diseñe programas destinados a abordarlos y supervise su aplicación.

O curre con demasiada frecuencia, sin embargo, que esta colaboración resulta imposible o difícil si las relaciones de la empresa con el sindicato son particularmente antagónicas. Las empresas se oponen a veces a la "intromisión" del sindicato en el funcionamiento y la actividad del lugar de trabajo, y se muestran reticentes frente al movimiento sindical en la medida en que éste sensibiliza a los afiliados respecto a los posibles peligros del centro de trabajo y les estimula a reclamar indemnizaciones por enfermedad o accidente de trabajo en casos que considera insuficiente 0 erróneamente fundados. Por su parte, los sindicatos se sienten frecuentemente obligados a adoptar una postura "agresiva" frente a lo que consideran falta de interés de la empresa.

\section{Reformas recomendadas}

La reforma de los sistemas de indemnización es una cuestión compleja en la que, necesariamente, deben intervenir varias partes interesadas (los trabajadores y sus representantes, los propietarios y directivos de las empresas, las entidades aseguradoras de los riesgos profesionales, los organismos estatales y los legisladores), todas las cuales poseen intereses adquiridos que defender. Sin embargo, la enorme importancia de lo que está en juego - la salud, el bienestar y la productividad de los trabajadores y de las personas a su cargo- confiere especial urgencia a la reforma de estos sistemas. A continuación se examinan algunas de las reformas que se han recomendado.

\section{Fiabilidad y comparabilidad de las estadísticas y del análisis de las mismas}

Se realizan actualmente esfuerzos por establecer la comparabilidad internacional de las estadísticas. Ejemplo plausible de estos effuerzos es la fórmula única para los países europeos. Se han adoptado directivas que recogen las prácticas actuales y que se basan en la frecuencia o gravedad de los casos por sectores económicos, por agentes físicos o químicos, o por las circunstancias que rodean el accidente.

Esta fórmula no se desvía sustancialmente de las prácticas actuales, como la seguida por la CNA suiza, por lo que no cabe esperar que permita superar los sesgos ya indicados. En todo caso, las autoridades suizas han reaccionado de modo favorable a las nuevas disposiciones sobre la participación de los especialistas en la salud y seguridad en el trabajo en el ámbito de la 
empresa, especialmente a la idea de que la información sobre el riesgo, en lugar de depender tan sólo de las estadísticas de las compañías de seguros, provenga también de estudios epidemiológicos rigurosos.

Los Estados miembros de la U nión Europea parecen haberse adherido al principio de una fórmula uniforme para la recogida de datos. En cambio, en Estados U nidos, un estudio recientemente realizado ha puesto de manifiesto que el proyecto de creación de un banco de datos de los casos amparados por el seguro no tiene idénticas posibilidades de prosperar, según Johnson y Schmieden (1992), a pesar de la dimensión de la población asegurada y de los gastos realizados por las compañías de seguros.

En Estados U nidos, la indemnización de los trabajadores en caso de enfermedad o lesión profesional es una actividad importante, con casi 91,3 millones de trabajadores asegurados en 1988 y casi 34.000 millones de dólares abonados en prestaciones, con un coste para las empresas, en ese ejercicio, de más de 43.000 millones de dólares. En la actualidad, los costes de indemnización de los trabajadores se incrementan más rápidamente que otros costes de asistencia sanitaria, circunstancia que no parece haber sido percibida por muchas empresas, que centran su preocupación en la subida en espiral de los costes del seguro de enfermedad de sus trabajadores, a los que muchos atribuyen toda o parte de la culpa. En contraste con lo que ocurre en Europa, parece mucho menos probable que en Estados Unidos se cree una base de datos unificada. Sin embargo, se ha indicado que sería conveniente facilitar el acceso a la información sobre la indemnización de los trabajadores a las personas interesadas en conocerlos, induciendo a las bibliotecas y a los centros de datos de las ciencias de la salud a que recojan y difundan tales datos (Johnson y Schmieden 1992). Un estudio realizado por estos autores en 340 bibliotecas especializadas de los Estados Unidos y Canadá puso de manifiesto que sólo la mitad contaban con servicios de información en esta materia y que únicamente en el $10 \%$ se preveía la necesidad de contar en el futuro con un servicio de recogida de estos datos; la mayor parte de los centros encuestados, o bien se abstuvieron de responder, o bien señalaron que no había necesidad de realizar tal labor. Dada la creciente preocupación por el rápido incremento de los costes de indemnización por accidentes de trabajo, parece razonable pensar que las empresas, las entidades aseguradoras y sus consultores presionen en favor de la creación de estos centros de datos.

Es de subrayar que ésta no es la primera vez que se ha tomado este tipo de iniciativa en N orteamérica. Como consecuencia del informe elaborado en 1981 por la Comisión conjunta de investigación de las administraciones federal y provincial de 0 ntario sobre la seguridad en las minas e instalaciones mineras, se recomendó la creación de una base de datos que:

- formulase definiciones claras e inequívocas de los accidentes que se deben incluir

- elaborase un perfil de cada accidente notificable (cómo, cuándo, dónde, por qué, gravedad de la lesión, etc.) y de cada trabajador (edad, sexo, clase de trabajo, tiempo en el empleo, etc.)

- facilitase información básica de las características de la población activa en su conjunto (por ejemplo, niveles de cualificación, de formación y de experiencia), junto con información sobre los niveles de producción, las horas de trabajo, etc.

En la interpretación de las estadísticas disponibles, se debe hacer hincapié en los índices definidos como umbrales de tiempo de baja laboral, y conceder un mayor peso a los índices menos sujetos a la influencia de factores socioeconómicos (Léger y M acun 1990).

\section{Separar la indemnización de la prevención}

Se ha aducido que la finalidad de los sistemas de indemnización por accidentes de trabajo se debe circunscribir a la recaudación y asignación de los fondos destinados al pago de las prestaciones a los trabajadores previstas en la legislación aplicable, en tanto que la prevención de las lesiones y enfermedades profesionales es una materia distinta, cuya competencia debe confiarse a otras organizaciones.

M ikaelsson y Lister (1991), por ejemplo, apuntan a que el abuso de los sistemas de indemnización que se produce en Suecia pone seriamente en tela de juicio la validez de los datos recopilados en ese país sobre los accidentes y enfermedades, que no resultan en absoluto útiles como base del diseño de los programas de prevención. A firman que los sistemas suecos de indemnización permiten la interposición de múltiples recursos y se prestan a la arbitrariedad. Sus costes se han venido elevando rápidamente, en gran parte porque la indemnización se suele conceder sin pruebas suficientes de la relación entre el trabajo y la lesión o la enfermedad, debido a que las normas de tramitación desalientan la investigación rigurosa de la causa efectiva.

Esta tendencia a desdibujar o soslayar enteramente la cuestión de la relación causal hace que los datos suecos arrojen una idea confusa de las lesiones y enfermedades profesionales. Es posible que el número de casos comunicados de ciertas enfermedades, como los dolores lumbares, esté sobredimensionado, al mismo tiempo que es probable que se hayan pasado totalmente por alto las causas de otras enfermedades.

Es de subrayar en este punto que la nueva normativa sueca en materia de indemnización, influida por la proliferación de reclamaciones, especialmente por molestias lumbares, está en retroceso. Tal como funciona en la actualidad, el sistema no induce a las empresas a investigar y eliminar las causas reales de las lesiones y enfermedades profesionales. La investigación rigurosa de la naturaleza, la amplitud y el control de los riesgos profesionales se podría delegar en otros organismos previstos en diferentes disposiciones de la legislación sueca (véase "Estudio de caso: Suecia", en la página 26.30).

Burger (1989) va más allá, al recomendar que todas las lesiones y enfermedades profesionales se indemnicen sin condiciones previas y que los sistemas de este tipo se incorporen al régimen general de la seguridad social. Por otra parte, afirma que, si se mantiene el requisito de la prueba de la relación causal para el pago de la indemnización, será preciso que esa prueba se practique con rigor, observando todos los criterios tradicionalmente exigidos para la validez y calidad de la información médico-científica.

Fusión de la asistencia sanitaria general con la atención médica de los casos indemnizables

En algunos países, el tratamiento de las personas aquejadas de lesiones y enfermedades indemnizables está reservado a los médicos y profesionales sanitarios en posesión de la titulación específica que acredita sus conocimientos y cualificación en el tratamiento de tales problemas. Con esto se pretende garantizar la calidad de su asistencia.

En algunos casos, esta política ha surtido, justamente, los efectos contrarios. En efecto, la inmensa mayoría de las lesiones que atienden estos profesionales son relativamente leves y apenas precisan asistencia más allá de los primeros auxilios, por lo que revisten escaso interés profesional para los médicos. Por otra parte, en los países en que los honorarios legalmente establecidos para el tratamiento de estos casos son inferiores a los habituales, existe un incentivo económico para incrementar el 
número y la amplitud de los tratamientos. Por ejemplo, en el baremo de honorarios por el tratamiento de casos indemnizables vigente en el estado norteamericano de N ueva York se establece, para el tratamiento de cortes y laceraciones, un complemento de un dólar por cada punto de sutura, hasta un máximo de diez dólares. Esto hace que no sea infrecuente ver heridas pequeñas cerradas con diez puntos de sutura, incluso en casos en que bastaría la colocación de apósitos adhesivos. Además, por razones de cercanía a los lugares de trabajo, las consultas médicas y los ambulatorios dedicados al tratamiento de los casos amparados por el sistema de indemnización de los trabajadores suelen estar ubicados en distritos industriales, que no son por, regla general, las zonas más atractivas de las ciudades. Todo esto hace que la atención de las lesiones y enfermedades profesionales no ocupe un lugar destacado en la escala de preferencias de los profesionales de la medicina.

Además, desde otro punto de vista, en las áreas en que existe escasez de personal y de infraestructura médica, las enfermedades y lesiones profesionales deben tratarse forzosamente en el ambulatorio o la consulta más cercanos, que pueden estar dotados con carácter mínimo de medios específicos para el tratamiento de los problemas de salud relacionados con el trabajo. Este problema es particularmente acuciante en las áreas no urbanizadas ni industrializadas, así como para las empresas demasiado pequeñas para contar con un servicio propio de asistencia sanitaria a los empleados.

En el extremo opuesto de quienes abogan por separar la prevención de la indemnización se sitúan los que optarían por promoverla en el marco del sistema de indemnización por accidentes de trabajo. Es lo que se observa especialmente en Alemania, y también en Suiza, país en el que entró en vigor en 1984 la nueva Ley del seguro de accidentes, que abarca todo el campo de la seguridad en el trabajo. Entonces se creó la comisión federal de coordinación (CFST), integrada por representantes de la confederación y de los cantones, así como por delegados de la CNA y de otras entidades aseguradoras, tanto públicas como privadas

Entre las responsabilidades de la CSFT figura la elaboración de reglamentos técnicos en forma de directivas sobre prevención de accidentes y enfermedades profesionales. También es responsable de financiar los costes de inspección de los centros de trabajo por parte de los organismos competentes en materia de seguridad industrial (por ejemplo, reembolsando a los cantones).

La CNA es la principal entidad aseguradora de las enfermedades y lesiones profesionales y, en el ámbito de la seguridad industrial, supervisa el cumplimiento de las normas de prevención de accidentes de trabajo en unas 60.000 empresas: aquéllas que, en principio, exponen a sus trabajadores a los peligros más graves (por ejemplo, las que producen 0 utilizan explosivos 0 emplean una mayor cantidad de disolventes, y las industrias químicas). La CNA elabora asimismo directivas sobre los límites - que han de respetar supuestamente las empresas- de concentración de sustancias tóxicas en el trabajo.

En su calidad de organismo competente para aplicar la ley mencionada y sus reglamentos, la CNA está obligada a comunicar a las empresas y a sus trabajadores sus obligaciones respectivas. La empresa está obligada a tomar todas las medidas previstas en el reglamento de prevención de accidentes y enfermedades profesionales. L os trabajadores, por su parte, tienen la obligación de cumplir las instrucciones de la empresa en relación con la seguridad en el lugar de trabajo.

Durante las inspecciones de las fábricas que la CNA (u otros órganos supervisores, especialmente cantonales) realiza con el objeto de verificar el cumplimiento de la normativa, la empresa está obligada a permitir el acceso de los inspectores a todas las dependencias y lugares de trabajo. Si se descubre alguna infracción, la CNA apercibe a la empresa y fija un plazo para la subsanación de la infracción. Si no se atiende al apercibimiento, dispone, mediante orden ejecutiva, la adopción de las medidas pertinentes. En caso de incumplimiento, se puede elevar la categoría de riesgo de la empresa, con el consiguiente incremento de la prima. La entidad aseguradora (la CNA u otra) puede adoptar inmediatamente la decisión de incrementar la prima. A demás, el organismo ejecutivo (especialmente la CNA) puede adoptar medidas coercitivas, con asistencia, en su caso, las autoridades cantonales.

Si bien los servicios técnicos de la CNA participan en las visitas a las fábricas, también asesoran a las empresas en cuestiones de seguridad.

En el ámbito de las enfermedades profesionales, las empresas deben velar por que los trabajadores amparados por el sistema de indemnización se sometan a reconocimientos médicos preventivos realizados por el facultativo más próximo o por los servicios médicos de la propia CNA. Esta última determina el contenido de dichas exploraciones y decide en última instancia sobre la aptitud del trabajador para desempeñar el puesto de trabajo.

Todas las medidas técnicas y sanitarias que la empresa deba tomar para cumplir sus obligaciones legales serán a su cargo. Las actividades administrativas y de inspección del CFST se financian mediante una prima complementaria.

Tanto la CNA como las demás entidades aseguradoras están obligadas a facilitar al CFST la información necesaria para el desarrollo de su actividad, especialmente mediante la elaboración de estadísticas de accidentes y enfermedades profesionales. Cuando se promulgó un nuevo reglamento sobre los médicos de empresa y otros especialistas en temas de seguridad, la oficina federal de la seguridad social (O FAS) emitió su informe número 92.023/ 1992. En él se afirma que el análisis del riesgo no puede basarse únicamente en las estadísticas de accidentes y enfermedades profesionales disponibles para las autoridades (casos conocidos), sino también en los estudios epidemiológicos realizados tanto en Suiza como en el extranjero.

Por último, corresponde al CFST promover información y los conocimientos sobre la seguridad en el trabajo en todos los niveles. En Ginebra, el CFST organiza con la CNA la inspección de los lugares de trabajo, con el apoyo de investigadores universitarios, conferencias y cursillos prácticos sobre seguridad dedicados a las empresas ginebrinas y los terceros interesados. Esta iniciativa está patrocinada por una comisión tripartita, financiada principalmente por el cantón e integrada por representantes de la Administración, las empresas y los trabajadores.

\section{Abandono del criterio de la relación causal unidimensional en favor de un enfoque multifactorial de la relación entre la enfermedad y el riesgo en el lugar de trabajo}

En la mayoría de los accidentes de trabajo que producen lesiones o la muerte existe una relación causal clara y directa entre el incidente y el resultado traumático. Esta "regla de oro", sin embargo, es difícil de aplicar cuando se trata de enfermedades profesionales, que suelen obedecer a una multiplicidad de causas. La relación causal se ve complicada aún más por el largo período de latencia que transcurre entre la exposición inicial al riesgo y los síntomas detectables de la enfermedad. En muchas enfermedades profesionales, como el cáncer relacionado con el trabajo, resulta difícil, cuando no imposible, determinar una causa específica y relacionarla con un determinado riesgo o conjunto de riesgos presentes en un lugar de trabajo. Esto hace que, en lugar de acudir a los servicios de indemnización por enfermedad profesional, muchos trabajadores aquejados de estas enfermedades opten por el sistema general de asistencia sanitaria (representado 
en Estados U nidos por los seguros privados de enfermedad y por el programa M edicare para las personas de mayor edad, y por el plan M edicaid para los más pobres) y recurran al sistema público de asistencia social si necesitan ayuda financiera.

Por consiguiente, "a todos los efectos prácticos, las empresas contribuyen poco o nada a la atención de las enfermedades profesionales $\mathrm{y}$, de hecho, están subvencionadas por el sistema público de asistencia social y por los propios trabajadores" (M allino 1989).

Los resultados de un estudio realizado en la Suiza francófona (Rey y Bousquet 1995; Von Allmen y R amaciotti 1993) llegaron a esta misma conclusión. Los seguros de enfermedad se ven, pues, obligados a sufragar, a expensas de los asegurados y de los contribuyentes, los costes de unos problemas de salud directamente relacionados con la actividad desarrollada en el lugar de trabajo, como los dolores de espalda que sufren los trabajadores que transportan cargas pesadas.

Como las empresas no se consideran obligadas a subsanar los problemas de los puestos de trabajo que son, en todo caso, responsables de estos peligros para la salud, se produce una anomalía igualmente malsana desde el punto de vista de la prevención, que debe basarse en los casos registrados por los sistemas de indemnización de los trabajadores.

Para resolver estos problemas, $\mathrm{M}$ allino propone un enfoque que sólo exige demostrar que la exposición profesional ha constituido un factor coadyuvante de la enfermedad y no su causa directa, inmediata y única. Este enfoque es mucho más congruente con la moderna ciencia médica, que ha demostrado la multiplicidad de causas de numerosas enfermedades

Partiendo de una serie de supuestos basados en la totalidad de la población activa, M allino se remite a la denominada "regla del $30 \% "$. Si la incidencia de una determinada enfermedad en una muestra de trabajadores expuesta a un riesgo es un $30 \%$ superior a la registrada en una muestra comparable de población no expuesta, la enfermedad debe considerarse relacionada con el trabajo. Para poder optar a la indemnización por enfermedad profesional, el trabajador que la contraiga sólo tendrá que demostrar que se encontraba dentro del grupo expuesto al riesgo y que su nivel de exposición ha sido suficiente para contribuir a la aparición de la enfermedad (M allino 1989).

Es de subrayar que este método probabilístico ha sido recogido en la legislación de algunos países, como Suiza, en la que se reconocen dos categorías de enfermedades. En la segunda categoría se pueden incluir casos no previstos en la lista de enfermedades profesionales 0 no provocados por agentes químicos 0 físicos reconocidamente nocivos en el lugar de trabajo. En la práctica actual de la CNA, la admisibilidad de los casos individuales se basa también en el concepto de probabilidad, en especial por lo que respecta a los traumatismos del sistema musculosquelético.

\section{Promoción de la rehabilitación y vuelta al trabajo: propuestas de los terapeutas}

Un método importante para reducir los costes humanos y económicos de las enfermedades y lesiones amparadas por los sistemas de indemnización de los trabajadores se basa en promover la rehabilitación y la pronta vuelta al trabajo, sobre todo en el caso de las lesiones de la columna vertebral y otros trastornos musculosqueléticos, que gravan considerablemente el presupuesto de dichos sistemas en Estados U nidos y los países del norte de Europa (M ikaelsson y Lister 1991; A ronoff y cols. 1987).

Según Walsh y Dumitru (1988), los trabajadores que tienen más problemas para volver al trabajo después de una baja por enfermedad son los que gozan de un mejor seguro. Esta constatación justificaría la reforma de las relaciones entre las diversas partes interesadas. "Aunque se hacen progresos en el tratamiento, parece necesario modificar nuestro actual sistema de pago de las prestaciones, con objeto de optimizar la recuperación de las lesiones. Es preciso investigar el modo de reducir los antagonismos entre el paciente, la empresa y la entidad aseguradora."

Aronoff y cols. (1987), recordando los costes generados por los dolores de espalda en Estados U nidos, proponen adoptar sistemas de reeducación que permitan a los asegurados volver al trabajo y escapar de la trampa de la "incapacidad crónica".

"La deficiencia es un concepto médico, que hace referencia a una disminución de las funciones orgánicas o corporales. La incapacidad es un concepto jurídico, que remite a una limitación del rendimiento específico para determinadas tareas. El síndrome de incapacidad crónica es el estado en que se encuentran las personas que, estando en condiciones de trabajar, optan por permanecer en incapacidad. A menudo, la incapacidad es el resultado de una lesión menor que, no obstante, se complica con la inaptitud para afrontar otros problemas vitales. El síndrome se caracteriza por una baja laboral como mínimo de seis meses; la presentación de una reclamación de indemnización por incapacidad y el cobro de una indemnización; quejas por parte del paciente desproporcionadas a los hallazgos objetivos, falta de motivación para la recuperación y una actitud negativa ante la reincorporación al trabajo." (A ronoff y cols. 1987).

Von Allen y Ramaciotti (1993) han analizado el proceso que lleva al dolor lumbar crónico en las personas afectadas, adscritas a diferentes trabajos. La complejidad del problema se hace aún mas evidente durante una recesión económica, en la que se produce mayor movilidad funcional y las perspectivas de volver a un puesto de trabajo menos agotador se limitan progresivamente.

El síndrome de incapacidad crónica se suele asociar al dolor crónico. Se ha estimado, sobre la base de los datos recogidos en 1983 en Estados U nidos, que entre 75 y 80 millones de norteamericanos padecen dolor crónico que produce unos costes anuales de entre 60.000 y 65.000 millones de dólares. De esta cifra, unos 31 millones sufren dolores lumbares, y las dos terceras partes, aproximadamente, manifiestan experimentar limitaciones de su actividad social y laboral. El dolor crónico deja de tener una función de adaptación, para convertirse en la enfermedad misma (Aronoff y cols. 1987).

No todas las personas que sufren dolor crónico están incapacitadas; de hecho, muchas pueden volver a la actividad después de ser tratadas en centros específicos que siguen un enfoque multidisciplinario y atienden a los aspectos psicosociales del caso. EI éxito de estos tratamientos está en función del nivel de estudios, la edad (pues, lógicamente, los trabajadores de mayor edad tienen más dificultades que los más jóvenes para superar los trastornos mecánicos) y la duración de la baja laboral (Aronoff y cols. 1987).

Los trabajadores que en mayor medida dejan de percibir las prestaciones del sistema de indemnización por enfermedad profesional para reincorporarse al trabajo son, entre otros, los que se han puesto rápidamente en tratamiento y han sido remitidos sin pérdida de tiempo a los servicios de rehabilitación, los que logran sobreponerse realmente al dolor y aplican con éxito las técnicas de reducción del estrés, los que tienen un historial laboral positivo y los que se realizan en el empleo y experimentan un mayor nivel de satiffacción en el puesto de trabajo (Arondoff y cols. 1987).

En algunos sistemas de indemnización de los trabajadores, el pago de prestaciones cesa repentinamente y el caso se cierra tan pronto como el trabajador incapacitado regresa al trabajo. Si después la incapacidad recurre o se presentan nuevas complicaciones, el trabajador debe repetir los trámites administrativos y 
esperar más o menos tiempo para reanudar el cobro de las prestaciones. Esta circunstancia hace que muchas veces sea extraordinariamente difícil convencer a los trabajadores de que están lo bastante recuperados para regresar al trabajo. Para superar tal obstáculo, en algunos regímenes se establece un período de prueba, durante el cual prosigue el pago de las prestaciones, mientras el trabajador trata de reincorporarse a su antiguo puesto de trabajo o comprueba si la reconversión le ha hecho capaz de desempeñar otro. En estas condiciones, nada tiene que perder si el ensayo resulta infructuoso.

\section{Enfoques ergonómicos: desde el punto de vista de la prevención del riesgo}

H emos de agradecer fundamentalmente a los ergónomos francófonos (miembros de la SELF, sociedad internacional de ergónomos francófonos) que nos hayan mostrado la compleja red de conexiones entre el puesto de trabajo y los accidentes. Sobre la base de los estudios realizados por sus colaboradores en las minas de carbón, Faverge (1977) creó un método de análisis de los accidentes que todavía se aplica en el INRS de Francia.

Para que el método sea útil, no es preciso que los efectos sobre la salud sean serios y produzcan graves lesiones. Así es como se han establecido conexiones sumamente complejas entre el trabajo con pantallas de visualización y la fatiga visual (Rey, M eyer y Bousquet 1991).

El establecimiento de estas conexiones confiere a los ergónomos una base útil para proponer la adopción de medidas preventivas en los diferentes niveles del flujo de trabajo.

EI análisis ergonómico de los puestos de trabajo se ha convertido en una técnica de uso corriente fuera de la SELF, como lo prueba el hecho de que algunos de los autores que se citan posteriormente son tanto estadounidenses o canadienses como europeos.

La originalidad del análisis ergonómico de los puestos de trabajo reside en que no se puede prescindir de la participación del trabajador. Esto es así porque, además del conocimiento que el trabajador posee de los condicionamientos de su puesto de trabajo, su percepción del riesgo, como se ha indicado anteriormente, depende de muchos factores que son ajenos a los análisis técnicos de la situación que realizan los ingenieros y los especialistas en seguridad.

En la ejecución de sus tareas, el trabajador no siempre sigue al pie de la letra los consejos del especialista en materia de seguridad, sino que se guía igualmente por su actitud ante el trabajo y su percepción del riesgo. Como observan Walters y Haines (1988):

La percepción de los peligros por parte del trabajador se estructura y se expresa de forma diferente que el paradigma médico-tecnológico de la salud y seguridad en el trabajo. Las principales fuentes de información sobre los productos químicos, por ejemplo, no son los supervisores, los delegados de salud y seguridad ni los cursos de formación, sino la experiencia personal, las observaciones de los compañeros o, simplemente, las sensaciones. Los trabajadores utilizan un conjunto diferente de conocimientos empíricos que están incluidos en los conocimientos técnicos.

En $\mathrm{Q}$ uebec, M ergler (citado por Walters y $\mathrm{H}$ aines) señala (1987) que la experiencia de los trabajadores merece un mayor reconocimiento, aunque presentan alguna deficiencia. Su amplia experiencia en la realización de estudios de campo le ha mostrado que resulta difícil conocer la opinión de los trabajadores si éstos piensan que la revelación de sus condiciones de trabajo puede hacerles perder el empleo.

Durrafourg y Pélegrin (1993) se distancian aún más de las pautas de causalidad de las entidades aseguradoras y las autoridades responsables de la seguridad. En su opinión, para que la prevención sea efectiva, es preciso considerar la salud de los trabajadores y las condiciones de trabajo como un sistema global.

Si bien los riesgos importantes pueden ser una causa preponderante (por ejemplo, el nivel de ruido que se soporta o la presencia de una sustancia química nociva en un caso de intoxicación), no ocurre así con la mayoría de los problemas que afectan a las condiciones de trabajo, la higiene y la seguridad. Según Durrafourg y Pélegrin, en este caso el riesgo "está constituido por la intersección de las exigencias del trabajo, la condición de los trabajadores y las limitaciones que las circunstancias imponen al puesto de trabajo".

$\mathrm{Si}$, por ejemplo, los trabajadores mayores sufren menos accidentes que los menos antiguos, es porque "han adquirido un sentido de la prudencia y unas pautas eficaces para la evitación del peligro".

El análisis ergonómico debe hacer posible la identificación de "los factores a partir de los cuales es posible revalorizar el sentido de prudencia de los trabajadores y proporcionarles los medios que precisan para proteger su salud y seguridad."

En resumen, según los ergónomos y los médicos del trabajo con una formación moderna, el riesgo no se traduce únicamente en el conocimiento del entorno físico, químico y bacteriológico, sino también en el conocimiento del entorno social y de las características de los grupos de trabajadores. Habría que realizar un estudio en profundidad del puesto de trabajo, en el sentido ergonómico del término, por cada uno de los casos registrados. Este esfuerzo de análisis es realizado sólo parcialmente por los responsables (inspectores de trabajo, servicios de salud y seguridad de las empresas y servicios médicos), pero habría que avanzar en esta dirección para lograr una prevención efectiva.

\section{Equiparación de la protección social}

Enfrentados con unos gastos crecientes que sólo en parte se deben a los costes de indemnización de los trabajadores por accidente y enfermedad laboral y de los programas de prevención, las empresas están transfiriendo puestos de trabajo de los países industrializados a regiones menos desarrolladas, en las que los salarios y otras prestaciones suelen ser menores y la normativa y la administración de la salud y seguridad en el trabajo son menos gravosas. Ante la perspectiva de instalar medidas de seguridad a menudo costosas, algunas empresas optan por cerrar las fábricas y trasladarlas a otras áreas con costes salariales inferiores. D ado el consiguiente incremento del desempleo, es posible que muchos trabajadores no tengan un puesto de trabajo al que reincorporarse cuando finalizan su rehabilitación y opten por seguir percibiendo las prestaciones por incapacidad mientras pueden (Euzéby 1993).

Para afrontar la competencia de las regiones con niveles salariales inferiores, las empresas reducen sus plantillas y exigen una mayor productividad a los trabajadores que conservan. Dada la tendencia paralela a desestimar o diferir la solución de los problemas de seguridad en el lugar de trabajo, es posible que aumente el número de accidentes y lesiones y que se incremente la presión sobre los sistemas de indemnización de los trabajadores.

Al mismo tiempo, a medida que las cantidades y primas que las empresas abonan a los sistemas de indemnización de los trabajadores - que suelen consistir en un porcentaje de la nómina y basarse en el número de trabajadores empleados- se reducen al disminuir la plantilla, es posible que los recursos de estos sistemas experimenten igualmente una reducción. Esto ya se ha producido en Suiza, donde la CNA se ha visto forzada a reducir el personal. 
En Estados Unidos, una iniciativa legislativa tendente a reducir la función de la administración federal en la regulación y aplicación de la legislación sobre salud y seguridad y transferirla a los estados y entidades locales, no ha ido acompañada de créditos presupuestarios y de subvenciones de cuantía suficiente para desempeñar correctamente la función.

Tchopp (1995) aboga por una equiparación de la protección social en el ámbito internacional que contribuya a mantener los sistemas de indemnización de los trabajadores en el mismo nivel que los programas de prevención existentes en los países desarrollados y a mejorar las condiciones de trabajo y el bienestar de los países en vías de desarrollo. El autor subraya que el objetivo en esos países debe consistir en mejorar la vida de sus trabajadores.

\section{Conclusiones}

Aunque podría ser mejor, la labor de los sistemas de indemnización de los trabajadores en la prestación de asistencia sanitaria y servicios de rehabilitación, y en el pago de prestaciones por incapacidad a los trabajadores aquejados de lesiones relacionadas con el trabajo, se puede calificar de buena. En cambio, se observan importantes deficiencias en la gestión de las enfermedades profesionales. Esta podría mejorar significativamente si se extendiese la cobertura de la legislación aplicable a un mayor número de enfermedades profesionales no fingidas, se mejorasen los sistemas estadísticos y los estudios epidemiológicos que permiten conocer los efectos de esas enfermedades en el lugar de trabajo, y se prestase la debida atención a los avances médicos y científicos que establecen la multicausalidad de muchas de estas patologías.

La función de los sistemas de indemnización de los trabajadores en la prevención de las enfermedades y lesiones profesionales, al margen de la aportación de datos sobre su epidemiología, es problemática. La presunción de que la aplicación de unos sistemas eficaces de prevención permite reducir los impuestos y primas que abonan las empresas tal concepto, no siempre se cumple en la práctica. Algunos, incluso, abogan por separar las obligaciones de prevención de la gestión del sistema de indemnización de los trabajadores y delegarlas en otra organización, en la que los especialistas en salud y seguridad en el trabajo desempeñen una función más importante. Como mínimo, la prevención exige una adecuada regulación legal y una aplicación más rigurosa, a ser posible, en el plano internacional, con objeto de equiparar las condiciones existentes en los países en desarrollo con las que disfrutan los países desarrollados.

La O IT debe instar a los países miembros a elaborar políticas rigurosas en el campo de la prevención de accidentes y enfermedades profesionales, en el sentido más amplio de la expresión.

\section{- Prevencion, Rehabilitacion e INDEMNIZACION EN EL SISTEMA ALEMAN DE SEGURO DE ACCIDENTES}

\section{Dieter G reiner y Andreas Kranig}

\section{Fundamentos y desarrollo}

El sistema obligatorio de seguro de accidentes se creó como ramo autónomo de la seguridad social en virtud de la L ey del seguro de accidentes de 1884 y está en vigor desde 1885. Sus funciones son las siguientes:

- El sistema de seguro de accidentes, utilizando los medios adecuados, debe colaborar en la prevención de las enfermedades profesionales y de los accidentes relacionados con el trabajo. Esta función se debe ampliar en el futuro.

- El sistema ofrece una indemnización global de las lesiones o de los daños y perjuicios en caso de accidente relacionado con el trabajo o de enfermedad profesional. En este aspecto, su objetivo primordial es devolver la salud al asegurado y reintegrarle a la vida profesional y social (rehabilitación médica, profesional y social). A demás, concede prestaciones periódicas cuando los problemas de salud son de carácter permanente. Si se produce el fallecimiento, los familiares perciben pensiones y otras prestaciones en metálico.

A lo largo de su historia, el sistema se ha ido modificando y ampliando en muchos aspectos, especialmente por lo que respecta a las empresas amparadas (la cobertura es universal desde 1942), a la población asegurada (con la inclusión, en 1971, de los alumnos de preescolar, en edad escolar y universitarios), a los casos indemnizables (cobertura, desde 1925, de los accidentes in itinere, de los accidentes que se producen al manipular cualquier equipo durante el trabajo y de las enfermedades profesionales) y a la indización de las prestaciones en metálico (general a partir de 1957). También cabe destacar el perfeccionamiento continuo de los métodos, medidas y prácticas de prevención y rehabilitación.

\section{Estructura y organización}

L a gestión del seguro de accidentes corresponde actualmente, por mandato de la ley, a 110 entidades (B erufgenossenshaften), configuradas en su mayoría como "corporaciones de derecho público". Pueden distinguirse tres áreas:

- Seguro de accidentes de trabajo (incluidos los siniestros marítimos), gestionados por 35 entidades configuradas por sectores de actividad (minería, industria química, comercio, sector de la asistencia sanitaria, etc.);

- Seguro de accidentes agrarios, gestionado por 21 entidades de ámbito regional;

- Seguro de accidentes en el sector público, representado por 54 entidades que se corresponden, en su mayoría, con las diferentes divisiones de la administración pública (organismos federales, estatales y municipales, con fondos independientes para los servicios postales, los ferrocarriles y los cuerpos de bomberos)

El segmento más importante - el seguro de accidentes de trabajo- es objeto de atención preferente en el análisis que sigue. En su condición de corporaciones de derecho público, las (B erufgenossenshaften) son órganos administrativos y, por tanto, forman parte del ordenamiento jurídico. Por otra parte, son autónomas y autogestionadas en muchos aspectos. Los dos órganos de administración autónoma, esto es, la asamblea de delegados y el consejo de administración de cada entidad, están integrados, por partes iguales, por representantes elegidos por las empresas y los trabajadores. Estos órganos toman las decisiones pertinentes para la gestión del seguro de accidentes dentro del marco legal. Si bien los requisitos previos y el ámbito de las prestaciones están regulados por las leyes de forma casuística, el sistema de seguro de accidentes disfruta de un alto grado de autonomía de gestión y de toma de decisiones en la fijación de las primas y, sobre todo, en el campo de la prevención, que en el marco de la gestión autónoma se traduce en la promulgación de reglamentos de organización y de aplicación. Los órganos administrativos de las B erufgenossenshaften deciden igualmente en materia de organización, presupuestaria y de personal. La supervisión ejercida por las autoridades públicas garantiza la legalidad de las decisiones tomadas por los órganos de gestión y por el personal administrativo. 


\section{Tendencias de los índices de siniestralidad y de las finanzas}

El número de accidentes relacionados con el trabajo e in itinere experimentó una reducción sostenida durante muchos años, hasta que la tendencia se invirtió tras la incorporación de los nuevos estados federales en 1991. La tendencia del sistema de seguros de accidentes de trabajo puede resumirse indicando que el índice de siniestralidad - esto es, la frecuencia de accidentes de trabajo e in itinere por cada 1.000 trabajadores a tiempo completo- se redujo a menos de la mitad entre 1960 y 1990. Esta tendencia positiva es todavía más clara por lo que respecta a los accidentes graves indemnizables mediante prestaciones periódicas, cuya frecuencia se redujo a poco más de la tercera parte. En especial, los accidentes mortales se redujeron a la cuarta parte. El comportamiento de las enfermedades profesionales no se ha ajustado a esta tendencia y su evolución durante el período considerado no registra una tendencia definida. A medida que se añadían nuevas patologías a la lista de enfermedades profesionales, el número de casos se fue incrementado, tanto en el ámbito de la prevención como respecto a la rehabilitación.

La reducción generalizada en el número y la gravedad de los accidentes amparados por el sistema de seguro ha repercutido favorablemente en los costes. Por el contrario, otros factores han contribuido a incrementar los costes: la indización de las prestaciones en metálico, el incremento global de los costes de asistencia sanitaria, el aumento del número de asegurados, la ampliación de la cobertura del seguro - especialmente de las enfermedades profesionales - y los esfuerzos por perfeccionar e intensificar las medidas de prevención y rehabilitación del sistema. En conjunto, los gastos se incrementaron en menor medida que la base salarial utilizada para calcular las primas. $L a$ prima media del seguro de accidentes de trabajo se redujo del $1,51 \%$ en 1960 al $1,36 \%$ en 1990 . Los costes generados por la reunificación alemana indujeron un incremento de las primas, que se situaron en el 1,45\% en 1994.

La distribución de los costes entre las tres áreas de actuación (prevención, rehabilitación e indemnización económica) experimentó la siguiente evolución entre 1960 y 1994:

- La porción correspondiente a los costes de prevención aumentó del 2,6 al 7,1 \%, como consecuencia de la mejora, intensificación y expansión continuas de las medidas adoptadas.

- La porción correspondiente a los costes de rehabilitación (incluido el pago de prestaciones) aumentó del 20,4 al 31,2 \%. En este área, el incremento de los costes de la asistencia sanitaria no pudo ser absorbido por la disminución de la frecuencia de los accidentes.

- La porción correspondiente a los costes de las prestaciones periódicas y las pensiones se redujo del $77 \%$ al $61,7 \%$. A pesar de la indización de las pensiones y prestaciones periódicas, estos costes no crecieron en la misma medida que los de rehabilitación.

En los otros ramos del sistema alemán de seguridad social, las primas crecieron sustancialmente durante el período considerado. El coste medio de las primas en el conjunto de los ramos de la seguridad social era de 25,91 marcos por cada 100 marcos abonados en salarios en 1960. Esta cifra había aumentado a 40,35 marcos por cada 100 marcos pagados en 1994. La relación entre la prima media del seguro de accidentes y la prima total cotizada al sistema de seguridad social disminuyó del $5,83 \%$ en 1960 al 3,59 \% en 1994 . El porcentaje del producto nacional bruto representado por el seguro de accidentes se mantuvo en el entorno del 0,5\%. Esto significa que la economía sólo se vio aliviada en alguna medida de las cargas de las cotizaciones sociales en el área del seguro de accidentes.

Como se ha indicado anteriormente, un factor determinante de esta tendencia positiva ha sido la reducción de la frecuencia y de la gravedad de los accidentes. A demás, el sistema de seguro de accidentes ha logrado, gracias al desarrollo de los servicios de rehabilitación, prevenir o reducir el tiempo de recuperación de muchos casos de incapacidad de larga duración. Como consecuencia, el número de perceptores de prestaciones periódicas se ha mantenido prácticamente constante, a pesar del incremento del $40 \%$ del número de asegurados registrado durante el mismo período.

La reducción de la frecuencia de los accidentes se puede atribuir a numerosas causas y factores, como la modernización de los sistemas de producción (en especial, la automatización) y el cambio estructural del predominio del sector productivo al de los sectores de comunicaciones y servicios. El esfuerzo de prevención realizado por el sistema de seguro de accidentes ha contribuido sustancialmente a este progreso económico y humanitario.

\section{Principios y características fundamentales del sistema alemán de seguro de accidentes}

El objetivo del sistema es proporcionar una cobertura global de protección social a las personas afectadas de enfermedades profesionales o víctimas de accidentes relacionados con el trabajo. EI sistema exime igualmente a los responsables de los accidentes y enfermedades producidos en las fábricas de satisfacer las obligaciones contraídas con las víctimas. La actuación del sistema para alcanzar ambos objetivos ha descansado, desde su creación, en los siguientes principios fundamentales:

Se sustituye la responsabilidad de las empresas respecto a las lesiones profesionales por la obligación del sistema público de seguro de accidentes de abonar una prestación ("enervación de la responsabilidad de las empresas"). Q ueda, por tanto, excluido el ejercicio de acciones civiles contra la empresa 0 sus empleados.

U nicamente las empresas cotizan al sistema de seguro de accidentes, ya que asumen la responsabilidad de los riesgos de trabajo y el sistema se subroga en sus eventuales obligaciones.

Las acciones judiciales por responsabilidad civil de las empresas son reemplazadas por las prestaciones del seguro, basadas en el principio de indemnización de las lesiones.

Las prestaciones del seguro se abonan sin necesidad de acreditar formalmente la afiliación al seguro y sin el requisito de que la empresa comunique el siniestro en cuestión a la entidad aseguradora. Esto aporta una tutela más fiable y eficaz a todas las per sonas legalmente amparadas.

Por principio, las prestaciones del seguro se ofrecen al margen de toda noción de culpabilidad y sin necesidad de que los beneficiarios ejerciten acciones judiciales. Esto excluye de la relación laboral toda disputa relativa a la cuestión de la culpabilidad.

U na importante función complementaria del pago de las prestaciones es la prevención de los accidentes de trabajo y las enfermedades profesionales. EI sistema, en efecto, exime a la empresa de sus responsabilidades legales, pero no de la obligación de crear un entorno de trabajo seguro y saludable. Especial importancia reviste en este aspecto la íntima relación de la prevención con la rehabilitación y con las indemnizaciones económicas.

Los principios organizativos fundamentales se han expuesto ya anteriormente (configuración de las entidades como corporaciones de derecho público, capacidad de autogestión y estructuración por sectores económicos).

Las relaciones entre las diversas áreas de actuación están presididas por dos principios. El objetivo fundamental consiste en reducir en la máxima medida posible el número de casos 
indemnizables mediante la adopción de medidas preventivas ("prioridad de la prevención sobre la indemnización"). Al producirse un siniestro asegurado, el objetivo primordial debe consistir en ofrecer al asegurado la máxima rehabilitación médica, laboral y social posible. U nicamente entonces se procede a la indemnización de la incapacidad remanente mediante el pago de prestaciones en metálico ("rehabilitación antes que pensión").

En las secciones que siguen se expone la aplicación de esos principios dentro de las áreas específicas de responsabilidad del sistema de seguro de accidentes.

\section{Prevención}

La labor de prevención descansa en varios principios. El sistema de seguro de accidentes, que soporta los costes de los accidentes relacionados con el trabajo y las enfermedades profesionales en lo que atañe a la rehabilitación y la indemnización, debe, ante todo, poseer la capacidad de prevenir las lesiones en la medida de lo posible. Las empresas deben ser conscientes de que, aunque el seguro de accidentes se haya subrogado en sus obligaciones directas frente a los trabajadores, siguen siendo responsables de la salud y la seguridad en el trabajo. La vinculación entre el seguro y la prevención de accidentes debe mostrar a todas las partes interesadas - especialmente a las empresas- que la inversión en la seguridad del lugar de trabajo es rentable, básicamente en el aspecto humano - al evitar sufrimientos a las personas-, pero también desde el punto de vista económico, a través de la reducción de las primas del seguro de accidentes y de los costes causados por las lesiones a la empresa. La estructuración del sistema por sectores económicos y la implicación de los agentes interesados en el marco de la autonomía de gestión ha generado un considerable bagaje de experiencia en el campo de la prevención y ha promovido la aceptación y motivación de los afectados. Esta íntima relación entre el seguro de accidentes y la prevención marca la diferencia entre el sistema alemán y los existentes en la mayoría de los otros países, en los que la inspección de la seguridad en el trabajo suele encomendarse a funcionarios públicos. Por supuesto, también en Alemania se inspecciona oficialmente la seguridad en el lugar de trabajo, al margen de la supervisión realizada por los servicios de las entidades aseguradoras. Pero ambos servicios se complementan y colaboran entre sí. Las competencias de los órganos de inspección públicos (inspección de los lugares de trabajo) van más allá de los servicios de supervisión técnica a cargo de las entidades del seguro de accidentes (regulación de la jornada de trabajo, protección de grupos de alto riesgo, como los jóvenes y las mujeres embarazadas, protección ambiental).

EI mandato conferido legalmente al sistema de seguro de accidentes en materia de prevención se limita a las premisas básicas, concediéndose a los órganos de autogestión de las entidades respectivas una amplia autonomía en los detalles, especialmente por lo que respecta a las características específicas, dentro de los distintos sectores, aplicables a centros de trabajo concretos 0 conjunto de las instalaciones.

Los siguientes son los aspectos más importantes del concepto de prevención incorporado en el sistema:

Las Berufgenossenshaften cursan instrucciones - que tienen fuerza de ley para los asegurados y las empresas- para la prevención de accidentes en determinada áreas de riesgo. Están autorizadas para imponer sanciones (multas) a los que vulneren sus instrucciones, basadas en la experiencia adquirida y actualizadas continuamente en función del desarrollo tecnológico.

Cada entidad aseguradora cuenta con sus propios servicios especializados de supervisión, que además asesoran a las empresas. Los equipos están integrados por monitores especialmente cualificados - sobre todo, ingenieros y científicos- apoyados por especialistas en otras disciplinas aplicables en el sector de actividad en cuestión. Las competencias de los servicios de inspección se extienden, desde la prestación de asesoramiento relativo a las normas de obligado cumplimiento hasta el cierre parcial de una planta en caso de riesgo grave para la salud.

L as entidades aseguradoras ofrecen a los médicos de empresa y a los especialistas en cuestiones de seguridad asesoramiento, formación, información y asistencia en el trabajo. Los especialistas internos en seguridad laboral prestan un valioso asesoramiento a los servicios de inspección. Esta cooperación de ámbito sectorial, al hacer posible la detección anticipada de los peligros de accidente y de los riesgos sanitarios de origen profesional, permite adoptar medidas de prevención.

L os servicios de inspección de las entidades aseguradoras verifican si las empresas cumplen su obligación de contratar médicos del trabajo y especialistas en seguridad. A lgunas asociaciones sectoriales cuentan con sus propios equipos al respecto, que ponen a disposición de las empresas afiliadas que carecen de ellos.

La formación y educación continua de los responsables de aplicar las normas de seguridad laboral en los centros de trabajo es, básicamente, responsabilidad de las entidades aseguradoras. L os programas de formación se ajustan a las necesidades de los distintos sectores. Estos programas se diseñan y estructuran en función de los diversos niveles de responsabilidad en la empresa a los que están dirigidos. M uchas compañías de seguro de accidentes cuentan con centros de formación propios.

L as entidades aseguradoras plantean a los trabajadores y sus empresas cuestiones relativas a la seguridad en el lugar de trabajo y les mantienen informados y motivados para mejorar la prevención. La labor de prevención se ha centrado últimamente en la pequeña y mediana empresa.

Los servicios de inspección técnica de las entidades aseguradoras también asesoran a los trabajadores sobre los riesgos para la salud y la seguridad en el trabajo. A este respecto, adquiere especial relieve la cooperación con los comités de empresa, como representantes de los intereses de los mismos. Los trabajadores deben participar y aportar su experiencia en la organización del entorno de trabajo. A menudo, la solución práctica de los problemas de seguridad pasa por intensificar su participación. El aumento del nivel de seguridad puede redundar en una mayor motivación de los trabajadores y una mayor satisfacción en el trabajo, con efectos positivos en la productividad.

Los servicios de inspección técnica de las entidades aseguradoras realizan inspecciones rutinarias de los centros de trabajo e investigan los casos de accidente 0 de enfermedad profesional. Pueden realizar diversas mediciones y evaluaciones de los peligros en presencia, con objeto de proponer las medidas de prevención correspondientes. Los resultados de estas mediciones, del análisis de los lugares de trabajo y de sus problemas, junto con la experiencia acumulada por la medicina del trabajo, se recopilan aplicando modernos sistemas informáticos y se aplican a la mejora de la prevención.

Las entidades aseguradoras cuentan con centros de prueba especializados en la verificación de toda clase de equipos y elementos de seguridad. Los resultados de estas pruebas y el asesoramiento prestado por los fabricantes y operadores de equipos técnicos les aportan una información pormenorizada que más tarde aplican en la labor práctica de prevención en los centros de trabajo e incorporan a las normas nacionales, europeas e internacionales.

L as B erufgenossenshaften han realizado, promovido o financiado por su cuenta numerosos proyectos de investigación que responden a necesidades y aplicaciones prácticas y que han 
contribuido a mejorar la protección de la salud y la seguridad en el trabajo.

En interés de las empresas y de sus trabajadores, el esfuerzo de las entidades aseguradoras en el campo de la prevención de accidentes se orienta a ordenar las medidas de protección de la salud y la seguridad en el trabajo de la forma más eficiente y económica posible. Las estrategias de aplicación deben tener igualmente un carácter eminentemente práctico. También se supervisa la efectividad del esfuerzo de prevención.

\section{Ambito de la protección del seguro}

\section{Los asegurados}

Disfrutan de la cobertura del sistema de seguro de accidentes los trabajadores y el personal en formación. La cobertura se concede con independencia del sexo, la edad, el estado civil, la nacionalidad, el nivel de remuneración y la antigüedad en el empleo. Es igualmente independiente de que la empresa haya o no contratado con la entidad aseguradora y de que se encuentre al corriente del pago de las primas.

Los trabajadores a domicilio y los empleados en sectores de trabajo doméstico disfrutan del seguro por imperativo legal, al igual que las personas que reciben rehabilitación por cuenta de un organismo de la seguridad social y que los trabajadores de algunos sectores. Los restantes trabajadores se pueden incorporar voluntariamente al sistema.

En el sistema de seguro de accidentes agrario están amparados obligatoriamente los trabajadores, y los empleadores y los cónyuges de estos últimos.

En el seguro de accidentes en el sector público están incluidos, aparte de los trabajadores, muchos otros grupos, como los alumnos en edad preescolar y escolar y los universitarios (aunque no los funcionarios ni los militares). También disfrutan de cobertura las personas que realizan una labor de interés público y los reclusos que trabajan. U na gran parte de los beneficiarios de este ramo del seguro están exentos del pago de las primas, que es asumido por la administración federal, estatal o local.

\section{Los supuestos asegurados}

En el sistema de seguro de accidentes, los casos asegurados, o siniestros, son los accidentes de trabajo y las enfermedades profesionales. Se consideran relacionados con el trabajo los accidentes in itinere y los ocurridos con ocasión del manejo de cualquier equipo. Los criterios determinantes de la cobertura de un siniestro son los siguientes:

- Pertenencia a un grupo asegurado;

- Producción de una lesión corporal en virtud de un accidente relacionado con el trabajo;

- Ejercicio de una actividad amparada en el seguro en el momento de la producción del accidente o de la enfermedad; consideran actividades amparadas las que tienen una vinculación estrecha con la relación laboral;

- Un accidente o enfermedad producidos por una actividad amparada por el seguro.

La culpa del asegurado no enerva su derecho. Sin embargo, si las únicas causas sustantivas del accidente son imputables a la esfera no profesional - por ejemplo, si el siniestro se produce mientras el sujeto se halla bajo los efectos del alcohol o en el curso de una disputa violenta- , la cobertura no se hace efectiva. Tampoco se aplica ésta si las lesiones, aun habiéndose producido durante el desarrollo de una actividad asegurada, son el resultado de un problema de salud anterior; esto se aplica especialmente a los ataques cardíacos y las luxaciones de discos intervertebrales.

Las enfermedades profesionales (esto es, las reconocidas médicamente como producidas por causas específicas a las que determinados grupos de trabajadores están expuestos en mayor medida que el resto de la población) figuran en una lista oficial. Si surge información nueva respecto a una enfermedad no incluida en esta última, las entidades aseguradoras pueden reconocer, no obstante, la indemnización.

\section{Comunicación y registro estadístico de los casos amparados en el seguro}

Por regla general, las entidades aseguradoras abonan las prestaciones del seguro de accidentes sin necesidad de reclamación alguna del asegurado. Por tanto, los casos han de serles comunicados por otras vías; de hecho, los médicos, empresas y hospitales tienen la obligación de realizar la comunicación. A partir de estos partes se elabora una exhaustiva estadística de los accidentes y enfermedades profesionales.

\section{Rehabilitación}

El sistema está legalmente obligado a conceder prestaciones globales de rehabilitación médica, social y profesional al producirse un accidente 0 declararse una enfermedad profesional. Con este mandato se persigue, en la medida de lo posible, devolver la salud y reintegrar al paciente a la vida laboral y social. En el espíritu del principio anteriormente mencionado de "rehabilitación antes que prestación", el sistema presta todos los servicios de rehabilitación propios de una entidad aseguradora "en un único paquete". Esto permite gestionar un programa de rehabilitación ágil y coherente, adaptado al estado de salud, nivel de estudios y situación personal del paciente. La entidad aseguradora no se limita al pago de las prestaciones y al tratamiento del paciente. Por el contrario, dispone de personal médico especializado y equipado que le permite optimizar el proceso de rehabilitación, tanto en sus propios centros asistenciales - especialmente en el caso de las víctimas de quemaduras graves y de lesiones craneanas, cerebrales y de la médula espinal- como mediante la observación, la asistencia personalizada y, en su caso, la reconducción del proceso de rehabilitación. Se aplican los criterios siguientes:

\section{Rehabilitación médica}

La entidad aseguradora debe procurar que el tratamiento específico se inicie a la mayor brevedad posible después del accidente. En caso necesario, aquél corre a cargo de médicos especialistas o médicos del trabajo. En él deben participar médicos cualificados para el tratamiento de accidentados y con experiencia en cirugía y ortopedia, que dominen las técnicas médicas, y que, además, estén dispuestos a cumplir determinadas obligaciones hacia la entidad aseguradora, específicamente cumplimentando impresos y emitiendo informes. Al producirse un accidente, el paciente debe dirigirse inmediatamente a un médico que esté contratado por la entidad aseguradora y que reúna las condiciones anteriormente reseñadas, el cual iniciará la atención y decidirá si se debe realizar un tratamiento especializado - particularmente, en los casos de lesiones graves- o de medicina general.

En los casos de lesiones de extrema gravedad, el sistema de seguro de accidentes establece las máximas garantías para el tratamiento. Este se encuentra únicamente autorizado en hospitales dotados de recursos específicos y sometidos a inspección y a unas directrices concretas.

La realización y vigilancia del tratamiento se encomiendan a médicos que, al margen de la supervisión, elaboran informes 
para la entidad y, en su caso, proponen medidas ulteriores de rehabilitación.

El sistema de seguro de accidentes asume la totalidad de los gastos de tratamiento y rehabilitación médica, sin copago por parte del asegurado. Esta política responde al principio de indemnización de las lesiones que informa el sistema.

\section{Rehabilitación profesional}

Si la rehabilitación médica es insuficiente para restituir la capacidad laboral a las personas lesionadas, la entidad aseguradora debe facilitarles el acceso a la rehabilitación profesional. La ley establece que la rehabilitación se debe ajustar a las circunstancias de cada caso (gravedad de la incapacidad, nivel de estudios, cualificación e inclinaciones profesionales, edad del asegurado). La rehabilitación puede traducirse en la adopción de medidas concretas en el centro de trabajo, como la adaptación del puesto de trabajo a la incapacidad; la asistencia para la obtención de otro puesto en el mismo centro de trabajo o en otro distinto; o el apoyo financiero a la empresa que acepte emplear al trabajador. También se incluye en el régimen de rehabilitación la formación profesional, incluida la reconversión para un trabajo totalmente distinto.

Como el sistema se responsabiliza de la rehabilitación tanto médica como profesional, esta última se puede diseñar e iniciar antes de la conclusión de la primera, con participación de los médicos y del propio paciente. Esta tarea corresponde a los consejeros profesionales, empleados especialmente cualificados y experimentados de las entidades aseguradoras que se ocupan de visitar en el hospital a los pacientes con lesiones graves; asistir a los asegurados, especialmente en la búsqueda y elección de un programa de rehabilitación adecuado y efectivo; y permanecer con ellos hasta su reincorporación a la vida laboral.

\section{Rehabilitación social}

La rehabilitación médica y profesional es indispensable para que los pacientes puedan reanudar su vida anterior en la máxima medida posible. M ás allá de este objetivo, es preciso reintegrar a las personas que sufren afecciones de larga duración su capacidad para reanudar no sólo la vida laboral, sino también la actividad familiar social y cultural. A este fin, las entidades aseguradoras prestan igualmente servicios de rehabilitación social, que pueden consistir en la disponibilidad de vehículos para facilitar la movilidad del paciente, la realización de actividades deportivas para minusválidos orientadas a mejorar su salud y estimular su participación en la vida social, o la asistencia doméstica o la adaptación de la vivienda a las necesidades individuales.

\section{Prestaciones en metálico}

En el curso de rehabilitación, la empresa está obligada a continuar abonando el salario del trabajador asegurado durante el período inicial de la incapacidad laboral (un mínimo de seis semanas según el convenio colectivo). A partir de entonces, la entidad aseguradora abona una "prestación sustitutoria" mientras dura la rehabilitación médica. Por regla general, esta prestación por incapacidad tiene una cuantía igual al salario neto percibido en el momento del accidente, deducidas las retenciones correspondientes a la cotización del trabajador a la seguridad social y al seguro de desempleo (en la actualidad, casi un $13 \%$ ). Durante la rehabilitación profesional, se abona una prestación temporal sustitutoria del salario, que es algo menor que la prestación por incapacidad. Ambas prestaciones tienen por objeto mantener los ingresos de los asegurados y sus familias. EI mantenimiento del pago de las primas a los otros ramos del sistema de seguridad social evita que se produzcan déficit de cobertura.

\section{Indemnización mediante el pago de pensiones}

\section{Pensiones del seguro}

El sistema de seguros concede pensiones a los afectados por las secuelas de un accidente de trabajo o una enfermedad profesional. Estas pensiones sólo se conceden al finalizar el proceso de rehabilitación y presuponen la pérdida definitiva de la capacidad para generar ingresos (en general, al menos en un $20 \%$ ) durante un período de tiempo mínimo (más de trece semanas desde que se produce el accidente de trabajo). Su cuantía se calcula en función de la reducción de la capacidad de generar ingresos y de los ingresos anuales devengados).

La determinación del grado de pérdida de esta capacidad se rige por el principio de la "clasificación abstracta de la lesión". Por consiguiente, lo que se toma en consideración no es el lucro cesante (los salarios no percibidos), sino la pérdida de la capacidad para generar ingresos en el mercado de trabajo producida por un accidente laboral o una enfermedad profesional. $L$ a estimación de dicha pérdida está en función, básicamente, de la gravedad del problema de salud, que, a su vez, se determina sobre la base de un informe médico. Este sistema contribuye a minimizar los gastos de administración y mantiene en un mínimo asimismo las cargas tanto del asegurado como de su empresa. En la mayoría de los casos, la clasificación abstracta de la lesión opera de forma que la situación económica global del trabajador no es peor que antes del siniestro asegurado. En muchos casos, incluso, su situación mejora en cierta medida, en cuanto que la pensión contribuye al resarcimiento de los daños intangibles. La aplicación de los principios de "rehabilitación antes que pensión" y de clasificación abstracta de las lesiones reduce el riesgo de que los asegurados desarrollen una "mentalidad de pensionista". Aun cuando persistan los problemas de salud, éstos se sienten alentados a buscar un trabajo retribuido.

El principio de la clasificación abstracta de las lesiones se pondera mediante la aplicación de unos determinados factores de evaluación del daño, con el fin de garantizar en todos los casos el pago de una indemnización adecuada.

La segunda base de cálculo de las pensiones viene dada por los ingresos anuales devengados, que se definen como la suma de todos los salarios e ingresos por trabajo autónomo devengados por el asegurado durante el ejercicio precedente. Los ingresos anuales deben reflejar el nivel de vida que el asegurado tuviese al producirse el accidente.

En ciertas circunstancias, las pensiones por incapacidad se pueden capitalizar total o parcialmente.

\section{Pago de pensiones y otras prestaciones por fallecimiento a los sobrevivientes}

El cónyuge viudo, los huérfanos y, en determinadas circunstancias, los padres, tienen derecho a percibir una pensión al fallecer el asegurado de resultas de un accidente o enfermedad relacionado con el trabajo. Así se compensa la pérdida del sustento económico ocasionada por el fallecimiento. El cálculo se basa, como en las pensiones por accidente, en los ingresos devengados, y la cuantía se gradúa en función de las necesidades de los supervivientes (por ejemplo, si el fallecido ha dejado únicamente viuda o también hijos; o si sobreviven huérfanos de un solo progenitor 0 de ambos). Se tienen en cuenta los ingresos y prestaciones sustitutorias devengados, salvo por lo que respecta a los huérfanos menores de 18 años. En este último caso, se aplica el principio de la restitución de la pérdida y tan sólo las personas efectivamente a cargo del fallecido perciben la prestación en la cuantía proporcional requerida.

Además de las pensiones de los sobrevivientes, se abonan los gastos de traslado y de entierro. 
Las pensiones de viudedad se extinguen si el beneficiario contrae nuevo matrimonio; en este supuesto, se abona una suma a tanto alzado igual al doble de la pensión anual.

\section{Financiación y régimen jurídico de las primas}

Existen sustanciales diferencias entre las tres áreas del sistema de seguro de accidentes (del trabajo, agrario y del sector público), tanto con respecto a su financiación como al régimen jurídico de las primas. El análisis siguiente se limita al seguro de accidentes de trabajo.

Los costes del sistema de accidentes de trabajo se financian casi exclusivamente con las primas que abonan las empresas. Los ingresos atípicos generados por las demandas de resarcimiento por daños y perjuicios deducidas contra terceros (en especial, por accidentes de circulación), las plusvalías generadas por las ventas de activo fijo, los recargos por morosidad y las multas) tienen relativamente poca importancia. $\mathrm{Ha}$ de mencionarse en este punto que el sistema funciona sin la ayuda financiera del Estado. L os ingresos se recaudan y se aplican con el exclusivo fin de satisfacer las obligaciones legales, con expresa exclusión del ánimo de lucro.

Las primas aplicables a cada empresa se calculan sobre la base de los salarios de los trabajadores que generan obligación (o bien de los ingresos del trabajo o de la suma asegurada de la empresa). Se tienen especialmente en consideración la frecuencia de accidentes y la amenaza latente de éstos en el sector de actividad y en la empresa. Se distinguen tres niveles:

El primer nivel de primas se establece agrupando uno o más sectores económicos y confiándolos a una única entidad aseguradora, que actúa como grupo de riesgo común. Por ejemplo, se producen más y más graves siniestros en la construcción que en la fabricación de herramientas de precisión; por consiguiente, la prima media en una entidad aseguradora del primero de esos dos sectores será bastante mayor que la aplicada en una entidad del segundo de ellos.

En el segundo nivel, corresponde al de la entidad aseguradora, de que se trate, los distintos oficios afiliados a ella - como pueden ser los albañiles, los techadores y los vigilantes en el caso de la construcción- se clasifican, a su vez, en función de la frecuencia de los accidentes que sufren. La división global de los oficios en grupos de riesgo se traduce en unas tablas de riesgo específicas de la entidad aseguradora. Sobre esta base se evalúa a cada empresa concreta, después de asignar sus diversos segmentos a los correspondientes grupos de riesgo. Las tablas de riesgo se actualizan a partir de encuestas estadísticas quinquenales de los costes y la frecuencia de los accidentes. L os grupos de riesgo permiten diferenciar la cuantía de las primas correspondientes a los diversos oficios de una misma asociación sectorial.

En una tercera etapa, las primas se ajustan nuevamente a escala de cada empresa, aplicando como criterios correctores el número, la gravedad o el coste de los accidentes de trabajo (excluidos los accidentes in itinere) ocurridos durante los últimos uno a tres ejercicios económicos. Así, la entidad aseguradora está autorizada a reducir la prima de las empresas con índices de siniestralidad inferiores a la media. Puede igualmente regular las cuestiones de detalle (imposición de recargos, concesión de reducciones de primas o una combinación de ambas medidas).

La graduación de las primas para cada oficio y empresa concretos en función de la evolución de la siniestralidad trata de infundir a las empresas la idea de que el coste pertinente está vinculado también al esfuerzo - y el éxito- en la prevención, e inducirlas a trabajar en esa dirección.

El sistema de seguro de accidentes se financia mediante un sistema de imputación retroactiva para cubrir costes. La suma imputable es el exceso de los gastos sobre los ingresos, calculado retroactivamente respecto a cada ejercicio presupuestario. EI adeudo imputable se divide entre las empresas afiliadas a las respectivas entidades aseguradoras, de acuerdo con las primas calculadas (grupo de riesgo al que pertenece la empresa, salarios totales pagados en el período anual de la prima y, en su caso, recargo o descuento sobre ésta). Naturalmente, los costes corrientes se deben financiar por anticipado. La financiación proviene de la recaudación de fondos de maniobra y de las primas pagadas por anticipado. Para absorber las fluctuaciones de las primas a largo plazo, las entidades aseguradoras están obligadas a constituir fondos de reserva, que se invierten preferentemente en instalaciones utilizables en el cumplimiento de las obligaciones de este régimen, como los centros de formación y los hospitales especializados en el tratamiento de los accidentados.

Como las empresas no pueden calcular individualmente las primas del seguro, la entidad aseguradora lo hace por ellos y les comunica el importe.

En el sistema alemán de seguro de accidentes, organizado por sectores de actividad, los cambios estructurales en la economía pueden suponer una carga financiera insoportable para algunas asociaciones sectoriales, como la minería del carbón. EI número de trabajadores empleados en las minas se ha reducido fuertemente en los últimos decenios; sin embargo, la entidad aseguradora de la minería debe pagar pensiones que, a veces, datan de una época en que las plantillas eran un múltiplo de las actuales. Para aliviar el incremento, insostenible por más tiempo, del volumen de primas que habría que abonar en este sector económico, en 1968 se promulgó una ley por la que se distribuía la carga económica entre las diversas entidades aseguradoras. Las demás entidades aseguradoras están obligadas a aportar una derrama extraordinaria destinada a cubrir los desfases financieros entre las aseguradoras con derecho a equiparación. Con esta medida, los legisladores amplían el concepto básico de solidaridad, aplicado dentro de cada entidad aseguradora de accidentes, al conjunto de las empresas industriales.

\section{SEGURO E INDEMNIZACION DE LAS LESIONES PRO FESIONALES EN ISRAEL}

H aim Chayon

\section{Resumen de los objetivos y la cobertura}

\section{Cobertura}

El sistema israelí de indemnización por accidentes de trabajo está gestionado por el Instituto Nacional de Seguros en el marco de las disposiciones del capítulo 5 ("Seguro de las lesiones profesionales") del texto refundido de la Ley del seguro nacional (1995-5755).

\section{Asegurados y requisitos de la cobertura}

El sistema de indemnización por accidentes de trabajo se aplica de forma obligatoria a todas las empresas, que deben asegurar a sus trabajadores (excepto los miembros de la policía, los funcionarios de prisiones y los empleados de la defensa), independientemente de que lo sean por tiempo indefinido o con carácter temporal, de que devenguen un sueldo mensual o un jornal, y de que trabajen a tiempo completo o a tiempo parcial, incluidos los trabajadores autónomos, los trabajadores en período de formación profesional, los extranjeros residentes que trabajen en Israel, 
los reclusos que realicen trabajos, las personas sometidas a rehabilitación profesional, las personas que trabajen en empresas israelíes en el extranjero (en ciertos casos) y los trabajadores cuyo salario se fije por vía legislativa (como los miembros del $\mathrm{K}$ nesset 0 parlamento, los jueces y los alcaldes), cualesquiera que sean la edad y nacionalidad del trabajador.

\section{Riesgos asegurados}

La cobertura legal tiene por objeto ofrecer puntualmente a los trabajadores una asistencia eficaz en caso de accidente de trabajo, enfermedad profesional, incapacidad o fallecimiento.

$\mathrm{Si}$ un asegurado fallece como consecuencia de un siniestro asegurado (accidente de trabajo o enfermedad profesional), sus familiares (viudo o viuda, huérfanos, padres y otros familiares a su cargo) tienen derecho, en determinadas condiciones, a percibir las prestaciones por enfermedad profesional.

Se considera lesión profesional toda lesión, incapacidad o muerte causada por el trabajo. Se entiende por accidente de trabajo el que ocurre "durante y como consecuencia del trabajo realizado por cuenta de la empresa del trabajador". En el caso de los trabajadores autónomos, se denomina accidente de trabajo al producido "durante y como consecuencia del ejercicio de su profesión".

La cobertura del seguro se extiende a los accidentes que sufra el asegurado durante el desplazamiento (en un vehículo o semoviente, 0 andando) de su domicilio - 0 del lugar en que haya pernoctado- al trabajo, o viceversa, 0 desde un lugar de trabajo a otro, aunque la lesión sufrida tenga su origen en los peligros del tráfico rodado, siempre que la presencia del trabajador en el lugar del accidente obedezca a las exigencias de su trabajo.

El seguro ampara igualmente las enfermedades profesionales, que se definen en el artículo 2 del capítulo mencionado de la ley.

Se define como enfermedad profesional toda enfermedad contraída por causa del trabajo o durante la prestación de servicios por cuenta de la empresa, o bien, si se trata de un trabajador autónomo, la contraída como consecuencia del ejercicio de la profesión.

L as enfermedades profesionales se detallan en una lista homologada por el Instituto e incluida en los reglamentos.

Esta lista incluye las enfermedades causadas por lesiones producidas en el trabajo y asimismo las causadas por agentes físicos, químicos o biológicos o por determinadas modalidades de prestación laboral, además de las causadas evidentemente por el trabajo.

Todos los trabajadores, sin excepciones, disfrutan de la cobertura del seguro. Todas las empresas tienen la obligación de asegurar a todas las categorías de trabajadores.

La obligación de asegurar se aplica igualmente al Estado y al resto de los entes públicos respecto de sus trabajadores.

\section{Derecho a prestación}

\section{¿Quienes tienen derecho a prestación?}

- El asegurado que ha sufrido una lesión profesional (accidente de trabajo o enfermedad profesional) tiene derecho a percibir el subsidio por enfermedad.

- El asegurado que queda incapacitado como consecuencia de una lesión profesional tiene derecho a una pensión o subsidio de invalidez.

- El asegurado que sufre una incapacidad funcional igual o superior al $10 \%$ tiene derecho a rehabilitación profesional. M ás adelante se expone el método de determinación del grado de incapacidad.
Requisitos para optar a las prestaciones por lesión profesional EI subsidio por enfermedad se concede al asegurado que sufre un accidente de trabajo o contrae una enfermedad profesional que le produce incapacidad para realizar su anterior trabajo u ocupar otro puesto de trabajo adecuado y de resultas de la cual deja de trabajar.

Los subsidios y pensiones de invalidez (las prestaciones por incapacidad) se abonan siempre que se establece que la lesión se ha debido a un accidente de trabajo que ha causado una incapacidad al asegurado.

Los resultados de la lesión se evalúan contrastando el estado de salud de la víctima con el estado medio de las personas saludables de igual sexo y edad. En las pruebas de evaluación del grado de incapacidad se consideran los porcentajes fijados para cada tipo de lesión, mediante una ponderación individualizada; por ejemplo, la pérdida de un miembro tiene mayor importancia en unas profesiones que en otras.

Existen dos categorías de tribunales médicos responsables de la evaluación del grado de incapacidad:

- Tribunales de primera instancia;

- Tribunales de apelación.

U nos y otros establecen inicialmente la relación causal con el accidente de trabajo (lesión o enfermedad profesional) necesaria para declarar la incapacidad y el grado de tal relación. En cualquier caso, son independientes del organismo que recaba sus servicios. Se trata de entes de derecho cuasipúblico cuya función consiste en adoptar acuerdos y que no realizan labores administrativas. En su calidad de entes de derecho cuasipúblico, los tribunales médicos están sujetos al control de los tribunales de trabajo.

\section{Pago de prestaciones (pensiones y subsidios) a las personas a cargo del asegurado}

Para optar a una pensión, la viuda debe tener mas de 40 años de edad, ser incapaz de subvenir a sus necesidades o tener un hijo a su cargo; los viudos deben tener un hijo a su cargo. D efinición del concepto de "hijos" : a los efectos de esta normativa, se entienden por hijos los menores de 18 años y, en ciertos casos, de 22 años.

\section{Rehabilitación profesional}

Para optar a la rehabilitación profesional se exige que la lesión haya producido al asegurado una incapacidad para realizar su trabajo y ocupar su puesto anterior, o realizar cualquier otro trabajo adecuado, exigiéndose igualmente que sea necesaria la rehabilitación y que el asegurado se encuentre en condiciones de recibirla.

\section{Cotizaciones de los trabajadores autónomos}

EI retraso en el pago de las cotizaciones al seguro enerva la admisibilidad del trabajador o reduce el tipo de cálculo de las prestaciones en metálico. Los trabajadores autónomos que no se encuentren dados de alta en el Instituto $\mathrm{N}$ acional de Seguros al producirse la lesión no tienen derecho a percibir las prestaciones.

\section{Tipos de prestaciones}

LoS asegurados tienen derecho a dos tipos de prestaciones, a tenor de las disposiciones de la Ley del seguro nacional, en caso de accidente de trabajo o enfermedad profesional.

\section{Prestaciones en especie}

L as prestaciones en especie son las de atención médica, servicios durante la convalecencia y rehabilitación médica y profesional.

La atención médica comprende la hospitalización, la medicación y el suministro, reparación y reemplazo de prótesis ortopédicas y terapéuticas. Por regla general, se presta en el 
grado exigido por la lesión y sus secuelas durante la vida del asegurado. Esta prestación se realiza, por cuenta del Instituto, por las cajas del seguro de enfermedad, aprobadas, que tienen el carácter de servicios médicos homologados. Los servicios de rehabilitación profesional, son realizados por el Instituto directamente 0 a través de otras instituciones.

\section{Prestaciones en metálico}

Subsidio por enfermedad. Este subsidio se abona mientras dura la incapacidad laboral resultante de una lesión profesional, con un máximo de 182 días computados desde el siguiente a la producción de la lesión. La cuantía es de un $75 \%$ del salario considerado para el cálculo de la cotización al seguro durante el trimestre anterior a la lesión. El subsidio tiene un tope máximo (véase la Tabla 26.2).

El subsidio por enfermedad no se abona por los dos primeros días siguientes a la fecha de la lesión, a menos que el paciente se vea privado de trabajar durante un mínimo de 12 días.

Pensión de invalidez. Esta pensión se abona a los trabajadores que sufren una incapacidad mínima del $20 \%$ y consiste en una cantidad mensual que se fija en función del grado de incapacidad funcional, aplicado un tipo proporcional al salario y al grado de incapacidad. Los perceptores pertenecientes a los grupos de menores ingresos tienen derecho, además, a un "complemento de renta" (véase la Tabla 26.2).

Subsidio de invalidez. Se concede a las personas que padecen una incapacidad estimada entre el 5 y el $19 \%$ y consiste en un pago a tanto alzado equivalente al subsidio diario por enfermedad, multiplicado por una cifra igual a 21 veces el porcentaje de incapacidad.
Pensión especial. Se concede a las personas que padecen una incapacidad igual o superior al $75 \%$, así como a las que sufren una incapacidad del 65 al $74 \%$ y experimentan trastornos de locomoción. Esta pensión proporciona ayuda económica para sufragar los gastos personales y de transporte, hasta el tope máximo previsto en la ley.

Subsidio especial. Se abona a las personas que sufren una incapacidad igual o superior al $75 \%$, así como a las que padecen una incapacidad del 65 al $74 \%$ y experimentan trastornos de locomoción. Proporciona (en ciertas condiciones) ayuda para la compra de un coche, para la solución de los problemas de vivienda y para la adquisición de los aparatos y prótesis que la incapacidad requiera.

Prestación de rehabilitación profesional. Esta prestación cubre el diagnóstico y los servicios de orientación profesional, una subvención para rehabilitación durante un período de estudios (como complemento de la pensión de invalidez) y diversos gastos vinculados a los estudios, como los de desplazamiento, matrícula y compra del material de estudio; en ciertos casos, se conceden ayudas para la compra de herramientas de trabajo.

\section{Prestaciones en favor de personas a cargo del asegurado}

Pensión familiar. Asciende al $40 \%$ de la pensión que el asegurado habría tenido derecho a percibir si hubiese sufrido una incapacidad total, tomando en consideración el número de hijos. Los perceptores pertenecientes a los grupos de menores ingresos perciben, además, un "complemento de renta" (véase la Tabla 26.2)

Subsidio familiar. Se concede a las viudas que no han cumplido 40 años de edad al fallecer el trabajador asegurado y no tienen

Tabla 26.2 - Perceptores de las prestaciones por accidente de trabajo y enfermedad profesional en Israel ${ }^{(1)}$.

\begin{tabular}{|c|c|c|c|c|c|c|c|c|c|}
\hline \multirow[t]{3}{*}{ Período } & \multicolumn{2}{|c|}{ Pensiones familiares } & \multicolumn{2}{|c|}{ Pensiones de invalidez } & \multicolumn{4}{|c|}{ Pensiones de enfermedad } & \multirow[t]{3}{*}{ Período } \\
\hline & \multirow[b]{2}{*}{$\begin{array}{l}\text { Trabajadores } \\
\text { autónomos }\end{array}$} & \multirow[b]{2}{*}{$\begin{array}{l}\text { Trabajadores } \\
\text { por cuenta } \\
\text { ajena }\end{array}$} & \multirow[b]{2}{*}{$\begin{array}{l}\text { Trabajadores } \\
\text { autónomos }\end{array}$} & \multirow[b]{2}{*}{$\begin{array}{l}\text { Trabajadores } \\
\text { por cuenta } \\
\text { ajena }\end{array}$} & \multicolumn{2}{|c|}{ Número de días abonados a: } & \multicolumn{2}{|c|}{ Número de afectados } & \\
\hline & & & & & $\begin{array}{l}\text { Trabajadores } \\
\text { autónomos }\end{array}$ & $\begin{array}{l}\text { Trabajadores } \\
\text { por cuenta } \\
\text { ajena }\end{array}$ & $\begin{array}{l}\text { Trabajadores } \\
\text { autónomos }\end{array}$ & $\begin{array}{l}\text { Trabajadores } \\
\text { por cuenta } \\
\text { ajena }\end{array}$ & \\
\hline 1965 & & 891 & 150 & 1.766 & 132.948 & 747.803 & 6.455 & 54.852 & 1965 \\
\hline 1975 & & 2.134 & 508 & 4.183 & 237.112 & 1.067 .250 & 10.819 & 65.291 & 1975 \\
\hline 1980 & 382 & 2.477 & 950 & 6.592 & 23.617 & 1.017 .877 & 10.679 & 63.234 & $1980^{2}$ \\
\hline 1985 & 445 & 2.841 & 1.232 & 8.640 & 165.635 & 921.295 & 6.619 & 50.302 & 1985 \\
\hline 1986 & 455 & 2.883 & 1.258 & 8.760 & 169.035 & 964.250 & 6.472 & 51.351 & 1986 \\
\hline 1987 & 470 & 2.911 & 1.291 & 9.078 & 183.961 & 1.026 .114 & 6.959 & 50.075 & 1987 \\
\hline 1988 & 468 & 2.953 & 1.229 & 9.416 & 172.331 & 1.004 .906 & 6.683 & 47.608 & 1988 \\
\hline 1989 & 481 & 2.990 & 1.375 & 9.824 & 240.995 & 1.126 .001 & 8.259 & 51.197 & 1989 \\
\hline 1990 & 490 & 3.022 & 1.412 & 10.183 & 248.234 & 1.159 .645 & 5.346 & 51.367 & 1990 \\
\hline 1991 & 502 & 3.031 & 1.508 & 10.621 & 260.440 & 1.351 .342 & 8.470 & 55.827 & 1991 \\
\hline 1992 & 520 & 3.078 & 1.566 & 11.124 & 300.034 & 1.692 .430 & 9.287 & 64.926 & 1992 \\
\hline 1993 & 545 & 3.153 & 1.634 & 11.748 & 300.142 & 1.808 .848 & 8.973 & 65.728 & 1993 \\
\hline 1994 & 552 & 3.200 & 1.723 & 12.520 & 351.905 & 2.134 .860 & 9.650 & 71.528 & 1994 \\
\hline 1995 & 570 & 3.260 & 1.760 & 12.600 & 383.500 & 2.400 .000 & 9.500 & 73.700 & 1995 \\
\hline
\end{tabular}

1 La cifra anual de perceptores de la pensión de invalidez y de la pensión familiar corresponde al mes de abril de cada año. La cifra de perceptores de la persión de enfermedad corresponde al total de perceptores durante el año.

2 En 1980, la cifra anual de las pensiones de invalidez es la media mensual de los perceptores 
hijos a su cargo. Consiste en un pago a tanto alzado de una cuantía igual a 36 mensualidades de la pensión familiar.

Subsidio por matrimonio: Se concede al viudo o viuda que contrae nuevas nupcias y su importe equivale a 36 mensualidades de la pensión, abonables en dos plazos: uno justamente después de la celebración del nuevo matrimonio, y el otro, a los 36 meses. En estos casos, caduca el derecho a percibir la prestación en favor de los sobrevivientes.

Rehabilitación profesional: Se destina a financiar los estudios de formación profesional y consiste en el pago de los gastos de formación profesional o en una pensión de alimentos mientras duran los estudios, así como de diversos gastos relacionados con ellos.

Pensión de alimentos en favor de los huérfanos. Se abona a los huérfanos que dedican la mayor parte de su tiempo a los estudios de secundaria 0 de formación profesional y asciende al $9 \%$ del salario medio vigente el día 1 de enero, con sujeción a la verificación de los recursos del progenitor sobreviviente. Se actualiza aplicando el tipo de indemnización abonado durante el año.

Subsidio Bar-M itzah. Se abona a los varones que han cumplido trece años y a las niñas con doce años cumplidos, y asciende a las dos terceras partes del salario medio vigente el día 1 de enero, actualizado por aplicación del tipo de indemnización abonado durante el año.

Subsidio por fallecimiento. Se abona al fallecimiento de una persona que ha sufrido una incapacidad igual o superior al $50 \%$ y ha estado percibiendo una pensión de invalidez, a la muerte de una persona incapacitada que ha cumplido los 65 años en el caso de los varones o 60 años en el de las mujeres, o a la muerte de una persona que ha disfrutado del subsidio familiar. Consiste en una suma a tanto alzado que se abona al cónyuge de la persona fallecida (o bien, en su ausencia, al hijo) y cuyo importe es igual al salario medio vigente el día 1 de enero del año en que se produzca el fallecimiento, actualizado por aplicación del tipo de indemnización abonado durante el año. En el caso de los perceptores de los complementos de renta, el importe del subsidio es del $150 \%$ del salario medio vigente en la fecha indicada.

\section{Otros aspectos.}

\section{Rehabilitación}

El objetivo principal del Seguro de Lesiones Profesionales es promover el bienestar de los afectados propiciando su vuelta al trabajo. A tal fin, el Instituto financia la prestación de servicios de rehabilitación profesional a los asegurados que padecen una incapacidad laboral igual o superior al $10 \%$. Además, el beneficiario puede percibir cualquier rendimiento extraordinario de su trabajo personal, sin que esto afecte a su derecho a la pensión de invalidez que el Instituto abona.

\section{Ambito de la cobertura}

Como se ha indicado anteriormente, la cobertura del Instituto se extiende a personas que no tienen la condición de trabajadores por cuenta ajena en el sentido estricto del término, como los trabajadores autónomos, los alumnos de formación profesional y otras personas.

\section{Descripción del sistema}

\section{Historia}

La primera disposición laboral que se promulgó durante el $M$ andato británico en Palestina (1922-1948) fue la O rdenanza de indemnización por accidentes de trabajo, de 1922, que en 1947 fue sustituida por otra más moderna, inspirada en la ley inglesa de 1925. La principal aportación de estas dos normas legales fue la traslación a la realidad de I srael de las innovaciones inglesas en el campo de la indemnización por accidentes de trabajo 0 enfermedades profesionales.

Ambas disposiciones estuvieron en vigor hasta el 1 de abril de 1954, en que el K nesset aprobó la Ley del seguro nacional, por la que se confiaba al I nstituto $\mathrm{N}$ acional de Seguros el desempeño de las funciones establecidas. Fue esta la primera ley de seguridad social en prever una extensa gama de prestaciones establecidas por el Instituto o por imperativo legal, prácticamente inexistentes hasta entonces.

\section{En la ley se establecen los principales ramos del seguro:}

- Seguro de vejez y en favor de sobrevivientes;

- Seguro de lesiones profesionales;

- Seguro de maternidad.

A lo largo de los años ha sufrido numerosas modificaciones. Las más importantes en lo que respecta al régimen de indemnización por accidentes de trabajo o enfermedades profesionales han sido las siguientes:

- Inclusión de los trabajadores autónomos en el sistema de seguro (1957);

- Ampliación del concepto de "accidente de trabajo" a los ocurridos in itinere.

\section{Tipos de cobertura}

Se confía al Instituto $\mathrm{N}$ acional de Seguros la gestión del seguro de indemnización por accidentes de trabajo, que prevé el pago de prestaciones en metálico y en especie a los afectados. La cotización por parte de las empresas al fondo correspondiente les exime de toda responsabilidad extracontractual; sin embargo, pueden ser declaradas responsables en caso de negligencia. De las prestaciones reconocidas se deducen las abonadas por el Seguro Nacional.

A demás de los accidentes de trabajo, la cobertura del Instituto se extiende a las enfermedades profesionales, que se relacionan en el segundo anexo a los artículos 44 y 45 del Reglamento correspondiente. En dicha lista, casi exhaustiva, figuran 49 tipos de patologías relacionadas con el trabajo. El sistema de cobertura es de carácter mixto: además de las enfermedades profesionales incluidas en la lista, pueden ser objeto de indemnización, en determinadas condiciones, otras enfermedades de etiología profesional.

De acuerdo con la Ley del seguro nacional, se considera "enfermedad profesional" cualquiera que se defina como tal en el artículo 85 de la misma y que se contraiga como consecuencia del trabajo realizado por cuenta ajena o en el caso de los trabajadores autónomos, del ejercicio de la profesión.

\section{Principios informadores de la indemnización}

El objetivo básico de la normativa es garantizar a los afectados la percepción de las prestaciones previstas en la ley, independientemente de que su empresa haya cotizado o no al Instituto.

EI Consejo de Administración del Seguro Nacional ha facultado al Director de Reclamaciones del Instituto para decidir si una lesión o enfermedad relacionada con el trabajo es o no indemnizable. Si el reclamante no está conforme con la decisión, puede recurrir ante los tribunales de trabajo, cuyas sentencias son apelables, a su vez, ante el Tribunal Nacional de Apelaciones L aborales. 
El Instituto Nacional del Seguro presta asistencia letrada gratuita a los trabajadores que recurran a los tribunales de la jurisdicción laboral sobre la base de un informe pericial.

\section{Método de actualización de las prestaciones}

Las prestaciones por lesiones profesionales se reajustan a partir del 91a día en función del incremento experimentado por el salario medio el día 1 de enero siguiente a la fecha de pago y, durante el año, en función del incremento de los salarios debido a la inflación.

El subsidio por enfermedad (182 días) tributa en origen. Las prestaciones invalidez y de larga duración se actualizan en función del incremento de los precios al consumo y de la evolución experimentada por el salario medio respecto al vigente el 1 de enero. Ninguna de ellas está sujeta a tributación.

Cuando el asegurado cumple la edad de jubilación (65 años para los varones y 60 para las mujeres), puede optar entre uno $u$ otro tipo de prestaciones.

\section{Finanzas y cotizaciones}

Todas las empresas deben cotizar por sus empleados. Si un trabajador asegurado trabaja para varias empresas, cada una de éstas debe cotizar independientemente de las otras. Tanto los trabajadores autónomos como las personas que no tienen esta condición ni la de trabajadores por cuenta ajena deben pagar sus propias cotizaciones. Las empresas cotizan al Instituto Nacional del Seguro. Hasta el 31 de marzo de 1970, la tarifa media oscilaba entre el 0,5 y el $3 \%$ y, partir del 1 de abril de 1971, se situó entre el 0,7 y el $4 \%$. A partir del 1 de octubre de 1981, la tarifa mínima se fijó en el 0,7\%, y la máxima en el 2,4\%. A partir de 1 de julio de 1986 , la tarifa normal $(0,7 \%)$ se determina sin tomar en consideración el grado de riesgo presente en los diversos sectores, como se venía haciendo hasta 1986. Las tarifas se redujeron con efectos desde el 1 de abril de 1987 por causa de los bajos costes de mano de obra.

La cotización mensual de los trabajadores consiste en un porcentaje de sus ingresos mensuales; para las demás personas, el porcentaje se aplica a sus ingresos trimestrales.

Las cotizaciones se ajustan a los ingresos máximos y mínimos de los asegurados. A los efectos de su cálculo, cotización, los ingresos máximos se fijan en el cuádruplo del salario medio respecto de los trabajadores y de los demás asegurados.

En la Ley del seguro nacional se estipulan algunas exenciones al pago de las cotizaciones, como la que se aplica a los trabajadores que perciben el subsidio por enfermedad durante el período de percepción.

\section{Prevención}

La Ley del seguro nacional no regula la prevención de los accidentes relacionados con el trabajo. En su artículo 82 se mencionan las lesiones producidas por negligencia del asegurado. En tal caso, no se abona la prestación cuando la incapacidad laboral dura menos de diez días.

El Instituto Nacional del Seguro contribuye a financiar distintas entidades de prevención de accidentes, como el Instituto de Salud y Seguridad en el Trabajo.

EI Instituto Nacional del Seguro gestiona un fondo destinado a financiar diversos aspectos de la prevención de accidentes, como la investigación y el desarrollo de medios de experimentación de aplicación general en campos como la seguridad, la ingeniería, la medicina, la química industrial y la higiene.

\section{LA INDEMNIZACION POR ACCIDENTES DE TRABAJO EN JAPON}

\author{
Kazutaka Kogi y H aruko Suzuki
}

\section{Resumen del objetivo y cobertura}

\section{Cobertura}

\section{Riesgos asegurados}

EI sistema japonés de seguro de accidentes de trabajo es gestionado por el Estado a tenor de la Ley de indemnización por accidentes de trabajo de 1947. En ella se señala el objetivo de conferir a los trabajadores una protección rápida y eficaz en los supuestos de enfermedad, lesión, incapacidad o muerte sobrevenidos "por causa del desempeño de sus tareas". Este último concepto no se define en la normativa de desarrollo de la ley anteriormente citada. Sin embargo, los criterios aplicados por la administración pública son inequívocos, en el sentido de que el sistema se aplica a los casos de incapacidad, lesión o muerte resultante del empleo, esto es, "en situaciones de desempeño de las tareas en las que los trabajadores se encuentran sometidos al control de una empresa en las condiciones establecidas en los contratos de trabajo", y "por causa de accidente u otra circunstancia derivada del desempeño de las tareas". Por consiguiente, el sistema se aplica a todos los casos de lesión, incapacidad o muerte ocurridos durante el trabajo 0 in itinere. Es asimismo de aplicación a los "trastornos y enfermedades sufridos por los trabajadores que realizan trabajos cuyos riesgos pueden perjudicar la salud en caso de exposición repentina o prolongada a los mismos". Entre las enfermedades causadas por el desempeño de las tareas se incluyen tanto las resultantes de lesiones sufridas en el trabajo como las producidas por agentes físicos, químicos 0 biológicos, o por formas específicas de la prestación laboral, así como las causadas evidentemente por el trabajo.

\section{Sectores y trabajadores amparados}

El sistema de seguro de accidentes de trabajo se aplica obligatoriamente a todos los trabajadores de las empresas sometidas a la Ley de normas de trabajo. Se incluyen, pues, tanto los trabajadores con contrato indefinido como los temporales, los que trabajan a tiempo completo y los contratados a tiempo parcial, así como los jornaleros, con independencia de la dimensión de la empresa.

Todos los sectores disfrutan de la cobertura del sistema, con la excepción parcial de la agricultura, la silvicultura y la pesca. Las excepciones se limitan a las explotaciones agrarias de propiedad individual que emplean menos de cinco trabajadores, las explotaciones forestales que no emplean personal fijo y las empresas pesqueras que tienen menos de cinco trabajadores y operan en zonas sin una siniestralidad significativa. Los marineros, los trabajadores de la administración central y los de la administración local cuentan con sus propios sistemas de seguro de accidentes.

\section{Tipos de prestaciones}

El seguro abona las prestaciones siguientes:

- Asistencia médica: comprende, en principio, el tratamiento médico (en casos excepcionales, el reembolso en metálico de los gastos del mismo); 
- Subsidio de incapacidad temporal: se abona al asegurado que presenta incapacidad para trabajar y percibir ingresos por causa del tratamiento;

- Pensión de enfermedad: se abona si el paciente no se ha recuperado año y medio después del comienzo del tratamiento y el grado de incapacidad se mantiene a un determinado nivel:

- Pensión por minusvalía física: se gradúa en función del grado de minusvalía física que conserve el trabajador

- Subsidio familiar: se abona al cónyuge, hijos, padres, nietos, abuelos o hermanos que hayan dependido económicamente de los ingresos del trabajador fallecido;

- Subsidio por gastos de entierro;

- Subsidio de asistencia de enfermería: se abona por los gastos de asistencia de enfermería, permanente o discontinua, a los pacientes que perciban la pensión por minusvalía física en los grados 1 ó 2 o bien la pensión de enfermedad.

En los casos de enfermedad, incapacidad o muerte sobrevenidas in itinere se reconocen las prestaciones siguientes: (a) asistencia médica, (b) subsidio de incapacidad temporal, (c) pensión de enfermedad, (d) pensión por minusvalía física, (e) subsidio familiar, (f) subsidio por gastos de entierro, y (g) subsidio de asistencia de enfermería. Sus características respectivas son idénticas a las de las prestaciones previamente mencionadas.

Las prestaciones en metálico se calculan sobre la base del salario medio diario de los trabajadores afectados. El subsidio de incapacidad temporal equivale al $60 \%$ del salario medio diario y se abona a partir del cuarto día de ausencia del trabajo, conjuntamente con el complemento especial por incapacidad laboral, equivalente al $20 \%$ del salario medio diario. La empresa está obligada a pagar un $60 \%$ del salario medio durante los tres primeros días. La pensión de enfermedad, abonable a los trabajadores con incapacidad después de un año y medio, equivale a una cantidad que oscila entre 245 y 313 días del salario medio diario. La cuantía de la prestación por minusvalía física oscila entre 131 y 313 días del salario medio diario. El subsidio familiar es una suma a tanto alzado cuya cuantía varía de 153 a 245 días del salario medio diario.

Tanto el subsidio de incapacidad laboral como la pensión de enfermedad y el subsidio familiar están sometidos a un sistema de escala móvil que refleja la evolución de los salarios. Si, en un trimestre, la retribución media del conjunto de los trabajadores excede del $110 \%$ o queda por debajo del $90 \%$ de la remuneración media correspondiente al trimestre en que el trabajador en cuestión haya resultado afectado por un accidente 0 enfermedad, el salario medio diario utilizado en el cálculo del subsidio de incapacidad temporal se revisa automáticamente en función de la variación experimentada por la remuneración media. La pensión de enfermedad y el subsidio familiar se calculan de forma análoga si, en un año, la remuneración anual media de los trabajadores sobrepasa o queda por debajo de la correspondiente al año en que se produjo el accidente 0 enfermedad

\section{0 tros aspectos}

\section{Servicios asistenciales}

El objetivo del Seguro de Indemnización por Accidentes de Trabajo es fomentar el bienestar de los trabajadores facilitando la reincorporación de los damnificados a la vida social y laboral, prestar ayuda a los propios trabajadores 0 , en su caso, a los familiares que les sobrevivan, y crear condiciones de trabajo adecuadas. Por consiguiente, se prevé la prestación independiente de diversos servicios asistenciales y la adopción de una serie de medidas de prevención. La gestión de algunos de estos servicios corresponde a la Asociación de Servicios Asistenciales a los
Trabajadores, financiada por el sistema de seguro. Estos servicios asistenciales comprenden la construcción y gestión de hospitales para el tratamiento de las lesiones profesionales y de la médula espinal, la realización de sesiones de rehabilitación, la concesión de préstamos para vivienda, la asignación de ayudas para educación y asistencia familiar a largo plazo, la creación y gestión de centros de cuidados especiales para los trabajadores aquejados de lesiones profesionales, la prestación de servicios de ayuda a domicilio y el alquiler de aparatos ortopédicos y similares.

\section{Ambito de la cobertura}

L as pequeñas y medianas empresas y los trabajadores autónomos a quienes la naturaleza de su actividad hace aconsejable conceder el mismo grado de protección que a los trabajadores por cuenta ajena se pueden acoger igualmente al seguro de indemnización por accidentes de trabajo. Para ello, las pequeñas y medianas empresas deben delegar la gestión del seguro en una asociación sectorial, y los trabajadores autónomos han de afiliarse a una organización facultada para seguir los procedimientos pertinentes.

Tanto los trabajadores destinados en el extranjero por las empresas japonesas como los representantes de pequeñas y medianas empresas extranjeras disfrutan de la cobertura del seguro.

\section{Descripción del sistema}

\section{Historia}

La necesidad de indemnización de los trabajadores por las lesiones sufridas con ocasión de su trabajo fue reconocida por vez primera por la Ley de la minería de 1905 y la Ley industrial de 1911. Ambos textos legales establecieron la obligación de las empresas de prestar asistencia a los trabajadores víctimas de lesiones en el trabajo. La Ley del seguro de enfermedad de 1922 impuso la cobertura de las lesiones de corta duración sufridas, en el lugar de trabajo o fuera de él, por los trabajadores de las empresas sometidas a la misma. La cobertura se amplió posteriormente a las lesiones de larga duración y a los trabajadores de los sectores de la construcción, obras públicas y transporte. En 1947, finalizada la segunda Guerra M undial se inició una nueva etapa con la promulgación, de dos importantes leyes. La primera de ellas, la ley de normas laborales, recogió por vez primera el principio de la responsabilidad de las empresas y sustituyó concepto de "asistencia" por el de indemnización de las lesiones profesionales. Por su parte, la Ley de indemnización por accidentes de trabajo estableció un sistema de seguros gestionado por el recién creado M inisterio de Trabajo. El sistema de seguro, que se ha ido perfeccionando en virtud de las sucesivas modificaciones legales, funciona con independencia de los diversos regímenes de seguridad social existentes en el país.

\section{Tipos de cobertura del seguro}

El Seguro de Indemnización por Accidentes de Trabajo es un sistema estatal gestionado por la administración central. Cubre la totalidad de los accidentes de trabajo y enfermedades profesionales, además de los accidentes in itinere. Prevé, tanto la asistencia médica como la concesión de prestaciones en metálico. El seguro abona los gastos de asistencia médica y de rehabilitación amparados por el sistema, dado que ambos están excluidos de la cobertura de los sistemas de seguro de enfermedad.

Las empresas afiliadas quedan exentas de la obligación de indemnizar prevista en la Ley de indemnización por accidentes de trabajo en los supuestos previstos. No obstante, en algunos convenios colectivos se estipulan indemnizaciones complementarias que exceden de los niveles establecidos en el seguro estatal. Además, algunas empresas privadas están integradas en 
Tabla 26.3 - Primas del seguro de indemnización por accidentes de trabajo en Japón (abril de 1992).

\begin{tabular}{|c|c|c|}
\hline Sector & Tipo de actividad & Tarifa \\
\hline \multirow[t]{2}{*}{ Silvicultura } & Tala y transporte de madera & 0,142 \\
\hline & Otros & 0,041 \\
\hline \multirow[t]{2}{*}{ Pesca } & Pesca marítima (excepto lo que sigue) & 0,067 \\
\hline & Pesca con redes fijas y acuicultura & 0,042 \\
\hline \multirow[t]{4}{*}{ Minería } & Minería del carbón & 0,111 \\
\hline & Minería metálica y no metálica & 0,099 \\
\hline & Otros (excepto lo que sigue) & $0,040-0,072$ \\
\hline & Extracción de petróleo o de gas natural & 0,010 \\
\hline \multirow[t]{4}{*}{ Construcción } & $\begin{array}{l}\text { Construcción de centrales eléctricas } \\
\text { y túneles }\end{array}$ & 0,149 \\
\hline & Construcción de ferrocarriles & 0,068 \\
\hline & Construcción de carreteras & 0,049 \\
\hline & Otros & $0,025-0,038$ \\
\hline \multirow[t]{6}{*}{ Fabricación } & Cerámica & $0,020-0,027$ \\
\hline & Productos de la madera & 0,026 \\
\hline & Construcción y reparación de barcos & 0,023 \\
\hline & Productos metálicos & 0,022 \\
\hline & Fundición & 0,021 \\
\hline & Otros & $0,006-0,018$ \\
\hline \multirow[t]{4}{*}{ Transporte } & Carga y descarga de buques & 0,053 \\
\hline & $\begin{array}{l}\text { Otros tipos de manipulación de carga en } \\
\text { los puertos }\end{array}$ & 0,029 \\
\hline & $\begin{array}{l}\text { Formas de manipulación de carga } \\
\text { distintas de la anterior }\end{array}$ & 0,019 \\
\hline & Tráfico y transporte & 0,007 \\
\hline $\begin{array}{l}\text { Suministro de electri- } \\
\text { cidad, gas, agua y calor }\end{array}$ & & 0,006 \\
\hline \multirow[t]{2}{*}{ Otros } & Limpieza, incineración o industrias cárnicas & 0,014 \\
\hline & Otros & $0,006-0,012$ \\
\hline
\end{tabular}

regímenes del seguro de indemnización gestionados por compañías de seguros privadas.

Los conflictos en torno a la cuantía de la indemnización complementaria abonable a las víctimas de lesiones y enfermedades profesionales o a sus familiares se suelen sustanciar en los tribunales.

El seguro cubre todo tipo de lesiones profesionales, incluidas las producidas in itinere. Por lo que respecta a las enfermedades profesionales, éstas se detallan en una lista aneja al artículo 33 del R eglamento de aplicación (modificado en 1978) de la Ley de normas laborales. La lista es exhaustiva y agrupa las enfermedades en nueve categorías:

- Enfermedades causadas por lesiones resultantes del trabajo;

- Enfermedades causadas por agentes físicos (13 apartados);

- Enfermedades causadas por determinadas formas de prestación laboral que implican una tensión psíquica extrema (5 apartados);

- Enfermedades causadas por sustancias químicas y otros agentes (8 apartados);
- Neumoconiosis causada por el polvo en suspensión en algunos lugares de trabajo, así como las enfermedades complicadas por neumoconiosis incluidas en el Reglamento de aplicación de la Ley de neumoconiosis de 1960;

- Enfermedades causadas por bacterias, virus, y otros microorganismos patógenos (5 apartados);

- Enfermedades causadas por agentes o sustancias cancerígenos, o trabajos integrados en un proceso productivo cancerígeno (18 apartados);

- $O$ tras enfermedades indicadas por el M inistro de Trabajo;

- O tras enfermedades evidentemente causadas por el trabajo.

\section{Función de los interlocutores sociales}

Desarrollo de los criterios de indemnización

En un principio, el Seguro de Indemnización por Accidentes de Trabajo estaba financiado íntegramente por las empresas. La financiación parcial del sistema con fondos públicos comenzó en 1960, cuando se inició la indemnización de las enfermedades y lesiones de larga duración y el pago de subsidios fue reemplazado por la concesión de pensiones a los afectados de minusvalías físicas. En 1965 se inició la financiación pública de los gastos de gestión del seguro de indemnización de enfermedades y accidentes de trabajo y de sus prestaciones. Para ello se introdujeron sucesivas modificaciones en la Ley de indemnización de accidentes de trabajo, que, en un principio, era de aplicación exclusiva a las empresas con un mínimo de cinco trabajadores estables, con la excepción parcial de los sectores agrario, forestal y pesquero. Estas empresas están obligadas a afiliarse al sistema de seguros al iniciar su actividad. La O ficina de N ormas Laborales del M inisterio de Trabajo gestiona el sistema y sanciona a los infractores. Por consiguiente, las funciones respectivas de los trabajadores y las empresas son, básicamente, las mismas que cuando el sistema se creó.

\section{Tabla 26.4 • Empresas y trabajadores afiliados al seguro de indemnización por accidente de trabajo e importe de las prestaciones en Japón.}

$\begin{array}{lcllc}\begin{array}{l}\text { Ejercicio fiscal } \\ \text { (abril-marzo) }\end{array} & \begin{array}{l}\text { Número de } \\ \text { centros de } \\ \text { trabajo } \\ \text { (miles) }\end{array} & \begin{array}{l}\text { Número de } \\ \text { trabajadores } \\ \text { afiliados } \\ \text { (miles) }\end{array} & \begin{array}{l}\text { Importe de las } \\ \text { prestaciones } \\ \text { (millones de } \\ \text { yenes) }\end{array} & \begin{array}{l}\text { Número } \\ \text { de nuevos } \\ \text { beneficiarios } \\ \text { (miles) }\end{array} \\ 1960 & 808 & 16.186 & 27.172 & 874 \\ 1965 & 856 & 20.141 & 58.372 & 1.341 \\ 1970 & 1.202 & 26.530 & 122.019 & 1.650 \\ 1975 & 1.535 & 29.075 & 287.640 & 1.099 \\ 1980 & 1.840 & 31.840 & 567.288 & 1.099 \\ 1985 & 2.067 & 36.215 & 705.936 & 902 \\ 1986 & 2.110 & 36.697 & 724.260 & 859 \\ 1987 & 2.177 & 38.800 & 725.922 & 847 \\ 1988 & 2.270 & 39.725 & 733.380 & 832 \\ 1989 & 2.342 & 41.249 & 741.378 & 818 \\ 1990 & 2.421 & 43.222 & 753.128 & 798 \\ 1991 & 2.492 & 44.469 & 770.682 & 765 \\ 1992 & 2.542 & 45.832 & 791.626 & 726 \\ 1993 & 2.577 & 46.633 & 799.975 & 696 \\ 1994 & 2.604 & 47.008 & 806.932 & 675 \\ & & & & \end{array}$


Tabla 26.5 - Pago de prestaciones del seguro por sectores, en Japón.

\begin{tabular}{|c|c|c|c|c|c|c|}
\hline \multirow[t]{2}{*}{ Sector } & \multicolumn{2}{|c|}{ Centros de trabajo afiliados ${ }^{1}$} & \multicolumn{2}{|c|}{ Trabajadores afiliados ${ }^{1}$} & \multicolumn{2}{|c|}{ Importe de las prestaciones ${ }^{2}$} \\
\hline & Número & $(\%)$ & Número & $(\%)$ & (Miles de yenes) & $(\%)$ \\
\hline Silvicultura & 26.960 & $(1,0)$ & 126.166 & $(0,3)$ & 33.422 .545 & $(4,2)$ \\
\hline Pesca & 6.261 & $(0,3)$ & 56.459 & $(0,1)$ & 3.547 .307 & $(0,4)$ \\
\hline Minería & 6.061 & $(0,2)$ & 55.026 & $(0,1)$ & 58.847 .081 & $(7,3)$ \\
\hline Construcción & 666.500 & $(25,6)$ & 5.886 .845 & $(12,5)$ & 268.977 .320 & $(33,6)$ \\
\hline Fabricación & 544.275 & $(20,9)$ & 11.620 .223 & $(24,7)$ & 217.642 .629 & $(27,2)$ \\
\hline Transporte & 70.334 & $(2,7)$ & 2.350 .323 & $(5,0)$ & 64.536 .818 & $(8,1)$ \\
\hline Suministro de electricidad, gas, agua y calor & 1.962 & $(0,1)$ & 188.255 & $(0,4)$ & 1.344 .440 & $(0,2)$ \\
\hline Otros & 1.281 .741 & $(49,2)$ & 26.724 .978 & $(56,9)$ & 151.657 .177 & $(19,0)$ \\
\hline Total & 2.604 .094 & $(100 \%)$ & 47.008 .275 & $(100 \%)$ & 799.975 .317 & $(100 \%)$ \\
\hline
\end{tabular}

L as prestaciones concedidas a los trabajadores lesionados y, en su caso, a los familiares sobrevivientes han ido mejorando con las sucesivas modificaciones de la normativa legal, que han aumentado las prestaciones a largo plazo y en favor de los familiares, han revisado las prestaciones en función de la variación de los salarios, han ampliado la cobertura del seguro a los accidentes ocurridos in itinere y, en 1976, implantaron el sistema de complementos especiales y los servicios de asistencia a los trabajadores. En 1981 se regularon las conexiones entre el seguro de indemnización por accidentes de trabajo y el régimen legal general de la indemnización por daños y perjuicios. Se encuentra en vías de implantarse un sistema de prestaciones por asistencias de enfermería.

La determinación de la naturaleza profesional de las lesiones y enfermedades se basa en decisiones administrativas. Si el trabajador no se conforma con la decisión, puede solicitar un examen o arbitraje a cargo de un perito del Seguro de Indemnización por Accidentes de Trabajo nombrado por el M inistro de Trabajo. Si el interesado no está de acuerdo con la decisión del perito, puede solicitar que su caso sea revisado por el Consejo del Seguro de los Trabajadores. Si discrepa igualmente de la decisión de dicho organismo, puede acudir a los tribunales.

\section{Método de actualización}

El Consejo del Seguro de Indemnización por Accidentes de Trabajo, integrado por representantes de los trabajadores, las empresas y la universidad, establece las condiciones de funcionamiento del sistema. De hecho, se requiere su informe previo para el desarrollo del sistema y la modificación de las prestaciones. Tal informe se ha emitido en relación con las diversas revisiones de la legislación aplicable.

La doctrina establecida por las decisiones, tanto del sistema de revisión administrativa como de los tribunales de derecho civil, contribuye a la actualización de los niveles de prestación y de los criterios de aplicación.

\section{Finanzas}

Las primas son abonadas por las empresas a la administración pública. Su cuantía se calcula multiplicando la masa salarial total abonada a la plantilla de la empresa por la tarifa, que, a su vez, se establece para cada categoría de empresas sobre la base de la siniestralidad histórica y de otros factores. En la determinación de la tarifa aplicable a cada sector se aplican criterios de méritos. En la Tabla 26.3 se indica el sistema de tarifas vigente en abril de 1992.

A partir de 1997 se aplicarán, con carácter excepcional, reglas especiales de incremento o reducción de la tarifa según el sistema de méritos a las pequeñas y medianas empresas que hayan adoptado medidas especiales de protección de la salud y la seguridad de los trabajadores.

L os trabajadores lesionados 0 , en su caso, los familiares sobrevivientes, están obligados a facilitar la información precisa para la concesión de las prestaciones del seguro. Los trabajadores que reciban asistencia médica como consecuencia de lesiones sufridas en un accidente in itinere deben abonar previamente, en concepto de contribución al coste de los primeros auxilios, la suma de doscientos diez yens.

\section{Prevención}

En el marco del programa de bienestar de los trabajadores gestionado por el Seguro de Indemnización por Accidentes de Trabajo se adoptan las siguientes medidas de prevención:

- Creación y gestión de centros de salud laboral;

- Prestación de apoyo a las asociaciones de salud y seguridad en el trabajo.

Como consecuencia, se presta ayuda a diversas actividades de prevención a través de los fondos de seguros.

\section{Resumen de los costes históricos}

En la Tabla 26.4 se indica la variación del número de empresas y de trabajadores afiliados al sistema, así como el importe total anual de las indemnizaciones pagadas. $\mathrm{H}$ a de observarse que el sistema de escala móvil comenzó a aplicarse al cálculo de las pensiones en 1983, y que en 1990 se fijaron los topes mínimo y máximo del salario medio diario que se tiene en cuenta para fijar el subsidio de incapacidad temporal a los pacientes de larga duración. De la tabla se infiere que, si bien el número de trabajadores amparados ha aumentado de forma sostenida, el número de nuevos perceptores de las prestaciones se ha reducido desde 1988.

En 1994, el $25 \%$ de las prestaciones totales abonadas fueron a parar a asistencia médica, el $14 \%$ al subsidio de incapacidad temporal, el $6 \%$ se invirtió al subsidio por minusvalía física, el $39 \%$ a pensiones, y el $14 \%$ se abonó a subvenciones especiales. En la Tabla 26.5 se desglosan las prestaciones por sectores. 
- ESTUDIO DE CASO : SUECIA

Peter Westerholm

\section{Objetivos}

El sistema oficial sueco de indemnización por accidentes de trabajo y enfermedades profesionales está regulado por la Ley del seguro de lesiones profesionales de 1993. El régimen, concebido para funcionar en el marco del sistema sueco de seguridad social, se financia en parte con las cotizaciones de las empresas y en parte con cargo a los presupuestos del Estado.

El objetivo asignado legalmente a este régimen es el de indemnizar a los trabajadores por la pérdida de ingresos y por la merma comprobada de su capacidad para generar ingresos. Además, en gran parte del mercado de trabajo se aplica un sistema complementario, basado en convenios colectivos suscritos por los interlocutores sociales (organizaciones empresariales de los sectores público y privado, y organizaciones sindicales) de indemnización a la población asegurada por los daños a la salud y por la aparición de incapacidades y minusvalías: el denominado Seguro Laboral de Responsabilidad Objetiva (TFA). Por aplicación del principio de responsabilidad objetiva no se exige, para la admisión de una reclamación, que el interesado demuestre el comportamiento negligente de su empresa ni de tercero alguno implicado en el siniestro causante de la reclamación. Este sistema complementario no es público y no se encuentra regulado en las leyes, está cogestionado por las organizaciones empresariales y los sindicatos.

En los apartados siguientes se examina al sistema público de seguro sueco.

\section{Organización}

El sistema público se basa en los partes cumplimentados por los asegurados al producirse una lesión. Son asegurados las personas que tengan la condición de trabajadores por cuenta ajena en el momento de manifestarse la enfermedad o problema de salud. EI parte de seguro - un impreso que el trabajador debe cumplimentar - se entrega a la empresa, que debe hacerlo llegar a la oficina regional o local de la seguridad social. Tras examinarlo con la documentación adjunta, la Junta R egional de la Seguridad Social resuelve sobre la admisión o inadmisión de la reclamación.

Si el asegurado o un tercero interesado no se conforma con la resolución de la Junta, puede recurrir ante un tribunal administrativo, integrado en el sistema judicial.

El sistema vigente el 1 de enero de 1993 se basaba en tres principios fundamentales:

- El concepto de lesión profesional;

- El concepto de factores de riesgo en el trabajo;

- El concepto de causalidad entre el factor de riesgo y la enfermedad contraída.

\section{Lesiones profesionales}

El concepto de lesión profesional se desglosa en dos componentes: los accidentes de trabajo y las enfermedades profesionales. El elemento funcional del concepto es la lesión, que puede ser producida, bien por un accidente de trabajo, bien por un factor de riesgo presente en el actual lugar de trabajo o en un trabajo anterior. Por consiguiente, el concepto de lesión abarca tanto las consecuencias del daño físico producido por accidentes o enfermedades como las deficiencias causadas por diversos agentes físicos, químicos o psíquicos, o por otros factores ambientales presentes en el entorno del trabajo. El concepto de enfermedad, que se utiliza en un sentido muy lato, comprende tanto las enfermedades catalogadas por la O M S como las disfunciones, trastornos y deficiencias que el sujeto percibe como desviaciones de su salud. Esto significa que en Suecia no existe una lista oficial de enfermedades profesionales o relacionadas con el trabajo. Cualquier enfermedad o deficiencia, extendida tal como se ha expuesto, se puede diagnosticar y considerar de origen profesional, en función de las pruebas aportadas en apoyo de la solicitud de indemnización. Esto implica que, además de las enfermedades y los problemas de salud causados directamente por el trabajo o por factores presentes en el lugar de trabajo, se pueden incluir en el concepto de lesión profesional los elementos siguientes:

- La manifestación precoz de enfermedades que, aun pudiendo estar relacionadas con el trabajo, se den también en la población general sin vinculación alguna con las condiciones de trabajo;

- Las enfermedades o trastornos funcionales carentes de relación causal con las condiciones de trabajo, siempre que factores presentes en el lugar de trabajo puedan contribuir a empeorar 0 acelerar su proceso.

Este concepto amplio de lesión profesional se viene aplicando desde 1977 y no cambió con la modificación introducida en la ley el 1 de enero de 1993. No existe, pues, una lista cerrada de enfermedades profesionales, ni se hace distinción alguna entre las de origen profesional y las relacionadas con el trabajo. EI reconocimiento de un trastorno funcional o una enfermedad comunicado por la persona afectada (que se encuentre amparada por el sistema de seguridad social), como lesión profesional depende de las pruebas que aporte ésta.

Con la adopción de este concepto amplio se pretende que el sistema puede detectar los problemas de salud causados en todo 0 en parte por las condiciones de trabajo.

\section{Factores de riesgo en el lugar de trabajo}

La identificación de una lesión profesional está en función del descubrimiento de un factor de riesgo en el lugar de trabajo. A menos que se descubra algún factor de este tipo y se establezca su influencia en el origen de la lesión, la enfermedad o deficiencia resultante no se puede catalogar como lesión profesional.

Se considera factor de riesgo cualquier agente físico, químico o de otro tipo que pueda dañar la salud de los trabajadores. Se trata, sin embargo, de un concepto restringido. En efecto, en la ley no se incluyen entre los factores de riesgo los relacionados con el cierre de empresas, los conflictos laborales, la falta de apoyo social, la inadaptación a la cultura imperante en el lugar de trabajo ni circunstancias similares.

En la legislación vigente desde el 1 de enero de 1993 se define el factor de riesgo como aquél "que tiene muchas probabilidades de causar enfermedades o deficiencias".

En comparación con la normativa vigente hasta el 31 de diciembre de 1992, esta redacción supone una mayor exigencia de aportación de pruebas a los organismos de la seguridad social. A simismo, en la exposición de motivos de la nueva ley se especifica que la valoración de la peligrosidad de los factores de riesgo considerados se debe corresponder con la opinión mayoritaria - a ser posible, el consenso- de un equipo de especialistas médicos. Si se producen opiniones discrepantes entre los especialistas en la valoración del potencial de riesgo, no se cumple el criterio de "muchas probabilidades".

La estimación del factor de riesgo supone igualmente una valoración cuantitativa. La exposición al factor en cuestión se debe valorar en función de la duración, la intensidad y otros criterios apreciables en la determinación del riesgo potencial. 


\section{Causalidad}

Una vez establecida como muy probable la presencia o la existencia anterior de un factor de riesgo - lo que, en este contexto, implica asimismo una estimación cuantitativa- , el siguiente paso consiste en emitir un juicio definitivo sobre la plausibilidad de la existencia de una relación causal en el caso considerado. La regla de aplicación general consiste en exigir la acreditación de dicha relación causal para catalogar la enfermedad o el problema de salud como lesión profesional. En la normativa legal que estuvo en vigor hasta el 31 de diciembre de 1992, la apreciación de la relación causal era mucho más flexible. En efecto, dicha relación se presumía de jure una vez establecida la presencia probable de un factor de riesgo, sin posibilidad de prueba en contrario. A ctualmente se ha invertido la carga de la prueba y se exige acreditar suficientemente la existencia de la relación causal. En la práctica, esto implica la necesidad de considerar igualmente otros posibles nexos causales, entre los que cabe incluir el estilo de vida del afectado, su empleo del tiempo libre y sus circunstancias personales en general.

\section{Evaluación de la vulnerabilidad personal}

El principio fundamental que informa la normativa legal es que se debe asegurar a todos, al margen de sus deficiencias constitutivas y de su vulnerabilidad. La aplicación de este principio puede causar bastantes problemas, por ejemplo, en la evaluación de los problemas de salud asociados a las alergias y las reacciones de hipersensibilidad. A veces resulta extremadamente difícil emitir un juicio informado sobre el peso relativo del estado físico personal y de los factores profesionales y ambientales, respectivamente. En estos casos, la dificultad estriba en conocer y evaluar las propiedades del factor de riesgo. Este (que puede consistir, por ejemplo, en la exposición a un producto químico o a la contaminación atmosférica en el lugar de trabajo) puede resultar inocuo para la mayoría de las personas expuestas y nocivo para las personas especialmente sensibles.

\section{Prevención e indemnización por lesiones profesionales}

En Suecia, la normativa legal reguladora del pago de indemnizaciones a las víctimas de lesiones es independiente y carece de toda relación directa con el ordenamiento legal sobre protección de la salud en el trabajo. El índice de siniestralidad laboral o de morbilidad profesional no repercute en el nivel de las cotizaciones abonadas por las empresas. Existe, pues, un régimen de cotización fija.

Las competencias del sistema de indemnización por accidentes de trabajo se limitan al pago de prestaciones a los afectados de lesiones diagnosticadas como profesionales, y no se extienden en absoluto a la política de prevención.

0 tro tanto ocurre con la rehabilitación profesional, al margen de que se haya diagnosticado el origen profesional de una enfermedad o una lesión. Las empresas están obligadas a gestionar el inicio del proceso de rehabilitación de los trabajadores que hayan estado de baja durante un mínimo de cuatro semanas.

\section{Función de los interlocutores sociales}

La legislación de seguridad social no reconoce a los interlocutores sociales (esto es, los sindicatos y las organizaciones empresariales) participación alguna en la estimación o desestimación de las solicitudes de indemnización por lesiones profesionales. Por el lado de los empleadores, las empresas están obligadas a remitir a la seguridad social cualquier reclamación formulada por los trabajadores por causa de lesión profesional. L os sindicatos suelen ayudar a sus afiliados mediante la tramitación de sus reclamaciones, el análisis de sus condiciones de trabajo y la prestación de asesoramiento.

\section{Situación actual}

D esde la entrada en vigor de la nueva legislación, los organismos competentes han estado ocupados en el estudio de un ingente volumen de reclamaciones por lesiones formuladas en el marco de la normativa anterior. Esto hace que se tenga hasta ahora una experiencia limitada en la aplicación de la nueva ley y que las estadísticas oficiales sean incompletas.

Se experimenta en la actualidad la necesidad de elaborar directrices prácticas para la aplicación de la legislación. La Corporación del Seguro Laboral de Responsabilidad O bjetiva (TFA) y el Instituto Nacional sobre la Vida de Trabajo han editado recientemente un informe conjunto en el que se describe el alcance de los conocimientos sobre los factores patológicos y profesionales existentes en determinadas categorías de enfermedades. H asta el momento, se dispone de estudios sobre las enfermedades tumorales, las enfermedades del sistema nervioso, las enfermedades pulmonares y de la pleura, las enfermedades malignas, las patologías cardiovasculares, las enfermedades de la piel y la pérdida de audición relacionada con el trabajo (I nstituto Nacional sobre la Vida del Trabajo y Corporación del Seguro Laboral de Responsabilidad O bjetiva 1995). Se encuentra en preparación otro informe dedicado a los trastornos psíquicos y los desórdenes mentales relacionados con el estrés.

A comienzos del decenio de 1990, antes de modificarse la regulación legal de la indemnización por lesiones profesionales, todos los años se aceptaba una media de 50.000 a 55.000 reclamaciones por este concepto. EI número de accidentes de trabajo comunicados y reconocidos a partir de la modificación de la legislación ha oscilado entre 20.000 y 22.000 . L os trastornos del sistema musculosquelético han supuesto la mayor parte de las enfermedades profesionales comunicadas, con un $80 \%$ del total.

U no de los factores que más influyen en el número de lesiones profesionales comunicadas es la coordinación automática de las prestaciones recibidas, respectivamente, del sistema de indemnización por lesiones profesionales y del seguro general de enfermedad. En 1993, el período de coordinación se extendió de 90 a 180 días. Esto supone que las enfermedades y lesiones, incluso de origen profesional, sólo se indemnizan si ocasionan una baja laboral de larga duración (más de 180 días) o una incapacidad permanente. $\mathrm{La}$ indemnización correspondiente a los primeros 180 días se cobra del seguro general de enfermedad.

Se espera que el número de lesiones profesionales comunicadas $y$, por consiguiente, de casos reconocidos, comience a declinar en un futuro cercano. Los sistemas estadísticos oficiales no se han adaptado aún a los cambios legislativos. Esto supone que en la cifra oficial de lesiones profesionales comunicadas y reconocidas se incluyen tanto reclamaciones formuladas al amparo de la legislación anterior, como peticiones presentadas a tenor de la normativa vigente desde el 1 de enero de 1993. Por consiguiente, las actuales estadísticas oficiales no reflejan los efectos de las modificaciones legislativas mencionadas. 


\section{Referencias}

Abenhaim, L, S Suissa. 1987. Importance and economic burden of occupational back pain. I 0 ccup M ed 29:670-674.

Aronoff, GM , PW M CLary, A Witkower, M S Berdell. 1987. Pain treatment programs: Do they return workers to the workplace? I O ccup $M$ ed 29:123-136.

Berthelette, D. 1982. E ffects of Incentive Pay on W orker Safety. N o. 8062t. M ontreal: IR SST.

Brody, B, Y Letourneau, A Poirier. 1990. Indirect cost theory of work accident prevention. I 0 ccup Acc 13:255-270.

Burger, EJ. 1989. Restructuring workers' compensation to prevent occupational disease. Ann NY Acad Sci 572:282-283.

Choi, BCK. 1992. Definition, sources, magnitude, effect modifiers and strategies of reduction of the healthy worker effect. I 0 ccup M ed 34:979-988.

Cousineau, JM , R Lacroix, AM Girard. 1989. 0 ccupational $\mathrm{H}$ azard and $\mathrm{W}$ age $\mathrm{C}$ ompensating $\mathrm{D}$ ifferentials. $\mathrm{Ca}$ hier 2789. M ontreal: CR DE, U niv. de M ontreal.

Dejours, C. 1993. Ergonomics, occupational health and health status of groups of workers. En E rgonomics and $\mathrm{H}$ ealth, dirigido por $\mathrm{D}$ R amaciotti $y$ A Bousquet. G inebra: M edical $H$ ygiene.

Documento oficial sobre el seguro de lesiones profesionales. 1993. R ef. SFS 1976:380 con enmienda de SFS 1993:357 (en sueco).

Durrafourg, J, B Pélegrin. 1993. Prevention as a benefit. $\mathrm{En}$ Ergonomics and $\mathrm{H}$ ealth, dirigido por Ramaciotti y Bousquet. Ginebra: M edical H ygiene.

Euzéby, A. 1993. Financing the Social Security: E conomical E fficacy and Social R ights. G inebra: O IT.

Faverge, JM . 1977. R isk factor analysis of safety at the workplace. Rev E pidemiol Santé Publ 25:229-241.

François, M, D Liévin. 1993. Is there a specific risk for uncertain jobs? En Ergonomics and $\mathrm{H}$ ealth, dirigido por Ramaciotti y Bousquet. Ginebra: $M$ edical $\mathrm{H}$ ygiene.

G ressot, M , P R ey. 1982. Statistical analysis of occupational injuries using CNA data (Switzerland). Sozial-und Präventivmedizin 27:167-172.

H elmkamp, JC, CM Bone. 1987. The effect of time in a new job on hospitalization rates for accidents and injuries in the US Navy, 1977 through 1983. J 0 ccup M ed 29:653-659.

Instituto Nacional del Seguro de Responsabilidad Civil a Todo Riesgo en la Vida Laboral y e
M ercado de Trabajo. 1995. Enfermedades profesionales. Agentes peligrosos en el trabajo: Lesiones relacionadas con el trabajo (en sueco). Arbete och hälsa 16:1-219.

Johnson, M R, BA Schmieden. 1992. Development of a library-based information service for the subject of worker's compensation: A proposal. J O ccup M ed 34:975-977.

Judd, FK, GD Burrows. 1986. Psychiatry compensation and rehabilitation. M ed J Austral 144:131-135.

Laflamme, L, A Arsenault. 1984. Wage modes and injuries at the workplace. Ind R elat J 39:509-525.

Léger, JP, I M acun. 1990. Safety in South African industry: A nalysis of accident statistics. J 0 ccup M ed 11:197-220.

M allino, DL. 1989. Workers' compensation and the prevention of occupational disease. Ann NY Acad Sci 572:271-277.

M ikaelsson, B, C Lister. 1991. Swedish occupational injury insurance: A laudable programme in need of reform. Int Soc Sec R ev 44:39-50.

M orabia, A. 1984. The Italian Preventive System for the W orking Environment. Cahiers ECOTRA, No. 5. Ginebra: U niv. de Ginebra.

Niemcryk, SJ, CD Jenkins, RM Rose, MW Hurst. 1987. The prospective impact of psychological variables on rates of illness and injury in professional employees. J O ccup M ed 29:645-652.

O rganización Internacional del T rabajo (OIT). 1964. Convenio núm. 21 (1964) y R ecomendación núm. 21 (1964): Prestaciones en caso de accidentes de trabajo y enfermedades profesionales. Ginebra: OIT

-. 1993. Proceedings of the International Symposium on W ork-R elated D iseases: Prevention and $\mathrm{H}$ ealth Promotion (0 ctober 1992). Linz: O IT.

Rey, P, A Bousquet. 1995. Compensation for occupational injuries and diseases: Its effect upon prevention at the workplace. E rgonomics 38:475-486.

Rey, P, V Gonik, D Ramaciotti. 1984. Occupational $M$ edicine Inside the Swiss $H$ ealth System. Ginebra: Cahiers ECOTRA, No. 4. Ginebra: Univ. de Ginebra.

Rey, P, IJ M eyer, A Bousquet. 1991. Workers using VDT: Difficulties at their workplace and the attitude of the occupational physician in such a case. En E rgonomics, $H$ ealth and Safety, dirigido por Singleton y Dirkx. Leuven: Leuven U niv. Press.
Stonecipher, LJ, GC Hyner. 1993. H ealth practices before and after a worksite health screening. I 0 ccup M ed 35:297-305.

T chopp, P. 1995. C rises et mutations économiques: l'impact sur la sécurité sociale. Réalités Sociales. 29:75-83.

V on Allmen, M, D R amaciotti.1993. LBP occupation and everyday life. FNR S N 0. 402-7068.

Walsh, N, D Dumitru. 1988. The influence of compensation on recovery from LPB. En Back Pain in $\mathrm{W}$ orkers, dirigido por R ayo. Filadelfia: $\mathrm{H}$ anley $\&$ Belfus.

Walters, V, T H aines. 1988. Worker's use and knowledge of the "internal responsibility system". Limits to participation in occupational health and safety. Canadian H ealth Policy 14:411-423.

Warshaw, LJ. 1988. O ccupational stress. O ccup M ed: State Art R ev 3:587-593.

Yassi, A.1983. Recent developments in worker's compensation. I Conferencia Anual del Consejo Canadiense de M edicina del Trabajo, noviembre, Toronto.

\section{0 tras lecturas recomendadas}

Böckle, B. 1993. Injury Statistics, a Statistical Model. Informe núm. 23. Suiza: CFST.

Comité Mixto OIT/OMS sobre Medicina del Trabajo. 1989. E pidemiology of W ork- $R$ elated $D$ iseases and Accidents. Technical Report Series, No. 777. Ginebra: O M S.

Djordjevic, DDP. 1983. Multiphastic screening. En Enciclopedia de salud y seguridad en el trabajo (3a edición), dirigida por L Parmeggiani. Ginebra: OIT.

$H$ ansen, JA. 1993. OSHA regulation of ergonomic health. J 0 ccup M ed 35:42-46.

Hill, AB. 1971. Principles of M edical Statistics. Londres: Lancet.

Kochan, F. 1992. O ccupational diseases and possibility of preventing them. SSA/AP/PC/XX/I. Informe de la Comisión Permanente para la Prevención de Riesgos Profesionales, Acapulco, 22 de noviembre-l de diciembre.

LaD ou, L. 1991. The challenge of international occupational health. $\mathrm{ICOH}$ Quarterly $\mathrm{N}$ ewsletter 10(2):1-8

Muir, DC. 1995. Cause of occupational diseases. O ccup E nviron M ed 52(5):289-293. 


\section{CONTROL BIOLOGICO}

Director del capítulo

Robert Lauwerys

\section{Sumario}

Principios generales

Vito Foà y L orenzo Alessio $\ldots \ldots \ldots \ldots \ldots \ldots \ldots \ldots \ldots \ldots \ldots . \ldots \ldots \ldots \ldots$

Garantía de calidad

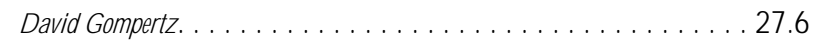

M etales y compuestos organometálicos

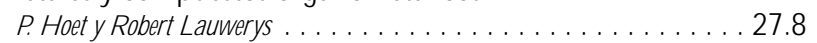

Disolventes orgánicos

M asayuki I keda............................ 27.13

Sustancias químicas genotóxicas

M arja Sorsa

Pesticidas

$M$ arco $M$ aroni y Adalberto Ferioli . . . . . . . . . . . . . 27.20 
Principios generales

Vito F oà y Lorenzo Alessio

\section{Conceptos básicos y definiciones}

En el lugar de trabajo, los métodos de higiene industrial sólo permiten determinar y controlar las sustancias químicas aerotransportadas, mientras que otros aspectos de los problemas causados por posibles agentes ambientales nocivos para los trabajadores, como la absorción cutánea, la ingestión y la exposición no relacionada con el trabajo, permanecen sin detectar y, por tanto, incontrolados. El control biológico ayuda a llenar esta laguna.

El control biológico se definió en 1980 en un seminario, patrocinado conjuntamente por la Comunidad Económica Europea (CEE), el National Institute for $\mathrm{O}$ ccupational Safety and $\mathrm{H}$ ealth, NIOSH y la Occupational Safety and Health Association, OSHA (Berlín, Yodaiken y Henman 1984) y celebrado en Luxemburgo, como la "determinación y evaluación de los agentes 0 de sus metabolitos presentes en tejidos, secreciones, excretas, aire espirado o cualquier combinación de los mismos con objeto de evaluar la exposición y el riesgo para la salud en comparación con una referencia adecuada". Se trata de una actividad repetitiva, regular y preventiva destinada a la adopción, en caso necesario, de medidas correctoras; no se debe confundir con los métodos diagnósticos.

El control biológico es una de las tres herramientas importantes para la prevención de enfermedades debidas a agentes tóxicos en el medio ambiente general o en el medio ambiente de trabajo, siendo las otras dos el control ambiental y la vigilancia de la salud.

La secuencia en el posible desarrollo de estas enfermedades se puede representar esquemáticamente de la forma siguiente: exposición al agente químico - dosis interna - efecto bioquímico o celular (reversible) - efectos sobre la salud- enfermedad. Las relaciones entre control ambiental, control biológico, control de la exposición y vigilancia de la salud se muestran en la Figura 27.1.

Cuando una sustancia tóxica (una sustancia química industrial, por ejemplo) está presente en el ambiente de trabajo, contamina el aire, el agua, los alimentos o las superficies en contacto con la piel; la cantidad de agente tóxico en estos medios se evalúa mediante el control ambiental.
Como consecuencia de la absorción, distribución, metabolismo y excreción, una cierta dosis interna del agente tóxico (la cantidad neta de un contaminante absorbida o que pasa a través del organismo en un intervalo de tiempo específico) pasa al organismo y puede detectarse en los fluidos corporales. Como consecuencia de su interacción con un receptor situado en el órgano crítico (el órgano que, en condiciones específicas de exposición, muestra el efecto adverso primero o más importante), se producen acontecimientos bioquímicos y celulares. Tanto la dosis interna como los acontecimientos bioquímicos y celulares desencadenados se pueden determinar mediante el control biológico.

$L$ a vigilancia de la salud fue definida en el citado seminario de la CEE/ NIO SH / O SHA de 1980 como "la exploración médico-fisiológica periódica de los trabajadores expuestos con objeto de proteger la salud y prevenir la enfermedad".

El control biológico y la vigilancia de la salud forman parte de un todo que puede abarcar desde la determinación de agentes 0 de sus metabolitos en el organismo mediante la evaluación de sus efectos bioquímicos o celulares, hasta la detección de signos de alteración precoz y reversible del órgano crítico. La detección de la enfermedad establecida queda fuera del alcance de estas evaluaciones.

\section{Objetivos del control biológico}

El control biológico se puede dividir en: (a) control de la exposición y (b) control del efecto, para lo cual se utilizan, respectivamente, indicadores de dosis interna y de efecto.

El objetivo del control biológico de la exposición es la evaluación del riesgo para la salud mediante la valoración de la dosis interna, realizando un cálculo de la cantidad corporal biológicamente activa de la sustancia química en cuestión. Trata de garantizar, pues, que la exposición del trabajador no alcanza niveles que puedan desencadenar efectos adversos. Un efecto se denomina "adverso" si existe una alteración de la capacidad funcional, una disminución de la capacidad para compensar problemas adicionales, una disminución de la capacidad para mantener la homeostasis (un estado estable de equilibrio) 0 un aumento de la sensibilidad a otros factores ambientales.

Dependiendo de la sustancia química y del parámetro biológico analizado, el término dosis interna puede tener diferentes significados (Bernard y Lauwerys 1987). En primer lugar, puede significar la cantidad de una sustancia química recientemente absorbida, por ejemplo, durante un solo turno de trabajo. A tal

Figura 27.1 - Relación entre control medioambiental, biológico y de la exposición y vigilancia de la salud.

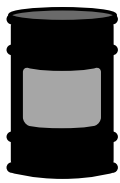

Fuente
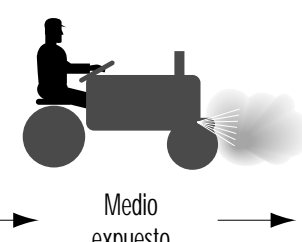

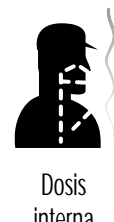

Dosis

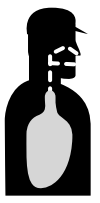

- Dosis diana

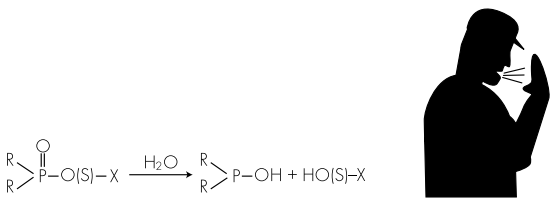

Efecto adverso (reversible) sobre la salud o celular

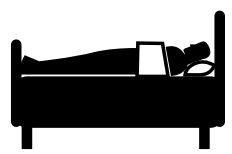

- Enfermedad
CONTROL MEDIOAMBIENTAL

CONTROL DE LA EXPOSICION
CONTROL BIOLOGICO$$
\text { (1) }
$$ 
efecto, se puede determinar la concentración del contaminante en el aire alveolar 0 en la sangre durante el propio turno de trabajo 0 al día siguiente (las muestras de sangre 0 de aire alveolar se pueden tomar hasta 16 horas después de terminado el período de exposición). En segundo lugar, en caso de que la sustancia química tenga un semiperíodo biológico prolongado - por ejemplo, metales en el torrente sanguíneo-, la dosis interna puede significar la cantidad absorbida durante un período de varios meses.

En tercer lugar, el término puede significar también la cantidad de sustancia química almacenada. En este caso representa un indicador de acumulación que estima la concentración de la sustancia química en órganos o tejidos de los que, una vez depositado, se libera lentamente. Por ejemplo, las determinaciones de DDT 0 de PCB en sangre pueden ofrecer esa estimación.

Por último, la dosis interna puede indicar la cantidad de sustancia química existente en el lugar donde ésta ejerce sus efectos, ofreciendo así información sobre la dosis biológica eficaz. En este sentido, una de sus utilidades más prometedoras e importantes es, por ejemplo, la determinación de aductos formados por sustancias químicas tóxicas con la proteína de la hemoglobina o con el ADN.

EI control biológico de los efectos trata de identificar las alteraciones precoces y reversibles que aparecen en el órgano crítico y que, al mismo tiempo, permiten identificar a los sujetos con signos de efectos secundarios adversos. En este sentido, representa la principal herramienta para la vigilancia de la salud de los trabajadores.

\section{Principales métodos de control}

El control biológico de la exposición se basa en la determinación de indicadores de dosis interna mediante la medida de:

- la cantidad de sustancia química a la que está expuesto el trabajador en sangre u orina (raramente en leche, saliva o grasa);

- la cantidad de uno o más metabolitos de la sustancia química en los mismos líquidos corporales;

- la concentración de compuestos orgánicos volátiles (disolventes) en el aire alveolar;

- la dosis biológicamente eficaz de los compuestos que han formado aductos con el ADN o con otras grandes moléculas y que, por tanto, poseen un efecto genotóxico potencial;

Se comentan seguidamente los factores que afectan a la concentración de la sustancia química y de sus metabolitos en sangre y en orina.

En lo que se refiere a la concentración en el aire alveolar, además del nivel de exposición ambiental, los factores implicados más importantes son la solubilidad y el metabolismo de la sustancia inhalada, la ventilación alveolar, el gasto cardíaco y la duración de la exposición (Brugnone y cols. 1980).

La utilización de aductos de ADN y hemoglobina para el control dela exposición humana a sustancias con potencial cancerígeno es una técnica muy prometedora para la determinación de exposiciones de bajo nivel. (E s preciso señalar, no obstante, que no todas las sustancias químicas que se unen a macromoléculas del organismo humano son genotóxicas, es decir, potencialmente cancerígenas.) La formación de aductos sólo es un paso en el complejo proceso de la carcinogénesis. 0 tros acontecimientos celulares, como la promoción de la reparación del ADN y la progresión, modifican sin lugar a dudas el riesgo de desarrollo de enfermedades como el cáncer. Por tanto, en el momento actual, las determinaciones de aductos se deben considerar limitadas al control de la exposición a sustancias químicas. Esto se examina con mayor detenimiento en el artículo "Sustancias químicas genotóxicas", dentro de este mismo capítulo.

El control biológico de los efectos se realiza mediante la determinación de indicadores de efecto, es decir, aquéllos que pueden identificar alteraciones precoces y reversibles. Con este método se obtiene una estimación indirecta de la cantidad de sustancia química unida a los puntos de acción y se pueden evaluar las alteraciones funcionales en el órgano crítico en una fase precoz.

Por desgracia, sólo cabe reseñar algunos ejemplos de aplicación de este método, a saber: (1) la inhibición de la pseudocolinesterasa por los insecticidas órganofosforados, (2) la inhibición de la $\delta$-dehidratasa del ácido aminolevulínico (ALA-D) por el plomo inorgánico, y (3) el aumento de la excreción urinaria de ácido d-glucárico y de las porfirinas en los sujetos expuestos a sustancias químicas inductoras de enzimas microsomales y/ o a agentes porfirogénicos (p. ej., hidrocarburos clorados).

\section{Ventajas y limitaciones del control biológico}

En relación con las sustancias que producen el efecto tóxico después de penetrar en el organismo humano, el control biológico permite una evaluación más centrada y focalizada del riesgo para la salud que el control ambiental. Un parámetro biológico que refleje la dosis interna permite comprender los efectos adversos sistémicos un poco mejor que cualquier determinación ambiental.

El control biológico ofrece numerosas ventajas sobre el control ambiental y, en particular, permite la evaluación de:

- la exposición durante un período prolongado;

- la exposición como consecuencia de la movilidad del trabajador en el medio ambiente de trabajo;

- la absorción de una sustancia por varias vías, incluida la cutánea;

- Ia exposición global como consecuencia de diferentes fuentes de contaminación, tanto en el trabajo como fuera de él;

- la cantidad de sustancia absorbida por el sujeto dependiendo de factores distintos del grado de exposición, como son el esfuerzo físico requerido por el trabajo, la ventilación o el clima

- la cantidad de sustancia absorbida por el sujeto depe;ndiendo de factores individuales que pueden influir en la farmacocinética del agente tóxico en el organismo, como la edad, el sexo, las características genéticas o el estado funcional de los órganos en que la sustancia tóxica experimenta biotransformación y eliminación.

A pesar de estas ventajas, el control biológico todavía presenta en la actualidad considerables limitaciones, las más significativas de las cuales son las siguientes:

- El número de sustancias que se pueden controlar biológicamente es bastante pequeño.

- En caso de exposición aguda, el control biológico sólo ofrece información útil sobre la exposición a sustancias que se metabolizan rápidamente, por ejemplo disolventes aromáticos.

- El significado de los indicadores biológicos no se ha definido claramente; por ejemplo, no siempre se sabe si los niveles de una sustancia medidos en material biológico reflejan una exposición actual o acumulativa (p. ej., cadmio y mercurio urinarios).

- En general, los indicadores biológicos de dosis interna permiten evaluar el grado de exposición, pero no proporcionan datos determinantes de la cantidad real presente en el órgano crítico.

- A menudo no se conocen las interferencias que en el metabolismo de la sustancia controlada puedan ejercer otras 
sustancias exógenas a las que el organismo está expuesto simultáneamente en el medio ambiente general y de trabajo.

- No siempre se conocen suficientemente las relaciones existentes entre los niveles de exposición ambiental y los niveles de los indicadores biológicos, por una parte, y entre los niveles de los indicadores biológicos y sus posibles efectos sobre la salud, por otra.

- EI número de indicadores biológicos para los que existen índices biológicos de exposición (BEI) es bastante limitado. Se precisa información de seguimiento para determinar si una sustancia que actualmente se considera incapaz de producir un efecto adverso puede ser considerada como peligrosa en el futuro.

- EI BEI suele corresponder al nivel de agente que comunmente puede obtenerse en un especimen tomado en un trabajador sano, que haya estado expuesto a niveles ambientales, de dicho agente, iguales al valor T LV-T W A.

\section{Información requerida para el desarrollo de métodos y criterios para la selección de pruebas biológicas}

Para la programación del control biológico se requieren las siguientes condiciones básicas:

- conocimiento del metabolismo de una sustancia exógena en el organismo humano (toxicocinética);

- conocimiento de las alteraciones que se producen en el órgano crítico (toxicodinámica);

- existencia de indicadores;

- existencia de métodos analíticos suficientemente exactos;

- posibilidad de empleo de muestras biológicas de fácil obtención en las que se puedan medir los indicadores;

- existencia de relaciones dosis-efecto y dosis-respuesta y conocimiento de las mismas;

- validez de predicción de los indicadores.

En este contexto, la validez de una prueba es el grado en que el parámetro considerado predice la situación tal como realmente es (es decir, tal como la mostrarían instrumentos de medición más exactos). La validez está determinada por la combinación de dos propiedades: sensibilidad y especificidad. Si una prueba posee una elevada sensibilidad, proporcionará pocos falsos negativos; si posee una especificidad elevada, proporcionará pocos falsos positivos (CCE 1985-1989).

\section{Relación entre exposición, dosis interna y efectos}

El estudio de la concentración de una sustancia en el medio ambiente de trabajo y la determinación simultánea de los indicadores de dosis y efecto en los sujetos expuestos permite obtener información acerca de la relación entre exposición en el trabajo y concentración de la sustancia en muestras biológicas, y entre esta última y los efectos precoces de la exposición.

El conocimiento de las relaciones entre la dosis de una sustancia y el efecto que produce es un requisito esencial para poner en marcha un programa de control biológico. La evaluación de esta relación dosis- efecto está basada en el análisis del grado de asociación existente entre el indicador de dosis y el indicador de efecto, y en el estudio de las variaciones cuantitativas de este último ante cualquier variación del indicador de dosis. (V éase también el capítulo Toxicología, donde se debaten con mayor detenimiento las relaciones vinculadas con la dosis.)

M ediante el estudio de la relación dosis-efecto es posible identificar la concentración de la sustancia tóxica para la que el indicador de efecto supera los valores considerados actualmente como no nocivos. Además, de esta forma también sería posible determinar el nivel sin efecto.
Dado que no todos los individuos de un grupo reaccionan de la misma manera, es necesario examinar la relación dosis-respuesta, en otras palabras, la forma en que el grupo responde a la exposición, evaluando la aparición del efecto en comparación con la dosis interna. El término respuesta indica el porcentaje de sujetos del grupo que muestran una variación cuantitativa específica en un indicador de efecto para cada dosis.

\section{Aplicaciones prácticas del control biológico}

La aplicación práctica de un programa de control biológico requiere información sobre: (1) el comportamiento de los indicadores utilizados en relación con la exposición, especialmente de los relativos al grado, la continuidad y la duración de la exposición, (2) el intervalo entre el fin de la exposición y la medición de los indicadores, y (3) los factores fisiológicos y patológicos distintos a la exposición que pueden alterar los niveles de los indicadores.

En los artículos siguientes se describe el comportamiento de diversos indicadores biológicos de dosis y efecto utilizados para controlar la exposición profesional a sustancias ampliamente utilizadas en la industria. Se evalúan la utilidad práctica y los límites de cada sustancia, prestando particular atención al momento del muestreo y a los factores de interferencia. Tales consideraciones serán útiles al establecer criterios para la selección de una prueba biológica.

\section{M omento del muestreo}

Para seleccionar el momento del muestreo es preciso tener en cuenta los diferentes aspectos cinéticos de la sustancia química; en particular, hay que conocer su absorción por los pulmones, el tracto gastrointestinal y la piel, su distribución posterior a los distintos compartimientos del organismo, su biotransformación y, finalmente, su eliminación. También es importante saber en qué lugares del organismo se puede acumular.

Con respecto a la exposición a sustancias orgánicas, el momento de recogida de las muestras biológicas es lo más importante, dada la diferente velocidad de los procesos metabólicos implicados y, en consecuencia, la excreción más o menos rápida de la dosis absorbida.

\section{Factores de interferencia}

La utilización correcta de los indicadores biológicos requiere un conocimiento exhaustivo de aquellos factores que, aunque independientes de la exposición, pueden afectar a los niveles de los indicadores biológicos. Los tipos más importantes de factores de interferencia son los siguientes.(Alessio, Berlin y Foà 1987).

Factores fisiológicos, tales como la dieta, el sexo, y la edad, por ejemplo, pueden influir en los resultados. El consumo de pescado y mariscos puede aumentar los niveles de arsénico en orina y de mercurio en sangre. Los valores de la protoporfirina eritrocitaria son significativamente mayores en las mujeres que en los varones con los mismos niveles sanguíneos de plomo. Los niveles de cadmio urinario aumentan con la edad.

Entre los hábitos personales que pueden distorsionar los niveles de los indicadores son particularmente importantes el consumo de tabaco y el de alcohol. El tabaquismo puede ocasionar la absorción directa de sustancias presentes de forma natural en las hojas del tabaco (p. ej., cadmio), o de contaminantes presentes en el medio ambiente de trabajo que se han depositado en los cigarrillos (p. ej., plomo), o de productos de combustión (p. ej., monóxido de carbono).

El consumo de alcohol puede influir en los niveles de los indicadores biológicos, ya que en las bebidas alcohólicas están presentes de forma natural sustancias como el plomo. Los grandes bebedores, por ejemplo, muestran niveles sanguíneos de plomo superiores a los de sujetos control. La ingestión de alcohol puede interferir con la biotransformación y la eliminación de 
compuestos industriales tóxicos; con una dosis única, el alcohol puede inhibir el metabolismo de numerosos disolventes, como el tricloroetileno, el xileno, el estireno y el tolueno, por su competitividad con las enzimas esenciales tanto para la metabolización del etanol como de los disolventes. La ingestión regular de alcohol puede afectar también al metabolismo de los disolventes en forma totalmente distinta, acelerando el metabolismo de los mismos, posiblemente por inducción del sistema oxidante de los microsomas. Dado que el etanol es la principal sustancia capaz de producir interferencia metabólica, es aconsejable determinar los indicadores de exposición a disolventes sólo en aquellos días en los que no se ha consumido alcohol.

Se dispone de menos datos acerca de los posibles efectos de los fármacos sobre los niveles de los indicadores biológicos. Se ha demostrado que la aspirina puede interferir en la transformación biológica de xileno en ácido metilhipúrico, y que el fenilsalicilato, fármaco muy utilizado como analgésico, puede aumentar de forma significativa los niveles urinarios de los fenoles. El consumo de antiácidos con aluminio puede elevar los niveles plasmáticos y urinarios de este metal.

Se han observado diferencias marcadas en distintos grupos étnicos en cuanto al metabolismo de disolventes muy utilizados, como el tolueno, el xileno, el tricloroetileno, el tetracloroetileno y el metilcloroformo.

Estados patológicos adquiridos pueden modificar los niveles de los indicadores biológicos. El órgano crítico puede comportarse de forma anómala con respecto a las pruebas de control biológico, debido tanto a la acción específica del agente tóxico como a otras razones. U n ejemplo de situaciones del primer tipo es el comportamiento de los niveles urinarios de cadmio: cuando se produce una enfermedad tubular causada por el cadmio, la excreción urinaria aumenta mucho y los niveles de la prueba ya no reflejan el grado de exposición. U n ejemplo del segundo tipo de situación es el aumento de los niveles de protoporfirina eritrocitaria observado en los sujetos con déficit de hierro y sin absorción anormal de plomo.

Modificaciones fisiológicas de los medios biológicos -la orina, por ejemplo-, en los que se basan las determinaciones de los indicadores biológicos, pueden modificar los valores de la prueba. Con fines prácticos, sólo es posible obtener muestras puntuales de orina de los individuos durante el trabajo, y dado que la densidad de estas muestras puede variar, significa que los niveles del indicador pueden fluctuar mucho en el curso de un sólo día.

Para obviar esta dificultad es aconsejable eliminar las muestras excesivamente diluidas o concentradas, según unos valores de densidad relativa o de creatinina seleccionados. En particular, se debe desechar la orina con una densidad relativa inferior a 1.010 o superior a 1.030, o con una concentración de creatinina inferior a 0,5 g/ I o superior a 3,0 g/ I. Diversos autores proponen también ajustar los valores de los indicadores de acuerdo con la densidad relativa o expresar esos valores de acuerdo con el contenido urinario de creatinina.

Los cambios patológicos en los medios biológicos también afectan considerablemente a los valores de los indicadores biológicos. Por ejemplo, en los sujetos anémicos expuestos a metales (mercurio, cadmio, plomo, etc. ), los niveles sanguíneos del metal pueden ser inferiores a los que serían de esperar de acuerdo con la exposición; ello es debido al bajo número de eritrocitos existentes para transportar el metal tóxico por la circulación sanguínea.

Por tanto, cuando las determinaciones de sustancias tóxicas o de sus metabolitos unidos a los eritrocitos se realizan en sangre total, siempre es aconsejable determinar el hematócrito, que proporciona una medida del porcentaje de células sanguíneas en la sangre total.

\section{Exposición combinada a varias sustancias tóxicas presentes en} el lugar de trabajo

En el caso de exposición combinada a varias sustancias tóxicas presentes en el lugar de trabajo, se pueden producir interferencias metabólicas que alteren el comportamiento de los indicadores biológicos, creando así graves problemas de interpretación. En los estudios en seres humanos se han demostrado interferencias, por ejemplo, en la exposición combinada a tolueno y xileno, xileno y etilbenceno, tolueno y benceno, hexano y metil etil cetona, y tetracloroetileno y tricloroetileno.

En particular, es preciso señalar que, cuando está inhibida la biotransformación de un disolvente, la excreción urinaria de su metabolito está reducida (posible infravaloración del riesgo), mientras que los niveles del disolvente en sangre y en aire espirado aumentan (posible sobrevaloración del riesgo).

Por tanto, en las situaciones en que es posible medir simultáneamente las sustancias y sus metabolitos para determinar el grado de interferencia inhibitoria, sería útil comprobar si los niveles de los metabolitos urinarios son inferiores a lo esperado y, al mismo tiempo, si la concentración de los disolventes en sangre y/o aire espirado es superior.

Se han descrito interferencias metabólicas para exposiciones combinadas en que las sustancias individualmente están presentes en niveles próximos, y en ocasiones inferiores, a los valores límites habitualmente aceptados. Sin embargo, no suelen ocurrir estas interferencias cuando los niveles de exposición a cada sustancia presente en el lugar de trabajo es baja.

\section{Utilización práctica de los indicadores biológicos}

Los indicadores biológicos se pueden utilizar en la práctica de la salud en el trabajo, con varios fines: (1) el control periódico de trabajadores individuales, (2) el análisis de la exposición de un grupo de trabajadores y (3) evaluaciones epidemiológicas. Las pruebas utilizadas deben presentar las características de precisión, exactitud, buena sensibilidad y especificidad, a fin de reducir el posible número de falsas interpretaciones.

\section{Valores de referencia y grupos de referencia}

Un valor de referencia es el nivel de un indicador biológico en la población general no expuesta profesionalmente a la sustancia tóxica en estudio. Es necesario referirse a estos valores para comparar los datos obtenidos mediante los programas de control biológico en una población supuestamente expuesta. Los valores de referencia no se deben confundir con los valores límites, que en general son los valores legales o directrices de exposición profesional y ambiental (A lessio y cols. 1992).

Cuando hay que comparar los resultados de los análisis de grupos, es preciso conocer la distribución de los valores en el grupo de referencia y en el grupo de estudio, porque sólo entonces es posible hacer una comparación estadística. En estos casos, resulta esencial conseguir que la población general (grupo de referencia) y el grupo expuesto sean homogeneos, con características similares en cuanto al sexo, edad, forma de vida y hábitos alimenticios.

Para obtener valores de referencia fiables, es preciso asegurarse de que los sujetos que constituyen el grupo de referencia nunca hayan estado expuestos a las sustancias tóxicas, ya sea profesionalmente 0 debido a condiciones particulares de contaminación ambiental.

Al evaluar la exposición a sustancias tóxicas se ha de tener cuidado para no incluir sujetos que, aunque no estén expuestos directamente a ellas, trabajen en el mismo lugar de trabajo, puesto que si, de hecho, tales sujetos están sometidos en realidad a una exposición indirecta, existe la posibilidad de que se infravalore la exposición del grupo. 
O tra práctica que se ha de evitar, aunque todavía está muy extendida, es la utilización, con fines de referencia, de valores descritos en la literatura procedentes de listas de casos de otros países y que pueden haber sido recogidos en regiones en las que existen diferentes situaciones de contaminación ambiental.

\section{Control periódico de trabajadores individuales}

Es obligatorio el control periódico de trabajadores individuales cuando los niveles de la sustancia tóxica en la atmósfera del medio ambiente de trabajo se aproximan al valor límite. Siempre que sea posible, es aconsejable comprobar simultáneamente un indicador de exposición y un indicador de efecto. Los datos así obtenidos deben compararse con los valores de referencia y con los valores límites propuestos para la sustancia en estudio (ACGIH 1993).

\section{Análisis de un grupo de trabajadores}

Es obligatorio el análisis de un grupo cuando los resultados de los indicadores biológicos utilizados pueden acusar el efecto de factores independientes de la exposición (dieta, concentración 0 dilución de la orina, etc.) y para los que existe una amplia gama de valores "normales".

Para que el estudio del grupo proporcione resultados útiles, éste debe ser lo bastante numeroso y homogéneo en cuanto a la exposición, el sexo y, en el caso de algunos agentes tóxicos, la antigüedad en el trabajo. Cuanto más constantes sean los niveles de exposición a lo largo del tiempo, más fiables serán los datos. Una investigación realizada en un lugar de trabajo donde los trabajadores cambien permanentemente de departamento 0 de trabajo tiene poco valor. Para la evaluación correcta de un estudio de grupo no basta con expresar los datos sólo como valores medios y valores límites. También es preciso tener en cuenta la distribución por frecuencia de los valores del indicador biológico en cuestión.

\section{Evaluaciones epidemiológicas}

Los datos obtenidos del control biológico de grupos de trabajadores se pueden utilizar también en estudios epidemiológicos transversales o prospectivos.

Los estudios transversales permiten comparar las situaciones existentes en diversos departamentos de la fábrica o en diferentes industrias y trazar mapas de riesgo de los procesos de fabricación. Hay que contar con la dificultad derivada de que los controles de calidad entre laboratorios no están todavía lo suficientemente extendidos; por tanto, no es posible garantizar que todos ellos den resultados comparables.

Los estudios prospectivos permiten evaluar el comportamiento de los niveles de exposición a lo largo del tiempo, a fin de comprobar, por ejemplo, la eficacia de las mejoras ambientales, o correlacionar el comportamiento de los indicadores biológicos a lo largo de los años con el estado de salud de los sujetos sometidos al control. Los resultados de tales estudios a largo plazo son muy útiles para resolver problemas que implican cambios en el tiempo. En el momento actual, el control biológico se utiliza principalmente para evaluar si la exposición actual se considera "segura", pero no para evaluar situaciones a lo largo del tiempo. Un nivel dado de exposición, considerado seguro en el momento actual, puede no tener este carácter en algún momento del futuro.

\section{Aspectos éticos}

El empleo del control biológico para la evaluación de una potencial toxicidad plantea algunas consideraciones éticas. U no de los objetivos que se persiguen con él es reunir suficiente información para decidir qué nivel de un efecto dado constituye un efecto indeseable; en ausencia de datos suficientes, cualquier perturbación será considerada indeseable. Es preciso valorar las implicaciones legales y reglamentarias de este tipo de información. Por tanto, hay que buscar el debate y el consenso sociales acerca del modo de utilizar los indicadores biológicos. En otras palabras, hay que educar a los trabajadores, las empresas, las comunidades y los responsables de la formulación de políticas acerca del significado de los resultados obtenidos por el control biológico, para que nadie se sienta indebidamente alarmado o satisfecho.

Debe mantenerse una comunicación adecuada con el individuo al que se ha realizado la prueba en lo que respecta a los resultados y a su interpretación. Además, hay que comunicar claramente a todos los participantes si la utilización de algunos indicadores es experimental o no.

El Código internacional de ética para los profesionales de la salud en el trabajo, presentado por la Comisión Internacional de M edicina del Trabajo en 1992, establece que "Ias pruebas biológicas y las demás investigaciones deben elegirse desde el punto de vista de su validez para la protección de la salud del trabajador implicado, teniendo en cuenta debidamente su sensibilidad, su especificidad y su valor predictivo". No deben realizarse pruebas "que no sean fiables o que no posean un valor predictivo suficiente en relación con los requisitos de la tarea del trabajador". (V éase el capítulo Aspectos éticos, que profundiza en el debate y recoge el texto del Código.)

\section{Tendencias normativas y prácticas}

EI control biológico sólo se puede llevar a cabo en relación con un número limitado de contaminantes ambientales, dada la limitada disponibilidad de datos de referencia adecuados. Existen, pues, importantes limitaciones a su uso para la evaluación de la exposición.

La O rganización M undial de la Salud (OM S), por ejemplo, sólo ha propuesto valores de referencia para el plomo, el mercurio y el cadmio, considerándolos como aquellos niveles en sangre y orina que no se acompañan de ningún efecto adverso detectable. La American Conference of Governmental Industrial $\mathrm{H}$ ygienists (ACGIH) ha establecido índices biológicos de exposición (BEI) para 26 compuestos; los BEI se definen como "valores de determinantes que son indicativos del grado de exposición integral a las sustancias químicas industriales" (ACGIH 1995).

\section{G ARANTIA DE CALIDAD}

\section{David G ompertz}

Tanto las decisiones que afectan a la salud, el bienestar y la capacidad de empleo de los trabajadores como el enfoque empresarial de los temas referentes a la salud y la seguridad de los mismos deben basarse en datos de buena calidad. Esta afirmación adquiere una importancia especial en relación con los datos de control biológico y, por tanto, corresponde a todo laboratorio que lleve a cabo determinaciones analíticas en muestras biológicas procedentes del mundo del trabajo garantizar la fiabilidad, exactitud y precisión de sus resultados. Tal responsabilidad se extiende al empleo de métodos adecuados para la recogida de muestras, de forma que los resultados lleguen adecuadamente al profesional sanitario responsable de la atención al trabajador. Todas estas actividades quedan comprendidas en la expresión genérica de garantía de calidad.

La actividad central en un programa de garantía de calidad es el control y mantenimiento de la exactitud y la precisión analíticas. Los laboratorios de control biológico se han desarrollado a 
menudo en un ambiente clínico y han tomado las técnicas y los principios de la garantía de calidad de la disciplina de la química clínica. De hecho, las determinaciones de sustancias químicas tóxicas y de los indicadores de efecto biológico en sangre y orina no difieren en esencia de las realizadas en la química clínica y en los laboratorios de farmacología clínica existentes en cualquier gran hospital.

Todo programa de garantía de calidad comienza con la selección y el establecimiento de un método adecuado. El paso siguiente es la elaboración de un método de control de calidad interno para mantener la precisión; el laboratorio necesita además estar seguro de la exactitud del análisis, lo que acaso exija una evaluación externa de la calidad (véase más adelante). Es importante advertir, con todo, que la garantía de calidad va más allá de estos aspectos de control de la calidad analítica.

\section{Selección del método}

Existen varios textos que presentan los métodos analíticos disponibles para el control biológico. Aunque constituyen una guía útil, el analista tiene ante sí un intenso trabajo si quiere conseguir datos de calidad adecuada. En cualquier programa de garantía de calidad es fundamental la elaboración de un protocolo de laboratorio en el que se especifique con detalle todo lo relacionado con la fiabilidad, la exactitud y la precisión. De hecho, la acreditación nacional de los laboratorios de química clínica, toxicología y medicina legal suele depender de la calidad de sus protocolos. La preparación de un protocolo adecuado exige mucho tiempo. Al establecer un método nuevo, a menudo es más rentable obtener de otro laboratorio existente un protocolo que haya demostrado ya su valía, por ejemplo, mediante validación en un programa internacional establecido de garantía de calidad. Para aplicar una técnica analítica específica, como la cromatografía en fase gaseosa en lugar de la cromatografía líquida de alta resolución, puede ser recomendable buscar otro laboratorio con un buen historial y que utilice ese mismo método. Para ello puede acudirse a publicaciones existentes 0 a los organizadores de distintos planes nacionales de evaluación de la calidad.

\section{Control de calidad interno}

La calidad de los resultados analíticos depende de la precisión del método seguido en la práctica, la cual depende a su vez del seguimiento estricto de un protocolo concreto. Lo mejor para evaluar la precisión es incluir "muestras de control de calidad" a intervalos regulares durante una serie analítica. Si se están practicando análisis de plomo en sangre, por ejemplo, pueden introducirse esas muestras cada seis u ocho muestras reales de los trabajadores. Cuando los métodos analíticos son más estables, puede reducirse el número de las muestras de control. En el caso del análisis de plomo en sangre, dichas muestras se preparan a partir de $500 \mathrm{ml}$ de sangre (humana o bovina), a la que se añade plomo inorgánico; luego se almacenan en fracciones individuales a baja temperatura (Bullock, Smith y W hitehead 1986). Antes de utilizar cada lote, se analizan 20 fracciones en series separadas en diferentes ocasiones para establecer el resultado medio de ese lote, así como su desviación estándar (W hitehead 1977). Con los dos valores obtenidos se traza un diagrama de control de Shewhart (Figura 27.2). En él se representan luego los resultados del análisis de las muestras de control de calidad incluidas en las siguientes series. EI analista utiliza entonces reglas de aceptación o de rechazo de una serie analítica, según que los resultados de las muestras se sitúen dentro de dos o tres desviaciones estándar (DE) de la media. Westgard y cols. (1981) han propuesto una secuencia de reglas, validadas mediante aplicaciones informáticas, para su aplicación a las muestras de control. Este método de control de calidad se describe en los libros de texto de química clínica; en Whitehead (1977) se muestra un método sencillo para la aplicación de la garantía de calidad. H ay que resaltar que estas técnicas dependen de la preparación y el análisis de muestras de control de calidad, independientemente de las muestras de calibración utilizadas en cada proceso analítico.

Este método se puede adaptar a una gama de ensayos de control biológico o de control del efecto biológico. Los lotes de muestras de sangre o de orina se pueden preparar añadiendo el tóxico o el metabolito a medir. También se pueden preparar fracciones de sangre, suero, plasma u orina y conservarlas congeladas o liofilizadas para la determinación de enzimas o de proteínas. En todo caso, hay que evitar el riesgo de infección del analista por muestras de sangre humana.

El seguimiento estricto de un protocolo concreto y de las reglas de aceptabilidad es un primer paso fundamental en cualquier programa de garantía de calidad. Todo laboratorio debe estar preparado para comentar su actuación en cuanto al control de calidad y a la evaluación de la calidad con los profesionales sanitarios que lo utilizan, así como para investigar los hallazgos sorprendentes o inusuales.

\section{Evaluación de calidad externa}

Una vez que el laboratorio ha dejado claro que puede obtener resultados con la precisión adecuada, el siguiente paso consiste en confirmar la exactitud de los valores medidos, es decir, la aproximación de estos con el valor real de la muestra. Resulta difícil realizarlo por los propios medios, aunque puede conseguirse participando en un plan externo de evaluación de la calidad. Se trata de algo habitual en la práctica química clínica desde hace tiempo, si bien todavía no se ha extendido en relación con el control biológico, salvo en el caso del análisis de plomo en sangre, para el que existen planes desde el decenio de 1970 (p. ej., Bullock, Smith y Whitehead 1986). La comparación de los resultados analíticos propios con los procedentes de otros laboratorios, que hayan analizado muestras del mismo lote, permite evaluar la exactitud conseguida. Se dispone de diversos planes nacionales e internacionales de evaluación de la calidad. Muchos de ellos acogen favorablemente la participación de nuevos laboratorios, ya que la validez de la media de los resultados (tomada como medida de la concentración real) aumenta con el número de participantes. Cuando éstos son muchos, aumenta además la capacidad para analizar la actuación de cualquiera de ellos en relación con su método analítico y puede advertirse, por tanto, sobre posibles alternativas. En algunos países se exige la participación en un plan de este tipo para obtener la acreditación como laboratorio. La OMS (1981) ha publicado directrices para el

Figura 27.2 - Diagrama de control de Shewhart para muestras de control de calidad.

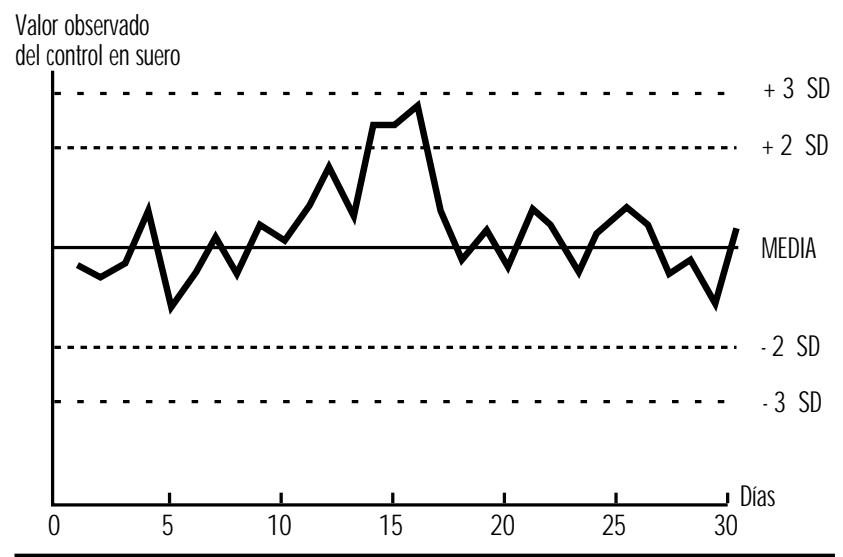


diseño y la realización de planes de evaluación de calidad externa.

En ausencia de planes de ese tipo, se puede comprobar la exactitud utilizando materiales certificados de referencia, que existen en el mercado para determinados análisis. Las muestras distribuidas por los planes de evaluación de calidad externa tienen las ventajas siguientes: (1) el analista no conoce previamente el resultado, (2) se presentan diversas concentraciones, y (3) al no tenerse que emplear métodos analíticos definitivos, los materiales utilizados son más baratos.

\section{Control de calidad preanalítico}

El effuerzo dedicado a conseguir una buena exactitud y precisión en el laboratorio se pierde si las muestras no han sido recogidas en el momento adecuado, han sufrido contaminación, se han deteriorado durante el transporte 0 han sido etiquetadas de forma inadecuada o incorrecta. Es rechazable asimismo la toma de muestras invasiva sin el cuidado adecuado de los materiales necesarios. Aunque la toma de muestras no suele estar bajo el control directo del analista del laboratorio, un programa completo de calidad del control biológico debe tener en cuenta estos factores, y el laboratorio ha de cuidar de que las jeringas y los envases de muestras estén libres de contaminación y se tengan instrucciones claras acerca de la técnica de muestreo y la conservación y transporte de las propias muestras. Actualmente se reconoce la importancia del momento correcto de la toma de muestras dentro del turno o de la semana de trabajo en función de la toxicocinética del agente evaluado y su dependencia de la toxicocinética del material (ACGIH 1993; HSE 1992); esta información se debe poner a disposición de los profesionales sanitarios responsables de la recogida de las muestras.

\section{Control de calidad postanalítico}

Unos resultados analíticos de buena calidad pueden tener poca utilidad para el individuo o para el profesional sanitario si no se comunican de forma interpretable y en el momento adecuado. Todo laboratorio de control biológico debe desarrollar métodos de información para alertar al profesional de atención a la salud que haya enviado las muestras acerca de posibles resultados anormales, inesperados o sorprendentes con suficiente antelación para que pueda emprender las acciones adecuadas. La interpretación de los resultados, especialmente los cambios en la concentración entre muestras sucesivas, depende a menudo del conocimiento de la precisión del ensayo. Dentro de las tareas de control de calidad global, desde la recogida de muestras hasta el envío de los resultados, los profesionales sanitarios deben recibir información relativa a la precisión y exactitud del laboratorio de control biológico, así como límites de referencia y límites de consulta y legales, que les ayuden a interpretar los resultados.

\section{- Metales y Compuestos ORGANOMETALICOS}

\section{P. H oet y R obert Lauwerys}

Desde hace algún tiempo se sabe que los metales y los compuestos organometálicos tóxicos, como el aluminio, antimonio, arsénico inorgánico, berilio, cadmio, cromo, cobalto, plomo, alquil plomo, mercurio metálico y sus sales, compuestos de mercurio orgánico, níquel, selenio y vanadio, presentan riesgos potenciales para la salud de las personas expuestas. En algunos casos se han realizado estudios epidemiológicos sobre las relaciones existentes entre dosis interna y efecto/ respuesta resultante en los trabajadores expuestos profesionalmente, lo que ha permitido proponer valores límite biológicos basados en consideraciones de salud (véase la Tabla 27.1).

U no de los problemas que plantea la determinación precisa y exacta de los metales en los materiales biológicos consiste en que las sustancias metálicas de interés suelen estar presentes en concentraciones muy bajas. Cuando el control biológico adopta la forma de toma de muestras y análisis de orina, como ocurre a menudo, se suele realizar en muestras "puntuales"; por tanto, suele ser aconsejable la corrección de los resultados según la dilución de la orina. La expresión de los resultados por gramo de creatinina es el método de estandarización más utilizado. LoS análisis realizados en muestras de orina demasiado diluida 0 demasiado concentrada no son fiables y se deben repetir.

\section{Aluminio}

En la industria, los trabajadores pueden verse expuestos a compuestos de aluminio inorgánico por inhalación y, posiblemente, también por ingestión de polvo que lo contenga. El aluminio se absorbe mal por vía oral, pero su absorción aumenta con la ingesta simultánea de citrato. La tasa de absorción del aluminio depositado en el pulmón es desconocida; la biodisponibilidad probablemente dependa de las características fisicoquímicas de la partícula. La orina es la principal vía de excreción del aluminio absorbido. La concentración de aluminio en el suero y en la orina está determinada tanto por la intensidad de una exposición reciente como por la cantidad total de aluminio corporal. En las personas no expuestas por su trabajo, la concentración sérica de aluminio suele ser inferior a $1 \mu \mathrm{g} / 100 \mathrm{ml}$ y en la orina rara vez supera los $30 \mu \mathrm{g} / \mathrm{g}$ de creatinina. En los sujetos con función renal normal, la excreción urinaria de aluminio es un indicador más sensible de exposición que su concentración en suero/ plasma.

Datos en soldadores sugieren que la cinética de la excreción de aluminio por la orina implica un mecanismo de dos pasos, el primero con un semiperíodo biológico de unas ocho horas. En los trabajadores que han estado expuestos durante varios años se produce una cierta acumulación del metal en el organismo; las concentraciones de aluminio en suero y en orina son sensibles también a la cantidad total de aluminio corporal. El aluminio se almacena en varios compartimientos del organismo y se excreta de ellos a diferentes velocidades a lo largo de muchos años. También se ha encontrado una elevada acumulación de aluminio en el organismo (hueso, hígado, cerebro) de pacientes con insuficiencia renal. Los pacientes sometidos a diálisis presentan riesgo de toxicidad ósea y/ o de encefalopatía cuando su concentración sérica de aluminio supera crónicamente los $20 \mu \mathrm{g} / 100 \mathrm{ml}$, aunque es posible detectar signos de toxicidad a concentraciones aún más bajas. La Comisión de las Comunidades Europeas ha recomendado que, para prevenir la toxicidad por aluminio, la concentración plasmática del mismo nunca supere los $20 \mu \mathrm{g} / 100 \mathrm{ml}$; una cifra superior a $10 \mu \mathrm{g} / 100 \mathrm{ml}$ hace aconsejables un control y una vigilancia de la salud más frecuentes, y una concentración superior a $6 \mu \mathrm{g} / 100 \mathrm{ml}$ ha de ser considerada como signo de aumento excesivo de la cantidad de aluminio corporal.

\section{Antimonio}

El antimonio inorgánico puede penetrar en el organismo por ingestión o por inhalación, si bien la tasa de absorción es desconocida. Los compuestos pentavalentes absorbidos se excretan principalmente por la orina, y los compuestos trivalentes por las heces. Es posible la retención de algunos de ellos después de una exposición prolongada. Las concentraciones normales de antimonio en el suero y en la orina probablemente sean inferiores a $0,1 \mu \mathrm{g} / 100 \mathrm{ml}$ y $1 \mu \mathrm{g} / \mathrm{g}$ de creatinina, respectivamente. 
Tabla 27.1 - M etales: Valores de referencia y límites biológicos propuestos por la A merican Conference of G overnmental Industrial Hygienists (ACG IH), Deutsche Forschungsgemeinschaft (DFG) y Lauwerys y Hoet (L y H).

\begin{tabular}{|c|c|c|c|c|c|}
\hline Metal & Muestra & $\begin{array}{l}\text { Valores de } \\
\text { referencia }{ }^{*} *\end{array}$ & Límite ACGIH (BEI) ${ }^{2}$ & Límite DFG (BAT) ${ }^{3}$ & Límites L y H4 (TMPC) \\
\hline \multirow[t]{2}{*}{ Aluminio } & Suero/ plasma & $<1 \mu \mathrm{g} / 100 \mathrm{ml}$ & & & \\
\hline & Orina & $<30 \mu \mathrm{g} / \mathrm{g}$ & & $\begin{array}{l}200 \mu \mathrm{g} / \mathrm{I} \text { ( fin de la } \\
\text { jornada) }\end{array}$ & $150 \mu \mathrm{g} / \mathrm{g}$ (fin de la jornada) \\
\hline Antimonio & Orina & $<1 \mu \mathrm{g} / \mathrm{g}$ & & & $35 \mu \mathrm{g} / \mathrm{g}$ (fin de la jornada) \\
\hline Arsénico & $\begin{array}{l}\text { Orina (suma de arsénico } \\
\text { inorgánico y metabolitos } \\
\text { metilados) }\end{array}$ & $<10 \mu \mathrm{g} / \mathrm{g}$ & $\begin{array}{l}50 \mu \mathrm{g} / \mathrm{g} \\
\text { (fin de la semana) }\end{array}$ & & $\begin{array}{l}50 \mu \mathrm{g} / \mathrm{g}(\mathrm{si} \text { TWA: } \\
\left.0,05 \mathrm{mg} / \mathrm{m}^{3}\right) ; 30 \mu \mathrm{g} / \mathrm{g} \\
\left(\text { si TWA: 0,01 mg/ } \mathrm{m}^{3}\right) \\
\text { (fin de la jornada) }\end{array}$ \\
\hline Berilio & Orina & $<2 \mu \mathrm{g} / \mathrm{g}$ & & & \\
\hline Cadmio & $\begin{array}{l}\text { Sangre } \\
\text { Orina }\end{array}$ & $\begin{array}{l}<0,5 \mu \mathrm{g} / 100 \mathrm{ml} \\
<2 \mu \mathrm{g} / \mathrm{g}\end{array}$ & $\begin{array}{l}0,5 \mu \mathrm{g} / 100 \mathrm{ml} \\
5 \mu \mathrm{g} / \mathrm{g}\end{array}$ & $\begin{array}{l}1,5 \mu \mathrm{g} / 100 \mathrm{ml} \\
15 \mu \mathrm{g} / \mathrm{l}\end{array}$ & $\begin{array}{l}0,5 \mu \mathrm{g} / 100 \mathrm{ml} \\
5 \mu \mathrm{g} / \mathrm{g}\end{array}$ \\
\hline $\begin{array}{l}\text { Cromo } \\
\text { (compuestos } \\
\text { solubles) }\end{array}$ & $\begin{array}{l}\text { Suero/ plasma } \\
\text { Orina }\end{array}$ & $\begin{array}{l}<0,05 \mu \mathrm{g} / 100 \mathrm{ml} \\
<5 \mu \mathrm{g} / \mathrm{g}\end{array}$ & $\begin{array}{l}30 \mu \mathrm{g} / \mathrm{g} \text { (fin de la jornada, } \\
\text { fin de la semana laboral); } \\
10 \mu \mathrm{g} / \mathrm{g} \text { (aumenta } \\
\text { durante el turno) }\end{array}$ & & $30 \mu \mathrm{g} / \mathrm{g}$ (fin de la jornada) \\
\hline \multirow[t]{3}{*}{ Cobalto } & Suero/ plasma & $<0,05 \mu \mathrm{g} / 100 \mathrm{ml}$ & & & \\
\hline & Sangre & $<0,2 \mu \mathrm{g} / 100 \mathrm{ml}$ & $\begin{array}{l}0,1 \mu \mathrm{g} / 100 \mathrm{ml} \text { (fin de la } \\
\text { jornada, fin de la semana } \\
\text { laboral) }\end{array}$ & $0,5 \mu \mathrm{g} / 100 \mathrm{ml}($ EKA)** & \\
\hline & Orina & $<2 \mu \mathrm{g} / \mathrm{g}$ & $\begin{array}{l}15 \mu \mathrm{g} / \text { I (fin de la jornada } \\
\text { laboral, fin de la semana } \\
\text { laboral) }\end{array}$ & $60 \mu \mathrm{g} / \mathrm{I}(\mathrm{EKA}) * *$ & $\begin{array}{l}30 \mu \mathrm{g} / \mathrm{g} \\
\text { (fin de la jornada laboral, } \\
\text { fin de la semana laboral) }\end{array}$ \\
\hline \multirow[t]{4}{*}{ Plomo } & Sangre (plomo) & $<25 \mu \mathrm{g} / 100 \mathrm{ml}$ & $\begin{array}{l}30 \mu \mathrm{g} / 100 \mathrm{ml} \\
\text { (no crítico) }\end{array}$ & $\begin{array}{l}\text { mujer <45 años: } \\
30 \mu \mathrm{g} / 100 \mathrm{ml} \\
\text { varón: } 70 \mu \mathrm{g} / 100 \mathrm{ml}\end{array}$ & $40 \mu \mathrm{g} / 100 \mathrm{ml}$ \\
\hline & ZPP en sangre & $\begin{array}{l}<40 \mu \mathrm{g} / 100 \mathrm{ml} \\
\text { de sangre } \\
<2,5 \mu \mathrm{g} / \mathrm{g} \mathrm{Hb}\end{array}$ & & & $\begin{array}{l}40 \mu \mathrm{g} / 100 \mathrm{ml} \text { de sangre } \\
3 \mu \mathrm{g} / \mathrm{g} \mathrm{Hb}\end{array}$ \\
\hline & Orina ( plomo) & $<50 \mu \mathrm{g} / \mathrm{g}$ & & & $50 \mu \mathrm{g} / \mathrm{g}$ \\
\hline & ALA en orina & $<4,5 \mathrm{mg} / \mathrm{g}$ & & $\begin{array}{l}\text { mujer <45 años: } \\
\quad 6 \mathrm{mg} / \mathrm{l} ; \\
\text { varón: } 15 \mathrm{mg} / \mathrm{I}\end{array}$ & $5 \mathrm{mg} / \mathrm{g}$ \\
\hline \multirow[t]{2}{*}{ Manganeso } & Sangre & $<1 \mu \mathrm{g} / 100 \mathrm{ml}$ & & & \\
\hline & Orina & $<3 \mu \mathrm{g} / \mathrm{g}$ & & & \\
\hline \multirow[t]{2}{*}{ Mercurio inorgánico } & Sangre & $<1 \mu \mathrm{g} / 100 \mathrm{ml}$ & $\begin{array}{l}1,5 \mu \mathrm{g} / 100 \mathrm{ml} \text { (fin de la } \\
\text { jornada, al término de la } \\
\text { semana laboral) }\end{array}$ & $5 \mu \mathrm{g} / 100 \mathrm{ml}$ & $\begin{array}{l}2 \mu \mathrm{g} / 100 \mathrm{ml} \text { (fin de la } \\
\text { jornada) }\end{array}$ \\
\hline & Orina & $<5 \mu \mathrm{g} / \mathrm{g}$ & $35 \mu \mathrm{g} / \mathrm{g}$ (previo al turno) & $200 \mu \mathrm{g} / \mathrm{I}$ & $50 \mu \mathrm{g} / \mathrm{g}$ (fin de la jornada) \\
\hline \multirow{2}{*}{$\begin{array}{l}\text { Níquel (compuestos } \\
\text { solubles) }\end{array}$} & Suero/ plasma & $<0,05 \mu \mathrm{g} / 100 \mathrm{ml}$ & & & \\
\hline & Orina & $<2 \mu \mathrm{g} / \mathrm{g}$ & & $45 \mu \mathrm{g} / \mathrm{I}(\mathrm{EKA}) * *$ & $30 \mu \mathrm{g} / \mathrm{g}$ \\
\hline Selenio & $\begin{array}{l}\text { Suero/ plasma } \\
\text { Orina }\end{array}$ & $\begin{array}{l}<15 \mu \mathrm{g} / 100 \mathrm{ml} \\
<25 \mu \mathrm{g} / \mathrm{g}\end{array}$ & & & \\
\hline \multirow[t]{3}{*}{ Vanadio } & Suero/ plasma & $<0,2 \mu \mathrm{g} / 100 \mathrm{ml}$ & & & \\
\hline & Sangre & $<0,1 \mu \mathrm{g} / 100 \mathrm{ml}$ & & & \\
\hline & Orina & $<1 \mu \mathrm{g} / \mathrm{g}$ & & $70 \mu \mathrm{g} / \mathrm{g}$ creatinina & $50 \mu \mathrm{g} / \mathrm{g}$ \\
\hline $\begin{array}{l}\text { - Los valores de orina son pc } \\
\text { Los valores de referencia S } \\
\text { Concentraciones máximas }\end{array}$ & $\begin{array}{l}\text { mo de creatitina. } * * E K A= \\
\text { tomado con algunas modificacio } \\
\text { isibles provisionales (TMPCS) tom }\end{array}$ & $\begin{array}{l}\text { uivalentes de exposición parc } \\
\text { s de Lauwerys y Hoet } 1993 . \\
\text { do de Lauwerys y Hoet } 1993\end{array}$ & $\begin{array}{l}\text { nateriales cancerígenos. } \\
{ }^{2} \text { De ACGIH 1996-97. }\end{array}$ & DFG 1996. & \\
\hline
\end{tabular}


Un estudio preliminar en trabajadores expuestos a antimonio pentavalente indicó que una exposición promedio ponderada en el tiempo de hasta $0,5 \mathrm{mg} / \mathrm{m}^{3}$ daba lugar a un aumento de la concentración urinaria de antimonio de $35 \mu \mathrm{g} / \mathrm{g}$ de creatinina durante el turno.

\section{Arsénico inorgánico}

El arsénico inorgánico puede penetrar en el organismo por los tractos gastrointestinal y respiratorio. El arsénico absorbido se elimina principalmente por el riñón, sin modificar o tras metilación. También se excreta por la bilis en forma de complejo con glutación.

Después de una única exposición oral a una dosis baja de arsenato, el $25 \%$ y el $45 \%$ de la dosis administrada se excreta por la orina en uno y cuatro días respectivamente.

Después de la exposición a arsénico trivalente o pentavalente inorgánico, la excreción urinaria está constituida en un 10 a un $20 \%$ por arsénico inorgánico, en un 10 a un $20 \%$ por ácido monometilarsónico, y en un 60 a un $80 \%$ por ácido cacodílico. Después de la exposición profesional a arsénico inorgánico, la proporción de sustancias arsenicales en la orina depende del momento del muestreo.

Los órganoarsenicales presentes en los organismos marinos también son absorbidos fácilmente por el tracto gastrointestinal, pero se excretan sin modificar en su mayor parte.

Los efectos tóxicos a largo plazo del arsénico (incluidos los que se producen sobre los genes) son consecuencia principalmente de la exposición a arsénico inorgánico. Por tanto, el control biológico pretende evaluar la exposición a los compuestos de éste. A tal efecto, el método de elección es la determinación específica de arsénico inorgánico ( $\left.A s_{i}\right)$, ácido monometilarsónico (M M A) y ácido cacodílico (DMA) en la orina. Con todo, puesto que el consumo de alimentos marinos podría influir en la tasa de excreción de DM A, los trabajadores sometidos a control deben abstenerse de tomar alimentos de origen marino durante las 48 horas previas a la recogida de orina.

En las personas no expuestas profesionalmente al arsénico inorgánico y que no han consumido recientemente alimentos de origen marino, la suma de estas tres sustancias arsenicales no suele superar los $10 \mu \mathrm{g} / \mathrm{g}$ de creatinina urinaria. Es posible encontrar valores más elevados en zonas geográficas en las que el agua de mesa contiene cantidades importantes de arsénico.

Se ha calculado que, en ausencia de consumo de alimentos marinos, una exposición promedio ponderada en el tiempo a 50 y a $200 \mu \mathrm{g} / \mathrm{m}^{3}$ de arsénico inorgánico da lugar a concentraciones urinarias medias de la suma de metabolitos $\left(\mathrm{As}_{i}, \mathrm{MMA}\right.$, DMA) en las muestras de orina posturno de 54 y $88 \mu \mathrm{g} / \mathrm{g}$ de creatinina, respectivamente.

En el caso de exposición a compuestos de arsénico inorgánico menos solubles (p. ej., arseniuro de galio), la determinación de arsénico en orina reflejará la cantidad absorbida, pero no la dosis total aportada al organismo (pulmón, tracto gastrointestinal).

El arsénico en el cabello es un buen indicador de la cantidad de arsénico inorgánico absorbida durante el período de crecimiento capilar. El arsénico orgánico de origen marino no parece ser captado por el cabello en el mismo grado que el arsénico inorgánico. La determinación de la concentración de arsénico a lo largo del cabello puede proporcionar información valiosa acerca del tiempo de exposición y la duración del período de exposición. Sin embargo, la determinación de arsénico en el cabello no se recomienda cuando el aire ambiente está contaminado por este compuesto, ya que no sería posible distinguir entre el arsénico endógeno y el depositado externamente. Los niveles de arsénico en los cabellos suelen ser inferiores a $1 \mathrm{mg} / \mathrm{kg}$. EI arsénico en las uñas posee el mismo significado.
Al igual que con los niveles urinarios, los niveles sanguíneos de arsénico pueden reflejar la cantidad de arsénico absorbida recientemente, pero todavía no se ha evaluado la relación entre la intensidad de la exposición al arsénico y su concentración en sangre.

\section{Berilio}

La vía principal de captación de berilio en las personas expuestas profesionalmente es la inhalación. La exposición prolongada puede dar lugar al almacenamiento de cantidades apreciables en los tejidos pulmonares y en el esqueleto, este último punto de almacenamiento. La eliminación del berilio absorbido se produce principalmente por la orina, y sólo en menor cantidad por las heces.

Los niveles de berilio se pueden determinar en sangre y en orina, aunque en el momento actual estos análisis sólo se utilizan como pruebas cualitativas para confirmar la exposición al metal, ya que no se sabe hasta qué punto la concentración de berilio en sangre y en orina puede estar influida por la exposición reciente y por la cantidad ya almacenada en el organismo. Además, es difícil interpretar los escasos datos publicados sobre la excreción de berilio en los trabajadores expuestos, ya que por lo general no se ha determinado adecuadamente la exposición externa y los métodos analíticos poseen sensibilidades y precisión diferentes. L os niveles urinarios y séricos normales de berilio probablemente sean inferiores a $2 \mu \mathrm{g} / \mathrm{g}$ de creatinina y a $0,03 \mu \mathrm{g} / 100 \mathrm{ml}$, respectivamente.

Sin embargo, el hallazgo de una concentración normal de berilio en la orina no es suficiente para excluir la posible exposición al metal en el pasado. De hecho, no siempre se ha encontrado un aumento de la excreción urinaria de berilio en los trabajadores expuestos al metal en el pasado y que posteriormente han desarrollado una granulomatosis pulmonar, enfermedad caracterizada por granulomas múltiples, es decir, nódulos de tejido inflamatorio, en los pulmones.

\section{Cadmio}

En el ambiente laboral, la absorción de cadmio tiene lugar principalmente por inhalación. Sin embargo, la absorción gastrointestinal puede contribuir también de forma significativa a la dosis interna de cadmio. U na característica importante del cadmio es su largo semiperíodo biológico en el organismo, que supera los 10 años. En los tejidos, se une principalmente a metaltioneína. En la sangre, se une sobre todo a los eritrocitos. A la vista de la propiedad del cadmio de acumularse, todo programa de control biológico de grupos de población expuestos crónicamente a este elemento debe intentar evaluar tanto la exposición actual como la total.

Mediante activación neutrónica, es posible actualmente realizar determinaciones in vivo de la cantidad de cadmio acumulada en los principales puntos de almacenamiento, el riñón y el hígado. Sin embargo, estas técnicas no son de utilización habitual. Hasta ahora, en la vigilancia de la salud de los trabajadores industriales 0 en los estudios a gran escala realizados en la población general, la exposición al cadmio se ha evaluado de forma indirecta mediante su determinación en orina y en sangre.

Todavía no se ha elucidado por completo la cinética detallada de la acción del cadmio en los seres humanos, aunque, con fines prácticos, se pueden formular algunas conclusiones relativas al significado de su presencia en sangre y en orina. En los trabajadores recientemente expuestos, los niveles de cadmio en sangre aumentan progresivamente $y$, transcurridos de cuatro a seis meses, alcanzan una concentración correspondiente a la intensidad de la exposición. En las personas con exposición mantenida durante un largo período, la concentración en la sangre 
refleja principalmente la absorción promedio durante los últimos meses. La influencia relativa de la cantidad corporal total de cadmio sobre el nivel sanguíneo del mismo puede ser más importante en las personas que hayan acumulado una gran cantidad del elemento y hayan dejado de estar expuestas. U na vez cesada la exposición, el nivel sanguíneo de cadmio desciende con relativa rapidez, con un semiperíodo inicial de dos a tres meses. Dependiendo de la cantidad en el organismo, el nivel puede, no obstante, permanecer más alto que en los sujetos control. Diversos estudios en seres humanos y en animales han indicado que el nivel de cadmio en la orina se puede interpretar de la forma siguiente: en ausencia de una sobreexposición aguda, y mientras no se supere la capacidad de almacenaje del riñón o no se produzca una nefropatía inducida por cadmio, el nivel de cadmio en la orina aumenta progresivamente con la cantidad almacenada en los riñones. En tales condiciones, que son las prevalentes sobre todo en la población general y en los trabajadores con una exposición moderada, existe una correlación significativa entre el cadmio urinario y el presente en los riñones. Si la exposición ha sido excesiva, los puntos de unión del cadmio en el organismo se ven progresivamente saturados y, a pesar de la exposición continua, la concentración del mismo en la corteza renal se estabiliza. A partir de esta fase, el cadmio absorbido ya no puede ser retenido en ese órgano y se excreta rápidamente por la orina. D esde ese momento, la concentración de cadmio en orina depende tanto de la cantidad total de cadmio en el organismo como de la absorción reciente. Si la exposición continúa, algunos sujetos pueden presentar lesión renal, que da lugar a un mayor aumento del cadmio urinario como consecuencia de la liberación del cadmio almacenado en el riñón y la disminución de la reabsorción del cadmio circulante. Sin embargo, después de un episodio de exposición aguda, los niveles urinarios de cadmio pueden aumentar de forma rápida y breve, sin que ello refleje un aumento de la cantidad total en el organismo.

Estudios recientes indican que la metaltioleína en orina posee el mismo significado biológico. Se han observado buenas correlaciones entre la concentración urinaria de metaltioleína y de cadmio, independientemente de la intensidad de la exposición y del estado de la función renal.

Los niveles normales de cadmio en sangre y en orina suelen ser inferiores a $0,5 \mu \mathrm{g} / 100 \mathrm{ml}$ y a $2 \mu \mathrm{g} / \mathrm{g}$ de creatinina, respectivamente. Son más elevados en fumadores que en no fumadores. En los trabajadores expuestos crónicamente, el riesgo de afectación renal es despreciable siempre que los niveles urinarios no superen los $10 \mu \mathrm{g} / \mathrm{g}$ de creatinina. D ebe evitarse toda acumulación de cadmio que pudiera dar lugar a una excreción urinaria superior a dicha cifra. Sin embargo, algunos datos indican que ciertos marcadores renales (cuyo significado en cuanto a la salud todavía es desconocido) pueden alterarse con valores urinarios de cadmio entre 3 y $5 \mu \mathrm{g} / \mathrm{g}$ de creatinina, por lo que parece razonable proponer un valor límite biológico inferior a $5 \mu \mathrm{g} / \mathrm{g}$ de creatinina. Para la sangre se ha propuesto un límite biológico de $0,5 \mu \mathrm{g} / 100 \mathrm{ml}$ en caso de exposición prolongada. Es posible, no obstante, que, en el caso de la población general expuesta al cadmio a través de los alimentos o el tabaco, o bien en el caso de los ancianos, que normalmente sufren un declinar de la función renal, el nivel crítico en la corteza renal sea menor.

\section{Cromo}

La toxicidad del cromo es atribuible principalmente a los compuestos hexavalentes, cuya absorción es relativamente mayor que la de los compuestos trivalentes. La eliminación se produce principalmente por vía urinaria.

En las personas sin exposición profesional al cromo, la concentración de este metal en suero y en orina no suele superar los $0,05 \mu \mathrm{g} / 100 \mathrm{ml}$ y los $2 \mu \mathrm{g} / \mathrm{g}$ de creatinina, respectivamente.
La exposición reciente a sales solubles de cromo hexavalente ( $p$. ej., en los galvanizadores y en los soldadores de acero inoxidable) se puede evaluar controlando el nivel de cromo en la orina al término de la jornada laboral. Estudios realizados por varios autores proponen la siguiente relación: una exposición promedio ponderada en el tiempo de 0,025 ó $0,05 \mathrm{mg} / \mathrm{m}^{3} \mathrm{de}$ cromo hexavalente se asocia a una concentración promedio de 15 ó $30 \mu \mathrm{g} / \mathrm{g}$ de creatinina al término del período de exposición, respectivamente. (Esta relación sólo es válida para grupos.) D espués de la exposición a $0,025 \mathrm{mg} / \mathrm{m}^{3}$ de cromo hexavalente, el valor inferior del límite de confianza del $95 \%$ es de unos $5 \mu \mathrm{g} / \mathrm{g}$ de creatinina. 0 tro estudio en soldadores de acero inoxidable halló que una concentración urinaria de cromo del orden de $40 \mu \mathrm{g} / \mathrm{l}$ corresponde a una exposición promedio de $0,1 \mathrm{mg} / \mathrm{m}^{3}$ de trióxido de cromo.

El cromo hexavalente atraviesa con rapidez las membranas celulares pero, una vez en el interior de la célula, es reducido a cromo trivalente. La concentración de cromo en los eritrocitos podría ser un indicador de la intensidad de la exposición al cromo hexavalente durante la vida de los eritrocitos, pero ello no se aplica al cromo trivalente.

Todavía no se ha evaluado la utilidad del control del cromo en orina para la estimación del riesgo para la salud.

\section{Cobalto}

U na vez absorbido, por inhalación y en cierto grado por vía oral, el cobalto (que tiene un semiperíodo biológico de unos pocos días) se elimina principalmente por la orina. La exposición a compuestos solubles de cobalto da lugar a un aumento de la concentración de este metal en la sangre y en la orina.

Las concentraciones de cobalto en sangre y en orina dependen principalmente de la exposición reciente. En los sujetos sin exposición profesional, el cobalto urinario suele ser inferior a $2 \mu \mathrm{g} / \mathrm{g}$ de creatinina y el cobalto sérico/ plasmático es inferior a 0,05 $\mu \mathrm{g} / 100 \mathrm{ml}$.

Con exposiciones TWA de $0,1 \mathrm{mg} / \mathrm{m}^{3}$ y $0,05 \mathrm{mg} / \mathrm{m}^{3}$, se han descrito respectivamente niveles urinarios medios que oscilan desde 30 a $75 \mu \mathrm{g} / \mathrm{I}$ y desde 30 a $40 \mu \mathrm{g} /$ I (utilizando muestras recogidas al término de la jornada laboral). El momento del muestreo es importante, ya que existe un aumento progresivo de los niveles urinarios de cobalto durante la semana laboral.

En los trabajadores expuestos a óxido de cobalto, sales de cobalto o polvo de metal cobalto en una refinería, se halló que una concentración TWA de $0,05 \mathrm{mg} / \mathrm{m}^{3}$ daba lugar a una concentración promedio de cobalto de 33 y de $46 \mu \mathrm{g} / \mathrm{g}$ de creatinina en la orina recogida al término de la jornada del lunes y del viernes, respectivamente.

\section{Plomo}

El plomo inorgánico, un tóxico acumulativo absorbido por los pulmones y por el tracto gastrointestinal, es sin duda el metal más estudiado; por ello, la fiabilidad de los métodos para evaluar la exposición reciente o la cantidad corporal de plomo por métodos biológicos es la mayor registrada entre todos los contaminantes metálicos.

En una situación de exposición estable, el plomo en sangre total se considera como el mejor indicador de la concentración de este metal en los tejidos blandos y, por tanto, de exposición reciente. Sin embargo, el incremento de los niveles sanguíneos de plomo $(\mathrm{Pb}-\mathrm{S})$ decrece progresivamente al aumentar los niveles de exposición al mismo. Cuando la exposición profesional ha sido prolongada, el cese de la misma no se asocia necesariamente a un retorno del $\mathrm{Pb}-\mathrm{S}$ al valor previo a la exposición (basal), debido a la continua liberación de plomo procedente de los depósitos tisulares. Los niveles sanguíneo y urinario normales de plomo son inferiores en general a $20 \mu \mathrm{g} / 100 \mathrm{ml}$ y $50 \mu \mathrm{g} / \mathrm{g}$ 
de creatinina, respectivamente. Estos niveles pueden variar en función de los hábitos dietéticos y del lugar de residencia de los sujetos. La O M S ha propuesto $40 \mu \mathrm{g} / 100 \mathrm{ml}$ como concentración tolerable máxima de plomo en sangre para los trabajadores varones adultos, y de $30 \mu \mathrm{g} / 100 \mathrm{ml}$ para las mujeres en edad fértil. En los niños, concentraciones más bajas se han asociado a efectos adversos sobre el sistema nervioso central. El nivel de plomo en la orina aumenta de forma exponencial con el aumento del $\mathrm{Pb}-\mathrm{S}$ y, en situación estable, es principalmente reflejo de una exposición reciente.

La cantidad de plomo excretada por la orina después de la administración de un agente quelante (p. ej., C aEDTA) refleja las reservas movilizables de plomo. En sujetos control, la cantidad excretada por orina en 24 horas después de la administración intravenosa de un gramo de EDTA no suele superar los $600 \mu \mathrm{g}$. Parece que, bajo exposición constante, los valores de plomo capaces de experimentar quelación reflejan sobre todo la suma total de plomo en sangre y tejidos blandos, con sólo una pequeña fracción derivada de los huesos.

Se ha desarrollado una técnica de fluorescencia por rayos-X para determinar la concentración de plomo en los huesos (falanges, tibia, calcáneo, vértebras) pero, en la actualidad, el límite de detección de la misma limita su utilización a las personas con exposición profesional.

Se ha propuesto la determinación de plomo en el cabello como método para evaluar la reserva movilizable de este metal. Sin embargo, en el ámbito profesional, resulta difícil distinguir entre el plomo de incorporación endógena al cabello y el simplemente adsorbido sobre su superficie.

Se ha utilizado la determinación de la concentración de plomo en la dentina que rodea la pulpa de los dientes de leche para calcular la exposición al plomo durante la primera infancia.

Para evaluar la intensidad de la exposición al plomo se pueden utilizar también parámetros que reflejen la interferencia de este metal en los procesos biológicos. Los parámetros biológicos empleados en la actualidad son la coproporfirina en orina (C O PRO -U ), el ácido delta-aminolevulínico en orina (ALA-U), la protoporfirina eritrocitaria (EP, o protoporfirina zinc), el ácido delta-aminolevulínico dehidratasa (ALAD), y la pirimidina-5'-nucleotidasa (P5N) en los eritrocitos. En situaciones estables, los cambios en estos parámetros tienen una correlación positiva (CO PRO-U, ALA-U, EP) o negativa (ALAD, P5N) con los niveles sanguíneos de plomo. La excreción urinaria de COPRO (sobre todo, el isómero III) y de ALA comienza a aumentar cuando la concentración sanguínea de plomo alcanza unos $40 \mu \mathrm{g} / 100 \mathrm{ml}$. La protoporfirina eritrocitaria comienza a aumentar significativamente a niveles sanguíneos de plomo de unos $35 \mu \mathrm{g} / 100 \mathrm{ml}$ en varones y de $25 \mu \mathrm{g} / 100 \mathrm{ml}$ en mujeres. Una vez terminada la exposición profesional al plomo, permanece elevada de forma desproporcionada con relación a los niveles reales de plomo en sangre. En este caso, el nivel de EP tiene una mejor correlación con la cantidad de plomo susceptible de quelación excretado por la orina que con el plomo en sangre.

El déficit ligero de hierro también produce una concentración elevada de protoporfirina en los eritrocitos. Las enzimas de dichos eritrocitos, ALAD y P5N, son muy sensibles a la acción inhibitoria del plomo. Dentro del rango de niveles sanguíneos de plomo de 10 a $40 \mu \mathrm{g} / 100 \mathrm{ml}$, existe una estrecha correlación negativa entre la actividad de ambas enzimas y el plomo en sangre.

\section{Alquil plomo}

En algunos países se utilizan el tetraetil plomo y el tetrametil plomo como agentes antidetonantes en los combustibles para automóviles. El plomo en sangre no es un buen indicador de exposición al alquil plomo, mientras que el plomo en orina parece ser útil para evaluar el riesgo de sobreexposición.

\section{Manganeso}

En el contexto laboral, el manganeso penetra en el organismo principalmente a través de los pulmones; la absorción por vía gastrointestinal es pequeña y probablemente dependa de un mecanismo homeostático. La eliminación tiene lugar principalmente por la bilis, mientras que por la orina sólo se excretan pequeñas cantidades.

Las concentraciones normales de manganeso en orina, sangre y suero o plasma suelen ser inferiores a $3 \mu \mathrm{g} / \mathrm{g}$ de creatinina, $1 \mu \mathrm{g} / 100 \mathrm{ml}$ y $0,1 \mu \mathrm{g} / 100 \mathrm{ml}$, respectivamente.

Parece que, en el plano individual, ni el manganeso en sangre ni el manganeso en orina tienen correlación con los parámetros de exposición externa.

N o parece haber una relación directa entre la concentración de manganeso en el material biológico y la gravedad de la intoxicación crónica por este metal. Es posible que, después de la exposición profesional al mismo, se pudieran detectar ya efectos adversos sobre el sistema nervioso central a niveles biológicos próximos a los valores normales.

\section{Mercurio metálico y sus sales inorgánicas}

La principal ruta de captación del mercurio metálico es la inhalación. La absorción gastrointestinal es despreciable. Las sales de mercurio inorgánico pueden ser absorbidas a través de los pulmones (inhalación de aerosol de mercurio inorgánico), o por el tracto gastrointestinal. Es posible la absorción cutánea de mercurio metálico y de sus sales inorgánicas.

El semiperíodo biológico del mercurio es del orden de dos meses en el riñón, pero mucho más prolongado en el sistema nervioso central.

El mercurio inorgánico se excreta principalmente por las heces y la orina. También se excretan pequeñas cantidades por las glándulas salivares, lacrimales y sudoríparas. En condiciones de exposición crónica existe, al menos a nivel de grupo, una relación entre la intensidad de la exposición reciente al vapor de mercurio y la concentración de mercurio en sangre u orina. Las primeras investigaciones, durante las cuales se utilizaron muestras estáticas para controlar el aire de las salas de trabajo en general, demostraron que una concentración promedio de mercurio-aire ( $\mathrm{Hg}$-aire) de $100 \mu \mathrm{g} / \mathrm{m}^{3}$ corresponde a unos niveles promedio de mercurio en sangre $(\mathrm{Hg}-\mathrm{S})$ y en orina $(\mathrm{H} \mathrm{g}-\mathrm{U})$ de $6 \mu \mathrm{g} \mathrm{Hg} / 100 \mathrm{ml}$ y de 200 a $260 \mu \mathrm{g} / \mathrm{l}$, respectivamente. Observaciones más recientes, en particular las que evalúan la contribución del microambiente externo próximo a las vías respiratorias de los trabajadores, indican que la relación de mercurio en aire $\left(\mu \mathrm{g} / \mathrm{m}^{3}\right) /$ orina $(\mu \mathrm{g} / \mathrm{g}$ creatinina)/ sangre $(\mu \mathrm{g} / 100 \mathrm{ml}$ ) es de aproximadamente 1/ 1,2/ 0,045.

Diversos estudios epidemiológicos en trabajadores expuestos a vapor de mercurio han demostrado que, para la exposición prolongada, los niveles de efecto crítico de $\mathrm{Hg}$-U y de $\mathrm{H} \mathrm{g-S}$ son de unos $50 \mu \mathrm{g} / \mathrm{g}$ de creatinina y de $2 \mu \mathrm{g} / 100 \mathrm{ml}$, respectivamente.

Sin embargo, algunos estudios recientes parecen indicar que ya es posible observar signos de efectos adversos sobre el sistema nervioso central o sobre el riñón con un nivel urinario de mercurio inferior a $50 \mu \mathrm{g} / \mathrm{g}$ de creatinina.

Los niveles normales en orina y en sangre suelen ser inferiores a $5 \mu \mathrm{g} / \mathrm{g}$ de creatinina y a $1 \mu \mathrm{g} / 100 \mathrm{ml}$, respectivamente. Estos valores pueden variar en función del consumo de pescado y del número de empastes dentarios con amalgama de mercurio. 


\section{Compuestos orgánicos de mercurio}

Los compuestos orgánicos de mercurio se absorben fácilmente por todas las vías. En la sangre, se encuentran principalmente en los eritrocitos (alrededor del $90 \%$ ). Es preciso hacer una distinción, no obstante, entre los compuestos alquílicos de cadena corta (principalmente metil mercurio), que son muy estables y resistentes a la biotransformación, y los derivados aril 0 alcoxialquil, que liberan mercurio inorgánico in vivo. Para estos últimos compuestos, la concentración de mercurio, tanto en sangre como en orina, posiblemente sea indicativa de la intensidad de la exposición.

En condiciones estables, el mercurio en sangre total y en el cabello tiene una buena correlación con la cantidad corporal total de metil mercurio y con el riesgo de que aparezcan signos de intoxicación por este compuesto. En las personas expuestas crónicamente a alquil mercurio, los signos más precoces de intoxicación (parestesias, alteraciones sensoriales) pueden aparecer cuando el nivel de mercurio en sangre y en el cabello supera los $20 \mu \mathrm{g} / 100 \mathrm{ml}$ y los $50 \mu \mathrm{g} / \mathrm{g}$, respectivamente.

\section{Níquel}

El níquel no es un tóxico acumulativo y casi toda la cantidad absorbida se excreta principalmente por la orina, con un semiperíodo biológico de 17 a 39 horas. En los sujetos no sometidos a exposición profesional, las concentraciones urinarias y plasmáticas de níquel suelen ser inferiores a $2 \mu \mathrm{g} / \mathrm{g}$ de creatinina y a $0,05 \mu \mathrm{g} / 100 \mathrm{ml}$, respectivamente.

Las concentraciones de níquel en plasma y en orina son buenos indicadores de exposición reciente al níquel metálico y a sus compuestos solubles (p. ej., durante la galvanización de níquel o la producción de baterías de níquel). L os valores dentro de los límites normales suelen indicar una exposición no significativa, mientras que los valores aumentados indican sobreexposición.

Para los trabajadores expuestos a compuestos solubles de níquel, se ha intentado proponer un valor límite biológico de $30 \mu \mathrm{g} / \mathrm{g}$ de creatinina (al final de la jornada) en orina.

En los trabajadores expuestos a compuestos de níquel ligeramente solubles o insolubles, los niveles elevados en los fluidos corporales suelen indicar una absorción significativa o una liberación progresiva de la cantidad almacenada en los pulmones; no obstante, se pueden depositar cantidades significativas de níquel en el tracto respiratorio (cavidades nasales, pulmones) sin una elevación significativa de su concentración plasmática 0 urinaria. Por tanto, los valores "normales" se deben interpretar con precaución y no indican necesariamente la ausencia de riesgos para la salud.

\section{Selenio}

El selenio es un oligoelemento esencial. Sus compuestos solubles parecen absorberse fácilmente por los pulmones y por el tracto gastrointestinal. El selenio se excreta principalmente por la orina, pero cuando la exposición es muy alta se puede excretar también en el aire exhalado, en forma de vapor de dimetilselenuro. Las concentraciones normales en suero y en orina dependen de la ingesta diaria, que puede variar considerablemente en las diferentes partes del mundo, pero en general son inferiores a $15 \mu \mathrm{g} / 100 \mathrm{ml}$ y a $25 \mu \mathrm{g} / \mathrm{g}$ de creatinina, respectivamente. La concentración en orina es sobre todo reflejo de exposición reciente. Todavía no se ha establecido la relación entre la intensidad de la exposición y la concentración de selenio en orina.

Parece que la concentración en plasma (o suero) y orina refleja principalmente una exposición a corto plazo, mientras que el contenido en selenio de los eritrocitos refleja una exposición más prolongada.
La determinación de selenio en sangre u orina proporciona cierta información sobre la situación de este metal. En la actualidad, se suele utilizar más para detectar un déficit que una sobreexposición. Puesto que los datos existentes relativos al riesgo para la salud de la exposición prolongada al selenio y a la relación entre riesgo potencial para la salud y niveles en medios biológicos son muy limitados, no se puede proponer un valor umbral biológico.

\section{Vanadio}

En la industria, el vanadio se absorbe principalmente por vía pulmonar. La absorción oral parece baja (menos del $1 \%$ ). Se excreta por la orina, con un semiperíodo biológico de unas 20 a 40 horas, y en menor grado por las heces. El vanadio urinario parece ser un buen indicador de exposición reciente, pero todavía no se ha establecido suficientemente la relación entre su captación y los niveles en orina. Se ha señalado que la diferencia entre las concentraciones urinarias antes del turno y después de éste permite evaluar la exposición durante la jornada de trabajo, mientras que el vanadio urinario determinado dos días después del cese de la exposición (lunes por la mañana) reflejaría la acumulación del metal en el organismo. En las personas no sometidas a exposición profesional, la concentración urinaria suele ser inferior a $1 \mu \mathrm{g} / \mathrm{g}$ de creatinina. Se ha propuesto un valor límite biológico provisional de $50 \mu \mathrm{g} / \mathrm{g}$ de creatinina (al término de la jornada) para el vanadio en orina.

\section{DisO LVENTES ORGANICOS}

Masayuki Ikeda

\section{Introducción}

L os disolventes orgánicos son volátiles y generalmente solubles en las grasas corporales (lipofílicos), aunque algunos, como el metanol y la acetona, son asimismo hidrosolubles (hidrofílicos). Se utilizan mucho, no sólo en la industria, sino también en productos de consumo, como pinturas, tintas, diluyentes, desengrasantes, agentes de limpieza en seco, quitamanchas, repelentes y similares. Aunque en relación con ellos es posible aplicar el control biológico para detectar posibles efectos sobre la salud, como los que afectan al hígado y al riñón, desde el punto de vista de la vigilancia de la salud de los trabajadores expuestos profesionalmente es preferible utilizar el mencionado control biológico para controlar la "exposición", no para proteger la salud, dado que se trata de un método lo bastante sensible para alertar mucho antes de que se produzcan tales efectos. También la exploración selectiva de los trabajadores para la detección de los que presentan una sensibilidad elevada (véase la sección sobre los marcadores de "sensibilidad") a la toxicidad por disolventes puede contribuir a la protección de su salud.

\section{Resumen de toxicocinética}

Los disolventes orgánicos son en general volátiles en condiciones normales, aunque la volatilidad varíe de unos a otros. Por tanto, la principal vía de exposición en el ámbito industrial es la inhalación. La tasa de absorción por la pared alveolar pulmonar es mucho más alta que por la pared del tracto gastrointestinal; para muchos disolventes habituales, como el tolueno, se considera normal una tasa de absorción pulmonar de un $50 \%$. Algunos, como el disulfuro de carbono y la N,N-dimetilformamida en estado líquido, pueden atravesar la piel intacta del ser humano en cantidades suficientes para ser tóxicas.

Cuando se absorben estos disolventes, una parte se exhala con la respiración sin sufrir biotransformación alguna, pero la mayor 
parte se distribuye por los órganos y tejidos ricos en lípidos como consecuencia de su lipofilia. La biotransformación tiene lugar principalmente en el hígado ( $y$, en menor grado, en otros órganos), haciéndose la molécula de disolvente más hidrófila, normalmente por un proceso de oxidación seguido de conjugación, y siendo excretada por los riñones a la orina en forma de metabolitos. U na pequeña parte se puede eliminar sin cambios por la orina.

Por tanto, desde un punto de vista práctico se dispone de tres materiales biológicos, orina, sangre y aire exhalado, para el control de la exposición a los disolventes. 0 tro factor relevante para la selección del material biológico es la velocidad de desaparición de la sustancia absorbida, medida por el semiperíodo biológico, es decir, el tiempo que necesita una sustancia para disminuir a la mitad su concentración original, es un parámetro cuantitativo. Así, los disolventes desaparecen del aire exhalado mucho antes que sus correspondientes metabolitos de la orina, lo que significa que tienen una semivida mucho más corta. Dentro de los metabolitos urinarios, el semiperíodo biológico varía dependiendo de la rapidez con que se metabolice el compuesto original, de modo que, con frecuencia, el momento del muestreo en relación con la exposición tiene una importancia crítica (véase más adelante). Un tercer aspecto que se ha de tener en cuenta al elegir un material biológico es la especificidad de la sustancia química objeto del análisis en relación con la exposición. Por ejemplo, el ácido hipúrico es un marcador de exposición al tolueno utilizado desde hace mucho tiempo, pero no sólo se forma naturalmente en el organismo, sino que también puede proceder de fuentes no laborales, como algunos aditivos de los alimentos, por lo cual ya no se considera como un marcador fiable cuando la exposición al tolueno es baja (inferior a $50 \mathrm{~cm}^{3} / \mathrm{m}^{3}$ ). En términos generales, los metabolitos urinarios han sido los más utilizados como indicadores de exposición a diversos disolventes orgánicos. EI disolvente en la sangre se analiza como medida cualitativa de exposición, porque suele permanecer menos tiempo en la misma y refleja mejor la exposición aguda, mientras que el disolvente en el aire exhalado es difícil de utilizar para calcular la exposición promedio, ya que su concentración en el aliento disminuye con mucha rapidez una vez concluida la exposición. El disolvente en la orina resulta prometedor como medida de la exposición, pero necesita su validación.

\section{Pruebas de exposición biológica para disolventes orgánicos}

Para aplicar el control biológico a la exposición a disolventes, es importante el momento del muestreo, como ya se ha indicado. En la Tabla 27.2 se muestran los momentos de muestreo recomendados para los disolventes habituales en los controles de exposición diaria en el trabajo. Cuando se va a analizar el propio disolvente, es preciso estar atento para evitar las posibles pérdidas (p. ej., evaporación en el aire ambiente), así como la contaminación ( $p$. ej., disolución del aire ambiente en el interior de la muestra) durante el proceso de manipulación de la muestra. En caso de que se precise transportar la muestra a un laboratorio distante o se haya de almacenar antes del análisis, se ha de tener cuidado para evitar pérdidas. Para los metabolitos se recomienda la congelación, mientras que para el análisis del disolvente se recomienda la refrigeración (pero no la congelación) en un envase hermético sin espacio aéreo (o, preferiblemente, en un vial de espacio de cabeza). En el análisis químico, el control de calidad es esencial para obtener resultados fiables (para más detalles, véase el artículo "Garantía de calidad" en este mismo capítulo). La información sobre los resultados debe hacerse respetando la ética (véase el capítulo Aspectos éticos en esta E nciclopedia).
Tabla 27.2 - Algunos ejemplos de sustancias químicas diana para el control biológico y momentos de muestreo.

\begin{tabular}{|c|c|c|c|}
\hline Disolvente & Sustancia química diana & $\begin{array}{l}\text { Orina/ } \\
\text { sangre }\end{array}$ & $\begin{array}{l}\text { Momento del } \\
\text { muestreo }^{1}\end{array}$ \\
\hline $\begin{array}{l}\text { Disulfuro de } \\
\text { carbono }\end{array}$ & Acido 2-tiazolidín-4-carboxílico & Orina & J V \\
\hline $\begin{array}{l}\text { N,N-dimetil- } \\
\text { formamida }\end{array}$ & N-metilformamida & Orina & LMXJV \\
\hline $\begin{array}{l}\text { 2-etoxietanol } \\
\text { y su acetato }\end{array}$ & Acido etoxiacético & Orina & $\begin{array}{l}\text { I V (final del } \\
\text { último turno) }\end{array}$ \\
\hline \multirow[t]{2}{*}{ Hexano } & 2,4-hexanodiona & Orina & LMXJ V \\
\hline & Hexano & Sangre & $\begin{array}{l}\text { confirmación de } \\
\text { la exposición }\end{array}$ \\
\hline Metanol & Metanol & Orina & LJXJ V \\
\hline \multirow[t]{3}{*}{ Estireno } & Acido mandélico & Orina & J V \\
\hline & Acido fenilglicoxílico & Orina & J V \\
\hline & Estireno & Sangre & $\begin{array}{c}\text { confirmación de } \\
\text { la exposición }\end{array}$ \\
\hline \multirow[t]{4}{*}{ Tolueno } & Acido hipúrico & Orina & MXJV \\
\hline & o-cresol & Orina & $M X J V$ \\
\hline & Tolueno & Sangre & $\begin{array}{l}\text { confirmación de } \\
\text { la exposición }\end{array}$ \\
\hline & Tolueno & Orina & $M X J V$ \\
\hline \multirow[t]{3}{*}{ Tricloroetileno } & Acido tricloroacético (TCA) & Orina & J V \\
\hline & $\begin{array}{l}\text { Total de compuestos triclo- } \\
\text { rados (suma de TCA y triclo- } \\
\text { roetanol libre y conjugado) }\end{array}$ & Orina & J V \\
\hline & Tricloroetileno & Sangre & $\begin{array}{c}\text { confirmación de } \\
\text { la exposición }\end{array}$ \\
\hline \multirow[t]{2}{*}{ Xilenos ${ }^{2}$} & Acidos metilhipúricos & Orina & $M X J V$ \\
\hline & Xilenos & Sangre & $M X J V$ \\
\hline
\end{tabular}

1 Final del turno de trabajo salvo indicación en contrario; los días de la semana indican los días de muestreo preferibles.

2 Tres isómeros, por separado o en cualquier combinación.

Fuente: Resumido de OMS 1996.

Para muchos disolventes existen varios métodos analíticos establecidos. Estos varían según la sustancia química, aunque en casi todos los desarrollados recientemente se utiliza para la separación por cromatografía gaseosa (CG ) o cromatografía líquida de alta resolución (HPLC). Se recomienda utilizar un muestreador automático y un procesador de datos para obtener un buen control de calidad en el análisis químico. Cuando se va a analizar el propio disolvente en sangre o en orina, es muy conveniente la aplicación de una técnica de espacio de cabeza en la CG (CG de espacio de cabeza), sobre todo si el disolvente es bastante volátil. En la Tabla 27.3 se presentan algunos ejemplos de los métodos establecidos para los disolventes habituales.

\section{Evaluación}

Se puede establecer una relación lineal de los indicadores de exposición (reseñados en la Tabla 27.3) con la intensidad de la misma para los correspondientes disolventes, ya sea realizando una encuesta entre los trabajadores expuestos profesionalmente a ellos, ya sea mediante la exposición experimental de voluntarios humanos. En este sentido, la ACGIH (1994) y la DFG (1994), por ejemplo, han establecido el índice biológico de exposición (BEI) y 
Tabla 27.3 - Algunos ejemplos de métodos analíticos para el control biológico de la exposición a disolventes orgánicos.

\begin{tabular}{|c|c|c|c|}
\hline Disolvente & $\begin{array}{l}\text { Sustancia química } \\
\text { diana }\end{array}$ & $\begin{array}{l}\text { Sangre/ } \\
\text { orina }\end{array}$ & Método analítico \\
\hline $\begin{array}{l}\text { Disulfuro de } \\
\text { carbono }\end{array}$ & $\begin{array}{l}\text { 2-Tiotiazolidina- } \\
\text { ácido 4-carboxílico }\end{array}$ & Orina & $\begin{array}{l}\text { Cromatografía líquida } \\
\text { de alta resolución con } \\
\text { detección ultravioleta } \\
\text { (UV-HPLC) }\end{array}$ \\
\hline $\begin{array}{l}\text { N,N-dimetil- } \\
\text { formamida }\end{array}$ & N-metilformamida & Orina & $\begin{array}{l}\text { Cromatografía de } \\
\text { gases con detección } \\
\text { termoiónica de llama } \\
\text { (FTD-GC) }\end{array}$ \\
\hline $\begin{array}{l}\text { 2. etoxietanol } \\
\text { y su acetato }\end{array}$ & Acido etoxiacético & Orina & $\begin{array}{l}\text { Extracción, derivación } \\
\text { y cromatografía de } \\
\text { gases con detección } \\
\text { por ionización de llama } \\
\text { (FID-GC) }\end{array}$ \\
\hline \multirow[t]{2}{*}{ Hexano } & 2,4-hexanodiona & Orina & $\begin{array}{l}\text { Extracción, (hidrólisis) y } \\
\text { FID-GC }\end{array}$ \\
\hline & Hexano & Sangre & $\begin{array}{l}\text { FID-GC con muestreo } \\
\text { automático }\end{array}$ \\
\hline Metanol & Metanol & Orina & $\begin{array}{l}\text { GC-FID con muestreo } \\
\text { automático }\end{array}$ \\
\hline \multirow[t]{3}{*}{ Estireno } & Acido mandélico & Orina & Desalado y UV-HPLC \\
\hline & Acido feniglioxílico & Orina & Desalado y UV.HPLC \\
\hline & Estireno & Sangre & $\begin{array}{l}\text { CG-FID con muestreo } \\
\text { automático }\end{array}$ \\
\hline \multirow[t]{4}{*}{ Tolueno } & Acido hipúrico & Orina & Desalado y HPLC-UV \\
\hline & o-cresol & Orina & $\begin{array}{l}\text { Hidrólisis, extracción y } \\
\text { CG-FID }\end{array}$ \\
\hline & Tolueno & Sangre & $\begin{array}{l}\text { CG-FID con muestreo } \\
\text { automático }\end{array}$ \\
\hline & Tolueno & Orina & $\begin{array}{l}\text { CG-FID con muestreo } \\
\text { automático }\end{array}$ \\
\hline \multirow[t]{3}{*}{ Tricloroetileno } & $\begin{array}{l}\text { Acido tricloroetileno } \\
\text { (TCA) }\end{array}$ & Orina & $\begin{array}{l}\text { Colorimetría o } \\
\text { esterificación y } \\
\text { cromatografía de } \\
\text { gases con detección } \\
\text { de captura electrónica } \\
\text { (ECD-GC) }\end{array}$ \\
\hline & $\begin{array}{l}\text { Total de compuestos } \\
\text { triclorados } \\
\text { (suma de TCA y } \\
\text { tricloroetanol libre } \\
\text { y conjugado) }\end{array}$ & Orina & $\begin{array}{l}\text { Oxidación y colorimetría, } \\
\text { o hidrólisis, oxidación, } \\
\text { esterificación y ECD-GC }\end{array}$ \\
\hline & Tricloroetileno & Sangre & $\begin{array}{l}\text { ECD-GC con muestreo } \\
\text { automático }\end{array}$ \\
\hline Xilenos & $\begin{array}{l}\text { Acidos metilhipúricos } \\
\text { (tres isómeros, } \\
\text { por separado } 0 \\
\text { combinados) }\end{array}$ & Orina & $\begin{array}{l}\text { GC-FID con muestreo } \\
\text { automático }\end{array}$ \\
\hline
\end{tabular}

el valor biológico de tolerancia (BT V), respectivamente, como los valores de las muestras biológicas que son equivalentes al límite de exposición profesional para las sustancias químicas aerotransportadas, es decir, el valor límite umbral (T LV) y la concentración máxima en el lugar de trabajo (M AK ), respectivamente. Se sabe, no obstante, que el nivel de la sustancia química diana en las muestras obtenidas en personas no expuestas puede variar en función, por ejemplo, de costumbres locales (p. ej., dieta) y que puede haber diferencias étnicas en el metabolismo del disolvente. Por tanto, es aconsejable establecer valores límite mediante el estudio de la población local implicada.

Al evaluar los resultados es preciso excluir cuidadosamente la existencia de exposición no profesional al disolvente (p. ej., por utilización de productos de consumo que lo contengan, o por inhalación intencionada) y la exposición a sustancias químicas que den origen a los mismos metabolitos (p. ej., algunos aditivos alimentarios). En caso de que exista una gran falta de correspondencia entre la intensidad de la exposición al vapor y los resultados del control biológico, la diferencia puede indicar la posibilidad de absorción cutánea. El consumo de cigarrillos inhibe el metabolismo de algunos disolventes (p. ej., tolueno), mientras que la ingesta aguda de etanol puede inhibir de forma competitiva el metabolismo del metanol.

\section{SU STANCIAS Q UIMICAS GENOTOXICAS}

\section{Marja Sorsa}

Para el control biológico en el ser humano se utilizan muestras de fluidos corporales o de otro material biológico de fácil obtención, bien para la determinación de la exposición a sustancias específicas 0 inespecíficas y/ 0 de sus metabolitos, o bien para la determinación de los efectos biológicos de esa exposición. El control biológico permite calcular la exposición individual total a través de diferentes vías (pulmones, piel, aparato digestivo) y fuentes (aire, dieta, forma de vida, u ocupación). También se sabe que, en situaciones de exposición compleja, presentes a menudo en los lugares de trabajo, diferentes agentes de exposición pueden interactuar unos con otros, aumentando o inhibiendo los efectos de los distintos compuestos. Además, dado que los individuos difieren en su constitución genética, muestran variabilidad en su respuesta a las exposiciones químicas. Por tanto, quizá sea más razonable buscar los efectos precoces directamente en los individuos o grupos expuestos que tratar de predecir los peligros potenciales de los complejos patrones de exposición a partir de datos pertenecientes a los distintos compuestos. Esta es una ventaja del biocontrol genético de los efectos precoces, método que emplea técnicas centradas en la lesión citogenética, mutaciones puntuales 0 aductos del ADN en tejidos humanos (véase el artículo "Principios generales", en este mismo capítulo).

\section{¿Qué es la genotoxicidad?}

La genotoxicidad de los agentes químicos es una característica química intrínseca, basada en el potencial electrofílico del agente para unirse con puntos nucleofílicos de macromoléculas celulares tales como el ácido desoxirribonucleico, ADN, el portador de la información hereditaria. La genotoxicidad es, por tanto, la toxicidad que se manifiesta en el material genético de las células.

La definición de genotoxicidad, tal como se comentó en un informe de consenso (IARC 1992), es amplia, e incluye efectos tanto directos como indirectos sobre el ADN: (1) la inducción de mutaciones (genéticas, cromosómicas, genómicas, recombinantes), que a nivel molecular son similares a los acontecimientos que se sabe están implicados en la carcinogénesis, (2) acontecimientos vicarios indirectos asociados a la mutagénesis (p. ej., síntesis de ADN no pautada (UDS), e intercambio de cromátidas hermanas (SCE), o (3) lesión del ADN (p. ej., la formación de aductos), que pueden dar lugar finalmente a mutaciones. 


\section{Genotoxicidad, mutagenicidad y carcinogenicidad}

Las mutaciones son cambios hereditarios permanentes en las líneas celulares, ya sea horizontalmente en las células somáticas o verticalmente en las células germinales (sexuales) del organismo. Pueden afectar, pues, al propio organismo a través de cambios en las células corporales, o bien pasar a otras generaciones a través de la alteración de las células sexuales. La genotoxicidad, por tanto, precede a la mutagenicidad, aunque en su mayor parte se repara y no llega a expresarse en forma de mutaciones. L as mutaciones somáticas están inducidas a nivel celular y, en el acontecimiento que puede llevar a la muerte celular 0 a la aparición de procesos malignos, pueden manifestarse como diversos trastornos de los tejidos o del propio organismo. Se cree que están relacionadas con los efectos del envejecimiento o con la producción de placas ateroscleróticas (véase la Figura 27.3 y el capítulo sobre Cáncer).

Las mutaciones en la línea celular germinal pueden transferirse al cigoto, el huevo fertilizado, y expresarse en la generación hija (véase también el capítulo Sistema reproductor). L os trastornos mutacionales más importantes encontrados en el recién nacido están producidos por la malsegregación de cromosomas durante la gametogénesis (desarrollo de las células germinales) y dan lugar a graves síndromes cromosómicos (p. ej., trisomía 210 síndrome de D own, y monosomía X o síndrome de Turner).

El paradigma de genotoxicología por exposición a efectos previstos se puede simplificar tal como se muestra en la Figura 27.3.

La relación entre genotoxicidad y carcinogenicidad está bien demostrada por diversos datos indirectos de investigación, tal como se muestra en la Figura 27.4.

Esta correlación proporciona la base para la aplicación de los biomarcadores de genotoxicidad al control biológico como indicadores del peligro de cáncer.

\section{Toxicidad genética en la identificación del peligro}

El papel de los cambios genéticos en la carcinogénesis subraya la importancia de las pruebas de toxicidad genética en la

Figura 27.3 - Representación esquemática del paradigma científico de la toxicología genética y el efecto sobre la salud humana.

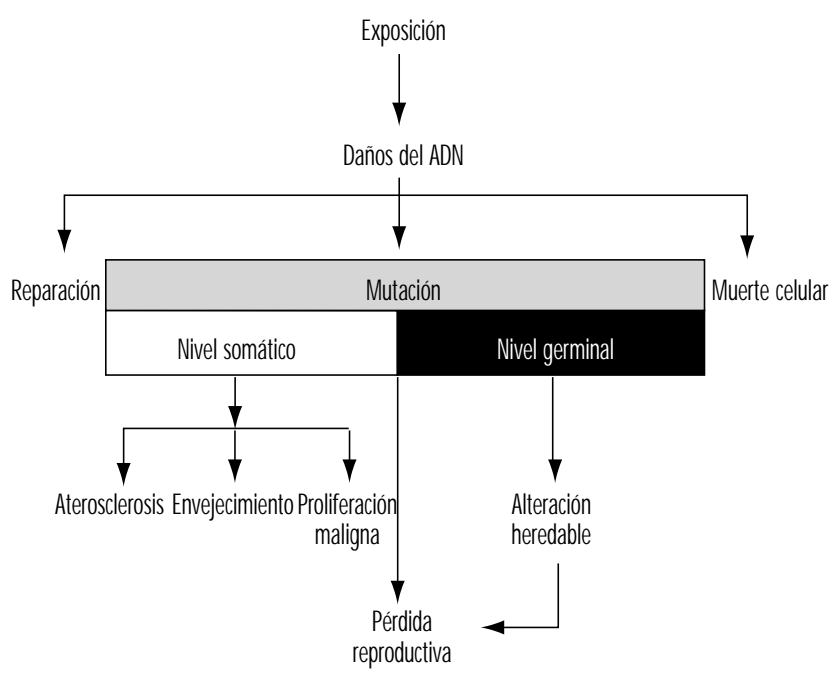

Figura 27.4 • Interrelaciones entre genotoxicidad y carcinogenicidad.

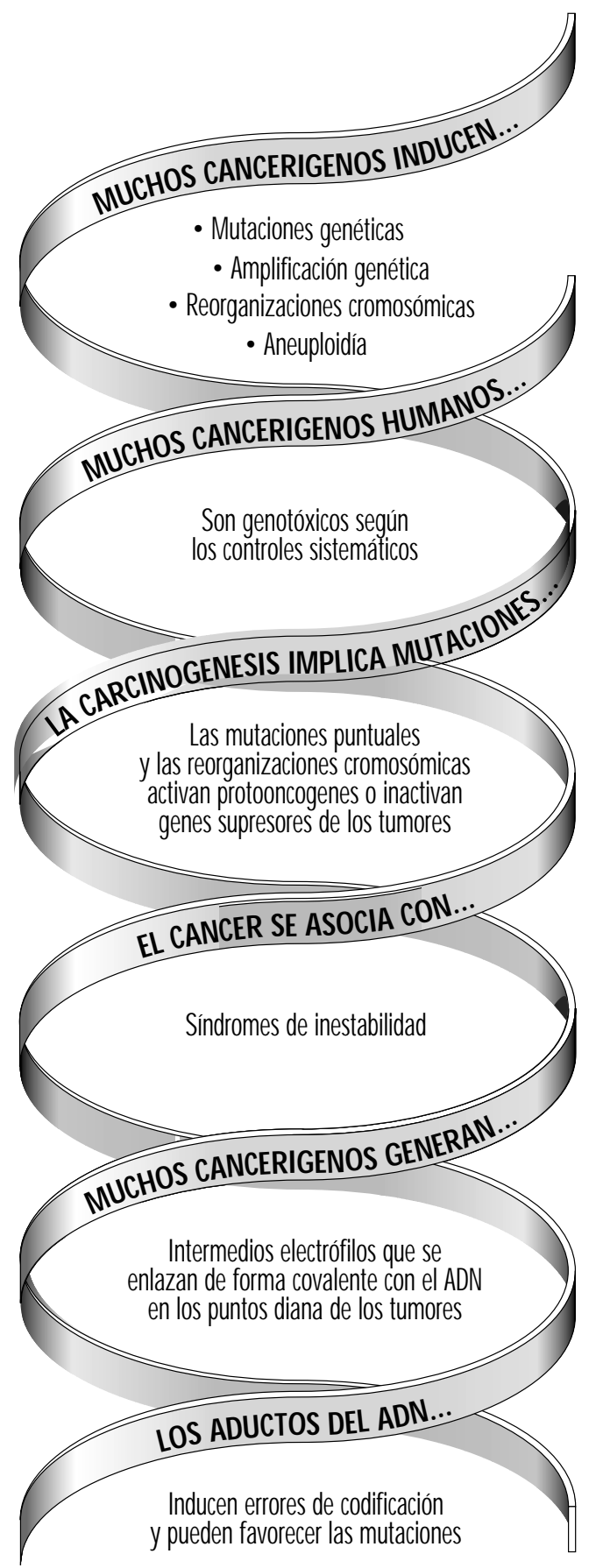

identificación de cancerígenos potenciales. Se han desarrollado diversos métodos de prueba a corto plazo que permiten detectar algunos de los criterios de valoración de genotoxicidad supuestamente relacionados con la carcinogénesis

Se han llevado a cabo varios estudios para comparar la carcinogenicidad de sustancias químicas con los resultados obtenidos al examinarlas en pruebas a corto plazo. La conclusión general ha sido que, a falta de una prueba única validada que proporcione información sobre todos los criterios de evaluación 
Tabla 27.4 - G enotoxicidad de los compuestos químicos evaluados en los Suplementos 6 y 7 de las monografías IARC (1986).

\begin{tabular}{lcc} 
& $\begin{array}{l}\text { Relación entre evidencia } \\
\text { de genotoxicidad/ }\end{array}$ \\
Clasificación de la carcinogenicidad & carcinogenicidad & $\%$ \\
1: cancerígenos humanos & $24 / 30$ & 80 \\
2A: probables cancerígenos humanos & $14 / 20$ & 70 \\
2B: posibles cancerígenos humanos & $72 / 128$ & 56 \\
3: no clasificable & $19 / 66$ & 29 \\
\hline
\end{tabular}

genéticos antes mencionados, es preciso comprobar cada sustancia química en más de un ensayo. A simismo, el valor de las pruebas de toxicidad genética a corto plazo para la predicción de carcinogenicidad química ha sido debatido y revisado en repetidas ocasiones. De acuerdo con tales revisiones, un grupo de trabajo de la Agencia Internacional para la Investigación sobre el Cáncer (IARC) llegó a la conclusión de que la mayor parte de los cancerígenos humanos dan resultados positivos en las pruebas a corto plazo utilizadas habitualmente, tales como el análisis de Salmonella y los ensayos de aberración cromosómica (Tabla 27.4). Sin embargo, es preciso tener en cuenta que los cancerígenos epigenéticos - como son los compuestos hormonalmente activos que pueden aumentar la actividad genotóxica sin ser ellos mismos genotóxicos- no se pueden detectar mediante las pruebas a corto plazo, las cuales sólo miden la actividad genotóxica intrínseca de una sustancia.

\section{Biocontrol genético}

El control genético utiliza métodos de toxicología genética para el control biológico de los efectos genéticos o para la evaluación de la exposición genotóxica en un grupo de individuos con exposición definida en el lugar de trabajo, en el ambiente o en la forma de vida. Por tanto, tiene la posibilidad de identificar precozmente las exposiciones genotóxicas de un grupo de personas y permite la identificación de poblaciones de alto riesgo y, por tanto, de prioridades de intervención. La utilización de biomarcadores de predicción en una población expuesta está justificada para ahorrar tiempo (en comparación con las técnicas

Tabla 27.5 - Biomarcadores utilizados en el control genético de exposiciones genotóxicas y muestras de células y tejidos más utilizadas.

$\begin{array}{ll}\begin{array}{l}\text { Marcador de control genético } \\ \text { Aberraciones cromosómicas (CA) }\end{array} & \text { Muestras celulares/ tisulares } \\ \begin{array}{l}\text { Intercambio de cromátidas hermanas } \\ \text { (SCE) }\end{array} & \text { Linfocitos } \\ \begin{array}{l}\text { Micronúcleos (MN) } \\ \text { Mutaciones puntuales } \\ \text { (p. ej., gen HPRT) }\end{array} & \begin{array}{l}\text { Linfocitos } \\ \text { Linfocitos y otros tejidos }\end{array} \\ \begin{array}{l}\text { Aductos del ADN } \\ \text { Aductos de proteínas }\end{array} & \text { ADN aislado de células/ tejidos } \\ \text { Roturas de cadenas de ADN } & \text { Hemoglobina, albúmina } \\ \text { Activación de oncogenes } & \text { ADN aislado de células/ tejidos } \\ \text { Mutaciones/ oncoproteínas } & \text { ADN o proteinas espećficas aisladas } \\ \text { Reparador de ADN } & \text { Diversas células y tejidos } \\ \end{array}$

epidemiológicas) y para evitar efectos finales innecesarios, como el cáncer (Figura 27.5).

Los métodos utilizados actualmente para el biocontrol de la exposición genotóxica y de los efectos biológicos precoces se reseñan en la Tabla 27.5. Las muestras empleadas deben cumplir varios criterios, entre ellos la facilidad de obtención y su comparabilidad con el tejido diana.

Los tipos de lesión del ADN identificables a escala molecular son la formación de aductos del ADN y la reorganización de la secuencia de ADN. A mbas lesiones se pueden detectar mediante mediciones de los aductos de ADN por diversas técnicas, como el posmarcado con 32P o la detección de anticuerpos monoclonales frente a los aductos de ADN. La medición de las roturas de la cadena de ADN se realiza convencionalmente utilizando elución alcalina 0 análisis de desovillado. Las mutaciones se pueden detectar obteniendo la secuencia de ADN de un gen específico, como el gen H PRT.

$\mathrm{H}$ an aparecido diversos informes metodológicos en los que se comentan con detalle las técnicas de la Tabla 27.5 (CCE 1987; IARC 1987, 1992, 1993).

La genotoxicidad también se puede controlar indirectamente mediante la medición de aductos de proteínas, es decir, en hemoglobina en lugar del ADN, o mediante el control de la actividad reparadora del ADN. En todos los casos, los resultados se deben aplicar al desarrollo de condiciones laborales seguras.

\section{Biocontrol citogenético}

Existe una relación teórica y empírica del cáncer con la lesión cromosómica. Los acontecimientos mutágenos que alteran la actividad o la expresión de los genes del factor de crecimiento son pasos clave de la carcinogénesis. Numerosos tipos de cáncer se han asociado a aberraciones cromosómicas específicas o inespecíficas. En varias enfermedades hereditarias humanas, la inestabilidad cromosómica se asocia a una mayor sensibilidad al cáncer.

El examen citogenético de las personas expuestas a sustancias químicas 0 a radiaciones cancerígenas y/ 0 mutagénicas puede mostrar efectos sobre su material genético. Los estudios de aberración cromosómica en las personas expuestas a radiaciones

Figura 27.5 - La predictividad de los biomarcadores permite adoptar medidas preventivas para reducir el riesgo para la salud de las poblaciones humanas.

\section{USO DE BIOMARCADORES}

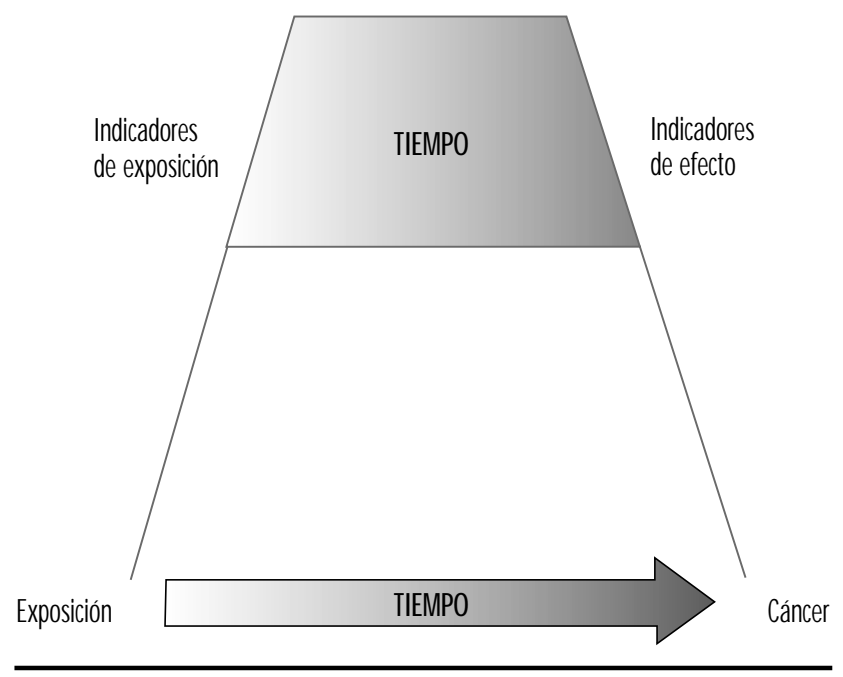


Figura 27.6 - Cromosomas linfocíticos humanos en metafase; se observa una mutación cromosómica inducida (fragmento acéntrico indicado por la flecha).

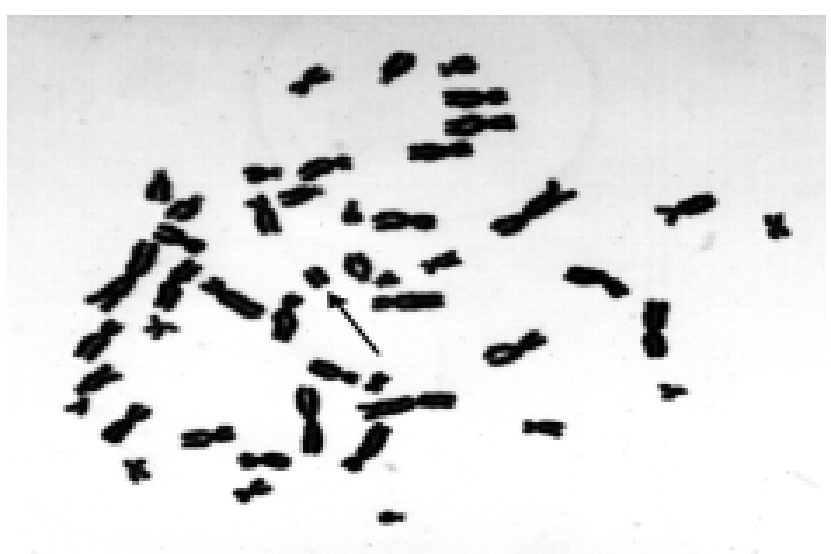

ionizantes se han aplicado a la dosimetría biológica durante decenios, pero hasta ahora sólo se dispone de resultados positivos bien documentados para un número limitado de cancerígenos químicos.

Entre las lesiones cromosómicas identificables al microscopio se encuentran las aberraciones cromosómicas (C A) estructurales, en las que se ha producido un cambio importante de la morfología (forma) de un cromosoma, y los intercambios de cromátidas hermanas (SCE), o intercambio simétrico de material cromosómico entre dos cromátidas hermanas; los micronúcleos (M N) pueden derivarse de fragmentos de cromosoma acéntricos 0 de la falta de cromosomas completos. Estos tipos de cambios se ilustran en la Figura 27.6.

Los linfocitos humanos en sangre periférica son células adecuadas para los estudios de vigilancia, debido a su fácil obtención y a su capacidad de integrar la exposición durante una vida relativamente prolongada. La exposición a diversos mutágenos químicos puede dar lugar a una mayor frecuencia de CA y/ o SCE en los linfocitos de la sangre de los individuos expuestos. A simismo, la extensión de la lesión tiene una relación aproximada con la exposición, aunque esto sólo se ha demostrado para algunas sustancias químicas.

C uando las pruebas citogenéticas en los linfocitos de sangre periférica demuestran que el material genético se ha lesionado, los resultados se pueden utilizar para calcular el riesgo, aunque sólo a nivel de población. U na mayor frecuencia de aberraciones cromosómicas en una población debe ser considerada como indicativa de un mayor riesgo de cáncer, si bien las pruebas citogenéticas como tales no permiten una predicción del riesgo individual de cáncer.

El significado para la salud de la lesión genética somática, tal como se observa a través de la estrecha ventana de una muestra de linfocitos de sangre periférica, posee poco o ningún significado, dado que la mayor parte de los linfocitos portadores de una lesión genética mueren y son reemplazados.

\section{Problemas de los estudios de biocontrol en seres humanos y su control}

Para la aplicación de cualquier método de biocontrol en seres humanos es necesario un riguroso diseño del estudio, ya que son muchos los factores interindividuales no relacionados con la exposición a las sustancias químicas específicas de interés que pueden afectar a las respuestas biológicas estudiadas. Dado que estos estudios son tediosos y difíciles en muchos aspectos, es muy importante una cuidadosa planificación previa. Para realizar estudios citogenéticos en seres humanos, un requisito previo ha de ser siempre la confirmación experimental del potencial de lesión cromosómica de los agentes causantes de la exposición.

En los estudios de biocontrol citogenético se han demostrado dos tipos principales de variaciones. $L$ a primera comprende factores técnicos asociados a discrepancias en la lectura de las preparaciones y a las condiciones del cultivo, en especial el tipo de medio, la temperatura y la concentración de sustancias químicas (como bromodesoxiuridina o citochalasina-B). También el momento del muestreo puede alterar la producción de aberraciones cromosómicas y, posiblemente, los hallazgos en cuanto a incidencia de SCE, en virtud de cambios en las subpoblaciones de linfocitos $T$ y $B$. En los análisis de micronúcleos, las diferencias metodológicas (p. ej., el empleo de células binucleadas inducidas por citochalasina-B) afectan de forma bastante evidente a los resultados.

Las lesiones inducidas en el ADN de los linfocitos por la exposición química que da lugar a la formación de aberraciones cromosómicas estructurales, intercambio de cromátidas hermanas y micronúcleos, debe persistir in vivo hasta que se extrae la sangre y posteriormente in vitro hasta que el linfocito cultivado comienza la síntesis de ADN. Es importante, por tanto, puntuar directamente las células después de la primera división (en el caso de aberraciones cromosómicas o de micronúcleos) o después de la segunda división (intercambio de cromátidas hermanas), a fin de obtener el mejor cálculo posible de la lesión inducida.

La puntuación constituye un elemento extremadamente importante en el biocontrol citogenético. Las preparaciones se deben asignar aleatoriamente y codificar para evitar en lo posible el sesgo debido al puntuador. $\mathrm{H}$ ay que mantener criterios de puntuación constantes y un control de la calidad y es preciso hacer análisis estadísticos y elaborar informes estandarizados. La segunda categoría de variabilidad abarca condiciones asociadas a los sujetos, tales como la edad, el sexo, la medicación y las infecciones. $L$ as variaciones individuales también pueden deberse a una sensibilidad genética a los agentes ambientales.

Es fundamental obtener un grupo control concurrente, lo más semejante posible en factores internos como el sexo y la edad, y asimismo en factores tales como el consumo de tabaco, las infecciones virales y vacunaciones, el consumo de alcohol y de drogas y la exposición radiológica. Además, es necesario obtener cálculos cualitativos (categoría en el trabajo, años de exposición) y cuantitativos (p. ej., muestras de aire de la zona de respiración para la realización de análisis químicos y de metabolitos específicos, si es posible) 0 datos de exposición al posible agente 0 agentes genotóxicos en el lugar de trabajo. Se debe prestar atención especial al adecuado tratamiento estadístico de los resultados.

\section{Aplicabilidad del biocontrol genético a la evaluación del riesgo de cáncer}

El número de agentes que se han demostrado repetidamente como inductores de cambios citogenéticos en el ser humano es relativamente limitado, aunque la mayor parte de los cancerígenos conocidos inducen lesiones en los cromosomas de los linfocitos.

El grado de lesión depende del nivel de exposición, como se ha demostrado, por ejemplo, con el cloruro de vinilo, el benceno, el óxido de etileno y los agentes anticancerosos alquilantes. Aun cuando los criterios de evaluación citogenética no sean muy sensibles o específicos en lo que se refiere a la detección de exposiciones en los ambientes industriales, los resultados positivos de tales pruebas han promovido la implantación de controles higiénicos incluso en ausencia de pruebas directas que 
relacionen las lesiones cromosómicas somáticas con resultados adversos para la salud.

Casi todas las experiencias en la aplicación del biocontrol citogenético procede de situaciones laborales de "alta exposición". $M$ uy pocas exposiciones han sido confirmadas por varios estudios independientes, en su mayor parte realizadas mediante biocontrol de las aberraciones cromosómicas. La base de datos de la A gencia Internacional para la Investigación sobre el $C$ áncer reseña, en sus volúmenes actualizados 43-50 de las monografías IARC, un total de 14 cancerígenos profesionales en los grupos 1, 2A o 2B, para los que existen datos citogenéticos humanos positivos, en su mayor parte apoyados por la correspondiente citogenética en animales (Tabla 27.6). Esta limitada base de datos da a entender que las sustancias químicas cancerígenas tienen tendencia a ser clastogénicas y que la clastogenicidad tiendea asociarse a los cancerígenos humanos conocidos. Está bastante claro, no obstante, que no todos los cancerígenos producen lesiones citogenéticas en los seres humanos 0 en los animales de experimentación in vivo. Los casos en que los datos en animales son positivos y los hallazgos en seres humanos son negativos pueden responder a diferencias en los niveles de exposición. Asimismo, las complejas y prolongadas exposiciones de los seres humanos en los lugares de trabajo quizá no sean comparables con los experimentos a corto plazo en animales.

Los estudios de genotoxicidad en seres humanos expuestos abarcan varios criterios de evaluación distintos de los criterios de evaluación cromosómicos, como la lesión del ADN, la actividad reparadora del ADN y los aductos del ADN y de las proteínas. Algunos de estos criterios pueden ser más adecuados que otros para la predicción del peligro cancerígeno. Los cambios genéticos estables (p. ej., redistribuciones cromosómicas, deleciones y mutaciones puntuales) son muy adecuados, ya que estos tipos de lesiones se sabe que están relacionados con la carcinogénesis. $L a$ significación de los aductos del ADN depende de su identificación química y de la prueba de que proceden de la exposición. Algunos criterios de valoración, como el SCE, la UDS, la SSB o la rotura de la cadena de AD N, son indicadores y/ o marcadores potenciales de acontecimientos genéticos; sin embargo, su valor es reducido en ausencia de un conocimiento mecánico de su capacidad para dar lugar a acontecimientos genéticos. Está claro que el marcador genético más adecuado en los seres humanos sería la inducción de una mutación específica que haya estado directamente asociada a carcinogenicidad del agente del estudio en roedores (Figura 27.7).

Figura 27.7 - Aplicabilidad de distintos tipos de biocontrol genético a la evaluación del riesgo de cáncer.

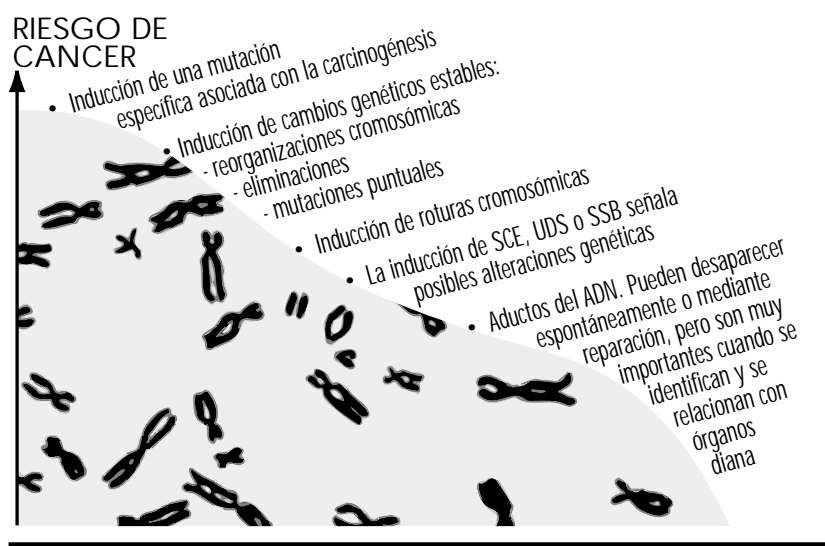

Tabla 27.6 • Cancerígenos humanos demostrados, probables y posibles para los cuales hay exposición profesional y para los cuales se han medido criterios citogenéticos en el hombre y en animales de experimentación.

\begin{tabular}{|c|c|c|c|c|c|c|}
\hline \multirow[b]{3}{*}{ Agente/ exposición } & \multicolumn{6}{|c|}{ Hallazgos citogenéticos ${ }^{1}$} \\
\hline & \multicolumn{3}{|c|}{ Seres humanos } & \multicolumn{3}{|c|}{ Animales } \\
\hline & $C A$ & SCE & MN & $C A$ & SCE & MN \\
\hline \multicolumn{7}{|l|}{ GRUPO 1, Cancerígenos humanos } \\
\hline Arsénico y compuestos de arsénico & $?$ & $?$ & & + & & + \\
\hline Amianto & & $?$ & & - & & - \\
\hline Benzeno & + & & & + & + & + \\
\hline $\begin{array}{l}\text { Bis/ clorometil) éter y clorometil metil } \\
\text { éter (calidad técnica) }\end{array}$ & $(t)$ & & & - & & \\
\hline Ciclofosfamida & + & + & & + & + & + \\
\hline Compuestos de cromo hexavalente & + & + & + & + & + & + \\
\hline Melfalán & + & + & & + & & \\
\hline Compuestos de níquel & + & - & & $?$ & & \\
\hline Radón & + & & & - & & \\
\hline Humo del tabaco & + & + & + & & + & \\
\hline Cloruro de vinilo & + & $?$ & & + & + & + \\
\hline
\end{tabular}

GRUPO 2A, Probables cancerígenos humanos

Acrilonitrilo

Adriamicina

Cadmio y compuestos de cadmio

Cisplatino

Epiclorohidrina

Dibromuro de etileno

Oxido de etileno

Formaldehído

GRUPO 2B, Posibles cancerígenos humanos

Clorofenoxi herbicidas (2,4-D

y $2,4,5-T)$

DDT

Dimetilformamida

Compuestos de plomo

Estireno

2,3,7,8-Tetraclorodibenzo-

para-dioxina

Humos de soldadura

1 CA, aberraciones cromosómicas; SCE, intercambio de cromátidas hermanas; MN, micronúcleos.

$(-)$ = relación negativa para un estudio; - = relación negativa;

$(+)=$ relación positiva para un estudio; $+=$ relación positiva;

$?=$ no se pueden extraer conclusiones; casillas en blanco $=$ no se ha estudiado

Fuente: IARC, 1987; actualizado en los volúmenes 43- 50 de las monografías IARC.

\section{Aspectos éticos del biocontrol genético}

Los rápidos avances en las técnicas de genética molecular, la creciente rapidez de conocimiento de la secuencia del genoma humano y la identificación del papel de los genes supresores tumorales y de los protooncogenes en la carcinogénesis humana 
suscitan problemas éticos en la interpretación, comunicación y utilización de este tipo de información personal. El rápido avance de las técnicas de análisis de los genes humanos pronto permitirá la identificación de más genes de sensibilidad hereditaria en individuos sanos asintomáticos (US O ffice of Technology Assessment, 1990), lo que llevará a su utilización en la exploración genética selectiva.

Surgirán muchas preguntas de contenido social y ético si la aplicación de la exploración genética selectiva se convierte pronto en una realidad. Ya en el momento actual se sospecha la existencia de unos 50 rasgos genéticos metabólicos, de polimorfismo enzimático y de reparación de ADN en las sensibilidades a enfermedades específicas, y existe una prueba diagnóstica con AD N para unas 300 enfermedades genéticas. ¿D ebe procederse a una exploración genética selectiva en el lugar de trabajo? ¿Q uién decide las personas que se han de someter a ella? ¿Cómo se utilizará la información en la toma de decisiones referentes al empleo? ¿Quién tendrá acceso a la información obtenida? ¿Cómo se comunicarán los resultados a la persona o personas afectadas? M uchas de estas preguntas están estrechamente relacionadas con las normas sociales y con los valores éticos vigentes. El principal objetivo debe ser la prevención de la enfermedad y del sufrimiento humano, pero se ha de mantener el respeto a la voluntad y a las premisas éticas del individuo. En la Tabla 27.7 se presentan algunas de las cuestiones éticas pertinentes que se deben responder adecuadamente antes de iniciar cualquier estudio de biocontrol en el lugar de trabajo, y que se analizan también en el capítulo Aspectos éticos.

Es preciso dedicar tiempo y esfuerzos a la fase de planificación de cualquier estudio de biocontrol genético, y hay que conseguir que todas las partes implicadas - trabajadores, empresas, y personal médico del lugar de trabajo- estén bien informadas con carácter previo y conozcan también los resultados a la conclusión del estudio. Con una atención adecuada y unos resultados fiables, el biocontrol genético contribuirá a garantizar unos lugares de trabajo más seguros y a mejorar la salud de los trabajadores.

\section{PESTICIDAs}

M arco M aroni y Adalberto Ferioli

\section{Introducción}

La exposición humana a los pesticidas presenta diferentes características según que tenga lugar durante la producción industrial o durante el uso de éstos (Tabla 27.8). La formulación de productos comerciales (mediante la mezcla de principios activos con otros coformulantes) presenta ciertas características de exposición comunes con el uso de pesticidas en la agricultura. De hecho, como la formulación tiene lugar habitualmente en pequeñas industrias que fabrican muchos productos distintos en operaciones sucesivas, los trabajadores quedan expuestos a cada uno de tales pesticidas durante un período breve. En salud pública y agricultura, el uso de cierta variedad de compuestos suele ser la norma, aunque en aplicaciones particulares (por ejemplo, los programas de defoliación del algodón o de control de la malaria) puede utilizarse un único producto.

La medición de indicadores biológicos de exposición es particularmente útil para los usuarios de pesticidas en los casos en que las técnicas convencionales de evaluación de exposición por medio del control del aire ambiental sean poco aplicables. Casi todos los pesticidas son sustancias liposolubles que penetran a través de la piel. En estas circunstancias, la absorción percutánea
Tabla 27.7 - Algunos principios éticos relacionados con la necesidad de saber en estudios de biocontrol genético profesional.

\begin{tabular}{|c|c|c|c|}
\hline \multirow[b]{2}{*}{ Información proporcionada } & \multicolumn{2}{|c|}{$\begin{array}{l}\text { Grupos a los que se proporciona } \\
\text { información }\end{array}$} & \multirow[b]{2}{*}{ Empresa } \\
\hline & $\begin{array}{l}\text { Sujetos } \\
\text { estudiados }\end{array}$ & $\begin{array}{l}\text { Servicio de salud } \\
\text { profesional }\end{array}$ & \\
\hline Lo que se está estudiando & 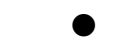 & 0 & 0 \\
\hline Por qué se realiza el estudio & 0 & 0 & 0 \\
\hline Posibles riesgos asociados & $\bullet$ & $\bullet$ & $\bullet$ \\
\hline Cofidencialidad & $\bullet$ & $\bullet$ & \\
\hline $\begin{array}{l}\text { Preparación para posibles } \\
\text { mejoras de higiene, se sugieren } \\
\text { reducciones de la exposición }\end{array}$ & & $\bullet$ & $\bullet$ \\
\hline
\end{tabular}

(dérmica) subraya la importancia del empleo de indicadores biológicos para evaluar el grado de exposición.

\section{Insecticidas organofosforados}

Indicadores biológicos de efecto. Las colinesterasas son las enzimas diana que explican la acción tóxica que los organofosforados $(O P)$ ejercen sobre especies de insectos y mamíferos. En el organismo humano hay dos tipos principales de colinesterasas: la acetilcolinesterasa (ACHE) y la colinesterasa plasmática (PCHE). L os OP causan efectos tóxicos en el hombre mediante la inhibición de la acetilcolinesterasa sináptica del sistema nervioso. También hay acetilcolinesterasa en los eritrocitos, pero se desconoce la función que desempeñan en estas células. L a colinesterasa plasmática es la denominación genérica de un grupo no homogéneo de enzimas presentes en las células gliales, el plasma, el hígado y algunos otros órganos. LoS OP inhiben también la $\mathrm{PCHE}$, pero esta inhibición no provoca trastornos funcionales conocidos.

La inhibición de las ACHE y PCHE hemáticas tiene una estrecha correlación con la intensidad y la duración de la exposición a los O P. Por tratarse de la misma diana molecular responsable de la toxicidad aguda de los O P en el sistema nervioso, la

Tabla 27.8 • Comparación de peculiaridades de la exposición durante la fabricación y el uso de pesticidas.

\begin{tabular}{|c|c|c|}
\hline & $\begin{array}{l}\text { Exposición durante } \\
\text { la producción }\end{array}$ & Exposición durante el uso \\
\hline $\begin{array}{l}\text { Duración de la } \\
\text { exposición }\end{array}$ & $\begin{array}{l}\text { Continua y } \\
\text { prolongada }\end{array}$ & Variable e intermitente \\
\hline Grado de exposición & Bastante constante & Extremadamente variable \\
\hline Tipo de exposición & $\begin{array}{l}\text { A uno o unos pocos } \\
\text { compuestos }\end{array}$ & A numerosos compuestos \\
\hline $\begin{array}{l}\text { Absorción a través de } \\
\text { la piel }\end{array}$ & Fácil de controlar & $\begin{array}{l}\text { Variable, en función de los } \\
\text { métodos de trabajo }\end{array}$ \\
\hline Control ambiental & Util & Rara vez informativo \\
\hline Control biológico & $\begin{array}{l}\text { Complementa el } \\
\text { control ambiental }\end{array}$ & Muy útil cuando lo hay \\
\hline
\end{tabular}

Fuente: OMS 1982a, modificado. 
Tabla 27.9 - G ravedad y pronóstico de la toxicidad aguda por compuestos O P a distintos grados de inhibición de la ACHE.

\begin{tabular}{|c|c|c|c|}
\hline $\begin{array}{l}\text { Inhibición } \\
\text { ACHE (\%) }\end{array}$ & $\begin{array}{l}\text { Grado de } \\
\text { intoxicación }\end{array}$ & Síntomas clínicos & Pronóstico \\
\hline $50-60$ & Leve & $\begin{array}{l}\text { Debilidad, cefalea, vahídos, náuseas, salivación, lagrimeo, miosis, espasmo bronquial } \\
\text { moderado }\end{array}$ & Convalecencia en 1-3 días \\
\hline $60-90$ & Moderado & $\begin{array}{l}\text { Debilitamiento brusco, alteraciones visuales, salivación excesiva, sudoración, vómitos, } \\
\text { diarrea, bradicardia, hipertonia, temblores de las manos y la cabeza, alteraciones } \\
\text { de la marcha, miosis, dolor torácico, cianosis de las membranas mucosas }\end{array}$ & Convalecencia en 1-2 semanas \\
\hline $90-100$ & Grave & $\begin{array}{l}\text { Temblor brusco, convulsiones generalizadas, trastornos psíquicos, cianosis intensiva, } \\
\text { edema pulmonar, coma }\end{array}$ & $\begin{array}{l}\text { Muerte por insuficiencia respiratoria } 0 \\
\text { cardiaca }\end{array}$ \\
\hline
\end{tabular}

ACHE hemática es un indicador más específico que la PCHE. Sin embargo, la sensibilidad de las ACHE y PCHE hemáticas a la inhibición por parte de los OP varía en función de estos compuestos; a igualdad de concentración en sangre, unos compuestos inhiben más la ACHE y otros inhiben más la PCHE.

$\mathrm{H}$ ay una correlación razonable entre la actividad hemática de ACHE y los signos clínicos de toxicidad aguda (Tabla 27.9). La correlación tiende a ser mejor cuando la tasa de inhibición es más rápida. Cuando la inhibición es lenta, como ocurre en casos de exposición crónica a bajas concentraciones, la correlación con la enfermedad puede ser baja o nula. $\mathrm{H}$ ay que señalar que la inhibición de la ACHE hemática no predice efectos crónicos o retardados.

\begin{tabular}{|c|c|c|}
\hline \multirow[t]{2}{*}{ Estado } & Actividad de ACHE & Actividad de PCHE \\
\hline & \multicolumn{2}{|c|}{ Personas sanas } \\
\hline $\begin{array}{l}\text { Variación } \\
\text { interindividual }^{1}\end{array}$ & $10-18 \%$ & $15-25 \%$ \\
\hline $\begin{array}{l}\text { Variación } \\
\text { intraindividual }^{1}\end{array}$ & $3-7 \%$ & $6 \%$ \\
\hline Diferencia entre sexos & No & $\begin{array}{l}10-15 \% \text { superior en } \\
\text { varones }\end{array}$ \\
\hline Edad & \multicolumn{2}{|l|}{$\begin{array}{l}\text { Reducida hasta } 6 \text { meses } \\
\text { de edad }\end{array}$} \\
\hline Peso & & Correlación positiva \\
\hline Colesterol sérico & & Correlación positiva \\
\hline Variación estacional & No & No \\
\hline Variación circadiana & No & No \\
\hline Menstruación & & Menor \\
\hline \multirow[t]{2}{*}{ Embarazo } & & Menor \\
\hline & \multicolumn{2}{|c|}{ Estados patológicos } \\
\hline Menor actividad & Leucemia, neoplasia & $\begin{array}{l}\text { Hepatopatía; uremia; } \\
\text { cáncer; insuficiencia } \\
\text { cardíaca; reacciones } \\
\text { alérgicas }\end{array}$ \\
\hline Mayor actividad & $\begin{array}{l}\text { Policitemia; talasemia; } \\
\text { otras discrasias hemá- } \\
\text { ticas congénitas }\end{array}$ & $\begin{array}{l}\text { Hipertiroidismo; otros } \\
\text { estados de ritmo } \\
\text { metabólico elevado }\end{array}$ \\
\hline \multicolumn{3}{|c|}{1 Fuente: Augustinsson 1955 y Gage 1967.} \\
\hline
\end{tabular}

Se han observado variaciones de las actividades de ACHE y PCHE en sujetos sanos y en condiciones fisiopatológicas determinadas (Tabla 27.10). Por tanto, la sensibilidad de estas pruebas como medio de control de la exposición a O P puede elevarse adoptando como referencia valores individuales previos a la exposición; a continuación se comparan las actividades de la colinesterasa después de la exposición con los valores basales individuales. Los valores de referencia de actividad de la colinesterasa en la población deben usarse sólo cuando no se conocen los niveles de la enzima previos a la exposición (Tabla 27.11).

A ser posible, las muestras de sangre se tomarán en el curso de las dos horas siguientes a la exposición; es preferible la venipunción a la extracción de sangre capilar del dedo o el lóbulo de la oreja, porque el punto de muestreo podría estar contaminado por restos de pesticida acumulados en la piel de los sujetos expuestos. Es recomendable tomar tres muestras secuenciales para establecer un valor basal normal para cada trabajador antes de la exposición (O M S 1982b).

Se conocen varios métodos analíticos para determinar los valores hemáticos de ACHE y PCHE. Según la O M S, el método espectrofotométrico de Ellman (Ellman y cols. 1961) debe utilizarse como método de referencia.

Indicadores biológicos de exposición. Para controlar la exposición a OP se ha utilizado la determinación en orina de metabolitos derivados de la porción alquilfosfato de la molécula OP 0 de residuos generados por hidrólisis del enlace P-X (F igura 27.8).

Metabolitos alquilfosfato Los metabolitos alquilfosfato de tectables en orina y el compuesto parental principal del que pueden originarse se recogen en la Tabla 27.12. Los alquilfosfatos de la orina son indicadores sensibles de exposición a compuestos

Tabla 27.11 - Actividades de la colinesterasa en sujetos sanos sin exposición a O P medidas por métodos seleccionados.

\begin{tabular}{|c|c|c|c|}
\hline Método & Sexo & ACHE* & PCHE* \\
\hline \multirow{2}{*}{$\begin{array}{l}\text { Michel }^{1} \\
(\Delta \mathrm{pH} / \mathrm{h})\end{array}$} & Hombre & $0,77 \pm 0,08$ & $0,95 \pm 0,19$ \\
\hline & Mujer & $0,75 \pm 0,08$ & $0,82 \pm 0,19$ \\
\hline $\begin{array}{l}\text { Titulometría }{ }^{1} \\
(\mu \mathrm{mol} / \mathrm{min} \mathrm{ml})\end{array}$ & Hombre/ mujer & $13,2 \pm 0,31$ & $4,90 \pm 0,02$ \\
\hline \multirow{2}{*}{$\begin{array}{l}\text { Ellman modificado } 2 \\
\text { (UI/ ml) }\end{array}$} & Hombre & $4,01 \pm 0,65$ & $3,03 \pm 0,66$ \\
\hline & Mujer & $3,45 \pm 0,61$ & $3,03 \pm 0,68$ \\
\hline
\end{tabular}

* resultado medio, \pm desviación estándar.

Fuente: ${ }^{1}$ Laws $1991 . \quad 2$ Alcini y cols. 1988. 
Figura 27.8 - Hidrólisis de insecticidas O P.

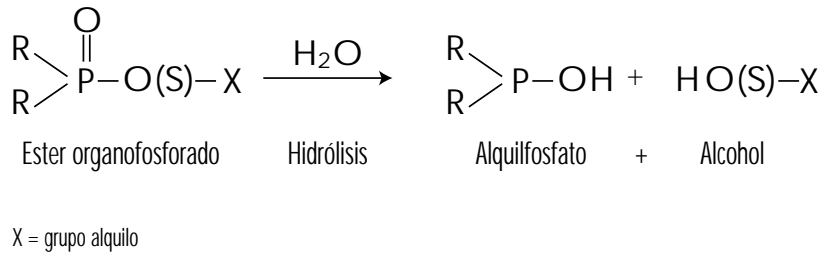

OP; la excreción urinaria de estos metabolitos suele ser detectable a un nivel de exposición al cual no puede detectarse la inhibición de colinesterasa plasmática o eritrocítica. Se ha medido la excreción urinaria de alquilfosfatos para distintas condiciones de exposición y para varios compuestos OP (Tabla 27.13). En unos pocos estudios se ha establecido una relación entre dosis externas de $O P$ y concentraciones urinarias de alquilfosfatos; en algunos se ha demostrado también que hay una relación significativa entre actividad de colinesterasa y concentraciones urinarias de alquilfosfatos.

Los alquilfosfatos suelen excretarse con la orina en poco tiempo. Las muestras recogidas poco después de la jornada laboral son adecuadas para la determinación de metabolitos.

La medición de los alquilfosfatos en orina exige una técnica analítica bastante refinada, basada en la derivación de compuestos y la detección mediante cromatografía de gas-líquido (Shafik y cols. 1973a; R eid y Watts 1981).

Residuos hidrolíticos. El p-nitrofenol (PNP) es el metabolito fenólico del paratión, metilparatión y etilparatión, EPN. La medición del PNP en la orina (C ranmer 1970) se ha utilizado ampliamente y ha demostrado buenos resultados para evaluar la exposición al paratión. EI PNP urinario tiene una buena correlación con la dosis de paratión absorbida. Con concentraciones urinarias de PNP de hasta $2 \mathrm{mg} / \mathrm{l}$, la absorción de paratión no provoca síntomas y la reducción de actividad de colinesterasa observada es escasa o nula. La excreción del PNP es rápida, y las concentraciones urinarias de este compuesto son muy pequeñas 48 horas después de la exposición. Por tanto, las muestras de orina deben recogerse poco tiempo después de aquélla.

Tabla 27.12 - A lquilfosfatos detectables en orina como metabolitos de pesticidas O P.

\begin{tabular}{|c|c|c|}
\hline Metabolito & Abreviatura & Principales compuestos parentales \\
\hline Monometilfosfato & MMP & Malatión, paratión \\
\hline Dimetilfosfato & DMP & $\begin{array}{l}\text { Diclorvos, triclorfón, mevinfos, } \\
\text { malaoxón, dimetoato, fenclorfos }\end{array}$ \\
\hline Dietilfosfato & DEP & $\begin{array}{l}\text { Paraoxón, demetón-oxón, } \\
\text { diazinón-oxón, diclorfentión }\end{array}$ \\
\hline Dimetiltiofosfato & DMTP & $\begin{array}{l}\text { Fenitrotión, fenclorfos, malatión, } \\
\text { dimetoato }\end{array}$ \\
\hline Dietiltiofosfato & DETP & $\begin{array}{l}\text { Diazinón, demetón, paratión, } \\
\text { fenclorfos }\end{array}$ \\
\hline Dimetilditiofosfato & DMDTP & Malatión, dimetoato, azinfos-metilo \\
\hline Dietilditiofosfato & DEDTP & Disulfotón, forato \\
\hline Acido fenilfosfórico & & Leptofos, EPN \\
\hline
\end{tabular}

Tabla 27.13 - Ejemplos de concentraciones urinarias de alquilfosfatos medidas en distintas condiciones de exposición a O P.

\begin{tabular}{|c|c|c|c|}
\hline Compuesto & $\begin{array}{l}\text { Condiciones } \\
\text { de exposición }\end{array}$ & $\begin{array}{l}\text { Vía de } \\
\text { exposición }\end{array}$ & $\begin{array}{l}\text { Concentraciones de } \\
\text { metabolitos }^{1}(\mathrm{mg} / \mathrm{l})\end{array}$ \\
\hline Paratión ${ }^{2}$ & $\begin{array}{l}\text { Intoxicación } \\
\text { oral no } \\
\text { mortal }\end{array}$ & Oral & $\begin{array}{l}\text { DEP }=0,5 \\
\text { DETP }=3,9\end{array}$ \\
\hline Disulfotón² & Formuladores & $\begin{array}{l}\text { Dérmical } \\
\text { inhalación }\end{array}$ & $\begin{array}{l}\text { DEP }=0,01-4,40 \\
\text { DETP }=0,01-1,57 \\
\text { DEDTP }=<0,01-0,05\end{array}$ \\
\hline Forato $^{2}$ & Formuladores & $\begin{array}{l}\text { Dérmica/ } \\
\text { inhalación }\end{array}$ & $\begin{array}{l}\text { DEP }=0,02-5,14 \\
\text { DETP }=0,08-4,08 \\
\text { DEDTP }=<0,01-0,43\end{array}$ \\
\hline Malatión ${ }^{3}$ & Pulverizadores & Dérmica & DMDTP $=<0,01$ \\
\hline Fenitrotión ${ }^{3}$ & Pulverizadores & Dérmica & $\begin{array}{l}\text { DMP }=0,01 \cdot 0,42 \\
\text { DMTP }=0,02 \cdot 0,49\end{array}$ \\
\hline Monocrotofos ${ }^{4}$ & Pulverizadores & $\begin{array}{l}\text { Dérmical } \\
\text { inhalación }\end{array}$ & $D M P=<0,04-6,3 / 24 h$ \\
\hline \multicolumn{4}{|c|}{$\begin{array}{l}\text { Véanse las abreviaturas en la Tabla } 27.12 . \\
\text { Dillon y Ho } 1987 . \\
\text { Richter } 1993 . \\
\text { Van Sittert y Dumas } 1990 .\end{array}$} \\
\hline
\end{tabular}

\section{Carbamatos}

Indicadores biológicos de efecto. Los carbamatos comprenden insecticidas, fungicidas y herbicidas. La toxicidad de los insecticidas carbámicos se debe a la inhibición de la ACHE sináptica; los herbicidas y fungicidas carbámicos actúan según un mecanismo de toxicidad distinto. Por tanto, la valoración de la actividad de la colinesterasa en eritrocitos (ACHE) o plasma (PCHE) permite controlar únicamente los insecticidas carbámiCos. La ACHE suele ser más sensible a los inhibidores de carbamato que la PCHE. Normalmente, es posible observar síntomas colinérgicos en trabajadores expuestos a carbamatos con una actividad de ACHE en sangre inferior al $70 \%$ del nivel individual basal (O M S 1982a).

La inhibición de las colinesterasas por los carbamatos es rápidamente reversible. Por tanto, pueden obtenerse resultados negativos falsos si transcurre demasiado tiempo entre la exposición y el muestreo biológico o entre éste y el análisis. Para evitar estos problemas, se recomienda recoger muestras de sangre y analizarlas en el curso de las cuatro horas siguientes a la exposición. Deben preferirse los métodos analíticos que permiten determinar la actividad colinesterásica inmediatamente después de recoger las muestras de sangre, tal como se ha descrito para los organofosforados.

Indicadores biológicos de exposición. La medida de la excreción urinaria de metabolitos de carbamatos como método para controlar la exposición humana se ha aplicado hasta la fecha sólo a unos pocos compuestos y en estudios limitados; la Tabla 27.14 resume los datos relevantes. C omo los carbamatos se excretan rápidamente con la orina, las muestras recogidas poco después del término de la exposición son las adecuadas para la determinación de metabolitos. $\mathrm{H}$ an documentado métodos analíticos para medir metabolitos de carbamato en orina Dawson y cols. (1964); DeBernardinis y Wargin (1982); y Verbek y cols. (1990). 
Tabla 27.14 - Concentraciones urinarias de metabolitos del carbamato medidas en estudios de campo.

\begin{tabular}{|c|c|c|c|c|c|}
\hline Compuesto & $\begin{array}{l}\text { Indice } \\
\text { biológico }\end{array}$ & $\begin{array}{l}\text { Condiciones } \\
\text { de exposición }\end{array}$ & $\begin{array}{l}\text { Concentraciones } \\
\text { medioambientales }\end{array}$ & Resultados & Referencias \\
\hline Carbaril & $\begin{array}{l}\alpha \text {-naftol } \\
\alpha \text {-naftol } \\
\alpha \text {-naftol }\end{array}$ & $\begin{array}{l}\text { formuladores } \\
\text { mezcladores/ aplicadores } \\
\text { población no expuesta }\end{array}$ & $0,23-0,31 \mathrm{mg} / \mathrm{m}^{3}$ & $\begin{array}{l}x=18,5 \mathrm{mg} / \mathrm{I}^{1} \text {, tasa de excreción máx. }=80 \mathrm{mg} / \text { día } \\
x=8,9 \mathrm{mg} / \mathrm{l} \text {, intervalo }=0,2-65 \mathrm{mg} / \mathrm{I} \\
\text { intervalo }=1,5-4 \mathrm{mg} / \mathrm{I}\end{array}$ & OMS 1982a \\
\hline Pirimicarb & metabolitos $\mathrm{I}^{2}$ y $\mathrm{V}^{3}$ & aplicadores & & intervalo $=1-100 \mu \mathrm{g} / \mathrm{I}$ & Verberk y cols. 1990 \\
\hline
\end{tabular}

\section{Ditiocarbamatos}

Indicadores biológicos de exposición. Los ditiocarbamatos (DTC) se usan ampliamente en fungicidas, y se agrupan en tres clases: tiuranos, dimetilditiocarbamatos y etileno-bis-ditiocarbamatos.

El disulfuro de carbono $\left(\mathrm{CS}_{2}\right)$ y su principal metabolito, el ácido 2-tiotiazolidina-4-carboxílico (TTCA), son metabolitos comunes a casi todos los DTC. Se ha observado un aumento significativo de las concentraciones urinarias de estos compuestos en distintos estados de exposición y para varios pesticidas DTC . La etilen tiourea (ET U) es un importante metabolito urinario de los etilen-bis-ditiocarbamatos. También puede estar presente como impureza en formulaciones comerciales. Como se ha determinado que la ETU es un compuesto teratogénico y carcinogénico para ratas y otras especies y se ha asociado además con toxicidad tiroidea, se utiliza de forma generalizada para controlar la exposición al etilen-bis-ditiocarbamato. La ETU no es específica de ningún compuesto, y puede originarse a partir del maneb, mancozeb o zineb.

Se ha propuesto medir los metales presentes en los DTC como alternativa para controlar la exposición a estos compuestos. Se ha observado que la excreción urinaria de manganeso aumenta en trabajadores expuestos al mancozeb (Tabla 27.15).

EI CS 2 , el TTCA y el manganeso se hallan normalmente en la orina de sujetos no expuestos. Por tanto, se recomienda medir las concentraciones urinarias de los mismos antes de la exposición. L as muestras de orina deben recogerse en la mañana siguiente al término de la exposición. M aroni y cols. (1992) han publicado métodos analíticos de medición del $\mathrm{CS}_{2}$, el TTCA y la ETU.

\section{Piretroides sintéticos}

Indicadores biológicos de exposición. L os piretroides sintéticos son insecticidas similares a las piretrinas naturales. Estudios con voluntarios han permitido identificar metabolitos urinarios apropiados para el control biológico de la exposición. Excretan el metabolito ácido 3-(2,2'-dicloro-vinil)-2,2'-dimetil-ciclopropano carboxílico $\left(\mathrm{Cl}_{2} \mathrm{CA}\right)$ sujetos a los que se ha administrado permetrina o cipermetrina por vía oral; el análogo bromado $\left(\mathrm{Br}_{2} \mathrm{CA}\right)$ lo excretan sujetos tratados con deltametrina. En los voluntarios tratados con cipermetrina se ha identificado también un metabolito fenoxi, el ácido 4-hidroxi fenoxi benzoico (4-HPBA). Sin embargo, estos ensayos no se han aplicado muy a menudo al control de exposiciones profesionales debido a la complejidad de las técnicas analíticas necesarias (Eadsforth, Bragt y van Sittert 1988; Kolmodin-Hedman y cols. 1982). En fumigadores expuestos a cipermetrina, se han detectado concentraciones urinarias de $\mathrm{Cl}_{2} \mathrm{CA}$ comprendidas entre 0,05 y $0,18 \mathrm{mg} / \mathrm{l}$; en formuladores expuestos a $\alpha$-cipermetrina, las concentraciones urinarias de 4-H PBA han resultado inferiores a $0,02 \mathrm{mg} / \mathrm{l}$.

Para la determinación de metabolitos se recomienda la recogida de orina de 24 horas, a partir de la exposición.

Tabla 27.15 - Concentraciones urinarias de metabolitos del ditiocarbamato medidas en estudios de campo.

\begin{tabular}{|c|c|c|c|c|c|}
\hline Compuesto & Indice biológico & $\begin{array}{l}\text { Condiciones } \\
\text { de exposición }\end{array}$ & $\begin{array}{l}\text { Concentraciones } \\
\text { medioambientales* } \\
\pm \text { desviación estándar }\end{array}$ & Resultados \pm desviación estándar & Referencias \\
\hline \multirow[t]{2}{*}{ Ziram } & $\begin{array}{l}\text { Disulfuro de } \\
\text { carbono } \\
\left(\mathrm{CS}_{2}\right)\end{array}$ & formuladores & $1,03 \pm 0,62 \mathrm{mg} / \mathrm{m}^{3}$ & $3,80 \pm 3,70 \mu \mathrm{g} / \mathrm{I}$ & Maroni y cols. 1992 \\
\hline & $\Pi \mathrm{TA}^{1}$ & formuladores & & $0,45 \pm 0,37 \mu \mathrm{g} / \mathrm{l}$ & \\
\hline Maneb/ Mancozeb & ETU2 & aplicadores & & intervalo $=<0,2-11,8 \mu \mathrm{g} / \mathrm{I}$ & Kurttio y cols. 1990 \\
\hline Mancozeb & Manganeso & aplicadores & $57,2 \mu \mathrm{g} / \mathrm{m}^{3}$ & $\begin{array}{l}\text { antes de la exposición: 0,32 } \pm 0,23 \mu \mathrm{g} / \mathrm{g} \\
\text { creatinina; } \\
\text { después de la exposición: 0,53 } \pm 0,34 \mu \mathrm{g} / \mathrm{g} \\
\text { creatinina }\end{array}$ & Canossa y cols. 1993 \\
\hline Media según Maroni y & 1992 & ido 2-tiotiazolidir & 2 ETU = etilentiourea. & & \\
\hline
\end{tabular}




\section{Organoclorados}

Indicadores biológicos de exposición. LoS insecticidas organoclorados (O C) se utilizaron mucho en los decenios de 1950 y 1960. Posteriormente, su uso se abandonó en muchos países por su persistencia y la consiguiente contaminación del medio ambiente.

El control biológico de la exposición a los $\mathrm{O} C$ puede hacerse por la determinación de pesticidas intactos o de sus metabolitos en sangre 0 en suero (Dale, Curley y Cueto 1966; Barquet, Morgade y Pfaffenberger 1981). Después de la absorción, el aldrín se metaboliza rápidamente en dieldrín, y puede medirse como tal en sangre. El endrín tiene un semiperíodo en sangre muy breve; por tanto, la concentración hemática de este compuesto sólo es útil para determinar niveles de exposición recientes. La determinación del metabolito urinario anti-12-hidroxi-endrín ha demostrado también su utilidad para controlar la exposición al endrín (van Sittert y Tordoir 1987).

Para algunos compuestos $\mathrm{OC}$, se han demostrado correlaciones significativas entre la concentración de indicadores biológicos y el inicio de los efectos tóxicos. Se han relacionado casos de toxicidad por exposición a aldrín y dieldrín con niveles en sangre de este último superiores a $200 \mu \mathrm{g} / \mathrm{l}$. Se ha señalado una concentración en sangre de lindano de $20 \mu \mathrm{g} / \mathrm{I}$ como nivel crítico superior en cuanto a los síntomas neurológicos. N o se han documentado efectos adversos agudos en trabajadores con concentraciones hemáticas de endrín inferiores a $50 \mu \mathrm{g} / \mathrm{l}$. La ausencia de efectos adversos precoces (inducción de enzimas hepáticas microsomiales) se ha demostrado en exposiciones repetidas a endrín con concentraciones urinarias de anti-12-hidroxi-endrín inferiores a $130 \mu / g$ de creatinina; y en exposiciones repetidas a DDT con concentraciones séricas de DDT 0 DDE inferiores a $250 \mu \mathrm{g} / \mathrm{l}$.

Pueden encontrarse bajas concentraciones de $\mathrm{OC}$ en la sangre o la orina de la población general. $\mathrm{H}$ e aquí algunos ejemplos de valores observados: concentraciones hemáticas de lindano de hasta $1 \mu \mathrm{g} / \mathrm{l}$; de dieldrín de hasta $10 \mu \mathrm{g} / \mathrm{l}$; de DDT o DDE de hasta $100 \mu \mathrm{g} / \mathrm{l}$; y de anti-12-hidroxi-endrín de hasta $1 \mu \mathrm{g} / \mathrm{g}$ de creatinina. Por tanto, se recomienda hacer una evaluación de los valores basales antes de la exposición.

Las muestras de sangre de los sujetos expuestos deben tomarse inmediatamente después del final de una sola exposición. En condiciones de exposición a largo plazo, el momento de recogida de las muestras de sangre no es crítico. Al final de la exposición deben recogerse muestras puntuales de orina para determinar metabolitos urinarios.

\section{Triazinas}

Indicadores biológicos de exposición. La medición de la excreción urinaria de metabolitos triazínicos y del compuesto parental sin modificar se ha aplicado a sujetos expuestos a atrazina en estudios limitados. La Figura 27.9 representa los perfiles de excreción urinaria de metabolitos atrazínicos de un trabajador industrial expuesto a concentraciones de atrazina comprendidas entre 174 y $275 \mu \mathrm{mol} /$ turno de trabajo (Catenacci y cols. 1993). Como otras clorotriazinas (simazina, propazina, terbutilazina) siguen la misma ruta de biotransformación de la atrazina, pueden determinarse las concentraciones de metabolitos triazínicos desalquilados para controlar la exposición a todos los herbicidas clorotriazínicos.

La determinación de compuestos sin modificar en la orina puede ser útil como medio de confirmación cualitativa de la naturaleza del compuesto que ha dado lugar a la exposición. Para la determinación de metabolitos se recomienda recoger la
Figura 27.9 • Perfiles de excreción urinaria de los metabolitos de la atrazina.
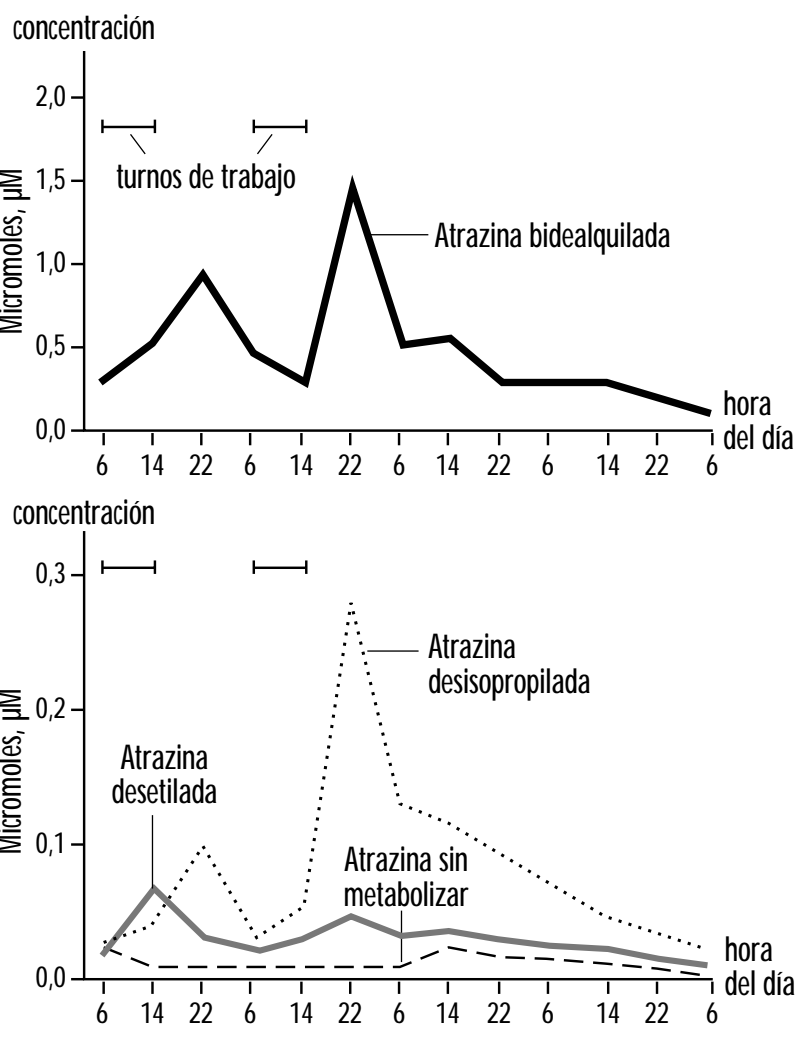

orina durante un período de 24 horas a partir del inicio de la exposición.

Recientemente, utilizando técnicas de enzimoinmunoensayo (prueba ELISA), se ha identificado un conjugado ácido mercaptúrico de la atrazina como principal metabolito urinario de ésta en trabajadores expuestos. Este compuesto se ha hallado en concentraciones al menos 10 veces superiores a las de cualesquiera otros productos desalquilados. Se ha observado una relación entre exposición acumulativa dérmica y por inhalación y la cantidad total del conjugado ácido mercaptúrico excretada a lo largo de un período de 10 días (Lucas y cols. 1993).

\section{Derivados cumarínicos}

Indicadores biológicos de efecto. LoS rodenticidas cumarínicos inhiben la actividad de las enzimas del ciclo de la vitamina $\mathrm{K}$ en el hígado de los mamíferos, incluido el hombre (Figura 27.10), y causan una reducción proporcional a la dosis de la síntesis de los factores coagulantes, en particular de los factores II (protrombina), VII, IX y X. Los efectos anticoagulantes se manifiestan cuando las concentraciones plasmáticas de factores coagulantes disminuyen por debajo de aproximadamente el $20 \%$ de lo normal.

Estos antagonistas de la vitamina $\mathrm{K}$ se han agrupado en compuestos llamados de "primera generación" (por ejemplo, warfarina) y de "segunda generación" (por ejemplo, brodifacoum, difenacoum); éstos últimos se caracterizan por un semiperíodo biológico muy prolongado (100 a 120 días).

La determinación del tiempo de protrombina se usa de forma generalizada en el control de la exposición a las cumarinas. Sin embargo, esta prueba sólo es sensible a reducciones del factor de 
Figura 27.10 - Ciclo de la vitamina $\mathrm{K}$.

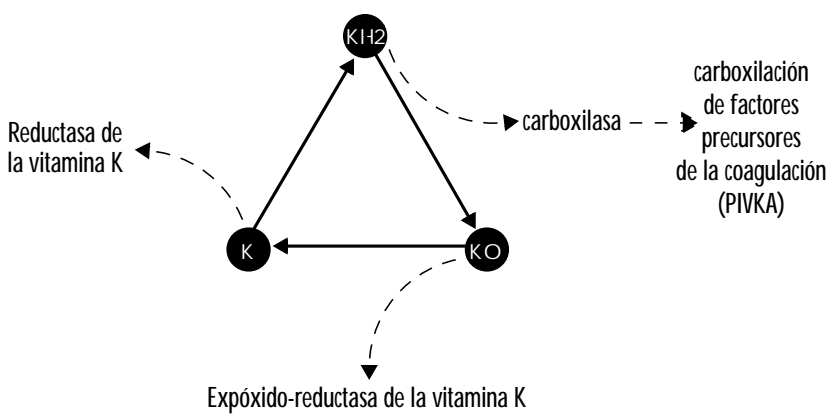

$\mathrm{K}=$ vitamina $\mathrm{K} \quad \mathrm{KO}=$ epóxido de la vitamina $\mathrm{K} \quad \mathrm{KH} 2 \mathrm{=}$ forma activa de la vitamina $\mathrm{K}$

coagulación de aproximadamente el $20 \%$ de los valores plasmáticos normales, y no sirve para detectar los efectos precoces de la exposición. Para este fin se recomienda determinar la concentración plasmática de protrombina.

En el futuro, estas pruebas pueden ser reemplazadas por la determinación de precursores del factor de coagulación (PIVKA), que son sustancias detectables en la sangre sólo en caso de bloqueo por cumarinas del ciclo de la vitamina $\mathrm{K}$.

En condiciones de exposición prolongada, el momento de recogida de la sangre no es crítico. En casos de sobreexposición aguda, el control biológico debe mantenerse durante al menos cinco días después del episodio, dada la latencia del efecto anticoagulante. Para aumentar la sensibilidad de estas pruebas se recomienda hacer lecturas de valores basales antes de la exposición.

Indicadores biológicos de exposición. Se ha propuesto la medida de cumarinas no modificadas en sangre para controlar la exposición humana. Sin embargo, la experiencia de aplicación de estos índices es muy limitada, debido en especial a que las técnicas analíticas son mucho más complejas (y están menos normalizadas) que las necesarias para controlar los efectos sobre el sistema de coagulación (Chalermchaikit, Felice y M urphy 1993).

\section{Herbicidas fenóxicos}

Indicadores biológicos de exposición. LoS herbicidas de fenoxiacetato apenas sufren biotransformación en los mamíferos. En el hombre, más del $95 \%$ de una dosis de ácido 2,4-diclorofenoxiacético (2,4-D) se excreta inalterada en la orina en el curso de cinco días; también los ácidos 2,4,5-triclorofeno-oxiacético (2,4,5-T) y metilfenoxiacético (M CPA) se excretan en su mayor parte inalterados con la orina pocos días después de su absorción oral. Se ha aplicado la medida de compuestos inalterados en orina para controlar la exposición profesional a estos herbicidas. En estudios de campo se ha observado que las concentraciones urinarias de trabajadores expuestos oscilan entre 0,10 y $8 \mu \mathrm{g} / \mathrm{I}$ para el 2,4-D; entre 0,05 y 4,5 $\mu \mathrm{g} / \mathrm{I}$ para el 2,4,5-T; y entre menos de 0,1 y $15 \mu \mathrm{g} / \mathrm{I}$ para el M CPA. Se recomienda recoger la orina de 24 horas, empezando en el momento en que termine la exposición, para determinar compuestos inalterados. Draper (1982) ha documentado métodos analíticos para medir herbicidas fenóxicos en orina.

\section{Compuestos de amonio cuaternario}

Indicadores biológicos de exposición. El diquat y el paraquat son herbicidas escasamente transformados por el organismo humano. Debido a su elevada solubilidad en agua, se excretan rápidamente y sin sufrir alteraciones con la orina. Con frecuencia se han observado concentraciones urinarias inferiores al límite analítico de detección $(0,01 \mu \mathrm{g} / \mathrm{l})$ en trabajadores expuestos al paraquat; en países tropicales, se han observado concentraciones de hasta $0,73 \mu \mathrm{g} / \mathrm{I}$ después de la manipulación incorrecta de paraquat. Se han documentado concentraciones urinarias de diquat inferiores al límite analítico de detección $(0,047 \mu \mathrm{g} / \mathrm{I})$ en sujetos con exposiciones dérmicas de 0,17 a $1,82 \mu \mathrm{g} / \mathrm{h}$ y con exposiciones por inhalación inferiores a $0,01 \mu \mathrm{g} / \mathrm{h}$. Lo ideal es utilizar para el análisis muestras de orina de 24 horas tomadas a partir del final de la exposición. Si esto no es posible, puede utilizarse una muestra puntual tomada al final de la jornada.

La determinación de las concentraciones séricas de paraquat es útil con fines de pronóstico en caso de intoxicación aguda; los pacientes con concentraciones séricas de paraquat de hasta $0,1 \mu \mathrm{g} / \mathrm{I} 24$ horas después de la ingestión tienen probabilidades de sobrevivir.

Summers (1980) ha revisado los métodos analíticos de determinación de paraquat y diquat.

\section{Pesticidas diversos}

4,6-dinitro-o-cresol (DNOC). EI DNOC es un herbicida lanzado en 1925, pero su utilización ha ido disminuyendo poco a poco por sus elevada toxicidad para plantas y animales. Como sus concentraciones en sangre tienen correlación, dentro de ciertos límites, con la gravedad de los efectos adversos para la salud, se ha propuesto medir el DNO C en sangre para controlar exposiciones profesionales y para evaluar el curso clínico en casos de intoxicación.

Pentaclorofenol. El pentaclorofenol (PCP) es un biocida de amplio espectro con acción pesticida contra malas hierbas, insectos y hongos. Se ha recomendado la medición del PCP inalterado en sangre o en orina como índice adecuado de control de exposición profesional (Colosio y cols. 1993), ya que estos

Tabla 27.16 - 0 tros índices propuestos en la bibliografía para el control biológico de exposición a pesticidas.

\begin{tabular}{lll} 
Compuesto & \multicolumn{1}{c}{ Indice biológico } \\
Bromofos & Orina & Sangre \\
Captán & Bromofos & Bromofos \\
Carbofurano & Tetrahidroftalimida & \\
Clordimeform & 3-hidroxicarbofurano & \\
& Derivados de \\
4-cloro-o-toluidina & \\
Clorobenzilato & p-p-1-Diclorobenzofenona \\
Dicloropropeno & Metabolitos del ácido \\
& mercaptúrico & \\
Fenitrotión & p-nitrocresol & \\
Ferbam & & Tiram \\
Fluazifop-butilo & Fluazifop & \\
Flufenoxurona & & Flufenoxurona \\
Glifosato & Glifosato & \\
Malatión & Malatión & Malatión \\
Compuestos organoestannicos & Sn & Sn \\
Trifenomorf & Trifenilcarbinol, morfolina & \\
Ziram & & Tiram \\
\hline
\end{tabular}


Tabla 27.17 - Valores biológicos límite recomendados (en 1996).

\begin{tabular}{|c|c|c|c|c|c|}
\hline Compuesto & Indice biológico & $\left.B E\right|^{1}$ & $\mathrm{VBT}^{2}$ & $\mathrm{LBBS}^{3}$ & $V_{L} B^{4}$ \\
\hline Inhibidores de ACHE & ACHE en sangre & $70 \%$ & $70 \%$ & $70 \%$ & \\
\hline DNOC & DNOC en sangre & & & $20 \mathrm{mg} / \mathrm{l}$ & \\
\hline Lindano & Lindano en sangre & & $0,02 \mathrm{mg} / \mathrm{I}$ & $0,02 \mathrm{mg} / \mathrm{l}$ & \\
\hline Paratión & PNP en orina & $0,5 \mathrm{mg} / \mathrm{I}$ & $0,5 \mathrm{mg} / \mathrm{l}$ & & \\
\hline \multirow[t]{2}{*}{ Pentaclorofenol (PCP) } & PCP en orina & $2 \mathrm{mg} / \mathrm{l}$ & $0,3 \mathrm{mg} / \mathrm{I}$ & & \\
\hline & PCP en plasma & $5 \mathrm{mg} / \mathrm{l}$ & $1 \mathrm{mg} / \mathrm{l}$ & & \\
\hline Dieldrín/ Aldrín & Dieldrín en sangre & & & & $100 \mu \mathrm{g} / \mathrm{I}$ \\
\hline Endrín & Anti-12-hidroxiendrín en orina & & & & $130 \mu \mathrm{g} / \mathrm{I}$ \\
\hline DDT & DDT y DDE en suero & & & & $250 \mu \mathrm{g} / \mathrm{I}$ \\
\hline \multirow[t]{2}{*}{ Cumarinas } & Tiempo de protrombina en plasma & & & & $10 \%$ por encima del valor basal \\
\hline & Concentración de protrombina en plasma & & & & $60 \%$ del valor basal \\
\hline MCPA & MCPA en orina & & & & $0,5 \mu \mathrm{g} / \mathrm{I}$ \\
\hline 2,4-D & 2,4-D en orina & & & & $0,5 \mu \mathrm{g} / \mathrm{l}$ \\
\hline
\end{tabular}

1 Los índices biológicos de exposición (BEI) están recomendados por la American Conference of Governmental Industrial Hygienists (ACGIH 1995).

2 Los valores biológicos de tolerancia (VBT) están recomendados por la Investigación de Riesgos para la Salud de los Compuestos Químicos en el Area de Trabajo (DFG 1992).

${ }^{3}$ Los límites biológicos (LBBS) están recomendados por un grupo de estudio de la OMS (OMS 1982a).

${ }^{4}$ Los valores límite biológicos (VLB) son una propuesta de un grupo de estudio del Comité Científico de Pesticidas de la Comisión Internacional de Salud en el Trabajo (Tordoir y cols. 1994).

Si se sobrepasa este valor, es necesario volver a evaluar las condiciones de trabajo.

parámetros mantienen una correlación significativa con la carga orgánica de PCP. En trabajadores con exposición prolongada al PCP, el momento de recogida de muestras de sangre no es crítico; las muestras puntuales de orina deben tomarse la mañana siguiente a la exposición.

Shafik y cols. (1973b) han descrito un método multirresiduo para medir pesticidas halogenados y nitrofenólicos.

En la Tabla 27.16 se recogen otras pruebas propuestas para el control de la exposición a pesticidas.

\section{Conclusiones}

Se han aplicado indicadores biológicos para controlar la exposición a pesticidas en diversos estudios experimentales y de campo.
A lgunas pruebas, como las de colinesterasa en sangre o las de determinación de ciertos pesticidas inalterados en orina 0 sangre, han sido validadas por una amplia experiencia. Para estas pruebas se han propuesto límites biológicos de exposición (Tabla 27.17).

0 tras pruebas, en particular las de metabolitos en sangre 0 en orina, adolecen de mayores limitaciones, sea por dificultades analíticas 0 por limitaciones en la interpretación de los resultados.

Este campo de estudio se encuentra en rápida evolución y, dada la enorme importancia del empleo de indicadores biológicos para evaluar la exposición a estas sustancias, se desarroIlarán y validarán continuamente nuevas pruebas.

\section{Referencias}

Alcini, D, M M aroni, A Colombi, D X aiz, V Foà. 1988. Evaluation of a standardised European method for the determination of cholinesterase activity in plasma and erythrocytes. M ed Lavoro 79(1):42-53.

Alessio, L, A Berlin, V Foà. 1987. Influence factors other than exposure on the levels of biological indicators. En Occupational and Environmental Chemical $H$ azards, dirigido por V Foà, FA Emmett, $M M$ aroni y A Colombi. Chichester: Wiley.

Alessio, L, L A postoli, L M inoia, E Sabbioni. 1992. From macro- to micro-doses: R eference values for toxic metals. En Science of the Total Environment, dirigido por $L$ Alessio, $L$ A postoli, $L$ M inoia y $E$ Sabbioni. N ueva Y ork: Elsevier Science.

American Conference of Governmental Industria Hygienists (ACGIH). 1997. 1996-1997 Threshold Limit Values for Chemical Substances and Physical Agents and Biological Exposure Indices. Cincinnati, O hio: ACGIH.
- . 1995. 1995-1996 Threshold Limit Values for Chemical Substances and Physical Agents and Biological Exposure Indices. Cincinnati, O hio: ACGIH .

Augustinsson, K B. 1955. The normal variation of human blood cholinesterase activity. Acta Physiol Scand 35:40-52.

Barquet, A, C M orgade, CD Pfaffenberger. 1981. Determination of organochlorine pesticides and metabolites in drinking water, human blood, serum and adipose tissue. J T oxicol Environ $\mathrm{H}$ ealth 7:469-479.

Berlin, A, RE Yodaiken, BA Henman. 1984. Assessment of Toxic Agents at the Workplace. Roles of Ambient and Biological Monitoring. Actas del seminario internacional celebrado en Luxemburgo, 8-12 de diciembre de 1980. L ancaster, R eino U nido: M artinus N ijhoff.

Bernard, A, R Lauwerys. 1987. General principles for biological monitoring of exposure to chemicals. En Biological M onitoring of Exposure to Chemicals:
Organic Compounds, dirigido por $\mathrm{MH} \mathrm{HO}$ y $\mathrm{KH}$ Dillon. N ueva Y ork: Wiley.

Brugnone, F, L Perbellini, E Gaffuri, P Apostoli. 1980. Biomonitoring of industrial solvent exposure of workers' alveolar air. Int Arch Occup Environ $H$ ealth 47:245-261.

Bullock, DG, NJ Smith, TP Whitehead. 1986. External quality assessment of assays of lead in blood. Clin Chem 32:1884-1889.

Canossa, E, G Angiuli, G Garasto, A Buzzoni, E De Rosa. 1993. Dose indicators in farm workers exposed to mancozeb. M ed L avoro 84(1):42-50.

Catenacci, G, F Barbieri, M Bersani, A Ferioli, D Cottica, M M aroni. 1993. Biological monitoring of human exposure to atrazine. Toxicol Letters 69:217-222.

Chalermchaikit, T, LJ Felice, MJ M urphy. 1993. Simultaneous determination of eight anticoagulant rodenticides in blood serum and liver. I Anal T oxicol 17:56-61. 
Colosio, C, F Barbieri, M Bersani, H Schlitt, M $M$ aroni. 1993. M arkers of occupational exposure to pentachlorophenol. B Environ Contam Tox 51:820-826

Comisión Europea. 1983. Biological indicators for the assessment of human exposure to industrial chemicals. En EUR 8676 EN, dirigido por L Alessio, A Berlin, R R oi y M Boni. Luxemburgo: Comisión Europea.

-. 1984. Biological indicators for the assessment of human exposure to industrial chemicals. En EUR 8903 EN , dirigido por L Alessio, A Berlin, R R oi y $M$ Boni. Luxemburgo: Comisión Europea.

-.1986 . Biological indicators for the assessment of human exposure to industrial chemicals. En EUR 10704 EN, dirigido por L Alessio, A Berlin, R R oi y M Boni. Luxemburgo: Comisión Europea.

-. 1987. Biological indicators for the assessment of human exposure to industrial chemicals. En EUR $11135 \mathrm{EN}$, dirigido por L Alessio, A Berlin, R R oi y M Boni. Luxemburgo: Comisión Europea.

- . 1988a. Biological indicators for the assessment of human exposure to industrial chemicals. En EUR 11478 EN, dirigido por L Alessio, A Berlin, R R oi y M Boni. Luxemburgo: Comisión Europea.

-. 1988b. Indicators for Assessing Exposure and Biological Effects of Genotoxic Chemicals. EUR 11642 Luxemburgo: Comisión Europea.

- 1989. Biological indicators for the assessment of human exposure to industrial chemicals. En EUR 12174 EN, dirigido por $L$ Alessio, A Berlin, R R oi y $M$ Boni. Luxemburgo: Comisión Europea.

Cranmer, M . 1970. Determination of p-nitrophenol in human urine. B E nviron Contam T ox 5:329-332.

Dale, WE, A Curley, C Cueto. 1966. Hexane extractable chlorinated insecticides in human blood. Life Sci 5:47-54.

Dawson, JA, DF H eath, JA Rose, EM Thain, JB $W$ ard. 1964. The excretion by humans of the phe nol derived in vivo from 2-isopropoxyphenyl- $\mathrm{N}$ methylcarbamate. B ull W H 0 30:127-134.

DeBernardis, M J, WA Wargin. 1982. High performance liquid chromatographic determination of carbaryl and 1 naphtol in biological fluids. J Chromatogr 246:89-94.

Deutsche Forschungsgemeinschaft (DFG). 1996. $M$ aximum Concentrations At the W orkplace (M AK) and Biological Tolerance Values (CBAT) for W orking $M$ aterials. Informe núm. 28. $\mathrm{VCH}$. Weinheim, Alemania: Comisión de investigación de los riesgos para la salud de los compuestos químicos en el lugar de trabajo.

-. 1994. List of MAK and BAT Values 1994 Weinheim, Alemania: $\mathrm{VCH}$.

Dillon, HK, MH H o. 1987. Biological monitoring of exposure to organophosphorus pesticides. En Biological $M$ onitoring of Exposure to Chemicals: Organic Compounds, dirigido por $\mathrm{HK}$ Dillon y $\mathrm{MH} \mathrm{Ho}$ Nueva Y ork: Wiley.

Draper, WM. 1982. A multiresidue procedure for the determination and confirmation of acidic herbicide residues in human urine. J Agricul $\mathrm{Food}$ Chem 30:227-231.

Eadsforth, CV, PC Bragt, NJ van Sittert. 1988 Human dose-excretion studies with pyrethroid insecticides cypermethrin and alphacypermethrin: Relevance for biological monitoring. Xenobiotica 18:603-614.

Ellman, GL, KD Courtney, V Andres, RM Featherstone. 1961. A new and rapid colorimetric determination of acetylcholinesterase activity. Biochem Pharmacol 7:88-95.

Gage, JC. 1967. The significance of blood cholinesterase activity measurements. Residue Rev 18:159-167.
H ealth and Safety Executive (H SE). 1992. Biological $M$ onitoring for Chemical Exposures in the W orkplace. N ota orientativa EH 56. Londres: H M SO

Agencia Internacional para la Investigación sobre el Cáncer (IARC). 1986. IARC M onographs On the $E$ valuation of $C$ arcinogenic R isks to $H$ umans - An $U$ pdating of (Selected) IARC M onographs from Volumes 1 to 42. Suplemento 6: G enetic and related effects; Suplemento 7: O verall evaluation of carcinogenicity. Lyon: IARC.

- . 1987. M ethod for D etecting DNA D amaging Agents in $H$ umans: Applications in Cancer Epidemiology and Prevention. IARC Scientific Publications, No 89, dirigido por $\mathrm{H}$ Bartsch, $\mathrm{K} \mathrm{H}$ emminki e IK $O$ 'N eill. Lyon: IAR C.

-. 1992. M echanisms of Carcinogenesis in Risk Identification. IARC Scientific Publications, No. 116, dirigido por H Vainio. Lyon: IARC.

-. 1993. DNA Adducts: Identification and Biological Significance. IARC Scientific Publications, N 0. 125, dirigido por $\mathrm{K} \mathrm{H}$ emminki. Lyon: IAR C

Kolmodin-Hedman, B, A Swensson, M Akerblom. 1982. O ccupational exposure to some synthetic pyrethroids (permethrin and fenvalerate). Arch T oxicol 50: 27-33.

K urttio, P, T V artiainen, K Savolainen, 1990. Environmental and biological monitoring of exposure to ethylenebisdithiocarbamate fungicides and ethylenethiourea. Br J Ind M ed 47:203-206.

Lauwerys, R, P Hoet. 1993. Industrial Chemical Exposure: Guidelines for Biological M onitoring. Boca R aton: Lewis.

Laws, ERJ. 1991. Diagnosis and treatment of poisoning. En $H$ andbook of Pesticide Toxicology, dirigido por WJJ Hayes y ERJ Laws. N ueva Y ork: Academic Press

Lucas, AD, AD Jones, MH Goodrow, SG Saiz. 1993. Determination of atrazine metabolites in human urine: Development of a biomarker of exposure. Chem Res T oxicol 6:107-116.

Maroni, M, A Ferioli, A Fait, F Barbieri. 1992. $M$ essa a punto del rischio tossicologico per l'uomo connesso alla produzione ed uso di antiparassitari. Prev 0 ggi 4:72-133.

Organización M undial de la Salud (OM S). 1981. External Quality Assessment of $\mathrm{H}$ ealth Laboratories. EURO Reports and Studies 36. Copenhague: O ficina R egional de la O M S para Europa.

-. 1982a. Field Survey of Exposure to Pesticides, Standard Protocol. Documento núm. VBC/82.1 Ginebra: OMS.

-. 1982b. Recommended $H$ ealth- $B$ ased Limits in Occupational Exposure to Pesticides. Technical Report Series, N 0. 677. Ginebra: O M S.

-. 1994. Guidelines in Biological M onitoring of Chemical Exposure at the W orkplace. V ol. 1. G inebra: O M S.

Reid, SJ, RR Watts. 1981. A method for the determination of diaklyl phosphate residues in urine. J Anal T oxicol 5.

Richter, E. 1993. Organophosphorus Pesticides: A Multinational Epidemiologic Study. Copenhague: Programa de Salud en el Trabajo y Oficina R egional de la OM S para Europa.

Shafik, MT, DE Bradway, HR Enos, AR Yobs. 1973a. Human exposure to organophosphorous pesticides: A modified procedure for the gas-liquid chromatographic analysis of the alkyl phosphate metabolites in urine. J Agricul Food Chem 21:625629.

Shafik, MT, HC Sullivan, HR Enos. 1973b. Multiresidue procedure for halo- and nitrophenols: Measurements of exposure to biodegradable pesticides yielding these compounds as metabolites. I Agricul Food Chem compounds

Summers, LA. 1980. The Bipyridylium H erbicides. Londres: A cademic Press.
Tordoir, WF, M M aroni, F He. 1994. Health surveillance of pesticide workers: A manual for occupational health professionals. T oxicology 91.

US O ffice of Technology Assessment. 1990. Genetic $M$ onitoring and Screening in the Workplace OTA-BA-455. Washington, DC: US Government Printing $O$ ffice.

van Sittert, NJ, EP Dumas. 1990. Field study on exposure and health effects of an organophosphate pesticide for maintaining registration in the Philippines. M ed Lavoro 81:463-473.

van Sittert, NJ, WF Tordoir. 1987. Aldrin and dieldrin. En Biological Indicators for the Assessment of $H$ uman $E$ xposure to Industrial $C$ hemicals, dirigido por $L$ Alessio, A Berlin, M Boni y R Roi. Luxemburgo: Comisión Europea.

Verberk, MM, DH Brouwer, EJ Brouer, DP Bruyzeel. 1990. Health effects of pesticides in the flower-bulb culture in $\mathrm{H}$ olland. $\mathrm{M}$ ed Lavoro 81(6):530-541.

Westgard, J O, PL Barry, M R H unt, T Groth. 1981. A multirule Shewhart chart for quality control in clinical chemistry. Clin Chem 27:493-501.

Whitehead, TP. 1977. Quality Control in Clinical Chemistry. Nueva Y ork: Wiley.

\section{O tras lecturas recomendadas}

Aitio, A, G Becking, A Berlin, A Bernard, V Foà, D K ello, E K rug, A Léonard, G Nordberg. 1987 Seminario internacional sobre los indicadores en los materiales biológicos humanos para evaluar la exposición y/o los efectos biológicos de los compuestos químicos genotóxicos. Copenhague: O ficina R egional de la O M S para Europa.

Bartsch, H, K Hemminki, IK O'N eill. 1988. M ethod for Detecting DNA Damaging Agents in $H$ umans: Applications in Cancer E pidemiology and Prevention. $\mathrm{Vol}$. 89. Lyon: IARC

Comisión Europea (CCE), Programa Internacional de Seguridad Química, O ficina Regional de la O rganización M undial de la Salud para Europa, e Instituto de Medicina del Trabajo (Finlandia). 1987. International W orkshop on Indicators in $\mathrm{H}$ uman Biological M aterials for Assessing Exposure to and/ or B iological $E$ ffects of $G$ enotoxic Chemicals. Luxemburgo: Comisión Europea.

-. 1992. From macro- to micro-doses: Reference values for toxic metals. En Science in the Total Environment, dirigido por $L$ Alessio, P Apostoli, L Minoia y E Sabbioni. Nueva York: Elsevier Science. Número especial.

Clarkson, T, L Friberg, G N ordberg, P Sager. 1988. B iological M onitoring of T oxic M etals. Nueva York: Plenum Press.

Fiserova-Berferova, V, N O gata. 1990. Biological $\mathrm{M}$ onitoring of Exposure to Industrial Chemicals. Cincinnati, O hio: ACGIH.

Friberg, L, G N ordberg, V V oulk. 1986. H andbook on the Toxicology of M etals. Vol. II. Amsterdam: Elsevier Science.

H ayes, WJ, Jr, ER Laws Jr. 1991. H andbook of Pesticide T oxicology. N ueva Y ork: A cademic Press.

He, F. 1993. Biological monitoring of occupational pesticide exposure. Int Arch $O$ ccup Environ $\mathrm{H}$ ealth 65:69-76.

H emminki, K, A Dipple, D Shuter, EE K adlubar, D Segerback, H Bartsch. 1993. DNA Adducts: Identification and Biological Significance. IARC Scientific Publication, N 0. 125. Lyon: IARC.

K rishanan, K, J Brodeur. 1991. Toxicological consequences of combined exposure to environmental pollutants. ACE S 3:1-106.

O rganización M undial de la Salud (O M S). 1980. T in and Organotin Compounds. Environmental $\mathrm{H}$ ealth Criteria, N o. 15. Ginebra: O M S. 
-. 1984a. 2,4-Dichlorophenoxyacetic Acid (2,4D). Environmental $\mathrm{H}$ ealth Criteria, No. 29. Ginebra: OMS

$-.1984 b$. Paraquat and Diquat. Environmental $\mathrm{H}$ ealth Criteria, N 0. 39. Ginebra: O M S.

-. 1986a. Carbamate Pesticides: A General Introduction. Environmental $\mathrm{H}$ ealth Criteria, N o. 64. Ginebra: OMS.

-. 1986b. Organophosphorus Insecticides: A Genera Introduction. Environmental $\mathrm{H}$ ealth Criteria, No. 63. Ginebra: OM S.
-. 1988. Dithiocarbamate Pesticides, E thylenethiourea and Propylenethiorea: A General Introduction. Environmental $\mathrm{H}$ ealth C riteria, N 0.78. G inebra: O M S.

-. 1989a. Aldrin and Dieldrin. Environmental $\mathrm{H}$ ealth Criteria, N 0. 91. G inebra: O M S.

-. 1989b. Cypermethrin. Environmental Health Criteria, N 0. 82. G inebra: O M S.

-. 1989c. Permethrin. Environmental $\mathrm{H}$ ealth Criteria, N o. 94. Ginebra: O M S

-. 1990a. Deltamethrin. Environmental Health Criteria, N o. 97. Ginebra: O M S
-. 1990b. Fenvalerate Environmental Health Criteria, N 0. 95. Ginebra: O M S.

-. 1990c. Tributyltin Compounds. Environmental H ealth C riteria, N o. 116. Ginebra: OM S.

- . 1993. Biomarkers and Risk Assessment: Concepts and Principles. Environmental $\mathrm{H}$ ealth Criteria, N o. 155. Ginebra: OM S.

- . 1996a. Biological M onitoring of Chemical Exposure in the W orkplace. 2 vols. G inebra: O M S.

Vaino, H, PN Magee, DB M CGregor, AJ $M$ CM ichael. 1993. M echanisms of Carcinogenesis in Risk Identification. IAR C Scientific Publications, No. 116. Lyon: IARC. 
Directores del capítulo

F ranco $\mathrm{M}$ erletti, Colin L. Solkolney

Paolo Vineis

\section{Sumario}

M étodo epidemiológico aplicado a la salud y seguridad

en el trabajo

F ranco M erletti, Colin L. Soskolne

y Paolo Viness ............................... 28.2

Evaluación de la exposición

M. G erald 0 tt.

M edidas que resumen la exposición durante toda una vida laboral

Colin L. Soskolne.

M edición del efecto de una exposición

Shelia H oar Z ahm

Tipos de diseño de los estudios

Sven $\mathrm{H}$ ernberg. . . . . . . . . . . . . . . . . . . 28.16

Aspectos relacionados con la validez del diseño

del estudio

Anniej. Sasco . . . . . . . . . . . . . . . . . . . . . . . . 28.22

Consecuencias del error de medida aleatorio

Paolo Vineis y Colin L. Soskolne. . . . . . . . . . . . . . . . . 28.25

$M$ étodos estadísticos

Annibale Biggeri y $M$ ario B raga . . . . . . . . . . . . . . . . . . 28.26

Evaluación de la causalidad y ética en la investigación epidemiológica

Paolo Vineis. . .

Estudio de caso que ilustra los problemas metodológicos

en la vigilancia de las enfermedades profesionales

J ung-D er W ang. . . . . . . . . . . . . . . . . . . . . 28.33

Cuestionarios en la investigación epidemiológica

Steven D. Stellman y Colin L. Soskolne.

Amianto: perspectiva histórica

L aw rence Garfinkel.

(20)




\section{- MeTOdO EPIDEMIOLOGICO APLICADO A LA SALUD Y SEGURIDAD EN EL TRABAJO}

\author{
Franco M erletti, Colin L. Soskolne \\ y Paolo Vineis
}

\section{Epidemiología}

La epidemiología se considera la ciencia básica para la medicina preventiva y una fuente de información para la formulación de políticas de salud pública. Se han propuesto varias definiciones de la epidemiología, la más sencilla de las cuales es la siguiente: la epidemiología es el estudio de la aparición de enfermedades y de otras características relacionadas con la salud en poblaciones humanas y animales. Los epidemiólogos estudian la frecuencia de las enfermedades y la variación de dicha frecuencia en distintos grupos de personas; es decir, estudian la relación causa-efecto entre exposición y enfermedad. Las enfermedades no se producen de manera aleatoria; tienen causas - muchas de ellas de origen humano- que pueden evitarse. Por consiguiente, muchas enfermedades podrían prevenirse si se conocieran sus causas. Los métodos epidemiológicos han sido cruciales para identificar numerosos factores etiológicos que, a su vez, han justificado la formulación de políticas sanitarias encaminadas a la prevención de enfermedades, lesiones y muertes prematuras.

¿Cuál es la función de la epidemiología y cuáles son sus puntos fuertes y débiles cuando se aplican sus definiciones y conceptos a la salud en el trabajo? En este capítulo se abordan estas preguntas y las maneras de investigar los peligros para la salud en el trabajo utilizando técnicas epidemiológicas. En el presente artículo se presentan las ideas que se desarrollan en el resto del capítulo.

\section{Epidemiología del trabajo}

La epidemiología del trabajo se ha definido como el estudio de los efectos de las exposiciones en el lugar de trabajo sobre la frecuencia y distribución de enfermedades y lesiones en la población. Por consiguiente, se trata de una disciplina orientada a la exposición, que mantiene vínculos con la epidemiología y con la higiene industrial (Checkoway y cols. 1989). Como tal, utiliza métodos similares a los empleados por la epidemiología en general.

El principal objetivo de la epidemiología del trabajo es la prevención, mediante la identificación de las consecuencias para la salud, de las exposiciones en el lugar de trabajo. Este objetivo subraya el enfoque preventivo de la epidemiología del trabajo. De hecho, todas las investigaciones realizadas en el campo de la salud y seguridad en el trabajo deberían tener fines preventivos. Por consiguiente, los conocimientos epidemiológicos pueden y deben ser aplicados rápidamente. Aunque el interés de la salud pública debe prevalecer siempre en la investigación epidemiológica, pueden existir otros intereses creados. Los investigadores deben tomar precauciones para reducir al mínimo su influencia en el diseño, desarrollo e interpretación de los estudios (Soskolne 1985; Soskolne 1989).

Un segundo objetivo de la epidemiología del trabajo es utilizar los resultados obtenidos en entornos específicos para reducir o eliminar peligros en el conjunto de la población. Así pues, además de facilitar información sobre los efectos para la salud de las exposiciones en el lugar de trabajo, los resultados de los estudios de la epidemiología del trabajo sirven también para estimar el riesgo de la población general sometida a dosis menores de las mismas exposiciones. La contaminación ambiental provocada por procesos y productos industriales suele generar niveles más bajos de exposición que los experimentados en el lugar de trabajo.

La epidemiología del trabajo puede aplicarse a distintos niveles:

- Vigilancia para describir la aparición de enfermedades en diferentes categorías de trabajadores y proporcionar las primeras señales de advertencia de peligros profesionales desconocidos.

- Generación y puesta a prueba de una hipótesis sobre el efecto nocivo de determinada exposición y la cuantificación de dicho efecto.

- Evaluación de una intervención (por ejemplo, una medida preventiva como la reducción de los niveles de exposición) midiendo los cambios en el estado de salud de una población a lo largo del tiempo.

El papel etiológico que las exposiciones profesionales pueden desempeñar en el desarrollo de enfermedades, lesiones y muerte prematura se identificó hace ya mucho tiempo y forma parte de la historia de la epidemiología. En el año 1700, Bernardino Ramazzini, el fundador de la medicina del trabajo y uno de los primeros en resucitar y ampliar la tradición hipocrática según la cual la salud depende de factores externos naturales, escribió en su "De Morbis Artificum Diatriba" (Ramazzini 1705; Saracci 1995):

El médico tiene que hacer muchas preguntas a sus pacientes. H ipócrates dice en D e Affectionibus: "A una persona enferma se le debe preguntar qué le duele, por qué razón, desde hace cuántos días, qué come y cómo son sus deposiciones. A todas estas preguntas debe añadirse otra: ¿En qué trabaja?"

Este resurgimiento de la observación clínica y de la atención a las circunstancias que rodean la aparición de una enfermedad llevaron a Ramazzani a identificar y describir muchas de las enfermedades profesionales que más tarde serían estudiadas por los médicos y epidemiólogos del trabajo.

Aplicando este enfoque, Pott fue el primero en sugerir en 1775 (Pott 1775) la posible relación entre un cáncer y una profesión (Clayson 1962). Sus observaciones sobre el cáncer de escroto en los deshollinadores empezaban con una descripción de la enfermedad y continuaban así:

El destino de estas personas es particularmente sombrío: en su infancia suelen recibir un trato brutal y, si no mueren de hambre y frío, se ven obligados a introducirse en estrechas chimeneas, algunas de ellas todavía calientes, en las que sufren contusiones, quemaduras y asfixia. Cuando llegan a la pubertad, son particularmente propensos a desarrollar una de las enfermedades más molestas, dolorosas y mortales.

Sobre esta última circunstancia, ya no existe ninguna duda, aunque quizás no se le haya prestado suficiente atención para darla a conocer. 0 tras personas desarrollan cáncer en esas mismas partes del cuerpo; pero lo mismo ocurre con el cólico de Poitou y la consiguiente parálisis, que afecta a otras personas además de a los trabajadores del plomo, aunque éstos sean particularmente propensos a la enfermedad; y lo mismo ocurre con los deshollinadores para el cáncer de escroto y de testículos.

En estas personas, la enfermedad parece tener su origen en el hollín que se introduce en los pliegues del escroto; en principio, no parece ser una enfermedad de origen sexual (...) en este caso las personas son jóvenes y su estado de salud es bueno, al menos al principio; la enfermedad les sobreviene por su profesión y, con toda probabilidad, por causas locales; esta última circunstancia puede presuponerse por el 
hecho de que siempre afecte a la misma zona. Todo ello hace que sea (en principio) un caso muy diferente del cáncer que aparece en un hombre de edad avanzada.

Esta primera descripción que se realizó de un cáncer profesional sigue siendo un modelo de lucidez. Se define claramente la naturaleza de la enfermedad, la profesión de los enfermos y el agente etiológico probable. Se indica una mayor incidencia de cáncer de escroto en los deshollinadores, aunque no se aportan datos cuantitativos para fundamentar esta afirmación.

Cincuenta años después, Ayrton-Paris observó en 1822 (Ayrton-Paris 1822) una elevada frecuencia de cáncer de escroto en los fundidores de cobre y estaño de Cornwall y supuso que el humo de arsénico podría ser el agente etiológico. Von Volkmann publicó en 1874 un informe sobre los tumores de piel en los trabajadores expuestos a parafina en Sajonia y, poco después, en 1876, Bell sugirió que el petróleo de esquisto bituminoso producía cáncer de piel (Von Volkmann 1874; Bell 1876). A partir de entonces, los informes sobre el origen profesional del cáncer se hicieron cada vez más frecuentes (Clayson 1962).

U na de las primeras enfermedades profesionales descritas fue el cáncer de pulmón en los mineros de Schneeberg $(\mathrm{H}$ arting y H esse 1879). U n reciente estudio de casos ha demostrado que la epidemia de cáncer de pulmón en Schneeberg sigue siendo un grave problema de salud pública más de un siglo después de que se observara por primera vez, en 1879. En la historia de la medicina del trabajo pueden encontrarse algunos intentos de identificar un "incremento" en la enfermedad e incluso de cuantificarlo. Por ejemplo, como recuerda Axelson (1994), W.A. Guy estudió en 1843 la "tisis pulmonar" en los trabajadores de las imprentas y observó un riesgo mayor en los tipógrafos que en los prensistas; para ello utilizó un diseño similar al de los estudios de casos y controles (Lilienfeld y Lilienfeld 1979). Sin embargo, hasta principios del decenio de 1950 no se empezaron a desarrollar la epidemiología moderna y su metodología. Las principales contribuciones a este desarrollo fueron los estudios del cáncer de vejiga en trabajadores expuestos a colorantes (Case y H osker 1954) y del cáncer de pulmón en trabajadores expuestos a gases (D oll 1952).

\section{Cuestiones relacionadas con la epidemiología del trabajo}

En los artículos de este capítulo se describen los principios y las herramientas de la investigación epidemiológica. Dichos artículos se centran en la evaluación de la exposición experimentada por los trabajadores y en las enfermedades que aparecen en estas poblaciones. En este capítulo se plantean también otras cuestiones relacionadas con la elaboración de conclusiones válidas sobre las posibles relaciones causales entre la exposición a sustancias peligrosas y la aparición de enfermedades.

D eterminar la historia de las exposiciones a las que ha estado sometida una persona durante toda su vida laboral constituye el núcleo de la epidemiología del trabajo. La información que puede facilitar un estudio epidemiológico depende, en primer lugar, de la calidad y la extensión de los datos disponibles sobre la exposición. En segundo lugar, los efectos en la salud (o las enfermedades) que interesan al epidemiólogo del trabajo tienen que determinarse con exactitud en un grupo de trabajadores claramente definido y accesible. Finalmente, el epidemiólogo debe disponer de datos sobre otros factores que puedan influir en la enfermedad de interés, de manera que cualquier efecto de las exposiciones profesionales que se demuestre en el estudio pueda atribuirse a la exposición profesional per se, en lugar de a otras causas conocidas de la enfermedad en cuestión. Por ejemplo, en un grupo de trabajadores expuestos a una sustancia química de la que se sospecha que produce cáncer de pulmón, es posible que algunos trabajadores fumen o hayan fumado, siendo esto otra causa de cáncer de pulmón. En este caso, los epidemiólogos del trabajo tienen que determinar qué exposición (o qué factor de riesgo: la sustancia química, el tabaco o una combinación de los dos) es responsable del aumento de riesgo de cáncer de pulmón en el grupo de trabajadores estudiado.

\section{Evaluación de la exposición}

Si el epidemiólogo sabe únicamente que una persona trabajaba en un determinado sector industrial, los resultados de su estudio sólo podrán relacionar los efectos sobre la salud con dicho sector. Si dispone de datos sobre la exposición de los trabajadores según su profesión, sólo podrá extraer directamente conclusiones en lo que se refiere a la profesión. Se pueden hacer inferencias indirectas sobre las exposiciones a sustancias químicas, aunque es preciso determinar su fiabilidad en cada caso. Sin embargo, cuando el epidemiólogo tiene acceso, por ejemplo, a información sobre el departamento o/ y a la descripción del puesto de trabajo de cada trabajador, podrá extraer conclusiones a ese nivel más detallado de la experiencia en el lugar de trabajo. Cuando el epidemiólogo (en colaboración con un higienista industrial) dispone de información sobre las sustancias con las que trabaja una persona, éste sería el nivel más detallado de la información de que puede disponer sobre la exposición, salvo las raras ocasiones en las que se conoce la dosimetría. Es más, los resultados de estos estudios pueden facilitar a la industria información muy útil para crear lugares de trabajo más seguros.

H asta ahora, la epidemiología ha sido una especie de disciplina "caja negra", ya que ha estudiado la relación entre exposición y enfermedad (los dos extremos de la cadena etiológica), sin considerar los mecanismos intermedios. Este enfoque, a pesar de su aparente falta de refinamiento, ha sido extremadamente útil. De hecho, todas las causas conocidas de cáncer en el ser humano, por ejemplo, se han descubierto con las herramientas de la epidemiología.

El método epidemiológico se basa en los registros existentes: cuestionarios, descripción de los puestos de trabajo u otros "estimadores" de la exposición. Con ellos, la realización de los estudios epidemiológicos y la interpretación de sus resultados resultan relativamente sencillas.

Sin embargo, las limitaciones de este enfoque simplificado de la evaluación de la exposición se han hecho evidentes en los últimos años, cuando los epidemiólogos han tenido que enfrentarse a problemas más complejos. Restringiendo nuestras consideraciones a la epidemiología del cáncer profesional, la mayoría de los factores de riesgo conocidos se han descubierto por los elevados niveles de exposición en el pasado, el número limitado de exposiciones en cada puesto de trabajo, las grandes poblaciones de trabajadores expuestos y una estrecha correspondencia entre la información sobre los anteriores "estimadores" y las exposiciones químicas ( $p$. ej., industria del calzado y benceno, astilleros y amianto, etc.). H oy en día, la situación es bastante diferente. Los niveles de exposición son considerablemente menores en los países occidentales (un hecho que debe tenerse siempre en cuenta); los trabajadores con puestos de trabajo similares se ven expuestos a numerosas sustancias químicas y mezclas diferentes (p. ej., agricultores); resulta más difícil encontrar poblaciones homogéneas de trabajadores expuestos y éstas suelen ser de pequeño tamaño, y la correspondencia entre la información sobre los "estimadores" y la exposición real es cada vez más débil. En este contexto, la sensibilidad de las herramientas epidemiológicas se reduce como consecuencia de la clasificación errónea de la exposición.

Por otra parte, la epidemiología se ha basado en variables de valoración "siniestras", como la muerte en la mayoría de los 
estudios de cohortes. Sin embargo, los trabajadores preferirían algo diferente a los "recuentos de cadáveres" cuando se estudian los efectos potenciales en la salud de las exposiciones profesionales. Por consiguiente, el uso de indicadores más directos de la exposición y de la respuesta inicial ofrecería algunas ventajas. Los marcadores biológicos pueden proporcionar justamente la herramienta necesaria.

\section{M arca dores biológicos}

El uso de marcadores biológicos, como los niveles hemáticos de plomo o las pruebas de la función hepática, no es una novedad en la epidemiología del trabajo. Sin embargo, la utilización de técnicas moleculares en los estudios epidemiológicos ha permitido el uso de biomarcadores para evaluar la exposición en los órganos diana, determinar la sensibilidad y establecer un diagnóstico precoz de las enfermedades.

Los posibles usos de los biomarcadores en el contexto de la epidemiología del trabajo son:

- evaluación de la exposición cuando las herramientas epidemiológicas tradicionales resultan insuficientes (particularmente en el caso de dosis y riesgos de pequeña magnitud)

- determinación del papel etiológico de sustancias o agentes químicos individuales en exposiciones múltiples o mixtas

- estimación de la carga total de la exposición a sustancias químicas con el mismo mecanismo de acción

- investigación de mecanismos patogenéticos

- estudio de la susceptibilidad individual (p. ej., polimorfismos metabólicos, reparación del ADN) (Vineis 1992)

- clasificación más exacta de la exposición y/ o la enfermedad, aumentando así la potencia estadística.

Estas aplicaciones han suscitado un gran entusiasmo en la comunidad científica pero, como ya se ha comentado antes, la complejidad metodológica del uso de estas nuevas "herramientas moleculares" debe precavernos contra un optimismo excesivo. L os biomarcadores de las exposiciones químicas (como aductos de ADN ) presentan algunas limitaciones:

1. En general reflejan exposiciones recientes y, por consiguiente, tienen un uso limitado en los estudios de casos y controles; en los estudios de cohortes, requieren muestreos repetidos durante largos períodos de tiempo.

2. Aunque tengan una elevada especificidad y reduzcan los errores de clasificación de la exposición, la interpretación de los resultados sigue siendo difícil.

3. Cuando se investigan exposiciones químicas complejas (p. ej., contaminación atmosférica o humo ambiental del tabaco), el biomarcador puede reflejar un componente particular de la mezcla que no es el mismo que produce el efecto biológico.

4. En muchas situaciones, no se sabe si el biomarcador refleja la exposición de interés, una variable correlacionada con la exposición de interés, la susceptibilidad individual o los primeros estadíos de la enfermedad, limitando así la inferencia etiológica.

5. El uso de la mayoría de los biomarcadores exige una prueba costosa, un procedimiento invasivo o ambas cosas, condicionando así el tamaño y la potencia estadística del estudio.

6. Un biomarcador de la exposición no es más que un sustituto del objetivo real de una investigación epidemiológica que, por regla general, se centra en una exposición ambiental evitable (T richopoulos 1995; Pearce y cols. 1995).

M ás importante incluso que las limitaciones metodológicas es el riesgo de que las técnicas moleculares desvíen nuestra atención de la identificación de riesgos en el medio ambiente exógeno, a la identificación de personas en situación de alto riesgo y, seguidamente, a la evaluación personalizada del riesgo midiendo el fenotipo, la carga de aductos y las mutaciones adquiridas. Como nos ha advertido M cM ichael, nuestra atención se centraría en una forma de evaluación clínica que poco tiene que ver con una evaluación propia de la epidemiología de la salud pública. El hecho de centrar nuestra atención en las personas podría distraernos del importante objetivo de salud pública: la creación de un medio ambiente menos peligroso (M CM ichael 1994).

El uso de biomarcadores plantea otras dos cuestiones importantes:

1. El uso de biomarcadores en la epidemiología del trabajo debe ir acompañado de una política clara en lo que se refiere al consentimiento del interesado. El trabajador puede tener distintas razones para negarse a cooperar. U na razón muy práctica es, por ejemplo, que la identificación de una alteración en un marcador dé la respuesta precoz, como el intercambio de cromátidas hermanas, implica la posibilidad de que dicho trabajador sea discriminado por las entidades aseguradoras y las empresas por su mayor propensión a la enfermedad. U na segunda razón hace referencia a la detección genética. Puesto que la distribución de los genotipos y fenotipos varía según el grupo étnico, las oportunidades profesionales para las minorías pueden verse perjudicadas por la detección genética. En tercer lugar, pueden existir dudas sobre la capacidad predictiva de las pruebas genéticas. El valor predictivo depende de la prevalencia de la enfermedad que la prueba intenta detectar, de manera que si la enfermedad es poco frecuente, el valor predictivo será pequeño y la utilidad de la prueba de detección será cuestionable. Hasta ahora, ninguna de las pruebas de detección genética se ha considerado aplicable en la práctica (A shford y cols. 1990).

2. Antes de utilizar los biomarcadores, deben establecerse los principios éticos. Un equipo de trabajo interdisciplinario de la O ficina Técnica de la Confederación Europea de Sindicatos, con el apoyo de la Comisión de las Comunidades Europeas (V an Damme y cols. 1995), ha evaluado estos principios en el caso de los biomarcadores utilizados para establecer la susceptibilidad individual a enfermedades. Su informe ha corroborado la opinión de que este tipo de pruebas deben realizarse sólo con la finalidad de prevenir enfermedades en la población activa. Entre otras consideraciones, estas pruebas no deben nunca utilizarse para:

- Seleccionar a los que tienen una mayor capacidad física para el trabajo;

- Evitar la adopción de medidas preventivas, como la identificación y eliminación de los factores de riesgo o la mejora de las condiciones en el lugar de trabajo.

- Crear, constatar o aumentar las desigualdades sociales.

- Aplicar en el lugar de trabajo unos principios éticos diferentes a los que deben defenderse en una sociedad democrática.

- O bligar a la persona que solicita empleo a revelar más datos personales que los estrictamente necesarios para conseguir el puesto de trabajo.

Finalmente, cada vez existen más evidencias sobre la considerable variación de la activación o inactivación metabólica de las sustancias peligrosas (y en particular de los cancerígenos) en las poblaciones humanas, dependiendo en parte de factores genéticos. Además, la variabilidad de la sensibilidad individual a los cancerígenos puede ser especialmente importante con pequeños niveles de exposición profesional y ambiental (Vineis y cols. 1994). Estas observaciones pueden influir mucho en las decisiones normativas que centran el proceso de evaluación de riesgos en los más susceptibles (V ineis y M artone 1995). 


\section{Diseño y validez de los estudios}

El artículo de Hernberg sobre los diseños de los estudios epidemiológicos y sus aplicaciones en la medicina del trabajo se centra en el concepto de la "base del estudio", definida como la morbilidad experimentada (con relación a alguna exposición) por una población cuando se realiza su seguimiento durante un cierto período de tiempo. Por consiguiente, la base del estudio no es sólo una población (es decir, un grupo de personas), sino la morbilidad experimentada por esa población durante un cierto período de tiempo (M iettinen 1985, Hernberg 1992). Si se adopta este concepto unificador de la base del estudio, es importante reconocer que los diferentes diseños de los estudios (p. ej., diseños de casos controles y cohortes) son simplemente formas diferentes de "recolectar" información sobre la exposición y la enfermedad a partir de la misma base del estudio; no son enfoques diametralmente diferentes.

En el artículo publicado por Sasco sobre la validez del diseño de un estudio, se define la confusión y se reconoce su importancia. Los investigadores que participan en un estudio de exposiciones profesionales deben considerar siempre la posible existencia de una confusión y nunca se hará hincapié suficiente en la necesidad de que la identificación de las posibles variables de confusión forme parte integral del diseño y análisis de cualquier estudio. En la epidemiología del trabajo, deben considerarse dos aspectos relacionados con la confusión:

1. Debe investigarse la posible existencia de una confusión negativa; por ejemplo, algunas poblaciones industriales pueden estar sometidas a un bajo nivel de exposición a factores de riesgo asociados al estilo de vida porque no se permite fumar en el lugar de trabajo; los sopladores de vidrio fuman menos que la población general.

2. Cuando se considera la confusión, tiene que estimarse su dirección y su posible repercusión, sobre todo cuando no se dispone de datos suficientes para controlarla. Por ejemplo, el tabaquismo es un importante factor de confusión que siempre debe tenerse en cuenta en la epidemiología del trabajo. Sin embargo, cuando no se dispone de datos sobre el consumo de tabaco (como suele ocurrir en los estudios de cohortes), es poco probable que el tabaco pueda explicar un aumento considerable del riesgo en un grupo profesional. Este problema se ha descrito con elegancia en un artículo de Axelson (1978) y se comenta más a fondo en otro de Greenland (1987). En los estudios que se han publicado con datos detallados sobre la profesión y el tabaquismo, este factor de confusión no parece distorsionar demasiado las estimaciones de la asociación entre cáncer de pulmón y profesión ( $V$ ineis y Simonato 1991). Es más, el hecho de que se sospeche la existencia de una confusión no siempre invalida las asociaciones. Por otra parte, los investigadores corren también el riesgo de extraer conclusiones erróneas por la existencia de sesgos de observación y selección que no se han detectado y, en consecuencia, éstos deben recibir la misma importancia que las posibles variables de confusión a la hora de diseñar un estudio (Stellman 1987).

El tiempo y las variables relacionadas con el tiempo, como la edad de riesgo, la fecha natural, el tiempo transcurrido desde la contratación, el tiempo transcurrido desde la primera exposición y la duración de la exposición, así como el tratamiento de estas variables en la etapa del análisis, son algunas de las cuestiones metodológicas más complejas en la epidemiología del trabajo, que no se abordan en este capítulo, aunque el lector puede remitirse a dos importantes y recientes referencias metodológicas (Pearce 1992; R obins y cols. 1992).

\section{Estadística}

El artículo sobre estadística de Biggeri y Braga y el título de este capítulo indican que los métodos estadísticos no pueden separarse de la investigación epidemiológica, y ello por dos motivos: (a) unos conocimientos adecuados de estadística pueden constituir una valiosa ayuda para diseñar correctamente una investigación y (b) la estadística y la epidemiología comparten un patrimonio común y toda la base cuantitativa de la epidemiología se fundamenta en la noción de probabilidad (Clayton 1992; Clayton y $\mathrm{H}$ ills 1993). En muchos de los restantes artículos de este capítulo, se evalúan evidencias empíricas y evidencias de relaciones causales hipotéticas utilizando argumentos probabilísticos y diseños adecuados de los estudios. Por ejemplo, se insiste en la necesidad de estimar el riesgo como medida de interés, como tasas o riesgos relativos, y de construir intervalos de confianza en torno a esos estimadores, en lugar de realizar pruebas estadísticas de probabilidad (Poole 1987; G ardner y Altman 1989; Greenland 1990). Se incluye una breve introducción al razonamiento estadístico utilizando la distribución binomial. La estadística debe ser la compañera inseparable del razonamiento científico. Pero no sirve de nada si una investigación no se diseña y desarrolla correctamente. Los estadísticos y epidemiólogos son conscientes de que la elección de los métodos determina el objeto de nuestras observaciones y la extensión de las mismas. Por consiguiente, la elección cuidadosa del diseño tiene una importancia crucial para garantizar la validez de las observaciones.

\section{Etica}

En el último artículo, escrito por Vineis, se plantean los aspectos éticos de la investigación epidemiológica. En esta introducción debemos recordar que la epidemiología es una disciplina que, por definición, está orientada a la prevención. Los aspectos éticos específicos relacionados con la protección de los trabajadores y la población en su conjunto exigen el reconocimiento de que:

- Los estudios epidemiológicos realizados en entornos profesionales no deben en ningún caso retrasar las medidas preventivas en el lugar de trabajo.

- La epidemiología del trabajo no estudia factores relacionados con el estilo de vida, sino situaciones en las que el trabajador poco o nada puede hacer para controlar la exposición. Esto implica un compromiso particular con la prevención eficaz y la divulgación inmediata de información a los trabajadores y a la opinión pública.

- La investigación descubre peligros para la salud y facilita los conocimientos necesarios para adoptar medidas preventivas. También deben considerarse los problemas éticos de no realizar una investigación cuando ésta es factible.

- La notificación a los trabajadores de los resultados de los estudios epidemiológicos es una cuestión tanto ética como metodológica en la comunicación de riesgos. L os estudios para evaluar la posible repercusión y eficacia de la notificación deben recibir una elevada prioridad (Schulte y cols. 1993).

\section{E nseñanza de la epidemiología del trabajo}

Los especialistas en epidemiología del trabajo pueden tener distintas trayectorias académicas. M edicina, enfermería y estadística son algunas de las disciplinas más frecuentes de los que se especializan en este campo. En N orteamérica, casi la mitad de los epidemiólogos han recibido formación científica, mientras que la otra mitad son doctores en medicina. En otros países, la mayoría de los especialistas en epidemiología del trabajo son médicos. En $\mathrm{N}$ orteamérica, los epidemiólogos que proceden del campo de la medicina se consideran "expertos en contenido", mientras que los que proceden del campo de las ciencias se consideran "expertos metodológicos". Siempre es conveniente que un 
experto en contenido trabaje en equipo con un experto metodológico para diseñar y realizar el mejor estudio posible.

La especialidad de la epidemiología del trabajo no sólo exige conocimientos sobre métodos epidemiológicos, estadística e informática, sino también sobre toxicología, higiene industrial y registros de enfermedades (M erletti y Comba 1992). En los grandes estudios, es posible que los datos tengan que cruzarse con registros de enfermedades, razón por la cual es útil conocer las fuentes de datos sobre la población. También son importantes los conocimientos sobre organización de la mano de obra y administración de empresas. Las tesis de los estudios de tercer ciclo y las disertaciones doctorales confieren a los alumnos los conocimientos necesarios para realizar grandes estudios basados en registros y en encuestas de los trabajadores.

\section{Proporción de una enfermedad atribuible a la profesión}

La proporción de una enfermedad que puede atribuirse a exposiciones profesionales, ya sea en un grupo de trabajadores expuestos o en la población general, se comenta, al menos en lo que se refiere al cáncer, en otra sección de esta Enciclopedia. Aquí debemos recordar que si se calcula un estimador, éste debe referirse a una enfermedad específica (y un lugar específico en el caso del cáncer), un período de tiempo específico y una región geográfica específica. Además, dicho estimador debe basarse en medidas exactas de la proporción de personas expuestas y del nivel de exposición. Esto significa que la proporción de una enfermedad imputable a una profesión variará de muy pequeña o nula en algunas poblaciones, a muy grande en otras situadas en zonas industriales en las que, por ejemplo, casi el $40 \%$ de los casos de cáncer de pulmón pueden atribuirse a exposiciones profesionales (V ineis y Simonato 1991). Las estimaciones que no se basan en un análisis detallado de estudios epidemiológicos correctamente diseñados pueden considerarse, en el mejor de los casos, como suposiciones informadas, cuyo valor es limitado.

\section{Transferencia de industrias peligrosas}

La mayoría de los estudios epidemiológicos se realizan en el mundo desarrollado, donde la legislación y el control de los peligros profesionales conocidos han reducido el riesgo de enfermedades en las últimas décadas. Pero al mismo tiempo muchas de las industrias peligrosas se han transferido al mundo en desarrollo (Jeyaratnam 1994). Sustancias químicas que se han prohibido en Estados U nidos o Europa se fabrican ahora en los países en desarrollo. Por ejemplo, la pulverización del amianto se ha transferido de Estados U nidos a M éxico y la producción de bencidina se ha transferido de los países europeos a la antigua Yugoslavia y a Corea (Simonato 1986; LaD ou 1991; Pearce y cols. 1994).

Un signo indirecto del nivel de riesgo profesional y de las malas condiciones de trabajo en los países en desarrollo es la epidemia de intoxicaciones agudas que está teniendo lugar en algunos de ellos. Según un estudio, todos los años se producen unas 20.000 muertes por intoxicación aguda con pesticidas, aunque es probable que esta cifra esté muy subestimada (K ogevinas y cols. 1994). Se cree que el $99 \%$ de todas las muertes por intoxicación aguda con pesticidas se producen en países en desarrollo que tan sólo consumen el $20 \%$ de las sustancias agroquímicas del mundo (K ogevinas y cols. 1994). Esto significa que la reducción de los riesgos profesionales que sugieren las investigaciones epidemiológicas podría deberse simplemente al hecho de que la mayoría de las investigaciones se realizan en el mundo desarrollado. Es posible que los riesgos profesionales hayan sido transferidos a los países en desarrollo o incluso que la carga mundial total de exposiciones profesionales haya aumentado (Vineis y cols. 1995).

\section{E pidemiología veterinaria}

Por razones obvias, la epidemiología veterinaria no está directamente relacionada con la higiene industrial ni con la epidemiología del trabajo. No obstante, los estudios epidemiológicos en animales pueden proporcionar claves sobre las causas ambientales y profesionales de las enfermedades por varias razones:

1. El período de vida de los animales es relativamente corto en comparación con el del ser humano y el período de latencia de las enfermedades (p. ej., la mayoría de los cánceres) es más corto en los animales que en el hombre. Esto significa que una enfermedad que aparece en un animal salvaje o doméstico puede servir como episodio centinela para alertarnos de la presencia de un agente ambiental potencialmente tóxico 0 cancerígeno para el ser humano antes de que se haya identificado por otros medios (G lickman 1993).

2. Los marcadores de las exposiciones, como los aductos de hemoglobina o el nivel de absorción y excreción de toxinas, pueden medirse en animales salvajes o domésticos para evaluar la contaminación ambiental de fuentes industriales (Blondin y V iau 1992; R eynolds y cols. 1994; H ungerford y cols. 1995).

3. Los animales no están expuestos a ciertos factores que pueden confundir los estudios en poblaciones humanas y, por tanto, las investigaciones en poblaciones animales pueden realizarse sin tener en cuenta esos posible factores de confusión. Por ejemplo, un estudio del cáncer de pulmón en perros podría detectar una importante asociación entre la enfermedad y la exposición al amianto (supongamos que por la profesión de sus amos, relacionada con el amianto, o su proximidad a fuentes industriales de amianto). Claramente, este tipo de estudio eliminaría el efecto de confusión del tabaquismo activo.

Los veterinarios hablan de una revolución epidemiológica en la medicina veterinaria (Schwabe 1993) y ya se han publicado varios libros de texto sobre esta disciplina (Thrusfield 1986; $M$ artin y cols. 1987). Es cierto que la identificación de muchos peligros ambientales y profesionales ha sido el resultado de los esfuerzos conjuntos de los epidemiólogos especializados en poblaciones humanas y animales. Entre otras importantes contribuciones, destaca el efecto de los fenoxiherbicidas en ovejas y perros (Newell y cols. 1984; Hayes y cols. 1990), así como el efecto de los campos magnéticos (R eif y cols. 1995) y de los pesticidas (principalmente pulguicidas) contaminados con compuestos similares al amianto en perros (G lickman y cols. 1983).

\section{Participación en la investigación, divulgación de los resultados y prevención}

Es importante reconocer que muchos estudios epidemiológicos en el campo de la higiene industrial se inician como consecuencia de los problemas y preocupaciones de los propios trabajadores (Olsen y cols. 1991). En numerosas ocasiones, los trabajadores - expuestos en el pasado o en el presente- conocen la existencia de un problema antes de que sea confirmado por los investigadores. La epidemiología del trabajo puede enfocarse como una manera de "explicar" los problemas experimentados por los trabajadores, de recoger y agrupar sistemáticamente los datos y de realizar inferencias sobre las causas profesionales de sus problemas de salud. Por otra parte, los propios trabajadores, sus representantes y los responsables de su salud son las personas más adecuadas para interpretar los datos recogidos. Por consiguiente, siempre deben participar activamente en cualquier investigación que se realice en un lugar de trabajo. Sólo su participación directa podrá garantizar que el lugar de trabajo siga siendo un lugar seguro cuando los investigadores lo hayan abandonado. La finalidad de un estudio es utilizar sus resultados para la prevención de enfermedades y discapacidades y su éxito depende en 
gran medida de que los trabajadores expuestos participen en la obtención e interpretación de los resultados. La importancia y el uso de los resultados de una investigación en un proceso de reclamación de indemnización para un trabajador que haya sufrido daños como consecuencia de exposiciones en el lugar de trabajo queda fuera del ámbito de este capítulo. El lector que desee profundizar en este tema puede remitirse a otros autores (Soskolne, Lilienfeld y Black 1994).

En algunos lugares, los enfoques participativos para asegurar que se realicen investigaciones epidemiológicas en el lugar de trabajo se han convertido en la práctica habitual, pudiendo adoptar la forma de comités que supervisan las investigaciones de principio a fin. Estos comités están constituidos por representantes de los trabajadores, la dirección y/ o el gobierno. Cuando los representantes de todos los grupos interesados participan en el proceso de investigación, la divulgación de los resultados puede realizarse con mayor eficacia y credibilidad, al ser "uno de los suyos" quien supervisa la investigación y presenta los resultados a sus propios compañeros. De esta forma, es probable que se consiga el máximo nivel de prevención eficaz.

Este y otros enfoques participativos en la investigación de la salud en el trabajo se acometen con la participación de los que experimentan o se ven afectados de alguna manera por el problema relacionado con la exposición de interés y deberían ser cada vez más frecuentes en todos los estudios epidemiológicos (L aurell y cols. 1992). Conviene recordar que, aunque el objetivo del análisis en los estudios epidemiológicos es estimar la magnitud y la distribución del riesgo, la investigación participativa tiene también como finalidad la prevención del riesgo (Loewenson y Biocca 1995). Esta complementariedad de la epidemiología y la prevención eficaz forma parte del mensaje que se pretende transmitir en esta E nciclopedia y en este capítulo.

\section{M antener la perspectiva de la salud pública}

Aunque los avances en la metodología epidemiológica, en el análisis de los datos y en la evaluación y medición de la exposición (como las nuevas técnicas biológicas moleculares) son importantes y positivos, pueden también contribuir al enfoque reduccionista, más centrado en los individuos que en las poblaciones. Se ha dicho que:

(...) la epidemiología ha dejado en gran medida de formar parte de un enfoque interdisciplinario para conocer las causas de las enfermedades en las poblaciones y se ha convertido en un conjunto de métodos genéricos para medir asociaciones entre exposiciones y enfermedades en individuos... En la actualidad, se descuidan los factores sociales, económicos, culturales, históricos, políticos y otros factores de la población como importantes causas de enfermedades... La epidemiología debe volver a integrarse en la salud pública y debe redescubrir la perspectiva de la población (Pearce 1996).

Los epidemiólogos del trabajo y del medio ambiente tienen que desempeñar un papel importante, no sólo para desarrollar nuevos métodos y aplicaciones epidemiológicos, sino también para asegurar que dichos métodos se integren siempre en la perspectiva adecuada de la población.

\section{- EVALUACION De LA EXPOSICION}

\section{M, Gerald Ott}

La evaluación de la exposición es una etapa fundamental en la identificación de los peligros en el lugar de trabajo mediante la investigación epidemiológica. El proceso de evaluación de la exposición puede subdividirse en una serie de actividades, entre ellas las siguientes:

1. Compilación de un inventario de agentes y mezclas potencialmente tóxicos presentes en el medio ambiente de trabajo estudiado.

2. Determinación de cómo tienen lugar las exposiciones y qué probabilidad hay de que varíen entre los trabajadores.

3. Selección de medidas o índices adecuados para cuantificar las exposiciones.

4. R ecogida de datos que permitan asignar a los participantes del estudio valores de exposición cualitativos o cuantitativos para cada medida. Siempre que sea posible, estas actividades deben realizarse bajo la dirección de un higienista industrial cualificado.

L os estudios de higiene industrial suelen ser objeto de críticas referentes a la deficiente evaluación de las exposiciones. Estas deficiencias pueden tener como resultado una clasificación errónea diferencial o no diferencial de la exposición y el consiguiente sesgo o pérdida de precisión en los análisis de la relación entre exposición y efecto. Los esfuerzos que se están realizando para mejorar la situación se reflejan en las conferencias internacionales celebradas recientemente y en los textos dedicados a este tema (ACGIH 1991; Armstrong y cols. 1992; Proceedings of the $C$ onference on Retrospective A ssessment of $O$ ccupational Exposures in Epidemiology 1995). Los avances técnicos están creando nuevas oportunidades para mejorar la evaluación de la exposición. Entre estos avances figuran las mejoras en los instrumentos analíticos, un mayor conocimiento de los procesos farmacocinéticos y el descubrimiento de nuevos biomarcadores de la exposición. Debido a que los estudios de la salud en el trabajo dependen con frecuencia de datos históricos sobre la exposición, con respecto a la cual no se emprendió ningún control específico, la necesidad de una evaluación retrospectiva de la exposición añade una nueva dimensión a la complejidad de estos estudios. Sin embargo, las evaluaciones y la fiabilidad de las mismas siguen mejorando (Siemiatycki y cols. 1986). La validación de las evaluaciones prospectivas de la exposición plantea lógicamente menos problemas.

El término exposición se refiere a la concentración de un agente en la frontera entre el individuo y el medio ambiente. En general, se presume que hay exposición cuando se sabe que un agente está presente en el medio ambiente de trabajo y existe una expectativa razonable de que el trabajador esté en contacto con dicho agente. La exposición puede expresarse en concentración media ponderada en el tiempo (TWA) durante un período de 8 horas, que es una medida de la intensidad de la exposición promediada durante un turno de trabajo de 8 horas. La concentración pico es la concentración promediada durante un período de tiempo más corto, por ejemplo, 15 minutos. La exposición acumulada es el producto de la intensidad media y la duración de la exposición (p. ej., una concentración T WA durante 8 horas multiplicada por los años que el trabajador ha estado expuesto a esa concentración media). Dependiendo de la naturaleza del estudio y de los efectos de interés sobre la salud, será conveniente evaluar la concentración pico, la concentración media, la exposición acumulada o la exposición diferida.

Por el contrario, la dosis se refiere al depósito o absorción de un agente por unidad de tiempo. La dosis o ingesta diaria de un agente puede estimarse combinando los datos de las mediciones ambientales con hipótesis tipificadas sobre otros factores, como la frecuencia respiratoria o la penetración dérmica. 0 tra alternativa consiste en estimar la dosis basándose en los datos del control biológico. Lo ideal es medir la dosis en el órgano diana de interés. 
Los factores más importantes en la evaluación de la exposición son:

1. Identificación de los agentes relevantes.

2. Determinación de su presencia y de sus concentraciones en los medios ambientales oportunos (p. ej., atmósfera, superficies de contacto).

3. Evaluación de las vías probables de entrada (inhalación, absorción por la piel, ingestión), la evolución de la exposición con el tiempo (variación diaria) y la duración acumulada de la exposición expresada en semanas, meses 0 años.

4. Evaluación de la eficacia de los controles técnicos y personales (p. ej., uso de prendas de protección y respiradores que pueden reducir las exposiciones) y, por último.

5. Características personales y otras consideraciones que pueden modular las concentraciones en el órgano diana.

Estas consideraciones incluyen el nivel de actividad física en el trabajo y el estado de salud previo de los trabajadores. La atención a la evaluación de la exposición a agentes que persisten en el medio ambiente 0 que tienden a acumularse en el organismo (p. ej., ciertos metales, radionúclidos o compuestos orgánicos estables) debe recibir una atención especial. Las concentraciones de estos materiales en el organismo pueden aumentar de manera perniciosa incluso con concentraciones ambientales aparentemente bajas.

Aunque la situación puede ser bastante compleja, con frecuencia no lo es. M uchas de las valiosas contribuciones a la identificación de peligros profesionales han sido realizadas por estudios en los que simplemente se ha utilizado el sentido común para evaluar la exposición. Las fuentes de información que pueden ser útiles para identificar y categorizar las exposiciones son:

1. Encuestas a los trabajadores.

2. Registros del personal y de la producción (registros del trabajo, descripción de los puestos de trabajo, historias de las instalaciones y de los procesos e inventarios químicos).

3. O pinión de los expertos.

4. R egistros de higiene industrial (muestras de área, personal y superficies, vigilancia para asegurar el cumplimiento de las normas, informes detallados de encuestas y peligros para la salud).

5. Encuestas con trabajadores veteranos o jubilados.

6. Datos del control biológico.

La descripción más detallada posible de las exposiciones individuales ofrece una serie de ventajas. Es evidente que la probabilidad de éxito de un estudio aumentará en la medida en que las exposiciones de interés se describan correctamente. En segundo lugar, la credibilidad de los resultados aumenta cuando se controla mejor la posibilidad de confusión. Por ejemplo, los controles y los casos expuestos difieren en su situación de exposición, pero pueden diferir también en otros factores, medidos 0 no, que expliquen la enfermedad de interés. Sin embargo, cuando puede establecerse un gradiente de exposición en la población del estudio, es menos probable que persista el mismo grado de confusión en los subgrupos expuestos, reforzando así los resultados globales del estudio.

\section{Matrices de empleo-exposición}

U no de los enfoques más prácticos y utilizados para la evaluación de la exposición consiste en estimar indirectamente las exposiciones basándose en la descripción de los puestos de trabajo. Las matrices de empleo-exposición pueden ser muy útiles cuando se dispone de historias laborales completas y existe una constancia razonable tanto en las tareas como en las exposiciones asociadas a los puestos de trabajo investigados. A mayor escala, se han establecido grupos estándar de sectores industriales y puestos de trabajo partiendo de los datos del censo recogidos de forma rutinaria o de los datos profesionales recogidos en los certificados de defunción. L amentablemente, la información que se mantiene en estos grandes sistemas de registro suele limitarse a la profesión "actual" o "habitual". Además, estos grupos estándar no tienen en cuenta las condiciones presentes en lugares de trabajo específicos, razón por la cual tienen casi siempre que considerarse estimadores aproximados de la exposición.

Por lo que respecta a los estudios de casos y controles que se realizan fuera del lugar de trabajo utilizando los registros existentes, puede conseguirse una evaluación detallada de la exposición recurriendo a la opinión de expertos para convertir los datos de las historias laborales obtenidos mediante encuestas personales en evaluaciones semicuantitativas de las exposiciones probables a agentes concretos (Siemiatycki y cols. 1986). Para la evaluación de la exposición, puede solicitarse la ayuda de expertos como químicos e higienistas industriales, por sus conocimientos y su familiaridad con los distintos procesos industriales. Combinando los datos detallados del cuestionario con los conocimientos sobre los procesos industriales, este enfoque ha permitido caracterizar diferencias de exposición en los lugares de trabajo.

Las matrices de empleo-exposición se han utilizado también con éxito en estudios de una empresa o un sector industrial específico (Gamble y Spirtas 1976). Las empresas suelen conservar en sus archivos de personal las historias laborales de cada trabajador (una lista cronológica de los departamentos o puestos de trabajo de cada trabajador a lo largo de toda su vida profesional), que permiten conocer la historia laboral completa de los trabajadores desde que trabajaban en ese lugar. Estos datos pueden ampliarse mediante encuestas personales de los participantes en el estudio. El siguiente paso consiste en realizar un inventario de todas las descripciones de puestos de trabajo y designaciones de departamentos 0 áreas de trabajo durante el período del estudio. Esta lista puede llegar fácilmente a contener cientos o miles de entradas en las grandes fábricas con procesos múltiples o en distintas empresas dentro de un mismo sector de la industria, cuando incluye todos los puestos de trabajo relacionados con la producción, el mantenimiento, la investigación, la ingeniería, los servicios de apoyo y la administración que han existido a lo largo del tiempo (con frecuencia durante varias décadas), y si se consideran los cambios en los procesos industriales. La consolidación de los datos puede facilitarse mediante la creación de un archivo informatizado de todas las historias laborales y utilizando rutinas de edición para unificar la terminología de la descripción de los puestos de trabajo. L os puestos de trabajo que ocasionan exposiciones relativamente homogéneas pueden combinarse para simplificar el proceso de vincular las exposiciones a puestos de trabajo concretos. Sin embargo, la agrupación de puestos de trabajo y lugares de trabajo debe respaldarse, siempre que sea posible, con datos de mediciones recogidos utilizando una estrategia de muestreo adecuada.

Incluso cuando las historias laborales están informatizadas, el establecimiento de vínculos retrospectivos entre los datos sobre la exposición y los trabajadores puede ser una tarea difícil. Con toda seguridad, las condiciones del lugar de trabajo habrán cambiado a medida que haya cambiado la tecnología, la demanda de productos y la legislación. En muchas industrias pueden producirse también cambios en las formulaciones de los productos y en las pautas estacionales de producción. Aunque es posible que se mantengan registros permanentes de algunos de estos cambios, es menos probable que se conserven registros sobre los cambios estacionales y otros cambios marginales en los procesos y la producción. Por otra parte, los trabajadores 
pueden haber recibido formación para realizar trabajos múltiples y rotar entre distintos puestos de trabajo en función de la demanda de productos. Todas estas circunstancias aumentan la complejidad de los perfiles de exposición de los trabajadores. No obstante, existen también lugares de trabajo que han permanecido relativamente invariables durante muchos años. En el análisis final, cada lugar de trabajo debe evaluarse considerando sus circunstancias particulares.

En última instancia, tendrá que resumirse la historia de las exposiciones de cada trabajador a lo largo de toda su vida laboral. Se ha demostrado que la manera de resumir dichas historias tiene una influencia considerable en las medidas finales del riesgo de exposición-efecto (Suárez-Almazor y cols 1992), razón por la cual debe seleccionarse con gran precaución la medida más adecuada para resumir la exposición.

\section{Higiene industrial: mediciones ambientales}

El control de las exposiciones en el trabajo es una actividad continua fundamental para la protección de la salud de los trabajadores. Por consiguiente, es posible que ya existan registros de higiene industrial en el momento de planificar un estudio epidemiológico. En tal caso, los datos deben analizarse para determinar en qué medida abarcan a toda la población de interés, qué período de tiempo cubren y con qué facilidad pueden relacionarse las mediciones con puestos de trabajo, áreas de trabajo y personas. Estas consideraciones servirán de ayuda tanto para evaluar la viabilidad del estudio epidemiológico como para identificar lagunas en los datos que pueden subsanarse con un muestreo adicional de la exposición.

La cuestión de cómo relacionar mejor los datos de las mediciones con puestos de trabajo y personas concretas tiene una especial importancia. La toma de muestras de áreas y zonas de respiración puede ser útil para que los higienistas industriales identifiquen las fuentes de emisión y adopten las medidas correctoras oportunas, pero su utilidad será menor para caracterizar las exposiciones reales de los trabajadores, a no ser que se hayan realizado estudios minuciosos en el tiempo de las actividades laborales de los trabajadores. Por ejemplo, la vigilancia continua de un área puede detectar exposiciones muy altas en ciertos momentos del día, pero no indica si los trabajadores se encontraban o no en ese área de trabajo en ese momento.

Los datos obtenidos de las muestras per sonales suelen proporcionar estimaciones más exactas de las exposiciones de los trabajadores siempre que la muestra seleccionada sea representativa, se tenga debidamente en cuenta el uso de prendas personales de protección y las condiciones de los procesos y las tareas de los puestos de trabajo se mantengan relativamente constantes de un día a otro. Las muestras personales pueden relacionarse directamente con trabajadores concretos mediante el uso de identificadores personales. Estos datos pueden generalizarse a otros empleados que ocupan el mismo puesto de trabajo o a otros períodos de tiempo. Sin embargo, Rappaport y cols. (1993), basándose en su propia experiencia, han advertido que las concentraciones de la exposición pueden variar mucho incluso entre trabajadores asignados a grupos de exposición considerados homogéneos. También en este caso tendrá que recurrirse a la opinión de los expertos para decidir si puede presumirse la homogeneidad de los grupos de exposición.

Los investigadores han combinado con éxito las matrices de puestos de trabajo y exposiciones con la utilización de los datos de las mediciones ambientales para estimar las exposiciones en de las celdas de la matriz. Si existen lagunas en los datos de las mediciones, éstas pueden llenarse mediante el uso de modelos de exposición. Para ello, será en general necesario desarrollar un modelo que relacione las concentraciones ambientales con otros determinantes de las concentraciones de la exposición que sean más fáciles de evaluar (p. ej., volúmenes de producción, características físicas de las instalaciones, como uso de sistemas de ventilación aspirante, volatilidad del agente y naturaleza de la actividad laboral). EI modelo se construye para entornos laborales con concentraciones ambientales conocidas y, a continuación, se utiliza para estimar concentraciones en entornos laborales similares en los que no se han realizado mediciones, pero sobre los que se dispone de información acerca de parámetros como ingredientes y volúmenes de producción. Este enfoque puede ser particularmente útil para la estimación retrospectiva de las exposiciones.

O tra importante cuestión relacionada con la evaluación es el tratamiento de la exposición a mezclas. En primer lugar, desde un punto de vista analítico, las técnicas disponibles no siempre son capaces de detectar por separado compuestos químicamente relacionados y eliminar las interferencias causadas por otras sustancias presentes en la muestra. Por consiguiente, tienen que evaluarse las limitaciones de los procedimientos analíticos utilizados para obtener los datos de las mediciones y modificar en consecuencia los objetivos del estudio. En segundo lugar, puede ocurrir que algunos agentes se utilicen casi siempre conjuntamente y, por consiguiente, que estén presentes más o menos en las mismas proporciones relativas en todo el medio ambiente de trabajo estudiado. En esta situación, los análisis estadísticos internos per se no servirán para saber si los efectos se deben a uno u otro agente 0 a una combinación de ambos. Este tipo de juicios sólo podrán emitirse una vez revisados otros estudios realizados en lugares que no están expuestos a las mismas mezclas de agentes. Finalmente, cuando unos materiales se sustituyen por otros dependiendo de las especificaciones del producto (p. ej., utilización de diferentes colorantes para obtener los contrastes de color deseados), puede que sea imposible atribuir efectos a un agente específico.

\section{Control biológico}

Los biomarcadores son alteraciones moleculares, bioquímicas 0 celulares que pueden medirse en medios biológicos como tejidos, células o fluidos corporales del ser humano. U na importante razón para desarrollar biomarcadores de la exposición es obtener una estimación de la dosis interna de un determinado agente. Este enfoque es especialmente útil cuando es posible que existan múltiples vías de exposición (p. ej., inhalación y absorción de la piel), cuando se utilizan prendas de protección de manera intermitente o cuando las condiciones de la exposición son imprevisibles. El control biológico puede ser especialmente útil cuando se sabe que los agentes de interés tienen una vida media biológica relativamente largas. Desde el punto de vista estadístico, las ventajas del control biológico frente al control ambiental pueden observarse hasta con agentes que tienen una vida media de tan sólo diez horas, dependiendo del grado de variabilidad ambiental (D roz y Wu 1991). La larga vida media de materiales como las dioxinas cloradas (medidas en años) convierten a estos compuestos en candidatos ideales para el control biológico. Al igual que con los métodos analíticos para la medición de las concentraciones atmosféricas, deben tenerse en cuenta las posibles interferencias. Por ejemplo, antes de utilizar un determinado metabolito como biomarcador, debe determinarse si otras sustancias comunes, como las contenidas en ciertas medicaciones 0 en el humo del tabaco, podrían metabolizarse para formar ese mismo metabolito. En general, el uso del control biológico para la evaluación de la exposición exige conocimientos básicos de farmacocinética.

Las mediciones suelen realizarse en el aire exhalado, la orina y la sangre. Las muestras de aire exhalado son útiles para 
caracterizar exposiciones elevadas y de corta duración a disolventes que se han producido unos minutos 0 unas horas antes del momento de recoger la muestra. Las muestras de orina suelen recogerse para determinar las velocidades de excreción de los metabolitos del compuesto de interés. Las muestras de sangre pueden recogerse para la medición directa del compuesto, para la medición de metabolitos o para la determinación de aductos de ADN o proteínas (p. ej., aductos de albúmina o hemoglobina, y aductos de ADN en los linfocitos circulantes). También pueden tomarse muestras de las células de tejidos accesibles, como las células epiteliales de la zona bucal, para identificar aductos de ADN.

La determinación de la actividad de la colinesterasa en los hematíes y en el plasma constituye un ejemplo del uso de alteraciones bioquímicas para medir la exposición. Los pesticidas organofosforados inhiben la actividad de la colinesterasa y, por consiguiente, la medición de esta actividad antes y después de una exposición probable a estos compuestos puede ser un indicador útil de la intensidad de la exposición. Sin embargo, a medida que se progresa a lo largo del espectro de alteraciones biológicas, se hace cada vez más difícil distinguir entre biomarcadores de la exposición y del efecto. En general, las medidas del efecto no suelen ser específicas de la sustancia de interés, motivo por el cual en algunas ocasiones se tienen que descartar otras posibles explicaciones del efecto para justificar el uso de ese parámetro como medida de la exposición. Las medidas de la exposición deben estar directamente relacionadas con el agente de interés o deben constituir una base adecuada para relacionar una medida indirecta con el agente. A pesar de estos requisitos, el control biológico ofrece un gran potencial para mejorar la evaluación de la exposición en los estudios epidemiológicos.

\section{Conclusiones}

Para realizar comparaciones en los estudios de epidemiología del trabajo, se necesita un grupo de trabajadores expuestos y un grupo de trabajadores no expuestos. Este tipo de distinciones son aproximadas, pero pueden ayudar a identificar las áreas problemáticas. Sin embargo, cuanto más refinada sea la medida de la exposición, más útil será el estudio desde el punto de vista de su capacidad para identificar y desarrollar programas de intervención orientados al objetivo adecuado.

\section{- MEDIDAS QUE RESUMEN LA EXPOSICION DURANTE TODA UNA VIDA LABORAL}

\section{Colin L. Soskolne}

Los investigadores pueden considerarse afortunados cuando tienen a su disposición una cronología detallada de las experiencias de los trabajadores durante toda su vida laboral, que les ofrece una revisión histórica de los puestos de trabajo que han ocupado a lo largo de su vida. Para estos trabajadores, puede crearse una matriz de empleo-exposición, que permite asociar todos los puestos de trabajo que ha ocupado un trabajador con información específica sobre la exposición.

Las historias detalladas de la exposición deben resumirse con fines analíticos para detectar pautas evidentes que podrían causar problemas de salud y seguridad en el lugar de trabajo. Podemos imaginar una lista de, por ejemplo, 20 puestos de trabajo que un trabajador ha ocupado a lo largo de toda su vida profesional. Existen varias formas de resumir los datos sobre la exposición (para cada uno de los 20 puestos de trabajo en este ejemplo) teniendo en cuenta la duración y/ o la concentración, dosis o nivel de exposición.

Sin embargo, conviene recordar que las conclusiones de un estudio pueden ser diferentes según el método elegido (SuárezAlmazor y cols. 1992). En la Tabla 28.1, se ofrece el ejemplo de cinco medidas que resumen la exposición a lo largo de toda la vida profesional de un trabajador.

Indice de exposición acumulada. EI índice de exposición acumulada es equivalente a la "dosis" en los estudios toxicológicos y representa la suma, durante toda una vida laboral, de los productos de la dosis y la duración de la exposición en cada uno de los sucesivos puestos de trabajo. El tiempo se incluye entre sus unidades.

D osis media. La dosis media es la suma de los productos de la dosis y la duración de la exposición en cada uno de los sucesivos puestos de trabajo (p. ej., es decir, el índice de exposición acumulada) dividida por el tiempo total de exposición a cualquier dosis mayor de cero. La dosis media no incluye el tiempo entre sus unidades; esa medida será similar para una persona expuesta durante un largo período a una dosis pequeña que para una persona expuesta durante un corto período a una dosis elevada. Si se utiliza un diseño de casos y controles emparejados, la dosis media corresponde a la dosis media de exposición por unidad de tiempo de exposición. Se trata de una dosis media durante todo el tiempo real de exposición al agente considerado.

D osis máxima. La dosis máxima se determina analizando la historia laboral de un trabajador para determinar la dosis máxima de exposición a la que ha estado expuesto dicho trabajador durante al menos 7 días seguidos durante el período de observación. La dosis máxima podría representar de manera incorrecta la exposición durante toda la vida laboral de una persona, porque su cálculo se basa en un procedimiento de maximización en lugar de promediación y, por consiguiente, no incluye entre sus unidades la duración de la exposición.

D osis media ponderada en el tiempo. La dosis media ponderada en el tiempo es el índice de exposición acumulada dividido por el tiempo total de empleo. En cualquier diseño de casos y controles emparejados, este valor corresponde a la dosis media durante el tiempo total de empleo. Es diferente a la dosis media, ya que ésta corresponde a la media sólo durante el tiempo total de exposición real. Por consiguiente, la dosis media ponderada en el tiempo puede considerarse como una exposición media por

Tabla 28.1 • Fórmulas y dimensiones o unidades de las cinco medidas que resumen la exposición durante toda una vida laboral.

\begin{tabular}{|c|c|c|}
\hline $\begin{array}{l}\text { Medida de la } \\
\text { exposición }\end{array}$ & Fórmula & $\begin{array}{l}\text { Dimensiones/ } \\
\text { Unidades }\end{array}$ \\
\hline $\begin{array}{l}\text { Indice de exposición } \\
\text { acumulada }\end{array}$ & $\Sigma$ (dosis $\times$ tiempo de exposición) & dosis y tiempo \\
\hline Dosis media & $\begin{array}{l}\Sigma(\text { dosis } \times \text { tiempo de } \\
\text { exposición) / tiempo total } \\
\text { de exposición }\end{array}$ & dosis \\
\hline Dosis máxima & $\begin{array}{l}\text { dosis máxima de exposición } \\
\text { durante } \geq 7 \text { días }\end{array}$ & dosis \\
\hline $\begin{array}{l}\text { Dosis media ponderada } \\
\text { en el tiempo }\end{array}$ & $\begin{array}{l}\Sigma \text { (dosis } \times \text { tiempo de } \\
\text { exposición) / tiempo total } \\
\text { de empleo }\end{array}$ & dosis \\
\hline $\begin{array}{l}\text { Tiempo total de } \\
\text { exposición }\end{array}$ & $\Sigma$ tiempo de exposición & tiempo \\
\hline
\end{tabular}

Adaptado de Suarez-Almazor y cols. 1992. 
unidad de tiempo durante todo el período de empleo con independencia de la exposición per se.

T iempo total de la exposición. El tiempo total de exposición es la suma de todos los períodos de tiempo asociados con la exposición y se expresa en unidades de tiempo. Esta medida resulta atractiva por su simplicidad. Sin embargo, los efectos en la salud deben relacionarse, no sólo con la duración de la exposición química, sino también con la intensidad de dicha exposición (concentración o dosis, por ejemplo).

Es evidente que la utilidad de una medida para resumir la exposición depende del peso que asigne a la duración de la exposición, al nivel de exposición o a ambas. Por consiguiente, diferentes medidas pueden producir diferentes resultados (Walker y Blettner 1985). Lo ideal es que la medida seleccionada se base en un conjunto de hipótesis justificables en relación con el mecanismo biológico postulado sobre la asociación del agente o la enfermedad objeto del estudio (Smith 1987). Sin embargo, este procedimiento no siempre es posible. Muchas veces se desconoce el efecto biológico de la duración de la exposición o la concentración del agente estudiado. En este contexto, el uso de diferentes medidas de la exposición puede ser útil para sugerir un mecanismo por el cual la exposición ejerce su efecto.

Cuando no existen modelos contrastados para evaluar la exposición, se recomienda utilizar distintas medidas de la exposición acumulada durante toda la vida laboral para estimar el riesgo. Este enfoque facilitará la comparación de los resultados obtenidos por distintos estudios.

\section{- MEDICION DEL EFECTO DE UNA EXPOSICION}

Shelia H oar Zahm

La epidemiología mide la aparición de enfermedades y cuantifica las asociaciones entre enfermedades y exposiciones.

\section{Medidas de la aparición de enfermedades}

La aparición de enfermedades puede medirse con frecuencias (recuentos), pero se describe mejor con tasas, que constan de tres elementos: el número de personas afectadas (numerador), el número de miembros de la población fuente o basal (es decir, la población en situación de riesgo) de la que proceden las personas afectadas, y el período de tiempo abarcado. EI denominador de la tasa es el total de personas-tiempo experimentado por la población fuente. Las tasas permiten realizar comparaciones más útiles que los recuentos entre poblaciones de diferentes tamaños. EI riesgo, la probabilidad de que una persona desarrolle una enfermedad en un determinado plazo de tiempo, es una proporción que varía entre 0 y 1 y no es una tasa per se. La tasa de ataque, la proporción de miembros de una población que se ven afectados durante un período de tiempo específico, es técnicamente una medida del riesgo, no una tasa.

La morbilidad específica por enfermedades incluye la incidencia, que corresponde al número de nuevas personas en las que se diagnostica la enfermedad de interés. La prevalencia se refiere al número de casos existentes y la mortalidad, al número de personas que fallecen.

La incidencia se define como el número de nuevos casos diagnosticados durante un período de tiempo específico, mientras que la tasa de incidencia es ese número dividido por el total de personas-tiempo en la población fuente (Tabla 28.2). En el caso del cáncer, las tasas suelen expresarse como tasas anuales por 100.000 personas. Las tasas de otras enfermedades comunes pueden expresarse para un menor número de personas. Por
Tabla 28.2 - Medidas de la aparición de enfermedades: población hipotética observada durante un período de cinco años.

\begin{tabular}{|c|c|}
\hline Nuevos casos diagnosticados & 10 \\
\hline $\begin{array}{l}\text { Casos vivos previamente } \\
\text { diagnosticados }\end{array}$ & 12 \\
\hline Fallecidos, todas las causas* & 5 \\
\hline $\begin{array}{l}\text { Fallecidos, enfermedad de } \\
\text { interés }\end{array}$ & 3 \\
\hline Personas en la población & 100 \\
\hline Años observados & 5 \\
\hline Incidencia & 10 personas \\
\hline Tasa anual de incidencia & $\frac{10 \text { personas }}{100 \text { personas } \times 5 \text { años }}=2.000 / 100.000$ por año \\
\hline $\begin{array}{l}\text { Prevalencia instantánea } \\
\text { (al final del quinto año) }\end{array}$ & $(10+12-3)=19$ personas \\
\hline $\begin{array}{l}\text { Prevalencia durante un } \\
\text { período (cinco años) }\end{array}$ & $(10+12)=22$ personas \\
\hline Tasa anual de muerte & $\frac{5 \text { personas }}{100 \text { personas } \times 5 \text { años }}=1.000 / 100.000$ por año \\
\hline Tasa anual de mortalidad & $\frac{3 \text { personas }}{100 \text { personas } \times 5 \text { años }}=600 / 100.000$ por año \\
\hline
\end{tabular}

* Para simplificar los cálculos, en este ejemplo se supone que todos los fallecimientos se producen al final del período de cinco años, de manera que las 100 personas de la población vivieron durante todo ese período.

ejemplo, las tasas de defectos congénitos suelen expresarse por 1.000 nacidos vivos. La incidencia acumulada, la proporción de personas que se convierten en casos durante un cierto período de tiempo, es una medida del riesgo medio de una población.

La prevalencia puede ser prevalencia instantánea, el número de casos de una enfermedad en un determinado punto en el tiempo, y la prevalencia durante un período, el número total de casos de una enfermedad que se sabe que han existido en algún momento durante un período específico.

La mortalidad, que se refiere a los fallecidos en lugar de a los nuevos casos diagnosticados de la enfermedad, refleja los factores que causan la enfermedad, así como los factores relacionados con la calidad de la asistencia médica, como la exploración selectiva, el acceso a la asistencia médica y la disponibilidad de tratamientos eficaces. En consecuencia, la generación de hipótesis y la investigación etiológica pueden facilitar más información y ser más fáciles de interpretar que los datos sobre la mortalidad. Sin embargo, los datos sobre la mortalidad suelen ser más fáciles de obtener que los datos sobre la incidencia cuando se trata de grandes poblaciones.

En general, se acepta que el término tasa de muerte significa la tasa de muerte por todas las causas, mientras que la tasa de mortalidad es la tasa de muerte por una causa específica. Para una enfermedad determinada, la tasa de mortalidad de los casos (técnicamente una proporción, no una tasa) es el número de personas que mueren como consecuencia de la enfermedad durante un período de tiempo determinado dividido por el número de personas con esa enfermedad. El complemento de la tasa de mortalidad de los casos es la tasa de supervivencia. $L$ a tasa de supervivencia a cinco años es una referencia común para enfermedades crónicas como el cáncer. 
La aparición de una enfermedad puede variar entre distintos subgrupos de una población o dentro del mismo subgrupo a lo largo del tiempo. La medida de una enfermedad para una población completa, sin considerar ningún subgrupo, se denomina tasa bruta. Por ejemplo, la tasa de incidencia para todos los grupos de edad es una tasa bruta. Las tasas correspondientes a determinados grupos de edad son las tasas específicas por edades. Para comparar dos o más poblaciones con diferentes distribuciones de edad, deben calcularse las tasas ajustadas por edades (o tasas estandarizadas por edades) para cada población, multiplicando la tasa específica de cada grupo de edad por el porcentaje de ese grupo de edad en la población de referencia (p. ej., una de las poblaciones del estudio, la población de Estados U nidos en 1970) y, a continuación, sumando todos los grupos de edades para obtener una tasa global ajustada por edades. Las tasas pueden ajustarse de acuerdo con otros factores distintos a la edad, como raza, sexo o tabaquismo, si se conocen las tasas específicas por categorías.

El control y la evaluación de datos descriptivos pueden proporcionar claves sobre la etiología de la enfermedad, identificar subgrupos de alto riesgo que deben ser objeto de programas de intervención o exploración selectiva, y facilitar datos sobre la eficacia de dichos programas. Las fuentes de información que más se utilizan para las actividades de vigilancia son los certificados de defunción, las historias médicas, los registros del cáncer, los registros de otras enfermedades (p. ej., registros de defectos congénitos, registros de enfermedades renales en fase terminal), los registros de exposiciones profesionales, los registros de seguros de enfermedad o discapacidad y los registros de indemnización de los trabajadores.

\section{Medidas de la asociación}

La epidemiología intenta identificar y cuantificar factores que influyen en las enfermedades. El enfoque más sencillo de todos consiste en comparar la frecuencia de una enfermedad entre las personas expuestas a un factor sospechoso con su frecuencia en las personas no expuestas. La magnitud de la asociación entre exposición y enfermedad puede expresarse en términos absolutos 0 relativos. ( $V$ éase el recuadro de las páginas 28.14-15.)

Los efectos absolutos se miden con diferencias de tasas y diferencias de riesgos (T abla 28.3). La diferencia de tasas es una primera tasa menos una segunda tasa. Por ejemplo, si la tasa de incidencia de leucemia en los trabajadores expuestos al benceno es de 72 por 100.000 personas-año y la tasa entre los trabajadores no expuestos es de 12 por 100.000 personas-año, la diferencia de tasas es de 60 por 100.000 personas-año. La diferencia de riesgos es la diferencia en los riesgos o en la incidencia acumulada y puede oscilar entre -1 y 1.

Los efectos relativos se basan en cocientes de tasas o medidas del riesgo en lugar de en diferencias. U n cociente de tasas es la tasa en una población dividida por la tasa en otra. El cociente de tasas se denomina también cociente de riesgos, riesgo relativo, tasa relativa, y tasas relativas de incidencia (o de mortalidad). La medida es adimensional y varía entre 0 e infinito. Cuando la tasa es similar en dos grupos (es decir, cuando la exposición no tiene ningún efecto), la tasa relativa es igual a la unidad (1). Cuando una exposición aumenta el riesgo, la tasa relativa es mayor de 1 ; por el contrario, un factor de protección dará lugar a un cociente entre 0 y 1 . El riesgo relativo en exceso es el riesgo relativo menos 1 . Por ejemplo, un riesgo relativo de 1,4 puede expresarse también como un riesgo relativo en exceso del $40 \%$.

En los estudios de casos y controles (llamados también estudios de casos y referentes), se identifican personas con la enfermedad (casos) y personas sin la enfermedad (controles 0 referentes). Se comparan las exposiciones a las que han estado expuestos los dos grupos en el pasado. La probabilidad de ser un caso expuesto se compara con la probabilidad de ser un control expuesto. Al no disponerse del recuento total de las personas expuestas y no expuestas en las poblaciones fuente, no se pueden calcular las tasas de enfermedad. En su lugar, se pueden comparar los casos expuestos con los controles expuestos calculando la probabilidad relativa o el índice de probabilidades (Tabla 28.4).

Para indicar la intensidad de una asociación, se utilizan las medidas relativas del efecto más que las medidas absolutas. No obstante, las medidas absolutas pueden reflejar mejor la repercusión de una asociación para la salud pública. U n pequeño incremento relativo de una enfermedad común, como una cardiopatía, puede afectar a un mayor número de personas (mayor diferencia de riesgo) y tener mayor repercusión en la salud pública que un gran incremento relativo (pero una pequeña diferencia absoluta) de una enfermedad rara, como el angiosarcoma de hígado.

\section{Pruebas de significación}

Las pruebas de significación estadística suelen realizarse en medidas del efecto para evaluar la probabilidad de que el efecto observado difiera de la hipótesis nula (es decir, ausencia de efecto). Aunque muchos estudios, especialmente en otros campos de la investigación biomédica, expresan la significación con valores $p$, los estudios epidemiológicos suelen expresarla mediante intervalos de confianza (IC) (también llamados límites de confianza). Por ejemplo, un intervalo de confianza del $95 \%$ es un rango de valores para la medida del efecto que incluye la medida estimada obtenida de los datos del estudio y cuya probabilidad de incluir el valor real es del $95 \%$. L os valores que quedan fuera de ese intervalo tienen pocas probabilidades de incluir la medida real del

Tabla 28.3 - Medidas de asociación en un estudio de cohortes.

$\begin{array}{llll} & \text { Casos } & \text { Persona-años en riesgo } & \text { Tasa por } 100.000 \\ \text { Expuestos } & 100 & 20.000 & 500 \\ \text { No expuestos } & 200 & 80.000 & 250 \\ \text { Total } & 300 & 100.000 & 300\end{array}$

Diferencia de tasas $(D T)=500 / 100.000-250 / 100.000$ $=250 / 100.000 \mathrm{al}$ año

$(146,06 / 100.000-353,94 / 100,000)^{*}$

Tasa relativa

(o riesgo relativo) $(R R)=\frac{100 / 20.000}{200 / 80.000}=\frac{500}{250}=2,0(1,6-2,5) *$

Riesgo atribuible en los expuestos $\left(\mathrm{RA}_{\mathrm{e}}\right)=100 / 20.000-200 / 80.000$ $=250 / 100.000$ al año

Porcentaje de riesgo atribuible en los expuestos $\left(R A_{e} \%\right)=$

$$
\frac{R R-1}{R R} \times 100=\frac{2,0-1}{2,0} \times 100=50 \%(36 \%-61 \%)
$$

Riesgo atribuible en la población (RAP) $=300 / 100.000-200 / 80.000$ $=50 / 100.000$ al año

Porcentaje de riesgo atribuible en la población (RAP \%) =

$$
\frac{300 / 100.000-200 / 80.000}{300 / 100.000}
$$

* Se indican entre paréntesis los intervalos de confianza del $95 \%$ calculados utilizando las fórmulas del recuadro de la página siguiente. 
Tabla 28.4 - Medidas de asociación en estudios de casos y controles: exposición al polvo de madera y adenocarcinoma de la cavidad nasal y de los senos paranasales.

$\begin{array}{lcc} & \text { Casos } & \text { Controles } \\ \text { Expuestos } & 18 & 55 \\ \text { No expuestos } & 5 & 140 \\ \text { Total } & 23 & 195\end{array}$

Probabilidad relativa (índice de probabilidad) $(\mathrm{OR})=$ $\frac{18 \times 140}{55 \times 5}=9,2(3,2-25,9) *$

Porcentaje de riesgo atribuible en los expuestos $\left(R A_{e} \%\right)=$

$$
\frac{O R-1}{O R} \times 100=\frac{9,2-1}{9,2} 100=89,1 \%(69,1 \%-96,1 \%) *
$$

Porcentaje de riesgo atribuible en la población (RAP \%) =

$$
\begin{aligned}
& \frac{P_{0}(O R-1)}{1+P_{0}(O R-1)} \times 100=\frac{0,28(9,2-1)}{1+0,28(9,2-1)} \times 100=70 \%(32,2 \%-91,8 \%) * \\
& \quad \text { donde } P_{0}=\text { proporción de controles expuestos }=55 / 195=0,28
\end{aligned}
$$

* Se indican entre paréntesis los intervalos de confianza del $95 \%$ calculados utilizando las fórmulas del recuadro de la página siguiente.

Fuente: Adaptado de Hayes y cols. 1986

efecto. Si el intervalo de confianza para una tasa relativa incluye la unidad, no existe diferencia estadísticamente significativa entre los grupos comparados.

Los intervalos de confianza facilitan más información que los valores $\mathrm{p}$. Un valor $\mathrm{p}$ elevado puede deberse al elevado valor de la medida de la asociación (p. ej., tasa relativa, diferencia de riesgos) o al gran tamaño de las poblaciones del estudio. Por ejemplo, una pequeña diferencia en las tasas de una enfermedad en una población grande puede dar lugar a un valor $p$ altamente significativo. $L$ as razones de este elevado valor $p$ no pueden deducirse del propio valor p. Por el contrario, los intervalos de confianza permiten diferenciar estos dos factores. En primer lugar, la magnitud de efecto puede discernirse por los valores de la medida del efecto y los números abarcados por el intervalo. Los riesgos relativos elevados indican, por ejemplo, un mayor efecto. En segundo lugar, el tamaño de la población afecta a la anchura del intervalo de confianza. Las poblaciones pequeñas con estimaciones estadísticamente inestables generan intervalos de confianza más anchos que las grandes poblaciones.

EI nivel de confianza elegido para expresar la variabilidad de los resultados (la "significación estadística") es arbitrario, pero generalmente se utiliza el $95 \%$, que corresponde a un valor $p$ de 0,05 . Un intervalo de confianza del $95 \%$ tiene una probabilidad del $95 \%$ de contener la medida real del efecto. A lgunas veces se utilizan otros niveles de confianza, como el $90 \%$.

Las exposiciones pueden ser dicotómicas (p. ej., expuestos y no expuestos) o pueden abarcar muchos niveles de exposición. Las medidas del efecto (es decir, la respuesta) pueden variar según el nivel de exposición. La evaluación de la relación entre exposición y respuesta es una parte importante de la interpretación de los datos epidemiológicos. El análogo a la relación entre exposición y respuesta en los estudios animales es la relación entre "dosis y respuesta". Si la respuesta aumenta con el nivel de exposición, existe una mayor probabilidad de que la asociación sea causal que si no se observa ninguna tendencia. Entre las pruebas estadísticas utilizadas para evaluar la relación entre exposición y respuesta figuran la prueba ampliada de $\mathrm{M}$ antel y la prueba de la tendencia de chi cuadrado.

\section{Estandarización}

Para tener en cuenta otros factores además de la principal exposición de interés y la enfermedad, las medidas de la asociación pueden estandarizarse mediante técnicas de estratificación o regresión. La estratificación consiste en dividir la población en grupos homogéneos con respecto a un factor ( $p$. ej., sexo, edad, tabaquismo). Seguidamente se calculan los riesgos relativos o índices de probabilidades para cada estrato, así como las medias globales ponderadas de los riesgos relativos o índices de probabilidades. Estos valores globales reflejan la asociación entre la exposición principal y la enfermedad ajustada al factor de estratificación; es decir, la asociación una vez eliminados los efectos del factor de estratificación.

Una tasa relativa estandarizada es el cociente entre dos tasas estandarizadas. En otras palabras, una tasa relativa estandarizada es la media ponderada de las tasas relativas por estratos, de manera que los coeficientes de ponderación para cada estrato corresponden a la distribución de personas-tiempo en el grupo no expuesto 0 de referencia. Las tasas relativas de dos 0 más grupos puede compararse cuando se utilizan los mismos coeficientes de ponderación. Pueden construirse intervalos de confianza tanto para las tasas relativas como para las tasas relativas estandarizadas.

La tasa de mortalidad relativa estandarizada es la media ponderada de las tasas relativas específicas por edades, en donde los coeficientes de ponderación (es decir, personas-tiempo en situación de riesgo) se obtienen del grupo del estudio y las tasas se obtienen de la población de referencia, es decir, la situación contraria a la de otras tasas relativas estandarizadas. La población habitual de referencia es la población general, cuyas tasas de mortalidad pueden conocerse fácilmente y cuyo tamaño hace que dichas tasas sean más estables que las tasas de una cohorte 0 subgrupo no expuesto de la población de trabajadores estudiada. L a estandarización indirecta consiste en utilizar los coeficientes de ponderación de la cohorte en lugar de los de la población de referencia. La tasa de mortalidad relativa estandarizada es el cociente entre el número observado de muertes en una cohorte y el número esperado, calculándose éste a partir de las tasas de la población de referencia (el cociente suele multiplicarse por 100 para su presentación). Cuando no existe asociación, la tasa de mortalidad relativa estandarizada es igual a 100. En general no se puede comparar dos o más tasas de mortalidad relativas estandarizadas, ya que las tasas se obtienen de la población de referencia pero los coeficientes de ponderación se obtienen del grupo del estudio. Esta incapacidad de establecer comparaciones suele olvidarse en la interpretación de los datos epidemiológicos, con el resultado de que pueden extraerse conclusiones erróneas.

\section{Efecto del trabajador sano}

Es muy habitual que las cohortes de trabajadores presenten una tasa de mortalidad total menor que la población general, incluso aunque se encuentren en situación de mayor riesgo de mortalidad por ciertas causas como consecuencia de las exposiciones en el lugar de trabajo. Este fenómeno, llamado efecto del trabajador sano, refleja el hecho de que el estado de salud de cualquier subgrupo de la población activa suele ser, en conjunto, mejor que el de la población general, ya que ésta incluye tanto a los trabajadores como a todo tipo de personas incapacitadas para el trabajo como consecuencia de enfermedades y discapacidades. La tasa global de mortalidad en la población general suele ser mayor que en la población activa. La magnitud de este efecto varía según la causa de mortalidad. 
Estimadores instantáneos e intervalos de confianza para las medidas de la aparición de enfermedades y de la asociación
Medida
Estimador instantáneo
Intervalo de confianza del 95\%
Tasa de incidencia (TI)$$
\frac{d}{p a} \quad T I \pm 1,96 \sqrt{\frac{d}{p a^{2}}}
$$
Prevalencia (P)
$\frac{d}{T}$
$P \pm 1,96 \sqrt{\frac{P(1-P)}{T}}$
donde $d=$ número de casos, $p a=$ persona-años, y $T=$ población total
Tasa de mortalidad relativa estandarizada (TM RE)

$$
\frac{d}{E}=\frac{\text { Casos observados }}{\text { C asos esperados }} \quad \text { TM RE }_{1}=\frac{d}{E}\left(1-\frac{1}{9 d}-\frac{1,96}{3 \sqrt{d}}\right)^{3}
$$
$\mathrm{TMRE}_{\mathrm{S}}=\frac{d+1}{E}\left(1-\frac{1}{9(d+1)}+\frac{1,96}{3 \sqrt{d+1}}\right)^{3}$

Tipos de estudios epidemiológicos y sus medidas de asociación y aparición de enfermedades

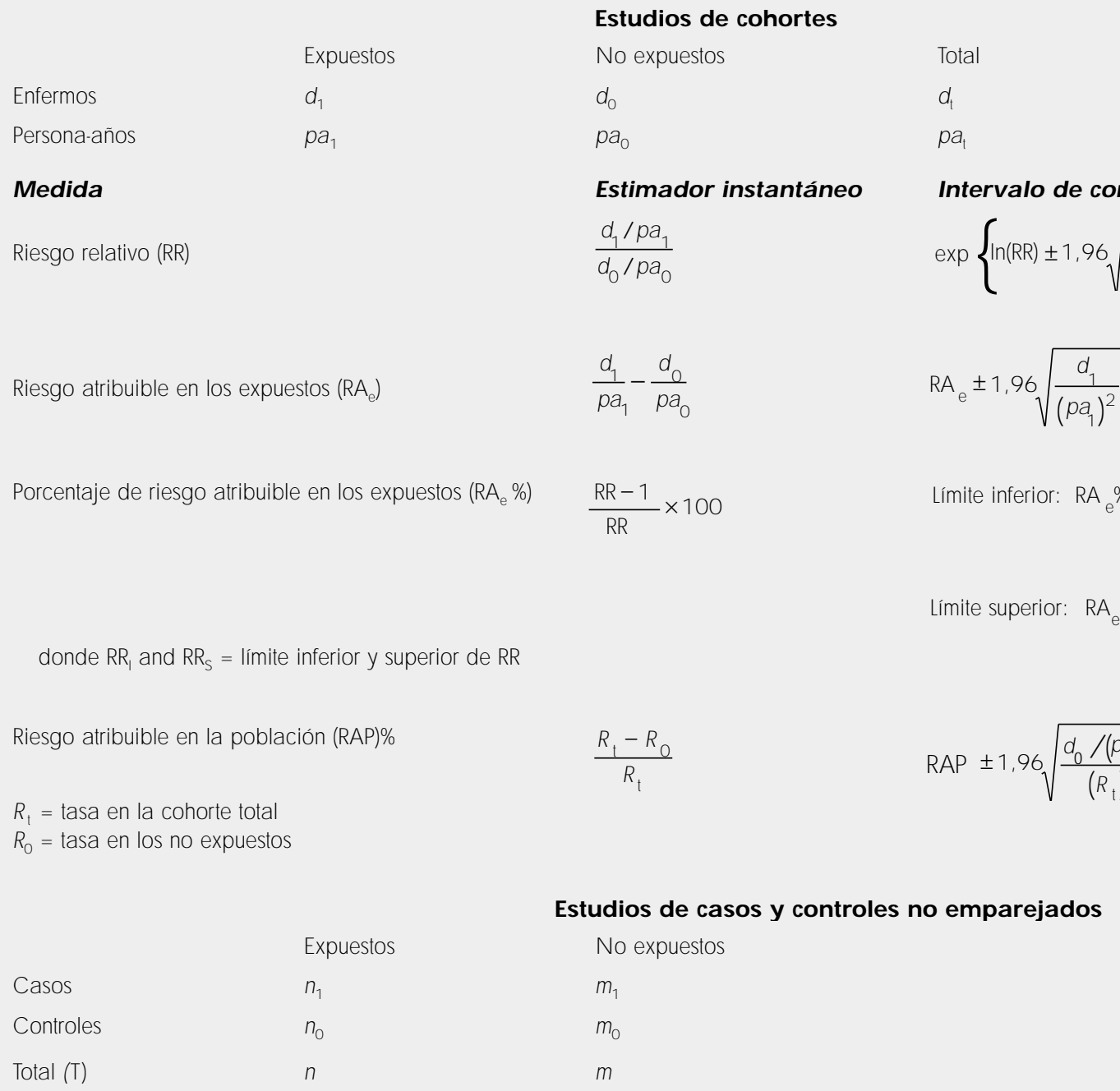




\section{Estudios de casos y controles no emparejados (continuación)}

\section{Medida}

O dds Ratio (O R)

\section{Estimador instantáneo}

$\frac{n_{1} m_{0}}{n_{0} m_{1}}$

$$
\frac{O R-1}{O R} \times 100
$$

Porcentaje de riesgo atribuible en los expuestos (RA $\mathrm{e}_{\mathrm{e}} \%$

$$
\frac{P_{0}(0 R-1)}{1+P_{0}(O R-1)}
$$

Intervalo de confianza del 95\%

$$
\exp \left\{n(O R) \pm 1,96 \sqrt{\frac{1}{n_{1}}+\frac{1}{n_{0}}+\frac{1}{m_{1}}+\frac{1}{m_{0}}}\right\}
$$

$\mathrm{RA}_{\mathrm{e}} \%_{\mathrm{L}}=\frac{O \mathrm{R}_{1}-1}{0 \mathrm{R}_{1}} \times 100$

$R A_{e} \%_{S}=\frac{O R_{S}-1}{O R_{S}} \times 100$

$$
\text { Límite superior }=\frac{1}{1+\frac{1-\mathrm{RAP}}{\mathrm{RAP}} \cdot \frac{1}{\exp (\mathrm{FE})}}
$$

donde
$P_{0}=$ proporción de controles expuestos, $F E=$ Factor de error $=1,96 \sqrt{\left(\frac{n_{1}}{n n_{0}}+\frac{m_{1}}{m m_{0}}\right)\left(\frac{m_{0} m}{n_{1} m-m_{1} n}\right)^{2}}$

\section{Estudios de casos y controles emparejados}

\section{Controles expuestos}

Casos expuestos

Casos no expuestos

donde $f=$ frecuencia de parejas

\section{Medida}

0 dds Ratio (O R)

Porcentaje de riesgo atribuible en los expuestos ( $\mathrm{RA}_{\mathrm{e}} \%$ )

donde $O R_{1}$ y $O R_{S}=$ límites inferior y superior de $O R$

Riesgo atribuible en la población (RAP)\%

$$
\frac{P_{1}(O R-1)}{1+P_{1}(O R-1)}
$$

\section{Estimador instantáneo}

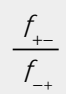

$$
\frac{O R-1}{O R} \times 100
$$

Intervalo de confianza del $95 \%$

$\exp \left\{\ln (\mathrm{OR}) \pm 1,96 \sqrt{\frac{1}{f_{+-}}+\frac{1}{f_{-+}}}\right\}$

$R A_{e} \%_{L}=\frac{O R_{1}-1}{O R_{1}} \times 100$

$\mathrm{RA}_{\mathrm{e}}{ }{ }_{\mathrm{S}}=\frac{0 \mathrm{R}_{\mathrm{S}}-1}{O \mathrm{R}_{\mathrm{S}}} \times 100$

Ĺmite inferior $=\frac{1}{1+\frac{1-R A P}{R A P} \cdot \exp (F E)}$

Ĺmite superior $=\frac{1}{1+\frac{1-R A P}{R A P} \cdot \frac{1}{\exp (F E)}}$ 
Por ejemplo, parece tener una menor importancia para el cáncer en general que para la enfermedad pulmonar obstructiva crónica. La razón de ello es que la mayoría de los cánceres no son probablemente la consecuencia de una predisposición que actúe como criterio para la selección de los trabajadores a una edad más joven. Este efecto del trabajador sano tiende a disminuir con el tiempo en cualquier grupo de trabajadores.

\section{Mortalidad proporcional}

En algunas ocasiones, no se dispone de la tabulación completa de una cohorte (es decir, personas-tiempo en situación de riesgo) y sólo existe información sobre los fallecidos o algún subgrupo de los fallecidos de la cohorte ( $p$. ej., fallecidos entre los trabajadores jubilados y actuales, pero no entre los trabajadores que abandonaron el empleo antes de percibir una pensión). El cálculo de las personas-años exige métodos especiales para evaluar las personas-tiempo, entre ellos las tablas de vida. Cuando no se dispone de información sobre el total de personas-tiempo para todos los miembros de la cohorte, con independencia de su situación de enfermedad, no se pueden calcular las tasas relativas estandarizadas ni las tasas de mortalidad relativas estandarizadas. En su lugar, puede utilizarse la tasa de mortalidad relativa proporcional ( $T M R P)$, que es el cociente entre el número observado de fallecidos por una causa específica y el número previsto, basado éste en la proporción de todos los fallecidos por esa causa específica en la población de referencia multiplicada por el número total de fallecidos en el grupo del estudio, multiplicado por 100.

La proporción de fallecidos por todas las causas tiene que sumar 1 (T M RP $=100)$ y, por esta razón, puede ocurrir que se obtengan unas tasas de mortalidad relativas proporcionales en exceso, cuando de hecho están artificialmente infladas por déficit reales en otras causas de muerte. Asimismo, algunos déficit aparentes pueden reflejar simplemente un exceso real de otras causas de muerte. Por ejemplo, si los pilotos de las avionetas fumigadoras presentan un exceso real de mortalidad por accidente, el requisito matemático de que la T M R P por todas las causas combinadas sume 100 puede hacer que algunas causas de muerte parezcan deficientes aunque, en realidad, la mortalidad por esas causas sea mayor. Para mitigar este posible problema, los investigadores interesados principalmente en el cáncer pueden calcular las tasas de mortalidad relativas proporcionales por cáncer (T M R PC). Estas tasas comparan el número observado de muertes por cáncer con el número previsto, basado éste en la proporción de las muertes totales por cáncer (en lugar de por todas las causas) para el cáncer de interés en la población de referencia, multiplicado por el número total de muertes por cáncer en el grupo del estudio, multiplicado por 100. Así, la TMRPC no se verá afectada por una aberración (exceso o déficit) en una causa de muerte que nada tiene que ver con el cáncer, como accidentes, cardiopatías o enfermedades pulmonares no malignas.

Los estudios de las tasas de mortalidad relativas proporcionales pueden analizarse mejor utilizando índices de probabilidad de la mortalidad, un método que consiste esencialmente en analizar los datos como si fueron los de un estudio de casos y controles. Los "controles" son el subgrupo de todas las muertes que se cree que no están relacionadas con la exposición estudiada. Por ejemplo, en un estudio cuyo principal interés fuera el cáncer, el índice de probabilidad de la mortalidad podría calcularse comparando la exposición en los fallecidos por cáncer con la exposición en los fallecidos por enfermedades cardiovasculares. Este enfoque, como la T M R PC, evita los problemas de la T M R P que pueden surgir cuando la fluctuación en una causa de muerte afecta al riesgo aparente de otra simplemente porque la T M R P total debe ser igual a 100. Sin embargo, la elección de las causas de la mortalidad que actuarán como controles es crítica. Como ya se ha dicho, esas causas no deben estar relacionadas con la exposición, aunque la posible relación entre exposición y enfermedad puede desconocerse para muchas enfermedades potenciales de control.

\section{Riesgo atribuible}

Existen medidas que expresan los casos de una enfermedad que pueden atribuirse a una exposición si la asociación observada entre exposición y enfermedad es causal. El riesgo atribuible en los expuestos $\left(\mathrm{R} \mathrm{A}_{\mathrm{e}}\right.$ ) es la tasa de la enfermedad en los expuestos menos la tasa de la enfermedad en los no expuestos. En los estudios de casos y controles no se pueden medir directamente las tasas de enfermedad, de manera que el $R A_{e}$ sólo puede calcularse en estudios de cohortes. 0 tra medida más intuitiva es el porcentaje de riesgo atribuible en los expuestos ( $R A_{e} \%$ ), que puede obtenerse en ambos tipos de estudios. El RA $\mathrm{RA}_{\mathrm{e}} \%$ es la proporción de casos que aparecen en la población expuesta y que pueden atribuirse a la exposición (véanse las fórmulas en las Tablas 28.3 y 28.4). EI $\mathrm{RA}_{\mathrm{e}} \%$ es la tasa relativa (o el índice de probabilidades) menos 1 , dividido por la tasa relativa (o índice de probabilidades), multiplicado por 100.

El riesgo atribuible en la población (R AP) y el porcentaje de riesgo atribuible en la población (R AP \% ), o fracción etiológica, indica los casos de una enfermedad en la población total, compuesta por personas expuestas y no expuestas, que se deben a la exposición si la asociación observada es causal. EI R AP puede obtenerse de un estudio de cohortes (Tabla 28.3) y el R AP \% puede calcularse tanto en estudios de cohortes como de casos y controles (Tablas 28.3 y 28.4).

\section{Representatividad}

Ya se han descritos algunas medidas del riesgo, todas las cuales utilizan una serie de métodos para el recuento de episodios y presumen la representatividad de dichos episodios en el grupo definido. Para explicar cualquier diferencia observada entre los resultados de distintos estudios, es esencial conocer los métodos que se han utilizado.

\section{TIPOS DE DISEÑO DE LOS ESTUDIOS}

\section{Sven H ernberg}

El epidemiólogo está interesado en conocer la relación entre variables, principalmente entre variables de exposición y efecto. N ormalmente, los epidemiólogos desean averiguar si la presencia de una enfermedad está relacionada con la presencia de un agente específico (exposición) en la población. Las posibles maneras de estudiar esta relación varían considerablemente. Se puede identificar a todas las personas expuestas al agente y realizar su seguimiento para medir la incidencia de la enfermedad y compararla con la de una población no expuesta. También se pueden obtener muestras de las poblaciones expuestas y no expuestas sin tener que realizar un recuento completo de ellas. U na tercera alternativa consiste en identificar a todas las personas que desarrollan la enfermedad de interés en un determinado período de tiempo ("casos") y a un grupo adecuado de personas que no la desarrollan (una muestra de la población fuente de los casos) y determinar si las pautas de exposición difieren entre los dos grupos. EI seguimiento de los participantes del estudio es otra posibilidad (en los llamados estudios longitudinales). En estos estudios, existe un intervalo de tiempo desde el momento en que se produce la exposición hasta el momento en que aparece la enfermedad. 0 tra alternativa consiste en realizar 
un estudio transversal de la población, midiendo tanto la exposición como la enfermedad en el mismo punto en el tiempo.

En este artículo, se describen los tipos de estudios más comunes: cohortes, casos y referentes (casos y controles) y transversales. Para preparar el escenario de la descripción, consideremos una gran fábrica de rayón de viscosa situada en una pequeña ciudad. Se ha iniciado una investigación para determinar si la exposición al disulfuro de carbono aumenta el riesgo de enfermedades cardiovasculares. Existen varias alternativas para el diseño de la investigación, algunas claramente más adecuadas que otras. La primera estrategia consiste en identificar a todos los trabajadores que han estado expuestos al disulfuro de carbono y realizar su seguimiento para determinar la mortalidad cardiovascular.

\section{Estudios de cohortes}

En un estudio de cohortes, todos los participantes comparten un episodio común, la exposición. En un estudio clásico de cohortes, primero se identifica a un grupo definido de personas expuestas y luego se realiza el seguimiento de todas ellas y se registra su morbilidad y/ o mortalidad. Además de la exposición cualitativa habitual, la cohorte debe definirse también aplicando otros crite rios de selección, como rango de edades, sexo (mujeres, hombres o ambos), duración mínima e intensidad de la exposición, ausencia de otras exposiciones, etc., para aumentar la validez y eficiencia del estudio. Al inicio del estudio, ningún miembro de la cohorte debe presentar la enfermedad estudiada, de acuerdo con el conjunto empírico de criterios utilizados para medir la enfermedad.

Si, por ejemplo, en un estudio de cohortes sobre los efectos del disulfuro de carbono en la morbilidad coronaria, la cardiopatía coronaria se mide empíricamente como infartos clínicos, las personas que al inicio del estudio tuviesen antecedentes de infartos coronarios tendrían que ser excluidas de la cohorte. Sin embargo, podrían aceptarse alteraciones electrocardiográficas sin antecedentes de infarto. Por el contrario, si la aparición de nuevos cambios electrocardiográficos fuera la medida empírica del resultado, los miembros de la cohorte tendrían que tener también electrocardiogramas normales al inicio del estudio.

La morbilidad (en términos de incidencia) o la mortalidad de una cohorte expuesta debe compararse con la de una cohorte de referencia que debe ser lo más parecida posible a la cohorte expuesta en todos los aspectos relevantes, excepto en la exposición, para estimar el riesgo relativo de enfermedad o muerte por la exposición. El uso de una cohorte similar, pero no expuesta, como población de referencia, es siempre preferible a la práctica habitual (e incorrecta) de comparar la morbilidad o la mortalidad de la cohorte expuesta con las tasas nacionales estandarizadas por edades, porque la población general no cumple los requisitos más elementales para la validez de la comparación. La tasa de morbilidad relativa estandarizada que se obtiene de esta comparación suele subestimar el riesgo relativo real debido a la existencia de un sesgo en la cohorte expuesta que impide la comparación entre las dos poblaciones. Este sesgo de comparación se denomina "efecto del trabajador sano". Sin embargo, no se trata de un "efecto" real, sino de un sesgo causado por una confusión negativa originada por la rotación selectiva en función de la salud en una población de trabajadores. (L as personas con peor estado de salud tienden a salir de las cohortes "expuestas" o a no entrar nunca en ellas y su destino final suele ser el grupo de desempleados de la población general.)

Puesto que la cohorte "expuesta" se define en función de una cierta exposición, sólo pueden estudiarse simultáneamente los efectos causados por esa única exposición (o mezcla de exposiciones). Por otra parte, el diseño de cohortes permite estudiar varias enfermedades al mismo tiempo. También pueden estudiarse

Tabla 28.5 - Formato habitual de las tablas de frecuencias para presentar los datos de una cohorte.

Componente de la tasa de enfermedad

Casos de enfermedad o muerte

Número de personas en la cohorte

simultáneamente diferentes manifestaciones de la misma enfermedad; por ejemplo, angina de pecho, cambios electrocardiográficos, infarto de miocardio clínico y mortalidad coronaria. Los estudios de cohortes, además de ser adecuados para poner a prueba hipótesis específicas (p. ej., "la exposición al disulfuro de carbono causa cardiopatía coronaria"), pueden responder también a la pregunta más general de: “QQué enfermedades causa esa exposición?"

Por ejemplo, en un estudio de cohortes para investigar el riesgo de mortalidad por cáncer de pulmón en los trabajadores de las fundiciones, los datos sobre la mortalidad se obtienen del registro nacional de causas de muerte. Aunque el estudio tiene como objetivo determinar si el polvo de las fundiciones causa cáncer de pulmón, esa fuente de datos permite obtener, con el mismo esfuerzo, información sobre todas las demás causas de muerte. Por consiguiente, pueden estudiarse al mismo tiempo otros posibles riesgos para la salud.

Un estudio de cohortes puede ser retrospectivo (histórico) 0 prospectivo (simultáneo). En ambos casos, la estructura del diseño es la misma. En algún momento o período de tiempo, se realiza el recuento de las personas expuestas y se mide el efecto de la exposición en todas las personas hasta una determinada fecha. La diferencia entre los estudios prospectivos y retrospectivos es el momento de realizar el estudio. En los estudios retrospectivos, dicha fecha ya ha pasado; en los prospectivos, hay que esperar a que llegue.

En el diseño retrospectivo, la cohorte se define en algún momento del pasado (por ejemplo, los expuestos el 1 de enero de 1961 o los expuestos en el trabajo entre 1961 y 1970). A continuación, se realiza el seguimiento de la morbilidad y/o la mortalidad de todos los miembros de la cohorte hasta el presente. Aunque "todos" significa también que debe realizarse el seguimiento de los que hayan abandonado el trabajo, en la práctica rara vez se consigue una cobertura del $100 \%$. No obstante, cuanto más completo sea el seguimiento, mayor será la validez del estudio.

En el diseño prospectivo, la cohorte se define en el presente 0 durante algún período futuro y, a continuación, se realiza el seguimiento de la morbilidad en el futuro.

Cuando se realizan estudios de cohortes, el seguimiento debe durar lo suficiente para que las variables de valoración tengan tiempo de manifestarse. En algunas ocasiones, aunque sólo se dispone de registros históricos que abarcan un corto período de tiempo en el pasado, sigue siendo conveniente utilizar esa fuente de datos, ya que así podrá reducirse el período de seguimiento prospectivo y se podrán conocer antes los resultados del estudio. En un caso así, podrían combinarse los diseños retrospectivos y prospectivos de cohortes. En la Tabla 28.5 , se muestra el formato habitual de las tablas de frecuencia para presentar los datos de una cohorte.

La proporción observada de enfermos en la cohorte expuesta se calcula como:

$$
\mathrm{R}_{1}=\mathrm{c}_{1} / \mathrm{N}_{1},
$$

y la de la cohorte de referencia como:

$$
R_{0}=c_{0} / N_{0} \text {. }
$$


Seguidamente, el riesgo relativo ( $R$ ) se expresa como:

$$
R R=\frac{C_{1} / N_{1}}{C_{0} / N_{0}}
$$

$N_{0}$ y $N_{1}$ suelen expresarse en unidades de personas-tiempo en lugar de como el número de miembros de las poblaciones. $L a$ unidad persona-años se calcula para cada persona por separado. $M$ uchas veces los miembros de una cohorte entran en la misma durante un cierto período de tiempo, pero en distintos momentos. Por consiguiente, sus períodos de seguimiento empezarán en fechas diferentes. U na vez que esas personas mueren 0 experimentan el episodio de interés, dejan de estar "en situación de riesgo" y no deben seguir contribuyendo al denominador de persona-años.

Si el riesgo relativo es mayor de 1, la morbilidad de la cohorte expuesta es mayor que la de la cohorte de referencia, y viceversa. El riesgo relativo es una estimación puntual y debe calcularse el correspondiente intervalo de confianza (IC). Cuanto mayor sea el estudio, más estrecho será el intervalo de confianza. Si el RR $=1$ no se incluye en el intervalo de confianza (p. ej., si el IC del $95 \%$ es de 1,4 a 5,8), el resultado puede considerarse "estadísticamente significativo" a ese nivel de probabilidad (en este ejemplo, $\alpha=0,05$ ).

Si la población general se utiliza como población de referencia, $c_{0}$ se sustituye por la cifra "esperada", $E\left(c_{1}\right)$, que se obtiene de las tasas de morbilidad o mortalidad estandarizadas por edades de esa población (es decir, el número de casos que habrían ocurrido en la cohorte de no haber tenido lugar la exposición de interés). De esta forma se obtiene la tasa de mortalidad (o morbilidad) relativa estandarizada, TMRE. Por consiguiente,

$$
\text { TMRE }=\frac{C_{1}}{E\left(C_{1}\right)} \times 100
$$

También debe indicarse un intervalo de confianza para la TMRE. Cuando se publica un estudio, siempre es preferible indicar intervalos de confianza que valores $p$, porque la prueba de significación estadística no tiene sentido si la población general es la de referencia. Este tipo de comparación introduce un importante sesgo (el efecto del trabajador sano descrito antes), y la prueba de significación estadística, concebida en un principio para la investigación experimental, genera confusión en presencia de un error sistemático.

Supóngase que la pregunta que se investiga es si el polvo de cuarzo produce cáncer de pulmón. Normalmente el polvo de cuarzo se produce conjuntamente con otros cancerígenos, como los productos derivados del radón y los gases de escape de motores diesel en las minas, o los hidrocarburos poliaromáticos en las fundiciones. Los trabajadores de las canteras de granito no están expuestos a esos otros cancerígenos. Por consiguiente, el problema puede estudiarse mejor en los trabajadores de las canteras de granito.

Supóngase que se reclutan los 2.000 trabajadores contratados en 20 canteras entre 1951 y 1960 para formar la cohorte y se realiza el seguimiento de la incidencia de cáncer (o sólo la mortalidad), que se inicia diez años después de la primera exposición (para dejar un tiempo de inducción) y finaliza en 1990. Esto supone un período de seguimiento de 20 a 30 años (dependiendo del año de entrada) 0 , pongamos como media, un seguimiento durante 25 años de la mortalidad (o morbilidad) por cáncer en los 1.000 trabajadores de las canteras que eran específicamente trabajadores del granito. Debe registrarse la historia de la exposición de todos los miembros de la cohorte. Los trabajadores que hayan abandonado las canteras deben ser localizados, y se debe registrar su historia de exposición posterior. En países a cuyos habitantes se asigna un número de identificación único, se trata de un procedimiento sencillo regido principalmente por las leyes nacionales sobre la protección de datos. Cuando no existe un sistema semejante, la localización de los trabajadores para su seguimiento puede ser extremadamente difícil. Si existen registros adecuados de mortalidad 0 morbilidad, puede consultarse el registro nacional de causas de muerte para obtener la mortalidad total por cáncer y la mortalidad específica para distintos tipos de cáncer (en el caso del cáncer, el registro nacional del cáncer es la mejor fuente de información porque contiene diagnósticos más exactos y porque también facilita datos sobre la incidencia (o morbilidad)). Las tasas de mortalidad (o tasas de incidencia por cáncer) pueden compararse con los "números previstos", que se obtienen de las tasas nacionales utilizando como base las personas-años de la cohorte expuesta.

Supóngase que se han encontrado 70 casos mortales de cáncer de pulmón en la cohorte, cuando el número previsto (el número que se habría producido de no haber existido la exposición) es de 35. Así:

$$
\begin{aligned}
C_{1}=70, E\left(C_{1}\right) & =35 \\
& \frac{C_{1}}{E\left(C_{1}\right)} \times 100=200(95 \% \text { IC : } 160-250)
\end{aligned}
$$

Por consiguiente, la TM RE $=200$, lo que indica que el riesgo de morir por cáncer de pulmón es dos veces mayor en los expuestos. Si se dispone de datos detallados sobre la exposición, la mortalidad por cáncer puede estudiarse como una función de diferentes períodos de latencia (pongamos 10, 15, 20 años), del trabajo en diferentes canteras (diferentes tipos de granito), diferentes períodos históricos, diferentes intensidades de exposición, etc. Sin embargo, los 70 casos no pueden subdividirse en demasiadas categorías, ya que su número se haría rápidamente demasiado pequeño para poder realizar análisis estadísticos.

Estos dos tipos de estudios de cohortes presentan ventajas y desventajas. La mayoría de los estudios retrospectivos tan sólo permiten determinar la mortalidad, ya que normalmente no se dispone de datos sobre las manifestaciones más leves. L os registros del cáncer constituyen una excepción, posiblemente junto con algunos otros registros, como los de accidentes cerebrovasculares 0 altas hospitalarias. La evaluación retrospectiva de la exposición plantea siempre problemas y la calidad de los datos sobre la exposición suele ser bastante mala en este tipo de estudios, pudiendo enmascarar el efecto. Por otra parte, al haber ocurrido ya los casos, tienen la ventaja de poder disponer mucho antes de los resultados; por ejemplo, en el plazo de dos o tres años.

U n estudio de cohortes prospectivo es más fácil de planificar para atender las necesidades del investigador y los datos sobre la exposición pueden recogerse de una manera más exacta y sistemática. Asimismo, permite medir diferentes manifestaciones de una enfermedad, repetir las mediciones tanto de la exposición como de sus efectos, estandarizar todas las mediciones y comprobar su validez. Pero si se trata de una enfermedad con un largo período de latencia (como el cáncer), tendrá que pasar mucho tiempo-incluso 20 ó 30 años-antes de poder conocer los resultados del estudio, tiempo durante el cual pueden suceder muchas cosas, por ejemplo, la rotación de los investigadores, la mejora de las técnicas para medir la exposición, la remodelación o el cierre de las fábricas que participan en el estudio, etc. Todas estas circunstancias ponen en peligro el éxito del estudio. Por otra parte, los estudios prospectivos suelen ser más costosos que los retrospectivos, pero esto se debe principalmente al número mucho mayor de mediciones realizadas (vigilancia repetida de la exposición, reconocimientos médicos, etc.) y no al coste del registro de los fallecimientos. Por consiguiente, los costes por unidad de información no son necesariamente superiores a los de los estudios retrospectivos. Considerando todo lo anterior, puede 
decirse que los estudios prospectivos son más adecuados para enfermedades con períodos de latencia relativamente cortos y que requieran un corto período de seguimiento, mientras que los estudios retrospectivos son preferibles para las enfermedades con largos períodos de latencia.

\section{Estudios de casos y controles (o de casos y referentes)}

Volvamos a la fábrica de rayón de viscosa. Si se han perdido las listas de los trabajadores expuestos, no podrá realizarse un estudio de cohortes retrospectivo. Podría realizarse un estudio de cohortes prospectivo, pero tendría que transcurrir mucho tiempo antes de que pudieran conocerse los resultados. 0 tra posibilidad sería comparar a las personas que mueren por cardiopatía coronaria en una ciudad durante un cierto período de tiempo con una muestra de la población total en el mismo grupo de edad.

EI diseño clásico de casos y controles (o casos y referentes) se basa en el muestreo de una población dinámica (abierta, caracterizada por la rotación de sus miembros). Esta población puede ser la de todo un país, un distrito o un municipio (como en nuestro ejemplo), o puede ser una población definida por criterios administrativos, como la de los pacientes ingresados en un hospital. Tanto los casos como los controles (referentes) se obtienen de esta población definida.

La técnica consiste en identificar todos los casos de la enfermedad de interés que existen en un punto en el tiempo (casos prevalentes) o que han ocurrido durante un cierto período de tiempo (casos incidentes). A sí, los casos pueden extraerse de los registros de morbilidad o mortalidad o recabarse directamente de los hospitales o de otras fuentes de diagnósticos válidos. Los controles se obtienen de una muestra de esa misma población, ya sea excluyendo o no los casos. 0 tra posibilidad consiste en seleccionar como controles a pacientes con otras enfermedades, pero esos pacientes deben ser representativos de la población de la que proceden los casos. Pueden seleccionarse uno o más controles (es decir, referentes) para cada caso. EI muestreo es lo que diferencia este tipo de estudio de los estudios de cohortes, ya que en éstos se examina la población total. No hace falta decir que las ventajas de los estudios de casos y controles en términos de ahorro de costes son considerables, pero es importante que la muestra sea representativa de la población total de la que se obtienen los casos (es decir, la "base del estudio"); de lo contrario, puede incorporarse un sesgo al estudio.

Una vez identificados los casos y controles, se registran sus historias de exposición por medio de cuestionarios, encuestas 0 , en algunos casos, aprovechando los registros existentes ( $p$. ej., registros de nóminas de los que puede deducirse la historia profesional de los trabajadores). Los datos pueden obtenerse de los propios participantes 0 , cuando estos han fallecido, de sus familiares más próximos. Para asegurar una memoria simétrica, es importante que la proporción de fallecidos y vivos sea la misma en los casos y en los controles, ya que los familiares próximos suelen facilitar menos detalles sobre la historia profesional que los propios trabajadores. La información sobre la pauta de exposición entre los casos frente a los controles proporciona una estimación del índice de probabilidades (OR ), una medida indirecta del riesgo de desarrollar la enfermedad en los expuestos frente al riesgo en los no expuestos.

El diseño de los estudios de casos y controles se basa en la información sobre la exposición obtenida de pacientes con determinada enfermedad (es decir, los casos) y de una muestra de personas no enfermas (es decir, los controles) de la misma población de la que proceden los casos. Por este motivo, sólo puede investigarse la relación entre la exposición y una enfermedad, aunque permite el estudio simultáneo del efecto de varias exposiciones diferentes. El estudio de casos y referentes es adecuado para responder a preguntas específicas de investigación, por ejemplo, "¿Está la cardiopatía coronaria causada por la exposición a disulfuro de carbono?", pero también ayuda a responder preguntas más generales como "¿Qué exposiciones pueden causar esta enfermedad?"

Tomemos como ejemplo la pregunta de si la exposición a disolventes orgánicos produce cáncer primario de hígado en Europa. Los casos de cáncer primario de hígado, una enfermedad relativamente poco frecuente en Europa, se obtienen del registro nacional del cáncer en el país en cuestión. Supongamos que la serie de casos está formada por todos los cánceres que han ocurrido durante un período de tres años. Por consiguiente, la base de la población del estudio es un seguimiento durante tres años de toda la población de ese país. Los controles se obtienen de una muestra de personas sin cáncer de hígado que pertenecen a la misma población. Por razones de comodidad (para poder muestrear los controles de la misma fuente), se pueden utilizar como controles los pacientes con otro tipo de cáncer no relacionado con la exposición a disolventes. El cáncer de colon no tiene ninguna relación conocida con la exposición a disolventes; por consiguiente, los controles pueden seleccionarse entre pacientes con este tipo de cáncer. (EI uso de controles con cáncer minimiza el sesgo de memoria, ya que la exactitud de la historia facilitada por casos y controles es, en conjunto, simétrica. No obstante, si existiera alguna relación en ese momento desconocida entre el cáncer de colon y la exposición a disolventes que se demostrara más adelante, este tipo de controles causaría una subestimación del riesgo real, no una exageración del mismo.)

Para conseguir una mayor potencia estadística, pueden seleccionarse dos controles por cada caso de cáncer de hígado. (Pueden seleccionarse más de dos controles, pero la disponibilidad de fondos suele ser un factor limitante. Si se dispusiera de fondos ilimitados, quizás lo óptimo sería seleccionar hasta cuatro controles. A partir de cuatro, se aplica la ley de los rendimientos decrecientes.) Una vez obtenido el permiso adecuado de las autoridades responsables de la protección de los datos, se contacta con los casos y controles o con sus familiares próximos, normalmente enviándoles por correo un cuestionario en el que se solicita una historia profesional detallada, con especial énfasis en una lista cronológica de los nombres de todas las empresas, los departamentos de trabajo, las tareas de los puestos de trabajo y el tiempo que ha trabajado en cada puesto. Estos datos pueden obtenerse de los familiares aunque con cierta dificultad y, desde luego, lo que no suelen recordar son los nombres de las sustancias químicas o de los productos comerciales. El cuestionario debe incluir también preguntas sobre posibles variables de confusión, como consumo de alcohol, exposición a alimentos que contienen aflatoxinas o infecciones como hepatitis $B$ y $C$. Para obtener una tasa de respuesta suficientemente alta, se envían dos recordatorios con tres semanas de intervalo a todos los que no hayan respondido al cuestionario. De esta forma, se suele conseguir una tasa final de respuesta superior al $70 \%$. Seguidamente, las historias profesionales son analizadas por un higienista industrial que no sabe si los encuestados son casos 0 controles y que clasifica la exposición a disolventes como elevada, intermedia, leve, inexistente o desconocida. Los diez años de exposición inmediatamente anteriores al diagnóstico del cáncer se excluyen, porque es biológicamente imposible que los cancerígenos de tipo iniciador puedan ser la causa del cáncer con un período de latencia tan corto (aunque los promotores sí podrían serlo, de hecho). En esta etapa, se pueden diferenciar también los tipos de exposición a disolventes. Al haberse obtenido unas historias profesionales completas, se pueden analizar también otras exposiciones que no se incluyen en la hipótesis inicial del estudio. A continuación pueden calcularse los índices de 
Tabla 28.6 - Ejemplo de presentación de los datos de casos y controles.

\begin{tabular}{lll} 
& \multicolumn{2}{l}{ Clasificación de la exposición } \\
& Expuestos & No expuestos \\
Casos & $c_{1}$ & $c_{0}$ \\
No casos & $n_{1}$ & $n_{0}$
\end{tabular}

probabilidad de la exposición a cualquier disolvente, a ciertos disolventes, a mezclas de disolventes, a diferentes intensidades de la exposición y durante diferentes períodos de tiempo en relación con el diagnóstico del cáncer. Conviene excluir del análisis a las personas con exposición desconocida.

Los casos y controles pueden muestrearse y analizarse como series independientes o como grupos emparejados. El emparejamiento significa que la selección del control para cada caso se basa en determinadas características 0 atributos que permiten formar parejas (o conjuntos, si se selecciona más de un control para cada caso). El emparejamiento suele realizarse en función de uno o más de esos factores, como edad, estado vital, tabaquismo, año en que se diagnosticó el caso, etc. En nuestro ejemplo, los casos y controles se emparejan en función de la edad y el estado vital. (EI estado vital es importante, ya que los pacientes suelen proporcionar una historia más detallada de las exposiciones que sus familiares próximos y la simetría es esencial para la validez del estudio). En la actualidad, se recomienda restringir el emparejamiento porque este procedimiento puede introducir una confusión negativa (que enmascare el efecto).

Si un control se empareja con un caso, el diseño se llama diseño de parejas. Siempre que el coste de seleccionar un mayor número de controles no sea prohibitivo, la selección de más de un referente por caso aumenta la estabilidad del estimador del O R y, por consiguiente, la eficiencia del estudio en relación con su tamaño.

En la Tabla 28.6 se indica la manera de presentar los resultados de un estudio de casos y controles no emparejados.

A partir de esta tabla, puede calcularse la probabilidad de exposición en los casos y la de exposición en la población (los controles) y dividir ambas para obtener el índice de probabilidades de la exposición, OR (odds ratio). Para los casos, la probabilidad de exposición es $c_{1} / c_{0}$, y para los controles es $n_{1} / n_{0}$. EI OR se calcula entonces como:

$$
O R=\frac{c_{1} / c_{0}}{n_{1} / n_{0}}=\frac{c_{1} n_{0}}{c_{0} n_{1}}
$$

Si el número de casos expuestos es relativamente mayor que el de los controles expuestos, el O R será mayor de 1 y viceversa. Al igual que para el riesgo relativo, también tienen que calcularse e indicarse los intervalos de confianza para el $O R$.

Supongamos otro ejemplo, el de un centro de medicina del trabajo de una gran empresa que atiende a 8.000 empleados expuestos a distintos tipos de polvo y otros agentes químicos. En nuestro caso, estamos interesados en la relación entre la exposición a mezclas de polvo y la bronquitis crónica. El estudio incluye el seguimiento de esta población durante un año. $\mathrm{H}$ emos establecido los criterios de diagnóstico para la bronquitis crónica como "tos y expectoración por las mañanas durante tres meses en dos años consecutivos". L os criterios para la exposición "positiva" al polvo se definen antes de que se inicie el estudio. Todos los pacientes que visitan el centro médico y que cumplen estos criterios durante el período de un año se consideran un caso y el siguiente paciente que solicita asistencia médica por problemas no pulmonares se selecciona como control. Supongamos que se reclutan 100 casos y 100 controles durante el período del estudio. Supongamos también que 40 casos y 15 controles se clasifican como expuestos al polvo. Así:

$$
c_{1}=40, c_{0}=60, n_{1}=15, y n_{0}=85 \text {. }
$$

En consecuencia,

$$
\mathrm{OR}=\frac{40 \times 85}{60 \times 15}=3,78
$$

En el ejemplo anterior, no se ha considerado la posibilidad de que exista una confusión que distorsione el OR por diferencias sistemáticas en los casos y los controles con relación a una variable como la edad. U na forma de reducir el sesgo sería emparejar los controles y casos en función de la edad u otros factores sospechosos. De esta manera se obtendrían los datos que aparecen en la Tabla 28.7.

El análisis se centra en las parejas discordantes: es decir, "caso expuesto, control no expuesto" $\left(f_{+-}\right)$; y "caso no expuesto, control expuesto" $\left(f_{-+}\right)$. Cuando los dos miembros de una pareja están o no expuestos, la pareja se ignora. EI OR en un estudio de parejas se define como:

$$
O R=\frac{f_{++}}{f_{-+}}
$$

En un estudio de la asociación entre el cáncer nasal y la exposición a polvo de madera, participaron un total de 164 parejas de casos y controles. En sólo una pareja, tanto el caso como el control habían estado expuestos y, en 150 parejas, ni el control ni el caso habían estado expuestos. Estas parejas se excluyeron del resto del estudio. En 12 parejas, el caso, pero no el control, había estado expuesto, y en una pareja, el control, pero no el caso. Así pues:

$$
\text { OR }=\frac{f_{+-}}{f_{-+}}=\frac{12}{1}=12(95 \% \text { IC } 1,56-92,29)
$$

$y$, al no estar la unidad dentro de este intervalo, el resultado es estadísticamente significativo; es decir, existe una asociación estadísticamente significativa entre el cáncer nasal y la exposición al polvo de madera.

Los estudios de casos y controles son más eficientes que los estudios de cohortes cuando la enfermedad es poco frecuente; de hecho, pueden constituir la única alternativa posible. Sin embargo, también pueden utilizarse para estudiar enfermedades frecuentes. Si la exposición es poco frecuente, el mejor diseño epidemiológico o el único posible es el estudio de una cohorte basada en la exposición. Por supuesto, las exposiciones comunes también pueden estudiarse con diseños de cohortes. La elección entre diseños de cohortes o casos y controles cuando tanto la exposición como la enfermedad son frecuentes suele depender de ciertas consideraciones relacionadas con la validez.

Al basarse los estudios de casos y controles en datos retrospectivos de la exposición, generalmente recurriendo a la memoria de los participantes, el punto débil de este diseño es la inexactitud de la información sobre la exposición, cuyo resultado

\begin{tabular}{lcl}
\hline Tabla 28.7 & $\begin{array}{l}\text { Presentación de los datos de casos y } \\
\text { controles si se empareja un control con } \\
\text { cada caso. }\end{array}$ \\
Casos & Exposición $(+)$ & Referentes \\
Exposisión $(+)$ & $\mathrm{f}_{++}$ & $\mathrm{f}_{+-}$ \\
Exposición $(-)$ & $\mathrm{f}_{-+}$ & $\mathrm{f}_{--}$ \\
\hline
\end{tabular}


puede ser el enmascaramiento del efecto por una clasificación errónea (simétrica) no diferencial de la exposición. Además, algunas veces la memoria puede ser asimétrica entre los casos y controles, creyéndose en general que los casos recuerdan "mejor" (sesgo de memoria). La memoria selectiva puede introducir un sesgo de magnificación del efecto por la clasificación errónea (asimétrica) diferencial de la exposición. La ventaja de los estudios de casos y controles es su eficacia con relación al coste y su capacidad para resolver un problema con relativa rapidez. Gracias a las técnicas de muestreo, se pueden investigar poblaciones diana muy grandes (p. ej., a través de los registros nacionales del cáncer), aumentando así la potencia estadística del estudio. En países en los que la legislación sobre la protección de los datos o la ausencia de unos registros adecuados de población y morbilidad no permite realizar estudios de cohortes, los estudios de casos y controles basados en los hospitales puede ser la única forma práctica de realizar una investigación epidemiológica.

\section{M uestreo de casos y controles dentro de una cohorte (estudios de casos y controles anidados en una cohorte)}

Un estudio de cohortes puede diseñarse también para realizar el seguimiento de una muestra en lugar de la población completa. Este diseño se denomina estudio de casos y controles "anidados" en una cohorte. EI método de muestreo dentro de la cohorte establece diferentes criterios para la selección de la cohorte, porque en este caso las comparaciones se realizan dentro de la misma cohorte. Por consiguiente, la cohorte debe incluir, no sólo a los trabajadores sometidos a elevadas exposiciones, sino también a trabajadores sometidos a exposiciones menores e incluso a trabajadores no expuestos, para conseguir contrastes de exposición dentro de la misma cohorte. Es importante que estos requisitos diferentes para la selección de la cohorte se tengan en cuenta a la hora de reclutar a sus miembros. Si se realiza un primer análisis de toda una cohorte a la que se le aplica como criterio de selección una exposición "elevada" y más adelante se realiza un estudio de casos y controles "anidado" en esa misma cohorte, la sensibilidad del estudio se reduce. El efecto se enmascara porque los contrastes de exposición son insuficientes "por diseño", al no existir variabilidad en la exposición experimentada por los miembros de la cohorte.

Sin embargo, siempre que la cohorte presente una amplia variedad de situaciones de exposición, los estudios de casos y controles anidados en una cohorte resultan muy atractivos. Se reclutan todos los casos que aparecen en la cohorte durante el período de seguimiento para formar la serie de casos, pero sólo se obtiene una muestra de los demás miembros de la cohorte para formar la serie de controles. Seguidamente, los investigadores obtienen información detallada sobre la exposición, como en el diseño tradicional de casos y controles, entrevistando a los casos y controles (o a sus familiares próximos), analizando los registros del personal de las empresas, construyendo matrices de puestos de trabajo y exposición, o combinando dos o más de estos métodos. Los controles pueden emparejarse con los casos o pueden tratarse como series independientes.

La estrategia del muestreo puede ser menos costosa que la recopilación exhaustiva de información sobre todos los miembros de la cohorte. En particular, al estudiarse sólo una muestra de los controles, pueden dedicarse más recursos a realizar una evaluación detallada y exacta de la exposición de todos los casos y controles. Sin embargo, este tipo de diseño plantea los mismos problemas de potencia estadística que los estudios clásicos de cohortes. Para conseguir una potencia estadística adecuada, la cohorte debe incluir siempre un número "adecuado" de casos expuestos, dependiendo de la magnitud del riesgo que se intenta detectar.

\section{Diseños de estudios transversales}

En un sentido científico, un diseño transversal es una sección transversal de la población del estudio, sin tener en cuenta ninguna consideración relacionada con el tiempo. Tanto la exposición como la morbilidad (prevalencia) se miden en el mismo punto en el tiempo.

Desde el punto de vista etiológico, este tipo de estudio presenta muchas limitaciones, en parte porque sólo hace referencia a la prevalencia, y pasan por alto la incidencia. La prevalencia es una medida compuesta que depende tanto de la incidencia como de la duración de la enfermedad. Esto determina que los estudios transversales tengan que limitarse a enfermedades de larga duración. 0 tro problema incluso más grave es el marcado sesgo negativo causado por la eliminación, por problemas de salud, de las personas más sensibles a los efectos de la exposición en el grupo de expuestos. Por ello, los problemas etiológicos se resuelven mejor con diseños longitudinales. De hecho, los estudios transversales no permiten extraer ninguna conclusión sobre si la exposición precede a la enfermedad 0 viceversa. El diseño transversal sólo tiene sentido etiológico si existe una relación en tiempo real entre la exposición y el resultado, lo que significa que la exposición tiene que tener efectos inmediatos. Sin embargo, la exposición puede medirse transversalmente de manera que represente un período más largo en el pasado ( $p$. ej., el nivel sanguíneo de plomo) y su efecto medirse en términos de prevalencia ( $p$. ej., velocidades de conducción nerviosa). Este estudio sería, por tanto, una mezcla de diseño longitudinal y transversal, y no una simple sección transversal de la población del estudio.

\section{Encuestas descriptivas transversales}

Las encuestas transversales suelen ser más útiles para fines prácticos y administrativos que científicos. Los principios epidemiológicos pueden aplicarse a las actividades sistemáticas de vigilancia en el contexto de la higiene industrial, entre ellas las siguientes:

- Observación de la morbilidad asociada a una profesión, un área de trabajo o determinadas exposiciones.

- Encuestas periódicas de los trabajadores expuestos a peligros profesionales conocidos.

- Exploración de los trabajadores que entran en contacto con nuevos peligros para la salud.

- Programas de control biológico.

- Encuestas sobre la exposición para identificar y cuantificar los peligros.

- Programas de exploración selectiva en diferentes grupos de trabajadores.

- Evaluación de la proporción de trabajadores que requieren controles preventivos o periódicos (p. ej., presión arterial, cardiopatía coronaria).

Es importante elegir unos indicadores que sean representativos, válidos y específicos para todo tipo de encuestas. Al contrario que para el diagnóstico clínico, en una encuesta o en un programa de exploración selectiva sólo pueden realizarse un número reducido de pruebas y, por consiguiente, el valor predictivo de estas pruebas es importante. Los métodos poco sensibles no detectan la enfermedad de interés, mientras que los métodos muy sensibles producen demasiados resultados falsos positivos. Todas las actividades orientadas a la detección de casos (es decir, exploración selectiva) deben incluir también mecanismos para prestar asistencia a las personas que han dado resultados "positivos", tanto en términos de diagnóstico como de tratamiento. De lo contrario, el único resultado de estas actividades será la frustración, pudiendo el estudio causar más daños que beneficios. 


\section{- ASPECTOS RELACIONADOS CON LA VALIDEZ DEL DISEÑO DEL ESTUDIO}

Annie J. Sasco

\section{La necesidad de la validez}

La epidemiología tiene como finalidad facilitar información sobre las enfermedades que afectan a las poblaciones. En particular, puede utilizarse para obtener información sobre las causas profesionales de los problemas de salud. Esta información se deriva de los estudios realizados en grupos de personas que presentan una enfermedad, comparándolas con personas que no presentan dicha enfermedad. 0 tro enfoque consiste en analizar las enfermedades que aparecen en personas sometidas a ciertas exposiciones en su trabajo y compararlas con las pautas de esas mismas enfermedades en las personas que no están sometidas a dichas exposiciones. De esta forma, se puede estimar el riesgo de enfermedad asociado a exposiciones específicas. Si se pretende que la información obtenida de este tipo de estudios pueda utilizarse para diseñar programas de prevención, identificar enfermedades profesionales e indemnizar debidamente a los trabajadores afectados por las exposiciones, estos estudios deben ser válidos.

La validez puede definirse como la capacidad de un estudio para reflejar la situación real. Un estudio válido es, por consiguiente, aquel que mide correctamente la asociación (ya sea positiva, negativa o inexistente) entre una exposición y una enfermedad y que describe la dirección y la magnitud de un riesgo real. Se pueden distinguir dos tipos de validez: interna y externa. La validez interna es la capacidad de un estudio para reflejar lo que realmente les sucede a los participantes del estudio; la validez externa refleja lo que podría ocurrir en la población.

La validez hace referencia a la fiabilidad de la medición y no debe confundirse con la precisión de la medición, que es una función del tamaño del estudio y de la eficiencia del diseño del estudio.

\section{Validez interna}

Se dice que un estudio es internamente válido cuando está libre de sesgos y, por consiguiente, refleja fielmente la asociación entre exposición y enfermedad que existe en la población del estudio. La observación de un riesgo de enfermedad asociado a una exposición puede ser, de hecho, el resultado de una asociación real, en cuyo caso será válida, pero puede también reflejar la influencia de sesgos que ofrecen una imagen distorsionada de la realidad.

En general, se distinguen tres tipos de sesgos, llamados también errores sistemáticos:

- Sesgo de selección.

- Sesgo de información u observación.

- Confusión.

Estos tres tipos de sesgos se describen brevemente a continuación, utilizando ejemplos extraídos del contexto de la higiene industrial.

\section{Sesgo de selección}

El sesgo de selección se produce cuando la selección de los participantes en el estudio se ve influida por el conocimiento de la situación de exposición de los posibles participantes. Por consiguiente, este problema sólo existe cuando la enfermedad ha tenido ya lugar en el momento de seleccionar a los participantes. En el contexto epidemiológico, esta situación suele darse en los estudios de casos y controles o en los estudios retrospectivos de cohortes y significa que una persona tiene más probabilidades de ser considerada un caso si se sabe que ha estado expuesta. Existen tres tipos de circunstancias que pueden producir este hecho y que dependerán también de la gravedad de la enfermedad.

\section{Sesgo de autoselección}

Este tipo de sesgo ocurre cuando las personas que saben que han estado expuestas en el pasado a productos cuyo riesgo se conoce o sospecha y que están convencidas de que su enfermedad es el resultado de la exposición a los mismos, acuden al médico porque presentan síntomas que otras personas, no expuestas, probablemente habrían pasado por alto. Esta situación es más probable en el caso de enfermedades cuyos síntomas no siempre se advierten. Un ejemplo puede ser la pérdida prematura de un embarazo 0 los abortos espontáneos en enfermeras que están en contacto con fármacos utilizados para el tratamiento del cáncer. Estas mujeres conocen la fisiología reproductiva mejor que la mayoría y, si están preocupadas por su capacidad reproductiva, es posible que reconozcan o etiqueten como aborto espontáneo lo que otras mujeres considerarían tan sólo como un retraso en la menstruación. O tro ejemplo de este sesgo en un estudio retrospectivo de cohortes, citado por Rothman (1986), es el estudio de la leucemia realizado por el Center for Disease Control (CDC) en los soldados que estuvieron presentes en las pruebas atómicas de N evada. En este estudio, la cohorte estuvo constituida por el $76 \%$ de los soldados presentes durante dichas pruebas a las que se realizó un seguimiento. De este $76 \%$, los investigadores localizaron al $82 \%$, pero otro $18 \%$ contactó con los investigadores por iniciativa propia cuando oyeron hablar del estudio. En el $82 \%$ de los soldados con los que el CDC se puso en contacto, se presentaron cuatro casos de leucemia; en el $18 \%$ de los soldados que se remitieron por iniciativa propia a los investigadores, se presentaron otros cuatro casos. Esto sugiere claramente que la capacidad de los investigadores para identificar a las personas expuestas estuvo relacionada con el riesgo de leucemia.

\section{Sesgo del diagnóstico}

Este tipo de sesgo se produce cuando la probabilidad de que los médicos diagnostiquen una enfermedad es mayor si ya conocen las exposiciones a las que han estado sometidos los pacientes. Por ejemplo, cuando la mayoría de las pinturas se fabricaban con plomo, uno de los síntomas de una enfermedad de los nervios periféricos, Ilamada neuritis periférica con parálisis, se conocía como la "caída de muñeca" de los pintores. El hecho de conocer la profesión del paciente facilita el diagnóstico de la enfermedad incluso en sus primeros estadíos, ya que la identificación del agente etiológico es mucho más difícil si los participantes del estudio no saben que han estado expuestos al plomo en sus trabajos.

\section{Sesgo resultante de la negativa a participar en un estudio} Cuando las personas, sanas o enfermas, reciben la invitación de participar en un estudio, existen una serie de factores que influyen en la decisión de aceptar o no dicha invitación. La buena disposición a responder cuestionarios de longitud variable, que a veces indagan sobre asuntos delicados, o a facilitar muestras de sangre 0 de otros materiales biológicos, puede estar determinada por el propio interés de la persona. Si una persona sabe que ha podido estar expuesta en el pasado, puede prestarse a responder al cuestionario con la esperanza de ayudar a encontrar la causa de la enfermedad. Por el contrario, si piensa que no ha estado expuesta a nada peligroso o si no está interesada en conocer los resultados del estudio, puede rechazar la invitación a participar en él. El resultado puede ser la selección de aquellas personas que finalmente serán los participantes del estudio en comparación con todas aquellas que podrían haberlo sido. 


\section{Sesgo de información}

Este tipo de sesgo se llama también sesgo de observación y afecta al efecto para la salud en los estudios de seguimiento y a la evaluación de la exposición en los estudios de casos y controles.

\section{Evaluación diferencial del efecto para la salud en estudios prospectivos de seguimiento (cohortes)}

Al inicio del estudio se definen dos grupos: los expuestos y los no expuestos. Si la búsqueda de casos difiere en estos dos grupos, se incorporará un sesgo de diagnóstico. Por ejemplo, consideremos una cohorte de personas expuestas a una emisión accidental de dioxina en determinado sector industrial. Se establece un sistema de seguimiento para los trabajadores sometidos a el evadas exposiciones que consiste en reconocimientos médicos y control biológico a intervalos regulares, mientras que el resto de los trabajadores siguen recibiendo la asistencia habitual. En esta situación, es muy probable que se identifiquen más casos de enfermedad en el grupo sometido a una estrecha vigilancia, lo que podría dar como resultado una sobrestimación del riesgo.

\section{Pérdidas diferenciales en los estudios retrospectivos de cohortes}

En los estudios retrospectivos de cohortes puede producirse el mecanismo inverso al descrito en el apartado anterior. En estos estudios, el proceso habitual consiste en consultar los archivos de todas las personas que han trabajado en determinada industria en el pasado y evaluar la morbilidad o mortalidad posterior a su empleo. Lamentablemente, estos archivos suelen estar incompletos y el hecho de que una persona no aparezca en ellos puede deberse a su situación de exposición, a su enfermedad o a ambas cosas. Por ejemplo, en un reciente estudio realizado en la industria química de los trabajadores expuestos a aminas aromáticas, se detectaron ocho tumores en un grupo de 777 trabajadores que habían sido sometidos a exploración citológica selectiva para la detección de tumores urinarios. En total, sólo se observó la ausencia de 34 historias, lo que suponía una pérdida del $4,4 \%$ en el archivo de evaluación a la exposición; sin embargo, en lo que respecta a los casos de cáncer de vejiga, faltaban los datos de exposición correspondientes a dos de los ocho casos, o un $25 \%$. Esto demuestra que la probabilidad de pérdida fue mayor para las historias de las personas que se convirtieron en casos que para las historias de otros trabajadores, lo cual puede deberse a una mayor rotación del puesto de trabajo en la empresa (posiblemente relacionada con los efectos de la exposición), o a dimisión, despido o mera casualidad.

\section{Evaluación diferencial de la exposición en estudios de casos y controles}

En los estudios de casos y controles, la enfermedad ya se ha producido en el momento de iniciarse el estudio y debe recopilarse información sobre las exposiciones en el pasado. La actitud de los encuestadores o de los participantes puede introducir un sesgo en el estudio. La información suele ser recogida por encuestadores expertos que pueden o no conocer la hipótesis de la investigación. Por ejemplo, si se realiza un estudio de casos y controles del cáncer de vejiga basado en la población en una región altamente industrializada, es probable que el personal del estudio conozca el hecho de que determinadas sustancias químicas, como las aminas aromáticas, son factores de riesgo para el cáncer de vejiga. Si también saben quién ha desarrollado la enfermedad y quién no, es probable que realicen encuestas más minuciosas a los casos de cáncer de vejiga que a los controles. Es posible que intenten recabar información más detallada sobre los empleos anteriores de los casos, buscando sistemáticamente la exposición a aminas aromáticas y, por el contrario, que registren de forma más rutinaria los empleos de los controles. El sesgo resultante se denomina sesgo por sospecha de exposición.
L os propios participantes pueden ser también responsables de este tipo de sesgo. Es lo que se llama sesgo de memoria para distinguirlo del sesgo del encuestador. En ambos casos, el sesgo se produce como resultado de la sospecha de exposición. Las personas enfermas pueden sospechar que su enfermedad es de origen profesional y, por consiguiente, intentarán recordar con la mayor exactitud posible todos los agentes peligrosos a los que han podido estar expuestos. En el caso de que hayan manipulado productos indefinidos, es posible que recuerden mejor los nombres de sustancias químicas precisas, particularmente si se les muestra una lista de productos sospechosos. Por el contrario, la probabilidad de que los controles pasen por el mismo proceso mental es menor.

\section{Confusión}

La confusión se produce cuando la asociación observada entre la exposición y la enfermedad es en parte el resultado de la combinación del efecto de la exposición estudiada y de otro factor. Supongamos, por ejemplo, que hemos observado un mayor riesgo de cáncer de pulmón en los soldadores. Inmediatamente nos veremos tentados a concluir que existe una relación causal entre la exposición a los gases de soldadura y el cáncer de pulmón. Sin embargo, sabemos también que el tabaco es uno de los principales factores de riesgo para el cáncer de pulmón. Por consiguiente, si disponemos de información, lo primero que haremos será comprobar si los soldadores y otros participantes del estudio fuman o no. Es posible que los soldadores fumen más que otros trabajadores. Si así fuera, sabríamos ya que el tabaco está asociado con el cáncer de pulmón y, al mismo tiempo, habríamos observado que en nuestro estudio el tabaco está también asociado a la profesión de soldador. En términos epidemiológicos, eso significa que el tabaquismo, al estar relacionado tanto con el cáncer de pulmón como con la profesión de soldador, está confundiendo la asociación entre la profesión de soldador y cáncer de pulmón.

\section{Interacción o modificación del efecto}

Al contrario que todos los sesgos descritos antes, principalmente los relacionados con la selección, información y confusión, la interacción no es un sesgo producido por problemas en el diseño o en el análisis del estudio, sino que refleja la realidad y su complejidad. Un ejemplo de este fenómeno es el siguiente: la exposición a radón es un factor de riesgo para el cáncer de pulmón, como también lo es el tabaquismo. Además, el tabaquismo y la exposición al radón tienen efectos diferentes sobre el riesgo de cáncer de pulmón dependiendo de que actúen conjuntamente o por separado. La mayoría de los estudios de higiene industrial sobre este tema se han realizado en mineros que trabajan bajo tierra, y algunos de ellos han dado resultados contradictorios. En conjunto, sugieren una interacción entre el tabaquismo y la exposición al radón para producir cáncer de pulmón. Esto significa que la exposición al radón aumenta el riesgo de cáncer incluso en los no fumadores, pero que la magnitud del riesgo asociado al radón es mucho mayor en los fumadores que en los no fumadores. En términos epidemiológicos, decimos que el efecto es multiplicativo. Al contrario que la confusión descrita antes, la interacción no tiene simplemente que controlarse, sino que también debe analizarse y describirse con detalle, ya que refleja lo que está sucediendo en un plano biológico y no es meramente la consecuencia de un mal diseño del estudio. Su explicación conduce a una interpretación más válida de los resultados del estudio.

\section{Validez externa}

E ste aspecto sólo puede abordarse una vez comprobada la validez interna del estudio. Si estamos convencidos de que los resultados 
obtenidos en el estudio reflejan asociaciones que son reales, podemos preguntarnos si dichos resultados son extrapolables a una población mayor de la que proceden los participantes del estudio, 0 incluso a otras poblaciones que son idénticas 0 al menos muy parecidas. La pregunta más habitual es si los resultados obtenidos en el hombre pueden extrapolarse a la mujer. Durante años, los estudios y, en especial, las investigaciones de la epidemiología del trabajo, se han realizado exclusivamente en hombres. Los estudios de los trabajadores de industrias químicas realizados en el decenio de 1960 en Estados U nidos, Reino U nido y Suecia observaron en todos los casos riesgos más elevados de ciertos tipos de cáncer, principalmente leucemia, linfoma y cáncer de páncreas. Por lo que ya sabemos de los efectos de la exposición a disolventes y a otras sustancias químicas, podríamos deducir que el trabajo de laboratorio conlleva también un mayor riesgo de cáncer para las mujeres. Esto se demostró cuando, a mediados del decenio de 1980 , se publicó el primer estudio sobre las trabajadoras de industrias químicas, con resultados similares a los obtenidos en el hombre. M erece la pena recordar que se observó también un mayor riesgo de otros cánceres, como tumores de mama y de ovarios, que hasta entonces sólo se habían relacionado con factores endógenos o reproductivos, pero cuya posible relación con otros factores ambientales se está empezando a sospechar. Todavía queda mucho por investigar sobre factores determinantes relacionados con el trabajo de los cánceres femeninos.

\section{Estrategias para un estudio válido}

Un estudio perfectamente válido no puede existir nunca, pero el investigador es responsable de evitar, 0 al menos reducir al mínimo, el mayor número posible de sesgos. En general, esto resulta más fácil de conseguir durante la etapa de diseño del estudio, aunque también puede realizarse durante el análisis.

\section{Diseño del estudio}

Los sesgos de selección e información pueden evitarse mediante un cuidadoso diseño de los estudios epidemiológicos, una aplicación rigurosa de todas las directrices establecidas para las actividades del día a día y una atención meticulosa a los procedimientos de garantía de calidad para la realización del estudio sobre el terreno. La confusión puede controlarse en la etapa del diseño o del análisis.

\section{Selección}

Los criterios para clasificar a los participantes como casos deben definirse explícitamente. No se puede, 0 al menos no se debe, intentar estudiar trastornos clínicos que no se haya definido antes claramente. Una forma de reducir al mínimo el efecto que puede tener el hecho de conocer la exposición en la evaluación de la enfermedad es seleccionar sólo los casos graves que se habrían diagnosticado también sin información sobre la historia del paciente. Los estudios sobre el cáncer suelen limitarse a los casos con pruebas histológicas de la enfermedad, para evitar la inclusión de lesiones dudosas. Esto significará también que los grupos del estudio se han definido claramente. Por ejemplo, en la epidemiología del cáncer se sabe claramente que los cánceres de diferentes tipos histológicos que afectan a un mismo órgano pueden tener factores de riesgo diferentes. Si el número de casos es suficiente, conviene distinguir entre adenocarcinoma de pulmón y carcinoma pulmonar de células escamosas. Cualesquiera que sean los criterios finales de selección, deben siempre definirse y describirse claramente. Por ejemplo, debe indicarse el código exacto de la enfermedad utilizando la Clasificación Internacional de Enfermedades (CIE) y, en el caso del cáncer, la Clasificación Internacional de Enfermedades-O ncología (CIE-O).

U na vez establecidos los criterios, los investigadores deben intentar conseguir el máximo número de participantes. El rechazo a participar en un estudio casi nunca se produce al azar $y$, por consiguiente, introduce sesgos. Lo primero que debe hacerse es presentar el estudio a los médicos que atienden a los pacientes. Su aprobación es necesaria para establecer contacto con los pacientes y, por consiguiente, deben estar convencidos de la utilidad del estudio. Un argumento que suele convencerles es el interés del estudio para la salud pública. Sin embargo, en esta etapa no conviene discutir la hipótesis exacta del estudio, para evitar influencias no deseadas en los médicos. No se les debe pedir que asuman funciones complementarias; es más fácil convencer a los profesionales sanitarios de que presten su apoyo al estudio cuando los investigadores les facilitan medios para realizar las tareas adicionales que requiere el estudio, además de la asistencia rutinaria. $\mathrm{Ni}$ los encuestadores ni los recopiladores de datos deben conocer el estado de salud de los pacientes.

L os investigadores deben tener el mismo cuidado con la información que facilitan a los participantes. Deben realizar una descripción general y neutral del objetivo del estudio, pero que al mismo tiempo resulte convincente y persuasiva. Es importante que los participantes comprendan todos los aspectos relacionados con la confidencialidad de la información y el interés del estudio para la salud pública, evitando al mismo tiempo la jerga médica. En la mayoría de los casos, no se considera adecuado recurrir a incentivos económicos o de otra índole, aunque deben cubrirse todos los gastos que puedan tener los participantes. Por último, aunque no menos importante, la población general debe tener conocimientos científicos suficientes para comprender la importancia de la investigación. Cuando el estudio exija rellenar algún cuestionario u obtener muestras biológicas para su conservación 0 análisis, los investigadores tendrán que explicar a todos los participantes los beneficios y los riesgos de su participación en el estudio. N unca se debe recurrir a la coacción para obtener un consentimiento informado. Cuando los estudios se basan exclusivamente en registros, los investigadores deben conseguir la aprobación previa de los organismos responsables de garantizar la confidencialidad de dichos registros. En tales casos, normalmente se evita solicitar el consentimiento informado a todos y cada uno de los participantes, siendo suficiente con la aprobación del sindicato o de las autoridades competentes. Las investigaciones epidemiológicas no constituyen una amenaza para la vida privada de las personas, sino una ayuda potencial para mejorar la salud de la población. Antes de realizar un estudio, éste tendrá que ser aprobado por un consejo de revisión institucional (o un comité de ética), para lo cual deberá ajustarse a casi todo lo que se ha comentado en los apartados precedentes.

\section{Información}

En los estudios de seguimiento prospectivo, los medios utilizados para evaluar la situación de morbilidad o mortalidad deben ser idénticos para los participantes expuestos y no expuestos. En particular, no deben utilizarse distintas fuentes de información, como sería el caso de consultar un registro centralizado de mortalidad sólo para los participantes no expuestos y utilizar los datos obtenidos de la vigilancia activa intensiva de los participantes expuestos. I gualmente, la causa de mortalidad debe obtenerse de forma estrictamente comparable en los dos grupos. Esto significa que si se utiliza un sistema para conseguir acceso a documentos oficiales sobre la población no expuesta, que suele ser la población general, no se debe nunca pensar en obtener información más precisa a través de historias médicas o encuestas de los propios participantes o sus familias en el subgrupo de los expuestos.

En los estudios retrospectivos de cohortes, se debe intentar determinar la medida en que la población del estudio se compara con la población de interés. D ebemos ser conscientes de las posibles pérdidas diferenciales en los grupos expuestos y 
no expuestos cuando se utilizan distintas fuentes de información sobre la composición de la población. Por ejemplo, puede que sea útil comparar las listas de nóminas con las listas de miembros de un sindicato $u$ otras listas profesionales. Todas las discrepancias deben conciliarse y el protocolo adoptado para el estudio debe seguirse de cerca.

En los estudios de casos y controles, existen otras formas de evitar los sesgos. $\mathrm{Ni}$ los encuestadores, ni el personal del estudio, ni los participantes, deben conocer la hipótesis exacta del estudio. Si no saben qué asociación se está estudiando, la probabilidad de que intenten dar la respuesta esperada será menor. No obstante, mantener la ignorancia del personal del estudio sobre la hipótesis de la investigación es con frecuencia bastante difícil. El encuestador casi siempre sabe cuáles son las exposiciones de mayor interés, así como quién es un caso y quién es un control. Por consiguiente, tenemos que confiar en su honestidad y en sus conocimientos en metodología de investigación básica que debe haber adquirido como parte de su formación profesional; la objetividad es, en todos los pasos, el pilar de la ciencia.

$\mathrm{M}$ antener la ignorancia de los participantes del estudio sobre el objeto exacto de la investigación resulta más sencillo. En general, unas explicaciones básicas y claras sobre la necesidad de recoger datos para ampliar los conocimientos sobre la salud y la enfermedad serán suficientes y satisfarán los requisitos del comité de ética.

\section{Confusión}

La confusión es el único sesgo que puede controlarse en la etapa del diseño del estudio 0 , siempre que se disponga de información adecuada, en la etapa del análisis. Si, por ejemplo, la edad se considera un posible factor de confusión de la asociación que interesa porque está asociada al riesgo de enfermedad (p. ej., el cáncer es más frecuente en personas de edad avanzada) y también a la exposición (las condiciones de la exposición varían con la edad o con factores relacionados con la edad, como cualificación, puesto de trabajo y duración del empleo) existen varias soluciones. La más sencilla consiste en limitar el estudio a un rango de edades específico (por ejemplo, reclutar sólo a hombres caucasianos de 40 a 50 años). Con este tipo de estudios se simplifica el análisis, aunque tienen también la desventaja de limitar la aplicación de los resultados a un único grupo de edad o étnico. 0 tra solución es el emparejamiento por edades, que consiste en seleccionar para cada caso un referente de la misma edad. La idea del emparejamiento resulta atractiva, aunque puede ser difícil de poner en práctica cuando aumenta el número de factores de emparejamiento. Por otra parte, una vez que los casos y controles se emparejan en función de un factor, se hace imposible evaluar el efecto de dicho factor en la aparición de la enfermedad. La última solución consiste en disponer de información suficiente sobre los posibles factores de confusión en la base de datos del estudio para comprobar su efecto durante la etapa del análisis. Esto puede hacerse mediante un análisis estratificado sencillo o utilizando herramientas más complejas como el análisis multivariante. Sin embargo, debe recordarse que el análisis nunca podrá compensar un estudio mal diseñado o mal realizado.

\section{Conclusión}

La posibilidad de introducir sesgos en la investigación epidemiológica se conoce desde hace mucho tiempo. Los sesgos no constituían un motivo de gran preocupación cuando se estudiaban asociaciones estrechas (como el tabaco y el cáncer de pulmón), ya que una cierta inexactitud no causaba un problema demasiado grave. Sin embargo, ahora que ha llegado el momento de evaluar factores de riesgo más débiles, la necesidad de mejorar las herramientas adquiere una importancia crucial. Esto supone la necesidad de unos diseños excelentes y la posibilidad de combinar las ventajas de los diseños tradicionales, como los estudios de casos y controles o de cohortes, con enfoques más innovadores, como los estudios de casos y controles anidados en una cohorte. Asimismo, el uso de biomarcadores puede proporcionar los medios para obtener evaluaciones más exactas de las exposiciones en el pasado y en el presente, así como en los primeros estadíos de la enfermedad.

\section{CONSECUENCIAS DEL ERROR DE MEDIDA ALEATO RIO}

Paolo Vineis y Colin L. Soskolne

Los errores en la medición de la exposición pueden tener diferentes consecuencias en lo que se refiere a la relación entre exposición y enfermedad, dependiendo de la distribución de los mismos. Si se realiza un estudio epidemiológico ciego (es decir, si las medidas se realizan sin conocer el estado de enfermedad 0 salud de los participantes del estudio), cabe esperar que el error en la medición se distribuya uniformemente entre los distintos estratos de la enfermedad o el estado de salud.

En la Tabla 28.8 se ofrece un ejemplo. Supongamos que reclutamos una cohorte de personas expuestas a un tóxico para investigar una enfermedad frecuente. La situación de exposición se determina sólo en el momento del reclutamiento $\left(T_{0}\right)$, y no en ningún momento posterior durante el seguimiento. Sin embargo, supongamos que durante el año siguiente una serie de personas cambian su situación de exposición: en el momento $\mathrm{T}_{1}$, 250 de las 1.200 personas expuestas en un principio han dejado de estarlo, mientras que 150 de las 750 personas inicialmente no expuestas al tóxico han empezado a estarlo. Por consiguiente, en el momento $T_{1}, 1.100$ personas están expuestas y 850 no lo están. Como consecuencia, habremos "clasificado erróneamente" la situación de exposición al basarnos en la medición inicial de la misma en el momento $\mathrm{T}_{0}$. Seguidamente, se realiza el seguimiento de estas personas durante 20 años (en el momento $T_{2}$ ) y se evalúa el riesgo acumulado de enfermedad. (EI supuesto que se hace en este ejemplo es que sólo la exposición durante más de un año constituye un riesgo.)

La clasificación errónea depende, en este ejemplo, del diseño del estudio y de las características de la población, más que de las limitaciones técnicas de la medición de la exposición. El efecto del error en la clasificación es tal que el cociente "real" de 2,0 entre el riesgo acumulado en las personas expuestas y no expuestas se convierte en un cociente "observado" de 1,49 (Tabla 28.8). Esta subestimación del riesgo relativo se produce como consecuencia de la "difuminación" de la relación entre exposición y enfermedad, que ocurre cuando la clasificación errónea de la enfermedad, como en este caso, se distribuye de manera uniforme de acuerdo con la enfermedad o el estado de salud (es decir, la medida de la exposición no se ve influida por el hecho de que la persona sufra la enfermedad de interés).

Por el contrario, cuando la clasificación errónea de la exposición no se distribuye de manera uniforme según el efecto de interés, puede subestimarse o sobrestimarse la asociación de interés. En el ejemplo anterior, podríamos haber introducido un sesgo, y no sólo una difuminación de la relación etiológica, si la clasificación de la exposición dependiera de la enfermedad o del estado de salud de los trabajadores. Esta situación puede producirse, por ejemplo, cuando se recogen muestras biológicas de un grupo de trabajadores expuestos y de un grupo de trabajadores no expuestos para identificar cambios precoces relacionados con la exposición en el trabajo. Puede ocurrir que las muestras de los trabajadores expuestos se analicen con más detenimiento que las 
Tabla 28.8 - Cohorte hipotética de 1.959 personas (expuestas y no expuestas), reclutadas en el momento $T_{0}$ y cuyo estado de salud se determina en $\mathrm{T}_{2}$.

\begin{tabular}{llll}
\multicolumn{3}{c}{ Tiempo } & \\
& $\mathrm{T}_{0}$ & $\mathrm{~T}_{1}$ & $\mathrm{~T}_{2}$ \\
Trabajadores expuestos & 1.200 & $\begin{array}{c}250 \text { interrumpen la } \\
\text { exposición }\end{array}$ & $\begin{array}{l}1.100 \\
(1.200-250+150)\end{array}$
\end{tabular}

Casos de enfermedad en el momento $T_{2}=220$ en los trabajadores expuestos

$\begin{array}{llll}\text { Trabajadores no } & 750 & 150 \text { inician la } & 850 \\ \text { expuestos } & & \text { exposición } & (750-150+250)\end{array}$

Casos de enfermedad en el momento $T_{2}=85$ en los trabajadores no expuestos

El riesgo real de enfermedad en el momento $\mathrm{T}_{2}$ es del $20 \%$ en los trabajadores expuestos (220/1.100), y del $10 \%$ en los trabajadores no expuestos $(85 / 850)$ (riesgo relativo $=2,0)$.

Riesgo estimado a $T_{2}$ de enfermedad en los clasificados como expuestos a $T_{0}$ : $20 \%$ (riesgo real en los expuestos) $\times 950(1.200-250)+10 \%$ (riesgo real en los no expuestos) $\times 250=(190+25) / 1200=17,9 \%$

Riesgo estimado a $\mathrm{T}_{2}$ de la enfermedad en los clasificados como no expuestos a $\mathrm{T}_{0}: 20 \%$ (riesgo real en los expuestos) $\times 150+10 \%$ (riesgo real en los no expuestos) $\times 600(750-150)=(30+60) / 750=12 \%$

Riesgo relativo estimado $=17,9 \% / 12 \%=1,49$

muestras de los trabajadores no expuestos. La curiosidad científica puede hacer que el investigador realice mediciones de otros biomarcadores en las personas expuestas (entre ellos, por ejemplo, aductos de ADN en linfocitos o marcadores urinarios de daños oxidativos en el $A D N$ ), porque piense que esas personas son "más interesantes" desde el punto de vista científico. Esta es una actitud bastante frecuente que, sin embargo, puede introducir un grave sesgo.

\section{- Metodos estadisticos}

\section{Annibale Biggeri y M ario Braga}

Existe un intenso debate sobre la función de la estadística en la investigación epidemiológica de las relaciones etiológicas. En la epidemiología, la estadística es, fundamentalmente, un conjunto de métodos para evaluar los datos obtenidos en poblaciones humanas (y también animales). En particular, la estadística es una técnica para la cuantificación y medición de fenómenos inciertos. Todas las investigaciones científicas sobre los aspectos variables y no determinísticos de la realidad pueden beneficiarse de la metodología estadística. En la epidemiología, la variabilidad es una característica intrínseca a la unidad de observación: una persona no es una entidad determinística. Aunque los diseños experimentales podrían mejorarse para que cumplieran más estrictamente los supuestos de la estadística en lo que se refiere a la variación aleatoria, este enfoque no es demasiado frecuente por razones éticas y prácticas. En su lugar, la epidemiología se centra en la investigación observacional que tiene asociada a ella fuentes aleatorias y otras fuentes de variabilidad.

La teoría estadística se ocupa de la manera de controlar la variabilidad no estructurada en los datos para poder realizar inferencias válidas de observaciones empíricas. Cuando no se puede explicar la conducta de una variable del fenómeno estudiado, la estadística supone que se trata de una variable aleatoria, es decir, desviaciones no sistemáticas de un estado natural promedio (véase una crítica de estos supuestos en Greenland 1990).

La ciencia se basa en evidencias empíricas para demostrar la validez de sus modelos teóricos de episodios naturales. De hecho, los métodos basados en la teoría estadística determinan el grado en que las observaciones del mundo real se ajustan a la idea que los científicos tienen de un fenómeno y que expresan mediante un modelo matemático. Por esta razón, la selección de los métodos estadísticos, basados en las matemáticas, tiene que realizarse con precaución, ya que existen multitud de ejemplos sobre "cómo mentir con las estadísticas". Así pues, los epidemiólogos deben estar seguros de la validez de las técnicas que utilizan para medir el riesgo de enfermedad. En particular, deben interpretar con mucha precaución los resultados tanto estadísticamente significativos como no significativos.

El primer significado del término estadística se refiere a cualquier cantidad calculada que resume un conjunto de valores. Los índices o estadísticas descriptivas, como la media aritmética, la mediana o la moda, se utilizan con frecuencia para resumir la información obtenida de una serie de observaciones. Tradicionalmente, estos descriptores resumen eran utilizados por los Estados con fines administrativos, razón por la cual se les llamó estadísticas. En epidemiología, las estadísticas más utilizadas se derivan de comparaciones inherentes a la naturaleza de la epidemiología, que se plantea preguntas como: "¿Es mayor el riesgo de enfermedad en una población que en otra?". Cuando se realiza este tipo de comparaciones, el riesgo relativo es una medida habitual de la intensidad de la asociación entre una característica y la probabilidad de una enfermedad y es el que se aplica con más frecuencia a la investigación etiológica. EI riesgo atribuible se utiliza principalmente en los campos de la medicina preventiva y la salud pública y mide también la asociación entre una característica y la aparición de una enfermedad, aunque haciendo hincapié en el beneficio obtenido, en términos del número de casos evitados por una intervención que elimina el factor en cuestión.

El segundo significado del término estadística hace referencia al conjunto de técnicas y a la teoría de la inferencia estadística. Se trata de una forma particular de lógica inductiva que establece las normas para realizar una generalización válida a partir de un determinado conjunto de observaciones empíricas. La generalización será válida sólo si se cumplen ciertos requisitos. Esta es la segunda forma en que un uso inadecuado de la estadística puede decepcionarnos: en la epidemiología observacional, es muy difícil estar seguro de que se cumplen los supuestos de las técnicas estadísticas. Por consiguiente, los análisis de la sensibilidad y los estimadores robustos son requisitos esenciales para realizar correctamente cualquier análisis de datos. Las conclusiones finales deben basarse también en toda la información disponible y no exclusivamente en los resultados de las pruebas estadísticas a las que se someten las hipótesis.

\section{Definiciones}

U na unidad estadística es el elemento en el que se realizan las observaciones empíricas. Puede ser una persona, una muestra biológica o una materia prima. N ormalmente, las unidades estadísticas son elegidas independientemente por el investigador, aunque algunas veces pueden establecerse diseños más complejos. Por ejemplo, en los estudios longitudinales se realiza una serie de determinaciones a lo largo del tiempo en un conjunto de personas. En este tipo de estudios, las unidades estadísticas son un conjunto de determinaciones que no son independientes, sino estructuradas por sus respectivas relaciones con cada persona 
estudiada. La ausencia de independencia o la correlación entre las unidades estadísticas merece una especial atención en el análisis estadístico.

Una variable es una característica medida en una unidad estadística. D ebe diferenciarse de una constante, que es una característica fija. Por ejemplo, en un estudio de poblaciones humanas, la presencia de cabeza y tórax es una constante, mientras que el sexo de un participante del estudio es una variable.

Las variables se evalúan utilizando diferentes escalas de medición. La primera distinción que puede realizarse es entre escalas cualitativas y cuantitativas. $L$ as variables cualitativas expresan diferentes modalidades 0 categorías. Si las modalidades no pueden clasificarse u ordenarse unas con relación a las otras-por ejemplo, modalidades de color de pelo o sexo- se trata de una variable nominal. Si las categorías pueden ordenarse-como la gravedad de una enfermedad-la variable se denomina ordinal. Cuando la variable consiste en un valor numérico, hablamos de una escala cuantitativa. Una escala discreta significa que la variable sólo puede adoptar unos valores concretos-por ejemplo, valores enteros para el número de casos de una enfermedad. Las escalas continuas se utilizan para las medidas que producen números reales. Las escalas continuas se dice que son escalas de intervalo cuando el valor nulo tiene un significado meramente convencional; es decir, cuando el valor cero no significa una cantidad cero, por ejemplo, una temperatura de cero grados Celsius no significa una energía térmica cero. En ese caso, sólo las diferencias entre valores tienen sentido (esta es la razón del término escala de "intervalo"). Un valor nulo real indica una escala de cociente. En este tipo de escala, los cocientes de valores también tienen sentido; de hecho, un cociente doble significa una cantidad doble. Por ejemplo, decir que un organismo tiene una temperatura dos veces mayor que un segundo organismo significa que tiene dos veces la energía térmica del segundo organismo, siempre que la temperatura se mida en una escala de cociente (p. ej., en grados Kelvin) El conjunto de valores que puede adoptar una variable se llama dominio de la variable.

Tabla 28.9 • Indices de la tendencia central y la dispersión según la escala de medición.

\begin{tabular}{|c|c|c|c|c|}
\hline \multirow[b]{3}{*}{ Indices } & \multirow[b]{3}{*}{ Definición } & \multicolumn{3}{|c|}{ Escala de medición } \\
\hline & & \multicolumn{2}{|c|}{ Cualitativa } & \multirow{2}{*}{$\begin{array}{l}\text { Cuantitativa } \\
\text { Intervalo/ } \\
\text { cociente }\end{array}$} \\
\hline & & Nominal & Ordinal & \\
\hline $\begin{array}{l}\text { Media } \\
\text { aritmética }\end{array}$ & $\begin{array}{l}\text { Suma de valores } \\
\text { observados dividida } \\
\text { por número total de } \\
\text { observaciones }\end{array}$ & & & $x$ \\
\hline Mediana & $\begin{array}{l}\text { Valor en el punto medio } \\
\text { de la distribución } \\
\text { observada }\end{array}$ & & $x$ & $x$ \\
\hline Moda & Valor más frecuente & $x$ & $x$ & $x$ \\
\hline Intervalo & $\begin{array}{l}\text { Valores superior e inferior } \\
\text { de la distribución }\end{array}$ & & $x$ & $x$ \\
\hline Varianza & $\begin{array}{l}\text { Suma de la diferencia al } \\
\text { cuadrado de cada valor y } \\
\text { la media dividido por el } \\
\text { número total de } \\
\text { observaciones menos } 1\end{array}$ & & & $x$ \\
\hline
\end{tabular}

\section{Paradigmas estadísticos}

L a estadística se ocupa de la manera de generalizar a partir de un conjunto de observaciones. Este conjunto de mediciones empíricas se denomina muestra. A partir de una muestra, se pueden calcular algunas estadísticas descriptivas para resumir la información recogida.

La información básica que suele necesitarse para caracterizar un conjunto de medidas hace referencia a la tendencia central y a la variabilidad de dichas medidas. La elección entre distintas alternativas depende de la escala utilizada para medir un fenómeno y de la finalidad del cálculo de las estadísticas. En la Tabla 28.9 se describen diferentes medidas de la tendencia central y la variabilidad (o dispersión) y se asocian con la correspondiente escala de medición.

Las estadísticas descriptivas calculadas se llaman estimadores cuando las utilizamos como un sustituto de la cantidad análoga de la población de la que se ha seleccionado la muestra. Los equivalentes de los estimadores en la población son constantes llamadas parámetros. Utilizando diferentes métodos estadísticos, se pueden obtener diferentes estimadores del mismo parámetro. U n estimador debe ser válido y preciso.

El paradigma de la población y la muestra implica que la validez puede garantizarse por la forma de seleccionar la muestra de la población. EI muestreo aleatorio o probabilístico es la estrategia habitual. Si todos los miembros de la población tienen la misma probabilidad de ser incluidos en la muestra, ésta debe ser, como promedio, representativa de la población y cualquier desviación de las expectativas puede atribuirse al azar. El muestreo aleatorio permite también calcular la probabilidad de que se produzca una desviación de las expectativas. EI mismo tipo de razonamiento puede aplicarse a los estimadores calculados para la muestra con respecto a los parámetros de la población. Tomemos, por ejemplo, la media aritmética de la muestra como un estimador del valor medio de la población. Cualquier diferencia, si es que existe, entre la media de la muestra y la media de la población se atribuye a fluctuaciones aleatorias en el proceso de selección de los miembros incluidos en la muestra. Si la muestra se ha seleccionado aleatoriamente, podremos calcular la probabilidad de cualquier valor de esa diferencia. Si la desviación entre el estimador de la muestra y el parámetro de la población no puede atribuirse al azar, se dice que el estimador está sesgado. El diseño de la observación o el experimento da validez a los estimadores y el paradigma estadístico fundamental es el del muestreo aleatorio.

En medicina se adopta un segundo paradigma cuando la finalidad del estudio es la comparación entre diferentes grupos. Un ejemplo típico es el de los ensayos clínicos controlados: se selecciona a una serie de pacientes con características similares en función de unos criterios definidos previamente. En esta etapa no se tiene en cuenta la representatividad. Todos los pacientes reclutados para el estudio son asignados, mediante un procedimiento aleatorio, al grupo de tratamiento que recibirá el tratamiento convencional más el nuevo fármaco del estudio, 0 al grupo de control que recibirá el tratamiento convencional y un placebo. En este diseño, la asignación aleatoria de los pacientes a cada uno de los grupos sustituye a la selección aleatoria de los miembros de la muestra. El estimador de la diferencia entre los dos grupos puede evaluarse estadísticamente porque, según la hipótesis de la ineficacia del nuevo fármaco, podemos calcular la probabilidad de cualquier diferencia distinta a cero.

En epidemiología, no existe la posibilidad de formar aleatoriamente los grupos de personas expuestas y no expuestas. Pese a ello, podemos utilizar los métodos estadísticos como si los grupos analizados se hubieran seleccionado o asignado aleatoriamente. $L$ a validez de este supuesto depende fundamentalmente del diseño del estudio. Este punto es especialmente importante y 
subraya la mayor importancia del diseño de los estudios epidemiológicos frente a las técnicas estadísticas en la investigación biomédica.

\section{Señal y ruido}

El término variable aleatoria se aplica a una variable para la que puede suponerse una cierta probabilidad asociada a cada uno de sus valores. L os modelos teóricos de la distribución de la probabilidad de una variable aleatoria son modelos de población. EI equivalente en la muestra es la distribución de frecuencias de la muestra. Esta es una forma útil de presentar un conjunto de datos; consiste en un plano cartesiano con la variable de interés representada en el eje horizontal y la frecuencia o la frecuencia relativa en el eje vertical. Esta representación gráfica nos permite ver fácilmente cuál es el valor o los valores más frecuentes y cómo la distribución se concentra en torno a ciertos valores centrales, como la media aritmética.

Para las variables aleatorias y sus distribuciones de probabilidad, utilizamos los términos parámetros, valor medio esperado (en lugar de media aritmética) y varianza. Estos modelos teóricos describen la variabilidad en un fenómeno. En la teoría de la información, la señal está representada por la tendencia central (por ejemplo, el valor medio) y el ruido se mide por el índice de dispersión (como la varianza).

Para explicar la inferencia estadística, utilizaremos el modelo binomial. En las siguientes secciones, se explicarán los conceptos de estimaciones puntuales, intervalos de confianza, pruebas de hipótesis, probabilidad de decisiones erróneas y potencia de un estudio.

\section{Un ejemplo: la distribución binomial}

En la investigación biomédica y en la epidemiología, el modelo más importante de variación estocástica es la distribución binomial, que se basa en el supuesto de que la mayoría de los fenómenos se comportan como una variable nominal con sólo dos categorías; por ejemplo, presencia o ausencia de una enfermedad, supervivencia o muerte, recuperación o enfermedad. En dichas circunstancias, estamos interesados en la probabilidad de éxito, es decir, en el episodio de interés (p. ej., presencia de enfermedad, supervivencia o recuperación) y en los factores que pueden alterarla. Consideremos $n=3$ trabajadores y supongamos que estamos interesados en la probabilidad, $\pi$, de que presenten una deficiencia visual (sí/ no). N uestras observaciones podrían dar los resultados que aparecen en la Tabla 28.10.

La probabilidad de cualquiera de estas combinaciones de episodios se obtiene fácilmente considerando $\pi$, la probabilidad

$\begin{array}{cccc}\text { Tabla } 28.10 & \begin{array}{c}\text { Posibles resultados de un experimento } \\ \text { binomial }\left(s_{1}=1, \text { no }=0\right) \text { y sus } \\ \text { probabilidades }(n=3) .\end{array} \\ \text { Trabajador } & \text { Probabilidad } \\ \text { A } & \text { B } & \text { C } & (1-\pi)(1-\pi)(1-\pi) \\ 0 & 0 & 0 & \pi(1-\pi)(1-\pi) \\ 1 & 0 & 0 & (1-\pi) \pi(1-\pi) \\ 0 & 1 & 0 & (1-\pi)(1-\pi) \pi \\ 0 & 0 & 1 & (1-\pi) \pi \pi \\ 0 & 1 & 1 & \pi(1-\pi) \pi \\ 1 & 0 & 1 & \pi \pi(1-\pi) \\ 1 & 1 & 0 & \pi \pi \pi \\ 1 & 1 & 1 & \end{array}$

Tabla 28.11 • Posibles resultados de un experimento binomial (sí $=1$, no $=0$ ) y sus probabilidades $(n=3)$.

$\begin{array}{ll}\text { Número de éxitos } & \text { Probabilidad } \\ 0 & (1-\pi)^{3} \\ 1 & 3 \pi(1-\pi)^{2} \\ 2 & 3 \pi^{2}(1-\pi) \\ 3 & \pi^{3}\end{array}$

(individual) de éxito, que es constante para cada persona e independiente de otros resultados. Puesto que estamos interesados en el número total de éxitos y no en una secuencia ordenada específica, podemos reorganizar la tabla de la siguiente forma (véase Tabla 28.11) y, en general, expresar la probabilidad de x éxitos $\mathrm{P}(\mathrm{x})$ como:

$$
P(x)=\frac{n !}{x !(n-x) !} \pi^{x}(1-\pi)^{n-x}
$$

donde $x$ es el número de éxitos y el símbolo $x$ ! indica la suma factorial de $x$, es decir, $x !=x \cdot(x-1) \cdot(x-2) \ldots \cdot 1$.

$C$ uando consideramos el episodio "estar enfermo/ no estar enfermo", la probabilidad individual, $\pi$ se refiere al estado en el que se presume a la persona; en epidemiología, esta probabilidad se denomina "prevalencia". Para estimar $\pi$, utilizamos la proporción de la muestra:

$$
p=x / n
$$

con una varianza:

$$
\sigma_{p}^{2}=\frac{\pi(1-\pi)}{n}
$$

En una serie hipotética infinita de muestras replicadas del mismo tamaño, obtendríamos diferentes proporciones de la muestra $p=x / n$, con probabilidades dadas por la fórmula binomal. Para cada proporción de la muestra, se estima el valor "real" de $\pi$ y, a partir de la distribución binominal, se estima un intervalo de confianza para $\pi$ (es decir, el conjunto de valores probables de $\pi$ ) teniendo en cuenta los datos observados y un nivel de confianza definido previamente (pongamos $95 \%$ ). Este intervalo de confianza corresponde al conjunto de valores de $\pi$ con una probabilidad $x$ mayor que el valor especificado previamente (pongamos 2,5\%). En un experimento hipotético en el que observáramos $x=15$ éxitos en $n=30$ ensayos, la probabilidad estimada de éxito sería:

$$
p=x / n=15 / 30=0,5
$$

El intervalo de confianza del $95 \%$ para $\pi$, obtenido de la Tabla 28.12, es 0,334 - 0,666. Cada entrada de la tabla indica la probabilidad de $x=15$ éxitos en $n=30$ ensayos calculada con la fórmula binominal. Por ejemplo, para $\pi=0,30$, obtenemos de:

$$
P(x)=\frac{30 !}{15 !(30-15) !} 0,3^{15}(1-0,3)^{30-15}=0,0116
$$

Si n es grande y p se aproxima a 0,5, podemos utilizar una aproximación basada en la distribución gaussiana:

$$
p-z_{\alpha / 2} \sqrt{\frac{p(1-p)}{n}} \leq \pi \leq p+z_{\alpha / 2} \sqrt{\frac{p(1-p)}{n}}
$$

donde $z_{\alpha / 2}$ indica el valor de la distribución gaussiana convencional para una probabilidad

$$
P\left(|z| \geq z_{\alpha / 2}\right)=\alpha / 2 \text {; }
$$


Tabla 28.12 - Distribución binomial. Probabilidades para diferentes valores de para $x=15$ éxitos en $n=30$ ensayos.

$\begin{array}{ll}\pi & \text { Probabilidad } \\ 0,200 & 0,0002 \\ 0,300 & 0,0116 \\ 0,334 & 0,025 \\ 0,400 & 0,078 \\ 0,500 & 0,144 \\ 0,600 & 0,078 \\ 0,666 & 0,025 \\ 0,700 & 0,0116\end{array}$

siendo 1 - $\alpha$ el nivel de confianza elegido. En el ejemplo considerado, $p=15 / 30=0,5 ; n=30 y$, a partir de la tabla gaussiana convencional, $z_{0,025}=1,96$. El intervalo de confianza del $95 \%$ corresponde al conjunto de valores 0,321 - 0,679, que se obtienen al sustituir $p=0,5, n=30$ y $z_{0,025}=1,96$ en la anterior ecuación para la distribución gaussiana. 0 bsérvese que estos valores se aproximan a los valores exactos calculados antes.

Las pruebas estadísticas de las hipótesis incluyen un procedimiento de decisión sobre el valor de un parámetro de la población. Supongamos que, en el anterior ejemplo, deseamos confirmar la propuesta de que existe un riesgo elevado de deficiencia visual en los trabajadores de una cierta fábrica. La hipótesis científica que tenemos que demostrar con nuestras observaciones empíricas es: "Ios trabajadores de cierta fábrica tienen un mayor riesgo de deficiencia visual". Los estadísticos corroboran esta hipótesis demostrando la falsedad de la hipótesis contraria "no existe un riesgo mayor de deficiencia visual". A partir de ahí, se realiza la demostración matemática per absurdum y, en lugar de demostrar una afirmación, las evidencias empíricas se utilizan sólo para demostrar que es falsa. La hipótesis estadística se denomina hipótesis nula. El segundo paso consiste en especificar un valor para el parámetro de esa probabilidad de distribución utilizada para elaborar un modelo de la variabilidad en las observaciones. En nuestro ejemplo, al ser un fenómeno binario (es decir, presencia/ ausencia de deficiencias visuales), elegimos la distribución binominal con un parámetro $\pi$, la probabilidad de deficiencia visual. Supongamos que, según la hipótesis nula, $\pi=0,25$. Este valor se selecciona en función de la información que se haya obtenido sobre el problema y la información que ya existiera sobre la prevalencia habitual de deficiencia visual en las poblaciones no expuestas (es decir, distintas a los trabajadores). Supongamos que nuestros datos sobre los 30 trabajadores examinados dan un estimador de $p=0,50$.

¿Podemos rechazar la hipótesis nula?

Si la respuesta es afirmativa, ien favor de que hipótesis alternativa?

Siempre que las evidencias indiquen que la hipótesis nula debe ser rechazada, tenemos que formular una hipótesis alternativa. Las hipótesis alternativas no direccionales (simétricas) indican que el parámetro de la población es diferente al valor establecido en la hipótesis nula. Las hipótesis alternativas direccionales (asimétricas) indican que el parámetro de la población es mayor (o menor) que el valor nulo. Aplicando la hipótesis nula, podemos calcular la distribución de probabilidad de los resultados en nuestro ejemplo. En la Tabla 28.13 se indica, para $\pi=0,25$ y $n=30$, las probabilidades [véase ecuación (1)] y las probabilidades acumuladas:
Tabla 28.13 - Distribución binomial. Probabilidades de éxito para $\pi=0,25$ en $n=30$ ensayos.

\begin{tabular}{lll}
$X$ & Probabilidad & Probabilidad acumulada \\
0 & 0,0002 & 0,0002 \\
1 & 0,0018 & 0,0020 \\
2 & 0,0086 & 0,0106 \\
3 & 0,0269 & 0,0374 \\
4 & 0,0604 & 0,0979 \\
5 & 0,1047 & 0,2026 \\
6 & 0,1455 & 0,3481 \\
7 & 0,1662 & 0,5143 \\
8 & 0,1593 & 0,6736 \\
9 & 0,1298 & 0,8034 \\
10 & 0,0909 & 0,8943 \\
11 & 0,0551 & 0,9493 \\
12 & 0,0291 & 0,9784 \\
13 & 0,0134 & 0,9918 \\
14 & 0,0054 & 0,9973 \\
15 & 0,0019 & 0,9992 \\
16 & 0,0006 & 0,9998 \\
17 & 0,0002 & 1,0000 \\
3 & 0 & 0 \\
30 & 0,0000 & 1,0000 \\
\hline
\end{tabular}

$$
C P(x)=\sum_{i=0}^{i-x} P_{(i)}
$$

A partir de esta tabla, obtenemos la probabilidad de que $x \geq 15$ trabajadores presenten deficiencia visual

$$
P(x \geq 15)=1-P(x<15)=1-0,9992=0,0008
$$

Esto significa que es altamente improbable que observemos 15 o más trabajadores con deficiencia visual si experimentan la misma prevalencia de la enfermedad que en las poblaciones no expuestas. Por consiguiente, podemos rechazar la hipótesis nula y afirmar que existe una mayor prevalencia de deficiencia visual en la población de trabajadores de nuestro estudio.

Cuando $n \cdot \pi \geq 5$ y $n \cdot(1-\pi) \geq 5$, podemos utilizar la aproximación gaussiana:

$$
z=\frac{P-\pi \mid-\frac{1}{2 n}}{\sqrt{\frac{\pi(1-\pi)}{n}}}=\frac{0,5-0,25-\frac{1}{60}}{\sqrt{\frac{0,25 \times 0,75}{30}}}=\frac{0,233}{0,079}=2,95
$$

De la tabla de la distribución gaussiana normal, obtenemos:

$$
\mathrm{P}(|z|>2,95)=0,0008
$$

que concuerda con los resultados exactos. A partir de esta aproximación, podemos ver que la estructura básica de la prueba estadística de una hipótesis consiste en el cociente entre la señal y el ruido. En nuestro caso, la señal es $(p-\pi)$, la desviación observada con respecto a la hipótesis nula, mientras que el ruido es la desviación estándar de P : 


$$
\sigma=\sqrt{\frac{\pi(1-\pi)}{n}}
$$

Cuanto mayor sea el cociente, menor será la probabilidad del valor nulo $\pi$.

Cuando tomamos decisiones sobre hipótesis estadísticas, podemos incurrir en dos tipos de errores: el error tipo I, que consiste en rechazar la hipótesis nula cuando es cierta, o el error tipo II, que consiste en aceptar una hipótesis nula que es falsa. El nivel de probabilidad, o valor $p$, es la probabilidad de cometer un error tipo I, expresada con la letra griega $\alpha$. Este valor se calcula a partir de la distribución de probabilidad de las observaciones aplicando la hipótesis nula. El procedimiento habitual consiste en definir previamente un nivel de error $\alpha$ (p. ej., $5 \%$, $1 \%$ ) y rechazar la hipótesis nula cuando el resultado de nuestra observación tenga una probabilidad igual o inferior al llamado nivel crítico.

La probabilidad de un error tipo II se expresa con la letra griega $\beta$. Para calcularla, tenemos que especificar, en la hipótesis alternativa, un valor para el parámetro estudiado (en nuestro ejemplo, un valor para $\pi$ ). L as hipótesis alternativas genéricas (diferente de, mayor de, menor de) no son útiles. En la práctica, lo que nos interesa es el valor $\beta$ para un conjunto de hipótesis alternativas, o su complemento, que se llama potencia estadística de la prueba. Por ejemplo, si el valor del error ase establece en un $5 \%$, en la Tabla 28.13 encontramos:

$$
\mathrm{P}(\mathrm{x} \geq 12)<0,05
$$

según la hipótesis nula $\pi=0,25$. Si observáramos al menos $x=12$ éxitos, rechazaríamos la hipótesis nula. En la Tabla 28.14 se indican los valores $\beta$ y las potencias para $x=12$.

En nuestro caso, los datos no pueden discriminar si $\pi$ es mayor que el valor nulo de 0,25 pero menor que 0,50 , porque la potencia del estudio es demasiado pequeña (<80 \%) para los valores de $\pi<0,50$; es decir, la sensibilidad de nuestro estudio es del $8 \%$ para $\pi=0,3,22 \%$ para $\pi=0,35, \ldots, 64 \%$ para $\pi=0,45$.

La única forma de conseguir un error $\beta$ más pequeño o una mayor potencia sería aumentando el tamaño del estudio. Por ejemplo, en la Tabla 28.15 se indican los valores $\beta$ y las potencias para $n=40$. C omo cabría esperar, deberíamos ser capaces de detectar un valor $\pi$ mayor de 0,40.

El diseño de un estudio se basa en un cuidadoso escrutinio del conjunto de hipótesis alternativas que deben considerarse. La potencia del estudio debe garantizarse con un tamaño adecuado de la muestra.

La literatura epidemiológica insiste en la importancia de obtener estimadores fiables del riesgo. Por consiguiente, es más importante indicar los intervalos de confianza (ya sean del $95 \%$ o del $90 \%$ ) que un valor $p$ de la prueba de una hipótesis. Siguiendo el mismo tipo de razonamiento, la interpretación de

Tabla 28.14 - Error tipo II y potencia para $x=12$, $n=30, \alpha=0,05$

$\begin{array}{lll}\pi & \beta & \text { Potencia } \\ 0,30 & 0,9155 & 0,0845 \\ 0,35 & 0,7802 & 0,2198 \\ 0,40 & 0,5785 & 0,4215 \\ 0,45 & 0,3592 & 0,6408 \\ 0,50 & 0,1808 & 0,8192 \\ 0,55 & 0,0714 & 0,9286\end{array}$

los resultados obtenidos en estudios de pequeño tamaño debe realizarse con precaución. Como consecuencia de la pequeña potencia estadística de estos estudios, incluso los efectos de magnitud intermedia podrían pasarse por alto y, por otro lado, los efectos de gran magnitud no podrían volver a replicarse.

\section{Métodos avanzados}

La complejidad de los métodos estadísticos utilizados en el contexto de la medicina del trabajo ha aumentado en los últimos años. En el campo de los modelos estadísticos se han producido importantes avances. La familia de modelos no gaussianos de N elder y Wedderburn (M odelos L ineales G eneralizados) ha realizado una de las contribuciones más importantes a la ciencia de la epidemiología del trabajo, en donde las variables de interés son binarias (p. ej., supervivencia/ muerte) o recuentos (p. ej., número de accidentes laborales).

Este fue el punto de partida para una aplicación cada vez mayor de los modelos de regresión como alternativa a los análisis más tradicionales basados en tablas de contingencia (análisis simples y estratificados). La regresión logística, de Poisson y de Cox se utilizan ahora rutinariamente para el análisis de estudios longitudinales y de casos y controles, respectivamente. Estos modelos son semejantes a la regresión lineal para las variables de respuesta categórica y tienen la ventaja de que proporcionan directamente la medida epidemiológica de la asociación de interés. Por ejemplo, los coeficientes de regresión de Poisson son el logaritmo de las tasas relativas, mientras que los de la regresión logística son el logaritmo de los índices de probabilidad.

Tomando estos modelos como punto de referencia, los avances en el campo de los modelos estadísticos han tomado dos direcciones principales: modelos para medidas categóricas repetidas y modelos que amplían los Modelos Lineales Generalizados (M odelos Aditivos Generalizados). En ambos casos, lo que se intenta es aumentar la flexibilidad de las herramientas estadísticas para poder abordar los problemas de mayor complejidad que se dan en la realidad. L os modelos de medidas repetidas son necesarios en muchos estudios de epidemiología del trabajo donde las unidades de análisis son a escala subindividual. Por ejemplo:

1. En el estudio del efecto de las condiciones de trabajo sobre la tendinitis del túnel carpiano tienen que considerarse las dos manos de la persona, que no son independientes la una de la otra.

2. El análisis de las tendencias en el tiempo de los contaminantes ambientales y su efecto en el sistema respiratorio de los niños puede realizarse utilizando modelos extremadamente flexibles, puesto que la relación funcional exacta entre dosis y respuesta es difícil de conocer. 
En el contexto de la estadística bayesiana se ha producido un desarrollo paralelo y probablemente más rápido. La barrera práctica al uso de los métodos bayesianos se eliminó con la introducción de los métodos basados en la informática. Los procedimientos de $\mathrm{M}$ onte $\mathrm{Carlo}$, como los sistemas de muestreo de Gibbs, han evitado la necesidad de la integración numérica para el cálculo de las distribuciones posteriores, que era la mayor dificultad de los métodos bayesianos. Las aplicaciones de los modelos bayesianos a problemas reales y complejos ocupan un espacio cada vez mayor en las revistas especializadas. Por ejemplo, los análisis geográficos y las correlaciones ecológicas en áreas pequeñas y los modelos de predicción del SIDA se realizan cada vez con mayor frecuencia utilizando los métodos bayesianos. Estos avances son importantes porque representan, no sólo otras soluciones estadísticas alternativas, sino porque el método bayesiano puede considerarse una estrategia más adecuada.

\section{- Evaluacion de la cau Salidad y ETICA EN LA INVESTIGACION EPIDEMIOLOGICA}

Paolo Vineis

En los anteriores artículos de este capítulo se ha explicado la importancia del diseño de los estudios para poder realizar inferencias válidas de las observaciones epidemiológicas. Aunque se ha dicho que las inferencias en la epidemiología observacional son débiles por la naturaleza no experimental de esta disciplina, los ensayos controlados randomizados y otros diseños experimentales no son intrínsecamente superiores a un estudio observacional correctamente planificado (Cornfield 1954). Sin embargo, el diseño de un estudio debe analizarse con detenimiento para identificar posibles fuentes de sesgo y confusión y poder extraer inferencias correctas. Los sesgos pueden dar resultados tanto falsos positivos como falsos negativos.

En este artículo, se comentan algunas de las directrices que se han propuesto para evaluar la naturaleza causal de las observaciones epidemiológicas. Además, aunque unos procedimiento científicos rigurosos constituyen una premisa para que la investigación epidemiológica sea éticamente correcta, existen otras cuestiones importantes relacionadas con la ética. Por consiguiente, hemos dedicado este artículo al análisis de los problemas éticos que pueden surgir cuando se realizan estudios epidemiológicos.

\section{Evaluación de la causalidad}

Varios autores han abordado el tema de la evaluación de la causalidad en la epidemiología (H ill 1965; Buck 1975; Ahlbom 1984; M aclure 1985; M iettinen 1985; Rothman 1986; Weed 1986; Schlesselman 1987; $M$ aclure 1988; Weed 1988; $K$ arhausen 1995). Uno de los principales temas de debate es si la epidemiología utiliza o debería utilizar los mismos criterios para la determinación de la relación entre causa y efecto que se utilizan en otras ciencias.

Las causas no deben confundirse con los mecanismos. Por ejemplo, el amianto es una causa del mesotelioma, mientras que la mutación oncogénica es un mecanismo supuesto. Dependiendo de las evidencias existentes, es probable que (a) diferentes exposiciones externas puedan actuar en las mismas etapas del mecanismo y (b) normalmente no existe una secuencia fija y necesaria de etapas en el mecanismo para la progresión de la enfermedad. Por ejemplo, la carcinogénesis se interpreta como una secuencia de transiciones estocásticas (probabilísticas) de la mutación de un gen a la proliferación celular y, de nuevo, a la mutación de un gen que finalmente produce cáncer. Además, la carcinogénesis es un proceso multifactorial; es decir, puede verse afectada por diferentes exposiciones externas, pero ninguna de ellas es necesaria en una persona susceptible. Es probable que este modelo pueda aplicarse a otras enfermedades además del cáncer.

La naturaleza multifactorial y probabilística de la relación entre exposición y enfermedad complica la determinación del efecto de una exposición específica. Por otra parte, la naturaleza observacional de la epidemiología nos impide realizar experimentos que podrían aclarar las relaciones etiológicas alterando deliberadamente el curso de los acontecimientos. La observación de una asociación estadística entre exposición y enfermedad no significa que la asociación sea causal. Por ejemplo, la mayoría de los epidemiólogos han interpretado la asociación entre exposición a los gases de escape de los motores diesel y el cáncer de vejiga como causal, aunque otros afirman que los trabajadores expuestos a estos gases (principalmente camioneros y taxistas) fuman con más frecuencia que las personas no expuestas. Según esto, la relación observada estaría "confundida" por un factor de riesgo bien conocido, como es el tabaquismo.

Considerando la naturaleza probabilística y multifactorial de la mayoría de las asociaciones entre exposición y enfermedad, los epidemiólogos han establecido un conjunto de directrices para detectar las relaciones que probablemente son causales. Las directrices propuestas originalmente por Sir Bradford H ill para las enfermedades crónicas (1965) son las siguientes:

- Intensidad de la asociación.

- E fecto dosis-respuesta.

- Ausencia de ambigüedad temporal.

- Reproducibilidad de las observaciones.

- Plausibilidad biológica.

- Coherencia de las evidencias.

- Especificidad de la asociación.

Estos criterios deberían considerarse sólo como directrices generales o herramientas prácticas; de hecho, la evaluación causal científica es un proceso iterativo centrado en las mediciones de la relación entre exposición y enfermedad. Sin embargo, los criterios de $\mathrm{H}$ ill suelen utilizarse como una descripción práctica y concisa de los procedimientos de inferencia causal en la epidemiología.

Consideremos el ejemplo de la relación entre cloruro de vinilo y angiosarcoma de hígado aplicando los criterios de $\mathrm{H}$ ill.

La expresión habitual de los resultados de un estudio epidemiológico es una medida del grado de asociación entre la exposición y la enfermedad (primer criterio de Hill). Un riesgo relativo ( $R$ ) mayor de 1 significa que existe una asociación estadística entre la exposición y la enfermedad. Por ejemplo, si la tasa de incidencia de angiosarcoma de hígado es normalmente de 1 por 10 millones de habitantes, pero es de 1 por 100.000 en los trabajadores expuestos a cloruro de vinilo, el R R es 100 (es decir, las personas que trabajan con cloruro de vinilo tienen un riesgo 100 veces mayor de desarrollar angiosarcoma que las personas que no trabajan con esta sustancia).

La probabilidad de que la asociación sea causal es mayor cuando el riesgo aumenta al aumentar los niveles de exposición (efecto dosis-respuesta, segundo criterio de Hill) y cuando la relación temporal entre la exposición y la enfermedad tiene una explicación biológica (la exposición precede al efecto y la duración del período de "inducción" es compatible con un modelo biológico de la enfermedad; tercer criterio de H ill). A simismo, la 
probabilidad de que una asociación sea causal es mayor cuando otros investigadores obtienen resultados similares replicando las observaciones en circunstancias diferentes ("reproducibilidad", cuarto criterio de $\mathrm{Hill}$ ).

EI análisis científico de los resultados exige una evaluación de la plausibilidad biológica (quinto criterio de $\mathrm{Hill}$ ), que puede realizarse de diferentes formas. Por ejemplo, un criterio sencillo consiste en comprobar si la "causa" sospechada es capaz de llegar al órgano diana ( $p$. ej., las sustancias inhaladas que no llegan al pulmón no pueden circular por el organismo). También pueden ser útiles las evidencias obtenidas de estudios animales: la aparición de angiosarcoma de hígado en animales tratados con cloruro de vinilo respalda claramente la asociación observada en el hombre.

La coherencia interna de las observaciones (por ejemplo, el $R \mathrm{R}$ aumenta en ambos sexos de forma similar) es un importante criterio científico (sexto criterio de Hill). La causalidad es más probable cuando la relación es muy específica; es decir, cuando implica causas raras y/ o enfermedades raras, un tipo histológico concreto 0 un determinado subgrupo de pacientes (séptimo criterio de $\mathrm{Hill}$ ).

La "inducción enumerativa" (la simple enumeración de casos de asociación entre exposición y enfermedad) es insuficiente para describir las etapas inductivas en el razonamiento causal. En general, los procedimientos de inducción enumerativa tienen como resultado una observación compleja y confusa, porque las diferentes cadenas causales 0 , con más frecuencia, la auténtica relación causal y otras exposiciones irrelevantes se enmarañan. En estos casos, se tienen que descartar otras explicaciones alternativas por "inducción eliminatoria" para demostrar que una asociación es probablemente causal porque no se ve "confundida" por otras. U na definición simple de una explicación alternativa es "un factor extraño cuyo efecto se mezcla con el efecto de la exposición de interés, distorsionando la estimación del riesgo que conlleva la exposición de interés" (Rothman 1986).

El objetivo de la inducción es ampliar los conocimientos, mientras que el objetivo de la deducción es "transmitir la verdad" (G iere 1979). EI razonamiento deductivo se utiliza para analizar con detenimiento el diseño del estudio e identificar asociaciones que no son empíricamente reales, sino tan sólo lógicas. Este tipo de asociación no es un hecho constatado, sino una necesidad lógica. Por ejemplo, el sesgo de selección se produce cuando el grupo expuesto se selecciona entre las personas enfermas (como cuando un estudio de cohortes se inicia reclutando como "expuestos" a cloruro de vinilo a un grupo de casos de angiosarcoma de hígado) o cuando el grupo no expuesto se selecciona entre personas sanas. En ambos casos, la asociación que se observa entre exposición y enfermedad es necesariamente (lógicamente) pero no empíricamente real (V ineis 1991).

En conclusión, incluso cuando se considera la naturaleza observacional (no experimental) de la epidemiología, ésta no utiliza procedimientos de inferencia que difieran sustancialmente de los tradicionales en otras disciplinas científicas (H ume 1978; Schaffner 1993).

\section{Aspectos éticos de la investigación epidemiológica}

Debido a las sutilezas que conlleva la inferencia de causas, los epidemiólogos deben tener un especial cuidado al interpretar sus estudios. De hecho, la interpretación plantea algunas cuestiones de naturaleza ética.

Los aspectos éticos de la investigación epidemiológica han sido objeto de un intenso debate (Schulte 1989; Soskolne 1993; Beauchamp y cols. 1991). La razón es evidente: los epidemiólogos, especialmente los que están especializados en higiene industrial y medio ambiente, suelen estudiar aspectos que tienen importantes repercusiones económicas, sociales y sanitarias. Los resultados, ya sean negativos o positivos, de la asociación entre la exposición a determinadas sustancias químicas y la aparición de enfermedades, pueden repercutir en la vida de miles de personas, influir en las decisiones económicas y, por consiguiente, condicionar seriamente las decisiones políticas. Así pues, el epidemiólogo puede estar sometido a intensas presiones y verse tentado o alentado por terceros para alterar - de forma marginal o considerable- la interpretación de los resultados de sus investigaciones.

Entre los diversos aspectos relevantes, la transparencia en la recogida de datos, en la codificación, en la informatización y en el análisis es básica para que el investigador pueda demostrar la ausencia de sesgos. El derecho de los participantes en una investigación epidemiológica a que se les proteja contra la publicación de información confidencial (cuestiones relacionadas con la confidencialidad) es otra cuestión crucial que puede entrar en conflicto con la transparencia.

Desde el punto de vista de las conductas inadecuadas que pueden surgir especialmente en el contexto de la inferencia causal, las preguntas que deben responder las directrices éticas son:

- ¿Q uién posee los datos y cuánto tiempo tienen que conservarse éstos?

- ¿Qué constituye un registro fiable del trabajo que se ha realizado?

- ¿Contemplan las subvenciones públicas en su presupuesto los costes asociados a unos procedimientos adecuados de documentación, archivo y análisis repetido de los datos?

- ¿Participa el investigador principal en el análisis repetido de sus datos realizado por un tercero?

- ¿Existen normas prácticas para la conservación de los datos?

- ¿D eben establecer los expertos en epidemiología del trabajo y del medio ambiente un contexto que facilite el escrutinio o la auditoría de los datos?

- ¿Hasta qué punto previenen unas prácticas adecuadas de conservación de los datos conductas incorrectas y acusaciones de conductas incorrectas?

- ¿Q ué constituye una conducta incorrecta en la epidemiología del trabajo y del medio ambiente con relación a la gestión de los datos, la interpretación de los resultados y la intervención en procesos judiciales?

- ¿Cuál es el papel que deben desempeñar los epidemiólogos y/ o sus asociaciones profesionales en la elaboración de los códigos de práctica y en la selección de los indicadores/ resultados para su evaluación? ¿Qué papel deben desempeñar como expertos en los procesos judiciales?

- ¿Qué papel deben desempeñar las asociaciones u organizaciones profesionales en lo que respecta a las cuestiones relacionadas con la ética y el derecho? (Soskolne 1993)

O tros aspectos cruciales de la epidemiología del trabajo y del medio ambiente se refieren a la participación de los trabajadores en las fases preliminares de los estudios y a la comunicación de los resultados de los estudios a las personas que han participado en ellos y que se ven directamente afectadas (Schulte 1989). Lamentablemente, la participación de los trabajadores reclutados para estudios epidemiológicos en debates conjuntos sobre los objetivos del estudio, la interpretación de los resultados y la posible aplicación de éstos (que pueden tanto beneficiarles como perjudicarles), no constituye la práctica habitual.

Estas preguntas han sido respondidas en parte por un conjunto de directrices publicadas recientemente (Beauchamp y cols. 1991; CIOMS 1991). Sin embargo, las asociaciones 
profesionales de epidemiólogos del trabajo deben debatir a fondo todas estas cuestiones éticas en sus respectivos países y, posiblemente, adoptar un conjunto de directrices éticas adecuadas al contexto nacional, aunque siempre respetando las normas internacionales sobre los códigos de práctica.

\section{- ESTUDIO DE CASO QUE ILUSTRA LOS PROBLEMAS METO DOLOGICOS EN LA VIGILANCIA DE LAS ENFERMEDADES PROFESIONALES}

Jung-Der Wang

La documentación sobre las enfermedades profesionales en un país como Taiwan constituye todo un reto para los médicos del trabajo. Al no existir un sistema que incluya fichas técnicas de seguridad, los trabajadores no suelen conocer las sustancias químicas con las que trabajan. Puesto que muchas enfermedades profesionales tienen largos períodos de latencia y no presentan ningún síntoma hasta que son clínicamente evidentes, el reconocimiento y la identificación de su origen profesional es con frecuencia muy difícil.

Para facilitar la vigilancia de las enfermedades profesionales, hemos accedido a bases de datos que proporcionan una lista completa de sustancias químicas de uso industrial y sus síntomas específicos. Combinándolo con el enfoque epidemiológico de conjeturas y refutaciones, que consiste en considerar y descartar todas las posibles explicaciones alternativas, hemos identificado más de diez tipos de enfermedades profesionales y un brote de botulismo. Recomendamos que se aplique un enfoque similar en los países que se encuentren en una situación parecida y que se prepare y utilice un sistema que incluya fichas de identificación (p. ej., fichas técnicas de seguridad) de todas y cada una de las sustancias químicas, de manera que puedan identificarse fácilmente y, de esta forma, prevenir enfermedades profesionales.

\section{Hepatitis en una imprenta cromotipográfica}

En 1985, tres trabajadores de una imprenta cromotipográfica tuvieron que ser hospitalizados con manifestaciones de hepatitis aguda. Uno de ellos presentaba también insuficiencia renal aguda. La prevalencia de la hepatitis vírica es muy elevada en Taiwan y, en consecuencia, debíamos considerar el origen vírico entre las etiologías más probables. Asimismo, debíamos considerar el consumo de alcohol y drogas y la exposición a disolventes orgánicos en el lugar de trabajo. Al no existir en Taiwan un sistema que incluya fichas técnicas de seguridad, ni los trabajadores ni la empresa conocían todas las sustancias químicas que se utilizaban en la imprenta (Wang 1991).

Tuvimos que elaborar una lista de agentes hepatotóxicos y nefrotóxicos a partir de distintas bases de datos toxicológicas. Seguidamente, dedujimos todas las posibles inferencias de las anteriores hipótesis. Por ejemplo, si la causa fuera el virus de la hepatitis A (VHA), deberíamos observar anticuerpos (I gM VHA) en los trabajadores afectados; si la causa fuera el virus de la hepatitis $B$, deberíamos observar un mayor número de portadores de antígenos de superficie B (HBsAg) en los trabajadores afectados que en los no afectados. Si el alcohol fuera la principal causa, deberíamos observar un mayor abuso del alcohol o alcoholismo crónico en los trabajadores afectados; si la causa fuera un disolvente tóxico (p. ej., cloroformo), deberíamos encontrarlo en el lugar de trabajo.
Realizamos una evaluación médica completa de todos los trabajadores. En seguida descartamos la etiología vírica y la hipótesis del alcohol, al no existir evidencias que las apoyaran.

Por el contrario, 17 de los 25 trabajadores de la fábrica dieron resultados anormales en las pruebas de la función hepática y se observó una asociación significativa entre la presencia de alteraciones hepáticas y el hecho de haber trabajado recientemente en alguna de las tres salas en las que se había instalado un sistema de aire acondicionado interconectado para refrigerar las máquinas de impresión. La asociación persistió después de estratificar a los trabajadores según su situación de portador de la hepatitis B. Posteriormente se averiguó que el incidente se produjo después del uso inadvertido de un "agente de limpieza" (que era tetracloruro de carbono) para limpiar una bomba en la máquina de impresión. Además, una prueba de simulación de la operación de limpieza de la bomba reveló unas concentraciones atmosféricas de tetracloruro de carbono de 115 a 495 ppm, que pueden producir lesiones hepáticas. En otro intento de verificar la anterior observación, eliminamos el tetracloruro de carbono del lugar de trabajo y comprobamos que no se produjeron nuevos casos y que todos los trabajadores afectados mejoraron una vez alejados del lugar de trabajo durante 20 días. Por consiguiente, nuestra conclusión fue que el brote se debía al uso de tetracloruro de carbono.

\section{Síntomas neurológicos en una imprenta cromotipográfica}

En septiembre de 1986, un aprendiz que trabajaba en una imprenta cromotipográfica de $\mathrm{C}$ hang-H wa desarrolló repentinamente paresia bilateral aguda y parálisis respiratoria. EI padre de la víctima nos informó por teléfono de que otros trabajadores presentaban síntomas similares. Puesto que en otras imprentas cromotipográficas ya se habían producido casos de enfermedades profesionales causadas por exposiciones a disolventes orgánicos, nos trasladamos al lugar de trabajo para determinar la etiología barajando la hipótesis de una posible intoxicación con disolventes (Wang 1991).

Sin embargo, nuestra práctica habitual consistía en considerar también todas las hipótesis alternativas, entre ellas otros problemas médicos, como el deterioro funcional de las neuronas motoras superiores, las neuronas motoras inferiores y la conexión neuromuscular. También en este caso, consideramos todos los posibles resultados que podían deducirse de las anteriores hipótesis. Por ejemplo, si la causa fuera un disolvente ya relacionado con la polineuropatía (p. ej., n-hexano, metilbutilcetona, acrilamida), podría afectar también a la velocidad de conducción nerviosa; si existieran otros problemas médicos que afectaran a las neuronas motoras superiores, existirían síntomas de deterioro de la consciencia y/ o movimientos involuntarios.

Las observaciones en el lugar de trabajo revelaron que los trabajadores afectados mantenían perfectamente la consciencia durante todo el proceso clínico. U n estudio de la velocidad de la conducción nerviosa en los tres trabajadores afectados demostró que las neuronas motoras inferiores estaban intactas. L os trabajadores no presentaban movimientos involuntarios ni antecedentes de medicación antes de la aparición de los síntomas y la prueba de la neostigmina también dio negativa. Se observó una asociación significativa entre la enfermedad y el hecho de haber desayunado en la cafetería de la imprenta el 26 o el 27 de septiembre; los siete trabajadores afectados frente a 7 de los 32 trabajadores no afectados habían desayunado en la imprenta esos dos días. 0 tras pruebas detectaron la presencia de la toxina botulínica tipo $\mathrm{A}$ en las latas de cacahuetes fabricadas por una empresa sin licencia y una muestra demostró también el crecimiento de Clostridium botulinum. Un último estudio de refutación consistió en eliminar dichos productos del mercado, con el 
resultado de que no apareció ningún caso nuevo. Esta investigación documentó los primeros casos de botulismo por un producto alimenticio en Taiwan.

\section{Lesiones premalignas de la piel en los trabajadores de las fábricas de paraquat}

En junio de 1983, dos trabajadores de una fábrica de paraquat visitaron una clínica dermatológica quejándose de máculas hiperpigmentadas bilaterales con alteraciones hiperqueratósicas en algunas zonas de las manos, el cuello y la cara expuestas al sol. Algunas muestras de la piel presentaban también alteraciones bowenoides. Puesto que ya se habían notificado otros casos de lesiones malignas y premalignas de la piel en trabajadores de las fábricas de 4'-4'-bipiridil, en seguida sospechamos una causa profesional. Sin embargo, teníamos que considerar también todas las demás causas (o hipótesis) alternativas de cáncer de piel, como exposición a radiación ionizante, alquitrán de hulla, brea, hollín u otros hidrocarburos poliaromáticos. Para descartar todas estas conjeturas, realizamos un estudio en 1985, visitando las 28 fábricas que alguna vez habían realizado la producción o envasado de paraquat, examinando los procesos de fabricación y explorando a los trabajadores (Wang y cols. 1987; Wang 1993).

Exploramos a 228 trabajadores, ninguno de los cuales habían estado expuestos a los cancerígenos de la piel antes citados, excepto la luz solar y la bipiridina y sus isómeros. U na vez excluidos los trabajadores con exposiciones múltiples, observamos que uno de los siete directivos y dos de los 82 trabajadores que se dedicaban al envasado del paraquat habían desarrollado lesiones hiperpigmentadas de la piel, en comparación con la totalidad de los tres trabajadores que participaban en la cristalización y centrifugación de la bipiridina. Además, los 17 trabajadores con lesiones hiperqueratósicas o bowesianas tenían antecedentes de exposición directa al bipiridil y a sus isómeros. Cuando mayor era el tiempo de exposición al bipiridil, mayor era la probabilidad de desarrollar lesiones de la piel, que no podían explicarse por la exposición a la luz solar o por la edad, como demostró la estratificación y el análisis de regresión logística. Por consiguiente, atribuimos provisionalmente las lesiones de la piel a una combinación de exposiciones al bipiridil y a la luz solar. Para refutar esta hipótesis, realizamos un seguimiento para comprobar si, una vez aislados todos los procesos que causaban exposición al bipiridil, se producía algún nuevo caso. No apareció ningún otro caso.

\section{Discusión y conclusiones}

Los anteriores tres ejemplos demuestran la importancia de adoptar un enfoque refutacional y utilizar una base de datos de enfermedades profesionales. El primero nos hace siempre considerar las hipótesis alternativas junto con las hipótesis intuitivas iniciales, mientras que la segunda nos proporciona una lista detallada de agentes químicos que pueden guiarnos hasta la etiología real. U na posible limitación de este enfoque es que sólo podemos considerar las explicaciones que seamos capaces de imaginar. Si nuestra lista de alternativas está incompleta, podemos dejar la pregunta sin respuesta o darle una respuesta equivocada. Por consiguiente, la existencia de una base de datos de enfermedades profesionales es crucial para el éxito de esta estrategia.

Nuestro equipo dedicó mucho tiempo a construir nuestra propia base de datos. Sin embargo, la base de datos O SH -RO M publicada recientemente, que contiene la base de datos NIOSHTIC con más de 160.000 resúmenes, es una de las más completas para este fin, como ya se describe en otro lugar de esta Enciclopedia. Es más, si se produce una nueva enfermedad profesional, podemos buscar en esta base de datos para descartar todos los agentes etiológicos conocidos, sin olvidarnos de ninguno. En una situación así, podemos intentar identificar 0 definir el nuevo agente (o entorno profesional) con la mayor especificidad posible para solucionar primero el problema y luego poner a prueba otras hipótesis. El caso de las lesiones premalignas de la piel en los trabajadores del paraquat es un buen ejemplo de ello.

\section{CUESTIONARIOSEN LA INVESTIGACION EPIDEMIO LOGICA}

\author{
Steven D. Stellman y Colin L. Soskolne
}

\section{Importancia de los cuestionarios en la investigación epidemiológica}

Los estudios epidemiológicos suelen realizarse para responder a una serie de preguntas específicas que relacionan la exposición de las personas a sustancias o situaciones peligrosas con efectos posteriores en la salud, como cáncer o muerte. Casi todas las investigaciones de este tipo se basan en un cuestionario que constituye la herramienta básica para la recogida de datos. Incluso cuando tienen que realizarse mediciones físicas en el medio ambiente de trabajo y, especialmente, cuando tienen que recogerse materiales biológicos, como suero de las personas expuestas y no expuestas que participan en el estudio, el cuestionario es esencial para caracterizar correctamente la exposición, así como para registrar las características personales y de otro tipo de una forma organizada y sistemática.

El cuestionario desempeña una serie de funciones críticas para la investigación:

- Facilita datos sobre las personas que posiblemente no podrían obtenerse de ninguna otra fuente, como los registros del lugar de trabajo o mediciones ambientales.

- Permite centrar los estudios en problemas específicos del lugar de trabajo.

- Facilita información basal frente a la que podrán evaluarse los futuros efectos en la salud.

- Facilita información sobre las características de los participantes que son necesarias para un análisis e interpretación adecuados de la relación entre exposición y resultado, especialmente en lo que se refiere a las posibles variables de confusión, como edad o educación, y otras variables relacionadas con el estilo de vida que pueden influir en el riesgo de la enfermedad, como tabaquismo y dieta.

\section{Importancia del diseño del cuestionario para los objetivos globales del estudio}

Aunque el cuestionario suele ser el componente más visible de un estudio epidemiológico, especialmente para los trabajadores y otros participantes en el estudio, es sólo una herramienta y, de hecho, los investigadores lo suelen llamar un "instrumento". En la Figura 28.1 se representan de una forma muy general las distintas etapas en el diseño de una encuesta, desde su concepción hasta la recogida y análisis de los datos. En la figura se indican cuatro tipos de actividades que se desarrollan en paralelo durante un estudio: muestreo, cuestionario, actividades y análisis. La figura muestra claramente la relación entre las distintas etapas del diseño del cuestionario y el plan general del estudio, desde la preparación de un esquema inicial hasta la elaboración de un primer borrador, tanto del cuestionario como de los códigos asociados al mismo, seguido por las pruebas piloto realizadas en una subpoblación seleccionada, una o más revisiones dependiendo de los resultados de las pruebas piloto y la elaboración del cuestionario definitivo para la recogida de datos reales sobre el 
Figura 28.1 - Etapas de una encuesta.
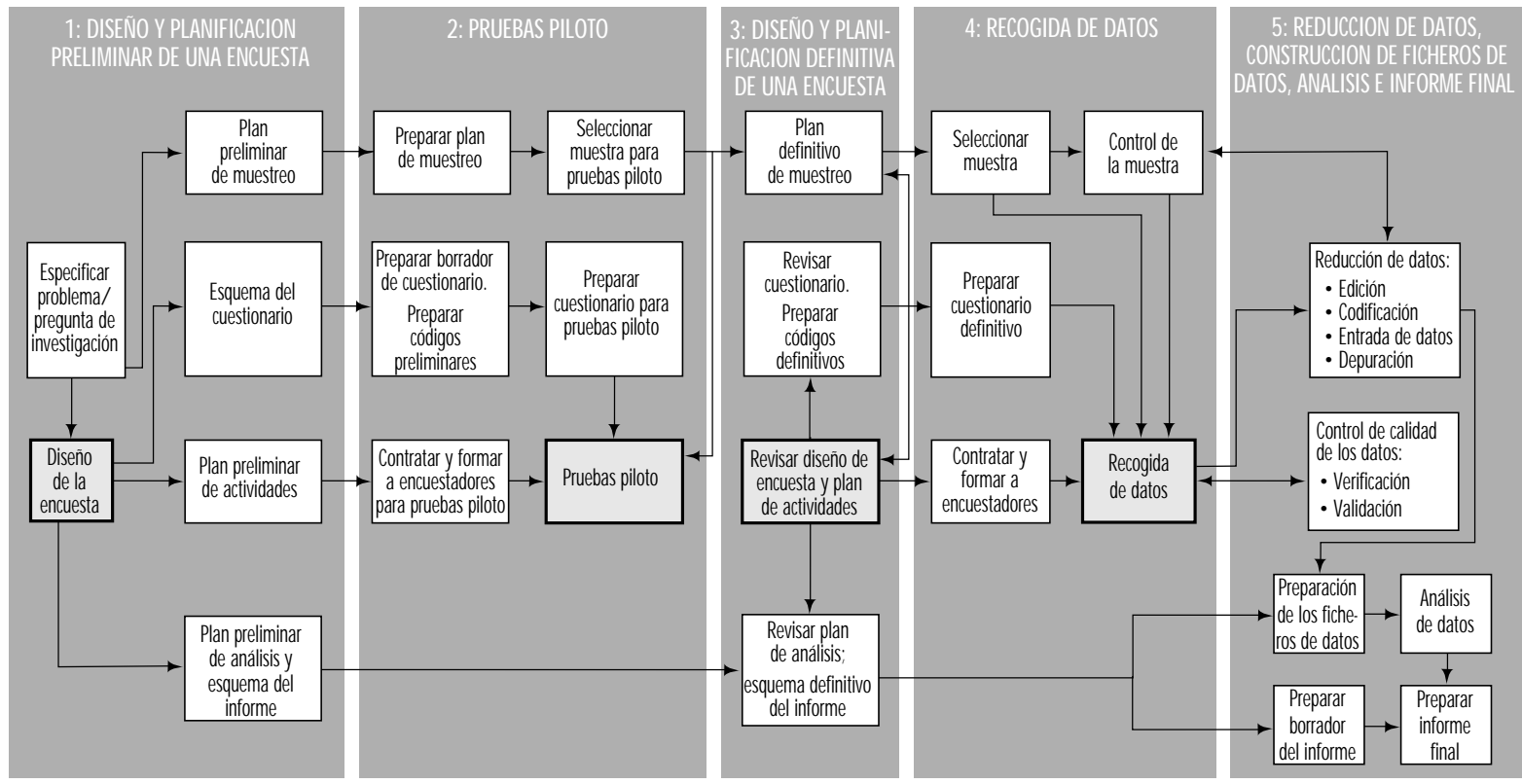

Fuente: CZaja y Blair 1996.

terreno. Lo más importante en este contexto es que cada etapa del diseño del cuestionario se realiza conjuntamente con la etapa correspondiente de la creación y mejora de plan general de muestreo y del diseño operativo para la administración del cuestionario.

\section{Tipos de estudios y cuestionarios}

Los objetivos del estudio determinan la estructura, la longitud y el contenido del cuestionario. Estas características del cuestionario dependen también del método escogido para la recogida de datos, que suele corresponder a una de las siguientes tres modalidades: en persona, por correo o por teléfono. Cada una de ellas presenta ventajas y desventajas que afectan, no sólo a la calidad de los datos, sino también a la validez de todo el estudio.

EI cuestionario enviado por correo es la modalidad menos costosa y permite llegar a los trabajadores de una amplia zona geográfica. Al ser las tasas globales de respuesta relativamente bajas (normalmente del 45 al $75 \%$ ), el cuestionario no puede ser demasiado complejo, ya que existen pocas oportunidades 0 ninguna de aclarar las preguntas y puede que sea difícil saber si las posibles respuestas a las preguntas sobre la exposición crítica 0 a otras preguntas difieren sistemáticamente entre los que responden y los que no responden al cuestionario. La configuración física y el lenguaje deben adaptarse al nivel de educación de los participantes potenciales y el cuestionario debe poder cumplimentarse en un período de tiempo bastante corto, normalmente de 20 a 30 minutos.

Los cuestionarios por teléfono pueden utilizarse en estudios basados en poblaciones - es decir, encuestas de una muestra de una población geográficamente definida- y constituyen un método práctico para actualizar la información contenida en los archivos existentes. Estos cuestionarios pueden ser más largos y complejos que los cuestionarios enviados por correo, tanto en términos de lenguaje como de contenido y, al ser administrados por encuestadores expertos, el mayor coste de las encuestas telefónicas puede compensarse en parte adaptando la estructura física del cuestionario para conseguir una administración más eficiente (como saltos de unas preguntas a otras). Las tasas de respuesta suelen ser mayores que las de los cuestionarios enviados por correo, pero están sometidas a sesgos relacionados con el uso cada vez más frecuente de contestadores automáticos, las personas que rechazan la encuesta, las personas que no pueden ser contactadas y los problemas de las poblaciones con una cobertura telefónica limitada. Este tipo de sesgos suelen estar relacionados con el diseño del muestreo y no específicamente con el cuestionario. Aunque los cuestionarios administrados por teléfono se utilizan desde hace tiempo en $\mathrm{N}$ orteamérica, su viabilidad en otras partes del mundo todavía no se ha establecido.

Las encuestas personales ofrecen la mayor posibilidad de recoger datos complejos y exactos. Son las más costosas, puesto que exigen la formación y el desplazamiento de encuestadores profesionales. La estructura física y el orden de las preguntas pueden establecerse para optimizar el tiempo de administración. Los estudios con encuestas personales suelen conseguir mayores tasas de respuesta y están sometidos a menos sesgos en las respuestas. Con este tipo de encuesta, la probabilidad de que el encuestador averigüe si el participante es un caso (en un estudio de casos y controles) o si está sometido a la exposición de interés (en un estudio de cohortes) es mayor. Por lo tanto, deben tomarse precauciones para que el encuestador mantenga la objetividad, enseñándole a evitar preguntas y lenguajes corporales que puedan provocar respuestas sesgadas.

Cada vez es más frecuente el uso de un diseño híbrido del estudio para evaluar situaciones complejas de exposición, que consiste en una encuesta personal o telefónica para sondear y aclarar las dudas de los participantes, seguida por un cuestionario enviado por correo para recoger datos relacionados con el estilo de vida, como tabaquismo y dieta. 
Figura 28.2 • Relación entre validez y fiabilidad.
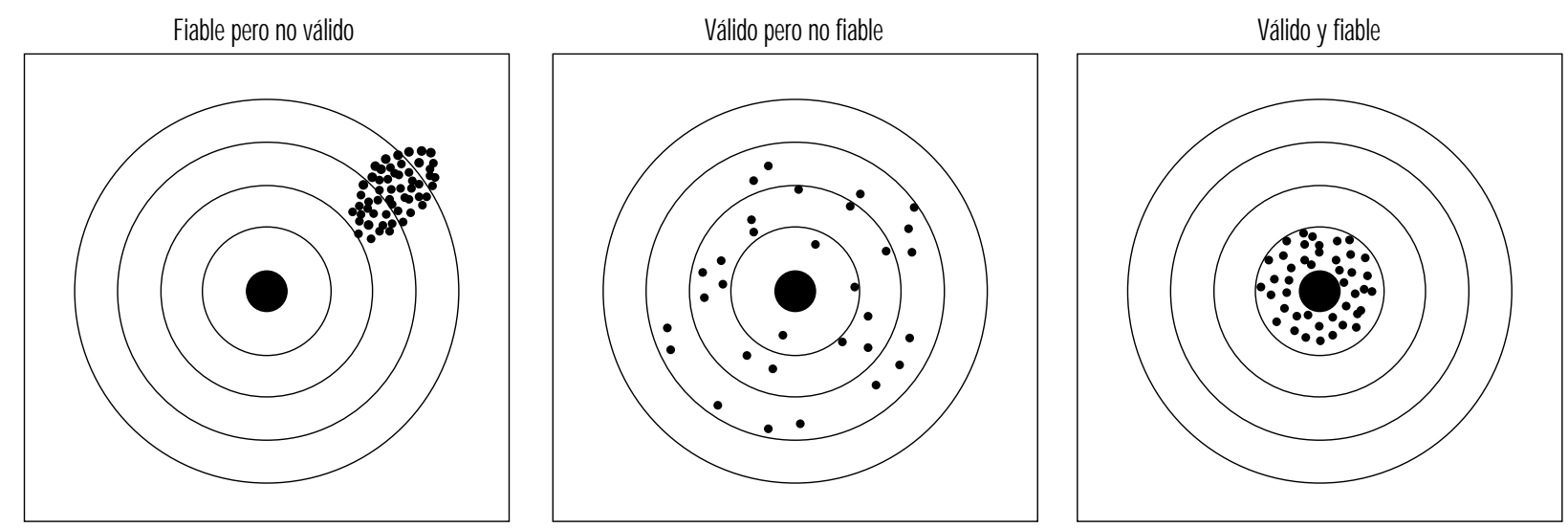

Fuente: Babbie 1992

\section{Confidencialidad y otras cuestiones relacionadas con los participantes del estudio}

Puesto que la finalidad de un cuestionario es obtener datos sobre las personas, su diseño debe respetar las normas establecidas para un tratamiento ético de los seres humanos. Estas directrices se aplican en la misma medida a los datos obtenidos a través de un cuestionario que a las muestras biológicas, como sangre y orina, 0 a las pruebas genéticas. En Estados Unidos y en muchos otros países, no puede realizarse ningún estudio en seres humanos con fondos públicos sin que primero el correspondiente Comité de Revisión Institucional haya aprobado el lenguaje y el contenido del cuestionario. Esta aprobación tiene como finalidad garantizar que las preguntas se limiten a los fines legítimos del estudio y que no se viole el derecho de los participantes del estudio a responder voluntariamente a las preguntas. Los participantes deben recibir la garantía de que su participación en el estudio será totalmente voluntaria y que su negativa a responder a las preguntas o incluso a participar en el estudio no conllevará ninguna sanción ni modificará su relación con la empresa o el médico.

Los participantes deben también recibir garantías de que el investigador protegerá la confidencialidad de la información que faciliten, adoptando las medidas necesarias para mantener la seguridad física y la inviolabilidad de los datos. Para ello, muchas veces se requiere la separación física de la información referente a la identidad de los participantes de los ficheros informáticos de datos. U na práctica habitual es advertir a los participantes del estudio que sus respuestas al cuestionario sólo se utilizarán en informes estadísticos conjuntamente con las respuestas de otros participantes y que no serán reveladas a la empresa, al médico u a otras partes.

\section{Aspectos del diseño del cuestionario relacionados con la medición}

Uno de los principales fines de un cuestionario es obtener datos sobre algún aspecto o atributo de una persona, ya sea en forma cualitativa o cuantitativa. Algunos atributos son tan sencillos como el peso, la altura o la edad, mientras que otros pueden ser mucho más complejos, como la respuesta al estrés de una persona. Las respuestas cualitativas, como el sexo, suelen convertirse en variables numéricas. Todas estas medidas pueden caracterizarse en términos de validez y fiabilidad. La validez es el grado en que una cifra obtenida de un cuestionario se aproxima a su valor real, que posiblemente se desconoce. La fiabilidad es la probabilidad de obtener los mismos resultados al repetir determinada medición, con independencia de que dicho resultado se aproxime o no al valor "real". En la Figura 28.2 se representa la relación que existe entre estos dos conceptos. Como puede observarse, una medición puede ser válida pero no fiable, fiable pero no válida, o válida y fiable.

A lo largo de los años, los investigadores han diseñado numerosos cuestionarios para responder a preguntas de interés general. Como ejemplo, podemos citar el Test de Aptitud Escolar, que mide el potencial de un alumno para conseguir futuros logros académicos o el Inventario M ultifásico de Personalidad de $\mathrm{M}$ innesota (M M PI), que mide determinadas características psicosociales. En el capítulo sobre psicometría, se describen otros indicadores psicológicos. Existen también escalas fisiológicas como el cuestionario sobre la función pulmonar del British M edical Research Council (BM RC). Estos instrumentos ofrecen una serie de ventajas importantes. La principal de ellas es que ya se han desarrollado y probado en numerosas poblaciones y se conoce su fiabilidad y validez. Antes de diseñar un nuevo cuestionario, siempre es recomendable utilizar estas escalas si encajan en el objetivo del estudio. No sólo ahorran el esfuerzo de "reinventar la rueda", sino que aumentan la probabilidad de que los resultados del estudio sean aceptados como válidos por la comunidad científica. Asimismo, y siempre que se utilicen correctamente, aumentan la validez de las comparaciones entre los resultados de diferentes estudios.

Las anteriores escalas son ejemplos de dos importantes tipos de medidas que suelen utilizarse en los cuestionarios para cuantificar conceptos que posiblemente no pueden medirse con la objetividad total con que se mide la altura 0 el peso, 0 que requieren muchas preguntas para describir con detalle una pauta de conducta específica. En términos más generales, los índices y las escalas son dos herramientas para convertir los datos en una cifra que resuma las respuestas a un conjunto de preguntas. Ya se han ofrecido antes ejemplos de índices fisiológicos y psicológicos y también se utilizan con frecuencia para medir conocimientos, actitudes y conductas. En pocas palabras, un índice corresponde generalmente a una puntuación que se obtiene mediante el recuento del número de respuestas a un conjunto de preguntas relacionadas que se aplican a un participante del estudio. Por ejemplo, si un cuestionario incluye una lista de enfermedades, un índice de la historia de la enfermedad podría ser el número total de enfermedades que ha padecido el encuestado. U na escala es una medida compuesta que se basa en la intensidad con la que un participante responde a una o más 
preguntas relacionadas. Por ejemplo, la escala Likert, que suele utilizarse en los estudios sociológicos, se construye típicamente con frases con las que uno puede asentir claramente, asentir débilmente, abstenerse de opinar, disentir débilmente 0 disentir claramente, de manera que la respuesta se puntúa del 1 al 5 . Las escalas e índices pueden sumarse o combinarse de alguna otra manera para ofrecer una imagen bastante compleja de las características físicas, psicológicas, sociales o de la conducta del participante.

La validez merece una consideración especial porque es un reflejo de la "verdad". L os tres tipos principales de validez son la validez de la expresión, del contenido y del criterio. La validez de la expresión es una cualidad subjetiva de un indicador que asegura que la pregunta se formula de una manera clara y sin ambigüedades. La validez del contenido asegura que las preguntas sirven para medir la dimensión de la respuesta que interesa al investigador. La validez del criterio (o predictiva) se deriva de una evaluación objetiva del grado de aproximación de la medición obtenida mediante un cuestionario y una magnitud medida por otros medios; por ejemplo, el grado en que la medición de la ingesta de $V$ itamina $A$ que se obtiene mediante un cuestionario se corresponde con el consumo real de vitamina A basado en el consumo de alimentos según los registros dietéticos.

\section{Contenido, calidad y longitud del cuestionario}

Redacción. La redacción de las preguntas es tanto un arte como una destreza profesional, razón por la cual sólo pueden darse unas directrices muy generales. En general, las preguntas deben redactarse de forma que:

1. Provoquen la respuesta del participante.

2. Se basen en los conocimientos que poseen los propios participantes.

3. T engan presente las limitaciones y el marco personal de referencia de los participantes, de manera que éstos comprendan fácilmente el significado y la finalidad de las preguntas.

4. Provoquen una respuesta basada en los propios conocimientos de los participantes, sin que éstos tengan que realizar suposiciones, excepto, quizá, en el caso de las preguntas sobre actitudes y opiniones.

Secuencia y estructura de las preguntas. Tanto el orden como la presentación de las preguntas puede influir en la calidad de la información recogida. Un cuestionario típico, ya sea autoadministrado o leído por un encuestador, contiene un prólogo en el que se presenta el estudio y se explica su objetivo al encuestado, se facilita la información adicional que necesita el encuestado y se le intenta motivar para que responda a las preguntas. La mayoría de los cuestionarios contienen una sección especial para recoger información demográfica, como edad, sexo, raza y otras variables sobre los antecedentes del participante, incluidas las posibles variables de confusión. El principal objeto de la recogida de datos, como la naturaleza del lugar de trabajo y la exposición a sustancias específicas, suele ocupar una sección diferente del cuestionario, normalmente precedida por un prólogo para recordar al participante aspectos específicos del puesto de trabajo o del lugar de trabajo y crear un contexto adecuado que permita formular preguntas más detalladas. Las preguntas destinadas a establecer cronologías a lo largo de toda una vida profesional deben organizarse de tal manera que se reduzca al mínimo el riesgo de omisiones cronológicas. Al final del cuestionario, es habitual agradecer al encuestado su participación.

$T$ ipos de preguntas. L a persona que diseña el cuestionario debe decidir si utilizará preguntas abiertas, a las que el participante contesta con sus propias palabras, o preguntas cerradas que requieren una respuesta definida o la elección entre un reducido número de posibles respuestas. L as preguntas cerradas ofrecen la ventaja de que, al presentar las posibles alternativas al encuestado, evitan respuestas improvisadas y reducen al mínimo las largas divagaciones que pueden ser imposibles de interpretar. Sin embargo, requieren que el diseñador del cuestionario prevea de antemano todas las posibles respuestas para evitar la pérdida de información, especialmente cuando se trata de situaciones imprevistas que ocurren en muchos lugares de trabajo. A simismo, requieren una correcta planificación de las pruebas piloto. El investigador debe también decidir si se permite una categoría de respuesta "no sabe" y en qué medida.

L ongitud. La longitud del cuestionario debe ser tal que consiga un equilibrio entre el deseo de obtener la información más detallada posible para lograr los objetivos del estudio y el peligro de que, si el cuestionario es demasiado largo, en algún momento los encuestados pierdan interés, dejen de responder o respondan de mala gana, con inexactitud y sin pensar la respuesta para acabar cuanto antes. Por otra parte, un cuestionario muy corto pueda obtener una elevada tasa de respuesta, pero sin lograr los objetivos del estudio. Puesto que la motivación de los encuestados depende con frecuencia de su interés personal en el resultado del estudio, como la mejora de las condiciones de trabajo, su tolerancia ante un cuestionario largo variará ampliamente, sobre todo si algunos participantes (como los trabajadores de una determinada fábrica) están más interesados que otros (como las personas contactadas mediante marcación telefónica aleatoria). Este equilibrio puede lograrse con pruebas piloto y experiencia. L os cuestionarios administrados por un encuestador deben registrar la hora de comienzo y fin de la encuesta, para así poder calcular su duración. Esta información es útil para evaluar el nivel de calidad de los datos.

L enguaje Es esencial utilizar el lenguaje de la población encuestada para que todo el mundo comprenda las preguntas. Es posible que el diseñador de la encuesta tenga primero que familiarizarse con la lengua vernácula local, que puede variar dentro de un mismo país. Incluso en países con el mismo idioma oficial, como Gran Bretaña o Estados U nidos o países de América Latina de habla hispana, las variaciones en las lenguas locales pueden dificultar la interpretación. Por ejemplo, en Estados U nidos, la palabra "té" significa simplemente una bebida, mientras que en Gran Bretaña, puede significar "una taza de té", "una merienda cena", o "la principal comida de la tarde", dependiendo de la localidad y el contexto. Es especialmente importante evitar la jerga científica, excepto si cabe esperar que los participantes del estudio posean conocimientos técnicos específicos.

Claridad y preguntas manipuladoras. Aunque las preguntas cortas suelen ser más claras, existen excepciones, especialmente cuando se trata de un tema complejo que necesita una introducción. No obstante, las preguntas cortas aclaran las ideas y reducen al mínimo las palabras innecesarias. A simismo, reducen la posibilidad de sobrecargar al encuestado con demasiada información que tiene que digerir. Si la finalidad del estudio es obtener información objetiva sobre la situación laboral de los encuestados, es importante que las preguntas se redacten de una forma neutral y que se eviten las preguntas "manipuladoras" que pueden favorecer una determinada respuesta, como "¿Está de acuerdo en que las condiciones de su lugar de trabajo son nocivas para la salud?"

Formato de cuestionario. El formato de un cuestionario puede influir en el coste y la eficiencia de un estudio, más en el caso de los cuestionarios autoadministrados que en los cuestionarios cumplimentados por encuestadores. Si un cuestionario autoadministrado es complejo o difícil de leer, es posible que el encuestado lo rechace o lo rellene sin prestarle demasiada atención. Incluso los cuestionario diseñados para ser leídos en voz alta por los encuestadores tienen que imprimirse con un tipo de letra 
clara y fácil de leer y los saltos entre preguntas deben indicarse claramente para que no se interrumpa el flujo de preguntas y se reduzcan al mínimo los cambios de página y el tiempo necesario para localizar la siguiente pregunta.

\section{Problemas de validez}

\section{Sesgo}

El principal enemigo en la recogida de datos objetivos es el sesgo, que se produce como resultado de diferencias sistemáticas e imprevistas entre diferentes grupos de personas: casos y controles en un estudio de casos y controles y expuestos y no expuestos en un estudio de cohortes. El sesgo de información se produce cuando dos grupos de participantes interpretan o responden de manera diferente a la misma pregunta. Esto ocurre, por ejemplo, cuando las preguntas requieren conocimientos técnicos especiales de un lugar de trabajo 0 de las exposiciones en el mismo, que poseerán los trabajadores expuestos pero no necesariamente la población general de la que se obtienen los controles.

La participación de familiares próximos en lugar de los trabajadores enfermos o fallecidos puede introducir un sesgo, ya que probablemente los familiares recordarán la información de una manera diferente y con menos exactitud que los propios trabajadores. La introducción de este tipo de sesgo es especialmente probable en estudios en los que se realizan algunas encuestas directamente a los participantes del estudio, mientras que otras se realizan a los familiares o compañeros de los participantes del estudio. En cualquiera de estas situaciones, debe reducirse cualquier efecto que pueda tener el hecho de que el encuestador conozca la enfermedad o la situación de exposición del trabajador encuestado. No siempre se puede mantener la "ceguera" de los encuestadores y por ello es importante que, durante la formación de los encuestadores, se insista en la necesidad de mantener la objetividad y evitar preguntas sesgadas 0 un lenguaje corporal inconsciente. Asimismo, debe vigilarse la actuación de los encuestadores durante todo el estudio.

El sesgo de memoria se produce cuando los casos y controles "recuerdan" de manera diferente las exposiciones o las situaciones en el trabajo. Es posible que los casos hospitalizados como consecuencia de una enfermedad de posible origen profesional recuerden su historia médica o sus exposiciones profesionales con más detalle que las personas contactadas al azar por teléfono. U n sesgo cada vez más frecuente es el Ilamado sesgo por conveniencia social que describe la tendencia de las personas a subestimar, ya sea de manera consciente o no, sus "malos hábitos" como el tabaquismo o el consumo de alimentos con alto contenido en grasas y colesterol, y a sobrestimar los "buenos hábitos" como el ejercicio.

EI sesgo de respuesta se produce cuando la probabilidad de que un grupo de participantes del estudio, como los trabajadores sometidos a una determinada exposición profesional, cumplimente los cuestionarios o participe de alguna otra manera en el estudio es mayor que en las personas no expuestas. Este tipo de situación puede producir una estimación sesgada de la asociación entre exposición y enfermedad. El sesgo de respuesta puede sospecharse cuando las tasas de respuesta o el tiempo que se tarda en rellenar un cuestionario o responder a una encuesta difieren considerablemente entre los grupos (p. ej., casos y controles, expuestos y no expuestos). El sesgo de respuesta varía dependiendo de la modalidad de administración del cuestionario. Los cuestionarios que se envían por correo suelen ser devueltos por aquellos que están personalmente interesados en los resultados del estudio y tienen más probabilidades de ser ignorados o rechazados por personas seleccionadas al azar de la población general. M uchos investigadores que utilizan encuestas por correo incorporan un mecanismo de seguimiento para maximizar las tasas de respuesta, que puede consistir en segundos y terceros recordatorios por correo, así como contactos telefónicos posteriores con las personas que no han respondido a la encuesta.

En las encuestas telefónicas, entre ellas las que seleccionan los controles mediante marcación digital aleatoria, suele existir un conjunto de reglas o un protocolo que define el número de intentos que deben realizarse para contactar con los encuestados potenciales, a qué hora del día deben realizarse las llamadas y si éstas deben realizarse por la noche 0 durante los fines de semana. Cuando se realizan estudios basados en hospitales, suele registrarse el número de pacientes que rechazan la invitación a participar en el estudio, así como los motivos de dicho rechazo. En todos estos casos, se registran distintas medidas de las tasas de respuesta para evaluar el nivel de cobertura de la población diana.

EI sesgo de selección se produce cuando la probabilidad de que un grupo de participantes responda a la encuesta o participe de alguna otra manera en el estudio es mayor, con el posible resultado de una estimación sesgada de la relación entre exposición y enfermedad. Para evaluar si se ha producido un sesgo de selección y la subestimación o sobrestimación de la exposición, pueden compararse los datos demográficos, como el nivel de educación, de los que responden y los que no responden al cuestionario. Por ejemplo, si los participantes con menor nivel de educación tienen menores tasas de respuesta que los participantes con mayor nivel de educación, y si se sabe que una determinada profesión o el hábito del tabaquismo es más frecuente en los participantes con menor nivel de educación, es probable que se produzca un sesgo de selección que subestime la exposición en esa profesión o categoría de tabaquismo.

La confusión es un importante tipo de sesgo de selección que se produce cuando la selección de los encuestados (casos y controles en un estudio de casos y controles, o expuestos y no expuestos en un estudio de cohortes) depende en cierta medida de una tercera variable, algunas veces desconocida para el investigador. Si no se identifica ni controla esta variable, puede producir una subestimación o sobrestimación imprevisible de los riesgos de enfermedad asociados a las exposiciones profesionales. La confusión suele controlarse manipulando el propio diseño del estudio (p. ej., mediante el emparejamiento de casos y controles dependiendo de la edad o de otras variables) 0 en la etapa del análisis. En otros artículos de este capítulo se describen con detalle estas técnicas.

\section{Documentación}

En cualquier estudio de investigación, todos los procedimientos del estudio deben documentarse con detalle, de manera que los miembros del personal, incluidos los encuestadores, supervisores e investigadores, sepan claramente cuales son sus respectivas obligaciones. En la mayoría de los estudios basados en cuestionarios, se prepara un manual de codificación en el que se describe pregunta por pregunta todo lo que el encuestador tiene que conocer más allá de la redacción literal de las preguntas, incluyendo instrucciones para la codificación de las respuestas categóricas. Este manual puede incluir también instrucciones explícitas para sondear al encuestado, indicando en qué preguntas se permite el sondeo y en qué preguntas no se permite. En muchos estudios, los encuestadores obtienen respuestas nuevas e imprevistas que deben registrar en el manual de codificación. Los encuestadores deben ser informados puntualmente de cualquier adición, cambio o nuevas instrucciones.

\section{Planificación, pruebas piloto y revisión}

C omo puede observarse en la Figura 28.1, el diseño de un cuestionario exige una cuidadosa planificación. Todos los cuestionarios tienen que ser sometidos a pruebas piloto en distintas etapas para 
tener la seguridad de que las preguntas "funcionan", es decir, que se comprenden y producen respuestas de la calidad deseada. Es conveniente poner a prueba las nuevas preguntas en grupos de voluntarios y seguidamente interrogarles para comprobar que se comprenden bien y para conocer los tipos de problemas 0 ambigüedades que plantean. Estos resultados pueden utilizarse para revisar el cuestionario, repitiendo el procedimiento todas las veces que sea necesario. Este grupo de voluntarios se denomina a veces "grupo de enfoque".

Todas las investigaciones epidemiológicas requieren pruebas piloto, no sólo de los cuestionarios, sino también de los procedimientos del estudio. Un cuestionario correctamente diseñado logra su finalidad sólo si puede administrarse eficientemente a los participantes del estudio y esto se puede conseguir realizando pruebas piloto e introduciendo los ajustes necesarios.

\section{Formación y supervisión de los encuestadores}

En los estudios que se realizan mediante encuestas telefónicas o personales, el encuestador desempeña una función crítica. Esta persona es responsable, no sólo de formular las preguntas a los participantes del estudio y anotar sus respuestas, sino también de interpretar dichas respuestas. Incluso aunque la encuesta tenga una estructura muy rígida, los encuestados pueden solicitar aclaraciones de preguntas 0 dar respuestas que no encajen en ninguna de las categorías de respuesta contempladas. En dichos casos, el trabajo del encuestador consiste en interpretar la pregunta o la respuesta considerando los fines del investigador. Para hacer este trabajo de una manera eficaz y coherente, necesita una formación adecuada y la supervisión de un investigador 0 director con experiencia. Cuando en un estudio participa más de un encuestador, la formación de los encuestadores es especialmente importante para asegurar la uniformidad en la formulación de las preguntas y la interpretación de las respuestas. En muchos proyectos de investigación, esta uniformidad se consigue mediante programas de formación en grupo que se repiten periódicamente (p. ej., todos los años) para mantener al día las destrezas de los encuestadores. Los seminarios de formación suelen abordar con detalle los siguientes temas:

- Introducción general al estudio.

- Aspectos relacionados con el consentimiento informado y la confidencialidad.

- Manera de presentar la encuesta y de interaccionar con los encuestados.

- Significado pretendido de cada pregunta.

- Instrucciones para el sondeo, es decir, ofrecer al encuestado la oportunidad de aclarar o detallar las respuestas.

- Descripción de los problemas típicos que se plantean durante las encuestas.

La supervisión de un estudio exige con frecuencia observar la actuación de los encuestadores, pudiéndose grabar las encuestas para su análisis posterior. U na práctica habitual es que el supervisor revise personalmente todos los cuestionarios antes de aprobarlos y remitirlos al personal encargado de la entrada de datos. EI supervisor establece y vigila la aplicación de las normas de conducta de los encuestadores y, en algunos estudios, repite las encuestas a una serie de participantes como control de la fiabilidad.

\section{Recogida de datos}

La distribución de los cuestionarios a los participantes del estudio y su posterior recogida para el análisis de los datos se realiza utilizando una de las tres modalidades descritas antes: por correo, por teléfono y en persona. Algunos investigadores organizan e incluso realizan ellos mismos esta función en sus respectivas instituciones.
Aunque el hecho de que un investigador se familiarice de primera mano con la dinámica de las encuestas tiene un mérito considerable, es más eficaz con relación al coste y preferible para la calidad de los datos que esta labor sea realizada por encuestadores profesionales bajo la supervisión del equipo de investigación.

Algunos investigadores contratan a empresas especializadas en encuestas. Estas empresas prestan una serie de servicios que incluyen una o más de las siguientes actividades: distribución y recogida de cuestionarios, encuestas telefónicas o personales, obtención de muestras biológicas como sangre u orina, procesamiento de los datos, análisis estadístico y redacción del informe. Con independencia del nivel de apoyo que reciban, los contratistas suelen ser responsables de facilitar información sobre las tasas de respuesta y la calidad de los datos. N o obstante, el investigador es siempre el último responsable de la integridad científica de su estudio.

\section{Fiabilidad y repetición de encuestas}

La calidad de los datos puede evaluarse por segunda vez volviendo a entrevistar a una muestra de los participantes iniciales del estudio. De esta forma se puede determinar la fiabilidad de las primeras encuestas y estimar la repetibilidad de las respuestas. No es necesario volver a administrar todo el cuestionario; normalmente es suficiente con un subconjunto de las preguntas. Las pruebas estadísticas pueden utilizarse para evaluar la fiabilidad del conjunto de preguntas formuladas a los mismos participantes en momentos diferentes, así como para evaluar la fiabilidad de las respuestas dadas por diferentes participantes e incluso por los encuestados por diferentes encuestadores (es decir, evaluaciones del mismo y de distintos encuestadores).

\section{Tecnología para el procesamiento de los cuestionarios}

Los avances en la tecnología informática han creado muchas formas diferentes de introducir en un ordenador los datos de los cuestionarios y ponerlos a disposición del investigador para su análisis. Existen tres formas fundamentalmente diferentes para la entrada de los datos: en tiempo real (es decir, a medida que el paciente responde a la encuesta), métodos tradicionales de entrada a través del teclado y métodos de entrada óptica de los datos.

\section{Entrada de datos asistida por ordenador}

M uchos investigadores utilizan hoy en día los ordenadores para recoger las respuestas a preguntas formuladas mediante encuestas personales o telefónicas. Los investigadores suelen utilizar ordenadores personales programados para presentar las preguntas secuencialmente y que permiten al encuestador introducir la respuesta en el mismo momento. Las empresas de encuestas telefónicas han desarrollo sistemas análogos llamados sistemas de encuesta telefónica asistida por ordenador (CATI). Estos métodos ofrecen dos importantes ventajas frente a los cuestionarios en papel tradicionales. En primer lugar, las respuestas se pueden verificar al instante frente a la serie de respuestas admitidas y comprobar su coherencia con las respuestas anteriores, de manera que cualquier discrepancia podrá llamar inmediatamente la atención tanto del encuestador como del encuestado. De esta forma, se reduce en gran medida la tasa de errores. En segundo lugar, pueden programarse los saltos entre preguntas para reducir al mínimo el tiempo de administración del cuestionario.

El método más común para informatizar los datos sigue siendo la entrada a través del tedado realizada por un operador cualificado. En el caso de estudios muy grandes, los cuestionarios suelen enviarse a una empresa subcontratada que está especializada en la entrada de datos. Muchas de estas empresas 
utilizan equipos especializados que permiten que un operador introduzca a través del teclado los datos del cuestionario (un procedimiento llamado a veces perforar por teclado por razones históricas) y que un segundo operador vuelva a teclear los mismo datos, un proceso llamado verificación del tecleado. Los datos introducidos por el segundo operador se comparan con los del primero, para verificar que se han introducido correctamente. Los procedimientos de aseguramiento de la calidad pueden programarse para comprobar que todas las respuestas están dentro del rango permitido y que son coherentes con otras respuestas. Los ficheros de datos resultantes pueden entregarse al investigador en disco, cinta o a través de medios electrónicos como módem o redes informáticas.

En el caso de estudios más pequeños, existen en el mercado multitud de programas para ordenadores personales con funciones de entrada de datos que emulan a los sistemas más especializados. Entre estos programas figuran bases de datos como dBase, Foxpro y M icrosoft Access y hojas de cálculo como Microsoft Excel y Lotus 1-2-3. Asimismo, muchos paquetes informáticos incluyen funciones de entrada de datos cuya principal finalidad es el análisis estadístico de los datos, como SPSS, BMDP y EPI INFO.

L os sistemas ópticos se utilizan con frecuencia para introducir los datos de cuestionarios especiales. Los lectores de marcas ópticas 0 los sensores ópticos se utilizan para leer las respuestas a cuestionarios que están especialmente diseñados para que los participantes introduzcan los datos marcando pequeños rectángulos o círculos (llamados "códigos de burbuja"). Este tipo de cuestionarios son más eficientes cuando cada persona rellena su propio cuestionario. Los equipos más sofisticados y costosos pueden leer caracteres escritos a mano, pero en la actualidad no existe una técnica eficiente para la entrada de datos en estudios a gran escala.

\section{Archivo de cuestionarios y manuales de codificación}

Al ser la información un recurso de gran valor y estar sometida a la interpretación y a otras influencias, los investigadores reciben algunas veces la petición de comparar sus datos con los de otros investigadores. Esta petición puede estar motivada por distintas razones, desde el sincero interés de difundir un informe hasta la existencia de dudas sobre la validez del análisis y la interpretación de los datos.

Para hacer frente a las sospechas o sugerencias de falsificación o manipulación de los datos, es muy importante que el investigador conserve los registros originales en los que se basan los datos publicados para que puedan ser auditados. A demás de los cuestionarios originales y/o los ficheros informatizados de los datos en bruto, el investigador debe conservar el manual de codificación utilizado en el estudio y los registros de todas las modificaciones de los datos que se hayan realizado durante la codificación, informatización y análisis de los datos, para que puedan ser revisados. Por ejemplo, si se ha modificado el valor de un dato porque aparecía inicialmente como un valor muy alejado, dicha modificación y los motivos de la misma deben hacerse constar en el registro para una posible auditoría futura de los datos. Este tipo de información es también importante para la elaboración de informes, ya que ayuda a recordar cómo se han procesado los datos en los que se basan los resultados presentados.

Por todas estas razones, una vez finalizado el estudio, el investigador tiene la obligación de asegurar que todos los datos básicos se conserven correctamente archivados durante un período de tiempo razonable y que puedan ser recuperados si alguien los solicita en el futuro.

\section{AMIANTO : PERSPECTIVA HISTO RICA}

\section{Lawrence Garfinkel}

Existen una serie de ejemplos de peligros en el lugar de trabajo que se citan con frecuencia para ilustrar, no sólo los posibles efectos nocivos para la salud asociados a exposiciones en el lugar de trabajo, sino también para explicar cómo un enfoque sistemático del estudio de las poblaciones de trabajadores puede demostrar importantes relaciones entre exposición y enfermedad. U no de estos ejemplos es el del amianto. En un artículo de Lawrence Garfinkel se recuerda la sencilla elegancia con la que e $D$ r. I rving J. Selikoff demostró el mayor riesgo de cáncer en los trabajadores del amianto. Dicho artículo se ha reproducido aquí tan solo con unas ligeras modificaciones y con la autorización del CA-A Cancer J ournal for Clinicians (Garfinke 1984). Las tablas proceden del artículo original de Dr. Selikoff y sus colaboradores (1964).

La exposición al amianto se ha convertido en un problema de salud pública de magnitud considerable, con ramificaciones que se extienden más allá del campo inmediato de los profesionales sanitarios para caer dentro de las competencias de legisladores, jueces, abogados, educadores y otros cargos públicos. Como resultado, las enfermedades relacionadas con el amianto han atraído el creciente interés de los médicos y de las autoridades sanitarias, así como de los consumidores y la opinión pública en general.

\section{Antecedentes históricos}

El amianto es un mineral muy útil al que se han dado distintos usos a lo largo de los siglos. Los estudios arqueológicos realizados en Finlandia han encontrado restos de fibras de amianto en loza del año 2500 a.C. En el siglo $V$ a.C., se utilizaba para fabricar mechas de lámparas. H erodoto ya hablaba del uso de prendas de vestir fabricadas con amianto para la incineración de cadáveres alrededor del 456 a.C. El amianto se utilizó en las armaduras del siglo XV y en la fabricación de prendas de vestir, guantes, calzado y bolsos en Rusia hacia 1720. Aunque no se sabe cuándo se desarrolló el arte de tejer el amianto, ya desde antiguo combinaba el lino. La producción comercial de amianto se inició en Italia en torno a 1850 para la fabricación de papel y prendas de vestir.

La explotación de las minas de amianto en Canadá y Sudáfrica alrededor de 1880 redujo los costes y estimuló la fabricación de los productos de amianto. Poco después se inició la explotación minera y la producción de amianto en Estados Unidos, I talia y Rusia. En Estados Unidos, la utilización del amianto como aislante de tuberías aumentó su producción y fue seguida al poco tiempo por otros usos distintos, como guarniciones de freno, tuberías de cemento, prendas protectoras, etc.

La producción en Estados U nidos aumentó de unas 6.000 toneladas en 1900 a unas 650.000 toneladas en 1975, aunque en 1982 la producción se redujo a unas 300.000 toneladas y en 1994, a 33.000 toneladas.

Parece ser que Plinio EI Joven (61-113 a.C.) ya se refirió a la enfermedad de los esclavos que trabajaban con el amianto. En el siglo XVI aparecen referencias a la enfermedad profesional asociada con la minas de amianto, pero hasta 1906 no aparece la primera referencia a la fibrosis pulmonar de los trabajadores del amianto en Inglaterra. Poco después se empezó a hablar de la mayor tasa de mortalidad de los trabajadores que participaban en las aplicaciones de la fabricación del amianto en Francia e Italia, pero la enfermedad inducida por el amianto no se reconoció hasta 1924 en Inglaterra. En 1930, Wood y G loyne habían declarado 37 casos de fibrosis pulmonar.

La primera referencia al carcinoma de pulmón en un paciente con "silicosis inducida por el amianto" apareció en 1935. Le siguieron varios informes sobre otros casos. En 1947, 1949 y 
Tabla 28.16 • Hombre-años de experiencia de 632 trabajadores del amianto expuestos a polvo de amianto durante 20 o más años.

\begin{tabular}{lrrrr} 
Edad & \multicolumn{4}{c}{ Período de tiempo } \\
& $1943-47$ & $1948-52$ & $1953-57$ & $1958-62$ \\
$35-39$ & 85,0 & 185,0 & 7,0 & 11,0 \\
$40-44$ & 230,5 & 486,5 & 291,5 & 70,0 \\
$45-49$ & 339,5 & 324,0 & 530,0 & 314,5 \\
$50-54$ & 391,5 & 364,0 & 308,0 & 502,5 \\
$55-59$ & 382,0 & 390,0 & 316,0 & 268,5 \\
$60-64$ & 221,0 & 341,5 & 344,0 & 255,0 \\
$65-69$ & 139,0 & 181,0 & 286,0 & 280,0 \\
$70-74$ & 83,0 & 115,5 & 137,0 & 197,5 \\
$75-79$ & 31,5 & 70,0 & 70,5 & 75,0 \\
$80-84$ & 5,5 & 18,5 & 38,5 & 23,5 \\
$85+$ & 3,5 & 2,0 & 8,0 & 13,5 \\
Total & $1.912,0$ & $2.478,0$ & $2.336,5$ & $2.011,0$
\end{tabular}

1951 se publicaron informes sobre el elevado porcentaje de cáncer de pulmón en pacientes que fallecían de amiantosis. En 1955, R ichard Doll demostró en Inglaterra un mayor riesgo de cáncer de pulmón en personas que habían trabajado en una fábrica de amianto desde 1935 y un riesgo especialmente elevado en los que llevaban trabajando más de 20 años.

\section{Observaciones clínicas}

Con estos antecedentes, el Dr. Irving Selikoff inició sus observaciones clínicas de la enfermedad relacionada con el amianto. En aquel entonces, el Dr. Selikoff era un científico de gran prestigio. Entre los éxitos que ya había logrado, fue el primero en desarrollar y utilizar la isoniazida para el tratamiento de la tuberculosis, motivo por el cual recibió un Premio Lasker en 1952.

A principios del decenio de 1960, trabajaba en Paterson (Nueva Jersey) como médico especialista en enfermedades torácicas y había observado numerosos casos de cáncer de pulmón en los trabajadores de una fábrica de amianto de la zona. Decidió ampliar sus observaciones a dos locales del sindicato de trabajadores de aislamientos de amianto, cuyos miembros estaban también expuestos a las fibras de amianto. Se dio cuenta de que seguían existiendo muchas personas que no creían que el cáncer de pulmón estuviera relacionado con la exposición al amianto y de que sólo mediante un estudio exhaustivo de la población total expuesta podría convencerles. Existía la posibilidad de que la exposición a amianto en la población estuviera relacionada con otros tipos de cáncer, como mesotelioma pleural y peritoneal, como ya se había sugerido en otros estudios, y quizás también con cáncer en otros lugares. La mayoría de los estudios previos de los efectos del amianto en la salud se habían centrado en los trabajadores de las minas y fábricas de amianto. Era importante saber si la inhalación de amianto afectaba también a otros grupos expuestos al amianto.

EI Dr. Selikoff había oído hablar de los logros del Dr. E. Cuyler $\mathrm{H}$ ammond, en aquel entonces Director de la Sección de Investigación Estadística de la American Cancer Society (ACS), y decidió pedirle su colaboración para el diseño y análisis del estudio. El Dr. Hammong había publicado años antes el primer estudio prospectivo sobre el tabaquismo y la salud.

EI Dr. H ammond se dio cuenta inmediatamente de la posible importancia de un estudio sobre los trabajadores del amianto. Aunque estaba muy ocupado en el análisis de los datos del nuevo estudio prospectivo de la ACS, el Estudio de la Prevención del Cáncer I (CPS I) que se había iniciado unos años antes, aceptó en seguida colaborar en su "tiempo libre". Sugirió que el análisis se limitara a los trabajadores que tuvieran como mínimo 20 años de experiencia laboral, por ser los que habrían estado sometidos al mayor nivel de exposición al amianto.

Tabla 28.17 - N úmero observado y esperado de
fallecimientos en 632 trabajadores del
a mianto expuestos a polvo de amianto
durante 20 o más años.
Período de tiempo

blanca, EE.UU.)

Total cáncer, todos los sitios

$\begin{array}{lccccc}\begin{array}{l}\text { Observada } \\ \text { (trabajadores del }\end{array} & 13,0 & 17,0 & 26,0 & 39,0 & 95,0 \\ \begin{array}{l}\text { amianto) } \\ \begin{array}{l}\text { Esperada } \\ \text { (varones de raza }\end{array}\end{array} & 5,7 & 8,1 & 13,0 & 9,7 & 36,5 \\ \text { blanca EF UU) } & & & & & \end{array}$

blanca, EE.UU.)

Cáncer de pulmón y pleura

$\begin{array}{llllll}\text { Observada } & 6,0 & 8,0 & 13,0 & 18,0 & 45,0\end{array}$

(trabajadores del

amiantol

$\begin{array}{llllll}\text { Esperada } & 0,8 & 1,4 & 2,0 & 2,4 & 6,6\end{array}$

(varones de raza

blanca. EE.UU.)

Cáncer de estómago, colon y recto

\begin{tabular}{|c|c|c|c|c|c|}
\hline $\begin{array}{l}\text { Observada } \\
\text { (trabajadores del } \\
\text { amianto) }\end{array}$ & 4,0 & 4,0 & 7,0 & 14,0 & 29,0 \\
\hline $\begin{array}{l}\text { Esperada } \\
\text { (varones de raza } \\
\text { blanca. EE.UU.) }\end{array}$ & 2,0 & 2,5 & 2,6 & 2,3 & 9,4 \\
\hline \multicolumn{6}{|l|}{ Otros cánceres } \\
\hline $\begin{array}{l}\text { Observada } \\
\text { (trabajadores del } \\
\text { amianto) }\end{array}$ & 3,0 & 5,0 & 6,0 & 7,0 & 21,0 \\
\hline $\begin{array}{l}\text { Esperada } \\
\text { (varones de raza } \\
\text { blanca, EE.UU.) }\end{array}$ & 2,9 & 4,2 & 8,4 & 5,0 & 20,5 \\
\hline
\end{tabular}


El equipo se completó con Janet $\mathrm{K}$ affenburgh, una investigadora adjunta al Dr. Selikoff en el Mount Sinai Hospital, que ayudó al Dr. Hammond a preparar las listas de los trabajadores que participarían en el estudio, indicando sus edades y la fechas de empleo, y a obtener datos sobre las circunstancias de su muerte y las causas para que se abriera un expediente en la sede del sindicato. Esta información fue posteriormente transferida a fichas que el $\mathrm{Dr}$. $\mathrm{H}$ ammond y Janet $\mathrm{K}$ affenburgh ordenaron en el cuarto de estar de la casa del primero.

EI Dr. Jacob Churg, un patólogo del Barnert Memorial H ospital Center de Paterson, Nueva Jersey, fue el encargado de realizar la verificación patológica de las causas de muerte.

El diseño final fue un "estudio prospectivo realizado retrospectivamente". La naturaleza de los registros del sindicato permitió realizar un análisis de un estudio de largo alcance en un período de tiempo relativamente corto. A unque sólo participaron 632 varones, representaban 8.737 hombre-años de exposición al riesgo (véase Tabla 28.16) y durante el período de 20 años de observación de 1943 a 1962 se produjeron 255 fallecimientos (véase la Tabla 28.17). Como puede observarse en la Tabla 28.17 el número observado de fallecidos superó en todos los casos al número esperado, demostrando la asociación entre la exposición a amianto en el lugar de trabajo y una mayor tasa de mortalidad por cáncer.

\section{Importancia del trabajo}

Este estudio constituyó un viraje decisivo en nuestro conocimiento sobre la enfermedad relacionada con el amianto y estableció la dirección de las futuras investigaciones. El artículo del Dr. Selikoff ha sido citado al menos 261 veces en las publicaciones científicas. Con el apoyo financiero de la ACS y el National Institutes of $\mathrm{H}$ ealth, el Dr. Selikoff, el Dr. Hammond y un equipo cada vez mayor de mineralogistas, médicos torácicos, radiólogos, patólogos, higienistas y epidemiólogos, siguieron estudiando distintas facetas de la enfermedad del amianto.
U n importante artículo publicado en 1968 describió el efecto sinergístico del tabaco en la exposición al amianto (Selikoff, Hammond y Churg 1968). Los estudios se ampliaron para incluir a los trabajadores de la producción del amianto, a personas expuestas indirectamente al amianto en sus trabajos (trabajadores de los astilleros, por ejemplo) y a personas con exposición al amianto en sus hogares.

En un análisis posterior que contó con la participación de H erbert Seidman, M BA, Vicepresidente Adjunto de Epidemiología y Estadística de la American Cancer Society, el grupo demostró que incluso la exposición de corta duración al amianto producía un riesgo significativamente mayor de cáncer que se mantenía incluso 30 años más tarde (Seidman, Selikoff y $\mathrm{H}$ ammond 1979). En este primer estudio de 632 trabajadores de aislamientos, sólo se produjeron tres casos de mesotelioma, pero las investigaciones posteriores demostraron que el $8 \%$ de todas las muertes de los trabajadores del amianto se debían a mesotelioma pleural y peritoneal.

A medida que las investigaciones científicas del Dr. Selikoff se ampliaron, él y sus colaboradores realizaron importantes contribuciones para reducir la exposición al amianto, introduciendo innovaciones en las técnicas de higiene industrial, persuadiendo a los legisladores de la urgencia del problema del amianto, evaluando los problemas del pago de pensiones de discapacidad a trabajadores afectados por la enfermedad del amianto, e investigando la distribución general de las partículas de amianto en los abastecimientos de agua y en la aire ambiental.

EI Dr. Selikoff consiguió también atraer la atención de la comunidad médica y científica al problema del amianto organizando conferencias sobre el tema y participando en numerosas reuniones científicas.

M uchas de sus charlas informativas sobre el problemas de la enfermedad del amianto se dirigieron especialmente a abogados, jueces, presidentes de grandes empresas y directivos de entidades aseguradoras

\section{Referencias}

Actas de la Conferencia sobre evaluación retrospectiva de las exposiciones profesionales en epidemiología, Lyon, 13-15 de abril de 1994. 1995. Lyon: IARC.

Ahlbom, A. 1984. Criteria of causal association in epidemiology. En $\mathrm{H}$ ealth, Disease, and Causal Explanations in $M$ edicine, dirigido por $L$ Nordenfelt y BIB Lindahl. Dordrecht: D R eidel.

American Conference of Government Industrial $\mathrm{H}$ ygienists (ACGIH). 1991. Exposure Assessment for $\mathrm{E}$ pi-demiology and $\mathrm{H}$ azard Control, dirigido por SM R appaport y TJ Smith. Chelsea, M ichigan: Lewis.

Armstrong, BK, E White, R Saracci. 1992. Principles of Exposure $M$ easurement in $E$ pidemiology. Oxford: O xford U niv. Press.

Ashford, NA, Cl Spadafor, DB H attis, CC Caldart 1990. M onitoring the W orker for Exposure and Disease Baltimore: Johns H opkins U niv. Press.

Axelson, 0. 1978. Aspects on confounding in occupational health epidemiology. Scand J W ork Environ $\mathrm{H}$ ealth 4:85-89.

- . 1994. Some recent developments in occupational epidemiology. Scand J W ork Environ H ealth 20 (número especial):9-18.

Ayrton-Paris, JA. 1822. Pharmacologia.

Babbie, E. 1992. The Practice of Social Research. Belmont, California: Wadsworth.

Beauchamp, TL, RR Cook, WE Fayerweather, GK Raabe, WE Thar, SR Cowles, GH Spivey. 1991.
Ethical Guidelines for Epidemiologists | Clin E pidemiol 44 Supl. I:151S-169S.

Bell, B. 1876. Paraffin epithelioma of the scrotum. E dinburgh $M$ ed J 22:135

Blondin, O, C Viau. 1992. Benzo(a)pyrene-blood protein adducts in wild woodchucks used as biological sentinels of environmental polycyclic aromatic hydrocarbons contamination. Arch E nviron Contam T oxicol 23:310-315.

Buck, C. 1975. Popper's philosophy for epidemiologists. Int J E pidemiol 4:159-168.

Case, RAM, ME Hosker. 1954. Tumour on the urinary bladder as an occupational disease in the rubber industry in England and Wales. Brit J Prevent Soc M ed 8:39-50.

Checkoway, $H$, NE Pearce, DJ Crawford-Brown. 1989. Research M ethods in Occupational E pidemiology. NuevaY ork: 0 xford U niv. Press.

Clayson, DB. 1962. Chemical Carcinogenesis. Londres: JA Churchill.

Clayton, D. 1992. Teaching statistical methods in epidemiology. En Epidemiology. W hat You Should Know and W hat You Could D o, dirigido por J O Isen y D T richopoulos. Oxford: Oxford U niv. Press.

Clayton, D, M Hills. 1993. Statistical Models in E pidemiology. N ueva Y ork: O xford U niv. Press.

Cornfield, J. 1954. Statistical relationships and proof in medicine. Am Stat 8:19-21.

Consejo de Organizaciones Internacionales de Ciencias M édicas (CIOM S). 1991. International
Guidelines for E thical Review of E pidemiologic Studies. Ginebra: CIOM S

Czaja, R I Blair. 1996. Designing Surveys. Thousand $O$ aks, California: Pine Forge Press.

Doll, R. 1952. The causes of death among gas-workers with special reference to cancer of the lung. B rit I Ind M ed 9:180-185.

-. 1955. M ortality from lung cancer in asbestos workers. B rit J Ind M ed 12:81-86.

Droz, PO, MM Wu. 1991. Biological monitoring strategies. En Exposure Assessment for E pidemiology and $\mathrm{H}$ azard Control, dirigido por SM Rappaport y TJ Smith. Chelsea, M ichigan: Lewis.

Gamble, J, R Spirtas. 1976. Job classification and utilization of complete work histories in occupational epidemiology. J M ed 18:399-404.

Gardner, MJ, DG Altman. 1989. Statistics W ith Confidence Confidence Intervals and Statistical Guidelines. Londres: BM J Publishing H ouse.

Garfinkel, L. 1984. Classics in oncology; E. Cuyler Hammond, ScD. Ca-Cancer I ournal for Clinicians. 38(1): 23-27

Giere, RN. 1979. U nderstanding Scientific Reasoning. N ueva Y ork: $H$ olt $R$ inehart $\&$ W inston.

Glickman, LT. 1993. Natural exposure studies in pet animals: Sentinels for environmental carcinogens. $V$ et $\mathrm{C}$ an Soc N ewslttr 17:5-7.

Glickman, LT, LM Domanski, TG Maguire, RR Dubielzig, A Churg. 1983. Mesothelioma in pet dogs associated with exposure of their owners to asbestos. Environmental R esearch 32:305-313. 
Gloyne, SR . 1935. T wo cases of squamous carcinoma of the lung occurring in asbestosis. Tubercle 17:5-10.

- 1951. Pneumoconiosis: Histological survey of necropsy material in 1,205 cases. Lancet 1:810-814.

Greenland, S. 1987. Q uantitative methods in the review of epidemiological literature. E pidemiol $\mathrm{Rer}$ 9:1-30.

-. 1990. Randomization, statistics, and causal inference. E pidemiology 1:421-429.

$\mathrm{H}$ arting, FH, W H esse. 1879. Der Lungenkrebs, die bergkrankheit in den Schneeberger Gruben. Vierteljahrsschr Gerichtl M ed Offentl Gesundheitswesen CAPS 30:296-307.

Hayes, RB, JW Raatgever, A de Bruyn, M Gerin. 1986. Cancer of the nasal cavity and paranasal sinuses, and formaldehyde exposure. Int I Cancer 37:487-492.

Hayes, HM, RE Tarone, HW Casey, DL Huxsoll. 1990. Excess of seminomas observed in vietnam service US military working dogs. I N atl Cancer Inst 82:1042-1046.

$\mathrm{H}$ ernberg, S. 1992. Introduction to O ccupational E pidemiology. Chelsea, M ichigan: L ewis.

Hill, AB. 1965. The environment and disease: Association or causation? Proc Royal Soc M ed 58:295-300.

H ume, D. 1978. A T reatise of $\mathrm{H}$ uman Nature Oxford: Clarendon Press.

H ungerford, LL, H L T rammel, JM Clark. 1995. The potential utility of animal poisoning data to identify human exposure to environmental toxins. $V$ et $H$ um T oxicol 37:158-162.

Jeyaratnam, J. 1994. Transfer of hazardous industries. En Occupational Cancer in Developing Countries, dirigido por NE Pearce, E M atos, $\mathrm{H}$ Vainio, P Boffetta y M K ogevinas. Lyon: IARC.

$K$ arhausen, LR. 1995. The poverty of Popperian epidemiology. Int J E pidemiol 24:869-874.

Kogevinas, M, P Boffetta, N Pearce. 1994. O ccupational exposure to carcinogens in developing countries. En O ccupational Cancer in Developing Countries, dirigido por NE Pearce, E $M$ atos, $\mathrm{H}$ Vainio, $\mathrm{P}$ Boffetta, M K ogevinas. Lyon: IARC.

L aD ou, J. 1991. D eadly migration. T ech R ev 7:47-53.

Laurell, AC, M Noriega, S M artinez, J Villegas. 1992. Participatory research on workers' health. Soc Sci M ed 34:603-613.

Lilienfeld, AM, DE Lilienfeld. 1979. A century of case-control studies: progress? Chron D is 32:5-13.

Loewenson, R, M Biocca. 1995. Participatory approaches in occupational health research. $M$ ed Lavoro 86:263-271.

Lynch, K M , WA Smith. 1935. Pulmonary asbestosis. III Carcinoma of lung in asbestos-silicosis. Am J Cancer 24:56-64.

Maclure, M. 1985. Popperian refutation in epidemiolgy. Am J E pidemiol 121:343-350.

- . 1988. R efutation in epidemiology: Why else not? En Causal Inference, dirigido por KJ Rothman. Chestnut Hill, M assachussetts: Epidemiology Resources.

M artin, SW, AH M eek, P Willeberg. 1987. Veterinary E pidemiology. D es M oines: I owa State U niv. Press.

M CM ichael, AJ. 1994. Invited commentary -"M olecular epidemiology": N ew pathway or new travelling companion? Am J E pidemiol 140:1-11.

Merletti, F, P Comba. 1992. O ccupational epidemiology. En T eaching E pidemiology. W hat Y ou Should Know and W hat You Could Do, dirigido por J O Isen y D Trichopoulos. Oxford: Oxford U niv. Press.

M iettinen, O S. 1985. Theoretical E pidemiology. Principles of $O$ ccurrence R esearch in M edicine. N ueva Y ork: John Wiley $\&$ Sons
Newell, KW, AD R oss, RM Renner. 1984. Phenoxy and picolinic acid herbicides and small-intestinal adenocarcinoma in sheep. L ancet 2:1301-1305.

O Isen, J, F M erletti, D Snashall, K Vuylsteek. 1991. Searching for Causes of Work-Related Diseases. An Introduction to E pidemiology At the W ork Site Oxford: $O$ xford M edical Publications, O xford U niv. Press.

Pearce, N. 1992. Methodological problems of time-related variables in occupational cohort studies. Rev E pidmiol M ed Soc Santé Publ 40 Supl: 43-54.

1996. Traditional epidemiology, modern epidemiology and public health. Am J Public $\mathrm{H}$ ealth 86(5): 678-683.

Pearce, N, E Matos, H Vainio, P Boffetta, M K ogevinas. 1994. O ccupational cancer in developing countries. IARC Scientific Publications, No. 129. Lyon: IARC.

Pearce, N, S De Sanjose, P Boffetta, M K ogevinas, R Saracci, D Savitz. 1995. Limitations of biomarkers of exposure in cancer epidemiology. E pidemiology 6:190-194.

Poole, C. 1987. Beyond the confidence interval. Am J Public H ealth 77:195-199.

Pott, P. 1775. Chirurgical O bservations. Londres: $\mathrm{H}$ awes, Clarke \& Collins

R amazzini, B. 1705. De M orbis Artificum D iatriva. T ypis Antonii Capponi. M utinae, M DCC. Londres: Andrew Bell \& $O$ thers.

Rappaport, SM, H K romhout, E Symanski. 1993. Variation of exposure between workers in homogeneous exposure groups. Am Ind $\mathrm{H}$ yg Assoc ] 54(11):654-662.

Reif, JS, K S Lower, GK O gilvie. 1995. Residential exposure to magnetic fields and risk of canine lymphoma. Am | E pidemiol 141:3-17.

Reynolds, PM, JS Reif, HS Ramsdell, JD Tessari. 1994. Canine exposure to herbicide-treated lawns and urinary excretion of 2,4dichlorophenoxyacetic acid. Canc E pidem, Biomark and Prevention 3:233-237.

Robins, JM, D Blevins, G Ritter, M Wulfsohn. 1992. $G$-estimation of the effect of prophylaxis therapy for pneumocystis carinii pneumonia on the survival of Aids patients. E pidemiology 3:319-336.

Rothman, KJ. 1986. M odern E pidemiology. Boston: Little, Brown \& Co.

Saracci, R. 1995. Epidemiology: Y esterday, today, tomorrow. En Lectures and Current Topics in Epidemiology. Florencia: Programa Europeo de Educación sobre Epidemiología.

Schaffner, K F. 1993. D iscovery and Explanation in B iology and $M$ edicine $C$ hicago: U niv. of $C$ hicago Press.

Schlesselman, JJ. 1987. "Proof" of cause and effect in epidemiologic studies: Criteria for judgement. Prevent M ed 16:195-210.

Schulte, P. 1989. Interpretation and communcication of the results of medical field investigations. I $\mathrm{OC}$ cup $M$ ed 31:5889-5894.

Schulte, PA, WL Boal, JM Friedland, JT Walker, LB Connally, LF Mazzuckelli, LJ Fine. 1993. $M$ ethodological issues in risk communications to workers. Am I Ind M ed 23:3-9.

Schwabe, CW. 1993. The current epidemiological revolution in veterinary medicine. Part II. Prevent Vet $M$ ed 18:3-16.

Seidman, H, IJ Selikoff, EC H ammond. 1979. Short-term asbestos work exposure and long-term observation. Ann NY Acad Sci 330:61-89.

Selikoff, IJ, EC H ammond, J Churg. 1968. Asbestos exposure, smoking and neoplasia. JAMA 204:106-112.

-. 1964. Asbestos exposure and neoplasia. J AM A 188, 22-26.

Siemiatycki, J, L R ichardson, M Gérin, M Goldberg, $\mathrm{R}$ Dewar, M Désy, S Campbell, S Wacholder.
1986. Associations between several sites of cancer and nine organic dusts: Results from an hypothesis-generating case-control study in M ontreal, 1979-1983. Am J E pidemiol 123:235-249.

Simonato, L. 1986. O ccupational cancer risk in developing countries and priorities for epidemiological research. Presentado en el Simposio internacional sobre salud y medio ambiente en los países subdesarrollados, $\mathrm{H}$ aicco.

Smith, TJ. 1987. Exposure asssessment for occupational epidemiology. Am । Ind $M$ ed $12: 249-268$

Soskolne, CL. 1985. Epidemiological research, interest groups, and the review process. I Publ $H$ ealth Policy 6(2):173-184.

- . 1989. Epidemiology: Q uestions of science, ethics, morality and law. Am J E pidemiol 129(1):1-18.

-. 1993. Introduction to misconduct in science and scientific duties. I Expos Anal Environ Epidemiol 3 Supl. 1:245-251.

Soskolne, CL, D Lilienfeld, B Black. 1994. Epidemiology in legal proceedings in the U nited States. En The Identification and Control of Environmental and Occupational Diseases. Advances in M odern Environmental T oxicology: Part 1, dirigido por MA M ellman y A U pton. Princeton: Princeton Scientific Publishing.

Stellman, SD. 1987. Confounding. Prevent M ed 16:165-182.

Suarez-Almazor, ME, CL Soskolne, K Fung, GS Jhangri. 1992. Empirical assessment of the effect of different summary worklife exposure measures on the estimation of risk in case-referent studies of occupational cancer. Scand I W ork Environ $\mathrm{H}$ ealth 18:233-241.

Thrusfield, M V . 1986. Veterinary E pidemiology. Londres: Butterworth H einemann.

Trichopoulos, D. 1995. Accomplishments and prospects of epidemiology. En Lectures and Current Topics in Epidemiology. Florencia: Programa Europeo de Educación sobre Epidemiología.

Van Damme, K, L Cateleyn, E H eseltine, A H uici, M Sorsa, N van Larebeke, P Vineis. 1995. Individual susceptibility and prevention of occupational diseases: scientific and ethical issues. Exp M ed 37:91-99.

Vineis, P. 1991. Causality assessment in epidemiology. Theor M ed 12:171-181.

V ineis, P. 1992. U ses of biochemical and biological markers in occupational epidemiology. Rev E pidmiol M ed Soc SantéPubl 40 Supl 1: 63-69.

Vineis, P, T M artone. 1995. Genetic-environmental interactions and low-level exposure to carcinogens. E pidemiology 6:455-457.

V ineis, P, L Simonato. 1991. Proportion of lung and bladder cancers in males resulting from occupation: A systematic approach. Arch Environ $H$ ealth 46:6-15.

V ineis, P, CL Soskolne. 1993. Cancer risk assessment and management: An ethical perspective. I 0 ccup $M$ ed 35(9):902-908

V ineis, P, H Bartsch, N Caporaso, AM Harrington, FF K adlubar, MT Landi, C M alaveille, PG Shields, P Skipper, G T alaska, SR T annenbaum. 1994. Genetically based N-acetyltransferase metabolic polymorphism and low level environmental exposure to carcinogens. Nature 369:154-156.

Vineis, P, K Cantor, C Gonzales, E Lynge, V Vallyathan. 1995. O ccupational cancer in developed and developing countries. Int I Cancer 62:655-660.

V on Volkmann, R. 1874. U eber Theer-und R usskrebs. Klinische W ochenschrift 11:218.

Walker, AM , M Blettner. 1985. Comparing imperfect measures of exposure. Am J E pidemiol 121:783-790. 
Wang, JD. 1991. From conjectures and refutation to the documentation of occupational diseases in T aiwan. Am J Ind M ed 20:557-565.

-. 1993. Use of epidemiologic methods in studying diseases caused by toxic chemicals. I Natl Publ $H$ ealth Assoc 12:326-334.

Wang, JD, WM Li, FC Hu, KH Fu. 1987. O ccupational risk and the development of premalignant skin lesions among paraquat manufacturers. B rit J Ind $M$ ed 44:196-200.

Weed, DL. 1986. O $n$ the logic of causal inference. Am J E pidemiol 123:965-979.

-. 1988. Causal criteria and popperian refutation En Causal Inference, dirigido por KJ Rothman. Chestnut Hill, Massachussetts: Epidemiology Resources.

Wood, WB, SR Gloyne. 1930. Pulmonary asbestosis. Lancet 1:445-448.

Wyers, H. 1949. Asbestosis. Postgrad M ed J 25:631-638.

\section{O tras lecturas recomendadas}

Ahlbom, A, S Norell. 1984. Introduction to M odern Epidemiology. Chestnut $\mathrm{H}$ ill, $\mathrm{M}$ assachussetts: Epidemiology R esources.

Armitage, P. 1971. Statistical M ethods in Medical Research. Londres: Blackwell.

Beauchamp, TL. 1991. Ethical guidelines for epidemiologists. J Clin Epidemiol 44 Supl 1:151-169.

Beaglehole, R, R Bonita, T K jellstrom. 1993. Basic E pidemiology. Ginebra: O rganización Mundial de la Salud (OM S).

Bouyer, J, D H émon, S Cordier, F Derriennic, I Stucker, B Stengel, J Clavel. 1993. E pidémiologie
Principes et méthodes quantitatives. París: Editions INSERM

Breslow, NE, NE Day. 1980. Statistical M ethods in Cancer R esearch. V ol. 1 The analysis of case-control studies. IARC Scientific Publications, No. 32. Lyon: Agencia Internacional para la Investigación sobre el Cáncer (IARC).

Breslow, NE, NE Day. 1987. Statistical methods in cancer research. Vol. II The design and analysis of cohort studies. IARC Scientific Publications, No. 82 Lyon: A gencia Internacional para la Investigación sobre el Cáncer (IARC).

Bunge, M. 1963. Causality. Cleveland, O hio: M eridian Books.

Carmines, EG, RA Zeller. 1979. Reliability and Validity Assessment. Beverly Hills, California: Sage Univ. Press

Converse, JM, S Presser. 1986. Survey Questions. $H$ andcrafting the Standardized Questionnaire. Beverly $H$ ills, California: Sage U niv. Press.

Dabis, F, J Drucker, A M oren. 1992. Epidémiologie d'intervention. París: Arnette.

Egbert, DS, AJ Gerger. 1936. Pulmonary asbestosis and carcinoma: Report of a case with necropsy findings. Am R ev T ubercul Pulmon D is 34:143-150.

Esteve, J, E Benhamou, L R aymond. 1994. Statistical $M$ ethods in Cancer R esearch. Lyon: IAR C.

Fraumeni, JFJ, SS Devesa, RN Hoover, LJ K inlen. 1993. E pidemiology of cancer. En Cancer: Principles and Practice of Oncology, dirigido por VTJ DeV ita, S Hellman y SA Rosenberg. Filadelfia: JB Lippincott.

H ammond, EC, D H orn. 1958. Smoking and death rates: Report on 44 months of follow-up of
187,783 men. II Death rates by cause. IAM A 166:1159-1308.

Hennekens, CH, JE Buring. 1987. E pidemiology in M edicine. Boston: Little, Brown \& Co.

K arvonen, M, MI M ikheev. 1986. E pidemiology of occupational health. Publicaciones Regionales de la OMS, European Series No. 20. Copenhague: O ficina R egional de la O rganización M undial de la Salud para Europa.

K leinbaum, DG, LL K upper, H M orgenstern. 1982. Epidemiologic Research: Principles and Quantitative $M$ ethods. Belmont: Lifetime Learning.

Leung, HM, LL K upper. 1981. Comparisons of confidence intervals for attributable risk. Biometrics 37:293-302

Lynch, K M , WA Smith. 1935. Pulmonary asbestosis. III Carcinoma of lung in asbestos-silicosis. Am I Cancer 24:56-64.

M acM ahon, B, TF Pugh. 1970. E pidemiology: Principles and $M$ ethods. Boston: Little, Brown \& C 0 .

Merewether ERA. 1947. Annual Report of the Chief Inspector of Factories. Londres: Her Majesty's Stationery $\mathrm{O}$ ffice.

M onson, RR. 1990. Occupational E pidemiology. Boca R aton: $C R C$ Press.

Nordmann, M. 1938. Der berufskrebs der asbestarbeiter. Z fschr K rebsforsch 47:288-302.

R umeau-R ouquette, C, G Bréart, R Padieu. 1981. M éthodes en epidémiologie. París: Flammarion $M$ édecine Sciences

Selikoff, IJ, DHK Lee. 1978. Asbestos and Disease N ueva Y ork: A cademic Press.

W oolson, RF. 1987. Statistical M ethods for the Analysis of Biomedical D ata. N uevaY ork: Wiley. 
Directores del capítulo W olfgang $L$ aurig y

J oachim V edder

\section{Sumario}

Introducción

W olfgang L aurig y J oachim Vedder

OBJETIVOS, PRINCIPIOSYMETODOS

$\mathrm{N}$ aturaleza y objetivos de la ergonomía

W illiam T. Singleton .

A nálisis de actividades, tareas y sistemas de trabajo

Véronique D e Keyser . . .

Ergonomía y normalización

F riedhelm N achreiner.

Listas de comprobación

Pranab Kumar Nag. . .

\section{ASPECTOS FISICOSY PSICOLOGICOS}

Antropometría

M elchiorre $M$ asali . . . . . . . . . . . . . . . . 29.26

Trabajo muscular

J uhani Smolander y Veikko L ouhevaara . .

Postura en el trabajo

I lkka Kuorinka. .

Biomecánica

Frank D arby. . . .

Fatiga general

É tienne G randjean

Fatiga y recuperación

R olf $\mathrm{H}$ elbig y W alter Rohmert . .

\section{ASPECTOS PSICOLOGICOS}

Carga mental de trabajo

W infried $\mathrm{H}$ acker

Vigilancia

H erbert $H$ euer. ...

Fatiga mental

\section{ASPECTOS ORGANIZATIVOS DEL TRABAJO}

Organización del trabajo

E berhard U lich y Guddla G rote. . . . . . . . . . . . . . . . . . . . . . . . 29.52

Privación del sueño

Kazutaka Kogi. . .

DISEÑO DE LOS SISTEMASDE TRABAJO

Puestos de trabajo

Roland Kadefors.

Herramientas

T.M . Fraser . . . . . . . . . . . . . . . . . . . . . . . . . . . . . . . . 29.66

Controles, indicadores y paneles

Karl H. E. Kroemer . . . . . . . . . . . . . . . . . . . . . . 29.69

Diseño y tratamiento de la información

Andries F. Sanders ......................... 29.77

DISEÑO PARA TODOS

Diseño para grupos específicos

J oke H. Grady-van den N ieuwboer. . . . . . . . . . . . . . . . . . . . . . 29.82

Diferencias culturales

H oushang Shahnavaz

Trabajadores de edad avanzada

Antoine L avilley Serge Volkoff

Trabajadores con necesidades especiales

J oke H. G rady-van den N ieuwboer. . . . . . . . . . . . . . . . . . . . . . . 29.94

DIVERSIDAD E IMPORTANCIA DE LA ERGONOMIA:

DOSEJEMPLOS

Diseño de sistemas en la fabricación de diamantes I ssachar Gilad. . . . . . . . . . . . . . . . . . . . . . . . . . . . . . . . 29.99

Violación de los principios del diseño ergonómico:

Chernobil

Vladimir M. M unipov. 


\section{INTRODUCCION}

\section{Wolfgang Laurig y Joachim Vedder}

En la tercera edición de la Enciclopedia de la O IT, publicada en 1983, la ergonomía se resumió en un artículo de tan sólo cuatro páginas. D esde la publicación de la tercera edición, ha habido un cambio importante en el énfasis y en la comprensión de las interrelaciones entre salud y seguridad: el mundo ya no puede clasificarse tan fácilmente en medicina, seguridad y prevención de riesgos. Durante la última década, en casi todas las ramas del sector de producción y servicios se ha hecho un gran esfuerzo por mejorar la productividad y la calidad. Este proceso de reestructuración ha generado una experiencia práctica que demuestra claramente que la productividad y la calidad están directamente relacionadas con el diseño de las condiciones de trabajo. Una medida económica directa de la productividad, los costes del absentismo por enfermedad, está relacionada con las condiciones de trabajo. Así, debería ser posible aumentar la productividad y la calidad y evitar el absentismo prestando más atención a la concepción de las condiciones de trabajo.

En resumen, una hipótesis simple de la ergonomía moderna podría ser: el dolor y el agotamiento causan riesgos para la salud, pérdidas en la productividad y disminución de la calidad, que son las medidas de los costes y beneficios del trabajo humano.

Esta sencilla hipótesis puede ser contrastada con la medicina del trabajo, que generalmente se ocupa exclusivamente de establecer la etiología de las enfermedades profesionales. EI objetivo de la medicina del trabajo es establecer las condiciones en las que se minimice la probabilidad de desarrollar dichas enfermedades. Empleando los principios de la ergonomía, estas condiciones pueden definirse más fácilmente en forma de demandas y limitaciones de carga. Puede decirse que la medicina del trabajo establece "limitaciones a través de estudios médico-científicos". La ergonomía tradicional considera que su papel consiste en definir los métodos que permiten poner en práctica las limitaciones que establece la medicina del trabajo, a través del diseño y la organización del trabajo. Así, la ergonomía tradicional podría definirse como aquella que desarrolla "correcciones a través de estudios científicos", donde "correcciones" son todas aquellas recomendaciones para la concepción del trabajo en las que se presta atención a los límites de carga sólo para evitar los riesgos para la salud. U na característica de estas recomendaciones correctivas es que quienes las practican se quedan finalmente solos en su tarea de aplicarlas, ya que no existe un trabajo de equipo multidisciplinario.

El objetivo original cuando se inventó la ergonomía, en 1857, contrasta con esta "ergonomía correctiva":

.. un enfoque científico que nos permitirá cosechar, en

beneficio propio y de los demás, los mejores frutos del trabajo de toda la vida con el mínimo esfuerzo y la máxima satisfacción (Jastrzebowski 1857).

Etimológicamente, el término "ergonomía" proviene del griego "nomos", que significa norma, y "ergo", que significa trabajo. Podría proponerse que la ergonomía debería desarrollar "normas" para una concepción prospectiva del diseño más encaminada hacia el futuro. Al contrario de la "ergonomía correctiva", la idea de la ergonomía prospectiva se basa en aplicar recomendaciones ergonómicas que tienen en cuenta, simultáneamente, los márgenes de beneficios (L aurig 1992).

Las normas básicas para el desarrollo de este enfoque pueden deducirse de la experiencia práctica y fortalecerse con los resultados de la higiene del trabajo y las investigaciones ergonómicas. En otras palabras, el término ergonomía prospectiva significa buscar alternativas en el diseño del trabajo que eviten la fatiga y el agotamiento del trabajador, con el objeto de promover la productividad humana ("...en beneficio propio y de los demás"). Este enfoque global de la ergonomía prospectiva incluye el diseño del equipo y del lugar de trabajo, así como el diseño de las condiciones de trabajo determinadas por una cantidad cada vez mayor de procesamiento de la información y una organización del trabajo en continua evolución. La ergonomía prospectiva es, por lo tanto, un enfoque interdisciplinario de investigadores y médicos de muy diversos campos unidos por el mismo objetivo, y parte de una base general para una concepción moderna de la salud y la seguridad en el trabajo (UNESC O 1992).

Con este criterio, el capítulo de E rgonomía de la cuarta edición de la E nciclopedia de la O IT abarca los diferentes grupos de conocimientos y experiencias orientados hacia las características y capacidades del trabajador y que tienen como objetivo el uso óptimo del recurso "trabajo humano" haciendo el trabajo más "ergonómico", es decir, más humano.

La elección de los temas y de la estructura de los artículos de este capítulo sigue la estructura de las preguntas típicas del campo, tal como se practica en la industria. El capítulo comienza con los objetivos, principios y métodos de la ergonomía y los artículos siguientes abarcan los principios fundamentales de las ciencias básicas, como la fisiología y la psicología. Con esta base, los siguientes artículos tratan sobre los aspectos principales de la concepción ergonómica de las condiciones de trabajo, desde la organización del trabajo hasta el diseño de productos. "Diseño para todos" hace énfasis en un enfoque ergonómico basado en las características y capacidades del trabajador, un concepto que con frecuencia se olvida en la práctica. La importancia y la diversidad de la ergonomía se muestra en dos ejemplos al final del capítulo, y también se refleja en el hecho de que muchos otros capítulos de esta edición de la Enciclopedia de la OIT, como Calor y frío, Ruido, Vibraciones y Pantallas de visualización de datos, y prácticamente todos los capítulos de las secciones Gestión de la Seguridad y Prevención, G estión y Política, están directamente relacionados con la ergonomía.

\section{OBJETIVOS, PRINCIPIOS Y METODOS}

\section{- Nat URALEZA Y O BJETIVOS DE LA ERGONOMIA}

\section{William T. Singleton}

\section{Definición y campo de actividad}

E rgonomía significa literalmente el estudio o la medida del trabajo. En este contexto, el término trabajo significa una actividad humana con un propósito; va más allá del concepto más limitado del trabajo como una actividad para obtener un beneficio económico, al incluir todas las actividades en las que el operador humano sistemáticamente persigue un objetivo. Así, abarca los deportes y otras actividades del tiempo libre, las labores domésticas, como el cuidado de los niños o las labores del hogar, la educación y la formación, los servicios sociales y de salud, el control de los sistemas de ingeniería o la adaptación de los mismos, como sucede, por ejemplo, con un pasajero en un vehículo.

El operador humano, que es el centro del estudio, puede ser un profesional cualificado que maneje una máquina compleja en 
un entorno artificial, un cliente que haya comprado casualmente un aparato nuevo para su uso personal, un niño dentro del aula o una persona con una discapacidad, recluida a una silla de ruedas. El ser humano es sumamente adaptable, pero su capacidad de adaptación no es infinita. Existen intervalos de condiciones óptimas para cualquier actividad. U na de las labores de la ergonomía consiste en definir cuáles son estos intervalos y explorar los efectos no deseados que se producirán en caso de superar los límites; por ejemplo, qué sucede si una persona desarrolla su trabajo en condiciones de calor, ruido o vibraciones excesivas, o si la carga física o mental de trabajo es demasiado elevada o demasiado reducida.

La ergonomía examina no sólo la situación pasiva del ambiente, sino también las ventajas para el operador humano y las aportaciones que éste/ ésta pueda hacer si la situación de trabajo está concebida para permitir y fomentar el mejor uso de sus habilidades. L as habilidades humanas pueden caracterizarse no sólo en relación al operador humano genético, sino también en relación a habilidades más específicas, necesarias en situaciones determinadas, en las que resulta crucial un alto rendimiento. Por ejemplo, un fabricante de automóviles deberá tener en cuenta el tamaño y la fuerza física de los posibles conductores de un determinado modelo para garantizar que los asientos sean cómodos; que los controles se identifiquen con facilidad y estén accesibles; que la visibilidad, tanto delantera como trasera, sea buena y que los indicadores interiores sean fáciles de leer. También deberá considerar la facilidad para entrar y salir del coche. En cambio, el diseñador de un coche de carreras considerará que el conductor tiene una constitución atlética, por lo que la facilidad para entrar o salir del vehículo, por ejemplo, no será tan importante e intentará ajustar todo el diseño del vehículo al tamaño y preferencias de un conductor determinado, para asegurar que éste pueda desarrollar todo su potencial y habilidad como conductor o conductora.

En cualquier situación, actividad o tarea, lo más importante es la persona o personas implicadas. Se supone que la estructura, la ingeniería y otros aspectos tecnológicos están ahí para servir al operador, y no al contrario.

\section{Historia y estado}

H ace aproximadamente un siglo, se reconoció que las jornadas y condiciones de trabajo en algunas minas y fábricas eran intolerables, en términos de salud y seguridad, y que era indispensable aprobar leyes que establecieran límites admisibles en estos aspectos. El establecimiento y determinación de esos límites puede considerarse como el comienzo de la ergonomía. Este fue, además, el principio de todas las actividades que ahora encuentran un medio de expresión a través del trabajo de la O rganización Internacional del Trabajo (O IT).

El proceso de investigación, desarrollo y aplicación de estas leyes fue lento hasta la segunda G uerra M undial. Este acontecimiento aceleró enormemente el desarrollo de máquinas e instrumentos tales como vehículos, aviones, tanques y armas, y mejoró sensiblemente los dispositivos de navegación y detección. Los avances tecnológicos proporcionaron una mayor flexibilidad para permitir la adaptación al operador, una adaptación que se hizo cada vez más necesaria, porque el rendimiento humano limitaba el rendimiento del sistema. Si un vehículo motorizado sólo puede alcanzar una velocidad de algunos kilómetros por hora, no hay por qué preocuparse del rendimiento del conductor, pero si la velocidad máxima del vehículo se multiplica por diez o por cien, entonces el conductor tiene que reaccionar con más rapidez y no tiene tiempo para corregir errores y evitar desastres. De forma parecida, a medida que mejora la tecnología disminuye la necesidad de preocuparse por los fallos mecánicos o eléctricos, por ejemplo, y se puede centrar la atención en las necesidades del conductor.

De este modo, la ergonomía, como adaptación de la tecnología de la ingeniería a las necesidades del trabajador, es cada vez más necesaria y más factible, gracias a los avances tecnológicos.

El término ergonomía empezó a utilizarse alrededor de 1950, cuando las prioridades de la industria en desarrollo comenzaron a anteponerse a las prioridades de la industria militar. Singleton (1982) describe detalladamente el desarrollo de la investigación y sus aplicaciones, a lo largo de los 30 años siguientes. Algunas organizaciones de las $\mathrm{N}$ aciones U nidas, en especial la O IT y la OMS, comenzaron su actividad en este campo en el decenio de 1960.

El principal objetivo de la industria inmediatamente después de la posguerra, al igual que el de la ergonomía, era el aumento de la productividad. Este era un objetivo viable para la ergonomía, ya que gran parte de la productividad industrial estaba determinada directamente por el esfuerzo físico de los trabajadores: la velocidad del montaje y la proporción de movimientos y levantamientos de pesos determinaban la magnitud de la producción. Gradualmente, la energía mecánica sustituyó al esfuerzo muscular humano. Sin embargo, el aumento de la energía también produce más accidentes, por el sencillo principio de que los accidentes son la consecuencia directa de la aplicación de la energía en el momento erróneo y en el lugar equivocado. Cuando las cosas se producen con mayor rapidez, las posibilidades de accidentes aumentan. Así, la preocupación de la industria y el objetivo de la ergonomía comenzó a cambiar, poco a poco, de la productividad a la seguridad; esto ocurrió entre los años 60 y principios de los 70. Durante este tiempo, gran parte del sector de fabricación cambió de la producción por lotes a la producción en cadena y en proceso y, como consecuencia, la función del operador también cambió de la participación directa a las labores de control e inspección. Esto disminuyó la frecuencia de los accidentes, al alejar al operador de la escena de acción, pero en ocasiones, aumentó la gravedad de los accidentes debido a la velocidad y energía inherentes al proceso.

Cuando la producción está determinada por la velocidad de funcionamiento de las máquinas, la actividad se reduce a mantener el sistema en marcha; es decir, el objetivo es la fiabilidad. El operador se convierte en un controlador, un mecánico y un encargado de mantenimiento, en lugar de ser un manipulador directo.

Aunque esta descripción histórica de los cambios en las industrias de fabricación durante la posguerra podría sugerir que el ergónomo ha ignorado sistemáticamente una serie de problemas y ha intentado solucionar otros, esto no ha sido así, por distintos motivos. Como ya se ha dicho, el campo de la ergonomía abarca mucho más que el de las industrias de fabricación. Además de la ergonomía de la producción está la ergonomía del producto 0 del diseño, es decir, la adaptación de la máquina o el producto al usuario. En la industria automovilística, por ejemplo, la ergonomía es importante no sólo en la fabricación de piezas y en las líneas de producción, sino también en relación con el futuro conductor, pasajero y encargado de mantenimiento. Actualmente, la revisión de la calidad de la ergonomía de los vehículos: la conducción, la comodidad de los asientos, el manejo, los niveles de ruido y vibración, la facilidad de acceso a los controles, la visibilidad interior y exterior, etc., es algo frecuente en el marketing de los coches y en la valoración crítica de los mismos por terceros.

Como se indicó anteriormente, el rendimiento humano generalmente se optimiza dentro de un intervalo de tolerancias de una variable relevante. La mayoría de los primeros ergónomos 
intentaban reducir el esfuerzo muscular realizado y la amplitud y diversidad de los movimientos al objeto de que no se superaran los límites tolerables. Los grandes cambios en el mundo laboral y la llegada del ordenador, han ocasionado el problema contrario. El espacio de trabajo con un ordenador, a menos que esté bien diseñado desde el punto de vista ergonómico, puede ocasionar una postura demasiado fija, falta de movimientos del cuerpo y una repetición excesiva de ciertos movimientos articulares.

Esta breve revisión histórica pretende mostrar que, aunque el desarrollo de la ergonomía ha sido continuo, los problemas han ido aumentando cada día más antes de que se lograra solucionar los existentes. Sin embargo, los conocimientos aumentan y cada vez son más fiables y válidos; los principios del consumo energético no dependen de cómo o porqué se consume la energía; las consecuencias de las posturas son las mismas para los asientos en un avión que frente a un ordenador; una parte importante de la actividad humana se realiza en la actualidad, frente a pantallas de visualización y existen principios bien establecidos, basados en pruebas de laboratorio y estudios de campo.

\section{Ergonomía y disciplinas afines}

El desarrollo de una técnica con bases científicas, que está en un punto intermedio entre las bien consolidadas tecnologías de la ingeniería y la medicina, se superpone inevitablemente con otras disciplinas. En términos de su base científica, gran parte del conocimiento ergonómico deriva de las ciencias humanas: anatomía, fisiología y psicología. Las ciencias físicas también han contribuido, por ejemplo, la solución de problemas de la iluminación, de la temperatura, del ruido o de las vibraciones.

La mayor parte de los pioneros de la ergonomía en Europa trabajaron en las ciencias humanas, motivo por el que la ergonomía está en un punto de equilibrio entre la fisiología y la psicología. Un enfoque fisiológico es necesario para abordar problemas tales como el consumo de energía, las posturas y aplicación de fuerzas, como en el levantamiento de pesos. Un enfoque psicológico permite estudiar problemas tales como la presentación de la información y el grado de satisfacción en el trabajo. Naturalmente, existen muchos problemas, como el estrés, la fatiga y el trabajo por turnos, que requieren un enfoque mixto de las ciencias humanas.

M uchos de los pioneros de este campo en EE.UU. trabajaban en el terreno de la psicología experimental o de la ingeniería y por esta razón sus denominaciones ingeniería humana o factores humanos, reflejan una diferencia en el enfoque, aunque no en los contenidos de interés, con los ergónomos europeos. Esto explica también por qué la higiene industrial, debido a su estrecha relación con la medicina, principalmente con la medicina del trabajo, se considera en Estados U nidos como algo distinto de los factores humanos o la ergonomía. Esta diferencia es menos evidente en otras partes del mundo. La ergonomía se centra en el operador humano en acción; la higiene industrial se centra en el riesgo de un determinado ambiente para el operador humano. Así, el interés central de un higienista industrial es el riesgo tóxico, algo que está fuera del ámbito del ergónomo. El higienista industrial se preocupa por los efectos sobre la salud, a corto o a largo plazo; el ergónomo, naturalmente, se preocupa por la salud, pero también por otras consecuencias, como la productividad, el diseño del trabajo o del espacio de trabajo. La seguridad y la higiene son aspectos generales que atañen tanto a la ergonomía como a la higiene industrial, a la salud laboral y a la medicina del trabajo. Por tanto, no es sorprendente que en las grandes instituciones de investigación, diseño o producción, estos temas aparezcan agrupados. Ello permite que un grupo de expertos en cada uno de estos temas contribuyan de forma especializada al problema general de la salud, no sólo de los trabajadores de la institución, sino también de aquellos que resultan afectados por sus actividades y productos. En instituciones dedicadas al diseño o a la prestación de servicios, el ergónomo deberá estar más estrechamente relacionado con los ingenieros y otros técnicos.

Por lo anterior, es evidente que la naturaleza interdisciplinaria de la ergonomía y el hecho de que se trate de una disciplina relativamente reciente dificulta su inclusión en la organización existente. Al ser una actividad relacionada con las personas, se superpone con muchos otros campos de actividad, ya que las personas son el recurso básico y más generalizado de cualquier organización. La forma de incluirla dependerá de la historia y de los objetivos de cada organización en particular. El criterio principal es que los objetivos de la ergonomía se comprendan y se valoren adecuadamente y que los mecanismos necesarios para la implementación de las recomendaciones se elaboren dentro de la organización.

\section{Objetivos de la ergonomía}

Es evidente que las ventajas de la ergonomía pueden reflejarse de muchas formas distintas: en la productividad y en la calidad, en la seguridad y la salud, en la fiabilidad, en la satisfacción con el trabajo y en el desarrollo personal.

Este amplio campo de acción se debe a que el objetivo básico de la ergonomía es conseguir la eficiencia en cualquier actividad realizada con un propósito, eficiencia en el sentido más amplio, de lograr el resultado deseado sin desperdiciar recursos, sin errores y sin daños en la persona involucrada o en los demás. No es eficaz desperdiciar energía o tiempo debido a un mal diseño del trabajo, del espacio de trabajo, del ambiente o de las condiciones de trabajo. Tampoco lo es obtener los resultados deseados a pesar del mal diseño del puesto, en lugar de obtenerlos con el apoyo de un buen diseño.

El objetivo de la ergonomía es garantizar que el entorno de trabajo esté en armonía con las actividades que realiza el trabajador. Este objetivo es válido en sí mismo, pero su consecución no es fácil por una serie de razones. El operador humano es flexible y adaptable y aprende continuamente, pero las diferencias individuales pueden ser muy grandes. Algunas diferencias, tales como las de constitución física y fuerza, son evidentes, pero hay otras, como las diferencias culturales, de estilo o de habilidades que son más difíciles de identificar.

En vista de lo complejo de la situación, podría parecer que la solución es proporcionar un entorno flexible, en el que el operador humano pueda optimizar una forma específicamente adecuada de hacer las cosas. D esgraciadamente, este enfoque no siempre se puede llevar a la práctica, ya que la forma más eficiente no siempre resulta obvia y, en consecuencia, el trabajador puede seguir haciendo una cosa durante años de forma inadecuada o en condiciones inaceptables.

Así, es necesario adoptar un enfoque sistemático: partir de una teoría bien fundamentada, establecer objetivos cuantificables y contrastar los resultados con los objetivos. Los distintos objetivos posibles se detallan a continuación.

\section{Salud y seguridad}

No cabe duda de que existen objetivos relacionados con la salud y la seguridad, pero la dificultad surge del hecho de que ninguno de estos conceptos se puede medir directamente: sus logros se valoran por su ausencia más que por su presencia. Los datos en cuestión siempre están relacionados con aspectos derivados de la salud y la seguridad.

En el caso de la salud, la mayor parte de las evidencias se basan en estudios a largo plazo, en poblaciones y no en casos individuales. Por lo tanto, es necesario mantener registros 
detallados durante largos períodos de tiempo para poder adoptar un enfoque epidemiológico a través del cual puedan identificarse y cuantificarse los factores de riesgo. Por ejemplo, ¿cuál debería ser el máximo de horas al día o al año que debe permanecer un trabajador en un puesto con un ordenador? Dependerá del diseño del puesto, del tipo de trabajo y del tipo de persona (edad, capacidad visual, habilidades, etc.). Los efectos sobre la salud pueden ser muy diversos, desde problemas en las muñecas hasta fatiga mental, por ello es necesario realizar estudios globales que cubran poblaciones amplias y estudiar, al mismo tiempo, las diferencias entre unas poblaciones y otras.

La seguridad es más directamente medible en sentido negativo, en términos de tipos y frecuencias de los accidentes y lesiones. Resulta complicado definir los distintos tipos de accidentes e identificar los múltiples factores causales y, con frecuencia, no hay una buena correlación entre el tipo de accidente y el grado de daño producido, de ninguno a fatal.

Sin embargo, durante los últimos cincuenta años se ha acumulado una gran cantidad de datos relacionados con la salud y la seguridad, y se han descubierto consecuencias que pueden ser relacionadas con teorías, leyes y normas y con principios operativos en determinados tipos de situaciones.

\section{Productividad y eficacia}

La productividad suele definirse en términos de producción por unidad de tiempo, mientras que la eficacia incorpora otras variables, en particular la relación resultado-inversión. La eficacia incorpora el coste de lo que se ha hecho en relación con los logros, y en términos humanos, esto implica la consideración de los costes para el operador humano.

En la industria, la productividad es relativamente fácil de medir: la cantidad producida puede contarse y el tiempo invertido en producir es fácil de determinar. Los datos sobre productividad suelen utilizarse en comparaciones del tipo antes/ después de la modificación de métodos, situaciones o condiciones de trabajo. Esto implica asumir una serie de suposiciones, como la equivalencia entre el esfuerzo y otros costes, porque se basa en el principio de que el operador humano rendirá tanto como lo permitan las circunstancias. Si la productividad aumenta, esto significa que las circunstancias son mejores. $\mathrm{H}$ ay muchas razones para recomendar este sencillo enfoque, a condición de que se utilice teniendo en cuenta los posibles factores de confusión que pueden enmascarar lo que está ocurriendo realmente. L a mejor garantía de ello es intentar asegurarse de que nada ha cambiado entre la situación anterior y la posterior, con excepción de los aspectos que se están estudiando.

La eficacia es la medida más global, pero también la más difícil de determinar. Por lo general, debe definirse específicamente para cada situación particular, y en la valoración de los resultados de cualquier estudio deberá comprobarse que la definición es relevante y válida para las conclusiones obtenidas. Por ejemplo, ¿montar en bicicleta, es más eficaz que andar? M ontar en bicicleta es más productivo en términos de la distancia que es posible recorrer en un tiempo determinado, y más eficaz en términos de la energía consumida por unidad de distancia 0 , si se trata de un ejercicio realizado dentro de casa, porque la bicicleta es más sencilla y económica que otro tipo de aparatos. Por otra parte, la finalidad del ejercicio podría ser el consumo de energía por motivos de salud, o la subida de una montaña en un terreno difícil; en estas circunstancias, caminar será más eficaz. Así, la medida de la eficacia sólo tiene sentido en un contexto bien definido.

\section{Fiabilidad y calidad}

Como se indicó anteriormente, en los sistemas de alta tecnología (por ejemplo, transporte aéreo de pasajeros, refinerías de crudo 0 plantas de generación de energía), la medida clave es la fiabilidad, más que la productividad. Los controladores de dichos sistemas vigilan el rendimiento y contribuyen a la productividad y a la seguridad haciendo los ajustes precisos para garantizar que las máquinas automáticas están conectadas y funcionan dentro de sus límites. Todos estos sistemas se encuentran en un estado de máxima seguridad cuando están inactivos, o cuando funcionan dentro de las condiciones de funcionamiento proyectadas; son más peligrosos cuando se mueven entre estados de equilibrio, por ejemplo, durante el despegue de un avión o cuando se está deteniendo un sistema de proceso. U na alta fiabilidad es una característica clave no sólo por motivos de seguridad, sino también porque una interrupción o parada no planificada resulta extremadamente costosa. La fiabilidad es fácil de medir después de obtenido el resultado, pero es muy difícil de predecir, a menos que se haga por referencia a resultados anteriores de sistemas similares. Cuando algo va mal, el error humano es invariablemente una causa que contribuye, pero no siempre significa que se trate de un error del controlador. Los errores humanos pueden originarse en la fase de diseño y durante la puesta en marcha y el mantenimiento. Actualmente se acepta que estos sistemas de alta tecnología, tan complejos, requieren un estudio ergonómico considerable y continuo desde el diseño hasta la valoración de cualquiera de los fallos que puedan producirse.

La calidad está en relación con la fiabilidad, pero es muy difícil, si no imposible, de medir. Tradicionalmente, en los sistemas de producción en cadena y por lotes, la calidad se controlaba inspeccionando el producto terminado, pero en la actualidad se combinan la producción y el mantenimiento de la calidad. Así, cada operador tiene una responsabilidad paralela, como inspector. Esto suele resultar más efectivo, pero puede significar el abandono de la política de incentivos basada simplemente en las tasas de producción. En términos ergonómicos, lo normal es tratar al operador como una persona responsable y no como un robot programado para una actividad repetitiva.

\section{Satisfacción en el trabajo y desarrollo personal}

Si se parte del principio de que el trabajador u operador humano debe ser tratado como una persona y no como un robot, se desprende que deberían valorarse sus responsabilidades, actitudes, creencias y valores. Esto no es nada fácil, ya que hay muchas variables en juego, en su mayoría detectables pero no cuantificables, y enormes diferencias individuales y culturales. Sin embargo, gran parte del effuerzo se concentra actualmente en el diseño y la organización del trabajo, con el fin de asegurar que la situación sea lo más satisfactoria posible, desde el punto de vista del operador. Es posible realizar algunas mediciones utilizando técnicas de encuesta y se dispone de algunos criterios basados en ciertas características del trabajo, como la autonomía y el grado de responsabilidad. Estos esfuerzos requieren tiempo y dinero, pero pueden obtenerse considerables beneficios si se escuchan las sugerencias, opiniones y actitudes de las personas que están realizando el trabajo. Su enfoque puede no ser el mismo que el del "diseñador" externo del trabajo, y puede no coincidir con los supuestos del organizador o planificador del trabajo. Estas diferencias de opinión son importantes y pueden llegar a producir un cambio positivo en la estrategia, por parte de todos los implicados.

No hay duda de que el ser humano aprende continuamente si está rodeado de las condiciones adecuadas. La clave es proporcionarle información sobre la actuación pasada y presente, que podrá utilizar para mejorar la actuación futura. M ás aún, tal información actuará como un incentivo del rendimiento. De esta forma todo el mundo gana: la persona que ejecuta el trabajo y los responsables, en un sentido más amplio, de esta ejecución. De esto puede concluirse que hay mucho que ganar 
con una mejora en la ejecución del trabajo, inclusive para el desarrollo personal. El principio de que el desarrollo personal debe ser un aspecto en la aplicación de la ergonomía, requiere mayores habilidades por parte del diseñador y del organizador, pero si se logran aplicar adecuadamente, mejorarán todos los aspectos de la actuación humana antes mencionados.

Con frecuencia, aplicar con éxito la ergonomía sólo consiste en desarrollar la actitud o el punto de vista idóneos. Las personas son, inevitablemente, el factor central de cualquier esfuerzo humano, y por tanto, es inherentemente importante considerar sistemáticamente sus méritos, limitaciones, necesidades y aspiraciones.

\section{Conclusión}

La ergonomía es el estudio sistemático de las personas en su entorno de trabajo con el fin de mejorar su situación laboral, sus condiciones de trabajo y las tareas que realizan. El objetivo es adquirir datos relevantes y fiables que sirvan de base para recomendar cambios en situaciones específicas y para desarrollar teorías, conceptos, directrices y procedimientos más generales que contribuyan a un continuo desarrollo de los conocimientos en el campo de la ergonomía.

\section{- ANALISIS DE ACTIVIDADES, TAREAS Y SISTEMAS DE TRABAJO}

\section{Véronique De Keyser}

Es difícil hablar de análisis del trabajo fuera de la perspectiva de los recientes cambios del mundo industrializado, ya que la naturaleza de las actividades y las condiciones en las que se desarrollan han evolucionado notablemente durante estos últimos años. Los factores que han dado lugar a estos cambios han sido numerosos, pero hay dos cuyo impacto puede considerarse crucial. Por un lado, los avances tecnológicos, con su marcha vertiginosa, y los tremendos cambios producidos por las tecnologías de la información, han revolucionado muchas trabajos (De K eyser 1986). Por otra parte, la incertidumbre del mercado económico ha exigido una mayor flexibilidad en la gestión del personal y la organización del trabajo. Si bien los trabajadores tienen ahora una visión más amplia del proceso de producción, como un proceso menos rutinario e indudablemente más sistemático, también es verdad que han perdido los vínculos exclusivos con un entorno, un equipo o una herramienta de producción. No es fácil contemplar estos cambios con serenidad, pero tenemos que enfrentarnos al hecho de que se ha creado un nuevo panorama industrial, en ocasiones más enriquecedor para aquellos trabajadores que pueden encontrar su lugar en él, pero también lleno de trampas y dificultades para aquellos que resultan marginados o excluidos. No obstante, en las empresas está surgiendo una idea que ha confirmado los experimentos piloto realizados en muchos países: es posible dirigir los cambios y amortiguar sus efectos adversos utilizando análisis adecuados y aplicando todos los recursos de negociación entre las distintas partes. $Y$ es dentro de este contexto en el que deben realizarse los análisis actuales del trabajo, como herramientas que nos permitirán describir mejor las tareas y actividades para así poder dirigir intervenciones de distinta índole, como la formación, el establecimiento de nuevos sistemas de organización o el diseño de herramientas y sistemas de trabajo. $\mathrm{H}$ ablamos de análisis en plural porque existen muchos tipos de análisis, en función de los contextos teóricos y culturales en los que se han desarrollado, de los objetivos concretos que persiguen, de la evidencia que recogen o del interés de sus autores por lo específico o por lo general. Aquí nos limitaremos a presentar algunas características de los análisis del trabajo y haremos hincapié en la importancia del trabajo colectivo. N uestras conclusiones mostrarán otros caminos, que los límites de este texto no nos permiten analizar en profundidad.

\section{Algunas características de los análisis del trabajo}

\section{E I contexto}

Si el objetivo primordial de cualquier análisis del trabajo es describir lo que el trabajador hace, o lo que debería hacer, ubicarlo de forma más precisa en su contexto parece, a menudo, indispensable a los investigadores. Todos mencionan, cada uno según sus propios puntos de vista, pero de forma similar, los conceptos contexto, situación, entorno, esfera de trabajo, mundo laboral o medio ambiente de trabajo. EI problema no está tanto en los distintos matices que tienen estos términos, como en la selección de las variables que es necesario determinar para poder darles un sentido útil. En realidad, el mundo es enorme y la industria, compleja, y las características a las que podríamos hacer referencia son innumerables. Entre los autores que han escrito sobre este campo pueden distinguirse dos tendencias. La primera contempla la descripción del contexto como un medio para captar el interés del lector y proporcionarle un marco semántico adecuado. La segunda tiene una perspectiva teórica diferente: pretende aunar contexto y actividad, y describe únicamente aquellos elementos que son capaces de influir en el comportamiento de los trabajadores.

\section{El marco semántico}

EI contexto tiene un poder evocador. Para un lector informado, es suficiente leer algo sobre un operador en una sala de control, inmerso en un proceso continuo, para formarse una imagen de su trabajo mediante mandos y vigilancia a distancia, en el que predominarán las tareas de detección, diagnóstico y ajuste. ¿Q ué variables son necesarias determinar para crear un contexto suficientemente claro? Todo depende del lector. Sin embargo, en las publicaciones sobre este tema destacan algunas variables clave. La naturaleza del sector económico, el tipo de producción o de servicio, o el tamaño y emplazamiento geográfico del lugar analizado, resultan muy útiles. Los procesos de producción, las herramientas o máquinas y su nivel de automatización permiten proponer ciertas restricciones o determinadas cualificaciones necesarias. La estructura del personal, junto con la edad y el nivel de cualificación y experiencia, son datos cruciales cuando el análisis se refiere al campo formativo o de flexibilidad organizativa. La organización del trabajo que se establezca dependerá más de la filosofía de la empresa que de su tecnología. Su descripción incluye los planes de trabajo, el grado de centralización de la toma de decisiones y los tipos de control que se ejercen sobre los trabajadores. En determinados casos pueden añadirse otros elementos relacionados con la historia y cultura de la empresa, su situación económica, las condiciones de trabajo y las reestructuraciones, fusiones e inversiones. Existen tantos sistemas de clasificación como autores, y hay numerosas listas descriptivas en circulación. En Francia se ha hecho un esfuerzo especial para generalizar métodos descriptivos simples, que contemplan la valoración de determinados factores en función de si son o no satisfactorios para el trabajador (R NUR 1976; G uelaud y cols. 1977).

\section{La descripción de los factores relevantes en función de la actividad}

La taxonomía de los sistemas complejos descritos por R asmussen, Pejtersen y Schmidts (1990) representa uno de los intentos más ambiciosos de abarcar al mismo tiempo el contexto y su influencia sobre el operador. La idea básica es integrar 
sistemáticamente los distintos elementos que los componen y sacar a relucir los grados de libertad o las limitaciones con las que pueden desarrollarse las estrategias individuales. Su ambicioso objetivo la convierte en algo difícil de manejar, pero el uso de diversas formas de representación, entre ellas los gráficos, para ilustrar las limitaciones, tiene un valor heurístico que seguramente resultará atractivo a muchos lectores. $\mathrm{H}$ ay otros enfoques con un objetivo más definido. Lo que buscan los autores es una selección de aquellos factores que pueden influir sobre una actividad determinada. Por ello Brehmer, interesado en el control de procesos en un entorno cambiante, propone una serie de características temporales propias del contexto que afectan al control y a la anticipación del operador (véase Figura 29.1). La tipología de este autor se ha desarrollado a partir de "micromundos", simulaciones por ordenador de situaciones dinámicas, pero el propio autor, como otros posteriormente, lo utilizó para la industria de procesos continuos (Van Daele 1992). En algunas actividades, la influencia del entorno es bien conocida y la selección de los factores no resulta demasiado difícil. Así, si nos interesa la frecuencia cardíaca en el entorno laboral, generalmente nos limitaremos a describir la temperatura del aire, los esfuerzos físicos que imponen la tarea o la edad y el entrenamiento del sujeto, incluso aunque sepamos que procediendo así estamos excluyendo factores importantes. Para otros, la elección es más difícil. Algunos estudios sobre el error humano, por ejemplo, muestran que los factores capaces de producirlos son numerosos (R eason 1989). Algunas veces, cuando el conocimiento teórico no basta, el proceso estadístico que conjuga contexto y análisis de la actividad será el único que nos permita desentrañar los factores contextuales importantes (Fadier 1990).

\section{¿La tarea o la actividad?}

\section{La tarea}

La tarea se define por sus objetivos, sus exigencias y los medios necesarios para realizarla con éxito. U na función que se desempeña en el seno de una empresa suele estar representada por una serie de tareas. La tarea realizada se diferencia de la tarea encomendada, programada por la firma por diversas razones: las estrategias de los operadores varían en y entre los individuos, el entorno fluctúa y los acontecimientos que se producen al azar requieren respuestas que suelen estar fuera de la estructura del trabajo programado. Por último, la tarea no siempre se programa con un conocimiento adecuado de sus condiciones de ejecución. De ahí que sean necesarias adaptaciones en tiempo real. Pero incluso si la tarea se actualiza durante la actividad hasta el punto de ser modificada, sigue siendo el punto de referencia central.

Los cuestionarios, inventarios y taxonomías de las tareas son abundantes, sobre todo en las publicaciones anglosajonas: el lector puede encontrar excelentes revisiones en Fleishman y Q uaintance (1984) y en Greuter y Algera (1987). Algunos de estos instrumentos no son más que meras listas de elementos, (por ejemplo, los verbos de acción para ilustrar las tareas) que se van comprobando de acuerdo a la función estudiada. 0 tros han adoptado un principio jerárquico, caracterizando una tarea como una serie de elementos relacionados entre sí, ordenados de lo general a lo particular. Estos métodos están normalizados y pueden aplicarse a un gran número de funciones; son sencillos de utilizar y reducen significativamente la fase analítica. Pero cuando se trata de definir un trabajo específico, son demasiado estáticos y generales para resultar útiles.

A continuación están aquellos instrumentos que requieren una mayor habilidad por parte del investigador, ya que los elementos de análisis no están predeterminados y es el investigador quien tiene que caracterizarlos. A este grupo pertenece la
Figura 29.1 - Criterios y subcriterios de la taxonomía de (1990).

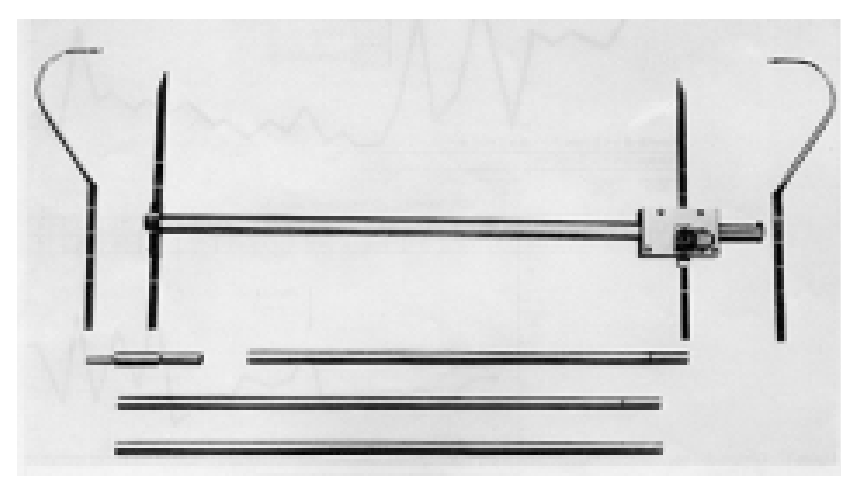

ya desfasada técnica del incidente crítico de Flanagan (1954), en la que el observador describe una función por referencia a sus dificultades e identifica los incidentes a los que el individuo tendrá que enfrentarse.

Esta es también la trayectoria adoptada por el análisis de la tarea cognitiva (Roth y Woods 1988). Esta técnica pretende sacar a la luz los requisitos cognitivos de un trabajo. Una manera de realizarlo es desglosando el trabajo en objetivos, exigencias y medios. La Figura 29.2 muestra cómo la tarea de un anestesista, caracterizada en primer lugar por el objetivo muy global de la supervivencia del paciente, puede subdividirse en una serie de objetivos secundarios, que pueden a su vez clasificarse en acciones y medios que serán empleados. Fueron necesarias más de cien horas de observación en el entorno operativo y entrevistas posteriores con anestesistas, para obtener este "retrato" sinóptico de los requisitos de la función. Esta técnica, aunque muy laboriosa, resulta útil para determinar si todos los objetivos de una tarea están dotados de los medios necesarios para conseguirlos. A demás, permite comprender la complejidad de una tarea (sus dificultades específicas y sus objetivos conflictivos, por ejemplo) y facilita la interpretación de determinados errores humanos. Pero adolece, al igual que otros métodos, de la ausencia de un lenguaje descriptivo (Grant y Mayes 1991). A demás, no permite formular hipótesis en relación con la naturaleza de los procesos cognitivos que entran en juego para obtener los objetivos en cuestión.

Otros enfoques han analizado los procesos cognitivos asociados con determinadas tareas, estableciendo hipótesis relacionadas con el proceso de la información necesario para llevarlas a cabo. Un modelo cognitivo de este tipo, frecuentemente empleado, es el de R asmussen (1986) que establece, según la naturaleza de la tarea y lo familiar que ésta resulte para el sujeto, tres niveles posibles de actividad basados en los hábitos y reflejos adquiridos gracias a la habilidad, en procedimientos adquiridos mediante normas, o en procedimientos basados en el conocimiento. Pero también se siguen utilizando otros modelos 0 teorías que alcanzaron su nivel máximo de popularidad durante el decenio de 1970. Por ejemplo, la teoría del control óptimo, que considera al hombre como controlador de las discrepancias entre los objetivos asignados y los objetivos observados, sigue aplicándose ocasionalmente a los procesos cognitivos. También la elaboración de modelos mediante la conexión de tareas relacionadas entre sí y las gráficas de flujo continúan inspirando a los autores de análisis de tareas cognitivas. La Figura 29.3 ofrece una descripción simplificada de las secuencias conductuales en 
Figura 29.2 - Análisis cognitivo de la tarea: anestesia general.

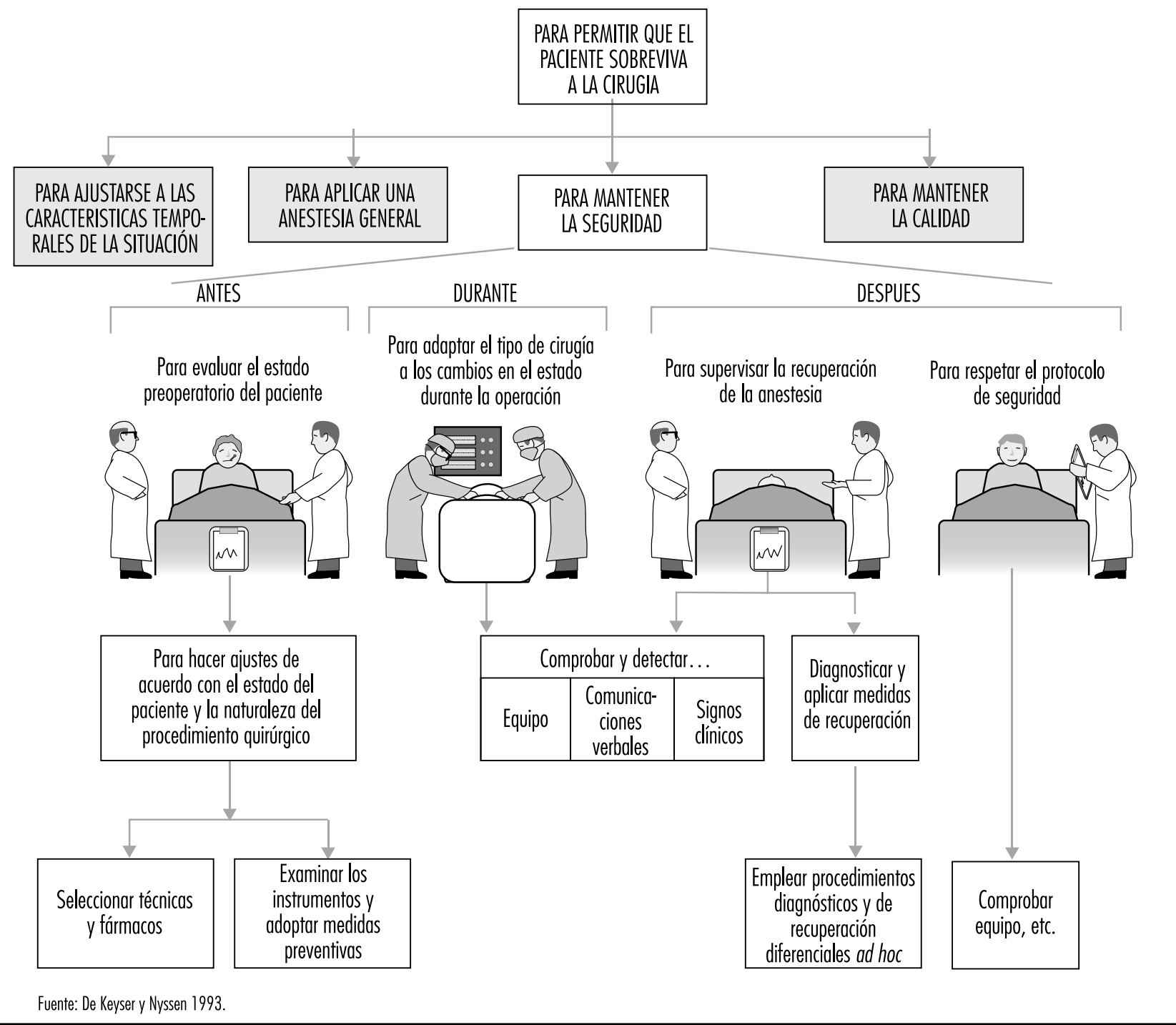

una tarea de control de energía y establece una hipótesis sobre determinadas operaciones mentales. Todos estos intentos reflejan la preocupación de los investigadores por aunar en la misma descripción los elementos del contexto, la tarea propiamente dicha y los procesos cognitivos subyacentes, además de reflejar el carácter dinámico del trabajo.

Desde el advenimiento de la organización científica del trabajo, el concepto de tarea encomendada ha sido duramente criticado, ya que se ha considerado que representa una imposición a los trabajadores de tareas que, no sólo se han diseñado sin tener en cuenta sus necesidades, sino que además van acompañadas, a menudo, de un tiempo específico de ejecución, una restricción no muy bien acogida por muchos trabajadores. Aunque el aspecto impositivo es actualmente bastante más flexible y los trabajadores contribuyen con mayor frecuencia al diseño de tareas, la asignación de un tiempo a la tarea sigue siendo necesaria para la planificación y programación y, por ello, un componente esencial en la organización del trabajo. Pero la cuantificación del tiempo no debe percibirse como un aspecto negativo. Constituye un valioso indicador de la carga de trabajo. U na forma simple y muy extendida, de medir la presión de tiempos que se ejerce sobre un trabajador consiste en determinar el cociente del tiempo necesario para la ejecución de una tarea, dividido por el tiempo disponible. Cuanto más próximo esté este cociente de la unidad, mayor será la presión (Wickens 1992). Además, esta cuantificación puede utilizarse para una gestión flexible y adecuada del personal. Tomemos el caso de las enfermeras, en el que la técnica del análisis predictivo de las tareas se ha generalizado, por ejemplo, en el reglamento canadiense Planning of Required Nursing (PR N 80) (K epenne 1984) 0 en alguna de sus variantes europeas. G racias a tales listas de tareas, acompañadas por el tiempo medio de ejecución, se puede establecer cada mañana, en función del número de pacientes y sus condiciones de salud, un programa de cuidados y la distribución del personal. Lejos de ser una limitación, la normativa PR N 80 ha demostrado, en un gran número de hospitales, la existencia de una situación de escasez de personal auxiliar, ya que la técnica permite establecer una diferencia (véase Figura 29.4) entre lo deseado y lo observado, entre el número de personas necesarias y disponibles, e incluso entre las tareas planificadas y las realizadas. Los tiempos calculados representan sólo tiempos medios y las fluctuaciones que se 
Figura 29.3 - Descripción simplificada de los determinantes de una secuencia de comportamientos en una tarea de control de energía: caso de consumo inaceptable de energía.

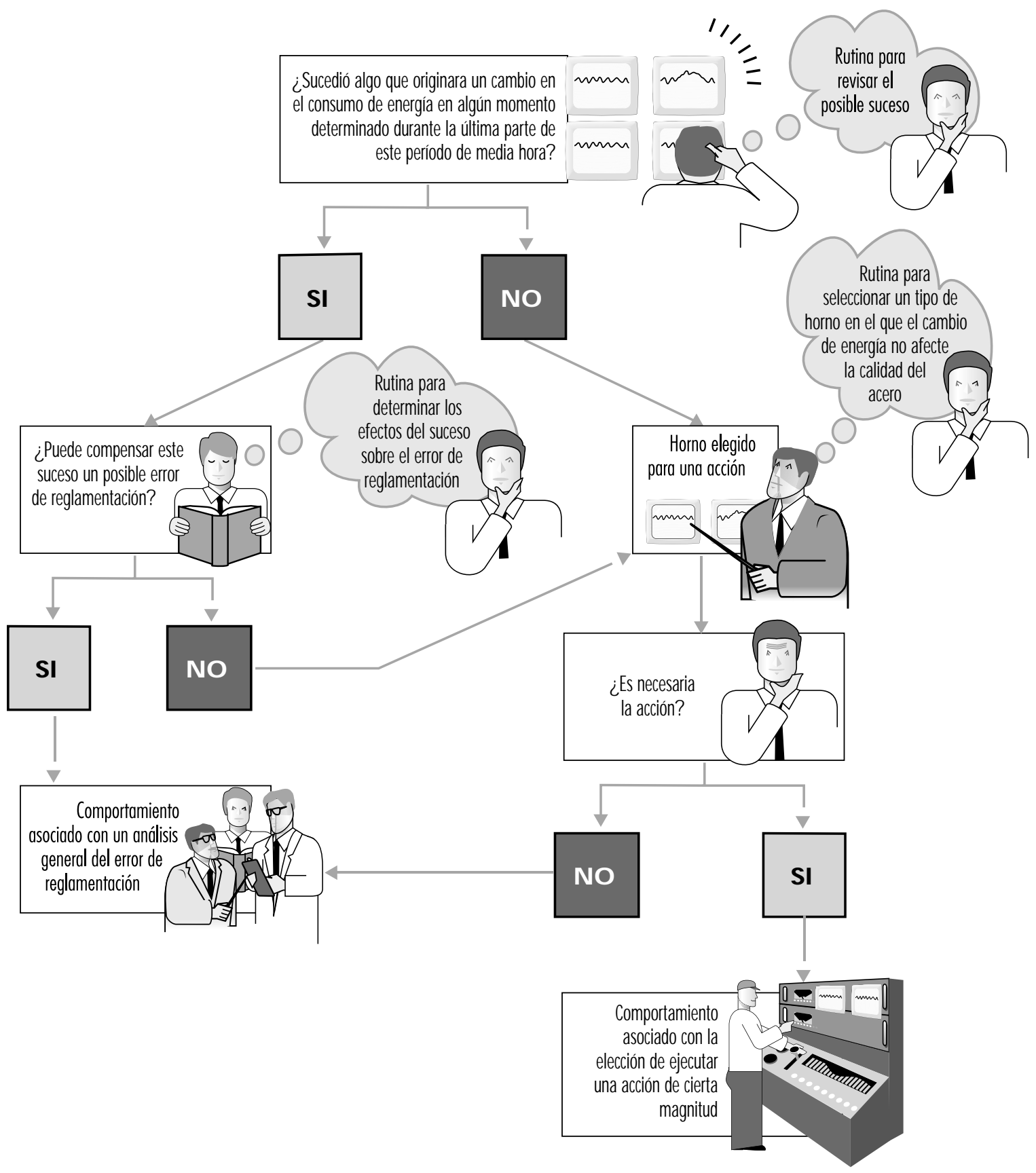

Fuente: Bainbridge 1981

producen en situaciones reales no siempre permiten aplicarlos, pero este aspecto negativo se puede compensar con una organización flexible, que contemple los ajustes y que permita al personal participar en la realización de los mismos.

\section{Actividad, pruebas y rendimiento}

Una actividad se define como el conjunto de conductas y recursos que el trabajador utiliza para desarrollar un trabajo, es decir, la transformación o producción de bienes, o la prestación de un servicio. Esta actividad se puede estudiar a través de la observación de formas distintas. Faverge (1972) ha descrito cuatro formas de análisis. La primera es el análisis de gestos y posturas, en el que el observador localiza, en la actividad visible del trabajador, tipos de acciones que pueden identificarse y que se repiten durante la realización de un trabajo. Estas actividades suelen ir acompañadas de una respuesta precisa, como la frecuencia cardíaca, que nos permite valorar la carga física asociada a cada actividad. La segunda forma de análisis se hace en términos de adquisición de información. Lo que se descubre a través de la observación directa, o con la ayuda de cámaras o registros de los movimientos oculares, es 
Figura 29.4 - Discrepancias entre la cantidad de personal presente y necesaria de acuerdo con PRN 80.

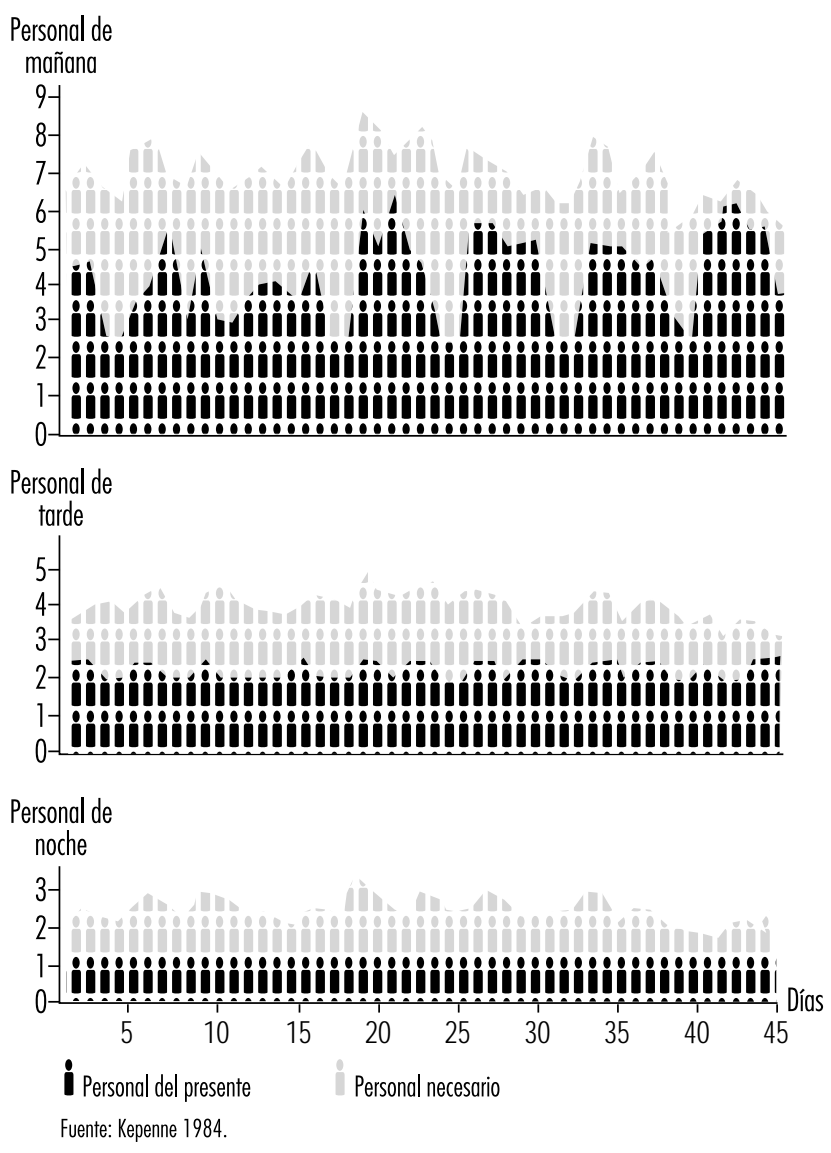

el conjunto de señales que recoge el operador en el campo de información que le rodea. E ste análisis resulta particularmente útil en la ergonomía cognitiva, para tratar de comprender mejor la forma en que el trabajador procesa la información. La tercera forma de análisis se realiza en términos de regulación. La idea es identificar los ajustes que introduce el operador en la actividad con el fin de responder a las fluctuaciones del entorno o a los cambios que sufra su propia situación. Aquí encontramos la intervención directa del contexto en el análisis. U no de los proyectos de investigación más citados en este campo es el de Sperandio (1972). Este autor estudió la actividad de los controladores aéreos y detectó importantes cambios de estrategia cuando aumentaba el tráfico aéreo. Sperandio los interpretó como un intento por simplificar la actividad, manteniendo un nivel de carga aceptable, al tiempo que continuaban cumpliendo los requisitos de la tarea. EI cuarto tipo de análisis es el de procesos de pensamiento. Este tipo de análisis ha sido muy utilizado en la ergonomía de puestos sumamente automatizados. En realidad, el diseño de soportes informáticos, en especial los soportes inteligentes, requiere entender perfectamente la forma de razonar del operador para resolver ciertos problemas. EI razonamiento, que forma parte del proceso de planificación, anticipación y diagnóstico ha sido objeto de análisis (puede encontrarse un ejemplo en la Figura 29.5). Sin embargo, las pruebas de que existe actividad mental sólo pueden inferirse. Fuera de algunos aspectos observables de la conducta, como por ejemplo los movimientos del ojo o el tiempo que se emplea en resolver un problema, la mayoría de estos análisis se centran en la provocación de la respuesta verbal. Durante los últimos años se ha hecho especial hincapié en el conocimiento necesario para realizar determinadas actividades, y los investigadores han tratado de no considerarlas como un postulado inicial del análisis, sino dejar que se manifestaran durante el propio análisis.

Estos esfuerzos han demostrado que es posible obtener rendimientos casi idénticos con niveles muy diferentes de conocimiento, siempre y cuando los operadores sean conscientes de sus limitaciones y apliquen estrategias adaptadas a sus capacidades. Por ello, en nuestro estudio realizado sobre la puesta en marcha de una planta termoeléctrica (De Keyser y Housiaux 1989), aquélla fue realizada tanto por ingenieros como operadores. LoS conocimientos teóricos y de procedimientos que estos dos grupos poseían, comprobados por medio de entrevistas y cuestionarios, eran muy diferentes. Los trabajadores, concretamente, a veces comprendían de forma errónea las variables que intervenían en las conexiones funcionales de los procesos. A pesar de ello, la actuación de ambos grupos fue muy similar, pero los trabajadores tuvieron en cuenta más variables para controlar la puesta en marcha de la planta y realizaron verificaciones más frecuentes. Amalberti (1991), que ha mencionado la existencia de metaconocimientos que permiten a los expertos controlar sus propios recursos, obtuvo también los mismos resultados.

¿Q ué tipo de prueba o evidencia de que existe actividad sería conveniente obtener? Su naturaleza, como ya hemos visto, depende en gran medida de la forma de análisis planteado. Su forma varía en función del grado de rigor metodológico del observador. Las pruebas provocadas se distinguen de las espontáneas y las concomitantes de las posteriores. En términos generales, cuando la naturaleza del trabajo lo permite, debe optarse por las pruebas concomitantes y espontáneas, que no presentan ciertos inconvenientes, como pueda ser la escasa fiabilidad de la memoria, la interferencia del observador, el efecto de racionalizar la reconstrucción por parte del sujeto u otros similares. Para ilustrar estas distinciones, tomaremos como ejemplo las

Figura 29.5 - Análisis de la actividad mental. Estrategias del control de procesos con tiempos de respuesta prolongados: necesidad de soporte informático para el diagnóstico.

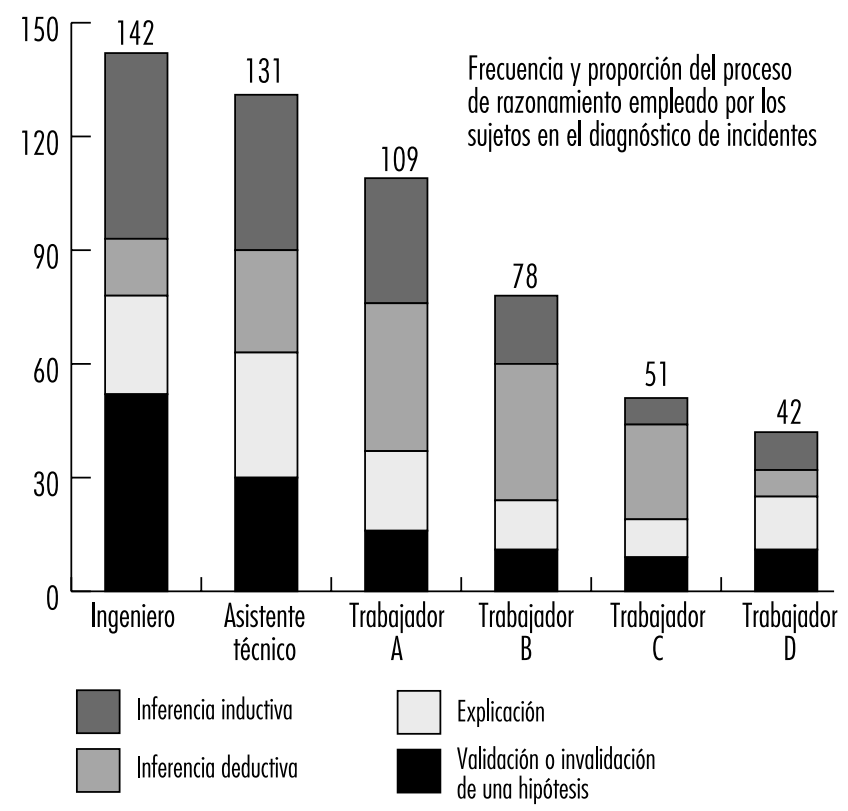

Fuente: Hoc 1989 
verbalizaciones. Las verbalizaciones espontáneas son intercambios verbales o monólogos que se expresan de forma espontánea, sin que el observador lo haya pedido. Las verbalizaciones provocadas son aquellas que se realizan a solicitud del observador, como cuando se pide al sujeto que "piense en alto", algo muy común en la literatura cognitiva. A mbas pueden realizarse en tiempo real, durante el trabajo, y por tanto, son concomitantes. También pueden ser posteriores, como sucede con las entrevistas, o con las verbalizaciones de los sujetos cuando ven su trabajo en una cinta de vídeo. Por lo que respecta a la validez de las verbalizaciones, es conveniente recordar las dudas suscitadas por la controversia entre N isbett y De Camp Wilson (1977) y White (1988) y las precauciones sugeridas por numerosos autores, conscientes de su importancia en el estudio de la actividad mental y dadas las dificultades metodológicas que conllevan (Ericson y Simon 1984; Savoyant y Leplat 1983; Caverni 1988; Bainbridge 1986).

La organización de estas pruebas, su proceso y su formalización requieren un lenguaje descriptivo y, en ocasiones, un análisis que va más allá de la observación "in situ". Por ejemplo, las actividades mentales que se deducen de las pruebas continúan siendo hipotéticas. Actualmente suelen describirse utilizando un lenguaje derivado de la inteligencia artificial, haciendo uso de las representaciones en forma de esquemas, normas de producción y redes conectadas entre sí. Además, se ha extendido mucho el uso de simulaciones por ordenador de los "micromundos" para localizar con precisión determinadas actividades mentales, aunque la validez de los resultados obtenidos de estas simulaciones informatizadas, en vista de la complejidad del mundo industrial, es objeto de debate. Por último, es necesario mencionar los modelos cognitivos de algunas actividades mentales obtenidos "in situ". Entre los más conocidos están el diagnóstico del operador de una planta nuclear, realizado en Ispra (Decortis y Cacciabue 1990), y la planificación del piloto de combate perfeccionado en el Centre d'études et de recherches de médecine aérospatiale (CER M A) (A malberti y cols. 1989).

La cuantificación de las discrepancias entre el rendimiento de estos modelos y el de los trabajadores reales, es un campo muy productivo en los análisis de actividades. El rendimiento es el resultado de la actividad, la respuesta final dada por el sujeto a los requisitos de la tarea. Se expresa a nivel de producción: productividad, calidad, error, incidentes, accidentes e incluso, a un nivel más global, absentismo y rotación. Pero también se debe identificar a nivel individual: la expresión subjetiva de la satisfacción, el estrés, la fatiga o la carga de trabajo, y muchas respuestas fisiológicas son también indicadores del rendimiento. Sólo el conjunto completo de los datos permite interpretar la actividad, es decir, juzgar si va más allá de los objetivos perseguidos, a la vez que se mantiene dentro de los límites humanos. $\mathrm{H}$ ay un conjunto de normas que sirven de guía, hasta cierto punto, al observador. Pero estas normas no son situacionales: no tienen en cuenta el contexto, sus fluctuaciones y la situación del trabajador. Por esto que, en la ergonomía del diseño, aunque existen reglas, normas y modelos, se aconseja al diseñador que compruebe el producto, utilizando prototipos tan pronto como sea posible, y que evalúe la actividad y el rendimiento del usuario.

\section{¿Trabajo individual o colectivo?}

Aunque en la inmensa mayoría de los casos el trabajo es una actividad colectiva, la mayoría de los análisis del trabajo se centran en tareas 0 actividades individuales. Sin embargo, la realidad es que la evolución tecnológica, al igual que la organización del trabajo, hace hincapié actualmente en la distribución del trabajo, ya sea entre hombres y máquinas, o simplemente dentro de un grupo. ¿Q ué vías han explorado los autores para tener en cuenta

esta distribución (R asmussen, Pejtersen y Schmidts 1990)? Estos autores se centran en tres aspectos: la estructura, la naturaleza de los intercambios y la labilidad estructural.

\section{Estructura}

Tanto si consideramos la estructura como elemento del análisis de los trabajadores, o de los servicios, o incluso de diferentes ramas de una empresa pertenecientes a una red, la descripción de los vínculos que los mantienen unidos sigue representando un problema. Estamos familiarizados con los organigramas que utilizan las empresas para presentar la estructura de mandos, cuyas distintas formas reflejan la filosofía de organización de la empresa: una organización muy jerarquizada según la estructura taylonista, una organización horizontal, o incluso tipo matriz, si se desea una estructura más flexible. Existen otras descripciones posibles para la distribución de actividades, como se muestra en el ejemplo de la Figura 29.6. Recientemente, la necesidad de que las empresas representen sus intercambios de información a nivel global ha conducido a un replanteamiento de los sistemas de información. Gracias a algunos lenguajes descriptivos, por ejemplo, el diseño de esquemas o las matrices de entidad-relaciones-atributos, la estructura de las relaciones a nivel colectivo puede describirse actualmente de forma abstracta y servir como trampolín para la creación de sistemas de gestión informatizados.

\section{Natura leza de los intercambios}

La mera descripción de los vínculos que unen las entidades dice muy poco del propio contenido de los intercambios. Naturalmente, puede especificarse la naturaleza de la relación:

Figura 29.6 - Diseño integrado del ciclo de vida.

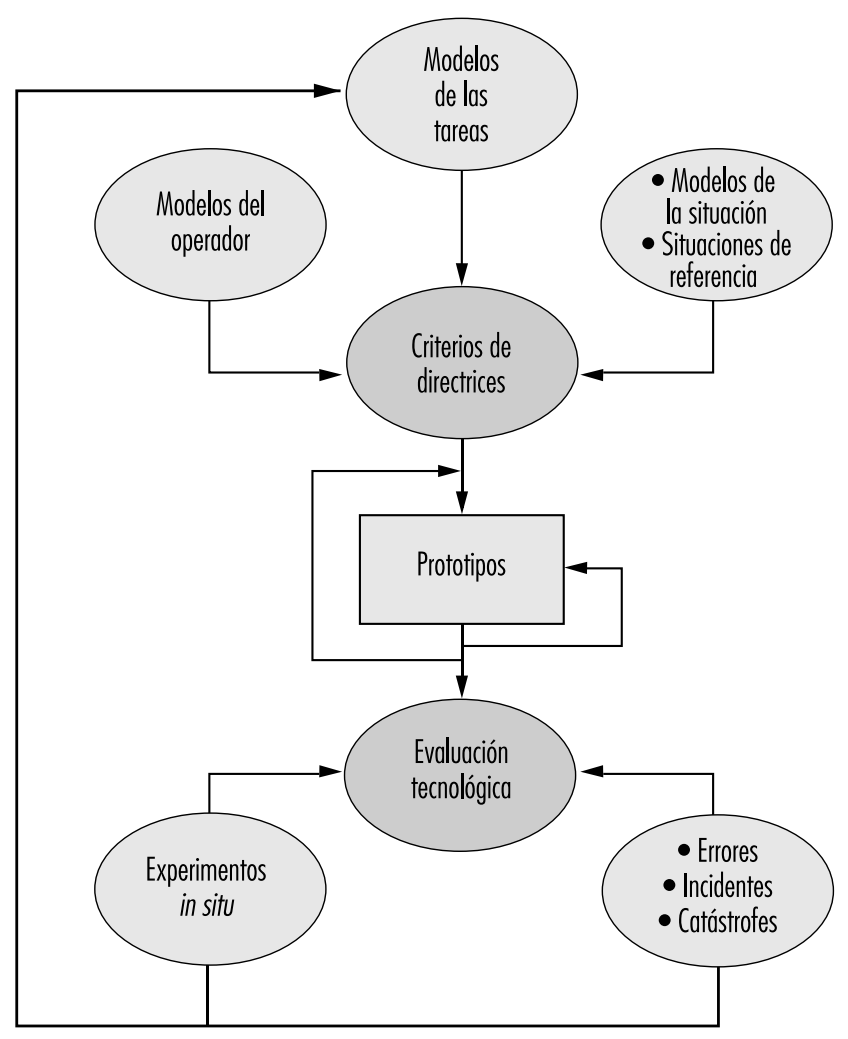


movimiento de un lugar a otro, transferencia de la información, dependencia jerárquica, etc., pero esto no siempre resulta adecuado. El análisis de la comunicación entre equipos se ha convertido en un medio privilegiado de captar la propia naturaleza del trabajo colectivo, teniendo en cuenta los temas mencionados, la creación de un lenguaje común en un equipo, la modificación de la comunicación en situaciones críticas, etc. (Tardieu, N anci y Pascot 1985; Rolland 1986; N avarro 1990; Van Daele 1992; Lacoste 1983; M oray, Sanderson y V incente 1989). El conocimiento de estas interacciones es especialmente útil para crear herramientas informáticas, en particular, los mecanismos de ayuda en la toma de decisiones para comprender los errores. Falzon (1991) describe detalladamente las distintas fases y las dificultades metodológicas relacionadas con el uso de estas pruebas.

\section{Labilidad estructural}

El trabajo sobre las actividades en lugar de sobre las tareas, ha abierto el campo de la labilidad estructural, es decir, de las constantes reconfiguraciones del trabajo colectivo por la influencia de factores contextuales. Estudios como el de Rogalski (1991), que analizó durante un largo período las actividades colectivas relacionadas con los incendios forestales en Francia, o los de Bourdon y Weill Fassina (1994), que estudiaron la estructura organizacional establecida para hacer frente a los accidentes ferroviarios, tienen gran valor informativo. Estos estudios muestran claramente cómo el contexto moldea la estructura de los intercambios, el número y el tipo de actores que intervienen en los mismos, la naturaleza de las comunicaciones y el número de parámetros esenciales para el trabajo. Cuanto más fluctúe este contexto, más alejadas de la realidad estarán las descripciones fijas de la tarea. El conocimiento de esta labilidad y un mejor entendimiento de los fenómenos que tienen lugar dentro de ella, son esenciales para planificar los imprevistos y para proporcionar una formación más adecuada a quienes participan en un trabajo colectivo durante una crisis

\section{Conclusiones}

Las diversas fases del análisis del trabajo descritas son una parte iterativa en cualquier ciclo de diseño de factores humanos (véase Figura 29.6). En el diseño de un objeto técnico, sea una herramienta, un puesto de trabajo o una fábrica, en el que los factores humanos sean importantes, es necesario contar con cierta información a tiempo. En general, el comienzo del ciclo de diseño se caracteriza por una necesidad de obtener datos relacionados con las restricciones medioambientales, los tipos de trabajos que se van a realizar y las diversas características de los usuarios. Esta información inicial permite que las especificaciones de los objetos resultantes tengan en consideración los requisitos del trabajo. Pero, en cierto sentido, éste es solo un modelo burdo en comparación con la situación real del trabajo. Esto explica por qué es necesario que los modelos y prototipos, desde su creación, permitan la evaluación no sólo de los trabajos, sino también de las actividades de los futuros usuarios. En consecuencia, mientras que el diseño de las imágenes de un monitor en una sala de control puede estar basado en un minucioso análisis cognitivo del trabajo que se va a realizar, sólo un análisis basado en los datos de la actividad permitirá determinar con precisión si el prototipo será útil en la situación real de trabajo (Van Daele 1988). U na vez que el objeto técnico terminado se pone en funcionamiento, se da un gran valor al rendimiento de los usuarios y a las situaciones disfuncionales, tales como los accidentes o los errores humanos. La recopilación de este tipo de información permite hacer correcciones finales que aumentarán la fiabilidad y la capacidad de uso del objeto terminado. Tanto la industria nuclear como la industria aeronáutica son buenos ejemplos: la retroinformación operativa implica informar de cada incidente que se haya producido. De esta forma, el bucle de diseño se cierra en un círculo completo.

\section{ERGONOMIA Y NORMALIZACION}

Friedhelm Nachreiner

\section{Orígenes}

La normalización en el campo de la ergonomía tiene una historia relativamente reciente. Comenzó a principios del decenio de 1970, cuando se fundaron los primeros comités a nivel nacional (por ejemplo en Alemania, dentro del instituto de normalización DIN) y posteriormente a nivel internacional, tras la fundación de la ISO (O rganización Internacional de Normalización), con la creación del TC (Comité Técnico) 159 "Ergonomía”, en 1975. Entre tanto, la normalización de la ergonomía tuvo lugar también a nivel regional, por ejemplo, a nivel europeo dentro del CEN (Comité europeo de normalización), que creó su Comité T écnico 122 "Ergonomía" en 1987. La existencia de este último comité pone de relieve que una de las razones para establecer comités para la normalización de los principios y conocimientos ergonómicos está en las reglamentaciones legales (o casi legales), especialmente de lo referente a la salud y seguridad, que requieren la aplicación de los principios y hallazgos ergonómicos en el diseño de productos y sistemas de trabajo. Leyes nacionales, que requerían la aplicación de principios y hallazgos ergonómicos, fueron la razón de que el gobierno alemán creara un comité de ergonomía en 1970; las directivas europeas, especialmente la Directiva de máquinas (referida a principios de seguridad), motivó el establecimiento de un comité ergonómico a nivel europeo. Dado que las reglamentaciones legales no son, ni pueden ser, demasiado específicas, la tarea de definir los principios y hallazgos que se deberían aplicar, fue asumida por los comités de normalización ergonómica. Particularmente a nivel europeo, se reconoce que la normalización en ergonomía puede contribuir a la tarea de armonizar y equiparar las condiciones de seguridad de las máquinas, ayudando así a eliminar las barreras al libre comercio de maquinaria en el continente.

\section{Perspectivas}

La normalización de la ergonomía comenzó con un punto de vista marcadamente protector, aunque preventivo, promoviendo el desarrollo de normas ergonómicas con el objetivo de proteger a los trabajadores contra los efectos adversos, a diferentes niveles de protección de la salud. Los normas ergonómicas se redactaron con los siguientes propósitos:

- garantizar que las tareas asignadas no sobrepasaran las capacidades del trabajador,

- prevenir lesiones o cualquier efecto dañino para la salud del trabajador, tanto permanentes como transitorios, a corto o a largo plazo, incluso cuando las tareas en cuestión pudieran realizarse, durante un corto espacio de tiempo, sin efectos negativos,

- conseguir que las tareas o condiciones de trabajo no provocaran daño alguno, incluso cuando la recuperación fuera posible con el tiempo.

La normalización internacional, que no estaba tan estrechamente asociada a la legislación, siempre intentó abrir vías para la publicación de normas que fueran más allá de la prevención y protección contra los efectos adversos (por ejemplo, especificando 
, activamente, unas condiciones de trabajo óptimas para promover el bienestar y el desarrollo personal del trabajador, aś como la efectividad, eficiencia, fiabilidad y productividad del sistema de trabajo.

En este punto, se hace evidente que la ergonomía, y especialmente la normalización ergonómica, tiene dimensiones sociales y políticas únicas. M ientras que el planteamiento protector con respecto a la salud y seguridad, es generalmente aceptado con normalidad por todas las partes implicadas (patronal, sindicatos, administración y expertos en ergonomía), a todos los niveles de normalización, el planteamiento activo no es aceptado de igual modo por todas las partes. La razón podría ser que, especialmente donde la legislación requiere la aplicación de principios ergonómicos (y, por tanto, explícita o implícitamente la aplicación de normas ergonómicas), algunas de las partes creen que dichas normas podrían limitar su libertad de acción o negociación. Puesto que las normas internacionales tienen un carácter menos obligatorio (la transferencia de estos temas a las normas nacionales se deja a discreción de los comités nacionales de normalización) el planteamiento activo se ha desarrollado más a nivel internacional de la normalización ergonómica.

EI hecho de que hubiera ciertos reglamentos que limitaran de hecho las competencias de aquéllos para los que eran de aplicación, sirvió para desacelerar el proceso de normalización en ciertas áreas, como por ejemplo, en asuntos relacionados con las Directivas Europeas en el artículo 118a del A cta U nica Europea, relativas a la salud y seguridad en el uso y empleo de máquinas en el lugar de trabajo, y en el diseño de sistemas y lugares de trabajo. Por otra parte, para las directivas regidas por el artículo $100 a$, relativas a la salud y la seguridad en el diseño de máquinas con vistas al libre comercio de dicha maquinaria en la Unión Europea, la normalización ergonómica europea es mandatada por la Comisión Europea.

Desde el punto de vista de la ergonomía, sin embargo, es difícil comprender por qué la ergonomía del diseño de la máquina debería ser diferente de la del uso y manejo de la misma dentro de un sistema de trabajo. Esperemos que en el futuro se abandone la distinción entre ergonomía protectora y activa, ya que parece ser más perjudicial que benéfica para el desarrollo de un conjunto coherente de normas ergonómicas.

\section{Tipos de normas ergonómicas}

La primera norma ergonómica internacional desarrollada (basada en una norma DIN nacional alemana) fue la ISO 6385 "Principios ergonómicos en el diseño de los sistemas de trabajo" (1981). Es la norma básica de la serie de normas ergonómicas y define el marco para normas ergonómicas posteriores, al definir conceptos básicos y señalar los principios generales para el diseño ergonómico de los sistemas de trabajo: tareas, herramientas, maquinaria, lugares de trabajo, espacio de trabajo, entorno y organización del trabajo. Esta norma internacional, actualmente en revisión, sirve de norma directriz, y como tal, ofrece recomendaciones y consejos. Sin embargo, no ofrece especificaciones técnicas o físicas que haya que cumplir. Estas pueden hallarse en otro tipo de normas, las normas de especificación, por ejemplo, sobre antropometría o condiciones térmicas. C ada una de estas normas tiene funciones diferentes. Mientras las normas directrices pretenden mostrar al usuario "qué hacer y cómo hacerlo" e indican los principios que se deben respetar, por ejemplo, con respecto a la carga de trabajo mental, las normas de especificaciones dan a los usuarios información detallada, por ejemplo, sobre las distancias de seguridad o procedimientos de medición que deben cumplirse, y cuyo cumplimiento con esas prescripciones se puede comprobar mediante procedimientos específicos. Esto no es siempre posible con las normas directrices, aunque a pesar de su relativa falta de especificidad, se puede determinar cuándo y cómo se han inclumplido sus directrices. U na subclase de normas de especificaciones son las normas de "base de datos", que proporcionan al usuario datos ergonómicos relevantes, como dimensiones corporales, etc.

L as normas CEN se clasifican como de tipo A, B o C, dependiendo de su ámbito y campo de aplicación. Las de tipo A son normas generales, básicas, que sirven para todo tipo de aplicaciones; las de tipo $B$ son específicas para un área de aplicación (lo que significa que la mayoría de las normas ergonómicas incluidas en CEN serán de este tipo); las de tipo C son específicas para alguna clase de maquinaría, como por ejemplo, para las taladradoras manuales.

\section{Comités de normalización}

L as normas ergonómicas, como otras normas, son redactadas por los Comités T écnicos (TC) correspondientes, sus subcomités (SC) o por grupos de trabajo (WG). Para ISO sería el TC 159, para CEN, el TC 122, y a nivel nacional, los respectivos comités nacionales. Además de los comités ergonómicos, la ergonomía es también tratada en los comités técnicos de seguridad de las máquinas (comité TC 114 de CEN, comité TC 199 de ISO) con los que se mantiene una estrecha relación y cooperación. También se mantienen relaciones con otros comités para los que la ergonomía puede ser importante. La responsabilidad sobre las normas ergonómicas, sin embargo, recae únicamente sobre los comités de ergonomía.

Un gran número de organizaciones se encarga también de la elaboración de normas ergonómicas, por ejemplo la IEC (Comisión Electrotécnica Internacional), CENELEC, o los respectivos comités nacionales del campo electrotécnico; CCITT (Comité consultivo internacional de las organizaciones telefónicas y telegráficas) 0 ET SI (I nstituto Europeo de Normas de Telecomunicación) en el campo de las telecomunicaciones; ECM A (A sociación Europea de Fabricantes de O rdenadores) en el campo de los sistemas informáticos; y CAM AC (A sociación de Control y M edida Asistidos por 0 rdenador) en el campo de las nuevas tecnologías en la producción, por citar algunos. Algunos de estos comités se relacionan entre sí para no duplicar el trabajo o evitar especificaciones incoherentes. Con algunas organizaciones (por ejemplo, el IEC) se han llegado a formar comités técnicos conjuntos para cooperar en áreas de interés común. Con otros comités, sin embargo, no existe ninguna coordinación o cooperación. El objetivo principal de estos comités es elaborar normas ergonómicas específicas para su campo de actividad. Dado que el número de organizaciones es muy alto, se ha convertido en algo bastante complicado, si no imposible, el obtener una visión general completa de la normalización ergonómica. Este capítulo se limitará a analizar la normalización ergonómica en los comités europeos e internacionales.

\section{Estructura de los comités de normalización}

La estructura de los Comités de normalización ergonómica es bastante parecida en todos los casos. Normalmente hay un comité técnico responsable de la ergonomía dentro de cada organismo de normalización. Dicho comité (por ejemplo, el TC 159 en ISO ) toma las decisiones de lo que hay que normalizar y cómo organizar y coordinar la actividad dentro del comité, pero a este nivel no se suelen elaborar las normas. Por debajo de este comité hay otros subcomités. Por ejemplo, ISO tiene subcomités (SC) responsables de un determinado campo de normalización; por ejemplo: el SC, encargado de los principios generales ergonómicos; el SC 3, para temas de antropometría y biomecánica; el SC 4, para la interacción hombre-máquina; y el SC 5, para el ambiente físico de trabajo. El comité TC 122 del CEN tiene 
grupos de trabajo (WG), bajo la responsabilidad de los comités técnicos (TC), que se constituyen con el fin de tratar campos más específicos dentro de la normalización ergonómica. Los subcomités del comité TC 159 actúan como comités directivos en su campo de responsabilidad y realizan la primera votación, pero no suelen preparar las normas. Esto se hace en sus grupos de trabajo (WG ), compuestos por expertos nombrados por los comités nacionales, mientras que a las reuniones de los comités y subcomités asisten delegaciones nacionales que representan los puntos de vista de sus respectivos países. D entro de CEN, las responsabilidades no están demasiado señaladas a nivel del grupo de trabajo (WG ), son tanto comités directivos como comités de producción de normas, aunque una gran cantidad de trabajo se realiza en grupos "ad hoc", compuestos por miembros de los WG (designados por sus comités nacionales), y creados para preparar los borradores de una norma. Los grupos de trabajo (WG ) dentro de los subcomités (SC) de 150 hacen el trabajo de normalización a nivel práctico, es decir, preparan borradores, trabajan en los comentarios, identifican las necesidades de normalización y preparan propuestas para los subcomités (SC) y comités (TC), que tomarán las decisiones o acciones apropiadas.

\section{Preparación de las normas ergonómicas}

La elaboración de normas ergonómicas ha cambiado mucho en los últimos años, debido a la importancia que se da a su desarrollo a nivel internacional. Al principio, las normas nacionales, preparadas por expertos de un sólo país en su comité nacional y acordadas por las partes interesadas de ese país, por medio de una votación específica eran trasladadas como propuesta al subcomité responsable (SC), y al grupo de trabajo del TC 159 de $1 S O$ y, tras una votación formal, llegaban al comité técnico (TC) que se encargaba de elaborar una norma internacional. El grupo de trabajo del TC 159, compuesto por expertos en ergonomía (y expertos propuestos por las partes interesadas) de todos los organismos participantes (los organismos nacionales de normalización) que quisieran cooperar en ese proyecto, trabaja sobre los datos recibidos y prepara un borrador de trabajo (WD). Cuando el grupo de trabajo llega a un acuerdo sobre ese borrador, se convierte en el borrador del comité (CD) y se distribuye entre los organismos miembros del subcomité (SC) para su aprobación y comentarios. Si el borrador recibe el apoyo necesario de los organismos miembros del SC (al menos dos tercios de votos a favor) y tras incorporarse los comentarios de los comités nacionales por el grupo de trabajo en la versión corregida, el borrador de la norma internacional (DIS) se somete a la votación de todos los miembros del comité técnico 159. En caso de recibir el apoyo necesario en esta votación (y quizá tras haberse incorporado los cambios editoriales, esta versión será publicada) como una Norma Internacional (IS) por parte de ISO. La votación del comité y loS subcomités se basa en las votaciones a nivel nacional y los comentarios de los expertos o de las partes interesadas de cada país se aportan a través de los organismos miembros. En el comité técnico 122 de CEN, el procedimiento es bastante parecido, con la excepción de que no hay subcomités bajo la responsabilidad del comité técnico y de que las votaciones tienen lugar con un sistema ponderado de votación (según el tamaño del país), mientras en ISO la regla es: un país, un voto. Si el borrador es rechazado en cualquier fase del proceso, se debe revisar y someterse de nuevo a votación, a no ser que el grupo de trabajo (WG) decida que no se puede hacer una revisión con garantías de alcanzar el acuerdo.

Las normas internacionales se convierten en nacionales si los comités nacionales votan a favor. En cambio, las normas europeas (EN) deben convertirse necesariamente en nacionales, por los miembros de CEN retirando aquellas normas propias del país que contradigan a la norma europea; lo que significa que estas normas armonizadas EN tendrán efecto en todos los países de miembros de CEN y, debido a su influencia comercial, en todos aquellos países que pretendan vender bienes a un comprador de un país miembro de CEN.

\section{Cooperación ISO CEN}

Para evitar que haya normas que entren en conflicto y la duplicación del trabajo, además de permitir que los países no miembros de CEN tomen parte en los estudios desarrollados por CEN, se ha llegado a un acuerdo de cooperación entre ISO y CEN, (el llamado Acuerdo de Viena), que regula las formalidades y establece un proceso de votación paralelo que permite que se vote sobre los mismos borradores tanto en CEN como en ISO, si los comités responsables así lo acuerdan. Entre los comités de ergonomía la tendencia es evidente: tratar de no duplicar el trabajo, (ya que hay pocos recursos humanos y financieros), evitar especificaciones que entren en conflicto, e intentar conseguir un conjunto coherente de normas ergonómicas basado en la división del trabajo. M ientras que el comité técnico CEN 122 está vinculado a las decisiones de la UE, y ésta le mandata sus temas de trabajo para estipular las especificaciones de las directivas europeas, el comité 159 de ISO goza de libertad absoluta para normalizar lo que considere necesario o apropiado en el campo de la ergonomía. Esta situación ha conducido a cambios en el énfasis de ambos comités, centrándose el europeo en la maquinaria y temas relacionados con la seguridad y el de ISO en áreas donde se reflejan intereses de mercado más amplios que los meramente europeos (por ejemplo, el trabajo con PVD o el diseño de las salas de control para industrias de proceso y similares), en áreas donde se trata del funcionamiento de las máquinas (como el diseño de los sistemas de trabajo) 0 en áreas como el ambiente o la organización del trabajo. La intención, sin embargo, es transferir los resultados de los trabajos de una a otra organización, para contribuir a la creación de un conjunto de normas ergonómicas aplicable en todo el mundo.

El procedimiento formal para la producción de normas sigue siendo el mismo hoy en día, pero debido a la importancia que ha adquirido el ámbito internacional o europeo, cada vez se transfieren más actividades a estos comités. Los borradores se crean directamente en estos comités y ya no se basan en normas nacionales preexistentes. U na vez que se ha tomado la decisión de desarrollar una norma, el trabajo empieza directamente en uno de estos niveles supranacionales, basándose en cualquier información disponible, comenzando a veces desde cero. Esto cambia el papel de los comités nacionales de una manera drástica.

M ientras anteriormente desarrollaban sus propias normas, de acuerdo con sus procedimientos nacionales, ahora tienen la tarea de observar, adaptar e influir sobre el trabajo a nivel supranacional a través de los expertos que trabajen en las normas, 0 de comentarios hechos en los diferentes niveles de la votación (dentro de CEN se detienen los proyectos nacionales si coinciden con uno similar que esté siendo elaborado a nivel europeo). Esto hace que la tarea sea incluso más complicada, puesto que la influencia sólo se ejerce de manera indirecta y la preparación de normas ergonómicas no es una cuestión científica, sino de negociación, consenso y acuerdo (pues depende de las implicaciones políticas que la norma pudiera llegar a tener). É sta es una de las razones por las que la elaboración de una norma europea o internacional puede llegar a tardar años y no llega a reflejar los cambios más recientes en ergonomía. Las normas ergonómicas internacionales se deben examinar cada cinco años y, si fuera necesario, someterse a revisión. 


\section{Campos de la normalización ergonómica}

La normalización internacional comenzó con una serie de directrices sobre los principios ergonómicos generales en el diseño de los sistemas de trabajo; estos principios quedaron reflejados en la ISO 6385, que está siendo revisada para incorporar los nuevos avances. EI CEN ha creado una norma similar (EN 614, Parte 1, 1994), orientada principalmente al campo de la maquinaria y la seguridad, y está elaborado una segunda parte con directrices sobre el diseño de las tareas como ampliación de esta norma básica. De este modo, CEN resalta la importancia de las tareas del operador en el diseño de la maquinaria o de los sistemas de trabajo, para los que se han de diseñar las herramientas 0 máquinas adecuadas.

O tra área donde los conceptos y directrices se han plasmado en la creación de normas es el campo de la carga mental de trabajo. La primera parte de la ISO 10075, define términos y conceptos (p. ej. fatiga, monotonía, vigilancia reducida) y la segunda parte (todavía en fase de DIS a finales de los noventa) mostrará las directrices para el diseño de sistemas de trabajo, con respecto a la carga mental para evitar posibles daños.

El subcomité 3 del comité técnico 159 de ISO y el grupo de trabajo 1 del comité técnico 122 de CEN elaboran las normas sobre antropometría y biomecánica, tocando, entre otros temas, los métodos de medición antropométrica, las dimensiones corporales, las distancias de seguridad y acceso, la evaluación de las posturas de trabajo y el diseño de los puestos de trabajo con relación a la maquinaria, los límites recomendados de fuerza física y los problemas de la manipulación manual de cargas.

El subcomité 4 de ISO muestra el modo en que los cambios tecnológicos y sociales afectan a la normalización ergonómica. El subcomité 4 comenzó siendo el de "señales y controles", normalizando los principios para mostrar la información y diseñar los mandos de control, siendo uno de sus temas las pantallas de visualización de datos (PVD) utilizadas en tareas de oficina. Pronto se pudo ver que normalizar la ergonomía de las PVD no era suficiente si no se producía la normalización del entorno del puesto de trabajo como un sistema de trabajo, que abarcara áreas como el hardware (pantallas, teclados, dispositivos de introducción de datos sin teclado, puestos de trabajo, etc.), el medio ambiente de trabajo (la iluminación, por ejemplo), la organización del trabajo (por ejemplo, las exigencias de la tarea) y el software (como los principios de diálogo, los diálogos a través de menús y mediante manipulación directa). Esto condujo a una norma con varias partes (ISO 9241) sobre Ios "requisitos ergonómicos para el trabajo de oficina con PVD", que actualmente contiene 17 partes, 3 de las cuales han alcanzado ya la categoría de IS (norma internacional). Esta norma será adoptada por CEN (como EN 29241) y especificará las disposiciones establecidas por la Directiva sobre PVD (90/ 270 EEC) de la UE, aunque sea una directiva bajo el artículo 118a del Acta Ú nica Europea. Esta serie de normas proporciona directrices y especificaciones, dependiendo del objeto de cada parte de la norma, e introduce un nuevo concepto de normalización, enfocado sobre la aplicación por el usuario, que podría ayudar a resolver algunos de los problemas de la normalización en el campo de la ergonomía. Esto se describe con más detalle en el capítulo U nidades de presentación visual de datos.

El enfoque sobre la aplicación por el usuario se basa en la idea de que el objetivo de la normalización es prevenir los daños y conseguir que el operador tenga unas condiciones de trabajo óptimas, pero no establecer especificaciones técnicas per se. La especificación sólo se considera un medio para conseguir un fin: el óptimo rendimiento del usuario, sin problemas de daños. Esto es lo importante, sin dar demasiada importancia al cumplimiento de una u otra especificación física. Para esto debe especificarse, en primer lugar, el rendimiento óptimo deseado (por ejemplo, realizando la lectura en la pantalla) y en segundo lugar, las especificaciones técnicas que se deben desarrollar para permitir que el usuario realice su cometido al mejor nivel posible. El fabricante es libre de seguir estas especificaciones que aseguran que el producto cumple con los requisitos ergonómicos. 0 bien, puede demostrar que, en comparación con un producto que se sabe que cumple los requisitos (bien por el cumplimiento con las especificaciones técnicas de la norma o bien por un funcionamiento óptimo probado), el nuevo producto cumple tan bien o mejor con los requisitos de funcionamiento como el producto de referencia, tanto si cumple las especificaciones técnicas de la norma como si no. En la misma norma se indica el procedimiento de conformidad que debe seguirse para ver si el producto cumple los requisitos de la norma para la aplicación por el usuario.

Este planteamiento ayuda a superar dos problemas. Las normas, en virtud de sus especificaciones, basadas en el estado de los conocimientos (y la tecnología) en el momento de su elaboración, pueden restringir nuevos desarrollos. Las especificaciones basadas en una tecnología concreta (por ejemplo, los tubos de rayos catódicos) pueden ser inadecuadas para otras tecnologías. Independientemente de la tecnología, el usuario de una pantalla, por ejemplo, debería ser capaz de leer y comprender eficazmente la información mostrada, sin importar la técnica utilizada, ya sea una pantalla de cristal líquido o de rayos catódicos. El rendimiento, en este caso, no se puede evaluar sólo en términos de resultados (rapidez o precisión), sino también en términos de confor y esfuerzo.

El segundo problema que puede ser abordado con este enfoque es el derivado de las interacciones entre las condiciones. La especificación física suele ser unidimensional y no considera otras condiciones. Sin embargo, en el caso de los efectos interactivos, esta actitud puede originar confusión o errores. Al especificar requisitos de rendimiento, y dejar que sea el fabricante quien busque los medios para lograrlos, cualquier solución que satisfaga esos requisitos será aceptable. EI tratar la especificación como un medio para conseguir un fin representa una perspectiva auténticamente ergonómica.

O tra norma con un planteamiento de sistema de trabajo está siendo elaborada por el subcomité 4, y se relaciona con el diseño de salas de control, por ejemplo, de centrales eléctricas o industrias de procesos. Se espera elaborar una norma con varias partes (ISO 11064), en la que se recojan diferentes aspectos como el diseño de la sala de control, el diseño de los puestos de trabajo y el diseño de los dispositivos de entrada o presentación de datos para el control del proceso. Dado que estos temas de trabajo y el enfoque adoptado van más allá de los problemas de diseño “de pantallas y controles", el subcomité 4 ha sido rebautizado como el comité de la "interacción hombre-sistema".

Los problemas ambientales, especialmente los relacionados con las condiciones térmicas o la comunicación en ambientes ruidosos, se tratan en el subcomité 5 , donde se preparan normas sobre métodos de medición, métodos para la estimación del estrés térmico, las condiciones de confor térmico, la producción de calor metabólico, y sobre las señales visuales y auditivas de peligro, el nivel de interferencias en la comunicación oral y la valoración de dicha comunicación.

El comité técnico 122 del CEN cubre, más o menos, los mismos campos, aunque dando una importancia distinta a estos aspectos y con una estructura de grupos de trabajo diferente. Se pretende, sin embargo, que por medio de la división del trabajo entre los comités, y la mutua aceptación de los resultados de su trabajo, se logre desarrollar un conjunto útil de normas ergonómicas. 


\section{- LISTAS DE COMPROBACION}

\section{Pranab Kumar Nag}

Los sistemas de trabajo abarcan tanto las variables macro-organizativas como el subsistema personal, el subsistema tecnológico y el ambiente externo. El análisis de los sistemas de trabajo es, por tanto, sobre todo un esfuerzo por comprender la distribución de funciones entre el trabajador y el equipo técnico, y la división del trabajo entre las personas en un entorno sociotécnico. Este análisis puede contribuir a la toma de decisiones (informadas) para mejorar los sistemas de seguridad, la eficacia en el trabajo, el desarrollo tecnológico y el bienestar físico y mental de los trabajadores.

Los investigadores examinan los sistemas de trabajo en función de enfoques divergentes (mecanicista, biológico, perceptual/ motor, motivacional), con los correspondientes resultados individuales y de organización (Campion y Thayer 1985). La selección de los métodos para el análisis del sistema de trabajo viene impuesta por los enfoques que se hayan elegido y por el objetivo particular que se persigue, por el contexto organizativo, por las características humanas y del trabajo y por la complejidad tecnológica del sistema que se está estudiando (Drury 1987). L os cuestionarios y las listas de comprobación son los medios más comunes para elaborar bases de datos por parte de los encargados de la planificación organizativa a la hora de priorizar los planes de acción en las áreas de selección y asignación de personal, para la compensación del rendimiento, para la gestión de la seguridad e higiene, para el diseño del sistema hombre-máquina y el diseño o reestructuración del trabajo. Los métodos de inventario o listas de comprobación, como el Cuestionario del Análisis de Posición, PAQ en inglés ( $M$ cCormick 1979), el Inventario de los Componentes del Trabajo (Banks y M iller 1984), el Análisis Diagnóstico del Trabajo (Hackman y O Idham 1975) y el Cuestionario M ultimétodo para el Diseño de un Trabajo (C ampion 1988), son los instrumentos más populares y están dirigidos a varios objetivos.

EI PAQ tiene seis divisiones principales, que comprenden 189 ítems sobre la conducta, necesarios para valorar el rendimiento en el trabajo, y siete apartados complementarios relacionados con la compensación económica:

- Entrada de la información (dónde y cómo se obtiene la información sobre los trabajos que se van a realizar) (35 ítems).

- Proceso mental (tratamiento de la información y toma de decisiones durante la realización del trabajo) (14 ítems).

- Resultados en términos de trabajo (trabajo físico realizado, herramientas e instrumentos utilizados) (50 ítems).

- R elaciones interpersonales (36 ítems).

- Situación de trabajo y contexto de la tarea (contextos físicos y sociales) (18 ítems).

- O tras características de la tarea (planificación, exigencias de la tarea) (36 ítems).

El Inventario de los Componentes del Trabajo Mark II contiene siete secciones. $L$ a sección de introducción trata de los detalles de la organización, la descripción de las tareas y los datos personales del empleado. 0 tras secciones son:

- Herramientas y equipo: uso de más de 200 herramientas y equipos (26 ítems).

- Exigencias físicas y de percepción: fuerza, coordinación, atención selectiva (23 ítems).

- Demandas matemáticas: uso de números, trigonometría, aplicaciones prácticas, como trabajo con planos y dibujos (127 ítems).
- Exigencias de comunicación: preparación de cartas, utilización de códigos, entrevistas (19 ítems).

- Toma de decisiones y responsabilidad: decisiones sobre métodos, orden del trabajo, normas y temas relacionados (10 ítems).

- Condiciones de trabajo y características del mismo.

Los métodos de perfil tienen ciertos elementos en común: (1) un conjunto integral de factores de trabajo utilizados para seleccionar la categoría del mismo, (2) una escala de valoración que permite evaluar las exigencias de la tarea y (3) la valoración de las características del trabajo de acuerdo con la estructura organizativa y los requisitos socio-técnicos. El método "Les profils des postes" , otro instrumento para trazar el perfil de la tarea desarrollado por la Organización Renault (RNUR 1976), contiene una tabla de entrada de las variables que representan las condiciones de trabajo y proporciona a los encuestados una escala de cinco puntos, en la que pueden seleccionar el valor de cada variable desde muy satisfactorio a muy deficiente, mediante el registro normalizado de las respuestas. $L$ as variables cubren (1) el diseño del puesto de trabajo, (2) el ambiente físico, (3) los factores de carga física, (4) la tensión nerviosa, (5) la autonomía del trabajo, (6) las relaciones, (7) la repetitividad y (8) el contenido del trabajo.

EI AET (Análisis Ergonómico del Trabajo) (Rohmert y Landau 1985), se creó tomando como base el concepto de estrés-tensión. Cada uno de los 216 apartados del AET está codificado: un código define los estresores, indicando si el elemento del trabajo puede o no calificarse como estresante, otros definen el grado de estrés asociado con un trabajo y otros, por último, describen la duración y frecuencia del estrés durante el turno de trabajo.

\section{EI AET se compone de tres partes:}

- Parte A. El Sistema hombre-trabajo (143 ítems), que incluye los objetos del trabajo, herramientas y equipos, y el ambiente de trabajo que constituye las condiciones físicas, organizativas, sociales y económicas del trabajo.

- Parte B. El Análisis de la tarea contiene 31 ítems, clasificados en función de los distintos tipos de objetos de trabajo, como materiales y objetos abstractos, y de las tareas relacionadas con el trabajador

- Parte C. El Análisis de las exigencias del trabajo (42 ítems), comprende los elementos de percepción, decisión y respuesta/ actividad (EI suplemento del AET, H-AET trata sobre las posturas y movimientos del cuerpo en las actividades de montaje industrial).

En general, las listas de comprobación adoptan uno de estos dos enfoques: (1) el orientado a la tarea (por ejemplo, el AET, Les profils des postes) y (2) el orientado al trabajador (por ejemplo, el PAQ). Los inventarios de tareas y perfiles ofrecen una sutil comparación de las tareas complejas y del perfil profesional de las tareas y determinan los aspectos del trabajo que se consideran a priori como factores imprescindibles para mejorar las condiciones laborales. El énfasis del PAQ está en la clasificación de familias o clusters (Fleishman y Quaintence 1984; M ossholder y Arvey 1984; Carter y Biersner 1987), deduciendo la validez de los acomponentes del trabajo y el estrés del mismo (Jeanneret 1980; Shaw y R iskind 1983).

Desde el punto de vista médico, tanto el AET como los métodos del perfil permiten comparar las limitaciones y aptitudes cuando son necesarios (Wagner 1985). El cuestionario nórdico es un ejemplo del análisis ergonómico del puesto de 
trabajo (Ahonen, Launis y Kuorinka 1989), y abarca los siguientes aspectos:

- espacio de trabajo

- actividad física general

- actividades de levantamiento de cargas

- posturas de trabajo y movimientos

- riesgo de accidentes

- contenido de la tarea

- limitaciones del trabajo

- comunicación y contactos personales del trabajador

- toma de decisiones

- repetitividad del trabajo

- atención

- condiciones de iluminación

- temperatura ambiente

- ruido.

Entre las desventajas del formato de las listas de comprobación para fines generales utilizadas en el análisis ergonómico del trabajo están las siguientes:

- Con algunas excepciones (por ejemplo, el AET o el cuestionario nórdico), hay una carencia general de normas ergonómicas y protocolos de evaluación con relación a los distintos aspectos del trabajo y del entorno.

- Hay muchas diferencias en la construcción general de las listas de comprobación en lo referente a la manera de determinar las características de las condiciones laborales, la forma de anotación y los criterios y métodos de comprobación.

- La evaluación de la carga física de trabajo, de las posturas y de los métodos de trabajo es limitada debido a la falta de precisión en el análisis de las operaciones de trabajo, en relación con la escala de niveles relativos de estrés.

- Los principales criterios de valoración de la carga mental del trabajador son el grado de complejidad de la tarea, la atención necesaria para realizarla y el ejercicio de las habilidades mentales. Las listas de comprobación existentes hacen más hincapié en el uso excesivo de los mecanismos de pensamiento concreto que en el escaso uso de mecanismos de pensamiento abstracto.

- En la mayoría de listas de comprobación, los métodos de análisis conceden una mayor importancia a la tarea del puesto, en contraposición al análisis del trabajo, de la compatibilidad del trabajador y la máquina, etc. En las listas de comprobación ergonómicas se suele dar menos importancia a los determinantes psicosociales, que son fundamentalmente subjetivos y contingentes.

Un lista de comprobación elaborada sistemáticamente nos obliga a investigar los factores de las condiciones de trabajo que son visibles o fáciles de modificar, y nos permite entrar en un diálogo social con los empresarios, empleados y otros implicados. Debería tenerse cierta precaución en relación con la ilusión de simplicidad y eficiencia de las listas de comprobación, así como, con sus enfoques técnicos y de cuantificación. La versatilidad de una lista de comprobación o de un cuestionario puede lograrse incluyendo módulos específicos que se adecuen a unos objetivos específicos. Por tanto, la selección de variables está muy relacionada con la finalidad que se atribuye al análisis de los sistemas de trabajo; esto determina el enfoque general para elaborar una lista de comprobación fácil de entender.

La "Lista de comprobación ergonómica" que se muestra a continuación puede utilizarse para varios fines. La obtención de los datos de la lista de comprobación y el tratamiento informático de los mismos es relativamente sencillo, si se responde a los enunciados primarios y secundarios (véanse más adelante). La $\mathrm{H}$ oja de evaluación resumida de la página 29.25 puede utilizarse para trazar un perfil y agrupar el conjunto de ítems seleccionados, que pueden ser la base para la toma de decisiones sobre los sistemas de trabajo. El proceso de análisis suele llevar mucho tiempo y los usuarios de estos instrumentos deben tener una amplia formación ergonómica, tanto teórica como práctica, para la evaluación de los sistemas de trabajo. 


\section{USTA DE COMPROBACION ERGONOMICA}

Aquí se dan unas directrices generales para elaborar un lista de comprobación de los sistemas de trabajo con estructura modular, que abarca cinco aspectos fundamentales (mecánico, biológico, de percepción/motor, técnico y psicosocial). La importancia de los módulos varía según la naturaleza del trabajo que se va a analizar, los aspectos específicos del país o población objeto del estudio, las prioridades organizativas y el uso que se pretende dar a los resultados del análisis.

Los encuestados marcarán el "enunciado primario" con "Sí o No". L as respuestas afirmativas indican la ausencia aparente de un problema, y dejan abierta la posibilidad de aconsejar un escrutinio posterior más preciso. Las respuestas negativas indican la necesidad de una evaluación y una mejora ergonómica. Las respuestas a los "enunciados secundarios" se distinguen porque tienen un solo dígito en la escala de gravedad de acuerdo/ desacuerdo que se indica a continuación.

0 No sabe o no aplicable

1 D esacuerdo absoluto

2 Desacuerdo

3 Ni acuerdo ni desacuerdo

4 Acuerdo

5 Acuerdo absoluto

\section{A. Organización, trabajador y tarea}

Respuesta/ puntuación

El diseñador de la lista de trabajo puede proporcionar un dibujo o fotografía para mostrar el trabajo y el puesto en estudio.

1. Descripción de la organización y las funciones.

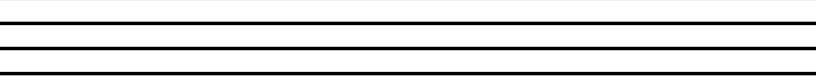

2. Características del trabajador: Breve descripción del grupo de trabajo.

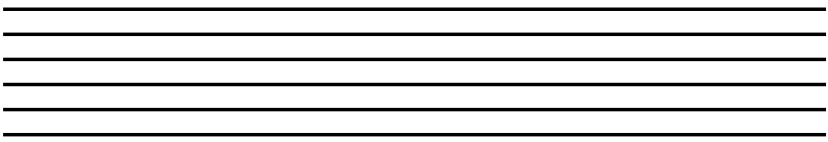

3. Descripción de la tarea: Lista de actividades y materiales que se utilizan.

Indique brevemente los riesgos.

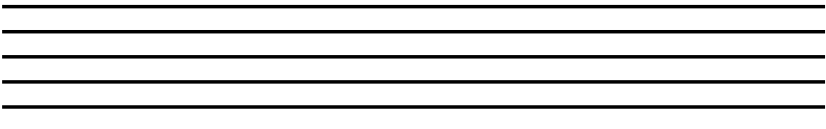

B. Aspecto técnico

Respuestas/ puntuación

I. E specialización del puesto de trabajo

4. Los modelos del trabajo o de la tarea son simples y poco complicados.

Sí/ No

Si la respuesta es $\underline{\mathrm{N} o}$, valore lo siguiente: (de 0 a 5 )

4.1 La asignación del trabajo es específica para el operario.

4.2 Las herramientas y los métodos de trabajo son especiales para el propósito de la tarea.

4.3 Volumen de producción y calidad del trabajo.

4.4 El empleado desempeña múltiples tareas.
11. H abilidades requeridas

5. El trabajo requiere una actividad motora simple.

Sí/ No

Si la respuesta es $\underline{\mathrm{No}}$, valore lo siguiente: (de 0 a 5 )

5.1 El puesto requiere conocimientos y habilidades especializados.

5.2 El puesto exige una formación para adquirir esas habilidades.

5.3 El trabajador comete frecuentes errores en su trabajo.

5.4 El puesto exige una rotación frecuente, reglada.

5.5 Las operaciones están marcadas por una máquina 0 automatizadas.

Comentarios y sugerencias para la mejora, ítems 4 a 5.5:

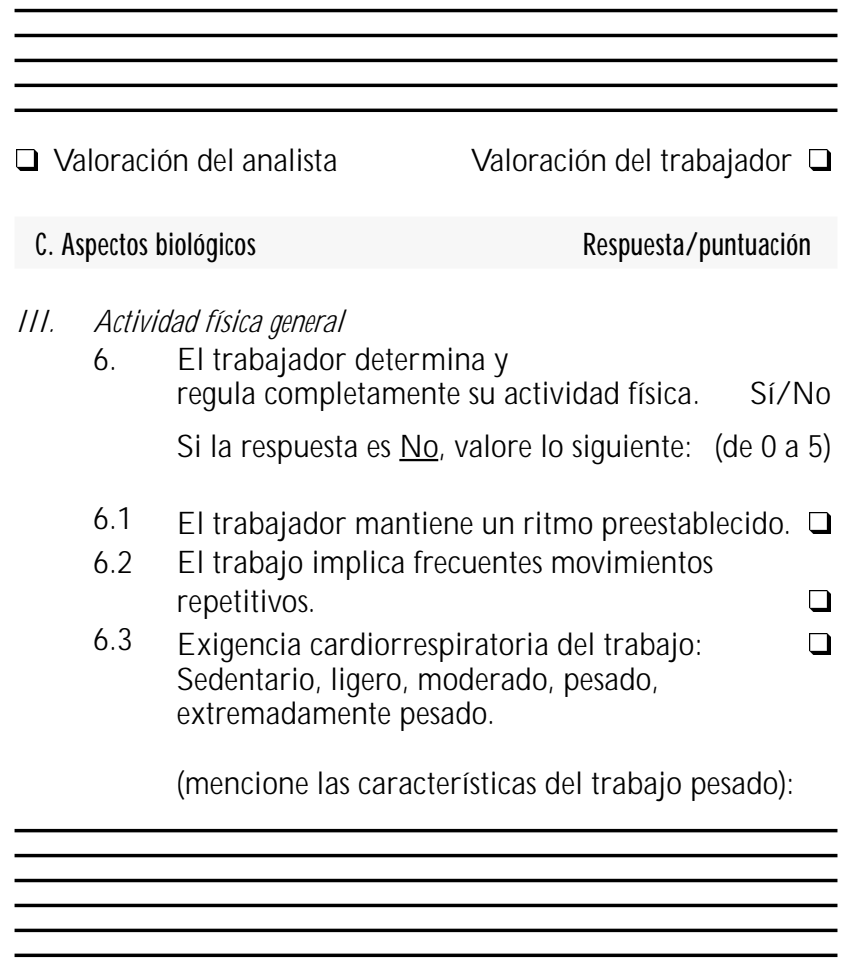


(de 0 a 5) V. D iseño del lugar o del espacio de trabajo

El lugar de trabajo debe ilustrarse mediante diagramas que mues-

6.4 El trabajo exige aplicar una gran

fuerza muscular.

tren los espacios libres y las zonas de alcance:

6.5 El trabajo (empuñar herramientas, manejo de un volante, de un pedal de freno) es predominantemente estático.

6.6. El trabajo exige una posición de trabajo fija (sentado o de pie).

IV. M anipulación manual de cargas (M M C)

$\mathrm{N}$ aturaleza de los objetos manipulados: animados/ inanimados, tamaño y forma.
7. El trabajo requiere una M M C mínima. Sí/ No Si la respuesta es $\underline{\mathrm{N}} \underline{\mathrm{O}}$, especifique el trabajo:
7.1 Tipo de trabajo: (elija uno) empujar, tirar, girar, levantar, bajar, transportar (especificar ciclo de repetición):

7.2 Peso de la carga $(\mathrm{kg})$ : (elija uno) 5-10, 10-20, 20-30, 30-40, >40.

7.3 Distancia horizontal sujeto-carga (cm): (elija una) $<25,25-40,40-55,55-70,>70$.

7.4 Altura a la que el sujeto carga. (elija una) A nivel del: suelo, rodilla, cintura, pecho, hombro.

7.5 La ropa impide las tareas de M M C.

8. La posición de la tarea no presenta riesgo de lesión corporal.

Si la respuesta es $\underline{\mathrm{No}}$, valore lo siguiente: (de 0 a 5 )

8.1 La tarea puede modificarse para reducir la carga que se debe manipular.

8.2 Los materiales pueden empaquetarse en tamaños estándar.

8.3 El tamaño o la posición de las asas de los objetos puede mejorarse.

8.4 Los trabajadores no adoptan métodos seguros para la manipulación de cargas.

8.5 Las ayudas mecánicas pueden reducir el sobreesfuerzo.

Indique cada elemento si se dispone de grúas u otras ayudas mecánicas.

Sugerencias para la mejora, ítems 6 a 8.5:
9. El lugar de trabajo es compatible con las dimensiones humanas.

Si la respuesta es $\underline{\mathrm{N} o}$, valore lo siguiente: (de 0 a 5)

9.1 La distancia de trabajo está fuera del alcance normal en el plano horizontal o vertical $(>60 \mathrm{~cm})$.

9.2 La altura de la mesa o del plano de trabajo es fija o escasamente regulable.

9.3 No hay espacio para operaciones secundarias (ej.: inspección, mantenimiento).

9.4 El puesto de trabajo tiene obstáculos, salientes o bordes pronunciados.

9.5 La superficie de trabajo o el suelo son resbaladizos, irregulares, inestables o están llenos de obstáculos.

10. La disposición de los asientos es adecuada (sillas cómodas, buen apoyo postural).

Si la respuesta es $\underline{\mathrm{N} 0}$, indique las causas: (de 0 a 5 )

10.1 Las dimensiones del asiento (altura del asiento, respaldo) no coinciden con las dimensiones humanas.

10.2 El asiento es escasamente regulable.

10.3 El asiento de trabajo no proporciona apoyo o soporte (bordes verticales o tapicería muy rígida) para trabajar con la maquinaria.

10.4 Ausencia de mecanismos amortiguadores de las vibraciones en el asiento.

11. Existen suficientes elementos auxiliares para la seguridad en el puesto de trabajo.

$\mathrm{Si}$ la respuesta es $\mathrm{No}$, indique lo siguiente:

11.1 No hay espacio para colocar las herramientas o los efectos personales.

11.2 Puertas, accesos de entrada y salida o pasillos demasiado estrechos.

11.3 Diseño inadecuado de mangos, escaleras, escalerillas o barandillas.

11.4 Los asideros de pies y manos exigen posturas forzadas de las extremidades.

11.5 Los apoyos no se distinguen por su posición, forma o diseño

11.6 U so de guantes o calzado que limiten para trabajar y manejar los controles de los equipos. 
Sugerencias para la mejora, ítems 9 a 11.6:

VI. Postura de trabajo

12. El trabajo permite una postura relajada. Sí/ No $\mathrm{Si}$ la respuesta es $\underline{\mathrm{N} 0}$, valore lo siguiente: (de 0 a 5 )

12.1 Trabajo con los brazos levantados por encima del hombro y/ o separados del cuerpo.

12.2 H iperextensión de la muñeca; y demanda de mucha fuerza.

12.3 El cuello y los hombros no forman un ángulo de unos $15^{\circ}$.

12.4 Espalda inclinada y girada.

12.5 Las caderas y las piernas no tienen un buen apoyo cuando se está sentado.

12.6 M ovimiento asimétrico del cuerpo, sólo hacia un lado.

12.7 M encione los motivos de la postura forzada:

(1) posición de la máquina,

(2) diseño del asiento,

(3) manejo del equipo,

(4) puesto o espacio de trabajo.

12.8 Especifique el código OWAS. (Si desea una descripción detallada del método OWAS, consulte K arhu y cols. 1981.)

Sugerencias para la mejora, ítems 12 a 12.7:

VII. M edio ambiente de trabajo

(Indique las mediciones siempre que sea posible)

RUIDO

[I dentifique las fuentes de ruido, tipo y duración de la exposición; consulte IL O 1984].

13. El nivel de ruido es inferior al máximo nivel recomendado. (U tilice la tabla siguiente.)

\begin{tabular}{|c|c|c|c|}
\hline $\begin{array}{l}\text { Puntua- } \\
\text { ción }\end{array}$ & $\begin{array}{l}\text { El trabajo no } \\
\text { requiere } \\
\text { comunicación } \\
\text { verbal }\end{array}$ & $\begin{array}{l}\text { El trabajo requiere } \\
\text { comunicación } \\
\text { verbal }\end{array}$ & $\begin{array}{l}\text { El trabajo } \\
\text { requiere } \\
\text { concentración }\end{array}$ \\
\hline 1 & inferior a $60 \mathrm{dBA}$ & inferior a $50 \mathrm{dBA}$ & inferior a $45 \mathrm{dBA}$ \\
\hline 2 & $60-70 \mathrm{dBA}$ & $50-60 \mathrm{dBA}$ & $45-55 \mathrm{dBA}$ \\
\hline 3 & $70-80 \mathrm{dBA}$ & $60-70 \mathrm{dBA}$ & $55-65 \mathrm{dBA}$ \\
\hline 4 & $80-90 \mathrm{dBA}$ & $70-80 \mathrm{dBA}$ & $65-75 \mathrm{dBA}$ \\
\hline 5 & superior a $90 \mathrm{dBA}$ & superior a $80 \mathrm{dBA}$ & superior a $75 \mathrm{dBA}$ \\
\hline
\end{tabular}

Indique su puntuación de acuerdo 0

desacuerdo (0-5)

14. Los ruidos nocivos se eliminan en su origen.

Si la respuesta es $\underline{\mathrm{N} O}$, valore los motivos: (De 0 a 5 )

14.1 No hay un aislamiento eficaz contra el ruido.

14.2 No se han tomado medidas de emergencia contra el ruido

( ej.: limitación del tiempo de trabajo,

utilización de equipos de protección personal).

15. CLIMA

Especique las condiciones climáticas.

Temperatura

H umedad

Temp. radiante

Corrientes

16. El clima es confortable

Si la respuesta es $\underline{\mathrm{N} o}$, valore lo siguiente: (D e 0 a 5)

16.1 Sensación térmica (elija una):

fría, fresca, neutra, cálida, excesivamente calurosa

16.2 L os dispositivos de ventilación (ventiladores, ventanas, aire acondicionado) son inadecuados. $\square$

16.3 No se han aplicado medidas que regulen los límites de exposición (si existen, explíquelas).

16.4 L os trabajadores no utilizan prendas para protegerse o procurarse calor .

16.5 No hay fuentes o agua fresca disponibles cerca.

17. ILUMINACION

El lugar de trabajo, las máquinas están bien iluminados en todo momento. S Sí/ No

Si la respuesta es $\underline{\mathrm{No}}$, valore lo siguiente: (De 0 a 5)

17.1 La iluminación es suficientemente intensa.

17.2 La iluminación del área de trabajo es adecuadamente uniforme.

17.3 El parpadeo es escaso o inexistente.

17.4 L a formación de sombras no causa problemas.

17.5 L os reflejos molestos son escasos 0 inexistentes. 
17.6 La dinámica del color (objetos resaltados por el calor, calidez del color) es adecuada.

18. POLVO, HUMO, ELEMENTOSTÓXICOS El ambiente está libre de polvo, humos y sustancias tóxicas excesivos.

Si la respuesta es $\underline{\mathrm{N} o}$, valore lo siguiente:

18.1 La ventilación y los sistemas de extracción no son eficaces para la salida de humos, vapores y polvo.

18.2 Faltan medidas de protección para situaciones de emergencia por escape o contacto con sustancias tóxicas o peligrosas. Indique los compuestos químicos tóxicos:

18.3 M uestreo irregular de las sustancias químicas tóxicas en el lugar de trabajo.

18.4 Falta de equipos de protección personal (por ejemplo guantes, zapatos, mascarillas, delantales).

19. RADIACION

Los trabajadores están bien protegidos contra la radiación.

$\mathrm{Si}$ la respuesta es $\mathrm{No}$, indique el grado de exposición (consulte la lista de comprobación ISSA, E rgonomía):

19.1 Radiación UV (200 nm - $400 \mathrm{~nm})$.

19.2 Radiación IR (780 nm - $100 \mu \mathrm{m})$.

$19.3 \mathrm{R}$ adiactividad/ rayos $\times(<200 \mathrm{~nm})$.

$19.4 \mathrm{M}$ icroondas (1 mm - $1 \mathrm{~m})$.

19.5 Láseres (300 nm - 1,4 $\mu \mathrm{m})$.

19.60 tros (menciónelo):

20. VIBRACIONES

Las máquinas pueden accionarse sin que se transmitan vibraciones al cuerpo del operador.

Sí/ No

Si la respuesta es $\underline{\mathrm{No}}$, valore lo siguiente: (D e 0 a 5)

20.1 La vibración se transmite a todo el cuerpo a través de los pies.

20.2 La transmisión de la vibración se produce a través del asiento (por ejemplo, máquinas móviles que el operador maneja sentado).

20.3 La vibración se transmite a través del sistema mano-brazo (por ejemplo, herramientas manuales, máquinas que el operador maneja mientras camina).
20.4 Exposición prolongada a una fuente continua o repetitiva de vibraciones.

20.5 Las fuentes de la vibración no pueden aislarse ni eliminarse.

20.6 Identifique las fuentes de la vibración.

Comentarios y sugerencias, ítems 13 a 20:

VIII. O rganización del tiempo de trabajo

Indique el horario de trabajo: horas de trabajo/ día/ semana/ año, incluido el trabajo estacional y el sistema de turnos.

21. La presión del tiempo de trabajo es mínima.

Si la respuesta es $\underline{\mathrm{N} O}$, valore lo siguiente:

21.1 El trabajo se realiza de noche.

21.2 El trabajo implica realizar horas extras. Especifique la duración media aproximada:

21.3 Las tareas pesadas están desigualmente distribuidas durante los turnos.

21.4 El personal trabaja a un ritmo o con un límite de tiempo predeterminado.

21.5 No se han incorporado medidas contra la fatiga o sistemas de pausas suficientes (utilice criterios cardiorrespiratorios para indicar lo pesado del trabajo).

Comentarios y sugerencias, ítems 21 a 21.5:

\section{\ Valoración del analista}

Valoración del trabajador $\square$

D. Aspecto perceptual o motor

Respuestas/ puntuación

IX. Dispositivos de visualización

22. Los dispositivos de visualización (calibres, metros, señales de alarma) pueden leerse fácilmente.

Si la respuesta es $\underline{\mathrm{N} o}$, valore las dificultades:

22.1 Iluminación insuficiente (consulte el ítem no 17).

22.2 Posición forzada de la cabeza/ ojos respecto a la línea de visión. 
22.3 El estilo de los números o la progresión numérica de los mismos en los dispositivos de presentación de la información produce confusión y provoca errores de lectura.

22.4 No hay dispositivos digitales de presentación de la información para realizar lecturas precisas.

22.5 La distancia de lectura es demasiado grande para poder leer con precisión.

22.6 La información visual no se entiende fácilmente.

22.7 La información visual cambia antes de que se pueda realizar alguna acción.

23. L L as señales de emergencia se reconocen fácilmente.

Si la respuesta es $\underline{\mathrm{N} 0}$, valore los motivos:

23.1 Las señales visuales o auditivas no son conformes con el proceso de trabajo.

23.2 Las señales intermitentes están fuera del campo visual.

23.3 Las señales auditivas no son audibles.

24. La forma en que están dispuestos los dispositivos de presentación de la información es lógica.

Sí/ No

Si la respuesta es $\underline{\mathrm{N} 0}$, valore lo siguiente:

24.1 L os dispositivos de presentación de la información no se distinguen por su forma, posición, color o tono.

24.2 Los dispositivos críticos de presentación de la información, y de uso frecuente, están alejados de la línea central de visión.

X. Controles

25. L os controles (interruptores, botones, grúas, volantes, pedales) son fáciles de manejar.

Si la respuesta es $\underline{\mathrm{N} o}$, las causas son:

25.1 La posición de los controles de manos o pies es incómoda.

25.2 L os controles o herramientas no están accesibles.

25.3 Las dimensiones de los controles no se ajustan a la parte del cuerpo que los maneja.

25.4 Es necesario ejercer mucha fuerza para activar los controles.

25.5 L os controles requieren gran precisión y velocidad.

25.6 Los controles no tienen la forma adecuada para un buen agarre.

25.7 Los controles no tienen los colores o símbolos tipificados para su identificación.
25.8 L os controles provocan una sensación desagradable (calor, frío, vibración).

26. L L as señales y controles (combinados) son compatibles con una respuesta humana fácil y natural.

$\mathrm{Si}$ la respuesta es $\underline{\mathrm{No}}$, valore lo siguiente:

26.1 No están suficientemente próximos unos de otros.

26.2 L as señales o controles no están dispuestos secuencialmente según sus funciones 0 frecuencia de uso.

26.3 Las operaciones con los dispositivos de presentación de la información o con los controles se hacen en secuencia, sin que haya tiempo suficiente para completar la operación (esto provoca una sobrecarga sensorial).

26.4 Falta de coherencia en la dirección del movimiento del dispositivo de presentación de la información o del control (por ejemplo, el movimiento del control hacia la izquierda no produce un movimiento de la unidad hacia la izquierda).

C omentarios y sugerencias, ítems 22 a 26.4:

Valoración del analista

Valoración del trabajador

E. Aspectos técnicos

Respuestas/ puntuación

$X I$. M aquinaria

27. La máquina (carretilla transportadora, carretilla elevadora, máquina herramienta) es fácil de conducir y manejar.

Si la respuesta es $\underline{\mathrm{N}}$, valore lo siguiente:

27.1 La máquina es inestable durante el funcionamiento.

27.2 El mantenimiento de la maquinaria es deficiente.

27.3 No se puede regular la velocidad de manejo de la máquina.

27.4 El volante o manillar se maneja estando de pie.

27.5 L os mecanismos operativos entorpecen los movimientos del cuerpo en el puesto de trabajo.

27.6 R iesgo de accidentes debido a la falta de protección en la máquina. 
27.7 La maquinaria no está equipada con señales de advertencia.

27.8 La máquina no cuenta con un sistema adecuado para amortiguar las vibraciones.

27.9 Los niveles de ruido de la máquina superan los límites legales (consulte los ítems no 13 y 14).

27.10 M ala visibilidad de partes de la máquina y zona adyacente (consulte los ítems no 17 y 22).

XII. H erramientas o instrumentos pequeños

28. Las herramientas o instrumentos que se proporcionan a los operarios son cómodos de manejar.

$\mathrm{Si}$ la respuesta es $\underline{\mathrm{No}}$, valore lo siguiente:

28.1 La herramienta o instrumento no tiene asa o correa para transportarla.

28.2 La herramienta no puede utilizarse con ambas manos indistintamente.

28.3 El peso excesivo de la herramienta provoca hiperextensión de la muñeca.

28.4 La forma y posición del mango no están diseñadas para un buen agarre.

28.5 L as herramientas mecánicas no están diseñadas para manejarse con las dos manos.

28.6 Los bordes cortantes del equipo 0 herramienta pueden causar lesiones.

28.7 No suelen utilizarse accesorios (guantes, etc.) para manejar herramientas que producen vibración.

28.8 Los niveles de ruido de las herramientas mecánicas superan los limites aceptables (consulte el item no 13).

Sugerencias para la mejora, ítem 27 a 28.8:
Sugerencias para la mejora, ítems 29 a 29.5:

Valoración del analista

Valoración del trabajador $\square$

F. Aspecto psicosocial

Respuestas/ puntuación

XIV. Autonomía en el trabajo

30. El trabajo permite la autonomía (por ejemplo, libertad respecto al método de trabajo, al rendimiento, al tiempo de trabajo, al control de calidad).

Si la respuesta es $\underline{\mathrm{N}} \underline{\mathrm{n}}$, las causas posibles son:

30.1 Falta de flexibilidad en el horario de inicio o finalización del trabajo.

30.2 No hay apoyo organizativo, en cuestión de asistencia en el trabajo.

30.3 Número insuficiente de personal para realizar la tarea (trabajo en equipo).

30.4 Rigidez en los métodos y condiciones de trabajo.

$X V$. R etroinformación en el trabajo (intrínseca y extrínseca)

31. El trabajo permite la retroinformación directa sobre la calidad y la cantidad del rendimiento personal.

Si la respuesta es $\underline{\mathrm{No}}$, los motivos son: $\quad$ (D e 0 a 5 )

31.1 No se puede participar en la información y toma de decisiones.

31.2 Limitaciones para el contacto social por barreras físicas.

31.3 Dificultad de comunicación debido al alto nivel de ruido.

31.4 Aumento en la demanda de atención por el ritmo de la máquina.

Si la respuesta es $\underline{\mathrm{N} o}$, valore

lo siguiente:

(De 0 a 5$)$

29.1 Los accesorios de la máquina no se pueden montar y desmontar fácilmente.

29.2 Los puntos peligrosos, las partes móviles y las instalaciones eléctricas no tienen la protección adecuada.

29.3 El contacto directo o indirecto de partes del cuerpo con la maquinaria puede ser peligroso.

29.4 La inspección y el mantenimiento de la máquina es difícil.

29.5 No hay instrucciones claras disponibles para el manejo mantenimiento y seguridad de la máquina.
31.50 tras personas (directivos, compañeros) informan al trabajador sobre su eficacia y rendimiento en el trabajo.

idad y definición de tareas

32. El trabajo comprende diversas tareas y deja lugar para la espontaneidad por parte del trabajador.

Si la respuesta es $\underline{\mathrm{N} o}$, valore lo siguiente:

32.1 Las funciones y los objetivos del trabajador son ambiguos.

32.2 La maquinaria, el proceso o el grupo de trabajo imponen restricciones de trabajo. 
32.3 La relación trabajador-máquina suscita conflictos en relación con el comportamiento que se espera del operador.

32.4 El nivel de estimulación es limitado (por ejemplo, un entorno visual y auditivo siempre invariable).

32.5 El trabajo es muy aburrido.

32.6 Campo de trabajo limitado para la ampliación de tareas.

XVII. I dentificación con la tarea y significado

33. Al trabajador se le asigna una serie de tareas y él organiza su propio tiempo para llevarlas a cabo (p.ej.: planifica y ejecuta el trabajo e inspecciona y controla los productos).

Valore su acuerdo o desacuerdo (0-5)

34. El trabajo es importante en la organización. Es reconocido y valorado por los demás.

(Valore su acuerdo o desacuerdo)

XVIII. Sobrecarga y subcarga mental

35. El trabajo consiste en tareas para las que existen sistemas de información y comunicación claros y bien definidos.

Si la respuesta es $\underline{\mathrm{N} o}$, valore lo siguiente:

35.1 Se proporciona una extensa información relacionada con el trabajo.

35.2 Es necesario manejar información en situaciones de presión (por ejemplo, maniobras de emergencia en el control de procesos).

35.3 Sobrecarga de información y gestualización (por ejemplo, tarea de montaje compleja, que no requiere una motivación especial).

35.4 O casionalmente se desvía la atención a otra información distinta de la necesaria para la tarea en cuestión.

35.5 La tarea consiste en una acción motora simple y repetitiva, sólo requiere una atención superficial.
35.6 Las herramientas y equipos no están previamente posicionados para evitar distracciones.

35.7 H ay que realizar elecciones múltiples para la toma de decisiones y para la valoración de los riesgos.

(C omentarios y sugerencias, ítems 30 a 35.7)

$X I X$. Formación y promoción

36. El trabajo ofrece oportunidades para mejorar los conocimientos y las habilidades para el cumplimiento de las tareas.

Si la respuesta es $\underline{\mathrm{No}}$, las causas posibles son:

36.1 No hay posibilidad de promocionar a puestos superiores.

36.2 No hay cursos periódicos de formación para los trabajadores, específicos para el puesto de trabajo.

36.3 Los programas e instrumentos de formación no son fáciles de aprender y utilizar.

36.4 No hay planes de pago de incentivos.

$X X$. Compromiso con la organización

37. Existe un compromiso definido en relación con la eficacia de la organización y el bienestar físico, mental y social.

Valore el grado de disponibilidad de lo siguiente:

37.1 El papel del individuo en la organización es ambiguo y fuente de conflictos.

37.2 Servicios médicos 0 administrativos para la intervención preventiva en situaciones de riesgo.

37.3 M edidas promocionales para controlar el absentismo en el grupo de trabajo.

37.4 N ormas efectivas sobre seguridad.

37.5 Inspecciones laborales y control de mejores prácticas de trabajo.

37.6 Acciones de seguimiento y control de accidentes y lesiones. 
HOJA DE EVALUACION RESUMIDA

A. Breve descripción de la organización, las características del trabajador y la tarea

\begin{tabular}{|c|c|c|c|c|c|c|c|c|c|c|c|}
\hline \multirow[t]{2}{*}{ Módulos } & \multirow{2}{*}{\multicolumn{2}{|c|}{ Secciones }} & \multirow{2}{*}{$\begin{array}{l}\text { № de } \\
\text { ítems } \\
\text { valorados }\end{array}$} & \multicolumn{6}{|c|}{ Gravedad consensuada } & \multirow{2}{*}{$\begin{array}{l}\text { Gravedad } \\
\text { relativa } \\
(\%)\end{array}$} & \multirow{2}{*}{$\begin{array}{l}\text { № de ítems } \\
\text { para interven- } \\
\text { ción inmediata }\end{array}$} \\
\hline & & & & 0 & 1 & 2 & 3 & 4 & 5 & & \\
\hline \multirow[t]{2}{*}{ B. Técnicos } & I. & Especialización laboral & 4 & & & & & & & & \\
\hline & II. & Requisitos de habilidad & 5 & & & & & & & & \\
\hline \multirow[t]{6}{*}{ C. Biológicos } & III. & Actividad física general & 5 & & & & & & & & \\
\hline & IV. & Manipulación manual de cargas & 6 & & & & & & & & \\
\hline & V. & Diseño del lugar o espacio de trabajo & 15 & & & & & & & & \\
\hline & VI. & Postura de trabajo & 6 & & & & & & & & \\
\hline & VII. & Medio ambiente de trabajo & 28 & & & & & & & & \\
\hline & VIII. & Organización del tiempo de trabajo & 5 & & & & & & & & \\
\hline \multirow{2}{*}{$\begin{array}{l}\text { D. Percep- } \\
\text { tual/ motor }\end{array}$} & IX. & Dispositivos de visualización & 12 & & & & & & & & \\
\hline & $X$ & Controles & 10 & & & & & & & & \\
\hline \multirow[t]{3}{*}{ E. Técnicol } & $\mathrm{Xl}$. & Maquinaria & 10 & & & & & & & & \\
\hline & & Herramientas o implementos pequeños & 8 & & & & & & & & \\
\hline & XIII. & Seguridad en el trabajo & 5 & & & & & & & & \\
\hline \multirow[t]{7}{*}{ F. Psicosocial } & XIV. & Autonomía en el trabajo & 5 & & & & & & & & \\
\hline & $X V$. & Retroinformación en el trabajo & 5 & & & & & & & & \\
\hline & & Diversidad y definición de tareas & 6 & & & & & & & & \\
\hline & XVII. & Identidad con la tarea y significado & 2 & & & & & & & & \\
\hline & $X V I I I$. & Sobrecarga o subcarga mental & 7 & & & & & & & & \\
\hline & $X \mid X$ & Formación y promoción & 4 & & & & & & & & \\
\hline & $X X$ & Compromiso con la organización & 6 & & & & & & & & \\
\hline \multicolumn{12}{|c|}{ Evaluación global } \\
\hline \multicolumn{3}{|c|}{ Gravedad consensuada de los módulos } & \multicolumn{9}{|c|}{ Comentarios } \\
\hline \multicolumn{2}{|c|}{ A } & $\square$ & & & & & & & & & \\
\hline \multicolumn{2}{|l|}{ B } & $\square$ & & & & & & & & & \\
\hline \multicolumn{2}{|l|}{ C } & $\square$ & & & & & & & & & \\
\hline \multicolumn{2}{|l|}{ D } & $\square$ & & & & & & & & & \\
\hline \multicolumn{2}{|l|}{ E } & $\square$ & & & & & & & & & \\
\hline \multicolumn{2}{|l|}{$\mathrm{F}$} & $\square$ & & & & & & & & & \\
\hline & & & Analista de & a & & & & & & & \\
\hline
\end{tabular}




\section{- ANTRO POMETRIA}

M elchior re M asali*

La antropometría es una rama fundamental de la antropología física. Trata el aspecto cuantitativo. Existe un amplio conjunto de teorías y prácticas dedicado a definir los métodos y variables para relacionar los objetivos de diferentes campos de aplicación. En el campo de la salud y seguridad en el trabajo y de la ergonomía, los sistemas antropométricos se relacionan principalmente con la estructura, composición y constitución corporal y con las dimensiones del cuerpo humano en relación con las dimensiones del lugar de trabajo, las máquinas, el entorno industrial y la ropa.

\section{Variables antropométricas}

U na variable antropométrica es una característica del organismo que puede cuantificarse, definirse, tipificarse y expresarse en una unidad de medida. L as variables lineales se definen generalmente como puntos de referencia que pueden situarse de manera precisa sobre el cuerpo. Los puntos de referencia suelen ser de dos tipos: esquelético-anatómicos, que pueden localizarse y seguirse palpando las prominencias óseas a través de la piel, y las referencias virtuales, que se definen como distancias máximas 0 mínimas utilizando las ramas de un pie de rey.

Las variables antropométricas tienen componentes tanto genéticos como medioambientales y pueden utilizarse para definir la variabilidad individual o de la población. La elección de las variables debe estar relacionada con el objetivo específico de la investigación y tipificarse con otro tipo de investigaciones en el mismo campo, ya que el número de variables descrito en la literatura es extremadamente grande: se han descrito hasta 2.200 variables para el cuerpo humano.

Las variables antropométricas son principalmente medidas lineales, como la altura o la distancia con relación al punto de referencia, con el sujeto sentado o de pie en una postura tipificada; anchuras, como las distancias entre puntos de referencia bilaterales; longitudes, como la distancia entre dos puntos de referencia distintos; medidas curvas, o arcos, como la distancia sobre la superficie del cuerpo entre dos puntos de referencia, y perímetros, como medidas de curvas cerradas alrededor de superficies corporales, generalmente referidas en al menos un punto de referencia o a una altura definida.

0 tras variables pueden requerir métodos o instrumentos especiales. Por ejemplo, el espesor de los pliegues de la piel se mide con un calibrador especial de presión constante. Los volúmenes se calculan o se miden por inmersión en agua. Para obtener información completa sobre las características de la superficie corporal, puede trazarse una matriz de puntos de superficie mediante técnicas bioestereométricas.

\section{Instrumentos}

A pesar de que se han descrito y utilizado instrumentos antropométricos complejos para obtener datos de forma automatizada, los instrumentos antropométricos básicos son bastante simples y fáciles de utilizar. Debe tenerse mucho cuidado para evitar errores comunes derivados de una mala interpretación de los puntos de referencia o de una postura incorrecta del sujeto.

El instrumento antropométrico más corriente es el antropómetro y consiste en una varilla rígida de 2 metros de largo con dos escalas de medición que permiten determinar las

* Este artículo está adaptado de la 3a edición de la Encidopedia de Salud y Seguridad en el Trabajo.
Figura 29.7 - Antropómetro.

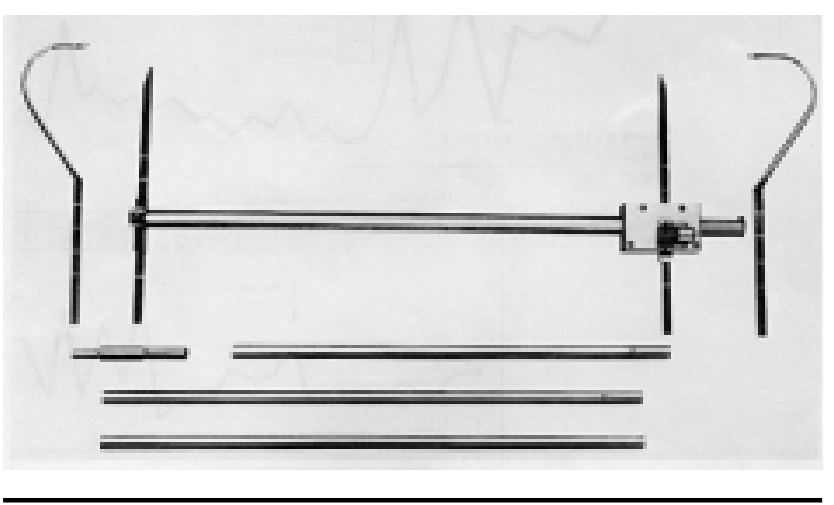

dimensiones corporales verticales, como la altura de los puntos de referencia desde el suelo o el asiento, y las dimensiones transversales, como las anchuras.

G eneralmente, la varilla puede dividirse en 3 ó 4 secciones acoplables entre sí. Un accesorio deslizante con un extremo recto 0 curvo permite medir alturas desde el suelo o diámetros a partir de un punto fijo. Existen antropómetros más complejos con una sola escala que sirve para medir tanto alturas como diámetros, lo que evita errores en la elección de las escalas, o que cuentan con un dispositivo de lectura electrónico o mecánico digital (Figura 29.7).

U n estadiómetro es un antropómetro fijo, que por lo general se utiliza únicamente para medir la estatura y que se encuentra frecuentemente asociado con una báscula de escala transversal.

Para medir los diámetros transversales pueden utilizarse distintos tipos de calibradores: los pelvímetros, para mediciones de hasta $600 \mathrm{~mm}$ o los cefalómetros, para medidas de hasta $300 \mathrm{~mm}$. Este último es particularmente adecuado para mediciones de la cabeza cuando se utiliza junto con un compás extensible (Figura 29.8)

La tabla para pies se utiliza para medir los pies y la tabla para cabeza proporciona las coordenadas cartesianas de la cabeza

Figura 29.8 - Pie de rey y compás de espesores.

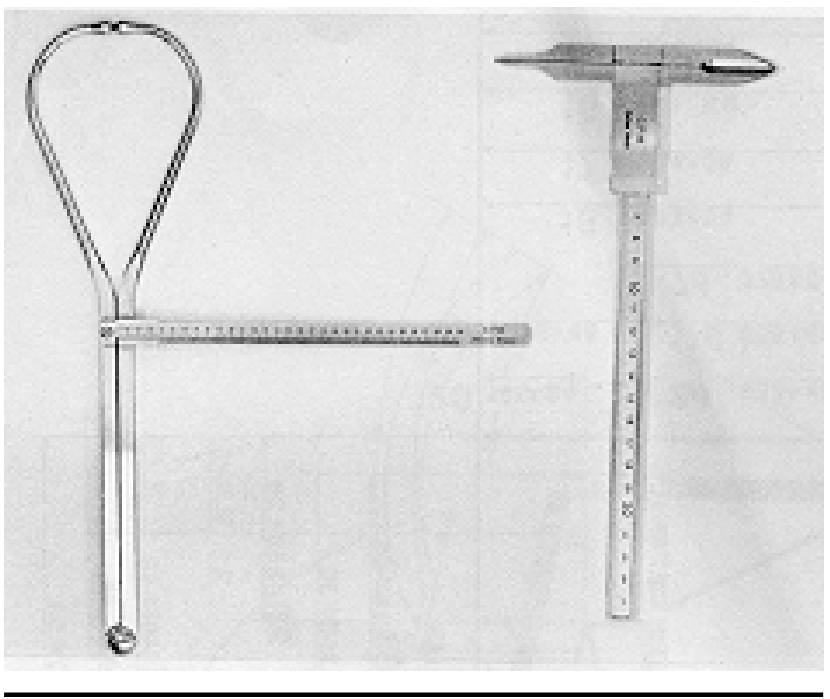


Figura 29.9 - Conjunto básico de variables antropométricas.
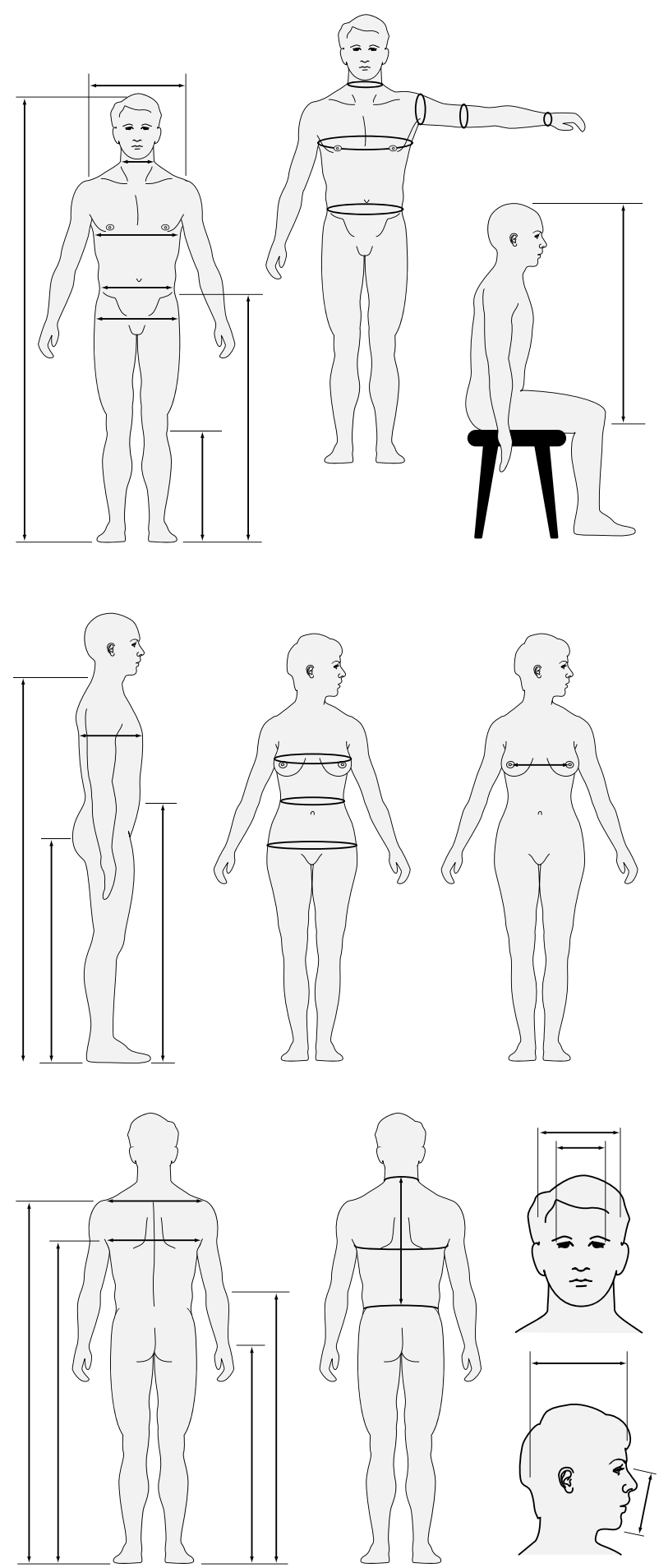

llustración de algunas de las medidas que se indican en la Tabla 29.1.

cuando se orienta en el "plano de Frankfurt", un plano horizontal que pasa a través de los puntos de referencia del porion y orbital de la cabeza. Las dimensiones de la mano pueden medirse con un calibrador o con un dispositivo especial compuesto por cinco escalas deslizantes.
El grosor de los pliegues de la piel puede medirse con un calibrador de pliegues de piel de presión constante (generalmente $9,81 \times 10^{4} \mathrm{~Pa}$-, que es la presión que ejerce un peso de $10 \mathrm{~g}$ sobre un área de $1 \mathrm{~mm}^{2}$ ).

Para los arcos y contornos, generalmente se utiliza una cinta de acero estrecha y flexible de sección plana. Debe evitarse el uso de cintas metálicas que tienden a enderezarse solas.

\section{Sistemas de variables}

Un sistema de variables antropométricas es un conjunto coherente de medidas corporales obtenidas para resolver un problema específico.

En el campo de la ergonomía y la seguridad, el problema principal consiste en adaptar el equipo y el espacio de trabajo a las personas y determinar las tallas exactas de la ropa.

El equipo y el espacio de trabajo requieren principalmente mediciones lineales de las extremidades y de segmentos corporales, que pueden calcularse fácilmente a partir de las alturas y diámetros de referencias. El tamaño de la ropa, en cambio, se basa principalmente en las mediciones de arcos, contornos y longitudes determinadas con una cinta flexible. Ambos sistemas pueden combinarse de acuerdo con las necesidades.

En cualquier caso, es absolutamente necesario contar con una referencia espacial precisa para cada medición. Por lo tanto, los puntos de referencia deben estar relacionados con alturas y diámetros y cada arco o contorno debe tener un punto de referencia definido. También deben indicarse las alturas y las pendientes.

En un estudio concreto, el número de variables debe limitarse al mínimo para evitar un estrés innecesario al sujeto y al operador.

El conjunto básico de variables para el espacio de trabajo se ha reducido a 33 variables medidas (Figura 29.9) más 20 derivadas de cálculos sencillos. Para un estudio militar con fines generales, Hertzberg y sus colaboradores utilizaron 146 variables. Para el diseño de ropa y con fines biológicos generales, el Ente italiano de la moda (Ente I taliano della M oda) utiliza un conjunto de 32 variables de uso general y 28 variables técnicas. La norma alemana (DIN 61 516) de control de dimensiones corporales para el diseño de ropa incluye 12 variables. La recomendación de la O rganización Internacional de N ormalización (ISO ) para las mediciones antropométricas incluye una lista básica de 36 variables (véase Tabla 29.1). L as Tablas I nternacionales de Datos A ntropométricos publicadas por la O IT indican 19 dimensiones corporales para las poblaciones de 20 regiones distintas del mundo (Jürgens, Aune y Pieper 1990).

\section{Precisión y errores}

La precisión en las dimensiones de los organismos vivos debe considerarse de forma estocástica, ya que el cuerpo humano es sumamente impredecible, tanto como estructura estática como dinámica.

Un solo individuo puede crecer o cambiar su masa muscular o la cantidad de grasa, sufrir cambios a nivel esquelético como consecuencia del envejecimiento, la enfermedad o un accidente o modificar su comportamiento o su postura. Distintos sujetos tienen proporciones diferentes, no sólo en cuanto a sus dimensiones generales. Los sujetos altos no son sólo versiones alargadas de los más bajos: los tipos de constitución y los somatotipos varían probablemente más que las dimensiones generales.

El uso de maniquíes, en especial los que representan a los percentiles estándar 5, 50 y 95 para los estudios de ajuste, puede conducir a error si no se tienen en cuenta las variaciones en las proporciones corporales. 
Tabla 29.1 - Lista fundamental antropométrica básica.

1.1 Alcance hacia adelante (hasta el puño, con el sujeto de pie, erguido, contra una pared)

1.2 Estatura (distancia vertical del suelo al vértex)

1.3 Altura de los ojos (del suelo al vértice interior del ojo)

1.4 Altura de los hombros (del suelo al acromion)

1.5 Altura del codo (del suelo a la depresión radial del codo)

1.6 Altura de la entrepierna (del suelo al hueso púbico)

1.7 Altura de la punta de los dedos (del suelo al eje de agarre del puño)

1.8 Anchura de los hombros (anchura biacromial)

1.9 Anchura de la cadera, de pie (distancia entre caderas)

2.1 Altura sentado (desde el asiento hasta el vértex)

2.2 Altura de los ojos, sentado (desde el asiento hasta el vértice interior del ojo)

2.3 Altura de los hombros, sentado (del asiento al acromion)

2.4 Altura del codo, sentado (del asiento al punto más bajo del codo doblado)

2.5 Altura de las rodillas (desde el apoyo de los pies hasta la superficie superior del muslo)

2.6 Longitud de la parte inferior de la pierna (altura de la superficie de asiento)

2.7 Longitud del antebrazo (de la parte posterior del codo doblado al eje del puño)

2.8 Profundidad del cuerpo, sentado (profundidad del asiento)

2.9 Longitud de rodilla-nalga (desde la rótula hasta el punto más posterior de la nalga)

2.10 Distancia entre codos (distancia entre las superficies laterales de ambos codos)

2.11 Anchura de cadera, sentado (anchura del asiento)

3.1 Anchura del dedo índice, proximal (en la articulación entre las falanges medial y proximal)

3.2 Anchura del dedo índice, distal (en la articulación entre las falanges medial y distal)

3.3 Longitud del dedo índice

3.4 Longitud de la mano (de la punta del dedo medio al estiloide)

3.5 Anchura de la mano (en los metacarpios)

3.6 Perímetro de la muñeca

4.1 Anchura del pie

4.2 Longitud del pie

5.1 Perímetro de la cabeza (en la glabela)

5.2 Arco sagital (de la glabela al inión)

5.3 Longitud de la cabeza (de la glabela al opistocráneo)

5.4 Anchura de la cabeza (máximo a la altura de las orejas)

5.5 Arco bitragial (sobre la cabeza y entre las orejas)

6.1 Circunferencia de la cintura (en el ombligo)

6.2 Altura de la tibia (del suelo al punto más alto en el borde anteromedial del glenoide de la tibia)

6.3 Altura cervical sentado (hasta la punta de la apófisis espinosa de la séptima vértebra cervical).
Pueden derivarse errores de la mala interpretación de los puntos de referencia y del uso incorrecto de los instrumentos (errores personales), del uso de instrumentos poco precisos o inexactos (errores instrumentales) o de los cambios posturales del sujeto (errores del sujeto). Estos últimos pueden deberse a dificultades en la comunicación si los antecedentes culturales 0 lingüísticos del sujeto son distintos de los del operador.

\section{Tratamiento estadístico}

L os datos antropométricos deben ser analizados mediante procedimientos estadísticos, especialmente en el campo de los métodos de inferencia, en los que se aplican métodos de una sola variable (media, moda, percentiles, histogramas, análisis de varianza, etc.), de dos variables (correlación, regresión) o de múltiples variables (correlación y regresión múltiples, análisis factorial, etc.). Se han desarrollado varios métodos gráficos basados en aplicaciones estadísticas para clasificar los tipos humanos (antropometrogramas, morfosomatogramas).

\section{Muestreo y análisis}

Dado que no es posible obtener datos antropométricos de la población completa (excepto en los pocos casos en que la población es particularmente pequeña), generalmente es necesario tomar muestras de la población. El punto inicial de cualquier análisis antropométrico debería ser la definición aleatoria de la muestra. Para mantener el número de sujetos medidos en un nivel razonable, generalmente es necesario recurrir a muestras estratificadas con múltiples fases. Esto permite una subdivisión más homogénea de la población en varias clases o estratos.

La población puede subdividirse por sexo, grupo de edades, área geográfica, variables sociales, actividad física, etc.

Las formas de análisis deben diseñarse teniendo en cuenta tanto el procedimiento de medición como el tratamiento de los datos. D ebe realizarse un estudio ergonómico preciso del procedimiento de medición con el fin de reducir la fatiga del operador y los posibles errores. Por este motivo, las variables deben agruparse de acuerdo con el instrumento utilizado y ordenarse secuencialmente para reducir la cantidad de flexiones que debe realizar el operador.

Para reducir el efecto de los errores personales, un solo operador debe realizar el análisis. Si es necesario que participe más de un operador, estos deberán entrenarse para garantizar que las mediciones sean reproducibles.

\section{Antropometría poblacional}

Aún sin considerar el tan criticado concepto de "raza", las poblaciones humanas son muy variables tanto en lo referente al tamaño de los individuos como a la distribución de los tamaños. En general, las poblaciones humanas no son estrictamente mendelianas; son, en general, el resultado de la suma de caracteres. En ocasiones, dos o más poblaciones, con distintos orígenes y grado de adaptación, viven juntas en la misma zona sin que haya mezcla entre ellas. Esto complica la distribución teórica de las características. Desde el punto de vista antropométrico, los sexos son poblaciones distintas. Las poblaciones de empleados pueden no corresponder exactamente a la población biológica de la misma zona como consecuencia de una posible selección de aptitudes o de una autoselección debido a la elección del trabajo.

L as poblaciones de distintas áreas pueden diferir como consecuencia de distintas condiciones de adaptación o de estructuras biológicas y genéticas.

Cuando es importante realizar un ajuste preciso, es necesario realizar un análisis en una muestra aleatoria. 


\section{Estudios de adaptación y regulación}

La adaptación del espacio o equipo de trabajo al usuario puede depender no sólo de las dimensiones corporales, sino también de otras variables como la tolerancia a la incomodidad y al tipo de actividades, ropa, herramientas y condiciones medioambientales. Puede utilizarse la siguiente combinación: una lista de comprobación de factores relevantes, un simulador y una serie de estudios de ajuste en los que se utilice una muestra de individuos elegidos para representar el intervalo de tamaños corporales de la población de usuarios esperada.

El objetivo es determinar los intervalos de tolerancia para todos los individuos. Si los intervalos se superponen, es posible seleccionar un intervalo final más estrecho que no esté fuera de los límites de tolerancia de ninguno de los individuos. Si no hay superposición, será necesario hacer que la estructura sea ajustable o bien, proporcionarla en distintos tamaños. Si hay más de dos dimensiones ajustables, el individuo puede no ser capaz de decidir cuál de los posibles ajustes sea el más adecuado para él.

La capacidad de adaptación puede ser un tema complicado, especialmente cuando las posturas incómodas producen fatiga. Así, es necesario proporcionar al usuario indicaciones precisas, ya que, frecuentemente, éste sabe muy poco acerca de sus propias características antropométricas. En general, un diseño preciso debería reducir la necesidad de ajustes al mínimo. En cualquier caso, es preciso recordar siempre que el tema de la investigación es la antropometría, y no sólo la ingeniería.

\section{Antropometría dinámica}

L a antropometría estática puede proporcionar una gran cantidad de información sobre el movimiento si se ha elegido un conjunto adecuado de variables. Sin embargo, cuando los movimientos son complicados y se desea realizar un buen ajuste con el entorno industrial, como sucede con la mayoría de las interfaces usuariomáquina y persona-vehículo, es necesario realizar un análisis preciso de las posturas y los movimientos. Esto puede hacerse por medio de simulaciones adecuadas, que permiten el trazado de las líneas de alcance, o de fotografías. En este último caso, una cámara equipada con una lente telescópica y una varilla antropométrica, colocada en el plano sagital del sujeto, permiten realizar fotografías estandarizadas con poca distorsión de la imagen. Pequeñas etiquetas en las articulaciones del sujeto permiten el seguimiento exacto de los movimientos.

0 tra forma de estudiar los movimientos es establecer los cambios posturales de acuerdo con una serie de planos horizontales y verticales que pasan a través de las articulaciones. Nuevamente, con el uso de modelos humanos informatizados y los sistemas de diseño asistido por ordenador (CAD), es posible incluir la antropometría dinámica en el diseño del lugar de trabajo ergonómico.

\section{TRABAJO MUSCULAR}

\section{Juhani Smolander y} Veikko Louhevaara

\footnotetext{
El trabajo muscular en las actividades laborales

En los países industrializados, aproximadamente el $20 \%$ de los trabajadores continúan desarrollando trabajos que requieren un esfuerzo muscular (Rutenfranz y cols. 1990). El número de trabajos físicos pesados convencionales se ha reducido pero, en cambio, muchos trabajos se han vuelto más estáticos, asimétricos y sedentarios. En los países en desarrollo, el esfuerzo muscular de todo tipo sigue siendo una práctica muy extendida.
}

El trabajo muscular en las actividades laborales puede dividirse, en general, en cuatro grupos: el trabajo muscular dinámico pesado, la manipulación manual de materiales, el trabajo estático y el trabajo repetitivo. El trabajo muscular dinámico pesado lo hallamos en las actividades forestales, agrícolas y en la construcción. La manipulación manual de materiales es común, por ejemplo, en las labores de enfermería, transporte y almacenaje, mientras que el trabajo estático existe en las oficinas, en la industria electrónica y en las tareas de mantenimiento y reparación. Las tareas repetitivas pueden encontrarse, por ejemplo, en las industrias de procesamiento de alimentos y de la madera.

Es importante destacar que la manipulación manual de materiales y el trabajo repetitivo son básicamente trabajos musculares dinámicos o estáticos, o una combinación de ambos.

\section{Fisiología del trabajo muscular}

\section{Trabajo muscular dinámico}

En el trabajo dinámico, los músculos esqueléticos implicados se contraen y relajan rítmicamente. EI flujo sanguíneo que llega a los músculos aumenta para satisfacer las necesidades metabólicas. Este aumento del flujo sanguíneo se logra incrementando el bombeo del corazón (gasto cardíaco), reduciendo el flujo que llega a las áreas inactivas, como los riñones y el hígado, y aumentando el número de vasos sanguíneos abiertos en la musculatura que está interviniendo en el trabajo. La frecuencia cardíaca, la presión sanguínea y el consumo de oxígeno en los músculos, aumentan en relación directa a la intensidad del trabajo. También aumenta la ventilación pulmonar, debido a la mayor profundidad de las respiraciones y al aumento de la frecuencia respiratoria. La finalidad de la activación de todo el sistema cardiorrespiratorio es mejorar la llegada de oxígeno a los músculos implicados. El nivel de consumo de oxígeno, medido durante un trabajo muscular dinámico pesado, indica la intensidad del trabajo. El consumo máximo de oxígeno $\left(\mathrm{VO}_{2 \max }\right)$ indica la capacidad máxima de la persona para el trabajo aeróbico. Los valores de consumo de oxígeno pueden traducirse en gasto energético (1 litro de oxígeno consumido por minuto corresponde a aproximadamente $5 \mathrm{kcal} / \mathrm{min} 021 \mathrm{~kJ} / \mathrm{min}$ ).

En el caso del trabajo dinámico, cuando la masa muscular activa es pequeña (por ejemplo, en los brazos), la capacidad máxima de trabajo y el consumo máximo de oxígeno son menores que en el trabajo dinámico realizado con músculos de mayor tamaño. A igual producción de trabajo externo, el trabajo dinámico con músculos pequeños provoca mayores respuestas cardiorrespiratorias (por ejemplo, frecuencia cardíaca, presión sanguínea) que el trabajo con músculos grandes (Figura 29.10).

\section{Trabajo muscular estático}

En el trabajo estático, la contracción muscular no produce movimientos visibles, por ejemplo, en un miembro. El trabajo estático aumenta la presión en el interior del músculo lo que, junto con la compresión mecánica, ocluye la circulación total o parcial de la sangre. El aporte de nutrientes y de oxígeno al músculo y la eliminación de productos metabólicos finales del mismo quedan obstaculizados. De esta forma, en los trabajos estáticos, los músculos se fatigan con más facilidad que en los trabajos dinámicos.

La característica circulatoria más destacada del trabajo estático es el aumento de la presión sanguínea. La frecuencia cardíaca y el gasto cardíaco no varían mucho. Por encima de una determinada intensidad de esfuerzo, la presión de la sangre aumenta en relación directa con la intensidad y la duración del esfuerzo. Además, a igual intensidad relativa del esfuerzo, el trabajo estático realizado con grandes grupos musculares 
Figura 29.10 - Trabajo estático frente a trabajo dinámico.

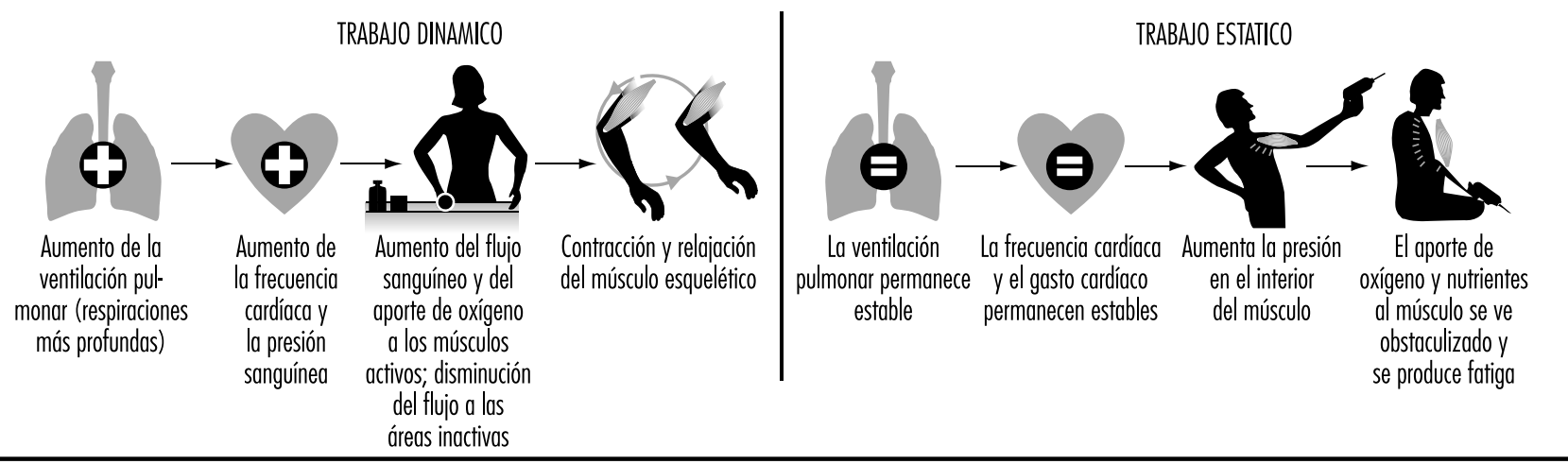

produce una mayor respuesta de la presión sanguínea que el trabajo con músculos más pequeños. (V éase la Figura 29.10.)

En principio, la regulación de la ventilación y de la circulación en el trabajo estático es similar a la del trabajo dinámico, pero las señales metabólicas de los músculos son más fuertes y provocan un patrón de respuestas diferente.

\section{Consecuencias de la sobrecarga muscular en las actividades laborales}

El grado de carga física que experimenta un trabajador en el curso de un trabajo muscular depende del tamaño de la masa muscular que interviene, del tipo de contracciones musculares (estáticas o dinámicas), de la intensidad de las contracciones y de las características individuales.

$M$ ientras la carga de trabajo muscular no supere la capacidad física del trabajador, el cuerpo se adaptará a la carga y se recuperará rápidamente una vez terminado el trabajo. Si la carga muscular es demasiado elevada, se producirá fatiga, se reducirá la capacidad de trabajo y la recuperación será más lenta. Las cargas más elevadas o la sobrecarga prolongada puede ocasionar daños físicos en forma de enfermedades profesionales o relacionadas con el trabajo. Por otro lado, el trabajo muscular de cierta intensidad, su frecuencia y su duración, también puede tener un efecto de entrenamiento, como, por otra parte, unas exigencias musculares excesivamente bajas pueden tener efectos de desentrenamiento. Estas relaciones se representan mediante el llamado concepto de estrés-tensión expandido desarrollado por Rohmert (1984) (Figura 29.11).

En general, hay pocas pruebas epidemiológicas de que la sobrecarga muscular sea un factor de riesgo para las enfermedades. Sin embargo, en trabajos con grandes demandas físicas, sobre todo entre trabajadores de más edad, suelen detectarse problemas de salud, incapacidades y sobrecargas subjetivas de trabajo. Además, muchos factores de riesgo de enfermedades musculosqueléticas relacionadas con el trabajo están relacionados con distintos aspectos de la carga de trabajo muscular, como la aplicación de fuerzas, las posturas inadecuadas, el levantamiento de pesos y las sobrecargas repentinas.

U no de los objetivos de la ergonomía ha sido determinar límites aceptables para las cargas de trabajo muscular que podrían aplicarse para evitar la fatiga y las enfermedades. M ientras la prevención de efectos crónicos es el objetivo de la epidemiología, la fisiología se centra especialmente en los efectos a corto plazo, es decir, en la fatiga producida por una determinada tarea o durante una jornada laboral.

\section{Carga de trabajo aceptable en el trabajo muscular dínámico pesado}

La valoración de la carga de trabajo aceptable en tareas dinámicas se ha basado tradicionalmente en la medida del consumo de oxígeno (o en el correspondiente gasto energético). El consumo de oxígeno puede medirse en campo con relativa facilidad mediante aparatos portátiles (sacos de D ouglas, espirómetro de $M$ ax Planck, Oxylog, Cosmed), o puede estimarse a partir de los registros de frecuencia cardíaca, que se obtienen con bastante fiabilidad en el lugar de trabajo, por ejemplo, con un SportTester. La utilización de la frecuencia cardíaca en la estimación del consumo de oxígeno exige una calibración individual frente al consumo de oxígeno medido durante un trabajo estándar realizado en el laboratorio, es decir, el investigador debe conocer el consumo de oxígeno de un individuo a una frecuencia cardíaca determinada. Los registros de frecuencia cardíaca deberán

Figura 29.11 - Modelo de estrés tensión expandida modificado por Rohmert (1984).

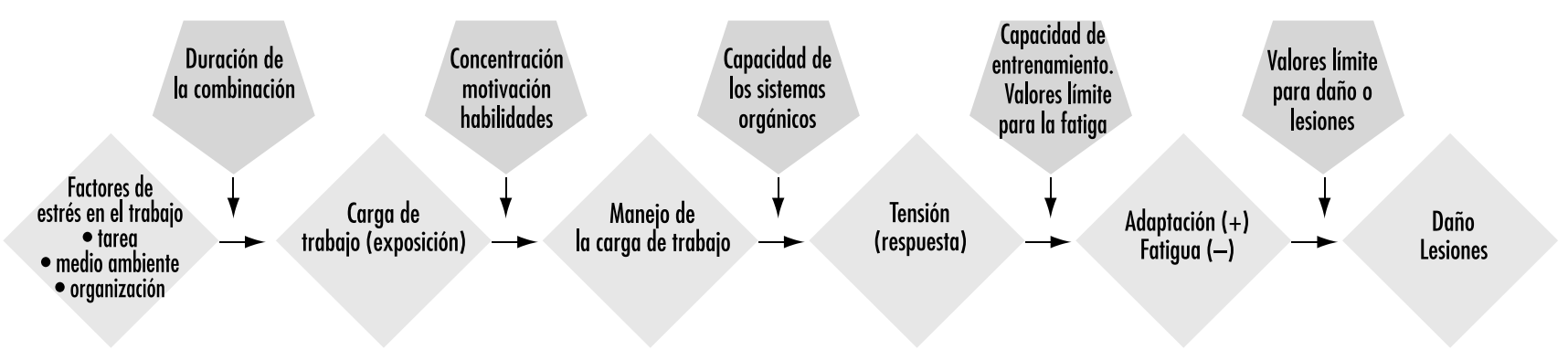


Figura 29.12 • A nálisis de las cargas de trabajo aceptables.

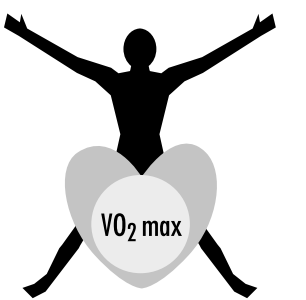

$\mathrm{VO}_{2 \text { max }}$ es el consumo máximo de oxígeno del individuo

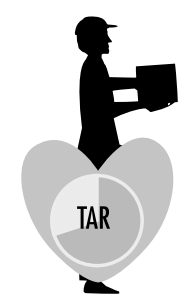

La TAR es el porcentaje de consumo de oxígeno durante el trabajo

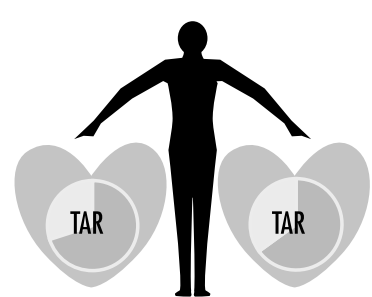

La TAR recomendada es entre un $30 \%$ y un $35 \%$
Los límites de frecuencia cardíaca, en porcentaje, son una aproximación a la TAR (carga de trabajo relativa)

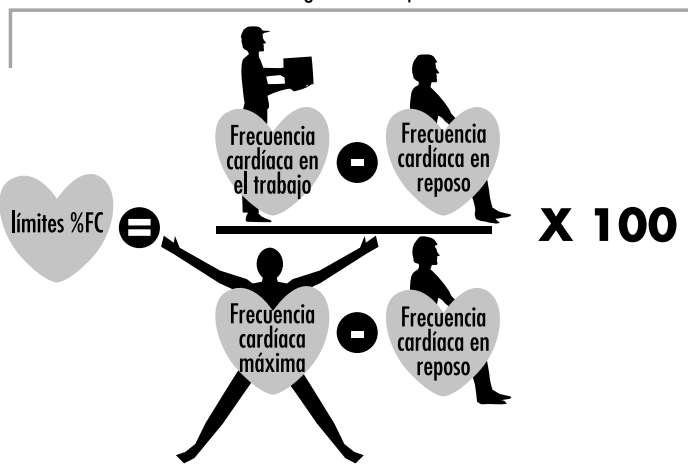

El valor de la frecuencia cardíaca máxima puede medirse en una prueba de ejercicio o tomarse de las tablas publicadas específicas para cada edad manejarse con cuidado, ya que a veces se ven afectados por factores como la forma física, la temperatura ambiente, los factores psicológicos y el tamaño de la masa muscular activa. Así, las medidas de la frecuencia cardíaca pueden conducir a una sobreestimación del consumo de oxígeno, de la misma forma que los valores de consumo de oxígeno pueden dar lugar a una subestimación de la tensión fisiológica global, al reflejar sólo los requerimientos energéticos.

La carga de trabajo relativa se define como la fracción (porcentaje) del consumo de oxígeno del trabajador, medido durante el trabajo, en relación a su $\mathrm{VO}_{2 \max }$ medido en el laboratorio. Si sólo se dispusiera de las medidas de la frecuencia cardíaca, se podría hacer un cálculo aproximado de la carga de trabajo relativa, calculando el porcentaje de frecuencia cardíaca desplazada (\% FC desplazada) con la denominada fórmula de K arvonen, como en la Figura 29.12.

EI VO ${ }_{2 \max }$ suele medirse en un ergociclómetro 0 en una cinta sinfín, cuya eficiencia mecánica es elevada (20-25 \%). Cuando la masa muscular activa es pequeña o el componente estático es elevado, el VO ${ }_{2 \max }$ y la eficacia mecánica serán menores que en el caso de un ejercicio realizado por grupos de músculos grandes. Por ejemplo, se ha detectado que, cuando ordenan paquetes postales, el valor de $\mathrm{VO}_{2 \max }$ de los trabajadores es sólo del $65 \%$ del máximo medido en un ergociclómetro, y la eficiencia mecánica de la tarea es inferior al $1 \%$. Cuando las recomendaciones se basen en el consumo de oxígeno, el tipo de prueba para calcular el valor máximo debe aproximarse a la tarea real tanto como sea posible. Este objetivo, sin embargo, es difícil de conseguir.

Según el estudio clásico de Åstrand (1960) la carga de trabajo relativa no debería superar el $50 \%$ durante una jornada laboral de 8 horas. En sus experimentos, al $50 \%$ de la carga de trabajo, disminuye el peso corporal, la frecuencia cardíaca no alcanza un estado de uniformidad y la incomodidad subjetiva aumenta a lo largo del día. Esta autora recomienda un límite del $50 \%$ de la carga de trabajo relativa, tanto para hombres como para mujeres. M ás tarde averiguó que los obreros de la construcción determinan espontáneamente un nivel de carga de trabajo relativa del $40 \%$ (entre 25-55 \%) durante un día de trabajo. Algunos estudios más recientes han mostrado que el nivel de la carga de trabajo relativa aceptable es inferior al $50 \%$. La mayoría de los autores recomiendan que sea de un 30-35\% para toda la jornada laboral.
O riginalmente, los niveles aceptables de la carga de trabajo relativa fueron desarrollados para el trabajo muscular dinámico puro, algo que raramente se produce en la vida laboral real. Puede ocurrir que los niveles aceptables de la carga de trabajo relativa no se superen, por ejemplo, en un trabajo de levantamiento de pesos, pero la carga localizada sobre la espalda puede exceder, con mucho, los niveles aceptables. Sin embargo, a pesar de sus limitaciones, el cálculo de la carga de trabajo relativa se ha utilizado frecuentemente para valorar la carga física en distintos trabajos.

Además de las medidas o estimaciones del consumo de oxígeno, hay otros métodos disponibles en el campo de la fisiología que también son útiles para cuantificar la carga física en el trabajo dinámico pesado. Las técnicas de observación pueden aplicarse para calcular el gasto energético (por ejemplo, con la ayuda de la escala de E dholm ) (Edholm 1966). La valoración del esfuerzo percibido (RPE) indica la acumulación subjetiva de la fatiga. Los nuevos equipos portátiles de toma de presión sanguínea permiten realizar un análisis más detallado de las respuestas circulatorias.

\section{Carga de trabajo aceptable en la mani pulación manual de materiales}

La manipulación manual de materiales contempla tareas como levantar, transportar, empujar o tirar de diversas cargas externas. L a mayoría de las investigaciones realizadas en este campo se han centrado en los problemas de la zona lumbar, derivados de las tareas de levantamiento de pesos, especialmente desde el punto de vista biomecánico.

Se recomienda un nivel de carga de trabajo relativa del 21-35 \% para las labores de levantamiento de pesos, que es cuando la tarea puede compararse con el consumo máximo de oxígeno obtenido en una prueba de ergociclómetro.

Las recomendaciones basadas en la frecuencia cardíaca pueden ser absolutas o relativas, en función de la frecuencia cardíaca en reposo. Los valores absolutos para hombres y mujeres son 90-112 latidos por minuto durante la manipulación continua de materiales. Estos valores son aproximadamente los mismos que los recomendados para el aumento de la frecuencia cardíaca por encima de los niveles de reposo, es decir de 30 a 35 latidos por minuto. Estas recomendaciones también son aplicables al trabajo muscular dinámico pesado en hombres y mujeres jóvenes y sanos. Sin embargo, como ya se ha dicho antes, los 
datos relativos a la frecuencia cardíaca deberían tratarse con cuidado, ya que también están condicionados por otros factores distintos del trabajo muscular.

Las recomendaciones para determinar una carga de trabajo aceptable durante la manipulación manual de materiales, basadas en los análisis biomecánicos, abarcan diversos factores como el peso de la carga, la frecuencia de la manipulación, la altura a la que hay que levantar la carga, la distancia de la carga al cuerpo y las características físicas de la persona.

En un estudio de campo a gran escala (L ouhevaara, $\mathrm{H}$ akola y Ollila 1990), se averiguó que los varones sanos podían manejar paquetes postales con pesos comprendidos entre cuatro y cinco kilos, durante una jornada entera, sin mostrar signos de fatiga, ni objetiva ni subjetiva. La mayoría de los movimientos se realizaban por debajo del nivel del hombro, la frecuencia media era inferior a ocho paquetes por minuto y el número total de paquetes no alcanzaba los 1.500 por turno de trabajo. La frecuencia cardíaca media de los trabajadores fue de 101 latidos por minuto y su consumo medio de oxígeno de 1,0 l/ min, lo que correspondía al $31 \%$ de la carga de trabajo relativa en relación con el máximo alcanzado en la bicicleta.

La observación de las posturas en el trabajo y el empleo de la fuerza, según el método de OWAS, por ejemplo (K arhu, K ansi y K uorinka 1977), la valoración del esfuerzo percibido y el registro de la presión sanguínea mediante equipos portátiles son también formas adecuadas de valorar el esfuerzo y la tensión en la manipulación manual de materiales. También puede emplearse la electromiografía para valorar las tensiones locales, por ejemplo, en los músculos del brazo y de la espalda.

\section{Carga de trabajo aceptable para trabajos musculares estáticos}

El trabajo muscular estático se requiere principalmente en el mantenimiento de las posturas de trabajo. La duración de la contracción estática depende exponencialmente de la fuerza relativa de la contracción. Esto significa, por ejemplo, que cuando la contracción estática requiere un $20 \%$ de la fuerza máxima de contracción, la duración de la contracción será de cinco a siete minutos, y cuando la fuerza de contracción es del $50 \%$, el tiempo de duración de la contracción será de aproximadamente un minuto.

Algunos estudios anteriores indicaban que no se produce fatiga cuando la fuerza de contracción se sitúa por debajo del $15 \%$ de la fuerza máxima de contracción. Sin embargo, estudios más recientes han demostrado que la fuerza de contracción aceptable es específica para un músculo o grupo de músculos determinados y equivale a un 2-5\% de la fuerza estática máxima. L os límites de estas fuerzas son, sin embargo, difíciles de utilizar en situaciones prácticas porque requieren un registro electromiográfico.

El médico dispone de pocos métodos de campo para cuantificar la tensión producida por el trabajo estático. Algunos métodos de observación (como el de OWAS) permiten analizar la proporción de las posturas desfavorables, es decir, posturas que se desvían de las posiciones medias normales de las principales articulaciones. La medida de la presión sanguínea y la valoración del esfuerzo percibido pueden resultar útiles, pero la frecuencia cardíaca no es tan determinante.

\section{Carga de trabajo aceptable en el trabajo repetitivo}

El trabajo repetitivo realizado con grupos musculares pequeños es similar al trabajo muscular estático, desde el punto de vista de las respuestas circulatorias y metabólicas. Normalmente, en el trabajo repetitivo, los músculos se contraen más de 30 veces por minuto. Cuando la fuerza relativa de la contracción supera el $10 \%$ de la fuerza máxima, la duración de la contracción y la fuerza muscular empiezan a disminuir. Sin embargo, existe una variación individual muy grande en cuanto al tiempo de duración de la contracción. Por ejemplo, el tiempo de duración varía entre 2 y 50 minutos cuando el músculo se contrae entre 90 y 110 veces/ minuto para una fuerza relativa de contracción entre el 10 y el $20 \%$ (Laurig 1974).

Resulta difícil establecer criterios definitivos para el trabajo repetitivo, porque incluso un nivel de trabajo muy ligero como, por ejemplo, el uso del ratón de un ordenador, puede provocar aumentos de la tensión intramuscular, lo que puede conducir a veces a la hinchazón de las fibras musculares, la aparición de dolor y la disminución de la fuerza muscular.

Un trabajo estático y repetitivo de los músculos puede provocar fatiga y reducir la capacidad de trabajo a niveles muy bajos de fuerza relativa. Por lo tanto, la intervención ergonómica deberá tener como objetivo la reducción del número de movimientos repetitivos y de contracciones estáticas tanto como sea posible. Existen muy pocos métodos de estudio de campo para valorar la tensión ocasionada por el trabajo repetitivo.

\section{Prevención de la sobrecarga muscular}

Existen relativamente pocas evidencias epidemiológicas que demuestren que la carga muscular es nociva para la salud. Sin embargo, los estudios fisiológicos y ergonómicos sobre el trabajo indican que la sobrecarga muscular se traduce en fatiga (es decir, en una reducción de la capacidad de trabajo) y puede reducir también la productividad y la calidad del trabajo.

La prevención de la sobrecarga muscular puede estar dirigida al contenido del trabajo, al entorno laboral 0 al trabajador. La carga puede ajustarse mediante medios técnicos centrados en el entorno laboral, en las herramientas o en los métodos de trabajo. La forma más rápida de regular la carga muscular de trabajo es aumentar la flexibilidad del horario de trabajo a nivel individual. Esto supone diseñar un régimen de pausas que tenga en cuenta la carga de trabajo y las necesidades y capacidades de cada individuo.

El trabajo muscular estático y repetitivo debería mantenerse al mínimo. Las fases de trabajo dinámico pesado que se producen de forma ocasional pueden resultar útiles para el mantenimiento de una forma física basada en la resistencia. Probablemente, la actividad física más fácil de incorporar a una jornada laboral es andar a paso ligero o subir escaleras.

La prevención de la sobrecarga muscular, sobre todo, es difícil cuando la forma física o las habilidades de los trabajadores son deficientes. Un entrenamiento adecuado mejorará las habilidades laborales del trabajador y puede reducir las cargas musculares durante el trabajo. Además, el ejercicio físico regular, realizado durante el ocio o durante el trabajo, aumentará la fuerza muscular y la capacidad cardiorrespiratoria del trabajador.

\section{Postura en el trabajo}

Ilkka Kuorinka

La postura que adopta una persona en el trabajo: (la organización del tronco, cabeza y extremidades), puede analizarse y estudiarse desde distintos puntos de vista. La postura pretende facilitar el trabajo, y por ello tiene una finalidad que influye en su naturaleza: su relación temporal y su coste (fisiológico o de otro tipo) para la persona en cuestión. Existe una interacción muy 
Figura 29.13 - Las posturas con las manos demasiado elevadas o con la cintura doblada se cuentan entre las formas más comunes de crear una carga "estática".

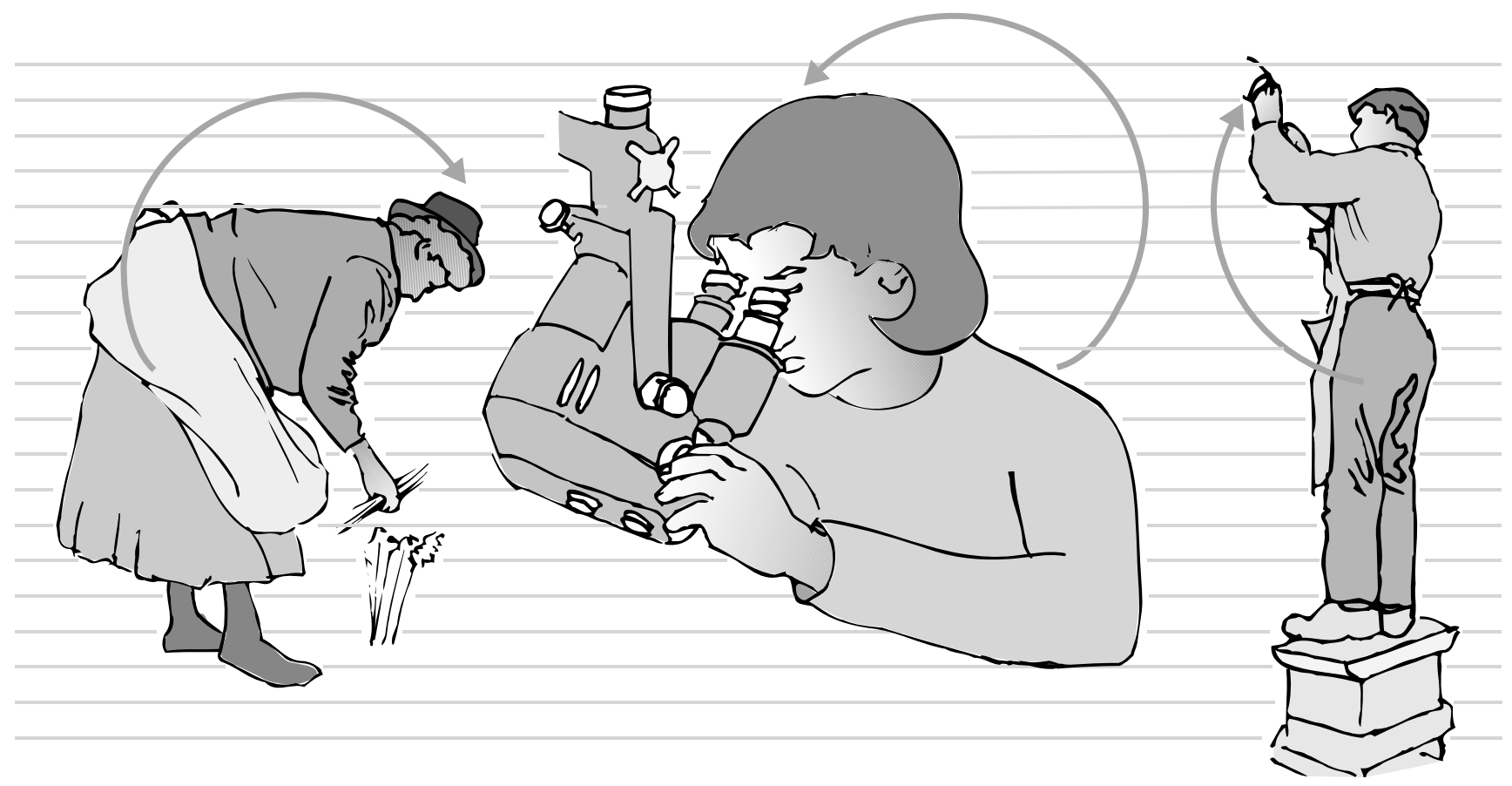

estrecha entre las capacidades fisiológicas del cuerpo y las características y los requisitos del trabajo.

La carga musculosquelética es un elemento necesario para las funciones del organismo e indispensable para el bienestar. D esde el punto de vista del diseño del trabajo, la cuestión es encontrar el equilibrio necesario entre la carga necesaria y la carga excesiva.

Las posturas han interesado a médicos e investigadores, por las siguientes razones:

1. La postura es la fuente de la carga musculosquelética. Excepto cuando estamos relajados, ya sea de pie, sentados o tumbados, los músculos tienen que ejercer fuerzas para equilibrar nuestra postura o controlar los movimientos. En las tareas pesadas típicas, por ejemplo, en la construcción o en el manejo manual de materiales pesados, las fuerzas externas, tanto dinámicas como estáticas, se suman a las fuerzas internas del cuerpo, creando a veces grandes cargas que pueden superar la capacidad de los tejidos. (V éase la Figura 29.13.) Incluso en una postura relajada, cuando el trabajo muscular tiende a cero, los tendones y las articulaciones pueden estar cargados y mostrar signos de fatiga. Un trabajo con una carga aparentemente baja (por ejemplo, el trabajo con un microscopio) puede convertirse en algo tedioso y extenuante cuando se realiza durante un largo período de tiempo.

2. La postura está en estrecha relación con el equilibrio y la estabilidad. De hecho, la postura está controlada por una serie de reflejos nerviosos, en los que la llegada de sensaciones táctiles y visuales procedentes del entorno desempeñan un importante papel. Algunas posturas, como las que se adoptan para alcanzar un objeto distante, son por naturaleza inestables. La pérdida del equilibrio es una causa inmediata común de los accidentes de trabajo. Algunas tareas se ejecutan en un entorno en el que no siempre puede garantizarse la estabilidad, por ejemplo, en el sector de la construcción.

3. La postura es la base de los movimientos precisos y de la observación visual. Muchas tareas requieren una serie de movimientos finos y hábiles de la mano, y una minuciosa observación del objeto de trabajo. En estos casos, la postura se convierte en la plataforma para estas acciones. La atención se dirige a la tarea, y los elementos posturales están destinados a apoyarla: la postura se vuelve más inmóvil, la carga muscular aumenta y se convierte en más estática. U n grupo de investigadores franceses demostró, en un estudio hoy clásico, que la inmovilidad y la carga musculosquelética aumentan en función de la tasa de trabajo (T eiger, Laville y Duraffourg 1974).

4. La postura es una fuente de información sobre los acontecimientos que tienen lugar en el trabajo. La observación de la postura puede ser intencionada o inconsciente. Se sabe que los supervisores experimentados así como los trabajadores emplean las observaciones posturales como indicadores del proceso laboral. En ocasiones, la observación de la postura no es un proceso consciente. Por ejemplo, en una torre de perforación petrolífera los trabajadores se valían de determinadas posturas para comunicarse con otros miembros del equipo durante las distintas fases de la tarea. E sto sucede en condiciones en las que no es posible contar con otro medio de comunicación.

\section{Seguridad, salud y posturas de trabajo}

Desde el punto de vista de la salud y la seguridad, todos los aspectos posturales descritos anteriormente pueden ser importantes. Sin embargo, las posturas causantes de enfermedades musculosqueléticas, como las dolencias en la zona lumbar, son las que han atraído más atención. L os problemas musculosqueléticos 
relacionados con el trabajo repetitivo también tienen que ver con las posturas.

El dolor en la zona lumbar es un término genérico para varios trastornos en esa zona. El dolor lumbar tiene diversas causas y la postura puede ser una de ellas. Los estudios epidemiológicos realizados han demostrado que un trabajo físicamente pesado provoca dolor lumbar y que la postura es un elemento clave de este proceso. $\mathrm{H}$ ay varios mecanismos posibles para explicar por qué ciertas posturas pueden provocar dolor lumbar. Las posturas que obligan a estar inclinado hacia adelante aumentan la carga sobre la espina dorsal y los ligamentos, que son especialmente vulnerables a las cargas cuando están girados. Las cargas externas, sobre todo las dinámicas, como las que originan las sacudidas o los resbalones, pueden aumentar notablemente las cargas en la espalda.

Desde el punto de vista de la seguridad y la salud en el trabajo, es importante identificar las malas posturas y otros elementos de esta índole, como parte del análisis de la seguridad y salud del trabajo en general.

\section{Registro y medición de las posturas de trabajo}

Las posturas pueden registrarse y medirse objetivamente mediante la observación visual o con técnicas de medida más 0 menos sofisticadas. También pueden registrarse utilizando esquemas de autovaloración. La mayoría de los métodos consideran la postura como un elemento dentro de un contexto más amplio, por ejemplo, como parte del contenido del propio trabajo, como sucede en el AET y en los llamados profils des postes (perfiles de puestos) de Renault (L andau y Rohmert 1981; R NU R 1976) o bien, como base para cálculos biomecánicos, que también toman en consideración otros aspectos.

A pesar de los avances en la tecnología de la medición, la observación visual sigue siendo el único método viable para el registro sistemático de las posturas en condiciones de campo. Y aunque la precisión de estas mediciones sigue siendo escasa, las observaciones de las posturas pueden ser una rica fuente de información sobre el trabajo en general.

La siguiente lista de métodos y técnicas de medición muestra una serie de ejemplos seleccionados:

1. Cumplimentación de cuestionarios de autoevaluación y diarios. LoS cuestionarios y diarios de autoevaluación son una forma económica de recopilar información sobre las posturas. Se basan en la percepción del propio sujeto y normalmente se aparta bastante de las posturas "objetivamente" observadas, pero puede, a pesar de todo, proporcionar datos importantes sobre la monotonía del trabajo.

2. Observación de las posturas. La observación de las posturas incluye el registro puramente visual de las posturas y sus componentes y los métodos de entrevista que permiten completar la información. Para estos métodos suele existir apoyo informático. $\mathrm{H}$ ay muchos métodos disponibles para la observación visual. El método puede consistir simplemente en un catálogo de acciones que incluye las posturas del tronco 0 las extremidades (por ejemplo, K eyserling 1986; V an der Beek, Van G aalen y Frings-Dresen 1992). EI método O WAS propone un esquema estructurado para la clasificación y la evaluación de las posturas del tronco y los miembros en los estudios de campo, (K arhu, K ansi y K uorinka 1977). Los métodos de registro y análisis pueden contener esquemas de anotación, algunos de ellos bastante detallados, como sucede con el método del diagrama de la postura de Corlett y Bishop (1976), y pueden proporcionar una valoración de la posición de muchos segmentos anatómicos para cada parte de la tarea (Drury 1987).
3. Análisis postural asistido por ordenador. Los ordenadores han ayudado al análisis postural en muchos aspectos. Los ordenadores portátiles y sus programas especiales permiten registrar fácilmente las posturas y analizarlas rápidamente. Persson y K ilbom (1983) desarrollaron el programa VIRA para el estudio de las extremidades superiores; K erguelen (1986) creó un paquete completo de registro y análisis de las tareas. Kivi y M attila (1991), diseñaron una versión informatizada del OWAS para el registro y el análisis.

El vídeo es normalmente parte integral de cualquier proceso de registro y análisis. EI US National Institute for $\mathrm{O}$ ccupational Safety and Health (NIOSH) ha presentado una serie de directrices para utilizar técnicas de vídeo en el análisis de riesgos (NIOSH 1990).

Los programas de ordenador para biomecánica y antropometría son una herramienta especializada que permite analizar determinados elementos posturales en la actividad laboral y en el laboratorio (por ejemplo, Chaffin 1969).

\section{Factores que afectan a las posturas de trabajo}

Las posturas que se adoptan en el trabajo tienen un objetivo, una finalidad fuera de sí mismas. Esto ocurre porque las posturas están relacionadas con las condiciones externas de trabajo. EI análisis postural que no tiene en cuenta el entorno de trabajo y la tarea en sí, tiene un interés limitado para los ergónomos.

Las características de las dimensiones del lugar de trabajo definen bastante bien las posturas, como en el caso de los trabajos que se realizan sentado, incluso en el caso de las tareas dinámicas, como el manejo de materiales en un lugar pequeño. Las cargas que hay que manejar, el peso y la naturaleza de las herramientas de trabajo, obligan al cuerpo a adoptar una postura determinada. Algunas tareas requieren que el peso del cuerpo se utilice para sostener una herramienta 0 para aplicar una fuerza sobre el objeto de trabajo como se muestra, por ejemplo, en la Figura 29.14.

Las diferencias individuales, la edad y el sexo influyen en las posturas. En realidad, se ha observado que una postura "típica" u "óptima", por ejemplo en la manipulación manual, es algo que pertenece a la ficción. Para cada individuo y cada situación laboral hay un número de posturas "óptimas" alternativas, desde el punto de vista de diferentes criterios.

\section{Ayudas y soportes para las posturas adoptadas durante el trabajo}

L os cinturones, las fajas lumbares y los aparatos ortopédicos están recomendados en tareas con riesgo de dolencia lumbar o musculosquelética de los miembros superiores. Se considera que estos elementos sirven de apoyo a los músculos, por ejemplo, para controlar la presión intra-abdominal y los movimientos de la mano. También sirven para limitar el rango de movimiento de los codos, las muñecas y los dedos. No existen pruebas de que el modificar los elementos posturales con estos elementos contribuya a evitar los problemas musculosqueléticos.

Los soportes posturales en el lugar de trabajo y en la maquinaria, como las asas, las almohadillas para arrodillarse y los apoyos para sentarse pueden resultar útiles a la hora de mitigar el dolor y las cargas posturales.

\section{Normativa sobre salud y seguridad en relación con los elementos posturales}

Las posturas o los elementos posturales nunca han estado sujetos a normas por sí mismos. Sin embargo, hay varios documentos que contienen comentarios, que hacen alguna referencia a las posturas o que incluyen la cuestión de las posturas como 
Figura 29.14 - Aspectos ergonómicos de la postura de pie.

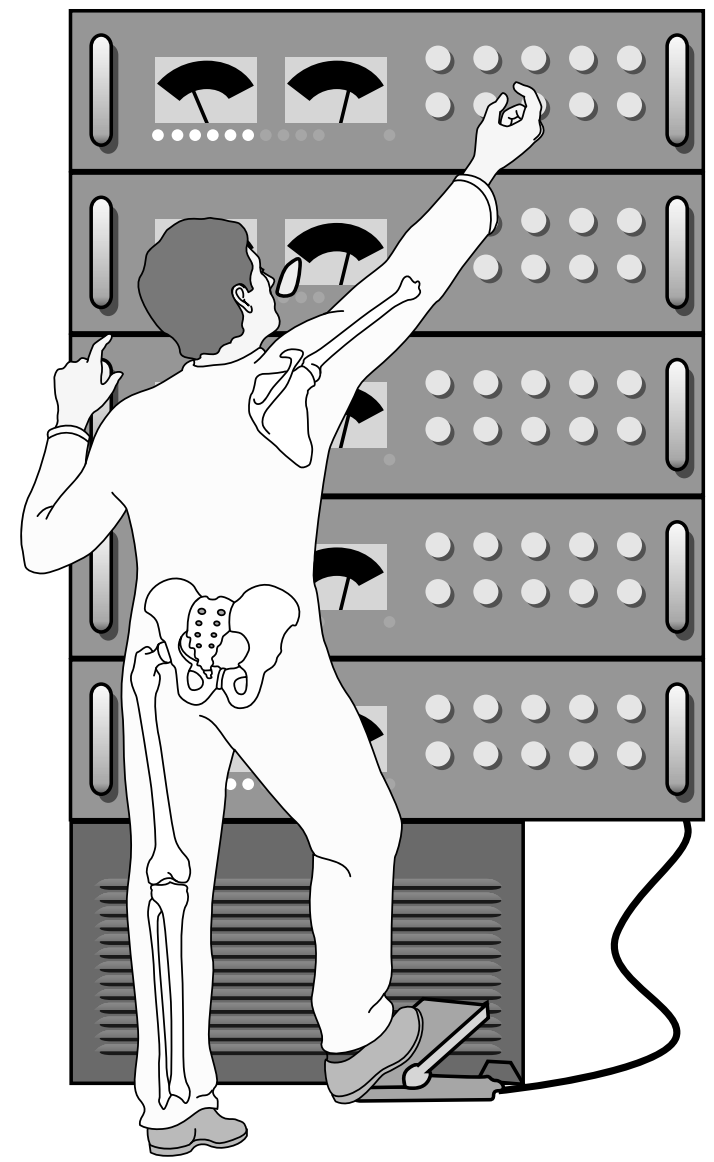

Cuando las articulaciones se estiran de forma incómoda, la presión puede causar una fatiga considerable. La postura de pie sobre una sola pierna puede producir una sobrecarga sobre la articulación de la cadera equivalente a dos y media veces el peso del cuerpo. Un buen ejemplo de cómo puede ocurrir esto lo encontramos en los casos en que un trabajador debe trabajar de pie, accionando un pedal mal colocado.

elemento integrante en la elaboración de una norma. No se dispone de una relación completa de la normativa existente. A continuación presentamos algunas referencias sólo a modo de ejemplo.

1. La O rganización Internacional del Trabajo publicó en 1967 una recomendación sobre las cargas máximas que deben manejarse. Aunque la recomendación no regula los elementos postulares como tales, muestra un interés significativo por la tensión postural. La recomendación está ya desfasada, pero ha servido a un objetivo muy importante al centrar la atención en los problemas relacionados con la manipulación manual de materiales.

2. Las guías del NIOSH sobre levantamiento de pesos (NIO SH 1981) no son propiamente normas, aunque hayan adquirido ese nivel. Las guías se refieren a los límites de peso para cargas, utilizando como base el emplazamiento de la carga, es decir, un elemento postural.

3. En la O rganización Internacional de Normalización y en la Comunidad Europea, las normas y las directivas sobre ergonomía existentes incluyen aspectos relacionados con los elementos posturales (CEN 1990 y 1991).

\section{BIOMECANICA}

Frank Darby

\section{Objetivos y principios}

La biomecánica es una disciplina que se encarga del estudio del cuerpo, como si éste se tratara simplemente de un sistema mecánico: todas las partes del cuerpo se comparan con estructuras mecánicas y se estudian como tales. Se pueden determinar las siguientes analogías:

- H uesos: palancas, elementos estructurales

- Masa muscular: volúmenes y masas

- Articulaciones: cojinetes y superficies articuladas

- Tejidos de recubrimiento de las articulaciones: lubricantes

- Músculos: motores, muelles

- Nervios: mecanismos de control y retroalimentación

- Ó rganos: suministro de energía

- Tendones: cuerdas

- Tejidos: muelles

- Cavidades corporales: globos

El objetivo principal de la biomecánica es estudiar la forma en que el organismo ejerce fuerza y genera movimiento. Esta disciplina se basa principalmente en la anatomía, las matemáticas y la física; las disciplinas afines son la antropometría (estudio de las medidas del cuerpo humano), la fisiología del trabajo y la cinemática (el estudio de los principios de la mecánica y la anatomía en relación con el movimiento humano).

Cuando se estudia la salud en el trabajo, la biomecánica ayuda a entender por qué algunas tareas provocan daños 0 enfermedades. Algunos de los efectos adversos sobre la salud son la tensión muscular, los problemas en las articulaciones o los problemas de espalda y la fatiga.

Las tensiones y contracturas de espalda, así como otros problemas más graves que afectan a los discos intervertebrales, son ejemplos habituales de accidentes de trabajo que pueden evitarse. Estos suelen producirse debido a una sobrecarga repentina, pero también pueden indicar que el cuerpo ha estado aplicando fuerzas excesivas durante muchos años. Los problemas pueden aparecer de forma repentina, o pueden tardar tiempo en manifestarse. Un ejemplo de estos problemas, que tarda algún tiempo en manifestarse es el llamado "dedo de costurera". En un trabajo reciente se describen las manos de una mujer que, tras 28 años de trabajo en una fábrica de prendas de vestir, además de coser en su tiempo libre, desarrolló una piel dura y gruesa que le impedía flexionar los dedos (Poole 1993). Esta mujer presentaba, sobre todo, una flexión anormal del dedo índice derecho, nódulos de $\mathrm{H}$ eberden muy prominentes en el índice y en el pulgar de la mano derecha y una callosidad importante en el dedo medio derecho, debida a la fricción constante de las tijeras. Al estudiar sus manos por rayos $X$, se observaron varios cambios degenerativos en las articulaciones interfalángicas distales de los dedos índice y medio de la mano derecha con pérdida de espacio articular, esclerosis articular (endurecimiento del tejido), osteofitos (protuberancias óseas que crecen en la articulación) y quistes óseos.

Una inspección del lugar de trabajo demostró que estos problemas se debían a la hiperextensión (doblar hacia arriba) repetida de la articulación distal del dedo. La sobrecarga mecánica y la limitación del flujo sanguíneo (apreciable porque el dedo se pone blanco) eran excesivas en estas articulaciones. Dichos problemas se desarrollaron como respuesta a la acción muscular repetida en un lugar distinto del músculo.

La biomecánica contribuye a sugerir diseños de tareas que eviten este tipo de lesiones o bien, a mejorar tareas mal 
diseñadas. Las soluciones a estos problemas particulares estarían en un cambio del diseño de las tijeras y en la modificación de las tareas de costura para eliminar la necesidad de las acciones realizadas.

D os principios importantes de la biomecánica son:

1. Los músculos funcionan por pares. Los músculos sólo pueden contraerse, de forma que en cada articulación deberá haber un músculo o grupo muscular que desplace la articulación en una dirección, y un músculo o grupo muscular correspondiente que la desplacen en la dirección opuesta. La Figura 29.15 ilustra lo anterior para la articulación del codo.

2. L os músculos se contraen más eficazmente cuando el par de músculos está en equilibrio relajado. El músculo actúa con mayor eficacia cuando se encuentra en el punto medio del recorrido de la articulación que flexiona. Esto sucede por dos motivos: en primer lugar, si el músculo trata de contraerse cuando está acortado, tirará del músculo opuesto que está alargado. Este último, al estar extendido, ejercerá una fuerza elástica contraria que el músculo contraído tendrá que vencer. La Figura 29.16 muestra la forma en que varía la fuerza del músculo en función de su longitud.

En segundo lugar, si el músculo trata de contraerse en otro punto que no sea el punto medio del recorrido del movimiento de la articulación, funcionará en desventaja mecánica. La Figura 29.17 ilustra el cambio de rendimiento mecánico del codo en tres posiciones diferentes.

De estos principios puede concluirse un criterio importante para el diseño del trabajo: el trabajo deberá organizarse de forma que se produzca con los músculos opuestos de cada articulación en equilibrio relajado. En la mayoría de las articulaciones, esto significa que la articulación deberá encontrarse en la zona media de su intervalo de movimiento.

Figura 29.15 • Los músculos esqueléticos trabajan por pares para iniciar o revertir un movimiento.

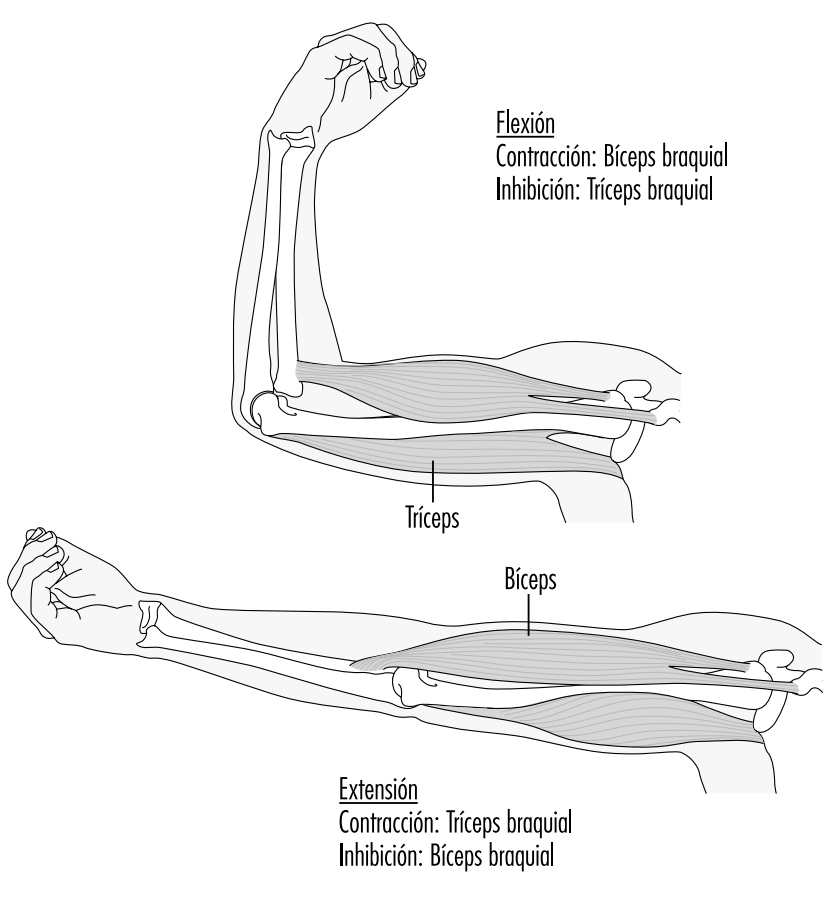

Figura 29.16 • La tensión muscular varía dependiendo de la longitud del músculo.

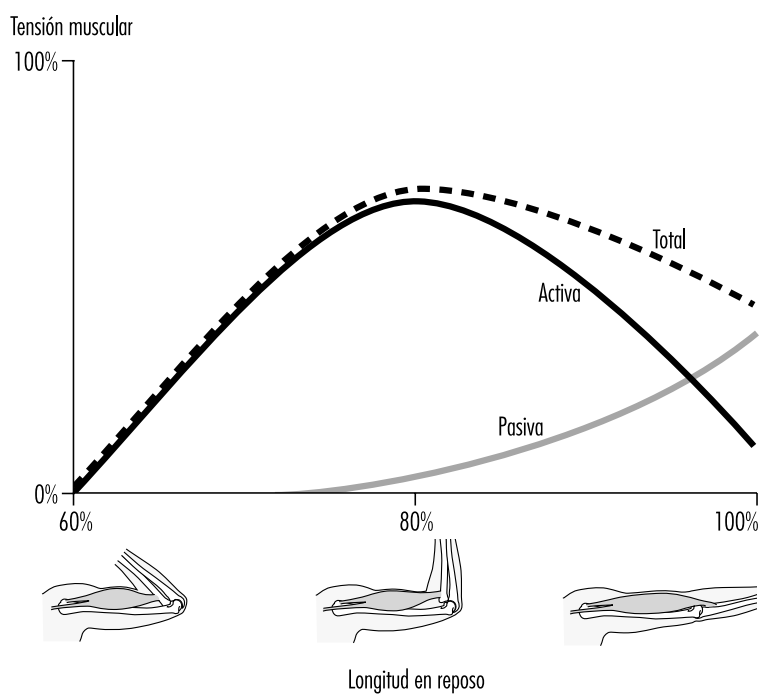

Esta norma también significa que la tensión muscular será mínima mientras se realiza la tarea. U n ejemplo de infracción de esta regla es el síndrome de uso excesivo (RSI) o lesión por esfuerzo repetitivo, que afecta a los músculos de la parte superior del antebrazo en personas que manejan teclados y que normalmente trabajan con la muñeca flexionada hacia arriba. A menudo, el operador adquiere este hábito por la forma en que está concebido el teclado o el puesto de trabajo.

Figura 29.17 - Posiciones idóneas para el movimiento de las articulaciones.
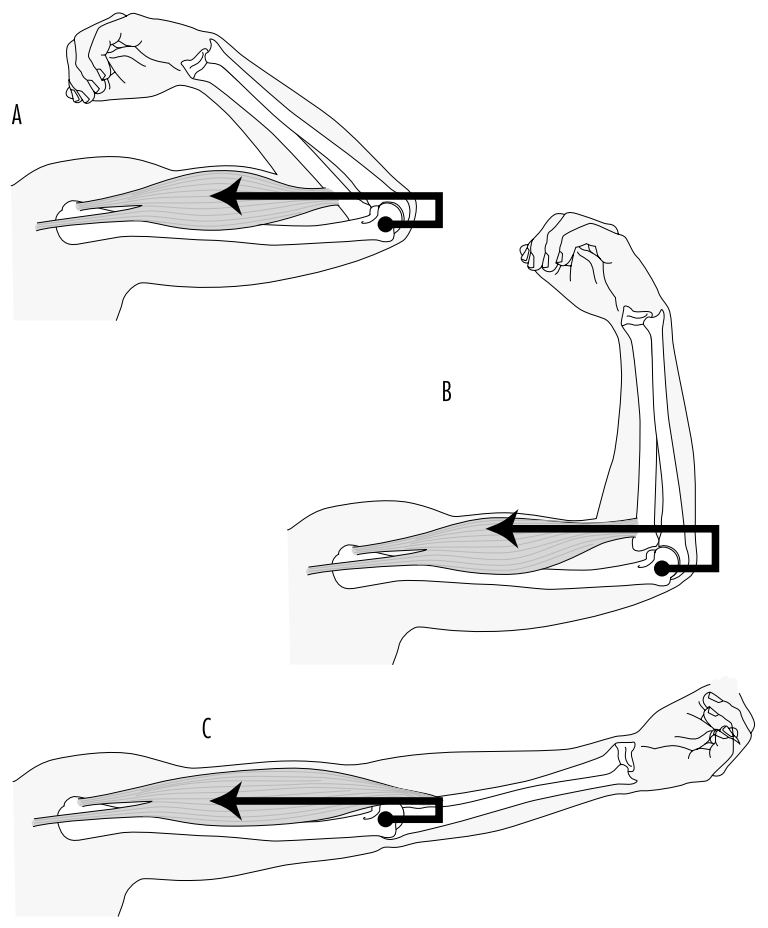

La ventaja mecánica para el movimiento de una articulación es máxima en el punto medio del movimiento de la articulación. Así, el antebrazo puede moverse con mayor fuerza en la posición B. 


\section{Aplicaciones}

A continuación se dan algunos ejemplos de la aplicación de la biomecánica.

\section{Diámetro idóneo de los mangos de las her ramientas}

El diámetro de un mango afecta a la fuerza que los músculos de la mano pueden aplicar a una herramienta. Los estudios han demostrado que el diámetro óptimo de un mango depende del uso que se vaya a dar a la herramienta. Para ejercer una presión a lo largo de la línea del mango, el mejor diámetro será el que permita que los dedos adopten un agarre con una ligera superposición del pulgar, es decir, unos $40 \mathrm{~mm}$. Para ejercer torsión, el diámetro óptimo está entre 50 y $65 \mathrm{~mm}$. Lamentablemente, la mayoría de los mangos tienen diámetros inferiores a los indicados.

\section{U so de alicates}

Los alicates tienen un tipo especial de mangos y la capacidad de ejercer una fuerza con unos alicates dependerá de la separación que exista entre ambos mangos, como se indica en la Figura 29.18.

\section{Postura sentada}

La electromiografía es una técnica que puede utilizarse para medir la tensión muscular. En un estudio sobre la tensión de los músculos extensores de la espalda en personas que trabajan sentadas, se observó que al inclinarse hacia atrás (con el respaldo reclinado) se reduce la tensión en estos músculos. Este efecto se explica porque el respaldo soporta la mayor parte del peso de la parte superior del cuerpo.

Los estudios de rayos $X$ de individuos en distintas posturas muestran que la posición en equilibrio relajado de los músculos que abren y cierran la articulación de la cadera corresponde a un ángulo de unos $135^{\circ}$. Este ángulo se aproxima bastante al que esta articulación adopta de forma natural (128 ) en situaciones de ingravidez (en el espacio). C uando se está sentado, con la cadera formando un ángulo de $90^{\circ}$, los tendones de las rodillas y la articulación de la cadera tienden a tirar de la zona sacra (la parte de la columna vertebral que conecta con la pelvis) forzándola a adoptar una posición vertical. El efecto que produce es la eliminación de la lordosis (curvatura) natural de la zona lumbar; las sillas deben tener un respaldo adecuado para corregir esta tendencia.

Figura 29.18 - Fuerza de la mordaza de unos alicates ejercida por hombres y mujeres, en función de la distancia de separación del mango.
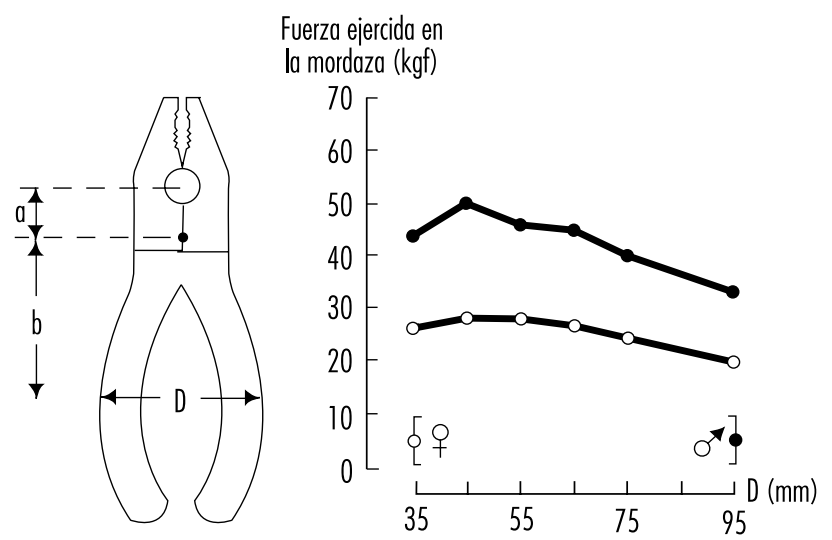

Fuente: Pheasant 1986

\section{Atornillar}

¿Por qué se insertan los tornillos en el sentido de las agujas del reloj? Esta práctica surgió probablemente de la percepción inconsciente de que los músculos que hacen girar el brazo derecho en el sentido de las agujas del reloj (la mayoría de las personas son diestras) son mayores, y por tanto más fuertes, que los músculos que lo hacen girar en el sentido contrario.

O bsérvese que las personas zurdas están en desventaja, cuando tratan de apretar un tornillo manualmente. Alrededor del nueve por ciento de la población es zurda, por lo que necesita herramientas especiales en algunas situaciones, como sucede con las tijeras y los abrelatas.

Un estudio de las personas que utilizaban destornilladores para una tarea de montaje reveló una relación más sutil entre un movimiento concreto y un problema de salud determinado. Se observó que cuanto más grande era el ángulo del codo (cuanto más recto estaba el brazo), más personas mostraban después una inflamación del mismo. La razón para que esto sucediera es que el músculo que hace girar el antebrazo (el bíceps) también tira de la cabeza del radio (un hueso del antebrazo) hacia el cóndido humeral (cabeza redondeada) del húmero (hueso de la parte superior del brazo). Al aumentar la fuerza ejercida sobre el codo en un ángulo mayor, aumenta la fuerza de fricción en el codo, con el consiguiente calentamiento de la articulación y la subsiguiente inflamación. Al aumentar el ángulo, el músculo tiene que traccionar con más fuerza para atornillar, de forma que se emplea una fuerza superior a la que habría sido necesaria con el codo en un ángulo de $90^{\circ}$. La solución consiste en acercar más el trabajo a los operarios para reducir el ángulo del codo a unos $90^{\circ}$.

L os casos anteriores demuestran que es necesario un conocimiento adecuado de la anatomía para aplicar la biomecánica en el lugar de trabajo. Los diseñadores de tareas tal vez necesiten consultar a expertos en anatomía funcional para anticiparse a los problemas antes mencionados. La publicación T he Pocket E rgonomist (Brown y Mitchell 1986), basada en la investigación electromiográfica, sugiere varias formas de reducir la incomodidad física en el trabajo.

\section{Manipulación manual de materiales}

El termino manipulación manual incluye las acciones de levantar, bajar, empujar, tirar, transportar, mover, sostener en vilo y refrenar, y está relacionado con gran parte de las actividades realizadas en la vida laboral.

La biomecánica tiene una importancia directa evidente en la manipulación manual, ya que los músculos deben moverse para realizar las tareas. La cuestión es qué cantidad de trabajo físico puede esperarse, razonablemente, que realice una persona. La respuesta depende de las circunstancias y, en realidad, hay que responder a tres preguntas. La respuesta a cada una de ellas se basa en criterios científicos:

1. ¿Q ué cantidades se pueden manipular sin producir daños al organismo (en forma, por ejemplo, de tensión muscular, deterioro de los discos o problemas articulares)? Esto se conoce como el criterio biomecánico.

2. ¿Q ué cantidades se pueden manejar sin que represente un esfuerzo excesivo para los pulmones (una respiración dificultosa, hasta el extremo del jadeo)? Esto se denomina criterio fisiológico.

3. ¿Q ué cantidad considera una persona que puede manipular cómodamente? Esto se llama criterio psicofísico.

Estos tres criterios son necesarios porque consideran tres reacciones totalmente diferentes que pueden producirse con el levantamiento de pesos. Si el trabajo se desarrolla a lo largo de todo 
un día, la preocupación se centrará en cómo se siente la persona en relación con ese trabajo, es decir, en el criterio psicofísico. Si la fuerza aplicada es grande, la preocupación fundamental será que los músculos y las articulaciones no se sobrecarguen hasta el punto de resultar lesionados (el criterio biomecánico). Por último, si la tasa de trabajo es demasiado grande, tal vez exceda el criterio fisiológico o la capacidad aeróbica de la persona.

$\mathrm{H}$ ay un gran número de factores que determinan la cantidad de carga ejercida sobre el cuerpo en una tarea de manipulación manual. Sobre todos ellos se pueden aplicar medidas de control.

\section{Posturas y movimientos}

Si la tarea requiere que la persona se gire o se estire para alcanzar algo, el riesgo de lesión será mayor. El puesto de trabajo puede rediseñarse para evitar estas acciones. Se producen más lesiones de espalda cuando el levantamiento se hace desde el suelo que cuando se hace desde una altura media; esto indica la necesidad de sencillas medidas de control. Esto también se aplica a las situaciones de levantamientos de pesos hasta una altura elevada.

La carga. La carga en sí también puede influir en la manipulación, debido a su peso y su ubicación. O tros factores, como su forma, su estabilidad, su tamaño y si resbala o no, también pueden incidir en la facilidad o dificultad que presente su manejo.

Organización y entorno. La forma en que está organizado el trabajo, tanto física como temporalmente, también influye en su manejo. Es mejor repartir el trabajo de descarga de un camión entre varias personas, durante una hora, que pedir a un trabajador que lo haga solo y emplee en ello todo el día. El entorno influye sobre la manipulación: la falta de luz, los obstáculos 0 desniveles en el suelo o una limpieza deficiente pueden hacer que la persona tropiece.

Factores personales. Las habilidades personales para la manipulación de objetos, la edad de la persona y la ropa que lleve puesta, también pueden influir. Es necesaria una formación adecuada para levantar pesos, que proporcione la información necesaria y que dé el tiempo suficiente para desarrollar las habilidades físicas requeridas para la manipulación de objetos. La gente joven corre mayores riesgos; y por otra parte, la gente mayor tiene menos fuerza y menos capacidad fisiológica. Las ropas ajustadas pueden aumentar la fuerza muscular requerida para desempeñar una tarea, ya que la persona tiene que vencer la presión de la ropa. Ejemplos típicos de esta situación son el uniforme de las enfermeras o los monos ajustados para trabajar por encima del nivel de la cabeza.

\section{Límites de peso recomendados}

Los puntos mencionados anteriormente indican que es imposible determinar un peso "seguro" en todas las circunstancias. LOS límites de peso varían arbitrariamente de un país a otro. A los estibadores indios, por ejemplo, se les "permitió" en una ocasión levantar $110 \mathrm{~kg}$, mientras que a los de la República D emocrática Alemana se les "limitó" a $32 \mathrm{~kg}$. Además, los límites de peso siempre han tendido a ser demasiado grandes: los $55 \mathrm{~kg}$ sugeridos en muchos países están ahora muy por encima de lo que se considera adecuado según las investigaciones científicas más recientes. EI National Institute for $\mathrm{O}$ ccupational Safety and $\mathrm{Health}$ (NIOSH) de Estados U nidos estableció $23 \mathrm{~kg}$ como límite de carga en 1991 (Waters y cols. 1993).

Cada tarea de levantamiento tiene que ser valorada de acuerdo con sus características. U na forma útil de determinar un límite de peso para una ejercicio de levantamiento es la fórmula desarrollada por el NIOSH :

$$
R W L=L C \times H M \times V M \times D M \times A M \times C M \times F M
$$

Donde:

RW L = límite de peso recomendado para la tarea en cuestión

$\mathrm{HM}=$ Factor horizontal $-\mathrm{H}$, distancia horizontal entre el centro de gravedad de la carga y el punto medio entre los tobillos (mínimo $15 \mathrm{~cm}$, máximo $80 \mathrm{~cm}$ )

$\mathrm{VM}=$ Factor vertical $-\mathrm{V}$, distancia vertical entre el centro de gravedad de la carga y el suelo al inicio del levantamiento (máximo $175 \mathrm{~cm}$ )

$\mathrm{DM}=$ Factor de desplazamiento $-\mathrm{D}$, desplazamiento vertical de la carga (mínimo $25 \mathrm{~cm}$, máximo $200 \mathrm{~cm}$ )

$\mathrm{AM}=$ Factor de asimetría $-\mathrm{A}$, ángulo de desviación de la tarea con relación al plano medio sagital

$C M=$ Factor de agarre $-C$, posibilidad de sujetar bien el bulto que se desea levantar. Se define en tablas de referencia

$\mathrm{FM}=$ Factor de frecuencia - $\mathrm{F}$, la frecuencia del levantamiento.

Todas las variables de longitud de la ecuación se expresan en centímetros. EI peso máximo recomendado por el $\mathrm{NIOSH}$ es $23 \mathrm{~kg}$. Este valor se ha reducido (el anterior era de $40 \mathrm{~kg}$ ) tras la observación de que en las tareas de levantamiento la distancia media de la carga al cuerpo al inicio del levantamiento es de $25 \mathrm{~cm}$ y no de $15 \mathrm{~cm}$, como se suponía en la versión anterior de la ecuación (NIOSH 1981).

Indicedelevantamiento. Si se compara el peso que se va a levantar en una tarea determinada con el RWL, se puede obtener un índice de levantamiento (LI) de acuerdo con la relación:

$$
L I=\text { (peso que se va a manipular)/ RW } L \text {. }
$$

Así, una aplicación muy útil de la ecuación del NIOSH es colocar las tareas de levantamiento por orden de gravedad, utilizando el índice de levantamiento para determinar las acciones prioritarias. $L a$ fórmula tiene una serie de limitaciones, pero hay que reconocer la importancia que tiene su aplicación. (V éase Waters y cols. 1993).

\section{Cálculo de la compresión discal en la columna vertebral impuesta por la tarea}

Existe un programa informático que permite calcular la compresión que una tarea de manipulación manual impone a la columna vertebral. Los programas bi y tridimensionales de predicción de la fuerza estática, elaborados por la U niversidad de M ichigan ("Backsoft") calculan la compresión vertebral. Los datos que es necesario introducir son:

- la postura en la que se realiza la actividad

- la fuerza ejercida

- la dirección en la que se ejerce la fuerza

- el número de manos que ejercen la fuerza

- el percentil de la población que se está estudiando.

Los programas bi y tridimensionales se diferencian en que el software en 3D permite hacer cálculos aplicables a posturas en tres dimensiones. El programa indica los datos sobre compresión y el porcentaje de la población seleccionada que hubiera sido capaz de realizar una determinada tarea sin sobrepasar los límites para seis articulaciones: tobillo, rodilla, cadera, primer disco lumbar (sacro), hombro y codo. Este método también tiene limitaciones que es necesario comprender perfectamente para poder obtener el máximo rendimiento del programa. 


\section{- FATIgA GENERAL}

\section{É tienne Grandjean*}

Los conceptos de fatiga y descanso nos resultan familiares por experiencia personal. La palabra "fatiga" se utiliza para indicar diferentes condiciones que causan, todas ellas, una disminución de la resistencia y de la capacidad de trabajo. El uso tan diverso del concepto de fatiga ha dado como resultado una confusión casi caótica, lo que hace necesario aclarar un poco las ideas actuales. D urante mucho tiempo, la fisiología ha distinguido entre la fatiga muscular y la fatiga general. La primera es un fenómeno doloroso agudo localizado en los músculos; la fatiga general, en cambio, se caracteriza por una disminución del deseo de trabajar. Este artículo se refiere únicamente a la fatiga general, también conocida como "fatiga psíquica" o "fatiga nerviosa", y al descanso necesario.

La fatiga general puede deberse a diferentes causas, entre las que destacan las que se muestran en la Figura 29.19. El efecto es como si, a lo largo del día, todas las tensiones experimentadas se acumularan en el organismo, produciendo gradualmente una sensación de fatiga que va en aumento. Esta sensación hace que el individuo deje de trabajar y funciona como un preludio fisiológico del sueño.

La fatiga es una sensación saludable si el individuo puede acostarse y descansar. Sin embargo, si el individuo decide no hacer caso de esta sensación y se fuerza a seguir trabajando, la sensación de fatiga aumentará hasta convertirse en una situación molesta y, a la larga, más fuerte que el individuo. Esta experiencia cotidiana demuestra claramente el significado biológico de la fatiga, que tiene un papel importante en el mantenimiento de la vida, similar al de otras sensaciones como, por ejemplo, la sed, el hambre, el temor, etc.

EI descanso se representa en la Figura 29.19 como el proceso de vaciar un barril. El fenómeno de descanso puede darse de forma normal si el organismo permanece tranquilo o si al menos una parte esencial del mismo no está sujeta a estrés. Esto explica lo importante que son los descansos de todo tipo durante la jornada, desde las pausas cortas durante el trabajo hasta el sueño nocturno. El símil del barril muestra lo necesario que es para una vida normal alcanzar un cierto equilibrio entre la carga total soportada por el organismo y la suma de las posibilidades de descanso.

\section{Interpretación neurofisiológica de la fatiga}

Los avances de la neurofisiología durante las últimas décadas han contribuido a una mejor comprensión de los fenómenos producidos por la fatiga sobre el sistema nervioso central.

Un fisiólogo, H ess, fue el primero en observar que la estimulación eléctrica de algunas estructuras del diencéfalo (concretamente, algunas de las estructuras del núcleo medial del tálamo), producían un efecto inhibidor gradual que se manifestaba como una disminución de la capacidad de reacción y una tendencia al sueño. Si la estimulación se prolonga durante cierto tiempo, se produce una relajación general seguida por un adormecimiento $y$, finalmente, el individuo se duerme. Posteriormente, se demostró que, a partir de estas estructuras, la inhibición activa puede extenderse a la corteza cerebral, en la que se localizan todos los fenómenos conscientes. Este hecho se refleja no sólo en el comportamiento, sino también en la actividad eléctrica de la corteza cerebral. 0 tros experimentos también han conseguido iniciar la inhibición desde otras regiones subcorticales.

\footnotetext{
* Este artículo está adaptado de la 3a edición de la Encidopedia de Salud y Seguridad en el Trabajo.
}

La conclusión que puede obtenerse de estos estudios es que existen estructuras localizadas en el diencéfalo y en el mesencéfalo que representan un sistema inhibidor eficaz y que desencadenan la fatiga y todos los fenómenos que la acompañan.

\section{Inhibición y activación}

Un gran número de experimentos realizados con animales y humanos han demostrado que la disposición para reaccionar depende no sólo de este sistema de inhibición sino también, fundamentalmente, de un sistema que funciona de manera antagónica, conocido como el sistema reticular ascendente de activación. Se sabe, a partir de los experimentos realizados, que la formación reticular contiene estructuras que controlan el grado de alerta y, como consecuencia, la disposición general para reaccionar. Existen enlaces nerviosos entre estas estructuras y la corteza cerebral a través de las cuales se ejercen influencias activadoras sobre la consciencia. El sistema activador recibe también la estimulación procedente de los órganos sensoriales. 0 tras conexiones nerviosas transmiten impulsos de la corteza cerebral, el área de percepción y pensamiento, al sistema de activación. De acuerdo con estos conceptos neurofisiológicos, es posible establecer que tanto los estímulos externos como las influencias que se originan en las áreas de consciencia pueden estimular, a través del sistema activador, la disposición a reaccionar.

Además, muchas otras investigaciones también han hecho posible concluir que la estimulación del sistema activador procede con frecuencia de los centros vegetativos, lo que hace que el organismo se oriente hacia un gasto de energía, hacia el trabajo, la lucha, la huida, etc (conversión ergotrópica de los órganos internos). Por el contrario, parece ser que la estimulación del sistema inhibidor en el campo de acción del sistema nervioso vegetativo hace que el organismo tienda al descanso, al restablecimiento de sus reservas de energía y a fenómenos de asimilación (conversión trofotrópica).

Figura 29.19 - Representación esquemática del efecto acumulativo de las causas cotidianas de fatiga.

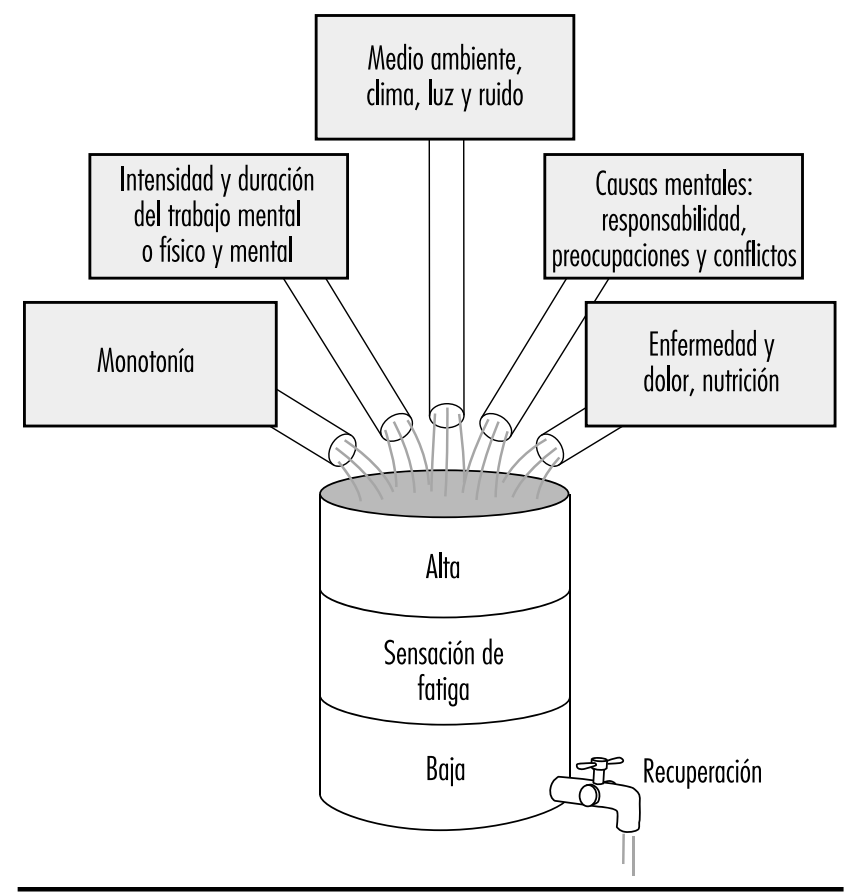


Si se resumen todos estos hallazgos neurofisiológicos, es posible establecer la siguiente teoría de la fatiga: el estado y la sensación de fatiga están condicionados por la reacción funcional de la consciencia en la corteza cerebral que está, a su vez, gobernada por dos sistemas mutuamente antagónicos: el sistema inhibidor y el sistema activador. A sí, la disposición de los humanos al trabajo depende en cada momento del grado de activación de estos dos sistemas: si domina el sistema inhibidor, el organismo caerá en un estado de fatiga; en cambio, si domina el sistema activador, mostrará una mayor disposición a trabajar.

Esta visión psicofisiolófica de la fatiga permite entender algunos de sus síntomas, que en ocasiones son difíciles de explicar. Así, por ejemplo, la sensación de fatiga puede desaparecer repentinamente cuando ocurre un suceso externo inesperado o cuando se desarrolla una tensión emocional. Está claro que en estos dos casos se ha estimulado el sistema activador. Por el contrario, si el entorno es monótono o si el trabajo resulta aburrido, el funcionamiento del sistema activador disminuye y el sistema inhibidor se vuelve dominante. Esto explica por qué la fatiga aparece en situaciones monótonas 0 sin que el organismo esté sujeto a ninguna carga de trabajo.

La Figura 29.20 muestra de forma esquemática el concepto de los sistemas mutuamente antagónicos de inhibición y activación.

\section{Fatiga clínica}

Todo el mundo sabe que la fatiga intensa, excesiva, que se acumula día tras día produce gradualmente un estado de fatiga crónica. En este caso, la sensación de fatiga se intensifica y no sólo se produce por la tarde, después del trabajo, sino también durante el día y, en ocasiones, incluso antes de comenzar a trabajar. U na sensación de malestar, frecuentemente de naturaleza emocional, suele acompañar a este estado. En las personas que padecen de fatiga se observan los siguientes síntomas: mayor emotividad psíquica (comportamiento antisocial, incompatibilidad), tendencia a la depresión (ansiedad sin motivación) y falta de energía con pérdida de iniciativa. Estos efectos psíquicos suelen ir acompañados por un malestar inespecífico y generalmente se manifiestan como síntomas psicosomáticos: dolores de cabeza, vértigo, alteraciones funcionales cardíacas y respiratorias, pérdida de apetito, trastornos digestivos, insomnio, etc.

Figura 29.20 • Representación esquemática del control de la disposición al trabajo a través de los sistemas inhibidor y activador.

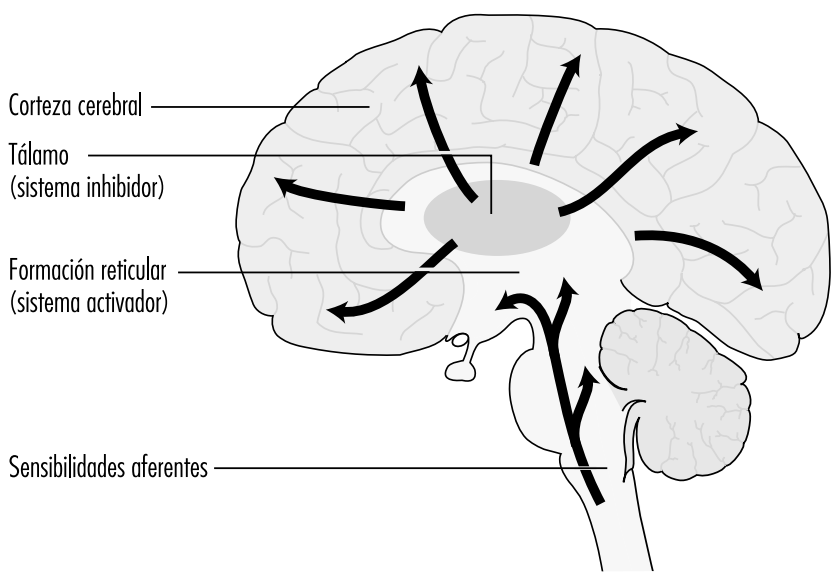

En vista de la tendencia de la fatiga crónica a producir síntomas de enfermedad, es justo que reciba el nombre de fatiga clínica. Existe una tendencia a un mayor absentismo y, en particular, a mayores ausencias durante períodos cortos. Esto parece deberse tanto a la necesidad de descanso como al aumento en la morbilidad. El estado de fatiga crónica ocurre especialmente en personas expuestas a dificultades o conflictos psíquicos. En ocasiones es muy difícil distinguir entre las causas externas e internas. De hecho, es casi imposible distinguir entre causa y efecto en la fatiga clínica: una actitud negativa hacia el trabajo, los superiores o el lugar de trabajo puede ser tanto la causa de la fatiga clínica como su resultado.

Las investigaciones han demostrado que las operadoras de conmutadores y el personal supervisor empleado en los servicios de telecomunicaciones muestra un aumento significativo de los síntomas fisiológicos de fatiga después del trabajo (tiempo de reacción visual, frecuencia crítica de fusión óptica, pruebas de destreza). Las investigaciones médicas muestran que en estos dos grupos de trabajadoras hay un aumento significativo de estados neuróticos, irritabilidad, dificultad para conciliar el sueño y una sensación crónica de lasitud, en comparación con un grupo similar de mujeres empleadas en las áreas técnicas de los sistemas de servicios postales, telefónicos y de telégrafos. La acumulación de síntomas no siempre se debe a una actitud negativa por parte de las mujeres afectadas hacia su trabajo o las condiciones de trabajo.

\section{Medidas preventivas}

No existe una panacea para la fatiga, pero puede hacerse mucho para aliviar el problema si se presta atención a las condiciones generales de trabajo y al entorno físico en el lugar de trabajo. Por ejemplo, puede conseguirse mucho con una distribución adecuada de las horas de trabajo, la previsión de períodos de descanso adecuados, servicios de cafetería y salas de descanso. También debe proporcionarse a los trabajadores períodos adecuados de vacaciones pagadas. El estudio ergonómico del lugar de trabajo puede ayudar a reducir la fatiga al garantizar que los asientos, las mesas y los bancos de trabajo tengan las dimensiones adecuadas y que el flujo de trabajo esté correctamente organizado. Además, el control del nivel de ruido, el aire acondicionado, la calefacción, la ventilación y la iluminación pueden tener un efecto beneficioso para retrasar la aparición de la fatiga en los trabajadores.

La monotonía y la tensión también pueden compensarse con el uso controlado del color y la decoración del entorno, intervalos de música y, en ocasiones, descansos para ejercicios físicos en el caso de los trabajadores sedentarios. La formación adecuada de los trabajadores y, en particular, del personal supervisor y directivo también tiene un papel importante.

\section{FATIGA Y RECUPERACION}

\section{Rolf H elbig y Walter Rohmert}

La fatiga y la recuperación son procesos periódicos en todos los organismos vivos. La fatiga puede describirse como un estado que se caracteriza por una sensación de cansancio combinada con una reducción o una variación no deseada en el rendimiento de la actividad (Rohmert 1973).

No todas las funciones del organismo humano se cansan como resultado del uso. Incluso cuando estamos dormidos, por ejemplo, seguimos respirando y nuestro corazón sigue latiendo sin pausa. O bviamente, las funciones básicas de respiración y la 
Figura 29.21 - Estrés, tensión y fatiga.

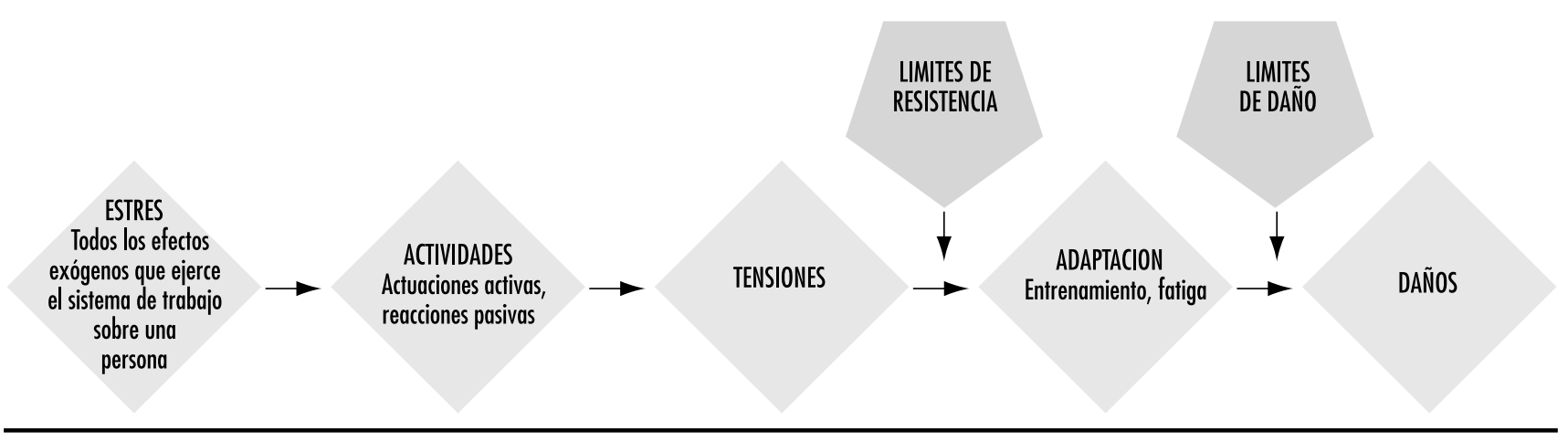

actividad cardíaca son posibles durante toda la vida sin fatiga y sin pausas para la recuperación.

Por otra parte, tras realizar un trabajo pesado durante un tiempo relativamente prolongado, se observa una disminución de la capacidad, que conocemos con el nombre de fatiga. Esto no se aplica únicamente a la actividad muscular. Los órganos sensoriales o los centros nerviosos también se fatigan. Sin embargo, el objetivo de todas las células es equilibrar la capacidad perdida por la actividad, un proceso conocido como recuperación.

\section{Estrés, tensión, fatiga y recuperación}

Los conceptos de fatiga y recuperación en el trabajo humano están estrechamente relacionados con los conceptos ergonómicos de estrés y tensión (R ohmert 1984) (Figura 29.21).

El estrés es la suma de todos los parámetros del sistema de trabajo que influyen sobre los trabajadores y que se perciben 0 se sienten principalmente a través del sistema receptor 0 que implican un trabajo del sistema efector. Los parámetros del estrés son el resultado de la tarea del trabajo (trabajo muscular 0 no muscular: los factores y dimensiones orientados hacia la tarea) y de las condiciones físicas, químicas y sociales bajo las que debe realizarse el trabajo (ruido, clima, iluminación, vibración, turnos de trabajo, etc.: los factores y dimensiones orientados hacia la situación).

La intensidad, dificultad, duración y composición de los factores de estrés, es decir, la distribución simultánea y sucesiva de estos requisitos específicos, producen un estrés combinado en el que todos los efectos exógenos del sistema de trabajo actúan sobre el trabajador. Este estrés combinado puede superarse activamente o soportarse pasivamente, en especial dependiendo del comportamiento del trabajador. El enfoque activo conlleva actividades dirigidas hacia la eficacia del sistema de trabajo, mientras que el enfoque pasivo produce reacciones, voluntarias 0 involuntarias, que tienen como objetivo principal minimizar el estrés. $L$ a relación entre el estrés y la actividad está relacionada de forma decisiva con las características individuales y las necesidades del trabajador. Los principales factores que influyen son aquellos que determinan el rendimiento y están relacionados con la motivación y la concentración, que a su vez están relacionados con la disposición, que depende de las habilidades y aptitudes del trabajador.

El estrés relacionado con el comportamiento, que se manifiesta en ciertas actividades, produce distintas tensiones individualmente. Estas tensiones pueden manifestarse como una reacción de los indicadores fisiológicos o bioquímicos (por ejemplo, como un aumento de la frecuencia cardíaca) o pueden ser perceptibles. Así, es posible clasificar las tensiones mediante una "escala psicofísica" que calcula la tensión tal como la percibe el trabajador. En un enfoque conductual, la existencia de tensiones también puede derivarse del análisis de una actividad. La intensidad con la que reaccionan los indicadores de la tensión (fisiológico-bioquímicos, conductuales o psicofísicos) depende tanto de la intensidad, duración y combinación de los factores de estrés como de las características individuales, la habilidad, las aptitudes y las necesidades del trabajador.

Aunque exista un nivel de estrés constante, los indicadores que se derivan de los campos de actividad, rendimiento y tensión pueden variar a lo largo del tiempo (efecto temporal). Estas variaciones temporales deben interpretarse como procesos de adaptación por parte de los sistemas orgánicos. Los efectos positivos producen una disminución de la tensión, mejorando la actividad 0 el rendimiento (por ejemplo, a través del entrenamiento). En el caso negativo, sin embargo, producen un aumento de la tensión, una disminución de la actividad o el rendimiento (por ejemplo, fatiga o monotonía).

Los efectos positivos pueden actuar si se mejoran las habilidades y aptitudes disponibles en el propio proceso de trabajo, por ejemplo, cuando se supera ligeramente el umbral de la estimulación de entrenamiento. En cambio, es probable que aparezcan efectos negativos si se superan los llamados límites de resistencia (Rohmert 1984) en el curso del proceso del trabajo. Esta fatiga reduce las funciones fisiológicas y psicológicas y esto puede compensarse a través de la recuperación.

Para restaurar los niveles de rendimiento originales, es necesario permitir períodos de descanso o al menos, períodos de menor estrés (Luczak 1993).

Cuando el proceso de adaptación tiene lugar más allá de los umbrales definidos, el sistema orgánico utilizado puede sufrir daños hasta el punto de ocasionar una pérdida parcial o total de su función. La disminución irreversible de las funciones puede ocurrir cuando el estrés es demasiado elevado (daño agudo) 0 cuando la recuperación es imposible durante un período prolongado (daño crónico). U n ejemplo típico de este tipo de daño es la pérdida de audición producida por el ruido.

\section{Modelos de fatiga}

La fatiga puede ser de muchos tipos, dependiendo de la forma y la combinación de las tensiones y aún no se ha podido establecer una definición general para la fatiga. En general, los procesos biológicos de la fatiga no pueden medirse de forma directa, por lo que las definiciones se basan principalmente en los síntomas de la fatiga. Estos síntomas pueden dividirse, por ejemplo, en las siguientes tres categorías:

1. Síntomas fisiológicos: la fatiga se interpreta como una disminución de la función de los órganos o del organismo completo. Pueden producirse reacciones fisiológicas, como el aumento 
Figura 29.22 - Tendencia principal de la fatiga y la recuperación.

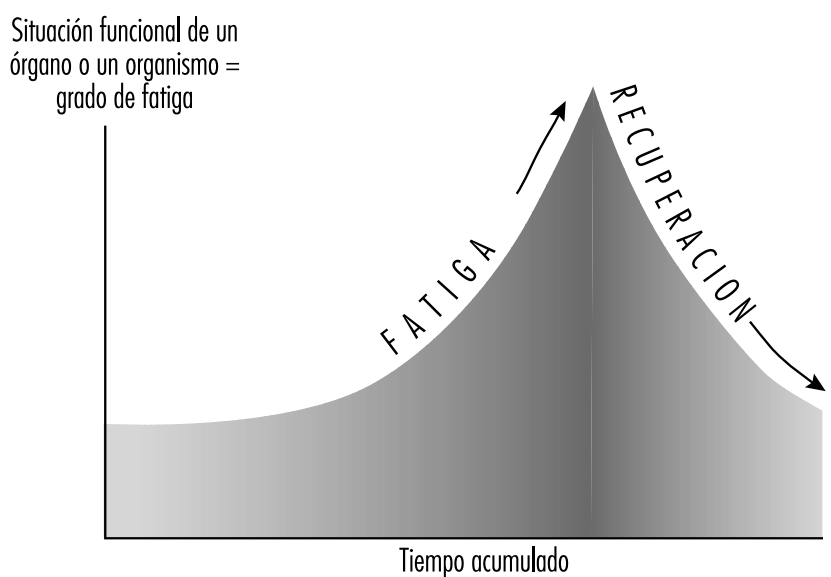

de la frecuencia cardíaca o de la actividad eléctrica muscular (L aurig 1970).

2. Síntoma sconductuales: la fatiga se interpreta principalmente como una disminución de los parámetros del rendimiento. Entre los ejemplos está el aumento en el número de errores cuando se realizan ciertas tareas o un aumento en la variabilidad del rendimiento.

3. Síntomas psicofísicos: la fatiga se interpreta como un aumento en la sensación de agotamiento y un deterioro sensorial, dependiendo de la intensidad, la duración y la composición de los factores de estrés.

En el proceso de la fatiga pueden aparecer los tres tipos de síntomas, pero en distintos momentos.

Las reacciones fisiológicas en los sistemas orgánicos, en especial las que están involucradas en el trabajo, pueden ser las primeras en aparecer. Posteriormente, puede aparecer la sensación de esfuerzo. Los cambios en el rendimiento se manifiestan generalmente como una disminución en la regularidad del trabajo o como un aumento en la cantidad de errores, aunque es posible que el rendimiento medio aún no se vea afectado. Por el contrario, con la motivación adecuada, el trabajador puede incluso intentar mantener el rendimiento a través de la fuerza de voluntad. El siguiente paso puede ser una clara disminución del

Figura 29.23 • Estrés en función del tiempo.

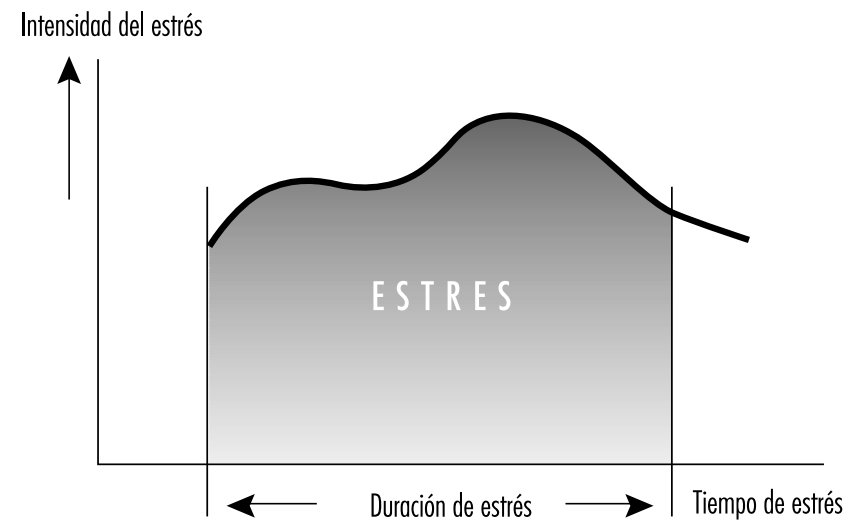

Tabla 29.2 • Fatiga y recuperación en función de los niveles de actividad.

\begin{tabular}{|c|c|c|c|}
\hline $\begin{array}{l}\text { Nivel de } \\
\text { actividad }\end{array}$ & Período & Fatiga por & Recuperación por \\
\hline Vida laboral & Décadas & $\begin{array}{l}\text { Esfuerzo excesivo } \\
\text { durante décadas }\end{array}$ & Jubilación \\
\hline $\begin{array}{l}\text { Fases de vida } \\
\text { laboral }\end{array}$ & Años & $\begin{array}{l}\text { Esfuerzo excesivo } \\
\text { durante años }\end{array}$ & Vacaciones \\
\hline $\begin{array}{l}\text { Secuencias de } \\
\text { turnos de } \\
\text { trabajo }\end{array}$ & $\begin{array}{l}\text { Meses } 0 \\
\text { semanas }\end{array}$ & $\begin{array}{l}\text { Régimen de turnos } \\
\text { desfavorable }\end{array}$ & $\begin{array}{l}\text { Fin de semana, días } \\
\text { libres }\end{array}$ \\
\hline $\begin{array}{l}\text { Un turno de } \\
\text { trabajo }\end{array}$ & Un día & $\begin{array}{l}\text { Estrés superior al } \\
\text { límite de resistencia }\end{array}$ & $\begin{array}{l}\text { Tiempo libre, } \\
\text { períodos de descanso }\end{array}$ \\
\hline Tareas & Horas & $\begin{array}{l}\text { Estrés superior al } \\
\text { límite de resistencia }\end{array}$ & Período de descanso \\
\hline $\begin{array}{l}\text { Parte de una } \\
\text { tarea }\end{array}$ & Minutos & $\begin{array}{l}\text { Estrés superior al } \\
\quad \text { límite de resistencia }\end{array}$ & $\begin{array}{l}\text { Cambio de factores } \\
\text { de estrés }\end{array}$ \\
\hline
\end{tabular}

rendimiento que termina con una caída brusca del mismo. Los síntomas fisiológicos pueden producir una crisis en el organismo, cambios en la estructura de la personalidad y agotamiento. EI proceso de fatiga se explica en la teoría de la desestabilización sucesiva (L uczak 1983).

La tendencia principal de la fatiga y la recuperación se muestra en la Figura 29.22.

\section{Pronóstico de la fatiga y la recuperación}

En el campo de la ergonomía, existe un interés especial por predecir la fatiga en función de la intensidad, la duración y la composición de los factores de estrés y por determinar el tiempo necesario para la recuperación. La Tabla 29.2 muestra estos

Figura 29.24 - Porcentaje de periodos de descanso para diversas combinaciones de fuerzas mantenidas y tiempo.

Tiempo de mantenimiento

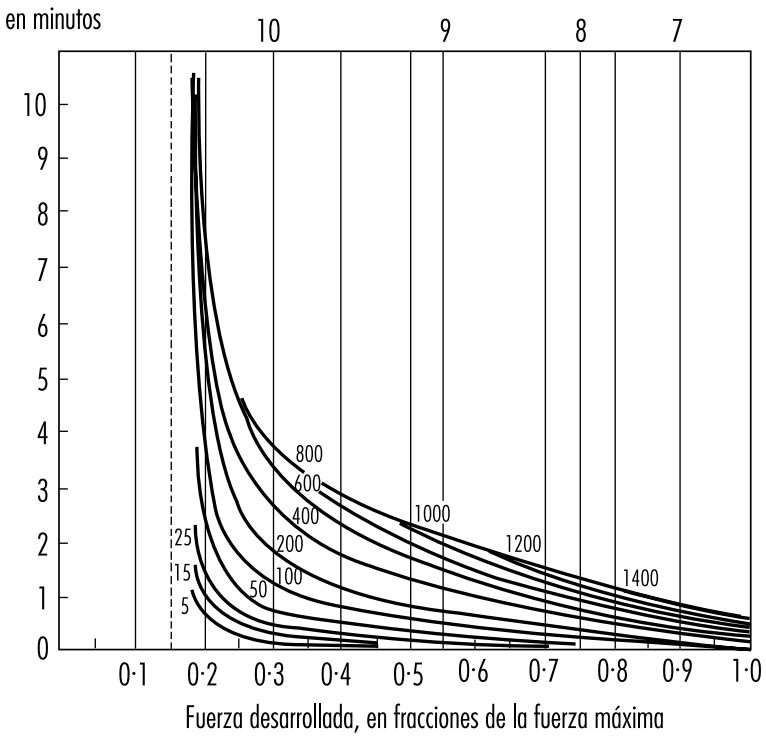


distintos niveles de actividad y períodos de consideración, las posibles causas de la fatiga y las distintas posibilidades de recuperación.

En el análisis ergonómico del estrés y la fatiga para determinar el tiempo de recuperación necesario, lo más importante es considerar un período de un día laborable. L os métodos de estos análisis comienzan por determinar los distintos factores de estrés en función del tiempo (L aurig 1992) (Figura 29.23).

Los factores de estrés se determinan a partir del contenido específico del trabajo y de las condiciones laborales. EI contenido del trabajo puede ser la producción de fuerza (por ejemplo, durante la manipulación de cargas), la coordinación de las funciones motoras y sensoriales (por ejemplo, durante el montaje o el uso de una grúa), la conversión de información en reacción (por ejemplo, en tareas de control), la transformación de información entrante en saliente (por ejemplo, al programar o traducir) y la producción de información (por ejemplo, al diseñar o resolver problemas). Las condiciones de trabajo pueden tener aspectos físicos (ruido, vibración, calor), químicos (agentes químicos) y sociales (por ejemplo, compañeros, turnos de trabajo).

En el caso más sencillo, existe un sólo factor de estrés importante, y los otros pueden considerarse irrelevantes. En estos casos, especialmente cuando los factores de estrés derivan del trabajo muscular, con frecuencia es posible calcular los períodos de descanso necesarios, puesto que se conocen los conceptos básicos.

Por ejemplo, el período de descanso suficiente en un trabajo muscular estático dependerá de la fuerza y de la duración de la contracción muscular como una función exponencial relacionada por un producto de acuerdo con la fórmula:

$$
\text { P.D. }=18 \cdot\left(\frac{t}{T}\right)^{1,4} \cdot\left(\frac{f}{F}-0,15\right)^{0,5} \cdot 100 \text { si } \frac{f}{F}>0,15
$$

donde

P.D. = Período de descanso como porcentaje de $t$

$\mathrm{t}=$ duración de la contracción (período de trabajo) en minutos

T = duración máxima posible de la contracción en minutos

$f=$ fuerza necesaria para la fuerza estática y

$F$ = fuerza máxima

La relación entre la fuerza, el tiempo de mantenimiento y el período de descanso se muestra en la Figura 29.24.

Existen leyes similares para el trabajo muscular dinámico pesado (Rohmert 1962), el trabajo muscular activo ligero (Laurig 1974) o un trabajo muscular industrial distinto (Schmidtke 1971). Es más difícil encontrar leyes similares para el trabajo no físico, por ejemplo, para el trabajo con ordenadores (Schmidtke 1965). Para una revisión de los métodos existentes para determinar los permisos de descanso, principalmente para el trabajo muscular aislado y para el trabajo no muscular, pueden consultarse los trabajos de Laurig (1981) y Luczak (1982).

Las situaciones en las que se combinan distintos factores de estrés y afectan simultáneamente al trabajador, como se muestra en la Figura 29.25, son bastante más complicadas (L aurig 1992).

La combinación de dos factores de estrés, por ejemplo, puede producir distintas reacciones de tensión dependiendo de las leyes de combinación. El efecto combinado de distintos factores de estrés puede ser indiferente, compensador 0 acumulativo.

En el caso de las leyes de la combinación indiferente, los distintos factores de estrés tienen un efecto sobre distintos subsistemas del organismo. Cada uno de estos subsistemas puede compensar la tensión sin que ésta alimente un subsistema común. La tensión total depende del factor de estrés más
Figura 29.25 • Combinación de dos factores de estrés.

Intensidad del estrés causado por transportar cargas

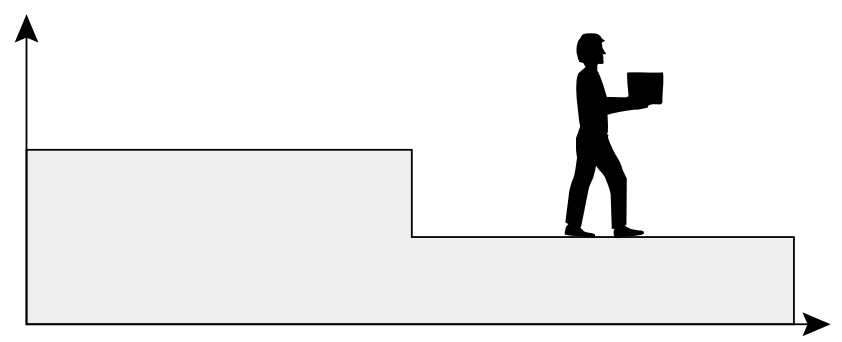

Intensidad del estrés causado por radiación térmica

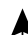
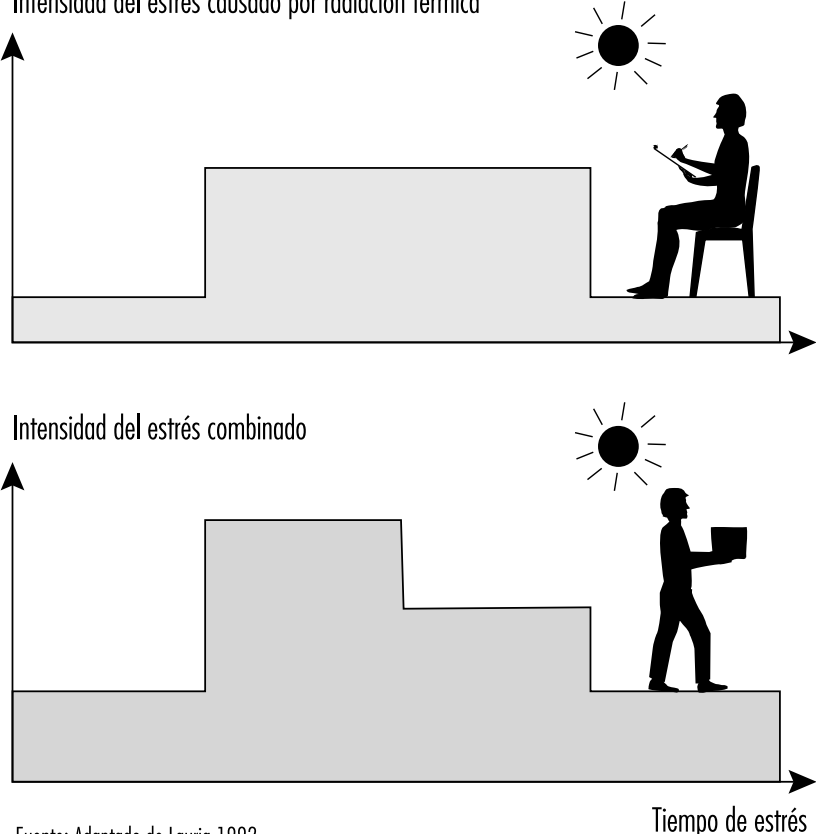

Fuente: Adaptado de Laurig 1992

elevado y, por lo tanto, no es necesario aplicar las leyes de superposición.

El efecto compensador se da cuando la combinación de distintos factores de estrés produce una tensión menor que cada uno de los factores de estrés por separado. La combinación de trabajo muscular y bajas temperaturas puede reducir la tensión total, ya que las bajas temperaturas contribuyen a que el organismo disipe el calor producido por el trabajo muscular.

El efecto acumulativo se produce por la superposición de varios factores de estrés, es decir, que deben pasar a través de

Tabla 29.3 • Reglas del efecto de combinación de dos factores de estrés sobre la tensión.

$\begin{array}{lllll} & \text { Frío } & \text { Vibración } & \text { lluminación } & \text { Ruido } \\ \text { Trabajo dinámico pesado } & - & + & 0 & 0 \\ \text { Trabajo muscular activo ligero } & + & + & 0 & 0 \\ \text { Trabajo muscular estático } & + & + & 0 & 0 \\ 0 \text { efecto indiferente; + efecto acumulativo; - efecto compensador. } \\ \text { Fuente: Adaptado de Bruder 1993. }\end{array}$


una especie de "cuello de botella" fisiológico. U n ejemplo podría ser la combinación de trabajo muscular y estrés por calor. A mbos factores de estrés afectan al sistema circulatorio como si se tratara de un cuello de botella común, produciéndose una tensión acumulada.

L os posibles efectos de combinación entre el trabajo muscular y las condiciones físicas se describen en Bruder (1993) (véase la Tabla 29.3).
En el caso de la combinación de más de dos factores de estrés, que es la situación normal en la práctica, existen muy pocos datos científicos. Lo mismo sucede con la combinación sucesiva de los factores de estrés, es decir, el efecto sobre la tensión de distintos factores de estrés que afectan sucesivamente al trabajador. Para estos casos, en la práctica, el tiempo necesario de recuperación se determina midiendo parámetros fisiológicos 0 psicológicos y utilizándolos como valores de integración.

\section{ASPECTOS PSICOLÓGICOS}

\section{- CARGa mental de trabajo}

\section{Winfried H acker}

\section{Carga mental frente a carga física}

El concepto de carga mental de trabajo (CM T) está adquiriendo cada vez más importancia ya que las tecnologías modernas, semiautomáticas e informáticas pueden imponer mayores exigencias en cuanto a las capacidades humanas mentales o de procesamiento de la información, tanto en las tareas administrativas como de fabricación. De este modo, especialmente en el campo de análisis del trabajo, evaluación de los requisitos para un puesto determinado y diseño del puesto, el concepto de "carga mental de trabajo", ha adquirido incluso más importancia que el de la carga física de trabajo tradicional.

\section{Definiciones de la carga mental de trabajo}

No existe una definición universal de carga mental de trabajo. La razón principal es que hay al menos dos definiciones y enfoques que cuentan con una base teórica sólida: (1) la CM T se considera, en términos de las exigencias de la tarea, como una variable independiente externa a la que los trabajadores tienen que enfrentarse de manera más o menos eficaz, y (2) la CMT se define en términos de interacción entre las exigencias de la tarea y las capacidades o recursos de la persona ( $\mathrm{H}$ ancock y Chignell 1986; Welford 1986; W ieland-Eckelmann 1992).

Aunque surgen de contextos diferentes, ambos enfoques son necesarios y ayudan a entender distintos problemas de forma bien fundamentada.

El enfoque de la interacción exigencias-recursos se desarrolló dentro del contexto de las teorías de adaptación o no adaptación entre personalidad y entorno, que tratan de explicar las reacciones que distinguen a unos individuos de otros ante condiciones y exigencias idénticas en el plano físico y psicosocial. A sí, este enfoque puede explicar las diferencias individuales en los patrones de reacciones subjetivas ante determinadas exigencias y condiciones de carga, por ejemplo, en términos de fatiga, monotonía, aversión afectiva, agotamiento o enfermedad (Gopher y D onchin 1986; $\mathrm{H}$ ancock y M eshkati 1988).

El enfoque relacionado con las exigencias de la tarea se desarrolló en el seno de aquellas ramas de la psicología laboral y la ergonomía que están más vinculados con el diseño de tareas, especialmente en lo que respecta al diseño de tareas nuevas y futuras, aún desconocidas: el denominado diseño prospectivo de tareas. EI concepto básico es el de estrés-tensión. L os requisitos de la tarea constituyen el estrés y los trabajadores tratan de adaptarse o de enfrentarse a las exigencias impuestas de la misma forma que lo harían con otras formas de estrés (H ancock y Chignell 1986). EI enfoque relacionado con las exigencias de la tarea intenta responder a la pregunta: ¿cómo diseñar una tarea para reducir en lo posible el impacto posterior, por lo general, aún desconocido, que tendrá sobre los trabajadores que vayan a desempeñarla?

Existen algunas características comunes en ambas conceptualizaciones de la CM T.

1. La CM T describe, sobre todo, los aspectos conocidos de la tarea, es decir, los requisitos y exigencias que las tareas imponen a los trabajadores, que podrían utilizarse para predecir el resultado de la misma.

2. L os aspectos mentales de CM T se conceptualizan en términos del procesamiento de la información. El procesamiento de la información incluye aspectos cognitivos, volitivos o de motivación, y emocionales, ya que las personas siempre evalúan las exigencias que tienen que cumplir y autorregulan su esfuerzo para llevarlas a cabo.

3. EI procesamiento de la información integra los procesos mentales, las representaciones (como el conocimiento o el modelo mental de una máquina) y los estados mentales (por ejemplo, estados de consciencia, grados de activación y, de manera menos formal, el estado de ánimo).

4. La CM T es una característica multidimensional de los requisitos de la tarea, ya que toda tarea se distingue por un par de aspectos relacionados entre sí, pero independientes, que deben considerarse por separado en el diseño de la misma.

5. La CMT tendrá un impacto multidimensional que determinará, al menos, (a) el comportamiento, por ejemplo, las estrategias y el rendimiento obtenido, (b) el bienestar subjetivo y percibido a corto plazo, con las consecuencias que tendrá para la salud a largo plazo y (c) los procesos psico-fisiológicos, por ejemplo, la alteración de la presión sanguínea en el trabajo, que pueden convertirse a largo plazo en un efecto positivo (facilitando, por ejemplo, la mejora de las aptitudes) 0 negativo (discapacidades o enfermedades).

6. D esde el punto de vista del diseño de tareas, la CM T no debe minimizarse, como sería necesario en el caso de contaminación del aire por cancerígenos, sino que debe ofrecer un equilibrio. Son necesarias ciertas exigencias mentales para mantener el bienestar, la salud y la cualificación, ya que dichas exigencias proporcionan los estímulos necesarios para la activación, las condiciones para mantenerse en forma y las opciones de aprendizaje/ entrenamiento. Una carencia de exigencias puede conducir a la "desactivación", a la pérdida de la forma física, a la descapacitación y al deterioro de la llamada motivación intrínseca (dependiente del contenido de la tarea). L os descubrimientos en este terreno conducen a la técnica del diseño de tareas que fomenten la personalidad y la salud (H acker 1986).

7. En cualquier caso, la CM T debe considerarse al realizar un análisis de tareas, en la evaluación de las exigencias de las tareas y en el diseño prospectivo y correctivo de tareas. 
Figura 29.26 - Tipos y consecuencias de las relaciones exigencias-recursos.

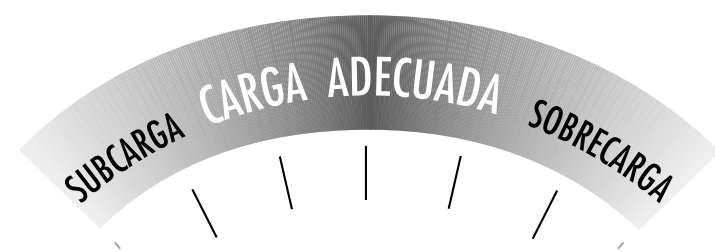

'

\begin{tabular}{|c|c|}
\hline CUALITATIVA & CUANTITATIVA \\
\hline Exigencias & \\
con suficiente & Las exigencias \\
frecuencia, & mentales son \\
pero simples y & muy escasas \\
concretos & \\
\hline
\end{tabular}

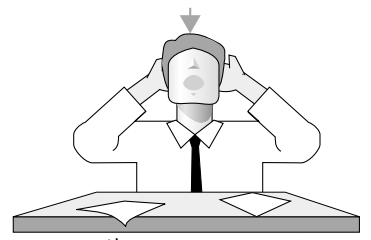

Aburrimiento, monotonía

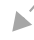
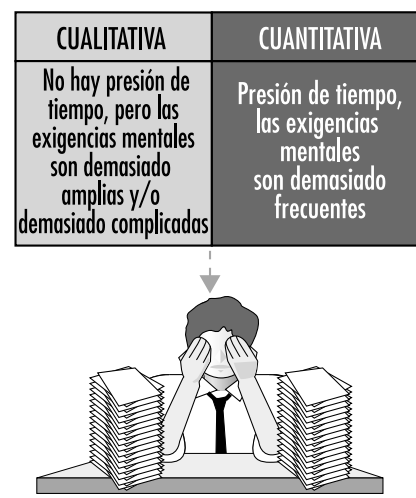

Fatiga mental. En casos extremos, frustración, posiblemente combinada con ansiedad

\section{Enfoques teóricos: enfoque exigencias-recursos}

Desde el punto de vista de la adaptación persona-entorno, la CMT y sus consecuencias pueden clasificarse de forma general en tres categorías, como muestra la Figura 29.26: subcarga, carga adecuada y sobrecarga. Esta clasificación es el resultado de las relaciones entre las exigencias de la tarea y los recursos o las capacidades mentales. Los requisitos de una tarea pueden superar, coincidir o ser inferiores a los recursos. Ambos tipos de inadaptación pueden ser el resultado de modalidades cualitativas o cuantitativas de inadaptación y tendrán consecuencias cualitativamente distintas, pero siempre negativas (ver Figura 29.26).

Algunas teorías intentan definir la carga mental a partir de los recursos o capacidades junto a las exigencias, es decir, la relación entre los recursos. Estas teorías del recurso podrían subdividirse en la teoría del volumen de recursos y la teoría de distribución de recursos (Wieland-Eckelmann 1992). La cantidad de recursos disponibles puede proceder de una sola fuente (teoría del recurso único) que determina el procesamiento. La disponibilidad de este recurso varía en función del estado de alerta (K ahneman 1973). Las teorías modernas de los recursos múltiples suponen un conjunto de recursos de procesamiento relativamente independientes entre sí. A sí, el rendimiento dependerá de si se está utilizando el mismo recurso o varios diferentes de forma simultánea y conjunta. L os recursos diferentes son, por ejemplo, los de codificación, procesamiento o respuesta (Gopher y Donchin 1986; Welford 1986). El problema más importante con este tipo de teorías surge al intentar identificar de manera fiable una o varias capacidades bien delimitadas para operaciones de procesamiento cualitativamente distintas.

Las teorías de distribución de los recursos suponen un cambio cualitativo del procesamiento en función de diversas estrategias. Dependiendo de las estrategias, pueden aplicarse distintos procesamientos y representaciones mentales para la realización

de una tarea. Por tanto, lo que interesa no será el volumen de recursos estables, sino la flexibilidad de las estrategias. De nuevo, sin embargo, quedan por responder preguntas de gran importancia, especialmente las relacionadas con los sistemas de diagnóstico de las estrategias.

\section{Valoración de la CM T: según el enfoque de exigencias-recursos}

Actualmente, no es posible medir con exactitud la CMT, ya que no existen unidades de medida definidas. Pero para estar seguros, la conceptualización y los instrumentos de valoración deben ajustarse a los criterios generales de diagnóstico, que son la objetividad, la fiabilidad, la validez y la utilidad. Sin embargo, se sabe muy poco de la calidad general de las técnicas 0 instrumentos propuestos.

$\mathrm{H}$ ay una serie de razones que explican las dificultades para valorar la CMT en función del enfoque exigencias-recursos (O 'D onnell y Eggemeier 1986). Todo intento de valoración de la CMT tiene que dar respuesta a preguntas como las siguientes: ¿tiene la tarea un fin en sí misma? ¿Persigue unos objetivos autodeterminados? ¿ 0 está dirigida a un objetivo impuesto por un mandato externo? ¿Q ué tipo de capacidades (procesamiento mental consciente, aplicación de conocimientos, etc.) son necesarias? ¿Se utilizan simultáneamente 0 de forma secuencial? ¿Existen diferentes estrategias y, si es así, cuáles son? ¿Q ué recursos necesitará el trabajador para afrontar la situación?

Los enfoques más estudiados tratan de valorar la CMT en términos de:

1. esfuerzo necesario (valoración del esfuerzo): este enfoque aplica, en algunas versiones psicofisiológicamente validados procedimientos de escalas, como los sugeridos por Bartenwerfer (1970) o Eilers, N achreiner y H änicke (1986), o

2. capacidad mental ocupada o residual (valoración de la capacidad mental) estos enfoques aplican las tradicionales técnicas de la doble tarea como, por ejemplo, las estudiadas por 0 'D onnell y Eggemeier (1986).

Ambos enfoques dependen en gran medida de los supuestos de las teorías del recurso único y, en consecuencia, tendrán que hacer frente a las preguntas formuladas anteriormente.

Valoración del esfuerzo. Las técnicas de valoración del esfuerzo como, por ejemplo, el procedimiento de escalas aplicado a una correlación percibida de la activación central general, desarrollado y validado por Bartenwerfer (1970), ofrece unas escalas verbales que pueden completarse con otras gráficas y valoran la parte que varía de forma unidimensional en el esfuerzo requerido percibido durante el cumplimiento de una tarea. Se pide a los sujetos que describan el esfuerzo percibido siguiendo los pasos de la escala que se les muestra.

Esta técnica cumple los criterios de calidad mencionados anteriormente. Entre sus limitaciones cabe destacar la unidimensionalidad de la escala, que cubre una parte esencial pero cuestionable del effuerzo percibido; la posibilidad, limitada 0 inexistente, de predecir el resultado de la tarea personal percibida, por ejemplo, en términos de fatiga, aburrimiento 0 ansiedad; y especialmente, el carácter formal o excesivamente abstracto del esfuerzo, que identificará y explicará muy poco los aspectos de la CMT que dependen del contexto, por ejemplo, las posibles aplicaciones útiles de la capacitación o las opciones de aprendizaje.

Valoración de la capacidad mental. La valoración de la capacidad mental consiste en la técnica de la doble tarea y en un procedimiento de interpretación de los datos relacionados con ella que se denomina característica del rendimiento operativo (CRO). Las técnicas de la doble tarea abarcan varios procedimientos. Su característica común es que se pide a los participantes que 
realicen simultáneamente dos tareas. La hipótesis fundamental es que, en una situación de doble tarea, cuanto menos se deteriore la tarea adicional o secundaria en comparación con la situación de tarea única, menores serán las exigencias de capacidad mental de la tarea primaria, y viceversa. El enfoque se ha ampliado en la actualidad y se están investigando distintas versiones de interferencias en condiciones de doble tarea. Por ejemplo: se indica a los sujetos que realicen dos tareas simultáneamente con variaciones de prioridad de las tareas. La curva de CRO muestra gráficamente los efectos de las posibles combinaciones de doble tarea que surgen al compartir recursos limitados para la realización simultánea de varias tareas.

Las críticas a este enfoque se centran principalmente en que cada tarea requerirá una cierta proporción de la capacidad consciente de procesamiento limitada y estable (frente a otra inconsciente, automatizada, implícita o tácita), en la hipotética relación aditiva para la que se requieren los dos tipos de capacidad, y en que es un enfoque limitado que sólo considera los datos sobre el rendimiento, lo que puede dar lugar a confusión por varias razones. En primer lugar, existen diferencias substanciales entre la sensibilidad de los datos de rendimiento y los datos subjetivamente percibidos. La carga percibida parece estar determinada, sobre todo, por la cantidad de recursos necesarios, normalmente operacionalizados en términos de memoria de trabajo, mientras que las medidas del rendimiento parecen estar determinadas, sobre todo, por la eficacia del reparto de recursos, dependiendo de la distribución de las estrategias (esta es la teoría de la disociación; véase Wickens y Yeh 1983). Por otra parte, las diferencias individuales de capacidad de procesamiento de la información y las características de personalidad pueden influir de forma importante sobre los indicadores de CMT, dentro de las áreas subjetiva (percibida), de rendimiento y psicofisiológica.

\section{Enfoques teóricos: enfoque de exigencias de la tarea}

Como ya se ha visto, las exigencias de las tareas son multidimensionales, por lo que no se pueden describir completamente en una sola dimensión, sea ésta el esfuerzo percibido o la capacidad residual mental consciente. U na descripción más profunda podría ser la de un perfil, en la que se aplica un patrón de las dimensiones de las características de la tarea seleccionado de forma teórica. El tema central será por tanto la conceptualización de la "tarea", especialmente en términos de contenido, y de "cumplimiento de la tarea", sobre todo en lo relacionado con la estructura y las fases de las acciones destinadas a la consecución de un objetivo. El papel que desempeña la tarea se refuerza por el hecho de que hasta el impacto de las condiciones contextuales sobre las personas (por ejemplo, la temperatura, el ruido o las horas de trabajo) depende de la tarea, ya que estos factores vienen condicionados por la tarea (Fisher 1986). $\mathrm{H}$ ay varios enfoques teóricos que coinciden en lo relativo a las dimensiones críticas de la tarea y que ofrecen una predicción válida de los resultados de la misma. En cualquier caso, el resultado de una tarea tendrá dos vertientes, ya que (1) el resultado perseguido debe lograse cumpliendo los criterios de rendimiento-resultados y (2) aparecerán una serie de efectos no buscados, tanto personales a corto plazo, como acumulativos a largo plazo, como la fatiga, el aburrimiento (la monotonía), las enfermedades laborales 0 la mejora de la motivación intrínseca, el conocimiento o las habilidades.

Valoración de la CM T. Los enfoques centrados en los requisitos de la tarea, como los de acciones completas frente a acciones parciales o el índice del potencial de motivación (para más detalles, véase $\mathrm{H}$ acker 1986), proponen como características indispensables de la tarea, para su análisis y evaluación, al menos las siguientes:

- autonomía temporal y de procedimiento, en relación con las decisiones sobre los objetivos autoimpuestos y, en consecuencia, transparencia, posibilidad de predicción y control de la situación laboral;

- la cantidad y la diversidad de las tareas secundarias, especialmente en lo relativo a la preparación, organización y comprobación de los resultados obtenidos, y de las acciones que las acompañan, es decir, si dichas acciones deben finalizarse cíclicamente, o si están fragmentadas;

- variedad ("nivel") de procesos y representaciones mentales reguladores de la acción. Estos pueden ser procesos mentalmente automatizados o convertidos en rutinarios, procesos basados en el conocimiento y experiencia anteriores o procesos intelectuales y de resolución de problemas. (También puede caracterizarse un conjunto jerarquizado en oposición a una fragmentación de tareas);

- cooperación requerida;

- exigencias u opciones de aprendizaje a largo plazo para identificar las características de estas tareas es necesario utilizar los procedimientos conjuntos de análisis de trabajo o tarea, con análisis de documentos, observación, entrevistas y discusiones de grupo, que deben integrarse en un diseño cuasi experimental (R udolph, Schönfelder y Hacker 1987). Hay varios instrumentos disponibles para el análisis de tareas, que pueden guiar y servir de ayuda a la hora de realizar el análisis. A lgunos de ellos contribuyen sólo al análisis en sí (por ejemplo, N ASA-T LX T ask L oad Index, H art y Staveland, 1988), mientras que otros son útiles para la evaluación y el diseño o rediseño. Un ejemplo de esto es el TBS-GA (T ätigkeitsbewertungs System für geistige Arbeit [Sondeo para el diagnóstico de tareas: trabajo mental]); véase $\mathrm{R}$ udolph, Schönfelder y $\mathrm{H}$ acker (1987).

\section{VIGILANCIA}

\section{Herbert H euer}

EI concepto de vigilancia se refiere al estado de alerta del observador humano en labores que requieren el registro y el procesamiento de señales. Las características esenciales de las tareas de vigilancia son su duración, relativamente prolongada, y la necesidad de detectar estímulos (señales) infrecuentes e imprevisibles en un escenario (fondo) en el que se producen otros estímulos y sucesos.

\section{Tareas de vigilancia}

El prototipo de tarea en que se basan los trabajos de investigación es el de los operadores de radar. A lo largo de la historia, sus resultados, aparentemente insatisfactorios durante la segunda Guerra M undial, han supuesto un reto en el estudio de la vigilancia. O tra tarea que requiere vigilancia es el proceso de inspección industrial. En general, cualquier tipo de tarea de seguimiento que requiera la detección de señales relativamente infrecuentes conlleva el riesgo de fallos a la hora de detectar estos sucesos críticos y de reaccionar ante ellos.

Las labores de vigilancia componen un conjunto heterogéneo y varían en distintas dimensiones, a pesar de sus características comunes. Una dimensión obviamente importante es la tasa de estímulos generales, así como el índice de estímulos "blanco". No siempre es posible definir una tasa de estímulos sin caer en la ambigüedad. Esto sucede con las tareas que requieren la 
detección de unos estímulos, que se presentan sobre unos estímulos de fondo, así como a la hora de detectar valores críticos en una tarea de seguimiento. U na distinción importante, aunque menos evidente, es la que existe entre las tareas de discriminación sucesiva y simultánea. En las tareas de discriminación simultánea tanto los estímulos "blanco" como los de fondo se presentan al mismo tiempo, mientras en las tareas de discriminación sucesiva, uno se presenta detrás del otro de forma que se plantean ciertos requisitos de memoria. Aunque la mayoría de las tareas de vigilancia requieren una detección de estímulos visuales, también se han estudiado otro tipo de estímulos. Los estímulos pueden restringirse a una sola posición espacial, o pueden proceder de fuentes diversas. Los estímulos "blanco" pueden diferir de los estímulos de fondo por sus características físicas, pero también por otras, más conceptuales, (como un patrón determinado de lecturas métricas que puede ser distinto de otros patrones). Naturalmente, la facilidad de detección de los estímulos blanco puede variar: algunos son fácilmente detectables, pero otros pueden resultar difíciles de discriminar de los estímulos de fondo. Los estímulos "blanco" pueden ser únicos 0 pueden existir en conjuntos, sin fronteras definidas que los diferencien de los estímulos de fondo, como sucede en muchas tareas de inspección industrial. La lista de dimensiones que diferencian a unas tareas de vigilancia de otras podría ampliarse, pero es suficiente para enfatizar la heterogeneidad de las tareas de vigilancia y los riesgos que conlleva la generalización de determinadas observaciones de conjunto.

\section{Variaciones en el rendimiento y disminución de la vigilancia}

La medida de rendimiento que se utiliza con más frecuencia en las tareas de vigilancia es la proporción de estímulos blanco, por ejemplo, los productos defectuosos detectados en un proceso de inspección industrial. Esto es sólo una estimación de la probabilidad de los llamados aciertos. Los estímulos blanco que pasan inadvertidos se llaman fallos. Aunque la tasa de aciertos es una medida adecuada, resulta relativamente incompleta. $\mathrm{H}$ ay una estrategia muy simple que permite lograr un $100 \%$ de aciertos: sólo hace falta clasificar todos los estímulos como estimulo blanco. Sin embargo, una tasa de aciertos del $100 \%$ suele ir acompañada por una tasa de falsas alarmas del $100 \%$, es decir, no sólo se detectan adecuadamente los estímulos blanco, sino que los estímulos de fondo se "detectan" incorrectamente. Esta línea de razonamiento deja bastante claro que siempre que haya falsas alarmas, es importante conocer su proporción además de la tasa de aciertos. 0 tra medida del rendimiento en una tarea de vigilancia es el tiempo necesario para responder a un estímulo blanco (tiempo de reacción).

El rendimiento en las tareas de vigilancia tiene dos atributos típicos. El primero es el bajo nivel general de rendimiento en estas tareas en comparación con una situación ideal para los mismos estímulos (períodos breves de observación, alta disposición del observador para la discriminación, etc.). El segundo es la llamada disminución de la vigilancia, la disminución del rendimiento en el curso de la observación, que puede iniciarse tras los primeros minutos. Ambas observaciones se refieren a la proporción de aciertos, pero también se dispone de datos sobre los tiempos de reacción. Aunque la disminución de la vigilancia es habitual en las tareas de vigilancia, no es universal.

Al investigar las causas de un rendimiento general deficiente y de la disminución de la vigilancia, debe establecerse una distinción entre los conceptos relacionados con las características básicas de la tarea y los conceptos relacionados con factores del organismo y de la situación, que nada tienen que ver con la tarea. Entre los factores relacionados con la tarea pueden distinguirse los factores estratégicos y los no estratégicos.
Figura 29.27 - Umbrales y capacidad de discriminación.
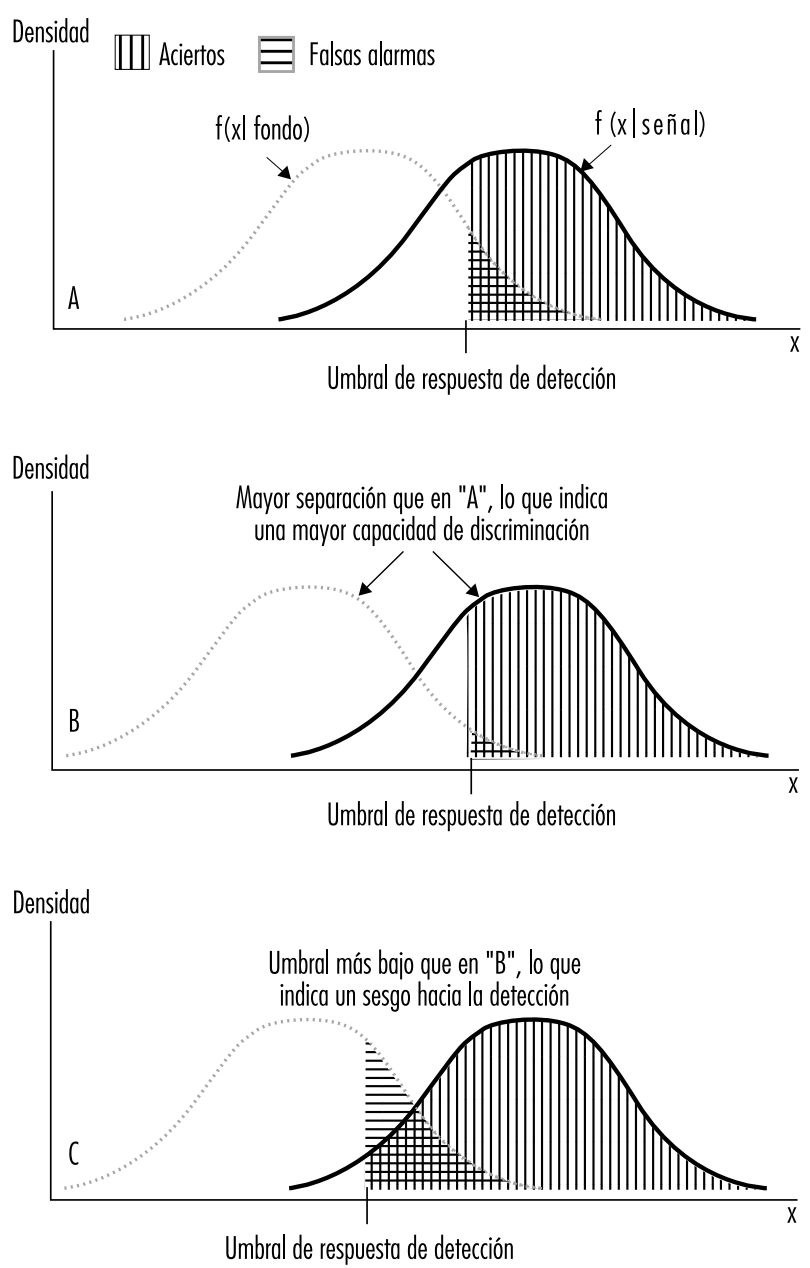

Umbral de la respuesta de detección y de la capacidad de discriminación en términos de una variable al azar, "prueba de la presencia de una señal" $[x]$, con diferentes funciones de densidad de probabilidad para valores de esta variable ante la presentación de estímulos "blanco" $[f(x \mid$ señal $)]$ y estímulos de fondo $[f(x \mid$ fondo $)]$.

\section{Procesos estratégicos en las tareas de vigilancia}

La detección de una señal, como por ejemplo un producto defectuoso, depende en parte de la estrategia utilizada por el observador, y en parte, de la capacidad de discriminación de la señal. La distinción se basa en la teoría de la detección de señales (T DS), y es necesario presentar algunos principios básicos de dicha teoría para destacar la importancia de esta discriminación. Consideremos una variable hipotética, definida como "prueba de la presencia de una señal". Siempre que se presente una señal, esta variable adquirirá algún valor y siempre que se presente un estímulo de fondo, su valor será inferior a la media. Se considera que el valor de la variable de prueba irá cambiando cada vez que se presente la señal. De esta forma, puede caracterizarse por la llamada función de densidad de la probabilidad, como se ilustra en la Figura 29.27. O tra función de densidad caracteriza los valores de la variable de prueba en las presentaciones de un estímulo de fondo. Cuando las señales son similares a los estímulos de fondo, las funciones se superponen, de forma que un valor de prueba determinado puede proceder de una señal 0 de un 
estímulo de fondo. La forma concreta de las funciones de densidad de la Figura 29.27 no es importante para el argumento.

La respuesta de detección por parte del observador se basa en la variable de prueba. Se parte de un umbral determinado para que se produzca una respuesta de detección, siempre que el valor de la variable de prueba esté por encima de dicho umbral. Como se ilustra en la Figura 29.27, el área bajo las funciones de densidad y a la derecha del umbral, corresponden a las probabilidades de aciertos y falsas alarmas. En la práctica, se puede hacer un cálculo aproximado de la separación de las dos funciones y la posición del umbral. La separación de las dos funciones de densidad caracteriza la capacidad de discriminación de los estímulos blanco frente a los estímulos de fondo, mientras la posición del umbral caracteriza la estrategia del observador. La variación del umbral da lugar a una variación conjunta de las proporciones de aciertos y falsas alarmas. Con un umbral alto, la proporción de aciertos y falsas alarmas será pequeña, mientras que con un umbral bajo, la proporción será grande. De este modo, seleccionar una estrategia (colocación del umbral) significa seleccionar una combinación determinada de tasas de aciertos y falsas alarmas entre las combinaciones posibles para una capacidad de discriminación determinada.

Dos factores importantes que influyen en la posición del umbral son los resultados y la frecuencia de las señales. EI umbral tendrá un valor bajo cuando haya mucho que ganar con un acierto y poco que perder si se produce una falsa alarma, y un valor alto cuando las falsas alarmas pueden resultar costosas y los beneficios de los aciertos son discretos. Un valor de umbral bajo puede deberse también a una proporción alta de señales, mientras la baja proporción de señales tiende a inducir valores de umbral más altos. El efecto de la frecuencia de las señales sobre el valor del umbral es un factor decisivo para el bajo rendimiento general, en términos de proporción de aciertos en las tareas de vigilancia, y para la disminución de la vigilancia.

La valoración de la disminución de la vigilancia en términos de los cambios estratégicos (cambios de umbral) exige que la reducción de la proporción de aciertos, en el curso de una observación, vaya acompañada por una reducción en la proporción de falsas alarmas. Así lo demuestran muchos estudios, y es probable que el rendimiento deficiente generalizado en las tareas de vigilancia (en comparación con una situación óptima) también se deba, al menos en parte, a los ajustes del umbral. En el curso de una observación, la frecuencia relativa de respuestas de detección coincide con la frecuencia relativa de los estímulos blanco, y este ajuste implica un alto valor de umbral con una proporción relativamente baja de aciertos y una proporción igualmente baja de falsas alarmas. A pesar de todo, se produce una disminución de la vigilancia como resultado de los cambios en la capacidad de discriminación más que por los cambios en los valores del umbral. Esta situación se ha observado sobre todo en las tareas de discriminación sucesiva con un índice relativamente alto de estímulos.

\section{Procesos no estratégicos en las tareas de vigilancia}

Aunque parte del rendimiento deficiente generalizado en una tarea de vigilancia y muchos casos de disminución de la vigilancia se pueden justificar en términos de ajustes estratégicos de los umbrales de detección a tasas bajas de señal, ésta no es la única causa. Durante la realización de una tarea de observación se producen cambios en el observador que pueden reducir considerablemente la capacidad para discriminar estímulos o producir cambios aparentes en el umbral, que no pueden considerarse como adaptación a las características de la tarea. En más de 40 años de investigación sobre las tareas de vigilancia se han identificado una serie de factores no estratégicos que contribuyen a que el rendimiento general sea deficiente y a que se produzca una disminución en la vigilancia.

U na respuesta correcta ante un estímulo "blanco" en una tarea de vigilancia exige una capacidad de registro sensorial suficientemente precisa, una posición adecuada del umbral y un vínculo entre los procesos de percepción y los procesos relacionados con las respuestas asociadas. D urante la tarea de observación, los observadores tienen que realizar un determinado conjunto de tareas, deben mantener una cierta disposición para dar una respuesta a los estímulos blanco de una determinada forma. Este es un requisito importante, ya que sin la existencia de un conjunto de tareas, el observador no podría responder a los estímulos blanco de la forma requerida. L as dos causas principales de errores pueden tener su origen en un registro sensorial impreciso y en los lapsus en la capacidad de respuesta a los estímulos objeto. L as hipótesis principales que explican estos fallos se describen brevemente a continuación.

La detección e identificación de estímulos es más rápida cuando no existe incertidumbre temporal o espacial en relación con su aspecto. La incertidumbre temporal o espacial puede reducir el rendimiento en las tareas de vigilancia. Esta es la predicción esencial de la teoría de la expectación. La disposición óptima del observador requiere una certeza temporal y espacial. O bviamente, las tareas de vigilancia no son perfectas en este aspecto. Aunque la teoría de la expectación se centra fundamentalmente en un bajo rendimiento generalizado, también puede servir para justificar determinados aspectos de la disminución de la capacidad de vigilancia. Con señales infrecuentes a intervalos aleatorios, pueden existir niveles elevados de disposición inicial en momentos en los que no se recibe una señal; además, las señales pueden producirse cuando el nivel de disposición es bajo. Esto elimina los niveles altos de disposición en general, de forma que, sean cuales sean los beneficios obtenidos, se desvanecerán en el curso de una tarea.

La teoría de la expectación está en estrecha relación con las teorías de la atención. Las variaciones de las teorías de la atención en las tareas de vigilancia están relacionadas, naturalmente, con las teorías dominantes de la atención en general. Consideremos que una definición de atención sea la "selección de un proceso" - la "selección de una acción". Según esta consideración, los estímulos del entorno se seleccionan y se procesan con una eficacia elevada cuando contribuyen al plan de acción o al conjunto de tareas dominantes. Como ya se ha dicho, la selección se beneficiará de la existencia de expectativas precisas relacionadas con cuándo y dónde se producirán esos estímulos. Pero los estímulos sólo se seleccionarán si el plan de acción (el conjunto de tareas) está activo. (Los conductores de automóviles, por ejemplo, reaccionan ante los semáforos, el tráfico, etc.; los pasajeros no suelen hacerlo, aunque ambos están prácticamente en la misma situación. La diferencia principal está entre los conjuntos de tareas de los dos: sólo el conjunto de tareas del conductor requiere una reacción ante los semáforos).

La selección de estímulos para su procesamiento se verá afectada cuando el plan de acción quede temporalmente desactivado, es decir, cuando el conjunto de tareas desaparezca durante un tiempo. Las tareas de vigilancia incluyen una serie de características que impiden el mantenimiento continuo del conjunto de tareas, como los ciclos cortos para procesar los estímulos, la falta de retroinformación y el pequeño reto que supone la motivación por la aparente dificultad de la tarea. Los denominados bloqueos pueden observarse en casi todas las tareas cognitivas sencillas de ciclo corto, como los cálculos aritméticos mentales simples o las respuestas rápidas en serie a señales sencillas. Se producen bloqueos similares en el mantenimiento de un conjunto de tareas durante la realización de una labor de vigilancia. No son inmediatamente reconocibles como respuestas 
retardadas, porque las reacciones son infrecuentes y los estímulos blanco que se presentan durante un período de ausencia del conjunto de tareas pueden no estar allí una vez terminada esa ausencia, de forma que se percibirá una falta en lugar de una reacción retardada. Los bloqueos se hacen más frecuentes a medida que aumenta el tiempo invertido en una tarea. Esto puede dar lugar a la disminución de la capacidad de vigilancia. Puede haber otros motivos para que se produzcan lapsus temporales de disponibilidad del conjunto adecuado de tareas como, por ejemplo, la distracción.

Algunos estímulos no se seleccionan en función del plan de acción activo, sino por sus características. Estos son estímulos intensos, nuevos, que afectan la sensibilidad del observador, que tienen un comienzo abrupto o que, por cualquier otro motivo, pueden requerir una acción inmediata independientemente del plan de acción del observador. Es difícil no detectar dichos estímulos. Estos atraen la atención de forma automática, como por ejemplo, en la respuesta de orientación, que implica un cambio de dirección de la mirada hacia la fuente del estímulo. Sin embargo, el hecho de prestar atención al timbre de una alarma no se considera normalmente una tarea de vigilancia. Además de los estímulos que atraen la atención por sus propias características, existen estímulos que se procesan automáticamente como consecuencia de la práctica. Estos parecen surgir de forma repentina del entorno. Este tipo de procesamiento automático requiere una amplia experiencia con el llamado mapa coherente, es decir, la asignación coherente de respuestas a los estímulos. U na vez se ha desarrollado el procesamiento automático de los estímulos, es probable que la disminución de la vigilancia sea muy pequeña o incluso inexistente.

Finalmente, la tarea de vigilancia se resiente por la falta de activación o "arousal". Este concepto se refiere de forma bastante global a la intensidad de la actividad neurológica, que va desde el sueño hasta un alto grado de excitación, pasando por la vigilia normal. U no de los factores que se piensa que afecta a la activación es la estimulación externa, que es bastante baja y uniforme en la mayoría de las tareas de vigilancia. A sí, la intensidad de la actividad del sistema nervioso central puede disminuir en el curso de una tarea de observación. Un aspecto importante de la teoría de la activación o del arousal es que relaciona el rendimiento durante la tarea de vigilancia con varios factores orgánicos o con factores de situación independientes de la tarea.

\section{La influencia de los factores de situación y orgánicos}

Una baja activación contribuye a un rendimiento deficiente en las tareas de vigilancia. Así, el rendimiento puede mejorar gracias a factores de situación que tienden a propiciar la activación, y puede verse reducido por aquellas medidas que reducen el nivel de activación. En el equilibrio, esta generalización es correcta para el nivel de rendimiento global registrado en las tareas de vigilancia, pero los efectos sobre la disminución de la vigilancia son inexistentes, o su observación es menos fiable en los distintos tipos de manipulación de la activación.

Una forma de aumentar el nivel de activación consiste en introducir ruidos adicionales. Sin embargo, la disminución de la capacidad de vigilancia no suele verse afectada y, en relación con el rendimiento general, los resultados son poco reproducibles: se han observado niveles de rendimiento mejorado, invariable y reducido. Tal vez la naturaleza compleja del ruido sea importante. Por ejemplo, puede resultar afectivamente neutro 0 molesto; puede tener no sólo capacidad de activación, sino también de distracción. Las consecuencias de la privación de sueño, que tiene un efecto desactivante, suelen ser más constantes. Por lo general, se reduce el rendimiento en la tarea de vigilancia y se ha comprobado que aumenta el descenso de la capacidad de vigilancia. También se han observado cambios en el rendimiento de la vigilancia cuando se utilizan fármacos depresores como las benzodiazepinas o el alcohol, o estimulantes como las anfetaminas, la cafeína o la nicotina.

Las diferencias individuales son una característica apreciable del rendimiento en las tareas de vigilancia. Aunque las diferencias individuales no son constantes en todos los tipos de tareas de vigilancia, sí suelen conservarse en las tareas similares. EI sexo y la inteligencia general tienen muy poco o ningún efecto. Con relación a la edad, el rendimiento de la vigilancia aumenta durante la infancia y empieza a decaer a partir de los sesenta años. Además hay muchas posibilidades de que una persona introvertida ofrezca un rendimiento superior al de una extrovertida.

\section{Aumento en el rendimiento de la vigilancia}

Las teorías y los datos existentes sugieren algunos medios para mejorar el rendimiento en las tareas de vigilancia. D ependiendo de lo específicas que sean las sugerencias, no resulta difícil elaborar listas más o menos extensas. A continuación se ofrecen algunas ideas generales, que tendrán que ser delimitadas según las exigencias de la tarea en cuestión, en relación con la facilidad de discriminación perceptiva, los ajustes estratégicos adecuados, la reducción de la incertidumbre, la eliminación de los efectos de los lapsus de atención y el mantenimiento de la activación.

Las tareas de vigilancia requieren una discriminación en condiciones no siempre óptimas. Se recomienda realizar estas discriminaciones de la forma más sencilla posible, o lo que es lo mismo, intentar que las señales sean lo más llamativas posible. Las medidas relacionadas con este objetivo general pueden ser simples (como la iluminación adecuada, o los períodos más largos de inspección por producto) o más sofisticadas, como el uso de dispositivos especiales para mejorar la visibilidad de los estímulos blanco. Las comparaciones simultáneas son más sencillas que las sucesivas, por lo que siempre será útil disponer de un estándar que sirva de referencia. Gracias a los dispositivos técnicos, a veces es posible presentar el estándar y el objeto que se va a examinar y alternarlos rápidamente, de forma que las diferencias aparezcan en forma de movimientos en la pantalla u otros cambios a los que el sistema visual sea especialmente sensible.

Para contrarrestar los cambios estratégicos del umbral que han ocasionado una proporción relativamente baja de detección correcta de estímulos blanco (y para hacer la tarea más amena, en términos de frecuencia de las acciones que hay que desempeñar), se ha sugerido la introducción de falsos estímulos blanco. Sin embargo, ésta no parece ser una buena solución. Los estímulos blanco falsos aumentarán la proporción general de aciertos, pero su utilización provocará una frecuencia superior de falsas alarmas. Además, la proporción de estímulos blanco no detectados entre todos los estímulos a los que no se responde (la salida de material defectuoso en una inspección industrial) no se verá necesariamente reducida. Parece más adecuado tener un conocimiento explícito de la importancia relativa de los aciertos y las falsas alarmas y quizá utilizar otras medidas para que la posición del umbral sea adecuada para discriminar entre los aciertos y los errores.

La incertidumbre espacial y temporal es un determinante decisivo para una capacidad de vigilancia deficiente. En algunas tareas, la incertidumbre espacial puede reducirse definiendo una determinada posición del objeto que se va a inspeccionar. Sin embargo, no hay mucho que hacer en cuanto a la incertidumbre temporal: el observador sería innecesario en una tarea de 
vigilancia, si fuera posible señalar con antelación cuándo se va a presentar un estímulo blanco. Lo que sí puede hacerse, en principio, es mezclar los objetos que se desea inspeccionar cuando los fallos tienden a producirse en grupos. Esto sirve para evitar los intervalos muy prolongados o muy breves entre los estímulos blanco.

$\mathrm{H}$ ay algunas sugerencias bastante obvias para reducir los lapsus de atención, o al menos su impacto en el rendimiento. Con la formación adecuada, se podría conseguir el procesamiento automático de cierto tipo de estímulos localizados, siempre que los estímulos localizados y de fondo no sean excesivamente cambiantes. La necesidad de un mantenimiento continuo del conjunto de tareas puede evitarse mediante descansos frecuentes, la rotación del trabajo, la ampliación de la tarea 0 el enriquecimiento de la misma. La introducción de la variedad puede ser tan simple como conseguir que el propio inspector saque el material que debe inspeccionar de una caja o de otro sitio. Así se introduce el elemento del ritmo personal, que puede contribuir a evitar la presentación de señales durante las desactivaciones temporales del conjunto de tareas. EI mantenimiento constante de un conjunto de tareas puede fomentarse con la retroinformación, el hecho de mostrar interés los supervisores y la consciencia del operador de la importancia de su tarea. $\mathrm{N}$ aturalmente, no es posible ofrecer una retroinformación adecuada del nivel de rendimiento en las tareas típicas de vigilancia; sin embargo, incluso la retroinformación que contenga información inadecuada o incompleta puede ser útil para motivar al observador.

También hay medidas que pueden ayudar a mantener un nivel adecuado de activación. El uso continuado de drogas es una posibilidad, pero es algo que nunca se encontrará entre las recomendaciones. La música de fondo puede ser útil, aunque también puede tener el efecto contrario. El aislamiento social durante las tareas de vigilancia deberá evitarse siempre que se pueda y durante los momentos del día con niveles bajos de activación, como las últimas horas de la noche, será necesario tomar medidas de apoyo, como por ejemplo períodos cortos de vigilancia.

\section{Fatiga mental}

\section{Peter Richter}

La tensión mental es una consecuencia normal del proceso de enfrentarse a la carga mental de trabajo (CMT). Las cargas prolongadas o las exigencias de un trabajo demasiado intensas pueden llegar a causar, a corto plazo, situaciones de sobrecarga (fatiga) y subcarga (monotonía, hastío) y a largo plazo, incluso otras consecuencias como síntomas de estrés y enfermedades laborales. Se puede mantener, sin embargo, una regulación estable de la actividad mientras dure la tensión por medio de cambios en el estilo de trabajo (variando las estrategias de obtención de información y toma de decisiones), rebajando el nivel de objetivos que se desea conseguir (redefiniendo las tareas y reduciendo los estándares de calidad) o a través de un aumento compensatorio del esfuerzo psicofisiológico y una disminución posterior del esfuerzo durante el horario de trabajo.

Esta idea del proceso de tensión mental se puede conceptualizar como un proceso de regulación de la actividad durante la imposición de factores de carga, que incluyen no sólo los componentes negativos de la tensión mental, sino también los aspectos positivos del aprendizaje tales como la acumulación, la armonización y reestructuración y la motivación (véase la Figura 29.28).
Figura 29.28 - Componentes del proceso de tensión y sus consecuencias.

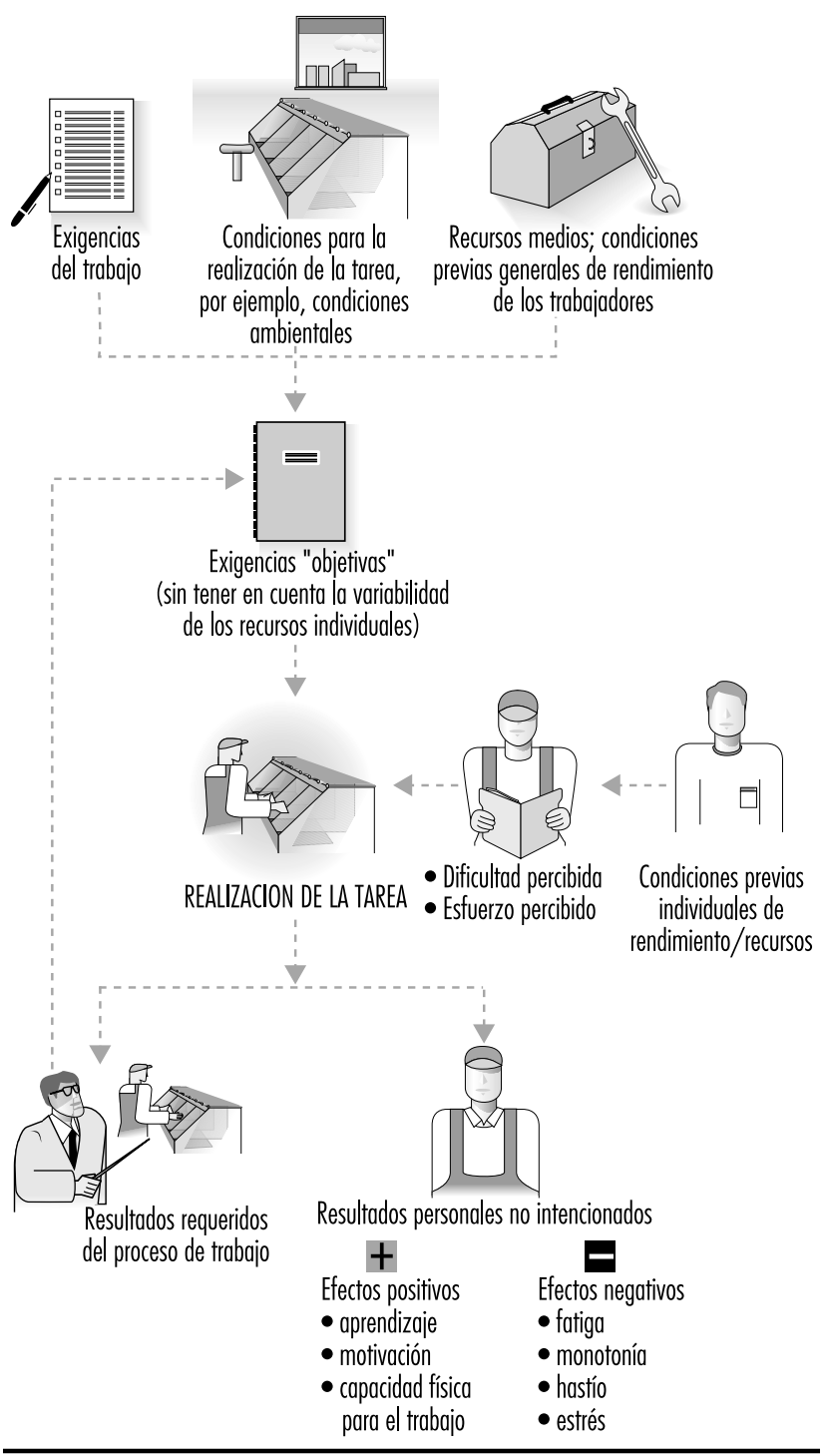

La fatiga mental se puede definir como un proceso reversible en el tiempo de disminución de la estabilidad de la conducta en el rendimiento, el estado de ánimo y la actividad después de un período prolongado de trabajo. Dicho estado es temporalmente reversible cambiando las exigencias del trabajo, las influencias del entorno o la estimulación; y completamente reversible a través de sueño.

La fatiga mental es una consecuencia de la realización de tareas con un alto nivel de dificultad, que implican, en su mayoría, el procesamiento de información o que tienen una duración muy prolongada. La recuperación de estas pérdidas lleva algún tiempo y no se produce de forma instantánea al cambiar las condiciones de la tarea, al contrario de lo que ocurre con la monotonía. Los síntomas de fatiga se advierten a varios niveles de regulación de la conducta: desajuste en la homeostasis entre el entorno y el organismo, desajuste de los procesos cognitivos en las actividades dirigidas a la consecución de objetivos y pérdida de estabilidad en la motivación para la consecución de metas y en el nivel de rendimiento. 
Se pueden identificar síntomas de fatiga mental en todos los subsistemas del sistema humano de procesamiento de la información:

- percepción: disminución de los movimientos oculares, de la discriminación de señales y del umbral

- procesamiento de la información: ampliación del tiempo de decisión, errores de acción, incertidumbre en las decisiones, bloqueo, "estrategias arriesgadas" en las secuencias de acciones, alteración de la coordinación sensoriomotora

- funciones de la memoria: lentitud en el almacenamiento de la información en la memoria inmediata, alteraciones de los procesos de repetición de lo almacenado en la memoria a corto plazo, retrasos en la transmisión de información almacenada en la memoria a largo plazo y en el proceso de búsqueda de información.

\section{Diagnóstico diferencial de la fatiga mental}

$\mathrm{H}$ ay criterios suficientes para diferenciar la fatiga mental de la monotonía, el hastío y el estrés (en sentido estricto) (Tabla 29.4).

\section{Grados de fatiga mental}

L a conocida fenomenología de la fatiga mental (Schmidtke 1966), los métodos válidos para su valoración y la gran cantidad de resultados experimentales y estudios de campo disponibles, nos ofrecen la posibilidad de valorar los estados de fatiga mental mediante una escala ordinal (H acker y R ichter 1984). Esta escala se basa en la capacidad del individuo para afrontar las cambios de conducta:

$N$ ivel 1: R endimiento óptimo y eficaz: no hay síntomas de disminución del rendimiento, del estado de ánimo o del nivel de activación.

Tabla 29.4 - Criterios de diferenciación entre las distintas consecuencias negativas de la tensión mental.

\begin{tabular}{|c|c|c|c|c|}
\hline Criterios & $\begin{array}{l}\text { Fatiga } \\
\text { mental }\end{array}$ & Monotonía & Hastío & Estrés \\
\hline $\begin{array}{l}\text { Condición } \\
\text { clave }\end{array}$ & $\begin{array}{l}\text { Inadaptación } \\
\text { por condi- } \\
\text { ciones de } \\
\text { sobrecarga }\end{array}$ & $\begin{array}{l}\text { Inadaptación } \\
\text { por condiciones } \\
\text { de subcarga }\end{array}$ & $\begin{array}{l}\text { Pérdida de la } \\
\text { percepción } \\
\text { del sentido } \\
\text { de la tarea }\end{array}$ & $\begin{array}{c}\text { Percepción de los } \\
\text { objetivos como } \\
\text { una amenaza }\end{array}$ \\
\hline $\begin{array}{l}\text { Estado de } \\
\text { ánimo }\end{array}$ & $\begin{array}{l}\text { Cansancio sin } \\
\text { aburrimiento } \\
\text { agotamiento }\end{array}$ & $\begin{array}{l}\text { Cansancio con } \\
\text { aburrimiento }\end{array}$ & Irritabilidad & $\begin{array}{l}\text { Ansiedad, miedo, } \\
\text { aversión }\end{array}$ \\
\hline $\begin{array}{l}\text { Evaluación } \\
\text { emocional }\end{array}$ & Neutral & Neutral & $\begin{array}{l}\text { Mayor aversión } \\
\text { afectiva }\end{array}$ & Mayor ansiedad \\
\hline Activación & $\begin{array}{r}\text { Disminución } \\
\text { constante }\end{array}$ & $\begin{array}{l}\text { Disminución no } \\
\text { constante }\end{array}$ & Aumento & Aumento \\
\hline Recuperación & $\begin{array}{r}\text { Requiere } \\
\text { mucho } \\
\text { tiempo }\end{array}$ & $\begin{array}{l}\text { Al poco tiempo } \\
\text { de cambiar } \\
\text { de tarea }\end{array}$ & 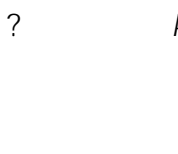 & $\begin{array}{l}\text { Alteraciones a } \\
\text { largo plazo } \\
\text { en la } \\
\text { recuperación }\end{array}$ \\
\hline Prevención & $\begin{array}{l}\text { Diseño de } \\
\text { tareas, } \\
\text { formación, } \\
\text { pausas cortas }\end{array}$ & $\begin{array}{l}\text { Enriquecimiento } \\
\text { del contenido } \\
\text { del trabajo }\end{array}$ & $\begin{array}{l}\text { Programación } \\
\text { por objetivos y } \\
\text { enriqueci- } \\
\text { miento del } \\
\text { trabajo }\end{array}$ & $\begin{array}{l}\text { Rediseño del } \\
\text { puesto, } \\
\text { gestión de } \\
\text { conflictos } \\
\text { y del estrés }\end{array}$ \\
\hline
\end{tabular}

Nivel 2: Compensación completa caracterizada por un aumento de la activación psicofisiológica periférica (por ejemplo, medida por un electromiograma de los músculos de los dedos), incremento perceptible del esfuerzo mental, aumento de la variabilidad de los criterios de actuación.

Nivel 3: Compensación adicional a la descrita en el nivel 2: errores en la acción, sensación de fatiga, mayor actividad psicofisiológica (compensatoria) en los indicadores centrales (ritmo cardíaco, presión sanguínea).

Nivel 4: E ficacia reducida, adicional a la descrita en el nivel 3: disminución de los criterios de rendimiento.

Nivel 5: Alteraciones funcionales aún mayores: alteraciones en las relaciones sociales y de cooperación en el trabajo, síntomas de fatiga crónica, como la pérdida de calidad del sueño y el cansancio vital.

\section{Prevención de la fatiga mental}

El diseño de la estructura de la tarea, el entorno, los períodos de descanso durante el trabajo y dormir el tiempo suficiente son los medios para reducir los síntomas de fatiga mental y para evitar que llegue a convertirse en crónica:

1. Cambios en la estructura de las tareas. El diseño de las condiciones previas para el aprendizaje adecuado y la organización de las tareas es un medio de fomentar el desarrollo de unas estructuras eficaces de trabajo, pero es también esencial para evitar los desajustes de la carga mental (sobrecarga o subcarga):

- Los obstáculos para el procesamiento de la información se pueden eliminar desarrollando representaciones internas de las tareas y organizando la información. El aumento de la capacidad cognitiva resultante ajustará las necesidades de información y los recursos de forma más eficaz.

- Las nuevas tecnologías centradas en el ser humano, gracias a su alta compatibilidad entre el orden de la información presentada y la tarea (N orman 1993) reducirán el esfuerzo mental necesario para recodificar la información y, en consecuencia, aliviaran los síntomas de fatiga y estrés.

- Una coordinación equilibrada entre los diferentes niveles de regulaciones (en relación con las habilidades, reglas y conocimientos) puede reducir el esfuerzo y, lo que es más, aumentar la fiabilidad humana en la realización de las tareas (R asmussen 1983).

- La formación de los trabajadores en secuencias de acciones encaminadas a la consecución de objetivos, antes de que se presenten los problemas, dará mayor sentido al esfuerzo mental al convertir el trabajo en algo más claro, más previsible y más controlable y disminuirá su nivel de activación psicofisiológica.

2. Implantación de sistemas de pausas breves en el trabajo. El efecto positivo de estos períodos de descanso depende de que se cumplan ciertas condiciones previas. Un mayor número de descansos cortos es más eficaz que un menor número de descansos largos, los efectos dependen de la existencia de un horario fijo y, por tanto, conocido de antemano. El contenido de los descansos debe compensar las necesidades físicas y mentales.

3. Tiempo suficiente de descanso y sueño. Programas especiales de atención al trabajador y técnicas de gestión del estrés, pueden reforzar la capacidad de relajación y prevenir el desarrollo de la fatiga crónica (Sethi, Caro y Schuler 1987). 


\section{- OrganizaCION DEL TRABAJO}

\section{E berhard U lich y Gudela Grote}

\section{Diseño de sistemas de producción}

Muchas empresas invierten grandes cantidades de dinero en sistemas informatizados de producción, pero al mismo tiempo no aprovechan al máximo sus recursos humanos, recursos cuyo valor puede aumentarse significativamente si se invierte en su formación. De hecho, el aprovechamiento del potencial del personal capacitado, en lugar de la utilización de complicados procesos de automatización puede, en determinadas circunstancias, no sólo reducir significativamente los costes de inversión, sino que también puede aumentar enormemente la flexibilidad y capacidad del sistema.

\section{Causas del uso ineficaz de la tecnología}

Las mejoras que las inversiones en tecnología moderna intentan introducir, en muchas ocasiones ni siquiera se llegan a alcanzar (Strohm, Kuark y Schilling 1993; Ulich 1994). Las principales causas de esta situación se relacionan con problemas en el campo de la propia tecnología, en la organización y en la capacitación del personal.

Pueden identificarse tres causas principales de los problemas con la tecnología:

1. T ecnología insuficiente. D ebido a la rapidez con que se producen los cambios tecnológicos, las comprobaciones de la utilidad de la nueva tecnología que aparece en el mercado se realiza a veces de forma inadecuada y se producen retrasos no planificados.

2. Tecnología inadecuada. La tecnología diseñada para las grandes empresas no siempre es adecuada para las más pequeñas. Cuando una pequeña empresa introduce un plan de producción y un sistema de control desarrollado para una gran empresa, puede privarse de la flexibilidad necesaria para conseguir el éxito e incluso para poder sobrevivir.

3. T ecnología excesivamente compleja. Cuando los diseñadores y otras personas encargadas del desarrollo tecnológico, emplean todos sus conocimientos de planificación para llevar a cabo lo que es técnicamente factible, sin tener en cuenta la experiencia de las personas que trabajan en la producción, el resultado puede ser un complejo sistema automatizado que no es fácil de manejar.

Los problemas de organización pueden atribuirse principalmente al continuo intento de aplicar la tecnología más avanzada en estructuras inadecuadas de organización. Por ejemplo, no tiene sentido introducir ordenadores de la tercera, cuarta y quinta generación en una organización de la segunda generación. Sin embargo esto es exactamente lo que hacen muchas empresas (Savage y Appleton 1988). En muchas empresas, la reestructuración radical de la organización es una condición previa necesaria para el uso correcto de las nuevas tecnologías. Esto incluye, en particular, un análisis de los conceptos de planificación y control de la producción. En última instancia, un autocontrol in situ llevado a cabo por operarios cualificados puede, en determinadas circunstancias, ser significativamente mas eficaz y económico que un sistema de planificación y control técnicamente muy desarrollado.
Los problemas referentes al grado de cualificación de los trabajadores surgen principalmente porque muchas empresas no se dan cuenta de la necesidad de tomar medidas al respecto al mismo tiempo que se introducen los sistemas de producción informatizados. Además, la formación se considera frecuentemente un coste que debe ser controlado y reducido al mínimo, más que como una inversión estratégica. De hecho, los retrasos que se producen en el sistema, y los consiguientes costes, podrían muchas veces reducirse si se diagnosticaran y se solucionaran los fallos a través de la competencia de los operarios, su conocimiento específico del sistema y su experiencia. Este es el caso, sobre todo, cuando las instalaciones de producción son demasiado reducidas (K öhler y cols. 1989). Lo anterior se aplica especialmente a la introducción de nuevos productos o versiones de un producto. Muchos ejemplos de utilización excesiva e ineficaz de la tecnología demuestran estas relaciones.

La consecuencia directa de este breve análisis es que la introducción de sistemas informatizados de producción sólo podrá tener éxito si está integrada dentro de un concepto global que intente optimizar conjuntamente la utilización de la tecnología, la estructura de la organización y el nivel de cualificación del personal.

\section{Desde la tarea al diseño de sistemas sociotécnicos}

Los conceptos psicológicos relacionados con trabajo en el diseño de producción se basan en la primacía de la tarea. Por una parte, la tarea constituye un interfaz entre el individuo y la organización (Volpert 1987). Por otra, la tarea relaciona el subsistema social con el subsistema técnico. "La tarea debe ser la articulación entre el sistema social y el técnico, enlazando el trabajo en el sistema técnico con su comportamiento correlativo en el sistema social" (Blumberg 1988).

Esto significa que un sistema sociotécnico, por ejemplo, un área de producción, se define principalmente por la tarea que tiene que realizarse. La distribución de trabajo entre el hombre y la máquina tiene un papel importante, ya que determina si la persona "funciona" como una extensión de la máquina, cumpliendo una función residual en un vacío de automatización, o si la máquina funciona como un brazo de la persona, desempeñando la función de herramienta que complementa la capacidad y aptitud humana. Para referirse a estas dos concepciones opuestas se utilizan los términos "orientado a la tecnología" y "orientado al trabajo" (U lich 1994).

\section{El concepto de tarea completa}

El principio de actividad completa (H acker 1986) o tarea completa desempeña una función central en los conceptos psicológicos relacionados con el trabajo al definir y repartir tareas entre el hombre y la máquina. Tareas completas son aquéllas "sobre las cuales el individuo ejerce un control personal considerable" y que "inducen una fuerza interior del individuo que lo lleva a terminarlas o a continuarlas". Las tareas completas contribuyen al "desarrollo de lo que se ha descrito como... 'orientación hacia la tarea', es decir, un estado en el que la tarea despierta, capta y dirige el interés del individuo" (Emery 1959). La Figura 29.29 resume las características de las tareas completas que deben tenerse en cuenta al tomar medidas dirigidas al diseño de sistemas de producción orientados al trabajo. 
Entre los ejemplos de consecuencias concretas para el diseño de producción que se desprenden del principio de la tarea completa están:

1. El establecimiento independiente de los objetivos, que pueden ser incorporados en otros de mayor rango, requiere apartarse de la planificación y control central en favor de un control descentralizado del puesto de trabajo, lo que proporciona la posibilidad de tomar decisiones propias, en un período específico de tiempo.

2. La autopreparación para la acción, en el sentido de realizar funciones de planificación, requiere la integración de tareas preparatorias del trabajo en el taller.

3. La selección de métodos significa por ejemplo, permitir que el diseñador decida si desea utilizar el tablero de dibujo en lugar de un sistema automatizado (una aplicación CAD, por ejemplo) para realizar ciertas subtareas, asegurándose que se han introducido en el sistema los datos requeridos por otras partes del proceso.

4. Las funciones de ejecución con sistemas de retroinformación del proceso para corregir acciones donde sea necesario requieren, en el caso de los procesos de trabajo encapsulados "ventanas abiertas al proceso" que ayuden a reducir al mínimo las distancias.

5. El control de la acción con retroinformación de los resultados implica que los operarios en el taller asumen funciones de inspección y control de calidad.

Estas indicaciones de las consecuencias que surgen al llevar a cabo el principio de la tarea completa dejan claras dos cosas: (1) en muchos casos, probablemente incluso en la mayoría de los casos, las tareas completas en el sentido descrito en la Figura 29.29 sólo pueden ser estructuradas como tareas de grupo, debido a la complejidad resultante y al ámbito asociado; (2) la reestructuración de tareas, especialmente cuando va unida a la ejecución del trabajo en grupo, requiere su integración en

Figura 29.29 - Características de las tareas completas.

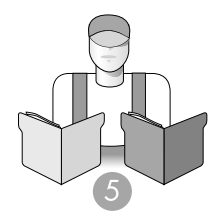

Control con retroinformación sobre los resultados y la posibilidad de comproba los resultados de las propias acciones frente a los objetivos establecidos

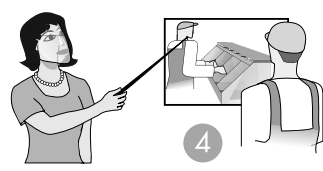

Funciones de rendimiento, con retroinformación sobre el rendimiento con el fin de una posible corrección de las acciones

Fuente: Ulich 1994. un concepto comprensivo de reestructuración global que abarque todos los niveles de la empresa.

Los principios estructurales que se aplican a los distintos niveles se resumen en la Tabla 29.5.

Las posibilidades de aplicar los principios para la estructuración de la producción, indicados en la Tabla 29.5, se ejemplifican con la propuesta de reestructuración de una empresa de producción mostrada en la Figura 29.30. Esta propuesta, unánimemente aprobada por los responsables de producción y por el equipo del proyecto formado con el propósito de llevar a cabo la reestructuración, también demuestra un distanciamiento fundamental de los conceptos tayloristas de división del trabajo y el mando. Los ejemplos de muchas empresas demuestran que la reestructuración del trabajo y de las estructuras de organización de acuerdo con estos modelos puede satisfacer tanto los criterios psicológicos de promoción de la salud, y desarrollo de la personalidad, como las exigencias de eficacia económica a largo plazo (véase Ulich 1994).

La argumentación anterior, descrita brevemente por razones de espacio, intenta aclarar tres puntos:

1. Conceptos como los aquí mencionados representan un alternativa a la "producción ajustada", en el sentido descrito por Womack, Jones y Roos (1990). M ientras en este último enfoque "cada espacio libre se suprime" y se mantiene una parcialización extrema de las actividades en el sentido taylorístico, en el enfoque que damos en estas páginas las tareas completas en grupo son las que desempeñan la función principal, con una amplia autorregulación.

2. Se modifica la trayectoria clásica de las carreras de los trabajadores especializados y en algunos casos se excluyen para la necesaria realización del principio de integración funcional, es decir, con la reintegración en el lugar de trabajo de lo que se conoce como funciones indirectamente productivas, tales como la preparación del trabajo, el mantenimiento, el control de calidad, etc., en el lugar de trabajo. Esto requiere una reorientación fundamental, en el sentido de reemplazar la cultura tradicional de la carrera por la cultura de las aptitudes.

3. Conceptos como los aquí mencionados suponen un cambio fundamental en las estructuras de poder corporativo que deben encontrar su contrapartida en el desarrollo de las correspondientes posibilidades de participación.

\section{Participación de los trabajadores}

En la sección anterior, se describieron tipos de organización del trabajo que tienen como característica básica la democratización de los niveles inferiores de la jerarquía de organización, aumentando la autonomía y la libertad de decisión en relación con el contenido del trabajo y con las condiciones del lugar donde se realiza. En esta sección, la democratización tiene un enfoque

Tabla 29.5 - Principios orientados al trabajo para la estructuración de la producción.

$\begin{array}{ll}\text { Nivel de organización } & \text { Principio estructural } \\ \text { Empresa } & \text { Descentralización } \\ \text { Unidad de organización } & \text { Integración funcional } \\ \text { Grupo } & \text { Auto-regulación }{ }^{1} \\ \text { Individual } & \text { Trabajo de producción cualificado }{ }^{1} \\ \text { Teniendo en cuenta el principio del diseño diferencial del trabaio. } \\ \text { Fuente: Ulich 1994. }\end{array}$

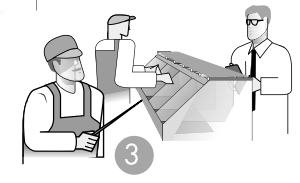

Selección de los medios incluido el grado de interacción necesario para conseguir los objetivos 
Figura 29.30 - Proposición para reestructurar una empresa de producción.

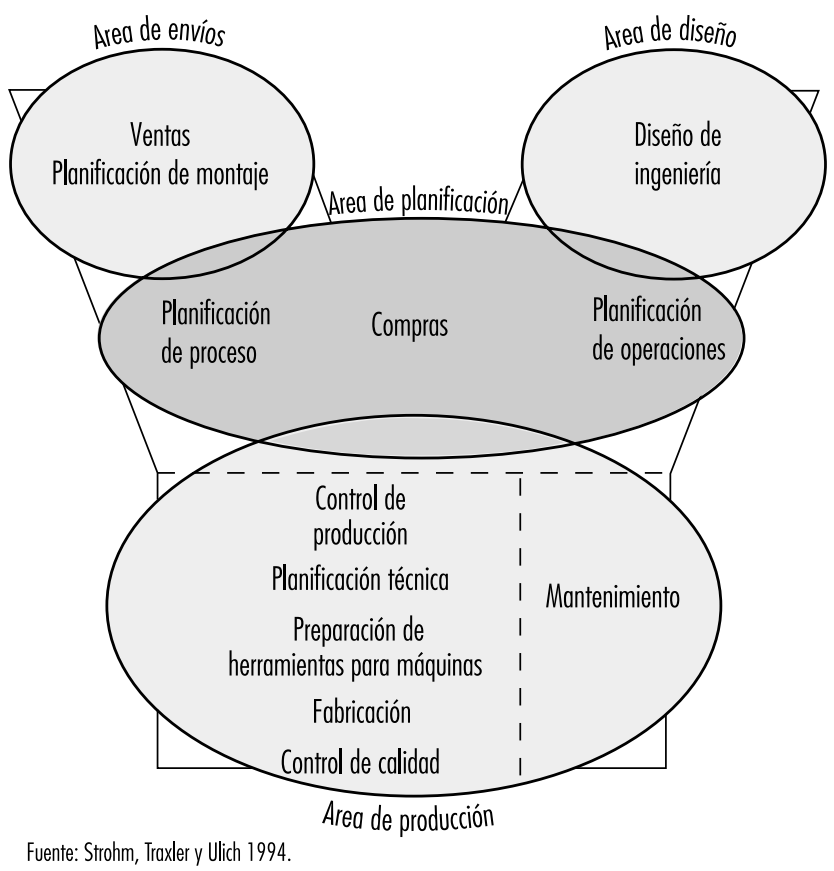

diferente, ya que considera la participación en la toma de decisiones en general. En primer lugar, se presenta el marco de definición de la participación, seguido de una discusión donde se investigan los efectos de la participación. Finalmente, se considera con cierto detalle el diseño de sistemas participativos.

\section{Marco de definición de la participación}

El desarrollo organizativo, el liderazgo, el diseño de sistemas y las relaciones laborales son ejemplos de la variedad de tareas y contextos donde la participación de considera importante. Un denominador común, que puede ser considerado como parte esencial de la participación, es que los individuos y los grupos tengan la oportunidad de promover sus intereses, influyendo en la elección de acciones alternativas en una situación determinada (Wilpert 1989). Sin embargo, para describir la participación con más detalle se necesitan varias dimensiones. Generalmente, las dimensiones que se sugieren son: (a) formal-informal, (b) directaindirecta (c) grado de influencia y (d) contenido de la decisión (D achler y Wilpert 1978; Locke y Schweiger 1979). La participación formal se refiere a una participación dentro de unas normas legales o preceptivas (por ejemplo, los procedimientos de negociación, las pautas para la dirección de un proyecto), mientras que la participación informal se basa en intercambios no prescritos, por ejemplo, entre supervisor y subordinado. La participación directa permite la influencia directa de las personas implicadas, mientras que la participación indirecta funciona a través de un sistema de representación. EI grado de influencia se describe normalmente mediante una escala que va desde "no informar a los empleados sobre una decisión", pasando por "informar a los empleados" y "consultar a los empleados", hasta la "toma de decisiones en común, con la participación de todas las partes implicadas". Por lo que se refiere a facilitar información sin ningún tipo de consulta o toma de decisiones en común, algunos autores argumentan que esto no representa en absoluto un bajo nivel de participación, sino simplemente una forma de "pseudo-participación"
(Wall y Lischeron 1977). Por último, es posible especificar el contenido de la decisión participativa en términos del área a la que afectará, por ejemplo, a nivel de cambio tecnológico u organizativo, a las relaciones laborales 0 a las decisiones operativas cotidianas.

H ornby y Clegg (1992) han desarrollado un esquema de clasificación bastante diferente de los derivados de las dimensiones presentadas hasta ahora. Basándose en un trabajo de Wall y Lischeron (1977), estos autores distinguen tres aspectos de los procesos participativos:

1. Ios tipos y niveles de interacciones entre las partes implicadas en una decisión

2. el flujo de información entre los participantes

3. la naturaleza y grado de influencia que las partes ejercen entre sí.

Posteriormente, Hornby y Clegg utilizaron estos aspectos como complemento del marco sugerido por Gowler y Legge (1978), en el que se describe las participaciones en función de dos variables organizativas, a saber, el tipo de estructura (mecánica frente a orgánica) y el tipo de proceso (estable frente a inestable). Como este modelo incluye ciertos supuestos sobre participación y sus relaciones con la organización, no puede utilizarse para clasificar tipos generales de participación. A quí se presenta como un intento de definir la participación en un contexto más amplio (ver Tabla 29.6). (En la última sección de este capítulo se comentará el estudio de Hornby y Clegg (1992) que también intenta demostrar los supuestos del modelo).

U na dimensión importante, normalmente no incluida en las clasificaciones de participación, es el objetivo organizativo que hay detrás de la elección de una estrategia participativa (D achler y Wilpert 1978). Lo más importante es que la participación puede producirse para cumplir con la norma democrática, sin tener en cuenta su influencia en la eficacia del proceso de toma de decisiones, en la calidad del resultado y en la aplicación de la decisión. Por otra parte, se puede elegir un procedimiento participativo para aprovecharse del conocimiento y experiencia de los individuos involucrados, o para asegurar la aceptación de una decisión. A menudo es difícil identificar los objetivos subyacentes en un determinado enfoque participativo y es frecuente encontrar varios objetivos a la vez, así es que esta dimensión no se puede utilizar fácilmente para clasificar la participación. Sin embargo, para entender el proceso participativo es una dimensión importante que debe tenerse en cuenta.

Tabla 29.6 • Participación en un contexto organizativo.

\begin{tabular}{|c|c|c|}
\hline \multicolumn{3}{|c|}{ Estructura organizativa } \\
\hline \multicolumn{3}{|c|}{$\begin{array}{l}\text { Procesos de } \\
\text { organización }\end{array}$} \\
\hline \multirow[t]{2}{*}{ Estables } & Reglamentados & Abiertos \\
\hline & $\begin{array}{l}\text { Interacción: vertical/ orden } \\
\text { Flujo de información: } \\
\text { no recíproco } \\
\text { Influencia: asimétrica }\end{array}$ & $\begin{array}{l}\text { Interacción: lateral/ consulta } \\
\text { Flujo de información: recíproco } \\
\text { Influencia: asimétrica }\end{array}$ \\
\hline \multirow[t]{2}{*}{ Inestables } & Arbitrarios & Reglamentados \\
\hline & $\begin{array}{l}\text { Interacción: ritualista/ aleatoria } \\
\text { Flujo de información: } \\
\text { no recíproco/ esporádico } \\
\text { Influencia: autoritaria }\end{array}$ & $\begin{array}{l}\text { Interacción: intensa/ aleatoria } \\
\text { Flujo de información: } \\
\text { reciproco/ interrogativo } \\
\text { Influencia: paternalista }\end{array}$ \\
\hline & e Hornby y Clegg 1992. & \\
\hline
\end{tabular}




\section{Investigación sobre los efectos de la participación}

Un supuesto ampliamente compartido mantiene que se puede alcanzar una mayor satiffacción y un mayor rendimiento productivo si se brinda la oportunidad de una participación directa en la toma de decisiones. En conjunto, la investigación apoya este supuesto, pero las pruebas no son inequívocas y muchos estudios se han criticado tanto desde el punto de vista metodológico como teórico (Cotton y cols. 1988; Locke y Schweiger 1979; Wall y Lischeron 1977). Cotton y cols. (1988) sostienen que la inconsistencia de las conclusiones se debe a diferencias en la forma de participación estudiada, por ejemplo, la participación informal y la propiedad por parte de los empleados se asocia con un alto grado de productividad y de satisfacción, mientras que una participación temporal es ineficaz en ambos aspectos

Aunque sus conclusiones fueron muy criticadas (Leana, Locke y Schweiger 1990), todos están de acuerdo en que la investigación sobre la participación se caracteriza, en general, por ciertas deficiencias que van desde problemas conceptuales, como los mencionados por Cotton y col. (1988), hasta problemas metodológicos, como las diferencias en los resultados basados en las diferentes operacionalizaciones de las variables dependientes (Wagner y Gooding 1987).

Por poner un ejemplo de las dificultades de la investigación de la participación, se describe brevemente el estudio clásico de Coch y French (1948) seguido por la crítica de Bartlem y Locke (1981). El objetivo del estudio era vencer la resistencia al cambio a través de la participación. A los operarios de una planta textil, donde se intercambian frecuentemente las distintas tareas, se les dio la oportunidad de participar, en distintos grados, en el diseño de sus nuevos trabajos. Un grupo de operarios participó en las decisiones (procedimientos detallados de trabajo para nuevas tareas e índices de productividad) a través de unos representantes elegidos, es decir, de varios operarios de su grupo. En dos grupos mas pequeños, todos los operarios participaron en las decisiones, y un cuarto grupo sirvió de control, sin permitírseles participación alguna. Previamente se había observado que a la mayoría de los operarios no les gustaban los cambios y les costaba más aprender los nuevos trabajos que el primer trabajo en la planta y que el absentismo y la rotación entre los operarios afectados por el cambio era superior que entre los operarios no afectados recientemente. Esto ocurría a pesar de que se repartió una prima por traslado, para compensar la pérdida inicial del incentivo de producción después del cambio a un nuevo puesto de trabajo. Tras comparar las tres condiciones experimentales, se comprobó que el grupo sin participación, considerado como grupo estándar, permaneció en un bajo nivel de producción durante el primer mes después del cambio, mientras que los grupos con participación plena recuperaron su productividad en pocos días, e incluso la sobrepasaron al final del mes.

El tercer grupo que participaba a través de sus representantes no se recuperó tan rápido, pero alcanzó su antigua productividad después de un mes. (También sucedió que este grupo no contaba con material suficiente para trabajar en la primera semana). No hubo rotación en los grupos con participación y se observó poca agresividad hacia la dirección de la empresa. La movilidad en el grupo sin participación fue del $17 \%$ y la actitud hacia la dirección era en general hostil. El grupo sin participación se disolvió después de un mes y se unió otra vez después de dos meses y medio para trabajar en una nueva tarea. Esta vez se les dio la oportunidad de participar en el diseño de su trabajo y mostraron la misma pauta de recuperación e incremento de productividad que los grupos con participación en el primer experimento. Coch y French explicaron los resultados basándose en un modelo general de resistencia al cambio, derivado del trabajo de L ewin (1951, véase más adelante).
Bartlem y Locke (1981) sostenían que estos datos no podían inter pretarse como apoyo de los efectos positivos de la participación porque había importantes diferencias entre los grupos en lo que se refiere a la explicación de la necesidad de cambios en las primeras reuniones con la dirección, la formación recibida, la manera en que se hacían los estudios de tiempos para establecer las tasas de producción, la cantidad de trabajo disponible y el tamaño del grupo. En su opinión, un pago justo por la producción y la confianza en la dirección era lo que producía los mejores resultados en los grupos que participaron, y no la participación en sí.

A parte de los problemas asociados con la investigación de los efectos de la participación, se conoce muy poco acerca de los procesos que dan como resultado estos efectos (por ejemplo, Wilpert 1989). En un estudio longitudinal sobre los efectos del diseño de trabajo participativo, Baitsch (1985) describió con detalle el proceso de desarrollo de aptitudes en un cierto número de empleados de base. Su estudio puede relacionarse con la teoría de Deci (1975) de la motivación intrínseca basada en la necesidad de ser competente e independiente. Lewin ( 1951) sugirió un marco teórico centrado en los efectos de la participación sobre la resistencia al cambio y propuso que los sistemas sociales alcanzan un equilibrio cuasi estacionario que se pierde con cualquier intento de cambio. Para que el cambio se produzca con éxito, las fuerzas a favor del cambio tienen que ser mas poderosas que las fuerzas de resistencia. La participación ayuda a reducir las fuerzas de resistencia tanto como a aumentar las fuerzas favorables, ya que las razones para la resistencia pueden discutirse y tratarse abiertamente y las preocupaciones y necesidades del individuo pueden integrarse en el cambio propuesto. Además, Lewin consideró que las decisiones comunes que resultan de los procesos de cambio participativo proporcionan el enlace entre la motivación por el cambio y los verdaderos cambios de conducta.

\section{Participación en el diseño de sistemas}

Dado el soporte empírico, aunque no completamente coherente, para la eficacia de la participación, así como su base ética en una democracia industrial, existe un acuerdo ampliamente extendido de que se debería seguir una estrategia participativa para el diseño de sistemas (G reenbaum y K yng 1991; M ajchrzak 1988; Scarbrough y Corbett 1992). Además, varios estudios de casos de procesos de diseño participativo han demostrado las ventajas específicas de la participación en el diseño de sistemas, por ejemplo, en relación con la calidad del diseño resultante, la satisfacción del usuario y el grado de aceptación (uso real) del nuevo sistema (M umford y $\mathrm{H}$ enshall 1979; Spinas 1989; U lich y cols. 1991).

La cuestión mas importante, no está en el "si" sino en el "cómo". Scarbrough y Corbett (1992) ofrecieron una visión global de distintos tipos de participación en diversas etapas del proceso de diseño (véase la Tabla 29.7). Como señalan, es bastante raro que el usuario participe en el diseño tecnológico y normalmente esta participación no va mas allá de la distribución de la información. La participación se produce principalmente en las últimas etapas de la aplicación y optimización del sistema técnico y durante el desarrollo de las opciones del diseño sociotécnico, es decir, en las opciones de diseño organizativo y del trabajo, en combinación con las opciones para el uso del sistema técnico. A demás de la resistencia de los directivos e ingenieros a la intervención de los usuarios en el diseño de sistemas técnicos y de las potenciales restricciones en la estructura de participación formal de la empresa, existe una importante dificultad en relación con la necesidad de métodos que permitan la discusión y evaluación de sistemas aún no existentes (Grote 1994). En el 
Tabla 29.7 • Participación de los usuarios en el proceso tecnológico.

\begin{tabular}{|c|c|c|}
\hline Fases del proceso & Tipo de participación & \\
\hline & Formal & Informal \\
\hline Diseño & $\begin{array}{l}\text { Consulta a los sindicatos } \\
\text { Prototipos }\end{array}$ & Rediseño por los usuarios \\
\hline Implantación & $\begin{array}{l}\text { Convenios de } \\
\text { nueva tecnología }\end{array}$ & Negociación de aptitudes \\
\hline & Convenios colectivos & $\begin{array}{l}\text { Negociación } \\
\text { Cooperación de los } \\
\text { usuarios }\end{array}$ \\
\hline Uso & Diseño del trabajo & $\begin{array}{l}\text { Rediseño informal del } \\
\text { puesto y las prácticas } \\
\text { de trabajo }\end{array}$ \\
\hline intade do scarhrou & Círculos de calidad & \\
\hline
\end{tabular}

desarrollo de software, los laboratorios de pruebas de utilidad pueden ayudar a superar esta dificultad, ya que dan la oportunidad a los futuros usuarios de una prueba previa.

Al considerar el proceso de diseño de sistemas y los procesos participativos, Hirschheim y K lein (1989) han resaltado los efectos de los supuestos implícitos y explícitos de quienes desarrollan el sistema y de los directivos, sobre tópicos como la naturaleza de la organización social, la naturaleza de la tecnología y su propia función en el proceso de desarrollo. El que los diseñadores del sistema se vean a sí mismos como expertos, catalizadores o emancipadores puede influir enormemente en el proceso de diseño y aplicación. También, como se ha dicho antes, hay que tener en cuenta un contexto organizativo más amplio, en el que se produce el diseño participativo. Hornby y Clegg (1992) proporcionaron algunas pruebas de la relación entre las características organizativas generales y la forma de participación elegida 0 , con más exactitud, la forma que se desarrolla en el curso del diseño y aplicación del sistema. Estos autores estudiaron la introducción de un sistema de información dentro de la estructura del proyecto participativo y con un compromiso explícito para la participación del usuario. Sin embargo los usuarios señalaron que habían tenido muy poca información sobre los cambios que se suponía que habían tenido lugar y muy poca influencia sobre el diseño del sistema y otras cuestiones relacionadas, como el diseño del trabajo y la seguridad en el mismo. Esta conclusión se interpretó en términos de la estructura mecanicista y del proceso inestable de la organización que fomentaban una participación "arbitraria" en lugar de la deseada participación abierta (véase la Tabla 29.6).

En conclusión, hay suficientes pruebas que demuestran las ventajas de las estrategias de cambio participativo. Sin embargo aún hay mucho que aprender sobre los procesos subyacentes y los factores que influyen, causan, moderan o impiden estos efectos positivos.

\section{- Privacion del sueño}

\section{Kazutaka Kogi}

Un individuo sano suele dormir varias horas diarias. Normalmente duerme durante la noche y encuentra dificilísimo permanecer despierto durante las horas que hay entre la medianoche y el amanecer, que es cuando habitualmente duerme. Si el individuo tiene que permanecer despierto durante estas horas, ya sea total o parcialmente, cae en un estado de pérdida forzosa del sueño, o privación del sueño, que suele percibirse en forma de cansancio. La necesidad de dormir, con distintos grados de somnolencia, se siente hasta que se consigue dormir lo suficiente. Por este motivo se dice que los períodos de privación del sueño provocan en una persona un déficit o falta de sueño.

La privación del sueño supone un problema especial para los trabajadores que no pueden dormir lo suficiente debido a su horario de trabajo (por ejemplo, en los trabajos nocturnos) 0 debido a que sus actividades de ocio son muy extensas. El trabajador de un turno de noche quedará privado de sueño hasta que tenga la oportunidad de dormir un rato al final del turno. Como el sueño durante las horas diurnas suele ser más corto de lo necesario, el trabajador no podrá recuperarse de su situación de falta de sueño hasta que disfrute de un período largo de sueño, especialmente, toda una noche. $\mathrm{H}$ asta ese momento, la persona va acumulando el déficit de sueño. U na situación parecida, el llamado jet lag, se produce en las personas que viajan entre dos zonas horarias distintas, con varias horas de diferencia. La privación de sueño que sufre el viajero se debe a que los períodos de actividad de la nueva zona horaria se corresponden con el período normal de sueño del lugar de origen. Durante los períodos de pérdida de sueño, los trabajadores se sienten cansados y su rendimiento se ve afectado de muchas formas. $H$ ay distintos grados de privación del sueño que se van incorporando a la vida diaria de los trabajadores que tienen que trabajar en horarios irregulares, por lo que es importante tomar medidas que permitan hacer frente a los efectos negativos de dicho déficit de sueño. Las principales condiciones de los horarios de trabajo irregulares que contribuyen a la privación del sueño se muestran en la Tabla 29.8.

En condiciones extremas la privación de sueño puede durar más de un día. En ese caso, la somnolencia y los cambios en el rendimiento aumentan a medida que se prolonga el período de privación. L os trabajadores, sin embargo, suelen dormir un poco antes de que la privación del sueño se convierta en algo prolongado. Si las horas dormidas de esta forma no son suficientes, los efectos de la escasez de sueño continuarán. Por esto es importante conocer no sólo los efectos de la privación del sueño en sus

Tabla 29.8 - Principales condiciones de un horario de trabajo irregular que contribuyen en distintos grados a la privación de sueño.

$\begin{array}{ll}\begin{array}{l}\text { Horario de trabajo irregular } \\ \text { Horario nocturno }\end{array} & \begin{array}{l}\text { Condiciones que producen la priva- } \\ \text { ción de sueño }\end{array} \\ \begin{array}{l}\text { Horario de madrugada o hasta muy } \\ \text { tarde por la noche } \\ \text { Largas jornadas de trabajo } \\ \text { o dos turnos seguidos }\end{array} & \begin{array}{l}\text { Sueño nocturno breve o ausente } \\ \text { Sueño más corto o interrumpido }\end{array} \\ \begin{array}{l}\text { Turno permanente de noche o de } \\ \text { madrugada }\end{array} & \text { Desfase del sueño } \\ \begin{array}{l}\text { Período corto entre turnos } \\ \text { Intervalos prolongados entre descansos consecutivo del sueño }\end{array} & \begin{array}{l}\text { Sueño corto e interrumpido } \\ \text { Trabajo en una zona horario distinta de déficit de sueño }\end{array} \\ \begin{array}{l}\text { Sueño ausente o breve durante las } \\ \text { horas "nocturnas" del lugar de } \\ \text { origen (jet lag) }\end{array} \\ \text { Períodos de tiempo libre desequilibrados } & \begin{array}{l}\text { Desfase del sueño, } \\ \text { períodos cortos de sueño }\end{array}\end{array}$


Figura 29.31 - Rendimiento, valoración del sueño y variables fisiológicas en un grupo de personas sometidas durante dos noches a la privación del sueño.
MEDIDAS CONDUCTUALES
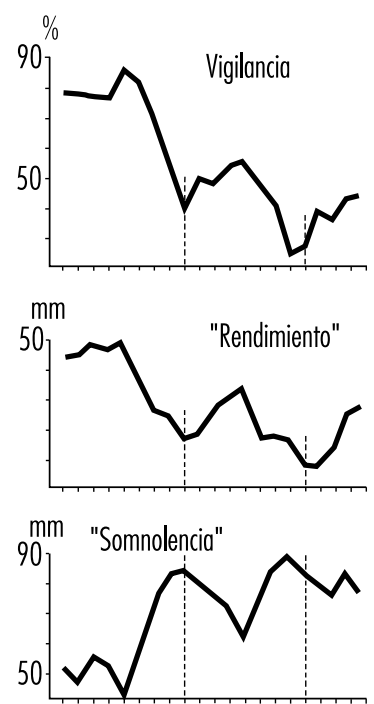

Fuente: Fröberg 1985.

\section{MEDIDAS PERIFERICAS}
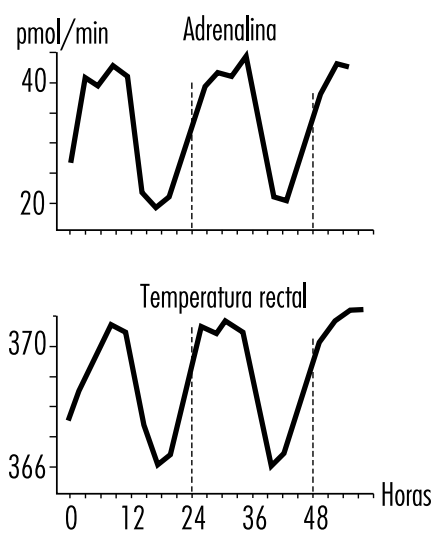

distintas formas, sino también la manera en que los trabajadores pueden recuperarse de ellos.

La compleja naturaleza de la privación del sueño se muestra en la Figura 29.31, que ofrece datos procedentes de estudios en laboratorio sobre los efectos de tres días de privación de sueño (Fröberg 1985). Los datos muestran tres cambios básicos, resultantes de la privación prolongada de sueño:

1. Hay una tendencia general a una disminución del rendimiento objetivo y de la valoración subjetiva de la eficacia del rendimiento.

2. Este declive cíclico está relacionado con la hora del día y se corresponde con las variables fisiológicas que tienen un ciclo circadiano. El rendimiento es mayor en la fase normal de actividad en la que, por ejemplo, la secreción de adrenalina y la temperatura del cuerpo son más altas, frente a los períodos destinados normalmente al sueño nocturno, que es cuando los valores fisiológicos son más bajos.

3. La autovaloración de la falta de sueño aumenta con el tiempo de privación continuada de sueño, con un claro componente cíclico asociado con el momento del día.

El hecho de que los efectos de la privación del sueño estén relacionados con los ritmos fisiológicos circadianos nos ayuda a comprender lo complejo de su naturaleza (Folkard y Akerstedt 1992). Estos efectos deberían considerarse como el resultado de un desfase del ciclo sueño-vigilia en la vida cotidiana.

L os efectos del trabajo continuado o de la privación de sueño no sólo reducen la capacidad para mantenerse alerta, sino que también disminuyen el rendimiento, aumentan la probabilidad de quedarse dormido, reducen el bienestar y la moral y merman la seguridad. Cuando dichos períodos de privación del sueño se repiten, como sucede en el caso de las personas que trabajan por turnos, su salud puede verse afectada (Rutenfranz 1982; K oller 1983; Costa y cols. 1990). Un objetivo importante de la investigación es determinar hasta qué punto la privación del sueño perjudica el bienestar de los individuos y cómo podemos utilizar mejor la función reparadora del sueño para reducir estos efectos.

\section{Efectos de la privación del sueño}

Durante una noche de privación de sueño y después de ésta, los ritmos fisiológicos circadianos del cuerpo humano parecen quedar interrumpidos. Por ejemplo, la curva de la temperatura corporal durante la primera jornada de trabajo en trabajadores del turno de noche tiende a mantener su patrón circadiano básico. Durante las horas nocturnas, la temperatura disminuye hasta las primeras horas de la mañana, vuelve a aumentar durante el día y vuelve a caer después del mediodía, tras alcanzar un máximo. Se sabe que los ritmos fisiológicos se "ajustan" a los ciclos invertidos de sueño-vigilia de los trabajadores nocturnos de forma gradual, en el curso de varios días en los que repite el turno de noche. Esto significa que los efectos sobre el rendimiento y la somnolencia son más significativos durante las horas nocturnas que durante el día. Los efectos de la privación del sueño tienen una relación variable con los ritmos circadianos originales observados en las funciones fisiológicas y psicológicas.

Los efectos de la privación del sueño sobre el rendimiento dependen del tipo de tarea que se vaya a realizar. Las características de las tareas inciden sobre estos efectos (Fröberg 1985; Folkard y M onk 1985; Folkard y A kerstedt 1992). G eneralmente, una tarea compleja es más vulnerable que una simple. EI rendimiento en una tarea que implique un gran número de dígitos 0 una codificación compleja se deteriora durante tres días de pérdida de sueño (Fröberg 1985; Wilkinson 1964). Las tareas escalonadas, a las que hay que responder a intervalos determinados, se deterioran más que las tareas que el operario hace a su propio ritmo. Como ejemplos prácticos de tareas vulnerables pueden mencionarse las reacciones en serie a estímulos definidos, las operaciones sencillas de clasificación, la grabación de mensajes codificados, la copia mecanográfica, el seguimiento por pantalla y la inspección continua. Los efectos de la privación de sueño sobre el rendimiento durante una actividad física intensa son también muy conocidos. Los efectos típicos de la privación prolongada de sueño sobre el rendimiento en una tarea visual se muestran en la Figura 29.32 (Dinges 1992). Los efectos son más pronunciados después de dos noches sin dormir (40-56 horas) que después de una noche (16-40 horas).

El grado en que se ve afectado el rendimiento en las tareas también parece depender de la forma en que inciden sobre él los componentes que "enmascaran" los ritmos circadianos. Por ejemplo, algunas medidas de rendimiento, como las tareas de memorización, se ajustan al trabajo nocturno de forma considerablemente más rápida que las tareas de tiempo de reacción en serie, por lo que pueden compensarse relativamente con sistemas de rotación rápida de turnos (Folkard y cols. 1993). Estas diferencias sobre los efectos de los ritmos del reloj fisiológico endógeno y sus componentes enmascaradores deben tenerse en cuenta a la hora de considerar la seguridad y la precisión del rendimiento bajo la influencia de la privación de sueño.

Un efecto particular de la privación del sueño sobre el rendimiento es la aparición de frecuentes "lapsus" o períodos sin respuesta (Wilkinson 1964; Empson 1993). Estos lapsus de rendimiento son períodos breves de baja capacidad para mantener la alerta o de sueño ligero. Pueden detectarse con registros en vídeo de la ejecución, con registros de los movimientos oculares o con electroencefalogramas (EEG). Una tarea prolongada (media hora o más), especialmente cuando es repetitiva, puede conducir más fácilmente a estos lapsus. Las tareas monótonas, como la repetición de reacciones simples o el seguimiento de señales infrecuentes son muy sensibles en este sentido. Por otro lado, una tarea nueva se ve menos afectada. El rendimiento en situaciones de trabajo cambiante también es más resistente. 
Figura 29.32 - Ajuste a las líneas de regresión de la velocidad de respuesta (la inversa del tiempo de respuesta) durante una tarea visual sencilla y no preparada de 10 minutos encomendada de forma repetida a adultos jóvenes sanos durante un período sin privación de sueño (5-16 horas), una noche sin dormir (16-40 horas) o dos noches sin dormir (40-56 horas).

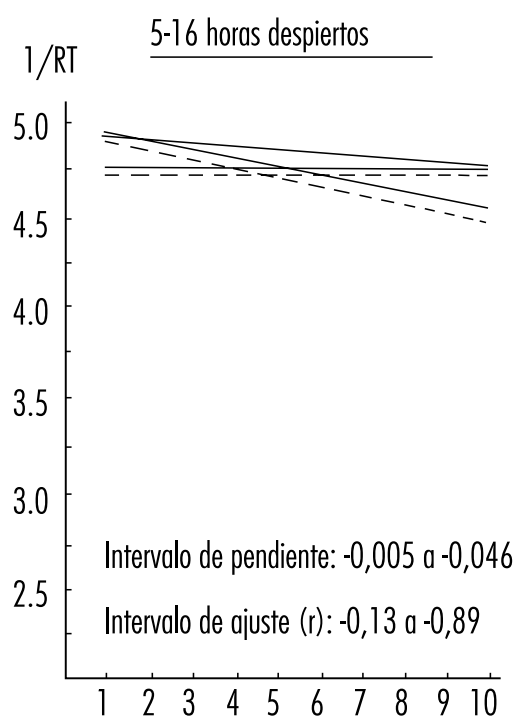

16-40 horas despiertos

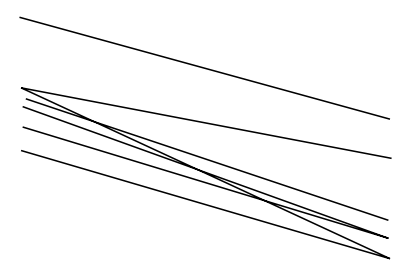

$-0,041$ a $-0,102$

$-0,80$ a $-0,95$

Fuente: Dinges 1992

Aunque es evidente que la privación de sueño produce una reducción gradual de la activación, es de esperar que los niveles de rendimiento entre lapsus estén menos afectados. Esto explica por qué el resultado de algunas pruebas de rendimiento indica una escasa influencia de la pérdida de sueño cuando las pruebas se hacen durante un período corto de tiempo. En una tarea de tiempo de reacción simple, los lapsus provocarían unos tiempos de respuesta muy prolongados, mientras el resto de los tiempos medidos no sufriría cambios. $\mathrm{H}$ ay que tener cuidado, por lo tanto, al interpretar los resultados de las pruebas relacionados con los efectos de la pérdida de sueño en situaciones reales.

La variación de la sensación de somnolencia durante la privación de sueño está relacionada obviamente con los ritmos circadianos fisiológicos y con los períodos de lapsus. La somnolencia aumenta enormemente durante el primer período del turno de noche, pero disminuye durante las horas diurnas siguientes. Si la privación del sueño se prolonga hasta la noche siguiente, se hará muy intensa durante las horas nocturnas (Costa y cols. 1990; $\mathrm{M}$ atsumoto y $\mathrm{H}$ arada 1994). $\mathrm{H}$ ay momentos en los que la necesidad de dormir que se siente es casi irresistible; estos momentos corresponden a la aparición de lapsus y de interrupciones de las funciones cerebrales, tal y como se ha registrado en Ios EEG. Transcurrido un tiempo, la somnolencia parece reducirse, pero a continuación se produce otro período de lapsus. Si se pregunta a los trabajadores sobre sus sensaciones de fatiga, sin embargo, suelen mencionar unos niveles cada vez mayores de fatiga y cansancio general que persisten a lo largo del período de privación del sueño y en los períodos entre lapsus. Se aprecia una ligera recuperación de los niveles subjetivos de fatiga durante el día que sigue a una noche de privación de sueño, pero la sensación de fatiga aumentan considerablemente en la noche segunda y siguientes de privación de sueño continuada.

Durante la privación del sueño, el peso del sueño por la interacción de la vigilia previa y la fase circadiana estará siempre presente en mayor o menor medida, pero la fragilidad de este estado en sujetos somnolientos también está afectada por los efectos del contexto (Dinges 1992). La somnolencia se ve afectada por la cantidad y el tipo de estímulos, por el interés que se ponga en el entorno y el significado del estímulo para un individuo en una situación de monotonía o que requiera una atención constante y que pueda llevar con más facilidad a la disminución de la vigilancia y a los lapsus. C uanto mayor sea la somnolencia fisiológica producida por la falta de sueño, más vulnerable será el individuo a la monotonía que lo rodea. La motivación y los estímulos pueden contribuir a anular este efecto ambiental, pero sólo durante un período limitado.

\section{Efectos de la privación parcial de sueño y la falta de sueño acumulada}

Si un individuo trabaja continuamente durante toda una noche, sin dormir, muchas de sus funciones de rendimiento se verán definitivamente deterioradas. Si el sujeto vuelve a estar en el turno de noche por segunda vez sin haber dormido nada, el descenso de su rendimiento seguirá su curso. Tras la tercera o cuarta noche de privación total del sueño, muy poca gente puede permanecer despierta y realizar sus tareas, aunque estén muy motivados. En la vida real, sin embargo, las condiciones de pérdida total del sueño raramente se dan. La gente suele dormir algo durante los turnos de noche siguientes. Pero los estudios realizados en varios países demuestran que el sueño diurno es casi siempre insuficiente para recuperarse del déficit de sueño contraído por el trabajo nocturno (K nauth y Rutenfranz 1981; Kogi 1981; ILO 1990). Como resultado, los déficits de sueño se van acumulando cuando el trabajador repite el turno de noche. También se producen faltas de sueño similares cuando los períodos de sueño se ven reducidos por la necesidad de seguir los cambios de turnos establecidos. Aunque sea posible dormir por la noche, una restricción en el sueño nocturno de sólo dos horas cada noche basta para provocar una falta de sueño en la mayoría de las personas. U na reducción así puede deteriorar el rendimiento y la capacidad de permanecer alerta (M onk 1991). 
Tabla 29.9 - Aspectos del sueño "por adelantado", "de mantenimiento" o "retrasado" como sustituto de un sueño nocturno normal.

\begin{tabular}{|c|c|c|c|}
\hline Aspecto & $\begin{array}{l}\text { Sueño } \\
\text { "por adelantado" }\end{array}$ & $\begin{array}{l}\text { Sueño "de } \\
\text { mantenimiento" }\end{array}$ & $\begin{array}{l}\text { Sueño } \\
\text { "retrasado" }\end{array}$ \\
\hline Ocasión & $\begin{array}{l}\text { Antes de un turno } \\
\text { nocturno } \\
\text { Entre turnos } \\
\text { nocturnos } \\
\text { Antes del trabajo } \\
\text { de madrugada } \\
\text { Siestas a última } \\
\text { hora de la tarde }\end{array}$ & $\begin{array}{l}\text { Trabajo nocturno } \\
\text { intermitente } \\
\text { Durante un turno } \\
\text { de noche } \\
\text { Turno alternado } \\
\text { de día } \\
\text { Tiempo libre } \\
\text { prolongado } \\
\text { Siestas de forma } \\
\text { irregular }\end{array}$ & $\begin{array}{l}\text { Después de un } \\
\text { turno de noche } \\
\text { Entre turnos de } \\
\text { noche } \\
\text { Tras un trabajo } \\
\text { vespertino } \\
\text { prolongado } \\
\text { Siestas durante } \\
\text { el día }\end{array}$ \\
\hline Duración & Generalmente breve & Breve por definición & $\begin{array}{l}\text { Generalmente } \\
\text { breve pero } \\
\text { más largo tras } \\
\text { un trabajo } \\
\text { vespertino } \\
\text { prolongado }\end{array}$ \\
\hline Calidad & $\begin{array}{l}\text { Mayor latencia para } \\
\text { conciliar el sueño } \\
\text { Malhumor al } \\
\text { levantarse } \\
\text { Sueño MOR reducido } \\
\text { Sueño de onda lenta } \\
\text { dependiente de la } \\
\text { vigilia previa }\end{array}$ & $\begin{array}{l}\text { Latencia breve } \\
\text { Malhumor al } \\
\text { levantarse } \\
\text { Fases iniciales de } \\
\text { sueño similares } \\
\text { a las de un } \\
\text { sueño nocturno } \\
\text { normal }\end{array}$ & $\begin{array}{l}\text { Latencia más corta } \\
\text { para el sueño MOR } \\
\text { Se despierta } \\
\text { con mayor } \\
\text { frecuencia } \\
\text { Mayor proporción } \\
\text { de sueño MOR } \\
\text { Mayor cantidad de } \\
\text { sueño de onda } \\
\text { lenta tras un } \\
\text { período largo } \\
\text { de vigilia }\end{array}$ \\
\hline $\begin{array}{l}\text { Interacción } \\
\text { con los } \\
\text { ritmos } \\
\text { circadianos }\end{array}$ & $\begin{array}{l}\text { Ritmos alterados; } \\
\text { ajuste relativa- } \\
\text { mente más rápido }\end{array}$ & $\begin{array}{l}\text { Conduce a la } \\
\text { estabilización de } \\
\text { los ritmos } \\
\text { originales }\end{array}$ & $\begin{array}{l}\text { Ritmos alterados; } \\
\text { ajuste lento }\end{array}$ \\
\hline
\end{tabular}

En la Tabla 29.9 se muestran ejemplos de las condiciones del sistema de turnos que contribuyen a la acumulación de la falta de sueño 0 a la privación parcial de sueño. Además del trabajo durante dos noches o más, los períodos de descanso reducidos entre turnos, los turnos de madrugada repetidos, los turnos de noche frecuentes y el reparto inadecuado de los días libres aceleran la acumulación de la falta de sueño.

La escasa calidad del sueño diurno o los períodos de sueño reducidos también son importantes. Durante el sueño diurno, la persona se despierta con más frecuencia, el sueño es menos profundo y de onda más lenta y la distribución de las fases MOR del sueño es diferente de la del sueño nocturno normal (Torsvall, Akerstedt y Gillberg 1981; Folkard y Monk 1985; Empson 1993). Por todo esto, el sueño diurno nunca puede ser tan profundo como el nocturno, aunque el entorno sea adecuado.

La Figura 29.33 ilustra la dificultad para tener una buena calidad de sueño debido a la diferencia de horarios de sueño en un sistema de turnos. En esta figura se muestra la duración del sueño en función del comienzo del período de sueño para ciertos trabajadores alemanes y japoneses, de acuerdo con un registro diario (K nauth y Rutenfranz 1981; Kogi 1985). Debido a la influencia circadiana, el sueño diurno es forzosamente corto. M uchos trabajadores pueden dormir un poco durante el día y a menudo, siempre que pueden, a última hora de la tarde.

En la vida real, los trabajadores por turnos adoptan una serie de medidas que les permiten hacer frente a la acumulación de la falta de sueño (Wedderburn 1989). Por ejemplo, muchos de ellos tratan de dormir "por adelantado" antes del turno de noche 0 duermen bastante cuando lo finalizan. Aunque estos esfuerzos no son completamente eficaces para compensar los efectos de la falta de sueño, son bastantes liberadores. Las actividades sociales y culturales pueden verse restringidas como parte de estas medidas de compensación. L as actividades de ocio que implican salir, por ejemplo, son menos frecuentes entre dos turnos de noche. Los horarios de sueño y su duración, además de la acumulación de la falta de sueño, dependen de circunstancias tanto sociales como relacionadas con el trabajo.

\section{Recuperación de la privación de sueño y medidas de salud}

El único medio eficaz para recuperarse de la falta de sueño es dormir. El efecto reparador del sueño es bien conocido (K ogi 1982). Como la recuperación mediante el sueño puede diferir en función de su horario y duración (Costa y cols. 1990), es fundamental saber cuándo y cuánto debería dormir la gente. En la vida diaria, lo mejor es siempre dormir una noche entera para acelerar la recuperación del déficit de sueño, pero normalmente se trata de reducir los efectos de la falta de sueño con pequeñas siestas en diferentes ocasiones, que sustituyen al sueño normal de una noche entera, del que se ha privado a la persona. La Tabla 29.9 muestra algunos aspectos de estos sueños de sustitución.

\section{Figura 29.33 • Duración media del sueño en función de la hora de inicio del sueño. Comparación entre los datos de trabajadores por turnos alemanes y japoneses.}

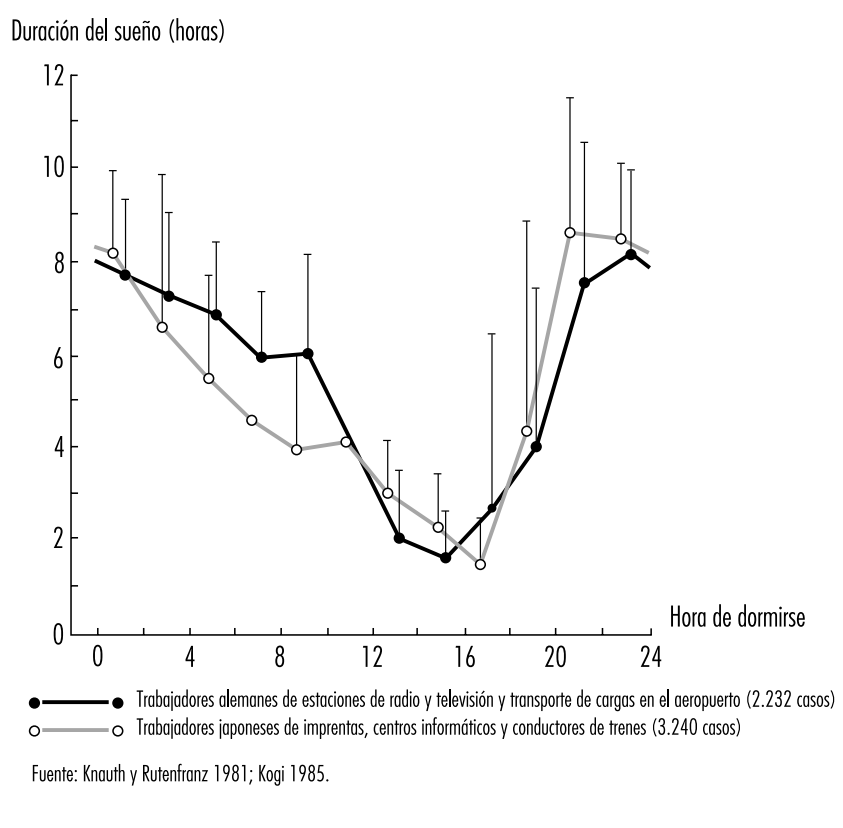


Para compensar la falta de sueño nocturno, lo normal es dormir de día, "por adelantado" o de forma "retrasada" (por ejemplo, antes y después del turno de noche). Este sueño coincide con la fase circadiana de actividad. Por ello, el sueño se caracteriza por una latencia más prolongada, un período de sueño de onda lenta más corto, una interrupción de las fases M OR y un desajuste de la vida social del individuo. L os factores sociales y ambientales son importantes para determinar el efecto reparador del sueño. Para considerar la eficacia de las funciones reparadoras del sueño debe tenerse en cuenta que la conversión completa de los ritmos circadianos de un trabajador por turnos es imposible en la vida real.

A este respecto, existe una interesante documentación sobre el "sueño de mantenimiento" (M inors y Waterhouse 1981; Kogi 1982; M atsumoto y $\mathrm{H}$ arada 1994). Cuando parte del sueño diario habitual se realiza durante el período normal (de noche) y el resto en períodos irregulares, los ritmos circadianos de la temperatura rectal y la secreción urinaria de diversos electrolitos pueden mantener un período de 24 horas. Esto significa que un corto sueño nocturno puede mantener los ritmos circadianos originales en los períodos siguientes.

Se puede considerar que el hecho de dormir un poco en distintos momentos del día puede tener una serie de efectos añadidos, vista la capacidad reparadora de cada tipo de sueño. Un enfoque interesante de los trabajadores de turnos de noche es la costumbre de dormir una siesta que normalmente dura unas cuantas horas. Los sondeos demuestran que estas pequeñas siestas nocturnas son habituales entre ciertos grupos de trabajadores del turno de noche. Este sueño de mantenimiento es eficaz para reducir la fatiga del trabajo nocturno (Kogi 1982) y puede reducir la necesidad del sueño reparador.

La Figura 29.34 compara la sensación subjetiva de fatiga durante dos turnos de noche consecutivos y el período de recuperación cuando no están trabajando entre un grupo que duerme un rato durante el turno de noche y otro que no lo hace (M atsumoto y Harada 1994). El efecto positivo de la siesta nocturna en la reducción de fatiga es obvio. Este efecto se prolonga durante gran parte del período de recuperación que sigue al trabajo nocturno. No hubo diferencias significativas entre estos dos grupos al comparar la duración del sueño diurno del grupo que no dormía "siesta" por la noche con el tiempo de sueño total (siesta nocturna más sueño diurno el día siguiente) del grupo que sí lo hacía. En resumen, una pequeña siesta nocturna permite cumplir parte de las necesidades de sueño esenciales sin esperar al día siguiente. Puede, por tanto, sugerirse que las siestas del turno de noche pueden contribuir, hasta cierto punto, a que el trabajador se recupere de la fatiga provocada por el trabajo y por la privación de sueño que lleva aparejada (Sakai y cols. 1984; Saito y M atsumoto 1988).

$\mathrm{H}$ ay que admitir, sin embargo, que no es posible establecer estrategias óptimas para que puedan aplicarlas todos los trabajadores que sufren privación de sueño. Esto se demuestra en la elaboración de la normativa internacional del trabajo para los turnos de noche, que recomienda una serie de medidas para los trabajadores que trabajan en este turno con frecuencia (K ogi y Thurman 1993).

La naturaleza variada de estas medidas y la tendencia hacia una mayor flexibilidad de los sistemas de turnos refleja un claro esfuerzo por aplicar unas estrategias flexibles de descanso (K ogi 1991). La edad, la capacidad física para el trabajo, los hábitos de sueño y otras diferencias individuales relacionadas con la tolerancia pueden desempeñar un papel importante (Folkard y M onk 1985; C osta y cols. 1990; H ärmä 1993). U na mayor flexibilidad en los programas de trabajo, junto con un mejor diseño de los mismos será muy útil a este respecto (K ogi 1991).
Figura 29.34 • Valoración media de la sensación subjetiva de fatiga durante dos turnos nocturnos consecutivos y durante el período de recuperación sin trabajo para grupos con o sin siesta.
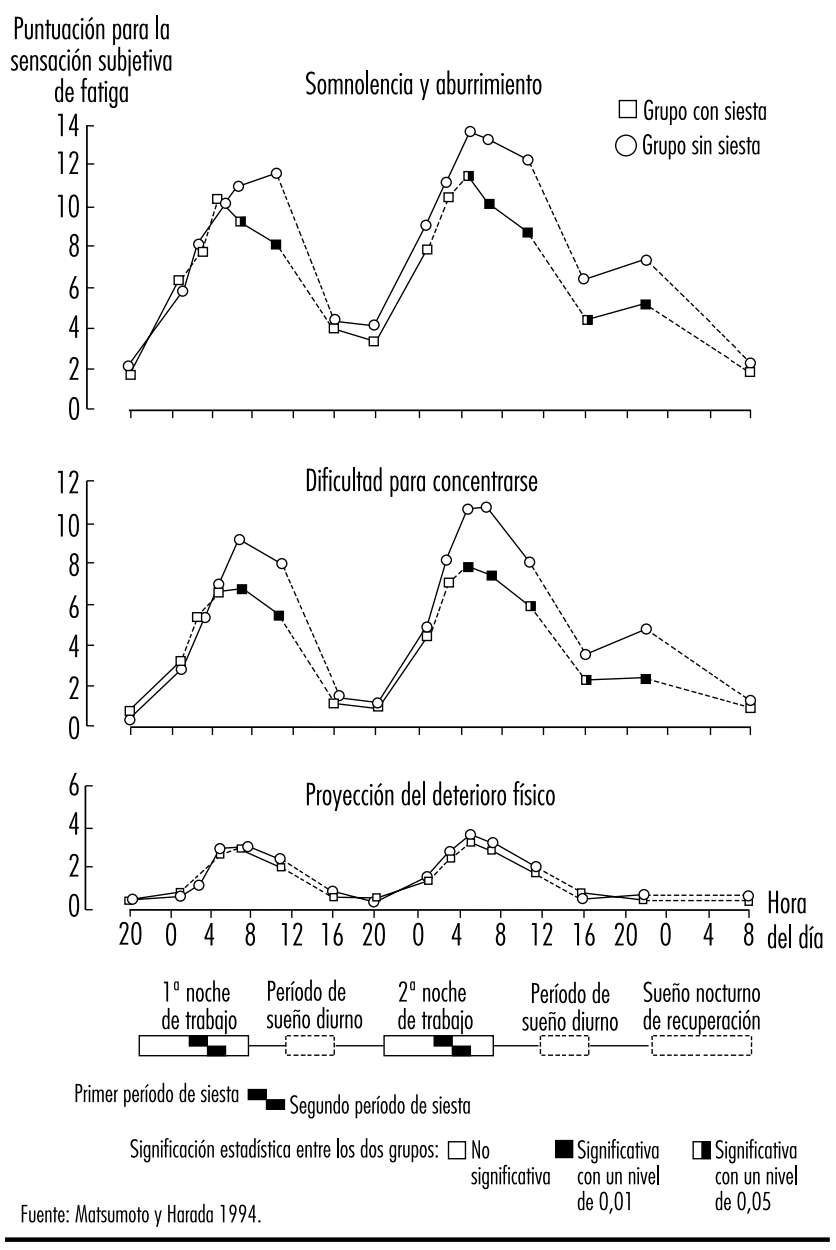

Las estrategias para dormir en situaciones de privación de sueño deberán depender del tipo de vida laboral y ser lo suficientemente flexibles para ajustarse a las situaciones individuales (K nauth, Rohmert y Rutenfranz 1979; Rutenfranz, K nauth y Angersbach 1981; Wedderburn 1991; M onk 1991). U na conclusión general es que la privación de sueño nocturno debe reducirse seleccionando unos programas de trabajo adecuados y facilitando la recuperación mediante el fomento de la posibilidad de dormir según las necesidades individuales, lo que incluye las siestas de sustitución y el sueño profundo nocturno, en períodos en los que la privación de sueño es reciente.

Es importante prevenir la acumulación de la falta de sueño. EI período de turno de noche, que priva a los trabajadores del sueño en la hora habitual, debería ser lo más reducido posible. Los intervalos entre uno y otro turno deberán ser suficientemente largos para permitir que el sueño sea suficiente. También resulta útil mejorar el ambiente para el sueño y adoptar una serie de medidas que se ajusten a las necesidades sociales. Por esto, cuando se trata de mejorar la salud de los trabajadores con frecuentes déficits de sueño, es indispensable el apoyo social para diseñar los horarios, los trabajos y las estrategias individuales para afrontarlos. 


\section{- Puestos de trabajo}

Roland Kadefors

\section{Un enfoque integral del diseño de los puestos de trabajo}

En ergonomía, el diseño del puesto de trabajo es una tarea fundamental. Se sabe que en cualquier entorno de trabajo, ya sea la oficina o el taller, un puesto de trabajo bien diseñado aumenta no sólo la salud y bienestar de los trabajadores, sino también la productividad y la calidad de los productos. $Y$ a la inversa, un puesto mal concebido puede dar lugar a quejas relacionadas con la salud 0 a enfermedades profesionales crónicas y a problemas para mantener la calidad del producto y el nivel de productividad deseado.

Para cualquier ergónomo, el párrafo anterior puede resultar trivial. También cualquier ergónomo reconocerá que la vida laboral en todo el mundo se caracteriza no sólo por la falta de aplicación de la ergonomía, sino por las patentes violaciones de sus principios básicos. Está bien claro que hay una gran falta de conciencia en lo relativo a la importancia del diseño del puesto de trabajo por parte de los responsables: ingenieros de producción, supervisores y directivos.

$H$ ay que destacar que existe una tendencia internacional relacionada con la labor industrial que parece subrayar la importancia de los factores ergonómicos: el aumento en la exigencia de una mejor calidad, una mayor flexibilidad de la producción y la precisión en la entrega del producto. Estas exigencias no son compatibles con el punto de vista tradicional que se aplica al diseño de los puestos de trabajo.

Aunque en la actualidad son los factores físicos del puesto del trabajo los que suponen la preocupación principal, debe tenerse en cuenta que el diseño físico del puesto de trabajo no puede separarse, en la práctica, de la organización de la tarea. Este principio quedará claro en el proceso de diseño descrito a continuación. La calidad del resultado final del proceso se apoya en tres puntos: el conocimiento ergonómico, su integración con las exigencias de productividad y calidad, y la participación. El proceso de ejecución de un nuevo puesto de trabajo debe favorecer esta integración y constituye el punto central de este artículo.

\section{Aspectos del diseño}

Los puestos de trabajo están pensados para el trabajo. Hay que reconocer que el punto de partida en el proceso de diseño de un puesto de trabajo es pensar que hay que cumplir un objetivo de producción determinado. El diseñador, normalmente un ingeniero de producto o cualquier otro directivo de nivel intermedio, concibe una visión interna del puesto de trabajo y comienza a poner en práctica lo que ha visto con sus medios de planificación. El proceso es iterativo: desde un primer intento muy básico, las soluciones se van afinando cada vez más. Es esencial que el aspecto ergonómico se tenga en cuenta en cada iteración, a medida que avanza el trabajo.

No debe olvidarse que el diseño ergonómico de los puestos de trabajo está estrechamente relacionado con la evaluación ergonómica de los mismos. En realidad, la estructura que hay que seguir se aplica tanto a los puestos que ya existen como a la fase de planificación.

En el proceso de diseño existe la necesidad de una estructura que garantice que se han tenido en cuenta todos los aspectos relevantes. La forma tradicional de enfrentarse a esto es elaborando unas listas con una serie de variables que no deben olvidarse. Sin embargo, las listas generales suelen ser largas y difíciles de utilizar, ya que en una situación determinada de diseño puede que sólo sea necesaria una parte de dicha lista. Por otro lado, en una situación práctica de diseño, algunas variables destacan como más importantes que las demás. E s necesaria una metodología que considere todos estos factores conjuntamente, como la que se propone en este artículo.

Las recomendaciones para el diseño de un puesto de trabajo deben basarse en una serie de exigencias. Debe tenerse en cuenta que, en general, no basta con ajustarse a los valores umbral para las variables individuales. Un propósito combinado y aceptado de productividad y mantenimiento de la salud hace necesario ir más allá que en el diseño tradicional. La cuestión de las molestias musculosqueléticas, en particular, es un aspecto fundamental en muchas de las situaciones de la industria, aunque este tipo de problemas no esté limitado en absoluto al entorno industrial.

\section{Proceso de diseño de un puesto de trabajo}

\section{Fases del proceso}

En los procesos de diseño y ejecución de un puesto de trabajo siempre existe una necesidad inicial de informar a los usuarios y organizar el proyecto de forma que éstos tengan una participación plena, para que el resultado final sea aceptado por todos. EI tratamiento de este objetivo no está dentro del ámbito de este artículo, que se centra en el problema de llegar a la solución idónea para el diseño físico del puesto de trabajo; sin embargo, el proceso de diseño permite la integración de dicho objetivo. En ese proceso siempre habrá que tener en cuenta las fases siguientes:

1. recabar las peticiones del usuario

2. establecer las prioridades de estas peticiones

3. transferir las peticiones a (a) especificaciones técnicas y (b) especificaciones del usuario

4. desarrollar de forma iterativa el diseño físico del puesto de trabajo

5. materializar el proyecto

6. período de pruebas de la producción

7. producción plena

8. evaluar e identificar los problemas de descanso

En este artículo nos centramos en las primeras cinco fases. M uchas veces, sólo se tiene en cuenta un subconjunto de estas fases para diseñar un puesto de trabajo. Esto se debe a varios motivos. Si el puesto de trabajo tiene un diseño estándar, como sucede en algunas situaciones de trabajo con PVD (pantalla de visualización de datos), algunos de estos pasos pueden suprimirse. Sin embargo, en la mayoría de los casos, la exclusión de algunos de los pasos de la lista da como resultado un puesto de calidad inferior a la que se consideraría aceptable. Este puede ser el caso cuando las limitaciones económicas o de tiempo son demasiado importantes, o cuando existe negligencia debido a la falta de conocimiento o previsión en los niveles directivos.

\section{Obtención de las peticiones de los usuarios}

Es fundamental identificar al usuario de un puesto de trabajo como miembro de una organización de producción que puede contribuir al diseño con sus opiniones cualificadas. Los usuarios pueden incluir, por ejemplo, trabajadores, supervisores, encargados de la planificación de la producción e ingenieros de 
producción, además del encargado de seguridad. La experiencia demuestra que todos estos trabajadores tienen un conocimiento personal que debe aprovecharse para el proceso.

La obtención de las peticiones del usuario deberá cumplir una serie de requisitos:

1. Apertura. No deberá aplicarse ningún filtro en la fase inicial del proceso. Todos los puntos de vista deberán tenerse en cuenta sin criticarse

2. No discriminación. Las opiniones de cualquier categoría deberán tratarse de forma equitativa en esta fase del proceso. D eberá otorgarse una consideración especial al hecho de que algunas personas pueden estar más dispuestas a participar que otras y existe el riesgo de que no dejen participar a los demás.

3. D esarrollo a través del diálogo. Debe existir una oportunidad para ajustar y desarrollar las peticiones mediante un diálogo entre los participantes de distintas procedencias. La asignación de prioridades deberá formar parte del proceso.

4. Versatilidad. EI proceso de recabar las peticiones de los usuarios deberá resultar razonable desde el punto de vista económico y no debe exigir la participación de especialistas 0 un consumo excesivo de tiempo de los participantes.

La serie anterior de criterios puede cumplirse utilizando una metodología basada en el desarrollo de la función de calidad (Q FD) de Sullivan (1986). Según este modelo, las peticiones del usuario pueden recogerse en una sesión en la que esté presente un grupo mixto de participantes compuesto por no más de ocho o diez personas. Todos los participantes recibirán una libreta con hojas adhesivas para notas. Se les pedirá que escriban todo lo que exigen de un puesto de trabajo, cada característica en una hoja de papel. Q uedarán cubiertos los aspectos relacionados con el entorno de trabajo y la seguridad, la productividad y la calidad. Esta actividad puede prolongarse todo lo que haga falta, normalmente entre diez y quince minutos. Después de esta sesión, se pedirá a los participantes, uno a uno, que lean sus opiniones y peguen sus notas en la pizarra de la sala, para que todo el grupo pueda verlas. Las peticiones se agruparán por categorías naturales, como iluminación, dispositivos para levantar pesos, equipos de producción, cuestiones de distancias y de flexibilidad. U na vez terminada la ronda, el grupo tendrá la ocasión de discutir y comentar todas las peticiones, por categorías, según su importancia y prioridad.

El conjunto de peticiones de los usuarios, obtenido en un proceso como el descrito, constituye la base para desarrollar la especificación de las peticiones. Se puede obtener información adicional de otras categorías de trabajadores, por ejemplo, diseñadores de productos, ingenieros de calidad o economistas. Pero lo principal es darse cuenta de cuál es la contribución potencial de los usuarios en este contexto.

\section{Establecimiento de prioridades en las peticiones}

En relación con el proceso de especificación, es fundamental que los distintos tipos de peticiones se consideren de acuerdo a su importancia. De no ser así, todos los aspectos tendrán que considerarse en paralelo, lo que puede complicar el diseño y hacer que la situación sea difícil de controlar. Por ello, las listas de comprobación que hay que elaborar pueden resultar difíciles de manejar en determinadas situaciones.

Es difícil trazar un esquema de prioridades que sirva para cualquier tipo de puesto de trabajo, pero si se considera que la manipulación manual de los materiales, herramientas 0 productos es un aspecto esencial del trabajo que se va a realizar en el puesto, hay muchas probabilidades de que los aspectos asociados con la carga musculosquelética estén en los primeros puestos de la lista de prioridades. La validez de este supuesto puede comprobarse en la fase de obtención de peticiones. Las peticiones importantes pueden, por ejemplo, estar asociadas con la tensión muscular y la fatiga, la necesidad de estirarse para alcanzar algo, la visibilidad o la facilidad de manipulación.

Es importante aceptar que tal vez no sea posible transformar todas las peticiones de los usuarios en especificaciones técnicas. Aunque las peticiones estén relacionadas con aspectos más sutiles, como la comodidad, pueden ser muy importantes y deberán tenerse en cuenta a lo largo del proceso.

\section{Variables de la carga musculosquelética}

De acuerdo con el razonamiento anterior, aplicaremos el criterio de que existe una serie de variables ergonómicas básicas relacionadas con la carga musculosquelética, que debe tenerse en cuenta como prioridad en el proceso de diseño, con el fin de eliminar el riesgo de trastornos musculosqueléticos relacionados con el trabajo. Este tipo de trastornos se caracterizan por dolor localizado en el sistema musculosquelético, que se desarrolla durante períodos de tiempo prolongados como resultado de tensiones repetidas en una parte determinada del cuerpo (Putz-Anderson 1988). L as variables básicas son (por ejemplo, Corlett 1988):

- exigencia de fuerza muscular

- exigencias de la postura de trabajo

- exigencias de tiempo

En relación con la fuerza muscular, los criterios pueden basarse en una combinación de factores biomecánicos, psicológicos y fisiológicos. Esta variable se aplica midiendo las necesidades de fuerza exterior, en términos de masa manipulada o fuerza requerida, por ejemplo, para manejar herramientas con mango. También pueden considerarse las cargas punta, en conexión con los trabajos más dinámicos.

La postura de trabajo: sus exigencias pueden evaluarse trazando (a) situaciones en las que las articulaciones se estiren más allá de su intervalo natural de movimiento y (b) algunas situaciones especialmente complicadas, como las que exigen arrodillarse, girarse 0 inclinarse, 0 trabajar con la mano por encima del nivel del hombro.

Las exigencias de tiempo pueden evaluarse trazando (a) un trabajo repetitivo, de ciclo corto y (b) un trabajo estático. La evaluación del trabajo estático puede afectar no sólo al mantenimiento de una postura o a la producción de una fuerza determinada durante períodos de tiempo prolongados. Desde el punto de vista de los músculos estabilizadores, especialmente en la articulación del hombro, el trabajo dinámico también puede tener una componente estática. Así, puede ser necesario considerar períodos más prolongados de movilización de las articulaciones.

La posibilidad de que una situación laboral se acepte en la práctica, se basa en las exigencias para la zona del cuerpo que se encuentra sometida a mayor tensión.

Es importante recordar que estas variables no deben considerarse independientemente, sino en conjunto. Por ejemplo, la necesidad de ejercer una gran fuerza puede ser aceptable si se produce de forma ocasional; la elevación del brazo por encima del nivel del hombro de vez en cuando no es un factor de riesgo. Pero las combinaciones de estas variables básicas sí deben tenerse en cuenta, y esto complica la definición de criterios.

En la R evised N IOSH equation for the design and evaluation of manual handling tasks (R evisión de la ecuación de NIOSH para el diseño y evaluación de las tareas de levantamiento manual) (Waters et al. 1993), este problema se aborda mediante una ecuación que establece los 
límites de peso y tiene en cuenta los siguientes factores: distancia horizontal, levantamiento de peso en vertical, asimetría en el levantamiento, acoplamiento manual y frecuencia de los levantamientos. De esta forma, los $23 \mathrm{~kg}$ de carga límite aceptable en condiciones ideales según los criterios biomecánicos, fisiológicos y psicológicos, pueden variar significativamente si se tienen en cuenta las particularidades de la situación laboral. La ecuación del NIOSH proporciona una base para evaluar el trabajo y el puesto de trabajo que conlleva tareas de levantamiento. Sin embargo, existen importantes limitaciones relacionadas con la posibilidad de aplicar la ecuación del NIO SH : por ejemplo, sólo pueden analizarse levantamientos que se realizan con ambas manos, ya que las pruebas científicas para el análisis de tareas de levantamiento realizadas con una sola mano aún no son definitivas. Esto demuestra la dificultad de aplicar las pruebas científicas al diseño del trabajo y del puesto de trabajo. En la práctica, las pruebas científicas deben combinarse con las opiniones de personas que tengan experiencia directa o indirecta en el tipo de trabajo en cuestión.

\section{El modelo del cubo}

La evaluación ergonómica de los puestos de trabajo es en gran medida un problema de comunicación, si se tiene en cuenta el complejo conjunto de variables. Se ha creado un modelo cúbico para la evaluación ergonómica de los puestos de trabajo basado en la discusión de prioridades antes descrita (K adefors 1993). EI primer objetivo fue crear una herramienta didáctica con fines comunicativos, basada en el supuesto de que la fuerza aplicada, la postura y las medidas de tiempo, constituyen unas variables básicas, prioritarias y relacionadas entre sí en la mayor parte de las situaciones.

Las exigencias se pueden agrupar en relación con su importancia, para cada una de las variables básicas. Se ha propuesto que esta agrupación se realice en tres niveles: (1) exigencias bajas, (2) exigencias medias o (3) exigencias altas. Los niveles de exigencia pueden determinarse mediante pruebas científicas 0 bien, mediante un enfoque de consenso en un grupo de usuarios. Estas dos alternativas no son mutuamente excluyentes y pueden producir resultados similares, pero probablemente con distintos grados de generalidad.

Como ya se ha dicho, las combinaciones de variables básicas determinan en gran medida el nivel de riesgo en relación con el desarrollo de problemas musculosqueléticos y los trastornos traumáticos acumulativos. Por ejemplo, la exigencia de un tiempo prolongado puede hacer que una situación laboral se convierta en algo inaceptable en los casos en los que hay al menos exigencias de nivel medio relacionadas con la fuerza y la postura. En el diseño y valoración de los puestos de trabajo es esencial que las variables más importantes se consideren de forma conjunta. Para esta evaluación se propone el modelo del cubo. Las variables básicas: fuerza, postura y tiempo, constituyen los tres ejes del cubo. Para cada combinación de exigencias puede definirse un subcubo; el modelo incorpora 27 de estos subcubos (véase la Figura 29.35).

Un aspecto básico del modelo es el grado de aceptación de las combinaciones de exigencias. En el modelo se propone un esquema de clasificación dividido en tres zonas: (1) la situación es aceptable, (2) la situación es condicionalmente aceptable o (3) la situación es inaceptable. Con fines didácticos, cada subcubo puede tener una textura o color determinado (por ejemplo, verde-amarillo-rojo). En este caso, la valoración también puede basarse en el usuario o en las pruebas científicas. La zona condicionalmente aceptable (amarilla) implica que "existe un riesgo de enfermedad o perjuicio que no puede ignorarse para la totalidad o parte de la población trabajadora en cuestión" (CEN 1994).

Para profundizar en este enfoque, resulta útil considerar un caso concreto: la evaluación de la carga depositada sobre el hombro con una sola mano en un proceso de manipulación de materiales a velocidad moderada. Se trata de un caso excelente, ya que en este tipo de situación es normalmente la estructura del hombro la que sufre la mayor tensión.

Con relación a la variable de fuerza, la clasificación puede basarse en este caso en la masa manipulada. Aquí, la exigencia de fuerza baja corresponde a niveles inferiores al $10 \%$ de la capacidad máxima de carga voluntaria (M V LC), que asciende aproximadamente a $1,6 \mathrm{~kg}$ en una zona de trabajo óptima. La exigencia de fuerza alta requiere más del $30 \%$ de la M V LC, aproximadamente $4,8 \mathrm{~kg}$. La exigencia de fuerza moderada queda entre estos límites. La tensión postural baja se produce cuando la parte superior del brazo está cerca del tórax. La tensión postural alta se

Figura 29.35 • "Modelo del cubo" para la evaluación ergonómica. Cada cubo representa una combinación de exigencias relacionadas con la fuerza, la postura y el tiempo. Color claro: combinación aceptable; gris: condicionalmente aceptable; negro: inaceptable.
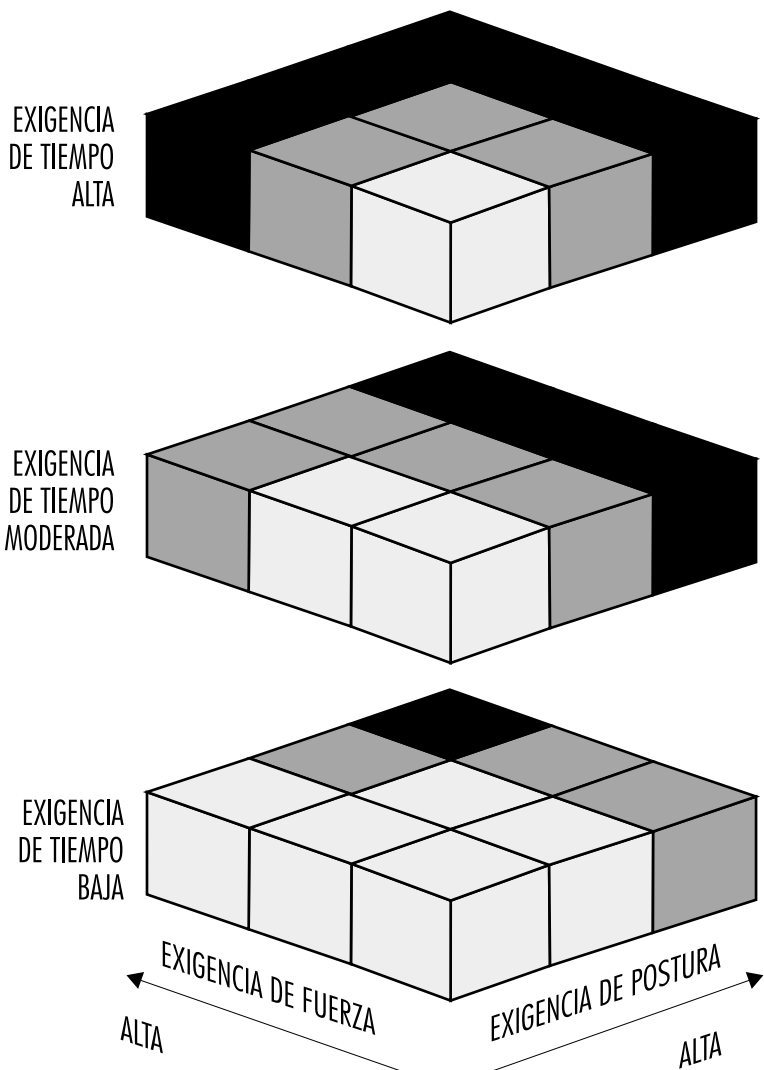

BAJA

BAJA

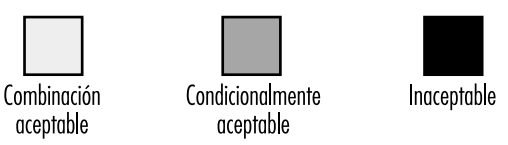


produce cuando la abducción o flexión del húmero supera los $45^{\circ}$. La tensión postural moderada se produce cuando el ángulo de abducción/ flexión se encuentra entre $15^{\circ}$ y $45^{\circ}$. La exigencia de tiempo alta se da cuando la manipulación lleva menos de una hora en un día de trabajo, o menos de 10 minutos diarios de forma continua. La exigencia de tiempo alta se produce cuando la manipulación tiene lugar durante más de cuatro horas por día de trabajo, o durante más de 30 minutos de forma continuada (sostenida o repetitiva). La exigencia de tiempo moderada se produce cuando la exposición queda entre estos dos límites.

En la Figura 29.35 se han asignado grados de aceptación a las combinaciones de exigencias. Por ejemplo, puede verse que las exigencias de tiempo altas sólo pueden combinarse con exigencias de fuerza y posturales bajas. El paso de lo inaceptable a lo aceptable es posible, reduciendo las exigencias en cualquier dimensión, pero la reducción de tiempo es la más eficaz en muchos casos. En otras palabras, en algunas ocasiones deberá modificarse el diseño del puesto de trabajo y en otras puede resultar más eficaz cambiar la organización del trabajo.

El uso de un grupo de consenso formado por usuarios para definir los niveles de exigencia y la clasificación del grado de aceptación puede mejorar considerablemente el proceso de diseño del puesto de trabajo, como se explica más adelante.

\section{Variables adicionales}

Además de las variables básicas ya comentadas, existe una serie de variables y factores que caracterizan al puesto de trabajo desde el punto de vista ergonómico, que hay que tener en cuenta, y que dependen de las condiciones particulares de la situación que se vaya a analizar. Entre éstas están:

- las precauciones para reducir el riesgo de accidentes,

- Ios factores medioambientales específicos, como el ruido, la iluminación y la ventilación,

- Ia exposición a los factores climáticos,

- la exposición a la vibración (por sostener herramientas),

- la facilidad para cumplir las exigencias de productividad y calidad.

Estos factores pueden considerarse de forma independiente hasta cierto punto; por lo que el enfoque de la lista de comprobación puede resultar útil. G randjean (1988) abarca en su libro los aspectos esenciales que es necesario tener en cuenta a este respecto. Konz (1990) proporciona, en sus directrices para la organización y el diseño del puesto de trabajo, una serie de preguntas que se centran en la relación entre el trabajador y la máquina en los sistemas de fabricación.

En el proceso de diseño que se ha seguido aquí, la lista de comprobación debe leerse junto con las peticiones expresadas por el usuario.

\section{Ejemplo de diseño de un puesto de trabajo: soldadura manual}

Como ejemplo ilustrativo (hipotético), se describe un proceso de diseño que conduce a la puesta en marcha de un puesto de soldadura manual (Sundin y cols.. 1994). La soldadura es una actividad que suele combinar grandes exigencias de fuerza muscular y grandes exigencias de precisión manual. El trabajo tiene un carácter estático. El soldador suele dedicarse exclusivamente a esa tarea. El ambiente suele ser hostil, con una combinación de exposición a altos niveles de ruido, humo y radiación óptica.

$\mathrm{L}$ a tarea consiste en diseñar un puesto de trabajo para soldadura M IG (metal gas inerte) de objetos de tamaño medio (hasta $300 \mathrm{~kg}$ ) en un taller. El taller tiene que ser flexible, ya que deben fabricarse diversos objetos. Las exigencias más importantes son las de productividad y calidad.
Se llevó a cabo un proceso Q FD para que los usuarios proporcionaran un conjunto de peticiones del puesto de trabajo. En este proceso participaron los soldadores, los ingenieros de producción y los diseñadores de producto. Las peticiones de los usuarios, que no se detallan aquí, abarcaban una amplia gama de aspectos, entre los cuales se encontraban la ergonomía, la seguridad, la productividad y la calidad.

U tilizando el modelo del cubo, el grupo identificó, por consenso, límites de carga altos, moderados y bajos:

1. Variable de fuerza. Se consideró una carga baja a una masa inferior a $1 \mathrm{~kg}$, y una carga alta, más de $3 \mathrm{~kg}$.

2. Variable de tensión postural. Las posturas adoptadas para trabajar que imponen una gran tensión son las que obligan a elevar los brazos, a girarse 0 inclinarse mucho, 0 a arrodillarse, además de situaciones en las que la muñeca debe mantenerse en posición de flexión/ extensión o desviación extremas. La tensión escasa se produce cuando la postura es erguida, de pie o sentado, y las manos están en las zonas de trabajo óptimas.

3. Variable de tiempo. Se considera una exigencia de tiempo baja cuando menos del $10 \%$ de la jornada laboral se dedica a soldar, y alta cuando se trata de más del $40 \%$. La exigencia moderada implica que la variable quede entre los límites indicados, o que la situación no está clara.

Según la valoración obtenida con el modelo del cubo (Figura 29.35) es evidente que las exigencias expresadas no se aceptarían si coincidieran las exigencias altas o moderadas de fuerza o tensión postural. Para poder reducir estas exigencias, era necesaria la manipulación mecánica de los objetos y la suspensión de herramientas. En torno a esta conclusión se produjo un consenso. U tilizando un sencillo programa de dibujo asistido por ordenador (CAD) llamado ROO M ER, se creó una biblioteca de equipos. Con esto resultaba muy sencillo diseñar y modificar, en estrecha colaboración con los usuarios, la disposición del puesto de trabajo. Este enfoque de diseño tiene enormes ventajas en comparación con la observación de planos, ya que da al usuario una visión inmediata del aspecto que tendrá el puesto de trabajo.

Figura 29.36 - Versión CAD de un puesto de trabajo de soldadura manual, conseguida durante el proceso de diseño.

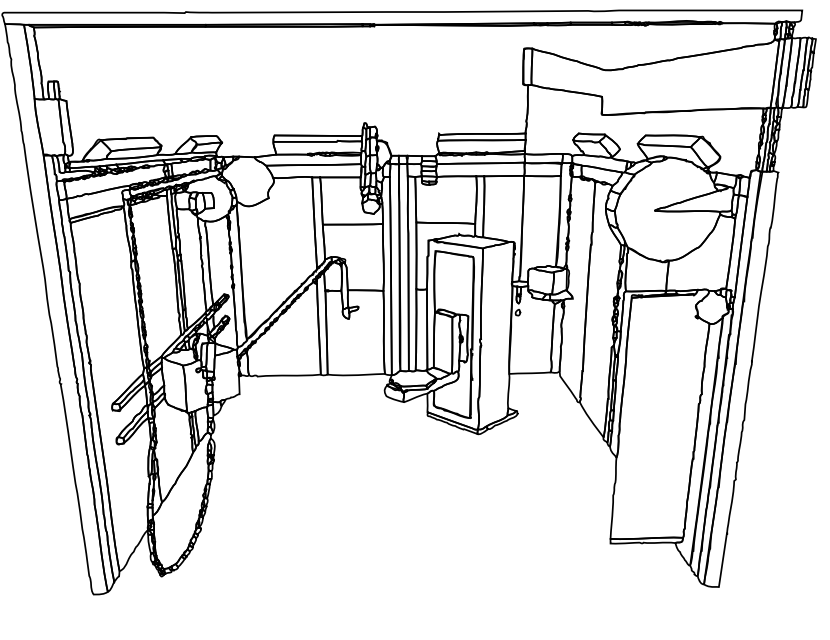


La Figura 29.36 muestra el puesto de soldadura al que se llegó utilizando el sistema CAD. Es un puesto que reduce las exigencias de fuerza y postura y que cumple prácticamente todos los requisitos residuales de los usuarios.

Basándose en los resultados de las primeras fases del proceso de diseño, se construyó físicamente un puesto de soldadura (Figura 29.37). Entre sus ventajas están:

1. Se facilita el trabajo en la zona más adecuada gracias a un dispositivo de manipulación controlado por ordenador para los objetos que se sueldan. $\mathrm{H}$ ay un montacargas, situado por encima del nivel de la cabeza, destinado al transporte. Como alternativa, se puede utilizar un dispositivo elevador para que la manipulación de objetos sea más sencilla.

2. La pistola de soldadura y la rectificadora están colgadas, reduciendo así la necesidad de fuerza. Pueden colocarse en cualquier parte del objeto que se está soldando. También se ha incluido una silla especial.

3. Todos los medios proceden de la parte superior, lo que significa que no hay cables por el suelo.

4. El puesto de trabajo tiene tres niveles de iluminación: general, puesto de trabajo y proceso. La iluminación del puesto de trabajo procede de elevadores que están por encima de los elementos de la pared. La luz de proceso está integrada en el brazo de extracción de humo de la soldadura.
5. El puesto de trabajo tiene tres niveles de ventilación: uno en el desplazamiento general y dos en el lugar de trabajo: uno con un brazo movible y otro integrado en la pistola de soldadura MIG. La ventilación del puesto de trabajo se controla con la pistola de soldadura.

6. Existen elementos para la absorción de ruido en tres paredes del lugar de trabajo. U na cortina de soldadura transparente cubre la cuarta pared. A sí el soldador puede estar informado de lo que sucede a su alrededor.

En una situación real es necesario hacer concesiones de varios tipos, ya que existen limitaciones económicas, de espacio, etc. D ebe tenerse en cuenta, sin embargo, que los soldadores autorizados son difíciles de encontrar en el sector industrial mundial y representan una inversión considerable. Casi ningún soldador llega a la jubilación como soldador activo. Mantener en el puesto a un soldador cualificado es positivo para todas las partes implicadas: el soldador, la empresa y la sociedad. Por ejemplo, hay muy buenas razones por las que un equipo de manipulación y posicionamiento de objetos debería formar parte de cualquier puesto de soldadura.

\section{Datos para el diseño de un puesto de trabajo}

Para poder diseñar un puesto de trabajo adecuado es necesario contar con una serie de datos básicos como datos

Figura 29.37 - Ejecución del puesto de trabajo de soldadura.

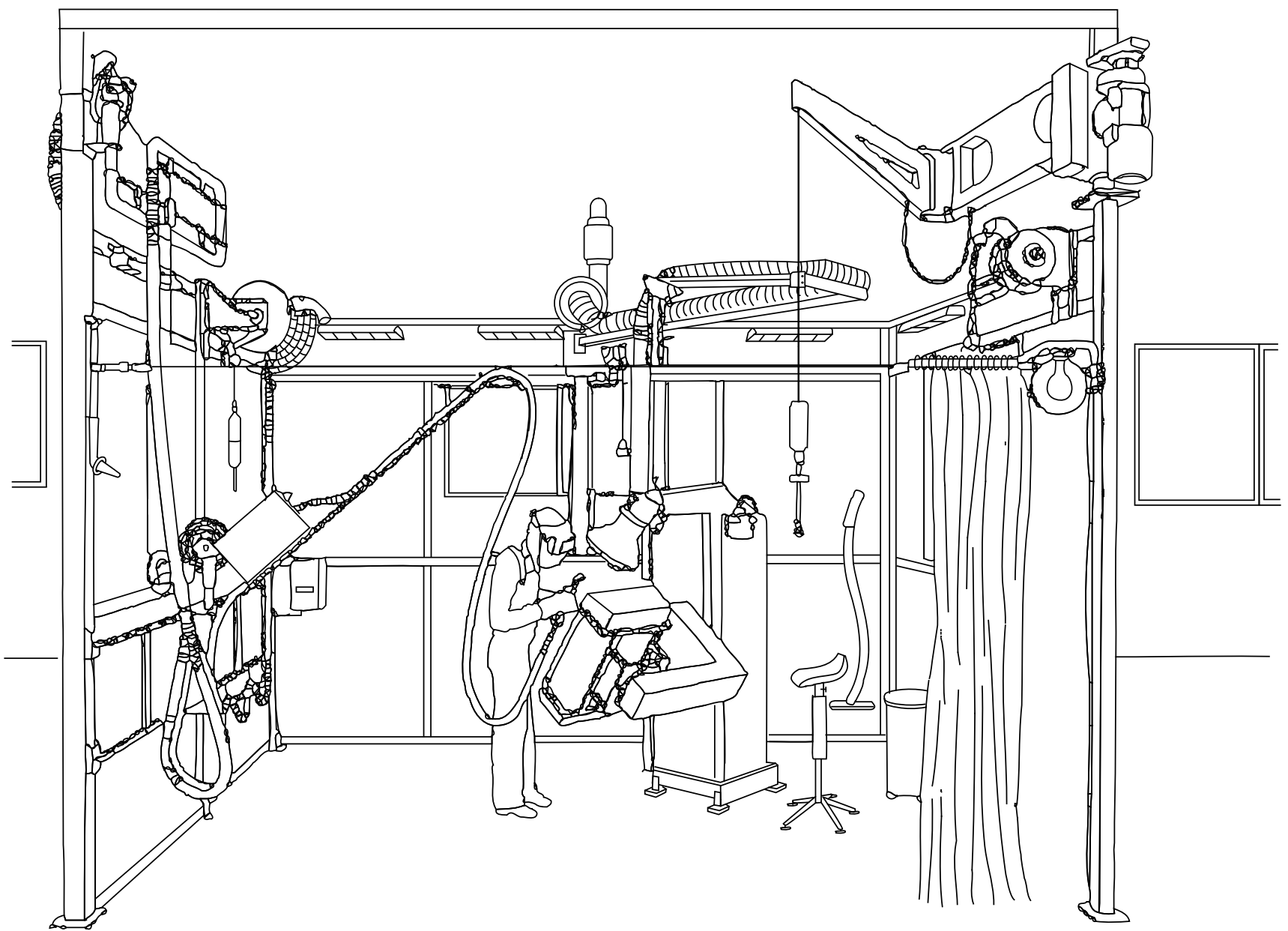


antropométricos de las categorías de usuarios, fuerza de levantamiento y otros datos sobre la capacidad de la población masculina y femenina, especificaciones de lo que constituye un puesto de trabajo óptimo, etc. En este artículo se hace referencia a algunas publicaciones clave.

El estudio más completo de prácticamente todos los aspectos del diseño de una tarea y un puesto de trabajo sigue siendo probablemente el libro de Grandjean (1988). La información sobre una amplia serie de aspectos antropométricos relevantes para diseñar un puesto de trabajo puede encontrarse en Pheasant (1986). Chaffin y Andersson (1984) ofrecen gran cantidad de datos antropométricos y biomecánicos. Konz (1990) ha presentado una guía práctica para diseñar puestos de trabajo que incluye una serie de reglas básicas. Los criterios de evaluación para las extremidades superiores, especialmente referidos a los trastornos traumáticos acumulativos, pueden encontrarse en Putz-Anderson (1988). Sperling y cols. (1993) ofrecen un modelo para la valoración del trabajo con herramientas manuales. En relación con el levantamiento manual, Waters y cols. (1993) han desarrollado y revisado la ecuación del NIOSH, resumiendo el conocimiento científico existente en este aspecto. La especificación de la antropometría funcional y las zonas de trabajo óptimas ha sido presentada, por ejemplo, por Rebiffé, Zayana y Tarrière (1969) y Das y Grady (1983a, 1983b). M ital y K arwowski (1991) han editado un libro de gran utilidad en el que se revisan distintos aspectos relacionados principalmente con el diseño de puestos de trabajo industriales.

La gran cantidad de datos necesarios para diseñar un puesto de trabajo, tomando en cuenta todos los aspectos importantes, hará necesario el uso de la actual tecnología de la información por los ingenieros de producto y otros cargos de responsabilidad. Es posible que en un futuro próximo aparezcan distintos sistemas para apoyar sus decisiones, por ejemplo, en forma de sistemas expertos o basados en el conocimiento. La obra de De Greve y Ayoub (1987), Laurig y Rombach (1989) y de Pham y O nder (1992) incluye informes sobre estos avances N o obstante, resulta muy difícil pensar en un sistema que permita al usuario final el acceso sin problemas a todos los datos importantes necesarios para realizar un diseño específico.

\section{HERRAMIENTAS}

\section{T.M. Fraser}

N ormalmente, una herramienta se compone de cabeza y mango, algunas veces con un eje 0 , en el caso de una herramienta mecánica, un cuerpo. Como la herramienta debe ajustarse a las necesidades de distintos usuarios, pueden surgir conflictos importantes que será necesario solucionar. Algunos de estos conflictos se derivan de las limitaciones en la capacidad del usuario y otros son intrínsecos a la herramienta. Deberá recordarse, sin embargo, que las limitaciones humanas son inherentes y normalmente invariables, mientras la forma y función de la herramienta están sujetas a un cierto grado de modificación. Así, con el fin de efectuar todos los cambios deseables, la atención deberá dirigirse en primer lugar a la forma de la herramienta, especialmente a lo que sirve de interfaz entre el usuario y la herramienta: el mango.

\section{La naturaleza del agarre}

Las características del agarre se han definido en términos de agarre de fuerza, agarre de precisión y agarre de gancho, con los que pueden llevarse a cabo prácticamente todas las actividades humanas manuales.
En un agarre de fuerza, como el que se aplica para clavar con un martillo, la herramienta se sujeta mediante una abrazadera formada por los dedos, parcialmente flexionados, y la palma de la mano, mientras que el dedo pulgar aplica una presión opuesta. En un agarre de precisión, como el que se utiliza cuando se ajusta un tornillo, la herramienta queda sujeta entre la parte flexora de los dedos y el pulgar, situado frente a éstos. U na modificación del agarre de precisión es el agarre tipo lápiz, que se explica por su propio nombre y que se utiliza para trabajos complicados. Un agarre de precisión proporciona sólo el $20 \%$ de la fuerza de un agarre de fuerza.

El agarre de gancho se emplea cuando no es necesario aplicar ninguna fuerza y sólo hace falta sujetar. Con este agarre, el objeto queda suspendido entre los dedos flexionados, con o sin la contribución del dedo pulgar. Las herramientas pesadas deberán diseñarse de forma que puedan transportarse con este tipo de agarre.

\section{Grosor del agarre}

En los agarres de precisión, el grosor recomendado varía entre 8 y 16 milímetros $(\mathrm{mm})$ para los destornilladores y entre 13 y $30 \mathrm{~mm}$ para estiletes. En los agarres de fuerza aplicados a un objeto más o menos cilíndrico, los dedos deberán rodear más de la mitad de la circunferencia, pero los dedos y el pulgar no deben llegar a unirse. Los diámetros recomendados van desde $25 \mathrm{~mm}$ hasta $85 \mathrm{~mm}$. El tamaño óptimo, que varía según el tamaño de la mano, está entre 55 y $65 \mathrm{~mm}$ para los hombres y entre 50 y $60 \mathrm{~mm}$ para las mujeres. Las personas con manos pequeñas no deben realizar tareas repetitivas que impliquen agarres de fuerza con mangos de diámetro superior a $60 \mathrm{~mm}$.

\section{Fuerza del agarre y dimensiones de la mano}

El uso de una herramienta requiere fuerza. Además de para sujetar, la fuerza de la mano se necesita principalmente para el uso de las herramientas que actúan como una palanca en cruz, como los alicates y las herramientas de compresión. La fuerza efectiva de compresión está en función de la fuerza aplicada y la distancia requerida por la herramienta. La distancia funcional máxima entre la punta del pulgar y la de los dedos que desempeñan la función de agarre tiene una media de $145 \mathrm{~mm}$ para los hombres y $125 \mathrm{~mm}$ para las mujeres, con variaciones étnicas. Para una distancia óptima, es decir, entre 45 y $55 \mathrm{~mm}$ para hombres y mujeres, la fuerza de agarre disponible para una acción a corto plazo va de 450 a 500 newtons para los hombres y 250 a 300 newtons para mujeres, pero en casos de acción repetitiva, se suelen recomendar 90-100 newtons para hombres y 50-60 newtons para las mujeres. Muchas tenazas 0 alicates de los que se utilizan habitualmente no se pueden utilizar con una sola mano, especialmente en el caso de las mujeres.

Cuando el mango es el de un destornillador o el de una herramienta similar, el par de torsión aplicable depende de la capacidad del usuario para transmitir la fuerza al mango, determinada tanto por el coeficiente de fricción que hay entre la mano y el mango, y el diámetro de este último. Las irregularidades en la forma del mango no tienen apenas incidencia en la capacidad para aplicar la torsión, aunque los bordes afilados pueden provocar incomodidades e incluso dañar los tejidos. EI diámetro de un mango cilíndrico que permita la máxima aplicación de torsión está entre 50 y 65 mm, mientras que para una esfera está entre 65 y $75 \mathrm{~mm}$.

\section{Mangos}

\section{Forma del mango}

La forma del mango deberá proporcionar el máximo contacto entre éste y la piel. D ebería ser estándar y general, normalmente 
de sección cilíndrica achatada o elíptica, con curvas largas y planos lisos, o un sector esférico, todo ello combinado de forma que se ajuste al contorno de la mano en posición de agarre. Dada su unión con el cuerpo de la herramienta, el mango también puede tomar la forma de estribo, en $\mathrm{T} 0$ en $\mathrm{L}$, pero la parte que está en contacto con la mano deberá tener un diseño básico.

El espacio que se abarca con los dedos es, naturalmente, complejo. EI uso de curvas simples es una solución pensada para que se ajuste a la variabilidad de las manos y los distintos grados de flexión. A este respecto, no es deseable fabricar un mango que tenga la forma de los dedos, con entrantes y salientes, ondulaciones y muescas, ya que, en realidad, estas modificaciones no se ajustarían a la mayoría de las manos y podrían, en un período prolongado de tiempo, provocar lesiones a los tejidos más sensibles. En particular, no se recomiendan las depresiones que superen los $3 \mathrm{~mm}$.

Una modificación de la sección cilíndrica es la hexagonal, que tiene un especial valor en el diseño de herramientas de pequeño calibre. Es más sencillo mantener un agarre estable en una sección hexagonal de pequeño calibre que en un cilindro. Las secciones cuadradas y triangulares también se han utilizado con cierto éxito. En estos casos, los bordes deben estar redondeados, para evitar las heridas debidas a la presión.

\section{Superficie y textura del agarre}

No es casualidad que durante milenios la madera haya sido el material elegido para fabricar mangos de herramientas en alicates y tenazas. Además de su atractivo estético, la madera siempre ha sido fácil de obtener y de trabajar aún por trabajadores no experimentados, y tiene elasticidad, conductividad térmica, resistencia a la fricción y es relativamente ligera en relación a su masa, todo lo cual la convierte en un material muy aceptable para éste y otros usos.

En los últimos años se ha extendido el uso de los mangos de metal y plástico para muchas herramientas, este último sobre todo para martillos y destornilladores ligeros. Un mango de metal, sin embargo, transmite más fuerza a la mano y es preferible colocarlo dentro de una protección de goma o plástico. La superficie de agarre debería ser ligeramente comprimible, siempre que sea posible, no conductora y suave, y su área lo más grande posible para asegurar una distribución de la presión en una zona lo más extensa posible. También se han utilizado mangos de espuma para reducir la percepción de la fatiga y la sensibilidad en la mano.

Las características de fricción de la superficie de la herramienta varían dependiendo de la presión ejercida por la mano, de la naturaleza de la superficie y de la contaminación que pueda existir por grasa o sudor. U n poco de sudor aumenta el coeficiente de fricción.

\section{Longitud del mango}

La longitud del mango está determinada por las dimensiones críticas de la mano y la naturaleza de la herramienta. En el caso de un martillo, que se utiliza con una sola mano en un agarre de fuerza, por ejemplo, la longitud ideal va de un mínimo de $100 \mathrm{~mm}$ a un máximo de unos $125 \mathrm{~mm}$. Los mangos cortos no resultan adecuados para los agarres de fuerza y los mangos de longitud inferior a los $19 \mathrm{~mm}$ no pueden sujetarse bien entre el pulgar y los dedos y resultan inadecuados para cualquier herramienta.

Idealmente, para una herramienta mecánica o una sierra manual que no sea una sierra de calar o de marquetería, el mango debería ajustarse a un nivel porcentual del 97,5 de la anchura de la mano cerrada, es decir, entre 90 y $100 \mathrm{~mm}$ en su eje largo y entre 35 y $40 \mathrm{~mm}$ en el corto.

\section{Peso y equilibrio}

EI peso no suele ser un problema tratándose de una herramienta de precisión. En los martillos pesados y las herramientas mecánicas resulta aceptable un peso comprendido entre $0,9 \mathrm{~kg}$ y $1,5 \mathrm{~kg}$, con un máximo de unos $2,3 \mathrm{~kg}$. Las herramientas con un peso superior a lo recomendado deberán sostenerse por medios mecánicos.

En el caso de una herramienta de percusión, como un martillo, es deseable que el peso del mango se reduzca todo lo posible, siempre que siga siendo compatible con la fuerza estructural y que la cabeza tenga todo el peso posible. En otras herramientas, el peso debe distribuirse de manera uniforme. En las herramientas con cabezas pequeñas y mangos voluminosos esto generalmente no es posible, pero el mango se puede aligerar a medida que se aumenta el volumen en relación al tamaño de la cabeza y del eje.

\section{Importancia de los guantes}

A veces los diseñadores de herramientas no tienen en cuenta que éstas no siempre se manipulan con las manos desnudas. El uso de guantes está muy generalizado por motivos de seguridad y de comodidad. Los guantes de seguridad no suelen abultar mucho, pero los guantes que se utilizan en climas fríos pueden ser muy grandes, interfiriendo no sólo con la retroinformación sensorial sino también en la capacidad de sujeción y agarre. El uso de guantes de piel o lana puede añadir $5 \mathrm{~mm}$ al grosor de la mano y $8 \mathrm{~mm}$ a la anchura del pulgar, mientras que los mitones gruesos pueden suponer un aumento de hasta 25 y $40 \mathrm{~mm}$, respectivamente.

\section{Usuarios diestros y zurdos}

La mayor parte de la población del hemisferio occidental es diestra. Algunas personas son ambidiestras desde el punto de vista funcional, y cualquiera puede aprender a utilizar, con mayor o menor eficacia, cualquiera de sus manos.

Aunque el número de personas zurdas es reducido, el mango de las herramientas deberá adaptarse siempre que sea posible para que puedan utilizarlo personas zurdas o diestras (por ejemplo, la colocación de un mango secundario en una herramienta mecánica o los orificios para introducir los dedos en tenazas y tijeras) a menos que esta medida resulte claramente ineficaz, como sucede en el caso de los cierres de tipo tornillo, que están diseñados para aprovechar la fuerza de los músculos supinadores del antebrazo en una persona diestra e impiden que la persona zurda los utilice con igual eficacia. E sta pequeña limitación tiene que ser aceptada, dado que la inclusión de roscas para zurdos no es una solución aceptable.

\section{Importancia del sexo}

En general, las manos de las mujeres suelen tener unas dimensiones más reducidas, su capacidad de agarre es menor, y poseen entre un 50 y un $70 \%$ menos fuerza que los hombres, aunque naturalmente, algunas mujeres del percentil superior tienen manos más grandes y una fuerza mayor que los hombres que se encuentran en el percentil más bajo. Existe, por tanto, un número significativo, aunque indeterminado, de personas, la mayoría mujeres, que tienen dificultades para manipular algunas herramientas manuales que han sido diseñadas teniendo en mente la mano masculina. Entre éstas están los martillos o alicates grandes, las herramientas de corte, engarce y grabado y los pelacables. El uso de estas herramientas por una mujer puede requerir la utilización no deseable de las dos manos, en lugar de una sola. En un puesto donde trabajen hombres y mujeres resulta esencial, por tanto, asegurarse de que las herramientas tienen el tamaño adecuado y que no sólo se ajustan a las necesidades de las 
mujeres, sino también a las de aquellos hombres cuyas manos tienen unas dimensiones propias de los percentiles más bajos.

\section{Consideraciones especiales}

La orientación del mango de la herramienta, siempre que sea posible, deberá permitir que la mano y el brazo permanezcan en su posición funcional natural, es decir, con la muñeca supinada algo más de la mitad, abducida unos $15^{\circ}$ y ligeramente flexionada en dirección dorsal, con el dedo meñique flexionado casi por completo, los demás un poco menos, y el pulgar aducido y ligeramente flexionado; una postura denominada a veces, erróneamente, la postura del apretón del manos (en un apretón de manos la muñeca no está supinada más de la mitad). La combinación de aducción y flexión dorsal de la muñeca, con la flexión variable de los dedos y del pulgar, genera un ángulo de agarre de unos $80^{\circ}$ entre el eje largo del brazo y una línea que pasa por el punto central del anillo creado por el pulgar y el índice, es decir, el eje transversal del puño.

Si se coloca la mano en una posición de desviación del cúbito, es decir, con la mano doblada hacia el dedo meñique como para utilizar unos alicates normales, se genera una presión en los tendones, los nervios y los vasos sanguíneos de la muñeca y pueden producirse una serie de trastornos, como la tenosinovitis, el síndrome del túnel carpiano y otros similares. Inclinando el mango y manteniendo la muñeca recta (es decir, inclinando la herramienta y no la mano), puede evitarse la compresión de los nervios, los tejidos blandos y los vasos sanguíneos. Aunque este principio se ha reconocido hace mucho, aún no ha sido aceptado del todo por los fabricantes de herramientas o por la mayoría de la gente. Tiene una aplicación particular en el diseño de herramientas de acción de palanca en cruz, como los alicates, así como de los cuchillos y los martillos.

\section{Alicates y herramientas de palanca en cruz}

Debe prestarse especial atención a la forma de los mangos de alicates y herramientas similares. L os alicates han tenido siempre mangos curvos de igual longitud; la curva superior se aproxima a la curva de la palma de la mano y la inferior a la de los dedos flexionados. Cuando se sostiene la herramienta en la mano, el eje entre los mangos está en línea con la mordaza de los alicates. En consecuencia, para manejarlos, es necesario mantener la muñeca en desviación ulnar extrema, es decir, inclinada hacia el dedo meñique, mientras se gira repetidamente. En esta posición el uso del segmento mano-muñeca-brazo es sumamente ineficaz y muy estresante para los tendones y las estructuras de las articulaciones. Si la acción es repetitiva, puede además originar distintos trastornos por sobreesfuerzo.

Para evitar este problema, ha aparecido recientemente una versión nueva y más adecuada desde el punto de vista ergonómico, de los alicates. En estos alicates el eje de los mangos se curva unos $45^{\circ}$ en relación con el eje de la mordaza. Los mangos son más gruesos, para permitir un agarre más eficaz, con menor presión localizada en los tejidos blandos. EI mango superior es proporcionalmente más largo, con una forma que se ajusta a la palma de la mano, en torno al lado ulnar. El extremo delantero del mango incorpora un soporte para el pulgar. EI mango inferior es más corto, con una protuberancia redondeada en el extremo delantero y una curva que se ajusta a los dedos flexionados.

Aunque lo anterior representa un cambio un poco radical, es posible hacer unas cuantas mejoras ergonómicas importantes a los alicates con relativa facilidad. Tal vez la más importante, cuando hace falta un agarre de fuerza, es aumentar el grosor de los mangos y aplanarlos ligeramente, con un soporte para el pulgar en el extremo superior del mango y un ligero ensanchamiento al otro extremo. Si no forma parte del diseño, esta modificación puede lograrse introduciendo en el mango básico de metal una lámina fija o desmontable no conductora hecha de goma o de cualquier otro material sintético, y quizá rugosa para mejorar su calidad táctil. No es aconsejable la introducción de formas anatómicas para los dedos. Para un uso repetitivo puede resultar adecuado incorporar un pequeño muelle en el mango, para facilitar su apertura después del cierre.

Los mismos principios se aplican a otras herramientas de palanca en cruz, especialmente en cuanto a la modificación del grosor y aplanamiento de los mangos.

\section{Cuchillos}

En el caso de un cuchillo para usos generales, es decir, no del tipo que se utiliza como un machete, sería deseable incluir un ángulo de $15^{\circ}$ entre el mango y la hoja, para reducir la presión sobre los tejidos blandos. EI tamaño y la forma de los mangos deberá ajustarse a lo indicado para otras herramientas, pero para adecuarlo a las manos de distintos tamaños, se ha sugerido la posibilidad de proporcionar dos tamaños de mango, uno para los usuarios que estén entre el percentil 50 y el 95, y otro para los que se encuentren entre el 5 y el 50. Para permitir que la mano ejerza la fuerza lo más cerca posible de la hoja, debería incorporarse a la parte superior del mango un soporte para apoyar el pulgar, ligeramente levantado.

Es necesaria una protección para evitar que la mano se deslice hacia la hoja. Esta protección puede ser de varias formas, como una espiga o un saliente curvo, de unos 10 ó $15 \mathrm{~mm}$ de longitud, que se proyecte hacia abajo desde el mango o en ángulo con el mismo, o un protector formado por un bucle de metal resistente que vaya desde la parte anterior al final del mango. El soporte para apoyar el pulgar también evita el deslizamiento.

EI mango deberá cumplir las directrices ergonómicas generales y tener una superficie elástica resistente a la grasa.

\section{Martillos}

Los requisitos que deben cumplir los martillos se han tratado anteriormente, con la excepción de lo relacionado con la curvatura del mango. Como ya se ha dicho, una inclinación forzada y repetitiva de la muñeca puede provocar daños en los tejidos. Inclinando la herramienta en lugar de la muñeca pueden reducirse estos daños. En relación con los martillos, se han estudiado varios ángulos, pero parece que la curvatura de la cabeza hacia abajo entre $10^{\circ}$ y $20^{\circ}$ puede aumentar la comodidad e incluso mejorar el rendimiento.

\section{Destor nilladores y rascadores}

Los mangos de los destornilladores y otras herramientas que se sujetan de forma parecida, como los rascadores, limas y cinceles, etc. tienen unas características especiales. Todos ellos, en una u otra ocasión, se utilizan con un agarre de fuerza o con un agarre de precisión. Cada una de estas posibilidades se basa en las funciones de los dedos y la palma de la mano para la estabilización y la transmisión de la fuerza.

Los requisitos generales de los mangos ya se han tratado. La forma más eficaz del mango de un destornillador, según se ha comprobado, es la de un cilindro modificado, redondeado en su extremo para acomodar la palma y ligeramente ensanchado allí donde se junta con el eje, para proporcionar apoyo a las puntas de los dedos. De este modo, la torsión se aplica principalmente por la acción de la mano, que se mantiene en contacto con el mango gracias a la presión aplicada desde el brazo y la resistencia de fricción de la piel. Los dedos, aunque transmiten algo de fuerza, desempeñan un papel más bien estabilizador, lo que resulta menos cansado, ya que hace falta menor fuerza. De esta forma el extremo redondeado del mango adquiere gran importancia. Si existen bordes afilados o rugosidades en esta parte 
redondeada, o en el punto en que esta se une con el mango, se formarán callos en la mano, produciéndose heridas, o la transmisión de la fuerza se transferirá hacia los dedos y el pulgar, menos eficaces y más fatigables. El eje suele ser cilíndrico, pero se ha diseñado uno triangular que proporciona un mejor apoyo a los dedos, aunque su utilización puede resultar más fatigosa.

Cuando el uso de un destornillador o herramienta similar es tan repetitivo que su utilización excesiva puede ocasionar lesiones, el manejo manual debería ser sustituido por un manejo mecánico, suspendiendo la herramienta de un cable situado por encima de la cabeza, de forma que resulte fácilmente accesible y que no entorpezca el trabajo.

\section{Sierras y herramientas eléctricas}

Las sierras de mano, con excepción de las caladoras y las sierras ligeras de metal (en las que lo más adecuado es un mango como el de los destornilladores), suelen tener un mango que adquiere la forma de un asa cerrada, unido a la hoja de la sierra.

EI mango suele llevar un bucle en el que se colocan los dedos. El bucle es un rectángulo con extremos curvos. Para permitir el uso de guantes debe tener unas dimensiones internas de unos 90 a $100 \mathrm{~mm}$ en el diámetro más largo y 35 a $40 \mathrm{~mm}$ en el más corto. El mango que queda en contacto con la palma deberá tener la forma cilíndrica aplanada antes mencionada, con curvas que se ajusten a las palmas de las manos y a los dedos flexionados. La anchura desde la curva exterior a la interior deberá ser de unos $35 \mathrm{~mm}$ y el grosor no inferior a los $25 \mathrm{~mm}$.

Curiosamente, la función de agarrar y sostener una herramienta eléctrica es muy similar a la de sostener una sierra, y en consecuencia, un tipo similar de mango será eficaz. EI mango en pistola común a todas las herramientas eléctricas es del tipo abierto que llevan algunas sierras, con los laterales curvos en lugar de planos.

La mayoría de las herramientas tienen que tener un mango, un cuerpo y una cabeza. La colocación del mango es importante. Lo ideal sería que el mango, el cuerpo y la cabeza estuvieran en línea, de forma que el mango estuviera unido a la parte posterior del cuerpo y que la cabeza sobresaliera por delante. La línea de acción es la línea del dedo índice extendido, de forma que la cabeza quede excéntrica al eje central del cuerpo. El centro de la masa de la herramienta, sin embargo, está delante del mango, y la torsión crea un movimiento de giro del cuerpo que la mano deberá vencer. En consecuencia, sería más adecuado colocar el mango principal directamente bajo el centro de la masa de forma que, en caso necesario, el cuerpo sobresalga por detrás del mango y también por delante. De forma alternativa, sobre todo en taladros pesados, puede colocarse un mango secundario bajo el taladro para que éste pueda controlarse con una u otra mano. Las herramientas mecánicas suelen controlarse mediante un gatillo incorporado al extremo delantero superior del mango que se dispara con el dedo índice. EI gatillo deberá estar diseñado para que pueda ser disparado por una u otra mano, y deberá contar con un mecanismo de bloqueo fácil de activar, para mantener la herramienta encendida cuando sea necesario.

\section{- CONTROLES, INDICADORES Y PANELES}

\section{Karl H. E. Kroemer}

A continuación vamos a examinar tres de las principales preocupaciones del diseño ergonómico. En primer lugar, los controles o dispositivos que transmiten energía y señales desde el operador hasta una pieza de una máquina; en segundo lugar, los indicadores o dispositivos de presentación de datos, que proporcionan información visual al operador sobre el estado de la maquinaria, y, por último, la combinación de controles y dispositivos de indicación en un panel o consola.

\section{Diseño para un operador que trabaja sentado}

Se tiene una mejor estabilidad y se gasta menos energía sentado que de pie, pero el espacio de trabajo se reduce, especialmente el de los pies. Sin embargo, es mucho más sencillo manejar los pedales estando sentado porque es necesario transferir sólo una pequeña parte del peso corporal al suelo. Si la dirección de la fuerza ejercida por el pie apunta en parte 0 en gran medida hacia adelante, debe facilitarse un asiento con un respaldo que permita ejercer más fuerza con el pie. Un ejemplo típico de esto es la colocación de los pedales de un automóvil, que están situados delante del conductor, más o menos por debajo de la altura del asiento. La Figura 29.38 muestra esquemáticamente las posiciones que pueden ocupar los pedales que maneja un operador sentado. $N$ ótese que las dimensiones específicas de ese espacio dependerán de la antropometría del operador real.

El espacio para situar los controles que se operan manualmente se encuentra sobre todo delante del cuerpo, dentro de un contorno más o menos esférico que está centrado con respecto al codo, al hombro 0 a algún punto que se encuentra entre estas dos articulaciones. La Figura 29.39 muestra un esquema del espacio en el que pueden situarse los controles. D esde luego, sus dimensiones específicas dependerán de la antropometría de los operadores.

El espacio para los dispositivos de indicación y los controles a los que hay que mirar está delimitado por una circunferencia parcial situada delante de los ojos y centrada con respecto a éstos. Así, la altura de referencia para los dispositivos de indicación y los controles dependerá de la altura de los ojos del operador sentado y de la posición del tronco y del cuerpo. La situación preferida para el objetivo visual que se encuentre a menos de un metro de distancia estará claramente más allá de la altura de los ojos y dependerá de la cercanía del objetivo y de la postura de la cabeza. Cuanto más cerca esté el objetivo, más abajo habrá que situarlo, preferiblemente dentro o cerca del plano medial (sagital medio) del operador.

Es conveniente describir la postura de la cabeza utilizando la "línea oreja-ojo" (K roemer 1993a) que, en una vista lateral, va desde la oreja derecha a la unión de las pestañas del ojo derecho, aunque la cabeza no esté inclinada (las pupilas quedan en el mismo nivel horizontal en una vista frontal). Se suele decir que la cabeza está "erguida" o "levantada" cuando el ángulo de inclinación P (véase la Figura 29.40 en la página 29.71) entre la línea oreja-ojo y el horizonte es de aproximadamente $15^{\circ}$, con los ojos por encima de la línea de la oreja. La colocación preferente de los blancos visuales es de $25^{\circ}-65^{\circ}$ por debajo de la línea oreja-ojo (LOSEE en la Figura 29.40), aunque debe tenerse en cuenta que la mayoría de la gente prefiere valores más bajos para blancos más cercanos. Aunque haya grandes variaciones en cuanto a ángulos preferidos de la línea de visión, la mayoría de las personas, especialmente a medida que se hacen mayores, prefieren observar objetivos más cercanos con ángulos LOSE E mayores.

\section{Diseño para un operador de pie}

EI control de un pedal por un operador que esta de pie debería ser necesario sólo de forma ocasional, ya que de otro modo, la persona tiene que pasar mucho tiempo apoyada sólo sobre un pie, mientras el otro acciona el pedal. O bviamente, el control simultáneo de dos pedales por parte de un operador que está en pie es prácticamente imposible. M ientras el operador está en pie, 
Figura 29.38 - Espacio normal y preferente para los pies (en $\mathrm{cm}$ ).
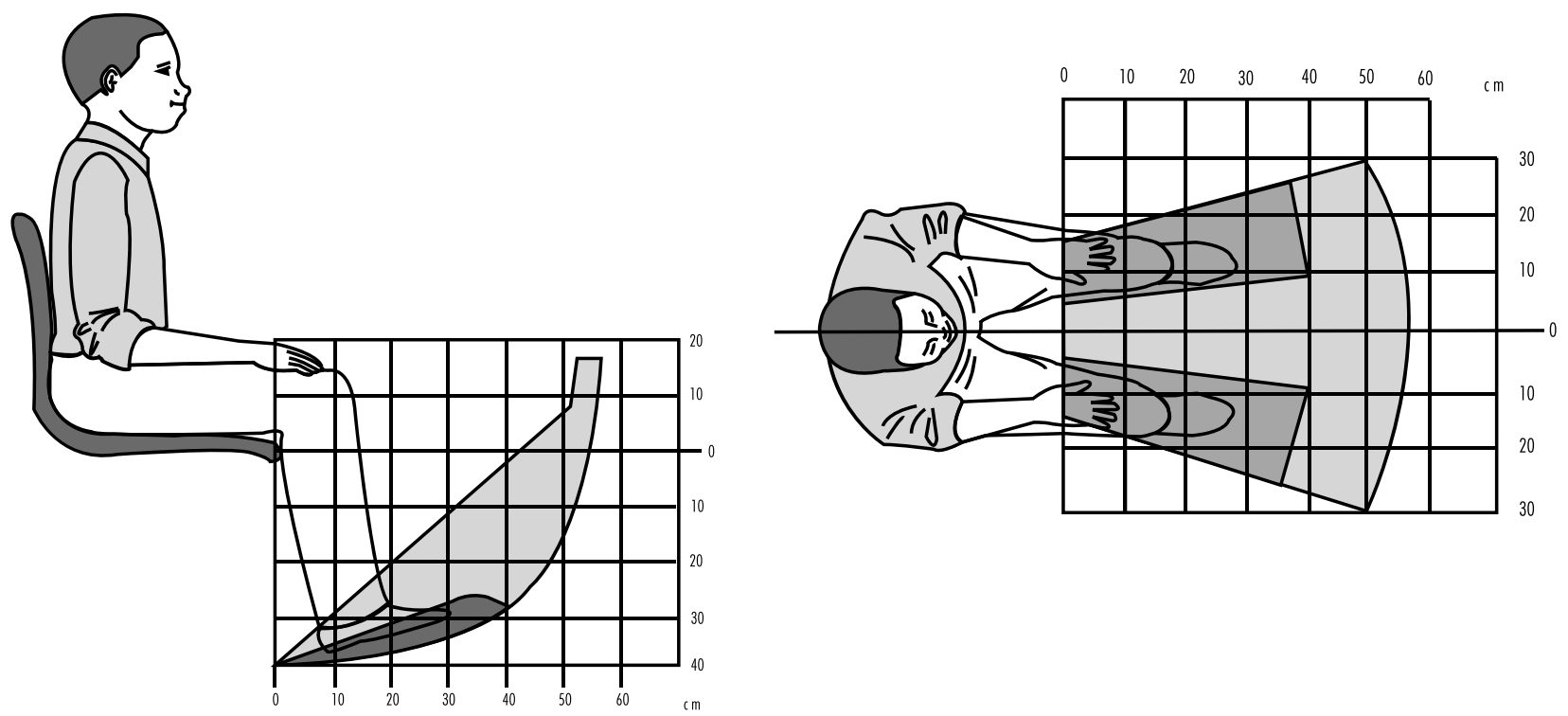

el espacio para colocar los pedales se limita a una pequeña zona situada por debajo del tronco y ligeramente delante del mismo. La posibilidad de caminar un poco proporcionaría más espacio para colocar los pedales, pero no resulta práctica en la mayoría de los casos debido a la distancia que hay que recorrer.

La colocación de los controles manuales para un operador que permanece en pie supone más o menos la misma zona que para un operador sentado, aproximadamente un semicírculo delante del cuerpo, con el centro cerca de los hombros del operador. El área para la colocación de dispositivos visuales también es similar a la adecuada para un operador sentado, es decir, un semicírculo centrado con respecto a los ojos del operador, prefiriéndose la sección inferior de dicha esfera. Los emplazamientos idóneos para los dispositivos de indicación y para los controles que tienen que estar a la vista dependerán de la postura de la cabeza, como se indicó anteriormente.

La referencia de la altura de los controles es la altura del codo del operador cuando la parte superior del brazo cuelga del hombro, sin apoyarse. La altura de los dispositivos de indicación y de los controles a los que debe mirar deberá deducirse por la altura de los ojos del operador. A mbos dependen de la antropometría del operador, que puede ser bastante diferente en una persona alta y en una baja, en un hombre y una mujer, o en personas de distinto origen étnico.

\section{Controles que se manejan con los pies}

Deben distinguirse dos tipos de controles accionados con los pies: uno se utiliza para transferir gran cantidad de energía o fuerza a una pieza de la maquinaria. Un ejemplo de esto es el pedal de una bicicleta o el pedal del freno en un vehículo mayor, que no sea de tipo asistido. El otro tipo, como un interruptor de encendido con el que la señal de control se transmite a la maquinaria, suele requerir sólo una pequeña cantidad de fuerza o energía. Aunque es conveniente considerar estos dos tipos extremos, hay muchas formas intermedias y corresponde al diseñador determinar cuáles de las recomendaciones siguientes se aplican mejor a la situación real.
Como ya se ha dicho, el uso repetido o continuado de un pedal sólo deberá realizarlo un operador sentado. Para controles destinados a transmitir gran cantidad de energía o fuerza, se aplicarán las siguientes normas:

- Situar los pedales debajo del cuerpo, ligeramente adelantados, para que puedan controlarse con la pierna casi estirada. El desplazamiento total de un pedal alternativo no deberá exceder los 0,15 m. Para los pedales giratorios, el radio deberá ser también de unos $0,15 \mathrm{~m}$. El desplazamiento lineal de un pedal de interruptor debe ser mínimo y no superar los 0,15 m.

- L os pedales deberán diseñarse de forma que la dirección de su desplazamiento y la fuerza del pie estén más o menos en la línea que va desde la cadera hasta el tobillo del operador.

- Los pedales que se controlan por flexión y extensión del pie, mediante la articulación del tobillo, deberán disponerse de forma que, en la posición normal, el ángulo entre la parte posterior de la pierna y el pie sea de aproximadamente $90^{\circ}$. Durante el funcionamiento, este ángulo puede aumentarse hasta $120^{\circ}$

- Los controles que se manejan con el pie y que sirven sólo para enviar señales a la maquinaria deberán tener dos posiciones discretas, como ENCENDIDO o APAGADO. Adviértase, sin embargo, que la distinción táctil entre las dos posiciones puede resultar difícil con el pie.

\section{Selección de los controles}

La selección entre distintos tipos de controles deberá realizarse de acuerdo con las siguientes necesidades o condiciones:

- manejo con la mano o con el pie,

- cantidad de energía o fuerza transmitida,

- aplicación de fuerza continua, como sucede con la conducción de un automóvil

- realización de "acciones discretas", por ejemplo (a) activación o desactivación de un equipo, (b) selección de uno o varios ajustes, como el cambio de canales de TV o radio, o (c) introducción de datos, como en el caso del teclado. 
Figura 29.39 - Espacio normal y preferente para las manos (en cm).

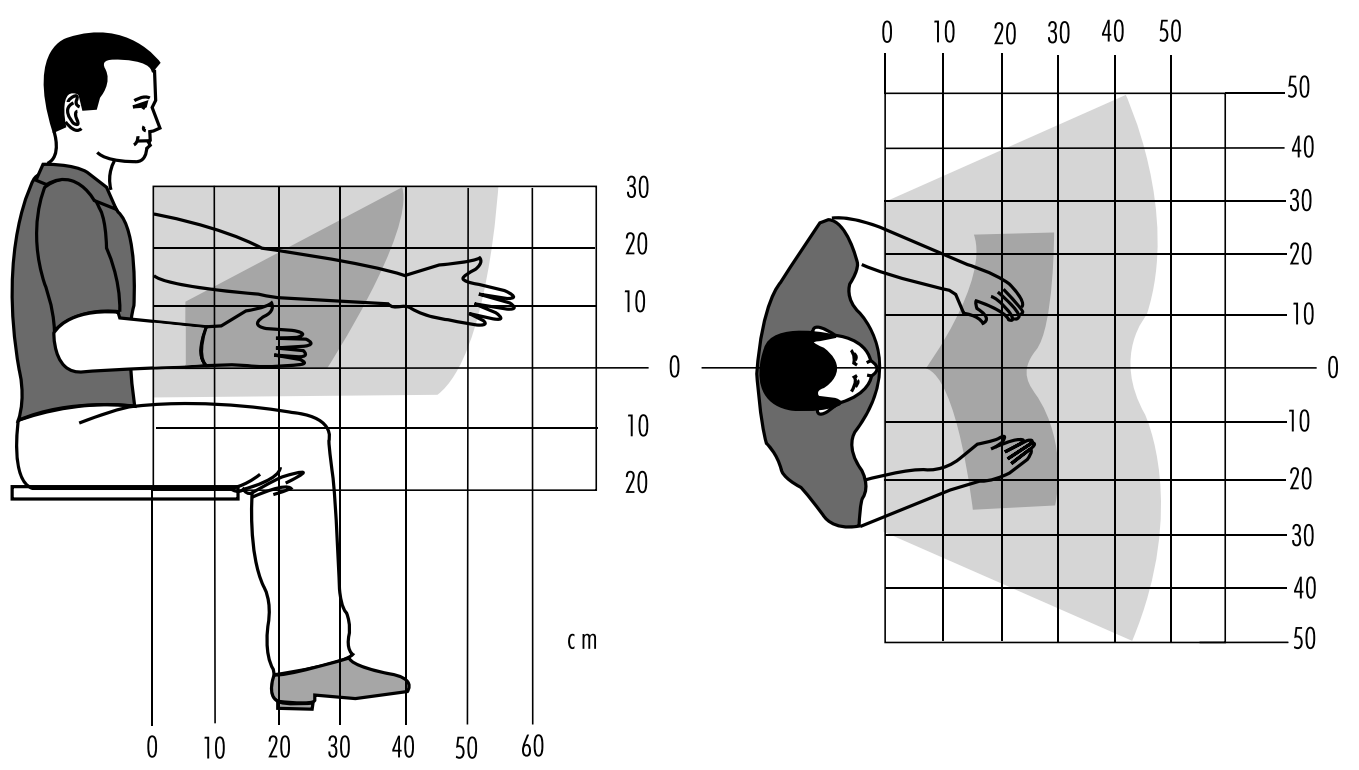

La utilidad funcional de los controles determina también los procesos de selección. L os principales criterios son los siguientes:

- El tipo de control deberá ser compatible con las expectativas típicas o habituales, por ejemplo, utilizar un botón 0 un interruptor para encender o apagar la luz, en lugar de un selector.

- Las características de tamaño y movimiento del control deberán ser compatibles con la experiencia y con las prácticas habituales, por ejemplo, utilizar un volante para manejar un automóvil con las dos manos, en lugar de una palanca.

- La dirección en que funciona un control deberá ser compatible con las expectativas comunes o los estereotipos (por ejemplo, un control de ENCENDIDO se pulsa o se tira de él, pero no se gira hacia la izquierda).

Figura 29.40 • Línea oreja-ojo.

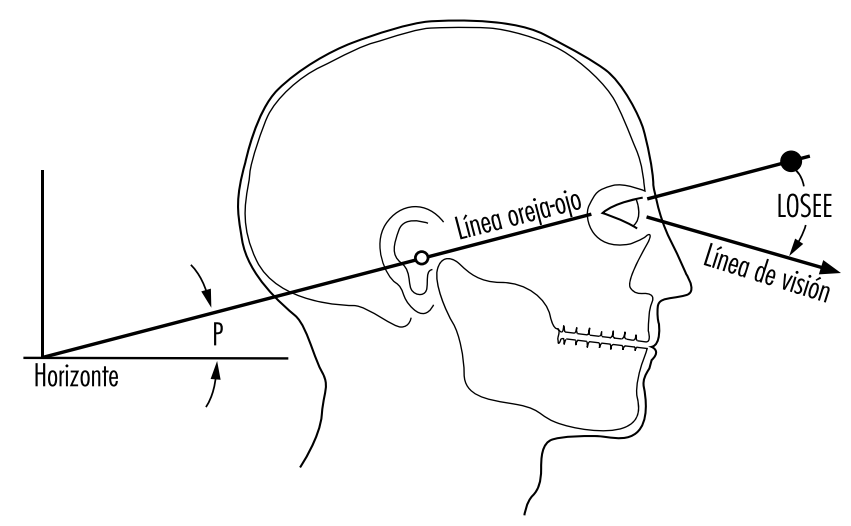

- La operación manual se aplica en controles que requieren poca fuerza y un ajuste preciso, mientras que los pedales son adecuados para los ajustes gruesos y que requieren más fuerza; sin embargo, en el uso común de los pedales, como en los pedales de freno de los coches, muchas veces no se cumple este principio.

- El control deberá ser "seguro", es decir, no podrá accionarse de forma accidental ni de manera que resulte excesiva 0 incoherente con su finalidad.

Las Tablas 29.10 y 29.11 pueden ayudar a seleccionar el control adecuado. Sin embargo, debe tenerse en cuenta que hay algunas normas "naturales" para seleccionar y diseñar los controles. La mayoría de las recomendaciones suelen ser empíricas y se aplican a dispositivos ya existentes y a estereotipos occidentales.

La Figura 29.41 presenta algunos ejemplos de controles de "detención", que se caracterizan por paradas o detenciones discretas en las que el control queda en posición de descanso. También muestra controles típicos "continuos" que pueden colocarse en cualquier punto de su intervalo de ajuste, sin que sea necesario fijarlos en una posición determinada.

El tamaño de los controles depende en gran medida de la experiencia anterior con varios tipos de control, y frecuentemente se debe al deseo de reducir el espacio necesario en un panel de control y de permitir la operación simultánea de otros controles adyacentes o de evitar la activación accidental. La selección de una serie de características de diseño también estará determinada por consideraciones como si los controles se situarán en exteriores 0 en un lugar protegido, en equipos estacionarios o en vehículos en movimiento, si se utilizarán guantes o mitones o se accionarán con las manos desnudas. Para más información, consúltense las lecturas recomendadas al final del capítulo.

$\mathrm{H}$ ay una serie de normas que rigen la disposición y la agrupación de los controles. Estas se indican en la Tabla 29.12. Para más detalles, compruebe las referencias que aparecen al final de esta sección y K roemer, K roemer y K roemer-Elbert (1994). 
Tabla 29.10 - Movimientos de control y efectos esperados.

\begin{tabular}{|c|c|c|c|c|c|c|c|c|c|c|c|}
\hline \multicolumn{12}{|c|}{ Dirección del movimiento de control } \\
\hline Función & Arriba & Derecha & Adelante & $\begin{array}{l}\text { Sentido de } \\
\text { las agujas } \\
\text { del reloj }\end{array}$ & $\begin{array}{l}\text { Presionar, } \\
\text { Apretar }\end{array}$ & Abajo & Izquierda & Retroceder Atrás & $\begin{array}{l}\text { Contrario } \\
\text { a las } \\
\text { agujas } \\
\text { del reloj }\end{array}$ & Tirar $^{1}$ & Empujar $^{2}$ \\
\hline Encender & $t^{3}$ & + & + & + & - & $t^{3}$ & & & & + & \\
\hline Apagar & & & & & & + & - & - & + & & - \\
\hline Derecha & & + & & - & & & & & & & \\
\hline Izquierda & & & & & & & + & - & & & \\
\hline Subir & + & & & & & & & - & & & \\
\hline Bajar & & & - & & & + & & & & & \\
\hline Retraer & - & & & & & & & + & & - & \\
\hline Extender & & & + & & & - & & & & & - \\
\hline Aumentar & - & - & + & - & & & & & & & \\
\hline Reducir & & & & & & - & - & + & - & & \\
\hline Abrir valor & & & & & & - & & & + & & \\
\hline Cerrar valor & & & & + & & - & & & & & \\
\hline
\end{tabular}

En blanco: no aplicable; + Preferente; - menos indicado.

${ }^{1}$ Control tipo gatillo. ${ }^{2}$ Interruptor de contrafase. ${ }^{3}$ Hacia arriba en Estados Unidos, hacia abajo en Europa.

Fuente: Modificado de Kroemer 1995

\section{Prevención del funcionamiento accidental}

A continuación se indican los medios más importantes de prevenir la activación accidental de los controles, algunos de los cuales pueden combinarse:

- Colocar y orientar el control de forma que el operador no pueda golpearlo ni moverlo por accidente en la secuencia normal de operaciones de control.

- Colocar el control a cierta distancia, protegerlo o rodearlo mediante barreras físicas.

- Cubrir el control o protegerlo mediante una horquilla, un sistema de bloqueo u otro medio que tenga que ser retirado para poder accionar el control.

- Dotar al control de una resistencia adicional mediante rozamiento viscoso o coulómbico, muelles o inercia, para que sea necesario aplicar un esfuerzo adicional para activarlo.

- Dotar al control de un sistema de retardo para que tenga que pasar por una posición determinada con un movimiento adicional, como sucede con la caja de cambios de un automóvil.

- Establecer una interrelación entre los controles, para que sea necesario accionar un control adicional para que el control crítico se active.

Adviértase que estos diseños suelen implicar una mayor lentitud en el control, lo que puede ser perjudicial en caso de emergencia.

\section{Dispositivos de entrada de datos}

Casi todos los controles pueden utilizarse para introducir datos en un ordenador u otro sistema de almacenamiento de información, pero los más habituales son los teclados con botones o teclas que se pulsan. En el teclado original de las máquinas de escribir, que se ha convertido en estándar para los teclados de ordenador, las teclas estaban dispuestas en una secuencia básicamente alfabética, que ha sido modificada por varias y a menudo extrañas razones. En algunos casos, las letras que con más frecuencia van unidas en los textos se encontraban muy separadas, para evitar que las antiguas teclas mecánicas se enganchasen al accionarse en una secuencia rápida. Las columnas de teclas se han dispuesto de forma mas o menos lineal, como sucede con las filas de teclas. Sin embargo, las puntas de los dedos no están alienadas de esa manera y no se mueven así cuando los dedos se flexionan o se extienden o cuando se mueven hacia los lados.

Se han hecho muchos intentos en los últimos cien años para mejorar el rendimiento de los teclados cambiando su disposición. Esta incluye la recolocación de teclas dentro de la disposición estándar o el cambio de la disposición total del teclado. Este se ha dividido en secciones independientes y se han añadido otras, como los teclados numéricos. La disposición de las teclas adyacentes puede cambiarse alterando el espaciado, separando una de otra o de las líneas de referencia. El teclado puede dividirse en secciones para la mano izquierda y la derecha, y dichas secciones pueden estar inclinadas hacia los lados, sesgadas o de forma oblicua.

La dinámica del funcionamiento de las teclas es importante para el usuario, pero difícil de valorar cuando está en acción. Así, las características de fuerza-desplazamiento de las teclas suelen describirse mediante pruebas estáticas, lo que no indica su funcionamiento real. En la práctica, las teclas de un teclado de ordenador tienen un desplazamiento muy pequeño (unos $2 \mathrm{~mm}$ ) y muestran cierta resistencia a "saltar", es decir, una reducción de la fuerza de operación, en el punto en el que se logra la activación de la tecla. En lugar de teclas independientes, algunos teclados se componen de membranas con una serie de interruptores debajo que, al pulsarlos, permiten la entrada de datos sin apenas desplazamiento. La principal ventaja de esta membrana es que impide la entrada de polvo y líquidos; sin embargo, no goza de la aceptación de muchos usuarios. 
Figura 29.41 - Algunos ejemplos de controles de "detención" y "continuos".

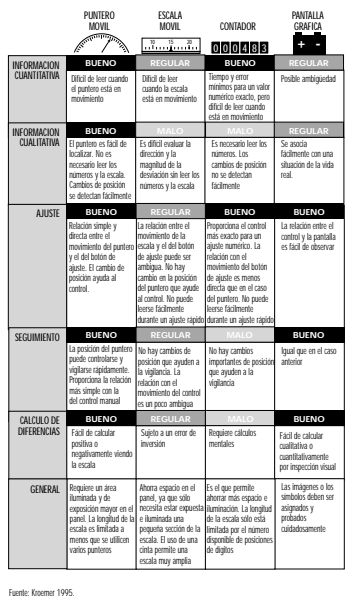

Existen alternativas al principio de "una tecla = un carácter"; es posible introducir los datos mediante una serie de combinaciones, por ejemplo, las secuencias, es decir, la activación simultánea de varios controles para generar un carácter. Esto exige mucho a la memoria del operador, pero requiere el uso de pocas teclas. Otros avances son el uso de controles que no pertenecen al formato binario de botón que se pulsa, sino palancas, selectores 0 sensores especiales, por ejemplo, colocados en guantes, que responden a los movimientos de los dedos de la mano.

Tradicionalmente, la escritura a máquina y la introducción de datos en ordenadores se han realizado por interacción mecánica entre los dígitos del operador y dispositivos como el teclado, el ratón, la bola de seguimiento o el lápiz luminoso. Pero hay otras formas de introducir los datos. El reconocimiento de voz parece ser una técnica prometedora, pero pueden emplearse otros métodos que utilicen, por ejemplo, la señalización, los gestos, las expresiones de la cara y del cuerpo, la mirada (la dirección de esta), los movimientos de la lengua, la respiración o un lenguaje de signos, para transmitir información y para introducir datos en el ordenador. El desarrollo técnico de este sector está en auge y, como ha sucedido con muchos dispositivos de introducción de datos no tradicionales utilizados para los juegos de ordenadores, la aceptación de dispositivos que no sean el tradicional teclado será totalmente viable en un futuro próximo. Para una discusión más amplia sobre los dispositivos de teclado actuales puede consultarse, por ejemplo, K roemer (1994b) y M cl ntosh (1994).

\section{Dispositivos de presentación de datos}

Los dispositivos de presentación de datos ofrecen información sobre el estado del equipo. Pueden necesitar de la percepción visual del operador (luces, escalas, contadores, tubos de rayos catódicos, paneles planos, etc.), de la auditiva (campanas, sirenas, mensajes grabados, sonidos generados electrónicamente, etc.) 0 de su sentido del tacto (controles con formas determinadas, B raille, etc.). Los rótulos, instrucciones escritas, advertencias 0 símbolos ("iconos") pueden considerarse tipos especiales de dispositivos de presentación de datos.

Las cuatro normas básicas para los dispositivos de indicación Son:

1. M ostrar sólo la información que resulte esencial para la realización correcta del trabajo.

2. Mostrar la información con la precisión necesaria para las decisiones y acciones del operador.

Tabla 29.11 - Relaciones controlefecto de los controles manuales comunes.

\begin{tabular}{|c|c|c|c|c|c|c|c|c|c|c|c|c|c|}
\hline Efecto & $\begin{array}{l}\text { Llave con } \\
\text { bloqueo }\end{array}$ & $\begin{array}{l}\text { Inte- } \\
\text { rruptor }\end{array}$ & Pulsador & Barra & $\begin{array}{l}\text { Botón } \\
\text { giratorio }\end{array}$ & $\begin{array}{l}\text { Rueda } \\
\text { discreta }\end{array}$ & $\begin{array}{l}\text { Rueda } \\
\text { continua }\end{array}$ & Manubrio & $\begin{array}{l}\text { Interruptor } \\
\text { oscilante }\end{array}$ & Palanca & $\begin{array}{l}\text { Joystick } \\
\text { o bola }\end{array}$ & $\begin{array}{l}\text { Interruptor } \\
\text { tipo } \\
\text { Legend }\end{array}$ & $\begin{array}{l}\text { Control } \\
\text { desli- } \\
\text { zable }^{1}\end{array}$ \\
\hline $\begin{array}{l}\text { Seleccionar ENCENDIDO } 0 \\
\text { APAGADO }\end{array}$ & + & + & + & $=$ & & & & & + & & & + & + \\
\hline $\begin{array}{l}\text { Seleccionar ENCENDIDO/ } \\
\text { EN ESPERA/ APAGADO }\end{array}$ & & - & + & + & & & & & & + & & + & + \\
\hline $\begin{array}{l}\text { Seleccionar } \\
\text { APAGADO/ MOD01/ MODO2 }\end{array}$ & & $=$ & - & + & & & & & & + & & + & + \\
\hline $\begin{array}{l}\text { Seleccionar una función entre } \\
\text { varias relacionadas }\end{array}$ & & - & + & & & & & & - & & & & $=$ \\
\hline $\begin{array}{l}\text { Seleccionar una de tres o más } \\
\text { alternativas discretas }\end{array}$ & & & & + & & & & & & & & & + \\
\hline $\begin{array}{l}\text { Seleccionar condiciones de } \\
\text { funcionamiento }\end{array}$ & & + & + & - & & & & & + & + & & & - \\
\hline Engranar o desengranar & & & & & & & & & & + & & & \\
\hline $\begin{array}{l}\text { Seleccionar una de dos } \\
\text { funciones mutuamente } \\
\text { excluyentes }\end{array}$ & & & + & & & & & & & & & + & \\
\hline Fijar un valor en una escala & & & & & + & & - & $=$ & & $=$ & $=$ & & + \\
\hline $\begin{array}{l}\text { Seleccionar un valor en pasos } \\
\text { discretos }\end{array}$ & & & + & + & & + & & & & & & & + \\
\hline $\begin{array}{l}\text { n blanco: no aplicable; t: preferente; } \\
\text { Calculado (no se sabe que existan exp } \\
\text { uente: Modificado de Kroemer } 1995 .\end{array}$ & $\begin{array}{l}: \text { menos indic } \\
\text { rimentos). }\end{array}$ & $\mathrm{ddo} ;=\mathrm{el} \mathrm{me}$ & nos indicado. & & & & & & & & & & \\
\hline
\end{tabular}


Tabla 29.12 • N ormas para la disposición de los controles.

\begin{tabular}{|c|c|}
\hline $\begin{array}{c}\text { Colocar para } \\
\text { facilitar su } \\
\text { operación }\end{array}$ & $\begin{array}{l}\text { Los controles deberán orientarse con respecto al operador. } \\
\text { Si el operador utiliza distintas posturas (como al conducir o } \\
\text { accionar una excavadora), los controles y sus indicadores } \\
\text { asociados deberán desplazarse junto con el operador para que } \\
\text { se conserve su disposición y operación aunque el operador } \\
\text { cambie de postura. }\end{array}$ \\
\hline $\begin{array}{l}\text { Primero los } \\
\text { controles } \\
\text { principales }\end{array}$ & $\begin{array}{l}\text { Los controles más importantes deberán tener la posición más } \\
\text { ventajosa para facilitar su operación y comprobación por el } \\
\text { operador. }\end{array}$ \\
\hline $\begin{array}{l}\text { Los controles } \\
\text { relacionados } \\
\text { por grupos, } \\
\text { juntos }\end{array}$ & $\begin{array}{l}\text { Los controles que deban accionarse de forma secuencial, y que } \\
\text { estén relacionados con una función determinada o que se } \\
\text { accionen juntos, deben estar dispuestos en grupos funcionales } \\
\text { junto con sus indicadores correspondientes. Dentro de cada } \\
\text { grupo funcional, los controles y los indicadores deben dispo- } \\
\text { nerse según su importancia y secuencia de operación. }\end{array}$ \\
\hline $\begin{array}{l}\text { Disponer para } \\
\text { accionar } \\
\text { secuencialmente }\end{array}$ & $\begin{array}{l}\text { Si los controles se accionan siguiendo un patrón determinado, } \\
\text { deberán disponerse de forma que se facilite la secuencia. Las } \\
\text { disposiciones más frecuentes son de izquierda a derecha } \\
\text { (preferentemente) o de arriba abajo }\end{array}$ \\
\hline Coherencia & $\begin{array}{l}\text { La disposición de los controles funcionalmente idénticos o simi- } \\
\text { lares debe ser igual en todos los paneles. }\end{array}$ \\
\hline $\begin{array}{l}\text { Control de emer- } \\
\text { gencia del } \\
\text { operador }\end{array}$ & $\begin{array}{l}\text { Si el operator queda incapacitado y suelta o retiene un } \\
\text { control, deberá existir un diseño de control de emergencia del } \\
\text { operador que ponga el sistema en un estado de funciona- } \\
\text { miento no crítico o que lo apague. }\end{array}$ \\
\hline $\begin{array}{l}\text { Seleccionar ade- } \\
\text { cuadamente los } \\
\text { códigos }\end{array}$ & $\begin{array}{l}\text { Existen varios medios para facilitar la identificación de los } \\
\text { controles, para indicar el efecto de su operación y para mostrar } \\
\text { su estado. Los principales medios de codificación son: } \\
\text { - Situación- Forma- Tamaño- Modo de operación- Rótulos } \\
\text { - Colores- Redundancia }\end{array}$ \\
\hline
\end{tabular}

Fuente: Modificado de Kroemer, Kroemer y Kroemer-Elbert 1994. Reproducido con autorización de Prentice-Hall. Reservados todos los derechos.

3. Presentar la información de la forma más directa, simple, comprensible y aprovechable.

4. Presentar la información de forma que un fallo o mal funcionamiento del propio indicador resulte inmediatamente obvio. La selección de un dispositivo indicador visual o auditivo dependerá de las condiciones y fines en cada situación. El objetivo del indicador puede ser proporcionar:

- información histórica sobre el estado anterior del sistema, como la trayectoria recorrida por un barco,

- información del estado actual del sistema, como por ejemplo, el texto que se ha introducido en un procesador de textos o la posición actual de un aeroplano,

- información predictiva, por ejemplo, sobre la futura posición de una nave, según unas determinadas coordenadas,

- instrucciones o comandos que indican al operador lo que debe hacer, e incluso cómo hacerlo.

Un indicador visual resulta más adecuado para un entorno ruidoso, cuando el operador debe permanecer en un puesto, cuando el mensaje es largo y complejo y, sobre todo, cuando trata de la situación espacial de un objeto. U n indicador acústico es más apropiado cuando el lugar de trabajo debe estar oscuro, cuando el operador se desplaza y cuando el mensaje es corto y sencillo, requiere atención inmediata y se refiere a acontecimientos y a indicaciones temporales.

\section{Indicadores visuales}

Existen tres tipos básicos de indicadores visuales: (1) el indicador de comprobación muestra si existe o no una determinada situación (por ejemplo, un piloto verde indica un funcionamiento normal); (2) el indicador cualitativo indica el estado de una variable cambiante, su valor aproximado, o su tendencia al cambio (por ejemplo, un puntero que se desplaza dentro de un intervalo "normal"); (3) el indicador cuantitativo muestra la información exacta que hay que comprobar (por ejemplo, si hay que encontrar un emplazamiento en un mapa, leer un texto o dibujar algo en un monitor de ordenador), o puede indicar un valor numérico exacto que debe leer el operador (por ejemplo, una hora o temperatura).

L as bases para el diseño de indicadores visuales son:

- organizar las pantallas de forma que el operador pueda localizarlas e identificarlas fácilmente, sin necesidad de buscarlas. Esto suele requerir que las pantallas se encuentran en el plano medial del operador y a la altura de los ojos o por debajo de ellos,

- agrupar las pantallas de forma funcional o secuencial de forma que el operador pueda utilizarlas con facilidad,

- asegurarse de que todas las pantallas están bien iluminadas 0 sean luminosas, estén adecuadamente codificadas y rotuladas según su función.

- Utilizar luces coloreadas para indicar el estado del sistema (como ENCENDIDO y APAGADO) o para avisar al operador de que el sistema o uno de sus subsistemas ha dejado de estar operativo y es necesario tomar medidas. El significado habitual de los colores de las luces se encuentra en la Figura 29.42. EI rojo intermitente indica que se ha producido una emergencia que requiere acción inmediata. U na señal de emergencia siempre es más eficaz cuando combina sonidos con la luz roja intermitente.

Para obtener información más detallada y compleja, especialmente información cuantitativa, se utiliza tradicionalmente uno de los cuatro tipos de dispositivos de presentación de datos indicados a continuación: (1) un puntero móvil con escala fija, (2) una escala móvil con puntero fijo, (3) contadores o (4) pantallas "gráficas", especialmente generadas por ordenador en un monitor. La Figura 29.43 indica las características principales de estos tipos de pantalla.

N ormalmente es preferible utilizar un puntero móvil en lugar de una escala móvil, ya sea ésta recta (horizontal o vertical),

Figura 29.42 - Código de colores de las luces de indicación.

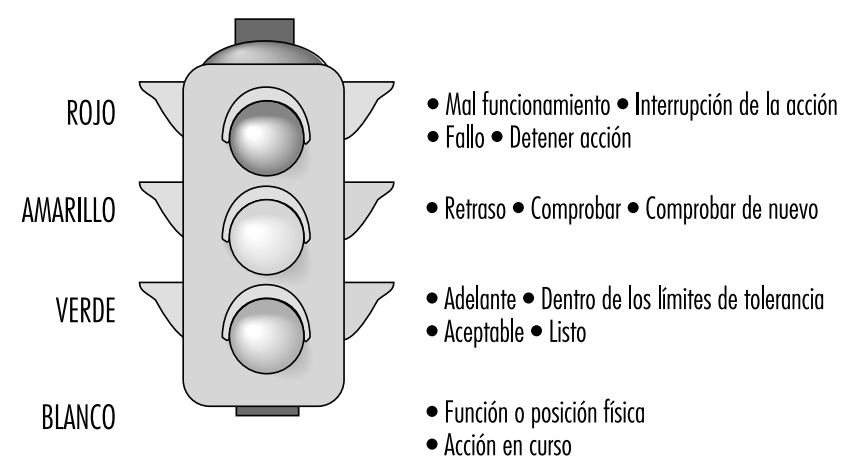


Figura 29.43 - Características de los indicadores visuales.

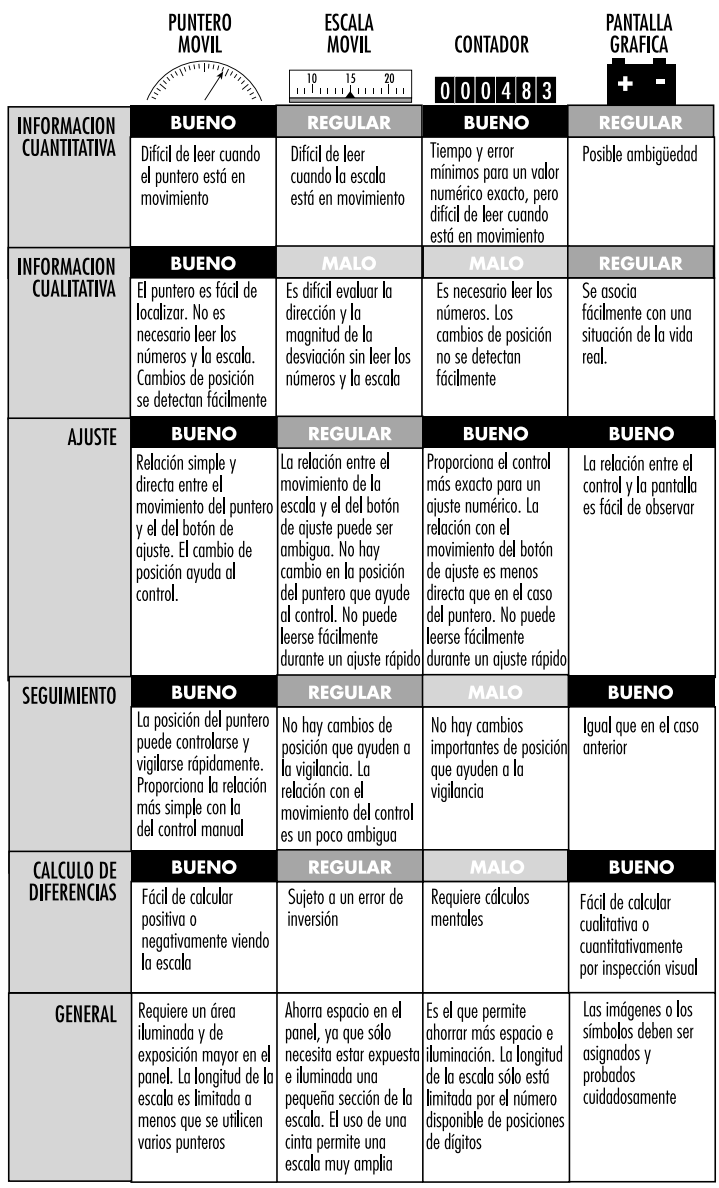

Fuente: Kroemer 1995

curva o circular. L as escalas deben ser sencillas y claras, con sus graduaciones y números dispuestos de forma que se puedan leer con rapidez y facilidad. L os números deberán encontrarse fuera de las marcas de la escala, para que el puntero no los oculte. EI puntero deberá terminar con la punta directamente sobre la marca. La escala deberá indicar las divisiones de forma que el operador pueda leerla sin problemas. Las marcas principales deberán ir numeradas. La mejor forma de marcar las progresiones es utilizando intervalos de una, cinco o diez unidades entre las marcas principales. Los números deben aumentar de izquierda a derecha, de abajo arriba o en el sentido de las agujas del reloj. Para obtener más detalles sobre las dimensiones recomendadas para las escalas, consúltense estándares como los indicados por Cushman y Rosenberg 1991 o K roemer 1994a.

Desde el decenio de 1980, los dispositivos mecánicos de indicación con puntero y escalas impresas se han ido sustituyendo por pantallas electrónicas con imágenes generadas por ordenador o dispositivos que emplean diodos emisores de luz (véase Snyder 1985a). La información que se muestra puede estar codificada de las formas siguientes:

- formas rectas o circulares,

- alfanumérica, es decir, letras, números, palabras o abreviaturas,

- figuras, imágenes, pictogramas, iconos, símbolos, en distintos niveles de abstracción, como la silueta de un avión en el horizonte,

- tonos de negro, blanco o gris,

- colores
Lamentablemente, en ocasiones las imágenes generadas electrónicamente son confusas, demasiado complejas o coloridas, difíciles de leer y requieren un enfoque exacto y mucha atención, lo que puede desviar la atención de la tarea principal, por ejemplo, cuando se conduce un coche. En estos casos, no se cumplen las tres primeras reglas básicas antes mencionadas. Por otro lado, muchos punteros electrónicos, marcas o símbolos alfanuméricos no cumplen las directrices del diseño ergonómico establecidas, especialmente cuando se forman mediante segmentos lineales, líneas de escáner o matrices de puntos. Aunque algunos de estos diseños defectuosos han sido tolerados por el usuario, la rápida innovación y las técnicas que han mejorado las pantallas han hecho posible la existencia de otras soluciones, aunque este mismo desarrollo acelerado está convirtiendo rápidamente a las indicaciones impresas, aunque sean habituales y comprensibles, en algo obsoleto. Por eso no aparecen en este texto. C ushman y Rosenberg (1991), K inney y H uey (1990), y Woodson, Tillman y Tillman (1991) han publicado revisiones sobre este tema.

En general, a las pantallas electrónicas les falta calidad. U na medida utilizada para valorar la calidad de la imagen es la función de transferencia de la modulación (MTF) (Snyder 1985b), que describe la resolución de la pantalla utilizando una señal especial de prueba de onda sinusoidal. Sin embargo, los criterios de los lectores en cuanto a las pantallas suelen ser muy variables (Dillon 1992).

L as pantallas monocromas tienen un solo color, normalmente verde, amarillo, ámbar o blanco (acromático). Si aparecen varios colores en la misma pantalla cromática, deberán ser fáciles de distinguir. Lo mejor es no utilizar más de tres o cuatro colores simultáneamente (preferiblemente, rojo, verde o naranja y cián o púrpura). Todos deberán distinguirse bien del fondo. En realidad la norma de diseño debería ser utilizar el contraste, es decir, utilizar el blanco y negro y después añadir el menor número de colores posible.

Figura 29.44 • Directrices para el uso de colores en los indicadores visuales.

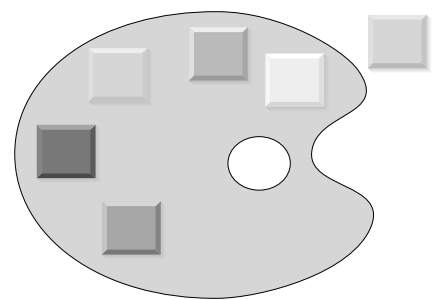

Limitar el número de colores en un indicador a cuatro 0 cinco si los usuarios no son experimentados o si el uso del indicador no es muy frecuente. Nunca deben utilizarse más de siete colores

Cada uno de los colores elegidos debe estar bien separados entre sí en cuanto a longitud de onda para maximizar las posibilidades de discriminación. No deben utilizarse colores que difieran sólo en la proporción de color primario (por ejemplo, distintos tonos de naranja).

Combinaciones sugeridas:

- verde, amarillo, naranja, rojo, blanco

- azul, cián, verde, amarillo, blanco

- cián, verde, amarillo, naranja, blanco

Adaptado de Cushman y Rosenberg 1991.
Evitar combinaciones del tipo:

- rojos con azules

- rojos con cián

- magenta con azules 
A pesar de las muchas variables que, independientemente 0 combinadas entre sí, afectan al uso de las pantallas complejas en color, Cushman y Rosenberg (1991) han elaborado unas directrices para el uso de color en las pantallas; que se indican en la Figura 29.44.

0 tras sugerencias son:

- el azul, preferiblemente no saturado, es un buen color para fondos y figuras grandes. Sin embargo, no debe utilizarse para textos, líneas finas o figuras pequeñas;

- el color de los caracteres alfanuméricos deberá contrastar con el del fondo;

- cuando se utilice el color, la forma o el brillo deberán ser características añadidas (por ejemplo, todos los símbolos amarillos son triángulos, todos los símbolos verdes son círculos, todos los símbolos rojos son cuadrados). La codificación redundante hará la pantalla mucho más aceptable a usuarios que tengan dificultad para apreciar el color;

- a medida que se aumenta el número de colores, debe aumentarse también el tamaño de los objetos en color;

- el rojo y el verde no deberán utilizarse para símbolos o figuras pequeñas que se encuentren en zonas periféricas de una pantalla grande;

Tabla 29.13 • Directrices para los rótulos.

Orientación El rótulo y la información impresa en él deberán estar orientados horizontalmente para que puedan leerse rápida y fácilmente. (Esto se aplica en los países en los que el operador está acostumbrado a leer en dirección horizontal, como en los países occidentales).

Colocación El rótulo debe colocarse muy próximo o sobre el elemento al que identifica.

Normalización La posición de los rótulos debe ser coherente en todo el equipo y el sistema.

Funciones del Un rótulo debe describir principalmente la función ("qué es lo equipo que hace") del elemento identificado.

Abreviaturas Pueden utilizarse abreviaturas comunes. Si es necesario utilizar una abreviatura nueva, su significado debe resultar obvio al lector.

Debe utilizarse la misma abreviatura para todos los tiempos verbales y para el singular y el plural de la palabra. Deben utilizarse mayúsculas, los puntos generalmente se omiten.

Brevedad La inscripción del rótulo debe ser lo más concisa posible sin distorsionar el significado o la información que se desea transmitir. Los textos no deben ser ambiguos ni redundantes.

Familiaridad Deben elegirse palabras que resulten familiares al operador.

Visibilidad y El operador debe poder leer fácilmente y de forma precisa a la legibilidad distancia de lectura prevista, en las peores condiciones de iluminación previstas y en las condiciones de vibración y movimiento previstas. Los factores importantes son: el contraste entre las letras y el fondo; la altura, anchura, anchura del trazo, espacios y tipo de letra; y la reflexión especular del fondo, la cubierta u otros componentes.

Fuente y tamaño La tipografía determina la legibilidad de la información escrita; de letra se refiere al estilo, tipo, disposición y aspecto de las letras.

Fuente: Modificado de Kroemer, Kroemer y Kroemer-Elbert 1994 (reproducido con autorización de Prentice-Hall; reservados todos los derechos).
- el uso de colores opuestos (rojo y verde, amarillo y azul) que aparezcan juntos en una relación objeto/fondo es a veces beneficioso y a veces perjudicial. No hay una norma que pueda ofrecerse: la solución tendrá que determinarse según los casos;

- evite el uso simultáneo de varios colores muy saturados de los extremos del espectro.

\section{Paneles de controles y dispositivos de presentación de datos}

Tanto los dispositivos de presentación de datos como los controles deberán disponerse en paneles delante del operador, es decir, cerca del plano medial de la persona. Como ya se ha dicho antes, los controles deberán estar a la altura del codo y las pantallas, a la altura de los ojos o un poco más bajas, tanto si el operador está sentado como si está de pie. Los controles que se manejen con menos frecuencia o los menos importantes, pueden colocarse más hacia los extremos o en la parte superior.

Con frecuencia, la información sobre el resultado de la operación de control se muestra en un instrumento. En este caso, el indicador deberá estar situado junto al control, de forma que éste pueda manipularse sin errores, con rapidez y comodidad. La asociación suele ser más clara cuando el control está directamente debajo o a la derecha del indicador. Debe tenerse cuidado de que la mano no tape el indicador cuando se maneja el control.

La gente suele esperar que exista una relación entre controles e indicadores, pero estas relaciones, a menudo aprendidas, generalmente dependen de la formación y la experiencia del operador, y no son fuertes. Las relaciones de movimiento esperadas están influidas por el tipo de control y de indicador. Cuando ambos son lineales o rotativos, la expectativa común es que sus movimientos se correspondan, es decir, que ambos se desplacen hacia arriba o en el sentido de las agujas del reloj. Cuando los movimientos son incongruentes, suelen aplicarse las reglas siguientes:

- Aumentar en el sentido de las agujas del reloj: al girar el control en el sentido de las agujas del reloj aumenta el valor visualizado.

- R egla de W arrick: se espera que un indicador (puntero) se mueva en la misma dirección que el control vinculado con el indicador.

La relación entre los desplazamientos del control y del indicador (proporción C/D o ganancia D/C) describe cuánto hay que mover un control para ajustar un indicador. Si es necesario un movimiento amplio del control para una pequeña variación del indicador, la relación C/ D es grande, lo que significa que el control tiene poca sensibilidad. Normalmente, para hacer un ajuste son necesarios dos movimientos: en primer lugar, un movimiento primario ("giratorio") rápido hasta un punto aproximado, y en segundo, un ajuste preciso, hasta llegar a la posición exacta. En algunos casos, se considera como proporción C/D óptima la que reduce al máximo la suma de estos dos movimientos. Sin embargo, la proporción más adecuada dependerá de las circunstancias determinadas de cada aplicación.

\section{Rótulos y advertencias}

\section{Rótulos}

Lo ideal sería que no hiciese falta poner ningún rótulo en un equipo o control para explicar su funcionamiento. N ormalmente, sin embargo, es necesario hacerlo para poder localizar, identificar, leer o manipular los controles, los indicadores u otros componentes del equipo. Los rótulos deben colocarse de forma que la información llegue al usuario de forma rápida y precisa. Para esto se dan instrucciones en la Tabla 29.13. 
El tipo de letra (fuente) debe ser simple, grueso y vertical, como Futura, H elvetica, Namel, Tempo o Vega. A dviértase que la mayoría de las fuentes generadas electrónicamente (a través de LED, pantallas de cristal líquido o matrices de puntos) suelen ser de menor calidad que las impresas; y debe intentarse que resulten legibles.

- La altura de los caracteres depende de la distancia de visualización:

distancia de visualización: $35 \mathrm{~cm}$, altura sugerida: $22 \mathrm{~mm}$ distancia de visualización: $70 \mathrm{~cm}$, altura sugerida: $50 \mathrm{~mm}$ distancia de visualización: $1 \mathrm{~m}$, altura sugerida: $70 \mathrm{~mm}$

distancia de visualización: 1,5 m, altura sugerida: al menos $1 \mathrm{~cm}$

- La proporción de anchura del trazo frente a altura del carácter deberá ser 1:8 a 1:6 para letras negras sobre fondo blanco y 1:10 a 1:8 para letras blancas sobre fondo negro.

- La proporción de anchura frente a altura del carácter deberá ser de 3:5.

- El espacio entre las letras deberá tener al menos la anchura de un trazo.

- El espacio entre las palabras deberá tener al menos la anchura de un carácter.

- Para texto continuo, deberán combinarse mayúsculas y minúsculas; para rótulos, deberán usarse sólo mayúsculas.

\section{Advertencias}

Lo ideal sería que todos los aparatos resultaran seguros al utilizarse. En la realidad, esto no siempre puede conseguirse con el diseño; en estos casos, es necesario avisar al usuario de los peligros asociados con el uso del producto y ofrecerle instrucciones para su manipulación segura, con el fin de evitar daños o lesiones

Es preferible contar con advertencias "activas", compuestas por un sensor que indique su utilización inadecuada y un dispositivo de alerta que avise a la persona del peligro. Sin embargo, en la mayoría de los casos se emplean advertencias "pasivas", por lo general una etiqueta pegada al aparato y una serie de instrucciones para la correcta manipulación del mismo que aparecen en el manual del usuario. Estas advertencia pasivas se basan en la capacidad del usuario para reconocer un peligro real o potencial, para recordar la advertencia y para actuar de forma prudente.

Los rótulos y las señales de las advertencias pasivas deben estar cuidadosamente diseñadas de acuerdo con la legislación vigente del país, las normativas nacionales e internacionales y teniendo en cuenta toda la información sobre ergonomía que pueda aplicarse. Las etiquetas y placas con advertencias pueden contener textos, gráficos e imágenes, e incluso combinaciones de gráficos y textos redundantes. Los gráficos, especialmente las imágenes y los pictogramas, pueden ser utilizados por personas de distintos ámbitos culturales, pero el diseño debe elegirse cuidadosamente. Sin embargo, los usuarios pueden percibir de distinta forma los peligros de que se avisa dependiendo de su edad y experiencia, etnia o entorno cultural. Por esto es preferible diseñar un producto seguro en lugar de aplicar advertencias a un producto de calidad inferior.

\section{- Diseño Y TRATAMIENTO DE LA INFORMACION}

\section{Andries F. Sanders}

Al diseñar un equipo, es muy importante tener en cuenta que un operario humano tiene determinados límites y capacidades para procesar la información. Estas capacidades y límites son de naturaleza muy variada y se pueden detectar a diferentes niveles. EI rendimiento en las condiciones reales de trabajo depende en gran manera de hasta qué punto se ha prestado la debida atención a estas capacidades y límites durante el diseño. A continuación se ofrece un breve descripción de los criterios más importantes relacionados con este tema. En algunos casos se hará referencia a otras secciones de este volumen, en las que se discute algún tema concreto de manera más detallada.

Al analizar la forma en que los seres humanos procesan la información, suelen distinguirse tres niveles: el nivel perceptivo, el nivel de decisión y el nivel motor. El nivel perceptivo se divide a su vez en otros tres niveles relacionados con el proceso sensorial, la diferenciación de características y la identificación de la percepción. En el nivel de decisión, el operario percibe la información y elige una reacción que se programa y se ejecuta a nivel motor. Esta sería la descripción del flujo de información en los casos de las reacciones más simples. Pero es evidente, sin embargo, que la información se puede acumular, combinar y diagnosticar antes de que provoque una respuesta. N uevamente, es posible que sea necesario seleccionar sólo una parte de la información para evitar una sobrecarga a nivel perceptivo. Finalmente, elegir la acción adecuada se convierte en un problema cuando hay varias opciones, unas mejores que otras. Aquí analizaremos los factores perceptivos y de decisión en el proceso de la información.

\section{Capacidades y límites perceptivos}

\section{Límites sensoriales}

La primera categoría de los límites en el proceso de la información es la sensorial. Su importancia en dicho proceso es evidente, ya que cuando las señales de información se acercan a los umbrales de percepción, el proceso se vuelve menos fiable. Esta afirmación puede parecer trivial, pero los problemas sensoriales no siempre se tienen en cuenta a la hora del diseño. Por ejemplo, los caracteres alfanuméricos de los carteles y señales informativas deberían ser lo suficientemente grandes como para distinguirse a la distancia adecuada, dependiendo siempre de la acción que se esté realizando. La legibilidad, sin embargo, no depende sólo del tamaño absoluto de los caracteres sino también del contraste y, debido a la inhibición lateral, de la cantidad de información en la señal. La legibilidad es un problema lo bastante importante como para que se adopten medidas especiales, particularmente en condiciones de baja visibilidad (por ejemplo, durante la conducción o el pilotaje con lluvia o niebla). La señales de tráfico y carretera más recientes han sido diseñadas teniendo en cuenta estos factores, pero los carteles informativos junto a los edificios y dentro de ellos son, con bastante frecuencia, prácticamente ilegibles. Las pantallas son otro de los ejemplos en el que los límites sensoriales de tamaño, contraste y cantidad de información tienen un papel importante. A nivel auditivo, algunos de los problemas sensoriales más importantes están relacionados con la comprensión de los mensajes verbales en ambientes ruidosos 0 a la baja calidad de los sistemas de transmisión o audición.

\section{Distinción de características}

Una vez se ha obtenido la suficiente información sensorial, la siguiente etapa en el proceso de la información es la de distinción de las características de dicha información. Las investigaciones más recientes demuestran que el análisis de las características precede a la percepción del significado. Este análisis es especialmente útil para localizar un objeto especial entre muchos otros. Por ejemplo, un valor esencial en una pantalla que contenga muchos otros valores se puede representar por medio de un color o tamaño diferente, y esta característica resaltará el valor de 
forma automática. Teóricamente, se considera que existen "mapas de características" para diferentes colores, tamaños, formas y otras características físicas. El valor de la atención a la característica dependerá de la activación diferencial de los mapas de características que pertenecen a la misma clase; por ejemplo, el color. La activación de un mapa de características dependerá, por lo tanto, de la posibilidad de discriminar las características distintas. Esto significa que cuando hay muchos colores en una pantalla, se activan la mayoría de los mapas de características de color de la misma manera y ninguno de los colores resalta más que los otros.

Del mismo modo, un único anuncio móvil nos resultaría llamativo, pero este efecto desaparece cuando nos encontramos con varios estímulos móviles en el campo visual. El principio de activación diferencial de los mapas de características se aplica también cuando se trata de punteros alineados que indican parámetros ideales. $L$ a desviación de un puntero puede indicarse con una inclinación de la línea, que se detecta rápidamente. Si esto es imposible, una desviación peligrosa podría indicarse por medio de un cambio de color. A sí, la regla general para el diseño es utilizar sólo unas pocas características de diferenciación en una pantalla y reservarlas para la información más importante. L a búsqueda de información significativa puede llegar a convertirse en algo difícil si algunas características se presentan juntas: por ejemplo, no es fácil localizar un objeto grande de color rojo en un conjunto de objetos pequeños de color rojo y de objetos verdes de todos los tamaños. Siempre que queramos diseñar elementos de búsqueda eficaces debemos evitar presentar varias características al mismo tiempo.

\section{Dimensiones integrales y separables}

Las características son separables cuando las podemos cambiar sin que afecte la percepción de las otras características del objeto. La longitud de las líneas de un histograma sería un buen ejemplo. En cambio, el término características integrales se refiere a aquellas características que, al cambiarse, alteran por completo la apariencia del objeto. Por ejemplo, no se pueden cambiar las características de la boca en una representación esquemática de la cara, sin alterar todo el aspecto del dibujo. El color y el brillo son características integrales, en el sentido de que no se puede cambiar un color sin alterar al mismo tiempo la impresión de brillo. L os principios de las características integrales y separables y de las propiedades emergentes derivadas de cambios en una sola característica de un objeto, se aplican en las llamadas representaciones integradas o diagnósticas. La justificación de estas representaciones es que se integran distintos parámetros en una sola representación en lugar de mostrar los parámetros individuales, y la composición total de esta representación puede indicar lo que está mal en un sistema.

La presentación de datos en las salas de control aún refleja el concepto de que cada medición individual debe tener su propio indicador. Esta representación fragmentada de las mediciones implica que el operario debe integrar la información de los diferentes indicadores para diagnosticar el posible problema. Cuando sucedió el accidente de la central nuclear de Three M ile Island, entre cuarenta y cincuenta indicadores registraron algún fallo, por lo que el operario tuvo que ir integrando la información de todas esas señales para poder diagnosticar qué había ocurrido realmente. Las representaciones íntegras podrían ayudar a diagnosticar los diferentes tipos de errores, ya que combinan varias medidas en un solo patrón. Los diferentes patrones de las representaciones íntegras también pueden ayudar a diagnosticar errores específicos.

Un ejemplo típico de representación de diagnóstico, propuesto para las salas de control de las centrales nucleares, puede verse en la Figura 29.45. En ella se muestra un número de mediciones en forma de radios de igual longitud, de modo que un polígono regular representa las condiciones normales, mientras cualquier distorsión puede relacionarse con los diferentes problemas del proceso.

$\mathrm{No}$ todas las representaciones integrales son igualmente distinguibles. Por ejemplo, una correlación positiva entre las dos dimensiones de un rectángulo provoca diferencias en el tamaño, pero mantiene la misma forma. En cambio, una correlación negativa provoca diferencias en la forma y mantiene el tamaño constante. Cuando la variación de dimensiones integrantes crea una nueva forma, revela una propiedad significativa del patrón, lo que se añade a la capacidad del operario para discriminar los patrones. Las nuevas propiedades que aparecen dependerán de la identidad y disposición de las partes, pero no se pueden identificar con ninguna parte individual.

Las representaciones de objetos y de configuración no son siempre beneficiosas. El mismo hecho de que sean integrales implica que las características de las variables individuales son más difíciles de percibir. Lo importante es que, por definición, las dimensiones integrales son interdependientes, lo que enmascara a los elementos individuales. Puede haber ocasiones en que esa situación sea inaceptable, aunque se desee aprovechar las propiedades de diagnóstico a través de patrones, típicas de la representación de objetos. U na solución podría ser un gráfico de barras tradicional. Por una parte, los gráficos de barras son fáciles de separar; y al mismo tiempo, cuando se colocan lo suficientemente juntos, las diferentes longitudes de las barras

Figura 29.45 • En una situación normal, todos los valores de los parámetros son iguales y forman un hexágono. En una situación anormal, algunos valores varían y crean una distorsión específica.
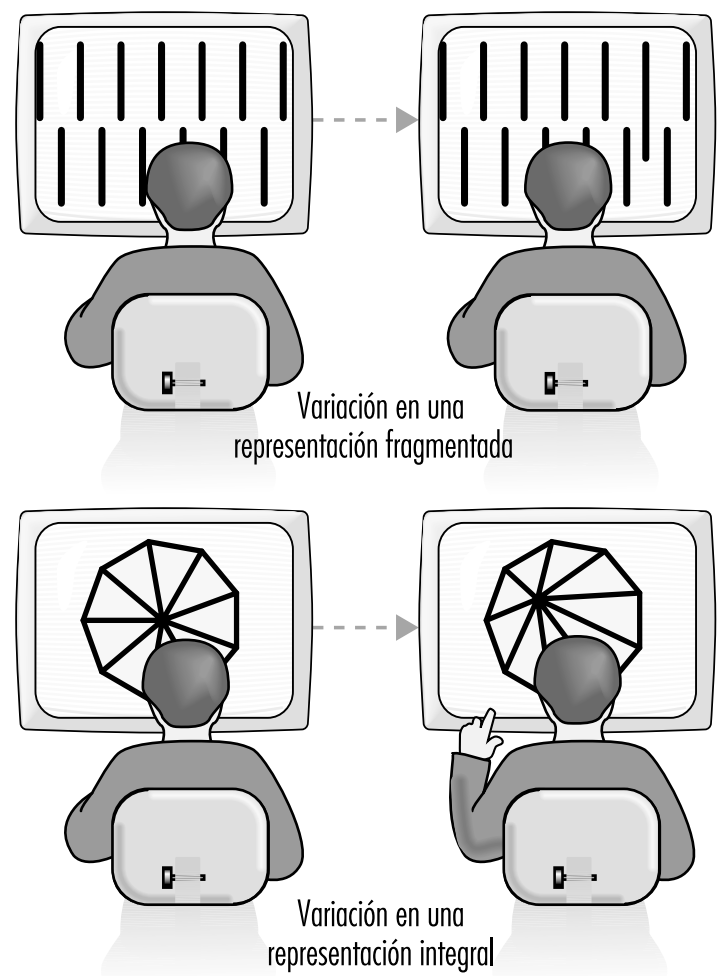
pueden constituir un patrón similar al de un objeto y útil para el diagnóstico.

Algunas representaciones de diagnóstico son mejores que otras. Su calidad depende de hasta qué punto la representación se ajusta al modelo mental de la tarea. Por ejemplo, el diagnóstico de errores, basado en las distorsiones de un polígono regular, como se ve en la Figura 29.45, puede que tenga poca relación con el campo semántico o la conceptualización de la tarea por parte del operario de la central nuclear. Las diferentes desviaciones de un polígono no se refieren de forma obvia al problema específico de la central. Así, el diseño de representación ideal es el que se basa en el modelo mental específico de la tarea. $\mathrm{H}$ ay que señalar que el tamaño de un rectángulo sólo es una representación útil cuando las dimensiones del producto sean la variable de interés.

L as representaciones más interesantes del objeto se basan, hoy en día, en métodos tridimensionales. Por ejemplo, una representación tridimensional del tráfico aéreo, en lugar de la representación bidimensional habitual del radar, puede ayudar al piloto a comprender mejor la posición de los otros aparatos. Este tipo de representación ha demostrado ser mucho mejor que la bidimensional, ya que sus símbolos indican si otro avión está por encima o por debajo del que se está pilotando.

\section{Condiciones distorsionadas}

La distorsión visual se da en diversas condiciones. Para algunos fines, como en el caso del camuflaje, los objetos se distorsionan intencionadamente para impedir su identificación. En otras ocasiones, por ejemplo con el aumento del brillo, las características pueden llegar a ser demasiado borrosas como para identificar el objeto. U no de los temas de investigación se ha referido al número mínimo de "líneas" que se necesitan en una pantalla o el "detalle" necesario para evitar la distorsión. Desafortunadamente, esta solución a la calidad de la imagen no ha llevado a un resultado claro y definitivo. El problema para identificar estímulos distorsionados, por ejemplo, un vehículo blindado camuflado, depende en gran medida de la presencia o ausencia de pequeños detalles específicos del objeto. El resultado es que no se puede formular ningún tipo de solución general en relación con la densidad de líneas, sólo hacer la afirmación, más bien trivial, de que la distorsión disminuye a medida que aumenta la densidad.

\section{Características de los símbolos alfanuméricos}

Uno de los temas más importantes en el proceso de distinción de las características es el número real de características que, en conjunto, definen un estímulo. Así pues, la legibilidad de caracteres recargados como la letra gótica es muy baja, debido a la gran cantidad de curvas. Para evitar la confusión, se debería acentuar la diferencia entre aquellas letras que presentan características muy similares, como la i y la I, o la c y la e Por la misma razón, se recomienda que los trazos que sobresalen de las letras tengan al menos un $40 \%$ de la altura total de la letra.

Es evidente que la discriminación entre las letras está determinada principalmente por el número de características que no comparten. Estas características son principalmente segmentos de líneas rectas y circulares en sentido horizontal, vertical u oblicuo, que pueden variar en tamaño, como en las mayúsculas y las minúsculas.

Es obvio que, aunque los caracteres alfanuméricos sean distinguibles por sí mismos, esta propiedad puede perderse cuando se combinan con otros elementos. Así, los dígitos 4 y $\mathbf{7}$ comparten muy pocas características, pero no se distinguen tan bien en un contexto mayor en el que el resto de los elementos son idénticos (por ejemplo, 384 y 387). Todo el mundo sabe que es más rápido leer un texto en minúsculas que en mayúsculas. Esto se suele atribuir al hecho de que las letras minúsculas tienen más características distintivas (por ejemplo, alto, bajo frente a ALTO, BAJO). Esta superioridad de las minúsculas, no se refiere sólo a los textos de lectura sino también a las señales de carretera que indican las ciudades y las salidas de las autopistas.

\section{Identificación}

El objetivo del proceso perceptivo se relaciona con la identificación e interpretación de lo percibido. Las limitaciones humanas que surgen a este nivel suelen relacionarse con la discriminación e interpretación adecuadas de lo que se percibe. Las aplicaciones de la investigación en discriminación visual son muy variadas y van desde los modelos alfanuméricos hasta la identificación de estímulos más generales. EI diseño de las luces de frenado de los coches puede servir como ejemplo para esta última categoría. Los accidentes por golpes traseros representan una proporción importante de los accidentes de tráfico y se deben, en parte, al hecho de que la posición de la luz de frenado junto a las luces traseras la convierte en algo poco discriminable y prolonga el tiempo de reacción del conductor. Como alternativa se ha desarrollado una luz única que se monta en el centro de la luna trasera al nivel de los ojos, más o menos, y que aparentemente ayuda a reducir la tasa de accidentes. En estudios experimentales en carretera, el efecto de esta luz de freno central parece ser menor cuando los participantes conocen la finalidad del estudio, lo que indica que la identificación de estímulos en su configuración tradicional mejora cuando los sujetos prestan especial atención a la tarea. A pesar del efecto positivo de la luz de frenado aislada, su identificación se podría mejorar aun más creando una señal de frenado más distinguible, dándole alguna forma especial, como un signo de exclamación "!" o incluso creando un icono.

\section{Juicios absolutos}

En el caso de los juicios absolutos sobre las dimensiones físicas, se observan límites de rendimiento muy estrictos y en ocasiones, contrarios a la intuición. Hay ejemplos relacionados con el código de colores de los objetos y el uso de los tonos en los sistemas auditivos de llamada. La realidad es que los juicios relativos son muy superiores a los absolutos. El problema con los juicios absolutos es que el código se ha de traducir a otra categoría. Por ejemplo, un color puede estar relacionado con un valor de resistencia eléctrica o un tono se puede asociar a un mensaje para una persona concreta. De hecho, el problema no es de identificación perceptiva sino de elección de respuesta, un tema que se discutirá más adelante en este artículo. Por ahora es suficiente señalar que no se deben utilizar más de cuatro o cinco colores 0 tonos para evitar la confusión. Cuando se necesiten más alternativas, se pueden añadir dimensiones adicionales, como intensidad, duración y número de tonos.

\section{Lectura de palabras}

L a importancia de leer las palabras como unidades separadas en el modo de impresión tradicional se ha demostrado en varios experimentos: la lectura es más difícil cuando se omiten los espacios, no se detectan los errores tipográficos y es muy difícil leer palabras que alternan mayúsculas y minúsculas (por ejemplo, ALTER nAndO). Algunos investigadores han dado mucha importancia al papel que desempeña la forma a la hora de leer unidades de palabras y sugieren que los analizadores de frecuencia espacial pueden ser importantes para identificar la forma de la palabra. Desde este punto de vista, el significado se obtendría a partir de la forma de la palabra y no del análisis letra por letra. Sin embargo, la aportación al análisis de la forma de la palabra se limita probablemente a pequeñas palabras comunes, como artículos y terminaciones, lo que coincide con el hecho de 
que los errores tipográficos en palabras pequeñas y terminaciones tienen pocas probabilidades de ser detectados.

Los textos en letra minúscula tienen ventaja sobre los textos en mayúsculas debido a la pérdida de características diferenciadoras en las mayúsculas. Pero esta ventaja no se da, y se puede incluso observar la tendencia contraria, cuando se trata de buscar una sola palabra. Puede ser que factores como el tamaño de la letra y las mayúsculas se confundan en la búsqueda. Las letras de mayor tamaño se detectan más rápidamente, lo que podría compensar la desventaja que supone la falta de características distintivas. Así pues, una palabra aislada se puede leer igual de bien en mayúsculas que en minúsculas, mientras que un texto continuo se lee más rápido en minúsculas. Detectar una palabra U NICA en mayúsculas entre muchas minúsculas es muy fácil, ya que se destaca del texto. Incluso sería más eficaz y rápido imprimir una única palabra en minúscula en negrita, en cuyo caso se combinan las ventajas de las características diferenciadoras y las del impacto visual.

El papel de la codificación en la lectura se ilustra claramente en la poca legibilidad de las antiguas pantallas de PVD de baja resolución, compuestas por matrices de puntos muy primarias y que sólo podían reproducir los caracteres alfanuméricos en forma de líneas rectas. Se descubrió que leer o buscar información en uno de esos monitores de baja resolución era bastante más lento que hacerlo en una copia impresa. El problema ha desaparecido con las pantallas actuales de alta resolución. Además de la forma de las letras hay otras diferencias adicionales entre leer de un papel o en una pantalla, entre los que se encuentra el espaciado de las líneas, el tamaño de los caracteres, el tipo de letra, el contraste entre los caracteres y el fondo, la distancia entre el lector y el texto, la cantidad de parpadeo y el hecho de que pasar las páginas en la pantalla se hace por un sistema de desplazamiento. La opinión generalizada de que es más lento leer de una pantalla de ordenador, aunque el nivel de comprensión es igual, puede deberse a una combinación de estos factores. LoS ordenadores actuales ofrecen una gran variedad de opciones en cuanto a fuente, tamaño, color, formato y estilo que puede llevarnos a pensar, equivocadamente, que el gusto personal es la razón principal.

\section{Iconos frente a palabras}

En algunos estudios se ha demostrado que el tiempo utilizado para elegir una palabra es menor que el de un icono equivalente, mientras que en otros estudios el tiempo fue casi el mismo. Hay quien dice que las palabras se leen más rápido porque son menos ambiguas. Incluso un icono relativamente simple, como una casa, podría provocar diferentes respuestas y, de esta manera, generar un conflicto de respuestas y disminuir la velocidad de reacción. Si se evita este conflicto, utilizando iconos no ambiguos es probable que la diferencia en la velocidad de reacción desaparezca. Es interesante señalar que, como en el caso de las señales de tráfico, los iconos son a menudo mejores que las palabras, incluso en aquellos casos en que la comprensión del lenguaje no se considera un problema. Esta paradoja se puede deber al hecho de que la legibilidad de las señales de tráfico es, en gran medida, una cuestión relacionada con la distancia desde la que se puede identificar dicha señal. Si están adecuadamente diseñados, esta distancia es mayor para los símbolos que para las palabras, ya que los dibujos permiten diferencias mucho mayores en cuanto a las formas y contienen menos detalles que las palabras. $L a$ ventaja de los dibujos nace del hecho de que la discriminación de las letras requiere un tamaño aparente de unos diez o doce minutos de arco y que la detección de las características es el primer paso para la discriminación. Al mismo tiempo, está claro que los signos sólo son mejores cuando (1) contienen pocos detalles, (2) son lo suficientemente distintos en cuanto a forma y (3) no son ambiguos.

\section{Capacidades y límites de decisión}

U na vez que lo percibido se ha identificado e interpretado, este proceso podría requerir una acción o respuesta. En este contexto la discusión se limitará a relaciones deterministas estímulo-respuesta 0 , en otras palabras, a condiciones en las que cada estímulo tiene una respuesta previamente fijada. En este caso, los mayores problemas para el diseño de herramientas y equipos están relacionados con temas de compatibilidad, es decir, hasta qué punto el estímulo identificado y su respuesta ya fijada tienen una relación "natural" o rutinaria. $\mathrm{H}$ ay condiciones en las que la falta de una relación óptima es intencionada, como en las abreviaturas. Generalmente una contracción como abrvtra es mucho peor que un recorte del tipo abrev. Teóricamente, esto se debe a la mayor redundancia que se da en las letras sucesivas de una palabra, lo que permite "rellenar" las últimas letras basándose en las primeras. U na palabra rota se puede aprovechar de este principio, lo que no es posible en las contracciones.

\section{M odelos mentales y compatibilidad}

En la mayoría de los problemas de compatibilidad existen respuestas estereotipadas derivadas de modelos mentales generalizados. La elección de la posición nula en una representación circular puede ser un buen ejemplo: las posiciones de las 12 en punto y las 9 en punto en un reloj se corrigen con mayor rapidez que las de las 3 y las 6 en punto. La razón puede ser que una desviación en el sentido de las agujas del reloj y el movimiento en la parte superior de la representación se experimentan como "aumentos" que requieren una respuesta que reduzca su valor. En los casos de las 3 y las 6 ambos principios entran en conflicto y se manejan de forma menos eficaz. En la forma de abrir y cerrar la puerta trasera de un automóvil puede observarse un estereotipo similar: la mayoría de la gente actúa según el estereotipo de que para cerrar se usa el movimiento en sentido de las agujas del reloj. Si el cierre se ha diseñado al contrario, el resultado suelen ser continuos errores y sentimientos de frustración.

Con respecto a los movimientos de control, el principio de compatibilidad se resume en el principio de Warrick, que describe la relación entre la posición de un mando de control y la dirección del movimiento en una pantalla. Si el mando de control está situado a la derecha de la pantalla, se supone que un movimiento en el sentido de las agujas del reloj hará subir el indicador. 0 tro ejemplo sería desplazarse a través de ventanas de ordenador: según el modelo mental de la mayoría de la gente, la dirección hacia arriba de una representación móvil sugiere que los valores suben de la misma manera que una mayor temperatura en un termómetro se indica por medio de una columna de mercurio con valores de abajo arriba. Existen problemas para aplicar este principio en una escala móvil con un puntero fijo. Cuando la escala de este tipo de indicadores se mueve hacia abajo, esto indica que su valor está aumentando. En este caso, se produce un conflicto con el estereotipo. Si la escala se invierte, los valores bajos quedarían en la parte superior de la escala, lo cual es también contrario a la mayoría de los estereotipos.

EI término proximidad compatibilidad se refiere a la correspondencia entre las representaciones simbólicas y los modelos mentales que la gente tiene de las relaciones funcionales o espaciales dentro de un sistema. Los temas de proximidad-compatibilidad se hacen más complejos cuanto más globales, primitivos o distorsionados sean los modelos mentales. Así pues, el diagrama de flujo de un proceso industrial totalmente automatizado se suele representar mediante un modelo técnico que puede no corresponder en absoluto con el modelo mental del 
proceso. En concreto, cuando el modelo mental de un proceso está incompleto o distorsionado, una representación técnica del progreso ayuda muy poco a desarrollarlo o corregirlo. Un ejemplo común de una mala proximidad-compatibilidad serían los planos de situación de salidas de urgencia en un edificio. Estos planos suelen ser totalmente inadecuados, llenos de detaIles poco significativos, especialmente para personas que sólo tienen una imagen mental global del edificio. La concordancia entre la lectura del mapa y la orientación se acerca más a lo que se ha llamado "conciencia situacional", que es particularmente importante en el espacio tridimensional durante un vuelo aéreo. $\mathrm{H}$ a habido desarrollos recientes en las representaciones tridimensionales de objetos que son un intento de conseguir un grado de proximidad-compatibilidad óptimo.

\section{Compatibilidad estímulo-respuesta}

Un ejemplo de compatibilidad estímulo-respuesta (E-R) sería el caso de la mayoría de los procesadores de texto, en los que se considera que los usuarios conocen la correspondencia entre los comandos y las combinaciones específicas de las teclas. EI problema está en que un comando y su combinación de teclas correspondiente no suelen tener ninguna relación con una situación anterior, lo que significa que la relación estímulo-respuesta entre teclas y orden se ha de adquirir mediante un difícil proceso de aprendizaje. EI resultado es que, incluso una vez adquirida la habilidad, la tarea sigue estando sujeta a ciertos errores. EI modelo interno del programa queda incompleto pues es fácil que se olviden las operaciones menos utilizadas, de manera que el usuario no puede recuperar la respuesta adecuada de su cerebro. EI texto que se ve en la pantalla tampoco se corresponde siempre con lo que se imprime, otro ejemplo de baja proximidad-compatibilidad. Son pocos los programas que utilizan un modelo interno espacial estereotípico en conexión con la relación estímulo-respuesta para el control de los comandos.

Se ha dicho, correctamente, que las relaciones preexistentes entre los estímulos espaciales y las respuestas manuales son mejores. Por ejemplo, la relación entre una respuesta señalizadora y la localización espacial o como la que existe entre los estímulos y las respuestas verbales. Existen un gran número de pruebas de que las representaciones verbales y espaciales son categorías cognitivas relativamente independientes con pocas interferencias, pero también con pocas correspondencias entre sí. Por lo tanto, una tarea espacial, como dar formato a un texto, se lleva a cabo mejor con movimientos espaciales como los del ratón, dejando el teclado para las órdenes verbales.

Esto no significa que el teclado sea ideal para llevar a cabo comandos verbales: la mecanografía sigue consistiendo básicamente en accionar manualmente una serie de ubicaciones espaciales arbitrarias, básicamente incompatibles con el procesamiento de las letras. Realmente, es otro ejemplo de tarea incompatible, que se domina únicamente a través de la práctica intensiva, perdiéndose la habilidad adquirida si no se práctica continuamente. Lo mismo se puede decir de la taquigrafía, que consiste en asociar símbolos escritos arbitrarios a estímulos verbales. Un ejemplo interesante de un método alternativo de teclado es el teclado de cuerda. El usuario maneja dos teclados, uno para la mano izquierda y otro para la derecha, cada uno con seis teclas. Cada letra del alfabeto corresponde a una combinación de teclas. Los resultados de este estudio mostraron un extraordinario ahorro del tiempo necesario para saber mecanografiar. Las limitaciones motoras limitaron la velocidad máxima de esta técnica, pero aún así, una vez finalizado el proceso de aprendizaje, el rendimiento del operario se aproximaba muchísimo al de la técnica convencional.

Un ejemplo clásico de un efecto de compatibilidad espacial se refiere a la disposición tradicional de los controles de los quemadores de una cocina: los quemadores se sitúan en una matriz de $2 \times 2$, mientras que los controles se sitúan en una fila horizontal, lo que provoca que las relaciones entre el quemador y su control se aprendan con dificultad y se olvidan fácilmente. Sin embargo, a pesar de los errores, el problema de encender el fuego, pasado cierto tiempo, se resuelve con facilidad. La situación es peor cuando uno se enfrenta con relaciones control-representación totalmente indefinidas. $\mathrm{H}$ ay muchos ejemplos de malas compatibilidad E-R en la relación control-representación de los aparatos de vídeo, las videocámaras y los televisores. EI resultado es que muchas de las opciones nunca se utilizan o se tienen que estudiar de nuevo cada vez que se desea utilizarlas. E I argumento de que todo está explicado en el manual, aunque sea cierta, no resulta útil ya que en la práctica, la mayoría de los manuales son incomprensibles para el usuario medio, en especial cuando se intenta describir acciones con términos verbales incompatibles.

\section{Compatibilidad estímuloestímulo (E-E) y respuesta-respuesta $(R-R)$}

Inicialmente, se distinguió entre la compatibilidad E-E y R-R y la compatibilidad E-R. Un ejemplo clásico de la compatibilidad E-E sería el intento, a finales del decenio de 1940, de complementar el sonar con señales visuales para lograr una mejor detección de la señal. U na de las soluciones fue incorporar un rayo de luz horizontal con perturbaciones verticales de izquierda a derecha y que no hacía sino reflejar de modo visual la señal potencial y el ruido de fondo. La señal consistía en una perturbación vertical ligeramente mayor. L os experimentos mostraron que la combinación no producía mejores resultados que la señal auditiva por sí sola. Esto se explicó por una baja compatibilidad E-E: la señal auditiva se percibe como un cambio de intensidad, por lo que el apoyo visual correspondiente a este cambio de tono debería ser un cambio de brillo, ya que éste es el cambio visual análogo al cambio de tono auditivo.

Es interesante observar que el grado de compatibilidad E-E se corresponda directamente con la habilidad de los individuos en una prueba de modalidades cruzadas. En este tipo de pruebas, se pide a los sujetos que indiquen la intensidad auditiva que corresponde a cierto brillo o peso. Este enfoque se ha vuelto bastante común en los estudios sobre el ajuste de las dimensiones sensoriales, ya que evita la asociación de estímulos sensoriales a cifras. La compatibilidad R-R se refiere a la correspondencia de movimientos simultáneos o sucesivos. Algunos movimientos se coordinan más fácilmente que otros, lo que nos muestra unas restricciones claras en relación con la forma más eficaz de realizar determinadas acciones, como por ejemplo, accionar sucesivamente varios controles.

L os ejemplos anteriores muestran claramente cómo los temas de compatibilidad intervienen en toda interacción hombre-máquina. EI problema es que los efectos de la baja compatibilidad suelen ser mitigados por una práctica extendida y, de esta manera, se mantienen encubiertos 0 no se tienen en cuenta. A demás, aún cuando las relaciones representación-control se practican con frecuencia y no parecen afectar al rendimiento, sigue existiendo una mayor probabilidad de error. La respuesta compatible errónea es pues un competidor de la respuesta incompatible correcta y es probable que aparezca en alguna ocasión, con el riesgo evidente de accidente. Además, la cantidad de práctica necesaria para dominar relaciones $E-R$ incompatibles es enorme y, básicamente, una pérdida de tiempo.

\section{Límites de la programación y la ejecución motora}

Uno de los límites de la programación motora se trató brevemente al comentar la compatibilidad R-R . El operario humano 
tiene problemas para llevar a cabo secuencias incongruentes de movimientos $y$, en particular, para cambiar de una secuencia incongruente a otra. Los resultados de los estudios sobre coordinación motora son importantes para el diseño de los controles en los que se hayan de usar ambas manos; aunque la práctica puede mejorar mucho este aspecto, como lo atestiguan los sorprendentes niveles en las habilidades acrobáticas.

M uchos principios comunes en el diseño de controles derivan de la programación motora, entre ellos la incorporación de una cierta resistencia a un control y de la retroinformación que indica que el manejo ha sido el adecuado. Una preparación motora adecuada es determinante para el tiempo de reacción. $L$ a reacción a un estímulo repentino e inesperado puede tardar un segundo más, un tiempo considerable cuando se necesita una reacción rápida, como la reacción a las luces de frenado del coche que va delante. Las reacciones no previstas son probablemente la causa principal de las colisiones en cadena. Las señales de aviso son beneficiosas para evitar dichas colisiones. Una aplicación importante de los estudios de ejecución de movimientos es la de la ley de Fitt, que relaciona el movimiento, la distancia y el tamaño del blanco al que se apunta. Esta ley parece ser bastante general, y puede aplicarse a una palanca, un ratón, un joystick, o un lápiz óptico. Entre otras cosas, se ha empleado para calcular el tiempo necesario para hacer correcciones en pantallas de ordenador.

Evidentemente, aún queda mucho por decir además de lo expuesto anteriormente. Por ejemplo, la discusión se ha limitado casi en su totalidad a los temas del flujo de información a nivel de una simple reacción de elección. No se han tratado temas más complejos, ni tampoco los problemas de retroinformación 0 anticipación en el control de información y la actividad motora. M uchos de los temas mencionados tienen una estrecha relación con los problemas de memoria y planificación del comportamiento, que tampoco se han tratado. Si se desea obtener una información más amplia, puede encontrarse, por ejemplo, en Wickens (1992).

\section{DISEÑO PARA TODOS}

\section{- Diseño PARA GRUPOS ESPECIFICOS}

\section{Joke H . G rady-van den Nieuwboer}

Al diseñar un producto o un proceso industrial, se piensa siempre en el trabajador "medio" y "sano". La información sobre las capacidades del ser humano, como la fuerza muscular, la flexibilidad corporal, el alcance del brazo y muchas otras características, se obtiene de los estudios empíricos llevados a cabo durante el reclutamiento militar y refleja datos y medidas válidas para el varón medio de unos veinte años. Pero la población activa está compuesta por personas de ambos sexos y de edades diferentes, por no hablar de la gran variedad de capacidades y tipos físicos, niveles de salud y estado físico, y capacidades funcionales. En el cuadro adjunto se ofrece una clasificación de las distintas clases de limitaciones funcionales según la O rganización M undial de la Salud. Actualmente, el diseño industrial no tiene en cuenta las capacidades (o discapacidades) de la mayoría de los trabajadores y debería tomar como punto de partida para el diseño un porcentaje más amplio de la población. Está claro que la carga apropiada para un joven de 20 años puede llegar a sobrepasar la capacidad de un trabajador de 15 o de 60 años. Compete al diseñador tener en cuenta tales diferencias, no sólo a nivel de eficacia, sino también para prevenir los accidentes y enfermedades laborales.

Los avances tecnológicos han ocasionado que el $60 \%$ de los puestos de trabajo en Europa y N orteamérica sean puestos en los que para realizar un trabajo hay que permanecer sentado. La carga física en el trabajo es, como media, mucho menor que antes, pero todavía quedan muchos puestos de trabajo que exigen esfuerzos físicos no adecuados para la capacidad humana. En algunos países en vías de desarrollo todavía no existen los recursos tecnológicos suficientes para mitigar de forma significativa la carga física que ha de soportar el trabajador. Y en los países tecnológicamente avanzados, aún es habitual que el diseñador tenga que adaptar sus planteamientos a las limitaciones impuestas por el producto o el proceso de producción, reduciendo u omitiendo cualquier concesión a los factores humanos relacionados con la discapacidad o con la prevención de posibles daños causados por la carga de trabajo. Para solucionar dichos problemas, se debe educar a los diseñadores para que presten más atención a estos factores y expresen los resultados de su estudio en un documento de requisitos del producto (PRD). EI PRD contiene el conjunto de requisitos que el diseñador debe cumplir para conseguir tanto un determinado nivel de calidad del producto como la satisfacción de las necesidades de las capacidades humanas en el proceso de producción. Aunque sea poco realista exigir que el producto se ajuste al PRD a todos los niveles debido a la necesidad de compromisos inevitables, el método que más se acerca al planteamiento para conseguir estos objetivos es el diseño ergonómico del sistema (SED), que se comentará a continuación, junto con otros dos enfoques alternativos.

\section{Diseño creativo}

Este planteamiento es característico de artistas y otros profesionales afines, cuyo trabajo implica un alto grado de originalidad. La esencia de este proceso de diseño es que el concepto se resuelve intuitivamente y por medio de la "inspiración", tratando los problemas según surgen, sin previsión o deliberación previa alguna. En ocasiones, el resultado no tendrá mucha semejanza con el concepto original, pero representa lo que el creador considera un producto auténtico. 0 tras veces, no pocas, el diseño es un fracaso. La Figura 29.46 muestra el camino seguido por del diseño creativo.

\section{Diseño de sistemas}

Este tipo de diseño nace de la necesidad de predeterminar las fases del diseño en un orden lógico. Cuando el diseño se va haciendo algo más complejo, es necesario dividirlo en tareas secundarias. Los diseñadores o equipos encargados de estas tareas secundarias son interdependientes, lo que convierte al diseño en un trabajo de equipo más que individual. Los campos de experiencia complementarios están distribuidos entre los componentes del equipo, y el diseño adquiere un carácter interdisciplinario.

El diseño de sistemas se orienta hacia la realización óptima de las complejas y bien definidas funciones del producto utilizando la tecnología más apropiada. Es un proceso costoso, pero los riesgos de fracaso se reducen considerablemente, en comparación con otro tipo de planteamientos menos organizados. La eficacia del diseño se compara con los objetivos formulados en el PRD. 


\section{Clasificación internacional de limitaciones funcionales de las personas}

La OMS (O rganización Mundial de la Salud) presentó en 1980 una clasificación de las limitaciones funcionales de las personas: el ICIDH (International Classification Impairment, Disability and Handicap). En esta clasificación se establecen diferencias entre los términos enfermedad, limitaciones y minusvalía.

Este modelo de referencia se creó para facilitar la comunicación internacional. Se presentó, por una parte, para servir de marco de referencia a quienes dictaminan las políticas de los diferentes países y por otra, para ayudar al diagnostico médico de las personas que padecen las consecuencias de enfermedades.

¿Por qué es necesario un marco de referencia? Este marco de referencia nace para mejorar la participación e integración de las personas con limitaciones prolongadas. Se mencionan dos objetivos principales:

- la perspectiva de la rehabilitación, es decir, la integración de las personas en la sociedad, ya sea en el trabajo, la escuela, las tareas del hogar, etc.

- la prevención de las enfermedades y sus posibles consecuencias; por ejemplo, discapacidad o minusvalía.

Desde el 1 de enero de 1994, esta clasificación es oficial. Las actividades posteriores a esta política son de naturaleza muy diversa: medidas informativas y educativas para grupos específicos, normativas para la protección de los trabajadores o exigencias de cuotas de empleo en las empresas, por ejemplo, al menos un $5 \%$ de trabajadores con discapacidades. La política en sí misma lleva, a largo plazo, hacia la integración y la no discriminación.

\section{Enfermedad}

Las enfermedades afectan a todas las personas. En ocasiones se pueden prevenir y en otras no. Algunas se pueden curar y otras no. Siempre que exista un medio, las enfermedades deben prevenirse y, si es posible, curarse.

\section{Limitaciones}

Una limitación es cualquier falta 0 alteración de alguna de las estructuras o funciones fisiológicas, psicológicas o a natómicas.

La forma en que se formulan las especificaciones en el PRD es muy importante. La Figura 29.47 muestra la relación entre el PRD y otras fases del proceso de diseño de sistemas.

Como muestra este esquema, no se tiene en cuenta la información que pueda proporcionar el usuario. U nicamente al final del proceso de diseño se permite que el usuario haga una crítica. Esto es totalmente inútil, tanto para el productor como para el usuario, ya que hay que esperar hasta el próximo ciclo de diseño (si alguna vez se produce), para corregir los errores a través de las modificaciones necesarias. Además, la información del usuario no suele estar sistematizada ni incluida en un nuevo PRD.

\section{Diseño ergonómico de sistemas (DES)}

EI DES es una versión del diseño de sistemas, adaptada para garantizar que se tenga en cuenta el factor humano en el proceso de diseño. La Figura 29.48 muestra el flujo de la información que aporta el usuario al PRD.

En el diseño ergonómico de sistemas, se considera al ser humano como parte del propio sistema: Ios cambios en las especificaciones del diseño se realizan considerando las capacidades cognitivas, físicas y mentales del trabajador, y el método se
El haber nacido con tres dedos en lugar de cinco no tiene por qué producir una discapacidad. Las capacidades de la persona y del grado de manipulación que alcance con esos tres dedos determinarán si existe 0 no una discapacidad. Sin embargo, cuando una persona no puede procesar adecuadamente las señales a nivel central en el cerebro, la limitación se convertirá en una discapacidad, ya que en la actualidad no existen métodos que permitan "curar" (solucionar) este problema.

\section{Discapacidad}

El concepto de discapacidad describe el nivel funcional de una persona que tiene dificultades en la realización de tareas. por ejemplo, dificultades para levantarse de la silla. Estas dificultades están relacionadas con la limitación, pero también con las circunstancias en las que alguien tiene que realizar una tarea. Alguien que necesite una silla de ruedas y viva en un país llano como Holanda tiene más posibilidades de desplazarse por sí mismo que alguien que viva en una zona montañosa como el Tíbet.

\section{Minusvalías}

Cuando los problemas se clasifican como minusvalías, se puede determinar los campos a los que afectan: por ejemplo, la inmovilidad o la dependencia física. Las minusvalías interfieren con la realización del trabajo, por ejemplo, la persona puede no ser capaz de desplazarse al lugar de trabajo o bien, una vez en el trabajo, puede necesitar ayuda para su higiene personal, etc.

Una minusvalía muestra las consecuencias negativas de la discapacidad y sólo se puede eliminar eliminando dichas consecuencias.

\section{Resumen y conclusiones}

La clasificación anterior y las políticas que conlleva ofrecen un marco de referencia internacional bien definido para el trabajo. En cualquier discusión sobre el diseño para grupos específicos, se necesitará este marco para definir las actividades y aplicar las ideas a través del diseño.

convierte un enfoque de diseño válido para cualquier sistema técnico en el que participen operarios humanos.

Por ejemplo, para examinar las implicaciones de las capacidades físicas del trabajador, la asignación de tareas en el diseño del proceso requerirá una selección cuidadosa de las tareas que van a realizar el trabajador y las máquinas, determinando qué tarea es más adecuada para que la realice el ser humano o la máquina. Evidentemente, el ser humano será siempre más eficaz a la hora de interpretar información incompleta; las máquinas, sin embargo, calculan más rápidamente cuando tienen todos los datos. Así, una máquina será la solución ideal para levantar grandes pesos; etc. Además, ya que se puede comprobar la interacción hombre-máquina en la fase de prototipo, se pueden eliminar errores de diseño que, de otra manera, se manifestarían en la fase de funcionamiento técnico.

\section{Métodos en la investigación del usuario}

No existe "el método ideal" ni una fórmula o directriz perfecta para realizar un diseño específico para trabajadores con discapacidades. Es una cuestión de sentido común, de búsqueda exhaustiva de todos los conocimientos relacionados con el problema y de aplicar todo esto para obtener los mejores resultados. 
Figura 29.46 - Diseño creativo.

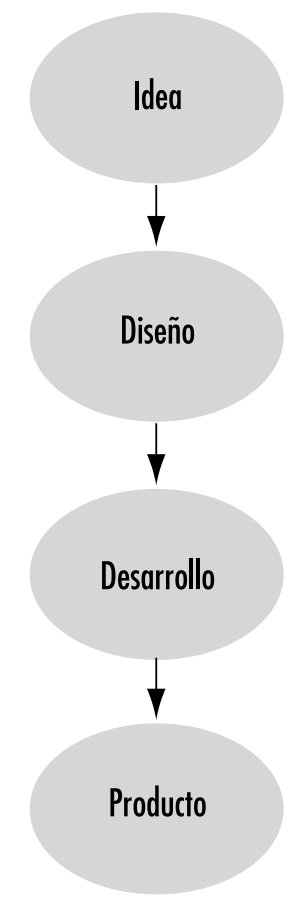

La información puede obtenerse de fuentes tales como:

- Los resultados de estudios publicados.

- La observación directa de la persona con una discapacidad en su puesto de trabajo y la descripción de sus dificultades concretas. Dicha observación se debe hacer en un momento en el que el trabajador acuse la fatiga, por ejemplo, al final del turno laboral. La razón es que cualquier solución en el diseño se debe adaptar a la fase más ardua del proceso de trabajo 0 a las fases que no hayan podido realizarse adecuadamente (o en absoluto) porque sobrepasen la capacidad física del trabajador.

- E ntrevistas. $\mathrm{H}$ ay que recordar que, dependiendo del diseño de la entrevista, la información obtenida puede ser demasiado subjetiva. Es preferible combinar la entrevista con la observación. L as personas con discapacidades muchas veces son renuentes a comentar sus dificultades, pero cuando se dan cuenta de que el investigador desea actuar en su beneficio, esta desconfianza disminuye. Con dicha técnica, a pesar de que lleva mucho tiempo, se obtienen muy buenos resultados.

- Cuestionarios. Una de las ventajas de los cuestionarios es que pueden aplicarse a grupos numerosos y al mismo tiempo, se puede obtener una información tan específica como se quiera. Sin embargo, se debe diseñar el cuestionario de manera que se obtenga una información realmente representativa del grupo al que se va a aplicar. Esto significa que el tipo de información que se desee obtener debe basarse en las entrevistas y en la observación de una muestra razonablemente pequeña de trabajadores y especialistas. En el caso de las personas con discapacidades, parece sensato incluir en dicha muestra a médicos y fisioterapeutas cuyas competencias incluyen la prescripción de ayudas especiales para las personas con discapacidades y que hayan examinado las capacidades físicas de dichos trabajadores.

- M ediciones físicas. Las mediciones realizadas con instrumentos del campo de la bio-instrumentación (por ejemplo, el nivel de actividad de los músculos o la cantidad de oxígeno que se consume en una tarea específica) 0 con métodos antropométricos (por ejemplo, las dimensiones lineales de los componentes del cuerpo, la movilidad de las extremidades, la fuerza muscular) son indispensables para todo proyecto de diseño orientado hacia el uso humano.

Los métodos descritos anteriormente son algunos de los más usuales para obtener datos relacionados con los seres humanos. También existen métodos para evaluar los sistemas hombre-máquina. U no de ellos, la simulación, consiste en construir copias físicas muy realistas. EI desarrollo de una representación, más o menos simbólica, de un sistema, es un ejemplo de un modelo. Ambos recursos son, por supuesto, útiles y necesarios cuando el sistema o producto del que se trata no exista o no se pueda utilizar para la realización de pruebas y experimentos. La simulación se utiliza muy a menudo en cursos de formación y para confeccionar modelos de investigación. Un montaje es una copia tridimensional a escala natural de un lugar de trabajo, compuesto a veces de materiales improvisados, que resulta de gran utilidad para probar las posibilidades del diseño con el propio trabajador discapacitado: de hecho, la mayoría de los problemas de diseño se pueden identificar con la ayuda de este tipo de modelos. O tra ventaja de esta solución es que aumenta la motivación del trabajador, al hacerle participar en el diseño de su futuro puesto de trabajo.

\section{Análisis de tareas}

En el análisis de tareas se someten a observación analítica diferentes aspectos de un trabajo concreto. Entre los aspectos estudiados están la postura de trabajo, la definición de los movimientos efectuados, la interacción con otros trabajadores, el

Figura 29.47 • Diseño de sistemas.

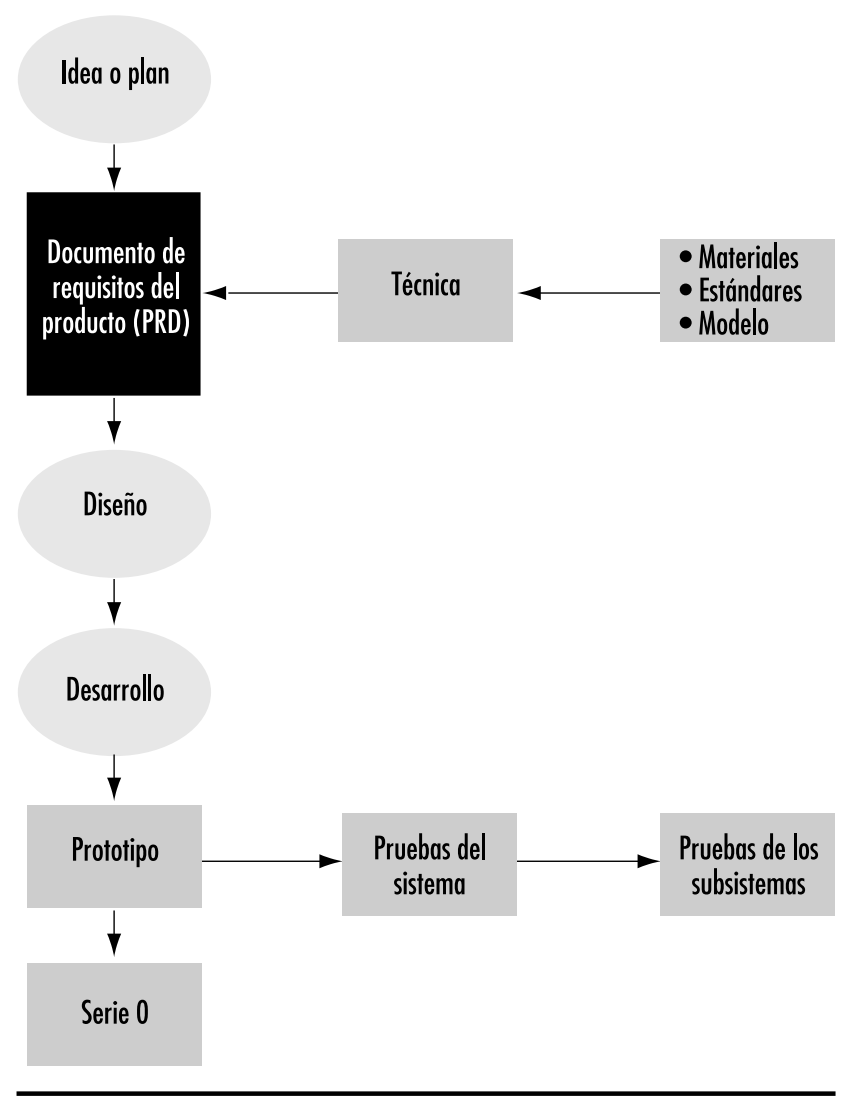


Figura 29.48 • Diseño ergonómico de sistemas.

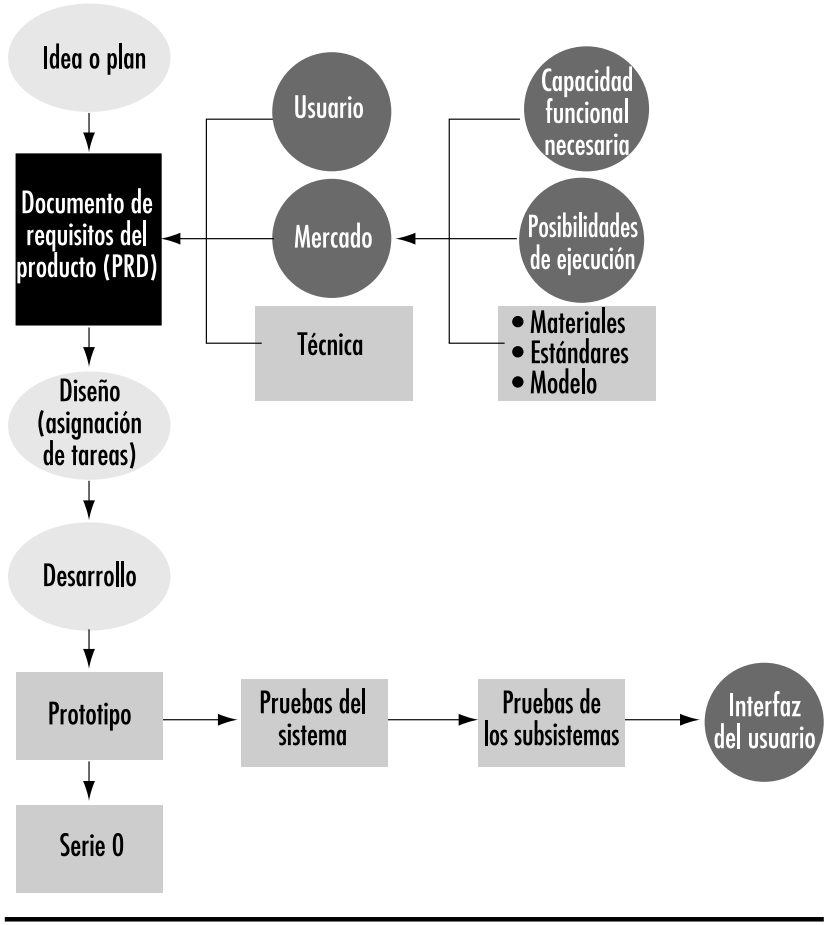

manejo de herramientas y máquinas, el orden lógico de las tareas secundarias, la eficacia de las operaciones, las condiciones estáticas (si el trabajador tiene que realizar tareas en la misma postura durante largos períodos de tiempo, o con gran frecuencia), las condiciones dinámicas (las diferentes condiciones físicas requeridas de los trabajadores), las condiciones materiales del entorno (como el frío en un matadero) o las condiciones inmateriales (como el estrés provocado por el entorno laboral o la propia organización del trabajo).

El trabajo de diseño para las personas con discapacidades tiene que basarse en extensas tareas de análisis, así como en un examen completo de las capacidades funcionales de dichas personas. La solución del diseño básico es un punto crucial: es más eficaz elaborar todas las posibles soluciones del problema que se tiene entre manos, sin ningún prejuicio, que producir un único concepto de diseño o un número limitado de conceptos. U sando la terminología propia del diseño, esta solución se denomina perspectiva general morfológica. Dada la multiplicidad de conceptos originales de diseño, se puede proceder a un análisis de los pros y los contras de cada posibilidad con relación al material utilizado, al método de construcción, a las características de la producción técnica, a la facilidad de manejo, etc. No sería la primera vez que más de una solución reúne todos los requisitos en la fase de prototipo, y hay que tomar la decisión final en una fase relativamente avanzada del proyecto.

Aunque parezca una forma muy laboriosa y lenta de realizar proyectos de diseño, en realidad el tiempo adicional invertido se compensa con los pocos problemas que se plantean en la etapa de desarrollo; por no hablar de que el resultado, ya sea un producto 0 un puesto de trabajo, guardará un equilibrio entre las necesidades del trabajador con discapacidades y las exigencias de su entorno laboral. Lamentablemente, esta última ventaja no suele afectar de ninguna manera al diseñador, ni siquiera en forma de retroinformación facilitada por el usuario final.

\section{Documento de requisitos del producto (PRD) y discapacidad}

Una vez se ha reunido y organizado toda la información relacionada con un producto, se debería elaborar una descripción, no sólo del producto, sino también de lo que se va a exigir de él, independientemente de la fuente o naturaleza de dichas exigencias. Tales exigencias pueden tener diferentes características. EI PRD deberá incluir las exigencias relacionadas con los datos del usuario u operador (medidas físicas, movilidad, fuerza muscular), datos técnicos (materiales, construcción, técnicas de producción, regulaciones de seguridad, etc.), e incluso conclusiones extraídas de estudios de posibilidad de realización.

EI PRD es el marco de referencia para el diseño, por lo que algunos diseñadores lo consideran una restricción no deseada de su creatividad, más que una motivación. A la vista de las dificultades que a veces implica la ejecución del PRD, hay que tener en mente que un fallo de diseño puede ser causa de problemas para la persona con discapacidades, que puede llegar a desistir de todo esfuerzo por conseguir el éxito en el mundo laboral o volverse una víctima del curso de su condición de discapacitado, aparte de los costes adicionales de tener que rediseñar el producto. Con este fin se crean los equipos de diseño multidisciplinarios, de manera que el diseñador no esté sólo en el trabajo de diseño para las personas con discapacidades, sino que cuente con el apoyo de otras disciplinas que le proporcionen la información médica y funcional necesaria para crear un PRD completo e integrarlo como marco de referencia del diseño.

\section{Pruebas de los prototipos}

Cuando se construye un prototipo, es necesario probarlo para detectar posibles errores. Tales comprobaciones deben realizarse

\section{Figura 29.49 - Modelo de utilidad de la tecnología de rehabilitación (MUTR) en combinación con el enfoque de diseño ergonómico de sistemas.}

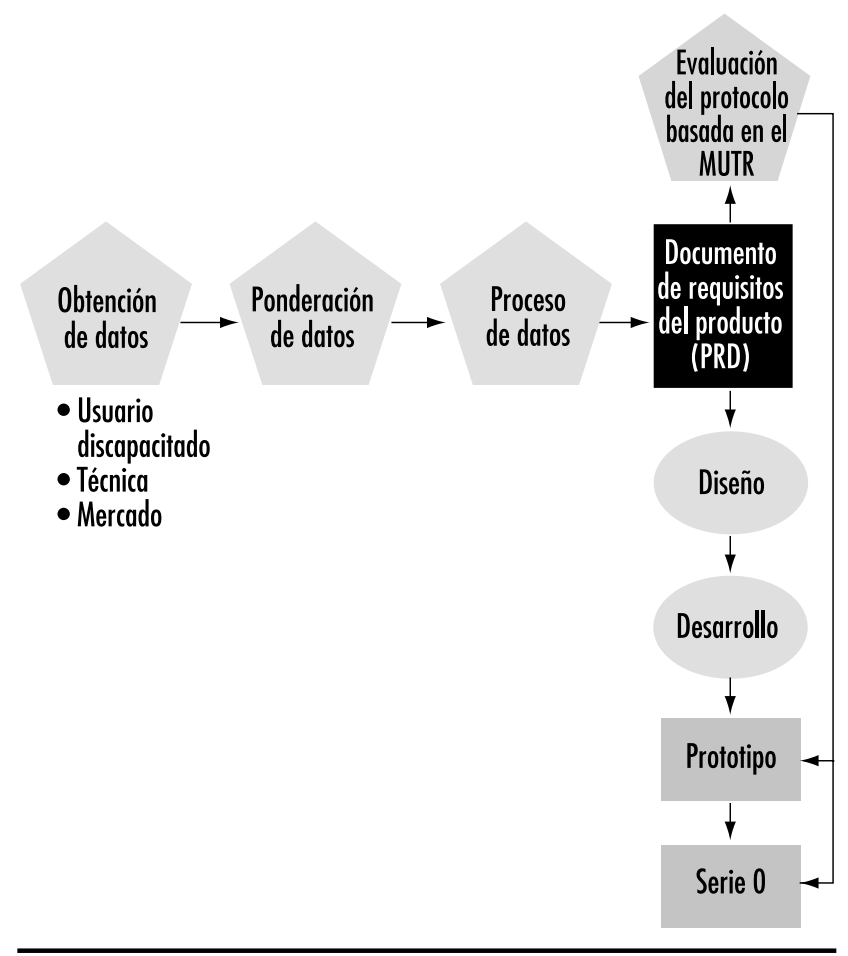


tanto desde el punto de vista de los sistemas y subsistemas técnicos, como desde el punto de vista de su utilidad en combinación con el usuario. Cuando el usuario es una persona con una discapacidad, habrá que tomar mayores precauciones. Cualquier error al que un trabajador sin discapacidad alguna puede responder con seguridad, podría dejar al trabajador con una discapacidad en una situación de riesgo, en la que quizá no podría evitar un accidente.

Las comprobaciones de los prototipos se deben realizar con un número reducido de trabajadores con una discapacidad (excepto si se trata de un único diseño), de acuerdo con un protocolo que se ajuste al PRD. Sólo por medio de estas pruebas empíricas se puede juzgar el grado de adecuación del diseño a las exigencias del PRD.

Aunque no siempre es posible generalizar los resultados obtenidos en grupos reducidos, éstos proporcionan información valiosa que el diseñador puede utilizar en la fase final del diseño 0 en futuros trabajos.

\section{Evaluación}

La evaluación de un sistema técnico (una situación de trabajo, máquina 0 herramienta) debe hacerse respecto a su PRD, no preguntando al usuario o comparándolo con diseños alternativos basados en su rendimiento físico. Por ejemplo, el diseñador de un refuerzo para la rodilla que base su diseño en investigaciones que demuestren que la inestabilidad en las rodillas se debe a una reacción tardía de los ligamentos posteriores, creará un producto que compense dicho retraso.

0 tro refuerzo, sin embargo, puede tener una finalidad distinta. Los métodos de evaluación actuales no muestran ninguna preocupación sobre cuándo, a qué pacientes y en qué condiciones hay que prescribir ayudas técnicas para el tratamiento de las discapacidades; precisamente el tipo de información que más necesitan los profesionales sanitarios.

Las investigaciones actuales tienden a obtener este tipo de información. Un modelo utilizado con el fin de descubrir los factores que determinan si es necesario usar estas ayudas, si un puesto de trabajo está bien diseñado o equipado para un trabajador con discapacidades, es el modelo de utilidad de la tecnología de rehabilitación (MUTR). EI modelo MUTR ofrece un marco de referencia para la evaluación de productos, maquinas o herramientas ya existentes, pero también se puede usar en combinación con un proceso de diseño como muestra la Figura 29.49.

La evaluación de los productos ya existentes demuestra que, por lo que respecta a las ayudas técnicas y puestos de trabajo, la calidad de loS PRD es bastante pobre. A veces no se registran adecuadamente los requisitos del producto; otras no se desarrollan lo suficiente como para que tengan alguna utilidad.

Los diseñadores deben aprender a documentar los requisitos de sus productos, incluidos los que se refieren a los usuarios con discapacidades. Nótese que, como muestra la Figura 29.49, la combinación del MUTR con el DES proporciona un marco de referencia que incluye los requisitos para los usuarios con discapacidades.

Los organismos responsables de la prescripción de dichos productos deben exigir a los fabricantes que evalúen sus productos antes de lanzarlos al mercado, una misión imposible ante la ausencia de verdaderos PR D.

La Figura 29.49 también muestra cómo garantizar que el resultado sea evaluado adecuadamente (según su PRD) con la ayuda del posible usuario a quien vaya dirigido. Depende de los organismos nacionales de salud el motivar a los diseñadores para que dirijan sus esfuerzos hacia este tipo de diseño y establecer las normativas apropiadas.

\section{DIFERENCIAS CULTURALES}

\section{H oushang Shahnavaz}

La cultura y la tecnología son interdependientes. La cultura es un aspecto importante del diseño, del desarrollo y de la utilización de la tecnología. Sin embargo, la relación entre cultura y tecnología es extremadamente compleja. Es necesario analizarla desde diversas perspectivas para poder tenerla en cuenta durante el diseño y la aplicación de la tecnología. K ingsley (1983), basándose en el trabajo realizado en Zambia, divide la adaptación tecnológica en cambios y ajustes a tres niveles: el del individuo, el de la organización social y el del sistema de valores culturales de la sociedad. Cada nivel tiene una fuerte dimensión cultural que requiere una consideración especial en el campo del diseño.

Al mismo tiempo, la tecnología misma forma parte inseparable de la cultura. Se configura, total o parcialmente, alrededor de los valores culturales de una sociedad concreta. Y como parte de esta cultura, la tecnología se convierte en una expresión del modo de vida y de pensamiento de dicha sociedad. Así, para que esa sociedad acepte, utilice y reconozca una tecnología como propia, ésta deberá ser congruente con la imagen general de la cultura de esa sociedad. La tecnología debe ser un complemento de la cultura, no un antagonista.

En este artículo se expondrán algunas de las complejidades relacionadas con el aspecto cultural de los diseños tecnológicos y se analizarán los diferentes problemas que se plantean en la actualidad, así como los conceptos y principios dominantes y cómo se pueden aplicar.

\section{Definición de cultura}

La definición del término cultura ha sido debatida reiteradamente por sociólogos y antropólogos durante décadas. La cultura se puede definir en muchos términos. K roeber y K luckhohn (1952) analizaron en su libro más de cien definiciones de cultura. Williams (1976) señala que el término cultura es una de las palabras más complicadas del idioma inglés. La cultura se ha definido, incluso, como el modo de vida de un pueblo. Como tal, incluye su tecnología y sus artefactos materiales: cualquier cosa que deba saberse para llegar a convertirse en un miembro funcional de la sociedad (G eertz 1973). Incluso se puede describir como "las formas simbólicas disponibles a nivel público a través de las cuales la sociedad puede experimentar y expresar significados", (K eesing, 1974) En resumen, Elzinga y Jamison (1981) lo expresaron claramente cuando dijeron que "la palabra cultura tiene significados diferentes en cada disciplina intelectual y en cada sistema de pensamiento".

\section{Tecnología: parte y producto de la cultura}

La tecnología se puede considerar tanto parte como producto de la propia cultura. Hace más de 60 años, el conocido sociólogo $M$ alinowsky ya incluía a la tecnología como parte de la cultura en la siguiente definición: "La cultura comprende artefactos, bienes, procesos técnicos, hábitos y valores, todos ellos heredados". Posteriormente, Leach (1965) consideró la tecnología como un producto cultural y "los artefactos, bienes y procesos técnicos" como "productos de la cultura".

En el ámbito tecnológico, el término "cultura" como elemento importante en el diseño, desarrollo y utilización de productos técnicos o sistemas, ha sido ignorado tanto por los proveedores como por los destinatarios de la tecnología. U na de las razones principales de tal actitud es la falta de información básica sobre las diferencias culturales.

En el pasado, los cambios tecnológicos han supuesto cambios significativos en las formas de vida, la organización social y los 
sistemas de valores de la población. El proceso de industrialización ha provocado cambios profundos y permanentes en los estilos de vida tradicionales de muchas sociedades anteriormente agrícolas, ya que dichos estilos de vida se consideraban incompatibles con la forma de organización del trabajo industrial. En situaciones de gran diversidad cultural, esto ha tenido consecuencias socioeconómicas negativas (Shahnavaz, 1991). Es un hecho reconocido que no se puede imponer una tecnología a una sociedad y creer que será asimilada y utilizada con tan sólo con un esfuerzo de formación (M artin y cols. 1991). Es responsabilidad del diseñador de la tecnología tener en cuenta los efectos directos e indirectos de la cultura y hacer que el producto sea compatible con el sistema cultural de valores del usuario y con el entorno en el que se pretende aplicar.

El impacto de la tecnología en muchos "países en vías de desarrollo industrial" (PVDI) ha sido algo más que una mejoría en la eficacia. La industrialización no supuso sólo la modernización de la producción y del sector servicios, sino, hasta cierto punto, una occidentalización de la sociedad. La transferencia de tecnología implica también una transferencia cultural.

La cultura, además de religión, la tradición y el idioma, que son parámetros importantes para el diseño y utilización de la tecnología, abarca otros aspectos, como las actitudes específicas hacia ciertos productos y tareas, normas de conducta, normas de etiqueta, tabúes, hábitos y costumbres. Para conseguir un diseño óptimo deben tenerse en cuenta todos estos aspectos.

Se dice incluso que las personas son un producto de las diferentes culturas. Sin embargo, todas las culturas de este mundo están entremezcladas debido fundamentalmente a las migraciones humanas a lo largo de la historia. No es de extrañar, por tanto, que en el mundo existan más culturas que naciones. Sin embargo, se pueden hacer algunas distinciones generales en cuanto a las diferencias sociales, profesionales y de organización debidas a la cultura, que podrían influir el diseño en general.

\section{Influencias restrictivas de la cultura}

Existe muy poca información sobre el análisis tanto teórico como empírico de las influencias restrictivas de la cultura sobre la tecnología y sobre cómo incorporar este tema en el diseño tecnológico tanto de las aplicaciones como de los equipos. Aunque se haya reconocido la influencia de la cultura en la tecnología (Shahnavaz 1991; Abeysekera, Shahnavaz y Chapman 1990; Alvares 1980; Baranson 1969), hay muy poca información disponible sobre el análisis teórico de las diferencias culturales con relación al diseño y la utilización de la tecnología. Hay aún menos estudios empíricos que cuantifiquen la importancia de las variaciones culturales y proporcionen recomendaciones sobre cómo tener en cuenta tales factores en el diseño de productos 0 sistemas (K edia y Bhagat, 1988). Sin embargo, cultura y tecnología se pueden analizar con cierto grado de claridad cuando se observan desde diferentes puntos de vista sociológicos.

\section{Cultura y tecnología: compatibilidad y preferencias}

La aplicación adecuada de la tecnología depende en gran medida de la compatibilidad de la cultura del usuario con las especificaciones del diseño. La compatibilidad se debe dar en todos los niveles de la cultura sociales, organizativos y profesionales. Por otro lado, la cultura puede tener una gran influencia en las preferencias o aptitudes de la gente a la hora de hacer uso de la tecnología. Esto se refiere a las preferencias por un determinado producto o sistema; a los conceptos de productividad y eficacia relativa; a la actitud hacia el cambio, a los logros y autoridad, así como con a la forma de utilizar la tecnología. Así pues, los valores culturales pueden afectar la capacidad y voluntad de las personas a la hora de seleccionar, usar y controlar la tecnología: ésta tiene que ser compatible para que los usuarios la elijan.

\section{Cultura social}

La cultura nacional o social, que contribuye a la formación de un modelo mental colectivo de la sociedad, influye sobre todo el proceso de aplicación y diseño de la tecnología, proceso que va desde la planificación y establecimiento de objetivos, hasta la definición de las especificaciones de diseño, sistemas de producción, gestión y mantenimiento, así como de formación y evaluación. El diseño de la tecnología, tanto de equipos como de aplicaciones, debería reflejar las variaciones socioculturales para obtener el máximo beneficio. Sin embargo, definir tales factores para su consideración en el diseño de tecnología es una tarea muy complicada. Hofstede (1980) ha propuesto cuatro estructuras dimensionales de culturas nacionales.

1. Oposición a la incertidumbre fuerte 0 débil. Esto está relacionado con el deseo de la gente de evitar situaciones ambiguas y hasta qué punto ha desarrollado la sociedad medios oficiales (en forma de normas y reglamentos) con este fin. Hofstede (1980) dio, por ejemplo, una alta puntuación a países como Japón y Grecia, y una baja puntuación a países como H ong K ong y Escandinavia.

2. Individualismo frente a colectivismo. Se refiere a la relación entre individuos y organizaciones en la sociedad. En las sociedades individualistas, lo que se espera de cada persona es que cuide de sus propios intereses. En cambio, en una cultura colectivista los vínculos sociales son muy fuertes. Algunos ejemplos de países individualistas son Estados U nidos y G ran Bretaña, mientras Colombia y Venezuela pueden ser consideradas culturas colectivistas.

3. Separación de poderes grande o pequeña. U na gran "separación de poderes" entre clases es característica de aquellas culturas donde las personas menos poderosas aceptan la distribución desigual del poder, de las jerarquías sociales y de su organización. Ejemplos de tal situación serían la India y Filipinas. U na pequeña separación de poderes es típica de países como Suecia o Austria.

4. M asculinas frente a femeninas. Las culturas que dan más importancia a los logros materiales se considera que pertenecen al primer grupo. Aquellas que dan más valor a la calidad de vida y otros logros menos tangibles pertenecen al segundo.

Glenn y Glenn (1981) han distinguido también entre tendencias "abstractas" y "de asociación" en una cultura nacional concreta. Argumentan que cuando personas pertenecientes a una cultura de asociación (como la oriental) tienen que resolver un problema cognitivo, dan mayor importancia al contexto, hacen un razonamiento global e intentan asociar varios hechos. En las sociedades occidentales predomina una cultura más abstracta y un pensamiento más racional. Basándose en estas dimensiones culturales, K edia y Bhagat (1988) han desarrollado un modelo conceptual para entender las limitaciones culturales en la transferencia de tecnología. Estos autores han formulado varias "propuestas" descriptivas que proporcionan información sobre las variaciones culturales entre diferentes países y su receptividad a la tecnología. La mayoría de las culturas se inclinan moderadamente hacia una u otra de estas categorías, pero tienen algunas características comunes.

El punto de vista tanto de los consumidores como el de los productores sobre el diseño y la utilización de la tecnología está muy influido por la cultura social. Las normas de seguridad de los productos para la protección de los consumidores y productores, así como para el cumplimiento de las normativas laborales, sistemas de inspección y aplicación son, en gran medida, el reflejo de la cultura social y del sistema de valores. 


\section{Cultura organizativa}

La organización de una empresa, su estructura, su sistema de valores, función y comportamiento son productos culturales de la sociedad en la que lleva a cabo sus actividades. Esto significa que lo que ocurre dentro de una empresa es fundamentalmente un reflejo directo de lo que ocurre en la sociedad en la que se encuentra (H ofstede 1983). La organización imperante en muchas empresas que llevan a cabo sus actividades en países en vías de desarrollo está influenciada tanto por las características del país productor de la tecnología como las del país receptor. Las organizaciones interpretan la sociedad en términos de su propia cultura, y hasta su grado de control depende, entre otras cosas, de los modelos de trasferencia tecnológica.

Dada la naturaleza cambiante de la organización actual y de la diversidad cultural de la población trabajadora, es más importante que nunca adoptar un programa organizativo adecuado para obtener unos resultados satisfactorios. Solomon (1989) describe un ejemplo de un programa para gestionar la diversidad cultural de una plantilla.

\section{Cultura profesional}

Los trabajadores que pertenecen a ciertas categorías profesionales pueden utilizar la tecnología de una manera específica. En un proyecto cuyo objetivo era desarrollar herramientas manuales, Wikström y cols. (1991) observaron que, contrariamente a lo que suponían los diseñadores en cuanto a la forma de utilizar y agarrar las cizallas (es decir, moviéndolas en sentido contrario a nuestro cuerpo), los profesionales las sostenían y manejaban en sentido contrario, como se muestra en la Figura 29.50. La conclusión fue que se debían hacer estudios de campo sobre las herramientas en los que participasen los usuarios reales para así obtener datos más importante sobre las características de las herramientas que se desea diseñar.

\section{Aplicación de las características culturales para un diseño óptimo}

De lo mencionado anteriormente se deduce que la cultura proporciona identidad y confianza y ayuda a formar una opinión sobre los objetivos y características de un "sistema humano-tecnológico y sobre la forma en que debería funcionar en un entorno concreto. En cualquier cultura existen características valiosas para el avance tecnológico. Si se consideran estas características en el diseño de los equipos y las aplicaciones, pueden servir de fuerza directriz para que la sociedad acepte la tecnología.

Un buen ejemplo serían las culturas de algunos países del sudeste asiático, muy influenciadas por el confucionismo y el budismo. La primera religión da mucha importancia, entre otras cosas, al aprendizaje y la lealtad, y considera como una virtud el adquirir nuevos conceptos.

El budismo nos muestra la importancia que tiene la armonía y el respeto por los seres humanos. Se dice que estas características culturales únicas han contribuido a crear el entorno adecuado para la introducción y aplicación de los equipos más avanzados y la tecnología organizativa que han aportado los japoneses (M atthews 1982).

Una estrategia bien pensada permitirá utilizar de la mejor manera las características de la cultura de una sociedad para promover los principios e ideas de la ergonomía. De acuerdo con M cW hinney: (1990) "Los hechos, para que se comprendan y usen con eficacia, deben estar integrados en historias. Es necesario recorrer diferentes caminos para liberar esa energía productiva, para liberar a la sociedad u organización de sus
Figura 29.50 - Uso de las tijeras para chapa por hojalateros profesionales (agarre inverso de la herramienta).

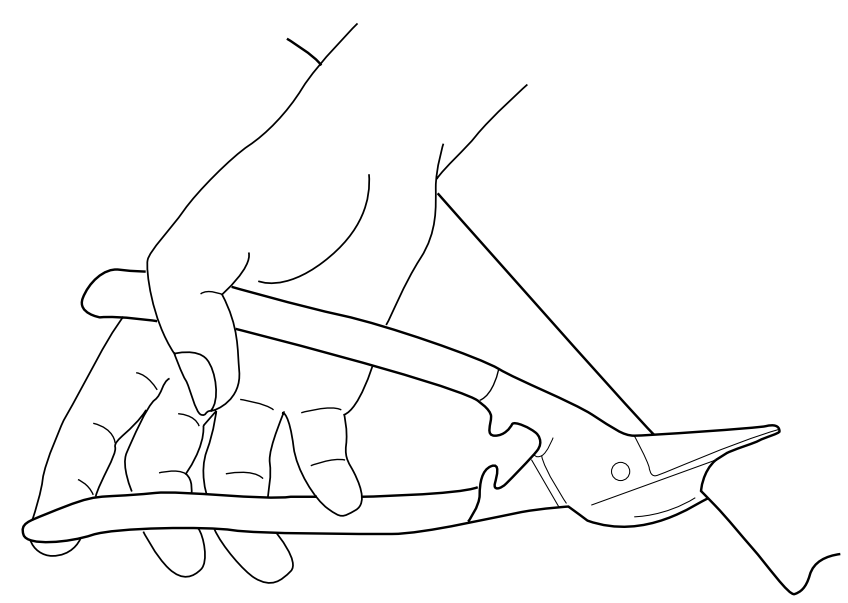

rasgos inhibitorios, para encontrar los caminos por los que fluya de forma natural. Ningún plan ni cambio puede ser eficaz sin incluirlo, conscientemente, en un proceso narrativo".

U n buen ejemplo del valor de la cultura en la estrategia de diseño es la mejora de la técnica de las "siete herramientas" para el control de calidad en Japón. Las "siete herramientas" son las armas que, como mínimo, tiene que llevar un samurai cuando sale a luchar. Los pioneros de los "grupos de control de calidad", cuando adaptaron sus nueve recomendaciones al entorno japonés, redujeron este número para aprovechar las ventajas de un término tan familiar, "las siete herramientas", para estimular la participación de todos los trabajadores en la estrategia de control de calidad (Lillrank y K ano 1989).

Sin embargo, otras características culturales pueden no ser tan beneficiosas para el desarrollo tecnológico. La discriminación femenina, la observación estricta del sistema de castas, los prejuicios racistas o de otro tipo, el considerar algunas tareas como denigrantes, son ejemplos de influencia negativa en el desarrollo de la tecnología.

En algunas culturas tradicionales, es el hombre el que debe aportar la mayor parte de los ingresos para el mantenimiento familiar. Estos hombres consideran el papel de las mujeres como trabajadoras al mismo nivel, y no digamos como supervisoras, con una clara falta de sensibilidad e incluso hostilidad. N egar la igualdad de derechos laborales de las mujeres y cuestionar la legitimidad de su autoridad laboral no parece muy apropiado para las necesidades actuales de organización, en las que se requiere la óptima utilización de los recursos humanos.

En relación al diseño de tareas y al contenido de trabajo, algunas culturas consideran denigrante el trabajo manual y de servicios. Esta situación se puede atribuir a experiencias pasadas relacionadas con el colonialismo, que recuerdan la relación amo-esclavo. En otras culturas existen fuertes prejuicios hacia tareas u ocupaciones relacionadas con "las manos sucias". Estas actitudes se reflejan en salarios más bajos que la media, lo que ha contribuido a la escasez de técnicos y trabajadores de mantenimiento (Sinaiko 1975).

D ado que son necesarias varias generaciones para cambiar los valores culturales con respecto a las nuevas tecnologías, lo más eficaz y menos costoso sería adaptar la tecnología a la cultura 
receptora de dicha tecnología, teniendo en cuenta las diferencias culturales en el diseño de equipos y aplicaciones.

\section{Consideraciones culturales en el diseño de productos y sistemas}

Es obvio que la tecnología está compuesta tanto por el hardware como por el software. Los componentes del hardware incluyen los bienes de capital y medios de producción, tales como productos industriales, equipos, edificios, lugares de trabajo y diseños físicos, la mayoría de los cuales se incluyen en el campo de la microergonomía. El software está compuesto por la programación y la planificación, las técnicas de gestión y organización, la administración, mantenimiento, formación y educación, la documentación y los servicios. De todos estos conceptos se ocupa la macroergonomía.

A continuación se muestran algunos ejemplos de influencias culturales que requieren una consideración especial a la hora del diseño desde el punto de vista de la micro y macroergonomía.

\section{Aspectos microergonómicos}

La microergonomía se ocupa del diseño de productos y sistemas con el objetivo de crear una interacción hombre-máquinaentorno que sea "útil". El concepto principal del diseño de un producto es su utilidad. Este concepto no sólo tiene en cuenta su fiabilidad y utilidad, sino también aspectos como la seguridad, la comodidad y el gusto.

El modelo interno del usuario (su modelo mental o cognitivo) tiene un papel importante en el diseño de la utilidad del producto. Para manejar o controlar un sistema de forma segura y eficaz, el usuario debe tener un modelo mental seguro y representativo del sistema en uso. Wisner (1983) asegura que: "La industrialización exigirá, en mayor o menor grado, un nuevo modelo mental". Es por esta razón por lo que la enseñanza oficial y la formación profesional, las experiencias y la cultura, se convierten en factores muy importantes a la hora de determinar la formación de un modelo cognitivo adecuado.

M eshkati (1989), al estudiar los factores micro y macroergonómicos del accidente de 1984 en U nion Carbide Bhopal, subrayó la importancia de la cultura de los operadores indios en el modelo mental inadecuado que tenían del funcionamiento de la planta. Confirmó que parte del problema se pudo haber debido a "La actuación de los trabajadores poco cualificados del Tercer $M$ undo, que estaban usando avanzados sistemas tecnológicos diseñados por otras personas con un historial educativo, cultural y psicosocial totalmente diferente". De hecho, muchos aspectos sobre la utilidad del diseño están influidos por la cultura del usuario. Por este motivo, un análisis cuidadoso del comportamiento, percepción y preferencias del usuario debería tener como resultado una mayor comprensión de las necesidades del usuario y de los requisitos necesarios para diseñar un producto 0 sistema tanto eficaz como aceptable.

Algunos de los aspectos microergonómicos relacionados con la cultura son:

1. Diseño de interfaces. Los aspectos emocionales humanos son un elemento esencial en el diseño de los productos. Factores como el color o la forma están incluidos en este grupo (K won, Lee y A hn 1993; Nagamachi 1992). El color se considera como el factor emocional más importante en el diseño de un producto. El tratamiento del color en el diseño de los productos refleja la disposición sentimental y psicológica de los usuarios, que varía dependiendo de los cada país. EI simbolismo del color puede variar también. Por ejemplo, el color rojo, indicativo de peligro en los países occidentales, simboliza un hecho favorable 0 de buen augurio en la India (Sen, 1984) y significa gozo o alegría en China.

El diseño de las señales y símbolos visuales que se usan en los espacios públicos están fuertemente relacionados con la cultura. La información visual occidental es difícil de interpretar para los no occidentales (D aftuar 1975; Fuglesang 1982).

2. Compatibilidad entre el control y la representación visual. La compatibilidad es la medida de cómo los movimientos espaciales de control, la representación visual o las relaciones conceptuales cumplen las expectativas del ser humano (Staramler 1993). Se refiere a lo que espera el usuario de la relación estímulo-respuesta, un tema fundamental en ergonomía para el manejo seguro y eficaz de un producto o sistema. U n sistema compatible es aquel que tiene en cuenta el comportamiento motor perceptual de las personas (del ciudadano medio). Sin embargo, como otros comportamientos humanos, el comportamiento motor perceptual también puede verse influido por la cultura. H su y Peng (1993) compararon el comportamiento de individuos chinos y americanos en el control de los quemadores de una cocina con cuatro quemadores. Se observaron diferentes estereotipos. Sus conclusiones fueron que los estereotipos se debían a las diferencias culturales, probablemente relacionadas con los hábitos de lectura y de exploración visual.

3. D iseño del lugar de trabajo. El diseño de los puestos de trabajo en la industria tiene como objetivo eliminar las posturas perjudiciales y mejorar el rendimiento del trabajador en relación a las necesidades biológicas y las preferencias del usuario, así como en relación a los requisitos de la tarea. $L$ as personas de diferentes culturas pueden preferir diferentes modos de sentarse 0 alturas de trabajo. En los países occidentales, las alturas de trabajo se sitúan al nivel del codo, en posición de sentado, para lograr el mayor confort y eficacia. Sin embargo, en muchas partes del mundo la gente se sienta en el suelo. L os trabajadores hindúes prefieren sentarse en cuclillas o cruzados de piernas, antes que permanecer de pie 0 sentarse en una silla. De hecho, se observa que incluso cuando se les proporcionan sillas, prefieren mantenerse fieles a sus costumbres. Daftuar (1975) y Sen (1984) han estudiado las ventajas e implicaciones de la postura india. T ras describir sus ventajas, Sen concluyó que: "Puesto que una gran parte de la población que forma parte del mercado mundial son miembros de sociedades donde el sentarse en cuclillas o en el suelo es la postura predominante, es poco afortunado que hasta ahora no se haya diseñado ninguna máquina para ser utilizada en esta posición". Así pues, las variaciones en el modo de sentarse se deberían considerar a la hora de diseñar máquinas y lugares de trabajo para mejorar el rendimiento y la comodidad del operario.

4. D iseño de equipos de protección. Existen limitaciones, tanto psicológicas como físicas, respecto a la obligación de llevar equipos de protección en algunas culturas. Por ejemplo, en ciertos países, los trabajos que necesitan ropa de protección se consideran como trabajos exclusivamente físicos, apropiados sólo para los trabajadores sin capacitación alguna. Consecuentemente, los ingenieros no suelen llevar ropa de protección. Por lo que se refiere a las limitaciones físicas, algunos grupos religiosos se ven obligados por su religión a llevar la cabeza cubierta (como los turbantes de los sijs de la India o el velo de las mujeres musulmanas), lo que dificulta el llevar cascos protectores. Así pues, es necesario realizar nuevos diseños de ropa de trabajo protectora que solucionen los problemas de seguridad laboral provocados por los aspectos culturales. 


\section{Aspectos macroergonómicos}

El término macroergonomía se refiere al diseño de la tecnología de software; es decir, el diseño adecuado de los sistemas de organización y gestión. Existen pruebas de que debido a las diferencias culturales, políticas y sociales, así como en los niveles de educación, muchos métodos de organización y dirección desarrollados en los países industrializados no se pueden aplicar en los países en vías de desarrollo (Negandhi 1975). En la mayoría de estos países, la organización jerárquica se caracteriza por una estructura en que la autoridad fluye de arriba abajo. No se da mucho valor a cuestiones como la democracia o la toma de decisiones compartida, que son temas clave en la gestión de la empresa actual, esenciales para la utilización adecuada de recursos humanos como la inteligencia, creatividad, ingenuidad y el potencial de resolución de problemas.

El sistema feudal de jerarquía social y su sistema de valores se practican también en la mayoría de las zonas industriales de los países en vías de desarrollo. Por ello, una organización y forma de gestión abiertas a la participación, de crucial importancia para el nuevo modelo de producción flexible y de motivación de la fuerza laboral parece un logro difícil de alcanzar. Sin embargo, también hay informes que confirman la conveniencia de introducir el sistema de trabajo autónomo, incluso en estas culturas (K etchum 1984).

1. E rgonomía abierta a la participación. Este es un enfoque macroergonómico útil para solucionar algunos problemas relacionados con el trabajo (Shahnavaz, Abeysekera y Johansson 1993; Noro e Imada 1991; Wilson 1991). Esta solución, muy utilizada en los países industrializados, se ha aplicado de diferentes formas, dependiendo de la cultura organizativa en que se haya incluido. En un estudio, Liker, N agamachi y Lifshitz (1988) compararon los programas de ergonomía abierta a la participación para disminuir los efectos del estrés en dos fábricas estadounidenses y dos japonesas. Su conclusión fue que: "Un programa de ergonomía abierta a la participación puede adquirir muchas formas. EI mejor programa para cualquier fábrica en cualquier país dependerá de su historia, su estructura y su cultura".

2. Sistemas de software. Las diferencias sociales y de organización debidas a la cultura deben ser un factor importante en el diseño de software y en la introducción de cambios en la organización. R especto a la tecnología de la información, De Lisi (1990) nos indica que no se podrán obtener todas las ventajas del trabajo en red hasta que las redes se ajusten a la cultura de organización existente.

3. O rganización y gestión del trabajo. En ciertas culturas, la familia es una institución tan importante que desempeña un papel fundamental en la organización del trabajo. Por ejemplo, entre algunas comunidades de la India, una profesión se considera responsabilidad de la familia y todos los miembros de la familia realizan el mismo trabajo (Chapanis 1975).

4. Sistema de mantenimiento. Los programas de mantenimiento (preventivos y regulares) son ejemplos en los que se debe adaptar la organización laboral a las restricciones culturales. La cultura tradicional en las sociedades agrícolas, predominante en muchos países en vías de desarrollo, no suele ser compatible con las exigencias del trabajo industrial y su organización. La actividad agrícola tradicional no requiere, por ejemplo, un programa de mantenimiento formal ni trabajo de precisión. No se suele realizar presionado por el horario. En el campo, el trabajo de mantenimiento se deja al poder reciclador de la naturaleza. El diseño de los programas de mantenimiento y los manuales para las actividades industriales deberían tener en cuenta estos límites culturales y proporcionar la supervisión y la formación adecuadas.
Zhang y Tyler (1990), en un estudio sobre el éxito de la instalación de una fábrica de producción de cables telefónicos en China, dirigida por una empresa estadounidense (Essex Company) afirmaron que: "A mbas partes son conscientes de que la aplicación directa de los modos de trabajo de la Essex no son siempre prácticos ni deseables debido a las diferencias culturales, filosóficas y políticas. Así, el socio chino se encargaba de modificar la información e instrucciones dadas por Essex para hacerlas compatibles con las condiciones existentes en C hina". También argumentan que la clave del éxito, a pesar de todas estas diferencias, fue la dedicación y el compromiso de ambas partes con un objetivo común, así como el respeto mutuo, la confianza y la amistad, que permitieron superar las diferencias.

La planificación de los turnos y horarios de trabajo es otro ejemplo de la organización del trabajo. En la mayoría de los países en vías de desarrollo existen problemas socioculturales asociados al trabajo por turnos. Entre estos problemas se incluyen las pésimas condiciones de vida y vivienda, la falta de servicios, el ambiente ruidoso y otros factores, que requieren el diseño de programas especiales para el trabajo por turnos. Además, en el caso de las trabajadoras, la jornada de trabajo suele durar más que las ocho horas que dura el turno de los hombres debido a la suma de las horas de trabajo, desplazamiento, el trabajo en casa y el cuidado de toda la familia. Por la influencia de la cultura, el trabajo por turnos y otros tipos de trabajo especiales requieren el diseño de horarios de descanso especiales para ser realmente eficaces y viables.

La flexibilidad en la jornada laboral debe tener en cuenta las diferencias entre culturas, como la siesta de los trabajadores chinos o las actividades religiosas como la oración de los musulmanes. En la cultura islámica, los trabajadores deben parar el trabajo para rezar varias veces al día y tienen que ayunar un mes al año desde la salida del sol hasta el ocaso. Todas estas restricciones culturales necesitan consideración especial.

Q ueda claro que muchas características macroergonómicas están influidas por la cultura y que estas características deben tenerse en cuenta si se quieren diseñar sistemas de software que funcionen eficazmente.

\section{Conclusión: diferencias culturales en el diseño}

Diseñar un producto o sistema útil no es tarea fácil. No existe un patrón que garantice el éxito. El trabajo del diseñador es crear la interacción óptima y armónica entre los cuatro componentes básicos de cualquier sistema tecnológico-humano: el usuario, la tarea, la tecnología y el entorno. Un sistema de trabajo puede ajustarse a una determinada combinación de estos factores, pero ser poco apropiado para otro. U no de los aspectos de diseño que puede contribuir a la utilidad del mismo, tanto si se trata de un producto individual o de un sistema complejo, es la consideración de los aspectos culturales que tienen una gran influencia sobre el usuario y sobre el entorno de trabajo.

Incluso si un ingeniero meticuloso diseña una interfaz hombre-máquina adecuada para ser utilizada en un entorno concreto, a menudo le es imposible prever los efectos de una cultura diferente sobre la utilidad del producto. Es difícil prevenir los posibles efectos culturales negativos cuando un producto se usa en un entorno diferente del inicialmente previsto. $Y$ puesto que no existen datos cuantitativos que reflejen las restricciones culturales, la única forma de que el ingeniero pueda hacer el diseño compatible con los factores culturales es integrar activamente a los usuarios en el proceso de diseño.

La mejor manera de integrar los aspectos culturales en el diseño es que el diseñador adopte una solución centrada en el usuario. El enfoque de diseño adaptado es un factor esencial que tiene una influencia inmediata en la utilidad del sistema diseñado. El diseñador debe tener en cuenta la importancia de este 
concepto básico y aplicarlo desde el comienzo mismo del proceso de diseño. Los principios básicos del diseño centrado en el usuario se pueden resumir así (Gould y Lewis 1985; Shackel 1986; Gould y cols. 1987; G ould 1988; Wang 1992):

1. Atención continua centrada en el usuario. El usuario debe formar parte activa del equipo de diseño durante todo el proceso (a saber, prediseño, diseño de detalles, fase de verificación y prueba del sistema).

2. Diseño integrado. El sistema se debe considerar como un todo, garantizando una solución completa. El equipo de diseño debe asegurarse de que todos los aspectos de la utilidad del sistema se desarrollen en paralelo.

3. Pruebas por parte del usuario desde los primeros pasos de diseño. $\mathrm{H}$ ay que conocer las reacciones del usuario probando prototipos o simulaciones mientras se lleva a cabo el trabajo en un entorno real, desde la fase de desarrollo inicial hasta que se obtenga el producto final.

4. Diseño iterativo. Los procesos de diseño, prueba y rediseño deben repetirse en ciclos regulares hasta que se consigan resultados de utilidad satisfactorios.

Cuando se trata de diseñar un producto a escala mundial, el diseñador tiene que pensar en las necesidades de los consumidores de todo el mundo. En este caso, quizá no sea posible adoptar la solución centrada en el usuario para conseguir que sea útil para todos los que vayan a utilizarlo y en múltiples entornos. El diseñador debe recurrir a una gran variedad de información, tanto formal como informal, referencias literarias, normas, directrices, principios prácticos y experiencias, para hacer una evaluación del diseño y debe garantizar la suficiente flexibilidad en el producto para satisfacer las necesidades de una población más amplia.

0 tro punto que debe considerarse es el hecho de que los diseñadores no lo saben todo. Necesitan la información proporcionada no sólo por los usuarios, sino también por las otras partes que participan en el proyecto: directivos, técnicos, trabajadores de mantenimiento y reparaciones, etc. En un proceso participativo, se deben compartir los conocimientos y experiencias para desarrollar un producto o sistema útil y aceptar la responsabilidad colectiva por su funcionalidad y seguridad. Al fin y al cabo, a todos les conviene que funcione.

\section{- TRABAJADO RES DE EDAD AVANZADA}

\section{Antoine L aville y Serge Volkoff}

La categoría de los trabajadores de edad avanzada varía según su condición funcional, que a su vez está influida por su historial laboral anterior. También depende del puesto de trabajo que ocupan y de la situación social, cultural y económica del país en el que viven.

Así pues, aquellos trabajadores que realizan un trabajo puramente físico son, con frecuencia, los que menor nivel de escolarización y preparación profesional tienen. Están sujetos al estrés causado por un trabajo agotador, que puede ser causa de enfermedades, y expuestos al riesgo de accidentes de trabajo. En este contexto, es más que probable que su capacidad física decline al final de su vida activa, un hecho que los convierte en trabajadores más vulnerables

Por el contrario, aquellos que han tenido la ventaja de tener un período más largo de escolarización seguido por una formación profesional que los prepara para el trabajo, suelen dedicarse a actividades en las que pueden poner en práctica los conocimientos adquiridos y aumentar progresivamente su experiencia. Con frecuencia, no trabajan en entornos de trabajo peligrosos y sus capacidades se aprecian y valoran más con el paso del tiempo.

Durante los períodos de expansión económica y escasez de mano de obra, se reconoce que los trabajadores de edad avanzada poseen mayor "conciencia laboral", realizan su trabajo con mayor regularidad y pueden mantener actualizada su experiencia. En los períodos de recesión y desempleo, sin embargo, se resaltará el hecho de que su rendimiento laboral es inferior al de los trabajadores más jóvenes y tienen menos capacidad para adaptarse a los cambios en las técnicas y organización del trabajo.

Dependiendo de los diferentes países, sus tradiciones culturales, sus costumbres y nivel de desarrollo económico, la consideración que reciben los trabajadores de edad avanzada y la solidaridad para con ellos resulta más o menos evidente y su protección está más o menos asegurada.

\section{La dimensión temporal en la relación edad-trabajo}

La relación entre los procesos de envejecimiento y el trabajo engloba una gran variedad de situaciones que se pueden considerar desde dos puntos de vista. Por una parte, el trabajo parece ser un factor de transformación para el trabajador a lo largo de su vida activa. Estas transformaciones pueden ser tanto negativas (por ejemplo, desgaste, pérdida de habilidad, enfermedades y accidentes) como positivas (por ejemplo, adquisición de conocimientos y experiencia). Por otra parte, es el trabajo el que revela los cambios relacionados con la edad, lo que da como resultado la marginación e incluso la exclusión del sistema laboral de aqueIlos trabajadores mayores expuestos a exigencias laborales excesivas para su capacidad de trabajo en decadencia o, por el contrario, les permite avanzar en su carrera profesional si en el contenido del trabajo se valora mucho la experiencia.

Así pues, la edad avanzada desempeña la función de "vector" en el que se registran cronológicamente los hechos de la vida de un trabajador, tanto dentro como fuera del trabajo. Alrededor de este eje se engranan los procesos de decadencia y progreso, que varían de un trabajador a otro. Para considerar los problemas de los trabajadores de edad avanzada dentro del concepto de capacidad de trabajo, es necesario tener en cuenta las características dinámicas de los cambios relacionados con la edad y la variabilidad de estos cambios a nivel individual.

La relación edad-trabajo se puede considerar a la luz de la evolución de tres elementos fundamentales:

1. El trabajo evoluciona. La tecnología avanza; la mecanización, la automatización, la informatización y los métodos de transferencia de información, entre otros factores, se están convirtiendo en algo generalizado. Los nuevos productos aparecen y desaparecen. Se descubren o se amplían nuevos factores de riesgo (por ejemplo, las radiaciones y los productos químicos), mientras que otros pierden importancia. Se transforma la organización del trabajo y gestión de la mano de obra, la distribución de las tareas y los horarios de trabajo. Algunos sectores de la producción se desarrollan, mientras que otros entran en declive. De una generación a otra, cambian las situaciones laborales que un trabajador debe afrontar durante su vida activa, sus demandas y las habilidades que de él se requieren.

2. La población laboral cambia. Las estructuras de edad se modifican a la par que los cambios demográficos, los medios de acceso al mercado laboral, la jubilación y la actitud ante el trabajo. El número de mujeres que se incorporan al mercado laboral sigue creciendo. Entre tanto, se produce una 
revolución en el campo de la educación, la formación profesional y el acceso a los sistemas de seguridad social. Todas estas transformaciones crean, al mismo tiempo, efectos generacionales y periódicos que tienen una influencia evidente en la relación edad-trabajo y que pueden preverse hasta cierto punto.

3. Por último, un punto que merece la pena destacar es que los cambios individuales se producen a lo largo de la vida laboral y con frecuencia se cuestionan los procesos de ajuste entre las características de un trabajo determinado y las personas que pueden realizarlo.

\section{Algunos procesos de envejecimiento orgánico y su relación con el trabajo}

Las principales funciones orgánicas implicadas en el desempeño del trabajo se desarrollan hasta alcanzar su plenitud alrededor de los 20 ó 25 años y declinan de manera apreciable de los 40 ó 50 años en adelante.

En particular, se puede observar un decaimiento en la fuerza muscular máxima y en el recorrido de las articulaciones. La reducción en la fuerza es del orden del $15-20 \%$ entre los 20 y los 60 años. Pero esto es únicamente una tendencia general y hay una variación muy considerable dependiendo de las personas. Además, esto ocurre con los esfuerzos y capacidades máximas; en trabajos que exigen un menor esfuerzo físico, el declive es mucho menor.

U na de las funciones más sensibles a la edad es la regulación postural. La dificultad no es evidente en las posturas de trabajo más comunes y estables (de pie o sentado), pero resulta obvia en situaciones de desequilibrio que requieren ajustes precisos, contracciones musculares bruscas o el movimientos de articulaciones con un ángulo muy pronunciado. Estos problemas se hacen mucho más graves cuando el trabajo se tiene que realizar sobre superficies inestables o resbaladizas, o cuando el trabajador sufre una sacudida inesperada. EI resultado es que los accidentes debidos a pérdidas de equilibrio son más frecuente entre trabajadores de edad avanzada.

La regulación del sueño se hace más irregular de los 40 ó 45 años en adelante. Se es más sensible a los cambios del horario de trabajo (tales como el trabajo nocturno o el trabajo por turnos) y a los entornos molestos (por ejemplo, el ruido o la luz). A esto le siguen cambios en la duración y calidad del sueño.

La termorregulación también se hace más difícil con la edad, lo que provoca problemas específicos a los trabajadores de edad avanzada en entornos calurosos, especialmente cuando tienen que realizar trabajos de cierta intensidad física.

Las funciones sensoriales se ven afectadas desde muy pronto; sin embargo, las deficiencias que provocan no suelen manifestarse antes de los 40 ó 50 años. La vista, como tal, sufre diversos cambios: se da una reducción en el grado de acomodación (que se puede corregir con el uso de lentes apropiadas) y también en el campo visual periférico, en la percepción de la profundidad, en la resistencia al deslumbramiento y en la transmisión de la luz a través del cristalino. L os inconvenientes resultantes sólo son apreciables en ciertas condiciones: iluminación insuficiente, cerca de fuentes de excesiva luminosidad, con objetos o textos demasiado pequeños o con mala presentación, etc.

El deterioro de la función auditiva afecta al umbral auditivo a frecuencias altas (sonidos más agudos), pero se manifiesta especialmente en la dificultad para diferenciar y reconocer las señales sonoras en entornos especialmente ruidosos. Así pues, la inteligibilidad de las palabras se hace más difícil en presencia de ruido ambiental o de fuerte reverberación.

Las demás funciones sensoriales se ven poco afectadas durante esta etapa de la vida.
De un modo general, se puede observar un deterioro orgánico particularmente apreciable en situaciones extremas. En cualquier caso, este tipo de entornos se debería modificar para evitar dificultades incluso entre los trabajadores más jóvenes. Por otra parte, los trabajadores de edad avanzada pueden compensar sus deficiencias por medio de estrategias personales, que han adquirido con la experiencia, cuando las condiciones y la organización del trabajo lo permiten: el uso de apoyos adicionales para posturas desequilibradas, levantamiento y carga de pesos con el mínimo esfuerzo, organización y sistematización de la exploración visual para obtener información útil, entre otros medios.

\section{Envejecimiento cognitivo: ralentización y aprendizaje}

Por lo que se refiere a las funciones cognitivas, lo primero que cabe observar es que la actividad laboral pone en juego los mecanismos básicos para recibir y procesar información, por una parte, y los conocimientos adquiridos a lo largo de la vida, por otra. Este conocimiento tiene que ver principalmente con el significado de los objetos, señales, palabras y situaciones (conocimiento "declarativo") y también con la manera de hacer las cosas (conocimiento de "procedimientos").

La memoria a corto plazo nos permite retener, durante unos segundos o minutos, la información útil detectada. El procesamiento de esta información se lleva a cabo por comparación con el conocimiento memorizado de manera permanente. El envejecimiento actúa sobre estos mecanismos de varias formas: (1) en virtud de la experiencia, enriquece el conocimiento, así como la capacidad para seleccionar el conocimiento más útil y el mejor método para procesarlo, especialmente en aquellas tareas que se llevan a cabo con una cierta frecuencia; sin embargo, (2) el tiempo utilizado para procesar esta información se prolonga debido al envejecimiento del sistema nervioso central y a la mayor fragilidad de la memoria a corto plazo.

Estas funciones cognitivas dependen mucho del entorno en el que hayan vivido los trabajadores y, por tanto, de su historia pasada, su formación y las situaciones laborales que hayan tenido que afrontar. L os cambios que se producen con la edad se manifiestan, como hemos visto, en una combinación muy variada de fenómenos de deterioro y reconstrucción, en los que cada uno de estos dos factores puede estar más o menos acentuado.

Si en el curso de su vida laboral los trabajadores han recibido únicamente una formación muy básica y han tenido que realizar tareas simples y repetitivas, su conocimiento será muy restringido y tendrán dificultades cuando se les exija la realización de tareas nuevas o con las que estén poco familiarizados. Si además tienen que realizar su trabajo dentro de unos límites de tiempo muy justos, los cambios que se han producido en sus funciones sensoriales y la ralentización en el procesamiento de información les colocará en inferioridad de condiciones. Si, por el contrario, han tenido períodos de escolarización y formación completos y han realizado una amplia gama de tareas, serán capaces de sacar todo el partido a sus habilidades de forma que compense las posibles deficiencias sensoriales o cognitivas relacionadas con el proceso de envejecimiento.

Por lo tanto, es fácil comprender el papel que desempeña la formación continua en la situación laboral de los trabajadores de edad avanzada. Los cambios en el trabajo hacen cada vez más necesaria esta formación continua, pero los trabajadores de mayor edad no suelen tener acceso a ella. Las empresas no creen que merezca la pena impartir cursos de formación a los trabajadores que están a punto de finalizar su vida activa, especialmente porque se cree que las dificultades en el aprendizaje aumentan con la edad. Incluso los mismo trabajadores, 
temerosos del fracaso, no se embarcan en un proceso de formación cuyos beneficios no ven claramente.

De hecho, con la edad, el modo de aprendizaje se modifica. $M$ ientras una persona joven registra el conocimiento que se le ha transmitido, una persona mayor necesita comprender la forma de organizar este conocimiento en relación con el que ya posee, cuál es su lógica y su justificación para el trabajo que realiza. La respuesta al problema de la formación de los trabajadores de mayor edad es, en primer lugar, el uso de metodologías específicas para cada edad, conocimiento y experiencia de cada persona, con períodos más largos de formación para los más mayores.

\section{Envejecimiento de hombres y mujeres en el trabajo}

$L$ as diferencias entre hombres y mujeres en función de la edad se sitúan en dos niveles diferentes. A nivel orgánico, las expectativas de vida suelen ser mayores para las mujeres, pero, la llamada expectativa de vida sin discapacidades es muy similar para ambos sexos: hasta los 65-70 años. M ás allá de esa edad, las mujeres suelen estar en situación de desventaja. Además, la máxima capacidad física de las mujeres es un $30 \%$ menor, como media, que la de los hombres, y esta diferencia generalmente persiste con el paso del tiempo; aunque hay una gran variabilidad en ambos grupos y superposiciones entre las dos distribuciones.

A nivel de carrera profesional hay grandes diferencias. En general, las mujeres han recibido menos formación profesional que los hombres cuando comienzan su vida laboral, suelen ocupar puestos para los que se requiere una menor capacitación y están peor pagadas y consideradas profesionalmente. Con la edad, estas personas tienden a ocupar puestos con mayores limitaciones, tanto a nivel de horarios, como en su contenido, que tiende a ser repetitivo. No se puede establecer ninguna diferencia en el desarrollo de la capacidad cognitiva entre los dos sexos sin tener en cuenta este contexto social en el que se desarrolla el trabajo.

Si la planificación de los puestos de trabajo ha de tener en cuenta estas diferencias, se debe favorecer especialmente la formación profesional inicial y continua de las mujeres y ayudarlas a desarrollar carreras en las que se aumente su experiencia y se reconozca su valor. Todas estas medidas se deben tomar, por supuesto, mucho antes de que finalice su vida activa.

\section{E nvejecimiento de la población activa: utilidad de los datos colectivos}

$\mathrm{H}$ ay al menos dos razones para abordar de forma colectiva y cuantificable el problema del envejecimiento de la población activa. La primera razón es que estos datos son necesarios para evaluar y prever los efectos del envejecimiento en un taller, servicio, empresa, sector o país. La segunda razón es que los principales componentes del envejecimiento son, en sí mismos, fenómenos sujetos a la probabilidad: no todos los trabajadores envejecen al mismo tiempo o al mismo ritmo; así pues, por medio de herramientas estadísticas podremos revelar, confirmar 0 valorar diferentes aspectos del envejecimiento.

El instrumento más simple que se utiliza en este campo es la descripción de las estructuras de edad y su evolución, expresada en términos relevantes para el trabajo: el sector económico, profesión, grupo de trabajos, etc.

Por ejemplo, cuando se observa que la estructura de edad de la plantilla de un taller se mantiene estable y joven, cabe preguntarse qué características del trabajo pueden desempeñar un papel selectivo con respecto a la edad. Si, por el contrario, dicha estructura es estable pero la media de edad es mayor, la función del taller será recibir empleados de otras secciones de la empresa. M erece la pena estudiar las razones de tales traslados y comprobar si el trabajo en este taller se ajusta a las características de una mano de obra de edad avanzada. Finalmente, si la estructura de edad cambia regularmente, reflejando únicamente los diferentes niveles de contratación de un año a otro, tendremos una situación donde los trabajadores "envejecen en su puesto de trabajo". A veces esta situación requiere un estudio especial, sobre todo si el número anual de contrataciones tiende a la baja, lo que orientará la estructura general hacia grupos de edad más avanzada.

La comprensión de estos fenómenos puede ser mayor si disponemos de datos cuantitativos sobre las condiciones de trabajo, los puestos que ocupan actualmente los trabajadores y, de ser posible, sobre los puestos de los que proceden. L os horarios, los períodos de estrés, la naturaleza de los esfuerzos realizados, el entorno de trabajo e incluso algunos componentes cognitivos, podrían ser objeto de un evaluación por parte de los propios trabajadores 0 de expertos. Es posible, pues, establecer una conexión entre las características del trabajo actual y el pasado y la edad de los trabajadores, y de esta manera dilucidar los mecanismos de selección que pueden desencadenar determinadas condiciones de trabajo a cierta edad.

Estas investigaciones se pueden mejorar también si se obtiene información sobre la salud de los trabajadores. Dicha información se puede obtener a partir de indicadores objetivos, tales como la tasa de accidentes de trabajo, o la tasa de absentismo laboral por enfermedad. Pero estos indicadores se deben usar con todo el cuidado metodológico posible porque, aunque reflejan las condiciones de salud relacionadas con el trabajo, también reflejan las estrategias de todos los implicados en dichas tasas: los propios trabajadores, la dirección y los médicos pueden tener estrategias al respecto, y no hay ninguna garantía de que estas estrategias no tengan en consideración la edad de los trabajadores. La comparación de estos indicadores entre diferentes edades es, con frecuencia, un proceso algo complejo.

Siempre que sea posible, se deberá recurrir a los datos obtenidos de la autoevaluación que los trabajadores realicen de su salud, o bien de las revisiones médicas. Los datos así obtenidos pueden referirse a ciertas enfermedades cuya prevalencia por edad hay que conocer mejor para poder prevenirlas. Pero el estudio del envejecimiento se basará, sobre todo, en la apreciación y observación de aquellas condiciones que todavía no han alcanzado el grado de enfermedad, tales como ciertos tipos de deterioros funcionales: de las articulaciones (dolor y limitaciones), de la vista y el oído, del sistema respiratorio, etc.; 0 incluso ciertas clases de dificultades o discapacidades: subir un escalón alto, hacer un movimiento preciso, mantener el equilibrio en una posición difícil, etc.

Establecer relaciones entre los datos de edad, trabajo y salud es un problema tan útil como complejo. Se pueden revelar varios tipos de conexiones 0 , al menos, se puede presumir su existencia. A veces se trata de una simple relación causal, en la que determinadas exigencias del trabajo aceleran algún tipo de deterioro funcional según se va envejeciendo. Pero éste no es el caso más habitual. Frecuentemente, podremos apreciar efectos de acumulación de restricciones en el conjunto de características de la salud, y al mismo tiempo el efecto de los mecanismos de selección, según los cuales aquellos trabajadores cuya salud se haya deteriorado podrían verse excluidos de ciertos tipos de trabajo (lo que los epidemiólogos Ilaman "el efecto del trabajador sano").

De esta manera se puede evaluar la fuerza de este conjunto de relaciones, confirmar ciertos conocimientos básicos de psicofisiología, y, sobre todo, obtener información útil para diseñar estrategias preventivas en relación con el envejecimiento en el trabajo. 


\section{Diferentes formas de acción}

Las medidas encaminadas a mantener a los trabajadores de edad avanzada en el mundo laboral, sin consecuencias negativas para ellos, deben seguir unas líneas generales:

1. No se debe considerar a este grupo de edad como una categoría aparte, sino considerar la edad como un factor de diversidad, entre otros, en la población activa. Si las medidas de protección adoptadas están demasiado dirigidas o exageradas, tenderán a marginar y debilitar la posición de los grupos que se pretende proteger.

2. Se deben anticipar los cambios individuales y colectivos relacionados con la edad, así como los cambios en las técnicas y organización del trabajo. La gestión de los recursos humanos se puede planificar por anticipado y preparar así los ajustes necesarios en la formación y la vida laboral de los trabajadores. El concepto de capacidad de trabajo puede así tener en cuenta, al mismo tiempo, las soluciones técnicas y organizativas y las características de la futura población activa.

3. La diversidad del desarrollo individual durante la vida laboral es otro de los factores que se debe considerar para poder crear condiciones de diversidad equivalente entre situaciones y profesiones.

4. Se debe prestar atención a favorecer el proceso de aprendizaje de habilidades propias del trabajo y ralentizar el proceso de deterioro.

De acuerdo con estos principios, se pueden definir distintas formas de acción inmediata. La acción de mayor prioridad está relacionada con las condiciones de trabajo que pueden crear problemas especialmente graves a los trabajadores de edad avanzada. Como ya hemos dicho antes, entre estas condiciones están al estrés postural, al esfuerzo excesivo, a los tiempos de producción demasiado estrictos (ej., trabajo en cadena o metas de producción demasiado altas), a entornos dañinos (temperatura, ruidos) o inadecuados (condiciones de luminosidad) de trabajo 0 al trabajo nocturno o por turnos.

La identificación sistemática de este tipo de restricciones en los puestos ocupados por trabajadores de edad avanzada, nos permitirá crear un inventario de problemas y una lista de acciones prioritarias. Este proceso de identificación se puede llevar a cabo por medio de listas de comprobación de inspecciones empíricas. También puede ser útil analizar la actividad realizada por los trabajadores, lo que permitirá relacionar sus comportamientos con las explicaciones que ellos mismos dan de sus dificultades. En ambos casos, las medidas del esfuerzo 0 de los parámetros ambientales pueden complementar las observaciones.

Sin embargo, no se pueden describir aquí líneas de acción concretas, ya que son específicas de cada situación laboral. EI uso de normas generales puede ser útil en algunas ocasiones, pero muy pocas normas tienen en cuenta los aspectos específicos del envejecimiento y cada una de estas normas se refiere a un campo específico, lo que inclina a considerar de forma individual a cada uno de los componentes de la actividad objeto de estudio.

A parte de medidas inmediatas, tener en cuenta el envejecimiento implica una planificación a largo plazo dirigida a ampliar la flexibilidad en el diseño de las situaciones de trabajo.

Esta flexibilidad se debe buscar primero en el diseño de las situaciones y equipo de trabajo. Los espacios de trabajo demasiado restringidos, las herramientas que no se pueden adaptar, los procedimientos poco flexibles, en resumen, aquellas características del puesto de trabajo que limitan la expresión de la diversidad humana a la hora de realizar una tarea, pueden perjudicar a una gran proporción de trabajadores de edad avanzada. Lo mismo se puede decir de determinadas organizaciones más restrictivas: una distribución de tareas completamente predeterminada, plazos de finalización del trabajo demasiado frecuentes y urgentes, $u$ órdenes demasiado estrictas o numerosas (que deben, sin embargo, ser toleradas cuando sean necesarias para alcanzar unos niveles mínimos de calidad de producción o de seguridad en el trabajo). La búsqueda de esta flexibilidad se convierte en la búsqueda de ajustes individuales y colectivos que faciliten una integración completa de los trabajadores de edad avanzada en el sistema de producción. U na de las condiciones para introducir con éxito estos ajustes es, evidentemente, el establecimiento de programas de formación para trabajadores de todas las edades, dirigidos a las necesidades específicas de cada grupo.

A sí pues, tener en cuenta el envejecimiento en el diseño de las situaciones de trabajo conlleva una serie de acciones coordinadas (reducción general de los esfuerzos excesivos, uso de todas las estrategias necesarias para la organización del trabajo y esfuerzo continuo por parte de los trabajadores para reciclarse y adquirir nuevas habilidades), que son más eficientes y baratas cuando se planifican a largo plazo y se ponen en marcha con tiempo. El envejecimiento de la población es un fenómeno lo suficientemente lento y previsible como para tomar las medidas adecuadas para reducir su incidencia en el trabajo.

\section{TRABAJADORES CON NECESIDADES ESPECIALES}

Joke H , Grady-van den Nieuwboer

\section{Diseñar para las personas con discapacidades es diseñar para todos}

$\mathrm{H}$ ay muchos productos en el mercado que son poco idóneos 0 inapropiados para la mayoría de los usuarios. ¿Q ué podríamos decir de esas puertas tan estrechas por las que una mujer embarazada, o una persona corpulenta, apenas pueden pasar? ¿Se pueden poner objeciones a su diseño si pasa todas las pruebas de funcionamiento mecánico? Es evidente que esas personas no pueden ser consideradas discapacitadas en el sentido físico, puesto que es posible que gocen de un perfecto estado de salud. Algunos productos hay que manejarlos durante bastante tiempo, antes de conseguir que realicen la función que se esperara de ellos; es el caso, por ejemplo, de algunos abrelatas baratos. Es evidente que a una persona sana, que tenga dificultades al utilizar este tipo de aparatos, no se le puede considerar discapacitada. EI diseñador que introduce en sus diseños ciertos aspectos de la interacción entre las personas y los productos, aumenta la utilidad funcional de sus diseños. Si el producto no tiene un buen diseño funcional, cualquier persona con una discapacidad mínima se podría considerar a sí mismo seriamente impedido. Así pues, es la interacción hombremáquina la que determina el valor de un diseño para todos los usuarios.

Es obvio que la tecnología está al servicio de los seres humanos y que su uso debe ampliar las capacidades de los mismos. Para las personas con discapacidades, esta ampliación debe ir un poco más lejos. Por ejemplo, en el decenio de 1980 se prestó especial atención al diseño de cocinas para personas con discapacidades. Toda la experiencia acumulada en este proceso tuvo influencia en los diseños de cocinas "normales"; en este aspecto, se puede considerar a la persona discapacitada un pionero. Las discapacidades y daños ocasionados en el trabajo (no se puede por menos que considerar como tales las quejas 
sobre el aparato musculosquelético que se escuchan de aquellos que trabajan sentados, algo muy frecuente hoy en día) requieren que se preste atención a los diseños, no sólo para evitar la repetición de las condiciones que causaron la dolencia, sino para desarrollar tecnologías compatibles con el usuario, adaptadas a las necesidades de aquellos ya afectados por trastornos relacionados con el trabajo.

\section{Diseños para la mayoría de las personas}

El diseñador no debe centrarse en grupos pequeños y poco representativos. Con determinados grupos, no se debe suponer que existan similitudes. Por ejemplo, un trabajador que haya sufrido un accidente, siendo adulto, no tiene por qué ser antropométricamente diferente a una persona sana y de similares características y puede considerarse que está dentro de la media. Pero si es un niño el que ha sufrido una lesión, cuando sea adulto tendrá una antropometría diferente, ya que los períodos de crecimiento habrán influido de forma regular y secuencial sobre su desarrollo muscular y mecánico. No se deben aventurar conclusiones al comparar a personas adultas de estos dos grupos. Se deben considerar dos grupos distintos, específicos, en el que uno pertenecería a la media normal. Pero cuando intentamos conseguir un diseño idóneo para, supongamos, el $90 \%$ de la población, deberá hacerse un esfuerzo mayor para aumentar este margen hasta un $95 \%$ con el fin de reducir la necesidad de realizar diseños para grupos específicos.

O tra manera de realizar un diseño para la población en general, es fabricar dos productos, con un diseño que se adapte de forma aproximada a los dos grupos de población con percentiles extremos. Se pueden construir sillas de dos tamaños, una con soportes que permitan ajustarla a una altura entre 38 y $46 \mathrm{~cm}$, y la otra entre 46 y $54 \mathrm{~cm}$. Ya existen, de hecho, dos tamaños de alicates, unos para la población con manos muy grandes y otros para las manos de las mujeres y de los hombres con manos más pequeñas.

Sería una buena política empresarial reservar anualmente una pequeña cantidad de dinero para analizar y mejorar la calidad de los puestos de trabajo, adaptándolos a los trabajadores, para prevenir enfermedades y discapacidades causadas por una excesiva carga física. Esto aumentaría la motivación de los trabajadores, que se darían cuenta de que la dirección trata de mejorar el entorno de trabajo, sobre todo cuando se toman medidas más o menos elaboradas: análisis de puestos de trabajo, construcción de modelos, mediciones antropométricas e incluso el diseño de puestos específicos para los trabajadores. En una empresa determinada se llegó a la conclusión de que había que volver a diseñar todos y cada uno de los puestos de una unidad, ya que causaban sobrecarga física debido a que los trabajadores debían permanecer demasiado tiempo de pie y también por las dimensiones inapropiadas cuando los trabajadores estaban sentados, así como por algunas otras deficiencias.

\section{Costes, beneficios y utilidad del diseño}

Los ergónomos realizan análisis de coste-beneficio para tener una visión interna de los resultados no económicos de las políticas económicas. Actualmente, la evaluación en el campo industrial y comercial, incluye el impacto positivo o negativo de una determinada política sobre el trabajador.

Los métodos de evaluación de la calidad y la utilidad son actualmente objeto de investigación. El modelo de utilidad de la tecnología de rehabilitación (MUTR), como se muestra en la Figura 29.51, se puede utilizar para evaluar la utilidad de un producto en la tecnología de la rehabilitación y para ilustrar los diferentes aspectos que determinan la utilidad del producto.

Desde un punto de vista estrictamente económico, se podrían especificar los costes de creación de un sistema en el que se pueda realizar una tarea, 0 en el que se pueda fabricar un cierto producto. Es innecesario decir que en estos términos, a cualquier empresa le interesa obtener el máximo beneficio de su inversión. Pero, ¿cómo se pueden determinar los costes reales de la realización de una tarea y la fabricación de un producto en relación con la inversión financiera, cuando se tienen en cuenta los distintos esfuerzos de los sistemas cognitivos, mentales y físicos de los trabajadores? De hecho, el juicio que se hace del rendimiento humano se basa, entre otros factores, en la percepción que los propios trabajadores tienen de lo que se debe hacer, en la visión de su propia valía al hacerlo y su opinión sobre la empresa. En realidad, la norma que tiene más validez en este contexto es la satisfacción intrínseca con el trabajo y esta satisfacción, junto con los objetivos de la empresa, constituye una de las principales razones para realizar este trabajo. El bienestar del trabajador y su rendimiento se basan en una amplia gama de experiencias, asociaciones y percepciones que determinan su

Figura 29.51 • Modelo de utilidad de la tecnología de rehabilitación (MUTR).

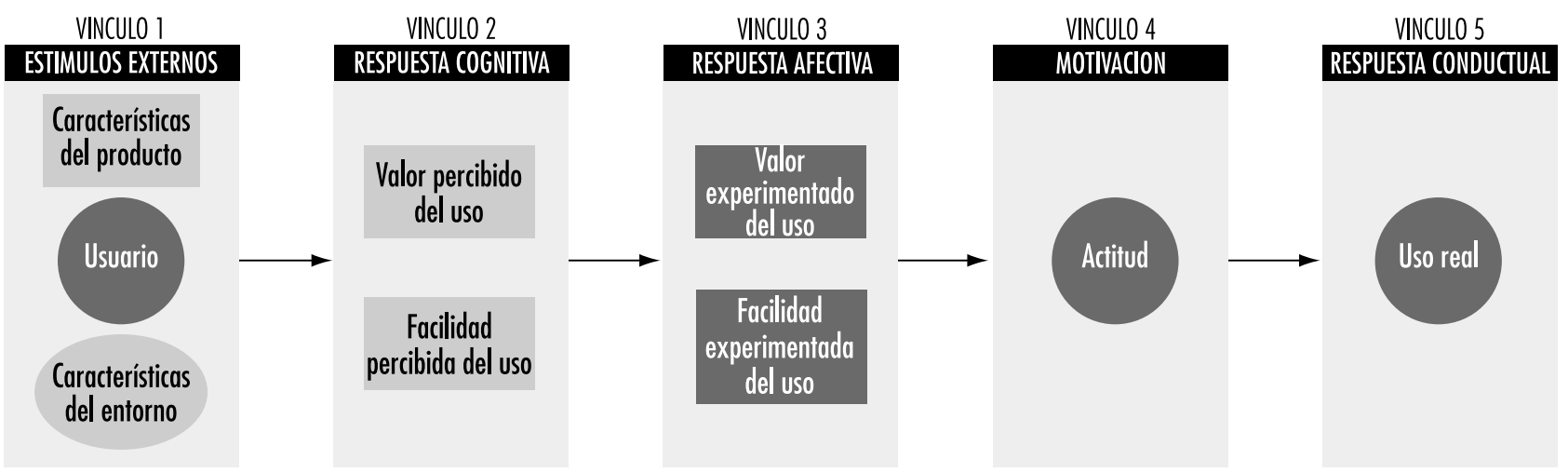

El modelo de utilidad de la tecnología de rehabilitación (MUTR) se desarrolló como una ayuda para el proceso de diseño (véase también la Figura 29.49)

Puede obtenerse información de los componentes vínculo 1 y 2 del MUTR en la fase previa al PRD. El prototipo puede evaluarse de acuerdo con los componentes 2 y 3 del MUTR y la serie 0 puede evaluarse de acuerdo con los componentes MUTR vínculos 2, 3, 4 y 5.

Fuente: Grady y de Vries 1994 
actitud hacia el trabajo y la calidad de su rendimiento. En esta teoría se basa el modelo MUTR .

Si no se acepta este punto de vista, será necesario considerar la inversión sólo en relación con resultados poco específicos y dudosos. Si ergónomos y médicos desean mejorar el entorno laboral de las personas con discapacidades para posibilitar una mejor y mayor utilización de las máquinas y herramientas utilizadas, encontrarán ciertas dificultades para justificar dichas inversiones financieras. Normalmente se ha intentado justificar el ahorro conseguido gracias a la prevención de accidentes y enfermedades laborales. Pero si los costes de las enfermedades laborales son sufragados por el estado y no por la empresa, financieramente aparecen como inexistentes y no se consideran como relacionados con el trabajo.

Sin embargo, cada vez existe una mayor conciencia de que la inversión que se realice para mejorar el entorno laboral es dinero bien empleado y se acepta que los costes "sociales" de las discapacidades laborales se traducen en costes adicionales para la economía del país, aparte de que se pierde algo más que dinero cuando un posible trabajador debe quedarse en casa, sin aportar nada a la sociedad. La inversión que se haga en los puestos de trabajo (adaptación de los puestos de trabajo, dotación de herramientas especiales o incluso ayudas para la higiene personal) puede no sólo dar al trabajador satisfacción laboral sino convertirle en alguien independiente y autosuficiente, sin necesidad de asistencia social.

Se puede realizar análisis de coste-beneficio para determinar si están justificadas las intervenciones en el puesto de trabajo en el caso de las personas con discapacidades. Los factores que se citan a continuación representan las fuentes de datos que deberían formar parte de tal análisis:

1. Personal

- Ausencia. ¿T iene el trabajador con discapacidad una buena ficha de asistencia al trabajo?

- ¿Es posible que se generen costes adicionales por la enseñanza de tareas especiales?

- ¿Se requieren cambios de personal? Si es así, sus costes también se han de tener en cuenta.

- ¿Se espera que aumenten las compensaciones por accidente?

2. Seguridad

- ¿lmplica el trabajo pensado para el trabajador discapacitado normativas de seguridad?

- ¿Se requieren normativas especiales de seguridad?

- ¿Se trata de un trabajo con un alto índice de accidentes o de situaciones de riesgo?

3. Factores médicos

- Se debe valorar la naturaleza y gravedad de la discapacidad del trabajador, con vistas a su posible reintegración al puesto de trabajo.

- También se debe tener en cuenta el alcance del absentismo laboral del trabajador en cuestión.

- ¿C uál es el carácter y frecuencia de los síntomas "menores" del trabajador y cómo se tratan? ¿Se pueden prever las consecuencias negativas del desarrollo futuro de enfermedades "menores" relacionadas sobre la eficacia del trabajador?

Por lo que respecta a los cálculos sobre la pérdida de tiempo de trabajo, estos cálculos se pueden hacer en términos de salarios, gastos generales, compensaciones y pérdida de producción. Estos análisis, descritos anteriormente, representan una manera racional de abordar el problema por el cual una empresa puede tomar una decisión adecuada sobre la posición en que se encuentra el trabajador con alguna discapacidad, en el sentido de si es mejor que vuelva a su puesto de trabajo y si la empresa ganará con su vuelta al trabajo.

En los párrafos anteriores, el diseño para un grupo más amplio de población se ha enfocado preferentemente desde el punto de vista de un diseño específico en relación con la utilidad, los costes y los beneficios de dicho diseño. Es especialmente complicado realizar los cálculos necesarios, en los que se incluyan todos los factores importantes, pero de momento, los investigadores continúan incorporando métodos que incluyen modelos nuevos en sus técnicas y estudios. En algunos países, como Holanda y Alemania, las políticas gubernamentales responsabilizan cada vez más a las empresas por los accidentes personales en el trabajo. Es de esperar que se produzcan cambios fundamentales en las políticas reguladoras y en las estructuras de los seguros laborales como resultado de esta tendencia. Es estos países, es una política más o menos establecida que un trabajador que sufre un accidente que lo incapacita para el trabajo que realiza, debe ser provisto de un puesto de trabajo adaptado o desarrollar otro trabajo dentro de la empresa. Estas políticas han convertido el tratamiento del trabajador discapacitado en uno de los grandes logros en la humanización del trato al trabajador.

\section{Trabajadores con capacidad funcional limitada}

L a escasez de datos de las investigaciones impide dar respuesta a la pregunta de si se diseña para las personas con discapacidades 0 para la media de la población. C asi no existen estudios sobre los trabajadores minusválidos. Sin embargo, para crear un documento de requisitos de un producto, O PRD, se necesita de un estudio empírico específico, en el que se recojan los datos por medio de observaciones y mediciones.

Al recopilar toda la información necesaria sobre el trabajador o usuario con discapacidades, debe considerarse no sólo su estado funcional actual, sino intentar prever cualquier posible cambio que se produzca como resultado del curso de esa condición crónica. De hecho, este tipo de información se puede obtener directamente del trabajador o lo puede proporcionar un médico especialista.

Al diseñar, por ejemplo, cualquier acción en el trabajo para la que sea necesario obtener determinados datos sobre la fuerza física de un trabajador, el diseñador no elegirá como dato para el cálculo la fuerza máxima que el trabajador discapacitado puede ejercer, sino que tendrá en cuenta cualquier posible disminución en la fuerza como resultado de la progresión de una condición crónica. De esta manera, el trabajador seguirá siendo capaz de utilizar las máquinas y herramientas adaptadas o diseñadas para él.

A demás, los diseñadores deberían tratar de evitar aquellos diseños que supongan movimientos y posiciones extremas del cuerpo, acomodando sus diseños a los términos medios. La mayoría de los cajones tienen tiradores en forma de una pequeña concha bajo la cual se colocan los dedos; para abrirlos, es necesario ejercer fuerza hacia arriba y hacia afuera. Esta maniobra exige una posición supina de la muñeca de 180으, el grado máximo de rotación en una articulación de este tipo. Este movimiento no presenta ninguna dificultad para una persona sana, siempre que se pueda abrir el cajón ejerciendo un ligero esfuerzo y no tenga que adoptar una postura difícil, pero se convierte en algo ciertamente complicado cuando el recorrido del cajón no es suave, o no se puede realizar el movimiento de la muñeca anteriormente descrito, convirtiéndose en una dificultad innecesaria y evitable para una persona con alguna discapacidad. U na solución tan simple como un tirador situado en posición vertical sería mecánicamente más eficaz y más fácil de manipular para la mayor parte de la población. 


\section{Capacidad funcional física}

Pasemos ahora a comentar las tres áreas principales de limitación de la capacidad funcional física; es decir, el sistema de locomoción, el sistema neurológico y el sistema energético. Los diseñadores comprenderían mejor las limitaciones del usuario o trabajador si consideraran los siguientes principios básicos de las funciones corporales.

EI sistema locomotor. El sistema locomotor está formado por huesos, articulaciones, tejido conectivo y músculos. La naturaleza de la estructura de las articulaciones determina la gama de posibles movimientos. La rodilla, por ejemplo, tiene un grado de movimiento y estabilidad distinto al de la articulación de la cadera 0 el hombro. Las diferentes características de las articulaciones determinan las posibles acciones de brazos, manos, piernas, etc. También hay diferentes tipos de músculos. El tipo de músculo, si pasa sobre una o dos articulaciones y su localización es lo que determina el sentido del movimiento, su velocidad y la fuerza que es capaz de ejercer, para cada parte del cuerpo.

El hecho de que la velocidad, dirección y fuerza del músculo se puedan reconocer y calcular es de gran importancia para el diseño. Para las personas con discapacidades, se debe tener en cuenta que la localización "normal" de los músculos está alterada, al igual que el margen de movimiento de las articulaciones. En una amputación, por ejemplo, un músculo puede funcionar sólo de forma parcial, o quizá se haya cambiado su posición; así es que se debe examinar cuidadosamente la capacidad física del paciente para establecer las funciones que puede realizar, de qué forma y por cuánto tiempo. Veamos un ejemplo.

U n carpintero de 40 años de edad perdió el pulgar y el dedo corazón de la mano derecha en un accidente $E n$ un intento por que el carpintero recuperara su capacidad para el trabajo, un cirujano le amputó uno de los dedos gordos del pie y se lo rémplantó en el lugar del pulgar. Tras un período de rehabilitación, el carpintero volvió al trabajo, pero le resultaba imposible desarrollar su tarea durante más de 3 ó 4 horas. Se procedió entonces a realizar un estudio de sus herramientas y se descubrió que eran inapropiadas para la estructura "anormal" de su mano. El especialista en rehabilitación, tras examinar la mano "rediseñada" del carpintero, desde el punto de vista de su nueva forma y capacidad funcional, pudo diseñar unas nuevas herramientas con una utilidad completa para la mano alterada. Se aligeró la carga sobre la mano de trabajador, que anteriormente era excesiva, y éste recobró su capacidad de trabajar durante largos períodos de tiempo.

E I sistema neurológico. El sistema neurológico se suele comparar con una sofisticadísima sala de control, con recopiladores de datos cuya finalidad es iniciar y gobernar movimientos y acciones, interpretando la información relacionada con diversos aspectos de los componentes posturales, mecánicos y químicos del cuerpo, entre otros. Este sistema incorpora, no sólo un sistema de retroinformación (por ejemplo, el dolor) que permite que se pongan en marcha medidas correctoras de posibles fallos, sino también una capacidad de anticipación que nos permite mantener un estado de equilibrio. Consideremos por ejemplo el caso de un trabajador que sin pensarlo, adopta una postura determinada para protegerse de una caída o del contacto con las partes peligrosas de una máquina.

En las personas con discapacidades, el procesamiento fisiológico de la información se puede ver deteriorado. Tanto los mecanismos de retroalimentación de la información como los de anticipación de las personas con discapacidades visuales están debilitados o no existen; lo mismo ocurre, a nivel auditivo, en las personas con problemas de audición. A demás, los circuitos reguladores más importantes son interactivos. Las señales sonoras tienen un efecto sobre el equilibrio de las personas, en combinación con los circuitos propioceptivos, que se encargan de situar nuestro cuerpo en el espacio por medio de los datos recogidos de músculos y articulaciones con la ayuda de las señales visuales. EI cerebro puede llegar a superar deficiencias importantes en estos sistemas, corrigiendo los errores en la codificación de la información y completando la que falte. M ás allá de ciertos límites, sobreviene la incapacidad. Pongamos como ejemplo dos casos concretos.

Caso 1. U na mujer de 36 años sufrió una lesión de columna verte bral en un accidente de automóvil. Es capaz de sentarse sin ayuda alguna y puede manejar una silla de ruedas manual. Su tronco tiene la estabilidad necesaria, pero no tiene sensibilidad en las piernas; esta falta de sensibilidad incluye la incapacidad para detectar los cambios de temperatura.

Se le ha preparado un lugar de trabajo en su casa en el que tiene que estar sentada (la cocina está diseñada para que pueda trabajar sentada). Las medidas de seguridad incluyen la instalación de un fregadero en una posición lo suficientemente aislada como para reducir al mínimo el riesgo de quemaduras que puede producir en sus piernas el agua caliente, ya que su incapacidad para procesar la información de la temperatura en las piernas la expone a sufrir quemaduras sin notarlo.

Caso 2. U na madre estaba bañando a su hijo de 5 años, el cual tenía el lado izquierdo paralizado. Sonó el timbre y la madre déó al niño solo para ir a abrir la puerta. D urante este tiempo, el niño abrió el grifo del agua caliente, sufriendo quemaduras. Por razones de seguridad, e baño debería haber tenido un termostato, preferiblemente uno que $\mathrm{el}$ niño no pudiera manipular.

El sistema de energía. Cuando el cuerpo humano tiene que realizar un esfuerzo físico, se producen diversos cambios fisiológicos, especialmente en forma de interacción entre las células musculares, aunque relativamente ineficaces. El "motor" humano convierte tan sólo el $25 \%$ de sus reservas de energía en actividades de tipo mecánico, dejando el resto para pérdidas térmicas. El cuerpo humano no es, pues, especialmente idóneo para realizar tareas físicas pesadas. Al cabo de un tiempo, aparece el cansancio, y si se va a desarrollar un trabajo pesado, hay que recurrir a las reservas de energía. Estas fuentes de energía se utilizan siempre que se realiza algún trabajo con rapidez, se comienza repentinamente (sin el calentamiento previo) o implica un cansancio profundo.

El organismo humano obtiene energía aeróbicamente (por medio del oxígeno de la sangre) y anaeróbicamente (tras consumirse el oxígeno aeróbico, se buscan las reservas, pequeñas pero importantes, de energía almacenadas en el tejido muscular). La necesidad de aire fresco en el puesto de trabajo nos lleva a prestar toda la atención al uso aeróbico del oxígeno. Las condiciones de trabajo que son lo suficientemente agotadoras como para requerir procesos anaeróbicos con mucha regularidad, son poco comunes, al menos en los países desarrollados. La disponibilidad de oxígeno atmosférico, relacionada directamente con el funcionamiento aeróbico, requiere ciertas condiciones:

- Presión atmosférica (aproximadamente 760 T orr. o 21,33 kPa a nivel del mar). La realización de tareas a determinada altitud se puede ver afectada por la falta de oxígeno; esta falta debería ser una consideración primordial cuando se trata de trabajadores que trabajan en tales condiciones.

- Para los trabajadores que realizan trabajos pesados, es necesario un sistema de ventilación para garantizar el recambio de aire y permitir que se incremente el volumen de aire respirado por minuto.

- El oxígeno ambiental llega al torrente sanguíneo a través de los alvéolos pulmonares, gracias a un proceso de difusión. A mayores presiones sanguíneas, la superficie de difusión es mayor, y aumenta la capacidad de oxígeno en la sangre. 
- El incremento de la difusión de oxígeno hacia los tejidos provoca un incremento de la superficie de difusión y, consecuentemente, del nivel de oxígeno.

- Las personas con ciertos problemas cardíacos sufren cuando, debido a un mayor gasto cardíaco (junto con el nivel de oxígeno) la circulación sanguínea cambia en favor de los músculos.

- A diferencia de lo que ocurre con el oxígeno, el "combustible" (fuente de energía) no necesita ser siempre provisto desde el exterior debido a las grandes reservas de glucosa y en especial, de grasa. En los trabajos más pesados se utiliza exclusivamente glucosa, debido a su alto valor energético. En los trabajos menos pesados, se utiliza la grasa, en una proporción que depende de cada persona. Veamos brevemente un caso general.

U na persona que sufra de asma 0 bronquitis, enfermedades que afectan a los pulmones, tiene serias limitaciones en el trabajo. Se debería analizar la tarea concreta de este trabajador en relación con factores como la carga física. E I entorno laboral también se debería analizar: un entorno con aire limpio contribuye sustancialmente al bienestar del trabajador. Además, la carga de trabajo se debería distribuir de manera equilibrada a lo largo del día, evitando los "picos" de cargas excesivas.

\section{Diseño específico}

En algunos casos, sin embargo, se deberán hacer diseños específicos 0 para grupos pequeños. Estas necesidades se plantearán cuando tanto las tareas como las necesidades para la persona discapacitada sean excesivas. Si los requisitos específicos necesarios no se pueden fabricar con los productos disponibles en el mercado, ni siquiera a través de adaptaciones, la solución es el diseño específico. Dejando aparte cuestiones humanitarias, sólo sabremos si estas soluciones son costosas o baratas a la luz de cuestiones como la capacidad de trabajo y su influencia en la viabilidad de la empresa. Diseñar un puesto de trabajo específico merecerá económicamente la pena cuando el trabajador con discapacidades tenga en mente continuar en dicho puesto durante largo tiempo y su trabajo, en términos de producción, represente un activo para la empresa. Si no es éste el caso, el trabajador siempre podría insistir en su derecho al trabajo, pero prevalecerá el sentido de la realidad y el pragmatismo. Estos problemas tan delicados se deben afrontar con un espíritu de cooperación y comunicación necesarios para buscar la solución más adecuada.

Las ventajas del diseño específico son las siguientes:

- El diseño se hace de forma personalizada: las soluciones y los problemas se ajustan a la perfección.

- El trabajador puede volver a la vida social y laboral.

- El trabajador puede ser autosuficiente, sin tener que depender de los servicios de asistencia social.

- Se evitan los cambios de personal que implicarían otras alternativas.

Las desventajas del diseño específico son:

- Es difícil que el diseño específico se pueda usar para otra persona, y menos aún para un gran grupo.

- A menudo es muy costoso.

- Estos productos de diseño suelen ser hechos a mano, por lo que no se aprovecha el ahorro que suponen los medios de producción en masa.

Caso 1. Por ejemplo, una recepcionista en silla de ruedas con problemas del habla. E ste problema ocasionaba que sus conversaciones fueran lentas. M ientras la empresa fue pequeña, no hubo ningún problema y desarrolló su trabajo de forma intachable durante varios años, pero cuando la empresa creció, sus discapacidades se convirtieron en algo problemático. Tenía que hablar más rápido y moverse con mayor rapidez, al go que no podía conseguir. Las soluciones que se buscaron se reducían a dos alternativas: la instalación de un equipo especial para compensar las deficiencias que disminuían la calidad de su trabajo, o que ella escogiera otro tipo de tarea, más de despacho u oficina, que no implicara un contacto con el público. Eligió la segunda opción y aún trabaja para la misma empresa.

Caso 2. U n delineante joven sufrió una grave lesión de la columna vertebral por haberse lanzado de cabeza en aguas poco profundas. Su lesión era lo suficientemente grave como para necesitar ayuda en su actividad diaria. Sin embargo, con ayuda de un programa de diseño asistido por ordenador (CAD), es capaz de ganarse la vida con el dibujo técnico y actualmente vive con su pareja y mantiene su independencia económica. Su lugar de trabajo es un estudio adaptado a sus necesidades y trabaja para una empresa con la que se comunica a todos los niveles por medio del ordenador, el fax y el teléfono. Para poder manejar su ordenador se tuvieron que hacer algunas modificaciones en el teclado, pero gracias a estas mejoras técnicas puede ganarse la vida por sí mismo.

La estrategia para el diseño específico no es diferente de la de otros tipos de diseño comentados anteriormente. El único problema imposible de resolver que se podría presentar en un proyecto de diseño específico, es que no se pueda alcanzar el objetivo deseado por motivos técnicos, es decir, que no se pueda construir. Por ejemplo, es probable que un enfermo de Parkinson, en cierto punto de la evolución de su enfermedad, muestre una tendencia a caer de espaldas. Una ayuda que evitara este problema sería la solución deseada, pero en el actual estado de la técnica no es posible construirla.

\section{Sistemas de diseño ergonómico y trabajadores con necesidades físicas especiales}

Las lesiones corporales se pueden tratar con intervenciones médicas para restaurar la función dañada, pero el tratamiento de la discapacidad o la incapacidad para realizar determinadas tareas pueden requerir medidas menos desarrolladas en comparación con la ciencia médica. Por lo que respecta a la necesidad de tratamiento de la discapacidad, la decisión depende de la gravedad de la discapacidad. U na vez que se ha decidido la necesidad de tratamiento, el diseñador o gestor pueden optar por aplicar una o varias de las siguientes opciones:

- eliminar una tarea,

- compensar la incapacidad de un trabajador para realizar una determinada tarea con la ayuda de una máquina o de otra persona,

- diferenciar el orden en que se ha de realizar la tarea, dividiéndola en subtareas más manejables,

- modificar las herramientas que es necesario utilizar,

- diseño especial de máquinas y herramientas.

Desde el punto de vista estrictamente económico, el tratamiento de la discapacidad implica:

- la modificación de la tarea,

- la modificación de las herramientas,

- el diseño de nuevas máquinas y herramientas.

La cuestión de la eficacia es siempre el punto de partida de cualquier modificación de herramientas o máquinas y se relaciona frecuentemente con los costes derivados de tales modificaciones, las características técnicas requeridas y los cambios funcionales que se desea incorporar en el nuevo diseño. La comodidad y el atractivo son, entre otras, dos cualidades que no deben ser pasados por alto. 
La siguiente consideración relacionada con los cambios que hay que realizar en máquinas o herramientas se refiere a si el aparato ha sido diseñado para uso general, en cuyo caso las modificaciones se harán sobre un producto ya existente, o si se va a diseñar para ajustarse a una discapacidad concreta. En este último caso, cada aspecto de la discapacidad del trabajador debe recibir una consideración ergonómica específica. Por ejemplo, un trabajador que haya sufrido un accidente cerebrovascular y que presente limitaciones en las funciones cerebrales como: afasia (dificultad para comunicarse), parálisis del brazo derecho y una paresia espástica que le impida elevar la pierna; requerirá los siguientes ajustes:

- un ordenador personal u otro dispositivo que permita al trabajador comunicarse,

- herramientas que se puedan utilizar con el brazo útil,

- una prótesis para recuperar la funcionalidad del pie afectado, así como para compensar la incapacidad del trabajador para andar.

¿Existe una respuesta general a la pregunta de cómo diseñar para el trabajador con alguna discapacidad? La solución del diseño ergonómico de sistemas (DES) es evidentemente ideal a este respecto. Las investigaciones relacionadas con la situación laboral o el tipo de producto, requieren de un equipo de diseño cuya finalidad es recopilar la información especial relacionada con un grupo específico de trabajadores con discapacidades 0 con un caso único de una persona con alguna discapacidad concreta. El equipo de diseño, al estar compuesto por diverso personal capacitado, tendrá una experiencia y una capacitación superiores a las de un único diseñador y sus conocimientos médicos y ergonómicos serán tan valiosos como los estrictamente técnicos.
Las limitaciones impuestas al diseño al recopilar los datos relacionados con los trabajadores con discapacidades se deben tratar con la misma objetividad y espíritu analítico que las impuestas por los datos equivalentes obtenidos de usuarios sin discapacidades. Al igual que se haría con estos últimos, se deben determinar los patrones de respuesta conductual, los perfiles antropométricos, los datos biomecánicos (alcance, fuerza, zona de movilidad, zona de manipulación, carga física, etc), los estándares ergonómicos y las normas de seguridad para los trabajadores discapacitados

Lamentablemente, nos vemos obligados a admitir que hay pocas investigaciones en favor de los trabajadores con discapacidades. Hay, es cierto, algunos estudios de antropometría, algunos más sobre biomecánica en el campo de las prótesis y la ortopedia, pero casi ninguno sobre la capacidad de carga física. El lector encontrará las referencias de estas publicaciones en la sección "O tras lecturas recomendadas", al final del capítulo. Aunque en ocasiones resulta sencillo obtener y aplicar estos datos, la mayor parte de las veces es una tarea difícil y en ocasiones, imposible.

Para estar seguro, hay que obtener datos objetivos, por muy grande que sea el esfuerzo y pocas las posibilidades de tener éxito, teniendo en cuenta que el número de personas con discapacidades que intervienen en estas investigaciones es muy reducido. Sin embargo, estas personas suelen participar voluntariamente en cualquier tipo de investigación que se les proponga. Tienen una conciencia clara de la importancia de su aportación al diseño y la investigación en este campo, ya que representa una inversión, no sólo para ellos mismos, sino para toda la comunidad de los discapacitados.

\section{DIVERSIDAD E IMPORTANCIA DE LA ERGONOMÍA: DOS EJ EMPLOS}

\section{- Diseño DE SISTEMAS EN LA FABRICACION DE DIAMANTES}

Issachar G ilad*

El diseño de los bancos de trabajo accionados manualmente y los métodos de trabajo en la industria del tallado de diamantes no ha cambiado desde hace cientos de años. Los estudios sobre salud laboral de los talladores de diamantes han identificado frecuencias elevadas de trastornos musculosqueléticos en las manos y brazos, en particular, neuropatía ulnar en el codo. Estos trastornos se deben a las altas exigencias musculosqueléticas que tiene que soportar la parte superior del cuerpo en la práctica de esta profesión predominantemente manual. En un estudio realizado en el "Technion Israel Institute of Technology" se investigaron los aspectos ergonómicos y las enfermedades de origen profesional relativas a las condiciones de seguridad en los trabajadores de la industria del tallado de diamantes. Las tareas en esta industria exigen una gran cantidad de manipulaciones que

* El autor agradece la ayuda de E. Messer y al Prof. W. Laurig por su contribución en los aspectos biomecánicos y de diseño y al Prof. $\mathrm{H}$. Stein y al Dr. R. L anger por su ayuda en los aspectos fisiológicos del proceso de tallado. La investigación fue subvencionada con un donativo del Comite para la Inves tigación y Prevención en la Salud y Seguridad en el Trabajo del M inisterio del Trabajo y Asuntos Sociales de I srael. requieren movimientos rápidos y frecuentes de las manos. Un estudio epidemiológico realizado entre 1989 y1992 en la industria israelí del diamante demostró que estos movimientos para el tallado de los diamantes son una causa frecuente de problemas de salud graves en las extremidades superiores y en la parte superior e inferior de la espalda. Cuando este tipo de riesgos profesionales afectan a los trabajadores, se produce una reacción en cadena que, a la larga, afecta también a la economía de esta industria.

Desde hace miles de años, los diamantes han sido objetos fascinantes, símbolos de belleza, riqueza y valor económico. $H$ ábiles artesanos y artistas han intentado, a lo largo de los siglos, crear belleza mejorando la forma y el valor de esta formación única de cristal de carbono. En comparación con los continuos avances en la creación artística con la piedra en bruto y el surgimiento de una gran industria internacional, la mejora en las condiciones de trabajo ha sido prácticamente nula. Cuando se visitan los museos de diamantes en Inglaterra, Sudáfrica e Israel, se llega a la conclusión histórica de que el lugar de trabajo tradicional para el tallado de diamantes no se ha modificado en cientos de años. Los bancos, herramientas y procesos de trabajo típicos para el tallado de diamantes descritos por V leeschdrager (1986), son comunes en los talleres de tallado de todo el mundo.

La evaluación ergonómica realizada en los talleres de fabricación de diamantes revela una carencia de ingeniería de diseño 
del puesto de trabajo de tallado, lo que ocasiona dolores de espalda y cuello y tensión en el brazo debido a la postura de trabajo. U n estudio de los micromovimientos y el análisis biomecánico de los patrones de movimiento involucrados en esta profesión indican movimientos muy intensos de las manos y los brazos que conllevan una gran aceleración, movimientos rápidos y un alto grado de repetitividad en ciclos muy cortos. Una investigación de los síntomas que presentan los talladores de diamantes muestra que a pesar de que el $45 \%$ de los trabajadores eran menores de 40 años y de que formaban parte de una población joven y sana, el $64 \%$ manifestaban dolores en los hombros, el $36 \%$, dolores en el brazo y el $27 \%$, dolores en el antebrazo. La acción de pulir se realiza con una gran presión de la mano sobre la herramienta, aplicada a un disco pulidor vibratorio.

La primera descripción conocida de un puesto de trabajo de tallado de diamantes data de 1568 y la realizó el orfebre italiano Benvenuto Cellini, quien escribió: "Un diamante se frota contra otro hasta que, por abrasión mutua, ambos adquieren la forma que el tallista experimentado desea conseguir". La descripción de Cellini podía haberse escrito en esta época: el papel del operador humano no ha cambiado en estos 400 años. Si se examinan las rutinas de trabajo, las herramientas manuales y la naturaleza de las decisiones involucradas en el proceso, se puede observar que la relación usuario-máquina prácticamente no ha cambiado. Esta situación es única en la industria, donde la aparición de los sistemas automatizados, la robótica y los sistemas informáticos ha cambiado completamente el papel del trabajador en el mundo actual. Sin embargo, el ciclo de trabajo del tallado ha resultado ser muy similar no sólo en Europa, donde comenzó el arte del tallado, sino también en el resto del mundo, ya sea en las modernas instalaciones de Estados $U$ nidos, Bélgica o Israel, especializadas en sofisticadas geometrías y diamantes de gran valor, 0 en las instalaciones de la India, China o Tailandia, que generalmente producen formas más populares y de un valor medio.

El proceso de tallado consiste en desgastar el diamante en bruto con polvo de diamante unido a la superficie del disco de pulido. Debido a su dureza, sólo resulta eficaz el desgaste por fricción contra un material de carbono similar para dar forma al diamante y conseguir la geometría y el brillo finales. El equipamiento del puesto de trabajo consiste en dos grupos básicos de elementos: los mecanismos del puesto y las herramientas manuales. El primer grupo incluye un motor eléctrico que hace girar un disco pulidor sobre un eje vertical cilíndrico, probablemente mediante un simple accionamiento directo, un tablero plano y sólido que rodea al disco pulidor, un banco para sentarse y una fuente de luz. Las herramientas manuales consisten en un soporte o mordaza para diamantes, que sujeta la piedra en bruto durante todas las fases de pulido y que generalmente se sostiene en la palma izquierda. El trabajo se amplifica con una lente convexa que se sostiene entre los dedos primero, segundo y tercero de la mano derecha, por la cual mira el ojo izquierdo. Este método de trabajo se impone a través de un estricto proceso de formación que, en la mayoría de los casos, no tiene en cuenta si el trabajador es diestro o zurdo. Durante el trabajo, el tallador adopta una postura inclinada para presionar el soporte contra el disco pulidor. Esta postura requiere que los brazos se apoyen sobre el tablero de trabajo con el fin de estabilizar las manos. Como resultado, el nervio ulnar es vulnerable a lesiones externas debidas a su posición anatómica. Este tipo de lesión es frecuente entre los talladores de diamantes y se ha aceptado como una enfermedad de origen profesional desde el decenio de 1950. El número de talladores de diamantes que existe actualmente en todo el mundo es de unos 450.000, de los cuales aproximadamente el $75 \%$ se localizan en el Lejano
0 riente, principalmente en la India, en donde la industria de los diamantes se ha expandido de forma importante en las dos últimas décadas. La acción de pulir se realiza manualmente, y cada una de las facetas se realiza por pulidores capacitados y experimentados en cierta parte de la geometría de la piedra. Los talladores constituyen la mayor parte (cerca de un $80 \%$ ) del total de la fuerza de trabajo de la industria del diamante. Por este motivo, es posible eliminar la mayor parte de los riesgos profesionales de esta industria mejorando el puesto de trabajo de los talladores de diamantes.

El análisis de los patrones de movimiento involucrados en el tallado muestra que la tarea incluye dos subtareas: la primera es una tarea sencilla, llamada el ciclo de pulido, que representa la operación básica de tallado del diamante, y la segunda es una tarea más importante, llamada el ciclo de las facetas, que implica una inspección final y un cambio de la posición de la piedra en el soporte. Todo el procedimiento incluye cuatro elementos básicos:

1. Pulido. La operación de tallado propiamente dicha.

2. Inspección. Cada pocos segundos, el operador inspecciona el avance en el tallado de la faceta con una lente de aumento.

3. Ajuste de la mordaza. Se realiza un ajuste angular en la cabeza del soporte del diamante (mordaza).

4. Cambio de piedra. El proceso de cambiar de faceta, que se realiza girando el diamante en un ángulo predeterminado. Pulir una faceta de un diamante requiere unas 25 repeticiones de estos cuatro elementos. El número de estas repeticiones depende de factores como la edad del operador, la dureza y las características de la piedra, la hora del día (debido a la fatiga del operador), etc. Como media, cada repetición dura unos cuatro segundos. El trabajo de Gilad (1993) muestra un estudio de micromovimientos realizado en el proceso de tallado y la metodología utilizada.

Dos de los elementos, el pulido y la inspección, se realizan en posturas de trabajo relativamente estáticas, mientras que las acciones llamadas "mano hacia el pulido" (M a P) y "mano hacia la inspección" (M a I) requieren movimientos cortos y rápidos del hombro, del codo y de la muñeca. La mayor parte de los movimientos de ambas manos se realizan por flexión-extensión y pronación-supinación del codo. La postura corporal, en especial de la espalda y cuello, y todos los demás movimientos con excepción de la desviación de la muñeca son relativamente invariables durante el trabajo normal. El soporte de la piedra, fabricado con una varilla de acero de sección cuadrada, se sostiene de forma que presiona los vasos sanguíneos y el hueso, lo que puede ocasionar una disminución del flujo sanguíneo a los dedos anular y meñique. La mano derecha sostiene la lente de aumento durante todo el ciclo de pulido, ejerciendo una presión isométrica sobre los tres primeros dedos. Durante la mayor parte del tiempo, las manos derecha e izquierda siguen patrones de movimiento paralelos, mientras que en el movimiento "mano hacia el pulido" la mano izquierda inicia el movimiento y la derecha comienza a moverse algo después. En el movimiento "mano hacia la inspección", este orden se invierte. Las tareas de la mano derecha son sujetar la lente de aumento sobre el ojo izquierdo, mientras tiene apoyada la mano izquierda (flexión del codo) o bien, presionar en la cabeza del soporte del diamante para mejorar el pulido (extensión del codo). Estos movimientos rápidos producen aceleraciones y desaceleraciones rápidas que tienen como finalidad la colocación precisa de la piedra en el disco de pulido, lo que requiere un alto nivel de destreza manual. D ebe señalarse que han de pasar muchos años antes de que se alcanza la pericia necesaria para convertir los movimientos de trabajo en acciones casi reflejas realizadas automáticamente. 
A primera vista, la tarea del tallado de diamantes es una tarea simple, y en cierto modo lo es, pero en realidad requiere una gran habilidad y experiencia. Al contrario de lo que sucede en las demás industrias, donde las materias primas y procesadas se controlan y fabrican de acuerdo con especificaciones precisas, el diamante en bruto no es homogéneo y cada cristal de diamante, grande 0 pequeño, debe comprobarse, clasificarse y tratarse individualmente. Además de la habilidad manual necesaria, el tallador debe tomar decisiones operativas en cada fase del pulido. Como resultado de la inspección visual, deben tomarse decisiones sobre factores como la corrección espacial angular (un juicio tridimensional), la cantidad y la duración de la presión que se debe aplicar, la posición angular de la piedra, el punto de contacto con el disco de pulido y otras más. Es necesario considerar un gran número de cuestiones importantes y todas en un tiempo medio de cuatro segundos. Es importante entender este proceso de toma de decisiones a la hora de diseñar las mejoras.

Antes de utilizar los resultados del análisis de movimientos para establecer mejores criterios de diseño ergonómico y de ingeniería en los puestos de trabajo de tallado, es necesario comprender otros aspectos involucrados en este sistema usuario-máquina único. En esta era de postautomatización, aún podemos encontrar que la fase de producción de la próspera y creciente industria del diamante permanece casi ajena a los enormes avances tecnológicos ocurridos en las últimas décadas. $M$ ientras que los demás sectores industriales han atravesado un proceso de continuo cambio tecnológico, que ha definido no sólo los métodos de producción sino los propios productos, la industria del diamante ha permanecido prácticamente estática. U na razón plausible para esta estabilidad puede ser el hecho de que ni el producto ni el mercado han sufrido cambios a través de los años. EI diseño y las formas de los diamantes son, en la práctica, casi invariables. Desde el punto de vista del comercio, no existe ninguna razón para cambiar el producto o los métodos. Además, puesto que la mayor parte del trabajo se realiza a través de la subcontratación de trabajadores individuales, la industria no tiene el problema de reglamentar la fuerza de trabajo, ni de ajustar el flujo de producción y el suministro de diamantes en bruto según las fluctuaciones del mercado. M ientras los métodos de trabajo no cambien, el producto tampoco cambiará. U na vez que la industria del diamante adopte una tecnología más avanzada y se automatice, el producto cambiará y se encontrará una mayor variedad de formas en el mercado. Sin embargo, los diamantes siguen teniendo una calidad casi mística que los distingue de otro tipo de productos, un valor que puede disminuir si llega a considerarse como otro elemento más de producción en serie. Recientemente, sin embargo, las presiones del mercado y el surgimiento de nuevos centros de producción, principalmente en el Lejano O riente, están poniendo en peligro a los antiguos centros establecidos en Europa. Esto está obligando a la industria a explorar nuevos métodos y sistemas de producción, y a examinar el papel del operador humano.

Al estudiar las posibilidades de mejora del puesto de trabajo del tallador, es preciso considerarlo como parte de un sistema usuario-máquina regido por tres factores principales: el factor humano, el factor tecnológico y el factor comercial. Un nuevo diseño que tenga en cuenta los principios ergonómicos proporcionará un punto de partida para una mejor "unidad" de producción en el sentido más amplio del término, es decir, un mayor confor durante la larga jornada laboral, un producto de mejor calidad y mayores tasas de producción. Se han considerado dos enfoques de diseño distintos. El primero de ellos conlleva el rediseño del puesto de trabajo existente, en el que el trabajador realizaría las mismas tareas. EI segundo consiste en considerar la tarea de tallado de una forma imparcial, con el objetivo de obtener un diseño óptimo de las tareas y de todo el puesto de trabajo. Un diseño global no debe basarse en el puesto de trabajo actual, sino en la futura tarea de tallado y debe generar soluciones de diseño que integren y optimicen las necesidades de los tres factores del sistema antes mencionados.

Actualmente, el operador humano realiza la mayoría de las tareas involucradas en el proceso de tallado. Estas tareas realizadas por el hombre dependen del "aprendizaje" y de la experiencia en el trabajo. Se trata de un complejo proceso psicofisiológico, sólo parcialmente consciente, basado en el principio de prueba y error que permite al operador ejecutar operaciones complejas con un buen nivel de predicción del resultado. Durante los ciclos periódicos diarios de miles de movimientos idénticos el "aprendizaje" se manifiesta en la activación automática de la memoria motora ejecutada con gran precisión. Para cada uno de estos movimientos automáticos, se realizan pequeñas correcciones en respuesta a la retroinformación recibida de los sentidos humanos como los ojos y los receptores de presión. En cualquier puesto de tallado de diamantes futuro, estas tareas se seguirán realizando de forma distinta. Por lo que respecta al propio material, en la industria del diamante, al contrario de lo que sucede en la mayoría de las demás industrias, el valor relativo de las materias primas es muy elevado. Esto explica la importancia de obtener el máximo partido posible al volumen (o peso) del diamante en bruto con el fin de conseguir una piedra neta lo mayor posible después del tallado. Esto es importante en todas las fases del proceso. La productividad y la eficacia no se miden con relación al tiempo únicamente, sino también al tamaño y precisión alcanzados.

Los cuatro elementos de trabajo repetitivos: "pulido", "mano a inspección", "inspección" y "mano a pulido" que se realizan en la acción de tallado, pueden clasificarse en las tres categorías principales: tareas motoras para los elementos de movimiento, tareas visuales para los elementos sensoriales, y control y gestión para los elementos de decisión. G ilad y M esser (1992) comentan las consideraciones de diseño para un puesto de trabajo ergonómico. La Figura 29.52 muestra un esquema de una unidad de

Figura 29.52 • Presentación esquemática de una celda de pulido.

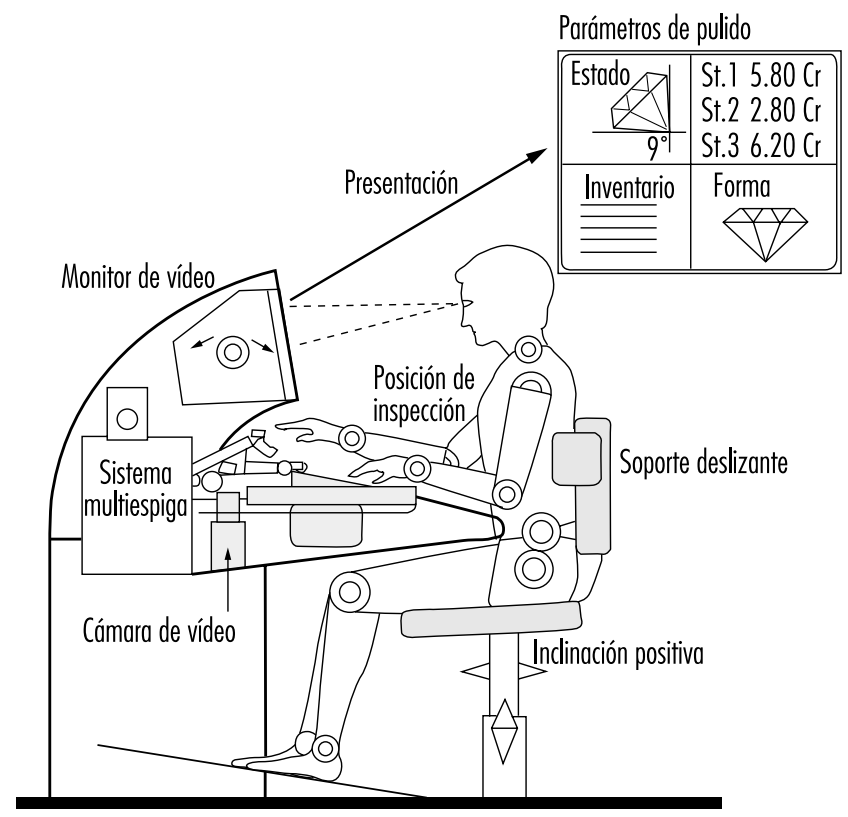


pulido avanzada. Sólo se indica la construcción general, ya que los detalles de este diseño están considerados como "secretos" profesionales. Se utiliza el término "unidad de pulido" ya que este sistema usuario-máquina incluye un enfoque totalmente nuevo del tallado de diamantes. Además de las mejoras ergonómicas, el sistema consta de dispositivos mecánicos y optoelectrónicos que permiten la fabricación de tres a cinco piedras al mismo tiempo. Se han transferido partes de las tareas visuales y de control a operadores técnicos y la gestión de la unidad de producción está mediada por una pantalla de visualización que proporciona información momentánea sobre la geometría, el peso y las opciones de movimiento con el fin de realizar las acciones óptimas. Este diseño hace avanzar al puesto de trabajo de tallado algunos pasos hacia la modernización, incorporando un sistema experto y un sistema de control visual que sustituyen al ojo humano en todo el trabajo rutinario. Los operadores pueden intervenir en cualquier momento, definir los datos y enjuiciar el funcionamiento de la máquina. EI manipulador mecánico y el sistema experto forman un sistema cerrado capaz de realizar todas las tareas de tallado. El operador seguirá encargándose de la manipulación de los materiales, el control de la calidad y la aprobación final. En este sistema avanzado, sería adecuado considerar el empleo de tecnología más avanzada, como un pulidor láser. A ctualmente, los láseres se utilizan para dividir y cortar diamantes. El uso de un sistema tecnológicamente avanzado cambiará radicalmente la descripción de la tarea humana. Disminuirá la necesidad de talladores cualificados, que se dedicarán exclusivamente al pulido de los diamantes grandes y más valiosos, probablemente bajo supervisión.

\section{- VIOLACION DE LOS PRINCIPIOS DEL DISEÑO ERGONOMICO: CHERNOBIL}

\section{Vladimir M. M unipov}

Las causas del accidente de Chernobil, ocurrido en 1986, se han atribuido indistintamente a los operadores, a la dirección de la central, al diseño del reactor y a la falta de adecuada información sobre seguridad en la industria nuclear soviética. Este artículo examina algunos de los fallos de diseño, de las deficiencias en el manejo y de los errores humanos que produjeron el desastre. Se examina la secuencia de hechos que llevaron al accidente, los problemas de diseño del reactor y de las barras de refrigeración y el curso del accidente mismo. Se tienen en cuenta también aspectos ergonómicos, y se sostiene la opinión de que la causa principal del accidente fue una inadecuada interacción hombre máquina. Por último, se mencionan las deficiencias que aún existen en el sistema nuclear soviético y se pone especial énfasis en que, a menos que aprendamos las lecciones ergonómicas, podría ocurrir otro desastre de características similares.

Todavía no se conoce la verdadera historia de Chernobil. EI secretismo, las reticencias a hablar, las verdades a medias e incluso las mentiras, mantienen ocultas las razones del accidente. U n amplio análisis de las causas del accidente resulta casi una tarea imposible. El principal problema que debe afrontar el investigador es la necesidad de reconstruir el accidente y el papel que desempeñó el factor humano en él, contando únicamente con los pequeños fragmentos de información disponibles para su estudio. El desastre de Chernobil es más que un grave accidente tecnológico; parte de las causas del desastre se encuentran en la administración y en la burocracia. Sin embargo, el objetivo principal de este artículo es considerar los fallos de diseño, las deficiencias de manejo y los errores humanos que se combinaron en el accidente de $C$ hernobil.

\section{¿De quién fue la culpa?}

El académico N.A. Dollezhal, diseñador en jefe de los tubos de presión de los reactores de agua en ebullición (R BM K ) utilizados en la central nuclear de Chernobil presentó en 1989 su visión personal de las causas del accidente. Su diagnóstico fue tajante, atribuyendo el accidente al hecho de que el personal no siguió los procedimientos correctos o "disciplina de producción". Señaló que los abogados que investigaron el accidente habían llegado a la misma conclusión. Según su opinión, "el fallo estuvo en el personal y no en un error de diseño o de fabricación". El supervisor de investigación de los RBM K corroboró esta opinión. En ningún momento se consideró la posibilidad de una falta de adecuación ergonómica como factor causal.

Sin embargo, los operadores expresaron una opinión distinta. El supervisor de turno de la cuarta unidad, A.F. A kimov, mientras agonizaba en un hospital por la dosis de radiación recibida durante el accidente, superior a 1.500 rads $(R)$ en un corto período de tiempo, seguía diciendo a sus padres que sus acciones habían sido correctas y que no entendía qué podía haber salido mal. Su insistencia reflejaba la absoluta confianza que tenía en un reactor, que se suponía totalmente seguro. A kimov aseguró que no tenía nada de qué culpar a su equipo. Los operadores estaban seguros de que sus acciones se ajustaban a las normas y en éstas ni siquiera se mencionaba la posibilidad de una explosión. (Curiosamente, la posibilidad de que el reactor se convirtiera en algo peligroso bajo ciertas condiciones sólo se introdujo en las normas de seguridad después del accidente de $\mathrm{C}$ hernobil). Sin embargo, a la luz de los problemas de diseño que se han revelado después, es muy significativo que los operarios no pudieran comprender por qué al introducir las barras en el núcleo se produjo tan terrible explosión, en lugar de detenerse la reacción nuclear como estaba previsto. En otras palabras, actuaron "correctamente" según las instrucciones para el mantenimiento y su modelo mental del sistema del reactor, pero el diseño del sistema no se ajustaba a ese modelo.

A la vista de las pérdidas humanas, seis personas (que representaban a la dirección de la central), fueron condenadas por haber violado las normas de seguridad de instalaciones potencialmente explosivas. El presidente del tribunal señaló que debían reanudarse las investigaciones sobre "quienes no tomaron las medidas necesarias para mejorar el diseño de la central". También mencionó la responsabilidad de los altos cargos del departamento, de las autoridades locales y de los servicios médicos. Pero, de hecho, el caso estaba cerrado. Nadie más fue declarado responsable del mayor desastre ocurrido en la historia de la tecnología nuclear.

Sin embargo, es necesario investigar todos los factores causales que se combinaron para producir el desastre con el fin de aprender una lección importante para el funcionamiento seguro de las plantas nucleares en el futuro.

\section{Secretismo: el monopolio de la información en} la investigación y la industria

EI fallo en la relación usuario-máquina que provocó el accidente de Chernobil en 1986 se puede atribuir, en alguna medida, a la política de secretismo, - la imposición de un monopolio informativo-, que regía la comunicación tecnológica en las clases dirigentes de la energía nuclear soviética. Un pequeño grupo de científicos e investigadores tenían el derecho a definir los principios y procedimientos básicos en la energía nuclear, un monopolio protegido por una política de secretismo. Como consecuencia de ello, las afirmaciones de los científicos soviéticos sobre la absoluta seguridad de las centrales nucleares no se 
pusieron en duda durante 35 años y el secretismo contribuía a ocultar la incompetencia de los encargados de la política nuclear civil. Casualmente, se ha llegado a saber que el secretismo se extendió también a la información relacionada con el accidente de Three Mile Island; el personal del resto de las centrales nucleares soviéticas no fue bien informado de este accidente. Ú nicamente se conocieron aquellos detalles que no contradecían la versión oficial sobre la seguridad de las centrales nucleares. Un informe sobre los aspectos de ingeniería humana en el accidente de Three M ile Island, presentado por el autor de este artículo en 1985, nunca se distribuyó a las personas relacionadas con la seguridad y la fiabilidad de las centrales nucleares.

Jamás se hizo público ningún accidente nuclear en la U nión Soviética, excepto los de las centrales nucleares de Armenia y Chernobil (1982), que merecieron una pequeña mención en el periódico Pravda. Al ocultar el verdadero estado del problema y no aprovechar las lecciones basadas en el análisis de accidentes, los dirigentes de la industria nuclear estaban allanando el camino para el accidente del 86 en Chernobil, a lo que favorecieron además la idea simplificada que se había implantado sobre las actividades de los operadores y la subestimación del riesgo implícito en el funcionamiento de las centrales nucleares.

Como señaló en 1990 un miembro del Comité de Expertos Estatales sobre las Consecuencias del Accidente de Chernobil: "Para no cometer más errores, hay que admitir y analizar todos nuestros errores anteriores. Es esencial determinar qué errores se debieron a nuestra inexperiencia y cuáles se debieron a un intento deliberado de esconder la verdad".

\section{El accidente de Chernobil de 1986}

\section{Planificación defectuosa de las pruebas}

El 25 de abril de 1986, la cuarta unidad de la central nuclear de Chernobil (Chernobil 4) estaba siendo preparada para una operación de mantenimiento rutinario. El plan era parar la unidad y realizar una prueba con los sistemas de seguridad desconectad os y totalmente desprovistos de los suministros normales de energía. Esta prueba se debía haber llevado a cabo antes de la puesta en marcha inicial de Chernobil 4. Sin embargo, el Comité Estatal tenía tanta prisa por inaugurar la central, que decidió posponer indefinidamente algunas pruebas "insignificantes". EI Certificado de Conformidad se firmó a finales de 1982. Así, el ingeniero jefe suplente actuó según los planes primeros, que presuponían la unidad totalmente inactiva; la planificación y orden de ejecución de la prueba se basaron en este supuesto implícito. En ningún momento realizó la prueba por iniciativa propia.

El programa de la prueba fue aprobado por el director de ingeniería. La energía durante la prueba debía provenir del rotor de la turbina después de apagarlo (durante su fase de rotación inducida por la inercia). M ientras sigue girando, la rueda móvil de la turbina genera energía que se puede usar en casos de emergencia. La falta total de energía en una central nuclear hace que se paren todos los mecanismos, incluidas las bombas de refrigeración del núcleo del reactor, lo que provocaría un grave accidente, ya que haría fundirse el núcleo. El objetivo de la prueba era comprobar la posibilidad de utilizar otros medios de generación de energía: la rotación por inercia de la turbina. No está prohibido llevar a cabo tales pruebas en centrales en producción, siempre que se haya elaborado el procedimiento adecuado y se hayan adoptado las precauciones de seguridad adicionales. El programa debe asegurar que dispone de una fuente de energía de seguridad durante todo el tiempo que dure la prueba. En otras palabras, la pérdida de energía se simula pero no es real. EI experimento sólo se puede realizar cuando el reactor está parado, esto es, una vez que se ha pulsado el botón de parada de emergencia y se han introducido las barras de control en el núcleo del reactor. Antes de esto, el reactor deberá estar en una condición estable y controlada, con el margen de reactividad especificado en el procedimiento operativo, con al menos 28 ó 30 barras de control introducidas en el núcleo.

El programa aprobado por el ingeniero jefe de la planta de Chernobil no cumplía ninguno de los requisitos anteriores. A demás, dicho programa proponía bloquear el sistema de refrigeración de emergencia del núcleo, poniendo así en peligro la seguridad de la central durante todo el tiempo que durara la prueba (unas cuatro horas). Cuando desarrollaron el programa, se dieron cuenta de que existía la posibilidad de que se disparase el sistema de refrigeración de emergencia del núcleo, lo que impediría completar la prueba. En el programa no se especificaba el método de purga de la alimentación de vapor a la turbina, puesto que la turbina ya no necesitaría vapor. Evidentemente, los implicados no conocían en absoluto la física del reactor. Los encargados de la energía nuclear estaban por lo visto tan poco cualificados como los que lo diseñaron, lo que explica por qué, cuando se remitió el programa a las autoridades responsables para su aprobación en enero de 1986, nunca se comentó esta deficiencia. También contribuyó la poca sensación de peligro. Debido a la ya citada política de secretismo alrededor de la energía nuclear, se había formado una opinión acerca de que las centrales nucleares eran seguras y fiables, y su funcionamiento estaba libre de todo accidente. La falta de respuesta oficial al programa no alertó al director de $C$ hernobil sobre la posibilidad de riesgo. Decidió seguir adelante con la prueba, llevando a cabo el programa sin ser certificado, aunque esto estuviera prohibido.

\section{Cambios en el programa de la prueba}

M ientras se llevaba a cabo la prueba, el personal no respetó las indicaciones incluidas en el programa, creando así nuevas posibilidades de accidente. El personal de Chernobil cometió seis infracciones o errores graves. De acuerdo con el programa original, el sistema de refrigeración de emergencia del núcleo estaba fuera de servicio, y éste fue uno de los errores mayores y más graves. Las válvulas de control de la entrada de agua se habían cerrado y bloqueado con anterioridad, de manera que era imposible abrirlas incluso manualmente. El sistema de refrigeración de emergencia se había desconectado para evitar una reacción térmica por la entrada de agua fría en el núcleo caliente del reactor. Tal decisión se basó en la firme creencia de que el reactor aguantaría. La "fe" en el reactor se apoyaba en el uso sin problemas del reactor en los diez años de funcionamiento de la planta. Se ignoró incluso un serio aviso: la fusión parcial del núcleo del reactor en la primera unidad de Chernobil en septiembre de 1982.

De acuerdo con el programa de prueba original, la parada del rotor se debía hacer desde una potencia entre 700 y $1.000 \mathrm{M} \mathrm{W}_{\text {th }}$ (megavatios térmicos). La parada del rotor se debía haber realizado con el reactor parado, pero se eligió otro camino, completamente desastroso: llevar a cabo la prueba con el reactor aún en marcha. Se hizo así para asegurar la "pureza" de la prueba.

En deter minadas condiciones de funcionamiento, es necesario cambiar o desconectar el control local de un conjunto de barras de control. Cuando se desconectó uno de estos sistemas locales (en los procedimientos para puesta en funcionamiento con baja energía se especifica la manera de hacerlo), el ingeniero de control del reactor principal no actuó rápidamente para corregir el desequilibrio en el sistema de control. Como consecuencia, la potencia cayó por debajo de $30 \mathrm{M} \mathrm{W}_{\text {th }}$, lo que causó el envenenamiento del reactor por los productos procedentes de la fisión (xenón y yodo). Si esto ocurre, es casi imposible restaurar las 
condiciones normales sin parar la prueba y esperar un día hasta que se elimine el envenenamiento. El ingeniero jefe de operaciones no quiso interrumpir la prueba y, a gritos, obligó a los operadores de la sala de control a comenzar a elevar el nivel de potencia (que se había estabilizado en $200 \mathrm{M} \mathrm{W}_{\text {th }}$ ). El envenenamiento continuó, pero no se podía seguir aumentando la potencia debido al poco margen de reactividad, de sólo 30 barras para un gran reactor. El reactor se hizo prácticamente incontrolable y potencialmente explosivo, porque, al intentar eliminar el envenenamiento, los controladores retiraron varias barras necesarias para mantener el margen de reactividad de seguridad, dejando inoperativo el sistema de parada de emergencia. Sin embargo, se decidió seguir adelante con la prueba. Este comportamiento se debió, quizá, al deseo de completar la prueba cuanto antes.

\section{Problemas debidos al diseño inadecuado del reactor y de las barras de control}

Para comprender mejor las causas del accidente es necesario señalar las graves deficiencias de diseño en las barras de control y del sistema de parada de emergencia. EI núcleo del reactor tiene una longitud de $7 \mathrm{~m}$, mientras que la longitud absorbente de las barras es de $5 \mathrm{~m}$, con $1 \mathrm{~m}$ de zonas huecas en las partes superior e inferior. Los extremos inferiores de las barras, que se sitúan bajo el núcleo cuando se insertan por completo, están rellenos de grafito. Con este diseño, al entrar las barras de control en el núcleo hay primero un metro de zonas huecas seguido de las partes absorbentes. En Chernobil 4, se habían retirado por completo 205 de un total de 211 barras. La reinserción simultánea de tantas barras provoca, en principio, un gran subida de la reactividad (un pico en la actividad de fisión), con la entrada en el núcleo de las partes de grafito y las partes huecas. En un reactor estable y controlado, esta subida no es preocupante, pero cuando se combinan tantas condiciones adversas se puede convertir en algo fatal, ya que provoca un escape inmediato de neutrones del reactor. La causa inmediata de este aumento de reactividad inicial es que el agua rompe a hervir en el núcleo del reactor. El crecimiento inicial en la reactividad reflejaba un inconveniente en particular: un coeficiente de vapor positivo debido al diseño del núcleo del reactor. Esta deficiencia en el diseño es uno de los fallos que provocaron errores de los operadores.

Estos graves fallos de diseño en el reactor y en las barras de control predeterminaron en realidad el accidente de Chernobil. En 1975, después del accidente de la central de Leningrado, y posteriormente, los especialistas avisaron de la posibilidad de otro accidente, en vista de las deficiencias de diseño del núcleo. Seis meses antes del desastre de Chernobil, A.A. Yadrikinsky, inspector de seguridad de la central de Kursk, envió una carta a M oscú en la que señalaba a los jefes de investigación y diseño ciertos defectos de diseño del reactor y del sistema de las barras de control y protección. El Comité Estatal de Supervisión de la Energía Nuclear hizo caso omiso de estos argumentos, considerándolos poco fundados.

\section{El curso del accidente}

El curso de los hechos fue el siguiente. Con la cavitación de la bomba de refrigeración del reactor, disminuyó la velocidad de flujo en el núcleo del reactor y el refrigerante comenzó a hervir en los tubos de presión. Entonces el supervisor de turno pulso el botón de parada de emergencia. Como respuesta, todas las barras de control (que se habían retirado) y las barras de parada de emergencia se introdujeron en el núcleo del reactor. Sin embargo, al ser las partes de grafito y las huecas las primeras en entrar en el núcleo, crearon un aumento de la reactividad; además entraron en el núcleo justo al principio de una generación masiva de vapor. La subida de la temperatura del núcleo produjo también el mismo efecto. Así pues, se combinaron tres condiciones adversas para el núcleo. Inmediatamente, el reactor se puso fuera de control. Esto se debió básicamente a los graves defectos de diseño del reactor $\mathrm{RBMK}$. Hay que recordar aquí que el sistema de refrigeración de emergencia del núcleo estaba fuera de servicio, bloqueado y precintado.

Lo que ocurrió después es bien conocido. El reactor resultó dañado. La mayor parte del combustible, grafito y otros componentes del núcleo del reactor estallaron. L os niveles de radiación en las proximidades de la unidad dañada se situaron entre los 1.000 y $15.000 \mathrm{R} / \mathrm{h}$, aunque en áreas más distantes o protegidas los niveles de radiación fueron considerablemente menores.

Al principio, el personal no se dio cuenta de lo que había pasado y repetían una y otra vez, "iEs imposible! iLo hemos hecho todo como debíamos!".

\section{Consideraciones ergonómicas en conexión con el informe soviético sobre el accidente}

El informe presentado por la delegación soviética en la reunión de la Asociación International de la Energía A tómica (AIEA) en el verano de 1986 proporcionó información verdadera sobre la explosión, pero sigue existiendo la duda de si se puso el énfasis en el lugar adecuado o si se trataron con demasiada benevolencia las deficiencias de diseño. El informe afirmaba que el comportamiento del personal se vio influido por el deseo de completar la prueba cuanto antes. A juzgar por el hecho de que el personal violó los procedimientos de preparación y realización de la prueba y fue poco cuidadoso al realizar el control del reactor, parecería que no estaba muy al tanto de los procesos que en realidad estaban acaeciendo en el reactor y que no tenía ninguna noción del peligro. De acuerdo con el informe:

"Los diseñadores del reactor no proporcionaron los sistemas de seguridad adicionales para prevenir un accidente en caso de que deliberadamente se anularan los sistema de seguridad y conjuntamente se produjera un incumplimiento de los procedimientos operativos, ya que tal combinación se consideraba bastante improbable. Por lo tanto, la causa inicial del accidente fue una improbable combinación de las condiciones y la violación del procedimiento por parte del personal de la central."

Se sabe que en el texto inicial del informe las palabras "personal de la central" iban seguidas por la frase "que puso de manifiesto los errores de diseño del reactor y de las barras del sistema de protección y control".

Los diseñadores consideraban bastante improbable la intervención de gente no cualificada en el control de la central y, por ello, no diseñaron los medios de seguridad necesarios. Los diseñadores, según su informe, consideraron lo sucedido como una situación improbable; pero surgen algunas preguntas : “¿H abían tenido en cuenta los diseñadores todas las posibles situaciones asociadas a la actuación humana en la central? Si la respuesta fuese positiva, ¿cómo se plasmaron en el diseño de la central?". Lamentablemente, la respuesta a la primera pregunta es negativa y deja áreas de la interacción usuario máquina indeterminadas. Como resultado, la formación para situaciones de emergencia, tanto teórica como práctica, se realizaba de acuerdo con un algoritmo de control casi primitivo.

$\mathrm{N}$ o se utilizaron los conceptos ergonómicos para diseñar los sistemas de control asistidos por ordenador, ni para diseñar las salas de control de las centrales nucleares. Sirva como ejemplo un caso particularmente grave: el indicador de uno de los parámetros esenciales del estado del núcleo del reactor (esto es, el número de barras de protección y control insertadas en el núcleo), estaba mal presentado en el panel de mandos de 
Chernobil 4, haciendo muy difícil su localización y comprensión. Sólo los operarios con más experiencia sabían interpretar los dispositivos de presentación de datos.

Los cálculos erróneos del proyecto y la falta de consideración de los factores humanos tuvieron el mismo resultado que una bomba de acción retardada. D ebe recalcarse que los defectos del núcleo y del sistema de control fueron la base para las posteriores acciones erróneas atribuidas a los operadores, por lo que la causa principal del accidente fue el diseño inadecuado de la interacción usuario-máquina. Los investigadores del desastre hicieron una llamada al "respeto para la ingeniería humana y la interacción hombre máquina; esta es la lección que nos enseñó Chernobil". Lamentablemente, es difícil abandonar las viejas ideas y los planteamientos estereotipados.

Desde 1976, el académico P.L. K apitza pareció prever un desastre por razones que podrían haberse evitado en Chernobil, pero sus estudios no se publicaron hasta 1989. En febrero de 1976, U S N ews and W orld Report, una revista semanal de noticias, publicó un reportaje sobre el incendio de la instalación nuclear de Browns Ferry en California. K apitza estaba tan preocupado por este accidente que lo mencionó en su informe titulado "Problemas globales y energía", presentado en Estocolmo en mayo de 1976. K apitza dijo en concreto:

“EI accidente puso de relieve que los métodos matemáticos utilizados para calcular la probabilidad de este tipo de sucesos no fueron los adecuados, ya que no tuvieron en cuenta los posibles errores humanos. Para resolver este problema es necesario tomar medidas para prevenir que el más mínimo accidente nuclear tome un rumbo desastroso."

A su vuelta de Estocolmo, Kapitza intentó publicar este trabajo en la revista Nauka i Z hizn (Ciencia y Vida), pero el trabajo fue rechazado, ya que se consideró que no era conveniente "alarmar a la gente". La revista sueca Ambio pidió a $\mathrm{K}$ apitza el artículo, pero al final tampoco lo publicó.

La Academia de Ciencias aseguró a K apitza que no podía ocurrir este tipo de accidentes en la URSS y como "prueba" definitiva, le entregaron las Normas de Seguridad para Centrales $\mathrm{N}$ ucleares recién publicadas. Estas normas contenían, por ejemplo, el siguiente artículo: "8.1. Las acciones del personal en caso de accidente nuclear se regirán por el procedimiento para hacer frente a las consecuencias del accidente".

\section{Después de Cher nobil}

Como consecuencia directa o indirecta del accidente de Chernobil, se están elaborando y poniendo en marcha medidas para hacer más seguro el funcionamiento de las instalaciones nucleares actuales y para mejorar el diseño y construcción de las futuras. En particular, se han tomado medidas para hacer que el sistema de parada de emergencia sea más rápido y para que el personal no pueda desconectarlo deliberadamente. El diseño de las barras de control se ha modificado también y se ha incrementado su número.

Además, el procedimiento para condiciones anormales anterior a Chernobil indicaba a los operadores que mantuvieran el reactor en marcha, mientras que según el actual, se debe parar. Los nuevos reactores que se diseñan hoy en día son, por así decirlo, inherentemente seguros. $\mathrm{H}$ an aparecido nuevas áreas de investigación que antes de C hernobil se ignoraban o no existían, como el análisis probabilístico de seguridad y los ensayos de seguridad en bancos de prueba.

Sin embargo, según el anterior ministro de Industria y Energía N uclear de la URSS, V. Konovalov, el número de deficiencias, paradas e incidentes en las centrales nucleares es todavía alto. Los estudios muestran que esto se debe, principalmente, a la baja calidad de los componentes, a los errores humanos y a las soluciones inadecuadas dadas por los cuerpos de ingenieros y diseñadores. La calidad de los trabajos de construcción y de las instalaciones deja también mucho que desear.

Las modificaciones y los cambios en el diseño se han convertido en algo habitual. Como resultado, y en combinación con una formación inadecuada, las cualificaciones de los operadores son bajas. El personal debe mejorar sus conocimientos y habilidades en el curso de su trabajo, basándose en la experiencia adquirida durante el funcionamiento de la central.

\section{Aún quedan muchas lecciones ergonómicas por aprender} Incluso los sistemas de control de seguridad más efectivos y sofisticados no aseguran una total fiabilidad de las centrales si no se tienen en cuenta los factores humanos. Se preparan ya programas para la formación profesional del personal en el Instituto Federal de Ciencia e Investigación, y hay planes de aumentar este esfuerzo considerablemente. $\mathrm{H}$ ay que admitir, sin embargo, que la ingeniería humana aún no forma parte integral del diseño, construcción, pruebas y funcionamiento de las centrales nucleares.

En 1988, el antiguo M inisterio de Energía Nuclear de la URSS contestó, a una pregunta oficial, que durante el período 1990-2000 no habría ninguna necesidad de especialistas en ingeniería humana con titulación de grado secundario o superior, puesto que no se había producido ninguna petición por parte de las centrales nucleares o de las empresas.

Para resolver muchos de los problemas mencionados en este artículo, es necesario llevar a cabo investigaciones multidisciplinarias en las que participen físicos, diseñadores, ingenieros industriales, operadores, especialistas en ingeniería humana, psicólogos y expertos en otros campos. O rganizar este trabajo conjunto conlleva grandes dificultades, en especial las relacionadas con el monopolio de algunos científicos sobre la "verdad" en el campo de la energía nuclear y del monopolio de los operadores sobre la información de la puesta en funcionamiento de las centrales nucleares. Sin una completa información, no se pueden dar diagnósticos sobre las centrales nucleares, desde el punto de vista de la ingeniería humana, ni proponer, en caso necesario, formas para eliminar sus deficiencias, ni tampoco desarrollar un sistema de medidas para prevenir accidentes.

En las centrales nucleares de la antigua U nión Soviética, el estado de los medios técnicos de diagnóstico, control e informatización actuales están muy lejos de las normas internacionales aceptadas; los métodos de control de las centrales son innecesariamente complicados y confusos; no hay programas avanzados para la formación del personal; el apoyo que los diseñadores ofrecen a los operarios es mínimo y los formatos de los manuales de funcionamiento son bastante anticuados.

\section{Conclusiones}

En septiembre de 1990, tras una investigación más completa, dos antiguos empleados de Chernobil fueron liberados de prisión antes de cumplir sus condenas. Algún tiempo después, se liberó al resto del personal antes del tiempo previsto. Muchas de las personas relacionadas con la fiabilidad y seguridad de las centrales nucleares piensan actualmente que el personal actuó correctamente, aunque estas acciones correctas hayan producido la explosión. El personal de Chernobil no puede considerarse responsable de la inesperada magnitud del accidente.

En un intento por identificar a los responsables del desastre, el tribunal se basó en la opinión de los especialistas técnicos que, en este caso, eran los diseñadores de la central nuclear de C hernobil. Como resultado de esto, se puede aprender una importante lección de Chernobil: mientras el principal documento legal, para identificar la responsabilidad en caso de desastre en instalaciones tan complejas como las centrales nucleares, sea 
algo así como un manual de mantenimiento producido y modificado exclusivamente por los diseñadores de estas instalaciones, será técnicamente muy difícil determinar las causas reales de los desastres y tomar todas las precauciones necesarias para evitarlos.

Además, persiste la duda de si los operadores deben seguir estrictamente las instrucciones de mantenimiento en caso de desastre 0 si deben actuar de acuerdo con sus conocimientos, experiencia e intuición, en una forma que puede llegar incluso a ser opuesta a las instrucciones o estar ligada inconscientemente con el riesgo de una sanción grave.

Por desgracia, debemos reconocer que todavía no se ha encontrado la respuesta a la pregunta clave: " ¿Q uién tuvo la culpa del accidente de Chernobil?". Se busca a los responsables entre los políticos, físicos, administradores y operadores, así como entre los ingenieros encargados del desarrollo del proyecto. El condenar a simples obreros, como en el caso de Chernobil, o pedir a un sacerdote que bendiga la central nuclear, como se hizo en la unidad de Smolensk en 1991, no son las medidas más adecuadas para garantizar un funcionamiento seguro y fiable de las centrales nucleares.

Q uienes consideran el desastre de Chernobil como un desafortunado incidente que no puede volver a ocurrir deben tener en cuenta que una de las características humanas fundamentales es cometer errores, y esto se aplica no sólo a los operadores, sino también a los científicos e ingenieros. $\mathrm{H}$ acer caso omiso de los principios ergonómicos sobre las interacciones usuario-máquina en cualquier campo técnico o industrial puede producir errores cada vez más frecuentes y más graves.

Así, es necesario diseñar instalaciones técnicas como las centrales nucleares de forma que los posibles errores puedan descubrirse antes de que ocurra un accidente grave. M uchos principios ergonómicos se han originado al tratar de prevenir errores, por ejemplo, en el diseño de indicadores y controles. Sin embargo, incluso en la actualidad se violan estos principios en muchas de las instalaciones técnicas de todo el mundo.

Los operadores de instalaciones complejas deben estar altamente cualificados, no sólo para las operaciones de rutina, sino también en cuanto a los procedimientos necesarios en caso de que se produzca una desviación en el funcionamiento normal. Un conocimiento sólido de la física y de la tecnología de los procesos ayudarán al personal a reaccionar mejor en una situación crítica. Este tipo de cualificaciones sólo puede obtenerse a través de una intensa formación.

Los avances constantes de las interfaces usuario-máquina en todos los tipos de aplicaciones técnicas, con frecuencia como resultado de accidentes más o menos graves, muestran que el problema de los errores humanos y por lo tanto, de la interacción usuario-máquina, aún no está totalmente resuelto. Es necesaria la continua investigación ergonómica y la consiguiente aplicación de los resultados obtenidos con el fin de hacer que la interacción usuario-máquina sea más fiable, especialmente en el caso de las tecnologías con un alto potencial destructivo, como las centrales nucleares. Chernobil constituye un serio aviso de lo que puede pasar si la gente, tanto científicos e ingenieros como administradores y políticos, olvida la necesidad de incluir la ergonomía en el proceso de diseño y operación de las instalaciones técnicas complejas.

$\mathrm{H}$ ans Blix, Director General de la AIEA, ha recalcado este problema con el siguiente símil: se dice que el problema de la guerra es demasiado grave como para dejarlo sólo en manos de los generales, y Blix añade "Los problemas de la energía nuclear son demasiado graves como para dejarlos sólo en manos de los expertos nucleares".

\section{Referencias}

A beysekera, JDA, H Shahnavaz, LJ Chapman. 1990. Ergonomics in developing countries. En Advances in Industrial E rgonomics and Safety, dirigido por B Das. Londres: T aylor \& Francis.

Ahonen, M, M Launis, T K uorinka. 1989. E rgonomic W orkplace Analysis. Helsinki: Instituto Finlandés de M edicina del Trabajo.

Alvares, C. 1980. H omo Faber: T echnology and Culture in India, China and the W est from 1500 to Present D ay. La $H$ aya: $M$ artinus $N$ ijhoff.

Amalberti, R, M Bataille, G Deblon, A Guengant, JM Paquay, C V alot, JP M enu. 1989. D éveloppement d'aides intelligentes au pilotage: $\mathrm{F}$ ormalisation psychologique et informatique d'un modèle de comportement du pologage de combat engagé en mission de pènètration. París: R apport CERMA

Amalberti, R. 1991. Savoir-faire de l'opérateur: aspects théoriques et pratiques en ergonomie. En $M$ odele en analyse du travail, dirigido por $R$ Amalberti, $M$ de $M$ ontmollin y J Thereau. Liège: $M$ ardaga.

Astrand, I. 1960. Aerobic work capacity in men and women with special reference to age. Acta Physiol Scand 49 Supl. 169:1-92.

Bainbridge, L. 1981. Le contrôleur de processus. B Psychol X X X IV :813-832.

-. 1986. Asking questions and accessing knowledge. Future Comput Sys 1:143-149.

Baitsch, C. 1985. Kompetenzentwicklung und partizipative Arbeitsgestaltung. Berna: H uber.

Banks, MH, RL Miller. 1984. Reliability and convergent validity of the job component inventory. J O ccup P sychol 57:181-184.
Baranson, J. 1969. Industrial T echnology for D eveloping E conomies. N ueva Y ork: Praeger.

Bartenwerfer, H. 1970. Psychische Beanspruchung und Erdmüdung. En $\mathrm{H}$ andbuch der Psychologie, dirigido por A Mayer y B Herwig. Göttingen: Hogrefe

Bartlem, CS, E Locke. 1981. The Coch and French study: A critique and reinterpretation. $\mathrm{H}$ um Relat 34:555-566.

Blumberg, M. 1988. T owards a new theory of job design. En E rgonomics of $H$ ybrid Automated Systems, dirigido por $W$ Karwowski, HR Parsaei y MR Wilhelm. Amsterdam: Elsevier.

Bourdon, F, A Weill Fassina. 1994. Réseau et processus de coopération dans la gestion du trafic ferroviaire. Travail $\mathrm{H}$ um. Numéro spécial consacre au travail collectif.

Brehmer, B. 1990. Towards a taxonomy for microworlds En T axonomy for an Analysis of W ork Domains. Procedings of the First M OH AW C W orkshop, dirigido por B Brehmer, $M$ de Montmollin y J Leplat. R oskilde: R iso N ational Laboratory.

Brown DA, R M itchell. 1986. The Pocket E rgonomist. Sidney: G roup $O$ ccupational $H$ ealth Centre.

Bruder. 1993. Entwicklung eines wissensbusierten Systems zur belastungsanalytisch unterscheidbaren E rholungszeit. Düsseldorf: VDI-V erlag.

Campion, M A, PW Thayer. 1985. Development and field evaluation of an inter-disciplinary measure of job design. J Appl Psychol 70:29-43.

Campion, M A. 1988. Interdisciplinary approaches to job design: A constructive replication with extensions. | Appl Psychol 73:467-481.
Carter, RC, RJ Biersner. 1987. Job requirements derived from the Position Analysis $Q$ uestionnaire and validity using military aptitude test scores. J 0 ccup Psychol 60:311-321.

Caverni, JP. 1988. La verbalisation comme source d'observables pour l'étude du fonctionnnement cognitif. En Psychologie cognitive: M odèles et méthodes, dirigido por JP Caverni, C Bastien, P M endelson y $G$ Tiberghien. Grenoble: Presses Univ. de Grenoble.

Chaffin, DB, G Andersson. 1984. O ccupational B iomechanics. N ueva Y ork: W iley.

Chaffin, DB. 1969. A computerized biomechanical model-development of and use in studying gross body actions. J Biomech 2:429-441.

Chapanis, A. 1975. E thnic Variables in H uman Factors E ngineering. Baltimore: Johns H opkins U niversity.

Coch, L, JR P French. 1948. O vercoming resistance to change. $H$ um R elat 1:512-532.

Comité Europeo de Normalización (CEN). 1990. E rgonomic Principles of the D esign of W ork Systems. EEC Council Directive 90/269/EEC, M inimal health and safety requirements for manual handling of loads. Bruselas: CEN.

- 1991. CEN Catalogue 1991: Catalogue of European Standards. Bruselas: CEN.

- . 1994. Safety of M achinery: E rgonomic D esign Principles. Part 1: T erminology and General Principles. Bruselas: CEN.

Corlett, EN, RP Bishop. 1976. A technique for assessing postural discomfort. E rgonomics 19:175-182.

Corlett, N. 1988. The investigation and evaluation of work and workplaces. E rgonomics 31:727-734. 
Costa, G, G Cesana, K K ogi, A Wedderburn. 1990. Shiftwork: health, sleep and performance. Frankfurt: Peter Lang.

Cotton, JL, DA Vollrath, $\mathrm{KL}$ Froggatt, $\mathrm{ML}$ Lengnick-H all, KR Jennings. 1988. Employee participation: Diverse forms and different outcomes. A cad M anage R ev 13:8-22.

Cushman, WH, DJ R osenberg. 1991. H uman Factors in Product D esign. Amsterdam: Elsevier.

Dachler, HP, B Wilpert. 1978. Conceptual dimensions and boundaries of participation in organizations: A critical evaluation. Adm Sci Q 23:1-39.

Daftuar, CN. 1975. The role of human factors in underdeveloped countries, with special reference to India. En Ethnic Variable in $\mathrm{H}$ uman $\mathrm{Factor}$ Enginering, dirigido por Chapanis. Baltimore: J ohns H opkins U niversity.

Das, B, RM Grady. 1983a. Industrial workplace layout design. An application of engineering anthropometry. E rgonomics 26:433-447.

- . 1983b. The normal working area in the horizontal plane. A comparative study between Farley's and Squire's concepts. E rgonomics 26:449-459.

De K eyser, V , A H ousiaux. 1989. T he $\mathrm{N}$ ature of $\mathrm{H}$ uman Expertise. Rapport Intermédiaire Politique Scientifique. Liège: U niversidad de Liège.

De Keyser, V, AS Nyssen. 1993. Les erreurs humaines en anesthésie. T ravail $\mathrm{H}$ um 56:243-266.

De K eyser, V. 1986. De l'évolution des métiers. En T raité de psychologie du travail, dirigido por C LevyLeboyer y JC Sperandio. París: Presses U niversitaires de France.

-. 1992. M an within the Production Line. Actas de la 40 Conferencia Brite EuRam, 25-27 de mayo, Sevilla, E spaña. Bruselas: CEE.

De Lisi, PS. 1990. Lesson from the steel axe: Culture, technology and organizational change. Sloan $M$ anage $R$ ev 32:83-93.

Deci, EL. 1975. Intrinsic M otivation. Nueva York Plenum Press.

Decortis, F, PC Cacciabue. 1990. M odèlisation cognitive et analyse de l'activité. En M odèles $€$ pratiques de l'analyse du travail, dirigido por $\mathrm{R}$ Amalberti, M M ontmollin y J Theureau. Bruselas: $M$ ardaga.

DeGreve, TB, MM Ayoub. 1987. A workplace design expert system. Int I Ind E rg 2:37-48.

Dillon, A. 1992. R eading from paper versus screen: A critical review of the empirical literature. E rgonomics 35:1297-1326

Dinges, DF. 1992. Probing the limits of functional capacity: The effects of sleep loss on short-duration tasks. En Sleep, Arousal, and Performance, dirigido por RJ Broughton y RD O gilvie. Boston: Birkhäuser.

Drury, CG . 1987. A biomechanical evaluation of the repetitive motion injury potential of industrial jobs. Sem 0 ccup M ed 2:41-49.

Edholm, OG. 1966. The assessment of habitual activity. En Physical Activity in $\mathrm{H}$ ealth and Disease dirigido por $\mathrm{K}$ Evang y $\mathrm{K}$ Lange-Andersen. O slo: U niversitetterlaget.

Eilers, K, F Nachreiner, K H änicke. 1986. Entwicklung und Überprüfung einer Skala zur Erfassung subjektiv erlebter Anstrengung. Z eitschrift für Arbeitswissenschaft 40:215-224.

Elias, R. 1978. A medicobiological approach to workload. Note N o. 1118-9178 in Cahiers D e N otes D ocumentaires- Sécurité Et H ygiène Du T ravail. París: INRS.

Elzinga, A, A Jamison. 1981. Cultural Components in the Scientific Attitude to Nature: $E$ astern and W estern M ode Discussion paper No. 146. Lund: Univ. de Lund, Instituto de Política de Investigación.

Emery, FE. 1959. Characteristics of Socio-T echnical Systems. D ocumento núm. 527. Londres: T avistock.
Empson, J. 1993. Sleep and D reaming. Nueva Y ork: $H$ arvester Wheatsheaf

Ericson, K A, H A Simon. 1984. Protocol Analysis: Verbal Reports As D ata. Cambridge, M assachussetts: MIT Press.

Fadier, E. 1990. Fiabilité humaine: méthodes d'analyse et domaines d'application. En Les facteurs humains de la fiabilité dans les systèmes complexes, dirigido por J Leplat y G De T erssac. Marsella: 0 ctares.

Falzon, P. 1991. Cooperative dialogues. En Distributer Decision M aking. Cognitive M odels for Cooperative W orks, dirigido por J R asmussen, B Brehmer y J Leplat. Chichester: Wiley.

Faverge, JM . 1972. L'analyse du travail. En T raité de psychologie appliqueé, dirigido por M R euchlin. París: Presses U niversitaires de France.

Fisher, S. 1986. Stress and Strategy. Londres: Erlbaum.

Flanagan, JL. 1954. The critical incident technique. Psychol Bull 51:327-358.

Fleishman, EA, M K Q uaintance. 1984. T oxonomies of $H$ uman Performance: The Description of $H$ uman T asks. Nueva Y ork: Academic Press.

Flügel, B, H G reil, K Sommer. 1986. Anthropologischer Atlas. Grundlagen und Daten. D eutsche D emokratische R epublik. Berlín: V erlag tribüne.

Folkard, S, P T otterdell, D M inors, J Waterhouse. 1993. Dissecting circadian performance rhythms Implications for shiftwork. Ergonomics 36(1-3):283-88.

Folkard, S, T A kerstedt. 1992. A three-process mode of the regulation of alertness sleepiness. En Sleep, A rousal and Performance, dirigido por RJ Broughton y BD O gilvie. Boston: Birkhäuser.

Folkard, S, TH M onk, M C Lobban. 1978. Short and long-term adjustment of circadian rhythms in "permanent" night nurses. E rgonomics 21:785-799.

Folkard, S, TH M onk. 1985. H ours of work: Temporal factors in work scheduling. Chichester: Wiley.

Fröberg, JE. 1985. Sleep deprivation and prolonged working hours. En H ours of W ork: T emporal Factors in W ork Scheduling, dirigido por S Folkard y TH M onk. Chichester: Wiley.

Fuglesang, A. 1982. A bout U nderstanding I deas and Observations on Cross-Cultural Communication. U ppsala: Dag H ammarskjöld Foundation.

Geertz, C. 1973. The Interpretation of Cultures. Nueva Y ork: Basic Books

Gilad, I, E Messer, 1992. Biomechanics considerations and ergonomic design in diamond polishing. En Advances in Industrial E rgonomics and Safety, dirigido por Kumar. Londres: Taylor \& Francis.

Gilad, I. 1993. Methodology for functional ergonomic evaluation of repetitive operations. En Advances in Industrial $\mathrm{E}$ gonomics and Safety, dirigido por Nielsen y Jorgensen. Londres: Taylor \& Francis

Glenn, ES, CG Glenn 1981. M an and M ankind: Conflict and Communication between Cultures. N orwood, Nueva Jersey: Ablex.

Gopher, D, E Donchin. 1986. Workload-An examination of the concept. En $H$ andbook of Perception and $\mathrm{H}$ uman Performance, dirigido por $\mathrm{K}$ Boff, L Kaufman y JP Thomas. Nueva York Wiley.

Gould, JD, C Lewis. 1985. Designing for usability: $\mathrm{K}$ ey principles and what designers think. Commun ACM 28:300-311.

Gould, JD, SJ Boies, S Levy, JT Richards, J Schoonard. 1987. The 1984 Olympic message system: A test of behavioral principles of the design. Commun ACM 30:758-769.

Gould, JD. 1988. H ow to design usable systems. En $\mathrm{H}$ andbook of $\mathrm{H}$ uman $\mathrm{C}$ omputer Interaction, dirigido por M H elander. Amsterdam: Elsevier.
Gowler, D, K L egge. 1978. Participation in context: T owards a synthesis of the theory and practice of organizational change, part I. I M anage Stud 16:150-175.

Grady, JK, J de V ries. 1994. RAM : T he Rehabilitation T echnology Acceptance M odel as a Base for an Integral Product Evaluation. Instituut voor Research, Ontwikkeling en Nascholing in de Gezondheidszorg (IRON) y Universidad de T wente, D epartamento de Ingeniería Biomédica.

Grandjean, E. 1988. Fitting the Task to the $M$ an. Londres: T aylor \& Francis.

Grant, S, T M ayes. 1991. Cognitive task analysis? En $\mathrm{H}$ uman-Computer Interactionand Complex Systems, dirigido por GS Weir y J Alty. Londres: A cademic Press

Greenbaum, J, M K yng. 1991. Design At W ork: Cooperative Design of Computer Systems. Hillsdale Nueva Jersey: Lawrence Erlbaum.

Greuter, MA , JA Algera. 1989. Criterion development and job analysis. En Assessment and Selection in Organizations, dirigido por $\mathrm{P}$ Herlot Chichester: Wiley.

Grote, G. 1994. A participatory approach to the complementary design of highly automated work systems. En H uman Factors in Organizational Design and $\mathrm{M}$ anagement, dirigido por $\mathrm{G}$ Bradley y $\mathrm{HW}$ $\mathrm{H}$ endrick. A msterdam: Elsevier.

Guelaud, F, M-N Beauchesne, J Gautrat, G Roustang. 1977. Pour une analyse des conditions du travail ouvrier dans I'entreprise. París: A. Colin.

Guillerm, R, E Radziszewski, A Reinberg. 1975. Circadian rhythms of six healthy young men over a 4-week period with night-work every $48 \mathrm{~h}$ and 2 per cent $\mathrm{C} 02$ atmosphere. En Experimental Studies of Shiftwork, dirigido por P Colquhoun, S Folkard, $P$ K nauth y J R utenfranz. O pladen: W estdeutscher Werlag.

H acker, W, P Richter. 1994. Psychische Fehlbeanspruchung. E rmüdung, M onotonie, Sättigung, Stress. H eidelberg: Springer.

H acker, W. 1986. Arbeitspsychologie. En Schriften zur Arbeitpsychologie, dirigido por E Ulich. Berna: H uber.

H ackman, JR, GR O Idham. 1975. Development of the job diagnostic survey. I Appl Psychol 60:159-170.

H ancock, PA, M H Chignell. 1986. T oward a Theory of $M$ ental W ork Load: Stress and Adaptability in $H$ uman- $M$ achine Systems. Proceedings of the IEEE International Conference on Systems, $M$ an and Cybernetics. Nueva Y ork: IEEE Society.

$\mathrm{H}$ ancock, PA, N M eshkati. 1988. H uman M ental W orkload. Amsterdam: N orth H olland.

H anna, A (dir.). 1990. Annual D esign R eview ID. 37 (4).

H ärmä, M. 1993. Individual differences in tolerance to shiftwork: a review. E rgonomics 36:101-109.

Hart, S, LE Staveland. 1988. Development of NASA-TLX (Task Load Index): Results of empirical and theoretical research. En $H$ uman $M$ ental W ork Load, dirigido por PA H ancock y N M eshkati. A msterdam: $\mathrm{N}$ orth $\mathrm{H}$ olland.

H irschheim, R, HK K lein. 1989. Four paradigms of information systems development. Commun ACM 32:1199-1216.

Hoc, JM. 1989. Cognitive approaches to process control. En Advances in Cognitive Science, dirigido por $\mathrm{G}$ T iberghein. Chichester: $\mathrm{H}$ orwood.

H ofstede, G. 1980. Culture's Consequences: International Differences in W ork-Related Values. Beverly Hills, California: Sage Univ. Press.

-. 1983. The cultural relativity of organizational practices and theories. I Int Stud :75-89.

H ornby, P, C Clegg. 1992. U ser participation in context: A case study in a UK bank. Behav Inf T echnol 11:293-307. 
H osni, DE, 1988. The transfer of microelectronics technology to the third world. T ech M anage Pub T M 1:391-3997

H su, S-H, Y Peng. 1993. Control/ display relationship of the four-burner stove: A reexamination. $\mathrm{H}$ um $\mathrm{F}$ actors 35:745-749.

Jastrzebowski, W. 1857. R ys ergonomiji czyli Nauki o Pracy, opartej naprawdach poczerpnietych Nauki Przyrody. Przyoda i Przemysl 29:227-231.

Jeanneret, PR. 1980. Equitable job evaluation and classification with the Position Analysis Q uestionnaire. Compens R ev 1:32-42.

Jürgens, HW, IA Aune, U Pieper. 1990. Internationa data on anthropometry. O ccupational Safety and $H$ ealth Series. G inebra: OIT.

K adefors, R. 1993. A model for assessment and design of workplaces for manual welding. En The E rgonomics of M anual W ork, dirigido por WS M arras, W K arwowski y L Pacholski. Londres: Taylor \& Francis.

K ahneman, D. 1973. Attention and E ffort. Englewood Cliffs, N ueva Jersey: Prentice $\mathrm{H}$ all.

K arhu, O, P K ansi, I K uorinka. 1977. Correcting working postures in industry: A practical method for analysis. Appl E rgon 8:199-201.

K arhu, O, R H arkonen, P Sorvali, P V epsalainen. 1981. O bserving working postures in industry: Examples of OWAS application. Appl Ergon 12:13-17.

K edia, BL, R S Bhagat. 1988. Cultural constraints on transfer of technology across nations: Implications for research in international and comparative management. Acad M anage R ev 13:559-571.

K eesing, RM. 1974. Theories of culture. Annu Rev Anthropol 3:73-79.

K epenne, P. 1984. La charge de travail dans une unité de soins de médecine. M émoire. Liège: U niversidad de Liège.

K erguelen, A. 1986. L'observation systématique en ergonomie: Élaboration d'un logiciel d'aide au recueil et à l'analyse des données. Tesis doctoral sobre Ergonomía, Conservatoire $\mathrm{N}$ ational des Arts et $M$ étiers, París.

K etchum, L. 1984. Sociotechnical design in a third world country: The railway maintenance depot at Sennar in Sudan. H um R elat 37:135-154.

K eyserling, WM . 1986. A computer-aided system to evaluate postural stress in the workplace. Am Ind $H$ yg Assoc ) 47:641-649.

K ingsley, PR. 1983. Technological development Issues, roles and orientation for social psychology. En Social Psychology and D eveloping Countries, dirigido por Blacker. N ueva Y ork: Wiley.

K inney, JS, BM Huey. 1990. Application Principles for Multicolored Displays. Washington, DC: National Academy Press.

K ivi, P, M M attila. 1991. Analysis and improvement of work postures in building industry: Application of the computerized OWAS method. Appl Ergon 22:43-48

K nauth, P, J R utenfranz. 1981. Duration of sleep related to the type of shift work, en Night and shiftwork: biological and social aspects, dirigido por A Reinberg, $N$ Vieux y $P$ Andlauer. Oxford Pergamon Press.

K nauth, P, W Rohmert, I Rutenfranz. 1979. Systemic selection of shift plans for continuous production with the aid of work-physiological criteria. Appl Ergon 10(1):9-15

K ogi, K, JE Thurman. 1993. Trends in approaches to night and shiftwork and new international standards. E rgonomics 36:3-13.

K ogi, K. 1982. Sleep problems in night and shift work. II. Shiftwork: Its practice and improvement. I $H$ um E rgol:217-231.
- 1981. Comparison of resting conditions between various shift rotation systems for industrial workers, en Night and shift work. Biological and social aspects, dirigido por A Reinberg, N Vieux y $P$ Andlauer. Oxford: Pergamon.

-. 1985. Introduction to the problems of shiftwork. En Hours of W ork: Temporal Factors in W ork-Scheduling, dirigido por S Folkard y $\mathrm{TH}$ M onk. Chichester: Wiley.

-. 1991. Job content and working time: The scope for joint change. E rgonomics 34:757-773.

K öhler, C, M von Behr, H H irsch-K reinsen, B Lutz, C Nuber, R Schultz-Wild. 1989. Alternativen der Gestaltung von Arbeits- und Personalstrukturen bei rechnerintegrierter Fertigung. En Strategische 0 ptionen der Organisations- und Personalentwicklung be CIM Forschungsbericht KfK-PFT 148, dirigido por Institut für Sozialwissenschaftliche Forschung. $\mathrm{K}$ arlsruhe: Projektträgerschaft Fertigungstechnik.

K oller, M. 1983. H ealth risks related to shift work An example of time-contingent effects of long-term stress. Int Arch O cc E nv H ealth 53:59-75.

K onz, S. 1990. Workstation organization and design. E rgonomics 32:795-811.

K roeber, AL, C K luckhohn. 1952. Culture, a critical review of concepts and definitions. En Papers of the Peabody M useum. Boston: U niv. de $\mathrm{H}$ arvard.

K roemer, K HE, H B K roemer, K E K roemer-Elbert. 1994. E rgonomics: $H$ ow to D esign for $E$ ase and $E$ fficiency. Englewood C liffs, N ueva Jersey: Prentice H all.

K roemer, $\mathrm{K} \mathrm{HE}$. 1993. O peration of ternary chorded keys. Int J H um Comput Interact 5:267-288.

- . 1994a. Locating the computer screen: H ow high, how far? E rgonomics in D esign (enero):40.

-. 1994b. Alternative keyboards. En Proceedings of the Fourth International Scientific Conference W W DU ' 94. M ilán: U niv. de M ilán.

-. 1995. Ergonomics. En Fundamentals of Industrial $\mathrm{H}$ ygiene, dirigido por BA Ploog. Chicago: National Safety Council.

K won, K S, SY Lee, BH Ahn. 1993. An approach to fuzzy expert systems for product colour design. En $T$ he $E$ rgonomics of $M$ anual $W$ ork, dirigido por $M$ aras, K arwowski, Smith y Pacholski. Londres: T aylor \& Francis.

Lacoste, M. 1983. Des situations de parole aux activités interprétives. Psychol $F$ ranç 28:231-238.

Landau, K, W Rohmert. 1981. AET-A New J ob Analysis M ethod. Detroit, M ichigan: Conferencia Anual de la AlIE.

Laurig, W, V Rombach. 1989. Expert systems in ergonomics: Requirements and an approach. E rgonomics 32:795-811.

Laurig, W. 1970. Elektromyographie als arbeitswissenschaftliche U ntersuchungsmethode zur B eurteilung von statischer M uskelarbeit. Berlín: Beuth.

-. 1974. Beurteilung einseitig dynamischer M uskelarbeit Berlín: Beuth

1981. Belastung, Beanspruchung und Erholungszeit bei energetisch-muskulärer Arbeit-Literaturexpertise. In F orschungsbericht $\mathrm{Nr}$. 272 der Bundesanstalt für Arbeitsschutz und Unfallforschung Dortmund. Bremerhaven: W irtschaftsverlag N W.

-. 1992. Grundzüge der E rgonomie. Erkenntnisse und Prinzipien. Berlín, K öln: Beuth V erlag.

Leach, ER. 1965. Culture and social cohesion: An anthropologist's view. En Science and Culture, dirigido por $\mathrm{H}$ olten. Boston: $\mathrm{H}$ oughton $\mathrm{M}$ ifflin.

Leana, CR, EA Locke, DM Schweiger. 1990. Fact and fiction in analyzing research on participative decision making: A critique of Cotton, $\mathrm{V}$ ollrath, Froggatt, Lengnick-Hall, and Jennings. Acad $M$ anage $R$ ev 15:137-146.

Lewin, K. 1951. Field Theory in Social Science. Nueva York: $\mathrm{H}$ arper.
Liker, JK, M Nagamachi, YR Lifshitz. 1988. A Comparitive Analysis of Participatory Programs in US and J apan M anufacturing Plants. Ann Arbor, Michigan: Univ. de Michigan, Center for Ergonomics, Industrial and $O$ perational Engineering

Lillrank, B, N K ano. 1989. Continuous Improvement: Quality Control Circles in J apanese Industries. Ann Arbor, M ichigan: U niv. de M ichigan, Center for Japanese Studies.

Locke, EA, DM Schweiger. 1979. Participation in decision making: O ne more look. En Research in Organizational Behavior, dirigido por BM Staw. Greenwich, Connecticut: JAI Press.

Louhevaara, V, T H akola, H Ollila. 1990. Physical work and strain involved in manual sorting of postal parcels. E rgonomics 33:1115-1130.

Luczak, H. 1982. B elastung, B eanspruchung und Erholungszeit be informatorisch- mentaler Arbeit Literaturexpertise Forschungsbericht der B undesanstalt für Arbeitsschutz und U nfallforschung Dortmund. Bremerhaven: Wirtschaftsverlag NW.

- 1983. Ermüdung. En Praktische Arbeitsphysiologie dirigido por W R ohmert y J R utenfranz. Stuttgart: G eorg T hieme V erlag.

— . 1993. Arbeitswissenschaft. Berlín: Springer V erlag.

Majchrzak, A. 1988. The Human Side of Factory A utomation. San Francisco: J ossey-Bass.

M artin, T, J Kivinen, JE Rijnsdorp, M G Rodd, WB Rouse. 1991. Appropriate automation-integrating technical, human, organization, economic and cultural factors. Automatica 27:901-917.

M atsumoto, K, M Harada. 1994. The effect of night-time naps on recovery from fatigue following night work. E rgonomics 37:899-907.

$M$ atthews, R. 1982. Divergent conditions in the technological development of India and J apan. Lund Letters on T echnology and Culture, N o. 4. Lund: Univ. de Lund, Instituto de Política de Investigación.

M cCormick, EJ. 1979. I ob Analysis: M ethods and Applications. Nueva York: American M anagement Association.

M clntosh, DJ. 1994. Integration of VDU s into the US office work environment En Proceedings of the Fourth International Conference W W DU '94. M ilán: Univ. de Milán.

M CW hinney, 1990. The Power of M yth in Planning and Organizational Change, 1989 IEEE Technics, Culture and Consequences. Torrence, California: IEEE LOS Angeles C ouncil.

M eshkati, N. 1989. An etiological investigation of micro and macroergonomics factors in the Bhopal disaster: Lessons for industries of both industrialized and developing countries. Int J Ind E rg 4:161-175.

M inors, DS, JM Waterhouse. 1981. Anchor sleep as a synchronizer of rhythms on abnormal routines. Int ] Chronobiology: 165-188.

M ital, A, W K arwowski. 1991. Advances in H uman F actors/ E rgonomics. Amsterdam: Elsevier.

M onk, TH. 1991. Sleep, Sleepiness and Performance Chichester: Wiley.

M oray, N PM Sanderson, K Vincente 1989 Cognitive task analysis for a team in a complex work domain: A case study. Actas del $2^{\circ}$ Congreso europeo sobre los enfoques de la ciencia cognitiva al control de procesos, Siena, I talia.

M organ, CT, A Chapanis, JS III Cork, M W Lund. 1963. $H$ uman E ngineering Guide to Equipment D esign. Nueva Y ork: M CG raw-H ill.

M ossholder, KW, RD Arvey. 1984. Synthetic validity: A conceptual and comparative review. J Appl Psychol 69:322-333.

M umford, E, H enshall. 1979. A Participative A pproach to Computer Systems Design. Londres: Associated Business Press 
Nagamachi, M. 1992. Pleasantness and K ansei engineering. En M easurement Standards. Taejon, Corea: Instituto Coreano de Investigación de Normas y Publicaciones Científicas.

National Institute for Occupational Safety and $\mathrm{H}$ ealth (NIOSH). 1981. W ork Practices Guide for $M$ anual Lifting. Cincinnati, O hio: US Department of $\mathrm{H}$ ealth and $\mathrm{H}$ uman Services.

-. 1990. OSHA Instruction CPL 2.85: Directorate of Compliance Programs: Appendix C, Guidelines Auggested By NIOSH for Videotape Evaluation of W ork Station for Upper Extremities Cumulative Trauma Disorders. Washington, DC: US Department of $\mathrm{H}$ ealth and $H$ uman Services.

Navarro, C. 1990. Functional communication and problem-solving in a bus traffic-regulation task. Psychol Rep 67:403-409.

Negandhi, ART. 1975. M odern Organizational B ehaviour. $K$ ent: $K$ ent U niv..

Nisbett, RE, TD De Camp Wilson. 1977. Telling more than we know. Psychol R ev 84:231-259.

Norman, DA. 1993. Things That M ake Us Smart. R eading: Addison-W esley.

Noro, K, AS Imada. 1991. Participatory Ergonomics. Londres: Taylor \& Francis.

O 'D onnell, RD, FT Eggemeier. 1986. Work load assessment methodology. En $\mathrm{H}$ andbook of Perception and $\mathrm{H}$ uman Performance Cognitive Processes and Performance, dirigido por $K$ Boff, $L$ K aufman y JP Thomas. NuevaY ork: Wiley.

Organización de las $\mathrm{Naciones} U$ Unidas para la Educación, la Ciencia y la Cultura (UNESCO). 1992. E rgonomics I mpact of Science on Society. V ol. 165. Londres: T aylor \& Francis.

O rganización Internacional de N ormalización (ISO). 1980. Draft Proposal for Core List of Anthropometric M easurements ISO/TC 159/SC 3 N 28 DP 7250. Ginebra: ISO

- 1996. ISO/DIS 7250 Basic Human Body $M$ easurements for T echnological D esign. Ginebra: ISO.

Organización Internacional del Trabajo (OIT). 1990.T he hours we work: new work schedules in policy and practice. Cond W or Dig 9.

Organización Japonesa para la Promoción del Diseño Industrial (IIDPO). 1990. Good Design Products 1989. T okio: JIDPO.

Pagels, HR, 1984. Computer culture: The scientific intellectual and social impact of the computer. Ann NY Acad Sci :426.

Persson, 」, \& Kilbom. 1983. VIRA-En Enkel Videofilmteknik $F$ ör Registrering $O$ chAnalys Av Arbetsställningar 0 ch-R örelser. Solna, Suecia: U ndersökningsrapport,A rbetraskyddsstyrelsen.

Pham, DT, HH Onder. 1992. A knowledge-based system for optimizing workplace layouts using a genetic algorithm. E rgonomics 35:1479-1487.

Pheasant, S. 1986. B odyspace, Anthropometry, E rgonomics and D esign. Londres: T aylor \& Francis.

Poole, CJM. 1993. Seamstress' finger. B rit J Ind M ed 50:668-669.

Putz-Anderson, V. 1988. Cumulative T rauma D isorders. A $M$ anual for $M$ usculoskeletal Diseases of the $U$ pper Limbs. Londres: T aylor \& Francis.

Rasmussen, J, A Pejtersen, K Schmidts. 1990. En T axonomy for Analysis of W ork D omains. Proceedings of the First MOHAWC Workshop, dirigido por B Brehmer, $M$ de $M$ ontmollin y J Leplat. R oskilde: $\mathrm{R}$ iso $\mathrm{N}$ ational Laboratory.

Rasmussen, J. 1983. Skills, rules, and knowledge: Sinds, signs, symbols and other distinctions in human performance models. IEEE T Syst M an Cyb 13:257-266

-. 1986. A framework for cognitive task analysis in systems design. In Intelligent D ecision Support in Process Environments, dirigido por $\mathrm{E} H$ ollnagel, G M ancini y DD Woods. Berlín: Springer.
R eason, J. 1989. H uman E rror. Cambridge: CU P.

Rebiffé, R, O Zayana, C Tarrière. 1969.

Détermination des zones optimales pour l'emplacement des commandes manuelles dans l'espace de travail. E rgonomics 12:913-924.

R égie nationale des usines R enault (R NUR). 1976. es profils de poste: $M$ ethode d'analyse des conditions de travail. París: M asson-Sirtes.

Rogalski, J. 1991. Distributed decision making in emergency management: U sing a method as a framework for analysing cooperative work and as a decision aid. En D istributed D ecision M aking. Cognitive Models for Cooperative Work, dirigido por J Rasmussen, B Brehmer y J Leplat. Chichester: Wiley.

R ohmert, W, K L andau. 1985. A N ew T echnique of J ob Analysis. Londres: T aylor \& Francis.

R ohmert, W. 1962. U ntersuchungen über M uskelermüdung und Arbeitsgestaltung. Berna: Beuth-V ertrieb.

-. 1973. Problems in determining rest allowances. Part I: U se of modern methods to evaluate stress and strain in static muscular work. Appl Ergon 4(2):91-95.

- 1984. D as Belastungs-Beanspruchungs-K onzept. Z Arb wiss 38:193-200.

Rolland, C. 1986. Introduction à la conception des systèmes d'information et panorama des méthodes disponibles. Génie L ogiciel 4:6-11.

Roth, EM, DD Woods. 1988. Aiding human performance. I. Cognitive analysis. Travail $\mathrm{H}$ um 51:39-54.

Rudolph, E, E Schönfelder, W H acker. 1987. $T$ ätigkeitsbew ertungssystem für geistige arbeit mit und ohne Rechnerunterstützung (T BS-GA). Berlín: Psychodiagnostisches Zentrum der H umboldt-U niversität.

Rutenfranz, J, J IImarinen, F K limmer, H K ylian. 1990. Work load and demanded physical performance capacity under different industrial working conditions. En F itness for A ged, D isabled, and Industrial Workers, dirigido por M Kaneko. Champaign, Illinois: H uman K inetics Books.

R utenfranz, J, P K nauth, D Angersbach. 1981. Shift work research issues. En B iological R hythms, Sleep and Shift W ork, dirigido por LC Johnson, DI T epas, WP Colquhoun y MJ Colligan. Nueva York: Spectrum Publications Medical and Scientific Books.

Rutenfranz, J. 1982. O ccupational health measures for night- and shiftworkers. II. Shiftwork: Its practice and improvement. J H um E rgol:67-86.

Saito, Y, K Matsumoto, 1988. Variations of physiological functions and psychological measures and their relationship on delayed shift of sleeping time. J ap J Ind $\mathrm{H}$ ealth 30:196-205.

Sakai, K, A Watanabe, N O nishi, H Shindo, K K imotsuki, H Saito, K K ogl. 1984. Conditions of night naps effective to facilitate recovery from night work fatigue. I Sci L ab 60: 451-478.

Savage, CM, D Appleton. 1988. CIM and Fifth Generation M anagement. Dearborn: CASA/SME T echnical C ouncil.

Savoyant, A, J Leplat. 1983. Statut et fonction des communications dans l'activité des équipes de travail. Psychol F ranç 28:247-253.

Scarbrough, H, JM Corbett. 1992. T echnology and O rganization. Londres: R outledge.

Schmidtke, H. 1965. DieE rmüdung. Berna: H uber

—. 1971. U ntersuchungen über den E rholunggszeitbedarf be verschiedenen Arten gewerblicher Tätigkeit. Berlín: Beuth-V ertrieb.

Sen, RN. 1984. Application of ergonomics to industrially developing countries. Ergonomics 27:1021-1032.

Sergean, R. 1971. M anaging Shiftwork. Londres: G ower Press.
Sethi, AA, DHJ Caro, RS Schuler. 1987. Strategic $M$ anagement of $T$ echnostress in an Information Society. Lewiston: H ogrefe.

Shackel, B. 1986. Ergonomics in design for usability. En People and Computer: D esign for U sability, dirigido por MD Harrison y AF Monk. Cambridge: Cambridge U niv. Press.

Shahnavaz, H, J A beysekera, A Johansson. 1993. Solving multi-factorial work-environment problems through participatory ergonomics: C ase study: VDT operators. En Ergonomics of $M$ anual Work, dirigido por E Williams, S M arrs, W Karwowski, JL Smith y L Pacholski. Londres: Taylor \& Francis.

Shahnavaz, H. 1991. T ransfer of T echnology to Industrially Developing Countries and $\mathrm{H}$ uman $\mathrm{F}$ actors Consideration TULEA 1991: 22, 23024. Univ. de Luleå, Luleå, Suecia: Centro de Ergonomía de los Países Subdesarrollados.

Shaw, JB, JH Riskind. 1983. Predicting job stress using data from the Position Analysis Q uestionnaire (PAQ ). J A ppl Psychol 68:253-261.

Shugaar, A. 1990. Ecodesign: New products for a greener culture. Int $\mathrm{H}$ erald T rib, 17.

Sinaiko, WH. 1975. Verbal factors in human engineering: Some cultural and psychological data. En $E$ thnic Variables in $H$ uman $F$ actors Enginering, dirigido por A Chapanis. Baltimore: Johns H opkins U niv..

Singleton, WT . 1982. The B ody At W ork. Cambridge: CUP.

Snyder, HL. 1985a. Image quality: M easures and visual performance. En Flat Pane Displays and CRT s, dirigido por LE T annas. N ueva Y ork: Van Nostrand R einhold.

-. 1985b. The visual system: Capabilities and limitations. En Flat Pand Displays and CRTS, dirigido por LE Tannas. Nueva York: $V$ an Nostrand R einhold.

Solomon, CM. 1989. The corporate response to work force diversity. Pers 」 68:42-53.

Sparke, P. 1987. M odern J apanese D esign. Nueva Y ork: EP Dutton.

Sperandio, JC. 1972. Charge de travail et régulation des processus opératoires. T ravail $H$ um 35:85-98.

Sperling, L, S Dahlman, L Wikström, A Kilbom, R Kadefors. 1993. A cube model for the classification of work with hand tools and the formulation of functional requirements. Appl Ergon 34:203-211.

Spinas, P. 1989. U ser oriented software development and dialogue design. En W ork W ith Computers: Organizational, $\mathrm{M}$ anagement, Stress and $\mathrm{H}$ ealth Aspects, dirigido por M J Smith y G Salvendy. Amsterdam: Elsevier.

Staramler, JH. 1993. The Dictionary of H uman Factors E rgonomics. Boca $R$ aton: $C R C$ Press.

Strohm, O, P T roxler, E Ulich. 1994. Vorschlag für die Restrukturierung eines Produktionsbetriebes. Zurich: Institut für A rbietspsychologie der ET H .

Strohm, O, JK Kuark, A Schilling. 1993. Integrierte Produktion: Arbeitspsychologische K onzepte und empirische Befunde, Schriftenreihe Mensch, Technik, Organisation. En $\mathrm{CIM}-\mathrm{H}$ erausforderung an M ensch, Technik, Organisation, dirigido por G Cyranek y E Ulich. Stuttgart, Zurich: Verlag der Fachvereine.

Sullivan, LP. 1986. Quality function deployment: A system to assure that customer needs drive the product design and production process. Q uality Progr :39-50.

Sundin, A, J Laring, J Bäck, G Nengtsson, R $K$ adefors. 1994. An Ambulatory W orkplace for M anual $W$ elding: Productivity through E rgonomics. M anuscript. G öteborg: Lindholmen Development.

Tardieu, H, D Nanci, D Pascot. 1985. Conception d'un système d'information. París: Editions d'O rganisation. 
Teiger, C, A Laville, J Durafourg. 1974. Taches répétitives sous contrainte de temps et charge de travail. Rapport $n^{\circ}$ 39. Laboratoire de physiologie du travail et d'ergonomie du CNAM .

Torsvall, L, T Akerstedt, M. Gillberg. 1981. Age, sleep and irregular workhours: a field study with EEG recording, catecholamine excretion and self-ratings. Scand J W or Env H ealth 7:196-203.

Ulich, E, M Rauterberg, T M oll, T Greutmann, 0 Strohm. 1991. Task orientation and user-oriented dialogue design. En Int J H uman-C omputer Interaction 3:117-144.

Ulich, E. 1994. Arbeitspsychologie 3. Auflage Zurich Verlag der Fachvereine and Schäffer-Poeschel.

V an Daele, A. 1988. L'écran de visualisation ou la communication verbale? Analyse comparative de leur utilisation par des opérateurs de salle de contrôle en sidérurgie. T ravail H um 51(1):65-80,

— . 1992. La réduction de la complexité par les opérateurs dans le contrôle de processus continus. contribution à l'étude du contrôle par anticipation et de ses conditions de mise en carvre. Liège: U niversidad de Liège.

Van der Beek, AJ, LC Van Gaalen, MHW Frings-D resen. 1992. Working postures and activities of lorry drivers: A reliability study of on-site observation and recording on a pocket computer. Appl E rgon 23:331-336.

V leeschdrager, E. 1986. H ardness 10: diamonds. París

Volpert, W. 1987. Psychische Regulation von Arbeitstätigkeiten. In Arbeitspsychologie. Enzklopüdie der Psychologie, dirigido por $U$ Kleinbeck $y$ J R utenfranz. Göttingen: H ogrefe.

Wagner, JA y R Z Gooding. 1987. Effects of societal trends on participation research. Adm Sci 0 32:241-262.

Wagner, R . 1985. Job analysis at AR BED. E rgonomics 28:255-273.

Wall, TD y JA Lischeron. 1977. W orker Participation: A Critique of the Literature and Some Fresh Evidence Londres: M cG raw-Hill.

Wang, WM-Y. 1992. U sability Evaluation for H uman-C omputer Interaction ( $\mathrm{Cl})$. Luleå, Suecia: U niversidad T ecnológica de $L$ uleå.

Waters, TR, V Putz-Anderson, A Garg, LJ Fine. 1993. R evised NIOSH equation for the design and evaluation of manual handling tasks. Ergonomics 36:749-776.

Wedderburn, A. 1991. Guidelines for shiftworkers Bulletin of E uropean Shiftwork Topics (BEST) No. 3. Dublín: Fundación Europea para la M ejora de las Condiciones de Vida y de T rabajo.

W elford, AT . 1986. M ental workload as a function of demand, capacity, strategy and skill. Ergonomics 21:151-176.

White, PA. 1988. K nowing more about what we tell: 'Introspective access' and causal report accuracy, 10 years later. B rit J P sychol 79:13-45.

Wickens, C. 1992. Enginering Psychology and H uman Performance. Nueva Y ork: $\mathrm{H}$ arper C ollins.

Wickens, CD, YY Yeh. 1983. The dissociation between subjective work load and performance: A multiple resources approach. En Actas del 27 Congreso Anual de la Human Factors Society. Santa M ónica, California: H uman Factors Society.

Wieland-Eckelmann, R. 1992. Kognition, Emotion und Psychische B eanspruchung. Göttingen: H ogrefe.
Wikström.L, S Byström, S Dahlman, C Fransson, $\mathrm{R}$ K adefors, \& K ilbom, E Landervik, L Lieberg, L Sperling, J Öster. 1991. Criterion for Selection and Development of $\mathrm{H}$ and $\mathrm{T}$ ools. Estocolmo: Instituto $\mathrm{N}$ acional de M edicina del T rabajo.

Wilkinson, RT . 1964. Effects of up to 60 hours sleep deprivation on different types of work. E rgonomics 7:63-72.

Williams, R. 1976. Keywords: A Vocabulary of Culture and Society. G lasgow: Fontana.

Wilpert, B. 1989. M itbestimmung. En Arbeits- und $O$ rganisationspsychologie. Internationales $\mathrm{H}$ andbuch in Schlüsselbegriffen, dirigido por S G reif, $\mathrm{H}$ Holling $y$ $\mathrm{N}$ Nicholson. M unich: Psychologie V erlags U nion.

Wilson, JR, EN Corlett. 1990. Evaluation of $H$ uman W ork: A Practical Ergonomics M ethodology. Londres: T aylor \& Francis.

Wilson, JR. 1991. Participation: A framework and foundation for ergonomics. I O ccup Psychol 64:67-80.

Wisner, A. 1983. Ergonomics or anthropology: A limited or wide approach to working condition in technology transfer. En Proceedings of the First International Conference on Ergonomics of Developing Countries, dirigido por Shahnavaz y Babri. Luleå, Suecia: U niversidad T ecnológica de Luleå.

Womack, J, T Jones, D Roos. 1990. T he M achine T hat Changed the W orld. N ueva Y ork: M acmillan.

Woodson, WE, B Tillman, P Tillman. 1991. H uman Factors D esign $\mathrm{H}$ andbook. N ueva $\mathrm{Y}$ ork: $\mathrm{M} \mathrm{CG}$ raw-H ill.

Zhang, YK, JS Tyler. 1990. The establishment of a modern telephone cable production facility in a developing country. A case study. En las actas del simposio internacional sobre comunicaciones alámbricas y por cable. Illinois.

Zinchenko, V, V M unipov. 1989. Fundamentals of E rgonomics. M oscú: Progress.

\section{0 tras lecturas recomendadas}

Amphoux, L. 1976. Fatigue. Instantanés médicaux pathologie du travail, intoxications, maladies par agents physiques. En E ncyclopédie M édico-Chirurgicale París: Les éditions techniques.

Birren, JE, K Warner Schaie. 1990. Handbook of the Psychology of A ging. N ueva Y ork: A cademic Press.

Bourlière, F. 1982. Gérontologie, Biologie Et Clinique París: Flammarion.

Bugard, P, EJ Caille, L Crocq, B Ely, M Henry, L Petrescu, A Reinberg. 1974. CIS 76-281 Stress, Fatigue, and Depression in Everyday Life. Vol. 1 y 2. París: Editions D oin.

Carter, FA, EN Corlett. 1982. Accidents and Shiftwork. Dublín: Fundación Europea para la M ejora de las Condiciones de Vida y de T rabajo.

Charness, M. 1985. Aging and Human Performance. Nueva Y ork: Wiley.

Colligan, MJ, RR R osa. 1990. Shiftwork effects on social and family life. En Shiftwork, dirigido por AJ Scott. Filadelfia: $\mathrm{H}$ anley \& Belfus.

Davies, BT, H Shahnawaz. 1977. CIS 77-1774 An anthropometer for use in developing countries. E rgonomics 20(3):317-320.

Drury, CG, B Paramore, HP V an Cott, SM Grey, EN Corlett. 1987. Task analysis. En H andbook of
H uman Factors, dirigido por G Salvendy. Nueva Y ork: Wiley.

Fraser, TM. 1989. The W orker At W ork. Londres: T aylor \& Francis.

Freivalds, A. 1987. The ergonomics of tools. Int Rev E rgon 1:43-75.

Gadbois, C. 1991. Round the clock operations in hospitals: Shift scheduling, task demands and work organisation. R esumen del Simposio internacional sobre turnos de trabajo y exigencias del puesto de trabajo, 11-12 de julio, París.

Graf, 0. 1922. Über lohnendste Arbeitspausen bei geistiger Arbeit. Psychol Arbeiten 7:548-611.

Grieco, A, M M asali. 1971. Setting up a method for the measurement of anthropometric parameters with a view to the ergonomic design of workplaces. $M$ ed L avoro 62(11):505-531.

$\mathrm{H}$ amelin, P. 1981. Les conditions temporelles de travail des conducteurs routiers et la sécurite routière. T ravail $\mathrm{H}$ um 44:5-21.

ISSA. N.d. W.G. 3 E.: Checklist for a Classification of $M$ achines $O n$ the Basis of Ergonomic Principles, International Section ' $M$ achine Safety' On the Prevention of $O$ ccupational Accidents and D iseases. M annheim: ISSA.

Konz, S. 1979. Handtools. En W ork Design Columbus, 0 hio: $\mathrm{G}$ rid.

M cE wan, YW. 1978. Flexible working arrangements in continuous shift production. Pers R ev :12-19.

Minors, DS, JM Waterhouse. 1983. Circadian rhythm amplitude-is it related to rhythm adjustment and/ or worker motivation? E rgonomics 26:229-241.

M ital, A, A K ilborn. 1992. Design, selection and use of hand tools to alleviate trauma of the upper extremeties: Part I- Guidelines for the practitioner. Part II- The scientific basis for the guide. Int J Ind E rg 10:1-21

Nowak, E. 1978. CIS 78-2068 Determination of the spatial reach area of the arms for workplace design purposes. E rgonomics 21(7) (julio):493-507.

O rganización Internacional del Trabajo (OIT). 1984. Protection of $W$ orkers against Noise and Vibration in the W orking Environment, an ILO Code of Practice Ginebra: OIT

Robinson, PK y cols. N.d. Aging and Technological Advances. Presented At NAT O Conference Series III, $H$ uman F actors, Volume 24.

Rohmert, W. 1975. Anthropometric elements of ergonomics. Bulletin del'AISS:25-35.

—. 1983. Formen menschlicher Arbeit. En Praktische Arbeitsphysiologie, dirigido por W Rohmert y J R utenfranz. Stuttgart: G eorg T hieme V erlag.

Tichauer, ER. 1978. The Biomechanical Basis of E rgonomics. N ueva Y ork: Wiley Interscience.

V idacek, S, L K aliterna, B R adosevic-V idacek. 1987. Predictive validity of individual difference measures for health problems in shiftworkers: Preliminary results. En Contemporary Advances in Shiftwork Research, dirigido por A O ginski, J Pokorski y J Rutenfranz. Cracovia: Academia M édica.

V ieillissement et travail. 1989. T ravail H um 52:1-3.

Webb Associates. 1972. CIS 74-802 Anthropometry for Respirator Sizing. Cincinnati, O hio: NIOSH. 


\section{HIGIENE INDUSTRIAL}

Director del capítulo

Robert F. H errick

\section{Sumario}

O bjetivos, definiciones e información general

B erenicel. Ferrari Goelzer. . . . . . . . . . . . . . . . . . . . . . . . 30.2

Identificación de peligros

Linnéa Lillienberg. . . . . . . . . . . . . . . . . . . . 30.11

Evaluación del medio ambiente de trabajo

Lori A. Todd. . . .......................... 30.15

$\mathrm{H}$ igiene industrial: control de las exposiciones mediante

la intervención

J ames Stewart. . . . . . . . . . . . . . . . . . 30.25

Fundamentos biológicos para evaluar la exposición

Dick H ederik . . . . . . . . . . . . . . . . . . . . . . . . . . . . 30.27

Límites de exposición profesional

D ennis J . Paustenbach . . . . . . . . . . . . . . . . . . . . 30.31 


\section{- O BJETIVOS, DEFINICIONESE INFORMACION GENERAL}

\section{Berenice I. Ferrari G oelzer}

El trabajo es esencial para la vida, el desarrollo y la satisfacción personal. Por desgracia, actividades indispensables, como la producción de alimentos, la extracción de materias primas, la fabricación de bienes, la producción de energía y la prestación de servicios implican procesos, operaciones y materiales que, en mayor o menor medida, crean riesgos para la salud de los trabajadores, las comunidades vecinas y el medio ambiente en general.

N o obstante, la generación y la emisión de agentes nocivos en el medio ambiente de trabajo pueden prevenirse mediante intervenciones adecuadas para controlar los riesgos, que no sólo protegen la salud de los trabajadores, sino que reducen también los daños al medio ambiente que suelen ir asociados a la industrialización. Si se elimina una sustancia química nociva de un proceso de trabajo, dejará de afectar a los trabajadores y tampoco contaminará el medio ambiente.

La profesión que se dedica específicamente a la prevención y control de los riesgos originados por los procesos de trabajo es la higiene industrial. Los objetivos de la higiene industrial son la protección y promoción de la salud de los trabajadores, la protección del medio ambiente y la contribución a un desarrollo seguro y sostenible.

L a necesidad de la higiene industrial para proteger la salud de los trabajadores no debe subestimarse. Incluso cuando se puede diagnosticar y tratar una enfermedad profesional, no podrá evitarse que ésta se repita en el futuro si no cesa la exposición al agente etiológico. $\mathrm{M}$ ientras no se modifique un medio ambiente de trabajo insano, seguirá teniendo el potencial de dañar la salud. Sólo si se controlan los riesgos para la salud podrá romperse el círculo vicioso que se ilustra en la Figura 30.1.

Sin embargo, las acciones preventivas deben iniciarse mucho antes, no sólo antes de que se manifieste cualquier daño para la salud, sino incluso antes de que se produzca la exposición. El medio ambiente de trabajo debe someterse a una vigilancia continua para que sea posible detectar, eliminar y controlar los agentes y factores peligrosos antes de que causen un efecto nocivo; ésta es la función de la higiene industrial.

Además, la higiene industrial puede contribuir también a un desarrollo seguro y sostenible, es decir, "a asegurar que [el desarrollo] atienda las necesidades del presente sin comprometer la capacidad de las futuras generaciones para atender sus necesidades" (C omisión M undial sobre M edio Ambiente y Desarrollo 1987). Para atender las necesidades de la actual población mundial sin agotar ni dañar los recursos mundiales y sin generar consecuencias negativas para la salud y el medio ambiente, hacen falta conocimientos y medios para influir en la acción (O M S 1992a); esto, aplicado a los procesos de trabajo, está estrechamente relacionado con la práctica de la higiene industrial.

La salud en el trabajo requiere un enfoque interdisciplinario con la participación de disciplinas fundamentales, una de las cuales es la higiene industrial, además de otras como la medicina y la enfermería del trabajo, la ergonomía y la psicología del trabajo. En la Figura 30.2 se presenta un esquema de los ámbitos de actuación de los médicos del trabajo y los higienistas industriales.

Es importante que los responsables de la toma de decisiones, los directivos y los propios trabajadores, así como todos los profesionales de la salud en el trabajo, comprendan la función básica que desempeña la higiene industrial para proteger la salud de los trabajadores y el medio ambiente, así como la necesidad de disponer de profesionales especializados en este campo.
Figura 30.1 - Interacciones entre las personas y el medio ambiente.
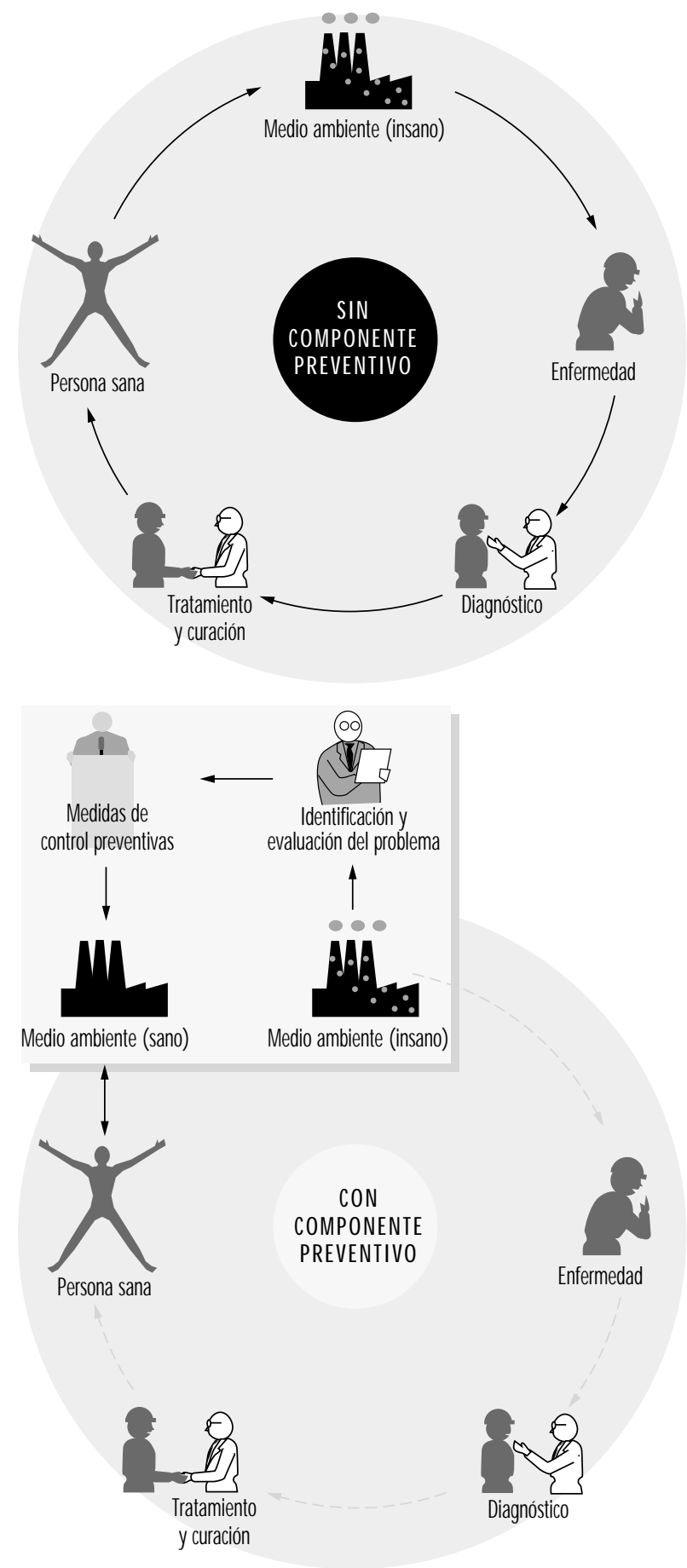

Tampoco debe olvidarse la estrecha relación que existe entre la salud en el trabajo y la salud ambiental, puesto que la prevención de la contaminación de fuentes industriales mediante procesos adecuados de tratamiento y evacuación de residuos y desechos peligrosos debe iniciarse en el lugar de trabajo. (V éase "Evaluación del medio ambiente de trabajo"). 


\section{Conceptos y definiciones}

\section{Higiene industrial}

La higiene industrial es la ciencia de la anticipación, la identificación, la evaluación y el control de los riesgos que se originan en el lugar de trabajo o en relación con él y que pueden poner en peligro la salud y el bienestar de los trabajadores, teniendo también en cuenta su posible repercusión en las comunidades vecinas y en el medio ambiente en general.

Existen diferentes definiciones de la higiene industrial, aunque todas ellas tienen esencialmente el mismo significado y se orientan al mismo objetivo fundamental de proteger y promover la salud y el bienestar de los trabajadores, así como proteger el medio ambiente en general, a través de la adopción de medidas preventivas en el lugar de trabajo.

L a higiene industrial no ha sido todavía reconocida universalmente como una profesión; sin embargo, en muchos países está creándose un marco legislativo que propiciará su consolidación.

\section{El técnico en higiene industrial}

El técnico en higiene industrial es "una persona competente para realizar mediciones del medio ambiente del trabajo", pero no para "realizar las interpretaciones, juicios y recomendaciones que se exigen a un higienista industrial". El técnico en higiene

\section{Higienista industrial}

Un higienista industrial es un profesional capaz de:

- prever los riesgos para la salud que pueden originarse como resultado de procesos de trabajo, operaciones y equipos y, en consecuencia, asesorar sobre su planificación y diseño.

- identificar y conocer, en el medio ambiente de trabajo, la presencia (real o potencial) de agentes químicos, físicos y biológicos y otros factores de riesgo, a sí como su intera cción con otros factores que pueden afectar a la salud y el bienestar de los trabajadores

- conocer las posibles vías de entrada de agentes en el organismo humano y los efectos que esos agentes y otros factores pueden tener en la salud

- evaluar la exposición de los trabajadores a agentes y factores potencialmente nocivos y evaluar los resultados

- evaluar los procesos y los métodos de trabajo, desde el punto de vista de la posible generación y emisión/ propagación de agentes y otros factores potencialmente nocivos, con objeto de eliminar la exposición o reducirla a niveles aceptables

- diseñar y recomendar estra tegias de control y evaluar su eficacia solo o en colaboración con otros profesionales para asegurar un control eficaz y económico

- participar en el análisis del riesgo global y la gestión de un agente, proceso o lugar de trabajo, y contribuir al establecimiento de prioridades para la gestión de riesgos

- conocer el marco jurídico para la práctica de la higiene industrial en su país

- educar, formar, informar y asesorar a personas de todos los niveles en todos los aspectos de la comunicación de riesgos

- trabajar con eficacia en un equipo interdisciplinario en el que participen también otros profesionales

- identificar los agentes y factores que pueden tener un impacto medioambiental y comprender la necesidad de integrar la práctica de la higiene industrial con la protección del medio a mbiente Debe tenerse en cuenta que una profesión no sólo consiste en un conjunto de conocimientos, sino también en un código de ética; las asociaciones nacionales de higienistas industriales, así como la Asociación Internacional para la Higiene Industrial (AIHI), tienen sus propios códigos de ética (O M S 1992 b).
Figura 30.2 - Ambitos de actuación de los médicos del trabajo y los higienistas industriales.

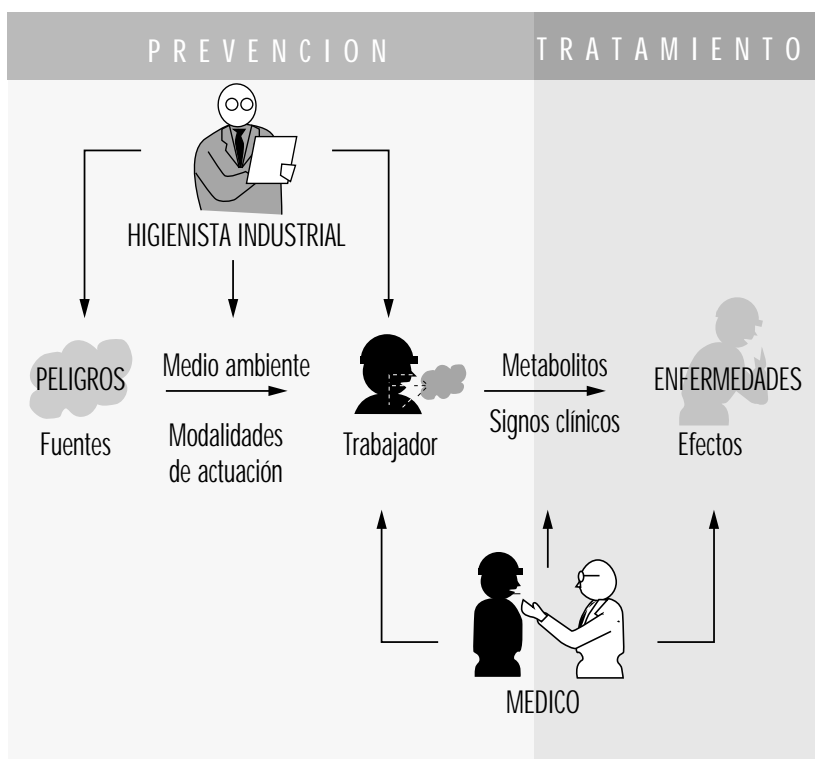

Fuente: Por cortesía del Prof. M. Guillemin. Institut universitaire romand de Santé au Travail, Lausana, Suiza (ligeramente modificado).

industrial puede alcanzar el nivel necesario de competencias en un campo general o especializado (O M S 1992b).

\section{Asociación Internacional para la Higiene Industrial (AIHI)}

La AIHI se creó formalmente en una reunión celebrada en M ontreal el 2 de junio de 1987. En la actualidad, la AIH I cuenta con la participación de 19 asociaciones nacionales de higiene industrial y más de diecinueve mil miembros de diecisiete países.

EI principal objetivo de la AIHI es promover y desarrollar la higiene industrial en todo el mundo para que alcance un elevado nivel de competencia profesional, a través de medios como el intercambio de información entre organizaciones e individuos, el desarrollo de los recursos humanos y la promoción de un alto nivel de práctica ética. Las actividades de la AlHI incluyen reuniones científicas y la publicación de un boletín. Los miembros de las asociaciones nacionales afiliadas son automáticamente miembros de la AIHI; también pueden afiliarse como miembros individuales, si residen en países en los que todavía no se ha implantado una asociación nacional.

\section{Certificación}

Además de una definición aceptada de la higiene industrial y de la función que desempeña el higienista industrial, es preciso establecer sistemas de certificación para garantizar unos niveles aceptables de competencia y práctica en el campo de la higiene industrial. La certificación se refiere a un sistema formal basado en los procedimientos necesarios para adquirir y mantener los conocimientos, las destrezas y la competencia de los profesionales (Burdorf 1995).

$\mathrm{La} \mathrm{AlHI}$ ha promovido un estudio sobre los sistemas nacionales de certificación que existen en la actualidad (Burdorf 1995), junto con la formulación de recomendaciones para promover la cooperación internacional con el fin de garantizar la calidad de los higienistas industriales profesionales. Entre estas recomendaciones figuran las siguientes: 
- "armonización de los niveles de competencia y práctica de los profesionales de la higiene industrial";

- "creación de un organismo internacional formado por profesionales de la higiene industrial para analizar la calidad de los actuales sistemas de certificación".

0 tras propuestas de este informe hacen referencia a aspectos como la "reciprocidad" y la "aceptación mutua de las designaciones nacionales, con objeto de conseguir un sistema universal con una designación aceptada a escala internacional".

\section{La práctica de la higiene industrial}

Las etapas clásicas de la práctica de la higiene industrial son las siguientes:

- identificación de posibles peligros para la salud en el medio ambiente de trabajo;

- evaluación de los peligros, un proceso que permite valorar la exposición y extraer conclusiones sobre el nivel de riesgo para la salud humana;

- prevención y control de riesgos, un proceso que consiste en desarrollar e implantar estrategias para eliminar o reducir a niveles aceptables la presencia de agentes y factores nocivos en el lugar de trabajo, teniendo también en cuenta la protección del medio ambiente.

El enfoque ideal de la prevención de riesgos es "una actuación preventiva anticipada e integrada", que incluya:

- evaluación de los efectos sobre la salud de los trabajadores y del impacto ambiental, antes de diseñar e instalar, en su caso, un nuevo lugar de trabajo;

- selección de la tecnología más segura, menos peligrosa y menos contaminante ("producción más limpia");

- emplazamiento adecuado desde el punto de vista ambiental;

- diseño adecuado, con una distribución y una tecnología de control apropiadas, que prevea un manejo y una evacuación seguros de los residuos y desechos resultantes;

- elaboración de directrices y normas para la formación del personal sobre el correcto funcionamiento de los procesos, métodos seguros de trabajo, mantenimiento y procedimientos de emergencia.

La importancia de anticipar y prevenir todo tipo de contaminación ambiental es decisiva. Por fortuna, existe una creciente tendencia a considerar las nuevas tecnologías desde el punto de vista de los posibles impactos negativos y su prevención, desde el diseño y la instalación del proceso hasta el tratamiento de los residuos y desechos resultantes, aplicando un enfoque integral. Algunas catástrofes ambientales que se han producido tanto en países desarrollados como en países en desarrollo podrían haberse evitado mediante la aplicación de estrategias de control y procedimientos de emergencia adecuados en el lugar de trabajo.

Los aspectos económicos deben analizarse en términos que van más allá de la mera consideración del coste inicial; otras alternativas más caras, que ofrecen una buena protección de la salud y del medio ambiente, pueden resultar más económicas a largo plazo. La protección de la salud de los trabajadores y del medio ambiente debe iniciarse mucho antes de lo que habitualmente se hace. L os responsables del diseño de nuevos procesos, maquinaria, equipos y lugares de trabajo deberían disponer siempre de información técnica y asesoramiento sobre higiene industrial y ambiental. Por desgracia, muchas veces este tipo de información se consigue demasiado tarde, cuando la única solución posible es costosa y difícil de aplicar con efecto retroactivo
0, peor todavía, cuando las consecuencias han sido ya desastrosas.

\section{Identificación de riesgos}

La identificación de riesgos es una etapa fundamental en la práctica de la higiene industrial, indispensable para una planificación adecuada de la evaluación de riesgos y de las estrategias de control, así como para el establecimiento de prioridades de acción. Un diseño adecuado de las medidas de control requiere, asimismo, la caracterización física de las fuentes contaminantes y de las vías de propagación de los agentes contaminantes.

La identificación de riesgos permite determinar:

- los agentes que pueden estar presentes y en qué circunstancias;

- la naturaleza y la posible magnitud de los efectos nocivos para la salud y el bienestar.

La identificación de agentes peligrosos, sus fuentes y las condiciones de exposición requiere un conocimiento exhaustivo y un estudio detenido de los procesos y operaciones de trabajo, las materias primas y las sustancias químicas utilizadas o generadas, los productos finales y los posibles subproductos, así como la eventual formación accidental de sustancias químicas, descomposición de materiales, quema de combustibles o presencia de impurezas. La determinación de la naturaleza y la magnitud potencial de los efectos biológicos que estos agentes pueden causar si se produce una exposición excesiva a ellos exige el acceso a información toxicológica. Las fuentes internacionales de información en este campo son el Programa Internacional de Seguridad de las Sustancias Q uímicas (IPQ S), la A gencia I nternacional para la Investigación sobre el Cáncer (IARC) y el Registro internacional de productos químicos potencialmente tóxicos, Programa de las Naciones Unidas para el Medio Ambiente (R IPQ PT-PNU M A).

Los agentes que plantean riesgos para la salud en el medio ambiente de trabajo pueden agruparse en las siguientes categorías: contaminantes atmosféricos; sustancias químicas no suspendidas en el aire; agentes físicos, como el calor y el ruido; agentes biológicos; factores ergonómicos, como unas posturas de trabajo o procedimientos de elevación de pesos inadecuados, y factores de estrés psicosocial.

\section{Evaluaciones de higiene industrial}

L as evaluaciones de higiene industrial se realizan para valorar la exposición de los trabajadores y para obtener información que permita diseñar o establecer la eficiencia de las medidas de control.

La evaluación de la exposición de los trabajadores a riesgos profesionales, como contaminantes atmosféricos, agentes físicos y agentes biológicos se aborda más adelante en este capítulo. No obstante, aquí se hacen algunas observaciones generales para conocer mejor el campo de la higiene industrial.

Es importante tener en cuenta que la evaluación de riesgos no es un fin en sí misma, sino que debe entenderse como parte de un procedimiento mucho más amplio que comienza en el momento en que se descubre que determinado agente, capaz de producir un daño para la salud, puede estar presente en el medio ambiente de trabajo, y concluye con el control de ese agente para evitar que cause daños. La evaluación de riesgos facilita la prevención de riesgos, pero en ningún caso la sustituye.

\section{Evaluación de la exposición}

El objetivo de la evaluación de la exposición es determinar la magnitud, frecuencia y duración de la exposición de los trabajadores a un agente. Se han elaborado directrices al respecto tanto en el ámbito nacional como internacional; por ejemplo, la norma 
EN 689, elaborada por el Comité Européen de Normalisation (Comité Europeo de N ormalización, CEN 1994).

EI procedimiento más habitual para evaluar la exposición a contaminantes atmosféricos consiste en evaluar la exposición a la inhalación, para lo cual es preciso determinar la concentración atmosférica del agente a la que están expuestos los trabajadores (0, en el caso de las partículas suspendidas en el aire, la concentración atmosférica de la fracción relevante, p. ej., la "fracción respirable") y la duración de la exposición. No obstante, cuando existen otras vías distintas a la inhalación que contribuyen significativamente a la absorción de una sustancia química, puede emitirse un juicio erróneo si sólo se evalúa la exposición a la inhalación. En tales casos tiene que evaluarse la exposición total, y una herramienta muy útil para ello es el control biológico.

La práctica de la higiene industrial se ocupa de tres tipos de situaciones:

- estudios iniciales para evaluar la exposición de los trabajadores;

- control/vigilancia de seguimiento:

- evaluación de la exposición para estudios epidemiológicos.

Una de las principales razones para determinar si existe una exposición excesiva a un agente peligroso en el medio ambiente de trabajo es decidir si se necesita alguna intervención. Esto consiste con frecuencia, aunque no siempre, en comprobar si se respeta una norma adoptada, que suele expresarse en términos de un límite de exposición profesional. La determinación de la exposición "en el peor de los casos" puede ser suficiente para lograr este objetivo. De hecho, si se espera que la exposición sea muy grande o muy pequeña en comparación con los valores límite, la exactitud y precisión de las evaluaciones cuantitativas pueden ser menores que cuando se espera una exposición cercana a los valores límites. De hecho, cuando los peligros son evidentes, puede ser más conveniente empezar por invertir en controles y realizar evaluaciones ambientales más precisas una vez introducidos dichos controles.

Las evaluaciones de seguimiento son necesarias en numerosas ocasiones, especialmente cuando existe la necesidad de instalar 0 mejorar las medidas de control o cuando se prevén cambios en los procesos o materiales utilizados. En estos casos, las evaluaciones cuantitativas cumplen una importante función de vigilancia para:

- evaluar la validez, comprobar la eficiencia o detectar posibles fallos en los sistemas de control;

- averiguar si se han producido variaciones en los procesos, por ejemplo en la temperatura de funcionamiento o en las materias primas, que hayan modificado la situación de exposición.

Siempre que se realiza una evaluación de higiene industrial en relación con un estudio epidemiológico para obtener datos cuantitativos sobre la relación entre exposición y efectos para la salud, las características de la exposición deben describirse con un alto grado de exactitud y precisión. En este caso, deben caracterizarse adecuadamente todos los niveles de exposición, ya que no sería suficiente, por ejemplo, caracterizar sólo la exposición correspondiente al peor de los casos. Sería ideal, aunque difícil en la práctica, que en todo momento pudieran mantenerse registros precisos y exactos de la exposición, ya que en el futuro podrían necesitarse datos diacrónicos sobre la exposición. Para que los datos de la evaluación sean representativos de la exposición de los trabajadores y para no malgastar recursos, debe diseñarse y aplicarse una estrategia adecuada de muestreo, teniendo en cuenta todas las posibles fuentes de variabilidad. Las estrategias de muestreo, así como las técnicas de medición, se describen en "Evaluación del medio ambiente de trabajo".

\section{Interpretación de los resultados}

El grado de incertidumbre en la estimación de un parámetro de la exposición, como la concentración media real de un contaminante atmosférico, se determina mediante el tratamiento estadístico de los resultados obtenidos de diferentes mediciones (p. ej., muestreo y análisis). La fiabilidad de los resultados dependerá del coeficiente de variación del "sistema de medición" y del número de mediciones. U na vez lograda una fiabilidad aceptable en los resultados, el siguiente paso consiste en considerar las consecuencias de la exposición para la salud: ¿qué significa para la salud de los trabajadores expuestos ahora?, ¿en un futuro próximo?, ¿a lo largo de su vida profesional? ¿tendrá repercusión en las futuras generaciones?

EI proceso de evaluación termina sólo cuando se interpretan los resultados de las mediciones a la vista de los datos (algunas veces llamados "datos sobre la evaluación de riesgos") obtenidos de la toxicología experimental, estudios epidemiológicos y clínicos y, en algunos casos, ensayos clínicos. D ebe aclararse que el término evaluación de riesgos se ha utilizado para hacer referencia a dos tipos de evaluaciones: la evaluación de la naturaleza y la magnitud del riesgo unido a la exposición a sustancias químicas y otros agentes, en general, y la evaluación del riesgo para determinado trabajador o para un grupo concreto de trabajadores en un lugar de trabajo específico.

En la práctica de la higiene industrial, los resultados de la evaluación de la exposición suelen compararse con los límites de exposición profesional adoptados, cuya finalidad es ofrecer una orientación para evaluar los riesgos y establecer objetivos de control. Cuando la exposición supera esos límites, es preciso adoptar de inmediato una acción correctora, ya sea mejorando las medidas de control existentes 0 introduciendo nuevos controles. De hecho, las intervenciones preventivas deben iniciarse cuando la exposición alcanza el "nivel de acción", que varía según el país (p. ej., la mitad o la quinta parte del límite de exposición profesional). Un nivel de acción bajo es la mejor garantía para evitar problemas en el futuro.

Comparar los resultados de la evaluación de la exposición con los límites de exposición profesional es una simplificación, puesto que, entre otras insuficiencias, no se tienen en cuenta muchos factores que influyen en la absorción de sustancias químicas (como la susceptibilidad individual, la actividad física y la complexión corporal de cada individuo). Además, en la mayoría de los lugares de trabajo se produce una exposición simultánea a distintos agentes; de ahí que sea muy importante tener en cuenta las exposiciones combinadas y las interacciones entre distintos agentes, ya que las consecuencias para la salud de la exposición a un único agente pueden ser muy diferentes a las consecuencias de la exposición a ese mismo agente combinado con otros, especialmente cuando existe sinergia o potenciación de efectos.

\section{Mediciones de control}

Las mediciones que tienen como finalidad investigar la presencia de agentes y las pautas de los parámetros de exposición en el medio ambiente de trabajo pueden ser extremadamente útiles para planificar y diseñar medidas de control y métodos de trabajo. L os objetivos de estas mediciones son:

- identificar y caracterizar las fuentes contaminantes;

- localizar puntos críticos en recintos o sistemas cerrados (p. ej., fugas); 
- determinar las vías de propagación en el medio ambiente de trabajo;

- comparar diferentes intervenciones de control;

- verificar que el polvo respirable se ha depositado junto con el polvo grueso visible, cuando se utilizan nebulizadores de agua;

- comprobar que el aire contaminado no procede de un área adyacente.

Los instrumentos de lectura directa son extremadamente útiles para fines de control, especialmente los que permiten realizar un muestreo continuo y reflejan lo que sucede en tiempo real, detectando situaciones de exposición en las que de lo contrario no se repararía y que deben ser controladas. Ejemplos de este tipo de instrumentos son los detectores de fotoionización, los analizadores de infrarrojos, los medidores de aerosoles y los tubos indicadores. Cuando se realiza un muestreo para conocer el comportamiento de los contaminantes desde la fuente hasta el medio ambiente de trabajo, la exactitud y la precisión no son tan decisivas como lo son al evaluar la exposición.

U no de los avances recientes en este tipo de mediciones para fines de control son las técnicas de visualización, como la Picture M ix Exposure (PIMEX) (Rosen 1993). Este método combina una imagen de vídeo del trabajador con una escala que indica las concentraciones de contaminantes atmosféricos, medidas continuamente en la zona de respiración con un instrumento de control en tiempo real, lo cual permite observar cómo varían las concentraciones mientras se realiza el trabajo. Este método constituye una herramienta excelente para comparar la eficacia relativa de diferentes medidas de control, como ventilación y métodos de trabajo, lo cual contribuye a mejorar su diseño.

Las mediciones son también necesarias para evaluar la eficiencia de las medidas de control. En este caso, conviene tomar muestras ambientales de la fuente o del área, por separado o junto con las muestras personales, para evaluar la exposición de los trabajadores. Con objeto de garantizar la validez de este procedimiento, el lugar considerado "antes" y "después" de tomar las muestras (o mediciones), así como las técnicas utilizadas, deben ser iguales o equivalentes en sensibilidad, exactitud y precisión.

\section{Prevención y control de riesgos}

El principal objetivo de la higiene industrial es la aplicación de medidas adecuadas para prevenir y controlar los riesgos en el medio ambiente de trabajo. Las normas y reglamentos, si no se aplican, carecen de utilidad para proteger la salud de los trabajadores, y su aplicación efectiva suele exigir la implantación de estrategias tanto de vigilancia como de control. La ausencia de unas normas obligatorias por ley no debe ser obstáculo para la aplicación de las medidas necesarias a fin de prevenir exposiciones nocivas o de controlarlas para que se mantengan al nivel mínimo posible. Cuando es evidente que existen riesgos graves, deben introducirse controles incluso antes de realizar evaluaciones cuantitativas. En algunas ocasiones, puede ser necesario sustituir el concepto clásico de "identificación-evaluación-control" por el de "identificación-control-evaluación", o incluso por el de "identificación-control", si no existen recursos para evaluar los riesgos. Ejemplos de riesgos que, obviamente, obligan a adoptar medidas sin necesidad de realizar un muestreo ambiental previo son la galvanoplastia realizada en una sala pequeña y poco ventilada, o la utilización de un martillo perforador 0 un equipo de limpieza por chorro de arena sin controles ambientales ni equipo de protección. Cuando se identifica este tipo de peligros para la salud, la necesidad inmediata es el control, y no la evaluación cuantitativa.
Las medidas preventivas deben interrumpir de alguna manera la cadena por la cual el agente peligroso — sustancia química, polvo, fuente de energía - se transmite de la fuente al trabajador. Las medidas de control pueden clasificarse en tres grandes grupos: controles técnicos, prácticas de trabajo y medidas personales.

El enfoque más eficiente para prevenir riesgos consiste en introducir controles técnicos que eviten las exposiciones profesionales actuando en el medio ambiente de trabajo y, en consecuencia, reduciendo la necesidad de que los trabajadores o las personas que pueden verse expuestas tengan que poner algo de su parte. Las medidas técnicas suelen exigir la modificación de algunos procesos o estructuras mecánicas. Su finalidad es eliminar o reducir el uso, la generación o la emisión de agentes peligrosos en la fuente 0 , cuando no se pueda eliminar la fuente, prevenir o reducir la propagación de agentes peligrosos en el medio ambiente de trabajo:

- encerrándolo;

- eliminándolos en el momento en que salen de la fuente;

- interfiriendo en su propagación;

- reduciendo su concentración o intensidad.

Las mejores intervenciones de control son las que consisten en alguna modificación de la fuente, ya que permiten eliminar el agente peligroso o reducir su concentración o intensidad. La fuente puede reducirse con medidas como la sustitución de materiales, la sustitución o la modificación de procesos o equipos y la mejora del mantenimiento de los equipos.

Cuando no se puede modificar la fuente, o cuando esta modificación no es suficiente para alcanzar el nivel deseado de control, deben prevenirse la emisión y la difusión de agentes peligrosos en el medio ambiente de trabajo interrumpiendo sus vías de transmisión, con medidas de aislamiento (p. ej., sistemas cerrados, recintos), ventilación localizada, instalación de barreras y defensas 0 aislamiento de los trabajadores.

0 tras medidas que ayudan a reducir las exposiciones en el medio ambiente de trabajo son un diseño adecuado del lugar de trabajo, la ventilación por dilución o desplazamiento, una buena limpieza y un almacenamiento adecuado. La colocación de etiquetas y señales de advertencia puede ayudar a los trabajadores a aplicar unos métodos seguros de trabajo. Un programa de control puede requerir también sistemas de vigilancia y de alarma, como son los detectores de monóxido de carbono alrededor de los hornos, de sulfuro de hidrógeno en las plantas de depuración de aguas residuales y de falta de oxígeno en recintos cerrados.

Las prácticas de trabajo constituyen una parte importante del control; por ejemplo, en relación con trabajos en los que la postura del trabajador puede influir en la exposición, según se incline más o menos. La postura del trabajador puede afectar a las condiciones de exposición (p. ej., zona de respiración con relación a la fuente contaminante, posibilidad de absorción por la piel).

Por último, la exposición profesional puede evitarse o reducirse colocando una barrera protectora ante el trabajador, en el punto crítico de entrada del agente peligroso (boca, nariz, piel, oídos), es decir, mediante el uso de instrumentos de protección personal. No obstante, antes de recurrir a este tipo de equipo, deben estudiarse todas las demás posibilidades de control, ya que constituye el medio menos satisfactorio para el control rutinario de la exposición, especialmente a contaminantes atmosféricos.

O tras medidas preventivas personales son la educación y la formación, la higiene personal y la limitación de la duración de la exposición. 
Las evaluaciones continuas mediante controles ambientales y vigilancia médica deben formar parte de toda estrategia de control y prevención de riesgos.

Una tecnología adecuada para controlar el medio ambiente de trabajo debe incluir, asimismo, medidas para prevenir la contaminación ambiental (aire, agua, suelo), entre ellas un tratamiento adecuado de los residuos peligrosos.

Aunque la mayoría de las medidas de control que se mencionan aquí se refieren a los contaminantes atmosféricos, muchas pueden aplicarse también a otros tipos de riesgos. Por ejemplo, un proceso puede modificarse para que produzca menos contaminantes atmosféricos, menos ruido o menos calor. U na barrera de aislamiento puede separar a los trabajadores de una fuente de ruido, calor o radiación.

Con demasiada frecuencia, la prevención se centra en las medidas más conocidas, como la ventilación localizada y los equipos de protección personal, y no tiene debidamente en cuenta otras valiosas medidas de control, como el uso de tecnologías alternativas limpias, la sustitución de materiales, la modificación de procesos o la aplicación de buenas prácticas de trabajo. M uchas veces ocurre que los procesos de trabajo se consideran inmodificables cuando, en realidad, podrían introducirse cambios para prevenir con eficacia, o al menos reducir, los riesgos asociados.

La prevención y el control de riesgos en el medio ambiente de trabajo requieren conocimientos e ingenio. Un control eficaz no precisa necesariamente de medidas muy costosas y complicadas. En muchos casos, el riesgo puede controlarse con el uso de una tecnología adecuada, que puede ser tan sencilla como una pieza de material impermeable entre el hombro desnudo de un trabajador de un muelle y una bolsa de material tóxico que pueda absorberse a través de la piel. Puede controlarse también con mejoras sencillas, como la colocación de una barrera móvil entre una fuente de rayos ultravioleta y el trabajador, o la formación de los trabajadores en materia de prácticas seguras de trabajo.

Los aspectos que deben tenerse en cuenta para seleccionar una estrategia y una tecnología de control adecuadas son el tipo de agente peligroso (naturaleza, estado físico, efectos para la salud, vías de entrada en el organismo), el tipo de fuente(s), la magnitud y las condiciones de la exposición, las características del lugar de trabajo y la ubicación relativa de los puestos de trabajo.

Deben garantizarse las cualificaciones y los recursos necesarios para el diseño, la aplicación, el funcionamiento, la evaluación y el mantenimiento de los sistemas de control. Algunos sistemas, como la ventilación localizada, deben evaluarse en el momento de su instalación y verificarse periódicamente a partir de entonces. Sólo un control y un mantenimiento periódicos pueden asegurar una eficiencia continua, puesto que incluso los sistemas bien diseñados pueden perder sus características iniciales si no reciben el mantenimiento adecuado.

Las medidas de control deben integrarse en programas de prevención y control de riesgos, dotados de unos objetivos claros y una gestión eficiente, en los que participen equipos interdisciplinarios formados por higienistas industriales y otros profesionales de la salud y la seguridad en el trabajo, técnicos de producción, directivos y trabajadores. Tales programas deben abarcar también aspectos como la comunicación de los riesgos, la educación y la formación sobre prácticas seguras de trabajo y procedimientos de emergencia.

A simismo, deben considerarse los aspectos relacionados con la promoción de la salud, puesto que el lugar de trabajo es un entorno ideal para promover estilos de vida saludables en general y para alertar sobre los peligros de las exposiciones no profesionales causadas, por ejemplo, por practicar el tiro sin protectores adecuados o por fumar.

\section{Relación entre higiene industrial, evaluación de riesgos y gestión de riesgos}

\section{Evaluación de riesgos}

La evaluación de riesgos es una metodología que trata de caracterizar los tipos de efectos previsibles para la salud como resultado de determinada exposición a determinado agente, y de calcular la probabilidad de que se produzcan esos efectos en la salud, con diferentes niveles de exposición. Se utiliza también para caracterizar situaciones de riesgo concretas. Sus etapas son la identificación de riesgos, la descripción de la relación exposición-efecto y la evaluación de la exposición para caracterizar el riesgo.

La primera etapa se refiere a la identificación de un agente - por ejemplo, una sustancia química - como causa de un efecto nocivo para la salud (p. ej., cáncer o intoxicación sistémica). En la segunda etapa se establece qué grado de exposición causa qué magnitud de un efecto determinado en cuántas personas expuestas. Estos conocimientos son esenciales para inter pretar los datos obtenidos de la evaluación de la exposición.

La evaluación de la exposición forma parte de la evaluación de riesgos, tanto cuando se obtienen datos para caracterizar una situación de riesgo como cuando se obtienen datos para determinar la relación exposición-efecto basándose en estudios epidemiológicos. En este último caso, la exposición que ha dado lugar a determinado efecto relacionado con el trabajo o con causas ambientales tiene que caracterizarse con exactitud para garantizar la validez de la correlación.

Aunque la evaluación de riesgos es fundamental para muchas de las decisiones que deben tomarse en la práctica de la higiene industrial, tiene un efecto limitado en la protección de la salud de los trabajadores, a menos que se concrete en acciones preventivas reales en el lugar de trabajo.

La evaluación de riesgos es un proceso dinámico, ya que se adquieren nuevos conocimientos que a menudo revelan efectos nocivos de sustancias que hasta entonces se consideraban relativamente inocuas; por consiguiente, el higienista industrial debe tener en todo momento acceso a información toxicológica actualizada. O tra implicación es que las exposiciones deben controlarse siempre al nivel más bajo posible.

En la Figura 30.3 se exponen los diferentes elementos de la evaluación de riesgos.

\section{G estión de riesgos en el medio ambiente de trabajo}

No siempre se pueden eliminar todos los agentes que plantean riesgos para la salud en el trabajo, porque algunos son inherentes a procesos de trabajo indispensables o deseables; sin embargo, los riesgos pueden y deben gestionarse.

La evaluación de riesgos constituye una base para la gestión de los riesgos. Sin embargo, mientras que la evaluación de riesgos es un procedimiento científico, la gestión de riesgos es más pragmática y conlleva decisiones y acciones orientadas a prevenir, o reducir a niveles aceptables, la presencia de agentes que pueden ser peligrosos para la salud de los trabajadores, las comunidades vecinas y el medio ambiente, considerando también el contexto socioeconómico y de la salud pública.

La gestión de riesgos tiene lugar a diferentes niveles; las decisiones y acciones que se adoptan a escala nacional facilitan la práctica de la gestión de riesgos en el lugar de trabajo. La gestión de riesgos en el lugar de trabajo requiere información y conocimientos sobre:

- riesgos para la salud y su magnitud, descritos y clasificados de acuerdo con los resultados de la evaluación de riesgos;

- normas y requisitos legales;

- viabilidad tecnológica, desde el punto de vista de la tecnología de control disponible y aplicable; 
- aspectos económicos, como los costes del diseño, la aplicación, el funcionamiento y el mantenimiento de los sistemas de control, y análisis coste-beneficio (coste del control frente al beneficio económico que se deriva de controlar los riesgos profesionales y ambientales);

- recursos humanos (disponibles y necesarios);

- contexto socioeconómico y de salud pública; que sirven como base para tomar decisiones referentes a:

- definición de los objetivos del control;

- selección de unas estrategias y tecnologías de control adecuadas:

- asignación de prioridades de acción, teniendo en cuenta la situación de riesgo, así como el contexto socioeconómico y de salud pública (especialmente importante en los países subdesarrollados), para realizar acciones como las siguientes:

- identificación y búsqueda de recursos financieros y humanos (si aún no se dispone de los mismos);

- diseño de medidas de control específicas, que deben ser adecuadas para proteger la salud de los trabajadores y el medio ambiente, salvaguardando en la mayor medida posible los recursos naturales;

- aplicación de medidas de control, incluidas disposiciones para un funcionamiento, un mantenimiento y unos procedimientos de emergencia adecuados;

- establecimiento de un programa de prevención y control de riesgos, con una gestión adecuada que incluya vigilancia periódica.

Tradicionalmente, la profesión responsable de la mayoría de estas decisiones y acciones en el lugar de trabajo ha sido la higiene industrial.

Una decisión clave en la gestión de riesgos es la referente al riesgo aceptable (qué efecto puede aceptarse, si es que puede aceptarse, en qué porcentaje de la población trabajadora). Normalmente, aunque no siempre, esta decisión se toma en el ámbito de la política nacional y va seguida de la adopción de límites de exposición profesional y de la promulgación de reglamentos y normas sobre la salud en el trabajo. El higienista industrial, que debe conocer estos requisitos legales, es el responsable, normalmente, de definir los objetivos de control en el lugar de trabajo. Sin embargo, puede suceder que el propio higienista industrial tenga que tomar decisiones sobre el riesgo aceptable en el lugar de trabajo, por ejemplo, cuando no existen normas aplicables o éstas no abarcan todas las posibles exposiciones.

Todas estas decisiones y acciones deben integrarse en un plan realista, que requiere coordinación y colaboración interdisciplinaria y multisectorial. Aunque la gestión de riesgos implica enfoques pragmáticos, su eficiencia debe evaluarse científicamente. Por desgracia, las actividades relacionadas con la gestión de riesgos son, en la mayoría de los casos, un término medio entre lo que debería hacerse para evitar todos los riesgos y lo mejor que se puede hacer en la práctica, considerando las limitaciones económicas y de otros tipos.

La gestión de los riesgos relacionados con el medio ambiente de trabajo y con el medio ambiente en general debe coordinarse; no sólo son áreas que se solapan, sino que, en la mayoría de las situaciones, el éxito de una está vinculado al éxito de otra.

\section{Programas y servicios de higiene industrial}

La voluntad política y la toma de decisiones a escala nacional influirán, directa o indirectamente, en el establecimiento de programas o servicios de higiene industrial, ya sea en el sector público o privado. No se incluye en este artículo una descripción detallada de los tipos de programas y servicios de higiene industrial; sin embargo, existen unos principios generales que pueden aplicarse a numerosas situaciones y contribuir a su aplicación y funcionamiento eficientes.

U n servicio global de higiene industrial debe tener capacidad para realizar estudios preliminares adecuados, tomar muestras y realizar mediciones y análisis para evaluar y controlar los riesgos, así como para recomendar medidas de control, o incluso diseñarlas.

Los elementos clave de un programa o servicio global de higiene industrial son los recursos humanos y económicos, las instalaciones, el equipo y los sistemas de información. Estos recursos deben organizarse y coordinarse adecuadamente mediante una planificación cuidadosa y una gestión eficiente, y deben incluir también garantía de calidad y una evaluación continua del programa. El éxito de los programas de higiene industrial exige un respaldo político y el compromiso de la alta dirección. La obtención de recursos económicos no se aborda en este artículo.

\section{Recursos humanos}

El principal activo de un programa son unos recursos humanos adecuados, y es prioritario contar con ellos. Todo el personal

Figura 30.3. Elementos de la evaluación de riesgos.

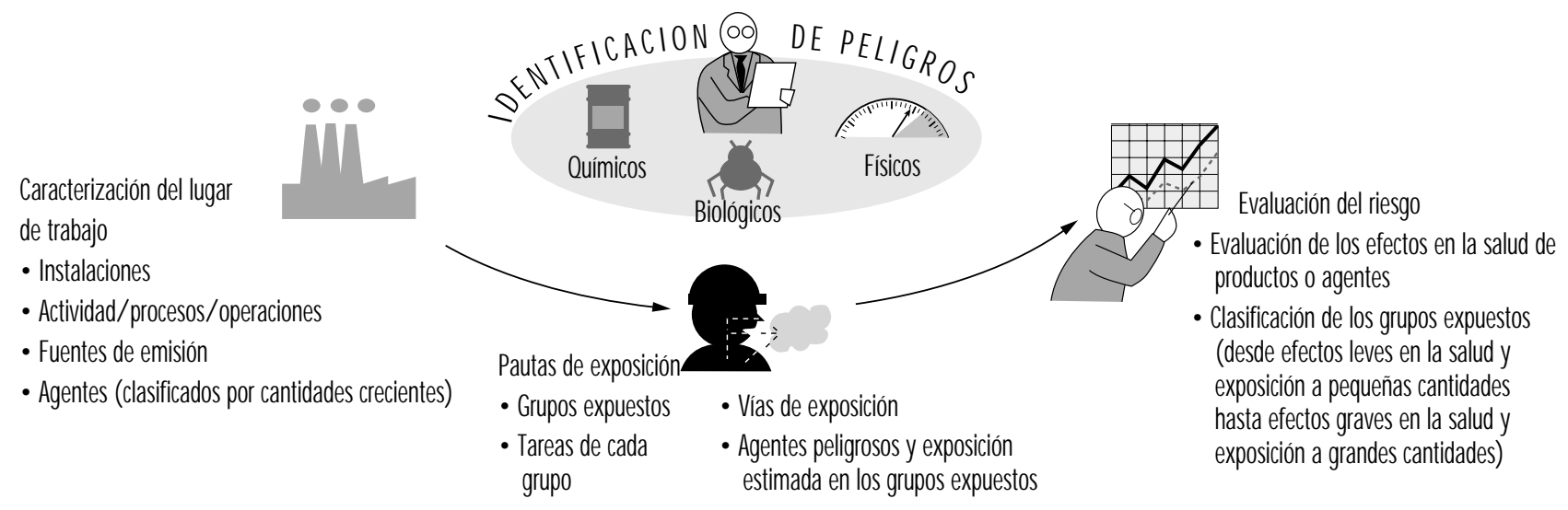


debe conocer claramente sus responsabilidades y la descripción de su puesto de trabajo. En caso necesario, deberán tomarse medidas de formación y educación. Los requisitos básicos de los programas de higiene industrial son:

- higienistas industriales: además de conocimientos generales sobre la identificación, la evaluación y el control de riesgos profesionales, los higienistas industriales pueden especializarse en áreas concretas, como la química analítica o la ventilación industrial; lo ideal es disponer de un equipo de profesionales con la debida formación en todos los aspectos de la práctica de la higiene industrial y en todas las áreas técnicas necesarias;

- personal de laboratorio, químicos (dependiendo de la amplitud del trabajo analítico);

- técnicos y ayudantes, para estudios de campo y para el trabajo de laboratorio, así como para el mantenimiento y la reparación de los instrumentos;

- especialistas en información y apoyo administrativo.

Un aspecto importante son las competencias profesionales, que no sólo deben adquirirse, sino también mantenerse. La educación continua, dentro o fuera del programa o servicio, debe abarcar, por ejemplo, actualizaciones legislativas, nuevos avances y técnicas y lagunas en los conocimientos. La participación en conferencias, simposios y seminarios contribuye también a mantener las competencias del personal.

\section{Salud y seguridad del personal}

La salud y la seguridad de todos los miembros del personal debe estar garantizada en los estudios de campo, los laboratorios y las oficinas. Los higienistas industriales pueden verse expuestos a riesgos graves y deben utilizar el equipo de protección personal adecuado. Dependiendo del tipo de trabajo, es posible que tengan que ser vacunados. Si se trata de un trabajo en zonas rurales, y dependiendo de la región, deberán administrarse, por ejemplo, antídotos contra mordeduras de serpiente. La seguridad en los laboratorios es un campo especializado que se comenta en otro apartado de esta E nciclopedia.

Los riesgos profesionales en las oficinas no deben subestimarse; por ejemplo, el trabajo con pantallas de ordenador y la fuente de contaminación interior, como las impresoras láser, las fotocopiadoras o los sistemas de aire acondicionado. También deben tenerse en cuenta los factores ergonómicos y psicosociales.

\section{Instalaciones}

L as instalaciones incluyen oficinas, sala(s) de reunión, laboratorios y equipos, sistemas de información y biblioteca. Las instalaciones deben estar correctamente diseñadas y tener en cuenta las necesidades futuras, ya que las modificaciones y adaptaciones posteriores suelen ser más costosas y consumir mucho tiempo.

\section{Laboratorios y equipos de higiene industrial}

Los laboratorios de higiene industrial deben tener, en principio, capacidad para realizar evaluaciones cualitativas y cuantitativas de la exposición a contaminantes atmosféricos (sustancias químicas y polvo), agentes físicos (ruido, estrés por calor, radiación, iluminación) y agentes biológicos. En el caso de la mayoría de los agentes biológicos, las evaluaciones cualitativas son suficientes para recomendar controles, y no es necesario realizar evaluaciones cuantitativas, normalmente más difíciles.

Aunque algunos instrumentos de lectura directa de la contaminación atmosférica pueden resultar limitados para los fines de la evaluación de la exposición, son extremadamente útiles para identificar los riesgos y sus fuentes, determinar las concentraciones pico y recoger datos para diseñar las medidas de control y verificar controles como los sistemas de ventilación. En relación con estos últimos (los sistemas de ventilación), se necesitan también instrumentos para comprobar la velocidad del aire y la presión estática.

Una de las posibles estructuras englobaría las siguientes unidades:

- equipos de campo (toma de muestras, lectura directa);

- laboratorio analítico;

- laboratorio de partículas;

- agentes físicos (ruido, temperatura, iluminación y radiación);

- taller para el mantenimiento y la reparación de instrumentos.

A la hora de seleccionar un equipo de higiene industrial, además de las características de funcionamiento tienen que considerarse siempre los aspectos prácticos asociados con las condiciones previstas de uso; por ejemplo, infraestructura disponible, clima, ubicación. Algunos de estos aspectos son la posibilidad de transportar el equipo, la fuente de energía necesaria, los requisitos de calibrado y mantenimiento y la disponibilidad de repuestos de los consumibles.

Sólo debe adquirirse un equipo si:

- existe una necesidad real;

- se dispone de personal cualificado para garantizar su correcto funcionamiento, mantenimiento y reparación;

- se ha desarrollado el procedimiento completo, ya que no tendría sentido comprar, por ejemplo, bombas de muestreo, si no se dispone de un laboratorio para analizar las muestras (o de un acuerdo con un laboratorio externo).

El calibrado de todas las mediciones y muestreos de higiene industrial, así como los equipos analíticos, deben formar parte de cualquier procedimiento y es preciso disponer de los equipos necesarios.

El mantenimiento y las reparaciones son esenciales para evitar que los equipos permanezcan parados durante demasiado tiempo. L os fabricantes de los equipos deben garantizar este tipo de servicio, ya sea mediante asistencia técnica directa o encargándose de la formación del personal.

Si se va a desarrollar un programa completamente nuevo, en un principio sólo debe adquirirse el equipo básico, que se irá completando a medida que se establezcan las necesidades y se garanticen las capacidades operativas. Sin embargo, incluso antes de disponer de equipo y de laboratorio y de que estos empiecen a funcionar, puede avanzarse mucho inspeccionando los lugares de trabajo con el fin de evaluar cualitativamente los riesgos para la salud y recomendando medidas para controlar los riesgos detectados. La falta de capacidad para realizar evaluaciones cuantitativas de las exposiciones no debe justificar nunca la pasividad frente a exposiciones obviamente peligrosas. E so es sobre todo cierto en situaciones en las que no se controlan los riesgos en el lugar de trabajo y es habitual que se alcancen elevadas exposiciones.

\section{Información}

Las principales fuentes de información son las bibliotecas (libros, revistas y otras publicaciones), las bases de datos (p. ej., en CD-ROM ) y las comunicaciones.

Siempre que sea posible, es conveniente disponer de ordenadores personales y lectores de CD-ROM así como de conexiones a INTERNET. Cada vez son más las posibilidades que ofrecen los servidores de información pública conectados en línea a una red (direcciones de World Wide Web y GOPHER), ya que permiten acceder a numerosas fuentes de información 
referente a la salud de los trabajadores, lo cual justifica plenamente la inversión realizada en ordenadores y comunicaciones. Este tipo de sistemas debe incluir correo electrónico (e-mail), que abre nuevos horizontes para la comunicación y el debate, ya sea individualmente 0 en grupo, al facilitar y promover el intercambio de información en todo el mundo.

\section{Planificación}

Una planificación puntual y minuciosa de la ejecución, la gestión y la evaluación periódica de un programa es esencial para garantizar el logro de sus objetivos y fines, haciendo el mejor uso de los recursos disponibles.

En un principio, debe obtenerse y analizarse la siguiente información:

- naturaleza y magnitud de los riesgos existentes, con objeto de establecer prioridades;

- requisitos legales (legislación, normas);

- recursos disponibles;

- infraestructura y servicios de apoyo.

Los procesos de planificación y organización incluyen las siguientes etapas:

- definición de la finalidad del programa o servicio, definición de los objetivos y del ámbito de actuación, considerando la demanda prevista y los recursos disponibles;

- asignación de recursos;

- definición de la estructura organizativa;

- perfil de los recursos humanos necesarios y planes para su desarrollo (cuando sea necesario);

- asignación clara de responsabilidades a los distintos servicios, equipos y personas;

- diseño y adaptación de las instalaciones;

- selección de equipos;

- requisitos operativos;

- establecimiento de mecanismos para la comunicación dentro y fuera del servicio;

- calendario.

L os costes operativos no deben subestimarse, ya que la falta de recursos puede dificultar seriamente la continuidad de un programa. Los siguientes son algunos requisitos que no pueden pasarse por alto:

- adquisición de consumibles (como filtros, tubos indicadores, tubos de carbón vegetal, reactivos), repuestos de los equipos, etc.

- mantenimiento y reparación de los equipos

- transporte (vehículos, combustible, mantenimiento) y viajes

- actualización de la información.

Los recursos deben aprovecharse al máximo mediante un estudio detenido de todos los elementos que deben considerarse como parte integrante de un servicio completo. Para el éxito de cualquier programa, es esencial distribuir los recursos de forma equilibrada entre las diferentes unidades (mediciones de campo, toma de muestras, laboratorios analíticos, etc.) y componentes (instalaciones y equipo, personal, aspectos operativos). A demás, la distribución de recursos debe permitir cierta flexibilidad, ya que es posible que los servicios de higiene industrial tengan que adaptarse para responder a las necesidades reales, las cuales deben evaluarse periódicamente.

Comunicar, compartir y colaborar son palabras clave para el éxito del trabajo en equipo y el desarrollo de las competencias individuales. Es necesario disponer de mecanismos eficaces de comunicación, dentro y fuera del programa, para conseguir el enfoque interdisciplinario que requiere la protección y la promoción de la salud de los trabajadores. Debe existir una estrecha interacción con otros profesionales de la salud en el trabajo, especialmente con los profesionales de la medicina y la enfermería del trabajo, los ergonomistas y los psicólogos del trabajo, así como con los profesionales de la seguridad. En el contexto del lugar de trabajo, han de participar también los trabajadores, el personal de producción y los directivos.

La ejecución de programas eficaces es un proceso gradual. Por consiguiente, en la fase de planificación debe elaborarse un calendario realista, de acuerdo con unas prioridades correctamente establecidas y considerando los recursos disponibles.

\section{G estión}

La gestión consiste en tomar decisiones referentes a los objetivos que deben alcanzarse y a las medidas que deben adoptarse para ello, con la participación de todos los interesados, así como en prever y evitar, o reconocer y resolver, los problemas que pueden crear obstáculos para realizar las tareas necesarias. D ebe tenerse en cuenta que los conocimientos científicos no garantizan necesariamente las competencias de gestión necesarias para dirigir un programa eficiente.

La importancia de implantar y seguir unos procedimientos correctos y una garantía de calidad es fundamental, puesto que existe una gran diferencia entre el trabajo hecho y el trabajo bien hecho. Por otra parte, los objetivos reales, y no las etapas intermedias, deben servir como referencia. La eficiencia de un programa de higiene industrial no debe medirse por el número de estudios realizados, sino por el número de estudios que dan lugar a acciones concretas para proteger la salud de los trabajadores.

U na buena gestión debe ser capaz de distinguir entre lo que llama la atención y lo que es importante; los estudios muy detallados que incluyen muestreo y análisis, y que generan resultados muy exactos y precisos, pueden ser muy impresionantes, pero lo verdaderamente importante son las decisiones y las medidas que se adoptan en consecuencia.

\section{G arantía de calidad}

El concepto de garantía de calidad, que abarca control de calidad y pruebas de aptitud, se refiere principalmente a las actividades de medición. Aunque estos conceptos se han asociado casi siempre a los laboratorios analíticos, su ámbito debe ampliarse para englobar también los muestreos y las mediciones.

En los casos en que sea preciso realizar análisis y muestreos, ambos procedimientos deberán considerarse como uno solo desde el punto de vista de la calidad. Puesto que ninguna cadena es más fuerte que el más débil de sus eslabones, el uso de instrumentos y técnicas con diferentes niveles de calidad en las distintas etapas de un mismo procedimiento de evaluación implica malgastar los recursos. La precisión y la exactitud de una balanza analítica de gran calidad no puede compensar el uso de una bomba de muestreo que tiene una velocidad de flujo inadecuada.

La actuación de los laboratorios debe examinarse para identificar y corregir las posibles fuentes de error. Es preciso adoptar un enfoque sistemático para mantener bajo control los numerosos detalles implicados. Es importante establecer en los laboratorios de higiene industrial programas de garantía de calidad, que engloben tanto controles internos de calidad, como evaluaciones externas de calidad (llamadas con frecuencia "pruebas de aptitud").

En lo que se refiere a la toma de muestras o a las mediciones realizadas con instrumentos de lectura directa (como los que se 
utilizan para la medición de agentes físicos), la calidad implica la existencia de procedimientos correctos y adecuados para:

- realizar estudios preliminares que incluyan la identificación de los posibles riesgos y de los factores que deben tenerse en cuenta para diseñar la estrategia;

- diseñar la estrategia de muestreo (o medición);

- seleccionar y utilizar metodologías y equipos de muestreo o medición, teniendo en cuenta tanto los fines de la investigación como los requisitos de calidad;

- ejecutar los procedimientos, incluido el control de tiempos;

- manipular, transportar y almacenar las muestras (en su caso).

Por lo que respecta al laboratorio analítico, la calidad implica la existencia de procedimientos adecuados y correctos de:

- diseño e instalación de los equipos;

- selección y utilización de métodos analíticos validados (0, en caso necesario, validación de los métodos analíticos);

- selección e instalación de instrumentos;

- suministros adecuados (reactivos, muestras de referencia, etc.)

En ambos casos, es indispensable disponer de:

- protocolos, procedimientos e instrucciones por escrito que sean claros;

- calibrado y mantenimiento rutinario de los equipos;

- personal formado y motivado para realizar correctamente los procedimientos establecidos;

- gestión adecuada;

- control de calidad interno;

- evaluación externa de la calidad o pruebas de aptitud (si procede).

A simismo, es esencial que existan procedimientos adecuados para el tratamiento de los datos obtenidos y la interpretación de los resultados, así como para su notificación y registro.

La acreditación de los laboratorios, definida por el CEN (EN 45001) como "el reconocimiento formal que un laboratorio de ensayos es competente para realizar determinados ensayos 0 tipos de ensayos", es una herramienta de control muy importante que debe promocionarse. D ebe abarcar tanto la toma de muestras como los procedimiento analíticos.

\section{Evaluación de los programas}

El concepto de calidad debe aplicarse a todas las etapas de la práctica de la higiene industrial, desde la identificación de riesgos hasta la ejecución de programas de prevención y control de riesgos. Desde este punto de vista, los programas y servicios de higiene industrial deben evaluarse periódica y críticamente para conseguir una mejora continua.

\section{Comentarios finales}

La higiene industrial es esencial para proteger la salud de los trabajadores y el medio ambiente. Su práctica consta de muchas etapas interrelacionadas que no tienen sentido por sí solas, sino que deben integrarse en una estrategia global.

\section{- IDENTIFICACION DE PELIGROS}

\section{Linnéa Lillienberg}

Un peligro en el lugar de trabajo puede definirse como cualquier condición que puede afectar negativamente al bienestar o a la salud de las personas expuestas. La identificación de los peligros en cualquier actividad profesional supone la caracterización del lugar de trabajo identificando los agentes peligrosos y los grupos de trabajadores potencialmente expuestos a los riesgos consiguientes. L os peligros pueden ser de origen químico, biológico 0 físico (véase Tabla 30.1). Algunos peligros del medio ambiente de trabajo son fáciles de identificar; por ejemplo, las sustancias irritantes, que tienen un efecto inmediato después de la exposición de la piel o la inhalación. O tros no son tan fáciles de identificar, por ejemplo, las sustancias químicas que se forman accidentalmente y que no tienen propiedades que adviertan de su presencia. Algunos agentes, como los metales (p. ej., plomo, mercurio, cadmio, manganeso), que pueden causar daños al cabo de varios años de exposición, pueden ser fáciles de identificar si se conoce el riesgo existente. Un agente tóxico puede no constituir un peligro si está presente en concentraciones pequeñas o si nadie está expuesto al mismo. Para saber qué peligros existen, es imprescindible identificar los agentes que pueden haber en el lugar de trabajo, conocer los riesgos que conllevan para la salud y las posibles situaciones de exposición.

\section{Identificación y clasificación de los peligros}

Antes de realizar una investigación de higiene industrial, debe definirse claramente su finalidad. La finalidad de una investigación de higiene industrial puede ser identificar los riesgos potenciales, evaluar los riesgos existentes en el lugar de trabajo, demostrar que se cumplen los requisitos normativos, evaluar las medidas de control o evaluar la exposición en relación con un estudio epidemiológico. Este artículo se centra en los programas destinados a identificar y clasificar los peligros en el lugar de trabajo. Son muchos los modelos y técnicas que se han desarrollado para identificar y evaluar los peligros presentes en el medio ambiente de trabajo, y su complejidad varía, desde simples listas de comprobación, estudios preliminares de higiene industrial, matrices de exposición profesional y estudios de riesgo y operabilidad, hasta perfiles de exposición profesional y programas de vigilancia en el trabajo (Renes 1978; Gressel y Gideon 1991; H olzner, H irsh y Perper 1993; Goldberg y cols. 1993; Bouyer y Hémon 1993; Panett, Coggon y Acheson 1985; Tait 1992). No existe una técnica concreta adecuada para todos los casos, pero todas las técnicas tienen componentes que pueden ser útiles en cualquier investigación. La utilidad de los modelos depende también del objetivo de la investigación, del tamaño del lugar de trabajo, del tipo de producción y de actividad y de la complejidad de las operaciones.

El proceso de identificación y clasificación de los peligros puede dividirse en tres elementos básicos: caracterización del lugar de trabajo, descripción de la pauta de exposición y evaluación de riesgos.

\section{Caracterización del lugar de trabajo}

Un lugar de trabajo puede tener desde unos cuantos empleados hasta varios miles, y en él pueden desarrollarse diferentes actividades (p. ej., fábricas, obras, edificios de oficinas, hospitales 0 explotaciones agrarias). En un lugar de trabajo pueden distinguirse áreas especiales, como departamentos o secciones, en las que se desarrollan diferentes actividades. En un proceso industrial, se observan diferentes etapas y operaciones en el proceso de producción, desde las materias primas hasta los productos terminados

El higienista industrial debe obtener información detallada sobre los procesos, las operaciones y otras actividades de interés, con el fin de identificar los agentes utilizados, entre ellos materias primas, materiales manipulados 0 añadidos en el proceso, productos primarios, productos intermedios, productos finales, productos de reacción y subproductos. 
Tabla 30.1 • Peligro de agentes químicos, biológicos y físicos.

$\begin{array}{ll}\text { Tipo de peligro } & \text { Descripción } \\ \text { PELIGROS } & \text { Las sustancias químicas penetran en el organismo principalmente por inhalación, } \\ \text { QUIMICOS } & \text { absorción de la piel o ingestión. El efecto tóxico puede ser agudo, crónico o de } \\ \text { ambos tipos. } & \\ \text { Corrosión } & \text { Las sustancias químicas corrosivas producen destrucción de tejidos en el lugar de } \\ & \text { contacto. La piel, los ojos y el sistema digestivo son las partes del organismo } \\ \text { afectadas con mayor frecuencia. } & \\ \text { Irritación } & \text { Los irritantes causan inflamación de los tejidos en el lugar en el que se depositan. } \\ & \text { Los irritantes de la piel pueden causar reacciones como eczema o dermatitis. } \\ & \text { Las sustancias que producen grave irritación respiratoria pueden causar disnea, } \\ & \text { respuestas inflamatorias y edema. } \\ \text { Reacciones } & \text { Los alérgenos o sensibilizantes químicos pueden causar reacciones alérgicas } \\ \text { alérgicas } & \text { dermatológicas o respiratorias. } \\ & \\ \text { Asfixia } & \text { Los asfixiantes ejercen su efecto al interferir con la oxigenación de los tejidos. } \\ & \text { Los asfixiantes simples son gases inertes que diluyen el oxígeno presente en } \\ & \text { la atmósfera por debajo de la concentración necesaria para que exista vida. } \\ & \text { Una atmósfera deficiente en oxígeno puede encontrarse en los tanques, la } \\ \text { bodega de los barcos, los silos o las minas. La concentración atmosférica de } \\ \text { oxígeno nunca debe ser inferior al } 19,5 \text { en en volumen. Los asfixiantes } \\ \text { químicos impiden el transporte de oxígeno y la oxigenación normal de la } \\ \text { sangre o impiden la oxigenación normal de los tejidos. }\end{array}$

Cáncer Los cancerígenos humanos conocidos son sustancias químicas de las que se ha demostrado claramente que causan cáncer en el ser humano. Los cancerígenos humanos probables son sustancias químicas de las que se ha demostrado claramente que causan cáncer en animales o de las que no se dispone de pruebas definitivas en cuanto al modo en que afectan al ser humano. El hollín y el alquitrán de hulla fueron las primeras sustancias químicas de las que se sospechó que causaban cáncer. Efectos
en el sistema
reproductor

Agentes tóxicos sistémicos congénitos. Las sustancias químicas embriotóxicas o fetotóxicas pueden causar aborto espontáneo.

Los agentes tóxicos sistémicos son agentes que causan lesiones en determinados órganos o sistemas del organismo.
Ejemplos

Acidos concentrados y álcalis, fósforo

Piel: ácidos, álcalis, disolventes, aceites

Respiratoria: aldehídos, polvo alcalino, amoniaco, dióxido de nitrógeno, fosgeno, cloro, bromo, ozono

Piel: colofonia ( resina), formaldehído, metales como el cromo o el níquel, algunos tintes orgánicos, endurecedores epoxídicos, trementina

Respiratorias: isocianatos, tintes reactivos a la fibra, formaldehído, polvos de bosques tropicales, níquel

Asfixiantes simples: metano, etano, hidrógeno, helio

Asfixiantes químicos: monóxido de carbono, nitrobenceno, cianuro de hidrógeno, sulfuro de hidrógeno

Conocidos: benceno (leucemia); cloruro de vinilo (angiosarcoma de hígado); 2-naftilamina, bencidina (cáncer de vejiga); amianto (cáncer de pulmón, mesotelioma); polvo de madera dura (adenocarcinoma nasal o de los senos nasales)

Probables: formaldehído, tetracloruro de carbono, dicromatos, berilio

Manganeso, disulfuro de carbono, éter monometilico y etílico de etilenglicol, mercurio

Compuestos orgánicos de mercurio, monóxido de carbono, plomo, talidomida, disolventes
Cerebro: disolventes, plomo, mercurio, manganeso Sistema nervioso periférico: n-hexano, plomo, arsénico, disulfuro de carbono

Sistema hematopoyético: benceno, éteres de etilenglicol Riñón: cadmio, plomo, mercurio, hidrocarburos clorados Pulmón: ślice, amianto, polvos de carbón (neumoconiosis)

Hepatitis B, tuberculosis, carbunco, brucelosis, tétanos, Chlamydia psittaci, Salmonella
Peligros
infecciosos
Los peligros biológicos pueden definirse como polvos orgánicos de distintas fuentes de origen biológico, como virus, bacterias, hongos, proteínas animales o sustancias vegetales, como productos de la degradación de fibras naturales. El agente etiológico puede derivarse de un organismo viable o de contaminantes o constituir un componente específico del polvo. Los peligros biológicos se dividen en agentes infecciosos y no infecciosos. Los peligros no infecciosos pueden dividirse a su vez en organismos viables, toxinas biógenas y alérgenos biógenos.

Las enfermedades profesionales por agentes infecciosos son relativamente poco comunes. Los trabajadores en situación de riesgo son los empleados de hospitales, el personal de los laboratorios, los agricultores, los trabajadores de mataderos, los veterinarios, los trabajadores de los zoológicos y los cocineros. La susceptibilidad varía mucho ( $p$. ej., las personas tratadas con fármacos inmunodepresores tendrán una elevada sensibilidad).

Continúa en la página siguiente. 
Tabla 30.1 • Peligro de agentes químicos, biológicos y físicos.

Continuación.

Tipo de peligro
Organismos
viables
y toxinas
biógenas

Alérgenos biógenos

\section{PELIGROS FISICOS}

Ruido

Vibración

Radiación ionizante

Radiación

no ionizante

Descripción fangos residuales y los trabajadores de los silos de cereales. madera muscular, y puede llegar a producir fibrosis pulmonar crónica. profesional más común en las demandas de indemnización. espalda. conizante están muy restringidos y controlados.
Los organismos viables incluyen hongos, esporas y micotoxinas; las toxinas biógenas incluyen endotoxinas, aflatoxinas y bacterias. Los productos del metabolismo de las bacterias y los hongos son complejos y numerosos y se ven afectados por la temperatura, la humedad y el tipo de sustrato en el que crecen. Desde el punto de vista químico, pueden ser proteinas, lipoproteínas o mucopolisacáridos. Las bacterias grampositivas y gramnegativas y mohos son ejemplos de estos organismos. Los trabajadores más expuestos a riesgo son los de las fábricas de algodón, los trabajadores del cáñamo y el lino, los de las plantas de tratamiento de aguas y

Los alérgenos biógenos pueden ser hongos, proteínas de origen animal, terpenos, ácaros y enzimas. Una parte considerable de los alérgenos biógenos en la agricultura procede de las proteínas de la piel de los animales, el pelo de los animales y las proteínas del material fecal y la orina. Pueden encontrase alérgenos en muchos entornos industriales, como los procesos de fermentación, la producción de fármacos, las panaderías, la producción de papel, el procesamiento de la

(serrado, producción, fabricación), así como en la biotecnología (producción de enzimas y vacunas, cultivo de tejidos) y la producción de especias. En personas sensibilizadas, la exposición a agentes alérgicos puede causar síntomas alérgicos como rinitis alérgica, conjuntivitis 0 asma. La alveolitis alérgica se caracteriza por síntomas respiratorios agudos, como tos, escalofríos, fiebre, cefaleas y dolor

Se considera ruido cualquier sonido no deseado que puede afectar negativamente a la salud y el bienestar de las personas o poblaciones. Algunos aspectos de los peligros del ruido son la energía total del sonido, la distribución de frecuencias, la duración de la exposición y el ruido de impulso. La agudeza auditiva es, en general, la primera capacidad que se ve afectada, con una pérdida o reduccion a $4.000 \mathrm{~Hz}$, seguida de pérdidas en el rango de frecuencias de 2.000 a $6.000 \mathrm{~Hz}$. El ruido puede producir efectos agudos como problemas de comunicación, disminución de la capacidad de concentración, somnolencia y, como consecuencia, interferencia con el rendimiento laboral. La exposición a elevados niveles de ruido (normalmente por encima de $85 \mathrm{dBA}$ ) o ruido de impulso (unos 140 $\mathrm{dBC}$ ) durante un período considerable de tiempo puede causar pérdida auditiva tanto temporal como crónica. La pérdida auditiva permanente es la enfermedad

La vibración tiene algunos parámetros en común con el ruido: frecuencia, amplitud, duración de la exposición y continuidad o intermitencia de la exposición. El método de trabajo y la destreza del operador parecen desempeñar un papel importante en la aparición de efectos nocivos a causa de la vibración. El trabajo manual con herramientas motorizadas se asocia a síntomas de trastornos circulatorios periféricos conocidos como "fenómeno de Raynaud" 0 "dedos blancos inducidos por la vibración". Las herramientas vibratorias pueden afectar también al sistema nervioso periférico y al sistema musculosquelético, reduciendo la fuerza de agarre y causando dolor lumbar y trastornos degenerativos de la

El efecto crónico más importante de la radiación ionizante es el cáncer, incluida la leucemia. La sobreexposición a niveles relativamente bajos de radiación se ha asociado a dermatitis en las manos y efectos en el sistema hematológico. Los procesos 0 actividades que pueden originar una sobreexposición a radiación

La radiación no ionizante es la radiación ultravioleta, la radiación visible, los rayos infrarrojos, los láseres, los campos electromagnéticos (microondas y radiofrecuencia) y radiación de frecuencia extremadamente baja. La radiación IR puede causar cataratas. Los láseres de alta potencia pueden causar lesiones oculares y dérmicas. Existe una preocupación creciente por la exposición a bajos niveles de campos electromagnéticos como causa de cáncer y como causa potencial de efectos adversos en la función reproductora de la mujer, especialmente por la exposición a pantallas visualizadoras de datos. Todavía no se sabe con certeza si existe una relación causal con el cáncer. No obstante, las revisiones más recientes de los conocimientos científicos disponibles concluyen en general que no existe asociación entre el uso de pantallas visualizadoras de datos y efectos adversos para la función reproductora.
Ejemplos

Bisinosis, "fiebre del grano", enfermedad del legionario

(n)

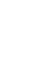

Asma profesional: lana, pieles, granos de trigo, harina, cedro rojo, ajo en polvo

Alveolitis alérgica: enfermedad del agricultor, bagazosis,

"enfermedad del avicultor", fiebre del humidificador, secuoiosis

Fundiciones, carpinterías, fábricas textiles, sector del metal

Máquinas de ajuste, máquinas cargadoras de minería, carretilla de horquilla elevadora, herramientas neumáticas, sierra de cadena

Reactores nucleares, tubos de rayos-x médicos y dentales, aceleradores de partículas, radioisótopos

Radiación ultravioleta: soldadura y corte con arco eléctrico; tratamiento de tintas, colas, pinturas, etc. con rayos UV: desinfección; control de productos

Radiación infrarroja: hornos, soplado de vidrio Láseres: comunicaciones, cirugía, construcción 
Conviene también identificar los aditivos y los catalizadores que intervienen en el proceso. $L$ as materias primas o el material añadido que se identifican sólo por su nombre comercial deben evaluarse en función de su composición química. El fabricante 0 el proveedor deben facilitar información o fichas toxicológicas de los productos.

Algunas etapas de un proceso pueden tener lugar en un sistema cerrado sin que ningún trabajador se vea expuesto, excepto cuando se realizan las tareas de mantenimiento 0 se produce un fallo en el proceso. Estos acontecimientos deben registrarse y deben tomarse las precauciones oportunas para prevenir la exposición a agentes peligrosos. O tros procesos tienen lugar en sistemas abiertos, con o sin ventilación localizada. En este caso debe facilitarse una descripción general del sistema de ventilación, incluido el sistema de ventilación localizada.

Siempre que sea posible, los peligros deben identificarse durante la planificación y el diseño de nuevas plantas o procesos, cuando todavía pueden realizarse cambios a tiempo para prevenir y evitar riesgos. Asimismo, deben identificarse y evaluarse las situaciones y los procedimientos que pueden desviarse del diseño previsto del proceso. La identificación de los peligros debe abarcar también las emisiones al medio ambiente exterior y la evacuación de los materiales residuales. La ubicación de las instalaciones, las operaciones, las fuentes de emisiones y los agentes deben agruparse de manera sistemática para formar unidades reconocibles en el análisis posterior de la exposición potencial. En cada unidad, las operaciones y los agentes deben agruparse en función de los efectos en la salud y la estimación de las cantidades emitidas al medio ambiente de trabajo.

\section{Pautas de exposición}

Las principales vías de exposición a los agentes químicos y biológicos son la inhalación y la absorción a través de la piel o por ingestión accidental. La pauta de exposición depende de la frecuencia del contacto con los peligros, la intensidad de la exposición y la duración de la misma. Asimismo, deben examinarse sistemáticamente las tareas que realizan los trabajadores. Es importante no limitarse a estudiar los manuales de trabajo, sino también lo que realmente sucede en el lugar de trabajo. La exposición puede afectar de forma directa a los trabajadores cuando realizan su trabajo, o de forma indirecta, si están situados en la misma zona general que la fuente de la exposición. Puede ser necesario centrarse primero en las tareas que presentan un elevado potencial de causar daño aunque la exposición sea de corta duración. $\mathrm{H}$ ay que tener en cuenta también las operaciones no rutinarias e intermitentes ( $p$. ej., mantenimiento, limpieza y cambios en los ciclos de producción), así como la variación de las tareas y las situaciones de trabajo a lo largo del año.

En puestos de trabajo similares, la exposición o la absorción pueden variar, según se utilicen o no equipos de protección personal. En las grandes fábricas, casi nunca puede realizarse una identificación de los peligros o una evaluación cualitativa de los peligros por cada uno de los trabajadores. Por consiguiente, los trabajadores que realizan tareas similares deben clasificarse en el mismo grupo de exposición. Las diferencias en las tareas, las técnicas de trabajo y la duración del trabajo generan diferencias considerables en la exposición y son factores que tienen que tenerse en cuenta. Se ha demostrado que las personas que trabajan al aire libre y las que trabajan sin ventilación localizada presentan mayor variabilidad de un día a otro que los grupos que trabajan en recintos cerrados con ventilación localizada (K romhout, Symanski and R appaport 1993). Para caracterizar a grupos con niveles similares de exposición, pueden utilizarse criterios como los procesos de trabajo, los agentes utilizados durante ese proceso o trabajo o las diferentes tareas incluidas en la descripción de un puesto de trabajo, en lugar de la descripción genérica del puesto. D entro de cada grupo, los trabajadores potencialmente expuestos deben clasificarse en función de los agentes peligrosos, las vías de exposición, los efectos de estos agentes en la salud, la frecuencia del contacto con los peligros, la intensidad de la exposición y su duración. Los diferentes grupos de exposición deben clasificarse según los agentes peligrosos y la exposición estimada para determinar cuáles son los trabajadores con mayor riesgo.

\section{Evaluación cualitativa de los peligros}

La determinación de los efectos que los agentes químicos, biológicos y físicos presentes en el lugar de trabajo pueden tener en la salud debe basarse en una evaluación de los estudios epidemiológicos, toxicológicos, clínicos y medioambientales disponibles. Puede obtenerse información actualizada sobre los riesgos que implican para la salud los productos y agentes utilizados en el lugar de trabajo en revistas sobre salud y seguridad, bases de datos sobre toxicidad y efectos en la salud, y publicaciones científicas y técnicas sobre el tema.

Las fichas toxicológicas de materiales deben actualizarse cuando sea necesario. Estas fichas toxicológicas registran los porcentajes de componentes peligrosos junto con el identificador químico del Chemical Abstracts Service, el número CAS, y el valor límite umbral (TLV), cuando se dispone del mismo. Asimismo, contienen información sobre los riesgos para la salud, los equipos de protección, las medidas preventivas, el fabricante 0 proveedor, etc. En algunas ocasiones, los datos sobre los componentes son bastante rudimentarios y tienen que complementarse con información más detallada.

A simismo, deben estudiarse los datos derivados de los controles y los registros de las mediciones. L os T LV ofrecen una orientación general para decidir si la situación es o no aceptable, aunque deben considerarse las posibles interacciones cuando los trabajadores están expuestos a varias sustancias químicas. LoS trabajadores deben clasificarse en grupos de exposición según los efectos en la salud de los agentes presentes y la exposición estimada (p. ej, desde leves efectos en la salud y baja exposición, hasta graves efectos en la salud y un elevada exposición estimada). Los trabajadores que obtengan mayor puntuación deben ser atendidos de forma prioritaria. Antes de iniciar cualquier actividad preventiva, puede ser necesario emprender un programa de control de la exposición. Todos los resultados deben documentarse y ser fácilmente localizables. En la Figura 30.3 se ilustra un plan de trabajo.

En las investigaciones de higiene industrial, pueden considerarse también los riesgos para el medio ambiente exterior como la contaminación y el efecto invernadero, o los efectos en la capa de ozono.

\section{Agentes químicos, biológicos y físicos}

Los riesgos pueden ser de origen químico, biológico o físico. En este apartado y en la Tabla 30.1 se ofrece una breve descripción de los distintos peligros, junto con ejemplos de entornos o actividades en los que se encuentran (Casarett 1980; International Congress on Occupational Health 1985; Jacobs 1992; Leidel, Busch y Lynch 1977; Olishifski 1988; Rylander 1994). En otros apartados de esta Enciclopedia puede encontrarse información adicional.

\section{Agentes químicos}

Las sustancias químicas pueden clasificarse en gases, vapores, líquidos y aerosoles (polvo, humo, niebla). 


\section{Gases}

Los gases son sustancias que pueden pasar a estado líquido o sólido por el efecto combinado de un aumento de la presión y una disminución de la temperatura. La manipulación de gases implica siempre un riesgo de exposición, a menos que el proceso se realice en un sistema cerrado. Los gases introducidos en contenedores o tuberías de distribución pueden sufrir fugas accidentales. En los procesos realizados a elevadas temperaturas (p. ej., operaciones de soldadura y gases de escape de los motores) también se forman gases.

\begin{abstract}
Vapores
L os vapores son la forma gaseosa de sustancias que normalmente se encuentran en estado líquido o sólido a temperatura ambiente y presión normal. Cuando un líquido se evapora, pasa a estado gaseoso y se mezcla con el aire que le rodea. Un vapor puede considerarse como un gas, cuya concentración máxima depende de la temperatura y de la presión de saturación de la sustancia. Todo proceso que incluye una combustión genera vapores 0 gases. L as operaciones de desengrase pueden realizarse mediante desengrase por fase de vapor o limpieza por impregnación con disolventes. Actividades como la carga y la mezcla de líquidos, pintura, nebulización, limpieza en general y limpieza en seco pueden generar vapores nocivos.
\end{abstract}

\section{Líquidos}

Los líquidos pueden estar compuestos de una sustancia pura o de una solución de dos o más sustancias (p. ej., disolventes, ácidos, compuestos alcalinos). Un líquido almacenado en un recipiente abierto se evapora parcialmente a la fase gaseosa. La concentración de equilibrio en la fase gaseosa depende de la presión de vapor de la sustancia, su concentración en la fase líquida y la temperatura. Las operaciones 0 actividades con líquidos pueden producir salpicaduras u otros contactos con la piel, además de vapores nocivos.

\section{Polvo}

El polvo se compone de partículas inorgánicas y orgánicas, que pueden clasificarse como inhalables, torácicas o respirables, dependiendo del tamaño de la partícula. La mayor parte del polvo orgánico es de origen biológico. El polvo inorgánico se genera en procesos mecánicos, como los de trituración, aserrado, corte, molienda, cribado o tamizado. El polvo puede dispersarse cuando se manipula material polvoriento o cuando es arrastrado por corrientes de aire causadas por el tráfico. La manipulación de materiales secos o en polvo para pesarlos, cargarlos, transportarlos 0 embalarlos genera polvo, al igual que otras actividades, como los trabajos de aislamiento y limpieza.

\section{Humo}

El humo está formado por partículas sólidas vaporizadas a elevada temperatura y condensadas en pequeñas partículas. La vaporización suele ir acompañada de una reacción química, como la oxidación. Las partículas que constituyen el humo son extremadamente pequeñas, normalmente menores de $0,1 \mu \mathrm{m}, \mathrm{y}$ suelen agregarse en unidades de mayor tamaño. Algunos ejemplos son los humos que se generan en las soldaduras, los cortes con plasma y otras operaciones similares.

\section{Nieblas}

La niebla está compuesta por gotas de líquido en suspensión, que se forman por condensación del estado gaseoso al pasar a estado líquido o por la fragmentación de un líquido en un estado disperso por salpicadura, formación de espuma o atomización. Algunos ejemplos son la niebla de aceite que se produce en las operaciones de corte y trituración, la niebla ácida de la galvanoplastia, la niebla ácida o alcalina de las operaciones de decapado
- la niebla de pintura pulverizada en las operaciones de pintura con pistola.

\section{EVALUACION DEL MEDIO AMBIENTE DE TRABAJO}

Lori A. Todd

\section{Vigilancia del riesgo y métodos de estudio}

L a vigilancia en el trabajo se realiza a través de programas activos para prever, observar, medir, evaluar y controlar las exposiciones a riesgos potenciales para la salud en el lugar de trabajo. La vigilancia suele exigir la participación de un equipo formado por un higienista industrial, un médico del trabajo, un profesional de la enfermería del trabajo, un agente de seguridad, un toxicólogo y un ingeniero. Dependiendo del medio ambiente de trabajo y del problema que se plantee, pueden utilizarse tres métodos de vigilancia: médica, ambiental y biológica. La vigilancia médica se utiliza para detectar la presencia 0 ausencia de efectos nocivos para la salud en un individuo como consecuencia de la exposición profesional a contaminantes, mediante exploraciones médicas y pruebas biológicas. La vigilancia ambiental se utiliza para documentar la exposición potencial a contaminantes de un grupo de trabajadores, midiendo la concentración de contaminantes en el aire, en muestras en bloque de materiales, y en las superficies. La vigilancia biológica se utiliza para documentar la absorción de contaminantes por el organismo y correlacionarla con los niveles de contaminantes de origen ambiental, midiendo la concentración de sustancias peligrosas o sus metabolitos en la sangre, la orina o el aire exhalado por los trabajadores.

\section{Vigilancia médica}

La vigilancia médica es necesaria porque la exposición a sustancias peligrosas puede causar o agravar algunas enfermedades. Exige un programa activo en el que participen profesionales que conozcan las enfermedades profesionales, su diagnóstico y su tratamiento. Los programas de vigilancia médica incluyen medidas para proteger, educar, controlar y, en algunos casos, indemnizar al trabajador. Pueden abarcar programas de selección previos al empleo, exploraciones médicas periódicas, pruebas especializadas para la detección precoz de alteraciones y daños causados por sustancias peligrosas, tratamiento médico y registro de datos. La selección previa al empleo consiste en evaluar el historial profesional y médico del candidato a un puesto de trabajo y los resultados de las exploraciones físicas. Se utilizan cuestionarios para obtener información sobre las enfermedades que se han sufrido en el pasado o las enfermedades crónicas (especialmente asma y enfermedades dérmicas, pulmonares y cardíacas), y sobre las exposiciones en anteriores trabajos. Los programas de selección previa a la contratación tienen implicaciones éticas y jurídicas si se utilizan para determinar la idoneidad de los candidatos para ocupar determinado puesto de trabajo. Sin embargo, son muy importantes cuando se utilizan para (1) mantener un registro de los anteriores trabajos y las exposiciones asociadas, (2) establecer el estado basal de la salud de un trabajador y (3) determinar la existencia de hipersensibilidad. Las exploraciones médicas pueden incluir pruebas audiométricas para detectar la pérdida de audición, pruebas visuales, pruebas de las funciones orgánicas, evaluación de la capacidad física para usar equipos de protección respiratoria y análisis basales de sangre y orina. Las exploraciones médicas periódicas son esenciales para evaluar y detectar tendencias cuando empieza 
a manifestarse un deterioro de la salud, y pueden incluir el control biológico de determinados contaminantes y el uso de otros biomarcadores

\section{Vigilancia ambiental y biológica}

La vigilancia ambiental y biológica comienza con un estudio de higiene industrial del medio ambiente de trabajo para identificar posibles riesgos y fuentes contaminantes y establecer la necesidad de realizar mediciones. En el caso de los agentes químicos, éstas pueden requerir la toma de muestras del aire, de superficies, de productos a granel y de materiales biológicos. En el caso de los agentes físicos, puede incluir mediciones del ruido, la temperatura y la radiación. Cuando está indicado realizar mediciones, el higienista industrial debe desarrollar una estrategia de muestreo que especifique los trabajadores, procesos, equipos y zonas de los que deben tomarse muestras, el número de muestras, la duración y frecuencia del muestreo y el método del mismo. Los estudios de higiene industrial varían en complejidad y enfoque dependiendo del objetivo de la investigación, el tipo y el tamaño del lugar de trabajo, y la naturaleza del problema. $\mathrm{N}$ o existen fórmulas rígidas para realizar los estudios; sin embargo, una preparación rigurosa antes de iniciar la inspección aumenta su eficacia y eficiencia. Las investigaciones que están motivadas por quejas y enfermedades de los trabajadores tienen la finalidad adicional de descubrir la causa de los problemas de salud. Los estudios de la calidad del aire interior se centran en las fuentes contaminantes tanto interiores como exteriores. Con independencia del riesgo profesional, el método general para estudiar y tomar muestras en el lugar de trabajo es similar; por consiguiente, en este capítulo se utilizarán los agentes químicos como modelo para la metodología.

\section{Vías de exposición}

La sola presencia de contaminantes laborales en el lugar de trabajo no implica necesariamente que exista un potencial significativo de exposición; el agente debe llegar al trabajador. En el caso de las sustancias químicas, la forma líquida o vaporizada del agente debe estar en contacto con el organismo, o ser absorbido por él, para producir un efecto nocivo en la salud. Si el agente está aislado en un recinto cerrado o es capturado por un sistema de ventilación localizada, el potencial de exposición será pequeño, con independencia de la toxicidad propia de la sustancia química.

La vía de exposición puede influir en el tipo de controles realizados y en el riesgo potencial. En el caso de los agentes químicos y biológicos, los trabajadores pueden estar expuestos a ellos por inhalación, contacto de la piel, ingestión e inyección; las vías más comunes de absorción en el medio ambiente de trabajo son el tracto respiratorio y la piel. Para valorar la inhalación, el higienista industrial debe observar la posibilidad de que las sustancias químicas queden suspendidas en el aire en forma de gases, vapores, polvo, humo o niebla.

La absorción de sustancias químicas a través de la piel es importante, sobre todo cuando existe un contacto directo por salpicadura, aspersión, humedecimiento o inmersión con hidrocarburos liposolubles y otros disolventes orgánicos. La inmersión incluye el contacto corporal con prendas contaminadas, el contacto de las manos con guantes contaminados y el contacto de manos y brazos con líquidos a granel. En el caso de algunas sustancias, como las aminas y los fenoles, la absorción a través de la piel puede ser tan rápida como la absorción de las sustancias inhaladas a través de los pulmones. Para algunos contaminantes, como los pesticidas y los tintes derivados de la bencidina, la absorción a través de la piel es la principal vía de entrada al organismo, mientras que la inhalación es una vía secundaria. Estas sustancias químicas pueden penetrar fácilmente en el organismo a través de la piel, acumularse allí y causar daños
Figura 30.4 - Contaminantes laborales.

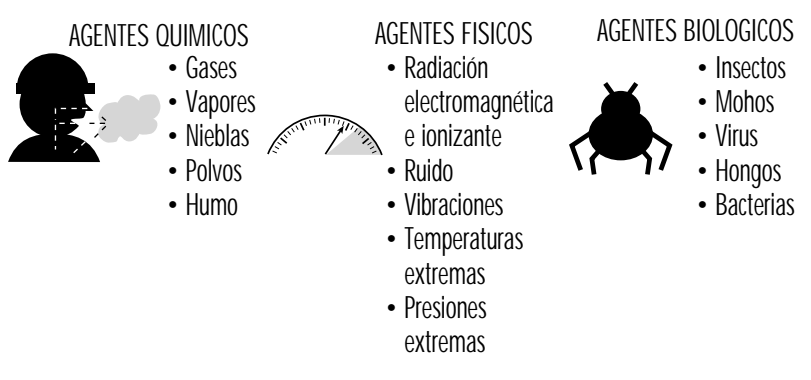

sistémicos. Cuando las reacciones alérgicas o los sucesivos lavados resecan y agrietan la piel, aumenta radicalmente el número y el tipo de sustancias químicas que pueden ser absorbidas por el organismo. La ingestión, una vía poco común de absorción de gases y vapores, puede ser importante para partículas como el plomo. La ingestión puede producirse al comer alimentos contaminados, al comer o fumar con las manos contaminadas y al toser y después tragar partículas inhaladas.

La inyección de materiales directamente en la corriente sanguínea se produce, por ejemplo, cuando los trabajadores sanitarios de los hospitales se pinchan sin querer la piel con agujas hipodérmicas, o cuando fuentes de alta presión liberan a

Figura 30.5 - O bservaciones y preguntas que deben hacerse en un estudio sobre el terreno.

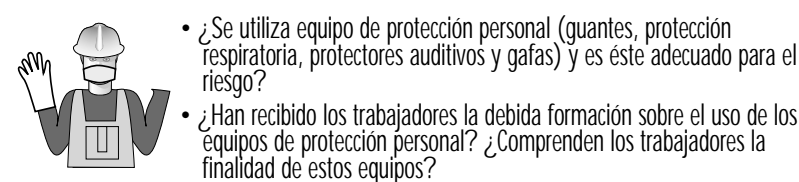
finalidad de estos equipos?

- ¿Cuál es la ubicación de los trabajadores con relación a las fuentes potenciales de exposición, incluidos agentes, equipo y procesos?

- ¿Se desplazan de sitio los trabajadores a lo largo del día o permanecen en un único lugar mientras realizan sus tareas?

- ¿Cuál es el uso, la ubicación y el mantenimiento de los sistemas de ventilación general y localizada?

- ¿Cuáles son la cantidades diarias medias de materiales utilizadas en los procesos?

- ¿Cuáles son las normas de limpieza? ¿Se guardan los trapos con restos de disolvente en recipientes abiertos en los que la evaporación puede crear exposiciones? ¿ Existen signos visibles de polvo? ¿Cómo se hace frente a los derrames accidentales y qué tratamiento reciben los residuos?

- ¿Regresan los trabajadores a su casa con prendas contaminadas?

- ¿Cómo se almacenan las sustancias químicas?

- ¿Se evacuan los residuos químicos de una manera apropiada?

- ¿Existe un ruido excesivo? ¿Es necesario hablar en voz muy alta 0 gritar para hacerse entender?

- ¿ Existe la posibilidad de que se liberen a la atmósfera sustancias químicas peligrosas? ¿Generan los procesos vapores por evaporación abierta, calentamiento, desecación y nebulización, o generan partículas suspendidas en el aire por explosión, trituración, molienda, iiado, soldadura, barrido o limpieza chorro con arena?

¿Existe la posibilidad de absorción por la piel? ¿ Está la piel del trabajador en contacto directo con los disolventes? ¿ Puede estar contaminado el interior de los guantes protectores? i Existe contaminación visual de las superficies con materiales que puedan pasar a las manos y brazos de los empleados?

- ¿Comen, beben o fuman los trabajadores en zonas contaminadas?

- Se quejan los trabajadores de efectos adversos en la salud (cefaleas, fatiga o irritación de los ojos, el tracto respiratorio o la piel)? 
gran velocidad proyectiles que contactan directamente con la piel. Las pistolas de pintura con bomba y los sistemas hidráulicos tienen una presión lo suficientemente elevada para perforar la piel e introducir sustancias directamente en el organismo.

\section{Inspección sobre el terreno}

La finalidad del estudio inicial, llamado inspección sobre el terreno, es recoger información de manera sistemática para juzgar si existe una situación potencialmente peligrosa y si es necesario realizar mediciones. El higienista industrial comienza la inspección sobre el terreno con una reunión inicial a la que pueden asistir representantes de la dirección, trabajadores, supervisores, enfermeros de empresa y delegados sindicales. Los higienistas industriales pueden influir mucho en el éxito del estudio y en cualquier medición posterior, creando un equipo de personas que se comuniquen libre y sinceramente entre sí y comprendan los objetivos y el ámbito de la inspección. Los trabajadores deben participar y estar informados de la inspección desde el principio para que la cooperación, y no el miedo, presida la investigación.

En la reunión, se solicitan diagramas de los procesos, planos de la fábrica, informes sobre inspecciones ambientales realizadas en el pasado, programas de producción, calendarios de mantenimiento de los equipos, documentación sobre los programas de protección personal y estadísticas sobre el número de trabajadores, los turnos y las quejas relacionadas con la salud. Todos los materiales peligrosos utilizados y producidos en las operaciones se identifican y cuantifican. Se elabora un inventario químico de productos, subproductos, productos intermedios e impurezas y se consultan todas las fichas toxicológicas de los materiales. Se anotan los calendarios de mantenimiento de los equipos, su edad y su estado, porque el uso de equipos antiguos puede incrementar las exposiciones debido a la falta de controles.

Después de la reunión, el higienista industrial realiza una inspección visual del lugar de trabajo, observando las operaciones y los métodos de trabajo, con el objetivo de identificar posibles contaminantes laborales, valorar el potencial de exposición, identificar la vía de exposición y estimar su duración y su frecuencia. En la Figura 30.4. se ofrecen ejemplos de contaminantes laborales. Esta inspección sobre el terreno sirve al higienista industrial para observar el lugar de trabajo y responder algunas preguntas. En la Figura 305 se ofrecen ejemplos de observaciones y preguntas.

Además de las preguntas que se indican en la Figura 30.5, deben formularse otras que pongan de manifiesto lo que no es inmediatamente obvio, por ejemplo:

1. Tareas no rutinarias y calendario de las actividades de mantenimiento y limpieza.

2. Cambios recientes en los procesos y sustituciones químicas.

3. Cambios físicos recientes en el medio ambiente de trabajo.

4. Cambios en las funciones de los puestos de trabajo.

5. R enovaciones y reparaciones recientes.

Las tareas no rutinarias pueden producir importantes exposiciones pico a sustancias químicas, que son difíciles de predecir y medir durante una jornada laboral normal. Los cambios en los procesos y las sustituciones químicas pueden alterar la emisión de sustancias al aire e influir en la exposición consiguiente. Los cambios en la distribución física de una zona de trabajo pueden alterar la eficacia de un sistema de ventilación. L os cambios en las funciones de los puestos de trabajo pueden determinar que algunas tareas sean realizadas por trabajadores sin experiencia en condiciones de mayor exposición. Las renovaciones y reparaciones pueden introducir en el medio ambiente de trabajo nuevos materiales y sustancias químicas que liberen compuestos químicos volátiles o irritantes.

\section{Estudios de la calidad del aire en el interior}

Los estudios de la calidad del aire en el interior se diferencian de los estudios tradicionales de higiene industrial porque suelen realizarse en lugares de trabajo no industriales que pueden estar expuestos a cantidades traza de sustancias químicas, ninguna de las cuales es aparentemente capaz, por sí sola, de causar enfermedades (Ness 1991). El objetivo de los estudios de la calidad del aire del interior es similar al de los estudios de higiene industrial en lo que se refiere a la identificación de las fuentes contaminantes y la recomendación de realizar mediciones. Sin embargo, los estudios de la calidad del aire en el interior están siempre motivados por quejas sobre la salud de los trabajadores. En muchos casos, los trabajadores presentan una serie de síntomas, como cefaleas, irritación de la garganta, letargo, tos, picores, náuseas o reacciones inespecíficas de hipersensibilidad, que desaparecen cuando regresan a su casa. Si los síntomas no desaparecen cuando los trabajadores abandonan el lugar de trabajo, deberán considerarse también exposiciones no profesionales, como las que puedan derivarse de las aficiones de tiempo libre, otros trabajos, contaminación atmosférica urbana, tabaquismo pasivo y exposiciones en el interior del hogar. Los estudios sobre la calidad del aire en el interior suelen utilizar cuestionarios para registrar los síntomas y quejas de los trabajadores y relacionarlos con el lugar en el que trabajan o la función que desempeñan. Las áreas que presentan la mayor incidencia vuelven a someterse a una nueva inspección. Las fuentes de contaminantes atmosféricos en interiores que han sido documentadas en estudios de la calidad del aire son:

- ventilación inadecuada (52 \%);

- contaminación originada en el interior del edificio (17\%);

- contaminación originada en el exterior del edificio (11 \%);

- contaminación microbiana (5\%);

- contaminación originada por los materiales de construcción (3\%);

- causas desconocidas (12\%).

En las investigaciones de la calidad del aire interior, la inspección sobre el terreno consiste esencialmente en una inspección del edificio y del medio ambiente para determinar las posibles fuentes contaminantes tanto dentro como fuera del edificio. Las fuentes contaminantes en el interior de un edificio son:

Figura 30.6 - O bservaciones y preguntas para un estudio sobre el terreno de la calidad del aire del interior.

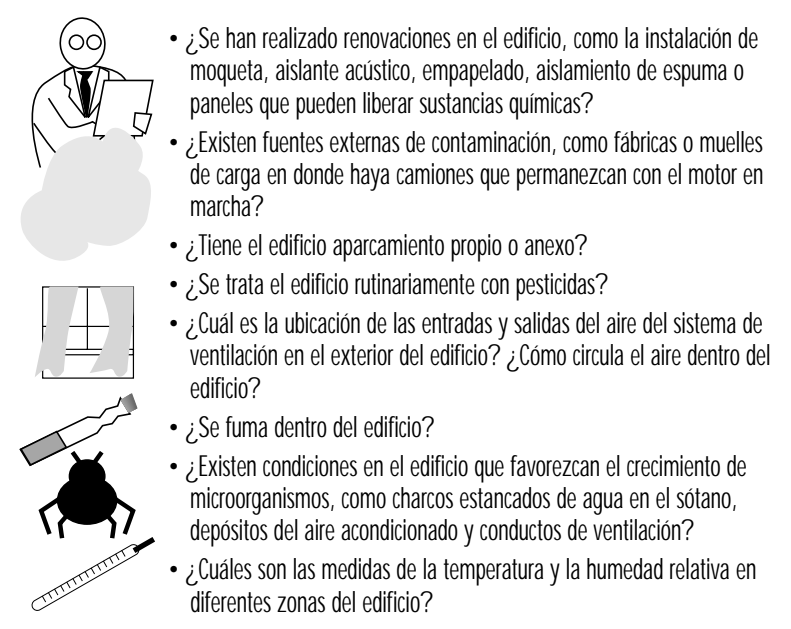


1. Materiales de construcción del edificio, como aislantes, tableros de conglomerado, materiales adhesivos y pinturas.

2. O cupantes humanos, que pueden liberar sustancias químicas de sus actividades metabólicas.

3. Actividades humanas como el consumo de tabaco.

4. Equipos como las fotocopiadoras.

5. Sistemas de ventilación que pueden estar contaminados por microorganismos.

Las observaciones y preguntas que pueden hacerse durante el estudio se enumeran en la Figura 30.6.

\section{Estrategias de muestreo y medición}

\section{Límites de exposición profesional}

Una vez finalizada la inspección sobre el terreno, el higienista industrial debe decidir si es o no necesario realizar un muestreo; la toma de muestras debe realizarse sólo si su finalidad está clara. El higienista industrial debe preguntarse: “¿Para qué servirán los resultados del muestreo y a qué preguntas responderán?". Tomar muestras y obtener cifras es relativamente fácil; mucho más difícil es interpretarlas.

Los datos obtenidos del muestreo atmosférico y biológico suelen compararse con los límites de exposición profesional $(\mathrm{OEL})$ recomendados u obligatorios. En muchos países se han establecido límites de exposición profesional para la exposición biológica y a la inhalación de agentes químicos y físicos. H asta la fecha, de las más de 60.000 sustancias químicas de uso comercial, unas 600 han sido evaluadas por distintas organizaciones y países. L os principios que justifican los límites son determinados por las organizaciones que los establecen. Los límites más utilizados, llamados valores límite umbral (TLV), son los que establece en Estados Unidos la Conferencia Americana de $\mathrm{H}$ igienistas Industriales del G obierno (A merican C onference of Governmental Industrial Hygienists, ACGIH). La mayoría de los OEL utilizados por la Administración para la Salud y Seguridad en el Trabajo (O ccupational Safety and Health Administration, OSHA) en Estados Unidos se basan en los TLV. Sin embargo, el Instituto Nacional para Salud y Seguridad en el Trabajo ( $N$ ational Institute for $\mathrm{O}$ ccupational Safety and $\mathrm{H}$ ealth, NIOSH) del Departamento de Salud y Servicios Humanos de Estados Unidos ha propuesto sus propios límites, Ilamados límites de exposición recomendados (REL).

En el caso de las exposiciones atmosféricas, existen tres tipos de T LV: la exposición media ponderada en el tiempo durante un período de ocho horas, T LV-T WA, para proteger contra efectos crónicos en la salud; un límite de exposición media a corto plazo durante quince minutos, TLV-STEL, para proteger contra efectos agudos en la salud, y un valor máximo instantáneo, TLV-C, para proteger contra sustancias químicas que producen asfixia o irritación inmediata. Las directrices sobre los niveles de exposición biológica se denominan índices de exposición biológica (BEI). Estas directrices representan la concentración de sustancias químicas en el organismo que corresponderían a la exposición a la inhalación de un trabajador sano dada una concentración atmosférica concreta. A demás de Estados U nidos, 50 países o grupos han establecido $0 \mathrm{EL}$, muchos de los cuales coinciden con los TLV. En el Reino U nido, los límites se denominan Límites de Exposición Profesional de la Dirección de Salud y Seguridad (OES) y, en Alemania, los O EL se denominan Concentraciones M áximas en el L ugar de Trabajo (M AK).

Se han establecido OEL para las exposiciones atmosféricas a gases, vapores y partículas, pero no se aplican todavía a las exposiciones atmosféricas a agentes biológicos. Por consiguiente, la mayoría de las investigaciones de la exposición a bioaerosoles comparan las concentraciones en el interior y en el exterior. Si las características y la concentración de organismos es diferente en el interior y en el exterior, puede existir un problema de exposición. No existen OEL para el muestreo de la piel o de superficies, y cada caso tiene que evaluarse por separado. Por lo que respecta al muestreo de superficies, las concentraciones suelen compararse con las concentraciones de fondo aceptables medidas en otros estudios o determinadas previamente en ese estudio. En el muestreo de la piel, las concentraciones aceptables se calculan en función de la toxicidad, la velocidad de absorción, la cantidad absorbida y la dosis total. Además, el control biológico de un trabajador puede utilizarse para investigar la absorción a través de la piel.

\section{Estrategia de muestreo}

U na estrategia de muestreo ambiental y biológico es un procedimiento para obtener mediciones de la exposición con un objetivo concreto. U na estrategia cuidadosamente diseñada y eficaz puede justificarse desde el punto de vista científico, aprovecha al máximo el número de muestras obtenidas, es eficaz con relación al coste y clasifica las necesidades por orden de prioridad. El objetivo de la estrategia de muestreo orienta las decisiones referentes a de qué deben tomarse muestras (selección de agentes químicos), dónde deben tomarse las muestras (personal, área 0 fuente), de quién deben tomarse muestras (de qué trabajador 0 grupo de trabajadores), cuánto debe durar el muestreo (en tiempo real o integrado), con qué frecuencia deben tomarse las muestras (cuántos días), cuántas muestras deben tomarse y cómo debe realizarse el muestreo (método analítico). Tradicionalmente, los muestreos realizados con fines reglamentarios consisten en breves campañas (uno o dos días) que se centran en las exposiciones en el peor de los casos. Aunque esta estrategia requiere un gasto mínimo de recursos y tiempo, en general consigue poca información y tiene escasa aplicación para evaluar las exposiciones profesionales a largo plazo. Para evaluar las exposiciones crónicas de una manera útil para los médicos del trabajo y los estudios epidemiológicos, las estrategias de muestreo deben prever la repetición de la toma de muestras a lo largo del tiempo en un gran número de trabajadores.

\section{Finalidad}

El objetivo de las estrategias de muestreo ambiental y biológico es evaluar la exposición de trabajadores concretos o evaluar fuentes contaminantes. EI control de los trabajadores se realiza para:

- evaluar las exposiciones individuales a tóxicos crónicos y agudos;

- responder a las quejas de los trabajadores relacionadas con la salud y los olores;

- definir la exposición basal para un programa de control a largo plazo;

- determinar si las exposiciones cumplen la normativa pública;

- evaluar la eficacia de los controles técnicos o de los procesos;

- evaluar las exposiciones agudas para respuestas de emergencia;

- evaluar la exposiciones en lugares con residuos peligrosos;

- evaluar la influencia de las prácticas de trabajo en la exposición;

- evaluar la exposición correspondiente a distintas tareas;

- investigar enfermedades crónicas como la intoxicación por plomo o mercurio;

- investigar la relación entre exposición en el trabajo y enfermedad profesional;

- realizar un estudio epidemiológico. 
Figura 30.7 • O bjetivos del control biológico.

- Evaluar las exposiciones por ingestión y absorción de la piel comparando la dosis medida en el organismo con los resultados de la toma de muestras del aire. Una elevada correlación entre la concentración ambiental de las sustancias químicas y la concentración en las mediciones biológicas podría indicar que la inhalación es la única vía de absorción.

- Estimar la carga corporal con fines de vigilancia médica.

- Investigar las quejas de los trabajadores que no estén justificadas según las mediciones ambientales. Si el control biológico indica unas concentraciones elevadas, puede haber exposición a sustancias químicas por vías distintas a la inhalación.

- Evaluar la eficacia de los equipos de protección personal, como guantes o protectores respiratorios, y las consecuencias de las prácticas de trabajo. Una protección respiratoria inadecuada podría tener como resultado la presencia de sustancias químicas o sus metabolitos en los fluidos corporales. Si las prácticas de trabajo o la protección de la piel son inadecuados, las mediciones biológicas podrían ser mayores de lo previsto, comparándolas con la concentración ambiental de las sustancias químicas.

- Evaluar la influencia de fuentes no presentes en el lugar de trabajo; los trabajadores pueden estar expuestos a sustancias químicas similares fuera del lugar de trabajo, lo cual daría lugar a unos resultados mayores de lo esperado en el muestreo biológico. En los trabajadores que utilizan cloruro de metileno para decapar la pintura de los muebles se han observado unos niveles más elevados de monóxido de carbono en sangre.

- Realizar una evaluación retrospectiva de la exposición. Las sustancias químicas con largas semividas, como el plomo y los bifenilos policlorados, permanecerán en el organismo mucho tiempo después de finalizada la exposición.

- Comprobar que se cumplen los límites de exposición biológica recomendados u obligatorios.

El control de la fuente y de la atmósfera ambiente se realiza para:

- establecer la necesidad de aplicar controles técnicos, como sistemas de ventilación localizada y cerramientos;

- evaluar las consecuencias de las modificaciones de equipos 0 procesos;

- evaluar la eficacia de los controles técnicos o de los procesos;

- evaluar las emisiones originadas por equipos o procesos;

- evaluar el cumplimiento de los requisitos reglamentarios una vez implantadas las acciones correctoras, como la retirada de amianto y plomo;

- responder a las quejas sobre la atmósfera interior, enfermedades de origen no profesional y olores;

- evaluar las emisiones en lugares con residuos peligrosos;

- investigar una respuesta de emergencia;

- realizar un estudio epidemiológico.

Cuando se realiza el control de los trabajadores, la toma de muestras del aire proporciona medidas estimadas de las dosis resultantes de la exposición por inhalación. El control biológico puede servir para conocer la dosis real de una sustancia química que penetra en el organismo a través de todas las vías de absorción: inhalación, ingestión, inyección y contacto con la piel. Así, el control biológico puede reflejar con mayor exactitud que el control atmosférico la carga corporal total y la dosis de una persona. Cuando se conoce la relación entre la exposición atmosférica y la dosis interna, el control biológico puede utilizarse para evaluar las exposiciones crónicas pasadas y presentes.

Los objetivos del control biológico se enumeran en la Figura 30.7 .

El control biológico tiene sus limitaciones y debe realizarse únicamente si logra objetivos que no pueden alcanzarse sólo con el control atmosférico (Fiserova-Bergova 1987). Se trata de un procedimiento invasivo, que requiere la toma de muestras directamente de los trabajadores. $L$ as muestras de sangre suelen constituir el medio biológico más útil de control; sin embargo, sólo se debe extraer sangre cuando se descartan otras pruebas no invasivas, como los análisis de orina o del aire exhalado. En el caso de la mayoría de las sustancias químicas industriales, no existen datos referentes a la trayectoria de las sustancias químicas absorbidas por el organismo, o los que hay son incompletos; por consiguiente, sólo se dispone de un número limitado de métodos analíticos de medición y muchos de ellos no son sensibles ni específicos.

L os resultados de los controles biológicos pueden variar considerablemente entre personas expuestas a las mismas concentraciones atmosféricas de sustancias químicas; la edad, el estado de salud, el peso, el estado nutricional, el consumo de fármacos, el tabaquismo, el consumo de alcohol, la medicación y el embarazo pueden influir en la absorción, distribución, metabolismo y eliminación de las sustancias químicas.

\section{¿De qué deben tomarse muestras?}

La mayoría de los lugares de trabajo están expuestos a múltiples contaminantes. L os agentes químicos se evalúan tanto individualmente como en agresiones múltiples y simultáneas a los trabajadores. Los agentes químicos pueden actuar independientemente dentro del organismo o interaccionar de una manera que potencie su efecto tóxico. La cuestión de qué debe medirse y cómo deben interpretarse los resultados depende del mecanismo de acción biológico de los agentes cuando se encuentran en el interior del organismo. Los agentes pueden evaluarse por separado si actúan de manera independiente en distintos sistemas orgánicos, como un irritante ocular o una neurotoxina. Si actúan sobre el mismo sistema orgánico, como sería el caso de dos irritantes respiratorios, su efecto combinado es importante. Si el efecto tóxico de la mezcla es igual a la suma de los efectos de cada uno de los componentes por separado, se habla de un efecto aditivo. Si el efecto tóxico de la mezcla es mayor que la suma de los efectos de cada agente por separado, el efecto combinado se califica de sinérgico. La exposición al humo del tabaco y la inhalación de fibras de amianto origina un riesgo de cáncer de pulmón mucho mayor que un simple efecto aditivo.

Tomar muestras de todos los agentes químicos presentes en un lugar de trabajo sería costoso y no siempre útil. El higienista industrial debe asignar prioridades en la lista de agentes potenciales, en función del riesgo, para determinar a qué agentes se debe prestar mayor atención.

L os factores que se tienen en cuenta para clasificar las sustancias químicas son:

- efecto independiente, aditivo o sinérgico de los agentes

- toxicidad inherente del agente químico

- cantidades utilizadas y generadas

- número de personas potencialmente expuestas

- duración y concentración previstas de la exposición

- confianza en los controles técnicos

- cambios previstos en los procesos o controles

- límites y directrices de exposición profesional.

\section{Dónde deben tomarse las muestras}

Para obtener la mejor estimación de la exposición de los empleados, se toman muestras del aire en la zona de respiración del trabajador (dentro de un radio de $30 \mathrm{~cm}$ alrededor de la cabeza); son lo que se denominan muestras personales. Para obtener muestras de la zona de respiración, el instrumento de muestreo se coloca directamente en el trabajador mientras dura la toma de muestras. Si las muestras del aire se toman cerca del 
Figura 30.8 - Factores que se tienen en cuenta para crear GEH basados en la zonificación.

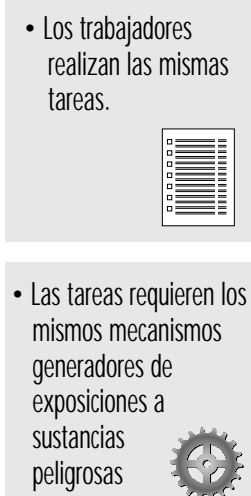

- Las tareas requieren los mismos mecanismos generadores de exposiciones a sustancias peligrosas

- Los trabajadores tienen pautas similares de movilidad en el área de trabajo

- La proximidad de
los trabajadores a
las fuentes
contaminantes
es similar

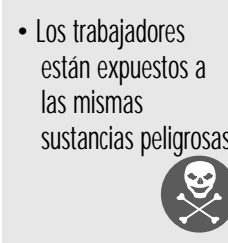

- Los trabajadores comparten la misma zona física de trabajo, incluidos la ventilación, la corriente de aire y los controles técnicos

trabajador, pero fuera de la zona de respiración, se denominan muestras ambientales. En las muestras ambientales se tiende a subestimar las exposiciones personales, y además no proporcionan una buena estimación de la exposición a la inhalación. Sin embargo, estas muestras son útiles para evaluar las fuentes y los niveles ambientales de contaminantes. Las muestras ambientales se toman recorriendo el lugar de trabajo con un instrumento portátil, o con estaciones fijas de muestreo. El muestreo ambiental se realiza rutinariamente en lugares de los que se quiere eliminar el amianto, para muestreos de seguridad e investigaciones del aire interior.

\section{¿De quién deben tomarse muestras?}

Para evaluar la exposición profesional, lo ideal es que se tomen muestras de cada trabajador durante muchos días a lo largo de un período de semanas o meses. Sin embargo, a menos que el lugar de trabajo sea pequeño ( $<10$ empleados), normalmente no se pueden tomar muestras de todos los trabajadores. Para reducir al mínimo la carga del muestreo en términos de coste y equipo y aumentar la eficacia del programa de muestreo, se toman muestras de un subconjunto de trabajadores en el lugar de trabajo, y se extrapolan los resultados al total de la plantilla.

Para seleccionar trabajadores que sean representativos de toda la plantilla, un planteamiento consiste en clasificar a los trabajadores en grupos con exposiciones teóricas similares, llamados grupos de exposición homogénea (GEH) (Corn 1985). Una vez formados los GEH, se selecciona al azar un subconjunto de trabajadores de cada grupo para el muestreo. Los métodos para determinar el tamaño adecuado de las muestras presuponen una distribución logarítmico normal de las exposiciones, una exposición media estimada y una desviación típica geométrica de 2,2 a 2,5. Los datos obtenidos de muestreos previos pueden permitir el uso de una desviación típica geométrica menor. Para clasificar a los trabajadores en distintos $G E H$, la mayoría de los higienistas industriales los observan en su puesto de trabajo y realizan una predicción cualitativa de su exposición.

Se aplican distintos criterios para formar los GEH; en general, los trabajadores pueden clasificarse según la similitud de su puesto de trabajo o área de trabajo. Cuando se utiliza la similitud del puesto de trabajo y del área de trabajo, el método de clasificación se denomina zonificación (véase Figura 30.8). Cuando están en suspensión en la atmósfera, los agentes químicos y biológicos pueden tener unas pautas de concentración espacial y temporal complejas e imprevisibles en el medio

ambiente de trabajo. Por consiguiente, la proximidad de la fuente al trabajador no siempre es el mejor indicador de similitud de la exposición. Las mediciones de la exposición realizadas en trabajadores con exposiciones teóricamente similares pueden revelar una variación mayor de la prevista. En estos casos, los grupos de exposición deben reconstruirse en conjuntos más pequeños de trabajadores, y la toma de muestras debe proseguir hasta que se compruebe que los trabajadores asignados a cada grupo tienen realmente exposiciones similares (R appaport 1995).

La exposición puede estimarse para todos los trabajadores, con independencia de su puesto de trabajo o riesgo, o puede estimarse sólo para los trabajadores que, en principio, están más expuestos; esto se denomina muestreo del peor caso. La selección de los trabajadores para el muestreo del peor caso puede basarse en criterios de producción, proximidad a la fuente, datos de muestreos anteriores, inventario y toxicidad química. EI método del peor caso se utiliza con fines reglamentarios y no ofrece una medida de la exposición media a largo plazo ni de la variabilidad de un día a otro. El muestreo en función de las tareas requiere la selección de trabajadores con tareas similares que no se realizan con carácter diario.

Existen muchos factores que influyen en la exposición y que pueden repercutir en el éxito de la clasificación de los GEH; entre ellos figuran los siguientes:

1. Los diferentes trabajadores casi nunca realizan el mismo trabajo, aunque la descripción de su puesto de trabajo sea igual, y rara vez sufren las mismas exposiciones.

2. Las formas de trabajar de los diferentes empleados pueden hacer que la exposición varíe significativamente.

3. Los trabajadores que se desplazan por toda el área de trabajo pueden verse expuestos imprevisiblemente a distintas fuentes contaminantes durante una jornada laboral.

4. Las corrientes de aire en el lugar de trabajo pueden aumentar de manera imprevisible las exposiciones de los trabajadores situados a una distancia considerable de una fuente.

5. Las exposiciones pueden estar condicionadas, no por las tareas del puesto de trabajo, sino por el medio ambiente de trabajo.

\section{Duración del muestreo}

La concentración de agentes químicos en muestras ambientales se puede medir directamente sobre el terreno, obteniendo resultados inmediatos (en tiempo real), o bien se pueden recoger muestras en distintos medios de muestreo 0 en bolsas de muestreo, a distintos tiempos, que son analizadas posteriormente en un laboratorio (muestreo integrado) (L ynch 1995). La ventaja del muestreo en tiempo real es que los resultados se obtienen rápidamente en el propio lugar de trabajo, y se pueden realizar mediciones de las exposiciones agudas a corto plazo. Sin embargo, los métodos en tiempo real son limitados porque no se dispone de ellos para todos los contaminantes de interés, ni tienen siempre la suficiente sensibilidad o exactitud analíticas para cuantificar los contaminantes estudiados. El muestreo en tiempo real puede no ser aplicable cuando el higienista industrial está interesado en exposiciones crónicas y necesita mediciones medias ponderadas en el tiempo para comparar con los O EL.

El muestreo en tiempo real se utiliza para realizar evaluaciones de emergencia, ya que permite hacer estimaciones brutas de la concentración, detectar fugas, controlar la atmósfera ambiente y la fuente, evaluar los controles técnicos, controlar las exposiciones a corto plazo que duran menos de 15 minutos, controlar exposiciones episódicas, y controlar sustancias químicas altamente tóxicas (monóxido de carbono), mezclas explosivas y procesos. Los métodos de muestreo en tiempo real 
pueden detectar la evolución de las concentraciones con el tiempo y facilitar de inmediato información cualitativa y cuantitativa. El muestreo ambiental integrado suele realizarse para controles personales, muestreo de zona o comparación de las concentraciones con OEL medios ponderados en el tiempo. Las ventajas del muestreo integrado son la disponibilidad de métodos para una gran variedad de contaminantes; su utilidad para identificar sustancias desconocidas; su elevada exactitud y especificidad y unos límites de detección normalmente muy bajos. Las muestras integradas que se analizan en un laboratorio deben contener suficiente contaminante para que se cumplan los requisitos analíticos mínimos de detección. Por consiguiente, las muestras se toman a lo largo de un período establecido previamente.

Además de los requisitos analíticos que ha de cumplir un método de muestreo, la duración del muestreo debe corresponderse con sus objetivos. La duración del muestreo de una fuente depende de la duración del proceso o el ciclo, o de los momentos en que se prevén concentraciones pico. Para el muestreo de los picos, las muestras deben tomarse a intervalos regulares durante todo el día, a fin de reducir al mínimo la desviación e identificar picos imprevistos. El período de muestreo debe ser lo suficientemente corto para que se identifiquen los picos y quede reflejado, al mismo tiempo, el período real de exposición.

La duración del muestreo personal depende del límite de exposición profesional, la duración de la tarea o el efecto biológico previsto. Los métodos de muestreo en tiempo real se utilizan para valorar las exposiciones agudas a sustancias químicas irritantes y asfixiantes, sensibilizantes y agentes alergénicos. El cloro, el monóxido de carbono y el sulfuro de hidrógeno son algunas sustancias químicas que pueden ejercer sus efectos con rapidez y en concentraciones relativamente bajas.

Cuando se estudian agentes que producen enfermedades crónicas, como el plomo y el mercurio, las muestras suelen tomarse durante un turno completo (siete horas o más por muestra) utilizando métodos de muestreo integrado. Para evaluar las exposiciones durante un turno completo, el higienista industrial toma una única muestra o una serie de muestras consecutivas que abarcan el turno completo. La duración del muestreo para exposiciones que tienen lugar durante menos tiempo del que dura un turno completo suele asociarse a determinadas tareas o procesos. La construcción, el mantenimiento de edificios y el mantenimiento de las carreteras son algunos trabajos en los que la exposición está vinculada a las tareas.

\section{¿C uántas muestras deben tomarse y con qué frecuencia?}

La concentración de contaminantes puede variar de un minuto a otro, de un día a otro o de una estación a otra, y puede existir variabilidad entre distintas personas y en una misma persona. La variabilidad de la exposición influye tanto en el número de muestras como en la exactitud de los resultados. L as variaciones de la exposición pueden deberse a diferencias en cuanto a las prácticas de trabajo, cambios en la emisión de contaminantes, al volumen de sustancias químicas utilizadas, a los cupos de producción, la ventilación, los cambios de temperatura, la movilidad del trabajador y la asignación de las tareas. La mayoría de las campañas de muestreo se realizan durante un par de días al año; por consiguiente, las medidas obtenidas no son representativas de la exposición. El período de muestreo es muy corto comparado con el período en el que no se toman muestras; el higienista industrial tiene que extrapolar al segundo los resultados obtenidos durante el primero. Para controlar la exposición a largo plazo, deben tomarse muestras repetidas a lo largo de varias semanas o meses de cada trabajador seleccionado de un GEH y deben caracterizarse las exposiciones correspondientes a todos los turnos.
Aunque es posible que durante el turno de día se desarrolle una mayor actividad, la supervisión durante el turno de noche puede ser menor y, en consecuencia, se observarían más negligencias en las prácticas de trabajo.

\section{Técnicas de medición}

\section{M uestreo activo y pasivo}

Los contaminantes se recogen en medios de muestreo, ya sea extrayendo activamente una muestra del aire a través del medio, o permitiendo pasivamente que el aire alcance el medio. El muestreo activo se realiza con una bomba alimentada por pilas, y el muestreo pasivo se realiza haciendo que los contaminantes alcancen el medio de muestreo por difusión o gravedad. Los gases, los vapores, las partículas en suspensión y los bioaerosoles se recogen mediante métodos activos de muestreo; los gases y los vapores pueden recogerse también mediante muestreo pasivo por difusión.

En el caso de los gases, los vapores y la mayoría de las partículas en suspensión, una vez tomada la muestra, se mide la masa del contaminante y se calcula la concentración dividiendo la masa por el volumen de aire muestreado. En el caso de gases y vapores, la concentración se expresa en partes por millón (ppm) $0 \mathrm{mg} / \mathrm{m}^{3}$, y en el caso de las partículas en suspensión, se expresa en $\mathrm{mg} / \mathrm{m}^{3}$ (Dinardi 1995).

En el muestreo integrado, las bombas utilizadas para tomar muestras del aire son un elemento decisivo del sistema de muestreo, ya que para calcular la concentración es preciso conocer el volumen de aire muestreado. Las bombas se seleccionan en función de la velocidad de flujo deseada, la facilidad de su mantenimiento y calibrado, su tamaño, su coste y su idoneidad para entornos peligrosos. El principal criterio de selección es la velocidad del flujo: las bombas de flujo lento $(0,5$ a $500 \mathrm{ml} / \mathrm{min})$ se utilizan para tomar muestras de gases y vapores; las bombas de flujo elevado ( 500 a $4.500 \mathrm{ml} / \mathrm{min}$ ) se utilizan para tomar muestras de partículas en suspensión, bioaerosoles, gases y vapores. Para que los volúmenes de las muestras sean exactos, las bombas deben ser calibradas con exactitud. El calibrado se realiza utilizando patrones primarios, como medidores electrónicos o manuales de pompas de jabón, que miden directamente el volumen, o métodos secundarios, como los medidores en húmedo, los gasómetros en seco y los rotámetros de precisión que se calibran con arreglo a métodos primarios.

\section{$G$ ases y vapores: medios de muestreo}

Los gases y los vapores se recogen utilizando tubos adsorbentes sólidos porosos, borboteador (impingers), detectores pasivos y bolsas. Los tubos adsorbentes son tubos de vidrio huecos que se rellenan con un sólido granular que permite adsorber sustancias químicas inalteradas en su superficie. L os adsorbentes sólidos son específicos para determinados grupos de compuestos; los adsorbentes utilizados habitualmente son el carbón vegetal, el gel de sílice y el Tenax. El adsorbente de carbón vegetal, una forma amorfa del carbono, carece de polaridad eléctrica y adsorbe preferiblemente gases y vapores orgánicos. El gel de sílice, una forma amorfa de sílice, se utiliza para recoger compuestos orgánicos polares, aminas y algunos compuestos inorgánicos. D ebido a su afinidad por los compuestos polares, adsorbe vapor de agua; por consiguiente, cuando la humedad es elevada, el agua puede desplazar las sustancias químicas menos polares del gel de sílice. EI Tenax, un polímero poroso, se utiliza para obtener muestras de compuestos orgánicos volátiles apolares que están presentes en concentraciones muy bajas. 
La capacidad de realizar tomas precisas de los contaminantes atmosféricos y evitar su pérdida depende de la frecuencia del muestreo, el volumen de las muestras y la volatilidad y concentración de los contaminantes atmosféricos. La eficacia de recogida de los adsorbentes sólidos puede resultar perjudicada por el aumento de la temperatura, la humedad, la velocidad del flujo, la concentración, el tamaño de las partículas del adsorbente y la diversidad de sustancias químicas. Al reducirse la eficacia de la recogida, se pierden sustancias químicas durante el muestreo y se subestiman las concentraciones. Para detectar la pérdida o la descomposición de sustancias químicas, los tubos con adsorbentes sólidos tienen dos secciones de material granular separadas por un tapón de espuma. La parte delantera se utiliza para recoger las muestras y la parte posterior se utiliza para determinar la descomposición. Se considera que se ha producido descomposición cuando al menos el 20-25\% del contaminante aparece en la sección posterior del tubo. EI análisis de contaminantes en los adsorbentes sólidos requiere la extracción del contaminante del medio utilizando un disolvente. Para cada lote de tubos de adsorbente y sustancias químicas recogidas, el laboratorio debe determinar la eficacia de la desorción; es decir, la eficacia de la eliminación de sustancias químicas del adsorbente por acción del disolvente. En el caso del carbón vegetal y el gel de sílice, el disolvente más utilizado es el disulfuro de carbono. En el caso del Tenax, las sustancias químicas se extraen mediante desorción térmica directamente en un cromatógrafo de fase gaseosa.

L os borboteadores (impingers) suelen ser frascos de vidrio con un tubo de entrada que permite introducir aire en el frasco atravesando una solución que recoge los gases y vapores por absorción, ya sea disolviéndose sin cambios o sufriendo una reacción química. Los borboteadores se utilizan cada vez menos para controlar los lugares de trabajo, especialmente para la toma de muestras del personal, porque pueden romperse y el medio líquido puede derramarse sobre el empleado. Existen distintos tipos de borboteadores, como las botellas lava-gases, los frascos de absorción en espiral, las columnas de cuentas de vidrio, los midget-impingers y los borboteadores de placa de vidrio sinterizado. Todos los borboteadores pueden utilizarse para recoger muestras de zona; el impactor más utilizado, el midget-impinger, puede utilizarse también para tomar muestras personales.

Los detectores pasivos o por difusión son pequeños, no contienen piezas móviles y sirven para obtener muestras tanto de contaminantes orgánicos como inorgánicos. La mayoría de los detectores de compuestos orgánicos utilizan carbón vegetal activado como medio para recoger la muestra. En teoría, cualquier compuesto que pueda ser muestreado utilizando un tubo con adsorbente de carbón vegetal y una bomba puede estudiarse también utilizando un detector pasivo. Estos detectores tienen una geometría diseñada a la medida para conseguir una velocidad de muestreo eficaz.

El muestreo se inicia al retirar la tapa del detector y finaliza cuando dicha tapa vuelve a colocarse en su sitio. La mayoría de los detectores por difusión son lo bastante precisos para determinar las exposiciones medias ponderadas en el tiempo durante ocho horas, pero no son adecuados para exposiciones de corta duración.

Las bolsas de muestreo pueden utilizarse para recoger muestras integradas de gases y vapores. Sus propiedades de permeabilidad y adsorción permiten conservar las muestras durante un día con una pérdida mínima. Las bolsas son de Teflon (politetrafluoroetileno) y Tedlar (fluoruro de polivinilo).

\section{Medio de muestreo: materias particuladas}

El muestreo del lugar de trabajo para detectar materias particuladas, 0 aerosoles, está experimentado algunos cambios en la actualidad; se tiende a sustituir los métodos tradicionales de muestreo por métodos de muestro selectivo granulométrico. En primer lugar, se describirán los métodos de muestreo tradicionales y, a continuación, los métodos granulométricos.

Los medios utilizados con mayor frecuencia para recoger aerosoles son los filtros de fibra o membrana. La eliminación de aerosoles de la corriente de aire se produce por colisión y adherencia de las partículas a la superficie del filtro. La elección del material del filtro depende de las propiedades físicas y químicas de los aerosoles de los que se desean obtener muestras, el tipo de muestreador y el tipo de análisis. Al seleccionar los filtros, debe considerarse la eficiencia de recogida, la caída de presión, la higroscopicidad, la contaminación de fondo, la resistencia y el tamaño de los poros, que puede variar de 0,01 a $10 \mu \mathrm{m}$. Los filtros de membrana se fabrican con distintos tamaños de poro y normalmente son de éster de celulosa, cloruro de polivinilo o politetrafluoroetileno. Las partículas se recogen en la superficie del filtro; por consiguiente, los filtros de membrana suelen utilizarse cuando se van a examinar las muestras con microscopio. Los filtros mixtos de éster de celulosa pueden disolverse fácilmente con ácido y se utilizan generalmente para recoger metales que serán analizados mediante absorción atómica. Los filtros nucleoporosos (policarbonatos) son muy fuertes y termoestables y se utilizan para tomar muestras y analizar fibras de amianto utilizando microscopia electrónica de transmisión. Los filtros de fibra suelen fabricarse con fibra de vidrio y se utilizan para tomar muestras de aerosoles como pesticidas y plomo.

Para estudiar la exposición a aerosoles en el lugar de trabajo, se puede tomar una muestra de un volumen conocido de aire a través de los filtros, medir el incremento total de masa $\left(\mathrm{mg} / \mathrm{m}^{3}\right.$ aire) (análisis gravimétrico), contar el número total de partículas (fibras/ cc) o identificar los aerosoles (análisis químico). Para el cálculo de masas, se puede medir el polvo total que entra en el aparato de muestreo o sólo la fracción respirable. Cuando se mide el polvo total, el aumento de la masa representa la exposición por sedimentación en todas las partes del tracto respiratorio. Los instrumentos para la toma de muestras del polvo total están sujetos a error debido a las fuertes corrientes de aire que atraviesan el instrumento 0 a su orientación inadecuada. Las corrientes de aire y los filtros orientados en vertical pueden determinar que se recojan demasiadas partículas y que se sobreestime la exposición.

Cuando se toman muestras del polvo respirable, el aumento de la masa representa la exposición por sedimentación en la región (alveolar) de intercambio de gases del tracto respiratorio. Para recoger sólo la fracción respirable se utiliza un preclasificador llamado ciclón que distorsiona la distribución del polvo suspendido en el aire. Los aerosoles pasan por el ciclón, se aceleran y forman torbellinos, haciendo que las partículas más pesadas sean arrojadas fuera de la corriente de aire y pasen a una sección de eliminación situada en la parte inferior del ciclón. L as partículas respirables menores de $10 \mu \mathrm{m}$ permanecen en la corriente de aire y son recogidas por el filtro para su posterior análisis gravimétrico.

Los errores de muestreo que se producen al realizar un muestro del polvo total y de la fracción respirable dan lugar a mediciones que no reflejan con exactitud la exposición o su relación con efectos negativos para la salud. Por consiguiente, se ha propuesto el uso de muestreos selectivos granulométricos para redefinir la relación entre el tamaño de las partículas, el efecto negativo en la salud y el método de muestreo. En el muestreo selectivo granulométrico, la medición de las partículas tiene en cuenta los tamaños asociados a efectos concretos en la salud. La Organización Internacional de Normalización (ISO) y la ACGIH han propuesto tres fracciones de masa particulada: masa particulada inhalable (MPI), masa particulada torácica 
(M PT ) y masa particulada respirable (M PR ). La M PI se refiere a las partículas que pueden penetrar por la nariz y la boca y sustituiría a la fracción total de masa tradicional. La M PT se refiere a las partículas que pueden penetrar en el sistema respiratorio superior una vez pasada la laringe. L a M PR se refiere a las partículas que pueden depositarse en la región de intercambio de gases del pulmón y sustituiría a la actual fracción de masa respirable. La adopción del muestreo selectivo granulométrico requiere en la práctica el desarrollo de nuevos métodos de muestreo de aerosoles y el establecimiento de límites de exposición profesional específicos para este tipo de muestreos.

\section{Medios de muestreo: materiales biológicos}

$\mathrm{H}$ ay pocos métodos normalizados para el muestreo de materiales biológicos o bioaerosoles. Aunque los métodos de muestreo son similares a los utilizados para otras partículas suspendidas en el aire, deben preservar la viabilidad de la mayoría de los bioaerosoles para que puedan cultivarse en el laboratorio. Por consiguiente, es más difícil recoger, almacenar y analizar las muestras. L a estrategia para el muestreo de bioaerosoles implica la recogida directa en un agar nutritivo semisólido o la recogida en un medio líquido y su cultivo posterior en placa, incubación durante varios días e identificación y cuantificación de las células que han crecido. Los grupos de células que se multiplican en el agar pueden contarse como unidades formadoras de colonias en el caso de bacterias u hongos viables y unidades formadoras de placas en el caso de virus activos. C on la excepción de las esporas, no se recomiendan los filtros para la recogida de bioaerosoles debido a que la deshidratación produce daños celulares.

Los microorganismos aerosolizados viables se recogen utilizando impactores de vidrio (AGI-30), muestreadores de rendija y borboteadores por inercia. El borboteador recoge los bioaerosoles en un medio líquido y el muestreador de rendija los recoge en portaobjetos de vidrio a elevados volúmenes y velocidades de flujo. El borboteador se utiliza con entre una y seis etapas, en cada una de las cuales se siembra una placa de Petri para separar las partículas según su tamaño.

La interpretación de los resultados del muestreo debe realizarse caso por caso, porque no existen límites de exposición profesional. Los criterios de evaluación deben fijarse antes del muestreo. Para las investigaciones de la atmósfera interior, en particular, las muestras tomadas fuera del edificio se utilizan como referencia basal. U na regla práctica es que las concentraciones deben ser diez veces mayores a la basal para que se pueda pensar que existe contaminación. Cuando se utilizan técnicas de cultivo en placas, es probable que se subestimen las concentraciones por la pérdida de viabilidad durante el muestreo y la incubación.

\section{Toma de muestras en la piel y en las superficies}

No existen métodos normalizados para evaluar la exposición de la piel a sustancias químicas y predecir la dosis. El muestreo de superficies se realiza principalmente para evaluar las prácticas de trabajo e identificar posibles fuentes de absorción a través de la piel o por ingestión. Para evaluar el potencial de absorción dérmica e ingestión, se utilizan dos tipos de métodos de muestreo de superficie: métodos directos, que consisten en tomar muestras en la piel del trabajador, y métodos indirectos, que consisten en la obtención de muestras por frotamiento de las superficies.

EI muestreo directo de la piel consiste en colocar gasas sobre la piel para absorber las sustancias químicas, lavar la piel con disolventes para separar los contaminantes o utilizar luz fluorescente para identificar los contaminantes presentes en la piel. Las gasas se colocan en diferentes partes del cuerpo y se dejan expuestas o se colocan debajo del equipo de protección personal. Al final de la jornada de trabajo, se retiran las gasas y se analizan en el laboratorio; la distribución de concentraciones en diferentes partes del cuerpo permite identificar las zonas de exposición de la piel. Este método es poco costoso y fácil de realizar; sin embargo, los resultados presentan limitaciones, ya que las gasas no constituyen modelos físicos adecuados de las propiedades de absorción y retención de la piel y miden concentraciones que no son necesariamente representativas de todo el cuerpo.

Los lavados de la piel consisten en enjuagar la piel con disolventes 0 introducir las manos en bolsas de plástico llenas de disolvente para medir la concentración de sustancias químicas en su superficie. Este método puede subestimar la dosis al recoger sólo la fracción no absorbida de las sustancias químicas.

El control con luz fluorescente se utiliza para identificar la exposición de la piel a sustancias químicas que son fluorescentes por naturaleza, como compuestos aromáticos polinucleares, y para identificar exposiciones a sustancias químicas a las que se han añadido intencionadamente compuestos fluorescentes. Para detectar la contaminación, se realiza un barrido de la piel con luz ultravioleta. La visualización de las zonas contaminadas permite que los trabajadores conozcan el efecto de las prácticas de trabajo en la exposición. En la actualidad, se están realizando investigaciones para cuantificar la intensidad fluorescente y relacionarla con la dosis

Los métodos de muestreo indirecto por frotamiento requieren el uso de gasas, filtros de fibra de vidrio o filtros de celulosa para frotar el interior de guantes o respiradores o las superficies. La eficacia de la recogida puede aumentar si se añaden disolventes. Seguidamente, las gasas o los filtros se analizan en el laboratorio. Para normalizar los resultados y poder realizar comparaciones entre distintas muestras, se utiliza una plantilla cuadrada para tomar muestras en un área de $100 \mathrm{~cm}^{2}$.

\section{Medios biológicos}

Las muestras de sangre, orina y aire exhalado son las más adecuadas para el control biológico rutinario, mientras que el pelo, la leche, la saliva y las uñas se utilizan con menos frecuencia. El control biológico se realiza mediante la recogida en el lugar de trabajo de muestras en serie de sangre y orina, y su posterior análisis en el laboratorio. Las muestras de aire exhalado se recogen en bolsas de Tedlar, pipetas de vidrio especialmente diseñadas al efecto o tubos con adsorbente y se analizan "in situ", utilizando instrumentos de lectura directa, 0 en el laboratorio. Las muestras de sangre, orina y aire exhalado se utilizan principalmente para medir el compuesto original no modificado (la misma sustancia química de la que se toman muestras en el aire del lugar de trabajo), sus metabolitos o un cambio bioquímico (compuestos intermedios) que ha sido inducido en el organismo. Por ejemplo, el plomo inorgánico se mide en la sangre para evaluar la exposición al plomo; el metabolito ácido mandélico se mide en la orina para determinar tanto la exposición al estireno como la del etilbenceno, y la carboxihemoglobina es el compuesto intermedio que se mide en la sangre para determinar la exposición a monóxido de carbono y cloruro de metileno. Para el control de la exposición, la concentración de un determinante ideal estará estrechamente correlacionada con la intensidad de la exposición. Para el control médico, la concentración de un determinante ideal estará estrechamente correlacionada con su concentración en el órgano diana.

El momento de tomar las muestras puede influir en la utilidad de las mediciones; las muestras deben recogerse en los momentos en que reflejen la exposición con mayor exactitud. El momento más oportuno depende de la semivida biológica de excreción de una sustancia química, que refleja la velocidad con que dicha sustancia es eliminada del organismo, y que puede variar de horas a años. La concentración en los órganos diana 
de las sustancias químicas con semivida biológica corta depende en gran medida de la concentración ambiental; la concentración en los órganos diana de las sustancias químicas con semivida biológica larga fluctúa muy poco en respuesta a las exposiciones ambientales. En el caso de las sustancias químicas con semivida biológica inferior a tres horas, las muestras deben tomarse justo al finalizar la jornada laboral, antes de que las concentraciones disminuyan rápidamente, para que quede reflejada la exposición durante ese día. En el caso de las sustancias químicas con semivida larga, como los bifenilos policlorados y el plomo, las muestras pueden tomarse en cualquier momento.

\section{Detectores en tiempo real}

Los instrumentos de lectura directa permiten cuantificar en tiempo real los contaminantes; la muestra se analiza dentro del equipo y no requiere análisis en un laboratorio exterior (M aslansky y M aslansky 1993). L os compuestos pueden medirse sin tener que recogerlos antes en distintos medios, transportarlos, almacenarlos y analizarlos. La concentración se lee directamente en un medidor, una pantalla, en una cinta de registro, un tabulador electrónico de datos, o por un cambio de color. Los instrumentos de lectura directa se utilizan principalmente para gases y vapores; existen también algunos instrumentos para detectar las partículas en suspensión. Los instrumentos varían en coste, complejidad, fiabilidad, tamaño, sensibilidad y especificidad. Existen aparatos muy sencillos, como tubos colorimétricos, que indican la concentración mediante un cambio de color, instrumentos específicos para una sustancia química, como los indicadores de monóxido de carbono, los indicadores de gases combustibles (explosímetros) y los medidores del vapor de mercurio, o instrumentos de reconocimiento, como los espectrómetros para infrarrojos, que analizan grandes grupos de sustancias químicas. Los instrumentos de lectura directa aplican distintos métodos físicos y químicos para analizar los gases y vapores, como la conductividad, la ionización, la potenciometría, la fotometría, losindicadores radiactivos y la combustión.

Los instrumentos portátiles de lectura directa que se utilizan con más frecuencia son los cromatógrafos de gases, los analizadores de vapores orgánicos y los espectrómetros para infrarrojos accionados por pilas. Los cromatógrafos de gases y los analizadores de vapores orgánicos se utilizan principalmente para controlar el medio ambiente en lugares en los que hay residuos peligrosos y para controlar el aire ambiental en las comunidades vecinas. Los cromatógrafos de gases con detectores adecuados son específicos y sensibles y pueden cuantificar sustancias químicas a concentraciones muy bajas. Los analizadores de vapores orgánicos suelen utilizarse para medir compuestos por grupos. Los espectrómetros para infrarrojos portátiles se utilizan principalmente para el control industrial y la detección de fugas, porque son sensibles y específicos para una amplia gama de compuestos.

Existen pequeños detectores personales de lectura directa para una serie de gases comunes (cloro, cianuro de hidrógeno, sulfuro de hidrógeno, hidrazina, oxígeno, fosgeno, dióxido de azufre, dióxido de nitrógeno y monóxido de carbono). Estos detectores acumulan las concentraciones medidas a lo largo de todo un día y permiten realizar una lectura directa de la concentración media ponderada en el tiempo, así como un perfil detallado del contaminante correspondiente a ese día.

Los tubos colorimétricos (tubos detectores) son fáciles de utilizar, baratos y sirven para una gran variedad de sustancias químicas. Pueden utilizarse para identificar rápidamente clases de contaminantes atmosféricos y realizar estimaciones aproximadas de concentraciones, que sirven para determinar los volúmenes y las velocidades del flujo de la bomba. Los tubos colorimétricos son tubos de vidrio llenos de material granular sólido impregnado con un agente químico que reacciona con un contaminante y produce un cambio de color. D espués de romper los dos extremos sellados de un tubo, uno de esos extremos se coloca en una bomba manual. Para tomar la muestra, el volumen recomendado de aire contaminado se hace pasar a través del tubo utilizando un número específico de bombeos para cada sustancia química. Generalmente, al cabo de dos minutos se produce un cambio de color o una alteración cromática en el tubo, cuya intensidad es proporcional a la concentración. Algunos tubos colorimétricos se han adaptado para muestreos de larga duración y se utilizan con bombas alimentadas por pilas que pueden funcionar durante períodos de hasta ocho horas. El cambio de color que se produce en el tubo representa una concentración media ponderada en el tiempo. LoS tubos colorimétricos son adecuados para realizar análisis tanto cualitativos como cuantitativos; sin embargo, su especificidad y exactitud son limitadas. La exactitud de los tubos colorimétricos no es tan elevada como la de los métodos de laboratorio o la de muchos otros instrumentos de lectura directa. Existen centenares de tubos, muchos de los cuales tienen sensibilidades cruzadas y pueden detectar más de una sustancia química. Este hecho puede causar interferencias que modifiquen las concentraciones medidas.

Los detectores de lectura directa para aerosoles no distinguen entre contaminantes y se utilizan normalmente para contar 0 determinar el tamaño de las partículas, más con fines de cribado que para determinar promedios de concentración ponderada en el tiempo o exposiciones agudas. Los instrumentos en tiempo real utilizan propiedades ópticas o eléctricas para determinar la masa total y respirable, realizar el recuento de partículas y determinar su tamaño. Los detectores de aerosoles por luz dispersa 0 los fotómetros para aerosoles detectan la luz que dispersan las partículas cuando pasan por su interior. Al aumentar el número de partículas, la cantidad de luz dispersada aumenta de forma proporcional a la masa. Los detectores de aerosoles por luz dispersa no sirven para distinguir entre distintos tipos de partículas; sin embargo, cuando se utilizan en un lugar de trabajo con un número limitado de tipos distintos de polvo, la masa puede atribuirse a determinado material. Los detectores de aerosoles fibrosos se utilizan para medir la concentración atmosférica de partículas como el amianto. Las fibras se orientan en un campo eléctrico oscilante y se iluminan con láser de helio y neón; los impulsos luminosos resultantes se detectan mediante un tubo fotomultiplicador. Los fotómetros de luz atenuada miden la extinción de luz por efecto de las partículas; la relación entre luz incidente y luz medida es proporcional a la concentración.

\section{Técnicas analíticas}

Existen muchos métodos para analizar las muestras de laboratorio de contaminantes. Algunas de las técnicas más habituales para cuantificar gases y vapores atmosféricos son la cromatografía de gases, la espectrometría de masas, la absorción atómica, la espectroscopia por rayos infrarrojos y UV y la polarografía.

La cromatografía de gases es una técnica que se utiliza para separar y concentrar sustancias químicas contenidas en mezclas para su posterior análisis cuantitativo. EI sistema consta de tres componentes principales: el sistema de inyección de la muestra, una columna y un detector. La muestra líquida o gaseosa se inyecta con una jeringa en una corriente de aire, que la transporta a través de una columna en donde se separan sus componentes. La columna está llena de materiales que interactúan de manera diferente con las distintas sustancias químicas y aminoran su desplazamiento. Esta diferente interacción hace 
que cada sustancia química se mueva a través de la columna a una velocidad diferente. Una vez separadas, las sustancias químicas pasan directamente a un detector, que puede ser de ionización de llama, fotoionización o captura de electrones. En un registrador de gráficos se registra una señal proporcional a la concentración. EI detector de ionización de llama se utiliza para casi todos los compuestos orgánicos, como hidrocarburos aromáticos, hidrocarburos de cadena lineal, cetonas y algunos hidrocarburos clorados. La concentración se mide por el incremento del número de iones que se produce cuando un hidrocarburo volátil se quema en una llama de hidrógeno. El detector de fotoionización se utiliza para compuestos orgánicos y algunos inorgánicos; es especialmente útil para compuestos aromáticos como el benceno y puede detectar hidrocarburos alifáticos, aromáticos y halogenados. La concentración se mide por el aumento del número de iones que se produce cuando la muestra es bombardeada con radiación ultravioleta. El detector por captura de electrones se utiliza principalmente para sustancias químicas que contienen halógenos; ofrece una respuesta mínima a los hidrocarburos, alcoholes y cetonas. La concentración se mide por el flujo de corriente entre los dos electrodos causado por la ionización del gas por radiactividad.

La espectrofotometría de masas sirve para analizar mezclas complejas de sustancias químicas presentes en cantidades traza. Suele utilizarse conjuntamente con un cromatógrafo de gases para separar y cuantificar los diferentes contaminantes.

La espectroscopia de absorción atómica se utiliza principalmente para cuantificar metales como el mercurio. La absorción atómica es la absorción de la luz de una determinada longitud de onda por un átomo libre en estado fundamental; la cantidad de luz absorbida depende de la concentración. Esta técnica es muy específica, sensible y rápida y puede aplicarse directamente a unos 68 elementos. L os límites de detección están en un rango próximo a ppb y hasta pequeñas ppm.

EI análisis por rayos infrarrojos es una técnica potente, sensible, específica y versátil. U tiliza la absorción de energía infrarroja para medir muchas sustancias químicas orgánicas e inorgánicas; la cantidad de luz absorbida es proporcional a la concentración. El espectro de absorción de un compuesto facilita información que permite describirlo y cuantificarlo.

La espectroscopia por absorción U V se utiliza para el análisis de hidrocarburos aromáticos cuando se sabe que existen pocas interferencias. La cantidad de absorción de luz U V es directamente proporcional a la concentración.

Los métodos polarográficos se basan en la electrolisis de una solución de muestra con un electrodo fácilmente polarizable y un electrodo no polarizable. Se utilizan para realizar análisis cualitativos y cuantitativos de aldehídos, hidrocarburos clorados y metales.

\section{- HIGIENE INDUSTRIAL: CONTROL DE LAS EXPOSICIONES MEDIANTE LA INTERVENCION}

James Stewart

Una vez que se identifica y evalúa un riesgo, debe decidirse qué intervenciones (métodos de control) son las más adecuadas para controlar ese riesgo concreto. Los métodos de control suelen dividirse en tres categorías:

1. Controles técnicos.

2. Controles administrativos.

3. Equipos de protección personal.
Como con cualquier otro cambio en los procesos de trabajo, el éxito de estas intervenciones depende de la formación que reciba el personal.

L os controles técnicos son cambios en los procesos o equipos que reducen o eliminan la exposición a un agente. Por ejemplo, la sustitución de una sustancia por otra menos tóxica o la instalación de un sistema de ventilación localizada que elimina los vapores generados durante una etapa del proceso, son ejemplos de controles técnicos. Algunos controles técnicos para el ruido son, por ejemplo, la instalación de materiales insonorizantes, cerramientos o silenciadores en las salidas de aire. 0 tro tipo de control técnico puede consistir en cambiar el propio proceso. Un ejemplo de este tipo de control sería la eliminación de una o más etapas desengrasantes en un proceso que antes requería tres etapas. Al eliminar la necesidad de realizar la tarea que producía la exposición, se controla la exposición total del trabajador. La ventaja de los controles técnicos es que requieren una participación relativamente pequeña del trabajador, que puede proseguir con su trabajo en un medio ambiente más controlado si, por ejemplo, los contaminantes se eliminan automáticamente de la atmósfera. Esto contrasta con la situación en la que se elige como método de control un respirador que debe llevar el trabajador mientras realiza la tarea en un lugar de trabajo "no controlado". A demás de instalar activamente controles técnicos en los equipos existentes, una empresa puede adquirir nuevos equipos que lleven incorporados esos controles u otros más eficaces. En general, el enfoque combinado suele ser el más eficaz (es decir, la instalación de algunos controles técnicos y el uso de equipos de protección personal hasta que se adquieran nuevos equipos con controles más eficaces, que permiten prescindir de los equipos de protección personal). Algunos ejemplos comunes de controles técnicos son:

- ventilación (ventilación tanto general como localizada);

- aislamiento (colocación de una barrera entre el trabajador y el agente);

- sustitución (sustitución por materiales menos tóxicos e inflamables, etc.);

- cambios en el proceso (eliminación de etapas peligrosas).

El higienista industrial debe tener en cuenta las tareas que realiza el trabajador y solicitar su participación en el diseño 0 elección de los controles técnicos. Por ejemplo, la instalación de barreras en el lugar de trabajo puede dificultar considerablemente la capacidad de un trabajador para realizar su trabajo y podría reducir su rendimiento. Los controles técnicos son el método más eficaz para reducir las exposiciones. Con frecuencia, son también el más caro. Puesto que los controles técnicos son eficaces y costosos, es importante que se consiga la máxima participación de los trabajadores en su elección y diseño. Así debería aumentar la probabilidad de que los controles reduzcan las exposiciones.

Los controles administrativos son cambios en la manera en que un trabajador realiza las tareas correspondientes a su puesto de trabajo; por ejemplo, reducción del tiempo de trabajo en una zona en la que se producen exposiciones, o cambios en las prácticas de trabajo, como rectificación de la posición del cuerpo para reducir la exposición. L os controles administrativos pueden aumentar la eficacia de una intervención, pero presentan varias desventajas:

1. La rotación de los trabajadores puede reducir la exposición media total durante una jornada de trabajo, pero aumenta el número de trabajadores que se verán sometidos a elevadas exposiciones durante períodos cortos de tiempo. A medida que se conoce más sobre los tóxicos y sus mecanismos de actuación, se sabe que las exposiciones pico de corta duración 
pueden representar un riesgo mayor del que se estimaría por su contribución a la exposición media.

2. La modificación de las prácticas de trabajo puede representar un importante reto de aplicación y seguimiento. La aplicación y el seguimiento de las prácticas de trabajo determinan su eficacia. Esta atención constante que requieren los controles administrativos supone un importante coste.

El equipo de protección personal está compuesto por los elementos que se entregan al trabajador para que los lleve puestos mientras realiza determinadas tareas (o todas ellas) de su puesto de trabajo; algunos de esos elementos son los respiradores, las gafas, los guantes protectores y las pantallas de protección facial. El equipo de protección personal suele utilizarse cuando los controles técnicos no han conseguido controlar la exposición a unos niveles aceptables o cuando dichos controles no son factibles (por razones operativas o de coste). El equipo de protección personal puede ofrecer una protección importante a los trabajadores si se lleva y se utiliza correctamente. En el caso de la protección de las vías respiratorias, el factor de protección (relación entre la concentración fuera y dentro del respirador) puede ser de 1.000 o más para los respiradores de aire suministrado con presión positiva o de hasta 10 para los respiradores que purifican el aire y ocupan la mitad de la cara. Los guantes (si se elige un modelo adecuado) pueden proteger las manos durante horas contra los disolventes. Las gafas protectoras ofrecen una protección eficaz contra las salpicaduras de sustancias químicas.

\section{Intervención: factores que deben considerarse}

En general, para reducir la exposición a unos niveles aceptables, se tienen que combinar distintos tipos de controles. Cualesquiera que sean los métodos elegidos, la intervención debe reducir la exposición y el riesgo resultante a un nivel aceptable. Existen, sin embargo, muchos otros factores que deben considerarse a la hora de elegir una intervención. Por ejemplo:

- eficacia de los controles;

- facilidad de uso para el trabajador;

- coste de los controles;

- idoneidad de las propiedades de advertencia del material;

- nivel aceptable de exposición;

- frecuencia de la exposición;

- vía(s) de exposición;

- requisitos reglamentarios sobre controles específicos.

\section{Eficacia de los controles}

La eficacia de los controles es, obviamente, un aspecto fundamental cuando se toman medidas para reducir las exposiciones. Cuando se compara un tipo de intervención con otra, se ha de tener en cuenta que el nivel de protección necesario justifique las dificultades que puede conllevar la intervención; un control excesivo es un desperdicio de recursos, que podrían utilizarse para reducir otras exposiciones o las exposiciones que afectan a otros empleados. Por otra parte, un control deficiente deja al trabajador expuesto a condiciones insanas. Un primer paso útil consiste en clasificar las intervenciones de acuerdo con su eficacia $y$, seguidamente, utilizar dicha clasificación para evaluar la importancia de los demás factores.

\section{Facilidad de uso}

Para que un control sea eficaz, es preciso que el trabajador pueda realizar las tareas de su puesto de trabajo al mismo tiempo que se aplica ese control. Por ejemplo, si el método de control elegido es una sustitución, el trabajador debe conocer los riesgos de la nueva sustancia química, recibir formación sobre los procedimientos seguros de manipulación, conocer los procedimientos correctos de evacuación, etc. Si el control consiste en un aislamiento, o colocación de un dispositivo que separa la sustancia del trabajador, éste debe dejar que el trabajador realice su trabajo. Si las medidas de control interfieren con las tareas del puesto de trabajo, el trabajador se resistirá a utilizarlas y posiblemente encontrará otras formas de realizar sus tareas, que conlleven una exposición mayor, en lugar de menor.

\section{Coste}

Todas las organizaciones disponen de unos recursos limitados. EI reto consiste en aprovechar al máximo dichos recursos. Cuando se identifican exposiciones peligrosas y se desarrolla una estrategia de intervención, el coste es un factor que debe tenerse en cuenta. La "mejor compra" no siempre será la solución de mayor o menor coste. El coste se convierte en un factor sólo después de haber identificado varios métodos viables de control. Entonces, el coste puede utilizarse como criterio para seleccionar aquellos controles que serán más eficaces en una determinada situación. Si el coste es el factor determinante desde el principio, es posible que se elijan controles deficientes o inadecuados o que éstos interfieran con el trabajo del empleado. Sería poco aconsejable elegir controles de bajo coste que interfiriesen y retrasaran un proceso de fabricación. El proceso perdería productividad y el coste sería mayor. En muy poco tiempo, el coste "real" de estos controles de "bajo coste" sería enorme. Los ingenieros industriales aportan su conocimiento de las instalaciones y los procesos en su conjunto; los ingenieros de producción, su conocimiento de las etapas y procesos de producción; los analistas financieros, su conocimiento de los problemas de asignación de recursos. Los higienistas industriales pueden aportar una perspectiva específica a este debate gracias a su conocimiento de las tareas de cada puesto de trabajo, su interacción con el equipo de fabricación y la manera en que funcionarán los controles en un entorno determinado. Este enfoque en equipo aumenta la probabilidad de elegir el control más adecuado (desde distintas perspectivas).

\section{Idoneidad de las propiedades de advertencia}

C uando se intenta proteger a un trabajador de un riesgo para la salud en el trabajo, deben tenerse en cuenta las propiedades que advierten de la presencia de un material, como su olor o la irritación que produce. Por ejemplo, si un empleado trabaja con un semiconductor en una zona en la que se utiliza arsenamina, la extrema toxicidad del gas supone un importante riesgo potencial. La situación se agrava por las escasas propiedades de advertencia de la arsenamina; los trabajadores no pueden detectar la arsenamina por la vista o el olfato hasta que su concentración no ha superado ya los niveles aceptables. En un caso así, no pueden aceptarse los controles que son marginalmente eficaces para mantener las exposiciones por debajo de unos niveles aceptables, porque los trabajadores no pueden detectar cuándo se superan esos niveles. La solución en este caso consiste en instalar controles técnicos que aíslen al trabajador del material. Además, debe instalarse un detector continuo de la arsenamina que advierta a los trabajadores de un eventual fallo de los controles técnicos. En situaciones en las que existe el riesgo de exposición de elevada toxicidad y escasas propiedades de advertencia, se practica la higiene industrial preventiva. El higienista industrial debe abordar cada problema de exposición con una actitud flexible y reflexiva.

\section{Nivel aceptable de exposición}

Si se estudia la aplicación de controles para proteger a un trabajador de una sustancia como la acetona, cuyo nivel aceptable de exposición puede ser del orden de 800 ppm, dicho nivel puede reducirse a 400 ppm 0 menos con relativa facilidad. EI ejemplo 
de la acetona contrasta con el control del 2-etoxietanol, cuyo nivel aceptable de exposición puede estar en el rango de 0,5 ppm. Para conseguir el mismo porcentaje de reducción $(0,5 \mathrm{ppm}$ a $0,25 \mathrm{ppm}$ ) probablemente se necesitarían diferentes controles. De hecho, con unos niveles de exposición tan bajos, el aislamiento del material puede convertirse en el principal medio de control. Cuando los niveles de exposición son elevados, la ventilación puede conseguir la reducción necesaria. Así pues, el nivel aceptable establecido (por el gobierno, la empresa, etc.) para una sustancia puede condicionar la elección de los controles.

\section{Frecuencia de la exposición}

El modelo clásico para evaluar la toxicidad utiliza la siguiente relación:

$$
\text { TIEMPO } \times \text { CONCENTRACION = DOSIS }
$$

La dosis, en este caso, es la cantidad de material que está disponible para su absorción. H asta ahora se ha hablado de intentar minimizar (reducir) el componente de la concentración en esta ecuación. También se puede reducir la duración de la exposición (la razón que justifica los controles administrativos). A sí se reduciría igualmente la dosis. El problema aquí no es que el trabajador pase cierto tiempo en una zona contaminada, sino la frecuencia con que realiza una operación (tarea). Esta distinción es importante. En el primer ejemplo, la exposición se controla alejando a los trabajadores de la zona en la que están expuestos a determinada cantidad de un agente tóxico. El esfuerzo de la intervención no está encaminado hacia el control de la cantidad de sustancia tóxica (en muchas situaciones, puede utilizarse un enfoque combinado). En el segundo caso, la frecuencia de la operación se utiliza para introducir los controles adecuados, no para establecer un horario de trabajo. Por ejemplo, si una operación, como el desengrasado, es realizada rutinariamente por un trabajador, los controles pueden consistir en medidas de ventilación, sustitución por un disolvente menos tóxico o incluso automatización del proceso. Si la operación se realiza con poca frecuencia (p. ej., una vez al trimestre), los equipos de protección personal pueden constituir una alternativa adecuada (dependiendo de muchos de los factores que se describen en esta sección). Como ilustran estos dos ejemplos, la frecuencia con que se realiza una operación puede afectar directamente a la selección de controles. Cualquiera que sea la situación de exposición, la frecuencia con que un trabajador realiza las tareas debe tenerse en cuenta a la hora de elegir los controles.

O bviamente, la vía de exposición influye en la elección del método de control. Si se trata de un irritante respiratorio, se considerará el uso de ventilación, respiradores, etc. El reto para el higienista industrial es identificar todas las vías de exposición. Por ejemplo, los éteres de glicol se utilizan como disolventes transportadores en las operaciones de impresión. Se puede medir su concentración atmosférica en la zona de respiración e introducir controles. Sin embargo, los éteres de glicol se absorben rápidamente a través de la piel intacta. La piel representa una importante vía de exposición y debe tenerse en cuenta. De hecho, si se usan unos guantes inadecuados, la exposición de la piel puede continuar mucho tiempo después de que se haya reducido la exposición ambiental (si el trabajador sigue utilizando los guantes contaminados). EI higienista debe evaluar la sustancia — sus propiedades físicas, químicas y toxicológicas para determinar qué vías de exposición son posibles y probables (dependiendo de las tareas que realiza el trabajador).

A la hora de elegir los controles, uno de los factores que deben tenerse en cuenta son los requisitos normativos al respecto. Puede haber códigos profesionales, reglamentos, etc., que impongan una determinada serie de controles. El higienista industrial puede actuar con flexibilidad respecto de los requisitos normativos, pero debe aplicar los controles mínimos obligatorios. O tro aspecto de los requisitos normativos es que los controles obligatorios pueden ser menos eficaces o entrar en conflicto con la opinión del higienista industrial. En estas situaciones, el higienista debe ser creativo y encontrar soluciones que satisfagan tanto los requisitos normativos como los objetivos de buena práctica de la organización.

\section{Formación e información}

Sea cual sea el tipo de intervención que se elija finalmente, deben facilitarse formación y otras vías de información para que los trabajadores conozcan las intervenciones, la razón por la que se han elegido, las reducciones de la exposición previstas y el papel que ellos desempeñan para conseguir esas reducciones. Sin la participación y el conocimiento de los trabajadores, es probable que las intervenciones fracasen o tengan una eficacia reducida. La formación sensibiliza a la plantilla respecto a la existencia de peligros. Esta sensibilización puede ser de gran valor para el higienista industrial que intenta identificar y reducir exposiciones nuevas o no detectadas previamente. La formación, el etiquetado y otras actividades relacionadas pueden formar parte de un programa de cumplimiento de los requisitos normativos. Sería conveniente verificar la legislación local, para tener la seguridad de que las medidas de formación o etiquetado adoptadas satisfacen tanto los requisitos legales como los operativos.

\section{Conclusión}

En esta breve descripción de las intervenciones, se han presentado algunos aspectos generales para estimular la reflexión. En la práctica, estas normas adquieren una gran complejidad y tienen con frecuencia importantes implicaciones para la salud de los trabajadores y de la empresa. El juicio profesional del higienista industrial es esencial para elegir los mejores controles. "M ejor" es un término que tiene muchos significados diferentes. El higienista industrial debe promover el trabajo en equipo y la colaboración de los trabajadores, la dirección y el personal técnico.

\section{FUNDAMENTOS BIOLOGICOS PARA EVALUAR LA EXPOSICION}

\section{Dick H eederik}

La evaluación de la exposición en el lugar de trabajo consiste en identificar y evaluar los agentes con los que un trabajador puede entrar en contacto. Se pueden construir índices de exposición que reflejen la cantidad de un agente presente en el medio ambiente en general 0 en el aire inhalado, y la cantidad de un agente que realmente se inhala, se traga o se absorbe por otras vías (ingesta). 0 tros índices reflejan la cantidad de agente que se reabsorbe (absorción) y la exposición en el órgano diana. La dosis es un término farmacológico o toxicológico utilizado para indicar la cantidad de una sustancia que se administra a una persona. La frecuencia de dosis es la cantidad de sustancia administrada por unidad de tiempo. La dosis de una exposición en el lugar de trabajo es difícil de determinar en la práctica, puesto que los procesos físicos y biológicos, como la inhalación, la absorción y la distribución de un agente en el organismo humano establecen entre la exposición y la dosis relaciones complejas no lineales. La incertidumbre sobre el nivel real de exposición a los agentes hace además que sea difícil cuantificar la relación existente entre exposición y efecto en la salud. 
Para muchas exposiciones profesionales, existe un intervalo de tiempo, durante el cual la exposición o la dosis alcanzan la mayor importancia, para el desarrollo de un determinado problema de salud o síntoma. Por consiguiente, la exposición, o la dosis, biológicamente importante sería la que se produce durante el intervalo de tiempo. Se cree que algunas exposiciones a cancerígenos en el lugar de trabajo tienen este tipo de intervalo de tiempo relevante. El cáncer es una enfermedad con un largo período de latencia y, por consiguiente, puede ocurrir que la exposición que causa el desarrollo definitivo de la enfermedad tenga lugar muchos años antes de que el cáncer se manifieste. Es, por tanto, un fenómeno arbitrario ya que lo que cabría esperar es que la exposición acumulada a lo largo de toda una vida profesional fuera el parámetro relevante. Es posible que la exposición que se produce en el momento de manifestarse la enfermedad no tenga especial importancia.

La pauta de exposición - continua, intermitente, con o sin picos agudos - puede ser también relevante. Es importante tenerla en cuenta tanto para los estudios epidemiológicos como para las mediciones ambientales que se utilizan para observar el cumplimiento de las normas sanitarias y los controles ambientales en el marco de los programas de prevención y control. Por ejemplo, si un efecto en la salud está causado por exposiciones pico, estos picos deben ser medidos para que puedan ser controlados. Las observaciones que sólo facilitan datos sobre exposiciones medias durante largos períodos de tiempo no tiene gran utilidad, puesto que los valores de desviación de los picos pueden quedar ocultos por la obtención del valor promedio $y_{\text {, }}$ desde luego, no pueden controlarse en el momento en que ocurren.

M uchas veces se desconoce la exposición o la dosis biológicamente relevante para un determinado efecto, porque las pautas de ingesta, absorción, distribución y eliminación, o los mecanismos de biotransformación, no se conocen con suficiente detalle. Tanto el conocimiento de la velocidad a la que un agente entra y abandona el organismo (cinética) como el de los procesos bioquímicos que sufre la sustancia (biotransformación) ayudan a determinar las relaciones entre exposición, dosis y efecto.

El control ambiental consiste en la medición y evaluación de los agentes presentes en el lugar de trabajo para evaluar la exposición ambiental y los consiguientes riesgos para la salud. EI control biológico consiste en la medición y evaluación de los agentes presentes en el lugar de trabajo o de sus metabolitos en los tejidos, secreciones o excreciones para evaluar la exposición y los riesgos para la salud. A lgunas veces se utilizan biomarcadores, como aductos del ADN, para medir la exposición. Los biomarcadores sirven también como indicadores de los mecanismos del propio proceso de la enfermedad, pero este es un tema complejo que se aborda con más detalle en el capítulo Control biológico y más adelante en esta sección.

El modelo básico de exposición-respuesta puede esquematizarse de la siguiente forma

$$
\begin{gathered}
\text { exposición } \rightarrow \text { absorción } \rightarrow \text { distribución, eliminación, } \\
\text { transformación } \rightarrow \text { dosis en el órgano diana objetivo } \rightarrow \\
\text { fisiopatología } \rightarrow \text { efecto }
\end{gathered}
$$

Dependiendo del agente, las relaciones entre exposición-absorción y exposición-ingesta pueden ser complejas. Para muchos gases pueden realizarse aproximaciones sencillas basadas en la concentración atmosférica del agente durante una jornada de trabajo y en la cantidad de aire inhalado. Para el muestreo del polvo debe tenerse en cuenta, además, que el depósito de las partículas es función de su tamaño. Las consideraciones sobre el tamaño pueden aumentar también la complejidad de la relación. En el capítulo Sistema respiratorio se facilitan más detalles sobre el aspecto de la toxicidad respiratoria.

La valoración de la exposición y la dosis es un elemento de la valoración cuantitativa del riesgo. Los métodos de evaluación del riesgo para la salud suelen constituir la base para establecer los límites de exposición correspondientes a los niveles de emisión de agentes tóxicos en el aire que se definen en las normas ambientales y laborales. EI análisis del riesgo para la salud proporciona una estimación de la probabilidad (riesgo) de que ocurran determinados efectos en la salud o una estimación del número de casos con esos efectos. EI análisis del riesgo para la salud permite establecer una concentración aceptable de un agente tóxico en el aire, el agua o los alimentos, dada una magnitud de riesgo aceptable elegida a priori. El análisis cuantitativo del riesgo ha encontrado una aplicación en la epidemiología del cáncer, lo que explica la importancia que se concede a la evaluación retrospectiva de la exposición. Sin embargo, otras estrategias más elaboradas de evaluación de la exposición se aplican también a evaluaciones tanto prospectivas como retrospectivas de la misma. Los principios de la evaluación de la exposición se han aplicado también al estudio de otros efectos, como las enfermedades respiratorias benignas (Wegman y cols. 1992; Post y cols. 1994). En este momento, predominan dos líneas de investigación. U na de ellas utiliza estimaciones de la dosis obtenidas de la información procedente de las mediciones ambientales, y la otra se basa en los biomarcadores como medidas de la exposición.

\section{Control de la exposición y predicción de la dosis}

Lamentablemente, el número de datos cuantitativos sobre muchos tipos de exposición es insuficiente para predecir el riesgo de desarrollar determinado efecto. Ya en 1924, Haber postuló que la gravedad del efecto en la salud $(H)$ es proporcional al producto de la concentración de la exposición $(X)$ y la duración de la exposición $(T)$ :

$$
H=X \cdot T
$$

La ley de $\mathrm{H}$ aber, que es como se denomina, constituyó la base para desarrollar la idea de que las mediciones de la exposición media ponderada en el tiempo (TWA) - es decir, mediciones realizadas y promediadas durante un cierto período de tiemposerían una medida útil de la exposición. Este supuesto sobre la validez de la media ponderada en el tiempo se ha cuestionado durante muchos años. En 1952, Adams y sus colaboradores afirmaron que "no existe ningún fundamento científico que justifique el uso de la media ponderada en el tiempo para integrar exposiciones variables ..." (en Atherly 1985). El problema es que muchas relaciones son más complejas que la relación que representa la ley de $\mathrm{H}$ aber. Existen muchos ejemplos de agentes cuyos efectos dependen más de su concentración que de la duración de la exposición. Por ejemplo, los estudios de laboratorio han aportado interesantes evidencias de que en ratas expuestas a tetracloruro de carbono, la pauta de exposición (continua frente a intermitente y con o sin picos) así como la dosis pueden modificar el riesgo observado de que las ratas experimenten cambios en la concentración de enzimas hepáticas (Bogers y cols. 1987). O tro ejemplo es el de los bioaerosoles, como la enzima $\alpha$-amilasa, un mejorador de la masa que puede causar enfermedades alérgicas a los trabajadores de la industria panadera (H ouba y cols. 1996). $\mathrm{N}$ o se sabe si el riesgo de desarrollar esta enfermedad depende principalmente de las exposiciones pico, de la exposición media 0 del nivel acumulado de exposición (Wong 1987; Checkoway y Rice 1992). No se dispone de información sobre las pautas temporales de la mayoría de los agentes, especialmente de los agentes que tienen efectos crónicos. 
Los primeros modelos de las pautas de exposición y la estimación de la dosis fueron publicados en los decenios de 1960 y 1970 por Roach (1966; 1977). Roach demostró que la concentración de un agente alcanza un valor de equilibrio en el receptor tras una exposición de duración infinita, porque la eliminación contrarresta la absorción del agente. En una exposición de ocho horas, este nivel de equilibrio puede alcanzar un valor del $90 \%$ si la semivida del agente en el órgano diana es inferior a unas dos horas y media. Esto indica que la dosis en el órgano diana de los agentes con semivida corta está determinada por una exposición inferior a ocho horas. La dosis en el órgano diana es una función del producto del tiempo de exposición y la concentración de agentes con semivida larga. $R$ appaport (1985) ha aplicado un enfoque similar aunque más elaborado, y ha demostrado que la variabilidad de la exposición dentro de un mismo día tiene una influencia limitada cuando se trata de agentes con semivida larga. Introdujo el término efecto amortiguador en el receptor.

La información anterior se ha utilizado principalmente para extraer conclusiones sobre los tiempos medios adecuados para medir la exposición y a efectos de cumplimiento de los requisitos legales. Desde que se publicaron los artículos de Roach, se acepta que, para estimar la exposición a irritantes, deben tomarse muestras puntuales durante cortos intervalos medios de tiempo, mientras que para los agentes con semivida larga, como el amianto, tiene que estimarse la exposición media acumulada durante un período de tiempo largo. No obstante, hay que tener presente que la dicotomización entre estrategias de muestreo puntual y estrategias de exposición media acumulada durante ocho horas, según se ha adoptado en muchos países para cumplir los requisitos legales, constituye una aplicación extremadamente simple de los principios biológicos descritos.

En el artículo de Wegman y cols. (1992) se ofrece un ejemplo de cómo mejorar una estrategia de evaluación de la exposición basándose en los principios farmacocinéticos en el campo de la epidemiología. Estos autores aplicaron una interesante estrategia de evaluación de la exposición utilizando dispositivos de vigilancia continua para medir las exposiciones pico del personal al polvo y relacionarlas con síntomas respiratorios reversibles agudos cada 15 minutos. Un problema conceptual de este tipo de estudios, que los autores comentan con detalle en su artículo, es la definición de lo que es una exposición pico relevante para la salud. La definición del pico dependerá a su vez de consideraciones biológicas. R appaport (1991) formula dos requisitos para que las exposiciones pico tengan importancia etiológica en el proceso de la enfermedad: (1) el agente se elimina rápidamente del organismo, y (2) existe una velocidad no lineal de daño biológico durante una exposición pico. Las velocidades no lineales de daño biológico pueden estar relacionadas con cambios en la absorción, que a su vez están relacionados con los niveles de exposición, la sensibilidad del huésped, la sinergia con otras exposiciones, la participación de otros mecanismos de enfermedad a exposiciones más elevadas o niveles umbral para la progresión de la enfermedad.

Estos ejemplos indican también que los enfoques farmacocinéticos pueden servir para fines distintos de la estimación de la dosis. Los resultados de los modelos farmacocinéticos pueden utilizarse también para analizar la relevancia biológica de los índices de exposición existentes y para diseñar nuevas estrategias de evaluación de la exposición relevante para la salud.

Los modelos farmacocinéticos de la exposición pueden generar, asimismo, estimaciones de la dosis real en el órgano diana. Por ejemplo, en el caso del ozono, un gas irritante agudo, se han desarrollo modelos que predicen la concentración tisular en las vías respiratorias como función de la concentración media del ozono en el aire contenido en el pulmón a una cierta distancia de la tráquea, el radio de las vías respiratorias, la velocidad media del aire, la dispersión efectiva y el flujo de ozono del aire a la superficie del pulmón (Menzel 1987; Miller y 0 verton 1989). Este tipo de modelos pueden utilizarse para predecir la dosis de ozono en una región concreta de las vías respiratorias, dependiendo de las concentraciones ambientales de ozono y de las pautas de respiración.

En la mayoría de los casos, la estimación de la dosis en el órgano diana se basa en información sobre la pauta de exposición a lo largo del tiempo, los antecedentes profesionales y la información farmacocinética sobre la absorción, distribución, eliminación y transformación del agente. Todo el proceso puede describirse mediante una serie de ecuaciones que se resuelven matemáticamente. M uchas veces no se dispone de información sobre los parámetros farmacocinéticos en el ser humano y tienen que utilizarse estimaciones de los parámetros derivadas de experimentos animales. Existen ya varios ejemplos del uso de los modelos farmacocinéticos de la exposición para calcular las dosis. Las primeras referencias bibliográficas al uso de modelos para convertir los datos sobre la exposición en estimaciones de la dosis se remontan al artículo de Jahr (1974).

Aunque, en términos generales, las estimaciones de las dosis no se han validado y han tenido una aplicación limitada en los estudios epidemiológicos, se espera que la nueva generación de índices de exposición o dosis dé lugar a un análisis óptimo de la relación exposición-respuesta en los estudios epidemiológicos (Smith 1985, 1987). Un problema que todavía no se ha abordado en los modelos farmacocinéticos es el de las grandes diferencias que existen en la cinética de los agentes tóxicos en distintas especies y, por consiguiente, los efectos de la variación de los parámetros farmacocinéticos en distintas personas son de gran interés (D roz 1992).

\section{Control biológico y biomarcadores de la exposición}

El control biológico permite obtener una estimación de la dosis y, por consiguiente, suele considerarse superior al control ambiental. Sin embargo, la variabilidad de los índices que se emplean para el control Biológico puede ser considerable incluso en una misma persona. Para obtener una estimación aceptable de la dosis a la que se ve expuesta un trabajador, tienen que realizarse mediciones repetidas y el esfuerzo de medición puede llegar a ser mayor que el del control ambiental.

Este hecho se ilustra con un interesante estudio sobre los trabajadores de una fábrica de barcos de plástico reforzado con fibra de vidrio (R appaport y cols. 1995). La variabilidad de la exposición al estireno se evaluó midiendo repetidamente el contenido ambiental de estireno. Se midió el contenido de estireno en el aire exhalado por los trabajadores expuestos, así como los intercambios de cromátidas hermanas. Se demostró que un estudio epidemiológico que utilizase el estireno ambiental como medida de la exposición sería más eficiente, en términos del número de mediciones necesarias, que un estudio que utilizase los otros índices de exposición. Para medir el estireno en el aire se realizaron tres mediciones repetidas, a fin de calcular la exposición media a largo plazo con una precisión determinada. Para medir el estireno en el aire exhalado se realizaron cuatro mediciones repetidas en cada trabajador, mientras que para determinar los intercambios de cromátidas hermanas se realizaron 20 mediciones repetidas. Esta observación se explica por la relación entre señal y ruido, determinada por la variabilidad en la exposición de un día a otro y de un trabajador a otro, que fue más favorable en el caso del estireno ambiental que para los dos biomarcadores de la exposición. Así pues, aunque la relevancia biológica de un cierto indicador de la exposición sea óptima, el resultado de un análisis de exposición-respuesta puede seguir 
siendo insatisfactorio debido a una menor relación entre señal y ruido, que introduce un error de clasificación incorrecta.

D roz (1991) aplicó modelos farmacocinéticos para estudiar las ventajas de los métodos de evaluación de la exposición basados en la toma de muestras del aire comparados con los métodos de control Biológico dependientes de la semivida del agente. Demostró que el control biológico se ve también muy afectado por la variabilidad biológica, que no está relacionada con la variabilidad del ensayo toxicológico. Sugirió que el uso de indicadores biológicos no ofrece ninguna ventaja estadística cuando la semivida del agente considerado es inferior a unas diez horas.

Aunque parece más adecuado medir la exposición ambiental en lugar de un indicador biológico de su efecto por la variabilidad de la variable medida, se pueden encontrar otros argumentos en favor del uso de un biomarcador, incluso cuando eso suponga un mayor esfuerzo de medición, como cuando existe una considerable exposición dérmica. Para agentes como los pesticidas y algunos disolventes orgánicos, la exposición dérmica puede tener mayor relevancia que la exposición ambiental. U n biomarcador de la exposición incluiría esta vía de exposición, mientras que la medición de la exposición dérmica es compleja y sus resultados no son fáciles de interpretar (Boleij y cols. 1995). Los primeros estudios de trabajadores agrícolas en los que se utilizaron "parches" para evaluar la exposición dérmica detectaron importantes cantidades de pesticidas en la superficie corporal, dependiendo de las tareas que realizaba cada trabajador. Sin embargo, debido a la escasa información disponible sobre la absorción por la piel, todavía no pueden utilizarse los perfiles de exposición para calcular una dosis interna.

Los biomarcadores pueden ofrecer también ventajas considerables en la epidemiología del cáncer. C uando un biomarcador es un marcador precoz del efecto, su uso puede tener como resultado la reducción del período de seguimiento. Aunque todavía tienen que realizarse estudios de validación, los biomarcadores de la exposición o de la sensibilidad individual podrían dar lugar a estudios epidemiológicos más potentes y a estimaciones más precisas del riesgo.

\section{Análisis del intervalo de tiempo}

De forma paralela al desarrollo de los modelos farmacocinéticos, los epidemiólogos han explorado nuevos enfoques para el análisis de los datos, como el "análisis del marco temporal" para relacionar períodos relevantes de exposición con determinados efectos, y para considerar la influencia de las pautas temporales en la exposición o las exposiciones pico dentro del campo de la epidemiología del cáncer profesional (Checkoway y Rice 1992). Desde el punto de vista conceptual, esta técnica está relacionada con los modelos farmacocinéticos, ya que la relación entre exposición y resultado se optimiza asignando coeficientes de ponderación a los diferentes períodos, pautas y niveles de exposición. En los modelos farmacocinéticos, se cree que estos coeficientes de ponderación tienen un significado fisiológico y se estiman por adelantado. En el análisis del marco temporal, los coeficientes de ponderación se estiman a partir de los datos aplicando criterios estadísticos. H odgson y Jones (1990) ofrecen ejemplos de este método en su análisis de la relación entre la exposición al gas radón y el cáncer de pulmón en una cohorte de mineros del estaño en el Reino U nido. Seixas, Robins y Becker (1993) analizaron la relación entre la exposición al polvo y las enfermedades respiratorias en una cohorte de mineros del carbón en Estados Unidos. Un estudio muy interesante que pone de manifiesto la importancia del análisis del intervalo de tiempo es el realizado por Peto y cols. (1982). Estos autores demostraron que las tasas de mortalidad por mesotelioma en una cohorte de trabajadores de aislamientos parecían ser proporcionales a una función del tiempo transcurrido desde la primera exposición y la exposición acumulada. El tiempo transcurrido desde la primera exposición tenía especial relevancia, puesto que esta variable era una aproximación del tiempo necesario para que una fibra emigre de su lugar de depósito en los pulmones a la pleura. Este ejemplo demuestra que la cinética de depósito y migración determina en gran medida la función del riesgo. U n posible problema del análisis del marco temporal es que requiere información detallada sobre los períodos y niveles de exposición, lo cual dificulta su aplicación en muchos estudios de enfermedades crónicas.

\section{Comentarios finales}

En conclusión, los principios en los que se basan los modelos farmacocinéticos y los análisis del marco temporal o el intervalo de tiempo son ampliamente aceptados. Los conocimientos en este campo se han utilizado principalmente para desarrollar estrategias de evaluación de la exposición. Sin embargo, para hacer un

Figura 30.9 • Cronología de los límites de exposición profesional (O EL).

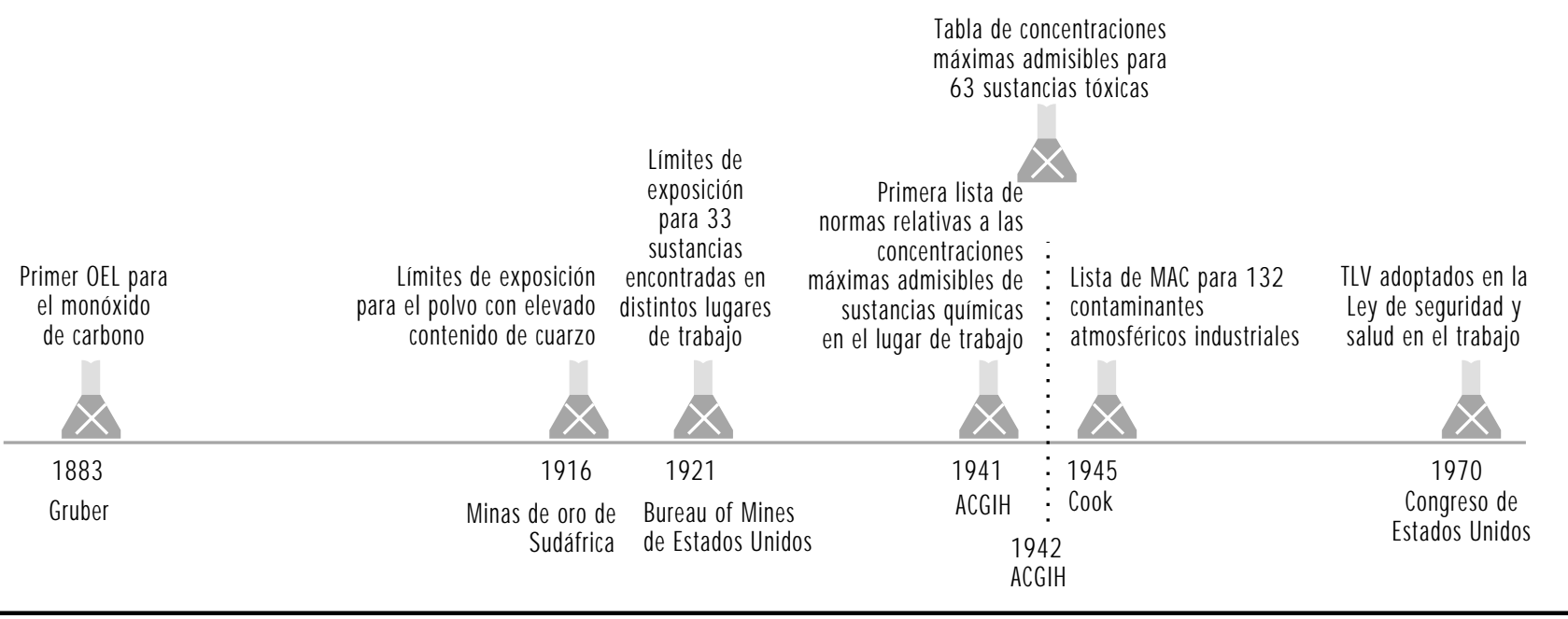


uso más elaborado de estos métodos, se requiere un considerable esfuerzo de investigación. Por consiguiente, el número de aplicaciones es aún limitado. Las aplicaciones relativamente sencillas, como el desarrollo de estrategias óptimas de evaluación de la exposición en función del efecto, son las que más se utilizan. U na importante cuestión en el desarrollo de biomarcadores de la exposición 0 el efecto es la validación de estos índices. Con frecuencia se supone que un biomarcador cuantificable permite predecir los riesgos para la salud mejor que los métodos tradicionales. Lamentablemente, muy pocos estudios de validación justifican este supuesto.

\section{- LIMITES DE EXPOSICION PROFESIONAL}

Dennis J. Paustenbach

\section{Historia de los límites de exposición profesional}

En los últimos 40 años, muchas organizaciones de distintos países han propuesto límites de exposición profesional $(O E L)$ para los contaminantes ambientales. Los límites o directrices que se han convertido gradualmente en los más aceptados en Estados Unidos y en la mayoría de los demás países son los que publica anualmente la Conferencia A mericana de $\mathrm{H}$ igienistas I ndustriales del Gobierno (ACGIH), que se denominan valores límite umbral (T LV) (LaNier 1984; C ook 1986; AC GIH 1994).

Desde que se establecieron $O E L$ para agentes potencialmente nocivos en el medio ambiente de trabajo, se ha demostrado repetidamente su utilidad (Stokinger 1970; Cook 1986; Doull 1994). La contribución de los O EL a la prevención o reducción al mínimo de las enfermedades profesionales es ahora un hecho ampliamente aceptado, pero durante muchos años estos límites no existían o no se respetaban (Cook 1945; Smyth 1956; Stokinger 1981; LaN ier 1984; Cook 1986).

Ya en el siglo XV se sabía que el polvo y las sustancias químicas suspendidas en el aire podían causar enfermedades y lesiones, pero no estaba claro cuáles eran las concentraciones y duración de la exposición a las que se podía esperar que esto ocurriera (R amazinni 1700).

Según Baetjer (1980): "A principios de este siglo, cuando la D ra. Alice $\mathrm{H}$ amilton inició su distinguida carrera en la medicina del trabajo, no se tomaban muestras del aire ni existían límites, pero tampoco eran necesarios. La sola observación de las condiciones de trabajo y de las enfermedades y la muerte de trabajadores demostraban directamente que existían exposiciones nocivas. Sin embargo, la necesidad de establecer niveles para una exposición segura se hizo pronto evidente."

L os primeros intentos de establecer un $\mathrm{OEL}$ se centraron en el monóxido de carbono, el gas tóxico al que más personas están expuestos en su lugar de trabajo (para una cronología del desarrollo de los OEL, véase la Figura 30.9. EI trabajo de $M$ ax Gruber en el Instituto de Higiene de Munich se publicó en 1883. En su artículo, describía la exposición de dos gallinas y doce conejos a concentraciones conocidas de monóxido de carbono durante un período de hasta 47 horas a lo largo de tres días; su conclusión fue que: "El límite para que se manifieste el efecto nocivo del monóxido de carbono se encuentra con toda probabilidad en una concentración de 500 partes por millón, pero con seguridad (en no menos de) 200 partes por millón." Para llegar a esta conclusión, el propio Gruber había inhalado monóxido de carbono. No presentó sensaciones ni síntomas molestos después de tres horas de exposición durante dos días consecutivos a concentraciones de 210 partes por millón y 240 partes por millón (C ook 1986).

Las primeras y más extensas series de experimentos con animales sobre los límites de exposición fueron las realizadas por K .B. Lehmann y otros investigadores bajo su dirección. En una serie de publicaciones que hacían referencia a un período de 50 años, describieron sus estudios con amoniaco, cloruro de hidrógeno (gas), hidrocarburos clorados y muchas otras sustancias químicas (Lehmann 1886; L ehmann y Schmidt-K ehl 1936).

K obert (1912) publicó una de las primeras tablas de límites de exposición aguda. Contenía las concentraciones correspondientes a 20 sustancias clasificadas como: (1) rápidamente mortales para el ser humano y los animales, (2) peligrosas en el plazo de media hora a una hora, (3) de media hora a una hora sin trastornos graves, y (4) sólo se observan síntomas mínimos. En su artículo "Interpretations of permissible limits", Schrenk (1947) observa que "los valores indicados para el ácido clorhídrico, el cianuro de hidrógeno, el amoniaco, el cloro y el bromo bajo el epígrafe 'sólo síntomas mínimos al cabo de varias horas' en el citado artículo de K obert coinciden con los valores habitualmente aceptados en las actuales tablas de concentración máxima admisible (M ACs) para exposiciones declaradas". Sin embargo, los valores correspondientes a algunos de los disolventes orgánicos más tóxicos, como el benceno, el tetracloruro de carbono y el disulfuro de carbono, superaban con creces a los que se aplicaron posteriormente (C ook 1986).

Una de las primeras tablas de límites de exposición elaboradas en Estados U nidos fue la publicada por el Bureau of $M$ ines de Estados U nidos (Fieldner, K atz y Kenney 1921). Aunque su título no lo indica, las 33 sustancias enumeradas son las que se encuentran en los lugares de trabajo. Cook (1986) observó también que la mayoría de los límites de exposición establecidos durante el decenio de 1930, excepto para el polvo, se basaban en experimentos bastante cortos con animales. U na notable excepción fue el estudio sobre la exposición crónica al benceno realizado por Leonard Greenburg, del Public $\mathrm{H}$ ealth Service de Estados Unidos, bajo la dirección de un comité del National Safety Council (N SC 1926). De este trabajo se derivó una exposición aceptable para el ser humano basada en experimentos animales de larga duración.

Según Cook (1986), los límites admisibles para las exposiciones al polvo establecidos antes de 1920 se basaban en la exposición de los trabajadores de las minas de oro de Sudáfrica, donde el polvo generado por las operaciones de perforación tenía un elevado contenido de sílice libre cristalino. En 1916, se estableció un límite de exposición de 8,5 millones de partículas por pie cúbico de aire (mppcf) para el polvo con un contenido de cuarzo del $80 \%$ al $90 \%$ (Phthisis Prevention Committee 1916). $M$ ás adelante, el nivel se redujo a 5 mppcf. C ook señala también que, en Estados U nidos, las normas aplicadas para el polvo, basadas también en la exposición de los trabajadores, fueron recomendadas por $\mathrm{H}$ iggins y sus colaboradores después de realizar un estudio en las minas de cinc y plomo del suroeste de Missouri en 1917.

EI nivel inicial establecido para el polvo con alto contenido de cuarzo era de diez mppcf, apreciablemente mayor que el establecido en los estudios sobre el polvo realizados posteriormente por el Public Health Service de Estados Unidos. En 1930, el M inisterio de Trabajo de la URSS publicó un decreto en el que se establecían concentraciones máximas admisibles para 12 sustancias industriales tóxicas.

La lista más completa de límites de exposición profesional hasta 1926 contenía 27 sustancias (Sayers 1927). En 1935, Sayers y $D$ alle Valle publicaron las respuestas fisiológicas a cinco concentraciones de 37 sustancias, siendo la quinta la concentración máxima admisible para exposiciones prolongadas. 


$\begin{array}{ll}\text { País/ Provincia } & \text { Tipo de norma } \\ \text { Argentina } & \text { Los OEL son esencialmente los mismos que los TLV establecidos por la ACGIH en 1978. La principal diferencia respecto de la lista de la ACGIH } \\ & \text { es que en ésta no se establecen STEL (límites de exposición para períodos cortos) para } 144 \text { sustancias (del total de 630), mientras que en } \\ \text { Argentina, para esas sustancias, el valor que se aplica como TWA aparece también en la categoría de STEL } & \text { Eustralia } \\ & \text { El National Health and Medical Research Council (NHMRC) adoptó en } 1952 \text { una edición revisada de Occupational Health Guide Threshold Limit } \\ & \text { Values (1990-91). Los OEL no tienen categoría legal en Australia, excepto cuando se incorporan específicamente en la ley por referencia. Los } \\ & \text { TLV de la ACGIH se publican en Australia como anexO a las guías de la salud en el trabajo, revisadas junto con las revisiones de la ACGIH en } \\ \text { años impares. }\end{array}$

Austria

Los valores recomendados por el Comité de Expertos de la Comisión de la Protección de los Trabajadores para la Evaluación de los Valores MAC (concentración máxima admisible), en cooperación con el Instituto General de Prevención de Accidentes del Sindicato de Trabajadores Químicos, son considerados obligatorios por el Ministerio Federal de Administración Social. Son responsables de su aplicación los Inspectores del Trabajo, de conformidad con la Ley de protección del trabajo.

Bélgica La Administración de Higiene y Medicina del Trabajo del Ministerio de Empleo y Trabajo utiliza los TLV de la ACGIH como directriz.

Brasil

Desde 1978, se han utilizado los TLV de la ACGIH como base para la legislación brasileña sobre la salud en el trabajo. Como la semana laboral en Brasil es normalmente de 48 horas, los valores de la ACGIH se ajustaron de acuerdo con una fórmula desarrollada para este fin. La lista de la ACGIH fue adoptada sólo para los contaminantes ambientales que en ese momento tenían aplicación a escala nacional. El Ministerio de Trabajo ha actualizado los límites y ha establecido valores para otros contaminantes, de acuerdo con las recomendaciones de la Fundación Fundacentro de Seguridad y Medicina del Trabajo.

Canadá (y provincias)

Alberta

Cada provincia tiene su propia normativa:

LOS OEL están regulados en la Ley de seguridad y salud en el trabajo, Reglamento sobre riesgos químicos, que exige al empresario que garantice que los trabajadores no estén expuestos por encima de esos límites.

Columbia Británica Los Reglamentos sobre salud y seguridad industrial establecen requisitos legales aplicables a la mayor parte de la industria de la provincia, que hacen referencia a la lista actual de TLV para contaminantes ambientales publicada por la ACGIH.

Manitoba

El Departamento de Medio Ambiente y Seguridad y Salud en el Lugar de Trabajo es responsable de la legislación y de su aplicación con relación a los OEL. Las directrices que se utilizan actualmente para interpretar el riesgo para la salud son los TLV de la ACGIH, con la excepción de los cancerígenos, para los cuales se prescribe un nivel de exposición cero "en la medida en que sea razonablemente posible".

New Brunswick Los límites aplicados corresponden a la última versión de la ACGIH y, en caso de infracción, es la versión publicada en el momento de la infracción la que dicta el cumplimiento.

Territorios del Noroeste La División de Seguridad de los Territorios del Noroeste del Departamento de Justicia y Servicios regula la seguridad en el lugar de trabajo de los trabajadores no federales de acuerdo con la última edición de los TLV de la ACGIH.

Nueva Escocia La lista de OEL es la misma que la de la ACGIH publicada en 1976, con sus posteriores modificaciones y revisiones.

Ontario La normativa referente a una serie de sustancias peligrosas se aplica en virtud de la Ley de salud y seguridad en el trabajo y se publica en folletos distintos para cada sustancia, en los que se incluyen el nivel de exposición admisible y los códigos para los equipos respiratorios, las técnicas para medir las concentraciones ambientales y estrategias de control médico.

Quebec Los niveles de exposición admisibles son similares a los TLV de la ACGIH y los niveles de exposición admisibles para los contaminantes ambientales en el lugar de trabajo son de obligado cumplimiento.

Chile

La concentración máxima de once sustancias que pueden causar efectos agudos, graves o fatales no puede superarse en ningún caso. Los valores límite establecidos en Chile coinciden con los TLV de la ACGIH, a los que se aplica un factor de 0,8 para considerar la semana laboral de 48 horas.

Dinamarca LOS OEL incluyen valores para 542 sustancias químicas y 20 sustancias particuladas. En general, la ley obliga a que estos límites no se superen como medias ponderadas en el tiempo. Los datos de la ACGIH se utilizan para definir los límites. Aproximadamente el $25 \%$ de los valores son diferentes a los de la ACGIH, y casi todos estos son algo más estrictos.

Ecuador Ecuador no ha incorporado a su legislación una lista de niveles de exposición admisibles. Los TLV de la ACGIH se utilizan como orientación para una buena práctica de la higiene industrial.

Finlandia $\quad$ LOS OEL se definen como las concentraciones que se consideran peligrosas al menos para algunos trabajadores expuestos durante largos períodos de tiempo. Mientras que la ACGIH tiene como principio que casi todos los trabajadores pueden verse expuestos a las sustancias por debajo del TLV sin padecer efectos adversos, el punto de vista en Finlandia es que cuando las exposiciones superan el valor límite, pueden producirse efectos perjudiciales para la salud.

Alemania El valor MAC es "la concentración máxima admisible de un compuesto químico presente en el aire de una zona de trabajo (como gas, vapor, materia particulada) que, según los actuales conocimientos, no daña la salud de la mayoría de los trabajadores ni causa otras molestias. En estas condiciones, la exposición puede repetirse y prolongarse durante un período diario de ocho horas, considerando una semana laboral media de 40 horas ( 42 horas por semana como promedio durante cuatro semanas sucesivas para las empresas que tengan cuatro turnos de trabajo) (...) Se utilizan criterios fundamentados científicamente para la protección de la salud, antes de tener en cuenta su viabilidad técnica o económica."

Continúa en lapágina siguiente. 


\begin{abstract}
País/Provincia Tipo de norma
Irlanda En general se usan los TLV más recientes de la ACGIH. Sin embargo, la lista de la ACGIH no está incorporada en las leyes o reglamentos nacionales.

Países Bajos Los valores MAC están tomados en gran parte de la lista de la ACGIH, así como de la República Federal de Alemania y el NIOSH. El valor MAC se define como la "concentración en la atmósfera del lugar de trabajo que, de acuerdo con los actuales conocimientos, en general no daña la salud de los trabajadores ni de su descendencia ni siquiera después de una exposición repetida de larga duración durante toda una vida laboral."

Filipinas Se utilizan los TLV de la ACGIH de 1970, excepto 50 ppm para el cloruro de vinilo y 0,15 mg/ m³ para el plomo, los compuestos inorgánicos, el humo y el polvo.

Federación Rusa La ex URSS estableció muchos de sus límites con el objetivo de eliminar cualquier posibilidad de efectos, aunque fueran reversibles. Estas respuestas subclínicas y plenamente reversibles a las exposiciones en el lugar de trabajo se han considerado, hasta la fecha, demasiado restrictivas en Estados Unidos y en la mayoría de los demás países. De hecho, debido a las dificultades económicas y técnicas para conseguir unos niveles tan bajos de contaminantes ambientales en el lugar de trabajo, existen pocos indicios de que estos límites se hayan alcanzado realmente en los países que los han adoptado. En cambio, los límites parecen servir más como objetivos idealizados que como límites cuyo logro suponga para los fabricantes una obligación legal y un compromiso moral

Estados Unidos Al menos seis grupos recomiendan límites de exposición aplicables en el lugar de trabajo: los TLV de la ACGIH, los Límites de Exposición Recomendada (REL) propuestos por el National Institute for Occupational Safety and Health (NIOSH), los Límites de Exposición Ambiental en el Lugar de Trabajo (WEEL) desarrollados por la American Industrial Hygiene Association (AIHA), los límites para contaminantes ambientales en el lugar de trabajo propuestos por el Comité Z-37 del American National Standards Institute (EAL), las guías sobre el lugar de trabajo propuestas por la American Public Health Association (APHA 1991), y las recomendaciones de las administraciones locales, estatales o regionales. Además, el Departamento de Trabajo ha establecido unos límites de exposición admisibles (PEL) que tienen categoría de ley y que, por tanto, tienen que cumplirse obligatoriamente en el lugar de trabajo. La Occupational Safety and Health Administration (OSHA) es la responsable de hacer cumplir estos límites.
\end{abstract}

Fuente: Cook 1986

Lehmann y Flury (1938) y Bowditch y cols. (1940) publicaron distintos artículos en los que presentaban tablas con un único valor para exposiciones repetidas a cada sustancia.

Muchos de los límites de exposición desarrollados por Lehmann se incluyeron en una monografía publicada por primera vez en 1927 por $\mathrm{H}$ enderson y Haggard (1943), y unos años después en el Schadliche Gase de Flury y Zernik (1931). Según Cook (1986), este libro se consideró la referencia autorizada sobre los efectos de gases, vapores y polvo nocivos en el lugar de trabajo, hasta que se publicó el segundo volumen del Patty's I ndustrial H ygiene and T oxicology (1949).

Las primeras listas de límites relativos a la exposición química en la industria, llamados concentraciones máximas admisibles (ó M AC), se elaboraron en 1939 y 1940 (Baetjer 1980). Representaban el consenso de la American Standard Association y una serie de higienistas industriales que habían formado la ACGIH in 1938. Estos "límites propuestos" fueron publicados en 1943 por James Sterner. A principios de 1940, se reunió un comité de la ACGIH para emprender la tarea de identificar los niveles seguros de exposición a sustancias químicas en el lugar de trabajo, reuniendo todos los datos que pudieran relacionar el nivel de exposición a un agente tóxico con la probabilidad de que se produjera un efecto adverso (Stokinger 1981; LaN ier 1984). La primera serie de valores fue publicada en 1941 por este comité, que estaba compuesto por Warren Cook, M anfred Boditch (según los informes, el primer higienista empleado por la industria en Estados Unidos), William Fredrick, Philip D rinker, Lawrence Fairhall y Alan D ooley (Stokinger 1981).

En 1941, un comité (denominado Z-37) de la American Standards Association, que más tarde se convirtió en el American National Standards Institute, estableció su primer límite de 100 ppm para el monóxido de carbono. En 1974, el comité había publicado ya boletines independientes sobre 33 límites de exposición a polvos y gases tóxicos.
En la reunión anual de la ACGIH en 1942, el recién creado Subcomité de Límites U mbral presentó en su informe una tabla de 63 sustancias tóxicas con las "concentraciones máximas admisibles de contaminantes atmosféricos", basadas en listas elaboradas por distintos servicios estatales de higiene industrial. El informe contenía la siguiente advertencia: "L a tabla no debe interpretarse como expresión de las concentraciones seguras recomendadas. El material se presenta sin comentarios" (Cook 1986).

En 1945, Cook publicó una lista de 132 contaminantes ambientales industriales con sus concentraciones máximas admisibles, incluidos los valores establecidos en ese momento en seis estados, así como los valores recomendados para el control de enfermedades profesionales por los organismos federales y las concentraciones máximas admisibles que parecían mejor documentadas por las referencias a investigaciones originales (C ook 1986).

En la reunión anual de la ACGIH celebrada en 1946, el Subcomité de Límites U mbral presentó su segundo informe con valores para 131 gases, vapores, polvos, humos y nieblas, y 13 polvos minerales. Los valores se compilaron de la lista publicada por el subcomité en 1942, de la lista publicada por Warren Cook en Industrial M edicine (1945) y de los valores publicados por el Comité Z-37 de la A merican Standards A ssociation. El comité insistió en que la "lista de valores CMA (M.A.C.) que se presenta... está sujeta a revisión anual".

\section{Uso previsto de los OEL}

LoS TLV de la ACGIH y la mayoría de los demás OEL utilizados en Estados Unidos y en otros países son límites que se refieren a las concentraciones ambientales de sustancias y representan condiciones en las que "se cree que casi todos los trabajadores pueden estar repetidamente expuestos día tras día sin efectos nocivos para la salud" (ACGIH 1994). (V éase Tabla 30.2) 
En algunos países, el OEL corresponde a una concentración que garantiza la protección de prácticamente todo el mundo. Es importante reconocer que, a diferencia de algunos límites de exposición relativos a contaminantes ambientales, aguas contaminadas 0 aditivos alimentarios establecidos por otros grupos profesionales u organismos normativos, la exposición al TLV no previene necesariamente las molestias o lesiones para todas las personas expuestas (Adkins y cols. 1990). La ACGIH admitió hace tiempo que, debido a la gran variabilidad de la susceptibilidad individual, un pequeño porcentaje de trabajadores puede experimentar molestias debido a la presencia de algunas sustancias en concentración igual o inferior al límite umbral y que un porcentaje aún menor puede verse afectado más seriamente por el agravamiento de una enfermedad preexistente o por el desarrollo de una enfermedad profesional (Cooper 1973; ACGIH 1994). A sí se señala claramente en la introducción al folleto anual de la ACGIH Threshold Limit Values for Chemical Substances and Physical Agents and Biological Exposure Indices (ACGIH 1994).

Esta limitación, aunque quizás lejos de ser ideal, se considera práctica, ya que tradicionalmente se ha considerado que, por limitaciones técnicas o económicas, es inviable mantener unas concentraciones ambientales tan bajas como para proteger a las personas hipersensibles. $\mathrm{H}$ asta cerca de 1990, esta limitación de los T LV no se había considerado grave. A la vista de las considerables mejoras logradas desde mediados del decenio de 1980 en la capacidad analítica, los instrumentos de vigilancia/ muestreo del personal, las técnicas de control biológico y el uso de robots como control técnico fiable, estamos ahora tecnológicamente capacitados para considerar límites de exposición profesional más estrictos.

La información sobre cada T LV y su justificación se publica periódicamente en Documentation of the $T$ hreshold Limit Values (ACGIH 1995). O tros países publican de vez en cuando algún tipo de documentación sobre los OEL. Antes de interpretar 0 ajustar un límite de exposición, debe consultarse siempre la justificación o documentación del correspondiente $\mathrm{OEL}$, así como los datos específicos que se consideraron para establecerlo (ACGIH 1994).

Los TLV se basan en la mejor información obtenida de la experiencia industrial y los estudios experimentales realizados con seres humanos y animales y, siempre que es posible, de una combinación de estas fuentes (Smith y O lishifski 1988; ACGIH 1994). La razón que justifica el establecimiento de determinados valores límite difiere según la sustancia. Por ejemplo, la protección contra eventuales daños para la salud puede ser un factor importante en algunos casos, mientras que en otros el criterio puede ser lograr una ausencia razonable de irritación, narcosis, molestias $u$ otras formas de estrés. $L a$ antigüedad y la exhaustividad de la información que se utiliza como base para establecer los límites de exposición profesional varía también según la sustancia; en consecuencia, la precisión de cada TLV es diferente. Deben consultarse siempre los TLV más recientes y su documentación (o equivalente) para evaluar la calidad de los datos que sirvieron como base para establecer ese valor.

Aunque en todas las publicaciones que contienen OEL se insiste en que deben utilizarse únicamente para establecer niveles seguros de exposición de las personas en el lugar de trabajo, se han utilizado también en otras situaciones. Por esta razón, todos los límites de exposición deben ser interpretados y aplicados sólo por profesionales que tengan conocimientos de higiene industrial y toxicología. El Comité T LV (ACGIH 1994) no pretendía que se utilizaran, o se modificaran para ser utilizados:

- como índice relativo de riesgo o toxicidad;

- para evaluar la contaminación atmosférica fuera del lugar de trabajo;
- para estimar los riesgos de exposiciones continuas e ininterrumpidas o de otros períodos prolongados de trabajo ;

- como prueba para diagnosticar o destacar la presencia de una enfermedad o condición física;

- para ser adoptados en países cuyas condiciones de trabajo difieren de las de Estados U nidos.

EI Comité T LV y otros grupos que establecen O EL advierten que estos valores no deben "utilizarse directamente" ni extrapolarse para predecir niveles seguros de exposición en otros entornos. N o obstante, si se conocen los fundamentos científicos de los valores recomendados y los métodos correctos para extrapolar los datos, pueden utilizarse para predecir niveles admisibles de exposición para muchos tipos diferentes de situaciones de exposición y horarios de trabajo (ACGIH 1994; Hickey y Reist 1979).

\section{Principios y enfoques del establecimiento de límites de exposición}

L os T LV fueron establecidos en un principio sólo para ayudar a los higienistas industriales, a quienes se reconocía libertad de criterio para aplicar esos valores. No debían ser utilizados con fines jurídicos (Baetjer 1980). Sin embargo, en 1968, la Ley de contratos públicos de Walsh-H ealey, en Estados U nidos, incorporó la lista de TLV de 1968, que incluía unas 400 sustancias químicas. En Estados U nidos, cuando se aprobó la Ley de salud y seguridad en el trabajo ( $O$ ccupational Safety and $\mathrm{H}$ ealth $\mathrm{Act}$, O SH A), se exigió que todos los límites fueran valores establecidos por consenso nacional o valores establecidos por el gobierno federal.

Los límites de exposición aplicados a los contaminantes ambientales en el lugar de trabajo se basan en la premisa de que, aunque todas las sustancias químicas son tóxicas en determinada concentración cuando la exposición a ellas se prolonga durante un cierto período de tiempo, existe una concentración (es decir, dosis) para todas las sustancias a la que no se produce ningún efecto nocivo, sea cual sea la frecuencia con que se repita la exposición. U na premisa similar se aplica a las sustancias cuyos efectos se limitan a irritación, narcosis, molestias y otras formas de estrés (Stokinger 1981; ACGIH 1994).

Figura 30.10 - Datos que suelen utilizarse para establecer un límite de exposición profesional.

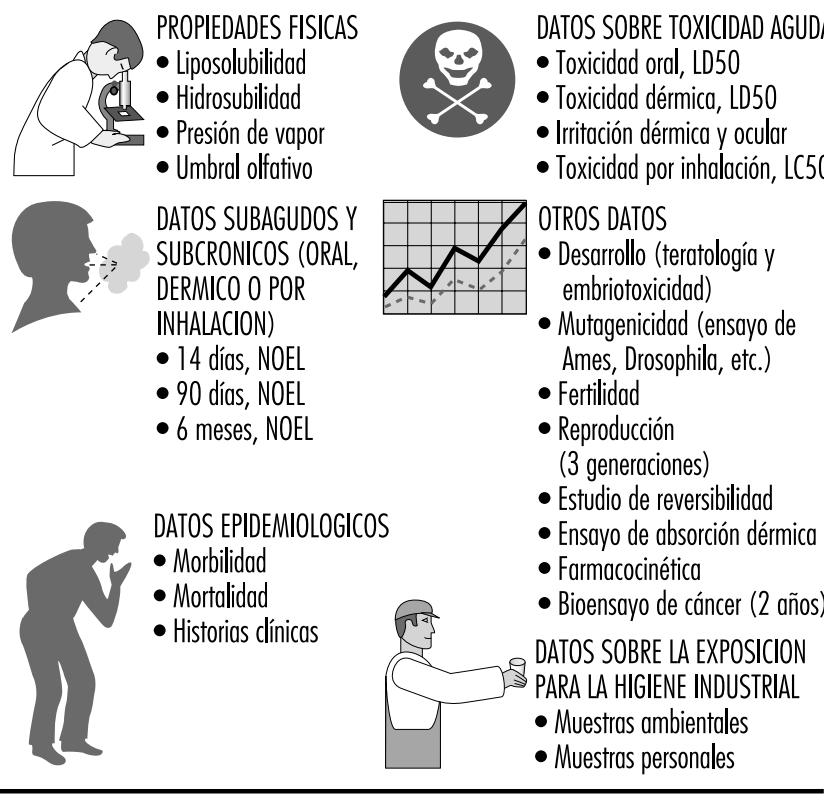


Estos principios difieren por tanto de los aplicados a agentes físicos como la radiación ionizante y a algunos cancerígenos químicos, puesto que no siempre existe un umbral o dosis con riesgo cero (Stokinger 1981). El concepto del efecto umbral es motivo de controversia y existen científicos de prestigio que se manifiestan tanto a favor como en contra de las teorías al respecto (Seiler 1977; Watanabe y cols. 1980; Stott y cols. 1981; Butterworth y Slaga 1987; Bailer y cols. 1988; Wilkinson 1988; Bus y Gibson 1994). Teniendo esto en cuenta, algunos límites de exposición profesional propuestos por distintos organismos normativos a principios del decenio de 1980 corresponden a niveles que, aunque no garantizan una ausencia completa de riesgos, estos riesgos no son mayores que los riesgos profesionales clásicos, como electrocuciones, caídas, etc. Incluso en lugares de trabajo en los que no se utilizan sustancias químicas industriales, el riesgo global de sufrir una lesión fatal es casi de uno por mil. Este es el razonamiento que se ha utilizado para justificar la elección de este criterio de riesgo teórico de cáncer para establecer los T LV aplicados a cancerígenos químicos (R odricks, Brett y Wrenn 1987; Travis y cols. 1987).

Los límites de exposición profesional establecidos tanto en Estados Unidos como en otros países se derivan de una gran variedad de fuentes. L os T LV de 1968 (adoptados por la O SH A en 1970 como legislación federal) se basaban principalmente en la experiencia humana. Esta observación puede sorprender a muchos higienistas que han empezado a ejercer su profesión hace poco, puesto que indica que, en la mayoría de los casos, los límites de exposición se han establecido después de haber comprobado que una sustancia es tóxica, irritante o produce otros efectos no deseados en el ser humano. Como cabría esperar, muchos de los límites de exposición más recientes para las toxinas sistémicas, especialmente los límites internos establecidos por los fabricantes, se han basado principalmente en ensayos de toxicología realizados en animales, en lugar de esperar a observar efectos adversos en los trabajadores expuestos (Paustenbach y Langner 1986). Sin embargo, ya en 1945, el Comité TLV reconoció el valor de los experimentos animales que, de hecho, constituyen la segunda fuente de información más común en la que se han basado estas directrices (Stokinger 1970).

En los últimos 40 años se han propuesto y utilizado diversos enfoques para deducir OEL a partir de datos obtenidos en animales. El enfoque aplicado por el Comité TLV y otros organismos no difiere significativamente del utilizado por la Food and Drug Administration (FDA) de Estados U nidos para establecer la dosis diaria admisible de aditivos alimentarios. Los higienistas industriales que tienen que interpretar los OEL pueden extraer conclusiones útiles del enfoque aplicado por la FDA para establecer los límites de exposición a aditivos alimentarios y contaminantes (D ourson y Stara 1983).

Se han descrito también los enfoques metodológicos que pueden aplicarse para establecer los límites de exposición en el lugar de trabajo basándose exclusivamente en los datos obtenidos con animales (Weil 1972; O M S 1977; Zielhuis y van der K reek 1979a, 1979b; Calabrese 1983; Dourson y Stara 1983; Leung y Paustenbach 1988a; Finley y cols. 1992; Paustenbach 1995). Aunque estos enfoques implican cierto grado de incertidumbre, parecen ser mucho mejores que la extrapolación cualitativa al ser humano de los resultados obtenidos en experimentos con animales.

A proximadamente el $50 \%$ de los T LV de 1968 se derivaron de datos humanos y el $30 \%$ de datos animales. En 1992, casi el $50 \%$ se derivaron principalmente de datos animales. Los criterios utilizados para establecer los TLV pueden clasificarse en cuatro grupos: morfológicos, funcionales, bioquímicos y varios (molestias, cosméticos). De los T LV basados en datos humanos, la mayoría se derivan de los efectos observados en trabajadores que estuvieron expuestos a la sustancia durante muchos años. En consecuencia, la mayoría de los T LV actuales se han basado en los resultados de las mediciones en el lugar de trabajo y en observaciones cualitativas y cuantitativas de la respuesta humana (Stokinger 1970; Park y Snee 1983). Los T LV establecidos recientemente para nuevas sustancias químicas se han basado principalmente en los resultados de estudios animales, más que en la experiencia humana (Leung y Paustenbach 1988b; Leung y cols. 1988).

En 1968, sólo la mitad de los T LV estaban destinados principalmente a prevenir efectos tóxicos sistémicos. A proximadamente el $40 \%$ se basaban en la irritación y cerca del $2 \%$ tenían como objetivo la prevención del cáncer. En 1993, aproximadamente el $50 \%$ pretendían prevenir efectos sistémicos, el $35 \%$ prevenir irritación y el $5 \%$ prevenir el cáncer. En la Figura 30.10 se ofrece un resumen de los datos que suelen utilizarse para establecer los O EL.

\section{Límites para los irritantes}

Hasta 1975, los OEL destinados a prevenir la irritación se basaban principalmente en experimentos humanos. Desde entonces, se han desarrollado varios modelos animales experimentales (K ane y Alarie 1977; Alarie 1981; Abraham y cols. 1990; N ielsen 1991). También se ha utilizado otro modelo basado en las propiedades químicas para establecer $\mathrm{OEL}$ preliminares referentes a bases y ácidos orgánicos (L eung y Paustenbach 1988).

\section{Límites para los cancerígenos}

En 1972, el Comité de la ACGIH empezó a distinguir entre cancerígenos humanos y animales en su lista de TLV. Según Stokinger (1977), uno de los motivos de esta distinción era ayudar a que los participantes en los debates (representantes sindicales, trabajadores y opinión pública) se centraran en aquellas sustancias químicas a las que era más probables que se produjeran exposiciones en el lugar de trabajo.

\section{¿Garantizan los TLV protección suficiente a los trabajadores?}

En 1988, muchas personas empezaron a expresar preocupación por el grado de protección de la salud que ofrecían los TLV. La pregunta clave que se planteaba era la siguiente, ¿qué porcentaje de la población activa está verdaderamente protegida contra los efectos nocivos para la salud cuando está expuesta a un T LV?

Castleman y Ziem (1988) y Ziem y Castleman (1989) afirmaron que los criterios científicos utilizados para establecer los límites eran inadecuados y que habían sido elaborados por higienistas con intereses creados en los sectores que pretendían regular.

Estos artículos generaron una gran polémica, tanto en contra como en defensa del trabajo de la ACGIH (Finklea 1988; Paustenbach 1990a, 1990b, 1990c; Tarlau 1990).

En un estudio de seguimiento realizado por Roach y R appaport (1990), se intentó cuantificar el margen de seguridad y la validez científica de los TLV. Los autores concluyeron que existían graves incoherencias entre los datos científicos disponibles y la interpretación realizada en Documentation por el Comité TLV en 1976. Señalaron también que los TLV reflejaban probablemente lo que el Comité percibía como realista y factible en ese momento. Tanto los análisis de R oach y R appaport como los de Castleman y Ziem han sido respondidos por la ACGIH, que ha insistido en la inexactitud de sus críticas.

Aunque el mérito de los análisis de Roach y Rappaport y de Ziem y Castleman seguirá siendo objeto de debate durante varios años, es evidente que el proceso mediante el cual se establecerán los TLV y otros OEL probablemente nunca volverá a 
ser el mismo que el aplicado entre 1945 y 1990. Es posible que en los próximos años, la justificación y el riesgo inherente de un TLV se describan más explícitamente en la documentación de cada uno de estos valores. También es cierto que la definición de "prácticamente seguro" o "riesgo insignificante" con respecto a la exposición en el lugar de trabajo cambiará a medida que cambien los valores de la sociedad (Paustenbach 1995, 1997).

El grado de reducción que sin duda se producirá en los TLV y otros OEL en los próximos años variará en función del tipo de efecto nocivo para la salud que se intente prevenir (depresión del sistema nervioso central, toxicidad aguda, olor, irritación, efectos en el desarrollo, u otros). N o está claro en qué medida se basará el Comité TLV en modelos predictivos de la toxicidad ni qué criterios de riesgo adoptará de cara al nuevo siglo.

\section{Normas y horarios de trabajo no tradicionales}

El efecto del trabajo por turnos en la capacidad, longevidad, mortalidad y bienestar general de los trabajadores no se conoce todavía con exactitud. En algunos sectores se han introducido los llamados turnosy horarios de trabajo no tradicionales para intentar eliminar, 0 al menos reducir, algunos de los problemas causados por el trabajo por turnos normal, que consiste en tres turnos de ocho horas al día. Un tipo de horario de trabajo que se califica de no tradicional es el que establece períodos de trabajo que duran más de ocho horas y un número variable de días laborales a la semana (por ejemplo, jornadas de 12 horas, tres díasa la semana). 0 tro tipo de horario de trabajo no tradicional implica en una serie de exposiciones breves al agente químico o físico durante un determinado horario de trabajo (por ejemplo, un horario en el que una persona está expuesta a una sustancia química durante 30 minutos, cinco veces al día, dejando que transcurra una hora entre dos exposiciones sucesivas). L a última categoría de horario no tradicional es el "caso crítico" de personasque se ven continuamente expuestasa un contaminante ambiental (por ejemplo, naves espaciales, submarinos).

Las semanas laborales comprimidas constituyen un tipo de horario de trabajo no tradicional que se ha utilizado principalmente en sectores no industriales. Se trata de un trabajo a tiempo completo (casi 40 horas semanales) que se realiza en menos de cinco días a la semana. En la actualidad existen muchos tipos de horarios comprimidos, pero los más comunes son los siguientes: (a) cuatro días de trabajo a la semana con jornadas de diez horas; (b) tres días de trabajo a la semana con jornadas de 12 horas; (c) cuatro días y medio de trabajo a la semana con jornadas de nueve horas y un día con jornada de cuatro horas (normalmente el viernes), y (d) el plan cinco/ cuatro nueve que consiste en alternar semanas de cinco y cuatro días de trabajo con jornadas de nueve horas (Nollen y Martin 1978; Nollen 1981).

Los trabajadores que tienen un horario de trabajo no tradicional representan sólo el $5 \%$ de la población activa. De ellos, sólo entre 50.000 y 200.000 norteamericanos que trabajan con horarios de trabajo no tradicionales lo hacen en industrias en las que están expuestos rutinariamente a niveles significativos de sustancias químicas en suspensión en el aire. En Canadá, se cree que el porcentaje de trabajadores de la industria química con horario de trabajo no tradicional es mayor (Paustenbach 1994).

\section{Un enfoque para establecer OEL internacionales}

Como señala Lundberg (1994), un reto que tienen por delante todos los comités nacionales es identificar un enfoque científico común para establecer OEL. Los proyectos internacionales conjuntos resultan ventajosos para las partes implicadas, puesto que la redacción de documentos, estableciendo criterios es un proceso que consume tiempo y dinero (Paustenbach 1995).
Esta fue la idea cuando el Consejo de M inistros de los Estados Nórdicos decidió en 1977 establecer el Grupo de Expertos Nórdicos. La tarea que se encomendó a este grupo fue la de elaborar documentos basados en criterios científicos que sirvieran como base común a los organismos normativos de los cinco países nórdicos (D inamarca, Finlandia, Islandia, N oruega y Suecia) para establecer los O EL. Los documentos elaborados por el Grupo de Expertos dieron lugar a la definición de un efecto crítico y de relaciones dosis-respuesta y dosis-efecto. El efecto crítico es el efecto adverso que se produce con el nivel más bajo de exposición. No se analizan los factores de seguridad ni se propone un OEL numérico. Desde 1987, el Grupo de Expertos $\mathrm{N}$ órdicos publica estos documentos todos los años también en inglés.

Lundberg (1994) ha propuesto un enfoque normalizado que todos los distritos deberían utilizar. Según su propuesta, debe elaborarse un documento con las siguientes características:

- Un documento con criterios normalizados debe reflejar los conocimientos actualizados que se han publicado en la bibliografía científica.

- La bibliografía utilizada como referencia debe estar compuesta preferiblemente por artículos científicos revisados por la comunidad científica y, si no, al menos que hayan sido publicados. No deben utilizarse las comunicaciones personales. La transparencia ante el público en general y, especialmente, ante los trabajadores, reducirá el tipo de recelos que últimamente han suscitado los documentos publicados por la AC GIH .

- El comité científico debe estar constituido por científicos independientes procedentes del ámbito académico o del sector público. Si el comité cuenta entre sus miembros con representantes científicos de la industria, tanto los empresarios como los trabajadores deben estar representados.

- Todos los estudios epidemiológicos y experimentales pertinentes deben ser analizados con detenimiento por el comité científico, especialmente los "estudios clave" que ofrezcan datos sobre el efecto crítico. D eben describirse todos los efectos observados.

- Deben estudiarse las posibilidades de control ambiental y biológico. También deben analizarse a fondo estos datos, incluidos los datos toxicocinéticos.

- Deben facilitarse los datos que permitan establecer las relaciones entre dosis-respuesta y dosis-efecto. En la conclusión debe establecerse el nivel de efecto no observable o el nivel más bajo con efecto observado (LOEL) para cada efecto observado. En caso necesario, deberán explicarse las razones por las que determinado efecto es el efecto crítico. De esta forma, se tiene en cuenta la importancia toxicológica de un efecto.

- Deben describirse específicamente las propiedades mutagénicas, cancerígenas y teratogénicas, así como los efectos alérgicos e inmunológicos.

- Debe facilitarse una lista de referencias para todos los estudios descritos. Si en el documento se especifica que sólo se han utilizado estudios relacionados con el tema, no será preciso facilitar una lista de referencias no utilizadas ni explicar la razón de que no se hayan utilizado. Por otra parte, puede ser interesante indicar las bases de datos que se han utilizado para buscar la bibliografía.

En la práctica, existen sólo pequeñas diferencias en la forma en que se establecen los OEL en distintos países. Por consiguiente, debería ser relativamente fácil llegar a un acuerdo sobre las características de un documento de criterios normalizado que contenga información clave. Desde este punto de vista, la decisión sobre la amplitud del margen de seguridad incorporado en el límite debería tomarse en el ámbito de la política nacional. 


\section{Referencias}

Abraham, MH, GS Whiting, Y Alarie et al. 1990 $\mathrm{H}$ ydrogen bonding 12. A new QSAR for upper respiratory tract irritation by airborne chemicals in mice. Q uant Struc Activity R elat 9:6-10.

Adkins, LE et al. 1990. Letter to the Editor. Appl Occup Environ $\mathrm{H}$ yg 5(11):748-750.

Alarie, Y. 1981. Dose response analysis in animal studies: Prediction of human responses. Environ $\mathrm{H}$ ealth Persp 42:9-13

American Conference of Governmental Industria $\mathrm{H}$ ygienists (ACGIH ). 1994. 1993-1994 T hreshold Limit Values for Chemical Substances and Physical Agents and Biological Exposure Indices. Cincinnati: ACGIH.

-. 1995. Documentation of Threshold Limit Values. Cincinnati: ACGIH.

Baetjer, AM . 1980. The early days of industrial hygiene: Their contribution to current problems. Am Ind $\mathrm{H}$ yg Assoc) 41:773-777.

Bailer, JC, EAC Crouch, R Shaikh, D Spiegelman. 1988. One-hit models of carcinogenesis: Conservative or not? R isk A nal 8:485-490.

Bogers, M , LM Appelman, VJ Feron, et al. 1987. Effects of the exposure profile on the inhalation toxicity of carbon tetrachloride in male rats. J Appl Toxico 7:185-191.

Boleij, JSM, E Buringh, D Heederik, H K romhour. 1995. Occupational $\mathrm{H}$ ygiene for Chemical and Biological A gents. Amsterdam: Elsevier.

Bouyer, J, D H émon. 1993. Studying the performance of a job exposure matrix. Int J E pidemiol 22(6) Suppl. 2:S65-S71.

Bowditch, M, DK D rinker, P D rinker, H H Haggard, A $\mathrm{H}$ amilton. 1940. Code for safe concentrations of certain common toxic substances used in industry. J Ind $\mathrm{H}$ yg T oxicol 22:251.

Burdorf, A. 1995. Certification of O ccupational H ygienists- A Survey of Existing Schemes Throughout the W orld Estocolmo: International O ccupational $\mathrm{H}$ ygiene Association (IOHA).

Bus, JS, JE Gibson. 1994. Body defense mechanisms to toxicant exposure. En Patty's Industrial $\mathrm{H}$ ygiene and Toxicology, dirigido por $R L$ Harris, L Cralley y LV Cralley. N ueva Y ork: Wiley.

Butterworth, BE, T Slaga. 1987. Nongenotoxic M echanisms in Carcinogenesis: Banbury Report 25. Cold Spring $\mathrm{H}$ arbor, Nueva York: Cold Spring $\mathrm{H}$ arbor Laboratory.

Calabrese, EJ. 1983. Principles of Animal Extrapolation. N ueva Y ork: Wiley.

Casarett, LJ. 1980. En Casarett and D oull's T oxicology: T he Basic Science of Poisons, dirigido por J Doull, CD $\mathrm{K}$ laassen, y M O Amdur. Nueva Y ork: M acmillan.

Castleman, BI, GE Ziem. 1988. Corporate Influence on Threshold Limit V alues. Am J Ind M ed 13(5).

Comité Européen de Normalisation (CEN). 1994 W orkplace Atmoshperes-Guidance for the Assessment of Exposure to Chemical Agents for Comparison W ith Limit $V$ alues and $M$ easurement Strategy. EN 689, preparado por el Comité T écnico 137 del CEN. Bruselas: CEN.

Cook, WA. 1945. M aximum allowable concentrations of industrial contaminants. Ind M ed 14(11):936-946.

—. 1986. O ccupational Exposure Limits- W orldwide. Akron, Ohio: American Industrial $\mathrm{Hygiene}$ Association (AIHA).

Cooper, WC. 1973. Indicators of susceptibility to industrial chemicals. J 0 ccup M ed 15(4):355-359.

Corn, M. 1985. Strategies for air sampling. Scand J W ork E nviron $\mathrm{H}$ ealth 11:173-180.

Checkoway, H, CH Rice. 1992. Time-weighted averages, peaks, and other indices of exposure in occupational epidemiolgy. Am J Ind M ed 21:25-33.
Dinardi, SR. 1995. Calculation M ethods for Industrial $\mathrm{H}$ ygiene. Nueva Y ork: $\mathrm{V}$ an N ostrand R einhold.

Doull, J. 1994. The ACGIH Approach and Practice. Appl $O$ ccup E nviron $\mathrm{H}$ yg 9(1):23-24.

Dourson, M J, JF Stara. 1983. Regulatory history and experimental support of uncertainty (safety) factors. Regul T oxicol Pharmacol 3:224-238.

Droz, PO. 1991. Quantification of concomitant biological and air monitoring results. Appl Ind $\mathrm{H}$ yg 6:465-474.

-. 1992. Q uantification of biological variability. Ann 0 ccup $H$ ealth 36:295-306.

Fieldner, AC, SH K atz, SP K enney. 1921. Gas M asks for Gases $M$ et in Fighting Fires. Bulletin No. 248. Pittsburgh: USA Bureau of M ines.

Finklea, JA. 1988. Threshold limit values: A timely look. Am J Ind M ed 14:211-212.

Finley, B, D Proctor, DJ Paustenbach. 1992. An alternative to the USEPA's proposed inhalation reference concentration for hexavalent and trivalent chromium. R egul T oxicol Pharmacol 16:161-176.

Fiserova-Bergerova, V. 1987. Development of using $\mathrm{BEIs}$ and their implementation. Appl Ind $\mathrm{H}$ yg 2(2):87-92.

Flury, F, F Zernik. 1931. Schadliche Gase, Dampfe, N ebel, R auch-und Staubarten. Berlín: Springer.

Goldberg, $M, H$ K romhout, $P$ Guénel, AC Fletcher, M Gérin, DC Glass, D Heederik, $T$ Kauppinen, A Ponti. 1993. Job exposures matrices in industry. Int J E pidemiol 22(6) Suppl. 2:S10-S15.

Gressel, M G, JA Gideon. 1991. An overview of process hazard evaluation techniques. Am Ind $\mathrm{H}$ yg Assoc J 52(4):158-163.

H enderson, Y, H H H aggard. 1943. N oxious $G$ ases and the Principles of Respiration Influencing their Action. Nueva Y ork: R einhold.

Hickey, JLS, PC Reist. 1979. Adjusting occupational exposure limits for moonlighting, overtime, and environmental exposures. Am Ind $\mathrm{Hyg}$ Assoc J 40:727-734

H odgson, JT, RD Jones. 1990. M ortality of a cohort of tin miners 1941-1986. Br J Ind M ed 47:665-676.

Holzner, CL, RB Hirsh, JB Perper. 1993. M anaging workplace exposure information. Am Ind $\mathrm{H}$ yg Assoc J 54(1):15-21.

Houba, R, D Heederik, G Doekes, PEM van Run. 1996. Exposure sensitization relationship for alpha-amylase allergens in the baking industry. Am J Resp Crit Care M ed 154(1):130-136.

International Congress on $\mathrm{O}$ ccupational $\mathrm{H}$ ealth $(\mathrm{ICOH})$. 1985. Invited lectures of the XXI International Congress on $\mathrm{O}$ ccupational $\mathrm{H}$ ealth, Dublin. Scand I W ork E nviron H ealth 11(3):199-206.

Jacobs, RJ. 1992. Strategies to recognize biological agents in the work environment and possibilities for setting standards for biological agents. 1 Conferencia científica internacinal de la $10 \mathrm{HA}$, Bruselas, Bélgica, 7-9 diciembre 1992.

Jahr, J. 1974. Dose-response basis for setting a quartz threshold limit value. Arch E nviron $\mathrm{H}$ ealth 9:338-340.

K ane, LE, Y Alarie. 1977. Sensory irritation to formaldehyde and acrolein during single and repeated exposures in mills. Am Ind $\mathrm{H}$ yg Assoc J 38:509-522.

K obert, R. 1912. The smallest amounts of noxious industrial gases which are toxic and the amounts which may perhaps be endured. Comp Pract Toxicol $5: 45$

K romhout, H, E Symanski, SM Rappaport. 1993. Comprehensive evaluation of within-and between-worker components of occupational exposure to chemical agents. Ann O ccup $\mathrm{H}$ yg 37:253-270.
LaNier, M E. 1984. Threshold Limit Values: Discussion and 35 Year Index with Recommendations (TLVS: 1946-81). Cincinnati: ACGIH

Lehmann, K B. 1886. Experimentelle Studien über den Einfluss T echnisch und $\mathrm{H}$ ygienisch Wichtiger Gase und Dampfe auf Organismus: Ammoniak und Salzsauregas. Arch $H$ yg 5:1-12.

Lehmann, K B, F Flury. 1938. T oxikologie und $H$ ygiene der T echnischen L osungsmittel. Berlín: Springer.

Lehmann, KB, L Schmidt-K ehl. 1936. Die 13 Wichtigsten Chlorkohlenwasserstoffe der Fettreihe vom Standpunkt der Gewerbehygiene. Arch $\mathrm{H}$ yg Bakteriol 116:131-268.

Leidel, NA, KA Busch, JR Lynch. 1977. NIOSH $O$ ccupational Exposure Sampling Strategy $M$ anuel. Washington, DC: NIOSH.

Leung, HW, DJ Paustenbach. 1988a. Setting occupational exposure limits for irritant organic acids and bases based on their equilibrium dissociation constants. Appl Ind $\mathrm{H}$ yg 3:115-118.

-. 1988b. Application of pharmokinetics to derive biological exposure indexes from threshold limit values. Amer Ind $\mathrm{H}$ yg Assoc f 49:445-450.

Leung, HW, FJ Murray, DJ Paustenbach. 1988. A proposed occupational exposure limit for $2,3,7,8$ - TCDD. Amer Ind H yg A ssoc J 49:466-474.

Lundberg, P. 1994. National and international approaches to occupational standard setting within Europe. Appl O ccup Environ H yg 9:25-27.

Lynch, JR. 1995. M easurement of worker exposure. En Patty's Industrial $\mathrm{H}$ ygiene and Toxicology, dirigido por RL Harris, L Cralley y LV Cralley. Nueva York: Wiley.

M aslansky, CJ, SP M aslansky. 1993. Air M onitoring Instrumentation. Nueva York: Van Nostrand Reinhold.

M enzel, DB. 1987. Physiological pharmacokinetic modelling. Environ Sci T echnol 21:944-950.

Miller, FJ, JH Overton. 1989. Critical issues in intra-and interspecies dosimetry of ozone. En Atmospheric Ozone Research and Its Policy Implications, dirigido por T Schneider, SD Lee, GJR Wolters, y LD G rant. Amsterdam: Elsevier.

National Academy of Sciences (NAS) y National R esearch Council (NRC). 1983. Risk Assessment in the Federal Government: $M$ anaging the Process. Washington, DC: NAS

National Safety Council (NSC). 1926. Final Report of the Committee of the Chemical and Rubber Sector on Benzene. Washington, DC: National Bureau of Casualty and Surety U nderwriters.

Ness, SA. 1991. Air M onitoring for Toxic Exposures. Nueva Y ork: $V$ an $N$ ostrand R einhold.

Nielsen, GD. 1991. M echanisms of activation of the sensory irritant receptor. CRC Rev Toxicol 21:183-208.

Nollen, SD. 1981. The compressed workweek: Is it worth the effort? Ing Eng :58-63.

Nollen, SD, VH M artin. 1978. Alternative W ork Schedules. Part 3: T he Compressed W orkweek. Nueva York: AM ACOM

Olishifski, JB. 1988. Administrative and clinical aspects in the chapter Industrial $\mathrm{H}$ ygiene. $\mathrm{En}$ $O$ ccupational Medicine: Principles and Practical Applications, dirigido por C Zenz. Chicago: Year Book M edical.

Organización M undial de la Salud (OMS) 1977. $M$ ethods used in Establishing Permissible Levels in $O$ ccupational Exposure to $\mathrm{H}$ armful Agents. Technical Report No. 601 . Ginebra: Organización Internacional del Trabajo (OIT).

- . 1992a. O ur Planet, O ur H ealth. R eport of the WH O Commission on $\mathrm{H}$ ealth and Environment. Ginebra: OMS. 
- 1992b. $O$ ccupational $H$ ygiene in E urope: D evelopment of the Profession. European Occupational Health Series No. 3. Copenhague: O ficina Regional de la OMS para Europa.

Panett, B, D Coggon, ED Acheson. 1985. Job exposure matrix for use in population based studies in England and Wales. Br I Ind $\mathrm{M}$ ed 42:777-783.

Park, C, R Snee. 1983. Q uantitative risk assessment State of the art for carcinogenesis. F und Appl Toxicol 3:320-333.

Patty, FA. 1949. Industrial H ygiene and T oxicology. V ol. II. N ew Y ork: Wiley.

Paustenbach, DJ. 1990a. H ealth risk assesment and the practice of industrial hygiene. Am Ind $\mathrm{H}$ yg Assoc J 51:339-351.

-. 1990b. O ccupational exposure limits: Their critical role in preventative medicine and risk management. Am Ind H yg A ssoc I 51:A332-A 336.

- . 1990c. What Does the R isk Assessment Process T el us about the TLVs? Presentado en la Conferencia conjunta de 1990 sobre higiene industrial. V ancouver, BC, 24 octubre.

- 1994. Occupational exposure limits, pharmacokinetics, and unusual workshifts. En Patty's Industrial H ygiene and Toxicology. Vol. IIIa (4th edn.) Nueva Y ork:Wiley.

-.1995 . The practice of health risk assessment in the U nited States (1975-1995): H ow the US and othe countries can benefit from that experience. $\mathrm{H}$ um E co Risk Assess 1:29-79.

- . 1997. O SH A's program for updating the permissible exposure limits (PELs): Can risk assessment help "move the ball forward"? Risk in Perspectives 5(1):1-6. $\mathrm{H}$ arvard U niversity School of Public H ealth.

Paustenbach, DJ, RR Langner. 1986. Setting corporate exposure limits: State of the art. Am Ind $\mathrm{H}$ yg Assoc 47:809-818

Peto, J, H Seidman, IJ Selikoff. 1982. M esothelioma mortality in asbestos workers: implications for models of carcinogenesis and risk assessment. $\mathrm{Br} \mid$ Cance 45:124-134.

Phthisis Prevention Committee. 1916. Report of M iners. J ohannesburg: Phthisis Prevention Committee

Post, WK, D Heederik, H Kromhout, D K romhout. 1994. O ccupational exposures estimated by a population specific job-exposure matrix and 25-year incidence rate of chronic non-specific lung disease (CNSLD): The Zutphen Study. Eur Resp J 7:1048-1055

R amazinni, B. 1700. De M orbis Atrificum D iatriba [D iseases of $W$ orkers]. Chicago: The U niv. of Chicago Press.

Rappaport, SM. 1985. Smoothing of exposure variability at the receptor: Implications for health standards. Ann O ccup H yg 29:201-214.

-. 1991. Assessment of long-term exposures to toxic substances in air. Ann 0 ccup H yg 35:61-121.

-. 1995. Interpreting levels of exposures to chemica agents. En Patty's Industrial $H$ ygiene and Toxicology, dirigido por RL Harris, L Cralley, y LV Cralley. Nueva Y ork: Wiley.

Rappaport, SM , E Symanski, JW Yager, LL K upper 1995. The relationship between environmenta monitoring and biological markers in exposure assessment. E nviron H ealth Persp 103 Suppl. 3:49-53.

Renes, LE. 1978. The industrial hygiene survey and personel. En Patty's Industrial H ygiene and Toxicology, dirigido por GD Clayton y FE Clayton. Nueva York: Wiley.
R oach, SA. 1966. A more rational basis for air sampling programmes. Am Ind H yg Assoc ] 27:1-12.

-. 1977. A most rational basis for air sampling programmes. Am Ind H yg A ssoc I 20:67-84.

Roach, SA, SM Rappaport. 1990. But they are not thresholds: A critical analysis of the documentation of threshold limit values. Am I Ind M ed 17:727-753.

Rodricks, JV, A Brett, G Wrenn. 1987. Significant risk decisions in federal regulatory agencies. R egul T oxicol Pharmacol 7:307-320.

R osen, G. 1993. PIM EX -combined use of air sampling instruments and video filming: Experience and results during six years of use. Appl 0 ccup Environ $\mathrm{H}$ yg $8(4)$

Rylander, R. 1994. Causative agents for organic dust related disease: Proceedings of an international workshop, Sweden. Am J Ind M ed 25:1-11.

Sayers, R R. 1927. T oxicology of gases and vapors. En International Critical Tables of Numerical Data, Physics, Chemistry and T oxicology. N ueva Y ork: M CG raw-H ill.

Schrenk, H H. 1947. Interpretation of permissible limits Am Ind $H$ yg Assoc $Q$ 8:55-60.

Seiler, JP. 1977. A pparent and real thresholds: A study of two mutagens. En Progress in Genetic Toxicology, dirigido por D Scott, BA Bridges y FH Sobels. Nueva Y ork: Elsevier Biomedical.

Seixas, NS, TG Robins, M Becker. 1993. A nove approach to the characterization of cumulative exposure for the study of chronic occupational disease. Am J E pidemiol 137:463-471.

Smith, RG, JB Olishifski. 1988. Industrial toxicology. En Fundamentals of Industrial $\mathrm{H}$ ygiene, dirigido por JB O lishifski. Chicago: N ational Safety C ouncil.

Smith, TJ. 1985. Development and application of a model for estimating alveolar and interstitial dust levels. Ann O ccup H yg 29:495-516.

- 1987. Exposure assessment for occupational epidemiology. Am J Ind M ed 12:249-268.

Smyth, HF. 1956. Improved communication: Hygienic standard for daily inhalation. Am Ind $\mathrm{H}$ yg Assoc $\mathrm{Q}$ 17:129-185.

Stokinger, HE. 1970. Criteria and procedures for assessing the toxic responses to industrial chemicals En Permissible Levels of T oxic Substances in the W orking Environment. Ginebra: OIT.

- 1977. The case for carcinogen TLV's continues strong. 0 ccup H ealth Safety 46 (M arch-A pril):54-58.

—. 1981. Threshold limit values: Part I. D ang Prop Ind $M$ ater $R$ ep ( $M$ ay-June):8-13.

Stott, WT, RH Reitz, AM Schumann, PG Watanabe 1981. Genetic and nongenetic events in neoplasia. Food Cosmet T oxicol 19:567-576.

Suter, AH . 1993. Noise and conservation of hearing. En $H$ earing Conservation $M$ anual. M ilwaukee, Wisc: Council for Accreditation in O ccupational Hearing Conservation.

Tait, K. 1992. The Workplace Exposure Assessment Expert System (WORK SPERT). Am Ind H yg Assoc ] 53(2):84-98.

Tarlau, ES. 1990. Industrial hygiene with no limits. A guest editorial. Am Ind H yg Assoc) 51:A9-A 10.

Travis, CC, SA Richter, EA Crouch, R Wilson, $E$ Wilson. 1987. Cancer risk management: A review of 132 federal regulatory decisions. Environ Sci T echnol 21(5):415-420

Watanabe, PG, RH Reitz, AM Schumann, M J M CK enna, PJ Gehring. 1980. Implications of the mechanisms of tumorigenicity for risk assessment. En
The Scientific B asis of T oxicity Assessment, dirigido por M Witschi. Amsterdam: Elsevier.

Wegman, DH, EA Eisen, SR Woskie, and $\mathrm{X} \mathrm{Hu}$. 1992. M easuring exposure for the epidemiologic study of acute effects. A m J Ind M ed 21:77-89.

Weil, CS. 1972. Statistics versus safety factors and scientific judgment in the evaluation of safety for man. Toxicol Appl Pharmacol 21:454-463.

Wilkinson, CF. 1988. Being more realistic about chemical carcinogenesis. Environ Sci T echnol 9:843-848.

Wong, 0.1987. An industry wide mortality study of chemical workers occupationally exposed to benzene. II Dose-response analyses. $\mathrm{Br}$ ] Ind $\mathrm{M}$ ed 44:382-395.

World Commission on Environment and Development (WCED). 1987. O ur Common Future Brundtland R eport. Oxford: O U P.

Zielhuis, RL, van der FW K reek. 1979a. Calculations of a safety factor in setting health based permissible levels for occupational exposure. A proposal. I. Int Arch Occup Environ $\mathrm{H}$ ealth 42:191-201.

Ziem, GE, BI Castleman. 1989. Threshold limit values: $\mathrm{H}$ istorical perspective and current practice. J Occup M ed 13:910-918.

\section{0 tras lecturas recomendadas}

American Conference of Governmental Industrial H ygienists (ACGIH ). 1988. ACGIH -T LV T hreshold Limit Values and Biological Exposure Indices for 1988-1989. Cincinnati: ACGIH.

—. 1991. Threshold Limit Values for Chemical Substances and Physical Agents and Biological Exposure Indices, 1990-1991. Cincinnati: ACGIH

Atherly, GA. 1985. Critical review of time-weighted average as an index of exposure and dose, and of its key elements. Am Ind H yg Assoc f 46:481-487.

Centre of International Projects. 1982. E nglish-R ussian Glossary of Selected Terms in Preventive Toxicology. M oscús: Programa de las $\mathrm{N}$ aciones U nidas para (PNUMA).

Firenze, RJ. 1973. Guide to Occupational Safety and $H$ ealth $M$ anagement. Dubuque, Ind: Hunt Publishing.

Hickey, JLS, PC Reist. 1977. Application of occupational exposure limits to unusual work schedules. Am Ind H yg Assoc |38:613-621.

M agnuson, HI. 1965. Soviet and American standards for industrial health. Arch Environ $H$ ealth 10:542-545

National Safety Council (NSC). 1988a. Accident Prevention $M$ anual for Industrial Operations. Washington, DC: NSC

- 1988b. Fundamentals of Industrial Hygiene. Washington, DC: NSC

Sayers, RR, JM DalleV alle. 1935. Prevention of occupational diseases other than those that are caused by toxic dust. M ech E ng 57:230-234.

US Department of Labor. 1972. OSHA General Industry-Safety and H ealth Standards 29 CFR 1910. Washington,DC: US D epartment of Labor.

Zielhuis, RL, van der FW K reek. 1979b. Calculations of a safety factor in setting health based permissible levels for occupational exposure. A proposal. II. Comparison of extrapolated and published permissible levels. Int Arch 0 ccup E nviron $H$ ealth 42:203-215. 


\section{PROTECCION PERSONAL}

Director del capítulo

Robert F. H errick

\section{Sumario}

Aspectos generales y principios de la protección personal

Robert $F$. H errick ............................. 31.2

Protectores de ojos y cara

Kikuzi Kimura. .......................... 31.3

Protección de pies y piernas

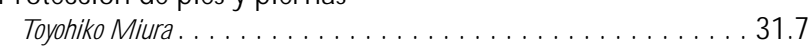

Protección de la cabeza

I sabelle Balty y Alain M ayer $\ldots \ldots \ldots \ldots \ldots \ldots \ldots \ldots \ldots \ldots \ldots \ldots \ldots$

Protección de los oídos

J ohn R. Franks y E lliott H. B erger . . . . . . . . . . . . . . . 31.11

Ropa protectora

S. Z ack M ansdorf. . . . . . . . . . . . . . . . . . . . . . . 31.17

Protección respiratoria

Thomas J. Nelson. . . . . . . . . . . . . . . . . . . . 31.22 


\section{- ASPECTOS GENERALES Y PRINCIPIOS DE LA PROTECCION PERSONAL}

\section{Robert F. H errick}

La cuestión de la protección personal debe considerarse en el contexto de los métodos de control para la prevención de las lesiones y enfermedades profesionales. Este artículo contiene una exposición técnica pormenorizada de los tipos de protección personal disponibles, los riesgos para los que puede estar indicado su uso y los criterios de selección del equipo de protección apropiado. En los casos en que procede, se resumen las homologaciones, certificados y normas que se aplican a los dispositivos y equipos de protección. Al manejar esta información, es esencial tener siempre presente que la protección personal debe considerarse un último recurso de reducción del peligro en el lugar de trabajo. En la jerarquía de métodos que pueden utilizarse para controlar los peligros en el lugar de trabajo, la protección personal no es un método de primera elección. De hecho, debe utilizarse sólo cuando los posibles controles técnicos o de ingeniería que reducen el peligro (mediante métodos como el aislamiento, el cierre, la ventilación, la sustitución u otros cambios de proceso) y los controles administrativos (como reducir el tiempo de trabajo con peligro de exposición) ya se han aplicado en la máxima extensión viable. (V éase "Prevención y control de riesgos mediante la intervención".) Sin embargo, hay casos en que la protección personal es necesaria, a corto o a largo plazo, para reducir el riesgo de enfermedad y lesión profesional. En tales casos, el equipo y los dispositivos de protección personal deben utilizarse como parte de un programa global que abarque la evaluación completa de los peligros, la selección y adecuación correctas del equipo, la formación y la educación de las personas que han de utilizarlo, las operaciones de mantenimiento y reparación necesarias para mantenerlo en buen estado de servicio y el compromiso conjunto de directivos y trabajadores con el buen resultado del programa de protección.

\section{Elementos de un programa de protección personal}

La sencillez aparente de ciertos equipos de protección personal puede llevar a subestimar el esfuerzo y los gastos necesarios para utilizarlo de manera eficaz. Aunque algunos instrumentos, como los guantes o el calzado protector, son relativamente simples, los equipos de protección respiratoria y otros aparatos pueden ser muy complejos. L os factores que dificultan la protección personal eficaz están intrínsecamente vinculados con todo método que se basa en la modificación del comportamiento humano para reducir el riesgo y no en la incorporación de la protección en el origen del riesgo. Con independencia del tipo concreto de equipo protector, todo programa de protección personal debe comprender unos elementos deter minados.

\section{Evaluación del peligro}

Para que la protección personal constituya una respuesta eficaz a un problema de riesgo profesional, es preciso conocer plenamente la naturaleza del propio riesgo y su relación con el medio ambiente de trabajo en su conjunto. Aunque esto parece tan obvio que apenas debería ser necesario mencionarlo, la sencillez aparente de muchos instrumentos protectores induce a prescindir de este paso de evaluación. Las consecuencias de proporcionar dispositivos y equipos protectores inadecuados para los riesgos y el medio ambiente global de trabajo van desde la resistencia o la negativa a llevar un equipo que resulta inapropiado hasta la merma del rendimiento laboral y el riesgo de lesión e incluso muerte del trabajador. Para lograr un equilibrio adecuado entre riesgo y medida de protección, es preciso conocer la composición y magnitud (concentración) de los peligros (incluidos los agentes químicos, físicos y biológicos), el tiempo durante el cual debe el dispositivo ejercer un nivel determinado de protección y la naturaleza de la actividad física que puede realizarse mientras se usa el equipo. Esta evaluación preliminar del peligro constituye una etapa de diagnóstico esencial que debe realizarse antes de elegir la protección adecuada.

\section{Selección}

La etapa de selección está determinada en parte por la información obtenida en la evaluación del riesgo, combinada con los datos sobre el rendimiento de la medida de protección que se prevé utilizar y el grado de exposición que seguirá habiendo una vez aplicada la medida de protección personal. Además de estos factores basados en el rendimiento, hay directrices y normas prácticas de selección de equipos, en particular de aparatos de protección respiratoria. Los criterios de selección de los aparatos de protección respiratoria se han formalizado en publicaciones como R espirator D ecision L ogic, del Instituto Nacional para la Salud y la Seguridad en el Trabajo ( $N$ ational Institute for $O$ ccupational Safety and Health, NIOSH ) de Estados U nidos. EI mismo tipo de lógica puede aplicarse a la selección de otros tipos de equipos y dispositivos protectores en función de la naturaleza y la magnitud del peligro, el grado de protección proporcionado y la cantidad o concentración del agente peligroso que seguirá existiendo y que se considerará aceptable mientras se utilicen los dispositivos de protección. Al elegir dispositivos y equipos de protección es importante tener en cuenta que su objetivo no es reducir el riesgo y la exposición a cero. Los fabricantes de equipos de protección respiratoria, protectores auditivos y otros dispositivos similares facilitan datos sobre el rendimiento de su equipo, entre ellos los factores de protección y atenuación. Combinando tres datos esenciales - naturaleza y magnitud del riesgo, grado de protección proporcionado y nivel admisible de exposición y riesgo mientras se usa el equipo- se pueden seleccionar equipos y dispositivos para proteger debidamente a los trabajadores.

\section{Ajuste}

Todos los dispositivos de protección deben ajustarse correctamente para que proporcionen el grado de protección para el cual se han diseñado. Además de influir en su rendimiento, el ajuste constituye un factor importante para la aceptación del equipo y la motivación de las personas que lo utilizan. Es poco probable que se utilicen de la manera prevista los instrumentos de protección mal ajustados o incómodos. En el peor de los casos, los dispositivos mal ajustados, como la ropa o los guantes, pueden constituir un peligro cuando se trabaja entre máquinas. L os fabricantes de equipos y dispositivos protectores ofrecen un gama de tallas y diseños, y los trabajadores deben disponer de los protectores adecuados para desempeñar las funciones previstas.

En el caso de los protectores respiratorios, hay normas específicas como las publicadas por la Administración para la Salud y la Seguridad en el Trabajo de Estados U nidos. El principio del ajuste adecuado se aplica a todos los equipos y dispositivos protectores, con independencia de que lo exija o no una norma determinada.

\section{Formación y educación}

Como las características de los dispositivos protectores obligan a modificar el comportamiento humano para aislar al trabajador del medio ambiente de trabajo (en lugar de aislar la fuente del riesgo del medio ambiente), es poco probable que los programas de protección personal den buenos resultados si no abarcan la 
educación y formación completas del trabajador. Un sistema que controle la exposición en el origen (como un sistema de ventilación aspirante local) puede funcionar eficazmente sin intervención directa del trabajador. Por el contrario, la protección personal exige la participación y el compromiso totales de quienes la utilizan y de los directivos que la proporcionan.

Los responsables de la gestión y el funcionamiento del programa de protección personal deben estar formados en la selección del equipo adecuado, la verificación de su correcto ajuste a quienes lo utilizan, la naturaleza de los peligros frente a los cuales el equipo debe ofrecer protección y las consecuencias del mal funcionamiento o el fallo del equipo. También deben saber reparar, mantener y limpiar el equipo, así como identificar los daños y desgastes que se produzcan durante su uso.

Quienes utilizan equipos y dispositivos protectores deben conocer la necesidad de protección, los motivos por los cuales se utiliza en lugar (o además) de otros métodos de control y las ventajas que se derivan de su empleo. $\mathrm{H}$ ay que explicar con claridad las consecuencias de la exposición sin protección y la forma en que el usuario puede detectar si el equipo no funciona correctamente. Los usuarios deben recibir formación sobre métodos de inspección, ajuste, uso, mantenimiento y limpieza del equipo protector y deben conocer las limitaciones de dicho equipo, sobre todo en situaciones de emergencia.

\section{Mantenimiento y reparación}

Para diseñar cualquier programa de protección personal es imprescindible evaluar de forma completa y realista los costes de mantenimiento y reparación del equipo. Los dispositivos protectores están sujetos a degradación paulatina de su rendimiento en el uso normal y a fallos completos en condiciones extremas, como las emergencias. Al considerar los costes y las ventajas de utilizar la protección personal como medio de control de riesgos, es muy importante tener en cuenta que los costes de iniciar un programa suponen sólo una parte de los gastos totales de mantenimiento del programa a lo largo del tiempo. Las actividades de mantenimiento, reparación y sustitución del equipo deben considerarse costes fijos de ejecución del programa, pues son esenciales para conservar la eficacia de la protección. Estas consideraciones sobre el programa deben comprender ciertas decisiones básicas, por ejemplo, si deben emplearse dispositivos protectores de un solo uso (de usar y tirar) o reutilizables y, en este segundo caso, cuál es la duración del servicio razonablemente previsible antes de que sea necesario sustituirlos. Estas decisiones pueden ser muy obvias, como ocurre en el caso de los guantes o mascarillas de protección respiratoria de un solo uso; pero en muchas otras ocasiones es preciso evaluar con atención si resulta eficaz reutilizar trajes 0 guantes protectores contaminados por el uso anterior. La decisión de desechar o reutilizar un dispositivo protector caro debe adoptarse después de estimar con detenimiento el riesgo de exposición que implicaría para un trabajador la degradación de la protección o la contaminación del propio dispositivo. Los programas de mantenimiento y reparación del equipo deben prever la toma de decisiones de este tipo.

\section{Resumen}

El equipo y los dispositivos de protección son elementos esenciales de toda estrategia de control del riesgo. Pueden utilizarse eficazmente si se conoce bien el lugar que ocupan en la jerarquía de control. El uso de equipos y dispositivos protectores debe apoyarse en un programa de protección personal que garantice el funcionamiento de la protección en las condiciones de uso previstas y que quienes deben llevarla sepan usarla correctamente en su actividad laboral.

\section{Protectores De OJOS Y CARA}

Kikuzi Kimura

Para proteger los ojos y la cara se utilizan gafas, gafas con montura integral, pantallas faciales y elementos parecidos que impiden la penetración de partículas y cuerpos extraños, compuestos químicos corrosivos, humos, láseres y radiaciones. Con frecuencia es necesario proteger toda la cara frente a las radiaciones 0 los peligros de naturaleza mecánica, térmica 0 química. En ocasiones, una pantalla facial protege también los ojos, pero en muchos casos éstos exigen un protector específico, sea independiente 0 en forma de complemento del protector facial.

Son muchas las actividades profesionales que requieren protección de los ojos y la cara. Entre los peligros cabe citar las partículas volantes, los vapores y sólidos corrosivos, los líquidos o vapores utilizados para pulir, esmerilar, cortar, hacer voladuras, aplastar, galvanizar o realizar otras operaciones químicas, la luz intensa que se emplea en los trabajos con láser y la radiación ultravioleta o infrarroja que emiten los equipos de soldadura y los hornos. $\mathrm{H}$ ay numerosos tipos de protectores de los ojos y la cara adecuados para cada clase de peligro. Cuando éste es grave, es preferible proteger la cara completa. En caso necesario se emplean protectores del rostro en forma de capucha 0 de casco, así como pantallas faciales. La protección específica de los ojos puede lograrse con gafas o gafas con montura integral.

Los dos problemas básicos que plantea el uso de protectores de los ojos y la cara son: (1) cómo proporcionar una protección eficaz que resulte aceptable durante muchas horas de trabajo sin resultar excesivamente incómoda, y (2) la impopularidad de este tipo de protectores a consecuencia de las limitaciones que imponen a la visión. La visión periférica está limitada por los lados de la montura y el puente de la nariz, que puede alterar la visión binocular; además, el empañado es un inconveniente constante. En climas o entornos de trabajo calurosos, los objetos que tapan la cara llegan a ser intolerables y puede descartarse su uso. A corto plazo, también plantean dificultades las operaciones inter mitentes, pues los trabajadores pueden olvidar la protección o mostrarse poco inclinados a usarla. Antes de plantearse la posibilidad de utilizar equipos de protección personal es preciso considerar siempre la mejora del medio ambiente de trabajo. Antes de usar protectores de los ojos y la cara (o al mismo tiempo), hay que proteger las máquinas y herramientas (con protectores interbloqueados), eliminar los gases y el polvo mediante sistemas de ventilación aspirante, apantallar las fuentes de calor o radiaciones y los puntos que puedan lanzar partículas, como las muelas abrasivas y los tornos. Si los ojos y la cara pueden protegerse por medio de pantallas transparentes 0 con tabiques de tamaño y calidad adecuados, por ejemplo, deben preferirse estas opciones al uso de la protección personal de los ojos.

$\mathrm{H}$ ay seis tipos básicos de protectores de los ojos y la cara:

1. G afas, con o sin protectores laterales; (Figura 31.1).

2. G afas con montura integral (Figura 31.2).

3. Pantallas que protegen las cuencas oculares y la parte central del rostro (Figura 31.3).

4. Tipo casco, que protegen por completo la parte frontal del rostro (Figura 31.4).

5. Pantallas protectoras de mano (Figura 31.4).

6. Capuchas que cubren por completo la cabeza, como los cascos de buzo (Figura 31.4).

Algunas gafas con montura integral pueden usarse por encima de las lentes con cristales correctores. Suelen ser de material duro y es preferible graduarlas con la supervisión de un oftalmólogo. 
Figura 31.1 - Tipos comunes de gafas de protección ocular, con y sin protectores laterales.

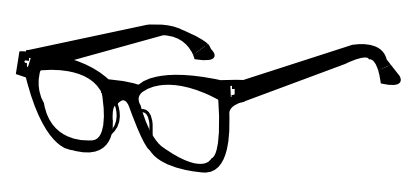

Sin protectores

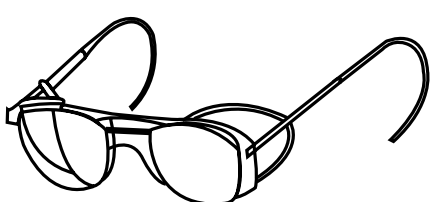

Protectores completos

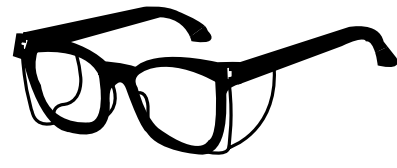

Semiprotectores

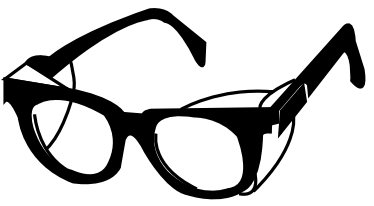

Protectores desmontables

\section{Protección frente a peligros concretos}

Lesiones traumáticas y químicas. Se utilizan pantallas faciales 0 protectores oculares para resguardarse de partículas volantes, humos, polvo y peligros de carácter químico. Son tipos comunes las gafas (frecuentemente con protectores laterales), gafas con montura integral, las pantallas oculares de plástico y las pantallas faciales. L os protectores tipo casco se utilizan cuando el riesgo de lesión previsto puede llegar desde varias direcciones. Los que tienen forma de capucha y de casco de buzo se usan en operaciones de chorro de arena y soplado. Como protección frente a cuerpos extraños se utilizan plásticos transparentes de diversos tipos, vidrio endurecido y malla de alambre. Frente a productos químicos se emplean gafas cerradas con lentes de plástico o vidrio

Figura 31.2 - Ejemplos de gafas de montura integral de protección ocular.

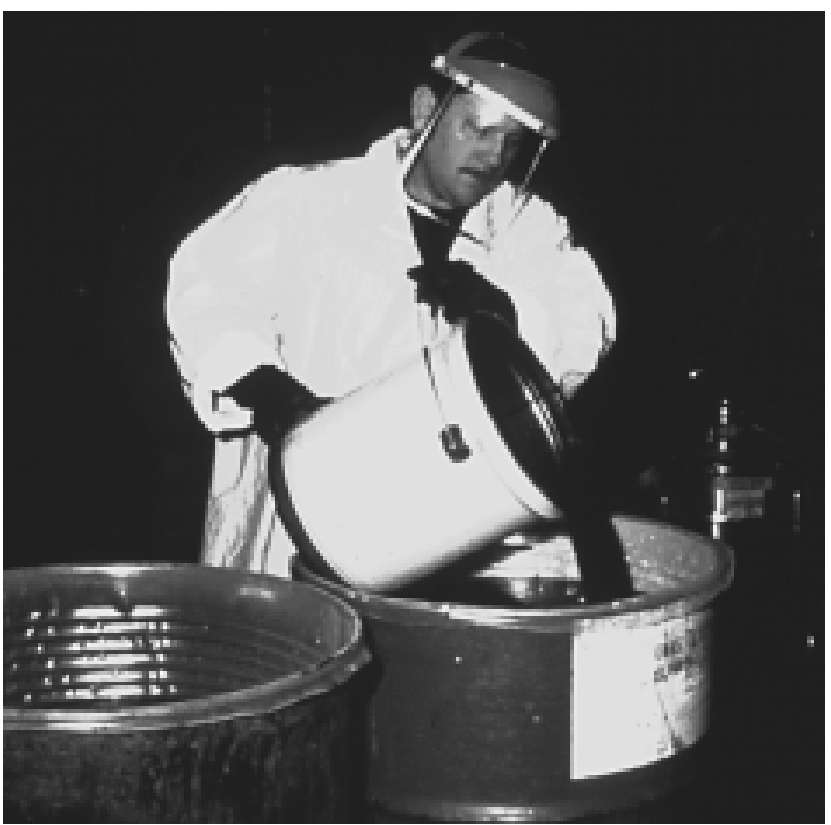

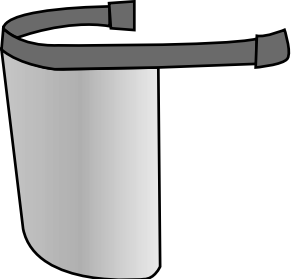

Resina acrilica

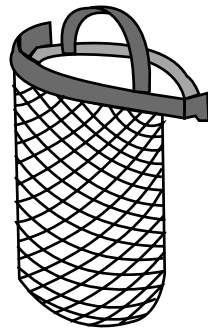

Malla de alambre

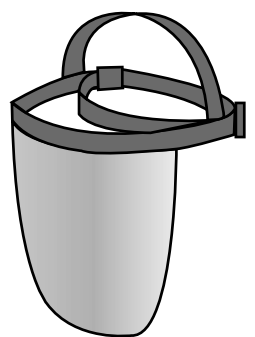

Resina acńlica y pantallas oculares de plástico, así como cascos tipo buzo y pantallas faciales de plástico.

Entre los materiales de uso común están los policarbonatos, las resinas acrílicas y los plásticos con base de fibra. LoS primeros son eficaces frente al impacto, pero no resisten bien los agentes corrosivos. Los protectores acrílicos son más débiles frente a los impactos, pero protegen adecuadamente de los peligros de carácter químico. Los plásticos con base de fibra presentan la ventaja de que incorporan un revestimiento antivaho que también evita los efectos electrostáticos. Por ello, este tipo de plásticos puede emplearse, no sólo para trabajos físicos ligeros y durante la manipulación de compuestos químicos, sino también en el moderno trabajo en salas limpias.

Radiación térmica. Las pantallas faciales y los protectores oculares frente a la radiación infrarroja se emplean sobre todo en trabajos con horno y otros trabajos que suponen la exposición a fuentes de radiación a temperatura elevada. C asi siempre es necesario protegerse al mismo tiempo frente a chispas y objetos proyectados ardientes. Los tipos más usados son los de casco y las pantallas faciales. En cuanto a los materiales, se utilizan mallas de alambre metálico, chapas de aluminio

Figura 31.4 - Protectores para soldadura.

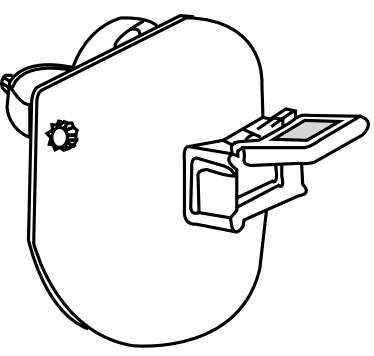

Tipo casco con mirilla móvil

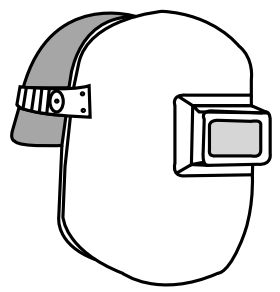

Para usar con casco, con mirilla fija

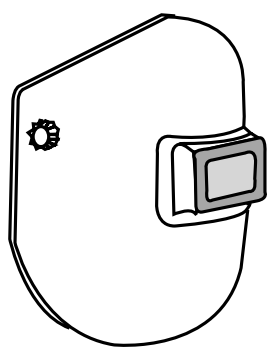

Tipo casco con mirilla fija

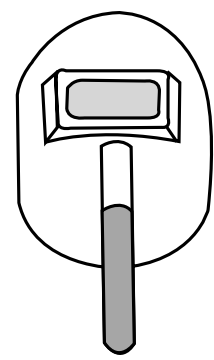

Pantalla de mano 
Tabla 31.1 - Requisitos de transmitancia (ISO 4850-1979).

\begin{tabular}{|c|c|c|c|c|c|c|}
\hline \multirow[t]{3}{*}{$\begin{array}{l}\text { Número de } \\
\text { escala }\end{array}$} & \multirow{2}{*}{\multicolumn{2}{|c|}{$\begin{array}{c}\text { Transmitancia máxima en el espectro } \\
\text { ultravioleta } \\
\text { Multiplicado por } t(\lambda)\end{array}$}} & \multicolumn{2}{|c|}{ Transmitancia luminosa } & \multicolumn{2}{|c|}{$\begin{array}{c}\text { Transmitancia media máxima en el } \\
\text { espectro infrarrojo }\end{array}$} \\
\hline & & & & $\tau_{V}$ & $\tau_{\text {NIR }}$ & $\tau_{\text {MIR }}$ \\
\hline & $\begin{array}{l}313 \mathrm{~nm} \\
\%\end{array}$ & $\begin{array}{l}365 \mathrm{~nm} \\
\%\end{array}$ & $\begin{array}{l}\text { máxima } \\
\%\end{array}$ & $\begin{array}{l}\text { mínima } \\
\%\end{array}$ & $\begin{array}{l}\text { IR próximo } \\
1.300 \text { a } 780 \mathrm{~nm} \\
\%\end{array}$ & $\begin{array}{l}\text { IR medio } \\
2.000 \text { a } 1.300 \mathrm{~nm} \\
\%\end{array}$ \\
\hline 1,2 & 0,0003 & 50 & 100 & 74,4 & 37 & 37 \\
\hline 1,4 & 0,0003 & 35 & 74,4 & 58,1 & 33 & 33 \\
\hline 1,7 & 0,0003 & 22 & 58,1 & 43,2 & 26 & 26 \\
\hline 2,0 & 0,0003 & 14 & 43,2 & 29,1 & 21 & 13 \\
\hline 2,5 & 0,0003 & 6,4 & 29,1 & 17,8 & 15 & 9,6 \\
\hline 3 & 0,0003 & 2,8 & 17,8 & 8,5 & 12 & 8,5 \\
\hline 4 & 0,0003 & 0,95 & 8,5 & 3,2 & 6,4 & 5,4 \\
\hline 5 & 0,0003 & 0,30 & 3,2 & 1,2 & 3,2 & 3,2 \\
\hline 6 & 0,0003 & 0,10 & 1,2 & 0,44 & 1,7 & 1,9 \\
\hline 7 & 0,0003 & 0,037 & 0,44 & 0,16 & 0,81 & 1,2 \\
\hline 8 & 0,0003 & 0,013 & 0,16 & 0,061 & 0,43 & 0,68 \\
\hline 9 & 0,0003 & 0,0045 & 0,061 & 0,023 & 0,20 & 0,39 \\
\hline 10 & 0,0003 & 0,0016 & 0,023 & 0,0085 & 0,10 & 0,25 \\
\hline 11 & Valor inferior o igual & 0,00060 & 0,0085 & 0,0032 & 0,050 & 0,15 \\
\hline 12 & a la transmitancia & 0,00020 & 0,0032 & 0,0012 & 0,027 & 0,096 \\
\hline 13 & admitida a $365 \mathrm{~mm}$ & 0,000076 & 0,0012 & 0,00044 & 0,014 & 0,060 \\
\hline 14 & & 0,000027 & 0,00044 & 0,00016 & 0,007 & 0,04 \\
\hline 15 & & 0,0000094 & 0,00016 & 0,000061 & 0,003 & 0,02 \\
\hline 16 & & 0,0000034 & 0,000061 & 0,000029 & 0,003 & 0,02 \\
\hline
\end{tabular}

Las Tablas 31.1 - 31.6 se han tomado de ISO 4850:1979 y se han reproducido con licencia de la Organización Internacional de Normalizasción (ISO). Estas normas pueden solicitarse a cualquier miembro de la ISO 0 a ISO Central Secretariat, Case postale 56, 1211 Ginebra 20, Suiza. El copyright sigue siendo propiedad de ISO.

perforadas o placas metálicas similares y pantallas de plástico aluminizado o con revestimientos de oro. U na pantalla facial de malla de alambre puede reducir la radiación térmica entre un $30 \%$ y un $50 \%$. Las de plástico aluminizado protegen bien frente al calor radiante. En la Figura 31.3 se ilustran algunos ejemplos de pantallas faciales protectoras frente a radiaciones térmicas.

\begin{tabular}{|c|c|c|c|c|}
\hline \multirow[t]{2}{*}{ Trabajo realizado } & \multicolumn{4}{|c|}{ I = caudal de acetileno en litros por hora } \\
\hline & $\mid \leq 70$ & $70<1 \leq 200$ & $200<1 \leq 800$ & $1>800$ \\
\hline $\begin{array}{l}\text { Soldadura con gas y } \\
\text { con latón de metales } \\
\text { pesados }\end{array}$ & 4 & 5 & 6 & 7 \\
\hline $\begin{array}{l}\text { Soldadura con flujos de } \\
\text { emisión (sobre todo } \\
\text { aleaciones ligeras) }\end{array}$ & $4 a$ & $5 a$ & $6 a$ & $7 a$ \\
\hline
\end{tabular}

Soldadura. O perarios, soldadores y ayudantes deben llevar gafas de montura integral, cascos o pantallas que proporcionen la máxima protección ocular en cada tipo de trabajo de soldadura y corte. No sólo es necesario protegerse eficazmente frente a la luz y la radiación intensas, sino también frente a los impactos en el rostro, la cabeza y el cuello. Los protectores de plástico o nylon reforzados con fibra de vidrio son eficaces, pero bastante caros. Como material protector se emplean mucho las fibras vulcanizadas. Como se ilustra en la Figura 31.4, para proteger los ojos y la cara al mismo tiempo se usan protectores

Tabla 31.3 - Grados ${ }^{1}$ de protección que deben utilizarse en operaciones de corte con oxígeno.

\begin{tabular}{|c|c|c|c|}
\hline \multirow[t]{2}{*}{ Trabajo realizado } & \multicolumn{3}{|c|}{ Caudal de oxígeno en litros por hora } \\
\hline & 900 a 2.000 & 2.000 a 4.000 & 4.000 a 8.000 \\
\hline Corte con oxígeno & 5 & 6 & 7 \\
\hline
\end{tabular}


Tabla 31.4 - Grados ${ }^{1}$ de protección que deben utilizarse en operaciones de corte con arco de plasma.

\begin{tabular}{lccc} 
Trabajo realizado & \multicolumn{3}{c}{$\mid=$ Intensidad en amperios } \\
Corte térmico & $I \leq 150$ & $150<\mid \leq 250$ & $250<\mid \leq 400$ \\
& 11 & 12 & 13
\end{tabular}

1 Según las condiciones de uso, puede emplearse la escala inmediatamente superior o inferior. Fuente: 1504850.

de tipo casco y de sujeción manual. A continuación se describen los filtros que deben utilizarse en las distintas operaciones de soldadura y corte.

$B$ andas de espectro amplio. D urante las operaciones de soldadura y corte y en los hornos se emiten radiaciones en las bandas ultravioleta, visible e infrarroja del espectro, todas ellas potencialmente nocivas para los ojos. Pueden usarse protectores tipo gafas o gafas de montura integral, como losilustradosen lasFiguras 31.1 y 31.2 y protectores de soldadura, como los que se muestran en la Figura 31.4. En trabajos de soldadura suelen emplearse protectores de casco y de sujeción manual, a veces combinados con gafas o gafas de montura integral. $\mathrm{H}$ ay que señalar que también debe usar protección el ayudante del soldador.

L os valores y tolerancias de transmitancia de distintos tipos de filtros y placas filtrantes de protección ocular frente a luz de intensidad elevada se recogen en la Tabla 31.1. Las Tablas 31.2 a 31.6 ofrecen una guía para elegir el filtro adecuado en función del grado de protección.

Constituye una novedad el uso de placas filtrantes fabricadas con superficies de cristal soldadas que se oscurecen y aumentan la capacidad de protección en cuanto se enciende el arco de soldadura. Este oscurecimiento es casi instantáneo, y en algunos tipos se produce en tan sólo 0,1 ms. La buena visibilidad que proporcionan las placas cuando no se está soldando puede favorecer su uso.

R ayos de láser. No hay ningún filtro que proteja frente a todas las longitudes de onda del láser. Los distintos tipos de láser varían en longitud de onda; hay tipos que emiten haces de distintas longitudes y otrosen losque estevalor se modifica con ayuda desistemas

Tabla 31.5 - Grados ${ }^{1}$ de protección que deben utilizarse en operaciones de soldadura o vaciado con arco eléctrico.

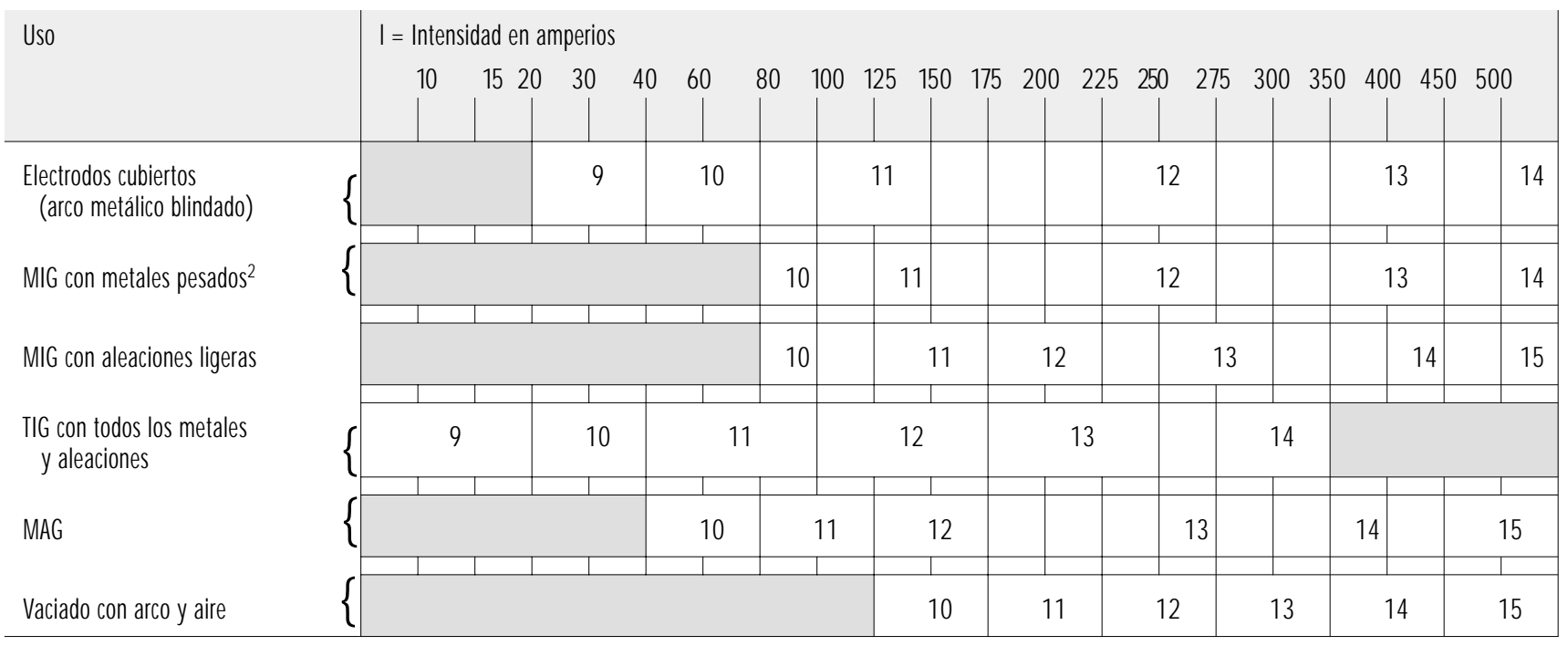

1 Según las condiciones de uso, puede emplearse la escala inmediatamente superior o inferior.

2 La expresión "metales pesados" se aplica a los aceros, las aleaciones del acero, el cobre y sus aleaciones, etc.

NOTA: Las zonas sombreadas corresponden a los intervalos dentro de los cuales no suelen emplearse operaciones de soldadura en la práctica actual de soldadura manual.

Fuente: ISO 4850.

Tabla 31.6 - Grados de protección que deben utilizarse en operaciones de soldadura directa con arco de plasma.

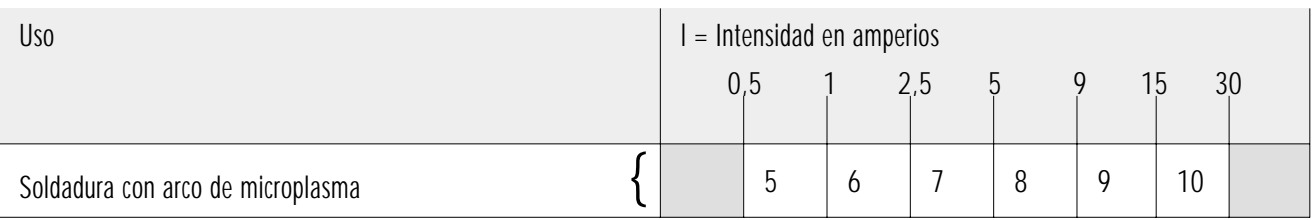

1 Según las condiciones de uso, puede emplearse la escala inmediatamente superior 0 inferior.

Las zonas sombreadas corresponden a los intervalos dentro de los cuales no suelen emplearse operaciones de soldadura en la práctica actual de soldadura manual. Fuente: ISO 4850. 
ópticos. Por tanto, las empresas en las que se trabaja con láser no pueden limitarse al uso de protectores de láser genéricos para evitar las quemaduras oculares de sus trabajadores. N o obstante, los operarios de láser necesitan con frecuencia protección ocular. Se comercializan gafas y gafas de montura integral de formas similares a las ilustradas en las Figuras 31.1 y 31.2. Cada tipo de protector presenta una atenuación máxima a una longitud de onda de láser determinada y la protección disminuye rápidamente a otras longitudes. Es esencial elegir el protector ocular adecuado para el tipo de láser, la longitud de onda y la densidad óptica. EI dispositivo empleado debe proteger frente a reflejos y luces dispersas y hay queadoptar las máximas precauciones para prever y evitar la exposición a radiaciones nocivas.

Cuando se trabaja con protectores oculares y faciales hay que prestar la atención debida a la comodidad y la eficacia. Es importante encomendar el ajuste y la adaptación de estos dispositivos a una persona que haya recibido alguna formación en este terreno. Cada trabajador debe disponer de un protector de uso personal, aunque en talleres grandes pueden suministrarse en común con operaciones de limpieza y tratamiento antivaho. La comodidad es particularmente importante cuando se trabaja con protectores de capucha y casco, pues el calor que producen llega a ser casi insoportable (este efecto puede evitarse con tubos de ventilación). Siempre que los riesgos del proceso de trabajo lo permitan, conviene aprovechar la ventaja psicológica de ofrecer al trabajador la posibilidad de elegir entre distintos tipos de protección.

Los protectores deben examinarse con regularidad para comprobar que se encuentran en orden de servicio. $\mathrm{H}$ ay que cerciorarse de que proporcionan protección adecuada en todo momento, incluso cuando se usan instrumentos de corrección de la vista.

\section{- PROTECCION DE PIES Y PIERNAS}

\section{Toyohiko Miura}

Las lesiones de pies y piernas son comunes en muchos sectores industriales. La caída de un objeto pesado puede lesionar el pie, en particular los dedos, en cualquier lugar de trabajo, pero sobre todo en industrias pesadas, como la minería, la fabricación de productos metálicos, la ingeniería, la construcción y el montaje. Las quemaduras de las extremidades inferiores por metal fundido, chispas o compuestos químicos corrosivos son frecuentes en talleres de fundición, siderurgia del hierro y el acero, fabricación de productos químicos, etc. Los compuestos ácidos y alcalinos y muchos otros agentes pueden causar dermatitis o eccema. A demás, los pies pueden lesionarse al gol pear contra algún objeto 0 al pisar en salientes afilados, como ocurre en el sector de la construcción.

Las mejoras en el medio ambiente de trabajo han hecho de las perforaciones y laceraciones causadas por pisar inadvertidamente clavos salientes y otros objetos agudos un accidente menos común, pero continúan produciéndose lesiones por trabajar en suelos húmedos o inundados, sobre todo si se usa calzado inadecuado.

\section{Tipos de protección.}

El tipo de protección del pie y la pierna debe elegirse en función del peligro. En ciertas industrias ligeras pueden ser suficientes los zapatos normales. M uchas mujeres, por ejemplo, usan calzado que les resulta cómodo, como sandalias o zapatillas viejas 0 zapatos con tacones muy altos o desgastados. Esta práctica debe
Figura 31.5 - Zapatos de seguridad.

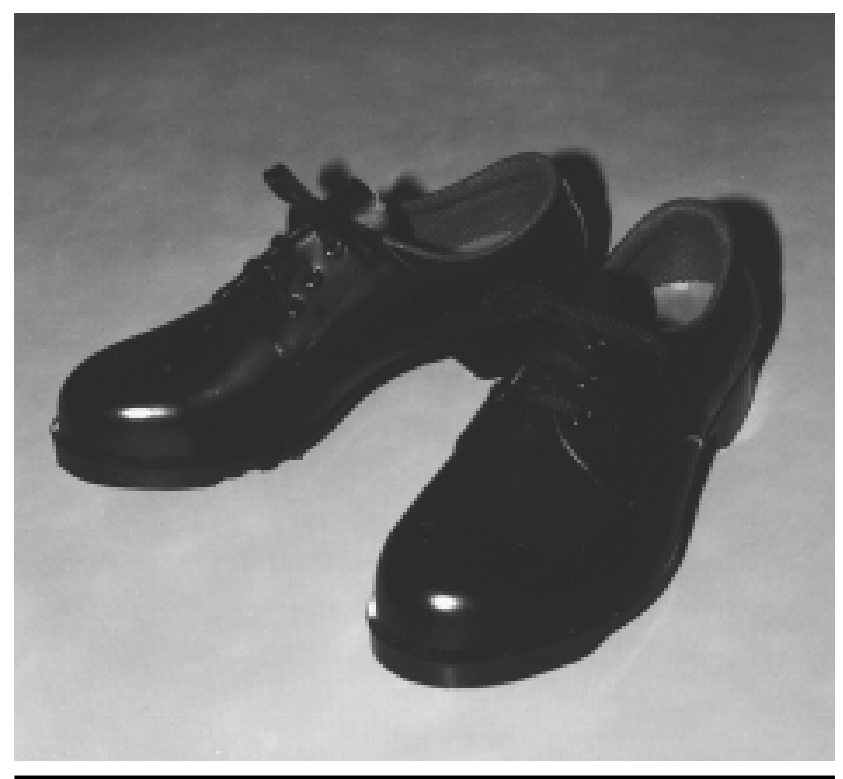

desaconsejarse, porque este tipo de calzado puede provocar accidentes.

En ocasiones bastan unos zapatos protectores o unos zuecos y en otros casos hay que usar botas o polainas (véanse las Figuras 31.5, 31.6 y 31.7). La altura del calzado - hasta el tobillo, la rodilla o el muslo- depende del peligro, pero también deben tenerse en cuenta la comodidad y la movilidad. Así, en algunos casos es mejor usar zapatos con polainas que botas altas.

Los zapatos y botas de protección pueden ser de cuero, caucho, caucho sintético o plástico y pueden estar cosidos,

Figura 31.6 - Botas de protección térmica.

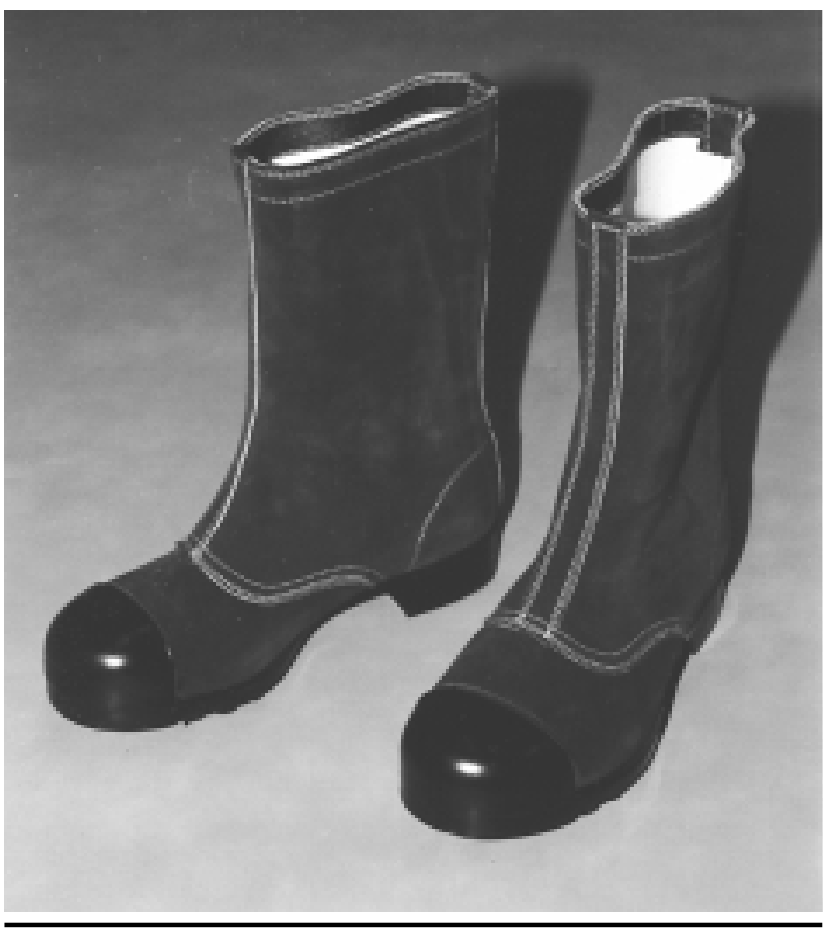


Figura 31.7 - Zapatillas de seguridad.

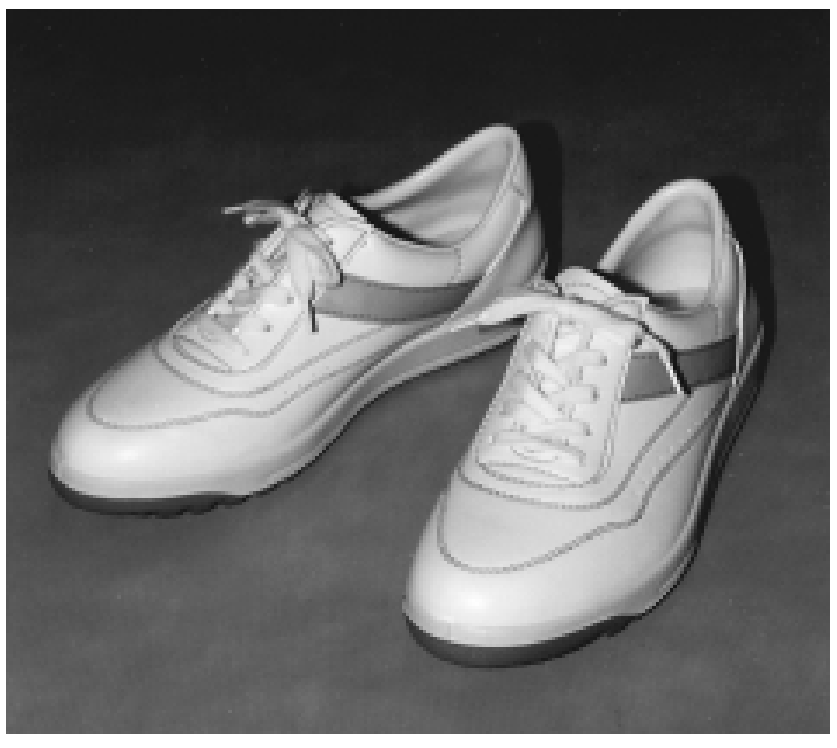

vulcanizados o moldeados. Como los dedos de los pies son las partes más expuestas a las lesiones por impacto, una puntera metálica es un elemento esencial en todo calzado de seguridad cuando haya tal peligro. Para mejorar la comodidad, la puntera puede ser razonablemente delgada y ligera, y por ello suele fabricarse en acero rápido al carbono. Esta puntera de seguridad puede añadirse a muchos tipos de botas y zapatos. En algunos trabajos en los que la caída de objetos supone un peligro especial, los zapatos de seguridad pueden cubrirse con unas defensas metálicas externas

Para evitar el riesgo de resbalamiento se usan suelas externas de caucho o sintéticas en diversos dibujos; esta medida es particularmente importante cuando se trabaja en pisos que pueden mojarse 0 volverse resbaladizos. EI material de la suela es mucho más importante que el dibujo, y debe presentar un coeficiente de fricción elevado. En obras de construcción es necesario utilizar suelas reforzadas a prueba de perforación; hay también plantillas internas metálicas para añadir al calzado que carece de esta clase de protección.

Cuando hay peligro de descargas eléctricas, el calzado debe estar íntegramente cosido o pegado o bien vulcanizado directamente y sin ninguna clase de clavos ni elementos de unión conductores de la electricidad. En ambientes con electricidad estática, el calzado protector debe estar provisto de una suela externa de caucho conductor que permita la salida de las cargas eléctricas.

Ahora es de uso común el calzado de doble propósito con propiedades antielectrostáticas y capaz de proteger frente a descargas eléctricas generadas por fuentes de baja tensión. En este último caso hay que regular la resistencia eléctrica entre la plantilla interna y la suela externa con el fin de que el calzado proteja dentro de un intervalo de tensiones determinado.

Antes las únicas consideraciones eran la seguridad y la durabilidad, pero ahora también se tiene en cuenta la comodidad del trabajador y se buscan cualidades como ligereza, comodidad, e incluso diseño atractivo. Las zapatillas deportivas de seguridad son un ejemplo de este tipo de calzado. El diseño y el color pueden utilizarse como símbolo de identidad corporativa, un asunto que en algunos países, como Japón, suscita un interés especial.
Las botas de caucho sintético protegen bien frente a las lesiones de origen químico. El material no debe sufrir una reducción superior al $10 \%$ en la resistencia a la tensión o el alargamiento después de estar sumergido durante 48 horas a temperatura ambiente en una solución de ácido clorhídrico al $20 \%$.

En medios donde las quemaduras causadas por metales fundidos o productos químicos constituyan un peligro destacado, es importante que los zapatos o botas no tengan lengüeta y que los cordones salgan por la parte superior y no se enganchen por dentro.

Las polainas y espinilleras de caucho o metálicas sirven para proteger la pierna por encima de la línea del calzado, en especial frente al riesgo de quemaduras. A veces hay que utilizar rodilleras, sobre todo cuando el trabajo obliga a arrodillarse, como ocurre en algunos talleres de fundición y moldeo. Cerca de fuentes de calor intenso hay que usar zapatos, botas o polainas protectoras aluminizadas.

\section{Uso y mantenimiento}

Todo calzado protector debe mantenerse limpio y seco cuando no se usa y debe sustituirse tan pronto como sea necesario. C uando varias personas comparten las mismas botas de caucho hay que organizar la desinfección sistemática entre usos para evitar la transmisión de infecciones de los pies. El uso de botas 0 zapatos excesivamente apretados y pesados favorece la aparición de micosis en los pies.

El éxito de cualquier calzado protector depende de su aceptabilidad, un hecho que ahora se refleja de forma generalizada en la muy superior atención que se presta al diseño. L a comodidad es una cualidad irrenunciable, y el calzado debe ser todo lo ligero que permita su utilidad. Deben evitarse los zapatos que pesen más de dos kilogramos el par.

A veces la legislación obliga a la empresa a proporcionar protección de seguridad para pies y piernas. M uchas firmas interesadas en aplicar programas avanzados y no sólo en cumplir las obligaciones legales han observado que resulta muy eficaz organizar la venta a precios ventajosos en el lugar de trabajo. Cuando el material de seguridad se ofrece a precio de mayorista o a plazos cómodos de pagar, los trabajadores suelen estar más dispuestos a adquirir y utilizar equipos mejores. Este método permite controlar mejor el tipo de protección que se obtiene y utiliza. No obstante, muchos convenios y reglamentos consideran obligación de la empresa proporcionar a los trabajadores ropa de faena y equipo protector.

Figura 31.8 • Ejemplo de elementos esenciales de la estructura de un casco de seguridad.

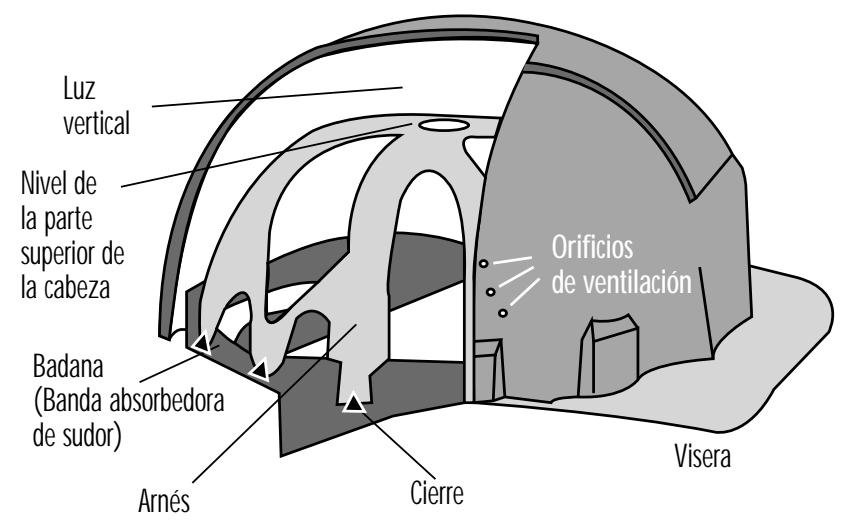




\section{- Proteccion de la CABeza}

Isabelle Balty y Alain M ayer

\section{Lesiones en la cabeza}

Las lesiones en la cabeza son bastante comunes en la industria y suponen entre el $3 \%$ y el $6 \%$ de todas las lesiones laborales en los países industrializados. Suelen ser graves y causan por término medio la pérdida de unas tres semanas de trabajo. Estas lesiones son casi siempre consecuencia de golpes provocados por el impacto de objetos contundentes, como herramientas o tornillos que caen desde varios metros de altura; en otros casos es el trabajador el que se golpea al caer al suelo o chocar contra algún objeto fijo.

\section{Se han registrado distintos tipos de lesiones:}

- perforación del cráneo por aplicación de una fuerza excesiva sobre una zona muy localizada, como ocurre cuando se entra en contacto directo con un objeto punzante 0 afilado;

- fractura del cráneo o de las vértebras cervicales cuando se aplica una fuerza excesiva sobre una superficie mayor, que somete al cráneo a una tensión superior a su elasticidad o a la resistencia a la compresión de la región cervical de la columna;

- lesión cerebral sin fractura del cráneo como consecuencia del desplazamiento súbito del cerebro dentro de la cabeza, con el resultado de contusión, conmoción cerebral, hemorragia cerebral o trastornos circulatorios.

Aunque esencial, es difícil determinar los parámetros físicos responsables de estos distintos tipos de lesión; la abundante documentación dedicada a este asunto revela un desacuerdo considerable. Algunos especialistas consideran que la fuerza es el principal factor, mientras que otros sostienen que la clave está en la energía o la cantidad de movimiento; otras opiniones vinculan la lesión cerebral con la aceleración, la tasa de aceleración o un índice de choque específico, como HIC, GSI o WSTC. En la mayor parte de los casos intervienen en mayor o menor grado todos estos factores. Se puede afirmar que nuestro conocimiento de los mecanismos del choque de la cabeza es por el momento sólo parcial o contradictorio. La tolerancia de la cabeza al choque se determina experimentalmente en cadáveres 0 animales, y no es fácil extrapolar los valores así obtenidos a personas vivas.

Según los resultados del análisis de accidentes sufridos por trabajadores de la construcción protegidos con casco, parece que se producen lesiones de cabeza a consecuencia de choques cuando la cantidad de energía es superior a unos 100 J.

$\mathrm{H}$ ay otros tipos de lesiones menos frecuentes pero que no deben infravalorarse: quemaduras por salpicadura de líquidos calientes o corrosivos 0 materiales fundidos, o descargas eléctricas debidas al contacto accidental de la cabeza con conductores que están al descubierto.

\section{Cascos de seguridad}

El principal objetivo del casco de seguridad es proteger la cabeza de quien lo usa de peligros y golpes mecánicos. También puede proteger frente a otros riesgos de naturaleza mecánica, térmica 0 eléctrica.

Para reducir las consecuencias destructivas de los golpes en la cabeza, el casco debe cumplir las siguientes condiciones:

1. Limitar la presión aplicada al cráneo distribuyendo la carga sobre la mayor superficie posible. Esto se logra dotándolos de un arnés lo suficientemente grande para que pueda adaptarse bien a las distintas formas del cráneo, combinado con un armazón duro de resistencia suficiente para evitar que la cabeza entre en contacto directo con objetos que caigan accidentalmente 0 contra los que golpee el usuario (Figura 31.8). Por tanto, el armazón debe resistir la deformación y la perforación.

Tabla 31.7 - Cascos de seguridad: requisitos de ensayo de la norma ISO 3873-1997.

\section{Característica \\ Pruebas obligatorias}

Absorción de impactos

Resistencia a la penetración

Pruebas opcionales

Resistencia dieléctrica

Rigidez lateral

Prueba de baja temperatura

\section{Descripción}

Criterios

Se deja caer una masa hemisférica de $5 \mathrm{~kg}$ desde una altura de $1 \mathrm{~m}$ y se mide la fuerza transmitida por el casco a una falsa cabeza fija.

La prueba se repite con un casco a temperaturas de $-10^{\circ}$, $+50^{\circ} \mathrm{C} v$ en condiciones de humedad.

Se golpea el casco dentro de una zona de $100 \mathrm{~mm}$ de diámetro situada en su punto más alto con un punzón cónico de $3 \mathrm{~kg}$ de peso y un ángulo de punta de $60^{\circ}$.

La prueba debe realizarse en las condiciones que hayan arrojado el peor resultado en la prueba de impacto.

El casco se expone durante $10 \mathrm{~s}$ a la llama de un mechero Bunsen de $10 \mathrm{~mm}$ de diámetro alimentado por propano.

Se llena el casco con una solución de CINa y se sumerge en un baño de esta misma solución. Se aplica una tensión de $1.200 \mathrm{~V}$ a $50 \mathrm{~Hz}$ y se miden las fugas eléctricas.

Se coloca el casco de lado entre dos placas paralelas y se somete a una fuerza de compresión de $430 \mathrm{~N}$

Se somete el casco a las pruebas de impacto y penetración a una temperatura de $-20^{\circ} \mathrm{C}$.
El armazón exterior no debe arder durante más de $5 \mathrm{~s}$ después de haber retirado la llama.

La punta del punzón no debe entrar en contacto con la cabeza falsa.

\section{La intensidad de la corriente de fuga no debe ser superior a} $1,2 \mathrm{~mA}$.

La deformación bajo carga no debe ser superior a $40 \mathrm{~mm}$ y la deformación permanente no debe exceder de $15 \mathrm{~mm}$.

El casco debe satisfacer los requisitos indicados para estas dos pruebas. 
2. Desviar los objetos que caigan por medio de una forma adecuadamente lisa y redondeada. Los cascos con rebordes salientes tienden a parar los objetos que caen en lugar de a desviarlos y, por tanto, absorben algo más de energía cinética que los totalmente lisos.

3. Disipar y dispersar la posible energía que se les transmita de modo que no pase en su totalidad a la cabeza y el cuello. Esto se logra por medio revestimiento del arnés, que debe estar bien sujeto al armazón duro y absorber los golpes sin desprenderse de él. También debe ser suficientemente flexible para deformarse por efecto del impacto sin tocar la superficie interior del armazón. Esta deformación, que absorbe casi toda la energía del choque, está limitada por la cantidad de espacio libre entre el armazón duro y el cráneo, y por la elongación máxima que tolera el arnés antes de romperse. Por tanto, la rigidez o dureza del arnés debe atender tanto a la cantidad máxima de energía que puede absorber como a la tasa progresiva a la que el golpe puede transmitirse a la cabeza.

Los cascos utilizados para trabajos especiales deben cumplir otros requisitos, como la protección frente a salpicaduras de metal fundido, en la industria del hierro y del acero, o frente a descargas eléctricas por contacto directo en trabajos de electricidad.

Los materiales empleados en la fabricación de cascos y arneses deben conservar sus propiedades protectoras durante mucho tiempo y en todas las condiciones climatológicas previsibles, como sol, lluvia, calor, heladas, etc. También deben ofrecer buena resistencia a la llama y resistir sin romperse caídas de algunos metros contra superficies duras.

\section{Pruebas de rendimiento}

La norma internacional ISO 3873-1977 se publicó en 1977 como resultado del trabajo del Subcomité dedicado al estudio de "cascos industriales de seguridad". Esta norma, aprobada prácticamente por todos los Estados miembros de la ISO, describe las características esenciales que debe cumplir un casco de seguridad y los métodos de prueba relacionadas con éstas. Las pruebas pueden dividirse en dos grupos (véase la Tabla 31.7):

1. Pruebas obligatorias: se aplican a todos los tipos de cascos, sea cual sea el uso al que estén destinadas: capacidad de absorción de golpes, resistencia a la perforación y resistencia a la llama.

2. Pruebas opcionales: se aplican a cascos de seguridad diseñados para grupos de usuarios especiales: resistencia dieléctrica, resistencia a la deformación lateral y resistencia a bajas temperaturas.

La resistencia al envejecimiento de los materiales plásticos utilizados en la fabricación de cascos no está especificada en la norma ISO 3873-1977, pero esta especificación debería exigirse en cascos de plástico. U na prueba sencilla consiste en exponer el casco a una lámpara de xenón de alta presión de 450 watios con ampolla de cuarzo durante 400 horas a una distancia de $15 \mathrm{~cm}$ y comprobar a continuación si todavía resiste la prueba de perforación apropiada.

Se recomienda someter los cascos utilizados en la industria del hierro y del acero a una prueba de resistencia a las salpicaduras de metal fundido. U na forma rápida de comprobar el comportamiento en estas circunstancias consiste en verter 300 gramos de metal fundido a $1.300^{\circ} \mathrm{C}$ sobre la parte superior del casco y comprobar que no ha pasado nada al interior.

La norma europea EN 397 adoptada en 1995 especifica requisitos y métodos de ensayo para estas dos importantes características.

\section{Elección de un casco de seguridad}

Todavía no se ha inventado el casco ideal que proporcione protección y comodidad perfectas en todas las situaciones. De hecho, protección y comodidad son exigencias frecuentemente contradictorias. En lo que se refiere a la protección, hay que elegir el casco considerando los peligros frente a los que se busca protección y las condiciones de uso, prestando especial atención a las características de los productos de seguridad disponibles.

\section{Consideraciones generales}

Es aconsejable que se utilicen cascos que cumplan las recomendaciones de la norma ISO 3873 (o equivalente). La norma europea EN 397-1993 se utiliza como referencia para la certificación de cascos en aplicación de la Directiva 89/686/ CEE. El equipo sujeto a esta certificación (casi todo el material de protección personal) se somete obligatoriamente a la certificación por un tercero antes de comercializarlo en Europa. En cualquier caso, los cascos deben cumplir los siguientes requisitos:

1. Un buen casco de seguridad para uso general debe tener un armazón exterior fuerte, resistente a la deformación y la perforación (si es de plástico, ha de tener al menos $2 \mathrm{~mm}$ de grosor); un arnés sujeto de manera que deje una separación de 40 a $50 \mathrm{~mm}$ entre su parte superior y el armazón; y una banda de cabeza ajustable sujeta al revestimiento interior que garantice una adaptación firme y estable (véase la Figura 31.8).

2. La mejor protección frente a la perforación la proporcionan los cascos de materiales termoplásticos (policarbonatos, ABS, polietileno y policarbonato con fibra de vidrio) provistos de un buen arnés. L os cascos de aleaciones metálicas ligeras no resisten bien la perforación por objetos agudos 0 de bordes afilados.

3. No deben utilizarse cascos con salientes interiores, ya que pueden provocar lesiones graves en caso de golpe lateral. D eben estar provistos de un relleno protector lateral que no sea inflamable ni se funda por el calor. Para este fin sirve un acolchado de espuma rígida y resistente a la llama de 10 a $15 \mathrm{~mm}$ de espesor y al menos $4 \mathrm{~cm}$ de anchura.

4. Los cascos fabricados con polietileno, polipropileno o ABS tienden a perder la resistencia mecánica por efecto del calor, el frío y la exposición al sol fuerte 0 a fuentes intensas de radiación ultravioleta (UV). Si este tipo de cascos se utilizan con regularidad al aire libre o cerca de fuentes de UV , como las estaciones de soldadura, deben sustituirse al menos una vez cada tres años. En estas condiciones conviene utilizar cascos de policarbonato, poliéster o policarbonato con fibra de vidrio, ya que resisten mejor el paso del tiempo. En todo caso, el casco debe desecharse si se decolora, se agrieta, desprende fibras o cruje al combarlo.

5. También debe desecharse el casco si ha sufrido un golpe fuerte, aunque no presente signos visibles de haber sufrido daños.

\section{Consideraciones particulares}

Los cascos fabricados con aleaciones ligeras o provistos de un reborde lateral no deben utilizarse en lugares de trabajo expuestos al peligro de salpicaduras de metal fundido. En estas circunstancias se recomiendan los de poliéster con fibra de vidrio, tejidos fenólicos, policarbonato con fibra de vidrio 0 policarbonato.

Cuando hay peligro de contacto con conductores eléctricos desnudos, deben utilizarse exclusivamente cascos de materiales termoplásticos. Deben carecer de orificios de ventilación y los remaches y otras posibles piezas metálicas no deben asomar por el exterior del armazón. 
Los cascos destinados a personas que trabajan en lugares altos, en particular los montadores de estructuras metálicas, deben estar provistos de barboquejo con una cinta de aproximadamente $20 \mathrm{~mm}$ de anchura y capaz de sujetar el casco con firmeza en cualquier situación.

Los cascos construidos en su mayor parte de polietileno no son recomendables para trabajar a temperaturas elevadas. En estos casos son más adecuados los de policarbonato, policarbonato con fibra de vidrio, tejido fenólico o poliéster con fibra de vidrio. El arnés debe ser de un material tejido. Si no hay peligro de contacto con conductores desnudos, el armazón puede llevar orificios de ventilación.

En situaciones en las que haya peligro de aplastamiento hay que usar cascos de poliéster o policarbonato reforzados con fibra de vidrio y provistos de un reborde de al menos $15 \mathrm{~mm}$ de anchura.

\section{Consideraciones de comodidad}

Además de la seguridad hay que considerar los aspectos fisiológicos de comodidad del usuario.

EI casco debe ser lo más ligero posible y, en cualquier caso, no pesar más de 400 gramos. El arnés debe ser flexible y permeable a los líquidos y no irritar ni lesionar al usuario; por ello, los de material tejido son preferibles a los de polietileno. La badana de cuero, completa o media, es necesaria para absorber el sudor y reducir la irritación de la piel; por motivos higiénicos, debe sustituirse varias veces a lo largo de la vida del casco. Para mejorar la comodidad térmica, el armazón debe ser de color claro y tener orificios de ventilación con una superficie comprendida entre 150 y $450 \mathrm{~mm}^{2}$. Es imprescindible ajustar bien el casco al usuario para garantizar la estabilidad y evitar que se deslice y limite el campo de visión. La forma de casco más común dentro de las diversas comercializadas es la de "gorra", con visera y reborde alrededor. En canteras y obras de demolición protege mejor un casco de este tipo pero con un reborde más ancho, en forma de "sombrero". Cuando se trabaja a cierta altura es preferible utilizar cascos sin visera ni reborde, con forma de "casquete" ya que estos elementos podrían entrar en contacto con las vigas 0 pilares entre los que deben moverse a veces los trabajadores, con el consiguiente riesgo de pérdida del equilibrio.

\section{Accesorios y otros protectores de la cabeza}

L os cascos pueden estar equipados con pantallas protectoras de los ojos o la cara hechas de plástico, malla metálica o filtros ópticos. Pueden contar también con protectores de los oídos, cintas para sujetar el casco firmemente a la barbilla o a la nuca, y protectores de cuello o capuchas de lana para abrigarse del frío o el viento (Figura 31.9). En minas y canteras subterráneas se usan soportes para bombilla y cable.

Figura 31.9 - Ejemplos de cascos de seguridad con barboquejo (a), filtro óptico (b) y faldilla de lana para proteger el cuello del viento y el frío (c).
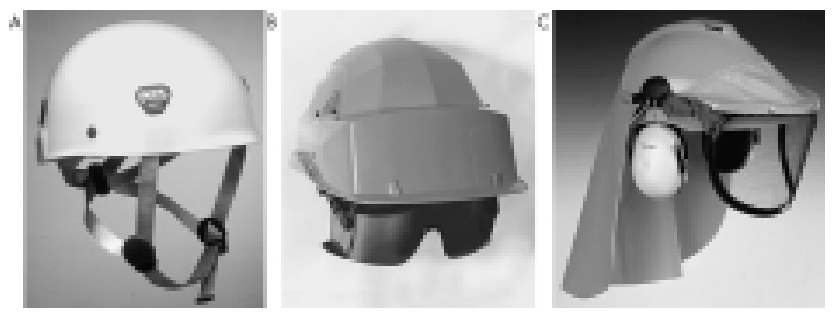

H ay también equipos protectores de la cabeza pensados para proteger al trabajador de la suciedad, el polvo, las abrasiones de la piel y los chichones. A veces se llaman chichoneras y son de plástico ligero o de lino. Cuando se trabaja cerca de máquinas herramientas, como taladradoras, tornos, devanaderas, etc., en las que hay peligro de que se enrede el pelo, puede usarse una gorra de lino con una redecilla, redecillas con visera o un simple turbante, siempre que no tengan puntas sueltas.

\section{Higiene y mantenimiento}

Todo el equipo protector de la cabeza se debe limpiar y verificar con regularidad. Si el casco presenta hendiduras o grietas o indicios de envejecimiento o deterioro del arnés, debe desecharse. $L a$ limpieza y desinfección son particularmente importantes si el usuario suda mucho o si el casco deben compartirlo varios trabajadores.

Los materiales que se adhieran al casco, tales como yeso, cemento, cola o resinas, se pueden eliminar por medios mecánicos o con un disolvente adecuado que no ataque el material del que está hecho el armazón exterior. También se puede usar agua caliente, un detergente y un cepillo de cerda dura.

La desinfección se realiza sumergiendo el casco en una solución apropiada, como formol al 5 \% o hipoclorito sódico.

\section{Proteccion De LOS OIDOS}

\section{John R. Franks y Elliott H. Berger}

\section{Protectores para los oídos}

No se sabe cuándo se observó por primera vez que taparse los oídos con las palmas de las manos o taponar los canales auditivos con los dedos reducía la intensidad del sonido no deseado - es decir, del ruido-, pero esta técnica elemental se ha utilizado durante muchas generaciones como última línea defensiva frente a los ruidos fuertes. Por desgracia, esta tecnología impide el uso de casi todas las demás. L os protectores de los oídos, una solución obvia al problema, reducen el ruido obstaculizando su trayectoria desde la fuente hasta el canal auditivo. Adoptan formas muy variadas, como ilustra la Figura 31.10.

Los tapones para los oídos se llevan en el canal auditivo externo. Se comercializan tapones premoldeados de uno o varios tamaños normalizados que se ajustan al canal auditivo de casi todo el mundo. Los modelables se fabrican en un material blando que el usuario adapta a su canal auditivo de modo que forme una barrera acústica. L os tapones a la medida se fabrican individualmente para que encajen en el oído del usuario. $\mathrm{H}$ ay tapones auditivos de vinilo, silicona, elastómeros, algodón y cera, lana de vidrio hilada y espumas de celda cerrada y recuperación lenta.

Los tapones externos se sujetan aplicándolos contra la abertura del canal auditivo externo y ejercen un efecto similar al de taponarse los oídos con los dedos. Se fabrican en un único tamaño y se adaptan a la mayor parte de los oídos. Se sujetan con un arnés de cabeza ligero que ejerce una presión leve.

L as orejeras están formadas por un arnés de cabeza de metal o de plástico que sujeta dos copas circumauriculares hechas casi siempre de plástico. Este dispositivo encierra por completo el pabellón auditivo externo y se aplica herméticamente a la cabeza por medio de una almohadilla de espuma plástica 0 rellena de líquido. Casi todas las orejeras tienen un revestimiento interior que absorbe el sonido transmitido a través del armazón diseñado para mejorar la atenuación por encima de aproximadamente $2.000 \mathrm{~Hz}$. En algunos de estos dispositivos, el arnés de cabeza puede colocarse por encima de la cabeza, por detrás del cuello y por debajo de la barbilla, aunque la 
Figura 31.10 - Ejemplos de distintos tipos de protectores auditivos.

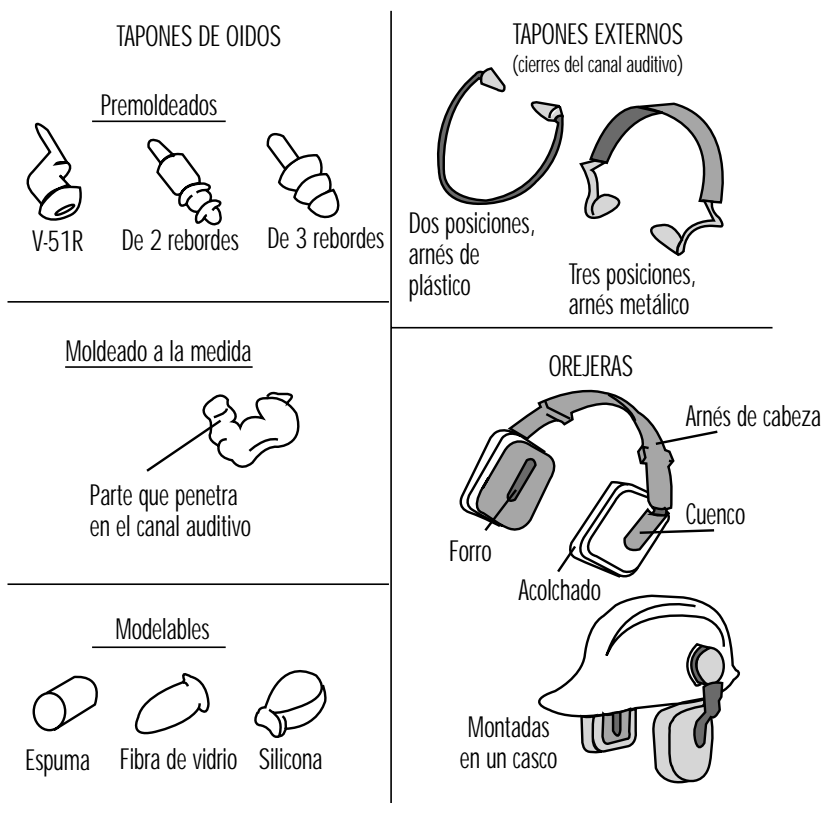

Adaptado con licencia de Nixon y Berger 1991.

protección que proporcionan en cada posición varía. 0 tros se montan en un casco rígido, pero suelen ofrecer una protección inferior, porque esta clase de montura hace más difícil el ajuste de las orejeras y no se adapta tan bien como la diadema a la diversidad de tamaños de cabeza.

En Estados Unidos hay 53 fabricantes y distribuidores de protectores auditivos que, en julio de 1994, comercializaban 86 modelos de tapones, 138 de orejeras y 17 de tapones externos. Pese a esta diversidad, los tapones de espuma de usar y tirar representan más de la mitad de los protectores auditivos utilizados en Estados U nidos.

\section{La última línea defensiva}

La forma más eficaz de evitar la pérdida auditiva debida al ruido es mantenerse lejos de zonas con ruidos peligrosos. En muchos entornos de trabajo podría rediseñarse el proceso de producción de manera que los trabajadores pudiesen operar desde salas de control cerradas y aisladas acústicamente. En estos recintos el ruido se reduce hasta un nivel que no supone ningún peligro y permite mantener en ellas una comunicación oral sin obstáculos. La siguiente medida en orden de eficacia para evitar la pérdida auditiva debida al ruido es reducir éste en el origen, de modo que deje de ser peligroso. Esto suele hacerse diseñando equipos silenciosos o adaptando dispositivos de control a los equipos en uso.

Cuando no es posible evitar el ruido o reducirlo en su origen, los protectores de los oídos se convierten en el último recurso. Como última línea defensiva carecen de red de seguridad y es fácil que disminuya su eficacia.

U na forma de limitar la eficacia de los protectores auditivos es no utilizarlos durante todo el tiempo. La Figura 31.11 ilustra lo que ocurre: a la larga, por muy buena protección que proporcione el diseño del dispositivo, esa protección se ve reducida a medida que se acorta el tiempo de uso. Los trabajadores que se quitan uno de los tapones o se levantan una de las orejeras para hablar con un compañero en un medio ruidoso pueden ver gravemente mermada la protección auditiva.

\section{Sistemas de valoración y formas de utilizarlos}

$\mathrm{H}$ ay muchas formas de valorar los protectores auditivos. LoS métodos más comunes son los de una sola cifra, como la Noise Reduction Rating (NRR) (EPA 1979) utilizada en Estados Unidos, y la Single N umber R ating (SNR) utilizada en Europa (ISO 1994). O tro método europeo de valoración es el H M L (ISO 1994), que se sirve de tres números para clasificar los protectores. Por último, hay métodos basados en la atenuación de los protectores auditivos para cada banda de octava de la escala; este método se denomina el largo o de banda de octava en Estados U nidos y de valor de protección asumido en Europa (ISO 1994).

Todos estos métodos utilizan la atenuación auditiva real a valores umbral provocada por los protectores según se determina en el laboratorio de acuerdo con las normas relevantes. En Estados U nidos las pruebas de atenuación se basan en la norma ANSI S3.19, M étodo de M edida de la protección auditiva real de los protectores de los oídos y la atenuación física de las orejeras (ANSI 1974). Aunque esta norma ha sido reemplazada por otra más nueva (ANSI 1984), la Environmental Protection Agency (EPA) de Estados U nidos controla el valor de NRR que figura en las etiquetas de los protectores auditivos y exige que se aplique la norma más antigua. En Europa, las pruebas de atenuación se rigen por la norma ISO 4869-1 (ISO 1990).

En general, los métodos de laboratorio exigen que se determinen los umbrales auditivos del campo acústico con los protectores colocados y sin ellos. En Estados U nidos, los protectores debe ajustarlos el experimentador, mientras que en Europa es el sujeto, ayudado por el experimentador, quien se encarga de esta tarea. L a diferencia entre los umbrales del campo acústico determinados con y sin los protectores es la atenuación auditiva real en el umbral. Se recopilan datos correspondientes a un grupo de sujetos, en este momento diez en Estados U nidos con tres ensayos cada uno y 16 en Europa, con un ensayo cada uno. Para cada banda de octava ensayada se determinan la atenuación media y la desviación típica correspondiente.

Figura 31.11 • Disminución de la protección eficaz a medida que aumenta el tiempo sin usarla en una jornada de 8 horas (basado en una tasa de cambio de $3 \mathrm{~dB}$ ).

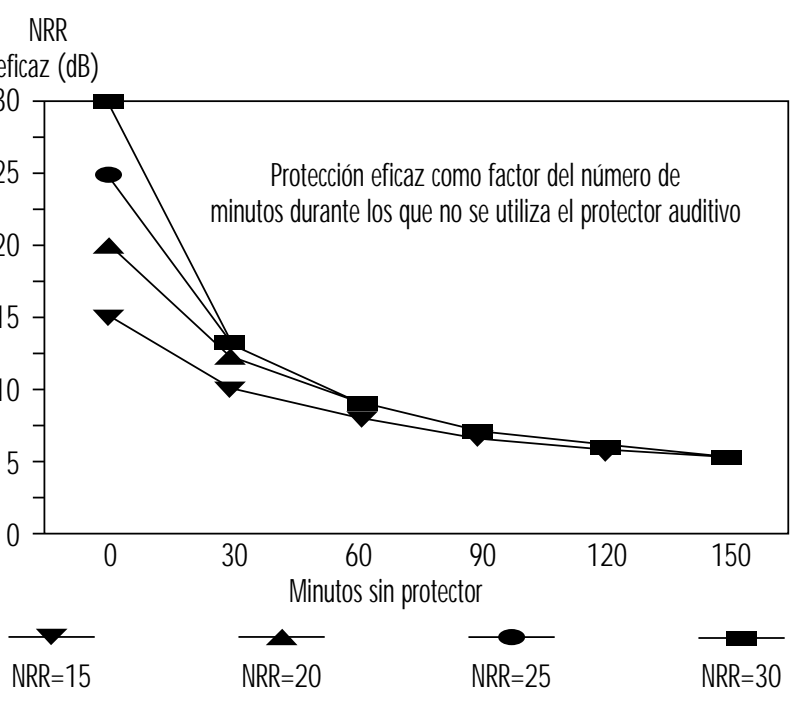


Tabla 31.8 • Ejemplo de cálculo de la puntuación de reducción de ruido (N RR) de un protector auditivo.

Procedimiento:

1. Tabular las intensidades de presión sonora de un ruido con energía constante por octava ajustado arbitrariamente para simplificar el cálculo a una intensidad de 100 dB en cada octava.

2. Tabular los ajustes para la escala ponderada C para cada centro de octava.

3. Sumar las líneas 1 y 2 para obtener las intensidades ponderadas $C$ por octava y combinarlas logarítmicamente para determinar la presión sonora ponderada $C$.

4. Tabular los ajustes para la escala ponderada A en el centro de cada octava.

5. Sumar las líneas 1 y 4 para obtener la intensidad ponderada A por octava.

6. Tabular la atenuación proporcionada por el dispositivo.

7. Tabular las desviaciones típicas de la atenuación (multiplicadas por 2) proporcionada por el dispositivo.

8. Restar los valores de las atenuaciones medias ( paso 6) y sumar los valores de las desviaciones típicas multiplicadas por 2 (paso 7 ) a los valores ponderados A (paso 5 ) para obtener las intensidades ponderadas A por octava dentro del dispositivo tal como se haya ajustado y ensayado en el laboratorio. Combinar logarítmicamente las intensidades ponderadas A por octava para obtener la intensidad sonora ponderada A efectiva cuando se utiliza el dispositivo.

9. Restar de la intensidad de presión sonora ponderada C (paso 3) la intensidad de la presión sonora ponderada A (paso 8) y un factor de seguridad de 3 dB para obtener el NRR.

\begin{tabular}{|c|c|c|c|c|c|c|c|c|}
\hline \multirow[t]{2}{*}{ Pasos } & \multicolumn{8}{|c|}{ Frecuencia central de la octava en $\mathrm{Hz}$} \\
\hline & 125 & 250 & 500 & 1000 & 2000 & 4000 & 8000 & $d B X$ \\
\hline 1. Intensidad sonora supuesta por octava & $\begin{array}{l}10 \\
0,0\end{array}$ & 100,0 & 100,0 & 100,0 & 100,0 & 100,0 & 100,0 & \\
\hline 2. Corrección de ponderación $C$ & $-0,2$ & 0,0 & 0,0 & 0,0 & $-0,2$ & $-0,8$ & $-3,0$ & \\
\hline 3. Intensidades ponderadas $\mathrm{C}$ por octava & 99,8 & 100,0 & 100,0 & 100,0 & 99,8 & 99,2 & 97,0 & $107,9 \mathrm{dBC}$ \\
\hline 4. Corrección ponderada A & $\begin{array}{c}-1 \\
6,1\end{array}$ & $-8,6$ & $-3,2$ & 0,0 & $+1,2$ & $+1,0$ & $-1,1$ & \\
\hline 5. Intensidades ponderadas A por octava & 83,9 & 91,4 & 96,8 & 100,0 & 101,2 & 101,0 & 98,9 & \\
\hline 6. Atenuación del protector auditivo & 27,4 & 26,6 & 27,5 & 27,0 & 32,0 & $46,0^{1}$ & $44,2^{2}$ & \\
\hline 7. Desviación típica $\times 2$ & 7,8 & 8,4 & 9,4 & 6,8 & 8,8 & $7,3^{3}$ & $12,8^{4}$ & \\
\hline 8. Intensidades ponderadas A estimadas por octava & 64,3 & 73,2 & 78,7 & 79,8 & 78,0 & 62,3 & 67,5 & $84,2 \mathrm{dBA}$ \\
\hline
\end{tabular}

9. $N R R=107,9-84,2-3=20,7$

(Paso $3-$ Paso $8-3 \mathrm{~dB}^{5}$ )

1 Atenuación media a 3.000 y $4.000 \mathrm{~Hz}$. ${ }^{2}$ Atenuación media a 6.000 y $8.000 \mathrm{~Hz}$. ${ }^{3}$ Suma de las desviaciones típicas a 3.000 y $4.000 \mathrm{~Hz}$. $\quad{ }^{4}$ Suma de las desviaciones típicas a 6.000 y $8.000 \mathrm{~Hz}$. $5 \mathrm{El}$ factor de corrección de $3 \mathrm{~dB}$ tiene por objeto compensar la incertidumbre espectral debida a que el ruido bajo el cual debe utilizarse el protector auditivo puede desviarse del espectro de ruido con energía constante por octava utilizado para calcular el NRR.

En la Tabla 31.8 se describen, para ilustrar el debate, los métodos NRR y de banda de octava.

La escala NR R puede utilizarse para determinar el nivel acústico protegido, es decir, la presión acústica real ponderada $\mathrm{A}$ en el oído, restándolo del nivel acústico ambiental ponderado $\mathrm{C}$. Así, si el nivel acústico ambiental ponderado $C$ es de $100 \mathrm{dBC}$ y el valor NRR del protector es de $21 \mathrm{~dB}$, el nivel acústico protegido sería igual a $79 \mathrm{dBA}(100-21=79)$. Si sólo se conoce el nivel acústico ambiental ponderado $A$, se utiliza una corrección de 7 dB (Franks, T hemann y Sheris 1995). Así, si el nivel acústico ponderado $A$ es de $103 \mathrm{dBA}$, el nivel acústico protegido sería de $89 \mathrm{dBA}(103-[21-7]=89)$.

El método de la banda de octava exige conocer los niveles acústicos ambientales por octava (no hay ninguna técnica abreviada). Muchos medidores acústicos modernos determinan al mismo tiempo los niveles ambientales por octava, ponderado $\mathrm{C}$ y ponderado A. Sin embargo, no hay dosímetros que proporcionen datos por octava. El cálculo por el método de la banda de octava se describe a continuación y se ilustra en la Tabla 31.9.

Las correcciones de desviación típica sustractiva aplicadas en los métodos de banda de octava y NRR tienen por objeto utilizar las medidas de variabilidad de laboratorio para ajustar las estimaciones de protección de manera que se correspondan con los valores esperados para la mayor parte de los usuarios (el $98 \%$ con una corrección igual a dos veces la desviación típica o el 84 \% con una corrección igual a una vez la desviación típica) que utilizan los protectores en condiciones idénticas a las empleadas en el ensayo. Como es lógico, la idoneidad de estos ajustes depende en buena parte de la validez de las desviaciones típicas estimadas en el laboratorio.

Comparación entre los métodos de la banda de octava y NRR

Los cálculos de los métodos de la banda de octava y NRR pueden compararse restando el valor NRR $(20,7)$ de la presión acústica ponderada $C$ para el espectro de la Tabla 31.9 $(95,2 \mathrm{dBC})$ para predecir el nivel real cuando se lleva el protector auditivo $(74,5 \mathrm{dBA})$. Este resultado se compara favorablemente con el valor de 73,0 dBA calculado mediante el método de la banda de octava en la Tabla 31.9. Parte de la disparidad entre las dos estimaciones se debe al uso del factor de seguridad espectral aproximado de $3 \mathrm{~dB}$ incorporado en la línea 9 de la Tabla 31.8. Este factor tiene por objeto compensar los errores derivados del uso de un ruido supuesto en lugar de uno 
Tabla 31.9 - Ejemplo de método de cálculo de banda de octava de la reducción de ruido ponderada A correspondiente a un protector auditivo en un medio ruidoso conocido.

Procedimiento:

1. Tabular las intensidades de ruido medioambiental medidas por octava.

2. Tabular los ajustes de ponderación A para el centro de cada octava de frecuencias.

3. Sumar los resultados de los pasos 1 y 2 para obtener las intensidades ponderadas A por octava. Combinar logarítmicamente estas intensidades para obtener la intensidad medioambiental de ruido ponderada $A$.

4. Tabular la atenuación proporcionada por el dispositivo para cada octava.

5. Tabular las desviaciones típicas de la atenuación (multiplicada por 2) que proporciona el dispositivo en cada octava.

6. Obtener las intensidades ponderadas A por octava dentro del protector restando la atenuación media (paso 4) de las intensidades por octava ponderadas A (paso 3) y sumando la desviación típica de las atenuaciones multiplicada por 2 (paso 5). Las intensidades ponderadas A por octava se combinan logarítmicamente para obtener la intensidad sonora efectiva ponderada A cuando se usa el protector. La reducción de ruido ponderada A estimada en un medio ambiente dado se calcula restando la intensidad sonora ponderada A dentro del protector de la intensidad sonora medioambiental (resultado del paso 3 menos resultado del paso 6).

Pasos

1. Intensidades sonoras medidas por octava
2. Corrección ponderada A
3. Intensidades ponderadas A por octava
4. Atenuación del protector auditivo
5. Desviación típica $\times 2$
6. Intensidades protegidas ponderadas A estimadas por octava
(Paso 3 - Paso $4+$ Paso 5 )

\begin{tabular}{rrrrrrrr}
\multicolumn{10}{c}{ Frecuencia central de la octava en $\mathrm{Hz}$} \\
125 & 250 & 500 & 1.000 & 2.000 & 4.000 & 8.000 & dBA \\
85,0 & 87,0 & 90,0 & 90,0 & 85,0 & 82,0 & 80,0 & \\
$-16,1$ & $-8,6$ & $-3,2$ & 0,0 & $+1,2$ & $+1,0$ & $-1,1$ & \\
68,9 & 78,4 & 86,8 & 90,0 & 86,2 & 83,0 & 78,9 & 93,5 \\
27,4 & 26,6 & 27,5 & 27,0 & 32,0 & 46,01 & $44,2^{2}$ & \\
7,8 & 8,4 & 9,4 & 6,8 & 8,8 & $7,3^{3}$ & $12,8^{4}$ & \\
49,3 & 60,2 & 68,7 & 69,8 & 63,0 & 44,3 & 47,5 & 73,0
\end{tabular}

${ }^{1}$ Atenuación media a 3.000 y $4.000 \mathrm{~Hz} . \quad 2$ Atenuación media a 6.000 y $8.000 \mathrm{~Hz} . \quad 3$ Suma de desviaciones típicas a 3.000 y $4.000 \mathrm{~Hz}$. 4 Suma de desviaciones típicas a 6.000 y $8.000 \mathrm{~Hz}$.

real. Según la pendiente del espectro y la forma de la curva de atenuación del protector auditivo, las diferencias entre los dos métodos pueden ser mayores de lo ilustrado en este ejemplo.

\section{Fiabilidad de los datos de las pruebas}

Por desgracia, los valores de atenuación y las correspondientes desviaciones típicas obtenidas en los laboratorios de Estados Unidos y, en menor medida, de Europa no son representativos de los obtenidos por los usuarios en su trabajo diario. Berger, Franks y Lindgren (1996) revisaron 22 estudios de protectores auditivos en condiciones reales y descubrieron que los valores comunicados por los laboratorios de Estados U nidos en la etiqueta exigida por la EPA sobrestimaban la protección en un factor comprendido entre el $140 \%$ y casi el $2.000 \%$. La sobrestimación era máxima para los tapones auditivos y mínima para las orejeras. Desde 1987, el National Institute for O ccupational Safety and $\mathrm{H}$ ealth (NIO SH) de Estados U nidos recomienda que el valor NRR atribuido a las orejeras se reduzca en un $25 \%$, el atribuido a los tapones modelables en un $50 \%$ y el atribuido a los tapones moldeados en un $70 \%$ antes de realizar los cálculos de nivel acústico con el protector auditivo (R osenstock 1995).

\section{Variabilidad dentro del laboratorio y entre laboratorios}

0 tra consideración, aunque con repercusiones menos importantes que los aspectos relacionados con las condiciones reales que acaban de comentarse, es la relativa a la validez y la variabilidad dentro del laboratorio y a las diferencias entre laboratorios. Esta última puede ser considerable (Berger, Kerivan y $M$ intz 1982) y afectar a los valores calculados de octava y NRR, tanto en términos de cálculos absolutos como de clasificación. Por tanto, incluso la clasificación de los protectores auditivos basada en valores de atenuación es preferible basarla por el momento en datos obtenidos en un único laboratorio.
Figura 31.12 - O rejeras bien y mal ajustadas y consecuencias para la atenuación.
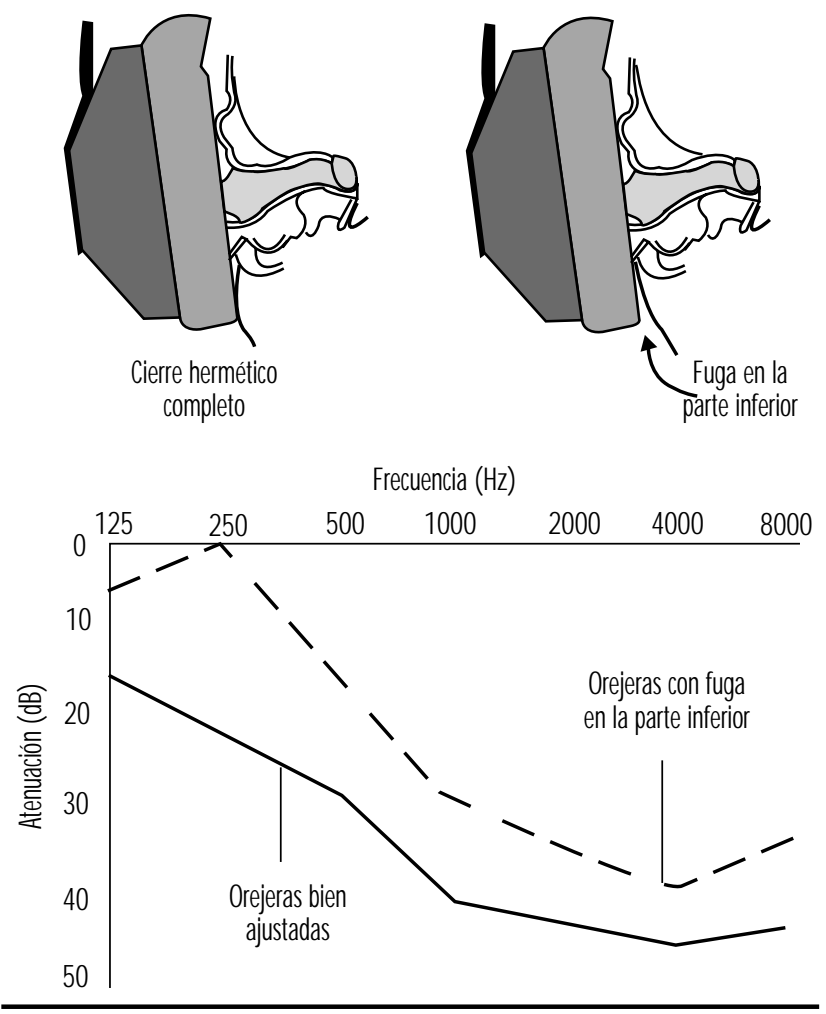


\section{Aspectos importantes en los que basar la elección de protectores}

Al elegir un protector auditivo hay que considerar varios aspectos importantes (Berger 1988). EI más importante es la idoneidad del protector para el ruido ambiental en el que debe utilizarse. La M odificación sobre conservación del oído de la Norma sobre ruidos de la O SH A (1983) recomienda que el nivel acústico en el interior del protector sea, como máximo de $85 \mathrm{~dB}$. EI NIO SH ha recomendado que el nivel acústico dentro del protector no supere los $82 \mathrm{dBA}$, con el fin de que el riesgo de pérdida auditiva inducida por el ruido sea mínimo (R osenstock 1995).

En segundo lugar, la protección no debe ser excesiva. Si el nivel acústico protegido está más de $15 \mathrm{~dB}$ por debajo del valor deseado, el protector induce una atenuación excesiva y se considera que el usuario está excesivamente protegido y, por tanto, se siente aislado del entorno (BSI 1994). Puede resultar difícil escuchar la voz y las señales de advertencia y el usuario se retirará el protector cuando necesite comunicarse (como ya se ha comentado) y verificar las señales de aviso o deberá modificarlo para reducir su atenuación. En cualquiera de los dos casos, la protección se reducirá hasta el extremo de no impedir la pérdida auditiva.

En la actualidad es difícil determinar con exactitud los niveles acústicos protegidos, puesto que las atenuaciones y desviaciones típicas y los valores de NRR resultantes están sobreestimados. N o obstante, la aplicación de los factores de reducción recomendados por el NIOSH mejoraría la exactitud a corto plazo de estas determinaciones.

La comodidad es un aspecto decisivo. Llevar un protector auditivo nunca puede ser tan cómodo como no llevar ninguno. Cubrir u obstruir el oído causa muchas sensaciones no naturales, que van desde la alteración del sonido de la propia voz a consecuencia del "efecto de oclusión" (véase más adelante) hasta la sensación de ocupación del oído o de presión sobre la cabeza. L as orejeras y los tapones resultan más incómodos en ambientes calurosos porque aumentan la transpiración. El usuario necesita tiempo para acostumbrarse a las sensaciones y la incomodidad que provoca el protector. N o obstante, si experimenta incomodidades como dolor de cabeza a consecuencia de la presión del arnés de cabeza o dolor en el canal auditivo provocado por los tapones se le deberían proporcionar dispositivos protectores de otro tipo.

Si se utilizan orejeras o tapones reutilizables hay que adoptar medidas para mantenerlos limpios. En el caso de las orejeras, el usuario debe disponer de repuestos, como almohadillas o revestimientos interiores del cuenco. Cuando se usan tapones de usar y tirar, hay que disponer de suficientes unidades nuevas para reponer. Si se emplean tapones reutilizables, hay que instalar un dispositivo de limpieza. Los usuarios de tapones a la medida deben contar con instalaciones para limpiarlos y con tapones nuevos para sustituir a los desgastados o rotos.

El trabajador estadounidense medio está expuesto a 2,7 peligros profesionales al día (Luz y cols. 1991). Estos peligros pueden exigir el uso de otros dispositivos de protección, como cascos, pantallas oculares o equipos de protección respiratoria. Es importante que el protector auditivo elegido sea compatible con otros dispositivos de seguridad. El Compendium of $\mathrm{H}$ earing Protective Devices (Franks, Themann and Sherris 1995) del $\mathrm{N}$ IO SH tiene tablas que, entre otras cosas, indican la compatibilidad de cada protector auditivo con otros dispositivos de seguridad.

\section{El efecto de oclusión}

El efecto de oclusión describe el aumento de la eficacia con que el sonido transmitido por el hueso llega al oído a frecuencias inferiores a $2.000 \mathrm{~Hz}$ cuando el canal auditivo se obstruye con el dedo o con un tapón o se cubre con orejeras. La magnitud del efecto de oclusión depende de la forma de tapar el oído. El efecto máximo se obtiene cuando se bloquea la entrada del canal auditivo. Las orejeras de cuenco grande y los tapones insertados profundamente provocan el efecto de oclusión mínimo (Berger 1988). El efecto de oclusión suele inducir a los trabajadores a resistirse a utilizar protectores porque les desagrada el sonido de su propia voz, que perciben más fuerte y amortiguada.

\section{Efecto sobre la comunicación}

Debido al efecto de oclusión que causan la mayor parte de los protectores auditivos, la propia voz tiende a sonar más fuerte (como los protectores reducen el ruido ambiental, la voz suena más alta que cuando se desprotegen los oídos). Para adaptarse al mayor volumen de su propia voz, casi todos los usuarios tienden a bajarla considerablemente. Bajar la voz en un medio ruidoso donde el interlocutor lleva también protectores auditivos contribuye a dificultar la comunicación. Además, incluso sin efecto de oclusión, casi todos los usuarios elevan la voz en sólo 5 a $6 \mathrm{~dB}$ por cada $10 \mathrm{~dB}$ de aumento del ruido ambiental (efecto Lombard). Por tanto, la combinación de voz más baja a consecuencia del uso de protectores auditivos y de una elevación insuficiente para compensar el ruido ambiental afecta gravemente a la capacidad de los usuarios de protectores auditivos para escucharse y entenderse en ambientes ruidosos.

\section{Funcionamiento de los protectores del oído}

\section{Orejeras}

La función básica de las orejeras es cubrir el oído externo con un cuenco que forma un cierre acústico atenuador del ruido. La

\section{Figura 31.13 • Tapón de espuma para los oídos, bien y mal ajustado, y consecuencias para la atenuación.}
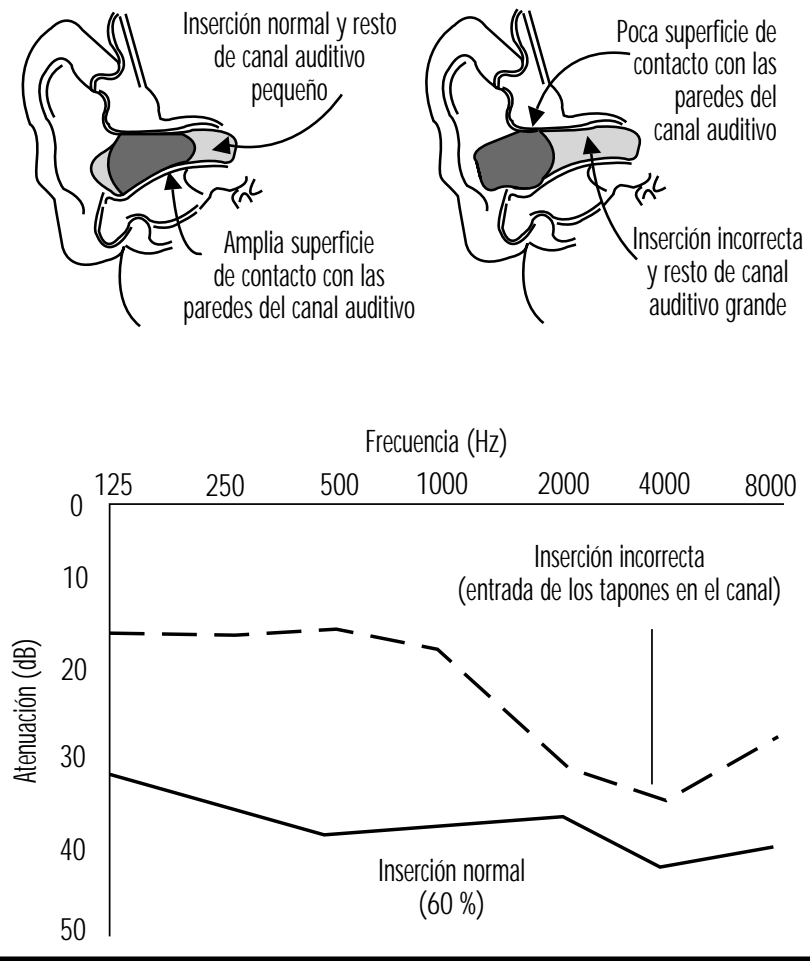
Figura 31.14 - Tapón premoldeado para los oídos, bien y mal ajustado, y consecuencias para la atenuación.
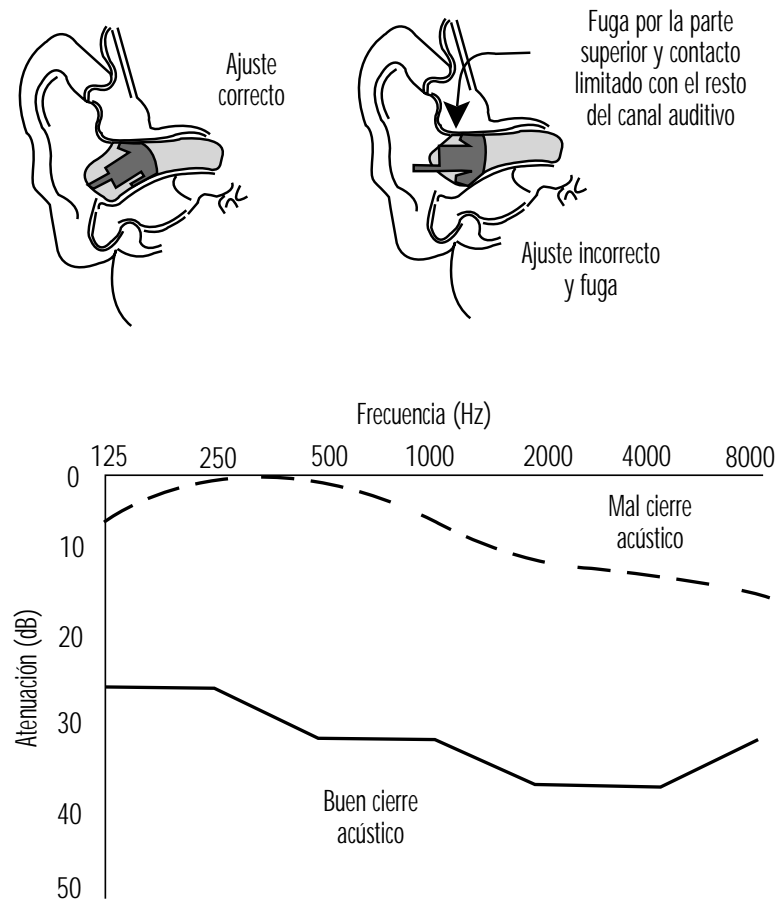

forma del cuenco y el tipo de almohadillado y la tensión del arnés de cabeza de sujeción son los factores que determinan en un grado mayor la eficacia con que las orejeras atenúan el ruido ambiental. La Figura 31.12 ilustra una orejera bien ajustada con buen cierre en todo el perímetro del pabellón auditivo y otra con una fuga bajo la almohadilla. El gráfico incluido en la misma figura muestra que, mientras que la orejera bien adaptada proporciona buena atenuación a todas las frecuencias, la mal adaptada no produce prácticamente ninguna atenuación de las frecuencias bajas. Casi todas las orejeras proporcionan una atenuación que se acerca a la conducción ósea, de aproximadamente $40 \mathrm{~dB}$, para frecuencias de $2.000 \mathrm{~Hz}$ o superiores. La capacidad de atenuación de bajas frecuencias de unas orejeras bien ajustadas está determinada por factores de diseño y materiales, como el volumen del cuenco, la superficie de la abertura del cuenco, la presión del arnés de cabeza o el peso.

\section{Tapones}

La Figura 31.13 ilustra un tapón de espuma bien ajustado y plenamente insertado (alrededor del $60 \%$ de su longitud queda dentro del canal auditivo) y otro mal ajustado que se limita a cerrar la entrada del canal auditivo sin apenas penetrar en el interior. El primero presenta buena atenuación a todas las frecuencias, mientras que el tapón de espuma mal ajustado induce una atenuación claramente menor. Bien ajustado, el tapón de espuma puede proporcionar una atenuación que se acerca a la conducción ósea a muchas frecuencias. Cuando el ruido es muy intenso, las diferencias de atenuación entre tapones de espuma bien y mal ajustados pueden ser suficiente para impedir 0 no impedir la pérdida de audición inducida por el ruido.

La Figura 31.14 ilustra un tapón premoldeado bien ajustado y otro mal ajustado. En general, los tapones premoldeados no proporcionan el mismo grado de atenuación que los de espuma o las orejeras bien ajustados. No obstante, cuando están bien ajustados proporcionan una atenuación suficiente para la mayor parte de los ruidos industriales. Sin embargo, cuando están mal ajustados presentan una atenuación muy inferior, que es nula a 250 y $500 \mathrm{~Hz}$. En algunos usuarios se ha observado una ganancia a estas frecuencias, lo que significa que el ruido protegido es más intenso que el ambiental, de manera que el trabajador está expuesto a un riesgo de sufrir pérdida de audición inducida por el ruido mayor que si no llevase protectores.

\section{Protección acústica doble}

Para algunos ruidos ambientales, en especial cuando la exposición diaria equivalente supera un valor de aproximadamente $105 \mathrm{dBA}$, un solo protector auditivo puede ser insuficiente. En estas situaciones el usuario puede utilizar al mismo tiempo orejeras y tapones para lograr una protección complementaria de 3 a $10 \mathrm{~dB}$, limitada primordialmente por la conducción ósea de la cabeza. La atenuación cambia muy poco cuando se usan distintas orejeras con los mismos tapones, pero mucho cuando se utilizan distintos tapones con las mismas orejeras. Cuando se emplea protección doble la elección de los tapones determina de forma decisiva la atenuación por debajo de $2.000 \mathrm{~Hz}$, mientras que a este valor y por encima de él prácticamente todas las combinaciones de orejeras y tapones proporcionan una atenuación más 0 menos igual a la conducción ósea.

\section{Interferencias con gafas y dispositivos de protección personal utilizados en la cabeza}

L as gafas de seguridad, los protectores respiratorios y otros dispositivos que interrumpen el cierre circumauricular de las orejeras pueden degradar la atenuación. Las gafas, por ejemplo, pueden reducir la atenuación en determinadas octavas en 3 a 7 dB.

\section{Dispositivos de respuesta plana}

Los tapones y orejeras de respuesta plana proporcionan una atenuación aproximadamente uniforme para frecuencias comprendidas entre 100 y $8.000 \mathrm{~Hz}$. Estos dispositivos mantienen la misma respuesta de frecuencia que el oído sin obstruir y no distorsionan la audición de las señales acústicas (Berger 1991). L os tapones y orejeras corrientes, además del efecto de reducción del nivel acústico, dan la sensación de que se han eliminado los agudos de la señal. L os protectores auditivos de atenuación plana dan la sensación de que sólo se ha reducido el volumen, pues las características de atenuación se "sintonizan" mediante resonadores, amortiguadores y diafragmas. La atenuación plana puede ser importante para usuarios con pérdida de audición a frecuencias elevadas, cuando es importante conservar la comprensión de la voz sin prescindir de los protectores y para quienes necesitan conservar un sonido de calidad elevada, como los músicos. H ay tanto orejeras como tapones de respuesta plana, pero ambos presentan el inconveniente de que el grado de atenuación que proporcionan es siempre inferior al de los dispositivos corrientes.

\section{Dispositivos pasivos sensibles a la amplitud}

Los protectores auditivos pasivos sensibles a la amplitud carecen de circuitos electrónicos y están diseñados para permitir la comunicación oral en períodos de silencio; la atenuación que proporcionan, escasa cuando el nivel de ruido es bajo, aumenta con la intensidad acústica. Están provistos de orificios, válvulas 0 diafragmas que provocan una atenuación no lineal, que suele comenzar cuando el nivel sonoro sobrepasa una presión acústica de $120 \mathrm{~dB}$. Por debajo de este valor, los dispositivos de orificios y válvulas actúan como protectores auditivos abiertos que 
proporcionan una atenuación máxima de $25 \mathrm{~dB}$ a las frecuencias más altas y muy escasa a $1.000 \mathrm{~Hz} 0$ menos. Pocas actividades profesionales o recreativas, fuera de las competiciones de tiro al blanco (sobre todo en exteriores) se prestan al uso de este tipo de protectores si se pretende evitar la pérdida de audición inducida por el ruido.

\section{Dispositivos activos sensibles a la amplitud}

Los protectores auditivos activos sensibles a la amplitud tienen circuitos electrónicos y su finalidad es similar a la descrita para los protectores pasivos. U tilizan un micrófono colocado en el exterior del cuenco o sujeto junto al tapón auditivo y un circuito electrónico que proporciona una amplificación cada vez menor, que puede llegar a ser nula, cuando aumenta el ruido ambiental. Al nivel de conversación normal, estos dispositivos proporcionan una ganancia igual a uno (esto significa que el habla se percibe como si no se utilizase protector) 0 una ligera amplificación. EI objetivo es mantener el nivel acústico por dentro del protector a un valor inferior a un campo difuso de $85 \mathrm{dBA}$. Algunas orejeras disponen de un canal por cada oído y permiten conservar cierta capacidad de localización de la fuente sonora; otras llevan sólo un micrófono. La fidelidad (naturalidad) de estos sistemas depende del fabricante. Debido a los circuitos electrónicos internos, estos dispositivos proporcionan en estado pasivo, con los circuitos desconectados, una atenuación entre cuatro y seis decibelios menor que la obtenida con orejeras similares sin dispositivo.

\section{Reducción activa del ruido}

$L$ a reducción activa del ruido es una idea antigua, pero su aplicación a los protectores auditivos es relativamente nueva. Algunos dispositivos funcionan captando el sonido dentro del cuenco auricular, invirtiendo la fase y retransmitiendo el ruido invertido hacia el interior del protector para neutralizar el sonido entrante. $\mathrm{O}$ tros funcionan capturando el sonido exterior, modificando su espectro para tener en cuenta la atenuación e introduciendo el ruido invertido en el cuenco auricular; los circuitos electrónicos sincronizan el sonido invertido enviado hacia el interior del cuenco con el ruido transmitido a través de éste. La reducción activa se limita a las bajas frecuencias, por debajo de $1.000 \mathrm{~Hz}$; la atenuación máxima es de 20 a $25 \mathrm{~dB}$ y tiene lugar a $300 \mathrm{~Hz} 0$ menos. Pero una parte de la atenuación proporcionada por el sistema de reducción activa del ruido se limita a compensar la pérdida de capacidad de atenuación de las orejeras debida a la incorporación en el interior de los cuencos de los circuitos electrónicos necesarios para lograr el efecto de reducción activa. En la actualidad estos dispositivos cuestan entre 10 y 50 veces más que los pasivos. Si la electrónica falla, el usuario puede quedar insuficientemente protegido y sufrir un ruido más intenso que con el circuito compensador desconectado. La generalización de los dispositivos activos debería ir acompañada de la reducción del coste y la ampliación del campo de aplicación.

\section{El protector auditivo óptimo}

El protector auditivo óptimo es aquél que el usuario está dispuesto a llevar voluntariamente durante todo el tiempo. Se estima que aproximadamente el $90 \%$ de los trabajadores del sector manufacturero de Estados Unidos que operan en ambientes ruidosos están expuestos a intensidades inferiores a 95 dBA (Franks 1988) y necesitan una atenuación comprendida entre 13 y $15 \mathrm{~dB}$ para quedar adecuadamente protegidos. $\mathrm{H}$ ay una gama muy amplia de protectores auditivos que proporcionan una atenuación suficiente; lo difícil es descubrir el que cada trabajador está dispuesto a utilizar durante todo el tiempo de exposición al ruido.

\section{ROPA PROTECTORA}

\section{S. Zack Mansdorf}

\section{Riesgos}

$\mathrm{H}$ ay varias categorías generales de riesgos para el cuerpo de los que es posible protegerse con ropa especializada; estas categorías comprenden los riesgos de naturaleza química, física y biológica. Se resumen en la Tabla 31.10.

\section{Riesgos químicos}

La ropa protectora es un medio de control utilizado habitualmente para reducir la exposición del trabajador a compuestos químicos potencialmente tóxicos o peligrosos cuando no es posible aplicar otros métodos de control. Muchos compuestos químicos son peligrosos por más de un motivo (el benceno, por ejemplo, es tóxico e inflamable). En el caso de los compuestos químicos hay que prestar atención al menos a tres aspectos decisivos: (1) el efecto potencialmente tóxico de la exposición; (2) las vías de entrada probables, y (3) el potencial de exposición asociado con el trabajo. De estos tres aspectos, la toxicidad del material es el más importante. Algunas sustancias plantean únicamente un problema de limpieza (como los aceites y grasas), mientras que otras (como el contacto con cianhídrico líquido) pueden resultar inmediatamente peligrosas para la vida y la salud (IDLH ). En particular, el factor decisivo es la toxicidad o peligrosidad de la sustancia por vía transcutánea. 0 tros efectos negativos del contacto con la piel, además de la toxicidad, son la corrosión, la inducción de cáncer de piel y ciertos traumas físicos, como quemaduras y cortes.

Un ejemplo de compuesto cuya toxicidad es máxima por vía transcutánea es la nicotina, que presenta una permeabilidad excelente a través de la piel pero, en general, no resulta peligrosa por inhalación (salvo cuando se autoadministra). Este es sólo uno de los muchos casos en que la vía transdérmica supone un peligro mucho más importante que el de otras vías de penetración. Como ya se ha sugerido, hay muchas sustancias que en principio no son tóxicas pero que sí resultan peligrosas para la piel por su naturaleza corrosiva o por otro motivo. De hecho, algunos materiales y compuestos químicos pueden resultar más peligrosos cuando se absorben a través de la piel que los cancerígenos sistémicos más temidos. Por ejemplo: una sola exposición de la piel sin proteger a ácido fluorhídrico (a una concentración superior al $70 \%$ ) puede ser mortal. En este caso, una quemadura que afecte sólo al $5 \%$ de la superficie basta para provocar la muerte a consecuencia del efecto del ión fluoruro. 0 tro ejemplo de riesgo dérmico, aunque no de carácter agudo, es la inducción de cáncer de piel por sustancias como el alquitrán de hulla. El plomo inorgánico es un ejemplo de material muy tóxico para el hombre pero escasamente peligroso por vía transcutánea. En este caso, el riesgo de la contaminación del cuerpo o la ropa estriba en que el producto se puede absorber por inhalación o ingestión, ya que no atraviesa la piel intacta.

U na vez evaluadas las vías de penetración y la toxicidad de los materiales, hay que estimar la probabilidad de exposición. ¿Están los trabajadores en contacto con el compuesto en una medida suficiente para quedar visiblemente mojados o la exposición es improbable y la ropa protectora se utiliza simplemente como medida de protección redundante? Si el material es mortal, el trabajador debe disponer del máximo grado de protección posible, aunque la probabilidad de contacto sea remota. Si la exposición representa un riesgo mínimo (una enfermera que manipula una solución de alcohol isopropílico en agua al $20 \%$, por ejemplo), el grado de protección no ha de ser necesariamente infalible. Esta elección lógica se basa 
esencialmente en una estimación de los efectos adversos del material combinada con otra de la probabilidad de la exposición.

\section{Propiedades de resistencia química de las barreras}

En los decenios de 1980 y 1990 se han publicado trabajos de investigación que revelan la difusión de disolventes y otros compuestos químicos a través de ropa protectora "a prueba de líquidos". Una prueba de investigación estándar consiste, por ejemplo, en aplicar acetona a caucho de neopreno (del grosor utilizado habitualmente en la confección de guantes). D espués del contacto directo con la acetona en la superficie externa normal, el disolvente puede detectarse normalmente en la cara interna (el lado que está en contacto con la piel) al cabo de 30 minutos, si bien en pequeñas cantidades. Esta penetración de un compuesto a través de una barrera protectora se llama permeación. El fenómeno de permeación consiste en la difusión de compuestos químicos a escala molecular a través de la ropa protectora. O curre en tres fases: absorción del compuesto en la superficie de la barrera, difusión a través de ésta y desorción en la superficie interna normal de la barrera. El tiempo transcurrido desde el contacto inicial del compuesto en la superficie externa hasta su detección en la interna se llama tiempo de permeación. La velocidad de permeación es el ritmo uniforme de movimiento del compuesto químico a través de la barrera una vez alcanzado el equilibrio.

Casi todas las pruebas actuales de resistencia a la permeación se prolongan durante períodos de hasta ocho horas, para reproducir los turnos de trabajo normales. No obstante, estas pruebas se realizan en condiciones de contacto directo de líquidos 0 gases que normalmente no se encuentran en el medio ambiente de trabajo. Por tanto, cabe argumentar que las pruebas incluyen un "factor de seguridad" considerable. Sin embargo, hay hechos que neutralizan esta hipótesis, como que la prueba de permeación es estática, mientras que el medio de trabajo es dinámico (esto significa que los materiales están sometidos a flexión y presión al sujetar y hacer otros movimientos); o que los guantes o prendas pueden encontrarse dañados. A la vista de la falta de datos publicados sobre permeabilidad de la piel y toxicidad dérmica, el enfoque adoptado por la mayoría de los profesionales de la salud y la seguridad es elegir una barrera que no presente permeación mientras dure el trabajo o la tarea (por lo general ocho horas), una idea que en lo esencial no considera la dosis. Se trata de un planteamiento conservador, pero es importante señalar que en este momento no hay ninguna barrera que proporcione resistencia a la permeación frente a todos los compuestos químicos. Cuando los tiempos de permeación son breves, el profesional de la salud y la seguridad debe elegir las barreras que mejor se comporten (es decir, que tengan la velocidad de permeación más baja) y considerar otras medidas de control y mantenimiento (como cambiar la ropa con regularidad).

Además del proceso de permeación descrito, el profesional de la salud y la seguridad debe considerar otras dos importantes propiedades de resistencia a los compuestos químicos: la degradación y la penetración. La degradación es un cambio perjudicial que afecta a una o varias propiedades físicas del material protector a consecuencia del contacto con el compuesto químico. Así, el polímero polivinil alcohol (PVA) proporciona una buena barrera frente a casi todos los disolventes orgánicos, pero se degrada en presencia de agua. El caucho de látex, muy utilizado para fabricar guantes quirúrgicos, es resistente al agua, pero fácilmente soluble en disolventes como el tolueno y el hexano; por tanto, es inútil como protección frente a estos compuestos. Por otra parte, la alergia al látex puede inducir reacciones graves en algunas personas.
Se llama penetración al flujo de un compuesto químico a través de pequeños cortes o perforaciones o de otros defectos de la ropa protectora de escala no molecular. La mejor barrera de protección será inútil si se perfora o se rompe. La protección frente a la penetración es importante cuando la exposición es improbable 0 infrecuente y la toxicidad 0 el peligro son mínimos. La penetración suele ser motivo de preocupación en la ropa utilizada como protección frente a salpicaduras.

Se han publicado varias guías con datos de resistencia a los compuestos químicos (muchas de ellas se encuentran también en formato electrónico). A demás de estas guías, casi todos los fabricantes de los países desarrollados industrialmente publican también datos actualizados de resistencia química y física de sus productos.

\section{Riesgos físicos}

Como se señala en la Tabla 31.10, son riesgos físicos las condiciones térmicas, la vibración, la radiación y los traumas, y todos ellos pueden afectar adversamente a la piel. Se clasifican como riesgos térmicos los efectos nocivos del frío y el calor extremos sobre la piel. L os atributos protectores de la ropa en relación con estos riesgos dependen de su grado de aislamiento; en cambio, la ropa que debe proteger frente a llamaradas y arco eléctrico debe presentar propiedades de resistencia a la llama abierta.

La ropa especializada puede proporcionar protección limitada frente a algunas formas de radiaciones ionizantes y no ionizantes. En general, la eficacia de la ropa que protege frente a radiaciones ionizantes se basa en el principio del apantallamiento (como los mandiles y guantes forrados de plomo, por ejemplo); en cambio, la ropa que protege frente a radiaciones no ionizantes, como las microondas, se basa en la conexión a tierra 0 el aislamiento. Las vibraciones excesivas pueden afectar adversamente a distintas partes del cuerpo, sobre todo las manos. La minería (con perforadoras manuales) y la reparación de carreteras (en la que se utilizan martillos y cinceles neumáticos) son ejemplos de ocupaciones en las que la excesiva vibración que sufren las manos puede provocar degeneración ósea y pérdida de circulación. Los traumas de la piel a consecuencia de riesgos físicos (cortes, abrasiones, etc.) son comunes en muchas ocupaciones, como la construcción o el despiece de carne. A hora hay ropa especializada (también guantes) resistente a los cortes, que se utiliza en tareas como el despiece de carne y la silvicultura (con sierras de cadena). Las propiedades de estas prendas se basan en una resistencia esencial al corte 0 en la inclusión de una masa de fibras suficiente para atascar las piezas móviles (la sierra de cadena, por ejemplo).

\begin{tabular}{ll}
\hline Tabla $31.10 \cdot$ & $\begin{array}{c}\text { Ejemplos de categorías de riesgos } \\
\text { dérmicos. }\end{array}$ \\
Riesgo & Ejemplos \\
Químico & Toxinas dérmicas \\
& Toxinas sistémicas \\
& Corrosivos \\
& Alérgenos \\
Físico & Peligros térmicos ( calor) frío) \\
& Vibración \\
& Radiación \\
& Traumáticos \\
Biológico & Patógenos para el hombre \\
& Patógenos para los animales \\
& Nocivos para el medio ambiente
\end{tabular}


Tabla 31.11 • Requisitos comunes de comportamiento físico, químico y biológico.

$\begin{array}{ll}\begin{array}{l}\text { Riesgo } \\ \text { Térmico } \\ \text { Fuego }\end{array} & \begin{array}{l}\text { Característica de comportamiento exigida } \\ \text { Valor de aislamiento } \\ \text { Aislamiento y resistencia a la llama }\end{array} \\ \text { Abrasión mecánica } & \text { Resistencia a la abrasión; resistencia a la tensión } \\ \text { Cortes y perforaciones } & \text { Resistencia al corte } \\ \text { Químico y toxicológico } & \text { Resistencia a la permeación } \\ \text { Biológico } & \text { "A prueba de líquidos"; (resistente a la punción) } \\ \text { Radiológico } & \text { Normalmente resistente al agua o a las partículas } \\ & \text { (para radionúclidos) }\end{array}$

Materiales comunes para ropa de protección Algodón grueso y otros tejidos naturales

Guantes aluminizados; guantes tratados resistentes a la llama; otros tejidos especiales

Tejidos gruesos; cuero

Malla metálica; fibras aromáticas de poliamida y otros tejidos especiales

Materiales poliméricos y elastómeros; (incluido el látex)

\section{Riesgos biológicos}

Son riesgos biológicos la infección por agentes y enfermedades comunes al hombre y los animales, y el medio ambiente de trabajo. Esta clase de riesgos han recibido mucha atención a consecuencia de la difusión del SIDA y la hepatitis, que se transmiten con la sangre. Por tanto, los puestos de trabajo que puedan suponer exposición a la sangre o los fluidos orgánicos suelen exigir el uso de ropa y guantes resistentes a los líquidos. Las enfermedades transmitidas por los animales mediante la manipulación (el ántrax, por ejemplo) se conocen desde hace mucho tiempo y requieren medidas de protección similares a las utilizadas para manipular los patógenos transportados por la sangre que afectan al hombre. Son ambientes de trabajo que pueden presentar riesgos debidos a agentes biológicos los laboratorios clínicos y microbiológicos y otros ambientes de trabajo especiales.

\section{Tipos de protección}

En un sentido general, el concepto de ropa de protección incluye todos los elementos que forman un conjunto protector (bata,

Figura 31.15 - Ropa y guantes de protección para trasvasar productos químicos.

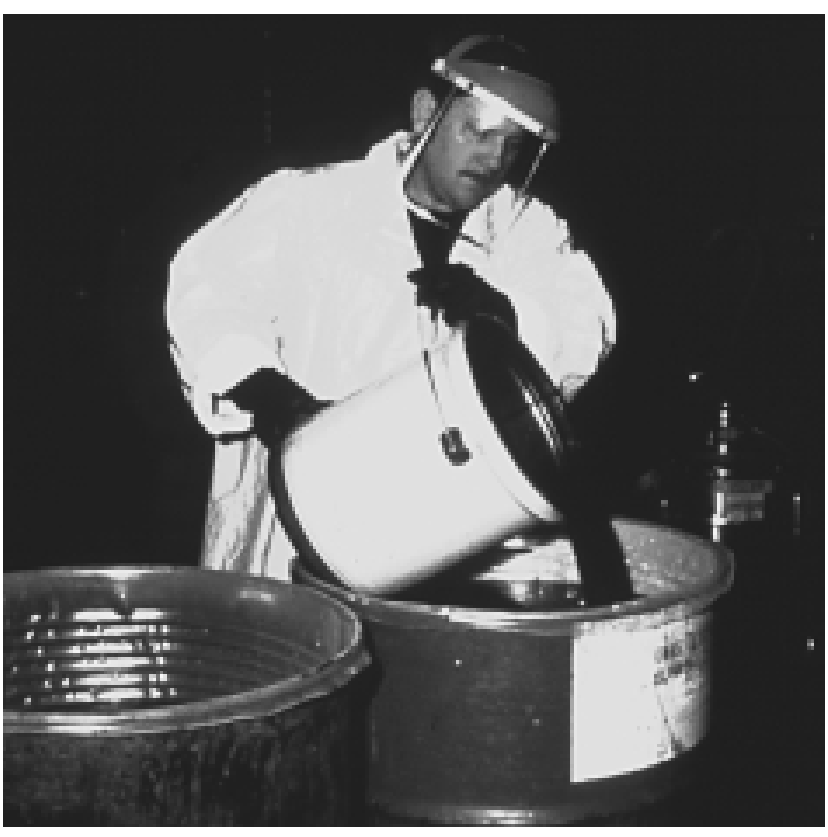

guantes y botas, por ejemplo). Por tanto, la ropa de protección abarca desde el dedal que evita los cortes causados por los cantos de las hojas de papel hasta el traje aislante completo con equipo de respiración autónomo que se utiliza en las situaciones de emergencia que siguen a los vertidos de compuestos químicos.

La ropa de protección puede ser de materiales naturales (algodón, lana y cuero, por ejemplo), sintéticos (nylon) o distintos polímeros (plásticos y cauchos, como el butilo, el cloruro de polivinilo o el polietileno de cloro). Los materiales tejidos, cosidos o con poros por cualquier otro motivo (no resistentes a la penetración ni a la impregnación por líquidos) no deben utilizarse en

Figura 31.16 - Dos trabajadores con trajes de protección química de distinta configuración.

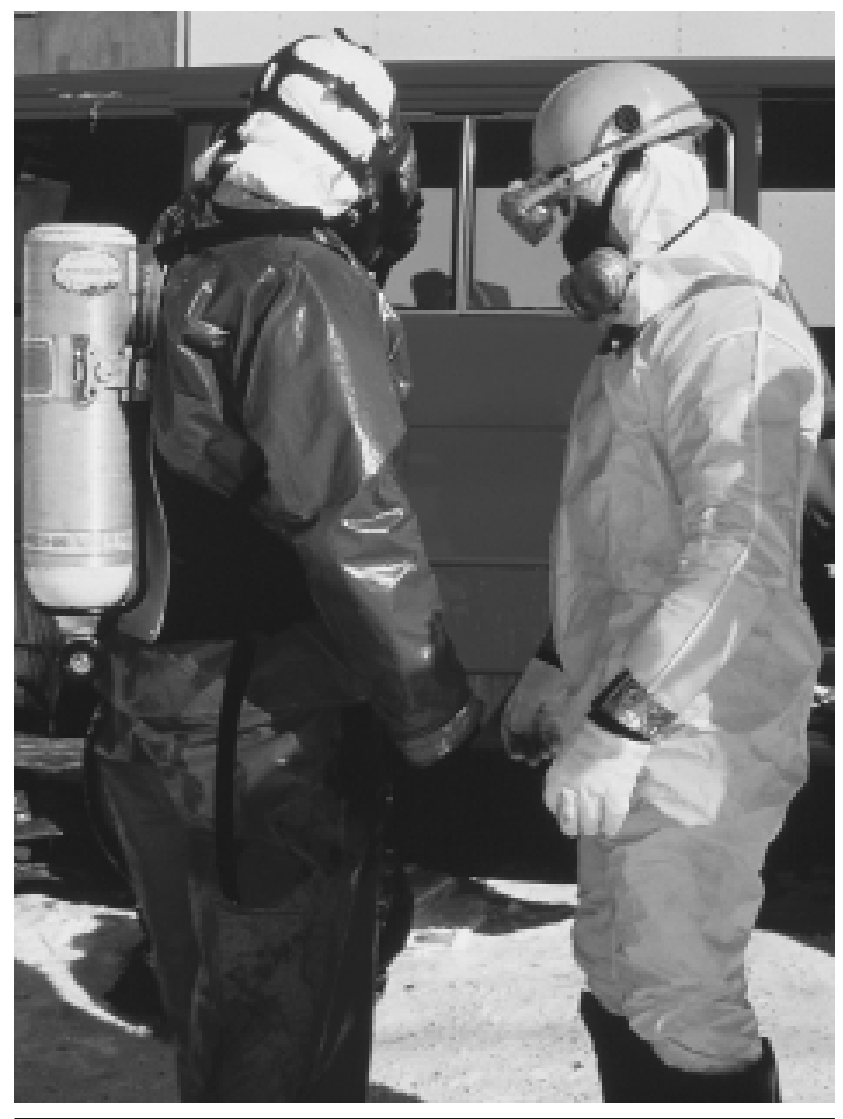


Figura 31.17 - Distintos tipos de guantes resistentes a los compuestos químicos.

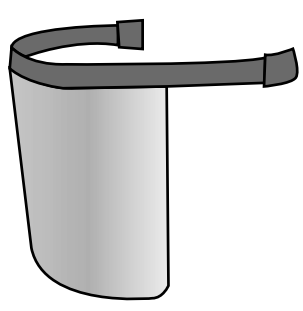

Resina acrílica

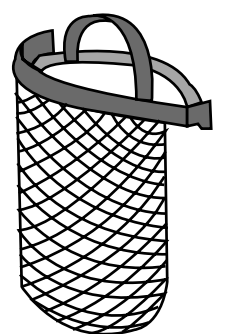

Malla de alambre

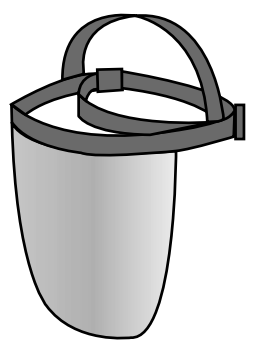

Resina acrílica situaciones que exigen protección frente a líquidos o gases. Los tejidos y materiales porosos tratados o incombustibles por su naturaleza se utilizan habitualmente en la protección frente a llamaradas y arco eléctrico (en la industria petroquímica, por ejemplo), aunque no protegen frente a las temperaturas constantemente elevadas. $\mathrm{H}$ ay que señalar que la lucha contra incendios exige ropa especializada resistente a la llama y que proporcione impermeabilidad frente al agua y aislamiento térmico (protección frente a temperaturas elevadas). Algunas aplicaciones exigen también protección infrarroja (IR ), que se logra superponiendo una película aluminizada (lucha contra incendios producidos por combustibles derivados del petróleo, por ejemplo). En la Tabla 31.11 se resumen las necesidades de comportamiento físico, químico y biológico y los materiales protectores de uso común en la protección frente a riesgos.

La configuración de la ropa protectora varía mucho en función del uso a que vaya destinada. N o obstante, los elementos normales son casi siempre similares a las prendas de uso común (pantalones, chaqueta, capucha, botas y guantes). En aplicaciones como la resistencia a la llama o la manipulación de metales fundidos se utilizan elementos especiales, como calzones, brazaletes y mandiles fabricados con fibras o materiales naturales 0 sintéticos, tratados o sin tratar (un ejemplo histórico sería el amianto). La ropa protectora frente a riesgos químicos suele ser de confección más especializada, como se ilustra en las Figuras 31.15 y 31.16.

Se comercializan guantes de protección química de polímeros y combinaciones muy diversos; así, hay guantes de algodón recubiertos de polímeros (mediante inmersión) que presentan las propiedades deseadas. (V éase la Figura 31.17). Algunos de los nuevos "guantes" de hoja metálica o capas múltiples tienen sólo dos dimensiones (planos) y, por tanto, imponen algunas limitaciones ergonómicas, aunque a cambio presentan una elevada resistencia química. Estos guantes suelen funcionar mejor cuando se lleva sobre el guante plano interior otro exterior de material polimerizado (esta técnica se llama de doble enguantado) que ajusta el primero a la forma de la mano. Hay guantes de polímeros de muchos grosores, desde los muy ligeros $(<2 \mathrm{~mm})$ hasta los muy gruesos (>5 mm), con o sin forros o sustratos interiores (cañamazo). También son muy variables las longitudes, que oscilan entre aproximadamente $30 \mathrm{~cm}$ para proteger las manos y unos $80 \mathrm{~cm}$, que cubren desde el hombro hasta la mano. La longitud óptima depende del tipo de protección necesaria pero, en general, el guante debe llegar al menos hasta la muñeca, para evitar la penetración de líquidos en el interior (véase la Figura 31.18).
También es muy variable la altura de las botas, que va desde el pie hasta la altura de la cadera. Las de protección química sólo se comercializan en una gama limitada de polímeros, pues deben presentar además una elevada resistencia a la abrasión. Entre los polímeros y cauchos utilizados habitualmente para fabricar botas resistentes a los compuestos químicos están el PVC y los cauchos de butilo y neopreno. También se comercializan botas especiales de materiales laminados en las que se utilizan otros polímeros, pero son bastante caras y, por el momento, sólo se encuentran en algunos países.

$\mathrm{H}$ ay prendas de protección química de una sola pieza totalmente cerrada (a prueba de gases) con guantes y botas incorporados o formada por varias piezas (pantalones, chaqueta, capucha, etc.). Algunos de los materiales protectores utilizados para fabricar conjuntos están formados por varias capas 0 láminas. Estos materiales multicapa suelen emplearse cuando se usan polímeros cuyas propiedades de integridad física y resistencia a la abrasión no permiten la fabricación ni el uso de las prendas 0 guantes (tales como el caucho de butilo frente al teflón ${ }^{\circledR}$ ). Entre los tejidos utilizados habitualmente como soporte están el nylon, el poliéster, las aramidas y la fibra de vidrio. Estos sustratos se recubren o laminan con polímeros, como el cloruro de polivinilo (PVC), el teflón ${ }^{\circledR}$, el poliuretano y el polietileno.

En el curso del último decenio ha experimentado un crecimiento enorme el uso de polietileno y materiales microporosos no tejidos en la fabricación de trajes de usar y tirar. Estos trajes confeccionados por hilado, a veces llamados incorrectamente "de papel", se fabrican mediante un proceso especial que une las fibras en lugar de tejerlas. Son prendas baratas y muy ligeras. Los materiales microporosos no recubiertos (llamados "transpirables", porque permiten cierto grado de transmisión del vapor de agua $y$, por tanto, son menos estresantes) y los unidos por hilado son útiles como protección frente a partículas, pero normalmente no son resistentes a los compuestos químicos y los líquidos. También se comercializa ropa unida por hilado con distintos revestimientos, como polietileno y Saranex ${ }^{\circledR}$. Según las características del recubrimiento, estas prendas pueden proporcionar buena resistencia química a la mayor parte de las sustancias comunes

\section{Homologación, certificación y normas}

L a comercialización, confección y diseño de ropa protectora varían mucho de unos a otros lugares del mundo. Como era de esperar, también varían los requisitos de homologación, normas y certificación. No obstante, se aplican normas de comportamiento voluntarias similares en Estados U nidos (por ejemplo, las normas de la

Figura 31.18 - Guantes de fibra natural de longitud suficiente para proteger la muñeca.

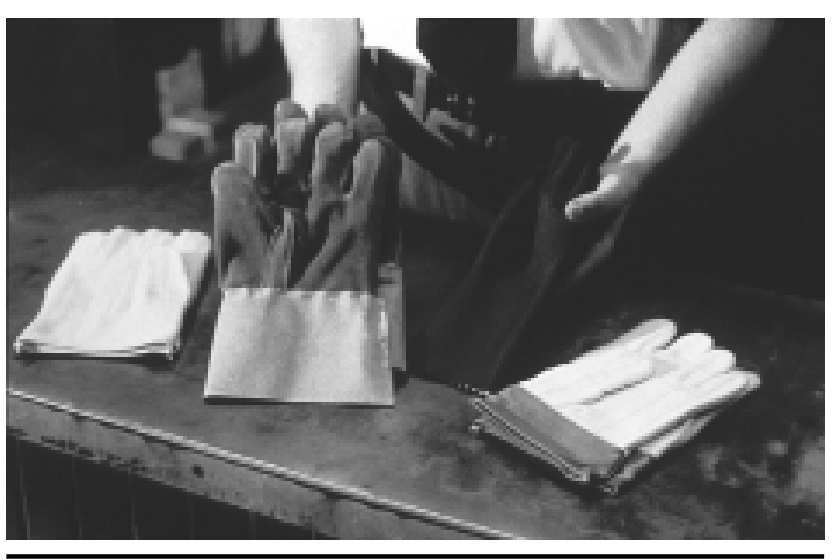


American Society for Testing and M aterials, ASTM), Europa (normas del Comité Europeo de N ormalización, CEN) y algunas zonas de Asia (normas locales, como las de Japón). La elaboración de normas de comportamiento de alcance mundial ha comenzado gracias al trabajo del grupo ComitéT écnico 94 para el Equipo y la Ropa de Protección Personal de la O rganización Internacional de N ormalización. M uchas de las normas y métodos de ensayo para medir el comportamiento creados por este grupo se basan en normas CEN o de otrospaíses, como la AST M deE stadosU nidos.

En los territorios de Estados U nidos, M éxico y buena parte de Canadá no se exige certificación ni homologación para la ropa protectora, aunque hay excepciones que afectan a aplicaciones especiales, como la aplicación de pesticidas (regulada por los requisitos de las etiquetas de los pesticidas). No obstante, hay muchas organizaciones que publican normas voluntarias, como la ASM T ya mencionada, la National Fire Protection Association (NFPA) de Estados U nidos y la Canadian Standards O rganization (CSO) de Canadá. Estas normas voluntarias influyen sustancialmente en la comercialización y venta de ropa protectora y, por tanto, actúan de forma muy similar a las normas obligatorias.

En Europa, la fabricación de equipo de protección personal está regulada por la Directiva de la Comunidad Europea $89 / 686 / C E E$, que define los productos amparados por ella y los clasifica en distintas categorías. En las categorías de equipo protector en las que el riesgo no es mínimo y en las cuales el usuario no puede identificar fácilmente el peligro, el equipo de protección debe cumplir determinadas normas de calidad y fabricación detalladas en la Directiva.

Dentro de la Comunidad Europea no pueden comercializarse productos de protección que no lleven la marca de la CE (Comunidad Europea). Para recibir esta marca es necesario cumplir ciertos requisitos de ensayo y garantía de calidad.

\section{Capacidades y necesidades individuales}

Salvo en unos pocos casos, el uso de ropa y equipo de protección disminuye la productividad y aumenta la incomodidad del trabajador. También puede perjudicar a la calidad, porque la ropa de protección incrementa las tasas de error. La ropa de protección química e ignífuga obliga a considerar una serie de normas generales relativas a los conflictos inevitables entre comodidad del trabajo, eficacia y protección. En primer lugar, cuanto más gruesa sea la barrera, tanto mejor (aumento del tiempo de permeación o mejor aislamiento térmico); pero cuanto más gruesa sea la barrera, tanto menor es la facilidad de movimientos y la comodidad del usuario. Las barreras gruesas también aumentan el potencial de estrés por calor. En segundo lugar, las barreras que proporcionan muy buena resistencia química tienden a incrementar la incomodidad del trabajo y el estrés por calor, porque normalmente también actúan como barrera frente a la transmisión de vapor de agua (transpiración). En tercer lugar, cuanto mayor sea la protección general, tanto mayores serán el tiempo necesario para realizar una tarea determinada y la probabilidad de cometer errores. $\mathrm{H}$ ay asimismo algunas tareas en las que el uso de ropa protectora puede incrementar determinados tipos de riesgo (en las proximidades de maquinaria móvil, por ejemplo, el riesgo de estrés por calor es mayor que el químico); se trata de una situación rara, pero debe tenerse en cuenta.

$\mathrm{H}$ ay que pensar también en las limitaciones físicas que impone la ropa protectora. Un trabajador equipado con un par de guantes gruesos, por ejemplo, no será capaz de realizar fácilmente tareas que exigen mucha destreza o movimientos repetitivos. Un pintor que trabaje con pistola protegido por un mono totalmente cerrado no podrá mirar hacia los lados ni hacia arriba o hacia abajo, pues el equipo de protección respiratoria y el visor del mono casi siempre limitan la visión. Estos son sólo algunos ejemplos de las limitaciones ergonómicas asociadas con el uso de ropa y equipo de protección.

Al elegir la ropa protectora hay que considerar siempre la situación de trabajo. La solución óptima es seleccionar el grado mínimo de ropa y equipo de protección necesarios para realizar el trabajo de forma segura.

\section{Educación y formación}

Es esencial proporcionar educación y formación adecuadas a los usuarios de ropa protectora. La educación y la formación deben comprender los siguientes aspectos:

- Naturaleza y magnitud de los riesgos;

- Condiciones en las que debe llevarse la ropa de protección;

- Ropa de protección necesaria;

- Uso y limitaciones de la ropa de protección que vaya a asignarse:

- Forma de inspeccionar, ponerse, quitarse, ajustarse y llevar correctamente la ropa protectora;

- En caso necesario, métodos de descontaminación;

- Signos y síntomas de sobreexposición o fallo de la ropa;

- Procedimientos de primeros auxilios y emergencia;

- Conservación, duración, cuidado y eliminación correctos de la ropa protectora.

La formación debe cubrir al menos todos los elementos que acaban de mencionarse y cualquier otra información relevante no facilitada al trabajador en otros programas. No obstante, es conveniente proporcionar a los usuarios de la ropa un resumen de todos los puntos enseñados en ocasiones anteriores. Si, por ejemplo, ya se han explicado a los trabajadores los signos y síntomas de la sobreexposición, como parte de la formación necesaria para manipular productos químicos, convendría insistir de nuevo en los síntomas asociados con la exposición dérmica importante y con la inhalación. Por último, los trabajadores deben tener la oportunidad de probar la ropa protectora pensada para un puesto determinado antes de que se haga la selección definitiva.

El conocimiento del peligro y de las limitaciones de la ropa protectora no sólo reduce el riesgo para el trabajador, sino que también permite al profesional de la salud y la seguridad solicitar información adecuada y precisa sobre la eficacia del equipo de protección.

\section{Mantenimiento}

La conservación, inspección, limpieza y reparación de la ropa protectora son aspectos importantes para la protección global que estos productos proporcionan al usuario.

$\mathrm{H}$ ay ropa protectora que presenta limitaciones de conservación, como una duración máxima predeterminada, necesidad de protección frente a la radiación UV (luz solar, antorcha de soldar, etc.), el ozono, la humedad o extremos de temperatura, 0 prohibición de plegar el producto. Así, las prendas de caucho natural exigen por lo general todas las precauciones que acaban de indicarse. M uchos de los monos de polímero cerrados pueden dañarse si se guardan doblados en lugar de colgados rectos. $\mathrm{H}$ ay que consultar estas limitaciones de conservación al distribuidor 0 el fabricante.

El usuario debe inspeccionar la ropa protectora con frecuencia (por ejemplo, después de cada uso). Puede utilizarse la técnica de inspección por parte de los compañeros para que éstos participen en asegurar la integridad de la ropa protectora que tienen que usar. Como política de gestión, es también aconsejable encargar a los supervisores que inspeccionen (a intervalos adecuados) la ropa protectora de uso habitual. Los criterios de inspección dependen del uso previsto del elemento protector, aunque normalmente incluye el examen de desgarramientos, 
agujeros, imperfecciones y degradación. Como ejemplo de técnica de inspección, los guantes de polímero utilizados como protección frente a líquidos deben llenarse de aire para comprobar si son estancos frente a las fugas.

La limpieza de la ropa protectora de varios usos debe hacerse con cuidado. Las fibras naturales se pueden limpiar con métodos de lavado normales si no están contaminadas con materiales tóxicos. Los procedimientos de limpieza apropiados para fibras y materiales sintéticos suelen ser limitados. A sí, algunos productos tratados para que presenten resistencia a la llama pierden eficacia si no se limpian correctamente. La ropa utilizada como protección frente a compuestos no solubles en agua casi nunca puede descontaminarse lavándola con agua y un jabón o un detergente corrientes. Ensayos realizados con ropa de aplicadores de pesticidas indican que los métodos de lavado corrientes son ineficaces frente a muchos de estos productos. La limpieza en seco no es recomendable en ningún caso, pues con frecuencia resulta ineficaz y puede degradar o contaminar las prendas. Es importante consultar al fabricante 0 al distribuidor de la ropa antes de intentar métodos de limpieza cuya inocuidad no se conozca de forma específica.

En general, la ropa de protección no se puede arreglar. Algunas prendas, como los monos de polímero totalmente cerrados, admiten ciertas reparaciones. No obstante, hay que consultar con el fabricante antes de hacer ningún arreglo.

\section{Uso y mal uso}

U so. Por encima de todo, la selección y el uso correctos de la ropa protectora deben basarse en una evaluación de los riesgos asociados con la tarea que exige protección. A la luz de esta evaluación es posible elaborar una definición pormenorizada de los requisitos de comportamiento y las limitaciones ergonómicas del trabajo. Por último, puede hacerse una selección que equilibre protección del trabajador, facilidad de uso y coste.

Un planteamiento más formal consiste en elaborar un programa modelo escrito; de esta forma se reducen las probabilidades de error, se mejora la protección del trabajador y se aborda de manera coherente la selección y el uso de la ropa protectora. El programa modelo podría constar de los siguientes elementos:

1. Programa de organización y un plan administrativo.

2. M etodología de evaluación del riesgo.

3. Evaluación de otras opciones de control para proteger al trabajador.

4. C riterios de comportamiento de la ropa protectora.

5. Criterios de selección y procedimientos de determinación de la elección óptima.

6. Especificaciones de compra de la ropa protectora

7. Plan de validación de la selección realizada.

8. En su caso, criterios de descontaminación y reutilización.

9. Programa de formación del usuario.

10. Plan de auditoría que garantice la aplicación sistemática de los procedimientos.

$\mathrm{M}$ al uso. $\mathrm{H}$ ay diversos ejemplos de mal uso de la ropa protectora frecuentes en la industria. EI mal uso suele ser consecuencia del desconocimiento de las limitaciones de la ropa protectora por parte de la dirección, los trabajadores o ambos. U n ejemplo claro de práctica incorrecta es el uso de ropa protectora no resistente a la llama abierta para trabajadores que manipulan disolventes inflamables o que trabajan en situaciones en las que hay llamas abiertas, hulla en combustión o metales fundidos. La ropa protectora confeccionada con polímeros, como el polietileno, puede resistir la combustión, pero al mismo tiempo fundirse y adherirse a la piel, lo que provoca quemaduras todavía más graves.
U n segundo ejemplo común es la reutilización de ropa protectora (incluidos los guantes) cuando algún compuesto químico ha contaminado su interior, de manera que la exposición del trabajador aumenta con cada uso. U na variación frecuente de este problema consiste en el uso de guantes de fibras naturales (cuero o algodón, por ejemplo) o el calzado personal para trabajar con compuestos químicos líquidos. Si éstos salpican las fibras naturales, quedarán retenidos durante mucho tiempo y migrarán hasta la piel. 0 tra variante del mismo error consiste en llevar la ropa de trabajo a casa para lavarla, una práctica que puede exponer a una familia completa a compuestos químicos nocivos, si la ropa de faena se limpia junto con el resto de las prendas familiares. Como muchos compuestos no son solubles en agua, pueden difundirse a otras prendas sólo por acción mecánica. Se han documentado varios de estos casos de difusión de contaminantes, sobre todo en industrias de fabricación de pesticidas 0 tratamiento de metales pesados (como la intoxicación de familias de trabajadores que manipulan mercurio o plomo). Estos no son sino unos pocos de los ejemplos más llamativos de mal uso de la ropa protectora. Estos problemas se evitan sencillamente conociendo el uso correcto y las limitaciones de este tipo de prendas. El fabricante y los expertos en salud y seguridad deben proporcionar esta información.

\section{Proteccion RESPIRATORIA}

ThomasJ. Nelson

En algunas industrias, el aire contaminado por polvos, humos, neblinas, vapores o gases potencialmente nocivos puede ser perjudicial para el trabajador. Es importante controlar la exposición a estos materiales para reducir el riesgo de enfermedades profesionales causadas por respirar el aire contaminado. La mejor forma de controlar la exposición es reducir al mínimo la contaminación en el lugar de trabajo. Esto puede lograrse por medio de medidas de control técnico (encerrar o limitar la operación con ayuda de equipos de ventilación general y local y uso de materiales menos tóxicos). Cuando sea inviable aplicar medidas de control técnico eficaces o mientras se están implantando o evaluando, hay que usar equipos de protección respiratoria para proteger la salud del trabajador. Para que los equipos de protección respiratoria funcionen como está previsto, es necesario instaurar un programa adecuado y bien planificado de equipos de protección respiratoria.

\section{Riesgos respiratorios}

Los riesgos para el aparato respiratorio pueden presentar la forma de contaminantes 0 de falta de oxígeno suficiente. Las partículas, gases 0 vapores que constituyen los contaminantes atmosféricos pueden estar asociados con distintas actividades (véase la Tabla 31.12).

El oxígeno es un componente normal del medio ambiente imprescindible para sostener la vida. En términos fisiológicos, la deficiencia de oxígeno es una reducción de la disponibilidad de este elemento para los tejidos del organismo. Puede deberse a la reducción del porcentaje de oxígeno en el aire o a la disminución de su presión parcial (la presión parcial de un gas es igual a la concentración relativa del gas de que se trate multiplicada por la presión atmosférica total). La forma más común de deficiencia de oxígeno en ambientes de trabajo es la reducción del porcentaje de oxígeno a consecuencia del desplazamiento de este elemento por otro gas en un espacio limitado. 
Tabla 31.12 - Riesgos materiales asociados con actividades determinadas.

\begin{tabular}{|c|c|c|}
\hline Tipo de riesgo & Fuentes 0 actividades típicas & Ejemplos \\
\hline Polvos & $\begin{array}{l}\text { Coser, pulir con muela, pulir } \\
\text { con arena, desmenuzar, } \\
\text { chorro de arena }\end{array}$ & Serrín, carbón, polvo de silice \\
\hline Humos & $\begin{array}{l}\text { Soldadura autógena, solda- } \\
\text { dura con latón, fundición }\end{array}$ & $\begin{array}{l}\text { Humos de óxidos de plomo, } \\
\text { zinc, hierro }\end{array}$ \\
\hline Nebulizaciones & $\begin{array}{l}\text { Pintura con pistola, chapado } \\
\text { de metales, mecanización }\end{array}$ & $\begin{array}{l}\text { Neblinas de pintura, neblinas } \\
\text { de aceite }\end{array}$ \\
\hline Fibras & $\begin{array}{l}\text { Productos de aislamiento y } \\
\text { fricción }\end{array}$ & Amianto, fibra de vidrio \\
\hline Gases & $\begin{array}{l}\text { Soldadura, motores de } \\
\text { combustión, tratamiento de } \\
\text { aguas }\end{array}$ & $\begin{array}{l}\text { Ozono, dióxido de carbono, } \\
\text { monóxido de carbono, cloro }\end{array}$ \\
\hline Vapores & $\begin{array}{l}\text { Desengrasado, pintura, } \\
\text { productos de limpieza }\end{array}$ & $\begin{array}{l}\text { Cloruro de metileno, tolueno, } \\
\text { alcoholes minerales }\end{array}$ \\
\hline
\end{tabular}

\section{Tipos de equipos de protección respiratoria}

L os equipos de protección respiratoria se clasifican en función del tipo de cobertura que proporcionan al aparato respiratorio (cobertura de entradas) y del mecanismo mediante el cual protegen al usuario del contaminante 0 de la deficiencia de oxígeno. Estos mecanismos son la purificación o el suministro de aire.

\section{Cobertura de entradas}

Las "entradas" al aparato respiratorio son la nariz y la boca. Para que un equipo de protección respiratoria funcione debe estar aislado por un cierre que, de algún modo, separe el aparato respiratorio del usuario del medio respirable, y que al mismo tiempo permita la entrada de una cantidad suficiente de oxígeno. $\mathrm{H}$ ay coberturas estancas y sueltas.

Las coberturas estancas pueden adoptar la forma de mascarilla, semimáscara, máscara o boquilla. La mascarilla cubre la nariz y la boca. La superficie de cierre se extiende desde el puente de la nariz hasta debajo de los labios (la cuarta parte de la cara). La semimáscara forma un cierre que va desde el puente de la nariz hasta la parte inferior de la barbilla (la mitad de la cara). El cierre de la máscara completa llega desde encima de los ojos (por debajo de la línea del pelo) hasta por debajo de la barbilla (cubre la cara completa).

El mecanismo de cobertura de la boquilla es ligeramente distinto: el usuario muerde una pieza de caucho conectada al equipo de protección respiratoria y se obstruye la nariz con una pinza. De este modo quedan cerradas las dos entradas del aparato respiratorio. Estos equipos de protección respiratoria de boquilla se usan sólo en situaciones en las que hay que huir de una atmósfera peligrosa; como su aplicación es muy especializada, no volverán a tratarse en este capítulo.

Las coberturas de mascarilla, semimáscara o máscara pueden utilizarse con equipos purificadores o suministradores de aire. EI tipo de boquilla sólo se utiliza con purificadores.

Las coberturas sueltas, como sugiere su nombre, no se basan en una superficie cerrada herméticamente para proteger el aparato respiratorio del trabajador, sino que cubren la cara, la cabeza o la cabeza y los hombros y proporcionan un medio ambiente inocuo. También se incluyen en este apartado los monos que cubren el cuerpo completo (pero no las prendas que se llevan sólo para proteger la piel, como los monos antisalpicaduras). Como no cierran la cara, las coberturas sueltas sólo funcionan con equipos que suministran un caudal de aire; éste debe ser superior al aire necesario para respirar, con el fin de evitar que el contaminante del exterior del equipo de protección respiratoria penetre en el interior.

\section{Equipos de protección respiratoria purificadores del aire}

En estos aparatos el aire del medio ambiente pasa a través de un elemento purificador que retiene los contaminantes. EI aire atraviesa el elemento purificador impulsado por la acción respiratoria (equipos de protección respiratoria de presión negativa) o por un ventilador (equipos de protección respiratoria purificadores mecánicos).

El tipo de elemento purificador del aire determina los contaminantes retenidos. Para retener aerosoles se utilizan filtros de diversa eficacia. La elección depende de las propiedades del aerosol; normalmente, el tamaño de la partícula es la característica más importante. $\mathrm{H}$ ay cartuchos químicosque sellenan con un material elegido específicamente para absorber un vapor o un gas contaminantes o para reaccionar con ellos.

\section{Equipos de protección respiratoria suministradores de aire}

Estos equipos de protección respiratoria suministran una atmósfera respirable con independencia de la que reine en el lugar de trabajo. El tipo llamado equipo semiautónomo admite tres modos de funcionamiento: demanda, caudal continuo o demanda de presión. L os aparatos que funcionan en los modos de demanda y demanda de presión pueden combinarse con semimáscaras y máscaras completas. Los de caudal continuo admiten también un casco o capuz o una mascarilla facial suelta.

Un segundo tipo de equipo de protección respiratoria suministrador de atmósfera, llamado aparato respirador autónomo, está equipado con una fuente de aire incorporada. Puede utilizarse sólo para escapar de una atmósfera peligrosa o para entrar y salir de ella. El aire está contenido a presión en una botella o se genera mediante una reacción química.

Algunos equipos de protección respiratoria semiautónomos están equipados con una pequeña botella de aire comprimido que permite al usuario salir indemne si se corta el suministro principal.

\section{Equipos mixtos}

Algunos esquipos de protección respiratoria especializados pueden funcionar tanto en modo de suministro como de purificación del aire; son los llamados equipos mixtos.

\section{Programas de protección respiratoria}

Para que un equipo de protección respiratoria funcione correctamente, es preciso elaborar un programa de protección respiratoria mínimo. Con independencia del tipo de equipo de protección respiratoria utilizado, el número de personas que intervengan y la complejidad del equipo de protección respiratoria que se utilice, todo programa debe incluir una serie de consideraciones básicas. En el caso de programas sencillos, los requisitos pueden ser mínimos. En programas más amplios, la tarea es complicada.

Considérese, a modo de ilustración, la necesidad de mantener registros de las pruebas de ajuste del equipo. En programas de una o dos personas, la fecha de la última prueba, el ajuste del equipo de protección respiratoria ensayado y el método pueden consignarse en una simple ficha; en un programa amplio, con centenares de usuarios, puede ser necesario crear una base de datos informatizada con un sistema de seguimiento de las personas que deben someterse a pruebas de ajuste.

En los seis apartados siguientes se exponen los requisitos de un buen programa. 


\section{Administración del programa}

La responsabilidad del programa de equipos de protección respiratoria debe asignarse a una sola persona, denominada administrador del programa. Esta tarea se asigna a una sola persona con el fin de que la dirección sepa con claridad quién es el responsable. Tan importante como esto es conceder a esta persona la autoridad necesaria para tomar decisiones y ejecutar el programa.

El administrador del programa debe tener conocimientos suficientes de protección de las vías respiratorias para supervisar el programa de equipos de protección respiratoria de forma segura y eficaz. Son responsabilidades del administrador del programa supervisar los riesgos respiratorios, mantener registros y evaluar el programa.

\section{Procedimientos operativos escritos}

Los procedimientos escritos se utilizan para documentar el programa, de modo que cada participante sepa lo que hay que hacer, quién es el responsable de cada actividad y cómo debe ejecutarse. El documento de procedimiento debe incluir una declaración de los objetivos del programa. En esta declaración se debe afirmar con claridad que la dirección de la empresa es responsable de la salud de los trabajadores y de la aplicación del programa de equipos de protección respiratoria. Un documento escrito que cubra los procedimientos esenciales de un programa de equipos de protección respiratoria debe cubrir las funciones siguientes:

- elección de equipo de protección respiratoria;

- mantenimiento, inspección y reparación;

- formación de los trabajadores y los supervisores y de la persona que entrega los equipos de protección respiratoria;

- pruebas de ajuste;

- actividades administrativas, entre ellas compra, control de inventario y mantenimiento de registros;

- control de los riesgos;

- supervisión del uso del equipo de protección respiratoria;

- evaluación médica;

- suministro de equipos de protección respiratoria para situaciones de emergencia;

- evaluación del programa.

\section{Formación}

La formación es un elemento importante de todo programa de equipos de protección respiratoria. Necesitan formación el supervisor de quienes utilizan los equipos de protección respiratoria, los propios usuarios y quien entrega a éstos los equipos de protección respiratoria. El supervisor necesita saber lo suficiente del equipo de protección respiratoria en uso y de por qué se usa como para poder vigilar si se utiliza correctamente; en cuanto a la persona que entrega el equipo de protección respiratoria al usuario, necesita tener formación suficiente para estar segura de que proporciona el equipo correcto.

Los trabajadores que utilizan equipos de protección respiratoria deben recibir formación inicial y actualizaciones periódicas. La formación debe comprender la explicación y descripción de lo siguiente:

1. Naturaleza del peligro para las vías respiratorias y posibles efectos sobre la salud si el equipo de protección respiratoria no se utiliza correctamente.

2. M otivo por el que se ha elegido un tipo de equipo de protección respiratoria determinado.

3. Funcionamiento y limitaciones del equipo de protección respiratoria.

4. Forma de poner el equipo de protección respiratoria en funcionamiento y de comprobar que funciona correctamente y está bien ajustado.
5. Forma de mantener, inspeccionar y guardar el equipo de protección respiratoria.

6. Si se utilizan equipos de protección respiratoria de presión negativa, hay que enseñar la forma de hacer la prueba de ajuste.

\section{M antenimiento del equipo de protección respiratoria}

El mantenimiento del equipo de protección respiratoria comprende limpieza regular, inspección de daños y sustitución de piezas desgastadas. El fabricante es la mejor fuente de información sobre cómo realizar las operaciones de limpieza, inspección, reparación y mantenimiento.

Los equipos de protección respiratoria deben limpiarse e higienizarse periódicamente. Si deben utilizarlos varias personas, es preciso limpiarlos e higienizarlos antes de que los usen otros. L os reservados para situaciones de emergencia deben limpiarse e higienizarse después de cada uso. Esta operación no debe descuidarse, pues quizá sea necesario realizar ajustes especiales para que el equipo de protección respiratoria funcione correctamente, tales como controlar las temperaturas de las soluciones de limpieza con el fin de no dañar los elastómeros del dispositivo. A demás, puede ser necesario limpiar algunas piezas con cuidado o de una forma especial para no estropearlas. EI fabricante del equipo de protección respiratoria sugerirá algún procedimiento.

Después de limpiar e higienizar los equipos de protección respiratoria, deben inspeccionarse para determinar si se encuentran en buenas condiciones de servicio, si hay que sustituir 0 reparar piezas o si deben tirarse. El usuario debe estar suficientemente formado y familiarizado con el equipo de protección respiratoria para ser capaz de inspeccionarlo inmediatamente antes de cada uso con el fin de cerciorarse de que se halla en buen estado de servicio.

Los equipos de protección respiratoria reservados para situaciones de emergencia deben inspeccionarse periódicamente (se sugiere una frecuencia de una vez al mes). Estos equipos de protección respiratoria deben limpiarse e inspeccionarse después de cada uso y antes de volver a almacenarlos.

En general, la inspección comprenderá una verificación de la estanqueidad de las conexiones; del estado de la cobertura de las entradas de las vías respiratorias, el arnés de cabeza, las válvulas y los tubos de conexión, los conjuntos de sujeción, las manqueras, filtros, cartuchos, cajas filtrantes, indicador de final de vida útil, componentes eléctricos y fecha de caducidad, y del correcto funcionamiento de reguladores, alarmas y otros sistemas de advertencia.

$\mathrm{H}$ ay que prestar especial atención a la inspección de elastómeros y piezas de plástico, frecuentes en este tipo de equipos. Las piezas de caucho y otros elastómeros se pueden inspeccionar, para determinar su flexibilidad y los signos de deterioro, estirando y doblando el material y observando los posibles signos de agrietamiento o desgaste. Las válvulas de inhalación y exhalación suelen ser delgadas y se dañan con facilidad. También hay que vigilar la acumulación de jabones y otros productos de limpieza en las superficies de hermeticidad y los asientos de las válvulas; el deterioro y la acumulación pueden provocar fugas excesivas a través de las válvulas. Las piezas de plástico deben inspeccionarse para averiguar si han sufrido daños, como el desgaste 0 la rotura de hilos de rosca en los cartuchos, por ejemplo.

Las botellas de aire y oxígeno debe inspeccionarse para determinar si están plenamente cargadas según las instrucciones del fabricante. Algunos tipos deben inspeccionarse periódicamente para verificar si el metal no está dañado u oxidado. Estas verificaciones pueden incluir la prueba hidrostática periódica de integridad de la botella. 
Las piezas defectuosas deben sustituirse por recambios suministrados por el propio fabricante. Algunas piezas pueden parecer similares a las de otros fabricantes, pero quizá se comporten de forma distinta una vez montadas en el equipo de protección respiratoria. Los encargados de las reparaciones deben haber recibido formación sobre la forma de mantener y montar los equipos de protección respiratoria.

Los equipos semiautónomos y autónomos exigen un grado de formación más elevado. Las válvulas reductoras y de admisión, los reguladores y las alarmas sólo deben ajustarlos y repararlos el fabricante del equipo de protección respiratoria o un técnico formado por él.

Los equipos de protección respiratoria que no cumplan los criterios de inspección deben retirarse del servicio inmediatamente y repararse o sustituirse.

Los equipos de protección respiratoria deben almacenarse correctamente. Pueden sufrir daños si no se protegen de agentes físicos y químicos como vibraciones, luz solar, calor, frío extremo, humedad excesiva o compuestos dañinos. Los elastómeros utilizados para fabricar la pieza facial se dañan fácilmente si no se protegen. Los equipos de protección respiratoria no se deben guardar en lugares como cajas de herramientas o armarios roperos, salvo que estén protegidos de contaminación y daños.

\section{Evaluaciones médicas}

Debido al estrés a que someten al aparato respiratorio, los equipos de protección respiratoria pueden afectar a la salud de quienes los utilizan. Es recomendable que un médico evalúe a cada uno de los usuarios de equipos de protección respiratoria para determinar si pueden Ilevar estos equipos sin dificultad. Es el médico quien debe determinar en qué consistirá la evaluación médica, y puede exigir o no que esta evaluación de la salud incluya un reconocimiento médico.

Para realizar esta tarea, el médico debe recibir información sobre el tipo de equipo de protección respiratoria utilizado y el tipo y la duración del trabajo que debe ejecutarse mientras se utiliza el equipo. En la mayor parte de los casos, una persona sana normal no se verá afectada por el uso del equipo de protección respiratoria, sobre todo si éste es un modelo ligero del tipo depurador del aire.

Q uien se prevea que habrá de utilizar un equipo de protección respiratoria autónomo en condiciones de emergencia deberá someterse a una evaluación más detenida. El peso del aparato de protección respiratoria autónomo contribuirá considerablemente a la carga de trabajo que se debe realizar.

\section{Equipos de protección respiratoria homologados}

M uchos gobiernos disponen de sistemas para probar y homologar el funcionamiento de los equipos de protección respiratoria que se van a emplear en su jurisdicción. En estos casos hay que utilizar un equipo de protección respiratoria homologado, puesto que la propia homologación indica que el equipo ha superado algunos requisitos de rendimiento mínimos. Si el gobierno no exige homologación formal, es probable que cualquier equipo homologado de forma válida proporcione mayores garantías de funcionamiento correcto que otro que no se ha sometido a ninguna clase de ensayos de homologación.

\section{Dificultades que afectan a los programas de equipos de protección respiratoria}

$\mathrm{H}$ ay varios aspectos de uso del equipo de protección respiratoria que pueden dificultar la gestión de un programa de equipos de protección respiratoria, como el pelo facial y la compatibilidad con gafas y otros equipos protectores utilizados junto con el equipo de protección respiratoria.

\section{Pelo facial}

EI pelo facial puede plantear un problema práctico a la hora de gestionar un programa de equipos de protección respiratoria. Algunos trabajadores llevan barba por motivos estéticos y a otros les resulta difícil afeitarse porque sufren una afección médica que hace que el pelo se curve y crezca hacia el interior de la piel después del afeitado. Al inhalar, se instaura dentro del equipo de protección respiratoria una presión negativa y, si el cierre con la cara no es estanco, pueden penetrar contaminantes; esto afecta tanto a los equipos de protección respiratoria purificadores como a los de suministro de aire. La dificultad estriba en cómo ser ecuánime y permitir a los trabajadores que lleven barba o bigote $y$, al mismo tiempo, proteger su salud.

Varios estudios de investigación demuestran que el pelo facial en la superficie de cierre de un equipo de protección respiratoria estanco provoca fugas excesivas. Estos estudios demuestran también que la magnitud de las fugas provocadas por el pelo es tan variable que no es posible determinar si los trabajadores recibirán protección adecuada, incluso si los equipos de protección respiratoria se han ajustado a la medida. Esto significa que un trabajador con barba o bigote equipado con un equipo de protección respiratoria estanco podría no quedar suficientemente protegido.

El primer paso para resolver este problema consiste en determinar si puede utilizarse un equipo de ajuste suelto. Por cada tipo de equipo de protección respiratoria de ajuste estanco - salvo los equipos de protección respiratoria autónomos y los mixtos de evacuación y semiautónomos- hay otro de ajuste suelto que proporciona una protección similar.

O tra opción consiste en destinar a los trabajadores afectados a puestos que no exijan el uso de equipo de protección respiratoria. La última opción posible es obligar al trabajador a afeitarse. Si al trabajador le resulta difícil esta solución por motivos de salud, en la mayor parte de los casos se puede encontrar una solución médica que le permita afeitarse y utilizar equipo de protección respiratoria.

\section{G afas y otros equipos protectores}

Algunos trabajadores usan gafas para ver $y$, en determinados medios industriales, hay que llevar gafas de seguridad, normales 0 de montura ajustada para proteger los ojos de las partículas volantes. Al llevar un equipo de protección respiratoria de tipo semimáscara, las gafas pueden interferir con el ajuste del equipo de protección respiratoria en la zona del puente de la nariz. Si se utiliza una máscara completa, las patillas interrumpirán la superficie de cierre y provocarán fugas.

A continuación se proponen algunas soluciones para estas dificultades. Si se usa semimáscara, primero se realiza una prueba de ajuste durante la cual el trabajador debe llevar las gafas o elementos protectores que puedan interferir con el funcionamiento del equipo de protección respiratoria. El ensayo de ajuste sirve para demostrar que las gafas u otros accesorios no interfieren con el funcionamiento del equipo de protección respiratoria.

En el caso de los equipos de protección respiratoria de máscara completa, las opciones posibles son utilizar lentes de contacto o gafas especiales montadas dentro de la mascarilla (casi todos los fabricantes proporcionan monturas especiales con este fin). En ocasiones se ha pensado que no deben utilizarse lentes de contacto con equipos de protección respiratoria, pero la investigación ha demostrado que los trabajadores pueden usar las dos cosas al mismo tiempo sin ninguna dificultad. 
Figura 31.19 - Guía de selección de equipos de protección respiratoria.

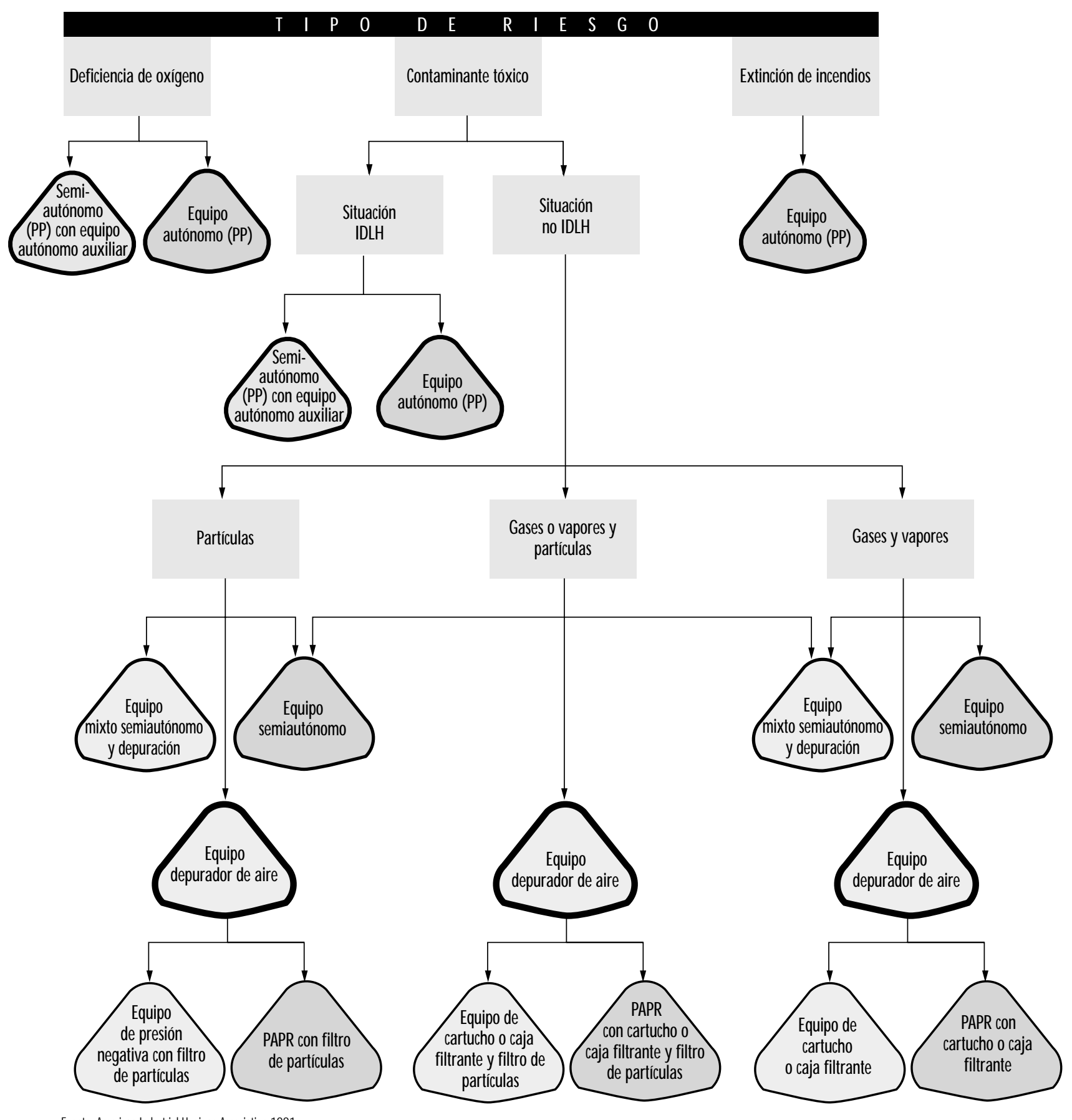

\section{Propuesta de procedimiento de elección de equipo de protección respiratoria}

Para elegir un equipo de protección respiratoria hay que analizar cómo se utilizará y conocer las limitaciones de cada tipo. Son consideraciones generales lo que hará el trabajador, la forma de utilizar el equipo de protección respiratoria, la ubicación del trabajo y cualesquiera limitaciones que el equipo de protección respiratoria pueda imponer al trabajo, como se ilustra esquemáticamente en la Figura 31.19.
Para elegir el equipo de protección respiratoria adecuado, hay que tener en cuenta la actividad del trabajador y su situación dentro de la zona peligrosa (por ejemplo, hay que saber si estará dentro de la zona peligrosa continuamente o de forma intermitente durante el turno de trabajo y si el trabajo es ligero, medio o pesado). En el caso de uso continuo y trabajo pesado, sería preferible utilizar un equipo de protección respiratoria de peso ligero.

Las condiciones ambientales y el grado de esfuerzo que deba realizar el usuario del equipo de protección respiratoria pueden 
afectar a la duración de éste. Así, el esfuerzo físico extremo puede hacer que el usuario agote la reserva de aire de un equipo de protección respiratoria autónomo, cuya duración en servicio se reducirá a la mitad o menos.

Un factor importante que debe tenerse en cuenta es el tiempo durante el cual debe llevarse equipo de protección respiratoria. También hay que prestar atención al tipo de tarea que debe realizarse con el equipo de protección respiratoria: rutinaria, no rutinaria, de urgencia o de salvamento.

$\mathrm{H}$ ay que considerar también la localización del área peligrosa en relación con el área segura en la que hay aire respirable. Este conocimiento permitirá planificar la salida de los trabajadores en caso de emergencia y la entrada para realizar operaciones de mantenimiento y salvamento. Si hay mucha distancia hasta la zona con aire respirable o si el trabajador necesita sortear obstáculos o subir escaleras, los equipos de aire suministrado pueden no ser buena idea.

Si hay posibilidades de deficiencia de oxígeno, hay que medir el contenido de oxígeno del espacio de trabajo de que se trate. La clase de equipo de protección respiratoria que puede utilizarse (de purificación o suministro de aire) dependerá de la presión parcial de oxígeno. Como los purificadores de aire sólo limpian el aire, debe haber suficiente oxígeno en la atmósfera para mantener la vida.

Para elegir el equipo de protección respiratoria, es necesario examinar cada operación a fin de cerciorarse de los posibles riesgos (determinación de riesgos) y elegir un tipo o clase de equipo que proporcione una protección adecuada.

\section{Etapas de la determinación de riesgos}

Para determinar las propiedades de los contaminantes que puedan hallarse presentes en el lugar de trabajo hay que consultar con la fuente principal de esta información, que es el proveedor del material. Muchos proveedores proporcionan a sus clientes una ficha técnica de seguridad que contiene datos sobre la identidad de los materiales que forman un producto y aporta información sobre los límites de exposición y toxicidad.

$\mathrm{H}$ ay que determinar si hay algún límite de exposición publicado, como un valor límite umbral (T LV), límite de exposición permisible, concentración máxima admisible o cualquier otro límite de exposición o estimación de toxicidad de los contaminantes de que se disponga. Es preciso averiguar si se conoce un valor de concentración inmediatamente peligrosa para la vida 0 la salud (IDLH) del contaminante. Cada equipo de protección respiratoria tiene alguna limitación de uso basada en el grado de exposición. $\mathrm{H}$ ace falta algún tipo de límite para determinar si el equipo de protección respiratoria proporcionará una protección suficiente.

$\mathrm{H}$ ay que averiguar si hay alguna norma sanitaria legalmente obligatoria que afecte al contaminante de que se trate (como las hay para el plomo o el amianto). En caso afirmativo, puede haber equipos de protección respiratoria obligatorios que ayuden a estrechar el abanico de selección.

El estado físico del contaminante es una característica importante. Si se trata de un aerosol, hay que determinar o estimar el tamaño de las partículas. También es importante la presión de vapor de los aerosoles a la temperatura máxima prevista del medio ambiente de trabajo.

$\mathrm{H}$ ay que determinar si el contaminante presente puede absorberse a través de la piel, provocar insensibilización de ésta o ser irritante o corrosivo para los ojos o la piel. En el caso de contaminantes gaseosos o en forma de vapor, hay que averiguar si hay alguna concentración que produce un olor, sabor o irritación conocidos.

Una vez conocida la identidad del contaminante, es preciso determinar su concentración. Esto suele hacerse recogiendo el material en una muestra de medio y analizándolo en el laboratorio. A veces la evaluación puede hacerse estimando exposiciones, como se describe a continuación.

\section{Estimación de la exposición}

Para determinar el peligro no siempre es necesario tomar muestras. La exposición puede estimarse estudiando datos relativos a tareas similares o calculando sobre un modelo. Tanto los modelos como el razonamiento sirven para estimar la exposición máxima probable, en la que puede basarse la elección de equipo de protección respiratoria. (EI modelo más básico adecuado para ello es el de evaporación: se deja evaporar una cantidad conocida de material en un espacio de aire, se determina la concentración de vapor y se estima la exposición. Pueden hacerse ajustes para compensar los efectos de la dilución o la ventilación.)

0 tras fuentes posibles de información sobre exposición son los artículos de revistas o publicaciones profesionales que recogen datos de exposición correspondientes a distintos sectores industriales. Las asociaciones profesionales y los datos recogidos en programas de higiene para procesos similares son también fuentes valiosas.

Para adoptar medidas de protección basadas en una exposición estimada hay que hacer un juicio basado en la experiencia relativa al tipo de exposición de que se trate. Por ejemplo: los datos de control atmosférico de tareas anteriores no serán útiles la primera vez que se produzca una interrupción súbita de una

Tabla 31.13 - Factores de protección asignados según AN SI.Z88.2 (1992).

\begin{tabular}{|c|c|c|c|c|}
\hline \multirow[t]{2}{*}{ Tipo de equipo } & \multicolumn{4}{|c|}{ Cobertura de la entrada a las vías respiratorias } \\
\hline & $\begin{array}{l}\text { Semimás- } \\
\text { cara }^{1}\end{array}$ & $\begin{array}{l}\text { Máscara } \\
\text { completa }\end{array}$ & $\begin{array}{l}\text { Cascol } \\
\text { capuz }\end{array}$ & $\begin{array}{l}\text { Careta } \\
\text { suelta }\end{array}$ \\
\hline Purificador del aire & 10 & 100 & & \\
\hline \multicolumn{5}{|l|}{ Suministro de aire } \\
\hline ARA (demanda) ${ }^{2}$ & 10 & 100 & & \\
\hline Semiautónomo (demanda) & 10 & 100 & & \\
\hline Purificación asistida & 50 & $1.000^{3}$ & $1.000^{3}$ & 25 \\
\hline \multicolumn{5}{|c|}{ Respiradores de línea de aire (semiautónomo) } \\
\hline \multicolumn{5}{|c|}{ Semiautónomo con aire comprimido } \\
\hline Demanda de presión & 50 & 1.000 & - & - \\
\hline Caudal continuo & 50 & 1.000 & 1.000 & 25 \\
\hline \multicolumn{5}{|c|}{ Aparato respirador autónomo (ARA) } \\
\hline $\begin{array}{l}\text { Presión positiva (demanda } \\
\text { circuito abierto/ cerrado) }\end{array}$ & - & 4 & - & - \\
\hline
\end{tabular}

1 Incluye la mascarilla, la semimáscara de usar y tirar y la semimáscara con careta de elastómero.

2 Los equipos autónomos de demanda no deben utilizarse en situaciones de emergencia, como la extinción de incendios. 3 Los factores de protección indicados corresponden a filtros y absorbentes de eficacia elevada (cartuchos y cajas). En el caso de filtros de polvo debe utilizarse un factor de protección asignada de 100 debido a sus limitaciones. ${ }^{4}$ Aunque actualmente se considera que los de presión positiva proporcionan el máximo grado de protección de las vías respiratorias, de un número limitado de estudios recientes de simulación del lugar de trabajo se concluye que no todos los usuarios logran factores de protección de 10.000. Teniendo en cuenta estos datos limitados, no es posible atribuir un factor de protección asignado definitivo para equipos autónomos de presión positiva. A efectos de planificación de emergencias en las que puedan estimarse las concentraciones de sustancias peligrosas, debe utilizarse un factor de protección no superior a 10.000.

Nota: Los factores de protección asignados no son aplicables a los respiradores de huida. En el caso de los equipos de protección respiratoria combinados (equipos semiautónomos con filtro depurador del aire), el factor de protección depende del modo de funcionamiento.

Fuente: ANSI Z88.2 1992 
línea de distribución. La posibilidad de un accidente de este tipo debe preverse antes de que pueda determinarse la necesidad de un equipo de protección respiratoria, y la elección del tipo adecuado se puede basar en una estimación de la concentración probable del contaminante y su naturaleza. Así, en una operación que obligue a manejar tolueno a temperatura ambiente no haría falta más protección que la proporcionada por una conducción continua de aire, puesto que no cabe esperar una concentración de tolueno superior a su valor de IDLH, que es de $2.000 \mathrm{ppm}$. Por el contrario, en caso de rotura de una conducción de dióxido de azufre estaría indicado un dispositivo más eficaz (un equipo de protección respiratoria de suministro de aire con una botella de emergencia, por ejemplo), pues una fuga de este tipo provoca fácilmente concentraciones ambientales de contaminante superiores al valor de IDLH de 20 ppm. En el siguiente apartado se examina con mayor detenimiento la elección de equipo de protección respiratoria.

\section{Etapas de selección de un equipo de protección respiratoria concreto}

Cuando no es posible determinar qué contaminante potencialmente peligroso puede estar presente, la atmósfera se considera inmediatamente peligrosa para la vida o la salud. En estas circunstancias hace falta un dispositivo aparato de protección respiratoria autónomo o una conducción de aire con una botella de emergencia. Asimismo, si no se dispone de ningún límite u orientación de exposición y no es posible estimar la toxicidad, la atmósfera se considera IDLH y se utiliza un aparato de protección respiratoria autónomo (véase más adelante el apartado sobre atmósferas IDLH).

En algunos países hay normas muy específicas sobre equipos de protección respiratoria que pueden utilizarse en ciertas situaciones para compuestos determinados. Si hay una norma específica para un contaminante, deben cumplirse las exigencias legales.

En atmósferas pobres en oxígeno, el tipo de equipo de protección respiratoria elegido depende de la presión parcial y la concentración de oxígeno y de la concentración de los otros contaminantes posibles.

\section{Indice de peligro y factor de protección asignado}

La concentración medida o estimada de un contaminante se divide por su límite o valor orientativo de exposición para obtener el índice de peligro correspondiente. Se elige un equipo de protección respiratoria en relación con este contaminante, que tenga un factor de protección asignado (FPA) superior al valor del índice de peligro (el factor de protección asignado mide el comportamiento estimado de un equipo de protección respiratoria). En muchos países se asigna a la semimáscara un factor de protección de diez. Se supone que la concentración en el interior del equipo de protección respiratoria se reduce en un factor de diez, es decir, en el FPA.

El factor de protección asignado figura en cualquier reglamento vigente sobre uso de equipos de protección respiratoria o en la American $N$ ational Standard for Respiratory Protection (ANSI Z88.2 1992). Los FPA de la ANSI se recogen en la Tabla 31.13.

Así, para una exposición al estireno (límite de exposición de 50 $\mathrm{ppm}$ ) con todos los datos medidos en el lugar de trabajo inferiores a 150 ppm, el índice de peligro es de 3 (es decir, $150 \div 50=3$ ). U n equipo de protección respiratoria de semimáscara con un factor de protección asignado de 10 garantizará que la mayor parte de los datosno medidos estarán muy por debajo del límite asignado.

En algunos casos en los que se toman muestras del "peor caso posible" o en los que sólo se recogen unos pocos datos, hay que utilizar el sentido común para decidir si los datos son suficientes para hacer una evaluación aceptablemente fiable de los niveles de exposición. Si, por ejemplo, se han tomado dos muestras para una tarea de corta duración que representa el "peor caso" para esa tarea y las dos muestras están por debajo del doble del límite de exposición (índice de peligro de 2), un equipo de protección respiratoria de semimáscara (con un FPA de 10) sería probablemente apropiado y, sin la menor duda, una máscara completa de flujo continuo (con un FPA de 1.000) proporcionaría una protección suficiente. La concentración de contaminante debe ser también inferior a la concentración de uso máximo del cartucho - la caja (esta información la proporciona el fabricante del equipo de protección respiratoria).

\section{Aerosoles, gases y vapores}

Si el contaminante es un aerosol, hay que utilizar un filtro que se elige en función de su eficacia en relación con las partículas de que se trate. La documentación proporcionada por el fabricante orientará sobre la elección del filtro. Si, por ejemplo, el contaminante es una pintura, laca o esmalte, puede usarse un filtro especial para nebulizaciones de pintura. $\mathrm{H}$ ay también filtros especiales para humos o partículas de polvo de tamaño superior al normal.

En el caso de gases y vapores, hay que facilitar información suficiente sobre el fallo del cartucho. Como indicadores de que el contaminante ha atravesado el cartucho se utilizan el olor, el sabor o la irritación. Por tanto, la concentración a la que se hacen perceptibles el olor, el sabor o la irritación debe ser inferior al límite de exposición. Si el contaminante es un gas 0 un vapor con poca capacidad de advertencia, suele recomendarse el uso de un equipo de protección respiratoria de suministro de aire.

Pero en ocasiones no pueden utilizarse equipos de protección respiratoria de suministro de aire, sea por falta de tal suministro o por necesidades de movilidad del trabajador. En este caso se pueden emplear dispositivos depuradores, pero deben estar provistos de un indicador que señale el final de la vida útil del dispositivo de manera que el usuario esté advertido antes de la penetración del contaminante. O tra opción es crear un programa de cambio de cartuchos basado en los datos de servicio, la concentración esperada, la pauta de uso y la duración de la exposición.

\section{Elección de equipos de protección respiratoria para situaciones de emergencia e IDLH}

C omo ya se ha señalado, se supone que se dan condiciones ID L H cuando se desconoce la concentración de un contaminante. Además, es prudente considerar todos los recintos cerrados que contienen una concentración de oxígeno inferior al 20,9\% como inmediatamente peligrosos para la vida o la salud. Los recintos cerrados presentan riesgos únicos. La falta de oxígeno en recintos cerrados causa muchas muertes y lesiones graves. Cualquier reducción del porcentaje de oxígeno demuestra, como mínimo, que el recinto cerrado de que se trate no está suficientemente ventilado.

En condiciones IDLH a presión atmosférica normal pueden utilizarse dos tipos de equipos de protección respiratoria: aparato de protección respiratoria autónomo de presión positiva o una combinación de equipo de protección respiratoria de suministro de aire con una botella de emergencia. Cuando se utilizan equipos de protección respiratoria en condiciones ID L H debe haber al menos una persona de vigilancia en una zona segura; esta persona debe disponer de equipo adecuado para ayudar a los usuarios del equipo de protección respiratoria en caso de dificultades. $\mathrm{H}$ ay que mantener las comunicaciones entre el vigilante y el usuario. 


\section{Figura 31.20 - Método cuantitativo del acetato de isoamilo para comprobar el ajuste.}

Determinación del umbral olfativo

1. Hacen falta tres recipientes de vidrio de un litro con cierres metálicos (siven los botes de conserva corrientes). (Nota: algunos fabricantes comercializan un conjunto de materiales para probar el ajuste que contiene todos los elementos y soluciones necesarios.)

2. Las soluciones deben prepararse con agua inodora (destilada o mineral, por ejemplo) a una temperatura de aproximadamente $25^{\circ} \mathrm{C}$.

3. La solución de reserva de acetato de isoamilo (AIA) (también llamado acetato de isopentilo) se prepara añadiendo $1 \mathrm{ml}$ de AlA puro a $800 \mathrm{ml}$ de aqua inodora en un recipiente de un litro y agitando durante 30 segundos. Esta solución debe renovarse al menos una vez a la semana.

4. La solución para la prueba olfativa se prepara en un segundo recipiente añadiendo 0,4 $\mathrm{ml}$ de solución de reserva a $500 \mathrm{ml}$ de agua inodora con un cuentagotas 0 una pipeta limpios. Agitar durante 30 segundos y dejar en reposo durante dos 0 tres minutos, de modo que la concentración de AIA por encima del líquido pueda alcanzar el equilibrio. Esta solución se conserva sólo durante un día.

5. Se prepara un control neutro con $500 \mathrm{ml}$ de agua inodora.

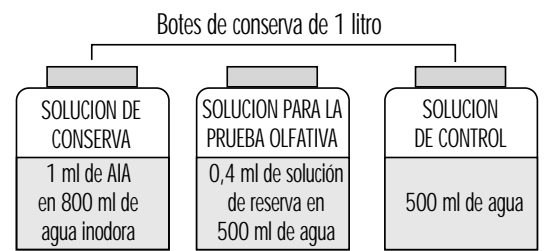

6. La prueba de selección debe realizarse en una sala distinta de la utilizada para la prueba de ajuste propiamente dicha. Ambas han de estar ventiladas de forma independiente y con eficacia; no deben estar conectadas a ningún sistema de ventilación por recirculación.

7. Hay que colocar una etiqueta de identificación en los botes que contienen la solución para la prueba olfativa y de control.

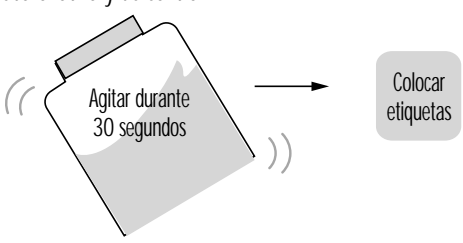

8. Se pide al sujeto que compruebe si los cierres están bien apretados y que a continuación agite los botes. Luego debe abrirlos uno después de otro, aspirar en la misma boca del recipiente e indicar cuál de los dos huele a plátano.

9. Las soluciones utilizadas para hacer esta prueba deben prepararse en una zona separada de la reservada a la prueba, para evitar la fatiga olfativa de los sujetos examinados.

10. Si el sujeto no logra identificar correctamente el recipiente que contiene la solución de la prueba olfativa, no debe someterse a la determinación cuantitativa del ajuste con AlA.
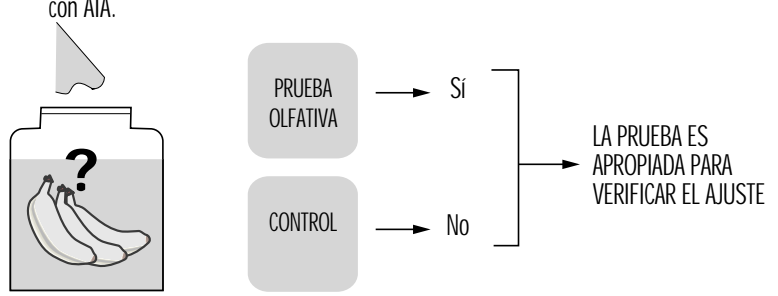

Prueba de ajuste

1. La cámara de comprobación del ajuste debe ser esencialmente similar a un barril de 55 galones (208 litros) suspendido boca abajo sobre una plataforma circular de unos $60 \mathrm{~cm}$ de diámetro, de modo que esta plataforma quede a unos $15 \mathrm{~cm}$ de la parte superior de la cabeza del sujeto. También hay que montar un pequeño gancho en el centro de la cara interna de la tapa superior de la cámara.

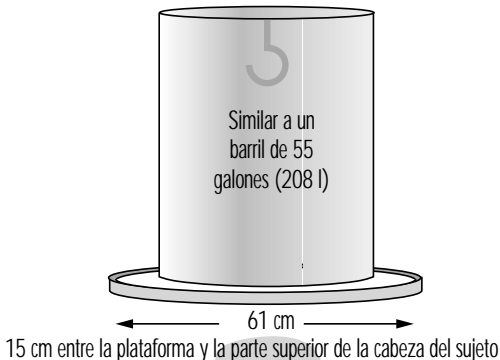

2. Los equipos de protección respiratoria utilizados para el ajuste o para la prueba de ajuste deben estar provistos de cartuchos contra vapores orgánicos o de alguna otra forma de protección frente a esta clase de vapores. El cartucho o la mascailla debe cambiarse al menos una vez a la semana.

3. Después de elegir, colocar y ajustar correctamente un equipo, el sujeto examinado debe llevarlo puesto a la sala de prueba del ajuste. Esta sala debe estar separada de la utilizada para la prueba olfativa y la elección del equipo; debe estar también bien ventilada, quizá con una campana y un extractor de laboratorio, para evitar la contaminación general de la sala.

4. Hay que pegar una copia de los ejercicios de prueba al interior de la cámara de prueba.
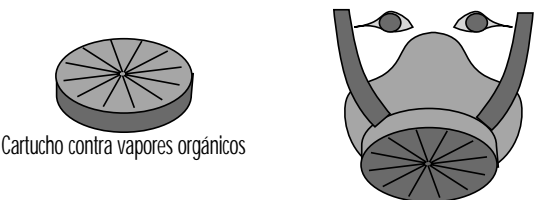

5. Antes de que entre en la cámara de prueba se entrega al sujeto una toalla de aproximadamente 15 por $12 \mathrm{~cm}$, de papel o de otro material poroso absorbente, de una sola capa, doblado por la mitad e impregnado con 0,75 $\mathrm{ml}$ de AlA puro. La toalla se cuelga del gancho situado en la parte superior de la cámara.

6. Antes de realizar los ejercicios se esperan dos minutos para que la concentración de AlA alcance el valor adecuado para la prueba. Este tiempo puede aprovecharse para hablar con el sujeto, explicarle en qué consiste la prueba de ajuste, hacerle ver la importancia de que coopere, describirle la finalidad de los ejercicios de cabeza o hacer una demostración de algunos de ellos.

7. Cada ejercicio debe realizarse durante 30060 segundos.

8. Si en cualquier momento de la prueba el sujeto detecta el olor a plátanos del AIA, debe salir rápidamente de la cámara de prueba y abandonar la sala para evitar la fatiga olfativa.

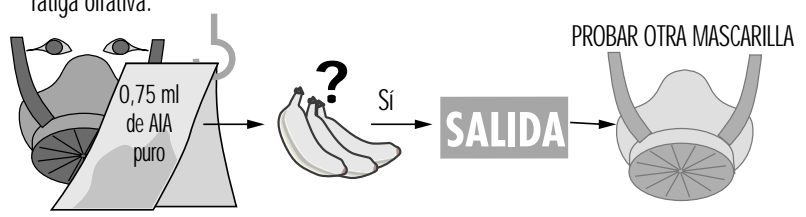

9. Al volver a la sala de selección, el sujeto debe quitarse el equipo de protección respiratoria, repetir la prueba de sensibilidad olfativa, elegir y colocarse otro equipo, volver a la cámara de prueba, etc. La operación continúa hasta dar con un equipo que ajuste. Si no pasa el ensayo de sensibilidad olfativa, el sujeto debe esperar alrededor de cinco minutos antes de repetirlo. Por lo general, la sensibilidad se recupera después de este período.

10. Cuando se encuentra un equipo que supera la prueba, se demuestra su eficacia para el sujeto haciendo que abra el cierre facial y aspire antes de salir de la cámara.

11. Los sujetos que hayan pasado bien esta prueba pueden recibir un dispositivo con un factor de protección no superior a 10. 
Figura 31.21 - Método cuantitativo del aerosol de sacarina para comprobar el ajuste.

Determinación del umbral gustativo

1. Se utiliza un recinto de prueba de aproximadamente $30 \mathrm{~cm}$ de diámetro y $35 \mathrm{~cm}$ de altura y transparente al menos por su parte delantera. Debe permitir el libre movimiento de la cabeza con el equipo de protección respiratoria puesto. (Nota: algunos fabricantes comercializan un conjunto de materiales para probar el ajuste que contiene todos los elementos y soluciones necesarios.)

2. El recinto de prueba debe tener un orificio de aproximadamente $2 \mathrm{~cm}$ de diámetro situado frente a la zona de la nariz y la boca del sujeto para colocar en él la boquilla nebulizadora.

3. Antes de realizar la prueba de selección hay que explicarle al sujeto toda la rutina de selección y prueba.

4. El sujeto se coloca el recinto de prueba sobre la cabeza. Para realizar la prueba del umbral gustativo debe respirar por la boca.

5. Valiéndose de un nebulizador médico DeVilbiss Modelo 40 o equivalente, el encargado de realizar la prueba debe pulverizar la solución de comprobación del umbral hacia el recinto. Este nebulizador debe estar claramente identificado para diferenciarlo del que contiene la solución de prueba (véase más adelante).

6. La solución de comprobación del umbral contiene 0,83 g de sacarina sódica (USP) en agua. Se prepara añadiendo $1 \mathrm{ml}$ de la solución de comprobación del ajuste (véase más adelante) a $100 \mathrm{ml}$ de agua.

Solución de comprobación de

0,83 g de sacarina sódica

$$
\text { (USP) en agua }
$$
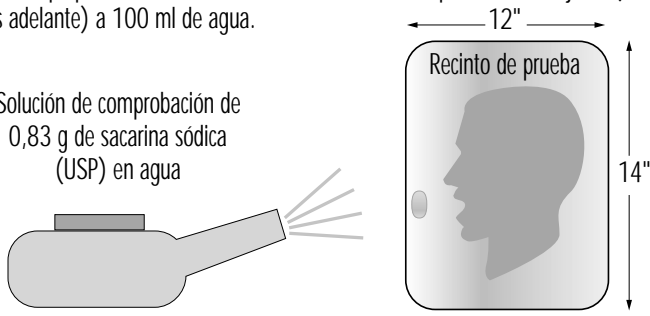

7. Para producir el aerosol, se aprieta con firmeza hasta el fondo la perilla del nebulizador y a continuación se suelta y se deja que se distienda por completo.

8. Se aprieta la perilla diez veces rápidamente dirigiendo el aerosol hacia el recinto y se pregunta al sujeto si nota el sabor de la sacarina. Si el nebulizador se utiliza correctamente, se enviará aproximadamente $1 \mathrm{ml}$ de líquido por cada diez movimientos de compresión de la perilla.

9. Si la primera respuesta es negativa, se vuelve a accionar el nebulizador otras diez veces en sucesión rápida y se vuelve a preguntar al sujeto si percibe el sabor de la sacarina.

10. Si la segunda respuesta es negativa, se efectúa una tercera serie de diez nebulizaciones rápida y se vuelve a preguntar al sujeto si percibe el sabor de la sacarina.

11. El realizador de la prueba anota el número de nebulizaciones necesario para inducir

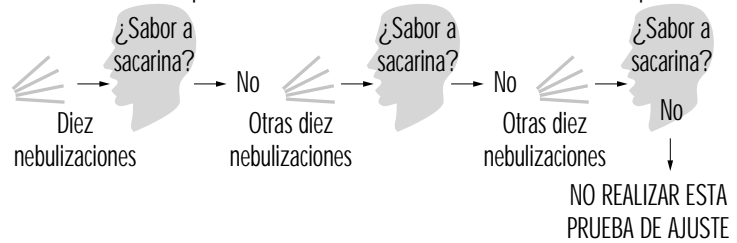

12. Si no detecta el sabor de la sacarina después de 30 nebulizaciones, el sujeto no debe realizar la prueba de ajuste de la sacarina.

13. Si se obtiene respuesta, se pide al sujeto que anote el sabor percibido para utilizarlo como referencia en la prueba de ajuste.
Prueba de ajuste

1. En la prueba de ajuste se utiliza el mismo recinto ya descrito.

2. Los equipos objeto de la prueba se eligen tal como ya se ha descrito. El equipo de protección respiratoria debe estar equipado con un filtro para partículas.

3. El sujeto debe llevar el equipo durante varios minutos antes de iniciar la prueba.

4. El sujeto debe colocar la cabeza en el recinto mientras lleva el equipo elegido.

5. El sujeto no puede comer, beber (salvo agua) ni mascar chicle durante los 15 minutos anteriores al inicio de la prueba.

6. Se utiliza un segundo nebulizador médico DeVilbiss Modelo 40 o equivalente para pulverizar en el recinto la solución de prueba de ajuste. Este nebulizador debe estar claramente etiquetado para diferenciarlo del utilizado para administrar la solución de umbral gustativo

7. La solución de prueba de ajuste se prepara añadiendo $83 \mathrm{~g}$ de sacarina sódica a

$100 \mathrm{ml}$ de agua caliente.

8. Como en la prueba anterior, el sujeto debe respirar por la boca.

Solución de prueba de ajuste

de 83 g de sacarina sódica

(USP) en $100 \mathrm{ml}$ de agua caliente.
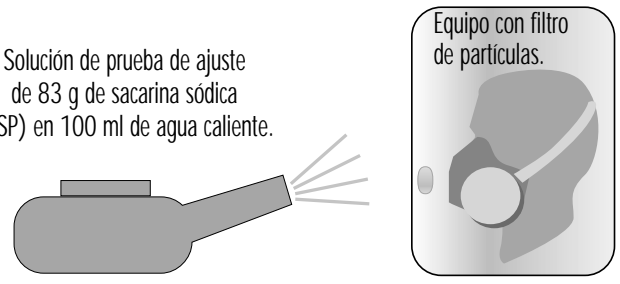

9. Se inserta el nebulizador en el orificio frontal del recinto y se pulveriza la solución de prueba siguiendo la misma técnica descrita para la determinación del umbral gustativo y administrando el mismo número de nebulizaciones (10, 20 ó 30).

10. Después de generar el aerosol se pide al sujeto que realice los ejercicios descritos con anterioridad.

11. Cada 30 segundos se renueva la concentración de aerosol administrando la mitad de las nebulizaciones utilizadas inicialmente $(5,10$ ó 15).

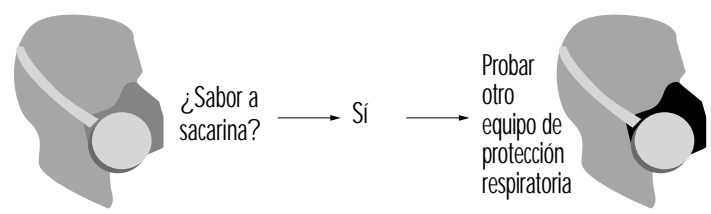

12. El sujeto debe indicar al experimentador si en algún momento detecta sabor a sacarina.

13. Si detecta sacarina se considera que el ajuste no es satisfactorio y se prueba otro equipo.

14. Los sujetos que hayan pasado bien esta prueba pueden recibir un dispositivo con un factor de protección no superior a 10
M ientras trabaje en la atmósfera IDLH, el usuario debe estar equipado con un arnés y conducciones de seguridad que permitan llevarlo a una zona segura en caso necesario.

\section{Atmósferas pobres en oxígeno}

En términos estrictos lo único que importa de la deficiencia de oxígeno es su presión parcial en una atmósfera determinada. La deficiencia de oxígeno puede deberse a una reducción en el porcentaje de este gas en la atmósfera, a una disminución de la presión 0 a las dos cosas. A altitudes elevadas, la menor presión atmosférica total puede determinar una presión parcial de oxígeno muy baja.

El hombre necesita una presión parcial de oxígeno de aproximadamente $95 \mathrm{~mm} \mathrm{Hg}$ (torr) para sobrevivir. El valor exacto varía de unas personas a otras en función de su salud y su capacidad de aclimatación a condiciones de baja presión de oxígeno. 
El citado valor de $95 \mathrm{~mm} \mathrm{H}$ g equivale a un $12,5 \%$ de oxígeno al nivel del mar 0 a un $21 \%$ a una altitud de 4.270 m. Una atmósfera de estas características puede afectar adversamente a quien presente poca tolerancia a las bajas concentraciones de oxígeno 0 a quien no esté aclimatado y deba realizar un trabajo que exija una agudeza mental considerable o que suponga estrés acusado.

Para evitar efectos adversos, los equipos de protección respiratoria de suministro de aire deben funcionar a presiones parciales de oxígeno más elevadas, del orden de $120 \mathrm{~mm} \mathrm{Hg} \mathrm{o} 16 \%$ de oxígeno al nivel del mar. En todas las decisiones que afecten a personas que deban trabajar en atmósferas pobres en oxígeno debe intervenir un médico. Puede haber valores de concentración porcentual o presión parcial de oxígeno legalmente obligatorios que exijan el uso de equipos de protección respiratoria de suministros de aire con ajustes distintos de las orientaciones generales propuestas aquí.

\section{Algunos procedimientos de prueba del ajuste}

Todas las personas que deban utilizar un equipo de protección respiratoria estanco de presión negativa han de someterse periódicamente a pruebas de ajuste. Todas las caras son distintas y un equipo de protección respiratoria determinado podría no ajustarse a la cara de un usuario concreto. La falta de ajuste permite la entrada de aire contaminado en el equipo de protección respiratoria y reduce la protección que éste proporciona. Es preciso repetir la prueba de ajuste periódicamente y siempre que el usuario experimente algún cambio que pueda interferir con el cierre facial de la mascarilla, como alguna cicatriz de cierto tamaño, cambios odontológicos o cirugía reconstructiva o estética. Al hacer las pruebas de ajuste, el usuario debe llevar todo el equipo protector que utilice en el trabajo y que pueda afectar a la hermeticidad, como gafas graduadas o de protección, pantalla facial o casco de soldadura. El equipo de protección respiratoria debe llevar también la configuración de uso y estar provisto del cartucho o la caja de barbilla.

\section{M étodos de prueba de ajuste}

L as pruebas de ajuste tienen por objeto determinar si un modelo y talla determinados de mascarilla se ajustan a la cara de un individuo. Antes de hacer las pruebashay que informar al sujeto del uso y funcionamiento correctos del equipo de protección respiratoria y explicarle la finalidad de la prueba y la forma de realizarla. El usuario del equipo de protección respiratoria debe comprender queselepidequeelija el model o queseajustede forma más cómoda. Cada equipo de protección respiratoria tiene un tamaño y una forma propias y, si ajusta bien y se utiliza correctamente, proporcionará una protección adecuada.

Ningún tamaño ni modelo de equipo de protección respiratoria se ajusta a todas las caras. Los distintos tamaños y modelos se adaptan a una gama más amplia de tipos faciales; por tanto, hay que disponer de un número suficiente de tallas y modelos entre los cuales elegir uno apropiado.

Se empieza por pedir al sujeto que realiza la prueba que se coloque cada una de las mascarillas en la cara y descarte las que obviamente no se ajustan de forma cómoda. Normalmente, la selección empieza con una semimáscara y, si no se logra un buen ajuste, se prueba con una mascarilla completa (hay un pequeño porcentaje de usuarios que no pueden llevar ninguna clase de semimáscara).

El sujeto debe hacer una comprobación de ajuste a presión positiva o negativa siguiendo las instrucciones del fabricante antes de iniciar la prueba. A continuación podrá realizar esta prueba siguiendo uno de los métodos que se indican a continuación. $\mathrm{H}$ ay otros métodos, entre ellos los cuantitativos, que utilizan instrumentos para medir las fugas hacia el interior del equipo de protección respiratoria. Los métodos descritos en este capítulo son cualitativos y no necesitan equipo de ensayo costoso; se trata de los protocolos (1) del acetato de isoamilo (IAA) y (2) del aerosol de solución de sacarina.

Ejercicios de prueba. Durante la prueba de ajuste, el usuario debe realizar varios ejercicios para comprobar que el equipo de protección respiratoria permite realizar una serie de acciones básicas y necesarias. Se recomiendan los seis ejercicios siguientes: postura erguida en descanso, respiración normal, respiración profunda, mover la cabeza de un lado a otro, mover la cabeza hacia arriba y hacia abajo y hablar (véanse las Figuras 31.20 y 31.21 ).

\section{Referencias}

American Industrial Hygiene Association (AIHA). 1991. Respiratory Protection: A M anual and Guideline Fairfax, Virginia: AIH A.

American National Standards Institute (ANSI). 1974 $M$ ethod for the $M$ easurement of $R$ eal- $E$ ar Protection of $H$ earing Protectors and Physical Attenuation of E armuffs Documento núm. S3.19-1974 (ASA Std 1-1975). Nueva York: ANSI.

- 1984. M ethod for the M easurement of Real-Ear Attenuation of $\mathrm{H}$ earing Protectors. Documento núm. S12.6-1984 (ASA ST D55-1984). NuevaY ork: ANSI.

- . 1989. Practice for $O$ ccupational and $E$ ducational $E$ ye and Face Protection. Documento núm. ANSI Z 87.1-1989. Nueva Y ork: ANSI

-. 1992. American National Standard for Respiratory Protection. Documento núm. ANSI Z 88.2. Nueva York: ANSI.

Berger, EH. 1988. Hearing protectors - Specifications, fitting, use and performance. En $\mathrm{H}$ earing $\mathrm{C}$ onservation in Industry, Schools and the M ilitary, dirigido por DM Lipscomb. Boston: College-H ill Press.

-. 1991. Flat-response, moderate-attenuation and level-dependent H PD s: How they work, and what they can do for you. Spectrum 8 Supl. 1:17.
Berger, EH, JR Franks, F Lindgren. 1996. International review of field studies of hearing protector attenuation. $\mathrm{En}$ Proceedings of the $\mathrm{Fifth}$ International Symposium: effects of $\mathrm{N}$ oise on $\mathrm{H}$ earing dirigido por A Axelsson, $H$ Borchgrevink, L $\mathrm{H}$ ellstrom, RP $\mathrm{H}$ amernik, D Henderson y RJ Salvi. Nueva Y ork: Thieme M edical.

Berger, EH, JE Kerivan, F Mintz. 1982. Inter-laboratory variability in the measurement of hearing protector attenuation. I Sound Vibrat 16(1):14-19.

British Standards Institute (BSI) 1994. H earing Protectors - Recommendations for Selection, U se, Care and $M$ aintenance - Guidance D ocument. D ocumento núm. BSI EN 458:1994. Londres: BSI.

Bureau of Labour Statistics. 1980. W ork I njury R eport An Administrative Report On Accidents Involving Foot Injuries. Washington, DC: Bureau of Labour Statistics, D epartment of L abour.

Comité Europeo de Normalización (CEN). 1993. Industrial Safety $\mathrm{H}$ elmets. Norma europea EN 397-1993. Bruselas: CEN

Comunidad Económica Europea (CEE) 1989. Directiva 89/686/CEE sobre la aproximación de las disposiciones legales y reglamentarias de los Estados miembros en materia de equipos de protección individual. Luxemburgo: CEE.
Federal Register. 1979. Noise Labeling Requirements for $H$ earing Protectors. Fed. regist. 44 (190), 40 CFR, part 211: 56130-56147. Washington, DC: GPO.

1983. Occupational Noise Exposure Hearing Conservation Amendment: Final Rule. Fed regist.. 48 (46): 9738-9785. Washington, D C: G PO

-. 1994. Respiratory Protection. Fed regist. Título 29, Sección 1910, Subsección 134. Washington, DC: GPO

Franks, JR. 1988. Number of workers exposed to occupational noise. Sem Hearing 9(4): 287-298, dirigido por W. M elnick.

Franks, JR, CL Themann, C Sherris. 1995. The $\mathrm{NIOSH}$ Compendium of $\mathrm{H}$ earing Protection Devices. Publication No. 95-105. Cincinnati, O hio: NIOSH.

Luz, I, S M elamed, T Najenson, N Bar, M S Green. 1991. The structured ergonomic stress level (E-S-L) index as a predictor of accident and sick leave among male industrial employees. En Proceedings of the ICCE $F 90$ Conference, dirigido por $L$ Fechter. Baltimore: ICCEF.

$\mathrm{M}$ arsh, JL. 1984. Evaluation of saccharin qualitative fitting test for respirators. Am Ind $\mathrm{Hyg}$ Assoc J 45(6):371-376.

M iura, T. 1978. Calzado e higiene de los piés (en japonés). T okio: Bunka Publishing Bureau. 
-. 1983. Eye and face protection. En Enciclopedia de salud y seguridad en el trabajo, 3a edición. Ginebra: OIT.

$\mathrm{N}$ ational Institute for $\mathrm{O}$ ccupational Safety and $\mathrm{H}$ ealth (NIOSH). 1987. NIOSH Respirator Decision Logic. Cincinnati, O hio: NIOSH, Division of Standards Development and T echnology T ransfer.

National Safety Council. N.d. Safety H ats, Data Sheet 1-561 R ev 87. Chicago: National Safety Council.

Nelson, TJ, OT Skredtvedt, JL Loschiavo, SW Dixon. 1984. Development of an improved qualitative fit test using isoamyl acetate. J Int Soc Respir P rot 2(2):225-248

Nixon, CW, EH Berger. 1991. Hearing protection devices. En $\mathrm{H}$ andbook of Acoustical M easurements and $\mathrm{N}$ oise Control, dirigido por CM H arris. Nueva Y ork: $\mathrm{M}$ CG raw-Hill.

N orma europea (EN). 1995. Specification for welding filters with switchable luminous transmittance and welding filters with dual luminous transmittance. Borrador final ref. no. pr EN 379: 1993E.

O rganización Internacional de Normalización (ISO) 1977. Industrial Safety H elmets. ISO 3873. Ginebra: ISO.

- . 1979. Personal Eye Protectors for $W$ edding and R elated $T$ Techniques - Filters - U tilization and T ransmittance Requirement. Norma international ISO 4850. Ginebra: ISO .

- 1981. Personal EyeProtectors - Filters and E ye Protectors against $L$ aser R adiation. ISO 6161-1981. Ginebra: ISO .

- 1990. A coustics - $\mathrm{H}$ earing Protectors - Part 1: Subjective $M$ ethod for the M easurement of Sound Attenuation. ISO 4869-1:1990(E). G inebra: ISO

- . 1994. A coustics - H earing Protectors - Part 2: E stimation of Effective A-W eighted Sound Pressure Levels When $H$ earing Protectors Are W orn. ISO 4869-2:1994(E). Ginebra: ISO .
Pritchard, JA. 1976. A Guide to Industrial Respiratory Protection. Cincinnati, O hio: NIOSH.

R osenstock, LR. 1995. Carta con fecha 13 de marzo de 1995 de L. Rosenstock, Director del National Institute for O ccupational Safety and Health, a James R. Petrie, Presidente del Comité de la M ine Safety and $\mathrm{H}$ ealth Administration, US Department of $L$ abour

Scalone, AA, RD Davidson, DT Brown. 1977. Development of $T$ est $M$ ethods and Procedures for $F$ oot Protection. Cincinnati, O hio: $\mathrm{NIOSH}$.

\section{0 tras lecturas recomendadas}

H ead protection at work. 1986. J O ccup Acc 8(3):157-

M ayer, A, S Salsi, JP G rosdemange. 1974. Cascos de seguridad industrial. Resultado de pruebas, detalles del proceso de fabricación, criterios de selección (en francés). N otes Sci T ech 14. 


\section{SISTEMAS DE NOTIFICACION Y VIGILANCIA}

Director del capítulo

Steven D. Stellman

\section{Sumario}

Sistemas de vigilancia y notificación de enfermedades profesionales

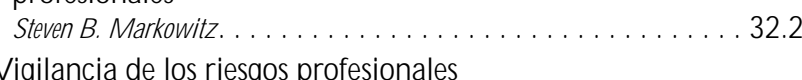

D avid $H$. W egman y Steven D. Stellman . . . . . . . . . . . . . . 32.8

Vigilancia en los países en vías de desarrollo

$D$ avid Koh y KeSeng Chia. . . . . . . . . . . . . . . . . . 32.11

Desarrollo y aplicación de un sistema de clasificación de

lesiones y enfermedades profesionales

Elyce Biddle.............................. 32.13

Análisis del riesgo de lesiones y enfermedades no mortales en el lugar de trabajo

$J$ ohn W. R user. . . . . . . . . . . . . . . . . . . . . . . . . . . . . . 32.20

Estudio de caso: protección del trabajador y

estadísticas sobre accidentes y enfermedades

profesionales-H V BG, Alemania

$M$ artin $B$ utz y B urkhard $H$ offmann

Estudio de caso: W ismut- las consecuencias de la exposición al uranio

$\mathrm{H}$ enz $\mathrm{O}$ tten y $\mathrm{H}$ orst Schulz.

Estrategias y técnicas de medición para la evaluación de la exposición en epidemiología

Frank B ochmann y $\mathrm{H}$ elmut B lome.

Estudio de caso: encuestas de higiene industrial

en China

Zhi Su.... 


\section{SISTEMAS DE VIGILANCIA Y NOTIFICACION DE ENFERMEDADES PROFESIONALES}

\section{Steven B. Markowit}

La vigilancia de las enfermedades y lesiones profesionales consiste en el control sistemático de los episodios relacionados con la salud en la población activa, con el fin de prevenir y controlar los riesgos profesionales, así como las enfermedades y lesiones asociadas a ellos. La vigilancia de las enfermedades y lesiones profesionales tiene cuatro componentes esenciales (Baker, M elius y M illar 1988; Baker 1986).

1. Recopilar información sobre los casos de enfermedades y lesiones profesionales.

2. Depurar y analizar los datos.

3. Divulgar los datos ya organizados a las partes interesadas, entre ellas trabajadores, sindicatos, empresas, organismos públicos y la opinión pública.

4. U tilizar los datos en la planificación de intervenciones para modificar los factores que producen esos episodios relacionados con la salud.

La vigilancia de la salud en el trabajo se ha descrito de una manera más concisa como recuento, evaluación y actuación (L andrigan 1989).

La vigilancia suele referirse a dos amplios conjuntos de actividades en el campo de la salud en el trabajo. La vigilancia de la salud pública se refiere a las actividades emprendidas por las administraciones públicas dentro de sus respectivos ámbitos de competencia para controlar y realizar el seguimiento de las enfermedades y lesiones profesionales. Este tipo de vigilancia se basa en una población; es decir, en la población activa. Los episodios registrados son diagnósticos sospechados o establecidos de enfermedad o lesión profesional. Estas son las actividades que se describen en el presente artículo.

La vigilancia médica se refiere a la administración de pruebas y la aplicación de procedimientos médicos a trabajadores en concreto que se encuentran en situación de riesgo de morbilidad profesional, con el fin de detectar algún trastorno de origen profesional. La vigilancia médica suele tener un ámbito de aplicación amplio y constituye el primer paso para detectar la presencia de un problema relacionado con el trabajo. Si una persona o una población se ven expuestas a una toxina de efectos conocidos, y las pruebas y procedimientos se orientan a la detección de la posible presencia de uno o más efectos en esas personas, la actividad de vigilancia se denomina exploración médica selectiva (Halperin y Frazier 1985). U n programa de vigilancia médica implica, por tanto, la administración de pruebas y la aplicación de procedimientos a un grupo de trabajadores con exposiciones comunes para identificar a posibles pacientes de enfermedades profesionales y detectar en los participantes pautas patológicas posiblemente producidas por esas exposiciones. Este tipo de programas suelen desarrollarse bajo los auspicios de un empresa o un sindicato.

\section{Funciones de la vigilancia de la salud en el trabajo}

U na primera función de la vigilancia de la salud en el trabajo es la identificación de la incidencia y prevalencia de enfermedades y lesiones profesionales conocidas. La recopilación de datos epidemiológicos descriptivos de la incidencia y prevalencia mediante un procedimiento fiable y exhaustivo es un requisito previo esencial para la adopción de un enfoque racional del control de las enfermedades y lesiones profesionales. La evaluación de la naturaleza, magnitud y distribución de estas enfermedades y lesiones en cualquier ámbito geográfico exige la disponibilidad de una buena base de datos epidemiológica. Sólo mediante una evaluación epidemiológica de las dimensiones de una enfermedad profesional se puede determinar su importancia relativa para otros problemas de salud pública, la necesidad de recursos y la urgencia de establecer un marco jurídico común. A demás, la recopilación de datos sobre incidencia y prevalencia permite analizar las tendencias de enfermedades y lesiones profesionales en diferentes grupos, lugares y períodos. La detección de estas tendencias es útil para establecer las prioridades y estrategias de control e investigación, así como para evaluar la eficacia de cualquier intervención que se emprenda (Baker, M elius y M illar 1988).

U na segunda función general de la vigilancia de la salud en el trabajo es la identificación de casos individuales de enfermedades y lesiones profesionales, para así estar en condiciones de detectar y evaluar a otras personas dentro del mismo lugar de trabajo que puedan estar en situación de riesgo. Este proceso permite asimismo instaurar medidas de control para reducir las condiciones peligrosas asociadas con la aparición del caso índice (Baker, M elius y M illar 1988; Baker, H onchar y Fine 1989). Se define como caso índice de una enfermedad o lesión profesional la primera persona enferma o lesionada en un lugar de trabajo que recibe asistencia médica y, por consiguiente, la primera en llamar la atención sobre la existencia de un riesgo en el lugar de trabajo y sobre otros trabajadores que puedan encontrarse también en situación de riesgo. 0 tro objetivo de la identificación de casos es conseguir que la persona afectada reciba un seguimiento clínico adecuado, aspecto importante teniendo en cuenta la escasez de especialistas en medicina del trabajo ( $M$ arkowitz y cols. 1989; C astorino y R osenstock 1992).

Finalmente, la vigilancia de la salud en el trabajo es un medio importante de descubrir nuevas relaciones entre los agentes presentes en el lugar de trabajo y las enfermedades asociadas, dado que no se conoce todavía la toxicidad potencial de la mayoría de las sustancias químicas utilizadas en el lugar de trabajo. El descubrimiento de enfermedades raras, de pautas patológicas o de sospechas de asociación entre determinada exposición y una enfermedad mediante las actividades de vigilancia en el lugar de trabajo puede facilitar información esencial para una evaluación científica más profunda del problema y la posible constatación de nuevas enfermedades profesionales.

\section{Obstáculos para la identificación de enfermedades profesionales}

Existen varios factores importantes que dificultan la capacidad de los sistemas de vigilancia y notificación de enfermedades profesionales para cumplir las funciones antes descritas. En primer lugar, es imprescindible identificar la causa o causas subyacentes de cualquier enfermedad para poderla registrar y notificar. Sin embargo, los modelos médicos tradicionales que hacen hincapié en la asistencia sintomática y curativa no siempre dan prioridad a la identificación y eliminación de la causa subyacente. Es más, muchos proveedores de asistencia sanitaria carecen de la formación adecuada para sospechar que el trabajo puede ser la causa de una enfermedad (Rosenstock 1981) y no obtienen sistemáticamente la historia de exposiciones profesionales de sus pacientes (Institute of M edicine 1988). Este hecho no debe sorprendernos, puesto que en Estados U nidos, por ejemplo, los estudiantes de medicina reciben por lo general tan sólo seis horas de formación en medicina del trabajo durante sus cuatro años de estudios en la facultad (Burstein y Levy 1994).

Ciertos rasgos característicos de las enfermedades profesionales aumentan la dificultad de su identificación. Salvo algunas excepciones - sobre todo, angiosarcoma de hígado, 
mesotelioma maligno y neumoconiosis- la mayoría de las enfermedades potencialmente causadas por exposiciones profesionales tienen también causas no relacionadas con el trabajo. Esta inespecificidad hace que resulte difícil demostrar la contribución del trabajo a la aparición de la enfermedad. De hecho, la interacción de las exposiciones profesionales con otros factores de riesgo puede aumentar considerablemente el riesgo de una enfermedad, como ocurre con la exposición al amianto y el tabaquismo. En el caso de enfermedades profesionales crónicas, como el cáncer y las enfermedades respiratorias crónicas, suele existir un largo período de latencia entre el inicio de la exposición profesional y la aparición de la patología clínica. Por ejemplo, el mesotelioma maligno suele tener un período de latencia de 35 o más años y se presenta a veces en trabajadores ya jubilados, lo que reduce aún más la posibilidad de que las sospechas del médico se dirijan a una posible etiología profesional.

0 tra causa de la frecuente subestimación de las enfermedades profesionales es que nunca se ha evaluado la toxicidad potencial de la mayoría de las sustancias químicas existentes en el mercado. En un estudio del $\mathrm{N}$ ational Research Council de Estados U nidos realizado en el decenio de 1980, se constató la ausencia de información sobre la toxicidad de aproximadamente el $80 \%$ de las 60.000 sustancias químicas de uso comercial. Incluso en el caso de las sustancias sometidas a una regulación más estricta y sobre las que existe más información - medicamentos y aditivos alimentarios- sólo está razonablemente completa la información sobre los posibles efectos adversos de un pequeño número de agentes (N RC 1984).

En ocasiones, los trabajadores tienen dificultades para obtener información exacta sobre las exposiciones tóxicas en que se ven envueltos. A pesar de las mejoras que se han introducido en algunos países, como en Estados U nidos en el decenio de 1980, muchos trabajadores no están informados sobre la naturaleza peligrosa de los materiales que manipular. Incluso cuando disponen de esa información, el nivel de exposición a distintos agentes en los diferentes puestos de trabajo que ocupa una persona a lo largo de toda su vida profesional puede ser difícil de determinar. Como resultado, incluso los proveedores de asistencia sanitaria más sensibilizados respecto a la necesidad de obtener información profesional de sus pacientes pueden verse incapaces de hacerlo.

Las empresas constituyen una excelente fuente de información sobre las exposiciones profesionales y la aparición de enfermedades relacionadas con el trabajo. Sin embargo, muchas de ellas carecen de los conocimientos especializados necesarios para evaluar el nivel de exposición en el lugar de trabajo o para determinar si una enfermedad está relacionada con el trabajo. Por otra parte, los desincentivos económicos ligados al hallazgo del origen profesional de una enfermedad puede desalentarles de hacer un uso adecuado de esa información. El posible conflicto de intereses entre la salud financiera de la empresa y la salud física y mental de los trabajadores representa un importante obstáculo para la mejora de la vigilancia de las enfermedades profesionales.

\section{Registros y otras fuentes de datos específicas sobre las enfermedades profesionales}

\section{Registros inter nacionales}

$L$ os registros internacionales de enfermedades profesionales constituyen un importante avance en el campo de la salud en el trabajo. Su ventaja evidente es que permiten realizar grandes estudios para determinar el riesgo de enfermedades poco frecuentes. En el decenio de 1980 se crearon dos registros internacionales de enfermedades profesionales.
Tabla 32.1 - N úmero de casos de angiosarcoma de hígado registrados en to do el mundo, por países y años en que se inició la producción de cloruro de vinilo.

\begin{tabular}{|c|c|c|c|}
\hline País/ Región & $\begin{array}{l}\text { Número de } \\
\text { industrias } \\
\text { productoras } \\
\text { de PVC }\end{array}$ & $\begin{array}{l}\text { Año en el que } \\
\text { se inició la } \\
\text { producción } \\
\text { de PVC }\end{array}$ & $\begin{array}{l}\text { Número de } \\
\text { casos de } \\
\text { angiosarcoma } \\
\text { de hígado }\end{array}$ \\
\hline Estados Unidos & 50 & (1939?) & 39 \\
\hline Canadá & 5 & (1943) & 13 \\
\hline Alemania Occidental & 10 & (1931) & 37 \\
\hline Francia & 8 & (1939) & 28 \\
\hline Reino Unido & 7 & $(1940)$ & 16 \\
\hline $\begin{array}{l}\text { Otros países de Europa } \\
\text { Occidental }\end{array}$ & 28 & (1938) & 15 \\
\hline Europa Oriental & 23 & (antes de 1939) & 6 \\
\hline Japón & 36 & $(1950)$ & 3 \\
\hline $\begin{array}{l}\text { América Central y } \\
\text { del Sur }\end{array}$ & 22 & (1953) & 0 \\
\hline Australia & 3 & (1950s) & 0 \\
\hline Oriente Medio & 1 & (1987) & 0 \\
\hline Total & 193 & & 157 \\
\hline
\end{tabular}

Fuente: Bennett, B. World Register of Cases of Angiosarcoma of the Liver (ASL) due to Vinyl Chloride Monomer, 1 de enero de 1990.

La Agencia Internacional para la Investigación sobre el Cáncer (IARC) creó en 1984 el Registro Internacional de Personas Expuestas a Fenoxiherbicidas y Contaminantes (IARC 1990). En 1990 había inscritos 18.972 trabajadores de 19 cohortes en diez países. Por definición, todos ellos trabajaban en industrias que utilizaban fenoxiherbicidas y/ o clorofenoles, principalmente industrias de fabricación/ formulación de estas sustancias o usuarias de las mismas. Aunque ya se ha estimado la exposición en estas cohortes (K auppinen y cols. 1993), todavía no se han publicados los análisis de la incidencia y mortalidad por cáncer.

Bennet, de ICI Chemicals and Polymers L imited, está organizando en Inglaterra un registro internacional de casos de angiosarcoma del hígado (ASH). La exposición profesional al cloruro de vinilo es la única causa conocida de esta enfermedad. LoS casos son declarados por un grupo voluntario de científicos en empresas que fabrican cloruro de vinilo, organismos públicos y universidades. En 1990, se declararon a este registro 157 casos de ASH diagnosticados entre 1951 y 1990 en 11 países 0 regiones. Como puede observarse en la Tabla 32.1, la mayoría de los casos registrados corresponden a países en los que la fabricación de cloruro de polivinilo se inició antes de 1950. Asimismo, se han registrado seis agrupamientos de diez o más casos de ASH en instalaciones de Norteamérica y Europa (Bennett 1990).

\section{Encuestas oficiales}

En algunos países, las empresas están obligadas a declarar las lesiones y enfermedades profesionales que tienen lugar en sus instalaciones. Al igual que cualquier otra información sobre el 
lugar de trabajo, como la relativa al número de trabajadores, los salarios o las horas extraordinarias, los datos sobre lesiones y enfermedades son recopilados a veces sistemáticamente por organismos públicos para fines vinculados a la vigilancia de la salud en el trabajo.

En Estados U nidos, la O ficina de Estadísticas Laborales (Bureau of Labor Statistics, BLS) del Departamento de Trabajo publica desde 1972 la Annual Survey of 0 ccupational Injuries and Illnesses (Encuesta anual de lesiones y enfermedades profesionales), en cumplimiento de lo previsto por la Ley sobre la salud y seguridad en el trabajo (BLS 1993b). La encuesta facilita las cifras y tasas de enfermedades y lesiones de origen profesional declaradas por las empresas privadas (BLS 1986). De ella se excluyen las explotaciones agrícolas con menos de 11 trabajadores, los trabajadores autónomos y los trabajadores de la administración local, estatal y federal. La última encuesta se realizó en 1992 y refleja los datos del cuestionario administrado a una muestra aleatoria estratificada de unas 250.000 empresas del sector privado en Estados U nidos (BLS 1994).

L as empresas rellenan el cuestionario de la encuesta de la BLS basándose en el registro escrito de lesiones y enfermedades profesionales que tienen obligación de mantener de acuerdo con lo exigido por la $\mathrm{O}$ ccupational Safety and Health Administration (O SH A) (R egistro 200 de la O SHA). Dicho registro ha de mantenerse a disposición de cualquier inspector de la OSHA, aunque no exista la obligación legal de remitirlo a ésta, salvo en el caso de las empresas incluidas en la muestra de la encuesta anual de la BLS (BLS 1986).

La encuesta de la BLS presenta algunos defectos ampliamente reconocidos que limitan su capacidad para ofrecer un recuento completo y exacto de las enfermedades profesionales en Estados U nidos (Pollack y K eimig 1987). Ante todo, los datos son facilitados por las propias empresas. L as enfermedades que los trabajadores no declaren a éstas como de origen profesional no serán notificadas por las mismas. La falta de declaración por parte de los trabajadores puede deberse a su temor a las posibles consecuencias. O tro problema importante es que, a menudo, los médicos de las empresas pasan por alto la relación entre la enfermedad diagnosticada y el trabajo, especialmente cuando se trata de patologías crónicas. L as enfermedades profesionales que aparecen en los trabajadores jubilados no están sometidas a ningún requisito de notificación de la $\mathrm{BLS}$. De hecho, es poco probable que la empresa correspondiente tenga conocimiento de la aparición de una enfermedad de este tipo en un trabajador ya jubilado. Muchas enfermedades profesionales crónicas con largos períodos de latencia, entre ellas el cáncer y las enfermedades pulmonares, se manifiestan con frecuencia después de la jubilación y, por lo tanto, la mayoría de estos casos no se incluyen en los datos recogidos por la BLS. Estas limitaciones fueron reconocidas por la propia BLS en un reciente informe sobre su encuesta anual (BLS 1993a). De hecho, en respuesta a las recomendaciones de la National Academy of Sciences, la BLS modificó el diseño y realizó una nueva encuesta nacional en 1992.

Según ésta, hubo 457.000 casos de enfermedad profesional en el sector privado en Estados U nidos (BLS 1994). Esta otra representa un incremento del $24 \%, 089.100$ casos, más sobre los 368.300 registrados en la encuesta anual realizada por la BL S en 1991. La incidencia de nuevas enfermedades profesionales fue en 1992 de 60,0 por 10.000 trabajadores.

Los trastornos asociados a traumatismos repetidos, como el síndrome del túnel carpiano, la tendinitis de la muñeca y del codo o la pérdida auditiva, son las enfermedades profesionales que más predominan en las encuestas anuales de la BLS desde 1986 (Tabla 32.2). En 1992 representaron el $62 \%$ del total de
Tabla 32.2 - N úmero de nuevos casos de enfermedades profesionales por categorías de enfermedad-Encuesta A nual de la 0 ficina de Estadísticas Laborales de Estados Unidos, 1986 frente a 1992.

\begin{tabular}{|c|c|c|c|}
\hline $\begin{array}{l}\text { Categoría de } \\
\text { enfermedad }\end{array}$ & 1986 & 1992 & $\begin{array}{l}\text { \% Variación } \\
1986-1992\end{array}$ \\
\hline Enfermedades de la piel & 41.900 & 62.900 & $+50,1 \%$ \\
\hline $\begin{array}{l}\text { Enfermedades } \\
\text { pulmonares causadas } \\
\text { por el polvo }\end{array}$ & 3.200 & 2.800 & $-12,5 \%$ \\
\hline $\begin{array}{l}\text { Enfermedades respirato- } \\
\text { rias causadas por } \\
\text { agentes tóxicos }\end{array}$ & 12.300 & 23.500 & $+91,1 \%$ \\
\hline Intoxicaciones & 4.300 & 7.000 & $+62,8 \%$ \\
\hline $\begin{array}{l}\text { Trastornos causados por } \\
\text { agentes físicos }\end{array}$ & 9.200 & 22.200 & $+141,3 \%$ \\
\hline $\begin{array}{l}\text { Trastornos asociados a } \\
\text { traumatismos repetidos }\end{array}$ & 45.500 & 281.800 & $+519,3 \%$ \\
\hline $\begin{array}{c}\text { Todas las demás } \\
\text { enfermedades } \\
\text { profesionales }\end{array}$ & 20.400 & 57.300 & $+180,9 \%$ \\
\hline Total & 136.900 & 457.400 & $+234,4 \%$ \\
\hline $\begin{array}{l}\text { Total excluidos trauma- } \\
\text { tismos repetidos }\end{array}$ & 91.300 & 175.600 & $+92,3 \%$ \\
\hline $\begin{array}{l}\text { Empleo medio anual en } \\
\text { el sector privado, } \\
\text { Estados Unidos }\end{array}$ & 83.291 .200 & 90.459 .600 & $+8,7 \%$ \\
\hline
\end{tabular}

Fuentes: Occupational Injuries and IIInesses in the United States by Industry, 1991. Departamento de Trabajo de Estados Unidos, Oficina de Estadísticas Laborales, mayo 1993. Datos no publicados, Departamento de Trabajo de Estados Unidos, Oficina de Estadísticas Laborales, diciembre, 1994.

casos registrados. 0 tras categorías destacables corresponden a las enfermedades de la piel, las enfermedades pulmonares y los trastornos asociados a traumatismos físicos.

Aunque los trastornos asociados a traumatismos repetidos representan claramente la mayor proporción del aumento en el número de casos de enfermedades profesionales, se produjo también un incremento del $50 \%$ en la incidencia registrada de otras enfermedades profesionales en los seis años transcurridos entre 1986 y 1992, período en el que la tasa de empleo en Estados U nidos aumentó sólo en un 8,7\%

Este aumento del número y la tasa de enfermedades profesionales registradas por las empresas y notificadas a la BLS en los últimos años en Estados U nidos merece ser considerado. El rápido incremento se debe a un cambio en la incidencia de las enfermedades y asimismo a un cambio en su detección y notificación. En comparación, durante ese mismo período, de 1986 a 1991, la tasa de lesiones profesionales por 100 trabajadores a tiempo completo registrada por la BLS aumentó de 7,7 en 1986 a 7,9 en 1991 , lo que supone un simple aumento del 2,6 \%. El número de fallecimientos registrados en el lugar de trabajo tampoco aumentó mucho durante la primera mitad del decenio de 1990.

\section{Vigilancia a escala de empresa}

A demás de la encuesta realizada por la BLS, muchas empresas de Estados U nidos someten a sus trabajadores a vigilancia médica y, 
por consiguiente, generan un gran volumen de información médica que es importante para la vigilancia de la salud pública en lo que respecta a las enfermedades profesionales. Los programas correspondientes persiguen varios fines: cumplir la normativa de la OSH A; mantener el buen estado de salud de los trabajadores mediante la detección y el tratamiento de enfermedades no profesionales; asegurarse de que están físicamente capacitados para realizar las tareas de sus puestos de trabajo, incluida la necesidad de utilizar, en su caso, un respirador; y realizar una vigilancia epidemiológica para detectar pautas de exposición y enfermedad. Estas actividades implican un considerable consumo de recursos y podrían contribuir notablemente a la vigilancia de la salud pública para la detección de enfermedades profesionales. Por desgracia, los datos recogidos no son uniformes, su calidad es heterogénea y el acceso a los mismos resulta difícil desde el exterior de las empresas, motivos por los cuales sólo se han aplicado de forma limitada a la vigilancia de la salud en el trabajo (Baker, M elius y M illar 1988).

La OSH A impone también a las empresas la realización de una serie de pruebas médicas a los trabajadores expuestos a ciertos agentes tóxicos. O bliga asimismo a la práctica de reconocimientos médicos y la obtención de historias médicas y profesionales en el caso de los trabajadores expuestos a catorce sustancias claramente relacionadas con el cáncer de páncreas y pulmón. L os datos obtenidos no se notifican sistemáticamente a los organismos públicos ni a otros bancos de datos centralizados, y no están accesibles a los efectos de los sistemas de notificación de enfermedades profesionales.

\section{Vigilancia de los trabajadores del sector público}

LoS sistemas de notificación de enfermedades profesionales pueden ser diferentes para los trabajadores del sector privado y del sector público. Por ejemplo, en Estados U nidos, la encuesta anual de enfermedades y lesiones profesionales ya mencionada realizada por el Departamento de Trabajo de la administración federal (encuesta anual de la BLS) excluye a los trabajadores del sector público. Sin embargo, éstos constituyen una parte importante de la población activa, representando en 1991 cerca del $17 \%$ del total $(18,4$ millones de trabajadores), tres cuartas partes de los cuales trabajan para la administración estatal y local.

En Estados U nidos, es el Programa Federal de Indemnización de los Trabajadores el que recoge información sobre las enfermedades profesionales entre los trabajadores de la administración federal. En 1993 se concedieron indemnizaciones por enfermedad profesional a 15.000 de estos trabajadores, lo que supone una tasa de 51,7 casos por 10.000 trabajadores a tiempo completo (Slighter 1994). En el ámbito estatal y local, algunos estados conocen el número y la tasa de las enfermedades profesionales. Según un reciente estudio de los trabajadores de la administración estatal y local de Nueva Jersey, un estado industrializado bastante grande, en 1990 se produjeron 1.700 casos de enfermedades profesionales, lo que supone una incidencia de 50 por 10.000 trabajadores (R oche 1993). L as tasas correspondientes a la administración federal y a otras administraciones son notablemente congruentes con las del sector privado, según se registra en la encuesta anual de la BLS. La distribución de enfermedades por tipos de trabajador varían entre los trabajadores del sector público y los del sector privado, como consecuencia de sus distintos tipos de trabajo.

\section{Informes sobre la indemnización de los trabajadores}

Los sistemas de indemnización de los trabajadores constituyen una herramienta para la vigilancia de la salud en el trabajo que resulta en principio atractiva, ya que se supone que, en este caso, la relación entre la enfermedad y el trabajo ha sido sometida al análisis de expertos. Este tipo de sistemas suelen registrar los casos de enfermedades agudas cuya causa es fácil de determinar, como intoxicaciones, inhalación aguda de toxinas respiratorias 0 dermatitis.

Lamentablemente, el uso de estos registros como fuente fidedigna de datos para la vigilancia de la salud en el trabajo presenta graves limitaciones, tales como la ausencia de unos requisitos normalizados de admisibilidad, la inexistencia de criterios comunes para la definición de los casos, la ausencia de incentivos para que los trabajadores y las empresas soliciten la indemnización, la falta de detección por parte de los médicos de enfermedades profesionales crónicas con largos períodos de latencia y la larga duración del período que suele transcurrir entre la solicitud y la obtención de la indemnización. El resultado neto de estas limitaciones es que los sistemas de indemnización de los trabajadores no registran muchas de las enfermedades profesionales.

Así, en un estudio realizado por Selikoff a principios del decenio de 1980, menos de la tercera parte de los trabajadores del sector del aislamiento de Estados U nidos que sufrían discapacidades causadas por enfermedades relacionadas con el amianto, tales como asbestosis y cáncer, habían solicitado las prestaciones de indemnización y aún menos habían recibido éstas (Selikoff 1982). En otro estudio realizado por el Departamento de Trabajo de Estados U nidos acerca de los trabajadores que declararon una discapacidad de origen profesional, se observó que menos del $5 \%$ recibían las prestaciones pertinentes (USDOL 1980). En un estudio más reciente realizado en el estado de Nueva York, se habló que el número de personas hospitalizadas por neumoconiosis superaba con creces el número de nuevos beneficiarios de las prestaciones de indemnización durante un período de tiempo similar (M arkowitz y cols. 1989). Puesto que los sistemas de indemnización de los trabajadores registran episodios simples relacionados con la salud, como dermatitis y lesiones musculosqueléticas, con mucha más frecuencia que enfermedades complejas con largos períodos de latencia, el uso de esos datos da lugar a una imagen distorsionada de la verdadera incidencia y distribución de las enfermedades profesionales.

\section{Informes de los laboratorios}

Los laboratorios clínicos pueden constituir una excelente fuente de información sobre la presencia de niveles excesivos de una serie de toxinas en los líquidos corporales. O frecen la ventaja de que pueden informar puntualmente sobre dichas alteraciones, sobre los programas de control de calidad existentes y sobre los requisitos que les impongan los organismos públicos para la concesión de la correspondiente licencia a los laboratorios. En Estados U nidos, muchos estados les exigen la notificación de los resultados de los análisis practicados en una serie de muestras. Los agentes de uso industrial sometidos a este requisito de notificación son el plomo, el arsénico, el cadmio y el mercurio, así como las sustancias que reflejan exposición a plaguicidas. (M arkowitz 1992).

En Estados U nidos, el $\mathrm{N}$ ational Institute for $\mathrm{O}$ ccupational Safety and Health (NIOSH) empezó en 1992 a recopilar los resultados de los análisis de los niveles plasmáticos de plomo en adultos dentro del programa de Vigilancia y Epidemiología del Plomo en la Sangre de Adultos (C howdhury, Fowler y M ycroft 1994). A finales de 1993, 20 estados que representaban el $60 \%$ de la población de Estados U nidos exigían ya la notificación al NIOSH de los niveles plasmáticos elevados de plomo y otros 10 estados estaban desarrollando un sistema de recogida y notificación de datos al respecto. En 1993 había 11.240 adultos con niveles plasmáticos de plomo iguales 0 superiores a 25 
microgramos por decilitro de sangre en los 20 estados que exigían su notificación. La gran mayoría de las personas afectadas (más del $90 \%$ ) se veían expuestas al plomo en sus respectivos lugares de trabajo. Casi la cuarta parte de ellas (3.199) presentaban niveles plasmáticos superiores o iguales a $40 \mathrm{ug} / \mathrm{dl}$, el límite umbral al que la $\mathrm{O}$ ccupational Safety and $\mathrm{H}$ ealth $\mathrm{Admi-}$ nistration exige la adopción de medidas para proteger a los trabajadores contra la exposición al plomo en el lugar de trabajo.

La notificación de elevados niveles de toxinas al correspondiente departamento estatal de salud puede ir seguida por investigaciones de salud pública. Las entrevistas confidenciales para el seguimiento de las personas afectadas permiten la rápida identificación de los lugares de trabajo en el que se produce la exposición, la clasificación del caso según el trabajo y el sector industrial, la estimación del número de otros trabajadores potencialmente expuestos en ese lugar de trabajo y la garantía de un seguimiento médico adecuado (Baser y M arion 1990). Tras las visitas al lugar de trabajo, pueden recomendarse medidas voluntarias para reducir la exposición o, en caso necesario, informar a las autoridades competentes para que obliguen a aplicar la ley.

\section{Informes de los médicos}

En un intento de imitar la estrategia utilizada con éxito para la vigilancia y el control de las enfermedades infecciosas, un número cada vez mayor de estados ha impuesto a los médicos la obligación de declarar determinadas enfermedades profesionales (Freund, Seligman and Chorba 1989). En 1988, 32 estados exigían a los médicos dicha notificación, aunque en 10 de ellos tal obligación se limitaba a una enfermedad profesional concreta, normalmente la intoxicación por plomo o por plaguicidas. En otros estados, como Alaska y M aryland, se extendía a la totalidad de las enfermedades profesionales. En la mayoría de los estados, las notificaciones se utilizan únicamente para el recuento de personas afectadas. Sólo en la tercera parte de los estados que han impuesto la notificación, la remisión de un informe de enfermedad profesional da lugar a alguna actividad de seguimiento, como la inspección del lugar de trabajo (M uldoon, Wintermeyer y Eure 1987).

Pese al mayor interés que se ha suscitado por la salud en el trabajo en los últimos tiempos, la notificación oficial de enfermedades profesionales por parte de los médicos es deficiente (Pollack y Keimig 1987; Wegman y Froines 1985). Incluso en California, estado en el que existe desde hace varios años un sistema de este tipo (Primer Informe del M édico sobre Enfermedades y Lesiones Profesionales) y en el que se registraron casi 50.000 enfermedades profesionales en 1988 , el cumplimiento de este requisito de notificación por parte de los médicos se considera insuficiente (BLS 1989).

U na prometedora innovación en el ámbito de la vigilancia de la salud en el trabajo en Estados U nidos es el nuevo concepto del proveedor centinela, que se encuadra en una iniciativa emprendida por el NIOSH, denominada Sistema de Notificación de Episodios Centinela para Riesgos Profesionales (SENSOR). Se denomina proveedor centinela el médico o proveedor de asistencia sanitaria que prestará asistencia probablemente a los trabajadores con trastornos de origen profesional, debido a su especialidad o situación geográfica. Puesto que los proveedores centinela representan un pequeño conjunto dentro del total de los proveedores de asistencia sanitaria, les resulta fácil a los departamentos de salud organizar para ellos un sistema activo de notificación de enfermedades profesionales que abarque actividades de sensibilización, educación e información puntual. Según un reciente informe de tres estados que participan en el programa SENSOR, se consiguió que el número de informes médicos sobre el asma profesional aumentase rápidamente cuando los departamentos de salud establecieron programas concertados de educación y sensibilización para identificar y reclutar a proveedores centinela ( $M$ atte, $H$ offman and Rosenman 1990).

\section{Centros especializados en medicina del trabajo}

Un nuevo recurso en el campo de la vigilancia de la salud en el trabajo ha consistido en la creación de centros de medicina del trabajo no vinculados al lugar de trabajo y especializados en el diagnóstico y tratamiento de enfermedades profesionales. En la actualidad, existen varias decenas de centros de este tipo en Estados Unidos, que tienen encomendadas determinadas funciones para la mejora de la vigilancia de la salud en el trabajo. (Welch 1989). La primera de ellas se refiere a la detección de casos - es decir, la identificación de episodios centinela relacionados con la salud en el trabajo-, dados sus conocimientos especializados en medicina del trabajo. En segundo lugar, pueden servir como laboratorios para el desarrollo y perfeccionamiento de protocolos de seguimiento de las enfermedades profesionales. En tercer lugar, pueden actuar como recursos de remisión clínica primaria para el diagnóstico y la evaluación de trabajadores de lugares de trabajo en los que ya se haya producido un caso índice de una enfermedad profesional.

En Estados U nidos, los centros de medicina del trabajo han creado una asociación nacional (Association of O ccupational and Environmental Clinics) para darse a conocer y para colaborar en investigaciones científicas y clínicas (Welch 1989). En algunos estados, como el de Nueva York, el departamento de salud ha organizado una red de centros de este tipo que reciben financiación estable a través de un recargo en las primas del seguro de indemnización de los trabajadores (M arkowitz y cols. 1989). L os centros correspondientes colaboran en el desarrollo de sistemas de información, la elaboración de protocolos clínicos, y la educación de los profesionales y están empezando a generar un considerable volumen de información sobre el número de casos de enfermedades profesionales en ese estado.

\section{Utilización de estadísticas vitales y otros datos generales sobre la salud}

\section{Certificados de defunción}

El certificado de defunción es un instrumento que puede ser muy útil para la vigilancia de las enfermedades profesionales en muchos países del mundo. La mayoría de los países mantienen un registro de defunciones. Para aumentar la uniformidad y facilitar la comparación de los asientos, se promueve el uso de la Clasificación Internacional de Enfermedades para identificar la causa del fallecimiento. Es más, en muchos territorios, los certificados de defunción incluyen información sobre la profesión y el sector industrial en el que trabajaba el fallecido. Una limitación importante en lo que atañe a la vigilancia de las enfermedades profesionales es la ausencia de una relación unívoca entre exposiciones profesionales y causas específicas de muerte.

El uso de los datos de mortalidad es más importante en el caso de enfermedades claramente causadas por exposiciones profesionales. Entre ellas hay que citar la neumoconiosis y un tipo de cáncer, el mesotelioma maligno de pleura. En la Tabla 32.3 se indica el número de fallecimientos que pueden atribuirse a estos diagnósticos como causa subyacente de muerte y como una de las varias causas de muerte que aparecen en los certificados de defunción en Estados U nidos. La causa subyacente de mortalidad se considera la principal causa de muerte, mientras que la lista de múltiples causas incluye todos los procesos que se consideran importantes como contribución a la muerte.

En 1991 se produjeron 1.237 fallecimientos como consecuencia de enfermedades pulmonares relacionadas con la exposición al polvo, entre ellos 693 fallecimientos por neumoconiosis 
Tabla 32.3 - Mortalidad causada por neumoconiosis y mesotelioma maligno de la pleura. Causa subyacente y causas múltiples, Estados Unidos, 1990 y 1991.

\begin{tabular}{|c|c|c|c|}
\hline \multirow[t]{2}{*}{ Código ClE-9 } & \multirow[t]{2}{*}{ Causa de mortalidad } & \multicolumn{2}{|c|}{ Número de fallecidos } \\
\hline & & $\begin{array}{l}\text { Causa } \\
\text { subyacente } \\
1991\end{array}$ & $\begin{array}{l}\text { Causas } \\
\text { múltiples } \\
1990\end{array}$ \\
\hline 500 & $\begin{array}{l}\text { Neumoconiosis de los trabaja- } \\
\text { dores del carbón }\end{array}$ & 693 & 1.990 \\
\hline 501 & Asbestosis & 269 & 948 \\
\hline 502 & Silicosis & 153 & 308 \\
\hline \multirow[t]{2}{*}{$503-505$} & Otras neumoconiosis & 122 & 450 \\
\hline & Subtotal & 1.237 & 3.696 \\
\hline \multirow{3}{*}{$\begin{array}{l}163,0 \\
163,1 \text { y } \\
163,9\end{array}$} & $\begin{array}{l}\text { Mesotelioma maligno de } \\
\text { pleura }\end{array}$ & 452 & 553 \\
\hline & & & \\
\hline & Total & 1.689 & 4.249 \\
\hline
\end{tabular}

Fuente: National Center for Health Statistics de Estados Unidos.

en trabajadores del carbón y 269 fallecimientos por asbestosis. En el caso del mesotelioma maligno, se produjo un total de 452 fallecimientos por mesotelioma pleural. No se puede determinar el número de fallecimientos causados por mesotelioma maligno del peritoneo, también relacionado con la exposición profesional al amianto, ya que los códigos de la Clasificación Internacional de Enfermedades no son específicos para el mesotelioma maligno en ese lugar.

En la Tabla 32.3 se indica también el número de fallecidos en Estados U nidos en 1990 por neumoconiosis y mesotelioma maligno de la pleura, cuando estas enfermedades aparecen como una de las causas múltiples de muerte en el certificado de defunción. En el caso de la neumoconiosis, un dato importante es el número total de certificados en el que aparece como una de las causas múltiples de muerte, ya que ésta suele coexistir con otras enfermedades pulmonares crónicas.

Es importante considerar el grado en que la neumoconiosis puede subestimarse y, por consiguiente, no aparecer en los certificados de defunción. EI análisis más extenso del infradiagnóstico de neumoconiosis ha sido realizado por Selikoff y sus colaboradores (Selikoff, H ammond y Seidman 1979; Selikoff y Seidman 1991) entre los trabajadores de aislamientos en Estados U nidos y Canadá. Entre 1977 y 1986, 123 trabajadores de este tipo fallecieron por causas atribuidas al amianto en los certificados de defunción. Cuando los investigadores analizaron las historias médicas, las radiografías de tórax y la patología tisular, atribuyeron a la asbestosis 259 casos de trabajadores de aislamientos fallecidos durante esos dos años. Por consiguiente, más de la mitad de la mortalidad por neumoconiosis se pasó por alto en este grupo, pese a que ya se sabía que presenta una elevada exposición al amianto. Lamentablemente, no existe un número suficiente de estudios sobre el infradiagnóstico de neumoconiosis en los certificados de defunción para poder realizar una corrección fiable de las estadísticas de mortalidad.

La mortalidad debida a otras causas no específicamente relacionadas con las exposiciones profesionales se ha utilizado también en el ámbito de la vigilancia de las enfermedades profesionales cuando en los certificados de defunción se indica la profesión o sector industrial al que pertenecía el fallecido. EI análisis de estos datos en una región específica durante un cierto período puede facilitar información sobre la incidencia y prevalencia de una enfermedad según sus causas en diferentes profesiones y sectores industriales. Ciertamente, por esta vía no puede determinarse el efecto de los factores profesionales en los casos examinados. Sin embargo, las diferencias de incidencia de una enfermedad en distintas profesiones y sectores da a entender que algunos factores presentes en el lugar de trabajo podrían ser importantes y proporciona claves para realizar estudios más detallados. 0 tras ventajas de este enfoque son la posibilidad de estudiar profesiones que suelen desarrollarse en muchos lugares de trabajo diferentes (por ejemplo, instalación de cocinas o servicios de limpieza en seco), el uso de datos recopilados de manera sistemática, el mayor tamaño de la muestra, el coste relativamente bajo y la importancia del resultado para la salud (Baker, M elius y M illar 1988; Dubrow, Sestito y Lalich 1987; M elius, Sestito y Seligman 1989).

En las últimas décadas, se han publicado varios estudios de este tipo sobre la mortalidad de origen profesional en Canadá (Gallagher y cols. 1989), Gran Bretaña (R egistrar General 1986) y Estados U nidos (Guralnick 1962, 1963a y 1963b). En los últimos años, M ilham ha utilizado este método para analizar la distribución profesional de todos los varones que fallecieron entre 1950 y 1979 en el estado de Washington (E stados U nidos). Comparó la proporción de fallecimientos debidos a una causa específica en un grupo profesional con la correspondiente proporción en todas las profesiones. De esta forma obtuvo los coeficientes proporcionales de mortalidad (M ilham 1983). Como ejemplo de los resultados que cabe obtener con este método, Milham observó que 10 de las 11 profesiones con probable exposición a campos eléctricos y magnéticos presentaban un mayor coeficiente proporcional de mortalidad por leucemia (M ilham 1982). Este fue uno de los primeros estudios de la relación entre la exposición profesional a la radiación electromagnética y el cáncer, y ha ido seguido por muchos otros que han corroborado esas primeras observaciones (Pearce y cols. 1985; M CD owell 1983; Linet, M alker y M CL aughlin 1988).

Como resultado del esfuerzo de colaboración entre el $\mathrm{N} I O \mathrm{SH}$, el National Cancer Institute y el National Center for $\mathrm{H}$ ealth Statistics durante el decenio de 1980, se han publicado recientemente los análisis de las pautas de mortalidad por profesiones y sectores industriales entre 1984 y 1988 en 24 estados norteamericanos (Robinson y cols. 1995). En estos estudios se evaluaron 1,7 millones de fallecimientos. Los autores confirmaron algunas relaciones ya conocidas entre exposición y enfermedad, y observaron nuevas asociaciones entre determinadas profesiones y ciertas causas específicas de mortalidad. LoS autores insisten en que los estudios de mortalidad de origen profesional pueden ser útiles para señalar la necesidad de realizar estudios adicionales, evaluar los resultados de otros estudios e identificar oportunidades para la promoción de la salud.

$M$ ás recientemente, Figgs y sus colegas del National Cancer Institute de Estados U nidos utilizaron esta base de datos de la mortalidad de origen profesional en 24 estados para analizar la relación entre ciertas profesiones y el linfoma no Hodgkin (LNH) (Figgs, D osemeci y Blair 1995). Se realizó un estudio de casos y controles que incluyó unos 24.000 fallecimientos por LNH que tuvieron lugar entre 1984 y 1989 y se confirmó el mayor riesgo de LNH en agricultores, mecánicos, soldadores, reparadores, operadores de máquinas y una serie de profesiones no manuales.

\section{Datos de altas hospitalarias}

Los diagnósticos de los pacientes hospitalizados representan una excelente fuente de información para la vigilancia de las enfermedades profesionales. Los recientes estudios realizados en varios 
estados norteamericanos demuestran que los datos de altas hospitalarias pueden ser más sensibles que los registros de las indemnizaciones de los trabajadores y las estadísticas vitales para detectar enfermedades que son específicas de ciertos entornos laborales, como la neumoconiosis (M arkowitz y cols. 1989; Rosenman 1988). En el estado de Nueva York, por ejemplo, una media de 1.049 personas eran hospitalizadas todos los años por neumoconiosis a mediados del decenio de 1980, frente a 193 nuevos casos de indemnizaciones concedidas a trabajadores y 95 muertes registradas todos los años por dicha enfermedad durante el mismo período de tiempo (M arkowitz y cols. 1989).

Además de permitir un recuento más exacto del número de pacientes con enfermedades profesionales, los datos de altas hospitalarias pueden ser útiles para detectar o modificar las condiciones del lugar de trabajo causantes de la enfermedad. Así, Rosenman evaluó en Nueva Jersey los lugares de trabajo en que habían trabajado personas hospitalizadas por silicosis y observó que, en la mayoría de ellos, nunca se habían tomado muestras del aire para detectar la presencia de sílice, nunca habían sido inspeccionados por las autoridades federales competentes $(\mathrm{OSH} A)$ y no se realizaba ninguna vigilancia médica para la detección de la silicosis (Rosenman 1988).

La utilización de los datos de altas hospitalarias para la vigilancia de las enfermedades profesionales ofrece las ventajas de su disponibilidad, su bajo coste, su relativa sensibilidad para las enfermedades graves y su razonable exactitud. Los principales inconvenientes son la falta de información sobre la profesión y la el sector industrial, así como la incertidumbre de los controles de calidad (M elius, Sestito y Seligman 1989; Rosenman 1988). Por otra parte, esta base de datos sólo incluiría a las personas con enfermedad suficientemente graves para necesitar hospitalización y, por consiguiente, no podría reflejar todo el espectro de morbilidad asociada a las enfermedades profesionales. No obstante, es probable que en los próximos años se haga un uso cada vez mayor de los datos de altas hospitalarias para la vigilancia de las enfermedades profesionales.

\section{Encuestas nacionales}

Las encuestas especiales de vigilancia realizadas a escala nacional o regional pueden constituir una fuente de información más detallada que los registros demográficos habituales. En Estados U nidos, el National Center for $\mathrm{H}$ ealth Statistics (NCHS) realiza periódicamente dos encuestas nacionales de salud que son útiles para la vigilancia de las enfermedades profesionales: la Encuesta Nacional de Entrevistas sobre la Salud (NHIS) y la Encuesta Nacional de Exploración Dietética y Médica (NHANES). La primera es una encuesta nacional de la población diseñada para estimar la prevalencia de problemas de salud en una muestra de hogares representativos de la población civil no institucionalizada de Estados U nidos (U SD H H S 1980). U na importante limitación es que se basa en la descripción que las personas hacen de sus propios problemas de salud. Los datos profesionales e industriales facilitados por las personas encuestadas se utilizaron en el pasado decenio para evaluar las tasas de discapacidad por profesiones y sectores industriales (U SDH H S 1980), evaluar la prevalencia del tabaquismo según la profesión (Brackbill, Frazier y Shilling 1988) y registrar las opiniones de los trabajadores sobre los riesgos profesionales a los que se enfrentan (Shilling y Brackbill 1987).

C on la ayuda del NIOSH, en 1988 se incluyó un Suplemento de Salud en el Trabajo (N HIS-O H S) para obtener estimaciones basadas en la población de la prevalencia de una serie de enfermedades que pueden estar asociadas al trabajo (USDHHS 1993). En 1988 se muestrearon unos 50.000 hogares y se entrevistó a 27.408 personas con empleo en ese momento. Entre los trastornos de salud mencionados por el NHIS-O HS se encuentran lesiones relacionadas con el trabajo, afecciones dermatológicas, trastornos por traumatismos repetidos, irritación de ojos, nariz y garganta, pérdida auditiva y dolor de espalda.

En el primer análisis realizado por el NHIS-OHS, Tanaka y sus colaboradores estimaron que, en 1988, la prevalencia nacional del síndrome del túnel carpiano relacionado con el trabajo fue de 356.000 casos (Tanaka y cols.). De las 675.000 personas estimadas con dolor persistente de mano y diagnóstico del síndrome del túnel carpiano, más del $50 \%$ de los encuestados declararon que su proveedor de asistencia sanitaria afirmaba que sus molestias en la muñeca estaban causadas por actividades profesionales. Esta estimación excluye a los trabajadores que permanecieron inactivos durante los 12 meses previos a la encuesta y que podrían haberse visto discapacitados por un síndrome del túnel carpiano de origen profesional.

A diferencia de la NHIS, la NH ANES evalúa directamente el estado de salud de una muestra de probabilidad de 30.000 a 40.000 personas en Estados U nidos, realizando exploraciones físicas y pruebas de laboratorio, además de recabar información mediante un cuestionario. La NHANES se llevó a cabo dos veces en el decenio de 1970 y la última se realizó en 1988. La NHANES II, realizada a finales del decenio de 1970, recogió información limitada sobre los indicadores de la exposición al plomo y una serie de plaguicidas. Iniciada en 1988, La NHANES III recogió otros datos sobre enfermedades y exposiciones profesionales, prestando una especial atención a las enfermedades respiratorias y neurológicas de origen profesional (USDH HS 1994).

\section{Resumen}

Los sistemas de vigilancia y notificación de enfermedades profesionales han mejorado notablemente desde mediados del decenio de 1980. Su mayor eficacia se da en las enfermedades única o casi únicamente causadas por exposiciones profesionales, como la neumoconiosis y el mesotelioma maligno. La identificación y notificación de otras enfermedades depende de la capacidad de relacionar las exposiciones en el lugar de trabajo con los problemas de salud. Existen numerosas fuentes de datos que pueden contribuir a la vigilancia de las enfermedades profesionales, aunque todas ellas presentan importantes limitaciones en términos de calidad, exhaustividad y fiabilidad. Los principales obstáculos para mejorar el sistema de notificación son el desinterés por la prevención en la asistencia sanitaria, la formación insuficiente de los profesionales de la asistencia sanitaria y los conflictos inherentes entre las empresas y los trabajadores al reconocer que una enfermedad está relacionada con el trabajo. A pesar de estos factores, es probable que en el futuro se sigan introduciendo mejoras en los sistemas de vigilancia y notificación de enfermedades profesionales.

\section{VIGILANCIA DE LOS RIESG OS PROFESIONALES}

David H. Wegman y Steven D. Stellman

Se denomina vigilancia de los riesgos el proceso mediante el cual se evalúan la distribución y las tendencias seculares de los niveles de uso y exposición a los riesgos de enfermedad y lesión (Wegman 1992). En el contexto de la salud pública, la vigilancia de los riesgos consiste en la identificación de los procesos de trabajo o los trabajadores expuestos a altos niveles de riesgos específicos en determinados sectores industriales y categorías de puestos de trabajo. Al no tratarse de una actividad centrada en los episodios de enfermedad, su utilización como base para las 
intervenciones de salud pública exige la demostración previa de una relación clara entre la exposición y el resultado. De esa forma, la vigilancia puede justificarse partiendo del supuesto de que la reducción de la exposición dará lugar a una menor incidencia de la enfermedad. EI uso adecuado de la información derivada de la vigilancia de los riesgos permite intervenir a tiempo y prevenir enfermedades profesionales. Su principal ventaja es, por consiguiente, que elimina la necesidad de esperar a que se produzcan casos de enfermedad evidente o incluso de muerte antes de adoptar medidas para la protección de los trabajadores.

La vigilancia de riesgos ofrece al menos otras cinco ventajas, que se complementan con las de la vigilancia de enfermedades. En primer lugar, la identificación de episodios peligrosos suele ser mucho más fácil que la identificación de casos de enfermedades profesionales, especialmente cuando éstas tienen largos períodos de latencia, como ocurre con el cáncer. En segundo lugar, al centrarse en los riesgos (no en las enfermedades) tiene la ventaja de dirigir la atención a exposiciones que terminarán por ser controladas. Por ejemplo, la vigilancia del cáncer de pulmón puede basarse en su incidencia en los trabajadores del amianto. Sin embargo, una importante proporción de los casos de cáncer de pulmón en esta población podría deberse al consumo de tabaco, ya sea como un factor independiente o como un factor que interactúa con la exposición al amianto, de manera que es posible que tenga que estudiarse a un gran número de trabajadores para detectar un pequeño número de cánceres relacionados con el amianto. Por otra parte, la vigilancia de la exposición al amianto podría facilitar información sobre los niveles y pautas de exposición (puestos de trabajo, procesos 0 industrias) en los lugares de trabajo en los que existe un control más deficiente. Así, aunque no se hiciera un recuento real de los casos de cáncer de pulmón, podrían adoptarse las medidas adecuadas para reducir o eliminar la exposición.

En tercer lugar, no todas las exposiciones tienen como resultado la enfermedad y, por ello, se producen episodios de riesgo con una frecuencia mucho mayor que episodios de enfermedad, lo que permite detectar una nueva pauta o una variación con el tiempo mucho más fácilmente que con la vigilancia de enfermedades. Esta ventaja ofrece la oportunidad de hacer un mayor uso de los episodios centinela. Un episodio centinela puede ser simplemente la presencia de una exposición (p. ej., a berilio), detectada a través de una medición directa en el lugar de trabajo; la presencia de una exposición excesiva, detectada mediante el control de un biomarcador (p. ej., niveles plasmáticos elevados de plomo); o un parte de accidente (por ejemplo, el vertido de una sustancia química).

Una cuarta ventaja de la vigilancia de riesgos es que los datos recogidos con este fin no infringen el derecho a la intimidad individual. La confidencialidad de las historias médicas no se ve en peligro y se evita la posibilidad de estigmatizar a una persona con la etiqueta de una enfermedad. Este aspecto es especialmente importante en entornos industriales en los que el puesto de trabajo de una persona puede verse en peligro o cuando la posible reclamación de una indemnización puede influir en la elección que realice el médico entre los distintos diagnósticos alternativos.

Finalmente, la vigilancia de riesgos puede aprovechar las ventajas de sistemas diseñados para otros fines. Como ejemplos de sistemas que ya existen para la recogida continua de información sobre los riesgos, pueden citarse los registros del uso de sustancias tóxicas o el vertido de materiales peligrosos, los registros de ciertas sustancias peligrosas y la información recogida por las autoridades para comprobar el cumplimiento de las normas. En muchos aspectos, el higienista industrial está ya bastante familiarizado con el uso de los datos de la exposición para fines de vigilancia.

Los datos obtenidos de la vigilancia de riesgos pueden complementarse con los de la vigilancia de enfermedades para establecer o confirmar la asociación entre un riesgo y una enfermedad, así como para otras aplicaciones de salud pública. Por otra parte, estas dos fuentes de datos pueden servir para decidir la necesidad de adoptar medidas correctoras. Los datos de la vigilancia a escala nacional (como los derivados del Sistema de Información para una G estión Integrada de la O SH A sobre los resultados de las muestras tomadas para determinar el cumplimiento de las normas de salud en el trabajo - véase más adelante) sirven para fines distintos que los datos de la vigilancia de riesgos en el lugar de trabajo, permitiendo éstos un enfoque y un análisis mucho más detallados. Los datos nacionales pueden ser extremadamente importantes para centrar las inspecciones en el cumplimiento de los requisitos legales o para determinar cuál es la distribución probable de riesgos que impondrá demandas específicas a los servicios médicos de una región. Sin embargo, la vigilancia de riesgos en el lugar de trabajo proporciona el nivel de detalle necesario para realizar un análisis en profundidad de las tendencias a lo largo del tiempo. En algunas ocasiones, se observa una tendencia que es independiente de que se hayan introducido cambios en los controles, sino que se produce como respuesta a cambios en los productos que no se harían evidentes si los datos se agregaran por regiones. Tanto los datos nacionales como los datos obtenidos en un lugar de trabajo concreto pueden ser útiles para determinar si existe la necesidad de realizar otros estudios científicos u organizar programas educativos para los trabajadores y la dirección.

Combinando los datos sobre la vigilancia de riesgos obtenidos durante las inspecciones de una gran variedad de industrias aparentemente sin relación, algunas veces se pueden identificar grupos de trabajadores cuyas altas exposiciones podrían pasarse por alto de otro modo. Por ejemplo, al analizar las concentraciones atmosféricas de plomo medidas por los inspectores de la O SH A entre 1979 y 1985, se identificaron 52 industrias en que los límites de exposición permisibles (PEL) se superaban en más de la tercera parte de las inspecciones (Froines y cols. 1990). Entre esas industrias figuraban la de fundición primaria y secundaria, la de fabricación de baterías, la de fabricación de pigmentos y la de fundición de cobre/ bronce.

Todas ellas presentan tradicionalmente altos niveles de exposición al plomo y las exposiciones excesivas indican un control deficiente de riesgos ya conocidos. De hecho, en ellas abundan los lugares de trabajo bastante pequeños, como los talleres de fundición secundaria del plomo, en los que es poco probable que los directores o trabajadores realicen muestreos sistemáticos de la exposición, hasta el punto de desconocer la existencia de graves problemas de exposición al plomo. A parte de los altos niveles de exposición ambiental al plomo que cabía esperar en estos lugares de trabajo, se observó que más de la tercera parte de los casos en los que se superaban los PEL correspondían a talleres de pintura de una gran variedad de entornos industriales. Ya se sabía que los pintores de carpintería metálica estaban en situación de riesgo por la exposición al plomo, pero se había prestado poca atención a otras industrias con pequeños talleres de pintura de maquinaria o componentes de maquinaria. En ellos, los trabajadores pueden verse sometidos a exposiciones peligrosas y, sin embargo, no se les suele considerar trabajadores del plomo porque trabajan en una industria no vinculada al plomo. En cierto sentido, esta encuesta aportó evidencias de un riesgo que se conocía pero que se había olvidado hasta que volvió a identificarse al analizar los datos derivados de la vigilancia. 


\section{Objetivos de la vigilancia de riesgos}

Los programas de vigilancia de riesgos pueden tener distintos objetivos y estructuras. En primer lugar, permiten orientar las intervenciones y ayudan a evaluar los programas existentes y planificar otros nuevos. EI uso adecuado de la información resultante puede hacer posible la detección precoz de un fallo en el sistema y llamar la atención sobre la necesidad de mejorar los controles o realizar algunas reparaciones antes de que los trabajadores sufran exposiciones excesivas o enfermedades. Asimismo, puede demostrar la necesidad de establecer normas nuevas o revisar las existentes para un riesgo concreto. En segundo lugar, los datos derivados de la vigilancia pueden incorporarse a las proyecciones de las enfermedades en el futuro para planificar el uso de recursos tanto médicos como de otro tipo para garantizar el cumplimiento de la normativa vigente. En tercer lugar, gracias al uso de metodologías de exposición normalizadas, los trabajadores de distintos niveles pueden aportar datos sobre un país, una ciudad, un sector de la industria, una fábrica o incluso un puesto de trabajo. Esta flexibilidad permite orientar las actividades de vigilancia, ajustarlas según sea necesario y mejorarlas a medida que se dispone de nueva información o se resuelven viejos problemas y aparecen otros nuevos. Finalmente, los datos de la vigilancia de riesgos deben servir para la planificación de los estudios epidemiológicos, al identificar las áreas en que los estudios serían más fructíferos.

\section{Ejemplos de vigilancia de riesgos}

R egistro de cancerígenos- Finlandia. En 1979, Finlandia estableció un sistema nacional de notificación obligatoria del uso de 50 cancerígenos en la industria. Las tendencias observadas durante los primeros siete años de vigencia se publicaron en 1988 (Alho, K auppinen y Sundquist 1988). M ás de las dos terceras partes de los trabajadores expuestos trabajaban con sólo tres tipos de cancerígenos: cromatos, níquel y compuestos inorgánicos, 0 amianto. La vigilancia de riesgos reveló así que un número sorprendentemente pequeño de compuestos causaban la mayoría de las exposiciones y, de esta forma, los esfuerzos pudieron centrarse en el control de éstas.

0 tra utilidad importante del registro consiste en evaluar las razones de que algunas sustancias incluidas en la lista "salgan" del sistema, es decir, por qué el uso de un cancerígeno se declara en una encuesta pero no en las siguientes. El $20 \%$ de estas salidas correspondieron a exposiciones que seguían produciéndose, pero que no se declaraban. En consecuencia, se tomó la decisión de educar e informar a las industrias encuestadas sobre la importancia de una notificación rigurosa. 0 tro $38 \%$ de las salidas se debieron al cese de la exposición, en más de la mitad de los casos por haberse sustituido la sustancia cancerígena por otra no cancerígena. Es posible que los resultados de los informes del sistema de vigilancia promuevan este tipo de sustituciones. Casi todas las demás salidas se produjeron como resultado de la eliminación de las exposiciones en virtud de controles técnicos, cambios en los procesos o una reducción considerable en el uso de la sustancia o en la duración de la exposición. Sólo el $5 \%$ de las salidas se produjeron como resultado del uso de equipos de protección individual. Este ejemplo demuestra cómo un registro de las exposiciones puede constituir una buena fuente de información sobre el uso de cancerígenos y los cambios que experimenta este uso con el tiempo.

Encuesta N acional de Exposiciones Profesionales (NOES). EI NIOSH realizó dos Encuestas Nacionales de Exposiciones Profesionales (NOES) con diez años de separación para estimar el número de trabajadores y lugares de trabajo potencialmente expuestos a una amplia gama de riesgos. Se prepararon mapas nacionales y estatales en los que se representaban los distintos aspectos estudiados, tales como la pauta de exposición al formaldehído de los trabajadores y lugares de trabajo (Frazier, Lalich y Pedersen 1983). Superponiendo estos mapas sobre mapas de mortalidad por causas específicas (p. ej., cáncer de los senos nasales), se pueden realizar exámenes ecológicos sencillos para generar hipótesis que luego se investigan mediante un estudio epidemiológico adecuado.

A simismo, se analizaron las variaciones observadas entre las dos encuestas: por ejemplo, la proporción de instalaciones con exposición potencial a ruido continuo que carecían de controles operativos (Seta y Sundin 1984). Al analizar los datos por sectores industriales, se observaron pocos cambios en la construcción (del 92,5 \% a 88,5 \%), frente al acusado descenso en el sector de las sustancias químicas y productos relacionados (del $88,8 \%$ al 38,0 \%) o en el caso de los distintos servicios de reparación (del $81,1 \%$ al $21,2 \%$ ). Esta reducción podría deberse a la aprobación de la L ey sobre salud y seguridad en el trabajo, a los convenios colectivos aprobados, al temor a responsabilidades legales y a la mayor sensibilización de los trabajadores.

Actuaciones inspectoras (respecto a la exposición) (OSH A). La O SH A lleva más de veinte años inspeccionado los lugares de trabajo para evaluar la validez de los controles de la exposición. LoS datos obtenidos en gran parte de este tiempo se han introducido en una base de datos, el Sistema de Información Integrada de G estión (O SH A/I M IS). Se han analizado las tendencias a largo plazo de algunas exposiciones entre 1979 y 1987. En el caso del amianto, existen claros indicios de la eficacia de los controles. Por el contrario, en lo que respecta al ślice y al plomo, aunque se redujo el número de muestras recogidas para la exposición, sigue siendo elevado el número de casos de sobreexposiciones a ambas sustancias. Los datos indican también que el número de inspecciones en las que se superan los límites de exposición permaneció esencialmente constante. Estos datos pueden ser muy útiles a la $\mathrm{O}$ SH A para planificar estrategias que faciliten el cumplimiento de la normativa sobre el sílice y el plomo.

La base de datos mencionada se ha utilizado también para realizar un análisis cuantitativo de los niveles de exposición al sílice en nueve sectores y en los correspondientes puestos de trabajo de los mismos (Froines, Wegman y Dellenbaugh 1986). Los límites de exposición se superaron en menor o mayor grado, desde un $14 \%$ (fundiciones de aluminio) hasta un $73 \%$ (alfarerías). En las alfarerías, se analizaron varios puestos de trabajo y se observó que la proporción en que se superaban los límites de exposición oscilaba entre el $0 \%$ (peones) y el $69 \%$ (esmaltadores). El grado en que se superaba el límite de exposición variaba, pues, según el puesto de trabajo. Así, por ejemplo, la exposición de los esmaltadores era, por término medio, dos veces superiores al límite de exposición, mientras que la exposición de los nebulizadores de esmalte/ barniz era, por término medio, ocho veces superior al límite. Este nivel de detalle debería ser útil tanto para los directivos y trabajadores del sector, como para los organismos públicos responsables de controlar las exposiciones profesionales.

\section{Resumen}

En este artículo se ha descrito la finalidad de la vigilancia de los riesgos, los beneficios que pueden derivarse la misma y algunas de sus limitaciones. Asimismo, se han ofrecido varios ejemplos que demuestran la utilidad de esta información para la salud pública. Sin embargo, la vigilancia de los riesgos no debe sustituir a la vigilancia de las enfermedades no infecciosas. En 1977, un grupo de trabajo del NIOSH insistió en la interdependencia relativa de los dos principales tipos de vigilancia, declarando:

La vigilancia de los riesgos y la vigilancia de las enfermedades no pueden realizarse ignorando una a la otra. La correcta caracterización de los riesgos asociados a diferentes 
sectores o profesiones, junto con la información toxicológica y médica referente a los riesgos, puede señalar los sectores 0 grupos profesionales que deben ser objeto de una vigilancia epidemiológica (C raft y cols. 1977).

\section{Vigilancia en los Paises en VIAS De DESARROLLO}

\section{David Koh y Kee-Seng Chia}

Se estima que más del $80 \%$ de la población mundial habita en países en vías de desarrollo de Africa, Próximo O riente, Asia, Sudamérica y Centroamérica. Estos países suelen encontrarse en situación de desventaja económica y muchos de ellos tienen una economía fundamentalmente rural y agrícola. Por lo demás, varían en muchos aspectos y presentan diferentes aspiraciones, sistemas políticas y nivel de desarrollo industrial. El estado de salud de su población suele ser peor que en el de los países desarrollados, reflejándose en la mayor tasa de mortalidad infantil y la menor esperanza de vida.

Existen varios factores que contribuyen a la necesidad de vigilar la salud y la seguridad en el trabajo en los países en vías de desarrollo. En primer lugar, muchos de ellos se están industrializando rápidamente y muchos de los nuevos sectores son de pequeño tamaño. En esa situación, los servicios de salud y seguridad en el trabajo suelen ser muy limitados o inexistentes. Por otra parte, estos países son con frecuencia los destinatarios de la transferencia de tecnología de países desarrollados. Algunas de los sectores más peligrosos que tienen dificultades para operar en países con una legislación más estricta y mejor aplicada en materia de higiene industrial se "exportan" a aquéllos.

En segundo lugar, en lo que respecta a la mano de obra, el nivel de estudio de los trabajadores suele ser menor en los países en vías de desarrollo y con frecuencia no se enseñan métodos de trabajo seguros. La mano de obra infantil suele ser más abundante. Los grupos correspondientes son relativamente más vulnerables a los riesgos para la salud en el trabajo. Además, el estado de salud inicial de los trabajadores suele ser peor.

Estos factores hacen que los trabajadores de los países en vías de desarrollo sean los más vulnerables del mundo y los que se enfrentan a los mayores riesgos para la salud en el lugar de trabajo.

\section{Los efectos del trabajo en la salud son diferentes de los que se observan en los países desarrollados}

La obtención de datos sobre los efectos en la salud es importante con vistas a la prevención y a la fijación de prioridades para las intervenciones destinadas a resolver los problemas de salud en el trabajo. Sin embargo, la mayor parte de los datos disponibles sobre morbilidad no son aplicables a los países en vías de desarrollo, por haberse obtenido en países desarrollados.

En los países en vías de desarrollo, los efectos para la salud de los riesgos en el lugar de trabajo pueden ser de naturaleza diferente que en los países desarrollados. L as enfermedades de origen claramente profesional, como la intoxicación por sustanciasquímicaso la neumoconiosis, causadas por elevados niveles de toxinas en el lugar de trabajo, siguen teniendo una elevada incidencia en aquéllos países, aunque se hayan reducido considerablemente en los paísesdesarrollados.

Por ejemplo, en el caso de la intoxicación por plaguicidas, los efectos agudos sobre la salud, o incluso la muerte, causados por exposiciones elevadas son motivo de gran preocupación en los países agrícolas en vías de desarrollo, mientras que en los países desarrollados tienen más importancia los efectos crónicos derivados de la exposición prolongada a dosis pequeñas de estos productos. De hecho, el coste de la morbilidad causada por las intoxicaciones agudas por plaguicidas es, en algunos países en vías de desarrollo, incluso mayor que el de otros problemas tradicionales de salud pública, como la difteria, la tosferina y el tétanos.

Así pues, también los países en vías de desarrollo necesitan algún sistema de vigilancia de la morbilidad profesional. La información obtenida será útil para evaluar la magnitud del problema, fijar la prioridad de las intervenciones, asignar recursos y evaluar posteriormente el impacto.

Lamentablemente, este tipo de información obtenida de las actividades de vigilancia no suele existir en los países en vías de desarrollo. Los programas de vigilancia que se utilizan en los países desarrollados no siempre son adecuados para ellos ni probablemente puedan adoptarse en su totalidad por los diversos problemas que dificultan las actividades de vigilancia.

\section{Problemas de vigilancia en los países en vías de desarrollo}

U na vez aceptado que los países en vías de desarrollo necesitan un sistema de vigilancia de los problemas de salud y seguridad en el trabajo, su aplicación real suele estar plagada de dificultades.

Estas dificultades proceden del control deficiente del desarrollo industrial, de la ausencia de legislación y servicios relacionados con la medicina del trabajo o su deficiente infraestructura, de la insuficiente formación de los profesionales de la higiene industrial, de la escasez de servicios médicos y de unos sistemas deficientes de notificación de enfermedades. M uchos países no disponen de información sobre la población activa ni sobre la población general, o dicha información es inadecuada.

O tro importante problema es que, en muchos países en vías de desarrollo, la higiene industrial no recibe una elevada prioridad en los programas nacionales de desarrollo.

\section{Actividades de vigilancia de la salud y la seguridad en el trabajo}

La vigilancia de la salud y la seguridad en el trabajo implica la realización de actividades tales como el control de los episodios peligrosos, las lesiones y los accidentes mortales en el trabajo. También incluye la vigilancia de las enfermedades profesionales y del medio ambiente de trabajo. Probablemente la recogida de información sobre lesiones y accidentes mortales en el trabajo resulte más fácil, puesto que estos episodios se definen y reconocen con bastante facilidad. Por el contrario, la vigilancia del estado de salud de los trabajadores, incluidas las enfermedades profesionales y la situación del medio ambiente de trabajo, plantea más dificultades.

Así pues, en el resto de este artículo se hará mención principalmente de la vigilancia de las enfermedades profesionales. Los principios y enfoques que en él se describen pueden aplicarse a la vigilancia de lesiones y accidentes mortales en el trabajo, que son también una causa muy importante de morbilidad y mortalidad en los trabajadores de los países en vías de desarrollo.

La vigilancia de la salud de los trabajadores en los países en vías de desarrollo no debe limitarse a las enfermedades profesionales, sino que ha de englobar también las enfermedades comunes de la población activa, ya que los principales problemas de salud no siempre son de origen profesional, sino que se deben a otras enfermedades comunes, sobre todo infecciosas, como la tuberculosis y las enfermedades de transmisión sexual. La información recogida será útil para planificar y asignar recursos de asistencia sanitaria para la promoción de la salud de la población activa. 


\section{Algunas estrategias para superar los problemas relacionados con la vigilancia}

¿Q ué tipos de vigilancia de la salud en el trabajo son más adecuados en los países en vías de desarrollo? En general, hay que recomendar sistemas que utilicen mecanismos sencillos y tecnología ya existente y apropiada, teniendo en cuenta al mismo tiempo los tipos de sectores y riesgos profesionales importantes en el país.

\section{Utilización de los recursos existentes}

El sistema de vigilancia de la salud en el trabajo puede aprovechar los recursos existentes, como los servicios de asistencia sanitaria o de salud ambiental. Así, las actividades correspondientes pueden integrarse en las funciones encomendadas al personal de asistencia sanitaria primaria, a los inspectores de salud pública $\mathrm{y} / \mathrm{o}$ a los técnicos de medio ambiente.

Para que esto sea posible hay que dar primero a los profesionales de la asistencia sanitaria primaria y de la salud pública la formación necesaria para poder reconocer las enfermedades potencialmente relacionadas con el trabajo e incluso realizar evaluaciones sencillas de los lugares de trabajo desde la perspectiva de la salud y seguridad en el trabajo. Es indudable que han de contar con una formación apropiada para realizar esas tareas.

A partir de ahí, pueden recopilar datos sobre las condiciones de trabajo y las enfermedades asociadas a actividades laborales durante el desempeño de sus actividades cotidianas. La información así obtenida puede canalizarse a centros regionales y, de éstos, a un organismo central responsable tanto de controlar las condiciones de trabajo y la morbilidad por enfermedades profesionales como de resolver esos problemas.

\section{Registros de fábricas y procesos de trabajo}

Además de un registro de enfermedades, puede crearse un registro de fábricas y procesos de trabajo, en el que se incluyan las fábricas existentes con los correspondientes procesos de trabajo y materiales utilizados. La información deberá actualizarse periódicamente, a medida que se introduzcan nuevos procesos de trabajo o materiales. Cuando este tipo de registro es obligatorio según la legislación nacional, ha de exigirse con carácter global.

Por supuesto, en los sectores de pequeña magnitud no suelen mantener estos registros. En tales casos, podría obtenerse información básica mediante estudios sencillos sobre el terreno y evaluaciones de los tipos de sector y las condiciones de trabajo. La responsabilidad de estas evaluaciones podría recaer también en los profesionales de la asistencia sanitaria primaria y de la salud pública.

Cuando existe este tipo de registro, es imprescindible una actualización periódica de los datos, quizá exigida legalmente. Una alternativa sería exigir la actualización a las fábricas de los sectores de alto riesgo.

\section{Notificación de enfermedades profesionales}

Pueden adoptarse disposiciones exigiendo la notificación de una serie de enfermedades profesionales. Previamente a la aplicación de estas normas habrá que dar publicidad a la cuestión y educar a las personas. Un paso previo es determinar las enfermedades que deben notificarse y las personas responsables de esta notificación. Por ejemplo, en Singapur los médicos que sospechan la existencia de alguna de las enfermedades profesionales incluidas en la Tabla 32.4 tienen la obligación de notificarlo al M inisterio de Trabajo. Por supuesto, las listas de este tipo han de adaptarse a la economía del país y ser revisadas periódicamente y actualizadas. Es más, las personas responsables de la notificación deben recibir la formación adecuada para saber reconocer, o al menos sospechar, la presencia de las enfermedades.
Tabla 32.4 - Ejemplo de lista de enfermedades profesionales notificables.

$\begin{array}{ll}\text { Intoxicación por anilinas } & \text { Dermatitis industrial } \\ \text { Antrax } & \text { Intoxicación por plomo } \\ \text { Intoxicación por arsénico } & \text { Angiosarcoma de hígado } \\ \text { Asbestosis } & \text { Intoxicación por manganeso } \\ \text { Barotrauma } & \text { Intoxicación por mercurio } \\ \text { Intoxicación por berilio } & \text { Mesotelioma } \\ \text { Bisinosis } & \text { Sordera producida por el ruido } \\ \text { Intoxicación por cadmio } & \text { Asma profesional } \\ \text { Intoxicación por disulfito de carbono } & \text { Intoxicación por fósforo } \\ \text { Ulceración con cromo } & \text { Silicosis } \\ \text { Intoxicación crónica por benceno } & \text { Anemia tóxica } \\ \text { Lesiones por aire comprimido } & \text { Hepatitis tóxica }\end{array}$

Para garantizar el éxito de los sistemas de notificación, se necesita un seguimiento continuo y una actuación encaminada a conseguir el cumplimiento de la legislación. De lo contrario, se limitará su utilidad. Por ejemplo, a partir de 1985 se impuso en Singapur la obligación de notificar e indemnizar los casos de asma profesional. Se creó también un centro médico especializado en enfermedades pulmonares. A pesar de estos esfuerzos, se confirmaron sólo un total de 17 casos. Estos datos contrastan con los de Finlandia, país en el que se declararon 179 casos de asma profesional tan sólo en 1984. La población de Finlandia, con 5 millones de habitantes, no es más del doble que la de Singapur. Es probable que esta insuficiencia del régimen de notificación del asma profesional se deba a la dificultad del diagnóstico. M uchos médicos no están familiarizados con las causas y las características del asma profesional. Así pues, una vez declarada la obligatoriedad de la notificación de una enfermedad, es importante seguir educando a los profesionales sanitarios, las empresas y los trabajadores.

Cuando el sistema de notificación se establece por primera vez, es posible que permita una evaluación más exacta de la prevalencia de las enfermedades profesionales. Por ejemplo, el número de casos declarados de pérdida auditiva inducida por el ruido en Singapur se multiplicó por seis cuando se impuso la obligación de realizar reconocimientos médicos a todos los trabajadores expuestos al ruido. Por consiguiente, si la notificación es relativamente completa y exacta y puede obtenerse un población satisfactoria, quizá sea posible estimar incluso la incidencia de la enfermedad y su riesgo relativo.

Como en muchos sistemas de notificación y vigilancia, la función más importante es la de alertar a las autoridades sobre la aparición de casos índice en el lugar de trabajo. Acto seguido habrá que proceder a investigaciones adicionales 0 intervenciones en el lugar de trabajo. De lo contrario, se desaprovecharán los esfuerzos de la notificación.

\section{Otras fuentes de información}

En los países en vías de desarrollo, los sistemas de vigilancia de los problemas de salud en el trabajo suelen infrautilizar la información médica de tipo hospitalario o ambulatorio. Los centros correspondientes pueden y deben incorporarse al sistema de notificación de ciertas enfermedades, como las intoxicaciones agudas y lesiones laborales. Los datos obtenidos de ellos permiten 
determinar además los problemas de salud más frecuentes de los trabajadores, y pueden utilizarse para planificar las actividades de promoción de la salud en el lugar de trabajo.

Toda esta información suele recogerse con carácter rutinario y se necesitan muy pocos recursos adicionales para transmitir los datos a las autoridades responsables de la salud y seguridad en el trabajo en un país en vías de desarrollo.

0 tra posible fuente de información son las compañías de seguros de indemnización o los tribunales. Finalmente, si se dispone de los recursos necesarios, pueden crearse algunos centros regionales de medicina del trabajo, a los cuales se remita a los pacientes y que cuenten con profesionales más cualificados, capacitados para investigar cualquier enfermedad que sospechen relacionada con el trabajo.

También puede utilizarse la información contenida en los registros de enfermedades. En muchas de las grandes ciudades de los países en vías de desarrollo existen registros del cáncer. Aunque es posible que la historia profesional que se obtenga de ellos no esté completa ni sea exacta, seguramente serán útiles para un control preliminar de los grandes grupos profesionales. La utilidad de los datos contenidos en estos registros será mayor si se dispone también de registros de trabajadores expuestos a determinados riesgos, a fin de poder establecer comparaciones cruzadas.

\section{Cruce de datos}

Aunque el cruce de datos parezca atractivo y se haya utilizado ya con cierto éxito en algunos países desarrollados, posiblemente no sea un enfoque adecuado o posible en los países en vías de desarrollo, al no disponer éstos de la infraestructura necesaria. Por ejemplo, es posible que no existan registros de enfermedades ni de los lugares de trabajo o, si existen, que no estén informatizados ni puedan cruzarse fácilmente.

\section{Ayuda de los organismos inter nacionales}

Los organismos internacionales, como la Organización Internacional del Trabajo, la O rganización M undial de la Salud y entidades como la Comisión Internacional de Medicina del Trabajo, pueden contribuir a solucionar algunos problemas de la vigilancia de la salud y seguridad en el trabajo en un país. Asimismo, pueden organizar cursos de formación u ofrecer oportunidades de formación a los profesionales de la asistencia sanitaria primaria.

El uso compartido de información entre países regionales con sectores industriales y problemas de salud en el trabajo similares también suele ser útil.

\section{Resumen}

Los servicios de salud y seguridad en el trabajo son importantes para los países en vías de desarrollo, sobre todo por la rápida industrialización de la economía, la vulnerabilidad de la población activa y el control deficiente de los riesgos para la salud en el lugar de trabajo.

Para el desarrollo y prestación de servicios de salud en el trabajo, es importante contar, también en estos países, con algún sistema de vigilancia de las enfermedades profesionales, que permita justificar, planificar y establecer prioridades para la legislación y los servicios pertinentes y evaluar los resultados de las medidas adoptadas.

Los sistemas de vigilancia que existen en los países desarrollados no siempre son adecuados para los países en vías de desarrollo. Los que se establezcan en éstos deben tener en cuenta el tipo de sectores existentes y los riesgos que son importantes. LoS sistemas más adecuados son los que utilizan mecanismos sencillos de vigilancia, así como tecnología ya existente y apropiada.

\section{DESARROLLO Y APLICACION DE UN SISTEMA DE CLASIFICACION DE LESIONES Y ENFERMEDADES PROFESIONALES}

Elyce Biddle

L os sistemas de vigilancia de lesiones y enfermedades en el lugar de trabajo constituyen un recurso crítico para la gestión y reducción de las lesiones y enfermedades profesionales. Proporcionan datos esenciales que pueden utilizarse para identificar problemas en el lugar de trabajo, desarrollar estrategias correctoras y prevenir así futuras lesiones y enfermedades. Estos objetivos pueden lograrse con unos sistemas de vigilancia que registren con considerable detalle las características de las lesiones que se producen en el lugar de trabajo. Para que tenga la máxima utilidad, tales sistemas deben ser capaces de responder a cuestiones como qué lugares de trabajo son más peligrosos, qué lesiones producen la mayor pérdida de tiempo de trabajo 0 incluso qué parte del organismo sufre lesiones con más frecuencia.

En este artículo se describe un sistema exhaustivo de clasificación elaborado por la O ficina de Estadísticas Laborales del Departamento de Trabajo de Estados U nidos (BLS). EI sistema se ha elaborado para atender las necesidades de analistas de la política estatal y federal, investigadores de la salud y la seguridad, empresas, organizaciones de trabajadores, profesionales de la seguridad, entidades aseguradoras y otros sectores interesados en promover la salud y la seguridad en el lugar de trabajo.

\section{Antecedentes}

D urante varios años, la BLS recogió tres tipos básicos de información sobre las lesiones y enfermedades profesionales:

- Sector, ubicación geográfica del incidente y jornadas de trabajo perdidas por su causa.

- Características del trabajador afectado, como edad, sexo y profesión.

- Forma en que se ha producido el incidente o exposición, objetos o sustancias implicadas, naturaleza de la lesión o enfermedad y parte del cuerpo afectada.

Este sistema de clasificación, aunque útil, era algo limitado y no atendía todas las necesidades antes descritas. En 1989 se decidió revisarlo para atender mejor las necesidades de los distintos usuarios.

\section{El sistema de clasificación}

En septiembre de 1989, la BLS creó un grupo de trabajo para que estableciese los requisitos de un sistema que describiera "con exactitud la naturaleza del problema de salud y seguridad en el trabajo" (O SH A 1970). El grupo con la ayuda de una serie de especialistas en salud y seguridad de los sectores público y privado para elaborar un sistema de clasificación nuevo y más amplio.

En primer lugar, se establecieron los criterios que debían regir las distintas estructuras de codificación. El sistema debía que tener una estructura jerárquica para ofrecer la máxima flexibilidad a los distintos usuarios de los datos sobre lesiones y enfermedades profesionales. Debía ser, en la medida de lo posible, compatible con la Clasificación Internacional de Enfermedades, 9ạ edición, M odificación C línica (CIE-9-C M ) de la O M S (1977). D ebía atender las necesidades de otros organismos públicos relacionados con la salud y la seguridad. Finalmente, debía tener en 
cuenta las distintas características de los episodios mortales y los no mortales.

En 1989 y 1990 se elaboraron y publicaron para su comentario los borradores de las estructuras de clasificación de las características de los casos. Se tomaban como base la naturaleza de la lesión o enfermedad, la parte del cuerpo afectada, la fuente de la lesión o enfermedad, la descripción del episodio o exposición y la fuente secundaria. Se recibieron y tuvieron en cuenta los comentarios del personal de la BLS y de otros organismos públicos, como la $\mathrm{O}$ ccupational Safety and $\mathrm{H}$ ealth Administration, la Employment Standards Administration y el NIOSH, después de lo cual el sistema estuvo preparado para una prueba sobre el terreno.

Se realizaron en cuatro estados las pruebas piloto de las estructuras para la recopilación de datos sobre lesiones y enfermedades no mortales, así como su aplicación práctica al Censo de Accidentes $M$ ortales en el Trabajo. Se analizaron los resultados obtenidos y en el otoño de 1991 estaban finalizadas las revisiones.

La versión definitiva del sistema de clasificación, publicada en 1992, comprende cinco estructuras de codificación de las características de los casos, una estructura de codificación de la profesión y una estructura de codificación del sector. El sector se clasifica de acuerdo con el Manual de Clasificación Industrial Normalizada (O M B, 1987) y la profesión, de acuerdo con el Indice Alfabético de Profesiones de la O ficina del Censo (O ficina del Censo 1992). Por su parte, el Sistema de Clasificación de Lesiones y Enfermedades Profesionales de la BLS utiliza para codificar las siguientes cinco características de los casos:

- Naturaleza de la enfermedad o lesión.

- Parte del cuerpo afectada.

- Episodio o exposición.

- Fuente de la lesión o enfermedad.

- Fuente secundaria de la lesión o enfermedad.

Además de los correspondientes códigos numéricos, que representan condiciones o circunstancias específicas, cada estructura de codificación incluye ayudas para la identificación y selección del código correcto. Estas ayudas son: definiciones, reglas de selección, párrafos descriptivos, listas alfabéticas y criterios de edición para cada una de las estructuras. Las reglas de selección ofrecen orientación para elegir siempre el código adecuado cuando se dude entre dos o más. L os párrafos descriptivos ofrecen información adicional sobre los códigos, como qué es lo que se incluye o excluye en cada uno de ellos. Por ejemplo, el código correspondiente al ojo incluye el globo ocular, el cristalino, la retina y las pestañas. Las listas alfabéticas permiten localizar rápidamente el código numérico correspondiente a una característica específica. Finalmente, los criterios de edición son herramientas de garantía de calidad que pueden utilizarse para determinar qué combinaciones de código son incorrectas antes de su selección final.

\section{Códigos de la naturaleza de la lesión o enfermedad}

La estructura de codificación titulada naturaleza de la lesión o enfermedad describe las características físicas fundamentales. Sirve como base para las demás clasificaciones del caso. U na vez que se ha identificado la naturaleza de la lesión o enfermedad, las restantes cuatro clasificaciones describen las circunstancias asociadas a ella. La estructura de clasificación de la naturaleza de la lesión o enfermedad contiene siete divisiones:

- Lesiones y trastornos traumáticos.

- Enfermedades y trastornos sistémicos.

- Enfermedades infecciosas y parasitarias.
- Neoplasias, tumores y cáncer.

- Síntomasy afecciones mal definidas.

- O tras afecciones o trastornos.

- Enfermedades, afecciones o trastornos múltiples.

Antes de decidir la versión final de esta estructura, se evaluaron dos sistemas similares de clasificación para su posible adopción o emulación. U no de ellos, contenido en la norma Z16.2 (ANSI 1963) del American National Standards Institute (ANSI), dirigida a la prevención de accidentes, no contiene el número suficiente de categorías de enfermedad que necesitan muchos organismos para desempeñar correctamente sus funciones.

Por su parte, la CIE-9-CM, diseñada para la clasificación de la información sobre morbilidad y mortalidad y utilizada por gran parte de la comunidad médica, contiene códigos suficientemente detallados de las enfermedades. Sin embargo, los elevados requisitos de formación y conocimientos técnicos de los usuarios y recopiladores de estas estadísticas hacen su uso prohibitivo.

La estructura finalmente adoptada es la de un híbrido que combina el método de aplicación y las reglas de selección de ANSI Z1 6.2 con las divisiones básicas de la CIE-9-CM. Así, las divisiones del sistema se corresponden directamente con las de esta última. Por ejemplo, la división BLS que identifica a las enfermedades infecciosas y parasitarias corresponde directamente al Capítulo 1, Enfermedades infecciosas y parasitarias, de la CIE-9-CM.

La primera división incluye las lesiones y trastornos traumáticos, los efectos de agentes externos y las intoxicaciones, y corresponde al Capítulo 17 de la CIE-9-CM. Las lesiones y enfermedades correspondientes en ella suelen ser el resultado de un único incidente, episodio o exposición, e incluyen afecciones como fracturas, contusiones, cortes y quemaduras. En el medio ambiente de trabajo, esta división engloba la gran mayoría de los casos declarados.

Existen una serie de situaciones que requieren una detenida consideración al establecer las reglas de selección de códigos en esta división. La revisión de los casos mortales revela dificultades en la codificación de ciertos tipos de accidentes. Por ejemplo, las fracturas mortales suelen deberse directa 0 indirectamente a lesiones mortales en órganos vitales, como el cerebro o la columna vertebral. Para registrar los daños mortales causados por este tipo de lesiones, se tuvieron que introducir algunas categorías e instrucciones de codificación específicas.

Las heridas por arma de fuego constituyen una categoría diferente, con instrucciones especiales para aquellos casos en los que se producen también amputaciones o parálisis. Para respetar los criterios inspiradores del sistema de codificación, las lesiones, parálisis y amputaciones más graves tienen preferencia sobre las lesiones menos graves producidas por un arma de fuego.

Las respuestas a las preguntas que aparecen en los partes de accidente que deben remitir las empresas no siempre describen correctamente la lesión o enfermedad. Si en una parte se indica tan sólo que el trabajador se lesionó "en la espalda", no hay base para considerar si se trata de una dislocación, distensión, dorsopatía o cualquier otra enfermedad concreta. Para resolver el problema, se han establecido códigos individuales para las descripciones inespecíficas de lesiones o enfermedades tales como "llaga", "herida" o "dolor".

Finalmente, esta división incluye unos códigos para clasificar las combinaciones más frecuentes de afecciones derivados del mismo incidente. Por ejemplo, un trabajador puede sufrir tanto arañazos como contusiones en un mismo incidente.

Cinco de las restantes divisiones de esta estructura de clasificación se dedican a la identificación de enfermedades y trastornos profesionales. Incluyen códigos para identificar determinadas 
afecciones que presentan un interés especial para los profesionales de la salud y la seguridad. En los últimos años, son cada vez más las enfermedades y trastornos que se han relacionado con el entorno de trabajo, pero esta relación rara vez se ha reflejado en los sistemas de clasificación existentes. El sistema de la BLS incluye una lista muy amplia de enfermedades y trastornos específicos, como el síndrome del túnel carpiano, la legionella, la tendonitis y la tuberculosis.

\section{Parte del cuerpo a fectada}

La estructura de clasificación titulada parte del cuerpo afectada especifica la parte del cuerpo directamente afectada por la lesión 0 enfermedad. Cuando se relaciona con el código de la naturaleza de la lesión o enfermedad, se obtiene una imagen completa de los daños sufridos: amputación de dedo, cáncer de pulmón, fractura de mandíbula. Este sistema comprende ocho divisiones:

- Cabeza.

- Cuello, incluida la garganta.

- Tronco.

- Extremidades superiores

- Extremidades inferiores.

- Sistemas orgánicos.

- Pluralidad de partes del cuerpo.

- O tras partes del cuerpo.

C uando se analizaron las posibles alternativas para concretar esta parte teóricamente sencilla del sistema de clasificación, se plantearon tres cuestiones. La primera de ellas fue si debía codificarse la parte externa (brazo, tronco, pierna) afectada por la lesión o enfermedad o la parte interna (corazón, pulmones, cerebro).

Los resultados de las pruebas indicaron que la consideración de la parte interna del organismo afectada era adecuada para las enfermedades y trastornos, pero extremadamente confusa cuando se aplicaba a muchas de las lesiones traumáticas, como los cortes o contusiones. La BLS optó por codificar la parte externa afectada en el caso de la mayoría de las lesiones traumáticas y la parte interna afectada en el caso de las enfermedades (si procedía).

La segunda cuestión que se planteó fue la relativa a la clasificación de las enfermedades que afectan a varios sistemas. Por ejemplo, la hipotermia, un trastorno de baja temperatura corporal por la exposición al frío, puede afectar a los sistemas nervioso y endocrino. En un caso así, el personal paramédico tendría dificultades para elegir el código correcto y podría verse obligado a dedicar mucho tiempo a la investigación sin obtener nada en claro. Por este motivo, el sistema de la BLS prevé una única división, "sistemas orgánicos", que incluye uno solo 0 varios de éstos

La tercera cuestión que se suscitó se refería a la identificación de las combinaciones típicas de lesiones en las extremidades superiores e inferiores. Los informes remitidos por las empresas sobre los incidentes ocurridos a los trabajadores demostraron que estas combinaciones, como la de mano y muñeca, estaban justificadas.

\section{E pisodio o exposición}

El sistema de clasificación titulado episodio o exposición describe la forma en que se produzco o causó la enfermedad o lesión. Para identificar la forma principal de lesión o exposición a una sustancia o situación peligrosa, se prevén las siguientes ocho divisiones:

- Contacto con objetos y equipos.
- Caídas

- Reacciones y esfuerzos corporales.

- Exposición a sustancias o ambientes nocivos.

- Accidentes de tráfico.

- Incendios y explosiones.

- Agresiones y actos violentos.

- 0 tros episodios o exposiciones.

Los incidentes causantes de lesiones están constituidos con frecuencia por varios episodios. Como ejemplo, puede considerarse lo que ocurre en un accidente de tráfico: un coche golpea la valla, cruza la mediana y choca contra un camión. El conductor sufre varias lesiones al golpearse contra el interior del coche y cortarse con los cristales. Si se codificaran los microepisodios - por ejemplo, golpe contra el parabrisas o corte con un cristal que sale despedido-, podría pasarse por alto el hecho más general de que la persona ha sufrido un accidente de tráfico.

En estos casos de episodios múltiples, hay una serie de episodios que deben considerarse primarios y tener prioridad sobre los microepisodios asociados a ellos. Estos episodios primarios son:

- Agresiones y actos violentos.

- Accidentes de tráfico.

- Incendios.

- Explosiones.

D entro de estos grupos se ha establecido también un orden de prioridad, ya que muchas veces se solapan: por ejemplo, en un accidente de tráfico puede producirse un incendio. Pues bien, el orden de prioridad es aquél en el que aparecen en la lista. Las agresiones y actos violentos reciben la máxima prioridad. Los códigos de esta división describen el tipo de violencia en general, mientras que el arma se describe en el código correspondiente a la fuente. Los accidentes de tráfico les siguen en prioridad, seguidos de los incendios y las explosiones.

Estos dos últimos episodios, incendios y explosiones, se combinan en una única división. Puesto que suelen producirse simultáneamente, se ha establecido un orden de prioridad entre ellos. De acuerdo con la Clasificación Suplementaria de Causas Externas de la CIE-9, los incendios reciben prioridad sobre las explosiones (USPHS 1989).

Al seleccionar los códigos de este sistema se ha previsto la identificación de trastornos en los que no ha habido contacto y que están relacionados con las actividades y la ergonomía del trabajo. Suelen consistir en daños en nervios, músculos o ligamentos causados por movimientos de torsión o incluso movimientos simples del cuerpo, como ocurre cuando un trabajador se "disloca" la espalda al agacharse para recoger algo. En la actualidad se reconoce ampliamente que el síndrome del tunel carpiano está relacionado con acciones repetitivas, como la utilización de un teclado, la mecanografía, las actividades de corte e incluso la utilización de una caja registradora. La división denominada "reacciones y esfuerzos corporales" identifica los incidentes que no se producen por contacto ni por impacto.

La división denominada "exposición a sustancias o ambientes nocivos" alude a forma concreta de exposición: inhalación, contacto de la piel, ingestión o inyección. Incluye una categoría para identificar la transmisión de un agente infeccioso por el pinchazo de una aguja, así como otros incidentes no causados por impactos, como cuando el trabajador resulta dañado por una corriente eléctrica o por las condiciones ambientales, como un frío extremo.

Las divisiones denominadas "contacto con objetos y equipos" y "caídas" son las que englobarán la mayoría de los episodios por impacto que causan lesiones a los trabajadores. 


\section{Fuente de la lesión o enfermedad}

El sistema de clasificación titulado fuente de la lesión o enfermedad identifica el objeto, sustancia, movimiento corporal o exposición que produce o causa directamente la lesión o enfermedad. Si un trabajador se corta en la cabeza al recibir el impacto de un ladrillo que se ha caído, el ladrillo es la fuente de la lesión. Existe una relación directa entre la fuente y la naturaleza de la lesión o enfermedad. Si un trabajador se resbala en una mancha de aceite y cae al suelo, rompiéndose un codo, la fractura es producida por el golpe contra el suelo, por lo que el suelo es la fuente de la lesión. Este sistema de codificación contiene diez divisiones:

- Sustancias y productos químicos.

- Recipientes.

- Muebles y accesorios

- Maquinaria.

- Componentes y materiales

- Personas, plantas, animales y minerales.

- Estructuras y superficies.

- H erramientas, instrumentos y equipos.

- Vehículos.

- 0 tras fuentes.

Las definiciones generales y los conceptos de codificación del nuevo Sistema de Clasificación de la Fuente de la BLS proceden del sistema de clasificación ANSI Z1 6.2. Sin embargo, la tarea de elaborar una lista de códigos más completa y jerárquica fue en un principio terrible, porque prácticamente todos los elementos o sustancias del mundo pueden considerarse como una fuente de lesión o enfermedad. Y no sólo eso, sino que también pueden clasificarse como tales todas las piezas 0 componentes de todo lo que existe en el mundo. Para aumentar la dificultad, habría que agrupar a todos los candidatos para su inclusión en tan sólo diez categorías.

Al revisar los datos históricos sobre lesiones y enfermedades profesionales, se identificaron varios ámbitos en los que la estructura precedente de codificación era inadecuada u obsoleta. Las secciones correspondientes a maquinaria y herramientas necesitaban ampliarse y actualizarse. No existía ningún código aplicable a los ordenadores. Con las nuevas tecnologías, la lista de herramientas eléctricas había quedado obsoleta y muchos de los elementos de la lista de herramientas manuales eran eléctricos: destornilladores, martillos, etc. Los usuarios pedían asimismo que se ampliara y actualizara la lista de sustancias químicas. La O ccupational Safety and $\mathrm{H}$ ealth Administration exigía un mayor nivel de detalle en algunos equipos, como diversos tipos de andamios, carretillas elevadoras y máquinas de construcción y explotación maderera.

La parte más difícil era la organización de los elementos que debían asignarse a las distintas divisiones y a los diferentes grupos dentro de una misma división. Para aumentar la dificultad, las categorías de códigos tenían que ser mutuamente excluyentes. Sin embargo, cualesquiera que fuesen las categorías que se establecieran, había muchos elementos que encajaban por lógica en dos o más divisiones. Por ejemplo, existía consenso general sobre la necesidad de prever categorías diferentes para los vehículos y para las máquinas. Sin embargo, los expertos no se ponían de acuerdo sobre la inclusión de algunos equipos, como las máquinas asfaltadoras o las carretillas elevadoras, entre las máquinas o los vehículos.

O tro tema que se debatió fue la manera de agrupar las máquinas dentro de la división de maquinaria. Las alternativas consistían en asociarlas con un determinado proceso o industria (por ejemplo, maquinaría agrícola o equipos de jardinería), agruparlas por funciones (máquinas de imprenta, equipos de calefacción y refrigeración) 0 agruparlas según el tipo de objeto tratado (metales, madera). Incapaces de encontrar una única solución que sirviera para todo tipo de máquinas, la BLS decidió elaborar una lista que clasifica algunos tipos de maquinaria según el sector (maquinaria agrícola, máquinas de construcción y explotación maderera), otros según su función general (máquinas para la manipulación de materiales, equipos de ofimática) y otros según los materiales tratados (metales, madera). Cuando existe la posibilidad de solapamiento (p. ej. una máquina de carpintería que se utilice en trabajos de construcción) el sistema indica la categoría a la que deba asignarse la máquina, para conseguir que los códigos sean mútuamente excluyentes.

Se han establecido también códigos especiales para recabar información sobre lesiones o enfermedades en el sector de la asistencia sanitaria, que se ha convertido en uno de los principales sectores de empleo en Estados Unidos y uno de los que presenta problemas de salud y seguridad más graves. Como ejemplo, muchos de los organismos públicos que ayudaron a desarrollar el sistema de clasificación recomendaron la inclusión de un código para pacientes y residentes de centros de asistencia sanitaria, puesto que los profesionales de la enfermería y los auxiliares clínicos pueden lesionarse al intentar alzar, mover 0 prestar otros cuidados a sus pacientes.

\section{Fuente secundaria de la lesión o enfermedad}

La BLS y otros usuarios de los datos coinciden en que el sistema de clasificación de la fuente de lesión o enfermedad profesional indica el objeto que produce la lesión o enfermedad, pero algunas veces no refleja otras importantes aportaciones al episodio. En el sistema precedentes, por ejemplo, si un trabajador se golpeaba con un trozo de madera que salía despedido de una sierra atascada, la madera era la fuente de la lesión, pero no se indicaba el hecho de que la sierra fuera eléctrica. Si un trabajador sufría quemaduras durante un incendio, la llama era la fuente de la lesión, pero no se indicaba la causa del incendio.

Para evitar esta posible pérdida de información, la BLS estableció una fuente secundaria de la lesión o enfermedad que "identifica el objeto, sustancia o persona que generó la fuente de la lesión o enfermedad o contribuyó al episodio o exposición". Las normas específicas para la selección de este código hacen hincapié en la identificación de máquinas, herramientas, equipos u otras sustancias generadoras de energía (como líquidos inflamables) que no se identifican en la fuente principal. En el primero de los ejemplos anteriores, la sierra eléctrica sería la fuente secundaria, puesto que lanzó la pieza de madera. En el último ejemplo, la fuente secundaria sería la sustancia que provocó la ignición (grasa, gasolina, etc.).

\section{Requisitos para la aplicación del sistema: revisión, verificación y validación}

La preparación de un sistema de clasificación exhaustivo es sólo un paso para recopilar y facilitar a los usuarios información fidedigna sobre las lesiones y enfermedades que se originan en el lugar de trabajo. Es importante que los profesionales sepan cómo se aplica ese sistema de una manera exacta, uniforme y acorde con el diseño previsto.

La primera medida de garantía de calidad consistió en impartir una formación exhaustiva a las personas responsables de asignar los códigos del sistema de clasificación. Se organizaron cursos de iniciación, de nivel intermedio y avanzados para enseñar técnicas normalizadas de codificación. Un pequeño grupo de personas que participaron en estos cursos se encargaron de organizar otros cursos iguales para el personal interesado en todo el territorio de Estados U nidos.

Se incorporaron controles electrónicos de edición para ayudar en el proceso de revisión, verificación y validación de las características y los datos demográficos de los casos. Se establecieron 
Tabla 32.5 • Ejemplos del sistema de códigos de clasificación de enfermedades y lesiones, 0 ficina de Estadísticas Laborales de Estados Unidos.

Código de la naturaleza de la lesión o enfermedad- Ejemplos

0* Lesiones y enfermedades traumáticas

08* Lesiones y enfermedades por traumatismos múltiples

080 Lesiones y enfermedades por traumatismos múltiples, sin especificar

081 Cortes, abrasiones, contusiones

082 Dislocaciones y contusiones

083 Fracturas y quemaduras

084 Fracturas y otras lesiones

085 Quemaduras y otras lesiones

086 Lesiones intracraneales y lesiones en órganos internos

089 Otras combinaciones de lesiones y trastornos traumáticos, S.C.

Código de episodio o exposición - Ejemplos

1* Caídas

$11 *$

113 Caída desde una escalera

114 Caída desde materiales apilados 0 amontonados

115* Caída desde un tejado

1150 Caída desde un tejado, sin especificar

1151 Caída a través de una abertura en el tejado

1152 Caída a través de la superficie del tejado

1153 Caída a través de un tragaluz

1154 Caída desde el borde de un tejado

1159 Caída desde un tejado, S.c.

116 Caída desde un andamio, plataforma

117 Caída desde las vigas de un edificio u otras estructuras de acero

118 Caída desde vehículos parados

119 Caída a un plano inferior, s.c.
Código de la fuente de la lesión o enfermedad- Ejemplos

$7 *$ Herramientas, instrumentos y equipos

72* Herramientas manuales- eléctricas

722* Herramientas de corte manuales, eléctricas

7220 Herramientas de corte manuales, eléctricas, sin especificar

7221 Seguetas, eléctricas

7222 Cinceles, eléctricos

7223 Cuchillos, eléctricos

7224 Sierras, eléctricas, excepto seguetas

7229 Herramientas de corte manuales, eléctricas, S.C.

723* Herramientas manuales de percusión y clavado, eléctricas

7230 Herramientas manuales de percusión, eléctricas, sin especificar

7231 Martillos, eléctricos

7232 Martillos perforadores, eléctricos

7233 Máquinas punzonadoras, eléctricas

Código de la parte del cuerpo afectada- Ejemplos

2* Tronco

23* Espalda, incluida la columna vertebral, médula espinal

230 Espalda, incluida la columna vertebral, médula espinal, sin especificar

231 Región lumbar

232 Región torácica

233 Región sacra

234 Región del coxis

238 Regiones múltiples de la espalda

239 Espalda, incluida la columna vertebral, médula espinal, s.c.

$*$ = nombres de división, grupo principal 0 grupo; $\quad$ S.C. $=$ sin clasificar en otro lugar los criterios de lo que puede y no puede combinarse y se introdujo un sistema automatizado para detectar combinaciones erróneas. Este sistema contiene más de 550 grupos de comprobaciones cruzadas para verificar que los datos introducidos superen los controles de calidad. Por ejemplo, un caso que identifique el síndrome del tunel carpiano como causa de lesión de una rodilla sería considerado como un error. Este sistema automatizado identifica también códigos no válidos, es decir, que no existen en el sistema de clasificación.

Es evidente que los controles de edición no pueden ser nunca lo suficientemente estrictos para detectar todos los datos sospechosos. Debe comprobarse la lógica global de éstos. Por ejemplo, según la información recogida durante años sobre la parte del cuerpo afectada, casi el $25 \%$ de los casos mencionan la espalda. Este porcentaje constituye un punto de referencia para el personal que debe validar los datos. Un análisis de tabulaciones cruzadas de la sensibilidad global facilita también información sobre la aplicación más o menos correcta del sistema. Finalmente, existen algunos episodios especiales y raros, como la tuberculosis de origen profesional, que deben validarse. Un aspecto importante de un sistema de validación exhaustivo podría consistir en volver a establecer contacto con la empresa para verificar la exactitud de su informe, aunque para ello se necesitan recursos adicionales.

\section{Ejemplos}

En la Tabla 32.5 se ofrecen algunos ejemplos de cada uno de los cuatro sistemas de clasificación de enfermedades y lesiones, para ilustrar el nivel de detalle y la riqueza del sistema final. La potencia del sistema en su conjunto se demuestra en la Tabla 32.6, en la que se señalan las características que se tabularon para un conjunto de lesiones relacionadas: las caídas. Además de las caídas totales, se distingue entre las caídas en un mismo plano, las caídas a un plano más bajo y los saltos a un plano más alto. Puede observarse, por ejemplo, que la probabilidad de sufrir una caída es mayor en los trabajadores de 25 a 34 años, los operadores de máquinas y peones, los trabajadores de industrias manufactureras y los que tienen menos de cinco años de experiencia en su actual empleo (datos no representados). 
Tabla 32.6 - N úmero y porcentaje de lesiones y enfermedades profesionales relacionadas con caídas, que no tienen consecuencias fatales pero que causan baja laboral, por tipos de trabajadores y características del caso, Estados Unidos 1993.

\begin{tabular}{|c|c|c|c|c|c|c|c|c|c|c|}
\hline \multirow[t]{2}{*}{ Características } & \multicolumn{2}{|l|}{$\begin{array}{l}\text { Total } \\
\text { episodios }\end{array}$} & \multicolumn{2}{|l|}{$\begin{array}{l}\text { Total } \\
\text { caídas }\end{array}$} & \multicolumn{2}{|c|}{$\begin{array}{l}\text { Caída a un } \\
\text { plano inferior }\end{array}$} & \multicolumn{2}{|c|}{$\begin{array}{l}\text { Salto a un } \\
\text { plano inferior }\end{array}$} & \multicolumn{2}{|c|}{$\begin{array}{l}\text { Caída en el } \\
\text { mismo plano }\end{array}$} \\
\hline & Número & $\%$ & Número & $\%$ & Número & $\%$ & Número & $\%$ & Número & $\%$ \\
\hline Total & 2.252 .591 & 100,0 & 370.112 & 100,0 & 111.266 & 100,0 & 9.433 & 100,0 & 244.115 & 100,0 \\
\hline \multicolumn{11}{|l|}{ Sexo: } \\
\hline Varones & 1.490 .418 & 66,2 & 219.199 & 59,2 & 84.868 & 76,3 & 8.697 & 92,2 & 121.903 & 49,9 \\
\hline Mujeres & 735.570 & 32,7 & 148.041 & 40,0 & 25.700 & 23,1 & 645 & 6,8 & 120.156 & 49,2 \\
\hline \multicolumn{11}{|l|}{ Edad: } \\
\hline 14 a 15 años & 889 & 0,0 & 246 & 0,1 & 118 & 0,1 & - & - & 84 & 0,0 \\
\hline 16 a 19 años & 95.791 & 4,3 & 15.908 & 4,3 & 3.170 & 2,8 & 260 & 2,8 & 12.253 & 5,0 \\
\hline 20 a 24 años & 319.708 & 14,2 & 43.543 & 11,8 & 12.840 & 11,5 & 1.380 & 14,6 & 28.763 & 11,8 \\
\hline 25 a 34 años & 724.355 & 32,2 & 104.244 & 28,2 & 34.191 & 30,7 & 3.641 & 38,6 & 64.374 & 26,4 \\
\hline 35 a 44 años & 566.429 & 25,1 & 87.516 & 23,6 & 27.880 & 25,1 & 2.361 & 25,0 & 56.042 & 23,0 \\
\hline 45 a 54 años & 323.503 & 14,4 & 64.214 & 17,3 & 18.665 & 16,8 & 1.191 & 12,6 & 43.729 & 17,9 \\
\hline 55 a 64 años & 148.249 & 6,6 & 37.792 & 10,2 & 9.886 & 8,9 & 470 & 5,0 & 27.034 & 11,1 \\
\hline 650 más años & 21.604 & 1,0 & 8.062 & 2,2 & 1.511 & 1,4 & 24 & 0,3 & 6.457 & 2,6 \\
\hline \multicolumn{11}{|l|}{ Profesión: } \\
\hline $\begin{array}{l}\text { Directivos y profesionales altamente } \\
\text { cualificados }\end{array}$ & 123.596 & 5,5 & 26.391 & 7,1 & 6.364 & 5,7 & 269 & 2,9 & 19.338 & 7,9 \\
\hline Apoyo técnico, comercial y administrativo & 344.402 & 15,3 & 67.253 & 18,2 & 16.485 & 14,8 & 853 & 9,0 & 49.227 & 20,2 \\
\hline Servicios & 414.135 & 18,4 & 85.004 & 23,0 & 13.512 & 12,1 & 574 & 6,1 & 70.121 & 28,7 \\
\hline Agricultura, silvicultura y pesca & 59.050 & 2,6 & 9.979 & 2,7 & 4.197 & 3,8 & 356 & 3,8 & 5.245 & 2,1 \\
\hline $\begin{array}{l}\text { Producción de precisión, trabajos manuales } \\
\text { especializados y reparaciones }\end{array}$ & 366.112 & 16,3 & 57.254 & 15,5 & 27.805 & 25,0 & 1.887 & 20,0 & 26.577 & 10,9 \\
\hline $\begin{array}{l}\text { Operadores, fabricadores y obreros no } \\
\text { especializados }\end{array}$ & 925.515 & 41,1 & 122.005 & 33,0 & 42.074 & 37,8 & 5.431 & 57,6 & 72.286 & 29,6 \\
\hline \multicolumn{11}{|l|}{ Naturaleza de la lesión. enfermedad: } \\
\hline Dislocaciones, distensiones & 959.163 & 42,6 & 133.538 & 36,1 & 38.636 & 34,7 & 5.558 & 58,9 & 87.152 & 35,7 \\
\hline Fracturas & 136.478 & 6,1 & 55.335 & 15,0 & 21.052 & 18,9 & 1.247 & 13,2 & 32.425 & 13,3 \\
\hline Cortes, laceraciones, punciones & 202.464 & 9,0 & 10.431 & 2,8 & 2.350 & 2,1 & 111 & 1,2 & 7,774 & 3,2 \\
\hline Contusiones, magulladuras & 211.179 & 9,4 & 66.627 & 18,0 & 17.173 & 15,4 & 705 & 7,5 & 48,062 & 19,7 \\
\hline Lesiones múltiples & 73.181 & 3,2 & 32.281 & 8,7 & 11.313 & 10,2 & 372 & 3,9 & 20.295 & 8,3 \\
\hline Con fracturas & 13.379 & 0,6 & 4.893 & 1,3 & 2.554 & 2,3 & 26 & 0,3 & 2.250 & 0,9 \\
\hline Con dislocaciones & 26.969 & 1,2 & 15.991 & 4,3 & 4.463 & 4,0 & 116 & 1,2 & 11.309 & 4,6 \\
\hline Sensibilidad dolorosa, Dolor & 127.555 & 5,7 & 20.855 & 5,6 & 5.614 & 5,0 & 529 & 5,6 & 14,442 & 5,9 \\
\hline Dolor de espalda & 58.385 & 2,6 & 8.421 & 2,3 & 2.587 & 2,3 & 214 & 2,3 & 5.520 & 2,3 \\
\hline Otras & 411.799 & 18,3 & 50.604 & 13,7 & 15.012 & 13,5 & 897 & 9,5 & 33.655 & 13,8 \\
\hline \multicolumn{11}{|l|}{ Parte del cuerno afectada: } \\
\hline Cabeza & 155.504 & 6,9 & 13.880 & 3,8 & 2.994 & 2,7 & 61 & 0,6 & 10.705 & 4,4 \\
\hline Ojos & 88.329 & 3,9 & 314 & 0,1 & 50 & 0,0 & 11 & 0,1 & 237 & 0,1 \\
\hline Cuello & 40.704 & 1,8 & 3.205 & 0,9 & 1.097 & 1,0 & 81 & 0,9 & 1.996 & 0,8 \\
\hline Tronco & 869.447 & 38,6 & 118,369 & 32,0 & 33.984 & 30,5 & 1.921 & 20,4 & 80.796 & 33,1 \\
\hline Espalda & 615.010 & 27,3 & 72.290 & 19,5 & 20.325 & 18,3 & 1.523 & 16,1 & 49.461 & 20,3 \\
\hline Hombros & 105.881 & 4,7 & 16.186 & 4,4 & 4.700 & 4,2 & 89 & 0,9 & 11.154 & 4,6 \\
\hline
\end{tabular}

Continúa en la página siguiente. 
Tabla 32.6 - N úmero y porcentaje de lesiones y enfermedades profesionales relacionadas con caídas, que no tienen continuación. consecuencias fatales pero que causan baja laboral, por tipos de trabajadores y características del caso, Estados Unidos 1993.1

\begin{tabular}{|c|c|c|c|c|c|c|c|c|c|c|}
\hline \multirow[t]{2}{*}{ Características } & \multicolumn{2}{|l|}{$\begin{array}{l}\text { Total } \\
\text { episodios }\end{array}$} & \multicolumn{2}{|l|}{$\begin{array}{l}\text { Total } \\
\text { caídas }\end{array}$} & \multicolumn{2}{|c|}{$\begin{array}{l}\text { Caída a un } \\
\text { plano inferior }\end{array}$} & \multicolumn{2}{|c|}{$\begin{array}{l}\text { Salto a un } \\
\text { plano inferior }\end{array}$} & \multicolumn{2}{|c|}{$\begin{array}{l}\text { Caída en el } \\
\text { mismo plano }\end{array}$} \\
\hline & Número & $\%$ & Número & $\%$ & Número & $\%$ & Número & $\%$ & Número & $\%$ \\
\hline \multicolumn{11}{|l|}{ Fuente de la lesión o enfermedad: } \\
\hline Sustancias químicas, productos químicos & 43.411 & 1,9 & 22 & 0,0 & - & - & - & - & 16 & 0,0 \\
\hline Recipientes & 330.285 & 14,7 & 7.133 & 1,9 & 994 & 0,9 & 224 & 2,4 & 5.763 & 2,4 \\
\hline Mobiliario, accesorios & 88.813 & 3,9 & 7.338 & 2,0 & 881 & 0,8 & 104 & 1,1 & 6.229 & 2,6 \\
\hline Maquinaria & 154.083 & 6,8 & 4.981 & 1,3 & 729 & 0,7 & 128 & 14 & 4.035 & 1,7 \\
\hline Componentes y materiales & 249.077 & 11,1 & 6.185 & 1,7 & 1.016 & 0,9 & 255 & 2,7 & 4.793 & 2,0 \\
\hline Movimiento o posición del trabajador & 331.994 & 14,7 & - & - & - & - & - & - & - & - \\
\hline Suelo, superficies del suelo & 340.159 & 15,1 & 318.176 & 86,0 & 98.207 & 88,3 & 7.705 & 81,7 & 208.765 & 85,5 \\
\hline Herramientas manuales & 105.478 & 4,7 & 727 & 0,2 & 77 & 0,1 & 41 & 0,4 & 600 & 0,2 \\
\hline Vehículos & 157.360 & 7,0 & 9.789 & 2,6 & 3.049 & 2,7 & 553 & 5,9 & 6.084 & 2,5 \\
\hline Paciente que recibe asistencia sanitaria & 99.390 & 4,4 & 177 & 0,0 & 43 & 0,0 & 8 & 0,1 & 90 & 0,0 \\
\hline Otras & 83.813 & 3,7 & 15.584 & 4,2 & 6.263 & 5,6 & 414 & 4,4 & 7.741 & 3,2 \\
\hline \multicolumn{11}{|l|}{ Sector industrial: } \\
\hline Agricultura, silvicultura y pesca ${ }^{2}$ & 44.826 & 2,0 & 8.096 & 2,2 & 3.636 & 3,3 & 301 & 3,2 & 3.985 & 1,6 \\
\hline Minería $^{3}$ & 21.090 & 0,9 & 3.763 & 1,0 & 1.757 & 1,6 & 102 & 1,1 & 1.874 & 0,8 \\
\hline Construcción & 204.769 & 9,1 & 41.787 & 11,3 & 23.748 & 21,3 & 1.821 & 19,3 & 15.464 & 6,3 \\
\hline Fabricación & 583.841 & 25,9 & 63.566 & 17,2 & 17.693 & 15,9 & 2.161 & 22,9 & 42.790 & 17,5 \\
\hline Transporte y servicios públicos ${ }^{3}$ & 232.999 & 10,3 & 38.452 & 10,4 & 14.095 & 12,7 & 1.797 & 19,0 & 21.757 & 8,9 \\
\hline Comercio mayorista & 160.934 & 7,1 & 22.677 & 6,1 & 8.119 & 7,3 & 1.180 & 12,5 & 12.859 & 5,3 \\
\hline Comercio minorista & 408.590 & 18,1 & 78.800 & 21,3 & 15.945 & 14,3 & 1.052 & 11,1 & 60.906 & 24,9 \\
\hline Finanzas, seguros y sector inmobiliario & 60.159 & 2,7 & 14.769 & 4,0 & 5.353 & 4,8 & 112 & 1,2 & 9.167 & 3,8 \\
\hline Servicios & 535.386 & 23,8 & 98.201 & 26,5 & 20.920 & 18,8 & 907 & 9,6 & 75.313 & 30,9 \\
\hline \multicolumn{11}{|l|}{ Número de días de baja laboral: } \\
\hline Casos de baja laboral durante 1 día & 366.054 & 16,3 & 48.550 & 13,1 & 12.450 & 11,2 & 1.136 & 12,0 & 34.319 & 14,1 \\
\hline Casos de baja laboral durante 2 días & 291.760 & 13,0 & 42.912 & 11,6 & 11.934 & 10,7 & 1.153 & 12,2 & 29.197 & 12,0 \\
\hline Casos de baja laboral durante 3-5 días & 467.001 & 20,7 & 72.156 & 19,5 & 20.167 & 18,1 & 1.770 & 18,8 & 49.329 & 20,2 \\
\hline Casos de baja laboral durante 6-10 días & 301.941 & 13,4 & 45.375 & 12,3 & 13.240 & 11,9 & 1,267 & 13,4 & 30,171 & 12,4 \\
\hline Casos de baja laboral durante 11-20 días & 256.319 & 11,4 & 44.228 & 11,9 & 13.182 & 11,8 & 1.072 & 11,4 & 29.411 & 12,0 \\
\hline Casos de baja laboral durante 21-30 días & 142.301 & 6,3 & 25.884 & 7,0 & 8.557 & 7,7 & 654 & 6,9 & 16.359 & 6,7 \\
\hline $\begin{array}{l}\text { Casos de baja laboral durante } 310 \\
\text { más días }\end{array}$ & 427.215 & 19,0 & 91.008 & 24,6 & 31.737 & 28,5 & 2.381 & 25,2 & 55.329 & 22,7 \\
\hline Mediana de días de baja laboral & 6 días & & 7 días & & 10 días & & 8 días & & 7 días & \\
\hline
\end{tabular}

${ }^{1}$ Los días de baja laboral son los que tienen esta consideración jurídica, con 0 sin actividad laboral restringida. 2 Excluidas las explotaciones agrícolas con menos de 11 trabajadores. $\quad 3$ Los datos ajustados a las definiciones de la OSHA sobre los trabajadores de la minería del carbón, de los metales y de los no metales, y sobre los trabajadores del transporte ferroviario son facilitados a la BLS por la Administración de Seguridad y Salud en las Minas del Departamento de Trabajo de Estados Unidos, la Administración Ferroviaria Federal y el Departamento de Transporte de Estados Unidos. Los contrastistas mineros independientes se excluyen de las industrias mineras del carbón, metales y no metales.

NOTA: Debido al efecto del redondeo y a la exclusión de datos de las respuestas no clasificables, es posible que la suma de los datos no se corresponda con el total. Los guiones indican datos que no cumplen las directrices de publicación. Las estimaciones de las lesiones y enfermedades profesionales se basan en una muestra científicamente seleccionada de empresas. La muestra utilizada fue una de las muchas posibles, cada una de las cuales habría producido estimaciones diferentes. El error típico relativo es una medida de la variación de las estimaciones en todas las posibles muestras que podrían haberse seleccionado. El porcentaje de los errores típicos relativos de estas estimaciones oscila entre menos del $1 \%$ y el $58 \%$.

Encuesta de Lesiones y Enfermedades Profesionales, Oficina de Estadísticas Laborales, Departamento de Trabajo de Estados Unidos, abril 1995. 
Los accidentes se asociaron con más frecuencia con trabajos en el suelo 0 en superficies a ras de suelo, y las lesiones sufridas con más frecuencia fueron las dislocaciones o distensiones de espalda, causantes de la baja laboral durante más de un mes.

Es evidente que este tipo de datos pueden tener una importante repercusión en los programas de prevención de accidentes y enfermedades relacionados con el trabajo. Pese a ello, no indican qué profesiones o sectores son los más peligrosos, puesto que hay profesiones muy peligrosas que cuentan con un pequeño número de trabajadores. La determinación de los niveles de riesgo asociados a ciertas profesiones y sectores se expone en el siguiente artículo "A nálisis del riesgo de lesiones y enfermedades no mortales en el lugar de trabajo".

\section{- ANALISIS DEL RIESGO DE LESIONES Y ENFERMEDADES NO MORTALES EN EL LUGAR DE TRABAJO}

John W. Ruser

La O ficina de Estadísticas L aborales de los E stados U nidos clasifica las lesiones y enfermedades no mortales en el lugar de trabajo según las características del trabajador y del caso, utilizando datos de la Encuesta sobre Lesiones y Enfermedades Profesionales que se realiza en el país. Aunque estos recuentos permiten identificar a los grupos de trabajadores que experimentan el mayor número de lesiones en el lugar de trabajo, no miden el riesgo. De hecho, un determinado grupo puede sufrir muchas lesiones en el lugar de trabajo simplemente por el gran número de trabajadores que lo compongan y no porque los trabajos que realizan sean especialmente peligrosos.

Para cuantificar el riesgo real, los datos sobre lesiones en el lugar de trabajo deben relacionarse con una medida de exposición al riesgo, como el número de horas trabajadas, medida de la utilización de mano de obra que puede obtenerse de otras encuestas. La tasa de lesiones no mortales en el lugar de trabajo en un grupo de trabajadores puede calcularse dividiendo el número de lesiones registradas en ese grupo por el número de horas trabajadas durante ese mismo período de tiempo. La tasa así obtenida representa el riesgo de lesión por hora de trabajo:

$$
\text { T asa de lesiones }=\frac{\begin{array}{c}
\text { Numero de lesiones sufridas } \\
\text { durante un cierto periodo de tiempo }
\end{array}}{\begin{array}{l}
\text { Horas trabajadas por todos los miembros } \\
\text { del grupo durante ese periodo de tiempo }
\end{array}}
$$

Una forma sencilla de comparar el riesgo de lesión entre distintos grupos de trabajadores es calcular el riesgo relativo:

$$
\text { Riesgo relativo }(R R)=\frac{\begin{array}{c}
\text { Tasa de lesiones para } \\
\text { un cierto grupo de trabajadores }
\end{array}}{\begin{array}{l}
\text { Tasa de lesiones para un grupo } \\
\text { de referencia de trabajadores }
\end{array}}
$$

El grupo de referencia puede ser un grupo especial de trabajadores, tal como el conjunto de directivos y de profesionales muy cualificados, o bien estar constituido por la totalidad de los trabajadores. En cualquier caso, el riesgo relativo ( $R R$ ) corresponde al cociente de proporciones que suele utilizarse en los estudios epidemiológicos (R othman 1986). Es algebraicamente equivalente al porcentaje de todas las lesiones que ocurren en un determinado grupo, dividido entre el porcentaje de horas trabajadas por ese grupo. Cuando el R R es mayor de 1,0, indica que
Tabla 32.7 • Riesgo de lesiones y enfermedades profesionales. $^{1}$

$\begin{array}{lccc}\begin{array}{l}\text { Profesión } \\ \text { Porcentaje }\end{array} & \begin{array}{l}\text { Casos de } \\ \text { lesiones y } \\ \text { enfermedades }\end{array} & \begin{array}{l}\text { Horas } \\ \text { trabajadas }\end{array} & \begin{array}{l}\text { Indice de } \\ \text { Riesgo }\end{array} \\ \text { relativo }\end{array}$

Porcentaje de lesiones y enfermedades, horas trabajadas e índice de riesgo relativo de lesiones y enfermedades profesionales que causan baja laboral, por profesiones, trabajadores no agrícolas del sector privado de 15 o más años de edad, Estados Unidos, 1993.

2 Excluye los empleados domésticos y los trabajadores de servicios de protección en el sector público

3 Excluye los trabajadores de servicios de protección en el sector público

${ }^{4}$ Excluye los trabajadores de industrias de producción agrícola

Fuentes: Encuesta de Enfermedades y Lesiones Profesionales de la BLS, 1993

Encuesta de la población, 1993

los miembros de este grupo tienen una probabilidad mayor de sufrir lesiones que los miembros del grupo de referencia; cuando el $R R$ es inferior a 1,0, indica que, como promedio, los miembros de este grupo experimentan un menor número de lesiones por hora. 
En las tablas siguientes, se indica cómo los índices de riesgo relativo de diferentes grupos permiten identificar a quienes tienen un mayor riesgo de sufrir una lesión en el lugar de trabajo. Los datos sobre lesiones proceden de la Encuesta de L esiones y E nfermedades Profesionales de 1993 (BLS 1993b) y miden el número de lesiones y enfermedades que han dado lugar a la baja. El cálculo se basa en la estimación de las horas trabajadas al año, obtenida de los ficheros de microdatos de las encuestas de la población realizadas por la O ficina del Censo en 1993 (O ficina del C enso 1993).

En la Tabla 32.7 se presentan los datos por profesiones de la proporción de lesiones en el lugar de trabajo, la proporción de horas trabajadas y su coeficiente, que corresponde al RR de lesiones y enfermedades que dan lugar a la baja. El grupo de referencia es "Conjunto de profesiones no agrícolas del sector privado" con trabajadores de 15 o más años de edad, que corresponde al $100 \%$. Como ejemplo, el grupo "O peradores de máquinas y peones" experimentó el $41,64 \%$ de todas las lesiones y enfermedades, pero contribuyó tan sólo en un $18,37 \%$ al número total de horas trabajadas por la población de referencia. Por consiguiente, el RR de los "O peradores de máquinas y peones" es de $41,64 / 18,37=2,3$. En otras palabras, los trabajadores de este grupo profesional tienen como promedio una tasa de lesiones y enfermedades 2,3 veces mayor que el conjunto de trabajadores no agrícolas del sector privado. Es más, su probabilidad de sufrir una lesión grave es casi 11 veces superior a la de los directivos y profesionales muy cualificados.

Los distintos grupos profesionales pueden clasificarse según el nivel de riesgo simplemente comparando sus índices $R R$. EI R R más alto que aparece en la Tabla (3.6) corresponde a "manipuladores, limpiadores de equipos, ayudantes y obreros no especializados", mientras que el grupo con menor riesgo es el de los directivos y profesionales altamente cualificados $(R R=0,2)$. También pueden hacerse otras interpretaciones más complicadas. Aunque la tabla da a entender que los trabajadores menos cualificados ocupan puestos con mayor riesgo de lesión y enfermedad, incluso dentro de los trabajadores manuales la tasa de riesgo es mayor entre los menos cualificados, como los operadores de máquinas y peones, que entre los más cualificados, como los trabajadores de la producción de precisión, los trabajadores manuales especializados y los encargados de las reparaciones.

En la descripción anterior, el RR se basa en las lesiones y enfermedades dan lugar a la baja, puesto que estos datos se recopilan y conocen desde hace mucho tiempo. Utilizando el sistema de clasificación nuevo y más amplio de la Encuesta de Lesiones y Enfermedades Profesionales, los investigadores pueden ahora analizar con detalle lesiones y enfermedades específicas.

Como ejemplo, en la Tabla 32.8 se indica el RR del mismo conjunto de grupos profesionales, pero restringido a un único resultado, "Afecciones por movimientos repetitivos" (código de episodio 23) que dan lugar a la baja, distinguiendo por profesiones y sexo. Las afecciones por movimientos repetitivos son, entre otras, el síndrome del túnel carpiano, la tendonitis y ciertas dislocaciones y distensiones. El grupo más afectado por este tipo de lesiones son claramente las mujeres que trabajan como operadoras de máquinas, montadoras e inspectoras ( $R=7,3)$, seguido por el grupo de mujeres que trabajan como manipuladoras, limpiadoras de máquinas, ayudantes y obreras no especializadas $=7,1$ )

La tabla muestra sorprendentes diferencias en el riesgo de afecciones por movimientos repetitivos en función del sexo del trabajador. En conjunto, la mujer tiene una probabilidad 2,5 veces mayor que el hombre de causar bajas por afecciones por movimiento repetitivos $(2,5=1,5 / 0,6)$. En todo caso, esta
Tabla 32.8 • Indice de riesgo relativo de enfermedades por movimientos repetitivos que causan baja laboral durante varios días, por profesiones y sexo, trabajadores no agrícolas del sector privado de 150 más años de edad, Estados Unidos, 1993.

\begin{tabular}{|c|c|c|c|}
\hline Profesión & Total & Hombres & Mujeres \\
\hline $\begin{array}{l}\text { Todas las profesiones no agrícolas del sector } \\
\text { privado }\end{array}$ & 1,0 & 0,6 & 1,5 \\
\hline $\begin{array}{l}\text { Directivos y profesionales altamente } \\
\text { cualificados }\end{array}$ & 0,2 & 0,1 & 0,3 \\
\hline Ejecutivos, administradores y gerentes & 0,2 & 0,0 & 0,3 \\
\hline Profesionales especializados & 0,2 & 0,1 & 0,3 \\
\hline Apoyo técnico, comercial y administrativo & 0,8 & 0,3 & 1,1 \\
\hline Técnicos y apoyo relacionado & 0,6 & 0,3 & 0,8 \\
\hline Profesiones relacionadas con las ventas & 0,3 & 0,1 & 0,6 \\
\hline $\begin{array}{l}\text { Apoyo administrativo, incluido personal de } \\
\text { oficinas }\end{array}$ & 1,2 & 0,7 & 1,4 \\
\hline Prestación de servicios ${ }^{1}$ & 0,7 & 0,3 & 0,9 \\
\hline Servicios de protección ${ }^{2}$ & 0,1 & 0,1 & 0,4 \\
\hline $\begin{array}{l}\text { Prestación de servicios, excepto servicios } \\
\text { de protección }\end{array}$ & 0,7 & 0,4 & 0,9 \\
\hline $\begin{array}{l}\text { Profesiones relacionadas con la agricultura, } \\
\text { la silvicultura y la pesca }{ }^{3}\end{array}$ & 0,8 & 0,6 & 1,8 \\
\hline $\begin{array}{l}\text { Producción de precisión, oficios y } \\
\text { reparaciones }\end{array}$ & 1,0 & 0,7 & 4,2 \\
\hline Mecánicos y reparadores & 0,7 & 0,6 & 2,4 \\
\hline Profesiones relacionadas con la construcción & 0,6 & 0,6 & - \\
\hline $\begin{array}{l}\text { Profesiones relacionadas con actividades } \\
\text { de extracción }\end{array}$ & 0,1 & 0,1 & - \\
\hline $\begin{array}{l}\text { Profesiones relacionadas con la producción } \\
\text { de precisión }\end{array}$ & 1,8 & 1,0 & 4,6 \\
\hline $\begin{array}{l}\text { Operadores, fabricadores y obreros no } \\
\text { especializados }\end{array}$ & 2,7 & 1,4 & 6,9 \\
\hline $\begin{array}{l}\text { Operadores de máquinas, montadores e } \\
\text { inspectores }\end{array}$ & 4,1 & 2,3 & 7,3 \\
\hline $\begin{array}{l}\text { Profesiones relacionadas con el transporte y } \\
\text { desplazamiento de materiales }\end{array}$ & 0,5 & 0,5 & 1,6 \\
\hline Manipuladores, limpiadores de equipos, & 2,4 & 1,4 & 7,1 \\
\hline
\end{tabular}

1 Excluye empleados domésticos y trabajadores de servicios de protección en el sector público 2 Excluye trabajadores de servicios de protección en el sector público

3 Excluye trabajadores en industrias de producción agrícola

Nota: Los guiones largos - indican que esos datos no cumplen las directrices de publicación. Fuente: Calculado de la Encuesta de Lesiones y Enfermedades Profesionales de la BLS, 1993; Encuesta de la población, 1993.

diferencia no refleja simplemente una diferencia entre las profesiones del hombre y de la mujer. La mujer tienen un mayor riesgo en todos los principales grupos profesionales, así como en los grupos menos agregados que aparecen en la tabla. Su riesgo relativo frente al hombre es especialmente alto en profesiones no manuales o relacionadas con las ventas. La mujer tiene una probabilidad seis veces mayor que el hombre de causar baja como consecuencia de lesiones causadas por movimientos 
repetitivos en profesiones relacionadas con las ventas, la producción de precisión, los trabajos manuales especializados y las reparaciones.

\section{- EST UDIO DE CASO : PROTECCION DEL TRABAJADOR Y ESTADISTICAS SO BRE ACCIDENTES Y ENFERMEDADES PRO FESIONALES- H VBG, ALEMANIA}

\author{
Martin Butz y Burkhard H offmann
}

\section{Las Berufsgenossenschaften (BG) alemanas}

Dentro del sistema alemán de seguridad social, el seguro obligatorio de accidentes cubre los accidentes producidos en el trabajo e in itinere, así como las enfermedades profesionales. Se estructura en tres áreas:

- seguro de accidentes en la industria (representado por los BG )

- seguro de accidentes en la agricultura

- seguro de accidentes del sector público.

Las 35 Berufsgenossenschaften (mutuas de accidentes de trabajo, BG) cubren los diferentes sectores de la economía. Son responsables de 39 millones de trabajadores asegurados de 2,6 millones de empresas. Cubren a todas las personas que ocupan un puesto de trabajo o se encuentran en período de prácticas, con independencia de su edad, sexo o nivel de ingresos. Su organización nacional es la Federación Central de Berufsgenossenschaften (H VBG).

Según la ley, las BG deben de utilizar todos los medios adecuados para prevenir los accidentes en el lugar de trabajo y las enfermedades profesionales, prestar primeros auxilios eficaces y servicios óptimos de rehabilitación médica, profesional y social, y pagar las prestaciones a los trabajadores lesionados y enfermos y a sus supervivientes. Se reúnen, así la prevención, la rehabilitación y la indemnización.

L as primas para financiar estas prestaciones son pagadas íntegramente por las empresas. En 1993, las empresas industriales pagaron una media de 1,4 marcos por cada 100 marcos de salario, o el 1,44\%. En conjunto, las primas ascendieron a 16.000 millones de marcos, de los cuales el $80 \%$ se dedicaron a rehabilitación y pensiones. El resto se utilizó principalmente para programas de prevención.

\section{Protección de la salud y la seguridad en el trabajo}

La empresa es responsable de la salud y la seguridad de sus trabajadores. El ámbito jurídico de esta responsabilidad se define en las leyes y disposiciones oficiales, así como en reglamentos para la protección del personal adoptados por las BG, que complementan y concretan la legislación nacional. El sistema de protección de las BG destaca por su carácter práctico, por su constante adaptación a las necesidades de la industria y a los avances tecnológicos, y por su apoyo eficaz a las empresas y a los trabajadores.

Las funciones de protección de las BG, que son asumidas principalmente por el Servicio de Inspección (TAD) de las BG y por el Servicio de M edicina del Trabajo (AM D), son:

- A sesoramiento y motivación de las empresas.

- Supervisión de las medidas de protección de los trabajadores en la industria.

- Servicio de medicina del trabajo.

- Información y formación de los trabajadores.
- Comprobación de la seguridad de máquinas y equipos.

- Iniciación, desarrollo y financiación de la investigación.

La responsabilidad de la protección de los trabajadores de la industria incumbe a las empresas que deben disponer para ello de personal debidamente cualificado: principalmente, especialistas en seguridad en el trabajo (directores de seguridad, técnicos de seguridad e ingenieros de seguridad) y médicos de empresa. Las empresas con 20 o más trabajadores deben designar a uno o más responsables de la seguridad. Las funciones de las empresas con relación a los especialistas en seguridad en el trabajo y a los médicos de empresa están establecidas en disposiciones de las asociaciones profesionales específicas para el sector y el nivel de riesgo existente. $C$ uando se dispone de un especialista en seguridad en el trabajo o de un médico de empresa hay que crear asimismo un comité de seguridad en el trabajo, constituido por un representante de la empresa, dos representantes de los trabajadores, el médico de la empresa, especialistas en seguridad en el trabajo y responsables de la seguridad. El personal de primeros auxilios, cuya formación es responsabilidad delasBG, pertenecetambién a la organización de seguridad en el trabajo de la empresa.

El servicio de medicina del trabajo tiene una especial importancia. Todos los trabajadores que están expuestos a riesgos para la salud deben someterse a los mismos reconocimientos médicos, cuyos resultados han de evaluarse siguiendo las directrices establecidas. En 1993 se realizaron unos cuatro millones de reconocimientos médicos preventivos en el lugar de trabajo por parte de médicos especialmente autorizados. En menos del $1 \%$ de ellos se detectaron problemas de salud.

Los trabajadores que están en contacto con materiales peligrosos o cancerígenos pueden solicitar un reconocimiento médico incluso después de haber abandonado la actividad peligrosa. Las BG han creado servicios específicos para ellos; en concreto, los tres siguientes:

- Servicio de R econocimientos Periódicos (ODIN)

- Servicio Central de R egistro de los Trabajadores Expuestos al Polvo de Amianto (ZAs)

- O ficina Central de Asistencia de W ismut (ZeBW is).

En 1993, estos tres servicios atendieron en conjunto a unas 600.000 personas. La obtención de datos de estos reconocimientos médicos ayuda a mejorar la asistencia individualizada y a mejorar la investigación científica para la detección precoz de los casos de cáncer.

\section{Estadísticas de accidentes de trabajo}

O bjetivo. EI principal objetivo de la elaboración de estadísticas de accidentes de trabajo es aumentar la seguridad mediante la evaluación e interpretación de los datos sobre los accidentes ocurridos, incluidos en los partes correspondientes. Todos los años, los Servicios de Inspección T écnica de las BG investigan entre el $5 \%$ y el $10 \%$ de los accidentes (aproximadamente 100.000).

O bligación de notificación de las empresas. Las empresas están obligadas a notificar a su BG en el plazo de tres días todos los accidentes que tengan lugar en sus instalaciones y que den lugar a muerte 0 a la baja laboral durante tres 0 más días naturales ("accidente en el lugar de trabajo declarable obligatoriamente"). Lo mismo se aplica a los accidentes ocurridos in itinere. No hay que notificar los accidentes que sólo causen daños materiales 0 la baja del trabajador durante menos de tres días. Cuando hay que efectuar la declaración, se utiliza el denominado "Parte de accidente" (Figura 32.1). Así pues, el período de baja laboral es el factor que determina la obligación o no de notificación de un accidente, con independencia de la gravedad de la lesión. Si el accidente causa la baja laboral durante más de tres días, ha de 
Figura 32.1 • Ejemplo de un impreso de notificación de accidente.

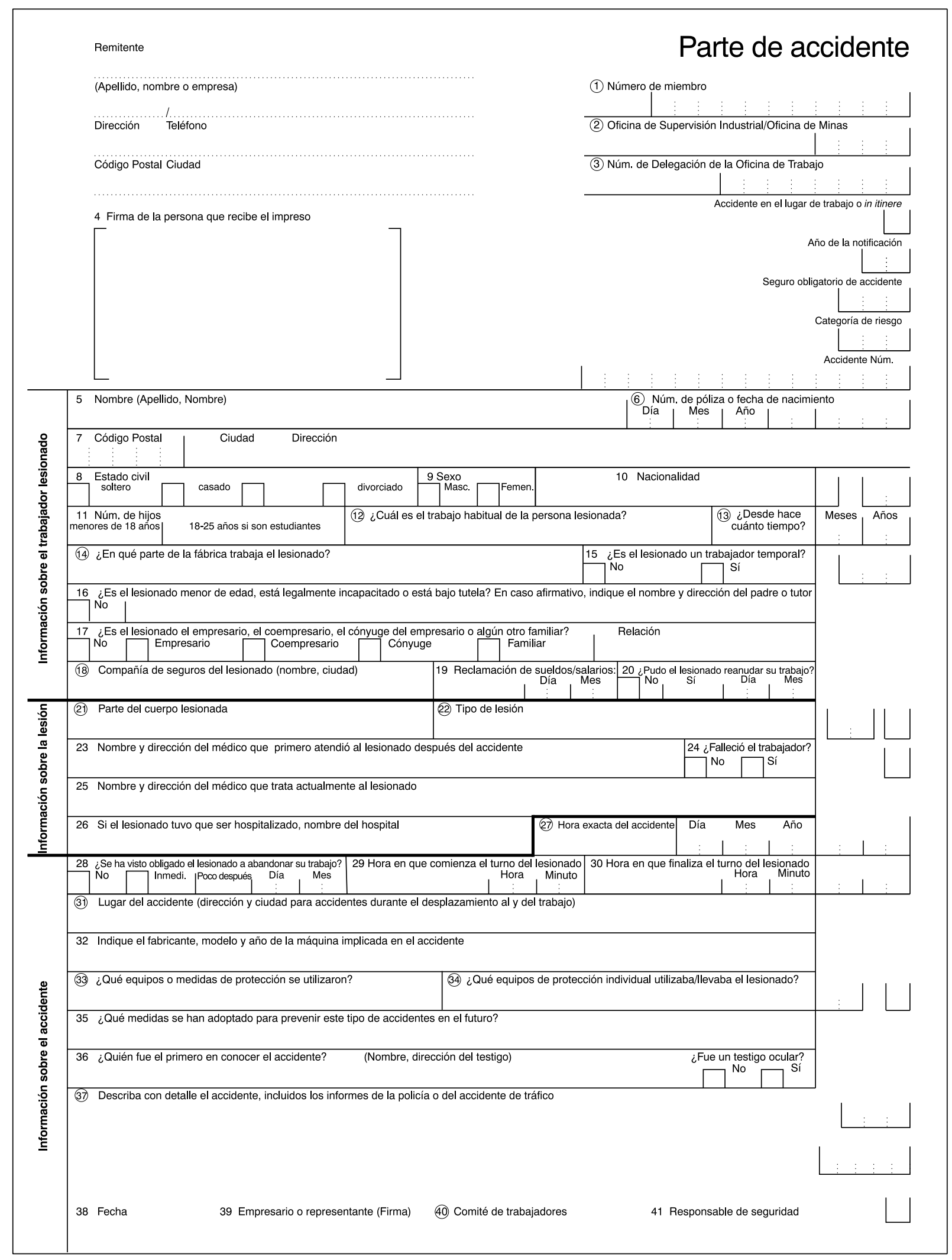


Figura 32.1 • Ejemplo de un impreso de notificación de accidente.

\section{Explicación del parte de accidente}

\section{Explicaciones generales}

¿Cuándo debe presentarse un parte de accidente?

Cuando un accidente en el lugar de trabajo o durante el desplazamiento al y del trabajo (p. ej., un accidente en el desplazamiento entre la vivienda y el lugar de trabajo) produzca incapacidad laboral durante más de 3 días naturales o la muerte del asegurado.

¿Quién debe presentar el parte El empresario o su representante están obligados a presentar el parte. de accidente?

¿Cuántas copias del parte de accidente deben remitirse?

Tienen que enviarse 2 copias a la entidad aseguradora (p. ej., asociación profesional) Tiene que enviarse 1 copia a la oficina de supervisión industrial/oficina de minas (sólo para los miembros de asociaciones profesionales de industria).

¿A dónde deben enviarse?

1 copia tiene que entregarse al comité de empresa.

1 copia es para el empresario.

En caso de accidentes mortales, tiene que enviarse 1 copia adicional a la policía local.

¿En qué plazo de tiempo debe enviarse el parte de accidente?

¿Qué debe hacerse en caso de accidentes graves, masivos y

El empresario o su representante deben enviar el parte en el plazo de 3 días desde que tienen noticia del accidente.

Los accidentes mortales, especialmente los accidentes graves y los accidentes masivos, deben declararse inmediatamente por teléfono o telegrama a la entidad aseguradora responsable y, en el caso mortales

de asociaciones profesionales de industria, a la oficina de supervisión industrial/oficina de minas.

\section{Explicaciones sobre las preguntas marcadas con $\bigcirc$.}

Deje los espacios verdes en blanco

(1) Debe indicar el número de asegurado ( $p$. ej., en el caso de una asociación profesional, el número de miembro que aparece en la tarjeta de sindicado o en la póliza de seguro).

(2) El responsable es la oficina de supervisión industrial u oficina de minas en la zona en la que se produjo el accidente. En el caso de accidentes in itinere, es responsable la oficina de supervisión industrial/oficina de minas donde está situada la empresa.

(3) Debe indicar el número asignado a la empresa por la oficina de trabajo.

6) Indique el número de asegurado en la compañía del seguro de pensión obligatorio. Si el lesionado no ha recibido un número de asegurado, indique la fecha de nacimiento.

La fecha de nacimiento de un asegurado nacido el 1 de febrero de 1934 debe indicarse de la siguiente forma:

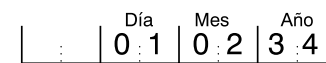

(12) No escriba aquí "trabajador", "empleado" o "empresario", sino p. ej., "personal de ventas", "personal administrativo", "decorador", etc.

(13) Indique aquí la fecha desde que el trabajador lesionado realiza el trabajo al que se hace referencia en la casilla (12).

(14) Ejemplos: 2 Carl St., 5 Cologne, "departamento de alimentación", "almacén", "oficina", "taller", "limpieza", etc.

(18) Nombre y dirección de la entidad aseguradora en el caso del seguro de enfermedad obligatorio con derecho a retribución por enfermedad; en otros casos, indique el tipo de seguro (p. ej., seguro privado, seguro de enfermedad para jubilados, asistencia familiar, seguro voluntario con una compañía de seguro de enfermedad obligatorio).

(21) Ejemplos: "parte inferior del brazo derecho", o "pie izquierdo y parte derecha de la cabeza".

22 Ejemplos: "contusión", "dislocación", "fractura de hueso", "quemadura", etc.

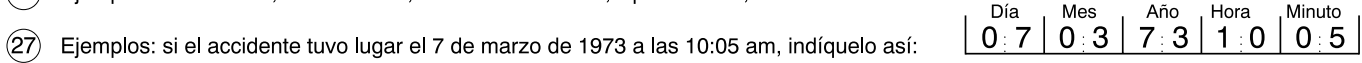
En el caso de los accidentes que ocurren entre la media noche y la 1:00 am, la hora es 00 (no 24).

(31) Ejemplos: "recepción", "en la vivienda/en las escaleras de la empresa", "almacén de muebles en 3 Army St., 5 Cologne-Bruck", o (en el caso de un accidente durante el desplazamiento a y del trabajo), "en la intersección entre Spring St. y Main St. en 53559 Rheinbach".

(33) Ejemplos: "prendas protectoras", "cuña de separación", "andamio", "barrera", "señal de advertencia", etc.

(34) Ejemplos: "casco de seguridad", "calzado de seguridad", "gafas de seguridad", "delantal resistente a las perforaciones", etc.

(37) Incluye también:

-zona en la que trabaja el lesionado (p. ej., departamento de moda femenina, supervisión financiera, vendedor con vehículo). -objeto que causó el accidente (p. ej., escalera plegable, suelo resbaladizo).

-actividad que realizaba el lesionado en el momento de producirse el accidente (atender a los clientes, limpiar el almacén, etc.)

(40) Si no existe un comité de trabajadores (comité de personal), debe indicarlo. 
declararse, aunque parezca leve. Este requisito de tres días facilita la reclamación posterior de una indemnización. La falta de envío del parte o su remisión fuera de plazo constituye una infracción de la normativa, que puede ser castigada por la BG con sanciones de hasta 5.000 marcos alemanes.

Notificación del médico que asiste al trabajador lesionado. Para optimizar la rehabilitación médica y determinar el período que el trabajador estará de baja, éste recibe tratamiento de un médico especialista contratado por la BG correspondiente. Puesto que se impone a dicho médico la obligación de notificar el accidente a la BG, ésta tiene conocimiento del mismo aunque la empresa no haya enviado (puntualmente) el parte, y puede además solicitar a la misma que lo haga. Este sistema de notificación doble (por la empresa y por el médico) garantiza que la BG tenga conocimiento de todos los accidentes de trabajo cuya notificación sea obligatoria. A partir de los datos contenidos en el parte de accidente remitido por la empresa y en el informe del médico, la BG puede comprobar si se trata jurídicamente de un accidente de trabajo que encaje dentro de su competencia. Según el diagnóstico médico, puede además, en caso necesario, actuar rápidamente para asegurar un tratamiento óptimo del trabajador.

La descripción correcta y completa de las circunstancias del accidente es especialmente importante para la prevención, ya que permite al Servicio de Inspección T écnica de la BG extraer conclusiones sobre máquinas y equipos defectuosos que exija la adopción inmediata de medidas con objeto de prevenir accidentes similares. En el caso de accidentes graves o mortales, la legislación exige a la empresa la notificación inmediata a la BG, la cual procede a una investigación sin demora. La cuantía de las primas es fijada asimismo por la BG, teniendo en cuenta el número y el coste de los accidentes que se hayan producido en la empresa. En esta operación se utiliza un procedimiento de bonificación y penalización establecido por la ley, de forma que una parte de la prima se determina en función de la tendencia de accidentes en la empresa. EI resultado puede ser una prima de mayor o menor cuantía, creándose así incentivos económicos para que las empresas mejoren las condiciones de seguridad en el lugar de trabajo.

Colaboración de los representantes de los trabajadores y los responsables de la seguridad. Todos los partes de accidentes deben ser firmados también por el comité de empresa (Betriebsrat) y los responsables de la seguridad (si existen), para que conozcan la situación global de los accidentes en su empresa y puedan ejercer su derecho a colaborar en cuestiones relacionadas con la seguridad en el lugar de trabajo.

Compilación de estadísticas de accidentes de trabajo. Basándose en la información que la $B G$ recibe sobre cualquier accidente de trabajo a través del parte remitido por la empresa y el informe del médico, los hechos se traducen en números estadísticos codificados. La codificación abarca, entre otras, tres áreas:

- D escripción del lesionado (edad, sexo, puesto de trabajo).

- Descripción de la lesión (parte del cuerpo afectada, tipo de lesión).

- Descripción del accidente (lugar, objeto causante del accidente y circunstancias de éste).

La codificación es realizada por especialistas en datos muy cualificados que conocen a fondo la organización de los sectores industriales correspondientes, utilizando una lista de códigos de accidentes y lesiones que contiene más de 10.000 entradas. Para conseguir unas estadísticas de máxima calidad, las clasificaciones se actualizan periódicamente adaptándolas, por ejemplo, a los nuevos avances tecnológicos. Es más, el personal de codificación participa periódicamente en cursos de formación y los datos son sometidos a pruebas formales lógicas y de contenido y sensibilidad. Tabla 32.9 - N úmero de accidentes en el lugar de trabajo.
Alemania, 1981-93.

\begin{tabular}{llcc} 
Año & \multicolumn{3}{c}{ Accidentes en el lugar de trabajo } \\
& $\begin{array}{l}\text { Accidentes } \\
\text { notificables }\end{array}$ & $\begin{array}{c}\text { Nuevos casos } \\
\text { de pensión }\end{array}$ & Fallecimientos \\
1981 & 1.397 .976 & 40.056 & 1.689 \\
1982 & 1.228 .317 & 39.478 & 1.492 \\
1983 & 1.144 .814 & 35.119 & 1.406 \\
1984 & 1.153 .321 & 34.749 & 1.319 \\
1985 & 1.166 .468 & 34.431 & 1.204 \\
1986 & 1.212 .064 & 33.737 & 1.069 \\
1987 & 1.211 .517 & 32.537 & 1.057 \\
1988 & 1.234 .634 & 32.256 & 1.130 \\
1989 & 1.262 .374 & 30.840 & 1.098 \\
1990 & 1.331 .395 & 30.142 & 1.086 \\
1991 & 1.587 .177 & 30.612 & 1.062 \\
1992 & 1.622 .732 & 32.932 & 1.310 \\
1993 & 1.510 .745 & 35.553 & 1.414
\end{tabular}

Fuente: Federación Central de Mutuas de Accidentes de Trabajo (HVBG), Alemania.

\section{U sos de las estadísticas sobre accidentes de trabajo}

Una importante función de estas estadísticas es describir las circunstancias de los accidentes de trabajo. En la Tabla 32.9 pueden observarse las tendencias en los accidentes notificados, los nuevos casos de pensiones por accidente y los accidentes de trabajo mortales entre 1981 y 1993. En la columna 3 ("N uevos casos de pensiones") se indica el número de nuevos beneficiarios que, por la gravedad del accidente sufrido, recibieron durante ese año una pensión concedida por alguna BG.

Para evaluar el riesgo medio de accidente de un asegurado, se divide el número de accidentes de trabajo por el tiempo real trabajado y se obtiene una tasa de accidentes. La tasa por millón de horas trabajadas se utiliza para comparaciones internacionales e interanuales. En la Figura 32.2 puede observarse la variación de esta tasa entre 1981 y 1993.

Estadísticas de accidentes por sectores industriales. Además de describir las tendencias generales, las estadísticas de accidentes de trabajo pueden desglosarse por sectores industriales. Por ejemplo: “¿Cuántos accidentes de trabajo con máquinas portátiles de rectificado se han producido en los últimos años en el sector metalúrgico?; ¿cómo y dónde se han producido? y ¿qué lesiones han causado?" Este tipo de análisis puede ser útil para muchas personas e instituciones, como ministerios, organismos de control, institutos de investigación, universidades, empresas y expertos en seguridad en el trabajo (Tabla 32.10).

Por ejemplo, como puede observarse en la Tabla 32.10, el número de accidentes de trabajo con máquinas portátiles de rectificado que se declararon en el sector metalúrgico fue aumentando progresivamente desde mediados del decenio de 1980 hasta 1990. Luego, entre 1990 y 1991, se observa un incremento repentino. Se trata de un artefacto debido a la inclusión, desde principios de 1991, de las cifras correspondientes a la nueva Alemania reunificada. ( $L$ as primeras cifras se refieren sólo a la R epública Federal de Alemania).

O tros datos incluidos en los partes de accidente revelan que no todos los accidentes con máquinas portátiles de rectificado de 
Figura 32.2 - Frecuencia de accidentes en el lugar de trabajo.

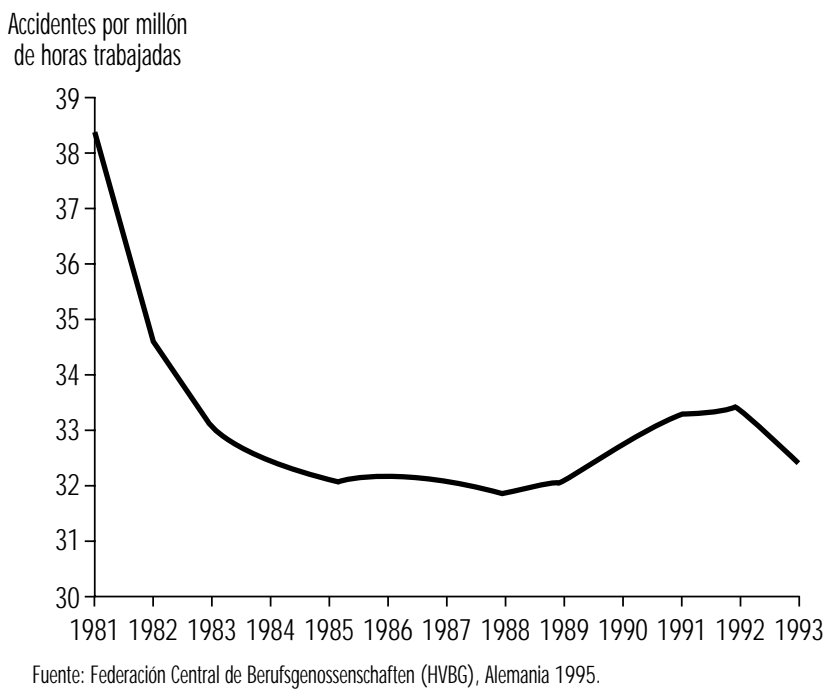

metales tienen lugar principalmente en empresas del sector metalúrgico. Estas máquinas, que también se utilizan para cortar tuberías, barras de hierro y otros objetos, se emplean con frecuencia en el sector de la construcción. En consecuencia, casi la tercera parte de los accidentes se producen en empresas de construcción. El trabajo con máquinas portátiles de rectificado en el sector metalúrgico produce sobre todo lesiones en la cabeza y las manos. Las lesiones más comunes en la cabeza son las que afectan a los ojos y a la zona que los rodea, y están causadas por piezas rotas, esquirlas y chispas. Esta herramienta portátil lleva una muela abrasiva que gira a gran velocidad y la persona que la maneja puede sufrir heridas en las manos si pierde el control de la misma. El elevado número de lesiones en los ojos demuestra la importancia y obligación de que la empresa insista en el uso de gafas de seguridad siempre que se

Tabla 32.10 - Accidentes en el lugar de trabajo con máquinas portátiles de rectificado en el trabajo de metalurgia, Alemania, 1984-93.

$\begin{array}{lll}\text { Año } & \begin{array}{l}\text { Accidentes } \\ \text { notificables }\end{array} & \begin{array}{l}\text { Nuevos casos } \\ \text { de pensión }\end{array} \\ 1984 & 9.709 & 79 \\ 1985 & 10.560 & 62 \\ 1986 & 11.505 & 76 \\ 1987 & 11.852 & 75 \\ 1988 & 12.436 & 79 \\ 1989 & 12.895 & 76 \\ 1990 & 12.971 & 78 \\ 1991 & 19.511 & 70 \\ 1992 & 17.180 & 54 \\ 1993 & 17.890 & 70\end{array}$

Fuente: Federación Central de Mutuas de Accidentes de Trabajo (HVBG), Alemania. realicen trabajos de rectificado de metales con esta máquina portátil.

Comparación de tasas de accidentes dentro de un sector y entre distintos sectores industriales. Aunque en 1993 se produjeron cerca de 18.000 accidentes con máquinas portátiles de rectificado en el trabajo de la metalurgia, frente a sólo 2.800 accidentes con sierras eléctricas manuales en los trabajos de carpintería, no puede concluirse automáticamente que ese tipo de máquina imponga un mayor riesgo a los trabajadores de la metalurgia. Para evaluar el riesgo de accidentes en determinados sectores industriales, debe primero relacionarse el número de accidentes con una medida de la exposición al riesgo, como pueden ser las horas trabajadas (véase "Análisis del riesgo de lesiones y enfermedades no mortales en el lugar de trabajo"). Sin embargo, no siempre se dispone de esta información. En tales casos, puede obtenerse otra tasa, que corresponda a la proporción de accidentes graves entre todos los accidentes notificados. Comparando la proporción de lesiones graves con máquinas portátiles de rectificado en los trabajos metalúrgicos y con sierras circulares portátiles en los trabajos de carpintería, se demuestra que la tasa de lesiones graves es diez veces mayor con éstas que con aquéllas, observación importante para establecer prioridades entre las medidas de seguridad en el lugar de trabajo. Este tipo de análisis comparativo del riesgo es un importante componente de la estrategia global de prevención de accidentes de trabajo.

\section{Estadísticas de enfermedades profesionales}

\section{Definición y notificación}

En Alemania, la enfermedad profesional se define legalmente como aquélla cuya causa puede atribuirse a una actividad profesional de la persona afectada. Existe una lista oficial de enfermedades profesionales. Por consiguiente, la evaluación de si una enfermedad es o no de origen profesional es una cuestión tanto médica como jurídica, que se remite por ley a la BG. Si se

\section{Tabla 32.11 - Número de casos de enfermedades profe-} sionales, Alemania, 1980-93.

$\begin{array}{lllll}\text { Año } & \begin{array}{l}\text { Notificación } \\ \text { de enfermedades } \\ \text { profesionales } \\ \text { sospechadas }\end{array} & \begin{array}{l}\text { Casos } \\ \text { reconocidos de } \\ \text { enfermedades } \\ \text { profesionales }\end{array} & \begin{array}{l}\text { Con } \\ \text { pensión }\end{array} & \begin{array}{l}\text { Fallecidos } \\ \text { por enferme- } \\ \text { dades } \\ \text { profesionales }\end{array} \\ 1980 & 40.866 & 12.046 & 5.613 & 1.932 \\ 1981 & 38.303 & 12.187 & 5.460 & 1.788 \\ 1982 & 33.137 & 11.522 & 4.951 & 1.783 \\ 1983 & 30.716 & 9.934 & 4.229 & 1.557 \\ 1984 & 31.235 & 8.195 & 3.805 & 1.558 \\ 1985 & 32.844 & 6.869 & 3.439 & 1.299 \\ 1986 & 39.706 & 7.317 & 3.317 & 1.548 \\ 1987 & 42.625 & 7.275 & 3.321 & 1.455 \\ 1988 & 46.280 & 7.367 & 3.660 & 1.363 \\ 1989 & 48.975 & 9.051 & 3.941 & 1.281 \\ 1990 & 51.105 & 9.363 & 4.008 & 1.391 \\ 1991 & 61.156 & 10.479 & 4.570 & 1.317 \\ 1992 & 73.568 & 12.227 & 5.201 & 1.570 \\ 1993 & 92.058 & 17.833 & 5.668 & 2.040\end{array}$

Fuente: Federación Central de Mutuas de Accidentes de Trabajo (HVBG), Alemania. 
Tabla 32.12 - Enfermedades infecciosas de origen profesional reconocido, Alemania, 1980-93.

$\begin{array}{lll}\text { Año } & \begin{array}{l}\text { Total } \\ \text { casos reconocidos }\end{array} & \begin{array}{l}\text { De los cuales: } \\ \text { hepatitis vírica }\end{array} \\ 1980 & 1173 & 857 \\ 1981 & 883 & 736 \\ 1982 & 786 & 663 \\ 1983 & 891 & 717 \\ 1984 & 678 & 519 \\ 1985 & 417 & 320 \\ 1986 & 376 & 281 \\ 1987 & 224 & 152 \\ 1988 & 319 & 173 \\ 1989 & 303 & 185 \\ 1990 & 269 & 126 \\ 1991 & 224 & 121 \\ 1992 & 282 & 128 \\ 1993 & 319 & 149\end{array}$

Fuente: Federación Central de Mutuas de Accidentes de Trabajo (HVBG), Alemania.

sospecha que una enfermedad puede ser de origen profesional, no basta con demostrar que el trabajador sufre, por ejemplo, un eczema. Se necesitan otros datos sobre las sustancias utilizadas en el trabajo y su potencial de causar daños en la piel.

E laboración de estadísticas de enfermedades profesionales. Al ser las BG responsables de indemnizar a los trabajadores con enfermedades profesionales y, al mismo tiempo, de prestarles servicios de rehabilitación y prevención, tienen un considerable interés en la aplicación de las estadísticas derivadas de los informes sobre enfermedades profesionales. Estas estadísticas se utilizan, entre otras cosas, para centrar las medidas preventivas en los sectores y profesiones de alto riesgo y divulgar los resultados a la opinión pública, la comunidad científica y las autoridades políticas.

Para facilitar estas actividades, las BG iniciaron en 1975 una serie de estadísticas de enfermedades profesionales que contienen datos sobre todos los informes de enfermedades profesionales y su decisión final - si se reconoció o rechazó el origen profesional de la enfermedad-, explicando las razones de tal decisión en cada caso. Esta base de datos contiene información anónima sobre:

- La persona (sexo, año de nacimiento, nacionalidad.

- El diagnóstico.

- La exposición a riesgos.

- Las decisiones jurídicas, entre ellas las referentes a la solicitud de una indemnización, la determinación de la discapacidad y cualquier otra medida adoptada por las BG

Resultados de las estadísticas de enfermedades profesionales. Una importante función de las estadísticas de enfermedades profesionales es el descubrimiento de tendencias en la aparición de estas enfermedades a lo largo del tiempo. En la Tabla 32.11 se indica el número de enfermedades notificadas de origen supuestamente profesional, el número total de casos reconocidos de enfermedad profesional y el pago de pensiones, así como el número de casos mortales entre 1980 y 1993. D ebe decirse que estos datos no son fáciles de interpretar, puesto que las definiciones y criterios varían ampliamente. Es más, durante ese período el número de enfermedades profesionales oficialmente reconocidas aumentó de 55 a 64. Asimismo, las cifras de 1991 en adelante corresponden a la Alemania reunificada, mientras que las anteriores corresponden sólo a la República Federal de A lemania.

E jemplo: enfermedades infecciosas. En la Tabla 32.12 puede observarse el descenso del número de casos reconocidos de enfermedades infecciosas durante el período de 1980 a 1993. En la tabla se hace referencia específicamente a la hepatitis viral, para la que puede observarse una clara tendencia descendente desde mediados del decenio de 1980, cuando los trabajadores de los servicios sanitarios en situación de riesgo fueron vacunados preventivamente. Así, las estadísticas de enfermedades profesionales pueden servir no sólo para detectar una elevación de las tasas de enfermedad, sino también para demostrar el éxito de las medidas de protección. La reducción de las tasas de enfermedad puede tener, por supuesto, otras explicaciones. En Alemania, por ejemplo, la reducción en el número de casos de silicosis que se ha producido en los últimos veinte años se debe principalmente al descenso del número de puestos de trabajo en el sector de la minería.

\section{Fuentes de información}

La H VBG, como organización nacional de las BG, centraliza las estadísticas comunes y publica análisis y folletos. Es más, considera la información estadística como un aspecto de la información general que ha de recabar para poder desempeñar muchas de sus funciones como entidad aseguradora de los trabajadores. Por este motivo, en 1978 se creó el Sistema de Información Central de las BG (ZIGUV), que prepara publicaciones relevantes y las pone a disposición de las BG.

La seguridad en el lugar de trabajo implica un enfoque interdisciplinario e integrado que exige un acceso óptimo a la información. Las BG han tomado en Alemania este camino sin dudarlo y, por consiguiente, realizan una importante contribución a la eficiencia del sistema alemán de seguridad en el trabajo.

\section{ESTUDIO DE CASO : WISMUT-LAS CONSECUENCIAS DE LA EXPOSICION AL URANIO}

H einz Otten y H orst Schulz

\section{Desarrollo histórico}

La actividad minera en las montañas de Erz se remonta al siglo X II y, de hecho, esta región es famosa desde 1470 por sus minas de plata. H acia el año 1500, aparecen en los escritos de A grícola los primeros informes sobre una enfermedad propia de los mineros. En 1879, Haerting y $\mathrm{H}$ esses reconocieron esta enfermedad como cáncer de pulmón, aunque en aquella época no se sabía claramente cuál era su causa. En 1925 se añadió el "cáncer de pulmón de Schneeberg" a la lista de enfermedades profesionales.

El material a partir del cual Marie Curie aisló el radio y el polonio procedía del escorial del Joachimstal (Jachymov) en Bohemia. En 1936, las mediciones de radón realizadas por R ajewsky cerca de Schneeberg confirmaron la relación ya sospechada entre el radón en los pozos de las minas y el cáncer de pulmón.

En 1945, la U nión Soviética intensificó su programa de investigación de armas nucleares. La búsqueda de uranio se extendió a las montañas de Erz, ya que allí las condiciones para la 
Figura 32.3 • Zonas mineras de SDAG W ismut en Alemania 0 riental.

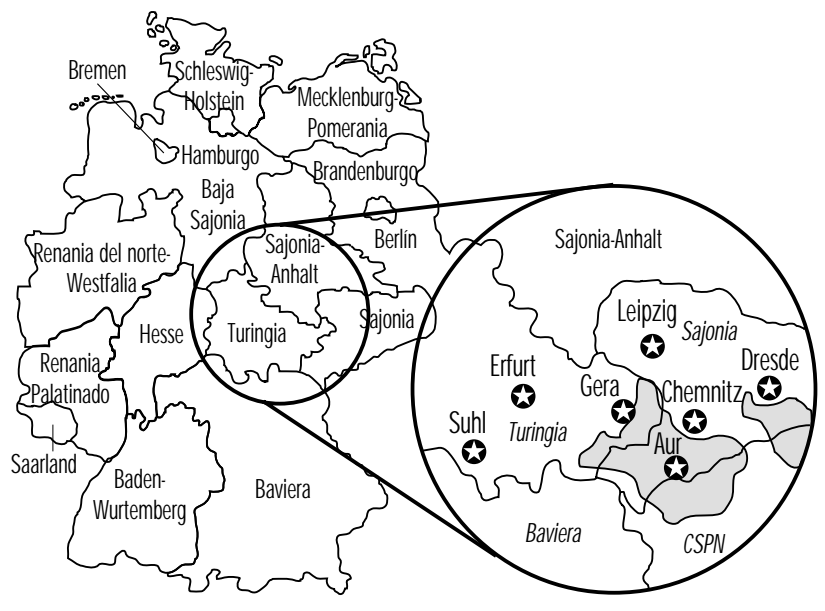

minería eran mejores que en los depósitos soviéticos. Tras las prospecciones iniciales, la administración militar soviética ocupó todo el área y la declaró zona de acceso restringido.

Entre 1946 y 1990, la Compañía Soviética Wismut (SAG), posteriormente llamada Compañía Soviético-Alemana Wismut (SDAG), explotó las minas de uranio de Turingia y Sajonia (Figura 32.3). En aquel entonces, la U nión Soviética se esforzaba por obtener suficiente cantidad de uranio para la construcción de su primera bomba atómica. Al no disponer de equipos adecuados, el nivel necesario de producción sólo podía conseguirse prescindiendo de medidas de seguridad. Las condiciones de trabajo fueron especialmente malas entre los años 1946 y

Figura 32.4 • Empleados de W ismut 1946-90.

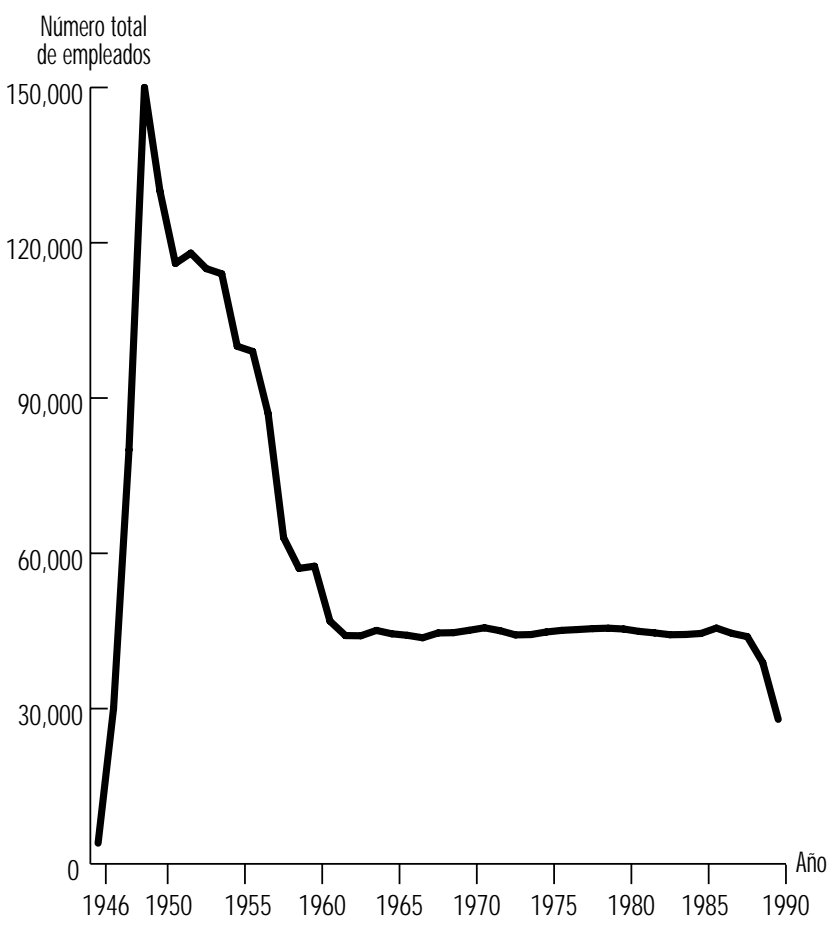

1954. Según un informe médico de SAG Wismut, 1.281 mineros sufrieron accidentes mortales y 20.000 padecieron lesiones $u$ otros efectos nocivos para la salud tan sólo en la segunda mitad de 1949.

En la Alemania de la posguerra, la U nión Soviética consideraba el trabajo en las minas de uranio como una forma de reparaciones. Prisioneros, reclutas y "voluntarios" fueron movilizados, de modo que al principio no había casi ningún trabajador cualificado. En total, Wismut empleó a entre 400,000 y 500,000 personas (Figura 32.4).

Las malas condiciones de trabajo, la falta de tecnología adecuada y la intensa presión a la que estaban sometidos los trabajadores causaron un número extremadamente alto deaccidentesy enfermedades. Las condiciones de trabajo empezaron a mejorar gradualmente a principios de 1953, cuando se inició la participación alemana en la empresa soviética.

Entre 1946 y 1955 se realizaron perforaciones en seco, que generaban elevadas concentraciones de polvo. No se disponía de ventilación artificial y, como resultado, se alcanzaban concentraciones de radón muy altas. La salud de los trabajadores se vio también gravemente afectada por la extrema dureza de los trabajos, la falta de equipos adecuados, la indisponibilidad de prendas de seguridad y los largos turnos de trabajo (200 horas al mes)

El nivel de exposición variaba de pozo a pozo y a lo largo del tiempo. La medición sistemática de la exposición se introdujo además progresivamente, como puede observarse en la Figura 32.5. La exposición a radiación ionizante (expresada en M eses Nivel de Trabajo (WLM ) sólo puede estimarse de forma muy aproximada (Tabla 32.13). En la actualidad, las comparaciones con las situaciones de exposición a radiación en otros países, las mediciones realizadas en condiciones experimentales y las evaluaciones de los informes por escrito permiten una estimación más precisa del nivel de exposición.

A demás del polvo de roca, los trabajadores estaban expuestos a otras sustancias nocivas para la salud, como polvo de uranio, arsénico, amianto y emisiones de los explosivos. Sufrían también los efectos físicos del ruido, las vibraciones en brazos y manos y las vibraciones de todo el cuerpo. En esas condiciones, la silicolisis y los carcinomas bronquiales relacionados con la radiación dominaron el registro de enfermedades profesionales entre 1952 y 1990 (T abla 32.14).

Figura 32.5 • Registros de la exposición de la antigua SDAG W ismut

$\begin{array}{llllllllll}1945 & 1950 & 1955 & 1960 & 1965 & 1970 & 1975 & 1980 & 1985 & 1990\end{array}$

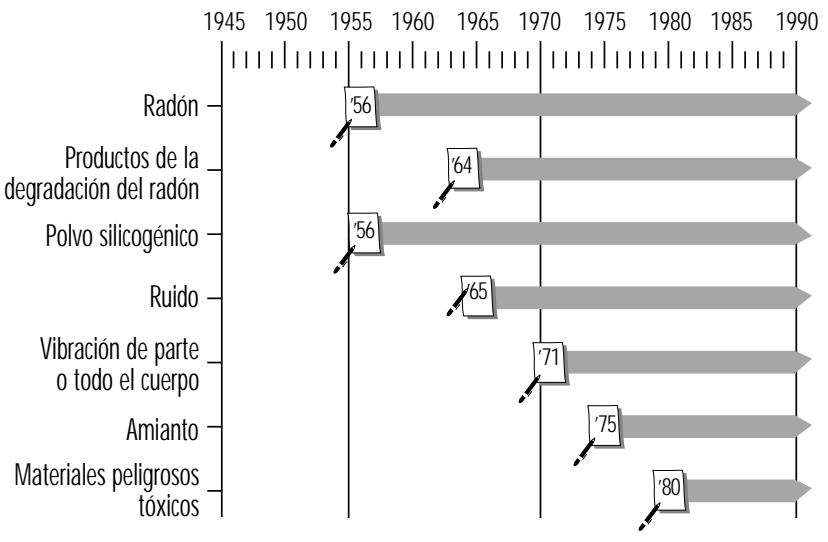


Tabla 32.13 • Estimación de la exposición a radiación ( $N$ ivel de Trabajo M eses/ Año) en las minas de $\mathrm{W}$ ismut

$\begin{array}{ll}\text { Año } & \text { WLM/ Año } \\ 1946-1955 & 30-300 \\ 1956-1960 & 10-100 \\ 1961-1965 & 5-50 \\ 1966-1970 & 3-25 \\ 1971-1975 & 2-10 \\ 1976-1989 & 1-4\end{array}$

Aunque con el tiempo los servicios médicos de SAG / SDAG Wismut fueron mejorando el nivel de asistencia a los mineros, incluida la realización de reconocimientos médicos anuales, no se analizaban sistemáticamente los efectos de las actividades de extracción minera en la salud de los trabajadores. Las condiciones de producción y trabajo se mantenían en estricto secreto; la empresa Wismut era autónoma y, desde el punto de vista de su organización, podía considerarse un "estado dentro de un estado".

La verdadera magnitud del problema no se conoció hasta 1989-90, cuando se produjo la reunificación alemana. En diciembre de 1990, se cerraron las minas de uranio en Alemania. Desde 1991, las Berufsgenossenschaften (mutuas de accidentes de trabajo y enfermedades profesionales), como gestoras del seguro obligatorio de accidente, son responsables del registro e indemnización de todos los accidentes o enfermedades profesionales relacionados con las actividades de la antigua Wismut. Eso significa que son responsables de prestar a las personas afectadas la mejor asistencia médica posible y recoger toda la información relevante sobre la salud y seguridad en el trabajo.

En 1990, seguían pendientes unas 600 reclamaciones de indemnización por cáncer de bronquios al sistema de seguridad social de Wismut, habiéndose resuelto en años anteriores unos

Tabla 32.14 - Resumen completo de las enfermedades profesionales conocidas en las minas de uranio de W ismut 1952-90.

\begin{tabular}{|c|c|c|c|}
\hline & $\begin{array}{l}\text { Lista } \\
\text { Núm. } \\
\text { BKVO }{ }^{1}\end{array}$ & $\begin{array}{l}\text { Número } \\
\text { absoluto }\end{array}$ & $\%$ \\
\hline Enfermedades causadas por el cuarzo & 40 & 14.733 & 47,8 \\
\hline $\begin{array}{l}\text { Tumores malignos o pretumores } \\
\text { causados por radiación ionizante }\end{array}$ & 92 & 5.276 & 17,1 \\
\hline $\begin{array}{l}\text { Enfermedades causadas por vibración } \\
\text { corporal parcial }\end{array}$ & 54 & - & - \\
\hline $\begin{array}{l}\text { Enfermedades de tendones y articula- } \\
\text { ciones de las extremidades }\end{array}$ & $71-72$ & 4.950 & 16,0 \\
\hline $\begin{array}{l}\text { Deficiencia auditiva causada por el } \\
\text { ruido }\end{array}$ & 50 & 4.664 & 15,1 \\
\hline Enfermedades de la piel & 80 & 601 & 1,9 \\
\hline Otras & - & 628 & 2,1 \\
\hline \multicolumn{2}{|l|}{ Total } & 30.852 & 100 \\
\hline \multicolumn{4}{|c|}{$\begin{array}{l}\text { I Clasificación de enfermedades profesionales de la antigua RDA. } \\
\text { Fuente: Informes anuales del Sistema de Salud de Wismut. }\end{array}$} \\
\hline
\end{tabular}

1.700 casos de cáncer de pulmón. Desde 1991, los Berufsgenossenschaften responsables han proseguido 0 reabierto estos procesos de reclamación. Basándose en extrapolaciones científicas (Jacobi, Henrichs y Barclay 1992; Wichmann, Brüske$\mathrm{H}$ ohlfeld y Mohner 1995), se estima que en los próximos 10 años se detectarán entre 200 y 300 casos de cáncer de bronquios en antiguos trabajadores de Wismut.

\section{El presente: después del cambio}

Las condiciones de producción y trabajo en las minas de SDAG Wismut dejaron su huella tanto en los trabajadores como en el medio ambiente de Turingia y Sajonia. De acuerdo con la legislación de la República Federal de Alemania, el gobierno federal asumió la responsabilidad de limpiar el medio ambiente de la región afectada. El coste de estas actividades durante el período de 1991-2005 se ha estimado en 13.000 millones de marcos alemanes

Cuando la RDA se unió a la República Federal de Alemania en 1990, las Berufsgenossenschaften, como gestoras del seguro obligatorio de accidente, se hicieron cargo del problema de las enfermedades profesionales en la antigua R DA. Tras considerar las condiciones particulares de Wismut, decidieron crear un servicio especial. En la medida de lo posible, y respetando las leyes sobre protección de la intimidad, las Berufsgenossenschaften se hicieron con los registros sobre las antiguas condiciones de trabajo. Así, cuando la empresa se disolviera por razones económicas, no se perderían todas las pruebas que pudieran servir para justificar las reclamaciones de los trabajadores afectados por una enfermedad. El 1 de enero de 1992, la Federación creó la "O ficina Central de Asistencia de Wismut" (ZeBWis), responsable del tratamiento médico, la detección precoz y la rehabilitación de lesiones y enfermedades profesionales.

El objetivo de la ZeBWis de prestar una asistencia médica adecuada a los antiguos trabajadores de las minas de uranio ha dado lugar a cuatro actividades básicas de vigilancia de la salud:

- Organización de campañas de exploración selectiva para el diagnóstico precoz y el tratamiento de enfermedades.

- Documentación de los resultados de esas exploraciones selectivas y cruce con los datos resultantes de los procedimientos de detección de enfermedades profesionales.

- Análisis científico de los datos.

- Ayuda a la investigación sobre la detección precoz y el tratamiento de las enfermedades.

La exploración selectiva es un servicio que se ofrece a los trabajadores expuestos para garantizar un diagnóstico precoz siempre que sea posible. Los aspectos éticos, científicos y económicos de los procedimientos de exploración selectiva requieren un detenido análisis que queda fuera del contexto de este artículo.

La ZeBWis ha organizado también un programa de medicina del trabajo, basado en la sólida estructura de la asociación sindical, para realizar reconocimientos médicos especiales de los trabajadores. En este programa se incluyen métodos de reconocimiento conocidos para la protección contra la exposición en las minas y la radiación. L os componentes del programa corresponden a los principales agentes de exposición: polvo, radiación y otros materiales peligrosos.

La vigilancia médica continua de los antiguos trabajadores de Wismut está orientada principalmente a la detección precoz y el tratamiento de los carcinomas bronquiales resultantes de la exposición a radiación 0 a otros materiales cancerígenos. M ientras que la relación entre radiación ionizante y cáncer de pulmón se ha demostrado ya con un grado de certidumbre 
adecuado, los efectos sobre la salud de la exposición a radiación durante largos períodos de tiempo y pequeñas dosis han sido menos investigados. Los conocimientos actuales se basan en datos de los supervivientes a las bombas atómicas de H iroshima y N agasaki, así como en estudios internacionales de los trabajadores de las minas de uranio.

La situación en Turingia y Sajonia es excepcional, debido al número significativamente mayor de personas que se vieron sometidas a una variedad mucho mayor de exposiciones. Por consiguiente, esta experiencia ha permitido adquirir un gran volumen de conocimientos científicos. Con estos nuevos datos, se podrá realizar un análisis científico del efecto sinérgico de la radiación y la exposición a cancerígenos como arsénico, amianto o emisiones de motores diesel como causa del cáncer de pulmón. La detección de carcinomas bronquiales aplicando las modernas técnicas de exploración debería ser el centro de una parte importante de las futuras investigaciones científicas.

Datos obtenidos del sistema de salud de Wismut

En respuesta a los gravísimos problemas de lesiones y enfermedades que sufrían sus trabajadores, Wismut se vio obligada a crear su propio servicio de salud, que realizaba, entre otras cosas, reconocimientos médicos anuales con radiografías de tórax. En los últimos años, se crearon otras unidades de reconocimiento para la detección de enfermedades profesionales. Al haberse hecho cargo el servicio médico de Wismut, no sólo de la medicina del trabajo, sino también de toda la asistencia médica de los trabajadores y de sus familias, SDAG Wismut disponía en 1990 de una completa información sanitaria sobre muchos de los antiguos y actuales trabajadores de Wismut. Además de la información completa sobre los reconocimientos médicos de los trabajadores y un archivo completo de las enfermedades profesionales, existe un archivo completo con más de 792.000 radiografías.

En Stollberg, el sistema de salud de Wismut tenía un departamento central de patología en el que se recogía material histológico y patológico detallado de los mineros, así como de los habitantes de la zona. En 1994, este material fue entregado al Centro de Investigación sobre el Cáncer de Alemania (DKFZ) en $\mathrm{H}$ eidelberg, para su conservación en lugar seguro y su investigación. U na parte de los registros del antiguo sistema de salud se transfirió primero al seguro obligatorio de accidentes. Para ello, ZeBWis estableció un archivo temporal en el Pozo 371 de $\mathrm{H}$ artenstein (Sajonia). Estos registros se utilizan para tramitar las reclamaciones de indemnización, preparar y prestar servicios de medicina del trabajo y realizar estudios científicos. Además de ser utilizados por las Berufsgenossenschaften, los registros están a disposición de expertos y médicos autorizados en el contexto de su trabajo clínico y del tratamiento de los antiguos trabajadores de Wismut.

El núcleo de estos archivos está constituido por las historias completas de los trabajadores con enfermedades profesionales (45.000), junto con las correspondientes historias del seguimiento de dichas enfermedades (28.000), las historias sobre la vigilancia de las personas expuestas al polvo (200.000), así como registros documentales específicos con los resultados de los reconocimientos periódicos y la determinación de la capacidad física para el trabajo. La ZeBW is mantiene también en este archivo los informes de las autopsias del departamento de anatonopatología de Stollberg.

Estos últimos informes, así como las historias del seguimiento de enfermedades profesionales, se han preparado para el procesamiento de los datos. Estas dos fuentes de información se utilizarán para realizar un estudio epidemiológico completo en el que participarán 60.000 personas y que será organizado por el $M$ inisterio federal de M edio Ambiente.
A demás de los datos sobre exposición al radón y a sus subproductos, los registros sobre exposición de los antiguos trabajadores de Wismut a otros agentes tienen un interés especial para las Berusnossenschaften. Así, la actual Wismut $\mathrm{GmbH}$ dispone de una lista de los resultados de las mediciones realizadas desde principios del decenio de 1970 hasta la actualidad de la exposición a polvo silicogénico, polvo de amianto, polvo de metales pesados, polvo de madera, polvo de explosivos, vapores tóxicos, gases del soldeo, emisiones de motores diesel, ruido, vibraciones de todo o de parte del cuerpo y trabajos físicos duros. Las mediciones correspondientes a los años 1987-1990 se encuentran archivadas en medios electrónicos.

Esta información es importante para el análisis retrospectivo de las exposiciones en las minas de uranio de Wismut. Constituye también la base para construir una matriz de exposiciones profesionales que relacione exposiciones y tareas para fines de investigación.

Para completar la información, el departamento conserva otros registros que contienen datos médicos de Wismut $\mathrm{G} \mathrm{mbH}$, entre otros: historias de pacientes atendidos en centros ambulatorios, partes de accidente elaborados por la anterior empresa e inspecciones de seguridad en el trabajo, historias clínicas de lesiones y enfermedades profesionales, pruebas biológicas de exposición, rehabilitación médica de los trabajadores e informes de enfermedades neoplásicas.

Sin embargo, no todos los archivos de Wismut - principalmente los que constan en papel- se diseñaron para una evaluación centralizada. Por consiguiente, con la disolución de SDAG Wismut el 31 de diciembre de 1990 y la disolución del sistema sanitario de la empresa, se planteó la cuestión de qué hacer con esos registros únicos.

\section{Localización de los antiguos trabajadores}

La primera tarea de la ZeBW is fue identificar a las personas que habían trabajo bajo tierra o en las instalaciones de preparación y averiguar su actual paradero. Su número ascendía a unas 300.000. Al no tener la mayoría de los registros de la empresa un formato común que pudiera utilizarse para el procesamiento de datos, se tuvo que emprender la laboriosa tarea de revisar uno por uno todos los expedientes, obtenidos de los archivos de casi 20 lugares distintos.

El siguiente paso consistió en recopilar las estadísticas vitales y las direcciones de esas personas. La información contenida en los antiguos registros de personal y nóminas no fue útil para este fin. M uchas de las direcciones ya no eran válidas, en parte por el nuevo nombre que habían recibido las calles, plazas y carreteras tras la firma del Tratado de la unificación. El R egistro Central de $\mathrm{H}$ abitantes de la antigua RDA tampoco sirvió de mucho, ya que la información que contenía no estaba completa.

Estas personas pudieron ser finalmente localizadas gracias a la ayuda de la A sociación de Entidades de Gestión de Seguros de Pensiones, a través de la cual se consiguieron las direcciones de casi 150.000 personas para ofrecerles servicios gratuitos de medicina del trabajo.

Para que los médicos pudieran tener una idea de los riesgos y las exposiciones a los que estaban sujetos sus pacientes por sus antecedentes laborales o profesionales, se construyó una matriz de puestos de trabajo y exposiciones.

\section{Servicios de medicina del trabajo}

Para realizar estos reconocimientos, la ZeBW is contrató a unos 125 médicos especializados en medicina del trabajo con experiencia en el diagnóstico de enfermedades causadas por el polvo y la radiación. Estos médicos trabajan bajo la dirección de la ZeBWis y están repartidos por todo el territorio de la República Federal, a fin de que las personas afectadas sean sometidas a los 
reconocimientos necesarios cerca de su lugar de residencia. La intensa formación de los médicos participantes ha permitido que en todos los centros se realicen reconocimientos rutinarios de alta calidad. La distribución de impresos con el mismo formato a todos estos médicos permite recoger los datos de interés aplicando unas ciertas normas, que luego se transfieren a los centros de datos de la ZeBWis. Asignando a cada médico un número óptimo de pacientes, realizan un número adecuado de reconocimientos al año para mantener al día su práctica y experiencia. Gracias al intercambio de información y a la educación continua, los médicos tienen siempre acceso a información actualizada. Todos los médicos tienen experiencia en la evaluación de radiografías de tórax de acuerdo con las directrices de la O IT de 1980 (O rganización Internacional del Trabajo 1980).

Esta base de datos, cada vez mayor como resultado de los reconocimientos rutinarios, permitirá facilitar los resultados preliminares a los médicos y expertos en la valoración de riesgos que participan en este programa de detección de enfermedades profesionales. Asimismo, ofrece una base para la detección de síntomas o enfermedades específicos que aparecen en determinadas situaciones de riesgo.

\section{El futuro}

Comparando el número de personas que trabajaron en las minas de Wismut y/ o en las instalaciones de preparación con el número de trabajadores de las minas de uranio en el mundo occidental, es evidente que, aunque con grandes lagunas, los datos disponibles constituyen una base extraordinaria para ampliar nuestros conocimientos científicos. M ientras que el análisis del riesgo de cáncer de pulmón realizado en 1994 por Lubin y cols. (1994) incluyó aproximadamente a 60.000 personas afectadas y a unos 2.700 casos de cáncer de pulmón en 11 estudios, ahora se dispone de los datos de unos 300.000 antiguos trabajadores de Wismut. $\mathrm{H}$ asta la fecha han muerto al menos 6.500 personas por cáncer de pulmón inducido por la radiación. Es más, Wismut nunca recogió información sobre la exposición del gran número de personas expuestas a radiación ionizante 0 a otros agentes.

Para poder establecer un diagnóstico óptimo de las enfermedades profesionales, así como para su investigación científica, se necesita la información más precisa posible sobre la exposición. Esta necesidad se ha tenido en cuenta en dos proyectos de investigación que están siendo patrocinados o realizados por las Berufsgenossenschaften. Se ha preparado una matriz de puestos de trabajo y exposiciones consolidando las mediciones realizadas in situ, analizando los datos geológicos, utilizando información sobre cifras de producción y, en algunos casos, reconstruyendo las condiciones de trabajo durante los primeros años de W ismut. Este tipo de datos es un requisito previo para llegar a conocer mejor, a través de estudios de cohortes 0 estudios de casos y controles, la naturaleza y extensión de las enfermedades que se producen como resultado del trabajo en las minas de uranio. Así podrá llegarse también a conocer mejor el efecto de la exposición a dosis pequeñas durante largos períodos de tiempo y los efectos acumulados de la radiación, el polvo y otros materiales cancerígenos. Este tipo de estudios están ahora empezando a realizarse o planificarse. Con la ayuda de especímenes biológicos recogidos en los antiguos laboratorios de anatomía patológica de Wismut, podrán ampliarse los conocimientos científicos sobre los distintos tipos de cáncer de pulmón, los efectos interactivos entre polvo silicogénico y radiación y los efectos de otros materiales cancerígenos peligrosos que se inhalan 0 ingieren. Estos planes están siendo actualmente desarrollados por el DK FZ. L os centros de investigación alemanes y otros grupos de investigación, como el NIOSH y el National Cancer Institute (NCI) de Estados Unidos, han empezado a colaborar en este terreno.
O tros grupos de trabajo de países como la República Checa, Francia y Canadá cooperan también en el estudio de los datos sobre la exposición.

No se sabe bien hasta qué punto la exposición a la radiación en las minas de uranio puede producir otros cánceres además del de pulmón. A petición de las asociaciones profesionales, se ha desarrollado un modelo (Jacobi y Roth 1995) para establecer en qué condiciones los cánceres de boca y garganta, hígado, riñón, piel y huesos pueden estar causados por condiciones de trabajo similares a las de Wismut.

\section{ESTRATEGIAS Y TECNICAS DE MEDICION PARA LA EVALUACION DE LA EXPOSICION EN EPIDEMIOLOGIA}

Frank Bochmann y Helmut Blome

En otros artículos de este capítulo se han descrito los principios generales de la vigilancia médica de las enfermedades profesionales y la vigilancia de las exposiciones. En este artículo se describen algunos principios de los métodos epidemiológicos que pueden utilizarse para atender las necesidades de vigilancia. La aplicación de estos métodos debe realizarse teniendo en cuenta los principios básicos de la medición física, así como los métodos habituales para la recogida de datos epidemiológicos.

La epidemiología permite cuantificar la asociación entre la exposición dentro y fuera del lugar de trabajo a factores de estrés fisicoquímico o conductas y enfermedades resultantes, y de este modo puede facilitar información útil para diseñar intervenciones y programas de prevención (Coenen, 1981; C oenen y Engels 1993). El diseño de este tipo de estudios suele depender de la disponibilidad de datos y la posibilidad de acceder al lugar de trabajo y a los archivos del personal. En las condiciones más favorables, la exposición puede evaluarse con las mediciones realizadas por un higienista industrial en talleres o fábricas en funcionamiento; los reconocimientos médicos directos de los trabajadores se utilizan para determinar los posibles efectos en la salud. Este tipo de evaluaciones pueden realizarse prospectivamente para estimar el riesgo de enfermedades como el cáncer durante los siguientes meses o años. Sin embargo, lo más habitual es que las exposiciones en el pasado tengan que reconstruirse históricamente extrapolando los niveles actuales 0 utilizando mediciones registradas en el pasado que no siempre facilitan toda la información necesaria. En este artículo se ofrecen algunas directrices y se describen algunas de las limitaciones de las estrategias de medición y documentación que afectan a la valoración epidemiológica de los riesgos para la salud en el lugar de trabajo.

\section{Mediciones}

En la medida de lo posible, las mediciones deben ser cuantitativas en lugar de cualitativas, porque los datos cuantitativos pueden someterse a técnicas estadísticas más potentes. Los datos empíricos suelen clasificarse como nominales, ordinales, intervalos y coeficientes. Los datos nominales son descriptores cualitativos que diferencian sólo tipos, como diferentes departamentos dentro de una fábrica o diferentes sectores de la industria. Las variables ordinales pueden ordenarse de "poco" a "mucho" sin expresar otras relaciones cuantitativas. Por ejemplo, se distingue entre "expuesto" y "no expuesto", o bien entre no fumador $(=0)$, fumador moderado $(=1)$, fumador intermedio $(=2)$ y gran fumador $(=3)$. Cuanto mayor es el valor numérico, mayor es la intensidad del tabaquismo. La mayoría de los valores 
de las mediciones se expresan utilizando coeficientes o escalas de intervalos, en las que una concentración de $30 \mathrm{mg} / \mathrm{m}^{3}$ es el doble que una concentración de $15 \mathrm{mg} / \mathrm{m}^{3}$. Las variables que se expresan como coeficientes poseen un valor cero absoluto (como la edad), mientras que las variables que se expresan como intervalos (como $\mathrm{Cl}$ ) no lo poseen.

\section{Estrategia de medición}

La estrategia de medición tiene en cuenta la información sobre el lugar en el que se actúa, las condiciones ambientales (p. ej., humedad, presión atmosférica) durante la medición, la duración de ésta y la técnica empleada ( $\mathrm{H}$ ansen y Whitehead 1988; Ott 1993).

L os requisitos legales suelen obligar a realizar mediciones de las medias ponderadas en el tiempo (TWA) durante un período de ocho horas de losniveles de sustancias peligrosas. Sin embargo, no todas las per sonas trabajan en turnos de ocho horasy losniveles de exposición pueden fluctuar dentro del mismo turno. Un valor medido para el puesto de trabajo de una persona puede considerarserepresentativo del valor del turno deocho horassi la duración de la exposición es mayor de seis horas durante el turno. Como criterio práctico, deben obtenerse muestras durante al menos dos horas. Cuando los intervalos de tiempo son demasiado cortos, las muestras tomadaspueden indicar concentraciones másaltaso más bajas, de manera que la concentración se subestime o sobrestime para ese turno (R appaport 1991). Por consiguiente, algunas veces resulta útil combinar varias mediciones o mediciones realizadas durantevariosturnosen una única media ponderada en el tiempo o utilizarmedicionesrepetidasconperíodosmáscortosdemuestreo.

\section{Validez de la medición}

Los datos de vigilancia deben cumplir unos criterios claramente definidos. La técnica de medición no debe influir en los resultados durante el proceso de medición (reactividad). La medición debe ser objetiva, fiable y válida. Los resultados no deben verse influidos por la técnica de medición utilizada (objetividad de la ejecución), ni por la lectura o documentación del técnico que realiza la medición (objetividad de la evaluación). En las mismas condiciones deben obtenerse los mismos valores de medición (fiabilidad); debe medirse el objeto de interés (validez) y las interacciones con otras sustancias 0 exposiciones no deben influir indebidamente en los resultados.

\section{Calidad de los datos sobre la exposición}

F uentes de datos. U n principio básico de la epidemiología es que las mediciones realizadas en individuos son preferibles a las realizadas en grupos. Por consiguiente, la calidad de los datos de vigilancia epidemiológica va aminorándose en el siguiente orden:

1. Mediciones directas realizadas en personas; información sobre niveles de exposición y progresión en el tiempo.

2. M ediciones directas realizadas en grupos; información sobre los niveles actuales de exposición en determinados grupos de trabajadores (algunas veces expresados como matrices de puestos de trabajo y exposiciones) y su variación en el tiempo.

3. M ediciones resumidas o reconstruidas para personas; estimación de la exposición a partir de los registros de la empresa, listas de compras, descripción de líneas de productos, entrevistas con los trabajadores.

4. Mediciones resumidas o reconstruidas para grupos; estimación histórica de índices de exposición basados en grupos.

En principio, la exposición debe determinarse siempre con la mayor precisión posible, utilizando valores documentados de la medición con el tiempo. Por desgracia, muchas veces sólo se dispone de las exposiciones medidas indirectamente 0 reconstruidas históricamente para estimar la relación entre exposición y resultado, aunque existan desviaciones considerables entre las exposiciones medidas y los valores de exposición reconstruidos a partir de los registros de la empresa y las entrevistas con los trabajadores (Ahrens y cols. 1994; Burdorf 1995). L a calidad de los datos se va aminorando en el siguiente orden: medición de la exposición, índice de exposición relacionado con la actividad, registros de la empresa y entrevistas con los trabajadores.

E scalas de exposición. L a necesidad de disponer de datos cuantitativos derivados de los controles para la vigilancia y la epidemiología va considerablemente más allá de los rígidos requisitos legales de los valores umbral. El objetivo de una investigación epidemiológica es determinar la relación entre dosis y efecto teniendo en cuenta las posibles variables de confusión. Debe utilizarse la información más precisa posible, que en general se expresa con una escala de alto nivel (p. ej., escala de coeficiente). La separación en valores umbrales más grandes 0 más pequeños, o la codificación en fracciones de los valores umbrales (p. ej., 1/ 10, 1/4, 1/ 2 del valor umbral), como se realiza algunas veces, se basa por lo general en datos ordinales que son estadísticamente más débiles.

R equisitos de documentación. A demás de la información sobre las concentraciones y el material y tiempo de medición, deben describirse las condiciones externas de la medición, incluyendo los equipos utilizados, la técnica de medición, el motivo de la medición y otros detalles técnicos relevantes. La finalidad de esta documentación es garantizar la uniformidad de las mediciones de un estudio a otro y permitir comparaciones entre distintos estudios.

Los datos de exposiciones y resultados para la salud recogidos de personas suelen estar sujetos a la legislación de protección de la intimidad, que varía de un país a otro. La documentación de la exposición y del estado de salud debe cumplir esas normas.

\section{Requisitos epidemiológicos}

Los estudios epidemiológicos intentan establecer una relación etiológico entre exposición y enfermedad. En esta sección se consideran algunos aspectos de las mediciones de vigilancia que afectan a esta evaluación epidemiológica del riesgo.

T ipo de enfermedad. Un punto de partida común de los estudios epidemiológicos es la observación clínica de un agrupamiento de casos de una determinada enfermedad en un área de actividad de la empresa. A continuación, se formulan hipótesis sobre los posibles factores etiológicos biológicos, químicos 0 físicos. Dependiendo de la disponibilidad de datos, se estudian estos factores (exposiciones) utilizando un diseño retrospectivo 0 prospectivo. El tiempo que transcurre entre el inicio de la exposición y la aparición de la enfermedad (latencia) afecta también al diseño del estudio. El período de latencia puede variar considerablemente. Las infecciones producidas por algunos enterovirus tienen un período de latencia/ incubación de 2 a 3 horas, mientras que los períodos de latencia para el cáncer suelen ser de 20 a 30 años. Por consiguiente, los datos sobre la exposición para un estudio del cáncer deben abarcar un período considerablemente mayor que para el brote de una enfermedad infecciosa. $L$ as exposiciones que comenzaron en un pasado distante pueden continuar hasta la aparición de la enfermedad. 0 tras enfermedades asociadas a la edad, como las de carácter cardiovascular y los accidentes cerebrovasculares, pueden aparecer en los grupos expuestos una vez iniciado el estudio y deben considerarse causas competidoras. También puede suceder que las personas clasificadas como "no enfermas" sean simplemente personas que todavía no han manifestado los síntomas clínicos de la enfermedad. Por consiguiente, la vigilancia médica continua de las poblaciones expuestas no debe interrumpirse. 
Potencia estadística. Como ya se ha dicho, las mediciones deben expresarse con la escala de mayor nivel posible (escala de coeficientes) para optimizar la potencia estadística de obtención de resultados estadísticamente significativos. L a potencia depende a su vez del tamaño de la población total del estudio, la prevalencia de la exposición en esa población, la tasa basal de la enfermedad y la magnitud del riesgo de la enfermedad que está causada por la exposición estudiada.

Sistemas obligatorios de clasificación de enfermedades. Existen varios sistemas para codificar los diagnósticos médicos. Los más comunes son la CIE-9 (Clasificación Internacional de Enfermedades) y la SN O M ED (N omenclatura Sistemática de M edicina). La CIE-O (oncología) es una particularización de la CIE para la codificación de cánceres. El uso del sistema de clasificación CIE es legalmente obligatorio en muchos sistemas sanitarios del mundo, especialmente en los países occidentales. Sin embargo, también la clasificación SNOMED puede codificar posibles factores etiológicos y condiciones. M uchos países han desarrollado sistemas de codificación especializados para clasificar las lesiones y enfermedades, que incluyen también las circunstancias del accidente o la exposición. (V éanse los artículos “Estudio de caso: Protección del trabajador y estadísticas sobre accidentes y enfermedades profesionales-H V BG, A lemania" y "D esarrollo y aplicación de un sistema de clasificación de lesiones y enfermedades profesionales" en este mismo capítulo.)

Las mediciones que se realizan con fines científicos no están sujetas a los requisitos legales que se aplican a las actividades obligatorias de vigilancia, como la determinación de si se han superado los límites umbral en un determinado lugar de trabajo. El análisis de las mediciones y registros de la exposición es útil para verificar posibles desviaciones. (V éase, por ejemplo, el artículo "Vigilancia de riesgos profesionales" en este mismo capítulo.)

Tratamiento de exposiciones combinadas. Las enfermedades tienen con frecuencia varias causas. Por consiguiente, se han de registrar de la forma más completa posible todos los factores etiológicos sospechosos (exposiciones/variables de confusión) para poder distinguir los efectos de los distintos agentes nocivos sospechosos y los efectos de otras variables de confusión o contribuyentes, como el consumo de tabaco. Las exposiciones en el trabajo suelen ser combinadas ( $p$. ej., mezclas de disolventes; gases de soldeo como níquel y cadmio; y en minería, polvo fino, cuarzo y radón ). 0 tros factores de riesgo del cáncer son el tabaquismo, el consumo excesivo de alcohol, una alimentación inadecuada y la edad. A demás de las exposiciones químicas, los factores de estrés físico (vibración, ruido, campos electromagnéticos) son posibles desencadenantes de enfermedades y deben considerarse como factores etiológicos potenciales en los estudios epidemiológicos.

Las exposiciones a agentes o factores múltiples de estrés pueden producir efectos de interacción, de manera que el efecto de una exposición se potencie o reduzca por otras exposiciones simultáneas. Un ejemplo típico es la relación existente entre el amianto y el cáncer de pulmón, que es mucho más pronunciada en los fumadores. Un ejemplo de la mezcla de exposiciones químicas y físicas es el escleroderma sistémico progresivo (ESP), que está probablemente causado por una exposición combinada a vibración, mezclas de disolventes y polvo de cuarzo.

Consideración de los sesgos. EI sesgo es un error sistemático en la clasificación de las personas entre los grupos de "expuestos/ no expuestos" o "enfermos/ no enfermos". Pueden distinguirse dos tipos de sesgos: sesgo en la observación (información) y sesgo en la selección. El sesgo en la observación (información) se produce al utilizar diferentes criterios para clasificar a las personas en los grupos de enfermos/ no enfermos. Puede crearse cuando en un estudio participan personas con profesiones de riesgo conocido y que ya pueden estar sometidas a una mayor vigilancia médica que la población de referencia. Con respecto al sesgo en la selección, existen dos posibilidades. Los estudios de casos y controles comienzan separando a las personas con la enfermedad pertinente de las que no presentan esa enfermedad y, seguidamente, se analizan las diferencias de exposición entre estos dos grupos. L os estudios de cohortes determinan las tasas de enfermedad en grupos con exposiciones diferentes. En todos estos tipos de estudios, el sesgo en la selección se produce cuando la información sobre la exposición afecta a la clasificación de las personas como enfermas y no enfermas o cuando la información sobre la presencia de la enfermedad afecta a la clasificación de las personas como expuestas o no expuestas. U n ejemplo habitual de sesgo en la selección en los estudios de cohortes es el "efecto del trabajador sano", que se produce cuando las tasas de la enfermedad en los trabajadores expuestos se comparan con las de la población general. El resultado puede ser una subestimación del riesgo de contraer la enfermedad, ya que la población activa suele seleccionarse de la población general por su buen estado de salud permanente, determinado con frecuencia mediante reconocimientos médicos, mientras que la población general contiene tanto a los sanos como a los enfermos.

Variables de confusión. La confusión es un fenómeno por el cual una tercera variable (de confusión) altera la estimación de la asociación entre una factor supuestamente etiológico y una enfermedad. Este fenómeno puede ocurrir cuando la selección de sujetos (casos y controles en los estudios de casos y controles 0 personas expuestas y no expuestas en los estudios de cohortes) depende en cierta medida de una tercera variable desconocida para el investigador. Las variables asociadas sólo con la exposición o la enfermedad no constituyen un factor de confusión. Una variable sólo produce confusión cuando cumple tres condiciones:

- Constituye un factor de riesgo para la enfermedad.

- Se asocia a la exposición en la población estudiada.

- No forma parte del proceso etiológico desde la exposición hasta la aparición de la enfermedad.

No siempre se puede predecir si una variable es o no un probable factor de confusión antes de empezar a recoger datos para un estudio. Aunque una variable se haya considerado un factor de confusión en un estudio anterior, es posible que no esté asociada con la exposición en un nuevo estudio con una población diferente. Por ejemplo, si todos los sujetos son similares con respecto a una variable (p. ej., sexo), esa variable no puede ser un factor de confusión en ese estudio en particular. El efecto de confusión de una determinada variable sólo puede tenerse en cuenta ("controlarse") si la variable se mide conjuntamente con la exposición y los resultados para la salud. Dicho efecto puede controlarse estadísticamente de forma aproximada estratificando la variable de confusión, o de manera más precisa utilizando la regresión y otras técnicas multivariantes.

\section{Resumen}

Los requisitos de la estrategia de medición, la tecnología de medición y la documentación sobre los lugares de trabajo pueden establecerse con carácter obligatorio en términos de vigilancia del valor límite umbral. La normativa sobre protección de los datos se aplica también a la protección de los secretos de la empresa y los datos personales. Estos requisitos exigen la comparabilidad de los resultados de las mediciones y el empleo de una tecnología de medición objetiva, válida y fiable. 0 tros requisitos impuestos por la epidemiología hacen referencia a la representatividad de las mediciones y a la posibilidad de establecer relaciones entre exposiciones y efectos posteriores para la salud. Las mediciones 
pueden ser representativas de ciertas tareas; por ejemplo, pueden reflejar la exposición típica durante ciertas actividades 0 en departamentos específicos, o la exposición típica de determinados grupos de personas. Es conveniente que los datos de las mediciones puedan atribuirse directamente a las personas estudiadas, para lo cual debe incluirse, junto con la documentación de la medición, información sobre las personas que han trabajado en ese lugar cuando se realizó la medición o establecer un registro que permita esa atribución directa. Los datos epidemiológicos recogidos en personas son generalmente preferibles a los obtenidos en grupos.

\section{- ESTUDIO DE CASO : ENCUESTAS DE HIGIENE INDUSTRIAL EN CHINA}

Zhi Su

Para conocer la magnitud de los problemas de higiene industrial en China, el M inisterio de Sanidad Pública (M SP) ha organizado una serie de encuestas de ámbito nacional, entre ellas las siguientes:

- Una encuesta sobre la exposición profesional al benceno, plomo, mercurio, T NT y organofosfatos (1979-81).

- Un estudio epidemiológico retrospectivo sobre los cánceres de origen profesional en trabajadores expuestos a ocho sustancias químicas (1983-85).
- Una encuesta epidemiológica sobre la neumonoconiosis (1952-86).

- Una encuesta sobre los problemas de higiene industrial en pequeñas empresas y las estrategias de intervención desarrolladas (1984-85, 1990-92).

Los resultados de estas encuestas han constituido una base muy importante para la formulación de las políticas y reglamentos nacionales. Al mismo tiempo, el M SP ha establecido un sistema nacional de notificación de enfermedades profesionales. Desde 1983 se publica el Informe Anual sobre la Situación $\mathrm{N}$ acional de la $\mathrm{H}$ igiene Industrial. El Centro Nacional de $\mathrm{N}$ otificación de Enfermedades (CNNE) compila y analiza los datos, transfiriéndolos seguidamente al M SP. Los Institutos de H igiene Industrial (I HI) y las Estaciones de Prevención E pidémica (EPE) disponen de oficinas a escala de todas la circunscripciones administrativas, desde el municipio hasta la provincia, para la notificación de problemas de higiene industrial. La notificación sigue un procedimiento anual "ascendente", excepto cuando se produce un episodio de intoxicación aguda que afecta a tres 0 más casos o cuando se produce una muerte, en cuyo caso los centros médicos que primero atienden al trabajador tienen la obligación de notificarlo al IH I local y también directamente al M SP en un plazo de 24 horas. La información que ha de facilitarse con carácter anual es la siguiente: nuevos casos registrados de enfermedades profesionales con derecho a indemnización y resultados de los reconocimientos médicos de los trabajadores y del control de los ambientes de trabajo (M SP 1991). En la actualidad, China intenta informatizar el sistema de notificación y ampliar su red de ordenadores, que por el momento se extiende del centro nacional a las oficinas provinciales.

\section{Referencias}

Agencia Internacional para la Investigación sobre e Cáncer (IARC). 1990. Phenoxy acid herbicides and contaminants: Description of the IARC international register of workers. Am J Ind $M$ ed 18:39-45.

Agricola, G. 1556. De R e M etallica. Traducido por HC H oover y LH H oover. 1950. Nueva Y ork: Dover.

Ahrens, W, K H Jöckel, P Brochard, U Bolm-Audorf, K G rossgarten, Y I watsubo, E O rlowski, H Pohlabeln, $F$ Berrino. 1993. R etrospective assessment of asbestos exposure. I. Case-control analysis in a study of lung cancer: Efficiency of job-specific questionnaires and job-exposure-matrices. Int I E pidemiol 1993 Supl. 2:S83-S95.

Alho, J, T K auppinen, E Sundquist. 1988. U se of exposure registration in the prevention of occupational cancer in Finland. Am J Ind $\mathrm{M} \mathrm{ed}$ 13:581-592.

American National Standards Institute (ANSI). 1963. American National Standard M ethod of Recording Basic Facts Relating to the Nature and $O$ ccurrence of $W$ ork Injuries. Nueva York: ANSI.

Baker, EL. 1986. Comprehensive Plan for Surveillance of Occupational IIIness and Injury in the U nited States. Washington, DC: NIOSH.

Baker, EL, PA H onchar, LJ Fine. 1989. Surveillance in occupational illness and injury: Concepts and content. Am J Public H ealth 79:9-11.

Baker, EL, JM M elius, JD M illar. 1988. Surveillance of occupational illness and injury in the U nited States: Current perspectives and future directions. J Publ $H$ ealth Policy 9:198-221.

Baser, M E, D M arion. 1990. A statewide case registry for surveillance of occupational heavy metals absorption. Am J Public H ealth 80:162-164.
Bennett, B. 1990. W orld R egister of Cases of Angiosarcoma of the Liver (ASL) due to Vinyl Chloride M onomer: $\mid \mathrm{Cl}$ R egistry.

Brackbill, RM, TM Frazier, S Shilling 1988 Smoking characteristics of workers, 1978-1980. Am $J$ Ind $M$ ed 13:4-41.

Burdoff, A. 1995. Reducing random measurement-error in assessing postural load on the back in epidemiologic surveys. Scand J W ork E nviron $\mathrm{H}$ ealth 21:15-23.

Bureau of Labor Statistics (BLS). 1986. Record Keeping Guidelines for Occupational Injuries and IIInesses. Washington, DC: US D epartment of Labor. 1989. California Work Injuries and Illness. Washington, DC: U S D epartment of L abor.

-. 1992. Occupational Injury and IIIness Classification $M$ anual. Washington, DC: US Department of Labor.

-. 1993a. O ccupational I njuries and IIInesses in the U nited States by Industry, 1991. Washington, DC: US Department of Labor.

-. 1993b. Survey of Occupational Injuries and IIInesses. W ashington, DC : US D epartment of $L$ abor.

-. 1994. Survey of Occupational Injuries and IIInesses, 1992. Washington, DC: US D epartment of Labor.

Bureau of the Census. 1992. Alphabetic List of Industries and $O$ ccupations. W ashington, DC: U S G overnment Printing 0 ffice.

-. 1993. Current Population Survey, J anuary through December 1993 (M achine Readable Data Files). W ashington, DC: Bureau of the Census.

Burstein, JM, BS Levy. 1994. The teaching of occupational health in U nited States medical schools. Little improvement in nine years. Am J Public H ealth 84:846-849.
Castorino, J, L R osenstock. 1992. Physician shortage in occupational and environmental medicine. Ann Intern M ed 113:983-986.

Checkoway, H, NE Pearce, DJ Crawford-Brown. 1989. Research M ethods in Occupational E pidemiology. Nueva Y ork: Oxford U niv. Press.

Chowdhury, NH, C Fowler, FJ M ycroft. 1994. Adult blood lead epidemiology and surveillance- $U$ nited States, 1992-1994. M orb M ortal W ekly Rep 43:483-485.

Coenen, W. 1981. Estrategias de medición y conceptos de documentación para la recogida de materiales de trabajo peligrosos. Prevención de accidentes (en alemán). M od U nfallverhütung:52-57.

Coenen, W, LH Engels. 1993. Control de riesgos en el trabajo. Investigación para desarrollar nuevas estrategias preventivas (en alemán). B G 2:88-91.

Craft, B, D Spundin, R Spirtas, V Behrens. 1977. D raft report of a task force on occupational health surveillance. $\mathrm{En} \mathrm{H}$ azard Surveillance in $\mathrm{O}$ ccupational Disease, dirigido por J Froines, DH Wegman y $\mathrm{E}$ Eisen. Am J Pub H ealth 79 (Suplemento) 1989.

Dubrow, R, JP Sestito, NR Lalich, CA Burnett, JA Salg. 1987. D eath certificate-based occupational mortality surveillance in the U nited States. Am J Ind $M$ ed 11:329-342.

Figgs, LW, M Dosemeci, A Blair. 1995. U nited States non-Hodgkin's lymphoma surveillance by occupation 1984-1989: A twenty-four-state death certificate study. Am J Ind M ed 27:817-835.

Frazier, TM , NR Lalich, DH Pederson. 1983. U ses of computer generated maps in occupational hazard and mortality surveillance. Scand J W ork Environ $H$ ealth 9:148-154.

Freund, E, PJ Seligman, TL Chorba, SK Safford, JG Drachmann, H F H ull. 1989. M andatory reporting 
of occupational diseases by clinicians. J AM A 262:3041-3044.

Froines, JR, DH Wegman, CA Dellenbaugh. 1986 An approach to the characterization of silica exposure in US industry. Am J Ind M ed 10:345-361.

Froines, JR, S Baron, DH Wegman, S O'Rourke. 1990. Characterization of the airborne concentrations of lead in US industry. Am J Ind M ed 18:1-17.

Gallagher, RF, WJ Threlfall, PR Band, JJ Spinelli. 1989. O ccupational M ortality in British Columbia 1950-1984. V ancouver: Cancer C ontrol Agency of British Columbia.

Guralnick, L. 1962. M ortality by occupation and industry among men 20-46 years of age: U nited States, 1950 Vital Statistics-Special Reports 53 (2) Washington, DC: National Center for $\mathrm{H}$ ealth Statistics.

-. 1963a. M ortality by industry and cause of death among men 20 to 40 years of age: U nited States, 1950. V ital Statistics-Special R eports, 53(4). W ashington, DC: $\mathrm{N}$ ational Center for $\mathrm{H}$ ealth Statistics.

- .1963b. M ortality by occupation and cause of death among men 20 to 64 years of age: U nited States, 1950. V ital Statistics-Special Reports 53(3). Washington, DC: $\mathrm{N}$ ational $\mathrm{C}$ enter for $\mathrm{H}$ ealth Statistics.

$\mathrm{H}$ alperin, WE, TM Frazier. 1985. Surveillance for the effects of workplace exposure. Ann Rev Public $H$ ealth 6:419-432.

$\mathrm{H}$ ansen, DJ, LW Whitehead. 1988. The influence of task and location on solvent exposures in a printing plant. Am Ind H yg Assoc J 49:259-265.

$\mathrm{H}$ aerting, FH, W H esse. 1879. Der Lungenkrebs, die Bergkrankheit in den Schneeberger Gruben V ierteljahrsschr gerichtl. Medizin und Öffentl. Gesundheitswesen 31:296-307.

Institute of M edicine. 1988. Role of the Primary Care Physician in $\mathrm{O}$ ccupational and Environmental $\mathrm{M}$ edicine. W ashington, DC: N ational A cademy Press.

Jacobi, W, K Henrichs, D Barclay. 1992 $V$ erursachungswahrschenlichkeit von L ungenkrebs durch die berufliche Strahlenexposition von U ran-Bergarbeitem der W ismut AG. N euherberg: GSF-Bericht S-14/ 92.

Jacobi, W, P Roth. 1995. Risiko und Verursachungs-W ahrscheinlichkeit von extrapulmonalen Krebserkrankungen durch die berufliche Strahlenexposition von Beschäftigten der enemaligen. Neuherberg: GSF-Bericht S-4/ 95.

$K$ auppinen, $T, M$ Kogevinas, $E$ Johnson, $H$ Becher, PA Bertazzi, HB de M esquita, D Coggon, L Green, M Littorin, E Lynge. 1993. Chemical exposure in manufacture of phenoxy herbicides and chlorophenols and in spraying of phenoxy herbicides. Am I Ind M ed 23:903-920.

Landrigan, PJ. 1989. Improving the surveillance of occupational disease. Am J Public $\mathrm{H}$ ealth 79:1601-1602

Lee, HS, WH Phoon. 1989. O ccupational asthma in Singapore. J 0 ccup M ed, Singapore 1:22-27.

Linet, MS, H Malker, JK M CLaughlin. 1988. Leukemias and occupation in Sweden. A registry-based analysis. Am J Ind M ed 14:319-330.

ubin, JH, JD Boise, RW Hornung, C Edling, GR Howe, E K unz, RA Kusiak, HI Morrison, EP Radford, JM Samet, M Tirmarche, A Woodward, TS X iang, D A Pierce. 1994. Radon and L ung Cance Risk: A I oint Analysis of $11 \mathrm{U}$ nderground $M$ iners Studies. Bethesda, $\mathrm{M}$ aryland: National Institute of $\mathrm{H}$ ealth (NIH).

Markowitz, S. 1992. The role of surveillance in occupational health En Environmental and O ccupational M edicine, dirigido por W Rom. Boston: Little, Brown.

Markowitz, SB, E Fischer, MD Fahs, I Shapiro, P Landrigan. 1989. O ccupational disease in $\mathrm{New}$ Y ork State. Am J Ind M ed 16:417-435.
M atte TD, RE H offman, KD Rosenman, $M$ Stanbury. 1990. Surveillance of occupational asthma under the SENSOR model. Chest 98:173S-178S.

M CD owell, ME. 1983. Leukemia mortality in electrical workers in England and Wales. Lancet $1: 246$.

Melius, JM, JP Sestito, PJ Seligman. 1989. Occupational disease surveillance with existing data sources. Am J Public H ealth 79:46-52.

M ilham, S. 1982. M ortality from leukemia in workers exposed to electrical and magnetic fields. N ew E ngl J M ed 307:249.

-. 1983. O ccupational M ortality in W ashington State 1950-1979. NIOSH publication No. 83-116. Springfield, Virginia: National Technical Information Service.

Muldoon, JT, LA Wintermeyer, JA Eure, L Fuortes, JA M erchant, LSF Van, TB Richards. 1987. Occupational disease surveillance data sources 1985. Am J Public H ealth 77:1006-1008.

National Research Council (NRC). 1984. Toxicity Testing Strategies to Determine $N$ eeds and Priorities. Washington, DC: N ational A cademic Press.

O ffice of M anagement and Budget (OM B). 1987. Standard Industrial Classification $\mathrm{M}$ anual. Washington, DC: U S G overnment Printing O ffice.

O rganización Internacional del Trabajo (OIT) 1980. Guidelines for the $U$ se of I 0 International Classification of Radiographs of Pneumoconioses. O ccupational Safety and $\mathrm{H}$ ealth Series, N o. 22. G inebra: OIT.

Organización Mundial de la Salud (OMS). 1977. $M$ anual of the International Statistical Classification of D iseases, Injuries, and Causes of D eath, Based on the Recommendations of the Ninth R evision Conference, 1975. Ginebra: O M S.

OSH A. 1970. Ley de seguridad y salud en el trabajo de 1970. Ley pública 91-596, 91으 Congreso de Estados U nidos.

Ott, G. 1993. Propuestas estratégicas para la técnica de medición de la incidencia de daños (en alemán) $D$ räger $H$ eft 355:2-5.

Pearce, NE, RA Sheppard, JK H oward, J Fraser, BM Lilley. 1985. Leukemia in electrical workers in $\mathrm{N}$ ew Zealand. L ancet ii:811-812.

Phoon, WH. 1989. Occupational diseases in Singapore. J 0 ccup M ed, Singapore 1:17-21.

Pollack, ES, DG K eimig (dirs.). 1987. Counting Injuries and IIInesses in the W orkplace: Proposals for a B etter System. W ashington, DC: N ational A cademy Press.

Rajewsky, B. 1939. Bericht über die Schneeberger Untersuchungen. Z eitschrift für Krebsforschung 49:315-340.

Rappaport, SM. 1991. Assessment of long-term exposures to toxic substances in air. Ann $\mathrm{O}$ ccup $\mathrm{H}$ yg 35:61-121.

R egistrar General. 1986. O ccupation M ortality, Decennial Supplement for England and W ales, 1979-1980, 1982-1983 Part I Commentary. Series DS, No. 6. Londres: $\mathrm{H}$ er $\mathrm{M}$ ajesty's Stationery $\mathrm{O}$ ffice.

Robinson, C, F Stern, W Halperin, $\mathrm{H}$ Venable, M Petersen, T Frazier, C Burnett, N Lalich, J Salg, J Sestito. 1995. Assessment of mortality in the construction industry in the United States, 1984-1986. Am J Ind M ed 28:49-70.

R oche, LM . 1993. U se of employer illness reports for occupational disease surveillance among public employees in N ew Jersey. J O ccup M ed 35:581-586.

R osenman, K D. 1988. U se of hospital discharge data in the surveillance of occupational disease. Am J Ind M ed 13:281-289.

Rosenstock, L. 1981. O ccupational medicine: Too long neglected. Ann Intern M ed 95:994.

Rothman, KJ. 1986. M odern E pidemiology. Boston: Little, Brown \& Co.
Seifert B. 1987. Estrategia y procedimiento de medición para la investigación del aire del interior. Técnica de medición y protección ambiental (en alemán). 2:M 61-M 65.

Selikoff, IJ. 1982. Disability Compensation for Asbestos-Associated D isease in the U nited States. Nueva Y ork: M t. Sinai School of M edicine.

Selikoff, IJ, EC Hammond, H Seidman. 1979. $M$ ortality experience of insulation workers in the United States and Canada, 1943-1976. Ann NY Acad Sci 330:91-116.

Selikoff, IJ, H Seidman. 1991. Asbestos-associated deaths among insulation workers in the U nited States and Canada, 1967-1987. Ann NY Acad Sci 643:1-14.

Seta, JA, DS Sundin. 1984. T rends of a decade-A perspective on occupational hazard surveillance 1970-1983. M orb M ortal W edkly Rep 34(2):15SS-24SS

Shilling, S, RM Brackbill. 1987. O ccupational health and safety risks and potential health consequences perceived by US workers. Publ $H$ ealth Rep 102:36-46.

Slighter, R. 1994. Comunicación personal, U nited States 0 ffice of W orker's Compensation Program, 13 de septiembre de 1994.

Tanaka, S, DK Wild, PJ Seligman, WE Halperin, VJ Behrens, V Putz-Anderson. 1995. Prevalence and work-relatedness of self-reported carpal tunnel syndrome among US workers-Analysis of the occupational health supplement data of 1988 national health interview survey. Am J Ind $\mathrm{M}$ ed 27:451-470.

Teschke, K, SA M arion, A Jin, RA Fenske, C van Netten. 1994. Strategies for determining occupational exposure in risk assessment. A review and a proposal for assessing fungicide exposures in the lumber industry. Am Ind $\mathrm{Hyg}$ Assoc 55:443-449.

Ullrich, D. 1995. M étodos para determinar la contaminación en el interior. Calidad del aire en el interior (en alemán). BIA-R eport 2/ 95,91-96.

US Department of $\mathrm{H}$ ealth and Human Services (USDH H S). 1980. Industrial Characteristics of Persons Reporting M orbidity D uring the $H$ ealth Interview Surveys Conducted in 1969-1974. Washington, DC: USDHHS.

-. Julio 1993. Vital and $H$ ealth Statistics $H$ ealth Conditions among the Currently E mployed: U nited States 1988. Washington, DC: USDH HS

-. Julio 1994. Vital and $H$ ealth Statistics Plan and $O$ peration of the Third National $\mathrm{H}$ ealth and Nutrition Examination Survey, 1988-94. Vol. No. 32. Washington, DC: USDH S

US D epartment of Labor (USD O L). 1980. An Interim Report to Congress on $O$ ccupational Diseases. Washington, DC: US Government Printing O ffice.

US Public Health Service (USPHS), 1989. The International Classification of Diseases, 9th Revision, Clinical Modification. Washington, DC: US G overnment Printing 0 ffice

W egman, DH . 1992. H azard surveillance. Capítulo 6 en Public $H$ ealth Survellance, dirigido por W $\mathrm{H}$ alperin, EL Baker y RR Ronson. NuevaY ork: $V$ an N ostrand R einhold.

Wegman, DH, JR Froines. 1985. Surveillance needs for occupational health. Am I Public $\mathrm{H}$ ealth 75:1259-1261.

Welch, L. 1989. The role of occupational health clinics in surveillance of occupational disease. Am Public $\mathrm{H}$ ealth 79:58-60.

Wichmann, HE, I Brüske-H ohlfeld, M Mohner. 1995. Stichprobenerhebung und Auswertung von Personaldaten der $\mathrm{W}$ ismut $\mathrm{H}$ auptverband der gewerblichen $\mathrm{Be}$ rufsgenossenschaften. Forschungsbericht 617.0-WI-02, Sankt Augustin. 

Directora del capítulo Ellen K. Silbergeld

\section{Sumario}

Introducción Ellen K. Silbergeld . . .

PRINCIPIOS GENERALES DE LA TOXICOLOGIA

Definiciones y conceptos

Bo Holmberg, Fohan Högberg

y Gunnar Fohanson. . .

Toxicocinética

Dušan Djurić.

Organo diana y efectos críticos

Marek Jakubowski .

Efectos de la edad, el sexo y otros factores

Spomenka Telišman............................ 33.18

Determinantes genéticos de la respuesta tóxica

Daniel W. Nebert y Ross A. McKinnon. . . . . . . . . . . . . . . . 33.21

\section{MECANISMOS DE LA TOXICIDAD}

Introducción y conceptos

Philip G. Watanabe ............

Lesión celular y muerte celular

Benjamin F. Trump

e Irene K. Berezesky.

Toxicología genética

R. Rita Misra

y Michael P. Waalkes . .

Inmunotoxicología

Goseph G. Vos y Henk van Loveren. . . . . . . . . . . . . . . . . . . 33.39

Toxicología de órganos diana

Ellen K. Silbergeld.

\section{METODOS DE ENSAYO EN TOXICOLOGIA}

Biomarcadores

Philippe Grandjean . .

Evaluación de la toxicidad genética

David M. DeMarini

y James Huff

Ensayos de toxicidad in vitro

Foanne Zurlo. .

Relaciones estructura-actividad

Ellen K. Silbergeld .

\section{TOXICOLOGIA REGULADORA}

La toxicología en la regulación de la salud y la seguridad Ellen K. Silbergeld . . . . . . . . . . . . . . . . . . . . . . . . 33.57

Principios de la identificación de los peligros: el enfoque japonés

Masayuki Ikeda........................ 33.57

El enfoque estadounidense de la evaluación del riesgo de los tóxicos para la reproducción y agentes neurotóxicos Ellen K. Silbergeld . . . . . . . . . . . . . . . . . . . . . . . . 33.60

Enfoques en la identificación de los peligros: la IARC Harri Vainio y fulian Wilbourn . . . . . . . . . . . . . . . . . . . 33.65

Apéndice: evaluaciones globales de carcinogenicidad para los humanos: monografías de la IARC,

volúmenes 1-69 (836).

Evaluación del riesgo de carcinogenicidad: otros enfoques

Cees A. van der Heijden . . . . . . . . . . . . . . . . . . . . . . . . . 33.76 


\section{INTRODUCCION}

\section{Ellen K. Silbergeld}

La toxicología es el estudio de los venenos o, en una definición más precisa, la identificación y cuantificación de los efectos adversos asociados a la exposición a agentes físicos, sustancias químicas y otras situaciones. En ese sentido, la toxicología es tributaria, en materia de información, diseños de la investigación y métodos, de la mayoría de las ciencias biológicas básicas y disciplinas médicas, de la epidemiología y de determinadas esferas de la química y la física. La toxicología abarca desde estudios de investigación básica sobre el mecanismo de acción de los agentes tóxicos hasta la elaboración e interpretación de pruebas normalizadas para determinar las propiedades tóxicas de los agentes. Aporta una importante información tanto a la medicina como a la epidemiología de cara a comprender la etiología de las enfermedades, así como sobre la plausibilidad de las asociaciones que se observan entre éstas y las exposiciones, incluidas las exposiciones profesionales. Cabe dividir la toxicología en disciplinas normalizadas, como la toxicología clínica, la forense, la de investigación y la reguladora; otra clasificación hace referencia a los sistemas o procesos orgánicos que se ven afectados, y tenemos entonces la inmunotoxicología o la toxicología genética; puede presentarse también desde el punto de vista de sus funciones, y entonces se habla de investigación, realización de ensayos y evaluación de los riesgos.

La presentación completa de la toxicología en esta Enciclopedia no es una tarea fácil. El presente capítulo no contiene un compendio de información sobre la toxicología o sobre los efectos adversos de determinados agentes concretos. Esta última información es más fácil obtenerla en las bases de datos que se están actualizando continuamente y a las que se hace referencia en la última sección de este capítulo. Tampoco se pretende situar la toxicología en el contexto de sus subdisciplinas específicas, como la toxicología forense. Se ha pretendido más bien ofrecer una información que sea de interés para todos los tipos de actividades toxicológicas y para la utilización de la toxicología en diversas especialidades y esferas de la medicina. Los temas que se tratan en este capítulo se han enfocado de una manera esencialmente práctica y con miras a integrarlos en los fines generales de la Enciclopedia en su conjunto. Al elegir los temas se ha procurado asimismo facilitar las referencias cruzadas dentro de la obra.

En la sociedad moderna, la toxicología es ya un elemento importante de la salud ambiental y de la salud en el trabajo. Ello es así porque muchas organizaciones, tanto gubernamentales como no gubernamentales, utilizan la información toxicológica para evaluar y regular los peligros presentes tanto en el lugar de trabajo como en el medio ambiente general. La toxicología es un componente crucial de las estrategias de prevención, pues proporciona información sobre peligros potenciales en los casos en que no hay una exposición humana amplia. Los métodos de la toxicología son asimismo muy utilizados por la industria en el desarrollo de productos, pues permiten obtener una información valiosa para el diseño de determinadas moléculas o formulaciones.

El capítulo se inicia con cinco artículos sobre los principios generales de la toxicología, principios que es importante tener en cuenta al abordar la mayoría de los temas de esta disciplina . Los primeros principios generales se refieren a la comprensión de las relaciones entre la exposición externa y la dosis interna. En la terminología moderna, con "exposición" se hace referencia a las concentraciones o cantidad de una sustancia con que están en contacto los individuos o las poblaciones -las cantidades presentes en un determinado volumen de aire o de agua, o en una determinada masa de suelo. El término "dosis" se refiere a la concentración o cantidad de una sustancia que hay en el interior de una persona u organismo expuesto. En el ámbito de la salud laboral, las normas y directrices suelen expresarse en términos de exposición, o de concentraciones límite permisibles en situaciones concretas, como por ejemplo en el aire del lugar de trabajo. Esos límites de exposición se basan en hipótesis o informaciones sobre la relación entre la exposición y la dosis; no obstante, es frecuente que no se pueda obtener información sobre la dosis interna. Así, en muchos estudios sobre salud laboral, sólo cabe establecer asociaciones entre la exposición y la respuesta o efecto. En algunos casos se han establecido normas basadas en la dosis (por ejemplo, niveles permisibles de plomo en sangre o de mercurio en orina). Aunque estas medidas presentan una correlación más directa con la toxicidad, sigue siendo no obstante necesario, a efectos de controlar los riesgos, calcular retrospectivamente los niveles de exposición asociados con esos efectos.

El siguiente artículo trata de los factores y hechos que determinan las relaciones entre la exposición, la dosis y la respuesta. Los primeros factores tienen que ver con la captación, la absorción y la distribución - los procesos que determinan el transporte efectivo de las sustancias desde el medio externo hasta el cuerpo, por vías de entrada como la piel, los pulmones o el aparato digestivo. Esos procesos se sitúan en la interfase entre los seres humanos y su medio ambiente. En el caso de los segundos factores, los del metabolismo, se trata de comprender la forma en que el cuerpo hace frente a las sustancias que ha absorbido. Algunas sustancias se transforman mediante procesos metabólicos de la célula, que pueden incrementar o reducir su actividad biológica.

Para mejorar la interpretación de los datos toxicológicos se han elaborado los conceptos de órgano diana y efecto crítico. Dependiendo de la dosis, la duración y la ruta de exposición, y también de factores del huésped como la edad, muchos agentes tóxicos pueden inducir diversos efectos en los órganos y organismos. Una de las misiones principales de la toxicología es identificar el efecto o grupos de efectos importantes con miras a prevenir enfermedades irreversibles o debilitadoras. Una parte destacada de esa tarea es la identificación del órgano que se ve afectado en primer lugar o que se ve más afectado por un agente tóxico: es lo que se denomina el "órgano diana". Una vez en el órgano diana es necesario identificar el hecho o hechos importantes que indican la intoxicación o daño, a fin de comprobar que el órgano se ha visto afectado más allá de su variabilidad normal. Es lo que se denomina el "efecto crítico"; puede ser el primer hecho en una sucesión de fases fisiopatológicas (como la excreción de proteínas de bajo peso molecular como efecto crítico en la toxicidad renal), o puede ser el efecto primero y potencialmente irreversible de un proceso patológico (como la formación de un aducto de ADN en la carcinogénesis). Estos conceptos son importantes en el ámbito de la salud en el trabajo porque definen los tipos de toxicidad y la enfermedad clínica asociados con determinadas exposiciones, y en la mayoría de los casos la reducción de la exposición está orientada a prevenir no tanto cualquier tipo de efecto en cualquier órgano cuanto los efectos críticos en los órganos diana.

En los dos artículos siguientes se estudian importantes factores del huésped que afectan a muchos tipos de respuestas a muchos tipos de agentes tóxicos. Se trata de los determinantes genéticos, o factores heredados de susceptibilidad/resistencia, y de la edad, el sexo y otros factores como la dieta o la existencia simultánea de una enfermedad infecciosa. Esos factores pueden afectar también a la exposición y la dosis modificando la captación, la absorción, la distribución y el metabolismo. Como muchos de estos factores presentan variaciones en las poblaciones de 
trabajadores de todo el mundo, es esencial que los especialistas en salud en el trabajo y los encargados de formular las políticas comprendan la forma en que esos factores pueden contribuir a la variabilidad de las respuestas entre unas poblaciones y otras y entre individuos de una misma población. Estas consideraciones son especialmente importantes en las sociedades con poblaciones heterogéneas. La variabilidad de las poblaciones humanas es un elemento que hay que tener en cuenta al evaluar los riesgos de las exposiciones profesionales y al extraer conclusiones racionales del estudio de organismos no humanos en las investigaciones o ensayos toxicológicos.

En la sección siguiente se ofrecen dos panoramas generales de la toxicología desde el punto de vista de sus mecanismos. Desde la óptica mecanicista, los toxicólogos modernos estiman que todos los efectos tóxicos se manifiestan en primer lugar a nivel celular; por consiguiente, las respuestas celulares son las primeras indicaciones del contacto del cuerpo con un agente tóxico. Se considera además que esas respuestas comprenden toda una serie de hechos, desde la lesión hasta la muerte. Se denomina lesión celular a unos procesos específicos que utilizan las células, que es la unidad mínima de organización biológica dentro de los órganos, para responder al problema que se les plantea. Entre esas respuestas figuran cambios en la función de procesos celulares, como los de la membrana y su capacidad de captar, liberar o excluir sustancias, la síntesis dirigida de proteínas a partir de aminoácidos y el recambio de componentes celulares. Esas respuestas pueden ser comunes a todas las células lesionadas, o pueden ser específicas de determinados tipos de células pertenecientes a determinados sistemas orgánicos. La muerte celular es la destrucción de células de un sistema orgánico como consecuencia de una lesión celular irreversible o no compensada. Los agentes tóxicos pueden causar la muerte celular como un proceso agudo que se revela de varias maneras, como perjudicando la transferencia de oxígeno, pero otras veces la muerte celular es consecuencia de una intoxicación crónica. Después de la muerte celular puede producirse una sustitución en algunos sistemas orgánicos pero no en todos, aunque en algunas circunstancias la proliferación de células inducida por la muerte celular puede considerarse una respuesta tóxica. Aun cuando no hay muerte celular, las lesiones celulares reiteradas pueden inducir una tensión en los órganos que pone en peligro su función y que afecta a su descendencia.

Se examinan después en el capítulo varios temas más específicos, que se agrupan en las categorías siguientes: mecanismos, métodos de ensayo, regulación y evaluación del riesgo. En la mayoría de los artículos sobre los mecanismos se analizan más los sistemas diana que los órganos diana. Esto refleja la práctica habitual de la toxicología y la medicina modernas, que no estudian tanto órganos aislados como sistemas orgánicos. Así, por ejemplo, la sección de toxicología genética no se centra en los efectos tóxicos de los agentes sobre un órgano específico, sino más bien en el material genético como diana de la acción tóxica.
Análogamente, en el artículo sobre inmunotoxicología se examinan los diversos órganos y células del sistema inmunitario como dianas de los agentes tóxicos. En los artículos sobre los métodos de la toxicología se ha adoptado un punto de vista eminentemente práctico: se describen los métodos de identificación de los peligros que se utilizan en la actualidad en muchos países, es decir, los métodos para obtener información relacionada con las propiedades biológicas de los agentes.

Figuran a continuación cinco artículos sobre la aplicación de la toxicología en el establecimiento de normas y la formulación de políticas, desde la identificación de los peligros hasta la evaluación de los riesgos. Se presenta la práctica habitual en varios países, así como la de la IARC. En estos artículos el lector entenderá cómo se integra la información obtenida en los ensayos toxicológicos con inferencias básicas y mecanicistas para obtener la información cuantitativa que se utiliza para establecer los niveles de exposición o adoptar otras medidas de control de los peligros en el lugar de trabajo y en el medio ambiente general.

El lector interesado en información detallada sobre determinados agentes tóxicos y sus exposiciones puede consultar el resumen de las bases de datos toxicológicos existentes que figura en el Volumen III (véase "Bases de datos de toxicología" en el capítulo Manejo seguro de las sustancias químicas, que contiene información sobre muchas de estas bases de datos, sus fuentes de información, métodos de evaluación e interpretación y formas de acceso). Junto con la Enciclopedia, esas bases de datos ofrecen a los especialistas en salud en el trabajo, a los trabajadores y a las empresas la posibilidad de obtener y utilizar información toxicológica actualizada, así como la evaluación de los agentes tóxicos efectuada por organismos nacionales e internacionales.

En este capítulo se estudian sobre todo los aspectos de la toxicología que tienen que ver con la salud y la seguridad en el trabajo. Por esa razón no se abordan específicamente las subdisciplinas de la toxicología clínica y la toxicología forense. En esas subdisciplinas, y también en el campo de la salud ambiental, se utilizan muchos de los mismos principios y enfoques que aquí se describen. Esos principios y enfoques son igualmente aplicables a la evaluación de los efectos de los agentes tóxicos sobre poblaciones no humanas, cuestión que ocupa un lugar importante en las políticas ambientales de muchos países. Aunque se ha puesto especial interés en recoger las perspectivas y experiencias de los expertos y técnicos de todos los sectores y de muchos países, es posible que el lector advierta un cierto sesgo hacia los científicos académicos del mundo desarrollado. Aunque la directora del capítulo y los autores de los artículos son de la opinión de que los principios y la práctica de la toxicología son internacionales, es muy posible que se pongan de manifiesto aquí los problemas del sesgo cultural y la escasez de experiencia. La directora del capítulo espera que los lectores de la Enciclopedia ayuden a ampliar lo más posible la perspectiva en las sucesivas actualizaciones y ampliaciones de esta importante obra de referencia.

\section{PRINCIPIOS GENERALES DE LA TOXICOLOGIA}

\section{DEFINICIONES Y CONCEPTOS}

\section{Bo Holmberg, Johan Högberg y Gunnar Johanson}

\section{Exposición, dosis y respuesta}

Toxicidad. La capacidad intrínseca que posee un agente químico de producir efectos adversos sobre un órgano.

Xenobióticos. "Sustancias extrañas", es decir, extrañas al organismo. Lo contrario son los compuestos endógenos. Entre los xenobióticos figuran los fármacos, las sustancias químicas industriales, los venenos presentes en la naturaleza y los contaminantes del medio ambiente.

Peligro. La posibilidad de que la toxicidad sea efectiva en un contexto o situación determinados.

Riesgo. La probabilidad de que se produzca un efecto adverso específico. Suele expresarse como el porcentaje de casos de una población dada durante un determinado período de tiempo. La estimación del riesgo puede basarse en casos reales o en una proyección de casos futuros a partir de extrapolaciones. 
Las expresiones categorías de toxicidad y clasificación de la toxicidad se utilizan a veces en el ámbito de las actividades de regulación. Las categorías de toxicidad se refieren a una calificación arbitraria de las dosis o niveles de exposición que causan efectos tóxicos. Se habla así de "sumamente tóxico", "muy tóxico", "moderadamente tóxico", etc. Lo más frecuente es que estas expresiones se apliquen a la toxicidad aguda. La clasificación de la toxicidad se refiere a la agrupación de las sustancias químicas en categorías generales conforme a su efecto tóxico principal. Se habla así de sustancias alergénicas, neurotóxicas, carcinógenas, etc. Esta clasificación puede ser útil en el ámbito administrativo como advertencia y como información.

La relación dosis-efecto es la relación entre la dosis y el efecto a nivel individual. Un incremento de la dosis puede incrementar la intensidad de un efecto o su gravedad. Puede obtenerse una curva de dosis-efecto a nivel de todo el organismo, de la célula o de la molécula diana. Hay algunos efectos tóxicos, como la muerte o el cáncer, que no tienen grados, sino que son efectos "de todo o nada".

La relación dosis-respuesta es la relación entre la dosis y el porcentaje de individuos que presentan un determinado efecto. $\mathrm{Al}$ incrementarse la dosis lo normal es que aumente el número de individuos afectados en la población expuesta.

El establecimiento de las relaciones dosis-efecto y dosis-respuesta es esencial en toxicología. En los estudios médicos (epidemiológicos) suele utilizarse como criterio para aceptar una relación causal entre un agente y una enfermedad el hecho de que el efecto o la respuesta sean proporcionales a la dosis.

Pueden establecerse varias curvas de dosis-respuesta respecto de una misma sustancia química - una curva para cada tipo de efecto. En la mayoría de los efectos tóxicos (cuando se estudian en poblaciones grandes), la curva de dosis-respuesta tiene una forma sigmoidea. Hay por lo general un intervalo de dosis bajas en el que no se detecta respuesta alguna; al aumentar la dosis, la respuesta sigue una curva ascendente que normalmente llega a una meseta cuando la respuesta es del $100 \%$. La curva de dosis-respuesta refleja las variaciones entre individuos de una misma población. La pendiente de la curva varía según la sustancia química de que se trate y también entre los diferentes tipos de efectos. En el caso de algunas sustancias que tienen efectos específicos (carcinógenos, iniciadores, mutágenos) la curva de dosis-respuesta podría ser lineal desde la dosis cero dentro de un determinado intervalo de dosis. Esto significa que no hay un umbral y que hasta las dosis pequeñas representan un riesgo. Por encima de ese intervalo de dosis, el riesgo puede incrementarse a una tasa superior a la lineal.

La variación de la exposición a lo largo del día y la duración total de la exposición a lo largo de toda la vida del sujeto pueden ser importantes para el resultado (respuesta) ya sea como un nivel de dosis media, promediado o incluso integrado. Los picos de exposición muy altos pueden ser más nocivos que un nivel de exposición más uniforme. Así ocurre en el caso de algunos disolventes orgánicos. En el de algunas sustancias carcinógenas, en cambio, se ha demostrado experimentalmente que el fraccionamiento de una única dosis en varias exposiciones con la misma dosis total puede ser más eficaz en la producción de tumores.

La dosis suele definirse como la cantidad de un xenobiótico que entra en un organismo (en unidades como $\mathrm{mg} / \mathrm{kg}$ de peso corporal). La dosis puede expresarse de diferentes maneras (más o menos informativas): dosis de exposición, que es la concentración en el aire del contaminante que se inhala durante un determinado período de tiempo (en el ámbito de la higiene industrial, normalmente ocho horas), o dosis absorbida o retenida (llamada también carga corporal en higiene industrial), que es la cantidad presente en el cuerpo en un determinado momento durante la exposición o después de ella. La dosis tisular es la cantidad de sustancia en un determinado tejido, y la dosis diana es la cantidad de sustancia (por lo general un metabolito) unida a la molécula crítica. La dosis diana puede expresarse en $\mathrm{mg}$ de sustancia química unida por mg de una determinada macromolécula del tejido. Para la aplicación de este concepto se precisa información sobre el mecanismo de la acción tóxica a nivel molecular. La dosis diana está asociada con más precisión al efecto tóxico. La dosis de exposición y la carga corporal pueden obtenerse con más facilidad, pero su relación con el efecto es menos precisa.

En el concepto de dosis se suele incluir un elemento temporal, aun cuando no se exprese siempre. Según la ley de Haber, la dosis teórica es $\mathrm{D}=\mathrm{ct}$, donde $\mathrm{D}$ es la dosis, c es la concentración del xenobiótico en el aire y t la duración de la exposición a la sustancia química. Cuando este concepto se utiliza al nivel de órganos o moléculas diana, puede utilizarse la cantidad por $\mathrm{mg}$ de tejido o de molécula en un período de tiempo determinado. $\mathrm{El}$ aspecto temporal suele ser más importante para comprender las exposiciones reiteradas y los efectos crónicos que en el caso de las exposiciones únicas y los efectos agudos.

Se producen efectos aditivos cuando hay una exposición a una combinación de sustancias químicas en la que simplemente se suman las diversas toxicidades individuales $(1+1=2)$. Cuando varias sustancias actúan a través del mismo mecanismo se presupone la aditividad de sus efectos, aunque no siempre ocurre así en la realidad. La interacción entre varias sustancias puede tener como resultado una inhibición (antagonismo), en la que el efecto es menor de lo que sería la suma de los efectos individuales $(1+1<2)$. También puede ocurrir lo contrario, es decir, que una combinación de sustancias produzca un efecto mayor que la suma de los efectos individuales (mayor respuesta entre individuos o incremento de la frecuencia de respuesta en una población), y entonces se habla de sinergismo $(1+1>2)$.

El tiempo de latencia es el tiempo que transcurre entre la primera exposición y la aparición de un efecto o respuesta observable. Esta expresión suele utilizarse en el caso de los efectos de los carcinógenos, en los que los tumores pueden aparecer mucho tiempo después del comienzo de la exposición y a veces mucho tiempo después de que ésta haya cesado.

Un umbral de dosis es un nivel de la dosis por debajo del cual no hay ningún efecto observable. Se cree que existen umbrales en el caso de determinados efectos, como los efectos tóxicos agudos, pero no en el de otros, como los efectos carcinógenos (por iniciadores de la formación de aductos de ADN).

No obstante, la mera ausencia de respuesta en una población dada no debe entenderse como prueba de la existencia de un umbral. La ausencia de respuesta podría deberse a sencillos fenómenos estadísticos: es posible que un efecto adverso que se produce con baja frecuencia no sea detectable en una población pequeña.

La $\mathrm{DL}_{50}$ (dosis letal) es la dosis que produce una mortalidad del $50 \%$ en una población animal. La $\mathrm{DL}_{50}$ solía considerarse en la bibliografía más antigua como una medida de la toxicidad aguda de las sustancias químicas. A mayor $\mathrm{DL}_{50}$, menor toxicidad aguda. De una sustancia química muy tóxica (con una $\mathrm{DL}_{50}$ baja) se dice que es potente. No hay una correlación necesaria entre la toxicidad aguda y la toxicidad crónica. La $\mathrm{DE}_{50}$ (dosis efectiva) es la dosis que produce en el $50 \%$ de los animales un efecto específico no letal.

El NOEL (NOAEL) es el nivel sin efecto (adverso) observado, o la dosis más alta que no produce efecto tóxico. Para establecer un NOEL se necesitan múltiples dosis, una población amplia e información complementaria para garantizar que la ausencia de respuesta no es un mero fenómeno estadístico. El LOEL es la mínima dosis efectiva observada en una curva de dosis-respuesta, (es decir, la dosis mínima) que produce un efecto. 
Un factor de seguridad es un número convencional, arbitrario, por el que se divide el NOEL o el LOEL obtenidos en experimentos con animales para establecer una dosis permisible provisional en los seres humanos. Suele utilizarse en la esfera de la toxicología alimentaria, pero puede emplearse también en la toxicología laboral. A veces se utiliza también un factor de seguridad para extrapolar a poblaciones mayores datos obtenidos en poblaciones pequeñas. Los factores de seguridad van de $10^{0}$ a $10^{3}$. Típicamente, un factor de seguridad de 2 puede ser una protección suficiente contra efectos menos graves (como la irritación), mientras que en efectos muy graves (como el cáncer) puede utilizarse hasta un factor de 1.000. Sería conveniente sustituir la expresión factor de seguridad por factor de protección o incluso por factor de incertidumbre. Ello reflejaría mejor las incertidumbres científicas, como si datos de dosis-respuesta exactos pudieran trasladarse de animales a seres humanos para una determinada sustancia química, efecto tóxico o circunstancia de exposición.

Las extrapolaciones son estimaciones teóricas, cualitativas o cuantitativas, de la toxicidad (extrapolaciones del riesgo) que se obtienen trasladando datos de una especie a otra o bien una serie de datos de dosis-respuesta (generalmente en el intervalo de dosis altas) a zonas de la dosis-respuesta sobre las que no existen datos. Por lo general han de hacerse extrapolaciones para predecir las respuestas tóxicas fuera del intervalo de observación. Para las extrapolaciones se elaboran modelos matemáticos que se basan en el conocimiento del comportamiento de la sustancia química en el organismo (modelos toxicocinéticos) o en el conocimiento de las probabilidades estadísticas de que se produzcan determinados hechos biológicos (modelos biológicos o mecanicistas). Algunos organismos nacionales han elaborado complejos modelos de extrapolación como método formalizado de predecir riesgos con fines de regulación. (Véase más adelante en este mismo capítulo el análisis de la evaluación del riesgo.)

Los efectos sistémicos son efectos tóxicos que se producen en tejidos alejados de la ruta de absorción.

El órgano diana es el órgano principal o más sensible afectado tras la exposición. Una misma sustancia química que entra en el cuerpo por diferentes rutas de exposición, tasa de dosis, sexo y especie puede afectar a diferentes órganos diana. La interacción entre las sustancias químicas, o entre las sustancias químicas y otros factores, puede afectar también a diferentes órganos diana.

Los efectos agudos son los que se producen tras una exposición limitada y poco tiempo después de ésta (horas, días), y pueden ser reversibles o irreversibles.

Los efectos crónicos se producen tras una exposición prolongada (meses, años, decenios) y/o persisten después de que haya cesado la exposición.

La exposición aguda es una exposición de corta duración, mientras que la exposición crónica es una exposición de larga duración (a veces toda la vida).

La tolerancia a una sustancia química es el fenómeno que se produce cuando repetidas exposiciones tienen como resultado una respuesta más baja de la que sería de esperar sin tratamiento previo.

\section{Captación y disposición}

\section{Procesos de transporte}

Difusión. Para entrar en el organismo y llegar al lugar en el que producen el daño, las sustancias extrañas han de atravesar varias barreras, entre ellas las células y sus membranas. La mayoría de las sustancias tóxicas atraviesa las membranas pasivamente, por difusión. Por este proceso, las moléculas hidrosolubles pequeñas pasan por los canales acuosos, y las moléculas liposolubles se disuelven en la parte lipídica de la membrana y después la atraviesan por difusión. El etanol, que es una pequeña molécula hidro y liposoluble, se difunde rápidamente a través de las membranas celulares

Difusión de ácidos y bases débiles. Los ácidos y bases débiles pueden atravesar fácilmente las membranas en su forma liposoluble no ionizada, mientras que las formas ionizadas son demasiado polares para pasar. El grado de ionización de estas sustancias depende del $\mathrm{pH}$. Si entre un lado y otro de una membrana hay un gradiente de $\mathrm{pH}$, se acumularán en sólo uno de los lados. La excreción urinaria de los ácidos y bases débiles depende en gran medida del $\mathrm{pH}$ de la orina. El $\mathrm{pH}$ fetal o embrionario es algo más alto que el $\mathrm{pH}$ materno, lo que produce una ligera acumulación de ácidos débiles en el feto o embrión.

Difusión facilitada. El paso de una sustancia puede verse facilitado por transportadores presentes en la membrana. La difusión facilitada se asemeja a los procesos enzimáticos en que se produce con la mediación de una proteína y en que es muy selectiva y saturable. Hay otras sustancias que pueden inhibir el transporte facilitado de los xenobióticos.

Transporte activo. Algunas sustancias atraviesan las membranas celulares mediante un transporte activo. Ese transporte se realiza con la mediación de proteínas transportadoras en un proceso análogo al de las enzimas. El transporte activo es similar a la difusión facilitada, pero puede producirse en contra de un gradiente de concentración. Necesita un aporte de energía, y un inhibidor metabólico puede bloquear el proceso. Los contaminantes ambientales casi nunca se transportan activamente. Una excepción es la secreción y reabsorción activas de metabolitos ácidos en los túbulos renales.

La fagocitosis es un proceso en virtud del cual células especializadas, como los macrófagos, capturan ("engloban") partículas y después las digieren. Esta modalidad de transporte desempeña un papel importante por ejemplo en la eliminación de partículas de los alveolos.

Transporte en los flujos corporales. Las sustancias se mueven asimismo por el cuerpo con el movimiento del aire en el sistema respiratorio durante la respiración y con los movimientos de la sangre, la linfa o la orina.

Filtración. Debido a la presión hidrostática u osmótica, grandes cantidades de agua atraviesan los poros del endotelio. Todo soluto que sea suficientemente pequeño se filtrará junto con el agua. Hay cierto nivel de filtración en el lecho de capilares de todos los tejidos, pero es importante sobre todo en la formación de la orina primaria en el glomérulo renal.

\section{Absorción}

La absorción es el paso de una sustancia del medio ambiente al organismo. Por lo general se entiende no sólo como el hecho de atravesar la barrera tisular sino también como su llegada ulterior a la circulación sanguínea.

Absorción pulmonar. Los pulmones son la principal ruta de depósito y absorción de pequeñas partículas suspendidas en el aire, gases, vapores y aerosoles. En el caso de los gases y vapores muy hidrosolubles, una parte importante de la absorción se produce en la nariz y el árbol respiratorio, pero en el caso de las sustancias menos solubles se produce principalmente en los alveolos pulmonares. Los alveolos poseen una superficie enorme (alrededor de $100 \mathrm{~m}^{2}$ en los humanos). Además, la barrera de difusión es sumamente pequeña, sólo dos delgadas capas de células y una distancia de micras entre el aire alveolar y la circulación sanguínea sistémica. Ello hace que los pulmones sean un órgano muy eficiente para el intercambio no sólo de oxígeno y dióxido de carbono, sino también de otros gases y vapores. En general, la difusión por la pared alveolar es tan rápida que no limita la captación. La velocidad de absorción, sin embargo, depende más del flujo (ventilación pulmonar, gasto cardíaco) y de la 
solubilidad (coeficiente de reparto sangre/aire). Otro factor importante es la eliminación metabólica. La importancia relativa de estos factores en la absorción pulmonar varía mucho según la sustancia de que se trate. La actividad física tiene como consecuencia un aumento de la ventilación pulmonar y del gasto cardíaco, y un descenso del riego sanguíneo en el hígado (y por ende de la velocidad de biotransformación). En el caso de muchas sustancias inhaladas ello hace que aumente notablemente la absorción pulmonar.

Absorción percutánea. La piel es una barrera muy eficiente. Aparte de su función termorreguladora, protege al organismo de los microorganismos, la radiación ultravioleta y otros agentes nocivos, y también de la pérdida de agua excesiva. La distancia de difusión en la dermis es del orden de décimas de milímetro. Además, la capa de queratina opone mucha resistencia a la difusión de la mayoría de las sustancias. No obstante, en el caso de algunas sustancias suele producirse una absorción dérmica significativa con resultado de toxicidad - sustancias liposolubles muy tóxicas como por ejemplo los insecticidas organofosforados y los disolventes orgánicos. Lo más frecuente es que esa absorción significativa se produzca como consecuencia de la exposición a sustancias líquidas. La absorción percutánea de vapores puede ser importante en el caso de los disolventes con presión de vapor muy baja y gran afinidad por el agua y la piel.

Absorción gastrointestinal. Se produce tras la ingestión accidental o deliberada de las sustancias. A veces se tragan partículas de mayor tamaño originalmente inhaladas y depositadas en el tracto respiratorio, de donde llegan a la faringe por transporte mucociliar. Prácticamente todas las sustancias solubles se absorben de manera eficiente desde el tracto grastrointestinal. El bajo $\mathrm{pH}$ del intestino puede facilitar por ejemplo la absorción de los metales.

Otras rutas. En los ensayos de toxicidad y otros experimentos pueden utilizarse, por razones de comodidad, rutas de administración especiales que son muy poco frecuentes y por lo general no se dan en la exposición profesional. Entre esas rutas figuran las inyecciones intravenosas (IV), subcutáneas (sc), intraperitoneales (ip) e intramusculares (im). En general, las sustancias se absorben más deprisa y de manera más completa por esas rutas, especialmente por la inyección IV. Ello hace que se produzcan breves pero importantes picos de concentración que pueden incrementar la toxicidad de una dosis.

\section{Distribución}

La distribución de una sustancia dentro del organismo es un proceso dinámico que depende de las velocidades de absorción y eliminación, así como del flujo sanguíneo en los diferentes tejidos y de las afinidades de éstos por la sustancia. Las moléculas hidrosolubles pequeñas no cargadas, los cationes monovalentes y la mayoría de los aniones se difunden con facilidad y acaban por conseguir una distribución relativamente uniforme por todo el cuerpo.

El volumen de distribución es la cantidad de una sustancia que hay en el cuerpo en un momento determinado dividida por la concentración en la sangre, el plasma o el suero en ese momento. Este valor no tiene nada que ver con el volumen físico, pues muchas sustancias no se distribuyen de manera uniforme por el organismo. Un volumen de distribución inferior a $1 \mathrm{l} / \mathrm{kg}$ de peso corporal indica una distribución preferencial en la sangre (o en el suero o en el plasma), mientras que los valores superiores a 1 indican una preferencia por los tejidos periféricos, como el tejido adiposo en el caso de las sustancias liposolubles.

La acumulación es la retención de una sustancia en un tejido o en un órgano a unos niveles superiores a los de su concentración en la sangre o el plasma. Puede tratarse también de una acumulación gradual en el organismo a lo largo del tiempo. Muchos xenobióticos son muy liposolubles y tienden a acumularse en el tejido adiposo, mientras que otros tienen una especial afinidad por el hueso. En el hueso, por ejemplo, el calcio puede intercambiarse por cationes de plomo, estroncio, bario y radio, mientras que los grupos hidroxilo pueden intercambiarse por flúor.

Barreras. Los vasos sanguíneos del cerebro, los testículos y la placenta tienen unas características anatómicas especiales que inhiben el paso de las moléculas grandes, como las proteínas. Esas características, que suelen denominarse barreras hematoencefálica, hematotesticular y hematoplacentaria, pueden dar la falsa impresión de que impiden el paso de cualquier sustancia, pero la realidad es que tienen poca o ninguna importancia en el caso de los xenobióticos capaces de atravesar por difusión las membranas celulares.

Unión a la sangre. Las sustancias pueden unirse a los glóbulos rojos o a componentes del plasma, o pueden estar también en forma libre en la sangre. El monóxido de carbono, el arsénico, el mercurio orgánico y el cromo hexavalente tienen una gran afinidad por los glóbulos rojos, mientras que el mercurio inorgánico y el cromo trivalente prefieren las proteínas plasmáticas. Hay otras sustancias que también se unen a las proteínas del plasma. Sólo la fracción libre puede llegar por filtración o difusión a los órganos de eliminación. Por consiguiente, la unión a la sangre puede incrementar el tiempo de retención de una sustancia en el organismo y sin embargo reducir su captación por los órganos diana.

\section{Eliminación}

La eliminación es la desaparición de una sustancia del cuerpo. Puede consistir en su excreción al exterior del organismo o en su transformación en otras sustancias que no son captadas por un determinado método de medición. La velocidad de desaparición puede expresarse mediante la constante de eliminación, la vida media biológica o el aclaramiento.

Curva de concentración-tiempo. La curva de concentración en sangre (o plasma) en relación con el tiempo es una forma cómoda de describir la captación de un xenobiótico por el organismo y su desaparición de él.

$\mathrm{El}$ área bajo la curva $(\mathrm{ABC})$ es la integral de la concentración en la sangre (plasma) a lo largo del tiempo. Cuando no hay saturación metabólica u otros procesos no lineales, la $\mathrm{ABC}$ es proporcional a la cantidad de sustancia absorbida.

La vida media biológica (o vida media) es el tiempo que se necesita, a partir del momento en que cesa la exposición, para reducir a la mitad la cantidad presente en el organismo. Como muchas veces es difícil valorar la cantidad total de una sustancia, se emplean métodos de medición como la concentración en sangre (plasma). El concepto de vida media debe utilizarse con prudencia, ya que ésta puede modificarse, por ejemplo, con la dosis y la duración de la exposición. Además, muchas sustancias poseen complejas curvas de declinación, con varias vidas medias.

La biodisponibilidad es la fracción de una dosis administrada que entra en la circulación sistémica. Cuando no hay aclaramiento presistémico, o metabolismo de primer paso, la fracción es 1 . En la exposición oral, el aclaramiento presistémico puede deberse al metabolismo en el contenido gastrointestinal, las paredes intestinales o el hígado. El metabolismo de primer paso reduce la absorción sistémica de la sustancia y en cambio incrementa la absorción de sus metabolitos. Ello puede hacer que se modifique el cuadro de toxicidad.

El aclaramiento es el volumen de sangre (plasma) por unidad de tiempo del que se ha eliminado por completo una sustancia. 
Para distinguirlo del aclaramiento renal, se suele hablar por ejemplo de aclaramiento total, metabólico o sanguíneo (plasmático).

El aclaramiento intrínseco es la capacidad que poseen las enzimas endógenas de transformar una sustancia, y se expresa también en volumen por unidad de tiempo. Si el aclaramiento intrínseco de un órgano es muy inferior al flujo sanguíneo, se dice que el metabolismo está limitado por la capacidad. A la inversa, si el aclaramiento intrínseco es muy superior al flujo sanguíneo, se dice que el metabolismo está limitado por el flujo.

\section{Excreción}

La excreción es la salida del organismo de una sustancia y de sus productos de biotransformación.

Excreción en la orina y la bilis. El principal órgano excretor es el riñón. Algunas sustancias, especialmente los ácidos de alto peso molecular, se excretan con la bilis. Una fracción de las sustancias biliares excretadas puede reabsorberse en el intestino. Este proceso, denominadocirculación enterohepática, es habitual en las sustancias conjugadas tras la hidrólisis intestinal del conjugado.

Otras rutas de excreción. Algunas sustancias, como los disolventes orgánicos y productos de descomposición como la acetona, son lo suficientemente volátiles para que una fracción considerable pueda excretarse en el aire espirado después de la inhalación. Pequeñas moléculas hidrosolubles y también liposolubles se segregan fácilmente al feto a través de la placenta y a la leche en los mamíferos. Para la madre, la lactancia puede ser una ruta excretora cuantitativamente importante en el caso de sustancias liposolubles persistentes. Los hijos pueden estar expuestos secundariamente a través de la madre durante el embarazo y durante la lactancia. Los compuestos hidrosolubles pueden excretarse hasta cierto punto en el sudor y la saliva, pero estas rutas son en general de escasa importancia. No obstante, como se produce y se traga un gran volumen de saliva, la excreción por esta vía puede contribuir a la reabsorción del compuesto. Algunos metales como el mercurio se excretan uniéndose de manera permanente a los grupos sulfhidrilo de la queratina presente en el pelo.

\section{Modelos toxicocinéticos}

Los modelos matemáticos son instrumentos importantes para entender y describir la captación y disposición de sustancias extrañas. Estos modelos son en su mayoría compartimentales, es decir, representan al organismo dividido en uno o más compartimentos. Un compartimento es un volumen química y físicamente teórico en el que se supone que la sustancia se distribuye de manera homogénea e instantánea. Los modelos sencillos pueden expresarse como una suma de términos exponenciales, mientras que los más complicados exigen efectuar procedimientos numéricos en ordenador para resolverlos. Los modelos pueden subdividirse en dos categorías: descriptivos y fisiológicos.

En los modelos descriptivos, el ajuste a los datos medidos se realiza modificando los valores numéricos de los parámetros del modelo o incluso la propia estructura de éste. La estructura del modelo normalmente tiene poco que ver con la estructura del organismo. Las ventajas del enfoque descriptivo son que se realizan pocos supuestos y que no se necesitan datos adicionales. Un inconveniente es que no son demasiado útiles para efectuar extrapolaciones.

Los modelos fisiológicos se construyen a partir de datos fisiológicos y anatómicos y otros datos independientes. Después el modelo se depura y se valida mediante su comparación con datos experimentales. Una ventaja de los modelos fisiológicos es que pueden utilizarse para realizar extrapolaciones. Por ejemplo, puede predecirse la influencia de la actividad física en la captación y disposición de sustancias inhaladas a partir de ajustes fisiológicos conocidos de la ventilación y el gasto cardíaco. Un inconveniente es que requieren una gran cantidad de datos independientes.

\section{Biotransformación}

La biotransformación es un proceso que lleva a una conversión metabólica de los compuestos extraños (xenobióticos) presentes en el organismo. Suele denominarse también metabolismo de xenobióticos. Por regla general, el metabolismo convierte los xenobióticos liposolubles en grandes metabolitos hidrosolubles que pueden excretarse con facilidad.

La biotransformación se realiza principalmente en el hígado. Todos los xenobióticos captados en el intestino son transportados al hígado por un único vaso sanguíneo (la vena porta). Cuando se capta en pequeñas cantidades, una sustancia extraña puede metabolizarse completamente en el hígado antes de llegar a la circulación general y a otros órganos (efecto de primer paso). Los xenobióticos inhalados se distribuyen por la circulación general hasta llegar al hígado. En ese caso sólo se metaboliza en el hígado una fracción de la dosis antes de llegar a otros órganos.

Las células hepáticas contienen diversas enzimas que oxidan los xenobióticos. Por lo general, esa oxidación activa el compuesto - lo hace más reactivo que la molécula precursora. En la mayoría de los casos, el metabolito oxidado vuelve a ser metabolizado por otras enzimas en una segunda fase. Esas enzimas conjugan el metabolito con un sustrato endógeno, de manera que la molécula se hace más grande y más polar, lo cual facilita la excreción.

También en otros órganos como el pulmón y el riñón hay enzimas que metabolizan los xenobióticos. En esos órganos pueden desempeñar funciones específicas y cualitativamente importantes en el metabolismo de determinados xenobióticos. A veces metabolitos formados en un órgano se metabolizan aún más en otro. También pueden participar en la biotransformación las bacterias intestinales.

Los metabolitos de xenobióticos pueden excretarse por los riñones o a través de la bilis. Pueden exhalarse también a través de los pulmones, o unirse a moléculas endógenas del organismo.

Entre biotransformación y toxicidad hay una relación compleja. Puede entenderse la biotransformación como un proceso necesario para la supervivencia. Protege al organismo de la toxicidad impidiendo que se acumulen en él sustancias nocivas. Sin embargo, en ese proceso pueden formarse, como productos intermedios, metabolitos reactivos que son potencialmente nocivos. Este fenómeno se denomina activación metabólica. De esta manera, la biotransformación puede también inducir toxicidad. Metabolitos intermedios oxidados que no se conjugan pueden unirse a estructuras celulares y dañarlas. Cuando por ejemplo un metabolito de xenobiótico se une al ADN puede inducirse una mutación (véase "Toxicología genética"). Si el sistema de biotransformación está sobrecargado, puede producirse una destrucción masiva de proteínas esenciales o de membranas lipídicas. Y ello puede desembocar en muerte celular (véase "Lesión celular y muerte celular").

Metabolismo es una palabra que suele utilizarse indistintamente con biotransformación. Indica las reacciones químicas de descomposición o síntesis que se producen en el cuerpo gracias a la acción catalizadora de las enzimas. En el organismo se metabolizan los nutrientes procedentes de los alimentos, los compuestos endógenos y los xenobióticos.

Se habla de activación metabólica cuando un compuesto menos reactivo se convierte en una molécula más reactiva. Este fenómeno se da generalmente durante las reacciones de la Fase 1. 
Se habla de desactivación metabólica cuando una molécula activa o tóxica se convierte en un metabolito menos activo. Este fenómeno se da generalmente durante las reacciones de la Fase 2. En algunos casos un metabolito desactivado puede reactivarse, por ejemplo mediante escisión enzimática.

Las reacciones de la Fase 1 son el primer paso en el metabolismo de los xenobióticos. Suelen consistir en la oxidación del compuesto. Por lo general, la oxidación hace que el compuesto sea más hidrosoluble y facilita las reacciones ulteriores.

Las enzimas citocromo P450 son un grupo de enzimas que oxidan preferentemente los xenobióticos en reacciones de la Fase 1. Estas enzimas están especializadas en hacer frente a determinados grupos de xenobióticos que poseen determinadas características. También utilizan como sustratos moléculas endógenas. Las enzimas citocromo P450 son inducidas por los xenobióticos de una manera específica. La obtención de datos sobre la inducción del citocromo $\mathrm{P} 450$ puede proporcionar información de la naturaleza de exposiciones anteriores (véase "Determinantes genéticos de la respuesta tóxica").

Por reacciones de la Fase 2 se entiende el segundo paso del metabolismo de los xenobióticos. Suelen consistir en que el compuesto oxidado se conjuga con una molécula endógena, es decir, se acopla a ella. Esta reacción incrementa aún más su hidrosolubilidad. Muchos metabolitos conjugados se excretan activamente en el riñón.

Las transferasas son un grupo de enzimas que catalizan reacciones de la Fase 2. Conjugan los xenobióticos con compuestos endógenos como el glutatión, aminoácidos, el ácido glucurónico o sulfatos.

El glutatión es una molécula endógena, un tripéptido, que se conjuga con xenobióticos en reacciones de la Fase 2. Está presente en todas las células (y en altas concentraciones en las células hepáticas) y suele ofrecer protección contra xenobióticos activados. Cuando el glutatión se agota pueden producirse reacciones tóxicas entre metabolitos xenobióticos activados y proteínas, lípidos o ADN.

Se habla de inducción cuando enzimas que participan en la biotransformación intensifican su actividad o aumentan en cantidad como respuesta a la exposición a xenobióticos. En algunos casos, al término de unos pocos días la actividad enzimática puede haberse multiplicado varias veces. La inducción suele estar equilibrada, de manera que las reacciones de la Fase 1 y de la Fase 2 se incrementan simultáneamente. Ello puede llevar a una biotransformación más rápida y puede explicar la tolerancia. A la inversa, una inducción desequilibrada puede aumentar la toxicidad.

Puede haber una inhibición de la biotransformación cuando dos xenobióticos son metabolizados por la misma enzima. Los dos sustratos tienen que competir entre sí, y por lo general uno de ellos es el elegido. En ese caso el segundo sustrato no se metaboliza, o sólo se metaboliza lentamente. Como en el caso de la inducción, la inhibición puede incrementar o reducir la toxicidad.

La activación del oxígeno es un fenómeno que pueden desencadenar los metabolitos de determinados xenobióticos. Pueden autooxidarse bajo la producción de especies de oxígeno activado. Esas especies derivadas del oxígeno, entre las que figuran el superóxido, el peróxido de hidrógeno y el radical hidroxilo, pueden dañar el ADN y lípidos y proteínas de las células. La activación del oxígeno interviene también en los procesos inflamatorios.

Se observa una variabilidad genética entre individuos en muchos genes que codifican enzimas de la Fase 1 y la Fase 2. La variabilidad genética puede explicar por qué determinados individuos son más susceptibles que otros a los efectos tóxicos de los xenobióticos.

\section{TOXICOCINETICA}

Dušan Djuric

El organismo humano es un complejo sistema biológico que está organizado en diversos niveles, desde el molecular-celular hasta el de los tejidos y órganos. Es un sistema abierto, que intercambia materia y energía con su medio ambiente a través de numerosas reacciones bioquímicas que están en equilibrio dinámico. El medio ambiente puede estar contaminado por diversos tóxicos.

Cuando moléculas o iones tóxicos penetran en ese sistema férreamente coordinado desde el medio en que un individuo trabaja o vive pueden verse perturbados, reversible o irreversiblemente, los procesos bioquímicos normales de la célula, o incluso producirse lesiones y muerte de la célula (véase "Lesión celular y muerte celular").

El proceso de penetración de un tóxico desde el medio ambiente hasta los lugares en que va a producir su efecto tóxico dentro del organismo puede dividirse en tres fases:

1. La fase de exposición, que comprende todos los procesos que se producen entre diversos tóxicos y/o la influencia que tienen sobre ellos los factores ambientales (luz, temperatura, humedad, etc.). Los tóxicos pueden sufrir transformaciones químicas, degradación, biodegradación (por microorganismos) y desintegración.

2. La fase toxicocinética, que comprende la absorción de los tóxicos en el organismo y todos los procesos subsiguientes:transporte por los fluidos corporales, distribución y acumulación en tejidos y órganos, biotransformación en metabolitos y eliminación del organismo (excreción) de los tóxicos y/o metabolitos.

3. La fase toxicodinámica, que se refiere a la interacción de los tóxicos (moléculas, iones, coloides) con lugares de acción específicos en las células o dentro de ellas - receptores-, con el resultado último de un efecto tóxico.

En esta sección nos ocuparemos exclusivamente de los procesos toxicocinéticos que se producen en el interior del organismo humano tras la exposición a tóxicos presentes en el medio ambiente.

Las moléculas o iones tóxicos presentes en el medio ambiente penetran en el organismo a través de la piel y las mucosas o a través de las células epiteliales del tracto respiratorio y el tracto gastrointestinal, según cuál sea el punto de entrada. Esto significa que las moléculas y los iones tóxicos han de atravesar membranas celulares de esos sistemas biológicos, así como un complejo sistema de membranas interiores de la célula.

Todos los procesos toxicocinéticos y toxicodinámicos se producen en el nivel molecular-celular. Son muchos los factores que influyen en esos procesos, y que cabe dividir en dos grupos básicos:

- La constitución química y las propiedades fisicoquímicas de los tóxicos.

- La estructura de la célula, especialmente las propiedades y función de las membranas que rodean la célula y sus orgánulos interiores.

\section{Propiedades fisicoquímicas de los tóxicos}

In 1854 el toxicólogo ruso E.V. Pelikan empezó a estudiar la relación existente entre la estructura química de una sustancia y su actividad biológica, es decir, la relación estructura-actividad. La estructura química determina directamente las propiedades fisicoquímicas, algunas de las cuales son responsables de la actividad biológica. 
A la hora de definir la estructura química se pueden utilizar como descriptores numerosos parámetros, que cabe dividir en varios grupos:

\section{Fisicoquímicos:}

- Generales: punto de fusión, punto de ebullición, presión de vapor, constante de disociación $(\mathrm{pK} a)$, coeficiente de partición de Nernst $(\mathrm{P})$, energía de activación, calor de reacción, potencial de reducción, etc.

- Eléctricos: potencial de ionización, constante dieléctrica, momento dipolar, coeficiente masa/carga, etc.

- Quimicocuánticos: carga atómica, energía de enlace, energía de resonancia, densidad electrónica, reactividad molecular, etc.

2. Estéricos: volumen, forma y superficie de la molécula, forma de la subestructura, reactividad molecular, etc.

3. Estructurales: número de enlaces, número de anillos (en compuestos policíclicos), grado de ramificación, etc.

En el caso de cada tóxico es necesario seleccionar una serie de descriptores relacionados con un determinado mecanismo de actividad. No obstante, desde el punto de vista toxicocinético hay dos parámetros que son de importancia general para todos los tóxicos:

- El coeficiente de partición de Nernst (P), que establece la solubilidad de las moléculas tóxicas en el sistema bifásico octanol (aceite)-agua, la cual está en correlación con su lipo o hidrosolubilidad. Este parámetro influye considerablemente en la distribución y acumulación de las moléculas tóxicas en el organismo.

- La constante de disociación $\left(\mathrm{pK}_{a}\right)$, que define el grado de ionización (disociación electrolítica) de las moléculas de un tóxico en cationes y aniones a un determinado $\mathrm{pH}$. Esta constante representa el pH al que se consigue una ionización del $50 \%$. Las moléculas pueden ser lipófilas o hidrófilas, pero los iones son solubles exclusivamente en el agua de los fluidos y tejidos corporales. Conociendo el $\mathrm{pK}_{a}$ se puede calcular, mediante la ecuación de Henderson-Hasselbach, el grado de ionización de una sustancia para cada $\mathrm{pH}$.

En el caso de los polvos y aerosoles inhalados influyen también en su toxicocinética y toxicodinámica el tamaño, la forma, la superficie y la densidad de las partículas.

\section{Estructura y propiedades de las membranas}

La célula eucariótica de los organismos humanos y animales está rodeada por una membrana citoplasmática que regula el transporte de sustancias y mantiene la homeostasis celular. También poseen membranas los orgánulos de la célula (núcleo, mitocondrias). El citoplasma celular está compartimentado por intrincadas estructuras membranosas, el retículo endoplásmico y el aparato de Golgi (endomembranas). Todas estas membranas son similares desde el punto de vista estructural, pero varían en su contenido de lípidos y proteínas.

El marco estructural de las membranas es una capa doble o bicapa de moléculas de lípidos (fosfolípidos, esfingolípidos, colesterol). El elemento fundamental de una molécula de fosfolípido es el glicerol, con dos de sus grupos $-\mathrm{OH}$ esterificados por ácidos grasos alifáticos de 16-18 átomos de carbono, y el tercer grupo esterificado por un grupo fosfato y un compuesto nitrogenado (colina, etanolamina, serina). En los esfingolípidos, la base es la esfingosina.

La molécula de lípidos es anfipática porque consta de una "cabeza" hidrófila polar (aminoalcohol, fosfato, glicerol) y una "cola" formada por dos líneas gemelas que es apolar (ácidos grasos). La bicapa lipídica está organizada de tal manera que las cabezas hidrófilas constituyen la superficie exterior e interior de la membrana, mientras que las colas lipófilas se extienden hacia el interior de la membrana, que contiene agua, diversos iones y moléculas.

Las proteínas y glicoproteínas se insertan en la bicapa lípidica (proteínas intrínsecas) o se unen a la superficie de la membrana (proteínas extrínsecas). Estas proteínas contribuyen a la integridad estructural de la membrana, pero pueden funcionar también como enzimas, transportadores, paredes porosas o receptores.

La membrana es una estructura dinámica que puede desintegrarse y reconstruirse con otra proporción distinta de lípidos y proteínas, según sus necesidades funcionales.

La regulación de la entrada y salida de sustancias en la célula es una de las funciones básicas de las membranas exterior e interiores. Algunas moléculas lipófilas pasan directamente a través de la bicapa lipídica. El transporte de las moléculas e iones hidrófilos se efectúa a través de los poros. Las membranas responden a los cambios de condiciones abriendo o cerrando determinados poros de diversos tamaños

En el transporte de sustancias, incluidas las tóxicas, a través de la membrana intervienen los procesos y mecanismos siguientes:

- Difusión a través de la bicapa lipídica.

- Difusión a través de los poros.

- Transporte por un transportador (difusión facilitada).

Procesos activos:

- Transporte activo por un transportador.

- Endocitosis (pinocitosis).

\section{Difusión}

Es el movimiento de moléculas e iones a través de la bicapa lipídica o de poros desde una zona de alta concentración, o de alto potencial eléctrico, a otra de escasa concentración o potencial ("a favor de corriente"). La diferencia de concentración o de carga eléctrica es la fuerza impulsora que influye en la intensidad del flujo en ambas direcciones. En el estado de equilibrio, las entradas serán iguales a las salidas. La velocidad de difusión obedece a la ley de Fick, que dice que es directamente proporcional a la superficie de membrana disponible, a la diferencia en el gradiente de concentración (carga) y al coeficiente de difusión característico, e inversamente proporcional al grosor de la membrana.

Las moléculas lipófilas pequeñas atraviesan fácilmente la capa de lípidos de la membrana, según el coeficiente de partición de Nernst.

Las moléculas lipófilas grandes, las moléculas hidrosolubles y los iones utilizan para atravesar la membrana los canales acuosos de los poros. En el caso de las moléculas influyen su tamaño y su configuración espacial. En el caso de los iones, además del tamaño es decisivo el tipo de carga. Las moléculas proteicas de las paredes de los poros pueden cargarse positiva o negativamente. Los poros estrechos tienden a ser selectivos - los ligandos con carga negativa permiten pasar sólo a los cationes, y los que tienen carga positiva sólo a los aniones. Cuando el diámetro del poro es mayor el factor dominante es el flujo hidrodinámico, que permite pasar a iones y moléculas según la ley de Poiseuille. Esta filtración es una consecuencia del gradiente osmótico. En algunos casos los iones pueden entrar mediante determinadas moléculas complejas - ionóforas - que pueden ser producidas por microorganismos de efecto antibiótico (nonactina, valinomicina, gramacidina, etc.). 


\section{Difusión facilitada o catalizada}

Para este proceso es necesario que haya en la membrana un transportador, por lo general una molécula proteica (permeasa). El transportador se une selectivamente a determinadas sustancias, en una especie de conjunto sustrato-enzima. Otras moléculas similares (incluidas las tóxicas) pueden competir por el transportador específico hasta que se alcanza el punto de saturación. Los tóxicos pueden competir por el transportador, y cuando se unen a él de manera irreversible el transporte se bloquea. Cada tipo de transportador presenta una velocidad de transporte característica. Cuando el transporte se efectúa en ambas direcciones se habla de intercambio por difusión.

\section{Transporte activo}

En el transporte de algunas sustancias que son vitales para las células se utiliza un tipo especial de transportador, que es capaz de realizar su función en contra del gradiente de concentración o de potencial eléctrico ("contra corriente"). Este transportador es muy estereoespecífico y puede saturarse.

Para este tipo de transporte "contra corriente" se requiere energía. La energía necesaria se obtiene mediante la escisión (hidrólisis) catalítica de moléculas de ATP a ADP por la enzima adenosin trifosfatasa (ATP-asa)

Los tóxicos pueden interferir ese transporte inhibiendo de manera competitiva o no competitiva el transportador o también inhibiendo la actividad de la ATP-asa.

\section{Endocitosis}

La endocitosis se define como un mecanismo de transporte en el que la membrana celular rodea material invaginándose para formar una vesícula que lo transporta por la célula. Cuando el material es líquido, el proceso se denomina pinocitosis. En algunos casos el material está unido a un receptor, y el conjunto es transportado por una vesícula de la membrana. Este tipo de transporte lo utilizan especialmente las células epiteliales del tracto gastrointestinal, así como las células del hígado y el riñón.

\section{Absorción de tóxicos}

Las personas se hallan expuestas a numerosos tóxicos que están presentes en el medio ambiente profesional o general, y que pueden penetrar en el organismo humano por tres vías de entrada principales:

- A través del tracto respiratorio, por inhalación de aire contaminado.

- A través del tracto gastrointestinal, por ingestión de comida y bebida contaminadas.

- A través de la piel, por penetración dérmica, también llamada percutánea.

En el caso de la exposición en la industria, la principal vía de entrada de tóxicos es la inhalación, seguida por la penetración percutánea. En la agricultura, los casos de exposición a plaguicidas por absorción a través de la piel equivalen prácticamente a los casos en que se combinan la inhalación y la penetración percutánea. En la población general, la exposición se produce sobre todo por ingestión de comida y bebida contaminadas, seguida de la inhalación y, con menos frecuencia, de la penetración percutánea.

\section{Absorción por el tracto respiratorio}

La absorción en los pulmones es la principal vía de entrada de numerosos tóxicos que están en suspensión en el aire (gases, vapores, humos, nieblas, polvos, aerosoles, etc.).

El tracto respiratorio (TR) es un sistema ideal para el intercambio de gases, pues posee una membrana cuya superficie es de $30 \mathrm{~m}^{2}$ (espiración) a $100 \mathrm{~m}^{2}$ (inspiración profunda), tras la cual hay una red de unos $2.000 \mathrm{~km}$ de capilares. Este sistema, que se ha ido desarrollando a lo largo de la evolución, está contenido en un espacio relativamente pequeño (la cavidad torácica) y cuenta con la protección de las costillas.

Desde el punto de vista anatómico y fisiológico, el TR puede dividirse en tres compartimientos:

- La parte superior o compartimiento nasofaríngeo (NF), que se inicia en los orificios de la nariz y se extiende hasta la faringe y la laringe; funciona como un sistema de acondicionamiento del aire

- El árbol traqueobronquial (TB), integrado por numerosos tubos de diversos tamaños que llevan el aire a los pulmones.

- El compartimiento pulmonar $(\mathrm{P})$, que consta de millones de alveolos (sacos de aire) dispuestos en formas arracimadas.

El epitelio de la región nasofaríngea absorbe fácilmente los tóxicos hidrófilos. Todo el epitelio de las regiones NF y TB está recubierto por una película de agua. Los tóxicos lipófilos se absorben parcialmente en las regiones NF y TB, pero sobre todo en los alveolos mediante su difusión por las membranas alveolocapilares. La velocidad de absorción depende de la ventilación pulmonar, el gasto cardíaco (flujo sanguíneo por los pulmones), la solubilidad del tóxico en la sangre y su velocidad de metabolización.

El intercambio de gases se realiza en los alveolos. La pared alveolar consta de un epitelio, un armazón intersticial de membrana basal, tejido conectivo y el endotelio capilar. La difusión de los tóxicos es muy rápida por estas capas, que tienen alrededor de $0,8 \mu \mathrm{m}$ de grosor. En los alveolos, el tóxico pasa de la fase área a la fase líquida (sangre). La velocidad de absorción (distribución aire/sangre) de un tóxico depende de su concentración en el aire alveolar y del coeficiente de partición de Nernst de la sangre (coeficiente de solubilidad).

En la sangre, el tóxico puede disolverse en la fase líquida por simples procesos físicos o puede unirse a las células sanguíneas y/o los componentes del plasma en función de su afinidad química o por adsorción. La sangre contiene un $75 \%$ de agua, y por eso los gases y vapores hidrófilos son muy solubles en el plasma (por ejemplo los alcoholes). Los tóxicos lipófilos (como el benceno) suelen unirse a células o macromoléculas como la albúmina.

En el momento mismo en que se inicia la exposición pulmonar se producen dos procesos contrarios: absorción y desorción. El equilibrio entre ambos depende de la concentración de tóxico en el aire alveolar y en la sangre. Al comienzo de la exposición la concentración de tóxico en la sangre es 0 , y la retención en la sangre casi del $100 \%$. Al proseguir la exposición, se alcanza un equilibrio entre absorción y desorción. Los tóxicos hidrófilos alcanzan rápidamente ese equilibrio, y la velocidad de absorción depende más de la ventilación pulmonar que del flujo sanguíneo. Los tóxicos lipófilos necesitan más tiempo para llegar al equilibrio, y por eso la velocidad de absorción está determinada por el flujo de sangre no saturada.

El depósito de partículas y aerosoles en el TR depende de factores físicos y fisiológicos, así como del tamaño de las partículas. En resumen, cuanto más pequeña es la partícula tanto más dentro del TR llega en su penetración.

La retención baja y relativamente constante de partículas de polvo en el pulmón de personas muy expuestas (como los mineros) sugiere la existencia de un sistema muy eficaz de eliminación de las partículas. En la parte superior del TR (traqueobronquial), la eliminación corre a cargo de un manto mucociliar. En la parte pulmonar funcionan tres mecanismos distintos: 1) manto mucociliar, 2) fagocitosis y 3) penetración directa de las partículas a través de la pared alveolar. 
Las primeras 17 de las 23 ramas del árbol traqueobronquial poseen células epiteliales ciliadas. Merced a sus impulsos, esos cilios están moviendo constantemente un manto mucoso hacia la boca. Las partículas depositadas en ese manto mucociliar se tragan en la boca (ingestión). La superficie del epitelio alveolar también está recubierta de un manto mucoso, que se mueve hacia el manto mucociliar. A ello hay que añadir que las células móviles especializadas — los fagocitos - engloban partículas y microorganismos en los alveolos y migran en dos posibles direcciones:

- Hacia el manto mucociliar, que los transporta hasta la boca.

- Por los espacios intercelulares de la pared alveolar hasta llegar al sistema linfático del pulmón; las partículas también pueden penetrar directamente por esta vía.

\section{Absorción por el tracto gastrointestinal}

Se pueden ingerir tóxicos mediante deglución accidental, consumo de alimentos y bebidas contaminados o deglución de partículas procedentes del TR.

Todo el canal digestivo, desde el esófago hasta el ano, está construido básicamente de la misma manera: una capa mucosa (epitelio) bajo la cual hay tejido conectivo y después una red de capilares y músculo liso. El epitelio externo del estómago es muy rugoso para incrementar la superficie de absorción/secreción. El intestino contiene gran cantidad de pequeños salientes (vellosidades), que absorben los materiales por "bombeo". La superficie activa de absorción en el intestino es de unos $100 \mathrm{~m}^{2}$.

En el tracto gastrointestinal (TGI) todos los procesos de absorción presentan gran actividad:

- transporte transcelular por difusión a través de la capa lipídica y/o los poros de las membranas celulares, así como filtración por los poros

- difusión paracelular a través de las zonas de contacto entre unas células y otras

- difusión facilitada y transporte activo

- endocitosis y mecanismo de bombeo de las vellosidades.

Algunos iones metálicos tóxicos utilizan sistemas de transporte especializados para elementos esenciales: el talio, el cobalto y el manganeso utilizan el sistema del hierro, mientras que el plomo parece que utiliza el sistema del calcio.

Son muchos los factores que influyen en la velocidad de absorción de tóxicos en las diversas partes del TGI:

- Las propiedades fisicoquímicas de los tóxicos, especialmente el coeficiente de partición de Nernst y la constante de disociación; en el caso de las partículas es importante su tamaño - a menor tamaño, mayor solubilidad.

- La cantidad de alimentos presente en el TGI (efecto de dilución).

- El tiempo de permanencia en cada parte del TGI (desde unos minutos en la boca hasta una hora en el estómago y muchas horas en el intestino).

- La superficie de absorción y la capacidad de absorción del epitelio.

- El pH local, que rige la absorción de tóxicos disociados; en el $\mathrm{pH}$ ácido del estómago se absorben con más rapidez los compuestos ácidos no disociados.

- El peristaltismo (movimiento intestinal por acción de los músculos) y el flujo sanguíneo local.

- Las secreciones gástricas e intestinales, que transforman los tóxicos en productos más o menos solubles; la bilis es un agente emulsionante que produce complejos más solubles (hidrotropía)
- La exposición combinada a otros tóxicos, que puede producir efectos de sinergia o de antagonismo en los procesos de absorción.

- La presencia de agentes complejantes/quelantes.

- La acción de la microflora del TGI (alrededor de 1,5 kg), unas 60 especies distintas de bacterias que pueden biotransformar los tóxicos.

Es necesario mencionar también la circulación enterohepática. Los tóxicos y/o metabolitos polares (glucurónidos y otros conjugados) se excretan con la bilis al duodeno. Allí las enzimas de la microflora los hidrolizan, y los productos liberados pueden reabsorberse y llegar al hígado por la vena porta. Este mecanismo es muy peligroso en el caso de las sustancias hepatotóxicas, pues permite su acumulación temporal en el hígado.

En el caso de los tóxicos que se biotransforman en el hígado en metabolitos menos tóxicos o no tóxicos, la ingestión puede ser una vía de entrada menos peligrosa. Tras ser absorbidas en el TGI, las sustancias son transportadas por la vena porta hasta el hígado, donde pueden detoxificarse parcialmente por biotransformación.

\section{Absorción por la piel (dérmica o percutánea)}

La piel (con una superficie de $1,8 \mathrm{~m}^{2}$ en una persona adulta) recubre la superficie del cuerpo junto con las membranas mucosas de los orificios corporales. Es una barrera contra los agentes físicos, químicos y biológicos, manteniendo la integridad y homeostasis del cuerpo y realizando muchas otras funciones fisiológicas.

La piel consta básicamente de tres capas: la epidermis, la piel propiamente dicha (dermis) y el tejido subcutáneo (hipodermis). Desde el punto de vista toxicológico la que más nos interesa aquí es la epidermis. Está constituida por muchas capas de células. La capa superior es una superficie irregular de células muertas aplanadas (estrato córneo), bajo la cual hay una capa continua de células vivas (estrato córneo compacto) seguida de una típica membrana lipídica y después por los estratos lúcido, granuloso y mucoso. La membrana lipídica es una barrera protectora, pero en las partes velludas de la piel penetran por ella tanto los folículos pilosos como los canales de las glándulas sudoríparas. Así pues, la absorción por la piel puede producirse por cualquiera de los mecanismos siguientes:

- Absorción transepidérmica por difusión a través de la membrana (barrera) lipídica, sobre todo de sustancias lipófilas (disolventes orgánicos, plaguicidas, etc.) y en pequeña medida de algunas sustancias hidrófilas a través de los poros.

- Absorción transfolicular alrededor del tallo del pelo hasta penetrar en el folículo piloso, evitando así la barrera de la membrana; esta absorción se produce únicamente en las zonas de la piel que tienen vello.

- Absorción a través de los conductos de las glándulas sudoríparas, que tienen una sección transversal de entre el 0,1 y el $1 \%$ aproximadamente de la superficie total de piel (la absorción relativa presenta esa misma proporción).

- Absorción a través de la piel cuando ésta sufre lesiones mecánicas, térmicas o químicas o por enfermedades cutáneas; en esos casos se produce una horadación de las capas de la piel, incluida la barrera lipídica, lo que abre la puerta a la entrada de agentes tóxicos y nocivos.

La velocidad de absorción percutánea depende de muchos factores:

- La concentración del tóxico, el tipo de vehículo (medio) y la presencia de otras sustancias. 
- El contenido hídrico de la piel, su pH y su temperatura, el flujo sanguíneo local, la transpiración, la superficie de piel contaminada y el grosor de la piel.

- Características anatómicas y fisiológicas de la piel debidas al sexo y la edad, a variaciones individuales, a diferencias entre diversos grupos étnicos y razas, etc.

Transporte de los tóxicos por la sangre y la linfa

Tras ser absorbidos por alguna de esas vías de entrada, los tóxicos llegan a la sangre, la linfa u otros fluidos corporales. La sangre es el principal vehículo de transporte de los tóxicos y sus metabolitos.

La sangre es un órgano líquido en circulación que lleva a las células el oxígeno y $\mathrm{l}$ as sustancias vitales que necesitan y extrae de ellas los productos de desecho del metabolismo. Contiene asimismo componentes celulares, hormonas y otras moléculas que intervienen en muchas funciones fisiológicas. Impulsada por la actividad del corazón, la sangre corre por el interior de un sistema circulatorio de vasos que es relativamente estanco y que está en condiciones de alta presión. Debido a la alta presión hay una parte del líquido que se escapa del sistema por filtración. El sistema linfático realiza la labor de drenaje gracias a su delicada malla de pequeños capilares linfáticos, de finas paredes, que se ramifican por los tejidos y órganos blandos.

La sangre es una mezcla de una fase líquida (plasma, $55 \%$ ) y células sólidas (45\%). El plasma contiene proteínas (albúminas, globulinas, fribrinógeno), ácidos orgánicos (láctico, glutámico, cítrico) y muchas otras sustancias (lípidos, lipoproteínas, glicoproteínas, enzimas, sales, xenobióticos, etc.). Los componentes celulares de la sangre son los eritrocitos (Er), los leucocitos, los reticulocitos, los monocitos y las plaquetas.

Los tóxicos se absorben en forma de moléculas y de iones. En el $\mathrm{pH}$ de la sangre, algunos tóxicos forman partículas coloidales, que sería la tercera forma presente en el líquido. Las moléculas, los iones y los coloides de tóxicos se pueden transportar por la sangre de diversas maneras:

- Uniéndose física o químicamente a los componentes de la sangre, sobre todo a los Er.

- Disolviéndose físicamente en el plasma en estado libre.

- Uniéndose a uno o varios tipos de proteínas plasmáticas, formando compuestos con los ácidos orgánicos o enlazándose con otras fracciones del plasma.

En su mayoría, los tóxicos presentes en la sangre se encuentran unos en estado libre en el plasma y otros unidos a los eritrocitos y componentes del plasma. La distribución depende de la afinidad de las sustancias tóxicas por esos componentes. Todas las fracciones se encuentran en un equilibrio dinámico.

Algunos tóxicos son transportados por los elementos de la sangre - sobre todo por los eritrocitos, muy raras veces por los leucocitos. Pueden adsorberse en la superficie de los eritrocitos o pueden unirse a los ligandos estromáticos. Cuando penetran en el eritrocito pueden unirse al hemo (por ejemplo, el monóxido de carbono y el selenio) o a la globina $\left(\mathrm{Sb}^{111}, \mathrm{Po}^{210}\right)$. Algunos de los tóxicos que transportan los eritrocitos son el arsenio, el cesio, el torio, el radón, el plomo y el sodio. El cromo hexavalente se une exclusivamente a los eritrocitos, y el cromo trivalente a las proteínas plasmáticas. En el caso del zinc hay una competencia entre los eritrocitos y el plasma. Alrededor del $96 \%$ del plomo lo transportan los eritrocitos. El mercurio orgánico se une sobre todo a los eritrocitos, mientras que el mercurio inorgánico lo transporta esencialmente la albúmina del plasma. Las fracciones pequeñas de berilio, cobre, telurio y uranio son transportadas por los eritrocitos.

La mayor parte de los tóxicos la transportan el plasma o sus proteínas. Están presentes muchos electrólitos como iones en un equilibrio con moléculas no disociadas libres o unidas a las fracciones plasmáticas. Esta fracción iónica de los tóxicos es muy difusible, lo que hace que penetre en los tejidos y órganos atravesando las paredes de los capilares. En el plasma puede haber gases y vapores disueltos.

Las proteínas plasmáticas ofrecen a la absorción de tóxicos una superficie total de entre 600 y $800 \mathrm{~km}^{2}$. Las moléculas de albúmina poseen alrededor de 109 ligandos catiónicos y 120 aniónicos a disposición de los iones. Muchos iones son transportados parcialmente por la albúmina (por ejemplo el cobre, el zinc y el cadmio), al igual que compuestos como los dinitro- y ortocresoles, los derivados nitro- y halogenados de hidrocarburos aromáticos y los fenoles.

Las moléculas de globulina (alfa y beta) transportan pequeñas moléculas de tóxicos así como algunos iones metálicos (cobre, zinc y hierro) y partículas coloidales. El fibrinógeno tiene afinidad por determinadas moléculas pequeñas. En la unión de las tóxicos con las proteínas plasmáticas participan muchos tipos de enlaces: fuerzas de Van der Waals, atracción de cargas, asociación entre grupos polares y apolares, puentes de hidrógeno y enlaces covalentes.

Las lipoproteínas plasmáticas transportan tóxicos lipófilos como los PCB. Las otras fracciones del plasma son también un vehículo de transporte. La afinidad de los tóxicos por proteínas plasmáticas sugiere su afinidad por proteínas de los tejidos y órganos durante la fase de distribución.

Los ácidos orgánicos (láctico, glutamínico, cítrico) forman complejos con algunos tóxicos. Los elementos alcalinotérreos y los pertenecientes al grupo de las tierras raras, así como algunos elementos pesados en forma de cationes, forman complejos asimismo con ácidos orgánicos oxi- y amino. Todos estos complejos son por lo general difusibles y se distribuyen con facilidad por los tejidos y órganos.

Agentes fisiológicamente quelantes del plasma, como la transferrina y la metalotioneína, compiten con los ácidos orgánicos y con los aminoácidos para conseguir cationes con los que formar quelatos estables.

Los iones libres difusibles, algunos complejos y algunas moléculas libres pasan fácilmente de la sangre a los tejidos y órganos. La fracción libre de los iones y moléculas está en equilibrio dinámico con la fracción unida. La concentración de un tóxico en la sangre determinará la velocidad de su distribución por los tejidos y órganos, o su paso de éstos a la sangre.

\section{Distribución de los tóxicos en el organismo}

El organismo humano puede dividirse en los compartimentos siguientes: 1) órganos internos, 2) piel y músculos, 3) tejidos adiposos, 4) tejidos conectivos y huesos. Esta clasificación se basa principalmente en el grado de perfusión vascular (sanguínea) en orden de mayor a menor. Por ejemplo, los órganos internos (incluido el cerebro), que representan sólo el $12 \%$ del peso corporal total, reciben alrededor del $75 \%$ del volumen total de sangre. En cambio, los tejidos conectivos y los huesos $(15 \%$ del peso corporal total) reciben sólo un $1 \%$ del volumen total de sangre.

Por lo general, los órganos internos, que están muy perfundidos, consiguen la concentración más alta de tóxicos en el tiempo más corto, así como un equilibrio entre la sangre y ese compartimento. La captación de tóxicos por tejidos menos perfundidos es mucho más lenta, pero la retención es superior y el tiempo de permanencia mucho más largo (acumulación) debido a la escasa perfusión.

Hay tres componentes que son de gran importancia para la distribución intracelular de los tóxicos: el contenido de agua, los lípidos y las proteínas presentes en las células de los diversos tejidos y órganos. El orden de compartimentos antes señalado se 
corresponde también en gran medida con el orden decreciente de contenido de agua en sus células. Los tóxicos hidrófilos se distribuyen más rápidamente a los fluidos y células del cuerpo que tienen un alto contenido de agua, y los tóxicos lipófilos a las células que tienen un mayor contenido de lípidos (tejido graso).

El organismo posee algunas barreras que obstaculizan la penetración de algunos grupos de tóxicos, sobre todo los hidrófilos, en determinados órganos y tejidos, como por ejemplo las siguientes:

- La barrera hematoencefálica (o cerebroespinal), que limita la entrada de moléculas grandes y tóxicos hidrófilos en el cerebro y el SNC; consiste en una capa muy tupida de células endoteliales; pueden atravesarla por tanto los tóxicos lipófilos.

- La barrera placentaria, que tiene un efecto similar sobre la penetración de los tóxicos en el feto desde la sangre de la madre.

- La barrera histohematológica en las paredes de los capilares, que es permeable para las moléculas de tamaño pequeño y mediano y para algunas de las de mayor tamaño, así como para los iones.

Como se ha señalado anteriormente, sólo las formas libres de los tóxicos en el plasma (moléculas, iones, coloides) están disponibles para penetrar por las paredes de los capilares que participan en la distribución. Esa fracción libre está en equilibrio dinámico con la fracción unida. La concentración de los tóxicos en la sangre está en equilibrio dinámico con su concentración en los órganos y tejidos, lo que determina su retención (acumulación) o su salida de ellos.

Afectan también a la distribución el estado general del organismo, el estado funcional de los órganos (especialmente la regulación neurohumoral), el equilibrio hormonal y otros factores.

La retención de un tóxico en un determinado compartimento es por lo general temporal, y puede redistribuirse a otros tejidos. La retención y la acumulación se basan en la diferencia entre las velocidades de absorción y eliminación. La duración de la retención en un compartimento se expresa mediante la vida media biológica, que es el tiempo que tarda en reducirse al $50 \%$ la cantidad de tóxico presente en el tejido u órgano, por redistribución, translocación o eliminación del organismo.

Durante la distribución y la retención en diversos órganos y tejidos tienen lugar procesos de biotransformación. Esta produce metabolitos más polares y más hidrófilos, que se eliminan con más facilidad. Una velocidad de biotransformación baja de un tóxico lipófilo tiene por lo general como consecuencia su acumulación en un compartimento.

Desde el punto de vista de su afinidad, de su tendencia a retenerse y acumularse en un determinado compartimento, los tóxicos pueden dividirse en cuatro grupos principales:

1. Los tóxicos solubles en los fluidos corporales, que se distribuyen de manera uniforme en función del contenido de agua de los compartimentos. De esta forma se distribuyen muchos cationes monovalentes (por ejemplo, litio, sodio, potasio o rubidio) y algunos aniones (por ejemplo, cloro o bromo).

2. Los tóxicos lipófilos, que presentan una fuerte afinidad por los órganos y tejidos que son ricos en lípidos (SNC y tejido graso y adiposo respectivamente).

3. Los tóxicos que forman partículas coloidales, que son atrapadas por células especializadas del sistema reticuloendotelial (SRE) de los órganos y tejidos. Los cationes tri y tetravalentes (lantano, cesio, hafnio) se distribuyen en el SRE de los tejidos y órganos.

4. Los tóxicos que presentan una fuerte afinidad por los huesos y el tejido conectivo (elementos osteotrópicos o "buscadores de hueso"), como los cationes divalentes (por ejemplo, calcio, bario, estroncio, radón, berilio, aluminio, cadmio o plomo).

\section{Acumulación en tejidos ricos en lípidos}

En el "hombre estándar" de $70 \mathrm{~kg}$, alrededor del $15 \%$ del peso corporal es tejido adiposo, proporción que con la obesidad puede llegar hasta el $50 \%$. Pero esa fracción lípida no está distribuida de manera uniforme. El cerebro (SNC) es un órgano rico en lípidos, y los nervios periféricos están rodeados por las células de Schwann, ricas en lípidos, que constituyen la llamada vaina de mielina. Todos estos tejidos se prestan a la acumulación de tóxicos lipófilos. En este compartimento se pueden distribuir numerosos tóxicos no electrólitos y no polares que tengan un coeficiente de partición de Nernst adecuado, así como numerosos disolventes orgánicos (alcoholes, aldehídos, cetonas, etc.), hidrocarburos clorados (incluidos insecticidas organoclorados como el DDT), algunos gases inertes (radón), etc.

En el tejido adiposo se acumulan tóxicos debido a su escasa vascularización y a su menor velocidad de biotransformación. En este caso la acumulación de tóxicos puede ser una especie de "neutralización" temporal, pues no hay dianas para el efecto tóxico. No obstante, siempre hay un peligro potencial para el organismo, pues los tóxicos presentes en este compartimento pueden volver a la circulación.

El depósito de tóxicos en el cerebro (SNG) o en el tejido rico en lípidos de la vaina de mielina del sistema nervioso periférico es muy peligroso. Los neurotóxicos se depositan aquí directamente junto a sus dianas. Los tóxicos retenidos en el tejido rico en lípidos de la glándulas endocrinas pueden producir trastornos hormonales. Pese a la barrera hematoencefálica, son muchos los neurotóxicos de carácter lipófilo que llegan al cerebro (SNG): anestésicos, disolventes orgánicos, plaguicidas, tetraetilplomo, organomercuriales, etc.

\section{Retención en el sistema reticuloendotelial}

En cada tejido y órgano hay un determinado porcentaje de las células que está especializado en la actividad fagocitaria, es decir, en capturar microorganismos, partículas, coloides, etc. Es lo que se llama el sistema reticuloendotelial (SRE), que comprende células tanto fijas como móviles (fagocitos). Estas células están presentes en forma no activa. El incremento del número de esos microbios o de esas partículas activa las células hasta llegar a un punto de saturación.

Las tóxicos en forma de coloides son capturados por el SRE de los órganos y tejidos. La distribución depende del tamaño de las partículas coloidales. Las mayores se retienen preferentemente en el hígado. Cuando son de menor tamaño, se produce una distribución más o menos uniforme entre el bazo, la médula ósea y el hígado. La eliminación de los coloides desde el SRE es muy lenta, aunque las partículas pequeñas se eliminan algo más deprisa.

\section{Acumulación en los huesos}

Se han identificado unos 60 elementos que son osteotrópicos, es decir, "buscadores de hueso".

Los elementos osteotrópicos pueden dividirse en tres grupos:

1. Elementos que representan o sustituyen a componentes fisiológicos del hueso. De veinte de ellos hay cantidades considerables, mientras que los demás están presentes como elementos traza. En condiciones de exposición crónica, también pueden penetrar en la matriz mineral de las células óseas metales tóxicos como el plomo, el aluminio y el mercurio.

2. Los elementos alcalinotérreos y otros elementos que forman cationes y que tienen un diámetro iónico similar al del calcio son intercambiables con éste en el mineral óseo. Asimismo, algunos aniones son intercambiables con aniones (fosfato, hidroxilo) del mineral óseo. 
3. Elementos que forman microcoloides (tierras raras) pueden adsorberse en la superficie del mineral óseo.

El esqueleto de un "hombre estándar" representa del 10 al $15 \%$ del peso corporal total, lo que ofrece grandes posibilidades para el depósito de tóxicos osteotrópicos. El hueso es un tejido sumamente especializado que está integrado, en volumen, por un $54 \%$ de minerales y un $38 \%$ de matriz orgánica. La matriz mineral del hueso es hidroxiapatita, $\mathrm{Ca}_{10}\left(\mathrm{PO}_{4}\right)_{6}(\mathrm{OH})_{2}$, en la que la relación $\mathrm{Ca} / \mathrm{P}$ es más o menos de 1,5/1. La superficie de mineral en que puede producirse la adsorción es de aproximadamente $100 \mathrm{~m}^{2}$ por $\mathrm{g}$ de hueso.

La actividad metabólica de los huesos del esqueleto puede dividirse en dos categorías:

- el hueso metabólico activo, en el que se producen con gran amplitud procesos de resorción y formación de hueso nuevo, o de remodelación del hueso existente

- el hueso estable, que tiene una tasa baja de remodelación o crecimiento.

En el feto, los recién nacidos y los niños de corta edad, el hueso metabólico (o "esqueleto disponible") representa casi el $100 \%$ del esqueleto. Con la edad la proporción de hueso metabólico se va reduciendo. La incorporación de tóxicos durante la exposición aparece en el hueso metabólico y en compartimentos de renovación más lenta.

La incorporación de tóxicos al hueso se efectúa de dos maneras:

1. En el caso de los iones, se produce un intercambio con los cationes de calcio fisiológicamente presentes, o con los aniones (fosfato, hidroxilo).

2. En el caso de los tóxicos que forman partículas coloidales, se produce una adsorción en la superficie mineral.

\section{Reacciones de intercambio de iones}

El mineral óseo, la hidroxiapatita, presenta un complejo sistema de intercambio de iones. Los cationes de calcio pueden intercambiarse con otros cationes diversos. Los aniones presentes en el hueso también se pueden intercambiar con otros aniones: fosfato con citrato y carbonato, hidroxilo con flúor. Los iones que no son intercambiables pueden adsorberse en la superficie mineral. Cuando se incorporan iones tóxicos al mineral, la superficie puede cubrirse con una nueva capa de mineral, integrando el tóxico en la estructura del hueso. El intercambio de iones es un proceso reversible, y depende de la concentración de iones, el $\mathrm{pH}$ y el volumen del fluido. Así, por ejemplo, un incremento del calcio en la dieta puede reducir el depósito de iones tóxicos en la retícula mineral. Ya se ha señalado que el porcentaje de hueso metabólico desciende con la edad, aunque el intercambio de iones continúa. Con el paso de los años se produce una resorción del mineral óseo que resta efectivamente densidad al hueso. En ese punto pueden liberarse tóxicos presentes en el hueso (plomo por ejemplo).

Alrededor del $30 \%$ de los iones que se incorporan a los minerales óseos están unidos más débilmente y pueden ser objeto de intercambio, de captura por agentes quelantes naturales y de excreción, con una vida media biológica de 15 días. El otro 70 \% está unido con más fuerza. La movilización y excreción de esa fracción presenta una vida media biológica de 2,5 años o más según el tipo de hueso (procesos de remodelación).

Los agentes quelantes (Ca-EDTA, penicilamina, BAL, etc.) pueden movilizar cantidades considerables de algunos metales pesados, e incrementar en gran medida su excreción por la orina.

\section{Adsorción de coloides}

Las partículas coloidales se adsorben como una película en la superficie mineral $\left(100 \mathrm{~m}^{2}\right.$ por $\left.\mathrm{g}\right)$ por la acción de las fuerzas de Van der Waals o por quimiadsorción. Una vez en la superficie mineral, esta capa de coloides se recubre con la capa siguiente de minerales formados, con lo que los tóxicos se entierran aún más en la estructura del hueso. La tasa de movilización y eliminación depende de los procesos de remodelación.

\section{Acumulación en el pelo y las uñas}

El pelo y las uñas contienen queratina, con grupos sulfhidrilo capaces de quelar cationes metálicos como el mercurio y el plomo.

\section{Distribución del tóxico en el interior de la célula}

Recientemente ha cobrado importancia la cuestión de la distribución de los tóxicos, en especial de algunos metales pesados, en el interior de las células de tejidos y órganos. Gracias a las técnicas de ultracentrifugación, se pueden separar diversas fracciones de la célula para determinar su contenido de iones metálicos y otros tóxicos.

Estudios con animales han revelado que, una vez que han penetrado en la célula, algunos iones metálicos se unen a una proteína concreta, la metalotioneína. Esta proteína, de bajo peso molecular, está presente en las células del hígado, el riñón y otros órganos y tejidos. Sus grupos sulfhidrilo pueden unirse a seis iones por molécula. Una mayor presencia de iones metálicos induce la biosíntesis de esta proteína. El inductor más potente son los iones de cadmio. La metalotioneína sirve también para mantener la homeostasis de los vitales iones de cobre y zinc. Puede unirse al zinc, el cobre, el cadmio, el mercurio, el bismuto, el oro, el cobalto y otros cationes.

\section{Biotransformación y eliminación de los tóxicos}

Mientras están retenidos en las células de diversos tejidos y órganos, los tóxicos están expuestos a enzimas que pueden biotransformarlos (metabolizarlos), produciendo metabolitos. Hay muchas vías para la eliminación de los tóxicos y/o metabolitos: en el aire espirado por el pulmón, en la orina a través del riñón, en la bilis a través del TGI, en el sudor a través de la piel, en la saliva a través de la mucosa de la boca, en la leche a través de las glándulas mamarias, y en el pelo y las uñas a través del crecimiento y recambio celulares normales.

La eliminación de un tóxico absorbido depende de la ruta de entrada. En el pulmón, el proceso de absorción/desorción se inicia inmediatamente, y los tóxicos se eliminan parcialmente con el aire espirado. La eliminación de tóxicos absorbidos por otras rutas es un proceso prolongado y se inicia una vez que han sido transportados por la sangre, para acabar completándose después de su distribución y biotransformación. Durante la absorción existe un equilibrio entre las concentraciones de un tóxico en la sangre y en los tejidos y órganos. La excreción reduce su concentración en la sangre y puede inducir su paso de los tejidos a la sangre.

En la velocidad de eliminación de los tóxicos y de sus metabolitos influyen numerosos factores:

- Las propiedades fisicoquímicas de los tóxicos, en especial el coeficiente de partición de Nernst $(\mathrm{P})$, la constante de disociación $\left(\mathrm{pK}_{a}\right)$, la polaridad, la estructura molecular, la forma y el peso.

- El nivel de exposición y el tiempo de eliminación desde la exposición.

- La ruta de entrada. 
- los compartimentos corporales en los que se hayan distribuido, pues tienen distintas velocidades de intercambio con la sangre y distintos grados de perfusión sanguínea

- la velocidad de la biotransformación de tóxicos lipófilos a metabolitos más hidrófilos

- el estado de salud general del organismo y, en especial, de los órganos excretores (pulmón, riñón, TGI, piel, etc.)

- la presencia de otros tóxicos que pueden interferir en la eliminación

Cabe distinguir a este respecto dos grupos de compartimentos: 1) el sistema de intercambio rápido - en estos compartimentos, la concentración de tóxico en el tejido es similar a la de la sangre; y 2) el sistema de intercambio lento, donde la concentración del tóxico en el tejido es más alta que en la sangre debido a los fenómenos de unión y acumulación - el tejido adiposo, el esqueleto y el riñón pueden retener temporalmente algunas sustancias, como por ejemplo el arsénico y el zinc.

Un tóxico puede excretarse simultáneamente por dos o más vías excretoras, aunque lo normal es que predomine una de ellas.

Los científicos están elaborando modelos matemáticos para describir la excreción de un tóxico determinado. Esos modelos se basan en el movimiento de salida desde uno de los compartimentos o de los dos (sistema de intercambio), en la biotransformación, etc.

\section{Eliminación en el aire espirado por el pulmón}

La eliminación por el pulmón (desorción) es típica de los tóxicos muy volátiles (como por ejemplo los disolventes orgánicos). Los gases y vapores que son poco solubles en la sangre se eliminan rápidamente por esta vía, mientras que los tóxicos que son muy solubles en la sangre se eliminan por otras vías.

Los disolventes orgánicos absorbidos por el TGI o por la piel se excretan parcialmente en el aire espirado en cada paso de la sangre por el pulmón, siempre que tengan una presión de vapor suficiente. Este es el fundamento de los alcoholímetros que se utilizan para comprobar si un conductor está en estado de embriaguez. La concentración de $\mathrm{CO}$ en el aire espirado está en equilibrio con el contenido de $\mathrm{CO}-\mathrm{Hb}$ en la sangre. El gas radiactivo radón aparece en el aire espirado debido a la desintegración del radio acumulado en el esqueleto.

La eliminación de un tóxico en el aire espirado en relación con el tiempo transcurrido desde la exposición suele expresarse mediante una curva de tres fases. La primera fase representa la eliminación de la sustancia desde la sangre, con una vida media corta. La segunda fase, más lenta, representa la eliminación debida al intercambio entre la sangre y los tejidos y órganos (sistema de intercambio rápido). La tercera fase, sumamente lenta, indica el intercambio entre la sangre y el tejido graso y el esqueleto. Si un tóxico no se ha acumulado en esos compartimentos, la curva será de dos fases. En algunos casos es posible también una curva de cuatro fases.

Una forma de evaluar las exposiciones profesionales es determinar los gases y vapores presentes en el aire espirado en el tiempo transcurrido desde la exposición.

\section{Excreción renal}

El riñón es un órgano especializado en la excreción de numerosos tóxicos y metabolitos hidrosolubles, lo que contribuye a mantener la homeostasis del organismo. Cada riñón posee alrededor de un millón de nefrones capaces de realizar la función excretora. La excreción renal es un hecho sumamente complejo que comprende tres mecanismos distintos:

- La filtración glomerular por la cápsula de Bowman.

- El transporte activo en el túbulo proximal.

- El transporte pasivo en el túbulo distal.
La excreción renal de un tóxico por la orina depende del coeficiente de partición de Nernst, la constante de disociación, el pH de la orina, el tamaño y forma de las moléculas, la velocidad de la conversión metabólica en metabolitos más hidrófilos y el estado de salud del riñón.

La cinética de la excreción renal de un tóxico o de su metabolito puede expresarse en una curva de dos, tres o cuatro fases, según cuál sea la distribución de la sustancia en los diversos compartimentos corporales, que presentan distintas tasas de intercambio con la sangre.

\section{Saliva}

Algunos fármacos e iones metálicos pueden excretarse en la saliva a través de la mucosa de la boca - por ejemplo, el plomo ("línea del plomo"), el mercurio, el arsénico y el cobre, así como bromuros, yoduros, alcohol etílico, alcaloides, etc. Después los tóxicos se degluten y llegan al TGI, donde pueden reabsorberse o eliminarse en las heces.

\section{Sudor}

Muchos no electrólitos pueden eliminarse parcialmente por la piel en el sudor: alcohol etílico, acetona, fenoles, disulfuro de carbono e hidrocarburos clorados.

\section{Leche}

Muchos metales y disolventes orgánicos y algunos plaguicidas organoclorados (DDT) se segregan a través de la glándula mamaria en la leche materna. Esta vía puede ser peligrosa para los niños lactantes.

\section{Pelo}

Puede utilizarse el análisis del pelo como indicador de la homeostasis de algunas sustancias fisiológicas. También puede evaluarse mediante este tipo de bioensayo la exposición a algunos tóxicos, especialmente los metales pesados.

La eliminación de tóxicos del organismo puede incrementarse recurriendo a métodos como los siguientes:

- translocación mecánica mediante lavado gástrico, transfusión de sangre o diálisis

- creación de condiciones fisiológicas que movilicen los tóxicos a través de la dieta, modificando el equilibrio hormonal o mejorando la función renal mediante la administración de diuréticos

- la administración de agentes que forman complejos (citratos, oxalatos, salicilatos, fosfatos) o quelatos (Ca-EDTA, BAL, ATA, DMSA, penicilamina); este método está indicado sólo en personas sometidas a estricto control médico. Suelen administrarse, como medida terapéutica, agentes quelantes para eliminar metales pesados del organismo de trabajadores expuestos. Este método se utiliza también para evaluar la carga corporal total y el nivel de una exposición anterior.

\section{Determinaciones de la exposición}

La determinación de los tóxicos y los metabolitos presentes en la sangre, el aire espirado, la orina, el sudor, las heces y el pelo es un método cada vez más empleado para evaluar la exposición humana (ensayos de exposición) y/o el grado de intoxicación. Esa es la razón de que se hayan establecido recientemente límites de exposición biológica (valores de concentración máxima permisible (MAC), índices de exposición biológica (BEI). Mediante esos bioensayos se halla la "exposición interna" del organismo, es decir, su exposición total tanto en el medio ambiente profesional como en el general, y debida a todas las rutas de entrada (véase "Biomarcadores" en "Métodos de ensayo en toxicología"). 


\section{Efectos combinados debidos a la exposición múltiple}

En el medio ambiente profesional y/o general, las personas suelen estar expuestas simultánea o consecutivamente a diversos agentes físicos y químicos. Hay que tener en cuenta también que algunas personas toman fármacos, fuman, consumen alcohol y alimentos que contienen aditivos, etc. Esto significa que lo más frecuente es que se produzca una exposición múltiple. Los agentes físicos y químicos pueden interactuar entre sí en cada fase de los procesos toxicocinéticos y/o toxicodinámicos, con el resultado de tres posibles efectos:

1. Independiente. Cada agente produce un efecto distinto debido a que sus mecanismos de acción son distintos.

2. Sinérgico. El efecto combinado es mayor que el de cada agente por separado. Aquí se pueden distinguir dos tipos: a) aditivo, cuando el efecto combinado es igual a la suma de los efectos producidos por separado por cada agente, y b) potenciador, cuando el efecto combinado es mayor que la suma de los efectos individuales.

3. Antagonista. El efecto combinado es menor que la suma de los efectos individuales.

No obstante, raras veces se estudian los efectos combinados. Se trata de estudios muy complejos por la combinación de diversos factores y agentes.

Cabe concluir que cuando el organismo humano está expuesto de manera simultánea o consecutiva a dos o más tóxicos es necesario considerar la posibilidad de que existan algunos efectos combinados, que pueden acelerar o desacelerar los procesos toxicocinéticos.

\section{ORGANO DIANA Y EFECTOS CRITICOS}

\section{Marek Jakubowski}

El objetivo prioritario de la toxicología profesional y ambiental es mejorar la prevención o la limitación sustancial de los efectos que tiene sobre la salud la exposición a agentes peligrosos en el medio ambiente general y profesional. Con ese fin se han elaborado sistemas para evaluar cuantitativamente el riesgo relacionado con una determinada exposición (véase "Toxicología reguladora").

Los efectos de una sustancia química sobre un determinado sistema u órgano están relacionados con la magnitud de la exposición y con el carácter agudo o crónico de ésta. Habida cuenta de la diversidad de efectos tóxicos que se producen incluso en un solo sistema u órgano, se ha propuesto una línea de pensamiento uniforme acerca del órgano crítico y el efecto crítico con miras a evaluar los riesgos y desarrollar "concentraciones límite recomendadas basadas en criterios de salud para las sustancias tóxicas" presentes en los diferentes medios ambientales.

Desde el punto de vista de la medicina preventiva es especialmente importante la identificación precoz de los efectos adversos, sobre la base del supuesto general de que la prevención o la limitación de los primeros efectos pueden impedir que aparezcan otros efectos más graves.

Este planteamiento se ha aplicado a los metales pesados. Aunque los metales pesados, como el plomo, el cadmio y el mercurio, pertenecen a un grupo específico de tóxicos en el que el efecto crónico de su actividad depende de su acumulación en los órganos, las definiciones que se ofrecen a continuación fueron publicadas por el Grupo de Trabajo sobre Toxicidad de los Metales (Nordberg 1976).

Se ha adoptado la definición de órgano crítico que propuso este grupo de trabajo, pero con una leve modificación: se ha sustituido el término metal por la expresión sustancia potencialmente tóxica (Duffus 1993).

El que un determinado órgano o sistema se considere crítico depende no sólo de la toximecánica del agente peligroso, sino también de la vía de absorción y de la población expuesta.

- Concentración celular crítica: la concentración en la que se producen en la célula cambios funcionales adversos, sean reversibles o irreversibles.

- Concentración crítica en un órgano: la concentración media en el órgano en el momento en el que el tipo más sensible de células del órgano alcanza la concentración crítica.

- Organo crítico: el órgano que primero alcanza la concentración crítica del metal en determinadas circunstancias de exposición y en una población dada.

- Efecto crítico: punto definido en la relación entre la dosis y el efecto en el individuo, a saber, el punto en el que se produce un efecto adverso en la función celular del órgano crítico. A un nivel de exposición inferior al que provoca una concentración crítica del metal en el órgano crítico, pueden producirse algunos efectos que no deterioran la función celular en sí, aunque son detectables por medio de pruebas bioquímicas y de otro tipo. Esos efectos se denominan efectos subcríticos.

En ocasiones no está claro el significado biológico de la expresión "efecto subcrítico"; puede equivaler a un biomarcador de exposición, a un índice de adaptación o a un precursor del efecto crítico (véase "Biomarcadores" en "Métodos de ensayo en toxicología"). Esta última posibilidad puede ser especialmente importante de cara a las actividades profilácticas.

En la Tabla 33.1 se ofrecen ejemplos de órganos y efectos críticos respecto de diferentes sustancias químicas. En la exposición ambiental crónica al cadmio, donde la ruta de absorción es de importancia menor (las concentraciones de cadmio en el aire oscilan entre 10 y $20 \mu \mathrm{g} / \mathrm{m}^{3}$ en las zonas urbanas y entre 1 y $2 \mu \mathrm{g} / \mathrm{m}^{3}$ en las zonas rurales), el órgano crítico es el riñón. En el contexto profesional, donde el TLV llega a $50 \mu \mathrm{g} / \mathrm{m}^{3}$ y la principal ruta de exposición es la inhalación, se consideran críticos dos órganos: el pulmón y el riñón.

En el caso del plomo, los órganos críticos en los adultos son el sistema hematopoyético y el sistema nervioso periférico, donde los efectos críticos (por ejemplo una elevada concentración de protoporfirina eritrocitaria libre (FEP), un aumento de la excreción de ácido delta-aminolevulínico en la orina o un deterioro de la conducción de los nervios periféricos) se manifiestan cuando el nivel de plomo en sangre (que es un índice de la absorción de plomo en el sistema) se acerca a 200-300 $\mu \mathrm{g} / \mathrm{l}$. En los niños pequeños el órgano crítico es el sistema nervioso central (SNC), y se ha comprobado que los síntomas de disfunción detectados con el uso de una batería de pruebas psicológicas aparecen en las poblaciones examinadas incluso a concentraciones del orden de unos $100 \mu \mathrm{g} / \mathrm{l}$ de plomo en la sangre.

Se han formulado otras definiciones que quizás reflejen mejor el significado de este concepto. Según la OMS (1989), el efecto crítico es "el primer efecto adverso que aparece cuando se alcanza en el órgano crítico el umbral de concentración o dosis (crítica). Los efectos adversos que, como el cáncer, no tienen un umbral de concentración definido suelen considerarse críticos. La decisión de si un efecto es crítico o no es una cuestión de juicio de experto". En las directrices para elaborar los Environmental Health Criteria Documents del Programa Internacional de Seguridad de las Sustancias Químicas (IPCS), el efecto crítico se describe como "el efecto adverso que se considera más adecuado para determinar la cantidad tolerable que puede entrar en el cuerpo". Esta última definición se formuló directamente con miras a evaluar los límites de exposición en el medio ambiente 
Tabla 33.1 • Ejemplos de órganos críticos y efectos críticos.

\begin{tabular}{|c|c|c|}
\hline Sustancia & Organo crítico en exposición crónica & Efecto crítico \\
\hline \multirow[t]{3}{*}{ Cadmio } & Pulmón & $\begin{array}{l}\text { Sin umbral: } \\
\text { Cáncer de pulmón (unidad riesgo } 4,6 \text { × 10-3) }\end{array}$ \\
\hline & Riñón & $\begin{array}{l}\text { Con umbral: } \\
\left.\text { Mayor excreción urinaria de proteínas de bajo peso molecular ( } b_{2}-M, R B P\right)\end{array}$ \\
\hline & Pulmón & Enfisema, leves cambios funcionales \\
\hline \multirow[t]{2}{*}{ Plomo } & $\frac{\text { Adultos }}{\text { Sistema hematopoyético }}$ & $\begin{array}{l}\text { Mayor excreción urinaria de ácido delta-aminolevulínico (ALA-U); mayor concentración de } \\
\text { protoporfirina eritrocitaria libre (FEP) en los eritrocitos }\end{array}$ \\
\hline & Sistema nervioso periférico & Menor velocidad de conducción del impulso nervioso en las fibras lentas \\
\hline \multirow[t]{2}{*}{ Mercurio (elemental) } & $\underline{\text { Niños de corta edad }}$ & \\
\hline & Sistema nervioso central & Descenso del $\mathrm{Cl}$ y otros efectos sutiles; temblor mercurial (dedos, labios, párpados) \\
\hline Mercurio (mercúrico) & Riñón & Proteinuria \\
\hline \multirow[t]{3}{*}{ Manganeso } & $\frac{\text { Adultos }}{\text { Sistema nervioso central }}$ & Deterioro de funciones psicomotoras \\
\hline & $\frac{\text { Niños }}{\text { Pulmón }}$ & Síntomas respiratorios \\
\hline & Sistema nervioso central & Deterioro de funciones psicomotoras \\
\hline Tolueno & Membranas mucosas & Irritación \\
\hline Cloruro de vinilo & Hígado & Cáncer (angiosarcoma, unidad riesgo 1 x 10-6) \\
\hline Acetato de etilo & Membranas mucosas & Irritación \\
\hline
\end{tabular}

general, basados en consideraciones de salud. En este contexto, parece que lo más esencial es determinar qué efecto puede considerarse adverso. Conforme a la terminología actual, el efecto adverso es el "cambio en la morfología, fisiología, crecimiento, desarrollo o tiempo de vida de un organismo que tiene como resultado un deterioro de la capacidad de compensar una tensión adicional o un aumento de la susceptibilidad a los efectos nocivos de otras influencias ambientales. La decisión de si un efecto es adverso o no es una cuestión que requiere el juicio del experto".

En la Figura 33.1 se presentan curvas de dosis-respuesta hipotéticas respecto de diversos efectos. En el caso de la exposición al plomo, $A$ puede representar un efecto subcrítico (inhibición de la ALA-deshidratasa eritrocitaria), $B$ el efecto crítico (incremento de la zinc-protoporfirina eritrocitaria o incremento de la excreción de ácido delta-aminolevulínico), $C$ el efecto clínico (anemia) y $D$ el efecto letal (muerte). En el caso de la exposición al plomo está ampliamente demostrado que determinados efectos de la exposición dependen de la concentración de plomo en la sangre (contrapartida práctica de la dosis), ya sea en forma de relación dosis-respuesta o en relación con diferentes variables (sexo, edad, etc.). La determinación de los efectos críticos y de la relación dosis-respuesta correspondiente a esos efectos en los seres humanos permite predecir la frecuencia de un efecto dado a una determinada dosis o su contrapartida (concentración en el material biológico) en una población.

Los efectos críticos pueden ser de dos tipos: los que se estima que tienen un umbral y aquellos otros en los que puede haber cierto riesgo a cualquier nivel de exposición (carcinógenos genotóxicos y mutágenos de células germinales: sin umbral). Siempre que sea posible, la evaluación del riesgo se ha de basar en datos humanos adecuados. Para determinar los efectos con umbral en la población general se han de elaborar hipótesis sobre el nivel de exposición (cantidad tolerable que puede entrar en el cuerpo, biomarcadores de la exposición) como es que la frecuencia del efecto crítico en la población expuesta a un agente peligroso dado se corresponda con la frecuencia de ese efecto en la población general. En la exposición al plomo, la concentración máxima de plomo en sangre recomendada para la población general $(200 \mu \mathrm{g} / \mathrm{l}$, mediana inferior a $100 \mu \mathrm{g} / \mathrm{l})(\mathrm{OMS}$ 1987) está prácticamente por debajo del valor de umbral del efecto crítico supuesto (alto nivel de protoporfirina eritrocitaria libre), aunque no por debajo del nivel asociado a los efectos sobre el SNC en los niños o sobre la tensión arterial en los adultos. En general, cuando la evaluación de la seguridad se basa en los datos obtenidos en estudios bien hechos sobre poblaciones humanas que definen un nivel sin efecto adverso observable, se considera adecuado aplicar un factor de incertidumbre de 10. En el caso de la exposición profesional, los efectos críticos pueden referirse a una determinada parte de la población (por ejemplo el $10 \%$ ). En consecuencia, en la exposición profesional al plomo la

Figura 33.1 - Curvas hipotéticas de dosis-respuesta para diversos efectos.

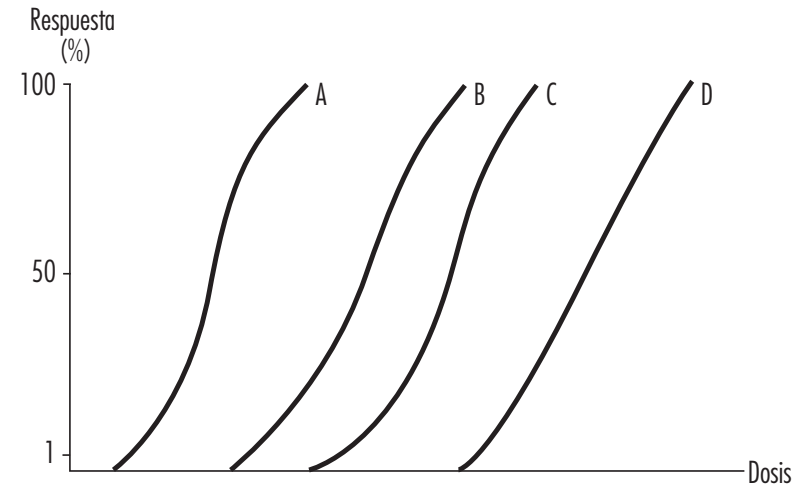


concentración de plomo en sangre recomendada basada en criterios de salud se ha establecido en $400 \mathrm{mg} / \mathrm{l}$ en los hombres donde un $10 \%$ de la población presente un nivel de ALA-U de $5 \mathrm{mg} / \mathrm{l}$ como respuesta a unas concentraciones de $\mathrm{PbB}$ de 300 a $400 \mathrm{mg} / \mathrm{l}$. En el caso de la exposición laboral al cadmio (partiendo de que el efecto crítico es el aumento de la excreción urinaria de proteínas de bajo peso molecular), se ha estimado como valor admisible un nivel de 200 ppm de cadmio en la zona cortical del riñón, pues ese efecto se ha observado en el $10 \%$ de la población expuesta. En muchos países se está considerando actualmente (es decir, en 1996) la posibilidad de rebajar estos dos valores.

No hay un consenso claro sobre la metodología adecuada para evaluar el riesgo de las sustancias químicas en las que el efecto crítico puede no tener umbral, como los carcinógenos genotóxicos . Para la evaluación de esos efectos se han adoptado diversos enfoques basados en gran parte en la caracterización de la relación dosis-respuesta. Como en el plano social y político no se acepta el riesgo de los carcinógenos para la salud, en documentos tales como las Air Quality Guidelines for Europe (OMS 1987) se ofrecen únicamente, para los efectos sin umbral, valores como la unidad riesgo a lo largo de toda la vida (es decir, el riesgo asociado a la exposición a lo largo de toda la vida a $1 \mu \mathrm{g} / \mathrm{m}^{3}$ del agente peligroso) (véase "Toxicología reguladora").

En la actualidad, el componente básico de las actividades de evaluación del riesgo es la determinación del órgano crítico y los efectos críticos. Las definiciones tanto de efecto crítico como de efecto adverso reflejan la responsabilidad de decidir qué efectos de entre los que se observan en un determinado órgano o sistema deben considerarse críticos, y ello está directamente relacionado con la determinación ulterior de los valores recomendados respecto de una determinada sustancia química en el medio ambiente general - por ejemplo, las Air Quality Guidelines for Europe (OMS 1987) o los límites de exposición laboral basados en criterios de salud (OMS 1980). Determinar el efecto crítico desde el intervalo de efectos subcríticos puede llevar a una situación en la que los límites recomendados sobre concentraciones de sustancias tóxicas en el medio ambiente general o profesional quizás sean en la práctica imposibles de mantener. Es posible que considerar como crítico un efecto que puede superponerse a los efectos clínicos tempranos lleve a adoptar valores con los que pueden desarrollarse efectos adversos en una parte de la población. La decisión de considerar crítico o no un determinado efecto sigue siendo responsabilidad de los grupos de expertos especializados en toxicidad y evaluación del riesgo.

\section{- EFECTOS DE LA EDAD, EL SEXO Y OTROS FACTORES}

Spomenka Telišman

Suele haber entre los seres humanos amplias diferencias en la intensidad de la respuesta a las sustancias químicas tóxicas, así como variaciones en la susceptibilidad de un individuo a lo largo de su vida. Ello puede atribuirse a diversos factores que pueden afectar a la velocidad de absorción, la distribución en el cuerpo y la velocidad de biotransformación y/o excreción de una determinada sustancia. Aparte de los factores hereditarios conocidos, cuya relación con el aumento de la susceptibilidad a la toxicidad química en los seres humanos está claramente demostrada (véase "Determinantes genéticos de la respuesta tóxica"), intervienen factores como los siguientes: las características constitucionales relacionadas con la edad y el sexo; los estados patológicos preexistentes o un deterioro de la función de un órgano (no hereditario, es decir, adquirido); los hábitos alimentarios, el hábito de fumar, el consumo de alcohol y el empleo de fármacos; la exposición concomitante a biotoxinas (diversos microorganismos) y a factores físicos (radiación, humedad, temperaturas sumamente bajas o altas o presiones barométricas especialmente idóneas para la presión parcial de un gas), así como situaciones concomitantes de ejercicio físico o tensión psicológica, y las exposiciones anteriores, profesionales y/o ambientales, a una determinada sustancia, en particular la exposición concomitante a otras sustancias no necesariamente tóxicas (por ejemplo, a metales esenciales). Las posibles contribuciones de estos factores al aumento o la reducción de la susceptibilidad a efectos adversos sobre la salud, así como sus mecanismos de acción, son específicos de cada sustancia química. Por consiguiente, en esta sección se presentarán únicamente los factores más comunes, los mecanismos básicos y algunos ejemplos característicos; el lector interesado en información específica sobre una determinada sustancia química podrá encontrarla en otras secciones de la Enciclopedia.

Según la fase en la que actúan estos factores (absorción, distribución, biotransformación o excreción de la sustancia), los mecanismos pueden clasificarse en general en dos categorías basadas en las consecuencias básicas de la interacción: 1) un cambio en la cantidad de sustancia presente en un órgano diana, es decir, en el lugar o lugares del organismo en que produce su efecto (interacciones toxicocinéticas), o 2) un cambio en la intensidad de una respuesta específica a la cantidad de sustancia presente en un órgano diana (interacciones toxicodinámicas). En ambos tipos de interacción, los mecanismos más frecuentes están relacionados con la competencia con otra u otras sustancias por unirse a los mismos compuestos que intervienen en su transporte por el organismo (por ejemplo, proteínas específicas del suero) y/o por utilizar una misma vía de biotransformación (por ejemplo, unas enzimas determinadas), lo que tiene como consecuencia un cambio en la velocidad o secuencia con que se pasa de la reacción inicial al efecto adverso final sobre la salud. No obstante, tanto las interacciones toxicocinéticas como las toxicodinámicas pueden influir en la susceptibilidad individual a una determinada sustancia química. La influencia de varios factores concomitantes puede producir tres tipos de efectos: a) efectos aditivos :la intensidad del efecto combinado es igual a la suma de los efectos de los diversos factores por separado, b) efectos sinérgicos: la intensidad del efecto combinado es superior a la suma de los efectos de los diversos factores por separado, o c) efectos antagónicos: la intensidad del efecto combinado es inferior a la suma de los efectos de los diversos factores por separado.

La cantidad de una sustancia tóxica o de su metabolito característico en el lugar o lugares en que producen su efecto en el cuerpo humano puede determinarse con más o menos exactitud mediante control biológico, es decir, eligiendo el espécimen biológico correcto y el momento óptimo para obtener la muestra, teniendo en cuenta las vidas medias biológicas de esa sustancia tanto en el órgano crítico como en el compartimento biológico que se mide. No obstante, en general falta información fiable sobre otros posibles factores que podrían influir en la susceptibilidad individual entre los humanos, y en consecuencia los conocimientos que tenemos sobre la influencia de diversos factores se basan en su mayoría en datos obtenidos en animales de experimentación.

Hay que subrayar que en algunos casos existen diferencias relativamente grandes entre los humanos y otros mamíferos en cuanto a la intensidad de la respuesta a un nivel y/o duración equivalentes de la exposición a muchas sustancias tóxicas; por ejemplo, parece que los humanos son considerablemente más sensibles que las ratas (animales que se emplean con frecuencia en los estudios experimentales) a los efectos adversos que producen sobre la salud varios metales tóxicos. Algunas de esas 
diferencias pueden atribuirse al hecho de que las vías de transporte, distribución y biotransformación de diversas sustancias dependen en gran medida de cambios sutiles en el $\mathrm{pH}$ tisular y en el equilibrio redox del organismo (como ocurre con la actividad de diversas enzimas), y también al hecho de que el sistema redox de los humanos es considerablemente distinto del de las ratas.

Así ocurre evidentemente en el caso de importantes antioxidantes como la vitamina $\mathrm{G}$ y el glutatión (GSH), que son esenciales para mantener el equilibrio redox y que desempeñan una función de protección contra los efectos adversos de los radicales libres derivados del óxigeno o de un xenobiótico que intervienen en diversos estados patológicos (Kehrer 1993). A diferencia de la rata, el hombre no puede autosintetizar la vitamina $\mathrm{C}$, y tanto los niveles como la velocidad de recambio del GSH eritrocitario son en el hombre considerablemente inferiores a los de la rata. Los humanos carecen asimismo de algunas de las enzimas antioxidantes protectoras que sí poseen las ratas y otros mamíferos (por ejemplo, se piensa que la GSH-peroxidasa tiene escasa actividad en el esperma humano). Estos son ejemplos de la vulnerabilidad potencialmente mayor a la tensión oxidativa en los humanos (sobre todo en células sensibles como por ejemplo las del esperma, que es aparentemente más vulnerable a las influencias tóxicas que el de las ratas), lo que puede tener como resultado una respuesta diferente o una mayor susceptibilidad a la influencia de diversos factores en los humanos en comparación con otros mamíferos (Telišman 1995).

\section{Influencia de la edad}

En comparación con los adultos, los niños de corta edad suelen ser más susceptibles a la toxicidad química porque sus volúmenes de inhalación y su velocidad de absorción gastrointestinal son relativamente mayores debido a la mayor permeabilidad del epitelio intestinal, y también porque sus sistemas enzimáticos detoxificantes están inmaduros y la velocidad de excreción de sustancias químicas tóxicas es relativamente menor. Parece que en las primeras fases de su desarrollo el sistema nervioso central es especialmente susceptible a la neurotoxicidad de diversas sustancias, como por ejemplo el plomo y el metilmercurio. Por el contrario, las personas de edad avanzada pueden ser susceptibles porque han pasado por exposiciones químicas anteriores y poseen unos mayores depósitos corporales de algunos xenobióticos, o también por el deterioro preexistente de la función de órganos diana y/o de las enzimas pertinentes, lo que hace que su velocidad de detoxificación y excreción sea más baja. Todos esos factores pueden contribuir a debilitar las defensas del organismo - una menor capacidad de reserva, lo que produce una mayor susceptibilidad a exposiciones ulteriores a otros peligros. Por ejemplo, las enzimas citocromo $\mathrm{P} 450$ (que intervienen en las rutas de biotransformación de casi todas las sustancias químicas tóxicas) pueden inducirse o ver reducida su actividad debido a la influencia de diversos factores que están presentes a lo largo de toda la vida (como hábitos alimentarios, hábito de fumar, alcohol, administración de fármacos y exposición a xenobióticos ambientales).

\section{Influencia del sexo}

Se han descrito diferencias de susceptibilidad relacionadas con el género con respecto a muchas sustancias tóxicas (aproximadamente 200), diferencias que se dan también en muchas especies de mamíferos. Parece que en general los hombres son más susceptibles a las toxinas renales, y las mujeres a las toxinas hepáticas. Las causas de estas diferencias de respuesta entre hombres y mujeres se han relacionado con sus diferencias en una gran variedad de procesos fisiológicos (por ejemplo, las mujeres pueden excretar una mayor cantidad de algunas sustancias tóxicas en las hemorragias menstruales y en la leche transfiriéndolas al feto, pero sin embargo experimentan una tensión adicional durante el embarazo, el parto y la lactancia), actividades enzimáticas, mecanismos de reparación genética y factores hormonales, así como con la presencia de depósitos de grasa relativamente mayores en las mujeres, lo que produce una mayor acumulación de algunos tóxicos lipófilos, como los disolventes orgánicos y algunos fármacos.

\section{Influencia de los hábitos alimentarios}

Los hábitos alimentarios tienen una importante influencia en la susceptibilidad a la toxicidad química, sobre todo porque una nutrición adecuada es esencial para que el sistema de defensa química del cuerpo funcione correctamente y contribuya a mantener el buen estado de salud. Ingerir una cantidad suficiente de metales esenciales (incluidos metaloides) y proteínas, especialmente de aminoácidos que contienen azufre, es necesario para biosintetizar diversas enzimas detoxificantes y para aportar la glicina y el glutatión que precisan las reacciones de conjugación con compuestos endógenos y exógenos. Los lípidos, especialmente los fosfolípidos, y los elementos lipotrópicos (donantes de grupos metilo) son necesarios para la síntesis de las membranas biológicas. Los hidratos de carbono aportan la energía que se precisa en varios procesos de detoxificación y también el ácido glucurónico necesario para la conjugación de sustancias tóxicas y sus metabolitos. El selenio (metaloide esencial), el glutatión y vitaminas como la $\mathrm{C}$ (hidrosoluble), la E y la A (liposolubles) desempeñan una importante función antioxidante (por ejemplo, en el control de la peroxidación de los lípidos y en el mantenimiento de la integridad de las membranas celulares), además de ofrecer protección frente a las sustancias tóxicas retirando los radicales libres. A ello hay que añadir que diversos componentes de la dieta (contenido de proteínas y fibra, minerales, fosfatos, ácido cítrico, etc.), así como la cantidad de alimentos ingerida, pueden influir considerablemente en la tasa de absorción gastrointestinal de muchas sustancias tóxicas (por ejemplo, la tasa media de absorción de las sales de plomo solubles tomadas con las comidas es de aproximadamente el $8 \%$, frente a alrededor del $60 \%$ cuando se ingieren en ayunas). No obstante, la dieta misma puede ser también una fuente de exposición individual a diversas sustancias tóxicas (por ejemplo, niveles considerablemente incrementados de ingesta diaria y acumulación de arsénico, mercurio, cadmio y/o plomo en las personas que consumen pescado contaminado).

\section{Influencia del hábito de fumar}

El hábito de fumar puede influir en la susceptibilidad individual a muchas sustancias químicas tóxicas debido a las diversas posibilidades de interacción con el gran número de compuestos que están presentes en el humo de los cigarrillos (sobre todo hidrocarburos aromáticos policíclicos, monóxido de carbono, benceno, nicotina, acroleína, algunos plaguicidas, cadmio y, en menor medida, plomo y otros metales tóxicos, etc.), algunos de los cuales pueden acumularse en el cuerpo humano a lo largo de toda la vida, incluida la fase prenatal (por ejemplo el plomo y el cadmio). Las interacciones se producen principalmente porque diversas sustancias compiten por el mismo o los mismos lugares de unión para su transporte y distribución por el organismo y/o por la misma ruta de biotransformación en la que intervienen determinadas enzimas. Por ejemplo, algunos componentes del humo de los cigarrillos pueden inducir enzimas citocromo P450, mientras que otros pueden reducir su actividad, con lo que se ven 
afectadas las rutas de biotransformación habituales de otros muchos tóxicos, como los disolventes orgánicos y algunos fármacos. El consumo intenso de cigarrillos a lo largo de un período prolongado puede reducir considerablemente los mecanismos de defensa del organismo al disminuir la capacidad de reserva con la que éste hace frente a la influencia adversa de otros factores del tipo de vida habitual.

\section{Influencia del alcohol}

El consumo de alcohol (etanol) puede influir de varias maneras en la susceptibilidad a muchas sustancias tóxicas. Puede influir en la velocidad de absorción y en la distribución de determinadas sustancias en el cuerpo - por ejemplo, incrementando la velocidad de absorción gastrointestinal del plomo, o reduciendo la velocidad de absorción pulmonar del vapor de mercurio al inhibir la oxidación que es necesaria para retener el vapor de mercurio inhalado. El etanol puede influir también en la susceptibilidad a diversas sustancias modificando temporalmente el pH tisular e incrementando el potencial redox derivado del metabolismo del etanol, pues tanto la oxidación del etanol a acetaldehído como la oxidación del acetaldehído a acetato producen un equivalente de nicotinamida-adenin dinucleótido reducido $(\mathrm{NADH})$ e hidrógeno $\left(\mathrm{H}^{+}\right)$. Como la afinidad de los metales y metaloides tanto esenciales como tóxicos por diversos compuestos y tejidos está influida por el pH y por los cambios en el potencial redox (Telišman 1995), incluso una ingesta moderada de etanol puede producir una serie de consecuencias como las siguientes: 1) redistribución del plomo acumulado durante mucho tiempo en el organismo humano a favor de una fracción biológicamente activa, 2) sustitución de zinc esencial por plomo en una o varias de las enzimas que contienen zinc, lo que afecta a la actividad enzimática, o influencia del plomo movilizado sobre la distribución en el organismo de otros metales y metaloides esenciales, como el cadmio, el hierro, el cobre y el selenio, 3) incremento de la excreción urinaria del zinc, etc. Esos posibles efectos se ven intensificados a veces por el hecho de que las bebidas alcohólicas pueden contener una cantidad apreciable de plomo, procedente de los recipientes o del proceso de elaboración (Prpić-Majić y cols. 1984; Telišman y cols. 1984; 1993).

Otra razón habitual de los cambios de susceptibilidad relacionados con el etanol es que muchas sustancias tóxicas, como por ejemplo diversos disolventes orgánicos, comparten la misma ruta de biotransformación, la de las enzimas citocromo P450. En función de la intensidad de la exposición a los disolventes orgánicos así como de la cantidad y frecuencia del etanol ingerido (es decir, consumo de alcohol agudo o crónico), el etanol puede reducir o incrementar las velocidades de biotransformación de diversos disolventes orgánicos y de esa forma influir en su toxicidad (Sato 1991).

\section{Influencia de los fármacos}

El uso frecuente de diversos fármacos puede influir en la susceptibilidad a sustancias químicas tóxicas sobre todo porque muchos fármacos se unen a proteínas séricas e influyen de esa manera en

Tabla 33.2 • Efectos básicos de posibles interacciones múltiples de los principales metales y metaloides tóxicos y/o esenciales en los mamíferos.

\author{
Metal o metaloide tóxico Efectos básicos de la interacción con otro metal o metaloide \\ Aluminio (Al) Reduce la velocidad de absorción de Ca y deteriora el metabolismo de Ca; la deficiencia de Ca en la dieta incrementa la velocidad \\ de absorción de Al. \\ Deteriora el metabolismo de los fosfatos. \\ Los datos sobre interacciones con Fe, Zn y Cu son equívocos (es decir, sobre el posible papel de mediador de otro metal). \\ Arsénico (As) Afecta a la distribución de Cu (incremento en riñón y descenso en hígado, suero y orina). Deteriora el metabolismo de Fe (incremento en \\ hígado con descenso concomitante del hematocrito). Zn reduce la velocidad de absorción de As inorgánico y reduce la toxicidad de As. \\ Se reduce la toxicidad de As y viceversa. \\ Cadmio (Cd) Reduce la velocidad de absorción de Ca y deteriora el metabolismo de Ca; la deficiencia de Ca en la dieta incrementa la velocidad \\ de absorción de Cd. \\ Deteriora el metabolismo de los fosfatos incrementando su excreción urinaria. \\ Deteriora el metabolismo de Fe; la deficiencia de Fe en la dieta incrementa la velocidad de absorción de Cd. \\ Afecta a la distribución de Zn; Zn reduce la toxicidad de Cd, pero su influencia en la velocidad de absorción de Cd es equívoca. \\ El Se reduce la toxicidad de $C d$. \\ Mn reduce la toxicidad de Cd en exposiciones bajas. \\ Los datos sobre la interacción con Cu son equívocos (es decir, sobre el posible papel de mediador de Zn o de otro metal). \\ Los niveles altos de Pb, Ni, Sr, Mg o Cr(III) en la dieta pueden reducir la velocidad de absorción de Cd. \\ Mercurio $(\mathrm{Hg}) \quad$ Afecta a la distribución de Cu (incremento en hígado). \\ Zn reduce la velocidad de absorción de $\mathrm{Hg}$ inorgánico y reduce la toxicidad de $\mathrm{Hg}$ \\ El Se reduce la toxicidad de $\mathrm{Hg}$. \\ Cd incrementa la concentración de $\mathrm{Hg}$ en el riñón, pero al mismo tiempo reduce la toxicidad de $\mathrm{Hg}$ en el riñón (por influencia de \\ la síntesis de metalotioneína inducida por (d) \\ Plomo (Pb) Deteriora el metabolismo de Ca; la deficiencia de Ca en la dieta incrementa la velocidad de absorción de Pb inorgánico y la toxicidad de Pb. \\ Deteriora el metabolismo de Fe; la deficiencia de Fe en la dieta incrementa la toxicidad de Pb, pero su influencia en la velocidad \\ de absorción de $\mathrm{Pb}$ es equívoca. \\ Deteriora el metabolismo de Zn e incrementa su excreción urinaria; la deficiencia de Zn en la dieta incrementa la velocidad de absorción \\ de Pb inorgánico y la toxicidad de $\mathrm{Pb}$. \\ Se reduce la toxicidad de $\mathrm{Pb}$. \\ Los datos sobre interacciones con Cu y Mg son equívocos (es decir, sobre el posible papel de mediador de Zn o de otro metal).
}

Nota: Los datos se refieren sobre todo a estudios experimentales con ratas, pues en general no existen datos clínicos y epidemiológicos pertinentes (especialmente sobre relaciones cuantitativas de dosis-respuesta) (Elsenhans y cols. 1991; Fergusson 1990; Telišman y cols. 1993). 
el transporte, la distribución o la velocidad de excreción de diversas sustancias, y también porque pueden inducir las enzimas detoxificantes pertinentes o deprimir su actividad (por ejemplo las citocromo P450), lo que afecta a la toxicidad de sustancias que tienen la misma ruta de biotransformación. Característico de ambos mecanismos es el aumento de la excreción urinaria de ácido tricloroacético (metabolito de varios hidrocarburos clorados) cuando se toman salicilatos, sulfonamidas o fenilbutazonas, así como el aumento de la hepato y nefrotoxicidad del tetracloruro de carbono cuando se toma fenobarbital. Además, algunos fármacos contienen una cantidad considerable de una sustancia química potencialmente tóxica, por ejemplo los antiácidos, que contienen aluminio, o los preparados que se emplean en el tratamiento de la hiperfosfatemia por insuficiencia renal crónica.

\section{Influencia de la exposición concomitante a otras sustancias químicas}

Los cambios de la susceptibilidad a efectos adversos sobre la salud debidos a la interacción de diversas sustancias químicas (es decir, los posibles efectos aditivos, sinérgicos o antagónicos) se han estudiado casi exclusivamente en animales de experimentación, sobre todo en la rata. Carecemos de estudios epidemiológicos y clínicos a este respecto. Ello es motivo de especial preocupación habida cuenta de que en los humanos la intensidad de respuesta o la diversidad de efectos adversos de varias sustancias químicas son relativamente mayores que en la rata y otros mamíferos. Aparte de los que se han publicado en el ámbito de la farmacología, los datos que poseemos se refieren en su mayoría únicamente a combinaciones de dos sustancias químicas distintas pero pertenecientes a un mismo grupo, como diversos plaguicidas, disolventes orgánicos o metales y metaloides esenciales y/o tóxicos.

La exposición combinada a varios disolventes orgánicos puede producir diversos efectos aditivos, sinérgicos o antagónicos (dependiendo de cuál sea la combinación de disolventes, de su intensidad y de la duración de la exposición), debido sobre todo a su capacidad de influirse mutuamente en sus biotransformaciones respectivas (Sato 1991).

Otro ejemplo característico son las interacciones de metales y metaloides esenciales y/o tóxicos, pues intervienen en la posible influencia de la edad (por ejemplo, la acumulación en el organismo de plomo y cadmio ambientales a lo largo de toda la vida), el sexo (por ejemplo, la deficiencia de hierro frecuente en las mujeres), los hábitos alimentarios (por ejemplo, una mayor ingespa en la dieta de metales y metaloides tóxicos y/o una ingesta deficiente en la dieta de metales y metaloides esenciales), el hábito de fumar y el consumo de alcohol (por ejemplo, exposición adicional al cadmio, el plomo y otros metales tóxicos) y el empleo de fármacos (por ejemplo, por una única dosis de antiácido se incrementa en 50 veces la cantidad de aluminio que como promedio diario se ingiere en los alimentos). La posibilidad de que la exposición a varios metales y metaloides produzca en los humanos diversos efectos aditivos, sinérgicos o antagonistas puede ilustrarse con ejemplos básicos relacionados con los principales elementos tóxicos (véase la Tabla 33.2), pero aparte de eso pueden producirse otras interacciones porque los elementos esenciales también pueden influirse entre sí por ejemplo, el efecto antagonista, bien conocido, del cobre en la velocidad de absorción gastrointestinal, así como en el metabolismo del zinc, y viceversa). La causa principal de todas estas interacciones es la competencia de los diversos metales y metaloides por un mismo lugar de unión (especialmente el grupo sulfhidrilo, - $\mathrm{SH}$ ) en diversas enzimas, metaloproteínas (especialmente la metalotioneína) y tejidos (por ejemplo, las membranas celulares y las barreras orgánicas). Esas interacciones pueden desempeñar un papel notable en el desarrollo de varias enfermedades crónicas que están mediadas por la acción de radicales libres y tensión oxidativa (Telišman 1995).

\section{DETERMINANTES GENETICOS DE LA RESPUESTA TOXICA}

\author{
Daniel W. Nebert y Ross A. McKinnon
}

Hace mucho tiempo que se sabe que cada persona responde de una manera distinta a las sustancias químicas presentes en el medio ambiente. La reciente explosión de la biología molecular y de la genética ha permitido entender mejor la base molecular de esa variabilidad. Entre los principales determinantes de la respuesta individual a las sustancias químicas figuran importantes diferencias entre más de una docena de superfamilias de enzimas, clasificadas colectivamente en enzimas metabolizantes de xenobióticos (agentes extraños al organismo) y enzimas metabolizantes de fármacos. Aunque tradicionalmente se ha considerado que desempeñan una función de detoxificación, estas enzimas también pueden convertir una serie de compuestos inertes en productos intermedios muy tóxicos. Recientemente se han identificado numerosas diferencias, unas sutiles y otras más obvias, en los genes que codifican esas enzimas, diferencias que se ha demostrado que producen notables variaciones de la actividad enzimática. Hoy se sabe con seguridad que cada individuo posee su propia dotación de enzimas metabolizantes de xenobióticos, diversidad que podría entenderse como una especie de "huella dactilar metabólica". Es la compleja interacción de todas esas superfamilias de enzimas distintas lo que en última instancia determina no sólo el destino y el potencial de toxicidad de una sustancia química en un individuo dado, sino también la evaluación de la exposición. En el presente artículo hemos elegido, para exponer los notables progresos que se han realizado en la comprensión de la respuesta individual a las sustancias químicas, la superfamilia de enzimas citocromo P450. Gracias al desarrollo de unos ensayos relativamente sencillos que están basados en el ADN y orientados a identificar alteraciones de genes específicos en esas enzimas, se están obteniendo hoy predicciones más fiables de la respuesta individual a la exposición química. Esperamos que el resultado final sea la toxicología preventiva. En otras palabras, cada individuo podría saber a qué sustancias químicas es especialmente sensible, lo que le permitiría evitar problemas de toxicidad o de cáncer que antes eran impredecibles.

Aunque no se suele tener conciencia de ello, los seres humanos están expuestos todos los días a una avalancha de innumerables sustancias químicas distintas. Muchas de esas sustancias son sumamente tóxicas, y proceden de una amplia variedad de fuentes ambientales y alimentarias. La relación entre esas exposiciones y la salud humana ha sido y sigue siendo una de las preocupaciones esenciales de la investigación biomédica en todo el mundo.

Veamos algunos ejemplos de ese bombardeo químico. En el vino tinto se han aislado y caracterizado más de 400 sustancias químicas. Se estima que un cigarrillo encendido produce al menos 1.000 sustancias químicas. En los cosméticos y jabones perfumados hay asimismo innumerables sustancias químicas. Otra fuente importante de exposición química es la agricultura: solamente en los Estados Unidos, las explotaciones agrarias reciben más de 75.000 sustancias químicas al año en forma de plaguicidas, herbicidas y fertilizantes; tras su captación por las plantas y por los animales que pastan, así como por los peces en los cursos de agua próximos, esas sustancias químicas son 
ingeridas por los seres humanos (al final de la cadena alimentaria). Otras dos fuentes de grandes concentraciones de sustancias químicas que entran en el organismo son a) los fármacos de uso habitual y b) la exposición a sustancias peligrosas en el lugar de trabajo a lo largo de toda la vida profesional.

Está ya plenamente confirmado que la exposición química puede afectar negativamente a muchos aspectos de la salud humana, provocando enfermedades crónicas y el desarrollo de numerosos tipos de cáncer. En el último decenio más o menos ha empezado a desentrañarse el fundamento molecular de muchas de esas relaciones. Además, se ha comprobado que las personas presentan notables diferencias de susceptibilidad a los efectos nocivos de la exposición química.

En los actuales intentos de predecir la respuesta humana a la exposición química se combinan dos enfoques fundamentales (Figura 33.2): la vigilancia del grado de exposición humana mediante marcadores biológicos (biomarcadores) y la predicción de la respuesta probable de un individuo a un nivel de exposición determinado. Aunque los dos enfoques son muy importantes, hay que hacer hincapié en que difieren claramente uno de otro. En este artículo nos centraremos en los factores genéticos que subyacen a la susceptibilidad individual a una exposición química determinada.

Este ámbito de investigación se suele denominar en términos generales ecogenética o farmacogenética (Kalow 1962 y 1992). Muchos de los recientes avances en la determinación de la susceptibilidad individual a la toxicidad química se derivan de un mejor conocimiento de los procesos por los que los seres humanos y otros mamíferos detoxifican las sustancias químicas, así como de la notable complejidad de los sistemas enzimáticos que intervienen en esos procesos.

Describiremos en primer lugar la variabilidad de las respuestas tóxicas en los seres humanos. Presentaremos después algunas de las enzimas responsables de esas variaciones en la respuesta, debidas a diferencias en el metabolismo de las sustancias extrañas. A continuación veremos en detalle la historia y nomenclatura de la superfamilia citocromo P450. Se describirán brevemente cinco polimorfismos humanos $\mathrm{P} 450$ y otros no $\mathrm{P} 450$, que son responsables de diferencias en la respuesta humana a las sustancias tóxicas. Examinaremos a continuación un ejemplo concreto para hacer hincapié en que las diferencias genéticas individuales pueden influir en la evaluación de la exposición cuando ésta haya sido determinada por control ambiental. Por último nos referiremos al papel que desempeñan esas enzimas metabolizantes de xenobióticos en las funciones críticas de la vida.

\section{Variaciones de la respuesta tóxica en la población humana}

Los toxicólogos y farmacólogos suelen hablar de dosis letal media para el $50 \%$ de la población $\left(\mathrm{DL}_{50}\right)$, de dosis máxima tolerable media para el $50 \%$ de la población $\left(\mathrm{DMT}_{50}\right)$ y de dosis efectiva media de un determinado fármaco para el $50 \%$ de la población $\left(\mathrm{DE}_{50}\right)$. Pero ¿cómo nos afectan estas dosis a cada uno de nosotros como individuos? En otras palabras, un individuo muy sensible puede verse 500 veces más afectado o tener 500 veces más probabilidades de verse afectado que el individuo más resistente de una población; para esas personas no tendrían mucho sentido los valores de la $\mathrm{DL}_{50}$ (ni los de la $\mathrm{DMT}_{50}$ y la $\mathrm{DE}_{50}$ ). Los valores de

Figura 33.2 - Interrelaciones entre evaluación de la exposición, diferencias étnicas, edad, dieta, nutrición y evaluación de la susceptibilidad genética - factores todos que afectan al riesgo individual de toxicidad y cáncer.

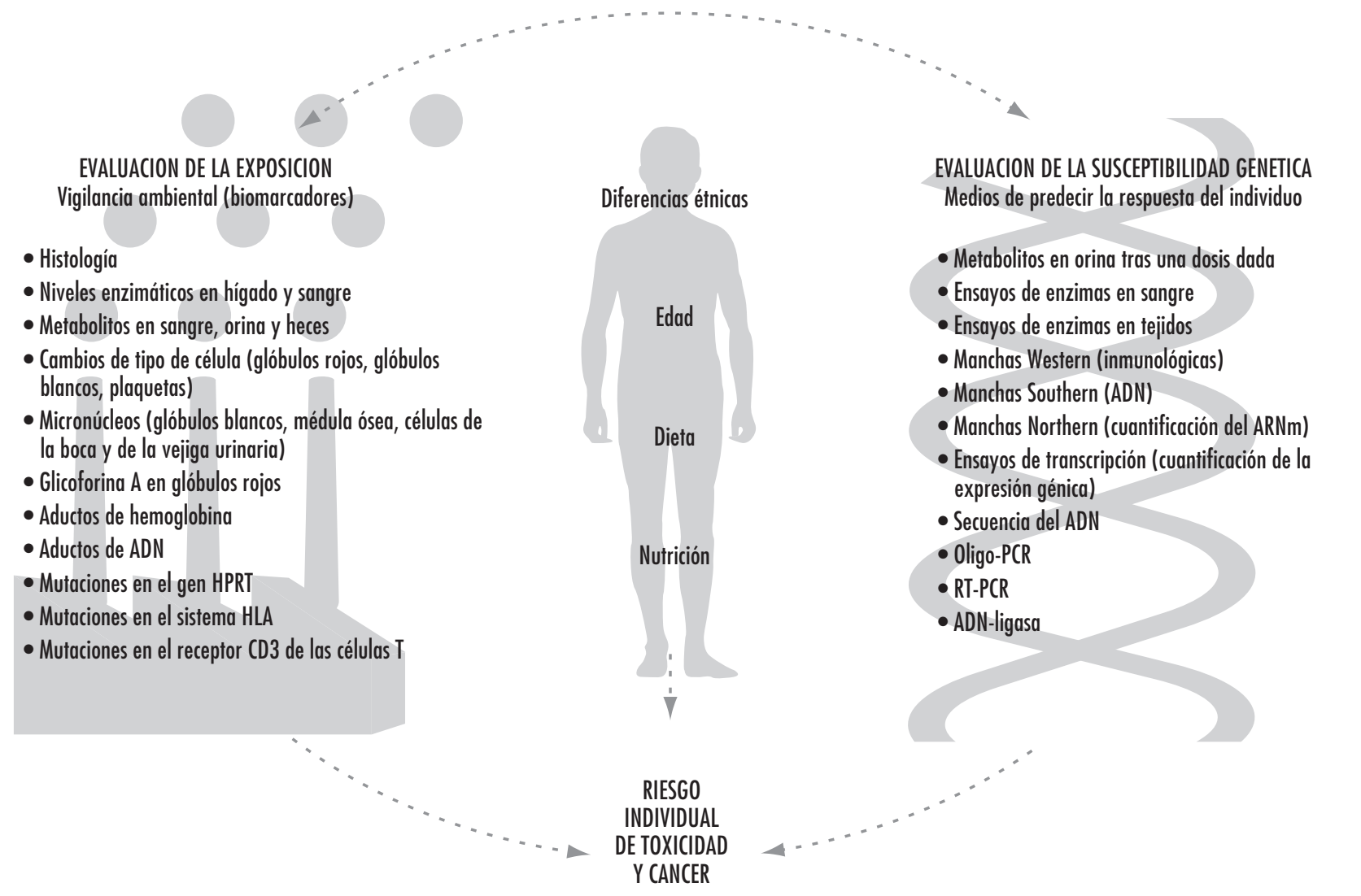


Figura 33.3 • Relación genérica entre cualquier respuesta tóxica y la dosis de cualquier agente químico o físico ambiental.

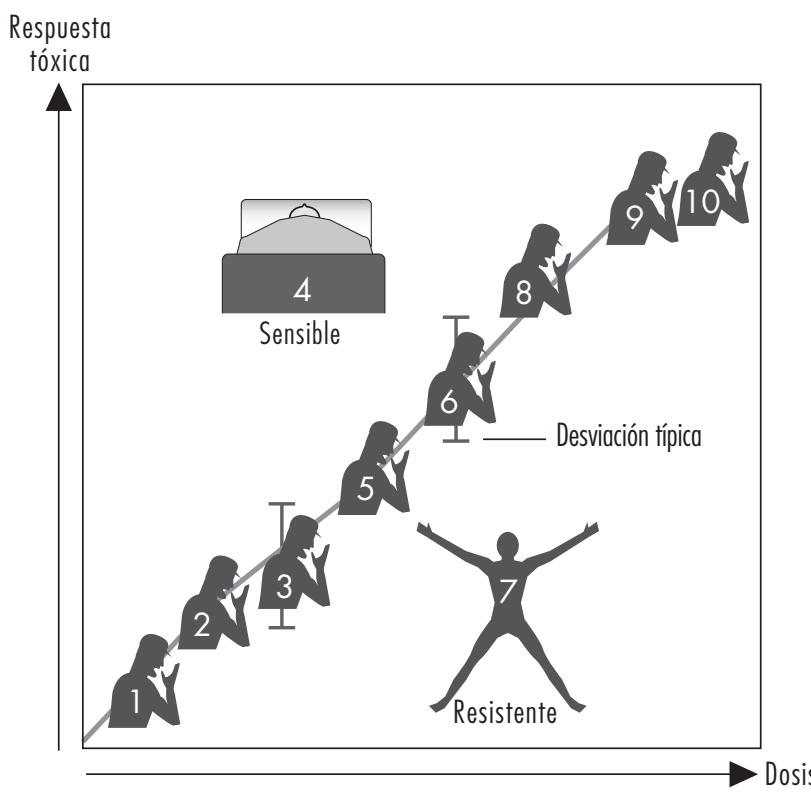

estas tres dosis sólo tienen sentido cuando se refieren a la población en su conjunto.

En la Figura 33.3 se presenta una hipotética relación dosisrespuesta respecto de una respuesta tóxica en individuos de una población determinada. Este diagrama genérico podría referirse a un carcinoma broncogénico en respuesta al número de cigarrillos fumados, a un cloracne como función de los niveles de dioxina en el lugar de trabajo, a un asma como función de las concentraciones de ozono o aldehído en el aire, a unas quemaduras en la piel en respuesta a la radiación ultravioleta, a un descenso del tiempo de coagulación por ingestión de aspirina o a unos trastornos gastrointestinales en respuesta al número de chiles jalapeños ingeridos. En todos esos casos, generalmente se observa que cuanto mayor es la exposición mayor es también la respuesta tóxica. La mayor parte de la población presentará la media y desviación típica de la respuesta tóxica como función de la dosis. El "marginal resistente" (abajo a la derecha en la Figura 33.3) es un individuo que responde menos a dosis o exposiciones altas. El "marginal sensible" (arriba a la izquierda) es un individuo que responde de una manera exagerada a una dosis o exposición relativamente pequeña. Estos individuos "marginales", con sus diferencias extremas de respuesta en comparación con la mayoría de los individuos de la población, presentan a veces importantes variantes genéticas que pueden ayudar a los científicos a entender los mecanismos moleculares que subyacen a una respuesta tóxica.

Utilizando a esos individuos en estudios sobre familias, científicos de diversos laboratorios han empezado a comprobar la importancia que tiene la herencia mendeliana en una respuesta tóxica determinada. Después se puede recurrir a la biología molecular y a los estudios genéticos para delimitar el mecanismo subyacente a nivel genético (genotipo) que es responsable de la enfermedad de origen ambiental (fenotipo).

\section{Enzimas metabolizantes de xenobióticos o de fármacos}

¿Cómo responde el organismo a la enorme cantidad de sustancias químicas exógenas a las que está expuesto? Los seres humanos y otros mamíferos han desarrollado sistemas de enzimas metabólicas sumamente complejos, que comprenden más de una docena de superfamilias enzimáticas distintas. Prácticamente todas las sustancias químicas a las que están expuestos los seres humanos son modificadas por esas enzimas para que sea más fácil eliminar del cuerpo la sustancia extraña. Se suele agrupar a esas enzimas bajo las denominaciones genéricas de enzimas metabolizantes de fármacos y enzimas metabolizantes de xenobióticos. En realidad ambas expresiones son poco apropiadas. En primer lugar, muchas de esas enzimas no sólo metabolizan fármacos, sino también cientos de miles de sustancias químicas procedentes del medio ambiente y de la dieta. En segundo lugar, todas esas enzimas utilizan asimismo, como sustratos, compuestos normales del organismo; ninguna de ellas metaboliza sólo sustancias químicas extrañas.

Desde hace más de cuatro décadas, los procesos metabólicos mediados por esas enzimas se suelen clasificar como reacciones de Fase I o de Fase II (Figura 33.4). Las reacciones de la Fase I ("funcionalización") suelen comportar modificaciones estructurales relativamente menores de la sustancia original mediante oxidación, reducción o hidrólisis para obtener un metabolito más hidrosoluble. Es frecuente que las reacciones de la Fase I "den pie" a que el compuesto se vuelva a modificar después en las reacciones de la Fase II. Las reacciones de la Fase I están mediadas básicamente por una superfamilia de enzimas de gran versatilidad, conocidas con el término colectivo de citocromo P450, aunque también pueden intervenir otras superfamilias (Figura 33.5).

Las reacciones de la Fase II comportan el acoplamiento de una molécula endógena hidrosoluble y una sustancia química (sustancia original o metabolito de la Fase I) con miras a facilitar la excreción. Las reacciones de la Fase II suelen calificarse de "conjugación" o "derivación". El nombre con que se conoce a las superfamilias de enzimas que catalizan las reacciones de la Fase II suele derivarse del radical endógeno que participa en la

Figura 33.4 • Expresión clásica de las Fases I y II de las enzimas metabolizantes de xenobióticos o de fármacos.

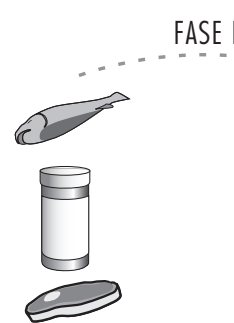

Fármacos, alimentos
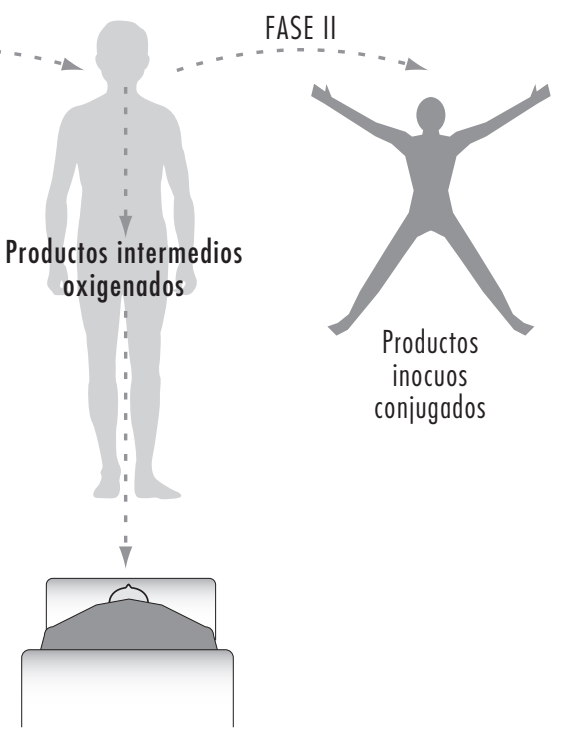

Cáncer, mutación, toxicidad

Aunque en la mayoría de los casos el resultado final es la detoxicación, hay algunos compuestos originales inertes que son potenciados por enzimas en el metabolismo de la Fase I, con lo que se reactivan productos intermedios que intervienen en la carcinogénesis, la mutagénesis y la toxicidad. 
Figura 33.5 - Ejemplos de enzimas metabolizantes de fármacos.

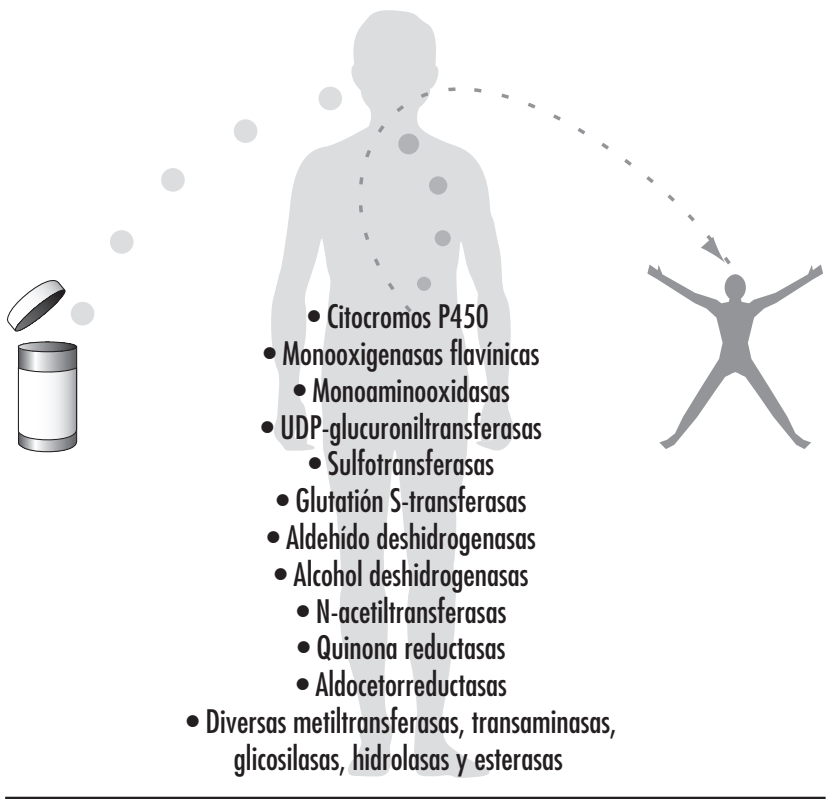

conjugación: por ejemplo, $\mathrm{N}$-acetiltransferasas cuando hay acetilación, sulfotransferasas cunado hay sulfatación, glutatión transferasas cuando se trata de conjugación con el glutatión y UDP-glucuroniltransferasas cuando se trata de glucuronación (Figura 33.5). Aunque el principal órgano del metabolismo de los fármacos es el hígado, algunas enzimas metabolizantes de fármacos se encuentran con niveles bastante altos en el tracto gastrointestinal, las gónadas, el pulmón, el cerebro y el riñón, y enzimas de ese tipo están sin duda presentes en cierto modo en todas las células vivas.

\section{Las enzimas metabolizantes de xenobióticos: espadas de doble filo}

A medida que se han ido conociendo mejor los procesos biológicos y químicos que provocan las anomalías de la salud humana se ha ido poniendo cada vez más de manifiesto que las enzimas metabolizantes de xenobióticos funcionan de una manera ambivalente (Figura 33.4). En la mayoría de los casos, las sustancias liposolubles se convierten en metabolitos hidrosolubles, más fáciles de excretar. Se ha comprobado, sin embargo, que en muchas ocasiones las mismas enzimas son capaces de transformar otras sustancias inertes en moléculas sumamente reactivas. Esos productos intermedios pueden interactuar después con macromoléculas celulares como las proteínas y el ADN. Así pues, en todas las sustancias químicas a las que están expuestos los seres humanos puede darse una competencia entre la ruta de activación metabólica y la de detoxificación.

\section{Breves nociones de genética}

En la genética humana, cada gen (locus) está situado en uno de los 23 pares de cromosomas. Los dos alelos (uno en cada cromosoma del par) pueden ser iguales, pero pueden ser también diferentes. Por ejemplo, los alelos $B$ y $b$, en los que $B$ (ojos marrones) es dominante sobre $b$ (ojos azules): los individuos del fenotipo de ojos marrones pueden tener el genotipo $B B$ o el $B b$, mientras que los del fenotipo de ojos azules sólo pueden tener el genotipo $b b$.

Se habla de polimorfismo cuando dos o más fenotipos heredados de manera estable (rasgos) — derivados del mismo gen o los mismos genes - se mantienen en la población, muchas veces por razones que no son necesariamente obvias. Para que un gen sea polimórfico el producto génico no tiene que ser esencial para el desarrollo, el vigor reproductivo u otro proceso vital crítico. De hecho, se suele hablar de "polimorfismo equilibrado", en el que los heterozigotos tienen una clara ventaja de supervivencia sobre los homozigotos (por ejemplo, resistencia a la malaria frente a hemoglobina falciforme), para explicar el mantenimiento de un alelo en la población con unas frecuencias altas para las que no se conoce ninguna otra razón (González y Nebert 1990).

\section{Polimorfismos humanos de las enzimas metabolizantes de xenobióticos}

Hace más de cuatro decenios que se conocen diferencias genéticas en el metabolismo de diversos fármacos y sustancias químicas ambientales (Kalow 1962 y 1992). Esas diferencias suelen denominarse polimorfismos farmacogenéticos o, en un sentido más amplio, ecogenéticos. Estos polimorfismos consisten en variantes alélicas que se dan con una frecuencia relativamente alta en la población y están generalmente asociadas a aberraciones en la expresión o función enzimática. Antes los polimorfismos solían identificarse cuando se obtenían respuestas inesperadas a agentes terapéuticos. Más recientemente, la tecnología de recombinación del ADN ha permitido a los científicos identificar con precisión las alteraciones en los genes que son responsables de algunos de esos polimorfismos. Se han caracterizado así polimorfismos en muchas enzimas metabolizantes de fármacos - tanto de la Fase I como de la Fase II. A medida que se van identificando cada vez más polimorfismos se está comprobando con creciente certeza que cada individuo puede poseer su propio bagaje de enzimas metabolizantes de fármacos. Esa diversidad podría calificarse de "huella dactilar metabólica". Es la compleja interacción de las diversas superfamilias de enzimas metabolizantes de fármacos en un individuo cualquiera lo que en última instancia determinará su respuesta particular a una determinada sustancia química (Kalow 1962 y 1992; Nebert 1988; González y Nebert 1990; Nebert y Weber 1990).

\section{Expresión en cultivo celular de enzimas humanas metabolizantes de xenobióticos}

¿Cómo podemos mejorar la predicción de las respuestas tóxicas humanas a las sustancias químicas? Los avances en la definición de la multiplicidad de enzimas metabolizantes de fármacos han de ir acompañados de un conocimiento preciso de qué enzimas determinan el destino metabólico de las distintas sustancias. Datos derivados de estudios de laboratorio con roedores han proporcionado sin duda una información útil. No obstante, las notables diferencias que presentan las enzimas metabolizantes de xenobióticos entre unas especies y otras obligan a ser prudentes a la hora de extrapolar los datos a las poblaciones humanas. Para resolver ese problema, muchos laboratorios han desarrollado sistemas con los que se pueden elaborar en cultivo diversas líneas celulares que producen enzimas humanas funcionales estables y en altas concentraciones (González, Crespi y Gelboin 1991). Se ha conseguido así producir satisfactoriamente enzimas humanas en diversas líneas celulares procedentes de fuentes como bacterias, levaduras, insectos y mamíferos.

Con miras a definir de una manera aún más precisa el metabolismo de las sustancias químicas se ha conseguido producir también múltiples enzimas en una única línea celular (González, Crespi y Gelboin 1991). Esas líneas celulares aportan una información valiosa sobre las enzimas concretas que intervienen en la metabolización de un determinado compuesto y de sus metabolitos probablemente tóxicos. Combinándolos después con los conocimientos relativos a la presencia y nivel de una enzima en los tejidos humanos, esos datos deben ser de gran utilidad para predecir la respuesta. 


\section{Gitocromo P450}

\section{Historia y nomenclatura}

El citocromo P450 es una de las superfamilias de enzimas metabolizantes de fármacos más estudiadas, pues presenta una enorme variabilidad individual en la respuesta a las sustancias químicas. "Citocromo P450" es una expresión genérica que se emplea por comodidad para describir una amplia superfamilia de enzimas que desempeñan un papel crucial en el metabolismo de innumerables sustratos endógenos y exógenos. La expresión se utilizó por vez primera en 1962 para describir un pigmento desconocido de las células que, cuando se reducía y unía al monóxido de carbono, producía un pico de absorción característico a 450 $\mathrm{nm}$. Desde principios del decenio de 1980, la tecnología de clonación del ADN viene ofreciendo una importante información sobre las múltiples enzimas citocromo P450. Hasta la fecha se han identificado más de 400 genes distintos del citocromo P450 en animales, plantas, bacterias y levaduras. Se ha estimado que una especie cualquiera de mamíferos, como los humanos, puede poseer 60 o más genes P450 distintos (Nebert and Nelson 1991). Esa gran cantidad de genes $\mathrm{P} 450$ ha obligado a elaborar un sistema de nomenclatura (Nebert y cols. 1987; Nelson y cols. 1993). Propuesto por vez primera en 1987 y actualizado cada dos años, ese sistema de nomenclatura se basa en comparaciones de la evolución divergente de la secuencia de aminoácidos entre proteínas P450. Los genes P450 se dividen en familias y subfamilias: se agrupan en una familia las enzimas que presentan una similitud de aminoácidos superior al $40 \%$, y en una subfamilia las que presentan una similitud del $55 \%$. Los genes P450 se denominan con la raíz CYP seguido de un número arábigo que designa a la familia P450, una letra que indica la subfamilia y otro número arábigo que designa el gen de que se trate (Nelson y cols. 1993; Nebert y cols. 1991). Así, CrP1A1 significa el gen P450 1 de la familia 1 y de la subfamilia A.

En febrero de 1995 había 403 genes CMP en la base de datos, integrada por 59 familias y 105 subfamilias. Entre ellas figuran ocho familias eucarióticas inferiores, 15 familias vegetales y 19 familias bacterianas. Las 15 familias de genes P450 humanos comprenden 26 subfamilias, en 22 de las cuales se ha trazado el mapa de localizaciones cromosómicas en la mayor parte del genoma. Algunas secuencias son claramente ortólogas en muchas especies - por ejemplo, se ha encontrado solamente un gen CIP17 (17 $\alpha$-hidroxilasa esteroidea) en todos los vertebrados examinados hasta la fecha; otras secuencias de una subfamilia están en cambio muy duplicadas, lo que hace imposible identificar pares ortólogos (por ejemplo, la subfamilia CrP2C). Es interesante que los humanos y las levaduras compartan un gen ortólogo en la familia CYP51. Los lectores interesados en más información sobre la superfamilia P450 disponen de amplia bibliografía al respecto (Nelson y cols. 1993; Nebert y cols. 1991; Nebert y McKinnon 1994; Guengerich 1993; González 1992).

El éxito de la nomenclatura del $\mathrm{P} 450$ ha hecho que se elaboraran sistemas terminológicos similares para las UDP-glucuroniltransferasas (Burchell y cols. 1991) y las flavin-monooxigenasas (Lawton y cols. 1994). Y se están elaborando sistemas de nomenclatura análogos basados en la evolución divergente para otras superfamilias de enzimas metabolizantes de fármacos (por ejemplo, sulfotransferasas, epoxihidrolasas y aldehído deshidrogenasas).

Recientemente se dividió la superfamilia de genes P450 de mamíferos en tres grupos (Nebert y McKinnon 1994): los que intervienen principalmente en el metabolismo de sustancias químicas extrañas, los que intervienen en la síntesis de diversas hormonas esteroideas y los que participan en otras funciones endógenas importantes. Para la predicción de la toxicidad, las más importantes son las enzimas P450 metabolizantes de xenobióticos.

\section{Enzimas P450 metabolizantes de xenobióticos}

Las enzimas P450 que intervienen en el metabolismo de compuestos extraños y fármacos aparecen casi siempre en las familias CYP1, CYP2, CYP3 y CYP4. Estas enzimas P450 catalizan muchas reacciones metabólicas distintas, y es frecuente que una sola de ellas sea capaz de metabolizar numerosos compuestos diferentes. Además, muchas enzimas $\mathrm{P} 450$ pueden metabolizar un mismo compuesto en diferentes lugares. Asimismo, un compuesto puede ser metabolizado en el mismo y único lugar por varias enzimas $\mathrm{P} 450$, aunque a velocidades distintas.

Una propiedad muy importante de las enzimas P450 metabolizantes de fármacos es que muchos de estos genes son inducibles por las mismas sustancias que les sirven de sustrato. En cambio, otros genes P450 son inducidos por no sustratos. Este fenómeno de inducción enzimática es la base de muchas interacciones entre fármacos que son importantes desde el punto de vista terapéutico.

Aunque están presentes en muchos tejidos, en concreto, estas enzimas $\mathrm{P} 450$ se encuentran con niveles relativamente altos en el hígado, que es donde más se metabolizan los fármacos. Algunas de las enzimas P450 metabolizantes de xenobióticos muestran actividad hacia determinados sustratos endógenas (por ejemplo, el ácido araquidónico). No obstante, está extendida la idea de que, en su mayoría, esas enzimas P450 metabolizantes de xenobióticos no desempeñan funciones fisiológicas de importancia, aunque hasta el momento no se ha establecido experimentalmente. Es probable que la disrupción homozigótica selectiva, o "knock-out", de determinados genes P450 metabolizantes de xenobióticos con métodos de "targeting" de genes (mutaciones dirigidas) en ratones ofrezca pronto información inequívoca sobre las funciones fisiológicas de los P450 metabolizantes de xenobióticos (véase un análisis de esta técnica en Capecchi 1994).

En contraste con las familias que codifican enzimas P450 que participan básicamente en procesos fisiológicos, las que codifican enzimas P450 metabolizantes de xenobióticos presentan una notable especificidad de especie y suelen contener muchos genes activos por subfamilia (Nelson y cols. 1993; Nebert y cols. 1991). Dada la aparente ausencia de sustratos fisiológicos, es posible que las enzimas P450 de las familias CYP1, CYP2, CYP3 y CYP4 que han aparecido a lo largo de los últimos cientos de millones de años se hayan desarrollado como un medio de detoxificar sustancias químicas extrañas presentes en el medio ambiente y en la dieta. La evolución de las P450 metabolizantes de xenobióticos se habría producido claramente a lo largo de un período de tiempo muy anterior al de la síntesis de la mayoría de las sustancias químicas sintéticas a las que los seres humanos se hallan expuestos en la actualidad. Es posible que los genes de esas cuatro familias se desarrollaran y diferenciaran en los animales debido a su exposición a metabolitos vegetales durante los últimos 1.200 millones de años - en el proceso que gráficamente se ha denominado "la guerra entre los animales y las plantas" (González y Nebert 1990). En esa guerra las plantas desarrollaron nuevas sustancias químicas (fitoalexinas) como mecanismo de defensa para impedir su ingestión por animales, y éstos a su vez respondieron desarrollando nuevos genes $\mathrm{P} 450$ para adaptarse a esa diversificación de los sustratos. Han hecho más plausible esta hipótesis los ejemplos que se han descrito recientemente de guerra química entre plantas e insectos y entre plantas y hongos, con detoxificación de sustratos tóxicos por el citocromo P450 (Nebert 1994).

Figura a continuación una breve introducción a varios de los polimorfismos de las enzimas P450 humanas metabolizantes de 
xenobióticos en los que se cree que los determinantes genéticos de la respuesta tóxica tienen una gran importancia. Hasta hace poco tiempo, se pensaba en polimorfismos $\mathrm{P} 450$ cuando se producía una variación inesperada en las respuestas de los pacientes a los agentes terapéuticos que se les habían administrado. Incluso varios polimorfismos $\mathrm{P} 450$ se bautizaron con el nombre de los fármacos con los que se identificaron por vez primera. Las investigaciones más recientes se han centrado en cambio en la identificación de las enzimas P450 concretas que intervienen en el metabolismo de sustancias químicas en las que se observa variación y en la caracterización precisa de los genes P450 que intervienen. Como se ha señalado antes, la actividad mensurable de una enzima P450 hacia una sustancia química modelo puede denominarse fenotipo. Las diferencias alélicas en un gen P450 respecto de cada individuo es lo que se llama el genotipo P450. A medida que se va perfeccionando el análisis de los genes P450 se están conociendo mejor las bases moleculares precisas de fenómenos de variación fenotípica documentados con anterioridad.

\section{La subfamilia CYP1A}

La subfamilia CYP1A comprende dos enzimas presentes en los humanos y en todos los demás mamíferos: en la nomenclatura P450 normalizada se denominan CYP1A1 y CYP1A2. Estas enzimas son muy interesantes, pues intervienen en la activación metabólica de muchos procarcinógenos y son inducidas también por varios compuestos de interés toxicológico, como la dioxina. Por ejemplo, la CYP1Al activa metabólicamente a muchos compuestos presentes en el humo de los cigarrillos. La CYP1A2 activa metabólicamente a muchas arilaminas - asociadas con el cáncer de vejiga urinaria- que se utilizan en la industria de los colorantes químicos. La CYP1A2 también activa metabólicamente a la 4-(metilnitrosamino)-1-(3-piridil)-1-butanona (NNK), que es una nitrosamina derivada del tabaco. La CYP1A1 y la CYP1A2 presentan asimismo niveles altos en los pulmones de los fumadores de cigarrillos, debido a su inducción por los hidrocarburos policíclicos contenidos en el humo. Por consiguiente, se estima que los niveles de actividad de la CYP1A1 y la CYP1A2 son importantes determinantes de la respuesta individual a muchas sustancias químicas potencialmente tóxicas.

$\mathrm{El}$ interés toxicológico por la subfamilia CIP1A se intensificó considerablemente en 1973 al publicarse un informe en el que se establecía una correlación entre el nivel de inducibilidad de la CYP1Al en los fumadores de cigarrillos y la susceptibilidad individual al cáncer de pulmón (Kellermann, Shaw y LuytenKellermann 1973). Numerosos laboratorios se han centrado en determinar las bases moleculares de la inducción de la CYP1A1 y la CYP1A2.

El proceso de inducción está mediado por una proteína, denominada receptor $\mathrm{Ah}$, a la que se unen dioxinas y otras sustancias estructuralmente afines. El nombre $A h$ se deriva de que muchos inductores de la CYP1A son aril hidrocarburos. Es interesante que las diferencias en el gen que codifica el receptor Ah entre varias estirpes de ratones tengan como resultado notables diferencias en materia de respuesta química y toxicidad. También en los humanos parece que hay un polimorfismo en el gen del receptor Ah: aproximadamente una décima parte de la población muestra una elevada inducción de CYP1Al y puede tener un riesgo mayor que el de las otras nueve décimas partes de desarrollar determinados tipos de cáncer inducidos por sustancias químicas. El papel del receptor $\mathrm{Ah}$ en el control de las enzimas de la subfamilia CYP1A y su función como determinante de la respuesta humana a la exposición química han sido objeto recientemente de varios trabajos (Nebert, Petersen y Puga 1991; Nebert, Puga y Vasiliou 1993).
¿Hay otros polimorfismos que pudieran controlar el nivel de proteínas CYP1A en una célula? Se ha identificado también un polimorfismo en el gen CRP1A1, que parece que influye en el riesgo de cáncer de pulmón entre los fumadores de cigarrillos japoneses, aunque ese mismo polimorfismo no parece afectar al riesgo en otros grupos étnicos (Nebert y McKinnon 1994).

\section{CYP2C19}

Hace muchos años que están bien documentadas las variaciones de la velocidad con que los individuos metabolizan el fármaco anticonvulsivo (S)-mefenitoína (Guengerich 1989). Entre el 2 \% y el $5 \%$ de los caucásicos y hasta el $25 \%$ de los asiáticos presentan una deficiencia de esta actividad y pueden tener un riesgo mayor de toxicidad al administrárseles este fármaco. Se sabe hace mucho tiempo que en esta deficiencia enzimática interviene un miembro de la subfamilia CYP2C humana, pero la base molecular precisa de este fenómeno ha sido objeto de considerable controversia. La razón principal de la dificultad era la existencia de seis o más genes en esa subfamilia. No obstante, recientemente se ha demostrado que la causa principal de la deficiencia es una mutación de una sola base en el gen CYP2C19 (Goldstein y de Morais 1994). Se ha elaborado asimismo un sencillo método, basado en la reacción en cadena de la polimerasa (PCR) en el $\mathrm{ADN}$, para identificar rápidamente esta mutación en las poblaciones humanas (Goldstein y de Morais 1994).

\section{CYP2D6}

La variación de genes P450 que mejor se ha caracterizado es probablemente la que se refiere al CYP2D6. Se han descrito más de una docena de ejemplos de mutaciones, reordenaciones y deleciones que afectan a este gen (Meyer 1994). Sugirió por vez primera la existencia de este polimorfismo, hace veinte años, la variabilidad clínica de la respuesta de los pacientes a un agente hipotensor, la debrisoquina. Por eso a las alteraciones del gen CYP2D6 que afectan a la actividad enzimática se las conoce colectivamente como polimorfismo de la debrisoquina.

Antes de que se empezaran a realizar estudios basados en el ADN se clasificaba a las personas, conforme a las concentraciones del metabolito en las muestras de orina, en las que son grandes metabolizadoras de bradisoquina y en las que son poco metabolizadoras (PM y EM en inglés). Hoy está claro que las alteraciones del gen CYP2D6 tienen como resultado no sólo que hay unos individuos que metabolizan ampliamente la debrisoquina y otros que la metabolizan de manera escasa, sino también que otros realizan esa función de manera ultrarrápida. Las alteraciones del gen CYP2D6 están relacionadas en su mayoría con una deficiencia parcial o total de la función enzimática; no obstante, recientemente se ha descrito a individuos de dos familias que poseen múltiples copias funcionales del gen CYP2D6, lo que da lugar a un metabolismo ultrarrápido de los sustratos CYP2D6 (Meyer 1994). Este notable descubrimiento arroja una luz nueva sobre el amplio espectro de actividad de la enzima CYP2D6 observado anteriormente en estudios sobre poblaciones. Las alteraciones en la función de la CYP2D6 son de especial importancia porque esta enzima metaboliza más de 30 fármacos que se prescriben habitualmente. Por consiguiente, la función CIP2D6 de un individuo determina de manera importante su respuesta tanto terapéutica como tóxica al tratamiento administrado. Incluso se ha sostenido recientemente que para utilizar sin riesgos los fármacos psiquiátricos y cardiovasculares es necesario tener en cuenta la condición del paciente respecto al CYP2D6.

También se ha estudiado con detalle el papel del polimorfismo CTP2D6 como determinante de la susceptibilidad individual a enfermedades humanas como el cáncer de pulmón y la enfermedad de Parkinson (Nebert y McKinnon 1994; Meyer 
1994). Aunque es difícil establecer conclusiones por haberse empleado diversos protocolos, la mayoría de los estudios parece indicar que existe una asociación entre los que son grandes metabolizadores de debrisoquina (fenotipo EM) y el cáncer de pulmón. No están claras por el momento las razones de esa asociación. No obstante, se ha comprobado que la enzima CYP2D6 metaboliza la NNK, que es una nitrosamina derivada del tabaco.

Se espera que con el perfeccionamiento de los ensayos basados en el ADN - que permitirán valorar de una manera más precisa la condición de una persona respecto al CYP2D6se pueda aclarar la relación exacta que existe entre la CYP2D6 y el riesgo de enfermedad. Mientras que el gran metabolizador puede estar vinculado a la susceptibilidad al cáncer de pulmón, el escaso metabolizador (fenotipo PM) parece estar asociado con la enfermedad de Parkinson de causa desconocida. Aunque estos estudios son también difíciles de comparar, parece que los individuos que tienen menos capacidad de metabolizar los sustratos de la CYP2D6 (como la debrisoquina) poseen un riesgo de 2 a 2,5 veces mayor de desarrollar la enfermedad de Parkinson.

\section{CYP2E1}

El gen CYP2E1 codifica una enzima que metaboliza muchas sustancias químicas, como fármacos y numerosos carcinógenos de bajo peso molecular. Esta enzima es interesante también porque es muy inducible por el alcohol y puede tener que ver con la lesión hepática inducida por sustancias como el cloroformo, el cloruro de vinilo y el tetracloruro de carbono. La enzima se halla básicamente en el hígado, y su nivel presenta notables variaciones entre unos individuos y otros. Un minucioso análisis del gen CYP2E1 ha llevado a identificar varios polimorfismos (Nebert and McKinnon 1994). En algunos estudios se ha notificado una relación entre la presencia de determinadas variaciones estructurales en el CYP2E1 y una aparente reducción del riesgo de cáncer de pulmón; no obstante, hay claras diferencias interétnicas que obligan a clarificar esa posible relación.

\section{Subfamilia CYP3A}

Debido a su similitud en la secuencia de aminoácidos, se han identificado cuatro enzimas humanas como miembros de la subfamilia CYP3A. Las enzimas CYP3A metabolizan muchos fármacos de uso habitual, como la eritromicina y la ciclosporina. También es un sustrato de la CYP3A la aflatoxina B1, que es un contaminante alimentario carcinógeno. Uno de los miembros de la subfamilia humana CYP3A, la CYP3A4, es la principal enzima P450 en el hígado humano y está presente también en el tracto gastrointestinal. Como ocurre con muchas otras enzimas P450, el nivel de CYP3A4 varía mucho entre unos individuos y otros. Una segunda enzima, la CYP3A5, se encuentra sólo en alrededor del $25 \%$ de los hígados, por razones genéticas que aún no conocemos. Todavía no se ha establecido la importancia de la variabilidad de la CYP3A4 y la CYP3A5 como factor genético determinante de la respuesta tóxica (Nebert y McKinnon 1994).

\section{Polimorfismos de otras enzimas (no P450)}

Existen también numerosos polimorfismos en otras superfamilias de enzimas metabolizantes de xenobióticos (por ejemplo, glutatión transferasas, UDP-glucuroniltransferasas, paraoxonasas, deshidrogenasas, N-acetiltransferasas y flavín-monooxigenasas). Como en última instancia la toxicidad de cualquier producto intermedio generado por enzimas $\mathrm{P} 450$ depende de la eficiencia de las reacciones ulteriores de detoxificación de la Fase II, el papel que desempeña la combinación de múltiples polimorfismos enzimáticos es importante para determinar la susceptibilidad a enfermedades inducidas por sustancias químicas. Por consiguiente, es probable que el equilibrio metabólico entre las reacciones de la Fase I y la Fase II (Figura 33.4) sea un factor importante en las enfermedades humanas inducidas por sustancias químicas y en los determinantes genéticos de la respuesta tóxica.

\section{Polimorfismo del gen GSTM1}

Un ejemplo muy estudiado de polimorfismo en una enzima de la Fase II es el que se refiere a un miembro de la superfamilia de enzimas glutatión S-transferasas, designado como GST mu o GSTM1. Esta enzima es de gran interés toxicológico porque al parecer interviene en la detoxificación ulterior de los metabolitos tóxicos que produce la enzima CYP1Al a partir de sustancias químicas presentes en el humo de los cigarrillos. El polimorfismo identificado en este gen de glutatión transferasa consiste en la ausencia total de enzima funcional en nada menos que la mitad del total de caucásicos estudiados. Parece que esta falta de una enzima de la Fase II está asociada a una mayor susceptibilidad al cáncer de pulmón. $\mathrm{Al}$ agrupar a los individuos sobre la base tanto de los genes CIP1A1 variantes como de la deleción o presencia de un gen GSTM1 funcional, se ha demostrado que el riesgo de contraer cáncer de pulmón inducido por el hábito de fumar varía de manera significativa (Kawajiri, Watanabe y Hayashi 1994). En concreto, los individuos que mostraban una única y rara alteración del gen CYP1A1 y además ausencia del gen GSTM1 presentaban un riesgo más alto (hasta nueve veces mayor) de contraer cáncer de pulmón cuando estaban expuestos a un nivel relativamente bajo de humo de cigarrillos. Es interesante que aparentemente hay diferencias interétnicas en la importancia de los genes variantes, lo que hace necesario proseguir los estudios para determinar el papel exacto de esas alteraciones en la susceptibilidad a la enfermedad (Kalow 1962; Nebert y McKinnon 1994; Kawajiri, Watanabe y Hayashi 1994).

\section{Efecto sinérgico de dos o más polimorfismos sobre la respuesta} tóxica

Una respuesta tóxica a un agente ambiental puede verse muy exacerbada por la combinación de dos deficiencias farmacogenéticas en un mismo individuo, por ejemplo los efectos combinados del polimorfismo de la N-acetiltransferasa (NAT2) y el de la glucosa-6-fosfato deshidrogenasa (G6PD).

La exposición profesional a arilaminas constituye un grave riesgo de cáncer de la vejiga urinaria. Desde los refinados estudios de Cartwright en 1954 se sabe que la condición del sujeto con respecto a los $\mathrm{N}$-acetiladores es un determinante del cáncer de vejiga inducido por azocolorantes. Hay una correlación muy significativa entre el fenotipo de acetilador lento y la presencia de cáncer de vejiga, así como con el grado de invasibilidad de este cáncer en la pared de la vejiga. Por el contrario, hay una asociación significativa entre el fenotipo de acetilador rápido y la incidencia de carcinoma colorectal. Se han clonado y secuenciado los genes de la N-acetiltransferasa (NAT1, NAT2), y gracias a los ensayos basados en el ADN es posible hoy detectar las más de una docena de variantes alélicas que explican el fenotipo de acetilador lento. El gen NAT2 es polimórfico y responsable de la mayor parte de la variabilidad observada en la respuesta tóxica a sustancias químicas (Weber 1987; Grant 1993).

La glucosa-6-fosfato deshidrogenasa (G6PD) es una enzima crítica en la generación y el mantenimiento del NADPH. La actividad baja o nula de la G6PD puede producir hemólisis grave inducida por fármacos o xenobióticos, debido a la ausencia de niveles normales de glutatión reducido (GSH) en los glóbulos rojos de la sangre. La deficiencia de G6PD afecta al menos a trescientos millones de personas en todo el mundo. Más del $10 \%$ de los varones afroamericanos presentan el fenotipo 
menos grave, mientras que algunas comunidades de Cerdeña presentan el "tipo mediterráneo", que es más grave, con una frecuencia de nada menos que una de cada tres personas. El gen G6PD se ha clonado y localizado en el cromosoma X, y el gran número de mutaciones puntuales distintas explica el alto grado de heterogeneidad fenotípica que se observa en los individuos con deficiencia de G6PD (Beutler 1992).

Se ha comprobado que la tiozalsulfona, que es un fármaco sulfarilamínico, provoca una distribución bimodal de anemia hemolítica en la población tratada. Cuando se les trata con determinados fármacos, los individuos en los que a la deficiencia de G6PD se suma el fenotipo de acetilador lento se ven más afectados que los que presentan sólo la deficiencia de G6PD o sólo el fenotipo de acetilador lento. Los individuos que reúnen ambas condiciones son al menos 40 veces más susceptibles a la hemólisis inducida por la tiozalsulfona que los acetiladores rápidos con niveles normales de G6PD.

Influencia de los polimorfismos genéticos en la evaluación de la exposición

Para la evaluación y control biológico de la exposición (Figura 33.2) se precisa también información sobre la constitución genética de cada individuo. Dada una exposición idéntica a una sustancia química peligrosa, el nivel de aductos de hemoglobina (o de otros biomarcadores) podría variar en dos o tres órdenes de magnitud entre unas personas y otras en función de la "huella dactilar metabólica" de cada una de ellas.

Se ha estudiado la misma farmacogenética combinada en trabajadores de una fábrica de productos químicos de Alemania (Tabla 33.3). Los aductos de hemoglobina entre trabajadores expuestos a anilina y acetanilida presentaban niveles mucho más altos en los acetiladores lentos con deficiencia de G6PD que en los individuos con los otros posibles fenotipos farmacogenéticos combinados. Este estudio tiene importantes consecuencias para la evaluación de la exposición. Los datos obtenidos en él demuestran que, aunque dos individuos puedan estar expuestos al mismo nivel ambiental de sustancias químicas peligrosas en el lugar de trabajo, la cantidad de exposición (a través de biomarcadores como los aductos de hemoglobina) puede estimarse en dos o más órdenes de magnitud menos debido a la predisposición genética subyacente del individuo. Análogamente, el riesgo resultante de un efecto adverso sobre la salud puede variar en dos o más órdenes de magnitud.

\section{Diferencias genéticas tanto en las uniones como en el metabolismo}

Hay que hacer hincapié en que lo que se ha dicho aquí sobre el metabolismo es aplicable también a las uniones. Las diferencias hereditarias de unión de los agentes ambientales afectan considerablemente a la respuesta tóxica. Por ejemplo, las diferencias en el gen cdm del ratón pueden influir profundamente en la

Tabla 33.3 • Aductos de hemoglobina en trabajadores expuestos a anilina y acetanilida.

\begin{tabular}{|c|c|c|c|c|}
\hline \multicolumn{2}{|c|}{ Tipo de acetilador } & \multicolumn{3}{|c|}{ Deficiencia de G6PD } \\
\hline Rápido & Lento & No & Sí & Aductos de $\mathrm{Hgb}$ \\
\hline+ & & + & & 2 \\
\hline+ & & & + & 30 \\
\hline & + & + & & 20 \\
\hline & + & & + & 100 \\
\hline
\end{tabular}

Fuente: Adaptado de Lewalter y Korallus 1985.
Figura 33.6 - Procesos generales de la toxicidad.

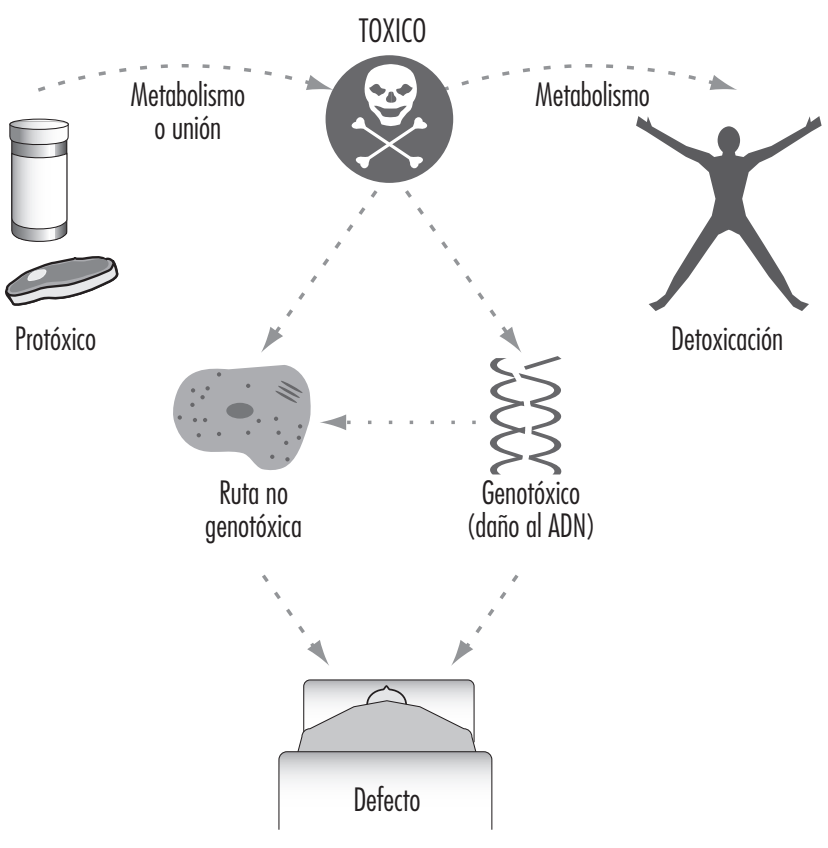

sensibilidad individual a la necrosis testicular inducida por cadmio (Taylor, Heiniger y Meier 1973). Las diferencias en la afinidad de unión del receptor Ah afectan probablemente a la toxicidad y el cáncer inducidos por la dioxina (Nebert, Petersen y Puga 1991; Nebert, Puga y Vasiliou 1993).

En la Figura 33.6 se resume el papel que desempeñan el metabolismo y las uniones en la toxicidad y el cáncer. Los agentes tóxicos, tal como existen en el medio ambiente o tras su metabolismo o unión, provocan sus efectos bien por una ruta genotóxica (en la cual se produce un daño para el ADN), bien por una ruta no genotóxica (en la que el daño para el ADN y la mutagénesis no se producen necesariamente). Es interesante que se haya comprobado recientemente que los agentes "clásicos" que dañan al ADN pueden operar a través de una ruta de transducción de una señal de transducción no genotóxica que es GSH-dependiente y que se inicia en la superficie de la célula o cerca de ella en ausencia de ADN y fuera del núcleo celular (Devary y cols. 1993). No obstante, las diferencias genéticas en materia de metabolismo y de uniones siguen siendo los factores que más determinan el control de las diferentes respuestas tóxicas individuales

\section{Enzimas metabolizantes de fármacos y función celular}

Las variaciones de origen genético en el funcionamiento de las enzimas metabolizantes de fármacos son de gran importancia para determinar la respuesta individual a las sustancias químicas. Esas enzimas son esenciales para el destino y el curso temporal de una sustancia química extraña tras la exposición.

Como se indica en la Figura 33.6, la importancia de las enzimas metabolizantes de fármacos para la susceptibilidad individual a la exposición química puede ser de hecho una cuestión mucho más compleja de lo que cabe deducir de este sencillo análisis del metabolismo de los xenobióticos. En otras palabras, a lo largo de los dos últimos decenios se ha hecho mucho hincapié en los mecanismos genotóxicos (mediciones de los aductos de ADN y de proteínas). No obstante, ¿y si los 
mecanismos no genotóxicos fueran al menos tan importantes como los genotóxicos en la producción de las respuestas tóxicas?

Como se ha señalado anteriormente, no se han definido con precisión las funciones fisiológicas de muchas enzimas metabolizantes de fármacos que intervienen en el metabolismo de los xenobióticos. Nebert (1994) ha propuesto que, habida cuenta de que están presentes en este planeta desde hace más de 3.500 millones de años, las enzimas metabolizantes de fármacos eran en su origen (y hoy lo siguen siendo esencialmente) responsables de la regulación de los niveles celulares de muchos ligandos no peptídicos importantes para la activación transcripcional de genes que afectan a las funciones de crecimiento, diferenciación, apoptosis, homeostasis y neuroendocrinas. Además, la mayoría de los agentes ambientales, si no todos, producen su toxicidad actuando de una manera agonista o antagonista sobre señal de transducción (Nebert 1994). Sobre la base de esta hipótesis, la variabilidad genética de las enzimas metabolizantes de fármacos puede tener efectos muy considerables sobre muchos procesos bioquímicos críticos que se desarrollan en la célula, provocando con ello importantes diferencias en la respuesta tóxica. Es posible sin duda que esta hipótesis pueda explicar muchas reacciones adversas idiosincráticas que aparecen en pacientes a los que se les ha administrado fármacos de uso habitual.

\section{Conclusiones}

En el último decenio se ha avanzado notablemente en el conocimiento de la base genética de las diferencias de respuesta a las sustancias químicas presentes en los fármacos, los alimentos y los contaminantes ambientales. Las enzimas metabolizantes de fármacos influyen de manera profunda en la forma en que los humanos responden a las sustancias químicas. Como seguimos ampliando nuestros conocimientos sobre la multiplicidad de las enzimas metabolizantes de fármacos, cada vez estamos más preparados para evaluar mejor el riesgo de toxicidad de muchos fármacos y sustancias químicas ambientales. El ejemplo más claro es probablemente el caso de la enzima CYP2D6, de la superfamilia citocromo P450. Mediante ensayos basados en el ADN que son de relativa sencillez es posible predecir la respuesta probable de cualquier fármaco que sea metabolizado predominantemente por esta enzima; y gracias a esa predicción se podrán utilizar de una manera más segura unos tratamientos que aunque valiosos son potencialmente tóxicos.

En el futuro asistiremos sin duda a una explosión de la identificación de nuevos polimorfismos (fenotipos) relacionados con las enzimas metabolizantes de fármacos. Esa información estará acompañada, con miras a identificar los fenotipos de las poblaciones humanas, de unos ensayos basados en el ADN que serán mejores y mínimamente invasivos.

Esos estudios deben ser particularmente útiles para evaluar el papel de las sustancias químicas en las muchas enfermedades ambientales cuyo origen hoy desconocemos. Es probable también que el análisis de las combinaciones de varios polimorfismos de estas enzimas (véase por ejemplo la Tabla 33.3) constituya un área de investigación especialmente fecunda. Esos estudios clarificarán la función de las sustancias químicas en el origen de los diversos tipos de cáncer. Gracias al conjunto de esa información se podrán formular consejos cada vez más individualizados sobre la forma de evitar sustancias químicas que tienen probabilidades de provocar problemas individuales. Es el campo de la toxicología preventiva. Y es indudable que ese asesoramiento ayudará en gran medida a todas las personas a hacer frente a la carga química cada vez mayor a la que estamos expuestos.

\section{- INTRODUCCION Y CONCEPTOS}

\section{Philip G. Watanabe}

La toxicología mecanicista estudia cómo interactúan los agentes químicos o físicos con los organismos vivos para producir la toxicidad. Conocer el mecanismo de la toxicidad de una sustancia permite prevenirla mejor y diseñar sustancias químicas más deseables; es la base de la terapia en los casos de sobreexposición, y muchas veces permite comprender mejor procesos biológicos fundamentales. En el contexto de esta Enciclopedia se hará hincapié en el empleo de animales para predecir la toxicidad humana. La toxicología puede subdividirse en toxicología mecanicista, descriptiva, reguladora, forense y ambiental (Klaassen, Amdur y Doull 1991). Y en todas ellas es conveniente comprender los mecanismos fundamentales de la toxicidad.

\section{Ventajas de comprender los mecanismos de la toxicidad}

Comprender el mecanismo por el que una sustancia produce toxicidad ayuda de diversas maneras a las varias subdisciplinas de la toxicología. La información mecanicista ayuda a los organismos oficiales responsables de la regulación a establecer límites de seguridad de la exposición humana jurídicamente vinculantes. Ayuda a los toxicólogos a recomendar líneas de acción para limpiar o corregir lugares contaminados y, junto con las propiedades físicas y químicas de la sustancia o combinación de sustancias, puede utilizarse para determinar el equipo de protección específico que se precisa. Los conocimientos mecanicistas son útiles también para establecer la base de la terapia y diseñar nuevos fármacos para el tratamiento de las enfermedades humanas. En la toxicología forense, el mecanismo de la toxicidad explica muchas veces la forma en que un agente químico o físico puede producir la muerte o la incapacidad.

Si se comprende el mecanismo de la toxicidad, la toxicología descriptiva puede ser un instrumento útil para predecir los efectos tóxicos de sustancias químicas relacionadas. Es importante entender, no obstante, que la falta de información mecanicista no disuade a los profesionales de la salud de sus esfuerzos por proteger la salud humana. Para establecer unos niveles de exposición seguros se utilizan decisiones prudentes basadas en estudios con animales y en la experiencia humana. Tradicionalmente se ha venido estableciendo un margen de seguridad utilizando el "nivel sin efecto adverso" o un "nivel más bajo con efecto adverso" obtenidos en los estudios con animales (mediante modelos de exposiciones repetidas) y dividiendo ese nivel por un factor de 100 en la exposición profesional y de 1.000 en otros tipos de exposición ambiental humana. El éxito de este procedimiento se puede comprobar en los pocos casos de efectos adversos sobre la salud de los trabajadores que pueden atribuirse a la exposición química allí donde en el pasado se establecieron y respetaron unos límites de exposición adecuados. Además, la esperanza de vida humana sigue aumentando, y también la calidad de vida. En general, el empleo de datos sobre toxicidad ha permitido establecer controles obligatorios y voluntarios eficaces. El conocimiento pormenorizado de los mecanismos tóxicos 
mejorará la predecibilidad de los nuevos modelos de riesgo que se están elaborando en la actualidad y tendrá como resultado un perfeccionamiento continuo.

Comprender los mecanismos ambientales es una cuestión compleja, y es necesario conocer previamente los fenómenos de perturbación y homeostasis (equilibrio) del ecosistema. Aunque esta cuestión no se examina en este artículo, una mejor comprensión de los mecanismos tóxicos y sus consecuencias últimas en un ecosistema ayudaría a los científicos a adoptar decisiones prudentes sobre el manejo de los materiales de desecho municipales e industriales. La gestión de los desechos es un ámbito de investigación cada vez más amplio, y seguirá teniendo mucha importancia en el futuro.

\section{Técnicas para estudiar los mecanismos de la toxicidad}

La mayoría de los estudios mecanicistas se inicia con una descripción toxicológica referida a animales o a observaciones clínicas en humanos. Idealmente, los estudios con animales comprenden cuidadosas observaciones clínicas y de comportamiento, un minucioso examen bioquímico de los elementos de la sangre y la orina en busca de signos de deterioro funcional en los principales sistemas biológicos del cuerpo, y una evaluación post-mortem de todos los sistemas orgánicos, mediante examen microscópico, para comprobar la lesión (véanse las directrices de ensayos de la OCDE; las directivas de la UE sobre evaluación química; las normas sobre ensayos de la Environmental Protection Agency (EPA) de los Estados Unidos, y la normativa sobre sustancias químicas del Japón). En los humanos, y con la excepción del examen post-mortem, todo ello equivale a un concienzudo examen físico que se realiza en un hospital a lo largo de dos o tres días.

Comprender los mecanismos de la toxicidad es el arte y la ciencia de la observación, de la creatividad en la selección de técnicas para ensayar diversas hipótesis y de la integración innovadora de signos y síntomas en una relación causal. Los estudios mecanicistas se inician con la exposición, hacen un seguimiento de la distribución temporal y el destino en el organismo (farmacocinética) y miden el efecto tóxico resultante a algún nivel del sistema y a algún nivel de dosis. $\mathrm{Al}$ provocar la toxicidad, sustancias diferentes pueden actuar a niveles diferentes del sistema biológico.

\section{Exposición}

En los estudios mecanicistas, la ruta de exposición suele ser la misma que en la exposición humana. La ruta es importante porque puede haber efectos locales en el lugar de la exposición y además efectos sistémicos una vez que la sustancia ha sido absorbida en la sangre y distribuida por todo el cuerpo. Un ejemplo sencillo pero revelador de un efecto local sería la irritación y eventual corrosión de la piel tras la aplicación de soluciones ácidas o alcalinas fuertes como las que se emplean para limpiar superficies duras. Análogamente, puede producirse irritación y muerte celular en las células que revisten los orificios nasales y/o el pulmón tras la exposición a vapores o gases irritantes, como óxidos de nitrógeno u ozono. (Ambos están presentes en la contaminación atmosférica.) Tras la absorción de una sustancia química en la sangre a través de la piel, el pulmón o el tracto gastrointestinal, la concentración en cualquier órgano o tejido está controlada por muchos factores que determinan la farmacocinética de esa sustancia en el cuerpo. Como veremos más adelante, el cuerpo es capaz no sólo de detoxificar sino también de activar diversas sustancias químicas.

\section{Farmacocinética y toxicidad}

La farmacocinética describe el marco temporal de la absorción, distribución, metabolismo (transformaciones bioquímicas en el organismo) y eliminación o excreción de las sustancias químicas. Estas variables farmacocinéticas pueden tener mucha importancia en relación con los mecanismos de toxicidad, y en algunos casos pueden determinar si se produce o no toxicidad. Por ejemplo, si un material no se absorbe en cantidad suficiente no habrá toxicidad sistémica (en el interior del cuerpo). A la inversa, es posible que una sustancia química muy reactiva que se ha detoxificado rápidamente (en segundos o minutos) por la acción de enzimas digestivas o hepáticas no tenga tiempo para provocar toxicidad. Algunas sustancias y mezclas halogenadas policíclicas, y también algunos metales como el plomo, no producirían una toxicidad significativa si su excreción fuera rápida; pero su acumulación hasta llegar a niveles suficientemente altos determina su toxicidad, pues la excreción no es rápida (a veces se mide en años). Afortunadamente, son muy pocas las sustancias químicas que se retienen durante tanto tiempo en el cuerpo. La acumulación de un material inocuo tampoco induce toxicidad. La velocidad con que una sustancia química se elimina del cuerpo y se detoxifica es lo que suele expresarse como su vida media, que es el tiempo que se necesita para que el $50 \%$ de ella sea excretado o convertido en una forma no tóxica.

No obstante, si una sustancia química se acumula en una determinada célula u órgano, ello puede ser motivo para examinar más a fondo su toxicidad potencial en ese órgano. Más recientemente se han elaborado modelos matemáticos para extrapolar de los animales a los humanos variables farmacocinéticas. Tales modelos farmacocinéticos son sumamente útiles para generar hipótesis y determinar si el animal de experimentación puede ser un buen representante del ser humano. Sobre esta cuestión hay una amplia bibliografía (Gehring y cols. 1976; Reitz y cols. 1987; Nolan y cols. 1995). En la Figura 33.7 se muestra un ejemplo simplificado de modelo fisiológico.

Figura 33.7 • Modelo farmacocinético simplificado.

ENTRADA

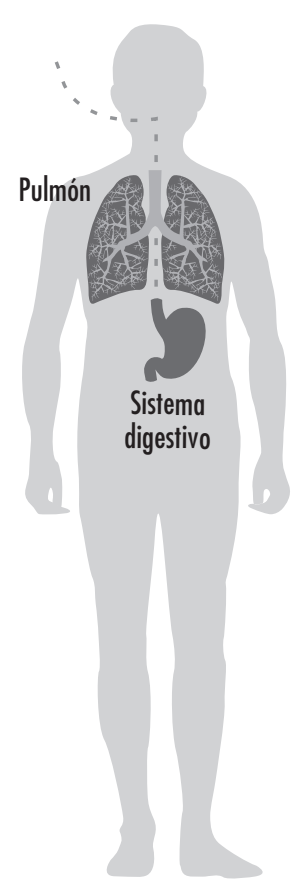

FLUJO

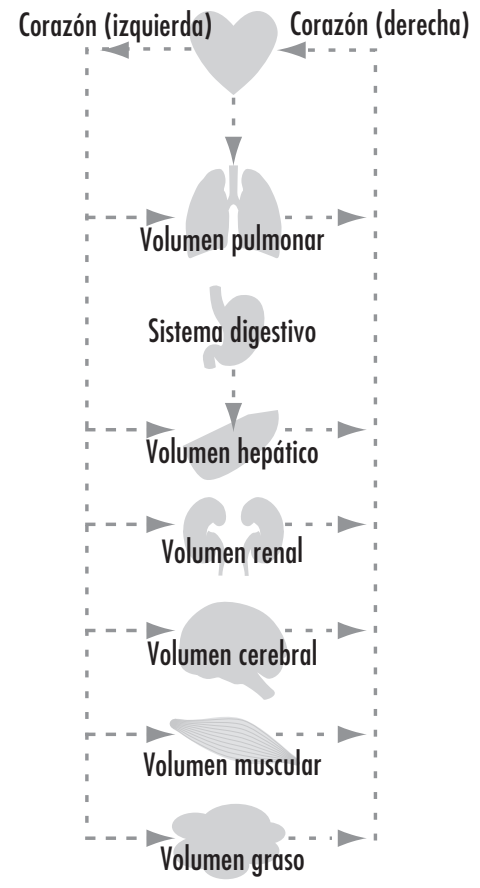




\section{Posible afectación adversa de distintos niveles y sistemas}

La toxicidad puede describirse a diferentes niveles biológicos. La lesión puede evaluarse en la totalidad de la persona (o animal), en los sistemas orgánicos, en las células o en las moléculas. Los sistemas orgánicos son los siguientes: inmunitario, respiratorio, cardiovascular, renal, endocrino, digestivo, musculoesquelético, sanguíneo, reproductivo y nervioso central. Son órganos decisivos el hígado, el riñón, el pulmón, el cerebro, la piel, los ojos, el corazón, los testículos u ovarios y otros órganos principales. Entre los efectos adversos a nivel celular/bioquímico figuran la interferencia de la función proteínica normal y de la función de los receptores endocrinos, la inhibición del metabolismo energético y la inhibición o inducción de enzimas por xenobióticos (sustancias extrañas). Entre los efectos adversos a nivel molecular figuran las alteraciones de la función normal de la transcripción ADN-ARN, de la unión de receptores específicos citoplasmáticos y nucleares, y de los genes o productos génicos. En última instancia, el deterioro funcional de un sistema orgánico importante suele deberse a alteraciones moleculares en determinadas células diana de ese órgano. Sin embargo, no siempre es posible, ni tampoco necesario, determinar en el nivel molecular el origen de un mecanismo. Se puede diseñar una intervención y una terapia sin conocer por completo la diana molecular. No obstante, conocer el mecanismo concreto de toxicidad incrementa el valor predictivo y la fiabilidad de las extrapolaciones a otras sustancias. La Figura 33.8 es un diagrama de los diversos niveles en los que se puede detectar una interferencia de los procesos fisiológicos normales. Las flechas indican que las consecuencias para un individuo pueden determinarse de arriba abajo (de la exposición y la farmacocinética a la toxicidad en el sistema/órgano) o de abajo arriba (del cambio molecular y el efecto celular/químico a la toxicidad en el sistema/órgano).

\section{Ejemplos de mecanismos de la toxicidad}

Hay mecanismos de la toxicidad que son directos y sencillos, pero también otros que son muy complejos. Son frecuentes las diferencias de tipo y mecanismo de la toxicidad y de nivel de efecto en función de que los efectos adversos se deban a una dosis única, alta y aguda (como una intoxicación accidental) o a la exposición repetida a una dosis más baja (exposición profesional o ambiental). En los ensayos, el procedimiento clásico es administrar una dosis única y alta mediante intubación directa en el estómago de un roedor o mediante exposición a una atmósfera de gases o vapores durante un período de dos a cuatro horas, según cual sea la forma que más se asemeje a la exposición humana. Se observa a los animales durante un período de dos semanas a partir de la exposición y después se examinan sus principales órganos externos e internos para comprobar las lesiones. Los ensayos a base de dosis repetidas pueden durar desde meses hasta años. En el caso de las especies de roedores se considera que dos años es un plazo suficiente para el estudio crónico (toda la vida) de evaluación de la toxicidad y carcinogenicidad, mientras que en el caso de los primates no humanos dos años se consideraría un plazo de estudio subcrónico (menos que toda la vida) para evaluar la toxicidad debida a dosis repetidas. Tras la exposición se realiza un examen completo de todos los tejidos, órganos y fluidos para determinar si se han producido efectos adversos.

\section{Mecanismos de la toxicidad aguda}

Los ejemplos que figuran a continuación son específicos de los efectos agudos por dosis altas, que pueden desembocar en la muerte o en una incapacidad grave. No obstante, en algunos casos la intervención puede producir efectos transitorios y totalmente reversibles. El resultado estará determinado por la dosis o por la gravedad de la exposición. Figura 33.8 - $\begin{aligned} \text { Representación de los mecanismos de la } \\ \text { toxicidad. }\end{aligned}$
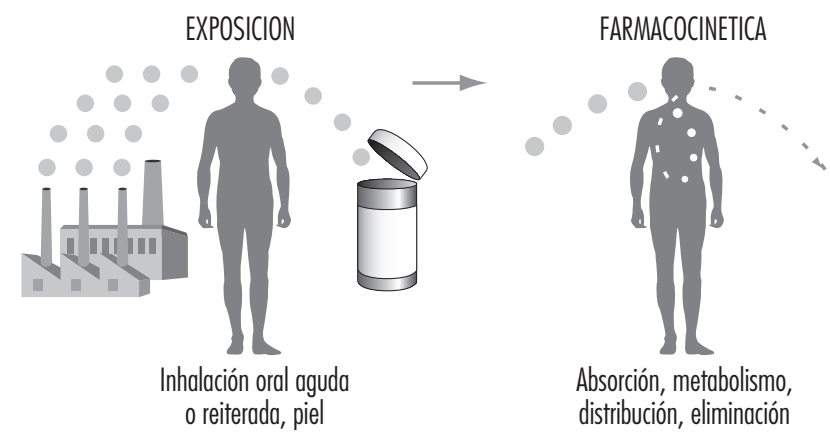

Absorción, metabolismo, distribución, eliminación

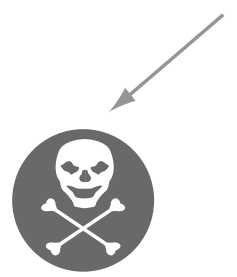

Efecto tóxico

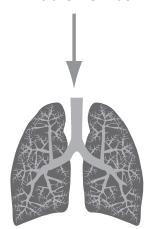

Nivel sistémico/orgánico (SNC, pulmón, sistema reproductor, etc.)

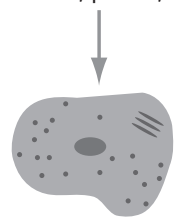

Nivel celular/bioquímico

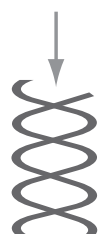

Nivel molecular (ADN, ARN, proteínas)

Asfixiantes simples. En el caso de los gases inertes y algunas otras sustancias no reactivas, el mecanismo de toxicidad es la falta de oxígeno (anoxia). Estas sustancias químicas, que hacen que el sistema nervioso central (SNC) se vea privado de oxígeno, se denominan asfixiantes simples. Cuando una persona entra en un espacio cerrado que contiene nitrógeno sin oxígeno suficiente, en su cerebro se agota inmediatamente el oxígeno, lo que lleva a la pérdida de conciencia y finalmente a la muerte si no se la saca rápidamente de allí. En casos extremos (oxígeno casi cero), la pérdida de conciencia puede sobrevenir a los pocos segundos. La salvación de la persona depende del rápido traslado a un entorno oxigenado. Cuando ese traslado se demora, la persona puede sobrevivir pero con un daño cerebral irreversible debido a la muerte de neuronas, que no se regeneran.

Asfixiantes químicos. El monóxido de carbono $(\mathrm{CO})$ compite con el oxígeno por unirse a la hemoglobina (en los glóbulos rojos de la sangre) y por lo tanto priva a los tejidos del oxígeno necesario 
para el metabolismo energético; la consecuencia puede ser la muerte celular. La intervención consiste en alejar a la persona de la fuente de $\mathrm{CO}$ y administrarle oxígeno. El uso directo de oxígeno está basado en la acción tóxica del CO. Otro potente asfixiante químico es el cianuro. El ion cianuro interfiere el metabolismo celular y la utilización de oxígeno para obtener energía.

El tratamiento con nitrito de sodio hace que la hemoglobina de los glóbulos rojos se transforme en metahemoglobina. Esta tiene una mayor afinidad de unión por el ion cianuro que la diana celular del cianuro. En consecuencia, la metahemoglobina se une al cianuro y lo mantiene alejado de las células diana. Esta es la base de la terapia con antídotos.

Depresores del sistema nervioso central (SNC). En el caso de diversas sustancias que como algunos disolventes son reactivas o que se transforman en productos intermedios reactivos, la toxicidad aguda se caracteriza por sedación o pérdida de la conciencia. Se ha formulado la hipótesis de que la sedación/anestesia se debe a una interacción del disolvente con las membranas celulares del SNC, que reduce su capacidad de transmitir señales eléctricas y químicas. Aunque la sedación pueda considerarse como una forma leve de toxicidad y fuera la base del desarrollo de los primeros anestésicos, hay que recordar que "la dosis hace al veneno". Si se administra por ingestión o inhalación una dosis suficiente, el animal puede morir por parada respiratoria. Cuando no se produce muerte anestésica, este tipo de toxicidad suele ser fácilmente reversible cuando se aleja al sujeto de la exposición o la sustancia se redistribuye o se elimina del cuerpo.

Efectos cutáneos. Los efectos adversos en la piel pueden ir, según la sustancia que los causa, desde la irritación hasta la corrosión. Las soluciones ácidas y alcalinas fuertes son incompatibles con el tejido vivo y son corrosivas, por lo que producen quemaduras químicas y posible cicatrización. La formación de la cicatriz se debe a la muerte de células de la capa profunda de la dermis, que es la responsable de la regeneración. Con concentraciones más bajas el efecto puede limitarse a irritación de la primera capa de la piel.

Otro mecanismo tóxico específico de la piel es el de la sensibilización química. Veamos un ejemplo. Se produce sensibilización cuando el 2,4-dinitroclorobenceno se une a proteínas naturales de la piel y el sistema inmunitario reconoce como material extraño ese complejo proteico alterado. $\mathrm{Al}$ responder a ese material extraño, el sistema inmunitario activa unas células especiales para eliminar la sustancia extraña liberando unos mediadores (citoquinas) que provocan una erupción o dermatitis (véase "Inmunotoxicología"). Es la misma reacción del sistema inmunitario que se produce en la exposición a la planta llamada "zumaque venenoso" (género Rhus). La sensibilización inmunitaria es muy específica de cada sustancia química, y se precisan al menos dos exposiciones para que se desencadene la respuesta. La primera exposición sensibiliza (hace que las células reconozcan la sustancia), y las exposiciones ulteriores ponen en marcha la respuesta inmunitaria. Para tratar a personas sensibilizadas suele ser eficaz interrumpir el contacto y aplicar una terapia sintomática con cremas antiinflamatorias que contienen esteroides. En casos graves o rebeldes se utiliza junto con el tratamiento tópico un inmunosupresor que actúa a nivel sistémico, como la prednisona.

Sensibilización pulmonar. El diisocianato de tolueno (TDI) provoca una respuesta de sensibilización inmunitaria, pero su diana es el pulmón. La sobreexposición a TDI en individuos susceptibles provoca edema pulmonar (acumulación de líquido), constricción bronquial y dificultad respiratoria. Es una enfermedad grave, que requiere alejar al individuo de otras posibles exposiciones ulteriores. El tratamiento es sobre todo sintomático. La sensibilización cutánea y pulmonar está relacionada con la dosis. Exceder el nivel establecido de exposición profesional puede producir efectos adversos.

Efectos oculares. Las lesiones oculares van desde el enrojecimiento de la capa exterior (típico de las piscinas) hasta la formación de cataratas en la córnea y lesiones en el iris (parte coloreada del ojo). Cuando se estima que no se van a producir lesiones graves se realizan ensayos de irritación ocular. Muchos de los mecanismos que provocan corrosión cutánea pueden producir también lesiones oculares. Las sustancias corrosivas para la piel, como ácidos y álcalis fuertes ( $\mathrm{pH}$ inferior a 2 y superior a 11,5 respectivamente), no se ensayan en los ojos de animales porque en la mayoría de los casos provocarían corrosión y ceguera debido a un mecanismo similar al que produce la corrosión cutánea. También los agentes tensoactivos como los detergentes y surfactantes pueden producir lesiones oculares, desde irritación hasta corrosión. Un grupo de sustancias que exige prudencia es el de los surfactantes de carga positiva (catiónicos), que pueden producir quemaduras, opacidad permanente de la córnea y vascularización (formación de vasos sanguíneos). Otra sustancia química, el dinitrofenol, tiene un efecto específico de formación de cataratas. Parece que está relacionado con la concentración de esta sustancia en el ojo, que es un ejemplo de especificidad en la distribución farmacocinética.

Con esta relación de ejemplos, en modo alguno exhaustiva, se ha pretendido ofrecer al lector un panorama de los diversos mecanismos de la toxicidad aguda.

\section{Mecanismos de la toxicidad subcrónica y crónica}

Cuando se administra una dosis única y elevada, algunas sustancias químicas no presentan el mismo mecanismo de toxicidad que cuando se administran repetidamente en dosis bajas pero tóxicas. Cuando se administra una dosis única y elevada cabe siempre la posibilidad de que se supere la capacidad de la persona para detoxificar o excretar la sustancia, y ello puede provocar una respuesta tóxica distinta de la que se produce cuando se administran repetidamente dosis más bajas. Un buen ejemplo a este respecto es el alcohol. Dosis altas de alcohol producen efectos primarios en el sistema nervioso central, mientras que la repetición de dosis más bajas produce lesión hepática.

Inhibición de la acetilcolinesterasa. Los plaguicidas organofosforados, por ejemplo, tienen en su mayoría escasa toxicidad para los mamíferos hasta que son activados metabólicamente, sobre todo en el hígado. El principal mecanismo de acción de los organofosforados es la inhibición de la acetilcolinesterasa (AChE) en el cerebro y el sistema nervioso periférico. La AChE es la enzima que normalmente pone fin a la estimulación provocada por el neurotransmisor acetilcolina. La inhibición leve de la AChE a lo largo de un período prolongado no se ha asociado con efectos adversos. A niveles de exposición altos, la incapacidad de poner fin a esa estimulación neuronal produce una sobreestimulación del sistema nervioso colinérgico, lo que en última instancia provoca toda una serie de síntomas, como parada respiratoria a la que sigue la muerte si no se trata. El tratamiento fundamental consiste en administrar atropina, que bloquea los efectos de la acetilcolina, y cloruro de pralidoxima, que reactiva la AchE inhibida. Por consiguiente, tanto la causa como el tratamiento de la toxicidad por organofosforados se abordan desde el conocimiento de la base bioquímica de los mecanismos de toxicidad de estas sustancias.

Activación metabólica. Muchas sustancias químicas, como el tetracloruro de carbono, el cloroformo, el acetilaminofluoreno, las nitrosaminas y el paraquat, se activan metabólicamente liberando radicales libres u otros productos intermedios reactivos que inhiben o interfieren la función celular normal. A niveles de 
exposición altos ello produce la muerte celular (véase "Lesión celular y muerte celular"). Aunque todavía desconocemos las interacciones y dianas celulares específicas, los sistemas orgánicos que poseen la capacidad de activar esas sustancias, como el hígado, el riñón y el pulmón, son todos dianas potenciales del efecto nocivo. Concretamente, determinadas células de un órgano tienen una mayor o menor capacidad de activar o detoxificar esos productos intermedios, y es esa capacidad lo que determina la susceptibilidad intracelular de un órgano. El metabolismo es una de las razones por las que el conocimiento de la farmacocinética, que describe esos tipos de transformaciones y la distribución y eliminación de esos productos intermedios, es importante para reconocer el mecanismo de acción de esas sustancias.

Mecanismos del cáncer. El cáncer es una multiplicidad de enfermedades, y, a pesar de que se está avanzando rápidamente en el conocimiento de determinados tipos de cáncer gracias a las muchas técnicas de biología molecular que se han desarrollado desde 1980, es aún mucho lo que queda por saber.

No obstante, está claro que el desarrollo del cáncer es un proceso de múltiples fases, y que hay unos genes críticos que son la clave de distintos tipos de cáncer. Las alteraciones del ADN (mutaciones somáticas) en algunos de esos genes críticos pueden provocar una mayor susceptibilidad o lesiones cancerosas (véase "Toxicología genética"). Contribuye a las mutaciones somáticas la exposición a sustancias químicas, naturales (en alimentos cocinados como la carne de vaca y el pescado) o sintéticas (como la bencidina, que se utiliza como colorante), o a agentes físicos (la radiación ultravioleta del sol, el radón procedente del suelo, la radiación gamma de las técnicas médicas o la actividad industrial).

Sin embargo, hay sustancias naturales y sintéticas (como los antioxidantes) y procesos de reparación del ADN que desempeñan una función protectora y mantienen la homeostasis. Está claro que la genética es un factor importante en el cáncer, pues síndromes patológicos genéticos como el xeroderma pigmentoso, en el que el ADN no se repara como sería normal, incrementan radicalmente la susceptibilidad al cáncer de piel derivado de la exposición a la luz ultravioleta del sol.

Mecanismos de la toxicidad reproductiva. Al igual que en el caso del cáncer, se conocen muchos mecanismos de la toxicidad que afecta a la reproducción y/o el desarrollo, pero es mucho lo que aún queda por descubrir. Se sabe que determinados virus (como el de la rubéola), infecciones bacterianas y fármacos (como la talidomida y la vitamina A) afectan negativamente al desarrollo. En un trabajo reciente de Khera (1991) revisado por Carney (1994) se ha comprobado que las anomalías del desarrollo observadas en ensayos realizados con etilenglicol en animales son atribuibles a metabolitos ácidos del metabolismo de la madre. Esto ocurre cuando el etilenglicol se metaboliza a metabolitos ácidos como los ácidos glicólico y oxálico. Los efectos ulteriores en la placenta y el feto parecen deberse a ese proceso de intoxicación metabólica.

\section{Conclusiones}

En este artículo hemos pretendido ofrecer un panorama de varios mecanismos de la toxicidad que conocemos y subrayar la necesidad de proseguir los estudios. Es importante entender que los conocimientos mecanicistas no son absolutamente necesarios para proteger la salud humana o ambiental. Pero gracias a ellos el profesional podrá predecir y tratar mejor la toxicidad. Las técnicas que actualmente se utilizan para elucidar un mecanismo concreto dependen del conocimiento colectivo de los científicos y de la opinión de los encargados de adoptar decisiones en el ámbito de la salud humana.

\section{LESION GELULAR Y MUERTE CELULAR}

Benjamin F. Trump
e Irene K. Berezesky

Prácticamente todos los esfuerzos de la medicina se dedican a impedir la muerte celular, en enfermedades como el infarto de miocardio, los accidentes cerebrovasculares, los traumatismos y el shock, o a provocarla, como en el caso de las enfermedades infecciosas y el cáncer. Es por consiguiente esencial comprender la naturaleza de los mecanismos que intervienen en ese proceso. La muerte celular se ha dividido en "accidental", es decir, causada por agentes tóxicos, isquemia, etc., y "programada", que es la que se produce en el desarrollo embriológico, como por ejemplo la formación de los dedos o la resorción de la cola en el renacuajo.

La lesión celular y la muerte celular tienen por ello importancia tanto fisiológica como patofisiológica. La muerte fisiológica de la célula es sumamente importante durante la embriogénesis y el desarrollo embrionario. El estudio de la muerte celular durante el desarrollo ha permitido obtener información nueva y de gran importancia sobre los procesos de genética molecular, gracias especialmente al análisis del desarrollo en los animales invertebrados. En esos animales se ha estudiado minuciosamente la localización precisa y la significación de las células que están destinadas a morir, y mediante las técnicas mutagenéticas clásicas se han identificado ya varios de los genes que intervienen en ese proceso. En los órganos adultos, el equilibrio entre la muerte celular y la proliferación celular controla el tamaño de los órganos. En algunos órganos, como la piel y el intestino, la renovación celular es continua. En la piel, por ejemplo, las células se van diferenciando al llegar a la superficie hasta que llegan a la fase de diferenciación terminal y a la muerte celular a medida que avanza la queratinización, con la formación de las llamadas "capas plegadas en zigzag".

Son muchas las clases de sustancias tóxicas que pueden inducir una lesión celular aguda y después la muerte. Tenemos así la anoxia y la isquemia, con sus análogos químicos como el cianuro de potasio; los carcinógenos químicos, que forman electrófilos que se unen con enlaces covalentes a proteínas de los ácidos nucleicos; sustancias oxidantes, que provocan la formación de radicales libres y lesión oxidativa; la activación del complemento, y diversos ionóforos de calcio. La muerte celular es también un importante componente de la carcinogénesis química; muchos carcinógenos químicos completos, a dosis carcinógenas, producen necrosis aguda e inflamación seguidas de regeneración y preneoplasia.

\section{Definiciones}

\section{Lesión celular}

La lesión celular se define como un hecho o estímulo, por ejemplo una sustancia química tóxica, que perturba la homeostasis normal de la célula, lo que hace que se produzcan diversos acontecimientos (Figura 33.9). Las dianas principales de la lesión letal que figura en el ejemplo son la inhibición de la síntesis del ATP, la interrupción de la continuidad de la membrana plasmática y la supresión de factores esenciales para el crecimiento.

Las lesiones letales acaban en la muerte de la célula al cabo de un período de tiempo variable, que depende de la temperatura, el tipo de célula y el estímulo; pero también pueden producirse lesiones subletales o crónicas - que provocan un estado de alteración de la homeostasis que, aunque anómalo, no desemboca en la muerte de la célula (Trump y Arstila 1971; Trump y Berezesky 1992; Trump y Berezesky 1995; Trump, Berezesky y Osornio-Vargas 1981). En los casos de lesión letal se observa 
Figura 33.9 • Lesión celular.

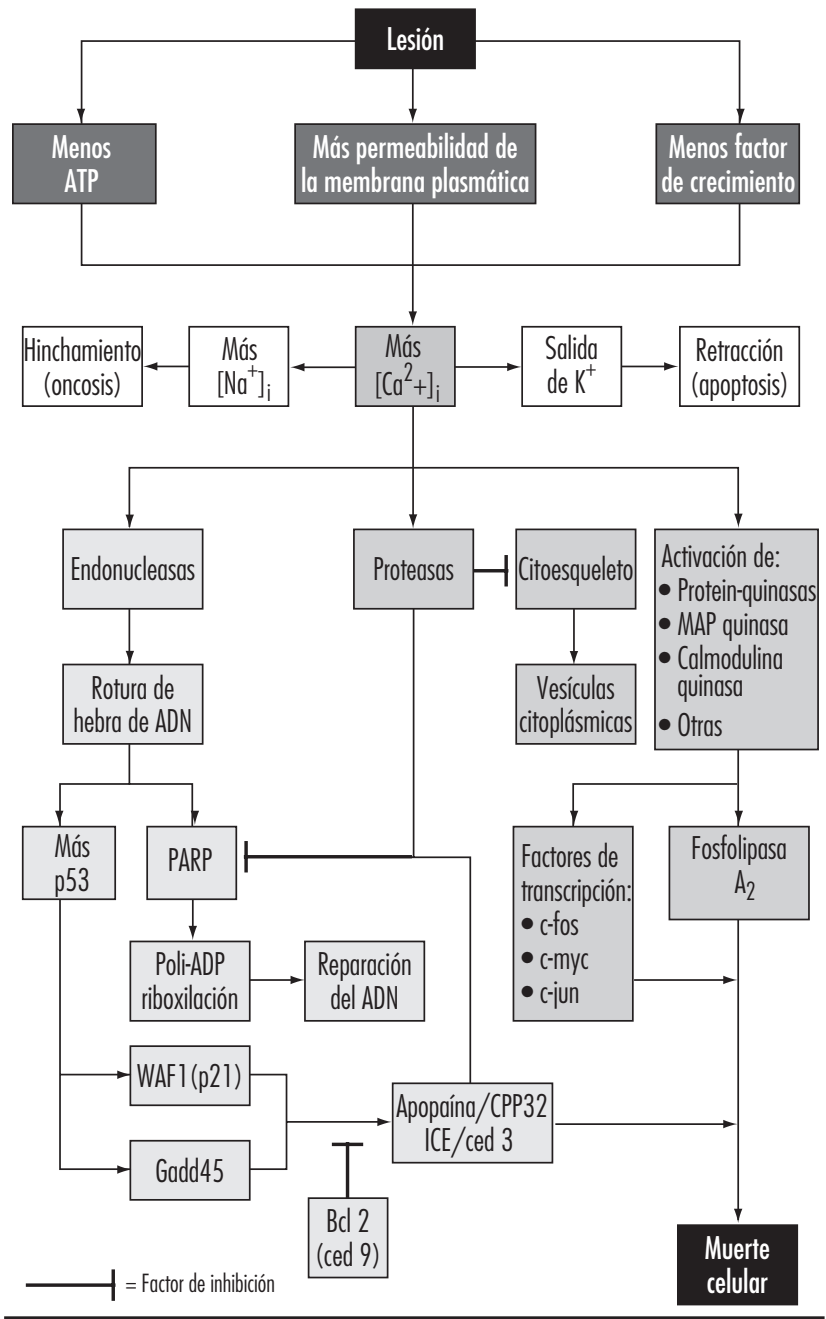

antes de la muerte celular lo que se llama la "fase preletal". Si durante ese tiempo se elimina el estímulo causante, la anoxia por ejemplo, la célula se recupera; sin embargo, llega un momento (el "punto sin retorno" o punto de muerte celular) en el que a pesar de eliminarse la causa de la lesión la célula no puede recuperarse, sino que pasa por un proceso de degradación e hidrólisis hasta llegar finalmente al equilibrio físicoquímico con el entorno. Es la fase que se conoce como necrosis. Durante la fase preletal se producen principalmente dos tipos de alteraciones, dependiendo de la célula y del tipo de lesión. Esos dos tipos de alteraciones se denominan apoptosis y oncosis.

\section{Apoptosis}

Este término se deriva del griego apo, "lejos de", y ptosis, "caer". Se eligió este nombre porque, durante este fase de alteración preletal, la célula se retrae y se forman en su periferia numerosas vesículas que después se desprenden y se alejan flotando. La apoptosis se da en diversos tipos de células a consecuencia de diversos tipos de lesión tóxica (Wyllie, Kerr y Currie 1980). Es especialmente pronunciada en los linfocitos, donde es el principal mecanismo de reposición de clones linfocíticos. Los fragmentos resultantes se convierten en los cuerpos basófilos que se observan en el interior de los macrófagos en los ganglios linfáticos. En otros órganos, la apoptosis se produce típicamente en células aisladas que se eliminan rápidamente, antes y después de la muerte, al fagocitar sus fragmentos células parenquimales vecinas o macrófagos. Cuando se produce en células aisladas con la fagocitosis subsiguiente, la apoptosis no suele provocar inflamación. Antes de morir, las células apoptóticas muestran un citosol muy denso con las mitocondrias normales o condensadas. El retículo endoplásmico (RE) es normal o está sólo ligeramente dilatado. La cromatina del núcleo está claramente acumulada a lo largo de la envoltura y alrededor del nucleolo. El contorno del núcleo es también irregular, y hay fragmentación nuclear. La condensación de la cromatina está asociada con una fragmentación del ADN que, en muchos casos, se produce entre nucleosomas, lo que explica el característico aspecto de escalera en la electroforesis.

En la apoptosis, el aumento de $\left[\mathrm{Ca}^{2+}\right]_{\mathrm{i}}$ puede estimular el flujo de salida de $\mathrm{K}^{+}$, que hace que la célula se retraiga, probablemente con necesidad de ATP. Por consiguiente, es más probable que deriven en apoptosis las lesiones que inhiben totalmente la síntesis de ATP. El incremento sostenido del $\left[\mathrm{Ca}^{2+}\right]_{\mathrm{i}}$ tiene diversos efectos deletéreos, como la activación de proteasas, endonucleasas y fosfolipasas. La activación de las endonucleasas provoca roturas sencillas y dobles del ADN, lo cual estimula a su vez un aumento de los niveles de p53, y poli-ADP riboxilación, así como de proteínas nucleares que son esenciales para la reparación del ADN. La activación de las proteasas modifica una serie de sustratos, como la actina y proteínas conexas, lo que lleva a la formación de vesículas. Otro sustrato importante es la poli (ADP-ribosa) polimerasa (PARP), que inhibe la reparación del ADN. El aumento del $\left[\mathrm{Ca}^{2+}\right]_{\mathrm{i}}$ está asociado también a la activación de una serie de protein-quinasas, como la MAP quinasa, la calmodulina quinasa y otras. Esas quinasas participan en la activación de factores de transcripción que inician la transcripción de genes inmediatos, como por ejemplo c-fos, c-jun y c-myc, y en la activación de la fosfolipasa $\mathrm{A}_{2}$, que tiene como resultado la permeabilización de la membrana plasmática y de las membranas intracelulares, como las membranas interiores de las mitocondrias.

\section{Oncosis}

Este tipo de alteración preletal se denominó oncosis, derivado del griego onkos, "hincharse", porque la célula empieza a aumentar de tamaño casi inmediatamente después de la lesión (Majno y Joris 1995). Y se hincha porque aumentan los cationes en el agua intracelular. El catión más responsable de que esto ocurra es el sodio, que normalmente está regulado para mantener el volumen celular. Sin embargo, en ausencia de ATP o cuando se inhibe la Na-ATPasa de la membrana plasmática, se pierde el control del volumen debido a la proteína intracelular, y siguen aumentando los cationes de sodio en el agua. Entre las primeras manifestaciones de la oncosis están por lo tanto un aumento del $\left[\mathrm{Na}^{+}\right]_{\mathrm{i}}$, que hace que la célula se hinche, y un aumento también del $\left[\mathrm{Ca}^{2+}\right]_{\mathrm{i}}$ debido bien a la entrada de espacio extracelular, bien a la liberación de depósitos intracelulares. Ello hace que se hinchen el citosol, el retículo endoplásmico y el aparato de Golgi, y que se formen vesículas acuosas en torno a la superficie de la célula. Las mitocondrias se condensan al principio, pero después se hinchan también, y considerablemente, al estar dañada la membrana mitocondrial interior. En este tipo de alteración preletal, la cromatina se condensa y en última instancia se degrada; no se observa sin embargo la configuración en escalera que es característica de la apoptosis.

\section{Necrosis}

Con el término necrosis se designa una serie de alteraciones que se producen después de la muerte celular, cuando la célula se convierte en detritos que son típicamente eliminados por la respuesta inflamatoria. Cabe distinguir dos tipos: la necrosis oncótica y la necrosis apoptótica. La necrosis oncótica suele darse 
en zonas amplias, por ejemplo en un infarto de miocardio, o regionalmente en un órgano que ha sufrido toxicidad química, como el túbulo proximal del riñón tras la administración de $\mathrm{HgCl}_{2}$. Se ven afectadas amplias zonas del órgano, y las células necróticas incitan rápidamente a una reacción inflamatoria, al principio aguda y después crónica. Si el organismo sobrevive, en muchos órganos siguen a la necrosis la eliminación de las células muertas y la regeneración, por ejemplo en el hígado o en el riñón después de una toxicidad química. La necrosis apoptótica, en cambio, se desarrolla típicamente a nivel de células individuales, y los detritos necróticos se forman en el interior de los fagocitos o macrófagos o de las células parenquimales vecinas. Entre las primeras manifestaciones de la necrosis celular están las interrupciones de la continuidad de la membrana plasmática y la aparición de densidades floculentas, que son proteínas desnaturalizadas dentro de la matriz mitocondrial. En algunas formas de lesión que inicialmente no interfieren la acumulación de calcio en las mitocondrias, se observan en el interior de éstas depósitos de fosfato de calcio. También se fragmentan de manera análoga otros sistemas membranosos, como el RE, los lisosomas y el aparato de Golgi. Al final, la cromatina del núcleo sufre una lisis resultado del ataque de hidrolasas lisosómicas. Tras la muerte celular, las hidrolasas lisosómicas desempeñan un papel importante en la eliminación de los detritos con el concurso de catepsinas, nucleolasas y lipasas, pues éstas tienen un $\mathrm{pH}$ ácido óptimo y pueden sobrevivir al $\mathrm{pH}$ bajo de las células necróticas mientras que otras enzimas celulares se han desnaturalizado y desactivado.

\section{Mecanismos}

\section{Estímulo inicial}

En el caso de las lesiones letales, las más comunes de las interacciones iniciales que desembocan en muerte celular son las que consisten en una interferencia del metabolismo de la energía, como en el caso de la anoxia, la isquemia o los inhibidores de la respiración, o en una glicólisis, como en el caso del cianuro de potasio, el monóxido de carbono, yodo-acetatos, etc. Como se ha señalado anteriormente, es característico que las dosis altas de compuestos que inhiben el metabolismo de la energía desemboquen en oncosis. El otro tipo frecuente de lesión inicial que deriva en muerte celular aguda es la modificación de la función de la membrana plasmática (Trump y Arstila 1971; Trump, Berezesky y Osornio-Vargas 1981). Puede consistir bien en un daño directo con permeabilización, como en los casos de trauma o de activación del complejo C5b-C9 del complemento, bien en un daño mecánico a la membrana celular, bien en la inhibición de la bomba de sodio-potasio $\left(\mathrm{Na}^{+}-\mathrm{K}^{+}\right)$por glicóxidos como la ouabaína. También producen lesión letal aguda ionóforos de calcio como la ionomicina o el A23187, que transportan rápidamente $\left[\mathrm{Ca}^{2+}\right]$ por el gradiente hasta la célula. En algunos casos, la alteración preletal sigue la pauta de la apoptosis; en otros, la de la oncosis.

\section{Rutas de señalización}

En muchos tipos de lesión se ven afectadas rápidamente la respiración y la fosforilación oxidativa en las mitocondrias. En algunas células, ello estimula la glicolisis anaeróbica, que es capaz de mantener el ATP, el cual sin embargo se inhibe cuando las lesiones son numerosas. La falta de ATP tiene como resultado que no se aporta energía a diversos e importantes procesos homeostáticos, sobre todo al control de la homeostasis iónica intracelular (Trump y Berezesky 1992; Trump, Berezesky y Osornio-Vargas 1981). Ello hace que aumente rápidamente el $\left[\mathrm{Ca}^{2}+\right]_{\mathrm{i}}$, y el incremento de $\left[\mathrm{Na}^{+}\right]$y $\left[\mathrm{Cl}^{-}\right]$hace que la célula se hinche. El aumento de $\left[\mathrm{Ca}^{2}+\right]_{\mathrm{i}}$ activa otros mecanismos de señalización que examinaremos más adelante, entre ellos una serie de quinasas, lo que puede provocar un incremento de la transcripción de genes inmediatos. $\mathrm{El}$ aumento del $\left[\mathrm{Ca}^{2}+\right]_{\mathrm{i}}$ modifica asimismo la función citoesquelética, con formación de vesículas y activación de endonucleasas, proteasas y fosfolipasas. Parece que éstas desencadenan muchos de los importantes efectos que hemos visto anteriormente, como el daño a la membrana por activación de las proteasas y lipasas, la degradación directa del ADN por activación de las endonucleasas y la activación de quinasas como la MAP quinasa y la calmodulina quinasa, que actúan como factores de transcripción.

Gracias a los numerosos trabajos dedicados al desarrollo en los invertebrados C. elegans y Drosophila, así como en células humanas y animales, se ha identificado una serie de genes "promuerte". Se ha comprobado asimismo que algunos de esos genes de invertebrados tienen análogos en los mamíferos. El gen ced-3, por ejemplo, que es esencial para la muerte celular programada en C. elegans, presenta actividad proteásica y una marcada homología con la enzima convertidora de interleucinas (ICE) de los mamíferos. Recientemente se ha descubierto un gen muy relacionado con aquel, llamado apopaína o prICE, en el que la homología es aún mayor (Nicholson y cols. 1995). En la Drosophila parece que el gen "cosechador" interviene en una señal que conduce a la muerte celular programada. Otros genes "promuerte" son la proteína de la membrana Fas y el p53, importante gen supresor de tumores que está ampliamente conservado. El p53 se induce al nivel proteico una vez que el $\mathrm{ADN}$ ha resultado dañado, y al fosforilarse actúa como factor de transcripción para otros genes como el gadd 45 y el waf- 1 , que intervienen en la señalización de la muerte celular. Parece que intervienen asimismo en algunos sistemas otros genes inmediatos-tempranos como c-fos, c-jun y c-myc.

Al mismo tiempo hay genes "antimuerte" cuya función es aparentemente la de contrarrestar a los genes "promuerte". El primero que se identificó de este grupo fue el ced-9 en C. elegans, que es homólogo del bcl-2 de los humanos. Esos genes actúan de una manera que aún desconocemos para impedir que toxinas genéticas o químicas maten a las células. Algunos datos recientes indican que el bcl-2 puede actuar como antioxidante. Se están dedicando hoy muchos esfuerzos a tratar de conocer los genes que intervienen y a encontrar la forma de activarlos o inhibirlos según los casos.

\section{TOXICOLOGIA GENETICA}

R. Rita Misra y Michael P. Waalkes

La toxicología genética es, por definición, el estudio de la forma en que agentes químicos o físicos afectan al complejo proceso de la herencia. Las sustancias químicas genotóxicas son compuestos capaces de modificar el material hereditario de las células vivas. La probabilidad de que una determinada sustancia cause un daño genético depende inevitablemente de diversas variables, como el nivel de exposición del organismo a la sustancia, la distribución y retención de ésta una vez que ha penetrado en el cuerpo, la eficiencia de los sistemas de activación metabólica y/o detoxificación en los tejidos diana y la reactividad de la sustancia o de sus metabolitos con macromoléculas críticas de las células. La probabilidad de que el daño genético produzca una enfermedad depende en última instancia de la naturaleza del daño, la capacidad que posee la célula de reparar o amplificar el daño genético, la oportunidad de expresar cualquier alteración que se haya inducido y la capacidad del cuerpo de reconocer y suprimir la multiplicación de células aberrantes. 
Figura 33.10 • Organización de la información hereditaria en los seres humanos: a) primaria, b) secundaria y c) terciaria.

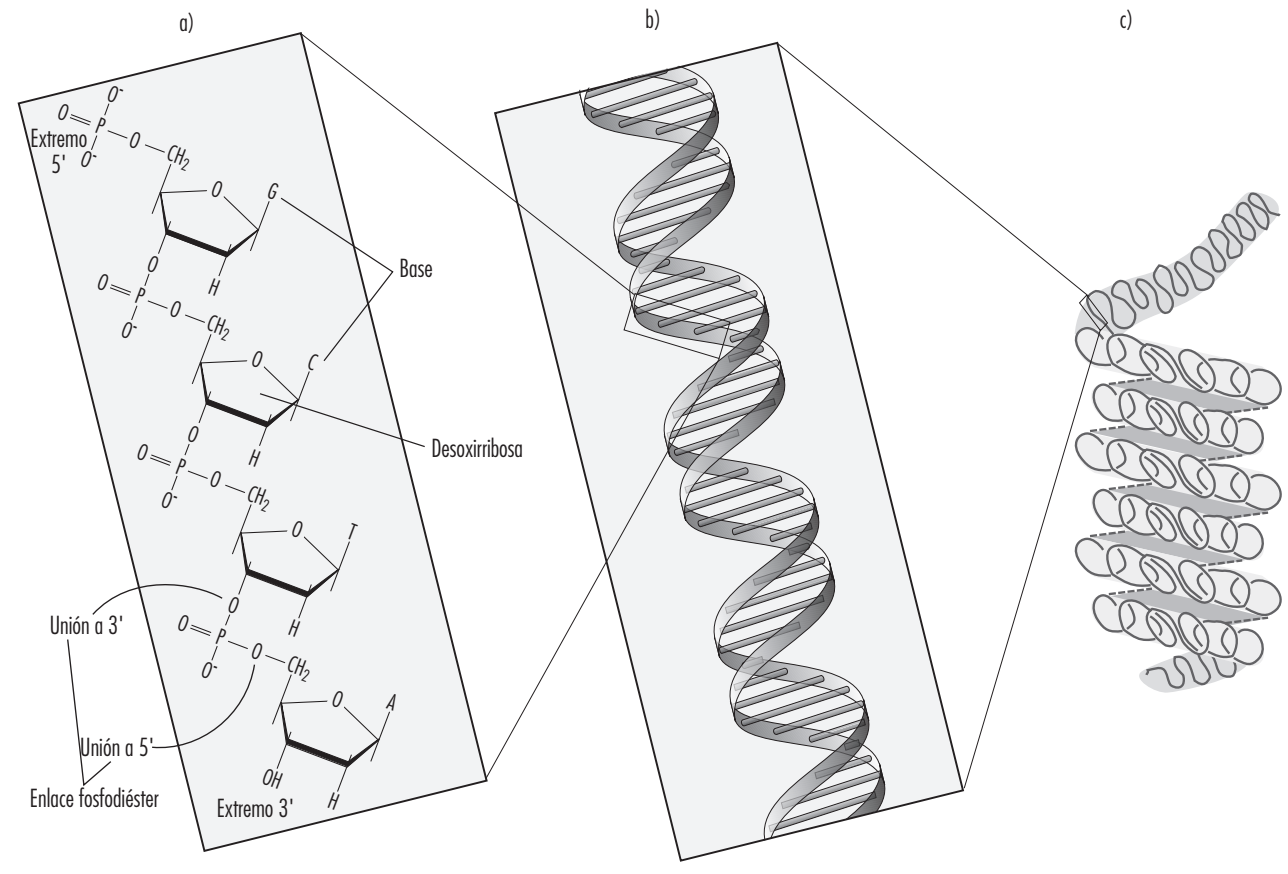

Figura 33.11 • Bioactivación de a) benzo(a)pireno y b) N-nitrosodimetilamina.

7,8-diol-9,10-epóxido

a)

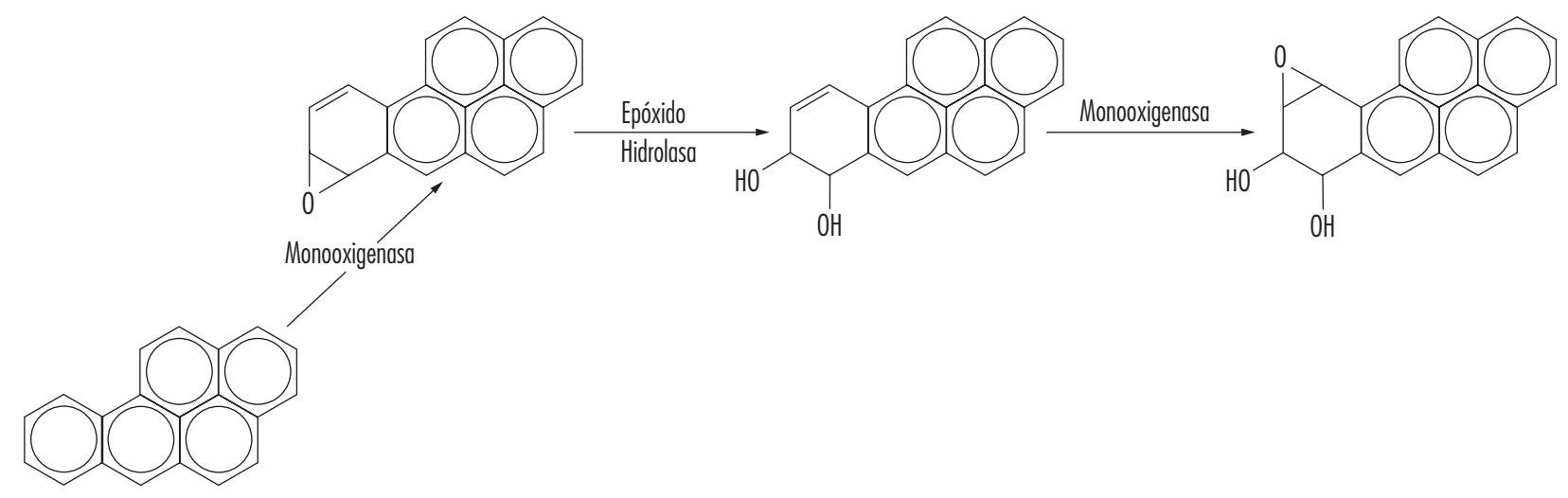

Enloce fosfodiéster

b)

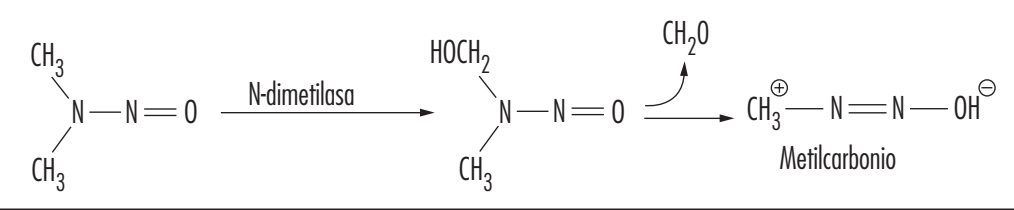


Figura 33.12 • Principales localizaciones del daño al ADN inducido por sustancias químicas.<smiles></smiles>

Adenina<smiles></smiles>

Citosina<smiles>[R]n1c[n+](C)c2c([Hg]C)[n+](C)c(N)[n+](C)c21</smiles>

Guanina<smiles></smiles>

Timina
En los organismos superiores, la información hereditaria está organizada en cromosomas. Los cromosomas son unas hebras muy condensadas de ADN asociado a proteínas. Dentro de cada cromosoma, cada molécula de ADN está configurada como un par de largas cadenas no ramificadas de subunidades de nucleótidos unidas por enlaces fosfodiéster que unen el carbono 5 de una unidad desoxirribosa al carbono 3 de la siguiente (Figura 33.10). Además, una de las cuatro bases de nucleótidos diferentes (adenina, citosina, guanina o timina) está unida a cada subunidad de desoxirribosa como las cuentas de un collar. En el sentido tridimensional, cada par de hebras de ADN forma una doble hélice en la que todas las bases están orientadas hacia el interior de la espiral. Dentro de la hélice, cada base de una hebra está asociada a su base complementaria de la otra hebra; el enlace hidrógeno impone un apareamiento fuerte y no covalente de la adenina con la timina y de la guanina con la citosina (Figura 33.10). Como la secuencia de bases de nucleótidos es complementaria a todo lo largo de la doble molécula de ADN, ambas hebras llevan esencialmente la misma información genética. De hecho, durante la replicación del ADN cada hebra sirve como molde para la producción de otra hebra nueva y equivalente.

Utilizando el ARN y una serie de proteínas, la célula acaba por descifrar la información codificada por la secuencia lineal de bases dentro de regiones específicas del ADN (genes) y produce proteínas que son esenciales para su supervivencia básica y para el crecimiento y diferenciación normales. En esencia, los nucleótidos funcionan como un alfabeto biológico que se utiliza para codificar la producción de aminoácidos, que son los componentes básicos de las proteínas.

Cuando se insertan nucleótidos incorrectos o se pierden nucleótidos, o cuando se añaden nucleótidos innecesarios durante la síntesis del ADN, el error se denomina mutación. Se ha estimado que se produce menos de una mutación por cada $10^{9}$ nucleótidos que se incorporan durante la replicación celular normal. Aunque las mutaciones no son necesariamente nocivas, las alteraciones que provocan una desactivación o una expresión excesiva de genes importantes pueden desembocar en diversos trastornos, como el cáncer, enfermedades hereditarias, anomalías del desarrollo, esterilidad y muerte embrionaria o perinatal. En muy raras ocasiones una mutación puede incrementar las posibilidades de supervivencia; esos casos son la base de la selección natural.

Aunque algunas sustancias químicas reaccionan directamente con el $\mathrm{ADN}$, en la mayoría de ellas se precisa una activación metabólica. En estos casos, son productos intermedios electrófilos, como los epóxidos o iones carbonio, los que en última instancia inducen las lesiones en diversos lugares nucleófilos del material genético (Figura 33.11). En otros casos, la genotoxicidad está mediada por productos secundarios de la interacción del compuesto con lípidos, proteínas u oxígeno intracelulares.

\section{Figura 33.13 • Diversos tipos de daño al complejo ADN-proteína.}

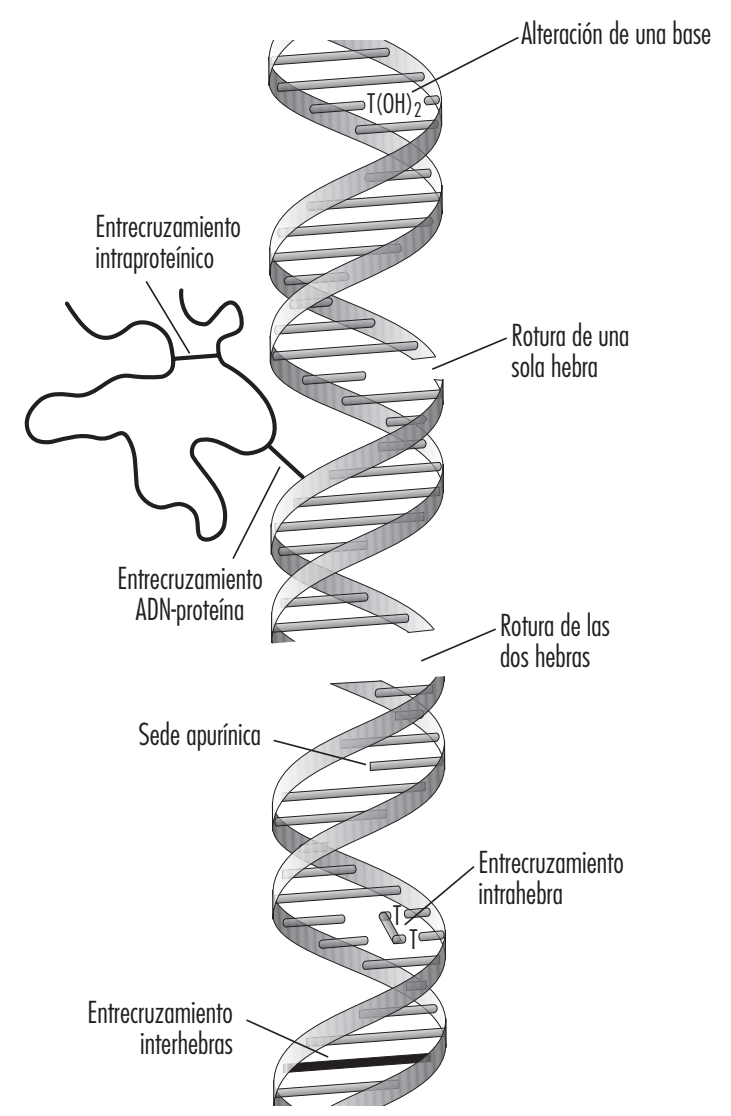




\begin{tabular}{|c|c|c|}
\hline Sindrome & Sintomas & Fenotipo celular \\
\hline Ataxia telangiectasia & $\begin{array}{l}\text { Deterioro neurológico } \\
\text { Inmunodeficiencia } \\
\text { Alta incidencia de linfoma }\end{array}$ & $\begin{array}{l}\text { Hipersensibilidad a la radiación ionizante y a algunos agentes alquilantes } \\
\text { Réplica mal regulada de ADN dañado (puede indicar menos tiempo } \\
\text { para la reparación del ADN) }\end{array}$ \\
\hline Síndrome de Bloom & $\begin{array}{l}\text { Anomalías del desarrollo } \\
\text { Lesiones en la piel expuesta } \\
\text { Alta incidencia de tumores del sistema inmunitario } \\
\text { y del tracto gastrointestinal }\end{array}$ & $\begin{array}{l}\text { Alta frecuencia de aberraciones cromosómicas } \\
\text { Sellado defectuoso de roturas asociadas a la reparación del ADN }\end{array}$ \\
\hline Anemia de Fanconi & $\begin{array}{l}\text { Retraso del crecimiento } \\
\text { Alta incidencia de leucemia }\end{array}$ & $\begin{array}{l}\text { Hipersensibilidad a agentes de entrecruzamiento } \\
\text { Alta frecuencia de aberraciones cromosómicas } \\
\text { Reparación defectuosa de entrecruzamientos en el ADN }\end{array}$ \\
\hline Cáncer de colon hereditario sin poliposis & Alta incidencia de cáncer de colon & $\begin{array}{l}\text { Reparación defectuosa del desemparejamiento del ADN (cuando se, } \\
\text { inserta durante la replicación, un nucleótido equivocado) }\end{array}$ \\
\hline Xeroderma pigmentoso & $\begin{array}{l}\text { Alta incidencia de epitelioma en las zonas } \\
\text { de piel expuestas } \\
\text { Deterioro neurológico (en muchos casos) }\end{array}$ & $\begin{array}{l}\text { Hipersensibilidad a la luz UV y a muchos carcinógenos químicos } \\
\text { Defectos en la reparación de excisión y/o reproducción de ADN dañado }\end{array}$ \\
\hline
\end{tabular}

Debido a su relativa abundancia en las células, las proteínas son la diana más frecuente de la interacción tóxica. No obstante, preocupa más la modificación del ADN por la importante misión de éste como regulador del crecimiento y la diferenciación a lo largo de múltiples generaciones de células.

Al nivel molecular, los compuestos electrófilos tienden a atacar al oxígeno y el nitrógeno del ADN. En la Figura 33.12 se indican los lugares que más se prestan a la modificación. Aunque también son dianas de la modificación química los oxígenos de los grupos fosfato del esqueleto del ADN, se estima que tiene más importancia biológica el daño a las bases, ya que estos grupos están considerados como los elementos primarios de información de la molécula de ADN.

Es característico que los compuestos que contienen un sola unidad electrófila causen la genotoxicidad produciendo monoaductos en el ADN. Análogamente, los compuestos que contienen dos o más unidades reactivas pueden reaccionar con dos centros nucleófilos distintos y de esa manera producir entrecruzamientos (crosslinks) intra o intermoleculares en el material genético (Figura 33.13). Los entrecruzamientos ADN-ADN y ADN-proteína pueden ser especialmente citotóxicos, pues pueden formar bloques completos para la replicación del ADN. Por razones obvias, la muerte de la célula elimina la posibilidad de que sufra una mutación o una transformación neoplásica. Los agentes genotóxicos pueden actuar también induciendo roturas en el esqueleto fosfodiéster, o entre bases y azúcares del ADN (produciendo lugares abásicos). Esas roturas pueden deberse directamente a reactividad química en el lugar del daño, o pueden producirse durante la reparación de uno de los tipos de lesión del ADN antes mencionados.

En los últimos treinta o cuarenta años se han desarrollado diversas técnicas para determinar el tipo de daño genético inducido por diversas sustancias químicas. Esos ensayos se describen con detalle en otro lugar de este capítulo y de la Enciclopedia.

La replicación errónea de "microlesiones", como masa de aductos, lugares abásicos o roturas de una sola hebra, puede acabar produciendo sustituciones de pares de bases de nucleótidos, o la inserción o supresión de cortos fragmentos de polinucleótidos en el ADN cromosómico. En cambio, las "macrolesiones", como masa de aductos, entrecruzamientos o roturas de las dos hebras, pueden desencadenar la adición, pérdida o reorganización de fragmentos cromosómicos relativamente grandes. En cualquier caso, las consecuencias pueden ser devastadoras para el organismo, pues cualquiera de esos hechos puede producir muerte celular, pérdida de función o transformación maligna de las células. Sabemos poco de la forma exacta en que el daño sufrido por el ADN provoca el cáncer. Actualmente se piensa que una parte del proceso puede ser la activación

Tabla 33.5 • Ejemplos de sustancias químicas que muestran genotoxicidad en células humanas.

\begin{tabular}{llll}
\hline Clase de sustancia & Ejemplo & Fuente de la exposición & Lesión genotóxica probable \\
Aflatoxinas & Aflatoxina B & Alimentos contaminados & Aductos de ADN abultados \\
Aminas aromáticas & 2-Acetilaminofluoreno & Ambiental & Aductos de ADN abultados \\
Aziridina quinonas & Mitomicina C & Quimioterapia por cáncer & $\begin{array}{c}\text { Monoaductos, entrecruzamientos interhebras y roturas } \\
\text { monohebra en el ADN. }\end{array}$ \\
Hidrocarburos clorados & Cloruro de vinilo & Ambiental & Monoaductos en el ADN \\
Metales y compuestos metálicos & Cisplatina & Quimioterapia por cáncer & Entrecruzamientos intra e interhebras en el ADN \\
& Compuestos de níquel & Ambiental & Monoaductos y roturas monohebra en el ADN \\
Mostazas nitrogenadas & Ciclofosfamida & Quimioterapia por cáncer & Monoaductos y entrecruzamientos interhebras en el ADN \\
Nitrosaminas & N-Nitrosodimetilamina & Alimentos contaminados & Monoaductos en el ADN \\
Hidrocarburos aromáticos policíclicos & Benzo(a)pireno & Ambiental & Aductos de ADN abultados \\
\hline
\end{tabular}


inadecuada de protooncogenes como el myc y el ras, y/o la desactivación de genes supresores de tumores que se han identificado recientemente, como el p53. La expresión anómala de uno u otro tipo de gen anula los mecanismos con que normalmente las células controlan la proliferación y/o diferenciación celular.

La mayoría de los datos experimentales indica que el desarrollo del cáncer tras exposición a compuestos electrófilos es relativamente infrecuente. Ello puede explicarse en parte por la capacidad intrínseca de la célula de reconocer y reparar el ADN dañado o por la imposibilidad de sobrevivir que tienen las células cuyo ADN está dañado. Durante la reparación se elimina el nucleótido de la lesión y otros nucleótidos contiguos y (utilizando la otra hebra como molde) se sintetiza un nuevo fragmento de ADN que se coloca en su lugar. Para que sea eficaz, la reparación del $\mathrm{ADN}$ debe producirse de manera muy precisa con anterioridad a la división celular, antes de que la mutación pueda propagarse.

Los estudios clínicos han demostrado que las personas con defectos heredados en su capacidad de reparar el ADN dañado suelen desarrollar cáncer y/o anomalías de desarrollo a una edad temprana (Tabla 33.4). Esos ejemplos proporcionan sólidos argumentos en el sentido de que la acumulación de daños al ADN está relacionada con la enfermedad humana. Análogamente, agentes que promueven la proliferación celular (como el acetato de tetradecanoilforbol) incrementan con frecuencia la carcinogénesis. En el caso de esos compuestos, la mayor probabilidad de transformación neoplásica puede ser una consecuencia directa del menor tiempo de que dispone la célula para llevar a cabo la adecuada reparación del ADN.

Las primeras teorías sobre la forma en que las sustancias químicas interactúan con el $\mathrm{ADN}$ se remontan a los estudios que se realizaron durante el desarrollo del gas mostaza con fines bélicos. Se amplió después el conocimiento de estos procesos cuando se trató de identificar agentes anticarcinógenos que detuvieran selectivamente la replicación de células tumorales en rápida división. La mayor preocupación de la opinión pública por los peligros ambientales ha impulsado nuevas investigaciones sobre los mecanismos y consecuencias de la interacción de sustancias químicas y material genético. En la Tabla 33.5 figuran ejemplos de diversos tipos de sustancias químicas que causan genotoxicidad.

\section{INMUNOTOXICOLOGIA}

\section{Joseph G. Vos y Henk van Loveren}

Las funciones del sistema inmunitario son proteger al cuerpo de agentes infecciosos invasores y realizar una labor de vigilancia inmunitaria frente a la aparición de células tumorales. El sistema inmunitario consta de una primera línea de defensa que es no específica, y que puede iniciar directamente reacciones de efectores, y de una parte específica adquirida en la que los linfocitos y anticuerpos poseen la capacidad específica de reconocer el antígeno y reaccionar a él.

Se ha definido la inmunotoxicología como "la disciplina que estudia los hechos que pueden desembocar en efectos no deseados como resultado de la interacción de los xenobióticos con el sistema inmunitario. Esos hechos no deseados pueden deberse a 1) un efecto directo y/o indirecto del xenobiótico (y/o de su producto de biotransformación) sobre el sistema inmunitario, o 2) una respuesta inmunológica del huésped al compuesto y/o su o sus metabolitos, o a antígenos del huésped modificados por el compuesto o sus metabolitos" (Berlin y cols. 1987).
Cuando el sistema inmunitario actúa como diana pasiva de las agresiones químicas, el resultado puede ser una reducción de la resistencia a las infecciones y a determinadas formas de neoplasia, o una desregulación/estimulación inmunitaria que puede agravar la alergia o la autoinmunidad. Cuando el sistema inmunitario responde a la especificidad antigénica del xenobiótico o del antígeno del huésped modificado por el compuesto, la toxicidad puede ponerse de manifiesto en forma de alergias o enfermedades autoinmunitarias.

Se han desarrollado modelos animales para investigar la inmunosupresión inducida por sustancias químicas, y algunos de esos métodos se han validado (Burleson, Munson y Dean 1995; IPCS 1996). Para la realización de ensayos se adopta un enfoque en tres niveles a fin de hacer una selección adecuada entre el enorme número de pruebas de que se dispone. En general, el objetivo del primer nivel es identificar los inmunotóxicos potenciales. Si se identifica una inmunotoxicidad potencial, se realizan ensayos de un segundo nivel para confirmar y caracterizar mejor los cambios observados. Las investigaciones de tercer nivel comprenden estudios especiales sobre el mecanismo de acción del compuesto. En esos estudios con animales de laboratorio se han identificado varios xenobióticos como inmunotóxicos que producen inmunosupresión.

La base de datos sobre los trastornos de la función inmunitaria en los humanos por efecto de sustancias químicas ambientales es limitada (Descotes 1986; National Research Council, Subcommittee on Immunotoxicology 1992). En los estudios clínicos y epidemiológicos encaminados a investigar el efecto de esas sustancias sobre la salud humana se han utilizado poco los marcadores de inmunotoxicidad. Como esos estudios tampoco han sido frecuentes, su interpretación no suele permitir extraer conclusiones inequívocas, debido por ejemplo al carácter no controlado de la exposición. Por esa razón, en la actualidad las decisiones sobre peligros y riesgos se basan en evaluaciones de la inmunotoxicidad en roedores que después se extrapolan a los seres humanos.

Las reacciones de hipersensibilidad, en especial el asma alérgico y la dermatitis por contacto, son importantes problemas de salud laboral en los países industrializados (Vos, Younes y Smith 1995). El fenómeno de la sensibilización por contacto se investigó en primer lugar en la cobaya (Andersen y Maibach 1985), que hasta hace poco ha sido la especie preferida para los ensayos de predicción. Hay muchos métodos de ensayo con cobayas, y los más utilizados son el ensayo de maximización y la prueba de oclusión de Buehler. Estos ensayos con cobayas y los nuevos métodos que se han desarrollado en los ratones, como las pruebas de inflamación de la oreja y el ensayo de ganglios linfáticos locales, proporcionan al toxicólogo los instrumentos necesarios para evaluar el peligro de sensibilización cutánea. Muy distinta es la situación en lo que se refiere a la sensibilización del tracto respiratorio: no hay por el momento métodos bien validados o ampliamente aceptados para identificar los alergenos respiratorios químicos, aunque en la cobaya y el ratón se ha avanzado en el desarrollo de modelos animales para la investigación de la alergia respiratoria de origen químico.

Los datos sobre seres humanos indican que los agentes químicos, en particular los fármacos, pueden causar enfermedades autoinmunitarias (Kammüller, Bloksma y Seinen 1989). Hay algunos modelos de enfermedades autoinmunitarias humanas que se basan en la experimentación con animales. Esos modelos comprenden tanto la patología espontánea (por ejemplo el lupus eritematoso sistémico en el ratón negro de Nueva Zelanda) como fenómenos de autoinmunidad inducidos por inmunización experimental con un autoantígeno de reacción cruzada (por ejemplo, la artritis inducida por el coadyuvante H37Ra en las ratas de la estirpe Lewis), y se aplican en la 
evaluacción preclínica de fármacos inmunosupresores. Se han estudiado muy poco las posibilidades de que esos modelos sirvan para evaluar si un xenobiótico intensifica la autoinmunidad inducida o congénita. Prácticamente no hay modelos animales adecuados para investigar la capacidad de las sustancias químicas de inducir enfermedades autoinmunitarias. Un modelo que se usa de manera limitada es el ensayo de ganglios linfáticos popliteales en el ratón. Al igual que en los humanos, los factores genéticos desempeñan un papel crucial en el desarrollo de la enfermedad autoinmunitaria en los animales de laboratorio, lo que limita el valor predictivo de esos ensayos.

\section{El sistema inmunitario}

La función principal del sistema inmunitario es defender al organismo de las bacterias, los virus, los parásitos, los hongos y las células neoplásicas. Se encargan de esa defensa, de una manera perfectamente sintonizada, diversos tipos de células y sus mediadores solubles. El sistema de defensa del huésped puede dividirse en general en resistencia no específica o innata e inmunidad específica o adquirida, ésta mediada por los linfocitos (Roitt, Brostoff yMale 1989).

Hay componentes del sistema inmunitario por todo el cuerpo (Jones y cols. 1990). El compartimento linfocítico se halla en los órganos linfoides (Figura 33.14). Se consideran órganos linfoides principales o centrales la médula ósea y el timo; los secundarios o periféricos son los ganglios linfáticos, el bazo y el tejido linfático presente en las superficies secretoras como las de los tractos gastrointestinal y respiratorio, que es el llamado tejido linfático asociado a mucosa (TLAM). Casi la mitad de los linfocitos del cuerpo se hallan en algún momento en el TLAM. Además, la piel es un importante órgano de inducción de respuestas inmunitarias a los antígenos presentes en ella. Destacan en ese proceso las células de Langerhans, en la epidermis, que desempeñan una función de presentación de antígenos.

En los órganos linfoides y también en lugares extraglanglionares hay células fagocíticas del linaje monocitos/macrófagos, lo que se llama el sistema fagocítico mononuclear; entre los fagocitos extraglanglionares figuran las células de Kupffer en el hígado, los macrófagos alveolares en el pulmón, los macrófagos mesangiales en el riñón y las células gliales en el cerebro. Los leucocitos polimorfonucleares están presentes sobre todo en la sangre y la médula ósea, pero se acumulan en los lugares en que se produce una inflamación.

\section{Defensa no específica}

Una primera línea de defensa contra los microorganismos es la constituida por una barrera física y química, como ocurre en la piel, el tracto respiratorio y el tracto digestivo. Esta barrera cuenta con la ayuda de mecanismos protectores no específicos entre los que figuran células fagocíticas, como los macrófagos y los leucocitos polimorfonucleares, que son capaces de destruir agentes patógenos, y células agresoras o "asesinas" naturales (NK), que pueden destruir por lisis células tumorales y células infectadas por virus. También participan en la respuesta no específica el llamado "sistema de complemento" y algunos inhibidores microbianos (como por ejemplo la lisozima).

\section{Inmunidad específica}

Tras el contacto inicial del huésped con el patógeno se inducen respuestas inmunitarias específicas. Lo más característico de esta segunda línea de defensa es el reconocimiento específico de los determinantes - los llamados antígenos o epítopes - de los patógenos por parte de receptores situados en la superficie celular de los linfocitos B y T. Una vez producida la interacción con el antígeno específico, se estimula a la célula que porta el receptor a
Figura 33.14 - Organos y tejidos primarios y secundarios del sistema linfático.

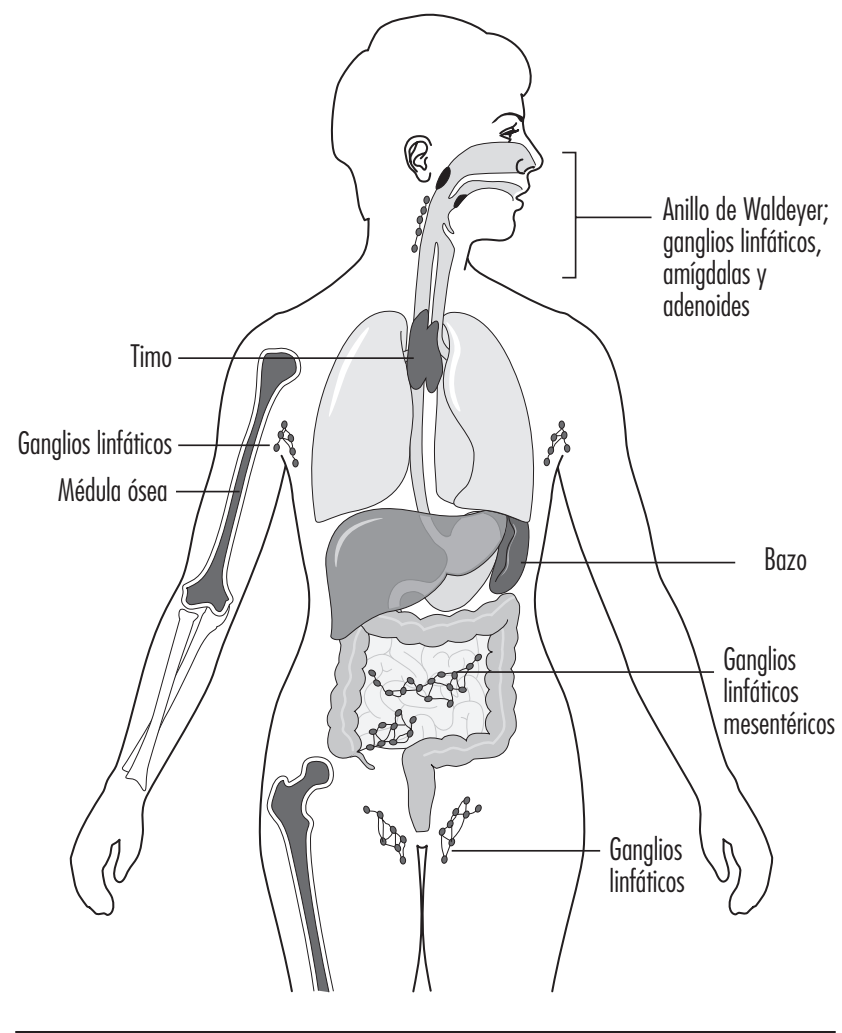

proliferar y diferenciarse, con lo que produce un clon de células hijas que son específicas para ese antígeno. Las respuestas inmunitarias específicas ayudan a la defensa no específica presentada a los patógenos estimulando la eficacia de las respuestas no específicas. Una característica fundamental de la inmunidad específica es que se desarrolla una memoria. El contacto secundario con ese mismo antígeno provoca una respuesta más rápida y más vigorosa, aunque no por ello menos regulada.

El genoma no tiene capacidad para contener los códigos de un número de receptores de antígenos suficiente para reconocer todos los antígenos distintos que pueden aparecer. El repertorio de especificidad se desarrolla mediante un proceso de reordenación de genes. Es un proceso aleatorio, durante el cual se producen diversas especificidades. Entre ellas figuran especificidades para autocomponentes, que no son deseables. Entra entonces en funcionamiento, para suprimir esas especificidades no deseables, un proceso de selección que se desarrolla en el timo (células T) o en la médula ósea (células B).

El funcionamiento normal de los efectores inmunitarios y la regulación homeostática de la respuesta inmunitaria dependen de una serie de productos solubles, agrupados bajo el nombre colectivo de citoquinas, que son sintetizados y segregados por los linfocitos y por otros tipos de células. Las citoquinas tienen efectos pleiotrópicos sobre las respuestas inmunitarias e inflamatorias. La respuesta inmunitaria precisa de la cooperación entre diferentes poblaciones de células - la regulación de las respuestas de los anticuerpos, la acumulación de células y moléculas inmunitarias en los lugares de inflamación, la puesta en marcha de respuestas agudas, el control de la función citotóxica de los macrófagos y muchos otros procesos que son esenciales para la resistencia del huésped. Esos procesos están influidos por 
las citoquinas, que actúan individualmente o de manera concertada, y en muchos casos dependen de ellas.

Se han determinado dos tipos de inmunidad específica: la inmunidad humoral y la inmunidad celular o mediada por células.

Inmunidad humoral. En el tipo humoral de inmunidad se estimulan los linfocitos B tras ser reconocido el antígeno por los receptores situados en la superficie de la célula. Los receptores de antígenos son en este caso las inmunoglobulinas (Ig). Las células B maduras (células plasmáticas) inician la producción de inmunoglobulinas antigenoespecíficas que actúan como anticuerpos en el suero o en las superficies de mucosa. Hay cinco clases principales de inmunoglobulinas: 1) la IgM, Ig pentamérica que posee una capacidad de aglutinación óptima y que es la primera que se produce tras la estimulación antigénica; 2) la IgG, que es la más importante Ig en circulación y que puede atravesar la placenta; 3) la IgA, que es una Ig secretora que protege las superficies de mucosa; 4) la $\mathrm{IgE}$, que se fija a los mastocitos o a los granulocitos basófilos que intervienen en las reacciones de hipersensibilidad inmediata, y 5) la $\mathrm{IgD}$, cuya función principal es actuar como receptor en los linfocitos B.

Inmunidad mediada por células. El tipo celular del sistema inmunitario específico está mediado por los linfocitos T. Estas células tienen también receptores de antígenos en sus membranas. Reconocen el antígeno cuando se lo presentan las células presentadoras de antígenos en el contexto de antígenos de histocompatibilidad. Esta es otra limitación de estas células además de su especificidad antigénica. Las células $\mathrm{T}$ funcionan como células colaboradoras de diversas respuestas inmunitarias (incluidas las humorales), actúan de mediadoras en el reclutamiento de células inflamatorias y, como células T citotóxicas, pueden matar células diana tras el reconocimiento antigenoespecífico.

\section{Mecanismos de inmunotoxicidad}

\section{Inmunosupresión}

La eficacia de la resistencia del huésped depende de que el sistema inmunitario funcione en su integridad, lo que a su vez exige que se disponga, en número suficiente y en forma operativa, de las células y moléculas componentes que orquestan las respuestas inmunitarias. En los seres humanos, las inmunodeficiencias congénitas suelen caracterizarse por defectos en determinadas líneas celulares precursoras, lo que tiene como resultado una producción menor o nula de células inmunitarias. Por analogía con las enfermedades de inmunodeficiencia humana tanto congénitas como adquiridas, la inmunosupresión inducida por sustancias químicas puede deberse simplemente a que hay pocas células funcionales (IPCS 1996). La ausencia o el menor número de linfocitos pueden tener efectos más o menos profundos sobre la condición inmunitaria. Algunos estados de imunodeficiencia y la inmunosupresión intensa, como por ejemplo en la terapia para trasplantes o citostática, se han asociado en particular con una mayor incidencia de infecciones oportunistas y de algunas enfermedades neoplásicas. Las infecciones pueden ser por bacterias, virus, hongos o protozoos, y el tipo predominante de infección depende de cuál sea la inmunodeficiencia asociada. Parece lógico que la exposición a sustancias inmunosupresoras presentes en el medio ambiente produzca formas más sutiles de inmunosupresión, que pueden ser difíciles de detectar. Por ejemplo, pueden llevar a una mayor incidencia de infecciones como la gripe o el resfriado común.

Habida cuenta de la complejidad del sistema inmunitario, con su amplia variedad de células, mediadores y funciones que forman una red compleja e interactiva, los compuestos inmunotóxicos encuentran muchas oportunidades para producir sus efectos. Aunque no se conoce bien la naturaleza de las lesiones iniciales inducidas por muchas sustancias químicas inmunotóxicas, cada vez se dispone de más información, derivada sobre todo de estudios con animales de laboratorio, sobre los cambios inmunobiológicos que tienen como resultado una depresión de la función inmunitaria (Dean y cols. 1994). Podrían producirse efectos tóxicos en las funciones críticas siguientes (se indican asimismo algunos ejemplos de compuestos inmunotóxicos que afectan a esas funciones):

- El desarrollo y expansión de diferentes poblaciones de células precursoras (el benceno tiene efectos inmunotóxicos a este nivel de células que provocan linfocitopenia).

- La proliferación de diversas células linfoides y mieloides así como de tejidos de sostén en los que esas células maduran y funcionan (los compuestos inmunotóxicos de organotina suprimen la actividad proliferativa de los linfocitos en el córtex del timo mediante citotoxicidad directa; la acción timotóxica de la 2,3,7,8-tetracloro-dibenzo-p-dioxina (TCDD) y otros compuestos conexos no se debe probablemente tanto a la toxicidad directa en los timocitos como a un deterioro de la función de las células epiteliales del timo).

- La captación, procesamiento y presentación de antígenos por los macrófagos y otras células que presentan antígenos (una de las dianas del 7,12-dimetilbenz(a)antraceno (DMBA) y del plomo es la presentación de antígenos por los macrófagos; una diana de la radiación ultravioleta son las células de Langerhans, que también presentan antígenos).

- La función reguladora de las células T-colaboradoras y T-supresoras (la función de las T-colaboradoras se ve afectada por las organotinas, el aldicarb, los bifenilos policlorados (PCB), la TCDD y el DMBA; la función de las T-supresoras se ve reducida por los tratamientos con ciclofosfamidas a dosis bajas).

- La producción de diversas citoquinas o interleucinas (el benzo(a)pireno (BP) suprime la producción de interleucina-1; la radiación ultravioleta altera la producción de citoquinas por los queratinocitos)

- La síntesis de diversas clases de inmunoglobulinas IgM e IgG, que se ve suprimida tras tratamiento con PCB y óxido de tribultitina (TBT) e incrementada tras exposición a hexaclorobenceno (HCB).

- La regulación y activación del complemento (por TCDD).

- La función citotóxica de las células T (el 3-metilcolantreno (3-MC), el DMBA y la TCDD suprimen la actividad citotóxica de las células $\mathrm{T}$ ).

- La función de las células agresoras o "asesinas" naturales (NK) (el ozono suprime la actividad de las NK pulmonares; el níquel reduce la actividad de las NK del bazo).

- Las funciones quimotáxicas y citotóxicas de los macrófagos y leucocitos polimorfonucleares (el ozono y el dióxido de nitrógeno reducen la actividad fagocítica de los macrófagos alveolares).

\section{Alergia}

La alergia puede definirse como los efectos adversos para la salud debidos a que se inducen y provocan respuestas inmunitarias específicas. Cuando se producen reacciones de hipersensibilidad sin intervención del sistema inmunitario se habla de pseudoalergia. En el contexto de la inmunotoxicología, la alergia es el resultado de una respuesta inmunitaria específica a determinadas sustancias químicas y fármacos. La capacidad de sensibilizar a un individuo que posee una sustancia está generalmente relacionada con su capacidad de unirse covalentemente a proteínas del organismo. Las reacciones alérgicas pueden adoptar diversas formas, que presentan diferencias con respecto tanto a los mecanismos 
inmunológicos que están en su base como a la velocidad de la reacción. Se han determinado cuatro tipos principales de reacciones alérgicas: las reacciones de hipersensibilidad del tipo I, que se deben a anticuerpos IgE y en las que los síntomas se manifiestan a los pocos minutos de que comience la exposición del individuo sensibilizado. Las reacciones de hipersensibilidad del tipo II se deben al daño o destrucción de células del huésped por la acción de anticuerpos. En este caso los síntomas aparecen en el plazo de unas horas. Las reacciones de hipersensibilidad del tipo III, o de Arthus, están también mediadas por anticuerpos, pero contra antígenos solubles, y se derivan de la acción local o sistémica de complejos inmunitarios. Las reacciones de hipersensibilidad del tipo IV, o retardada, se deben a los linfocitos T, y los síntomas suelen aparecer en un plazo de 24-48 horas después de la exposición del individuo sensibilizado.

Los dos tipos de alergia química que más interesan desde el punto de vista de la salud en el trabajo son la sensibilidad por contacto o alergia cutánea y la alergia del tracto respiratorio.

Hipersensibilidad por contacto. Son muchas las sustancias químicas que pueden causar sensibilización cutánea. Tras la exposición tópica de un individuo susceptible a un alergeno químico, se induce una respuesta de los linfocitos $\mathrm{T}$ en los ganglios linfáticos de drenaje. En la piel, el alergeno interactúa directa o indirectamente con las células de Langerhans de la epidermis, que transportan la sustancia a los ganglios linfáticos y la presentan en forma inmunogénica a los linfocitos $\mathrm{T}$ sensibles. Proliferan entonces los linfocitos $\mathrm{T}$ activados por el alergeno, con el resultado de una expansión clonal. El individuo está ya sensibilizado y responderá a una segunda exposición cutánea a esa misma sustancia química con una respuesta inmunitaria más agresiva, que producirá una dermatitis alérgica por contacto. La reacción inflamatoria de la piel que caracteriza a la dermatitis alérgica por contacto es secundaria al reconocimiento del alergeno en la piel por linfocitos $\mathrm{T}$ específicos. Esos linfocitos se activan, liberan citoquinas y producen una acumulación local de otros leucocitos mononucleares. Los síntomas aparecen entre 24 y 48 horas después de la exposición del individuo sensibilizado, y por ello la dermatitis alérgica por contacto es una forma de hipersensibilidad retardada. Entre los agentes que suelen provocar la dermatitis alérgica por contacto figuran sustancias químicas orgánicas (como el 2,4-dinitroclorobenceno), metales (como el níquel y el cromo) y productos vegetales (como el urusiol de plantas del género Rhus).

Hipersensibilidad respiratoria. La hipersensibilidad respiratoria suele considerarse una reacción del Tipo I. No obstante, en las reacciones de fase tardía y en los síntomas más crónicos asociados con el asma pueden intervenir procesos inmunitarios mediados por células (Tipo IV). Los síntomas agudos asociados a la alergia respiratoria se deben al anticuerpo $\operatorname{IgE}$, que se produce tras la exposición del individuo susceptible al alergeno químico inductor. El anticuerpo IgE se distribuye sistémicamente y se une, a través de los receptores de las membranas, a mastocitos de los tejidos vascularizados, entre ellos los del tracto respiratorio. Tras la inhalación de esa misma sustancia química se producirá una reacción de hipersensibilidad respiratoria. El alergeno se asocia con proteínas y se une al anticuerpo IgE-mastocitos entrecruzándose con él. Ello produce a su vez la desgranulación de los mastocitos, liberándose mediadores inflamatorios contenidos en sus gránulos, como histamina y leucotrienos. Esos mediadores producen broncoconstricción y vasodilatación, con el resultado de los síntomas de la alergia respiratoria: asma y/o rinitis. Entre las sustancias químicas que se sabe que producen hipersensibilidad respiratoria en los seres humanos figuran los anhídridos ácidos (como el anhídrido trimelítico), algunos diisocianatos (como el diisocianato de tolueno), sales de platino y algunos colorantes reactivos. Está demostrado que también la exposición crónica al berilio produce hipersensibilidad pulmonar.

\section{Autoinmunidad}

La autoinmunidad puede definirse como la estimulación de respuestas inmunitarias específicas que se dirigen contra "autoantígenos" endógenos. La autoinmunidad inducida puede tener su origen bien en alteraciones del equilibrio de los linfocitos T reguladores, bien en la asociación de un xenobiótico con componentes tisulares normales de manera que los hace inmunógenos ("autoalterados"). Los fármacos y sustancias químicas que sabemos que en ocasiones inducen o exacerban efectos como los de la enfermedad autoinmunitaria en individuos susceptibles son compuestos de bajo peso molecular (de peso molecular 100 a 500), que por lo general no están considerados inmunógenos en sí mismos. Es muy poco lo que se sabe del mecanismo de la enfermedad autoinmunitaria debida a exposición química. La enfermedad puede producirse directamente por medio de anticuerpos circulantes, indirectamente mediante la formación de complejos inmunitarios o como consecuencia de una inmunidad mediada por células, aunque lo más probable es que se produzca por una combinación de varios mecanismos. Se conoce mejor la patogénesis en el caso de los trastornos hemolíticos inmunitarios inducidos por fármacos:

- El fármaco puede unirse a la membrana del glóbulo rojo e interactuar con un anticuerpo farmacoespecífico.

- El fármaco puede alterar la membrana del glóbulo rojo de modo que el sistema inmunitario considera la célula como extraña.

- El fármaco y su anticuerpo específico forman complejos inmunitarios que se adhieren a la membrana del glóbulo rojo para producir la lesión.

- El glóbulo rojo se sensibiliza debido a la producción de autoanticuerpos de los propios glóbulos rojos.

Se ha comprobado que diversas sustancias químicas y fármacos, en particular estos últimos, inducen respuestas similares a las de la enfermedad autoinmunitaria (Kamüller, Bloksma y Seinen 1989). La exposición profesional a sustancias químicas puede producir en ocasiones síndromes similares a los de esta enfermedad. La exposición a cloruro de vinilo monomérico, tricloroetileno, percloroetileno, resinas epóxidas y polvo de sílice puede inducir síndromes similares a los de la esclerodermia. Se ha descrito un síndrome parecido al lupus eritematoso sistémico tras exposición a hidrazina. La exposición a diisocianato de tolueno se ha asociado a la inducción de púrpura trombocitopénica. Y se ha relacionado a metales pesados como el mercurio con algunos casos de glomerulonefritis inmunitaria compleja.

\section{Evaluación del riesgo para los seres humanos}

La evaluación del estado inmunitario de los seres humanos se realiza principalmente utilizando sangre periférica para analizar sustancias humorales como las inmunoglobulinas y el complemento, así como los leucocitos de la sangre para determinar su composición de subconjuntos y la funcionalidad de las subpoblaciones. Suelen ser los mismos métodos que se utilizaban para investigar la inmunidad humoral y mediada por células, así como la resistencia no específica de pacientes en los que se sospechaba una inmunodeficiencia congénita. Para los estudios epidemiológicos (por ejemplo, de poblaciones con exposición profesional), los parámetros deben seleccionarse sobre la base de su valor predictivo en poblaciones humanas, de modelos animales validados y de los mecanismos biológicos en que se basan los 
Tabla 33.6 • Clasificación de los ensayos con arreglo a los marcadores inmunitarios.

Categoría del ensayo
Básico - general
Debe incluirse con paneles generales
Básico - inmunitario

Básico - inmunitario

Debe incluirse en paneles generales

Centrado/reflejo

Deben incluirse cuando se indican por datos clínicos, sospechas de exposición, 0 resultados de ensayos anteriores

\section{Investigación}

Debe incluirse únicamente con poblaciones controladas y con un cuidadoso diseño del estudio

\author{
Características \\ Indicadores del estado de salud general y de los sistemas orgánicos
}

Indicadores generales del estado inmunitario

Coste relativamente bajo

Normalización de los métodos de ensayo entre laboratorios

Pueden interpretarse clínicamente los resultados que están fuera de los intervalos de referencia

Indicadores de funciones/hechos inmunitarios específicos Coste variable

Normalización de los métodos de ensayo entre laboratorios Pueden interpretarse clínicamente los resultados que están fuera de los intervalos de referencia

Indicadores de funciones/hechos inmunitarios generales o específicos Coste variable, aunque suele ser alto

En general, no normalización de los métodos de ensayo entre laboratorios

En general, no pueden interpretarse clínicamente los resultados que están fuera de los intervalos de referencia

\section{Ensayos específicos}

Nitrógeno ureico en sangre, glucosa en sangre, etc.

Recuentos sanguíneos completos

Niveles de $\lg G, \lg A$ e $\lg M$ en suero

Fenotipos con marcadores de superficie para

los principales subconjuntos de linfocitos

Genotipo de histocompatibilidad

Anticuerpos a agentes infecciosos

$\lg E$ total en suero

lgE alergenoespecífica

Autoanticuerpos

Pruebas de hipersensibilidad cutánea

Estallido oxidativo de granulocitos

Histopatología (biopsia tisular)

Ensayos de estimulación in vitro

Marcadores de superficie de la activación celular

Concentraciones de citoquinas en suero

Ensayos de clonalidad (de anticuerpos, celular, genética)

Ensayos de citotoxicidad marcadores (véase la Tabla 33.6). La estrategia con que se debe plantear la detección de efectos inmunotóxicos tras una exposición (accidental) a contaminantes ambientales $\mathrm{u}$ otros tóxicos depende en gran medida de las circunstancias, como por ejemplo del tipo de inmunodeficiencia que cabe esperar, del tiempo transcurrido entre la exposición y la evaluación del estado inmunitario, del grado de exposición y del número de individuos expuestos. El proceso de evaluar el riesgo inmunotóxico de un determinado xenobiótico en los humanos es sumamente difícil y muchas veces imposible, debido en gran parte a la presencia de diversos factores de confusión, de origen endógeno o exógeno, que influyen en la respuesta de los individuos al daño tóxico. Así sucede principalmente en los estudios que investigan el papel de la exposición química en las enfermedades autoinmunitarias, donde los factores genéticos desempeñan un papel decisivo.

Como raras veces se dispone de datos suficientes sobre los seres humanos, la evaluación del riesgo de inmunosupresión inducida por sustancias químicas se basa en la mayoría de los casos en estudios sobre animales. La identificación de los xenobióticos inmunotóxicos potenciales se realiza principalmente en estudios controlados con roedores. Los estudios de exposición in vivo constituyen a este respecto el planteamiento óptimo para estimar el potencial inmunotóxico de un compuesto, pues el sistema inmunitario y sus respuestas tienen un carácter multifactorial y complejo. Los estudios in vivo son cada vez más valiosos para determinar los mecanismos de la inmunotoxicidad. Además, al investigar los efectos del compuesto utilizando células de origen animal y humano pueden generarse datos para establecer comparaciones entre especies, que pueden utilizarse en el llamado "enfoque de paralelogramo" para mejorar el proceso de evaluación del riesgo: si se dispone de datos correspondientes a las tres esquinas del paralelogramo (animal in vivo y animal y humano in vitro) puede ser más fácil predecir el resultado en la esquina restante, es decir, el riesgo en los seres humanos.

Cuando la evaluación del riesgo de inmunosupresión inducida por sustancias químicas ha de basarse únicamente en datos de estudios con animales, puede plantearse la extrapolación al hombre aplicando factores de incertidumbre al nivel sin efecto adverso observable (NOAEL). Este nivel puede basarse en parámetros determinados en modelos pertinentes, como ensayos de resistencia del huésped y evaluación in vivo de reacciones de hipersensibilidad y producción de anticuerpos. Idealmente, la utilidad de este enfoque de la evaluación del riesgo exige una confirmación en estudios sobre humanos. Esos estudios deben combinar la identificación y medición del tóxico, datos epidemiológicos y evaluaciones del estado inmunitario.

Para predecir la hipersensibilidad por contacto se dispone de modelos con cobayas que vienen utilizándose en la evaluación del riesgo desde el decenio de 1970. Aunque sensibles y reproducibles, esos ensayos tienen limitaciones en la medida en que dependen de una evaluación subjetiva; este inconveniente puede superarse mediante métodos más recientes y más cuantitativos desarrollados en el ratón. En cuanto a la hipersensibilidad química inducida por inhalación o ingestión de alergenos, deben elaborarse y evaluarse ensayos desde el punto de vista de su valor predictivo para el hombre. En cuanto al establecimiento de niveles seguros de exposición profesional a alergenos potenciales, se ha de tener en cuenta la naturaleza bifásica de la alergia: la fase de sensibilización y la fase de reacción. La concentración necesaria para provocar una reacción alérgica en un individuo previamente sensibilizado es bastante más baja que la concentración necesaria para inducir la sensibilización en un individuo inmunológicamente intacto pero susceptible.

Como prácticamente no hay modelos animales para predecir la autoinmunidad inducida por sustancias químicas, se ha de insistir en la elaboración de tales modelos. Para ello es necesario avanzar en nuestro conocimiento de la inmunidad inducida por sustancias químicas en los humanos, incluido el estudio de marcadores genéticos y del sistema inmunitario con los que identificar a los individuos susceptibles. Ofrecen esa oportunidad los individuos que están expuestos a fármacos que inducen la autoinmunidad. 


\section{TOXICOLOGIA DE ORGANOS DIANA}

Ellen K. Silbergeld

El estudio y la caracterización de las sustancias químicas y otros agentes para determinar sus propiedades tóxicas suele realizarse sobre la base de determinados órganos y sistemas orgánicos. En este capítulo se estudian en profundidad dos dianas concretas: el sistema inmunitario y el gen. Se han elegido estos ejemplos porque son representativos de una diana que es un sistema orgánico complejo y de otra que es molecular y se halla dentro de la célula.

Para un análisis más completo de la toxicología de órganos diana el lector puede remitirse a textos de referencia en toxicología como los de Casarett y Doull, y Hayes. El Programa Internacional de Seguridad de las Sustancias Químicas (IPCS) ha publicado asimismo varios documentos sobre criterios de la toxicología de órganos diana, presentados por sistemas orgánicos.

Los estudios de toxicología de órganos diana suelen basarse en información que indica el potencial de efectos tóxicos específicos que tiene una sustancia, bien a partir de datos epidemiológicos, bien a partir de estudios sobre toxicidad general aguda o crónica, o basados también en el interés especial en proteger determinadas funciones orgánicas, como la reproducción o el desarrollo del feto.

En algunos casos, las autoridades reguladoras imponen expresamente la realización de ensayos específicos de toxicidad en órganos diana, como los ensayos de neurotoxicidad a que obliga la legislación estadounidense sobre plaguicidas (véase "El enfoque estadounidense de la evaluación del riesgo de los tóxicos para la reproducción y agentes neurotóxicos") y los de mutagenicidad a que obliga en el Japón la Ley de control de las sustancias químicas (véase "Principios de la identificación de los peligros: el enfoque japonés").

Como se ha indicado en "Organo diana y efectos críticos", la identificación de un órgano crítico se basa en la detección del órgano o sistema orgánico que primero presenta una respuesta adversa o que la presenta a las dosis o exposiciones más bajas. Esa información se utiliza después para diseñar investigaciones toxicológicas específicas o ensayos de toxicidad más definidos encaminados a obtener indicaciones más sensibles de la intoxicación en el órgano diana.

Los estudios de toxicología de órganos diana pueden utilizarse también para determinar los mecanismos de acción, que son de utilidad para evaluar el riesgo (véase "El enfoque estadounidense de la evaluación del riesgo de los tóxicos para la reproducción y agentes neurotóxicos").

\section{Métodos de los estudios de toxicidad en órganos diana}

Los órganos diana pueden estudiarse exponiendo organismos intactos y analizando detalladamente la función e histopatología en el órgano diana, o mediante la exposición in vitro de células, rodajas de tejido $\mathrm{u}$ órganos enteros mantenidos en cultivo durante períodos más o menos largos (véase "Introducción y conceptos" en "Mecanismos de la toxicidad"). En algunos estudios se dispone asimismo de tejidos de sujetos humanos, que pueden permitir validar hipótesis de extrapolación entre especies. No obstante, hay que tener en cuenta que esos estudios no ofrecen información sobre la toxicocinética relativa.

En general, los estudios de toxicidad en órganos diana tienen en común las características siguientes: examen histopatológico detallado del órgano diana, incluido el examen post mortem, pesaje de los tejidos y examen de los tejidos fijados; estudios bioquímicos de rutas críticas en el órgano diana, como por ejemplo importantes sistemas enzimáticos; estudios funcionales de la capacidad del órgano y de los componentes celulares para realizar las funciones metabólicas y de otro tipo que se espera de ellos, y análisis de los biomarcadores de la exposición y de efectos tempranos en las células del órgano diana.

En los estudios sobre órganos diana se integran a veces conocimientos pormenorizados de la fisiología del órgano, de su bioquímica y de su biología molecular. Por ejemplo, como la síntesis y secreción de proteínas de bajo peso molecular es un aspecto importante de la función renal, en los estudios de nefrotoxicidad se suele prestar especial atención a esos parámetros (IPCS 1991). Como la comunicación célula-célula es un proceso fundamental del funcionamiento del sistema nervioso, los estudios de neurotoxicidad sobre órganos diana pueden incluir mediciones neuroquímicas y biofisicas detalladas de la síntesis, captación, almacenamiento, liberación y unión a receptores de los neurotransmisores, así como la medición electrofisiológica de los cambios que se producen en el potencial de la membrana relacionados con esos procesos. En la toxicología de órganos diana se está haciendo mucho hincapié en el desarrollo de métodos in vitro como medio de sustituir el empleo de animales completos o reducirlo. Se han conseguido notables progresos en este ámbito en el caso de los tóxicos en la reproducción (Heindel y Chapin 1993).

En resumen, los estudios de toxicidad en órganos diana suelen realizarse como ensayos de orden superior para determinar la toxicidad. La selección de determinados órganos diana para ulteriores evaluaciones depende de los resultados de los ensayos a nivel de detección, como los ensayos de toxicidad aguda o subcrónica que utilizan la OCDE y la Unión Europea; algunos órganos y sistemas orgánicos diana pueden ser a priori candidatos para una investigación especial por el interés en prevenir determinados tipos de efectos nocivos sobre la salud.

\section{METODOS DE ENSAYO EN TOXICOLOGIA}

\section{- BiomarCADORES}

Philippe Grandjean

El término biomarcador, o marcador biológico en forma desarrollada, se define como un hecho que se produce en un sistema biológico, el cuerpo humano por ejemplo, y que puede medirse. Ese hecho se interpreta después como reflejo, o marcador, de un estado más general del organismo o de su esperanza de vida. En el ámbito de la salud en el trabajo, los biomarcadores suelen utilizarse como indicadores del estado de salud o del riesgo de enfermedad.
Se utilizan biomarcadores en estudios tanto in vitro como in vivo que pueden incluir a seres humanos. Los marcadores biológicos se clasifican por lo general en tres tipos concretos. Aunque algunos de ellos pueden ser difíciles de clasificar, suelen separarse en biomarcadores de la exposición, biomarcadores del efecto y biomarcadores de la susceptibilidad (véase la Tabla 33.7).

Dado un grado aceptable de validez, los biomarcadores pueden emplearse con varios fines. A nivel individual, un biomarcador puede utilizarse para apoyar o rechazar el diagnóstico de un determinado tipo de intoxicación o de otro efecto 
Tabla 33.7 • Ejemplos de biomarcadores de la exposición o del efecto que se emplean en los estudios toxicológicos relacionados con la salud en el trabajo.

\begin{tabular}{lll} 
Muestra & Medición & Objeto \\
Biomarcadores de la exposición & \\
Teijido adiposo & Dioxina & Exposición a dioxina \\
Sangre & Plomo & Exposición a plomo \\
Hueso & Aluminio & Exposición a aluminio \\
Aire espirado & Tolueno & Exposición a tolueno \\
Pelo & Mercurio & Exposición a metilmercurio \\
Suero & Benceno & Exposición a benceno \\
Orina & Fenol & Exposición a benceno \\
Biomarcadores del efecto & \\
Sangre & Carboxihemoglobina & Exposición a monóxido de \\
Glóbulos rojos & Zinc-protoporfirina & Exposición a plomo \\
Suero & Colinesterasa & Exposición a \\
& Microglobulinas & Exganofosforados \\
Orina & Aductos de ADN & Exposición a nefrotón a mutágenos \\
Glóbulos blancos & & \\
\hline
\end{tabular}

adverso inducido por sustancias químicas. En un sujeto sano, un biomarcador puede reflejar también una hipersusceptibilidad individual a determinadas exposiciones químicas y por consiguiente puede tomarse como base para la predicción del riesgo y el asesoramiento. En grupos de trabajadores expuestos pueden aplicarse algunos biomarcadores de la exposición para valorar el grado de cumplimiento con las normas de reducción de la contaminación o la eficacia de las medidas preventivas en general.

\section{Biomarcadores de la exposición}

Un biomarcador de la exposición puede ser un compuesto exógeno (o un metabolito) que se introduce en el cuerpo, un producto interactivo entre el compuesto (o metabolito) y un componente endógeno, o cualquier otro hecho relacionado con la exposición. Lo más habitual es que los biomarcadores de exposiciones a compuestos estables, como los metales, comprendan mediciones de las concentraciones del metal en muestras apropiadas, como la sangre, el suero o la orina. En el caso de las sustancias volátiles puede evaluarse su concentración en el aire espirado (tras la inhalación de aire libre de contaminación). Si el compuesto se metaboliza en el cuerpo, pueden elegirse uno o varios metabolitos como biomarcadores de la exposición; los metabolitos suelen determinarse en muestras de orina.

Los métodos de análisis modernos permiten en ocasiones separar los isómeros de los compuestos orgánicos, y determinar la especiación de los compuestos metálicos o coeficientes isotópicos de determinados elementos. Análisis más complejos permiten deteminar los cambios que se producen en la estructura del ADN u otras macromoléculas por la unión con sustancias químicas reactivas. Esas técnicas avanzadas adquirirán sin duda mucha más importancia en las aplicaciones de los estudios con biomarcadores, y es probable que al rebajarse los límites de detección y mejorarse la validez analítica los biomarcadores sean aún más útiles.

Se han producido avances especialmente prometedores en los biomarcadores de la exposición a sustancias químicas mutágenas. Se trata de compuestos reactivos que pueden formar aductos con macromoléculas, como proteínas o el ADN. Los aductos de ADN pueden detectarse en los leucocitos o en biopsias tisulares, y determinados fragmentos de ADN pueden excretarse en la orina. Por ejemplo, la exposición a óxido de etileno produce reacciones con bases del $\mathrm{ADN}$, y, tras la excisión de la base dañada, la N-7-(2-hidroxietil)guanina se elimina en la orina. Hay aductos que no se refieren directamente a una determinada exposición. Por ejemplo la 8-hidroxi-2'-desoxiguanosina indica que el ADN ha sufrido un daño oxidativo, pero esta reacción puede haber sido desencadenada por varios compuestos químicos, la mayoría de los cuales inducen también peroxidación lipídica.

Hay otras macromoléculas que también pueden modificarse por formación de aductos u oxidación. De especial interés, esos compuestos reactivos pueden generar aductos de hemoglobina que pueden utilizarse como biomarcadores de la exposición a los compuestos. La ventaja es que de una muestra de sangre pueden obtenerse grandes cantidades de hemoglobina y, dado que los glóbulos rojos tienen una vida de cuatro meses, los aductos formados con los aminoácidos de la proteína indican la exposición total durante ese período.

Los aductos pueden determinarse mediante técnicas sensibles como la cromatografía de lípidos de alta resolución, y también mediante algunos métodos inmunológicos. En general, los métodos analíticos son recientes y costosos, y precisan de más desarrollo y validación. Puede conseguirse una mayor sensibilidad utilizando el ensayo de postetiquetado ${ }^{32} \mathrm{P}$, que es una indicación no específica de que el ADN ha sufrido un daño. Todas esas técnicas son potencialmente útiles para la vigilancia biológica y se vienen aplicando en un número creciente de estudios. No obstante, se precisan métodos analíticos más sencillos y sensibles. Habida cuenta de la limitada especificidad de algunos métodos a exposiciones bajas, el hábito de fumar u otros factores pueden afectar de manera significativa a los resultados de la medición, con la consiguiente dificultad de interpretación.

La exposición a compuestos mutágenos, o a compuestos que se metabolizan a mutágenos, puede determinarse también evaluando la mutagenicidad de la orina de un individuo expuesto. La muestra de orina se incuba con una cepa de bacterias en la que una mutación puntual específica se expresa de una manera que puede medirse fácilmente. Si en la muestra de orina están presentes sustancias mutágenas, en la bacteria aumentará la tasa de mutaciones.

Los biomarcadores de la exposición han de evaluarse con respecto a la variación temporal de la exposición y a la relación de ésta con diferentes compartimentos. Así, para interpretar el resultado es necesario determinar, a partir de datos toxicocinéticos, el marco o los marcos temporales representados por el biomarcador, es decir, el grado en que la medida del biomarcador refleja una exposición o exposiciones pasadas y/o la carga corporal acumulada. Hay que tener en cuenta en particular el grado en que el biomarcador indica la retención de la sustancia en determinados órganos diana. Aunque en los estudios con biomarcadores suelen utilizarse muestras de sangre, la sangre periférica no se considera en general un compartimento propiamente dicho, aunque actúa como medio de transporte entre compartimentos. El grado en que la concentración en sangre refleja los niveles existentes en diferentes órganos varía considerablemente según la sustancia química de que se trate, y por lo general depende también de la duración de la exposición y del tiempo transcurrido desde ésta.

En ocasiones se utilizan datos de este tipo para clasificar a un biomarcador como indicador de la dosis absorbida (total) o de la dosis efectiva (es decir, de la cantidad que ha llegado al tejido diana). Por ejemplo, la exposición a un determinado disolvente 
puede evaluarse a partir de datos sobre la concentración real del disolvente en la sangre en un determinado momento después de la exposición. Esa medida reflejará la cantidad de disolvente que se ha absorbido en el cuerpo. Parte de la cantidad absorbida se exhalará debido a la presión de vapor del disolvente. Mientras está en circulación con la sangre, el disolvente interactuará con diversos componentes del cuerpo, y en última instancia será objeto de una descomposición enzimática. El resultado de los procesos metabólicos puede valorarse determinando los ácidos mercaptúricos específicos que se han producido por conjugación con el glutatión. La excreción acumulada de ácidos mercaptúricos puede reflejar mejor así la dosis efectiva que la concentración en sangre.

Acontecimientos de la vida como la reproducción y la senectud pueden afectar a la distribución de una sustancia química. La distribución de las sustancias en el cuerpo se ve notablemente afectada por el embarazo, y muchas de ellas pueden atravesar la barrera placentaria, con la consiguiente exposición del feto. La lactancia puede producir una excreción de sustancias químicas liposolubles, lo que se traduce en una menor retención en la madre y una mayor absorción en el niño. En las situaciones de pérdida de peso o en la osteoporosis pueden liberarse sustancias almacenadas, que producen después una nueva y prolongada exposición "endógena" de órganos diana. Hay otros factores que pueden afectar a la absorción, metabolismo, retención y distribución de compuestos químicos en un individuo, y existen algunos biomarcadores de la biosusceptibilidad (véase más adelante).

\section{Biomarcadores del efecto}

Los marcadores del efecto pueden ser componentes endógenos o medidas de la capacidad funcional, o cualquier otro indicador del estado o equilibrio del cuerpo o de un sistema orgánico afectado por la exposición. Suelen utilizarse como indicadores preclínicos de anomalías.

Los biomarcadores del efecto pueden ser específicos o no específicos. Los específicos son útiles porque indican un efecto biológico de una exposición concreta, por lo que aportan datos que pueden ser valiosos de cara a la prevención. Los biomarcadores no específicos no indican una causa individual del efecto, pero pueden reflejar el efecto total integrado debido a una exposición combinada. Por consiguiente, los dos tipos de biomarcadores pueden ser de considerable utilidad en el ámbito de la salud en el trabajo.

No hay una distinción clara entre biomarcadores de la exposición y del efecto. Por ejemplo, podría decirse que la formación de aductos refleja más un efecto que la exposición. No obstante, los biomarcadores del efecto suelen indicar cambios en las funciones de las células, de los tejidos o del cuerpo en su conjunto. Algunos investigadores incluyen entre los biomarcadores del efecto los cambios muy visibles, como un aumento del peso del hígado en animales de laboratorio expuestos o un defecto de crecimiento en los niños. En el contexto de la salud en el trabajo, los biomarcadores del efecto deben limitarse a los que indican cambios bioquímicos subclínicos o reversibles, como la inhibición de enzimas. El que se utiliza con más frecuencia es probablemente la inhibición de la colinesterasa motivada por determinados insecticidas (organofosforados y carbamatos). En la mayoría de los casos este efecto es totalmente reversible, y la inhibición de esta enzima refleja la exposición total a ese grupo concreto de insecticidas.

Algunas exposiciones no producen una inhibición de la enzima, sino por el contrario un aumento de su actividad. Así ocurre con varias enzimas pertenecientes a la familia P450 (véase "Determinantes genéticos de la respuesta tóxica"), que puden inducirse por la exposición a determinados disolventes e hidrocarburos poliaromáticos. Como esas enzimas se expresan principalmente en tejidos de los que puede ser difícil obtener material para biopsia, la actividad enzimática se determina indirectamente in vivo administrando un compuesto que es metabolizado por esa enzima concreta, y después se mide en la orina o el plasma el producto de descomposición.

Otras exposiciones pueden inducir la síntesis de una proteína protectora en el organismo. El mejor ejemplo es probablemente la metalotioneína, que se une al cadmio y fomenta la excreción de este metal; la exposición al cadmio es uno de los factores que contribuyen a una mayor expresión del gen de la metalotioneína. Puede que haya otras proteínas protectoras similares, pero hasta ahora no se han estudiado lo suficiente para aceptarlas como biomarcadores. Entre las candidatas a su posible utilización como biomarcadores están las llamadas "proteínas de estrés", antes llamadas proteínas de shock térmico, que son generadas por diversos organismos en respuesta a determinadas exposiciones adversas.

El daño oxidativo puede valorarse determinando la concentración de malondialdehído en el suero o la exhalación de etano. Análogamente, la excreción en la orina de proteínas de bajo peso molecular, como la albúmina, puede utilizarse como biomarcador precoz de daño renal. También pueden ser útiles como biomarcadores diversos parámetros que se emplean habitualmente en la práctica clínica (por ejemplo, los niveles hormonales o enzimáticos en el suero). No obstante, es posible que muchos de esos parámetros no sean lo suficientemente sensibles para detectar precozmente el problema.

Otro grupo de parámetros de este tipo es el que se refiere a los efectos genotóxicos (cambios en la estructura de los cromosomas). Esos efectos pueden detectarse examinando al microscopio glóbulos blancos en división celular. El daño grave a los cromosomas - aberraciones cromosómicas o formación de micronúcleos - puede observarse al microscopio. Se puede observar asimismo mediante la tinción de las células durante la división celular. La exposición a un agente genotóxico puede visualizarse después como un incremento del intercambio del colorante entre las dos cromatidas de cada cromosoma (intercambio entre cromatidas hermanas).

Las aberraciones cromosómicas están relacionadas con un aumento del riesgo de cáncer, pero no está tan clara la significación de esa tasa mayor de intercambio entre cromatidas hermanas.

Una evaluación más compleja de la genotoxicidad es la que se basa en determinadas mutaciones puntuales en células somáticas glóbulos blancos de la sangre o células epiteliales tomadas de la mucosa de la boca. Una mutación en un locus determinado puede hacer que las células sean capaces de crecer en un cultivo que contiene una sustancia química por lo demás tóxica (como la 6 -tioguanina).

Otra posibilidad es valorar un determinado producto génico (por ejemplo, las concentraciones en suero o en tejido de oncoproteínas codificadas por determinados oncogenes). Evidentemente, esas mutaciones reflejan el daño genotóxico total producido y pueden no indicar nada sobre la exposición causante.

Estos métodos aún no están lo suficientemente desarrollados para utilizarlos en la vigilancia de la salud en el trabajo, pero los rápidos avances que se están produciendo en esta línea de investigación sugieren que podrán emplearse dentro de no muchos años.

\section{Biomarcadores de la susceptibilidad}

Un marcador de la susceptibilidad, sea heredada o inducida, es un indicador de que el individuo es especialmente sensible al efecto 
de un xenobiótico o a los efectos de un grupo de xenobióticos. Se ha hecho hincapié sobre todo en la susceptibilidad genética, aunque hay otros factores que pueden tener al menos la misma importancia. La hipersusceptibilidad puede deberse a un rasgo heredado, a la constitución del individuo o a factores ambientales.

$\mathrm{La}$ capacidad de metabolizar determinadas sustancias químicas es variable y está determinada genéticamente (véase "Determinantes genéticos de la respuesta tóxica"). Parece que algunas enzimas de interés a este respecto están controladas por un único gen. Por ejemplo, la oxidación de sustancias químicas extrañas la realiza principalmente una familia de enzimas pertenecientes a la familia P450. Otras enzimas hacen los metabolitos más hidrosolubles por conjugación (por ejemplo, la $\mathrm{N}$-acetiltransferasa y la $\mu$-glutatión- $S$-transferasa). La actividad de esas enzimas está controlada genéticamente y presenta considerables variaciones. Como ya se ha señalado, la actividad puede determinarse administrando una pequeña dosis de un fármaco y determinando después la cantidad de metabolito presente en la orina. Ya se han caracterizado algunos genes, y se dispone de técnicas para determinar el genotipo. Estudios importantes sugieren que el riesgo de desarrollar determinadas formas de cáncer está relacionado con la capacidad de metabolizar compuestos extraños. Todavía hay que dar respuesta a muchas preguntas, lo que por el momento limita el empleo de estos biomarcadores de la susceptibilidad potencial en el ámbito de la salud en el trabajo.

Hay otros rasgos heredados, como las deficiencias de alfa $_{1}$-antitripsina o de glucosa-6-fosfato dehidrogenasa, que también reducen los mecanismos de defensa del cuerpo provocando de esa manera una hipersusceptibilidad a determinadas exposiciones.

La mayor parte de la investigación relacionada con la susceptibilidad se ha dedicado a la predisposición genética. Pero hay otros factores que también intervienen y que han quedado en cierto modo relegados. Por ejemplo, los individuos que padecen una enfermedad crónica pueden ser más sensibles a una exposición profesional. Asimismo, cuando un proceso patológico o una exposición anterior a sustancias tóxicas ha provocado un daño orgánico subclínico es probable que se haya reducido la capacidad de soportar una nueva exposición al tóxico. En ese caso pueden utilizarse como biomarcadores de la susceptibilidad indicadores bioquímicos de la función del órgano. El mejor ejemplo de esta hipersusceptibilidad es probablemente el que se refiere a las respuestas alérgicas. Si un individuo se ha sensibilizado a una determinada exposición, en su suero se pueden detectar anticuerpos específicos. Aun cuando el individuo no se haya sensibilizado, otras exposiciones actuales o pasadas pueden incrementar el riesgo de un efecto adverso relacionado con una exposición profesional.

Un problema importante es el de determinar el efecto conjunto de exposiciones combinadas en el lugar de trabajo. Además, la susceptibilidad puede ser mayor en los individuos que tienen determinados hábitos y toman fármacos. El humo del tabaco, por ejemplo, suele contener una cantidad considerable de cadmio. Así, con una exposición profesional al cadmio, una persona que fuma mucho y que ya ha acumulado cantidades sustanciales de este metal en el cuerpo tiene un mayor riesgo de contraer nefropatías relacionadas con el cadmio.

\section{Aplicaciones en el ámbito de la salud en el trabajo}

Los biomarcadores son sumamente útiles en la investigación toxicológica, y muchos de ellos pueden tener aplicación en la vigilancia biológica. No obstante, hay que reconocer también sus limitaciones. Hasta el momento muchos biomarcadores se han estudiado únicamente en animales de laboratorio. Es posible que las pautas toxicocinéticas de otras especies no sean necesariamente un reflejo de la situación en los humanos, y para extrapolar puede ser necesario realizar estudios de confirmación con voluntarios humanos. Hay que tener en cuenta asimismo las variaciones individuales debidas a factores genéticos o constitucionales.

En algunos casos, es posible que los biomarcadores de la exposición no sean viables en absoluto (por ejemplo, en el caso de sustancias de vida corta in vivo). Otras sustancias pueden almacenarse en órganos o afectar a órganos a los que no se puede acceder por los procedimientos habituales, como el sistema nervioso. La ruta de exposición puede afectar asimismo a la pauta de distribución y por consiguiente también a la medición del biomarcador y a su interpretación. Por ejemplo, es probable que las mediciones efectuadas con biomarcadores de la exposición no detecten la exposición directa del cerebro a través del nervio olfativo. En cuanto a los biomarcadores del efecto, muchos de ellos no son nada específicos, y el cambio puede deberse a múltiples causas, entre ellas factores relacionados con el tipo de vida del sujeto. Quizás especialmente en el caso de los biomarcadores de la susceptibilidad, la interpretación ha de ser muy prudente por el momento, pues sigue habiendo muchas incertidumbres sobre la significación global que tienen para la salud los genotipos individuales.

En el ámbito de la salud en el trabajo, el biomarcador ideal debe reunir varios requisitos. Ante todo, la muestra se ha de obtener y analizar de manera sencilla y fiable. Para conseguir la óptima calidad analítica es necesario normalizar los procedimientos, pero las necesidades concretas son muy variables. Son a ese respecto cuestiones importantes la preparación del individuo, el procedimiento de obtención de la muestra y la manipulación de ésta, y el procedimiento de medición; este último comprende factores técnicos, como métodos de calibración y garantía de la calidad, y factores humanos, como la formación y capacitación de los operadores.

Para que la documentación tenga validez analítica y un seguimiento adecuado en el futuro, los materiales de referencia han de basarse en matrices aplicables, con concentraciones adecuadas de sustancias tóxicas o de sus metabolitos a los niveles apropiados. Para que los biomarcadores se utilicen en vigilancia biológica o con fines de diagnóstico, los laboratorios responsables han de utilizar procedimientos analíticos bien documentados con características de rendimiento definidas, y deben dar acceso a su documentación para poder verificar los resultados. $\mathrm{Al}$ mismo tiempo, no obstante, hay que tener en cuenta las consecuencias económicas de caracterizar y utilizar materiales de referencia que complementen los procedimientos generales de garantía de la calidad. Así, la calidad posible de los resultados, y los fines con que éstos se utilizan, han de equilibrarse con el aumento de costes que comporta el control de la calidad, incluidos materiales de referencia, mano de obra e instrumental.

Otro requisito es que el biomarcador ha de ser específico, al menos en las circunstancias del estudio, respecto de un determinado tipo de exposición, con una relación claramente definida con el grado de exposición. De lo contrario es posible que el resultado de la medición del biomarcador sea demasiado difícil de interpretar. Para interpretar adecuadamente la medida que da un biomarcador de la exposición ha de conocerse la validez del diagnóstico (es decir, la traducción del valor del biomarcador a la magnitud de posibles riesgos para la salud). En esta esfera los metales son un paradigma de la investigación en materia de biomarcadores. Estudios recientes han puesto de manifiesto la complejidad y sutileza de las relaciones dosis-respuesta - la considerable dificultad de identificar niveles sin efecto y por lo tanto de definir las exposiciones tolerables. No obstante, estos estudios han puesto de manifiesto también los tipos de 
investigación y las mejoras que se necesitan para llegar a obtener la información que se precisa. En el caso de la mayoría de los compuestos orgánicos no se dispone aún de asociaciones cuantitativas entre las exposiciones y los efectos adversos sobre la salud correspondientes; en muchos casos ni siquiera se sabe con seguridad cuál es el principal órgano diana. Además, la evaluación de los datos de toxicidad y de las concentraciones del biomarcador suele verse complicada por el hecho de que no hay exposición a un compuesto único en ese momento, sino a una combinación de sustancias.

Antes de aplicar el biomarcador en el ámbito de la salud en el trabajo son necesarias algunas consideraciones adicionales. En primer lugar, el biomarcador ha de reflejar únicamente un cambio subclínico y reversible. En segundo lugar, como los resultados del biomarcador pueden interpretarse con respecto a riesgos para la salud, deben adoptarse medidas preventivas que han de ser realistas en el caso de que los datos del biomarcador sugieran la necesidad de reducir la exposición. En tercer lugar, ha de haber un acuerdo general en que el empleo del biomarcador en la práctica es aceptable desde el punto de vista ético.

Las mediciones de higiene industrial pueden compararse con los límites de exposición aplicables. Análogamente, los resultados obtenidos con biomarcadores de la exposición o del efecto pueden compararse con los límites de acción biológica, también llamados índices de exposición biológica. Esos límites han de basarse en el juicio de los clínicos y científicos de las disciplinas correspondientes, y los administradores encargados de "gestionar el riesgo" deben tener en cuenta los factores éticos, sociales, culturales y económicos pertinentes. La base científica debe incluir, en lo posible, relaciones dosis-respuesta complementadas con información sobre las variaciones de la susceptibilidad dentro de la población de riesgo. En algunos países, trabajadores y miembros de la población general intervienen en el proceso normativo con valiosas aportaciones, especialmente cuando la cuestión está rodeada de considerables incertidumbres científicas.

Una de las principales incertidumbres es cómo definir un efecto adverso para la salud que debe prevenirse - por ejemplo, si la formación de aductos como biomarcador de la exposición es en sí misma un efecto adverso (es decir, un biomarcador del efecto) que debe prevenirse. Es probable que se planteen difíciles cuestiones a la hora de decidir si es éticamente defendible establecer, respecto del mismo compuesto, límites distintos para la exposición ocasional por una parte y para la exposición profesional por otra.

En general, la información que se obtiene de los biomarcadores debe transmitirse a los individuos examinados en el contexto de la relación médico-paciente. Hay que tener especialmente en cuenta las cuestiones éticas cuando se trata de análisis con biomarcadores muy experimentales a los que aún no se puede dar una interpretación detallada en términos de riesgos reales para la salud. La población general, por ejemplo, dispone actualmente de una orientación limitada con respecto a la interpretación de los biomarcadores de la exposición salvo en el caso de la concentración de plomo en sangre. También es importante la confianza en los datos generados (es decir, si el muestreo se ha realizado de la manera apropiada y si en el laboratorio que ha intervenido se han aplicado buenos procedimientos de control

Tabla 33.8 • Ventajas e inconvenientes de los actuales métodos de identificación del riesgo de cáncer humano.

\begin{tabular}{ll} 
& Ventajas \\
\hline Estudios epidemiológicos & (1) los humanos son los indicadores últimos de la enfermedad; \\
(2) evaluación de poblaciones sensibles o susceptibles; \\
(3) cohortes de exposición profesional; (4) alertas de centinelas \\
ambientales
\end{tabular}

Bioensayos in vivo de larga duración

Bioensayos in vivo e in vitro de media y corta duración

Relaciones estructura química-actividad biológica

Inferencias mecanicistas
(1) evaluaciones prospectivas y retrospectivas (validación);

(2) excelente correlación con carcinógenos humanos identificados;

(3) se conocen los niveles y condiciones de exposición;

(4) se identifican la toxicidad química y los efectos de carcinogeni-

cidad; (5) obtención de resultados relativamente rápida;

(6) comparaciones cualitativas entre familias químicas;

(7) sistemas biológicos integradores e interactivos muy relacionados con los humanos

(1) más rápidos y baratos que otros ensayos; (2) muestras amplias que se multiplican con facilidad; (3) se miden parámetros biológicamente significativos (mutación, etc.); (4) pueden utilizarse como ensayos de detección selectiva para determinar qué sustancias van a someterse a bioensayos de larga duración

(1) relativamente fáciles, rápidas y baratas; (2) fiables para determinadas clases de sustancias (como nitrosaminas y colorantes de bencidina); (3) se establecen a partir de datos biológicos pero no dependen de experimentación biológica complementaria

(1) razonablemente precisas en determinadas clases de sustancias; (2) permiten depurar las hipótesis; (3) pueden orientar las evaluaciones del riesgo a las poblaciones sensibles

\section{Inconvenientes}

(1) generalmente retrospectivos (certificados de defunción, sesgos de recuerdo, etc.); (2) poco sensibles, costosos, largos; (3) a veces no se dispone de datos de exposición fiables o son difíciles de obtener; (4) exposiciones combinadas, múltiples y complejas; falta de cohortes de control adecuadas; (5) no se realizan experimentos en seres humanos; (6) detección del cáncer, no prevención

(1) raras veces se multiplican, exigen muchos recursos;

(3) pocas instalaciones adecuadas para experimentos de este tipo;

(4) problema en la extrapolación a otra especie; (5) suelen emplearse niveles de exposición muy superiores a los que experimentan los humanos; (6) la exposición a una única sustancia no refleja las exposiciones humanas, que por lo general son a múltiples sustancias al mismo tiempo

(1) los resultados in vitro no predicen totalmente los resultados in vivo; (2) generalmente específicos de organismos o de órganos; (3) potencias no comparables a animales completos 0 a los humanos

(1) no "biológicas"; (2) numerosas excepciones a las reglas formuladas; (3) retrospectivas y raras veces prospectivas (aunque cada vez lo son más)

(1) mecanismos de carcinogénesis química no definidos, múltiples y probablemente específicos de sustancia o de clase; (2) a veces no destacan las excepciones a los mecanismos generales 
de la calidad). Otro ámbito que genera una especial preocupación es el de la hipersusceptibilidad individual. Todas estas cuestiones han de tenerse en cuenta al proporcionar la retroinformación del estudio.

Todos los sectores de la sociedad afectados por un estudio con biomarcadores, o relacionados con su realización, han de intervenir en el proceso de adopción de decisiones sobre la forma de manejar la información generada por el estudio. Deben elaborarse, en los marcos jurídicos y sociales de la región o el país de que se trate, procedimientos específicos para prevenir o resolver los inevitables conflictos éticos. No obstante, cada situación plantea distintas dificultades y escollos, y no es posible elaborar un procedimiento único para la participación del público que cubra todas las aplicaciones de los biomarcadores de la exposición.

\section{- EVALUACION DE LA TOXICIDAD GENETICA}

David M. DeMarini y James Huff

Se trata de evaluar la capacidad que tienen los agentes de inducir cualquiera de los tres tipos generales de cambios (o mutaciones) que puede sufrir el material genético $(\mathrm{ADN})$ : cambios génicos, cromosómicos y genómicos. En organismos como los humanos, los genes se componen de ADN, que consta de una serie de unidades llamadas bases de nucleótidos. Los genes están organizados en estructuras físicas discretas que se denominan cromosomas. La genotoxicidad puede producir efectos importantes e irreversibles sobre la salud humana. El daño genotóxico es un paso crítico en la inducción del cáncer y puede intervenir también en la inducción de defectos de nacimiento y muerte fetal. Las tres clases de mutaciones que se han mencionado pueden producirse en cualquiera de los dos tipos de tejidos que poseen los organismos como el ser humano: los espermatozoides y óvulos (células germinales) y el tejido restante (células somáticas).

Los ensayos que miden la mutación génica son los que detectan la sustitución, adición o supresión de nucleótidos en un gen. Los ensayos que miden la mutación cromosómica son los que detectan rupturas o reordenaciones cromosómicas en las que intervienen uno o varios cromosomas. Los ensayos que miden la mutación genómica son los que detectan cambios en el número de cromosomas, fenómeno que se denomina aneuploidía. La evaluación de la toxicidad genética ha cambiado mucho desde que Herman Muller desarrolló en 1927 el primer ensayo de detección de agentes genotóxicos (mutágenos). Desde entonces se han desarrollado más de 200 ensayos que miden las mutaciones del ADN; no obstante, no llegan a diez los que normalmente se utilizan hoy para evaluar la toxicidad genética. En esta sección se examinan los ensayos, se describe lo que esos ensayos miden y se estudia su papel en la evaluación de la toxicidad.

\section{La identificación del riesgo de cáncer antes del desarrollo de la toxicología genética}

La toxicología genética es hoy una parte más del proceso global de evaluación del riesgo, y en los últimos tiempos ha cobrado más importancia como instrumento para predecir de manera fiable la actividad carcinógena. No obstante, hasta que se desarrolló la toxicología genética (antes de 1970) se utilizaban otros métodos para identificar los riesgos potenciales de cáncer en los humanos, métodos que siguen empleándose en la actualidad. Los métodos que se utilizan hoy para identificar los riesgos de cáncer humano pueden dividirse en seis categorías principales: estudios epidemiológicos, bioensayos in vivo de larga duración, bioensayos in vivo de duración media, bioensayos in vivo e in vitro de corta duración, inteligencia artificial (estructura-actividad) e inferencias mecanicistas.

En la Tabla 33.8 se presentan las ventajas e inconvenientes de esos métodos.

\section{Justificación y fundamento teórico de los ensayos de toxicología genética}

Aunque los tipos exactos y el número de ensayos que se utilizan para evaluar la toxicidad genética están evolucionando constantemente y varían según los países, los más frecuentes son los que se emplean para determinar 1) mutaciones génicas en bacterias y/o células de mamíferos en cultivo y 2) mutaciones cromosómicas en células de mamíferos en cultivo y/o médula ósea en ratones vivos. Algunos de los ensayos de esta segunda categoría pueden detectar también la aneuploidía. Aunque no detectan las mutaciones que se producen en las células germinales, estos ensayos se utilizan sobre todo porque los que son específicos para esas células son más costosos y complejos. No obstante, se realizan ensayos con células germinales en ratones cuando se desea obtener información sobre los efectos en ellas.

Estudios sistemáticos realizados a lo largo de un período de 25 años (1970-1995), especialmente en el Programa Nacional de Toxicología (NTP) de los Estados Unidos en Carolina del Norte, han llevado a que se utilice un número limitado de ensayos para detectar la actividad mutágena de los agentes. El criterio para evaluar la utilidad de los ensayos se basaba en su capacidad de detectar agentes que provocan cáncer en roedores y de los que se sospecha que provocan cáncer en los humanos (es decir, los carcinógenos). Esto se debe a que estudios realizados en los últimos decenios han indicado que las células cancerosas contienen mutaciones en determinados genes y que muchos carcinógenos son también mutágenos. Así, se considera que las células cancerosas contienen mutaciones de células somáticas, y las carcinogénesis se considera como un tipo de mutagénesis de células somáticas.

Los ensayos de toxicidad genética que más se utilizan en la actualidad se han seleccionado no sólo porque cuentan con una base de datos amplia, cuestan relativamente poco y son fáciles de realizar, sino también porque se ha demostrado que detectan muchos carcinógenos de los roedores y, presumiblemente, de los humanos. En consecuencia, se emplean ensayos de toxicidad genética para predecir la carcinogenicidad potencial de los agentes.

Un importante avance conceptual y práctico de la toxicología genética fue comprobar que muchos carcinógenos eran modificados por enzimas en el cuerpo, creándose formas alteradas (metabolitos) que eran muchas veces la forma carcinógena y mutágena última de la sustancia química original. Para reproducir ese metabolismo en una placa petri, Heinrich Malling demostró que un preparado obtenido a partir de hígado de roedor contenía muchas de las enzimas necesarias para realizar esa conversión o activación metabólica. Por eso en muchos ensayos de toxicidad genética realizados en placas o tubos (in vitro) se añaden preparados enzimáticos similares. Los preparados simples se denominan mezcla $\mathrm{S} 9$, y los purificados se llaman microsomas. Gracias a la ingeniería genética se dispone hoy de algunas células de bacterias y mamíferos que contienen algunos de los genes de roedores o humanos que producen esas enzimas, lo que reduce la necesidad de añadir la mezcla S9 o microsomas. 


\section{Ensayos y técnicas de toxicología genética}

Los principales sistemas bacterianos que se utilizan para detectar la toxicidad genética son el ensayo de mutagenicidad con Salmonella (Ames) y, en mucha menor medida, la cepa WP2 de Escherichia coli. Estudios realizados a mediados de la década de 1980 demostraron que sólo dos cepas del sistema Salmonella (TA98 y TA100) bastaban para detectar aproximadamente el $90 \%$ de los mutágenos de Salmonella conocidos. Así pues, son esas dos cepas las que más se utilizan con fines de detección, aunque se pueden utilizar otras en ensayos más amplios.

Los ensayos se realizan de diversas maneras, pero dos procedimientos generales son la incorporación en placa y la suspensión en líquido. En el ensayo de incorporación en placa, las células, la sustancia química que es objeto de la prueba y (si se desea) el S9 se añaden a un agar licuado y se vierten en la superficie de una placa petri con agar. El agar de la parte superior se endurece en unos minutos, y la placa se incuba durante dos o tres días; al cabo de ese tiempo las células mutantes han crecido lo suficiente para formar racimos detectables visualmente que se llaman colonias y que después se cuentan. El medio de agar contiene agentes selectivos o está compuesto por ingredientes tales que sólo permiten crecer a las células que acaban de sufrir la mutación. El ensayo de incubación en líquido es similar, excepto en que las células, el agente que es objeto del ensayo y el S9 se incuban juntos en líquido que no contiene agar licuado, y después las células se lavan para quitarle el agente del ensayo y el S9 y se siembran en el agar.

En las células de mamífero en cultivo, las mutaciones se detectan sobre todo en uno de estos dos genes: hprt y tk. Análogamente a los ensayos con bacterias, las líneas celulares de mamíferos (obtenidas de células de roedores o humanas) se exponen al agente en placas o tubos de cultivo de plástico y después se siembran en placas de cultivo que contienen un medio con un agente selectivo que permite crecer sólo a las células mutantes. Entre los ensayos de este tipo figuran los denominados CHO/HPRT, TK6 y linfoma $\mathrm{L} 5178 \mathrm{Y} / \mathrm{TK}^{+/-}$del ratón. Se utilizan también otras líneas celulares que contienen diversas mutaciones de la reparación del ADN y algunos genes humanos que intervienen en el metabolismo. Esos sistemas permiten recuperar las mutaciones que se han producido en el gen (mutación génica), así como las que han afectado a regiones del cromosoma contiguas al gen (mutación cromosómica). No obstante, este último tipo de mutación se recupera mucho mejor con los sistemas del gen tk que con los del gen hprt debido a la localización del primero.

Similares a los ensayos de incubación en líquido para detectar la mutagenicidad bacteriana, los ensayos de mutagenicidad en células de mamíferos suelen comprender la exposición de las células en placas o tubos de cultivo en presencia del agente del ensayo y de S9 durante varias horas. Después se lavan las células, se cultivan durante varios días más para que los productos génicos normales (tipo silvestre) puedan degradarse y se expresen y acumulen los nuevos productos mutantes, y después se siembran en un medio que contiene un agente selectivo que permite crecer solamente a las células mutantes. Como en los ensayos con bacterias, las células mutantes crecen formando colonias detectables visualmente que después se cuentan.

La mutación cromosómica se identifica básicamente mediante ensayos citogenéticos, que consisten en exponer roedores y/o células de roedores o humanas a la sustancia química en placas de cultivo, dejar que se produzcan una o varias divisiones celulares, teñir los cromosomas y después examinar visualmente los cromosomas al microscopio para detectar alteraciones en la estructura o el número de cromosomas. Aunque pueden buscarse diversos fenómenos, los dos actualmente aceptados por los organismos de regulación como más significativos son las aberraciones cromosómicas y una subcategoría denominada micronúcleos.

Se requiere una sólida formación y considerable experiencia para contar las células con aberraciones cromosómicas, lo que hace que sea un procedimiento costoso en tiempo y en dinero. En cambio, la detección de los micronúcleos requiere poca formación, y puede automatizarse. Los micronúcleos se presentan como pequeños puntos dentro de la célula que son distintos del núcleo, que contiene los cromosomas. Los micronúcleos se producen por rotura del cromosoma o por aneuploidía. Por la facilidad de contar los micronúcleos en comparación con las aberraciones cromosómicas, y como estudios recientes indican que los agentes que inducen aberraciones cromosómicas en la médula ósea de ratones vivos inducen también por lo general micronúcleos en este tejido, hoy es habitual medir los micronúcleos como indicación de la capacidad de un agente para inducir mutaciones cromosómicas.

Aunque se utilizan con mucha menos frecuencia que los ensayos que se acaban de describir, los que se realizan con células germinales son indispensables para determinar si un agente comporta un riesgo de mutaciones en estas células, mutaciones que pueden tener efectos sobre la salud de generaciones futuras. Los ensayos con células germinales más utilizados se realizan en el ratón, y comprenden sistemas que detectan 1) las translocaciones (intercambios) heredables entre cromosomas (ensayo de translocación heredable), 2) las mutaciones génicas o cromosómicas que afectan a genes específicos (ensayos específicos de locus, visibles o bioquímicos) y 3) las mutaciones que afectan a la viabilidad (ensayo de factor letal dominante). Como en el caso de los que se realizan con células somáticas, en estos ensayos la hipótesis de trabajo es que los agentes que dan positivo en ellos se consideran mutágenos potenciales de las células germinales humanas.

\section{Situación actual y perspectivas para el futuro}

En estudios recientes sólo se han necesitado tres tipos de información para detectar aproximadamente el $90 \%$ de una serie de 41 carcinógenos de roedores (es decir, carcinógenos y mutágenos de células somáticas supuestamente humanos). Esos tipos de información son: 1) el conocimiento de la estructura química del agente, especialmente si contiene unidades electrófilas (véase la sección sobre las relaciones estructura-actividad); 2) datos sobre la mutagenicidad en Salmonella, y 3) datos de un ensayo de toxicidad crónica de 90 días en roedores (ratones y ratas). De hecho, prácticamente todas las sustancias que la IARC ha declarado como carcinógenos humanos son detectables como mutágenos utilizando sólo el ensayo con Salmonella y el ensayo de micronúcleos en la médula ósea del ratón. La utilidad de estos ensayos de mutagenicidad para detectar carcinógenos humanos potenciales se ha confirmado aún más al comprobarse que en su mayoría los carcinógenos humanos lo son también en las ratas y los ratones (carcinógenos transespecies) y que los carcinógenos transespecies son en su mayoría mutágenos en Salmonella y/o inducen micronúcleos en la médula ósea del ratón.

Con los avances que se han producido en la tecnología del ADN, el proyecto del genoma humano y un mejor conocimiento del papel de la mutación en el cáncer, se están desarrollando nuevos ensayos de genotoxicidad que probablemente se incorporarán a los procedimientos de detección habituales. Entre ellos figura el empleo de células y roedores transgénicos. Los sistemas transgénicos son aquellos en los que se introduce en una célula u organismo un gen de otra especie. Por ejemplo, se están utilizando experimentalmente ratones transgénicos que permiten detectar la mutación en cualquier órgano o tejido del animal introduciendo en éste un gen bacteriano. Se dispone de células 
bacterianas, como Salmonella, y de células de mamíferos (incluidas líneas celulares humanas) que contienen genes que intervienen en el metabolismo de agentes carcinógenos/mutágenos, como los genes P450. Puede realizarse hoy el análisis molecular de las mutaciones efectivas inducidas en el transgen de roedores transgénicos, o en genes nativos como hprt o en los genes diana de Salmonella, de manera que puede determinarse con exactitud la naturaleza de las mutaciones inducidas por las sustancias químicas, lo que arroja luz sobre el mecanismo de acción de la sustancia y permite establecer comparaciones con mutaciones en humanos supuestamente expuestos a ese agente.

Los avances de la citogenética molecular permiten hoy evaluar con más detalle las mutaciones cromosómicas. Entre esos avances figura el empleo de sondas (pequeños fragmentos de ADN) que se unen (hibridizan) a determinados genes. Puede comprobarse después la forma en que los genes se reordenan en el cromosoma mediante las nuevas localizaciones de las sondas, que son fluorescentes y se observan fácilmente como los sectores coloreados de los cromosomas. La electroforesis en gel sobre una sola célula para determinar la rotura del ADN (que es el ensayo que suele denominarse "cometa") permite comprobar ese fenómeno en células sueltas y puede ser un instrumento de suma utilidad en combinación con técnicas citogenéticas para detectar el daño cromosómico.

Tras muchos años de utilización y tras generarse una base de datos amplia y sistemática, la evaluación de la toxicidad genética puede realizarse hoy con un escaso número de ensayos de coste relativamente reducido y en un tiempo relativamente corto (unas semanas). Los datos obtenidos pueden utilizarse para predecir la capacidad que posee un gen de ser carcinógeno/mutágeno de células somáticas en los roedores y, presumiblemente, en el ser humano. Ello permite limitar la introducción en el medio ambiente de agentes mutágenos y carcinógenos y desarrollar otros agentes distintos no mutágenos. De los estudios que se realicen en el futuro se deben derivar métodos aún mejores y de mayor capacidad de predicción que los ensayos actuales.

\section{ENSAYOS DE TOXICIDAD IN VITRO}

Joanne Zurlo

La aparición de complejas tecnologías en la biología molecular y celular ha impulsado una evolución relativamente rápida en las ciencias de la vida, entre ellas la toxicología. En efecto, la toxicología no se está centrando tanto en animales completos y poblaciones de animales completos como en las células y moléculas de animales y seres humanos individuales. A mediados del decenio de 1980 los toxicólogos empezaron a aplicar estos nuevos métodos a la evaluación de los efectos de las sustancias químicas sobre los sistemas vivos. Como progresión lógica, esos métodos se están adaptando a los fines de los ensayos de toxicidad. Estos avances científicos han contribuido junto con factores sociales y económicos a modificar la evaluación de la seguridad de los productos y del riesgo potencial.

Los factores económicos están específicamente relacionados con el volumen de materiales que se ha de ensayar. Cada año se introducen en el mercado gran cantidad de nuevos cosméticos, fármacos, plaguicidas, sustancias químicas y productos para el hogar. Y ha de evaluarse la toxicidad potencial de todos ellos. Hay además un retraso acumulado, pues sustancias químicas que ya se están utilizando no se ensayaron suficientemente en su día. La inmensa tarea de obtener información detallada sobre la seguridad de todas esas sustancias químicas utilizando los métodos de ensayo tradicionales con animales completos sería muy costosa en tiempo y en dinero, si es que fuera posible realizarla.

Se plantean asimismo cuestiones sociales relacionadas con la salud y seguridad públicas, y hay una creciente preocupación pública acerca del empleo de animales en ensayos de seguridad de productos. En lo que se refiere a la seguridad humana, los grupos de defensa del interés público y del medio ambiente han presionado considerablemente a los organismos gubernamentales para que apliquen normas más estrictas en materia de sustancias químicas. Un ejemplo reciente ha sido la petición de algunos grupos de defensa del medio ambiente de los Estados Unidos de que se prohibieran el cloro y los compuestos que contienen cloro. Una de las razones de esta actitud extrema reside en el hecho de que la mayoría de esos compuestos no ha sido objeto de ensayos suficientes. Desde la perspectiva de la toxicología, la idea de prohibir toda una clase de sustancias químicas diversas sólo porque contienen cloro es científicamente poco sólida e irresponsable. Con todo, desde la perspectiva del público es comprensible la petición de que se den garantías de que las sustancias químicas que se liberan en el medio ambiente no comportan un riesgo importante para la salud. Esta situación subraya la necesidad de elaborar métodos de evaluación de la toxicidad que sean más eficientes y más rápidos.

La otra preocupación social que ha afectado al ámbito de los ensayos de toxicidad es el bienestar de los animales. Los grupos que en todo el mundo se dedican a la protección de los animales, cada vez más numerosos, han expresado una considerable oposición al empleo de animales completos en ensayos de seguridad de productos. Se han lanzado campañas activas contra los fabricantes de cosméticos, productos para el hogar y de cuidado personal y fármacos en un intento de detener los ensayos con animales. En Europa, ello hizo que se aprobara la sexta modificación de la Directiva 76/768/CEE (la llamada "directiva sobre cosméticos"). La directiva dispone que los productos cosméticos o ingredientes de cosméticos que se hayan ensayado en animales a partir del 1 de enero de 1998 no podrán comercializarse en la Unión Europea, a menos que no haya otros métodos alternativos suficientemente validados. Aunque la prohibición no es aplicable a la venta de tales productos en los Estados Unidos o en otros países, la directiva afectará notablemente a las empresas que tienen mercados internacionales en los que está incluida Europa.

El concepto de otros métodos alternativos, que constituye la base del desarrollo de ensayos distintos de los que se realizan con animales completos, se define por la regla de la triple $R$ : reducir el número de animales empleados; refinar los protocolos, de manera que los animales sufran menos tensión o molestia, y remplazar los actuales ensayos con animales por ensayos in vitro (es decir, ensayos realizados fuera del animal vivo), modelos informatizados o ensayos en especies de invertebrados o de vertebrados inferiores. La regla de la triple $R$ se propuso en un libro que publicaron en 1959 dos científicos británicos, W.M.S. Russell y Rex Burch, y que se titulaba The Principles of Humane Experimental Technique. Russell y Burch mantenían que la única manera de conseguir resultados científicos válidos pasaba por el tratamiento humano de los animales, y pensaban que debían desarrollarse métodos para reducir y en última instancia sustituir el uso de animales. Pero los principios enunciados por Russell y Burch no tuvieron mucho eco en su día, y tuvieron que esperar a que a mediados del decenio de 1970 resurgiera el movimiento de defensa del bienestar de los animales. Hoy el concepto de las tres $R$ está presente, y en primera línea, en las actividades de investigación, realización de ensayos y formación.

En resumen, puede afirmarse que en el desarrollo de los métodos de ensayo in vitro han convergido diversos factores a lo largo de los últimos 10-20 años. No es fácil saber si cualquiera 
de esos factores por sí sólo hubiera tenido un efecto tan profundo sobre las estrategias de los ensayos de toxicidad.

\section{Concepto de los ensayos de toxicidad in vitro}

En esta sección nos ocuparemos únicamente de los métodos de evaluación de la toxicidad que se realizan in vitro, como una de las varias alternativas a los ensayos con animales completos. En otras secciones de este capítulo se examinan otras opciones distintas del uso de animales, como la elaboración de modelos informáticos y las relaciones estructura-actividad cuantitativas.

Los estudios in vitro se realizan generalmente en células o tejidos animales o humanos fuera del cuerpo. La expresión "in vitro" ("en vidrio") se refiere a los procedimientos que se realizan sobre material vivo o componentes de material vivo en placas petri o en tubos de ensayo en unas condiciones definidas. Lo contrario son los estudios "in vivo", es decir, realizados "en el animal vivo". Aunque es difícil, si no imposible, proyectar los efectos de una sustancia química sobre un organismo complejo cuando las observaciones se limitan a un único tipo de células en una placa, los estudios in vitro sí que proporcionan una notable cantidad de información sobre la toxicidad intrínseca, así como sobre los mecanismos celulares y moleculares de la toxicidad. Además, ofrecen muchas ventajas sobre los estudios in vivo, sobre todo que son en general más baratos y que pueden controlarse mejor las condiciones en que se realizan. A ello hay que añadir que, pese a que sigue siendo necesario contar con algunos animales para obtener las células que se van a cultivar in vitro, estos métodos pueden considerarse como alternativas válidas en el sentido de la "reducción" (pues se emplean muchos menos animales que en los estudios in vivo) y del "refinamiento" (porque eliminan la necesidad de someter a los animales a las consecuencias tóxicas adversas inevitables en los experimentos in vivo).

Para interpretar los resultados de los ensayos de toxicidad in vitro, determinar su utilidad potencial en la evaluación de la toxicidad y relacionarlos con el proceso toxicológico general in vivo, es necesario comprender qué parte del proceso toxicológico se está examinando. El proceso toxicológico completo consiste en unos fenómenos que se inician con la exposición del organismo a un agente físico o químico, prosiguen con las interacciones celulares y moleculares y acaban manifestándose en la respuesta del organismo completo. Los ensayos in vitro suelen limitarse a la parte del proceso toxicológico que se desarrolla al nivel celular y molecular. Los estudios realizados con este método pueden proporcionar información sobre por ejemplo las rutas metabólicas, la interacción de metabolitos activos con dianas celulares y moleculares y parámetros o "puntos finales" de la toxicidad que pueden medirse y que por lo tanto pueden utilizarse como biomarcadores moleculares de la exposición. Lo ideal sería conocer el mecanismo de toxicidad de todas las sustancias químicas, desde la exposición hasta la manifestación en el organismo, de tal manera que la información obtenida en los ensayos in vitro pudiera interpretarse y relacionarse íntegramente con la respuesta del organismo en su conjunto. Pero ello es prácticamente imposible, pues hasta el momento son relativamente pocos los mecanismos toxicológicos que se ha logrado elucidar en su totalidad. Por ello, los toxicólogos se enfrentan a una situación en la que los resultados de un ensayo in vitro no pueden utilizarse como una predicción totalmente exacta de la toxicidad in vivo porque se desconoce el mecanismo. No obstante, es frecuente que durante el proceso de desarrollo de un ensayo in vitro se logren comprender algunos componentes del mecanismo o mecanismos celulares y moleculares de la toxicidad.

Una de las cuestiones clave que están sin resolver en cuanto al desarrollo y realización de ensayos in vitro es la que se refiere a la consideración siguiente: ¿deben tener una base mecanicista, o basta con que sean descriptivos? Desde una perspectiva científica es incontestablemente mejor utilizar sólo ensayos de base mecanicista para sustituir a los ensayos in vivo. Pero, ante la ausencia de conocimientos mecanicistas completos, la posibilidad de desarrollar ensayos in vitro que sustituyan totalmente a los ensayos con animales enteros en el futuro próximo es casi nula. No obstante, ello no descarta la utilización de tipos de ensayos más descriptivos como instrumentos de detección precoz, como es el caso en la actualidad. Con esos métodos de detección se ha conseguido reducir notablemente el uso de animales. Por consiguiente, hasta que llegue el momento en que se genere más información mecanicista, puede ser necesario emplear de manera más limitada ensayos cuyos resultados simplemente tengan una buena correlación con los obtenidos in vivo.

\section{Ensayos de citotoxicidad in vitro}

En esta sección se describirán varios ensayos in vitro que se han desarrollado para evaluar el potencial citotóxico de una sustancia química. Son en su mayoría ensayos fáciles de realizar, y el análisis puede automatizarse. Un ensayo de citotoxicidad in vitro que se utiliza habitualmente es el ensayo rojo neutro. Se realiza en células en cultivo, y en la mayoría de las aplicaciones las células pueden mantenerse en placas de cultivo que contienen 96 pocillos, cada uno de $6,4 \mathrm{~mm}$ de diámetro. Como cada pocillo puede utilizarse para una sola determinación, este sistema permite emplear múltiples concentraciones de la sustancia así como controles positivos y negativos con un número suficiente de replicaciones para cada caso. Tras el tratamiento de las células con diversas concentraciones de la sustancia que se ensaya, que abarcan al menos dos órdenes de magnitud (por ejemplo, de $0,01 \mathrm{mM}$ a $1 \mathrm{mM}$ ), así como con sustancias de control positivo y negativo, las células se lavan y tiñen con rojo neutro, un colorante que puede absorber y retener únicamente las células vivas. La tinción puede realizarse nada más retirar la sustancia ensayada, y entonces se observan los efectos inmediatos, o puede realizarse también en diversos momentos posteriores para observar los efectos acumulados o retardados. La intensidad del color en cada pocillo corresponde al número de células vivas en ese pocillo. La intensidad del color se mide mediante un espectrofotómetro, que puede estar equipado con un lector de placas. El lector se programa para que proporcione mediciones individuales de cada uno de los 96 pocillos de la placa de cultivo. Esta metodología automatizada permite al investigador realizar rápidamente un experimento de concentración-respuesta y obtener datos útiles desde el punto de vista estadístico.

Otro ensayo de citotoxicidad relativamente sencillo es el que se realiza con la prueba MTT. El MTT (bromuro de 3[4,5-dimetiltiazol-2-il]-2,5-difeniltetrazolio) es un colorante de tetrazolio que se reduce a color azul por la acción de enzimas mitocondriales. Sólo las células con mitocondrias viables conservan la capacidad de efectuar esa reacción; por lo tanto, la intensidad del color está directamente relacionada con el grado de integridad de las mitocondrias. Es un ensayo útil para detectar compuestos citotóxicos generales, así como los agentes que tienen a las mitocondrias como diana específica.

También se utiliza como ensayo de citotoxicidad de amplio espectro la medida de la actividad de la lactico deshidrogenasa (LDH). Esta enzima está presente normalmente en el citoplasma de las células vivas y se libera en el medio de cultivo celular al permeabilizarse la membrana de las células muertas o moribundas que se han visto afectadas por un agente tóxico. Tras la aplicación de la sustancia ensayada a las células se retiran en diversos momentos pequeñas cantidades del medio de cultivo de las células para medir la cantidad de LDH liberada y determinar el curso temporal de la toxicidad. Aunque no permite más que una evaluación muy general de la citotoxicidad, el valor 
del ensayo de liberación de LDH reside en que es fácil de hacer y en que puede realizarse en tiempo real.

Se están desarrollando muchos métodos nuevos de detectar el daño celular. Los más sofisticados emplean sondas fluorescentes para medir diversos parámetros intracelulares, como la liberación de calcio y las alteraciones del $\mathrm{pH}$ y del potencial de la membrana. En general, esas sondas son muy sensibles y pueden detectar cambios celulares más sutiles, con lo que se reduce la necesidad de utilizar la muerte celular como punto final de la toxicidad. Además, muchos de esos ensayos de fluorescencia pueden automatizarse utilizando placas de 96 pocillos y lectores de placas fluorescentes.

Una vez que se han acopiado datos sobre una serie de sustancias químicas utilizando uno de estos ensayos, pueden determinarse las toxicidades relativas. La toxicidad relativa de una sustancia química, tal como se determina en un ensayo in vitro, puede expresarse como la concentración que produce un efecto del $50 \%$ en la respuesta de punto final en células no tratadas. Esta determinación se suele denominar $\mathrm{CE}_{50}$ (concentración efectiva en el $\underline{50} \%$ de las células) y puede utilizarse para comparar las toxicidades de diferentes sustancias químicas in vitro. (En las evaluaciones de la toxicidad relativa se utiliza también una expresión análoga, $\mathrm{CI}_{50}$, que indica la concentración de una sustancia que provoca una inhibición del $50 \%$ de un proceso celular, como por ejemplo la capacidad de absorber el rojo neutro.) No es fácil determinar si la toxicidad relativa in vitro de las sustancias químicas es comparable a sus toxicidades relativas in vivo, pues en el sistema in vivo intervienen muchos factores que crean confusión, como la toxicocinética, el metabolismo y los mecanismos de reparación y defensa. Además, como la mayoría de esos ensayos mide parámetros de la citotoxicidad general, no tienen una base mecanicista. Por consiguiente, la concordancia entre las toxicidades relativas in vitro e in vivo es meramente correlativa. Pese a los muchos problemas y dificultades que plantea la extrapolación de in vitro a in vivo, estos ensayos in vitro están resultando muy valiosos porque su realización es sencilla y poco costosa y porque pueden utilizarse como métodos de detección con los que seleccionar fármacos o compuestos muy tóxicos en las fases tempranas de su desarrollo.

\section{Toxicidad en órganos diana}

Suelen utilizarse también los ensayos in vitro para evaluar la toxicidad en órganos diana específicos. El diseño de estos ensayos plantea varios problemas, el principal de los cuales es que los sistemas in vitro no pueden mantener muchos de los rasgos del órgano in vivo. Muchas veces, cuando las células se extraen de animales y se ponen en cultivo, tienden a degenerar rápidamente y/o a desdiferenciarse, es decir, a perder sus especializaciones funcionales (como si fueran un órgano) y a hacerse más genéricas. Ello plantea un problema en el sentido de que en un breve período de tiempo, por lo general unos días, ya no sirven para evaluar los efectos organoespecíficos de un tóxico.

Muchos de estos problemas se están resolviendo gracias a los recientes avances de la biología molecular y celular. La información que se obtiene sobre el entorno celular in vivo puede utilizarse para modular las condiciones del cultivo in vitro. Desde mediados del decenio de 1980 se han descubiertos nuevos factores de crecimiento y citoquinas, y muchos de ellos pueden conseguirse hoy en el mercado. Añadiendo esos factores a las células en cultivo se las ayuda a que conserven su integridad y a veces también a que mantengan durante más tiempo su diferenciación funcional. Gracias a otros estudios básicos se van conociendo mejor asimismo las necesidades nutricionales y hormonales de las células cultivadas, de manera que pueden formularse nuevos medios de cultivo. También se ha avanzado recientemente en la identificación de las matrices extracelulares, tanto naturales como artificiales, en las que pueden cultivarse células. El cultivo de células en esas diversas matrices puede afectar profundamente tanto a su estructura como a su función. Una importante ventaja de estos avances es que se puede controlar de una manera compleja el entorno de las células en cultivo y examinar individualmente los efectos de esos factores sobre procesos celulares básicos y sobre las respuestas de las células a diferentes agentes químicos. En suma, esos sistemas pueden ser de gran utilidad para conocer los mecanismos organoespecíficos de la toxicidad.

Muchos estudios de toxicidad en órganos diana se realizan en células primarias, que por definición son las extraídas directamente de un órgano, y que por lo general tienen una vida en cultivo limitada. Desde el punto de vista de la evaluación de la toxicidad, los cultivos primarios de un único tipo de célula de un órgano presentan muchas ventajas. Desde una perspectiva mecanicista, esos cultivos son útiles para estudiar dianas celulares específicas de una sustancia. En algunos casos pueden cultivarse juntos dos o más tipos de células de un órgano, lo que tiene la ventaja añadida de que se pueden observar las interacciones célula-célula en respuesta a un tóxico. Se han diseñado sistemas de cocultivo para la piel que forman una estructura tridimensional semejante a la de la piel in vivo. También se pueden cocultivar células de distintos órganos — por ejemplo el hígado y el riñón. Los cultivos de este tipo suelen ser útiles para evaluar los efectos que provoca específicamente en las células renales una sustancia que debe bioactivarse en el hígado.

Los instrumentos de la biología molecular han desempeñado también un papel importante en el desarrollo de líneas celulares continuas que pueden ser de utilidad en los ensayos de toxicidad en órganos diana. Esas líneas celulares se generan mediante la transfección de células primarias con $\mathrm{ADN}$. En el procedimiento de transfección, las células y el ADN se tratan de tal manera que las primeras puedan absorber al segundo. El ADN, generalmente de un virus, posee uno o varios genes que, cuando se expresan, hacen posible que las células se inmortalicen (es decir, que sean capaces de vivir y crecer durante largo tiempo en el cultivo). También puede diseñarse el ADN de manera que su gen inmortalizador sea controlado por un promotor inducible. La ventaja de este tipo de construcción es que las células se dividen sólo cuando reciben el estímulo químico apropiado que permite expresarse al gen inmortalizador. Un ejemplo de estas construcciones es el gran gen antígeno $\mathrm{T}$ del Simian Virus 40 (SV40) (gen inmortalizador), que está precedido por la región promotora del gen de la metalotioneína, el cual es a su vez inducido por la presencia de un metal en el medio de cultivo. Así, una vez realizada la transfección de las células con el gen, éstas pueden tratarse con bajas concentraciones de zinc para estimular al promotor MT y poner en marcha la expresión del gen antígeno T. Bajo esas condiciones, las células proliferan. Cuando se retira el zinc del medio, las células dejan de dividirse y, en condiciones ideales, vuelven a un estado en el que expresan sus funciones tejidoespecíficas.

Junto con los avances de la tecnología de los cultivos celulares, la capacidad de generar células inmortalizadas ha contribuido en gran medida a que se hayan podido crear líneas celulares de muchos órganos distintos, entre ellos el cerebro, el riñón y el hígado. No obstante, antes de que esas líneas celulares puedan utilizarse como sustitutivos de los tipos genuinos han de caracterizarse con sumo cuidado para determinar hasta qué punto son realmente "normales".

Hay otros sistemas in vitro para estudiar la tocixicidad de órganos diana que están adquiriendo cada vez más complejidad. A medida que los sistemas in vitro van haciéndose más complejos, del cultivo de una célula sola al cultivo de órganos completos, se van haciendo más comparables con el medio in vivo pero al 
Tabla 33.9 • Comparación de sistemas in vitro empleados en estudios de hepatotoxicidad.

\begin{tabular}{|c|c|c|c|c|}
\hline Sistema & Complejidad (nivel de interacción) & $\begin{array}{l}\text { Capacidad de conservar funciones } \\
\text { hepatoespecíficas }\end{array}$ & Duración potencial del cultivo & $\begin{array}{l}\text { Capacidad de } \\
\text { controlar el medio }\end{array}$ \\
\hline $\begin{array}{l}\text { Líneas celulares } \\
\text { inmortalizadas }\end{array}$ & $\begin{array}{l}\text { algo célula-célula (varía según la línea } \\
\text { celular) }\end{array}$ & $\begin{array}{l}\text { de escasa a buena (varía según la línea } \\
\text { celular) }\end{array}$ & indefinida & excelente \\
\hline $\begin{array}{l}\text { Cultivos de hepatocitos } \\
\text { primarios }\end{array}$ & célula-célula & $\begin{array}{l}\text { de bastante buena a excelente (varía } \\
\text { según las condiciones de cultivo) }\end{array}$ & de días a semanas & excelente \\
\hline $\begin{array}{l}\text { Cocultivos de células } \\
\text { hepáticas }\end{array}$ & $\begin{array}{l}\text { célula-célula (entre células del mismo } \\
\text { tipo o de tipos distintos) }\end{array}$ & de buena a excelente & semanas & excelente \\
\hline Rodajas de hígado & $\begin{array}{l}\text { célula-célula (entre todos los tipos de } \\
\text { células) }\end{array}$ & de buena a excelente & de horas a días & buena \\
\hline Hígado aislado perfundido & $\begin{array}{l}\text { célula-célula (entre todos los tipos de } \\
\text { células) e intraórgano }\end{array}$ & excelente & horas & bastante buena \\
\hline
\end{tabular}

mismo tiempo, habida cuenta del mayor número de variables, va siendo cada vez más difícil controlarlos. Por consiguiente, lo que puede ganarse al pasar a un nivel superior de organización puede perderse por la incapacidad del investigador para controlar el entorno experimental. En la Tabla 33.9 se comparan algunas de las características de varios sistemas in vitro que se han utilizado para estudiar la hepatotoxicidad.

En los estudios toxicológicos se están utilizando cada vez más las capas de tejido obtenidas con corte de precisión. Se dispone hoy de nuevos instrumentos que permiten al investigador cortar rodajas de tejido uniformes en un entorno estéril. En comparación con los sistemas de cultivo celular, las rodajas tisulares tienen la ventaja de que están presentes todos los tipos de células del órgano y de que se mantienen la arquitectura y la comunicación intercelular de las condiciones in vivo. Así, pueden realizarse estudios in vitro para determinar el tipo de célula que es diana en un órgano y para investigar la toxicidad en órganos diana concretos. Un inconveniente de las capas es que degeneran rápidamente a partir de las 24 horas de cultivo, debido sobre todo a la escasa difusión de oxígeno a las células en su interior. No obstante, estudios recientes han indicado que puede conseguirse una oxigenación más eficiente mediante una suave rotación. Junto con el uso de un medio más complejo, se consigue así que las rodajas sobrevivan hasta 96 horas.

Los cultivos de tejido responden a un concepto similar al de las capas y pueden utilizarse también para determinar la toxicidad de sustancias químicas en órganos diana específicos. Los explantes tisulares se realizan extrayendo un pequeño trozo de tejido (o un embrión intacto en el caso de los estudios de teratogenicidad) y poniéndolo en cultivo para estudiarlo después. Los cultivos de tejidos han sido de utilidad en estudios sobre toxicidades de corta duración, como la irritación y erosión de la piel, estudios sobre los efectos del amianto en la tráquea y estudios de neurotoxicidad en el tejido cerebral.

Para evaluar la toxicidad en determinados órganos pueden utilizarse también órganos aislados perfundidos. Al igual que las capas y cultivos tisulares, en estos sistemas tienen la ventaja de que están presentes todos los tipos de células, pero sin que el tejido haya sufrido la tensión derivada de las manipulaciones a que obliga la preparación de las capas. Además, se mantienen las interacciones intraórgano. Un importante inconveniente es que se mantienen viables durante poco tiempo, lo que limita su uso en los ensayos de toxicidad in vitro. En cuanto a sus posibilidades de ser un método alternativo, estos cultivos pueden considerarse un paso adelante, pues los animales no sufren las consecuencias adversas del tratamiento in vivo con tóxicos. No obstante, su empleo no reduce significativamente el número de animales que se necesitan.
En resumen, existen varios tipos de sistemas in vitro para evaluar la toxicidad en órganos diana. Es posible obtener mucha información sobre los mecanismos de la toxicidad utilizando una o varias de esas técnicas. Pero sigue siendo difícil realizar extrapolaciones de un sistema in vitro, que representa una parte relativamente pequeña del proceso tóxico, al proceso completo tal como se produce in vivo.

\section{Ensayos in vitro sobre irritación ocular}

Desde la perspectiva del bienestar de los animales, el más discutido de los ensayos de toxicidad con animales completos es probablemente el ensayo de Draize sobre irritación ocular, que se realiza en conejos. Consiste en poner una pequeña dosis fija de una sustancia química en uno de los ojos del conejo, dejándose el otro como control. El grado de irritación e inflamación se puntúa en varios momentos después de la exposición. Se están dedicando muchos esfuerzos a elaborar metodologías que sustituyan a este ensayo, que se ha criticado no sólo por razones de humanidad sino también por la subjetividad de las observaciones y la variabilidad de los resultados. Es interesante señalar que, pese a las duras críticas que ha recibido, el ensayo de Draize ha sido de gran utilidad para predecir los irritantes del ojo humano, en particular las sustancias irritantes de leves a moderadas, que son difíciles de identificar con otros métodos. Es por tanto muy necesario encontrar alternativas in vitro.

La búsqueda de otros métodos que sustituyan al ensayo de Draize es complicada, aunque se prevé que culminará con éxito. Se han elaborado numerosas alternativas in vitro y de otro tipo, $\mathrm{y}$ en algunos casos se han puesto en práctica. Entre esas otras opciones que mejoran el ensayo de Draize, y que por definición son menos dolorosas o incómodas para los animales, figura el Ensayo Ocular de Poco Volumen, en el que se pone en el ojo del conejo una menor cantidad del material de ensayo, no sólo por razones de humanidad sino también para simular más fielmente las cantidades a las que una persona puede estar accidentalmente expuesta en la realidad. Otra mejora es que las sustancias que tienen un $\mathrm{pH}$ inferior a 2 o superior a 11,5 ya no se ensayan en animales, pues se sabe que producen una irritación ocular grave.

Se ha estimado que entre 1980 y 1989 se redujo en un $87 \%$ el número de conejos utilizados para determinar la capacidad de irritación ocular de cosméticos. Esa enorme reducción de los ensayos con animales completos se ha conseguido incorporando ensayos in vitro a un enfoque de tres niveles. Se trata de un proceso multifásico que se inicia con el examen concienzudo de los datos históricos de irritación ocular y con el análisis físico y químico de la sustancia que se va a evaluar. Si esos dos procesos no brindan información suficiente, entonces se realiza una 
batería de ensayos in vitro. Los datos adicionales que se obtienen en esos ensayos pueden ser entonces suficientes para evaluar la seguridad de la sustancia. Si no lo son, la última fase sería realizar ensayos in vivo limitados. Es muy evidente que con este enfoque se puede eliminar el uso de animales o al menos reducir drásticamente el número de los que se necesitan para predecir la seguridad de una sustancia.

La batería de ensayos in vivo que se utiliza como parte de esta estrategia de tres niveles depende de las necesidades de la actividad industrial de que se trate. El ensayo de irritación ocular se emplea en muchos sectores industriales, desde el de cosméticos y el farmacéutico hasta el de sustancias químicas industriales. No todos los sectores necesitan el mismo tipo de información, por lo que no es posible definir una única batería de ensayos in vitro. La batería se diseña generalmente para evaluar cinco parámetros: citotoxicidad, alteraciones de la fisiología y bioquímica del tejido, relaciones cuantitativas estructura-actividad, mediadores de la inflamación, y recuperación y reparación. Un ejemplo de ensayo para comprobar la citotoxicidad, que es una de las posibles causas de la irritación, es el ensayo rojo neutro en el que se utilizan células en cultivo (véase antes). Las alteraciones de la fisiología y bioquímica celulares por exposición a una sustancia química pueden ensayarse en cultivos de células epiteliales de la córnea humana. Otra opción que también han utilizado los investigadores es la de trabajar con globos oculares intactos o diseccionados de bovinos o pollos obtenidos en los mataderos. Muchos de los parámetros que se miden en estos cultivos de órganos completos son los mismos que se miden in vivo, como la opacidad e hinchazón de la córnea.

En las lesiones oculares inducidas por sustancias químicas suele producirse inflamación, y existen diversos ensayos para examinar este parámetro. Varios ensayos bioquímicos detectan la presencia de mediadores liberados durante el proceso inflamatorio, como el ácido araquidónico y las citoquinas. También puede utilizarse como indicador de la inflamación la membrana corioalantoica (CAM) del huevo de gallina. En este ensayo, se retira un pequeño fragmento de la cáscara de un embrión de pollo de entre 10 y 14 días para dejar al descubierto la membrana corioalantoica. Se le aplica la sustancia química y después, en diversos momentos, se comprueban los signos de inflamación, como por ejemplo la hemorragia vascular.

Uno de los procesos in vivo más difíciles de valorar in vitro es el de la recuperación y reparación de una lesión ocular. Un instrumento creado recientemente, el microfisiómetro de sílice, mide pequeñas alteraciones del $\mathrm{pH}$ extracelular y puede utilizarse para hacer un seguimiento de las células en cultivo en tiempo real. Se ha comprobado que este análisis muestra una correlación bastante buena con la recuperación in vivo, y se ha utilizado como ensayo in vitro para este proceso. Hemos hecho un breve repaso de los tipos de ensayos que se están empleando como alternativas a la prueba de Draize sobre irritación ocular. Es probable que en los próximos años se defina una serie completa de baterías de ensayos in vitro y que cada una de ellas sea validada para un fin específico.

\section{Validación}

La clave para que las metodologías de ensayo in vitro sean aceptadas por los órganos reguladores y se apliquen en la práctica es la validación, el proceso mediante el cual se establece la credibilidad de un ensayo para un determinado fin. Se ha intentado definir y coordinar el proceso de validación tanto en los Estados Unidos como en Europa. La Unión Europea creó en 1993 el Centro Europeo de Validación de Métodos Alternativos (ECVAM) para coordinar las actividades que se realizan en su territorio y cooperar con organizaciones de los Estados Unidos como el Johns Hopkins Centre for Alternatives to Animal Testing
(CAAT), que es una institución académica, o el Interagency Coordination Committee for the Validation of Alternative Methods (ICCVAM), integrado por representantes de los National Institutes of Health, la Environment Protection Agency (EPA), la Food and Drug Administration (FDA) y la Consumer Products Safety Commission.

La validación de los ensayos in vitro exige una considerable organización y planificación. Debe haber un consenso entre los órganos de regulación gubernamentales y los científicos, industriales y académicos sobre los procedimientos aceptables, y una supervisión suficiente por parte de un consejo científico consultivo para garantizar que los protocolos se ajustan a las normas establecidas. Los estudios de validación deben realizarse en una serie de laboratorios de referencia que utilicen conjuntos calibrados de sustancias químicas de un banco de sustancias, así como células o tejidos de una misma procedencia. Deben demostrarse tanto la repetibilidad intralaboratorio como la reproducibilidad interlaboratorios del ensayo candidato, y los resultados se han de someter al análisis estadístico adecuado. Una vez compilados los resultados de los diferentes componentes de los estudios de validación, el consejo científico consultivo puede formular recomendaciones sobre la validez del ensayo o ensayos candidatos para un determinado fin. Además, los resultados de los estudios deben publicarse en las revistas que circulan por la profesión e incorporarse a una base de datos.

La definición del proceso de validación es una tarea que está en curso actualmente. Cada nuevo estudio de validación proporcionará información útil para el diseño del estudio siguiente. La comunicación y la cooperación internacionales son básicas para el desarrollo rápido de una serie ampliamente aceptable de protocolos, sobre todo dada la urgencia que ha impuesto la aprobación de la directiva de la UE sobre cosméticos. Esta legislación puede aportar sin duda el impulso necesario para que se emprenda una seria campaña de validación. Hasta que no finalice ese proceso no podrán empezar a aceptarse los métodos in vitro, las diversas instancias reguladoras.

\section{Conclusiones}

Hemos visto en esta sección un panorama general de la situación actual de los ensayos de toxicidad in vitro. La ciencia de la toxicología in vitro es relativamente joven, pero se está desarrollando a un ritmo exponencial. El reto al que se ha de hacer frente en los años venideros es incorporar los conocimientos mecanicistas generados por los estudios celulares y moleculares al amplio conjunto de datos in vivo para obtener una descripción más completa de los mecanismos toxicológicos, así como para establecer un paradigma mediante el cual puedan utilizarse los datos in vitro para predecir la toxicidad in vivo. El aprovechamiento del valor intrínseco de estos métodos in vitro pasa necesariamente por la concertación de esfuerzos entre los toxicólogos y los representantes de los gobiernos.

\section{RELACIONES ESTRUCTURA-ACTIVIDAD}

\section{Ellen K. Silbergeld}

$\mathrm{El}$ análisis de las relaciones estructura-actividad (SAR) es la utilización de información sobre la estructura molecular de las sustancias químicas para predecir características importantes en materia de persistencia, distribución, captación-absorción y toxicidad. El método SAR es otra forma posible de identificar sustancias potencialmente peligrosas que promete ser de utilidad a las industrias y a los gobiernos a la hora de establecer las sustancias que prioritariamente deben seguir estudiándose o de adoptar decisiones tempranas sobre nuevas sustancias. Las actividades 
toxicológicas son cada vez más costosas y exigen cada vez más recursos. El aumento de la preocupación sobre los posibles efectos adversos de las sustancias químicas sobre las poblaciones humanas expuestas ha impulsado a los organismos reguladores y sanitarios a ampliar la variedad y sensibilidad de los ensayos de detección de peligros toxicológicos. Al mismo tiempo, las cargas reales y percibidas que las normativas legales imponen a la industria han hecho que a ésta le preocupe la viabilidad práctica de los métodos de ensayo y análisis de datos de toxicidad. En estos momentos, la determinación de la carcinogenicidad química depende del ensayo vitalicio de al menos dos especies, los dos sexos, a varias dosis y con minuciosos análisis histopatológicos de múltiples órganos, así como de la detección de cambios preneoplásicos en las células y órganos diana. En los Estados Unidos se estima que el coste de un bioensayo de carcinogenicidad es de más de tres millones de dólares (en dólares de 1995).

Aun cuando los recursos financieros fueran ilimitados, no habría suficientes toxicólogos formados para someter a ensayos a las aproximadamente 70.000 sustancias químicas que se producen hoy en el mundo. Se necesitarían siglos para realizar siquiera una evaluación de primer nivel de esas sustancias (NRC 1984). En muchos países ha aumentado la preocupación ética por el uso de animales en los ensayos de toxicidad, lo que ha supuesto una presión adicional sobre el uso de los métodos habituales. El análisis SAR se ha utilizado mucho en el sector farmacéutico para identificar moléculas que puedan utilizarse provechosamente en los tratamientos (Hansch y Zhang 1993). En la política ambiental y de salud en el trabajo, el análisis SAR se utiliza para predecir la dispersión de compuestos en el medio físicoquímico y para detectar las nuevas sustancias químicas cuya toxicidad potencial debe evaluarse más a fondo. Con arreglo a la Ley de control de las sustancias tóxicas (TSCA) de los Estados Unidos, la EPA viene utilizando desde 1979 un enfoque SAR para hacer una "primera selección" de las nuevas sustancias en el proceso de notificación previa a la fabricación (PMN); en Australia se utiliza un enfoque similar como parte de su procedimiento de notificación de nuevas sustancias químicas (NICNAS). En los Estados Unidos el análisis SAR es una base importante a la hora de determinar si hay razones suficientes para concluir que la manufactura, elaboración, distribución, uso o eliminación de una sustancia va a presentar un riesgo no razonable de daño para la salud humana o el medio ambiente, tal como dispone la sección $5 \mathrm{f}$ ) de la TSCA. Sobre la base del resultado de ese análisis, la EPA puede exigir después que se realicen ensayos reales de la sustancia conforme a la sección 6 de la TSCA.

\section{Fundamento del análisis SAR}

El fundamento científico del análisis SAR se basa en la hipótesis de que la estructura molecular de una sustancia química puede predecir importantes aspectos de su comportamiento en los sistemas fisicoquímicos y biológicos (Hansch y Leo 1979).

\section{Proceso del análisis SAR}

El proceso del análisis SAR comprende la identificación de la estructura química, con inclusión tanto de formulaciones empíricas como del compuesto puro; la identificación de sustancias de estructura análoga; la localización de bases de datos y bibliografía para obtener información sobre sus análogos estructurales, y el análisis de toxicidad y otros datos sobre esos análogos. En algunos casos, poco frecuentes, puede bastar la información sobre la estructura del compuesto para apoyar un análisis SAR, a partir de mecanismos de toxicidad muy conocidos. Se han compilado varias bases de datos sobre el análisis SAR, así como métodos informatizados para la predicción de la estructura molecular.

A partir de esa información, con el análisis SAR se pueden estimar los siguientes parámetros:
- parámetros fisicoquímicos: punto de ebullición, presión de vapor, hidrosolubilidad, coeficiente de partición octanol/agua

- parámetros de destino biológico/ambiental: biodegradación, absorción por el suelo, fotodegradación, farmacocinética

- parámetros de toxicidad: toxicidad en organismos acuáticos, absorción, toxicidad aguda en mamíferos (ensayo límite o $\mathrm{DL}^{50}$ ), irritación cutánea, pulmonar y ocular, sensibilización, toxicidad subcrónica, mutagenicidad.

Hay que señalar que no existen métodos de análisis SAR aplicables a parámetros tan importantes para la salud como la carcinogenicidad, la toxicidad del desarrollo, la toxicidad en reproducción, la neurotoxicidad, la inmunotoxicidad u otros efectos en los órganos diana. Ello se debe a tres razones: la ausencia de una base de datos amplia en la que probar las hipótesis SAR, la falta de conocimientos sobre los determinantes estructurales de la acción tóxica, y la multiplicidad de células diana y mecanismos que intervienen en esos parámetros (véase "El enfoque estadounidense de la evaluación del riesgo de los tóxicos en la reproducción y agentes neurotóxicos"). Se han hecho algunos intentos limitados de utilizar el análisis SAR para predecir la farmacocinética utilizando información sobre los coeficientes de partición y la solubilidad (Johanson y Naslund 1988). Se han realizado análisis SAR cuantitativos más amplios para predecir el metabolismo P450-dependiente de una serie de

Tabla 33.10 • Comparación entre predicciones SAR y datos de ensayos: análisis de la OCDE y el NTP.

\begin{tabular}{|c|c|c|c|}
\hline Parámetro & $\begin{array}{l}\text { Concordancia } \\
(\%)\end{array}$ & $\begin{array}{l}\text { Discordancia } \\
(\%)\end{array}$ & Número \\
\hline Punto de ebullición & 50 & 50 & 30 \\
\hline Presión de vapor & 63 & 37 & 113 \\
\hline Hidrosolubilidad & 68 & 32 & 133 \\
\hline Coeficiente de partición & 61 & 39 & 82 \\
\hline Biodegradación & 93 & 7 & 107 \\
\hline Toxicidad en peces & 77 & 22 & 130 \\
\hline Toxicidad en dafnia & 67 & 33 & 127 \\
\hline $\begin{array}{l}\text { Toxicidad aguda en mamíferos } \\
\left(\mathrm{DL}_{50}\right)\end{array}$ & 80 & $20^{1}$ & 142 \\
\hline Irritación cutánea & 82 & 18 & 144 \\
\hline Irritación ocular & 78 & 22 & 144 \\
\hline Sensibilización cutánea & 84 & 16 & 144 \\
\hline Toxicidad subcrónica & 57 & 32 & 143 \\
\hline Mutagenicidad $^{2}$ & 88 & 12 & 139 \\
\hline Mutagenicidad $^{3}$ & $82-94^{4}$ & $1-10$ & 301 \\
\hline $\begin{array}{l}\text { Carcinogenicidad }{ }^{3} \text { : } \\
\text { Bioensayo de dos años }\end{array}$ & $72-95^{4}$ & - & 301 \\
\hline
\end{tabular}

Fuente: Datos de la OCDE: comunicación personal de C. Auer, EPA, Estados Unidos. Sólo se utilizaron en este análisis parámetros sobre los que se disponía de predicciones SAR y datos de ensayos reales comparables. Datos del NTP: tomados de Ashby y Tennant 1991.

I Un problema fue que con el método SAR no se pudo predecir la toxicidad aguda en el 12\% de las sustancias ensayadas.

2 Datos de la OCDE, basados en la concordancia entre el ensayo de Ames y el análisis SAR.

3 Datos del NTP, basados en ensayos de genotoxicidad comparados con predicciones SAR en varias clases de "sustancias estructuralmente alarmantes".

${ }^{4}$ La concordancia variaba según las clases; la mayor se daba en los compuestos aromáticos amino/nitro, y la menor en las estructuras "misceláneas". 
compuestos y la unión de moléculas del tipo de la dioxina y los PCB al receptor "de dioxina" citosólico (Hansch y Zhang 1993).

Como se indica en la Tabla 33.10, se ha comprobado que los análisis SAR tienen una predecibilidad variable respecto de algunos de los parámetros antes señalados. En esa tabla se presentan datos de dos comparaciones de la actividad predicha con los resultados reales obtenidos por medición empírica o ensayos de toxicidad. Los análisis SAR realizados por expertos de la EPA de los Estados Unidos funcionaron peor en la predicción de las propiedades fisicoquímicas que en la de la actividad biológica, incluida la biodegradación. Respecto de los parámetros de toxicidad, donde mejor funcionaron los análisis SAR fue en la predicción de la mutagenicidad. Ashby y Tennant (1991) comprobaron también una buena capacidad de predicción de la genotoxicidad a corto plazo en su análisis de sustancias químicas del Programa Nacional de Toxicología (NTP) de los Estados Unidos. Ello no es de extrañar si tenemos en cuenta lo que hoy se sabe de los mecanismos moleculares de la genotoxicidad (véase "Toxicología genética") y del papel de la electrofilia en la unión al ADN. En cambio, los análisis SAR tendían a infrapredecir la toxicidad sistémica y subcrónica en los mamíferos y a sobrepredecir la toxicidad aguda en organismos acuáticos.
En el caso de otros parámetros de la toxicidad, como se ha señalado antes, la utilidad de los análisis SAR es menos demostrable. Las predicciones en mamíferos se ven complicadas por la falta de análisis SAR aplicables a la toxicocinética de moléculas complejas. No obstante, se han hecho algunos intentos de proponer principios SAR aplicables a parámetros complejos de la toxicidad en mamíferos (por ejemplo, véase en Bernstein (1984) un análisis SAR de tóxicos en reproducción potenciales en el varón). En la mayoría de los casos, la base de datos no es lo bastante amplia para probar rigurosamente las predicciones basadas en la estructura.

Por el momento cabe concluir que el análisis SAR puede ser útil sobre todo para establecer prioridades en la inversión de recursos en ensayos de toxicidad y para llamar la atención sobre peligros potenciales en una fase temprana. Sólo en el caso de la mutagenicidad es probable que el análisis SAR como tal pueda utilizarse de manera fiable como información en la que basar otras decisiones. Probablemente no hay ningún punto final de la toxicidad en el que el análisis SAR pueda ofrecer el tipo de información cuantitativa que, como se indica en otras partes de este capítulo y de la Enciclopedia, se necesita para evaluar el riesgo.

\section{TOXICOLOGIA REGULADORA}

\section{- La TOXICOLOGIA EN LA REGULACION DE LA SALUD Y LA SEGURIDAD}

\section{Ellen K. Silbergeld}

La toxicología desempeña un papel importante en la elaboración de normas y otras medidas de salud profesional. Las decisiones encaminadas a prevenir las lesiones y enfermedades profesionales se están basando cada vez más en información obtenible antes o en ausencia de los tipos de exposiciones humanas que proporcionarían datos definitivos sobre el riesgo, como por ejemplo los derivados de estudios epidemiológicos. Además, y tal como se ha señalado en este capítulo, los estudios toxicológicos pueden proporcionar una información precisa sobre la dosis y la respuesta en las condiciones controladas de la investigación de laboratorio, información que suele ser dificil de obtener en el contexto no controlado de las exposiciones profesionales. No obstante, esa información ha de evaluarse cuidadosamente para estimar la probabilidad de efectos adversos en los humanos, la naturaleza de esos efectos adversos y la relación cuantitativa entre las exposiciones y los efectos.

En muchos países se viene prestando una considerable atención, desde el decenio de 1980, a la elaboración de métodos objetivos para utilizar la información toxicológica en la adopción de decisiones de regulación. Tanto instancias gubernamentales como no gubernamentales han propuesto y utilizado en esos países unos métodos formalizados que suelen denominarse evaluación del riesgo. La evaluación del riesgo se ha definido de diversas maneras; básicamente es un proceso de evaluación en el que se maneja información toxicológica, epidemiológica y sobre la exposición y que trata de identificar y estimar la probabilidad de que se produzcan efectos adversos asociados a exposiciones a sustancias o condiciones peligrosas. La evaluación del riesgo puede ser cualitativa, en cuyo caso indica la naturaleza de un efecto adverso y una estimación general de su probabilidad, o puede ser también cuantitativa, con estimaciones del número de personas afectadas a determinados niveles de exposición. En muchos sistemas de regulación, la evaluación del riesgo se realiza en cuatro fases: identificación del peligro, que es la descripción de la naturaleza del efecto tóxico; evaluación de la relación dosis-respuesta, que es un análisis semicuantitativo o cuantitativo de la relación entre la exposición (o dosis) y la gravedad o probabilidad del efecto tóxico; evaluación de la exposición, en la que se evalúan los datos sobre el intervalo de exposiciones que probablemente van a sufrir poblaciones en su conjunto o subgrupos de ellas, y caracterización del riesgo, que es la compilación de toda la información anterior para obtener una magnitud del riesgo que cabe esperar en determinadas condiciones de exposición (sobre estos principios, véase NRG 1983).

En esta sección se presentan a manera de ejemplo tres enfoques de la evaluación del riesgo.

Es imposible ofrecer un compendio completo de los métodos de evaluación del riesgo que se utilizan en el mundo, y los casos que se han elegido no deben tomarse como modelos. Hay que señalar que se está tendiendo a armonizar los métodos de evaluación del riesgo, en parte para responder a disposiciones incluidas en los recientes acuerdos del GATT. En estos momentos están en curso dos procesos de armonización internacional de los métodos de evaluación del riesgo: en el Programa Internacional de Seguridad de las Sustancias Químicas (IPCS) y en la Organización para la Cooperación y el Desarrollo Económico (OCDE). Estas organizaciones mantienen también información actualizada sobre los enfoques nacionales de la evaluación del riesgo.

\section{PRINCIPIOS DE LA IDENTIFICACION DE LOS PELIGROS: EL ENFOQUE JAPONES}

Masayuki Ikeda

Como en muchos otros países, el riesgo debido a exposición a sustancias químicas está regulado en el Japón con arreglo a varias categorías de sustancias (véase la Tabla 33.11). Se ocupan de la cuestión distintos ministerios u organismos gubernamentales. En el caso de las sustancias químicas industriales en general, la 
Tabla 33.11 - Regulación legal de las sustancias químicas, Japón.

\begin{tabular}{|c|c|c|}
\hline Categoría & Ley & Ministerio \\
\hline $\begin{array}{l}\text { Alimentos y aditivos } \\
\text { alimentarios }\end{array}$ & Ley de higiene de los alimentos & MHW \\
\hline Productos farmacéuticos & Ley de productos farmacéuticos & MHW \\
\hline Estupefacientes & Ley de control de los estupefacientes & MHW \\
\hline $\begin{array}{l}\text { Sustancias químicas } \\
\text { agrícolas }\end{array}$ & $\begin{array}{l}\text { Ley de control de las sustancias químicas } \\
\text { agrícolas }\end{array}$ & MAFF \\
\hline $\begin{array}{l}\text { Sustancias químicas } \\
\text { industriales }\end{array}$ & Ley de control de las sustancias químicas & $\begin{array}{l}\text { MHW \& } \\
\text { MITI }\end{array}$ \\
\hline $\begin{array}{l}\text { Todas las sustancias } \\
\text { químicas excepto } \\
\text { las radiactivas }\end{array}$ & $\begin{array}{l}\text { Ley de regulación de los productos domés- } \\
\text { ticos que contienen sustancias peligrosas } \\
\text { Ley de control de las sustancias } \\
\text { tóxicas y nocivas } \\
\text { Ley de seguridad e higiene en el trabajo }\end{array}$ & $\begin{array}{l}\text { MHW } \\
\text { MHW } \\
\text { MOL }\end{array}$ \\
\hline Sustancias radiactivas & Ley de sustancias radiactivas & STA \\
\hline
\end{tabular}

Abreviaturas: MHW: Ministerio de Sanidad y Bienestar; MAFF: Ministerio de Agricultura, Silvicultura y Pesca; MITI: Ministerio de Comercio Internacional e Industria; MOL: Ministerio de Trabajo; STA: Ágencia de Ciencia y Tecnología.

normativa principal es la Ley sobre el Examen y la Regulación de Productos Fabricados, etc. de las sustancias químicas, abreviada como Ley de Control de las Sustancias Químicas (CSCL). Los organismos responsables son el Ministerio de Comercio Internacional e Industria y el Ministerio de Sanidad y Bienestar. Además, la Ley de Seguridad e Higiene en el Trabajo (del Ministerio de Trabajo) estipula que las sustancias químicas industriales han de pasar un examen de mutagenicidad y que, si se comprueba que una sustancia es mutágena, la exposición de los trabajadores a ella debe reducirse al mínimo aislando las instalaciones de producción, instalando sistemas locales de aspiración de gases, utilizando equipo de protección, etc.

Como las sustancias químicas industriales peligrosas se identifican básicamente con arreglo a la CSCL, en esta sección se describirá el marco de los ensayos de identificación de los peligros que se prescribe en dicha ley.

\section{El concepto de la Ley de Control de las Sustancias químicas}

La CSCL original fue aprobada por la Dieta (parlamento del Japón) en 1973 y entró en vigor el 16 de abril de 1974. Obedecía básicamente al deseo de prevenir la contaminación ambiental y los consiguientes efectos sobre la salud humana debidos a los PCB y sustancias análogas. Los PCB se caracterizan por 1) su persistencia en el medio ambiente (son escasamente biodegradables), 2) su creciente concentración a medida que se asciende por la cadena alimentaria (bioacumulación) y 3) su toxicidad crónica en los humanos. En consecuencia, la ley obligaba a examinar desde el punto de vista de esas características toda sustancia química industrial antes de su comercialización en el país. En paralelo con la aprobación de la ley, la Dieta decidió encargar a la Agencia de Medio Ambiente la vigilancia del medio ambiente general para determinar la posible existencia de contaminación química. La Dieta modificó después la ley en 1986 (entrada en vigor en 1987) para armonizarla con las actividades de la OCDE en materia de salud y medio ambiente, con la reducción de las barreras no arancelarias en el comercio internacional y sobre todo con el establecimiento de un conjunto de datos mínimo previo a la comercialización (MPD) y directrices sobre los ensayos anexos. Con la modificación de la ley se quería reflejar también un hecho que se había observado por entonces gracias a la vigilancia del medio ambiente: que sustancias como el tricloroetileno y el tetracloroetileno, que no tienen mucha capacidad de bioacumulación aunque son escasamente biodegradables y provocan toxicidad crónica, pueden contaminar el medio ambiente. Esas sustancias se detectaron en las aguas subterráneas de todo el país.

La ley clasifica las sustancias químicas industriales en dos categorías: sustancias existentes y sustancias nuevas. Las sustancias existentes son las que figuran en el "Inventario de Sustancias Químicas Existentes" (que se estableció al aprobar la ley original) y que ascienden a alrededor de 20.000, aunque la cifra depende de la denominación que tienen algunas sustancias en él. Las sustancias no incluidas en el Inventario se denominan "sustancias químicas nuevas". El Gobierno es responsable de la identificación del peligro que comportan las sustancias existentes, mientras que la empresa u otra entidad que desee introducir una nueva sustancia en el mercado japonés es responsable de la identificación del peligro de dicha sustancia. Se encargan de la aplicación de la ley dos ministerios gubernamentales: el Ministerio de Sanidad y Bienestar (MHW) y el Ministerio de Comercio Internacional e Industria (MITI), y la Agencia de Medio Ambiente puede expresar su opinión en caso necesario. Se excluyen, por estar reguladas por otras leyes, las sustancias radiactivas y determinadas sustancias tóxicas, estimulantes y narcóticas.

\section{Sistema de ensayos estipulado en la CSCL}

En la Figura 33.15 se presenta un diagrama del procedimiento de examen, que en principio es un sistema basado en varias fases. Todas las sustancias (véase más adelante la cuestión de las excepciones) deben someterse a un examen de biodegradabilidad in vitro. Si la sustancia es fácilmente biodegradable, se considera "segura". De lo contrario, se la somete a un examen de bioacumulación. Si se comprueba que posee "gran capacidad de acumulación", se solicitan datos de toxicidad completos sobre la base de los cuales la sustancia se clasifica como "sustancia química especificada de la clase 1", cuando se confirma su toxicidad, o sustancia "segura" en caso contrario. La sustancia que presenta una acumulación baja o nula se somete a ensayos de detección de toxicidad, que consisten en pruebas de mutagenicidad y en la administración de dosis repetidas durante 28 días a animales de experimentación (véanse detalles en la Tabla 33.12). Tras una evaluación completa de los datos de toxicidad, la sustancia se clasifica como "sustancia química designada" si los

Tabla 33.12 • Parámetros de ensayo según la Ley de control de las sustancias químicas, Japón.

\begin{tabular}{|c|c|}
\hline Parámetro & Diseño del ensayo \\
\hline Biodegradación & $\begin{array}{l}\text { Durante } 2 \text { semanas en principio, in vitro, con lodo } \\
\text { activado }\end{array}$ \\
\hline Bioacumulación & Durante 8 semanas en principio, con carpas \\
\hline $\begin{array}{l}\text { Detección selectiva de la } \\
\text { toxicidad } \\
\text { Ensayos de mutageni- } \\
\text { cidad }\end{array}$ & \\
\hline $\begin{array}{l}\text { Sistema bacteriano } \\
\text { Aberraciones } \\
\text { cromosómicas }\end{array}$ & $\begin{array}{l}\text { Ensayo de Ames y ensayo con } E \text {. coli, } \pm \text { mezcla } S \\
\text { células CHL, etc., } \pm \text { mezcla } S 9\end{array}$ \\
\hline $\begin{array}{l}\text { Administración de dosis } \\
\text { repetida durante } 28 \text { días }\end{array}$ & $\begin{array}{l}\text { Ratas, } 3 \text { niveles de dosis más control de NOEL, } \\
2 \text { semanas de ensayo de recuperación al nivel } \\
\text { de dosis más alto }\end{array}$ \\
\hline
\end{tabular}


Figura 33.15 - Diagrama del examen.

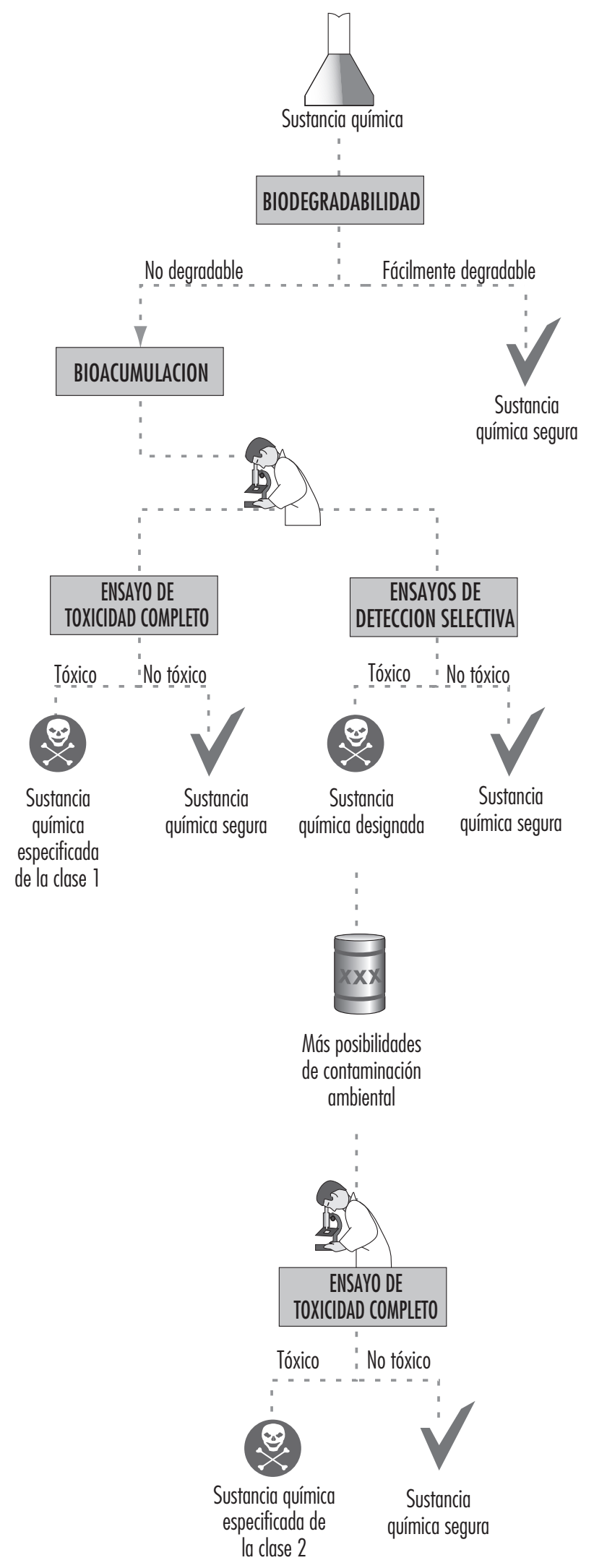

Tabla 33.13 • Características y regulación de las sustancias químicas clasificadas conforme a la Ley de control de las sustancias químicas, Japón.

\begin{tabular}{|c|c|c|}
\hline $\begin{array}{l}\text { Sustancia } \\
\text { química }\end{array}$ & Características & Regulación \\
\hline $\begin{array}{l}\text { Sustancias } \\
\text { químicas } \\
\text { especifi- } \\
\text { cadas de la } \\
\text { Clase l }\end{array}$ & $\begin{array}{l}\text { No biodegradables } \\
\text { Muy bioacumulables } \\
\text { Toxicidad crónica }\end{array}$ & $\begin{array}{l}\text { Necesaria autorización para } \\
\text { fabricar o importar }{ }^{1} \\
\text { Uso restringido }\end{array}$ \\
\hline $\begin{array}{l}\text { Sustancias } \\
\text { químicas } \\
\text { especifi- } \\
\text { cadas de la } \\
\text { Clase } 2\end{array}$ & $\begin{array}{l}\text { No biodegradables } \\
\text { Nada o poco bioacumulables } \\
\text { Toxicidad crónica } \\
\text { Sospecha de contaminación } \\
\text { ambiental }\end{array}$ & $\begin{array}{l}\text { Notificación de la cantidad que } \\
\text { se va a fabricar o importar } \\
\text { Directrices técnicas para } \\
\text { prevenir la contaminación/ } \\
\text { los efectos sobre la salud }\end{array}$ \\
\hline $\begin{array}{l}\text { Sustancias } \\
\text { químicas } \\
\text { designadas }\end{array}$ & $\begin{array}{l}\text { No biodegradables } \\
\text { Nada o poco bioacumulables } \\
\text { Sospecha de toxicidad crónica }\end{array}$ & $\begin{array}{l}\text { Notificación de la cantidad de } \\
\text { fabricación o importación } \\
\text { Estudio y revisión de la } \\
\text { bibliografía }\end{array}$ \\
\hline
\end{tabular}

I En la práctica no se autorizan.

datos indican toxicidad. Si no, se considera "segura". Cuando otros datos sugieren que hay muchas posibilidades de que esa sustancia contamine el medio ambiente, se piden datos de toxicidad completos a partir de los cuales, si son positivos, la sustancia designada se reclasifica como "sustancia química especificada de la clase 2". Si los datos son negativos, se considera "segura". Las características toxicológicas y ecotoxicológicas de las sustancias químicas especificadas de la clase 1 y de la clase 2 y de las sustancias designadas figuran en la Tabla 33.13 junto con una breve indicación de las medidas reguladoras.

No es necesario someter a ensayo a nuevas sustancias químicas de las que se va a utilizar una cantidad limitada (menos de $1.000 \mathrm{~kg} /$ empresa/año y menos de $1.000 \mathrm{~kg} /$ año en todo el país). Los polímeros se examinan conforme al diagrama de compuestos de alto peso molecular, que se establece sobre la hipótesis de que cuando la sustancia tiene un peso molecular

Figura 33.16 - Sustancias químicas especificadas y designadas conforme a la Ley de control de las sustancias químicas, Japón.

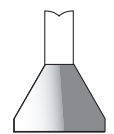

SUSTANCIAS QUIMICAS ESPECIFICADAS DE LA CLASE

1. PCBs

2. Naftaleno policlorado

3. Hexaclorobenceno

4. Aldrín

5. Dieldrín

6. Endrín

7. DDT

8. Clordano (heptacloro)

9. Oxido de bis(tributiltina)

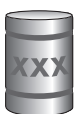

SUSTANCIAS QUIMICAS ESPECIFICADAS DE LA CLASE 2

1. Tetracloruro de carbono

2. Tetracloroetileno

3. Tricloroetileno

4-10. Siete compuestos de trifeniltina 11-23. Trece compuestos de tributiltina 
superior a 1.000 y es estable en el medio ambiente las posibilidades de que se absorba en el cuerpo son remotas.

\section{Resultados de la clasificación de sustancias químicas industriales a finales de1996}

En los 26 años transcurridos desde que la CSCL entró en vigor, en 1973, hasta finales de 1996, se examinaron 1.087 productos químicos existentes conforme a las versiones original y modificada de la ley. De esos 1.087, nueve (algunos se identifican por nombres genéricos) se clasificaron como "sustancias químicas especificadas de la clase 1". De los demás, 36 se clasificaron como "sustancias designadas", 23 de las cuales se reclasificaron como "sustancias químicas especificadas de la clase 2" y otras 13 siguieron siendo "designadas". En la Figura 33.16 se indican los nombres de las sustancias químicas especificadas de ambas clases. Se puede comprobar inmediatamente en la lista que las sustancias de la clase 1 son en su mayoría plaguicidas organoclorados además de los PCB y sus productos sustitutivos, salvo un herbicida. Las sustancias de la clase 2 son en su mayoría herbicidas, más tres disolventes a base de hidrocarburos clorados que se utilizaron mucho en el pasado.

En ese mismo período, desde 1973 hasta fines de 1996, se solicitó la aprobación de unas 2.335 sustancias químicas nuevas, de las que 221 (alrededor del 9,5 \%) se clasificaron como "designadas", pero no se clasificó ninguna como perteneciente a la clase 1 ni a la clase 2. Las demás se consideraron "seguras" y se aprobó su fabricación o importación.

\section{EL ENFOQUE ESTADOUNIDENSE DE LA EVALUACION DEL RIESGO DE LOS TOXICOS PARA LA REPRODUCCION Y AGENTES NEUROTOXICOS}

Ellen K. Silbergeld

La neurotoxicidad y la toxicidad en la reproducción son importantes esferas de la evaluación del riesgo, pues los sistemas nervioso y reproductor son muy sensibles a los efectos de los xenobióticos. Se han identificado muchos agentes como tóxicos para estos sistemas en los humanos (Barlow y Sullivan 1982; OTA 1990). Hay muchos plaguicidas que están diseñados deliberadamente para que trastornen la función reproductora y neurológica en los organismos diana, como los insectos, interfiriendo la bioquímica hormonal y la neurotransmisión.

Es difícil identificar sustancias potencialmente tóxicas para estos sistemas, y ello por tres razones interrelacionadas: en primer lugar, son unos de los sistemas biológicos humanos más complejos, y en general se reconoce que los modelos animales de la función reproductora y neurológica son insuficientes para representar hechos tan críticos como la cognición o las primeras fases del desarrollo embriofetal; en segundo lugar, no existen ensayos sencillos para identificar las sustancias que son potencialmente tóxicas para estos sistemas, y, en tercer lugar, estos sistemas contienen múltiples tipos de células y órganos, de manera que no se puede utilizar un solo grupo de mecanismos de toxicidad para inferir relaciones dosis-respuesta o predecir relaciones estructura-actividad (SAR). Además, se sabe que la sensibilidad tanto del sistema nervioso como del reproductor varía con la edad, y que en períodos críticos la exposición puede tener efectos mucho más graves que en otros momentos.

\section{Evaluación del riesgo de neurotoxicidad}

La neurotoxicidad es un importante problema de salud pública. Como se indica en la Tabla 33.14, ha habido varios episodios de neurotoxicidad humana en los que se han visto afectados miles de trabajadores y otros grupos de la población expuestos por liberación de productos industriales, alimentos o bebidas contaminados y otros vectores. La exposición profesional a neurotoxinas como el plomo, el mercurio, los insecticidas organofosforados y los disolventes clorados está muy extendida por todo el mundo (OTA 1990; Johnson 1978).

Las sustancias químicas pueden afectar al sistema nervioso actuando sobre cualquiera de las diversas dianas celulares o diversos procesos bioquímicos del sistema nervioso central o periférico. Los efectos tóxicos sobre otros órganos pueden afectar también al sistema nervioso, como en el caso de la encefalopatía hepática. Entre las manifestaciones de la neurotoxicidad cabe citar efectos sobre el aprendizaje (memoria, conocimiento, rendimiento intelectual...), los procesos somatosensoriales (sensación, percepción...), la función motora (equilibrio, marcha, control de movimientos adecuados...), la vida afectiva (personalidad, emociones...) y la función autónoma (control nervioso de la función endocrina y de los sistemas orgánicos internos). Los efectos tóxicos sobre el sistema nervioso suelen tener distinta sensibilidad y expresión en las diversas fases de la vida: durante el desarrollo, el sistema nervioso central puede ser especialmente susceptible a la agresión tóxica debido al amplio proceso de diferenciación celular, migración y contacto célula-célula que se produce en los humanos en ese período (OTA 1990). Además, el daño citotóxico al sistema nervioso puede ser irreversible porque después de la embriogénesis ya no hay reposición de neuronas. Aunque el sistema nervioso central (SNC) está en cierto modo protegido del contacto con los compuestos que se absorben gracias a un sistema de células muy tupido (la barrera hematoencefálica, integrada por células endoteliales de los capilares que revisten los vasos del cerebro), las sustancias tóxicas pueden conseguir entrar en él por tres mecanismos: los disolventes y compuestos lipófilos pueden atravesar la membrana celular; algunos compuestos pueden unirse a proteínas transportadoras endógenas cuya función es aportar nutrientes y biomoléculas al SNC, y proteínas pequeñas que si se inhalan pueden ser captadas directamente por el nervio olfativo y transportadas al cerebro.

\section{Autoridades reguladoras de los Estados Unidos}

En los Estados Unidos, la facultad de regular las sustancias desde el punto de vista de la neurotoxicidad está asignada legalmente a cuatro organismos: la Food and Drug Administration (FDA), la Environment Protection Agency (EPA), la Occupational Safety \& Hygiene Administration (OSHA) y la Consumer Products Safety Commission (CPSC). Mientras la OSHA regula generalmente las exposiciones profesionales a las sustancias químicas neurotóxicas (y otras), la EPA está facultada para regular las exposiciones profesionales y no profesionales a los plaguicidas con arreglo a la Ley federal sobre insecticidas, fungicidas y rodenticidas (FIFRA). La EPA regula también las sustancias nuevas antes de su fabricación y comercialización, lo que la obliga a examinar tanto los riesgos profesionales como los no profesionales.

\section{Identificación de los peligros}

Se definen como peligros neurotóxicos los agentes que afectan negativamente a la fisiología, bioquímica o integridad estructural del sistema nervioso o de una función del sistema nervioso que se expresa en el comportamiento (EPA 1993). La determinación de la neurotoxicidad intrínseca es un proceso difícil debido a la complejidad del sistema nervioso y a las múltiples formas en que aquélla se expresa. Algunos efectos pueden tardar en 


\begin{tabular}{|c|c|c|c|}
\hline Año(s) & Lugar & Sustancia & Comentarios \\
\hline 400 a.C. & Roma & Plomo & Hipócrates comprueba la toxicidad del plomo en los mineros. \\
\hline dec. 1930 & Estados Unidos (Sudeste) & TOCP & $\begin{array}{l}\text { Un compuesto que se suele añadir a los aceites lubrificantes contamina la bebida alcohólica "Ginger } \\
\text { Jake"; de } 20.000 \text { a } 100.000 \text { afectados, más de } 5.000 \text { de ellos por parálisis. }\end{array}$ \\
\hline dec. 1930 & Europa & Apiol (con TOCP) & Un fármaco abortivo que contiene TOCP provoca 60 casos de neuropatía. \\
\hline 1932 & Estados Unidos (California) & Talio & $\begin{array}{l}\text { Roban y utilizan para hacer tortas cebada rociada con sulfato de talio, empleado como rodenticida; } \\
13 \text { miembros de una familia hospitalizados con síntomas neurológicos; seis muertos. }\end{array}$ \\
\hline 1937 & Sudáfrica & TOCP & 60 sudafricanos afectados por parálisis tras emplear un aceite de cocina contaminado. \\
\hline 1946 & - & Tetraetilplomo & Más de 25 personas padecen trastornos neurológicos tras limpiar unos depósitos de gasolina. \\
\hline dec. 1950 & Japón (Minimata) & Mercurio & $\begin{array}{l}\text { Centenares de personas consumen pescado y marisco contaminados con mercurio procedente de una } \\
\text { fábrica de productos químicos; } 121 \text { intoxicados, } 46 \text { muertos, muchos recién nacidos con grave } \\
\text { daño neurológico. }\end{array}$ \\
\hline dec. 1950 & Francia & Organotina & La contaminación de Stallinon con trietilestaño produce más de 100 muertos. \\
\hline dec. 1950 & Marruecos & Manganeso & $\begin{array}{l}150 \text { mineros padecen intoxicación crónica por manganeso, con graves problemas neurológicos y de } \\
\text { conducta. }\end{array}$ \\
\hline $\begin{array}{l}\text { dec. } 1950- \\
\text { dec. } 1970\end{array}$ & Estados Unidos & AETT & $\begin{array}{l}\text { Se comprueba que un componente de perfumes es neurotóxico; se retira del mercado en 1978; } \\
\text { se desconocen sus efectos sobre la salud humana. }\end{array}$ \\
\hline 1956 & - & Endrín & $\begin{array}{l}49 \text { personas enferman tras consumir productos de panadería preparados con harina contaminada con } \\
\text { el insecticida endrín; algunos casos de convulsiones. }\end{array}$ \\
\hline 1956 & Turquía & $\mathrm{HCB}$ & $\begin{array}{l}\text { De } 3.000 \text { a } 4.000 \text { personas se intoxican con hexaclorobenceno, fungicida para grano; } \\
\text { tasa de mortalidad del } 10 \text { por ciento. }\end{array}$ \\
\hline 1956-1977 & Japón & Clioquinol & $\begin{array}{l}\text { Se comprueba que un fármaco para la diarrea del viajero causa neuropatía; } \\
\text { hasta } 10.000 \text { afectados a lo largo de dos decenios. }\end{array}$ \\
\hline 1959 & Marruecos & TOCP & Unos 10.000 afectados por consumir aceite de cocina contaminado con aceite lubrificante. \\
\hline 1960 & Iraq & Mercurio & $\begin{array}{l}\text { Pan contaminado con el mercurio que se emplea como fungicida para el grano; más de } \\
1.000 \text { afectados. }\end{array}$ \\
\hline 1964 & Japón & Mercurio & 646 afectados por metilmercurio. \\
\hline 1968 & Japón & $\mathrm{PCB}$ & Aceite de arroz contaminado con bifenilos policlorados; 1.665 afectados. \\
\hline 1969 & Japón & n-Hexano & $\begin{array}{l}93 \text { casos de neuropatía tras exposición a n-hexano, empleado en la fabricación de sandalias } \\
\text { de vinilo. }\end{array}$ \\
\hline 1971 & Estados Unidos & Hexaclorofeno & $\begin{array}{l}\text { Tras años de bañar a los bebés en agua con un } 3 \text { por ciento de hexaclorofeno se comprueba } \\
\text { que este desinfectante es tóxico para el sistema nervioso y otros sistemas. }\end{array}$ \\
\hline 1971 & Iraq & Mercurio & $\begin{array}{l}\text { Pan contaminado con el mercurio que se emplea como fungicida para el grano; } \\
\text { más de } 5.000 \text { intoxicados graves, } 450 \text { muertos en hospitales; sin documentar los efectos } \\
\text { en muchos bebés expuestos prenatalmente. }\end{array}$ \\
\hline 1973 & Estados Unidos (Ohio) & MIBK & $\begin{array}{l}\text { Trabajadores de una fábrica de textiles expuestos al disolvente; más de } 80 \text { con neuropatía, } \\
180 \text { con efectos menos graves. }\end{array}$ \\
\hline 1974-1975 & $\begin{array}{l}\text { Estados Unidos } \\
\text { (Hopewell, VA) }\end{array}$ & Clordecone (Kepone) & $\begin{array}{l}\text { Trabajadores de una fábrica de productos químicos expuestos al insecticida; más de } 20 \text { con graves } \\
\text { problemas neurológicos, más de } 40 \text { con efectos menos graves. }\end{array}$ \\
\hline 1976 & Estados Unidos (Texas) & Leptophos (Phosvel) & $\begin{array}{l}\text { Al menos nueve trabajadores padecen graves problemas neurológicos tras exposición al insecticida } \\
\text { durante el proceso de fabricación. }\end{array}$ \\
\hline 1977 & Estados Unidos (California) & $\begin{array}{l}\text { Dicloropropeno } \\
\text { (Telone II) }\end{array}$ & 24 personas hospitalizadas tras exposición al plaguicida Telone después de un accidente de tráfico. \\
\hline $1979-1980$ & $\begin{array}{l}\text { Estados Unidos } \\
\text { (Lancaster, TX) }\end{array}$ & BHMH (Lucel-7) & $\begin{array}{l}\text { Siete trabajadores de una fábrica de bañeras de plástico padecen graves } \\
\text { problemas neurológicos tras exposición a BHMH. }\end{array}$ \\
\hline dec. 1980 & Estados Unidos & MPTP & $\begin{array}{l}\text { Se comprueba que la falta de pureza en la síntesis de drogas ilegales provoca síntomas idénticos } \\
\text { a los de la enfermedad de Parkinson. }\end{array}$ \\
\hline 1981 & España & $\begin{array}{l}\text { Aceite tóxico } \\
\text { contaminado }\end{array}$ & $\begin{array}{l}20.000 \text { personas afectadas por una sustancia tóxica en el aceite, con más de } 500 \text { muertos; } \\
\text { numerosos casos de neuropatía grave. }\end{array}$ \\
\hline 1985 & Estados Unidos y Canadá & Aldicarb & $\begin{array}{l}\text { En California y otros estados del oeste y en British Columbia, más de } 1.000 \text { personas padecen } \\
\text { problemas neuromusculares y cardíacos tras consumir melones contaminados con este plaguicida. }\end{array}$ \\
\hline 1987 & Canadá & Acido domoico & $\begin{array}{l}129 \text { afectados y dos muertos por consumir mejillones contaminados con ácido domoico; } \\
\text { síntomas como pérdida de memoria, desorientación y ataques. }\end{array}$ \\
\hline
\end{tabular}


manifestarse, como la neurotoxicidad retardada de determinados insecticidas organofosforados. La determinación del peligro neurotóxico, incluida la consideración de las condiciones de exposición, dosis, duración y período en que se produce, exige por tanto prudencia y buen juicio.

La identificación de los peligros suele basarse en estudios toxicológicos de organismos intactos, en los que se valoran las funciones de comportamiento, cognoscitivas, motoras y somatosensoriales mediante diversos instrumentos de investigación que tienen en cuenta la bioquímica, la electrofisiología y la morfología (Tilson y Cabe 1978; Spencer y Schaumberg 1980). Difícilmente podría exagerarse la importancia que tiene la cuidadosa observación del comportamiento del organismo en su conjunto. La identificación de los peligros exige también que se evalúe la toxicidad en diferentes fases del desarrollo, desde las más tempranas (período intrauterino y primer período neonatal) hasta la senectud. En los humanos, la identificación de la neurotoxicidad comprende la evaluación clínica, con métodos de valoración neurológica, de aspectos como la función motora, fluidez del habla, reflejos, función sensorial, electrofisiología, ensayos neuropsicológicos y, en algunos casos, técnicas avanzadas de elaboración de imágenes cerebrales y electroencefalografía cuantitativa. La OMS ha desarrollado y validado una batería de pruebas esenciales de neurocomportamiento (NCTB), que contiene pruebas de la función motora, coordinación mano-ojo, tiempo de reacción, memoria inmediata, atención y estado de ánimo. Esta batería ha sido validada internacionalmente mediante un proceso coordinado (Johnson 1978).

También en la identificación de los peligros mediante el empleo de animales es esencial adoptar unos métodos de observación cuidadosos. La EPA de los Estados Unidos ha elaborado una batería de pruebas de observación funcional como ensayos de primer nivel para detectar y cuantificar los principales efectos neurotóxicos (Moser 1990). Este enfoque está presente también en los métodos de ensayo de toxicidad subcrónica y crónica de la OCDE. En una batería típica se determinan los parámetros siguientes: postura, marcha, movilidad, estimulación general y reactividad, y presencia o ausencia de temblor, convulsiones, lacrimeo, piloerección, salivación, micción o defecación excesivas, estereotipia, movimientos en círculo u otros comportamientos extraños. Entre los comportamientos que se provocan figuran la respuesta a manipulaciones, pinchazos en la cola o pequeños ruidos; el equilibrio y el reflejo de enderezamiento y la fuerza de agarre de los miembros traseros. En la Tabla 33.15 figuran algunos ensayos representativos y los agentes que se identifican con ellos.

A estos ensayos pueden seguir evaluaciones más complejas, que por lo general se realizan más en los estudios mecanicistas que en el contexto de la identificación de los peligros. Los métodos in vitro de identificación de los peligros de neurotoxicidad son limitados, pues no proporcionan indicaciones de los efectos sobre funciones complejas, como el aprendizaje, pero pueden ser muy útiles para definir las dianas de la toxicidad y mejorar la precisión de los estudios de dosis-respuesta en esos lugares (en OMS 1986 y EPA 1993 se analizan con detalle los principios y métodos de la identificación de neurotóxicos potenciales).

\section{Evaluación de la relación dosis-respuesta}

Como se ha estudiado en una sección anterior, la determinación de la relación entre la toxicidad y la dosis puede basarse en datos humanos cuando se dispone de ellos o en ensayos con animales.

Tabla 33.15 - Ejemplos de ensayos especializados para medir la neurotoxicidad.

\begin{tabular}{|c|c|c|}
\hline Función & Procedimiento & Agentes representativos \\
\hline \multicolumn{3}{|l|}{ Neuromuscular } \\
\hline Debilidad & $\begin{array}{l}\text { Fuerza de agarre; resistencia en natación; suspensión de barra; } \\
\text { función motora discriminativa; extensión de miembros posteriores }\end{array}$ & n-Hexano, metilbutilcetona, carbarilo \\
\hline Descoordinación & Barra giratoria, mediciones de la marcha & 3-Acetilpiridina, etanol \\
\hline Temblor & Escala de clasificación, análisis espectral & Clordecone, piretroides de tipo I, DDT \\
\hline Mioclonia, espasmos & Escala de clasificación, análisis espectral & DDT, piretroides de tipo II \\
\hline \multicolumn{3}{|l|}{ Sensorial } \\
\hline Toxicidad auditiva & Condicionamiento discriminante, modificación de reflejos & Tolueno, trimetilestaño \\
\hline Toxicidad visual & Condicionamiento discriminante & Metilmercurio \\
\hline Toxicidad somatosensorial & Condicionamiento discriminante & Acrilamida \\
\hline Sensibilidad al dolor & $\begin{array}{l}\text { Condicionamiento discriminante ("btration”); batería de observaciones } \\
\text { funcionales }\end{array}$ & Paratión \\
\hline Toxicidad olfativa & Condicionamiento discriminante & Metilbromuro de 3-metilindol \\
\hline \multicolumn{3}{|l|}{ Aprendizaje, memoria } \\
\hline Habituación & Reflejo de sobresalto & Diisopropilfluorofosfato (DFP) \\
\hline Condicionamiento clásico & $\begin{array}{l}\text { Membrana nictitante, aversión condicionada a sabores, evitación pasiva, } \\
\text { condicionamiento olfativo }\end{array}$ & $\begin{array}{l}\text { Aluminio, carbaril, trimetilestaño, IDPN, } \\
\text { (neonatal) }\end{array}$ \\
\hline $\begin{array}{l}\text { Condicionamiento operativo } \\
0 \text { instrumental }\end{array}$ & $\begin{array}{l}\text { Evitación en un sentido, evitación negativa en dos sentidos, evitación en } \\
\text { laberinto y laberinto de agua Biol, laberinto de agua Morris, laberinto de } \\
\text { brazos radiales, retraso en emparejamiento con la muestra, adquisición }\end{array}$ & $\begin{array}{l}\text { Clordecone, plomo (neonatal), hipervitaminosis A, esti- } \\
\text { reno, DFP, trimetilestaño, carbaril, plomo }\end{array}$ \\
\hline
\end{tabular}

Fuente: EPA 1993. 
En los Estados Unidos suele aplicarse a los neurotóxicos un enfoque basado en un factor de incertidumbre o seguridad. Para ello se determina primero el "nivel sin efecto adverso observable" (NOAEL) o el "nivel mínimo de efecto adverso observable" (LOAEL) y después se divide ese valor por factores de incertidumbre o seguridad (por lo general múltiplos de 10) para tener en cuenta aspectos como la falta de datos, la sensibilidad potencialmente mayor de los humanos y la variabilidad de la respuesta humana debido a la edad u otros factores. La cifra resultante se denomina dosis de referencia (RfD) o concentración de referencia (RfG). Para determinar el LOAEL o el NOAEL suele utilizarse el efecto que se produce al nivel de dosis más bajo en la especie animal más sensible. La conversión de dosis animales a exposiciones humanas se realiza mediante métodos normalizados de dosimetría transespecies, teniendo en cuenta las diferencias en materia de duración de la vida y duración de la exposición.

Este enfoque basado en un factor de incertidumbre parte de que existe un umbral, es decir, una dosis por debajo de la cual la sustancia no induce efecto adverso alguno. A veces es difícil determinar experimentalmente los umbrales correspondientes a determinados neurotóxicos; en esos casos se establecen sobre la base de hipótesis acerca del mecanismo de acción de la sustancia, hipótesis que pueden ser válidas o no para todos los neurotóxicos (Silbergeld 1990).

\section{Evaluación de la exposición}

En esta fase se valora la información sobre fuentes, rutas, dosis y duraciones de la exposición al neurotóxico en poblaciones humanas, subpoblaciones o incluso individuos. Esa información puede obtenerse de la vigilancia del medio ambiental o de muestras humanas, o también mediante estimaciones basadas en hipótesis normalizadas (como condiciones del lugar de trabajo y descripciones de empleos) o modelos de destino y dispersión en el medio ambiente (véanse unas directrices generales sobre los métodos de evaluación de la exposición en EPA 1992). En algunos casos limitados pueden utilizarse marcadores biológicos para validar conclusiones y estimaciones de la exposición; no obstante, son relativamente pocos los biomarcadores de neurotóxicos que pueden utilizarse.

\section{Caracterización del riesgo}

Para caracterizar el riesgo se combinan la identificación de los peligros, la relación dosis-respuesta y la evaluación de la exposición. En este proceso se establecen hipótesis en materia de extrapolación de dosis altas a dosis bajas y de animales a humanos, así como sobre la validez de los umbrales que se manejan y el empleo de los factores de incertidumbre.

\section{Toxicología en la reproducción: métodos de evaluación del riesgo}

En el ámbito de la reproducción, los peligros pueden afectar a múltiples parámetros funcionales y dianas celulares del ser humano, con consecuencias para la salud del individuo afectado y de las generaciones futuras. Pueden afectar al desarrollo del sistema reproductor tanto masculino como femenino, los comportamientos reproductores, la función hormonal, el hipotálamo y la pituitaria, las gónadas y las células germinales, la fecundidad, el embarazo y la duración de la función reproductora (OTA 1985). Además, sustancias mutágenas pueden afectar también a la función reproductora dañando la integridad de las células germinales (Dixon 1985).

Se sabe muy poco de la naturaleza y el grado de los efectos adversos de las exposiciones químicas sobre la función reproductora de las poblaciones humanas. Se dispone de relativamente poca información de vigilancia sobre parámetros como la fecundidad de hombres o mujeres, la edad de la menopausia en las mujeres o el recuento de espermatozoides en los hombres. Sin embargo, tanto hombres como mujeres trabajan en sectores industriales en los que pueden producirse exposiciones a sustancias peligrosas para su función reproductora (OTA 1985).

No vamos a recapitular en esta sección los elementos que son comunes a la evaluación del riesgo de los neurotóxicos y los tóxicos reproductores, sino que nos vamos a centrar en las cuestiones específicas de la evaluación del riesgo de los segundos. Como en el caso de los neurotóxicos, la legislación asigna la facultad de regular las sustancias químicas respecto de su toxicidad reproductora a la EPA, la OSHA, la FDA y la CPSC. De esos cuatro organismos, sólo la EPA tiene establecida una serie de directrices para la evaluación del riesgo de toxicidad en la reproducción. Además, el estado de California ha elaborado métodos al respecto en cumplimiento de una ley estatal, la conocida como Proposición 65 (Pease y cols. 1991).

$\mathrm{Al}$ igual que los neurotóxicos, los tóxicos en la reproducción pueden actuar afectando a varios órganos diana o lugares de acción molecular. Su evaluación presenta la complejidad adicional de tener que evaluar tres organismos distintos por separado y de manera conjunta: el hombre, la mujer y la descendencia (Mattison y Thomford 1989). Aunque un parámetro importante de la función reproductora es la generación de hijos sanos, la biología reproductora también tiene que ver con la salud de los organismos en las fases de desarrollo y madurez con independencia de su intervención en la procreación. Por ejemplo, la pérdida de la función ovulatoria por agotamiento natural o extracción quirúrgica de oocitos tiene efectos considerables sobre la salud de las mujeres, como cambios en la tensión arterial, el metabolismo de los lípidos y la fisiología del hueso. Las alteraciones en la bioquímica de las hormonas pueden afectar a la susceptibilidad al cáncer.

\section{Identificación de los peligros}

Un peligro en reproducción puede identificarse sobre la base de datos referidos a humanos o a animales. En general, los datos sobre humanos son relativamente escasos, debido a la necesidad de efectuar una vigilancia minuciosa para detectar las alteraciones en la función reproductora, como el recuento o la calidad de los espermatozoides, la frecuencia y duración del ciclo de ovulación o la edad de la pubertad. La detección de los peligros en reproducción mediante el acopio de información sobre tasas de fecundidad o datos sobre resultados de embarazos puede llevar a conclusiones erróneas por las medidas deliberadas de reducir la fecundidad que adoptan muchas parejas mediante métodos de planificación familiar. El seguimiento cuidadoso de determinadas poblaciones indica que las tasas de fracaso reproductor (aborto) pueden ser muy altas cuando se valoran biomarcadores tempranos del embarazo (Sweeney y cols. 1988).

Para identificar tóxicos en reproducción se suelen utilizar protocolos de ensayo con animales de experimentación. En la mayoría de esos sistemas, como los que han desarrollado en los Estados Unidos la FDA y la EPA e internacionalmente la OCDE en su programa de directrices para ensayos, los efectos de los agentes sospechosos se detectan examinando la fecundidad tras la exposición del macho y/o la hembra, observando los comportamientos sexuales en materia de apareamiento y realizando análisis histopatológicos de las gónadas y glándulas sexuales secundarias, como las glándulas mamarias (EPA 1994). En los estudios de toxicidad en la reproducción se suelen administrar a los animales dosis continuadas durante una o varias generaciones para detectar los efectos en el proceso reproductor integral así como los efectos en órganos reproductores específicos. Se recomiendan los estudios sobre varias generaciones, pues 
permiten detectar efectos que pueden ser inducidos por la exposición durante el desarrollo del sistema reproductor en el útero. En Estados Unidos, el Programa Nacional de Toxicología (NTP) ha elaborado un protocolo de ensayos especiales, denominado Evaluación de la Reproducción mediante Cría Continua (RACB). Se obtienen con él datos sobre los cambios en el espaciamiento temporal de los embarazos (que reflejan la función ovulatoria), así como el número y tamaño de las camadas a lo largo de todo el período del ensayo. Cuando se examina todo el período vital de la hembra se puede obtener información sobre abortos tempranos. Para detectar cambios en la función reproductora del macho pueden añadirse a la RACB mediciones del esperma. Un ensayo especial para detectar las pérdidas antes o después de la implantación es el ensayo de factor letal dominante, con el que se detectan los efectos mutágenos en la espermatogénesis del macho.

Se han elaborado también ensayos in vitro para detectar la toxicidad en reproducción (y del desarrollo) (Heindel y Chapin 1993). Se utilizan generalmente para complementar los resultados de ensayos in vivo, pues aportan más información sobre los lugares diana y el mecanismo de los efectos observados.
En la Tabla 33.16 se indican los tres tipos de parámetros que se utilizan al evaluar la toxicidad reproductora: toxicidad mediada por la pareja, toxicidad específica de la hembra y específica del macho. Los parámetros mediados por la pareja comprenden los que se pueden detectar tanto en estudios multigeneracionales como en un único organismo. Suelen incluir también la evaluación de la descendencia. Hay que señalar que la medición de la fecundidad en los roedores es por lo general insensible en comparación con esa misma medición en los humanos, y que es muy posible que se produzcan efectos adversos sobre la función reproductora a dosis más bajas que las que afectan de manera significativa a la fecundidad (EPA 1994). Entre los parámetros específicos del macho figuran los ensayos de letalidad dominante, así como la evaluación histopatológica de los órganos y el esperma, mediciones del nivel hormonal y marcadores del desarrollo sexual. La función espermática puede valorarse asimismo con métodos de fecundación in vitro para determinar la capacidad de penetración y capacitación que tienen las células germinales; esos ensayos son útiles porque son directamente comparables con las evaluaciones in vitro que se realizan en las clínicas de fecundidad humana, pero no aportan

Tabla 33.16 • Parámetros de toxicología en la reproducción.

\begin{tabular}{|c|c|}
\hline \multicolumn{2}{|r|}{ Parámetros mediados por la pareja } \\
\hline Estudios multigeneracionales & Otros parámetros reproductivos \\
\hline $\begin{array}{l}\text { Tasa de apareamiento, tiempo hasta apareamiento } \\
\text { (tiempo hasta embarazo }{ }^{1} \text { ) } \\
\text { Tasa de embarazos } \\
\text { Tasa de partos } \\
\text { Duración de la gestación } 1 \\
\text { Tamaño de la camada (total y vivos) } \\
\text { Número de crías vivas y muertas (tasa de muerte fetal') } \\
\text { Sexo de las crías }{ }^{1} \\
\text { Peso al nacer }{ }^{1} \\
\text { Pesos postnatales } \\
\text { Supervivencia de las crías }{ }^{1} \\
\text { Malformaciones y variaciones externas }{ }^{1} \\
\text { Reproducción de las crías }\end{array}$ & $\begin{array}{l}\text { Tasa de ovulación } \\
\text { Tasa de fecundación } \\
\text { Pérdidas antes de la implantación } \\
\text { Número de implantaciones } \\
\text { Pérdidas después de la implantación } 1 \\
\text { Malformaciones y variaciones internas } \\
\text { Desarrollo estructural y funcional postnatal }{ }^{1}\end{array}$ \\
\hline \multicolumn{2}{|r|}{ Parámetros específicos de los machos } \\
\hline Peso de los órganos & Testículos, epididímidos, vesículas seminales, próstata, pituitaria \\
\hline Examen visual e histopatología & Testículos, epididímidos, vesículas seminales, próstata, pituitaria \\
\hline Evaluación del esperma ${ }^{1}$ & Número (recuento) y calidad (morfología, motilidad) de los espermatozoides \\
\hline Niveles hormonales ${ }^{1}$ & Hormona luteinizante (LH), hormona estimulante del folículo (FSH), testosterona, estrógenos, prolactina \\
\hline Desarrollo & $\begin{array}{l}\text { Descenso de los testículos }{ }^{1} \text {, separación del prepucio, producción de esperma', distancia ano-genital, } \\
\text { normalidad de los genitales externos }\end{array}$ \\
\hline \multicolumn{2}{|r|}{ Parámetros específicos de las hembras } \\
\hline \multicolumn{2}{|l|}{ Peso corporal } \\
\hline Peso de los órganos & Ovario, útero, vagina, pituitaria \\
\hline Examen visual e histopatología & Ovario, útero, vagina, pituitaria, oviducto, glándula mamaria \\
\hline Normalidad del ciclo del estro (menstrual ${ }^{1}$ ) & Citología del flujo vaginal \\
\hline Niveless hormonales' & LH, FSH, estrógenos, progesterona, prolactina \\
\hline Lactancial & Crecimiento de las crías \\
\hline Desarrollo & $\begin{array}{l}\text { Normalidad de los genitales externos' }{ }^{1} \text {, orificio vaginal, citología del flujo vaginal, inicio del estro } \\
\left.\text { (menstruación }{ }^{1}\right)\end{array}$ \\
\hline Senectud (menopausia ${ }^{1}$ ) & Citología del flujo vaginal, histología ovárica \\
\hline
\end{tabular}


por sí mismos información sobre la relación dosis-respuesta. Entre los parámetros específicos de la hembra figura, además de la histopatología de órganos y las mediciones del nivel hormonal, la valoración de las secuelas de la reproducción, entre ellas la lactancia y el crecimiento de la descendencia.

En Estados Unidos, la identificación del peligro de una sustancia concluye con una evaluación cualitativa de los datos de toxicidad en virtud de la cual se determina si esa sustancia presenta evidencia suficiente o insuficiente de peligro (EPA 1994). La evidencia "suficiente" comprende datos epidemiológicos que indican de manera convincente la existencia de una relación causal (o su ausencia) sobre la base de estudios de cohortes o de casos y controles, o de series de casos bien fundamentadas. Los datos sobre animales, suficientes, pueden unirse a los datos humanos, limitados, para apoyar la conclusión respecto de un peligro de la reproducción: para considerarlos suficientes, a los estudios experimentales se les suele pedir que utilicen las directrices de la EPA sobre ensayos en dos generaciones, y han de incluir también un mínimo de datos que demuestren un efecto reproductor adverso en un estudio adecuado y bien realizado sobre una de las especies del ensayo. Unas veces se dispone de datos humanos limitados, pero otras no; no son imprescindibles a efectos de la identificación de los peligros. Para descartar un peligro en reproducción potencial, los datos sobre animales han de incluir un número suficiente de parámetros, tomados de más de un estudio, que indiquen la inexistencia de efectos reproductores adversos sobre el animal a dosis mínimamente tóxicas (EPA 1994)

\section{Evaluación de la relación dosis-respuesta}

Como en la evaluación de los neurotóxicos, la demostración de los efectos relacionados con la dosis es una parte importante de la evaluación del riesgo de los tóxicos para la reproducción. En los análisis de la relación dosis-respuesta se plantean dos problemas singulares: la complicada toxicocinética durante el embarazo y la necesidad de distinguir la toxicidad específica para la reproducción de la toxicidad general para el organismo. Ocurre a veces que animales debilitados, o animales con un nivel sustancial de toxicidad no específica (como pérdida de peso), no ovulan o no se aparean. La toxicidad materna puede afectar a la viabilidad del embarazo o al sostenimiento de la lactancia. Aunque demuestran una toxicidad, esos efectos no son específicos de la reproducción (Kimmel y cols. 1986). La valoración de la relación dosis-respuesta respecto de un parámetro determinado, como la fecundidad, debe realizarse en el contexto de una evaluación global de la reproducción y el desarrollo. Las relaciones dosis-respuesta de diferentes efectos pueden ser notablemente distintas, pero complicar pese a ello la detección. Por ejemplo, agentes que reducen el tamaño de la camada pueden no afectar al peso de los miembros de ésta, pues hay menos competencia para conseguir la nutrición intrauterina.

\section{Evaluación de la exposición}

Un importante componente de la evaluación de la exposición en el caso del riesgo para la reproducción es el que se refiere a la información sobre el momento y la duración de las exposiciones. Las medidas de la exposición acumulada pueden no ser lo bastante precisas, según cuál sea el proceso biológico que se ha visto afectado. Se sabe que exposiciones ocurridas en diferentes fases del desarrollo tanto masculino como femenino pueden producir resultados distintos tanto en los humanos como en los animales de experimentación (Gray y cols. 1988). También afecta al resultado la naturaleza temporal de la espermatogénesis y la ovulación. Los efectos sobre la espermatogénesis pueden ser reversibles si cesa la exposición; en cambio, la toxicidad sobre el oocito no es reversible, pues las hembras tienen un número fijo de células germinales que necesitan para la ovulación (Mattison y Thomford 1989).

\section{Caracterización del riesgo}

Al igual que en la neurotoxicidad, en la toxicidad para la reproducción se parte de la existencia de un umbral. No obstante, las acciones de compuestos mutágenos sobre las células germinales pueden considerarse una excepción a ese supuesto general. En el caso de otros parámetros se calcula una RfD o una RfC del mismo modo que con los neurotóxicos: determinando el NOAEL o el LOAEL y aplicando factores de incertidumbre adecuados. El efecto que se utiliza para determinar el NOAEL o el LOAEL es el punto final adverso más sensible de la especie de mamífero más apropiada o más sensible (EPA 1994). Los factores de incertidumbre tienen en cuenta aspectos como las variaciones entre especies y entre individuos de una especie, la posibilidad de definir un NOAEL auténtico y la sensibilidad del punto final detectado.

Las caracterizaciones del riesgo deben centrarse asimismo en subpoblaciones concretas en situación de riesgo, especificando en lo posible la composición por sexos, la situación en materia de embarazos y la edad. Pueden tenerse en cuenta también a los individuos especialmente sensibles, como mujeres lactantes, mujeres con un número reducido de oocitos, hombres con recuentos de espermatozoides bajos y adolescentes antes de la pubertad.

\section{ENFOQUES EN LA IDENTIFICACION DE LOS PELIGROS: LA IARC}

Harri Vainio y Julian Wilbourn

La identificación de los riesgos de carcinogenicidad para los humanos viene siendo desde 1971 el objetivo de la serie Monographs on the Evaluation of Carcinogenic Risks to Humans, que edita la Agencia Internacional para la Investigación sobre el Cáncer (IARC). Hasta la fecha se han publicado o están en preparación 69 volúmenes, con evaluaciones de la carcinogenicidad de 836 agentes o circunstancias de exposición (véase el Apéndice).

Estas evaluaciones cualitativas del riesgo carcinógeno para los humanos son equivalentes a la fase de identificación de los peligros en el sistema de evaluación del riesgo hoy generalmente aceptado, que comprende la identificación del peligro, la evaluación de la relación dosis-respuesta (incluidas extrapolaciones fuera de los límites de las observaciones), la evaluación de la exposición y la caracterización del riesgo.

El programa de las Monographs de la IARC tiene por objeto publicar evaluaciones cualitativas críticas sobre la carcinogenicidad para los humanos que presentan agentes (sustancias químicas, grupos de sustancias químicas, mezclas complejas, factores físicos o biológicos) o circunstancias de exposición (exposiciones profesionales, hábitos culturales) mediante la cooperación internacional basada en grupos de trabajo de expertos. Los grupos de trabajo preparan monografias sobre una serie de determinados agentes o exposiciones, y luego el volumen se publica y goza de una amplia distribución. Cada monografía consta de las partes siguientes: breve descripción de las propiedades físicas y químicas del agente; métodos para su análisis; descripción de cómo y cuánto se produce y de cuánto se utiliza; datos sobre su presencia y sus exposiciones humanas; resúmenes de informes de casos y estudios epidemiológicos sobre el cáncer en los humanos; resúmenes de ensayos experimentales de carcinogenicidad; breve descripción de otros datos biológicos pertinentes, como toxicidad y efectos genéticos, que 
pueden indicar su posible mecanismo de acción, y evaluación de su carcinogenicidad. La primera parte de este plan general se tiene que adaptar cuando se trata de agentes que no son sustancias químicas ni mezclas químicas.

Varios grupos especiales de expertos han elaborado los principios rectores de la evaluación de los carcinógenos, principios que se publican en el Preámbulo de las Monographs (IARC 1994a).

\section{Instrumentos para la identificación cualitativa del riesgo (peligro) de carcinogenicidad}

Se establecen asociaciones examinando los datos disponibles procedentes de estudios sobre personas expuestas, de bioensayos con animales de experimentación y de estudios sobre exposición, metabolismo, toxicidad y efectos genéticos tanto en humanos como en animales.

\section{Estudios sobre el cáncer en los humanos}

Hay tres tipos de estudios epidemiológicos que contribuyen a la evaluación de la carcinogenicidad: estudios de cohortes, estudios de casos y controles y estudios de correlación (o ecológicos). Pueden examinarse también informes de casos de cáncer.

Los estudios de cohortes y de casos y controles ponen en relación las exposiciones individuales que se estudian con la presencia de cáncer en los individuos y ofrecen, como medida principal de esa asociación, una estimación del riesgo relativo (coeficiente entre la incidencia en las personas expuestas y la incidencia en las no expuestas).

En los estudios de correlación, la unidad de investigación es por lo general poblaciones enteras (por ejemplo, determinadas zonas geográficas), y la frecuencia del cáncer se pone en relación con una medida global de la exposición de la población al agente. Como no se documentan las exposiciones individuales, en estos estudios es más difícil deducir una relación causal que en los de cohortes y de casos y controles. Los informes de casos obedecen generalmente a una sospecha, basada en la experiencia clínica, de que la concurrencia de dos hechos - es decir, una determinada exposición y la presencia de un cáncer- es mucho más frecuente de lo que cabría atribuir al azar. Las incertidumbres que rodean a la interpretación de los informes de casos y los estudios de correlación hacen que éstos no sean por sí solos, salvo en raras excepciones, una base suficiente para inferir una relación causal.

En la interpretación de los estudios epidemiológicos es necesario tener en cuenta la posible influencia de un sesgo o de factores de confusión. Por sesgo se entiende la presencia, en el diseño o ejecución del estudio, de factores que conducen a establecer una asociación errónea, más fuerte o más débil de la que existe en realidad, entre la enfermedad y un agente. Por factores de confusión se entienden una serie de factores que hacen que la relación con la enfermedad resulte más fuerte o más débil de lo que es en realidad debido a un asociación entre el factor causal aparente y otro factor que está asociado a un incremento o a una reducción de la incidencia de la enfermedad.

En la evaluación de los estudios epidemiológicos, las asociaciones fuertes (es decir, un riesgo relativo grande) indican causalidad con más probabilidad que las asociaciones débiles, aunque se reconoce que los riesgos relativos de pequeña magnitud no comportan una ausencia de causalidad y pueden ser importantes cuando se trata de una enfermedad extendida. Las asociaciones que se repiten en varios estudios del mismo diseño o utilizando distintos enfoques epidemiológicos o en diferentes circunstancias de exposición tienen más probabilidades de representar una relación de causalidad que las observaciones aisladas de un solo estudio. Se considera que el incremento del riesgo de cáncer al incrementar la cantidad de exposición es un claro indicio de causalidad, pero el hecho de que la respuesta no esté graduada no descarta necesariamente la existencia de una relación causal. La demostración de que el riesgo desciende tras cesar o reducirse la exposición en individuos o en poblaciones enteras apoya también la interpretación causal de los resultados.

Cuando varios estudios epidemiológicos indican que la asociación entre una exposición y el cáncer es escasa o nula, se puede aceptar que, entre todos ellos, contienen una evidencia que sugiere la ausencia de carcinogenicidad. Pero ha de considerarse y excluirse con certeza razonable la posibilidad de que el resultado observado se deba a la presencia de sesgo o de factores de confusión o a una clasificación errónea de la exposición o los datos. La evidencia que sugiere una ausencia de carcinogenicidad obtenida en varios estudios epidemiológicos es aplicable únicamente al tipo o tipos de cáncer, niveles de dosis e intervalos entre la primera exposición y la observación de la enfermedad que se han estudiado. En el caso de algunos tipos de cáncer humano, el período entre la primera exposición y el desarrollo de la enfermedad clínica es raras veces inferior a 20 años; en los períodos de latencia sustancialmente inferiores a 30 años no puede haber evidencia que sugiera ausencia de carcinogenicidad.

La evidencia relativa a la carcinogenicidad obtenida en estudios sobre humanos se clasifica en una de las categorías siguientes:

Evidencia suficiente de carcinogenicidad. Se ha establecido una relación de causalidad entre la exposición al agente, mezcla o circunstancia de exposición y el cáncer humano. Es decir, se ha observado una relación positiva entre la exposición y el cáncer en estudios en los que puede descartarse con razonable confianza la presencia de azar, sesgo o factores de confusión.

Evidencia limitada de carcinogenicidad. Se ha observado una asociación positiva entre la exposición al agente, mezcla o circunstancia de exposición y el cáncer, y es creíble su interpretación como relación de causalidad, pero no puede descartarse con confianza razonable la presencia de azar, sesgo o factores de confusión.

Evidencia inadecuada de carcinogenicidad. Los estudios que se han realizado no tienen la calidad, coherencia o representatividad estadística suficientes para poder llegar a una conclusión sobre la presencia o ausencia de una relación de causalidad, o no se dispone de datos sobre el cáncer en los humanos.

Evidencia que sugiere ausencia de carcinogenicidad. Hay varios estudios adecuados que abarcan todo el intervalo de niveles de exposición que pueden experimentar los seres humanos, y esos estudios se refuerzan mutuamente en no mostrar una asociación positiva entre la exposición al agente y el cáncer estudiado a ninguno de los niveles de exposición observados. La conclusión de "evidencia que sugiere ausencia de carcinogenicidad" se limita inevitablemente a las localizaciones del cáncer, condiciones y niveles de la exposición y duración de la observación abarcadas por los estudios realizados.

La aplicabilidad de una evaluación de la carcinogenicidad de una mezcla, proceso, actividad profesional o sector sobre la base de la evidencia obtenida en estudios epidemiológicos depende del tiempo y el lugar. Deben buscarse la exposición, proceso o actividad específicos que se estime que tienen más probabilidades de ser los responsables de cualquier exceso de riesgo, y la evaluación ha de delimitarse lo más estrictamente posible. El largo período de latencia del cáncer humano complica la interpretación de los estudios epidemiológicos.

Otra dificultad es el hecho de que los humanos están expuestos simultáneamente a diversas sustancias químicas, que pueden interactuar para incrementar o reducir el riesgo de neoplasia. 


\section{Estudios sobre carcinogenicidad en animales de experimentación}

Los estudios en los que se expone a animales de experimentación (por lo general ratones y ratas) a carcinógenos potenciales y después se examina en ellos la presencia o ausencia de cáncer se empezaron a realizar hace unos 50 años con el fin de plantear científicamente el estudio de la carcinogénesis química y de evitar algunos de los inconvenientes de utilizar sólo datos epidemiológicos sobre humanos. En todas las Monographs de la IARC se resumen los estudios publicados sobre carcinogenicidad en animales y se clasifica en una de las categorías siguientes el grado de evidencia de carcinogenicidad:

Evidencia suficiente de carcinogenicidad. Se ha establecido una relación de causalidad entre el agente o mezcla y una mayor incidencia de neoplasias malignas o de una combinación adecuada de neoplasias benignas y malignas en dos o más especies de animales o en dos o más estudios independientes sobre una misma especie realizados en épocas distintas, en laboratorios distintos o conforme a protocolos distintos. Excepcionalmente podría considerarse que un único estudio sobre una única especie aporta evidencia suficiente de carcinogenicidad cuando se presentan neoplasias malignas con una intensidad inusual respecto de su incidencia, localización, tipo de tumor o edad a la que se presentan.

Evidencia limitada de carcinogenicidad. Los datos sugieren un efecto carcinógeno, pero son demasiado limitados para formular una evaluación definitiva porque, por ejemplo, a) la evidencia de carcinogenicidad se limita a un único experimento, o b) quedan algunas dudas sin resolver acerca de la calidad del diseño, la realización o la interpretación del estudio, o c) el agente o mezcla aumenta la incidencia sólo de neoplasias benignas o de lesiones de potencial neoplásico incierto, o de determinadas neoplasias que pueden presentarse espontáneamente con altas incidencias en determinadas estirpes.

Evidencia inadecuada de carcinogenicidad. Los estudios no pueden interpretarse ni en el sentido de presencia ni en el de ausencia de efecto carcinógeno debido a importantes limitaciones cualitativas o cuantitativas, o porque no se dispone de datos sobre el cáncer en animales de experimentación.

Evidencia que sugiere ausencia de carcinogenicidad. Se dispone de estudios adecuados sobre un mínimo de dos especies que indican que, dentro de los límites de los ensayos utilizados, el agente o mezcla no es carcinógeno. La conclusión de evidencia que sugiere ausencia de carcinogenicidad se limita inevitablemente a las especies, localización del tumor y niveles de exposición que se han estudiado.

\section{Otros datos de interés para la evaluación \\ de la carcinogenicidad}

Entre los datos sobre los efectos biológicos en los humanos que son de especial interés figuran las consideraciones toxicológicas, cinéticas y metabólicas, así como la presencia de unión al ADN y la persistencia de lesiones en el $\mathrm{ADN}$ o daño genético en las personas expuestas. La información toxicológica, como la que se refiere a la citotoxicidad y regeneración, la unión a receptores y los efectos hormonales e inmunológicos, y los datos sobre cinética y metabolismo en animales de experimentación se resumen cuando se consideran de interés para el posible mecanismo de la acción carcinógena del agente. Los resultados de los ensayos para detectar efectos genéticos y afines se resumen respecto de todos los mamíferos, incluido el hombre, células de mamíferos en cultivo y sistemas de no mamíferos. Las relaciones estructura-actividad se mencionan cuando son relevantes.

Respecto del agente, mezcla o circunstancia de exposición que es objeto de la evaluación, los datos disponibles sobre parámetros u otros fenómenos de interés para los mecanismos de la carcinogénesis obtenidos en estudios sobre humanos y animales de experimentación y en ensayos tisulares y celulares se resumen en una o varias de las categorías descriptivas siguientes:

- Evidencia de genotoxicidad (es decir, cambios estructurales al nivel de los genes): por ejemplo, consideraciones de estructura-actividad, formación de aductos, mutagenicidad (efecto sobre genes específicos), mutaciones cromosómicas o aneuploidía.

- Evidencia de efectos sobre la expresión de genes pertinentes (es decir, cambios funcionales al nivel intracelular): por ejemplo, alteraciones de la estructura o cantidad del producto de un protooncogén o de un gen supresor de tumores, o alteraciones de la activación y desactivación metabólicas o de la reparación del ADN.

- Evidencia de efectos pertinentes sobre el comportamiento celular (es decir, cambios morfológicos o de comportamiento al nivel celular o tisular): por ejemplo, inducción de mitogénesis, proliferación celular compensatoria, preneoplasia e hiperplasia, supervivencia de células premalignas o malignas (inmortalización, inmunosupresión) o efectos sobre el potencial de metástasis.

- Evidencia obtenida de relaciones dosis-tiempo de efectos carcinógenos e interacciones entre agentes: por ejemplo, fase temprana frente a fase tardía, conforme a estudios epidemiológicos; inicio, promoción, progresión o conversión a malignidad, conforme a experimentos de carcinogenicidad en animales; toxicocinética.

Estas categorías no son excluyentes, y un agente puede aparecer en más de una de ellas. Así, por ejemplo, la acción de un agente sobre la expresión de los genes pertinentes podría resumirse en las categorías primera y segunda, aun cuando se supiera con razonable certeza que esos efectos tienen un origen genotóxico.

\section{Evaluaciones globales}

Por último, se consideran en su conjunto todos los resultados a fin de llegar a una evaluación global de la carcinogenicidad para los humanos de un agente, mezcla o circunstancia de exposición. La evaluación puede referirse a un grupo de sustancias químicas cuando los datos de apoyo indican que otros compuestos relacionados de los que no hay evidencia directa de su capacidad para inducir cáncer en humanos o animales pueden ser también carcinógenos, y en esos casos se añade al texto de la evaluación una justificación de dicha conclusión.

El agente, mezcla o circunstancia de exposición se describe en los términos que figuran en las categorías siguientes, y se indica el grupo al que se le ha asignado. La categorización de un agente, mezcla o circunstancia de exposición es una cuestión de juicio científico, en el que se debe reflejar la mayor o menor evidencia obtenida en estudios con humanos y animales de experimentación y en otros datos pertinentes.

\section{Grupo 1}

El agente (mezcla) es carcinógeno para los humanos. La circunstancia de exposición comporta exposiciones que son carcinógenas para los humanos.

Esta categoría se utiliza cuando hay evidencia suficiente de carcinogenicidad en los humanos. Excepcionalmente puede incluirse en esta categoría un agente (mezcla) respecto del que la evidencia en los humanos no llega a ser suficiente pero sí hay evidencia suficiente de carcinogenicidad en animales de experimentación y clara evidencia en humanos expuestos de que el agente (mezcla) actúa a través de un mecanismo de carcinogenicidad pertinente. 


\section{Grupo 2}

Están incuidos en esta categoría los agentes, mezclas y circunstancias de exposición respecto de los cuales, por uno de los extremos, el grado de evidencia de carcinogenicidad en los humanos es casi suficiente, así como aquellos otros respecto de los cuales, por el otro extremo, no hay datos humanos pero sí evidencia de carcinogenicidad en animales de experimentación. Sobre la base de la evidencia epidemiológica y experimental de carcinogenicidad y otros datos pertinentes, los agentes, mezclas y circunstancias de exposición se asignan bien al grupo 2A (probablemente carcinógenos para los humanos), bien al grupo 2B (posiblemente carcinógenos para los humanos).

Grupo 2A. El agente (mezcla) es probablemente carcinógeno para los humanos. La circunstancia de exposición comporta exposiciones que son probablemente carcinógenas para los humanos. Se utiliza esta categoría cuando hay evidencia limitada de carcinogenicidad en los humanos y evidencia suficiente de carcinogenicidad en animales de experimentación. En algunos casos puede clasificarse en esta categoría un agente (mezcla) cuando hay evidencia inadecuada de carcinogenicidad en los humanos y evidencia suficiente de carcinogenicidad en animales de experimentación y clara evidencia de que la carcinogénesis está llevada a cabo por un mecanismo que también opera en los humanos. Con carácter excepcional, puede clasificarse también en esta categoría un agente, mezcla o circunstancia de exposición únicamente sobre la base de evidencia limitada de carcinogenicidad en los humanos.

Grupo 2B. El agente (mezcla) es posiblemente carcinógeno para los humanos. La circunstancia de exposición comporta exposiciones que son posiblemente carcinógenas para los humanos. Se utiliza esta categoría para los agentes, mezclas y circunstancias de exposición respecto de los cuales hay la evidencia limitada de carcinogenicidad en los humanos y evidencia menos que suficiente de carcinogenicidad en animales de experimentación. Puede utilizarse también cuando hay evidencia inadecuada de carcinogenicidad en los humanos pero evidencia suficiente de carcinogenicidad en animales de experimentación. En algunos casos puede incluirse en este grupo un agente, mezcla o circunstancia de exposición respecto del cual hay evidencia inadecuada de carcinogenicidad en los humanos pero evidencia limitada de carcinogenicidad en animales de experimentación junto con evidencia complementaria a partir de otros datos relevantes.

\section{Grupo 3}

El agente (mezcla o circunstancia de exposición) no es clasiflicable en cuanto a su carcinogenicidad para los humanos. Se utiliza sobre todo esta categoría para los agentes, mezclas y circunstancias de exposición respecto de los cuales la evidencia de carcinogenicidad es inadecuada en los humanos e inadecuada o limitada en animales de experimentación.

Excepcionalmente pueden incluirse en esta categoría agentes (mezclas) respecto de los cuales la evidencia de carcinogenicidad es inadecuada en los humanos pero suficiente en los animales de experimentación cuando hay una clara evidencia de que el mecanismo de carcinogenicidad observado en los animales de experimentación no opera en los humanos.

\section{Grupo 4}

El agente (mezcla) es probablemente no carcinógeno para los humanos. Se incluyen en esta categoría los agentes o mezclas respecto de los cuales hay la evidencia que sugiere ausencia de carcinogenicidad en los humanos y en animales de experimentación. En algunos casos pueden clasificarse en este grupo agentes o mezclas respecto de los cuales hay evidencia inadecuada de carcinogenicidad en los humanos pero evidencia que sugiere ausencia de carcinogenicidad en los animales de experimentación, con el apoyo claro y sistemático de una amplia gama de otros datos relevantes.

Los sistemas de clasificación que ha elaborado el hombre no son lo suficientemente perfectos para abarcar todas las complejas entidades de la biología. No obstante, son útiles como principios de orientación y pueden modificarse a medida que se van consolidando nuevos conocimientos sobre la carcinogénesis. $\mathrm{Al}$ incluir un agente, mezcla o circunstancia de exposición en una u otra categoría es esencial basarse en los juicios científicos formulados por el grupo de expertos.

\section{Resultados hasta la fecha}

Hasta la fecha se han publicado o están en preparación 69 volúmenes de las Monographs de la IARC, en los que se evalúa la carcinogenicidad para los humanos de 836 agentes o circunstancias de exposición. Setenta y cuatro agentes o exposiciones se han evaluado como carcinógenos para los humanos (Grupo 1), 56 como probablemente carcinógenos para los humanos (Grupo 2A), 225 como posiblemente carcinógenos para los humanos (Grupo 2B) y uno como probablemente no carcinógeno para los humanos (Grupo 4). En el caso de 480 agentes o exposiciones, los datos epidemiológicos y experimentales disponibles no permitieron evaluar su carcinogenicidad para los humanos (Grupo 3).

\section{Importancia de los datos mecanicistas}

En el Preámbulo revisado, que apareció por vez primera en el volumen 54 de las Monographs de la IARC, se contempla la posibilidad de que un agente respecto del cual la evidencia epidemiológica de cáncer es menos que suficiente sea incluido en el Grupo 1 cuando hay evidencia suficiente de carcinogenicidad en animales de experimentación y clara evidencia en humanos expuestos de que el agente actúa a través de un mecanismo de carcinogenicidad aplicable a los humanos. A la inversa, un agente respecto del cual hay evidencia inadecuada de carcinogenicidad en los humanos y evidencia suficiente en animales de experimentación y clara evidencia de que el mecanismo de carcinogénesis no opera en los humanos puede colocarse en el Grupo 3 en vez de, como sería lo normal, en el Grupo 2B - posiblemente carcinógenos para los humanos.

En tres ocasiones se ha debatido recientemente la utilización de esos datos mecanicistas.

Aunque está en general aceptado que la radiación solar es carcinógena para los humanos (Grupo 1), los estudios epidemiológicos sobre cáncer humano por el empleo de lámparas de radiaciones UVA y UVB no proporcionan más que una evidencia limitada de carcinogenicidad. En tumores humanos de células escamosas de zonas de la piel expuestas al sol se han observado especiales sustituciones en tándem de bases (GC®TT) en genes supresores de tumores p53. Aunque la UVR puede inducir transiciones similares en algunos sistemas experimentales y las radiaciones UVB, UVA y UVC son carcinógenas en los animales de experimentación, los datos mecanicistas disponibles no le parecieron al grupo de trabajo lo suficientemente contundentes para clasificar las radiaciones UVB, UVA y UVC en un grupo superior al 2A (IARG 1992). En un estudio publicado después de la reunión (Kress y cols. 1992) se demostró la existencia de transiciones CG®TT en p53 en tumores cutáneos inducidos por la radiación UVB en el ratón, lo que podría sugerir que ésta debería clasificarse también como carcinógena para los humanos (Grupo 1).

El segundo caso en el que se estudió la posibilidad de incluir un agente en el Grupo 1 a pesar de no haber evidencia epidemiológica suficiente es el de la 4,4-metilen-bis(2-cloroanilina) (MOCA). La MOCA es carcinógena en perros y roedores y posee una amplia genotoxicidad. Se une al ADN mediante 
reacción con N-hidroxi MOCA, y los mismos aductos que se forman en los tejidos diana de la carcinogenicidad en los animales se han encontrado en células uroteliales de un reducido número de personas expuestas. Tras considerar largamente la posibilidad de pasar la MOCA a la categoría superior, el grupo de trabajo decidió finalmente clasificarla globalmente en el Grupo 2A, es decir, como probablemente carcinógena para los humanos (IARC 1993).

Durante una reciente evaluación del óxido de etileno (IARC 1994b), los estudios epidemiológicos disponibles proporcionaban una evidencia limitada de carcinogenicidad en los humanos mientras que los estudios con animales de experimentación daban evidencia suficiente de carcinogenicidad. El óxido de etileno se clasificó como carcinógeno para los humanos (Grupo 1) teniendo en cuenta otros datos pertinentes: 1) que el óxido de etileno induce un aumento sensible, persistente y relacionado con la dosis de la frecuencia de aberraciones cromosómicas e intercambios de cromatidial hermanas en linfocitos periféricos y micronúcleos de las células de la médula ósea de los trabajadores expuestos; 2) que se ha asociado con tumores malignos del sistema linfático y hematopoyético tanto en los humanos como en los animales de experimentación; 3) que induce un incremento relacionado con la dosis de la frecuencia de aductos de hemoglobina en los humanos expuestos e incrementos relacionados con la dosis del número de aductos tanto de ADN como de hemoglobina en los roedores expuestos; 4) que induce mutaciones génicas y translocaciones heredables en las células germinales de los roedores expuestos, y 5) que es un poderoso mutágeno y clastógeno a todos los niveles filogenéticos.

Ningún grupo de trabajo ha utilizado hasta el momento la posibilidad, contemplada en el Preámbulo, de que un agente respecto del cual hay evidencia suficiente de carcinogenicidad en animales se incluya en el Grupo 3 (en vez de en el Grupo 2B, en el que se clasificaría normalmente) cuando hay clara evidencia de que el mecanismo de carcinogenicidad que actúa en los animales no lo hace en los humanos. Se podría haber contemplado tal posibilidad en el caso del d-limoneno si hubiera habido evidencia suficiente de su carcinogenicidad en animales, pues hay datos que sugieren que la producción de $\alpha 2$-microglobulina en el riñón del macho de la rata está vinculada a los tumores renales observados.

Entre las muchas sustancias químicas que consideró prioritarias un grupo de trabajo especial que se reunió en diciembre de 1993 figuraban algunos mecanismos de acción intrínsecos que se proponen con frecuencia y se identificaban determinadas clases de agentes sobre la base de sus propiedades biológicas. El grupo de trabajo recomendó que, antes de que se evaluaran los agentes como los proliferantes de peroxisomas, fibras, polvos y agentes tirostáticos, dentro del programa de las Monografias se convocaran grupos de trabajo especiales para examinar los últimos conocimientos sobre sus mecanismos de acción correspondientes.

\section{APENDICE: EVALUACIONES GLOBALES DE CARGINOGENICIDAD PARA LOS HUMANOS: MONOGRAFIAS DE LA IARC, VOLUMENES 1-69 (836) ${ }^{1}$}

\section{Grupo 1: Garcinógenos para los humanos (74)}

\section{Agentes y grupos de agentes}

Aflatoxinas [1402-68-2] (1993)

Amianto [1332-21-4]

4-Aminodifenilo [92-67-1]

Anticonceptivos orales, combinados ${ }^{5}$

Anticonceptivos orales, secuenciales

Arsénico [7440-38-2] y compuestos de arsénico²

Azatioprina [446-86-6]

Benceno [71-43-2]

Bencidina [92-87-5]

Berilio [7440-41-7] y compuestos de berilio $(1993)^{3}$

Bis(2-cloroetil)-2-naftilamina (clornafacina) [494-03-1]

Bis(clorometil) éter [542-88-1] y clorometil metil éter

[107-30-2] (grado técnico)

Cadmio [7440-43-9] y compuestos del cadmio $(1993)^{3}$

Ciclofosfamida [50-18-0] [6055-19-2]

Ciclosporina [79217-60-0] (1990)

Clorambucil [305-03-3]

1-(2-Cloroetil)-3-(4-metilciclohexil)-1-nitrosourea

(metil-CGNU; semustina) [13909-09-6]

$1 \mathrm{El}$ número de Chemical Abstract figura entre corchetes; los años que aparecen entre paréntesis corresponden al año en que se publicó la evaluación con posterioridad al Suplemento 7-Grupo de Trabajo para agentes, mezclas o circunstancias de exposición incluidos en los Volúmenes 43 al 61 de las Monografías.

2 Esta evaluación se aplica al grupo de sustancias químicas como conjunto, no necesariamente a cada una de ellas como elemento dentro del grupo.

3 Evaluados como grupo.

4 Evaluación global por la que pasa de 2A a 1 con pruebas de apoyo a partir de otros datos relevantes para la evaluación de la carcinogenicidad y sus mecanismos.

$5 \mathrm{La}$ evidencia de que estos agentes poseen un efecto protector contra los cánceres de ovario y endometrio es concluyente.
Cloruro de vinilo [75-01-4]

Cromo[VI], compuestos de $(1990)^{3}$

Dietilsilbestrol [56-53-1]

Dimetanosulfonato de 1,4-butanediol (myleran) [55-98-1]

Erionita [66733-21-9]

Estrógenos, esteroideos ${ }^{2}$

Estrógenos, no esteroideos ${ }^{2}$

Estrógenos, terapia de sustitución con

Gas mostaza (mostaza de azufre) [505-60-2]

Helicobacter pylori (infección con) (1994)

Melfalán [148-82-3]

8-Metoxipsoraleno (metoxsaleno) [298-81-7] más

radiación ultravioleta $\mathrm{A}$

MOPP y otras quimioterapias combinadas, incluidos agentes alquilantes

2-Naftilamina [91-59-8]

Níquel, compuestos de $(1990)^{3}$

Opisthorchis viverrini (infección con) (1994)

Oxido de etileno ${ }^{4}$ [75-21-8] (1994)

Radiación solar (1992)

6 La evidencia de que este agente (tamoxifeno) reduce el riesgo de cáncer de mama contralateral es igualmente concluvente.

7 Evaluación global por la que pasa de $2 \mathrm{~A}$ a 1 con pruebas de apoyo a partir de otros datos relevantes para la evaluación de la carcinogenicidad y sus mecanismos.

8 Evaluación global por la que pasa de $2 \mathrm{~B}$ a $2 \mathrm{~A}$ con pruebas de apoyo a partir de otros datos relevantes.

9 Evaluación global por la que pasa de 3 a 2B con pruebas de apoyo a partir de otros datos relevantes.

10 Hay cierta evidencia de la relación inversa que existe entre el consumo de café y el cáncer de intestino grueso; el consumo de café no puede clasificarse por su carcinogenicidad para otros órganos. 
Radón [10043-92-2] y sus productos de desintegración (1988)

Schistosoma haematobium (infección con) (1994)

Sílice [14808-60-7] cristalina (inhalada en forma de cuarzo o cristobalita a partir de exposiciones profesionales)

Talco con fibras asbestiformes

Tamoxifeno [10540-29-1 $]^{6}$

Tiotepa [52-24-4] (1990)

Treosulfán [299-75-2]

Virus de la hepatitis B (infección crónica con) (1993)

Virus de la hepatitis C (infección crónica con) (1993)

Virus del papiloma en humanos, tipo 16 (1995)

Virus del papiloma en humanos, tipo 18 (1995)

Virus linfotrópico de células T en humanos, tipo I (1996)

\section{Mezclas}

Aceites de esquisto [68308-34-9]

Aceites minerales, no tratados o levemente tratados

Alquitranes de hulla [8007-45-2]

Bebidas alcohólicas (1988)

Betel mascado con tabaco

Breas de alquitrán de hulla [65996-93-2]

Hollines

Humo de tabaco

Mezclas analgésicas con fenacetina

Pescado salado (estilo chino) (1993)

Polvo de madera

Productos del tabaco, sin humo

\section{Exposiciones}

Aluminio, producción de

Auramina (fabricación de)

Calzado (fabricación y reparación de)

Caucho, industria del

Ebanistería y fabricación de muebles

Extracción de hematites (subterránea) con exposición a radón

Fundición siderúrgica

Gasificación del carbón

Isopropanol, fabricación de (proceso con ácidos fuertes)

Magenta, fabricación de (1993)

Nieblas de ácidos fuertes inorgánicos con ácido sulfúrico (exposición profesional) (1992)

Pintores (exposición profesional de los) (1989)

Producción de coque

\section{Grupo 2: Probablemente carcinógenos para los humanos $(56)$}

\section{Agentes y grupos de agentes}

Acrilamida [79-06-1] (1994) ${ }^{8}$

Acrilonitrilo [107-13-1]

Adriamicina $^{8}$ [23214-92-8]

Azacitidina $^{8}$ [320-67-2] (1990)

Benz $[\alpha]$ antraceno $^{8}[56-55-3]$

Benzo $[\alpha]$ pireno $^{8}[50-32-8]$

Biscloroetil nitrosourea (BCNU) [154-93-8]

Bromuro de vinilo [593-60-2]

1,3-Butadieno [106-99-0] (1992)

Captafol [2425-06-1] (1991)

Cisplatina ${ }^{8}$ [15663-27-1]

Clonorchis sinensis (infección con) ${ }^{8}$ (1994)

Cloranfenicol [56-75-7] (1990)

Clorhidrato de procarbazina ${ }^{8}[366-70-1]$

1-(2-Cloroetil)-3-ciclohexil-1-nitrosourea ${ }^{8}$ (CCNU)

[13010-47-4]
p-Cloro-o-toluidina [95-69-2] y sus sales de ácidos fuertes $(1990)^{3}$

Clorozotocina ${ }^{8}$ [54749-90-5] (1990)

Cloruro de dimetilcarbamoilo ${ }^{8}$ [79-44-7]

Colorantes derivados de la benzidina ${ }^{8}$

Dibenz $[a, h]$ antraceno $^{8}$ [53-70-3]

Dibromuro de etileno ${ }^{8}$ [106-93-4]

Epiclorhidrina ${ }^{8}$ [106-89-8]

Esteroides androgénicos (anabólicos)

$\mathcal{N}$-Etil- $\mathcal{N}$-nitrosourea ${ }^{8}$ [759-73-9]

Fenacetina [62-44-2]

Fluoruro de vinilo [75-02-5]

Formaldehído [50-00-0])

IQ $^{8}$ (2-Amino-3-metilimidazo[4,5-f]quinolina)

[76180-96-6] (1993)

4,4-Metileno bis(2-cloroanilina) (MOCA) ${ }^{8}$ [101-14-4] (1993)

$\mathcal{N}$-Metil- $\mathcal{N}$-nitro- $\mathcal{N}$-nitrosoguanidina ${ }^{8}$ (MNNG) [70-25-7]

$\mathcal{N}$-Metil- $\mathcal{N}$-nitrosourea ${ }^{8}[684-93-5]$

5-Metoxipsoraleno ${ }^{8}$ [484-20-8]

Mostazas nitrogenadas [51-75-2]

$\mathcal{N}$-Nitrosodietilamina ${ }^{8}[55-18-5]$

$\mathcal{N}$-Nitrosodimetilamina ${ }^{8}[62-75-9]$

Oxido de 7,8-estireno ${ }^{8}$ [96-09-3] (1994)

Radiación ultravioleta $\mathrm{A}^{8}$ (1992)

Radiación ultravioleta $\mathrm{B}^{8}$ (1992)

Radiación ultravioleta $\mathrm{C}_{8}(1992)$

Sulfato de dietilo [64-67-5] (1992)

Sulfato de dimetilo ${ }^{8}$ [77-78-1]

Tetracloroetileno [127-18-4]

Tricloroetileno [79-01-6]

Tris(2,3-dibromopropil)fosfato ${ }^{8}$ [126-72-7]

\section{Mezclas}

Bifenilos policlorados [1336-36-3]

Creosotas [8001-58-9]

Gases de escape de motores Diesel (1989)

Insecticidas no arsenicales (exposiciones profesionales en rociado y aplicación de) (1991)

Mate caliente (1991)

\section{Exposiciones}

Lámparas y camas de rayos ultravioleta (uso de) (1992) Peluqueros o barberos (exposición profesional de los) (1993) Refinado de petróleo (exposición profesional en el) (1989) Vidrio artístico, recipientes de vidrio y artículos de vidrio prensado (fabricación de) (1993)

\section{Grupo 2B: Posiblemente carcinógenos para los humanos (225)}

\section{Agentes y grupos de agentes}

A- $\alpha-\mathrm{C}$ (2-Amino-9H-pirido[2,3-b]indol) [26148-68-5]

Acetaldehído [75-07-0]

Acetamida [60-35-5]

Acetato de medroxiprogesterona [71-58-9]

Acetato de metilazoximetanol [592-62-1]

Acetato de vinilo [108-05-4] (1995)

Acido cafeico [331-39-5] (1993)

Acido cloréndico [115-28-6] (1990)

Acido nitrilotriacético [139-13-9] y sus sales $(1990)^{3}$

Acrilato de etilo[140-88-5]

AF-2 [2-(2-Furil)-3-(5-nitro-2-furil)acrilamida] [3688-53-7]

Aflatoxina M1 [6795-23-9] (1993)

p-Aminoazobenceno [60-09-3]

o-Aminoazotolueno [97-56-3]

2-Amino-5-(5-nitro-2-furil)-1,3,4-tiadiazol [712-68-5] 
Amitrol [61-82-5]

Anaranjado Oil SS [2646-17-5]

o-Anisidina [90-04-0]

Aramita [140-57-8]

Atrazina $^{9}$ [1912-24-9] (1991)

Auramina [492-80-8] (grado técnico)

Azaserina [115-02-6]

Azul CI Direct 15 [2429-74-5] (1993)

Azul Disperse 1 [2475-45-8] (1990)

Azul HC núm. 1 [2784-94-3] (1993)

Azul tripán [72-57-1]

Benzo[b]fluoranteno [205-99-2]

Benzo[j]fluoranteno [205-82-3]

Benzo[k]fluoranteno [207-08-9]

Bleomicinas [11056-06-7]

Bromato de potasio [7758-01-2]

Bromodiclorometano [75-27-4] (1991)

$\beta$-Butirolactona [3068-88-0]

Cicasina [14901-08-7]

Clordano [57-74-9] (1991)

Clordecone (Kepone) [143-50-0]

$p$-Cloroanilina [106-47-8] (1993)

4-Cloro-o- fenilendiamina [95-83-0]

Clorofenoles

Cloroformo [67-66-3]

1-Cloro-2-metilpropeno [513-37-1]

Cobalto [7440-48-4] y compuestos de cobalto ${ }^{3}(1991)$

Complejo hierro-dextrano [9004-66-4]

p-Cresidina [120-71-8]

Dacarbazina [4342-03-4]

Dantron (crisacina; 1,8-dihidroxiantraquinona)

[117-10-2] (1990)

Daunomicina [20830-81-3]

DDT [p,p'DDT, 50-29-3] (1991)

$\mathcal{N}, \mathcal{N}$-Diacetilbencidina [613-35-4]

2,4-Diaminoanisol [615-05-4]

4,4-Diaminodifenil éter [101-80-4]

2,4-Diaminotolueno [95-80-7]

Dibenz $[a, h]$ acridina [226-36-8]

Dibenz $\left[a_{2}\right]$ acridina [224-42-0]

7H-Dibenzo $[c, g]$ carbazol [194-59-2]

Dibenzo[a,e]pireno [192-65-4]

Dibenzo[a,h]pireno [189-64-0]

Dibenzo[a,i]pireno [189-55-9]

Dibenzo[a,l]pireno [191-30-0]

$p$-Diclorobenceno [106-46-7]

1,2-Dibromo-3-cloropropano [96-12-8]

3,3-Diclorobencidina [91-94-1]

3,3-Dicloro-4,4-diaminodifenil éter [28434-86-8]

1,2-Dicloroetano [107-06-2]

Diclorometano (cloruro de metileno) [75-09-2]

1,3-Dicloropropeno [542-75-6] (técnico)

Diclorvos [62-73-7] (1991)

Diepoxibutano [1464-53-5]

Diepóxido de 4-vinilciclohexeno [107-87-6] (1994)

1,2-Dietilhidrazina [1615-80-1]

Diglicidil resorcinol éter [101-90-6]

Dihidrosafrol [94-58-6]

Diisocianatos de tolueno [26471-62-5]

p-Dimetilaminoazobenceno [60-11-7]

trans-2-[(Dimetilamino)metilimino]-5-[2-(5-nitro-2-

furil)-vinil]-1,3,4-oxadiazol [25962-77-0]

2,6-Dimetilanilina (2,6-xilidina) [87-62-7] (1993)

3,3-Dimetilbencidina (o-tolidina) [119-93-7]

Dimetilformamida [68-12-2] (1989)

1,1-Dimetilhidrazina [57-14-7]
1,2-Dimetilhidrazina [540-73-8]

3,3-Dimetoxibencidina (o-Dianisidina) [119-90-4]

3,7-Dinitrofluoranteno [105735-71-5]

3,9-Dinitrofluoranteno [22506-53-2]

1,6-Dinitropireno [42397-64-8] (1989)

1,8-Dinitropireno [42397-65-9] (1989)

2,4-Dinitrotolueno [121-14-2]

2,6-Dinitrotolueno [606-20-2

1,4-Dioxano [123-91-1]

Esterigmatocistina [10048-13-2]

Estireno [100-42-5] (1994)

Estreptozotocina [18883-66-4]

Extractos de negro de humo

o-Fenilfenato de sodio [132-27-4]

Fenilglicidil éter [122-60-1] (1989)

Fenitoína [57-41-0]

Fenobarbital [50-06-6]

Fibras cerámicas

2-(2-Formilhidrazino)-4-(5-nitro-2-furil)tiazol [3570-75-0]

Ftalato de di(2-etilhexilo) [117-81-7]

Glicidaldehído [765-34-4]

Glu-P-1 (2-amino-6-metildipirido[1,2-a:3,2'- $d$ imidazol) [67730-11-4]

Glu-P-2 (2-aminodipirido[1,2-a:3,2-d] imidazol)

[67730-10-3]

Griseofulvina [126-07-8]

Helecho común

Heptacloro [76-44-8] (1991)

Herbicidas clorofenoxi

Hexaclorobenceno [118-74-1]

Hexaclorociclohexanos

Hexametilfosforamida [680-31-9]

Hidrazina [302-01-2]

Hidrocloruro de fenazopiridina [136-40-3]

Hidrocloruro de fenoxibenzamina [63-92-3]

Hidroxianisol butilado (BHA) [25013-16-5]

Indeno[1,2,3-cd]pireno [193-39-5]

Isopreno [78-79-5] (1994)

Lana de vidrio (1988)

Lana mineral (de escorias) (1988)

Lana mineral (de rocas) (1988)

Lasiocarpina [303-34-4]

Magenta [632-99-5] (con CI rojo básico 9) (1993)

MeA- $\alpha$-C (2-Amino-3-metil-9H-pirido[2,3-b] indol) [68006-83-7]

MeIQ (2-Amino-3,4-dimetilimidazo[4,5-flquinolina) [77094-11-2] (1993)

MeIQx (2-Amino-3,8-dimetilimidazo[4,5-f]quinoxalina) [77500-04-0] (1993)

Merfalán [531-76-0]

Metanosulfonato de etilo [62-50-0]

Metanosulfonato de metilo [66-27-3]

2-Metilaziridina (propilenimina) [75-55-8]

5-Metilcriseno [3697-24-3]

4,4-Metilendianilina [101-77-9]

4,4-Metileno bis(2-metilanilina) [838-88-0]

Metilmercurio, compuestos de $(1993)^{3}$

2-Metil-1-nitroantraquinona [129-15-7] (pureza incierta)

$\mathcal{N}$-Metil- $\mathcal{N}$-nitrosouretano [615-53-2]

Metiltiouracilo [56-04-2]

Metronidazol [443-48-1]

Mirex [2385-85-5]

Mitomicina C [50-07-7]

Monocrotalina [315-22-0]

5-(Morfolinometilo)-3-[(5-nitrofurfurilideno)amino]-

2-oxazolidinona [3795-88-8] 
Mostaza de uracilo [66-75-1]

Nafenopino [3771-19-5]

Níquel, metálico [7440-02-0] (1990)

Niridazol [61-57-4]

5-Nitroacenafteno [602-87-9]

2-Nitroanisol [91-23-6] (1996)

Nitrobenceno [98-95-3] (1996)

6-Nitrocriseno [7496-02-8] (1989)

Nitrofeno [1836-75-5], técnico

2-Nitrofluoreno [607-57-8] (1989)

1-[(5-Nitrofurfurilideno)amino]-2-imidazolidinona [555-84-0]

$\mathcal{N}$-[4-(5-Nitro-2-furil)-2-tiazolil] acetamida

[531-82-8]

1-Nitropireno [5522-43-0] (1989)

4-Nitropireno [57835-92-4] (1989)

2-Nitropropano [79-46-9]

$\mathcal{N}$-Nitrosodi- $n$-butilamina [924-16-3]

$\mathcal{N}$-Nitrosodietanolamina [1116-54-7]

$\mathcal{N}$-Nitrosodi- $n$-propilamina [621-64-7]

4-( $\mathcal{N}$-Nitrosometilamino)-1-(3-piridil)-1-butanona

(NNK) [64091-91-4]

3-(N-Nitrosometilamino)propionitrilo [60153-49-3]

$\mathcal{N}$-Nitrosometiletilamina [10595-95-6]

$\mathcal{N}$-Nitrosometilvinilamina [4549-40-0]

$\mathcal{N}$-Nitrosomorfolina [59-89-2]

$\mathcal{N}^{*}$-Nitrosonornicotina [16543-55-8]

$\mathcal{N}$-Nitrosopiperidina [100-75-4]

$\mathcal{N}$-Nitrosopirrolidina [930-55-2]

$\mathcal{N}$-Nitrososarcosina [13256-22-9]

Ocratoxina A [303-47-9] (1993)

Oxazepam [604-75-1] (1996)

$\mathcal{N}$-Oxido de mostazas nitrogenadas [126-85-2]

Oxido de propileno [75-56-9] (1994)

Palygorskita (attapulgita) [12174-11-7] (fibras largas: más de 5 micras) (1997)

Panfurán S (con dihidroximetilfuratricina [794-93-4])

Pentaclorofenol [87-86-5] (1991)

PhIP (2-Amino-1-metil-6-fenilimidazo[4,5-b]piridina) [105650-23-5] (1993)

Plomo [7439-92-1] y compuestos de plomo inorgánico ${ }^{3}$

Ponceau MX [3761-53-3]

Ponceau 3R [3564-09-8]

Progestinas

1,3-Propanosultona [1120-71-4]

Propiltiouracilo [51-52-5]

$\beta$-Propiolactona [57-57-8]

Rojo CI Acid 114 [6459-94-5] (1993)

Rojo CI Basic 9 [569-61-9] (1993)

Rojo Citrus núm. 2 [6358-53-8]

Sacarina [81-07-2]

Safrol [94-59-7]

Schistosoma japonicum (infección con) (1994)

Sulfalato [95-06-7]

Sulfato de diisopropilo [2973-10-6] (1992)

Tetracloruro de carbono [56-23-5]

Tetranitrometano [509-14-8] (1996)

Tioacetamida [62-55-5]

4,4-Tiodianilina [139-65-1]

Tiourea [62-56-6]

Tiourea de etileno [96-45-7]

$\alpha$-Toluenos clorados (cloruro de bencilo, cloruro de benzal, benzotricloruro)

o-Toluidina [95-53-4]

Triclormetina (hidrocloruro de trimustina) [817-09-4] (1990)

Trióxido de antimonio [1309-64-4] (1989)
Trp-P-1 (3-Amino-1,4-dimetil-5H-pirido[4,3-b]indol) [62450-06-0]

Trp-P-2 (3-Amino-1-metil-5H-pirido[4,3-b]indol) [62450-07-1]

Uretano [51-79-6]

4-Vinilciclohexeno [100-40-3] (1994)

Violeta de bencilo 4B [1694-09-3]

Virus de inmunodeficiencia humana tipo 2 (infección con) (1996)

Virus del papiloma en humanos: tipos distintos de $16,18,31$ y $33(1995)$

Mezclas

Betunes [8052-42-4], extractos de, refinados con vapor y con agua

Bifenilos polibromados [firemaster BP-6, 59536-65-1]

Café (vejiga urinaria) ${ }^{9}(1991)$

Carragenina [9000-07-1], degradada

Combustible para Diesel, embarcaciones (1989)

Encurtidos de verduras (tradicionales en Asia) (1993)

Fuel-oils, residuales (pesados) (1989)

Gases de escape de motores, gasolina (1989)

Gasolina (1989)

Humos de soldadura (1990)

Parafinas cloradas de longitud media de cadena de carbono C12 y grado medio de cloración de aproximadamente el $60 \%$ (1990)

Toxafeno (canfenos policlorados) [8001-35-2]

Toxinas derivadas de Fusarium moniliforme (1993)

\section{Exposiciones}

Carpintería y ebanistería

Limpieza en seco (exposiciones profesionales en) (1995)

Manufacturas textiles (trabajo en) (1990)

Procesos de impresión (exposiciones profesionales en) (1996)

\section{Grupo 3: Inclasificables en cuanto a su} carcinogenicidad para los humanos $(480)$

\section{Agentes y grupos de agentes}

Aceites isopropílicos

Acetato de bencilo [140-11-4]

Acetato de polivinilo [9003-20-7]

Acetato de vinilo [108-05-4]

Acido acrílico [79-10-7]

p-Acido aminobenzoico [150-13-0]

Acido 11-aminoundecanoico [2432-99-7]

Acido antranílico [118-92-3]

Acido dicloroacético [79-43-6] (1995)

Acido cis-9,10-epoxiesteárico [2443-39-2]

Acido hidroclórico [7647-01-0] (1992)

$\mathcal{N}$-Acido nitrosofólico [29291-35-8]

Acido parasórbico [10048-32-5]

Acido penicílico [90-65-3]

Acido poliacrílico [9003-01-4]

Acido shikímico [138-59-0]

Acido tánico [1401-55-4] y taninos

Acido tricloroacético [76-03-9] (1995)

Acrilato de $n$-butilo [141-32-2]

Acrilato de 2-etilhexilo [103-11-7] (1994)

Acrilato de metilo [96-33-3]

Acroleína [107-02-8]

Actinomicina D [50-76-0]

Adipato de di(2-etilhexilo) [103-23-1]

Afolato [52-46-0]

Agua potable clorada (1991) 
Alcohol polivinílico [9002-89-5]

Aldicarb [116-06-3] (1991)

Aldrín [309-00-2]

Almizcle ambrette [83-66-9] (1996)

Almizcle de xileno [81-15-2] (1996)

Amaranto [915-67-3]

Amarillo AB [85-84-7]

Amarillo Disperse 3 [2832-40-8] (1990)

Amarillo HC núm. 4 [59820-43-8] (1993)

Amarillo OB [131-79-3]

Amarillo Sunset FGF [2783-94-0]

Amarillo Vat 4 [128-66-5] (1990)

5-Aminoacenafteno [4657-93-6]

2-Aminoantraquinona [117-79-3]

1-Amino-2-metilantraquinona [82-28-0]

2-Amino-4-nitrofenol [99-57-0] (1993)

2-Amino-5-nitrofenol [121-88-0] (1993)

4-Amino-2-nitrofenol [119-34-6]

2-Amino-5-nitrotiazol [121-66-4]

Ampicilina [69-53-4] (1990)

Anaranjado CI Acid 3 [6373-74-6] (1993)

Anaranjado de acridina [494-38-2]

Anaranjado G [1936-15-8]

Anaranjado I [523-44-4]

Anestésicos, volátiles

Angelicina [523-50-2] más radiación ultravioleta A

Anhídrido succínico [108-30-5]

Anilina [62-53-3]

p-Anisidina [104-94-9]

Antantreno [191-26-4]

Antraceno [120-12-7]

Antralinato de cinamilo [87-29-6]

Aurotioglucosa [12192-57-3]

Aziridil benzoquinona [800-24-8]

Aziridina [151-56-4]

2-(1-Aziridinil)etanol [1072-52-2]

Azobenceno [103-33-3]

Azul Brilliant FCF, sal de disodio [3844-45-9]

Azul Evans [314-13-6]

Azul HC núm. 2 [33229-34-4] (1993)

Azul VRS [129-17-9]

Benz $[a]$ acridina [225-11-6]

Benz[c]acridina [225-51-4]

Benzo[c]fenantreno [195-19-7]

Benzo[ghi]fluoranteno [203-12-3]

Benzo [a] fluoreno [238-84-6]

Benzo[b]fluoreno [243-17-4]

Benzo[c]fluoreno [205-12-9]

Benzo[ghi]perileno [191-24-2]

Benzo[e]pireno [192-97-2]

$p$-Benzoquinona dioxima [105-11-3]

Bis(2,3-epoxiciclopentil)éter [2386-90-5] (1989)

Bis(2-cloroetil)éter [111-44-4]

Bis(2-cloro-1-metiletil)éter [108-60-1]

1,2-Bis(clorometoxi)etano [13483-18-6]

1,4-Bis(clorometoximetil)benceno [56894-91-8]

Bisfenol A diglicidil éter [1675-54-3] (1989)

Bis(2-hidroxietil)ditiocarbamato de potasio [23746-34-1]

Bisulfitos (1992)

Bromocloroacetonitrilo [83463-62-1] (1991)

Bromoetano [74-96-4] (1991)

Bromoformo [75-25-2] (1991)

Bromuro de metilo [74-83-9]

Butilhidroxitolueno (BHT) [128-37-0]

$\gamma$-Butirolactona [96-48-0]

Butoxipiperonilo [51-03-6]
Cafeína [58-08-2] (1991)

Cantaridina [56-25-7]

Captan [133-06-2]

Carbamato de metilo [598-55-0]

Carbamato de $n$-propilo [627-12-3]

Carbarilo [63-25-2]

Carbazol [86-74-8]

3-Carbetoxipsoraleno [20073-24-9]

Carboxilato de 3,4-epoxi-6-metilciclohexilmetil-

3,4-epoxi-6-metilciclohexano [141-37-7]

Carmoisina [3567-69-9]

Carragenina [9000-07-1], natural

Catecol [120-80-9]

Ciclamatos [ciclamato de sodio, 139-05-9]

Cicloclorotina [12663-46-6]

Ciclohexanona [108-94-1] (1989)

Ciclopenta[cd]pireno [27208-37-3]

Cimetidina [51481-61-9] (1990)

Citrato de clomifeno [50-41-9]

Citrinina [518-75-2]

Clofibrato [637-07-0]

Cloral [75-87-6] (1995)

Clordimeformo [6164-98-3]

Clorito de sodio [7758-19-2] (1991)

Cloroacetonitrilo [107-14-2] (1991)

Clorobencilato [510-15-6]

Clorodibromometano [124-48-1] (1991)

Clorodifluorometano [75-45-6]

Cloroetano [75-00-3] (1991)

4-Cloro- $m$-fenilendiamina [5131-60-2]

Clorofluorometano [593-70-4]

3-Cloro-2-metilpropeno [563-47-3] (1995)

Cloronitrobencenos [88-73-3; 121-73-3; 100-00-5] (1996)

Cloropreno [126-99-8]

Cloropropham [101-21-3]

Cloroquina [54-05-7]

Clorotalonilo [1897-45-6]

2-Cloro-1,1,1-trifluoroetano [75-88-7]

Cloruro de acriflavina [8018-07-3]

Cloruro de alilo [107-05-1]

Cloruro de benzoilo [98-88-4]

Cloruro de metilo [74-87-3]

Cloruro de polivinilo [9002-86-2]

Cloruro de vinilideno [75-35-4]

Colesterol [57-88-5]

Complejo hierro-dextrina [9004-51-7]

Complejo hierro-sorbitol-ácido cítrico [1338-16-5]

Copolímeros de acrilonitrilo-butadieno-estireno

Copolímeros de cloruro de vinilideno-cloruro de vinilo [9011-06-7]

Copolímeros de cloruro de vinilo-acetato de vinilo [9003-22-9]

Copolímeros de estireno-acrilonitrilo [9003-54-7]

Copolímeros de estireno-butadieno [9003-55-8]

Coroneno [191-07-1]

$m$-Cresidina [102-50-1]

Criseno [218-01-9]

Crisoidina [532-82-1]

Cromo[III], compuestos de (1990)

Cromo [7440-47-3], metálico (1990)

Crotonaldehído [4170-30-3] (1995)

Cumarina [91-64-5]

Dapsone [80-08-0]

Deltametrina [52918-63-5] (1991)

Diacetilaminoazotolueno [83-63-6]

Dialato [2303-16-4] 
1,2-Diamino-4-nitrobenceno [99-56-9]

1,4-Diamino-2-nitrobenceno [5307-14-2] (1993)

2,5-Diaminotolueno [95-70-5]

Diazepam [439-14-5]

Diazometano [334-88-3]

Dibenz $[a, c]$ antraceno [215-58-7]

Dibenz $[a, j]$ antraceno [224-41-9]

Dibenzo- $p$-dioxina (1997)

Dibenzodioxinas cloradas (distintas de TCDD)

Dibenzo-p-dioxinas policloradas (distintas de 2,3,7,

8-tetra-clorodibenzo- $p$-dioxina) (1997)

Dibenzo[a,e]fluoranteno [5385-75-1]

Dibenzofuranos policlorados (1997)

Dibenzo[h,rst]pentafeno [192-47-2]

Dibromoacetonitrilo [3252-43-5] (1991)

Dicloroacetileno [7572-29-4]

Dicloroacetonitrilo [3018-12-0] (1991)

o-Diclorobenceno [95-50-1]

trans-1,4-Diclorobuteno [110-57-6]

2,6-Dicloro-para-fenilendiamina [609-20-1]

1,2-Dicloropropano [78-87-5]

Dicofol [1 15-32-2]

Dieldrín [60-57-1]

Dietilditiocarbamato de sodio [148-18-5]

2,4-Difenildiamina [492-17-1]

Dihidrocloruro de manomustina [551-74-6]

Dihidroximetilfuratricina [794-93-4]

4,4-Diisocianato de 3,3-dimetoxibencidina [91-93-0]

Diisocianato de 4,4-metilendifenilo [101-68-8]

Diisocianato de 1,5-naftaleno [3173-72-6]

Diisocianato de polimetilenpolifenilo [9016-87-9]

4,4-Dimetilangelicina [22975-76-4] más radiación ultravioleta A

4,5-Dimetilangelicina [4063-41-6] más radiación ultravioleta A

$\mathcal{N}, \mathrm{N}-$ Dimetilanilina [121-69-7] (1993)

1,4-Dimetilfenantreno [22349-59-3]

Dimetoxano [828-00-2]

1,3-Dinitropireno [75321-20-9] (1989)

Dinitrosopentametilentetramina [101-25-7]

Dióxido de azufre [7446-09-5] (1992)

Dióxido de titanio [13463-67-7] (1989)

Disulfirán [97-77-8]

Ditranol [1143-38-0]

Doxefazepam [40762-15-0] (1996)

Droloxifeno [82413-20-5] (1996)

Dulcina [150-69-6]

Endrín [72-20-8]

Eosina [15086-94-9]

1,2-Epoxibutano [106-88-7] (1989)

Espironolactona [52-01-7]

Espumas de poliuretano [9009-54-5]

Estazolam [29975-16-4] (1996)

Estearato de glicidilo [7460-84-6]

Estrógenos-progestina, terapia de sustitución

Etileno [74-85-1] (1994)

Etionamida [536-33-4]

Eugenol [97-53-0]

Fenantreno [85-01-8]

Fenicarbazida [103-03-7]

Fenilbutazona [50-33-9]

$m$-Fenilendiamina [108-45-2]

p-Fenilendiamina [106-50-3]

o-Fenilfenol [90-43-7]

$\mathcal{N}$-Fenil-2-naftilamina [135-88-6]

Fenol [108-95-2] (1989)
Fenvalerato [51630-58-1] (1991)

Ferbam [14484-64-1]

Fibras acrílicas

Fibras modacrílicas

Fibrillas de p-aramida [24938-64-5] (1997)

Filamentos de vidrio (1988)

Fluometuron [2164-17-2]

Fluoranteno [206-44-0]

Fluoreno [86-73-7]

5-Fluoruracilo [51-21-8]

Fluoruro de vinilideno [75-38-7]

Fluoruros (inorgánicos, empleados en el agua potable)

Ftalato de butilbencilo [85-68-7]

Furazolidona [67-45-8]

Furfural [98-01-1] (1995)

Furosemida (Frusemida) [54-31-9] (1990)

Gemfibrozilo [25812-30-0] (1996)

Giromitrina [16568-02-8]

Hematites [1317-60-8]

Hexaclorobutadieno [87-68-3]

Hexacloroetano [67-72-1]

Hexaclorofeno [70-30-4]

Hidralazina [86-54-4]

Hidrato de cloral [302-17-0] (1995)

Hidrazida de ácido isonicotínico (isoniazida) [54-85-3]

Hidrazida maleica [123-33-1]

Hidroclorotiacida [58-93-5] (1990)

Hidrocloruro de pronetalol [51-02-5]

Hidrocloruro de semicarbazida [563-41-7]

Hidrogenofosfito de dimetilo [868-85-9] (1990)

Hidroquinona [123-31-9]

4-Hidroxiazobenceno [1689-82-3]

8-Hidroxiquinolina [148-24-3]

8-Hidroxiquinolina de cobre [10380-28-6]

Hidroxisenkirkina [26782-43-4]

Hipocloritos (1991)

Isatidina [15503-86-3]

Isofosfamida [3778-73-2]

Isopropanol [67-63-0]

Isosafrol [120-58-1]

Isotiocianato de alilo [57-06-7]

Isovalerato de alilo [2835-39-4]

Jacobine [6870-67-3]

Kaempferol [520-18-3]

$d$-Limoneno [5989-27-5] (1993)

Luces fluorescentes (1992)

Luteoskyrina [21884-44-6]

Malatión [121-75-5]

Malonaldehído [542-78-9]

Maneb [12427-38-2]

Marrón Sudan RR [6416-57-5]

Medfalán [13045-94-8]

Melamina [108-78-1]

6-Mercaptopurina [50-44-2]

Mercurio [7439-97-6] y compuestos inorgánicos de mercurio (1993)

Mesilato de hicantona [23255-93-8]

Metabisulfitos (1992)

Metacrilato de metilo [80-62-6] (1994)

Metacrilato de polimetilo [9011-14-7]

5-Metilangelicina [73459-03-7] más radiación ultravioleta A

1-Metilcriseno [3351-28-8]

2-Metilcriseno [3351-32-4]

3-Metilcriseno [3351-31-3]

4-Metilcriseno [3351-30-2]

6-Metilcriseno [1705-85-7] 
$\mathcal{N}$-Metil- $\mathcal{N}$,4-dinitrosoanilina [99-80-9]

4,4-Metilenbis( $\mathcal{N}, \mathrm{N}$-dimetil)bencenamina [101-61-1]

1-Metilfenantreno [832-69-9]

2-Metilfluoranteno [33543-31-6]

3-Metilfluoranteno [1706-01-0]

Metilglioxal [78-98-8] (1991)

$\mathcal{N}$-Metilolacrilamida [90456-67-0] (1994)

Metilparatión [298-00-0]

7-Metilpirido[3,4-c]psoraleno [85878-62-2]

Metotrexato [59-05-2]

Metoxicloro [72-43-5]

Monuron [150-68-5] (1991)

Morfolina [110-91-8] (1989)

Mostaza de estradiol [22966-79-6]

1,5-Naftalendiamina [2243-62-1]

1-Naftilamina [134-32-7]

1-Naftiltiourea (ANTU) [86-88-4]

Nitiacida [139-94-6]

5-Nitro-o-anisidina [99-59-2]

9-Nitroantraceno [602-60-8]

7-Nitrobenz[a] antraceno [20268-51-3] (1989)

6-Nitrobenzo[a]pireno [63041-90-7] (1989)

4-Nitrobifenilo [92-93-3]

3-Nitrofluoranteno [892-21-7]

Nitrofural (nitrofurazona) [59-87-0] (1990)

Nitrofurantoína [67-20-9] (1990)

1-Nitronaftaleno [86-57-7] (1989)

2-Nitronaftaleno [581-89-5] (1989)

3-Nitroperileno [20589-63-3] (1989)

2-Nitropireno [789-07-1] (1989)

$\mathcal{N}$-Nitrosoanabasina [37620-20-5]

$\mathcal{N}$-Nitrosoanatabina [71267-22-6]

$\mathcal{N}$-Nitrosodifenilamina [86-30-6]

$p$-Nitrosodifenilamina [156-10-5]

$\mathcal{N}$-Nitrosoguvacina [55557-01-2]

$\mathcal{N}$-Nitrosoguvacolina [55557-02-3]

$\mathcal{N}$-Nitrosohidroxiprolina [30310-80-6]

4-(N-Nitrosometilamino)-4-(3-piridil)-1-butanal (NNA) [64091-90-3]

3-(N-Nitrosometilamino)propionaldehído [85502-23-4]

$\mathcal{N}$-Nitrosoprolina [7519-36-0]

5-Nitro-o-toluidina [99-55-8] (1990)

Nitrovina [804-36-4]

Nylon 6 [25038-54-4]

Oleato de glicidilo [5431-33-4]

Opisthorchis felineus (infección con) (1994)

Oxido de decabromodifenilo [1163-19-5] (1990)

Oxido de hierro sacarado [8047-67-4]

Oxido de tris(1-aziridinil)fosfina [545-55-1]

Oxido de tris(2-metil-1-aziridinil)fosfina [57-39-6]

Oxido férrico [1309-37-1]

Oxifenbutazona [129-20-4]

Palygorskita (attapulgita) [12174-11-7] (fibras cortas: menos de 5 micras) (1997)

Paracetamol (acetaminofeno) [103-90-2] (1990)

Paratión [56-38-2]

Patulina [149-29-1]

Pentacloroetano [76-01-7]

Perileno [198-55-0]

Permetrina [52645-53-1] (1991)

Peróxido de benzoilo [94-36-0]

Peróxido de hidrógeno [7722-84-1]

Peróxido de lauroilo [105-74-8]

Petasitenina [60102-37-6]

Picloram [1918-02-1] (1991)

Pireno [129-00-0]
Pirido[3,4-c]psoraleno [85878-62-2]

Pirimetamina [58-14-0]

Pirrolidona de polivinilo [9003-39-8]

Plomo, compuestos orgánicos [75-74-1], [78-00-2]

Policloropreno [9010-98-4]

Poliestireno [9003-53-6]

Polietileno [9002-88-4]

Polipropileno [9003-07-0]

Politetrafluoroetileno [9002-84-0]

Polvo de carbón (1997)

Ponceau SX [4548-53-2]

Prazepam [2955-38-6] (1996)

Prednimustina [29069-24-7] (1990)

Prednisona [53-03-2]

Propham [122-42-9]

Propileno [115-07-1] (1994)

Ptaquilosida [87625-62-5]

Quercetina [117-39-5]

p-Quinona [106-51-4]

Quintoceno (pentacloronitrobenceno) [82-68-8]

Reserpina [50-55-5]

Resorcinol [108-46-3]

Retrorsina [480-54-6]

Rhodamina B [81-88-9]

Rhodamina 6G [989-38-8]

Riddelliína [23246-96-0]

Rifampicina [13292-46-1]

Ripazepam [26308-28-1] (1996)

Rojo CI Pigment 3 [2425-85-6] (1993)

Rojo D \& C núm. 9 [5160-02-1] (1993)

Rojo de metilo [493-52-7]

Rojo HC núm. 3 [2871-01-4] (1993)

Rojo Scarlet [85-83-6]

Rojo Sudan 7B [6368-72-5]

Rugulosina [23537-16-8]

Sales de proflavina

Sales de tetrakis(hidroximetil)fosfonio (1990)

Schistosoma mansoni (infección con) (1994)

Selenac de etilo [5456-28-0]

Selenac de metilo [144-34-3]

Selenio [7782-49-2] y compuestos de selenio

Senecifilina [480-81-9]

Senkirkina [2318-18-5]

Sepiolita [15501-74-3]

Sílice [7631-86-9], amorfa

Simacina [122-34-9] (1991)

Sinfitina [22571-95-5]

Sudan I [842-07-9]

Sudan II [3118-97-6]

Sudan III [85-86-9]

Sulfafurazol (sulfisoxazol) [127-69-5]

Sulfametoxazol [723-46-6]

Sulfato de fenelcina [156-51-4]

Sulfato de vinblastina [143-67-9]

Sulfato de vincristina [2068-78-2]

Sulfitos (1992)

Sulfonato de $p$-dimetilaminoazobencenodiazo y

sodio [140-56-7]

Sulfuro de bis(1-aziridinil)morfolinofosfina [2168-68-5]

Sulfuro de etileno [420-12-2]

Talco [14807-96-6], sin fibras asbestiformes

Telurac de etilo [20941-65-5]

Temazepam [846-50-4] (1996)

Teobromina [83-67-0] (1991)

Teofilina [58-55-9] (1991)

2,2,5,5-Tetraclorobencidina [15721-02-5] 
1,1,1,2-Tetracloroetano [630-20-6]

1,1,2,2-Tetracloroetano [79-34-5]

Tetraclorvinfós [22248-79-9]

Tetrafluoroetileno [116-14-3]

Thiram [137-26-8] (1991)

Tiouracilo [141-90-2]

Tolueno [108-88-3] (1989)

Tolueno de vinilo [25013-15-4] (1994)

Toremifeno [89778-26-7] (1996)

Toxinas derivadas de Fusarium graminearum, F. culmorum y

F. crookwellense (1993)

Toxinas derivadas de Fusarium sporotrichioides (1993)

Triclorfón [52-68-6]

Tricloroacetonitrilo [545-06-2] (1991)

1,1,1-Tricloroetano [71-55-6]

1,1,2-Tricloroetano [79-00-5] (1991)

Trietilenglicol diglidicil éter [1954-28-5]

Trifenileno [217-59-4]

Trifluralina [1582-09-8] (1991)

4,4,6-Trimetilangelicina [90370-29-9] más radiación ultravioleta

2,4,5-Trimetilanilina [137-17-7]

2,4,6-Trimetilanilina [88-05-1]

4,5,8-Trimetilpsoraleno [3902-71-4]

2,4,6-Trinitrotolueno [118-96-7] (1996)

Tris(aziridinil)-p-benzoquinona (triazicuona) [68-76-8]

2,4,6-Tris(1-aziridinil)-s-triazina [51-18-3]

Tris(2-cloroetil)fosfato [115-96-8] (1990)

1,2,3-Tris(clorometoxi)propano [38571-73-2]

Trisulfuro de antimonio [1345-04-6] (1989)

Verde Fast FCF [2353-45-9]

Verde Guinea B [4680-78-8]

Verde Light SF [5141-20-8]

$\mathcal{N}$-Vinil-2-pirrolidona [88-12-0]

Virus de la hepatitis D (1993)

Virus linfotrópico de células T en humanos, tipo II (1996)

Wollastonita [13983-17-0]

Xileno [1330-20-7] (1989)

2,4-Xilidina [95-68-1]

2,5-Xilidina [95-78-3]

Yoduro de metilo [74-88-4]

Zectran [315-18-4]

Zeolitas [1318-02-1] distintas de la erionita

(clinoptilolita, filipsita, mordenita, zeolita japonesa

no fibrosa, zeolitas sintéticas) (1997)

Zineb [12122-67-7]

Ziram [137-30-4] (1991)

\section{Mezclas}

Aceites minerales, muy refinados

Betel mascado, sin tabaco

Betunes [8052-42-4], refinados con vapor, residuo del

cracking y refinados con aire

Combustible para aviones a reacción (1989)

Combustibles para Diesel, destilados (ligeros) (1989)

Disolventes de petróleo (1989)

Fuel-oils, destilados (ligeros) (1989)

Mate (1990)

Petróleo crudo [8002-05-9] (1989)

Té (1991)

Terpenos policlorados (StrobaneR) [8001-50-1]

Tintas de imprenta (1996)

\section{Exposiciones}

Artículos de cuero (fabricación de)

Cuero (curtido y elaboración del)
Industria de la madera y aserraderos (incluida la corta) Papel y pasta de papel (manufactura de)

Pinturas (exposición profesional en manufactura de) (1989)

Tintes para el pelo (uso personal) (1993)

Vidrio plano y especial (manufactura de) (1993)

\section{Grupo 4: Probablemente no carcinógenos para los humanos (1)}

Caprolactama [105-60-2]

\section{EVALUACION DEL RIESGO DE CARCINOGENICIDAD: OTROS ENFOQUES}

\section{Cees A. van der Heijden}

Si bien los principios y métodos de la evaluación del riesgo que comportan las sustancias químicas no carcinógenas son similares en diferentes partes del mundo, llama la atención que en el caso de las sustancias carcinógenas la evaluación del riesgo se enfoque de muy diversas maneras. No sólo hay notables diferencias entre unos países y otros, sino incluso diversos organismos reguladores, comités y científicos especializados de un mismo país aplican o proponen enfoques distintos. En el caso de las sustancias no carcinógenas, la evaluación del riesgo es bastante sistemática y está relativamente consolidada debido en parte a que es una actividad más antigua y a que se conoce mejor la naturaleza de los efectos tóxicos en comparación con los de los carcinógenos, y hay por ello un alto grado de consenso y de confianza, tanto de los científicos como del público general, en los métodos que se utilizan y en sus resultados.

En el ámbito de las sustancias no carcinógenas se introdujeron factores de seguridad para compensar las incertidumbres que presentaban los datos toxicológicos (obtenidos en su mayor parte en experimentos con animales) y su aplicabilidad a poblaciones humanas grandes y heterogéneas. De esa manera, los límites recomendados o exigidos a las exposiciones humanas solían fijarse en una fracción (enfoque basado en un factor de seguridad o incertidumbre) de los niveles de exposición en animales que podían documentarse claramente como nivel sin efecto adverso observable (NOAEL) o como nivel mínimo de efecto adverso observable (LOAEL). Se partía entonces de que las propiedades peligrosas de las sustancias químicas no se manifestarían mientras la exposición humana no excediera de los límites recomendados. Esta práctica, de una forma algo más perfeccionada, sigue aplicándose hoy en la evaluación de los riesgos toxicológicos de muchos tipos de sustancias.

A finales del decenio de 1960 y principios del de 1970 los órganos reguladores, empezando por los de los Estados Unidos, se enfrentaron a un problema de creciente gravedad que hizo pensar a muchos científicos que el enfoque basado en un factor de seguridad era inadecuado o incluso peligroso. Se trataba de las sustancias químicas que en determinadas condiciones se había comprobado que incrementaban el riesgo de cáncer en los humanos o en animales de experimentación. A efectos operativos, esas sustancias se denominaron carcinógenos. La definición del término "carcinógeno" sigue siendo objeto de debates y controversias, y hay numerosas opiniones distintas sobre cuáles son las técnicas idóneas para identificar y clasificar los carcinógenos y el proceso de la inducción del cáncer por sustancias químicas.

El debate se inició en realidad mucho antes, cuando en el decenio de 1940 unos científicos descubrieron que carcinógenos 
químicos causaban el daño mediante un mecanismo biológico que era de un tipo totalmente distinto de los que producían otras formas de toxicidad. Esos científicos, utilizando principios derivados de la biología de los tipos de cáncer inducidos por la radiación, propusieron lo que se conoce como la hipótesis de "agentes sin umbral", que se consideró aplicable tanto a la radiación como a las sustancias químicas carcinógenas. Se partía de la idea de que toda exposición a un carcinógeno que llega a su diana biológica crítica, especialmente el material genético, e interactúa con ella puede incrementar la probabilidad (el riesgo) de que se desarrolle el cáncer.

Al mismo tiempo que se desarrollaba el debate científico sobre la cuestión del umbral iba creciendo en la opinión pública la preocupación por la influencia nociva de los carcinógenos químicos y por la urgente necesidad de proteger a la población de una serie de enfermedades reunidas bajo el nombre colectivo de cáncer. El público general y los políticos empezaron a considerar el cáncer, con su carácter insidioso y su largo período de latencia, más los datos que indicaban que su incidencia en la población general estaba aumentando, como un problema preocupante que justificaba la máxima protección. Los responsables de la regulación se enfrentaban al hecho de que en determinadas situaciones gran número de personas, a veces casi la población entera, estaban o podían estar expuestas a niveles relativamente bajos de sustancias químicas (en productos de consumo y fármacos, en el lugar de trabajo y en el aire, el agua, los alimentos y los suelos) que se habían identificado como carcinógenos en los humanos o en animales de experimentación en condiciones de exposición relativamente intensa.

Los responsables de la regulación se enfrentaban así a dos preguntas fundamentales que, en la mayoría de los casos, no podían responderse plenamente con los métodos científicos disponibles:

1. ¿Qué riesgo hay para la salud humana en el intervalo de exposiciones a sustancias químicas que está por debajo del intervalo, relativamente intenso y estrecho, en el que el riesgo de cáncer puede medirse directamente?

2. ¿Qué se puede decir de los riesgos para la salud humana cuando sólo se han determinado los riesgos de desarrollo del cáncer en animales de experimentación?

Las instancias reguladoras reconocieron la necesidad de partir de unos determinados supuestos que unas veces tenían una base científica pero que muchas otras no se apoyaban en datos experimentales. Para dar coherencia a las distintas actividades se adoptaron definiciones y series de supuestos específicos que fueran aplicables genéricamente a todos los carcinógenos.

\section{La carcinogénesis como proceso multifásico}

Datos de diversos tipos apoyan la conclusión de que la carcinogénesis química es un proceso multifásico impulsado por el daño genético y por alteraciones epigenéticas, y esta teoría está hoy ampliamente aceptada en las comunidades científicas de todo el mundo (Barrett 1993). Aunque el proceso de la carcinogénesis química suele separarse en tres fases -iniciación, promoción y progresión-, desconocemos el número de alteraciones genéticas que intervienen en él.

La iniciación comprende la inducción de una célula irreversiblemente alterada y, en los carcinógenos genotóxicos, equivale siempre a un hecho mutacional. Ya en 1914 Theodor Boveri formuló la hipótesis de que la mutagénesis era un mecanismo de la carcinogénesis, y después se ha comprobado que estaba en lo cierto en muchos de sus supuestos y predicciones. Como la más mínima cantidad de un carcinógeno que modifica el ADN puede provocar efectos mutágenos irreversibles y autorreplicantes, se estima que no existe un umbral. La promoción es el proceso en virtud del cual la célula iniciada se expande (clonalmente) mediante una serie de divisiones y produce lesiones (pre)neoplásicas. La cuestión de si durante esta fase de promoción las células iniciadas sufren otras alteraciones genéticas es objeto de intensa controversia.

Por último, en la fase de progresión esas células consiguen "inmortalizarse", y los tumores ya plenamente malignos pueden desarrollarse influyendo en la angiogénesis, evitando la reacción de los sistemas de control del huésped. Esta fase se caracteriza por un crecimiento invasivo y por la extensión del tumor, la mayoría de las veces en forma de metastásis. Durante la progresión se producen nuevas alteraciones genéticas debidas a la inestabilidad de las células en proliferación y de la selección.

Por consiguiente, hay tres mecanismos generales por los que una sustancia puede influir en el proceso multifásico de la carcinogenicidad. Una sustancia química puede inducir una determinada alteración genética, promover o facilitar la expansión clonal de una célula iniciada o estimular la progresión hacia la malignidad mediante cambios somáticos y/o genéticos.

\section{Proceso de evaluación del riesgo}

El riesgo puede definirse como la frecuencia predicha o efectiva de aparición de un efecto adverso en los humanos o el medio ambiente debido a una determinada exposición a un peligro. La evaluación del riesgo es un método de organizar sistemáticamente la información científica, incluidas sus incertidumbres, con miras a describir y calificar los riesgos para la salud que presentan sustancias, procesos, acciones o hechos peligrosos. Para ello es necesario evaluar la información pertinente y seleccionar los modelos que se van a emplear al extraer conclusiones de esa

Tabla 33.17 - Comparación de diversos procedimientos de extrapolación a dosis bajas.

\begin{tabular}{|c|c|c|c|c|c|c|}
\hline & EPA de EE.UU. (actual) & Dinamarca & CEE & Reino Unido & Países Bajos & Noruega \\
\hline $\begin{array}{l}\text { Carcinógenos } \\
\text { genotóxicos }\end{array}$ & $\begin{array}{l}\text { Procedimiento multifásico } \\
\text { lineal con el modelo de } \\
\text { dosis bajas más } \\
\text { apropiado }\end{array}$ & $\begin{array}{l}\text { MLE a partir de modelos } \\
\text { 1-hit y 2-hit más decisión } \\
\text { del mejor resultado }\end{array}$ & $\begin{array}{r}\text { No se especifica } \\
\text { procedimiento }\end{array}$ & $\begin{array}{l}\text { Sin modelo, expe- } \\
\text { riencia y juicio } \\
\text { científicos a partir } \\
\text { de todos los datos } \\
\text { disponibles }\end{array}$ & $\begin{array}{l}\text { Modelo lineal con } \mathrm{DT}_{50} \\
\text { (método Peto) } 0 \\
\text { "Método Holandés } \\
\text { Simple" si no hay } \\
\mathrm{DT}_{50}\end{array}$ & $\begin{array}{r}\text { No se especifica } \\
\text { procedimiento }\end{array}$ \\
\hline $\begin{array}{l}\text { Carcinógenos } \\
\text { no genotóxicos }\end{array}$ & Igual que arriba & $\begin{array}{l}\text { Modelo biológico de } \\
\text { Thorslund o modelo multi- } \\
\text { fásico o de Mantel-Bryan, } \\
\text { basado en el origen del } \\
\text { tumor y la relación dosis- } \\
\text { respuesta }\end{array}$ & $\begin{array}{c}\text { NOAEL y factores } \\
\text { de seguridad }\end{array}$ & $\begin{array}{l}\text { NOEL y factores de } \\
\text { seguridad para } \\
\text { establecer la } \\
\text { ingesta diaria } \\
\text { admisible (IDA) }\end{array}$ & $\begin{array}{l}\text { NOEL y factores de } \\
\text { seguridad para } \\
\text { establecer la IDA }\end{array}$ & \\
\hline
\end{tabular}


información. Es asimismo necesario reconocer explícitamente las incertidumbres y aceptar plenamente la posibilidad de que haya otras interpretaciones de los datos disponibles que sean científicamente plausibles. La terminología que se utiliza hoy en materia de evaluación del riesgo la propuso en 1984 la Academia Nacional de Ciencias de los Estados Unidos. Lo que antes era la evaluación cualitativa del riesgo se empezó a denominar caracterización/identificación de los peligros, y la evaluación cuantitativa se dividió en varios componentes: relación dosis-respuesta, evaluación de la exposición y caracterización del riesgo.

En la sección siguiente se analizarán brevemente estos componentes desde el punto de vista de los conocimientos actuales del proceso de la carcinogénesis (química). Se observará con claridad que la principal incertidumbre que persiste en la evaluación del riesgo de carcinogenicidad es la que plantea la relación dosis-respuesta a niveles de dosis bajos, que son los característicos de la exposición ambiental.

\section{Identificación de los peligros}

En este proceso se identifican los compuestos potencialmente carcinógenos para los humanos —en otras palabras, se identifican sus propiedades genotóxicas intrínsecas. La clasificación de los compuestos carcinógenos se efectúa combinando información procedente de distintas fuentes y relativa a distintas propiedades. En general se suele utilizar la información siguiente:

- Datos epidemiológicos (por ejemplo, sobre el cloruro de vinilo, el arsénico o el amianto).

- Datos sobre carcinogenicidad en animales.

- Actividad genotóxica/formación de aductos de ADN.

- Mecanismos de acción.

- Actividad farmacocinética.

- Relaciones estructura-actividad.

La clasificación de las sustancias químicas en grupos con arreglo a una evaluación de la calidad de la evidencia de carcinogénesis en animales o en el hombre, cuando se dispone de datos epidemiológicos, es un proceso clave de la identificación de los peligros. Los sistemas más conocidos para clasificar las sustancias químicas carcinógenas en categorías son los de la IARC (1987), la UE (1991) y la EPA (1986). En la Tabla 33.17 se resumen los criterios de clasificación que emplean estos organismos (por ejemplo, métodos de extrapolación a dosis bajas).

Una cuestión importante a la hora de clasificar los carcinógenos que tiene a veces consecuencias de gran alcance para su regulación es la distinción entre mecanismos de acción genotóxicos y no genotóxicos. En los Estados Unidos, la EPA parte por defecto de que, respecto de todas las sustancias que muestran actividad carcinógena en experimentos con animales, no existe umbral (o al menos no puede demostrarse la existencia de un umbral), de manera que en cualquier exposición hay algo de riesgo. Se suele decir así que los compuestos genotóxicos (los que dañan el ADN) son compuestos "sin umbral". La UE y muchos de sus miembros, como el Reino Unido, los Países Bajos y Dinamarca, establecen una distinción entre unos carcinógenos que son genotóxicos y otros de los que se piensa que producen tumores por mecanismos no genotóxicos. En el caso de los genotóxicos se utilizan procedimientos de estimación cuantitativa de la relación dosis-respuesta que parten de que no existe un umbral, aunque los procedimientos son a veces distintos de los que utiliza la EPA. En el caso de las sustancias no genotóxicas se estima que sí existe un umbral, y se parte de ese supuesto en los procedimientos que se utilizan para evaluar la relación dosis-respuesta. En este último caso, la evaluación del riesgo suele basarse en el empleo de un factor de seguridad, similar al que se aplica a las sustancias no carcinógenas.

Es importante tener en cuenta que estos sistemas distintos se desarrollaron para evaluar el riesgo en contextos y circunstancias diferentes. El sistema de la IARG no se creó con fines de regulación, aunque se ha utilizado como base para formular directrices en ese ámbito. La EPA pretendió que su sistema sirviera para determinar el momento en que se debía adoptar la decisión de realizar evaluaciones cuantitativas del riesgo, mientras que el sistema de la UE se utiliza actualmente para incluir un símbolo de peligro (clasificación) y unas determinadas advertencias sobre el riesgo en la etiqueta de la sustancia. Se analiza con más amplitud esta cuestión en un estudio reciente (Moolenaar 1994) sobre los procedimientos que utilizan ocho organismos gubernamentales y dos organizaciones independientes que se citan con frecuencia, la Agencia Internacional para la Investigación sobre el Cáncer (IARG) y la Conferencia Americana de Higienistas Industriales del Gobierno (ACGIH).

En general, los sistemas de clasificación no tienen en cuenta la amplia evidencia negativa de la que se suele disponer. Asimismo, en los últimos años se ha empezado a entender mucho mejor el mecanismo de acción de los carcinógenos. Se han ido acumulando datos que indican que algunos mecanismos de la carcinogenicidad son específicos de especies y no actúan en el hombre. Veamos algunos ejemplos de este importante fenómeno. En primer lugar, se ha demostrado recientemente, en estudios sobre la carcinogenicidad de las partículas diésel, que las ratas responden con tumores de pulmón a una fuerte carga de partículas en ese órgano. Sin embargo, no se observa cáncer de pulmón en mineros del carbón cuyos pulmones presentan cargas de partículas muy fuertes. En segundo lugar, se ha afirmado que los tumores renales en la rata macho no son significativos para el hombre, pues el elemento clave de esa respuesta "tumorgénica" es la acumulación en el riñón de $\alpha$ - 2 microglobulina, proteína que no existe en los humanos (Borghoff, Short y Swenberg 1990). También hay que mencionar a este respecto los trastornos de la función tiroidea en los roedores y la proliferación de peroxisomas o mitogénesis en el hígado del ratón.

Estos avances permiten interpretar con más precisión los resultados de un bioensayo de carcinogenicidad. Se están fomentando los estudios encaminados a conocer mejor los mecanismos de acción de la carcinogenicidad, pues es posible que gracias a ellos se pueda modificar el sistema de clasificación añadiéndole la categoría de sustancias no carcinógenas para los humanos.

\section{Evaluación de la exposición}

Suele pensarse que la evaluación de la exposición es el componente de la evaluación del riesgo que tiene menos incertidumbre intrínseca debido a que en algunos casos se pueden vigilar las exposiciones y a que se dispone de modelos relativamente bien validados. Pero ello es verdad sólo en parte, pues muchas de las evaluaciones de la exposición no se realizan aprovechando plenamente los distintos tipos de información disponibles. Por esa razón, sigue habiendo muchas posibilidades de mejorar las estimaciones de distribución de la exposición. Ello es así tanto en las evaluaciones de la exposición externa como en las de la exposición interna. Especialmente en el caso de los carcinógenos, el empleo de dosis en tejidos diana en vez de niveles de exposición externa para elaborar modelos sobre las relaciones dosis-respuesta permitiría realizar predicciones del riesgo más precisas, a pesar de que es necesario partir de muchos valores por defecto. Los modelos farmacocinéticos de base fisiológica para determinar la cantidad de metabolitos reactivos que llegan al tejido diana tienen potencialmente una gran utilidad para estimar esas dosis tisulares. 


\section{Garacterización del riesgo}

\section{Enfoques actuales}

El nivel de dosis o de exposición que provoca un efecto en un estudio con animales y la dosis probable que provoca un efecto similar en los humanos son un elemento clave de la caracterización del riesgo. Hay que evaluar la relación dosis-respuesta desde las dosis altas hasta las bajas y efectuar extrapolaciones entre especies. La extrapolación plantea un problema lógico, que es que los datos se extrapolan muchos órdenes de magnitud por debajo de los niveles de exposición experimentales, mediante modelos empíricos que no reflejan los mecanismos subyacentes de carcinogenicidad. Ello es contrario a un principio básico de la adaptación de modelos empíricos, que es no extrapolar fuera del intervalo de los datos observables. Por consiguiente, esa extrapolación empírica produce grandes incertidumbres, tanto desde el punto de vista estadístico como desde el biológico. No hay en la actualidad ningún procedimiento matemático que esté aceptado como el más idóneo para efectuar extrapolaciones a dosis bajas en materia de carcinogénesis. Los modelos matemáticos que se han utilizado para describir la relación entre la dosis externa administrada, el tiempo y la incidencia del tumor se basan en supuestos de distribución de la tolerancia o en supuestos mecanicistas, y a veces en ambas cosas a la vez. En la Tabla 33.18 figura un resumen de los modelos que se citan con más frecuencia (Kramer y cols. 1995).

Esos modelos de dosis-respuesta suelen aplicarse a datos sobre incidencia de tumores que corresponden a un número sólo limitado de dosis experimentales. Ello se debe al diseño normalizado del bioensayo que se utiliza. En vez de determinar la curva de dosis-respuesta completa, los estudios de carcinogenicidad suelen limitarse a tres (o dos) dosis relativamente altas, tomando como dosis más alta la dosis máxima tolerada (DMT). Esas dosis altas se utilizan para compensar el bajo nivel intrínseco de sensibilidad estadística de los bioensayos (del 10 al $15 \%$ con respecto a la base), debido a que, por razones prácticas y de otro tipo, se utiliza un número de animales relativamente reducido. Como no se dispone de datos para la región de dosis bajas (es decir, no pueden determinarse experimentalmente), es necesario extrapolar fuera del intervalo de observación. Respecto de casi todos los conjuntos de datos, la mayoría de los modelos antes enumerados se adapta igualmente bien al intervalo de dosis observado, debido al limitado número de dosis y animales. No obstante, en la región de dosis bajas esos modelos ofrecen divergencias de varios órdenes de magnitud, con lo que introducen grandes incertidumbres en el riesgo estimado para esos niveles de exposición bajos.

Como la forma real de la curva de dosis-respuesta en el intervalo de dosis bajas no puede generarse experimentalmente, para poder distinguir a este respecto entre los diversos modelos es esencial conocer los elementos mecanicistas del proceso de carcinogenicidad.

En numerosas revistas se discuten y se estudian con detalle los diversos aspectos de los diferentes modelos matemáticos de extrapolación Kramer y cols. (1995) y Park y Hawkins (1993).

\section{Otros enfoques}

Recientemente se han propuesto otros enfoques que se alejan de la práctica actual de elaboración de modelos matemáticos.

\section{Modelos de base biológica}

Los modelos de base biológica, como los de Moolgavkar-Venzon-Knudson (MVK), son hoy muy prometedores, pero por el momento no están lo suficientemente avanzados para utilizarlos
Tabla 33.18 • Modelos más citados de caracterización del riesgo de carcinogenicidad.

$\begin{array}{lll}\begin{array}{l}\text { Modelos de distribución } \\ \text { de la tolerancia }\end{array} & \text { Modelos mecanicistas } & \\ & \text { Modelos hit } & \text { Modelos biológicos } \\ \text { Logit } & \text { One-hit } & \text { Moolgavkar (MVK) } \\ \text { Probit } & \text { Multihit } & \text { Cohen y Ellwein } \\ \text { Mantel-Bryan } & \text { Weibull (Pike) } & \\ \text { Weibull } & \text { Multifásico (Armitage-Doll) } & \\ \text { Gamma Multihit } & \text { Multifásico lineal } & \end{array}$

Modelos basados en el tiempo hasta el tumor.

de manera habitual y exigen mucha más información específica de la que proporcionan actualmente los bioensayos. Estudios amplios (4.000 ratas) como los realizados sobre las $\mathrm{N}$-nitrosoalquilaminas indican el tamaño del estudio que se precisa para la recogida de tales datos, aunque pese a ello sigue sin ser posible extrapolar a dosis bajas. Mientras no se desarrollen más estos modelos sólo pueden utilizarse para estimaciones caso por caso.

\section{Enfoque basado en el factor de evaluación}

$\mathrm{El}$ empleo de modelos matemáticos para realizar extrapolaciones por debajo del intervalo de dosis experimental equivale en la práctica al sistema que se basa en la utilización de un factor de seguridad, con un factor de incertidumbre amplio y mal definido. La alternativa más sencilla sería aplicar el factor de evaluación al "nivel sin efecto" aparente o al "nivel mínimo ensayado". El nivel que se utiliza para ese factor de evaluación debe determinarse caso por caso teniendo en cuenta la naturaleza de la sustancia química y la población expuesta.

\section{Dosis fija (BMD)}

Este enfoque se basa en un modelo matemático adaptado a los datos experimentales incluidos en el intervalo observable para estimar o interpolar una dosis correspondiente a un nivel de efecto definido, como un incremento del 1, el 5 o el $10 \%$ en la incidencia de tumores $\left(\mathrm{DE}_{01}, \mathrm{DE}_{05}, \mathrm{DE}_{10}\right)$. Como un incremento del $10 \%$ es más o menos el cambio mínimo que puede determinarse estadísticamente en un bioensayo normalizado, la DE10 es apropiada para datos sobre el cáncer. Utilizando una dosis fija (BMD, "benchmark dose") situada dentro del intervalo observable del experimento se evitan los problemas que plantea la extrapolación de dosis. Las estimaciones de la BMD o de su límite de confianza inferior reflejan las dosis a las que se modifica la incidencia de tumores, pero son bastante insensibles al modelo matemático que se utilice. Este tipo de dosis puede utilizarse en la evaluación del riesgo como una medida de la potencia del tumor y, combinada con factores de valoración apropiados, para establecer niveles aceptables de la exposición humana.

\section{Umbral de regulación}

Krewski y cols. (1990) han estudiado el concepto de un "umbral de regulación" en el caso de los carcinógenos químicos. A partir de información contenida en la base de datos sobre la potencia de los carcinógenos (CPDB) respecto de 585 experimentos, la dosis correspondiente a un riesgo de 10-6 presentaba una distribución logarítmica más o menos normal en torno a una mediana de 70 a $90 \mathrm{ng} / \mathrm{kg} / \mathrm{d}$. Las exposiciones a niveles de dosis superiores a ese intervalo se considerarían inaceptables. La dosis se estimó mediante extrapolación lineal a partir de la $\mathrm{DT}_{50}$ (la dosis que induce toxicidad en el $50 \%$ de los animales del ensayo) y 
estaba dentro de un factor de cinco a diez de la cifra obtenida con el modelo multifásico lineal. Por desgracia, los valores de $\mathrm{DT}_{50}$ estarán relacionados con la DMT, lo que una vez más arroja dudas sobre la validez de la medición. No obstante, la $\mathrm{DT}_{50}$ estará muchas veces dentro del intervalo de los datos experimentales o muy cerca de él.

Este enfoque basado en el empleo de un umbral de regulación exigirá, antes de plantearse su utilización, que se examinen mucho más a fondo cuestiones biológicas, analíticas y matemáticas, y que se disponga de una base de datos mucho más amplia. Nuevas investigaciones sobre las potencias de diversos carcinógenos pueden arrojar más luz sobre este ámbito.

\section{Objetivos y futuro de la evaluación del riesgo de carcinógenos}

Si echamos la vista atrás a las expectativas originales de la regulación de los carcinógenos (ambientales), que eran conseguir una importante reducción del cáncer, podríamos decir que los resultados son al día de hoy decepcionantes. Con el paso de los años se fue comprobando que el número de casos de cáncer que se consideraban debidos a carcinógenos que podían ser objeto de regulación era desconcertantemente reducido. En relación con las grandes expectativas que impulsaron las actividades de regulación en el decenio de 1970, no se ha conseguido el objetivo previsto de reducir de manera importante la tasa de mortalidad por cáncer en cuanto a los efectos estimados de los carcinógenos ambientales, ni siquiera utilizando procedimientos de evaluación cuantitativa sumamente conservadores. La característica principal de los procedimientos de la EPA es que las extrapolaciones a dosis bajas se efectúan de la misma manera para todas las sustancias químicas, con independencia del mecanismo de formación de tumores que se observe en los estudios experimentales. Hay que señalar, no obstante, que este enfoque contrasta radicalmente con los adoptados por otros organismos gubernamentales. Como ya se ha indicado, la UE y varios gobiernos europeos - Alemania, Dinamarca, Francia, Italia, Países Bajos, Reino Unido, Suecia, Suiza- distinguen entre carcinógenos genotóxicos y no genotóxicos, y enfocan la estimación del riesgo de una manera distinta en una y otra categoría. En general, los carcinógenos no genotóxicos se tratan como tóxicos con umbral. No se determinan niveles de efecto, y se utilizan factores de incertidumbre para establecer un amplio margen de seguridad. Determinar si una sustancia química debe considerarse o no genotóxica es una cuestión propia de los debates científicos y exige el juicio atinado de los expertos.

La cuestión fundamental es la siguiente: ¿qué es lo que causa el cáncer en los humanos, y qué papel desempeñan a ese respecto los carcinógenos ambientales? Los aspectos hereditarios del cáncer en los humanos son mucho más importantes de lo que antes se preveía. La clave para conseguir avances significativos en la evaluación del riesgo de carcinogenicidad es conocer mejor las causas y mecanismos del cáncer. Los estudios sobre el cáncer están entrando en unos terrenos de extraordinario interés. La investigación molecular puede modificar radicalmente la forma en que entendemos la influencia de los carcinógenos ambientales y los enfoques del control y la prevención del cáncer, tanto en el medio ambiente general como en el lugar de trabajo. La evaluación del riesgo de carcinogenicidad ha de basarse en una comprensión de los mecanismos de acción que no estamos más que empezando a adquirir. Uno de los aspectos importantes es el del mecanismo del cáncer heredable y la interacción de los carcinógenos con ese proceso. Esos conocimientos tendrán que incorporarse a la metodología sistemática y coherente que ya existe para la evaluación del riesgo de carcinogenicidad.

\section{Referencias}

Agencia Internacional para la Investigación sobre el Cáncer (IARG). 1992. Solar and ultraviolet radiation. Lyon: IARC.

1993. Occupational Exposures of Hairdressers and Barbers and Personal Use of Hair Colourants: Some Hair Dyes, Cosmetic Colourants, Industrial Dyestuffs and Aromatic Amines. Lyon: IARC.

- 1994a. Preamble. Lyon: IARC.

- 1994b. Some Industrial Chemicals. Lyon: IARC.

Andersen, KE, HI Maibach. 1985. Contact allergy predictive tests on guinea pigs. Capítulo 14 en Current Problems in Dermatology. Basilea: Karger.

Ashby, J, RW Tennant. 1991. Definitive relationships among chemical structure, carcinogenicity and mutagenicity for 301 chemicals tested by the US NTP. Mutat Res 257:229-306.

Barlow, S, F Sullivan. 1982. Reproductive Hazards of Industrial Chemicals. Londres: Academic Press.

Barrett, JC. 1993a. Mechanisms of action of known human carcinogens. En Mechanisms of Carcinogenesi. in Risk Identification, dirigido por $\mathrm{H}$ Vainio, $\mathrm{PN}$ Magee, DB McGregor y AJ McMichael. Lyon: Agencia Internacional para la Investigación sobre el Cáncer (IARC).

1993b. Mechanisms of multistep carcinogenesis and carcinogen risk assessment. Environ Health Persp 100:9-20

Bernstein, ME. 1984. Agents affecting the male reproductive system: Effects of structure on activity. Drug Metab Rev 15:941-996.

Beutler, E. 1992. The molecular biology of G6PD variants and other red cell defects. Anпи Rev Med 43:47-59.
Bloom, AD, 1981. Guidelines for Reproductive Studies in Exposed Human Populations. White Plains, Nueva York: March of Dimes Foundation.

Borghoff, S, B Short, J Swenberg. 1990. Biochemical mechanisms and pathobiology of $\alpha$-2-globulin nephropathy. Annu Rev Pharmacol Toxicol 30:349.

Burchell, B, DW Nebert, DR Nelson, KW Bock, T Iyanagi, PLM Jansen, D Lancet, GJ Mulder, JR Chowdhury, G Siest, TR Tephly, PI Mackenzie. 1991. The UPD-glucuronosyltransferase gene superfamily: Suggested nomenclature based on evolutionary divergence. DNA Cell Biol 10:487-494.

Burleson, G, A Munson, J Dean. 1995. Modern Methods in Immunotoxicology. Nueva York: Wiley.

Capecchi, M. 1994. Targeted gene replacement. Sci Am 270:52-59.

Carney, EW. 1994. An integrated perspective on the developmental toxicity of ethylene glycol. Rep Toxicol 8:99-113.

Comisión Internacional de Protección Radiológica (ICRP). 1965. Principles of Environmental Monitoring Related to the Handling of Radioactive Materials. Report of Committee IV of The International Commission On Radiological Protection. Oxford: Pergamon.

Dean, JH, MI Luster, AE Munson, I Kimber. 1994. Immunotoxicology and Immunopharmacology. Nueva York: Raven Press.

Descotes, J. 1986. Immunotoxicology of Drugs and Chemicals. Amsterdam: Elsevier.

Devary, Y, G Rosette, JA DiDonato, M Karin. 1993. NFkB activation by ultraviolet light not dependent on a nuclear signal. Science 261:1442-1445.

Dixon, RL. 1985. Reproductive Toxicology. Nueva York: Raven Press.
Duffus, JH. 1993. Glossary for chemists of terms used in toxicology. Pure Appl Chem 65:2003-2122.

Elsenhans, B, K Schuemann, W Forth. 1991. Toxic metals: Interactions with essential metals. En Nutrition, Toxicity and Cancer, dirigido por IR Rowland. Boca Ratón: CRC Press.

Environmental Protection Agency (EPA). 1992. Guidelines for exposure assessment. Federal Reg 57:22888-22938.

- 1993. Principles of neurotoxicity risk assessment. Federal Reg 58:41556-41598.

1994. Guidelines for Reproductive Toxicity Assessment. Washington, DC: US EPA: Office of Research and Development.

Fergusson, JE. 1990. The Heavy Elements. Chap. 15 in Chemistry, Environmental Impact and Health Effects. Oxford: Pergamon.

Gehring, PJ, PG Watanabe, GE Blau. 1976. Pharmacokinetic studies in evaluation of the toxicological and environmental hazard of chemicals. New Concepts Saf Eval 1(Parte 1, Capítulo 8):195-270.

Goldstein, JA, SMF de Morais. 1994. Biochemistry and molecular biology of the human CrP2C subfamily. Pharmacogenetics 4:285-299.

Gonzalez, FJ. 1992. Human cytochromes P450: Problems and prospects. Trends Pharmacol Sci 13:346-352.

Gonzalez, FJ, CL Crespi, HV Gelboin. 1991. cDNA-expressed human cytochrome P450: A new age in molecular toxicology and human risk assessment. Mutat Res 247:113-127.

Gonzalez, FJ, DW Nebert. 1990. Evolution of the P450 gene superfamily: Animal-plant "warfare," 
molecular drive, and human genetic differences in drug oxidation. Trends Genet 6:182-186.

Grant, DM. 1993. Molecular genetics of the N-acetyltransferases. Pharmacogenetics 3:45-50.

Gray, LE, J Ostby, R Sigmon, J Ferrel, R Linder, R Cooper, J Goldman, J Laskey. 1988. The development of a protocol to assess reproductive effects of toxicants in the rat. Rep Toxicol 2:281-287.

Guengerich, FP. 1989. Polymorphism of cytochrome P450 in humans. Trends Pharmacol Sci 10:107-109.

1993. Cytochrome P450 enzymes. Am Sci 81:440-447.

Hansch, C, A Leo. 1979. Substituent Constants for Correlation Analysis in Chemistry and Biology. Nueva York: Wiley.

Hansch, G, L Zhang. 1993. Quantitative structure-activity relationships of cytochrome P450. Drug Metab Rev 25:1-48.

Hayes AW. 1988. Principles and Methods of Toxicology. $2^{\text {a }}$ ed. Nueva York: Raven Press.

Heindell, JJ, RE Chapin. 1993. Methods in Toxicology: Male and Female Reproductive Toxicology. Vol. 1 y 2 San Diego, California: Academic Press.

Johanson, G, PH Naslund. 1988. Spreadsheet programming - a new approach in physiologically based modeling of solvent toxicokinetics. Toxicol Letters 41:115-127.

Johnson, BL. 1978. Prevention of Neurotoxic Illness in Working Populations. Nueva York: Wiley.

Jones, JC, JM Ward, U Mohr, RD Hunt. 1990. Hemopoietic System, ILSI Monograph, Berlín: Springer Verlag.

Kalow, W. 1962. Pharmocogenetics: Heredity and the Response to Drugs. Filadelfia: WB Saunders.

1992. Pharmocogenetics of Drug Metabolism. Nueva York: Pergamon.

Kammüller, ME, N Bloksma, W Seinen. 1989 Autoimmunity and Toxicology. Immune Dysregulation Induced By Drugs and Chemicals. Amsterdam: Elsevier Sciences.

Kawajiri, K, J Watanabe, SI Hayashi. 1994. Genetic polymorphism of P450 and human cancer. En Cytochrome P450: Biochemistry, Biophysics and Molecular Biology, dirigido por MC Lechner. París: John Libbey Eurotext.

Kehrer, JP. 1993. Free radicals as mediators of tissue injury and disease. Crit Rev Toxicol 23:21-48.

Kellerman, G, GR Shaw, M Luyten-Kellerman. 1973. Aryl hydrocarbon hydroxylase inducibility and bronochogenic carcinoma. New Engl $f \mathrm{Med}$ 289:934-937.

Khera, KS. 1991. Chemically induced alterations maternal homeostasis and histology of conceptus: Their etiologic significance in rat fetal anomalies. Teratology 44:259-297.

Kimmel, CA, GL Kimmel, V Frankos. 1986. Interagency Regulatory Liaison Group workshop on reproductive toxicity risk assessment. Environ Health Persp 66:193-221.

Klaassen, CD, MO Amdur, J Doull (dirs.). 1991. Casarett and Doullś Toxicology. Nueva York: Pergamon Press.

Kramer, HJ, EJ HM Jansen, MJ Zeilmaker, HJ van Kranen, ED Kroese. 1995. Quantitative methods in toxicology for human dose-response assessment. RIVM-report nr. 659101004.

Kress, S, C Sutter, PT Strickland, H Mukhtar, J Schweizer, M Schwarz. 1992. Carcinogen-specific mutational pattern in the p53 gene in ultraviolet $\mathrm{B}$ radiation-induced squamous cell carcinomas of mouse skin. Cancer Res 52:6400-6403.

Krewski, D, D Gaylor, M Szyazkowicz. 1991. A model-free approach to low-dose extrapolation. Env H Pers 90:270-285.
Lawton, MP, T Cresteil, AA Elfarra, E Hodgson, J Ozols, RM Philpot, AE Rettie, DE Williams, JR Cashman, CT Dolphin, RN Hines, T Kimura, IR Phillips, LL Poulsen, EA Shephare, DM Ziegler. 1994. A nomenclature for the mammalian flavin-containing monooxygenase gene family based on amino acid sequence identities. Arch Biochem Biophys 308:254-257.

Lewalter, J, U Korallus. 1985. Blood protein conjugates and acetylation of aromatic amines. New findings on biological monitoring. Int Arch Occup Environ Health 56:179-196.

Majno, G, I Joris. 1995. Apoptosis, oncosis, and necrosis: An overview of cell death. Am 7 Pathol 146:3-15

Mattison, DR, PJ Thomford. 1989. The mechanism of action of reproductive toxicants. Toxicol Pathol 17:364-376.

Meyer, UA. 1994. Polymorphisms of cytochrome P450 CYP2D6 as a risk factor in carcinogenesis. En Cytochrome P450: Biochemistry, Biophysics and Molecular Biology, dirigido por MC Lechner. París: John Libbey Eurotext.

Moller, H, H Vainio, E Heseltine. 1994. Quantitative estimation and prediction of risk at the International Agency for Research on Cancer. Cancer Res 54:3625-3627.

Moolenaar, RJ. 1994. Default assumptions in carcinogen risk assessment used by regulatory agencies. Regul Toxicol Pharmacol 20:135-141.

Moser, VC. 1990. Screening approaches to neurotoxicity: A functional observational battery. 7 Am Coll Toxicol 1:85-93.

National Research Council (NRC). 1983. Risk Assessment in the Federal Government: Managing the Process. Washington, DC: NAS Press.

1989. Biological Markers in Reproductive Toxicity. Washington, DC: NAS Press.

1992. Biologic Markers in Immunotoxicology. Subcommittee on Toxicology. Washington, DC: NAS Press.

Nebert, DW. 1988. Genes encoding drug-metabolizing enzymes: Possible role in human disease. En Phenotypic Variation in Populations, dirigido por AD Woodhead, MA Bender y RC Leonard. Nueva York: Plenum Publishing.

1994. Drug-metabolizing enzymes in ligand-modulated transcription. Biochem Pharmacol 47:25-37.

Nebert, DW, WW Weber. 1990. Pharmacogenetics. En Principles of Drug Action. The Basis of Pharmacology, dirigido por WB Pratt y PW Taylor. Nueva York: Churchill-Livingstone.

Nebert, DW, DR Nelson. 1991. P450 gene nomenclature based on evolution. En Methods of Enzymology. Cytochrome P450, dirigido por MR Waterman y EF Johnson. Orlando, Florida: Academic Press.

Nebert, DW, RA McKinnon. 1994. Cytochrome P450: Evolution and functional diversity. Prog Liv Dis 12:63-97.

Nebert, DW, M Adesnik, MJ Coon, RW Estabrook, FJ Gonzalez, FP Guengerich, IC Gunsalus, EF Johnson, B Kemper, W Levin, IR Phillips, R Sato, MR Waterman. 1987. The P450 gene superfamily: Recommended nomenclature. DNA Cell Biol 6:1-11.

Nebert, DW, DR Nelson, MJ Coon, RW Estabrook, R Feyereisen, Y Fujii-Kuriyama, FJ Gonzalez, FP Guengerich, IC Gunsalas, EF Johnson, JC Loper, R Sato, MR Waterman, DJ Waxman. 1991. The P450 superfamily: Update on new sequences, gene mapping, and recommended nomenclature. DNA Cell Biol 10:1-14.

Nebert, DW, DD Petersen, A Puga. 1991. Human $\mathrm{AH}$ locus polymorphism and cancer: Inducibility of CYP1Al and other genes by combustion products and dioxin. Pharmacogenetics 1:68-78.

Nebert, DW, A Puga, V Vasiliou. 1993. Role of the $\mathrm{Ah}$ receptor and the dioxin-inducible $[\mathrm{Ah}]$ gene battery in toxicity, cancer, and signal transduction. Ann NT Acad Sci 685:624-640.

Nelson, DR, T Kamataki, DJ Waxman, FP Guengerich, RW Estabrook, R Feyereisen, FJ Gonzalez, MJ Coon, IC Gunsalus, O Gotoh, DW Nebert, K Okuda. 1993. The P450 superfamily: Update on new sequences, gene mapping, accession numbers, early trivial names of enzymes, and nomenclature. DNA Cell Biol 12:1-51.

Nicholson, DW, A All, NA Thornberry, JP Vaillancourt, CK Ding, M Gallant, Y Gareau, PR Griffin, M Labelle, YA Lazebnik, NA Munday, SM Raju, ME Smulson, TT Yamin, VL Yu, DK Miller. 1995. Identification and inhibition of the ICE/CED-3 protease necessary for mammalian apoptosis. Nature 376:37-43.

Nolan, RJ, WT Stott, PG Watanabe. 1995. Toxicologic data in chemical safety evaluation. Capítulo 2 en Patty's Industrial Hygiene and Toxicology, dirigido por LJ Cralley, LV Cralley y JS Bus. Nueva York: John Wiley \& Sons.

Nordberg, GF. 1976. Effect and Dose-Response Relationships of Toxic Metals. Amsterdam: Elsevier.

Office of Technology Assessment (OTA). 1985. Reproductive Hazards in the Workplace. Documento núm. OTA-BA-266. Washington, DC: Government Printing Office.

- 1990. Neurotoxicity: Identifying and Controlling Poisons of the Nervous System. Documento núm. OTA-BA-436. Washington, DC: Government Printing Office.

Organización de Cooperación y Desarrollo Económico (OCDE). 1993. US EPA/EC Foint Project On the Evaluation of (Quantitative) Structure Activity Relationships. París: OCDE.

Organización Mundial de la Salud (OMS). 1980. Recommended Health-Based Limits in Occupational Exposure to Heavy Metals. Technical Report Series, No. 647. Ginebra: OMS.

1986. Principles and Methods for the Assessment of Neurotoxicity Associated With Exposure to Chemicals. Environmental Health Criteria, No.60. Ginebra: OMS.

1987. Air Ouality Guidelines for Europe. European Series, No. 23. Copenhague: Publicaciones Regionales de la OMS

1989. Glossary of Terms On Chemical Safety for Use in IPCS Publications. Ginebra: OMS.

1993. The Derivation of Guidance Values for Health-Based Exposure Limits. Environmental Health Criteria, borrador no publicado. Ginebra: OMS.

Park, CN, NC Hawkins. 1993. Technology review; an overview of cancer risk assessment. Toxicol Methods 3:63-86.

Pease, W, J Vandenberg, WK Hooper. 1991. Comparing alternative approaches to establishing regulatory levels for reproductive toxicants: DBCP as a case study. Environ Health Persp 91:141-155.

Programa Internacional de Seguridad Química (IPCS). 1991. Principles and Methods for the Assessment of Nephrotoxicity Associated With Exposure to Chemicals, EHC 119. Ginebra: OMS

1996. Principles and Methods for Assessing Direct Immunotoxicity Associated With Exposure to Chemicals, EHC 180. Ginebra: OMS

Prpić-Majić, D, S Telišman, S Kezić. 1984. In vitro study on lead and alcohol interaction and the inhibition of erythrocyte delta-aminolevulinic acid dehydratase in man. Scand $\mathcal{f}$ Work Environ Health 10:235-238.

Reitz, RH, RJ Nolan, AM Schumann. 1987. Development of multispecies, multiroute pharmacokinetic models for methylene chloride 
and 1,1,1-trichloroethane. In Pharmacokinetics and Risk Assessment, Drinking Water and Health Washington, DC: National Academy Press.

Roitt, I, J Brostoff, D Male. 1989. Immunology. Londres: Gower Medical Publishing.

Sato, A. 1991. The effect of environmental factors on the pharmacokinetic behaviour of organic solvent vapours. Ann Occup Hyg 35:525-541.

Silbergeld, EK. 1990. Developing formal risk assessment methods for neurotoxicants: An evaluation of the state of the art. En Advances in Neurobehavioral Toxicology, dirigido por BL Johnson, WK Anger, A Durao y C Xintaras. Chelsea, Michigan: Lewis.

Spencer, PS, HH Schaumberg. 1980. Experimental and Clinical Neurotoxicology. Baltimore: Williams \& Wilkins.

Sweeney, AM, MR Meyer, JH Aarons, JL Mills, RE LePorte. 1988. Evaluation of methods for the prospective identification of early fetal losses in environmental epidemiology studies. $A m \quad \mathcal{J}$ Epidemiol 127:843-850.

Taylor, BA, HJ Heiniger, H Meier. 1973. Genetic analysis of resistance to cadmium-induced testicular damage in mice. Proc Soc Exp Biol Med 143:629-633.

Telišman, S. 1995. Interactions of essential and/or toxic metals and metalloids regarding interindividual differences in susceptibility to various toxicants and chronic diseases in man. Arh rig rada toksikol 46:459-476.

Telišman, S, A Pinent, D Prpić-Majić. 1993. Lead interference in zinc metabolism and the lead and zinc interaction in humans as a possible explanation of apparent individual susceptibility to lead. En Heavy Metals in the Environment, dirigido por RJ Allan y JO Nriagu. Edimburgo: CEP Consultants.

Telišman, S, D Prpić-Majić, S Kezić. 1984. In vivo study on lead and alcohol interaction and the inhibition of erythrocyte delta-aminolevulinic acid dehydratase in man. Scand $\mathcal{F}$ Work Environ Health 10:239-244.

Tilson, HA, PA Cabe, 1978. Strategies for the assessment of neurobehavioral consequences of environmental factors. Environ Health Persp 26:287-299.

Trump, BF, AU Arstila. 1971. Cell injury and cell death. En Principles of Pathobiology, dirigido por MF LaVia y RB Hill Jr. Nueva York: Oxford Univ. Press.

Trump, BF, IK Berezesky. 1992. The role of cytosolic $\mathrm{Ca} 2+$ in cell injury, necrosis and apoptosis. Cur Opin Cell Biol 4:227-232.

- 1995. Calcium-mediated cell injury and cell death. FASEB 7 9:219-228.

Trump, BF, IK Berezesky, A Osornio-Vargas. 1981 Cell death and the disease process. The role of cell calcium. En Cell Death in Biology and Pathology, dirigido por ID Bowen y RA Lockshin. Londres: Chapman \& Hall.

Vos, JG, M Younes, E Smith. 1995. Allergic Hyper-sensitivities Induced by Chemicals: Recommendation for Prevention Published on Behalf of the World Health Organization Regional Office for Europe. Boca Ratón, Florida: CRC Press.

Weber, WW. 1987. The Acetylator Genes and Drug Response. Nueva York: Oxford Univ. Press.

Wyllie, AH, JFR Kerr, AR Currie. 1980. Cell death: The significance of apoptosis. Int Rev Cytol 68:251-306

\section{Otras lecturas recomendadas}

Albert, RE. 1994. Carcinogen risk assessment in the US Environmental Protection Agency. Crit. Rev. Toxicol 24:75-85.
Alberts, B, D Bray, J Lewis, M Raff, K Roberts, JD Watson. 1988. Molecular Biology of the Cell. Nueva York: Garland Publishing.

Ariens, EJ. 1964. Molecular Pharmacology. Vol.1. Nueva York: Academic Press.

Ariens, EJ, E Mutschler, AM Simonis. 1978. Allgemeine Toxicologie [General Toxicology]. Stuttgart: Georg Thieme Verlag.

Ashby, J, RW Tennant. 1994. Prediction of rodent carcinogenicity for 44 chemicals: Results. Mutagenesis 9:7-15.

Ashford, NA, CJ Spadafor, DB Hattis, CG Caldart. 1990. Monitoring the Worker for Exposure and Disease. Baltimore: Johns Hopkins Univ. Press.

Balabuha, NS, GE Fradkin. 1958. Nakoplenie radioaktivnih elementov o organizme $I$ ih vivedenie [Acumulación de elementos radiactivos en el organismo y su excreción7. Moscú: Medgiz.

Balls, M, J Bridges, J Southee. 1991. Animals and Alternatives in Toxicology Present Status and Future Prospects. Nottingham, Reino Unido: The Fund for Replacement of Animals in Medical Experiments.

Berlin, A, J Dean, MH Draper, EMB Smith, F Spreafico. 1987. Immunotoxicology. Dordrecht: Martinus Nijhoff.

Boyhous, A. 1974. Breathing. Nueva York: Grune \& Stratton.

Brandau, R, BH Lippold. 1982. Dermal and Transdermal Absorption. Stuttgart: Wissenschaftliche Verlagsgesellschaft.

Brusick, DJ. 1994. Methods for Genetic Risk Assessment. Boca Raton: Lewis Publishers.

Burrell, R. 1993. Human immune toxicity. Mol Aspects Med 14:1-81.

Castell, JV, MJ Gómez-Lechón. 1992. In Vitro Alternatives to Animal Pharmaco-Toxicology. Madrid, España: Farmaindustria.

Chapman, G. 1967. Body Fluids and their Functions. Londres: Edward Arnold.

Committee on Biological Markers of the National Research Council. 1987. Biological markers in environmental health research. Environ Health Persp $74: 3-9$

Congreso de los Estados Unidos. 1990. Genetic Monitoring and Screening in the Workplace, OTA-BA-455. Washington, DC: US Government Printing Office.

Cralley, LJ, LV Cralley, JS Bus (dirs.). 1978. Patty's Industrial Hygiene and Toxicology. Nueva York: Witey.

Dayan, AD, RF Hertel, E Heseltine, G Kazantis, EM Smith, MT Van der Venne. 1990. Immunotoxicity of Metals and Immunotoxicology. Nueva York: Plenum Press.

Djuric, D. 1987. Molecular-cellular Aspects of Occupational Exposure to Toxic Chemicals. En Part 1 Toxicokinetics. Ginebra: OMS

Duffus, JH. 1980. Environmental Toxicology. Londres: Edward Arnold.

ECOTOC. 1986. Structure-Activity Relationship in Toxicology and Ecotoxicology, Monograph No. 8. Bruselas: ECOTOC.

Forth, W, D Henschler, W Rummel. 1983. Pharmakologie und Toxikologie. Mannheim: Bibliographische Institut

Frazier, JM. 1990. Scientific criteria for Validation of in VitroToxicity Tests. OECD Environmental Monograph, no. 36. París: OCDE.

1992. In Vitro Toxicity-Applications to Safety Evaluation. Nueva York: Marcel Dekker.

Gad, SC. 1994. In Vitro Toxicology. Nueva York: Raven Press.

Gadaskina, ID. 1970. Zhiroraya tkan I yadi [Tejidos grasos y productos tóxicos]. In Aktualnie Vaprosi promishlenoi toksikolgii Problemas actuales en la toxicología del trabajo], dirigido por NV Lazarev. Leningrado: Ministerio de Sanidad RSFSR.

Gaylor, DW. 1983. The use of safety factors for controlling risk. $f$ Toxicol Environ Health 11:329-336.

Gibson, GG, R Hubbard, DV Parke, 1983. Immunotoxicology. Londres: Academic Press.

Goldberg, AM. 1983-1995. Alternatives in Toxicology. Vol. 1-12. Nueva York: Mary Ann Liebert.

Grandjean, P. 1992. Individual susceptibility to toxicity. Toxicol Letters 64/65:43-51.

Hanke, J, JK Piotrowski. 1984. Biochemyczne podstawy toksikologii [Bases bioquímicas de la toxicología]. Varsovia: PZWL

Hatch, T, P Gross. 1954. Pulmonary Deposition and Retention of Inhaled Aerosols. Nueva York: Academic Press.

Consejo de Salud de los Países Bajos. Comité para la Evaluación de la Carcinogenicidad de las Sustancias Químicas. 1994. Risk assessment of carcinogenic chemicals in The Netherlands. Regul Toxicol Pharmacol 19:14-30.

Holland, WC, RL Klein, AH Briggs. 1967. Molekulaere Pharmakologie.

Huff, JE. 1993. Chemicals and cancer in humans: First evidence in experimental animals. Environ Health Persp 100:201-210.

Klaassen, CD, DL Eaton. 1991. Principles of toxicology. Capítulo 2 en Casarett and Doull's Toxicology, dirigido por CD Klaassen, MO Amdur y J Doull. Nueva York: Pergamon Press.

Kossover, EM. 1962. Molecular Biochemistry. Nueva York: McGraw-Hill.

Kundiev, YI. 1975.Vssavanie pesticidov cherez kozsu I profilaktika otravlenii [Absorción de pesticidas a través de la piel y prevención de intoxicaciones?. Kiev: Zdorovia.

Kustov, VV, LA Tiunov, JA Vasiljev. 1975. Komvinovanie deistvie promishlenih yadov [Efectos combinados de los productos tóxicos industriales]. Moscú: Medicina

Lauwerys, R. 1982. Toxicologie industrielle et intoxications professionelles. París: Masson.

Li, AP, RH Heflich. 1991. Genetic Toxicology. Boca Ratón: CRC Press.

Loewey, AG, P Siekewitz. 1969. Cell Structure and Functions. Nueva York: Holt, Reinhart and Winston.

Loomis, TA. 1976. Essentials of Toxicology. Filadelfia: Lea \& Febiger

Mendelsohn, ML, RJ Albertini. 1990. Mutation and the Environment, Parts A-E. Nueva York: Wiley Liss.

Mettzler, DE. 1977. Biochemistry. Nueva York: Academic Press.

Miller, K, JL Turk, S Nicklin. 1992. Principles and Practice of Immunotoxicology. Oxford: Blackwells Scientific

Ministerio de Comercio Internacional e Industria. 1981. Handbook of Existing Chemical Substances. Tokio: Chemical Daily Press.

- 1987. Application for Approval of Chemicals by Chemical Substances Control Law. (En japonés y en inglés). Tokio: Kagaku Kogyo Nippo Press.

Montagna, W. 1956. The Structure and Function of Skin. Nueva York: Academic Press.

Moolenaar, RJ. 1994. Carcinogen risk assessment: international comparison. Regul Toxicol Pharmacol 20:302-336.

National Research Council. 1989. Biological Markers in Reproductive Toxicity. Washington, DC: NAS Press.

Neuman, WG, M Neuman. 1958. The Chemical Dynamic of Bone Minerals. Chicago: The Univ. of Chicago Press.

Newcombe, DS, NR Rose, JC Bloom. 1992. Clinical Immunotoxicology. Nueva York: Raven Press. 
Organización Mundial de la Salud (OMS). 1975. Methods Used in USSR for Establishing Safe Levels of Toxic Substances. Ginebra: OMS.

Pacheco, H. 1973. La pharmacologie moleculaire. París: Presse Universitaire.

Piotrowski, 7K. 1971. The Application of Metabolic and Excretory Kinetics to Problems of Industrial Toxicology. Washington, DC: US Department of Health, Education and Welfare.

- 1983. Biochemical interactions of heavy metals Methalothionein. En Health Effects of Combined Exposure to Chemicals. Copenhague: Oficina Regional de la OMS para Europa.

Proceedings of the Arnold O. Beckman/IFCC Conference of Environmental Toxicology Biomarkers of Chemical Exposure. 1994. Clin Chem 40(7B)

Russell, WMS, RL Burch. 1959. The Principles of Humane Experimental Technique. Londres: Methuen \&
Co. Reprinted by Universities Federation for Animal Welfare, 1993.

Rycroft, RJG, T Menné, PJ Frosch, C Benezra. 1992. Textbook of Contact Dermatitis. Berlín: Springer-Verlag.

Schubert, J. 1951. Estimating radioelements in exposed individuals. Nucleonics 8:13-28.

Shelby, MD, E Zeiger. 1990. Activity of human carcinogens in the Salmonella and rodent bone-marrow cytogenetics tests. Mutat Res 234:257-261.

Stone, R. 1995. A molecular approach to cancer risk. Science 268:356-357.

Teisinger, J. 1984. Expositiontest in der Industrietoxikologie [Pruebas de exposición en la toxicología industrial]. Berlín: VEB Verlag Volk und Gesundheit.

VEB. 1981. Kleine Enzyklopaedie: Leben [Vida]. Leipzig: VEB Bibliographische Institut.
Weil, E. 1975. Elements de toxicologie industrielle [Elementos de la toxicología industrial]. París: Masson et Cie.

1978. Principles and Methods for Evaluating the Toxicity of Chemicals, Part 1. Environmental Health Criteria, No.6. Ginebra: OMS.

- 1981. Combined Exposure to Chemicals, Interim Document no.11. Copenhague: Oficina Regional de la OMS para Europa.

1986. Principles of Toxicokinetic Studies. Environmental Health Criteria, no. 57. Ginebra: OMS.

Yoftrey, JM, FC Courtice. 1956. Limphatics, Lymph and Lymphoid Tissue. Cambridge: Harvard Univ. Press.

Zakutinskiy, DI. 1959. Voprosi toksikologii radioaktionih veshchesto Problemas de toxicología de los materiales radiactivos]. Moscú: Medgiz.

Zurlo, J, D Rudacille, AM Goldberg. 1993. Animals and Alternatives in Testing: History, Science and Ethics. Nueva York: Mary Ann Liebert. 

ENCICLOPEDIA DE SALUD Y SEGURIDAD EN EL TRABAJO 



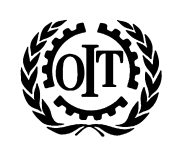

\title{
ENCICLOPEDIA DE SALUD Y SEGURIDAD EN EL TRABAJO
}

\author{
Directora de la publicación \\ Jeanne Mager Stellman, PhD \\ Subdirector general de la publicación \\ Michael McCann, PhD, ClH \\ Subdirectores dela publicación \\ Leon Warshaw, MD Carole Brabant, PhD \\ Redactores principales \\ John Finklea, MD, Dr PH Jacqueline Messite, MD \\ Georges H. Coppée, MD Steven L. Sauter, PhD \\ Vilma R. H unt, BDS, AM Jerry Spiegel, MA, MSC \\ Richard S. Kraus, PE, CSP Colin L. Soskolne, PhD \\ Wolfgang Laurig, Dr-Ing Benedetto Terracini, MD \\ Melvin L. Myers, BS, MPA \\ Gestión editorial \\ Chantal Dufresne, BA
}

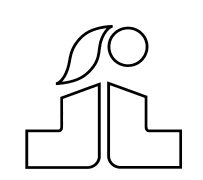


La edición original de esta obra ha sido publicada por la O ficina Internacional del Trabajo (G inebra) bajo el título "Encyclopaedia of 0 ccupational $\mathrm{H}$ ealth and Safety, fourth edition". Esta edición española se publica con la autorización de la O IT y bajo las condiciones del Acuerdo firmado entre la O ficina Internacional del Trabajo y el M inisterio de Trabajo y A suntos Sociales de España en materia de publicaciones.

Copyright (C) de la edición inglesa, O rganización Internacional del Trabajo, 1998

Copyright @ de la edición española, M inisterio de Trabajo y A suntos Sociales, 1998

Las denominaciones empleadas, en concordancia con la práctica seguida en $\mathrm{N}$ aciones $\mathrm{U}$ nidas, y la forma en que aparecen presentados los datos en las publicaciones de la O IT no implican juicio alguno por parte de la O ficina Internacional del Trabajo sobre la condición jurídica de ninguno de los países, zonas o territorios citados o de sus autoridades, ni respecto de la delimitación de sus fronteras.

La responsabilidad de las opiniones expresadas en los artículos, estudios y otras colaboraciones firmadas incumbe exclusivamente a sus autores y su publicación no significa que la O IT las sancione.

El lector asume que las partes facilitan la presente documentación sin garantía de ningún tipo. Las partes no se hacen responsables de la validez ni de la integridad de ninguno de los datos, incluidos errores, inexactitudes u omisiones, ni de las posibles consecuencias que implique la utilización de dichos datos. $\mathrm{Ni}$ los autores ni la OIT, ni las instituciones colaboradoras son responsables de los daños ni de cualquier otra reclamación o demanda que se deriven de la utilización de estos datos.

Las referencias a firmas, procesos o productos comerciales no implica aprobación alguna por la 0 ficina Internacional del Trabajo, y el hecho de que no se mencionen firmas, procesos o productos comerciales no implica desaprobación alguna.

La presente edición es la versión española de la cuarta edición inglesa, revisada y enriquecida con las aportaciones ofrecidas y destinadas a la misma por la O IT y con las peculiaridades y conceptos incorporados al cuerpo de la enciclopedia por especialistas, con objeto de hacer su utilización más asequible en los países de habla hispana. En la traducción, coordinación y financiación de la presente edición han colaborado:

- M inisterio de Sanidad y Consumo

- Instituto Nacional de la Salud

- Instituto Nacional de M edicina y Seguridad en el Trabajo

- M inisterio de Trabajo y Asuntos Sociales

- Instituto Nacional de Seguridad eH igiene en el Trabajo

- Agencia E spañola de Cooperación Internacional

- O ficina Internacional del Trabajo

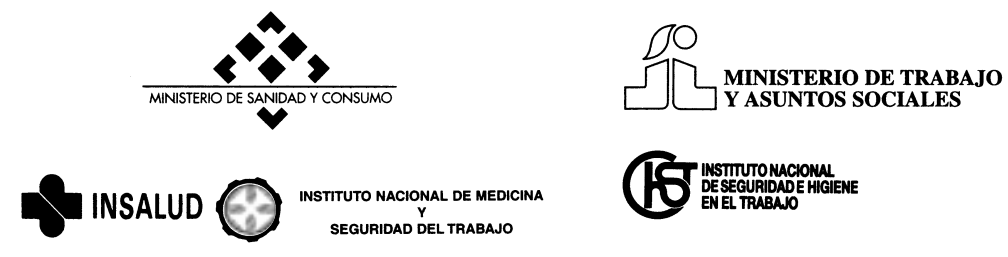

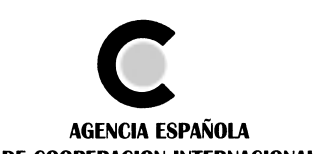

DE COOPERACION INTERNACIONAL

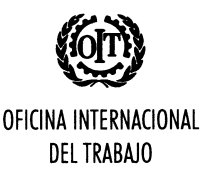

DEL TRABANO

Los editores agradecen la colaboración y confianza demostradas por la A sociación de M utuas de Accidentes de Trabajo en la elaboración de esta obra.

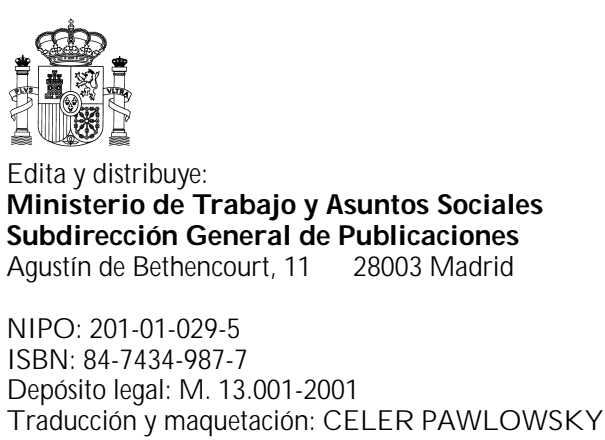




\section{AUTORES Y DIRECTORES}

Ursula Ackermann-Liebrich, MD, MSc

Profesora

D epartamento de M edicina Social y Preventiva

U niversidad de Basilea

Basilea

Suiza

Elena Adán Liébana, Chem Eng

T écnico en seguridad y salud en el trabajo

Centro $\mathrm{N}$ acional de Condiciones de Trabajo

Instituto Nacional de Seguridad e

$\mathrm{H}$ igiene en el Trabajo

Barcelona

España

\section{Alfred A. Amendola, PhD}

R esearch A ssociate P rofessor, A ssociate D irector

Safety Engineering Program

T exas A\&M U niversity

College Station, T exas

Estados U nidos

Yngve Anderberg, MD, PhD

Fire Safety D esign AB

Lund

Suecia

Ragnar Andersson, PhD, M Eng

D irector de programa de lesiones

D epartamento de Ciencias de la

Salud Pública

Instituto K arolinska

Sundbyberg

Suecia

\section{Diego Andreoni, Dr Ing}

Antiguo D irector general

Ente N azionale Prevenzione Infortuni

R oma

Italia

\section{Jean Arteau, Ing, PhD, MSc}

R esearcher

Safety and Engineering

Institute for $O$ ccupational Safety and

$\mathrm{H}$ ealth R esearch

M ontreal, Q uebec

Canadá

\section{Tomas Backström, PhD}

Investigador

Instituto Nacional de la V ida L aboral

Solna

Suecia
Gabriele Bammer, PhD

$\mathrm{N}$ ational Centre for Epidemiology and Population $\mathrm{H}$ ealth

Australian National U niversity

Canberra

Australia

Tamas Banky, Dr

D irección de D epartamento C ientífico de

P rotección contra el F uego

Instituto de Control de Calidad e

Innovación en la Construcción

Budapest

H ungría

\section{Julian Barling, PhD}

Professor of Organizational B ehavior

School of Business

$Q$ ueen's U niversity

$\mathrm{K}$ ingston, $\mathrm{O}$ ntario

Canadá

\section{Rosalind C. Barnett, PhD}

Senior Scholar in Residence

M urray R esearch C enter

W omen's Studies Program

Brandeis U niversity

W altham, M assachusetts

E stados U nidos

Peter J. Baxter, MD, MSc

Institute of Public $\mathrm{H}$ ealth

U niversity of $\mathrm{C}$ ambridge

Cambridge

Estados U nidos

\section{François Béland, PhD}

Professor

G roupe de $R$ echerche Interdisciplinaire en Santé

U niversity of $\mathrm{M}$ ontreal

M ontreal, Q uebec

Canadá

\section{Ron Bell, BSc}

$\mathrm{H}$ ead

Electrical and Control Systems U nit

$\mathrm{H}$ ealth and Safety Executive

Bootle, M erseyside

Estados U nidos

David Bennett, PhD, MA

National D irector

W orkplace H ealth, Safety and

Environment

Canadian Labour Congress

O ttawa, O ntario

Canadá
Alan J. Benson, MSc, MB, ChB, FRACS

Consultant

R oyal Air Force School of A viation M edicine

Farnborough, $\mathrm{H}$ ants

Reino U nido

María José Berenguer, M Chem

Directora

Laboratorio de E spectometría de M asas

Centro $\mathrm{N}$ acional de $\mathrm{C}$ ondiciones de Trabajo

Instituto Nacional de Seguridad e $\mathrm{H}$ igiene en el T rabajo

Barcelona

España

Mats Berg, MD

Departamento de D ermatología

H ospital K arolinska

Estocolmo

Suecia

Kenneth I. Berger, MD

Instructor of M edicine

Division of Pulmonary and $\mathrm{Critical} C$ are M edicine

New Y ork U niversity

Nueva Y ork, Nueva Y ork

Estados U nidos

\section{Ulf Bergqvist, Dr med sci, MSc \\ Techn}

Investigador

Departamento de M edicina del T rabajo Instituto Nacional del T rabajo

Solna

Suecia

Pier Alberto Bertazzi, MD, MPH

Profesor asociado

Instituto de M edicina del Trabajo

U niversidad de M ilán

M ilán

Italia

\section{Diane Berthelette, PhD}

Associate P rofessor

Department of Administrative Sciences

U niversity of Q uebec-M ontreal

M ontreal, Q uebec

Canadá

Ronald Bisset, MA, MSc

Scott Wilson R esource Consultants

Edimburgo, Escocia

R eino U nido 
Jacques H.M. Bittel, MD, DERBH

Jefe

D epartamento de Factores $\mathrm{H}$ umanos

Centro de Investigación de Servicio de Salud del Ejército Emile Pardé

La T ronche

Francia

\section{Massimo Bovenzi, MD}

F ísico, Profesor contratado de

higiene industrial

Instituto de M edicina del T rabajo

U niversidad de T rieste

Trieste

Italia

\section{Carole Brabant, PhD}

Subdirectora de publicación

E nciclopedia de Salud y Seguridad en el T rabajo

O ficina Internacional del T rabajo

Ginebra

Suiza

John Brazendale, BSc, MSc

Principal Specialist I nspector

$\mathrm{H}$ ealth and Safety Executive

Bootle, M erseyside

R eino U nido

\section{Cecilia Brighi}

D epartamento de Política Internacional

CIOSL Confederación Internacional de $O$ rganizaciones Sindicales L ibres

Roma

Italia

\section{Robert Bringer, PhD}

Staff V ice-P resident (R etired)

Environmental T echnology and Services 3M

St. Paul, M innesota

Estados U nidos

\section{Peter Bruckmann, PhD}

efe de división

Control Ambiental

L andesumweltamt, N ordrhein-W estfalen

Essen

Alemania

\section{Françoise Burhenne-Guilmin,} Dr Law

D irectora

Centro de la L ey del M edio A mbiente

U nión Internacional para la

Conservación de la $\mathrm{N}$ aturaleza

Bonn

Alemania
Ronald J. Burke, PhD

Professor

Faculty of Administrative Studies

Y ork U niversity

$\mathrm{N}$ orth Y ork, $\mathrm{O}$ ntario

Canadá

\section{Ahmet Çakir, Dr-Ing, F ErgS}

Presidente científico

Instituto Ergonómico de las

Ciencias del T rabajo y Sociales

Berlín

Alemania

Donald M. Campbell, FFPHM

Consultant in Public $\mathrm{H}$ ealth $\mathrm{M}$ edicine

Scottish Centre for Infection and

Environmental $\mathrm{H}$ ealth

Glasgow

R eino U nido

\section{Robert D. Caplan, PhD}

P rofessor of P sychology, Psychiatry and $B$ ehavioral Science

D epartment of Psychology

G eorge W ashington U niversity

W ashington, DC

Estados U nidos

\section{Pascale Carayon, PhD}

P rofesor visitante

E cole des $M$ ines de Nancy

Nancy

Francia

Associate P rofessor

D epartment of Industrial Engineering

U niversity of W isconsin

$M$ adison, Wisconsin

Estados U nidos

\section{Sue Cartwright, PhD}

Senior R esearch Fellow

$M$ anchester School of $M$ anagement

$U$ niversity of $M$ anchester

$M$ anchester

Estados U nidos

\section{Emilio Castejón Vilella, Ing Ind}

Director

Centro $\mathrm{N}$ acional de $\mathrm{C}$ ondiciones de Trabajo

Instituto $\mathrm{N}$ acional de Seguridad e $\mathrm{H}$ igiene en el Trabajo

Barcelona

España

Weiping Chen, MD, MSc

$H$ ealth R isk Assessment Specialist

$\mathrm{H}$ ealth Strategies and R esearch Division

Alberta $\mathrm{H}$ ealth

Edmonton, Alberta

Canadá
V. I. Chernyuk, MD, ScD

Profesor, D irector científico

Instituto de la Salud en el T rabajo

$\mathrm{K}$ iev

U crania

Robert N. Cherry Jr., PhD, MS

Colond and Director of A rmy R adiation Safety

HQDA (DACS-SF)

U.S. Army

Washington, DC

Estados U nidos

\section{Eric Chivian, MD}

D irector

C enter for $\mathrm{H}$ ealth and the $\mathrm{G}$ lobal

Environment

$\mathrm{H}$ arvard M edical School

Boston, $M$ assachusetts

Estados U nidos

Renzo Comini

R esponsable

DSG U nita' Centrale Sicurezza E d I giene del Lavoro

ENEL SpA

Roma

Italia

Cary L. Cooper, PhD, MBA, MSc

Professor of $O$ rganizational Psychology

Institute of Science and T echnology

$U$ niversity of $M$ anchester

$M$ anchester

R eino U nido

\section{Georges H. Coppée, MD}

J efe de sección médica

$R$ ama de Seguridad y Salud en

$$
\text { el Trabajo }
$$

O ficina Internacional del T rabajo

G inebra

Suiza

D. Wayne Corneil, SCD

D irector

O perations Eastern R egion

$\mathrm{H}$ ealth Canadá

O ttawa, O ntario

Canadá

\section{Robert Coyle}

Principal E nvironmental Specialist

European Bank for R econstruction and Development

Londres

R eino U nido 


\section{Derrick Crump, PhD}

Section $\mathrm{H}$ ead, Indoor Air Q uality

$M$ aterials $\mathrm{G}$ roup

Building R esearch Establishment

W atford

R eino U nido

\section{Göran Dahlström, MD}

J efe médico, D irector

Centro del Frío

$\mathrm{K}$ iruna

Suecia

J.C. Davies, PhD, MSc

Principal Programmer/ A nalyst

Computing Services D epartment

U niversity of Liverpool

Liverpool

R eino U nido

\section{Nicole Dedobbeleer, ScD}

Associate Professor of R esearch

D epartment of Social and Preventive M edicine

U niversity of M ontreal

M ontreal

Canadá

\section{Edouard I. Denisov, Cand tech}

sci

Investigador

Instituto de Salud en el Trabajo R AM S

M oscú

Federación Rusa

\section{S.K. Dheri}

I efe de bomberos

Servicio C entral de Bomberos

Nueva Delhi

India

\section{Leonard A. Dobrovolsky, MD, PhD, D Sci}

J efe

D epartamento de Información

Científica y M édica

Instituto de Salud Ambiental

$\mathrm{K}$ iev

U crania

Alexander E. Donagi, D Sc, MPH
Profesor
Facultad de M edicina
Universidad de T el Aviv
D irector
Centro de Información
Instituto de Seguridad e H igiene
$\quad$ en el T rabajo
T el Aviv
Israel

Marianne Döös, BSc

Investigadora

Instituto Nacional del T rabajo

Solna

Suecia

\section{Dennis P. Driscoll, PE, MSc}

President

Associates in A coustics Inc

Evergreen, Colorado

Estados U nidos

\section{Dougal Drysdale, BSc, PhD}

R eader in Fire and Safety E ngineering

Department of Civil and Environmental Engineering

U niversity of Edinburgh

Edimburgo, Escocia

R eino U nido

\section{Walter Dümmer, MPh}

A sesor técnico

A sociación de Seguridad Chilena

Santiago

Chile

\section{William W. Eaton, PhD, MS}

Professor

Department of $\mathrm{M}$ ental $\mathrm{H}$ ygiene

School of $\mathrm{H}$ ygiene and Public $\mathrm{H}$ ealth J ohns H opkins U niversity

Baltimore, $M$ aryland

Estados U nidos

\section{John Elias, MPH}

Senior $O$ ccupational $\mathrm{H}$ ygienist

O ccupational and Environmental

M edicine

$\mathrm{H}$ ealth Sciences C enter

Winnipeg, $M$ anitoba

Canadá

\section{Zuheir Ibrahim Fakhri, MBBS,}

\section{DIH, MSc OM, MD}

Consultor de salud ambienta

M inisterio de Salud

Riad

Arabia Saudí

\section{Anne-Marie Feyer, PhD}

Director

N ueva Zelanda 0 ccupational and Environmental $\mathrm{H}$ ealth R esearch C entre Dunedin

Nueva Zelanda

\section{John Finklea, MD, Dr PH}

$M$ edical 0 fficer

Center to Protect Workers' R ights

F ormer D irector

National Institute for $O$ ccupational Safety and $\mathrm{H}$ ealth

Washington, DC

Estados U nidos

\section{Brian Flannigan, PhD}

Department of Biological Sciences

H eriot-Watt U niversity

Edimburgo, Escocia

R eino U nido

\section{Dominique Folliot, MD}

Subjefa de departamento

Service Général de M édecine du T ravai París

Francia

\section{Richard Forster}

Lighting C onsultant

Crowthorne, Berkshire

R eino U nido

Bernard H. Fox, PhD

P rofessor of Psychiatry

School of M edicine

Boston U niversity

Boston, M assachusetts

Estados U nidos

T.J.R. Francis, MSc, PhD, MFOM $N$ aval M edical R esearch L aboratory

Naval Submarine Base

Groton, C onnecticut

Estados U nidos

\section{Marianne Frankenhaeuser, PhD, MA}

Profesora emérita de psicología

U niversidad de Estocolmo

Estocolmo

Suecia

\section{David Freestone, LLB, LLM}

L egal Adviser, Environment

E nvironmental and International Law Unit

L egal D epartment

W orld Bank

Washington, DC

Estados U nidos

\section{Jean G. French, Dr PH}

A djunct P rofessor

D epartment of E pidemiology

School of Public H ealth

U niversity of $\mathrm{N}$ orth $\mathrm{C}$ arolina

Chapel $\mathrm{H}$ ill, Carolina del $\mathrm{N}$ orte

Estados U nidos

\section{Daniel Ganster, PhD}

Professor, Chair

D epartment of $M$ anagement

U niversity of Arkansas

Fayetteville, Arkansas

Estados U nidos 


\section{Kenneth Gerecke}

Assistant R egional Administrator

$O$ ccupational Safety and $\mathrm{H}$ ealth

Administration

US D epartment of Labor

Filadelfia, Pensilvania

Estados U nidos

\section{Adrian Gheorghe, PhD, MSc}

Profesor de gestión industrial

Universidad Politécnica

Bucarest, Rumanía

D irector de investigación

Instituto Federal Suizo de T ecnología

Zurich

Suiza

\section{Berenice I. Ferrari Goelzer, CIH, MPH}

H igienista industrial

O ficina de Salud Ambiental

O rganización M undial de la Salud

Ginebra

Suiza

Des Gorman, MD, PhD

$H$ ead of $O$ ccupational M edicine

School of M edicine

U niversity of Auckland

Auckland

Nueva Zelanda

\section{Marilyn K. Gowing, PhD}

Director

Personnel R esources and D evelopment Center

Estados U nidos 0 ffice of Personnel

$M$ anagement

Washington, DC

Estados Unidos

Per-Ola Granberg, MD, PhD

Antiguo profesor de cirugía endocrina

$\mathrm{H}$ ospital K arolinska

Estocolmo

Suecia

\section{Martino Grandolfo, PhD}

Director

D epartamento de Física

Instituto Superiore di Sanità

R oma

Italia

\section{Casey C. Grant, PE}

Assistant Vice President

Codes and Standards Administration

National Fire Protection Association

International

Q uincy, M assachusetts

Estados U nidos
Michael J. Griffin, PhD

P rofessor of $H$ uman $F$ actors

Institute of Sound and V ibration R esearch

U niversity of Southampton

Southampton

R eino U nido

\section{Jop Groeneweg, PhD}

Investigador

Centro de Investigación de la Seguridad

U niversidad de Leiden

L eiden

Países Bajos

\section{Carsten Grønberg, MSc}

T écnico en investigación

L aboratorio Nacional RIS $\varnothing$

R oskilde

Dinamarca

\section{Xavier Guardino Solá, PhD}

I efe de departamento

Centro Nacional de Condiciones de Trabajo

Instituto $\mathrm{N}$ acional de Seguridad e $H$ igiene en el Trabajo

Barcelona

España

\section{Juan Guasch Farrás}

J efe de la Sección de C ondiciones de trabajo

Centro Nacional de $\mathrm{C}$ ondiciones de Trabajo

Instituto N acional de Seguridad e $\mathrm{H}$ igiene en el Trabajo

Barcelona

España

Tee L. Guidotti, MD, MPH

Professor, D irector

$\mathrm{O}$ ccupational $\mathrm{H}$ ealth Program

Faculty of M edicine

U niversity of A lberta

Edmonton, Alberta

Canadá

\section{K.C. Gupta, BE}

Director general

C onsejo de Seguridad Nacional Bombay

India

\section{Niels Jorn Hahn, MSc}

D irector gerente

Grupo de Trabajo para la R educción de R esiduos y el R eciclaje

ISWA

Copenhague

Dinamarca
Kari K. Häkkinen, PhD

D irección de desarrollo

D epartamento de Indemnización de los T rabajadores

Industrial Insurance Ltd.

$\mathrm{H}$ elsinki

Finlandia

\section{Andrew R. Hale, PhD}

P rofesor de ciencia de la seguridad

G rupo de Ciencia de la Seguridad

U niversidad de T ecnología de $D$ elft

D elft

Países Bajos

\section{L.D. Hamilton, MD, PhD}

Professor

Biomedical and Environmental Assessment $\mathrm{G}$ roup

Brookhaven $\mathrm{N}$ ational L aboratory

U pton, Nueva Y ork

Estados U nidos

Kjell Hansson Mild, PhD

Investigador

Instituto $\mathrm{N}$ acional del Trabajo

U meå

Suecia

Richard Helmer, PhD, MA

I efe

Salud Ambiental U rbana

O rganización M undial de la Salud

G inebra

Suiza

Visiting P rofessor

$U$ niversity of Surrey

G uildford

R eino U nido

\section{Ana Hernández Calleja}

T écnico en seguridad y salud en el trabajo

$\mathrm{C}$ entro $\mathrm{N}$ acional de $\mathrm{C}$ ondiciones de T rabajo

Instituto N acional de Seguridad e $\mathrm{H}$ igiene en el T rabajo

Barcelona

España

\section{I vanildo Hespanhol}

Saneamiento y Suministro de A gua a Comunidades

O rganización M undial de la Salud G inebra

Suiza

Raymond Hétu, PhD (fallecido)

Former Director

A coustic Group

M edical Faculty

$\mathrm{U}$ niversity of $\mathrm{M}$ ontreal

M ontreal, Q uebec

Canadá 
Manh Trung Ho, Ingciv

Antiguo subdirector

A plicaciones de Prevención

Instituto N acional de Seguridad

e Investigación

París

Francia

\section{Dietrich Hoffmann, PhD, MS}

Associate D irector

$\mathrm{N}$ aylor $\mathrm{D}$ ana Institute for $\mathrm{D}$ isease Prevention

A merican $\mathrm{H}$ ealth $\mathrm{F}$ oundation

V alhalla, Nueva Y ork

Estados U nidos

\section{Ingvar Holmér, PhD}

Profesor

D epartamento de Ergonomía

Instituto $\mathrm{N}$ acional de Trabajo

Solna

Suecia

\section{Vilma Hunt, BDS, AM}

Adjunct Professor

D epartment of Work Environment

$U$ niversity of $M$ assachusetts-L owell

L owell, M assachusetts

Estados U nidos

Joseph J. Hurrell, Jr., PhD

Senior R esearch E pidemiologist

$\mathrm{H}$ azard Evaluation and T echnical

Assistance Branch

$\mathrm{N}$ ational Institute for $\mathrm{O}$ ccupational

Safety and $\mathrm{H}$ ealth

Cincinnati, $\mathrm{O}$ hio

Estados U nidos

\section{Claire Infante-Rivard, MD, PhD, MPH}

Professor

D epartment of O ccupational $\mathrm{H}$ ealth

Faculty of M edicine

M cG ill U niversity

$M$ ontreal, Q uebec

Canadá

John M. Ivancevich, DBA

$H$ ugh $R$ oy and L illie Cranz Cullen Chair,

Professor of O rganizational B ehavior and

$M$ anagement

C ollege of Business Administration

$\mathrm{U}$ niversity of $\mathrm{H}$ ouston

$\mathrm{H}$ ouston, $\mathrm{T}$ exas

Estados U nidos

\section{David Jenkins, PhD, MA}

Adjunct P rofessor of P sychiatry and Preventive

$M$ edicine and $\mathrm{C}$ ommunity $\mathrm{H}$ ealth

U niversity of $\mathrm{N}$ orth Carolina

Chapel $\mathrm{H}$ ill, Carolina del Norte

Estados U nidos
Steve M. Jex, PhD

Associate P rofessor

Department of Psychology

U niversity of W isconsin-O shkosh

O shkosh, W isconsin

Estados U nidos

\section{Jeffrey V. Johnson, PhD}

Associate P rofessor of Social Science, M edicine and $\mathrm{O}$ ccupational $\mathrm{H}$ ealth

Johns $\mathrm{H}$ opkins School of $\mathrm{H}$ ygiene and Public Health

Baltimore, $M$ aryland

Estados U nidos

\section{Peter F. Johnson, MSc, Dipl Ed}

$M$ anager

Arup Fire Engineering

M elbourne, Victoria

Australia

\section{B. Juminer, PhD*}

Facultad de M edicina

$M$ eshed

R epública I slámica de I rán

Kirsten Jørgensen, PhD, MSc

J efe de departamento

O ficina de Documentación y Análisis

Servicio $D$ anés de M edio A mbiente en el Trabajo

Copenhague

Dinamarca

Friedrich Karl Käferstein,

\section{Dr med vet}

D irector

Programa de Seguridad y Ayuda Alimentarias

O rganización M undial de la Salud

Ginebra

Suiza

\section{Robert Karasek, PhD}

P rofessor of W ork E nvironment

U niversity of $M$ assachusetts-L owell

L owell, M assachusetts

Estados U nidos

Waldemar Karwowski, PhD

D irector, P rofessor of I ndustrial E ngineering

Center for Industrial Ergonomics

University of L ouisville

L ouisville, K entucky

Estados U nidos

Gwendolyn Puryear Keita, PhD

Associate E xecutive D irector

Public Interest Directorate

Director of Women's Programs

American Psychological Association

Washington, DC

Estados Unidos

\section{W. Larry Kenney, PhD}

Professor of Physiology and Kinesiology

Laboratory of $\mathrm{H}$ uman Performance

R esearch

Pennsylvania State U niversity

U niversity Park, Pensilvania

Estados U nidos

Eric P. Kindwall, MD

Associate P rofessor, D irector of $\mathrm{H}$ yperbaric $M$ edicine

$M$ edical C ollege of W isconsin

M ilwaukee, Wisconsin

Estados U nidos

\section{Urban Kjellén, PhD}

P rofesor de gestión de seguridad

D epartamento de E conomía Industrial y G estión de la T ecnología

U niversidad de Ciencia y

T ecnología de $\mathrm{N}$ oruega

Trondheim

N oruega

\section{Tord Kjellström, MD}

Dirección

O ficina de Salud A mbiental

M undial e Integrada

O rganización M undial de la Salud

Ginebra

Suiza

\section{Peter Knauth, Dr-Ing}

Profesor, I efe

D epartamento de Ergonomía

Instituto de Producción Industrial

Universidad de $\mathrm{K}$ arlsruhe

Karlsruhe

Alemania

\section{Bengt Knave, MD, PhD}

J efe del Secretariado y del Comité Internacionales Instituto $\mathrm{N}$ acional del Trabajo

Solna

Suecia

\section{Larry R. Kohler, PhD}

I mportancia del M edio A mbiente y e D esarrollo Sostenible

D epartamento de Condiciones y

M edio A mbiente de Trabajo

$O$ ficina Internacional del T rabajo

Ginebra

Suiza

Richard S. Kraus, PE, CSP

Principal

Petroleum Safety Consultants

Annandale, V irginia

Estados U nidos

\footnotetext{
${ }^{*}$ Colaborador de la 3a edición de esta Enciclopedia. La información biográfica no se ha actualizado.
} 
Yuri Kundiev, MD, Dr med sci Director

Instituto de Salud en el T rabajo

$\mathrm{K}$ iev

U crania

\section{Poul Lauridsen, MSc}

A sesor técnico

G rupo de T rabajo para la R educción de $R$ esiduos y el R eciclaje

ISWA

Copenhague

Dinamarca

\section{Wolfgang Laurig, Dr-Ing}

Profesor, D irector

Departamento de Ergonomía Institut für Arbeitsphysiologie

U niversidad de D ortmund

Alemania

\section{Tom B. Leamon, PhD, MSc}

Vice President

Liberty M utual Insurance G roup

$D$ irector

Liberty M utual R esearch C enter for

Safety and $\mathrm{H}$ ealth

$H$ opkinton, $M$ assachusetts

Estados U nidos

\section{Mark R. Lehto, PhD}

Associate P rofessor

School of Industrial Engineering

Purdue U niversity

West L afayette, Indiana

Estados U nidos

\section{Lennart Levi, MD, PhD}

P rofesor emérito, Antiguo director

Departamento de Investigación del Estrés

Instituto $\mathrm{K}$ arolinska

Estocolmo

Suecia

\section{Sture Lidén, MD, PhD}

\section{Profesor}

D epartamento de D ermatología

Instituto $\mathrm{K}$ arolinska

$\mathrm{H}$ ospital K arolinska

Estocolmo

Suecia

\section{Soo-Yee Lim, PhD}

National Research Council Associate

Applied Psychology and Ergonomics Branch

National Institute for $O$ ccupational Safety and $\mathrm{H}$ ealth

Cincinnati, O hio

Estados U nidos
Kari Lindström, PhD

Profesor de investigación

D epartamento de Psicología

Instituto Finlandés de M edicina del Trabajo

H elsinki

Finlandia

\section{Anthony Linehan, BA, FIOSH}

F ormer D irector of F ield 0 perations

H.M. Chief Inspector of Factories

$\mathrm{H}$ ealth and Safety Executive

D orset

R eino U nido

\section{Herbert I. Linn, MS}

Chief of Information $M$ anagement and D issemination Activity

Division of Safety R esearch

$\mathrm{N}$ ational Institute for $\mathrm{O}$ ccupational Safety and $\mathrm{H}$ ealth

M organtown, $V$ irginia $O$ ccidental

Estados U nidos

\section{Gordon M. Lodde, BS}

$\mathrm{H}$ ealth Physics C onsultant

M ount Joy, Pensilvania

Estados U nidos

\section{Wouter A. Lotens, PhD}

Je

D epartamento de M edio Ambiente de Trabajo

Instituto T NO de Investigación de Factores $\mathrm{H}$ umanos

Soesterberg

Países Bajos

Jacques B. Malchaire, PhD, MSc

Profesor de salud en el trabajo

U nidad de H igiene y Psicología del Trabajo

U niversidad C atólica de L ovaina

Bruselas

Bélgica

\section{Albert Marty, HTL Mech Eng \\ T écnico en seguridad para certificación de productos \\ O rganización $\mathrm{N}$ acional Suiza de Seguro de Accidentes

$$
\text { Lucerna }
$$ \\ Suiza}

\section{Christina Maslach, PhD \\ Professor \\ D epartment of Psychology \\ U niversity of C alifornia-Berkeley \\ Berkeley, California}

Estados Unidos

\section{R. Matthes, Dip-Ing}

I efe NIR D osimetría, Secretario científico

Institut für Strahlenhygiene

0 berschleissheim

Alemania

\section{Lucien Y. Maystre, MSc, Dip-Ing}

Dirección

Institut de G énie de l'E nvironnement

E cole Polytechnique Fédérale de L ausana

Lausana

Suiza

\section{Michael McCann, PhD}

Senior A ssociate E ditor

E ncyclopaedia of $O$ ccupational $H$ ealth and Safety International Labour O ffice

N ueva Y ork, Nueva Y ork

Estados U nidos

\section{Neil McManus, MSc, M Eng}

Consulting I ndustrial $\mathrm{H}$ ygienist

$\mathrm{N}$ orthW est $\mathrm{O}$ ccupational $\mathrm{H}$ ealth and Safety

N orth V ancouver, Columbia Británica Canadá

\section{Karlheinz Meffert, Dr-Ing}

D irector

Berufsgenossenschaftliches I nstitut für Arbeitssicherheit

$\mathrm{H}$ auptverband der gewerblichen Berufsgenossenschaften

Sankt Augustin

Alemania

\section{Claude Menguy, Dip Ing}

$D$ irector de departamento

$M$ ateriales y E strés A mbiental

L aboratorio C entral de Industrias

Electrónicas

Fontenay aux R oses

Francia

\section{Jacqueline Messite, MD}

Clinical Professor

D epartment of Environmental M edicine $\mathrm{N}$ ueva $\mathrm{Y}$ ork U niversity College

of M edicine

N ueva Y ork, Nueva Y ork

Estados U nidos

\section{Jean-Jacques Meyer, PhD}

Profesor de ergonomía, I efe de laboratorio Laboratorio de Ergonomía de la V isión Instituto de C iencias de la M edicina del Trabajo

Lausana

Suiza 
James M. Miller, PE, PhD

Professor

Industrial and O perations Engineering

University of $\mathrm{M}$ ichigan

Ann Arbor, M ichigan

Estados U nidos

\section{Timothy H. Monk, PhD \\ Professor of P sychiatry \\ W estern Psychiatric Institute and Clinic \\ U niversity of Pittsburgh \\ Pittsburgh, Pensilvania \\ Estados U nidos}

Michel Monteau

J efe de accidentol ogía

Instituto $\mathrm{N}$ acional de Investigación y Seguridad

$\checkmark$ andoeuvre

Francia

\section{Carles Muntaner, MD, PhD}

Assistant P rofessor

Institute of $\mathrm{O}$ ccupational and

Environmental $\mathrm{H}$ ealth/ Prevention

R esearch Center

W est $V$ irginia U niversity

M organtown, $\mathrm{V}$ irginia $\mathrm{O}$ ccidental

Estados U nidos

\section{Lawrence R. Murphy, PhD}

Research Psychologist

A pplied Psychology and Ergonomics Branch

$\mathrm{N}$ ational Institute for $\mathrm{O}$ ccupational Safety and $\mathrm{H}$ ealth

Cincinnati, $O$ hio

Estados U nidos

\section{Melvin L. Myers, BS, MPA}

$D$ eputy D irector

$O$ ffice of Extramural Coordination and Special Projects

$\mathrm{N}$ ational Institute for $\mathrm{O}$ ccupational Safety and $\mathrm{H}$ ealth

A tlanta, G eorgia

Estados U nidos

\section{Debra L. Nelson, PhD}

Professor

CBA Associates

O klahoma State U niversity

Stillwater, O klahoma

Estados U nidos

\section{Bodil Nielsen, Dr Phil}

Profesora asociada

Instituto August K rogh

U niversidad de C openhague

Copenhague

Dinamarca
Sarah A. Nunneley, MS, MD

Research P hysician

Air Force R esearch L aboratory

Brooks Air Force Base

San Antonio, T exas

Estados U nidos

\section{Tokuo Ogawa, MD, PhD}

Profesor emérito

U niversidad de M edicina de A ichi

Nagakute

Japón

Kristina Orth-Gomér, MD, PhD

Profesora

Departamento de Ciencias de la Salud Pública

Instituto K arolinska

Estocolmo

Suecia

\section{Suzanne C. Ouellette, PhD}

Professor of P sychology

Graduate School and U niversity Center

City U niversity of N ueva Y ork

Nueva Y ork, Nueva Y ork

Estados U nidos

\section{Kenneth C. Parsons, PhD}

Professor of E nvironmental E rgonomics

Department of H uman Sciences

L oughborough U niversity

L eicester

Reino U nido

Jonathan A. Patz, MD, MPH

A ssistant Scientist, D irector

Department of Environmental $\mathrm{H}$ ealth Sciences

Program on H ealth Effects of G lobal Environmental Change

Johns $\mathrm{H}$ opkins School of $\mathrm{H}$ ygiene and Public H ealth

Baltimore, $M$ aryland

Estados U nidos

\section{Dan Petersen, Ed D}

Professor

A rizona State U niversity

President

DPA Consulting Inc.

Tempe, Arizona

Estados U nidos

\section{Hans-Ulrich Pfeffer, Dr}

$\checkmark$ efe de departamento

Control Ambiental

L andesumweltamtN ordrheinW estfalen

Essen

Alemania
Chaya S. Piotrkowski, PhD

Professor

G raduate School of Social Service

Fordham U niversity

Nueva Y ork, N ueva Y ork

Estados U nidos

Thomas W. Planek, PhD, CSP

D irector

R esearch and Statistical Services

$\mathrm{N}$ ational Safety C ouncil

I tasca, Illinois

Estados U nidos

\section{Gustav Poinstingl, Dipl-Ing}

L eiter des Verkehrs-A rbeitsinspektorates Bundesministerium für öffentliche W irtschaft und Verkehr

Viena

Austria

Tessa M. Pollard, D Phil

L ecturer in B iological Anthropology

D epartment of Anthropology

U niversity of D urham

Durham

R eino U nido

Charles T. Pope

A rea Director

N orfolk Area O ffice

$\mathrm{O}$ ccupational Safety and $\mathrm{H}$ ealth

Administration

US D epartment of L abor

N orfolk, V irginia

Estados U nidos

\section{Sydney W. Porter Jr., BS}

A djunct P rofessor

G raduate Institute of Environmental Studies

D rexel U niversity

Ardmore, Pensilvania

Estados U nidos

Herbert C. Preul, PhD

Professor E meritus

D epartment of $C$ ivil and Environmental

Engineering

U niversity of C incinnati

Cincinnati, O hio

Estados U nidos

James Campbell Quick, PhD

Professor of Organizational B ehavior

U niversity of T exas

Arlington, T exas

Estados U nidos 
Fernando Ramos Pérez, Ind Eng Ingeniero de gestión, E specialista en prevención de riesgos

Servicio de Prevención de Accidentes Laborales

$\checkmark$ alencia

España

\section{A. Raouf, PhD \\ Rector \\ Instituto GIK \\ Topi, Swabi \\ Paquistán}

\section{John T. Reeves, MD}

Professor E meritus

D epartment of $M$ edicine and Pediatrics

U niversity of $\mathrm{C}$ olorado $\mathrm{H}$ ealth Sciences Center

Denver, Colorado

Estados U nidos

\section{Dietmar A.J. Reinert, Dr rer nat \\ Je efe dección \\ Berufsgenossenschaftliches I nstitut für \\ Arbeitssicherheit \\ $\mathrm{H}$ auptverband der gewerblichen \\ Berufsgenossenschaften \\ Sankt Augustin \\ Alemania}

Michael H. Repacholi, PhD, MSc R esponsable principal

A sesoramiento sobre Protección contra

la $R$ adiación y los Peligros $M$ undiales

O rganización M undial de la Salud

Ginebra

Suiza

\section{Toni Retsch, Dipl-Ing, ETH}

B ereichsleiter-AL M 2

O rganización Nacional Suiza de Seguros de Accidente

Lucerna

Suiza

\section{Paule Rey, MD, MPH}

Profesora emérita

Facultad de M edicina

Universidad de Ginebra

Ginebra

Suiza

\section{J. Rioux, PhD*}

Chaire de parasitologie

Faculté de médecine de $M$ ontpellier

M ontpellier

Francia
Jean-Marc Robert, PhD

Professor

$D$ epartment of $M$ athematics and Industrial Engineering

É cole Polytechnique

$M$ ontreal, $Q$ uebec

Canadá

\section{William N. Rom, MD, MPH}

Professor of M edicine

Division of Pulmonary and $\mathrm{C}$ ritical $\mathrm{C}$ are M edicine

$\mathrm{N}$ ew $\mathrm{Y}$ ork U niversity

N ueva Y ork, N ueva Y ork

Estados U nidos

\section{Isabelle Romieu, MD, ScD, MPH}

E pidemióloga médica

Centro Panamericano de la E cología y la Salud H umana

Ciudad de M éxico

M éxico

M. Gracia Rosell, IngTQ

I efa del laboratorio de cromatografía de gases

Instituto N acional de Seguridad e

$\mathrm{H}$ igiene en el Trabajo

Barcelona

España

Denise M. Rousseau, PhD

Professor of Organizational B ehavior

C arnegie M ellon U niversity

Pittsburgh, Pensilvania

Estados Unidos

Julia D. Royster, PhD

Environmental N oise C onsultants Inc.

$\mathrm{R}$ aleigh, $\mathrm{C}$ arolina del $\mathrm{N}$ orte

Estados U nidos

\section{Larry H. Royster}

D epartment of $M$ echanical Engineering

$\mathrm{N}$ orth C arolina State U niversity

$\mathrm{R}$ aleigh, $\mathrm{C}$ arolina del $\mathrm{N}$ orte

Estados U nidos

\section{Sven-Olof Ryding, PhD}

Profesor adjunto

Director gerente

Consejo Sueco EM AS

Estocolmo

Suecia

\section{Jorma Saari, Dr Tech}

Profesor

D epartamento de Seguridad

Instituto Finlandés de M edicina del Trabajo

Helsinki

Finlandia

\section{Gavriel Salvendy, PhD}

NE C P rofessor of I ndustrial E ngineering

School of Industrial Engineering

Purdue U niversity

W est L afayette, Indiana

Estados U nidos

\section{Steven L. Sauter, PhD}

Chief

A pplied Psychology and Ergonomics Branch

$\mathrm{N}$ ational Institute for $\mathrm{O}$ ccupational Safety and $\mathrm{H}$ ealth

Cincinnati, 0 hio

Estados U nidos

Gustave Savourey, MD, PhD

Investigador especialista en psicología

U nidad T ermofisiológica

Centro de Investigación, Servicio de Salud del Ejército Emile Pardé

La Tronche

Francia

John M. Schaubroeck, PhD

Associate P rofessor

C ollege of Business Administration

U niversity of N ebraska

Lincoln, N ebraska

Estados U nidos

Lawrence M. Schleifer, EdD

Adjunct Professor

D epartment of $\mathrm{H}$ ealth Education

$U$ niversity of $M$ aryland

Baltimore, $\mathrm{M}$ aryland

E stados U nidos

\section{Guido Schmitter, HTL}

I ngeniero de mecánica y seguridad

O rganización N acional Suiza de Seguros de Accidentes

Lucerna

Suiza

\section{Paul Schreiber, Dr rer nat}

Físico

Instituto Federal de Seguridad y

Salud en el T rabajo

Dortmund

Alemania

\section{Dietrich Schwela, PhD}

Salud A mbiental U rbana

O rganización M undial de la Salud

G inebra

Suiza

${ }^{*}$ Colaborador de la 3a edición de esta Enciclopedia. La información biográfica no se ha actualizado. 


\section{Helmut Seidel, Dr med sci}

J efe de grupo de investigación

E fectos biológicos de la vibración y del ruido

Bundesanstalt für Arbeitsschütz und

Arbeitsmedizin

Berlín

Alemania

\section{Hansjörg Seiler, PD, Dr jur}

Secretario del T ribunal de J usticia

Tribunal Federal Suizo (Bundesgericht)

L ausana

Suiza

\section{Harry S. Shannon, PhD, MSc}

Professor

$\mathrm{O}$ ccupational $\mathrm{H}$ ealth Programme

D epartment of Clinical E pidemiology and Biostatistics

M cM aster U niversity

$\mathrm{H}$ amilton, $\mathrm{O}$ ntario

Senior Scientist

Institute for W ork and $\mathrm{H}$ ealth

T oronto, 0 ntario

Canadá

\section{Victor Shantora, MSc}

D irector G enera

T oxics Pollution Prevention Directorate

Environment $\mathrm{C}$ anada

O ttawa, 0 ntario

Canadá

\section{Richard L. Shell, PhD}

Professor of I ndustrial E ngineering and E nvironmental $H$ ealth

D epartment of M echanical, Industrial and

N uclear Engineering

U niversity of Cincinnati

Cincinnati, 0 hio

Estados U nidos

\section{Arie Shirom}

Profesor

Facultad de Gestión

U niversidad de T el A viv

Tel Aviv

Israel

\section{Niu Shiru, PhD}

Profesor

Instituto de Salud y T écnica

Ambientales

A cademia China de M edicina Preventiva Pekín

China

\section{Marcel Simard, PhD}

Assistant P rofessor

School of Industrial Relations

$U$ niversity of $M$ ontreal

M ontreal, Q uebec

Canadá
Reinald Skiba, Dr-Ing

P rofesor de seguridad técnica/ producción

Bergische U niversitat-G esamthochschule

Wuppertal

Alemania

\section{David H. Sliney, PhD}

Commander

L aser $\mathrm{H}$ azards Branch

USA-CHPPM

A berdeen Proving G round, M aryland

Estados U nidos

\section{Gordon S. Smith, MB, MPH}

Associate Professor

Johns H opkins U niversity School of Public $\mathrm{H}$ ealth

Baltimore, $M$ aryland

Estados U nidos

Ian R. Smith, MSc

LAM P C oordinator

Program D evelopment

O ntario M inistry of Environment and Energy

T oronto, 0 ntario

Canadá

\section{Michael J. Smith, PhD}

Professor

Department of I ndustrial Engineering

$U$ niversity of $W$ isconsin

$M$ adison, Wisconsin

Estados U nidos

\section{Mike Smith, PhD}

$M$ anchester School of $M$ anagement Institute of Science and T echnology $U$ niversity of $\mathrm{M}$ anchester

$M$ anchester

R eino U nido

N. A. Smith, PhD

L ighting C onsultant

Doncaster

R eino U nido

Colin L. Soskolne, PhD

Professor, D irector of G raduate T raining

Department of Public H ealth Services

U niversity of Alberta

Edmonton, Alberta

Canadá

\section{Jerry Spiegel, MA, MSc}

Director

Pollution Prevention

$M$ anitoba Environment

Winnipeg, M anitoba

Canadá

\section{Bengt Springfeldt, PhD}

D epartamento de M edicina Social y

Salud Internacional

Instituto K arolinska

Sundbyberg

Suecia

Jeanne M. Stellman, PhD

Directora de la publicación

E nciclopedia de Salud y Seguridad en el T rabajo

O ficina Internacional de T rabajo

Ginebra

Suiza

School of Public Health

Columbia U niversity

N ueva Y ork, N ueva Y ork

Estados U nidos

Terje Sten, Cand

Investigador

División de Seguridad y Fiabilidad

Fundación para la Investigación

Científica e Industrial

Trondheim

N oruega

\section{Andrew Steptoe, DPhil, DSc}

Professor of P sychology

St. G eorge's H ospital M edical School

$U$ niversity of L ondon

Londres

R eino U nido

Tom F.M. Stewart, BSC

$M$ anaging $D$ irector

System C oncepts $L$ td.

Londres

R eino U nido

\section{Daniel Stokols, PhD}

P rofessor, D ean

School of Social Ecology

University of C alifornia-I rvine

Irvine, California

Estados U nidos

\section{Jerry Suls, PhD}

Professor

D epartment of Psychology

U niversity of I owa

lowa City, I owa

Estados U nidos

\section{Alice H. Suter, PhD}

Principal Consultant

Industrial Audiology and Community

$$
\text { N oise }
$$

Alice Suter and Associates

Ashland, 0 regón

Estados Unidos 
Naomi G. Swanson, PhD

Chief

M otivation and Stress R esearch Section

National Institute for 0 ccupational Safety and $\mathrm{H}$ ealth

Cincinnati, $\mathrm{O}$ hio

Estados U nidos

\section{Gary M. Taylor}

T aylor-Wagner Inc. Willowdale, O ntario

Canadá

\section{Benedetto Terracini, MD}

Antiguo jefe

U nidad de E pidemiología del Cáncer

H ospital U niversitario y U niversidad de Turín

Turín

Italia

\section{Lois E. Tetrick, PhD \\ Professor \\ Department of Psychology \\ U niversity of $\mathrm{H}$ ouston \\ H ouston, T exas \\ Estados U nidos}

\section{Töres Theorell, MD, PhD}

Profesor, D irector

Instituto Nacional de Factores

Psicosociales y Salud

Estocolmo

Suecia

\section{Dennis Tolsma, MPH}

$D$ irector, P revention and P ractice Analysis

$\mathrm{K}$ aiser Permanente $\mathrm{M}$ edical $\mathrm{C}$ are Program

Atlanta, G eorgia

Estados U nidos

\section{Rüdiger M. Trimpop, PhD \\ Profesor \\ D epartamento de Psicología Industrial y de 0 rganización \\ U niversidad de Y ena \\ Yena \\ Alemania}

\section{René Troxler, Dipl-Ing, HTL/ STV}

T écnico en seguridad

O rganización Suiza de

Seguros de Accidentes

Lucerna

Suiza

\section{Tom Tseng, PhD}

$M$ anager

Toxics Prevention Division

Environmental Protection Branch

Environment Canadá-O ntario R egion
D ownsview, 0 ntario

Canadá

\section{Arthur C. Upton, MD}

Clinical Professor

Environmental and Community M edicine

U M DNJ-R obert Wood Johnson

M edical School

Piscataway, N ueva J ersey

Estados U nidos

\section{Holger Ursin, MD}

Profesor

D epartmento de Psicología Biológica y $\mathrm{M}$ édica

U niversidad de Bergen

Bergen

N oruega

Johan Van de Kerckhove, Dr soc sci

Director

HIVA-VORMING

Profesor

$\mathrm{K}$ atholieke U niversiteit L euven

Pellenberg

Bélgica

\section{Mark A. Veazie, Dr PH}

National Institute for O ccupational Safety and $\mathrm{H}$ ealth

M organtown, V irginia 0 ccidental

Estados U nidos

\section{Pierre Verger, MD, MSc, MPH}

J efe de proyecto

L aboratorio de Epidemiología y A nálisis de R iesgos para la Salud Instituto de Protección Nuclear y Seguridad

Fontenay-aux-R oses

Francia

\section{Amiran D. Vinokur, PhD}

R esearch Scientist

Institute for Social R esearch

U niversity of $\mathrm{M}$ ichigan

Ann Arbor, M ichigan

Estados Unidos

\section{Jean-Jacques Vogt, MD}

Antiguo subdirector general

Institut $\mathrm{N}$ ational de $\mathrm{R}$ echerche et de Sécurité

París

Francia

\section{Georg Vondracek, Dipl-Ing}

D epartamento de M áquinas Industriales y Sistemas de Control

O rganización $\mathrm{N}$ acional de Seguros de Accidentes
Lucerna

Suiza

Peter Warr, PhD

Research P rofessor

Institute of W ork Psychology

U niversity of Sheffield

Sheffield

R eino U nido

David A. Warrell, DM, DSc

Professor, Director

Centre for T ropical M edicine

U niversity of $\mathrm{O}$ xford

Oxford

R eino U nido

\section{Leon J. Warshaw, MD}

Clinical Professor

D epartment of Environmental M edicine

$\mathrm{N}$ ew $\mathrm{Y}$ ork U niversity

$\mathrm{N}$ ueva Y ork, Nueva Y ork

Estados Unidos

\section{John V. Weil, MD}

D irector

C ardiovascular-Pulmonary R esearch Laboratory

U niversity of Colorado H ealth Sciences Center

Denver, Colorado

Estados U nidos

\section{Edmundo Werna, PhD}

I nvestigador

South Bank U niversity

Universidad de Sao Paulo

Sao Paulo

Brasil

John B. West, MD, PhD, DSc

Professor of M edicine and Physiology

D epartment of $M$ edicine

U niversity of California-San Diego

San Diego, California

Estados U nidos

\section{Gunnela Westlander, PhD \\ Profesora emérita \\ Departamento de Psicología \\ U niversidad de Estocolmo \\ Estocolmo \\ Suecia}

\section{Marion Wichmann-Fiebig, MSc}

D ezerucutin Schutz der A tmosphäre

L andesumweltamt des Landes N ordrhein-W estfalen 
Essen

Alemania

\section{Gerald J.S. Wilde, PhD}

Professor of Psychology

$Q$ ueen's U niversity

$\mathrm{K}$ ingston, O ntario

Canadá

\section{Ann M. Williamson, PhD}

School of Psychology

U niversity of N ew South W ales

Sidney

Australia

\section{Denis Winter}

Subdirección

División de Estudios de Accidentes

Instituto de Seguridad N uclear y

Protección

Fontenay-aux-R oses

Francia

Ernst L. Wynder, MD

President

A merican $\mathrm{H}$ ealth Foundation
Nueva Y ork, Nueva Y ork

Estados U nidos

Annalee Yassi, MD, MSc

D irector

O ccupational and Environmental

M edicine

$\mathrm{H}$ ealth Sciences $\mathrm{C}$ entre and $\mathrm{U}$ nit

$U$ niversity of $M$ anitoba

Winnipeg, M anitoba

Canadá

D. Zannini, PhD*

Instituto de M edicina del T rabajo

O spedale San M artino

Génova

I talia

José Luis Zeballos, MD, MPH

Pan A merican H ealth O rganization Washington, DC

Estados U nidos

\section{Bernhard M. Zimolong, PhD}

Profesor

Psicología del T rabajo y de 0 rganización
U niversidad de $\mathrm{R}$ uhr

Bochum

Alemania

\section{Thomas Zosel, BS}

$M$ anager

Environmental Initiatives

3M Inc.

St. Paul, M innesota

Estados U nidos

\section{Jozef Zurada, PhD}

Assistant P rofessor

Computer Information Systems

University of L ouisvillle

L ouisville, K entucky

Estados Unidos

\footnotetext{
* Colaborador de la 3a edición de esta Enciclopedia. La información biográfica no se ha actualizado.
} 



\section{II}

Factores Psicosociales y de O Rganizacion Riesgos Generales
El Medio Ambiente

Accidentesy Gestion de la Seguridad Productos Quimicos 



\section{SUMARIO}

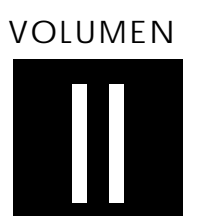

A utores y directores.

PARTE V. FACTORES PSICOSOCIALES Y DE ORGANIZACION

\section{Factores psicosociales y de organización}

\section{Steven L. Sauter,
Lawrence R. Murphy, Joseph J. H urrell y Lennart Levi, Directores del capítulo}

\section{TEORIAS DEL ESTRES DEL TRABAJO}

Factores psicosociales, estrés y salud

El modelo de demandas/ control: enfoque social, emocional y fisiológico del riesgo de estrés y desarrollo de comportamientos activos.

El apoyo social: un modelo interactivo del estrés Kristina Orth-Gomér

\section{FACT ORES INHERENTES AL TRABAJO}

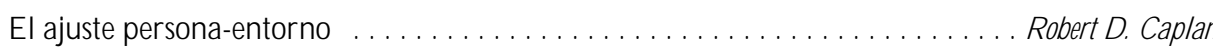

La carga de trabajo M arianne $F$ rankenhaeuser

La jornada de trabajo T imothy $\mathrm{H}$. M onk

El diseño del entorno . D aniel Stokols 34.22

Factores ergonómicos. M ichad J. Smith 34.25

Autonomía y control . D aniel Ganster 34.26

El ritmo del trabajo. Gavriel Salvendy 34.28

La supervisión electrónica del trabajo . Lawrence M. Schleifer 34.29

Claridad y sobrecarga de los roles asignados. . Steve M. J ex

\section{FACT ORES INTER PERSONALES}

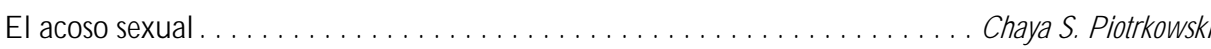

La violencia en el lugar de trabajo J ulian Barling

LA SEGURIDAD EN EL EM PLEO

L a ambigüedad sobre el futuro del empleo . J ohn M . I vancevich 34.34

El desempleo Amiram D. Vinokur

\section{FACT ORES MACROORGANIZATIVOS}

Gestión de la calidad total. . . . . . . . . . . . . . . . . . . . . . . D ennis Tolsma 34.37

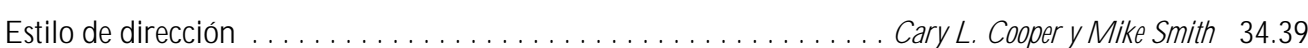

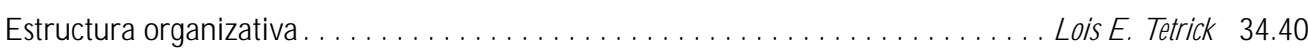

Clima y cultura organizativos ........................ D enise M. R ousseau 34.41

M edición y remuneración del rendimiento ..................... Richard L. Shell 34.43

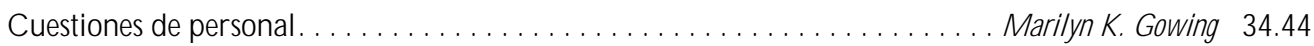

DESARR OLLO DE LA CARRERA PROFESIONAL

Socialización ........................ D ebra L. N elson y J ames Campbell Q uick 34.46

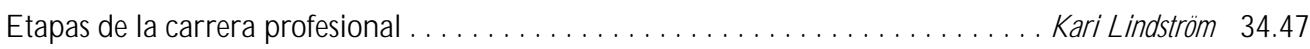


FACTORES INDIVIDUALES

Patrones de comportamiento de los tipos A y B C. D avid J enkins 34.49

Resistencia. . Suzanne C. Ouellette

Autoestima J ohn M. Schaubroeck

Locus de control Law rence R. M urphy y J oseph I. H urrell, I r.

Estilos de afrontamiento . R onald I. B urke 3 34.54

Apoyo social D. W ayne Corneil 34.55

Género, estrés en el trabajo y enfermedad . Rosalind C. B arnett 34.57

Aspectos étnicos . G wendolyn Puryear Keita

REACCIONES DE ESTRES

Algunos resultados fisiológicos agudos Andrew Steptoey Tessa M . Pollard 34.60

Resultados de comportamiento. Arie Shirom

Resultados en materia de bienestar Peter W arr

Reacciones inmunitarias H olger U rsin

EFECTOSCRONICOSEN LA SALUD

Enfermedades cardiovasculares. . T öres T heorell y J effrey V. J ohnson

Problemas gastrointestinales . . erry Suls

Cáncer . . B ernard H. Fox 34.68

Trastornos musculosqueléticos . Soo-Yee Lim, Steven L. Sauter y N aomi G. Swanson 34.70

Trastornos mentales Carles M untaner y W illiam W. E aton 34.72 Burnout Christina M aslach

\section{PREVENCION}

Resumen de las estrategias generales de prevención y control. .... . Cary L. C ooper y Sue C artw right

\section{O rganizaciones y salud y seguridad G unnela Westllander, Directora del capítulo}

Factores psicosociales y gestión organizativa $\ldots \ldots \ldots \ldots \ldots \ldots \ldots \ldots$ Gunnda W estlander

\section{PARTE VI. RIESGOS GENERALES}

36. Presión barométrica, aumento

Trabajo en situaciones de aumento de la presión barométrica . . . . . . . . . . . . . . E ric Kindwall Trastornos por descompresión

\section{Presión barométrica, reducción}

Aclimatación ventilatoria a grandes altitudes Walter Dümmer, Director del capítulo Efectos fisiológicos de la reducción de la presión barométrica. ... Kenneth I. B erger y W illiam N. R om Aspectos sanitarios asociados al trabajo a grandes altitudes............... ohn B. West Prevención de los peligros profesionales a grandes altitudes..............W alter D ümmer M edida cautelar: muestreo del aire Kenneth I. B erger y W illiam N. R om

Zuheir Ibrahim Fakhri, Director del capítulo

38. Riesgos biológicos

. Zuheir I. Fakhri

Riesgos biológicos en el lugar de trabajo . D. Z annin

A nimales acuáticos

y $B$. J uminer

A nimales venenosos terrestres David A. Warrell 
39. Desastres naturales y tecnológicos Pier Alberto Bertazzi, D irector del capítulo

C atástrofes y accidentes mayores $\ldots \ldots \ldots \ldots \ldots \ldots \ldots \ldots \ldots$. Pier Alberto B ertazzi

Preparación para las catástrofes $\ldots \ldots \ldots \ldots \ldots \ldots \ldots \ldots \ldots \ldots$. Peter $]$. Baxter

39.2

Actividades posteriores a las catástrofes. ........... . B enededto Terracini y U rsula Ackermann-Liebrich

Problemas relacionados con el clima ........................... ean F rench

Avalanchas: riesgos y medidas de protección . ...................... Gustav Poinstingl

Transporte de materiales peligrosos: sustancias químicas y radiactivas. ...... . D onald M . C ampbell

Accidentes por radiación

Pierre Verger y $D$ enis $W$ inter

Salud en el trabajo y medidas de seguridad en áreas agrarias

contaminadas por radionuclidos: la experiencia

de Chernóbil ......................... Yuri Kundiev, L eonard D obrovolsky y V. I. Chernyuk

Estudio de caso: el incendio de la fábrica de juguetes $K$ ader .......... Casey Cavanaugh $G$ rant

Consecuencias de las catástrofes: lecciones desde una perspectiva médica .... . . . J osé L uis Z eballos

40. Electricidad

Dominique Folliot, Directora del capítulo

Efectos fisiológicos de la electricidad $\ldots \ldots \ldots \ldots \ldots \ldots \ldots \ldots \ldots \ldots$.

Electricidad estática ....................................... Claude M enguy

Prevención y normas

Renzo Comin

41. Incendios

Conceptos básicos.

Casey C. G rant, D irector del capítulo

Fuentes de peligro de incendio.

ougal D rysdale

M edidas de prevención contra incendios

. Tamás B ánky

. Peter F. J ohnson

Y Yngve Anderberg

M edidas de protección pasiva contra incendios.

Gary Taylor

M edidas activas de protección contra incendios.

.. S. D heri

O rganización de la lucha contra incendios

Jean-Jacques Vogt, D irector del capítulo

42. Calor y frío

W. Larry Kenney

Respuestas fisiológicas a la temperatura ambiente

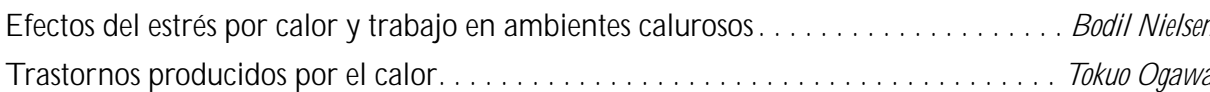

Prevención del estrés por calor $\ldots \ldots \ldots \ldots \ldots \ldots \ldots \ldots \ldots \ldots \ldots$ Sarah A. N unneley

Fundamentos físicos del trabajo en condiciones de calor

J acques $M$ alchaire

Evaluación del estrés por calor eíndices de estrés por calor.

Kenneth C. Parsons

Intercambio de calor a través de la ropa.

W outer A. L otens

Ambientes fríos y trabajo con frío . . Ingvar H olmér, Per-O la G ranberg y G oran D ahlstrom

Prevención del estrés por frío en condiciones extremas al aire libre . . . . . . . . . . . . . . . . . . . . . . acques $B$ ittel y $G$ ustave Savourey Indices de frío y normas sobre el frío $\ldots \ldots \ldots \ldots \ldots \ldots \ldots \ldots \ldots \ldots \ldots$ ngvar H olmér

43. H oras de trabajo

Peter Knauth, Director del capítulo

$\mathrm{H}$ oras de trabajo Peter Knauth

\section{Calidad del aire interior}

\section{Xavier G uardino Solá, D irector del capítulo}

Calidad del aire interior: introducción ...................... X avier G uardino Solá

$\mathrm{N}$ aturaleza y fuentes de los contaminantes químicos en el interior ............ D errick Crump

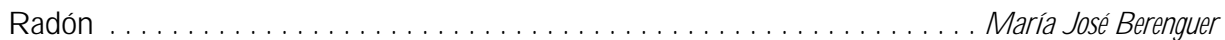

H umo de tabaco 
Regulación del consumo de tabaco . X avier Guardino Solá 44.16

D eterminación y valoración de los contaminantes químicos . M. Gracia R osell Farrás 44.17

Contaminación biológica . .. B rian F lannigan

R eglamentos, recomendaciones, normas y patrones.

M aría J osé $B$ erenguer

45. Control ambiental en interiores

Juan G uasch Farrás, D irector del capítulo

Control ambiental en interiores: principios generales. . . . . . . . . . . . A. H ernández Calleja El aire en interiores: métodos de control y depuración . . . . . E. A Aán L iébana y A. H ernández Calleja 45.2

$O$ bjetivos y principios de la ventilación general y de la ventilación de dilución . . . . E milio Castejón 45.7 Criterios de ventilación para edificios no industriales. . A. H ernández Calleja Sistemas de calefacción y aire acondicionado ............... . F. Ramos P érez y J. Guasch F arrás 45.14 El aire en interiores: ionización E. A dán Liébana y J. Guasch Farrás

\section{Iluminación}

Juan G uasch Farrás, D irector del capítulo

Tipos de lamparas e iluminación. Richard Forster 46.2

Condiciones necesarias para el confort visual . Fernando Ramos Pérez y Ana H ernández Calleja

47. Ruido

Alice H. Suter, D irectora del capítulo

$N$ aturaleza y efectos del ruido Alice H. Suter 47.2

M edición del ruido y evaluación de la exposición. E duard I. D enisov y German A. Suvorov

T écnicas de control del ruido . Dennis P. D riscoll Programas de conservación de la audición ............. L Larry H . R oyster y J ulia D oswell R oyster $\mathrm{N}$ ormas y reglamentaciones.

Alice H. Suter

48. Radiaciones ionizantes

R obert N. Cherry, Jr., D irector del capítulo

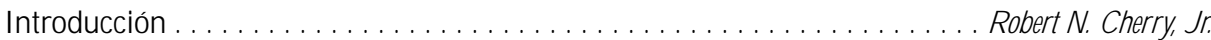

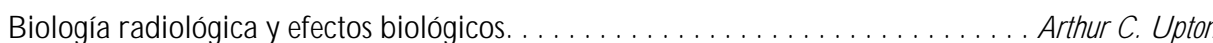

Fuentes de radiación ionizante. R obert N. Cherry, J r.

Diseño de puestos de trabajo para seguridad radiológica. Gordon M. Lodde Seguridad radiológica. R obert N. Cherry, I r.

Planificación de medidas y gestión de accidentes radiológicos. Sydney W. Porter, J r.

49. Radiaciones no ionizantes

Bengt Knave, D irector del capítulo

C ampos eléctricos y magnéticos y consecuencias para la salud . Bengt Knave 49.2

El espectro electromagnético: características físicas básicas. Kjell $\mathrm{H}$ ansson $\mathrm{M}$ ild $R$ adiación ultravioleta. David $H$. Sliney

R adiación infrarroja. R. M atthes 49.6

Luz y radiación infrarroja. . . D avid $H$. Sliney 49.14

Láseres. David $H$. Sliney

Campos de radiofrecuencia y microondas. . . .

50. Vibraciones

Michael J. G riffin, Director del capítulo

Vibraciones. . M ichael J. Griffin

Vibraciones de cuerpo completo . . H elmut Seidel y M ichael J. Griffin 
Vibraciones transmitidas a las manos. . . . . . . . . . . . . . . . . M assimo B ovenzi 50.8

$M$ areo inducido por el movimiento

51. Violencia

Leon J. Warshaw, Director del capítulo

La violencia en el lugar de trabajo

L eon J. W arshaw

52. Pantallas de visualización de datos Diane Berthelette, Directora del capítulo

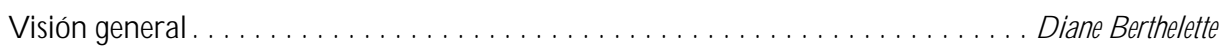
Características de los puestos de trabajo con pantallas de visualización de datos. . . . . A Ahmet Çakir

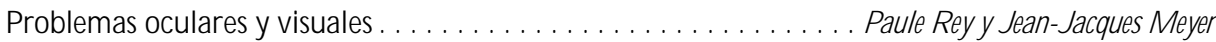

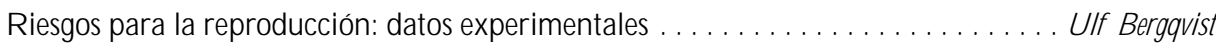

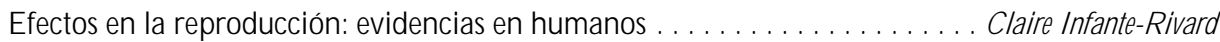
Trastornos musculosqueléticos ...........................Gabriele B ammer Problemas de la piel . . . . . . . . . . . . . . . . . . . . . . . . . M ats $B$ erg y Sture L idén Aspectos psicosociales del trabajo con PVD ............... M ichael J. Smith y Pascale C arayon Aspectos ergonómicos de la interacción ordenador/ hombre . . . . . . . . . . . ean-M arc R obert N ormas ergonómicas . Tom F. M. Stew art

\section{PARTE VII. EL MEDIO AMBIENTE}

\section{Riesgos ambientales para la salud}

\section{Annalee Yassi y T ord Kjellström,} Directores del capítulo

C onexiones entre la salud ambiental y la salud en el trabajo. ....... A Annale Yassi y Tord Kjellström

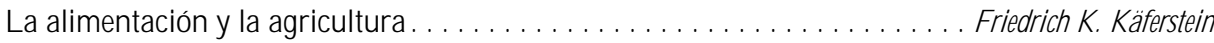
La contaminación industrial en los países en desarrollo . . . . . . . . . . . . . . . N iu Shiru L os países en desarrollo y la contaminación. . . . . . . . . . . . . . . . . . . T Ł L. Guidotti La contaminación del aire. I sabelle R omieu La contaminación del suelo . Tee L. Guidotti y Chen W eiping

La contaminación del agua. . I vanildo $\mathrm{H}$ espanhol y $\mathrm{R}$ ichard $\mathrm{H}$ elmer

La energía y la salud . ................................ . H amilton

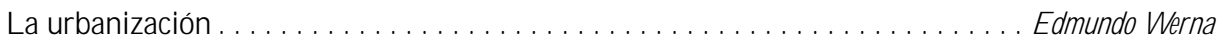

El cambio climático mundial y el agotamiento del ozono. . . . . . . . . . . . . onathan A. Patz

54. Política en materia de medio ambiente Larry R. Kohler, Director del capítulo Panorama: la salud y la seguridad en el trabajo y el medio ambiente: dos caras de la misma moneda . . . . . . . . . . . . . . . . . . . . . . 54.2

EI medio ambiente y el mundo del trabajo: un concepto integral del desarrollo sostenible, el medio ambiente y el medio ambiente de trabajo . ...... Larry $R$. Kohler

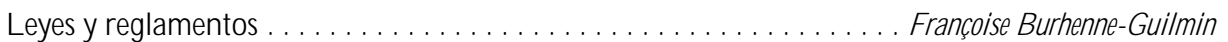
C onvenios internacionales sobre el medio ambiente. . . . . . . . . . . . . D avid F reestone

Evaluaciones de impacto ambiental . . Ron $B$ isset 54.15

Evaluación del ciclo vital (de la cuna a la tumba). . . . . . . . . . . . . . . Sven-0 ol $R$ yding Evaluación y comunicación de riesgos. . Adrian V. G heorghey H ansjörg Seiler 54.24

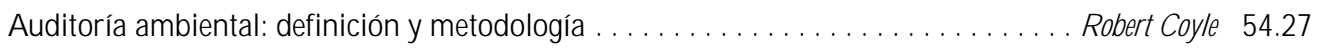
Estrategias de gestión del medio ambiente y protección de los trabajadores. . . . . . . Cecilia B righi 54.30 Control de la contaminación ambiental: la prevención de la contaminación como objetivo prioritario de la empresa. . . . . . . . . . . . . . . R obert P. B ringer y Tom Z ose 54.34 


\section{Control de la contaminación ambiental}

Jerry Spiegel y L ucien Y. Maystre, Directores del capítulo

Control y prevención de la contaminación ambiental. .......... . f erry Spiegel y L ucien Y. M aystre 55.2 Gestión de la contaminación atmosférica. ............... Dietrich Schw ela y B erenice G oelzer 55.3

Contaminación atmosférica: modelos de dispersión de

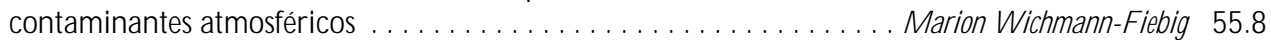

V igilancia de la calidad atmosférica . . . . . . . . . . . . . H ans-U Irich P feffer y Peter B ruckmann 55.12

Control de la contaminación atmosférica. . . . . . . . . . . . . . . . . . . . ohn E lias 55.20

Control de la contaminación del agua . . . . . . . . . . . . . . . . . . . . . erbert C. Preul 55.26

Proyecto de regeneración de aguas residuales en la R egión de Dan:

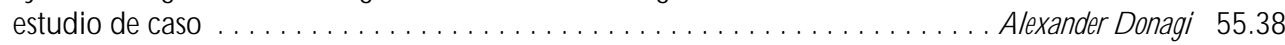

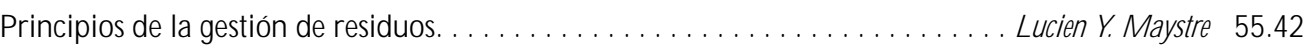

G estión y reciclado de residuos sólidos. . . . . . . . . . . . . . . N iels J orn H ahn y Poul S. L auridsen 55.44

Estudio de caso: control y prevención de la contaminación de

los $\mathrm{G}$ randes $\mathrm{L}$ agos de Canadá . . . . . . . . . . . . . . . T homas Tseng, V ictor Shantora el an R. Smith 55.46

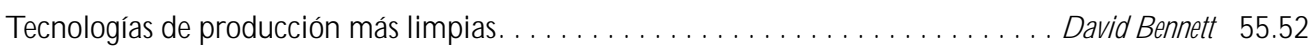

\section{PARTE VIII. ACCIDENTES Y GESTION DE LA SEGURIDAD}

\section{Prevención de accidentes}

Jorma Saari, Director del capítulo

Introducción orma Saari 56.2

Conceptos del análisis de accidentes $\ldots \ldots \ldots \ldots \ldots \ldots \ldots \ldots \ldots \ldots \ldots \ldots$ Kirsten $\mathrm{J}$ ørgensen

Teoría de las causas de los accidentes . . . . . . . . . . . . . . . . . . . . A Abdul $R$ aouf

Factores humanos en los modelos de accidentes Anne M arie Feyer y Ann M. W illiamson 56.6

M odelos de accidentes: homeostasis del riesgo Gerald J. S. W ilde 56.11

M odelos de accidentes Andrew R. H ale 56.14

M odelos de secuencia de accidentes Ragnar Andersson 56.18

M odelos de desviación de accidentes . U rban Kjellén 56.22

EI M AIM : modelo de información de accidentes de M erseyside ... H arry S. Shannon y J ohn Davies 56.24

Principios de la prevención: el planteamiento de la sanidad pública respecto a la reducción de las lesiones en el lugar de trabajo . . . Gordon S. Smith y M ark A. Veazie 56.28

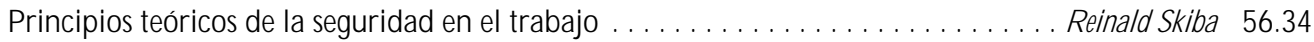
Principios de prevención: información sobre seguridad . . . . . . . M ark R. Lehto y J ames M . M iller 56.37 Costes de los accidentes relacionados con el trabajo . . . . . . . . . . . . . . . D iego Andreoni 56.42

57. Auditorías, inspecciones e investigaciones Jorma Saari, Director del capítulo Auditorías de seguridad y de gestión J ohan Van de Kerckhove 57.2

Análisis de riesgos: el modelo de causalidad de accidentes. J op G roeneweg 57.7

R iesgos de los equipos Carsten D. Groenberg 57.13

Análisis de riesgos: factores organizativos-M O RT . U rban Kjellén 57.19

Inspección en el lugar de trabajo y aplicación normativa . . . . . . . . . . . . . Anthony L inehan 57.21

A nálisis y presentación de informes: investigación de accidentes . . . . . . . . . . . . . M onteau 57.24

Comunicación y recopilación de estadísticas sobre accidentes Kirsten J orgensen

\section{Aplicaciones de la seguridad}

Kenneth Gerecke y Charles T. Pope, Directores del capítulo

A nálisis de sistemas. M anh Trung H O 58.2

Seguridad de las herramientas portátiles y de mano ......... D epartamento de Trabajo de E E .U U. 0 ccupational Safety and $\mathrm{H}$ ealth Administration; dirigido por Kenneth G erecke 58.5 
Partes móviles de máquinas T Tomas B ackström y M arianne D öos

Defensas de máquinas . D epartamento de Trabajo de la 0 ccupational Safety and $\mathrm{H}$ ealth $\mathrm{Administration;}$ dirigido por Kenneth G erecke 58.12

D etectores de presencia . . . . . . . . . . . . . . . . . . . . . . . . . . . . . . Paul Schreiber 58.24

D ispositivos para controlar, aislar y conmutar energía . . . . . . . . . . . . . . . . R ené T roxler 58.29

A plicaciones relacionadas con la seguridad. . . . . . . . . . . . . . D ietmar R einert y Karlheinz M effert 58.32

Software y ordenadores: sistemas híbridos automatizados. . . . . W aldemar Karwowski y J ozef Z urada 58.37

Principios del diseño de sistemas de control seguros. . . . . . . . . . . . . . G eorg Vondrack 58.43

Principios de seguridad para máquinas herramienta CNC ...................... Toni R etsch, Guido Schmitter y Albert M arty 58.51

Principios de seguridad para robots industriales ........ Toni R etsch, G uido Schmitter y Albert M arty 58.59 Sistemas de control de seguridad eléctricos, electrónicos y programables . . . . . . . . R on B ell 58.62

Requisitos técnicos para sistemas relacionados con la seguridad basados en dispositivos eléctricos, electrónicos y programables............ ohn B razendale y $R$ on $B$ ell 58.67

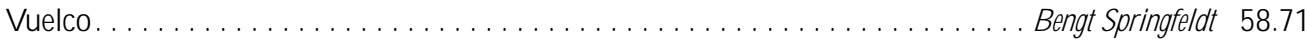

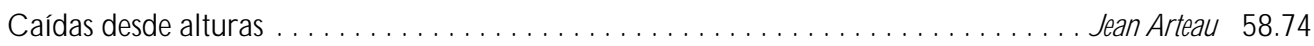

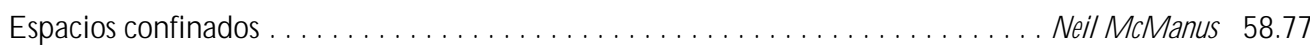

Principios de la prevención: manipulación de materiales y tráfico interno . . . . . . Kari H äkkinen 58.82

59. Política de seguridad y liderazgo Jorma Saari, Director del capítulo

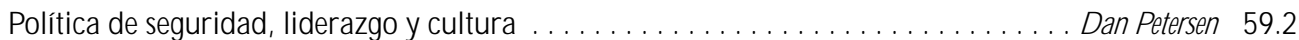

Cultura y gestión de la seguridad . . . . . . . . . . . . . . . . . . . . . . . . . . . M arcel Simard 59.4

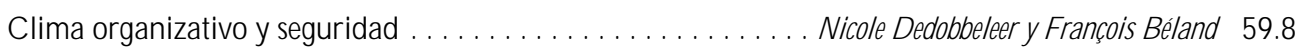

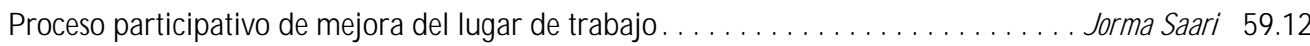

M étodos de toma de decisiones en el campo de la seguridad . . . . . . . . . . . . . . . Terjesten 59.19

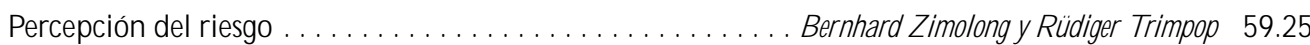

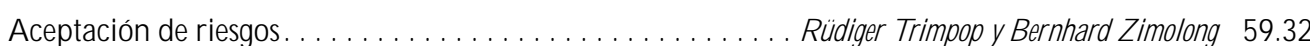

60. Programas de seguridad

Jorma Saari, Director del capítulo

Investigación de la seguridad en el trabajo: panorama general .......................... erbert I. L inn y Alfred A. A mendola 60.2

Servicios de la Administración pública . . . . . . . . . . . . . . . . . . . . . . Anthony Linehan 60.5

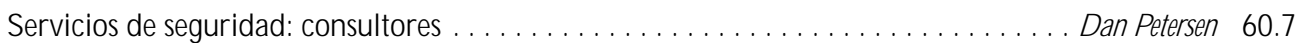

Ejecución de un programa de seguridad . . . . . . . . . . . . . . . . . . . . . . . Tom B. Leamon 60.11

El éxito en los programas de seguridad . . . . . . . . . . . . . . . . . . . Tom B. Leamon 60.13

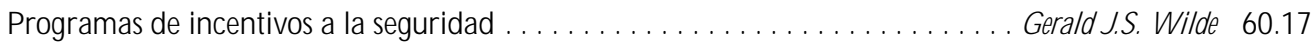

Promoción de la seguridad . . . . . . . . . . . . . . . . . . . . . Thomas W. Plank 60.20

Estudio de caso: campañas nacionales de salud y seguridad

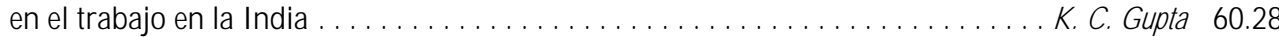

\section{PARTE IX. PRODUCTOS QUIMICOS}

61. U tilización, almacenamiento y transporte de productos químicos Jeanne Mager Stellman y Debra 0 sinsky,

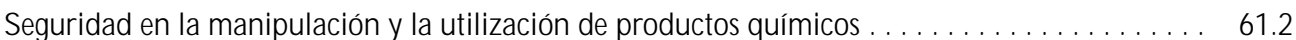

Sistemas de clasificación y etiquetado para

productos químicos . . . . . . . . . . . . . . . . . . Konstantin K. Sidorov el gor V. Sanotskiy

Seguridad en la manipulación y el almacenamiento de productos químicos . . . . . . . A. E. Q uinn 61.11 
Gases comprimidos: manipulación, almacenamiento y transporte . . A. T ürkdogan y K. R. M athisen 61.14

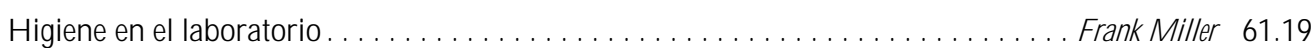
M étodos para el control localizado de contaminantes atmosféricos. . . . . . . . . L ouis D iB ernardinis 61.23 EI sistema de información química GEST IS: estudio de caso . . . . Karlheinz M effert y R oger Stamm 61.27

62. Minerales y productos químicos para la agricultura Debra 0 sindky y Jeanne Mager Stellman, Directoras del capítulo

M inerales.

Productos químicos para la agricultura $\ldots \ldots \ldots \ldots \ldots \ldots \ldots \ldots \ldots \ldots \ldots$ Gary A. Page 62.7

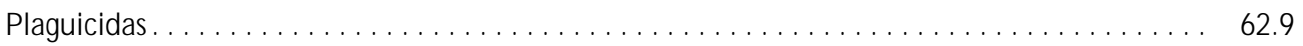

Directrices de la O M S para la clasificación de los plaguicidas según el riesgo . . . . . . . . . 62.18

63. Metales: propiedades químicas y toxicidad G unnar Nordberg,

Director del capítulo

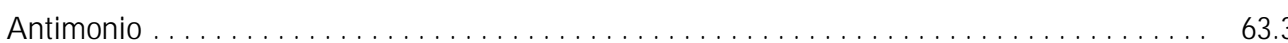

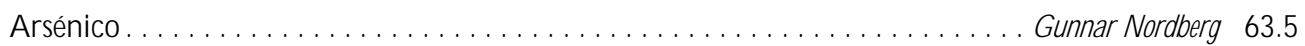

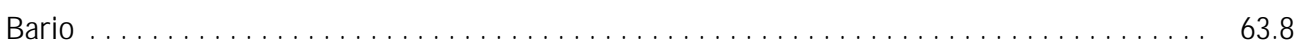

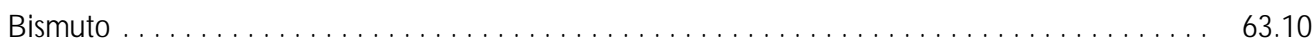

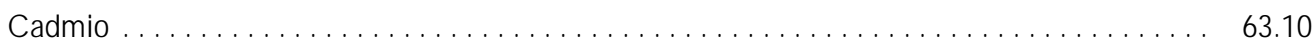

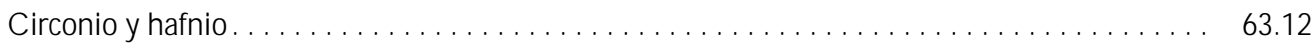

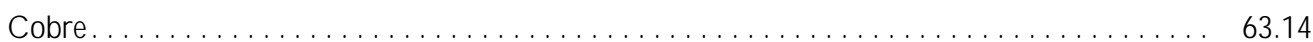

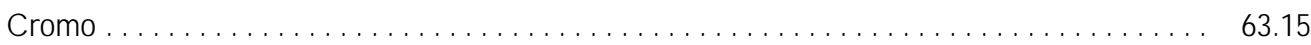

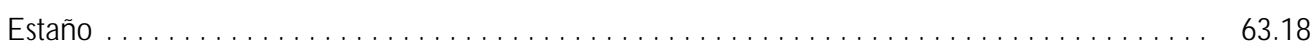

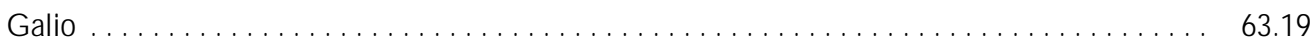

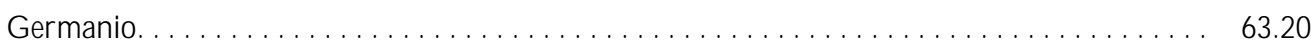

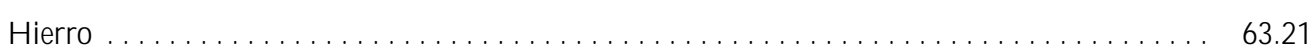

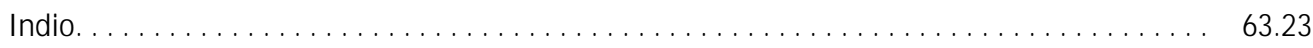

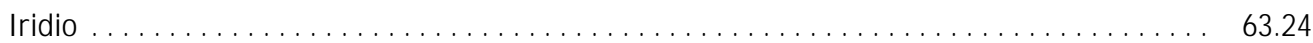

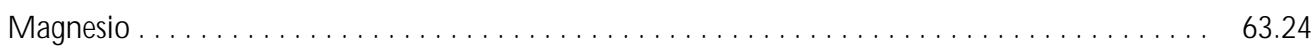

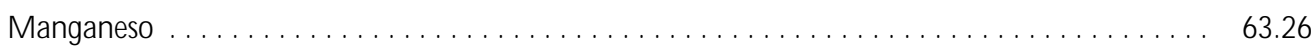

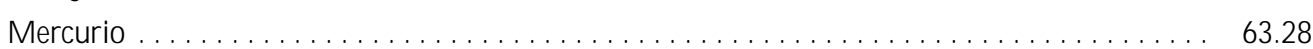

M etalcarbonilos (en especial, níquel carbonilo) . . . . . . . . . . . . . . . F. W illiam Sunderman, J r. 63.31

Molibdeno . . . . . . . . . . . . . . . . . . . . . . . . . . . . . . . . . . . . . . . . 63.33

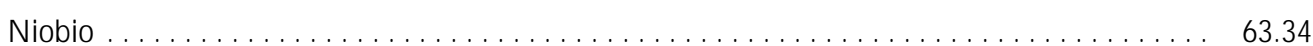

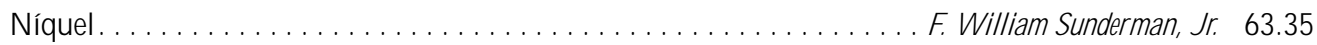

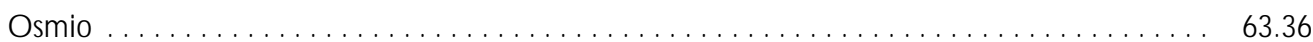

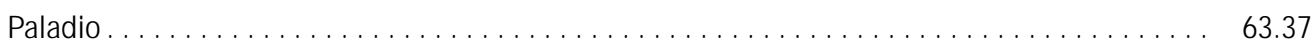

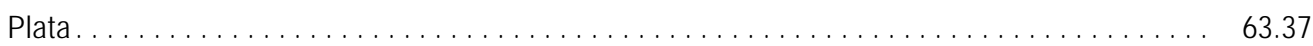

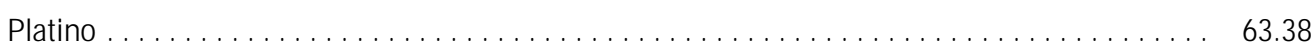

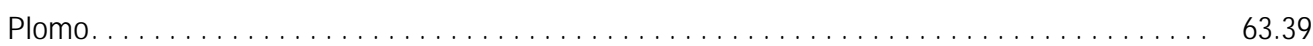

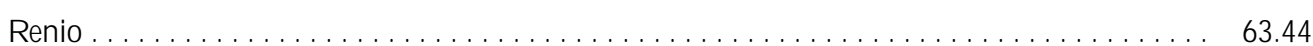

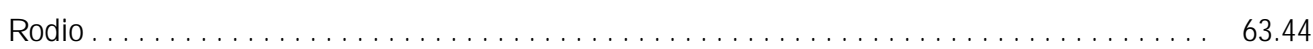

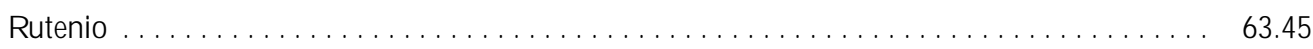

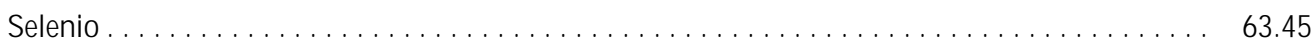

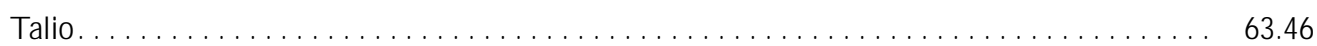

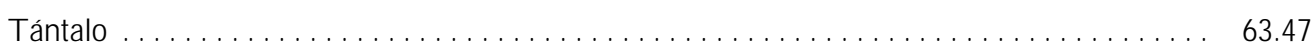

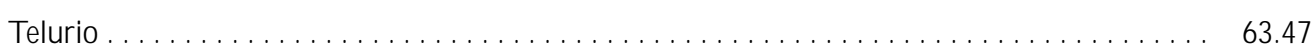


Titanio .

63.48

Tungsteno o wolframio

63.49

Vanadio

63.50

Zinc 63.51 


\section{FACTORES PSICOSOCIALES Y DE ORGANIZACION}

Directores del capítulo

Steven L. Sauter, Lawrence R. M urphy,

J oseph J . H urrell y Lennart Levi

\section{Sumario}

Factores psicosociales y organizativos

Steven L. Sauter, I oseph I. H urrell I r.,

Lawrence $R$. M urphy y L ennart L evi

TEORIAS DEL ESTRES DEL TRABAJO

Factores psicosociales, estrés y salud

L ennart Levi ......................

enfoque social, emocional y fisiológico del riesgo de

estrés y desarrollo de comportamientos activos

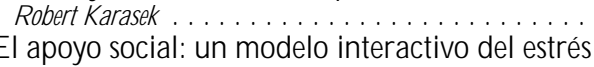

Kristina O rth-Gomér. . .

FACTORES INHERENTESAL TRABAJO

EI ajuste persona-entorno

Robert D. Caplan. . .

La carga de trabajo

M arianne Frankenhaeuser . . . . . . . . . . . . . . . . . . . . . 34.20

La jornada de trabajo

T imothy $\mathrm{H}$. M onk.......

El diseño del entorno

Daniel Stokols.

Factores ergonómicos

M ichael J. Smith ......................... 34.25

Autonomía y control

Daniel Ganster .................................... 34.26

EI ritmo del trabajo

Gavriel Salvendy ............................ 34.28

La supervisión electrónica del trabajo

Law rence M. Schleifer . . . . . . . . . . . . . . . . . . . . . . . . . . 34.29

Claridad y sobrecarga de los roles asignados

Steve M . J ex . . . . . . . . . . . . . . . . . . . . . . . . . . 34.31

FACTORESINTERPERSONALES

EI acoso sexual

Chaya S. Piotrkowski ... . . . . . . . . . . . . . . . . . . . . . . 34.32

La violencia en el lugar de trabajo

J ulian Barling.

LA SEGURIDAD EN EL EMPLEO

La ambigüedad sobre el futuro del empleo

J ohn M. I vancevich. . . . . . . . . . . . . . . . . . . . . . . . . . . . . . . . 34.34

El desempleo

Amiram D. Vinokur . . . . . . . . . . . . . . . . . 34.35

FACTORES MACROORGANIZATIVOS

Gestión de la calidad total

Dennis Tolsma.

Estilo de dirección

Cary L. Cooper y M ike Smith . . . . . . . . . . . . . . . . . . . . . 34.39

Estructura organizativa

L ois E. Tetrick. .

Clima y cultura organizativos

Denise M. R ousseau . . .
M edición y remuneración del rendimiento

Richard L. Shell. . . . . . . . . . . . . . . . . . . . . . . . . . . . . . 34.43

Cuestiones de personal

M arilyn $\mathrm{K}$. Gowing .......................... 34.44

DESARROLLO DE LA CARRERA PROFESIONAL

Socialización

Debra L. N elson y J ames Campbell Quick . . . . . . . . . . . . . . . . . . 34.46

Etapas de la carrera profesional

Kari Lindström . . . . . . . . . . . . . . . . . . . . . . . . . . . . 34.47

FACTORES INDIVIDUALES

Patrones de comportamiento de los tipos A y B

C. D avid J enkins . . . . . . . . . . . . . . . . . . . . . . . . . . . . . 34.49

Resistencia

Suzanne C. O uellette. ........................ 34.50

Autoestima

J ohn M. Schaubroeck. . . . . . . . . . . . . . . . . . . 34.52

Locus de control

Law rence R. M urphy y $\rfloor$ oseph $\rfloor$. H urrell, $\mid$ r. . . . . . . . . . . . . . . . 34.52

Estilos de afrontamiento

Ronald I. Burke. ............................... 34.54

A poyo social

D. W ayne Corneil. ........................... 34.55

Género, estrés en el trabajo y enfermedad

R osalind C. Barnett . . . . . . . . . . . . . . . . . . . . . . . . . . . 34.57

A spectos étnicos

G wendolyn Puryear Keita . . . . . . . . . . . . . . . . . . . . . 34.59

REACCIONES DE ESTRES

Algunos resultados fisiológicos agudos

Andrew Steptoe y Tessa M. Pollard . . . . . . . . . . . . . . . . . . . . . . 34.60

Resultados de comportamiento

ArieShirom ............................. 34.62

Resultados en materia de bienestar

Peter $W$ arr . . . . . . . . . . . . . . . . . . . . . . . . . . . . 34.64

Reacciones inmunitarias

H olger U rsin. . . . . . . . . . . . . . . . . . . . . . . . . . . . . 34.66

EFECTOS CRONICOSEN LA SALUD

Enfermedades cardiovasculares

Töres T heorell y J effrey V. J ohnson . . . . . . . . . . . . . . . . . 34.67

Problemas gastrointestinales

J erry Suls. . . . . . . . . . . . . . . . . . . . . . . . . . . . . . . . 34.68

Cáncer

Bernard H. Fox . ............................... 34.70

Trastornos musculosqueléticos

Soo-Yee L im, Steven L. Sauter y N aomi G. Swanson . . . . . . . . . . . . . . 34.72

Trastornos mentales

Carles M untaner y W illiam W. E aton . . . . . . . . . . . . . . . . . . . . 34.73

Burnout

Christina M aslach . . . . . . . . . . . . . . . . . . . . . . . . . . . . . . . 34.74

PREVENCION

Resumen de las estrategias generales de prevención y control

Cary L. Cooper y Sue Cartw right . . . . . . . . . . . . . . . . 34.75 


\section{- FACTO RES PSIC O SO CIALES Y DE ORGANIZACION}

\section{Steven L. Sauter, Joseph J. H ur rell Jr., Lawrence $R$. M urphy y L ennart Levi}

En 1966, mucho antes de que estrés en el trabajo y factores psicosociales se convirtieran en expresiones habituales, se presentó al M inistro de Sanidad estadounidense (Departamento de Salud y Servicios H umanos de Estados U nidos 1966) un informe especial titulado "Protecting the $\mathrm{H}$ ealth of Eighty M illion Workers - A N ational Goal for O ccupational Health". El informe se elaboró bajo los auspicios del National Advisory Environmental Health Committee con el fin de orientar los programas federales de salud en el trabajo. Entre otras muchas observaciones se señalaba en él que el estrés psicológico era un hecho cada vez más frecuente en el lugar de trabajo, donde presentaba "... nuevas y sutiles amenazas para la salud mental" y un posible riesgo de trastornos somáticos, como enfermedades cardiovasculares. Como factores que contribuían a esa situación se indicaban el cambio tecnológico y las crecientes exigencias psicológicas del trabajo. El informe concluía con una lista de más de 20 "problemas urgentes" que precisaban de una atención prioritaria, entre ellos la salud mental en el trabajo y los factores del lugar de trabajo que contribuían a esa situación.

Treinta años después hemos comprobado que el informe estaba muy acertado en sus predicciones. El estrés del trabajo se ha convertido en una de las principales causas de incapacidad laboral en N orteamérica y E uropa. En 1990, el 13 \% del total de casos de incapacidad de trabajadores que gestionó $\mathrm{N}$ orthwestern $\mathrm{N}$ ational Life, importante aseguradora estadounidense de accidentes de trabajo, se debían a trastornos en los que se suponía que existía una relación con el estrés del trabajo (N orthwestern $\mathrm{N}$ ational Life 1991). En un estudio realizado en 1985 por el National Council on Compensation Insurance se comprobó que una sola causa de baja laboral, la incapacidad psicológica debida a "estrés mental progresivo" en el trabajo, había llegado a representar el $11 \%$ del total de indemnizaciones por enfermedad profesional ( $\mathrm{N}$ ational Councilon Compensation Insurance 1985). ${ }^{1}$

La aparición de estos fenómenos es comprensible si tenemos en cuenta las exigencias del trabajo moderno. En un estudio de 1991 sobre los Estados miembros de la U nión E uropea se llegó a la conclusión de que "la proporción de los trabajadores que se quejan de problemas organizativos, que son especialmente propicios para la aparición del estrés, es superior a la proporción de los que se quejan de problemas físicos" (Fundación Europea para la M ejora de las C ondiciones de Vida y de Trabajo 1992). Análogamente, en un estudio sobre la población activa holandesa, éste más reciente, se observó que la mitad de los trabajadores de la muestra señalaron un ritmo de trabajo alto, tres cuartas partes de ellos señalaron escasas posibilidades de promoción y una tercera parte señalaron una escasa adecuación entre sus estudios y su empleo (H outman y Kompier 1995). En el caso de Estados U nidos disponemos de menos datos sobre la existencia de factores de riesgo de estrés en el lugar de trabajo. No obstante, en una reciente encuesta realizada a varios miles de trabajadores estadounidenses, más del $40 \%$ de los encuestados señalaron una carga de trabajo excesiva y afirmaron que al final de la jornada se encontraban "agotados" y "emocionalmente exhaustos" (Galinsky, Bond y Friedman 1993).

La repercusión de este problema en términos de pérdida de productividad, enfermedad y deterioro de la calidad de vida es sin duda enorme, aunque difícil de estimar de manera fiable. No

${ }^{1}$ En Estados U nidos se distingue entre indemnizaciones por enfermedad profesional e indemnizaciones por accidente en el trabajo; éstas superan ampliamente en número a las primeras. obstante, análisis recientes de datos de más de 28.000 trabajadores realizados por Saint Paul Fire and $M$ arine Insurance son interesantes y pertinentes. En ese estudio se comprobó que los problemas de salud notificados estaban más asociados a la presión de tiempo y otros problemas emocionales y personales en el trabajo que a cualquier otro estresor de la vida personal, más incluso que los problemas financieros o familiares o que la muerte de un ser querido (St. Paul Fire and M arine Insurance Company 1992).

De cara al futuro, los rápidos cambios en el tejido laboral y en la fuerza de trabajo plantean riesgos desconocidos, y posiblemente mayores, de estrés del trabajo. Por ejemplo, en muchos países la fuerza de trabajo está envejeciendo rápidamente, y ello en una época en la que la seguridad en el empleo es cada vez menor. En Estados Unidos, el fenómeno del redimensionamiento de las empresas mantenía prácticamente todo su vigor al entrar en la segunda mitad del decenio, con una tasa de más de 30.000 empleos perdidos al mes (R oy 1995). En el estudio antes citado de Galinsky, Bond y Friedman (1993), casi una quinta parte de los trabajadores pensaban que probablemente perderían su puesto de trabajo en el año siguiente. Al mismo tiempo, el número de trabajadores contingentes, que en general carecen de prestaciones sanitarias y de otros sistemas de seguridad, sigue creciendo y representa hoy alrededor del $5 \%$ de la fuerza de trabajo (U SBLS 1995).

En el presente capítulo pretendemos ofrecer una visión general de lo que hoy sabemos de las condiciones que conducen al estrés en el trabajo y a otros problemas conexos de salud y seguridad. Esas condiciones, normalmente denominadas factores psicosociales, comprenden aspectos del puesto de trabajo y del entorno de trabajo, como el clima o cultura de la organización, las funciones laborales, las relaciones interpersonales en el trabajo y el diseño y contenido de las tareas (por ejemplo, su variedad, significado, alcance, carácter repetitivo, etc.). EI concepto de factores psicosociales se extiende también al entorno existente fuera de la organización (por ejemplo, exigencias domésticas) y a aspectos del individuo (por ejemplo, personalidad y actitudes) que pueden influir en la aparición del estrés en el trabajo. Las expresiones organización del trabajo y factores organizativos se utilizan muchas veces de manera intercambiable con factores psicosociales para hacer referencia a las condiciones de trabajo que pueden conducir al estrés.

La presente sección de la Enciclopedia se inicia con descripciones de varios modelos de estrés en el trabajo que tienen interés científico en la actualidad, como el modelo de demandas-control del trabajo, el modelo de ajuste persona-entorno (P-E) y otros enfoques teóricos de la cuestión. Al igual que todas las concepciones contemporáneas del estrés en el trabajo, estos modelos tienen un elemento común: el estrés se conceptualiza en términos de la relación entre el trabajo y la persona. D esde este punto de vista, el estrés y el riesgo de problemas de salud aparecen cuando las exigencias del trabajo no se ajustan a las necesidades, expectativas o capacidades del trabajador. Este elemento central está implícito en la Figura 34.1, en la que se indican los elementos básicos del modelo del estrés que han adoptado los investigadores del $\mathrm{N}$ ational Institute for O ccupational Safety and Health (NIOSH). En este modelo, factores psicosociales relacionados con el trabajo (los denominados "estresores") producen unas reacciones psicológicas, de comportamiento y físicas que pueden acabar por influir en la salud. No obstante, como se indica gráficamente en la Figura 34.1, intervienen también factores individuales y contextuales (los llamados "moderadores del estrés") que influyen en los efectos de los estresores sobre la salud y el bienestar. (V éase en $\mathrm{H}$ urrell y Murphy 1992 una descripción más detallada del modelo del estrés utilizado por el NIOSH.) 
Figura 34.1 - Modelo de estrés del trabajo del N ational Institute for O ccupational Safety and Health (N IO SH).

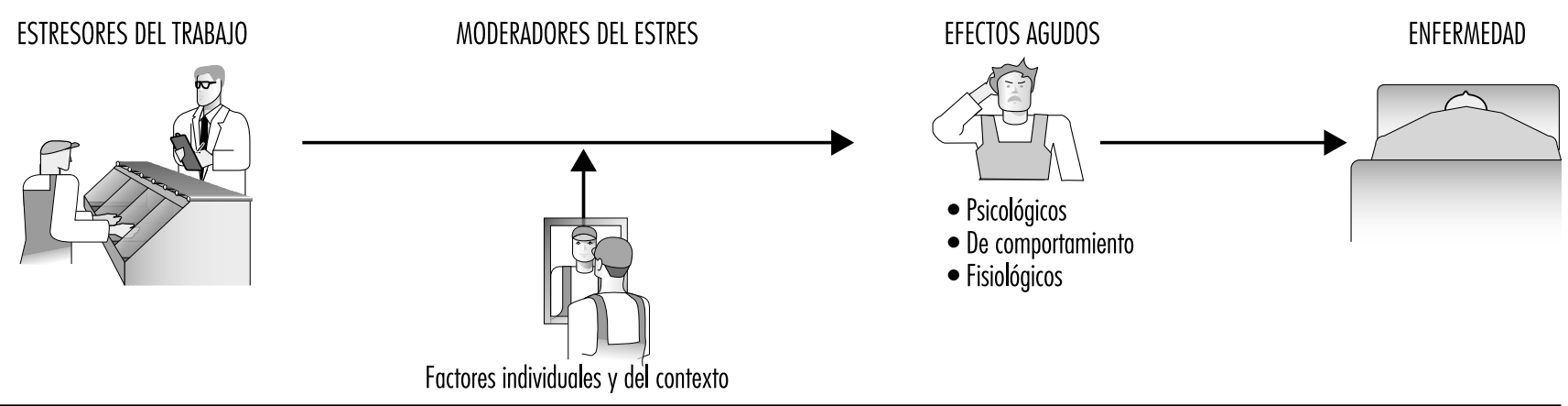

Sin embargo, al margen de esa similitud conceptual, hay también entre estos modelos unas diferencias teóricas que no carecen de importancia. Por ejemplo, a diferencia del modelo del NIOSH y del modelo de ajuste P-E, en los que se reconoce que en el lugar de trabajo hay gran cantidad de factores potenciales de riesgo psicosocial, el modelo de demandas-control del trabajo se centra sobre todo en un número más limitado de dimensiones psicosociales, relacionadas con la carga de trabajo psicológica y con la posibilidad que tienen los trabajadores de ejercer control (la llamada "Iatitud de toma de decisiones") sobre determinados aspectos de su trabajo. Además, tanto el modelo de demandas-control como el del NIOSH se distinguen de los modelos de ajuste P-E en la importancia que se da al individuo. En el modelo de ajuste P-E se hace hincapié en la percepción individual del equilibrio entre las características del puesto del trabajo y los atributos de la persona. Este papel central de las percepciones acerca la teoría del ajuste P-E a otra variante de la teoría del estrés atribuida a Lazarus (1966), en la que las diferencias individuales al valorar los estresores psicosociales y establecer estrategias para hacer frente a ellos determinan críticamente el resultado de estrés. En cambio, aunque no se niega la importancia de las diferencias individuales, en el modelo del NIOSH se da más importancia a factores del entorno al determinar el resultado de estrés, como sugiere la representación gráfica del modelo que se representa en la Figura 34.1. En esencia, este modelo sugiere que la mayoría de los estresores supondrá una amenaza para la mayoría de la gente durante la mayor parte del tiempo, con independencia de las circunstancias. Similar hincapié se observa en otros modelos del estrés y del estrés en el trabajo (por ejemplo, Cooper y M arshall 1976; K agan y L evi 1971; M atteson e I vancevich 1987).

Estas diferencias tienen importantes repercusiones cuando se trata tanto de orientar el estudio del estrés como de elaborar estrategias de intervención en el lugar de trabajo. En el modelo del NIOSH, por ejemplo, se propone la prevención primaria del estrés en el trabajo atendiendo primero a los estresores psicosociales en el lugar de trabajo, y en ese sentido el modelo es coherente con un modelo de prevención propio del ámbito de la salud pública. Aunque en el enfoque de salud pública se reconoce la importancia de los factores del huésped o la resistencia de éste en la etiología de la enfermedad, la primera línea de defensa en este enfoque consiste en erradicar o reducir la exposición a patógenos ambientales.

El modelo del estrés del NIOSH que se representa en la Figura 34.1 ofrece un marco de organización para el resto de esta sección. Tras analizar los modelos del estrés en el trabajo, se incluyen varios artículos breves en los que se resume lo que hoy sabemos sobre los estresores psicosociales en el lugar de trabajo y los moderadores del estrés. En esas subsecciones se abordan las condiciones que se han señalado ampliamente en la bibliografía como estresores y moderadores del estrés, así como temas de nuevo interés, como el clima de la organización y las etapas de la carrera profesional. R ealizados por destacadas autoridades en este campo, cada resumen ofrece una definición y una breve visión general de la bibliografía dedicada a esta cuestión. A demás, para que estos resúmenes sean de la máxima utilidad posible, se pidió a cada autor que incluyera información sobre los métodos de medición o evaluación y sobre las prácticas de prevención.

En la última subsección del capítulo se examinan los conocimientos actuales sobre una amplia gama de riesgos potenciales para la salud del estrés en el trabajo y sobre los mecanismos subyacentes relacionados con esos efectos. Se analizan así desde los temas de preocupación tradicionales, como los trastornos psicológicos y cardiovasculares, hasta nuevos temas como la inmunodepresión y las enfermedades del sistema musculosquelético.

En resumen, en los últimos años se han producido cambios sin precedentes en el diseño y las exigencias del trabajo, y el estrés ha pasado a ser un tema de gran interés en el ámbito de la salud en el trabajo. Esta sección de la Enciclopedia tiene por finalidad ayudar a comprender los riesgos psicosociales que plantea la evolución del entorno de trabajo, para de esa manera proteger mejor el bienestar de los trabajadores.

TEORIAS DEL ESTRES DEL TRABAJO

\section{- FACTO RES PSICO SO CIALES, EST RES Y SALUD}

Lennart Levi

En la terminología técnica, la tensión (inglés stress) es "una fuerza que deforma los cuerpos". En biología y medicina suele utilizarse el término estrés para denominar un proceso corporal, el plan general del cuerpo para adaptarse a todas las influencias, cambios, exigencias y tensiones a que está expuesto. Ese plan se convierte en acción, por ejemplo, cuando una persona es agredida en la calle, pero también cuando alguien está expuesto a sustancias tóxicas o a temperaturas extremas. A hora bien, no son sólo las exposiciones físicas las que activan ese plan, sino que también lo hacen las exposiciones mentales y sociales. Por ejemplo, cuando somos insultados por un superior, cuando nos 
recuerdan una experiencia desagradable, cuando esperan de nosotros que consigamos algo de lo que no nos sentimos capaces o cuando, con causa o sin ella, nos preocupamos por nuestro puesto de trabajo o por nuestro matrimonio.

Todos estos casos tienen algo en común, que es la forma en que el cuerpo intenta adaptarse. Ese denominador común - una especie de "reactivación" o "aceleración" - es el estrés. El estrés es, por lo tanto, un estereotipo en las respuestas del cuerpo a influencias, exigencias o presiones. Siempre hay en el cuerpo un cierto nivel de estrés, del mismo modo que, por establecer un paralelo un poco burdo, un país mantiene un cierto grado de preparación militar, incluso en tiempo de paz. De vez en cuando esa preparación se intensifica, unas veces por causa justificada y otras veces sin ella.

De esa manera el nivel de estrés afecta a la velocidad con que se producen en el cuerpo los procesos de desgaste. Cuanto más nos "aceleramos", tanto más deprisa hacemos funcionar el motor del cuerpo, y por consiguiente tanto más rápidamente se agota el "combustible" y se gasta el "motor". También sería válida otra metáfora: si se enciende una vela con una llama grande, y por los dos extremos, dará más luz, pero también tardará menos en consumirse. Se necesita una cierta cantidad de combustible, pues de lo contrario el motor se pararía, o la vela se apagaría; es decir, el organismo moriría. Así pues, el problema no es que el cuerpo tenga una respuesta de estrés, sino que el grado de estrés a que está sujeto - la velocidad con que se desgasta- sea demasiado alto. Esa respuesta de estrés está variando continuamente incluso en una misma persona, variación que depende en parte de la naturaleza y del estado del cuerpo y en parte de las influencias y exigencias externas - los estresores- a que el cuerpo está expuesto. (Por consiguiente, un estresor es algo que produce estrés.)

A veces resulta difícil determinar si en una situación concreta el estrés es bueno o es malo. Pensemos por ejemplo en el deportista exhausto en el podio de los vencedores, o en el ejecutivo que acaba de conseguir un buen nombramiento pero que está destrozado por el estrés. Ambos han conseguido su objetivo. En términos de puro éxito, se diría que en ambos casos el esfuerzo mereció la pena. En términos psicológicos, sin embargo, esa conclusión es más dudosa. Es posible que para llegar tan lejos hayan tenido que pasar por grandes penalidades, largos años de entrenamiento 0 interminables horas extraordinarias, por lo general a costa de la vida familiar. Desde el punto de vista médico, podría decirse que esos triunfadores han quemado la vela por los dos extremos. Y la consecuencia podría ser fisiológica: es posible que el deportista tenga una o dos roturas musculares, y que el ejecutivo tenga la tensión alta o padezca infarto de miocardio.

\section{El estrés en relación con el trabajo}

$\mathrm{H}$ ay un ejemplo que puede aclarar la forma en que las reacciones de estrés pueden producirse en el trabajo y las consecuencias que pueden tener desde el punto de vista de la salud y de la calidad de vida. Imaginemos la situación siguiente con un hipotético trabajador varón. Sobre la base de consideraciones económicas y técnicas, la dirección ha decidido dividir un proceso de producción en diversos componentes muy sencillos y primitivos que han de realizarse en una cadena de montaje. A partir de esa decisión se crea una estructura social y se pone en marcha un proceso que pueden constituir el punto de partida de una secuencia de acontecimientos que causan estrés y enfermedad. Al principio, el trabajador percibe la nueva situación como un estímulo psicosocial. Esas percepciones pueden estar además influidas por el hecho de que posiblemente el trabajador ha recibido anteriormente una amplia formación, y por lo tanto espera que le asignen una tarea que exija más alta cualificación, no que se reduzcan los niveles de capacidad. Asimismo, la experiencia anterior de trabajo en una cadena de montaje fue muy negativa (es decir, sus experiencias en un entorno anterior influyen en su reacción ante la nueva situación). Además, factores hereditarios hacen que tienda a reaccionar a los estresor con una subida de la presión arterial. Como está más irritable, es posible que su mujer le critique por aceptar el nuevo puesto y por llevar los problemas a casa. $Y$ como resultado de todos esos factores, acaso el trabajador reaccione a esos sentimientos de angustia aumentando su consumo de alcohol o experimentando reacciones fisiológicas indeseables, como un aumento de la presión arterial. Los problemas en el trabajo y en la familia continúan, y sus reacciones, que originalmente eran transitorias, se hacen habituales. Es posible que acabe padeciendo una ansiedad crónica, haciéndose alcohólico o siendo hipertenso crónico. Esos problemas incrementan a su vez sus dificultades en el trabajo y con su familia, y pueden incrementar también su vulnerabilidad fisiológica. Se pone así en marcha un círculo vicioso que podría terminar en un accidente cerebrovascular, un accidente laboral o incluso el suicidio. Este es un ejemplo de la programación externa que interviene en la forma en que un trabajador reacciona en su comportamiento, en su fisiología y en su vida social, con el resultado de una mayor vulnerabilidad, trastornos de salud e incluso la muerte.

\section{Condiciones psicosociales en la vida laboral actual}

Según una importante resolución de la O rganización Internacional del Trabajo (OIT) (1975), el trabajo no sólo debe respetar la vida y la salud de los trabajadores y dejarles tiempo libre para el descanso y el ocio, sino que también ha de permitirles servir a la sociedad y conseguir su autorrealización mediante el desarrollo de sus capacidades personales. Estos principios se expresaron ya en 1963, en un informe del Tavistock Institute de Londres (documento núm. T 813) que establecía las siguientes directrices generales para el diseño de los puestos de trabajo:

1. El puesto de trabajo debe ser razonablemente exigente en aspectos distintos de la pura soportabilidad y mínimamente variado.

2. El trabajador debe poder aprender en el puesto de trabajo y tener en él un aprendizaje continuo.

3. El puesto de trabajo debe comprender algún ámbito de toma de decisiones que el individuo pueda considerar personalmente suyo.

4. Debe existir cierto grado de apoyo social y reconocimiento en el lugar de trabajo.

5. El trabajador debe poder establecer una relación entre lo que hace o produce y la vida social.

6. EI trabajador debe sentir que el puesto de trabajo conduce a algún tipo de futuro deseable.

La O rganización de Cooperación y Desarrollo Económico (O CDE ) dibuja, en cambio, un panorama menos optimista de la realidad de la vida laboral cuando señala que:

- El trabajo se ha aceptado como una obligación y una necesidad para la mayoría de las personas adultas.

- El trabajo y los lugares de trabajo se han diseñado casi exclusivamente con criterios de eficiencia y de coste.

- Se ha aceptado que los recursos tecnológicos y de capital son los determinantes imperativos del carácter óptimo de los puestos de trabajo y los sistemas laborales.

- Los cambios se han debido en su mayor parte al deseo de alcanzar un crecimiento económico ilimitado. 
- La decisión sobre el diseño óptimo de los puestos de trabajo y la elección de los objetivos han quedado casi totalmente en manos de los directivos y especialistas en tecnología, con sólo una leve intromisión de la negociación colectiva y de la protección que ofrece la legislación.

- O tras instituciones de la sociedad han adoptado formas que contribuyen a sostener este tipo de sistema de trabajo.

A corto plazo, los beneficios de la evolución que se ha producido según esta enumeración de la OCDE han consistido en una mayor productividad a un coste menor, así como un incremento de la riqueza. No obstante, los inconvenientes a largo plazo de esa evolución son muchas veces el aumento del número de trabajadores insatisfechos, alienados y posiblemente con un mal estado de salud, lo cual, cuando se considera la sociedad en general, puede afectar a su vez a la esfera económica, aunque los costes económicos de esos efectos no se han tenido en cuenta sino hasta épocas muy recientes (Cooper, Luikkonen y Cartwright 1996; Levi y Lunde-Jensen 1996).

Tendemos asimismo a olvidar que, desde el punto de vista biológico, el género humano no ha cambiado mucho durante los últimos 100.000 años, mientras que su entorno - y en particular el entorno de trabajo- se ha modificado radicalmente, sobre todo durante el último siglo y en especial los últimos decenios. Ese cambio ha sido en parte a mejor; sin embargo, algunas de esas "mejoras" se han visto acompañadas por efectos secundarios inesperados. Por ejemplo, datos recopilados por la 0 ficina Central de Estadística de Suecia durante el decenio de 1980 pusieron de manifiesto que:

- El $11 \%$ del total de trabajadores suecos están expuestos continuamente a un nivel de ruido ensordecedor.

- El $15 \%$ realizan tareas en las que se ensucian mucho (aceite, pintura, etc.).

- El $17 \%$ tienen una jornada de trabajo incómoda, es decir, no sólo la jornada normal de día, sino también muy temprano o de madrugada, trabajo a turnos u otras jornadas irregulares.

- El $9 \%$ tienen una jornada laboral bruta diaria superior a 11 horas (este concepto incluye las horas de trabajo, las pausas de descanso, el tiempo de desplazamiento, las horas extraordinarias, etc.; en otras palabras, la parte del día que se reserva para el trabajo).

- El $11 \%$ tienen trabajos que se consideran "de ritmo muy elevado" y "monótonos".

- El $34 \%$ consideran que su trabajo es "mentalmente pesado".

- El $40 \%$ consideran que "no tienen influencia en la organización del tiempo para descansos".

- El 45 \% consideran que carecen de "oportunidades para aprender cosas nuevas" en su trabajo.

- El $26 \%$ tienen ante su trabajo una actitud instrumental. Estiman que "su trabajo no les brinda nada más que el salario, es decir, no tienen ningún sentimiento de satisfacción personal". El trabajo se considera estrictamente como un instrumento para obtener unos ingresos.

En su importante estudio sobre las condiciones de trabajo en los 12 Estados miembros de la U nión Europea en aquella época (1991/ 92), la Fundación Europea para la M ejora de las C ondiciones de Vida y de Trabajo (Paoli 1992) comprobó que el $30 \%$ de la fuerza de trabajo consideraba que su trabajo era un riesgo para su salud, que había 23 millones de personas que trabajaban de noche más del $25 \%$ del total de horas trabajadas, que una de cada tres señalaba que su trabajo era muy repetitivo y monótono, que uno de cada cinco varones y una de cada seis mujeres trabajaban bajo una "presión de tiempo constante" y que uno de cada cuatro trabajadores soportaba una fuerte carga o trabajaba en una postura forzada o dolorosa más de la mitad de su jornada.

\section{Principales estresores psicosociales en el trabajo}

Como ya se ha indicado, lo que causa el estrés es un deficiente "ajuste persona-entorno", objetiva o subjetivamente, en el trabajo 0 en otros lugares y en interacción con factores genéticos. Es como un zapato que no sienta bien: las exigencias del entorno no se corresponden con la capacidad individual, o las oportunidades que ofrece el entorno no están a la altura de las necesidades y expectativas del individuo. Por ejemplo, el individuo es capaz de realizar una cierta cantidad de trabajo, pero se le pide mucho más, o por el contrario no se le ofrece nada. 0 tro ejemplo sería que el trabajador necesita formar parte de una red social, experimentar una sensación de pertenencia, una sensación de que la vida tiene un significado, pero es posible que no se le dé la oportunidad de satisfacer esas necesidades en el entorno real, con lo que el "ajuste" es deficiente.

Todo ajuste dependerá tanto del "zapato" como del "pie", tanto de factores situacionales como de las características individuales y del grupo. Los principales factores situacionales que dan lugar a "desajustes" pueden clasificarse de la siguiente manera:

Sobrecarga cuantitativa. D emasiado que hacer, presión de tiempo y flujo de trabajo repetitivo. Son en buena medida las características típicas de la tecnología de producción en serie y del trabajo de oficina basado en la rutina.

Insuficiente carga cualitativa. Contenido demasiado limitado y monocorde, falta de variación en el estímulo, falta de demandas a la creatividad o a la solución de problemas, y escasas oportunidades de interacción social. Parece que estos trabajos se van haciendo más frecuentes con una automatización que no se ha diseñado de manera óptima y con un mayor empleo de los ordenadores tanto en las oficinas como en los procesos de fabricación, aunque es posible que haya casos de lo contrario.

Conflictos de roles. Todo el mundo tiene asignados varios roles a la vez. Somos los superiores de unos y los subordinados de otros. Somos hijos, padres, cónyuges, amigos y miembros de clubes 0 sindicatos. Es fácil que surjan conflictos entre nuestros diversos papeles, y esos conflictos suelen propiciar la aparición del estrés, como ocurre, por ejemplo, cuando las exigencias del trabajo chocan con las de un progenitor o hijo enfermo o cuando un supervisor se encuentra dividido entre la lealtad a sus superiores y la lealtad a sus compañeros y subordinados.

Falta de control sobre la situación personal. Es otra persona la que decide qué es lo que hay que hacer, cuándo y cómo; es lo que sucede, por ejemplo, en relación con el ritmo y los métodos de trabajo, cuando el trabajador carece de influencia, de control, de voz. 0 cuando hay incertidumbre o no existe una estructura evidente en la situación laboral.

Falta de apoyo social en casa y por parte del jefe o de los compañeros de trabajo.

Estresores físicos. Estos factores pueden influir en el trabajador tanto física como químicamente; basta con recordar los efectos directos que tienen sobre el cerebro los disolventes orgánicos. Es posible también que efectos psicosociales secundarios tengan su origen en la molestia que producen olores, luces deslumbrantes, ruidos, temperaturas o grados de humedad extremos, etc. Esos efectos pueden derivarse asimismo de que el trabajador es consciente de que está expuesto a peligros químicos que ponen en riesgo su vida o a riesgos de accidente, o los sospecha 0 los teme.

Por último, las condiciones de la vida real tanto en el trabajo como fuera de él suelen comportar una combinación de muchas exposiciones. Esas exposiciones podrían superponerse unas a otras en relación de adición o en sinergia. La gota que colma el vaso puede ser por consiguiente un factor del entorno bastante trivial, pero que se produce cuando ya se soporta una carga ambiental anterior muy considerable. 
Algunos de los estresores específicos de la industria merecen una atención especial, a saber, los que son característicos de:

- la tecnología de producción en serie;

- los procesos de trabajo muy automatizados,

- el trabajo a turnos.

Tecnología de producción en serie. A lo largo del pasado siglo, el trabajo experimentó un proceso de fragmentación, pasando de una actividad bien definida, con un producto final propio y reconocible, a una serie de subunidades, limitadas y muy específicas, que parecen guardar poca relación con el producto final. El creciente tamaño de muchas unidades fabriles ha tendido a crear como consecuencia una larga cadena de mando entre la dirección y los trabajadores individuales, acentuándose la distancia entre los dos grupos. El trabajador se aleja asimismo del consumidor, pues los rápidos procesos de marketing, distribución y venta interponen muchas etapas entre el productor y el consumidor.

De esa manera, la producción en serie suele comportar no sólo una marcada fragmentación del proceso de trabajo, sino también una reducción del control que el trabajador puede ejercer sobre ese proceso. Ello se debe en parte a que la organización del trabajo, su contenido y su ritmo están determinados por el sistema de máquinas. Todos estos factores suelen tener como resultado monotonía, aislamiento social, falta de libertad y presión de tiempo, con posibles efectos a largo plazo sobre la salud y el bienestar.

La producción en serie, además, favorece la introducción del salario a destajo. En ese sentido, cabe suponer que el deseo - o la necesidad- de ganar más puede en determinados momentos inducir al individuo a trabajar más de lo que es bueno para su organismo y a ignorar los "avisos" mentales y físicos, como la sensación de cansancio, los problemas nerviosos y trastornos funcionales de diversos órganos o sistemas orgánicos. 0 tro posible efecto es que el trabajador, volcado sobre el objetivo de incrementar la producción y sus ingresos, infrinja las normas de seguridad y con ello incremente el riesgo de contraer una enfermedad profesional y de sufrir accidentes él mismo y otras personas (como sucede a los conductores de camiones que cobran por servicio realizado).

Procesos de trabajo muy automatizados. En el trabajo automatizado, las tareas repetitivas y manuales las realizan las máquinas, y a los trabajadores se les dejan funciones que son básicamente de supervisión, vigilancia y control. Este tipo de trabajo es por lo general bastante cualificado, no está regulado en detalle y el trabajador tiene libertad para moverse. En consecuencia, la introducción de la automatización elimina muchos de los inconvenientes de la tecnología de producción en serie. No obstante, esto sucede sobre todo en las fases de la automatización en las que el operario está realmente ayudado por el ordenador y mantiene cierto control sobre sus servicios. En cambio, cuando las aptitudes y conocimientos del operario pasan gradualmente al ordenador - lo que es probable que ocurra cuando quienes adoptan la decisión son economistas y especialistas en tecnología- puede producirse un nuevo empobrecimiento del trabajo, con una reintroducción de la monotonía, el aislamiento social y la falta de control.

Vigilar un proceso suele exigir una atención sostenida y una disposición para actuar en cualquier momento de un período caracterizado por la monotonía, lo que no se ajusta a la necesidad que tiene el cerebro de recibir una corriente de estímulos razonablemente variada para mantener el estado de alerta óptimo. Está bien documentado que la capacidad para detectar señales críticas desciende rápidamente incluso durante la primera media hora cuando el entorno es monótono. Ello puede incrementar la tensión inherente al conocimiento de que un despiste pasajero e incluso un pequeño error pueden tener amplias y desastrosas consecuencias, tanto económicas como de otro tipo.

O tros aspectos críticos del control del proceso están relacionados con unas demandas muy especiales de las destrezas mentales. Los operarios trabajan con símbolos, con señales abstractas dispuestas en una serie de instrumentos, y no están en contacto con el producto real de su trabajo.

Trabajo a turnos. En el caso del trabajo a turnos, los cambios del ritmo biológico no coinciden necesariamente con las exigencias correspondientes del entorno. En estos casos el organismo puede "acelerarse", con lo que se produce una activación en un momento en el que el trabajador necesita dormir (por ejemplo, durante el día tras un turno nocturno), y en correspondencia se produce una desactivación durante la noche, cuando es posible que el trabajador tenga que trabajar y estar bien despierto.

Se añade a ello otra nueva complicación, ya que las personas que trabajan a turnos suelen vivir en un entorno social que no está pensado para atender a sus necesidades. Por último, aunque no menos importante, hay que señalar que los trabajadores por turnos han de adaptarse muchas veces a cambios regulares 0 irregulares en las exigencias del entorno, como es el caso de los turnos rotatorios.

En resumen, las exigencias psicosociales del lugar de trabajo moderno son con frecuencia distintas de las necesidades y capacidades de los trabajadores, lo que produce estrés y problemas de salud. En este análisis se ofrece sólo una instantánea de los estresores psicosociales presentes en el trabajo, y de cómo pueden surgir en el centro de trabajo de hoy esas condiciones no saludables. En las secciones que figuran a continuación se examinan con más detalle los estresores psicosociales con respecto a sus orígenes en los sistemas de trabajo y las tecnologías actuales, y también con respecto a su evaluación y control.

\section{EL MODELO DE DEMANDAS-CONTROL: ENFOQUE SOCIAL, EMOCIONAL Y FISIOLOGICO DEL RIESGO DE ESTRES Y DESARRO LLO DE COMPORTAMIENTOS ACTIVOS}

Robert Karasek

En su mayoría, las teorías iniciales sobre el estrés se elaboraron para describir las reacciones a un estrés agudo e "inevitable" en situaciones que eran una amenaza para la supervivencia biológica (Cannon 1935; Selye 1936). El modelo de demandas/ control se ha desarrollado, en cambio, en relación con entornos de trabajo en los que los "estresores" son crónicos, inicialmente no suponen una amenaza para la vida y son el producto de complejas decisiones humanas en materia de organización. En este caso, la controlabilidad del estresor es muy importante, y adquiere aún más importancia a medida que vamos desarrollando organizaciones sociales cada vez más complejas e integradas, con limitaciones cada vez más complejas del comportamiento individual. EI modelo de demandas/ control (K arasek 1976; K arasek 1979; K arasek y Theorell 1990), que se examina a continuación, se basa en las características psicosociales del trabajo: las demandas psicológicas que éste plantea y una cierta combinación de control de las tareas y uso de las capacidades (la llamada latitud de toma de decisiones). El modelo predice, en primer lugar, el riesgo de enfermedad relacionado con el estrés, y después los correlatos de comportamiento activo/ pasivo de los puestos de trabajo. Se ha 
utilizado principalmente en estudios epidemiológicos de enfermedades crónicas, como la enfermedad coronaria.

Desde el punto de vista pedagógico, es un modelo sencillo que puede ayudar a comprender claramente varias cuestiones importantes que son de interés para los análisis de la salud y la seguridad en el trabajo en el ámbito de la política social:

1. que las características de organización social del trabajo, y no sólo los riesgos físicos, producen enfermedades y lesiones;

2. que las consecuencias relacionadas con el estrés tienen que ver con la organización social de la actividad del trabajo y no sólo con sus exigencias;

3. que también la actividad social del trabajo afecta a los riesgos relacionados con el estrés, no sólo las características personales;

4. que la posibilidad tanto de un "estrés positivo" como de un "estrés negativo" puede explicarse en términos de combinaciones de demandas y control,

5. que ofrece un modelo sencillo (con una validez nominal básica) con el que empezar a analizar la respuesta personal al estrés en el caso de los empleados de comercio, los administrativos y otros trabajadores para los que ésta es una cuestión sensible.

M ás allá de las consecuencias del trabajo, el modelo también ofrece las perspectivas de los organizadores del trabajo, quienes están preocupados por los resultados de productividad. La dimensión "demanda psicológica" tiene que ver con "cuánto se trabaja"; la dimensión "latitud de toma de decisiones" refleja cuestiones de organización del trabajo, como las referentes a quién adopta las decisiones y quién realiza qué tareas. La hipótesis de aprendizaje activo del modelo describe los procesos de motivación del trabajo de alto rendimiento. La lógica económica de la máxima especialización laboral, que es la idea más aceptada en el pasado sobre el diseño de puestos de trabajo productivos, se opone en el modelo de demandas/ control a las consecuencias negativas para la salud. El modelo incluye perspectivas alternativas y de promoción de la salud sobre la organización del trabajo que hacen hincapié en la amplitud de las capacidades y la participación de los trabajadores y que pueden ofrecer asimismo ventajas económicas para los sistemas de fabricación innovadores y para los sectores de servicios debido a sus mayores posibilidades de aprendizaje y participación.

\section{Hipótesis del modelo demandas/ control}

\section{Funcionamiento psicosocial en el trabajo, basado en las demandas psicológicas y la latitud de toma de decisiones}

\section{Hipótesis de la tensión del trabajo}

La primera hipótesis es que las reacciones de tensión psicológica más negativas (fatiga, ansiedad, depresión y enfermedad física) se producen cuando las exigencias psicológicas del puesto de trabajo son grandes y en cambio es escasa la latitud de toma de decisiones del trabajador. (Figura 34.2, cuadro inferior derecho). Estas reacciones indeseables, de tipo estrés, que se producen cuando la actuación se combina con limitadas oportunidades para actuar 0 para afrontar el estresor, se denominan "tensión psicológica" (no se utiliza en este punto el término "estrés", pues lo definen de otra manera muchos grupos).

Por ejemplo, el trabajador de una línea de montaje tiene rígidamente limitado casi todo su comportamiento. En una situación de aumento de las exigencias ("aceleración"), se produce algo más que la mera respuesta constructiva de la activación: se produce una respuesta de tensión psicológica residual, que muchas veces es inútil y duradera y que se experimenta de manera negativa. Cuando se produce la avalancha a la hora del almuerzo (Whyte 1948), es la empleada del restaurante que no sabe cómo "controlar" el comportamiento de sus clientes (los que "se cuelan") la que experimenta la mayor tensión en el puesto de trabajo. Kerckhoff y Back (1968) describieron a unos trabajadores de la confección que estaban sometidos a una fuerte presión de plazos de entrega, con la consiguiente amenaza de despido. Llegaron a la conclusión de que cuando no se podían adoptar las medidas normalmente necesarias para hacer frente a las presiones del trabajo se producían en el comportamiento los síntomas de tensión más graves (desfallecimiento, histeria, contagio social). No es sólo la libertad de acción respecto de la manera de realizar la tarea formal lo que libera la tensión, sino que puede ser también la libertad para participar en los "rituales" informales, la pausa para el café o para fumar, 0 "zascandilear" un poco, que actúan como mecanismos complementarios de "liberación de la tensión" durante la jornada de trabajo (C sikszentmihalyi 1975). Se trata muchas veces de actividades sociales: - precisamente las actividades que según los métodos de Frederick Taylor (1991) (1967) se han de eliminar porque constituyen "movimientos despilfarrados" y "fingimientos". De ello se deduce que es necesario ampliar el modelo para incluir las relaciones sociales y el apoyo social.

En el modelo, la "latitud de toma de decisiones" se entiende como la aptitud del trabajador para controlar sus actividades y la utilización de sus capacidades, no para controlar a otras personas. Las escalas de esta latitud tienen dos componentes: la autoridad sobre las tareas - control socialmente predeterminado sobre aspectos pormenorizados del cumplimiento de las tareas (Ilamada también autonomía)- , y la discrecionalidad de las capacidades - control sobre el empleo de las capacidades por parte del individuo, también determinado socialmente en el trabajo [ (y muchas veces denominada variedad o "complejidad sustantiva" (H ackman y Lawler 1971; K ohn y Schooler 1973)]. En las jerarquías organizativas modernas, los niveles más altos de conocimiento legitiman el ejercicio de los niveles más altos de autoridad, y los trabajadores que tienen unas tareas de alcance limitado y especializadas están coordinados por directivos que gozan de unos niveles de autoridad más altos. La discrecionalidad de las capacidades y la autoridad sobre las decisiones están

Figura 34.2 • Modelo de exigencia psicológica/margen de toma de decisiones.

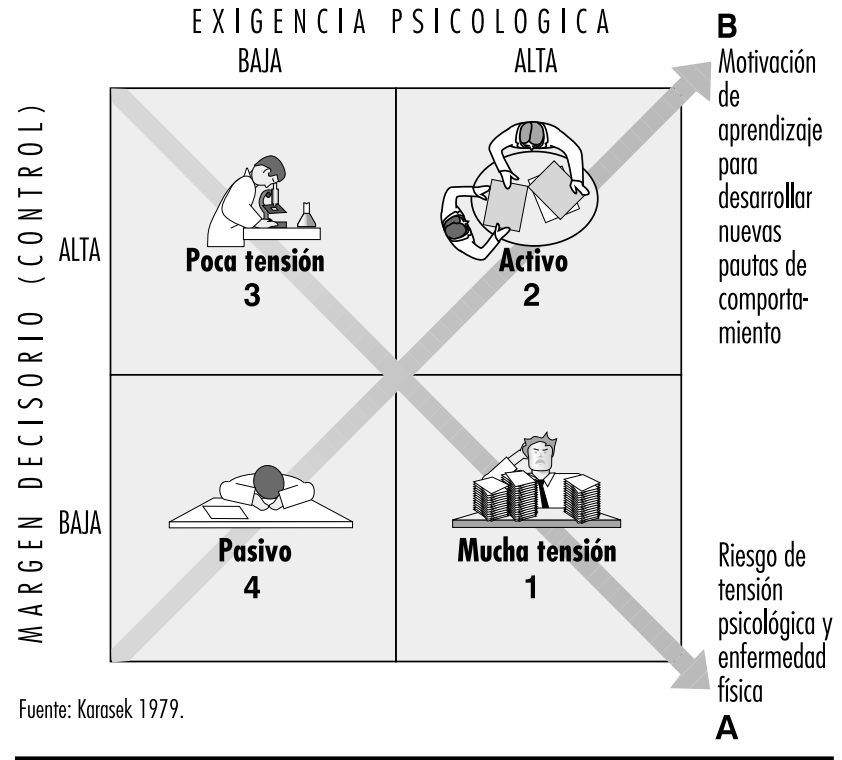


tan estrechamente relacionadas, tanto teórica como empíricamente, que muchas veces se combinan.

Entre los ejemplos de exigencias psicológicas del trabajo - "cuánto se trabaja" - figuran la imposición de plazos, la activación o estimulación mental necesaria para realizar la tarea y las cargas de coordinación. No se incluyen las demandas físicas del trabajo (aunque la estimulación psicológica implica esfuerzo físico). O tros componentes de las exigencias psicológicas del trabajo son estresores que se derivan de conflictos personales. Puede influir, evidentemente, el temor a perder el empleo 0 a que la preparación se quede obsoleta. Buck (1972) señala que, en líneas generales, los "requisitos de las tareas" (carga de trabajo) son, a pesar de la mencionada diversidad, el componente central de las exigencias psicológicas para la mayoría de los trabajadores. Aunque las mediciones sencillas de la jornada de trabajo, de intensidades moderadas, no parecen predecir claramente la enfermedad, una de las medidas de este tipo, la que se refiere al trabajo a turnos - especialmente cuando es rotatorio- , se asocia a problemas sociales sustanciales, así como a un incremento de la enfermedad.

Si bien se necesita un cierto nivel de "exigencias" para aprender cosas nuevas y tener un rendimiento eficaz en el trabajo (es decir, el interés), un nivel demasiado alto es evidentemente perjudicial. Ello se ha reflejado en la curva en forma de $U$ invertida con que se representa el nivel "óptimo" de exigencia en el conocido síndrome general de adaptación de Selye (1936) y en las teorías conexas y ya clásicas de Yerkes y D odson (1908) y Wundt (1922) sobre el estrés y el rendimiento. ${ }^{2}$ No obstante, los resultados de nuestras investigaciones indican que en la mayoría de las situaciones de trabajo se da un problema de exceso de carga, no de carga insuficiente.

\section{Hipótesis de aprendizaje activo}

Cuando el control sobre el trabajo es elevado y también son elevadas las demandas psicológicas, pero no abrumadoras (Figura 34.2, página anterior), los efectos sobre el comportamiento que se predicen son el aprendizaje y el crecimiento (es decir, la hipótesis de aprendizaje activo). Este tipo de trabajo se califica de "activo", pues estudios realizados tanto en Suecia como en Estados U nidos han demostrado que estos trabajadores son los más activos al margen de su vida laboral - en el ocio y en la actividad política - a pesar de las fuertes exigencias del trabajo (K arasek y Theorell 1990). Para este "trabajo activo" se predice únicamente una tensión psicológica media, pues gran parte de la energía que provocan muchos de los estresores del trabajo ("retos") se traducen en acción directa - solución eficaz de problemas-, de manera que queda poca tensión residual que cause trastornos. Esta hipótesis es paralela al "concepto de competencia" de White (1959): el estado psicológico de los individuos en circunstancias de reto personal se ve realzado al aumentar las "demandas": teoría de la motivación basada en el entorno. El modelo predice asimismo que los estímulos para el crecimiento y el aprendizaje que ofrecen estos entornos, cuando se producen en un contexto laboral, contribuyen a elevar la productividad.

En el modelo de demandas/ control se produce aprendizaje en situaciones que exigen tanto un gasto de energía psicológica individual (demandas o retos) como el ejercicio de la capacidad de toma de decisiones. Cuando el individuo que dispone de la

2Aunque la asociación en forma de $U$ de Selye entre demanda y estrés pretendía ser unidimensional a lo largo de un eje de estresantes, probablemente incluía también una segunda dimensión de "constricción" en sus experimentos con animales $-y$ por ello era en realidad un modelo compuesto del deterioro fisiológico relacionado con el estrés-, potencialmente similar a la situación de mucha exigencia y poco control que han comprobado otros investigadores (Weiss 1971) suficiente latitud de toma de decisiones hace una "elección" en cuanto a la mejor manera de afrontar un nuevo estresor, esa nueva respuesta de comportamiento, si es eficaz, se incorpora a su repertorio personal de estrategias similares (es decir, "aprende"). El nivel potencial de actividad en el futuro será más alto debido a que se ha ampliado la gama de soluciones a los retos del entorno, con el resultado de un aumento de la motivación. Las oportunidades para el reforzamiento constructivo de los patrones de comportamiento son óptimas cuando los retos existentes se corresponden con el control del individuo sobre las diversas opciones o con su capacidad para hacer frente a esos retos (C sikszentmihalyi 1975). La situación no será tan tajantemente simple (por tanto, tan poco importante) ni tan exigente como para que no se puedan adoptar medidas adecuadas debido a un alto nivel de ansiedad (la situación de "tensión" psicológica).

El modelo de demandas/ control predice que las situaciones de escasa exigencia y escaso control (Figura 34.2, arranque de la diagonal B) provocan un entorno de trabajo muy poco "motivador" que conduce a un "aprendizaje negativo" o a una pérdida gradual de capacidades adquiridas con anterioridad. Los datos que tenemos parecen indicar que, con el tiempo, las personas que trabajan en esos puestos se van distanciando de las actividades de ocio y de la actividad política al margen de su vida laboral (K arasek y Theorell 1990). Esos trabajos "pasivos" pueden ser el resultado de la "indefensión aprendida" que estudió Seligman (1975) a partir de una secuencia de situaciones de trabajo en las que se rechazaban las iniciativas de los trabajadores.

El hecho de que las exigencias del entorno puedan conceptualizarse así en términos tanto positivos como negativos es congruente con la idea comúnmente aceptada de que hay un estrés "bueno" y un estrés "malo". Los datos que demuestran que deben utilizarse al menos dos mecanismos distintos para describir el "funcionamiento psicológico" en el trabajo es una de las principales validaciones de la estructura pluridimensional del modelo de "demandas/control". La diagonal B ("activo" -"pasivo") comporta que los mecanismos de aprendizaje son independientes de los mecanismos de tensión psicológica (es decir, perpendiculares a ellos). Resulta así un modelo esquemático con dos grandes dimensiones de la actividad laboral y dos mecanismos psicológicos principales [que es la razón principal por la que se dice que es un modelo de "interacción" (Southwood 1978)]. (La prueba de las interacciones multiplicativas en los ejes es demasiado restrictiva en la mayoría de los tamaños de la muestra.)

\section{Aclaración de las definiciones de demandas y de control}

A veces se ha supuesto que el modelo de demandas/ control es congruente con un modelo de "necesidades y recursos", lo que permitiría un sencillo ajuste con el análisis hoy tan utilizado del "coste/ beneficio", restando los "beneficios" positivos de los "costes" negativos de las necesidades. El término "recursos" permite incluir muchos factores ajenos a la experiencia de trabajo inmediata del trabajador que son de evidente importancia. No obstante, la lógica de las hipótesis del modelo de demandas/ control no puede encorsetarse en un formato unidimensional. $\mathrm{H}$ ay que conservar la distinción entre la latitud de toma de decisiones y los estresores psicológicos, ya que el modelo predice tanto el aprendizaje como la tensión del trabajo, desde dos combinaciones distintas de demandas y control que no se prestan a una simple adición matemática. El "control" del trabajo no es un mero estresor negativo, y las "exigencias y retos" que se asocian a la falta de control no se asocian a un incremento del aprendizaje. Poner la latitud de toma decisiones por encima del proceso de trabajo reducirá el estrés del trabajador, pero 
incrementará su aprendizaje, mientras que las demandas psicológicas incrementarían tanto el aprendizaje como el estrés. Esta distinción entre demandas y control permite comprender la predicción, de otro modo poco clara, de los efectos de: a) la "responsabilidad", en la que en la práctica se combinan un alto nivel de exigencias y una amplia latitud de toma de decisiones; b) las "exigencias cualitativas del trabajo", donde se mide también la posibilidad de tomar decisiones sobre qué capacidades se han de emplear, y c) el "trabajo a destajo", en el que la latitud de toma de decisiones para trabajar más deprisa comporta casi directamente un incremento de las exigencias.

\section{Ampliación del modelo}

\section{H ipótesis de a poyo social}

Johnson ha ampliado de manera provechosa el modelo de demandas/control añadiéndole como tercera dimensión el apoyo social (Johnson 1986; K ristensen 1995). La hipótesis básica, que consiste en que los puestos de trabajo con grandes exigencias y escaso control $-y$ también un escaso apoyo social en el trabajo ("iso-tensión" alta) - son los que mayor riesgo de enfermedad presentan, se ha probado empíricamente con éxito en diversos estudios sobre enfermedades crónicas. Al añadir esta dimensión se reconoce claramente la necesidad de que cualquier teoría sobre el estrés en el trabajo evalúe las relaciones sociales en el lugar de trabajo (K arasek y T heorell 1990; Johnson y H all 1988). El hecho de que el apoyo social "amortigüe" la tensión psicológica puede depender del grado de integración social y emocional y de la confianza entre los compañeros de trabajo, supervisores, etc.: esto es, del "apoyo socioemocional" (Israel y Antonnuci 1987). Al añadirle el apoyo social, la perspectiva de demandas/ control resulta más útil cuando se trata de remodelar los puestos de trabajo. Los cambios en las relaciones sociales entre los trabajadores (es decir, los grupos de trabajo autónomos) y los cambios en la latitud de toma de decisiones son casi inseparables en los procesos de rediseño del trabajo, sobre todo en los procesos "participativos" (H ouse 1981).

No obstante, un tratamiento teórico completo de la repercusión de las relaciones sociales tanto sobre el estrés como sobre el comportamiento en el trabajo es algo muy complejo que requiere investigaciones más profundas. $L$ as asociaciones con los niveles de interacción con los compañeros de trabajo y los supervisores y la enfermedad crónica son menos sistemáticas que en el caso de la latitud de toma de decisiones, y las relaciones sociales pueden incrementar considerablemente, y también reducir, la estimulación del sistema nervioso que puede operar como vínculo entre la situación social y la enfermedad. Las dimensiones de la experiencia laboral que reducen el estrés en el trabajo no serían necesariamente las mismas que corresponden al comportamiento activo en el modelo de demandas/ control. L os intentos de facilitar las formas colectivas de comportamiento activo se centrarían probablemente en la distribución y en la capacidad de uso de las competencias, las estructuras y aptitudes de comunicación, las posibilidades de coordinación y las "aptitudes de inteligencia emocional" (Goleman 1995), así como en la confianza que tan importante es para el apoyo social.

\section{La profesión y las características psicosociales del trabajo}

Las características del trabajo pueden representarse mediante un diagrama de cuatro cuadrantes utilizando las características laborales medias de las distintas profesiones incluidas en el Censo de códigos profesionales de Estados Unidos (K arasek y Theorell 1990). En el cuadrante de trabajos "activos", con un alto nivel de exigencia y de control, figuran profesiones de gran prestigio: abogados, jueces, médicos, profesores, ingenieros, enfermeras y directivos de todo tipo. En el cuadrante de trabajos "pasivos", con un bajo nivel de exigencia y de control, figuran trabajadores administrativos como los empleados de almacenes y contables, los empleados de empresas de transporte y el personal de servicios de nivel bajo, como los conserjes. En el cuadrante de "mucha tensión", con un alto nivel de exigencia y un bajo nivel de control, figuran los operarios que siguen el ritmo de una máquina, como los montadores, cortadores, inspectores y manipuladores de cargas, así como otros trabajadores de servicios de nivel bajo, como camareros o cocineros. Son frecuentes las profesiones que tienen una presencia femenina dominante (costureras, camareras, telefonistas y otras trabajadoras de oficina con tareas automatizadas). Las profesiones de "poca tensión" en las que el ritmo lo marca el propio trabajador, como los empleados de reparaciones, vendedores, silvicultores, electricistas 0 naturalistas, suelen comportar un nivel considerable de formación y de fijación del propio ritmo.

Así pues, los ejecutivos y profesionales tienen un nivel de estrés moderado, no el máximo nivel como suele pensarse popularmente. Aunque sin duda existe el "estrés del directivo" debido al alto nivel de exigencia psicológica que acompaña a esos puestos, parece que las frecuentes oportunidades de tomar decisiones y de decidir cómo se realiza el trabajo son un importante moderador del estrés. A los niveles más altos, evidentemente, los trabajos ejecutivos consisten en tomar decisiones como exigencia psicológica básica, y ahí falla el modelo de demandas/ control. No obstante, está implícito que los ejecutivos podrían reducir su estrés si tomaran menos decisiones y los empleados de niveles inferiores estarían mejor si gozaran de más oportunidades de decidir, de tal modo que todos los grupos saldrían ganando si la capacidad decisoria se distribuyera de una manera más equitativa.

L os varones disponen con más frecuencia que las mujeres de un alto grado de control sobre su proceso de trabajo al nivel de tareas, con una diferencia tan grande como la que existe en sus salarios respectivos (K arasek y T heorell 1990). O tra importante diferencia por razón de sexo es que en las mujeres se da una correlación negativa entre el margen de toma de decisiones y las demandas: las mujeres con escaso control tienen también más exigencias. Esto significa que la probabilidad de que ocupen puestos de mucha tensión es varias veces mayor que la correspondiente al conjunto de la población activa. En cambio, los trabajos muy exigentes de los varones están acompañados generalmente por una latitud de toma de decisiones algo mayor ("autoridad con arreglo a la responsabilidad").

\section{Vinculaciones teóricas entre el modelo de demandas/control y otras perspectivas teóricas}

El modelo de demandas/control se deriva de la integración teórica de varias orientaciones científicas distintas. Así, queda fuera de los límites de una serie de tradiciones científicas consolidadas de las que ha tomado aportaciones o con las que suele contrastarse: la epidemiología y la sociología de la salud mental, la fisiología del estrés, la psicología cognitiva y la psicología de la personalidad. Algunas de esas teorías del estrés anteriores se centraban en una explicación causal basada en la persona, mientras que el modelo de demandas/ control predice una respuesta de estrés a las condiciones sociales y psicológicas del entorno. No obstante, el modelo de demandas/ control ha intentado establecer una serie de hipótesis de interrelación con las perspectivas que se basan en la persona. Asimismo se han propuesto vinculaciones con cuestiones de la organización social y la economía política a nivel macro, como la clase social. A continuación se examinan a diversos niveles esas integraciones y contrastes con otras teorías. Tales vinculaciones son el marco en el que se puede formular una serie de nuevas hipótesis científicas. 


\section{Contraste entre el modelo de demandas/control y el modelo psicológico cognitivo}

Uno de los ámbitos de la teoría del estrés es el que procede de una disciplina hoy popular, la psicología cognitiva. El principio básico del modelo cognitivo del funcionamiento psicológico humano es que son los procesos de percepción e interpretación del mundo exterior los que determinan el desarrollo de los estados psicológicos en el individuo. La carga mental de trabajo se define como la carga total de información que el trabajador debe percibir e interpretar cuando realiza sus tareas laborales (Sanders y M cC ormick 1993; Wickens 1984). H ay "sobrecarga" y estrés cuando esa carga de procesamiento de información humana es demasiado grande para las capacidades individuales de procesamiento de información. Este modelo ha gozado de gran aceptación porque establece un modelo de las funciones mentales humanas que en líneas generales responde al modelo conceptual que utilizan los ordenadores modernos, y por lo tanto se ajusta bien a una concepción "tecnológica" del diseño del trabajo. Pone de manifiesto la importancia de las sobrecargas de información, las dificultades de comunicación y los problemas de memoria. Funciona bien en el diseño de algunos aspectos de las interrelaciones entre las personas y los ordenadores y la vigilancia humana de procesos complejos.

N o obstante, la perspectiva de la psicología cognitiva tiende a restar importancia a los estresores "objetivos" presentes en el lugar de trabajo, por ejemplo, y hace hincapié en cambio en la importancia de la interpretación de la situación que hacen los individuos estresados. En su "enfoque de afrontamiento" de base cognitiva, Lazarus y Folkman (1986) proponen que el individuo "reinterpreta cognitivamente" la situación de tal manera que hace que parezca menos amenazante, con lo que reduce el estrés que se experimenta. Sin embargo, este enfoque podría ser perjudicial para los trabajadores en situaciones en las que los estresores del entorno son "objetivamente" reales y han de modificarse. 0 tra variante del enfoque cognitivo, más coherente con la potenciación del trabajador, es la teoría de la "autoeficacia/ motivación" propuesta por Bandura (1977), que hace hincapié en cómo se incrementa la autoestima cuando los individuos: a) definen un objetivo para un proceso de cambio; b) reciben una retroalimentación desde el entorno sobre los resultados positivos alcanzados, y c) consiguen avanzar de manera progresiva. En el modelo cognitivo hay varias omisiones que plantean problemas para una perspectiva del estrés basada en la salud en el trabajo y que entran en conflicto con el modelo de demandas/ control:

- No desempeñan ninguna función las "demandas" sociales y mentales del trabajo que no se traducen en carga de información (es decir, las tareas que requieren unas exigencias de organización social, conflictos y muchos plazos de tiempo no intelectuales).

- El modelo cognitivo predice que las situaciones que exigen tomar muchas decisiones son muy estresoras porque pueden sobrecargar la capacidad de procesamiento de información del individuo. Esto se opone directamente al modelo de demandas/ control, que predice una menor tensión en las situaciones de exigencia que dejan margen para la libertad de decisión. La mayoría de los datos epidemiológicos obtenidos en estudios sobre el terreno apoya el modelo de demandas/ control, pero los ensayos de laboratorio pueden generar también un efecto de sobrecarga cognitiva basada en la toma de decisiones.

- En el modelo cognitivo se omiten también los impulsos fisiológicos y las emociones primitivas, que suelen dominar la respuesta cognitiva en las situaciones de reto personal. A penas se examina la forma en que surgen en las situaciones sociales comunes entre los adultos tanto las emociones negativas como el comportamiento basado en el aprendizaje (excepto en el caso de Bandura antes citado).
Aunque se pasa por alto en el modelo cognitivo, la respuesta emocional es básica para el concepto de "estrés", pues el problema inicial de estrés suele ser lo que lleva a estados emocionales desagradables, como la ansiedad, el miedo y la depresión. Los "impulsos" y las emociones dependen en gran medida de las zonas límbicas del cerebro, una región cerebral distinta y más primitiva que el córtex, al que se refiere la mayoría de los procesos que describe la psicología cognitiva. El hecho de que no se haya elaborado una perspectiva integrada sobre el funcionamiento psicológico refleja posiblemente la dificultad de integrar diferentes líneas de investigación especializadas que se centran en dos sistemas neurológicos distintos del cerebro. No obstante, recientemente se han empezado a acumular datos sobre los efectos conjuntos de la emoción y la cognición. Parece que la conclusión es que la emoción es un determinante subyacente de la fuerza de las pautas de comportamiento, de la memoria y la cognición (D amasio 1994; G oleman 1995).

\section{Integración de las perspectivas sociológicas y emocionales del estrés}

\section{Desarrollo del modelo de demandas/ control}

Con el modelo de demandas/ control se quiso desde un principio integrar la comprensión de la situación social con las pruebas disponibles referentes a la respuesta emocional, a los síntomas de enfermedad psicosomática y al desarrollo de comportamientos activos en las principales esferas de la actividad vital de un adulto, sobre todo en el contexto del trabajo, que es una situación socialmente muy estructurada. No obstante, en el momento en que se estaba desarrollando el modelo, una probable plataforma para esa labor, la investigación sociológica centrada en la exploración de la enfermedad en grandes estudios de población, solía omitir el nivel detallado de las pruebas referentes a la respuesta social 0 personal, con lo cual hubo que realizar una importante labor de integración para desarrollar el modelo.

La primera idea integradora del modelo de demandas/ control - referente a la situación social y la respuesta emocional- incluyó los síntomas del estrés y relacionó dos tradiciones de estudio de la sociología y de la psicología social que eran relativamente unidimensionales. Por un lado, la tradición relativa a la vida estresada/ enfermedad ( $\mathrm{H}$ olmes y $\mathrm{R}$ ahe 1967; D ohrenwend y Dohrenwend 1974) postulaba que la enfermedad tenía su base únicamente en las exigencias sociales y psicológicas, olvidando el control de los estresores. Por otro lado, la importancia del control en el lugar de trabajo se había reconocido ya claramente en la bibliografía sobre la satisfacción en el trabajo (Kornhauser 1965): se utilizaban la autonomía de tareas y la variedad de capacidades para predecir la satisfacción en el trabajo, el absentismo o la productividad, con adiciones limitadas que reflejaban la relación social de los trabajadores con el empleo - pero apenas se mencionaba el elemento de la carga de trabajo. La integración de los diversos estudios contribuyó a cubrir las lagunas que había en la esfera de la enfermedad y la tensión mental. Sundbom (1971) observó síntomas de tensión psicológica en el "trabajo mentalmente pesado", que se medía efectivamente mediante preguntas relacionadas tanto con las presiones mentales fuertes como con la monotonía del trabajo (que presumiblemente representaba también un control limitado). La conclusión a la que se llegó tras combinar ambos estudios y líneas de investigación era que se necesitaba un modelo bidimensional para predecir la enfermedad: el nivel de exigencias psicológicas determinaba si un control escaso podía llevar a dos tipos de problemas notablemente distintos, la tensión psicológica o el repliegue pasivo.

La segunda idea integradora del modelo de demandas/ control relacionó la predicción de las pautas de comportamiento 
en relación con la experiencia de trabajo. Se observó que los resultados de comportamiento de la actividad laboral estaban también afectados por las dos mismas características generales del trabajo, si bien en una combinación distinta. Kohn y Schooler (1973) habían señalado que las orientaciones activas del trabajo eran la consecuencia de unos niveles altos tanto de capacidades como de autonomía, más una actividad psicológicamente exigente. Eran importantes correlatos en este caso las medidas de clase social. M eissner (1971) había comprobado también que el comportamiento de ocio estaba asociado positivamente con las oportunidades tanto de tomar decisiones en el trabajo como de realizar tareas mentalmente exigentes. La conclusión combinada de esos estudios era que el "reto" o activación mental era, por una parte, necesario para un aprendizaje eficaz y, por otra, podía contribuir a la tensión psicológica. EI "control" era la variable moderadora decisiva que determinaba si las exigencias del entorno llevaban a consecuencias de aprendizaje "positivas" o a consecuencias de tensión "negativas".

La combinación de estas dos hipótesis integradoras, predictivas de los resultados tanto en el campo de la salud como del comportamiento, es la base del modelo de demandas/ control. Los niveles de "demanda" son el factor contingente que determina si un control escaso conduce a la pasividad o a la tensión psicológica; y los niveles de "control" son el factor contingente que determina si las exigencias conducen al aprendizaje activo 0 a la tensión psicológica (K arasek 1976; 1979). Se ensayó después el modelo en una muestra nacional representativa en Suecia (K arasek 1976) para predecir tanto los síntomas de enfermedad como los correlatos de ocio y actividad política de las condiciones psicosociales del trabajo. L as hipótesis se confirmaron en las dos esferas, aunque evidentemente en los resultados figuraban muchos factores de confusión. Poco después de esas confirmaciones empíricas aparecieron otras dos formulaciones conceptuales, coherentes con el modelo de demandas/ control, que confirmaban la solidez de las hipótesis generales. Seligman (1976) observó depresión e indefensión aprendida en condiciones de intensa exigencia con escaso control. Simultáneamente, C sikszentmihalyi (1975) comprobó que de las situaciones que comportaban tanto retos psicológicos como altos niveles de competencia se derivaba una "experiencia activa" ("flujo"). Con el empleo de este modelo integrado se pudieron resolver algunas paradojas de los estudios sobre la satisfacción en el trabajo y la tensión mental (K arasek 1979): por ejemplo, que las cargas cualitativas de trabajo solían estar negativamente asociadas con la tensión (porque también reflejaban el control del individuo sobre la utilización de sus aptitudes). La aceptación más amplia del modelo por otros investigadores se produjo en 1979, tras la ampliación de la predicción empírica de la enfermedad coronaria, con la asistencia de Tores Theorell, médico con una notable experiencia en el campo de la epidemiología cardiovascular.

\section{Una segunda integración del modelo de demandas/ control: la respuesta fisiológica}

Estudios complementarios permitieron un segundo nivel de integración que vincula el modelo de demandas/control a la respuesta fisiológica. ${ }^{3}$ Los principales avances de la investigación

${ }^{3}$ En 1974 impulsó notablemente el desarrollo de la hipótesis sobre la tensión en el modelo de demandas/ control la observación de Dement (1969) de que la relajación vital relacionada con los sueños REM se inhibía en los gatos privados de sueño cuando se los "constreñía" mediante movimientos repetitivos (en cierto modo como una cadena de montaje) tras períodos de exposición a fuertes estresores psicológicos. La acción combinada de esos estresores exteriores y del escaso control sobre el entorno era esencial para producir esos efectos. L as consecuencias negativas, en términos de trastornos mentales, eran enormes y llevaban a perder la capacidad de coordinar los procesos fisiológicos más elementales. fisiológica habían identificado dos modalidades de adaptación de un organismo a su entorno. La respuesta de "fight-flight" ("Iucha o abandono") propuesta por Cannon (1914) se asocia sobre todo con la estimulación de la medula suprarrenal y con la secreción de adrenalina. Esta modalidad, que se produce en conjunción con una activación simpática del sistema cardiovascular, es claramente una forma de respuesta activa y enérgica en la que el cuerpo humano es capaz de utilizar la máxima energía metabólica en apoyo del esfuerzo mental y físico necesario para evitar las principales amenazas a su supervivencia. En la segunda modalidad de respuesta fisiológica, la respuesta de la corteza suprarrenal constituye una respuesta a la derrota, un repliegue en una situación en la que hay pocas posibilidades de victoria. Los estudios de Selye (1936) sobre el estrés se referían a la respuesta de la corteza suprarrenal en animales que estaban en una situación de estrés pero pasiva (es decir, los animales de experimentación estaban limitados al mismo tiempo que estresados, no en una situación de "lucha o abandono"). Henry y Stephens (1977) describen este comportamiento como la derrota 0 pérdida de vínculos sociales, que lleva al repliegue y a la sumisión en las interacciones sociales.

A principios del decenio de 1980, los estudios de Frankenhaeuser (1986) pusieron de manifiesto la congruencia de estas dos modalidades de la respuesta fisiológica con las principales hipótesis del modelo de demandas/ control, y de este modo pudo vincularse la respuesta fisiológica y la situación social con las formas de la respuesta emocional. En las situaciones de mucha tensión se eleva la secreción tanto de cortisol por la corteza suprarrenal como de adrenalina por la medula suprarrenal, mientras que en una situación en la que el individuo está sometido a un estresor controlable y predecible sólo se eleva la secreción de adrenalina (Frankenhaeuser, Lundberg y Forsman 1980). Se demostraba así una notable diferenciación de la respuesta psicoendocrina asociada con diferentes situaciones del entorno. Frankenhaeuser utilizó un modelo bidimensional con la misma estructura que el de demandas/ control, aunque utilizando dimensiones que etiquetaban la respuesta emocional personal. A sí, el "esfuerzo" indica la actividad estimuladora de la medula suprarrenal (las exigencias en el modelo de demandas/ control), y el estrés negativo ("distress") describe la actividad estimuladora de la corteza suprarrenal (falta de latitud de toma de decisiones en el modelo de demandas/ control). Las categorías de la respuesta emocional de Frankenhaeuser reflejan una vinculación más clara entre la emoción y la respuesta fisiológica, pero en esta modalidad el modelo de demandas/ control no refleja la asociación entre la sociología del trabajo y la respuesta fisiológica, que es otra de sus virtudes.

\section{Integración de la teoría del estrés basada en la persona: la} versión dinámica del modelo de demandas/ control

U na de las dificultades que planteaba el desarrollo del modelo de demandas/ control era la elaboración de una alternativa a la explicación socialmente conservadora de que los factores básicamente responsables del estrés son la percepción del trabajador 0 las orientaciones de su respuesta, como afirman algunas de las teorías del estrés basadas en la persona. Por ejemplo, resulta difícil aceptar la idea, difundida por estas últimas teorías, de que la mayoría de las reacciones de estrés se producen porque tipos de personalidad individual que son habituales suelen malinterpretar las tensiones del mundo real o son demasiado sensibles a ellas, y que esos tipos de personalidad pueden identificarse sobre la base de pruebas sencillas. De hecho, los datos a favor de tales efectos de la personalidad no han sido nunca tajantes, ni siquiera con los sistemas de medición más comunes [aunque se haya identificado una personalidad que rechaza el estrés, la alexitimia (Henry y Stephens 1977)]. El patrón de comportamiento de 
Tipo A, por ejemplo, se interpretó originalmente como la propensión del individuo a elegir actividades estresoras, pero los estudios en este ámbito se han reorientado en la actualidad hacia la personalidad "proclive a la agresividad" (Williams 1987). Evidentemente, la respuesta de agresividad podría tener un importante componente de respuesta al entorno. Una versión más generalizada del enfoque basado en la personalidad la hallamos en el modelo de "ajuste persona-entorno" (H arrison 1978), que propone que lo que reduce el estrés es una buena adaptación entre la persona y el entorno. También en este caso ha sido difícil especificar las características concretas de la personalidad que hay que medir. En todo caso, los enfoques basados en la respuesta personal/personalidad han estudiado el hecho evidente de que: a) las percepciones basadas en la personalidad son un componente importante del proceso de influencia del entorno sobre el individuo, y b) hay diferencias duraderas en las respuestas personales al entorno. Se elaboró de esta manera una versión del modelo de demandas/ control que era temporalmente dinámica, integrada y basada en el entorno y la persona.

La versión dinámica del modelo de demandas/control (Figura 34.3) integra los efectos del entorno con fenómenos individuales, como el desarrollo de la autoestima y el agotamiento prolongado. Esta versión dinámica integra los factores basados en la personalidad y el entorno construyendo dos hipótesis combinadas sobre la tensión original y los mecanismos de aprendizaje: a) que el estrés inhibe el aprendizaje, y b) que el aprendizaje, a largo plazo, puede inhibir el estrés. La primera hipótesis consiste en que altos niveles de tensión pueden inhibir la capacidad normal de aceptar un reto, y con ello inhibir el aprendizaje de cosas nuevas. Esos altos niveles de tensión pueden ser el resultado de una tensión psicológica duradera que se va acumulando con el tiempo y que pueden reflejarse en medidas basadas en aspectos individuales (Figura 34.3, flecha diagonal B). La segunda hipótesis es que del aprendizaje de cosas nuevas pueden derivarse sentimientos de dominio 0 confianza: una medida basada en el individuo. E sos sentimientos de dominio, a su vez, pueden llevar a reducir la percepción de los acontecimientos como estresores y a incrementar el éxito a la hora de hacer frente a ellos (Figura 34.3, flecha diagonal A). Así pues, los factores del entorno, a largo plazo, determinan en parte la personalidad, y posteriormente los efectos del entorno son moderados por esas orientaciones de la personalidad ya desarrolladas. En este modelo general podrían tener cabida las siguientes y más concretas medidas de respuesta personal: sentimientos de dominio, rechazo, alexitimia, ansiedad, agresividad, cansancio vital, agotamiento, consecuencias de estresores

Figura 34.3 - Asociaciones dinámicas entre la tensión del entorno y el aprendizaje y la evolución de la personalidad.

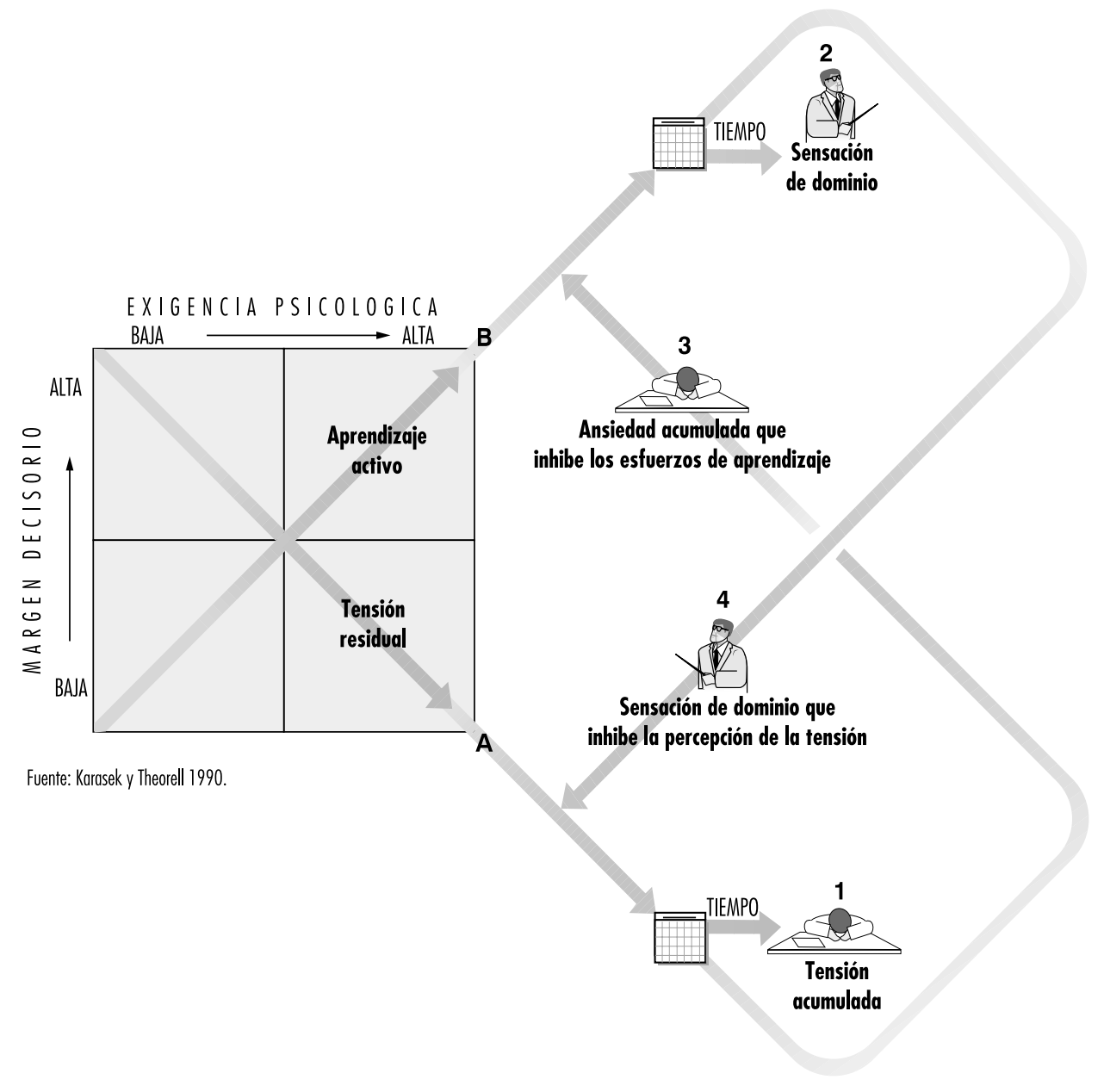


acumulados a lo largo de toda la vida y posiblemente componentes del comportamiento de tipo $A$.

El modelo dinámico ofrece la posibilidad de establecer dos "espirales" dinámicas del comportamiento a largo plazo. La dinámica de comportamiento positiva se inicia con el marco de trabajo activo, el mayor "sentimiento de dominio" y la mayor capacidad para hacer frente a los inevitables estresores del trabajo. E sos factores reducen a su vez la ansiedad acumulada y con ello incrementan la capacidad de aceptar nuevos retos de aprendizaje, con el resultado de un cambio de la personalidad aún más positivo y de una mejora del bienestar. La dinámica de comportamiento no deseable se inicia con el trabajo bajo una fuerte tensión, la acumulación de mucha tensión residual y la restricción de la capacidad de aceptar retos de aprendizaje. Esos factores llevan a su vez a que se reduzca la autoestima y aumenten las percepciones de estrés, con el resultado de un cambio de la personalidad aún más negativo y un deterioro del bienestar. Los datos sobre estos mecanismos secundarios se analizan en K arasek y Theorell (1990), aunque el modelo completo no se ha ensayado todavía. D os líneas de investigación prometedoras que se podrían integrar fácilmente con los estudios sobre la demandas/control son las que se refieren al "cansancio vital", junto con las variables respuestas a las exigencias de la vida (A ppels 1990), y a los métodos de "autoeficacia" de Bandura (1977), con la adquisición de capacidades y el desarrollo de la autoestima.

\section{El modelo de demandas/control y el sistema dinámico del estrés fisiológico}

Uno de los siguientes pasos que hay que dar en los estudios sobre demandas/ control es especificar de una manera más completa las vías fisiológicas del origen de la enfermedad. La respuesta fisiológica se entiende cada vez más como una respuesta de un sistema complejo. La fisiología de la respuesta de estrés en el ser humano - un comportamiento de "lucha o abandono", por ejemplo- es una combinación muy integrada de cambios en el gasto cardiovascular, la regulación del tallo cerebral, la interacción respiratoria, el control de la respuesta endocrina por el sistema límbico, la activación cortical general y cambios en el sistema circulatorio periférico. Es muy posible que el concepto de "estrés" sea muy relevante para los sistemas complejos, en los que intervienen múltiples subsistemas que interactúan entre sí y una causalidad compleja. ${ }^{4}$ D esde esta nueva perspectiva de los principios de la dinámica del sistema fisiológico se están definiendo muchas enfermedades como trastornos de la regulación del sistema ( $H$ enry y Stephens 1977; Weiner 1977) y se investigan los resultados de ajustes multifactoriales y dependientes del tiempo para llegar al equilibrio del sistema 0 , por el contrario, a la falta de equilibrio o "caos".

Interpretando tales observaciones desde la perspectiva de un modelo "generalizado" de demandas/ control, podríamos afirmar que el estrés tiene que ver con un desequilibrio del sistema en su conjunto, aun cuando funcionen bien partes de él. Todos los organismos han de tener mecanismos de control para integrar lo que hacen sus distintos subsistemas (por ejemplo, el cerebro, el corazón y el sistema inmune). El estrés (o la tensión del trabajo) sería un estado de sobrecarga que experimenta el "sistema de control" del organismo cuando trata de mantener el funcionamiento integrado frente a un número excesivo de retos del entorno ("alto nivel de exigencias"), y cuando falla la

4 En lugar de una relación de causa-efecto única e inequívoca como en las llamadas "ciencias positivas", en los modelos sobre el estrés las asociaciones causales son más complejas: puede haber muchas causas que se "acumulan" para producir un único efecto; una sola causa (el "estresor") puede producir numerosos efectos, y hay efectos que sólo se producen transcurrido un plazo de tiempo considerable. capacidad del sistema para controlar de una manera integrada sus submecanismos ("alto nivel de tensión"). Para poner orden en su caótico entorno, los sistemas internos de control fisiológico del individuo han de "hacer el trabajo" de mantener una regularidad fisiológica coordinada (por ejemplo, una frecuencia cardíaca constante) frente a las irregulares demandas del entorno. Cuando la capacidad de control del organismo está exhausta tras una excesiva labor de "organización" (estado de entropía baja, por analogía con la termodinámica), nuevas exigencias conducen a un exceso de fatiga o a una tensión debilitadora. Además, periódicamente todos los organismos han de llevar de nuevo sus sistemas de control al estado de descanso - períodos de sueño o relajación (estado de desorden relajado o entropía alta) - para poder acometer la siguiente serie de tareas de coordinación. Los procesos de coordinación del sistema o sus intentos de relajación pueden inhibirse si el sistema no puede actuar de una manera óptima, es decir, si no tiene posibilidades de controlar su situación o de hallar un estado de equilibrio interno satisfactorio. En general, la "falta de control" puede representar una restricción de la capacidad del organismo para utilizar todos sus mecanismos de adaptación con miras a mantener el equilibrio fisiológico frente a las exigencias, lo que lleva a un aumento de las cargas a largo plazo y del riesgo de enfermedad. En esa dirección podría ir en el futuro la investigación de los aspectos fisiológicos del modelo de demandas/ control.

Una conclusión potencialmente coherente es que, aunque el modelo de demandas/ control predice la mortalidad cardiovascular, no hay ningún factor de riesgo tradicional o indicador fisiológico que por sí solo parezca la vía principal de ese riesgo. Los estudios futuros pueden demostrar si esa vía son los "fallos de la dinámica del sistema".

\section{Implicaciones macrosociales del modelo de demandas/ control} Los modelos en los que se integran varias disciplinas científicas permiten efectuar predicciones más amplias acerca de las consecuencias de las instituciones sociales humanas sobre la salud. Por ejemplo, H enry y Stephens (1977) han señalado que en el mundo animal las "demandas psicológicas" se derivan de las responsabilidades profundamente "sociales" de hallar alimento y cobijo para la familia y de criar y defender a las crías; sería difícil imaginar situaciones de exigencias forzosas combinadas con un aislamiento social. El mundo del trabajo humano, en cambio, está organizado de tal manera que pueden producirse exigencias sin afiliación social alguna. De hecho, según los Principios de la dirección científica de Frederick Taylor (1911 (1967), la intensificación de las exigencias que se imponen a los trabajadores debe realizarse muchas veces de manera aislada, pues de lo contrario éstos se rebelarían contra el proceso iy volverían a la socialización, con su pérdida de tiempo! A demás de mostrar la utilidad de un modelo integrado, este ejemplo pone de manifiesto la necesidad de comprender aún mejor, desde el punto de vista social, la respuesta de estrés en los seres humanos (por ejemplo, añadiendo una dimensión de apoyo social al modelo de demandas/ control).

Para comprender el desarrollo económico y político en el futuro es especialmente necesario entender la respuesta de estrés de una manera integrada y con referencia a lo social. M odelos menos completos podrían ser engañosos. Por ejemplo, según el modelo cognitivo que ha dominado el diálogo público sobre el desarrollo social e industrial en el futuro (por ejemplo, la dirección en que se van a desarrollar las capacidades de los trabajadores, la vida en la sociedad de la información, etc.), un individuo es libre para interpretar - es decir, para reprogramar - su percepción de los hechos reales como estresores 0 no estresores. Desde el punto de vista social se deduce que, literalmente, podemos diseñar cualquier tipo de organización y que 
hemos de asumir la responsabilidad de adaptarnos a todas las tensiones que pueda producir. Sin embargo, muchas de las consecuencias fisiológicas del estrés tienen que ver con el "cerebro emocional" que reside en el sistema límbico, el cual tiene una estructura determinista con claras limitaciones respecto de las exigencias globales. Está claro que no es un sistema "infinitamente" reprogramable, como indican con claridad los estudios sobre el síndrome de estrés postraumático (Goleman 1995). No tener en cuenta los límites del sistema límbico - y la integración de la respuesta emocional y la integración social- puede conducirnos a una serie de conflictos básicos del desarrollo humano que son característicos de nuestro tiempo. Es posible que estemos desarrollando, sobre la base de las extraordinarias capacidades cognitivas de nuestro córtex cerebral, unos sistemas sociales que plantean unas exigencias imposibles, en forma de sobrecargas, a las funciones del sistema límbico, que son más básicas: pérdida de vínculos sociales, falta de posibilidades de control interno y restricción de la capacidad de visión global. En resumen, parece que estamos corriendo el riesgo de desarrollar organizaciones de trabajo para las que no estamos preparados desde el punto de vista sociobiológico. Estos resultados no son sólo la consecuencia de modelos científicos incompletos, sino que facilitan también un tipo equivocado de procesos sociales: procesos en los que se atiende a los intereses de algunos grupos con poder social a costa de imponer a otros unos niveles de disfunción social y personal que nunca habían experimentado antes.

\section{Clase social y mediciones psicosociales del trabajo}

En muchos casos, estresores de nivel individual pueden explicarse como el resultado causal de procesos sociales, dinámicos y político-económicos de mayor alcance. Así pues, es necesario establecer también vinculaciones teóricas con conceptos como el de clase social. Evaluar las asociaciones entre la situación social y la enfermedad plantea la cuestión de la relación que existe entre los factores psicosociales de demandas/ control y medidas generales de la circunstancia social, como la clase social. La medida de la latitud de toma de decisiones en el trabajo está en clara correlación, por supuesto, con la educación y con otras medidas de la clase social. Sin embargo, en la clase social se miden tradicionalmente efectos de ingresos y de educación que operan a través de mecanismos que son distintos de las vías psicosociales del modelo de demandas/ control. Es importante señalar que la dimensión de tensión en el trabajo es casi perpendicular a la mayoría de las medidas de clase social en las poblaciones nacionales [en cambio, la dimensión actividad/pasividad está muy correlacionada con la clase social entre los trabajadores de nivel alto (solamente)] (K arasek y Theorell 1990). En los empleos de nivel bajo parece que los aspectos de estrecha latitud de toma de decisiones contribuyen de manera más importante a la tensión psicológica que la distinción entre carga de trabajo mental y física, que es lo que tradicionalmente determina la pertenencia al grupo de los trabajadores no manuales o manuales. De hecho, el esfuerzo físico que es habitual en muchos empleos de tipo manual puede ser una protección frente a la tensión psicológica en algunas circunstancias. Aunque la tensión es efectivamente más común en los empleos de nivel bajo, las dimensiones psicosociales determinan un panorama de riesgo de tensión que es notablemente independiente de las medidas tradicionales de clase social.

Aunque se ha apuntado que las asociaciones observadas entre puesto de trabajo y enfermedad conforme al modelo de demandas/ control reflejan simplemente diferencias de clase social (G anster 1989; Spector 1986), los datos obtenidos en los estudios experimentales permiten rechazar tal opinión ( $\mathrm{K}$ arasek y Theorell 1990). En la mayoría de esos estudios con el modelo de demandas/ control se ha realizado controlando la variable clase social, y las asociaciones demandas/ control persisten dentro de los diversos grupos sociales. No obstante, las asociaciones con el modelo se confirman de manera más sistemática en el caso de los trabajadores manuales, mientras que en el de los trabajadores no manuales no son igual de sólidas (véase más adelante "Tensión en el trabajo y enfermedad cardiovascular") en todos los estudios, y lo son menos en los estudios dedicados a una sola profesión de tipo administrativo. (Evidentemente, en el caso de los directivos y profesionales de nivel muy alto la toma de decisiones puede ser en sí misma una exigencia significativa.)

El hecho de que las medidas tradicionales "de clase social" presenten a menudo unas asociaciones más débiles con los resultados de aflicción mental y enfermedad que el modelo de demandas/ control es, en realidad, un argumento a favor de las nuevas concepciones de la clase social. K arasek y Theorell (1990) definen un nuevo grupo de trabajadores psicosocialmente favorecidos y desfavorecidos, en el que hay "perdedores" desde el punto de vista del estrés en puestos rutinarios, comercializados y burocratizados, y "ganadores" en el trabajo intelectual muy creativo y centrado en el aprendizaje. Esa definición es coherente con un nuevo producto industrial basado en las aptitudes, propio de la "sociedad de la información", y con una nueva perspectiva de la política de clases.

\section{Cuestiones metodológicas}

\section{Objetividad de las mediciones psicosociales del trabajo}

EI método más utilizado para obtener datos sobre las características psicosociales del trabajo ha sido el de entregar a los trabajadores unos cuestionarios autoadministrados, pues son sencillos de manejar y asimismo es fácil diseñarlos para extraer los conceptos básicos cuando se trata de remodelaciones laborales (H ackman y O Idham JDS 1975), como en el Cuestionario sobre el contenido de los puestos de trabajo (Karasek 1985) y en el cuestionario sueco Statshalsan. Aunque están concebidos para medir el trabajo objetivo, estos instrumentos miden inevitablemente las características del puesto de trabajo tal como las percibe el trabajador. En este sistema puede haber sesgo en las variables que dependen del método de autoadministración, como la depresión, el cansancio o la insatisfacción. U na posible solución es agregar las respuestas a este tipo de encuestas por grupos de trabajo que tienen situaciones laborales similares, lo que diluye los sesgos individuales (K ristensen 1995). Esta es la base de sistemas muy utilizados que vinculan las características psicosociales con la profesión (Johnson y cols. 1996).

Se ha evaluado también la validez "objetiva" de las escalas psicosociales basadas en encuestas administradas: las correlaciones entre los datos así obtenidos y los procedentes de la observación de expertos suelen ser de un 0,70 o más en lo que atañe a la latitud de toma de decisiones, y menores $(0,35)$ en relación con las demandas del trabajo (Frese y Zapf 1988). También apoyan la validez objetiva las elevadas varianzas entre profesiones ( 40 a $45 \%$ ) de las escalas de latitud de toma de decisiones, que son mejores que en el caso de los ingresos (21\%) y en el del esfuerzo físico ( $25 \%$ ), factores que está aceptado que presentan grandes variaciones según la profesión ( $\mathrm{K}$ arasek y Theorell 1990). No obstante, entre profesiones sólo hay un $7 \%$ y un $4 \%$ de varianza de las exigencias psicológicas y del apoyo social respectivamente, lo que deja la posibilidad de que exista un importante componente individual en las contestaciones sobre estas medidas.

Sería conveniente contar con estrategias de medición más objetivas. Algunos métodos de evaluación objetiva bien conocidos son congruentes con el modelo de demandas/ control [en el caso de la latitud de toma de decisiones: VERA, Volpert y cols. (1983)]. No obstante, las observaciones de expertos 
presentan asimismo problemas: son costosas y laboriosas, y al evaluar las interacciones sociales no generan obviamente medidas más precisas. También comporta sesgos teóricos el concepto mismo de las mediciones "de expertos" normalizadas: es mucho más fácil "medir" las características de los puestos en una línea de montaje de nivel bajo, que son repetitivas y de fácil observación, que las tareas más heterogéneas de los directivos 0 profesionales de nivel alto. Así pues, la objetividad de las mediciones psicosociales está en relación inversa con la latitud de toma de decisiones que tiene el trabajador.

\section{Examen de algunos datos empíricos sobre el modelo de demandas/ control}

\section{Tensión en el trabajo y enfermedad cardiovascular (ECV)}

El modelo tiene su mejor apoyo empírico en las asociaciones entre la tensión en el trabajo y la enfermedad cardíaca. Recientemente han examinado ampliamente la cuestión Schnall, Landsbergis y Baker (1994), Landsbergis y cols. (1993) y K ristensen (1995). R esumiendo a Schnall, Landsbergis y Baker (1994) (actualizado por Landsbergis, comunicación personal con el autor en el otoño de 1995): 16 de 22 estudios han confirmado una asociación entre la tensión en el trabajo y la mortalidad cardiovascular mediante el empleo de muy diversas metodologías: 7 de 11 estudios de cohortes; 2 de 3 estudios transversales; 4 de 4 estudios de caso-control, y 3 de 3 estudios que utilizaban indicadores de síntomas de enfermedad. L os estudios más negativos se referían a las poblaciones de más edad (sobre todo de más de 55 años, en algunos casos con una jubilación bastante anterior) y se basaban principalmente en puntuaciones agregadas por profesiones que, aunque reducían el sesgo derivado del método de autoadministración, tenían poca potencia estadística. Parece que la hipótesis de la tensión en el trabajo es algo más coherente cuando predice la ECV en trabajadores manuales que cuando lo hace en trabajadores no manuales (M armot y Theorell 1988). L os factores tradicionales de riesgo de ECV, como el colesterol sérico, el tabaquismo e incluso la presión arterial, cuando se miden de la manera tradicional, han mostrado hasta el momento sólo unos efectos de tensión no sistemáticos o débiles. En cambio, métodos más complejos (presión arterial ambulatoria) dan resultados positivos sustanciales (T heorell y K arasek 1996).

\section{Tensión en el trabajo y trastornos psicológicos, absentismo}

En K arasek y Theorell (1990) se examinan las conclusiones en materia de trastornos psicológicos. Los estudios confirman en su mayoría una asociación con la tensión en el trabajo y se refieren a poblaciones ampliamente 0 nacionalmente representativas de una serie de países. Las limitaciones normales del estudio son el diseño transversal y el problema, difícil de evitar, de los cuestionarios autoadministrados sobre el trabajo y la tensión psicológica, aunque algunos estudios incluyen también una evaluación objetiva, por un observador, de las situaciones de trabajo y hay asimismo estudios longitudinales de apoyo. Aunque se ha afirmado que una tendencia, vinculada a la personalidad, a las emociones negativas exagera las asociaciones entre el trabajo y la tensión mental (Brief y cols. 1988), ello no podría aplicarse a varias conclusiones claras sobre el absentismo (North y cols. 1996; Vahtera U utela y Pentii 1996). En algunos estudios, las asociaciones son muy fuertes, y en varios de ellos se han extraído con un sistema de vinculaciones que reduce al mínimo el posible sesgo del método de autoadministración (con el riesgo de perder potencia estadística). Esos estudios confirman la existencia de asociaciones en el caso de una amplia gama de efectos de tensión psicológica: formas moderadamente graves de depresión, agotamiento, consumo de estupefacientes e insatisfacción vital y laboral, aunque las conclusiones también difieren según el efecto de que se trate. $\mathrm{H}$ ay asimismo una cierta diferenciación de las emociones negativas según la dimensión del modelo de demandas/ control de que se trate. El agotamiento, el ritmo acelerado o simplemente el "sentirse estresado" guardan una relación más clara con las demandas psicológicas, y presentan un nivel más alto en los directivos y profesionales. Los síntomas de tensión más graves, como la depresión, la pérdida de la autoestima y la enfermedad física, parecen asociados más claramente a un escaso margen de toma de decisiones, problema que está más extendido en los trabajadores de nivel bajo.

Tensión en el trabajo y trastornos musculosqueléticos y otras enfermedades crónicas

En otros campos se está demostrando también la utilidad del modelo de demandas/ control (véase K arasek y Theorell 1990). La predicción de trastornos musculosqueléticos profesionales en 27 estudios ha sido examinada por Bongers y cols. (1993) y por otros investigadores (Leino y H äøninen 1995; Faucett y Rempel 1994). Estos trabajos reafirman la utilidad predictiva del modelo de demandas/control/apoyo, sobre todo en el caso de los problemas de las extremidades superiores. En estudios recientes sobre trastornos del embarazo (Fenster y cols. 1995; Brandt y $\mathrm{N}$ ielsen 1992) se han puesto de manifiesto asimismo asociaciones con la tensión en el trabajo.

\section{Resumen y orientaciones para el futuro}

El modelo de demandas/ control/apoyo ha promovido en los últimos años gran número de estudios. $\mathrm{H}$ a contribuido a documentar de manera más concreta la importancia de los factores sociales y psicológicos en la estructura de las profesiones actuales como un factor de riesgo en el caso de las enfermedades y condiciones sociales más duras de la sociedad industrial. Empíricamente, el modelo ha arrojado resultados satiffactorios: se ha establecido una clara relación entre las condiciones de trabajo adversas (sobre todo una estrecha latitud de toma de decisiones) y la enfermedad coronaria.

No obstante, sigue siendo difícil precisar qué aspectos de las demandas psicológicas, o de la latitud de toma de decisiones, son los más importantes en el modelo, y para qué categorías de trabajadores. Para responder a estas preguntas hay que explicar los efectos fisiológicos y de microcomportamiento de las exigencias psicológicas, de la latitud de toma de decisiones y del apoyo social de manera más profunda que como se explica en la formulación original del modelo, y hay que probar al mismo tiempo la versión dinámica del mismo, incluidas las hipótesis sobre el comportamiento activo/ pasivo. Los estudios con el modelo de demandas/ control podrían ser más útiles en el futuro si se le añadieran una serie de hipótesis bien estructuradas, elaboradas mediante la integración con otras esferas intelectuales, como se ha señalado anteriormente (también en K arasek y Theorell 1990). Las hipótesis sobre el comportamiento activo/ pasivo, en particular, no han recibido toda la atención que merecen en los estudios relativos a los efectos sobre la salud.

Es preciso avanzar asimismo en otros ámbitos, sobre todo con nuevos enfoques metodológicos en el ámbito de las demandas psicológicas. Asimismo, hacen falta más estudios longitudinales, y avances metodológicos con los que reducir el sesgo derivado del método de autoadministración, y se han de introducir nuevas tecnologías de vigilancia fisiológica. Al nivel macro es necesario integrar con más claridad en el modelo los factores sociales de la profesión, como la capacidad de influencia a nivel colectivo y organizacional de los trabajadores en materia de toma de decisiones, las limitaciones a la comunicación, la inseguridad en el empleo y en los ingresos. $\mathrm{H}$ ay que estudiar más a fondo las vinculaciones con los conceptos de clase social, y hay que seguir investigando la solidez del modelo cuando se aplica a 
las mujeres y las vinculaciones entre la estructura del trabajo y la familia. Se ha de llegar, mediante nuevos diseños de los estudios, a los grupos de la población que tienen modalidades de empleo inseguras, y que presentan los niveles más altos de estrés: estos estudios son de especial interés en unos momentos en los que la economía mundial está modificando la naturaleza de las relaciones de trabajo. A medida que estamos más expuestos a las presiones de la economía mundial, se necesitan nuevos sistemas de medición a niveles macro para determinar la falta de control local y la mayor intensidad de la actividad laboral, lo que parece que hará más aplicable en el futuro el modelo de demandas/ control en su formulación general.

\section{- El APOYO SOCIAL: UN MODELO INTERACTIVO DEL ESTRES}

Kristina Orth-G omér

\section{El concepto de estrés}

Desde que bautizó y describió por vez primera este concepto $H$ ans Selye (Selye 1960), se han formulado varias definiciones del estrés. Sin embargo, con casi ninguna de ellas se ha conseguido captar lo que para una importante proporción de los investigadores en este campo es la esencia del concepto.

Esta ausencia de una definición común y generalmente aceptada puede tener varias explicaciones. U na de ellas acaso sea el concepto se ha difundido tanto y se ha utilizado en tantas situaciones y contextos distintos, y por tantos investigadores, profesionales y profanos, que ya no es posible llegar a un acuerdo sobre una definición común. 0 tra explicación es que realmente no exista una base empírica para una definición única. Es posible que el concepto sea tan múltiple que con un solo proceso simplemente no se explique el fenómeno completo. $\mathrm{H}$ ay una cosa clara: para examinar los efectos del estrés sobre la salud, es necesario incluir en el concepto más de un componente. La definición de Selye se refería a la reacción fisiológica de "lucha o abandono" en respuesta a una amenaza o un reto procedentes del entorno. Así, hacía referencia únicamente a la respuesta fisiológica individual. En el decenio de 1960 despertaron gran interés los llamados "acontecimientos vitales", es decir, las principales experiencias estresoras que se producen en la vida de una persona. En la obra de H olmes y Rahe (1967) se demostraba claramente que una acumulación de acontecimientos vitales era perjudicial para la salud. Esos efectos se comprobaron sobre todo en estudios retrospectivos. M ás difícil resultaba confirmar esas conclusiones en el sentido prospectivo ( $R$ ahe 1988).

En el decenio de 1970 se introdujo en el marco teórico otro concepto, el de la vulnerabilidad o resistencia del individuo expuesto a estímulos estresores. Cassel (1976) formuló la hipótesis de que la resistencia del huésped era un factor decisivo en el resultado de estrés y en el efecto del estrés sobre la salud. El hecho de que en muchos estudios no se hubiera tenido en cuenta la resistencia del huésped podría explicar por qué se habían obtenido tantos resultados incoherentes y contradictorios acerca del efecto del estrés sobre la salud. Según Cassel, hay dos factores esenciales a la hora de determinar el grado de resistencia de una persona: su capacidad para afrontar la situación y su apoyo social.

$\mathrm{H}$ oy se incluyen ya en la definición bastantes otras cosas además de las reacciones fisiológicas del "estrés de Selye": tanto los efectos sociales y del entorno, representados por ejemplo por los acontecimientos vitales, como la resistencia o vulnerabilidad del individuo expuesto a esos acontecimientos.
En el modelo de estrés-enfermedad propuesto por Kagan y Levi (1971) se establecen varias distinciones entre los diversos componentes (Figura 34.4). Esos componentes son los siguientes:

- estresores presentes en el entorno: estímulos sociales o psicológicos que provocan ciertas reacciones dolorosas

- el programa psicobiológico individual, que está predeterminado tanto por factores genéticos como por las experiencias y el aprendizaje de la primera parte de la vida

- reacciones individuales de estrés fisiológico (del tipo del "estrés de Selye" "). U na combinación de esos tresfactores puedellevar a

- precursores que pueden acabar por provocar el resultado final, que es

- la enfermedad física manifiesta.

Es importante señalar que, contrariamente a lo que pensaba Selye, se han identificado varias vías fisiológicas distintas por las que se producen los efectos de los estresores sobre la salud física. Entre ellas figuran no sólo la reacción que primero se describió, la del eje simpático-médula suprarrenal, sino también la acción del eje simpático-suprarrenal, que puede ser igualmente importante, así como la compensación que produce la regulación neurohormonal parasimpática del sistema gastrointestinal, que se ha observado que aminora y amortigua los efectos nocivos del estrés. Para que un estresor ponga en marcha esas reacciones se necesita una influencia nociva del programa psicobiológico; en otras palabras, tiene que haber una propensión individual a reaccionar a los estresores. Esa propensión individual está, por un lado, determinada genéticamente y, por otro, se basa en las experiencias y el aprendizaje de la primera infancia.

Si las reacciones de estrés fisiológico son lo bastante graves y duraderas, pueden acabar produciendo estados crónicos, 0 convertirse en precursores de la enfermedad. Un ejemplo de estos precursores es la hipertensión, que muchas veces está relacionada con el estrés y que puede llevar a una enfermedad somática manifiesta, como un accidente cerebrovascular o una enfermedad cardíaca.

0 tra característica importante del modelo es que los efectos de interacción de las variables que intervienen se anticipan en cada fase, lo que aumenta aún más la complejidad del modelo. Esa complejidad se representa mediante bucles de retroalimentación que van desde cada fase o factor del modelo a la fase 0 factor siguiente. El modelo es por lo tanto complejo; igual de compleja que es la naturaleza.

En estos momentos, nuestros conocimientos empíricos sobre la precisión de este modelo siguen siendo insuficientes y poco claros, pero mejorarán mediante la aplicación del modelo

Figura 34.4 • Componentes del estrés en el modelo de estrés-enfermedad de Kagan y Levi (1971).

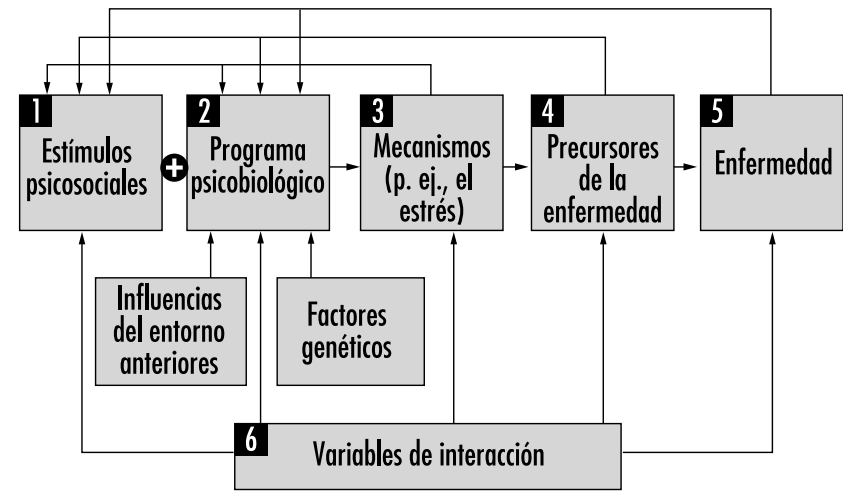

Fuente: Kagan y Levi 1971. 
interactivo a los estudios sobre el estrés. Por ejemplo, es posible que podamos predecir mejor las enfermedades si se intenta aplicar el modelo.

\section{Datos empíricos sobre la resistencia del huésped}

En nuestro grupo de investigación del Instituto $K$ arolinska de Estocolmo nos hemos centrado recientemente en los factores que fomentan la resistencia del huésped. Hemos formulado la hipótesis de que entre esos poderosos factores figuran los efectos de promoción de la salud que tienen las redes sociales que funcionan correctamente y el apoyo social.

N uestro primer intento de investigar los efectos de las redes sociales sobre la salud se centró en el conjunto de la población sueca, a un nivel "macroscópico". En cooperación con la O ficina Central de Estadística de Suecia pudimos evaluar los efectos de las interacciones autoevaluadas de las redes sociales sobre un resultado de salud, en este caso sobre la supervivencia (O rth-G omér y Johnson 1987).

Como muestra aleatoria de la población sueca adulta, 17.433 varones y mujeres respondieron a un cuestionario acerca de sus vínculos y redes sociales. El cuestionario se incluyó en dos de las encuestas sobre las condiciones de vida que se realizan anualmente en Suecia y con las que se pretende evaluar y medir el bienestar del país en términos tanto materiales como sociales y psicológicos. Sobre la base del cuestionario creamos un índice de interacción general en una red social que comprendía el número de miembros en la red y la frecuencia de contactos con cada miembro. M ediante un análisis de factores se identificaron siete fuentes de contactos: padres, hermanos, familia nuclear (cónyuge e hijos), parientes cercanos, compañeros de trabajo, vecinos, parientes lejanos y amigos. Se calcularon los contactos con cada una de estas fuentes y se sumaron los resultados en un índice total, que iba de 0 a 106.

Al relacionar esas encuestas sobre las condiciones de vida con el registro nacional de defunciones, pudimos investigar la repercusión que tenía sobre la mortalidad el índice de interacción con la red social. Dividiendo la población estudiada en tertiles según su índice comprobamos que los hombres y mujeres que se encontraban en el tertil inferior tenían invariablemente un riesgo de mortalidad más elevado que los que estaban en los tertiles medio y superior.

El riesgo de muerte era en el tertil inferior de cuatro a cinco veces más alto que en los otros tertiles, aunque esta asociación podría explicarse por muchos otros factores, como el hecho de que el aumento de la edad está relacionado con un mayor riesgo de muerte. Asimismo, al aumentar la edad se reduce el número de contactos sociales. En las personas enfermas y discapacitadas aumenta el riesgo de mortalidad, y es probable que se reduzca la amplitud de la red social. La morbilidad y la mortalidad son asimismo más altas en las clases sociales más bajas, y las redes sociales son asimismo más reducidas y los contactos sociales menos abundantes. Así pues, en cualquier análisis es necesario tener en cuenta estos y otros factores del riesgo de mortalidad. Pero incluso teniendo en cuenta esos factores se comprobó un incremento del riesgo estadísticamente significativo, del $40 \%$, asociado a una red social escasa entre las personas pertenecientes al tertil más bajo de la población. Es interesante señalar que no había ningún efecto adicional de promoción de la salud por estar en el tertil superior en comparación con el medio. Es posible que un gran número de contactos pueda suponer una tensión para el individuo al mismo tiempo que le protege de los efectos nocivos sobre su salud.

Así, sin saber ni siquiera ninguna otra cosa más sobre los estresores presentes en la vida de esos hombres y mujeres, pudimos confirmar que las redes sociales tienen un efecto favorable sobre la salud.
Las redes sociales no explican por sí solas los efectos observados. Es probable que el funcionamiento de una red social y la base de apoyo que ofrecen sus miembros sean más importantes que el tamaño de esa red en cuanto al número de personas que la componen. Además, es posible un efecto interactivo de diversos estresores. Se ha comprobado, por ejemplo, que los efectos del estrés relacionado con el trabajo son peores cuando falta también apoyo social e interacción social en el trabajo (K arasek y Theorell 1990).

A fin de explorar las cuestiones de la interacción, se han llevado a cabo estudios de investigación en los que se han utilizado diversas medidas para evaluar los aspectos tanto cualitativos como cuantitativos del apoyo social. Se han obtenido así varios resultados interesantes que son ilustrativos de los efectos sobre la salud que se han asociado con el apoyo social. Por ejemplo, en un estudio sobre la enfermedad cardíaca (infarto de miocardio y muerte súbita cardíaca) en una población de 776 varones de 50 años nacidos en $\mathrm{G}$ otemburgo, seleccionados aleatoriamente entre la población general y comprobado su buen estado de salud en un examen inicial, se observó que el tabaquismo y la falta de apoyo social eran los principales factores que predecían la enfermedad (0 rth-Gomér, Rosengren y Wilheemsen 1993). Entre otros factores de riesgo figuraban la hipertensión, los lípidos, el fibrinógeno y la vida sedentaria.

En el mismo estudio se demostró que los efectos de los acontecimientos vitales estresores eran perjudiciales únicamente en los varones que carecían de apoyo, en particular de apoyo emocional de una esposa, parientes cercanos o amigos. Los que carecían de ese apoyo y además habían pasado por varios acontecimientos vitales graves presentaban una mortalidad cinco veces mayor que la de los que gozaban de mucho apoyo emocional (Rosengren y cols. 1993).

O tro ejemplo de efectos interactivos se ofreció en un estudio de pacientes cardíacos a los que se examinó desde el punto de vista de los factores psicosociales, como la integración social y el aislamiento social, y de indicadores miocárdicos de pronóstico desfavorable, y después se les hizo un seguimiento durante diez años. Se evaluaron también la personalidad y el patrón de comportamiento, en particular el de Tipo A.

El tipo de comportamiento no afectaba por sí solo al pronóstico de los pacientes. De los del Tipo A murieron el $24 \%$, frente al $22 \%$ del Tipo B. Pero el panorama cambiaba cuando se tenían en cuenta los efectos interactivos con el aislamiento social.

Se pidió a los participantes en el estudio que describieran, utilizando un diario de actividades, todo lo que solían hacer por las tardes y los fines de semana en una semana normal. Esas actividades se dividieron después entre las que comportaban un ejercicio físico, las que implicaban principalmente en una relajación y se realizaban en casa y las que se realizaban con fines de recreo junto con otras personas. De esos tres tipos, la falta de actividades recreativas era el factor que más predecía la mortalidad. Los que nunca se dedicaban a ese tipo de actividades - denominados "socialmente aislados" en el estudio- tenían un riesgo de mortalidad más o menos tres veces mayor que los socialmente activos. Además, los hombres de tipo A que eran socialmente aislados tenían un riesgo de mortalidad aún mayor que los de cualquiera de las demás categorías ( 0 rth-Gomér, Undén y Edwards 1988).

Estos estudios ponen de manifiesto la necesidad de tener en cuenta varios aspectos del entorno psicosocial, los factores individuales y, por supuesto, los mecanismos de estrés fisiológico. Demuestran asimismo que el apoyo social es uno de los factores importantes en los efectos sobre la salud relacionados con el estrés. 


\section{FACTORES INHERENTES AL TRABAJO}

\section{- El AJUSTE PERSONA-ENTORNO}

Robert D. Caplan

La teoría del ajuste persona-entorno (PE) ofrece un marco para evaluar y predecir la forma en que las características personales y el entorno laboral determinan conjuntamente el bienestar del trabajador y, a la luz de ese conocimiento, la forma en que se puede elaborar un modelo para identificar puntos de intervención preventiva. Se han propuesto varias formulaciones del modelo PE, de las que las más conocidas son las de Dawis y Lofquist (1984), French, Rodgers y Cobb (1974), Levi (1972), M cG rath (1976) y Pervin (1967). Para examinar los componentes conceptuales de la teoría del ajuste PE y sus repercusiones en materia de investigación y aplicación podemos utilizar la teoría de French y otros, que se representa en la Figura 34.5.

Un ajuste deficiente puede contemplarse desde otras perspectivas: las necesidades del trabajador (ajuste necesidades-ofertas) y las exigencias del entorno de trabajo (ajuste exigencias- capacidades). La expresión "ajuste necesidades-ofertas" se refiere al grado en que las necesidades del trabajador, como la necesidad de utilizar sus aptitudes y capacidades, se corresponden con lo que le ofrece el entorno de trabajo, con las oportunidades que le brinda para satisfacer esas necesidades. El "ajuste exigencias-capacidades" se refiere al grado en que las aptitudes y capacidades del trabajador satisfacen las exigencias del trabajo. Estos dos tipos de ajuste pueden superponerse. Por ejemplo, una sobrecarga de trabajo puede hacer que no se satisfagan las exigencias del trabajador y al mismo tiempo amenazar la necesidad de que el trabajador satisfaga otras.

\section{Conceptualización de la persona (P) y el entorno (E)}

Entre las características de la persona (P) figuran tanto necesidades como capacidades. Entre las características del entorno $(E)$ figuran ofertas y oportunidades para satisfacer las necesidades del trabajador y exigencias que se plantean a sus capacidades. Para evaluar el grado en que $P$ es igual (o se ajusta), es mayor 0 es menor que $\mathrm{E}$, la teoría exige que $\mathrm{P}$ y $\mathrm{E}$ se midan en dimensiones comparables. Idealmente, $\mathrm{P}$ y $\mathrm{E}$ deben medirse en escalas de intervalos iguales con auténticos puntos cero. Por ejemplo, se podría evaluar el ajuste PE con respecto a la carga de trabajo en un operador de introducción de datos sobre la base tanto del número de pulsaciones por minuto que exige esa tarea $(E)$ como del número de pulsaciones del trabajador $(\mathrm{P})$. Los investigadores utilizan con frecuencia otra opción menos ideal, las escalas de tipo Likert. Por ejemplo, se podría evaluar hasta qué punto el trabajador desea controlar el ritmo de trabajo $(P)$ y cuánto control ofrece la tecnología del puesto $(E)$ utilizando una escala de clasificación, en la que un valor de 1 correspondería a falta total o casi total de control y un valor de 5 correspondería a un control completo.

\section{Distinción entre ajuste subjetivo y ajuste objetivo}

$E I$ ajuste subjetivo $\left(A_{s}\right)$ se refiere a las percepciones de $P$ y $E$ que tiene el trabajador, mientras que el ajuste objetivo $\left(A_{0}\right)$ se refiere a evaluaciones que en teoría no presentan sesgo subjetivo ni error. En la práctica hay siempre un error de medición, de manera que es imposible construir unas medidas auténticamente objetivas. En consecuencia, muchos investigadores prefieren establecer una distinción de trabajo entre el ajuste subjetivo y el ajuste objetivo, y así consideran medidas del ajuste objetivo aquellas que son relativamente, no en términos absolutos, inmunes a las fuentes de sesgo y error. Por ejemplo, se puede evaluar el ajuste PE objetivo respecto a la capacidad mecanográfica examinando el ajuste entre el número de pulsaciones por minuto que se exigen en la carga de trabajo efectiva asignada al trabajador $\left(E_{0}\right)$ y la capacidad de éste evaluada en una prueba objetiva de esa destreza profesional $\left(P_{0}\right)$. EI ajuste PE subjetivo podría evaluarse pidiendo al trabajador que estimara su capacidad de pulsaciones por minuto $\left(P_{S}\right)$ y el número de pulsaciones por minuto que exige su puesto de trabajo $\left(E_{s}\right)$.

Figura 34.5 • Esquema de la teoría del ajuste persona entorno (PE) de French, Rogers y Cobb (1974).

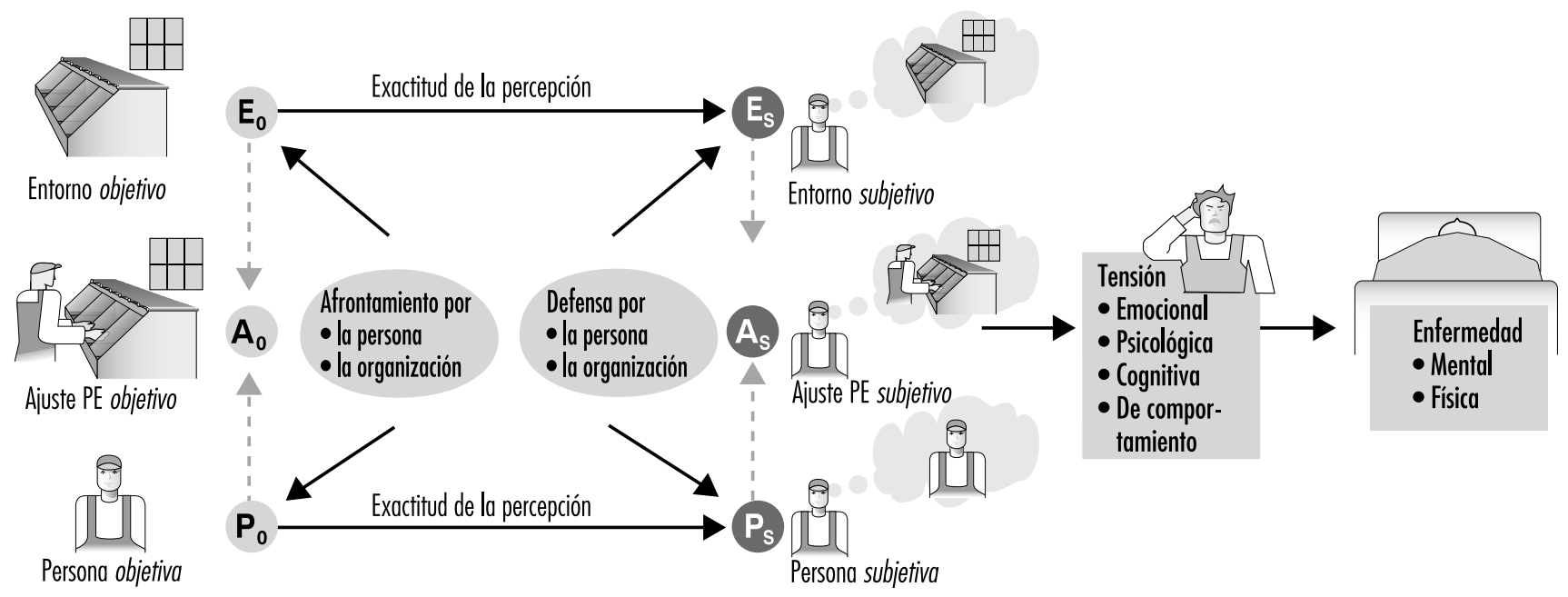

$\longrightarrow=$ Efectos principales $=---D=$ Posibles contribuciones conjuntas de Py E (adición e interacción)

Fuente: French, Rogers y Cobb 1974; figura adaptada de Harrison 1978. 
D ebido a las dificultades que presenta una medición objetiva, en la mayoría de las pruebas de la teoría del ajuste PE se han utilizado sólo medidas subjetivas de $P$ y $E$ (véase una excepción en Chatman 1991). Con éstas se ha obtenido información sobre diversas dimensiones, entre ellas el ajuste en materia de responsabilidad respecto del trabajo y el bienestar de otras personas, la complejidad del puesto de trabajo, la carga de trabajo cuantitativa y la ambigüedad de rol.

\section{Propiedades dinámicas del modelo de ajuste PE}

En la Figura 34.5 se representa la forma en que el ajuste objetivo influye en el ajuste subjetivo, el cual, a su vez, tiene efectos directos sobre el bienestar. El bienestar se desglosa en respuestas denominadas tensiones, que se consideran factores de riesgo de una enfermedad ulterior. Esas tensiones pueden comportar respuestas emocionales (por ejemplo, depresión, ansiedad), fisiológicas (por ejemplo, colesterol sérico, presión arterial), cognitivas (por ejemplo, baja autovaloración, atribuciones de culpa a uno mismo o a otros) y de comportamiento (por ejemplo, agresividad, cambios en el estilo de vida, consumo de estupefacientes y alcohol).

Según el modelo, los niveles y cambios del ajuste objetivo, ya se deban a una intervención planificada o a otras causas, no son siempre percibidos de manera fiel por el trabajador, de manera que surgen discrepancias entre el ajuste objetivo y el subjetivo. Es decir, un trabajador puede percibir un buen ajuste 0 un ajuste deficiente cuando objetivamente no es así.

Esta percepción errónea del trabajador puede proceder de dos fuentes. U na de ellas es la organización, la cual, de manera deliberada o no (Schlenker 1980), puede ofrecerle al trabajador información inadecuada sobre el entorno y sobre sí mismo. La otra fuente es el trabajador mismo, que puede no acceder a información disponible o que puede distorsionar defensivamente la información objetiva sobre lo que exige su puesto de trabajo 0 sobre sus capacidades y necesidades personales: Taylor (1991) cita un ejemplo de este tipo.

French, Rodgers y Cobb (1974) utilizan el concepto de defensas para referirse a los procesos por los que los trabajadores distorsionan los componentes del ajuste subjetivo, $P_{S}$ y $E_{S}$, sin cambiar los componentes correspondientes del ajuste objetivo, $P_{0}$ y $E_{0}$. Por extensión, la organización también puede tener sus propios procesos defensivos - por ejemplo, ocultaciones, negativas 0 exageraciones- encaminados a modificar las percepciones del ajuste subjetivo por el trabajador sin modificar de manera correspondiente el ajuste objetivo.

El concepto de "afrontamiento" está en cambio reservado a las respuestas y procesos cuya finalidad es alterar el ajuste obje-

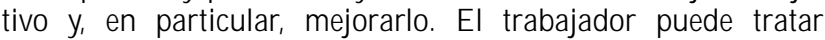
de afrontar la situación mejorando las aptitudes objetivas $\left(P_{0}\right)$ o modificando las exigencias y recursos objetivos del puesto de trabajo $\left(\mathrm{E}_{0}\right)$, por ejemplo modificando las tareas o las responsabilidades asignadas. Por extensión, la organización también puede aplicar estrategias de afrontamiento para mejorar el ajuste PE objetivo. Por ejemplo, puede introducir cambios en las estrategias de selección y promoción, en la formación y en el diseño de los puestos de trabajo para modificar el $E_{0}$ y la $\mathrm{P}_{0}$.

Esta diferenciación entre afrontamiento y defensa, por una parte, y ajuste objetivo y subjetivo, por otra, puede llevarnos a toda una serie de preguntas prácticas y científicas sobre las consecuencias de utilizar una u otra estrategia y sobre los métodos para distinguir entre los efectos de una y otra sobre el ajuste PE. Se deriva de la teoría que, para responder acertadamente a esas preguntas es preciso medir acertadamente tanto el ajuste PE objetivo como el subjetivo.

\section{Modelos estadísticos}

EI ajuste PE puede presentar relaciones no lineales con la tensión psicológica. En la Figura 34.6 se presenta como ilustración una curva en forma de U. El nivel más bajo de tensión psicológica en la curva se produce cuando el trabajador y las características del puesto están ajustados entre sí ( $P=E$ ). La tensión aumenta cuando las capacidades o necesidades del trabajador están por debajo de las exigencias o recursos del puesto respectivamente $(P<E$ o están por encima de ellas $(P>E)$. C aplan y sus colaboradores (1980) encontraron una relación en forma de $U$ entre el ajuste PE respecto a la complejidad del trabajo y síntomas de depresión en un estudio de trabajadores de 23 profesiones distintas.

\section{Eficacia del modelo}

Diversos enfoques de la manera de medir el ajuste PE demuestran las posibilidades que tiene el modelo de predecir el bienestar y el rendimiento. Por ejemplo, mediante la elaboración de un cuidadoso modelo estadístico se comprobó que el ajuste PE explicaba alrededor de un $6 \%$ más de varianza en la satisfacción en el trabajo de lo que lo hacían las mediciones de P o E por separado (Edwards y Harrison 1993). En una serie de siete estudios sobre contables en los que se medía el ajuste PE mediante un método de clasificación de tarjetas, los que tenían un rendimiento alto presentaban correlaciones más altas entre $P$ y $E$ (promedio de $r=0,47$ ) que los que tenían un rendimiento bajo (promedio de $r=0,26$; Caldwell y 0 'Reilly 1990). Se consideró que $\mathrm{P}$ eran los conocimientos, aptitudes y capacidades (CAC) del trabajador, y que $E$ eran los CAC correspondientes que exigía el puesto de trabajo. Un ajuste PE deficiente entre los valores del contable y los de la empresa servía también para predecir el rendimiento del trabajador (Chatman 1991).

Figura 34.6 • Hipotética relación en forma de U entre el ajuste persona-entorno y la tensión psicológica.

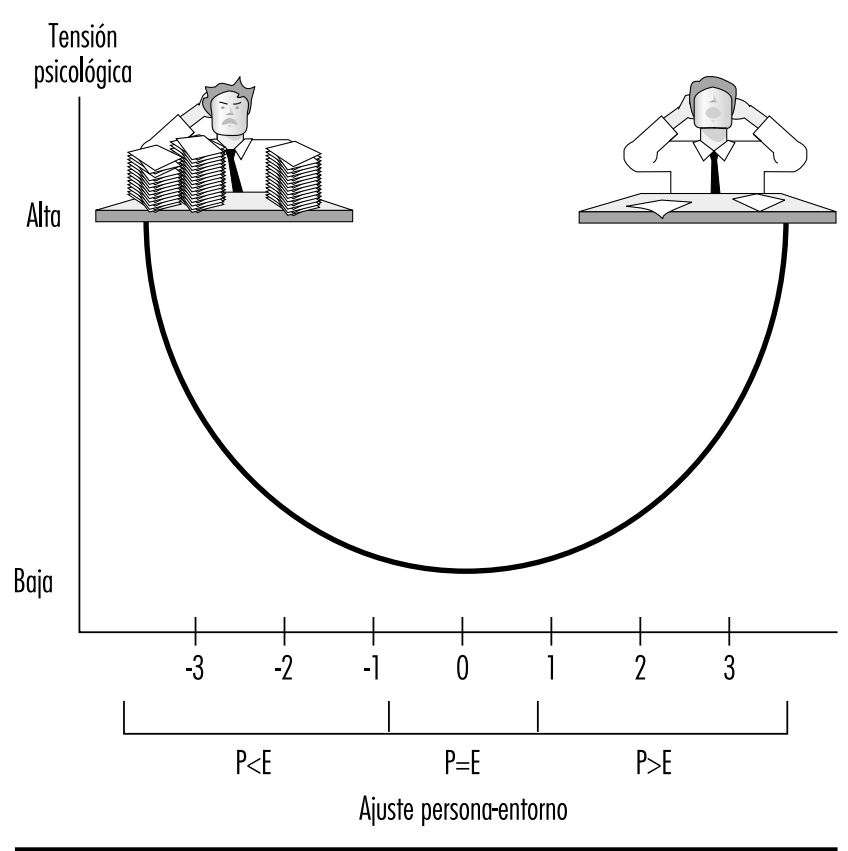




\section{- La CARGa de trabajo}

M arianne Frankenhaeuser

\section{Carga de trabajo y función cerebral}

El conocimiento de las necesidades, capacidades y limitaciones humanas ofrece una orientación cuando se trata de configurar las condiciones psicosociales del trabajo con miras a reducir el estrés y mejorar la salud en el trabajo (Frankenhaeuser 1989). L as investigaciones sobre el cerebro y el comportamiento han identificado las condiciones en las que se tiene un buen rendimiento y aquellas otras en las que el rendimiento se deteriora. Cuando la afluencia total de impresiones procedentes del mundo exterior cae por debajo de un nivel crítico y las exigencias del trabajo son demasiado bajas, las personas tienden a perder atención, a aburrirse y a perder su capacidad de iniciativa. En cambio, en condiciones de un flujo de estímulos excesivo y unas exigencias demasiado elevadas, pierden su capacidad de integrar mensajes, los procesos mentales se fragmentan y la capacidad de juicio se deteriora. Esa relación en forma de $U$ invertida entre la carga de trabajo y la capacidad cerebral es un principio biológico fundamental que tiene numerosas aplicaciones en la vida laboral. Expresada en términos de eficiencia a diversos niveles de carga de trabajo, significa que el nivel óptimo de funcionamiento mental se sitúa en el punto medio de una escala que va desde unas exigencias de trabajo muy bajas a otras muy altas. D entro de esa zona media el grado de exigencia es "el justo", y entonces el cerebro humano funciona de manera eficiente. La ubicación de esa zona óptima varía según las personas, pero lo decisivo es que hay mucha gente que se pasa toda la vida fuera de esa zona óptima que les podría ofrecer oportunidades para desarrollar plenamente sus posibilidades. Sus capacidades están siempre infrautilizadas o sobrecargadas.

Debe establecerse una distinción entre sobrecarga cuantitativa, que significa demasiada cantidad de trabajo en un período de tiempo determinado, y subcarga cualitativa, que significa que las tareas son demasiado repetitivas y carecen de variedad y dificultad (L evi, Frankenhaeuser y G ardell 1986).

Los investigadores han determinado una serie de criterios para definir el "trabajo saludable" (Frankenhaeuser y Johansson 1986; K arasek y Theorell 1990). En esos criterios se hace hincapié en la necesidad de que se dé a los trabajadores la oportunidad de: a) influir en su trabajo y controlarlo; b) comprender su contribución en un contexto más amplio; c) experimentar un sentimiento de comunidad y pertenencia en su lugar de trabajo, y d) desarrollar sus capacidades personales y aptitudes profesionales mediante un aprendizaje continuo.

\section{Vigilancia de las respuestas corporales en el trabajo}

Las personas han de enfrentarse a diferentes exigencias de trabajo cuya naturaleza y fuerza son valoradas a través del cerebro. Este proceso de valoración comporta una especie de estimación del grado de las exigencias en relación a las capacidades de afrontamiento propias. Toda situación que se perciba como una amenaza o como un reto que requieran un esfuerzo compensatorio está acompañada de la transmisión de señales desde el cerebro hasta la médula suprarrenal, que responde produciendo las catecolaminas adrenalina y noradrenalina. Estas hormonas del estrés nos ponen mentalmente alerta y físicamente preparados. Cuando la situación induce un sentimiento de incertidumbre e impotencia, los mensajes cerebrales llegan también a la corteza suprarrenal, que segrega cortisol, hormona que desempeña un papel importante en la defensa inmunológica del organismo (Frankenhaeuser 1986).
Con el perfeccionamiento de técnicas bioquímicas que permiten determinar cantidades cada vez más pequeñas de hormonas en la sangre, la orina y la saliva, las hormonas del estrés han llegado a desempeñar un papel de creciente importancia en los estudios sobre la vida laboral. Cuando es de corta duración, un aumento de estas hormonas suele ser beneficioso, y raras veces supone una amenaza para la salud. Pero a más largo plazo pueden aparecer efectos perjudiciales ( $\mathrm{H}$ enry y Stephens 1977; Steptoe 1981). Las subidas frecuentes o duraderas de los niveles de las hormonas del estrés durante la vida cotidiana pueden provocar cambios estructurales en los vasos sanguíneos, lo que a su vez puede conducir a la enfermedad cardiovascular. En otras palabras, unos niveles de estas hormonas sistemáticamente altos deben considerarse como señales de alarma, que nos dicen que la persona puede estar sometida a una presión excesiva.

Las técnicas de registro biomédicas permiten vigilar las respuestas corporales en el lugar de trabajo sin interferir en las actividades del trabajador. U tilizando estas técnicas de vigilancia ambulatoria se puede averiguar qué es lo que hace que suban la presión arterial o las pulsaciones o se tensen los músculos. Son informaciones importantes que, junto con ensayos realizados con las hormonas del estrés, han contribuido a identificar los factores tanto negativos como protectores relacionados con el contenido y la organización del trabajo. Así, cuando se investigan esos factores perjudiciales y protectores en el ambiente de trabajo se puede utilizar como "varas de medir" a las personas mismas. Este es uno de los modos en que el estudio del estrés humano y de la forma de afrontarlo puede ser de utilidad en la intervención y prevención en el lugar de trabajo (Frankenhaeuser y cols. 1989; Frankenhaeuser 1991).

\section{El control personal como "amortiguador"}

Datos obtenidos en estudios tanto epidemiológicos como experimentales apoyan la idea de que el control personal y el margen de toma de decisiones son importantes factores de "amortiguación" que ayudan a la gente a trabajar mucho y al mismo tiempo disfrutar de su trabajo y mantener una buena salud (K arasek y Theorell 1990). La posibilidad de ejercer un control puede "amortiguar" el estrés de dos maneras: en primer lugar, incrementando la satisfacción en el trabajo, lo que reduce las respuestas corporales al estrés, y en segundo lugar ayudando a asumir un papel activo y participativo en el trabajo. Los puestos de trabajo que permiten utilizar plenamente las capacidades incrementan la autoestima. Aunque sean exigentes y duros, pueden ayudar a desarrollar competencias que son útiles para hacer frente a fuertes cargas de trabajo.

El funcionamiento de las hormonas del estrés varía con la interacción de las respuestas emocionales positivas y negativas que genera la situación. Cuando las exigencias se experimentan como un reto positivo y manejable, lo normal es que se produzca mucha adrenalina, mientras que descansa el sistema de producción de cortisol. Cuando dominan los sentimientos negativos y de incertidumbre, aumentan tanto el cortisol como la adrenalina. Ello comporta que la carga total a que se somete al cuerpo, el "coste de conseguirlo", será inferior en un trabajo exigente pero placentero que en otro menos exigente pero tedioso, y parece que el hecho de que el cortisol tienda a mantenerse en niveles bajos en las situaciones controlables podría explicar los efectos positivos que el control personal tiene sobre la salud. Ese mecanismo neuroendocrino podría explicar los datos epidemiológicos obtenidos en estudios nacionales realizados en diferentes países, que indican que el nivel alto de exigencias y la sobrecarga tienen consecuencias negativas sobre la salud sobre todo cuando se combinan con un escaso control sobre las decisiones relacionadas con el trabajo 
(Frankenhaeuser 1991; K arasek y Theorell 1990; Levi, Frankenhaeuser y $\mathrm{G}$ ardell 1986).

\section{Carga de trabajo total de mujeres y hombres}

Para evaluar las cargas de trabajo relativas asociadas a las diferentes situaciones de la vida de hombres y mujeres es necesario modificar el concepto de trabajo para incluir en él la idea de carga de trabajo total, es decir, la carga combinada de exigencias relacionadas con el trabajo tanto remunerado como no remunerado. Se deben incluir, pues, todas las formas de actividad productiva, entendida como "el conjunto de cosas que hacen las personas que contribuyen a los bienes y servicios que otras personas utilizan y valoran" (K ahn 1991). Así, la carga de trabajo total de una persona comprende el empleo ordinario y las horas extras en el trabajo y asimismo las labores domésticas, el cuidado de los hijos, la atención a familiares de edad avanzada y enfermos y la colaboración con organizaciones de voluntariado o sindicatos. Según esta definición, las mujeres empleadas tienen una carga de trabajo superior a la de los hombres, en todas las edades y en todos los niveles profesionales (Frankenhaeuser 1993a, 1993b y 1996; K ahn 1991).

Debido a que la división del trabajo doméstico entre los cónyuges no se ha modificado mientras que la situación laboral de la mujer ha cambiado radicalmente, ha recaído sobre ésta una pesada carga de trabajo, con escasas oportunidades para el descanso vespertino (Frankenhaeuser y cols. 1989). H asta que se comprendan mejor las relaciones causales que existen entre la carga de trabajo, el estrés y la salud seguirá siendo necesario considerar las respuestas prolongadas de estrés, en particular las que muestran las mujeres de nivel directivo, como señales de alarma de posibles riesgos para la salud a largo plazo (Frankenhaeuser, Lundberg y C hesney 1991).

\section{- LA JORNADA DE TRABAJO}

Timothy H . M onk

\section{Introducción}

La organización y duración del tiempo que trabaja una persona constituyen aspectos muy importante de su experiencia de la situación laboral. La mayoría de los trabajadores piensan que se les paga por su tiempo más que explícitamente por sus esfuerzos, y de esa manera en la transacción que se realiza entre ellos y el empresario se intercambia tiempo por dinero. A sí, la calidad del tiempo que se intercambia es una parte muy importante de la ecuación. El tiempo que tiene un valor alto debido a su importancia para el trabajador en el sentido de que le permite dormir, relacionarse con la familia y los amigos y participar en los acontecimientos de la comunidad puede tener un precio más elevado - y por tanto exigir una compensación financiera adicionalque el de la "jornada" normal, tiempo durante el que muchos de los amigos y familiares del trabajador están también trabajando 0 estudiando. Puede alterarse también el equilibrio de la transacción haciendo que el tiempo que se pasa trabajando sea más gratificante para el trabajador, por ejemplo mejorando las condiciones de trabajo. El tiempo que dedica el trabajador a ir del trabajo a casa y viceversa es un tiempo perdido para su recreo, por lo que ha de considerarse también como "tiempo gris" ( $K$ nauth y cols. 1983) y, por consiguiente, como un "coste" para el trabajador. Así pues, es probable que alteren asimismo ese equilibrio medidas tales como la compresión de la jornada semanal, en la que se reduce el número de viajes a la semana, o la jornada flexible, que reduce el tiempo de los traslados porque le permite al trabajador evitar las horas punta.

\section{Bibliografía de referencia}

C omo ha señalado K ogi (1991), tanto en el sector industrial como en el de servicios hay una tendencia general a una mayor flexibilidad en la programación temporal del trabajo. Esta tendencia obedece a diversas razones, tales como el elevado coste del equipo de capital, la demanda de servicios las 24 horas del día por parte de los consumidores, la presión legislativa para reducir la duración de la jornada semanal y (en algunas sociedades, como Estados U nidos y Australia) la presión fiscal sobre el empresario para que tenga el menor número posible de trabajadores distintos. Para muchos trabajadores, el horario tradicional "de 9 a 5" 0 "de 8 a 4", de lunes a viernes, es algo que pertenece al pasado, debido bien a los nuevos sistemas de trabajo, bien al elevado número de horas extraordinarias que se les exigen.

Kogi señala que, así como el empresario se beneficia claramente de esa flexibilidad al poder ampliar la jornada de trabajo, ajustarse a la demanda del mercado y gozar de una mayor flexibilidad en la dirección de la empresa, es posible que los beneficios para el trabajador no sean tan claros. A menos que el sistema de horario flexible contenga elementos en virtud de los cuales el trabajador pueda tomar decisiones con respecto a su jornada concreta, muchas veces la flexibilidad puede significar un trastorno de su reloj biológico y de su vida doméstica. Asimismo, los turnos de trabajo ampliados pueden producir fatiga, poner en peligro la seguridad y la productividad e incrementar la exposición a peligros químicos.

\section{Trastornos biológicos debidos a una jornada de trabajo anormal}

La biología humana está específicamente orientada a la vigilia durante el día y al sueño durante la noche. Por consiguiente, todo horario que obligue al trabajador a estar despierto hasta muy entrada la noche o durante toda ella debido a la compresión de la jornada semanal, a la obligación de hacer horas extraordinarias o a un sistema de turnos trastornará su reloj biológico (M onk y Folkard 1992). Esos trastornos pueden evaluarse midiendo los "ritmos circadianos" de los trabajadores, que incluyen las fluctuaciones regulares que se producen a lo largo de las 24 horas en los signos vitales, la composición de la sangre y la orina, el estado de ánimo y la eficiencia de rendimiento (Aschoff 1981).

La medida que más se ha utilizado en los estudios sobre el sistema de turnos ha sido la temperatura corporal, que en condiciones normales muestra un ritmo claro, con un máximo hacia los ocho de la tarde y un mínimo hacia las cinco de la mañana, con una diferencia de alrededor de $0,7{ }^{\circ} \mathrm{C}$ entre uno y otro momento. Tras un cambio brusco de la rutina, la amplitud (magnitud) del ritmo se reduce y su fase (regulación) se enlentece para ajustarse al nuevo horario. $\mathrm{H}$ asta que se completa el proceso de ajuste, el sueño se ve trastornado y empeoran el estado de ánimo y la eficiencia de rendimiento. Estos síntomas podrían ser un equivalente, en el trabajo por turnos, de los problemas por diferencia horaria en los vuelos de larga distancia, y son a veces muy duraderos (K nauth y Rutenfranz 1976).

Un horario de trabajo anormal puede producir también problemas de salud. Aunque no es fácil cuantificar con precisión la magnitud exacta de estos efectos, parece que, además de los trastornos del sueño, los trastornos gastrointestinales (incluidas las úlceras pépticas) y la enfermedad cardiovascular se dan con más frecuencia en personas que trabajan por turnos (o han trabajado antes de esa manera) que en los trabajadores con jornada diurna (Scott y LaDou 1990). H ay también algunos datos provisionales que indican una mayor incidencia de síntomas psiquiátricos (C ole, L oving y K ripke 1990). 


\section{Trastornos sociales debidos a una jornada de trabajo anormal}

No sólo la biología humana es un obstáculo para las personas con una jornada de trabajo anormal: también lo es la sociedad humana. A diferencia del sueño nocturno de la mayoría, que está cuidadosamente protegidos por estrictos tabúes contra el exceso de ruido o el uso del teléfono por la noche, hábitos tales como despertarse tarde, dormir durante el día o echar la siesta, que son necesario para quienes tienen una jornada de trabajo anormal, son tolerados por la sociedad sólo a regañadientes. E stas personas también pueden verse privadas de los acontecimientos sociales que se producen por las tardes-noches y los fines de semana, lo que lleva a sentimientos de alienación.

Es no obstante en el ámbito familiar donde los trastornos sociales de una jornada de trabajo anormal pueden ser más devastadores. Ese tipo de jornada puede poner gravemente en peligro los papeles familiares que desempeña el trabajador como padre, cuidador, compañero social y pareja sexual, lo que produce falta de armonía en el matrimonio y problemas con los hijos (Colligan y R osa 1990). Además, los intentos del trabajador de rectificar, o de evitar, esos problemas sociales pueden tener como consecuencia una reducción del tiempo de sueño, lo que a su vez reduce la capacidad de atención y pone en peligro la seguridad y la productividad.

\section{Posibles soluciones}

Del mismo modo que los problemas que plantea la jornada de trabajo anormal tienen muchas facetas, han de tenerlas también las soluciones a los mismos. Las esferas principales que se han de abordar son las siguientes:

1. selección y educación del trabajador;

2. selección del horario de trabajo más adecuado,

3. mejora del entorno de trabajo.

La selección y educación del trabajador implican la identificación y el asesoramiento de quienes probablemente tienen problemas por un horario de trabajo anormal o prolongado (por ejemplo, los trabajadores de más edad o los que necesitan dormir más, lo que tienen más carga de trabajo en su hogar o los que pierden mucho tiempo en los desplazamientos). También debe ofrecérseles educación en materia de principios circadianos e higiene del sueño y asesoramiento familiar (M onk y Folkard 1992). La educación es un instrumento sumamente útil para ayudar a las personas con una jornada anormal a hacer frente a esa situación, y para aclararles por qué es posible que estén teniendo problemas. La selección del horario más adecuado debe iniciarse con una decisión respecto de cuántas horas de trabajo de ese tipo se necesitan en realidad. Por ejemplo, es posible que en muchos casos el trabajo nocturno pueda realizarse mejor a otras horas del día (K nauth y Rutenfranz 1982). H a de examinarse también la cuestión de cuál es el horario que mejor se adapta a la situación laboral, teniendo en cuenta la naturaleza del trabajo y las características demográficas de la fuerza de trabajo. La mejora del entorno de trabajo puede comportar medidas como elevar los niveles de iluminación y ofrecer servicios adecuados de cafetería durante la noche.

\section{Conclusiones}

La modalidad concreta de jornada de trabajo que se elige para un trabajador puede constituir un reto importante para su biología, su situación familiar y su papel en la comunidad. D eben adoptarse decisiones fundamentadas, tras un estudio de las necesidades de la situación laboral y las características demográficas de la fuerza de trabajo. Todo cambio de la jornada de trabajo debe estar precedido de un proceso detallado de investigación y consulta con los trabajadores, y seguido por estudios de evaluación.

\section{EL DISEÑO DEL ENTORNO}

Daniel Stokols

\section{Introducción}

En este artículo se examinan las relaciones que hay entre las características físicas del lugar de trabajo y la salud en el trabajo. H ablamos de diseño del lugar de trabajo en el sentido de una serie de condiciones físicas del entorno laboral que pueden observarse objetivamente, o registrarse 0 modificarse, mediante intervenciones de diseño arquitectónico, diseño de interiores y medidas urbanísticas. A efectos de este análisis, la salud en el trabajo se entiende en su sentido amplio, incluyendo en este concepto las diversas facetas del bienestar físico, mental y social del trabajador (O rganización M undial de la Salud 1948). Se examinan así muy diversos resultados de salud, como la satisfacción y el estado de ánimo del trabajador, la cohesión de los grupos de trabajo, la reducción del estrés, la prevención de las enfermedades y los accidentes, y los apoyos que puede prestar el entorno para la promoción de la salud en el lugar de trabajo.

A continuación se examinan los datos empíricos de que disponemos sobre las relaciones entre el diseño del lugar de trabajo y la salud en el trabajo. Con respecto a ese examen, en el que se destacan los efectos que tienen sobre la salud determinadas características concretas del diseño, es preciso hacer algunas consideraciones. En primer lugar, desde una perspectiva ecológica, el centro de trabajo funciona como un sistema complejo integrado por múltiples condiciones ambientales de carácter social y físico, que influyen de manera conjunta en el bienestar del trabajador (Levi 1992; M oos 1986; Stokols 1992). Así, las consecuencias que las condiciones del entorno tienen sobre la salud suelen ser acumulativas, y a veces comportan complejas relaciones, mediadas y moderadas, entre el entorno sociofísico y los recursos e inclinaciones personales (O Idham y Fried 1987; Smith 1987; Stellman y Henifin 1983). Además, aspectos constantes de la relación entre las personas y su medio, como el grado en que los trabajadores perciben que su situación es controlable, favorable desde el punto de vista social y compatible con sus necesidades y capacidades concretas, pueden tener una influencia más profunda sobre la salud en el trabajo que cualquier faceta concreta del diseño del lugar de trabajo (Caplan 1983; K arasek y Theorell 1990; Parkes 1989; Repetti 1993; Sauter, H urrell y Cooper 1989). L os resultados de los estudios que se examinan a continuación deben interpretase, por lo tanto, a la luz de esas consideraciones.

\section{Conclusiones de los estudios}

Las relaciones entre el diseño del centro de trabajo y la salud en el trabajo pueden examinarse a diversos niveles de análisis, como por ejemplo:

1. la disposición física de la zona de trabajo inmediata;

2. las características ambientales de la zona de trabajo;

3. la organización física de los edificios que albergan un determinado lugar de trabajo,

4. los servicios exteriores y las características urbanísticas de las instalaciones.

Los estudios se han centrado básicamente en los niveles primero y segundo del diseño del lugar de trabajo, y se ha prestado poca atención a los niveles tercero y cuarto.

\section{Características físicas de la zona de trabajo inmediata}

La zona de trabajo inmediata se extiende desde el núcleo que es la mesa o puesto de una persona hasta el recinto físico o límites imaginarios que rodean su espacio de trabajo. Se ha comprobado 
que hay varios aspectos de la zona de trabajo inmediata que influyen en el bienestar del trabajador. En algunos estudios se ha demostrado, por ejemplo, que el grado de cerramiento físico alrededor de la mesa o puesto de trabajo guarda una relación positiva con la percepción de intimidad por el trabajador, su satisfacción con el entorno de trabajo y su satisfacción laboral en general (Brill, M argulis y K onar 1984; Hedge 1986; M arans y Yan 1989; Oldham 1988; Sundstrom 1986; Wineman 1986). Además, las zonas de trabajo "abiertas" (escaso grado de cerramiento) se han relacionado con climas sociales más negativos en los grupos de trabajo (M oos 1986) y con informes más frecuentes de cefaleas entre el personal (H edge 1986). E s importante señalar, no obstante, que los posibles efectos sobre la salud del grado de cerramiento del puesto de trabajo pueden depender del tipo de actividad que se realiza (por ejemplo, tareas confidenciales frente a no confidenciales, 0 en equipo frente a individualizadas; véase Brill, M argulis y K onar 1984), de la categoría profesional (Sundstrom 1986), de los niveles de densidad social contiguos a la zona en que se trabaja (O Idham y Fried 1987) y de las necesidades de intimidad y protección del trabajador frente a otros estímulos (O Idham 1988).

En algunos estudios se ha demostrado que la existencia de ventanas en el entorno inmediato del trabajador (especialmente las que dan vista a paisajes naturales 0 a entornos de arquitectura paisajística), la exposición a elementos naturales de interiores (por ejemplo, plantas con macetas, fotos de zonas silvestres) y las oportunidades para personalizar la decoración del despacho o puesto personal están asociados a niveles más altos de satisfacción con el entorno y el trabajo y a niveles más bajos de estrés (Brill, M argulis y K onar 1984; Goodrich 1986; Kaplan y Kaplan 1989; Steele 1986; Sundstrom 1986). En algunos estudios (Becker 1990; H edge 1991; V ischer 1989) se ha comprobado que facilitar a los trabajadores el control localizado de las condiciones acústicas, de iluminación y de ventilación en sus zonas de trabajo está relacionado con unos niveles más altos de satisfacción con el entorno y con unos niveles más bajos de estrés. Por último, en varios programas de investigación se han documentado los beneficios para la salud asociados al empleo por los trabajadores de un mobiliario y equipo ajustable y adecuado desde el punto de vista ergonómico. Entre esos beneficios figuran unas tasas más bajas de fatiga visual, de lesiones por movimientos repetitivos y de dolores lumbares (Dainoff $y$ Dainoff 1986; Grandjean 1987; Smith 1987).

\section{Características a mbientales de la zona de trabajo}

$L$ as condiciones ambientales del entorno tienen su origen fuera de la zona de trabajo inmediata del individuo. Esas características generales del centro de trabajo influyen en el confort y bienestar de los trabajadores cuyos espacios personales están situados dentro de una zona común (por ejemplo, una serie de despachos situados en una misma planta de un edificio). Son ejemplos de esas características ambientales del entorno los niveles de ruido, la intimidad para la conversación, la densidad social, la iluminación y la calidad el aire, condiciones todas ellas que están típicamente presentes en una determinada parte del centro de trabajo. En varios estudios se han documentado los efectos negativos que sobre la salud tienen las molestias crónicas por ruido y los niveles bajos de intimidad para la conversación en el lugar de trabajo, incluidos unos niveles elevados de estrés fisiológico y psicológico y unos niveles bajos de satisfacción en el trabajo (Brill, $M$ argulis y K onar 1984; Canter 1983; K litzman y Stellman 1989; Stellman y Henifin 1983; Sundstrom 1986; Sutton y Rafaeli 1987). Los niveles altos de densidad social en las inmediaciones de la zona de trabajo personal se han relacionado asimismo con niveles elevados de estrés y con una menor satisfacción en el trabajo (O Idham 1988; O Idham y Fried 1987; O Idham y R otchford 1983).
También se ha comprobado que los sistemas de iluminación y ventilación de las oficinas tienen consecuencias sobre la salud. La iluminación indirecta con fluorescentes se asoció en un estudio a niveles más altos de satisfacción de los trabajadores y menor incidencia de fatiga visual, en comparación con la tradicional iluminación fluorescente de techo (H edge 1991). Se han presentado asimismo efectos positivos de la luz natural sobre la satisfacción de los trabajadores con el lugar de trabajo (Brill, M argulis y K onar 1984; Goodrich 1986; Vischer y M ees 1991). En otro estudio, trabajadores de oficina expuestos a sistemas de ventilación con aire enfriado mostraban tasas más altas de problemas en las vías respiratorias superiores y de síntomas físicos del llamado "síndrome del edificio enfermo" que otros cuyos edificios estaban equipados con sistemas de ventilación natural o mecánica (aire no enfriado y sin humidificar) (Burge y cols. 1987; H edge 1991).

Entre las características del entorno ambiental que se ha comprobado que mejoran el clima social y la cohesión de los grupos de trabajo figuran la existencia, junto a los despachos y puestos individualizados, de espacios orientados al trabajo en equipo (Becker 1990; Brill, M argulis y K onar 1984; Steele 1986; Stone y Luchetti 1985) y símbolos visibles de la identidad de la empresa y de los grupos de trabajo expuestos en vestíbulos, pasiIlos, salas de reunión y esparcimiento y otras zonas del edificio destinadas a usos colectivos (Becker 1990; Danko, Eshelman y H edge 1990; O rnstein 1990; Steele 1986).

\section{Organización general de los edificios e instalaciones}

Este nivel del diseño comprende las características físicas interiores de las instalaciones de trabajo que se ofrecen en todo un edificio, muchas de las cuales no se experimentan de forma inmediata desde el espacio concreto del trabajador ni desde los espacios contiguos. Por ejemplo, mejorar la integridad estructural de los edificios y su protección contra incendios y diseñar escaleras, pasillos y talleres para prevenir los accidentes son estrategias esenciales de la promoción de la salud y la seguridad en el centro de trabajo (Archea y Connell 1986; Danko, Eshelman y Hedge 1990). La disposición de un edificio, coherente con las necesidades de contigüidad de las dependencias que interactúan estrechamente entre sí dentro de una organización puede mejorar la coordinación y la cohesión entre los grupos de trabajo (Becker 1990; Brill, M argulis y Konar 1984; Sundstrom y Altman 1989). Se ha comprobado que facilitar la práctica del ejercicio físico en lugar de trabajo es una estrategia eficaz para potenciar las prácticas saludables de los trabajadores y controlar el estrés (O 'D onnell y $\mathrm{H}$ arris 1994). Por último, la existencia en el edificio de signos legibles y de una señalización clara, de cafeterías y comedores atractivos y de guardería se consideran estrategias de diseño que mejoran la satiffacción del personal y la gestión del estrés (Becker 1990; Brill, M argulis y K onar 1984; Danko, Eshelman y Hedge 1990; Steele 1986; Stellman y H enifin 1983; V ischer 1989).

\section{Lugares de recreo en el exterior y características urbanísticas}

Las condiciones ambientales exteriores, contiguas al edificio, pueden tener también consecuencias para la salud. En un estudio se comprobó que había una asociación entre el acceso de los trabajadores a zonas de recreo al aire libre y unos niveles reducidos de estrés (K aplan y K aplan 1989). O tros investigadores han sugerido que la ubicación geográfica y las características urbanísticas del centro de trabajo pueden influir en el bienestar mental y físico de los trabajadores en la medida en que faciliten el acceso a aparcamiento y zonas de tránsito público, restaurantes y comercios, buena calidad del aire en la zona y eviten zonas violentas o inseguras, por cualquier otra razón, en las cercanías del edificio (Danko, Eshelman y Hedge 1990; M ichelson 1985; Vischer y 
M ees 1991). No obstante, aún no se han evaluado en estudios experimentales los beneficios para la salud de esas estrategias de diseño.

\section{Orientaciones para futuros estudios}

Los estudios sobre el diseño del entorno y la salud en el trabajo realizados hasta ahora presentan algunas limitaciones y apuntan varias cuestiones que se han de investigar en el futuro. En primer lugar, las primeras investigaciones han hecho hincapié en los efectos sobre la salud de determinadas características del diseño (por ejemplo, el cerramiento del puesto de trabajo, el mobiliario, el sistema de iluminación), pero han pasado por alto la influencia conjunta que tienen sobre el bienestar determinados factores físicos, interpersonales y organizativos. Sin embargo, los beneficios que comporta para la salud la mejora del diseño del entorno pueden verse moderados por el clima social y por aspectos de la organización (por ejemplo, una estructura participativa frente a no participativa) del centro de trabajo (Becker 1990; Parkes 1989; K litzman y Stellman 1989; Sommer 1983; Steele 1986). L as interacciones entre las características físicas del diseño, las características de los trabajadores, las condiciones sociales en el trabajo y la salud en el trabajo merecen, por tanto, que se les preste una mayor atención en futuros estudios (Levi 1992; M oos 1986; Stokols 1992). Al mismo tiempo, un importante reto para la investigación futura es aclarar las definiciones operacionales de determinados elementos del diseño (por ejemplo, la oficina "abierta"), definiciones que han sido muy variadas en los estudios anteriores (Brill, M argulis y Konar 1984; M arans y Yan 1989; Wineman 1986).

En segundo lugar, se ha comprobado que las características de los empleados, como la categoría profesional, el sexo y diversos tipos de inclinaciones personales, afectan a las consecuencias del diseño del centro de trabajo sobre la salud (Burge y cols. 1987; O Idham 1988; Hedge 1986; Sundstrom 1986). Con todo, suele ser difícil separar los distintos efectos de las características del entorno y las diferencias individuales (las cuales quizá tengan tener que ver, por ejemplo, con el grado de cerramiento del puesto de trabajo, la comodidad del mobiliario y la categoría profesional) debido a correlaciones ecológicas entre esas variables (K litzman y Stellman 1989). En el futuro se han de incorporar a los estudios técnicas experimentales y estrategias de muestreo que permitan evaluar los efectos principales y sus interrelaciones, de los factores personales y del entorno sobre la salud en el trabajo. Además, será necesario elaborar criterios especializados sobre diseño y ergonomía para potenciar la salud de grupos de trabajadores diversos y vulnerables (por ejemplo, los trabajadores discapacitados, los de edad avanzada o las trabajadoras de una familia monoparental) (M ichelson 1985; O rnstein 1990; Steinfeld 1986).

En tercer lugar, las investigaciones acerca de los efectos del diseño del centro de trabajo sobre la salud han dependido en gran medida de métodos de encuesta con los que se evaluaban las percepciones de los trabajadores con respecto a su entorno de trabajo y su estado de salud, lo que impone algunas limitaciones a la interpretación de los datos (por ejemplo, la "varianza de método común") (K litzman y Stellman 1989; O Idham y Rotchford 1983).

Además, en la mayoría de esos estudios se han utilizado diseños de investigación transversales en vez de longitudinales, cuando estos últimos comprenden evaluaciones comparativas de grupos de intervención y control. En los estudios futuros se ha de hacer hincapié en los diseños de la investigación experimental sobre el terreno y en estrategias plurimetodológicas que combinen técnicas de encuesta con observaciones y registros más objetivos de las condiciones del entorno, exámenes médicos y mediciones fisiológicas.
Por último, las consecuencias que tienen sobre la salud las decisiones en materia de organización del edificio, servicios recreativos exteriores y características urbanísticas han recibido en los estudios realizados mucha menos atención que las decisiones relacionadas con las características ambientales más inmediatas de las zonas de trabajo. EI interés que tienen para la salud los aspectos tanto próximos como lejanos del diseño del centro de trabajo debe examinarse más a fondo en los estudios futuros.

\section{El papel del diseño del lugar de trabajo en la prevención de la enfermedad y la promoción de la salud}

En la Tabla 34.1, basada en el examen precedente de las conclusiones de las investigaciones, se resumen varios recursos de diseño del entorno y sus posibles beneficios para la salud. E sos recursos aparecen agrupados según los cuatro niveles de diseño que hemos señalado, subrayándose además las características físicas de los ambientes de trabajo que se han relacionado experimentalmente con una mejora de la salud mental, física y social (especialmente los de los niveles 1 y 2) o que se han identificado como puntos de influencia teóricamente plausibles para incrementar el bienestar de los trabajadores (por ejemplo, varias de las características incluidas en los niveles 3 y 4 ).

I dealmente, la incorporación de esos recursos al diseño de los entornos de trabajo debería combinarse con políticas en materia de organización y de gestión de las instalaciones que potenciaran al máximo las cualidades de promoción de la salud del centro de trabajo. Estas políticas empresariales comprenden los elementos siguientes:

1. la designación del centro de trabajo como zona "de no fumadores" (Fielding y Phenow 1988);

2. la especificación y utilización de mobiliario y equipo no tóxicos y adecuados desde el punto de vista ergonómico (D anko, Eshelman y H edge 1990);

3. el apoyo de la dirección a la personalización del espacio de trabajo por los empleados (Becker 1990; Brill, M argulis y K onar 1984; Sommer 1983; Steele 1986);

4. la adopción de criterios de diseño de los puestos que prevengan los problemas de salud relacionados con el trabajo basado en ordenadores y las tareas repetitivas ( $\mathrm{H}$ ackman y O Idham 1980; Sauter, H urrell y Cooper 1989; Smith y Sainfort 1989);

5. el establecimiento de programas de formación de los trabajadores en materia de ergonomía y salud y seguridad en el trabajo (Levy y Wegman 1988);

6. la adopción de programas de incentivos para animar a los trabajadores a practicar ejercicio físico y a cumplir los protocolos de prevención de accidentes (O 'D onnell y H arris 1994);

7. la implantación de programas de jornada flexible, trabajo a distancia, puestos de trabajo compartidos y vehículos compartidos para mejorar la eficacia de los trabajadores tanto a domicilio como en la sede de la empresa (M ichelson 1985; O rnstein 1990; Parkes 1989; Stokols y N ovaco 1981),

8. la intervención de los trabajadores en la planificación de las reubicaciones y renovaciones del lugar de trabajo y otras medidas de organización pertinentes (Becker 1990; Brill, Margulis y Konar 1984; Danko, Eshelman y Hedge 1990; M iller y M onge 1986; Sommer 1983; Steele 1986; Stokols y cols. 1990).

Es probable que las medidas de organización encaminadas a mejorar el bienestar de los trabajadores sean más eficaces cuando combinen estrategias complementarias de diseño del entorno y de gestión de las instalaciones, en vez de basarse exclusivamente en uno u otro de estos dos enfoques. 
Tabla 34.1 - Recursos de diseño del lugar de trabajo y posibles beneficios para la salud.

Niveles de diseño

del entorno

Zona de trabajo inmediata

Características ambientales de la zona de trabajo

Organización del edificio

Recreo exterior y características urbanísticas
Elementos de diseño del entorno en el lugar de trabajo

Cerramiento físico de la zona de trabajo

Mobiliario y equipo ajustables

Controles localizados del nivel acústico, la iluminación y la ventilación

Elementos naturales y decoración personalizada

Ventanas en la zona de trabajo

Intimidad para la conversación y control del ruido

Niveles confortables de densidad social

Buena combinación de espacios privados y de grupo

Símbolos de la identidad de la empresa y de los equipos

Iluminaciones natural, indirecta y enfocada a la zona de trabajo

Ventilación natural frente a sistemas de aire acondicionado

Contigüidad de unidades que interactúan

Legibilidad de signos y señalizaciones

Arquitectura resistente a accidentes

Atractivas zonas sociales y para comer

Guardería en el lugar de trabajo

Lugares destinados a ejercicio físico

Zonas de recreo próximas al edificio

Acceso a aparcamiento y tránsito público

Proximidad a restaurantes y comercios

Buena calidad del aire en la zona

Niveles bajos de violencia en la zona
Efectos emocionales, sociales y de salud física

Más intimidad y satisfacción en el trabajo

Reducción de: fatiga visual, fatiga por tareas repetitivas, dolor en la región lumbar

Mayor confort y menor estrés

Más sensación de identidad y participación en el lugar de trabajo

Satisfacción en el trabajo y reducción del estrés

Menor estrés fisiológico y emocional

Menor estrés fisiológico y emocional

Mejor clima social, cohesión

Mejor clima social, cohesión

Menos fatiga visual, más satisfacción

Tasas más bajas de problemas respiratorios

Más coordinación y cohesión

Menos confusión e incomodidad

Tasas más bajas de accidentes

Más satisfacción con el trabajo y en el lugar de trabajo

Comodidad para los trabajadores, menos estrés

Más prácticas saludables, menos estrés

Más cohesión, menos estrés

Comodidad para los trabajadores, menos estrés

Comodidad para los trabajadores, menos estrés

Mejor estado del sistema respiratorio

Tasas bajas de lesiones intencionadas

\section{- FACTORES ERGONOMICOS}

\section{Michael J. Smith}

Con este artículo pretendemos facilitar al lector la comprensión de la forma en que las condiciones ergonómicas pueden afectar a los aspectos psicosociales del trabajo, a la satisfacción de los trabajadores con su entorno laboral y a su salud y bienestar. La tesis principal es que, en lo que respecta al entorno físico, a las exigencias del trabajo y a los factores tecnológicos, un diseño inadecuado del entorno y de las actividades propias del puesto puede provocar en el trabajador percepciones negativas, estrés psicológico y problemas de salud (Smith y Sainfort 1989; Cooper y M arshall 1976).

La ergonomía industrial es la ciencia que estudia el ajuste del entorno y las actividades de trabajo a las capacidades, dimensiones y necesidades de las personas. Se ocupa, por tanto, del entorno físico, del diseño de los instrumentos y la tecnología, del diseño del puesto de trabajo, de las exigencias de las tareas, y de la carga fisiológica y biomecánica que éstas suponen para el organismo. Su objetivo es incrementar el grado de ajuste entre los trabajadores, los entornos en que trabajan, sus instrumentos y las exigencias de sus puestos. C uando ese ajuste es deficiente, pueden producirse estrés y problemas de salud. Las muchas relaciones que existen entre las exigencias del trabajo y el estrés psicológico se examinan en otro lugar de este mismo capítulo, así como en Smith y Sainfort (1989), donde se da una definición de la teoría del equilibrio entre el estrés y el diseño del trabajo. Se habla de equilibrio cuando se utilizan diferentes aspectos del diseño del trabajo para contrarrestar los estresores. Este concepto de equilibrio es importante al examinar los aspectos ergonómicos y la salud. Por ejemplo, las incomodidades y molestias que producen unas condiciones ergonómicas deficientes pueden hacer a una persona más vulnerable al estrés del trabajo y a trastornos psicológicos, o bien intensificar los efectos somáticos del estrés del trabajo.

Siguiendo a Smith y Sainfort (1989), cabe afirmar que el estrés del trabajo puede tener su origen en:

1. las exigencias del puesto, como una carga de trabajo elevada y un ritmo rápido;

2. el escaso contenido del puesto, que produzca aburrimiento y falta de sentido;

3. el grado limitado de control sobre el trabajo o latitud de toma de decisiones:

4. unas políticas y procedimientos en materia de organización que alienen a los trabajadores; 
5. un estilo de supervisión que afecte a la participación y la socialización;

6. la contaminación ambiental;

7. factores tecnológicos,

8. las condiciones ergonómicas.

Smith (1987) y Cooper y M arshall (1976) han examinado las características del lugar de trabajo que pueden producir estrés psicológico. Entre ellas figuran la carga de trabajo inadecuada, la fuerte presión, el entorno hostil, la ambigüedad de funciones, la falta de tareas estimulantes, la sobrecarga cognitiva, la mala relación con los supervisores, la falta de control sobre las tareas o la toma de decisiones, la mala relación con otros compañeros y la falta de apoyo social por parte de supervisores, compañeros y familiares.

Las características ergonómicas adversas del trabajo pueden producir trastornos visuales, musculares y psicológicos, como fatiga visual, vista cansada, irritación ocular, cefaleas, fatiga, dolores musculares, trastornos traumáticos acumulativos, dolores de espalda, tensión psicológica, ansiedad y depresión. En ocasiones estos efectos son temporales y desaparecen cuando la persona deja de trabajar o se le da la oportunidad de descansar en el trabajo, o cuando se mejora el diseño del entorno. Cuando la exposición a condiciones ergonómicas deficientes es crónica, existe el riesgo de que los efectos se conviertan en permanentes. Los trastornos visuales y musculares y los dolores de diversos tipos pueden provocar ansiedad. El resultado puede ser estrés psicológico o un agravamiento de los efectos de estrés de unas condiciones de trabajo adversas. Los trastornos visuales y del sistema musculosquelético que producen pérdida de función y discapacidad pueden provocar ansiedad, depresión, agresividad y melancolía. $\mathrm{H}$ ay una relación de sinergía entre los trastornos producidos por los desajustes ergonómicos, de tal modo que se crea un efecto de círculo vicioso en el que la incomodidad visual o muscular genera más estrés psicológico, lo cual lleva a su vez a una mayor sensibilidad en la percepción del dolor en los ojos y músculos, con aumento del estrés y así sucesivamente.

Smith y Sainfort (1989) han definido cinco elementos del sistema laboral que son importantes en el diseño del trabajo y que guardan relación con las causas y el control del estrés. Se trata de: 1) la persona; 2) el entorno físico del trabajo; 3) las tareas; 4) la tecnología, y 5) la organización del trabajo. Examinamos a continuación todos estos elementos, menos el relativo a la persona.

\section{El entorno físico del trabajo}

El entorno físico del trabajo produce unas exigencias sensoriales que afectan a la capacidad del trabajador para ver, oír y tocar adecuadamente, y comprende elementos tales como la calidad del aire, la temperatura y la humedad. Además, el ruido es una de las más destacadas de las condiciones ergonómicas que generan estrés (Cohen y Spacapan 1983). Cuando las condiciones físicas del trabajo provocan un "ajuste deficiente" con las necesidades y capacidades de los trabajadores, el resultado son fatiga generalizada, fatiga sensorial y frustración del rendimiento. Estas condiciones pueden conducir al estrés psicológico (Grandjean 1968)

\section{Factores de la tecnología y del puesto de trabajo}

Se ha comprobado que diversos aspectos de la tecnología causan problemas a los trabajadores, como los controles y "displays" (o señales) incompatibles, la respuesta deficiente de los controles, los "displays" con poca sensibilidad sensorial, la dificultad de manejo de la tecnología, la utilización de equipo que reduzca el rendimiento del trabajador y las averías del equipo (Sanders y M cCormick 1993; Smith y cols. 1992a). Los estudios han puesto de manifiesto que los empleados que tienen ese tipo de problemas presentan más estrés físico y psicológico (Smith y Sainfort 1989; Sauter, Dainoff y Smith 1990).

\section{Tareas}

D os factores ergonómicos muy críticos relacionados con las tareas que se han vinculado con el estrés del trabajo son las cargas de trabajo elevadas y la presión de tiempo (Cooper y Smith 1985). U na carga de trabajo excesiva 0 insuficiente produce estrés, al igual que las horas extraordinarias no deseadas. Cuando los trabajadores están sometidos a una presión de tiempo, por ejemplo para cumplir unos plazos, o la carga de trabajo es sistemáticamente alta, entonces el estrés es también elevado. 0 tros factores críticos relacionados con las tareas que se han asociado al estrés son la fijación del ritmo del proceso de trabajo por parte de una máquina, la falta de contenido cognitivo de las tareas y un escaso control sobre éstas.

Desde una perspectiva ergonómica, las cargas de trabajo deben establecerse utilizando métodos científicos de evaluación del tiempo y el movimiento (OIT 1986), y no por otros criterios, como la necesidad económica de recuperar la inversión de capital o la capacidad de la tecnología.

\section{Factores de organización}

$\mathrm{H}$ ay tres aspectos ergonómicos de la dirección del proceso de trabajo que se han identificado como fuentes posibles de estrés psicológico. Se trata del trabajo por turnos, el trabajo cuyo ritmo está marcado por una máquina (trabajo en una línea de montaje) y las horas extraordinarias no deseadas (Smith 1987). Se ha comprobado que el trabajo por turnos trastorna los ritmos biológicos y el funcionamiento psicológico básico (Tepas y M onk 1987; Monk y Tepas 1985). El trabajo en una línea de montaje o marcado por una máquina, que da lugar a tareas de ciclo corto con poco contenido cognitivo y escaso control del trabajador sobre el proceso, produce estrés (Sauter, H urrell y Cooper 1989). Las horas extraordinarias no deseadas pueden producir cansancio y reacciones psicológicas adversas, como agresividad y trastornos del estado de ánimo (Smith 1987). El trabajo cuyo ritmo está marcado por una máquina, las horas extraordinarias no deseadas y lo que se percibe como una falta de control sobre las actividades laborales se han relacionado también con la enfermedad psicogénica (C olligan 1985).

\section{AUTONOMIAY CONTROL}

\section{Daniel Ganster}

La autonomía y el control son conceptos que tienen una larga historia en el estudio del trabajo y la salud. La autonomía - el margen de discrecionalidad que tienen los trabajadores en cuanto a la forma de realizar su labor - está asociada sobre todo a las teorías que se refieren a la oportunidad de diseñar el trabajo de tal manera que sea intrínsecamente motivador, satisfactorio y conducente al bienestar físico y mental. Prácticamente en todas las teorías de ese tipo desempeña un papel central el concepto de autonomía. El control (que se define más adelante) se suele entender en un sentido más amplio que el de autonomía. De hecho, cabría considerar la autonomía como una forma especializada del concepto más general de control. Como de estos dos términos es el de control el que tiene más contenido, es el que utilizaremos en el resto del artículo.

En todo el decenio de 1980, el concepto de control constituyó el núcleo de la que fue probablemente la teoría más influyente sobre el estrés profesional (véase, por ejemplo, la revisión de la bibliografía sobre el estrés del trabajo que se hace en Ganster y 
Schaubroeck 1991b). Esta teoría, conocida generalmente como "modelo de la latitud de toma de decisiones en el trabajo" (K arasek 1979), fue el estímulo para que se realizaran muchos estudios epidemiológicos a gran escala que investigaron los efectos conjuntos que sobre la salud del trabajador tenía el control en combinación con diversas condiciones de trabajo exigente. Aunque ha habido cierta controversia sobre la forma precisa en que el control puede contribuir a determinar los resultados de salud, los epidemiólogos y los psicólogos de la organización han llegado a considerar el control como variable crítica a la que hay que dar mucha importancia en cualquier investigación de las condiciones que producen estrés psicosocial en el trabajo. La preocupación por los posibles efectos perjudiciales del escaso control de los trabajadores era tan grande que, por ejemplo, en 1987 el National Institute for Occupational Safety and Health (NIOSH) de Estados U nidos organizó un seminario especial con expertos en los campos de la epidemiología, la psicofisiología y la psicología industrial y de la organización para examinar desde un punto de vista crítico los datos relativos a la repercusión del control sobre la salud y el bienestar de los trabajadores. EI resultado de ese seminario fue un libro muy completo, J ob Control and Worker H ealth (Sauter, H urrell y Cooper 1989), en el que se examinan las líneas de investigación sobre este tema a nivel mundial. Tan generalizado reconocimiento del papel del control en el bienestar de los trabajadores tuvo también un reflejo en la política oficial con la Ley sobre el entorno de trabajo de Suecia (M inisterio de Trabajo 1987), en la que se afirma que "el objetivo ha de ser organizar el trabajo de manera que el propio trabajador pueda influir en su situación laboral". En el resto del presente artículo resumiremos el resultado de las investigaciones sobre el control con miras a aportar a los especialistas en salud y seguridad en el trabajo lo siguiente:

1. un análisis de los aspectos del control de los trabajadores que podrían ser importantes;

2. orientaciones acerca de la manera de evaluar el control sobre las tareas en el lugar de trabajo,

3. ideas sobre la forma de intervenir con miras a reducir los efectos nocivos de la falta de control en los trabajadores.

En primer lugar, ¿qué significa exactamente el término "control"? En su sentido más amplio, se refiere a la capacidad de los trabajadores para influir realmente en lo que sucede en su entorno laboral. Además, esta capacidad de influencia debe examinarse desde el punto de vista de los objetivos de los trabajadores. El término alude, pues, a la capacidad para influir en asuntos que son de interés para los objetivos personales del trabajador. Esta importancia de la capacidad de influir en el entorno laboral distingue al control del concepto de predictibilidad. Este último se refiere a la capacidad de una persona para predecir lo que se va a exigir de ella, por ejemplo, pero no comporta en modo alguno la capacidad de modificar esas exigencias. La falta de predictibilidad constituye una fuente de estrés por sí misma, sobre todo cuando produce un alto nivel de ambigüedad acerca de las estrategias de rendimiento adecuadas para funcionar con eficacia o incluso acerca de la seguridad en el futuro de la empresa. Hay que distinguir también entre control y otro concepto más general, el de complejidad del trabajo. Las primeras conceptualizaciones del control examinaban éste al mismo tiempo que aspectos del trabajo como el nivel de capacidades y la disponibilidad de interacción social. En nuestro análisis se distingue el control de estos otros ámbitos de la complejidad del trabajo.

$C$ abe considerar los distintos mecanismos mediante los cuales los trabajadores pueden ejercer control y los ámbitos en que se aplica éste. A sí, puede ejercerse control, por ejemplo, adoptando decisiones como personas individuales. Esas decisiones pueden referirse a las tareas que hay que realizar, el orden en que se pueden realizar y a las normas y procesos que deben seguirse para su realización, por poner sólo unos pocos ejemplos. El trabajador puede ejercer también cierto grado de control colectivo a través de la actuación de sus representantes o de la acción social con sus compañeros de trabajo. En cuanto a los ámbitos en que el control puede aplicarse, cabe mencionar el ritmo de trabajo, la cantidad y frecuencia de la interacción con otras personas, el entorno físico (iluminación, ruido e intimidad), las fechas de las vacaciones o incluso ciertas cuestiones de política en el centro de trabajo. Por último, cabe distinguir entre control objetivo y subjetivo. Es posible, por ejemplo, que un trabajador tenga la capacidad de elegir el ritmo de su trabajo pero no sea consciente de ello. Análogamente, es posible que una persona piense que puede influir en las políticas en el lugar de trabajo aun cuando tal posibilidad sea prácticamente nula.

¿Cómo puede el especialista en salud y seguridad en el trabajo evaluar el nivel de control en una situación de trabajo? Como se recoge en la bibliografía, se han adoptado básicamente dos enfoques. En el primero, se toma como eje la ocupación. En este caso se considera que todos los trabajadores de una ocupación determinada tienen el mismo nivel de control, pues se parte de que éste está determinado por la naturaleza misma de aquélla. El inconveniente obvio de este enfoque es que no se puede saber mucho de cómo les va a los trabajadores en un determinado centro de trabajo, donde su control puede estar determinado tanto por las políticas y prácticas de su empleador como por su condición profesional. Por ello, es más habitual hacer encuestas entre los trabajadores acerca de sus percepciones subjetivas del control. Se han elaborado con ese fin algunas medidas psicométricamente adecuadas y de sencilla aplicación. La escala de control del NIOSH (M CLaney y Hurrell 1988), por ejemplo, consta de 16 preguntas y permite evaluar el control en los ámbitos de tareas, decisión, recursos y entorno físico. Las escalas de ese tipo pueden incorporarse fácilmente a una evaluación de aspectos relativos a la salud y seguridad del trabajador.

¿Es el control un determinante significativo de la salud y seguridad del trabajador? Esta pregunta ha impulsado numerosos estudios a gran escala al menos desde 1985. Como la mayoría de éstos han revestido la forma de estudios de campo de carácter no experimental, en las que el control no se manipulaba deliberadamente, los datos tan sólo pueden indicar una correlación sistemática entre variables de control, por un lado, y de resultados de salud y seguridad, por otro. La falta de pruebas experimentales nos impide hacer afirmaciones causales directas, aunque la correlación muestra de manera bastante sistemática que los trabajadores con niveles más bajos de control se ven más afectados por problemas de salud mental y física. Parece claro, por tanto, que el aumento del control de los trabajadores es una estrategia viable para mejorar su salud y su bienestar. Es más discutible si el control interactúa con otras fuentes de estrés psicosocial para determinar los resultados de salud, es decir, si unos niveles altos de control contrarrestan los efectos nocivos de otras exigencias del trabajo. Es ésta una cuestión muy interesante, ya que, en caso afirmativo, resultaría que los efectos negativos de una carga de trabajo elevada, por ejemplo, pueden anularse incrementando simplemente el control del trabajador. Los datos no son lo bastante claros para afirmarlo rotundamente. Los investigadores que han presentado tales efectos de interacción son más o menos tantos como los que no lo han hecho. Por consiguiente, el control no debe considerarse una panacea que cure los problemas causados por otros estresores psicosociales.

Los trabajos realizados por los estudiosos de la organización sugieren que el aumento del control de los trabajadores puede mejorar de manera significativa su salud y su bienestar. A demás, 
es relativamente fácil establecer un diagnóstico de escaso control mediante breves encuestas. Si es así, ¿cómo puede intervenir el especialista en salud y seguridad para aumentar los niveles de control de los trabajadores? Como en el lugar de trabajo el control se ejerce en muchos ámbitos distintos, hay muchas maneras de proceder; desde ofrecer a los trabajadores oportunidades para participar en las decisiones que les afectan hasta remodelar a fondo los puestos de trabajo. Lo importante, sin duda, es que las medidas se orienten a ámbitos de control que se correspondan con los objetivos principales de los trabajadores y que se ajusten a las exigencias de la situación. Lo mejor para determinar cuáles son estos ámbitos probablemente sea hacerles participar en sesiones conjuntas de diagnóstico y resolución de problemas. En todo caso, hay que señalar que las modificaciones que deban introducirse en el lugar de trabajo para mejorar realmente el control implican cambios fundamentales en los sistemas y políticas de la gestión empresarial. Aumentar el control puede ser tan sencillo como instalar un interruptor que permita a los trabajadores que trabajen con una máquina controlar el ritmo de ésta, pero probablemente exija también cambios importantes en la capacidad de toma de decisiones de éstos. Así pues, los responsables de la toma de decisiones en la organización deben apoyar plena y activamente las actuaciones encaminadas a incrementar el control.

\section{EL RITMO DEL TRABAJO}

\section{G avriel Salvendy}

En este artículo se examinan las razones por las que se sigue en el lugar de trabajo el ritmo marcado por una máquina. Además, se expone una clasificación de este tipo de trabajo, se ofrece información sobre su repercusión sobre el bienestar de los trabajadores y se indican métodos para aliviar o reducir sus efectos.

\section{Ventajas del trabajo cuyo ritmo está marcado por una máquina}

La utilización efectiva del trabajo cuyo ritmo está marcado por una máquina tiene para una organización las ventajas siguientes:

Figura 34.7 • Clasificación del ritmo de trabajo.

\section{RITMO NO MARCADO POR UNA MAQUINA}

\begin{tabular}{|c|c|c|c|}
\hline$\left\{\begin{array}{c}\text { Ritmo realmente } \\
\text { no marcado }\end{array}\right.$ & Ritmo socialmente marcado & $\begin{array}{l}\text { Ritmo marcado por el } \\
\text { trabajador (autorregulado) }\end{array}$ & $\left.\begin{array}{l}\text { Ritmo marcado } \\
\text { por incentivos }\end{array}\right\}$ \\
\hline $\begin{array}{l}\text { No se impone ritmo } \\
\text { alguno, ni interno ni } \\
\text { externo. El trabajo se } \\
\text { realiza al ritmo que } \\
\text { decide el operario. }\end{array}$ & $\begin{array}{l}\text { Aunque ni la dirección ni una máquina } \\
\text { imponen un ritmo, los compañeros o el } \\
\text { grupo ejercen presión para que el trabajo se } \\
\text { realice a un ritmo determinado. Hay dos } \\
\text { clases de trabajo cuyo ritmo se marca } \\
\text { socialmente. Uno se refiere a los clientes: } \\
\text { cuando están haciendo cola esperando a } \\
\text { que se les atienda, ello afecta al ritmo de } \\
\text { trabajo, pues el operario intenta atenderlos } \\
\text { en un tiempo aceptable. El otro es la } \\
\text { presión del grupo para que se trabaje a un } \\
\text { ritmo establecido. Son claros ejemplos de } \\
\text { este tipo los que trabajan en espectáculos, }\end{array}$ & $\begin{array}{l}\text { Aunque no lo marca una } \\
\text { máquina, el ritmo del trabajo } \\
\text { obedece a los objetivos } \\
\text { establecidos por la dirección. Un } \\
\text { ejemplo es el control diario, } \\
\text { según el cual el trabajador debe } \\
\text { haber producido un número } \\
\text { determinado de artículos al } \\
\text { término de la jornada. Siempre } \\
\text { que cumpla ese objetivo, el } \\
\text { trabajador puede distribuir a su } \\
\text { gusto el tiempo que dedica a los } \\
\text { diversos ciclos. }\end{array}$ & $\begin{array}{l}\text { Consta de dos partes que se } \\
\text { suman: el componente de "ritmo } \\
\text { autorregulado" y la motivación } \\
\text { económica que lleva al trabajador } \\
\text { a producir por encima de ese } \\
\text { ritmo. Cuanto más supere ese } \\
\text { nivel de producción, tanto más } \\
\text { incrementará sus ingresos. Por } \\
\text { consiguiente, la intensidad y la } \\
\text { dureza del ritmo dependen de } \\
\text { cuánto quiere ganar el } \\
\text { trabajador. }\end{array}$ \\
\hline
\end{tabular}
conferenciantes, profesores y

deportistas.

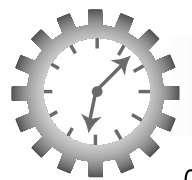

Cuando el ciclo del trabajo cuyo ritmo lo marca una máquina es sumamente largo, este sistema se acerca al de ritmo autorregulado. Cuanto más corto es el ciclo, menos variabilidad de rendimiento del trabajador puede tolerarse.

\section{RITMO MARCADO POR UNA MAQUINA}

$\begin{array}{ccc}\text { Ritmo influido } & \text { Ritmo con sistema de } & \text { Ritmo influido por la } \\ \text { por la duración del } & \text { stocks de amortiguación } & \text { velocidad del trabajo marcado } \\ \text { ciclo de trabajo } & \text { por una máguina }\end{array}$

El sistema de stocks de amortiguación consiste en que "un operario disponga al mismo tiempo de más de un componente 0 posición de alimentación" (Murrell 1965). No siempre que el ritmo lo marca una máquina se trabaja con este sistema. Al incluir en el diseño del proceso una amortiguación entre los puestos se puede reducir la dureza asociada al sistema de ritmo marcado por una máquina: cuanto mayores sean los stocks de amortiquación, menos duro será el ritmo de trabajo. Unos stocks sumamente grandes entre los puestos pueden reducir los efectos del sistema de ritmo marcado por una máquina hasta los niveles del sistema de ritmo autorregulado.
Si una buena jornada de trabajo se define como el $100 \%$, el trabajo cuyo ritmo lo marca una máquina se realiza con frecuencia a una velocidad de entre 100 y 125 . El efecto sobre el trabajador varía según la velocidad a que se realiza la tarea.

\section{Ritmo} continuo/discreto
Ambas modalidades son muy frecuentes en la industria. Por ejemplo, en las operaciones con cinta transportadora, ésta puede estar andando continuamente, en cuyo caso el operario trabaja en un entorno visual dinámico, 0 por el contrario puede estar programada para que se detenga de vez en cuando. En este último caso la cinta está parada durante una parte determinada del ciclo cuando el operario está trabajando. Al término de cada ciclo la cinta pasa al puesto de trabajo siguiente. Durante ese tiempo de transición (que suele ser de entre dos y ocho segundos), el operario puede realizar labores preparatorias para el ciclo siguiente 0 estar sin hacer nada. 
- Incrementa la satiffacción de los clientes: por ejemplo, facilita un servicio más rápido en los restaurantes "drive-in" cuando se asignan una serie de puestos para atender a los clientes de forma secuencial.

- Reduce los costes generales mediante el uso económico de tecnología avanzada, la reducción de las existencias de materias primas, la reducción de la superficie de fábrica y la reducción de los costes de supervisión.

- Reduce los costes directos al disminuir el tiempo de formación, rebajar los salarios por hora y aumentar el rendimiento productivo por unidad salarial.

- Contribuye a la productividad nacional al ofrecer empleo a trabajadores no cualificados y reducir los costes de producción de los bienes y servicios.

\section{Clasificación del trabajo cuyo ritmo lo marca una máquina}

En la Figura 34.7 se ofrece una clasificación de este tipo de trabajo.

\section{Efectos sobre el bienesta del trabajo cuyo ritmo está marcado por máquinas}

Este tipo de trabajo se ha investigado en el laboratorio, en la industria (mediante estudios monográficos y experimentos controlados) y en estudios epidemiológicos (Salvendy 1981).

Se han analizado 85 estudios referidos al trabajo cuyo ritmo está marcado por una máquina y al trabajo con ritmo autorregulado, de los cuales el $48 \%$ eran estudios de laboratorio, el $30 \%$ estudios industriales, el $14 \%$ estudios de revisión, el $4 \%$ estudios combinados en laboratorio e industriales y el $4 \%$ estudios teóricos (Burke y Salvendy 1981). D e las 103 variables utilizadas en ellos, el $41 \%$ eran variables fisiológicas, el $31 \%$ variables de rendimiento y el $27 \%$ variables psicológicas. De ese análisis se han podido extraer las siguientes conclusiones prácticas sobre el sistema de trabajo cuyo ritmo está marcado por una máquina frente al sistema de autorregulación, determinado por el propio trabajador:

- Las tareas que tienen una carga cognitiva o perceptual elevada se prestan más al sistema de autorregulación que al de ritmo marcado por una máquina.

- Para reducir el error y evitar la falta de productividad, los puestos deben asignarse en función de la personalidad y las capacidades del trabajador.

- Los operarios inteligentes, perspicaces, creativos y autosuficientes prefieren trabajar en tareas de ritmo autorregulado, no regulado por una máquina. (Véanse en la Tabla 34.2 unos perfiles psicológicos más completos.)

- Debe animarse a los trabajadores a que elijan una capacidad de carga de trabajo que sea la óptima para ellos en una situación dada.

$\begin{array}{ll}\text { Tabla 34.2 } & \begin{array}{l}\text { Perfiles psicológicos de los operarios que } \\ \text { prefieren el trabajo de ritmo autorregulado y } \\ \text { los que prefieren el trabajo con el ritmo } \\ \text { marcado por una máquina. }\end{array} \\ \text { Ritmo marcado por una máquina } & \text { Ritmo autorregulado } \\ \text { Menos inteligente } & \text { Más inteligente } \\ \text { Humilde } & \text { Asertivo } \\ \text { Práctico } & \text { Imaginativo } \\ \text { Directo } & \text { Sagaz } \\ \text { Dependiente del grupo } & \text { Autosuficiente }\end{array}$

Figura 34.8 • Efectos de la retroalimentación sobre el rendimiento en la reducción del estrés.

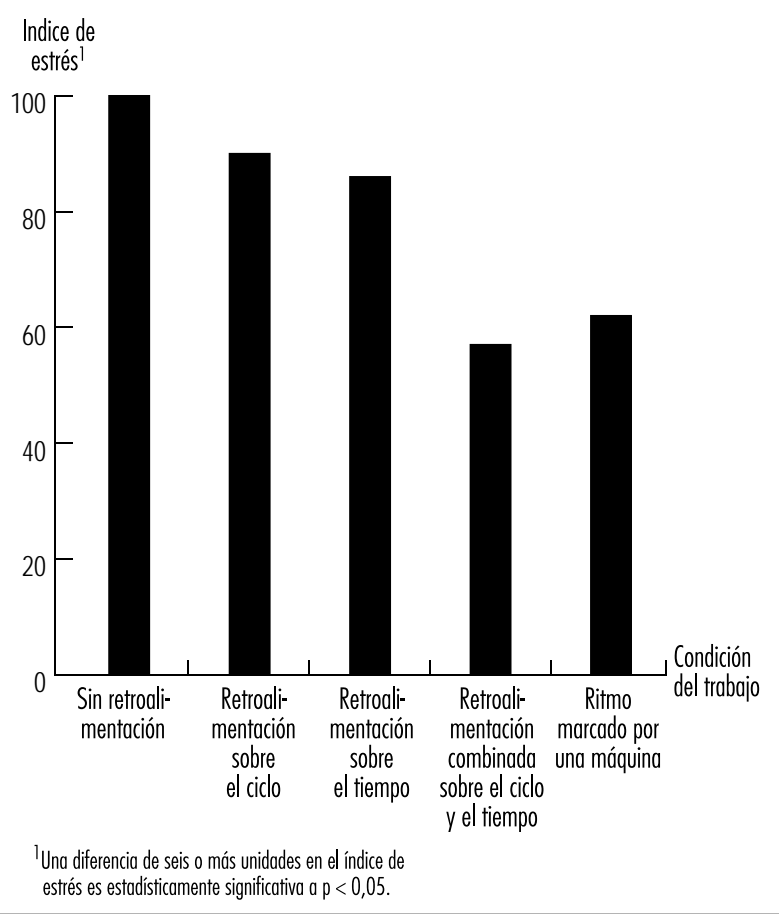

- Para mantener un nivel de activación elevado (o el nivel requerido para realizar la tarea), las sesiones de trabajo deben interrumpirse con períodos de descanso o con períodos en los que se realice otro tipo de trabajo. Esas pausas deben establecerse antes de que el estado de alerta empiece a disminuir.

- Las velocidades máximas de trabajo no son económicas y pueden someter a los trabajadores a una tensión excesiva si la situación se mantiene durante mucho tiempo. Por otra parte, una velocidad demasiado baja puede ser también perjudicial para el rendimiento de los trabajadores.

Al estudiar a trabajadores industriales durante todo un año en una situación experimentalmente controlada, en la que se recopilaron más de 50 millones de datos puntuales, se comprobó que el $45 \%$ de los trabajadores preferían las tareas de ritmo autorregulado, el $45 \%$ prefería el ritmo marcado por una máquina y al $10 \%$ no le gustaba ninguna de las dos modalidades (Salvendy 1976).

EI factor que más contribuye al estrés es la incertidumbre, que puede controlarse mediante retroalimentación sobre el rendimiento (véase la Figura 34.8) (Salvendy y K night 1983).

\section{LA SUPERVISION ELECTRONICA DEL TRABAJO}

Lawrence M. Schleifer

La informatización del trabajo ha hecho posible la aparición de un nuevo enfoque de la supervisión del trabajo, la llamada "supervisión electrónica del rendimiento" (SER). La SER se ha definido como "la recopilación, almacenamiento, análisis y notificación, por medios informáticos y de manera continua, de información sobre las actividades de los trabajadores" (U SOTA 1987). Aunque está prohibida en muchos países europeos, esta 
modalidad se está extendiendo por todo el mundo debido a intensas presiones competitivas para mejorar la productividad en una economía mundial.

La SER ha modificado el entorno psicosocial del trabajo. Afecta de manera importante a cuestiones como la supervisión del trabajo, las exigencias de carga de trabajo, la evaluación del rendimiento y su retroalimentación, las retribuciones, la justicia y la intimidad. Como resultado de todo ello, especialistas en salud en el trabajo, representantes de los trabajadores, organismos oficiales y medios de comunicación públicos han expresado su preocupación por sus efectos estresores (U SOTA 1987).

Tradicionalmente, el trabajo se ha supervisado mediante la observación directa del comportamiento de los trabajadores, el examen de muestras de trabajo, el análisis de informes sobre progresos realizados y el análisis de medidas de rendimiento (Larson y Callahan 1990). H istóricamente, los empresarios han tratado siempre de mejorar tales métodos. Considerada como una parte del proceso continuo de evaluación iniciado hace muchos años, la SER no es, por tanto, una novedad. Lo que sí es nuevo es su empleo, sobre todo en el trabajo de oficina y de servicios, para conocer el rendimiento del trabajador segundo a segundo, pulsación a pulsación, de tal modo que la dirección puede intervenir en cualquier momento mediante la adopción de medidas correctivas, la retroalimentación sobre el rendimiento, o la aplicación de incentivos salariales o medidas disciplinarias (Smith 1988). En la práctica, el supervisor humano es sustituido por un supervisor electrónico.

La SER se utiliza en actividades de oficina, como las que implican el empleo de procesadores de textos y la introducción de datos, para vigilar la producción en pulsaciones y los índices de error. L os empleados de reservas de compañías aéreas y los operadores de guías de apoyo son vigilados por ordenadores para determinar cuánto tardan en atender a los clientes y medir el intervalo de tiempo entre una llamada y otra. La SER se utiliza también en sectores económicos más tradicionales. Las empresas de transporte de mercancías, por ejemplo, utilizan ordenadores para vigilar la velocidad de los conductores y el consumo de combustible, y los fabricantes de neumáticos vigilan electrónicamente la productividad de los empleados del caucho. En suma, la SER se utiliza para establecer unos niveles óptimos de rendimiento, comprobar el rendimiento de los trabajadores, comparar el nivel real con los niveles predeterminados y, sobre la base de éstos, establecer programas de incentivos salariales (U SOTA 1987).

LoS defensores de la SER afirman que la supervisión electrónica y continua es esencial para obtener altos niveles de rendimiento y productividad en el trabajo contemporáneo. Aducen que permite a los directivos y a los supervisores organizar y controlar los recursos humanos, materiales y financieros. Concretamente, la SER permite:

1. incrementar el control sobre la variabilidad del rendimiento;

2. incrementar la objetividad y oportunidad de la evaluación del rendimiento y su retroalimentación;

3. dirigir de manera eficiente las grandes operaciones de oficina y de servicios al cliente mediante la supervisión electrónica del trabajo, y

4. establecer e imponer el cumplimiento de normas de rendimiento (por ejemplo, el número de impresos que se procesan a la hora).

Los partidarios de la supervisión electrónica afirman que el sistema tiene también ventajas desde la perspectiva del trabajador. Por ejemplo, puede ofrecer una retroalimentación regular del rendimiento en el trabajo que permite tomar medidas correctoras en caso necesario. Satisface también la necesidad de autoevaluación y reduce la incertidumbre sobre el rendimiento.
Pese a las posibles ventajas de la SER, hay preocupación por la posibilidad de que determinadas prácticas sean abusivas y constituyan una intromisión en la intimidad del trabajador (USOTA 1987). La cuestión de la intimidad se plantea sobre todo cuando los trabajadores no saben cuándo o con qué frecuencia están siendo vigilados. Como las organizaciones no suelen compartir con los trabajadores los datos sobre su rendimiento, otra cuestión relacionada con la intimidad es si debe dárseles acceso a sus expedientes de rendimiento o concederles el derecho a discutir una posible información errónea.

Los trabajadores han formulado también objeciones a la manera en que se han aplicado los sistemas de vigilancia (Smith, Carayon y M iezio 1986; Westin 1986). En algunos centros de trabajo, ésta se percibe como una práctica laboral injusta cuando se utiliza para medir el rendimiento individual, no el rendimiento colectivo. En particular, los trabajadores se han opuesto a su empleo para obligar al cumplimiento de unas normas de rendimiento que imponen una carga de trabajo excesiva. La vigilancia electrónica da también al proceso de trabajo un carácter más impersonal, al sustituir a un supervisor humano por un supervisor electrónico. Además, un afán excesivo en el aumento de la producción puede impulsar a los trabajadores a competir en vez de a cooperar entre ellos.

Se han propuesto varios paradigmas teóricos para explicar los posibles efectos estresores de la SER (Amick y Smith 1992; Schleifer y Shell 1992; Smith y cols. 1992b). U n supuesto fundamental del que parten muchos de estos modelos es que la SER influye indirectamente en la situación de estrés al intensificar la exigencia en materia de carga de trabajo, reducir el control sobre la actividad y reducir también el apoyo social. En la práctica, la SER produce cambios en el entorno psicosocial del trabajo que tienen como resultado un desequilibrio entre las exigencias del puesto y los recursos del trabajador para adaptarse a él.

$L$ a repercusión de la SER en el entorno psicosocial del trabajo se deja sentir a tres niveles del sistema laboral: la interrelación organización-tecnología, la interrelación puesto de trabajo-tecnología y la interrelación ser humano-tecnología (Amick y Smith 1992). El grado de transformación del sistema de trabajo y las subsiguientes consecuencias para el estrés dependen de las características intrínsecas del proceso de la SER, es decir, el tipo de información que se recopile, el método de recopilarla y el uso que se le da (Carayon 1993). Estas características de la SER pueden interactuar con diversos factores de diseño del puesto de trabajo e incrementar los riesgos de estrés.

$O$ tra perspectiva teórica es la que ve a la SER como un estresor que produce directamente tensión, con independencia de otros factores de estrés que tienen que ver con el diseño del puesto de trabajo (Smith y cols. 1992b; Carayon 1994). La SER puede generar, por ejemplo, miedo y tensión como resultado de que los trabajadores están siendo vigilados constantemente por el "Gran H ermano". Puede ser percibida también por los trabajadores como una intromisión en su intimidad sumamente amenazadora.

Con respecto a los efectos de estrés de la SER, datos empíricos obtenidos de experimentos controlados en laboratorio indican que puede producir trastornos del estado de ánimo (Aiello y Shao 1993; Schleifer, G alinsky y Pan 1995) y reacciones de hiperventilación por estrés (Schleifer y L ey 1994). En estudios de campo se ha demostrado asimismo que la SER altera los estresores del diseño del puesto de trabajo (por ejemplo, la carga de trabajo), los cuales a su vez generan tensión o ansiedad junto con depresión (Smith, Carayon y M iezio 1986; Ditecco y cols. 1992; Smith y cols. 1992b; Carayon 1994). Además, la SER se asocia a molestias musculosqueléticas entre trabajadores de telecomunicaciones y trabajadores de oficina dedicados a la 
introducción de datos (Smith y cols. 1992b; Sauter y cols. 1993; Schleifer, Galinsky y Pan 1995).

La utilización de la SER para imponer el cumplimiento de determinados niveles de rendimiento es quizás uno de los aspectos más estresores de este método de supervisión del trabajo (Schleifer y Shell 1992). En tales condiciones, puede ser conveniente ajustar esos niveles añadiéndoles un margen por estrés (Schleifer y Shell 1992): éste se aplicaría al tiempo del ciclo normal, como ocurre con otras medidas de este tipo ya tradicionales, como los descansos y las desaceleraciones de las máquinas. La concesión de ese margen por estrés optimizaría la exigencia en materia de carga de trabajo y fomentaría el bienestar al equilibrar las ventajas que para la productividad tiene la SER con los efectos estresores de este método de supervisión del trabajo, especialmente entre los trabajadores a los que les resulta difícil alcanzar los niveles de rendimiento exigidos por este sistema.

Más allá de cómo reducir al mínimo o impedir los posibles efectos de estrés de la SER, una cuestión más fundamental es determinar si este enfoque "taylorista" de la supervisión del trabajo tiene alguna utilidad en los centros de trabajo modernos. Las organizaciones utilizan cada vez más métodos de diseño de carácter sociotécnico, prácticas de "gestión total de la calidad", grupos de trabajo participativos y medidas del rendimiento de carácter más global que individual. A consecuencia de todo ello, es posible que la supervisión electrónica del trabajo aplicada individualmente no tenga cabida en los sistemas de trabajo de alto rendimiento. A ese respecto es interesante señalar que los países que han prohibido la SER (Suecia y Alemania, por ejemplo) son los que más rápidamente han adoptado los principios y las prácticas relacionados con los sistemas de trabajo de alto rendimiento.

\section{- CLARIDAD Y SOBRECARGA DE LOS ROLES ASIG NADOS}

Steve M. Jex

Se agrupa bajo el término "rol" el conjunto de comportamientos que se espera de un trabajador. Para comprender cómo se desarrollan los "roles" en una organización, es especialmente revelador ver el proceso a través de los ojos de un nuevo empleado. Desde el primer día de trabajo, a éste se le presenta una cantidad considerable de información con la que la organización quiere comunicarle las expectativas que tiene sobre sus roles. Parte de esa información se le presenta formalmente, mediante una descripción escrita del puesto y comunicaciones regulares con su supervisor. H ackman (1992), sin embargo, afirma que los trabajadores reciben también diversas comunicaciones informales (los llamados estímulos discrecionales), que tienen por finalidad configurar sus roles en la organización. Por ejemplo, un miembro de un claustro universitario joven que habla en exceso durante una reunión del departamento puede recibir miradas de desaprobación de colegas más veteranos. Esas miradas son sutiles, pero comunican mucho acerca de lo que se espera de un colega más joven.

Idealmente, el proceso de definición del rol de un trabajador debe realizarse de tal manera que éste tenga claro cuál es suyo. Por desgracia, muchas veces no ocurre así, y a los trabajadores les falta claridad sobre su rol: es lo que habitualmente se llama "ambigüedad de rol". Según Breaugh y Colihan (1994), es frecuente que los trabajadores no tengan claro cómo realizar sus tareas, cuándo se han de realizar algunas de ellas y los criterios por los que se va a juzgar su rendimiento. En algunos casos sencillamente es difícil darles una descripción inequívoca de su rol. Por ejemplo, cuando un puesto es relativamente nuevo, está aún "configurándose" en la organización. A demás, hay muchos casos en los que el trabajador como individuo tiene una enorme flexibilidad acerca del modo de realizar sus tareas, sobre todo en los puestos de gran complejidad. En muchos otros casos, sin embargo, la ambigüedad rol se debe simplemente a una deficiente comunicación entre los superiores y los subordinados 0 entre los miembros de los grupos de trabajo.

Otro problema que puede plantearse al comunicar a los trabajadores la información a este respecto es la sobrecarga de roles. Es decir, el rol implica demasiadas obligaciones para que un trabajador pueda realizarlas en un período de tiempo razonable. Esta sobrecarga puede deberse a varias razones. En algunas profesiones, es lo normal. Por ejemplo, los médicos en prácticas tienen una sobrecarga enorme, sobre todo como preparación para las exigencias del ejercicio de su profesión. En otros casos se debe a circunstancias temporales. Por ejemplo, cuando una persona deja una organización, es posible que haya que ampliar temporalmente los roles de otros trabajadores para compensar esa ausencia. En otros casos, las organizaciones no prevén las exigencias de los papeles que crean, o la naturaleza del rol de un trabajador cambia con el tiempo. Por último, es también posible que un trabajador asuma voluntariamente demasiadas responsabilidades.

¿Q ué consecuencias sufren los trabajadores en esas circunstancias de ambigüedad, sobrecarga o definición de rol? Años de investigación sobre la ambigüedad de funciones han demostrado que es un estado nocivo, asociado a efectos negativos de orden psicológico, físico y de comportamiento (Jackson y Schuler 1985). L os trabajadores que perciben una ambigüedad de rol sus puestos de trabajo tienden a estar insatisfechos con su trabajo, ansiosos y tensos, plantean numerosas quejas de problemas somáticos, tienden a estar ausentes del trabajo y pueden acabar abandonando el empleo. A una sobrecarga de roles le suele corresponder sobre todo el agotamiento físico y emocional. A demás, los estudios epidemiológicos han puesto de manifiesto que las personas sobrecargadas (medida la sobrecarga en horas de trabajo) pueden tener un mayor riesgo de enfermedad coronaria. Al examinar los efectos tanto de la ambigüedad como de la sobrecarga de roles, hay que tener en cuenta que la mayoría de los estudios son transversales (miden los estresores, o factores de estrés, y las consecuencias relacionados en un momento concreto) y que han analizado resultados manifestados por los propios trabajadores. Así pues, las deducciones que se pueden extraer sobre una relación causal son en cierto modo provisionales.

H abida cuenta de los efectos negativos de la ambigüedad y la sobrecarga de rol, es importante que las organizaciones reduzcan al mínimo, si no pueden eliminarlos, esos estresores. Como en muchos casos la ambigüedad se debe a una comunicación deficiente, es necesario tomar medidas para transmitir de una manera más eficaz las exigencias del puesto. En el libro Organization D evelopment, French y Bell (1990) describen intervenciones como la representación gráfica de las responsabilidades, el análisis de roles y la negociación de éstos. (Véase en Schaubroeck y cols. 1993 un ejemplo reciente de la aplicación de esa representación gráfica de las responsabilidades.) Todas esas técnicas están orientadas a lograr que las exigencias de los roles de los trabajadores sean explícitas y estén bien definidas. A demás, permiten a los trabajadores aportar su contribución al proceso de definición de su rol.

Una vez explícitas las obligaciones, puede ocurrir también que las responsabilidades no estén distribuidas de manera equitativa entre los trabajadores. Así, las intervenciones antes mencionadas pueden prevenir también la sobrecarga. Además, 
las organizaciones han de tratar de no quedarse estancadas en cuanto a las responsabilidades que corresponden al rol de cada individuo, revisando las descripciones de los puestos y efectuando análisis de los mismos (Levine 1983). Puede ser útil también animar a los trabajadores a que sean realistas en cuanto al número de responsabilidades que pueden asumir. En algunos casos, los trabajadores presionados para que asuman demasiado deberían demostrar más firmeza al negociar las responsabilidades de su rol.
C omo observación final, hay que recordar que la ambigüedad y la sobrecarga de rol son estados subjetivos. Es decir, los intentos de reducir esos estresores han de tener en cuenta las diferencias individuales. De hecho, a algunos trabajadores les puede gustar el reto que suponen esos factores. 0 tros, por el contrario, quizá los sientan como negativos. Cuando esto último sucede, las organizaciones deben rebajar esos factores, por razones morales, legales y económicas, a unos niveles manejables.

\section{FACTORES INTERPERSONALES}

\section{- El acoso seXual}

\section{Chaya S. Piotrkowski}

H istóricamente, el acoso sexual a las trabajadoras se ha ignorado, negado, presentado como trivial, tolerado e incluso implícitamente apoyado, atribuyéndoles la culpa a las propias mujeres (M ack innon 1978). Sus víctimas son casi en su totalidad mujeres, y éstas lo padecen desde que empezaron a "vender" su fuerza de trabajo fuera del hogar.

Aunque también existe acoso sexual fuera del lugar de trabajo, en el presente artículo nos centraremos únicamente en su presencia en el entorno laboral.

El acoso sexual no es expresión de una galantería inocente ni de una atracción mutua entre hombres y mujeres. Por el contrario, es un factor de estrés laboral que supone una amenaza para la integridad y seguridad psicológicas y físicas de la mujer, en un contexto en el que ésta tiene poco control debido al riesgo de represalias y el miedo a perder su medio de sustento. Como otros factores de estrés del trabajo, puede tener consecuencias negativas para la salud de las mujeres, incluso graves, y desde ese punto de vista está justificado que se considere como un problema de salud y seguridad en el trabajo (Bernstein 1994).

En Estados U nidos, el acoso sexual se considera básicamente como un caso concreto de conducta jurídicamente ilícita a la que se puede responder adecuadamente mediante actuaciones judiciales. En la Comunidad Europea tiende a considerarse más bien como una cuestión colectiva de salud y seguridad (Bernstein 1994).

Como las manifestaciones del acoso sexual son variables, es posible que no se coincida en las características que lo definen, ni siquiera cuando la cuestión está recogida en la legislación. En todo caso, hay algunos rasgos comunes que son generalmente aceptados por todos los que trabajan en este ámbito:

1. EI acoso sexual puede implicar tanto comportamientos sexuales verbales o físicos respecto a una mujer concreta (quid pro quo) como comportamientos más generales que creen un "entorno hostil" degradante, humillante e intimidatorio para las mujeres (M acK innon 1978).

2. Es desagradable y no deseado.

3. Puede presentar varios grados de gravedad.

Cuando se dirige a una mujer concreta, el acoso puede reflejarse en comentarios sexuales y comportamientos de seducción, en "proposiciones" y presiones para que ésta acepte citas, en tocamientos, en actos de coerción sexual mediante amenazas o sobornos e incluso en agresiones físicas y violación. En el caso de un "entorno hostil", que es probablemente lo más habitual, puede implicar chistes, insinuaciones y otros comentarios con carga sexual amenazadores y despreciativos para las mujeres; la presentación de carteles pornográficos o sexualmente explícitos; la práctica de gestos sexuales groseros, etc. Se puede añadir a esas características lo que a veces se denomina "acoso en función del sexo", esto es, la manifestación de observaciones discriminatorias en función del sexo en las que se desprecia la dignidad de la mujer.

A veces las propias mujeres no califican de acoso atenciones sexuales u observaciones sexuales no deseadas, que aceptan como comportamientos "normales" de los hombres (Gutek 1985). En general, las mujeres (especialmente si han sufrido acoso) tienden más a ver en determinadas situaciones casos de acoso sexual que los hombres, que suelen quitarles importancia, no dar crédito a la mujer concreta que se queja o atribuirle a ella la culpa por su actitud "provocadora" (Fitzgerald y O rmerod 1993). Se tiende también más a calificar de acoso sexual el que procede de un supervisor que el comportamiento similar de un compañero del mismo nivel (Fitzgerald y 0 rmerod 1993). Esta tendencia revela la importancia de la relación de poder diferencial que existe entre el que acosa y la víctima (M ack innon 1978). A modo de ejemplo, un comentario hecho por un supervisor masculino como un cumplido quizá sea sentido como algo amenazador por la destinataria, ante el temor de que lleve a una presión para obtener favores sexuales o desencadena una represalia ante una respuesta negativa, incluida la posible pérdida del empleo o una evaluación negativa.

Aun entre empleados del mismo nivel, a las mujeres les puede resultar difícil controlar el acoso sexual, y éste puede ser muy estresor para ellas. Esta situación puede darse cuando hay muchos más hombres que mujeres en un grupo de trabajo, se crea un entorno hostil y el supervisor es un varón (Gutek 1985; Fitzgerald y O rmerod 1993).

No se dispone de datos sobre el acoso sexual a nivel nacional, y es difícil obtener cifras fiables sobre su extensión. En Estados U nidos se ha estimado que el $50 \%$ de las mujeres experimentan alguna forma de acoso sexual durante su vida laboral (Fitzgerald y O rmerod 1993). Esas cifras son coherentes con encuestas realizadas en Europa (Bustelo 1992), aunque hay variaciones por países (K auppinen-Toropainen y Gruber 1993). También es difícil determinar el grado del acoso sexual, pues las mujeres a veces no lo definen con precisión y notifican menos de lo realmente sucedido. En ocasiones temen que se les eche a ellas la culpa, se les humille y no se las crea no se haga nada y la denuncia dé lugar a una represalia (Fitzgerald y O rmerod 1993). En tales casos intentan vivir con la situación o prefieren dejar el trabajo y arriesgarse a graves problemas económicos, a interrumpir su historial laboral y a tener problemas con las referencias (K oss y cols. 1994).

El acoso sexual reduce la satisfacción en el trabajo e incrementa la rotación, de manera que tiene costes para el empresario (G utek 1985; Fitzgerald y Ormerod 1993; K auppinen-Toropainen y 
G ruber 1993). Al igual que otros factores de estrés laboral, puede tener también efectos negativos sobre la salud, a veces bastante graves. Cuando el acoso es grave, como cuando hay una violación o un intento de violación, la mujer queda gravemente traumatizada. Incluso cuando es menos grave, puede dar origen a problemas psicológicos: la mujer se siente temerosa, culpable y avergonzada, deprimida, nerviosa y con menos confianza en sí misma. En ocasiones aparecen síntomas físicos, como dolores de estómago, cefaleas o náuseas. Puede haber problemas de comportamiento, como insomnio, desajustes en los hábitos dietéticos, problemas sexuales y dificultades en las relaciones con los demás (Swanson y cols. 1997).

A mbas formas de combatir el acoso, la más formal de Estados U nidos y la más informal de Europa, ofrecen enseñanzas ilustrativas (Bernstein 1994). En Europa, el acoso sexual se aborda a veces con métodos de resolución de conflictos en los que se acude a terceros (por ejemplo, la llamada "técnica del desafío" del Reino U nido). En Estados U nidos, el acoso sexual es un acto jurídicamente ilícito y da derecho a solicitar una indemnización, aunque no es fácil conseguir resultados satisfactorios. $\mathrm{H}$ ay que apoyar a las víctimas con actividades de asesoramiento en caso necesario, y ayudarlas a entender que no son culpables del acoso.

La prevención es la clave para luchar contra el acoso sexual. El Código de conducta de la Comisión Europea (Rubenstein y DeVries 1993) incluye orientaciones al respecto. Entre otras medidas, se recomiendan la adopción de políticas claras comunicadas con eficacia, la realización de actividades de formación y educación especiales para directivos y supervisores, la designación de un "defensor" que se ocupe de las quejas, la instauración de procedimientos formales de reclamación y de alternativas a los mismos, y el tratamiento disciplinario de los infractores Bernstein (1994) señala que la autorregulación obligatoria puede ser un enfoque viable.

Por último, es necesario que el acoso sexual se analice abiertamente como un problema laboral que preocupa de forma legítima a mujeres y hombres. Los sindicatos tienen un papel decisivo que desempeñar para lograr que esta cuestión ocupe un lugar predominante en el interés público. En última instancia, para poner fin al acoso sexual es necesario que hombres y mujeres lleguen a la igualdad social y económica y a la plena integración en todas las profesiones y centros de trabajo.

\section{- La VIOLENCIA EN EL LUgAR DE TRABAJO}

Julian Barling

La naturaleza, prevalencia, factores predictivos y posibles consecuencias de la violencia en el lugar de trabajo han empezado a atraer la atención tanto de los trabajadores y directivos como de los investigadores. Ello se debe a que cada vez se producen en el lugar de trabajo más actos violentos con resultado de muerte, que son por naturaleza muy llamativos. U na vez centrada la atención en la violencia de este tipo, está claro que hay varios problemas de que ocuparse, entre ellos su naturaleza (o definición), su prevalencia, los factores predictivos, sus consecuencias y, en última instancia, su prevención.

\section{Definición y prevalencia de la violencia en el lugar de trabajo}

La definición de la violencia en el lugar de trabajo y su prevalencia están estrechamente relacionadas.
Como hace relativamente poco tiempo que esta cuestión ha atraído la atención, no existe una definición uniforme de la misma. Este aspecto es importante por varias razones. En primer lugar, mientras no exista una definición uniforme, seguirá siendo imposible comparar las estimaciones de prevalencia procedentes de diversos estudios y lugares. En segundo lugar, la naturaleza de la violencia está vinculada a las estrategias de prevención e intervención. Por ejemplo, al examinar los casos de agresión con arma de fuego en el lugar de trabajo, se observa que unos son una continuación de conflictos familiares, mientras que otros reflejan específicamente estresores y conflictos relacionados con el trabajo. Aunque es indudable que en ambos casos el trabajador es la víctima, el control que tiene la organización en el primero de estos supuestos es más limitado y, por consiguiente, las repercusiones a efectos de intervención son distintas de las que se dan en las situaciones en las que las agresiones son una función directa de estresores y conflictos presentes en el lugar de trabajo.

Según algunas estadísticas, los actos de violencia con resultado de muerte en el lugar de trabajo son, en Estados U nidos, los que, dentro de esa categoría, presentan una tasa de crecimiento más elevada (por ejemplo, A nfuso 1994). En algunos estados (como el de Nueva York) los actos de violencia son la causa principal de muerte en el lugar de trabajo. Estadísticas como ésta han motivado que se preste una considerable atención a ellos. Con todo, las primeras indicaciones señalan que estos actos que son los que más llaman la atención (como el asesinato o la agresión con arma de fuego) son, también, los que más atraen a los investigadores, pero también los menos frecuentes. Son mucho más frecuentes la agresión verbal y psicológica contra superiores, subordinados o compañeros, que, en cambio, suscitan menos interés. Aceptada la idea de una estrecha relación entre las cuestiones de definición y las cuestiones de prevalencia, se diría que lo que se debe estudiar en la mayoría de los casos no es tanto la violencia como la agresión en el lugar de trabajo.

\section{Factores predictivos de la violencia en el lugar de trabajo}

Al consultar la bibliografía sobre esta cuestión se observa que casi toda la atención se ha centrado en la elaboración de un "perfil" del trabajador potencialmente violento o "agresivo" (por ejemplo, M antell y Albrecht 1994; Slora, Joy y Terris 1991). En la mayoría de los casos, los resultados son los siguientes: varón, blanco de 20 a 35 años de edad, "solitario", probablemente con problemas de alcohol y aficionado a las armas. A parte del número de falsos positivos a los que tal enfoque puede conducir, éste se basa en la identificación de los individuos predispuestos a las formas más extremas de violencia, e ignora el grupo, más amplio, responsable de la mayoría de los incidentes de agresión con menos violencia que se producen en el lugar de trabajo.

M ás allá de las características "demográficas", hay indicaciones de que algunos de los factores personales implicados en la violencia fuera del lugar de trabajo se suelen extender a éste. Así, se han relacionado con la violencia el abuso del alcohol, un historial general de agresiones en la vida actual o en la familia de procedencia y una baja autoestima.

M ás recientemente se ha adoptada la estrategia de identificar las condiciones físicas y psicosociales del lugar de trabajo más propicias para la violencia. Aunque esta investigación de los factores psicosociales está aún en sus comienzos, parece que los sentimientos de inseguridad en el empleo, las percepciones de que las políticas de la organización y su aplicación son injustas, un estilo severo de dirección y supervisión y la vigilancia electrónica aparecen asociados a la agresión y la violencia en el lugar de trabajo (Cámara de Representantes 1992; Fox y L evin 1994). 
En un intento de comprender los factores predictivos de la violencia en el lugar de trabajo, Cox y Leather (1994) se fijan en los factores predictivos de la agresión y la violencia en general. Esta última, señalan, puede estar asociado a la percepción de condiciones de aglomeración y a unos niveles extremos de calor y ruido. En todo caso, tales proposiciones no han sido todavía comprobadas empíricamente.

\section{Consecuencias de la violencia en el lugar de trabajo}

Los estudios realizados hasta la fecha sugieren que la violencia en el lugar de trabajo genera víctimas primarias y secundarias, unas y otras merecedoras del interés de los investigadores. L as víctimas evidentes o directas son los cajeros de los bancos o los empleados de los comercios que son asaltados, así como los propios trabajadores agredidos en el lugar de trabajo por compañeros actuales 0 pasados. No obstante, hay también víctimas secundarias, según la afirmación, constante en la bibliografía, de que gran parte del comportamiento humano procede de la observación de conductas ajenas, los testigos de la violencia en el trabajo. U nas y otras víctimas soportan efectos negativos, y hay que proseguir las investigaciones sobre el modo en que les afectan la agresión y la violencia en el lugar de trabajo.

\section{Prevención de la violencia en el lugar de trabajo}

La bibliografía sobre prevención de la violencia en el lugar de trabajo se centra, en general, en la selección previa, es decir, en la identificación previa de los individuos potencialmente violentos a fin de excluirlos del empleo en primera instancia (por ejemplo, $M$ antell y Albrecht 1994). Tales estrategias son de dudosa utilidad por razones éticas y jurídicas. D esde una perspectiva científica, es igualmente dudoso que se pueda identificar a los trabajadores potencialmente violentos con la precisión necesaria (es decir, sin un número inaceptablemente alto de falsos positivos). Está claro que para adoptar un enfoque preventivo hay que centrarse en los problemas presentes en el lugar de trabajo y en el diseño de los puestos. Según el razonamiento de Fox y L evin (1994), garantizar que las políticas y los procedimientos de la organización se caractericen por una justicia manifiesta será probablemente una técnica de prevención eficaz.

\section{Conclusiones}

La investigación sobre la violencia en el lugar de trabajo está en sus comienzos, pero cada vez recibe más atención. $\mathrm{H}$ ay por ello buenas perspectivas de que se avance en la comprensión, predicción y control de estas actuaciones.

\section{LA SEGURIDAD EN EL EMPLEO}

\section{- LA AMBIG ÜEDAD SOBRE EL FUTURO DEL EMPLEO}

\section{John M. Ivancevich}

Redimensionamiento de la empresa, despidos, reestructuración, remodelación, reducción de plantilla, fusiones, jubilación anticipada, recolocación: estos términos, que denotan cambios cada vez más familiares, se han convertido en habituales en la jerga de todo el mundo en los dos últimos decenios. Ante las dificultades surgidas, las empresas han prescindido de trabajadores de todos los niveles y han modificado muchos de los puestos conservados. En un solo ejercicio (1992-93) hubo pérdidas masivas de puestos de trabajo, por ejemplo, en Eastman Kodak (2.000), Siemens (13.000), Daimler-Benz (27.000), Phillips (40.000) e IBM (65.000) [(T he E conomist 1993, en "]ob Future A mbiguity" John M . Ivancevich)]. Se han producido recortes de empleo tanto en empresas con grandes beneficios como en empresas obligadas a reducir costes. Se prevé que esta tendencia de supresión de parte de los puestos de trabajo y de modificación de los existentes se mantenga incluso cuando retorne la fase de crecimiento económico.

¿Por qué se han generalizado de esta manera la pérdida y la modificación de los puestos de trabajo? No hay una respuesta sencilla que valga para todas las organizaciones o situaciones, aun cuando hay ciertos factores que parecen darse en la mayoría de los casos: pérdida de cuota de mercado, incremento de la competencia internacional y nacional, aumento de los costes laborales, obsolescencia de plantas y tecnologías, prácticas de gestión deficientes. La consecuencia, en cualquier supuesto, ha sido la decisión de la dirección de reducir o reestructurar los puestos de trabajo y de alterar el contrato psicológico con el trabajador.

La seguridad en el empleo o la certeza de una promoción profesional dentro de la empresa se han modificado de forma radical. Análogamente, se ha debilitado la fuerza vinculante del contrato psicológico tradicional entre el empresario y el trabajador con la salida de millones de empleados, directivos y no directivos. Las empresas de Japón fueron en una época famosas por ofrecer un empleo "de por vida". H oy, incluso en Japón son cada vez más los trabajadores, sobre todo de las grandes empresas, que han perdido la seguridad en el empleo. Como en el resto del mundo, se enfrentan a un fenómeno de incremento de la inseguridad en el empleo y a un ambiguo panorama en lo que respecta al futuro.

\section{La inseguridad en el empleo: una interpretación}

Según M aslow (1954), H erzberg, M ausner y Snyderman (1959) y Super (1957), las personas tienen una necesidad de seguridad. Los trabajadores se sienten seguros cuando tienen un trabajo permanente 0 cuando son capaces de controlar sus tareas. Por desgracia, no contamos con muchos estudios empíricos que hayan examinado a fondo esta necesidad de seguridad de los trabajadores (Kuhnert y Pulmer 1991; Kuhnert, Sims y Lahey 1989).

Sólo recientemente, ante fenómenos como las reducciones de plantilla, los despidos o las fusiones, han empezado los investigadores a interesarse por el concepto de inseguridad en el empleo. La naturaleza, causas y consecuencias de éste han sido estudiadas, por ejemplo, por Greenhalgh y Rosenblatt (1984), quienes definen el fenómeno como "la percepción por parte del trabajador de su impotencia para mantener la deseada continuidad en una situación de trabajo amenazada". En el marco teórico de estos autores, la inseguridad en el empleo se considera como una parte del entorno de la persona. En la bibliografía sobre el estrés, tal inseguridad se interpreta como un estresor que introduce una amenaza, la cual es interpretada y respondida por el individuo. Esta interpretación y respuesta pueden adoptar diversas formas: esforzarse menos por rendir, sentirse enfermo o bajo de forma, buscar otro empleo, tratar de hacer frente a la amenaza o buscar una mayor intearcción con los compañeros para amortiguar los sentimientos de inseguridad.

La teoría del estrés psicológico de Lazarus (Lazarus 1966; Lazarus y Folkman 1984) se centra en el concepto de evaluación 
cognitiva. Con independencia de la gravedad real del peligro al que se enfrente una persona, la aparición de un estrés psicológico depende de la forma en que éste evalúe la situación de amenaza (en este caso, la inseguridad en el empleo).

\section{Investigaciones sobre la inseguridad en e empleo}

Por desgracia, al igual que ocurre respecto a la seguridad en el empleo, hay pocos estudios bien diseñados sobre la inseguridad en el empleo. Estos, además, se basan en su mayoría en métodos de medición unitarios. Pocos investigadores interesados por el examen de los estresores en una situación de inseguridad general 0 de inseguridad en el trabajo han adoptado un enfoque de evaluación multifacético. Es comprensible que así sea por la escasez de recursos, pero el hecho cierto es que los problemas derivados de ello han limitado la comprensión de la cuestión. Los investigadores disponen de cuatro métodos básicos para medir la inseguridad en el empleo: la opinión del propio interesado, el rendimiento, la medición psicofisiológica y la medición bioquímica. Sigue siendo discutible si cada uno de ellos evalúa distintos aspectos de las consecuencias de la inseguridad en el empleo (Baum, Grunberg y Singer 1982). En todo caso, cada tipo de medición tiene una serie de inconvenientes que han de tenerse en cuenta.

A demás de los problemas de medición mencionados, hay que señalar que los estudios se centran sobre todo en la pérdida inminente 0 actual del empleo. Como han señalado algunos investigadores (G reenhalgh y R osenblatt 1984; R oskies y LouisGuerin 1990), se debería prestar más atención a "la preocupación por un deterioro notable de las condiciones de empleo". Parece lógico que este deterioro afecte a las aptitudes y el comportamiento de la persona.

Brenner (1987) ha examinado la relación entre el factor de inseguridad en el empleo, el desempleo y la mortalidad. Entiende que no es tanto el desempleo cuanto la incertidumbre, - la amenaza de inestabilidad, lo que causa una mayor mortalidad. L a amenaza de quedarse sin empleo o de perder el control de las actividades laborales puede tener fuerza suficiente para contribuir a la aparición de problemas psiquiátricos.

En un estudio realizado sobre 1.291 directivos, Roskies y L ouis-G uerin (1990) examinaron las percepciones de los trabajadores que se enfrentaban a despidos, así como las de personal directivo que trabajaba en empresas estables y con perspectivas de crecimiento. Eran una minoría los directivos que estaban estresados por la posibilidad de perder el trabajo de manera inminente. Era bastante mayor el número de los que estaban más estresados por el deterioro de las condiciones de trabajo y por la seguridad en el empleo a largo plazo.

Roskies, Louis-Guerin y Fournier (1993) han señalado en un estudio que la inseguridad en el empleo puede ser un importante estresor psicológico. En su estudio, realizado sobre el personal de una compañía aérea, llegan a la conclusión de que la inclinación de la personalidad (positiva o negativa) afecta a la repercusión de la seguridad en el empleo sobre la salud mental del trabajador.

\section{Cómo tratar el problema de la inseguridad en el empleo}

Las organizaciones tienen numerosas alternativas a los redimensionamientos, despidos y reducciones de plantilla. Un paso importante consiste en que la dirección muestre claramente que es consciente de las dificultades inherentes a la pérdida de trabajo y a la inseguridad laboral ante el futuro. Siempre caben otras opciones, como la reducción de la jornada, los recortes salariales generalizados, unos paquetes atractivos de jubilación anticipada, la formación para reconversión profesional o los programas de despido pactado (Wexley y Silverman 1993).

La instauración del mercado mundial ha supuesto un aumento de las exigencias y requisitos del trabajo. Para algunos, tales fenómenos supondrán nuevas oportunidades profesionales. Para otros, pueden agravar los sentimientos de inseguridad en el empleo. Es difícil saber con exactitud cómo responderán individualmente los trabajadores. En todo caso, los directivos deben tener muy presente que la inseguridad en el empleo puede tener consecuencias negativas. Además, han de aceptar que existe esa inseguridad y darle una respuesta. En cualquier caso, comprender mejor la idea de la inseguridad en el empleo y su posible repercusión negativa sobre el rendimiento, el comportamiento y las aptitudes de los trabajadores es un paso en la buena dirección.

Por supuesto, esto obliga a realizar estudios más rigurosos de la diversidad de consecuencias que la inseguridad en el empleo implica para determinados trabajadores. A medida que se vaya disponiendo de más información, los directivos tendrán que adoptar una actitud abierta para tratar de ayudar a los trabajadores a hacer frente a la inseguridad. La redefinición de la forma en que el trabajo se organiza y realiza debe convertirse en una alternativa válida a los métodos tradicionales de diseño de los puestos de trabajo. A los directivos les corresponde:

1. identificar y tratar de mitigar las fuentes de inseguridad en el empleo entre los trabajadores;

2. fomentar sentimientos de control y potenciación entre el personal, y

3. mostrar comprensión cuando los trabajadores expresan sentimientos de inseguridad en el empleo.

Puesto que es probable que la inseguridad en el empleo siga siendo una amenaza percibida por muchos trabajadores, aunque no todos, a los directivos les corresponde elaborar y aplicar estrategias dirigidas a abordar el problema. L os costes institucionales de una actitud de ignorancia de la inseguridad en el empleo son demasiado grandes para que los asuma una empresa. La capacidad de los directivos para tratar de manera eficiente a los trabajadores que se sienten inseguros en materia de empleo y de condiciones de trabajo se está convirtiendo en una medida de su capacidad de gestión.

\section{EL DESEMPLEO}

\section{Amiram D. Vinokur}

El término "desempleo" describe la situación de quien desea trabajar pero no encuentra un lugar donde le paguen por sus capacidades y su actividad. D esigna tanto la experiencia concreta de la persona que no encuentra un trabajo remunerado como la experiencia de todo un colectivo en una comunidad, una región geográfica o un país. Esta vertiente colectiva se expresa mediante la tasa de desempleo, es decir, el cociente entre el número de personas en busca de trabajo y la población activa total, integrada tanto por los empleados como por los desempleados. Se suele llamar trabajadores "desalentados" a los que desean tener un empleo remunerado pero han renunciado a seguir buscándolo. No figuran en las estadísticas oficiales como integrantes del grupo de trabajadores desempleados, pues ya no se consideran como parte de la población activa.

La O rganización de Cooperación y Desarrollo Económicos (OCDE) ofrece información estadística sobre la magnitud del desempleo en 25 países del mundo (OCDE 1995); en concreto, los países económicamente desarrollados de Europa y Norteamérica, junto con el Japón, N ueva Zelanda y Australia. Según el 
informe correspondiente a 1994, la tasa de desempleo total en esos países era del 8,1 \% (34,3 millones de personas). En los países desarrollados de Europa central y occidental, la tasa de desempleo era del 9,9\% (11 millones), en los países de Europa meridional del 13,7 \% (9,2 millones) y en Estados U nidos del 6,1 \% (8 millones). De los 25 países estudiados, sólo seis (A ustria, Islandia, Japón, M éxico, Luxemburgo y Suiza) tenían una tasa inferior al $5 \%$. En el informe se preveía un descenso global solamente leve (menos del 0,5\%) del desempleo en los años 1995 y 1996. Estas cifras indican que millones de personas seguirán siendo vulnerables a los efectos nocivos del desempleo en un futuro inmediato (R eich 1991).

M uchas per sonas están desempleadas en diversas épocas de su vida. En función de la estructura de la economía y de sus ciclos de expansión y retraimiento, el desempleo puede afectar a estudiantes que no hayan completado los estudios, a titulados superiores que tengan dificultades para ingresar en el mercado de trabajo, a mujeres que traten de recuperar un empleo remunerado tras criar a sus hijos, a excombatientes 0 a personas de edad avanzada que quieran complementar sus ingresos después de la jubilación. No obstante, en cualqueir momento derterminado, el segmento más importante de la población desempleada, por lo general entre el $50 \%$ y $60 \%$, es el de los trabajadores desplazados que han perdido su empleo. Los problemas asociados al desempleo se ponen de manifiesto sobre todo en este segmento, en parte debido a su magnitud. Por lo demás, el desempleo es también un grave problema para las minorías y los jóvenes. Sus tasas de desempleo suelen ser dos - tres veces más altas que las de la población general (U SD O L 1995).

L as causas fundamentales del desempleo tienen sus raíces en los cambios demográficos, económicos y tecnológicos. La reestructuración de las economías locales y nacionales suele dar lugar a períodos, al menos temporales, con tasas de desempleo elevadas. La tendencia a la mundialización de los mercados, junto con la aceleración de los cambios tecnológicos, favorece la competencia económica y la transferencia de industrias y servicios a nuevos lugares que ofrecen condiciones económicas más ventajosas en términos fiscales, una mano de obra más barata y una legislación laboral y ambiental menos estricta. Inevitablemente, esos cambios agravan los problemas de desempleo en zonas económicamente deprimidas.

La mayor parte de las personas depende de los ingresos de un puesto de trabajo para satisfacer sus propias necesidades vitales y las de su familia y mantener el nivel de vida al que están acostumbradas. Cuando pierden el empleo, padecen una notable reducción de sus ingresos. En Estados U nidos, la duración media del desempleo varía entre 16 y 20 semanas, con una mediana de 8-10 semanas (USDOL 1995). Si el período de desempleo que sigue a la pérdida del puesto de trabajo persiste cuando se agotan las prestaciones de desempleo, el trabajador en paro se enfrenta a una crisis económica. Esta crisis se manifiesta como una serie en cascada de acontecimientos estresores tales como, por ejemplo, la pérdida del coche por la imposibilidad de pagarlo, la ejecución de la hipoteca sobre la vivienda, la pérdida de atención médica o la escasez de alimentos. De hecho, son muchos los estudios realizados en Europa y en Estados U nidos que indican que las dificultades económicas son el resultado más frecuente del desempleo (Fryer y Payne 1986) y que estas dificultades influyen en otras repercusiones negativas del desempleo en otros ámbitos, en particular en la salud mental (K essler, Turner y H ouse 1988).

$\mathrm{H}$ ay abundantes datos que indican que la pérdida del puesto de trabajo y el desempleo producen un notable deterioro de la salud mental (Fryer y Payne 1986). EI resultado más frecuente de estas situaciones es la intensificación de la ansiedad, de los síntomas somáticos y de la sintomatología depresiva (Dooley, Catalano y Wilson 1994; $\mathrm{H}$ amilton y cols. 1990; K essler, H ouse y Turner 1987; Warr, Jackson y Banks 1988). Algunos datos indican asimismo que el desempleo aumenta más de dos veces el riesgo de depresión clínica (Dooley, Catalano y Wilson 1994). Además de los documentados efectos negativos del desempleo sobre la salud mental, existen algunos estudios que consideran el desempleo como un factor que influye en otros efectos (véase un análisis de esta cuestión en Catalano 1991). Entre estos resultados hay que mencionar el suicidio (Brenner 1976), la separación o el divorcio (Stack 1981; Liem y Liem 1988), el abandono y los malos tratos a los hijos (Steinberg, Catalano y Dooley 1981), el abuso del alcohol (Dooley, Catalano y H ough 1992; Catalano y cols. 1993a), la violencia en el lugar de trabajo (Catalano y cols. 1993b), los comportamientos delictivos (Allan y Steffensmeier 1989) y los accidentes de automóvil (Leigh y Waldon 1991). Por último, hay también algunos datos, basados principalmente en el método de self-report, que indican que el desempleo contribuye a la enfermedad física (Kessler, H ouse y Turner 1987).

Los efectos adversos del desempleo sobre los trabajadores en paro no se limitan a los períodos en que éstos carecen de trabajo. En la mayoría de los casos, cuando vuelven a encontrar trabajo, el nuevo empleo es considerablemente peor que el que perdieron. Incluso transcurridos cuatro años en el nuevo puesto, sus ingresos siguen siendo notablemente inferiores a los de los trabajadores similares quehan mantenido su empleo (Ruhm 1991).

Como las causas fundamentales de la pérdida del empleo y el desempleo tienen su origen en procesos sociales y económicos, las soluciones a sus efectos sociales negativos han de buscarse en políticas económicas y sociales amplias (Blinder 1987). Al mismo tiempo, es posible llevar a cabo programas basados en la comunidad para reducir la repercusión social y psicológica negativa del desempleo al nivel local. Está sobradamente demostrado que el reempleo reduce los síntomas de angustia y depresión y restablece el funcionamiento psicosocial a los niveles anteriores al desempleo (K essler, Turner y H ouse 1989; Vinokur, Caplan y Williams 1987). Por consiguiente, los programas dirigidos a los trabajadores en paro 0 a otras personas que buscan empleo deben encaminarse básicamente a promover y facilitar su reincorporación al empleo o su entrada en la fuerza de trabajo. Algunos de esos programas se han aplicado con éxito. Entre ellos cabe citar los que favorecen la creación de nuevas empresas que a su vez generen oportunidades de empleo (por ejemplo, Last y cols. 1995), y los centrados en la formación para la reconversión profesional (por ejemplo, Wolf y cols. 1995).

De los diversos programas que tienen por finalidad promover el reempleo, los más frecuentes son los de búsqueda de trabajo organizados en forma de clubes que ayudan a intensificar la búsqueda (Azrin y Beasalel 1982) o los seminarios centrados en la mejora de las aptitudes de búsqueda y la transición al reempleo en puestos de elevada cualificación (por ejemplo, Caplan y cols. 1989). Los análisis de coste/ beneficio han demostrado que estos programas de búsqueda de empleo son eficaces desde el punto de vista del coste (M eyer 1995; Vinokur y cols. 1991). Ciertos datos indican además que podrían prevenirse el deterioro de la salud mental y posiblemente la aparición de la depresión clínica (Price, van Ryn y Vinokur 1992).

A nálogamente, en los casos de reducción de plantilla, las empresas pueden reducir el alcance del desempleo ideando el modo de hacer participar a los trabajadores en el proceso de toma de decisiones pertinente (K ozlowski y cols. 1993; London 1995; Price 1990). Podría ocurrir que los trabajadores deseasen unir sus recursos y comprar la empresa, con lo que se evitarían los despidos; podría reducirse la jornada de trabajo para extender entre más personas los efectos de las medidas; sería 
posible llegar a un acuerdo sobre una reducción salarial para rebajar al mínimo los despidos; pueden seguirse cursos de reconversión profesional y/ o trasladarse a otras zonas para conseguir allí un nuevo empleo, o participar en programas de recolocación. Los empresarios pueden facilitar este proceso aplicando oportunamente un plan estratégico que ofrezca a los trabajadores amenazados por el despido los programas y servicios mencionados. Como ya se ha indicado, el desempleo tiene efectos perniciosos a nivel tanto personal como social. Una combinación de políticas públicas globales, estrategias flexibles de reducción de plantilla por parte de las empresas y programas basados en la comunidad puede ayudar a mitigar las consecuencias adversas de un problema que seguirá afectando a millones de personas en los años venideros.

\section{FACTORES MACROORGANIZATIVOS}

\section{- GESTION DE LA CALIDAD TOTAL}

\section{Dennis Tolsma}

U no de los fenómenos sociales más notables del presente siglo ha sido la aparición de una potente economía japonesa entre los escombros de la segunda Guerra M undial. Elementos fundamentales de este salto hacia la competitividad mundial fueron el compromiso de calidad y la decisión de demostrar la falsedad de la creencia de que los artículos japoneses eran imitaciones sin valor. Inspirados en las enseñanzas revolucionarias de Deming (1993), Juran (1988) y otros autores, los directivos e ingenieros japoneses aplicaron métodos que se han ido transformando en un sistema integral de gestión que parte del concepto básico de calidad. Este sistema supone, fundamentalmente, una evolución del pensamiento. Según el criterio tradicional, la calidad debía sopesarse con el coste de conseguirla. La concepción que D eming y Juran promovieron era que el aumento de la calidad permitía reducir los costes globales y que un esfuerzo sistemático por mejorar los procesos de trabajo contribuiría al logro de ambos objetivos. Los directivos japoneses adoptaron esta filosofía de la gestión, los ingenieros aprendieron a aplicar el control estadístico de la calidad, los trabajadores se formaron e interesaron por la mejora de los procesos, y los resultados han sido impresionantes (I shikawa 1985; Imai 1986).

Hacia 1980, alarmados por la reducción de sus cuotas de mercado y procurando ampliar su presencia en la economía mundial, los directivos europeos y norteamericanos empezaron a probar medios de recuperar su competitividad. En los quince años siguientes, cada vez más empresas llegaron a comprender los principios técnicos de la gestión de la calidad y empezaron a utilizarlos, inicialmente, en la producción industrial y, posteriormente, también en el sector de los servicios. A unque este sistema de gestión se conoce con diversos nombres, el que ha logrado mayor difusión es el de gestión de la calidad total (GCT). U na excepción a la regla es el sector de la asistencia sanitaria, en el que se suele utilizar la expresión mejora continua de la calidad (M C C ). R ecientemente se ha acuñado la expresión "reingeniería de los procesos de gestión" (R PG), aunque este nombre se aplica más al uso de unas técnicas concretas de mejora de los procesos que a la adopción de un sistema o filosofía integral de la gestión.

Si bien la GCT se ofrece en varias "versiones", conviene no perder de vista que es un sistema que comprende una filosofía de gestión y una serie de medios poderosos de mejorar la eficiencia de los procesos productivos. $L$ as distintas versiones de la CGT presentan algunos elementos comunes (Feigenbaun 1991; M ann 1989; Senge 1991).

- hincapié en la calidad;

- interés centrado en satisfacer las expectativas de los clientes ("satisfacción del cliente");

- apuesta por la participación e implicación de los trabajadores ("delegación de poder");
- enfoque de la organización como sistema ("optimización");

- vigilancia de los resultados estadísticos de los procesos ("gestión por hechos");

- liderazgo ("visión"),

- apuesta decidida por la formación (transformación en una "organización que aprende").

Por regla general, las organizaciones que aplican eficazmente la GCT se ven obligadas a introducir cambios en tres frentes.

Uno de estos frentes es la transformación, que implica actuaciones como la definición y comunicación de una visión del futuro de la organización, el cambio de la cultura de gestión desde una concepción vertical hacia una filosofía de participación de los trabajadores en la que se propugne la colaboración en lugar de la competencia y se centre el objeto de todo el trabajo en la satisfacción de las necesidades de los clientes. EI núcleo de la CGT es la concepción de la organización como un sistema de procesos correlacionados que constituye una herramienta básica para generar un esfuerzo completamente integrado por la mejora del rendimiento en todos los niveles. A menos que todos los trabajadores conozcan este punto de vista y el objetivo de la organización (el sistema) y sepan dónde encaja su trabajo en el mismo, el esfuerzo de formación en el uso de las herramientas de la GCT para la mejora de los procesos puede resultar poco menos que baldío. En todo caso, la ausencia de una verdadera transformación de la cultura organizativa, especialmente entre los niveles de mando inferiores, suele ser el escollo en que naufragan muchos esfuerzos de GCT. Según H eilpern (1989): “H emos llegado a la conclusión de que los principales obstáculos a la mejora de la calidad no son técnicos, sino de comportamiento". En contraste con los fallidos "círculos de calidad", en que se pretendía que los procesos de mejora fluyesen "hacia arriba", la GCT se basa en el liderazgo de la alta dirección y en la exigencia de que los directivos intermedios faciliten la participación de los trabajadores (H ill 1991).

El segundo pilar del éxito de la GCT es la planificación estraté gica. La materialización de la concepción y de los objetivos de una empresa se asocia al desarrollo y ejecución de un plan estratégico de calidad. Cierta empresa ha definido este punto como "un plan impulsado por los clientes para la aplicación de los principios de calidad a los objetivos clave de la organización y a la mejora continua de los procesos de trabajo" (Yarborough 1994). Es responsabilidad de la alta dirección - ciertamente, su obligación hacia los trabajadores, accionistas y beneficiarios en general- asociar su filosofía de la calidad a unos objetivos sólidos y viables que se encuentren dentro de las posibilidades razonables de la organización. Para Deming (1993), esto implica una "constancia del objetivo" y considera que su ausencia es una fuente de inseguridad para la organización. La intención fundamental de la planificación estratégica es dirigir la actividad de toda la organización al logro de sus objetivos básicos y a la posibilidad de reaccionar con agilidad a los 
cambios en el entorno. 0 bviamente, la planificación estratégica precisa y refuerza la necesidad de una participación de los mandos y trabajadores de todos los niveles en la concreción del esfuerzo de la sociedad hacia el logro de los objetivos (Shiba, Graham y Walden 1994).

Sólo después de haberse realizado correctamente estos dos cambios iniciales se puede abordar con perspectivas de éxito el tercero de ellos: la mejora continua de la calidad. L os incrementos de la calidad y, con ellos, la satisfacción de los clientes y la mejora de la posición competitiva son, en última instancia, una función de la aplicación generalizada de las técnicas de mejora de los procesos. En muchos programas de GCT se suele abordar este problema mediante una mayor inversión en formación y la asignación de trabajadores (por regla general, voluntarios) a los equipos responsables de la resolución de problemas. Un presupuesto básico de la GCT es la idea de que la persona que normalmente conoce mejor cómo se puede realizar mejor un trabajo es quien lo debe realizar en un momento determinado. La delegación de poder (inglés empowerment) en estos trabajadores para que efectúen cambios provechosos en sus respectivos procesos de trabajo se integra en la transformación cultural en la que se basa la G CT; dotar a esos mismos trabajadores del conocimiento, las capacidades y las herramientas necesarias para lograr este objetivo forma parte de la mejora permanente dela calidad.

La recopilación de datos estadísticos es una de las primeras medidas que adoptan los trabajadores y grupos de trabajo para conocer mejor los medios de mejorar los procesos de trabajo. Deming y otros autores elaboraron sus respectivos métodos a partir de la obra original elaborada por Shewhart en el decenio de 1920 (Schmidt y Finnigan 1992). Las principales herramientas utilizadas en la GCT son: a) el diagrama de Pareto, que permite determinar gráficamente los problemas que más frecuentemente se repiten y que, por lo tanto, se deben abordar antes; b) el diagrama de control estadístico, una herramienta estadística para determinar el grado de variabilidad del proceso no mejorado, y c) los diagramas de flujo, que reflejan exactamente cómo se realiza el proceso en un momento determinado. Es posible que la herramienta más versátil e importante sea el diagrama de Ishikawa (o diagrama de "espina de pescado") cuya invención se atribuye a K aoru Ishikawa (1985). Se trata de un medio sencillo, aunque eficaz, de que los miembros de un equipo de trabajo colaboren en la identificación de las causas fundamentales del problema estudiado y, por lo tanto, en la recomendación de los medios para mejorar los procesos.

Si se aplica correctamente, la GCT puede aportar muchos beneficios a los trabajadores y a la salud de éstos. Por ejemplo, su adopción puede surtir efectos indirectos. En términos muy generales, la organización que realiza su transformación para la calidad mejora sus perspectivas de supervivencia y de éxito económicos y, por lo tanto, las de su plantilla y, lo que es más importante, aumenta sus posibilidades de convertirse en una organización basada en el respeto a las personas. Los expertos en la GCT hablan, incluso, de "valores compartidos" como de algo que debe reflejarse en el comportamiento de directivos y trabajadores por igual. Estos valores se suelen divulgar a toda la organización en declaraciones formales 0 en declaraciones de intención e incluyen expresiones como "confianza", "respeto mutuo", "comunicación abierta" y "valoración de nuestra diversidad" (H oward 1990).

Esto induce a presumir que los lugares de trabajo basados en criterios de calidad son "más acogedores para el trabajador"; lugares en los que unos procesos mejorados por los mismos trabajadores son menos peligrosos y en los que reina un clima menos estresor. La lógica de la política de calidad exige incorporar ésta a un producto o servicio, no descubrir los fallos una vez se han producido. Se puede resumir en una palabra: prevención (Widfeldt y Widfelt 1992). Esta lógica es claramente compatible con la que inspira la política de salud pública de prevención en la salud en el trabajo. Como señala Williams (1993) en un ejemplo hipotético: "Si mejorasen la calidad y el diseño de las forjas en la industria de la fundición, se reduciría la exposición...a la vibración a medida que se requiriese un menor acabado de las forjas". Algunas pruebas circunstanciales que sustentan esta afirmación proceden de empresas satisfechas que citan los resultados de las medidas de higiene industrial o de las encuestas de opinión que revelan una mayor satisfacción de los trabajadores, así como en el mayor número de premios a la salud y seguridad en el trabajo concedidos a las instalaciones en que se aplica la GCT. Williams menciona, asimismo, dos estudios de casos realizados en entornos del Reino U nido que confirman los informes de tales empresas (Williams 1993).

Por desgracia, apenas existen estudios que demuestren de manera válida esta conclusión. Falta investigación basada en estudios controlados que aporten resultados en materia de salud, tomen en consideración la posibilidad de que se produzcan efectos tanto negativos como positivos, sobre la salud, y establezcan una relación causal de estas consideraciones con factores medibles de la filosofía de gestión y de la práctica de la GCT. Dado el papel preponderante que la GCT ha asumido en la economía mundializada de las empresas en el decenio de 1990, sería éste un proyecto de investigación con auténticas posibilidades de determinar si la GCT es, realmente, una herramienta eficaz dentro del abanico de medidas preventivas aplicables a la salud y seguridad en el trabajo.

N os movemos en un terreno bastante más firme cuando afirmamos que la GCT puede influir directamente en la salud en el trabajo si los esfuerzos por elevar la calidad se centran expresamente en la salud y seguridad. O bviamente, como el resto del trabajo en una empresa, la actividad vinculada a la salud laboral y ambiental comprende diversos procesos correlacionados a los que se aplican fácilmente las técnicas de mejora de los procesos. Uno de los criterios aplicables a los candidatos al premio Baldridge - el mayor premio a la competitividad otorgado a las empresas norteamericanas- es la mejora conseguida en el campo de la salud y seguridad en el trabajo. Yarborough describe cómo los altos directivos de cierta gran empresa enseñaron a los responsables del área de salud laboral y ambiental a utilizar la GCT con el resto de la organización y cómo la salud industrial y ambiental se integró en el plan estratégico corporativo de calidad (Yarborough 1994). El primer ejecutivo de una empresa norteamericana de suministro de servicios públicos que fue la primera organización extranjera en ganar el codiciado premio Deming conferido en Japón, comenta que se concedió a la seguridad una alta prioridad en el desarrollo de la GCT y asegura: "De los grandes indicadores de la calidad empleados en la empresa, el único que se dirige al cliente interno es la seguridad de los trabajadores". D efiniendo la seguridad como un proceso sujeto a mejora continua y adoptando las cifras de lesiones por cada 100 trabajadores como un indicador de la calidad, la empresa logró reducir a la mitad el índice de siniestralidad, que cayó a los niveles más bajos de su historia (H udiberg 1991).

En resumen, la GCT es un sistema integral de gestión basado en una filosofía de la gestión que hace hincapié en las dimensiones humanas del trabajo. La GCT se apoya en una serie de técnicas eficaces que permiten utilizar los datos obtenidos de los procesos de trabajo para documentar, analizar y mejorar continuamente estos procesos. 


\section{ESTILO DE DIRECCION}

\section{Cary L. Cooper y M ike Smith}

Selye (1974) postuló que la necesidad de convivir con otras personas es uno de los aspectos más estresores de la vida. Las buenas relaciones entre los miembros de un equipo de trabajo se consideran un elemento primordial de la salud personal y de la organización (C ooper y Payne 1988), en especial por lo que respecta a las relaciones entre superiores y subordinados. Las malas relaciones laborales se caracterizan por "la poca confianza, el bajo nivel de apoyo y el escaso interés por solucionar los problemas dentro de la organización" (C ooper y Payne 1988). La desconfianza tiene una correlación positiva con una acentuada ambigüedad de rol, que se traduce en unas comunicaciones inadecuadas y en un mayor estrés psicológico producido por la escasa satisfacción en el trabajo, la reducción del bienestar y la sensación de estar amenazado por el superior y los compañeros (K ahn y cols. 1964; French y Caplan 1973).

Unas relaciones de apoyo social en el trabajo favorecerán menos las fricciones personales asociadas a la rivalidad, a la política de despacho y a la competencia no constructiva (C ooper y Payne 1991). M cLean (1979) asegura que el apoyo social derivado de la cohesión del grupo, la confianza personal y la simpatía hacia el superior se asocia a un menor nivel de percepción de estrés en el trabajo y a una mejor salud. Un comportamiento desconsiderado del superior contribuye considerablemente a generar sentimientos de presión en el trabajo (M CL ean 1979). Una supervisión estrecha y una rígida supervisión del rendimiento constituyen otros tantos factores de estrés. A este respecto, se han realizado numerosos estudios que indican que un estilo de dirección caracterizado por la falta de consultas y comunicaciones efectivas, la imposición de restricciones injustificadas al comportamiento de los trabajadores y la ausencia de control sobre el propio trabajo se asocian a actitudes psicológicas y comportamientos negativos, como la adicción a la bebida como vía de escape y el consumo excesivo de tabaco (C aplan y cols. 1975), un mayor riesgo de enfermedades cardiovasculares (K arasek 1979) y otras manifestaciones del estrés. Por el contrario, el ofrecimiento de mayores oportunidades a los trabajadores de participar en el proceso de toma de decisiones contribuye a incrementar el rendimiento, reducir la rotación de personal y mejorar los niveles de bienestar físico y mental. El estilo participativo de gestión se debe aplicar igualmente a la participación de los trabajadores en la mejora de la seguridad en el lugar de trabajo. Así se contribuye a superar la apatía de los operarios, que suele considerarse uno de los factores causales de los accidentes (Robens 1972; Sutherland y Cooper 1986).

Debemos a Lewin (por ejemplo, en Lewin, Lippitt y White 1939) los primeros estudios en el campo de la relación entre estilo de gestión y estrés, en los que se documentaban los efectos estresores e improductivos de los estilos autoritarios de gestión. M ás recientemente, los trabajos de K arasek (1979) han puesto de relieve la importancia de practicar un estilo de gestión más participativo, en el que, los directivos permitan a los trabajadores ejercer un mayor control sobre su trabajo. En un estudio prospectivo, el autor demostró que el control sobre el puesto de trabajo (esto es, la libertad para aplicar la discrecionalidad intelectual personal) y la mayor libertad de programación del trabajo constituían importantes factores predictivos del riesgo de cardiopatía coronaria. La limitación de las posibilidades de participación y de autonomía se traduce en una mayor depresión, agotamiento y consumo de tranquilizantes, y en una mayor morbilidad. La sensación de incapacidad para introducir cambios en el puesto de trabajo y la ausencia de consultas figuran entre los estresores más comúnmente citados por los operarios de la industria siderúrgica (K elly y Cooper 1981), los trabajadores de las torres y plataformas de perforación de gas y petróleo del Mar del Norte (Sutherland y Cooper 1986) y muchos otros operarios (Cooper y Smith 1985). Por otra parte, como indican Gowler y Legge (1975), un estilo de gestión participativo puede generar factores específicos de estrés, como la discrepancia entre el poder formal y el real, la frustración por la erosión del poder formal, presiones conflictivas para conseguir una mayor participación y lograr unos niveles de producción elevados, y la resistencia de los subordinados a participar.

Aunque se han realizado numerosos estudios comparando los efectos de los estilos de gestión autoritarios y participativos sobre el rendimiento y la salud en el trabajo, existen también estudios concretos sobre el estilo de gestión (Jennings, Cox y Cooper 1994). Por ejemplo, L evingson (1978) ha descrito los efectos de los directivo "abrasivo". Estos directivos suelen ser inteligentes $\mathrm{y}$, tenaces y centrarse en los resultados (análogos a los de personalidad del tipo A), pero no funcionan tan en el plano emocional. Como señalan Q uick y Q uick (1984), la necesidad de perfección y la preocupación por uno mismo y el estilo crítico y condescendiente del director "abrasivo" genera una sensación de insuficiencia entre los subordinados. Como indica Levingston, si la personalidad abrasiva de un compañero resulta difícil y estresor de soportar, cuando se trata de un superior, las consecuencias pueden dañar gravemente las relaciones personales y resultar sumamente estresores para los subordinados.

Además, existen estudios y teorías que indican que los efectos sobre la salud y seguridad de los trabajadores del estilo y la personalidad de los directivos sólo son comprensibles en el contexto de la naturaleza de las tareas y del poder de aquéllos. Por ejemplo, según la teoría de la contingencia de Fiedler (1967), existen ocho grandes categorías de situaciones que se producen dentro de un grupo basadas en diversas combinaciones de dicotomías: a) relaciones cordiales entre el líder y los seguidores; b) estructuración impuesta por la tarea, y c) poder del líder. Las ocho categorías se pueden disponer en un continuo, en uno de cuyos extremos (primer octante) está un líder que mantiene buenas relaciones con los subordinados, realiza una tarea sumamente estructurada y posee considerable poder; y en el otro extremo (octante ocho) se encuentra un líder que se lleva mal con los miembros del grupo, tiene ante sí una tarea escasamente estructurada y disfruta de escaso poder. Por lo que respecta al estrés, puede decirse que los octantes forman un continuo desde un nivel bajo a un nivel elevado de estrés. Fiedler estudia igualmente dos clases de líderes: el que valora negativamente la mayor parte de las características del miembro del grupo que le resulta menos simpático (el líder con menor nivel de tolerancia) y el que aprecia numerosas cualidades positivas, incluso entre los miembros del grupo con que menos simpatiza (el líder de mayor nivel de tolerancia). Fiedler formula algunas predicciones específicas sobre la actuación del líder: indica que el líder de bajo nivel de tolerancia (el que no suele reconocer los méritos de los subordinados que no le son simpáticos) será más eficaz en los octantes uno y ocho, en los que los niveles de estrés son, respectivamente, muy bajos y muy elevados. Por otra parte, un líder con elevado nivel de tolerancia (capaz de reconocer los méritos, incluso de los miembros que detesta) será más eficaz en los octantes intermedios, en los que suele producirse un nivel de estrés intermedio. Estudios más modernos (como el de Strude y García 1981) han corroborado en líneas generales las ideas de Fiedler.

Según otras teorías del liderazgo, los líderes a directivos centrados en las tareas provocan estrés. Seltzer, N umerof y Bass (1989) Ilegaron a la conclusión de que los líderes intelectualmente estimulantes producen en los subordinados una mayor sensación de estar estresado y "quemados". M isumi (1985) 
descubrió que los líderes centrados en la producción provocan síntomas psicológicos de estrés. Bass (1992) estableció que, en experimentos de laboratorio, el liderazgo centrado en la producción genera mayores niveles de ansiedad y hostilidad. Por su parte, las teorías del liderazgo carismático y transformador (Burns 1978) se centran en los efectos de los líderes de este tipo en unos subordinados que suelen mostrar más autoestima y percibir un mayor significado en su trabajo. Está demostrado que este tipo de líder o directivo contribuye a reducir el nivel de estrés de los subordinados.

En líneas generales, por lo tanto, los directivos que muestran un comportamiento más "considerado", tienen un estilo participativo de gestión, se centran menos en la producción o las tareas y permiten que los subordinados ejerzan un mayor control sobre su trabajo, contribuyen en mayor medida a producir la morbilidad y el índice de siniestralidad laboral.

\section{- EST RUCTURA ORGANIZATIVA}

Lois E. Tetrick

En la mayoría de los artículos de este capítulo se abordan aspectos del entorno de trabajo cercanos a cada trabajador. En cambio, el objetivo del presente artículo consiste en examinar los efectos de ciertas características más lejanas, macroorganizativas de la empresa sobre la salud y el bienestar de los trabajadores. La pregunta es: ¿Existen modos de estructurar el entorno interno de las organizaciones que contribuyen a mejorar la salud de sus trabajadores o que, por el contrario, suponen para el personal un mayor riesgo de estrés? La mayoría de los modelos teóricos del estrés en el trabajo contienen variables de la estructura organizativa tales como la dimensión de la organización, la ausencia de participación en el proceso de toma de decisiones y la formalización (Beehr y N ewman 1978; K ahn y Byosiere 1992).

La estructura organizativa atañe a la distribución formal de los roles y funciones dentro de una organización que coordina los diversos subsistemas o funciones que la integran para conseguir más eficazmente el logro de sus objetivos (Porras y Robertson 1992). La estructura constituye, en sí misma, un conjunto armonioso de subsistemas destinados a facilitar el logro de la misión y los objetivos de la organización, y que determina la división del trabajo, las relaciones jerárquicas, las líneas formales de comunicación, los roles de cada subsistema organizativo y las relaciones entre esos subsistemas. Por lo tanto, puede considerarse como un sistema de mecanismos formales establecidos para facilitar la comprensibilidad y la predictibilidad de los acontecimientos, y el control de los mismos, propuestos por Sutton y Kahn (1987) como los tres antídotos asociados al trabajo contra los efectos del estrés y la tensión en la vida de la organización.

Una de las primeras características organizativas examinadas como posible factor de riesgo fue la dimensión de la organización. Contrariamente a lo que se afirma en la literatura dedicada al peligro de exposición a los agentes de riesgo en el entorno de trabajo, de que estas grandes plantas e instalaciones son más seguras por ser menos peligrosas y estar mejor equipadas para afrontar los posibles riesgos (E mmett 1991), inicialmente se supuso que las grandes organizaciones sometían a los trabajadores a un mayor riesgo de sufrir estrés en el trabajo. Se postuló que las grandes organizaciones suelen adoptar una estructura burocrática para afrontar una realidad cada vez más compleja. Dicha estructura burocrática se caracterizaría por una división del trabajo basada en la especialización funcional, una estructura jerárquica perfectamente definida, un conjunto de normas reguladoras de los derechos y obligaciones del personal, un trato impersonal a los trabajadores y una serie de procedimientos aplicables a las distintas situaciones que se producen en el trabajo (Bennis 1969). A parentemente, algunas de estas dimensiones de la estructura burocrática deberían, efectivamente, contribuir a mejorar o mantener la predictibilidad y comprensibilidad de los acontecimientos que se producen en el entorno de trabajo y, por consiguiente, a reducir el estrés en el trabajo. Sin embargo, parece igualmente que estas mismas dimensiones, específicamente la existencia de una jerarquía rígida, pueden provocar una reducción del control de los trabajadores sobre esos mismos acontecimientos.

Dadas las características citadas de la estructura burocrática, no resulta sorprendente que la dimensión de la organización, por sí misma, no haya recibido ningún apoyo firme como factor de riesgo macroorganizativo ( $K$ ahn y Byosiere 1992). No obstante, en la revisión de Payne y Pugh (1976) se aportan algunas pruebas de que el tamaño de la organización contribuye indirectamente a incrementar el estrés. Según los autores, en las grandes organizaciones se observa una reducción del volumen de comunicaciones, un aumento de la cantidad del trabajo y de las especificaciones de tareas y una menor coordinación. Estos efectos pueden contribuir a reducir tanto la predictibilidad y comprensibilidad de lo que sucede en el entorno de trabajo como el nivel de control sobre otros aspectos del trabajo, con el consiguiente incremento del riesgo de estrés (Tetrick y LaR occo 1987).

Estos hallazgos relativos a la dimensión de la organización han llevado a suponer que, aparentemente, la formalización y la centralización son los dos aspectos de la estructura organizativa que entrañan un mayor riesgo para los trabajadores. La formalización se asocia a los procedimientos y normas escritos que regulan la actividad de los trabajadores, y la centralización se asocia a la medida en que la capacidad de toma de decisiones en la organización se atribuye exclusivamente a los niveles superiores de la jerarquía. Pines (1982) recuerda que no es exactamente la centralización de una estructura burocrática la que genera estrés o de "burnout" ("estar quemado"), sino el papeleo innecesario, los trámites superfluos y los problemas de comunicación que la formalización genera. En efecto, los procedimientos y normas ambiguos pueden producir confusión y contradicciones que son causa de conflictividad e incomprensión respecto a las medidas que se deben adoptar en situaciones concretas. Por el contrario, unos procedimientos y normas excesivamente detallados pueden inducir entre los trabajadores tanto frustración como una sensación de incapacidad para alcanzar sus objetivos, sobre todo en las organizaciones orientadas al cliente. La inadecuación de las comunicaciones puede hacer que los trabajadores se sientan aislados y alienados por la falta de predictibilidad y comprensibilidad de los hechos que se producen en el entorno de trabajo.

Si bien se acepta que estos elementos del entorno de trabajo constituyen factores potenciales de riesgo, los resultados de la investigación empírica de la formalización y la centralización son escasamente consistentes. La ausencia de pruebas consistentes puede tener, como mínimo, dos causas. En primer lugar, muchos estudios parten de la presunción de que existe una única estructura organizativa, dotada de un nivel consistente de formalización y centralización en toda la organización. $\mathrm{H}$ all (1969) postuló la posibilidad de realizar un examen significativo de la organización enfocada como una totalidad: sin embargo, demostró que tanto el grado de formalización como el centro de toma de decisiones pueden variar de una unidad a otra. Por consiguiente, si se estudia un fenómeno característico de un determinado nivel, como el estrés laboral, quizás resulte más representativo investigar la estructura de las unidades menores que la de la organización en su conjunto. En segundo 
lugar, existen indicios que apuntan a la existencia de diferencias individuales en respuesta a las variables estructurales. Por ejemplo, Marino y White (1985) hallaron una relación directa entre la formalización y el estrés en el trabajo entre los individuos con un "locus de control" interno y una correlación inversa entre las personas propensas a creer que tienen escaso control sobre su entorno. Por otra parte, la falta de participación no estaba atenuada por el "locus de control" y se traducía en un mayor nivel de estrés en el trabajo. También parece haber diferencias culturales que influyen en las respuestas individuales a las variables estructurales, que revestirían importancia para las empresas multinacionales que operan en entornos internacionales (Peterson y cols. 1995). Estas diferencias culturales pueden servir igualmente para explicar la dificultad de adaptar los procedimientos y estructuras organizativos de otros países.

A pesar de la endeblez de las pruebas empíricas que identifican las variables estructurales como factores de riesgo psicosociales, se ha señalado que las organizaciones deben modificar sus estructuras, haciéndolas más "planas" y con un menor número de niveles jerárquicos 0 de canales de comunicación, más descentralizadas y con un mayor poder de toma de decisiones en los niveles inferiores, y más integrada y con un menor grado de especialización funcional (Newman y Beehr 1979). Estas propuestas son congruentes con las ideas de los teóricos de la organización que aseguran que la estructura burocrática tradicional podría no ser el modelo más eficiente o saludable de estructura organizativa (Bennis 1969). Tales conclusiones podrían adquirir incluso más relevancia a la luz de los progresos tecnológicos en los campos productivo y de las comunicaciones que caracterizan el lugar de trabajo de la era posindustrial (H irschhorn 1991).

En los dos últimos decenios se ha manifestado un considerable interés por el rediseño de las organizaciones para poder afrontar los peligros del entorno exterior resultantes de una mayor globalización y de la creciente competencia internacional en Norteamérica y en la Europa occidental (Whitaker 1991). Straw, Sandelands y Dutton (1988) propusieron que las empresas reaccionasen a las amenazas del entorno limitando la información y restringiendo el control. Esto redundaría, probablemente, en una disminución de la predictibilidad, la comprensibilidad y el control de los acontecimientos en el lugar de trabajo, con el consiguiente incremento del estrés experimentado por los trabajadores. Por consiguiente, unos cambios estructurales que eviten los efectos de esta rigidez frente a los peligros beneficiarían tanto a la organización como a la salud y el bienestar de los trabajadores.

M uchas empresas adoptan una estructura organizativa matricial para restructurar el entorno interno en respuesta a una mayor inestabilidad ambiental. Para Baber (1993), el tipo ideal de organización matricial es aquél en que se cruzan dos o más líneas jerárquicas, los objetivos se logran utilizando equipos de trabajo centrados en las tareas, transfuncionales y temporales, y los departamentos operativos subsisten como mecanismos para la ejecución de las tareas rutinarias del personal y el desarrollo profesional. Por consiguiente, la estructura matricial aporta a la organización la flexibilidad precisa para reaccionar a la inestabilidad del entorno, siempre que la diversificación de las capacidades y la rapidez en el aprendizaje confieran al personal la flexibilidad necesaria.

Si bien no existen aún observaciones empíricas que permitan conocer los efectos de esta estructura orgnizativa, algunos autores han indicado que la organización matricial puede aumentar el riesgo de estrés de los trabajadores. A sí, Q uick y Q uick (1994) aseguran que la multiplicidad de líneas jerárquicas (supervisores de tareas y funcionales) típica de la estructura matricial incrementa el riesgo de conflicto de roles. Asimismo,
H irschhorn (1991) afirma que, en la organizacion del trabajo postindustrial, los trabajadores deben afrontar nuevas situaciones que les obligan a realizar funciones de aprendizaje. Esto implica la necesidad de reconocer la propia incapacidad temporal y una pérdida de control que pueden agravar el estrés. Se evidencia, por lo tanto, que también existen factores potenciales de riesgo asociados a las nuevas estructuras organizativas del tipo matricial.

Los intentos de cambiar o rediseñar las organizaciones, independientemente del modelo concreto que se adopte, pueden contribuir a la generación de estrés, al perturbar la seguridad y la estabilidad, generando incertidumbre respecto al puesto, el rol y el status de las personas, y provocando conflictos que es preciso afrontar y superar (Golembiewsky 1982). Sin embargo, estos estresores pueden ser contrarrestados por los efectos reductores del estrés del cambio estructural, que suponen una mayor delegación de poder y de toma de decisiones en todos los niveles de la organización, unas comunicaciones más fluidas, la formación y la colaboración para el desarrollo del trabajo en equipo y la resolución de conflictos (Golembiewski 1982; Porras y Robertson 1992).

\section{Conclusiones}

Aunque en la literatura se indica que existen factores de riesgo en el trabajo asociados a diversas estructuras organizativas, los efectos de estos factores a nivel macro parecen ser indirectos. La estructura organizativa puede aportar un marco para mejorar la predictibilidad, comprensibilidad y control de los acontecimientos que se producen en el entorno de trabajo. Sin embargo, los efectos de esa estructura sobre la salud y el bienestar de los trabajadores aparecen mediatizados por características del entorno de trabajo más cercanas, como las relaciones personales y las características de los roles. La reestructuración de las organizaciones para promover la salud de los trabajadores y de la organización en sí exige flexibilidad en aquéllos y en ésta y atención a los sistemas sociotécnicos que coordinan las demandas tecnológicas con la estructura social dentro de la organización.

\section{CLIMA Y CULTURA ORGANIZATIVOS}

\section{Denise M. Rousseau}

El contexto organizativo del trabajo se compone de numerosos elementos, como liderazgo, estructura, recompensas, comunicaciones, etc., que se incluyen en los conceptos generales de clima y cultura organizativos. El clima se asocia a la percepción de la práctica organizativa comunicada por las personas que trabajan en un lugar (R ousseau 1988). En los estudios sobre el clima se han abordado muchos de los conceptos clave de la investigación organizativa. Son elementos del clima la comunicación (caracterizable, por ejemplo, por su mayor o menor apertura), el conflicto (constructivo o disfuncional), el liderazgo (que puede traducirse en apoyo u orientación) y la importancia concedida a las recompensas (según lo cual la organización se puede distinguir por una retroinformación positiva o negativa o por una orientación hacia la disciplina). Si se estudian juntas, se observa que las características de la organización se encuentran íntimamente imbricadas (por ejemplo, el liderazo y las recompensas). EI clima caracteriza las prácticas a distintos niveles de la organización (por ejemplo, clima de la unidad de trabajo y clima organizativo). Los estudios sobre el clima se centran en distintas actividades (por ejemplo, clima de seguridad, clima de servicio). El clima es, básicamente, la descripción del entorno de trabajo por parte de quienes participan directamente en él. 
La relación entre el clima y el bienestar de los trabajadores (esto es, la satisfacción, el estrés y la tensión en el trabajo) ha sido estudiada en profundidad. Como en la evaluación del clima se incluyen las principales dimensiones organizativas que afectan a los trabajadores, prácticamente todo estudio de la percepción que tienen los trabajadores de su entorno de trabajo puede considerarse un estudio sobre el clima. En los estudios se asocian distintos rasgos del clima (principalmente, el liderazgo, la apertura de las comunicaciones, el estilo de gestión participativo y la resolución de conflictos) a la satiffacción de los trabajadores e (inversamente) a los niveles de estrés (Schneider 1985). Los climas organizativos estresores se caracterizan por la limitada participación en la toma de decisiones, el uso del castigo y la retroinformación negativa (en lugar de las recompensas y la retroinformación positiva), la evitación de conflictos o la confrontación (en vez de la resolución de problemas) y la existencia de un modelo no cooperativo de relaciones dentro del grupo y con el líder. Los climas de apoyo social redundan en beneficio de la salud mental de los trabajadores, observándose una menor frecuencia de la ansiedad y la depresión en los entornos acogedores (R epetti 1987). L os investigadores observan que allí donde existe un clima colectivo (en que los miembros que interactúan entre sí comparten una misma concepción de la organización) las percepciones compartidas de las características indeseables de la organización se asocian a un estado de ánimo bajo y a manifestaciones de trastornos psicógenos (Colligan, Pennebaker y M urphy 1982). C uando la investigación del clima adopta un enfoque concreto, como ocurre en el estudio del clima de seguridad existente en una organización, se ha constatado que la falta de una comunicación abierta en materia de seguridad, la escasez de recompensas por la comunicación de los riesgos profesionales y otras características negativas del clima contribuyen a incrementar la frecuencia de los accidentes y lesiones relacionados con el trabajo (Zohar 1980).

Como el clima está presente en muchos niveles de la organización y puede implicar distintas prácticas, es preciso que la evaluación de los factores de riesgo profesional abarque sistemáticamente las relaciones (en la unidad de trabajo, el departamento 0 el conjunto de la organización) y las actividades (por ejemplo, la seguridad, la comunicación o las recompensas) que protagonizan los trabajadores. Los factores de riesgo asociados al clima pueden variar de un sector a otro de la organización.

La cultura está constituida por los valores, normas y formas de comportamiento compartidos por los miembros de la organización. Los investigadores identifican cinco componentes básicos de la cultura organizativa: presunciones básicas (creencias inconscientes que configuran las percepciones de los miembros en lo que respecta, por ejemplo, al tiempo, la hostilidad ambiental o la estabilidad), valores (preferencia por unos resultados sobre otros: por ejemplo, el servicio o el beneficio), normas de comportamiento (creencias sobre los comportamientos considerados correctos o incorrectos, como la forma de vestir y el trabajo en equipo), patrones de comportamiento (prácticas reiteradas observables, como la retroinformación sistematizada del rendimiento y la toma de decisiones por las instancias superiores) y artefactos (símbolos y objetos utilizados para expresar mensajes culturales, como los logotipos y los lemas definitorios de misiones). L os elementos culturales de naturaleza más subjetiva (las presunciones, valores y normas) reflejan la opinión e interpretación por parte de los trabajadores de su entorno de trabajo. Estos elementos subjetivos configuran el significado que los patrones de comportamiento y los artificios adquieren dentro de una organización. La cultura, como el clima, puede manifestarse en diversos niveles:

1. cultura dominante de la organización;
2. subculturas asociadas a unidades concretas, y

3. contraculturas, presentes en unidades de trabajo escasamente integradas en el conjunto de la organización.

L as culturas pueden ser fuertes (ampliamente compartidas por los miembros de la organización), débiles (no compartidas por la generalidad) 0 de transición (durante el período de sustitución de una cultura por otra).

En contraste con el clima, la cultura se aborda con menos frecuencia en los estudios como factor coadyuvante al bienestar de los trabajadores 0 al riesgo profesional. Esta pobreza investigativa es atribuible tanto a la relativa novedad de la cultura como concepto incluido en el estudio de las organizaciones como a la existencia de debates ideológicos sobre la naturaleza de la cultura, su medición (cuantitativa o cualitativa) y la idoneidad del concepto para un estudio transversal (Rousseau 1990). Según los estudios cuantitativos de la cultura centrados en los valores y en las normas de comportamiento, las normas basadas en el concepto de trabajo en equipo se asocian a un mayor nivel de satisfacción personal y a una menor tensión que las normas de orientación técnica o burocrática (Rousseau 1989). Por otra parte, el grado de congruencia de los valores del trabajador con los de la organización influye en el estrés y la satisfacción (O 'Reilly y Chatman 1991). Se ha podido establecer que las culturas débiles y las fragmentadas por conflictos de roles y desacuerdos entre los miembros provocan reacciones de estrés y crisis de identidad profesional (M eyerson 1990). La quiebra o la fragmentación de una cultura organizativa por causa de convulsiones políticas o económicas influye en el bienestar psíquico y físico de las personas, especialmente en el contexto de los redimensionamientos de empresas, reducciones de plantilla y otros fenómenos concurrentes de reestructuración organizativa (H irsch 1987). La ideoneidad de determinados modelos culturales (como el jerárquico o militarista) para la sociedad moderna se ha puesto en entredicho en diversos estudios sobre cultura (por ejemplo, H irschhorn 1984; R ousseau 1989) relativos al estrés y la salud de los trabajadores y a los consiguientes riesgos para el público en general (como los técnicos de las centrales nucleares y los controladores aéreos).

En la evaluación de los factores de riesgo a la luz de la información disponible sobre la cultura organizativa se debe prestar atención inicialmente a la medida en que los miembros de la organización comparten o no unos ciertos valores, normas y creencias básicos. Las diferencias en materia de función, educación y localización generan subculturas dentro de la organización y son la causa de que los factores de riesgo de origen cultural puedan variar dentro de ésta. Dado que las culturas tienden a la estabilidad y son resistentes al cambio, el conocimiento de la historia de las organizaciones puede facilitar la evaluación de los factores de riesgo, tanto desde la perspectiva de los rasgos culturales estables como desde el punto de vista de la cultura cambiante, así como de los acontecimientos recientes capaces de generar tensiones asociadas a la turbulencia (H irsch 1987).

Clima y cultura se solapan en cierta medida, ya que las percepciones de los patrones de comportamiento culturales constituyen buena parte del objeto de estudio de las investigaciones sobre el clima. C on todo, los miembros de una organización pueden describir las características organizativas (el clima) de forma similar $y$, sin embargo, interpretarlas de distinto modo, debido a influencias culturales y subculturales (R osen, Greenlagh y Anderson 1981). Por ejemplo, un modelo de liderazgo estructurado y escasa participación en la toma de decisiones se puede valorar como negativo y restrictivo desde una determinada perspectiva, y como positivo y legítimo desde otra. LoS 
factores sociales que reflejan la cultura organizativa conforman la interpretación que los miembros tienen de las características y actividades de la organización. Por consiguiente, parece más recomendable evaluar el clima simultáneamente con la cultura en el estudio de la influencia de la organización en el bienestar de sus miembros.

\section{- MEDICION Y REMUNERACION DEL RENDIMIENTO}

\section{Richard L. Shell}

Las empresas y administraciones públicas de todo el mundo utilizan diversas formas de retribución del esfuerzo físico y mental de los trabajadores. La remuneración implica un pago monetario por el esfuerzo humano y resulta necesaria para la subsistencia personal y familiar en la mayoría de las sociedades. El intercambio de trabajo por dinero constituye una práctica muy arraigada.

El aspecto estresor de la remuneración se asocia muy estrechamente a aquellos sistemas en los que se ofrecen incentivos a un esfuerzo humano extraordinario o sostenido. Aunque, evidentemente, puede haber estrés en cualquier entorno laboral en que la remuneración no se base en los incentivos, los niveles de effuerzo físico y mental muy superiores a los normales y capaces de producir lesiones o un estrés mental patológico se suelen producir principalmente en entornos caracterizados por determinadas formas de remuneración mediante incentivos.

\section{Medición del rendimiento y estrés}

La mayoría de las organizaciones utilizan uno u otro criterio de medición del rendimiento, constituyen un elemento esencial de los programas de incentivos. Se pueden aplicar medidas del rendimiento a la producción, la calidad, el tiempo de elaboración o cualquier otro indicador de la productividad. En 1883, Lord Kevin hizo el siguiente comentario sobre la medición: "Suelo decir que, si puedes medir y expresar en números lo que estás comentando, es que sabes algo sobre ello; pero, si no lo puedes medir y expresar en números, tienes un conocimiento escaso e insatisfactorio; quizás sea el principio del conocimiento, pero apenas te has acercado a la fase científica, cualquiera que sea la materia."

Las medidas del rendimiento deben estar íntimamente asociadas a los objetivos básicos de la organización. U na medida inadecuada del rendimiento suele tener escasa o nula influencia en el logro de los objetivos. Entre las críticas más comúnmente formuladas contra las medidas del rendimiento figuran la indefinición del objetivo, la vaguedad, la falta de conexión (incluso, la contradicción) con la estrategia de la empresa, la injusticia e incoherencia, y la posibilidad de que se utilicen exclusivamente para "castigar" a las personas. Por otra parte, las medidas pueden constituir valiosos puntos de referencia; no hay más que recordar el dicho: "Si no sabes dónde estás, no podrás llegar adonde quieres estar". EI resultado es que los trabajadores de todos los niveles de la organización adoptan en mayor medida los comportamientos utilizados para medir su rendimiento y por los que se les suele recompensar. Lo que se mide y se recompensa es lo que se hace.

Las medidas del rendimiento deben ser justas y coherentes para reducir el estrés entre los miembros de la plantilla. Existen a este respecto diversos métodos de medición, desde las estimaciones subjetivas (conjeturas) hasta la aplicación de técnicas planificadas. En el método basado en la cuantificación del trabajo, se define el rendimiento del 100 por ciento como el que se consigue con "un buen ritmo de trabajo durante la jornada". Se consideran aquí el esfuerzo laboral y la cualificación necesarios para que un trabajador medio y suficientemente formado pueda trabajar sin una fatiga excesiva en la producción de un trabajo de calidad durante un turno de trabajo. U n rendimiento del 100 por ciento no constituye el rendimiento máximo; refleja, por el contrario, el esfuerzo y la cualificación medios o normales en un grupo de trabajadores. En términos comparativos, un rendimiento del 70 por ciento se suele considerar el nivel mínimo tolerable, en tanto que un rendimiento del 120 por ciento refleja el esfuerzo y la cualificación incentivados que se exige al trabajador medio al que se ofrece una prima del 20 por ciento como mínimo por encima de la tarifa salarial mínima. Aunque se han establecido numerosos regímenes de pago de incentivos utilizando el referente del 120 por ciento, la cifra varía de un plan a otro. Los criterios globales recomendados para el diseño de los planes de incentivos consisten en conceder a los trabajadores la oportunidad de ganar entre el 20 y el 35 por ciento por encima de su salario base si aportan una cualificación normal y realizan un esfuerzo elevado de forma sostenida.

A pesar de su atractivo intrínseco, este método de medición basado en la cuantificación del trabajo plantea algunos problemas de estrés. Las medidas consideradas se fijan en función del rendimiento medio o normal de un determinado equipo de trabajo (esto es, de unas normas de trabajo basadas en el rendimiento colectivo y no en el individual). Esto significa que, por definición, un porcentaje considerable de los trabajadores que realizan una determinada tarea queden por debajo de la media (del rendimiento del 100 por ciento tomado como referencia), con lo que se genera un desequilibrio entre las demandas y los recursos que excede de los límites del effuerzo físico o mental. Los trabajadores que experimentan dificultades para lograr los niveles de rendimiento exigidos suelen experimentar estrés producido por la sobrecarga de trabajo, una retroinformación negativa de los supervisores y el riesgo de perder el empleo si su rendimiento se mantiene sostenidamente por debajo del referente del 100 por ciento.

\section{Programas de incentivos}

L os incentivos se vienen aplicando de una u otra forma desde hace mucho tiempo. Así, en el Nuevo Testamento (II Timoteo 2:6), dice san Pablo: "Los mejores frutos de la tierra deben ser para el labriego laborioso". En nuestros días, la mayor parte de las organizaciones se esfuerzan por mejorar la productividad y la calidad para mantener o mejorar su posición en el mundo empresarial. La mayoría de los trabajadores no se muestran dispuestos a realizar un esfuerzo extraordinario o sostenido sin algún tipo de incentivo. U nos programas de incentivos adecuadamente diseñados y aplicados pueden contribuir a este fin. En este sentido, es preciso establecer algún método de medición del rendimiento antes de poner en práctica un programa de incentivos. Existen tres grandes grupos de programas de incentivos: los financieros directos, los financierosindirectosy losintangibles (no financieros).

Los programas financieros directos se pueden aplicar a personas individuales 0 a equipos de trabajo. Los incentivos personales se calculan en función del rendimiento del trabajador, medido con arreglo a una norma, durante un determinado período. Los incentivos colectivos se aplican a dos o más trabajadores integrados en un equipo dedicado a la realización de tareas generalmente interdependientes. EI incentivo correspondiente a cada uno de los trabajadores del grupo suele estar en función tanto de su tarifa salarial base como del rendimiento logrado por el grupo durante el período de cálculo del incentivo.

El grado de motivación para mantener un nivel elevado de producción suele ser superior con los incentivos individuales, debido a la posibilidad de que el trabajador más productivo 
reciba un incentivo mayor. No obstante, a medida que las organizaciones evolucionan hacia un estilo de gestión participativo y hacia la delegación de poder ("empowerment") en grupos y equipos de trabajo, los incentivos colectivos suelen dar los mejores resultados globales. En efecto, el esfuerzo colectivo genera más mejoras globales que el esfuerzo individual. El sistema de participación en las ganancias (sistema de incentivos colectivos basado en la creación de equipos para la mejora continua y en el pago de un determinado porcentaje - por regla general, del 50 por ciento- de los incrementos de productividad que excedan de un determinado nivel de referencia) es una modalidad perfectamente adecuada al proceso de mejora continua.

Los programas financieros indirectos suelen ser menos eficaces que los anteriores, debido a su menor capacidad de motivación. Su principal ventaja consiste en que precisan una medición menos exacta y detallada del rendimiento. Se incluyen en este grupo de programas las políticas empresariales dirigidas a mejorar el estado de ánimo, a aumentar la productividad o a aportar algunos beneficios económicos a los trabajadores. $\mathrm{H}$ ay que subrayarse que en el método no se contempla una correlación exacta entre la producción del trabajador y los incentivos financieros. Como incentivos se utilizan unas tarifas salariales básicas relativamente altas, unas prestaciones sociales complementarias generosas, recompensas, pagas extraordinarias de final del ejercicio o sistemas de participación en beneficios.

Entre los incentivos intangibles se incluyen las recompensas que suponen escaso o nulo beneficio económico para los trabajadores. No obstante, si reciben una acogida favorable del personal, pueden contribuir a incrementar la productividad. Ejemplos de incentivos intangibles son el enriquecimiento del puesto de trabajo (que implica el aumento de los retos y de la satisfacción intrínseca de la realización de tareas específicas), la ampliación del puesto de trabajo (que implica la adición de nuevas tareas hasta completar una pieza o una unidad de trabajo o de producción), los programas de incentivos no financieros, los grupos de participación de los trabajadores y los permisos retribuidos.

\section{Resumen y conclusiones}

Los incentivos, de uno $u$ otro tipo, forman parte integrante de muchos programas de remuneración. En términos generales, los planes de incentivos se deben evaluar cuidadosamente para evitar que los trabajadores rebasen determinados límites ergonómicos 0 de tensión mental, sobre todo en el caso de los incentivos individuales directos. El problema es menos acuciante en los programas de incentivos colectivos - directos o indirectos- e intangibles.

Los incentivos son deseables porque fomentan la productividad y permiten a los trabajadores obtener ingresos complementarios $u$ otras prestaciones. L a participación en las ganancias es actualmente una de las mejores modalidades de pago de incentivos para las organizaciones constituidas por grupos 0 equipos de trabajo que estén dispuestas a ofrecer gratificaciones extraordinarias y mejorar el lugar de trabajo evitando el riesgo de que el propio plan surta efectos estresores.

\section{CUESTIONES DE PERSONAL}

Marilyn K. Gowing

\section{Trabajadores eventuales}

A escala mundial, tanto la utilización como el ordenamiento del trabajo eventual varían sensiblemente de un país a otro. Se considera trabajadores eventuales a los trabajadores temporales contratados, directamente o a través de agencias de empleo temporal, los trabajadores a tiempo parcial, sean voluntarios o no (entendiéndose que no lo son los que preferirían el trabajo a tiempo completo) y los autónomos. Las diferentes definiciones de estas categorías dificultan los estudios comparativos de ámbito internacional.

O verman (1993) comenta que el sector del empleo temporal en la Europa occidental es casi un 50 por ciento mayor que en Estados U nidos, donde sólo un $1 \%$ de la población empleada tiene carácter temporal. El trabajo temporal es casi inexistente en I talia y E spaña.

Auque se observan sensibles variaciones en las distintas subcategorías de trabajadores mencionadas, la mayoría de los trabajadores a tiempo parcial de los países europeos son mujeres que perciben salarios bajos. También en Estados U nidos los trabajadores eventuales suelen ser jóvenes, mujeres y miembros de grupos minoritarios. El nivel de protección legal de las condiciones de trabajo, la salud y otros aspectos del trabajo eventual varía sensiblemente de un país a otro. El rigor de ordenamiento legal de este tipo de trabajo es menor en Estados U nidos, el Reino U nido, Corea, Hong Kong, México y Chile que en otros países como Francia, Alemania, Argentina y Japón (O verman 1993). La adopción de normas legales en las que se reconozcan mayores niveles de prestaciones a los trabajadores eventuales contribuiría a reducir el problema del estrés entre los mismos. Por otra parte, sin embargo, el aumento de esta protección legal podría inducir a las empresas a contratar menos personal a causa de los costes sociales.

\section{Trabajo compartido}

Una solución alternativa al trabajo eventual es el denominado "trabajo compartido", que puede adoptar tres modalidades: dos trabajadores comparten las responsabilidades de un mismo puesto de trabajo a tiempo completo; esos mismos dos trabajadores comparten el puesto a tiempo completo y se distribuyen las tareas, por lo general, por proyectos o grupos de clientes; o bien dos trabajadores realizan tareas totalmente independientes y disociadas que, sin embargo, se consideran integrantes de un solo puesto de trabajo (M attis 1990). La investigación ha revelado que la mayor parte del trabajo compartido, como el eventual, es realizado por mujeres. Sin embargc, a diferencia de lo que ocurre con el trabajo eventual, los salarios y la jornada de trabajo suelen disfrutar de protección legal, y no es infrecuente que el sistema se aplique a la prestación de servicios profesionales 0 , incluso, directivos. Dentro de la U nión Europea, el trabajo compartido está más generalizado en el R eino U nido, donde se implantó inicialmente en el sector público (Lewis, Izraeli y Hootsmans 1992). La Administración Federal de Estados U nidos puso en práctica a principios del decenio de 1990 un programa nacional de trabajo compartido para el personal a su servicio; sin embargo, muchas administraciones estatales habían puesto ya en práctica programas de trabajo compartido para su personal desde 1983 (Lee 1983). El sistema de trabajo compartido permite compatibilizar el trabajo con las responsabilidades familiares.

Trabajo de localización flexible y trabajo en casa Se han acuñado diversos términos para designar el fenómeno del trabajo de lozación flexible y trabajo en casa: teletrabajo, puesto alternativo, trabajo a distancia, hogar electrónico, trabajo de localización independiente, puesto de trabajo lejano y oficina en el hogar. A los fines del presente artículo, se entiende por teletrabajo "el que se realiza en uno o más sitios prefijados, como el domicilio 0 un centro subsidiario de trabajo distinto de la oficina tradicional, en el que, al menos, una parte de las comunicaciones se realizan utilizando equipo de telecomunicaciones como 
ordenadores, teléfonos y aparatos de fax" (Pitt-Catsouphes y M archetta 1991).

Según estimaciones de LINK Resources, Inc., empresa privada dedicada a la supervisión de las telecomunicaciones en todo el mundo, en 1993 había 7,6 millones de "teletrabajadores" en Estados U nidos, de un total de 41,1 millones de viviendas en las que se realizaba trabajo a domicilio. El 81 por ciento del total de "teletrabajadores" colaboraba con empresas con menos de 100 empleados de un amplio espectro de sectores distribuidas en muchas áreas geográficas. En contraste con la situación observada en el campo del trabajo eventual y el trabajo compartido, realizado mayoritariamente por mujeres, el 53 por ciento de los "teletrabajadores" eran varones. Los estudios realizados en cincuenta empresas de Estados U nidos indicaron igualmente que la mayoría eran varones que desempeñaban funciones de supervisión (tanto de línea como de staff) o realizaban trabajos centrados en los clientes o que implicaban desplazamientos (M attis 1990). En 1992, en 1,5 millones de hogares de Canadá había al menos una persona que realizaba alguna actividad profesional desde su domicilio.

Lewis, Izraeli y H ootsman (1992) manifiestan que, en contra de lo inicialmente previsto, el teletrabajo no ha conquistado Europa, y añaden que se ha arraigado más en el R eino U nido y Alemania en la prestación de servicios profesionales, incluidos los de especialistas en informática y agentes de seguros.

Por su parte, una parte del trabajo que se realiza a domicilio, tanto en Europa, como en Estados U nidos se paga a destajo y se ha de ejecutar en unos plazos muy breves. Por regla general, mientras que los teletrabajadores suelen ser varones, el trabajo a domicilio, mal remunerado por el sistema de destajo y sin prestaciones sociales, es realizado principalmente por mujeres (H all 1990).

Las investigaciones más recientes se han centrado en determinar: a) el tipo de persona más idóneo para el trabajo a domicilio, b) el tipo de trabajo más adecuado para realizarse en casa, c) los métodos que coadyuven en mayor medida a la satisfacción con el trabajo a domicilio, y d) las razones que justifiquen el apoyo de la organización (H all 1990; Christensen 1992).

\section{Asistencia social}

La filosofía que informa las cuestiones y programas de bienestar y asistencia social varía en todo el mundo en función de la cultura de la nación de que se trate y de los valores que la sustentan. Ferber, O'Farrell y Allen (1991) explican algunas de las diferencias existentes entre la asistencia social que se presta en Estados Unidos, Canadá y Europa occidental.

Las recientes propuestas de reforma formuladas en Estados U nidos se decantan por una reforma en profundidad del sistema tradicional de asistencia pública en el sentido de obligar a lo beneficiarios a "ganarse" las prestaciones. Las estimaciones del coste del sistema de asistencia social oscilan entre los 15.000 y los 20.000 millones de dólares en los cinco años venideros, previéndose sustanciales ahorros de costes en el largo plazo. En Estados U nidos, los costes de gestión de programas de asistencia social como los de cartillas de alimentos, M edicaid y A sistencia a las Familias con Hijos Dependientes crecieron en un 19 por ciento entre 1987 y 1991, cifra que se corresponde con el incremento porcentual del número de beneficiarios.

En Canadá se ha puesto en práctica un programa de "trabajo compartido" como alternativa a los despidos y la asistencia social. Según el programa desarrollado por la Canada Employment and Immigration Commission (CEIC), las empresas pueden afrontar las recesiones acortando la semana de trabajo entre uno y tres días y reduciendo consecuentemente los salarios. La CEIC facilita al trabajador la percepción de las prestaciones regulares del seguro de desempleo correspondientes a los días no trabajados, lo que compensa a los afectados por la pérdida de ingresos salariales y les evita el trauma que supondría el despido. La duración del programa es de 26 semanas, con una prórroga de 12 semanas. Los trabajadores pueden utilizar para su formación las jornadas de trabajo compartido y la Administración federal canadiense reembolsa a la empresa un porcentaje sustancial de los costes directos de la formación a través del programa "C anadian Jobs Strategy".

\section{Cuidado de los niños}

El nivel de apoyo a los servicios de cuidado de los niños depende del sustrato sociológico cultural del país (Scharlach, Lowe y Schneider 1991). En las culturas en que:

1. se propugna la plena integración de la mujer en el lugar de trabajo,

2. se valora el cuidado de los niños como una función pública, más que como un problema de cada familia,

3. se valora el cuidado de los niños como una extensión del sistema educativo,

4. se aprecia la importancia y el valor formativo de las experiencias de la primera infancia,

se asignan más recursos a la financiación de esos programas. Por lo tanto, el estudio comparativo internacional se dificulta por la presencia de las cuatro condiciones citadas, y la "calidad" del cuidado de los menores puede ser una función de las necesidades de los niños y sus familias en los contextos culturales específicos.

En la Comunidad Europea, Francia tiene los programas más amplios de cuidados a los niños. Estas cuestiones se abordaron en el Reino Unido y los Países Bajos mucho más tarde. De hecho, en 1989, sólo el 3 por ciento de las empresas británicas facilitaban algún tipo de servicios de cuidados a los niños. Lamb y cols. (1992) describen diversos estudios de casos de prestación de cuidados no parentales a los niños en Suecia, Países Bajos, Italia, Reino U nido, Estados U nidos, Canadá, I srael, Japón, República Popular China, Camerún, Africa oriental y Brasil. U nas 3.500 empresas del total de 17 millones existentes en Estados U nidos ofrecen algún tipo de ayuda para la prestación de cuidados a los hijos de sus trabajadores. De esas empresas, unas 1.100 ofertan cuentas de gastos flexibles, 1.000 ofrecen servicios de información y consulta, y menos de 350 disponen de instalaciones de cuidados en sus propias instalaciones o en sus proximidades (Bureau of National A ffairs 1991).

Según un estudio realizado en Estados Unidos, el 44 por ciento de los hombres y el 76 por ciento de las mujeres con hijos menores de seis años habían faltado alguna vez al trabajo durante los tres meses precedentes por motivos familiares. LoS autores del estudio estimaron que las organizaciones investigadas habían abonado más de cuatro millones de dólares en salarios y prestaciones sociales a los trabajadores que se habían ausentado de su puesto por causas vinculadas al cuidado de los hijos (ver estudio realizado por G alinsky y H ughes en Fernández 1990). Según un estudio realizado en 1981 por la General Accounting $\mathrm{O}$ ffice de Estados U nidos, las empresas norteamericanas pierden unos 700 millones de dólares anuales por causa de unas políticas inadecuadas de concesión de permisos por maternidad.

\section{Cuidado de las personas de edad avanzada}

$M$ ientras que en Francia habrán de transcurrir 115 años y en Suecia 90, en Japón sólo se tardará 30 años (desde la redacción del presente artículo, en 1994), para que el porcentaje de personas de edad avanzada pase del 7 al 14 por ciento. Antes de que finalice el siglo $X X$, una de cada cuatro personas residentes en muchos Estados miembros de la U nión Europea tendrá más de 60 años. Sin embargo, hasta hace poco, había en Japón muy 
pocas instituciones dedicadas al cuidado de los ancianos, y el problema había suscitado muy escasa atención en el Reino U nido y otros países europeos (Lewis, Izraeli y Hootsmans 1992). En Estados U nidos existen unos cinco millones de ancianos que precisan ayuda para sus actividades cotidianas y para seguir incorporados a la vida social, y unos 30 millones de personas que han cumplido los 65 años. Más del $80 \%$ de la ayuda que precisan corre a cargo de sus propios familiares (Scharlach, Lowe y Schneider 1991).

L as investigaciones realizadas han demostrado que los trabajadores obligados a cuidar de personas de la tercera edad acusan un mayor nivel global de estrés en el trabajo que otros trabajadores (Scharlach, Lowe y Schneider 1991). En efecto, suelen quejarse tanto de estrés psicológico como de agotamiento físico y problemas económicos. Afortunadamente, las grandes multinacionales han comenzado a tomar conciencia de que los problemas familiares pueden ser causa de absentismo, reducción de la productividad y debilitamiento del estado de ánimo, y comienzan a ofrecer a sus trabajadores un "autoservicio de prestaciones". (EI término "autoservicio" se utiliza en este contexto para indicar que los trabajadores pueden elegir la opción más conveniente entre un abanico de posibles prestaciones). Tales prestaciones son, entre otras, los horarios de trabajo flexibles, la disponibilidad de horas retribuidas por enfermedad de un familiar, las consultas sobre las posibles fuentes de asistencia familiar, y una cuenta de reducción salarial por cuidado de familiares dependientes, que permite pagar la asistencia a los ancianos 0 los servicios de asistencia de día con sus ingresos brutos.

El autor desea manifestar su agradecimiento por la ayuda recibida de Charles Anderson, del Centro de Desarrollo y Recursos Humanos de la U nited States $O$ ffice of Personnel M anagement: Tony K iers, de C.A.L.L., de Canadian Work and Family Service; y Ellen Bankert y Bradley Googins, del Centro para el Trabajo y la Familia de la U niversidad de Boston, en la investigación y consulta de muchos de los trabajos citados en el presente artículo.

DESARROUO DE LA CARRERA PROFESIONAL

\section{SocializaCION}

\section{D ebra L. N elson y James Campbell Quick}

El proceso mediante el cual las personas ajenas a una organización se integran en la misma se conoce como socialización organizativa. M ientras que la atención de los estudios iniciales de la socialización se centraba en determinados indicadores de ajuste, como la satisfacción y el rendimiento en el puesto de trabajo, en investigaciones más recientes se ha subrayado la asociación entre la socialización organizativa y el estrés en el trabajo.

\section{La socialización como factor moderador del estrés en el trabajo}

La incorporación a una organización es una experiencia intrínsecamente estresor. Los recién llegados deben afrontar múltiples factores de estrés, como el conflicto y la ambigüedad de roles, los conflictos entre las obligaciones laborales y las responsabilidades domésticas, la política, la falta de tiempo y la sobrecarga de trabajo. Estos factores de estrés pueden producir síntomas de estrés. Sin embargo, los estudios realizados en el decenio de 1980 demuestran que un proceso de socialización adecuadamente gestionado puede contribuir a moderar la correlación entre los estresores y las tensiones.

Las investigaciones recientes del problema de la socialización han puesto de relieve dos dimensiones específicas:

1. adquisición de información durante la socialización;

2. apoyo de los supervisores durante el proceso.

La información adquirida por los recién llegados durante el proceso de socialización contribuye a moderar el considerable grado de incertidumbre que acompaña a sus esfuerzos por dominar las nuevas, tareas, roles y relaciones personales. A menudo, esta información se adquiere a través de programas de "orientación para la socialización". En ausencia de programas formales, o complementariamente a los mismos (allí donde existen), la socialización se produce de modo informal. Las investigaciones recientes apuntan a que los recién llegados que se esfuerzan por conseguir información se integran mejor en la organización (M orrison 1993). Por otra parte, los recién llegados que infravaloran los efectos de los factores de estrés en su nuevo puesto de trabajo manifiestan mayores síntomas de estrés negativo ("distress") (N elson y Sutton 1991).
El apoyo de los supervisores durante el proceso de socialización es particularmente importante. Los recién llegados que gozan del apoyo de sus supervisores muestran menor grado de estrés ocasionado por la frustración de sus aspiraciones (Fisher 1985) y menores síntomas psicológicos de estrés negativo (N elson y Q uick 1991). El apoyo de los supervisores puede contribuir, al menos, de tres formas, a que los recién incorporados superen los factores de estrés. En primer lugar, los supervisores pueden prestar un apoyo instrumental (como la fijación de un horario flexible) que contribuya a moderar los efectos de un determinado factor de estrés. En segundo lugar, pueden prestar un apoyo moral que refuerce el ánimo del recién llegado para luchar contra los factores de estrés. Por último, los supervisores pueden contribuir de forma importante a que los nuevos trabajadores comprendan mejor su nuevo entorno (L ouis 1980). Por ejemplo, pueden presentar las distintas situaciones a los recién llegados de forma que lesayude a valorarlascomo amenazadoraso no.

En resumen, los esfuerzos de socialización que aportan a los nuevos miembros información suficiente y el apoyo de sus supervisores pueden prevenir que esta situación estresora genere un estrés negativo.

\section{Evaluación de la socialización organizativa}

El proceso de socialización organizativa es un fenómeno dinámico, interactivo y comunicativo que se desarrolla en el tiempo. Esta complejidad explica la dificultad de evaluar los esfuerzos de socialización. Se han propuesto dos métodos generales al respecto. El primero es el basado en los modelos de las etapas de la socialización (Feldman 1976; Nelson 1987). Según estos modelos, la socialización constituye un proceso de transición de varias etapas, cada una de las cuales se caracteriza por una serie de variables clave. El segundo método se centra en las diversas estrategias de socialización que las organizaciones utilizan para ayudar a los recién llegados (Van M aanen y Schein 1979).

A mbos métodos parten del criterio de que existen varios resultados que marcan el éxito de la socialización: rendimiento, satisfacción en el puesto de trabajo, identificación con la organización, interés por el trabajo e intención de permanecer en la organización. Si la socialización modera el estrés, los síntomas de estrés negativo (concretamente, la presencia de un bajo nivel de estrés negativo) se deben incluir entre los indicadores del éxito de la socialización. 


\section{Efectos de la socialización en la salud}

Dado que la relación entre socialización y estrés sólo ha empezado a estudiarse en épocas recientes, en pocos estudios se han investigado sus efectos en la salud. No obstante, los resultados de las investigaciones realizadas apuntan a una asociación entre el proceso de socialización y la aparición de síntomas de estrés negativo. Los recién llegados que han valorado como positiva su interacción con los supervisores y otros nuevos miembros han acusado menores síntomas de tensión psicológica del tipo de la depresión y la falta de concentración (Nelson y Q uick 1991). Además, los que han previsto con mayor realismo los efectos de los factores de estrés han acusado menores niveles de síntomas tanto psicológicos (por ejemplo: irritabilidad) como fisiológicos (por ejemplo: náuseas o dolores de cabeza).

Puesto que la socialización es una experiencia estresora, sus efectos sobre la salud constituyen variables dignas de examen. Faltan estudios orientados en un amplio espectro de consecuencias para la salud, en los que se combinen los autoinformes de los síntomas de estrés negativo con medidas objetivas de salud.

\section{La socialización organizativa como intervención sobre el estrés}

Recientes investigaciones demuestran que la socialización organizativa constituye un proceso estresor que, si no se gestiona correctamente, puede producir síntomas de estrés negativo y otros problemas de salud. Las organizaciones pueden adoptar, al menos, tres medidas para facilitar el proceso a fin de conseguir unos resultados positivos de la socialización.

En primer lugar, la organización debe propiciar entre los nuevos miembros unas expectativas realistas respecto a los factores de estrés inherentes al nuevo puesto de trabajo. Esto puede lograrse mediante una presentación realista del nuevo puesto, en la que se describan los factores de estrés más comunes y los métodos más eficaces para afrontarlos (Wanous 1992). Si un recién llegado conoce perfectamente los problemas que le esperan, puede idear anticipadamente los medios de afrontarlos y, además, se sentirá menos traumatizado por los factores de estrés que le hayan sido comunicados por anticipado.

En segundo lugar, la organización debe poner a disposición de los recién llegados múltiples fuentes de información, como folletos, sistemas interactivos de información o líneas directas de fax y/ o teléfono (o la totalidad de estas fuentes). Las incertidumbres inherentes en la adaptación a un nuevo puesto de trabajo pueden ser abrumadoras, y el ofrecimiento de una asistencia basada en múltiples fuentes de información puede contribuir a despejar esas incertidumbres.

En tercer lugar, en el diseño de los programas de socialización se debe incluir expresamente la prestación de apoyo emocional. El supervisor es un elemento clave en la prestación de este apoyo emocional y su colaboración puede resultar extraordinariamente valiosa, emocional y psicológicamente, para los nuevos miembros (H irschhorn 1990). Este apoyo emocional puede encauzarse igualmente por otros canales, como la tutoría, los contactos con otros nuevos trabajadores y las actividades conjuntas con los compañeros más antiguos y experimentados.

\section{ETAPAS DE LA CARRERA PRO FESIONAL}

Kari Lindström

\section{Introducción}

El sistema de etapas de la carrera responde a una determinada perspectiva del desarrollo profesional. Al abordar la cuestión de las etapas de la carrera profesional, los investigadores suelen inspirarse en el modelo de L evinson de las etapas de desarrollo de la vida humana (Levinson 1986). Según este modelo, la vida de las personas pasa por distintas etapas, separadas por unos períodos de transición. En cada etapa se emprende una nueva actividad vital y se produce un ajuste psicológico (O rnstein, Cron y Slocum 1989). De esta forma, se pueden definir unas etapas específicas de la carrera profesional que, por regla general, se corresponden con las edades cronológicas. Aunque los tramos de edad correlacionados con cada etapa de la carrera varían sensiblemente de uno a otro estudio empírico, la etapa inicial de la carrera se suele hacer coincidir con el tramo de edad comprendido entre los 20 y los 34 años; la etapa intermedia, entre los 35 y los 50; y la última etapa de la carrera comprende entre los 50 y los 65 años.

Según el modelo de Super de desarrollo de la carrera profesional (Super 1957; O rnstein, Cron y Slocum 1989), las cuatro etapas de una carrera se configuran en torno de las funciones psicológicas cualitativamente diferentes de cada una de ellas. L as etapas se pueden definir, bien en función de la edad, bien de conformidad con criterios organizativos, profesionales o funcionales. U na misma persona puede reciclarse profesionalmente varias veces durante su carrera. Por ejemplo, según el Formulario para Adultos del Inventario de Intereses Profesionales, la etapa real de la carrera se puede definir a escala personal o del grupo. Este modelo permite evaluar los intereses y expectativas personales relativos a diversas tareas de desarrollo de la carrera (Super, Zelkowitz y Thompson 1981). Si se aplican criterios funcionales de evaluación, los dos primeros años se consideran un período de prueba. El período de afianzamiento, que dura entre dos y diez años, se caracteriza por el avance y crecimiento profesionales. A los diez años se inicia el período de mantenimiento, caracterizado por la conservación de lo conseguido. En la etapa de declive se produce el desarrollo de la propia imagen al margen del desarrollo de la carrera personal.

Dado que tanto los fundamentos teóricos de la definición de las etapas de la carrera como los criterios de medición que se utilizan en la práctica difieren entre uno y otro estudio, resulta evidente que los resultados concernientes a la relación entre el desarrollo de la carrera y las cuestiones que afectan a la salud y el puesto de trabajo difieren igualmente.

\section{Las etapas de la carrera como factor moderador del bienestar y la salud en el trabajo}

La mayoría de los estudios dedicados a las etapas de la carrera como elemento moderador entre las características del puesto de trabajo y la salud o el bienestar de los trabajadores se centran en el compromiso con la organización y en su relación con la satisfacción en el puesto de trabajo o con determinados comportamientos resultantes, como el rendimiento, la rotación del personal 0 el absentismo (Cohen 1991). También se ha estudiado la relación entre las características del puesto de trabajo y la tensión. E stadísticamente, el efecto moderador de las etapas de la carrera implica que la correlación media entre las medidas de las características del puesto de trabajo y el bienestar varía de una a otra de esas etapas.

El compromiso con el trabajo se suele desarrollar desde las primeras a las últimas etapas de la carrera, si bien se ha evidenciado que, entre los varones asalariados que realizan funciones profesionales, es más bajo en la etapa intermedia. En la etapa inicial, el trabajador siente una mayor necesidad de abandonar la organización y reubicarse (M orrow y M cElroy 1987). Entre el personal sanitario, las medidas de bienestar de las enfermeras se asocian más íntimamente al compromiso con la carrera y a los estímulos afectivo-organizativos (esto es, a la adhesión afectiva a la organización). El compromiso de continuidad (que está en función de la percepción de las posibles alternativas y del grado 
de sacrificio) y el compromiso normativo (lealtad hacia la organización) aumentan en las sucesivas etapas de la carrera (Reilley y O rsak 1991).

Se realizó un metaanálisis de 41 muestras referentes a la relación entre el compromiso con la organización y los resultados indicativos del bienestar. Las muestras se dividieron en diferentes grupos de acuerdo con dos criterios utilizados para la medición de la etapa de la carrera: la edad y la función. Como indicador de la etapa de la carrera, la edad influía significativamente en la rotación del personal y en las intenciones de cambiar de trabajo, mientras que la función dentro de la organización se asociaba al rendimiento en el puesto de trabajo y al absentismo. Los niveles bajos de compromiso con la organización se asociaban a un índice elevado de rotación del personal, principalmente en la etapa inicial de la carrera, mientras que, en la etapa final, idénticos bajos niveles de compromiso con la organización se vinculaban más bien al bajo rendimiento en el trabajo y a un absentismo elevado (C ohen 1991).

Se ha podido establecer que la relación entre las actitudes en el trabajo - por ejemplo, la satisfacción y el comportamiento en el trabajo- está moderada en considerable medida por la etapa de la carrera (por ejemplo, Stumpf y R abinowitz 1981). Se ha establecido asimismo que, entre los empleados públicos, la etapa de la carrera, definida en términos de la función ejercida, modera la relación entre la satisfacción en el puesto de trabajo y el rendimiento en éste, siendo esa relación más estrecha durante la etapa inicial. Esta tesis se ha visto confirmada por un estudio realizado con una muestra de vendedores. Entre los profesores de enseñanza superior, la relación entre satisfacción y rendimiento es de signo negativo durante los dos primeros años de desempeño del puesto.

La mayoría de los estudios dedicados a las etapas de la carrera se han centrado en los varones. Incluso en muchos de los estudios iniciales realizados en los primeros años del decenio de 1970, en los que no se hacía referencia al sexo de las personas incluidas en la muestra, resultaba evidente que la mayoría eran varones. O rnstein y Lynn (1990) verificaron hasta qué punto los modelos de Levinson y Super describían correctamente las diferentes actitudes e intenciones relativas a la carrera observadas entre las mujeres profesionales. Los resultados apuntan a que las etapas de la carrera basadas en la edad se relacionan con el compromiso con la organización, la intención de dejar el trabajo y el deseo de promoción. Estos hallazgos son, en líneas generales, similares a los observados entre los hombres (O rnstein, Cron y Slocum 1989). Sin embargo, no permiten confirmar la utilidad como medio predictivo de las etapas de la carrera definidas con criterios psicológicos.

Al diseñar los estudios del estrés, o bien se ha pasado por alto la edad $-y$, por consiguiente, la etapa de la carrera- 0 bien se la ha valorado como un factor perturbador y se han controlado sus efectos. H urrell, M CL aney y M urphy (1990) compararon los efectos del estrés en la etapa intermedia de la carrera con sus consecuencias en las etapas inicial y final de la misma, utilizando la edad como base de su clasificación de los funcionarios de correos de Estados U nidos. M ientras que los síntomas percibidos de mala salud no aparecían asociados a los factores de estrés laboral presentes en el estadio intermedio de la carrera, la presión del trabajo y la infrautilización de las capacidades eran factores predictivos de esos síntomas en las fases inicial y final de aquélla. La presión del trabajo se asociaba igualmente a ciertos síntomas somáticos en las etapas inicial y final de la carrera. $L a$ infrautilización de las capacidades se asociaba más estrechamente a la satisfacción en el puesto de trabajo y a los síntomas somáticos en la etapa intermedia de su carrera. El apoyo social influía más en la salud mental que en la física, fenómeno que resulta más acusado hacia la mitad de la carrera que en los años iniciales y finales. Dado que los datos proceden de un estudio transversal, los autores apuntan que también sería posible una explicación por cohortes de los resultados (H urrell, M CLaney y M urphy 1990).

Al agrupar a los trabajadores adultos de ambos sexos por grupos de edad, los de más edad mencionaron en mayor medida la sobrecarga y la responsabilidad como factores de estrés en el trabajo, mientras que, para los más jóvenes, aparecían en primer plano la insuficiencia (esto es, la falta de atractivo del trabajo), la indefinición de los roles y los estresores del entorno físico (O sipow, Doty y Spokane 1985). Los trabajadores de mayor edad comunicaron menos síntomas de todos los tipos de tensión, debido quizás a que poseían un mayor repertorio de capacidades cognitivo-racionales, de autoprotección y de afrontamiento, aprendidas obviamente durante su carrera, aun cuando también puede influir, la selección efectuada sobre la base de los síntomas. Es igualmente posible que el fenómeno obedezca a algún tipo de autoselección efectuada por las personas que abandonan los puestos de trabajo que les producen un estrés demasiado prolongado.

Estudios realizados entre varones que ocupaban puestos directivos en Finlandia y Estados U nidos han puesto de manifiesto que la relación entre las demandas y el control del trabajo, por una parte, y los síntomas psicosomáticos, por otra, variaba con las etapas (definidas en función de la edad) de la carrera profesional (Hurrell y Lindström 1992; Lindström y Hurrell 1992). Entre los directivos norteamericanos, las demandas y el control del trabajo influían significativamente en la manifestación de síntomas durante la etapa intermedia de la carrera, pero no en las etapas inicial y final, mientras que entre los directivos finlandeses, las jornadas prolongadas y el bajo nivel de control del trabajo contribuían a incrementar los síntomas de estrés en la primera etapa de la carrera, pero no en las posteriores. $L$ as diferencias entre los dos grupos pueden obedecer a divergencias entre las dos muestras estudiadas. En efecto, mientras que los directivos finlandeses, procedentes en su mayor parte de los oficios de la construcción, soportaban elevadas cargas de trabajo desde el principio de su carrera, sus colegas norteamericanos - empleados en el sector público- afrontaban las mayores cargas de trabajo en la etapa intermedia de su vida profesional.

Resumiendo los resultados de las investigaciones de los efectos moderadores de las distintas etapas de la carrera: la etapa inicial de ésta se caracteriza por un bajo nivel de compromiso con la organización, asociado a un elevado índice de rotación del personal, y por la presencia de estresores asociados a la percepción de problemas de salud y síntomas somáticos. Los resultados observados en la etapa intermedia son un tanto contradictorios: unas veces se produce una relación directa entre satisfacción en el trabajo y rendimiento; otras, esta relación es de signo inverso. En esta etapa, las demandas del trabajo y el escaso nivel de control del mismo estan relacionados con la frecuencia de los síntomas comunicados en determinadas categorías de trabajadores. En la fase final de la carrera profesional, el compromiso con la organización se correlaciona con un bajo nivel de absentismo y un mejor rendimiento. Los hallazgos relativos a la correlación entre los factores de estrés en el trabajo y la tensión se muestran incoherentes en esta última etapa. Existen, ciertamente, indicios de que una prevención efectiva contribuye a reducir los síntomas de tensión relacionada con el trabajo en la etapa final de la carrera.

\section{Actuaciones}

U nas medidas prácticas de ayuda a la gente para afrontar mejor las demandas específicas de cada una de las etapas de la carrera tendrían consecuencias beneficiosas. Especialmente útil sería la orientación profesional al inicio de la vida profesional. También 
se han recomendado las actuaciones orientadas a reducir los efectos negativos de la fase de estabilización de la carrera, ya que esta etapa puede resultar frustrante 0 , por el contrario, ofrecer la posibilidad de afrontar nuevas metas o de replantearse los objetivos personales (Weiner, Remer y R emer 1992). L os resultados de las exploraciones médicas realizadas en función de la edad de los trabajadores por los servicios de salud en el trabajo demuestran que los problemas de salud relacionados con el trabajo que provocan la disminución de la capacidad laboral se incrementan gradualmente y evolucionan cualitativamente con la edad. Así, mientras que en las dos primeras etapas de la carrera esos problemas se asocian a la necesidad de afrontar la sobrecarga de trabajo, hacia finales de la etapa intermedia y en la última fase de la carrera se complican progresivamente con la merma de las facultades psíquicas y de la salud física, circunstancias que ilustran la importancia de una intervención institucional precoz a escala individual (Lindström, Kaihilahti y Torstila 1988). Sin embargo, tanto en la investigación como en la actuación práctica es preciso tomar en consideración los patrones de movilidad y de rotación del personal, así como el rol que desempeña la propia profesión (y la situación de que se disfruta en la misma) en el desarrollo de la carrera personal.

FACTORES INDIVIDUALS

\section{- Patrones de COMPORTAMIENTO De LOSTIPOS A Y B}

\section{David Jenkins}

\section{Definición}

El patrón de comportamiento del Tipo A está constituido por una serie observable de comportamientos o una forma de vida que se caracterizan por un nivel considerable de hostilidad, competitividad, prisa, impaciencia, desasosiego, agresividad (a veces, enérgicamente reprimida), explosividad en el lenguaje y un elevado nivel de alerta acompañado de tensión muscular. Las personas con un fuerte comportamiento del Tipo A luchan contra la presión del tiempo y el reto de la responsabilidad (Jenkins 1979). El comportamiento del Tipo A no es un factor de estrés externo ni una reacción de tensión o incomodidad, sino, más bien, una forma de reaccionar. En el polo opuesto de este continuo se sitúan las personas del T ipo B, más relajadas, cooperadoras, uniformes en su ritmo de actividad y aparentemente más contentas de la vida y de quienes les rodean.

El continuo de comportamientos que van desde el T ipo A al B fue inicialmente estudiado y definido en 1959 por los cardiólogos $M$ eyer Friedman y R ay $\mathrm{H}$. Rosenman. A mbos definieron el Tipo A como típico de los varones jóvenes con cardiopatía isquémica.

La frecuencia e intensidad del comportamiento del Tipo A crecen a medida que las sociedades se industrializan y se hacen más competitivas y afanosas. Este tipo de comportamiento es más frecuente en las áreas urbanas que en las rurales, y entre el personal directivo y de ventas que entre los técnicos, los trabajadores manuales cualificados y los artistas, y su frecuencia es mayor entre las mujeres empresarias que en las amas de casa.

\section{Areas de investigación}

El comportamiento del Tipo A se ha estudiado en el campo de la psicología social y de la personalidad, la psicología industrial y de la organización, la psicofisiología, la enfermedad cardiovascular y la salud en el trabajo.

Las investigaciones realizadas en el campo de la psicología social y de la personalidad han arrojado considerable luz sobre el patrón de comportamiento del Tipo A como concepto psicológico importante. Las personas que obtienen una elevada puntuación en las medidas del Tipo A se comportan de forma congruente con la teoría del Tipo A. M uestran más impaciencia y agresividad en sus relaciones sociales y dedican más tiempo al trabajo que al ocio. Además, sus reacciones ante la frustración son más acusadas.
Las investigaciones que aplican el concepto del Tipo A en la psicología industrial y de la organización han incluido el estudio comparativo de diferentes profesiones y de las respuestas de los trabajadores al estrés en el trabajo. En situaciones de estrés externo similares, los trabajadores del Tipo A suelen manifestar mayor tensión física y emocional que los del T ipo B. Asimismo, suelen preferir los trabajos con altas demandas (comportamiento del tipo A 1990).

Rosenman y cols. (1975) fueron los primeros en informar del acusado aumento de la presión arterial y de los niveles de colesterol sérico y de catecolaminas en las personas del Tipo A, y esta observación ha sido confirmada posteriormente por muchos otros estudiosos. L os hallazgos de estas investigaciones demuestran que, aunque los niveles crónicos o básicos de estas variables fisiológicas suelen ser muy similares entre las personas de los Tipos A y B, las demandas del entorno, los problemas y las frustraciones generan reacciones mucho más acusadas en las del primer grupo que en las de este último. Las conclusiones de la literatura son un tanto incongruentes, debido, en parte, a que un mismo estímulo puede tener consecuencias fisiológicas distintas en los hombres y mujeres de distinta condición. Los estudios últimamente publicados se siguen decantando por los hallazgos positivos (Contrada y K rantz 1988).

La historia de los comportamientos de los Tipos A y B como factor de riesgo de cardiopatía isquémica ha seguido un curso común, consistente en un goteo seguido de un gran flujo de hallazgos positivos; a continuación, otro goteo que se transforma en un flujo mayor de hallazgos negativos y, finalmente, una intensa controversia (R eview Panel on Coronary-Prone Behavior and Coronary Heart Disease 1981). Una revisión de amplio espectro de la literatura actual pondría de manifiesto una mezcla de asociaciones positivas y de ausencia de asociación entre el comportamiento del Tipo A y la cardiopatía isquémica. El sentido general de estos hallazgos es que es más probable que el comportamiento del Tipo A se asocie positivamente a riesgo de cardiopatía isquémica:

1. en los estudios transversales y de casos-controles, y no en los estudios prospectivos;

2. en los estudios de poblaciones globales y grupos profesionales, y no en los estudios limitados a las personas con enfermedad cardiovascular o pertenecientes a otros grupos de riesgo de cardiopatía isquémica;

3. en las muestras de personas más jóvenes (menos de 60 años), y no en las poblaciones de más edad,

4. en los países que se encuentran aún en proceso de industrialización o que se hallan todavía en el cenit de su desarrollo económico. 
Lejos de poder descartarse como un factor de riesgo de cardiopatía isquémica, el patrón de comportamiento del Tipo A se debe estudiar en el futuro desde la hipótesis de que ese mayor riesgo se da en determinadas subpoblaciones y en entornos sociales muy concretos. Algunos hallazgos indican que la hostilidad puede ser el elemento más perjudicial del Tipo A.

U na novedad en este campo ha sido el estudio del comportamiento del Tipo A como factor de riesgo de lesiones y enfermedades leves y menos graves en grupos profesionales y de estudiantes. R esulta lógico presuponer que las personas agresivas e impacientes sufran más accidentes en el trabajo, los deportes y la carretera. Elander, West y French (1993) han demostrado empíricamente la certeza de tal aserto. M enos evidente resulta en el plano teórico la causa de que, en una extensa gama de sistemas fisiológicos, las enfermedades agudas leves sean más frecuentes entre las personas del $T$ ipo $A$ que en las del Tipo $B$; sin embargo, este ha sido el resultado obtenido en algunos estudios, como el de Suls y Sanders (1988). Al menos en algunos grupos, se ha podido determinar que el comportamiento del Tipo A se asociaba a un mayor nivel de riesgo de episodios leves de estrés emocional negativo. L as futuras investigaciones habrán de centrarse en la validez de estas asociaciones y los factores fisiológicos y psicológicos que subyacen en ellos.

\section{Métodos de medición}

Las primeras mediciones de los patrones de comportamiento de los T ipos A y B se realizaron en un contexto de investigación por el procedimiento de la entrevista estructurada (Structural Interview, SI). Se trata de una modalidad de entrevista clínica cuidadosamente planificada, compuesta por unas 25 preguntas que se formulan a distintas velocidades y con diferentes grados de provocación e intrusividad. El entrevistador precisa una formación especial para obtener la titulación que lo acredita para administrar e interpretar las entrevistas estructuradas, que, además, se suelen grabar para que puedan ser analizadas por otras personas que garanticen su fiabilidad. En el análisis comparativo de diversas medidas del comportamiento del Tipo A, la entrevista estructurada parece ser más válida para los estudios cardiovasculares y psicofisiológicos que los cuestionarios autoadministrados, aunque es poco lo que se sabe sobre su validez relativa en los estudios psicológicos y profesionales, dado que se usa mucho menos en esos contextos.

\section{Medidas autoadministradas}

La modalidad autoadministrada más conocida es la Encuesta de actividades de Jenkins (Jenkins Activity Survey, JAS), un cuestionario de elección múltiple, evaluado por ordenador. $\mathrm{H}$ a sido validada por comparación con la entrevista estructurada y con los criterios de cardiopatía isquémica presente y futura, así como una validez de constructo. La versión más utilizada es el Formulario $C$, un cuestionario de 52 elementos que Pshychological Corporation publicó en 1979 y que ha sido traducido a la mayoría de los idiomas europeos y asiáticos. La Encuesta consta de cuatro escalas: una escala general del Tipo A y escalas derivadas de análisis factoriales para la velocidad y la impaciencia, la identificación con el puesto de trabajo y la competitividad acentuada. La O rganización M undial de la Salud ha utilizado una versión abreviada de la escala del tipo A (13 elementos) en la realización de estudios epidemiológicos.

La Escala del Tipo A de Framingham (Framingham Type A Scale, FTAS) es un cuestionario de diez preguntas que ha demostrado su validez para la predicción de cardiopatías isquémicas futuras en varones y mujeres en el Framingham $\mathrm{H}$ eart Study (EE.UU.). A simismo, se ha utilizado internacionalmente en investigaciones cardiovasculares y psicológicas. EI análisis factorial la divide en dos factores, uno de los cuales se correlaciona con otras medidas del comportamiento del Tipo A, mientras que el otro se correlaciona con medidas de neuroticismo e irritabilidad.

La Escala de Clasificación de Bortner (Bortner Rating Scale, BRS) consta de catorce elementos, cada uno de los cuales adopta la forma de una escala analógica. En estudios posteriores se ha realizado un análisis de sus elementos y se ha logrado una mayor congruencia interna o un mayor índice de predictibilidad mediante la reducción de éstos a siete o doce. La E scala se ha utilizado ampliamente en traducciones internacionales. Aunque en el ámbito internacional se han desarrollado escalas complementarias del Tipo A, su aplicación se ha circunscrito en gran medida a las naciones en cuyos idiomas se han elaborado.

\section{Intervenciones prácticas}

D esde hace veinte 0 más años se intenta ayudar a las personas con rasgos muy acusados de comportamiento del Tipo A a cambiar hacia un comportamiento más cercano al del Tipo B. EI más importante de esos esfuerzos ha sido, probablemente, el realizado en el marco del Recurrent Coronary Prevention Project, desarrollado en el área de la bahía de San Francisco durante el decenio de 1980. El seguimiento a lo largo de varios años ha puesto de relieve los buenos resultados obtenidos con muchas personas y el hecho de que el índice de recurrencia de infarto de miocardio se redujo entre los destinatarios de estos effuerzos de suavización del comportamiento del Tipo A, respecto de las personas que sólo habían recibido consejo médico en materia cardiovascular (T horeson y Powell 1992).

Es difícil intervenir con éxito para modificar el patrón de comportamiento del Tipo A, debido a las múltiples ventajas que aporta a los sujetos, especialmente en el plano de la promoción profesional y las ganancias materiales. El programa en sí se debe diseñar cuidadosamente en función de criterios psicológicos eficaces, y los métodos de orientación colectiva se han revelado más eficaces que el consejo individual.

\section{RESISTENCIA}

\section{Suzanne C. Ouellette}

L as características de la resistencia se basan en una teoría existencial de la personalidad y permiten definirla como aquella actitud básica de una persona ante su lugar en el mundo que expresa simultáneamente su compromiso, control y disposición a responder ante los retos (K obasa 1979; K obasa, M addi y K ahn 1982). El compromiso se define como la propensión a comprometerse - en lugar de desmarcarse- en todo lo que se hace o se encuentra en la vida. Las personas comprometidas poseen un sentido existencial global que les permite encontrar significado e identificarse con las personas, los acontecimientos y las cosas del entorno. El control es la propensión a pensar, sentir y actuar como alguien influyente y no impotente frente a los distintos avatares de la vida. Las personas con sentido del control no tienen la pretensión ingenua de dirigir los acontecimientos y sus resultados, sino que, por el contrario, se sienten capaces de marcar una diferencia en el mundo utilizando su imaginación, sus conocimientos, sus habilidades y su capacidad de elección. El reto consiste en creer que el cambio y no la estabilidad es lo normal en la vida y que los cambios constituyen importantes incentivos para el crecimiento en lugar de amenazas a la seguridad. L ejos de ser unos aventureros temerarios, las personas con reto se muestran abiertas a las nuevas experiencias y poseen un grado de tolerancia hacia la ambigüedad que les permite mostrarse flexibles ante el cambio. 
Concebida inicialmente como reacción y correctivo de un sesgo pesimista de los estudios iniciales del estrés, en el que se hacía hincapié en la vulnerabilidad de las personas a ese problema, la hipótesis básica de la resistencia es que las personas que muestran elevados niveles de las tres características correlacionadas: compromiso, control y reto, están mejor dotadas para conservar su salud en situaciones de tensión que los individuos carentes de resistencia. L a resistencia como rasgo de la personalidad se caracteriza por un modo de reaccionar ante los hechos estresores de la vida que contribuye a reducir la tensión subsiguiente al estrés que es susceptible de provocar enfermedades somáticas y mentales.

El soporte fáctico inicial de la teoría de la resistencia provino de una serie de estudios retrospectivos y longitudinales de una extensa muestra de varones que ocupaban cargos intermedios y de alta dirección en una compañía telefónica del M edio 0 este de Estados Unidos en la época en que ésta se desgajó de American Telephone and Telegraph (ATT). Estos ejecutivos respondieron a una serie de cuestionarios anuales durante un período de cinco años, con el objeto de revisar las experiencias vitales estresoras en el trabajo y el hogar, la evolución de su salud física, los rasgos de personalidad, otros factores del trabajo, el apoyo social y los hábitos de salud. El hallazgo más significativo fue que, sometidos a acontecimientos y condiciones vitales altamente estresores, los que tenían un elevado nivel de resistencia eran mucho menos propenso a sufrir enfermedades somáticas que sus colegas con un bajo nivel de resistencia, resultado éste que se vio confirmado por los autoinformes de enfermedades y síntomas somáticos, y validados por las historias clínicas basadas en exploraciones médicas anuales. Estas investigaciones iniciales demostraron igualmente: a) la efectividad de la conjunción de la resistencia con el apoyo social y el ejercicio para proteger la salud física y mental; y b) la independencia de la resistencia, tanto de la frecuencia y gravedad de los acontecimientos vitales estresores, como de la edad, educación, estado civil y nivel laboral. Por último, el bagaje de conocimientos sobre la resistencia, logrado inicialmente como resultado de este estudio, favoreció la realización de nuevas investigaciones que demostraron la aplicabilidad general de los hallazgos sobre la resistencia a diversos grupos profesionales, como trabajadores de la compañía telefónica sin responsabilidades directivas, abogados y oficiales del Ejército de E stados U nidos (K obasa 1982).

A partir de los citados estudios iniciales, la teoría de la resistencia ha sido aplicada por numerosos investigadores que han trabajado en diversos contextos, tanto profesionales como de otro tipo, y que han aplicado un abanico de técnicas que oscilan desde los experimentos controlados hasta las investigaciones de campo de nivel más cualitativo (véanse distintas revisiones en M addi 1990; O rr y Westman 1990; O uellette 1993). Aunque la mayoría de estos estudios han servido, básicamente, para refrendar y ampliar la tesis original de la resistencia, en algunos casos se han impugnado los efectos moderadores de ésta y se han formulado críticas de las técnicas utilizadas en la medición de esa cualidad (Funk y Houston 1987; Hull, Van Treuren y Virnelli 1987).

Subrayando la capacidad individual para actuar correctamente en presencia de serios factores de estrés, los investigadores han confirmado los efectos positivos de la resistencia en numerosos grupos profesionales, incluidos, en diversas muestras obtenidas en Estados U nidos, conductores de autobuses, trabajadores de los servicios militares de asistencia a las víctimas de catástrofes aéreas, enfermeras empleadas en diversos contextos institucionales, profesores, personal en formación perteneciente a distintas profesiones, pacientes de enfermedades crónicas e inmigrantes asiáticos. En el ámbito internacional, se han realizado diversos estudios entre sendas muestras de empresarios japoneses y de reclutas de las fuerzas armadas israelíes. En ambos grupos se ha hallado una cierta asociación entre la resistencia y un menor nivel de problemas físicos y mentales y, con menor frecuencia, una significativa correlación entre los niveles de estrés y de resistencia que parece confirmar la función amortiguadora de la personalidad. Por otra parte, los hallazgos demuestran los efectos de la resistencia sobre la no-salud, como el rendimiento laboral y la satisfacción en el trabajo y también sobre "burnout". O tro importante estudio, realizado en su mayor parte sobre una muestra de alumnos de centros de enseñanza superior, ha confirmado la eficacia de los hipotéticos mecanismos a través de los cuales la resistencia surte sus efectos de protección de la salud. Estos estudios han puesto de relieve la influencia de la resistencia en la valoración individual del estrés (Wiebe y Williams 1992). I gualmente importantes a efectos de validación son los resultados de varios estudios menores que han aportado algunas evidencias de la correlación entre la activación psicofisiológica y la resistencia, así como de la relación entre la resistencia y diversos comportamientos de protección de la salud.

La práctica totalidad de las pruebas empíricas de una asociación entre resistencia y salud se basan en los datos generados por cuestionarios autoadministrados. En las publicaciones suelen mencionarse sobre todo el cuestionario mixto utilizado en la prueba prospectiva original de la resistencia y algunos otros derivados de ella. El cuestionario mixto, ajustado a la definición genérica de la resistencia que aparece al principio del presente artículo, se compone de preguntas extraídas de diversas pruebas de personalidad acreditadas, entre las que se incluyen InternalExternal L ocus of Control Scale, de Rotter (Rotter, Seeman y Liverant 1962), California Life Goals Evaluation Schedules, de $\mathrm{H}$ ahn ( $\mathrm{H}$ ahn 1966), Alienation versus Commitment Test, de $M$ addi ( $M$ addi, K obasa y Hoover 1979), y Personality Research Form, de Jackson (Jackson 1974). Los trabajos más recientes de desarrollo de cuestionarios han culminado en la elaboración de la Encuesta de Puntos de Vista Personales, o como M addi (1990) la denomina "la prueba de la resistencia de tercera generación". En este cuestionario se ha procurado subsanar muchos de los defectos señalados en el original, como el predominio de preguntas negativas y la inestabilidad de la estructuración de los factores de la resistencia. Por otra parte, algunos estudios realizados en Estados Unidos y el Reino U nido sobre muestras de trabajadores adultos han generado hallazgos significativos sobre la fiabilidad y validez de la medida de la resistencia. Sin embargo, no se han resuelto todos los problemas; así, en algunos informes se ha puesto de manifiesto la escasa fiabilidad intrínseca del componente de respuesta a los retos. 0 tra crítica va más allá del problema de la medición y suscita la cuestión conceptual de si la resistencia se debe interpretar en todos los casos como un fenómeno unitario y no como una realidad múltiple, integrada por componentes diferenciados que, en determinadas situaciones de estrés, pueden asociarse con la salud al margen de los demás. El futuro reto para los estudiosos de la resistencia consiste en precisar su determinación empírica y conservar, al mismo tiempo, la riqueza humana y conceptual de esta noción.

$\mathrm{Si}$ bien Maddi y Kobasa (1984) describen las experiencias infantiles y familiares que sustentan el desarrollo de la resistencia personal, éstos y otros estudiosos se han centrado en la definición de las intervenciones destinadas a fortalecer la resistencia de las personas adultas al estrés. D esde una perspectiva existencial, la personalidad se aprecia como algo que el individuo construye continuamente, y el entorno social de la persona, incluido su entorno de trabajo, se valora como positivo o negativo para el mantenimiento de la resistencia. M addi (1987 y 1990) ha aportado la descripción y la justificación más coherentes de las estrategias de actuación sobre la resistencia. En efecto, expone una combinación de estrategias de focalización, reconstrucción 
situacional y automejora compensatoria que el autor ha utilizado con éxito en sesiones de pequeños grupos para reforzar la resistencia y reducir los efectos negativos, tanto físicos como mentales, del estrés en el trabajo.

\section{- Autoestima}

John M. Schaubroeck

Un bajo nivel de autoestima (self-esteem, SE) se ha considerado desde hace mucho tiempo como uno de los factores causantes de trastornos fisiológicos y psicológicos (Beck 1967; R osenberg 1965; Scherwitz, Berton y Leventhal 1978). Desde el decenio de 1980, los investigadores de las organizaciones han venido estudiando la función moderada de la autoestima en la relación entre los estresores en el trabajo y los resultados individuales. Este proceso refleja el creciente interés de los investigadores por las medidas que hacen a una persona más o menos vulnerable al estrés.

L a autoestima se define como "el carácter favorable de la autoevaluación de las características individuales" (Brockner 1988). Brockner $(1983,1988)$ ha formulado la hipótesis de que las personas con baja autoestima (low SE s) suelen ser más vulnerables a los eventos del entorno que las que tienen un nivel elevado de autoestima. Brockner (1988) aporta numerosos indicios de que esta "hipótesis de plasticidad" explica diversos procesos desarroIlados en las organizaciones. En el principal estudio realizado de esta hipótesis se ha verificado la función moderadora de la autoestima en la relación entre los estresores vinculados a los roles asignados (conflicto de roles y ambigüedad de roles) y la salud y las actitudes afectivas. EI conflicto de roles (desacuerdo entre los roles asignados a una persona) y la ambigüedad de roles (falta de claridad del contenido del rol propio) suelen ser provocados en gran medida por circunstancias externas a la persona y, por consiguiente, según la hipótesis de la plasticidad, las personas con un elevado nivel de autoestima deben ser menos vulnerablesa ellos.

En un estudio realizado entre 206 enfermeras de un importante hospital del sudoeste de Estados U nidos, Mossholder, Bedeian y Armenakis (1981) hallaron que los autoinformes sobre ambigüedad de roles se asociaban inversamente a la satisfacción en el puesto de trabajo en las personas con bajo nivel de autoestima, pero no en las que tenían una elevada autoestima. Pierce y cols. (1993) utilizaron un criterio de medición basado en la organización de la autoestima para verificar la hipótesis de la plasticidad en 186 trabajadores de una empresa norteamericana de suministro de servicios públicos. En la muestra, la ambigüedad y el conflicto de rol sólo se relacionaban inversamente con la satisfacción en el puesto de trabajo entre los que tenían un bajo nivel de autoestima. Se pudo establecer una correlación similar con la medida basada en la organización de la autoestima respecto a la sobrecarga de rol, el apoyo del entorno y el apoyo de los supervisores

En los estudios anteriormente citados, la autoestima se consideraba un sucedáneo (esto es, un criterio de medición alternativo) de la autoevaluación de la competencia en el trabajo. Ganster y Schaubroek (1991a) especulan con la posibilidad de que, la función moderadora de la autoestima sobre los efectos de los estresores vinculados a los papeles asignados obedezca a la falta de confianza que las personas con bajo nivel de autoestima experimentan en su capacidad para influir en su entorno social, con el consiguiente debilitamiento de la capacidad de afrontar dichos estresores. En su estudio de una muestra de 157 bomberos norteamericanos, los autores descubrieron que el conflicto de roles sólo estaba relacionado positivamente con los trastornos somáticos de salud entre los sujetos con un bajo nivel de autoestima. Esta correlación no se manifestaba en la ambigüedad de roles.

En un análisis independiente de los datos generados por la muestra de enfermeras citadas en su primer estudio (M ossholder, Bedeian y Armenakis 1981), los autores (1982) hallaron que la interacción dentro del grupo de compañeras se relacionaba negativamente de forma más acusada con la tensión comunicada por los sujetos entre las personas con bajo nivel de autoestima que entre las que tenían una autoestima elevada. Del mismo modo, las personas con bajo índice de autoestima que informaban de una elevada interacción con el grupo de compañeras se mostraban menos inclinadas a abandonar la organización que los individuos con un nivel elevado de autoestima que informaban de un alto grado de interacción con el grupo de compañeras.

En la literatura se exponen diversas medidas de la autoestima. Probablemente, la más utilizada es el cuestionario de diez elementos desarrollado por Rosenberg (1965), que se utilizó en el estudio de Ganster y Schaubroek (1991a). M ossholder y cols. (1981, 1982) utilizaron la escala de autoconfianza Adjective Check List, desarrollada por Gough y Heilbrun (1965). La medida de la autoestima centrada en la organización que utilizaron Pierce y cols. (1993) era un instrumento de diez elementos desarrollado por Pierce y cols. (1989).

Los resultados de las investigaciones indican que la sensación de bienestar físico y la satisfacción de las personas con bajo nivel de autoestima se pueden mejorar, bien reduciendo la presencia de los estresores de rol, bien fomentando su nivel de autoestima. En un experimento aleatorio de campo, la actividad de clarificación de los roles en un contexto de desarrollo de la organización (comunicación entre supervisor y subordinado dirigida a clarificar el rol de este último y a conciliar las eventuales expectativas incompatibles), combinada con el establecimiento de un diagrama de responsabilidades (previa negociación y clarificación de los roles de los diversos departamentos), demostró su eficacia en la reducción de los conflictos de roles y de la ambigüedad de los roles (Schaubroeck y cols. 1993). Sin embargo, no parece probable que muchas organizaciones puedan y quieran realizar este ingente esfuerzo a menos que el estrés vinculado al rol se considere particularmente grave.

Brockner (1988) formuló una serie de métodos para que las organizaciones puedan fomentar la autoestima de su personal. Los sistemas de supervisión de las empresas constituyen uno de los campos con mayores perspectivas de mejora. En efecto, el ofrecimiento de una retroinformación de evaluación del rendimiento centrada más en los comportamientos que en las peculiaridades, el suministro de información descriptiva con resúmenes valorativos y la elaboración en un marco participativo de planes de mejora continua son sistemas menos propensos a repercutir negativamente en la autoestima de los trabajadores y pueden, incluso, reforzar ésta en algunos de ellos, que pueden así descubrir nuevos cauces para mejorar su rendimiento. I déntica importancia revisten las intervenciones de refuerzo positivo de las actuaciones positivas. Ciertos métodos de formación, como el dominio de destrezas (Wood y Bandura 1989), permiten igualmente el desarrollo de unas percepciones positivas de eficacia respecto a cada nueva tarea, lo cual constituye la base de la autoestima en el contexto de la organización.

\section{LOCUS DE CONTROL}

Lawrence R. M urphy y Joseph J. H urrell, Jr. La expresión "locus de control" (locus of control, LO C) designa un rasgo de la personalidad que refleja la creencia general de que las experiencias vitales están regidas, bien por los actos propios (locus 
de control interno), bien por influencias externas (locus de control externo). Las personas que tienen un locus de control interno se consideran capaces de controlar los hechos y circunstancias de la vida, incluidos los refuerzos asociados, esto es, los resultados que se perciben como recompensas de los propios comportamientos y actitudes. Por el contrario, las que tienen un locus de control externo creen que ejercen escaso control sobre los hechos y circunstancias vitales y atribuyen los refuerzos a poderosos factores extrínsecos o a la suerte.

La teoría del locus de control surgió de la teoría del aprendizaje social de Rotter (1954). Para medir el locus de control, Rotter (1966) desarrolló la "escala interna-externa (I-E)", que se ha venido aplicando en la mayoría de los estudios. N o obstante, los investigadores han cuestionado el carácter unidimensional de esta escala, y algunos aseguran que el locus de control es bidimensional (por ejemplo, un control personal y un control por el sistema social), mientras que para otros, es tridimensional (eficacia personal, ideología de control y control político). Las escalas últimamente desarrolladas para cuantificar el locus de control 0 bien son multidimensionales, o bien sirven para evaluar el locus de control en determinados campos, como la salud o el trabajo (H urrell y M urphy 1992).

Una de las conclusiones más reiteradas y generalizadas en la literatura general dedicada a las investigaciones es la asociación entre el locus de control externo y la mala salud física y mental (Ganster y Fusilier 1989). En varios estudios realizados en entornos laborales se han obtenido conclusiones similares; los trabajadores con un locus de control externo son más propensos a manifestar más agotamiento psíquico, insatisfacción en el puesto de trabajo y estrés, así como niveles inferiores de autoestima (K asl 1989). Estudios recientes indican que el locus de control modera la asociación entre los estresores vinculados al rol (ambigüedad de rol y conflicto de rol) y los síntomas de estrés negativo (C vetanovski y Jex 1994; Spector y 0 'C onnell 1994).

Sin embargo, varios factores contribuyen a dificultar la interpretación de los estudios que vinculan las creencias sobre el locus de control con los problemas de salud (K asl 1989). Por una parte, se puede producir un cierto solapamiento conceptual entre las medidas de la salud y las escalas del locus de control. En segundo lugar, puede existir un factor de sesgo, como la afectividad negativa, que provoque la asociación. Por ejemplo, en el estudio de Spector y $\mathrm{O}^{\prime} \mathrm{C}$ onnell (1994), las creencias sobre el locus de control se correlacionan más acusadamente con la afectividad negativa que con la percepción de autonomía en el trabajo y no se correlaciona con los síntomas de salud física. En tercer lugar, el sentido de la relación causal es ambiguo, pues es posible que la experiencia de trabajo modifique las creencias sobre el locus de control. Por último, en otros estudios no se ha puesto de relieve ningún efecto moderador del locus de control sobre el estrés en el trabajo ni sobre los resultados en materia de salud (H urrell y M urphy 1992).

No ha sido estudiada en profundidad la forma en que el locus de control modera la relación entre el estrés en el trabajo y la salud. U no de los métodos propuestos implica el recurso a unos comportamientos reactivos más eficaces y centrados en los problemas por parte de los individuos que tienen un locus de control interno. En cambio, los sujetos con un locus de control externo deben aplicar menos técnicas reactivas de resolución de problemas, puesto que consideran que los acontecimientos de la vida quedan fuera de su control. Existen indicios de que las personas con un locus de control interno utilizan más comportamientos reactivos centrados en las tareas y menos comportamientos reactivos centrados en las emociones que quienes poseen un locus de control externo (Hurrell y Murphy 1992). $\mathrm{O}$ tros hallazgos indican que, en las situaciones que se consideran modificables, las personas con un locus de control interno manifiestan un nivel elevado de reacciones orientadas a la resolución de problemas y bajos niveles de represión emocional, mientras que el patrón de comportamiento de los individuos con un locus de control externo es inverso. Es preciso tener presente que muchos estresores en el trabajo no son directamente controlables por el trabajador y que cualquier intento de modificarlos puede contribuir a empeorar los síntomas de estrés (Hurrell y M urphy 1992).

0 tro medio de lograr que el locus de control influya en la relación entre el estrés y la salud es a través del apoyo social, que constituye otro elemento moderador de la asociación entre estrés y salud. Fusilier, Ganster y M ays (1987) hallaron que el locus de control y el apoyo social determinan conjuntamente el modo de reaccionar de los trabajadores frente al estrés en el trabajo, y C ummins (1989) señaló que el apoyo social amortigua los efectos del estrés en el trabajo únicamente en los individuos con un locus de control interno y sólo si el apoyo se relaciona con el trabajo.

Si bien la cuestión del locus de control es un tema apasionante que ha generado muchas investigaciones, existen serios problemas metodológicos que afectan a los estudios en este campo y que es preciso abordar. Por ejemplo, la naturaleza caracteriológica (invariable) de las creencias sobre el locus de control ha sido cuestionada por algunas investigaciones que indican que las personas adoptan una orientación más externa a medida que envejecen y acumulan experiencias vitales como el desempleo. A demás, el locus de control puede ser el fruto de la medición de las percepciones del trabajador sobre el control del trabajo, en lugar de una característica permanente del trabajador. U n último grupo de estudios ha puesto de relieve la posibilidad de que las escalas del locus de control no sirvan únicamente para medir las creencias sobre el control, sino también la tendencia a adoptar maniobras defensivas y a mostrar ansiedad o propensión a los comportamientos del Tipo A (H arrell y M urphy 1992).

Por último, es poco lo que se ha investigado sobre la influencia del locus de control sobre la elección de profesión y sobre los condicionamientos recíprocos entre el locus de control y las percepciones del trabajo. Por lo que respecta a la cuestión primeramente citada, es posible que la diversa proporción en que distintas profesiones están presentes entre los individuos con un locus de control "interno" y "externo" demuestre el influjo del locus de control en la elección profesional (H urrell y M urphy 1992). Por otra parte, tales diferencias pueden reflejar la exposición al entorno de trabajo, del mismo modo que se considera que este último coadyuva al desarrollo del patrón de comportamiento del Tipo A. U na última posibilidad es que las diferencias profesionales en el locus de control se deban a un fenómeno de "deriva", esto es, a los movimientos de entrada y salida de los trabajadores de algunas profesiones por causa de la insatisfacción en el puesto de trabajo, los problemas de salud y los deseos de progreso.

En resumen, la literatura no ofrece una imagen nítida de la influencia de las creencias acerca del locus de control sobre las relaciones entre el estrés en el trabajo y la salud. Incluso en los campos en que la investigación ha llegado a conclusiones más o menos coherentes, el sentido de esta asociación se ve un tanto difuminado por influencias contradictorias (K asl 1989). Se precisan estudios en mayor profundidad para dar estabilidad a la teoría del locus de control y determinar los mecanismos y vías a través de los cuales el locus de control influye en las percepciones de los trabajadores y en su salud física y mental. LoS componentes de esta vía deben reflejar tanto la interacción del locus de control con otras características del trabajador como la interacción entre las creencias sobre el locus de control y los factores del entorno de trabajo, incluido el condicionamiento 
recíproco entre el entorno de trabajo y esas creencias. Los futuros estudios darán resultados menos ambiguos si incorporan medidas de las características personales asociadas (como el comportamiento del Tipo A o la ansiedad) y en ellos se utilizan criterios de medición específicos del ámbito del locus de control (como el trabajo).

\section{ESTILOS DE AFRONTAMIENTO}

Ronald J. Burke

Se ha definido el afrontamiento (coping) como los "esfuerzos por reducir los efectos negativos del estrés sobre el bienestar individual" (Edwards 1988). El afrontamiento, al igual que el propio estrés en el trabajo, es un proceso complejo y dinámico. Se desencadena por la percepción de determinadas situaciones como peligrosas, perjudiciales o generadoras de ansiedad (esto es, por la experiencia de estrés). Es una variable de diferenciación individual que modera la relación entre el estrés y los resultados del mismo.

Los distintos estilos de afrontamiento comprenden combinaciones caracteriológicas de pensamientos, creencias y comportamientos resultantes de la experiencia de estrés y pueden manifestarse independientemente del tipo de estresor. Un estilo de afrontamiento es una variable de disposición. Son sumamente estables en el tiempo y en distintas situaciones y, aunque influidas por los rasgos de la personalidad, son distintos de ellos. La distinción entre los dos conceptos reside en el plano de la generalidad o del nivel de abstracción. Ejemplos de estilos de afrontamiento del estrés, definidos en términos muy generales, son el monitor-atemperante (M iller 1979) y el represor-sensibilizador (H ouston y H odges 1970). Las diferencias individuales de personalidad, edad, experiencia, género, capacidad intelectual y estilo cognitivo influyen en la forma en que una persona afronta el estrés. En definitiva, son el resultado de la experiencia previa y del conocimiento adquirido.

Shanan (1967) ofrece una primera visión de lo que denomina estilo de afrontamiento adaptativo. EI "conjunto de respuestas" correspondiente se caracteriza por cuatro ingredientes: la disponibilidad de energía directamente enfocada a las posibles fuentes del problema; una distinción nítida entre los acontecimientos internos y externos a la persona; el enfrentamiento en lugar de la evitación de las dificultades externas; y el equilibrio de las demandas externas con las necesidades propias. Análogamente, Antonovsky (1987) afirma que, para ser eficaz, la persona debe estar motivada para el afrontamiento, haber clarificado la naturaleza y las dimensiones del problema y la realidad en que se produce, y haber seleccionado los recursos más adecuados al problema planteado.

La clasificación tipológica más común (Lazarus y Folkman 1984) distingue entre el estilo de afrontamiento centrado en los problemas (que incluye la búsqueda de información y la resolución de problemas) y el centrado en las emociones (que incluye la expresión y la regulación de las emociones). Ambos se complementan en ocasiones con un tercero, el estilo centrado en la valoración (cuyos componentes son: denegación, aceptación, comparación social, redefinición y análisis lógico).

M oos y Billings (1982) distinguen los estilos de afrontamiento siguientes:

- Activo-cognitivo. La persona procura controlar su valoración de la situación de estrés.

- Activo-de comportamiento. Implica un comportamiento directamente relacionado con la situación de estrés.

- D e evitación. La persona evita enfrentarse al problema.
M ás recientemente, G reenglas (1993) ha definido un estilo de afrontamiento denominado social, que integra factores sociales e interpersonales con factores cognitivos. $\mathrm{La}$ autora pone de relieve en su estudio la existencia de una relación significativa entre diversas clases de apoyo social y estilos de afrontamiento (como el centrado en los problemas y el centrado en las emociones). Las mujeres - que por regla general poseen una capacidad comparativamente mayor de interacción personalrecurren en mayor medida al estilo social.

Aún, se podría añadir otro estilo de afrontamiento: el preventivo, sobre el que existe copiosa literatura que en otro tiempo se consideraba al margen de esta cuestión y en la que se abordan los estilos de vida saludables (Roskies 1991). Wong y Reker (1984) indican que el estilo de afrontamiento preventivo busca favorecer el propio bienestar y reducir el riesgo de futuros problemas. Comprende actividades como el ejercicio físico y la relajación, así como el desarrollo de hábitos de alimentación y de sueño correctos, la planificación, la administración del tiempo y destrezas de apoyo social.

0 tro estilo de afrontamiento, que se ha definido como un aspecto general de la personalidad (Watson y Clark 1984), implica los conceptos de afectividad negativa (NA) y de afectividad positiva (PA). Las personas con una elevada afectividad negativa acentúan los aspectos negativos al evaluarse a sí mismas y al evaluar a los demás y a su entorno global, y muestran mayores niveles de estrés negativo. En cambio, las que poseen una elevada afectividad positiva realzan los aspectos positivos al evaluarse a sí mismas y al valorar a los demás y al mundo que les rodea. Presentan niveles inferiores de estrés negativo.

Estas dos actitudes pueden moldear la percepción personal del número e importancia tanto de los posibles estresores como de las posibles respuestas de afrontamiento (esto es, la percepción individual tanto de los recursos disponibles como de las estrategias de afrontamiento aplicables). Por consiguiente, las personas con una elevada afectividad negativa perciben la disponibilidad de un menor número de recursos y se muestran más propensas a utilizar estrategias ineficaces (derrotistas) - como la liberación de emociones, la evitación y la desvinculación- y menos predispuestas a la aplicación de estrategias más eficaces (como la acción directa y la reformulación cognitiva). Las personas con una elevada afectividad positiva confían más en sus recursos de afrontamiento y aplican estrategias más productivas.

El concepto del sentido de la coherencia (SO C) desarrollado por Antonovsky $(1979,1987)$ se solapa en considerable medida con la afectividad positiva. El autor define el sentido de la coherencia como una visión global del mundo como algo comprensible y significativo. Esta actitud permite al sujeto centrarse inicialmente en la situación concreta, para luego abordar el problema y las emociones asociadas al mismo. Las personas dotadas de un elevado sentido de la coherencia poseen la motivación y los recursos cognitivos precisos para seguir los comportamientos más idóneos para resolver el problema. A simismo, tienen una mayor capacidad para comprender la importancia de las emociones, para experimentarlas y controlarlas y para asumir la responsabilidad de su situación en lugar de culpar a los demás o proyectar en ellos sus propias percepciones. Numerosos estudios han corroborado la tesis de Antonovsky.

Los estilos de afrontamiento se pueden describir haciendo referencia a las dimensiones de complejidad y flexibilidad (Lazarus y Folkman 1984). Las personas que aplican estrategias variadas poseen un estilo de afrontamiento complejo, y las que prefieren una única estrategia reflejan un estilo simple. Q uienes aplican la misma estrategia en todas las situaciones tienen un estilo rígido, y quienes utilizan distintas estrategias en situaciones idénticas o diferenciadas hacen gala de un estilo flexible. Este último es probadamente más eficaz que el anterior. 
Los estilos de afrontamiento se evalúan, bien mediante cuestionarios autoadministrados, bien indagando de los sujetos, en entrevistas no estructuradas, cómo afrontan un determinado estresor. El cuestionario desarrollado por Lazarus y Folkman (1984), denominado "Ways of Coping Checklist", es el más utilizado para medir los estilos de afrontamiento centrados en los problemas y en las emociones. Por su parte, Dewe (1989) ha utilizado frecuentemente en sus investigaciones descripciones realizadas por los propios sujetos de las estrategias de afrontamiento que aplican.

Existen varias formas de intervención práctica en relación con los estilos de afrontamiento. En la mayoría de los casos, se aplican programas de formación y educación en los que se transmite a los participantes la información necesaria - combinada, en ocasiones, con ejercicios de autoevaluación- para examinar tanto su estilo preferido de afrontamiento como otros estilos alternativos y su utilidad respectiva. Aunque dicha información suele tener una acogida favorable entre sus destinatarios, no está demostrada su utilidad para ayudarles a afrontar los estresores de la vida real. De hecho, en los escasos estudios dedicados a los estilos de afrontamiento individual (Shinn y cols. 1984; Ganster y cols. 1982) se ha puesto de relieve la escasa utilidad práctica de esos programas educativos, particularmente en los casos en los que se ha realizado un seguimiento (M urphy 1988).

M atteson e I vancevich (1987) describen un estudio en el que se examinan los estilos de afrontamiento en el contexto de un programa más extenso de formación para la gestión del estrés. Se procuran mejoras en tres tipos de destrezas de afrontamiento: cognitivas, interpersonales y de resolución de problemas. Las habilidades de afrontamiento se centran en los problemas o en las emociones. Al primer grupo pertenecen las destrezas de resolución de problemas, de administración del tiempo, de comunicación y habilidades sociales, las de asertividad, los cambios del estilo de vida y las medidas directamente dirigidas a modificar las demandas del entorno. El objetivo de las destrezas centradas en las emociones consiste en aliviar el estrés negativo y facilitar el control de las emociones. Entre ellas figuran las de denegación, de expresión de los sentimientos y de relajación.

En la preparación del presente artículo se ha contado con la colaboración de la Escuela de Estudios A dministrativos de la U niversidad de York.

\section{APOYO SOCIAL}

\section{Wayne Corneil}

A mediados del decenio de 1970, los profesionales de la salud pública y, más concretamente, los epidemiólogos "descubrieron" la noción del apoyo social al estudiar las relaciones causales entre estrés, mortalidad y morbilidad (Cassel 1974; Cobb 1976). En los últimos diez años se ha producido un impacto en la literatura relativa al concepto de apoyo social en relación con el estrés relacionado con el trabajo. En cambio, en la psicología, el concepto de apoyo social ya se había incorporado plenamente a la práctica clínica. La terapia centrada en el cliente de Rogers (1942), de enfoque incondicionalmente positivo, constituye, básicamente, un método de apoyo social. En la pionera obra de Lindeman (1944) sobre la gestión del sufrimiento se subraya la función esencial del apoyo en la moderación de las crisis provocadas por la muerte de personas allegadas. En el modelo de Caplin (1964) de psiquiatría comunitaria preventiva se destaca la importancia de los grupos comunitarios y de apoyo.

Cassel (1976) adaptó el concepto de apoyo social a la teoría de la salud pública como medio de explicación de las diferencias observadas en algunas enfermedades que se consideraban relacionadas con el estrés. El autor quería averiguar las causas de que algunos individuos fuesen más resistentes al estrés que otros. La teoría de que el apoyo social fuese un elemento del proceso causal de las enfermedades parecía plausible, ya que Cassel había observado que tanto las personas como los animales que experimentaban estrés en compañía de "semejantes significativos" parecían experimentar menos consecuencias adversas que los individuos aislados. Cassel aseguró que el apoyo social podía actuar como elemento de protección contra el estrés.

Cobb (1976) amplió este concepto al observar que la simple presencia de otra persona no supone un apoyo social, añadiendo que se precisa un intercambio de "información", de la que identificó tres categorías:

- información que induce a la persona a sentirse querida o cuidada (apoyo emocional);

- información que produce la sensación de ser estimado y valorado (apoyo de la estima),

- información que fomenta el sentimiento de pertenencia a un sistema de intercomunicación y de obligaciones recíprocas.

Cobb observa que las personas que sufren episodios graves con carencia de apoyo social son diez veces más propensas a sufrir depresión, e indica que alguna forma de relación íntima o de apoyo social protege contra los efectos de las reacciones de estrés. Asegura igualmente que el apoyo social funciona a lo largo de la vida del sujeto y que afecta a diversas experiencias vitales, como el desempleo, las enfermedades graves y la pérdida de seres queridos. Cobb cita numerosos estudios, muestras, métodos y resultados como prueba fehaciente de que, si bien el apoyo social es un factor común en la modificación del estrés, no constituye por sí solo una panacea contra sus efectos.

Según Cobb, el apoyo social incrementa la capacidad de afrontamiento (manipulación del entorno) y facilita la adaptación (cambio autoinducido para mejorar la adaptación de la persona al entorno). Advierte, no obstante, que la mayoría de los estudios se centran en los estresores agudos y no permiten generalizar sobre la capacidad protectora del apoyo social frente a los efectos de los estresores crónicos o del estrés traumático.

En los años transcurridos desde la publicación de estos primeros estudios, los investigadores han dejado de valorar el apoyo social como un concepto unitario y se han esforzado por conocer los componentes del estrés social y del apoyo social.

$\mathrm{H}$ irsh (1980) enuncia cinco posibles elementos integrantes del apoyo social:

- apoyo emocional: cuidados, comodidad, amor, afecto y comprensión;

- estímulo: elogio, cumplidos; esto es, la medida en que la persona se siente alentada por quienes la ayudan a hacer acopio de valor, a albergar esperanzas, o a sobreponerse;

- asesoramiento: información útil para la solución de problemas; esto es, la medida en que la persona se considera informada;

- compañía: el tiempo pasado con la persona que presta ayuda; esto es, la medida en que el individuo no se siente solo,

- ayuda tangible: recursos materiales, como dinero o ayuda en la realización de las tareas; esto es, la medida en que la persona se siente aliviada de las cargas.

H ouse (1981) utiliza otro marco de referencia para el análisis del apoyo social en el contexto del estrés relacionado con el trabajo:

- emocional: empatía, cuidados, amor, confianza, estima o muestras de interés; 
- evaluativo: información aplicable a la autoevaluación; retroinformación proporcionada por terceros que resulte válida para la afirmación personal;

- informativo: sugerencias, consejos o información de utilidad para la solución de problemas,

- instrumental: asistencia directa en forma de dinero, tiempo o trabajo.

Para H ouse, el apoyo emocional es la forma más importante de apoyo social. En el lugar de trabajo, el apoyo de los supervisores constituye el factor principal, seguido del apoyo de los compañeros. Tanto la estructura y organización de la empresa como la naturaleza concreta de los puestos de trabajo existentes pueden contribuir a enriquecer o empobrecer la capacidad de prestar apoyo. H ouse halló que un mayor grado de especialización de las tareas y de división del trabajo da lugar a un mayor aislamiento de las actividades laborales y reduce las posibilidades de recibir apoyo.

El estudio dedicado por Pines (1983) a la situación de "burnout", concepto que se examina en otra parte de este mismo capítulo, muestra que el nivel de apoyo social en el trabajo es inversamente proporcional al de dicha sensación. El autor identifica seis aspectos significativos diferenciados del apoyo social que pueden modificar el fenómeno considerado. Los aspectos más destacados son: escucha, estímulo, asesoramiento, compañía y ayuda tangible.

Como se deduce de los anteriores análisis de los modelos desarrollados por varios autores, a pesar de los esfuerzos de la investigación por definir el concepto de apoyo social, no existe un consenso generalizado en torno a los componentes precisos del concepto, si bien se evidencia un considerable solapamiento entre los modelos.

\section{Interacción entre el estrés y el apoyo social}

Aunque existe una copiosa literatura dedicada al estrés y al apoyo social, subsiste aún una considerable discrepancia en torno a los mecanismos de interacción del estrés y el apoyo social. Un debate ya clásico es el de si el apoyo social tiene una influencia directa 0 indirecta en la salud.

\section{E fecto central/ efecto directo}

El apoyo social puede surtir un efecto directo o central al actuar de barrera frente a los efectos de un estresor. U n sistema de apoyo social puede suministrar la información o la retroinformación precisa para superar el estresor, y aportar al sujeto los recursos necesarios para reducir la intensidad del estrés. Asimismo, la autopercepción personal puede quedar moderada por la pertenencia a un grupo que aporta al sujeto confianza en sí mismo y una sensación de dominio y destreza que se traduce en un cierto sentido de control del entorno. Este fenómeno subyace en las teorías de Bandura (1986) sobre el control personal como moderador de los efectos del estrés. Parece existir un umbral mínimo de la magnitud de apoyo social precisa para gozar de buena salud, y todo incremento del nivel de apoyo social por encima de ese mínimo tiene menos importancia. Si se estima que el apoyo social surte un efecto directo - o central -, resulta posible elaborar una escala para medirlo (Cohen y Syme 1985; G ottlieb 1983).

Sin embargo, Cohen y Syme (1985) también aducen que una explicación alternativa a la consideración del apoyo social como efecto central es que, en lugar de ser el apoyo social por sí solo lo que contribuye a mejorar la salud, el aislamiento, o la falta de apoyo social, produce quebrantos de salud. Esta disyuntiva no ha sido resuelta. G ottlieb suscita la cuestión de lo que sucede cuando el estrés provoca la propia exclusión de la red social, como puede ocurrir en caso de catástrofe, accidente grave o pérdida del puesto de trabajo. Este efecto no se ha cuantificado aún.

\section{Amortiguación/ efecto indirecto}

Según la teoría de la amortiguación, el apoyo social media entre el estresor y la reacción a éste para reducir sus efectos. L a amortiguación puede, o bien modificar la percepción individual del estresor y así reducir su potencia, o bien reforzar la capacidad de afrontamiento personal. El apoyo social puede traducirse en una ayuda material en situaciones de crisis o propiciar los estados de ánimo precisos para generar respuestas adaptativas. Por último, puede constituir un factor modificador del estrés que contribuye a tranquilizar el sistema neuroendocrino y reducir la reactividad de la persona al estresor.

Pines (1983) observa que la dimensión relevante del apoyo social podría residir en el hecho de compartir una realidad social. Gottlieb indica que el apoyo social puede contrarrestar los sentimientos autorrecriminatorios y de temor de ser personalmente responsables de los problemas. La interacción con un sistema de apoyo social puede propiciar la disipación de los temores y coadyuvar al restablecimiento de una identidad social significativa.

\section{Otras cuestiones teóricas}

$\mathrm{H}$ asta ahora, el apoyo social se ha venido valorando en la investigación como un factor definido y estático. Aunque se ha suscitado la cuestión de su evolución en el tiempo, existe escasas pruebas fácticas del horizonte temporal del apoyo social (Gottlieb 1983; Cohen y Syme 1985). El apoyo social es, por supuesto, un proceso tan fluido como los estresores contra los que actúa. De hecho, varía a lo largo de la trayectoria vital del individuo, y se puede modificar también a corto plazo por efectos de algún hecho especialmente estresor (Wilcox 1981).

Es probable que el sentido real de esa fluidez consista en que el apoyo social cumple distintas funciones en el curso de las diferentes fases de desarrollo de un proceso o durante las diversas fases de una crisis. Por ejemplo, al inicio de una crisis, la información de apoyo puede ser más importante que la ayuda material. La fuente, la intensidad y el tiempo de prestación del apoyo constituyen otras tantas variables. Es preciso reconocer la correlación entre estrés y apoyo social. Ciertos factores de estrés influyen directamente por sí mismos en las posibilidades de apoyo. Por ejemplo, la muerte del cónyuge suele reducir la amplitud del sistema de apoyos y acarrear graves consecuencias al superviviente (G oldberg y cols. 1985).

El apoyo social no obra como una varita mágica en la reducción de los efectos del estrés. En determinadas circunstancias puede, incluso, exacerbarlo o causarlo. Así, Wilcox (1981) observa que las personas con una red más fuerte de lazos familiares experimentan más dificultades en asumir el divorcio, debido a que la familia se muestra menos predispuesta a aceptar la ruptura del vínculo como solución a los problemas conyugales. En los estudios de la drogadicción y la violencia en el seno de la familia se han puesto igualmente de relieve los posibles efectos seriamente negativos de la red social. De hecho, como apuntan Pines y Aronson (1981), buena parte de la labor de los profesionales de la salud mental consiste en deshacer los lazos destructivos, enseñar las técnicas de relación personal y ayudar a los pacientes a superar el rechazo social.

En múltiples estudios se ha utilizado un abanico de medidas del contenido funcional del apoyo social, caracterizada por su amplia fiabilidad y validez interpretativa. 0 tro problema metodológico es que esos análisis se basan en gran medida en cuestionarios autoadministrados. Las respuestas son, por tanto, necesariamente subjetivas y suscitan el interrogante de si lo importante es el hecho en sí o el nivel de apoyo social o si, por el 
contrario, lo es la percepción personal del apoyo y los resultados. Si lo fundamental es la percepción, es posible que otra variable, como el tipo de personalidad, influya tanto en el estrés como en el apoyo social (Turner 1983). Por ejemplo, según D ooley (1985), un tercer factor, como la edad o el nivel socioeconómico, pueden influir en la modificación tanto del apoyo social como de los resultados. Solomon (1986) aporta algunas pruebas que sustentan esta tesis en su estudio de una muestra de mujeres a quienes las dificultades económicas habían colocado en situación de interdependencia forzosa con familiares y amigos. La autora halló que estas mujeres optaban por liberarse de este tipo de relaciones en cuanto su situación económica lo permitía.

Thoits (1982) Ilama la atención sobre la relación causal inversa. Subraya la autora que algunos trastornos ahuyentan a los amigos y producen una pérdida de apoyo. Los estudios realizados por Peters-Golden (1982) y Maher (1982) sobre los pacientes de cáncer y el apoyo social parecen confirmar tal aserto.

\section{Apoyo social y estrés en el trabajo}

La investigación de la relación entre el apoyo social y el estrés en el trabajo revela que un afrontamiento eficaz de este último se vincula al empleo eficaz de sistemas de apoyo (Cohen y Ahearn 1980). Las actividades de afrontamiento eficaces se basan en la utilización de apoyos sociales formales e informales. Así, se aconseja a los trabajadores despedidos que se esfuercen por conseguir información y otros apoyos emocionales y materiales. El número de evaluaciones conocidas de la eficacia de este tipo de intervención es relativamente escaso. Sin embargo, se tiene la impresión de que el apoyo formal sólo es eficaz a corto plazo y de que los sistemas informales son necesarios para una respuesta a largo plazo. El esfuerzo por ofrecer un apoyo social formal de carácter institucional puede surtir efectos negativos, ya que, por ejemplo, el resentimiento y la frustración provocados por un despido o una quiebra puede volverse contra los autores de ese apoyo. Por otra parte, una dependencia prolongada del apoyo social puede generar un sentimiento de dependencia y reducir el nivel de autoestima.

En algunos grupos profesionales, como los marinos, bomberos y trabajadores de las plataformas marinas de explotación de petróleo, se crea una red densa, perdurable y bien definida de relaciones sociales que puede compararse a la red familiar. El trabajo en pequeños grupos y la necesidad de colaboración generan de forma natural una fuerte cohesión social y una relación de apoyo mutuo. La naturaleza, en ocasiones peligrosa, del trabajo fomenta el respeto mutuo, la confianza y la intimidad. Las personas que dependen entre sí para su superviviencia y bienestar tienden a desarrollar fuertes lazos de interdependencia.

Se echa en falta una investigación más profunda de la naturaleza del apoyo social necesario tanto en tiempos normales como en épocas de redimensionamiento o cambio organizativo importante. Por ejemplo, cuando se asciende a un trabajador a un puesto de supervisión, suele tener que distanciarse de quienes han sido sus compañeros de equipo. ¿Influye esta circunstancia en los niveles de apoyo social cotidiano que esa persona demanda o precisa? ¿Se desvía la fuente del apoyo hacia los otros supervisores, la familia u otro núcleo social? ¿Son diferentes los estresores en el trabajo que aquejan a quienes ocupan puestos de responsabilidad o autoridad? ¿Precisan esas personas distintos tipos, fuentes o funciones de apoyo social?

$\mathrm{Si}$ el objetivo de las intervenciones colectivas consiste igualmente en modificar las funciones del apoyo social o la naturaleza del sistema de apoyo, ¿surte esta circunstancia algún efecto preventivo en los futuros acontecimientos estresores?
¿Cuál será el efecto de la creciente incorporación de la mujer a estas profesiones? ¿l mpondrá su presencia alguna modificación de la naturaleza y funciones del apoyo que se presta a todos 0 , por el contrario, necesita cada sexo unos niveles o tipos diferentes de apoyo?

El lugar de trabajo constituye un escenario único para el estudio de la compleja red del apoyo social. Su condición de subcultura cerrada lo convierte en un medio experimental natural del estudio de la función del apoyo social, las redes sociales y su correlación con el estrés agudo, acumulativo y traumático.

\section{GENERO, ESTRESEN EL TRABAJO Y ENFERMEDAD}

\section{Rosalind C. Barnett}

¿Actúan los estresores en el trabajo de forma diferente en los hombres y las mujeres? Esta cuestión sólo se ha suscitado recientemente en la literatura sobre las enfermedades causadas por el estrés laboral. De hecho, la palabra género no aparece en el índice de la primera edición del $\mathrm{H}$ andbook of Stress (Goldberger y Breznitz 1982), ni en el de libros de consulta tan importantes como J ob Stress and Blue Collar Work (Cooper y Smith 1985) o J ob Control and Worker H ealth (Sauter, Hurrell y Cooper 1989). Asimismo, en una revisión aparecida en 1992 del tratamiento de las variables moderadoras y los efectos de la interacción en la literatura dedicada al estrés en el trabajo, no se menciona siquiera la influencia del género (H olt 1992). U na explicación de este estado de cosas reside en la historia de la psicología de la salud y seguridad en el trabajo, que, a su vez, refleja los estereotipos sexuales que impregnan nuestra cultura. Con la sola excepción de lo referente al aparato reproductor, cuando los investigadores han estudiado los problemas de la salud física y las lesiones físicas, se han centrado en el hombre y en las variantes de su trabajo, y cuando han estudiado los trastornos mentales, se han centrado normalmente en la mujer y en las variantes de su función social.

Como consecuencia de esta tendencia, hasta hace poco las "pruebas disponibles" acerca del efecto del trabajo sobre la salud física se han limitado casi exclusivamente a los hombres (H all 1992). Por ejemplo, los intentos de correlacionar el estrés con la cardiopatía coronaria se han centrado de forma exclusiva en los hombres y en determinados aspectos de su trabajo, y los investigadores ni siquiera se han interesado por los papeles conyugales o parentales de los sujetos estudiados (Rosenman y cols. 1975). Ciertamente, en muy pocos estudios de la asociación de las patologías con el estrés en el trabajo de los hombres se ha evaluado su situación conyugal o parental (C aplan y cols. 1975).

En cambio, el interés por la salud del aparato reproductor, la fertilidad y el embarazo se ha centrado básicamente en la mujer. No resulta sorprendente, por lo tanto, que "la investigación de los efectos de las exposiciones profesionales sobre la función reproductora haya sido mucho más extensa entre las mujeres que entre los hombres" (Walsh y Kelleher 1987). Por lo que respecta al estrés negativo psicológico, los esfuerzos por establecer correlaciones psicosociales, especialmente los estresores asociados a la necesidad de compatibilizar el trabajo con las demandas familiares, se han enfocado mayoritariamente a la mujer.

Al reforzar la idea de "esferas separadas" para hombres y mujeres, estas conceptuaciones y los paradigmas de investigación por ellas generados han impedido cualquier examen de la influencia del género y contribuido así a la limitación efectiva de esa influencia. La separación generalizada de ambos sexos en el 
lugar de trabajo (Bergman 1986; R eskin y H artman 1986) actúa igualmente como una barrera que impide el estudio del género como factor moderador. En efecto, si todos los hombres realizan "trabajos masculinos" y todas las mujeres se dedican a "trabajos femeninos", no tiene sentido preguntarse por el efecto moderador del género en la relación entre patologías y estrés en el trabajo: las condiciones de trabajo y el género se confundirían; la cuestión sólo adquiere sentido cuando algunas mujeres ocupan puestos de trabajo previamente destinados a los varones y algunos hombres se emplean en trabajos que suelen realizar las mujeres.

EI control es una de las tres estrategias aplicadas para abordar los efectos del género. Las otras dos consisten en pasar por alto tales efectos o en analizarlos (Hall 1991). En la mayor parte de los estudios de la salud se ha hecho abstracción del género o se ha procurado controlar sus efectos, y ésta es la causa tanto de la penuria de referencias al género anteriormente indicada como de la existencia de un cuerpo de investigaciones que han tendido a reforzar los estereotipos sobre la intervención del género en la asociación entre enfermedad y estrés en el trabajo. Tales estereotipos proyectan una imagen de la mujer esencialmente diferenciada del hombre en aspectos que la hacen menos vigorosa en el lugar de trabajo, y presentan al hombre como alguien relativamente inmune a los efectos de las experiencias externas al trabajo.

A pesar de estos comienzos, la situación empieza a cambiar. Ejemplo de esta evolución fue la publicación, en 1987, de $G$ ender and Stress (Barnett, Biener y Baruch 1987), primer estudio específicamente dedicado a la influencia del género en todas las etapas de la reacción al estrés. 0 tro ejemplo fue la aparición de la segunda edición del $\mathrm{H}$ andbook of Stress (Barnett 1992), uno de cuyos capítulos está dedicado a la influencia del género. Por otra parte, la tercera de las estrategias citadas - el análisis de la influencia del género- está cada vez más presente en los estudios recientes. Aunque esta estrategia encierra grandes posibilidades, también tiene escollos. O perativamente, consiste en analizar los datos relativos a hombres y mujeres y realizar una estimación tanto de los efectos principales como de las interacciones del género. Uno de los efectos más relevantes es que, después de controlar los demás predictores del modelo, hombres y mujeres difieren entre sí respecto al nivel de la variable de los resultados. L os análisis de los efectos interactivos se centran en la diferente reactividad; esto es, en si la relación entre un determinado estresor y los efectos sobre la salud difiere entre hombres y mujeres.

EI mayor potencial de esta línea de investigación consiste en que pone en tela de juicio las opiniones estereotipadas de hombres y mujeres, y su principal escollo es que todavía resulta posible extraer conclusiones erróneas sobre las diferencias entre género. Dado que el género se puede confundir con muchas otras variables en nuestra sociedad, es preciso tomar en consideración estas variables antes de poder extraer conclusiones respecto al género. Por ejemplo, las muestras de hombres y mujeres difieren, ineludiblemente, entre sí respecto a una serie de variables laborales y extralaborales que pueden influir presumiblemente en los efectos sobre la salud. Mayor importancia reviste la circunstancia de que en estas variables contextuales se incluyen el prestigio profesional, el salario, el trabajo a tiempo parcial o a tiempo completo, el estado civil, la educación, la situación laboral del cónyuge, la carga global de trabajo y la responsabilidad del cuidado de familiares menores 0 de edad avanzada. A demás, los elementos de juicio disponibles apuntan a la existencia de diferencias de género en diversas variables cognitivas, de personalidad, de comportamiento y del sistema social que se asocian a los efectos sobre la salud. Dichas variables son, entre otras, la búsqueda de sensaciones; la autoeficacia (sensación de competencia); el locus de control externo; la aplicación de técnicas de afrontamiento del estrés centradas en las emociones 0 en la resolución de problemas; la utilización de recursos sociales y del apoyo social; la adquisición de hábitos nocivos, como el tabaco o el alcoholismo; los comportamientos protectores, como el ejercicio, la dieta equilibrada y los regímenes de protección de la salud; la intervención médica precoz; y el poder social (Walsh, Sorensen y Leonard, en prensa). Cuanto mejor se controlen estas variables contextuales, más cerca se está de comprender los efectos intrínsecos del género en las relaciones estudiadas y, con ello, sí el género u otras variables asociadas a él constituyen los factores moderadores reales.

Según un ilustrativo estudio de K arasek (1990) los cambios de trabajo entre operarios producían menos efectos adversos en la salud, siempre que fuesen asociados a un mayor control sobre el trabajo. Este hallazgo era válido para los hombres, pero no para las mujeres. Análisis ulteriores indicaron que se confundía el género con el control del trabajo. Para las mujeres, uno "de los grupos menos agresivos -o poderosos- del mercado de trabajo" (K arasek 1990), los cambios de puesto de trabajo de línea implicaban a menudo una reducción del control, mientras que, para los hombres, los mismos cambios se traducían con frecuencia en un mayor control. Por consiguiente, era el poder, no el género, el responsable del efecto de esta interacción. Estos análisis nos inducen a precisar el interrogante sobre los efectos moderadores: ¿R eaccionan de distinto modo hombres y mujeres a los estresores en el lugar de trabajo debido a su condición intrínseca (biológica) o en virtud de sus distintas experiencias?

Aunque en pocos estudios se han analizado las interacciones vinculadas al género, en la mayoría se postula que, si se utilizan controles adecuados, la relación entre las condiciones de trabajo y sus efectos sobre la salud física y mental no se encuentra moderada por el género (Lowe y N orthcott 1988 describen uno de los estudios citados). En otras palabras, no hay indicios de que existan diferencias intrínsecas en la reactividad.

Los resultados obtenidos en una muestra aleatoria de parejas en las que marido y mujer trabajaban a tiempo completo ilustra esta conclusión en relación con el estrés negativo psicológico. En una serie de análisis transversales y longitudinales se utilizó un diseño de parejas maritales para controlar variables de ámbito individual como la edad, la educación, el prestigio profesional, la calidad del rol marital y para variables a nivel de pareja, el estado civil, los años de matrimonio y los ingresos del núcleo familiar (Barnett y cols. 1993; Barnett y cols. 1995; Barnett, Brennan y M arshall 1994). Las experiencias positivas en el puesto de trabajo se asociaban a bajos niveles de estrés negativo; la insuficiente prudencia en la utilización de las capacidades y la sobrecarga de trabajo se asociaban a elevados niveles de estrés negativo; las experiencias con los roles conyugales y parentales moderaban la relación entre la experiencia de trabajo y el estrés negativo; y la variación, a lo largo del tiempo, tanto de la discrecionalidad de las capacidades como de la sobrecarga de trabajo se asociaban individualmente a la evolución temporal del estrés negativo psicológico. El efecto del sexo no era significativo en ningún caso. Dicho de otra forma, la intensidad de la relación no se veía afectada por el género.

O tra excepción importante está relacionada con la integración de las minorías (véase, por ejemplo, Yoder 1991). Así, mientras que "resulta evidente e innegable que constituye una innegable ventaja pertenecer a la minoría masculina de una profesión femenina" (K adushin 1976), la afirmación contraria no es cierta. De hecho, las mujeres que se encuentran en minoría en un entorno profesional masculino experimentan sensibles desventajas. Esta diferenciación se explica claramente en función de las distintas posiciones de poder y status que hombres y mujeres ocupan en nuestra cultura. 
En términos generales, las investigaciones de los resultados de salud física no han puesto de relieve efectos significativos de interacción asociada al género. Las características de la actividad laboral influyen, por ejemplo, en la seguridad más que las características de los trabajadores, y las mujeres que ejercen profesiones tradicionalmente masculinas sufren los mismos tipos de lesiones con una frecuencia análoga a la de sus compañeros varones. Además, cuando las mujeres que desempeñan puestos de trabajo tradicionalmente masculinos sufren lesiones con mayor frecuencia, la causa suele residir en el deficiente diseño del equipo protector y no en una supuesta relativa incapacidad suya para realizar el trabajo (Walsh, Sorensen y L eonard, 1995).

Se imponen aquí dos salvedades. En primer lugar, en ningún estudio se han controlado la totalidad de las covariables asociadas al género, por lo que toda conclusión sobre los resultados en este ámbito constituye una mera hipótesis. En segundo lugar, la utilización de controles diferentes en los distintos estudios dificulta la comparación entre los mismos.

A medida que un número creciente de mujeres se incorpora a la población activa y accede a puestos de trabajo tradicionalmente desempeñados por los hombres, aumentan las posibilidades y la necesidad de analizar la influencia del género en la relación entre enfermedad y estrés en el trabajo. Por otra parte, las investigaciones futuras tendrán que redefinir la conceptualización y los criterios de medición del estrés incluyendo en ellos los factores de estrés que son importantes para las mujeres, ampliando el análisis de los efectos interactivos a estudios antes restringidos a muestras exclusivamente masculinas o femeninas, como los estudios de la salud del sistema reproductivo y de las manifestaciones de estrés producidas por factores ajenos al trabajo, y estudiar los efectos interactivos tanto de la raza y la clase social considerados aisladamente como de su conjunción con el género.

\section{Aspectos etnicos}

\section{G wendolyn Puryear Keita}

Se están produciendo profundos cambios en la población activa de muchas de las grandes naciones industrializadas del mundo a medida que la participación porcentual de las minorías étnicas en ellas se va incrementando. Sin embargo, muy pocos estudios del estrés en el trabajo se han centrado en las minorías étnicas. $L a$ modificación de la estructura demográfica de la población activa mundial obliga a pensar que esas minorías no podrán seguir siendo ignoradas. En el presente artículo se bosquejan algunos de los principales problemas de estrés en el trabajo que afectan a las minorías étnicas, principalmente en Estados Unidos, si bien muchos de los juicios que se vierten pueden considerarse extensivos a otros países.

En buena parte de las investigaciones del estrés en el trabajo, 0 bien se excluye a las minorías étnicas, o bien se incluye un número excesivamente reducido de miembros para realizar comparaciones significativas o para generalizar los resultados, 0 se facilita escasa información de la muestra para determinar el peso de la participación racial o étnica. En muchos estudios no se establecen distinciones entre las minorías étnicas y se las trata como si fuesen un grupo homogéneo, con lo que se desdibujan las diferencias demográficas, culturales, lingüísticas y de situación socioeconómica que se hayan detectado tanto entre las distintas minorías étnicas como dentro de cada una de ellas (O Imedo y Parron 1981).

A demás de hacer abstracción de las cuestiones raciales, en la inmensa mayoría de las investigaciones se pasan por alto las diferencias de clase y de género, así como las interacciones de clase por razas y por género. Por otra parte, se sabe muy poco de la utilidad transcultural de muchos de los procedimientos de evaluación. La documentación utilizada en ellos no se ha traducido correctamente, y tampoco existe una equivalencia acreditada entre la versión inglesa normalizada y las versiones en otros idiomas. Incluso en los casos en que la fiabilidad parece apuntar a una equivalencia entre diversos grupos étnicos o culturales, subsiste una cierta incertidumbre respecto a los síntomas de la escala que se han obtenido de forma fiable, esto es, respecto a si la fenomenología de un determinado trastorno es similar en diversos grupos (Roberts, Vernon y R hoades 1989).

Muchos métodos de evaluación no son directamente aplicables a las condiciones imperantes en los grupos minoritarios, por lo que los resultados suelen ser escasamente fiables. Por ejemplo, muchas escalas de estrés se basan en modelos del estrés basados en determinados cambios o reajustes indeseables. Sin embargo, en la realidad muchos miembros de las minorías sufren estrés derivado, en gran parte, de la vivencia de situaciones desagradables, como la pobreza, la marginación económica, la inadecuación del alojamiento, el desempleo, la delincuencia y la discriminación. Estos factores crónicos de estrés no suelen reflejarse en muchas de las escalas habituales. Los modelos en los que se conceptualiza el estrés como el resultado de la interacción entre determinados estresores crónicos y agudos y ciertos factores moderadores internos y externos son más adecuados para evaluar el estrés en las minorías y las poblaciones más pobres (Watts-J ones 1990).

Un importante estresor que afecta a las minorías étnicas es el consistente en los prejuicios y la discriminación que padecen como consecuencia de su condición minoritaria en una determinada sociedad (M artin 1987; James 1994). Es bien sabido que los miembros de las minorías sufren un nivel de prejuicios y discriminación mayor que los miembros de la mayoría. Asimismo, perciben un mayor grado de discriminación y menores oportunidades de progreso que los blancos (Galinsky, Bond y Friedman 1993). L os trabajadores en estas circunstancias son más propensos a sufrir "burnout" en su puesto de trabajo, se preocupan menos por trabajar duro y hacer bien su labor, manifiestan menos lealtad hacia su empresa, muestran menos satisfacción en el puesto de trabajo y una menor tendencia a la adopción de iniciativas, se sienten menos obligados a contribuir al éxito de la empresa y se plantean dejar su actual empleo antes que los otros trabajadores (G alinsky, Bond y Friedman 1993). A simismo, la percepción de situaciones de prejuicio y discriminación se correlaciona directamente con problemas de salud y con episodios de hipertensión arterial (James 1994).

U no de los temas principales de investigación en el ámbito del estrés en el trabajo ha sido el concerniente a la relación entre estrés y apoyo social. Sin embargo, se ha prestado muy escasa atención a esta variable en lo que respecta a las minorías étnicas. Los resultados de la investigación tienden a ser contradictorios. Por ejemplo, los trabajadores hispanos que manifestaban disfrutar de un mayor nivel de apoyo social acusaban menos tensión relacionada con el trabajo e informaban de menos problemas de salud (Gutierres, Sáenz y Green 1994); los trabajadores pertenecientes a las minorías étnicas que disfrutaban de menores niveles de apoyo emocional se mostraban más propensos a sufrir "burnout" en el trabajo y a presentar problemas de salud, episodios de estrés en el trabajo, estrés laboral crónico y frustración; esta relación era más acusada en las mujeres y el personal directivo que en los demás trabajadores (Ford 1985). En cambio, James (1994) no halló una relación significativa entre apoyo social y problemas de salud en una muestra de trabajadores afroamericanos.

La mayoría de los modelos de satisfacción en el trabajo se han elaborado y comprobado con muestras de trabajadores blancos. 
En los casos en que se han considerado minorías étnicas, se ha incluido en general tan sólo a afroamericanos y a menudo han quedado enmascarados los posibles efectos de la etnicidad (Tuch y M artin 1991). Las investigaciones disponibles sobre trabajadores afroamericanos suelen reflejar niveles de satisfacción en el trabajo más bajos que entre los blancos (Weaver 1978, 1980; Staines y Q uinn 1979; Tuch y M artin 1991). Al examinar esta diferencia, Tuch y M artin (1991) llegan a la conclusión de que, si bien los factores determinantes de la satisfacción en el trabajo son básicamente idénticos para todos, los afroamericanos tienen menos posibilidades de trabajar en condiciones que produzcan satisfacción en el trabajo. M ás concretamente, si bien las recompensas externas contribuyen a incrementar la satisfacción en el trabajo de los afroamericanos, éstos se encuentran en situación de desventaja respecto a los blancos en relación con dichas variables. Por otra parte, la pertenencia a la población trabajadora manual y a la población urbana contribuyen a reducir la satisfacción en el trabajo de los afroamericanos, que tienen un peso numéricamente desproporcionado en ambos grupos poblacionales. Wright, K ing y Berg (1985) hallaron que determinadas variables organizativas (por ejemplo, la autoridad en el puesto de trabajo, la cualificación para el mismo y la sensación de la posibilidad de progreso dentro de la empresa) constituían los mejores factores predictivos de la satisfacción en el trabajo de su muestra de mujeres de color situadas en puestos directivos, de acuerdo con sus anteriores investigaciones basadas en muestras de trabajadores predominantemente blancos.

Los trabajadores pertenecientes a minorías étnicas desempeñan en mayor proporción que sus compañeros de raza blanca trabajos en condiciones peligrosas. Bullard y Wright $(1986,1987)$ observan esta tendencia y comentan que las diferencias étnicas entre las víctimas de lesiones son, probablemente, el resultado de disparidades de orden étnico y racial en los ingresos, la educación, el tipo de empleo y otros factores socioeconómicos correlacionados con la exposición al peligro. O bservan que una de las razones más probables de este fenómeno es que las lesiones profesionales son, en gran medida, una función del puesto de trabajo y de la categoría profesional, y que los trabajadores pertenecientes a minorías étnicas suelen desempeñar profesiones más peligrosas.

Los trabajadores extranjeros que han entrado ilegalmente en el país suelen sufrir un estrés específico en el trabajo y ser objeto de trato discriminatorio. Soportan normalmente condiciones de trabajo inseguras y por debajo de los mínimos, y aceptan salarios inferiores al mínimo legal por miedo a ser denunciados a las autoridades de inmigración y tienen menos posibilidades de mejorar de empleo. Además, las normas de salud y seguridad en el trabajo, las instrucciones de uso y las advertencias se suelen redactar en inglés, y muchos inmigrantes, ilegales o no, carecen de los conocimientos precisos del idioma, tanto verbal como escrito (Sánchez 1990).

En algunos ámbitos de investigación se ha prescindido casi totalmente de las minorías étnicas. Por ejemplo, se han dedicado centenares de estudios al examen de las relaciones entre el comportamiento del Tipo A y el estrés en el trabajo. M ientras que los varones de raza blanca constituyen el grupo más ampliamente estudiado, los hombres y mujeres de los grupos étnicos minoritarios han quedado casi totalmente excluidos. Los estudios conocidos - por ejemplo, el que Adams y cols. (1986) realizaron sobre una muestra de estudiantes universitarios de primer año, y la investigación de una muestra de trabajadores de raza negra efectuada por Gamble y Matteson (1992) - ponen de manifiesto idéntica relación directa entre el comportamiento del Tipo A y el estrés manifestado que en las muestras de raza blanca.

Del mismo modo, existen escasos estudios sobre cuestiones como el control del trabajo y las demandas del trabajo en el caso concreto de las minorías étnicas, a pesar de tratarse de conceptos fundamentales para la teoría del estrés en el trabajo. La investigación disponible señala que dichos conceptos presentan la misma importancia fundamental para los trabajadores pertenecientes a las minorías étnicas. Por ejemplo, las enfermeras afroamericanas tituladas informan de que disfrutan de mucha menor capacidad decisoria y realizan trabajos más rutinarios (y peligrosos) que sus compañeras blancas, y consideran que esta discrepancia no se corresponde con unos niveles de formación distintos (M arshall y Barnett, 1991). Ciertamente, la existencia de una baja latitud de toma de decisiones en situaciones muy exigentes suele ser el rasgo más característico de los puestos de trabajo de bajo perfil socioeconómico, que son los que habitualmente desempeñan los trabajadores de las minorías étnicas (Waitzman y Smith 1994). Por su parte, los varones blancos de nivel medio y alto hacen una valoración de su puesto de trabajo sistemáticamente más elevada que sus compañeros pertenecientes a la minorías étnicas (y al sexo femenino) respecto a seis factores de diseño del trabajo (Fernández 1981).

Por lo tanto, parece evidente que la investigación no ha aclarado numerosos interrogantes relativos a las minorías étnicas en el campo del estrés en el trabajo y la salud en el trabajo. Estos interrogantes no se aclararán hasta tanto no se incluyan trabajadores de esos grupos de población en las muestras estudiadas y en el desarrollo y validación de los instrumentos de investigación.

\section{REACCIONES DE ESTRES}

\section{- AlgunOS RESULTADOS FISIOLOGICOS AGUDOS}

\section{Andrew Steptoe y Tessa M. Pollard}

Los ajustes fisiológicos agudos registrados en el laboratorio durante la realización de tareas psicomotrices o de resolución de problemas son el aumento de la frecuencia cardíaca y de la presión arterial; alteraciones del gasto cardíaco y de la resistencia vascular periférica; el aumento de la tensión muscular y la actividad electrodérmica (glándulas sudoríparas); perturbaciones del patrón respiratorio y modificaciones de la actividad gastrointestinal y de la función inmunológica. Las respuestas neuro- hormonales mejor estudiadas son las de las catecolaminas (adrenalina y noradrenalina) y el cortisol. La noradrenalina es el principal transmisor liberado por los nervios de la rama simpática del sistema nervioso autónomo. La adrenalina se segrega en la médula suprarrenal tras la estimulación del sistema nervioso simpático, mientras que la activación de la hipófisis por los centros nerviosos superiores del cerebro produce la liberación de cortisol por la corteza suprarrenal. Estas hormonas sustentan la activación autónoma durante los episodios de estrés y producen otros cambios agudos, como la estimulación del proceso regulador de la coagulación de la sangre y la liberación de energía almacenada a partir del tejido adiposo. Aunque es probable que este tipo de respuesta se produzca igualmente durante los 
episodios de estrés, se precisan investigaciones en que se simulen las condiciones de trabajo o en que se someta a prueba a las personas durante la realización normal de su trabajo para demostrar tales efectos.

Existen diversos métodos de vigilancia de estas respuestas. Para la evaluación de las respuestas autónomas a tareas con elevada exigencia, se utilizan técnicas psicofisiológicas convencionales (Cacioppo y Tassinary 1990). Los niveles de las hormonas del estrés se pueden medir en la sangre o la orina y asimismo, en el caso del cortisol, en la saliva. La actividad del sistema simpático asociada a situaciones de desafío se puede establecer igualmente midiendo la secreción de noradrenalina en las terminaciones nerviosas y mediante el registro directo de la actividad del sistema nervioso simpático con electrodos miniaturizados. La rama parasimpática o vagal del sistema nervioso autónomo suele responder al esfuerzo de realización de tareas reduciendo su actividad, fenómeno que, en determinados casos, se puede indizar registrando las variaciones de la frecuencia cardíaca o la arritmia sinusal. En los últimos años, el análisis del espectro de potencia de las señales de la frecuencia cardíaca y de la presión arterial ha permitido conocer unas bandas de onda típicamente asociadas a la actividad simpática y parasimpática. L as medidas de la potencia en estas bandas de onda se pueden utilizar para indizar el balance autónomo y han puesto de manifiesto una desviación en favor de la rama simpática a expensas de la parasimpática durante la ejecución de las tareas.

En muy pocas evaluaciones de laboratorio de las respuestas fisiológicas agudas se han simulado directamente las condiciones de trabajo. En cambio, se han investigado dimensiones de las exigencias de las tareas y de su ejecución que influyen en el trabajo. Por ejemplo, a medida que se incrementan las exigencias del trabajo ajustado a ritmos externos (bien a la imposición de una mayor cadencia o a la necesidad de resolver problemas más complejos), se observan un aumento del nivel de adrenalina, de la frecuencia cardíaca y de la presión arterial, una reducción de la variabilidad de la frecuencia cardíaca y un incremento de la tensión muscular. En comparación con lo que sucede con las tareas cuyo ritmo es autorregulado y que se ejecutan con idéntica cadencia, los ritmos fijados externamente producen un aumento de la presión arterial y de la frecuencia cardíaca (Steptoe y cols. 1993). En términos generales, el control personal de los estímulos potencialmente estresores reduce la actividad autónoma y neuroendocrina en comparación con las situaciones incontrolables, si bien el esfuerzo mismo de mantener el control de la situación tiene unos costes fisiológicos.

Frankenhaeuser (1991) ha indicado que los niveles de adrenalina se elevan cuando la persona recibe un estímulo mental 0 realiza una tarea exigente, y ocurre lo mismo con los niveles de cortisol cuando la persona se siente angustiada o descontenta. Aplicando estas conclusiones al estrés en el trabajo, Frankenhaeuser postula que las exigencias del trabajo pueden inducir a un mayor esfuerzo y, por tanto, un aumento de los niveles de adrenalina, en tanto que la falta de control sobre el puesto de trabajo es una de las causas del estrés negativo en el trabajo y tiende, por lo tanto, a aumentar los niveles de cortisol. Algunos estudios en los que se han comparado los niveles de estas hormonas en una muestra de personas durante su trabajo habitual con los niveles observados en esas mismas personas durante su tiempo libre muestran que la adrenalina suele aumentar durante el trabajo. Los efectos en lo que atañe a la noradrenalina son contradictorios y pueden depender de la magnitud de actividad física realizada en el trabajo y durante el tiempo libre. Asimismo, se ha observado una correlación positiva entre los niveles de adrenalina en el trabajo y el grado de exigencia del trabajo. Por el contrario, no se ha podido establecer que los niveles de cortisol se incrementen normalmente durante el trabajo, ni que varíen en función del grado de control sobre el puesto de trabajo. Según el "Air Traffic Controller Health Change Study", sólo un pequeño porcentaje de trabajadores experimentó una elevación sistemática de los niveles de cortisol con el aumento efectivo de la carga de trabajo (Rose y Fogg 1993).

Por consiguiente, entre las hormonas del estrés sólo se ha demostrado concluyentemente que la secreción de adrenalina aumenta durante el trabajo y que este aumento se corresponde con el nivel de exigencia de la tarea. $\mathrm{H}$ ay indicios de que, mientras que los niveles de prolactina aumentan en respuesta al estrés, los de testosterona se reducen. No obstante, existen escasos estudios del comportamiento de estas hormonas durante el trabajo. También se han observado variaciones sustanciales de la concentración de colesterol en sangre al aumentar la carga de trabajo, aunque estas observaciones no son concluyentes (N iaura, Stoney y H erbst 1992).

Por lo que respecta a las variables cardiovasculares, se ha comprobado reiteradamente que la presión arterial es mayor en los hombres y en las mujeres durante el trabajo que después del mismo o durante las horas equivalentes de los días de ocio. Este efecto se ha observado utilizando tanto métodos de automonitorización de la presión como instrumentos portátiles (o ambulatorios). La presión arterial se eleva especialmente durante los períodos de mayor exigencia del trabajo (Rose y Fogg 1993). A simismo, se ha demostrado que la presión arterial aumenta con las tensiones emocionales, por ejemplo, en estudios de personal sanitario que ha prestado sus servicios en accidentes. En todo caso, no siempre resulta fácil saber si las fluctuaciones de la presión arterial durante el trabajo se deben a las exigencias psicológicas o a la actividad física y a los cambios de postura exigidos por las tareas. Según el modelo de exigencia-control, el aumento de la presión arterial durante el trabajo está particularmente acentuado entre las personas que refieren una gran tensión en el trabajo (Schnall y cols. 1990).

No se ha podido establecer que la frecuencia cardíaca aumente de forma sostenida durante el trabajo. No obstante, pueden producirse elevaciones agudas de la misma como consecuencia de la interrupción del trabajo ocasionada, por ejemplo, por averías en el equipo. Los trabajadores de los servicios de urgencia, como los bomberos, experimentan una aceleración acusada de la frecuencia cardíaca en respuesta a las señales de alarma recibidas durante el trabajo. Por otra parte, un nivel elevado de apoyo social en el trabajo se asocia a una reducción de la frecuencia cardíaca. Las anomalías del ritmo cardíaco también puede ser ocasionada por unas condiciones de trabajo estresores; sin embargo, no se ha podido demostrar la naturaleza patológica de tales respuestas.

En las investigaciones del estrés en el trabajo se han detectado frecuentemente la presencia de problemas gastrointestinales (véase más adelante "Problemas gastrointestinales"). Por desgracia, no es fácil evaluar los factores fisiológicos que subyacen en estos problemas en el lugar de trabajo. Así, el estrés mental agudo produce efectos variables en la secreción de los ácidos gástricos, que aumenta sensiblemente en algunas personas y se reduce en otras. Los trabajadores por turnos son especialmente propensos a sufrir problemas gastrointestinales, habiéndose indicado la posibilidad de que éstos se deban a la desorganización de los ritmos diurnos del control del sistema nervioso central sobre la secreción de los ácidos gástricos. Empleando la radiotelemetría se han detectado anomalías de motilidad intestinal escasa en pacientes con síndrome de colon irritable durante su actividad cotidiana. Aunque se ha podido establecer que los trastornos de salud, incluidos los problemas gastrointestinales, varían correlativamente con la percepción de la carga de trabajo, no está claro si este fenómeno refleja unos 
cambios efectivos de las funciones fisiológicas o determinados patrones de percepción y comunicación de síntomas.

\section{- RESULTADOS DE COMPORTAMIENTO}

Arie Shirom

Aunque los investigadores discrepan a veces sobre el significado de la palabra estrés, existe un consenso básico acerca del principio de que el estrés relacionado con el trabajo puede influir en determinados comportamientos, como el absentismo, la drogadicción, las alteraciones del sueño, el tabaquismo y el consumo de café (K ahn y Byosiere 1992). En el presente capítulo se examinan algunos hallazgos recientes que sustentan esta asociación. Se hace hincapié en el rol etiológico del estrés relacionado con el trabajo respecto a cada uno de estos resultados. En ellos se observan algunas diferencias cualitativas en determinados aspectos. Por ejemplo, en contraste con lo que ocurre con otros resultados de comportamiento, que se valoran en su totalidad como perjudiciales para la salud, el absentismo, aunque perjudicial para la empresa, no resulta necesariamente nocivo para el trabajador Con todo, las investigaciones de estos resultados plantean algunos problemas comunes que se analizan en la presente sección.

Se han mencionado con anterioridad distintas definiciones del estrés en el trabajo. A modo de ilustración, debe subrayarse que el estrés se conceptúa, por una parte, como una serie de fenómenos y, por otra, como una exigencia permanente del lugar de trabajo. $R$ aras veces se han combinado ambos criterios de medición en un único estudio diseñado para predecir la clase de resultados de comportamiento que se estudian aquí. Idéntico juicio cabe formular sobre la combinación, en un mismo estudio, del estrés de origen familiar y el estrés en el trabajo para predecir cualquiera de estos resultados. La mayoría de los estudios mencionados en el presente capítulo son de diseño transversal y se basan en cuestionarios autoaplicados. En la mayoría de las investigaciones dedicadas a los resultados de comportamiento del estrés en el trabajo apenas se han investigado las funciones moderadoras o mediadoras de las variables de la personalidad predispositivas - como el patrón de comportamiento del Tipo A o la resistencia- 0 de las variables coyunturales, como el control del trabajo y el apoyo social. Raramente se han incluido las variables precedentes, como el estrés en el trabajo medido objetivamente, en el diseño de los estudios aquí examinados. Por último, en las investigaciones comentadas se han aplicado metodologías divergentes. Todas estas limitaciones inducen frecuentemente a la conclusión de que la operatividad del estrés en el trabajo como precursor de determinados resultados de comportamiento no está suficientemente contrastada.

Beehr (1995) se planteó la causa de que se hayan dedicado tan escasos estudios al examen sistemático de la asociación entre el estrés relacionado con el trabajo y la drogadicción, y adujo que tal pobreza investigativa podría deberse, en parte, a la incapacidad de los estudiosos para detectar tal asociación. A esta incapacidad cabría añadir la conocida reticencia de las publicaciones especializadas a reproducir estudios carentes de conclusiones. A título ilustrativo de la inconsistencia de los hallazgos que vinculan el estrés con la drogadicción, cabe considerar dos grandes muestras de ámbito nacional constituidas por trabajadores de Estados U nidos. En la primera de ellas, estudiada por French, Caplan y Van Harrison (1982), no se encontró una correlación significativa entre diversos tipos de estrés relacionado con el trabajo y la drogadicción o el consumo de tabaco y café durante el trabajo. La segunda muestra, correspondiente a una investigación anteriormente realizada por Mangione y Q uinn (1975), informó de dicha correlación.
El estudio de los resultados de comportamiento inducidos por el estrés se complica aún más si se considera que aquellos suelen aparecer por parejas o tríadas. Las diferentes combinaciones de resultados constituyen la norma y no la excepción. M ás adelante se mencionará la estrecha asociación del estrés con el tabaco y el café. Existe un ejemplo adicional de la comorbilidad del trastorno por estrés postraumático (TEPT), el alcoholismo y la drogadicción (K ofoed, Friedman y Peck 1993). Es ésta una característica fundamental de varios resultados de comportamiento que se examinan en el presente artículo, que ha inducido a la elaboración de esquemas de "diagnóstico doble" y "triple" y al desarrollo de métodos de tratamiento amplios y polifacéticos. Un ejemplo de esta estrategia es el método de tratamiento simultáneo del TEPT y la drogadicción (K ofoed, Friedman y Peck 1993).

El patrón de manifestación de varios resultados en una misma persona varía en función de sus antecedentes individuales y de los factores genéticos y ambientales. La literatura dedicada a los resultados del estrés tan sólo ha empezado a interesarse por las complejas cuestiones implicadas en la definición de los patrones concretos de morbilidad patofisiológicos y neurobiológicos que propician distintas combinaciones de tipos de resultados.

\section{Tabaquismo}

Existe un importante conjunto de estudios epidemiológicos, clínicos y patológicos en los que el consumo de cigarrillos se asocia a la aparición de la enfermedad cardiovasular y otras patologías crónicas. De ahí el interés por el proceso que conduce del estrés, incluido el estrés en el trabajo, al tabaquismo. Es conocida la eficacia del tabaco para aliviar el estrés y las respuestas emocionales de ansiedad e irritabilidad asociadas al mismo. Sin embargo, es igualmente sabido que estos efectos son transitorios (Parrott 1995). Las alteraciones del humor y del estado de ánimo se suelen repetir de forma cíclica entre un cigarrillo y otro. Esta espiral conduce directamente al tabaquismo (Parrott 1995). Por consiguiente, los fumadores experimentan únicamente un alivio momentáneo del estado de ansiedad e irritabilidad que sigue a la experiencia de estrés.

La etiología del tabaquismo es múltiple (como ocurre en la mayoría de los otros resultados de comportamiento que se estudian aquí). A modo de ejemplo, considérese un reciente estudio del tabaquismo entre los enfermeros. Esta categoría profesional, que constituye, con mucha diferencia, la más numerosa del sector de la asistencia sanitaria, tiene un consumo de tabaco superior a la media de la población adulta (Adriaanse y cols. 1991). Según este estudio, dicha conclusión es válida para los enfermeros de ambos sexos y obedece al estrés en el trabajo, a la falta de apoyo social y a la frustración de las expectativas que caracteriza a su socialización profesional. El tabaquismo de los enfermeros se valora como un problema de salud pública debido a la función de modelo que suelen desempeñar para los pacientes y sus familiares.

Según diversos estudios, los fumadores que manifiestan una elevada motivación por el tabaco insisten más en haber soportado un nivel de estrés superior al normal antes de empezar a fumar que en experimentar un grado de estrés inferior a la media después de iniciarse en el tabaquismo (Parrott 1995). Esto indica que los programas de gestión del estrés y reducción de la ansiedad en el lugar de trabajo pueden influir en la motivación por el consumo de tabaco. No obstante, las campañas contra el tabaquismo en el lugar de trabajo traen a un primer plano el conflicto entre salud y rendimiento. Por ejemplo, el tabaquismo constituye un riesgo para la salud de los pilotos; sin embargo, el rendimiento durante el vuelo de los que se ven impedidos de fumar antes y durante el vuelo se puede resentir por esta causa (Sommese y Patterson 1995). 


\section{Abuso de las drogas y del alcohol}

Un problema recurrente en los estudios es que los investigadores no suelen distinguir entre el simple hábito de beber y el abuso del alcohol (Sadava 1987). Este último se asocia a la aparición de problemas de salud y a la merma del rendimiento laboral. Es conocida la asociación de su etiología con una serie de factores. Entre ellos, en la literatura se mencionan los episodios previos de depresión, la falta de apoyo familiar, la impulsividad, la condición femenina, la concurrencia de la drogadicción y el estrés (Sadava 1987). Es importante distinguir entre el simple hecho de beber alcohol y el alcoholismo como vía de evasión, debido a la controversia actualmente en curso sobre los presuntos efectos beneficiosos del alcohol sobre el colesterol de las lipoproteínas de baja densidad 8LDL) y sobre la incidencia de enfermedades carciovasculares (Pohorecky 1991). Varios estudios han mostrado una relación en forma de J o en forma de U entre la ingestión de alcohol y la incidencia de enfermedades cardiovasculares.

La hipótesis de que la ingesta de alcohol, incluso en un estadio de abuso incipiente, sirve para reducir el estrés y la ansiedad no se acepta actualmente. Según la perspectiva actual, este comportamiento obedece a una serie de procesos contextualizados en uno o más modelos multifactoriales (G orman 1994). En las últimas investigaciones de los factores de riesgo del alcoholismo se han puesto de relieve aspectos socioculturales (esto es, la oferta de alcohol y la tolerancia, excusa 0 , incluso, promoción de su consumo), socioeconómicos (relativos al precio del alcohol), ambientales (dado que la regulación legal de la publicidad y de la autorización de la venta de alcohol influye en la propensión del público a consumirlo), interpersonales (como el hábito familiar de consumo) y profesionales, tales como el estrés en el trabajo (G orman 1994). Se deduce de esto que el estrés es sólo uno de varios componentes de un modelo multifactorial de explicación del abuso del alcohol.

El corolario práctico del modelo multifactorial de explicación del alcoholismo ha sido la disminución de la importancia concedida al estrés en el diagnóstico, prevención y tratamiento del abuso de sustancias en el lugar de trabajo. Como observa Peyser (1992) en su reciente revisión de la literatura, en determinadas situaciones de trabajo, como las que se ilustran posteriormente, es preciso prestar atención al estrés en el trabajo en la formulación de estrategias preventivas del abuso de sustancias.

A pesar del ingente volumen de estudios dedicados a la relación entre estrés y alcohol, los mecanismos de esa asociación no son totalmente conocidos. La hipótesis más ampliamente aceptada es que el alcohol perturba la valoración inicial que el sujeto realiza de la información estresora, restringiendo la activación de la información asociada previamente almacenada en la memoria a largo plazo (Petraitis, Flay y M iller 1995).

Los investigadores han descrito tres procesos básicos a través de los cuales las organizaciones pueden propiciar el consumo de bebidas, incluido el abuso del alcohol. En primer lugar, el hábito de beber, moderadamente o en exceso, puede verse influido por la implantación de normas internas sobre el consumo de alcohol en el puesto de trabajo, incluida la aplicación de una definición "oficial" de ámbito interno del abuso del alcohol y de los mecanismos para su control establecidos por la dirección. En segundo lugar, algunas condiciones de trabajo estresores, como una sobrecarga de trabajo sostenida, los ritmos de trabajo impuestos por las máquinas y la falta de control, pueden propiciar el abuso del alcohol como una estrategia de afrontamiento ante el estrés. En tercer lugar, algunas organizaciones fomentan directa o indirectamente la aparición de subculturas de adicción al alcohol de origen profesional, como las que se suelen desarrollar entre los conductores profesionales de vehículos pesados (James y Ames 1993).
En términos generales, el estrés se comporta de forma distinta en la promoción del hábito de beber en diferentes profesiones, grupos de edad, estratos étnicos y otros estamentos sociales. Así, es probable que el estrés constituya un factor importante de predisposición al consumo de alcohol entre los adolescentes, pero en mucha menor medida entre las mujeres, las personas de edad avanzada y los universitarios que beben para alternar socialmente (Pohorecky 1991).

Según el modelo de estrés social de la drogadicción (Lindenberg, Reiskin y Gendrop 1994), la propensión de los trabajadores al consumo de drogas está influida por el nivel de estrés ambiental, el apoyo social contra el estrés experimentado y los recursos personales, especialmente la competencia social. Existen indicios de que el abuso de las drogas entre los miembros de algunas minorías (como los jóvenes indoamericanos que viven en las reservas: véase 0 etting, $E$ dwards y Beauvais 1988) está influido por los efectos del estrés de aculturación en ese grupo. Por otra parte, esos mismos grupos sociales están sometidos a unas condiciones sociales adversas, como la pobreza, los prejuicios y las menores oportunidades de promoción económica, social y educativa.

\section{Consumo de cafeína}

La cafeína es la sustancia farmacológicamente activa de mayor consumo en todo el mundo. Sin embargo, las pruebas de sus posibles efectos en la salud humana, esto es, de sus eventuales consecuencias fisiológicas crónicas para los consumidores habituales, son todavía escasamente convincentes (Benowitz 1990). Se sospecha desde hace mucho tiempo que la exposición reiterada a la cafeína puede generar tolerancia a sus efectos fisiológicos (James 1994). Es sabido que el consumo de cafeína puede mejorar el rendimiento y la resistencia física durante una actividad prolongada a un ritmo cercano al máximo (N ehling y D ebry 1994). LoS efectos físiológicos de la cafeína se asocian al antagonismo de los receptores de adenosina y al aumento de la producción de catecolaminas plasmáticas (N ehling y D ebry 1994).

El estudio de la relación entre el estrés en el trabajo y la ingesta de cafeína se complica por la acusada interdependencia entre el consumo de café y el de tabaco (C onway y cols 1981). U n metaanálisis de seis estudios epidemiológicos (Swanson, Lee y Hopp 1994) revela que, mientras que alrededor del 86 por ciento de los fumadores son también bebedores de café, únicamente el 77 por ciento de los no fumadores consumen esta bebida. Se ha indicado que esta asociación se concreta a través de tres mecanismos centrales: a) un efecto condicionante; b) una interacción consistente en que la ingesta de cafeína propicia la activación, mientras que el consumo de nicotina la reduce; y c) el efecto combinado en ambas variables de una tercera. El estrés y, más concretamente, el estrés en el trabajo, puede ser esa tercera variable que influya en la ingesta tanto de cafeína como de nicotina (Swanson, Lee y H opp 1994).

\section{Trastornos del sueño}

La era moderna de la investigación en este campo se inició en el decenio de 1950, con el descubrimiento de que el sueño constituye un estado de gran actividad en lugar de una situación pasiva de ausencia de respuestas. El insomnio, que es la perturbación más frecuente del sueño, puede constituir un fenómeno transitorio o un padecimiento crónico. El estrés es, probablemente, la causa principal de los episodios transitorios de insomnio (G illin y Byerley 1990). El insomnio crónico suele deberse a un trastorno médico o psiquiátrico subyacente. Entre uno y dos tercios de los pacientes que sufren insomnio crónico padecen alguna patología psiquiátrica identificable (G illin y Byerley 1990).

U no de los hipotéticos mecanismos consiste en que el estrés influye en la perturbación del sueño a través de diversos cambios 
que se producen tanto a diversos niveles del sistema cerebral como en las funciones orgánicas bioquímicas que perturban los ritmos circadianos (Gillin y Byerly 1990). Algunos indicios apuntan a que las asociaciones anteriormente indicadas pueden verse moderadas por determinados rasgos de la personalidad, como el patrón de comportamiento del Tipo A (Koulack y Nesca 1992). El estrés y las perturbaciones del sueño pueden influirse mutuamente; el estrés puede provocar episodios transitorios de insomnio que, a su vez, generan más estrés e incrementan el riesgo de nuevos episodios de depresión y ansiedad (Partinen 1994).

El estrés crónico asociado a las tareas monótonas ejecutadas al ritmo marcado por las máquinas, combinado con la necesidad de vigilancia - situación común en las industrias manufactureras de proceso continuo- puede provocar perturbaciones del sueño que, a su vez, son causa de una disminución del rendimiento ( $K$ rueger 1989). Se tienen indicios de la existencia de efectos sinérgicos entre el estrés en el trabajo, los ritmos circadianos y la disminución del rendimiento (K rueger 1989). Varios estudios de los efectos de la reducción del tiempo de sueño del personal médico hospitalario han demostrado los efectos negativos de la interacción del insomnio con la sobrecarga de trabajo y un elevado nivel de activación sobre algunos aspectos importantes del rendimiento en el trabajo (Spurgeon y $\mathrm{H}$ arrington 1989).

El estudio de M attiason y cols. (1990) ofrece algunos hallazgos desconcertantes sobre la asociación del estrés laboral crónico, la perturbación del sueño y el incremento de los niveles de colesterol plasmático. En el estudio, 715 trabajadores varones de unos astilleros expuestos al estrés producido por el desempleo fueron sometidos a una comparación sistemática con 261 controles, antes y después de manifestarse el estrés producido por la inestabilidad económica. Se pudo establecer que, entre los trabajadores expuestos a la inseguridad en el puesto de trabajo, pero no entre los controles, las perturbaciones del sueño se correlacionaban positivamente con incrementos de los niveles globales de colesterol. Se trataba en este caso de un campo de estudio natural en el que se dejó transcurrir un período de incertidumbre de aproximadamente un año antes de que algunos trabajadores recibiesen la comunicación formal del despido previsto. Por consiguiente, el estrés estudiado era real e intenso, y podría considerarse crónico.

\section{Absentismo}

El absentismo puede valorarse como un comportamiento de afrontamiento del trabajador que refleja la interacción de su percepción de las exigencias y del control del trabajo, por una parte, con las condiciones autoevaluadas, tanto familiares como de salud, por otra. En el absentismo pueden apreciarse diversos aspectos esenciales, como su duración, frecuencia y causas. Se ha podido establecer a partir de una muestra europea que un 60 por ciento de las horas perdidas por absentismo laboral se deben a enfermedad (IIlgen 1990). Si el estrés debido al trabajo se incluye en estas enfermedades, debe existir alguna correlación entre el estrés de origen profesional y el tiempo de absentismo amparado en las bajas por enfermedad. Los estudios del absentismo se han centrado en los operarios y, además, en pocos de ellos se ha investigado el absentismo de forma sistemática (M CK ee, M arkham y Scott 1992). En el metaanálisis realizado por Jackson y Schuler (1985) de las consecuencias del estrés relacionado con las funciones se halló una correlación media de 0,09 entre la ambigüedad de los papeles y el absentismo, y de $-0,01$ entre el conflicto de rol y el absentismo. Como se pone de relieve en diversos estudios metaanalíticos de la literatura dedicada al absentismo, el estrés es sólo una de las múltiples variables que influyen en el fenómeno, por lo que no cabe plantearse una correlación estrecha entre ambas entidades (Beehr 1995).

Los estudios del absentismo indican que las características individuales del trabajador pueden mediatizar la asociación del absentismo con el estrés en el trabajo. Así, en la literatura se alude a la propensión a recurrir a la técnica de "afrontamiento" como respuesta al estrés en el trabajo y a la sensación de agotamiento emocional y de fatiga física (Saxton, Phillips y Blakeney 1991). A título ilustrativo de lo anterior, en el estudio realizado por K ristensen (1991) de varios miles de trabajadores de los mataderos industriales daneses a lo largo de un año se puso de manifiesto que quienes presentaban elevados niveles de estrés mostraban índices de absentismo mucho más elevados y que su percepción de su estado de salud se asociaba estrechamente a los episodios de absentismo por enfermedad.

Los hallazgos de diversos estudios acerca de la relación entre estrés y absentismo apoyan la conclusión favorable a un posible origen profesional (Baba y Harris 1989). Por ejemplo, el estrés en el trabajo de los directivos se suele correlacionar con el índice de absentismo, pero no con los días de baja por enfermedad, situación que no se produce entre los trabajadores de los talleres de producción (C ooper y Bramwell 1992). Se ha señalado que la naturaleza profesional de las manifestaciones de estrés que impelen a los trabajadores a faltar al trabajo explica en buena medida la escasa variación del absentismo justificado por el estrés en el trabajo en numerosos estudios (Baba y Harris 1989). Se ha establecido en varios estudios que, entre los operarios que realizan tareas consideradas estresores - esto es, las que poseen diversas de las características típicas del trabajo en las cadenas de montaje (concretamente, un ciclo operativo muy breve y un sistema de pago a destajo)- , el estrés en el trabajo constituye un eficaz factor predictivo de las ausencias sin causa justificada. (V éase una reciente revisión de dichos estudios en $M c K$ ee, M arkham y Scott 1992; y obsérvese que Baba y H arris 1989 no apoyan su conclusión de que el estrés en el trabajo constituye un eficaz factor predictivo de las ausencias sin causa justificada.)

Los estudios del absentismo y el estrés nos aportan un ilustrativo ejemplo de una limitación mencionada en la introducción. Consiste ésta en que en el diseño de la mayoría de las investigaciones de la correlación entre el estrés y los efectos en el comportamiento se echa en falta un tratamiento sistemático del estrés en el trabajo y los otros tipos de estrés. Según los estudios del absentismo, el estrés no relacionado con el trabajo contribuye en mayor medida que el estrés en el trabajo a la predicción del absentismo, lo que apoya la tesis de que el absentismo puede constituir, más un comportamiento no relacionado con el trabajo que profesional (Baba y $\mathrm{H}$ arris 1989).

\section{RESULTADOS EN MATERIA DE BIENESTAR}

Peter Warr

EI trabajo puede tener una repercusión sustancial en el bienestar afectivo de los trabajadores. A su vez, la calidad del bienestar de éstos en el trabajo influye en su comportamiento, en su toma de decisiones y en su interacción con los compañeros, y trasciende asimismo a la vida familiar y social.

Los estudios llevados a cabo en numerosos países han puesto de relieve la necesidad de definir el concepto en función de dos dimensiones individuales que pueden considerarse independientes entre sí (Watson, Clark y Tellegen 1988; Warr 1994) y a las que puede aludirse con las denominaciones de "placer" y 
Figura 34.9 - Los tres ejes principales para la medición del bienestar afectivo

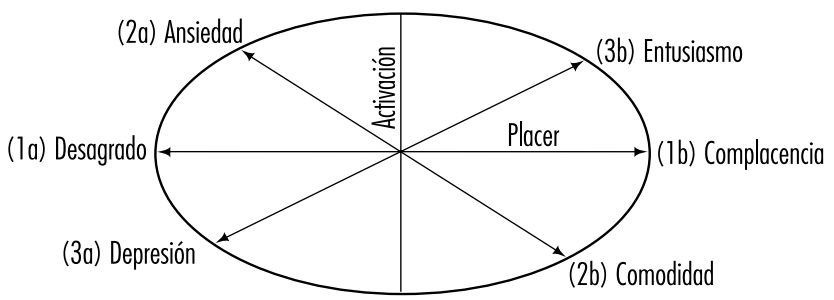

"activación”. Como se ilustra en la Figura 34.9, un determinado nivel de complacencia o desagrado puede coincidir con niveles altos o bajos de activación mental, y ésta puede ser placentera 0 desagradable. Para representar estas relaciones se utilizan tres ejes de bienestar, propuestos para la medición de las escalas que oscilan entre el desagrado y la complacencia, la ansiedad y la comodidad, y la depresión y el entusiasmo.

A menudo, la medición del bienestar vinculado al trabajo se ha limitado al eje horizontal, situando en sus extremos los estados de "sentirse mal" y de "sentirse bien". Este cálculo suele realizarse con referencia a una escala de satisfacción en el puesto de trabajo, y los datos se obtienen mediante la indicación por parte de los trabajadores de su acuerdo o desacuerdo con un conjunto de afirmaciones en las que se describen sus sentimientos respecto a su empleo. No obstante, en las escalas de satisfacción en el puesto de trabajo no se tienen en cuenta las diferencias en cuanto a la estimulación mental y, por esta razón, su capacidad descriptiva es relativamente limitada. Es necesario considerar otras formas de medir basadas en los otros dos ejes que aparecen en la Figura.

Una combinación de niveles bajos en el eje horizontal con una activación mental elevada (cuadrante superior izquierdo) tiene como consecuencia la existencia de estados de ansiedad y tensión; en cambio, un grado de placer bajo asociado a una activación mental igualmente restringida (cuadrante inferior izquierdo) da lugar a situaciones de depresión y sentimientos afines. Por otra parte, un nivel elevado de placer en el trabajo puede acompañarse de sensaciones positivas caracterizadas por el entusiasmo y la energía (3b) o por la comodidad y la relajación psicológica ( $2 b)$. En ocasiones, esta última distinción se describe mediante la contraposición entre satisfacción en el puesto de trabajo motivada (3b) y resignada o apática ( $2 b)$.

Al estudiar la repercusión de los factores organizativos y psicosociales en el bienestar de los trabajadores, es conveniente examinar los tres ejes. Para ello, se ha generalizado la utilización de cuestionarios. La satisfacción en el trabajo (1a a 1b) puede analizarse desde dos puntos de vista: general y específico. En el primer caso, se considera un conjunto global de sentimientos respecto al trabajo en su totalidad, mientras que en el segundo se tienen en cuenta los sentimientos referentes a aspectos concretos del mismo. Entre los más importantes figuran la remuneración, las condiciones de trabajo, los jefes y la naturaleza del trabajo desempeñado.

Estas formas diversas de satisfacción en el trabajo están interrelacionadas de manera positiva y, en ocasiones, resulta apropiado limitarse a medir la de carácter general y obviar las específicas. Una pregunta planteada habitualmente es "En conjunto, ¿está satisfecho con el trabajo que desempeña?". Las respuestas que suelen proponerse son muy insatisfecho, algo insatisfecho, moderadamente satisfecho, muy satisfecho y extremadamente satisfecho, y se puntúan de 1 a 5 respectivamente. En los estudios nacionales suele observarse que un $90 \%$ de los trabajadores se declaran satisfechos en cierta medida, por lo que muchas veces es necesario disponer de un instrumento de medición más sensible que permita obtener resultados más diferenciados.

$\mathrm{H}$ abitualmente se adopta un planteamiento polifacético, en el que se consideran varios aspectos. Por ejemplo, en diversos cuestionarios sobre satisfacción en el trabajo se pregunta por cuestiones como las condiciones de trabajo físicas, la libertad para elegir el propio método de trabajo, las relaciones con los compañeros, el reconocimiento recibido por el trabajo bien realizado, la relación con el jefe inmediato, el grado de responsabilidad asignado, el tipo de remuneración, la oportunidad de aplicar las capacidades propias, las relaciones entre el personal directivo y los trabajadores, la carga de trabajo, las posibilidades de promoción, el equipo disponible, la forma de gestionar la empresa, los horarios de trabajo, el grado de variedad del trabajo y la seguridad en el puesto. La satisfacción media puede calcularse teniendo en cuenta todos estos aspectos y, por ejemplo, puntuando cada respuesta de 1 a 5 (véase el párrafo precedente). Alternativamente, pueden calcularse valores separados para los aspectos que contribuyen a la "satisfacción intrínseca" (los referentes al contenido del trabajo en sí) y los que afectan a la "satisfacción extrínseca" (los vinculados al contexto del empleo, como los compañeros y las condiciones de trabajo).

A menudo, las escalas basadas en las respuestas de los interesados, que miden los ejes dos y tres, se han limitado a cubrir uno de los extremos de la distribución posible. Por ejemplo, en ciertas escalas de la ansiedad relacionada con el empleo, se pregunta a los trabajadores por sus sentimientos de tensión y preocupación en el puesto de trabajo (2a), pero no se comprueban además otras formas de influencia más positivas presentes en este eje (2b). Puede adoptarse el siguiente planteamiento al respecto, basado en los estudios elaborados en diversas instalaciones (Watson, Clark y Tellegen 1988; Warr 1990).

Los ejes 2 y 3 pueden examinarse proponiendo a los trabajadores la pregunta "En las últimas semanas, ¿cuándo se ha sentido así a causa de su empleo?" y las opciones de respuesta nunca, de vez en cuando, parte del tiempo, gran parte del tiempo, la mayor parte del tiempo y todo el tiempo (con puntuaciones que oscilan entre 1 y 6 , respectivamente). Los sentimientos cuestionados en el eje ansiedad-comodidad son los de tensión, ansiedad, preocupación, calma, comodidad y relajación. En el eje depresión-entusiasmo, se consideran los estados de depresión, pesimismo, infelicidad, motivación, entusiasmo y optimismo. En cada uno de los ejes, los tres primeros elementos deben puntuarse a la baja, de forma que una puntuación alta refleje en todo caso un bienestar elevado, y el conjunto de los seis deben presentarse en un orden aleatorio en el cuestionario. Puede estimarse una puntuación total o media para cada eje.

Generalmente, el bienestar afectivo no se determina exclusivamente por el entorno personal actual. Aunque las características del trabajo puedan tener un efecto sustancial, el bienestar es también una función de algunos aspectos de la personalidad; las personas difieren en su nivel de bienestar así como en sus reacciones a determinadas características del trabajo.

L as diferencias de personalidad importantes suelen describirse en función de las disposiciones afectivas continuas de las personas. El rasgo de la personalidad de la afectividad positiva (correspondiente al cuadrante superior derecho) se caracteriza por una visión generalmente optimista del futuro, emociones de tendencia positiva y comportamientos relativamente extrovertidos. Por otro lado, la afectividad negativa (correspondiente al cuadrante superior izquierdo) consiste en la disposición a experimentar estados emocionales negativos. En muchas situaciones, las personas con este tipo de afectividad tienden a sentirse nerviosos, ansiosos o disgustados; en ocasiones, la medición de 
este rasgo se basa en la utilización de escalas que permiten estimar el componente neurótico de la personalidad. Las afectividades negativa y positiva se consideran rasgos, es decir, son relativamente constantes de una situación a otra, mientras que el bienestar de una persona se concibe como un estado emocional variable en respuesta de las actividades de cada momento y las influencias del entorno.

En las medidas del bienestar se determinan necesariamente tanto el rasgo (la disposición afectiva) como el estado (el sentimiento en cada momento). Esta distinción debe tenerse en cuenta al examinar los resultados en materia de bienestar de una persona concreta, pero no constituye un problema sustancial en los estudios de los resultados medios correspondientes a un grupo de trabajadores. En las investigaciones longitudinales de los resultados colectivos, los cambios observados en materia de bienestar pueden atribuirse directamente a las alteraciones del entorno, ya que el bienestar básico de cada per sona se mantiene constante en todas las ocasiones de medida, mientras que, en los estudios de grupos de sección cruzada, la disposición afectiva media se concibe como una influencia elemental en todos los casos.

T éngase en cuenta asimismo que el bienestar afectivo puede considerarse desde dos puntos de vista. En la perspectiva más concreta, se hace referencia a un ámbito específico, como un centro de trabajo; en este caso, se aborda más bien el bienestar "relacionado con el trabajo" (analizado en el presente artículo) y se utilizan para su medición escalas en las que se estiman directamente los sentimientos de una per sona cuando se encuentra en su puesto de trabajo. No obstante, a veces interesa analizar el bienestar de mayor alcance, "exento de contexto" o "general" y la medición de este concepto más amplio exige la reducción de la especificidad. L os mismos tres ejes referidos deben examinarse en ambos casos, y se dispone de escalas más generales para el estudio de la satisfacción en la vida o distress general (eje 1), la ansiedad fuera decontexto (eje2) y la depresión fuera de contexto (eje3).

\section{- REACCIONES INMUNITARIAS}

\section{H olger U rsin}

Toda persona 0 animal sometido a estrés psicológico genera una respuesta general que comprende reacciones psicológicas y somáticas (corporales). Se trata de una respuesta general de alarma, una llamada a la activación o alerta general, que afecta a todas las reacciones fisiológicas, entre ellas las del sistema musculosquelético, el sistema vegetativo (sistema autónomo), el sistema endocrino y el sistema inmunitario.

A partir del decenio de 1960 comenzamos a comprender que el cerebro y, por su mediación, los factores psicológicos, regulan y controlan todos los procesos fisiológicos, ya sea directa o indirectamente. H asta entonces se creía que algunas partes grandes y esenciales de la fisiología se regulaban de forma "inconsciente", sin intervención alguna de los procesos cerebrales. Los nervios que regulan el funcionamiento del intestino, las glándulas endocrinas y del aparato cardiovascular eran "autónomos", o independientes del sistema nervioso central (SNC) y también la secreción hormonal y el sistema inmunitario escapaban a este control. Si embargo, hoy se sabe que el sistema nervioso autónomo está regulado por las estructuras límbicas del cerebro y que puede ser sometido a un control instrumental directo mediante procedimientos de aprendizaje clásicos e instrumentales. EI hecho de que el sistema nervioso central controle todos los proceso endocrinos ha sido ya sobradamente demostrado.

El último argumento en contra de la independencia entre el SNC y muchos procesos fisiológicos fue la evolución de la psicoinmunología. H oy se sabe que la interacción del cerebro (y los procesos psicológicos) puede influir en los procesos inmunitarios, bien a través del sistema endocrino, bien por inervación directa del tejido linfoide. Incluso los propios leucocitos pueden recibir influencias directas mediadas por moléculas señalizadoras liberadas por el tejido nervioso. Se ha demostrado que la pérdida de un ser querido puede deprimir la función de los linfocitos (Bartrop y cols., 1977) y que el condicionamiento de las respuestas inmunodepresoras de los animales (Cohen y cols., 1979) y de los procesos psicológicos influyen en su supervivencia (Riley, 1981); estos hallazgos han sido hitos fundamentales en el progreso de la psicoinmunología.

$\mathrm{H}$ oy se sabe también que el estrés psicológico altera las concentraciones de anticuerpos en la sangre, así como los niveles de las distintas poblaciones de leucocitos. U n período breve de estrés, de 30 minutos de duración, puede causar elevación de los linfocitos y de las células citolíticas naturales (NK, natural killer cells). L as situaciones de estrés más prolongadas se asocian a cambios de otras células inmunitarias. Se han descrito alteraciones de los recuentos de casi todos los tipos de leucocitos y de los niveles de inmunoglobulinas y de sus complementos; estos cambios afectan también a otros elementos importantes del sistema inmunitario total y de la "cascada inmunitaria". Se trata de cambios complejos que parecen producirse en ambos sentidos, ya que se han descrito tanto aumentos como disminuciones, y que parecen depender no sólo de la situación que provoca el estrés, sino también del tipo de afrontamiento y del mecanismo y defensa adoptado por la persona para hacer frente a la situación. Estos efectos resultan particularmente evidentes cuando se estudian los efectos de situaciones reales de estrés prolongado ("estrés vital"), como las relacionadas con el trabajo o con situaciones especialmente difíciles de la vida. Se han descrito relaciones sumamente específicas entre los estilos de afrontamiento y defensa y algunos subconjuntos de células inmunitarias (número de linfocitos, leucocitos y monocitos, recuentos totales de células T y NK ) (O Iff y cols. 1993).

La búsqueda de parámetros inmunitarios que sirvan como marcadores del estrés prolongado y mantenido no ha tenido el éxito deseado. Se ha visto que las relaciones entre las inmunoglobulinas y los factores de estrés son tan complejas que, comprensiblemente, no existe ningún marcador sencillo. Se sabe que tales relaciones pueden ser positivas o negativas. En lo que concierne a los perfiles psicológicos, la matriz de correlación entre cada uno de ellos y la misma batería de tests psicológicos revela distintos patrones, que varían de un grupo profesional a otro (Endresen y cols. 1991). D entro de cada grupo, los patrones parecen mantenerse estables durante largos períodos de tiempo, incluso hasta 3 años. No se sabe si existen factores genéticos que puedan influir en estas relaciones sumamente específicas entre estilos de afrontamiento y respuestas inmunitarias pero, si los hubiera, sus manifestaciones dependerían en gran medida de la interacción con los estresora de la vida. Tampoco se sabe si, conociendo los mecanismos de afrontamiento y defensa y la respuesta inmunitaria de una persona, se podría vigilar su nivel de estrés durante un período prolongado. Este tipo de investigación se está realizando en personal muy seleccionado como, por ejemplo, los astronautas.

El argumento básico según el cual las inmunoglobulinas podrían servir como marcadores básicos del riesgo para la salud contiene un error implícito importante. Según la hipótesis inicial, unos niveles circulantes bajos de inmunoglobulinas podrían indicar un estado de menor resistencia y de descenso de la competencia inmunitaria. Sin embargo, el hallazgo de niveles bajos puede no indicar un defecto de la resistencia sino, simplemente, que esa persona no ha sufrido provocación alguna por un agente infeccioso durante algún tiempo; de hecho, pueden indicar un estado de salud extraordinariamente bueno. LoS 
bajos niveles encontrados a veces en los astronautas que regresan a la tierra o en los investigadores que vuelven de la Antártida pueden no ser un indicio de estrés, sino tan sólo de la escasez de virus y bacterias en el medio ambiente en el que han vivido.

En la literatura médica pueden encontrarse numerosas anécdotas que sugieren que el estrés psicológico y los acontecimientos vitales críticos pueden influir en la evolución de enfermedades graves y menos graves. Para algunos, los placebos y la "medicina alternativa" ejercerían sus efectos a través de los mecanismos psicoinmunitarios. Se ha dicho que la disminución (o, a veces, el aumento) de la competencia inmunitaria traería consigo un aumento de la propensión a sufrir infecciones y estados inflamatorios crónicos, como la artritis reumatoide, tanto en animales como en el hombre. Se ha demostrado de forma convincente que el estrés psicológico modifica la respuesta inmunitaria frente a distintos tipos de inoculaciones. Los estudiantes sometidos al estrés de los exámenes refieren una mayor frecuencia de síntomas de enfermedad infecciosa durante ese período, que coincide con el nivel más bajo de respuesta inmunitaria celular (Glaser y cols. 1992). Algunos defienden que la psicoterapia, y en especial la enseñanza de técnicas cognitivas de gestión del estrés, asociada al ejercicio físico, podría influir en la respuesta de los anticuerpos frente a las infecciones víricas.
También se han encontrado ciertos hallazgos positivos en relación con el desarrollo del cáncer, pero son muy escasos. La controversia sobre una supuesta relación entre personalidad y sensibilidad al cáncer no ha sido resuelta. L os modelos utilizados hasta ahora deberían ampliarse para incluir mediciones de las respuestas inmunitarias a otros factores, como los asociados a la forma de vida, que pueden guardar relación con la psicología. No obstante, el cáncer a su vez puede ser una consecuencia directa de esa forma de vida.

Existen numerosas pruebas de que el estrés agudo altera la respuesta inmunitaria del hombre y de que el estrés crónico puede afectar también a estas funciones, pero ¿en qué medida son tales cambios indicadores válidos ý útiles del estrés profesional? ¿H asta qué punto son estos cambios inmunitarios (si es que se producen) factores de riesgo reales para la salud? En el momento deredactar este trabajo (1995) no existeaún consenso al respecto.

Sería necesario realizar ensayos clínicos serios y una investigación epidemiológica profunda para lograr avances en este campo. Sin embargo, este tipo de estudios exigiría más financiación de la que hoy disponen los investigadores. Este tipo de trabajo exige también un mayor conocimiento de la psicología del estrés, que no se encuentra al alcance de todos los inmunólogos, y un gran conocimiento de la forma en que actúa el sistema inmunitario, del que los psicólogos no siempre disponen.

\section{EFECTOS CRONICOS EN LA SALUD}

\section{- ENFERMEDADES CARDIO VASC ULARES}

\section{Töres Theorell y Jeffrey V. Johnson}

Las evidencias científicas que sugieren un aumento del riesgo de enfermedad cardiovascular con la exposición al estrés profesional comenzaron a acumularse a mediados del decenio de 1980 (Gardell 1981; Karasek y Theorell 1990; Johnson y Johansson 1991). La enfermedad cardiovascular (ECV) sigue siendo hoy día la principal causa de mortalidad en las sociedades económicamente desarrolladas y contribuye a incrementar los costes de la asistencia sanitaria en esos países. Las enfermedades del aparato cardiovascular comprenden la cardiopatía coronaria (CC), la enfermedad hipertensiva, la enfermedad cerebrovascular y otros trastornos del corazón y del aparato circulatorio.

La mayor parte de las manifestaciones de la cardiopatía coronaria se deben, en parte, al estrechamiento de las arterias coronarias causado por la aterosclerosis. Se sabe, a su vez, que la aterosclerosis coronaria se ve influida por una serie de factores, como la presencia de antecedentes familiares, el contenido de grasas saturadas en la dieta, el tabaquismo y el ejercicio físico. Excepto la herencia, todos estos factores se ven influidos por el medio ambiente de trabajo. U nas malas condiciones de trabajo pueden hacer que la persona no sienta deseos de abandonar el tabaco y adoptar una forma de vida más sana. En consecuencia, un entorno profesional desfavorable puede influir en la enfermedad coronaria a través de sus efectos en los factores de riesgo clásicos.

Los entornos profesionales estresores también influyen directamente en las concentraciones neurohormonales y en el metabolismo del corazón. La combinación de diversos mecanismos fisiológicos relacionados con actividades profesionales estresoras puede aumentar el riesgo de infarto de miocardio. La elevación de las hormonas movilizadoras de los depósitos energéticos que se produce durante los períodos de estrés excesivo puede aumentar la vulnerabilidad del corazón a la muerte del tejido muscular. Por el contrario, los niveles de las hormonas que reponen y reparan los depósitos energéticos, protegiendo así al músculo cardíaco frente a los efectos nocivos de las hormonas movilizadoras de energía, disminuyen durante los períodos de estrés. En los momentos de gran estrés emocional (y físico), los latidos del corazón se hacen más fuertes y rápidos durante períodos más largos de tiempo, de manera que el músculo cardíaco consume una cantidad excesiva de oxígeno y aumenta el riesgo de sufrir un ataque de corazón. El estrés puede alterar también el ritmo cardíaco. La alteración caracterizada por un aumento del ritmo cardíaco se Ilama taquicardia. Cuando la frecuencia cardíaca es tan rápida que el latido del corazón deja de ser eficaz, se produce un trastorno que puede causar la muerte: la fibrilación ventricular.

Los primeros estudios epidemiológicos sobre las condiciones psicosociales del trabajo asociadas a la ECV sugerían que una gran demanda profesional aumenta el riesgo de CC. Por ejemplo, en un estudio prospectivo realizado en empleados de la banca en Bélgica se observó que los que trabajaban en la banca privada presentaban una incidencia significativamente mayor de infarto de miocardio que los que lo hacían en la banca pública y que esta diferencia persistía incluso después de hacer los ajustes necesarios para tener en cuenta los factores de riesgo biomédico (K omitzer y cols. 1982). Este estudio indicó una posible relación entre las demandas profesionales (mayores en los bancos privados) y el riesgo de infarto de miocardio. O tros estudios iniciales demostraron asimismo una mayor incidencia de infarto de miocardio entre los trabajadores menos cualificados de las grandes empresas (Pell y d'Alonzo 1963). Estos hallazgos obligaron a plantearse la posibilidad de que el estrés psicológico no fuera un problema fundamental de las personas con mayores niveles de responsabilidad, como se había creído hasta entonces.

Desde principios del decenio de 1980 se han realizado numerosos estudios epidemiológicos para investigar la hipótesis específica derivada del modelo de Demanda/Control desarrollado por Karasek y otros (Karasek y Theorell 1990; Johnson y 
Johansson 1991). Según este modelo, los factores de estrés en el trabajo son el resultado de organizaciones del trabajo que combinan la exigencia de un elevado rendimiento con un bajo nivel de control sobre la forma en que se lleva a cabo el trabajo en cuestión. Según este modelo, el control del trabajo puede entenderse como la "libertad para tomar decisiones" o la autoridad para tomar decisiones relacionadas con las tareas que permite la organización del trabajo. Este modelo predice que los trabajadores expuestos a unas elevadas demandas y a un escaso control durante largos períodos de tiempo corren más riesgo de desarrollar un estado de activación neurohormonal que puede tener efectos fisiopatológicos nocivos para el sistema CV y aumentar con el tiempo el riesgo de cardiopatía coronaria aterosclerótica y el infarto de miocardio.

Entre 1981 y 1993, la casi totalidad de los 36 estudios que investigaron los efectos de unas grandes demandas y un bajo control en la enfermedad cardiovascular encontraron asociaciones positivas significativas. Estos estudios, con diseños experimentales distintos, se realizaron en Suecia, Japón, Estados U nidos, Finlandia y Australia. Se analizaron distintas variables, como morbilidad y mortalidad por ECV, factores de riesgo de CC (hipertensión, tabaquismo), índice de masa ventricular izquierda y síntomas de isquemia miocárdica. Recientemente se han publicado varios artículos de revisión en los que se resumen los resultados de todos estos estudios (K ristensen 1989; Baker y cols. 1992; Schnall, Landbergis y Baker 1994; Theorell y K arasek 1996). En opinión de los autores de estas revisiones, los estudios tienen una gran calidad epidemiológica y, además, los diseños más potentes son, en general, los que más apoyan los modelos de Demanda/ Control. En términos generales, puede decirse que los ajustes realizados para tener en cuenta los factores de riesgo cardiovascular habituales no eliminan ni reducen significativamente la magnitud de la asociación entre la combinación alta demanda/bajo control y el riesgo de enfermedad cardiovascular.

C onviene observar, no obstante, que la metodología utilizada en estos estudios fue muy diferente. La diferencia más importante es que en algunos estudios se utilizaron las descripciones hechas por los propios encuestados de su situación profesional, mientras que en otros se utilizó un método de "puntuación media" basado en la suma de las respuestas de una muestra representativa de la población nacional de trabajadores en cada categoría profesional. Los estudios del primer grupo fueron los que mostraron riesgos relativos más altos $(2,0-4,0$ frente a $1,3-2,0)$. Estos estudios sugerían un efecto mayor de las demandas psicológicas que los estudios que utilizaron datos agregados. Con independencia del método utilizado, las variables de control del trabajo mostraron asociaciones más constantes con el aumento del riesgo de ECV.

Recientemente se ha añadido el apoyo social relacionado con el trabajo al modelo de demanda/ control y se ha demostrado que los trabajadores expuestos a demandas elevadas, poco control y escaso apoyo presentan un riesgo dos veces mayor de morbilidad y mortalidad por ECV que los que tienen empleos de baja demanda, mucho control y fuerte apoyo Uohnson y $H$ all 1994). En la actualidad se está estudiando la exposición mantenida a la demanda, el control y el apoyo a lo largo de la "carrera profesional psicosocial". Para ello se obtienen descripciones de todos los trabajos realizados por los participantes durante toda su vida profesional y se utilizan puntuaciones profesionales para calcular la exposición durante toda la vida. Se ha estudiado también en los trabajadores suecos la "exposición total al control profesional" en relación con la incidencia de mortalidad cardiovascular. Incluso después de realizar los ajustes oportunos para considerar la edad, el hábito de fumar, el ejercicio físico, el origen étnico, el nivel de educación y la situación socioeconómica y tras un período de seguimiento de 14 años, se comprobó que el riesgo de mortalidad por enfermedad cardiovascular casi se duplicaba en los trabajadores expuestos a un control laboral total bajo (Johnson y cols. 1996).

Siegrist y sus colaboradores diseñaron y probaron en 1990 un modelo similar al de Demanda/Control, cuyas dimensiones esenciales son el "esfuerzo" y la "recompensa social", basándose en la hipótesis de que un gran esfuerzo no acompañado de recompensa social conlleva un aumento del riesgo de enfermedad cardiovascular. En un estudio realizado en trabajadores industriales, se comprobó que la combinación de un gran esfuerzo y la ausencia de recompensa permite predecir un aumento del riesgo de infarto de miocardio que es independiente de los factores de riesgo biomédico.

Se ha demostrado asimismo que otros aspectos de la organización del trabajo, como la existencia de turnos, se asocian a un mayor riesgo de ECV. La rotación constante entre jornadas laborales diurnas y nocturnas se asocia a un aumento del riesgo de infarto de miocardio (K ristensen 1989; T heorell 1992).

En el futuro, la investigación en este campo debería centrarse muy especialmente en la definición de las relaciones entre exposición al estrés profesional y el riesgo de ECV en las distintas clases sociales, sexos y grupos étnicos.

\section{Pro blemas gastro intest inales}

Jerry Suls

D esde hace muchos años se sabe que el estrés psicológico contribuye al desarrollo de la enfermedad ulcerosa péptica (que comprende las lesiones ulcerosas del estómago y del duodeno). $M$ ás recientemente, los investigadores y los profesionales sanitarios han propuesto también asociaciones entre el estrés y otros trastornos gastrointestinales tales como la dispepsia no ulcerosa (con sintomatología de dolor abdominal alto, malestar y náuseas persistentes en ausencia de una causa orgánica identificable) y el síndrome de colon irritable (definido como alteración del hábito intestinal asociada a dolor abdominal, en ausencia de signos físicos anormales). En este artículo se plantea el tema de si existen datos empíricos lo suficientemente potentes como para sugerir que el estrés psicológico actúa como factor de riesgo en la etiología o exacerbación de estos trastornos gastrointestinales.

\section{Ulcera gástrica y duodenal}

Se ha demostrado claramente que las personas expuestas a estrés agudo en el contexto de un traumatismo físico grave tienden a desarrollar úlceras. Sin embargo, resulta menos evidente que los estresores de la vida (como el despido o la muerte de un ser querido) puedan, por sí solos, precipitar o exacerbar la úlcera. Tanto la población general como los profesionales de la salud asocian las úlceras al estrés, quizá como consecuencia del enfoque psicoanalítico adoptado por Alexander hace ya muchos años (1950). Este autor propuso que las personas con tendencia a úlcera sufrían conflictos de dependencia en sus relaciones con los demás, así como una tendencia constitucional a la hipersecreción crónica de ácido gástrico. Se creía que la asociación entre esta tendencia y los conflictos de dependencia daba lugar al desarrollo de úlceras. Esta perspectiva psicoanalítica no ha recibido un gran apoyo empírico. Los pacientes ulcerosos no parecen mostrar mayores conflictos de dependencia que los grupos de control, aunque sí tienen mayores niveles de ansiedad, sumisión y depresión (Whitehead y Schuster 1985). No obstante, el grado de neurotización de algunos de estos pacientes suele ser leve y pocos son los que presentan signos psicopatológicos. En cualquier caso, los estudios sobre los trastornos emocionales de los pacientes con 
enfermedad ulcerosa se han realizado, en general, en personas que acuden al médico por esta causa y estas personas podrían no ser representativas del conjunto de la población ulcerosa.

La asociación entre estrés y úlcera se basa en el supuesto de que algunas personas tienen una predisposición genética a la hipersecreción de ácido en el estómago, especialmente durante las situaciones de estrés. De hecho, se han encontrado niveles altos de pepsinógeno en hasta dos terceras partes de los pacientes con úlcera duodenal y este aumento de la secreción de pepsinógeno se asocia también a la enfermedad ulcerosa péptica gástrica. Los trabajos de Brady y sus colaboradores (1958) en monos "ejecutivos" apoyaron en un principio la idea de que una forma de vida o una profesión estresora podían contribuir a la patogénesis de la enfermedad ulcerosa. Estos autores observaron que los monos obligados a presionar una palanca para evitar descargas eléctricas dolorosas (los supuestos monos "ejecutivos" que podían controlar el factor de estrés) sufrían úlceras gástricas con más frecuencia que los animales de control, sometidos a un número similar de descargas de igual intensidad. La analogía con los ejecutivos agresivos pareció muy convincente en aquel momento. Por desgracia, la ansiedad confundió los resultados de este estudio: en el laboratorio de Brady, los monos más ansiosos tenían más posibilidades de desempeñar el papel de "ejecutivos" porque eran los que aprendían antes a presionar la palanca. Los intentos posteriores de reproducir estos resultados con asignación aleatoria de los sujetos han fracasado. De hecho, las evidencias indican que cuando los animales carecen de control sobre los factores de estrés de su entorno, tienen más riesgo de desarrollar úlceras (Weiss, 1971). Por otra parte, los pacientes con úlcera suelen ser más tímidos e inhibidos, con una personalidad que poco tiene que ver con el estereotipo del ejecutivo ambicioso con tendencia a la úlcera. Por último, los modelos animales tienen sólo una utilidad limitada, ya que se centran en el desarrollo de la úlcera gástrica, mientras que la mayor parte de las úlceras humanas aparecen en el duodeno. Los animales de experimentación rara vez desarrollan úlceras duodenales en respuesta al estrés.

Los estudios experimentales que comparan las reacciones psicológicas de los pacientes ulcerosos con las de los sujetos normales frente a factores experimentales de estrés, no siempre revelan reacciones exageradas en los primeros. La premisa de que el estrés provoca un aumento de la secreción de ácido y que ésta, a su vez, causa la úlcera, se viene abajo cuando se considera que el estrés psicológico suele inducir una respuesta del sistema nervioso simpático. El sistema nervioso simpático tiende a inhibir, más que a favorecer, la secreción de ácido, que está mediada por el nervio esplácnico. A demás de la hipersecreción de ácido, se han propuesto otros factores etiológicos de la enfermedad ulcerosa: un vaciado gástrico demasiado rápido, una secreción insuficiente de bicarbonato y de moco e infección. En teoría, el estrés podría afectar a estos procesos, aunque no se dispone de evidencias que lo demuestren.

Se ha dicho que las úlceras son más frecuentes en tiempos de guerra, pero los problemas metodológicos de estos estudios obligan a valorarlos con prudencia. En algunas ocasiones se cita un estudio realizado en controladores del tráfico aéreo como evidencia de la importancia del estrés psicológico en la aparición de úlceras (C obb y Rose, 1973). No obstante, si bien los controladores tenían mayores probabilidades de declarar síntomas típicos de úlcera que el grupo de control formado por pilotos, la incidencia de úlcera confirmada no fue superior a la tasa observada en la población general.

Los estudios sobre acontecimientos vitales agudos también dibujan un cuadro confuso sobre la relación entre estrés y úlcera (Piper y Tennant, 1993). Son muchas las investigaciones que se han realizado, aunque casi todas ellas con muestras pequeñas y diseño transversal o retrospectivo. En su mayoría, no consiguieron demostrar que los pacientes ulcerosos vivieran más acontecimientos agudos que los sujetos de control sanos o los pacientes con enfermedades que no guardan relación con el estrés, como la colelitiasis o la litiasis renal. No obstante, es cierto que los pacientes con úlcera notificaron mayores factores de estrés crónicos relacionados con amenazas personales o frustraciones antes del inicio o la reactivación de la sintomatología. En dos estudios prospectivos se observó una relación entre la existencia de estrés o problemas familiares y el posterior desarrollo de úlcera. Por desgracia, en ambos estudios se utilizaron escalas con un solo criterio para medir el estrés. 0 tros investigadores han demostrado que el retraso en la cicatrización de las úlceras o su recidiva se asocia a mayores niveles de estrés, pero los índices de estrés utilizados en estos ensayos no habían sido previamente validados y algunos rasgos de la personalidad podrían haber actuado como factores de confusión.

En resumen, son pocas las evidencias que existen sobre la función del estrés en la etiología y exacerbación de las úlceras. Se necesitarían estudios prospectivos de población a gran escala sobre los acontecimientos vitales que utilizaran medidas validadas del estrés agudo y crónico e indicadores objetivos de la enfermedad ulcerosa. Por el momento sólo existe una débil evidencia de asociación entre estrés psicológico y úlcera

\section{Síndrome del colon irritable}

El síndrome del colon irritable (SCI) se consideró en el pasado un trastorno relacionado con el estrés, en parte porque se desconoce su mecanismo fisiológico, y en parte, porque una gran proporción de los afectados afirman que sus hábitos intestinales se alteraron a causa del estrés. Al igual que sucede con los estudios publicados sobre la úlcera, resulta difícil establecer la validez de los relatos retrospectivos sobre los factores de estrés y los síntomas en estos pacientes. En un intento de explicar sus molestias, los enfermos pueden asociar, erróneamente, los síntomas con los acontecimientos estresores. D os estudios prospectivos recientes han investigado esta cuestión y en ambos se ha observado que los acontecimientos estresores tienen poco que ver con la aparición del SCI. Whitehead y cols. (1992) solicitaron a una muestra de residentes en la comunidad afectados por el $\mathrm{SCI}$ que describieran los acontecimientos de su vida y sus síntomas a intervalos de tres meses. Sólo el $10 \%$ de la varianza de la sintomatología intestinal pudo atribuirse al estrés. Suls, Wan y Blanchard (1994) solicitaron a pacientes con $\mathrm{SCl}$ que anotaran en un diario los factores de estrés y los síntomas durante 21 días consecutivos. No pudieron encontrar evidencias sólidas de que el estrés en la vida diaria aumentara la incidencia o gravedad del síndrome. El estrés parece desempeñar un escaso papel en los cambios agudos del SCI.

\section{Dispepsia no ulcerosa}

Los síntomas de la dispepsia no ulcerosa (DNU) consisten en flatulencia y sensación de plenitud, eructos, borborigmo, náuseas y sensación de ardor. En un estudio retrospectivo, los pacientes con este cuadro notificaron un número mayor de acontecimientos vitales estresores y de dificultades crónicas amenazantes que los miembros sanos de la comunidad, pero otros investigadores no pudieron encontrar relación alguna entre el estrés vital y la dispepsia funcional. A demás, los pacientes con DNU tienden a presentar mayores grados de psicopatología, especialmente de trastornos por ansiedad. En ausencia de estudios prospectivos sobre estrés, son pocas las conclusiones que pueden extraerse (Bass 1986; W hitehead 1992).

\section{Conclusiones}

Pese a los numerosos estudios empíricos que se han realizado, no ha sido posible establecer todavía la existencia de una relación 
entre el estrés y el desarrollo de úlceras. Los gastroenterólogos actuales estudian sobre todo la herencia de los niveles de pepsinógeno, la secreción insuficiente de bicarbonato y moco y la infección por H eliobacter pylori como causas de la úlcera. Si el estrés influye de alguna manera en estos procesos, su contribución debe ser, probablemente, pequeña. Si bien el número de estudios sobre el efecto del estrés en el $\mathrm{SCl}$ y la DNU es menor, también en estos casos existen pocos datos que sugieran una relación entre el estrés y estos trastornos. En los tres trastornos resulta evidente que los pacientes sufren mayores grados de ansiedad que la población general, al menos entre las personas que solicitan atención médica (W hitehead 1992). No se sabe con seguridad si esta ansiedad es causa o consecuencia de la enfermedad gastrointestinal, aunque parece más probable lo segundo. En la práctica médica habitual, los pacientes ulcerosos reciben tratamiento farmacológico y rara vez se recomienda la psicoterapia. M uchos enfermos con $\mathrm{SCl}$ y DNU reciben ansiolíticos, probablemente porque todavía se desconoce el origen fisiológico de estos procesos. En los pacientes con $\mathrm{SCI}$ se han utilizado con cierto éxito técnicas de gestión del estrés (Blanchard y cols. 1992), aunque conviene advertir que este grupo responde también con facilidad al uso de placebos. Por último, los pacientes con úlcera, SCI o DNU pueden sentirse frustrados por el hecho de que sus familiares, sus amigos y los profesionales de la salud den por supuesto que su trastorno se debe al estrés.

\section{- CANCER}

Bernard H. Fox

Son muchos los factores de estrés que pueden alterar el equilibrio físico y/ o psicológico de la persona. Para una buena revisión general del estrés y de los factores de estrés profesional más frecuentes, se aconseja leer el artículo de Levi sobre las teorías del estrés profesional en este mismo capítulo.

Al abordar la cuestión de si el estrés profesional puede influir, o de hecho influye, en la epidemiología del cáncer, nos enfrentamos a numerosas limitaciones. En una búsqueda bibliográfica sólo pudimos encontrar un artículo sobre el estrés profesional real y el cáncer en conductores de autobuses urbanos (M ichaels y Zoloth 1991) y sólo algunos estudios que consideran esta cuestión en términos más generales. No podemos aceptar los resultados del estudio de M ichaels y Zoloth porque no tuvieron en cuenta ni los efectos de la elevada densidad de los gases de escape ni el hábito de fumar de los sujetos. Además, no se pueden extrapolar los hallazgos de otras enfermedades al cáncer debido a las enormes diferencias en sus mecanismos patogénicos.

No obstante, podemos describir lo que se sabe acerca de las relaciones entre los estresores más generales y el cáncer y, además, puede intentarse, razonablemente, extrapolar tales datos a la situación laboral. Diferenciamos las relaciones con el estrés por dos resultados: la incidencia de cáncer y el pronóstico del cáncer. La incidencia significa, evidentemente, la presencia de cáncer. Sin embargo, la incidencia puede establecerse bien por el diagnóstico clínico del médico, bien en la autopsia. Puesto que los tumores crecen lentamente (pueden pasar de 1 a 20 años entre la mutación maligna de una célula y la detección de la masa tumoral), los estudios de incidencia comprenden tanto la iniciación como el crecimiento. La influencia del estrés en el pronóstico sólo puede demostrarse estudiando a los pacientes con cáncer una vez establecido el diagnóstico.

Puede distinguirse entre estudios de cohortes y estudios de casos y controles. En este artículo nos limitaremos a los primeros, que miden el factor de interés, el estrés en este caso, en una cohorte de personas sanas para determinar la incidencia de cáncer o la mortalidad por esta causa después de varios años. No nos detendremos demasiado en los estudios de casos y controles, que comparan los factores de estrés en el momento 0 antes del diagnóstico declarados por los enfermos con cáncer (casos) y personas sin cáncer (controles). La razón de que les prestemos poca atención es, en primer lugar, que no se puede estar seguro de que el grupo de control sea verdaderamente equivalente al grupo de casos en lo que concierne a otros factores que pueden influir en la comparación. En segundo lugar, el cáncer puede producir, y de hecho produce, cambios físicos, psicológicos y de actitud que son, en general, negativos, lo que puede introducir sesgos en las conclusiones. En tercer lugar, se sabe que estos cambios hacen que los enfermos oncológicos mencionen con mayor frecuencia acontecimientos estresores (o acontecimientos más intensos), en comparación con los controles, lo que también hace que las conclusiones sean sesgadas y sugieran que los pacientes con cáncer experimentan acontecimientos estresores más frecuentes e intensos que el grupo de control (Watson y Pennebaker 1989).

\section{Estrés e incidencia de cáncer}

L a mayor parte de los estudios sobre estrés e incidencia de cáncer son estudios de casos y controles con resultados muy diversos. Ello se debe a que, en mayor o menor medida, no se controlaron los factores contaminantes. Como no sabemos a quienes creer, los ignoraremos aquí. Entre los estudios de cohorte, son muchos más lo que demuestran que las personas sometidas a mayores niveles de estrés no experimentan cáncer con más frecuencia que la población general que los que sugieren lo contrario (Fox 1995). A continuación se indican los resultados obtenidos en distintos grupos de personas expuestas al estrés.

1. Viudos y viudas. En un estudio finlandés en el que participaron 95.647 personas viudas, la tasa de mortalidad por cáncer sólo difirió en un $3 \%$ de la correspondiente a la población no viuda de edad equivalente a lo largo de un período de 5 años. En un estudio sobre las causas de mortalidad de 4.032 personas viudas realizado en el estado de M aryland durante los 12 años siguientes a la pérdida del cónyuge, no se produjeron más muertes por cáncer en este grupo que en los aún casados; de hecho, el número de fallecimientos fue ligeramente inferior. En Inglaterra y $\mathrm{G}$ ales, la $\mathrm{O}$ ficina de Censos y Encuestas de Población observó un ligero aumento de la incidencia de cáncer después de la muerte del cónyuge y tan sólo un aumento pequeño y no significativo de la mortalidad por cáncer.

2. Estado de ánimo depresivo. Un estudio ha demostrado un aumento de la mortalidad por cáncer en los años siguientes al diagnóstico de un estado de ánimo depresivo (Fox, 1989), pero otros cuatro estudios no han conseguido demostrar esta asociación. El estado de ánimo depresivo debe diferenciarse de la depresión que puede motivar la hospitalización. Sobre esta última no se han realizado estudios de cohortes a gran escala debidamente controlados y es, claramente, una depresión patológica no aplicable a la población trabajadora sana. Sin embargo, ni siquiera en este grupo de pacientes con depresión clínica la mayoría de los estudios más pequeños y mejor analizados han conseguido demostrar una mayor incidencia de cáncer.

3. U n grupo de 2.020 varones con edades comprendidas entre 35 y 55 años que trabajaban en una fábrica de productos eléctricos de Chicago fueron objeto de seguimiento durante 17 años después de ser sometidos a diversos tests. Los que 
presentaron las puntuaciones más altas en la escala de estado de ánimo deprimido tuvieron una tasa de mortalidad por cáncer 2,3 veces superior a la de los varones que alcanzaron las puntuaciones más altas en otras escalas no relacionadas con un estado de ánimo deprimido. Un colega del investigador principal realizó el seguimiento de la cohorte superviviente durante tres años más; durante ese período, la tasa de mortalidad por cáncer del conjunto del grupo con mayor puntuación en la escala del estado de ánimo deprimido fue tan sólo 1,3 veces superior a la del grupo de control. En un segundo estudio en el que participaron 6.801 adultos del condado de Alameda, en California, no se encontró exceso alguno de mortalidad por cáncer en el conjunto de las personas con estado de ánimo deprimido durante un seguimiento de 17 años. En un tercer estudio sobre 2.501 personas con estado de ánimo deprimido del condado de W ashington, en $M$ aryland, no se observó ningún aumento de la mortalidad por cáncer en los no fumadores a lo largo de un período de 13 años, en comparación con los sujetos de control que tampoco fumaban, pero sí en los fumadores. Más tarde, se comprobó que los resultados correspondientes a estos últimos eran erróneos por la presencia de un factor contaminante que había sido omitido por los investigadores. En un cuarto estudio sobre 8.932 mujeres llevado a cabo en el K aiser-Permanente Medical Center de Walnut Creek, California, tampoco se observó un aumento de la mortalidad por cáncer de mama a lo largo de un período de 11 a 14 años en las mujeres con estado de ánimo deprimido al inicio del estudio. En un quinto estudio, realizado en una muestra nacional aleatoria de 2.586 personas en la $\mathrm{N}$ ational $\mathrm{H}$ ealth and Nutrition Examination Survey de Estados U nidos, no se encontró una mayor mortalidad por cáncer en las personas que tenían un estado de ánimo deprimido cuando se midió utilizando dos escalas independientes del estado de ánimo. Cuando se combinan los resultados de todos estudios, con un total de 22.351 personas formadas por grupos muy distintos, se obtiene un fuerte argumento para rechazar los resultados contrarios de un único estudio en el que participaron 2.020 personas.

4. Otros factores de estrés. En un estudio de 4.581 varones hawaiianos de origen japonés con un seguimiento de 10 años, no se encontró aumento alguno de la incidencia de cáncer en los participantes que declararon un alto grado de acontecimientos estresores al comienzo de la investigación, en comparación con los que declararon niveles bajos. En otro estudio se investigó a 9.160 veteranos del ejército de Estados U nidos que habían sido prisioneros de guerra en el Pacífico y Europa durante la segunda G uerra M undial y la guerra de Corea. En estas personas, las tasas de mortalidad por cáncer entre 1946 y 1975 fueron iguales o inferiores a las de soldados emparejados por la zona de combate y la actividad de combate y que no habían caído prisioneros. En un estudio de 9.813 soldados americanos que se licenciaron en 1944 por "psiconeurosis", un diagnóstico vinculado al estrés crónico, se compararon las tasas de mortalidad por cáncer con las de un grupo equivalente de soldados que no padecía ese trastorno. La tasa de los "psiconeuróticos" no fue superior a la de los controles sino, por el contrario, ligeramente inferior, aunque sin alcanzar significancia estadística.

5. M enores niveles de estrés. En algunos estudios, aunque no en todos, se ha comprobado que unos niveles altos de apoyo social y relaciones sociales se asocian a un menor riesgo de cáncer en el futuro. Se han realizado tan pocos estudios sobre este tema y son tan poco convincentes las diferencias observadas que, a lo más que puede atreverse un revisor prudente es a sugerir la posibilidad de una verdadera relación. Se necesitarían evidencias más sólidas que las proporcionadas por los contradictorios estudios efectuados hasta la fecha.

\section{E strés y pronóstico de cáncer}

Este tema tiene menos interés porque son muy pocas las personas en edad de trabajar que padecen cáncer. N o obstante, conviene mencionar que, si bien algunos estudios han encontrado diferencias de supervivencia relacionadas con el nivel de estrés antes del diagnóstico de cáncer, otros no han podido demostrar diferencia alguna. Al juzgar estos hallazgos, convendría recordar otros paralelos, según los cuales no sólo los pacientes con cáncer, sino también los que sufren otras enfermedades, mencionan acontecimientos estresores del pasado con más frecuencia que las personas sanas, debido al cambio psicológico inducido por la propia enfermedad y por el hecho de saberse víctima de esa enfermedad. En lo que al pronóstico se refiere, algunos investigadores refieren mayores tasas de supervivencia en las personas que gozan de un buen apoyo social. Quizás a más apoyo se produzca menos estrés, y viceversa. En cuanto a la incidencia y al pronóstico de cáncer, los estudios existentes se atreven, como mucho, a sugerir una posible relación con el estrés (Fox 1995).

\section{Estudios en animales}

Podría resultar interesante observar los efectos del estrés en los experimentos con animales. Los resultados obtenidos con ensayos correctamente realizados son mucho más claros, pero no decisivos. Se ha observado que, en los animales con tumores víricossometidos a estrés, las neoplasias crecen con mucha más rapidez y la muerte se produce antes que en los no estresados. Sin emba rgo, en los tumores no víricos, es decir, en los inducidos experimentalmente en el laboratorio mediante la aplicación de carcinógenos químicos, ocurre justamente lo contrario. En estos casos, los animales estresados presentan menos tumores y sobreviven más tiempo que los no estresados (Justice 1985). No obstante, sólo entre el 3 y el $4 \%$ de las neoplasias malignas humanas de los países industrializados son de origen vírico; las demás se deben a estímulos físicos o químicos (tabaco, rayos $X$, sustancias químicas industriales, radiaciones nucleares como las producidas por el radón, exposición excesiva a la luz solar, etc.). En consecuencia, si se extrapolaran los resultados de los experimentos en animales, habría que llegar a la conclusión de que el estrés beneficia al hombre en lo que a la incidencia y supervivencia del cáncer se refiere. Por distintos motivos no procede llegar a semejante conclusión (Justice 1985; Fox 1981). Los resultados obtenidos en animales son útiles para generar hipótesis sobre los datos obtenidos en las persona, pero no pueden constituir la base para extraer conclusiones sobre las personas.

\section{Conclusión}

Dado el amplio abanico de factores de estrés investigados en la literatura (a largo plazo, a corto plazo, más grave, menos grave, de muchos tipos) y el predominio de resultados que sugieren una relación escasa o inexistente entre el estrés y la incidencia posterior de cáncer, parece razonable pensar que podrían aplicarse estos mismos resultados a la situación de trabajo. En cuanto al pronóstico del cáncer, los estudios realizados son demasiado escasos como para poder extraer conclusiones, ni siquiera provisionales, sobre su relación con los factores de estrés. No obstante, es posible que un mayor apoyo social reduzca ligeramente la incidencia y quizá aumente también la supervivencia. 


\section{- TRAST ORNOS MUSC ULOSQ UELETICOS}

\section{Soo-Yee Lim, Steven L. Sauter y Naomi G. Swanson}

En la literatura publicada sobre salud ocupacional son cada vez más los trabajos que demuestran la influencia de los factores psicosociales del trabajo en la aparición de trastornos musculosqueléticos, entre ellos el dolor en la parte baja de la espalda y los trastornos de los miembros superiores (Bongers y cols. 1993). LoS factores psicosociales del trabajo se definen como los aspectos del medio ambiente de trabajo (como las tareas, las presiones, las relaciones laborales) que pueden contribuir a la aparición de estrés en la persona (Lim y Carayon 1994, OTI 1986). En el presente artículo se resumen las evidencias existentes y los mecanismos subyacentes que relacionan los factores psicosociales del trabajo con los problemas musculosqueléticos, prestando especial atención a los estudios efectuados sobre los trastornos de los miembros superiores en trabajos de oficina. Se analizan también las posibles líneas de investigación en el futuro.

Entre 1985 y 1995 han sido muchos los estudios que relacionan los factores psicosociales con los trastornos musculares de las extremidades superiores en el medio ambiente de trabajo de las oficinas (para una revisión más amplia, véase M oon y Sauter, 1996). En Estados U nidos, esta relación comenzó a deducirse tras la investigación realizada por el $\mathrm{N}$ ational Institute for $\mathrm{O}$ ccupational Safety and H ealth (NIO SH) (Smith y cols. 1981), cuyos resultados indicaron que los operadores de pantallas de visualización de datos (PVD) que declaraban menos autonomía, asignación menos clara de rol, mayor presión y mayor supervisión eran también los que declaraban un mayor número de problemas musculosqueléticos, en comparación con sus compañeros que no trabajaban con PVD (Smith y cols. 1981).

E studios recientes, en los que se han empleado técnicas estadísticas de inferencia más potentes, han demostrado más claramente el efecto de los factores psicosociales del trabajo en la frecuencia de trastornos musculosqueléticos de las extremidades superiores de los trabajadores de oficinas. Por ejemplo, Lim y Carayon (1994) utilizaron métodos de análisis estructural para examinar la relación entre los factores psicosociales del trabajo y las molestias musculosqueléticas de los miembros superiores en una muestra de 129 oficinistas. Sus resultados demostraron que los factores psicosociales, tales como las presiones en el trabajo, el control de tareas y las cuotas de producción eran factores de predicción importantes de estos trastornos, sobre todo de problemas en la región cervical y en los hombros. En este estudio se controlaron los factores demográficos (edad, sexo, relación con la empresa, horas diarias de trabajo con ordenador) y otros factores de confusión (autoevaluación de trastornos de la salud, aficiones y uso del teclado fuera de las horas de trabajo) y pudo comprobarse que ninguno de ellos guardaba relación con estos problemas.

$\mathrm{H}$ ales y cols. (1994) obtuvieron resultados similares en un estudio del NIOSH sobre los problemas musculosqueléticos de 533 técnicos de telecomunicaciones de 3 ciudades diferentes. Se investigaron dos tipos de trastornos: a) síntomas musculosqueléticos de los miembros superiores determinados exclusivamente con un cuestionario y b) trastornos musculosqueléticos de las extremidades superiores posiblemente relacionados con el trabajo, determinados mediante una exploración física además del cuestionario. U tilizando técnicas de regresión se comprobó que factores tales como la presión en el trabajo y un escaso poder de decisión se asociaban tanto a la intensificación de los síntomas como al aumento de los signos físicos de enfermedad. En los trabajadores de la industria se han observado relaciones similares, aunque referidas sobre todo al dolor de espalda (Bongers y cols. 1993).
Los investigadores sugieren diversos mecanismos para explicar la relación entre factores psicosociales y problemas musculosqueléticos (Sauter y Swanson 1996; Smith y Carayon 1996; Lim 1994; Bongers y cols. 1993), que pueden clasificarse en cuatro categorías:

1. psicofisiológicos;

2. conductuales;

3. físicos,

4. perceptivos.

\section{M ecanismos psicofisiológicos}

Se ha demostrado que las personas sometidas a condiciones de trabajo psicológicamente estresores también presentan un mayor grado de activación autónoma (p. ej., mayor secreción de catecolaminas, aumento de la frecuencia cardíaca y de la presión arterial, incremento de la tensión muscular, etc.) (Frankenhaeuser y Gardell 1976). Se trata de una respuesta psicofisiológica normal de adaptación que prepara a la persona para la acción. No obstante, la exposición prolongada al estrés puede tener un efecto nocivo para la función musculosquelética y para la salud en general. Por ejemplo, la tensión muscular asociada al estrés puede aumentar la sobrecarga estática de los músculos, acelerando la fatiga muscular y las molestias asociadas (Westgaard y Bjorklund 1987; G randjean 1986).

\section{M ecanismos conductuales}

L as personas sometidas a estrés pueden modificar su conducta en el trabajo de una manera que aumenta la tensión musculosquelética. Por ejemplo, el estrés psicológico puede hacer que se aplique más fuerza de la necesaria durante el mecanografiado u otras tareas manuales, incrementando el desgaste y el cansancio del aparato musculosquelético.

\section{M ecanismos físicos}

Los factores psicosociales pueden modificar directamente las exigencias físicas (ergonómicas) del trabajo. Por ejemplo, es muy probable que un aumento de la presión para cumplir unos plazo de tiempo determinados conlleve un aumento del ritmo de trabajo(con mayor número de repeticiones) y de la tensión. Por el contrario, los trabajadores que ejercen un mayor control sobre sus tareas pueden ajustarlas para reducir la repetitividad (Lim y Carayon 1994).

\section{M ecanismos perceptivos}

Sauter y Swanson (1996) sugieren que la relación entre los factores de estrés biomecánico (p. ej., factores ergonómicos) y la aparición de problemas musculosqueléticos está mediada por procesos perceptivos que, a su vez, dependen de los factores psicosociales propios del lugar de trabajo. Por ejemplo, un trabajo rutinario y monótono puede hacer que los síntomas se manifiesten con mayor claridad que cuando se trata de tareas que exigen la atención del trabajador (Pennebaker y H all 1982).

Sería preciso hacer nuevas investigaciones para evaluar la importancia relativa de cada uno de estos mecanismos y sus posibles interacciones. Además, nuestro conocimiento de las relaciones causales entre los factores psicosociales del trabajo y los trastornos musculosqueléticos aumentarían con a) estudios de diseño longitudinal, b) métodos mejores para evaluar y diferenciar las exposiciones psicosociales y físicas, y c) métodos mejores para medir los resultados musculosqueléticos.

No obstante, existen ya numerosas evidencias que relacionan los factores psicosociales y los trastornos musculosqueléticos, pudiendo deducirse de ellas que las intervenciones psicosociales podrían, probablemente, contribuir a la prevención de tales trastornos en el lugar de trabajo. A este respecto, algunas 
publicaciones (NIOSH 1988; OIT 1986) contienen directrices para optimizar el medio ambiente psicosocial en el trabajo. Como sugieren Bongers y cols. (1993), debería prestarse una atención especial al apoyo que reciben los trabajadores y a su autonomía. Los efectos positivos de estas variables resultaron evidentes en el estudio efectuado por Westin (1990) en la Federal Express Corporation de Estados U nidos. Según este autor, tras un programa de reorganización del trabajo para lograr un entorno de "apoyo a los trabajadores" que mejorara la comunicación y redujera las presiones de trabajo y de tiempo, los signos y síntomas de trastornos musculosqueléticos fueron mínimos.

\section{- TRASTORNOS MENTALES}

Carles M untaner y William W. Eaton

\begin{abstract}
Introducción
Los trastornos mentales son una de las consecuencias crónicas del estrés profesional que más impacto social y económico tienen para la comunidad (Jenkins y Coney 1992; Miller y K elman 1992). Dos disciplinas, la epidemiología psiquiátrica y la sociología de la salud mental (Aneshensel, Rutter y Lachenbruch 1991), estudian los efectos de los factores psicosociales y organizativos del trabajo en los trastornos mentales. Estos estudios pueden clasificarse en cuatro enfoques teóricos y metodológicos distintos: a) estudios sobre una sola profesión, b) estudios de grandes categorías profesionales como indicadores de estratificación social, c) estudios comparativos entre categorías profesionales, y d) estudios sobre factores de riesgo psicosociales y organizativos específicos. Seguidamente analizaremos cada uno de estos enfoques y expondremos sus implicaciones para la investigación y la prevención.
\end{abstract}

\section{Estudios sobre una sola profesión}

Son muchos los estudios que se han centrado en una sola profesión. En algunos de los más recientes, se ha estudiado la depresión en secretarias (Garrison y Eaton 1992), profesionales y directivos (Phelan y cols. 1991; Bromet y cols. 1990), informáticos (M ino y cols. 1993), bomberos (Guidotti 1992), maestros (Schonfeld 1992), y "maquiladoras" (Guendelman y Silberg 1993). También recientemente se han relacionado el alcoholismo y las toxicomanías con la mortalidad de los conductores de autobús (M ichaels y Zoloth 1991) y de ciertos profesionales y directivos (Bromet y cols. 1990). Se han encontrado síntomas de ansiedad y depresión, como indicadores de un trastorno psiquiátrico subyacente, en trabajadores textiles, profesionales de la enfermería, maestros, trabajadores sociales, trabajadores de industrias petrolíferas en alta mar y médicos jóvenes (Brisson, Vezina y $V$ inet 1992; Fith-C ozens 1987; Fletcher 1988; M cG rath, Reid y Boore 1989; Parkes 1992). La ausencia de grupos de control impide establecer con exactitud la importancia de este tipo de estudios.

\section{Estudios de grandes categorías profesionales como indicadores de estratificación social}

EI uso de la profesión como indicador de estratificación social tiene una larga tradición en la investigación de la salud mental (Liberatos, Link y K elsey 1988). En Inglaterra, los trabajadores manuales no cualificados y los funcionarios de niveles más bajos presentan elevadas tasas de prevalencia de trastornos psiquiátricos menores (Rodgers 1991; Stansfeld y M armot 1992). Se ha demostrado una mayor prevalencia de alcoholismo en los trabajadores manuales de Suecia (0 jesjo 1980) y mayor todavía en los directivos japoneses (K awakami y cols. 1992). La imposibilidad de diferenciar entre los efectos de la profesión y los derivados de "la forma de vida" asociada a los estratos profesionales es una importante limitación en este tipo de estudios. Es asimismo cierto que la profesión es un indicador de estratificación social en un sentido diferente al de la clase social, ya que esta última implica el control de los medios de producción (Kohn y cols. 1990; M untaner y cols. 1994). Sin embargo, todavía no se han realizado estudios empíricos sobre trastornos mentales que hayan aplicado este concepto.

\section{Estudios comparativos entre categorías profesionales}

L as categorías profesionales del censo constituyen una fuente fácil de información para explorar asociaciones entre profesiones y trastornos mentales (Eaton y cols. 1990). Los análisis por grandes categorías profesionales del estudio de las Areas de Referencia Epidemiológica (ARE) demostraron una mayor prevalencia de depresión en los profesionales, administrativos y empleados de hogar (Roberts y Lee 1993). En otro gran estudio epidemiológico realizado en el condado de Alameda, se hallaron unas altas tasas de depresión en los operarios (K aplan y cols. 1991). En Estados Unidos se ha observado que las tasas de prevalencia durante 12 meses de alcoholismo son mayores en hombres con profesiones relacionadas con la artesanía $(15,6 \%)$ o con trabajos manuales poco especializados (15,2\%); en las mujeres, las profesiones relacionadas con la agricultura, la silvicultura y la pesca $(7,5 \%)$ o con servicios poco cualificados $(7,2 \%)$ parecen ser las que más riesgo tienen ( $\mathrm{H}$ arford y cols. 1992). Las tasas ARE de abuso y dependencia del alcohol fueron mayores en las profesiones relacionadas con el transporte, la artesanía y la agricultura (R oberts y Lee 1993). L os trabajadores del sector de los servicios, los conductores y los trabajadores no cualificados presentaron unas tasas más altas de alcoholismo en un estudio sobre la población sueca (Agren y R omelsjo 1992). En el estudio AR E, la prevalencia durante 12 meses del abuso y dependencia de drogas fue mayor en los agricultores $(6 \%)$, artesanos $(4,7 \%)$ y operadores, transportistas y obreros (3,3 \%) (Roberts y L ee 1993). El análisis ARE de la prevalencia combinada de todos los síndromes de abuso y dependencia de sustancias psicoactivas (Anthony y cols. 1992) reveló tasas de prevalencia más altas en obreros de la construcción, carpinteros, todas las profesiones relacionadas con la construcción, camareros, camareras, transportistas y profesiones itinerantes. En otro análisis ARE (M untaner y cols. 1991), y en comparación con las profesiones directivas, el riesgo de esquizofrenia (delirio y alucinaciones) fue mayor en los empleados de hogar, mientras que en los artistas y las profesiones relacionadas con la construcción se encontró un riesgo mayor de esquizofrenia según el criterio $A$ del manual diagnóstico y estadístico de los trastornos mentales (D SM -III) (APA 1980).

Se han realizado algunos estudios ARE sobre categorías profesionales más específicas. Además de especificar más claramente los entornos laborales, se ajustan los factores sociodemográficos que pueden confundir los resultados de estudios no controlados. Estos estudios revelan mayores tasas de prevalencia durante 12 meses de depresión mayor (superiores a la prevalencia del 3 - $5 \%$ en la población general) en operadores de equipos informáticos y encargados de la entrada de datos (13\%), mecanógrafos, abogados, profesores de educación especial y consejeros (10\%) (Eaton y cols. 1990). Tras ajustar los factores sociodemográficos, los abogados, profesores y consejeros seguían presentando tasas significativamente mayores que el conjunto de la población activa (Eaton y cols. 1990). En un análisis detallado de 104 profesiones, los obreros de la construcción, los trabajadores de la construcción más especializados, los conductores de camiones y los transportistas presentaron altas tasas de abuso y dependencia del alcohol (M andell y cols. 1992). 
Los estudios que comparan distintas categorías profesionales plantean los mismos problemas que los de estratificación social. U no de ellos es la posibilidad de que pasen inadvertidos factores de riesgo específicos. Además, los factores relacionados con la "forma de vida" propia de cada categoría profesional permiten también explicar los resultados.

\section{Estudios sobre factores de riesgo psicosociales y organizativos específicos}

La mayor parte de los estudios sobre estrés y trastornos mentales utilizan escalas desarrolladas a partir del modelo de Demanda/ Control de K arasek (K arasek y Theorell 1990) o parámetros derivados del D ictionary of 0 ccupational Titles (DOT) (C ain y Treiman 1981). Pese a las diferencias metodológicas y teóricas existentes entre estos sistemas, ambos miden dimensiones psicosociales similares (control, complejidad sustantiva y exigencias del puesto de trabajo) (M untaner y cols. 1993). Las exigencias del trabajo se han asociado a un trastorno depresivo mayor en trabajadores varones de centrales eléctricas (Bromet 1988). Se ha demostrado que los trabajos caracterizados por la ausencia de dirección, control o planificación median la relación entre el nivel socioeconómico y la depresión (Link y cols, 1993). No obstante, un estudio no pudo demostrar esta relación entre bajo control y depresión (Guendelman y Silberg 1993). También los efectos negativos relacionados con el trabajo, la carencia de recompensas intrínsecas del trabajo y los factores de estrés organizativo, como el conflicto de rol y la ambigüedad se han asociado a una depresión mayor (Phelan y cols. 1991). El consumo de grandes cantidades de alcohol y los problemas asociados al mismo se han relacionado con un exceso de horas de trabajo y la ausencia de recompensas intrínsecas del trabajo en los varones y con la inseguridad laboral en las mujeres en Japón (K awakami y cols. 1993), así como con unas elevadas exigencias laborales y un escaso control en Estados Unidos (Bromet 1988). También en los varones de este país, las grandes exigencias psicológicas o físicas y el escaso control resultaron factores predictivos del abuso o la dependencia de alcohol (Crum y cols. 1995). En otro análisis $A R E$, las grandes demandas físicas y la escasa cualificación fueron factores predictivos de dependencia de sustancias psicoactivas (M untaner y cols. 1995). En tres estudios realizados en Estados U nidos, las exigencias físicas y los riesgos asociados al trabajo fueron factores predictivos de esquizofrenia, delirio 0 alucinaciones (M untaner y cols. 1991; Link y cols. 1986; M untaner y cols. 1993). Las exigencias físicas se han asociado asimismo a enfermedad psiquiátrica en la población sueca (Lundberg 1991). Estos estudios sugieren la posibilidad de la prevención, puesto que se centran en factores de riesgo específicos y susceptibles de modificación.

\section{Implicaciones para la investigación y la prevención}

En el futuro convendría analizar las características demográficas y sociológicas de los trabajadores para definir con mayor detalle las distintas profesiones (M andell y cols. 1992). Cuando la profesión se considera un indicador de la estratificación social, tienen que realizarse los ajustes necesarios para tener en cuenta los factores de estrés no relacionados con el trabajo. Tienen que investigarse también los efectos de la exposición crónica a un lugar de trabajo poco democrático (Johnson y Johansson 1991). U na iniciativa importante para prevenir los trastornos psicológicos relacionados con el trabajo subraya la importancia de mejorar las condiciones laborales, los servicios, la investigación y la vigilancia (Keita y Sauter 1992; Sauter, Murphy y H urrell 1990).

Si bien algunos investigadores afirman que la reorganización del trabajo puede mejorar tanto la productividad como la salud de los trabajadores (K arasek y T heorell 1990), otros afirman que los objetivos de maximización de beneficios de las empresas están en conflicto con la salud mental de los trabajadores (Phelan y cols. 1991; M untaner y O 'Campo 1993; R alph 1983).

\section{BURNOUT}

\section{Christina M aslach}

El burnout ("estar quemado") es un tipo de respuesta prolongada a los estresores emocionales e interpersonales crónicos en el trabajo. Se ha conceptualizado como una experiencia de estrés individual embebida en un contexto de relaciones sociales complejas y que abarca el concepto que la persona tiene de sí misma y de los demás. Como tal, ha sido objeto de una atención especial en las profesiones relacionadas con la prestación de servicios en donde a) la relación entre proveedores y destinatarios constituye el eje central del trabajo y b) la prestación del servicio, la atención, el trato o la educación pueden ser experiencias altamente emocionales. Son varias las profesiones que cumplen estos criterios, entre ellas las relacionadas con la asistencia sanitaria, los servicios sociales, los servicios de salud mental, el derecho penal y la educación. Aunque la naturaleza del contacto entre proveedores y destinatarios difiere en cada una de estas profesiones, son semejantes en cuanto a que existe una relación estructurado centrada en torno al problema del destinatario (psicológico, social y/ o físico). No sólo es probable que el trabajo del proveedor conlleve una elevada carga emocional, sino que las soluciones pueden no ser fáciles, factor este que se suma a la frustración y ambigüedad de la situación profesional. La persona que trabaja continuamente con otras personas en tales circunstancias corre un gran riesgo de burnout. La definición operativa (y el parámetro de investigación correspondiente) más aceptada actualmente en la investigación sobre el burnout es un modelo de tres componentes, en el que el burnout se conceptualiza en términos de agotamiento emocional, despersonalización y menor realización personal ( $M$ aslach 1993; M aslach y Jackson 1981/ 1986). El agotamiento emocional se refiere a la sensación de haberse sobrepasado emocionalmente y haber agotado los recursos emocionales. La despersonalización implica una respuesta negativa, insensible o excesivamente despegada a las personas que suelen ser los receptores del servicio o la asistencia. La menor realización personal se refiere a una menor sensación de competencia y logros en el trabajo.

Este modelo multidimensional del burnout tiene implicaciones teóricas y prácticas importantes. Permite comprender mucho mejor esta forma de estrés laboral, ubicándolo en su contexto social e identificando las distintas reacciones psicológicas experimentadas por los diferentes trabajadores. Estas respuestas diferenciales pueden no ser una simple función de los factores individuales (como la personalidad), sino un reflejo del diferente impacto de los factores en las tres dimensiones del burnout. Por ejemplo, ciertas características del trabajo pueden influir en las fuentes de estrés emocional ( $y$, por tanto, en el agotamiento emocional) 0 en los recursos disponibles para enfrentarse con éxito a las demandas del trabajo (y, por tanto, en la realización personal). Este enfoque multidimensional supone también que las intervenciones dirigidas a prevenir el burnout deben ser planificadas y diseñadas según el componente específico que pretenden corregir. Es decir, posiblemente serán más eficaces los intentos de reducir el riesgo de agotamiento emocional, de prevenir la tendencia a la despersonalización o de aumentar la sensación de realización personal que otras estrategias más generales.

En consonancia con este marco social, la investigación empírica del burnout se ha centrado fundamentalmente en los factores 
contextuales y profesionales. Así, los estudios incluyen variables tales como las relaciones en el trabajo (con clientes, compañeros, supervisores) y en el hogar (familiares), la satisfacción con el trabajo, el conflicto y la ambigüedad de rol, el abandono del trabajo (rotación, absentismo), las expectativas, la carga de trabajo, el tipo de puesto de trabajo y la seguridad del mismo, la política institucional, etc. L os factores personales estudiados son, en su mayoría, variables demográficas (sexo, edad, estado civil, etc.). Además, se ha prestado cierta atención a variables de personalidad, salud personal, relaciones con la familia y los amigos (apoyo social en el hogar) y los valores y compromisos personales. En general, los factores propios del trabajo muestran una relación más estrecha con el burnout que los factores biográficos o personales. En cuanto a los antecedentes de agotamiento, los tres factores más importantes parecen ser el conflicto de rol, la carencia de control o autonomía y la ausencia de apoyo social en el trabajo. Estos efectos del burnout se encuentran con mayor frecuencia en las distintas formas de abandono e insatisfacción con el trabajo y suponen un deterioro de la calidad de la atención o los servicios prestados a los usuarios o pacientes. EI burnout parece estar correlacionado con algunos índices autoevaluados de disfunción personal, como problemas de salud, mayor consumo de alcohol y sustancias psicoactivas y conflictos conyugales y familiares. A parentemente el nivel de burnout se mantiene bastante estable a lo largo del tiempo, apoyando así la idea de que su carácter es más crónico que agudo (véase $\mathrm{K}$ leiber y Enzmann 1990; Schaufeli, M aslach y M arek 1993 para una revisión del tema).

Un tema para futuras investigaciones se refiere a los posibles criterios diagnósticos del burnout. Este ha sido descrito a menudo en términos de síntomas disfóricos tales como agotamiento, fatiga, pérdida de autoestima y depresión. Sin embargo, se admite que la depresión carece de contexto y puede aparecer en cualquier situación, mientras que el burnout está relacionado con el trabajo y es específico de la situación. 0 tros síntomas son la dificultad para concentrarse, irritabilidad y negativismo, así como una importante disminución del rendimiento laboral durante un período de varios meses. En general, se supone que los síntomas de agotamiento aparecen en personas "normales" que no sufren trastornos psicopatológicos ni enfermedades orgánicas identificadas previamente. Si realmente existieran síntomas distintivos, podría diagnosticarse y tratarse el burnout de forma individual.

U na vez demostrada la etiología contextual del burnout, se ha prestado mayor atención a las intervenciones sociales que a las personales. El apoyo social, sobre todo el prestado por los compañeros de trabajo, parece ser eficaz para reducir el riesgo de burnout. U na formación adecuada que prepare a la persona para enfrentarse a situaciones difíciles y estresores ayuda a adquirir una sensación de autoeficacia y dominio en estas tareas. La participación en un gran grupo comunitario o en un grupo de trabajo puede también contrarrestar la sensación de desamparo y pesimismo que suele existir cuando no se encuentran soluciones a largo plazo para los problemas del trabajador. 0 tros métodos para aumentar la autoeficacia personal y el control tratan de acentuar los aspectos positivos del trabajo y dotar de un mayor sentido a las tareas cotidianas.

Existe una tendencia creciente a considerar el burnout como un proceso dinámico, más que estático, y esta perspectiva tiene importantes implicaciones para los modelos de desarrollo y las medidas del proceso propuestos. Es de esperar que esta nueva perspectiva permita obtener nuevos datos que amplíen nuestros conocimientos sobre el burnout y permitan tanto a los individuos como a las instituciones un tratamiento más eficaz de este problema social.

\section{- RESUMEN DE LAS ESTRATEgIAS GENERALES DE PREVENCION Y CONTROL}

\section{Cary L. Cooper y Sue Cartwright}

Toda organización que pretenda conseguir y mantener el máximo bienestar mental, físico y social de sus trabajadores necesitará disponer de políticas y procedimientos que adopten un enfoque integrado de la salud y la seguridad. Especialmente deberán disponer de una política de salud mental con procedimientos de gestión del estrés, basados en las necesidades de la organización y de los trabajadores y sometidos periódicamente a revisión y evaluación.

Para la prevención del estrés pueden barajarse distintas alternativas, que pueden ser clasificadas como prevención primaria, secundaria o terciaria y centradas en distintas fases del proceso de desarrollo del estrés (C ooper y Cartwright 1994). La prevención primaria se refiere a las acciones dirigidas a reducir o eliminar los factores de estrés (es decir, los orígenes del estrés) y promover positivamente el medio ambiente de trabajo saludable y solidario. La prevención secundaria consiste en la detección y tratamiento precoces de la depresión y la ansiedad a través de la concienciación de los trabajadores y la promoción de las estrategias de control del estrés. L a prevención terciaria implica la rehabilitación y recuperación de las personas que han sufrido o sufren problemas graves de salud producidos por estrés.
Para desarrollar una política de empresa eficaz y global, los empresarios tienen que integrar estos tres enfoques (Cooper, L iukkonen y Cartwright 1996).

\section{Prevención primaria}

En primer lugar, la forma más efectiva de combatir el estrés consiste en eliminar su causa. Para ello puede que sea necesario modificar la política de personal, mejorar los sistemas de comunicación, rediseñar los puestos de trabajo, permitir una mayor participación en la toma de decisiones o conceder una mayor autonomía en los niveles más bajos. Aunque evidentemente las medidas necesarias variarán en cada organización según los tipos de factores de estrés propios de cada una, todas las intervenciones deben basarse en un diagnóstico previo o en una auditoría del estrés que permita identificar los factores de estrés y las personas afectadas por él.

N ormalmente, las auditorías del estrés se basan en cuestionarios autoaplicados que se distribuyen entre los trabajadores de toda la organización, de algunos departamentos o de algunos centros de trabajo. A demás de identificar las fuentes de estrés en el trabajo y las personas más vulnerables al mismo, estos cuestionarios permiten evaluar los niveles de satisfacción con el trabajo, la capacidad de afrontamiento y la salud física y mental, en comparación con otros grupos e industrias similares. Las auditorias del estrés son procedimientos muy eficaces para dirigir los recursos de una organización a las áreas que más los necesitan. También proporcionan un medio para controlar periódicamente la evolución con el tiempo de los niveles de estrés y la salud de 
los trabajadores, así como un punto de referencia para evaluar las intervenciones posteriores.

Con este fin se utilizan cada vez más instrumentos diagnósticos como el Indicador de estrés ocupacional (Cooper, Sloan y Williams 1988). En general, estos instrumentos son utilizados por los departamentos de salud ocupacional y/o recursos humanos, con la colaboración de un psicólogo. En las empresas más pequeñas, puede que exista la posibilidad de celebrar reuniones con los trabajadores o preparar cuestionarios que se administren de una manera más informal. En las reuniones con los trabajadores y en los cuestionarios tienen que abordarse los aspectos siguientes:

- contenido del trabajo y programa de trabajo;

- condiciones físicas del trabajo;

- condiciones de empleo y expectativas de los distintos grupos de trabajadores de la empresa;

- relaciones interpersonales en el trabajo,

- sistemas de comunicación y medidas de información.

O tra alternativa consiste en pedir a los trabajadores que rellenen un diario del estrés durante varias semanas, registrando todos los acontecimientos estresores vividos durante la jornada laboral. El conjunto de estos informes, agrupados por grupos 0 departamentos, puede ser de gran utilidad para identificar las fuentes generales y permanentes de estrés.

\section{Creación de entor nos saludables y redes de apoyo}

0 tro aspecto clave de la prevención primaria es la creación de un clima de apoyo que considere el estrés como una característica propia de la vida moderna y no como un signo de debilidad o incompetencia. L os trastornos mentales no discriminan a nadie, pudiendo afectar a cualquier persona, con independencia de su edad, su posición social o su profesión. Por tanto, los trabajadores no deben sentirse avergonzados por admitir que están teniendo dificultades.

Las organizaciones deben tomar medidas explícitas para erradicar el estigma asociado con tanta frecuencia a los problemas emocionales y para maximizar el apoyo prestado a sus trabajadores (Cooper y Williams 1994). Algunas medidas formales que pueden adoptarse en este sentido son:

- informar a los trabajadores de los mecanismos de apoyo y asesoramiento existentes en la organización, como los servicios de salud ocupacional.

- incorporar específicamente aspectos del desarrollo personal a los sistemas de valoración.

- ampliar y mejorar el "don de gentes" de los directivos y supervisores, para que adopten actitudes de apoyo y puedan enfrentarse con más facilidad a los problemas de los trabajadores.

Lo más importantes es que tanto las empresas como los sindicatos demuestren su compromiso de lucha contra el estrés y de protección de la salud mental en el trabajo. Para ello, puede que sea necesario mejorar los canales de comunicación y erradicar las normas culturales que favorecen el estrés de los trabajadores (p. ej., las normas culturales que incitan a los empleados a trabajar en exceso y durante muchas horas y a sentirse culpables por abandonar el trabajo "a la hora"). Las organizaciones que deseen crear un clima de apoyo deberán asimismo intentar anticiparse a factores de estrés nuevos o adicionales que pueden aparecer como consecuencia de cambios como reestructuraciones o introducción de nuevas tecnologías. Estos factores de estrés nuevos pueden combatirse con programas de formación 0 una mayor participación de los trabajadores. La comunicación y la participación de los trabajadores tienen una importancia fundamental para reducir el estrés en el contexto de un cambio organizativo.

\section{Prevención secundaria}

Las iniciativas correspondientes a esta categoría se centran, en general, en la formación y en la educación y consisten en actividades de concienciación y programas de adquisición de destrezas.

Los cursos de educación y gestión del estrés son útiles para ayudar a las personas a reconocer los síntomas del estrés en sí mismas y en los demás, así como para ampliar y desarrollar las destrezas y aptitudes necesarias para afrontar el estrés.

La forma y el contenido de estas actividades de formación son sumamente variables, desde simples técnicas de relajación, asesoramiento y planificación sobre la forma de vida o formación básica en técnicas de administración del tiempo, hasta la adquisición de destrezas para la resolución de problemas o el reforzamiento de la seguridad en uno mismo. Sus objetivos consisten en ayudar a los trabajadores a analizar los efectos psicológicos del estrés y a diseñar un plan personal para que puedan controlarlo (C ooper 1996).

Estos programas son muy beneficiosos para los trabajadores, cualquiera que sea su nivel, y resultan especialmente útiles para que los directivos sepan reconocer el estrés en sus subordinados y tomen conciencia de sus propias técnicas de gestión y de su impacto en los demás. Estos programas pueden ser de gran utilidad cuando se inician después de una auditoría del estrés.

\section{Programas de vigilancia y promoción de la salud}

Las organizaciones pueden también, con la ayuda de los profesionales de la salud ocupacional, emprender iniciativas que promuevan directamente una conducta beneficiosa para la salud en el lugar de trabajo, como las siguientes:

- chequeos periódicos y exploraciones selectivas;

- diseño de menús "saludables" en los comedores de las empresas;

- disponibilidad de instalaciones deportivas y clases de educación física;

- descuentos en algún gimnasio o centro de salud de la localidad;

- programas de protección cardiovascular;

- asesoramiento sobre el control del consumo de alcohol y la dieta (especialmente reducción del colesterol, la sal y los azúcares);

- programas para dejar de fumar,

- asesoramiento general sobre la forma de vida.

Las organizaciones que no disponen de instalaciones para un departamento de salud ocupacional pueden recurrir a organismos externos para que organicen una serie de programas de promoción de la salud. Los programas de promoción de la salud que existen desde hace tiempo en Estados U nidos han obtenido resultados espectaculares (K arasek y Theorell 1990). Por ejemplo, el Programa de Bienestar de la N ew York Telephone Company, cuyo objetivo era mejorar la salud cardiovascular, ahorró a la empresa 2,7 millones de dólares en costes de absentismo y tratamiento médico en el plazo de tan sólo un año.

Los programas de gestión del estrés y la forma de vida pueden ser especialmente útiles para ayudar a las personas a controlar los factores de estrés en el entorno que pueden haber sido identificados por la organización, pero que no pueden modificarse, p. ej., la inseguridad en el empleo.

\section{Prevención terciaria}

Un componente importante de la promoción de la salud en el lugar de trabajo es la detección precoz de los problemas de salud mental y la remisión inmediata de los afectados a un lugar donde puedan recibir tratamiento especializado. Casi todas las personas que desarrollan algún trastorno mental se recuperan por completo y pueden reincorporarse al trabajo. En general, es 
mucho más costosa la jubilación anticipada de una persona por causas médicas y la selección y formación de un sucesor que su recuperación y reincorporación al trabajo. Las organizaciones deben considerar dos aspectos especiales de la prevención terciaria:

\section{Asesoramiento}

Las organizaciones pueden proporcionar el acceso a servicios confidenciales de asesoramiento profesional para los trabajadores que tienen problemas en su lugar de trabajo o en su entorno familiar (Swanson y M urphy 1991). Estos servicios pueden ser proporcionados por asesores internos o por organismos externos, bajo la forma de un Programa de Asistencia a los Empleados (PAE).

LOS PAE proporcionan asesoramiento, información y/ o remisión a los servicios de asesoramiento o tratamiento apropiados. E stos servicios son confidenciales y suelen disponer de una línea de contacto durante las 24 horas del día. La facturación suele hacerse per cápita, calculando el número total de trabajadores y el número de horas de asesoramiento prestadas por el programa.

EI asesoramiento es una actividad muy especializada que requiere una gran formación. Es importante comprobar que los asesores dispongan de los conocimientos y las destrezas adecuadas y que tengan acceso a un entorno apropiado que les permita desarrollar sus actividades en un marco ético y en la más estricta intimidad.

Una vez más, la prestación de servicios de asesoramiento resulta especialmente eficaz en la lucha contra el estrés causado por factores que existen en una organización y que no pueden ser modificados (p. ej., la pérdida del empleo) o por factores que no tienen relación con el trabajo (p. ej., pérdida de un ser querido, divorcio) pero que, no obstante, repercuten en la vida laboral. También resulta útil para orientar a los trabajadores hacia los servicios que mejor pueden ayudarles a resolver sus problemas.

\section{Facilitar la reincorporación al trabajo}

Conviene recordar que, cuando un trabajador ha estado de baja por un motivo relacionado con el estrés, la reincorporación puede ser, por sí misma, una experiencia "estresora". Es importante que las organizaciones comprendan y acepten estas circunstancias. D ebe realizarse una entrevista de "reincorporación" para determinar si la persona afectada está preparada y desea reintegrarse a todos los aspectos de su vida laboral. Las negociaciones exigen una delicada relación entre el trabajador, la empresa y el médico. U na vez que la persona se ha reincorporado parcial 0 totalmente a su trabajo, las entrevistas de seguimiento suelen ser útiles para vigilar su progreso y su rehabilitación. U na vez más, la intervención del departamento de salud ocupacional puede tener una importancia fundamental en este proceso.

L as alternativas descritas en los párrafos anteriores no deben ser consideradas como mutuamente excluyentes sino, más bien, como complementarias. La formación sobre gestión del estrés, las actividades de promoción de la salud y los servicios de asesoramiento resultan útiles para aumentar los recursos físicos y psicológicos de la persona y ayudarla a modificar su valoración de la situación estresora y a afrontar mejor la angustia (Berridge, Cooper y Highley 1997). No obstante, son muchas las fuentes potenciales y persistentes de estrés y es probable que la persona se sienta carente de los recursos o del poder necesarios para efectuar el cambio (p. ej., estructura, estilo de gestión o cultura de la organización). Estos factores de estrés exigen la intervención de la propia organización para eliminar su efecto negativo a largo plazo en la salud de los trabajadores y sólo pueden ser identificados mediante una auditoría del estrés.

\section{Referencias}

Adams, LL, RE LaPorte, K A M atthews, TJ O rchard, LH K uller. 1986. Blood pressure determinants in a middle-class black population: The $U$ niversity of Pittsburgh experience. Prevent M ed 15: 232-242.

Adriaanse, H , J vanR eek, L Zanbelt, G Evers. 1991. Nurses' smoking worldwide. A review of 73 surveys of nurses' tobacco consuption in 21 countries in the period of 1959-1988. J ournal of N ursing Studies 28: 361-375.

Agren, G, A Romelsjo. 1992. M ortality and alcoholrelated diseases in Sweden during 1971-80 in relation of occupation, marital status and citizenship in 1970. Scand J Soc M ed 20: 134-142.

Aiello, JR, Y Shao. 1993. Electronic performance monitoring and stress: The role of feedback and goal setting. En Proceedings of the Fifth International Conference On $\mathrm{H}$ uman-Computer Interaction, dirigido por MJ Smith y G Salvendy. Nueva York: EIsevier.

A kselrod, S, D Gordon, JB M adwed, NC Snidman, BC Shannon, RJ Cohen. 1985. Hemodynamic regulation: Investigation by spectral analysis. Am J Physiol 241: H 867-H 875.

Alexander, F. 1950. Psychosomatic M edicine: Its Principles and Applications. Nueva Y ork: WW N orton

Allan, EA, DJ Steffensmeier. 1989. Y outh, underemployment, property crime: Differential effects of job availability and job quality on juvenile and young arrest rates. Am Soc R ev 54: 107-123.

Allen, T. 1977. M anaging the Flow of T echnology. C ambridge, M assachussetts: M IT Press.
Amick, BC, III, MI Smith. 1992. Stress, computerbased work monitoring and measurement systems: A conceptual overview. A ppl E rgon 23: 6-16.

Anderson, EA, AL M ark. 1989. M icroneurographic measurement of sympathetic nerve activity in humans. En $\mathrm{H}$ andbook of Cardiovascular B ehavioral M edicine, dirigido por N Schneiderman, SM Weiss y PG K aufmann. Nueva Y ork: Plenum.

Aneshensel, CS, CM Rutter, PA Lachenbruch. 1991. Social structure, stress and mental health: Competing conceptual and analytic models. Am Soc R ev 56: 166-178

Anfuso, D. 1994. Workplace violence. Pers J : 66-77.

Anthony, JC y cols. 1992. Psychoactive drug dependence and abuse: $M$ ore common in some occupations than others? J E mploy Assist Res 1: 148-186.

Antonovsky, A. 1979. H ealth, Stress and Coping: N ew Perspectives On M ental and Physical W ell-Being. San Francisco: Jossey-Bass.

-. 1987. U nravelling the M ystery of $\mathrm{H}$ ealth: $\mathrm{H}$ ow People $M$ anage Stress and Stay W ell. San Francisco: JosseyBass.

Appels, A. 1990. M ental precursors of myocardial infarction. B rit J Psychiat 156: 465-471.

Archea, J, BR Connell. 1986. Architecture as an instrument of public health: $M$ andating practice prior to the conduct of systematic inquiry. En Proceedings of the Seventeenth Annual Conference of the E nvironmental Design Research Association, dirigido por J Wineman, R Barnes y C Zimring. Washington, DC: Environmental D esign R esearch Association.

Aschoff, J. 1981. H andbook of Behavioral Neurobiology. V ol. 4. Nueva Y ork: Plenum.
Axelrod, J, JD R eisine. 1984. Stress hormones: Their interaction and regulation. Science 224: 452-459.

Azrin, NH , V B Beasalel. 1982. Finding a | ob. Berkeley, California: T en Speed Press.

Baba, VV, MJ H arris. 1989. Stress and absence: A cross-cultural perspective. Research in Personnel and H uman R esource M anagement Supl. 1: 317-337.

Baker, D P Schnall, PA L andsbergis. 1992. Epidemiologic research on the association between occupational stress and cardiovascular disease. En Behavioral M edicine: An Integrated Approach to $\mathrm{H}$ ealth and IIIness, dirigido por S Araki. Nueva York: Elsevier Science.

Bandura, A. 1977. Self-efficacy: Toward a unifying theory of behavioral change. Psychol Rev 84: 191215.

-. 1986. Social Foundations of Thought and Action: A Social Cognitive Theory. Englewood Cliffs: Prentice $\mathrm{H}$ all.

Barnett, BC. 1992. En H andbook of Stress, dirigido por L Goldberger y S Breznitz. Nueva York: Free Press.

Barnett, R C, L Biener, GK Baruch. 1987. Gender and Stress. Nueva Y ork: Free Press.

Barnett, RC, NL Marshall, SW Raudenbush, R Brennan. 1993. Gender and the relationship between job experiences and psychological distress: A study of dual-earner couples. I Personal Soc Psychol 65(5): 794-806

Barnett, RC, RT Brennan, NL M arshall. 1994. Forthcoming. Gender and the relationship between parent-role quality and psychological dis- 
tress: A study of men and women in dual-earne couples. J Fam I ssues.

Barnett, RC, RT Brennan, SW Raudenbush, NL $M$ arshall. 1994. G ender, the relationship between marital role-quality and psychological distress: A study of dual-earner couples. Psychol W omen Q 18 105-127

Barnett, RC, SW Raudenbush, RT Brennan, JH Pleck, NL M arshall. 1995. Change in job and marital experiences and change in psychological distress: A longitudinal study of dual-earner couples. J Personal Soc P sychol 69: 839-850.

Bartrop, RW, E Luckhurst, L Lazarus, LG K iloh, R Penny. 1977. Depressed lymphocyte function after bereavement. L ancet 1: 834-836.

Bass, BM. 1992. Stress and leadership. En Decision $\mathrm{M}$ aking and Leadership, dirigido por $\mathrm{F}$ H eller. C ambridge: Cambridge U niv. Press.

Bass, C. 1986. Life events and gastrointestinal symptoms. Gut 27: 123-126.

Baum, A, NE Grunberg, JE Singer. 1982. The use of psychological and neuroendocrinological measurements in the study of stress. H ealth Pyschology (V erano): 217-236.

Beck, AT . 1967. Depression: Clinical, Experimental, Theoretical Aspects. Nueva Y ork: H oeber.

Becker, FD. 1990. The T otal W orkplace: Facilities M anagement and the Elastic Organization. Nueva Y ork: V an N ostrand R einhold.

Beehr, TA, JE Newman. 1978. Job stress, employee health and organizational effectiveness: $A$ facet analysis, model and literature review. Pers Psychol 31: 665-669.

Beehr, TA. 1995. Psychological Stress in the W orkplace Londres, R eino U nido: R outledge.

Bennis, WG. 1969. O rganizational developments and the fate of bureaucracy. En Readings in Organizational Behavior and $\mathrm{H}$ uman Performance, dirigido por LL Cummings y WEJ Scott. Homewood, Illinois: R ichard D. Irwin, Inc. y T he D orsey Press.

Benowitz, NL. 1990. Clinical pharmacology of caffeine. Ann R ev M ed 41: 277-288.

Bergman, BR. 1986. The $E$ conomic $E$ mergence of $W$ omen. N ueva Y ork: Basic.

Bernstein, A. 1994. Law, culture and harassment. U niv Penn Law Rev 142(4): 1227-1311.

Berntson, G G, JT Cacioppo, K S Q uigley. 1993. Respiratory sinus arrhythmia: Autonomic origins physiological mechanisms, psychophysiological implications. Psychophysiol 30: 183-196.

Berridge, J, CL Cooper, C H ighley. 1997. Employee Assistance Programs and Workplace Counselling. Chichester y Nueva Y ork: Wiley.

Billings, AG, RH M oos. 1981. The role of coping responses and social resources in attenuating the stress of life events. J B ehav M ed 4(2): 139-157.

Blanchard, EB, SP Schwarz, J Suls, M A Gerardi, L Scharff, B Green, AE Taylor, C Berreman, HS $M$ alamood. 1992. T wo controlled evaluations of multicomponent psychological treatment of irritable bowel syndrome. B ehav R es T her 30: 175-189.

Blinder, AS. 1987. $\mathrm{H}$ ard $\mathrm{H}$ eads and Soft $\mathrm{H}$ earts: T ough $M$ inded $E$ conomics for a J ust Society. R eading, $M$ assachussetts: Addison-W esley.

Bongers, PM, CR de Winter, MAJ Kompier, VH Hildebrandt. 1993. Psychosocial factors at work and musculoskeletal disease. Scand J W ork E nviron $H$ ealth 19: 297-312.

Booth-K ewley, S, HS Friedman. 1987. Psychological predictors of heart disease: A quantitative review. Psychol Bull 101: 343-362.

Brady, JV, RW Porter, DG Conrad, JW Mason. 1958. A voidance behavior and the development of gastrointestinal ulcers. J Exp Anal B ehav 1: 69-73.
Brandt, LPA, CV Nielsen. 1992. Job stress and adverse outcome of pregnancy: A causal link or recall bias? Am J E pidemiol 135(3).

Breaugh, JA, JP C olihan. 1994. M easuring facets of job ambiguity: Construct validity evidence. J Appl Psychol 79: 191-202.

Brenner, M . 1976. Estimating the social costs of economic policy: implications for mental and physical health and criminal aggression. Informe al Servicio de Investigaciones del Congreso de la Biblioteca del Congreso y al Comité Económico $M$ ixto del Congreso. Washington, DC: US GPO

Brenner, MH. M arch 1987. Relations of economic change to Swedish health and social well-being, 1950-1980. Soc Sci M ed : 183-195.

Brief, AP, MJ Burke, JM George, BS Robinson, J Webster. 1988. Should negative affectivity render an unmeasured variable in the study of job stress? Appl Psychol 73: 193-198.

Brill, M, S M argulis, E K onar. 1984. U sing O ffice De sign to Increase Productivity. Buffalo, Nueva Y ork: W orkplace D esign and Productivity.

Brisson, C, M Vezina, A Vinet. 1992. Health problems of women employed in jobs involving psychological and ergonomic stressors: The case of garment workers in Q uebec. W omen $\mathrm{H}$ ealth 18: 4965.

Brockner, J. 1983. L ow self-esteem and behavioral plasticity: Some implications. En R eview of Personality and Social Psychology, dirigido por L Wheeler $y$ PR Shaver. Beverly H ills, California: Sage.

—. 1988. Self-E steem At W ork. Lexington, M assachussetts: H eath.

Bromet, EJ, DK Parkinson, EC Curtis, HC Schulberg, H Blane, LO Dunn, J Phelan, M A Dew, JE Schwartz. 1990. Epidemiology of depression and alcohol abuse/ dependence in a managerial and professional workforce. I O ccup M ed 32(10): 989995.

Bromet, EJ. 1988. Predictive effects of occupational and marital stress on the mental health of a male workforce. J Organ B ehav 9: 1-13.

Buck, V. 1972. W orking U nder Pressure. Londres: Staples.

Bullard, RD, BH Wright. 1986/ 1987. Blacks and the environment. $H$ umboldt J Soc Rel 14: 165-184.

Bureau of National Affairs (BNA). 1991. W ork and Family T oday: 100 Key Statistics. Washington, DC: BNA.

Burge, S, A H edge, S Wilson, JH Bass, A R obertson. 1987. Sick building syndrome: A study of 4373 of fice workers. Ann O ccup H yg 31: 493-504.

Burke, W, G Salvendy. 1981. H uman A spects of W orking On R epetitive M achine Paced and Self-Paced W ork: A Re view and Reappraisal. West Lafayette, Indiana: School of Industrial Engineering, Universidad de Purdue.

Burns, JM . 1978. Leadership. Nueva Y ork: Harper \& Row.

Bustelo, C. 1992. The "international sickness" of sexual harassment. W orld Press R ev 39: 24.

Cacioppo, JT , LG T assinary. 1990. Principles of Psychophysiology. Cambridge: Cambridge U niv. Press.

Cain, PS, DJ T reiman. 1981. The dictionary of occupational titles as a source of occupational data. Am Soc Rev 46: 253-278.

Caldwell, DF, CA O'R eilly. 1990. M easuring person-job fit with a profile-comparison process. J Appl Psychol 75: 648-657.

Cannon, WB. 1914. The emergency function of the adrenal medulla in pain and other emotions. Am J Physiol 33: 356-372.

-. 1935. Stresses and strains of homeostasis. Am J M ed Sci 189: 1-14.
Canter, D. 1983. The physical context of work. En The Physical Environment At W ork, dirigido por DJ O sborne y M M Grunberg. Chichester: Wiley.

Caplan, RD, AD Vinokur, RH Price, M van Ryn. 1989. Job seeking, reemployment and mental health: A randomized field experiment in coping with job loss. J A ppl Psychol 74(5): 759-769.

Caplan, RD, S Cobb, JR PJ French, R V an H arrison, $\mathrm{R}$ Pinneau. 1975. J ob Demands and W orker $H$ ealth: $M$ ain $E$ ffects and $O$ ccupational $D$ ifferences. Washington, DC: US Department of $\mathrm{H}$ ealth, Education, Welfare.

Caplan, RD, S Cobb, JRPJ French, RV Harrison, SR J Pinneau. 1980. I ob D emands and W orker $\mathrm{H}$ ealth. Ann Arbor, Michigan: Institute for Social Research.

Caplan, RD. 1983. Person-environment fit: Past, present, future. En Stress R esearch: I ssues for the E ighties, dirigido por CL Cooper. N ueva Y ork: Wiley.

Caplin, G. 1969. Principles of Preventive Psychiatry. Nueva Y ork: Basic Books

Carayon, P. 1993. Effect of electronic performance monitoring on job design and worker stress: A review of the literature and conceptual model. $\mathrm{H}$ um Factors 35(3): 385-396

-. 1994. Effects of electronic performance monitoring on job design and worker stress: R esults of two studies. Ent I H um Comput Interact 6: 177-190.

Cassel, J. 1976. The contribution of the social environment to host resistance. Am 」 E pidemiol 104: 107-123.

Cassel, JP. 1974. The contribution of the social environment to host resistance. American J ournal of $\mathrm{E} \mathrm{pi}$ demiology 104: 161-166.

Catalano, R, D Dooley, G Wilson, R Hough. 1993b. Job loss and alcohol abuse: A test using data from the Epidemiologic Catchment Area project. $H$ ealth Soc B ehav 34: 215-225.

Catalano, R, D Dooley, R Novaco, G Wilson, R H ough. 1993a-a. U sing ECA survey data to examine the effect of job layoffs on violent behavior. H osp Community Psychiat 44: 874-879.

Catalano, R. 1991. The health effects of economic insecurity. Am J Public H ealth 81: 1148-1152.

Chatman, JA. 1991. M atching people and organizations: Selection and socialization in public accounting firms. Adm Sci Q 36: 459-484.

Christensen, K. 1992. M anaging invisible employees: $\mathrm{H}$ ow to meet the telecommuting challenge. E mploy Relat T oday : 133-143.

Cobb, S, R M R ose. 1973. H ypertension, peptic ulcer, diabetes in air traffic controllers. J Am M ed Assoc 224(4): 489-492.

Cobb, S. 1976. Social support as a mediator of life stress. Psychosocial M edicine 38: 300-314.

Cohen, A. 1991. Career stage as a moderator of the relationships between organizational commitment and its outcomes: A meta-analysis. J 0 ccup Psychol 64: 253-268

Cohen, N, R Ader, N Green, D Bovbjerg. 1979. Conditioned suppression of thymus-independent antibody response. Psychosom M ed 41: 487-491.

Cohen, RL, FL Ahearn. 1980. H andbook for M ental $\mathrm{H}$ ealth C are of D isaster Victims. Baltimore: The Johns H opkins U niversity Press.

Cohen, S, S Spacapan. 1983. The after effects of anticipating noise exposure. En Noise As a Public $H$ ealth Problem, dirigido por G R ossi. M ilán: Centro Ricerche e Studi Amplifon.

Cohen, S, SL Syme. 1985. Social Support and Health. Nueva Y ork: A cademic Books.

Cole, RJ, RT Loving, DF K ripke. 1990. Psychiatric aspects of shiftwork. 0 ccup M ed 5: 301-314.

Colligan, MJ, JW Pennebaker, LR Murphy. 1982. M ass Psychogenic IIIness: A Social P sychological Analysis. $\mathrm{H}$ illsdale, Nueva Jersey: Erlbaum. 
Colligan, MJ, RR R osa. 1990. Shiftwork effects on social and family life. 0 ccup M ed 5: 315-322.

Colligan, MJ. 1985. An apparent case of mass psychogenic illness in an aluminium furniture assembly plant. En J ob Stress and Blue Collar W ork, dirigido por C Cooper y MJ Smith. Londres: John Wiley \& Sons

Contrada, RJ, DS K rantz. 1988. Stress, reactivity and type $A$ behavior: Current status and future directions. Ann B ehav M ed 10: 64-70.

Conway, TL, RR Vickers, HW Ward, RH Rahe 1981. O ccupational stress and variation in cigarette, coffee and alcohol consumption. J ournal of $H$ ealth \& Social B ehaviour 22: 155-165.

Cooper, C, J M arshall. 1976. O ccupational sources of stress: A review of the literature relating to coronary heart disease and mental ill health. I Occup Psychol 49: 11-28.

Cooper, C. 1996. H andbook of Stress, M edicine and $\mathrm{H}$ ealth. Boca R aton, Florida: CR C Press.

Cooper, CL, M J Smith. 1985. J ob Stress and Blue Collar W ork. N ueva Y ork: Wiley.

Cooper, CL, P Liukkonen, S Cartwright. 1996. Stress Prevention in the W orkplace: Assessing the Costs and $B$ ene fits to $O$ rganisations. Dublín: Fundación Europea.

Cooper, CL, R Payne. 1988. Causes, Coping, Conse quences of Stress At W ork. N ueva Y ork: W iley.

- . 1991. Personality and Stress: Individual D ifferences in the Stress P rocess. Chichester: Wiley.

Cooper, CL, RS Bramwell. 1992. Predictive validity of the strain component of the occupational stress indicator. Stress M edicine 8: 57-60.

Cooper, CL, S Cartwright. 1994. M ental $H$ ealth and Stress in the W orkplace: A Guide to E mployers. Londres: HMSO.

Cox, S, T Cox, M Thirlaway, C M acK ay. 1982. Effects of simulated repetitive work on urinary catecholamine excretion. E rgonomics 25: 1129-1141.

Cox, T, P L eather. 1994. The prevention of violence at work: Application of a cognitive behavioral the ory. En International R eview of Industrial and Organizational Psychology, dirigido por CL Cooper e IT R obertson. Londres: Wiley.

Crum, RM, C Mutaner, WW Eaton, JC Anthony. 1995. O ccupational stress and the risk of alcohol abuse and dependence. Alcohol, Clin Exp Res 19(3): 647-655.

C sikszentmihalyi, M . 1975. B eyond B oredom and Anxiety. San Francisco: Jossey-Bass.

Cummins, R. 1989. Locus of control and social support: Clarifiers of the relationship between job stress and job satisfaction. J Appl Soc Psychol 19: 772-788.

C vetanovski, J, SM Jex. 1994. L ocus of control of unemployed people and its relationship to psychological and physical health. W ork Stress 8: 60-67.

Dainoff, M J, M H Dainoff. 1986. People and Productivity. T oronto: $\mathrm{H}$ olt, R einhart, \& W inston of $\mathrm{C}$ anada.

Damasio, A. 1994. Descartes' E rror: E motion, Reason and the $\mathrm{H}$ uman B rain. Nueva Y ork: G rosset/ Putnam.

Danko, S, P Eshelman, A H edge. 1990. A taxonomy of health, safety, welfare, implications of interior design decisions. J Interior D es E duc Res 16: 19-30.

Dawis, RV, LH Lofquist. 1984. A Psychological Theory of $W$ ork Adjustment. M inneapolis, M innesota: U niversity of M innesota Press.

Dement, W. 1969. The biological role of REM sleep. En Sleep Physiology and Pathology: A Symposium, dirigido por A K ales. Filadelfia: JB Lippincott.

Deming, WE. 1993. The New E conomics for Industry, Government, E ducation. Cambridge, M assachussetts: M IT C enter for Advance Engineering Study.

D ewe, PJ. 1989. Examining the nature of work stress: Individual evaluations of stressful experiences and coping. H um R elat 42: 993-1013.
Ditecco, D, G C witco, A Arsenault, M Andre. 1992. $O$ perator stress and monitoring practices. Appl E rgon 23(1): 29-34.

Dohrenwend, BS, BP D ohrenwend. 1974. Stressful Life $E$ vents: T heir N ature and $E$ ffects. N ueva Y ork: W iley.

Dohrenwend, BS, L K rasnoff, AR Askenasy, BP Dohrenwend. 1978. Exemplification of a method for scaling life events: T he PER I life events scale. J $H$ ealth Soc B ehav 19: 205-229.

Dooley, D, R Catalano, G Wilson. 1994. Depression and unemployment: Panel findings from the Epidemiologic C atchment A rea study. Am J Community Psychol 22: 745-765.

Dooley, D, R Catalano, R H ough. 1992. U nemployment and alcohol disorder in 1910 and 1990: D rift versus social causation. J 0 ccup 0 rgan Psychol 65: 277-290.

Dooley, D. 1985. Causal inference in the study of social support. En Social Support and $\mathrm{H}$ ealth, dirigido por S Cohen y SL Syme. Nueva Y ork: Academic Books.

Douglas, R B, R Blanks, A Crowther, G Scott. 1988. A study of stress in West M idlands firemen, using ambulatory electrocardiograms. W ork Stress: 247250

Eaton, WW, JC Anthony, W M andel, R Garrison. 1990. O ccupations and the prevalence of major depressive disorder. J O ccup M ed 32(11): 10791087.

Edwards, JR, RV H arrison. 1993. Job demands and worker health: $A$ three dimensional reexamination of the relationship between person-environment fit and strain. J A ppl Psychol 78: 628-648.

Edwards, JR. 1988. The determinants and consequences of coping with stress. En Causes, Coping and Consequences of Stress At W ork, dirigido por CL C ooper y R Payne. Nueva Y ork: Wiley.

Elander, J, R West, D French. 1993. Behavioral correlates of individual differences in road-traffic crash risk: An examination of methods and findings. Psychol Bull 113: 279-294.

Emmett, EA. 1991. Physical and chemical agents at the workplace. En W ork, $\mathrm{H}$ ealth and Productivity, dirigido por GM Green y F Baker. Nueva Y ork: Oxford U niversity Press.

Endresen, IM , B Ellersten, C Endresen, AM $\mathrm{H}$ jelmen, R M atre, H U rsin. 1991. Stress at work and psychological and immunological parameters in a group of N orwegian female bank employees. W ork Stress 5: 217-227.

Esler, M, G Jennings, G Lambert. 1989. M easurement of overall and cardiac norepinephrine release into plasma during cognitive challenge. Psychoneuroendocrinol 14: 477-481.

Everly, GS, Jr, RH Feldman. 1985. O ccupational H ealth Promotion: $\mathrm{H}$ ealth Behavior in the W orkplace Nueva Y ork: John Wiley \& Sons.

Faucett, J, D Rempel. 1994. VDT-related musculoskeletal symptoms: Interactions between work and posture and psychosocial factors. Am J Ind M ed 26: 597-612.

Feigenbaum, AV. 1991. Total quality: An international imperative. En M aintaining the Total Quality Advantage, dirigido por BH Peters y JL Peters. N ueva Y ork: The Conference Board.

Feldman, DC. 1976. A contingency theory of socialization. Adm Sci Q 21: 433-452.

Fenster, L, C Schaefer, A M athur, RA H iatt, C Pieper, AE H ubbard, J V on Behren, S Swan. 1995. Psychological stress in the workplace and spontaneous abortion. Am J E pidemiol 142(11).

Ferber, MA, B O'Farrell, L Allen. 1991. W ork and Family: Policies for a Changing W orkforce. Washington, DC: N ational Academy Press.

Fernandez, JP. 1981. Racism and Sexism in Corporate Life. Lexington, M assachussetts: Lexington Books.
- . 1990. The Politics and R eality of F amily C are in Corporate A merica. Lexington, $M$ assachussetts: Lexington Books.

Fiedler, FE. 1967. A Theory of Leadership E ffectiveness. N ueva Y ork: M cG raw-H ill.

Fielding, JE, KJ Phenow. 1988. H ealth effects of involuntary smoking. N ew Engl J M ed 319: 14521460 .

Fisher, C. 1985. Social support and adjustment to work: A longitudinal study. J M anage 11: 39-53.

Fith-Cozens, J. 1987. Emotional distress in junior house officers. B rit M ed J 295: 533-536.

Fitzgerald, LF, AJ O rmerod. 1993. Breaking silence: The sexual harassment of women in academia and the workplace. En Psychology of W omen, dirigido por FL Denmark y M A Paludi. Londres: G reenwood Press.

Flechter, B. 1988. O ccupation, marriage and disease specific mortality concordance. Soc Sci M ed 27: 615-622.

Ford, DL. 1985. Facets of work support and employee work outcomes: An exploratory analysis. J $M$ anage 11: 5-20.

Fox, AJ, J Levin. 1994. Firing back: The growing threat of workplace homicide. Ann Am Acad Polit SS 536: 16-30.

Fox, BH. 1995. The role of psychological factors in cancer incidence and prognosis. Oncology 9(3): 245-253.

- . 1989. Depressive symptoms and risk of cancer. J Am M ed Assoc 262(9): 1231.

-. 1981. Psychosocial factors and the immune system in human cancer. En Psychoneuroimmunology, dirigido por $\mathrm{R}$ Ader. Nueva York: Academic Press.

Frankenhaeuser, M , B G ardell. 1976. Underload and overload in working life: 0 utline of a multidisciplinary approach. J ournal of $\mathrm{H}$ uman Stress 2: 35-46.

Frankenhaeuser, M, C L undberg, L Forsman. 1980. Dissociation between sympathetic-adrenal and pituitary-adrenal responses to an achievement situation characterized by high controllability: Comparison between Type $A$ and Type $B$ males and females. Biol Psychol 10: 79-91.

Frankenhaeuser, M, G Johansson. 1986. Stress at work: Psychobiological and psychosocial aspects. Ent Rev Appl Psychol 35: 287-299.

Frankenhaeuser, $M, U$ Lundberg, $M$ Fredrikson, $B$ M elin, M T uomisto, A-L M yrsten, M H edman, B Bergman-L osman, $L$ Wallin. 1989. Stress on and off the job as related to sex and occupational status in white-collar workers. I O rgan B ehav 10: 321-346.

Frankenhaeuser, M, U Lundberg, MA Chesney. 1991. W omen, W ork and $H$ ealth. Stress and O pportunities. Nueva Y ork: Plenum.

Frankenhaeuser, M. 1986. A psychobiological framework for research on human stress and coping. En Dynamics of Stress, dirigido por $\mathrm{MH}$ Appley y $\mathrm{R}$ Trumbull. Nueva Y ork: Plenum.

- . 1989. A biopsychosocial approach to work life issues. Ent J H ealth Serv 19: 747-758.

-. 1991. The psychophysiology of workload, stress and health: Comparison between the sexes. Ann Behav M ed 13: 197-204.

-. 1993a. Current issues in psychobiological stress research. En European Views in Psychology - Keynote Lectures, dirigido por M V artiainen. Helsinki: Acta Psychologica Fennica XIII.

- . 1993b. The measurement of the total workload of men and women. En A H ealthier W ork E nvironment . $B$ asic Concepts and $M$ ethods of $M$ easurements, dirigido por L Levi. G inebra: O M S.

—. 1996. Stress and gender. Eur Rev, Interdis I Acad Eur 4 
French, JR P, R D Caplan, R van $\mathrm{H}$ arrison. 1982. The $M$ echanisms of J ob Stress and Strain. Nueva York: Wiley.

French, JR P, R D C aplan. 1973. O rganizational stress and individual strain. En T he Failure of Success, dirigido por AJ M arrow. N ueva Y ork: Amacon.

French, JR P, W R odgers, S C obb. 1974. Adjustment as person-environment fit. En Coping and Adaption, dirigido por GV Coelho, DA Hamburg y JE Adams. N ueva Y ork: Basic Books.

French, WL, CH Bell. 1990. Organizational Development. Englewood Cliffs, Nueva Jersey: Prentice $\mathrm{H}$ all.

Frese, M, D Zapf. 1988. M ethodological issues in the study of work stress: $O$ bjective vs. subjective measurement of work stress and the question of longitudinal studies. En Causes, Coping and Consequences of Stress At W ork, dirigido por CL Cooper y R Payne. N ueva Y ork: Wiley.

Friedman, M, CE Thoresen, JJ Gill, D UImer, LII Powell, VA Prince y cols. 1986. Alteration of type A behavior and its effect on cardiac recurrences in post myocardial infarction patients; summary results of the Recurrent Coronary Prevention Project. Am H eart J 112: 653-665.

Fryer, D, R Payne. 1986. Being unemployed: A review of the literature on the psychological experience of unemployment. En International R eview of Industrial Organizational Psychology, dirigido por $\mathrm{CL}$ Cooper el R obertson. Chichester: Wiley.

Fundación Europea para la M ejora de las Condiciones de V ida y de Trabajo. 1992. First E uropean Suvey $O n$ the Work Environment 1991-1992. Luxemburgo: O ficina de Publicaciones O ficiales de la Comunidad Europea.

Funk, SC, BK Houston. 1987. A critical analysis of the hardiness scales' validity and utility. J Personal Soc Psychol 53: 572-578.

Fusilier, M R, DC Ganster, BT M ays. 1987. Effects of social support, role stress, locus of control on health. J $M$ anage 13: 517-528.

Galinsky, E, JT Bond, DE Friedman. 1993. H ighlights: The National Study of the Changing W orkforce. Nueva Y ork: Families and W ork Institute.

Gamble, G O, M T M atteson. 1992. Type A behavior, job satisfaction, stress among Black professionals. Psychol Rep 70: 43-50.

Ganster, DC, BT Mayes, WE Sime, GD Tharp. 1982. M anaging occupational stress: A field experiment. J Appl Psychol 67: 533-542.

Ganster, DC, J Schaubroeck. 1991a. R ole stress and worker health: An extension of the plasticity hypothesis of self-esteem. J Soc B ehav Personal 6: 349 360 .

- . 1991b. Work stress and employee health. J M anage 17: 235-271.

Ganster, DC, MR Fusilier. 1989. Control in the workplace. En International Review of Industrial and Organizational Psychology, dirigido por C Cooper e I R obertson. Chichester, R eino U nido: Wiley.

Ganster, DC. 1989. Worker control and well-being: A review of research in the workplace. En J ob Control and W orker $\mathrm{H}$ ealth, dirigido por SL Sauter, IJ H urrell y CL Cooper. N ueva Y ork: Wiley.

Gardell, B. 1981. Psychosocial aspects of industrial production methods. En Society, Stress and Disease dirigido por L Levi. O xford: O UP

Garrison, R, WW Eaton. 1992. Secretaries, depres sion and absenteeism. W omen $\mathrm{H}$ ealth 18: 53-76.

Gillin, JC, WF Byerley. 1990. The diagnosis and management of insomnia. New England J ournal of $M$ edicine 322: 239-248.

Glaser, R, JK K iecolt-G laser, RH Bonneau, W M alarkey, S K ennedy, J H ughes. 1992. Stress induced modulation of the immune response to recombinant hepatitits $B$ vaccine. Psychosom $M$ ed 54: 22-29.
Goldberg, E y cols. 1985. Depressive symptoms, social networks and social support of elderly women. American J ournal of E pidemiology : 448-456.

Goldberger, L, S Breznitz. 1982. H andbook of Stress. Nueva Y ork: Free Press.

Goldstein, I, LD Jamner, D Shapiro. 1992. Ambulatory blood pressure and heart rate in healthy male paramedics during a work day and a non-work day. H ealth P sychol 11: 48-54.

Goleman, D. 1995. E motional Intelligence. Nueva Y ork: Bantam Books.

Golemblewski, RT. 1982. O rganizational development $(O D)$ interventions: Changing interaction, structures, policies. En J ob Stress and Burnout Re search, Theory, Intervention Perspectives, dirigido por WE Paine. Beverly H ills: Sage Publications.

Goodrich, R. 1986. The perceived office: The office environment as experienced by its users. En B ehavioral Issues in Office Design, dirigido por JD Wineman. Nueva Y ork: $V$ an N ostrand R einhold.

Gorman, DM . 1994. Alcohol misuse and the predisposing environment. B ritish M edical Bulletin: 36-49.

Gottlieb, BH. 1983. Social Support Strategies. Beverly Hills: Sage.

Gough, H, A H eilbrun. 1965. The Adjective Check List $M$ anual. Palo Alto, California: Consulting Psychologists Press.

Gowler, D, K L egge. 1975. Stress and external relationships: The 'hidden' contract. En M anagerial Stress, dirigido por D Gowler y K Legge. Londres: Gower.

Grandjean, E. 1968. Fatigue: Its physiological and psychological significance. E rgonomics 11(5): 427436.

-. 1986. Fitting the T ask to the M an: An E rgonomic Approach. : T aylor and Francis.

-. 1987. E rgonomics in Computerized Offices. Londres: Taylor \& Francis.

Greenglass, ER. 1993. The contribution of social support to coping strategies. Appl Psychol Intern Rev 42: 323-340.

Greenhalgh, L, Z Rosenblatt. 1984. Job insecurity: T oward conceptual clarity. Acad M anage R ev (July): 438-448.

Guendelman, S, MJ Silberg. 1993. The health consequences of maquiladora work: Women on the US-M exican border. Am J Public Health 83: 37-44.

Guidotti, TL. 1992. Human factors in firefighting: Ergonomic-, cardiopulmonary-, psychogenic stress- related issues. Ent Arch $\mathrm{O}$ ccup E nviron $\mathrm{H}$ ealth 64: 1-12.

Gutek, B. 1985. Sex and the W orkplace San Francisco: Jossey-Bass.

Gutierres, SE, D Saenz, BL Green. 1994. Job stress and health outcomes among Anglo and $\mathrm{H}$ ispanic employees: A test of the person-environment fit model. En I ob Stress in a Changing W orkforce, dirigido por GP K eita y JJ Hurrell. Washington, DC: American Psychological Association.

H ackman, JR, EE Lawler. 1971. Employee reactions to job characteristics. J A ppl Psychol 55: 259-286.

H ackman, JR, GR O Idham. 1975. The job diagnostic survey. J Appl Psychol 60: 159-170.

-. 1980. W ork Redesign. Reading, M assachussetts: Addison-W esley.

H ackman, JR. 1992. G roup influences on individuals in organizations. $\mathrm{En} \mathrm{H}$ andbook of Industrial and Organizational Psychology, dirigido por M D D unnette y LM H ough. Palo Alto, California: Consulting Psychologists' Press.

$H$ ahn, M E. 1966. California Life Goals E valuation Schedule. Palo Alto, California: Western Psychological Services.

Hales, TR, SL Sauter, MR Peterson, LJ Fine, V Putz-Anderson, LR Schleifer, TT O chs, BP Ber- nard. 1994. M usculoskeletal disorders among visual display terminal users in a telecommunication company. E rgonomics 37(10): 1603-1621.

$H$ all, DT. 1990. T elecommuting and the $M$ anagement of W ork-H ome Boundaries. W orking Paper N 0. 90-05. Boston: Boston U niv. School of $\mathrm{M}$ anagement.

H all, E. 1991. Gender, work control and stress: A theoretical discussion and an empirical test. En T he Psychosocial W ork E nvironment: W ork O rganization; $D$ emocratization and $\mathrm{H}$ ealth, dirigido por JV Johnson y G Johansson. A mityville, N ueva Y ork: Baywook.

- . 1992. Double exposure: The combined impact of the home and work environments on psychosomatic strain in Swedish men and women. Ent J Health Serv 22: 239-260.

H all, RB. 1969. Entraorganizational structural variation: Application of the bureaucratic model. En Readings in O rganizational B ehavior and $H$ uman Performance, dirigido por LL Cummings y WEJ Scott. $\mathrm{H}$ omewood, Illinois: R ichard D. Irwin, Inc. y The Dorsey Press.

$\mathrm{H}$ amilton, LV, CL Broman, WS H offman, D Brenner. 1990. $\mathrm{H}$ ard times and vulnerable people: Initial effects of plant closing on autoworkers' mental health. I H ealth Soc B ehav 31: 123-140.

H arford, TC, DA Parker, BF Grant, DA Dawson. 1992. Alcohol use and dependence among employed men and women in the U nited States in 1988. Alcohol, Clin Exp Res 16: 146-148.

H arrison, R V . 1978. Person-environment fit and job stress. En Stress At W ork, dirigido por CL Cooper y R Payne. Nueva Y ork: Wiley.

H edge, A. 1986. O pen vs. enclosed workspaces: The impact of design on employees' reactions to their offices. En B ehavioral I ssues in O ffice D esign, dirigido por JD Wineman. Nueva Y ork: V an N ostrand Reinhold.

- . 1991. Design innovations in office environments. En Design Intervention: T oward a M ore H umane Architecture, dirigido por WFE Presiser, JC V ischer y ET White. N ueva Y ork: $V$ an N ostrand R einhold.

H eilpern, J. 1989. Are American companies 'hostile' to quality improvement? Q uality Exec (N oviembre).

Henderson, S, P Duncan-Jones, G Byrne. 1980 Measuring social relationships. The interview schedule for social interaction. Psychol M ed 10: 723-734.

H enry, JP, PM Stephens. 1977. Stress, H ealth, the Social Environment. A Sociobiologic Approach to M edicine. N ueva Y ork: Springer-V erlag.

Herzberg, F, B M ausner, BB Snyderman. 1959. The $M$ otivation to $W$ ork. N ueva $Y$ ork: Wiley.

H ill, S. 1991. Why quality circles failed but total quality management might succeed. $\mathrm{Br}$ ) Ind R elat (4 de diciembre): 551-568.

H irsch, PM . 1987. Pack Your Own Parachute. Reading, M assachussetts: Addison-W esley.

H irschhorn, L. 1991. Stresses and patterns of adjustment in the postindustrial factory. En W ork, $\mathrm{H}$ ealth and Productivity, dirigido por GM Green y $F$ Baker. Nueva Y ork: 0 xford U niversity Press.

$\mathrm{H}$ irsh, BJ. 1980. Natural support systems and coping with major life changes. Am J Comm Psych 8: 159171.

Hirshhorn, L. 1990. Leaders and followers in the postindustrial age: A psychodynamic view. J Appl B ehav Sci 26: 529-542.

-. 1984. B eyond M echanization. Cambridge, M assachussetts: M IT Press.

H olmes, TH, H R R ichard. 1967. The social readjustment rating scale. J Psychosomat $R$ es 11: 213-218.

H olt, R R. 1992. O ccupational stress. En $\mathrm{H}$ andbook of Stress, dirigido por L Goldberger y S Breznitz. Nueva Y ork: Free Press.

H oltmann, G, R K reibel, M V Singer. 1990. M ental stress and gastric acid secretion: Do personality 
traits influence the response? Digest Dis Sci 35: 998-1007.

H ouse, J. 1981. W ork Stress and Social Support. R eading, $M$ assachussetts: Addison-W esley.

H ouston, B, W Hodges. 1970. Situational denial and performance under stress. I Personal Soc Psychol 16: 726-730.

H outman, I, M K ompler. 1995. Risk factors and occupational risk groups for work stress in the $\mathrm{N}$ etherlands. En Organizational Risk Factors for J ob Stress, dirigido por S Sauter y L M urphy. Washington: American Psychological Association.

H oward, R. 1990. V alues make the company. $\mathrm{H}$ arvard Business R ev (Septiembre-O ctubre): 133-144.

Hudiberg, JJ. 1991. W inning W ith Quality -T he FPL Story. White Plains, Nueva York: Quality Resources.

H ull, JG, R R Van Treuren, S Virnelli. 1987. H ardiness and health: $A$ critique and alternative approach. J Personal Soc Psychol 53: 518-530.

H urrell JJ Jr, K Lindström. 1992. Comparison of job demands, control and psychosomatic complaints at different career stages of managers in Finland and the U nited States. Scand J W ork E nviron $\mathrm{H}$ ealth 18 Supl. 2: 11-13.

H urrell, JJ Jr, LR M urphy. 1992. Locus of control, job demands, worker health. En Individual Differences, Personality, Stress, dirigido por CL Cooper y R Payne. Chichester: J ohn Wiley \& Sons.

H urrell, JJ Jr, M A M CLaney, LR M urphy. 1990. The middle years: $\mathrm{C}$ areer stage differences. Prev $\mathrm{H}$ um Serv 8: 179-203.

Ihman, A, G Bohlin. 1989. The role of controllability in cardiovascular activation and cardiovascular disease: H elp or hindrance? En Stress, Personal Control and $\mathrm{H}$ ealth, dirigido por A Steptoe y A Appels. Chichester: Wiley.

Ilgen, DR. 1990. Health issues at work. American Psychologist 45: 273-283.

Imai, M. 1986. Kaizen: The Key to J apan's Competitive Success. N ueva Y ork: M cG raw-H ill.

Ishikawa, K. 1985. W hat Is T otal Quality Control? The J apanese W ay. Englewood Cliffs, Nueva Jersey: Prentice $\mathrm{H}$ all.

Israel, BA, T C A ntonucci. 1987. Social network characteristics and psychological well-being: A replication and extension. H ealth E duc Q 14(4): 461-481.

Jackson, DN. 1974. Personality Research Form M anual. N ueva Y ork: R esearch Psychologists Press.

Jackson, SE, RS Schuler. 1985. A meta-analysis and conceptual critique of research on role ambiguity and role conflict in work settings. O rgan B ehav $\mathrm{H}$ um Decision P roc 36: 16-78.

James, CR , CM Ames. 1993. R ecent developments in alcoholism: The workplace. Recent D evelop Alcohol 11: 123-146.

James, K. 1994. Social identity, work stress and minority worker's health. En J ob Stress in a Changing Workforce, dirigido por GP K eita y JJ Hurrell. W ashington, DC: APA.

Jenkins, CD. 1979. The coronary-prone personality. En Psychological Aspects of M yocardial Infarction and Coronary Care, dirigido por WD Gentry y RB Williams. St.L ouis: M osby.

Jenkins, R, N Coney. 1992. Prevention of M ental III $H$ ealth At W ork. A Conference. Londres: H M SO

Jennings, R, C Cox, CL Cooper. 1994. B usiness E lites: The Psychology of E ntrepreneurs and Intrapreneurs. Londres: R outledge.

Johansson, G, G A ronsson. 1984. Stress reactions in computerized administrative work. J O ccup B ehav 15: 159-181.

Johnson, JV, EM Hall. 1988. Job strain, workplace social support and cardiovascular disease: A cross-sectional study of a random sample of Swed- ish working population. Am J Public Health 78: 1336-1342.

- 1994. Social support in the work environment and cardiovascular disease. En Social Support and Cardiovascular D isease, dirigido por S Shumaker y $S$ C zajkowski. N ueva Y ork: Plenum Press.

Johnson, JV, G Johansson. 1991. T he Psychosocial W ork E nvironment: W ork Organization, Democratization and $\mathrm{H}$ ealth. Amityville, Nueva Y ork: Baywood.

Johnson, JV, W Stewart, EM Hall, P Fredlund, T Theorell. 1996. Long-term psychosocial work environment and cardiovascular mortality among Swedish men. Am J Public H ealth 86(3): 324-331.

Johnson, JV . 1986. The impact of workplace social support, job demands and work control upon cardiovascular disease in sweden. Tesis doctoral, U niversidad Johns H opkins.

Juran, JM . 1988. J uran On Planning for Q uality. Nueva Y ork: Free Press.

Justice, A. 1985. Review of the effects of stress on cancer in laboratory animals: The importance of time of stress application and type of tumor. Psychol Bull 98(1): 108-138.

K adushin, A. 1976. M en in a woman's profession. Social W ork 21: 440-447.

K agan, A, L L evi. 1971. Adaptation of the psychosocial environment to man's abilities and needs. En Society, Stress and D isease, dirigido por L Levi. N ueva Y ork: O xford U niversity Press.

Kahn, RL, DM Wolfe, RP Quinn, JD Snoek, RA R osenthal. 1964. O rganisational Stress: Studies in R ole Conflict and Ambiquity. Chichester: Wiley.

$\mathrm{K}$ ahn, RL, P Byosiere. 1992. Stress in organizations. $\mathrm{En} \mathrm{H}$ andbook of Industrial and Organizational Psychology, dirigido por MD Dunnette y LM H ough. Palo Alto, California: Consulting Psychology Press.

Kahn, RL. 1991. The forms of women's work. En $W$ omen, $W$ ork and $H$ ealth. Stress and $O$ pportunities, dirigido por M Frankenhaeuser, U Lundberg y MA Chesney. Nueva Y ork: Plenum.

K aplan, GA y cols. 1991. Psychosocial factors and the natural history of physical activity. Am J P rev M edicine 7: 12-17.

K aplan, R, S K aplan. 1989. The Experience of N ature: A Psychological Perspective. Nueva York: Cambridge U niv. Press.

K arasek, R, T Theorell. 1990. H ealthy W ork, Stress, Productivity and the Reconstruction of W orking Life. N ueva Y ork: Basic Books.

K arasek, RA. 1976. The impact of the work environment on life outside the job. T esis doctoral, M assachusetts Institute of Technology, Cambridge, $M$ assachussetts.

-. 1979. Job demands, job decision latitude, mental strain: Implications for job redesign. Adm Sci Q 24: 285-308.

- . 1985. T he J ob Content Q uestionnaire (J CQ) and U ser's Guide. Lowell, M assachussetts: JCQ Center, Department of Work Environment, Universidad de $M$ assachusetts $L$ owell.

- . 1990. Lower health risk with increased job control among white collar workers. J Organ Behav 11: 171-185.

K asl, SV. 1989. An epidemiological perspective on the role of control in health. En J ob Control and W orker $\mathrm{H}$ ealth, dirigido por SL Sauter, JJ H urrell Jr y CL Cooper. Chichester: Wiley.

K auppinen-T oropainen, K, JE Gruber. 1993. Antecedants and outcomes of woman-unfriendly experiences: A study of Scandanavian, former Soviet and American women. Psychol Women Q 17(4): 431-456.

K awakami, N, T H aratani, T H emmi, S Araki. 1992. Prevalence and demographic correlates of alcohol-related problems in Japanese employees. Social Psych Psychiatric E pidemiol 27: 198-202.
- 1993. R elations of work stress to alcohol use and drinking problems in male and female employees of a computer factory in Japan. Environ Res 62 : 314-324.

K eita, GP, SL Sauter. 1992. W ork and W ell Being: An A genda for the 1990 s. Washington, DC: APA

K elly, M, CL Cooper. 1981. Stress among blue collar workers: A case study of the steel industry. $\mathrm{Em}$ ployee R elations 3: 6-9.

K erckhoff, A, K Back. 1968. The J une Bug. Nueva Y ork: Appelton-C entury C roft.

K essler, RC, JB T urner, JS H ouse. 1988. The effects of unemployment on health in a community survey: $M$ ain, modifying and mediating effects. J Soc I ssues 44(4): 69-86.

-. 1989. U nemployment, reemployment, emotional functioning in a community sample. Am Soc R ev 54 648-657.

K essler, R C, JS H ouse, JB T urner. 1987. Unemployment and health in a community sample. J $\mathrm{H}$ ealth Soc B ehav 28: 51-59.

K leiber, D, D Enzmann. 1990. B urnout: 15 Y ears of Re search: An International Bibliography. Gottingen: $\mathrm{HO}$ grefe.

K litzman, S, JM Stellman. 1989. The impact of physical environment on the psychological wellbeing of office workers. Soc Sci M ed 29: 733-742.

$\mathrm{K}$ nauth, $\mathrm{P}, \mathrm{E}$ K iesswetter, W Ottmann, MJ K arvonen, J R utenfranz. 1983. T ime-budget studies of policemen in weekly or swiftly rotating shift systems. A ppl E rgon 14(4): 247-252.

K nauth, P, J Rutenfranz. 1976. Experimental shift work studies of permanent night, rapidly rotating, shift systems. I. Circadian rhythm of body temperature and re-entrainment at shift change. Ent A rch $\mathrm{O}$ ccup E nviron $\mathrm{H}$ ealth 37: 125-137.

-. 1982. Development of criteria for the design of shiftwork systems. J H um E rgol 11 Shiftwork: Its Practice and Improvement: 337-367.

K obasa, SC, SR M addi, S K ahn. 1982. H ardines and health: A prospective study. J Personal Soc Psychol 42: 168-177.

K obasa, SC. 1979. Stressful life events, personality and health: An inquiry into hardiness. J Personal Soc Psychol 37: 1-11.

-. 1982. The hardy personality: Toward a social psychology of stress and health. En Social P sychology of $\mathrm{H}$ ealth and IIIness, dirigido por G Sanders y J Suls. $H$ illsdale, N ueva Jersey: Erlbaum.

K ofoed, L, MJ Friedman, P Peck. 1993. Alcoholism and drug abuse in patients with PT SD. Psychiatry 64: 151-171.

K ogi, K. 1991. Job content and working time: The scope for joint change. E rgonomics 34(6): 757-773.

Kohn, M, C Schooler. 1973. O ccupational experience and psychological functioning: An assessment of reciprocal effects. Am Soc R ev 38: 97-118.

Kohn, ML, A Naoi, V Schoenbach, C Schooler y cols. 1990. Position in the class structure and psychological functioning in the U nited States, Japan, Poland. Am J Sociol 95(4): 964-1008.

K omitzer, M, F K ittel, M Dramaix, G de Backer. 1982. Job stress and coronary heart disease. Adv Cardiol 19: 56-61.

K ompier, M, L Levi. 1994. Stress At W ork: Causes, Effects, Prevention. A Guide for Small and M edium Sized Enterprises. Dublín: Fundación Europea.

K ornhauser, A. 1965. T he M ental $H$ ealth of the Industrial W orker. N ueva Y ork: Wiley.

K oss, MP, LA Goodman, A Browne, LF Fitzgerald, GP K eita, NF R usso. 1994. No Safe H aven. Washington, DC: APA Press.

K oulack, D, M N esca. 1992. Sleep parameters of Type A and B scoring college students. Perceptual and $\mathrm{M}$ otor Skills 74: 723-726. 
K ozlowski, SWJ, GT Chao, EM Smith, I Hedlund. 1993. O rganizational downsizing: Strategies, interventions, research implications. En International R eview of Industrial and O rganizational Psychology, dirigido por CL Cooper e I Robertson. Chichester: Wiley.

K ristensen, TS. 1989. Cardiovascular diseases and the work environment. A critical review of the epidemiologic literature on nonchemical factors Scand J W ork E nviron $\mathrm{H}$ ealth 15: 165-179.

—. 1991. Sickness absence and work strain among Danish slaughterhouse workers. An analysis of absence from work regarded as coping behaviour. Social Science and M edicine 32: 15-27.

- 1995. The Demand-Control-Support model: $M$ ethodological challenges for future research. Stress M edicine 11: 17-26.

K rueger, GP. 1989. Sustained work, fatigue, sleep loss and performance: A review of the issues. W ork and Stress 3: 129-141.

K uhnert, K W, R R Sims, M A Lahey. 1989. The relationship between job security and employee health. G roup 0 rgan Stud (A gosto): 399-410.

K uhnert, K W. 1991. J ob security, health, the intrinsic and extrinsic characteristics of work. Group Organ Stud : 178-192.

K umar, D, DL Wingate. 1985. The irritable bowel syndrome. Lancet ii: 973-977.

Lamb, ME, KJ Sternberg, CP H wang, AG Broberg. 1992. Child Care in Context: Cross-Cultural Perspectives. $\mathrm{H}$ illsdale, Nueva Jersey: Earlbaum.

Landsbergis, PA, PL Schnall, D Deitz, R Friedman, T Pickering. 1992. The patterning of psychological attributes and distress by "job strain" and social support in a sample of working men. J B ehav $M$ ed 15(4): 379-405.

Landsbergis, PA, SJ Schurman, BA Israel, PL Schnall, M K H ugentobler, J Cahill, D Baker 1993. Job stress and heart disease: Evidence and strategies for prevention. New Solutions (Verano): 42-58.

Larson, JRJ, C Callahan. 1990. Performance monitoring: $\mathrm{H}$ ow does it affect work productivity. J Appl Psychol 75: 530-538.

Last, LR, RWE Peterson, J Rappaport, CA Webb. 1995. C reating opportunities for displaced workers: Center for Commercial Competitiveness. En E mployees, Carers, J ob Creation: D eveloping Growth$O$ riented $H$ uman R esource Strategies and Programs, dirigido por M London. San Francisco: J ossey-Bass.

Laviana, JE. 1985. Assessing the Impact of Plants in the Simulated Office Environment: A H uman Factors Approach. Manhattan, Kansas: Departamento de $\mathrm{H}$ orticultura, U niversidad del Estado de K ansas.

Lazarus, RS, S Folkman. 1984. Stress, Appraisal, Coping. Nueva Y ork: Springer.

Lazarus, RS. 1966. Psychological Stress and Coping Process. Nueva Y ork: M cG raw-H ill.

Lee, P. 1983. T he Complete Guide to | ob Sharing. Nueva York: Walker \& Co

Leibson, B. 1990. Corporate child care: "Junior Execs" on the job. F aculty D esign M anage: 32-37.

Leigh, JP, HM Waldon. 1991. Unemployment and highway fatalities. I H ealth Policy 16: 135-156.

L eino, PI, V H änninen. 1995. Psychosocial factors at work in relation to back and limb disorders. Scand J W ork E nviron $\mathrm{H}$ ealth 21: 134-142.

Levi, L, M Frankenhaeuser, B Gardell. 1986. The characteristics of the workplace and the nature of its social demands. En Occupational Stress and Performance At $W$ ork, dirigido por $S$ W olf y AJ Finestone. Littleton, M assachussetts: PSG.

Levi, L, P L unde-Jensen. 1996. Socio-E conomic C osts of W ork Stress in T wo EU M ember States. A M ode for As sessing the Costs of Stressors At National Level. Dublín: Fundación Europea.
Levi, L. 1972. Stress and D istress in R esponse to Psychosocial Stimuli. N ueva Y ork: Pergamon Press.

-. 1981. Society, Stress and Disease Vol. 4: Working Life. O xford: O xford U niv Press.

- . 1992. Psychosocial, occupational, environmental, health concepts: R esearch results and applications. En W ork and W ell-Being: An Agenda for the 1990s, dirigido por GP K eita y SL Sauter. Washington, DC: APA.

Levine, EL. 1983. Everything Y ou Always W anted to Know A bout J ob Analysis. T ampa: M ariner.

Levinson, DJ. 1986. A conception of adult development. A merican P sychologist 41: 3-13.

Levinson, H. 1978. The abrasive personality. $\mathrm{H}$ arvard Bus Rev 56: 86-94.

Levy, BS, DH Wegman. 1988. O ccupational H ealth: Recognizing and Preventing W ork-R elated D isease. Boston: Little, Brown \& Co.

Lewin, K, R Lippitt, RK W hite. 1939. Patterns of aggressive behaviour in experimentally created social climates. J Soc Psychol 10: 271-299.

Lewis, S, DN Izraeli, H Hootsmans. 1992. DualEarner Families: International Perspectives. Londres: Sage.

Liberatos, P, BG Link, I K elsey. 1988. The measurement of social class in epidemiology. E pidemiol Rev 10: 87-121.

Liem, R, JH Liem. 1988. The psychological effects of unemployment on workers and their families. I Soc I ssues 44: 87-105.

Light, KC, JR Turner, AL H inderliter. 1992. Job strain and ambulatory work blood pressure in healthy young men and women. $\mathrm{H}$ ypertension 20 : 214-218.

Lim, SY, P C arayon. 1994. Relationship between physical and psychosocial work factors and upper extremity symptoms in a group of office workers. Proceedings of the 12 th T riennial Congress of the International E rgonomic Association. 6: 132-134.

Lim, SY. 1994. An integrated approach to upper extremity musculoskeletal discomfort in the office work environment: The role of psychosocial work factors, psychological stress, ergonomic risk factors. T esis doctoral, U niversidad de Wisconsin-M adison.

Lindeman, E. 1944. Symptomatology and management of acute grief. American I ournal of Psychiatry 101: 141-148.

Lindenberg, CS, HK Reiskin, SC Gendrop. 1994. The social system model of substance abuse among childbearing age women: $A$ review of the literature. J ournal of D rug E ducation 24: 253-268.

Lindström, K, J K aihilahti, I T orstila. 1988. I käkausittaiset T erveystarkastukset I a T yön M uutos Vakuutus- J a Pankkialalla (in Finnish W ith E nglish Summary). Espoo: Fondo Finlandés para el Ambiente de T rabajo.

Lindström, K, J H Hurrell Jr. 1992. Coping with job stress by managers at different career stages in Finland and the U nited States. Scand J W ork Environ $H$ ealth 18 Supl. 2: 14-17.

Link, B y cols. 1986. Socio-economic status and schizophrenia: Noisome occupational characteristics as a risk factor. Am Soc R ev 51: 242-258.

-. 1993. Socioeconomic status and depression: The role of occupations involving direction, control and planning. Am J Sociol 6: 1351-1387.

Locke, EA, DM Schweiger. 1979. Participation in decision-making: O ne more look. Res O rgan B ehav 1: 265-339.

London, M. 1995. E mployees, Careers, J ob Creation: De veloping Growth- $O$ riented $H$ uman R esource Strategies and Programs. San Francisco: Jossey-Bass.

Louis, MR. 1980. Surprise and sense-making: What newcomers experience in entering unfamiliar organizational settings. Adm Sci Q 25: 226-251.

Lowe, GS, HC N orthcott. 1988. The impact of working conditions, social roles, personal characteristics on gender differences in distress. W ork 0 ccup 15 : 55-77.

L undberg, 0. 1991. Causal explanations for class inequality in health-an empirical analysis. Soc Sci M ed 32: 385-393

Lundberg, $U, M$ Granqvist, $T$ Hansson, $M$ M agnusson, $L$ Wallin. 1989. Psychological and phsiological stress responses during repetitive work at an assembly line. W ork Stress 3: 143-153.

M acK innon, CA. 1978. Sexual $\mathrm{H}$ arassment of W orking W omen: A Case of Sex Discrimination. New Haven, Connecticut: $Y$ ale $U$ niv. Press.

M addi, SR, SC K obasa, M C Hoover. 1979. An alienation test. J ournal of $H$ umanistic Psychology 19: 73-76.

Maddi, SR, SC K obasa. 1984. The $H$ ardy Executive: $\mathrm{H}$ ealth U nder Stress. H omewood, Illinois: D ow-Jones Irwin.

M addi, SR . 1987. H ardiness training at Illinois Bell Telephone. En $\mathrm{H}$ ealth Promotion Evaluation, dirigido por JP O patz. Stevens Point, W isconsin: National W ellness Insitutue.

-. 1990. Issues and interventions in stress mastery. En Personality and Disease, dirigido por HS Friedman. Nueva Y ork: Wiley.

$M$ aher, EL. 1982. Anomic aspects of recovery from cancer. Social Science and M edicine 16: 907-912.

M andell, W y cols. 1992. Alcoholism and occupations: A review and analysis of 104 occupations. Alcohol, Clin Exp R es 16: 734-746.

M angione, TW, RP Q uinn. 1975. Job satisfaction, counterproductive behavior, drug use at work. J ournal of Applied Psychology 60: 114-116.

M ann, N. 1989. T he Keys to Excellence. The Story of D eming Philosophy. Los Angeles: Prestwick.

M antell, M , S Albrecht. 1994. T icking B ombs: D efusing Violence in the W orkplace. Nueva Y ork: Irwin Professional.

M arans, RW, X Y an. 1989. Lighting quality and environmental satisfaction in open and enclosed offices. I Architect Plan R es 6: 118-131.

M argolis, B, W K roes, R Q uinn. 1974. Job stress and unlisted occupational hazard. J O ccup M ed 16: 659-661.

M arino, KE, SE White. 1985. Departmental structure, locus of control, job stress: The effect of a moderator. J ournal of A pplied P sychology 70: 782-784.

M armot, M . 1976. Acculturation and coronary heart disease in Japanese Americans. En T he Contribution of the Social Environment to $\mathrm{H}$ ost Resistance, dirigido por JP C assel.

M armot, M y T T heorell. 1988. Social class and cardiovascular disease: The contribution of work. Int I H ealth Serv 18: 659-674.

M arshall, NL, RC Barnett. 1991. Race, class and multiple roles strains and gains among women employed in the service sector. W omen $H$ ealth 17: 1-19.

M artin, DD, RL Shell. 1986. M anagement of Professionals. N ueva Y ork: M arcel Dekker.

M artin, EV. 1987. Worker stress: A practitioner's perspective. En Stress $M$ anagement in W ork Setting, dirigido por LR M urphy y TF Schoenborn. Cincinnati, O hio: NIOSH

Maslach, C, SE Jackson. 1981/1986. The M aslach Burnout Inventory. Palo Alto, California: Consulting Psychologists.

Maslach, C. 1993. Burnout: A multidimentional perspective. En Professional Burnout, dirigido por WB Schaufeli, C Maslach y T Marek. Washington, DC: T aylor y Francis.

Maslow, AH. 1954. M otivation and Personality. Nueva Y ork: $\mathrm{H}$ arper.

M atteson, M T, JM Ivancevich. 1987. Controlling W ork Stress. San Francisco: J ossey-Bass. 
M attiason, I, F Lindgarden, JA Nilsson, T Theorell. 1990. Threat of unemployment and cardiovascular risk factors: Longitudinal study of quality of sleep and serum cholesterol concentrations in men threatened with redundancy. B ritish M edical J ournal 301: 461-466.

Mattis, M C. 1990. New forms of flexible work arrangements for managers and professionals: $M$ yths and realities. H um Resour Plan 13(2): 133-146.

M cGrath, A, N Reid, J Boore. 1989. O ccupational stress in nursing. Ent J N ursing Stud 26(4): 343-358.

M cG rath, JE. 1976. Stress and behavior in organizations. En $\mathrm{H}$ andbook of Industrial and $\mathrm{O}$ rganizational $\mathrm{Py}$ schology, dirigido por MD Dunnette. Chicago: $\mathrm{R}$ and $\mathrm{M}$ CN ally.

M cK ee, GH, SE Markham, DK Scott. 1992. Job stress and employee withdrawal from work. En Stress \& W ell-B eing At W ork, dirigido por JC Q uick, LR M urphy y JJ H urrel. Washington, D.C.: APA.

MCLaney, MA, JJ Hurrell Jr. 1988. Control, stress and job satisfaction. W ork Stress 2: 217-224.

M CLean, LA. 1979. W ork Stress. Boston: AddisonWesley.

M eisner, M . 1971. The long arm of the job. Industrial Relations: 239-260.

Meyer, BD. 1995. Lessons from the US unemployment insurance experiments. J $E$ con Lit 33: 91-131.

M eyerson, D. 1990. U ncovering socially undesirable emotions: Experience of ambiguity in organizations. Am B ehav Sci 33: 296-307.

M ichaels, D, SR Zoloth. 1991. M ortality among urban bus drivers. Ent J E pidemiol 20(2): 399-404.

M ichelson, W. 1985. F rom Sun to Sun: M aternal O bligations and Community Structure in the Lives of E mployed $W$ omen and Their Families. Totowa, Nueva Jersey: R owman \& Allanheld.

Miller, KI, PR M onge. 1986. Participation, satisfac tion, productivity: A meta-analytic review. Acad $M$ anage 29: 727-753.

M iller, LS, S K elman. 1992. Estimates of the loss of individual productivity from alcohol and drug abuse and from mental illness. En Economics and $M$ ental $H$ ealth, dirigido por RG Frank y M G M anning. Baltimore: Johns H opkins U niv. Press.

Miller, S. 1979. Controllability and human stress: $M$ ethod, evidence and theory. B ehav Res Ther 17 287-304.

M inisterio de Trabajo. 1987. Ley sueca sobre el ambiente de trabajo (con enmiendas) y R eglamento sueco sobre el ambiente de trabajo (con enmiendas). Estocolmo: M inisterio de Trabajo.

M ino, Y, T T suda, A Babazona, H Aoyama, S Inoue, $\mathrm{H}$ Sato, $\mathrm{H}$ O hara. 1993. Depressive states in workers using computers. Environmental Research 63(1): 54-59.

$M$ isumi, J. 1985. The Behavioural Science of $L$ eadership Concept: Third Leadership Symposium. Carbondale, IIlinois: U niversidad del Sur de Illinois.

M oleski, WH, JT Lang. 1986. O rganizational goals and human needs in office planning. En B ehaviora Issues in Office Design, dirigido por J Wineman. N ueva Y ork: $V$ an N ostrand R inehold.

M onk, T, D T epas. 1985. Shift work. En J ob Stress and Blue Collar W ork, dirigido por C Cooper y MJ Smith. Londres: John Wiley \& Sons.

M onk, TH, S Folkard. 1992. M aking Shift W ork T olerable. Londres: T aylor \& Francis.

Moon, S, SL Sauter. 1996. Psychosocial Factors and M usculosketetal Disorders in O ffice W ork. : T aylor and Francis, Ltd.

Moos, R, A Billings. 1982. Conceptualizing and measuring coping resources and process. $\mathrm{En} \mathrm{H}$ andbook of Stress: Theoretical and Clinical Aspects, dirigido por L Goldberger y S Breznitz. Nueva Y ork: Free Press.
M oos, RH . 1986. Work as a human context. En Psychology and W ork: Productivity, Change, Employment, dirigido por MS Pallak y R Perloff. Washington, DC: APA

M orrison, EW. 1993. Longitudinal study of the effects of information seeking on newcomer socialization. J Appl Psychol 78: 173-183.

M orrow, PC, JC M CElroy. 1987. Work commitment and job satisfaction over three career stages. I Vocationl B ehav 30: 330-346.

M ossholder, KW, AG Bedeian, AA A rmenakis. 1981. R ole perceptions, satisfaction, performance: M oderating effects of self-esteem and organizational level. O rgan B ehav H um Perform 28: 224-234.

- . 1982. Group process-work outcome relationships: A note on the moderating impact of self-esteem. A cad M anage) 25: 575-585.

M untaner, C y cols. 1993. Dimensions of the psychosocial work environment in five US metropolitan areas. W ork Stress 7: 351-363.

M untaner, C, A T ien, WW Eaton, R Garrison. 1991. $O$ ccupational characteristics and the occurence of psychotic disorders. Social Psych Psychiatric E pidemiol 26: $273-280$.

M untaner, C, JC Anthony, RM Crum, WW Eaton. 1995. Psychosocial dimensions of work and the risk of drug dependence among adults. Am J E pide miol 142(2): 183-190.

M untaner, C, P O 'C ampo. 1993. A critical appraisal of the Demand/ C ontrol model of the psychosocial work environment: E pistemological, social, behavioral and class considerations. Soc Sci M ed 36: 1509-1517.

M untaner, C, P Wolyniec, I M CG rath, A Palver. 1993. Work environment and schizophrenia: An extension of the arousal hypothesis to occupational self-selection. Social Psych Psychiatric E pidemiol 28: 231-238.

- 1994. Psychotic inpatients' social class and their first admission to state or private psychiatric hospitals in Baltimore. Am J Public H ealth 84: 287-289.

Murphy, LR. 1988. Workplace interventions for stress reduction and prevention. En Causes, Coping and Consequences of Stress At $W$ ork, dirigido por $C L$ Cooper y R Payne. Nueva Y ork: Wiley.

M urrell, K FH. 1965. A classification of pacing. Ent J Prod Res 4: 69-74.

National C ouncil on Compensation Insurance. 1985. E motional Stress in the W orkplace. New Legal Rights in the Eighties. Nueva York: National Council on Compensation Insurance.

National Institute for O ccupational Safety and H ealth (NIOSH). 1988. Prevention of W ork-R elated Psychological D isorders in Proposed National Strategies for the Prevention of L eading W ork-R elated D iseases and I njuries: NIOSH.

Nehling, A, G Debry. 1994. C affeine and sport activity: A review. Enternational J ournal of Sports M edicine 15: 215-223.

Nelson, DL, CD Sutton. 1991. The relationship between newcomer expectations of job stressors and adjustment to the new job. W ork Stress 5: 241-251.

Nelson, DL, JC Quick. 1991. Social support and newcomer adjustment in organization: Attachment theory at work? J O rgan B ehav 12: 543-554.

Nelson, DL. 1987. O rganizational socialization: A stress perspective. I O ccup B ehav 8: 3II-324.

N ewman, JE, TA Beehr. 1979. Personal and organizational strategies for handling job stress: A review of research and opinion. Personnel P sychology 32: 1-43.

Niaura, R, CM Stoney, PN H erbst. 1992. Biol Psychol 34: 1-43.

North, FM , SL Syme, A Feeney, M Shipley, M M armot. 1996. Psychosocial work environment and sickness absence among British civil servants: The Whitehall II study. Am J Public H ealth 86(3): 332.
Northwestern National Life. 1991. Employee burnout: America's newest epidemic. M inneapolis, $M$ innesotta: N orthern N ational Life.

N uckolls, K B y cols. 1972. Psychosocial assets, life crisis and the prognosis of pregnancy. American J ournal of E pidemiology 95: 431-441.

O 'D onnell, M P, JS H arris. 1994. $\mathrm{H}$ ealth Promotion in the W orkplace. N ueva Y ork: D elmar.

0 'R eilly, CA, JA Chatman. 1991. People and organizational culture: A profile comparison approach to assessing person-organization fit. Acad $M$ anage J 34: 487-516.

$O$ etting, ER, RW Edwards, F Beauvais. 1988. Drugs and native-American youth. Drugs and Society 3: 1-34.

Ö hman, A, G Bohlin. 1989. The role of controllability in cardiovascular activation and cardiovascular disease: $\mathrm{H}$ elp or hindrance? En Stress, Personal Control and $\mathrm{H}$ ealth, dirigido por A Steptoe y A Appels. Chichester: Wiley.

O jesjo, L. 1980. The relationship to alcoholism of occupation, class and employment. J O ccup M ed 22: 657-666.

O Idham, GR, NL R otchford. 1983. R elationships between office characteristics and employee reactions: A study of the physical environment. Adm Sci Q 28: 542-556.

O Idham, GR, Y Fried. 1987. Employee reactions to workspace characteristics. I A ppl Psychol 72: 75-80.

O ldham, GR. 1988. Effects of change in workspace partitions and spatial density on employee reactions: A quasi-experiment. I Appl Psychol 73: 253258.

O Iff, M, JF Brosschot, RJ Benchop, RE Ballieux, GLR Godaert, CI H eijnen, H Eursin. 1993. Defence and coping in relation to subjective health and immunology.

O Iff, M, JF Brosschot, RJ Benschop, RE Ballieux, GLR Godaert, CJ H eijnen, H U rsin. 1995. M odulatory effects of defense and coping on stressinduced changes in endocrine and immune parameters. Ent J B ehav M ed 2: 85-103.

O Imedo, EL, DL Parron. 1981. M ental health of minority women: Some special issues. J Prof Psychol 12: 103-111.

O rganización Internacional del T rabajo (O IT ). 1975. $M$ aking W ork $M$ ore H uman. R eport of the D irector $G$ eneral to the International L abour Conference. G inebra: O IT.

- . 1986. Entroduction to W ork Study. Ginebra: OIT

Organización M undial de la Salud (OM S). 1984. $\mathrm{H}$ ealth promotion: A discussion document on the concept and principles. H ealth Promot 1: 73-76.

Organización para la Cooperación y el Desarrollo Económico (O CDE). 1995. OE CD E conomic O utlook 57. París: OCDE.

O rnstein, S, I Lynn. 1990. Age vs stage models of career attitudes of women: A partial replication and extension. J ournal of Vocational B ehavior 36: 1-19.

O rnstein, S, WL Cron, JWJ Slocum. 1989. Life stage versus career stage: A comparative test of the theories of Levinson and Super. J Organ B ehav 10: 117133.

O rnstein, S. 1990. Linking environmental and industrial/organizational psychology. En International R eview of Industrial and Organizational Psychology, dirigido por CL Cooper e IT Robertson. Chichester: Wiley.

O rr, E, M Westman. 1990. Does hardiness moderate tress and how? A review. En On Coping Skills, SelfControl, Adoptive Behavior, dirigido por M Rosenbaum. Nueva Y ork: Springer.

O rth-Gomér, K, A R osengren, L Wilhelmsen. 1993. Lack of social support and incidence of coronary heart disease in middle-aged Swedish men. Psychosom M ed 55: 37-43. 
O rth-Gomér, K, A-L Undén, ME Edwards. 1990. Social isolation and mortality in ischemic heart disease. A ten year follow-up study of 150 middleaged men. Acta M ed Scand 224: 205-215

O rth-Gomér, K, A-L Undén. 1987. The measurement of social support in population surveys. Soc Sci M ed 24(1): 83-94.

- . 1990. Type A behavior, social support and coronary risk. Enteraction and significance for mortality in cardiac patients. Psychosom M ed 52: 59-72.

O rth-Gomér, K, JV Johnson. 1987. Social network interaction and mortality. A six year follow-up study of a random sample of the Swedish population. J Chron D is 40(10): 949-957.

O sipow, SH, RE Doty, AR Spokane. 1985. O ccupational stress, strain, coping across the life span. I $\checkmark$ ocat B ehav 27: 98-108.

O uellette, SC. 1993. Enquiries into hardiness. En $H$ andbook of Stress: Theoretical and Clinical Aspects, dirigido por L Goldberger y S Breznitz. Nueva Y ork: Free Press.

O verman, S. 1993. T emporary services go global. H R $M$ ag (August): 72-74.

Pagani, M, O Rimoldi, P Pizzinelli, R Furlan, W Crivellaro, D Liberati, S Cerutti, A M alliani. 1991. Assessment of the neural control of the circulation during psychological stress. I Autonom N erv Sys 35: 33-42.

Paoli, P. 1992. First E uropean Survey On the W ork Environment 1991-1992. Dublín: Fundación Europea.

Parkes, KR. 1989. Personal control in an occupational context. En Stress, Personal Control, H ealth, dirigido por A Steptoe y A Appels. Chichester: John Wiley \& Sons.

-. 1992. M ental health in the oil industry: A comparative study of onshore and offshore employees. Psychol M ed 22: 997-1009.

Parrot, AC. 1995. Stress modulation over the day in cigarette smokers. Addiction 20: 233-244.

Partinen, M. 1994. Sleep disorders and stress. J ournal of Psychosomatic R esearch 38: 89-91.

Payne, R, DS Pugh. 1976. Organizational structure and climate. En $\mathrm{H}$ andbook of Industrial and Organizational Psychology, dirigido por MD Dunnette. Chicago: $\mathrm{R}$ and $\mathrm{M} \mathrm{CN}$ ally Publishing $\mathrm{C}$ ompany.

Pell, S, CA d'Alonzo. 1963. Acute myocardial infarction in a large employed population: Report of six-year study of 1356 cases. J Am M ed Assoc 185: 831-841.

Pennebaker, JW, G H all. 1982. T he Psychology of Symptoms. N ueva Y ork: Springer-V erlag.

Pervin, LA. 1967. A twenty-college study of student $x$ college interaction using TAPE (Transactiona Analysis of Personality and Environment): R ationale, reliability, validity. J E duc P sychol 58: 290-302.

Peters-Golden, H. 1982. Breast cancer: V aried perceptions of social support in the illness experience. Social Science and M edicine 16: 483-491.

Peterson, M F, PB Smith, A Akande, S A yestaran, S Bochner, V Callan, N Guk Cho, JC Jusuino, M D'Amorim, P Francois, K H ofmann, PL K oopman, K Leung, TK Lim, S M ortazavi, J M unene M Radford, A Ropo, G Savage, B Setiadi, TN Sinha, R Sorenson, C V iedge. 1995. R ole conflict, abiguity and overload: A 21-nation study. Academy of $M$ anagement J ournal 38: 429-452.

Petraitis, J, BR Flay, T Q M iller. 1995. Reviewing theories of adolescent substance use: O rganizing pieces in the puzzle. Psychol Bull 117: 76-86.

Peyser, HS. 1992. Stress, ethylalcohol, alcoholism. En $H$ andbook of Stress: Theoretical and Clinical Aspects, dirigido por L Goldberger y S Breznitz. Nueva Y ork: Free Press.

Phelan, J, JE Schwartz, EJ Bromet, M A Dew, y cols. 1991. Work stress and depression in professiona and managerial employees. Psychol M ed 21: 9991012.

Pickering, T G. 1991. Ambulatory M onitoring and Blood Pressure V ariability. Filadelfia: Science Press.

Pierce, JL, DG Gardner, RB Dunham, LL Cummings. 1989. O rganization-based self esteem: Construct definition, measurement, validation. Acad M anagej 32: 622-648.

-. 1993. Moderation by organization-based selfesteem of role condition-employee response relationships. Acad M anageJ 36: 271-288.

Pines, AM , E Aronson. 1981. Burnout: From T edium to Personal Growth. N ueva Y ork: M acM illian.

Pines, AM . 1982. Changing organizations: Is a work environment without burnout an impossible goal? En I ob Stress and Burnout: Research, Theory, Intervention Perspectives, dirigido por WS Paine. Beverly Hills: Sage Publications.

-.1983 . Burnout and the buffering effects of social support. En Stress and Burnout in the H uman Service Professions, dirigido por BA Farber. Nueva York: Peramon Press.

Piper, DW, C T ennant. 1993. Stress and personality in patients with chronic peptic ulcer. J Clin Gastroenterol 16: 211-214.

Pitt-C atsouphes, M , A M archetta. 1991. A Coming of Age: T elework. Boston: Center on W ork and Family, Univ. de Boston.

Pohorecky, LA. 1991. Stress and alcohol interaction: An update of human research. Alcoholism Clinical and Experimental Research 15: 438-459.

Pollard, TM, G Ungpakorn, GA Harrison. 1992. Some determinants of population variation in cortisol levels in a British urban community. J B iosoc Sci 24: 477-485.

Porras, JI, PJ R obertson. 1992. O rganizational development: Theory, practice and research. En $\mathrm{H}$ andbook of Industrial and $\mathrm{O}$ rganizational Psychology, dirigido por M D Dunnette y LM H ough. Palo Alto, California: C onsulting Psychologists Press, Inc.

Price, RH , M van R yn, AD Vinokur. 1992. Impact of preventive job search intervention on the likelihood of depression among the unemployed. I $H$ ealth Soc B ehav 33: 158-167.

Price, RH. 1990. Strategies for managing plant closings and downsizings. $\mathrm{En}$ T he $\mathrm{H}$ uman Side of $\mathrm{Corpo-}$ rate Competitiveness, dirigido por D Fishman y C Cherniss. Beverly H ills: Sage.

Q uick, JC, JD Q uick. 1984. Organisational Stress and Preventive M anagement. N ueva Y ork: $M$ CG raw-H ill.

R agland, DR, RJ Brand. 1988. Type A behavior and mortality from coronary heart disease. N Engl J $M$ ed 318: 65-69.

Rahe, RH . 1988. R ecent life changes and coronary heart disease: 10 years' research. $E n H$ andbook of $\mathrm{L}$ ife Stress, Cognition and $\mathrm{H}$ ealth, dirigido por S Fisher yJ R eason. Nueva Y ork: Wiley.

Ralph, D. 1983. W ork and M adness. M ontreal: Black Rose Books.

Reich, RB. 1991. T he W ork of Nations: Preparing O urselves for 21 st Century Capitalism. Nueva Y ork: A.A. $\mathrm{K}$ nopf

R eilly, NP, CL O rsak. 1991. A career stage analysis of career and organizational commitment in nursing. J V ocat B ehav 39: 311-330.

R epetti, RL. 1987. Endividual and common components of the social environment at work and psychological well-being. I Personal Soc Psychol 52: 710-720.

- 1993. The effects of workload and the social environment at work on health. En $\mathrm{H}$ andbook of Stress: Theoretical, Clinical Aspects, dirigido por L Goldberger y $S$ Breznitz. Nueva Y ork: Free Press.

Reskin, BF, HT H artmann. 1986. W omen's W ork $M$ en's W ork: Sex Segregation On the J ob. Washington, DC: N ational Academy Press.
Review Panel on Coronary-Prone Behavior and Coronary Heart Disease. 1981. Coronary-prone behavior and coronary heart disease: A critical review. Circulation 63: 1199-1215.

Riad-Fahmy, D, GF Read, RF Walker, K Griffiths. 1982. Steroids in saliva for assessing endocrine functions. Endocr R ev 3: 367-395.

Riley, V. 1981. Psychoneuroendocrine influences on immune competence and neoplasia. Science 212: 1100-1109.

Roberts, RE, EU Lee. 1993. O ccupation and the prevalence of major depression, alcohol and drug abuse in the United States. Environ Res 61: 266278.

Roberts, RR, SW Vernon, HM R hoades. 1989. Effects of language and ethnic status on reliability and validity of the Center for Epidemiologic Studies Depression Scale with psychiatric patients. I N erv M ental D is 117: 581-592.

Robins, LN, DA R egier. 1990. Psychiatric Disorders in America. Nueva Y ork: Free Press.

Rodgers, B. 1991. Socio-economic status, employment and neurosis. Soc Psychiatry Psychiat E pidemiol 26: 104-114.

R ogers, CR . 1942. Counseling and Psychotherapy. Boston: $\mathrm{H}$ oughton-M ifflin.

Rose, R M , LF Fogg. 1993. D efinition of a responder: Analysis of behavior, cardiovascular and endocrine responses to varied workload in air traffic controllers. Psychosom M ed 55: 325-338.

Rosen, N, L Greenlagh, JC Anderson. 1981. The cognitive structure of industrial/labor relationships. Ent Rev Appl Psychol 30: 217-233.

Rosenberg, M. 1965. Society and Adolescent Self-Image. Princeton: Princeton U niv. Press.

Rosengren, A, K O rth-Gomér, $H$ Wedel, L Wilhelmsen. 1993. Stressful life events, social support, mortality in men born in 1933. Brit M ed J 307: 1102-1105.

Rosenman, RH, RJ Brand, CD Jenkins, M Friedman, R Straus, M Wurm. 1975. Coronary heart disease in the Western Collaborative Group Study: Final follow-up experience of 81 / 2 years. J Am M ed Assoc 233: 872-877.

Roskies, E, C Louis-Guerin, C Fournier. 1993. Coping with job insecurity: $\mathrm{H}$ ow does personality make a difference. J Organ B ehav (0 ctubre): 617630.

Roskies, E, C Louis-Guerin. 1990. Job insecurity in managers: Antecedents and consequences. J $\mathrm{Or}$ ganB ehav : 345-359.

Roskies, E. 1991. Endividual differences in health behavior. En Personality and Stress: Individual Differences in the Stress Process, dirigido por CL Cooper y $R$ Payne. N ueva Y ork: Wiley.

R otter, JB. 1954. Social Learning and Clinical Psychology. Englewood C liffs, Nueva Jersey: Prentice H all.

-.1966. G eneralized expectancies for internal versus external control of reinforcement. Psychol M onog 80: 1-28.

Rousseau, DM . 1988. The construction of climate in organizational research. En International R eview of Industrial and Organizational Psychology, dirigido por CL Cooper el R obertson. Londres: Wiley.

- . 1989. Price of success? Ind Crisis Q 3: 285-302.

-. 1990. Assessing organizational culture. En Organizational Climate and Culture, dirigido por B Schneider. San Francisco: Jossey-Bass.

Roy, DJ. 1995. Layoffs down, but will continue despite surging economy, analysts say. BNA L abor D aily.

R ozanski, A, CN Balcry, DS K rantz, J Friedman, K Resser, M M orell, S H ilton-Chalfen, L H estrin, J Bietendorf, DS Berman. 1988. M ental stress and the induction of silent myocardial ischemia in patients with coronary artery disease. N ew E ngl J $\mathrm{M}$ ed 318: 1005-1012. 
R ubenstein, M , I DeV ries. 1993. H ow to Combat Sexual $\mathrm{H}$ arassment: $\mathrm{A}$ Guide to I mplementing the $\mathrm{E}$ uropean $\mathrm{Com}$ mission Code of Practice Luxemburgo: Comisión de las $\mathrm{C}$ omunidades Europeas.

Ruhm, CJ. 1991. Are workers permanently scarred by job displacement? American E conomic R eview 81: 319-324.

Sadava, SW. 1987. Psychosocial interactionism and substance use. D rugs Society 2: 7-24.

Salvendy, G, JL K night. 1983. Circulatory tesponses to machine-paced and self-paced work: An industrial study, E rgonomics. 26(7): 713-717.

Salvendy, G. 1981. Classification and characterisitics of paced work. En M achine Pacing and $O$ ccupational Stress, dirigido por G Salvendy y MJ Smith. Londres: T aylor \& Francis.

- . 1976. Effects of equitable and inequitable financial compensation on operator's productivity, satisfaction and motivation. Enter J Prod Res. 14(2): 305-310.

Sanchez, C. 1990. A vulnerable work force. The W ashington Post, 7 de enero, D 1,D 5.

Sanders, M, EJ M CCormick. 1993. H uman Factors in E ngineering and D esign. N ueva Y ork: M CG raw-H ill.

Sauter, S, M Dainoff, MJ Smith. 1990. Promoting $\mathrm{H}$ ealth and Productivity in the Computerized Office: $M$ odels of Successful E rgonomic Interventions. Londres: T aylor and Francis.

Sauter, SL, JJ H urrell Jr, CL Cooper. 1989. J ob Control and W orker $H$ ealth. Chichester: John W iley \& Sons.

Sauter, SL, LR M urphy, IJ Hurrell Jr. 1990. Prevention of work related psychosocial disorders: A national strategy proposed by the $\mathrm{N}$ ational Institute for $\mathrm{O}$ ccupational $\mathrm{H}$ ealth and Safety (NIO SH ). Am Psychol 45: 1146-1158.

Sauter, SL, NG Swanson. 1996. An ecological model of musculoskeletal disorders in office work. En Psychosocial $\mathrm{F}$ actors and $\mathrm{M}$ usculoskeletal $\mathrm{D}$ isorders in $\mathrm{O}$ ffice W ork, dirigido por S M oon y SL Sauter. Londres: T aylor and Francis. En imprenta.

Sauter, SL, T H ales, B Bernard, L Fine, M Petersen, V Putz-Anderson, LM Schleifer, T O chs. 1993. Summary of two NIOSH studies of musculoskeletal disorders and VDT work among telecommunications and newspaper workers. En W ork W ith Display U nits '92, dirigido por A Luczak, A Cakir y G Cakir. Amsterdam: N orth $\mathrm{H}$ olland.

Saxton, M J, JS Phillips, R N Blakeney. 1991. Antecedents and consequences of emotional exhaustion in the airline reservations service center. $H$ uman Relations 44: 583-595.

Scharlach, AE, BF Lowe, EL Schneider. 1991. Elder Care and W ork Force: Blueprint for Action. Lexington, $M$ assachussetts: L exington.

Schaubroeck, J, DC Ganster, WE Sime, D Ditman. 1993. A field experiment testing supervisory role clarification. Pers Psychol 46: 1-25.

Schaufeli, WB, C M aslach, T M arek. 1993. Professional Burnout: Recent Developments in Theory and $R e$ search. Washington, DC: T aylor \& Francis.

Scherwitz, L, K Berton, H Leventhal. 1978. Type A Behavior, self-involvement, cardiovascular response. Psychosom M ed 40: 593-609.

Schleifer, LM, R Ley. 1994. End-tidal PCO 2 as an index of psychophysiological activity under high and low data-entry workload demands. Trabajo presentado en el primer congreso de la Sociedad Internacional para el Avance de la Psicofisiología R espiratoria, Saint Flour, Francia.

Schleifer, LM, RL Shell. 1992. A review and reap praisal of electronic performance monitoring, performance standards, stress allowances. Appl E rgon 23: 49-53.

Schleifer, LM , T Galinsky, CS Pan. 1995. M ood disturbance and musculoskeletal discomfort effects of electronic performance monitoring in a VDT data-entry task. En J ob Stress 2000: E mergent Issues, dirigido por GP K eita y SL Sauter. Washington, DC: APA

Schlenker, B. 1980. Impression M anagement. M ontery, California: Brooks Cole.

Schmidt, WH , JP Finnigan. 1992. The Race W ithout a Finish Line: America's Quest for Total Quality. San Francisco: Jossey-Bass.

Schnall, PL, C Pieper, JE Schwartz, RA K arasek, Y Schlussel, RB Devereux, A Ganau, M Alderman, K Warren, T G Pickering. 1990. The relationship between "job strain", work place diastolic blood pressure, left ventricular mass index. J Am M ed AsSoc 263: 1929-1935.

Schnall, PL, PA Landsbergis, D Baker. 1994. Job strain and cardiovascular disease. Annu Rev Publ $H$ ealth 15: 381-411.

Schneider, B. 1985. O rganizational behavior. Annu Rev Psychol 36: 573-611.

Schonfeld, IS. 1992. Assessing occupational stress in teachers: Depressive symptoms scales and neutral self-reports of the work environment. En Stress and $W$ ell Being At W ork: Assessments and Interventions for $O$ ccupational $M$ ental $H$ ealth, dirigido por RC Q uick, LR M urphy y JJ H urrell. Washington, DC: APA.

Schwartz, J, C Pieper, RA K arasek. 1988. A procedure for linking job characteristics to health surveys. Am J Public H ealth 78: 904-909.

Scott, AJ, J LaD ou. 1990. Shiftwork: effects on sleep and health with recommendations for medical surveillance and screening. 0 ccup M ed 5: 273-299.

Seligman, MEP. 1975. H elplessness. San Francisco: WH Freeman.

Seltzer, J, RE N umerof, BM Bass. 1989. T ransformation leadership: Is it a source of more or less burnout and stress. I H ealth H um Resource Admin 12: 174-185.

Selye, H. 1936. A syndrome produced by diverse noxious agents. N ature 138: 32

- . 1960. The concept of stress in experimental physiology. En Stress and Psychiatric Disorder, dirigido por IM T anner. O xford: Blackwell.

— . 1974. Stress W ithout D istress. Filadelfia: JB Lipincott.

— . 1976. T he Stress of L ife. N ueva Y ork: M CG raw-H ill.

Senge, P. 1991. T he Fifth D iscipline: T he Art and Practice of the L earning O rganization. N ueva Y ork: D oubleday.

Shanan, J. 1967. Adaptive coping. Behav Sci 16: 188196

Shiba, S, A Graham, D Walden. 1994. A New American TQM. Four Practical Revolutions in $M$ anagement. Cambridge, M assachussetts: Productivity Press.

Shinn, M, M R osario, H M orch, DE Chestnut. 1984 Coping with job stress and burnout in the human services. J Personal Soc Psychol 46: 864-876.

Siegrist, J, R Peter, A Junge, P Cremer, D Seidel. 1990. Low status control, high effort at work and ischemic heart disease: Prospective evidence from blue-collar men. Soc Sci M ed 31: 1127-1134.

Slora, K B, DS Joy, W T erris. 1991. Personnel selection to control employee violence. J B us P sychol 5: 417-426.

Smith, MJ, BGF Cohen, L Stammerjohn, A Happ. 1981. An investigation of health complaints and job stress in video display operators. $\mathrm{H}$ uman $\mathrm{F}$ actors 23: 389-400

Smith, MJ, P Carayon (1996): Work organization, stress, cumulative trauma disorders. Presented at the conference on Psychosocial Influence in O ffice Work CTD. Duke university, Nov. 11-12, 1993 En Psychosocial F actors and M usculoskeletal D isorders in Office W ork. dirigido por S M oon y S.L. Sauter.

Smith, MJ, P Carayon, K M iezio. 1986. M otivational, B ehavioral, Psychological Implications of E lectronic M onitoring of W orker Performance. Washington, DC: NTIS.
Smith, MJ, P Carayon, K Sanders, SY Lim, D LeGrande. 1992b. Employee stress and health complaints in jobs with and without electronic performance monitoring. Appl E rgon 23: 17-27.

Smith, M J, P C arayon, R Eberts, G Salvendy. 1992a. $\mathrm{H}$ uman-computer interaction. $\mathrm{En} \mathrm{H}$ andbook of Industrial Engineering, dirigido por $\mathrm{G}$ Salvendy. Nueva Y ork: John Wiley \& Sons.

Smith, M J, PC Sainfort. 1989. A balance theory of job design for stress reduction. Ent I Ind E rg 4: 67-79.

Smith, MJ. 1984. The physical, mental, emotional stress of VDT work. Comput Graph Appl 4(4): 23-27.

-. 1985. Machine-paced work and stress. En J ob Stress and Blue Collar W ork, dirigido por C Cooper y MJ Smith. Londres: John Wiley \& Sons

- . 1987. O ccupational stress. En $\mathrm{H}$ andbook of $\mathrm{H}$ uman Factors, dirigido por $G$ Salvendy. Nueva York: John W iley $\&$ Sons.

-. 1988. Electronic performance monitoring at the workplace: Part of a new industrial revolution. $\mathrm{H} \mathrm{u}$ man F actors Society B ull letin 31: 1-3.

Solomon, SR. 1986. Mobilizing social support networks in times of disaster. En T rauma an Its $W$ ake, dirigido por CR Figley. Nueva York: BrunnerM azel.

Sommer, R. 1983. Social D esign: Creating B uildings W ith $P$ eople in $M$ ind. $\mathrm{N}$ ew Jersey: Prentice $\mathrm{H}$ all.

Sommese, T, JC Patterson. 1995. Acute effects of cigarette smoking withdrawal: A review of the literature. Aviation, Space and E nvironmental M edicine 66: 164-167.

Southwood, KE. 1978. Substantive theory and statistical interaction: Five models. Am J Sociol 83: 1154-1203.

Spector, P. 1986. Perceived control by employees: A meta-analysis of studies concerning autonomy and participation at work. H um R elat 39: 1005-1016.

Spector, PE, BJ O 'C onnell. 1994. The contribution of personality trait, negative affectivity, locus of control, type $A$ to the subsequent reports of job stressors and job strains. I 0 ccup 0 rgan P sychol 67: 1-11.

Spurgeon, A, JM H arrington. 1989. Work performance and health of junior hospital doctors. A review of the literature. W ork and Stress 3: 117-128.

St. Paul Fire and $M$ arine. 1992. American W orkers U nder Pressure Technical Report. M inneapolis, M innesotta: St. Paul Fire and $M$ arine.

Stack, S. 1981. Divorce and suicide: A time series analysis, 1933-1970. J ournal of $F$ amily I ssues 2: 77-90.

Staines, G, R Q uinn. 1979. American workers evaluate the quality of their jobs. M onthly Labor R eview 102: 2-12.

Stansfeld, SA, M G M armot. 1992. Social class and minor psychiatric disorder in British civil servants. Psychol M ed 22: 739-749.

Steele, FI. 1986. $\mathrm{M}$ aking and $\mathrm{M}$ anaging $\mathrm{H}$ igh-Quality W orkplaces: An Organizational E cology. Londres: T eacher's C ollege Press.

Steinberg, L, R Catalano, D Dooley. 1981. Economic antecedents of child abuse and neglect. Child $D$ evelopment 52(3): 975-985.

Steinfeld, E. 1986. A case study in the development of a research-based building accessibility standard. En Proceedings of the Seventeenth Annual Environmental $D$ esign R esearch Association, dirigido por J Wineman, $R$ Barnes y C Zimring. Washington, DC: Environmental D esign R esearch Association.

Stellman, JM, M S H enifin. 1983. Office W ork Can Be Dangerous to $\mathrm{Y}$ our $\mathrm{H}$ ealth. A $\mathrm{H}$ andbook $\mathrm{O} n \mathrm{O}$ ffice $\mathrm{H}$ ealth and Safety $\mathrm{H}$ azards and W hat Y ou Can Do About T hem. N ueva Y ork: Fawcett C rest.

Steptoe, A G Fieldman, O Evans, L Perry. 1993. Control over work pace, job strain, cardiovascular responses in middle-aged men. J H ypertension 11: 751-759. 
Steptoe, A. 1981. Psychological F actors in Cardiovascular D isorders. Londres: A cademic Press.

—. 1990. Psychobiological stress responses. En Stress and $M$ edical Procedures, dirigido por M Johnston y J Wallace. O xford: OU P.

Stokols, D, A Churchman, T Scharf, S W right. 1990. Workers' experiences of environmental change and transition at the office. En On the M ove: ThePsychology of $\mathrm{Change}$ and $\mathrm{T}$ ransition, dirigido por $\mathrm{S}$ Fisher y CL C ooper. Chichester: J ohn W iley \& Sons.

Stokols, D, RW Novaco. 1981. T ransportation and well-being: An ecological perspective. En H uman Behavior and Environment: Advances in Theory and $\mathrm{Re}$ search, dirigido por J Wohlwill, P Everett e I Altman. N ueva Y ork: Plenum.

Stokols, D. 1992. Establishing and maintaining healthy environments: T oward a social ecology of health promotion. Am Psychol 47: 6-22.

Stone, PJ, R L uchetti. 1985. Y our office is where you are. $\mathrm{H}$ arvard B us R ev 2: 102-177.

Straw, BM, LE Sandelands, JE Dutton. 1988 Threat-rigidity effects in organizational behavior: A multilevel analysis. En Readings in Organizational Decline: Framew orks, R esearch, Prescriptions, dirigido por RI Sutton y DA Whetten. Cambridge, M assachussetts: Ballinger Publishing Company.

Strube, MJ, JE Garcia. 1981. A meta-analytic investigation of Fiedler's contingency model of leadership effectiveness. Psychol B ull 90: 307-321.

Stumpf, SA, S Rabinowitz. 1981. Career stage as a moderator of performance relationships with facets of job satisfaction and role perceptions. J Vocat B ehav 18: 202-218.

Suls, J, CK Wan, EB Blanchard. 1994. A multilevel data-analytic approach for evaluation of relationships between daily life stressors and symptomatology: Patients with irritable bowel syndrome. $\mathrm{H}$ ealth Psychol 13: 103-113.

Suls, J, GS Sanders. 1988. Type A behavior as a general risk factor for physical disorder. I B ehav $\mathrm{M} \mathrm{ed}$ 11: 201-226.

Sundborm, L. 1971. Condiciones del lugar de trabajo para la población trabajadora (en sueco). Estocolmo: Låginkom-stutredningen, Allmänna Förlaget.

Sundstrom, E, I Altman. 1989. Physical environments and work group effectiveness. En R esearch in O rganizational B ehavior. G reenwich, Connecticut: JAI.

Sundstrom, E. 1986. W orkplaces: The Psychology of the Physical Environment in Offices and Factories. Nueva Y ork: Cambridge U niv. Press.

-. 1987. Work environments: offices and factories. En $\mathrm{H}$ andbook of Environmental Psychology, dirigido por D Stokols e I Altman. Nueva Y ork: John Wiley \& Sons.

Super, DE, RS Zelkowitz, AS Thompson. 1981. Career D evelopment Inventory: A dult F orm 1. Nueva Y ork: T eachers' College, U niversidad de Columbia.

Super, DE. 1957. The Psychology of Careers. Nueva Y ork: $\mathrm{H}$ arper $\&$ Brothers.

Sutherland, VJ, CL Cooper. 1986. M an and Accidents $O$ ffshore: The Costs of Stress Among W orkers 0 n Oil and Gas Rigs. Londres: Dietsmann International.

Sutton, RI, A R afaeli. 1987. Characteristics of work stations as potential occupational stressors. Acad $M$ anage) 30: 260-276.

Sutton, RI, RL K ahn. 1987. Prediction, understanding and control as antidotes to organizational stress. En $\mathrm{H}$ andbook of $\mathrm{O}$ rganizational B ehavior, dirigido por JW Lorsch. Englewood Cliffs, Nueva Jersey: Prentice-H all.

Swanson, JA, JW Lee, JW H opp. 1994. C affeine and nicotine: A review of their joint use and possible interaction effects in tobacco withdrawal. Addictive B ehaviors 19: 229-256.

Swanson, NG, CS Piotrkowski, GP K eita, AG Becker. 1997. O ccupational stress and women's health. En Psychosocial and Behavioral Factors in W omen's $H$ ealth Care: A H andbook for M edical E ducation Practitioners and Psychologists, dirigido por $\mathrm{S} \mathrm{Gal}$ lant, GP K eita y R Royak-Schaler. Washington, DC: APA Press.

Taylor, FW. 1911. The Principles of Scientific M anage ment. N ueva Y ork: N orton \& Co

Taylor, SE. 1991. Asymmetrical effects of positive and negative events: The mobilizationminimization hypothesis. Psychological Bulletin 110(1): 67-85

T epas, D, T M onk. 1987. Work schedules. En H andbook of $H$ uman $F$ actors, dirigido por $G$ Salvendy. N ueva Y ork: John Wiley \& Sons.

Tetrick, LE, JM LaR occo. 1987. U nderstanding, prediction, control as moderators of the relationships between perceived stress, satisfaction, psychologica well-being. J ournal of A pplied Psychology 72: 538-543.

The death of corporate loyalty. 1993. E conomist 3 de abril, 63-64.

The R obens R eport: Safety and health at work. 1972. Londres: HM SO.

Theorell, T, RA K arasek. 1996. Current issues relating to psychosocial job strain and cardiovascular disease research. J O ccup H ealth Psychol 1(1): 9-26.

Theorell, T. 1992. The psychosocial environment, stress, coronary heart disease. En Coronary $\mathrm{H}$ eart $\mathrm{D}$ isease E pidemiology, dirigido por $\mathrm{M} \mathrm{M}$ armot y $\mathrm{P} \mathrm{EI}$ liot. O xford: OUP

Thoits, PA. 1982. Conceptual, methodological and theoretical problems in studying social support as a buffer against life stress. J ournal of $H$ ealth \& Social $B$ ehaviour 23: 145-159.

Thoresen, CE, LH Powell. 1992. Type A behavior pattern: New perspectives on theory, assessment and intervention.J Consult Clin Psychol 60: 595-604.

Tuch, SA, JK M artin. 1991. R ace in the workplace: Black/ White differences in the sources of job satisfaction. Sociol Q 23: 103-116.

T urner, RJ. 1983. Direct, indirect and moderating effects of social support on psychological distress and associated conditions. En Capítulo 3 de Psychosocial Stress: T rends in $T$ heory and R esearch, dirigido por $\mathrm{HB}$ $K$ aplan. Nueva Y ork: A cademic Press.

Type A behavior. 1990. J Soc Behav Personal 5(1): Número especial.

Undén, A-L, K O rth-Gomér, S Elofsson. 1991. Cardiovascular effects of social support in the work place: T wenty-four hour ECG monitoring of men and women. Psychosom M ed 53: 50-60.

Undén, A-L, K O rth-Gomér. 1989. Development of a social support instrument for use in population surveys. Soc Sci M ed 29(12): 1387-1392.

U nited States Bureau of Labor Statistics (USBLS). 1995. Contingent and Alternative Employment Arrange ments. W ashington, DC: U SBLS

U nited States Department of $\mathrm{H}$ ealth and Human Services (U SDH HS). 1966. Protecting the $\mathrm{H}$ ealth of E ighty M illion Americans: A National Goal for $\mathrm{Occupa}$ tional $\mathrm{H}$ ealth. Washington, DC: USDH HS.

U nited States Department of Labor. (U SD O L) 1995. M onthly R eview 118(7): 98-99.

U nited States H ouse of R epresentatives. 1992. A Post $O$ ffice T ragedy: The Shooting At R oyal Oak. Washington, DC: US Government Printing Office.(Informe al Committee on Post Office and Civil Service)

United States Office of Technology Assessment (U SO T A ). 1987. T he E lectronic Supervisor: N ew T echnology, N ew T ensions. Washington DC: USOTA

V ahtera, J, A U utela, J Pentii. 1996. The influence of objective job demands on registered sickness absence spells: D o personal, social and job related resources work as moderators?

V an M aanen, J, EH Schein. 1979. T oward a theory of organizational socialization. En R esearch in Organi- zational Behavior, dirigido por BM Staw. Greenwich, Connecticut: JAI.

Vener, KJ, S Szabo, JG M oore. 1989. The effect of shift work on gastrointestinal (GI) function: A review. Chronobiologia 16: 421-439.

Vinokur, A, M van Ryn, EM Gramlich, RH Price. 1991. Long-term follow-up and benefit-cost analysis of the Jobs Program: A preventive intervention for the unemployed. J ournal of Applied Psychology 756(2): 213-219.

Vinokur, A, RD Caplan, CC Williams. 1987. Effects of recent and past stresses on mental health: Coping with unemployment among $V$ ietnam veterans and nonveterans. J ournal of Applied Social Psychology 17(8): 710-730

Vischer, JC, WC M ees. 1991. O rganic design in the Netherlands: Case study of an innovative office building. En Design Intervention: Toward a M ore $\mathrm{H} \mathrm{U}$ mane Architecture, dirigido por WFE Presiser, JC Vischer y ET White. Nueva Y ork: V an N ostrand Reinhold.

Vischer, JC. 1989. Environmental Quality in Offices. N ueva Y ork: $V$ an N ostrand R inehold.

V olpert, W, R O esterreich, S Gablenz-K olakovic, T K rogoll, M Resch. 1983. M étodo para medir las de mandas de regulación en el trabajo: Análisis del proceso de planificación y razonamiento en la producción industrial (en alemán). Colonia: T üV.

W aitzman, NJ, K R Smith. 1994. The effects of occupational class transitions on hypertension: Racial disparities among working-age men. Am 」 Public $H$ ealth 84: 945-950.

Walsh, DC, G Sorensen, L Leonard. 1995. A "society and health" perspective on gender and health: Cigarette smoking as an exploratory case study. En Society and $\mathrm{H}$ ealth: Foundations for a N ation's $\mathrm{H}$ ealth, dirigido por BC Amick, S Levine, AR Tarlov y DC Walsh. Nueva Y ork: O xford U niv. Press.

Walsh, DC, SE K elleher. 1987. The "corporate perspective" on the health of women at work. En W omen and W ork: An Annual R eview, dirigido por $\mathrm{AH}$ Stromberg, L Larwood y BA Gutek. Newbury Park, Nueva Jersey: Sage.

Wanous, JP. 1992. Organizational Entry: Recruitment, Se lection, Socialization of $N$ ewcomers. R eading, M assachussetts: Addison-W esley.

Warr, PB, P Jackson, M Banks. 1988. U nemployment and mental health: Some British studies. J ournal of Social I ssues 44: 47-68.

Warr, PB. 1990. The measurement of well-being and other aspects of mental health. J 0 ccup Psychol 63: 193-210.

-. 1994. A conceptual framework for the study of work and mental health. W ork and Stress 8: 84-97.

Watson, D, L Clark. 1984. Negative affectivity: The disposition to experience aversive emotional states. Psychol Bull 96: 465-490.

Watson, D, LA Clark, A T ellegen. 1988. Development and validation of brief measures of positive and negative affect: The PANAS scales. J Personal Soc P sychol 54: 1063-1070.

Watts-Jones, D. 1990. Toward a stress scale for African-American women. Psychol W omen Q 14: 271-275.

W eaver, CN . 1978. Black-W hite correlates of job satisfaction. J Appl Psychol 63: 255-258.

-. 1980. Job satiffaction in the U nited States in the 1970's. J Appl Psychol 65: 364-367.

Weiner, A, R Remer, P Remer. 1992. Career plateauing: Implications for career development specialists. J Career D evel 19: 37-48.

W einer, H . 1977. Psychobiology of H uman D isease. Nueva York: Elesvier.

Weiss, JM . 1971. Effects of coping behavior in different warning signal conditions on stress pathology in rats. J Comp Physiol Psychol 77: 1-13. 
Westgaard.RH, R Bjorklund. 1987. Generation of muscle tension additional to postural muscle load. E rgonomics 30(6): 911-923.

Westin, AF. 1986. Privacy and $Q$ uality- $O f-W$ orklife I ssues in $\mathrm{E}$ mployee $\mathrm{M}$ onitoring. Washington, DC: U SO TA.

-. 1990. O rganizational culture and VDT policies: A case study of the Federal Express Corporation. En Promoting $\mathrm{H}$ ealth and Productivity in the Computerized Office, dirigido por SL Sauter, M Dianoff y M Smith. Londres: T aylor and Francis.

Wexley, K N, SB Silverman. 1993. W orking Scared. San Francisco: Jossey-Bass.

Whitaker, A. 1992. The transformation in work Post-Fordism. En Rethinking 0 rganization: N ew Directions in Organization, Theory and Analysis, dirigido por M Reed y M H ughes. N ewbury Park, C alifornia: Sage Publishing.

White, R. 1959. M otivation reconsidered: The concept of competence. Psychol R ev 66: 297-333.

Whitehead, WE, MD Crowell, IC Robinson, BR H eller, M M Schuster. 1992. Effects of stressful life events on bowel symptoms: Subjects with irittable bowel syndrome compared with subjects without bowel dysfunction. Gut 33: 825-830.

Whitehead, WE, M M Schuster. 1985. Gastrointestinal Disorders: Behavioral and Physiological Basis for Treatment. O rlando: Academic Press.

Whitehead, WE. 1992. Behavioral medicine approaches to gastrointestinal disorders. J Consult Clin Psychol 60: 605-612.

Whyte, WF. 1948. H uman R elations in the R estaurant Industry. N ueva Y ork: M CG raw-Hill.

W ickens, C. 1984. E ngineering P sychology and $H$ uman Performance. Columbus, O hio: M errill.

Widfeldt, AK, JR Widfeldt. 1992. T otal quality management in American industry. AAHON J ournal 40(7): 311-318.

W iebe, DJ, PG Williams. 1992. H ardiness and health: A social psychophysiological perspective on stress and adaptation. J Soc Clin Psychol 11: 238-262.

Wilcox, BL. 1981. Social support, lifestyles and psychological adjustment: A test of the buffering hypothesis. Am J Comm Psych 9: 371-386.

Williams, N R. 1993. The impact of total quality management on health and safety. Occup M ed 43(4): 173-174.

Williams, RBJ. 1987. Psychological factors in coronary artery disease: E pidemiologic evidence. CircuIation 76 Supl. 1: I77-I123.

Wineman, J. 1982. The office environment as a source of stress. En E nvironmental Stress, dirigido por GW Evans. Nueva Y ork: Cambridge U niv. Press.

- . 1986. B ehavioral I ssues in Office D esign. N ueva Y ork: $\mathrm{V}$ an N ostrand R inehold.

Wong, PT P, GT R eker. 1984. Coping behaviors of successful agers. Trabajo presentado en el XXX Congreso Anual de la Canadian Psychological Association, 0 ttawa.

Wood, R, A Bandura. 1989. Social cognitive theory of organization management. A cad M anage R ev 14 361-383.

Wright, R, SW K ing, WE Berg. 1985. Job satisfaction in the workplace: A study of Black females in management positions. J ournal of Social Service R esearch 8: 65-79.

Wundt, W. 1922. Introducción a la filosofía (en alemán). Leipzig: Alfred K roner.

Yarborough, CM . 1994. Strategic quality planning. J 0 ccup M ed 36(4): 414-417.

Yerkes, RM, JD Dodson. 1908. The relation of stimulus to rapidity of habit formation. I Comp N eurol Psychol 18: 482-495.
Yoder, JD. 1991. Rethinking tokenism: Looking beyond the numbers. $G$ ender Society 5: 178-192.

Zohar, D. 1980. Safety climate in industrial organizations. Theoretical and applied implications. J Appl Psychol 65: 96-102

\section{0 tras lecturas recomendadas}

Bockerstette, JA, RL Shell. 1993. T ime B ased M anufacturing. Nueva Y ork: M cG raw-H ill.

Broadhead, WF y cols. 1983. The epidemiological evidence for a relationship between social support and health. A merican J ournal of E pidemiology 117: 521-537.

Bureau of N ational Affairs (BNA). 1992. T he W ork and Family $M$ anager: Evolution of a $\mathrm{New} \mid \mathrm{ob}$. Special $\mathrm{Re}$ port N o. 45. Washington, DC: BNA.

Caplan, RD. 1987. Person-environment fit in organizations: Theories, facts, values. En O ccupational Stress and Organizational Effectiveness, dirigido por AW R iley y SJ Zaccaro. Nueva Y ork: Praeger.

Christensen, K. 1989. Flexible Staffing and Scheduling in U S Corporations. R esearch Bulletin N o. 240. Nueva York: The Conference Board.

Clark, ID. 1992. Balancing work and family: A study of the $C$ anadian work force. 0 ptimum : 25-29.

Colquhoun, WP, G Costa, S Folkard, P K nauth. 1996. Shiftwork: Problems and Solutions. Frankfurt: Peter Lang.

Congreso de Estados U nidos. 1992. A R eport of the Select Committee $O n$ Children, Youth and Families. Washington, DC: C ongreso de Estados U nidos.

Creedon, M A. 1987. I ssues for an Aging America: E mployees and $E$ Idercare - A B riefing B ook. B ridgeport: C enter for the Study of A ging, U niv. de Bridgeport.

Dunnette, M D, L H ough. 1992. T he $H$ andbook of Industrial and Organizational Psychology. Palo Alto, California: Consulting Psychologists Press.

Fein, M. 1986. Improved productivity through worker involvement. En W ork M easurement Principles and Practice, dirigido por RL Shell. Norcross, G eorgia: Industrial Engineering and $M$ anagement.

Fernandez, JP. 1986. Childcare and Corporate Productivity: Resolving F amily/ W ork Conflicts. Lexington, M assachussetts: H ealth.

Fox, BH. 1988. Psychogenic factors in cancer, especially its incidence. En Topics in $\mathrm{H}$ ealth Psychology, dirigido por S M aes, CD Spielberger, PB D efares eIG Sarason. Chichester: Wiley.

French, JRP, RD Caplan, RV H arrison. 1982. The $M$ echanism of I ob Stress and Strain. Chichester: Wiley.

Friedman, DE, E Galinsky. 1992. Work and family issues: A legitimate business concern. En W ork, Families and Organizations, dirigido por S Zedeck. San Francisco: J ossey-Bass.

Friedman, DE. 1988. Issues for an Aging America: Elder C are. Nueva Y ork: The Conference Board.

-. 1991. Linking W ork-Family Issues to the Bottom Line. N ueva Y ork: The Conference Board.

Galinsky, E, DE Friedman, CA Hernandez. 1991. T he Corporate R eference Guide to W ork-F amily Programs. N ueva Y ork: T he Conference Board.

$\mathrm{H}$ agman, N. 1988. Sexual $\mathrm{H}$ arassment $\mathrm{On}$ the $\mathrm{J}$ ob. Helsinki: Wahlstrom \& Widstrand.

H ewitt Associates. 1992. W ork and Family B enefits Provided By M ajor US E mployers in 1992: B ased On Practices of 1,026 Employers. Lincolnshire, Illinois: H ewitt Associates.

Hodson, WK. 1992. M aynard's Industrial Engineering $\mathrm{H}$ andbook. N ueva Y ork: M CG raw-Hill.

Johnson, BL. 1983. W orking W henever You W ant: All About Temporary Employment. Englewood Cliffs, $\mathrm{N}$ ueva Jersey: Prentice H all.
K arwowski, W, G Salvendy. 1994. Organization and $M$ anagement of Advanced $M$ anufacturing. Nueva Y ork: John Wiley $\&$ Sons.

K litzman, S, JS H ouse, BA Israel, R P M ero. 1990. Work stress, nonwork stress and health. J B ehav $M$ ed 13(3): 221-243.

Landy, FJ. 1989. The Psychology of W ork Behavior. H omewood, Illinois: Irwin.

Lewis, S. 1992. Work and families in the United $\mathrm{K}$ ingdom. En W ork, Families and Organizations, dirigido por S Zedeck. San Francisco: J ossey-Bass.

M undel, ME, DL Danner. 1994. M otion and Time Study: Improving Productivity. Englewood Cliffs, N ueva Jersey: Prentice $\mathrm{H}$ all.

Niebel, BW. 1993. M otion and T ime Study. H omewood, Illinois: Irwin.

Nye, D. 1988. Alternative Staffing Strategies. Washington, DC: BNA.

Parris, H. 1990. Balancing work and family responsibilities: Canadian employer and employee view points. H um R esour Plan 13(2).

Pervin, LA. 1989. Persons, situations, interactions: The history of a controversy and a discussion of theoretical models. A cad M anage R ev 14: 350-360.

Richter, J. 1992. Balancing work and family in I srael. En W ork, Families and Organizations, dirigido por $\mathrm{S}$ Zedeck. San Francisco: J ossey-Bass.

R ubenstein, M . 1987. The Dignity of W omen At W ork: A $\mathrm{R}$ eport $\mathrm{O} n$ the Problem of Sexual $\mathrm{H}$ arassment in the $\mathrm{M}$ em ber States of the E uropean Community. Ginebra: OIT.

Salvendy, G, W K arwowski. 1994. Design of W ork and $D$ evelopment of Personnel in Advanced $M$ anufacturing. N ueva Y ork: John Wiley $\&$ Sons.

Salvendy, G. 1987. H andbook of H uman F actors. Nueva Y ork: John Wiley \& Sons.

-. 1992. $H$ andbook of Industrial Engineering. Nueva Y ork: Wiley.

Schneider, B. 1990. Organizational Climate and Culture. San Francisco: Jossey-Bass.

Selye, H . 1936. The Stress of Life. Nueva Y ork: Crane, R ussek.

Spector, PE. 1988. D evelopment of the work locus of control scale. J 0 ccup Psychol 61: 335-340.

Sweeney, JJ, K N ussbaum. 1989. Solutions for the $\mathrm{New}$ W ork F orce. Washington, DC: Seven L ocks.

United States General Accounting O ffice (GAO). 1981. Productivity Sharing Programs: C an They Contribute to Productivity Improvement? Gaithersburg, M aryland: GAO

U nited States M erit Systems Protection Board. 1991. Balancing W ork Responsibilities and Family N eeds: T he $F$ ederal Civil Service R esponse. W ashington, D C : GPO.

United States Office of Personnel $M$ anagement 1992. A Study of the $W$ ork and Family $N$ eeds of the $F e d-$ eral W orkforce. A R eport to Congress By the $O$ ffice of Personnel $M$ anagement. Washington, DC: US O ffice of Personnel M anagement

Vanderkolk, BS, A Armstrong. 1991. The W ork and Family R evolution: $\mathrm{H}$ ow Companies Can Keep E mployees $\mathrm{H}$ appy and Business Profitable. Nueva Y ork: Facts on File.

Warr, PB. 1996. Employee well-being. En Psychology At W ork, dirigido por PB W arr. Londres: Penguin.

Watson, D, JW Pennebaker. 1989. Health complaints, stress, distress: The central role of negative affectivity. Psychol R ev 96(2): 234-254.

Zedeck, S. 1992. W ork, Families, Organizations. San Francisco: Jossey-Bass.

Zimmer, L. 1988. Tokenism and women in the workplace: The limits of gender-neutral theory. Social Prob 35: 64-77. 



\section{ORGANIZACIONES Y SALUD Y SEGURIDAD}

Directora del capítulo

Gunnela W estlander

\section{Sumario}

Factores psicosociales y gestión organizativa

Gunnela W estlander . . . 


\section{- Facto Res PSIC O SO CIALES Y geSt IO N ORGANIZATIVA}

\section{G unnela Westlander}

El término organización suele utilizarse en un sentido amplio; y no es extraño, pues la manifestación de la "organización" tiene numerosos aspectos. Puede afirmarse que el estudio de las organizaciones es en sí mismo una materia que carece de ubicación natural en una disciplina académica específica. Ciertamente que el concepto de organización ha pasado a ocupar una posición fundamental en la denominada ciencia de la gestión, que, en algunos países, es una asignatura independiente en el campo de los estudios empresariales. Ahora bien, en otras disciplinas, entre las que se cuenta la salud y la seguridad en el trabajo, también se han encontrado razones para reflexionar sobre la teoría de la organización y para determinar qué aspectos de la misma deben atenderse en los análisis de investigación.

La organización es importante no sólo para la gestión empresarial, sino también para la situación laboral de cada persona, tanto en lo que se refiere a su salud, como a sus oportunidades a corto y largo plazo de contribuir eficazmente al trabajo. Así, es fundamental que los especialistas en el ámbito de la salud y la seguridad en el trabajo conozcan la teoría, los conceptos y las formas de abordar la realidad social a la que hacen referencia los términos organización y desarrollo o cambio organizativo.

El sistema organizativo influye en las relaciones sociales que se establecen entre las personas que trabajan en una organización; de hecho, ese sistema está pensado para lograr unas relaciones sociales determinadas. En varios estudios sobre los aspectos psicosociales de la vida laboral se afirma que la configuración de una organización "engendra" unas relaciones sociales. La elección entre estructuras organizativas alternativas depende de varios motivos, algunos de ellos, nacen de un planteamiento concreto respecto a la coordinación organizativa y de la gestión. Hay un tipo de estructura que considera que una gestión organizativa es eficaz cuando se facilitan unas interacciones sociales específicas entre los miembros de la organización. La elección se realiza en función de los vínculos que se desee

Figura 35.1 • El modelo de vínculos de Likert.

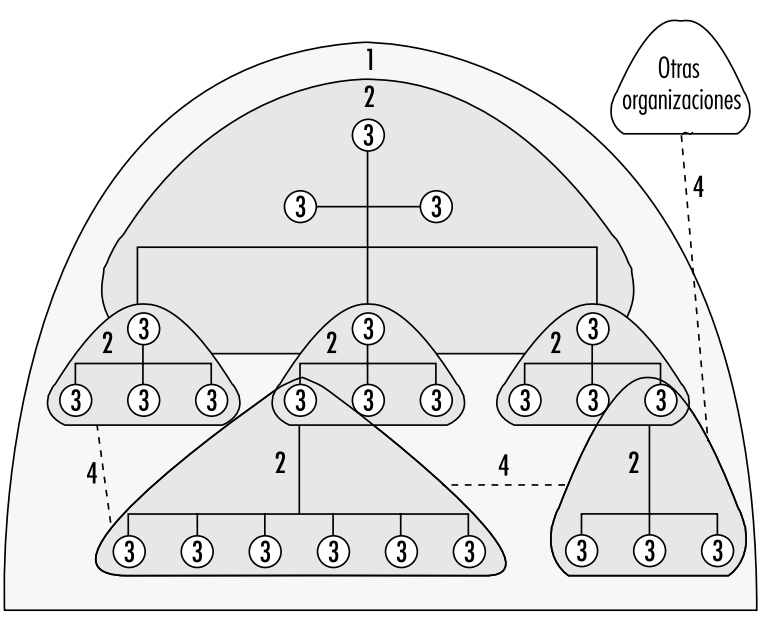

Clave para los números

1 La organización en general como objeto de análisis (3) El puesto de trabajo o el cargo como objeto de análisis

2 La unidad organizativa como objeto de análisis 4 _ Relaciones entre unidades y dentro de cada una de ellas como objeto de análisis establecer entre las personas para crear relaciones de interdependencia favorables a la organización, o, como suelen señalar los teóricos de la administración de empresas: "en función del modo en que se faciliten las combinaciones esenciales".

Rensis Likert (1961, 1967), uno de los miembros más destacados de la "escuela de las relaciones humanas", propuso una sólida visión del modo en que deben vincularse teóricamente los "subsistemas" jerárquicos en una estructura organizativa compleja. Likert subrayó la importancia de la unidad y la solidaridad entre los miembros de una organización. Según su concepción, el supervisor o gestor del trabajo cumple una doble función:

1. mantener la unidad y crear una sensación de pertenencia a un grupo de trabajo, y

2. representar a su grupo de trabajo en las reuniones con sus superior o sus iguales. De este modo se refuerzan los vínculos entre los niveles jerárquicos.

El "modelo de vínculos" de Likert se muestra en la Figura 35.1 Likert estableció un símil entre la familia y la interacción social que debería existir entre las diferentes unidades de trabajo que, en su concepción, funcionan como "familias organizativas". Estaba convencido de que cuando la dirección incentiva y ofrece oportunidades para consolidar las relaciones personales entre trabajadores de distintos niveles, cuenta con un instrumento poderoso para aumentar la eficacia organizativa y para unir al personal en el propósito de alcanzar los objetivos de la empresa. EI modelo de Likert intenta lograr una especie de "uniformidad de procedimiento" que permita consolidar la estructura organizativa establecida por la dirección. D esde principios del decenio de 1990 este modelo ha cobrado cada vez mayor importancia, y es uno de los que suele recomendarse.

El término organización puede referirse a la capacidad de los seres humanos; en este sentido, la organización es la combinación total de capacidad y, apurando el razonamiento, de sus efectos sinérgicos. 0 tra acepción opuesta a la anterior concede prioridad a la coordinación de las actividades de las personas necesaria para cumplir los objetivos de una empresa. Podemos denominarlo "convenio de organización", decidido por acuerdo de las partes. En este capítulo sobre la teoría de la organización, se parte de dicho concepto y se analiza a los miembros o los trabajadores que participan en el convenio desde el punto de vista de la salud en el trabajo.

\section{La estructura como concepto básico en la teoría de la organización}

E structura es un término habitual en la teoría de la organización y hace referencia a la forma del sistema organizativo destinada a garantizar la eficacia en la consecución de objetivos. Las actividades empresariales en la vida laboral pueden analizarse desde un enfoque estructural, que es el que ha gozado de mayor popularidad desde hace tiempo y el que ha contribuido mayoritariamente (desde un punto de vista cuantitativo) al conocimiento de que disponemos sobre las organizaciones. (A este respecto, los miembros de una nueva generación de investigadores en el campo de la organización han expresado ciertos recelos sobre el valor de este enfoque (Alvesson 1989; M organ 1986).

Al adoptar una perspectiva estructural, se da por hecho, en mayor o menor medida, que existe un orden acordado (estructura) respecto a la forma en que se realiza un conjunto de actividades. En función de este supuesto esencial, la cuestión de organización que nos ocupa se convierte en una cuestión relativa a la apariencia específica de dicha forma. ¿Con qué grado de detalle y de qué modo se describen las tareas de las personas que ocupan los distintos puestos de trabajo en los documentos oficiales publicados? ¿Q ué normas se aplican a las personas que 
ocupan puestos directivos? La información sobre modelos organizativos, disposiciones y relaciones específicas suele hallarse en documentos sobre instrucciones de dirección o descripciones de puestos de trabajo.

Se plantea una segunda cuestión, que se refiere al modo en que las actividades se organizan y se ajustan a actividades en la práctica: ¿qué uniformidades existen realmente y qué tipo de relaciones se dan entre las personas? EI propio planteamiento de esta cuestión significa que no debe esperarse una correspondencia exacta entre las formas de las actividades decretadas formalmente y las practicadas en la realidad. $\mathrm{H}$ ay varias razones que explican esta disparidad. O bviamente, no todas las fases del trabajo pueden estar contempladas por un conjunto de normas preestablecido. Asimismo, la definición teórica de las operaciones no suele ajustarse a la descripción de las actividades reales de los trabajadores y su interacción, ya que:

- La estructura oficial no se detallará a la perfección necesariamente, lo que permite la existencia de diversos márgenes para la coordinación y la cooperación en la práctica.

- El carácter normativo (especificado) de la estructura organizativa no encajará perfectamente con las formas que los miembros de la organización consideran eficaces para desarrollar sus actividades.

- Las normas o reglas fijadas en una organización generan niveles más altos o más bajos de motivación.

- La estructura normativa en sí presentará varios niveles de "visibilidad" en el seno de la organización, dependiendo del acceso de sus miembros a la información relevante.

En la práctica, probablemente es imposible que el ámbito de aplicación de las normas elaboradas describa de forma adecuada las rutinas seguidas habitualmente. Sencillamente, las normas no pueden abarcar la totalidad de las prácticas y las relaciones existentes entre los seres humanos. Su idoneidad dependerá del grado de detalle con el que se exprese la estructura oficial. En la evaluación de las organizaciones y en la elaboración de programas de prevención, es interesante e importante establecer el nivel de correspondencia entre las normas y las prácticas de las actividades organizativas.

La disparidad entre las normas y las prácticas (definiciones objetivas y subjetivas de la estructura organizativa) debe tenerse en cuenta, así como la diferencia entre la estructura organizativa percibida por un "investigador" y la imagen o percepción que un miembro determinado de la organización tiene de ella. La falta de correspondencia entre estas dos imágenes no sólo tiene un gran interés intelectual; también puede constituir un obstáculo para los componentes de la organización, en cuanto que la visión que tengan de ésta sea demasiado inadecuada para ser capaces de proteger y promover sus propios intereses.

\section{Algunas dimensiones estructurales básicas}

Las ideas y los principios relativos a la gestión de las organizaciones se han sucedido sin cesar, procurando en todos los casos ofrecer algo nuevo. A pesar de estas iniciativas, sigue siendo cierto que en la estructura organizativa oficial generalmente se estipula una forma de orden jerárquico y una división de responsabilidades. Así, se especifican los aspectos principales de la integración vertical y la responsabilidad funcional o autorización.

Por lo común la idea de la influencia vertical se encuentra en su forma clásica original más sencilla (véase la Figura 35.2). La organización está compuesta por un superior y un determinado número de subordinados, lo suficientemente limitado para que aquél ejerza un control directo. La forma dásica ampliada (véase la Figura 35.3) pone de manifiesto cómo puede establecerse una estructura organizativa compleja a partir de pequeños sistemas jerárquicos (véase la Figura 35.1). No obstante, en esta forma
Figura 35.2 • La forma organizativa clásica original.

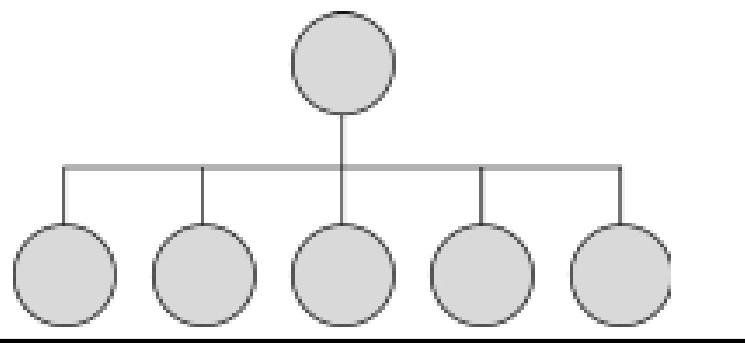

común y extendida de la organización clásica no se especifica necesariamente el carácter de la interacción horizontal entre las personas que ocupan puestos no directivos. U na estructura organizativa consta fundamentalmente de niveles de dirección (p. ej., una estructura "triangular", con unas pocas o varias capas situadas por debajo del vértice) y casi siempre refleja el deseo de una forma de organización ordenada jerárquicamente y más 0 menos acentuada. El principio básico es el de la "unidad de mando" (Alvesson 1989): se crea una cadena "de escalas" de autoridad, aplicada con mayor o menor grado de rigor de acuerdo con la naturaleza de la estructura organizativa seleccionada. Pueden establecerse largos canales verticales de influencia, que obligan al personal a enfrentarse a los inconvenientes de las cadenas interminables de mando y de las vías indirectas de comunicación cuando desean ponerse en contacto con un responsable en la toma de decisiones. Por otra parte, cuando sólo existen unos cuantos niveles de dirección (es decir, cuando la estructura organizativa es horizontal-véase la Figura 35.4), significa que la alta dirección concede menos importancia a la relación entre jefe y subordinado. La distancia entre la alta dirección y los trabajadores es más corta y las líneas de contacto más directas. Al mismo tiempo, cada gestor tendrá a su cargo un número relativamente elevado de subordinados; de hecho, en ocasiones serán tantos que no podrá ejercer un control directo sobre ellos. Por tanto, se asigna una mayor prioridad a la interacción horizontal, que se convierte en un factor necesario para lograr la eficacia operativa.

En una estructura organizativa plana, las normas relativas a la influencia vertical se especifican de modo elemental en un organigrama sencillo. Así pues, este esquema debe complementarse con instrucciones para el personal directivo y con descripciones detalladas de las instrucciones de trabajo.

L as estructuras jerárquicas pueden considerarse como medios de control normativos, que, a su vez, se caracterizan por ofrecer un

Figura 35.3 - La forma clásica a mpliada.

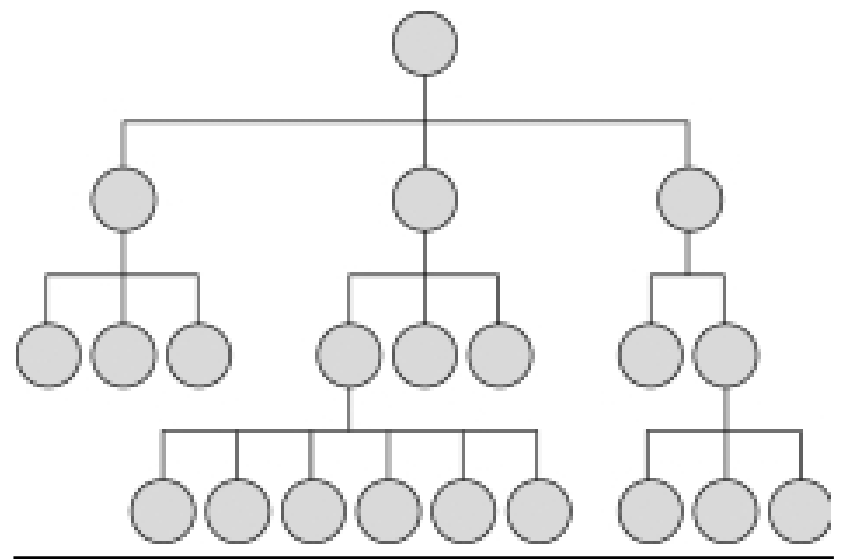


Figura 35.4 • La organización horizontal.

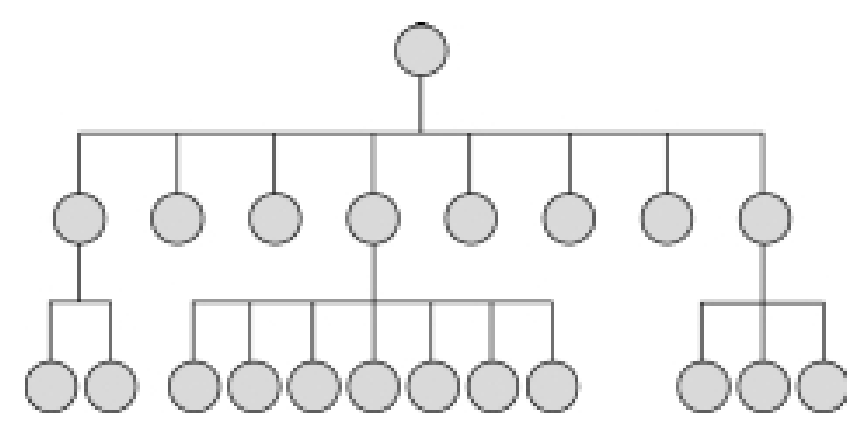

nivel mínimo de responsabilidad a los miembros de la organización. En este marco, se asigna con mayor o menor generosidad el ámbito de influencia y acción individual, que depende de las resoluciones adoptadas respecto a la descentralización de la toma de decisiones, la delegación de tareas, la formación de grupos de coordinación temporales y la estructura de las competencias presupuestarias. Cuando ese ámbito se acota, el margen de error de cada persona será menor. $\mathrm{H}$ abitualmente, el grado de libertad sólo puede deducirse del contenido de los documentos oficiales a los que se ha hecho referencia.

Además del orden jerárquico (influencia vertical), en la estructura organizativa oficial se especifica la forma (normativa) de división de la responsabilidad y, por tanto, la autoridad funcional . Podría decirse que el arte de dirigir una organización en su conjunto consiste en gran medida en estructurar todas sus actividades de modo que la combinación de las diferentes funciones establecidas tenga la mayor repercusión externa concebible. M ediante los nombres de las diversas partes (funciones) de la estructura se especifica, aunque sólo de forma aproximada, el modo en que la dirección ha concebido el desglose en varias secciones de actividades, cómo se combinarán éstas y de quién serán competencia. De aquí también pueden deducirse las exigencias fijadas sobre la autoridad funcional de los directivos.

\section{Modificación de las estructuras organizativas}

Existen diversas variantes sobre cómo puede desarrollarse una organización en su conjunto. U na de las cuestiones básicas es determinar cómo deben combinarse las actividades esenciales (producción de bienes o servicios) con otros elementos operativos necesarios, como la gestión de recursos humanos, la información, la administración, el mantenimiento, el marketing, etc. Una opción es crear grandes departamentos de administración, recursos humanos y finanzas adjuntos a las unidades productivas (organización funcional o "equipo de grupo"). En este tipo de disposición subyace el interés de la dirección en que el personal, en el ámbito de sus áreas especializadas, amplíe sus habilidades y pueda así prestar su asistencia y apoyo a las unidades mencionadas, reducir la carga asignada a éstas y promover su desarrollo.

U na alternativa a la "administración paralela" es dotar a las unidades productivas de personas que posean las administrativas especializadas exigidas. D e esta manera se facilita la cooperación más allá de los límites administrativos específicos, lo que redunda en beneficio de la unidad productiva en cuestión. Existen otras estructuras, basadas en las ideas relativas a las combinaciones funcionales, que fomentan las actividades de cooperación en las organizaciones. A menudo, éstas se ven obligadas a responder a un cambio del entorno operativo $y$, por tanto, se modifica la estructura. La transición de una estructura organizativa a otra puede exigir una profunda transformación de las formas de interacción y cooperación que se desean. Es posible que tales alteraciones no afecten a todos los miembros de la organización; con frecuencia, pasan inadvertidas para las personas que ocupan ciertos puestos de trabajo. Es importante tener en cuenta estos cambios al analizar dichas estructuras.

La determinación de los tipos de estructura existentes se ha convertido en una tarea de investigación fundamental para muchos teóricos en el campo de la administración de empresas (véase, por ejemplo, M intzberg 1983; M iller y M intzberg 1983), de acuerdo con la idea de que sería beneficioso que los investigadores pudieran establecer la naturaleza de las organizaciones y clasificarlas en categorías de fácil identificación. Por el contrario, otros investigadores han utilizado datos empíricos (basados en las observaciones de las estructuras organizativas) para demostrar que una descripción limitada a las estrictas tipologías dificulta la apreciación de los matices de la realidad (Alvesson 1989). En su opinión, es importante aprender de cada caso y no recurrir simplemente a la generalización inmediata de una tipología existente.

U n estudioso de la salud en el trabajo debe optar por este planteamiento basado en la realidad, ya que contribuye a una interpretación más adecuada de las condiciones en las que desarrolla su actividad cada trabajador.

\section{Estructuras paralelas}

Además de una estructura básica (que determina la influencia vertical y la distribución funcional de las actividades esenciales), una organización puede tener asimismo ciertas estructuras ad hoc, establecidas por un período de tiempo definido o indefinido. Se trata de las denominadas habitualmente "estructuras paralelas". Pueden instituirse por diversas razones, como la mejora de la competitividad de la empresa (sirven fundamentalmente a los intereses de ésta), como en el caso de la creación de redes, o la consolidación de los derechos de los trabajadores (actúan principalmente en beneficio de éstos), como los mecanismos de vigilancia (p. ej., los comités de salud y seguridad).

Puesto que el objetivo esencial de la vigilancia del entorno de trabajo consiste en promover la seguridad de los trabajadores, esta actividad suele organizarse en estructuras paralelas de carácter más bien permanente. Existen en muchos países y, con frecuencia, sus procedimientos operativos prescritos por la legislación nacional (véase el capítulo Relaciones laborales y gestión de recursos humanos) (Vol. I).

\section{Trabajo en red}

En el campo de la gestión empresarial moderna, trabajo en red es un término al que se ha asignado un uso específico. La creación de una red exige la organización de círculos de directivos de escala intermedia y de personas clave procedentes de diversas áreas de la entidad en cuestión con un fin concreto. La tarea de la red puede consistir en fomentar el desarrollo (p. ej., de los puestos de secretaría en toda la empresa), impartir formación (p. ej. al personal de todos los establecimientos minoristas) o proceder a una racionalización ( $p$. ej. del conjunto de rutinas internas de pedidos de la empresa). La tarea de la red suele implicar la mejora de las operaciones empresariales en algún aspecto concreto, de modo que la mejora alcance al conjunto de la organización.

En comparación con el modelo de vínculos de Likert, con el que se pretende fomentar la interacción vertical y horizontal dentro de cada escala de la estructura jerárquica y entre las diversas escalas, el objetivo de una red es agrupar a las personas según criterios diferentes a los ofrecidos por la estructura básica (pero no por una razón ajena a la de servir a los intereses de la 


\section{Trabajo en red}

Un ejemplo de trabajo en red es la iniciativa reciente de una empresa de Volvo encaminada a mejorar el nivel general de competencia de los operarios. La dirección estableció una red cuyos miembros podían elaborar un sistema de tareas ordenadas de acuerdo con el grado de dificultad. Un programa de formación al efecto garantizaba a los trabajadores la posibilidad de avanzar en una "escala profesional", con su correspondiente sistema salarial. Los componentes de la red fueron seleccionados entre los trabajadores con experiencia de distintos sectores del centro de producción y de diferentes niveles. Puesto que e sistema propuesto fue percibido como una innovación, la colaboración en la red se convirtió en un factor de motivación importante y el plan se materializó en el plazo más breve posible.

empresa). La creación de redes es promovida por la dirección con el fin de contrarrestar (aunque no desmantelar) la estructura jerárquica establecida (con sus divisiones funcionales), que ha acabado siendo demasiado lenta y pesada para responder a las nuevas demandas planteadas por el entorno. La creación de una red puede ser mejor que embarcarse en un arduo proceso de transformación y reestructuración de la organización en conjunto. De acuerdo con Charan (1991), la clave para garantizar la eficacia al crear redes está en que sea la alta dirección la que ponga éstas a funcionar y la que seleccione a sus miembros que deben estar muy motivados, ser enérgicos y comprometidos, rápidos y eficaces y capaces de difundir información con facilidad a otros trabajadores). Asimismo, los altos directivos deben vigilar las actividades desarrolladas en la red. En este sentido, la creación de redes consiste en un planteamiento "de arriba abajo". Con la autorización de la dirección y con fondos a su disposición, una red puede convertirse en una estructura poderosa capaz de penetrar hasta la base de la organización.

\section{Consecuencias para la salud y la seguridad}

Al especialista en salud en el trabajo puede resultarle de gran provecho averiguar la proporción en que intervienen la estructura básica y las estructuras paralelas establecidas entre las personas de la organización. ¿En qué toma parte activa cada persona? ¿Qué se exige de cada persona en lo que respecta a effuerzo y lealtad? ¿Cómo afecta esta exigencia a los encuentros y la cooperación entre colegas, compañeros de trabajo, directivos y otros participantes activos en contextos formales?

Para el especialista en salud en el trabajo interesado en cuestiones psicosociales, es importante ser consciente de que siempre hay algunas personas (ajenas o no a la organización) que han asumido o se les ha asignado la tarea de diseñar el conjunto de principios normativos que rigen las actividades. Tales "creadores de la organización" no actúan solos, sino que cuentan con la ayuda de personas leales a la estructura establecida. Algunas de ellas participan activamente en el proceso creativo utilizado y perfeccionando los principios. 0 tras son las representantes 0 "portavoces" del personal, ya sea colectivamente o de grupos específicos (véase la Figura 35.5). Además, existe un grupo numeroso de miembros de la plantilla que pueden caracterizarse como administradores de la forma prescrita de las actividades, si bien carecen de voz y voto respecto a su diseño y el método de su aplicación.

\section{Cambio organizativo}

Al estudiar el cambio organizativo, hemos adoptado una perspectiva basada en la consideración de los procesos. En el concepto de cambio organizativo se incluye desde el cambio en la macroestructura global de una empresa hasta las alteraciones en la asignación del trabajo y la coordinación de la actividad en unidades de menor tamaño definidas con precisión; puede tratarse de modificaciones en la administración o en la producción. De un modo u otro, la cuestión consiste en replantear las relaciones laborales entre trabajadores.

Figura 35.5 - La organización de la seguridad en el trabajo: una estructura paralela.

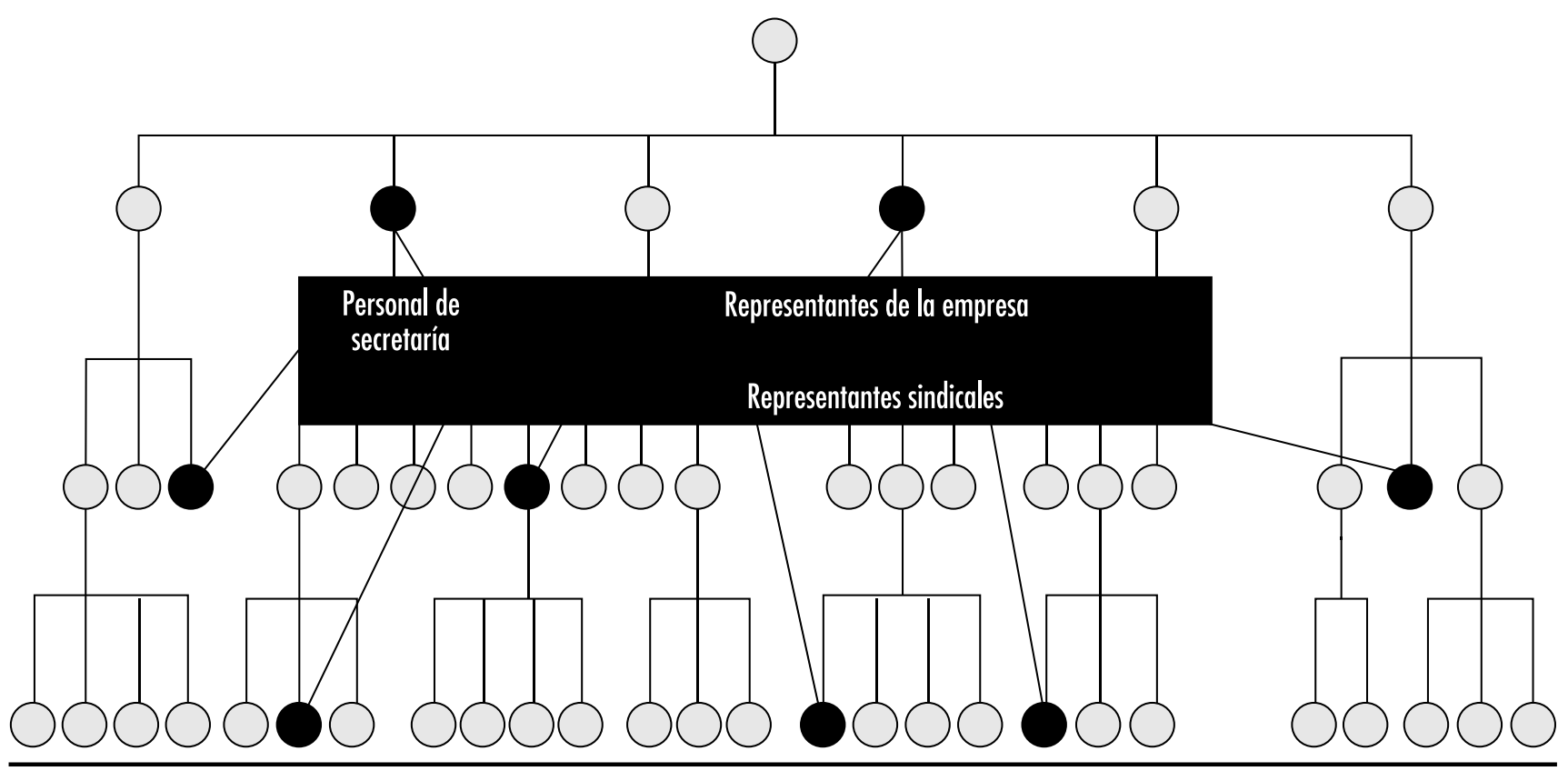




\section{Cambio organizativo como método-Salud en el trabajo como objetivo principal}

El cambio organizativo siguiente fue analizado en una de las principales empresas suecas de ingeniería. Es un buen ejemplo de cambio en el que el objetivo principal es mejorar el nivel de salud en el trabajo. Se trata de una gran industria en una zona rural, donde al personal de secretaría capacitado le resulta imposible encontrar con facilidad otro empleo. En la práctica, se les obliga a aceptar lo que esta gran empresa puede ofrecer si quieren desarrollar sus cualificaciones laborales específicas. La plantilla de secretarias estaba compuesta por unas 50 mujeres. En su mayoría estaban casadas con trabajadores de la empresa, por lo que su vinculación con la oferta de trabajo en la zona era doble. Los problemas habituales para las secretarias eran las obligaciones impuestas y las escalas salariales. La empresa no ofrecía oportunidades de desarrollo profesional, formación ni promoción, y su trabajo consistía fundamentalmente en tareas rutinarias sencillas, por lo que la cualificación de algunas de ellas se consideraba superior a la de su puesto. La dirección percibía los puestos de secretaria como "el final de la cadena", en lo que constituía una política de recursos humanos que generaban gran irritación entre las mujeres que los ocupaban. Los cambios laborales derivados de esta situación de descontento se desarrollaron en un período de cuatro años.

La intención era lograr una promoción profesional en el marco de la función de secretariado. El problema era que ni la dirección ni otras categorías de personal lo consideraban necesario. Así, las 50 secretarias tuvieron que procurar la consecución de sus objetivos frente a una firme oposición. A continuación se resume el modo en que progresaron sus iniciativas encaminadas a lograr el cambio paso a paso.

El problema se planteó inicialmente en una reunión del sindicato de trabajadores no manuales. Una de las secretarias asistió. Señaló que la mayoría de sus compañeras realizaban tareas que parecían corresponder a otras categorías profesionales. Se tomó nota del problema, pero no se adoptó ninguna medida. Posteriormente, algunas secretarias se dirigieron al comité sindical local y solicitaron al presidente la convocatoria de una reunión con varios de sus miembros ejecutivos. En esta reunión se debatieron las escalas salariales y el desarrollo profesional del personal de secretaría. N o obstante, el interés por estas cuestiones se redujo tras su celebración.

Un consultor interno se hizo cargo del problema e intentó, en vano, que el sindicato realizase algún tipo de seguimiento. Un segundo consultor interno, experto en evaluación de puestos de trabajo, pasó a ocuparse del problema. Junto con una empresa de consultoría, se llevó a cabo una encuesta entre las secretarias. EI resultado puso de manifiesto una insatisfacción generalizada.

A solicitud del sindicato y la dirección, los consultores orga nizaron diversas reuniones con las secretarias y sus superiores inmediatos.

En este caso se pretendía aclarar al personal directivo cuáles eran las condiciones de trabajo de las secretarias en la práctica y, de forma más explícita, cuáles eran sus deseos en materia de desarrollo profesional, siempre en el marco de sus obligaciones laborales. En estas reuniones se trabaja duramente. Salieron a la luz prejuicios y actitudes de oposición. Se elaboró una relación de problemas. Participaron un total de 45 directivos y 53 secretarias.

Los cambios en la organización afectan a la salud y el bienestar de sus miembros. La dimensión de la salud más fácilmente observable pertenece al ámbito psicosocial. Puede afirmarse que este tipo de transformación resulta muy absorbente para muchos trabajadores; supondrá un desafío positivo y los períodos de lasitud, cansancio e irritación son inevitables. Lo
Tras la culminación de esta fase de análisis, los consultores dieron por concluida su contribución.

Las secretarias decidieron asumir la labor por sí mismas en la fase siguiente. Entre todas las soluciones posibles, eligieron una estrategia económicoempresarial, ya que suponían que así aumentaría el interés de la dirección en la cuestión. Se dividieron en pequeños grupos de trabajo especializados (tecnología, ergonomía, compras, etc.). Cada grupo se encargó de elaborar propuestas de mejora del trabajo del personal de secretaría. Asimismo, calcularon los costes de cada propuesta.

En los años siguientes se crearon 22 grupos de trabajo para resolver varios problemas. Seis de ellos seguían funcionando 4 años después del inicio de su actividad. De su denominación puede deducirse el interés específico por la eficacia en cada caso: tecnología en el futuro, materiales de oficina, servicio de desplazamiento, medidas de ahorro en copias, formación, formación de la sensibilidad. Ganaron cada vez más atención para sus propuestas, muchas de las cuales se llevaron a la práctica.

De los estudios realizados por los grupos surgieron diversas medidas de racionalización. Ahora nadie lleva a cabo tareas innecesarias. Los manuscritos se aceptan como material de trabajo. Las secretarias sólo mecanografían en caso necesario. Se ha adquirido un sistema ofimático. La plantilla de secretarias perdió a 10 de sus miembros por desgaste (en su mayoría por traslado a otro lugar del país). Comenzaron a ser consultadas por el departamento de contratación de la empresa cuando una plaza de secretaria quedaba vacante. Se les solicitó la presentación de propuestas de reorganización que evitasen la incorporación de personal nuevo. Hasta el momento, 19 secretarias han sido ascendidas a una clasificación profesional superior, con una elevación de sueldo a medida que su trabajo exige una mayor cualificación. La dirección está satisfecha con los cambios organizativos realizados.

La idea original del proyecto era eliminar del trabajo de secretaria los contenidos innecesarios y poco cualificados, y añadir tareas que exigieran una mayor competencia. Este objetivo se consiguió y, simultáneamente, se descubrieron numerosos casos de duplicación de tareas y rutinas de trabajo interminables. Después de un cierto período, el proceso pudo continuar mediante otras vías. Se integró en la actividad del departamento de recursos humanos con la denominación de GRDS (G rupo de Referencia para el Desa rrollo del Secretariado).

Durante algún tiempo, este cambio organizativo pasó a ser conocido a escala nacional. Se invitó a algunos miembros de los grupos a participar en comités y conferencias por todo el país para explicar el proyecto.

Consecuencias para la salud psicosocial. Estos cambios laborales tuvieron una enorme importancia para las secretarias desde el punto de vista personal. Para la mayoría significó un aumento de la sensibilización respecto a su función profesional y a las oportunidades que existían de mejorar su actividad en la empresa. El espíritu de equipo se generalizó al afrontar los problemas en común. Como colectivo de trabajo, pudieron observar, paso a paso, el resultado de su tenacidad. La mejora de su calificación se debió a sus propios esfuerzos (W estlander 1991).

importante para los responsables de la salud en el trabajo es impedir que este tipo de sensaciones se vuelvan permanentes y convertirlas en un factor positivo. Debe prestarse atención a las actitudes más arraigadas respecto a la calidad del trabajo y a la retroalimentación obtenida en el campo de la propia competencia y del desarrollo personal, a las satiffacciones sociales 
(contactos, colaboración, sentimientos de "pertenencia", espíritu de equipo, cohesión) y a las emociones (seguridad, ansiedad, estrés y tensión) derivadas de la experimentación de dichas cuestiones. El éxito de un cambio organizativo debe valorarse teniendo en cuenta estos aspectos de la satisfacción en el puesto de trabajo.

Un concepto erróneo habitual que puede menoscabar la capacidad de responder positivamente al cambio organizativo es que las estructuras normativas constituyen meras formalidades sin importancia respecto al modo en que las personas actúan realmente y perciben las situaciones con las que se enfrentan. Q uienes trabajan bajo este equívoco creen que lo importante es "el sistema en la práctica", la manera en que las personas actúan en la "realidad". En ocasiones, este punto de vista puede parecer convincente, sobre todo en el caso de las organizaciones en las que no se ha aplicado un cambio estructural durante un período de tiempo considerable y el personal se ha acostumbrado al sistema organizativo existente. L os trabajadores se habitúan a un orden aceptado y comprobado, no piensan sobre lo que es normativo y lo que funciona únicamente en la práctica y no se preocupan mucho de si su propia "imagen" de la organización se corresponde con la oficial.

Por otra parte, debe tenerse en cuenta asimismo que las descripciones normativas pueden ofrecer aparentemente una visión de la realidad de una organización más precisa que la auténtica. La mera documentación por escrito y la imposición de un sello oficial no significa que estas aproximaciones constituyan una representación exacta de la organización en la práctica. $L$ a realidad puede diferir enormemente como, por ejemplo, cuando las descripciones normativas son tan anticuadas, que han perdido su valor en la actualidad.

Para optimizar la eficacia de la respuesta al cambio, es necesario diferenciar con precisión las normas y las prácticas de las organizaciones que lo experimentan. M uchos toman conciencia por primera vez de que las normas establecidas formalmente afectan e influyen en las interacciones personales cuando son testigos de un cambio estructural o intervienen en el mismo. El estudio de estas transformaciones requiere una perspectiva de proceso de la organización.

La adopción de una perspectiva de proceso conlleva el planteamiento del tipo de cuestiones siguientes:

- ¿Cómo interactuan en realidad las personas en una organización que ha sido estructurada de acuerdo con un determinado principio o modelo?

- ¿Cómo reaccionan las personas respecto a un orden formal prescrito de las actividades y cómo abordan esta situación?

- ¿Cómo reaccionan las personas respecto a un nuevo orden, propuesto o ya convenido y cómo abordan esta situación?

Se trata de obtener una visión general del modo en que se prevé que los trabajadores se relacionen entre sí, las formas de esta interrelación en la práctica y el carácter del estado de tensión entre el orden oficial y el aplicado en la práctica.

La incompatibilidad entre la teoría y la realidad en las organizaciones indica que no existe un modelo organizativo que siempre sea "el mejor" para definir una situación. La estructura seleccionada como modelo constituye un intento (acometido con mayor o menor grado de eficacia) de adaptar las actividades relacionadas con los problemas cuya resolución es considerada más urgente por la dirección en un determinado momento en el que es evidente que la organización debe someterse a un cambio.

La razón para efectuar una transición de una estructura a otra puede basarse en varias causas, como los cambios de las cualificaciones del personal, la necesidad de aplicar nuevos sistemas de remuneración o de ampliar o limitar la influencia de una determinada serie de funciones de la organización. La modificación de una estructura organizativa puede obedecer a uno o varios motivos estratégicos. A menudo, el factor impulsor del cambio es simplemente que la necesidad es tan grande que el objetivo afecta a la supervivencia de la organización. En ocasiones, se trata de asegurar ésta, en otras, de conseguirla. Los trabajadores pueden participar de un modo limitado o intervenir en absoluto. Las consecuencias del proceso de transformación benefician a unos y perjudican a otros. $\mathrm{H}$ a habido casos en los que el cambio de las estructuras organizativas se han hecho fundamentalmente con el fin de promover la salud y la seguridad en el trabajo del personal (Westlander 1991).

\section{El concepto de organización del trabajo}

$\mathrm{H}$ asta aquí nos hemos centrado en la organización en su conjunto. Es posible asimismo restringir el análisis al objeto del puesto de trabajo de un determinado trabajador y a la naturaleza de su colaboración con sus compañeros. El término más habitual que hemos encontrado para definir este concepto es el de organización del trabajo, empleado también en varias disciplinas y en diversos planteamientos de estudio.

En primer lugar, por ejemplo, el concepto de organización del trabajo se encuentra en la interacción tradicional sobre ergonomía ocupacional en la que se analiza el modo en que los equipos y las personas se adaptan entre sí en el trabajo. En lo que se refiere a los seres humanos, lo que importa es saber cómo reaccionan y se adecuan a los equipos. En cuanto a la presión y la eficacia, la variable tiempo de trabajo también es importante. Entre los aspectos relacionados con el tiempo figuran la duración de la actividad, los períodos de trabajo diurnos y nocturnos, el grado de regularidad y las oportunidades de recuperación ofrecidas mediante la programación de pausas y la posibilidad de períodos más prolongados de descanso y ocio. Se trata de condiciones de horario que deben ser administradas por la dirección y ser consideradas como factores organizativos de suma importancia en el ámbito de la investigación ergonómica. Puede afirmarse que el tiempo dedicado a la tarea de trabajo puede moderar la relación entre equipamiento y trabajador en lo que respecta a los efectos sobre la salud.

Existen además otros planteamientos ergonómicos más amplios: los análisis se extienden a la situación laboral en la que se utiliza el equipo. En este caso, se trata de que la adaptación entre dicha situación y el trabajador sea adecuada. En tales planteamientos, son los equipos, además de diversos factores de organización en el trabajo (como el objeto del puesto de trabajo, los tipos y la composición de las tareas, las responsabilidades, las formas de cooperación y de supervisión, el tiempo dedicado a todos sus aspectos), los que componen la compleja situación respecto a la que el trabajador reacciona, se adapta y actúa.

Son factores de organización del trabajo que se tienen en cuenta en análisis ergonómicos más amplios; la ergonomía suele contemplar el tipo de psicología industrial que se ocupa del objeto del puesto de trabajo de cada persona (clases y composición de las tareas) y otras demandas afines. Se piensa que estos factores actúan paralelamente a las condiciones físicas. De este modo, se convierte en una tarea del investigador adoptar una postura respecto a cuáles de estos factores y condiciones con los que se enfrenta regularmente cada trabajador contribuyen a la existencia de enfermedades (p. ej., estrés y tensión) y cuál es el carácter de esta influencia. Aislar causa y efecto es una empresa considerablemente más difícil en este caso que en los que se adopta un planteamiento ergonómico limitado.

Además de las condiciones de organización del trabajo a las que se expone regularmente un trabajador, hay otros fenómenos vinculados a ésta (como las políticas de contratación, los 
programas de formación, los sistemas salariales) que pueden afectarle más indirectamente, pero que siguen siendo decisivos en cuanto a lo que le ofrece su situación laboral inmediata. Ampliar el campo de estudio (y cabe preguntarse en todo caso si la ampliación ha sido suficiente) es de interés para el investigador que desee comprender la relación entre cada trabajador y las actividades en su conjunto.

\section{Psicología organizacional}

$M$ ientras que la psicología industrial se ocupa de las tareas profesionales y de las exigencias del puesto de trabajo en relación con la capacidad personal, la psicología organizacional se refiere a las personas definidas por el lugar que ocupan en una organización, como miembros de la misma más o menos visibles exteriormente y más o menos activos. El punto de partida del planteamiento organizacional es el funcionamiento de una empresa u organización y las distintas partes de éstas en las que intervienen personas.

La realización de actividades exige organización en varios aspectos: establecimiento de una estructura organizativa unificadora; desglose de las actividades en conjunto en tareas laborales identificables; creación de una estructura de tareas de acuerdo con ciertos principios específicos de distribución del trabajo. Así, deben instituirse sistemas de gestión, sistemas técnicos y rutinas de mantenimiento. En muchos casos, son necesarios también especiales sistemas de seguridad y de promoción de la salud en el trabajo que refuercen la organización de seguridad exigida por la legislación.

A demás de los requisitos estructurales relativos al desempeño de tareas, han de aplicarse sistemas de remuneración y control. D eben ponerse en funcionamiento sistemas de codeterminación, y de desarrollo de cualificaciones y formación (especialmente éstos, para lograr un dominio óptimo de los sistemas técnicos). Todos estos sistemas pueden describirse como factores organizativos. Se trata de actividades formalizadas, destinadas a alcanzar un objetivo específico, que tienen una existencia paralela en la empresa. Como ya se ha mencionado, pueden ser permanentes o adoptarse por un período de mayor o menor duración, pero todas ejercen algún tipo de influencia sobre las condiciones de trabajo de los miembros de la organización. Pueden analizarse desde diversas perspectivas psicosociales: como recursos de apoyo para el trabajador, como instrumentos de control utilizados por la dirección o como factores que favorecen la eficacia de directivos y trabajadores. La interacción entre los diversos sistemas organizativos es sumamente interesante: sus objetivos no siempre son compatibles y en ocasiones pueden llegar a enfrentarse. L os "soportes" de estos sistemas son seres humanos.

\section{El cambio organizativo y sus aspectos \\ psicosociales}

Para lograr la supervivencia de la organización, la dirección debe prestar una atención constante a lo que sucede en el entorno y estar preparada para el cambio en todo momento. Los cambios repentinos forzados por las influencias externas, como la pérdida de interés por parte de un cliente importante, las variaciones de la demanda, la aparición imprevista de nuevos competidores, las demandas de información de las autoridades públicas o las leyes que reestructuran el sector público, deben generar reacciones inmediatas y racionales de la dirección. A menudo, se opta por reorganizar total o parcialmente la actividad empresarial. En la mayoría de los casos, la situación no permite que se dé prioridad a las necesidades del individuo, ni que los trabajadores participen el tiempo necesario en las negociaciones sobre el cambio. Aun cuando éstas resulten constructivas, la dirección suele poner sus esperanzas en la obediencia y la confianza del personal. Los que quieran mantener su puesto de trabajo deben aceptar la situación.
K arasek (1992), en un estudio de los informes redactados para la OIT, clasifica los cambios organizativos en función de si se han concebido para estar "dirigidos por expertos" u "orientados a la participación". Los proyectos no presentaban diferencias nacionales en lo que se refiere a la importancia relativa otorgada a una y otra tendencia. Con todo, se afirma (Ivancevich y cols. 1990) que el papel desempeñado por la alta dirección es significativo en los proyectos de cambio organizativo diseñados para reducir el estrés en el trabajo y mejorar el bienestar y la salud de los trabajadores. Su intervención exige la colaboración del personal directivo y de los trabajadores y, posiblemente, también de la de expertos.

Cuando se producen cambios estructurales, es inevitable que se generalice la incertidumbre entre los miembros de una organización. A pesar de que todos experimentarán esta sensación, su grado y tipología variará en función del puesto que ocupe cada cual. Los requisitos previos para obtener una visión real de la eficacia o la ineficacia del proceso de cambio desarrollado por una empresa son completamente distintos para los directivos y para los trabajadores. Aun a riesgo de simplificar en exceso la cuestión, pueden citarse dos tipos de sensaciones de incertidumbre:

1. Consciencia de la incertidumbre relativa a la continuación de la existencia o el éxito de la organización. Es un tipo de incertidumbre habitual en los encargados de la toma de decisiones. "Ser consciente de la incertidumbre" significa que la persona en cuestión puede evaluar las ventajas e inconvenientes relativos de abordar una situación incierta. T iene la oportunidad de afrontar activamente la situación (p. ej., consiguiendo más información, intentando influir en los demás, etc.). Por otro lado, una persona puede reaccionar negativamente al cambio tratando de evitar la situación de diversos modos, como la búsqueda de otro empleo.

2. Ignorancia de la incertidumbre relativa a la continuación de la existencia 0 el éxito de la organización. Es un tipo de incertidumbre común en los trabajadores que no ocupan puestos vinculados a la toma de decisiones. "I gnorar la incertidumbre" significa que la persona en cuestión tiene dificultades para formarse una opinión y, en general, sólo tiene la oportunidad de reaccionar pasivamente (adoptando un planteamiento de esperar y ver, manteniéndose en un estado de intranquilidad e imprecisión, dejando que otros tomen medidas).

Desde un punto de vista psicológico, sobre todo al intentar evitar los efectos del trabajo en el entorno, estas distintas sensaciones de incertidumbre son muy importantes. U na parte se sentirá alienada respecto a la realidad subjetiva de la otra. La iniciativa del cambio en una organización suele partir de la escala jerárquica superior y su objetivo fundamental es aumentar la eficacia. L as actividades relacionadas con el cambio organizativo revitalizan el objeto del puesto de trabajo de los directivos, ya que suponen el abordaje de nuevas situaciones, que se conviertan en un reto positivo y, a menudo, en un estímulo. Para los trabajadores ajenos a la dirección, la reorganización es más condicional: sólo es positiva en la medida en que mejore 0 mantenga inalterada su situación laboral presente y futura.

Desde una perspectiva más general, las personas que ocupan puestos administrativos especializados y los expertos en organización pueden registrar un tercer patrón de reacción: la reorganización es interesante con independencia del resultado. Considerada como un experimento que permite conocer cómo resultan afectados los trabajadores y la actividad empresarial, es una información útil en el futuro para un administrador o un experto en organización en la misma o en otra empresa. 


\section{Aplicación de la psicología organizacional}

El directivo del Departamento de Proceso Electrónico de Datos (PED) de la empresa y el agente de reclamaciones del Departamento de Lesiones Profesionales colaboraron intensamente durante un período de unos seis meses. $\mathrm{N}$ unca antes habían tenido la oportunidad de trabajar juntos ni se conocían bien. El especialista en PED es jefe de su departamento, que forma parte de la administración financiera central de la empresa, inmediatamente por debajo de la dirección de la sede principal. El agente de reclamaciones es director de una de las unidades empresariales de la empresa, el Departamento de Lesiones Profesionales, situado geográficamente en otra zona de la ciudad.

El Departamento de PDE se encarga de racionalizar y remodelar permanentemente los formularios utilizados por la empresa, con el fin de simplificar y mejorar la eficacia del registro de documentos y la correspondencia entre las diversas unidades empresariales en la medida de lo posible.

El Departamento de Lesiones Profesionales se ocupa de gestionar las reclamaciones por lesión profesional de sus asegurados (círculo de clientes) de un modo riguroso y exacto, de forma que los clientes perciban que son tratados correctamente. El Departamento de PED cumple una función de racionalización en la empresa, mientras que el Departamento de Lesiones Profesionales está destinado a la atención al cliente en un área especializada de la actividad de seguros.

El agente de reclamaciones mantiene contactos diarios con otros directivos en su propio grupo de trabajo, así como con miembros de otros grupos incluidos en el Departamento de Lesiones Profesionales. Los contactos se realizan principalmente para analizar cuestiones relativas a las lesiones profesionales, que permitan la adopción de un consenso en el departamento respecto a los principios que rigen la satisfacción de las reclamaciones. El entorno en el que opera el Departamento es bastante cerrado y los contactos directos son escasos aparte de los que mantiene con su propio círculo de clientes. La comunicación con el resto de la empresa es extremadamente limitada.

El Departamento de PED forma parte del sistema de control financiero central de la empresa. Su jefe mantiene contactos breves pero regulares con todos los sectores de la empresa; de hecho, éstos son más frecuentes que los establecidos con el personal de departamentos paralelos de financiación central.

La razón fundamental que explica la colaboración entre el directivo del PED y el agente de reclamaciones de lesiones profesionales es que el Departamento del primero recibió instrucciones de la dirección de diseñar sus actividades de racionalización de forma que el personal directivo de la sección de seguros en las unidades empresariales aumentara su productividad, pudiendo así dar cabida a un círculo de clientes más extenso (en parte, mediante la oferta de nuevos tipos de pólizas y paquetes de seguros). El agente de reclamaciones se muestra reticente ante la propuesta del directivo de PED cuando éste le indica los motivos de la dirección. El agente desea alcanzar su propio objetivo y cumplir su función en la empresa, a saber, satisfacer las necesidades de los asegurados en cuanto a la administración rigurosa de las cuestiones sobre lesiones profesionales. Considera que este objetivo es incompatible con un mayor aumento de la productividad.

La interacción entre el directivo del Departamento de PED y el agente de reclamaciones se complica por factores relacionados con su distinta ubicación en la organización, sus diversos tipos de obligaciones y sus diferentes "puntos de vista" sobre las actividades en general. En otras palabras, los dos directivos tienen problemas de planteamiento (en este caso, problemas de rentabilidad) derivados de la disparidad de sus perspectivas.

Lo que hemos descubierto es la existencia de objetivos y fuerzas en conflicto, incorporadas en el diseño organizativo de las actividades, que constituyen una plataforma para la interacción entre dos directivos.
Los cambios de una organización son acciones complejas, no sólo porque deben introducirse variaciones prácticas, sino también porque suelen tener consecuencias psicológicas y psicosociales. Como resultado, el entorno de trabajo refleja la diferencia de intereses en los cambios propuestos y los diversos tipos de estrés psíquico. Asimismo, esta intrincada realidad social resulta difícil de estudiar de manera sistemática.

L os especialistas en economía de empresa, los sociólogos y los psicólogos difieren en su planteamiento respecto a la interpretación de los vínculos entre el cambio organizativo y las condiciones de trabajo individuales. La psicología industrial y de la organización centra su atención en los trabajadores y en las condiciones en las que desarrollan su actividad. Se intenta adquirir un conocimiento sistematizado sobre los efectos del cambio organizativo en la salud y las oportunidades laborales de los trabajadores, un enfoque que nos brinda información sobre las consecuencias para la salud mental en el trabajo.

Desde un punto de vista sociológico, las condiciones individuales afectadas por el cambio se analizan fundamentalmente con el fin de determinar, comprender y describir las consecuencias sobre las relaciones intergrupales e interorganizacionales. En las ciencias empresariales y de la administración puede existir interés por los aspectos psicológicos con el objeto de comprender ciertas actitudes y comportamientos de los miembros de la organización (en ocasiones, sólo de personas esenciales en cierto sentido) fundamentales para el progreso de las actividades de la empresa.

\section{Medición de los factores organizativos}

Los factores organizativos, la división del trabajo, la descentralización, los sistemas de remuneración no son objetos físicos. Son intangibles. No es posible aprehenderlos, y la mayoría se manifiestan en actividades e interacciones que desaparecen con mayor o menor rapidez, para ser sustituidos por otros nuevos. No es sorprendente que las dimensiones de la organización del trabajo susceptibles de "medición" (de manera aproximada a como lo son los factores físicos) sean también aquéllas que un investigador formado en el campo de las ciencias naturales encuentra más manejables y aceptables. El tiempo, por ejemplo, puede medirse objetivamente con instrumentos diseñados al efecto e independientes del ser humano. El modo en que se organiza el trabajo en lo que se refiere al tiempo (horas de trabajo, interrupción de la actividad y períodos de descanso de mayor duración) apenas causa problemas de medición importantes a los ergónomos. Por otra parte, la percepción personal de los aspectos del tiempo es psicológica, lo que resulta considerablemente más difícil de medir.

Asimismo, es relativamente más fácil para el investigador abordar los factores organizativos que adoptan una forma material. A sí ocurre cuando las instrucciones a los directivos, las descripciones de los puestos de trabajo y los procedimientos de trabajo se ponen por escrito, y cuando los sistemas de control y las distintas formas de coordinación del personal se documentan. EI análisis sistemático del contenido de estos textos proporciona información útil. No obstante, debe recordarse que la práctica real puede apartarse (en ocasiones significativamente) de lo 
establecido por escrito. En estos casos, no es fácil obtener una visión sistemática de las actividades y las actitudes de las personas.

\section{De los conceptos al estudio empírico}

La medición de los fenómenos organizativos se basa en varias fuentes de información:

- disposiciones por escrito de los procedimientos operativos y de coordinación;

- observación sistemática por parte de los investigadores del comportamiento en el trabajo y la interacción social;

- declaraciones de los trabajadores sobre sus comportamientos, interacciones, actividades, actitudes, intenciones y pensamientos;

- documentos sobre formulación de principios, acuerdos, actas de conferencias, perspectivas a largo plazo;

- opiniones de personas relevantes.

La decisión sobre la clase de información a la que debe concederse prioridad está relacionada por una parte con el tipo de factor organizativo que debe evaluarse y con las preferencias en cuanto a método y, por otra, con la generosidad de la organización para dejar que el investigador desarrolle su actividad del modo que prefiera.

La medición en el campo de la investigación de las organizaciones rara vez constituye una cuestión disyuntiva, sino que en la mayoría de los casos, es una tarea dependiente de múltiples fuentes.

Al medir el cambio organizativo es aún más necesario prestar atención a los rasgos característicos. L as relaciones interpersonales varían enormemente antes y poco después del inicio del cambio. A diferencia de los experimentos de laboratorio o de las reuniones, donde pueden realizarse cuestionarios colectivos, la situación (es decir, el proceso de cambio) no está bajo control. Los investigadores que estudian el cambio organizativo deberían considerar fascinante este proceso impredecible y no sentir irritación o impaciencia al respecto. Y lo mismo cabe decir para los sociólogos industriales. $L a$ idea de evaluar los efectos definitivos debe desecharse. Es necesario comprender que el trabajo preventivo consiste en estar disponible en todo momento y prestar el apoyo adecuado. Deben adoptarse precauciones especiales en el caso de las situaciones formales establecidas entre los superiores y los subordinados (trabajadores).

La evaluación de la investigación del cambio organizativo desde el punto de vista de la salud en el trabajo lleva a la conclusión de que el interés mostrado por esta cuestión, sobre todo en sus aspectos psicosociales, varía mucho cuando se están produciendo esos cambios. En algunos casos, el problema se ha dejado totalmente al azar, con una falta de interés o consideración absoluta por parte de la alta dirección, e incluso de los miembros de los comités de salud y seguridad. En otros, puede existir cierta preocupación, pero no se dispone de la experiencia para abordarla. Con todo, en ciertas ocasiones puede apreciarse una combinación de eficacia y razones sanitarias como motivo para iniciar el cambio organizativo. Los casos en los que el objetivo principal es conservar y mejorar la salud psicosocial de los trabajadores son muy escasos. N o obstante, la sensibilización respecto a la importancia de considerar la salud en el trabajo en todas las fases del cambio organizativo es cada vez mayor (Porras y R obertson 1992).

Durante la transformación de una organización, lo ideal sería que en las relaciones reinara un sentimiento de cooperación, al menos en cuestiones informales. Los recursos necesarios para llevar a cabo estas actividades existen en muchas empresas modernas, que cuentan con funciones especializadas en recursos humanos, departamentos de organización, departamentos de salud en el trabajo propios y representantes sindicales interesados en esta cuestión. En algunas de ellas, se siguen principios de prevención más explícitos, que orientan a los directivos de diversas escalas respecto a la utilización eficaz de todos estos recursos, y a los profesionales de las diversas funciones en cuanto a la consecución de una cooperación provechosa. Es de esperar que esta tendencia patente a considerar los distintos aspectos de la salud en el trabajo en la aplicación del cambio organizativo se generalice; lo que, en cualquier caso, requiere una mayor sensibilización de los expertos en la cuestión respecto a la importancia de conocer adecuadamente y las teorías sobre las condiciones organizativas.

\section{Referencias}

Alvesson, M. 1989. A flat pyramid: a symbolic processing of organizational structure. Int Studies $M$ anag Org 14(4):5-23

Charan, R. 1991. How networks reshape organizations - for results. H arvard Bus R ev Septiembre/ O Ctubre:104-115.

Ivancevich, JM, MT M atteson, SM Freedman, JS Phillips. 1990. Worksite stress management interventions. Am Psychol Febrero:252-261.

K arasek, R. 1992. Stress prevention through work reorganization: a summary of 19 international case studies. Cond W ork Dig 11(2):23-41.
Likert, R. 1961 y 1967. The Human Organization. N ueva Y ork: M CG raw Hill.

Miller, D and H M intzberg. 1983. The case of configuration. En B eyond M ethod: Strategies for Social Re search, dirigido por G Morgan. Beverly $\mathrm{H}$ ills, C alifornia: Sage Publications.

$M$ intzberg, $H$. 1983. Structure in Fives: D esigning E ffective Organizations. Englewood Cliffs: Prentice-H all.

M organ, G. 1986. I mages of Organizations. Beverly H ills: Sage Publications.

Porras, JI, PJ R obertson. 1992. O rganizational development: theory, practice, and research. En Capítulo 12 de $\mathrm{H}$ andbook of Industrial and Organiza- tional Psychology, dirigido por D Dunnette y LM $\mathrm{H}$ ough. Chicago: R and M cN ally College Publishing Company.

Westlander, G. 1991. O rganizational change and health at work. En The Psychosocial W ork Environment: W ork Organization, Democratization and $\mathrm{H}$ ealth, dirigido por JV Johnson y $G$ Johansson. Nueva York: Baywood Publishing Company,Inc.

\section{0 tras lecturas recomendadas}

Westlander, G. 1997. People At W ork: The SocioPsychological Context. En imprenta. 


\section{PRESION BAROMERICA,}

AUMENTO

Director del capítulo

T. J. R. Francis

\section{Sumario}

Trabajo en situaciones de aumento de la presión

barométrica

E ric Kindwall . . . . . . . . . . . . . . . . . . . . . . . . . 36.2

Trastornos por descompresión

D ees F. Gorman . . . . . . . . . . . . . . . . . . . . . . . . . . . . . . . 36.10 


\section{- TRABAJO EN SITUACIONES DE AUMENTO DE LA PRESION BAROMETRICA}

\section{Eric Kindwall}

La atmósfera contiene habitualmente un 20,93 \% de oxígeno. EI organismo humano está, por naturaleza, adaptado para respirar el oxígeno atmosférico a una presión de unos $160 \mathrm{mmH} \mathrm{g}$ a nivel del mar. A esta presión, la molécula que transporta el oxígeno a los tejidos, la hemoglobina, se encuentra saturada en un $98 \%$, aproximadamente. Si se eleva la presión de oxígeno, el aumento de la oxihemoglobina es escaso, pues su concentración inicial ya es prácticamente del $100 \%$. A hora bien, a medida que aumenta la presión, es posible que una cantidad significativa de oxígeno no consumido entre en solución física en el plasma sanguíneo. Afortunadamente, el organismo es capaz de tolerar un rango de presiones de oxígeno bastante amplio sin que se observen daños, al menos a corto plazo. Si la exposición se prolonga puede producir, a más largo plazo, problemas de toxicidad por oxígeno.

Cuando el trabajo requiere que se respire aire comprimido, como sucede en el buceo o durante el trabajo en cajones de aire comprimido, el déficit de oxígeno (hipoxia) no suele ser un problema, ya que el organismo queda expuesto a una mayor cantidad de oxígeno a medida que aumenta la presión absoluta. Un aumento de la presión al doble del valor normal duplica el número de moléculas inhaladas en cada inspiración de aire comprimido. Así, la cantidad de oxígeno inspirado equivale a un $42 \%$. Es decir, que un trabajador que respire aire a una presión de 2 atmósferas absolutas (ATA), o a $10 \mathrm{~m}$ por debajo de la superficie del mar, respira una cantidad de oxígeno equivalente a la que respiraría en la superficie utilizando una mascarilla de oxígeno al $42 \%$.

\section{Toxicidad por oxígeno}

En la superficie terrestre, los humanos pueden respirar un $100 \%$ de oxígeno de forma continua durante 24 a 36 horas sin ningún riesgo. Transcurrido ese tiempo, sobreviene la toxicidad por oxígeno (efecto Lorrain-Smith). Los síntomas de toxicidad pulmonar son: dolor subesternal, tos seca y no productiva, disminución de la capacidad vital y pérdida de la producción de surfactantes. La radiografía muestra lo que se conoce por atelectasia en parches; en casos de exposición prolongada, microhemorragia, y finalmente, fibrosis pulmonar permanente. Todas las etapas de la toxicidad por oxígeno, hasta la etapa de microhemorragia, son reversibles, pero una vez que ha aparecido la fibrosis, el proceso se vuelve irreversible. Cuando se respira oxígeno al $100 \%$ a 2 ATA (una presión de $10 \mathrm{~m}$ de agua de mar), los primeros síntomas de toxicidad por oxígeno comienzan a manifestarse a las seis horas aproximadamente. A hora bien, es posible duplicar ese tiempo, si se intercalan cada 20025 minutos períodos cortos (de unos cinco minutos) de respiración de aire.

Es posible respirar oxígeno a una presión inferior a 0,6 ATA sin efectos nocivos. Por ejemplo, un trabajador puede respirar oxígeno a 0,6 atmósferas de forma continua durante dos semanas sin que se vea mermada su capacidad vital. El nivel de la capacidad vital parece ser el indicador más sensible de la toxicidad precoz por oxígeno. Los buzos que trabajan a gran profundidad respiran mezclas de gases que contienen hasta 0,6 atmósferas de oxígeno en un medio compuesto por helio y nitrógeno. Seis décimas de atmósfera equivalen a respirar $60 \%$ de oxígeno a una presión de 1 ATA o a nivel del mar.

A presiones superiores a 2 ATA, la toxicidad pulmonar por oxígeno deja de ser el principal motivo de preocupación, ya que el oxígeno puede producir convulsiones como resultado de la toxicidad cerebral. Paul Bert fue el primero en describir en 1878, el efecto neurotóxico conocido como efecto de Paul Bert. Si una persona respirase de forma continua un aire con $100 \%$ de oxígeno a 3 ATA durante más de tres horas, probablemente presentaría convulsiones de tipo $\mathrm{Gran} \mathrm{M}$ al. A pesar de que el mecanismo de la toxicidad pulmonar y cerebral del oxígeno se ha investigado activamente durante más de 50 años, aún no se conoce completamente. Se sabe, sin embargo, que ciertos factores potencian la toxicidad y disminuyen el umbral de las convulsiones. $\mathrm{El}$ ejercicio, la retención de $\mathrm{CO}_{2}$, el uso de esteroides, la aparición de fiebre o escalofríos, la ingestión de anfetaminas, el hipertiroidismo y el miedo pueden afectar la tolerancia al oxígeno. Así, un individuo que como experiencia permanece quieto en una cámara seca presurizada, tiene una tolerancia muy superior a la de un buzo que trabaja sin cesar en agua fría debajo de un barco enemigo. El buzo militar puede experimentar frío y temor, realizar un ejercicio arduo y presentar una acumulación de $\mathrm{CO}_{2}$ si utiliza un circuito cerrado de oxígeno, y es posible que presente convulsiones al cabo de 10-15 minutos de trabajo a una profundidad de tan solo $12 \mathrm{~m}$, mientras que un paciente que permanece inmóvil en una cámara seca puede tolerar fácilmente una presión de 20 m durante 90 minutos sin riesgo grave de presentar convulsiones. Los buzos que realizan ejercicio pueden estar expuestos a presiones parciales de oxígeno de hasta 1,6 ATA durante períodos cortos de hasta 30 minutos, lo que equivale a respirar oxígeno al $100 \%$ a una profundidad de $6 \mathrm{~m}$. Conviene señalar que nadie debería exponerse a un aire con $100 \%$ de oxígeno a presiones superiores a 3 ATA ni por tiempos superiores a 90 minutos, ni siquiera en una situación de inactividad.

La susceptibilidad a las convulsiones varía considerablemente de un individuo a otro, y de un día a otro en el mismo individuo. De ahí la práctica inutilidad de los ensayos de "tolerancia al oxígeno". La administración de fármacos anticonvulsivos, como el fenobarbital o la fenitoína, evita las convulsiones por oxígeno, pero no reduce la lesión cerebral o de médula o espinal permanente cuando se exceden los límites de presión o de tiempo.

\section{M onóxido de carbono}

El monóxido de carbono es un contaminante grave del aire que respira un buzo o un trabajador de cajones de aire comprimido. Procede, por lo común, de los motores de combustión interna para los compresores y de la maquinaria próxima a ellos. Debe tenerse mucho cuidado para que las entradas de aire del compresor estén alejadas de cualquier fuente de escape del motor. Los motores Diesel suelen producir poco monóxido de carbono, pero producen grandes cantidades de óxidos de nitrógeno, que pueden ser muy tóxicos para los pulmones. En Estados U nidos, la normal actual de la administración federal para los niveles de monóxido de carbono en el aire inspirado es de 35 partes por millón (ppm) para una jornada laboral de 8 horas. Por ejemplo, en la superficie, una concentración de hasta 50 ppm no produciría ningún daño detectable, pero a una profundidad de $50 \mathrm{~m}$, al estar comprimido, produciría el efecto de $300 \mathrm{ppm}$. Es posible que la concentración produzca un nivel de hasta un $40 \%$ de carboxihemoglobina durante cierto tiempo. La cifra real de partes por millón analizada debe multiplicarse por el número de atmósferas a las que se administrará al trabajador.

Los buzos y las personas que trabajan en entornos de aire comprimido deben conocer los síntomas iniciales de intoxicación por monóxido de carbono, entre los que están las cefaleas, las náuseas, el mareo y la debilidad. Es importante asegurarse de que la entrada del compresor esté situada siempre contra el viento, para evitar la entrada de gases del tubo de escape del 
motor. Esta posición debe comprobarse continuamente cada vez que cambie la dirección del viento o la posición de la nave.

Durante muchos años, se pensó que el monóxido de carbono se mezclaba con la hemoglobina del organismo y daba lugar a la carboxihemoglobina, cuyo efecto letal se debía al bloqueo del transporte de oxígeno a los tejidos. En estudios posteriores se ha observado que, aunque ese efecto produce hipoxia tisular, no resulta fatal por sí mismo. El daño más grave es a nivel celular, debido a la toxicidad directa de la molécula de monóxido de carbono. La peroxidación de los lípidos de la membrana celular, que sólo puede detenerse con un tratamiento de oxígeno hiperbárico, parece ser la causa principal de la muerte y de las secuelas a largo plazo.

\section{Dióxido de carbono}

El dióxido de carbono es un producto normal del metabolismo y se elimina de los pulmones durante el proceso normal de respiración. Sin embargo, ciertos dispositivos de respiración pueden impedir su eliminación o provocar la acumulación de niveles elevados en el aire que inspira el buzo.

Desde un punto de vista práctico, el dióxido de carbono produce efectos nocivos en el organismo de tres maneras. En primer lugar, a concentraciones muy elevadas (superiores al $3 \%$ ), puede producir errores de juicio, que se manifiestan inicialmente en un estado de euforia injustificada, seguida por uno de depresión si la exposición se prolonga. No cabe duda de que las consecuencias pueden ser graves para el buzo que está bajo el agua y que necesita mantener una capacidad de juicio adecuada por motivos de seguridad. Si aumenta la concentración de $\mathrm{CO}_{2}$ hasta niveles superiores al $8 \%$, puede llegar a producir pérdida de consciencia. 0 tro efecto del dióxido de carbono es la exacerbación o el empeoramiento de la narcosis por nitrógeno (véase más adelante). El efecto del dióxido de carbono comienza a presiones parciales superiores a $40 \mathrm{~mm} \mathrm{Hg}$ (Bennett y Elliot 1993). U na $\mathrm{Po}_{2}$ elevada, como la que soportan los buzos, atenúa el impulso respiratorio debido al $\mathrm{CO}_{2}$ elevado $y$, en ciertas condiciones, es posible que aumente los niveles de éste lo suficiente como para producir la pérdida de consciencia en los buzos que tienen tendencia a retenerlo. Un último problema del dióxido de carbono a presiones elevadas es que el riesgo de convulsiones para un individuo que respire oxígeno al $100 \%$ a una presión superior a 2 ATA, aumenta de forma importante en función del aumento en los niveles de dióxido de carbono. La tripulación de los submarinos puede tolerar fácilmente una concentración de $\mathrm{CO}_{2}$ de $1,5 \%$ (treinta veces superior a la concentración normal en el aire atmosférico) durante dos meses sin que se produzcan efectos funcionales negativos. Un nivel de 500 ppm (es decir, diez veces superior a los niveles del aire normal), se considera seguro desde el punto de vista de los límites industriales. Ahora bien, la sola adición de un 0,5\% de $\mathrm{CO}_{2}$ a una mezcla de oxígeno al $100 \%$, puede predisponer a una persona a presentar convulsiones, si se respira a una mayor presión.

\section{Nitrógeno}

El nitrógeno es un gas inerte en relación con el metabolismo humano normal. No se combina químicamente con otros compuestos o elementos en el organismo. Sin embargo, cuando se respira a presiones elevadas origina un grave deterioro en la función mental del individuo.

El nitrógeno se comporta como un anestésico alifático a medida que aumenta la presión atmosférica, lo que eleva a su vez la concentración de nitrógeno. El nitrógeno cumple la hipótesis de $M$ eyer- $O$ verton, que afirma que la potencia anestésica de cualquier anestésico alifático es directamente proporcional a su relación de solubilidad aceite-agua. EI nitrógeno, cinco veces más soluble en grasa que en agua, produce un efecto anestésico que cumple exactamente con la citada relación .

En la práctica, es posible sumergirse a una profundidad de $50 \mathrm{~m}$ con aire comprimido, aunque los efectos de la narcosis por nitrógeno comienzan a manifestarse entre los 30 y los $50 \mathrm{~m}$. La mayoría de los buzos, sin embargo, pueden trabajar adecuadamente en estos parámetros. A profundidades superiores a $50 \mathrm{~m}$, suelen utilizarse mezclas de helio y oxígeno para evitar los efectos de la narcosis por nitrógeno. Se han realizado inmersiones con aire a profundidades ligeramente superiores a los $90 \mathrm{~m}$, pero a estas presiones extremas, los buzos prácticamente no eran capaces de realizar ninguna tarea y tenían grandes dificultades para recordar la misión que les había sido encomendada. Como se indicó antes, la acumulación excesiva de $\mathrm{CO}_{2}$ empeora el efecto del nitrógeno. D ebido a que la mecánica de la ventilación se ve afectada por la densidad del gas a altas presiones, se produce una acumulación automática de $\mathrm{CO}_{2}$ en los pulmones como consecuencia de los cambios en el flujo laminar en los bronquiolos y la disminución del impulso respiratorio. Por este motivo, en las inmersiones a profundidades superiores a los $50 \mathrm{~m}$, el aire puede ser sumamente peligroso.

El nitrógeno ejerce su efecto simplemente por hallarse disuelto en el tejido neural. Produce una ligera tumefacción de la membrana celular neuronal, que se vuelve más permeable a los iones sodio y potasio. Se piensa que la interferencia con el proceso normal de despolarización y repolarización es la responsable de los síntomas clínicos de la narcosis por nitrógeno.

\section{Descompresión}

\section{Tablas de descompresión}

Las tablas de descompresión indican el tiempo necesario para la descompresión de una persona expuesta a condiciones hiperbáricas, de acuerdo con la profundidad y el tiempo de exposición. Es posible hacer ciertas observaciones generales sobre los procedimientos de descompresión. Ninguna tabla de descompresión puede garantizar que no se vaya a presentar la enfermedad por descompresión (ED), y de hecho, como se describe más adelante, se han observado numerosos problemas con algunas de las tablas que se utilizan actualmente. Debe recordarse que durante cualquier proceso de descompresión normal, no importa cuán lento sea, se producen burbujas. De ahí que, aunque puede afirmarse que cuanto más lenta sea la descompresión, menor es la probabilidad de ED, en el límite inferior de la probabilidad, la ED se convierte en un fenómeno básicamente aleatorio.

\section{Habituación}

La habituación o aclimatación es un fenómeno que se presenta en los buzos y en los trabajadores en entornos de aire comprimido, en virtud del cual se vuelven menos susceptibles a la ED después de varias exposiciones. La aclimatación puede producirse al cabo de aproximadamente una semana de exposición diaria, pero se pierde tras una interrupción del trabajo de entre 5 días y una semana, o por un aumento repentino de la presión. Por desgracia, las empresas constructoras confían en la aclimatación para realizar trabajos que se consideran inadecuados en cualquier tabla de descompresión. Para aprovechar al máximo la utilidad de la aclimatación, los trabajadores nuevos suelen comenzar a trabajar la mitad del turno para permitir que se habitúen sin presentar ED. Por ejemplo, la Tabla japonesa 1, que se aplica actualmente a los trabajadores en entornos de aire comprimido, utiliza jornadas partidas, con una exposición al aire comprimido por la mañana y otra por la tarde y un intervalo de una hora en la superficie entre cada exposición. La descompresión de la primera exposición es de aproximadamente el $30 \%$ de la que indica la M arina de EE.UU., y la de la segunda, de sólo 
el $4 \%$. Sin embargo, la habituación permite esta desviación de la descompresión fisiológica. Los trabajadores con una susceptibilidad normal a la enfermedad por descompresión suelen abandonar voluntariamente este tipo de trabajo.

El mecanismo de habituación o aclimatación se desconoce. Con todo, aunque el trabajador no sienta dolor, pueden producirse daños cerebrales, óseos o tisulares. La resonancia magnética (R M ) del cerebro, en el caso de los trabajadores en entornos de aire comprimido revela hasta cuatro veces más cambios que los observados en controles realizados en personas de la misma edad (Fueredi, Czarnecki y K indwall 1991). Estos cambios reflejan probablemente infartos lagunares.

\section{Descompresión de los buzos}

La mayoría de los programas modernos de descompresión para buzos y trabajadores de cajones de inmersión se basan en modelos matemáticos similares a los desarrollados inicialmente por J.S. Haldane en 1908, a raíz de ciertas observaciones empíricas sobre los parámetros de descompresión permisibles. $\mathrm{H}$ aldane observó que las cabras toleraban una reducción de la presión a la mitad sin presentar síntomas. A partir de ahí, para facilitar los cálculos matemáticos, elaboró un modelo basado en cinco tejidos corporales distintos con diferentes velocidades de carga y descarga de nitrógeno, basándose en la ecuación clásica de semivida. A continuación, elaboró unas tablas de descompresión que no superaban la relación 2:1 en ninguno de los tejidos. Posteriormente, el modelo de $\mathrm{H}$ aldane se ha modificado empíricamente para ajustarlo a la tolerancia observada en los buzos. Sin embargo, todos los modelos matemáticos para la carga y la eliminación de gases tienen algún fallo, ya que no existe ninguna tabla de descompresión en la que la seguridad se mantenga o aumente a medida que aumenta el tiempo o la profundidad de la inmersión.

Las tablas de descompresión más fiables en este momento para el buceo con aire comprimido son probablemente las de la $M$ arina canadiense, conocidas como tablas DCIEM (D efence and $\mathrm{C}$ ivil Institute of Environmental M edicine). Estas tablas han sido comprobadas exhaustivamente con buzos no habituados en condiciones muy diversas y ofrecen una tasa muy baja de enfermedad por descompresión. Otras tablas de descompresión comprobadas en situaciones reales son las normas nacionales francesas, elaboradas originalmente por la empresa francesa de submarinismo Comex.

Las tablas de descompresión de la M arina de EE.UU. no son fiables, especialmente cuando se utilizan en condiciones límite. En la práctica, los buzos experimentados de la Marina de EE.UU. realizan la descompresión a mayor profundidad [3 $\mathrm{m}$ (10 pies)] o durante más tiempo que los indicados. L as T ablas de descompresión de aire para la exposición excepcional son particularmente poco fiables y su utilización ha dado lugar a enfermedad por descompresión en un $17 \%$ a $33 \%$ de todas las inmersiones experimentales. En general, las paradas de descompresión indicadas en las tablas de la M arina de EE.UU. se realizan a muy poca profundidad.

\section{Descompresión en el trabajo en cajones de aire comprimido y en la perforación de túneles}

Ninguna de las tablas descompresión de aire que requieren la respiración de aire durante la descompresión, muy utilizadas actualmente, resulta segura para los trabajadores de los túneles. En Estados U nidos, se ha demostrado que los programas de la administración federal vigentes en materia de descompresión (Estatutos del Departamento de Trabajo de EE.UU. 1971) que exige la $\mathrm{O}$ ccupational Safety and $\mathrm{H}$ ealth Administration (O SH A), producen ED en uno o más trabajadores el $42 \%$ de los días laborables, cuando se utilizan a presiones entre 1,29 y
2,11 bars. A presiones superiores a 2,45 bares, se ha demostrado que producen una incidencia del $33 \%$ de necrosis aséptica ósea (osteonecrosis disbárica). Las tablas británicas Blackpool también tienen fallos. Durante la construcción del metro de $\mathrm{H}$ ong $\mathrm{K}$ ong, el $83 \%$ de los trabajadores que utilizaron estas tablas presentaron síntomas de ED. Asimismo, se ha demostrado que producen una incidencia de osteonecrosis disbárica de hasta un $8 \%$ a presiones relativamente moderadas.

Las nuevas tablas de descompresión de oxígeno alemanas, elaboradas por Faesecke en 1992, se han utilizado con éxito en la construcción del túnel que atraviesa el canal de K iel. Las nuevas tablas de oxígeno francesas también parecen excelentes en teoría, pero aún no se han utilizado en un proyecto de gran envergadura.

Con la ayuda de un ordenador, que analizó los datos de inmersiones comerciales con 0 sin éxito recopilados durante 15 años, K indwall y Edel elaboraron las tablas de descompresión para cajones del US National Institute for O ccupational Safety and Health en 1983 (K indwall, Edel y M elton1983), a partir de un enfoque empírico que eliminaba los inconvenientes de los modelos matemáticos. Estos últimos se utilizaron únicamente para interpolaciones a partir de los datos reales. LoS resultados de la investigación en la que se basaron las tablas muestran que cuando se respiraba aire durante la descompresión, el programa de las tablas no producía ED. A hora bien, los tiempos utilizados eran excesivamente largos y, por lo tanto, poco prácticos para el sector de la construcción. Cuando se calculó la variante de oxígeno de la tabla, sin embargo, se observó que el tiempo de descompresión podía acortarse a tiempos similares, o incluso menores, a los de las tablas O SH A actuales, mencionadas antes. Las nuevas tablas se aplicaron posteriormente a individuos no habituados de distintas edades, a presiones entre 0,95 y 3,13 bars, variables en incrementos de 0,13 bars. Los niveles medios de trabajo se simularon mediante el levantamiento de peso y el uso del tapiz rodante durante la exposición. Los tiempos de exposición fueron lo más largos posible, combinando el tiempo de trabajo y el tiempo de descompresión y ajustándolos a una jornada laboral de ocho horas. Estos son los únicos programas que se utilizarán en la práctica real para el trabajo por turnos. No se describió ED durante las pruebas y la exploración y radiografías óseas no mostraron osteonecrosis disbárica. $\mathrm{H}$ asta la fecha, estos son los únicos programas de descompresión probados en laboratorio que existen para los trabajadores en entornos de aire comprimido.

\section{Descompresión del personal de las cámaras hiperbáricas}

Los programas de descompresión de aire de la Marina de EE.UU. se diseñaron para que la incidencia de ED no superara el $5 \%$. Se trata de un valor satisfactorio para el trabajo de inmersión, pero demasiado elevado para los trabajadores de las cámaras hiperbáricas en entornos clínicos. Los programas de descompresión para estos trabajadores se basan en los programas navales, pero debido a la frecuencia de la exposición, que suele estar en los límites de la tabla, es necesario prolongar notablemente los tiempos y sustituir por oxígeno el aire comprimido respirado durante la descompresión. Por prudencia, se recomienda realizar una parada de dos minutos mientras se respira oxígeno a una profundidad al menos tres metros mayor que la indicada en el programa de descompresión elegido. Por ejemplo, si la tabla de la M arina de EE.UU. indica una parada de descompresión de tres minutos a tres metros, respirando aire, después de una exposición de 101 minutos a 2,5 ATA, un programa de descompresión aceptable para un trabajador de una cámara hiperbárica sometido a la misma exposición incluiría una parada de dos minutos a $6 \mathrm{~m}$ respirando oxígeno, seguida por otra de 
diez minutos a $3 \mathrm{~m}$, respirando oxígeno. Cuando ponen en práctica los programas modificados de esta forma, la incidencia de ED entre los trabajadores es muy baja (K indwall 1994a).

A demás de proporcionar un "período de oxígeno" cinco veces superior para la eliminación del nitrógeno, el aporte de ese gas proporciona otras ventajas. Se ha demostrado que el aumento de la $\mathrm{PO}_{2}$ en la sangre venosa reduce la sedimentación sanguínea, la aglomeración de los leucocitos y el fenómeno de no reflujo, aumenta la flexibilidad de los eritrocitos y facilita su paso por los capilares, y contrarresta la disminución de la capacidad de deformación y filtrado de los leucocitos expuestos al aire comprimido.

Es evidente que todos los trabajadores que utilizan la descompresión con oxígeno han de recibir una formación adecuada y conocer el riesgo de incendios. No debe haber combustibles ni fuentes de ignición en el entorno de la cámara de descompresión; debe utilizarse un sistema de expulsión al exterior para extraer de la cámara el oxígeno exhalado y deben instalarse varios monitores con alarmas que se activen si el oxígeno de la cámara supera el $23 \%$.

El trabajo con aire comprimido o el tratamiento de pacientes clínicos en condiciones hiperbáricas puede tener unos resultados beneficiosos para el trabajo o para la remisión de la enfermedad, imposibles en otras condiciones. Si se siguen las normas para el uso seguro de estas técnicas, no hay riesgo significativo de daño disbárico para los trabajadores.

\section{Trabajo en cajones de aire comprimido y en la perforación de túneles}

En el sector de la construcción se hace necesario a veces excavar o perforar un túnel en un terreno totalmente saturado de agua, que se encuentra debajo del nivel freático local o en el fondo de un curso de agua, como un río o un lago. Un método, comprobado por la experiencia, de resolver esta situación es aplicar aire comprimido al área de trabajo para extraer el agua de la tierra, secándola lo suficiente para que pueda dinamitarse. Se ha aplicado tanto en los cajones de aire comprimido utilizados para la construcción de muelles como para la perforación de túneles en terrenos blandos (K indwall 1994b).

\section{Cajones de aire comprimido}

Un cajón de aire comprimido es simplemente un gran cajón invertido, de las mismas dimensiones que los cimientos del muelle, construido por lo general en dique seco y trasladado después al sitio al que está destinado, donde ha de colocarse con mucho cuidado. U na vez allí, se llena de agua y se hunde hasta que toca el fondo. Posteriormente, se aplica peso para desplazar la campana hacia abajo, a medida que se construye el muelle. EI objeto del cajón de aire comprimido es proporcionar un método para atravesar un terreno blando y apoyar el muelle sobre la roca sólida o sobre un estrato geológico adecuado que pueda soportar el peso. U na vez que se ha sumergido todo el cajón en el fondo, se introduce aire comprimido en el interior y se extrae el agua, dejando un suelo orgánico que los trabajadores de la campana pueden excavar. Los bordes de la campana consisten en cuñas cortantes de acero que siguen descendiendo a medida que se extrae la tierra de debajo de la campana y se aplica peso por la parte superior durante la construcción del pilar del muelle. Cuando se alcanza el lecho de roca, la cámara de trabajo se llena de hormigón y se convierte en la base permanente para la cimentación del muelle.

Los cajones de aire comprimido se han utilizado con éxito desde hace casi 150 años para trabajos de cimentación a profundidades de hasta 31,4 m por debajo del nivel medio del agua, como en el caso del muelle no 3 de $\mathrm{H}$ arbour Bridge en Auckland, Nueva Zelanda, en 1958.
El cajón de aire comprimido suele tener un cilindro de acceso para los trabajadores, que pueden descender por una escalera 0 por un ascensor mecánico, y otro cilindro independiente para los cangilones donde se coloca la tierra extraída. En cada uno de los extremos de los cilindros hay unas compuertas herméticas que permiten mantener constante la presión de la campana durante la entrada y la salida de trabajadores y materiales. La compuerta superior del cilindro para tierra tiene un collarín sellado por presión por el que puede deslizarse el cable elevador de los cangilones de tierra. La compuerta inferior se cierra antes de abrir la compuerta superior. D ependiendo del diseño, puede ser necesario un sistema de enclavamiento de las compuertas para mayor seguridad. La presión debe equilibrarse en ambos lados de la compuerta para poder abrirla. Puesto que las paredes del cajón están hechas por lo general de acero o de hormigón, no existen prácticamente escapes de la cámara cuando está presurizada, excepto por debajo de los bordes. La presión se eleva progresivamente hasta un valor ligeramente superior al necesario para equilibrar la presión del agua en el borde cortante de la cuña.

Las personas que trabajan en el cajón presurizado están expuestas al aire comprimido y pueden presentar los mismos problemas fisiológicos que los buzos que trabajan a gran profundidad. Entre estos están la enfermedad por descompresión, el barotrauma de los oídos, las cavidades sinusales y los pulmones y, si los programas de descompresión son inadecuados, el riesgo de necrosis aséptica ósea (osteonecrosis disbárica) a largo plazo.

Es importante establecer una velocidad de ventilación para eliminar el $\mathrm{CO}_{2}$ y los gases que emanan del suelo orgánico (en especial, metano), así como los humos producidos por las operaciones de soldadura o corte en la cámara de trabajo. U na norma general consiste en proporcionar seis metros cúbicos de aire por minuto por cada trabajador en la campana. También se debe considerar el aire que se pierde cuando se utilizan las esclusas para el paso del personal y los materiales. Puesto que el nivel del agua ha de mantenerse justo a la misma altura que el borde cortante, es necesario aplicar aire de ventilación, ya que el exceso de agua tiende a filtrarse por los bordes. Es necesaria una segunda fuente de aire, de la misma capacidad que la primera, con una fuente de alimentación independiente, para situaciones de emergencia en que fallen el compresor o la alimentación. En muchas zonas, esto es un requisito legal.

En ocasiones, si el suelo que se va a dinamitar es homogéneo y de arena, se instalan tubos de extracción que alcanzan la superficie. La presión en el cajón extrae la arena de la cámara de trabajo cuando el extremo del tubo de extracción se coloca en pozo, al que se vierte la arena excavada. Cuando aparece grava gruesa, rocas o bloques de minerales, éstos se fragmentan y se extraen utilizando los cangilones convencionales.

En caso de que el cajón no se hunda a pesar del peso añadido encima de la misma, puede ser necesario retirar a los trabajadores de la campana y reducir la presión de aire en la cámara de trabajo para que el cajón caiga. Debe añadirse hormigón, 0 permitir el paso de agua a los pozos de la estructura del muelle que rodean los cilindros de aire sobre el cajón para reducir la tensión sobre el diafragma de la parte superior de la cámara de trabajo. Cuando se inicia un trabajo con un cajón de aire comprimido, es necesario instalar estribos o soportes de seguridad en la cámara de trabajo para evitar que el cajón aplaste a los trabajadores en el caso de que caiga bruscamente. Por motivos prácticos, existen limitaciones a la profundidad a la que pueden bajarse los cajones de aire comprimido cuando los trabajadores acostumbran a colocar las minas manualmente en el suelo orgánico. Una presión de $3,4 \mathrm{~kg} / \mathrm{cm}^{2}$ en un barómetro (3,4 bars o $35 \mathrm{~m}$ de agua) es el límite máximo aceptable debido a la descompresión de los trabajadores. 
Los japoneses han desarrollado un sistema automatizado de cajón de aire comprimido y excavadora, en el cual se utiliza para la extracción una pala excavadora hidráulica, accionada por control remoto, que puede alcanzar todos los extremos del cajón. La pala excavadora, controlada por televisión desde la superficie, vierte la tierra orgánica en los cangilones, que se izan desde fuera de la campana. Con este sistema, el cajón puede descenderse hasta una presión ilimitada. L os trabajadores únicamente necesitan entrar a la cámara de trabajo cuando tienen que reparar la maquinaria excavadora, o bien retirar o destruir los obstáculos grandes que aparecen debajo de los bordes cortantes del cajón y que la pala excavadora controlada desde la superficie no puede retirar. En estos casos, los trabajadores entran por períodos cortos de tiempo, de forma similar a los buzos, y pueden respirar aire o una mezcla de gases a presión elevada para evitar la narcosis por nitrógeno.

Cuando el personal trabaja durante turnos prolongados en aire comprimido, a presiones superiores a $0,8 \mathrm{~kg} / \mathrm{cm}^{2}(0,8$ bars), deben realizar una descompresión por etapas. Para ello se acopla una gran cámara de descompresión, dentro del propio cajón, a la parte superior del cilindro de los trabajadores. Si no hay suficiente espacio, se acoplan al cilindro "cámaras de burbuja", pequeños recintos que admiten a un número reducido de trabajadores de pie. En ellas se realiza una descompresión preliminar, cuando el tiempo de exposición de los trabajadores ha sido relativamente corto. Posteriormente, con un exceso de gas considerable aún en su organismo, los trabajadores realizan una descompresión rápida hasta la superficie. Allí son trasladados inmediatamente a una cámara de descompresión normal, situada en ocasiones en un barco adyacente, donde, tras someterse de nuevo a la presurización, realizar una descompresión lenta. En el trabajo con aire comprimido, este proceso se denomina "trasiego" y fue bastante común tanto en Inglaterra como en el resto del mundo, pero actualmente está prohibido en Estados U nidos. EI objetivo es volver a presurizar a los trabajadores antes de transcurridos cinco minutos, cuando las burbujas pueden aumentar de tamaño y empezar a producir síntomas. Sin embargo, entraña un peligro en sí mismo, debido a la dificultad de trasladar un grupo grande de trabajadores de una cámara a otra. Si un trabajador tiene problemas para destaparse los oídos durante la represurización, puede poner en peligro a todo el grupo. Existe un procedimiento mucho más seguro, la "descompresión de superficie", utilizada por los buzos, en el que sólo se realiza la descompresión de uno o dos trabajadores al mismo tiempo. A pesar de todas las precauciones adoptadas en el proyecto del $\mathrm{H}$ arbour Bridge de Auckland, en ocasiones transcurrieron hasta ocho minutos antes de que pudiera presurizarse nuevamente a los trabajadores.

\section{Perforación de túneles con aire comprimido}

Debido al crecimiento de la población, los túneles son cada vez más importantes, tanto para la eliminación de aguas residuales, como para la construcción de vías rápidas y servicios ferroviarios subterráneos en los grandes centros urbanos. Y a menudo han de atravesar tierras blandas a una profundidad considerablemente inferior al nivel freático local. Cuando el túnel debe pasar por debajo de un río o un lago, la única forma de garantizar la seguridad de los trabajadores es llenando de aire comprimido el túnel. Esta técnica, conocida como "cámara de empuje", utiliza un escudo hidráulico en la parte anterior, con aire comprimido para retener el agua. Bajo los grandes edificios de los centros urbanos también es necesario el aire comprimido para evitar que ceda la superficie; de lo contrario, pueden cuartearse los cimientos y producirse hundimientos de las aceras y calles y daños en las tuberías y otros servicios.
Para presurizar un túnel se construyen muros de sostén transversales para proporcionar los límites de presión. En los túneles más pequeños, de menos de 3 metros de diámetro, se utiliza una esclusa simple o combinada para el acceso de trabajadores y materiales y para retirar la tierra excavada. L as puertas incluyen secciones de vía desmontables, de forma que puedan accionarse sin que se lo impidan los raíles de los vagones de tierra. Los muros de sostén tienen varias perforaciones para permitir el paso de aire a alta presión para las herramientas, y a baja presión para presurizar el túnel; de mangueras extintoras, de los cables de los barómetros, de las líneas de comunicaciones, de los cables de suministro eléctrico para el alumbrado y de la maquinaria y los tubos de succión para la ventilación y para la extracción del agua. A estos últimos se les denomina líneas de extracción o "líneas de limpieza".

El tubo de suministro de aire a baja presión, de 15 a $35 \mathrm{~cm}$ de diámetro, según el tamaño del túnel, debe llegar hasta el frente del área de trabajo para garantizar una buena ventilación para los trabajadores. Un segundo tubo de aire a baja presión, del mismo tamaño, debe extenderse también a través de ambos muros de sostén y terminar en el interior del muro interno, para suministrar aire en caso de una ruptura u obstrucción en el tubo principal de aire. Los tubos deben estar provistos de válvulas de aleteo que se cierran automáticamente para evitar la despresurización del túnel si se rompe el tubo de suministro. El volumen de aire necesario para ventilar eficazmente el túnel y mantener bajos los niveles de $\mathrm{CO}_{2}$ varía mucho en función de la porosidad del suelo y de la proximidad del recubrimiento de hormigón al escudo. En ocasiones, los microorganismos del suelo producen grandes cantidades de $\mathrm{CO}_{2}$, lo que hace necesario más aire. 0 tra propiedad útil del aire comprimido es que tiende a extraer de los muros los gases explosivos, como el metano y a expulsarlos del túnel. Esto es importante cuando se desea colocar minas en áreas en las que se han derramado solventes como gasolina 0 desengrasantes y han saturado el suelo.

La norma general, desarrollada por Richardson y M ayo (1960), es que el volumen de aire necesario puede calcularse multiplicando el área del frente de trabajo en metros cuadrados por seis y añadiendo seis metros cúbicos por trabajador. De esta forma se obtienen los metros cúbicos de aire necesarios por minuto. Si se utiliza esta cifra, pueden cubrirse prácticamente la mayor parte de las eventualidades.

La manguera contra incendios también debe extenderse hasta la parte anterior y estar provista de conexiones para mangueras cada seis metros, para utilizarse en caso de incendio. D ebe haber treinta metros de manguera imputrescible acoplada a las salidas principales de agua contra incendios.

En los túneles grandes, de más de cuatro metros de diámetro, deben existir dos esclusas: una, denominada compuerta de tierra, para el paso de los vagones de tierra y la otra, la esclusa del personal, colocada por lo general sobre la anterior, para el paso de los trabajadores. En los proyectos grandes, la esclusa del personal consta generalmente de tres compartimientos, de forma que los ingenieros, los electricistas, etc. puedan bloquear 0 desbloquear el acceso para cada cambio de turno que debe someterse a descompresión. Las grandes esclusas para el personal suelen construirse fuera del muro de sostén de hormigón principal, de manera que no tengan que soportar la fuerza compresora externa de la presión del túnel al abrirlas al aire exterior.

En los grandes túneles subacuáticos se levanta una pantalla de seguridad, que abarca la mitad superior del túnel, para proporcionar cierto grado de protección en caso de que el túnel se inunde repentinamente debido a una explosión durante la perforación bajo un río o un lago. La pantalla de seguridad suele colocarse lo más cerca posible del frente, lejos de la maquinaria 
de excavación. Se coloca un puente o paso colgante entre la pantalla y las esclusas, de manera que pase al menos un metro por debajo del borde inferior de la pantalla. Con ello se permite a los trabajadores el acceso a la esclusa del personal en caso de inundación repentina. La pantalla de seguridad también se utiliza para atrapar los gases ligeros que pueden ser explosivos; Puede pasarse una línea de limpieza a través de la pantalla y acoplarse a una línea de succión o extracción. Si se produce un fallo de la válvula, esto puede ayudar a purgar los gases ligeros del ambiente de trabajo. Debido a que la pantalla de seguridad

Tabla 36.1 - Instrucciones para los trabajadores en entornos de aire comprimido.

- Nunca "acorte" el tiempo de descompresión indicado por su superior y por el código oficial de descompresión utilizado. El tiempo que se gana no compensa el riesgo de enfermedad por descompresión (ED), una enfermedad que puede causar la muerte o discapacidades

- No se siente en una posición "encogida" durante la descompresión. Así se favorece la acumulación de burbujas de nitrógeno en las articulaciones y, por lo tanto, aumenta el riesgo de ED. Debido a que seguiráa eliminando nitrógeno de su organismo después de que haya salido del trabajo, evite también dormir o descansar en esta posición.

- Utilice agua tibia para ducharse o bañarse hasta seis horas después de la descompresión; el agua muy caliente puede originar o empeorar una situación de enfermedad por descompresión.

- La fatiga excesiva, la falta de sueño y el exceso de alcohol la noche previa también pueden contribuir a que se produzca la enfermedad por descompresión. Nunca debe ingerirse alcohol 0 aspirina como "tratamiento" para el dolor producido por la enfermedad por descompresión.

- La fiebre y las enfermedades, como un fuerte resfriado, aumentan el riesgo de enfermedad por descompresión. Asimismo, las tensiones musculares y las lesiones en fibras y ligamentos son sitios "favoritos" para que se inicie la ED.

- Si se presenta enfermedad por descompresión fuera del lugar de trabajo, póngase inmediatamente en contacto con el médico de la empresa o con un médico que tenga experiencia en tratar esta enfermedad. Leve puestos en todo momento su brazalete o insignia de identificación

- Deje todos los artículos de fumar en su taquilla. El aceite hidráulico es inflamable y en caso de iniciarse un incendio en el entorno cerrado del túnel, podrían producirse grandes daños y el cierre del trabajo, lo cual le dejaría sin empleo. Debido a que el aire es más denso en el interior del túnel por la compresión, los cigarrillos conducen el calor y se calientan tanto que no es posible sostenerlos a medida que se consumen.

- No lleve termos con el almuerzo a menos que recuerde aflojar la tapa durante la compresión; si no lo hace, el tapón se introducirá en la botella. Durante la descompresión, también debe aflojar la tapa para que la botella no explote. Los termos con un vidrio muy frágil pueden implosionar cuando se aplica presión, aunque la tapa esté suelta.

- Una vez que se cierra la compuerta de aire y comienza a aumentar la presión, observará que el aire se calienta. Esto se conoce como "calor de compresión" y es normal. Cuando deja de variar la presión, el calor se disipará y la temperatura volverá a ser normal. Durante la compresión, lo primero que notará es que se le taponan los oídos. A menos que logre "destaparlos" tragando, bostezando o tapándose la nariz e intentando "expulsar el aire por los oídos", sentirá dolor de oídos durante la compresión. Si no logra destaparse los oídos, indíqueselo al jefe de turno inmediatamente para que detenga la compresión, pues podría llegar a romperse el tímpano o experimentar una compresión grave del oído. Una vez que se haya alcanzado la presión máxima, ya no tendrá problemas con los oídos durante el resto del turno.

- Si tras la compresión siente en los oídos un zumbido, un pitido o sordera persistente durante varias horas, indíqueselo al médico especialista en aire comprimido para que evalúe la situación. En situaciones extremadamente graves, aunque muy poco frecuentes, puede resultar afectada una parte de la estructura del oído medio distinta al tímpano, si tiene mucha dificultad para destapar los oídos; en ese caso, el problema debe corregirse quirúrgicamente en los dos o tres primeros días para evitar un problema permanente.
- Si está resfriado o tiene un ataque de alergia, es preferible no someterse a la compresión hasta que lo haya superado. Los resfriados dificultan o hacen imposible equilibrar los oídos o senos nasales.

- En raras ocasiones, algunas personas pueden sentir dolor en un diente empastado. Sucede así si existe aire bajo el empaste que no puede equilibrarse fácilmente. Si le comenta el problema a su dentista, él encontrará la solución. Los dientes no empastados, incluso si tienen caries, no suelen presentar problemas.

- Los dientes postizos y las lentes de contacto blandas, así como las gafas normales, pueden utilizarse con total seguridad en el entorno de aire comprimido.

- Si alguien llegase a sufrir una lesión grave en el pecho, en la espalda o en la caja torácica mientras trabaja en el túnel presurizado, deberá tener especial cuidado antes y durante la descompresión. Si la víctima tiene una costilla rota que ha perforado el pulmón, el aire puede escapar del pulmón y colapsar el pulmón sano al expandirse en la caja torácica durante la descompresión. Cualquier persona de la que se sospeche que pueda tener una lesión de este tipo debe ser examinada por el médico especialista en aire comprimido antes de someterse a la descompresión. La descompresión deberá realizarse bajo la supervisión del médico.

- Durante la descompresión, el aire de la esclusa se enfriará. Se conoce como "enfriamiento por descompresión" y es un fenómeno completamente normal. También puede producirse niebla en la cámara. La temperatura volverá a ser normal y la niebla desaparecerá en cuanto la presión deje de variar y llegue a la superficie.

- Es muy importante que respire normalmente durante la descompresión y no retenga la respiración por ningún motivo; el aire debe entrar y salir libremente de los pulmones para evitar que se quede atrapado. Si esto sucediese, los pulmones se expandirían excesivamente y, en teoría, podrían romperse, lo que produciría la entrada de aire en el torrente sanguíneo, con consecuencias muy graves para el cerebro. Se conoce como embolismo por aire. Aunque se presenta en algunos buzos, nunca se ha demostrado que ocurra en los trabajadores de túneles. Sin embargo, debe saber que existe la posibilidad teórica y cuáles son los síntomas: pérdida de consciencia, parálisis de un lado del cuerpo, 0 una pupila de mayor tamaño que la otra. Si aparecen los síntomas, lo hacen inmediatamente (en segundos) después de la descompresión y no es posible que ocurran después. Si alguien pierde la consciencia al salir de la cámara, será llevado inmediatamente a la cámara de recompresión indicada y se notificará al médico especialista en aire comprimido.

- Si sigue sintiendo dolor, debilidad u hormigueo en cualquier parte del cuerpo después de salir de la cámara de descompresión, puede ser un indicio de enfermedad por descompresión. Si tiene sensación de "pinchazos" en las piernas o torpeza en las manos, los brazos y las piernas, debe considerarse como enfermedad por descompresión con burbujas en la médula espinal mientras no se demuestre lo contrario. Otros síntomas pueden ser vértigo y náuseas ("vahídos") o dificultad para respirar ("ahogo"). Si presenta cualquiera de estos síntomas, comuníqueselo inmediatamente al médico de la cámara de recompresión.

- Evite el uso de relojes con carátula redonda en la cámara de trabajo a menos que indiquen expresamente que son resistentes a la presión. En ocasiones, el aire comprimido puede introducirse en un reloj "impermeable" y al expandirse durante la descompresión, hacer que la carátula se caiga. Los relojes cuadrados son suficientemente permeables y esto no ocurre.

- No vuele en aviones comerciales o privados durante al menos 24 horas después de la descompresión de un turno de trabajo. No practique el submarinismo durante 24 horas antes y después del trabajo en aire comprimido. 
se extiende hasta casi la mitad del túnel, sólo puede emplearse en túneles de al menos 3,6 m. Debe advertirse a los trabajadores que se mantengan alejados del extremo abierto de la línea de limpieza, ya que pueden producirse accidentes graves si el tubo succiona la ropa que llevan puesta.

En la Tabla 36.1 se muestra una lista de instrucciones que deben proporcionarse a los trabajadores la primera vez que acceden al entorno de aire comprimido.

El médico o profesional de la salud en el trabajo para el proyecto del túnel tiene la responsabilidad de garantizar que se aplican las normas sobre pureza del aire así como todas las medidas de seguridad. El cumplimiento de los programas de descompresión elaborados también debe vigilarse cuidadosamente mediante un examen periódico de las gráficas de registro de presión del túnel y de las esclusas del personal.

\section{Trabajadores de cámaras hiperbáricas}

El tratamiento con oxígeno hiperbárico es cada vez más frecuente en todo el mundo; actualmente hay unas 2.100 instalaciones de cámaras hiperbáricas en funcionamiento. Muchas de estas cámaras son unidades con varios compartimientos, presurizados con aire comprimido a valores barométricos entre 1 y $5 \mathrm{~kg} / \mathrm{cm}^{2}$. Los pacientes respiran oxígeno al $100 \%$, a presiones de hasta $2 \mathrm{~kg} / \mathrm{cm}^{2}$. A presiones superiores, se les suministra una mezcla de gases para el tratamiento de la enfermedad por descompresión. Los trabajadores de las cámaras, sin embargo, suelen respirar aire comprimido y su exposición en la cámara es similar a la que está sometido un submarinista o un trabajador en un entorno de aire comprimido.

H abitualmente, el trabajador de una cámara con varios compartimientos es una enfermera, un terapeuta respiratorio, un antiguo submarinista o un técnico hiperbárico. Los requisitos físicos para estos trabajadores son similares a los de los trabajadores de los cajones de aire comprimido. A hora bien es importante recordar que una proporción importante del personal de las cámaras hiperbáricas son mujeres. Excepto en caso de embarazo, tienen la misma probabilidad de presentar efectos adversos por el trabajo en entornos de aire comprimido que los hombres. Cuando una mujer embarazada se expone al aire comprimido el nitrógeno atraviesa la barrera placentaria y se alcanza al feto. D urante la descompresión se forman burbujas de nitrógeno en el sistema venoso. Se trata de burbujas silenciosas que, si son pequeñas, no causan ningún daño, ya que se eliminan fácilmente por el filtro pulmonar. No es conveniente, sin embargo, dejar que las burbujas lleguen al feto. Los estudios realizados indican que es posible que el feto sufra daños en tales circunstancias. Según uno de ellos, los defectos neonatales son más frecuentes en los hijos de mujeres que han practicado el submarinismo durante el embarazo. D ebe evitarse la exposición de las mujeres embarazadas a las condiciones de las cámaras hiperbáricas y aplicarse políticas adecuadas que contemplen tanto los aspectos médicos como los legales. En virtud de lo cual, es necesario prestar información a las mujeres que trabajan en tales entornos sobre los riesgos que entrañan durante el embarazo, y organizar correctamente la asignación de tareas y ofrecer programas de educación sanitaria.

D ebe señalarse, sin embargo, que las pacientes embarazadas pueden recibir tratamiento en una cámara hiperbárica, ya que respiran oxígeno al $100 \%$, y por lo tanto, no tienen el riesgo de la embolización por nitrógeno. Se ha demostrado a partir de amplios estudios clínicos que la preocupación de que el feto tenga un mayor riesgo de presentar fibroplasia retrolental o retinopatía del recién nacido es infundada. Tampoco se ha relacionado el cierre prematuro del conducto arterial del paciente con la exposición.

\section{Otros peligros}

\section{Lesiones físicas}

\section{Buzos}

En general, los buzos están expuestos al mismo tipo de lesiones físicas que cualquier trabajador del sector de la construcción pesada. La rotura de cables, la caída de pesos, las contusiones por aplastamiento que originan las máquinas, las grúas, etc., son bastante comunes. Sin embargo, bajo el agua, el submarinista está expuesto a ciertas lesiones exclusivas, que no ocurren en ninguna otra actividad.

C onviene guardarse, sobre todo, de las lesiones por succión o atrapamiento. Cuando se trabaja en las proximidades de una abertura en el casco de un barco, en un cajón de aire comprimido cuyo nivel de agua es más bajo en el lado opuesto al que está el submarinista o en una presa, puede ocurrir este tipo de accidente. Los buzos suelen referirse a este tipo de situación como quedar atrapado por "agua pesada".

Para evitar situaciones peligrosas en las que un brazo, una pierna o todo el cuerpo pueda ser succionado por una abertura, como un túnel 0 un tubo, deben tomarse las precauciones máximas para precintar las válvulas de los tubos y las compuertas de inundación en los diques, de forma que no puedan abrirse mientras el submarinista está en el agua cerca de ellos. Lo mismo ocurre con las bombas y las tuberías de los barcos en las que el submarinista está trabajando.

Entre las lesiones que pueden producirse están: edema e hipoxia de la extremidad atrapada, suficiente para causar la necrosis del músculo; daño permanente a los nervios o incluso la pérdida de todo el miembro; 0 aplastamiento importante de una parte del cuerpo o del organismo completo, de forma que cause la muerte por trauma masivo. El atrapamiento en agua fría durante un período prolongado puede causar la muerte del submarinista por la exposición. Si el submarinista utiliza un equipo de buceo, cabe la posibilidad de quedarse sin aire y ahogarse antes de que pueda efectuarse el rescate, a menos que se le suministren tanques adicionales.

Es fácil que se produzcan lesiones por las hélices, que se evitan precintando la maquinaria principal de propulsión del barco mientras el submarinista está en el agua. D ebe recordarse, sin embargo, que los barcos con turbinas de vapor, cuando están en puerto, no dejan de girar las hélices, lentamente, mediante el virador, para evitar que las aspas de la turbina se enfríen y se distorsionen. Por eso, si un submarinista tiene que trabajar en una de las aspas (por ejemplo, para tratar de liberar cables enganchados), procurará mantenerse alejado cuando ésta se aproxime a la parte más estrecha, próxima al casco.

La compresión de todo el organismo es una lesión exclusiva de los buzos de profundidad que utilizan escafandras con un casco de cobre acoplado a la vestidura de caucho flexible. Si no existe una válvula de comprobación o válvula antiretorno en el punto en que el tubo de aire se conecta al casco, un corte del suministro de aire en la superficie origina un vacío inmediato en el casco, que puede succionar todo el cuerpo a su interior. Los efectos son instantáneos y devastadores. Por ejemplo, a una profundidad de $10 \mathrm{~m}$, se ejerce una fuerza de cerca de 12 toneladas sobre las partes blandas del traje del submarinista. Si se deja de presurizar el casco, esa fuerza empuja el cuerpo al interior del casco. Un efecto similar se produce si el submarinista cae repentinamente y no logra activar el aire de compensación. Pueden producirse lesiones graves o incluso la muerte si ocurre cerca de la superficie, ya que una caída de 10 metros desde la superficie reduce a la mitad el volumen de la vestidura. Si la caída ocurre entre 40 y $50 \mathrm{~m}$ de profundidad sólo se reduce el 
volumen en un $17 \%$. Tales cambios de volumen se explican por la ley de Boyle.

\section{Trabajadores de cajones de aire comprimido y túneles}

Los trabajadores de los túneles están expuestos a los accidentes habituales en la construcción pesada, con el problema adicional de una mayor incidencia de caídas y lesiones por los derrumbes. Es importante recordar que un trabajador lesionado en un entorno de aire comprimido que se haya roto las costillas ha de tratarse como si tuviera un neumotórax mientras no se demuestre lo contrario y, por lo tanto, debe tenerse mucho cuidado durante su descompresión. Si existe un neumotórax, debe resolverse a la presión de la cámara de trabajo antes de intentar la descompresión.

\section{Ruido}

Las lesiones por ruido en un entorno de aire comprimido pueden ser graves, ya que los motores de aire, los martillos neumáticos y los taladros nunca están adecuadamente equipados con silenciadores. Se han medido niveles de ruido superiores a $125 \mathrm{~dB}$ en cajones de aire comprimido y en túneles, cuyos efectos son dolor físico y lesiones permanentes al oído interno. El eco en el interior de un túnel 0 de un cajón de aire comprimido empeora el problema.

Muchos trabajadores en entornos de aire comprimido se muestran reacios al uso de protección para los oídos, con el argumento de que bloquear el sonido de un vagón de tierra que se aproxima puede ser peligroso. Su argumento no tiene una base real, ya que la protección para los oídos, en el mejor de los casos, atenúa el sonido pero no lo elimina. Además, el trabajador puede percibir la proximidad de los vagones de tierra en movimiento no sólo por el ruido, sino por otros indicios, como las sombras en movimiento y la vibración del suelo. Sí sería motivo de preocupación una oclusión hermética del conducto auditivo mediante protectores $u$ orejeras que ajustasen perfectamente. Si se impide el paso del aire al canal auditivo externo durante la compresión, puede producirse la compresión del oído externo, ya que el tímpano se ve impulsado hacia el exterior por el aire que entra al oído medio a través de las trompas de Eustaquio. Las orejeras protectoras habituales no suelen ser completamente herméticas. Durante la compresión, que representa una fracción mínima del tiempo total del turno de trabajo, pueden soltarse ligeramente en caso de que existan problemas para equilibrar la presión. Los tapones de fibra moldeados que se ajustan a la forma del canal externo protegen sin ser herméticos.

El objetivo es evitar un nivel medio de ruido superior a $85 \mathrm{dBA}$ durante mucho tiempo. Todos los trabajadores de entornos de aire comprimido deberían someterse a una audiometría antes de iniciar el trabajo, de forma que pudiera controlarse la pérdida de audición causada por el alto nivel de ruido.

L os tubos de suministro de aire de las cámaras hiperbáricas y de las esclusas de descompresión pueden equiparse con silenciadores eficaces. Es importante insistir sobre este punto, ya que el ruido de la ventilación puede resultar tan molesto a los trabajadores que dejen de ventilar adecuadamente la cámara. Es posible mantener una ventilación continua con un silenciador en la fuente de suministro que no produzca más de $75 \mathrm{~dB}$, aproximadamente el nivel de ruido en una oficina normal.

\section{Incendios}

El fuego es siempre una preocupación importante durante el trabajo en un túnel de aire comprimido y durante el funcionamiento de las cámaras hiperbáricas clínicas. C uando se trabaja en un cajón de aire comprimido con paredes y techo de acero y un suelo formado exclusivamente por tierra orgánica no combustible, puede producirse una falsa sensación de seguridad. Sin embargo, incluso en tales condiciones un incendio de origen eléctrico puede quemar los aislantes, sumamente tóxicos, y matar 0 incapacitar a una cuadrilla de trabajadores muy rápidamente. En los túneles con encofrado de madera debajo del hormigón el peligro es aún mayor, al igual que en los túneles en los que se ha utilizado aceite hidráulico y paja para calafatear, pueden representar un combustible adicional.

En condiciones hiperbáricas, el fuego es siempre más intenso, ya que hay más oxígeno para la combustión. Un aumento del $21 \%$ al $28 \%$ en el porcentaje de oxígeno doblará la velocidad de combustión. A medida que aumenta la presión, aumenta la cantidad de oxígeno para la combustión. Y el aumento es igual al porcentaje de oxígeno existente, multiplicado por el número de atmósferas en términos absolutos. Por ejemplo, a una presión de 4 ATA (equivalente a $30 \mathrm{~m}$ de agua de mar), el porcentaje efectivo de oxígeno es del $84 \%$ en aire comprimido. Con todo, debe recordarse que aunque la combustión se acelera notablemente en estas condiciones, no es igual a la velocidad de combustión con un $84 \%$ de oxígeno a una atmósfera. La razón está en que el nitrógeno presente en la atmósfera tiene un cierto efecto de extinción. El acetileno no puede utilizarse a presiones superiores a un bar, debido a sus propiedades explosivas. No obstante, es posible utilizar oxígeno y otros gases para cortar el acero. Ya se ha hecho de forma segura a presiones de hasta 3 bares, aunque ha de tenerse mucho cuidado y debe haber una persona con una manguera de incendios al lado para extinguir inmediatamente cualquier fuego que se inicie si una chispa entra en contacto con algo combustible.

Para que haya fuego es necesario que estén presentes tres elementos: el combustible, el oxígeno y una fuente de ignición. Si falta alguno de los tres, el fuego no se producirá. En condiciones hiperbáricas, es casi imposible eliminar el oxígeno, a menos que el equipo que se está utilizando pueda insertarse en el medio llenándolo o rodeándolo de nitrógeno. Si no puede eliminarse el combustible, debe evitarse la fuente de ignición. En el trabajo hiperbárico clínico, debe tenerse mucho cuidado para evitar que el porcentaje de oxígeno en la cámara de varios compartimentos aumente por encima del $23 \%$. A demás, todo el equipo eléctrico en el interior de la cámara debe ser intrínsecamente seguro, sin posibilidad de producir un arco eléctrico. El personal de la cámara debe utilizar ropa de algodón tratada para retardar la ignición. $\mathrm{H}$ a de existir un sistema de aspersión de agua, así como mangueras manuales contra incendios con una fuente independiente. Si ocurre un incendio en una cámara hiperbárica clínica, no existe la posibilidad de escapar inmediatamente, por lo que el fuego debe extinguirse utilizando la manguera y el sistema aspersor.

En las cámaras de un sólo compartimiento presurizadas con $100 \%$ de oxígeno, un incendio resulta mortal de forma instantánea para todos los ocupantes. El cuerpo humano es combustible en $100 \%$ de oxígeno, especialmente a presión elevada, por lo que en una cámara de un sólo compartimiento, el paciente debe utilizar únicamente ropa de algodón para evitar las chispas estáticas de los materiales sintéticos. No es necesario tratar la ropa, pues en caso de incendio no ofrecería protección. La única forma de evitar un incendio en una cámara de un sólo compartimiento llena de oxígeno es evitando completamente cualquier fuente de ignición.

En entornos con una presión de oxígeno elevada, a presiones superiores a $10 \mathrm{~kg} / \mathrm{cm}^{2}$, el calor adiabático debe considerarse como una posible fuente de ignición. Si el oxígeno a una presión de $150 \mathrm{~kg} / \mathrm{cm}^{2}$ pasa rápidamente a un colector a través de una válvula esférica de apertura rápida, puede producir un efecto "diesel" si existe una partícula de polvo por minúscula que sea. Esto puede producir una violenta explosión. Ya han ocurrido accidentes de este tipo, por lo que los sistemas con oxígeno a 
presión elevada no deben utilizar válvulas esféricas de apertura rápida.

\section{- TRAST ORNOS POR DESCOMPRESION}

Dees F. Gorman

Un gran número de trabajadores de diversos sectores deben someterse a una descompresión (una disminución de la presión ambiental) como parte de su rutina de trabajo. Entre ellos están los buzos, que pueden dedicarse a diversas ocupaciones; los trabajadores de los cajones de aire comprimido, los trabajadores de túneles, los trabajadores de cámaras hiperbáricas (en su mayoría enfermeras), el personal de aviación y los astronautas. La descompresión en estas personas puede originar, y de hecho lo hace, diversos trastornos, la mayor parte de los cuales se conocen bastante bien, aunque no todos. En algunos casos, y a pesar del tratamiento, los trabajadores lesionados pueden quedar discapacitados. Los trastornos por descompresión son objeto de una intensa labor de investigación.

\section{Mecanismo de las lesiones por descompresión}

\section{Principios de la captación y la liberación de gases}

La descompresión puede afectar a un trabajador hiperbárico por uno de dos mecanismos principales. El primero es consecuencia de la captación de gas inerte durante la exposición hiperbárica y la formación de burbujas en los tejidos durante y después de la descompresión subsiguiente. Generalmente se considera que los gases metabólicos (oxígeno y dióxido de carbono), no contribuyen a la formación de burbujas. Aunque se trata, con toda probabilidad, de una suposición falsa, el error consecuente es mínimo y, por lo tanto, en este capítulo la consideramos válida.

Durante la compresión (aumento de la presión ambiente) del trabajador y durante todo el tiempo que permanece en un entorno presurizado, la tensión del gas inerte inspirado y arterial aumenta en relación con la que ocurre en condiciones de presión atmosférica normal. Los tejidos captan los gases inertes hasta que se establece un equilibrio entre las tensiones del gas inerte inspirado, arterial y tisular. El tiempo transcurrido hasta alcanzar tal equilibrio varía desde menos de 30 minutos hasta más de un día, en función del tipo de tejido y de gas involucrados. En particular, varía dependiendo de:

- el aporte sanguíneo al tejido;

- la solubilidad del gas inerte en la sangre y en el tejido;

- la difusión del gas inerte en la sangre y en el tejido;

- la temperatura del tejido;

- la carga local de trabajo del tejido,

- la tensión local de dióxido de carbono del tejido.

En la descompresión posterior del trabajador hiperbárico hasta la presión atmosférica normal se invierte el proceso: el gas se libera de los tejidos y finalmente se espira. La velocidad de esta liberación está determinada por los factores antes indicados, pero, por motivos que no se conocen muy bien, parece ser más lenta que la captación. Y la eliminación del gas es aún más lenta si se forman burbujas. Los factores que influyen en la formación de burbujas son bien conocidos cualitativamente, pero no cuantitativamente. Para que se forme una burbuja, su energía debe ser suficiente para vencer la presión ambiente, la tensión de la presión superficial y la presión del tejido elástico. Las discrepancias entre las predicciones teóricas (de tensión superficial y de volúmenes críticos para el crecimiento de las burbujas) y la observación real de la formación de burbujas se explican por argumentos tales como la formación de burbujas en los defectos de la superficie del tejido (vasos sanguíneos) o por la formación continua de pequeñas burbujas de vida corta (núcleos) en el organismo (por ejemplo, entre los planos de los tejidos o en las áreas de formación de cavidades. Las condiciones previas para que el gas salga de la solución tampoco están claramente definidas, aunque es probable que las burbujas se formen siempre que la tensión de gas en los tejidos supere la presión ambiente. Una vez formadas, las burbujas producen lesiones (véase más adelante) y aumentan progresivamente su estabilidad al unirse e incorporar surfactantes a la superficie de la burbuja. Es posible que se formen burbujas sin descompresión si se cambia el gas inerte que respira el trabajador hiperbárico. El efecto es probablemente pequeño y los trabajadores en los que aparece repentinamente la enfermedad por descompresión después de un cambio en el gas inerte inspirado, muy probablemente tenían ya burbujas "estables" en sus tejidos.

Por consiguiente, es evidente que para una práctica del trabajo segura, debe utilizarse un programa de descompresión para evitar la formación de burbujas. Para esto, es necesario contar con un modelo de:

- la captación del gas o gases inertes durante la compresión y la exposición hiperbárica;

- la eliminación del gas o gases inertes durante y después de la descompresión,

- las condiciones para la formación de burbujas.

Es razonable afirmar que hasta la fecha no se cuenta con un modelo totalmente satisfactorio de la cinética y la dinámica de la descompresión y que los trabajadores hiperbáricos se basan en programas establecidos fundamentalmente por ensayo y error.

\section{E fecto de la ley de Boyle sobre el barotrauma}

El segundo mecanismo importante por el que la descompresión puede producir lesiones es el proceso del barotrauma. El barotrauma puede originarse por compresión o por descompresión. En el primer caso, los espacios de aire en el organismo que están rodeados por tejidos blandos ( $y$, por lo tanto, están sujetos al aumento en la presión ambiente, según el principio de Pascal) sufrirán una reducción de volumen (como bien predice la ley de Boyle: al duplicar la presión ambiente, el volumen de los gases se reduce a la mitad). El líquido desplaza al gas comprimido siguiendo una secuencia previsible:

- Los tejidos elásticos se desplazan (la membrana timpánica, las ventanas redonda y oval, el material de la mascarilla, la ropa, la caja torácica y el diafragma).

- La sangre se acumula en los grandes vasos dilatables (esencialmente en las venas).

- Una vez que se alcanza el límite de dilatación de los vasos sanguíneos, se asigna una extravasación de líquido (edema) y de sangre (hemorragia) hacia los tejidos blandos circundantes.

- Cuando se alcanza el límite de dilatación de los tejidos blandos circundantes, el líquido, primero, y después la sangre penetran en el propio espacio de aire

Esta secuencia puede interrumpirse en cualquier momento por un aporte adicional de gas en el espacio (por ejemplo, en el oído medio, cuando se realiza una maniobra de Valsalva) y concluye cuando se alcanza el equilibrio entre el volumen del gas y la presión del tejido.

Este proceso se invierte durante la descompresión: el volumen del gas aumenta, y si no se logra expulsar a la atmósfera, puede producir trauma local. En los pulmones, el trauma es debido a una sobredistensión o a un desgarre entre áreas adyacentes del pulmón que tienen una capacidad de dilatación significativamente distinta y por lo tanto se expanden a diferente velocidad. 


\section{Patogenia de los trastornos por descompresión}

Los trastornos por descompresión pueden dividirse en tres categorías: barotrauma, burbujas tisulares y burbujas intravasculares.

\section{Barotrauma}

Durante la compresión, cualquier espacio en el que haya gas puede sufrir un barotrauma, muy frecuente en los oídos. M ientras que la lesión del oído externo requiere la oclusión del canal auditivo externo (con tapones, cascos o cera), las lesiones de la membrana timpánica y del oído medio son frecuentes. La probabilidad de lesión aumenta cuando el trabajador tiene una patología del tracto respiratorio superior que produce una disfunción de las trompas de Eustaquio. Las posibles consecuencias son: congestión del oído medio (como se describió antes) y ruptura de la membrana timpánica. Es probable que se presente dolor de oídos y sordera conductiva. La entrada de agua fría al oído interno cuando la membrana timpánica está desgarrada produce vértigo es transitorio. El vértigo, y posiblemente también la sordera sensorioneural, se producen con mayor frecuencia como resultado del barotrauma del oído interno. Durante la compresión son frecuentes las lesiones del oído interno por una maniobra de Valsalva demasiado enérgica, que hace que la onda del líquido se transmita al oído interno a través del conducto del caracol. Es un tipo de lesión que se produce generalmente en el interior del oído interno; la rotura de las ventanas redonda y oval es menos común.

Los senos paranasales también suelen presentar el mismo tipo de problemas, generalmente debido al bloqueo de un orificio. A demás del dolor local y referido, es frecuente la epistaxis y la "compresión" de los nervios craneales. El nervio facial también puede verse afectado por el barotrauma del oído medio en personas con el canal del nervio auditivo perforado. 0 tras áreas a las que afecta el barotrauma compresivo, aunque más raramente, son los pulmones, los dientes, el intestino, y a algunas partes del equipo, como las mascarillas de buceo, los trajes de neopreno y los dispositivos para compensar la flotabilidad.

El barotrauma por descompresión ocurre más raramente que el barotrauma por compresión, pero sus consecuencias suelen ser peores. $L$ as dos áreas principalmente afectadas son los pulmones y el oído interno. No se ha descrito aún la lesión patológica típica del barotrauma pulmonar. Entre los mecanismos con los que se relaciona están la sobredistensión de los alvéolos (que produce una "apertura de los poros" o una ruptura mecánica de los alvéolos) y el desgarro del tejido pulmonar debido a una expansión diferencial local. Es probable que exista una tensión máxima en la base de los alvéolos y, puesto que los trabajadores submarinos suelen respirar en episodios cortos a prácticamente la capacidad pulmonar total, por un grupo en el que el riesgo de barotrauma aumenta, ya que la capacidad de dilatación es mínima a estos volúmenes. La liberación de gases del pulmón dañado puede realizarse a través del intersticio al hilio pulmonar, de ahí al mediastino y quizá incluso a los tejidos subcutáneos de la cabeza y el cuello. El gas intersticial puede producir disnea, dolor subesternal y tos de tipo productivo con esputos ligeramente manchados de sangre. Las consecuencias de la presencia del gas en la cabeza y el cuello son evidentes, y en ocasiones pueden impedir la fonación. La compresión cardíaca es sumamente rara. El gas de los pulmones con barotrauma puede escapar también al espacio pleural (produciendo un neumotórax) o a las venas pulmonares (convirtiéndose posteriormente en un émbolo de gas arterial). En general, el gas suele escapar hacia el intersticio y el espacio pleural o hacia las venas pulmonares. Afortunadamente, pocas veces concurren una lesión pulmonar y un embolismo arterial por gas.

\section{Burbujas en los tejidos autóctonos}

Si se forma una fase gaseosa durante la descompresión, suele ocurrir inicialmente en los tejidos. Estas burbujas tisulares pueden inducir la disfunción del tejido por diversos mecanismos mecánicos o bioquímicos.

En los tejidos con baja capacidad de dilatación, como los huesos largos, la médula espinal y los tendones, las burbujas pueden comprimir arterias, venas, vasos linfáticos y células sensoriales. En otros tejidos, las burbujas pueden causar la ruptura mecánica de las células o bien, a escala microscópica, de las vainas de mielina. Tal vez sea la solubilidad del nitrógeno en la mielina lo que explique las frecuentes afecciones del sistema nervioso en la enfermedad por descompresión entre los trabajadores que han estado respirando aire o una mezcla de oxígeno y nitrógeno. Las burbujas en los tejidos también pueden desencadenar una respuesta bioquímica a un "cuerpo extraño". Se trata de una respuesta inflamatoria que aclara quizá que una de las manifestaciones comunes de la enfermedad por descompresión sea un cuadro similar a la gripe. La importancia de la respuesta inflamatoria se ha demostrado en animales, en particular en conejos, en los que la inhibición de la respuesta impide la aparición de la enfermedad por descompresión. Entre las principales características de la respuesta inflamatoria están la coagulopatía (particularmente importante en animales, pero menos en humanos) y la liberación de cininas. Estas sustancias producen dolor y la extravasación de líquido. También se produce una hemoconcentración como consecuencia del efecto directo de las burbujas sobre los vasos sanguíneos. Finalmente, la microcirculación se ve afectada significativamente y, en general, el hematocrito depende en gran medida de la gravedad de la enfermedad. La corrección de la hemoconcentración beneficia significativamente el resultado final.

\section{Burbujas intravasculares}

Las burbujas venosas pueden formarse de novo, a medida que la solubilidad del gas disminuye, o pueden liberarse de los tejidos. Estas burbujas venosas viajan en la circulación sanguínea hasta los pulmones y quedan atrapadas en la vasculatura pulmonar. La circulación pulmonar es un filtro de burbujas sumamente eficaz debido a la presión arterial relativamente baja. En cambio, en la circulación sistémica, muy pocas burbujas quedan atrapadas por períodos prolongados debido a la presión arterial sistémica significativamente mayor. El gas de las burbujas atrapadas en los pulmones se difunde hacia los espacios aéreos pulmonares y se exhala. Sin embargo, mientras las burbujas están atrapadas pueden producir efectos adversos por un desequilibrio en la perfusión y ventilación pulmonares o por un aumento en la presión arterial pulmonar y, en consecuencia, de la presión venosa cardíaca derecha y central. El aumento en la presión cardíaca derecha puede originar el paso de sangre de "derecha a izquierda" a través de pasos pulmonares o de "defectos anatómicos" intracardíacos, de forma que las burbujas se convierten en émbolos arteriales de gas en lugar de llegar al "filtro" pulmonar. EI aumento en la presión venosa deteriora el retorno venoso desde los tejidos y, por tanto, el aclaramiento del gas inerte de la médula espinal, lo que puede dar lugar a un infarto hemorrágico venoso. Las burbujas venosas también reaccionan con los vasos y los componentes sanguíneos. El efecto que causan en los vasos sanguíneos es el desprendimiento de la capa surfactante de las células endoteliales, con lo que se eleva la permeabilidad vascular, que también puede verse comprometida por el desplazamiento físico de las células endoteliales. Sin embargo, aunque no se produzca tal lesión, la concentración de receptores glicoproteicos para los leucocitos polimorfonucleares aumenta en la superficie de las células endoteliales. Lo cual, junto con la estimulación directa de los leucocitos por las burbujas, produce la unión de los 
leucocitos a las células endoteliales (con la consiguiente reducción del flujo) y la infiltración posterior a los vasos sanguíneos y a través de ellos (diapédesis). La infiltración de leucocitos polimorfonucleares puede producir otros daños tisulares debido a la liberación de citocinas, radicales libres de oxígeno y fosfolipasas. En la sangre, las burbujas no sólo producen la activación y la acumulación de los leucocitos polimorfonucleares, sino también la activación de las plaquetas, la coagulación y el complemento y la formación de émbolos de grasa. En la circulación venosa, que puede dilatarse fácilmente, estos efectos no tienen gran importancia pero cuando ocurren en las arterias, es posible que reduzcan el flujo sanguíneo a niveles isquémicos.

Las burbujas arteriales (émbolos de gas) pueden producirse por:

- barotrauma pulmonar, que causa la liberación de burbujas a las venas pulmonares:

- el paso "forzado" de las burbujas a través de las arteriolas pulmonares (la toxicidad por oxígeno y el uso de broncodilatadores con efecto vasodilatador, como la aminofilina, favorecen este proceso),

- el paso directo de las burbujas de un canal vascular derecho a uno izquierdo sin pasar por el filtro pulmonar (por ejemplo, a través del foramen oval).

Una vez en las venas pulmonares, las burbujas vuelven a la aurícula izquierda, después al ventrículo izquierdo y finalmente son bombeadas a la aorta. En la circulación arterial, las burbujas se distribuyen de acuerdo con su flotabilidad y el flujo sanguíneo en los vasos grandes; en el resto, dependiendo únicamente del flujo sanguíneo. Esto explica la prevalencia de las embolias cerebrales, especialmente en la arteria cerebral media. La mayoría de las burbujas que entran en la circulación arterial pasan por los capilares sistémicos a la circulación venosa, vuelven al lado derecho del corazón y, habitualmente, terminan atrapadas por los pulmones. En su recorrido, las burbujas pueden interrumpir temporal mente alguna función. Si las burbujas quedan atrapadas en la circulación sistémica o no se redistribuyen antes de cinco a diez minutos, esta pérdida de función puede hacerse persistente. Si la embolia ocurre en circulación del tallo cerebral, puede resultar letal. Afortunadamente, la mayoría de las burbujas se redistribuyen a los pocos minutos de haber llegado al cerebro por vez primera y generalmente la función se recupera. Sin embargo, durante el trayecto, las burbujas causan las mismas reacciones vasculares (en los vasos sanguíneos y en la sangre) descritas anteriormente para las venas y la sangre venosa. C omo consecuencia, disminuye significativa y progresivamente el flujo sanguíneo cerebral, que puede llegar a un nivel incompatible con la función normal. En este momento el trabajador hiperbárico puede sufrir una recaída 0 un deterioro de la función. En general, unas dos terceras partes de los trabajadores hiperbáricos que sufren una embolia cerebral por gas arterial se recuperan espontáneamente, y aproximadamente un tercio recae.

\section{Presentación clínica de los trastornos por descompresión}

\section{Tiempo de aparición}

La enfermedad por descompresión se manifiesta a veces durante la descompresión. Suele suceder con el barotrauma del ascenso, en el que intervienen especialmente los pulmones. Con todo, la aparición de la mayoría de los trastornos por descompresión ocurre después de la descompresión. Los trastornos debidos a la formación de burbujas en los tejidos y en los vasos sanguíneos suele manifestarse en los minutos u horas siguientes a la descompresión. En el historial natural de gran parte de estas enfermedades por descompresión se observa una resolución espontánea de los síntomas. Sin embargo, algunos se resuelven espontáneamente sólo de forma parcial y es necesario aplicar un tratamiento. Se ha demostrado que cuanto antes se aplique el tratamiento mejor será el resultado. El historial de los trastornos por descompresión tratados es variable. En algunos casos, los problemas residuales se han resuelto en los 6 a 12 meses siguientes, mientras que en otros casos, no se han llegado a resolver los síntomas.

\section{M anifestaciones clínicas}

Una de las manifestaciones comunes de la enfermedad por descompresión es un cuadro similar a la influenza. 0 tros son los trastornos sensoriales, el dolor local, especialmente en las extremidades, además de otros síntomas neurológicos relacionados con las funciones superiores, los sentidos y el desgaste motor (es más raro que se vean afectados la piel y el sistema linfático). En algunos grupos de trabajadores hiperbáricos, la manifestación más común de la enfermedad por descompresión es el dolor. Puede tratarse de un dolor discreto en una o varias articulaciones, dolor de espalda o dolor referido (cuando el dolor se localiza en la misma extremidad que el déficit neurológico) o bien, menos frecuentemente, cuando la enfermedad por descompresión es aguda, de una sensación de dolor migratorio indefinido. Puede considerarse que las manifestaciones de la enfermedad por descompresión son proteicas. Cualquier enfermedad que se manifieste en un trabajador hiperbárico entre las 24 y las 48 horas siguientes a la descompresión debe considerarse relacionada con ella mientras no se demuestre lo contrario.

\section{Clasificación}

H asta hace poco tiempo, los trastornos de descompresión se clasificaban como:

\section{- barotrauma; \\ - embolia cerebral por gases arteriales, \\ - síndrome de descompresión.}

El síndrome de descompresión se subdividía en: tipo 1 (dolor, comezón, tumefacción y erupción cutánea); tipo 2 (todas las demás manifestaciones), y tipo 3 (manifestaciones tanto de embolia cerebral por gases arteriales como de síndrome de descompresión). Este sistema de clasificación surgió de un análisis de los resultados obtenidos con trabajadores de cajones de aire comprimido que utilizaban nuevos programas de descompresión. Actualmente, sin embargo, este sistema ha sido sustituido, ya que no es discriminatorio ni pronóstico y debido a que la concordancia en el diagnóstico entre varios médicos con experiencia es baja. La nueva clasificación de las enfermedades por descompresión reconoce la dificultad de distinguir entre una embolia cerebral por gases arteriales y el malestar por descompresión cerebral, así como entre los tres tipos de síndrome de descompresión. Todas las enfermedades por descompresión se clasifican actualmente como tales, según se indica en la Tabla 36.2. Su denominación va precedida de una descripción, en primer lugar, de la naturaleza de la enfermedad, del progreso de los síntomas, en segundo, y finalmente de una lista de los sistemas orgánicos en los que se manifiestan los síntomas (no se hacen suposiciones sobre la patología subyacente). Por ejemplo, un submarinista puede tener una enfermedad por descompresión de tipo neurológico agudo progresivo. En la clasificación completa de las enfermedades por descompresión se incluye un comentario sobre la presencia o ausencia de barotrauma y la carga de gas inerte probable. Estos dos factores son importantes tanto para el tratamiento como para determinar la posibilidad de que el paciente se reincorpore al trabajo. 
Tabla 36.2 - Sistema revisado de clasificación de las enfermedades por descompresión.

\begin{tabular}{llll} 
Duración & Evolución & Síntomas & \\
Aguda & Progresiva & Musculosqueléticos & \\
Crónica & $\begin{array}{l}\text { Resolución } \\
\text { espontánea }\end{array}$ & Cutáneos & $\begin{array}{l}\text { Enfermedad por } \\
\text { descomprensión } \\
+0- \\
\text { indicios de barotrauma }\end{array}$ \\
& Estática & Linfáticos & \\
& Con recaída & Neurológicos & \\
& & Vestibulares & \\
& & Cardiorrespiratorios & \\
\hline
\end{tabular}

\section{Gestión de primeros auxilios}

\section{Salvamento y reanimación}

El salvamento es necesario en algunos trabajadores hiperbáricos que desarrollan una enfermedad por descompresión; sobre todo en el caso de los buzos. El salvamento implica su traslado a una plataforma o campana de buceo 0 a la superficie. Es necesario elaborar determinadas técnicas de salvamento y practicarlas para que puedan aplicarse con éxito. En general, el salvamento de los buzos en el mar se realiza en posición horizontal. La razón es evitar posibles descensos letales del gasto cardíaco al exponer nuevamente al sujeto a la gravedad, ya que durante cualquier inmersión hay una pérdida progresiva de volumen sanguíneo que coincide con el desplazamiento de la sangre de la periferia hacia el tórax, con la diuresis consecuente. La posición horizontal debe mantenerse hasta que el submarinista esté, en caso necesario, en la cámara de recompresión.

Para la reanimación de un submarinista lesionado se siguen las mismas pautas que para cualquier otra reanimación. Es importante señalar, sin embargo, que la reanimación de un individuo hipotérmico debe continuar al menos hasta que se recupere la temperatura corporal. No existen pruebas de la eficacia de la reanimación en el agua de un submarinista lesionado. En general, lo mejor para el submarinista es el salvamento para trasladarlo a tierra o a una plataforma o campana de buceo.

\section{Reanimación con oxígeno y líquido}

Un trabajador hiperbárico con enfermedad por descompresión debe ser colocado en posición horizontal para minimizar el riesgo de que las burbujas se dispersen hasta el cerebro; nunca con la cabeza a un nivel más bajo, ya que puede afectar negativamente al resultado. Debe administrarse oxígeno al $100 \%$ mediante una válvula (activada por el paciente, si está consciente), o mediante una mascarilla ajustada, una velocidad de flujo elevada, y un sistema de depósito. Si es necesario prolongar la administración de oxígeno, deben intercalarse pulsos de aire para aliviar 0 retardar el desarrollo de la toxicidad pulmonar por oxígeno. Cualquier submarinista con enfermedad por descompresión debe ser rehidratado. Probablemente no exista la posibilidad de administrar líquidos por vía oral durante una reanimación aguda de un trabajador gravemente lesionado. En general, es difícil administrar líquidos por vía oral a una persona en posición horizontal. La administración oral de líquidos conlleva la interrupción de la administración de oxígeno; el efecto inmediato sobre el volumen sanguíneo suele ser insignificante. Por último, puesto que el tratamiento hiperbárico con oxígeno puede producir convulsiones, es conveniente que el intestino esté vacío. Lo ideal, por lo tanto, es hacer la reanimación con líquido por vía intravenosa. No existen pruebas de que las soluciones coloidales sean mejores que las soluciones cristalinas, y el líquido que se escoja no será más que una solución salina normal. No debe administrarse una solución que contenga lactato a un submarinista hipotérmico, ni una solución con dextrosa a alguien que tenga una lesión cerebral, ya que puede agravar la lesión. Es esencial que se mantenga un equilibrio hídrico preciso, ya que es probablemente la mejor forma de reanimar con éxito a un trabajador hiperbárico que sufra una enfermedad por descompresión. Los efectos sobre la vejiga son bastante frecuentes y la cateterización está justificada si no hay producción urinaria.

No existen fármacos de eficacia demostrada para el tratamiento de las enfermedades por descompresión, aunque la lignocaína (sustancia actualmente en fase de estudio clínico) tiene cada vez más partidarios. Se cree que la lignocaína actúa como estabilizador de las membranas y como inhibidor de la acumulación de leucocitos polimorfonucleares y de la adhesividad de los vasos sanguíneos provocada por las burbujas. Resulta interesante que una de las probables funciones del oxígeno hiperbárico sea también inhibir la acumulación y la adherencia de los leucocitos a los vasos sanguíneos. Por último, no existen pruebas de que el uso de inhibidores de la agregación plaquetaria, como la aspirina y otros anticoagulantes, sea beneficioso. Por el contrario, puesto que la enfermedad neurológica grave por descompresión está asociada a la hemorragia en el sistema nervioso central, el uso de este tipo de medicamentos puede estar contraindicado.

\section{Traslado}

El traslado de un trabajador hiperbárico con enfermedad por descompresión a las instalaciones de recompresión terapéutica debe realizarse lo antes posible, procurando siempre que no haya una descompresión adicional. La altitud máxima a la que un trabajador puede someterse a descompresión durante una evacuación médica en aviación es de $300 \mathrm{~m}$ sobre el nivel del mar. Durante el traslado, deben proporcionarse al paciente los primeros auxilios y la asistencia complementaria antes descritos.

\section{Tratamiento de recompresión}

\section{Aplicaciones}

El tratamiento definitivo de la mayoría de las enfermedades por descompresión es la recompresión en una cámara. La excepción a esta norma son los barotraumatismos sin embolismo por gas arterial asociado. La mayoría de las víctimas de barotrauma auditivo requieren audiometrías seriadas, descongestivos nasales, analgésicos y, si se sospecha un barotrauma del oído interno, reposo absoluto en cama. Es posible, sin embargo, que el oxígeno hiperbárico (y el bloqueo de los ganglios estrellados) sea un tratamiento eficaz para este último grupo de pacientes. 0 tro tipo de barotrauma que suele requerir tratamiento es el pulmonar, que habitualmente responde bien al oxígeno al $100 \%$ a presión atmosférica. A veces se hace necesaria la canulación torácica para el tratamiento de un neumotórax. En otros pacientes está indicada la recompresión precoz.

\section{Mecanismos}

El aumento en la presión ambiental reduce el tamaño de las burbujas y, por lo tanto, su estabilidad (al aumentar la tensión superficial). Estas burbujas más pequeñas tienen una mayor relación superficie-volumen, lo que favorece su difusión, y sus efectos de compresión y desgarro mecánicos sobre los tejidos son menores. También es posible que exista un volumen umbral de burbujas que estimule una reacción a "cuerpos extraños". 
Al reducir el tamaño de las burbujas, puede reducirse también este efecto. Por último, la disminución del volumen (longitud) de las columnas de gas atrapadas en la circulación sistémica favorece su distribución hacia las venas. O tra consecuencia de la recompresión en la mayoría de los casos es un aumento en la tensión de oxígeno inspirada $\left(\mathrm{P}_{\mathrm{i}} \mathrm{O}_{2}\right)$ y arterial $\left(\mathrm{P}_{2} \mathrm{O}_{2}\right)$. A sí se alivia la hipoxia, se reduce la presión del líquido intersticial, se inhibe la activación y la acumulación de leucocitos polimorfonucleares habitualmente causada por las burbujas y se reduce el hematocrito y, por lo tanto, la viscosidad de la sangre.

\section{Presión}

La presión ideal a la que debe tratarse la enfermedad por descompresión no está claramente definida, aunque suele optarse convencionalmente por 2,8 bars de presión absoluta (60fsw; $282 \mathrm{kPa}$ ), con un aumento posterior a 4 y 6 bars de presión absoluta si la respuesta en cuanto a signos y síntomas no es buena. Los experimentos en animales indican que una presión absoluta de 2 bares es una presión de tratamiento tan eficaz como una compresión mayor.

\section{Gases}

El gas ideal que debe respirar el paciente durante la recompresión terapéutica tampoco está claramente establecido. Las mezclas de oxígeno y helio pueden ser más eficaces para reducir el tamaño de las burbujas que el aire o el oxígeno al $100 \%$, aunque están actualmente en proceso de investigación. Se considera, a partir de los estudios in vivo, que la $\mathrm{P}_{i} \mathrm{O}_{2}$ ideal es de aproximadamente 2 bares de presión absoluta, aunque en los pacientes con lesiones craneoencefálicas, la tensión ideal es inferior a 1,5 bares absolutos. Asimismo, se desconoce la relación entre la dosis de oxígeno y la inhibición de la acumulación de leucocitos polimorfonucleares provocada por las burbujas.

\section{Asistencia complementaria}

El tratamiento en una cámara de recompresión de un trabajador hiperbárico lesionado no debe interferir con la administración de la asistencia complementaria necesaria, como ventilación, rehidratación y monitorización. Una cámara de recompresión adecuada debe tener una interfaz de trabajo con el equipo utilizado de forma rutinaria en las unidades de cuidados intensivos.

\section{Tratamiento e investigación de seguimiento}

La persistencia de los signos y síntomas y las recaídas de las enfermedades por descompresión son frecuentes, por lo que la mayoría de los trabajadores lesionados necesita varias sesiones de recompresión. No se interrumpirán hasta que la lesión se haya corregido y se mantenga sin cambios, 0 al menos hasta que no se hayan obtenido resultados positivos en dos sesiones sucesivas. La base de la investigación actual es la exploración neurológica clínica detallada (incluido el estado mental), ya que las técnicas existentes de diagnóstico por la imagen o de provocación conllevan una alta tasa de resultados positivos falsos (EEG, exploraciones óseas con radioisótopos, SPECT) o negativos (TC, R M , $P E T$, respuestas evocadas). Un año después de un episodio de enfermedad por descompresión, el trabajador debe someterse a una exploración por rayos $X$ para determinar si presenta osteonecrosis disbárica (necrosis aséptica) en los huesos largos.

\section{Resultados}

El resultado del tratamiento de recompresión para las enfermedades por descompresión depende completamente del grupo estudiado. La mayoría de los trabajadores hiperbáricos (por ejemplo, los buzos militares o de las plataformas petrolíferas) responden bien al tratamiento, y los déficits residuales significativos no son frecuentes. En cambio, muchas de las personas que practican el submarinismo recreativo y que deben recibir tratamiento para los trastornos por descompresión muestran peores resultados. Se desconocen las causas de esta diferencia. Las secuelas más comunes de la enfermedad por descompresión son, en orden decreciente de frecuencia: trastornos depresivos, problemas de memoria a corto plazo, síntomas sensoriales como insensibilidad, dificultad para orinar, disfunción sexual y dolores no identificados.

\section{Reincorporación al trabajo hiperbárico}

Afortunadamente, la mayoría de los trabajadores hiperbáricos pueden reintegrarse a su trabajo después de un episodio de enfermedad por descompresión. La incorporación debe retrasarse al menos durante un mes para permitir que las funciones fisiológicas vuelvan a la normalidad y no se recomienda si el trabajador ha sufrido un barotrauma pulmonar o tiene un historial de barotrauma grave o recurrente del oído interno. La reincorporación al trabajo también debe depender de:

- la gravedad de la enfermedad por descompresión en relación con el grado de exposición hiperbárica o estrés de descompresión;

- la respuesta al tratamiento,

- la ausencia de secuelas.

\footnotetext{
Referencias

Bennett, P y D Elliot (dirs.) 1993. The Physiology and $M$ edicine of D iving. Londres: WB Saunders.

Fueredi, GA, DJ Czarnecki, EP K indwall. 1991. M R findings in the brains of compressed-air tunnel workers: Relationship to psychometric results. Am J Neuroradiol 12(1):67-70.

K indwall, EP, PO Edel, HE M elton. 1983. Safe decompression schedules for caisson workers. Final report, National Institute of O ccupational Safety and $\mathrm{H}$ ealth, research grant no. 5R01O H 0094703, 1 de diciembre l.

K indwall, EP. 1994a. H yperbaric M edicine Practice. Flagstaff, A rizona: Best Publishers.

- . 1994b. M edical aspects of commercial diving and compressed-air work. En 0 ccupational M edicine, dirigido por C Zenz. St. Louis: M osby.
}

Richardson, HW, RS M ayo. 1960. Practical T unnel $D$ riving. Nueva Y ork: M CG raw-H ill.

US Bureau of Labor Statistics. 1971. Federal Register. Vol. 36 , no. 75 , parte 2 , subparte $S$, párrafo 1518.803, 17 de abril.

\section{0 tras lecturas recomendadas}

Actas del congreso sobre ingeniería y salud en el trabajo con aire comprimido organizado por el $\mathrm{St}$. Catherine's College, O xford. 1992. British $\mathrm{H}$ ealth and Safety Executive, Birdcage W alk, Londres.

Dutka, AJ. 1990. Therapy for dysbaric central nervous system ischaemia: Adjuncts to recompression. En $D$ iving A ccident $M$ anagement, dirigido por PB Bennet y
RE M oon. Bethesda, M aryland: Undersea and $H$ yperbaric $M$ edical Society.

Edmonds, C, C Lowry, J Pennefather. 1992. Diving and Subaquatic Medicine. Oxford: ButterworhH einemann.

Francis, TJR, DJ Smith. 1991. D escribing Decompression I IIness. Bethesda, M aryland: U ndersea and H yperbaric M edical Society.

Francis, TJR, Dr Gorman. 1993. Pathogenesis of the decompression disorders. En The Physiology and $M$ edicine of Diving, dirigido por PB Bennett y DH Elliot. Londres: WB Saunders.

M oon, RE, DF Gorman. 1993. T reatment of the decompression disorders. En The Physiology and M edicine of Diving, dirigido por PB Bennett y DH Elliot. Londres: WB Saunders. 


\section{PRESION BAROMEIRICA,}

REDUCCION

Director del capítulo

$W$ alter D ümmer

\section{Sumario}

Aclimatación ventilatoria a grandes altitudes

J ohn T. Reeves y J ohn V. W eil ..................... 37.2

Efectos fisiológicos de la reducción de la presión

barométrica

Kenneth I. B erger y W illiam N. R om

A spectos sanitarios asociados al trabajo a

grandes altitudes

J ohn B. W est ...

Prevención de los peligros profesionales a

grandes altitudes

W alter D ümmer .

M edida cautelar: muestreo del aire

Kenneth I. B erger y W illiam N. R om . . 


\section{- ACLIMATACION VENTILATORIA A GRANDES ALTITUDES}

\section{John T. Reeves y John V. Weil}

Cada vez es mayor el número de personas que trabajan a grandes altitudes. La minería, las actividades de algunas instalaciones recreativas, algunos medios de transporte, las nuevas tierras de cultivo y las campañas militares suelen implicar la exposición a grandes altitudes y exigen la actividad física y mental del hombre. Todas estas actividades demandan una mayor cantidad de oxígeno. A hora bien, a medida que se gana altura sobre el nivel del mar, la presión total del aire (presión barométrica, $P_{B}$ ) y el contenido de oxígeno del aire ambiental (parte de la presión total debida al oxígeno, $\mathrm{PO}_{2}$ ) van disminuyendo gradualmente, y con ellos el rendimiento del trabajo. Así pues, son principios que afectan a los lugares de trabajo. Por ejemplo, se ha comprobado que el tiempo necesario para hacer un túnel en Colorado, a $3.300 \mathrm{~m}$ fue un $25 \%$ que el que llevó a hacer una obra equivalente a nivel del mar, y que los efectos de la altitud contribuyeron al retraso. No sólo es mayor la fatiga muscular, sino que la función mental también se deteriora. La memoria, la capacidad de cálculo, la capacidad de decisión y la capacidad de juicio se alteran igualmente. Los científicos que trabajan en el observatorio de $\mathrm{M}$ ona $\mathrm{L}$ oa, en la isla de $\mathrm{H}$ awai, a una altitud superior a $4.000 \mathrm{~m}$ observaron que necesitaban más tiempo para hacer las operaciones de cálculo y de que cometían más equivocaciones que cuando estaban a nivel del mar. Dado que cada vez son mayores el ámbito, la magnitud, la variedad y la distribución de la actividad humana en el planeta, cada vez lo es también el número de personas que trabajan a grandes altitudes y, por tanto, los efectos de la altitud son hoy un aspecto de la salud en el trabajo.

Un factor decisivo en el rendimiento profesional a gran altitud es el mantenimiento del aporte de oxígeno a los tejidos. El ser humano (y otros animales) tiene defensas contra los estados de baja concentración de oxígeno (hipoxia). Entre ellas, destaca el aumento de la frecuencia respiratoria (ventilación), que comienza cuando la presión de oxígeno en la sangre arterial $\left(\mathrm{PaO}_{2}\right)$ disminuye (hipoxemia) y que se encuentra a todas las altitudes superiores al nivel del mar, se incrementa progresivamente al aumentar la altitud y es nuestro mecanismo de defensa más eficaz contra los bajos niveles de oxígeno en el medio ambiente. EI proceso por el que aumenta la respiración a grandes altitudes se llama aclimatación ventilatoria. Su importancia queda clara en la Figura 37.1, donde se aprecia una mayor concentración de oxígeno en la sangre arterial de las personas aclimatadas que en las no aclimatadas. Además, la importancia de la aclimatación en el mantenimiento de la presión arterial de oxígeno aumenta gradualmente al hacerlo la altitud. U na persona no aclimatada tiene pocas probabilidades de sobrevivir a altitudes superiores a $6.000 \mathrm{~m}$, mientras que los al pinistas aclimatados pueden llegar a la cumbre del Everest $(8.848 \mathrm{~m})$ sin suministro alguno de oxígeno.

\section{Mecanismo}

El estímulo del aumento de la ventilación a grandes altitudes nace, de forma casi exclusiva, en el tejido que controla la presión de oxígeno en la sangre arterial y que se halla en un órgano llamado cuerpo carotídeo, del tamaño aproximado de una cabeza de alfiler y situado en dos ramas minúsculas de las arterias carótidas, a la altura del ángulo de la mandíbula. Cuando la presión de oxígeno en la sangre arterial disminuye, estas células, similares a las neuronas (las células quimiorreceptoras), del cuerpo carotídeo registran el descenso y aumentan el ritmo de transmisión de sus impulsos a lo largo del IX par craneal, que los lleva directamente al centro de control respiratorio, situado en el tronco del encéfalo. Cuando dicho centro recibe un número mayor de impulsos, se activa y estimula el aumento de la frecuencia y profundidad de la respiración mediante una serie de vías nerviosas complejas, que actúan sobre el diafragma y los

Figura 37.1 - Aclimatación ventilatoria.
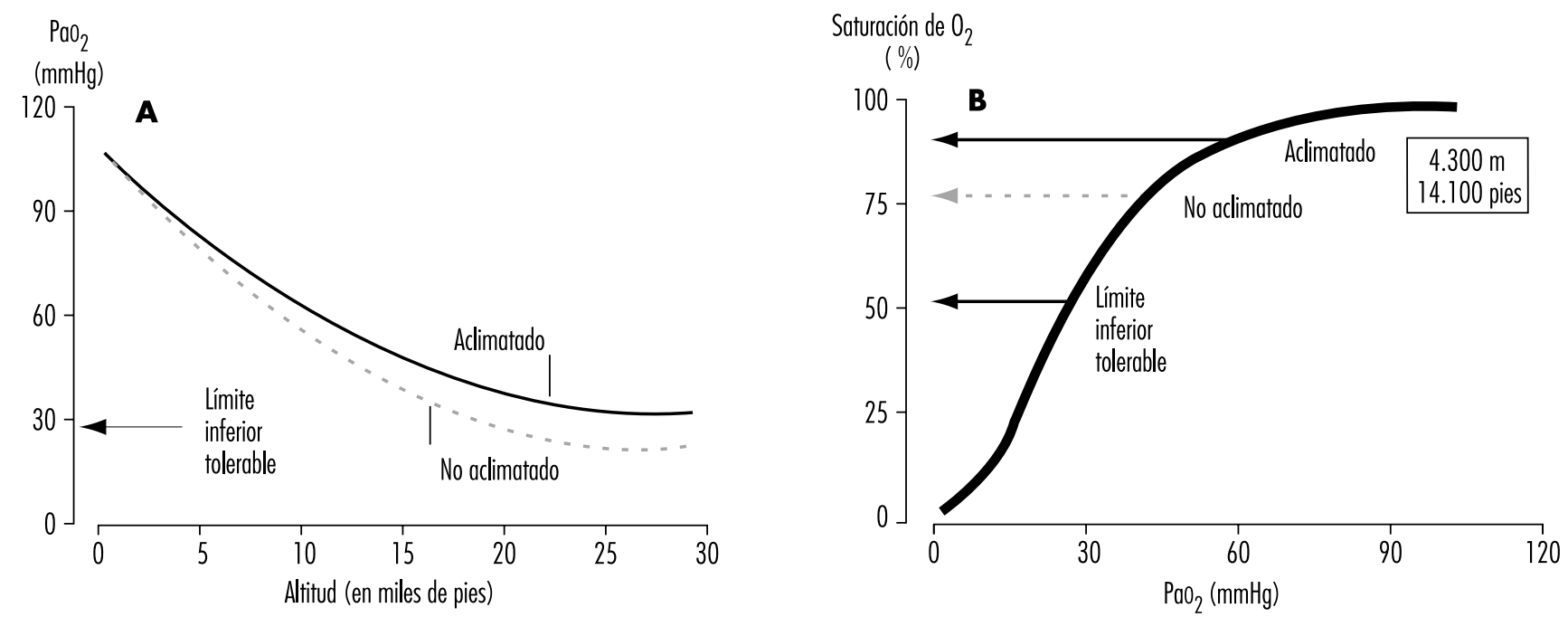

La presión arterial de oxígeno ( $\mathrm{PaO}_{2}$ ) desciende al aumentar la altitud, pero sus valores son mayores en los sujetos aclimatados que en los no aclimatados (Panel A) Cuando la PaO desciende por debajo de $60 \mathrm{mmHg}$, la capacidad de la hemoglobina para transportar oxígeno ( $\mathrm{O}_{2}$ por \% de saturación) se reduce de forma brusca. Por tanto, en términos de transporte de oxígeno sanguíneo, la aclimatación se hace cada vez más importante a medida que aumenta la altitud. (Panel B) 
Figura 37.2 - Sucesión de acontecimientos durante la aclimatación.

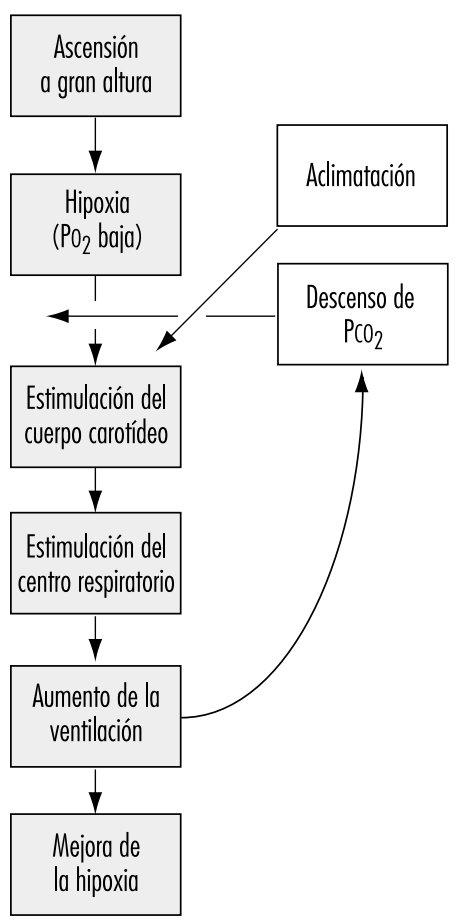

músculos de la pared del tórax. El resultado es un aumento del aire ventilado por los pulmones, como se indica en la Figura 37.2, lo que trae consigo un ascenso de la presión de oxígeno. Cuando una persona respira oxígeno o aire enriquecido con oxígeno, se produce el fenómeno contrario, de forma que las células quimiorreceptoras reducen su ritmo de activación, el número de impulsos que llegan al centro respiratorio desciende y la respiración disminuye. Estos diminutos órganos situados a ambos lados del cuello son muy sensibles a los pequeños cambios de la presión de oxígeno en la sangre y son prácticamente los responsables del mantenimiento del nivel de oxígeno del organismo, pues cuando ambos están dañados o son extirpados, no se produce incremento alguno de la ventilación cuando desciende la presión de oxígeno en la sangre. Así pues, uno de los factores más importantes en el control de la respiración es la presión arterial de oxígeno; el descenso del nivel de oxígeno en el aire conlleva un aumento de la respiración, mientras que su elevación induce la reducción de aquella. En ambos casos, el resultado es el esfuerzo del organismo por mantener constantes los niveles de la presión de oxígeno en la sangre.

\section{Evolución (factores que se oponen al aumento de la ventilación a grandes altitudes)}

La producción constante de energía requiere oxígeno, y cuando el aporte de éste a los tejidos disminuye (hipoxia), la función de los tejidos puede deteriorarse. El órgano más sensible a la falta de oxigenación es el cerebro y, como ya se ha indicado, los centros neuronales del sistema nervioso central son decisivos en el control de la respiración. Cuando respiramos una mezcla con bajo contenido en oxígeno, la respuesta inicial es un aumento de la ventilación, pero al cabo de unos 10 minutos, el incremento se amortigua hasta cierto punto. Si bien no se conoce la causa de este fenómeno, se ha atribuido a la depresión de alguna función nerviosa central relacionada con la vía de la respiración, y se ha denominado depresión ventilatoria hipóxica. Se ha observado su aparición poco después de ascender a grandes altitudes, aunque suele ser transitoria: que sólo dura varias horas, posiblemente para que se adapten los tejidos del sistema nervioso central.

No obstante, inmediatamente después del ascenso a una gran altura suele aumentar la ventilación, aunque debe transcurrir cierto tiempo para que alcance su máximo valor. Al llegar a una determinada altitud, la mayor actividad de los centros carotídeos hace que la ventilación aumente $y$, de este modo, se eleva la presión de oxígeno en la sangre arterial hasta el valor que tenía a nivel del mar. Ahora bien, los cuerpos carotídeos se hallan ante un dilema: el incremento de la respiración produce mayor excreción de dióxido de carbono (anhídrido carbónico, $\mathrm{CO}_{2}$ ) en el aire espirado. Con la presencia de $\mathrm{CO}_{2}$ en los tejidos del cuerpo se crea acidez en los medios acuosos, y con su ausencia (mediante la expiración), los líquidos orgánicos, incluida la sangre, se hacen más alcalinos, lo que altera el equilibrio ácido-base del organismo. El dilema se plantea porque la ventilación se controla no sólo para mantener constante la presión de oxígeno, sino también para conservar dicho equilibrio. EI $\mathrm{CO}_{2}$ regula la respiración en sentido opuesto al oxígeno. Así, cuando la presión de $\mathrm{CO}_{2}$ (es decir, el grado de acidez existente en algún lugar del interior del centro respiratorio) aumenta, la ventilación también lo hace; y cuando aquél disminuye, la ventilación disminuye también. Al llegar a una altitud elevada, cualquier incremento de la ventilación producido por el bajo contenido de oxígeno en el aire respirado inducirá una disminución de la presión de $\mathrm{CO}_{2}$, que origina alcalosis, y se opone a la ventilación (Figura 37.2). Ásí pues, el dilema para el organismo está en no poder mantener constantes a la vez la presión de oxígeno y el equilibrio ácido-base. Para restablecerlos, el hombre necesita muchas horas, e incluso días.

Una de las formas de restablecer el equilibrio es la excreción de bicarbonato por el riñón, formando una orina alcalina que compense la pérdida respiratoria de acidez y contribuya a recuperar los niveles propios del nivel del mar. La excreción renal de bicarbonato es un proceso relativamente lento. Por ejemplo, al pasar desde el nivel del mar a $4.300 \mathrm{~m}$ ), se requiere un período de aclimatación de entre siete y diez días (Figura 37.3). Esta acción de los riñones, que reduce la inhibición alcalina de la ventilación, solía considerarse la razón principal del lento aumento de la ventilación tras el ascenso, pero las investigaciones más recientes consideran decisivo el incremento gradual de la sensibilidad del cuerpo carotídeo para medir la hipoxia durante las horas o los días que siguen al ascenso. Es un período que se conoce como aclimatación ventilatoria, por el cual la ventilación aumenta como respuesta al descenso de la presión de oxígeno en la sangre, aunque también disminuye la presión de $\mathrm{CO}_{2}$. Como consecuencia del aumento de la ventilación y de la disminución de la presión de $\mathrm{CO}_{2}$, se produce una elevación simultánea de la presión de oxígeno en los alveolos pulmonares y en la sangre arterial.

Dado que, al llegar a una cierta altitud, puede originarse una depresión ventilatoria hipóxica transitoria y dado que la aclimatación es un proceso lento que comienza cuando la persona se halla en un ambiente con bajo contenido de oxígeno en el aire, la presión arterial de oxígeno mínima se alcanza inmediatamente después de la Ilegada. Luego, asciende con relativa rapidez durante los primeros días y más despacio los siguientes, como se muestra en la Figura 37.3. La hipoxia es, pues, más intensa al principio, por lo que la somnolencia y los síntomas asociados a la exposición a las grande altitudes son también peores durante las primeras horas o días. Con la aclimatación suele recuperarse la sensación de bienestar.

El tiempo necesario para que se produzca la aclimatación aumenta al hacerlo la altitud, según el principio de a mayores 

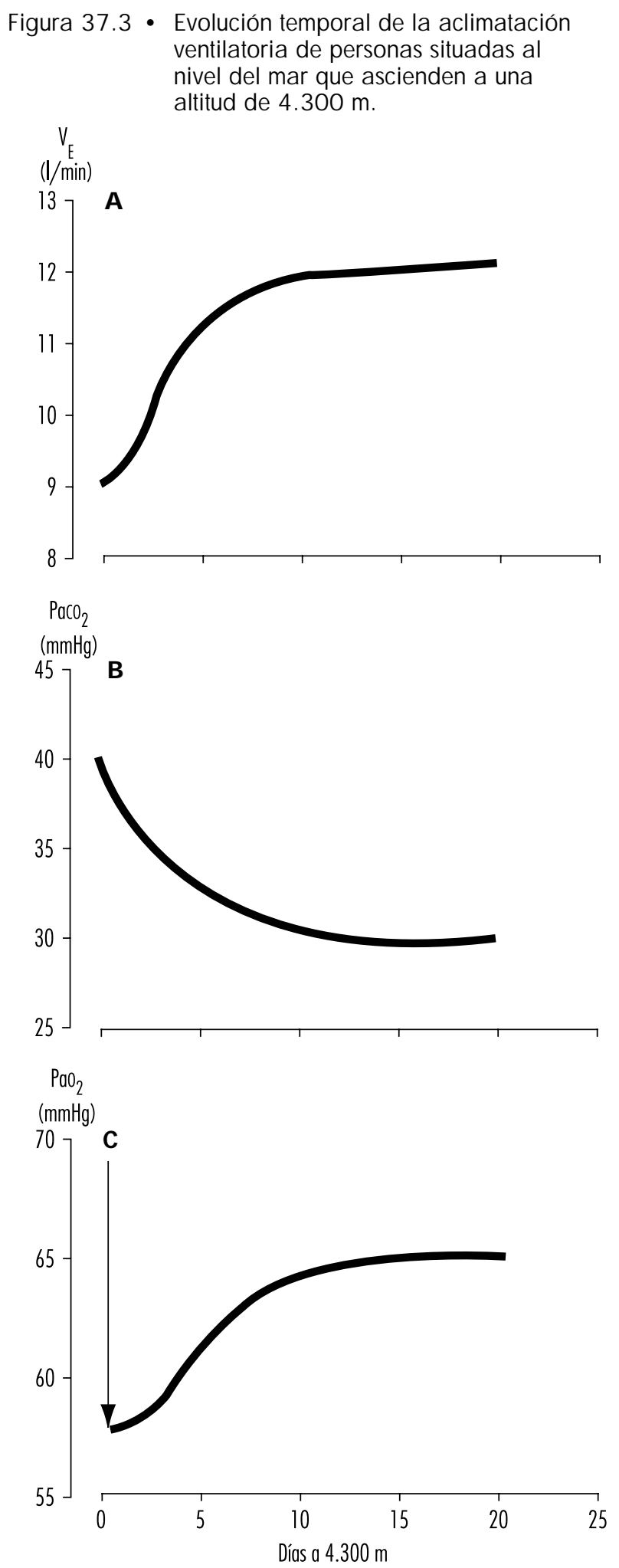

Aumento de la ventilación ( $\mathrm{V}_{\mathrm{E}}$, panel $\mathrm{A}$, disminución de la $\mathrm{PCO}$ alveolar) $\left[\mathrm{PaCO}_{2}\right.$ Panel $\mathrm{B}$ y aumento de la $\mathrm{PO}_{2}$ alveolar ( $\mathrm{PaO}$, panel $\mathrm{C}$ )]. (Las presiones de $\mathrm{O}_{2} \mathrm{y}^{2}$ $\mathrm{CO}_{2}$ en los alveolos pulmonares se hallan muy próximas a las de la sangre arterial y a menudo se emplean para efectuar mediciones no agresivas). incrementos de la ventilación y de los ajustes del equilibrio ácido-base, mayores serán los intervalos necesarios para que tenga lugar la compensación renal. A sí, un nativo de una zona situada a nivel del mar necesitará de tres a cinco días para aclimatarse a $3.000 \mathrm{~m}$, mientras que a altitudes superiores a $6.000 \mathrm{y}$ $8.000 \mathrm{~m}$, exigirá, si es que la logra, seis semanas o más (Figura 37.4). Cuando la persona aclimatada vuelve al nivel del mar, el proceso se invierte: la presión arterial de oxígeno se eleva hasta el valor del nivel del mar y la ventilación disminuye; el contenido de $\mathrm{CO}_{2}$ del aire espirado desciende y la presión de $\mathrm{CO}_{2}$ de la sangre y del centro respiratorio aumenta; el equilibrio ácido-base se desplaza hacia la acidez y los riñones deben conservar el bicarbonato para mantenerlo. Aunque el tiempo necesario para perder la aclimatación no se conoce a fondo, parece ser similar al período de aclimatación. Si así fuera, al regresar desde una gran altura se producirían, teóricamente, los fenómenos opuestos a los que tienen lugar durante la ascensión, aunque con una excepción importante: al bajar, las presiones arteriales de oxígeno se normalizan de inmediato.

\section{Variabilidad en función de las personas}

Naturalmente el tiempo necesario para lograr la aclimatación ventilatoria, y la magnitud de ésta, varía de unas personas a otras a una altitud dada y a la magnitud de la propia aclimatación conseguida. U na de las razones más importantes es la gran variación que existe entre los individuos en su respuesta a la hipoxia. Por ejemplo, si se mantiene constante la presión de $\mathrm{CO}_{2}$, a nivel del mar, de forma que no influya en la respuesta ventilatoria a las

\section{Figura 37.4 - En las personas que residen al nivel del mar, el tiempo necesario para lograr la aclimatación ventilatoria completa aumenta con la ascensión a altitudes gradualmente mayores.}

Días hasta la aclimatación completa

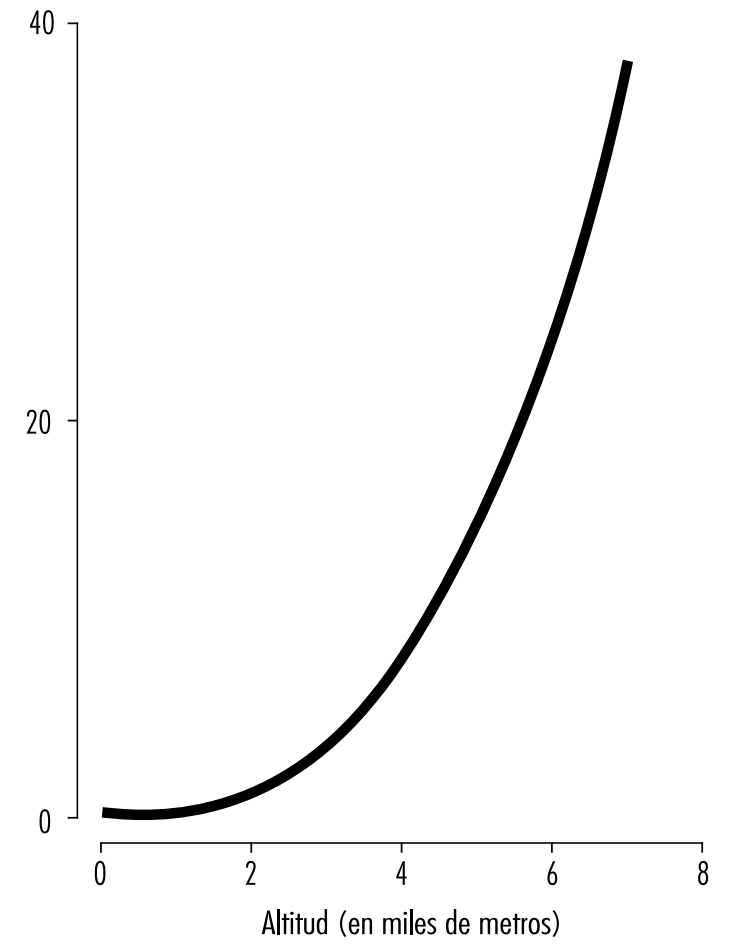


bajas concentraciones de oxígeno, en algunas personas normales el incremento de la ventilación es escaso o nulo, mientras que en otras se eleva, hasta quintuplicarse en algunos casos. La respuesta ventilatoria a las mezclas bajas en oxígeno parece ser una característica intrínseca del individuo, puesto que los comportamientos son más parecidos entre los miembros de una misma familia. Las personas que apenas responden al descenso de la concentración de oxígeno a nivel del mar parecen tener, como es de esperar, menores respuestas ventilatorias a las grandes altitudes a lo largo del tiempo. L as variaciones de la aclimatación dependen también de otros factores, como la variabilidad de la magnitud de la depresión respiratoria, de la función del centro respiratorio, de la sensibilidad a los cambios del equilibrio ácido-base y de la capacidad renal para excretar bicarbonato, pero ninguno de ellos ha sido estudiado a fondo.

\section{El sueño}

La mala calidad del sueño, en particular antes de haberse completado la aclimatación ventilatoria, aparte de ser frecuente, es un factor que puede afectar al rendimiento profesional. La respiración se ve alterada por circunstancias como el estado emocional, la actividad física, la ingestión de alimentos y el estado de alerta. Durante el sueño la ventilación disminuye y la capacidad respiratoria para responder a los bajos niveles de oxígeno, y a los altos de $\mathrm{CO}_{2}$. Asimismo, descienden la frecuencia y la profundidad de la respiración. Además, a grandes altitudes, donde el aire atmosférico contiene menos moléculas de oxígeno, la cantidad que de éste almacenan los alveolos pulmonares entre dos respiraciones es menor. Así pues, si la respiración se interrumpe durante algunos segundos (fenómeno llamado apnea, frecuente a grandes altitudes), la presión de oxígeno arterial disminuirá con mayor rapidez que a nivel del mar donde, en esencia, la reserva de oxígeno es mayor.

La interrupción periódica de la respiración durante las primeras noches que siguen al ascenso a una gran altura es un fenómeno casi universal y refleja el dilema respiratorio de la altitud descrito anteriormente, al trabajar de forma cíclica: la estimulación hipóxica incrementa la ventilación que, a su vez, reduce las concentraciones de dióxido de carbono, inhibe la respiración e incrementa la estimulación hipóxica, con lo que vuelve a estimularse la ventilación. Por lo común, el sujeto experimenta un período de apnea de 15 a 30 segundos, seguido de varias respiraciones profundas, que a menudo lo despiertan durante unos instantes y de una nueva pausa de apnea. La presión arterial de oxígeno desciende a veces en los períodos de apnea hasta niveles alarmantes. Debido a las repetidas ocasiones en que el sujeto se despierta, la calidad del sueño es deficiente, por lo que, aunque el tiempo total de sueño haya sido el normal, la persona se levanta con la sensación de haber pasado una noche inquieta 0 de no haber dormido. La administración de oxígeno elimina el ciclo de estimulación hipóxica y la inhibición alcalina anula la respiración periódica y restablece el sueño normal.

Los varones de edad madura, sobre todo, corren también el riesgo de sufrir apnea por otro motivo: la obstrucción intermitente de las vías respiratorias altas, que es la causa habitual de los ronquidos. Al nivel del mar, esta obstrucción en la parte posterior de las fosas nasales sólo origina un ruido molesto, pero a grandes altitudes, donde la reserva pulmonar de oxígeno es menor, puede provocar descensos importantes de la presión arterial de oxígeno y mala calidad del sueño.

\section{Exposición intermitente}

Existen situaciones de trabajo, especialmente en la cordillera de los Andes, en América del Sur, que obligan al trabajador a pasar varios días a altitudes superiores a $3.00004 .000 \mathrm{~m}$, y a pasar después varios días en su casa, a nivel del mar. Los horarios de trabajo (número de días a gran altitud, p. ej., de 4 a 14, y número de días a nivel del mar, p. ej., de 3 a 7) dependen de la situación económica del lugar de trabajo, más que de aspectos relacionados con la salud. Sin embargo, dentro de los factores económicos deberían considerarse los intervalos necesarios para lograr la aclimatación y para perderla. $\mathrm{H}$ a de prestarse una atención especial al bienestar del trabajador y su rendimiento laboral al llegar y durante uno o dos días después, valorando la fatiga, el tiempo necesario para llevar a cabo tareas rutinarias y no rutinarias y los errores cometidos. También deberían elaborarse estrategias para reducir al mínimo el tiempo necesario para la aclimatación y para mejorar el rendimiento durante las horas de vigilia.

\section{EFECTOS FISIOLOGICOS DE LA REDUCCION DE LA PRESION BAROMETRICA}

\section{Kenneth I. Berger y William N. Rom}

Los efectos más importantes de las grandes altitudes en el ser humano dependen de los cambios de la presión barométrica $\left(P_{B}\right)$ y de los cambios que ésta provoca en la presión de oxígeno del aire ambiental $\left(\mathrm{O}_{2}\right)$. La presión barométrica disminuye de forma logarítmica al aumentar la altitud, y puede calcularse mediante la ecuación siguiente:

$$
P_{B}=760\left(e^{-a / 7924}\right)
$$

donde $\mathrm{a}=$ altitud, expresada en metros. Además, la relación entre presión barométrica y altitud depende también de otros factores, como la distancia desde el Ecuador y la estación del año. West y Lahiri (1984) observaron que la medición directa de la presión barométrica cerca del Ecuador y en la cumbre del Everest $(8.848 \mathrm{~m})$ daba valores superiores a los calculados a partir de la atmósfera patrón de la O rganización de Aviación Civil Internacional $(\mathrm{OACl})$. El clima y la temperatura también influyen en la relación, puesto que un sistema meteorológico de bajas presiones puede reducir la presión y hacer que los que suben a una altitud dada estén "fisiológicamente más altos". Puesto que la presión parcial del oxígeno inspirado $\left(\mathrm{PO}_{2}\right)$ permanece constante al 20,93\% aproximadamente de la presión barométrica, el determinante más importante de la $\mathrm{PO}_{2}$ inspirada será, a cualquier altitud, la presión barométrica. En consecuencia, al disminuir ésta con la altitud, también lo hace el oxígeno inspirado, como se muestra en la Figura 37.5.

L a temperatura y la radiación ultravioleta también varían con la altitud. La primera disminuye con la altura, a un ritmo aproximado de $6,5^{\circ} \mathrm{C}$ por cada $1.000 \mathrm{~m}$. La segunda aumenta un $4 \%$ por cada $300 \mathrm{~m}$ a causa del menor espesor de la capa de nubes, del polvo y del vapor de agua. Además, la nieve puede reflejar hasta un $75 \%$ de la radiación ultravioleta, incrementando así la exposición en las grandes alturas. La supervivencia en grandes altitudes depende de la adaptación a cada uno de estos factores y de las medidas de protección contra ellos.

\section{Aclimatación}

Si bien el ascenso rápido a grandes altitudes suele provocar la muerte, los montañeros pueden ascender lentamente y sin problemas siempre que adopten medidas compensadoras de adaptación fisiológica. La aclimatación a grandes altitudes se basa en el mantenimiento de un aporte de oxígeno suficiente para cubrir las demandas metabólicas, pese al descenso de la $\mathrm{O}_{2}$ inspirada. Para lograr este objetivo, deben adaptarse todos los 


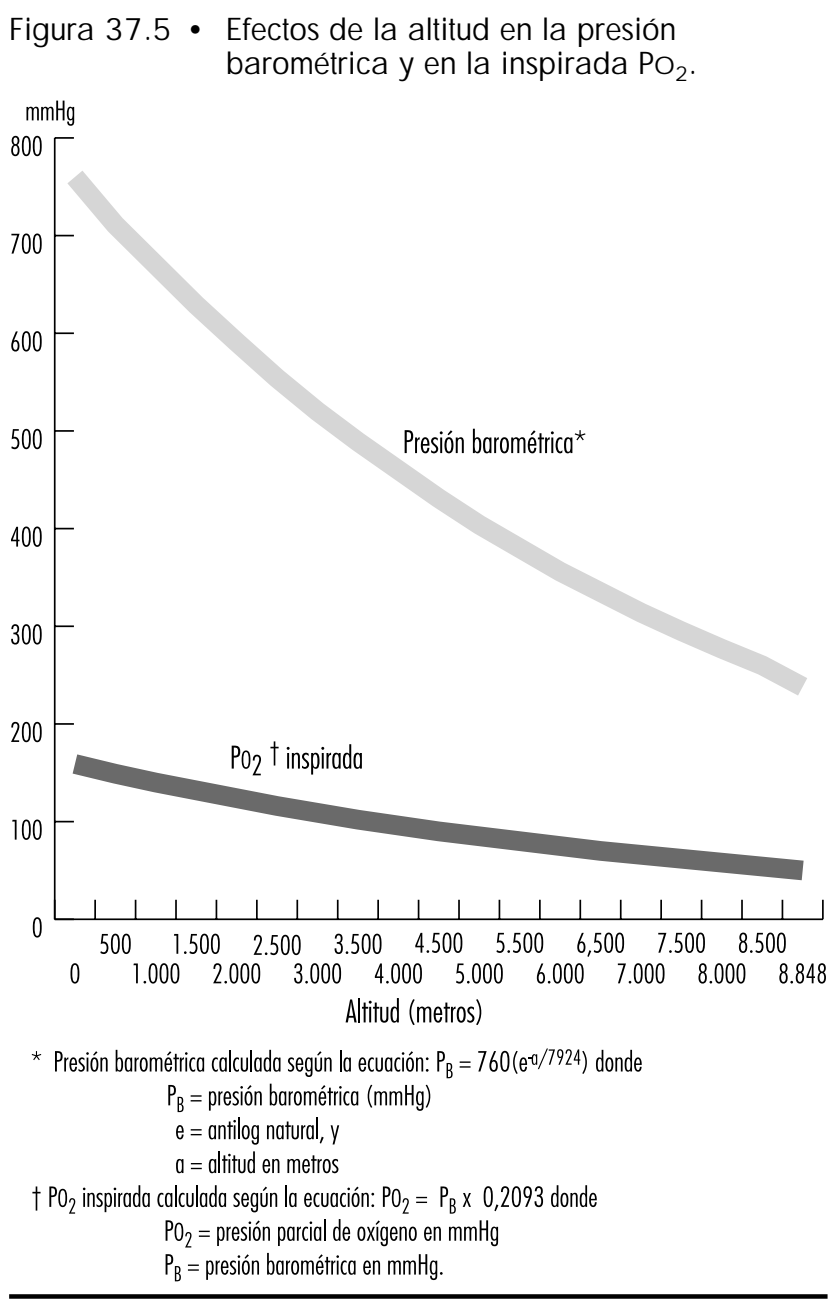

sistemas orgánicos del cuerpo relacionados con la captación de oxígeno, con su distribución a determinados órganos y con su liberación a los tejidos. A ntes de hablar de la captación y distribución del oxígeno es preciso conocer qué determina su contenido en la sangre. Cuando el aire penetra en el alveolo, la $\mathrm{PO}_{2}$ inspirada desciende hasta un nuevo nivel (denominado $\mathrm{Po}_{2}$ alveolar), a causa de dos factores: la mayor presión parcial del vapor de agua producida por la humidificación del aire inspirado y la mayor presión parcial del dióxido de carbono $\left(\mathrm{PCO}_{2}\right)$ debida a su excreción. Desde el alveolo, el oxígeno se difunde hacia la sangre a través de la membrana alveolocapilar gracias al gradiente existente entre la $\mathrm{PO}_{2}$ alveolar y la $\mathrm{PO}_{2}$ sanguínea. La mayor parte del oxígeno presente en la sangre se halla unido a la hemoglobina (oxihemoglobina), por lo que el contenido de oxígeno de la sangre depende directamente de la concentración de hemoglobina y del porcentaje de lugares de unión al $\mathrm{O}_{2}$ de ésta que se hallen saturados con oxígeno (saturación de la oxihemoglobina). Así pues, hay que entender la relación que existe entre la $\mathrm{PO}_{2}$ arterial y la saturación de la oxihemoglobina para poder comprender los factores que determinan el contenido de oxígeno en la sangre. En la Figura 37.6 se muestra una curva de disociación de la oxihemoglobina. Al aumentar la altitud, la $\mathrm{PO}_{2}$ inspirada disminuye y, por tanto, también lo hacen la $\mathrm{PO}_{2}$ arterial y la saturación de la oxihemoglobina. En sujetos normales, las altitudes superiores a $3.000 \mathrm{~m}$ van ligadas a una $\mathrm{PO}_{2}$ arterial tan baja, que la saturación de la oxihemoglobina desciende a menos de $90 \%$, (zona superior de la curva de disociación). Si la altitud aumenta aún más y se carece de mecanismos compensadores, es de esperar que la desaturación sea aún mayor.

Las adaptaciones de la ventilación que se producen a grandes altitudes protegen la presión parcial de oxígeno arterial contra los efectos de la disminución de las concentraciones de oxígeno en al aire ambiental y pueden dividirse en cambios agudos, subagudos y crónicos. El ascenso rápido a una gran altitud provoca un descenso de la $\mathrm{PO}_{2}$ inspirada que, a su vez, reduce la $\mathrm{PO}_{2}$ arterial (hipoxia). Para minimizar los efectos de la $\mathrm{PO}_{2}$ inspirada en la saturación de la oxihemoglobina arterial, la hipoxia de las grandes altitudes origina un aumento de la ventilación mediado por el cuerpo carotídeo (respuesta ventilatoria hipóxica, RVH). La hiperventilación incrementa la excreción de dióxido de carbono, a lo que sigue una disminución de la presión parcial de éste $\left(\mathrm{PCO}_{2}\right)$, primero en la sangre arterial y luego en los alveolos. La disminución de la $\mathrm{PCO}_{2}$ alveolar permite el ascenso de la $\mathrm{PO}_{2}$ alveolar $y$, por consiguiente, el aumento de la $\mathrm{PO}_{2}$ y del contenido de $\mathrm{O}_{2}$ arteriales. A hora bien, la mayor excreción de dióxido de carbono origina un descenso de la concentración de iones hidrógeno de la sangre $\left(\left[\mathrm{H}^{+}\right]\right)$, que trae consigo el desarrollo de alcalosis. Esta alcalosis inhibe la respuesta ventilatoria hipóxica. Así pues, el ascenso brusco a grandes altitudes provoca un incremento abrupto de la ventilación que está modulado por el desarrollo de alcalosis en la sangre.

Con la estancia durante varios días a gran altitud se producen nuevos cambios de la ventilación, conocidos habitualmente como aclimatación ventilatoria. La ventilación sigue aumentando a lo largo de varias semanas, a medida que el riñón compensa la alcalosis aguda mediante la excreción de iones bicarbonato, con el consiguiente aumento de $\left[\mathrm{H}^{+}\right]$en la sangre. Solía creerse que la compensación renal de la alcalosis hacía desaparecer la influencia inhibitoria de ésta en la respuesta ventilatoria hipóxica (RVH), que alcanzaba toda su plenitud. Sin embargo, las mediciones del $\mathrm{pH}$ sanguíneo han revelado que la alcalosis persiste pese al incremento de la ventilación. 0 tros

Figura 37.6 • Curva de disociación de la oxihemoglobina.

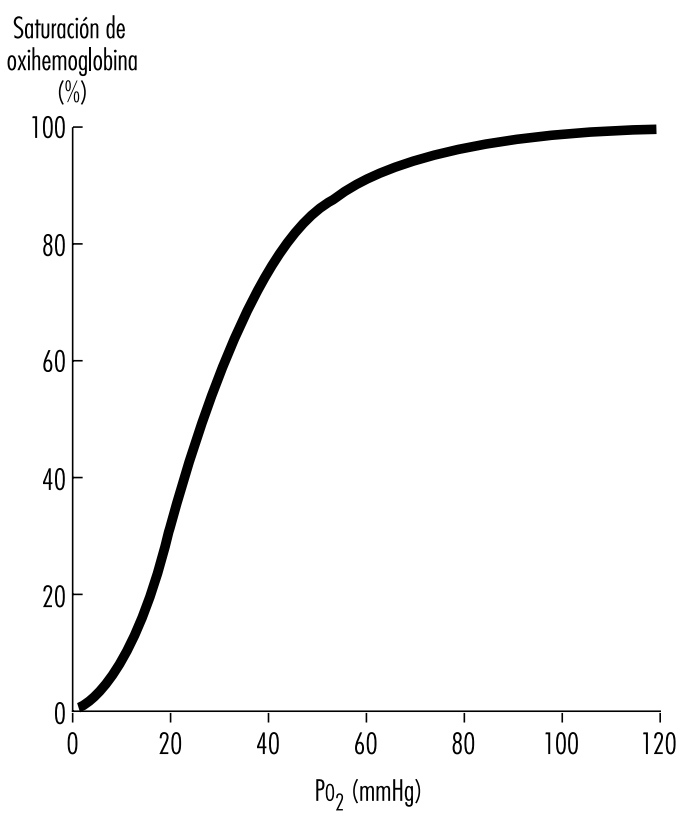

$\mathrm{PO}_{2}=$ presión parcial arterial de oxígeno. 
mecanismos propuestos son: (1) el retorno a la normalidad del $\mathrm{pH}$ del líquido cefalorraquídeo que rodea al centro de control respiratorio en el bulbo raquídeo, pese a la persistencia de la alcalosis sérica; (2) un aumento de la sensibilidad del cuerpo carotídeo a la hipoxia; (3) una mayor respuesta del centro de control respiratorio al $\mathrm{CO}_{2}$. U na vez lograda la aclimatación ventilatoria, la hiperventilación y la mayor RVH persisten durante algunos días después del regreso a altitudes más bajas, pese a la ausencia de hipoxia.

Con la residencia durante años a grandes altitudes tienen lugar nuevos cambios. Las mediciones efectuadas en nativos de estas regiones muestran una menor $\mathrm{RVH}$, en comparación con la de las personas aclimatadas, aunque no hasta los niveles observados en los que viven a nivel del mar. El mecanismo de esta menor RVH se desconoce, pero podría estar relacionado con una hipertrofia del cuerpo carotídeo y con el desarrollo de otros métodos de adaptación para conservar la oxigenación tisular, como un aumento de la densidad capilar, una mayor capacidad para el intercambio gaseoso en los tejidos, un mayor número y densidad de las mitocondrias, o un incremento de la capacidad vital.

A demás de su efecto en la ventilación, la hipoxia induce vasoconstricción del músculo liso vascular de las arterias pulmonares (vasoconstricción hipóxica). El consiguiente incremento de la resistencia vascular pulmonar y de la presión de las arterias pulmonares dirige la sangre de nuevo hacia los alveolos mejor ventilados, alejándola de los que tienen bajas $\mathrm{PO}_{2}$. De este modo, la perfusión arterial pulmonar se acopla a las unidades pulmonares mejor ventiladas y proporciona otro mecanismo para la conservación de la $\mathrm{PO}_{2}$ arterial.

A demás, un conjunto de adaptaciones del aparato cardiovascular y del sistema hematopoyético contribuye a facilitar la liberación de oxígeno a los tejidos. Al comienzo el ascenso a grandes altitudes, la frecuencia cardíaca aumenta, con el consiguiente incremento del gasto cardíaco. A lo largo de varios días, la pérdida de agua que se produce en las grandes alturas hace que el volumen plasmático disminuya, con lo que también lo hace el gasto cardíaco. Tras un nuevo intervalo, aumenta la producción de eritropoyetina, con lo que aumenta asimismo la concentración de hemoglobina, lo que permite a la sangre transportar más oxígeno. Junto a los mayores niveles de hemoglobina se produce un cambio en la avidez de ésta por unirse al oxígeno, lo que posiblemente contribuya a mantener la oxigenación tisular. Sería de esperar que se produjera un desplazamiento de la curva de disociación de la oxihemoglobina hacia la derecha, pues ello favorecería la liberación de oxígeno a los tejidos. Sin embargo, los datos obtenidos en la cumbre del Everest y en los experimentos de cámara hipobárica que simulan las condiciones de aquélla (West y Lahiri 1984, West y Wagner 1980, West y cols. 1983) indican que la curva se desplaza hacia la izquierda. Aunque este desplazamiento dificultaría el paso de oxígeno a los tejidos, podría resultar muy ventajoso en altitudes extremas, pues mejoraría la captación de oxígeno por los pulmones pese a la gran disminución de la $\mathrm{PO}_{2}$ inspirada $(43 \mathrm{mmHg}$ en la cumbre del Everest, en comparación con $149 \mathrm{mmHg}$ a nivel del mar).

El último eslabón de la cadena de aporte de oxígeno a los tejidos es la captación y utilización celular del $\mathrm{O}_{2}$. En teoría, pueden producirse dos adaptaciones. En primer lugar, la minimización del recorrido del oxígeno disuelto en la sangre desde el vaso sanguíneo hasta el lugar intracelular responsable del metabolismo oxidativo, las mitocondrias. En segundo lugar, puede haber alteraciones bioquímicas que mejoren la función mitocondrial. El primer mecanismo lo han propuesto varios estudios tras comprobar el aumento de la densidad capilar o del número de mitocondrias en el tejido muscular. Se ignora si estos cambios reflejan un reclutamiento 0 un desarrollo de nuevos capilares y mitocondrias, o si son un artefacto debido a la atrofia muscular. En cualquier caso, la distancia entre los capilares y las mitocondrias disminuiría, lo que facilitaría la difusión del oxígeno. Entre las modificaciones bioquímicas que podrían mejorar la función mitocondrial se encuentra la elevación de las concentraciones de mioglobina. Se trata de una proteína intracelular que se une al oxígeno con bajas $\mathrm{PO}_{2}$ tisulares y que facilita su difusión hacia las mitocondrias. La concentración de mioglobina aumenta con el entrenamiento atlético y guarda correlación con la capacidad aerobia de la fibras musculares. Aunque estas adaptaciones son beneficiosas en teoría, no se han logrado pruebas concluyentes.

L os primeros informes de los exploradores de las grandes altitudes refieren cambios de la función cerebral: disminución de la capacidad motora, sensitiva y cognoscitiva, con disminución de la habilidad para aprender nuevas tareas y dificultad para expresar informaciones verbalmente. Son deficiencias que pueden alterar la capacidad de juicio y provocar irritabilidad, lo que complica aún más los problemas propios de las grandes altitudes. Al volver al nivel del mar, estas alteraciones mejoran a lo largo de intervalos variables de tiempo; varios informes indican que la afectación de la memoria y de la capacidad de concentración persiste durante días o meses, y la menor capacidad de tabaleo se mantiene durante un año (H ornbein y cols. 1989). L as personas con mayor RVH son las más propensas a sufrir déficit prolongados, posiblemente porque el efecto beneficioso de la hiperventilación en la saturación de la oxihemoglobina arterial resulta contrarrestado por la hipocapnia (descenso de la $\mathrm{PCO}_{2}$ de la sangre), que provoca vasoconstricción de los vasos sanguíneos cerebrales y la consiguiente disminución del flujo sanguíneo cerebral.

En la exposición precedente se han descrito sólo los fenómenos que tienen lugar en condiciones de reposo. El ejercicio, que incrementa la demanda y el consumo de oxígeno, impone un esfuerzo adicional. $L a$ reducción del oxígeno del aire ambiental a grandes altitudes provoca un descenso de la captación máxima de oxígeno y, por tanto, reduce el ejercicio máximo. A demás, la menor $\mathrm{Po}_{2}$ inspirada afecta gravemente a la difusión del oxígeno en la sangre, como se demuestra en la Figura 37.7, que refleja la evolución de la difusión del oxígeno hacia los capilares alveolares. A nivel del mar, hay un exceso de tiempo para alcanzar el equilibrio entre la $\mathrm{PO}_{2}$ capilar terminal y la $\mathrm{PO}_{2}$ alveolar, mientras que en la cumbre del Everest, este equilibrio no llega a alcanzarse. La diferencia se debe a la menor concentración de oxígeno en el aire ambiental en las grandes altitudes, que conlleva una disminución del gradiente de difusión entre las $\mathrm{PO}_{2}$ alveolar y venosa. Con el ejercicio, el gasto cardíaco y el flujo sanguíneo aumentan, por lo que el tiempo de tránsito de los eritrocitos a través del capilar alveolar se reduce, contribuyendo a exacerbar el problema. Tras esta exposición, resulta evidente que el desplazamiento hacia la izquierda del $\mathrm{O}_{2}$ y de la curva de disociación de la hemoglobina que tienen lugar en las grandes altitudes es una compensación necesaria del menor gradiente de difusión del oxígeno en el alveolo.

$L$ as alteraciones del sueño son frecuentes entre los que viajan a grandes altitudes. La respiración periódica (C heyne-Stokes) es universal y se caracteriza por la alternancia de períodos de respiración rápida y superficial (hiperpnea) con otros sin respiración (apnea), que provocan hipoxia. La respiración periódica se acentúa en las personas más sensibles a la hipoxia, por lo que no afecta tanto a los viajeros con RVH más baja. No obstante, presentan períodos ininterrumpidos de hipoventilación que corresponden a reducciones ininterrumpidas de la saturación de oxihemoglobina. Se cree que el mecanismo de la respiración periódica está relacionado con el aumento de la RVH, que aumenta la ventilación como respuesta a la hipoxia. De hecho, 
Figura 37.7 • Evolución temporal de la tensión de oxígeno en el capilar alveolar.
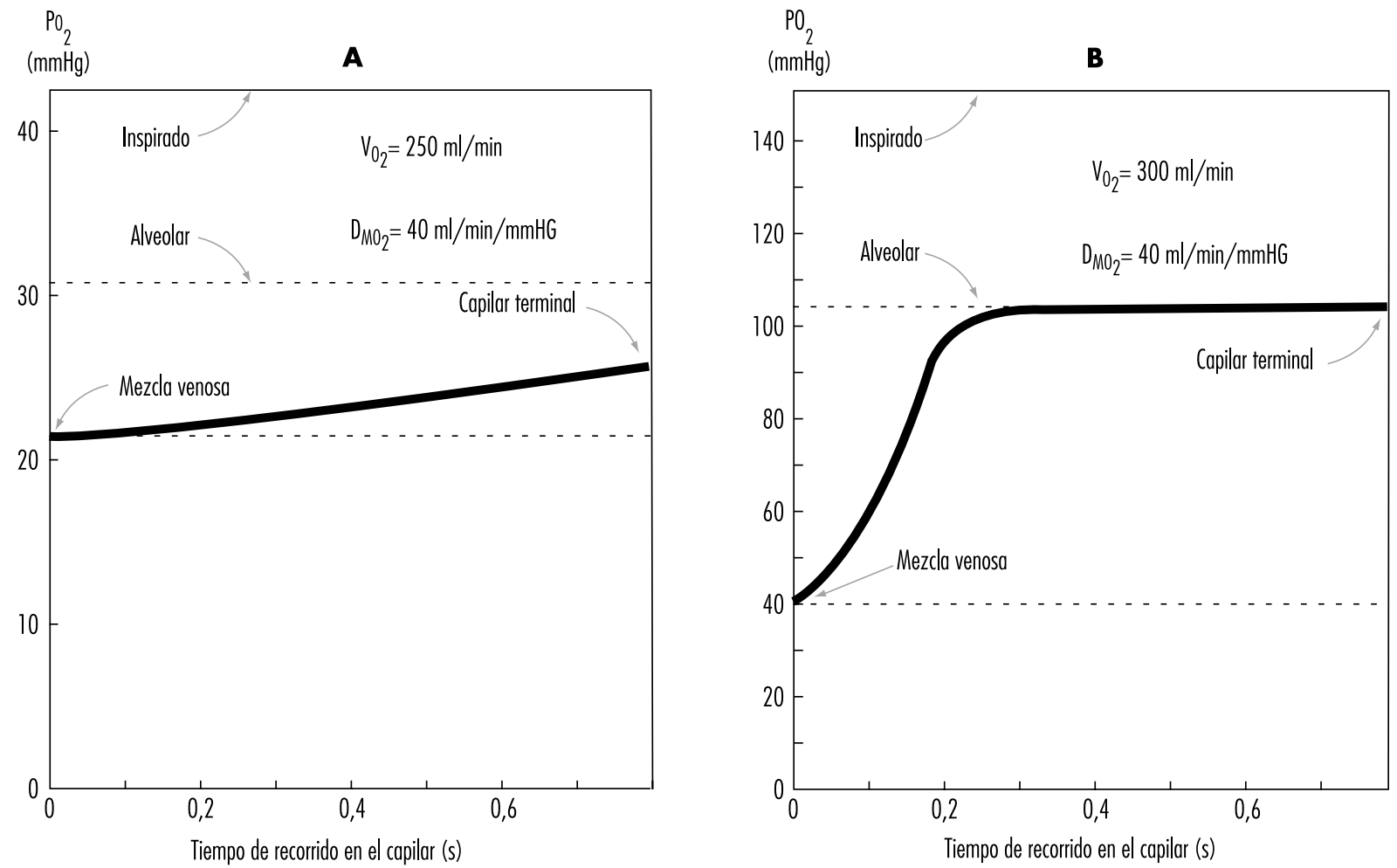

En el recuadro de la izquierda se muestra la evolución temporal calculada de la tensión de oxígeno en el alveolo capilar, en reposo en la cumbre del Everest, y al nivel del mar en el recuadro derecho. Al nivel del mar, sobra tiempo para el equilibrio entre la $\mathrm{PO}_{2}$ capilar terminal y la $\mathrm{PO}_{2}$ alveolar, mientras que en la cumbre del Everest no llega a producirse el equilibrio total. Tal diferencia se debe al menor nivel de oxígeno ambiental en las grandess altitudes, que origina un menor gradiente de difusión entre las $\mathrm{PO}_{2}$, alveolar y venosa.

el aumento de la RVH provoca un ascenso del pH de la sangre (alcalosis) que, a su vez, suprime la ventilación. A medida que la aclimatación progresa, la respiración periódica mejora. El tratamiento con acetazolamida reduce este trastorno y mejora la saturación arterial de la oxihemoglobina durante el sueño. Ahora bien, deben tomarse precauciones con los medicamentos y el alcohol que suprimen la ventilación, ya que pueden exacerbar la hipoxia del sueño

\section{Efectos fisiopatológicos de la reducción de la presión barométrica}

La complejidad de la adaptación fisiológica del ser humano a las grandes altitudes hace posible la diversidad de respuestas desfavorables. Aunque estos síndromes se describen por separado, en muchos aspectos son coincidentes. Es muy probable que enfermedades tales como la hipoxia aguda, el mal de montaña agudo, el edema pulmonar de las grandes altitudes y el edema cerebral de la grandes altitudes constituyan un espectro de anomalías que comparten una fisiopatología similar.

\section{Hipoxia}

La hipoxia se produce con el ascenso a grandes altitudes a causa del descenso de la presión barométrica y de la consiguiente disminución del oxígeno del aire ambiental. C on el ascenso rápido, la hipoxia se produce de forma aguda y el organismo no dispone de tiempo para adaptarse. En general, los alpinistas se encuentran protegidos contra ella gracias al tiempo que transcurre, que permite la aclimatación durante la subida. La hipoxia aguda es un problema tanto para los aviadores como para los equipos de rescate en entornos de gran altitud. La desaturación aguda de la oxihemoglobina, que desciende a valores por debajo de 40-60\%, origina pérdida de conciencia. Con desaturaciones menos graves aparecen cefalea, confusión, somnolencia y pérdida de la coordinación. Al mismo tiempo, la hipoxia induce un estado de euforia que Tissandier, durante su ascenso en globo en 1875, describió como "una alegría interior". Las desaturaciones más graves provocan la muerte. La hipoxia aguda responde rápida y completamente a la administración de oxígeno o al descenso.

\section{Mal de montaña agudo}

EI mal de montaña agudo (M M A) es el trastorno más frecuente en entornos de gran altitud y afecta a dos terceras partes de los que los visitan. Su incidencia depende de múltiples factores, tales como la velocidad del ascenso, la duración de la exposición, el grado de actividad y la sensibilidad individual. Es fundamental identificar a los afectados, a fin de evitar la progresión del proceso hacia un edema cerebral o pulmonar. La identificación se consigue mediante el reconocimiento de los signos y síntomas característicos que se producen en el entorno adecuado. En general, aparece dentro de las primeras horas siguientes a un rápido ascenso a altitudes superiores a $2.500 \mathrm{~m}$. Los síntomas más frecuentes son: cefalea, que es más intensa por la noche; pérdida de apetito, que puede ir acompañada de náuseas y vómitos; alteraciones del sueño y fatiga. Las personas con M M A suelen manifestar sensación de ahogo, tos y síntomas neurológicos, como déficit de memoria y alteraciones visuales 0 auditivas. La exploración física puede ser anodina, si bien la retención de líquidos es a menudo un signo precoz. Es posible que la 
patogenia de esta enfermedad guarde relación con una hipoventilación relativa, que incrementa el flujo sanguíneo cerebral y la presión intracraneal a través del aumento de la $\mathrm{PCO}_{2}$ arterial y la reducción de la $\mathrm{PO}_{2}$ arterial. Así se explicaría que las personas con mayor RVH tengan menos tendencia a desarrollarla. Los mecanismos de la retención de líquidos no se comprenden por completo, pero podrían estar relacionados con la alteración de los niveles del plasma para las proteínas las hormonas que regulan la excreción renal de agua; estos mecanismos reguladores podrían responder a la mayor actividad del sistema nervioso simpático observada en los pacientes con el mal de montaña agudo. La acumulación de agua, a su vez, conlleva el desarrollo de edema o tumefacción de los espacios intersticiales de los pulmones. Los casos más graves pueden evolucionar hacia el edema pulmonar o cerebral.

EI ascenso lento y gradual previene el desarrollo del mal de montaña agudo, ya que permite el tiempo suficiente para lograr una aclimatación adecuada. Puede ser decisivo para personas muy susceptibles o con antecedentes de haber padecido el trastorno. Además, la administración de acetazolamida antes 0 durante el ascenso puede prevenir o mejorar los síntomas de la enfermedad. La acetazolamida inhibe la acción de la anhidrasa carbónica en el riñón y provoca un aumento de la excreción de iones bicarbonato y agua, causando acidosis sanguínea. La acidosis estimula la respiración, por lo que aumenta la saturación de la hemoglobina arterial y se reduce la respiración periódica durante el sueño. G racias a este mecanismo, la acetazolamida acelera el proceso natural de aclimatación.

El tratamiento más eficaz del mal de montaña agudo es el descenso. El ascenso a altitudes aún mayores está contraindicado. Cuando no sea posible hacer descender al afectado, puede administrársele oxígeno. 0 tra posibilidad es llevar cámaras hiperbáricas ligeras en los equipos de las expediciones a las grandes alturas. Las bolsas hiperbáricas son muy útiles cuando no se dispone de oxígeno y el descenso es imposible. Existen también varios fármacos que mejoran los síntomas del mal de montaña agudo, como la acetazolamida y la dexametasona. EI mecanismo de acción de esta última no se conoce con seguridad, pero es posible que actúe disminuyendo la formación de edema.

\section{E dema pulmonar de las grandes alturas}

El edema pulmonar de las grandes alturas afecta aproximadamente a un 0,5 a un 2,0\% de las personas que ascienden a altitudes superiores a $2.700 \mathrm{~m}$ y es la causa más frecuente de muerte por enfermedad en las grandes alturas. Este edema aparece de 6 a 96 horas después del ascenso. L os factores de riesgo son similares a los del mal de montaña agudo y entre sus manifestaciones precoces más comunes deben citarse algunos síntomas de esta enfermedad, además de peor tolerancia al esfuerzo, mayor tiempo de recuperación después del ejercicio, disnea de esfuerzo y tos seca persistente. A medida que progresa, el paciente desarrolla disnea de reposo, signos audibles de congestión pulmonar y cianosis de las uñas y los labios. La patogenia de este trastorno no se conoce por completo, pero probablemente guarda relación con un aumento de la presión microvascular o con un aumento de la permeabilidad de la microvascularización que lleva al desarrollo de edema. Aunque la hipertensión pulmonar ayudaría a explicar esta patogenia, se ha observado elevación de la presión arterial pulmonar debida a la hipoxia, en todas las personas que ascienden a grandes altitudes, incluidas las que no desarrollan edema pulmonar. Desde luego, las personas propensas podrían desarrollar una constricción hipóxica desigual de las arterias pulmonares que provocara una mayor perfusión de la microvascularización en áreas localizadas donde la vasoconstricción hipóxica fuera escasa o nula. El aumento resultante de la presión y de las fuerzas de cizallamiento lesionaría las membranas capilares y traería consigo la formación de edema. Este mecanismo explica el carácter desigual y el aspecto que refleja en las exploraciones radiográficas del pulmón. Al igual que sucede en el mal de montaña agudo, las personas con menores RVH son las más propensas a desarrollar el edema pulmonar de las alturas, pues su saturación de oxihemoglobina es menor y, por tanto, su constricción pulmonar hipóxica es mayor.

La prevención del edema pulmonar de las grandes alturas es similar a la del mal de montaña agudo y comprende el ascenso gradual y el uso de acetazolamida. Recientemente se ha demostrado que el relajante muscular liso nifedipino resulta también beneficioso para la prevención de este trastorno en las personas con antecedentes de edema pulmonar de las alturas. A demás, es posible que el reposo sirva también como medida preventiva, aunque probablemente sólo en las personas que sufren ya grados subclínicos de la enfermedad.

El mejor tratamiento del edema pulmonar de las grandes alturas es el que se hace mediante evacuación asistida a una altitud menor, teniendo en cuenta que el afectado debe limitar sus esfuerzos. Tras el descenso, se produce una rápida mejoría y no suelen ser necesarias medidas adicionales, excepto el reposo en cama y la administración de oxígeno. Cuando el descenso es imposible, el tratamiento con oxígeno puede ser útil. Se han intentado numerosos tratamientos medicamentosos, y los que mejores resultados han dado son el diurético furosemida y la morfina. Ambos deben utilizarse con precaución, pues pueden causar deshidratación, descenso de la presión arterial y depresión respiratoria. Pese a la efectividad terapéutica del descenso, la mortalidad se mantiene en un $11 \%$ aproximadamente. Esta elevada tasa de mortalidad podría reflejar la ausencia de diagnóstico precoz o la imposibilidad de descender, asociada a la carencia de otros tratamientos.

\section{E dema cerebral de las grandes alturas}

El edema cerebral de las grandes alturas constituye la fase extrema del mal de montaña agudo, que ha progresado hasta causar una disfunción cerebral generalizada. Su incidencia no se conoce con seguridad, ya que resulta difícil diferenciar un caso grave del mal de montaña agudo de un caso leve de edema cerebral. Su patogenia es una ampliación de la patogenia de aquélla: la hipoventilación incrementa el flujo sanguíneo cerebral y la presión intracraneal, lo que deriva en edema cerebral. Sus síntomas iniciales son también idénticos. A medida que el edema progresa, aparecen otros síntomas neurológicos, como irritabilidad grave e insomnio, ataxia, alucinaciones, parálisis, convulsiones y, en último término, coma. La exploración ocular suele revelar tumefacción del disco óptico o edema de papila. También son frecuentes las hemorragias retinianas. Además, muchos casos de edema cerebral se asocian a edema pulmonar.

El tratamiento del edema cerebral de las grandes alturas es similar al de otros trastornos provocados por la altitud, y la medida más recomendable es el descenso. D ebe administrarse oxígeno para mantener la saturación de la hemoglobina por encima del $90 \%$. La formación de edema puede reducirse con corticosteroides como la dexametasona; se han empleado también los diuréticos, aunque su eficacia es incierta. LoS pacientes en coma pueden precisar tratamiento adicional, con mantenimiento de la respiración. La respuesta al tratamiento es variable, ya que los déficit neurológicos y el coma persisten durante días o semanas después del traslado a altitudes más bajas. La prevención del edema cerebral es similar a la de otros trastornos de las alturas.

\section{H emor ragias retinianas}

Las hemorragias retinianas son muy comunes y afectan hasta al $40 \%$ de las personas que ascienden a $3.700 \mathrm{~m}$, y al $56 \%$ de las 
que llegan a $5.350 \mathrm{~m}$. Suelen ser asintomáticas y su causa más probable es el aumento del flujo sanguíneo retiniano y la dilatación vascular debida a hipoxia arterial. Son más comunes en los que sufren cefaleas y tienden a aumentar con el esfuerzo agotador. A diferencia de otros síndromes de las alturas, las hemorragias retininanas no pueden prevenirse con acetazolamida ni con furosemida. Su resolución espontánea suele tener lugar en un plazo de dos semanas.

\section{Mal de montaña crónico}

El mal de montaña crónico (M M C) afecta a los residentes y a los que viven largas temporadas en las grandes alturas. La primera descripción que se hizo del mal reflejaba las observaciones de $M$ onge en los nativos de los Andes que vivían a altitudes superiores a $4.000 \mathrm{~m}$. D esde entonces, el mal de montaña crónico, o enfermedad de $M$ onge, se ha descrito en casi todos los habitantes de las grandes alturas, excepto en los sherpas. Afecta más a los varones que a las mujeres. Los afectados presentan plétora, cianosis y aumento de la masa celular sanguínea, lo que provoca síntomas neurológicos tales como cefalea, mareos, somnolencia y alteraciones de la memoria. Pueden desarrollar insuficiencia cardíaca derecha, también denominada cor pulmonale, debida a la hipertensión pulmonar y al gran descenso de la saturación de la oxihemoglobina. La patogenia exacta del trastorno se desconoce. Las mediciones hechas en personas afectadas revelan una menor respuesta ventilatoria hipóxica, hipoxemia grave que se exacerba durante el sueño, mayores concentraciones de hemoglobina y ascenso de la presión arterial pulmonar. Aunque parece probable que exista una relación causa-efecto, no se dispone de pruebas y las encontradas suelen ser confusas.

M uchos de los síntomas del mal de montaña crónico mejoran con el descenso hasta el nivel del mar. El traslado elimina el estímulo hipóxico de la eritropoyesis y la vasoconstricción pulmonar. 0 tros tratamientos alternativos pueden ser la flebotomía, para reducir la masa de eritrocitos, y el oxígeno a bajo flujo durante el sueño, para mejorar la hipoxia. La administración de medroxiprogresterona, un estimulante respiratorio, también ha resultado eficaz. El tratamiento durante diez semanas con este fármaco produjo en un estudio mejoría de la ventilación y de la hipoxia y descenso del recuento eritrocitario.

\section{Otros trastornos}

Los pacientes con enfermedad falciforme tienden a sufrir crisis vasooclusivas dolorosas en las grandes alturas. Incluso las altitudes moderadas de $1.500 \mathrm{~m}$ han precipitado las crisis en algunos casos, y las de $1.925 \mathrm{~m}$ se asocian a un riesgo de $60 \%$. Los pacientes con enfermedad falciforme que residen a $3.050 \mathrm{~m}$ en Arabia Saudita tienen el doble de crisis que los que habitan a nivel del mar. Además, los sujetos con el rasgo drepanocítico pueden sufrir el síndrome de infarto esplénico cuando ascienden a gran altura. Las etiologías más probables de este aumento del riesgo de crisis vasooclusiva son: deshidratación, aumento del recuento eritrocitario e inmovilidad. EI tratamiento de las crisis comprende el descenso al nivel del mar, el suministro de oxígeno y la hidratación intravenosa.

A penas existen datos sobre el riesgo de la mujer gestante cuando asciende a grandes altitudes. A unque las residentes habituales de las alturas corren mayores riesgos de sufrir hipertensión asociada al embarazo, no se ha descrito aumento de la tasa de muerte fetal intraútero. La hipoxia grave puede provocar malformaciones en el corazón fetal, pero ello sucede sólo en altitudes extremas 0 en presencia de edema pulmonar de las grandes alturas Así pues, el mayor riesgo de la gestante podría guardar relación con el aislamiento de la región, más que con ninguna complicación inducida por la altitud.

\section{ASPECTO S SANITARIOS ASO CIADOS AL TRABAJO A GRANDES ALTITUDES}

John B. West

Son muchas las personas que trabajan a grandes altitudes, especialmente en las ciudades y pueblos de los Andes americanos y en la meseta tibetana. Prácticamente todos son nativos que viven allí desde hace muchos años, quizá generaciones. Gran parte del trabajo es de carácter agrario; por ejemplo, en labores de pastoreo.

No obstante, este artículo se ocupa de otras cuestiones. U Itimamente se ha producido un gran aumento de las actividades comerciales realizadas en altitudes de 3.500 a $6.000 \mathrm{~m}$, tales como la minería en Chile y Perú en altitudes de $4.000 \mathrm{~m}$. Algunas de estas minas son muy grandes y emplean a más de 1.000 trabajadores. 0 tro ejemplo es el telescopio de Mauna $\mathrm{K}$ ea, en $\mathrm{H}$ awai, situado a una altitud de $4.200 \mathrm{~m}$.

Las minas de los Andes, algunas de las cuales datan de la época de la colonización española, han sido explotadas tradicionalmente por indígenas que llevan generaciones en esas altitudes. Sin embargo, desde hace poco tiempo se está acudiendo a trabajadores habituados al nivel del mar. El cambio se explica por varias razones, una de ellas es la escasez de habitantes en estas áreas remotas para trabajar en la minería. 0 tra, igualmente importante, es que la progresiva automatización de las minas exige el uso de máquinas grandes, cargadores y camiones, cuyo manejo requiere una cualificación de la que carecen. La tercera razón son las condiciones económicas para el desarrollo de estas minas. Si bien antes se establecían auténticas ciudades a su alrededor para alojar a los trabajadores y a sus familias y se las dotaba de los servicios auxiliares necesarios, como escuelas y hospitales, ahora se considera preferible que las familias vivan a nivel del mar y que los trabajadores suban y bajen a las minas. El motivo de este cambio no es puramente económico: la calidad de vida a $4.500 \mathrm{~m}$ de altitud es inferior que a altitudes menores (p. ej., los niños crecen más despacio). Por tanto, la decisión de hacer que las familias permanezcan al nivel del mar mientras los trabajadores se desplazan hacia la montaña se basa en razones socieconómicas sólidas.

Sin embargo, el desplazamiento de los trabajadores desde el nivel del mar hasta altitudes próximas a $4.500 \mathrm{~m}$ plantea numerosos problemas médicos, muchos de los cuales todavía no se comprenden en la actualidad. Es evidente que la mayoría de las personas que pasan del nivel del mar a tales altitudes desarroIlan inicialmente los síntomas. La tolerancia a la altura suele mejorar al cabo de dos o tres días. Sin embargo, la hipoxia grave de estas altitudes ejerce diversos efectos nocivos para el organismo humano. La capacidad máxima de trabajo disminuye y la fatiga aparece con mayor rapidez. También desciende la eficacia mental, y muchas personas tienen problemas para concentrarse. La calidad del sueño empeora, se interrumpe frecuentemente y la respiración es periódica (la respiración aumenta y disminuye tres o cuatro veces por minuto), con el consiguiente descenso de $\mathrm{la} \mathrm{PO}_{2}$ tras los períodos de apnea y reducción de la ventilación.

La tolerancia a las grandes alturas depende en gran medida de cada persona y suele ser difícil predecir la intolerancia. Muchas de las personas que desean trabajar a altitudes de $4.500 \mathrm{~m}$ descubren que son incapaces de hacerlo 0 que la calidad de vida es tan mala que se niegan a permanecer en la región. Aspectos tales como la selección de trabajadores con probabilidades de resistir las grandes altitudes y la distribución de su trabajo entre la montaña y el descanso con sus familias al nivel del mar son temas relativamente nuevos y todavía no bien comprendidos. 


\section{Reconocimiento previo al empleo}

Además del tipo habitual de reconocimiento médico previo al empleo, es preciso prestar especial atención al aparato cardiovascular, ya que el trabajo a grandes altitudes exige un gran esfuerzo a este sistema y al cardiorrespiratorio. Es preciso investigar a fondo la existencia de ciertos procesos, como la enfermedad pulmonar obstructiva crónica en sus primeras fases y el asma, que son mucho más discapacitantes en las grandes alturas, ya que requieren una elevada ventilación. También es probable que los grandes fumadores con síntomas iniciales de bronquitis tengan problemas para adaptarse a la altura. Es preciso realizar una espirometría forzada, además de la exploración habitual del tórax, incluida la radiografía. Siempre que sea posible, deberá efectuarse asimismo una prueba del esfuerzo, porque la intolerancia al mismo aumentará con la altitud.

Es preciso asimismo hacer una exploración cuidadosa del aparato cardiovascular, incluido un electrocardiograma de esfuerzo es posible. $\mathrm{H}$ ay que hacer recuentos sanguíneos para excluir a los trabajadores que presenten grados poco frecuentes de anemia o policitemia.

La vida a grandes altitudes aumenta el estrés psicológico de muchas personas, lo que obliga a hacer una historia meticulosa para excluir a los posibles trabajadores con problemas previos al comportamiento. En muchas minas modernas no se permite el consumo de alcohol. Los síntomas gastrointestinales son frecuentes en algunas personas cuando ascienden a grandes alturas, por lo que los trabajadores con historia de dispepsia pueden tener problemas de rendimiento laboral.

\section{Selección de trabajadores para las grandes altitudes}

Además de excluir a los que presenten problemas respiratorios 0 cardíacos, cuyo rendimiento será deficiente a grandes altitudes, sería muy útil hacer pruebas para determinar quiénes son los que pueden tolerar bien la altitud. Por desgracia, poco se sabe en la actualidad sobre los indicadores de la tolerancia a las grandes altitudes, aunque se están haciendo numerosas investigaciones al respecto.

EI mejor indicador de la tolerancia a las grandes alturas es, probablemente, la experiencia previa del trabajador. Si una persona ha sido capaz de trabajar a una altitud de $4.500 \mathrm{~m}$ durante varias semanas sin presentar problemas dignos de mención, es muy probable que pueda hacerlo de nuevo. Por el mismo motivo, una persona que haya intentado trabajar a gran altura sin poder tolerarlo es muy probable que vuelva a tener el mismo problema. En consecuencia, para seleccionar a los trabajadores debe prestarse especial atención a los empleos previos a grandes alturas. Sin embargo, es evidente que este criterio no puede aplicarse a todos los trabajadores, ya que el trabajo a grandes altitudes se quedaría sin mano de obra.

0 tro indicador posible es la magnitud de la respuesta ventilatoria a la hipoxia, que puede medirse al nivel del mar haciendo que el trabajador respire un aire con baja concentración de oxígeno y midiendo el aumento de la ventilación. $\mathrm{H}$ ay razones para creer que las personas con respuestas ventilatorias hipóxicas relativamente deficientes toleran mal las grandes altitudes. Por ejemplo, Schoene (1982) observó en 14 alpinistas unas respuestas ventilatorias hipóxicas bastante más elevadas que las resultantes de diez pruebas de control. Además, durante la American M edical Research Expedition al Everest en 1981 se hicieron diversas mediciones, demostrándose que la respuesta ventilatoria hipóxica medida antes y durante la expedición guardaba buena correlación con el rendimiento en alta montaña (Schoene, Lahiri y H ackett 1984). M asuyama, K imura y Sugita (1986) afirmaban que cinco montañeros que habían alcanzado $8.000 \mathrm{~m}$ en $\mathrm{K}$ anchenjunga presentaban mayores respuestas ventilatorias hipóxicas que otros cinco que no pudieron llegar hasta allí.

Sin embargo, esta correlación no es en modo alguno universal. En un estudio prospectivo de 128 alpinistas que ascendían a grandes altitudes, la medición de la respuesta ventilatoria hipóxica no guardaba relación con la altura alcanzada, mientras que sí se encontró esta relación con la medición de la captación máxima de oxígeno al nivel del mar (Richalet, $K$ erome y Bersch 1988). El estudio indicaba también que la respuesta de la frecuencia cardíaca a la hipoxia aguda podría ser un indicador útil del rendimiento en alta montaña. Se han hecho otros estudios en los que se ha comprobado una escasa correlación entre la respuesta ventilatoria a la hipoxia y el rendimiento en altitudes extremas (Ward, M illedge y West 1995).

El problema de muchos de estos estudios es que sus resultados son aplicables, por lo general, a altitudes mucho mayores que las que aquí nos interesan. También son muchos los ejemplos de montañeros con valores moderados de respuesta ventilatoria a la hipoxia que, sin embargo, toleran bien las grandes altitudes. No obstante, parece probable que una respuesta ventilatoria exageradamente deficiente sea un factor de riesgo para la tolerancia de altitudes incluso medias, como $4.500 \mathrm{~m}$.

Una manera de medir la respuesta ventilatoria hipóxica al nivel del mar es hacer que el sujeto respire repetidamente el aire de una bolsa que contenga $24 \%$ de oxígeno, $7 \%$ de dióxido de carbono y el resto de nitrógeno. Durante la respiración, se controlan las cifras de $\mathrm{PCO}_{2}$ que se mantienen constantes mediante una válvula de paso y un captador de dióxido de carbono. $\mathrm{L}$ a respiración puede mantenerse hasta que la $\mathrm{PO}_{2}$ inspirada descienda a $40 \mathrm{mmHg}(5,3 \mathrm{kPa})$ aproximadamente. Se hace una medición continua de la saturación arterial de oxígeno mediante oximetría de pulsación y se hace una gráfica comparativa de ventilación y saturación (Rebuck y Campbell 1974). 0 tra forma de medir la respuesta ventilatoria a la hipoxia consiste en determinar la presión de inspiración durante un breve intervalo de oclusión de las vías respiratorias, mientras el sujeto respira una mezcla pobre en oxígeno (W hitelaw, D erenne y M ilic-Emili 1975).

0 tro posible indicador de la tolerancia a las grandes alturas es la capacidad de trabajo en condiciones de hipoxia aguda al nivel del mar. En este caso, la deducción que se hace es que una persona incapaz de tolerar la hipoxia aguda tolerará mal la hipoxia crónica. Son pocas las pruebas a favor o en contra de esta hipótesis. La tolerancia a la hipoxia aguda fue uno de los criterios utilizados por los fisiólogos soviéticos para la selección de los montañeros que realizaron con éxito la expedición al Everest en 1982 (G azenko 1987). Por otra parte, los cambios que se producen durante la aclimatación son tan marcados, que no sería sorprendente que el rendimiento durante la hipoxia aguda guardara escasa correlación con la capacidad para trabajar durante la hipoxia crónica.

O tro indicador posible es el aumento de la presión arterial pulmonar durante la hipoxia aguda al nivel del mar, que puede medirse de forma no invasiva mediante ecografía Doppler en muchas personas. La lógica de esta prueba se basa principalmente en la correlación conocida entre el desarrollo de edema pulmonar de las grandes alturas y la magnitud de la vasoconstricción pulmonar hipóxica (Ward, Milledge y West 1995). No obstante, puesto que el edema pulmonar de las alturas no es frecuente en las personas que trabajan en altitudes de $4.500 \mathrm{~m}$, el valor práctico de esta prueba resulta dudoso.

La única manera de establecer si estas pruebas tienen valor práctico en la selección de los trabajadores sería hacer un estudio prospectivo acerca de la correlación entre los resultados de las exploraciones hechas al nivel del mar y la posterior evaluación de la tolerancia a las grandes alturas. Ello plantea la 
cuestión de cómo medir la tolerancia a las grandes alturas. La forma habitual de hacerlo es mediante cuestionarios como el de Lake Louise (Hackett y O elz 1992). Ahora bien, las respuestas a los mismos podrían estar sesgadas en una población formada por trabajadores que comprenden que su reconocimiento de que sufren intolerancia puede traer consigo el despido. Es verdad que existen mediciones objetivas de intolerancia a la altitud, como el abandono del empleo, la presencia de estertores pulmonares como signo de edema pulmonar subclínico y ataxia leve como indicio de edema cerebral subclínico. Sin embargo, estos signos sólo aparecen en personas que sufren intolerancia grave y un estudio basado exclusivamente en ellos sería muy poco revelador.

Conviene subrayar que no se ha demostrado el valor de estas posibles pruebas para determinar la tolerancia al esfuerzo en las grandes altitudes. D esde luego, las consecuencias económicas de emplear a un gran número de trabajadores que después no rinden satisfactoriamente en alta montaña son tales, que sería de enorme valor disponer de indicadores fidedignos. En la actualidad, se están realizando estudios para determinar si algunos de tales indicadores son válidos y factibles. Las mediciones tales como la respuesta ventilatoria hipóxica al nivel del mar no resultan especialmente difíciles. No obstante, deben ser hechas en un laboratorio experimentado y su coste sólo puede justificarse si ofrecen un valor predictivo significativo.

\section{Distribución del tiempo entre las grandes alturas y el nivel del mar}

Una vez más, repetiremos que este artículo trata de los problemas específicos de las actividades comerciales que, como la minería, se realizan a altitudes de unos $4.500 \mathrm{~m}$ y que emplean a trabajadores que distribuyen su tiempo entre el nivel del mar, donde viven sus familias, y la alta montaña, donde trabajan. Es evidente que esta distribución no se realiza cuando las personas viven siempre en la alta montaña.

La distribución óptima del tiempo entre las grandes alturas y el nivel del mar constituye un gran problema, y los turnos que se han aplicado hasta la fecha carecen prácticamente de fundamentos científicos. De hecho, suelen basarse en factores sociales, como el intervalo que los trabajadores desean permanecer sin ver a sus familiares. La justificación médica principal para el trabajo durante varios días seguidos a gran altitud se basa en las ventajas de la aclimatación. M uchas personas que desarrollan síntomas del mal de montaña agudo se sienten mucho mejor después de dos o cuatro días. Por tanto, han experimentado un proceso de aclimatación rápido en ese período. Además, se sabe que la respuesta ventilatoria a la hipoxia tarde de siete a diez días hasta que alcance el estado de equilibrio (Lahiri 1972; Dempsey y Forster 1982). El aumento de la ventilación es una de las características más importantes del proceso de aclimatación $y$, en consecuencia, parece razonable recomendar que el turno de trabajo a gran altitud se mantenga durante al menos diez días.

O tros rasgos de la aclimatación a las grandes alturas tardan mucho más tiempo en desarrollarse. Un ejemplo es la policitemia, que alcanza su estado de equilibrio al cabo de varias semanas. No obstante, conviene añadir que el valor fisiológico de la policitemia es mucho menos seguro de lo que se creyó en su día. De hecho, Winslow y M onge (1987) demostraron que las policitemas graves, observadas en ocasiones en los que residen permanentemente en altitudes de $4.500 \mathrm{~m}$, podrían ser contraproducentes, ya que a veces es posible aumentar el rendimiento laboral reduciendo el hematocrito mediante sangrías practicadas a lo largo de varias semanas.

0 tro aspecto importante es la velocidad de desaclimatación. Lo ideal es que los trabajadores no pierdan las ventajas conseguidas durante su estancia en la alta montaña cuando acuden junto a sus familias al nivel del mar. Por desgracia, se han hecho pocos estudios sobre la velocidad de desaclimatación, aunque algunas de las mediciones efectuadas indican que la velocidad de cambio de la respuesta ventilatoria es, en estos casos, inferior a la del proceso de aclimatación (Lahiri 1972).

0 tro aspecto práctico es el tiempo necesario para trasladar a los trabajadores desde el nivel del mar hasta la alta montaña y al revés. En una mina nueva de Collahuasi en el norte de Chile, el viaje en autobús desde la ciudad costera de Iquique, donde se espera que vivan la mayor parte de las familias, dura sólo algunas horas. A hora bien, si el trabajador reside en Santiago, el viaje puede prolongarse más de un día. En estas circunstancias, un turno de trabajo de tres o cuatro días a gran altitud sería claramente insuficiente, dado el tiempo destinado al transporte.

L os factores sociales son también fundamentales en cualquier distribución del tiempo que incluya períodos de alejamiento familiar. Aun cuando haya motivos médicos y fisiológicos para mantener períodos óptimos de aclimatación de 14 días, el hecho de que los trabajadores no desean mantenerse alejados de sus familias durante más de siete o diez días puede ser un argumento decisivo. Hasta ahora, la experiencia demuestra que las pautas de siete días de trabajo a gran altura seguidos de otros siete al nivel del mar, o de diez días a gran altura seguidos del mismo período al nivel del mar son, probablemente, las más aceptables.

Conviene observar que, con este tipo de turnos, el trabajador nunca llega a aclimatarse por completo a la altitud ni a desaclimatarse al nivel del mar. Por tanto, pasa todo su tiempo oscilando entre los dos extremos y nunca experimenta las ventajas ni de uno ni de otro estado. Además, algunos trabajadores manifiestan un gran cansancio cuando llegan al nivel del mar y pasan los primeros dos o tres días recuperándose. Es probable que este fenómeno guarde relación con la mala calidad del sueño, característica frecuente de la vida a grandes alturas. Son problemas que subrayan el desconocimiento que se tiene de los factores que determinan la mejor distribución del tiempo y la evidente necesidad de investigación en este campo.

Cualquiera que sea la pauta empleada, sería sumamente útil que los trabajadores pudieran dormir a una altitud inferior a la de su puesto de trabajo. $N$ aturalmente, que ello sea factible o no dependerá de la topografía de la región. No es posible dormir a menor altitud si ello supone varias horas de viaje, pues recortaría en exceso la jornada laboral. Sin embargo, si pudiera llegarse en un plazo, por ejemplo, de una hora a un asentamiento situado varios cientos de metros más abajo, ello mejoría en gran medida la calidad del sueño, la comodidad y sensación de bienestar de los trabajadores y su productividad.

\section{Enriquecimiento del aire ambiental con oxígeno para reducir la hipoxia de las grandes altitudes} Los efectos nocivos de las grandes altitudes se deben a la baja presión parcial de oxígeno en el aire. A su vez, ello se debe al hecho de que si bien la concentración del oxígeno es la misma que al nivel del mar, la presión barométrica es menor. Por desgracia, poco puede hacerse para contrarrestar esta "agresión climática", como la llamó Carlos Monge, el padre de la medicina de las grandes alturas en Perú (M onge 1948).

U na posibilidad es aumentar la presión barométrica en una zona restringida, en lo que se basa el principio de la bolsa de Gamow, empleada a veces en el tratamiento de urgencia. Sin embargo, resulta técnicamente difícil incrementar la presión de los espacios grandes y también existen problemas médicos asociados con la entrada o la salida a espacios con mayor presión. U n ejemplo es el dolor de oídos que se produce cuando se cierra la trompa de Eustaquio. 
La alternativa sería elevar la concentración de oxígeno en algunas áreas de las instalaciones, una propuesta relativamente nueva que parece muy prometedora (West 1995). Como se señaló anteriormente, incluso tras un período de aclimatación de siete a diez días a una altitud de $4.500 \mathrm{~m}$, la hipoxia intensa sigue reduciendo la capacidad de trabajo, la eficacia mental y la calidad del sueño. Por tanto, resultaría sumamente ventajoso poder reducir la magnitud de la hipoxia en algunas zonas de las instalaciones, si ello fuera factible.

Puede lograrse añadiendo oxígeno al aire normal de la ventilación de algunas habitaciones. A este respecto, resulta notable el valor de incluso unos niveles relativamente bajos de enriquecimiento de oxígeno. Se ha demostrado que cada incremento de $1 \%$ de la concentración de oxígeno (por ejemplo, de 21 a $22 \%$ ) reduce la altitud equivalente en $300 \mathrm{~m}$. La altitud equivalente es aquella que tiene la misma $\mathrm{PO}_{2}$ inspirada en el aire respirado que la habitación con atmósfera enriquecida en oxígeno. Así pues, a una altitud de $4.500 \mathrm{~m}$, el aumento de la concentración de oxígeno de una habitación de 21 a 26 \% reduciría la altitud equivalente en $1.500 \mathrm{~m}$. El resultado sería una altitud equivalente a $3.000 \mathrm{~m}$, fácil de tolerar. El oxígeno puede añadirse al aire normal de ventilación y por tanto formaría parte del sistema de acondicionamiento de aire. Todos esperamos que una habitación tenga una temperatura y humedad agradables. El control de la concentración de oxígeno sería un paso lógico en el control del entorno por el ser humano.

EI enriquecimiento con oxígeno es hoy posible gracias a la introducción de equipos relativamente baratos capaces de proporcionar grandes cantidades de oxígeno prácticamente puro. El concentrador de oxígeno más prometedor es el que utiliza un filtro molecular. Es un instrumento que adsorbe de forma preferente el nitrógeno y, que por tanto, produce un gas más rico en oxígeno a partir del aire. Con él resulta difícil obtener oxígeno puro, pero resulta fácil lograr mezclas de $90 \%$ de oxígeno en nitrógeno, que son igualmente útiles a los fines que nos ocupan. Si bien estos aparatos pueden trabajar de forma continua, en la práctica se alternan dos filtros moleculares: uno se purga mientras el otro lleva a cabo la adsorción activa de nitrógeno. El único requisito indispensable es la electricidad, que suele ser abundante en las minas modernas. Como indicador aproximado del coste del enriquecimiento con oxígeno, existe en el mercado un pequeño aparato capaz de producir 300 litros por hora de oxígeno al $90 \%$. El aparato se pensó para el tratamiento domiciliario de los pacientes con enfermedades pulmonares. Requiere una potencia de 350 watios y su conste inicial es de unos 2.000 dólares estadounidenses. Sólo con esta máquina es posible incrementar el contenido de oxígeno de una habitación en un 3 \% para una persona, con un nivel mínimo, pero aceptable, de ventilación. También existen grandes concentradores de oxígeno, que se emplean en la industria de la pulpa de papel. Asimismo el oxígeno líquido resulta más barato en ciertas circunstancias.

$H$ ay varias zonas en una mina en las puede valorarse la aplicación de oxígeno enriquecido. Por ejemplo, el despacho del director o la sala de conferencias, en las que suelen tomarse decisiones importantes. Así, en caso de crisis, como un accidente grave en la mina, esta instalación permitiría, probablemente, pensar con mayor claridad que en la atmósfera hipóxica habitual. Se sabe que las altitudes de $4.500 \mathrm{~m}$ alteran la función cerebral (Ward, Milledge y West 1995). O tro lugar en el que el enriquecimiento con oxígeno puede ser útil es el laboratorio donde se toman medidas de control de calidad, y asimismo en los dormitorios, para mejorar la calidad del sueño. Ensayos en doble ciego sobre la efectividad del enriquecimiento con oxígeno en altitudes cercanas a los 4.500 m serían fáciles de diseñar y deberían ser llevados a cabo lo antes posible.
También habría que tener en cuenta las posibles complicaciones del enriquecimiento con oxígeno. U na de las planteadas es el mayor peligro de incendio. Sin embargo, la concentración de oxígeno aumentada en $5 \%$ a una altitud de $4.500 \mathrm{~m}$ es menos inflamable que al nivel del mar (West 1996). Conviene recordar que, si bien el enriquecimiento con oxígeno incrementa la $\mathrm{PO}_{2}$, su valor sigue siendo muy inferior al medido al nivel del mar. La posibilidad de arder de la atmósfera depende de dos variables (R oth 1964):

- la presión parcial del oxígeno, que es mucho menor en el aire enriquecido a gran altitud que a nivel del mar;

- el efecto amortiguador de los componentes inertes $p$. ej. del aire (nitrógeno...).

Esta capacidad amortiguadora es algo menor en las grandes altitudes, pero el efecto neto sigue siendo una menor capacidad de incendios. Naturalmente, el oxígeno puro o casi puro es peligroso, por lo que deben tomarse las precauciones habituales en el suministro del gas desde el concentrador hasta el sistema de ventilación.

Se ha afirmado a veces que la pérdida de la aclimatación es un inconveniente del enriquecimiento de oxígeno pero, en realidad, no hay ninguna diferencia fundamental entre penetrar en una zona con una atmósfera enriquecida y descender a una altitud menor. Todo el mundo dormiría a menor altura si pudiera y, por tanto, no hay razón para no utilizar el enriquecimiento con oxígeno. Es cierto que la exposición frecuente a altitudes más bajas conlleva un grado de aclimatación menor, siendo todas las demás circunstancias iguales. Sin embargo, el objetivo final es un trabajo eficaz a la gran altitud de la mina y ello, presumiblemente, puede lograrse mejor enriqueciendo el aire respirado.

A veces se ha dicho que el enriquecimiento de la atmósfera incrementaría la responsabilidad legal de la mina en caso de que se produjera algún tipo de enfermedad asociado a la hipoxia. De hecho, lo contrario parece más razonable. Es posible que un trabajador que sufre, por ejemplo, un infarto de miocardio mientras trabaja en la alta montaña afirme que la altitud fue un factor desencadenante, mientras que un procedimiento destinado a reducir el problema hipóxico tendría que reducir las probabilidades de este trastorno.

\section{Tratamiento de urgencia}

En otras partes del capítulo se han expuesto ya los diferentes tipos de mal de altura: el mal de montaña agudo, el edema pulmonar de las grandes altitudes y el edema cerebral de las grandes altitudes. Poco puede añadirse que tenga relación directa con el contexto laboral.

Todo aquel que sufra un mal de altura deberá descansar. EI reposo puede ser suficiente para aliviar procesos tales como el mal de montaña agudo. Si es posible, deberá administrarse oxígeno con mascarilla. Ahora bien, si no hay mejoría o la situación se deteriora, el descenso es, con diferencia, el mejor tratamiento. Por lo común, cuando el proceso aparece en una gran instalación comercial, es fácil conseguir este descenso, ya que siempre se dispone de los medios de transporte adecuados. Todas las enfermedades relacionadas con la altitud suelen responder rápidamente al traslado a altitudes menores.

Toda instalación comercial puede disponer de una pequeña zona presurizada a la que trasladar al paciente, reduciendo la altitud equivalente mediante sistemas de bombeo de aire. En la práctica, este efecto suele conseguirse usando bolsas resistentes. U na de ellas es la conocida como bolsa Gamow, que recibe el nombre de su inventor. Sin embargo, la ventaja más importante de esta bolsa es su facilidad de transporte y puesto que esta característica no es realmente imprescindible en una instalación 
comercial, es probable que en estos casos sea más conveniente usar tanques grandes y rígidos, lo bastante espaciosos para que puedan albergar al paciente y al sanitario. Lógicamente, es fundamental disponer de una buena ventilación. Se ha demostrado que la elevación de la presión atmosférica en estas condiciones es, a veces, más eficaz en el tratamiento de las enfermedades relacionadas con la altitud que la administración de oxígeno a alta concentración. Se ignoran las razones que justifican este efecto.

\section{Mal de montaña agudo}

Suele tratarse de un trastorno autolimitante y el paciente se siente mucho mejor al cabo de uno o dos días. Su incidencia puede reducirse mediante acetazolamida (Diamox), uno o dos comprimidos de $250 \mathrm{mg}$ al día. Su administración puede iniciarse antes de comenzar el ascenso o cuando aparecen los síntomas. Incluso para las personas con síntomas leves, medio comprimido, tomado por las noches, mejora la calidad del sueño. Para la cefalea son útiles la aspirina o el paracetamol. Si el mal de montaña agudo es grave puede tratarse con dexametasona, con una dosis inicial de $8 \mathrm{mg}$ seguidos de $4 \mathrm{mg}$ cada seis horas. Sin embargo, el descenso es, con mucho, el mejor tratamiento de los trastornos graves.

\section{Edema pulmonar de las grandes alturas}

Es una complicación potencialmente grave del mal de montaña agudo y requiere atención inmediata. Una vez más, el mejor tratamiento es el descenso. M ientras se espera la evacuación, o si ésta no es posible, debe administrarse oxígeno in situ en una cámara de alta presión. También debe administrarse nifedipino (un bloqueante de los canales del calcio) en dosis de $10 \mathrm{mg}$ por vía sublingual, seguidos de $20 \mathrm{mg}$ en un preparado de liberación lenta. Este agente reduce la presión arterial pulmonar y suele ser muy eficaz. No obstante, el paciente debe ser transportado lo antes posible a una altitud más baja.

\section{E dema cerebral de las grandes alturas}

Se trata de una complicación que puede ser muy grave y es una indicación para el descenso inmediato. $M$ ientras se espera la evacuación, hay que administrar oxígeno o situar al paciente en una zona hiperbárica. También debe administrarse dexametasona, a una dosis inicial de $8 \mathrm{mg}$ seguida de $4 \mathrm{mg}$ cada seis horas.

Como se señaló anteriormente, las personas que desarrollan una enfermedad aguda de la montaña, un edema pulmonar de las grandes altitudes 0 un edema cerebral de las grandes altitudes tienden a sufrir recidivas cuando vuelven a ascender. Por tanto, si un trabajador desarrolla cualquiera de estos trastornos, debe intentarse buscar otro empleo para él a una altitud menor.

\section{- Prevencion de los peligros PR O FESIO N ALES A GRAN DES ALTITUDES}

Walter D ümmer

El trabajo a grandes altitudes produce distintas respuestas biológicas que se exponen en otras secciones de este capítulo. La respuesta de la hiperventilación a la altura debe traer consigo un aumento importante de la dosis total de sustancias peligrosas que puede inhalar por la persona sometida a una exposición profesional, en comparación con la que trabaja, en condiciones similares, al nivel del mar. Por tanto, se deduce que los límites de exposición de 8 horas, utilizados como referencia para calcular la exposición, deben reducirse. Por ejemplo, en Chile se observó que la progresión de la silicosis es más rápida en las minas situadas en grandes altitudes, lo que llevó a reducir el tiempo de exposición permitido de forma proporcional a la presión barométrica del puesto de trabajo, calculada en $\mathrm{mg} / \mathrm{m}^{3}$. Si bien esta medida puede suponer una corrección excesiva en altitudes intermedias, el error siempre jugará a favor del trabajador expuesto. Por otra parte, los valores límite umbral (T LV) expresados como partes por millón (ppm) no requieren ajustes, ya que tanto la proporción de contaminante por mol de oxígeno del aire como el número de moles de oxígeno que precisa el trabajador permanecen prácticamente constantes con las diferentes altitudes, aunque el volumen de aire que contiene un mol de oxígeno varíe con la altitud.

A fin de comprobar la veracidad de esta afirmación, el método de medición aplicado a la determinación de las concentraciones en ppm debe ser verdaderamente volumétrico, como ocurre con el aparato de O rsat o con los Bacharach Fyrite. L os tubos colorimétricos calibrados para leer en ppm no proporcionan mediciones verdaderamente volumétricas, ya que las marcas del tubo se deben, en realidad, a la reacción química que se produce entre el contaminante y algún reactivo contenido en ellos. Como en cualquier otra reacción química, las sustancias se combinan en proporción con el número de moles presentes, no en proporción con los volúmenes. La bomba manual de extracción de aire introduce un volumen constante de aire constante en el tubo, con independencia de la altitud. A gran altura, este volumen contendrá una masa menor de contaminante y la lectura será inferior a la concentración volumétrica real en ppm (Leichnitz 1977). Las lecturas se corrigen multiplicando el valor medido por la presión barométrica al nivel del mar y dividiendo el resultado por la presión barométrica en el sitio en que se hace el muestreo, usando las mismas unidades (torr o mbar) para ambas presiones.

M uestreadores por difusión: Las leyes de difusión de los gases indican que la eficacia en la recogida de los muestreadores por difusión es independiente de los cambios de la presión barométrica. Los trabajos experimentales de Lindenboom y Palmes (1983) demuestran que existen otros factores, aún no establecidos, que influyen en la recogida de $\mathrm{NO}_{2}$ en presiones menores. El error es de aproximadamente $3,3 \%$ a una altitud equivalente de $3.300 \mathrm{~m}$, y de $8,5 \%$ a $5.400 \mathrm{~m}$. Sería necesario hacer estudios adicionales para comprender esta variación y el efecto de la altitud en otros gases y vapores.

No se dispone de información sobre el efecto de la altitud en los detectores portátiles de gases calibrados en ppm, que están equipados con sensores electroquímicos de difusión, pero parece razonable prever que requieren la misma corrección que los métodos colorimétricos descritos anteriormente. Evidentemente, el mejor procedimiento consistiría en calibrarlos a la altitud deseada con una concentración conocida de un gas de prueba.

Los principios de funcionamiento y medición de los instrumentos electrónicos deberían ser estudiados cuidadosamente para establecer si requieren recalibración cuando se emplean en las grandes altitudes.

Bombas de muestreo: Estas bombas suelen ser volumétricas - es decir, desplazan un volumen fijo por revolución- pero, en general, son el último componente del equipo de muestreo y el volumen real del aire aspirado depende de la resistencia al flujo que oponen los filtros, la tubuladura, los medidores y los orificios que forman parte del mismo. Los rotómetros indican una velocidad de flujo inferior a la que realmente atraviesa el equipo de muestreo.

La mejor solución al problema del muestreo en grandes altitudes sería calibrar el instrumento en el mismo sitio en que se realiza el muestreo, evitando así las correcciones. Los fabricantes 
de bombas de muestreo han creado un laboratorio de calibración por película de bomba del tamaño de un maletín, fácil de transportar y que permite hacer una calibración rápida en las condiciones reales de trabajo. Este aparato incluye, incluso, una impresora que permite hacer registros permanentes de las calibraciones efectuadas.

\section{TLV y turnos de trabajo}

LoS T LV han sido especificados para la jornada laboral normal de 8 horas diarias y de 40 horas semanales. En el trabajo a grandes altitudes, hoy se tiende a trabajar más horas al día durante varios días y luego descender a la ciudad más próxima para descansar durante un período largo, manteniendo el tiempo medio de trabajo dentro de los límites legales en Chile, que son 48 horas semanales.

Las desviaciones de la jornada laboral normal de 8 horas obligan a estudiar la posible acumulación de sustancias tóxicas en el organismo, debida a la mayor exposición y a la reducción de los tiempos de destoxificación.

Las disposiciones chilena recientes en materia de salud profesional han adoptado el modelo "Brief y Scala" descrito por Paustenbach (1985) para reducir los TLV cuando se amplía la jornada laboral. A grandes altitudes, también debe utilizarse la corrección correspondiente a la presión barométrica. Este procedimiento suele traer consigo una reducción muy importante de los límites de exposición permisibles.

Cundo se trata de riesgos acumulativos que no son objeto de mecanismos de destoxificación, como la sílice, la corrección de la jornada laboral ampliada debe ser directamente proporcional al número real de horas trabajadas superiores a las habituales 2.000 horas al año.

\section{Peligros físicos}

Ruido: La presión del nivel sonoro inducida por el ruido de una amplitud dada, guarda correlación directa con la densidad del aire, al igual que la magnitud de la energía transmitida. Por tanto, una lectura obtenida con un medidor del nivel sonoro y el efecto

\section{Medida cautelar: muestreo del aire}

La monitorización y el mantenimiento de la salud en el trabajo exige una atención especial cuando las tareas se realizan a grandes altitudes. En estos casos, es previsible que las condiciones atmosféricas influyan en la exactitud del muestreo y de los instrumentos de medición calibrados para ser utilizados a nivel del mar. Por ejemplo, los dispositivos de muestreo activo se basan en bombas para introducir un volumen dado de aire en un medio de recogida. La medición exacta de la velocidad de flujo de la bomba es imprescindible para determinar el volumen de aire extraído por el aspirador y, por tanto, la concentración del contaminante. Las calibraciones de flujo suelen llevarse a cabo a nivel del mar. Sin embargo, los cambios de la densidad del aire asociados a la altitud pueden alterar la calibración e invalidar las mediciones efectuadas en estos entornos. 0 tros factores que influyen asimismo en la exactitud de los muestreos y de los instrumentos de medición a grandes altitudes son las variaciones de la temperatura y de la humedad relativa. Al valorar la exposición de los trabajadores a las sustancias inhaladas, también debe tomarse en consideración el aumento de la frecuencia ventilatoria que tiene lugar con la aclimatación. Puesto que esta frecuencia se eleva al ascender a grandes altitudes, es posible que los trabajadores se expongan a unas dosis totales excesivas de contaminantes profesionales, cuando las concentraciones medidas de los mismos sean inferiores a sus valores límite umbral.

Kenneth I. Berger y William N. Rom

de éste en el oído interno disminuyen en paralelo, por lo que no requieren corrección alguna.

Accidentes: La hipoxia ejerce una gran influencia en el sistema nervioso central, reduciendo el tiempo de respuesta y alterando la visión, por lo que es de esperar que produzca un aumento de la incidencia de accidentes. Por encima de $3.000 \mathrm{~m}$, el rendimiento de las personas que efectúan tareas críticas se beneficiaría con suplementos de oxígeno. 


\section{Referencias}

Dempsey, JA, HV Forster. 1982. M ediation of ventilatory adaptations. Physiol R ev 62:262-346.

Gazenko, OG (dir.) 1987. Fisiología humana a elevadas altitudes (en ruso). M oscú: N auka.

H ackett, PH, O O elz. 1992. The Lake L ouise consensus on the definition and quantification of altitude illness. En H ypoxia and M ountain M edicine, dirigido por JR Sutton, G Coates y CS H ouston. Burlington: $\mathrm{Q}$ ueen $\mathrm{C}$ ity Printers.

H ornbein, TF, BD Townes, R B Schoene, JR Sutton, CS H ouston. 1989. The cost to the central nervous system of climbing to extremely high altitude. N ew Engl J M ed 321:1714-1719.

Lahiri, S. 1972. Dynamic aspects of regulation of ventilation in man during acclimatization to high altitude. R esp Physiol 16:245-258.

Leichnitz, K. 1977. U se of detector tubes under extreme conditions (humidity, pressure, temperature). Am Ind H yg A ssoc f 38:707.

Lindenboom, RH, ED Palmes. 1983. Effect of reduced atmospheric pressure on a diffusional sampler. Am Ind H yg Assoc 」4 44:105.

M asuyama, S, H K imura, T Sugita. 1986. Control of ventilation in extreme-altitude climbers. I Appl Physiol 61:500-506.

M onge, C. 1948. Acclimatization in the Andes: $\mathrm{H}$ istorical Confirmations of "Climatic Aggression" in the D evelopment of Andean M an. Baltimore: Johns Hopkins U niv. Press.

Paustenbach, DJ. 1985. O ccupational exposure limits, pharmacokinetics and unusual work schedules. En Patty's Industrial $\mathrm{H}$ ygiene and Toxicology, dirigido por LJ Cralley y LV C ralley. N ueva Y ork: Wiley.
Rebuck, AS, EJ Campbell. 1974. A clinical method for assessing the ventilatory response to hypoxia. Am R ev R espir D is 109:345-350.

Richalet, J-P, A K eromes, B Bersch. 1988. Physiological characteristics of high altitude climbers. Sci Sport 3:89-108.

Roth, EM . 1964. Space Cabin Atmospheres: Part II, Fire and Blast $\mathrm{H}$ azards. NASA R eport SP-48. Washington, DC: NASA

Schoene, R B, S Lahiri, PH H ackett. 1984. Relationship of hypoxic ventilatory response to exercise performance on Mount Everest. I Appl Physiol 56:1478-1483.

Schoene, RB. 1982. Control of ventilation in climbers to extreme altitude. J Appl Physiol 53:886-890.

Ward, M P, JS M illedge, JB W est. 1995. H igh Altitude $M$ edicine and Physiology. L ondres: Chapman \& $\mathrm{H}$ all.

West, JB, PD Wagner. 1980. Predicted gas exchange on the summit of Mount Everest. Resp Physiol 42:1-16.

West, JB, S Lahiri. 1984. H igh Altitude and M an. Bethesda, M aryland: American Physiological Society.

West, JB, SI Boyer, DI Graber, PH H ackett, KH M aret, JS M illedge, R M Peters, CJ Pizzo, M Samaja, FH Sarnquist, RB Schoene, RM Winslow. 1983. $M$ aximal exercise at extreme altitudes on M ount Everest. J Appl Physiol. 55:688-698.

West, JB. 1995. O xygen enrichment of room air to relieve the hypoxia of high altitude. Resp Physiol 99:225-232.

-. 1997. Fire hazard in oxygen-enriched atmospheres at low barometric pressures. Aviat Space E nviron M ed. 68: 159-162.

Whitelaw, WA, JP D erenne, J M ilic-Emili. 1975. O cclusion pressure as a measure of respiratory center output in conscious man. Resp Physiol 23:181-199.
Winslow, RM, CC M onge. 1987. H ypoxia, Polycythe mia, and Chronic M ountain Sickness. Baltimore: Johns H opkins U niv. Press.

\section{0 tras lecturas recomendadas}

Bisgard, GE. 1994. The role of arterial chemoreceptors in ventilatory acclimatization to hypoxia. En Arterial Chemoreceptors, dirigido por RG O'R egan, $P$ Nolan, DS McQ ueen y DJ Patterson. Nueva Y ork: Plenum Press.

H ackett, PH, RC Roach. 1995. H igh-altitude medicine. En W ilderness M edicine, dirigido por PS Auerbach. St. Louis: M osby.

Reeves, JT, RE M cC ullough, LG M oore, A Cymerman, JV Weil. 1993. Sea-level PCO2 relates to ventilatory acclimatization at $4,300 \mathrm{~m}$. I Appl Physiol 75:1117-1122.

R om, WN . 1992. H igh altitude environments. En Environmental and $O$ ccupational $M$ edicine, dirigido por WN Rom. Boston: Little, Brown \& Co.

Schoene, R B, PH H ackett, TF H ornbein. 1994. High altitude. En T extbook of Respiratory M edicine, dirigido por JF M urray y JA Nadel. Filadelfia: WB Saunders.

Weil, JV. 1986. Ventilatory control at high altitude. $\mathrm{En} \mathrm{H}$ andbook of Physiology, Respiratory System, dirigido por NS Cherniack, JG Widdicomb, AP Fishman. Bethesda, M aryland: American Physiological Society.

White, DP, K Gleeson, CK Pickett, AM Rannels, A Cymerman, JV Weil. 1987. Altitude acclimatization: Influence on periodic breathing and chemoresponsiveness during sleep. I Appl Physiol 63:401-412. 


\section{RIESGOS BIOLOGICOS}

Director del capítulo

Zuher Ibrahim F akhri

\section{Sumario}

R iesgos biológicos en el lugar de trabajo

Zuheir I. Fakhri............................ 38.2

Animales acuáticos

D. Zannini ............................ 38.5

A nimales venenosos terrestres

J.A. Rioux y B. J uminer. . . . . . . . . . . . . . . . . . . . . 38.7

Características clínicas de la mordedura de serpiente

$D$ avid $A$. W arrell . . . . . . . . . . . . . . . . . . . . . . 38.8 


\section{- RIESG OS BIOLOGICOSEN EL LUGAR DE TRABAJO}

\section{Zuheir I. Fakhri}

La valoración de los riesgos biológicos en el lugar de trabajo se ha centrado hasta ahora en los agricultores, los trabajadores de los servicios sanitarios y el personal de los laboratorios, todos los cuales presentan un riesgo considerable de efectos nocivos para la salud. La detallada recopilación de riesgos biológicos realizada por D utkiewicz y cols. (1988) demuestra que también los trabajadores de muchas otras profesiones están expuestos a ellos (Tabla 38.1).

Dutkiewicz y cols. (1988) realizaron una clasificación taxonómica de los microorganismos y las plantas (tabla 38.2, página siguiente), así como de los animales (tabla 38.3, pág. 4), que pueden representar un riesgo biológico en los lugares de trabajo.

\section{Microorganismos}

Los microorganismos constituyen un grupo amplio y diverso de organismos que existen como células aisladas o agrupadas (Brock y M adigan 1988). En este aspecto, las células microbianas se diferencian de las células de los animales y las plantas, ya que éstas son incapaces de vivir de forma aislada en la naturaleza y sólo pueden existir como parte de organismos pluricelulares.

Tabla 38.1 - Entornos laborales con posible exposición de los trabajadores a agentes biológicos.

\begin{tabular}{|c|c|}
\hline Sector & Ejemplos \\
\hline Agricultura & $\begin{array}{l}\text { Cultivo y recolección } \\
\text { Ganadería } \\
\text { Silvicultura } \\
\text { Pesca }\end{array}$ \\
\hline Productos agrícolas & $\begin{array}{l}\text { Mataderos, plantas de envasado de } \\
\text { alimentos } \\
\text { Almacenes: silos para cereales, tabaco } \\
\text { y otros procesamientos } \\
\text { Procesamiento de pelo y cuero animal } \\
\text { Fábricas textiles } \\
\text { Procesamiento de la madera: aserraderos, } \\
\text { papeleras, fábricas de corcho }\end{array}$ \\
\hline \multicolumn{2}{|c|}{ Cuidado de animales de laboratorio } \\
\hline Asistencia sanitaria & Cuidado de pacientes: médico, dental \\
\hline \multicolumn{2}{|c|}{$\begin{array}{l}\text { Productos farmacéuticos y de origen } \\
\text { vegetal }\end{array}$} \\
\hline Cuidados personales & Peluquería, quiropodia \\
\hline \multicolumn{2}{|l|}{$\begin{array}{l}\text { Laboratorios clínicos y de } \\
\text { investigación }\end{array}$} \\
\hline Biotecnología & Centros de producción \\
\hline \multicolumn{2}{|l|}{ Centros ambulatorios } \\
\hline Mantenimiento de edificios & Edificios "enfermos" \\
\hline \multicolumn{2}{|c|}{$\begin{array}{l}\text { Plantas de depuración de aguas } \\
\text { residuales y fertilizantes }\end{array}$} \\
\hline $\begin{array}{l}\text { Sistemas industriales para e } \\
\text { tratamiento de residuos }\end{array}$ & \\
\hline
\end{tabular}

Son muy pocas las regiones de nuestro planeta que carecen de vida microbiana, porque los microorganismos presentan una gama asombrosa de capacidades metabólicas y energéticas que les permiten sobrevivir en condiciones letales para otras formas de vida.

Las cuatro grandes clases de microorganismos que pueden interactuar con los seres humanos son las bacterias, los hongos, los virus y los protozoos. Representan un peligro para los trabajadores por su amplia distribución en el medio ambiente de trabajo. Los microorganismos más importantes en términos de riesgo profesional se indican en las Tablas 38.2 y 38.3 .

\section{Existen tres fuentes principales de este tipo de microbios:}

1. los que aparecen como consecuencia de la descomposición biológica de sustratos asociados a ciertas profesiones (p. ej., el heno molido que causa neumonitis por hipersensibilidad);

2. los que se asocian a ciertos tipos de hábitats (p. ej., bacterias presentes en las redes de abastecimiento de agua),

3. los que proceden de individuos que hospedan a un agente patógeno (p. ej., tuberculosis).

EI aire ambiental puede estar contaminado o transportar niveles importantes de microorganismos potencialmente nocivos (Burrell 1991). Los edificios modernos, sobre todo los diseñados para fines comerciales y administrativos, constituyen un nicho ecológico único, con un medio ambiente, una fauna y una flora propios (Sterling y cols. 1991). Sus posibles efectos nocivos en los trabajadores se describen en otros capítulos de esta Enciclopedia.

El agua constituye un importante vehículo para la transmisión de infecciones extraintestinales. A través del contacto con el agua, ya sea por motivos profesionales, recreativos 0 incluso terapéuticos, se pueden contraer una serie de organismos patógenos (Pitlik y cols. 1987). La naturaleza de las enfermedades no entéricas transmitidas a través del agua suele depender de la ecología de los agentes patógenos acuáticos. $\mathrm{H}$ ay dos tipos básicos de infecciones: superficiales, que afectan a mucosas y zonas de la piel previamente dañadas o intactas; y sistémicas, que son infecciones con frecuencia graves que pueden ocurrir cuando el sistema inmunológico está deprimido. U na gran variedad de organismos acuáticos, entre ellos los virus, las bacterias, los hongos, las algas y los parásitos, pueden invadir al huésped a través de vías extraintestinales, como la conjuntiva, la mucosa respiratoria, la piel y los genitales.

Aunque la propagación zoonótica de enfermedades infecciosas sigue produciéndose en los animales de laboratorios utilizados para la investigación biomédica, el número de epidemias declaradas se ha reducido gracias a la adopción de procedimientos veterinarios y de cría de animales domésticos más rigurosos, la utilización de animales criados para fines comerciales y la institución de programas adecuados para proteger la salud del personal (Fox y Lipman 1991). También es importante para prevenir las enfermedades zoonóticas en el personal, que los animales que haya en las instalaciones modernas estén debidamente protegidos para evitar la entrada de parásitos y vectores biológicos. No obstante, en estos lugares pueden encontrarse agentes zoonóticos conocidos, microorganismos recién descubiertos o nuevas especies animales hasta entonces desconocidas como portadoras de microorganismos zoonóticos, y sigue existiendo la posibilidad de transmisión de enfermedades infecciosas de los animales a los seres humanos.

EI diálogo activo entre veterinarios y médicos sobre el riesgo de enfermedades zoonóticas, las especies animales implicadas y los métodos de diagnóstico, son indispensables para el éxito de cualquier programa de prevención. 


\section{Entornos laborales con riesgos biológicos}

El personal médico y de laboratorio y otros trabajadores de los servicios sanitarios, así como los de las profesiones relacionadas con estas actividades, están expuestos a infección por microorganismos si no se adoptan las medidas adecuadas de prevención. Entre los numerosos riesgos biológicos a que se exponen los trabajadores de los hospitales están el virus de la inmunodeficiencia humana $(\mathrm{VIH})$, la hepatitis $\mathrm{B}$, el herpesvirus, la rubéola y la tuberculosis (H ewitt 1993).

EI trabajo en el sector agrícola se asocia a una gran diversidad de riesgos profesionales. La exposición a polvo orgánico, a microorganismos suspendidos en el aire y a sus toxinas, puede producir enfermedades respiratorias (Zejda y cols. 1993), entre ellas bronquitis crónica, asma, neumonitis por hipersensibilidad, síndrome tóxico del polvo orgánico y enfermedad pulmonar obstructiva crónica. Dutkiewicz y cols. (1988) analizaron muestras de material procedente de silos para identificar los agentes potenciales que causan los síntomas del síndrome tóxico y el síndrome orgánico. Encontraron niveles muy elevados de bacterias aerobias totales y hongos. Aspergillus fumigatus fue el hongo predominante, mientras que los bacilos, los organismos gramnegativos (especies de Pseudomonas, Alcaligenes, Citrobacter y Klebsiella) y los actinomicetos fueron las bacterias más frecuentes. Estos resultados muestran que el contacto con material aerosolizado de silos conlleva un riesgo de exposición a elevadas concentraciones de microorganismos, de los cuales $A$. fumigatus y las bacterias productoras de endotoxinas son los agentes patógenos más probables.

La exposición durante cortos períodos de tiempo a determinados polvos de la madera puede producir asma, conjuntivitis, rinitis o dermatitis alérgica. A lgunos microorganismos termófilos presentes en la madera son patógenos para el ser humano, y la inhalación de esporas de actinomicetos presentes en las astillas de madera almacenada se ha relacionado con enfermedades humanas (Jacjels 1985).

A continuación se ofrecen algunos ejemplos de enfermedades profesionales específicas:

1. El hongo Penicillium camemberti var. candidum se utiliza para fabricar algunos tipos de quesos. La presencia elevada de anticuerpos precipitantes de este hongo en las muestras de sangre de los trabajadores, junto con las causas clínicas de los síntomas respiratorios, indican una relación etiológica entre los síntomas respiratorios y la elevada exposición a este hongo (Dahl y cols. 1994).

2. Los microorganismos (bacterias y hongos) y las endotoxinas son agentes potenciales de riesgo profesional en las plantas de procesamiento de la patata (D utkiewicz 1994). Se ha establecido una correlación significativa entre la presencia de precipitinas contra antígenos microbianos y los síntomas generales y respiratorios relacionados con el trabajo, que presentaban el $45,9 \%$ de los trabajadores examinados.

3. El personal de los museos y las bibliotecas está expuesto a mohos (p. ej., Aspergillus, Pencillium) que, cuando se dan ciertas condiciones, contaminan los libros (Kolmodin-Hedman y cols. 1986). Los síntomas habituales consisten en ataques febriles, tiritonas, náuseas y tos.

4. La utilización de microscopios con las mismas lentes oculares en distintos turnos de trabajo puede originar infecciones oftalmológicas. Entre los microorganismos responsables se ha identificado el Staphylococcus aureus (O Icerst 1987).

\section{Prevención}

El conocimiento de los principios de la epidemiología y de la transmisión de enfermedades infecciosas es esencial en los métodos utilizados para el control del organismo causante.
Tabla 38.2 - Virus, bacterias, hongos y plantas: riesgos biológicos conocidos en el lugar de trabajo.

\begin{tabular}{lcccc}
\multicolumn{1}{c}{$\begin{array}{l}\text { Infec- } \\
\text { ción }\end{array}$} & $\begin{array}{l}\text { Infección } \\
\text { zoo- } \\
\text { nosis }\end{array}$ & $\begin{array}{l}\text { Respuesta } \\
\text { alérgica }\end{array}$ & $\begin{array}{l}\text { Toxina } \\
\text { inhalable }\end{array}$ & Toxina Carcino- \\
génico
\end{tabular}


Tabla 38.3 • Los animales como fuente de riesgos profesionales.

\begin{tabular}{|c|c|c|c|c|c|}
\hline & Infección & $\begin{array}{l}\text { Infección }{ }^{1} \\
\text { Zoonosis }\end{array}$ & $\begin{array}{l}\text { Respuesta } \\
\text { alérgica }\end{array}$ & Toxina & Vector $^{2}$ \\
\hline \multicolumn{6}{|c|}{ Invertebrados no artrópodos } \\
\hline Protozoos & $x$ & $x$ & & & \\
\hline Esponjas & & & & $x$ & \\
\hline Celentéreos & & & & $x$ & \\
\hline Platelmintos & $x$ & $x$ & & & \\
\hline Ascárides & $x$ & $x$ & $x$ & & \\
\hline Briozoos & & & & $x$ & \\
\hline Tunicados & & & $x$ & & \\
\hline \multicolumn{6}{|l|}{ Artrópodos } \\
\hline Crustáceos & & & $x$ & & \\
\hline \multicolumn{6}{|l|}{ Arácnidos } \\
\hline Arañas & & & & $x(B)^{3}$ & \\
\hline Chinches & $x$ & & $x$ & $x(B)$ & $x$ \\
\hline Garrapatas & & & & $x(B)$ & $x$ \\
\hline \multicolumn{6}{|l|}{ Insectos } \\
\hline Cucarachas & & & $x$ & & \\
\hline Escarabajos & & & $x$ & & \\
\hline Polillas & & & $x$ & $x$ & \\
\hline Moscas & & & & $x(B)$ & $x$ \\
\hline Abejas & & & $x$ & $x(B)$ & \\
\hline \multicolumn{6}{|l|}{ Vertebrados } \\
\hline Peces & & & $x$ & $x(B)$ & \\
\hline Anfibios & & & $x$ & & \\
\hline Reptiles & & & & $x(B)$ & \\
\hline Aves & & & $x$ & & \\
\hline Mamíferos & & & $x$ & & \\
\hline
\end{tabular}

1 Infección-zoonosis: causa infección o invasión transmitida por animales vertebrados.

2 Vector de virus, bacterias o parásitos patógenos.

${ }^{3}$ Los tóxicos B producen toxina o veneno trasmitido por picadura o mordedura.

Fuente: Dutkiewicz y cols. 1988.

Los trabajadores deben someterse a exploraciones médicas previas y periódicas para detectar enfermedades profesionales de origen biológico. Existen una serie de principios generales para realizar las exploraciones médicas y detectar los efectos nocivos para la salud de las exposiciones en el lugar de trabajo, incluyendo el caso de los riesgos biológicos. En otros capítulos de esta Enciclopedia se describen algunos procedimientos específicos. Por ejemplo, en Suecia, la Federación de Agricultores inició un programa de servicios de medicina preventiva en el trabajo para los agricultores (Hoglund 1990). El principal objetivo de este programa era prevenir las enfermedades y lesiones relacionadas con el trabajo y prestar asistencia sanitaria a los agricultores que sufrieran problemas médicos de origen profesional.

Cuando se producen brotes de enfermedades infecciosas, no siempre se pueden adoptar las medidas preventivas adecuadas, si previamente no se ha identificado la enfermedad. Un ejemplo de ello fueron los brotes de fiebre hemorrágica viral de C rimeaCongo (FHCC) entre el personal de los hospitales de los Emiratos Arabes Unidos (Dubai), Pakistán y Sudáfrica (Van Eeden y cols. 1985).

\section{Vertebrados: serpientes y lagartos}

En las regiones cálidas y templadas, las mordeduras de serpiente suponen un peligro mortal para ciertas categorías de trabajadores: agricultores, taladores de bosques, trabajadores de la construcción y de las obras públicas, pescadores, buscadores de setas, encantadores de serpientes, empleados de zoológicos y personal de laboratorio encargado de la preparación de sueros antiveneno. La gran mayoría de las serpientes son inofensivas para el ser humano, pero otras pueden causar lesiones graves por sus mordeduras venenosas; las especies peligrosas se encuentran tanto entre las serpientes terrestres (colúbridos y vipéridos) como entre las acuáticas (hidrofidios) (R ioux y Juminer 1983).

Según la O rganización M undial de la Salud (O M S 1995), las mordeduras de serpiente causan unas 30.000 muertes al año en Asia, unas 1.000 muertes en A frica y otras tantas en Sudamérica. En determinados países se dispone de estadísticas más detalladas. En M éxico, todos los años se registran más de 63.000 mordeduras de serpiente y picaduras de escorpión, que en total originan más de 300 muertes. En Brasil se producen al año unas 20.000 mordeduras de serpiente y entre 7.000 y 8.000 picaduras de escorpión, con una tasa de mortalidad del 1,5\% para las mordeduras de serpiente y entre un $0,3 \%$ y un $1 \%$ para las picaduras de escorpión. Según un estudio realizado en O uagadougou, Burkina Faso, en la periferia de las ciudades se producen 7,5 mordeduras de serpiente por 100.000 habitantes $y$, en las zonas rurales, más de 69 por 100.000 habitantes, alcanzando aquí la tasa de mortalidad un $3 \%$.

Las mordeduras de serpiente son también un problema en los países desarrollados. En Estados U nidos se registran todos los años unas 45.000 mordeduras de serpiente, aunque debido a la facilidad de acceso a la asistencia médica el número de muertes anuales oscila entre 9 y 15. En Australia, en donde existen algunas de las serpientes más venenosas del mundo, se estima que el número anual de mordeduras de serpiente oscila entre 300 y 500 , con un promedio de dos muertes.

L os cambios medioambientales, particularmente la deforestación, pueden haber causado la desaparición de muchas especies de serpientes en Brasil. Sin embargo, el número de casos declarados de mordeduras de serpiente no se ha reducido, ya que en algunas de las zonas deforestadas han proliferado otras especies, en ocasiones más peligrosas (O M S 1995).

\section{Saurios (lagartos)}

Sólo existen dos especies de lagartos venenosos, ambas pertenecientes al género H eloderma: $H$. suspectum (monstruo de Gila) y $H$. horridum. Un veneno similar al de los vipéridos penetra en las heridas producidas por los colmillos anteriores curvos de estos lagartos, si bien las mordeduras en seres humanos son poco frecuentes y la recuperación es generalmente rápida (Rioux y Juminer 1983).

\section{Prevención}

L as serpientes no suelen atacar a los seres humanos salvo que se sientan amenazadas, se las moleste o se las pise. En regiones infestadas de serpientes venenosas, los trabajadores deben protegerse las extremidades inferiores y llevar consigo suero antiveneno monovalente 0 polivalente. A las personas que trabajan en una zona de peligro a más de media hora de viaje del puesto más cercano de primeros auxilios, se les recomienda que lleven consigo un equipo antiveneno que contenga una jeringa esterilizada. En cualquier caso, los trabajadores deben saber que las 


\section{Normas internacionales y riesgos biológicos}

En la normativa laboral de muchos países se incluyen los riesgos biológicos en su definición de las sustancias nocivas o tóxicas. Sin embargo, en la mayoría de los marcos reguladores, los riesgos biológicos se restringen principalmente a los microorganismos o agentes infecciosos. Algunos reglamentos de la 0 ccupational Safety and Health Administration (OSHA) de Estados Unidos contienen disposiciones relativas a los riesgos biológicos, las más específicas de las cuales son las referentes a la vacuna contra la hepatitis B y los patógenos transmitidos por la sangre. Los riesgos biológicos también se mencionan en disposiciones de aplicación más amplia ( $p$. ej., las relativas a comunicación de riesgos, las especificaciones sobre señalización para prevenir accidentes y las directrices para la elaboración de planes de desarrollo personal).

Aunque no sea objeto de ningún reglamento específico, la identificación y la prevención de los peligros relacionados con animales, insectos o vegetales se mencionan en otros reglamentos de la OSHA referentes a entornos laborales específicos: por ejemplo, sobre telecomunicaciones, sobre campos de trabajo temporales y sobre el transporte de pulpa de madera (este último incluye directrices relativas a los equipos de primeros auxilios para las mordeduras de serpiente).

Una de las normativas más detalladas para el control de los riesgos biológicos en el lugar de trabajo es la Directiva europea no 90/679. En ella se definen los agentes biológicos como "microorganismos, incluidos los modificados genéticamente, los cultivos celulares y los endoparásitos humanos, que pueden provocar cualquier tipo de infección, alergia o toxicidad", y los agentes biológicos se clasifican en cuatro grupos dependiendo de su nivel de riesgo de infección. La Directiva abarca la determinación y evaluación de los riesgos y las obligaciones de los empresarios en términos de sustitución o reducción de riesgos (mediante medidas de control técnico, higiene industrial, protección colectiva y personal, etc.), información (de los trabajadores, sus representantes y las autoridades competentes), vigilancia de la salud, vacunación y mantenimiento de registros. Los Anexos contienen información detallada sobre las medidas de control para diferentes "niveles de contención" dependiendo de la naturaleza de las actividades, la valoración del riesgo para los trabajadores y la naturaleza del agente biológico en cuestión.

mordeduras, incluso las producidas por las serpientes más venenosas, rara vez son mortales, porque la cantidad de veneno inyectada es generalmente pequeña. Algunos encantadores de serpientes consiguen inmunizarse mediante inyecciones repetidas de veneno, pero no se ha desarrollado todavía ningún método científico para la inmunización humana (R ioux y Juminer 1983).

\section{- AN IMALES ACUATICOS}

\section{Zannini*}

En casi todas las divisiones taxonómicas (phyla) existen animales acuáticos peligrosos para el ser humano. Los trabajadores entran en contacto con estos animales en el transcurso de diversas actividades, como la pesca de superficie y submarina, la instalación y manipulación de equipos relacionados con la extracción de petróleo bajo el agua, la construcción subacuática y las

*A daptado de la tercera edición, E nciclopedia de salud y seguridad en el trabajo. investigaciones científicas, y por lo tanto estar expuestos a riesgos para su salud. La mayoría de las especies peligrosas habitan en aguas cálidas o templadas.

\section{Características y comportamiento}

Poríferos. La esponja común pertenece a este phylum. Los pescadores que tocan esponjas (entre ellos los buzos, los buceadores con equipo autónomo y otros buceadores), pueden contraer dermatitis de contacto, que origina irritación cutánea y vesículas o ampollas. La "enfermedad de los buceadores de esponjas" de la región mediterránea está causada por los tentáculos de un pequeño celentéreo (Sagartia rosea) que parasita a la esponja. La dermatitis conocida como "musgo rojo" se produce en los pescadores de ostras de América del Norte por contacto con una esponja de color escarlata que se encuentra en la concha de las ostras. Se han registrado casos de alergia de tipo 4 . El veneno secretado por la esponja Suberitus ficus contiene histamina y sustancias antibióticas.

Celentéreos. Están representados por numerosas familias de la clase conocida como $\mathrm{H}$ idrozoo, que incluye a la M illepora $\mathrm{O}$ corales (coral urticante, coral de fuego), la Physalia (Physalia physalis, avispa marina, carabela portuguesa), la Scyphozoa (medusas) y la Actiniaria (anémona urticante), todos los cuales se encuentran en todas partes del océano. La característica común de estos animales es su capacidad de producir urticaria por la inyección de un potente veneno almacenado en una célula especial (nidoblasto) con un filamento hueco que estalla cuando se toca el tentáculo y penetra en la piel de la víctima. Las distintas sustancias contenidas en el veneno originan síntomas como prurito intenso, congestión hepática, dolor y depresión del sistema nervioso central. Entre dichas sustancias se han identificado talasio, congestina, equinotoxina (que contiene 5-hidroxitriptamina y tetramina) e hipnotoxina, respectivamente. LoS efectos en la persona dependen de la extensión del contacto con los tentáculos y, por consiguiente, del número de pinchazos microscópicos, que puede llegar a varios millares, e incluso causar la muerte de la víctima en cuestión de minutos. D ebido a la amplia distribución de estos animales por todo el mundo, se producen numerosos incidentes, aunque el número de casos mortales es relativamente bajo. Los efectos en la piel se caracterizan por un prurito intenso y por la formación de pápulas de color rojo brillante y aspecto moteado, que se transforman en pústulas y ulceraciones. La persona siente un dolor intenso similar a una descarga eléctrica. 0 tros síntomas son: dificultad para respirar, ansiedad generalizada, alteraciones cardíacas, colapso, náuseas, vómitos, pérdida de conciencia y shock primario.

E quinodermos. A este grupo pertenecen las estrellas y los erizos de mar. Ambos poseen órganos venenosos (pedicelarios), pero no son peligrosos para el ser humano. Las púas del erizo de mar penetran en la piel y dejan un fragmento profundamente clavado, lo que produce una infección secundaria seguida de la formación de pústulas y granuloma persistente, muy molestas si las heridas están cerca de tendones o ligamentos. Entre los erizos de mar, sólo de Acanthaster planci parece tener espinas venenosas que pueden ocasionar trastornos generales como vómitos, parálisis y aturdimiento.

M oluscos. Entre los animales pertenecientes a este phylum se encuentran los conivalvos, que pueden ser peligrosos. Viven en fondos de mar arenosos y parecen tener una estructura venenosa formada por una rádula con dientes en forma de aguja, que se proyecta fuera de la boca y puede atacar a la víctima cuando la concha se toca imprudentemente con la mano desnuda. El veneno actúa en los sistemas neuromuscular y nervioso central. La penetración en la piel de un diente produce isquemia temporal, cianosis, embotamiento, dolor y parestesia a medida 
que el veneno se propaga gradualmente por el organismo. 0 tros efectos posteriores son: parálisis de los músculos voluntarios, falta de coordinación, visión doble y confusión general. La muerte puede sobrevenir por parálisis respiratoria y colapso circulatorio. Se han registrado unos 30 casos, 8 de los cuales resultaron mortales.

Platelmintos. A esta clase pertenecen el E irythoe complanata y el $H$ ermodice caruncolata, conocidos como "gusanos espinosos". E stán cubiertos por numerosos apéndices en forma de espina o púa que contienen un veneno (nereistotoxina) con efecto neurotóxico e irritante tópico.

Polizoos (Briozoos). Este grupo está constituido por animales que forman colonias con aspecto de planta, semejantes a los musgos gelatinosos y que se incrustan con frecuencia en rocas y conchas. Una variedad, conocida como Alcyonidium, produce una dermatitis urticante en los brazos y el rostro de los pescadores al retirar este "musgo" de sus redes. También puede causar un eczema alérgico.

Seláceos (Condrictios). Entre los animales pertenecientes a este phylum se encuentran los tiburones, las rayas y las mantas. Los tiburones viven en aguas poco profundas, en donde buscan a sus presas y pueden atacar a las personas. M uchas variedades tienen una o dos espinas largas y venenosas delante de la aleta dorsal, que contienen un veneno débil todavía no identificado. Las espinas producen una herida que ocasiona un dolor inmediato e intenso con irritación, inflamación y edema. 0 tro gran peligro de estos animales es su mordedura, ya que la disposición de sus dientes afilados en varias filas puede causar laceraciones y desgarros graves que producen un shock inmediato, hemorragia aguda y ahogamiento de la víctima. El peligro que representan los tiburones ha sido objeto de un intenso debate y todas las variedades parecen ser particularmente agresivas. Es muy difícil predecir su comportamiento, aunque se cree que se sienten atraídos por el movimiento y por el color claro de los nadadores, así como por la sangre y las vibraciones que producen los peces $u$ otras presas tras ser atrapadas. Las rayas y las mantas son organismos grandes y planos con una larga cola provista de una o más espinas o sierras que pueden ser venenosas. El veneno contiene serotonina, 5-nucleotidasa y fosfodiesterasa, y puede causar vasoconstricción generalizada y parada cardiorrespiratoria. Rayas y mantas viven en regiones arenosas de aguas costeras, en donde pueden esconderse bien, siendo fácil que los bañistas pisen alguna sin darse cuenta. La raya reacciona levantando la cola y proyectando la espina contra la víctima. De esta forma pueden causar heridas profundas en alguna extremidad 0 incluso penetración en un órgano interno, como el peritoneo, el pulmón, el corazón o el hígado, especialmente en el caso de niños. $L$ a herida puede originar también dolor intenso, inflamación, edema linfático y otros síntomas generales como shock primario y colapso cardiocirculatorio. $L$ as lesiones en órganos internos pueden ocasionar la muerte en un plazo de horas. Los incidentes con rayas y mantas son unos de los más frecuentes, produciéndose cerca de 750 todos los años en Estados U nidos. Son animales igualmente peligrosos para los pescadores, a los que se recomienda que les corten la cola tan pronto como los suban a bordo. Algunas especies de rayas, como la torpedo y la narcine, poseen órganos eléctricos en el dorso que, cuando se les estimula por simple contacto, producen descargas eléctricas de entre 8 y 220 voltios, suficientes para atontar e inmovilizar momentáneamente a la víctima, aunque ésta suele recuperarse sin complicaciones.

0 steictios. Muchos peces de este phylum poseen espinas dorsales, pectorales, caudales y anales, conectadas a un órgano venenoso cuya principal finalidad es la defensa. Si al pez se le molesta, se le pisa o se le agarra, eriza las espinas, que pueden penetrar en la piel e inyectar el veneno. Suelen atacar a los buceadores que están buscando peces, o si se les molesta por contacto accidental. Se han registrado numerosos incidentes de este tipo debido a que los peces de este phylum están muy extendidos, al que pertenece también el pez gato, presente tanto en aguas saladas como dulces (América del Sur, Africa occidental y los Grandes Lagos), el pez escorpión (Scorpaenidae), el pez traquino (Trachinus), el pez sapo, el pez cirujano y otros. Las heridas producidas por estos peces son generalmente dolorosas, sobre todo en el caso del pez gato y del pez traquino, que originan enrojecimiento o palidez, inflamación, cianosis, embotamiento, edema linfático y difusión hemorrágica en los tejidos circundantes. Puede aparecer gangrena o infección flebítica y neuritis periférica colateral con la herida. 0 tros síntomas son: desvanecimiento, náuseas, colapso, shock primario, asma y pérdida de conciencia. Todos ellos representan un grave peligro para los trabajadores subacuáticos. En el pez gato se ha identificado un veneno neurotóxico y hemotóxico, y en el caso del traquino se han aislado varias sustancias, como la 5-hidroxitriptamina, la histamina y la catecolamina. Algunos peces gato y peces astrónomo de aguas dulces, así como la anguila eléctrica (E lectrophorus), poseen órganos eléctricos (véase el epígrafe Seláceos).

H idrofidios. Se trata de un grupo (serpientes marinas) que se encuentra principalmente en los mares de Indonesia y M alasia; se han identificado unas 50 especies, entre ellas Pelaniis platurus, Enhydrina schistosa e $\mathrm{H}$ ydrus platurus. EI veneno de estas serpientes es muy similar al de la cobra, aunque es entre 20 y 50 veces más tóxico; está formado por una proteína básica de bajo peso molecular (eurobotoxina), que afecta a las conexiones neuromusculares bloqueando la acetilcolina y provocando miolisis. Por fortuna, las serpientes de mar generalmente no atacan y muerden sólo cuando se las pisa, molesta o cuando reciben un fuerte golpe; además, inyectan poco o ningún veneno con sus colmillos. L os pescadores son los que más expuestos están a este riesgo, representando el $90 \%$ de todos los incidentes declarados, la mayoría de ellos producidos por pisar a la serpiente en el fondo del mar o por que ésta queda atrapada en las redes. Las serpientes son probablemente responsables de miles de los accidentes profesionales atribuidos a los animales acuáticos, pero rara vez tienen consecuencias graves y sólo un pequeño porcentaje de accidentes graves tienen consecuencias mortales. LoS síntomas son en su mayor parte leves y poco dolorosos. Los efectos suelen sentirse al cabo de dos horas y empiezan con dolor muscular, rigidez de nuca, desorientación y trismo, y en ocasiones, náuseas y vómitos. En el plazo de unas horas aparece mioglobinuria (presencia de proteínas complejas en la orina). La muerte puede sobrevenir por parálisis de los músculos respiratorios, insuficiencia renal por necrosis tubular o parada cardíaca por hiperpotasemia.

\section{Prevención}

Debe hacerse todo lo posible por evitar el contacto con las espinas de estos animales cuando se les manipula, a menos que se utilicen unos guantes gruesos. Asimismo, se debe tener un enorme cuidado al vadear o caminar sobre fondos marinos arenosos. El equipo de los submarinistas ofrece protección contra las medusas y los distintos celentéreos, así como contra las mordeduras de serpiente. Nunca debe molestarse a los animales más peligrosos y agresivos y han de evitarse las zonas en las que existan medusas, ya que son difíciles de ver. Si una serpiente de mar queda atrapada en un cabo, éste debe cortarse dejando que la serpiente se vaya. Ante la presencia de tiburones, existen una serie de principios que deben respetarse: las personas deben mantener los pies y las piernas fuera del agua y acercar el barco lentamente a la orilla y dejarlo inmóvil; los bañistas no deben permanecer en el agua con un pez agonizando o sangrando, y 
tampoco atraer la atención del tiburón, ya sea con colores brillantes o joyas, ruidos o explosiones, luces intensas o movimientos de las manos. U n buceador no debe nunca bucear sólo.

\section{- ANIMALES VENENOSOS TERRESTRES}

\section{J.A. Rioux y B. Juminer*}

Todos los años se producen millones de picaduras de escorpiones y reacciones anafilácticas a insectos, por las que mueren miles de seres humanos. En T únez se registran anualmente entre 30.000 y 45.000 casos de picaduras de escorpión que causan entre 35 y 100 muertes, la mayoría de ellas en niños. El envenenamiento (efectos tóxicos) es un riesgo profesional para las poblaciones que se dedican a la agricultura y la silvicultura en estas regiones.

Entre los animales que pueden ocasionar lesiones en los seres humanos por acción de sus venenos están los invertebrados, como los arácnidos (arañas, escorpiones, arañas del desierto), los ácaros (chinches y garrapatas), quilópodos (ciempiés) y hexápodos (abejas, avispas, mariposas y mosquitos).

\section{Invertebrados}

\section{Arácnidos (arañas- Aranea)}

Todas las especies son venenosas, pero en la práctica sólo un número reducido de ellas atacan al ser humano. El envenenamiento por picadura de araña puede ser de dos tipos:

1. Envenenamiento cutáneo, cuando la picadura produce al cabo de unas horas un edema alrededor de la marca cianótica y forma posteriormente una ampolla; también puede aparecer una necrosis local extensa. La cicatrización de picaduras de arañas como las del género Lycosa (p. ej., la tarántula) puede ser un proceso lento y difícil.

2. Envenenamiento neurológico causado por el veneno exclusivamente neurotóxico de las migalas (Latrodectus ctenus), que produce lesiones graves y de rápida aparición, tétanos, temblores, parálisis de las extremidades y, en ocasiones, shock mortal; este tipo de envenenamiento es relativamente común entre los trabajadores de la silvicultura y la agricultura y particularmente grave en niños. En el Amazonas, el veneno de la araña "viuda negra" (Latrodectus mactans) se utiliza para envenenar flechas.

Prevención. En las zonas donde existe el peligro de que existan arañas venenosas, el lugar habilitado para dormir debe estar provisto de mosquiteras, y los trabajadores deben utilizar calzado y prendas de trabajo que les confieran una protección adecuada.

\section{E scorpiones (E scorpiónidos)}

Son arácnidos que tienen un aguijón afilado y venenoso en el extremo del abdomen con el que infligen una dolorosa picadura, cuya gravedad varía según la especie, de la cantidad de veneno inyectada y de la estación (la más peligrosa es al final del período de hibernación de los escorpiones). En la región mediterránea, América del Sur y M éxico, los escorpiones originan más víctimas que las serpientes venenosas. M uchas especies son nocturnas y menos agresivas durante el día. Las especies más peligrosas (Buthidae) se encuentran en las regiones áridas y tropicales; su veneno es neurotrópico y muy tóxico. En todos los casos, la picadura de escorpión produce en el acto síntomas locales intensos (dolor agudo, inflamación), seguidos por manifestaciones generales, como tendencia al desvanecimiento, salivación, estornudos,

*Adaptado de la tercera edición, E nciclopedia de salud y seguridad en el trabajo. lagrimeo y diarrea. El desenlace es fatal en los niños de corta edad. Las especies más peligrosas son las del género Androctonus (Africa subsahariana), Centrurus (M éxico) y T ituus (Brazil). El escorpión no ataca espontáneamente al hombre y sólo pica cuando se siente en peligro, cuando se ve acorralado o cuando alguien sacude 0 se pone las botas o prendas de vestir que le servían de refugio. Los escorpiones son muy sensibles a los pesticidas halogenados (p. ej., el DDT).

\section{Arañas del desierto (Solpúgidas)}

Este orden de arácnidos se encuentra principalmente en las estepas y zonas subdesérticas del Sáhara, los A ndes, A sia M enor, M éxico y Texas, y no es venenoso. No obstante, las arañas del desierto son extremadamente agresivas, pueden tener un tamaño de hasta $10 \mathrm{~cm}$ de diámetro y su aspecto es terrorífico. En casos excepcionales, las heridas producidas por estos animales pueden ser graves si son muchas. Las solpúgidas son depredadores nocturnos y pueden atacar a una persona mientras duerme.

\section{Chinches y garrapatas (Acorinas)}

L as garrapatas son arácnidos chupadores de sangre en todas las etapas de su ciclo vital y la "saliva" que inyectan a través de sus órganos de alimentación puede tener efectos tóxicos. El envenenamiento es en ocasiones grave, sobre todo en los niños (parálisis por garrapata), y a veces va acompañado de supresión de los reflejos. En casos excepcionales sobreviene la muerte por parálisis bulbar (particularmente cuando la garrapata se agarra al cuero cabelludo). Las chinches son hematófagas sólo en la etapa de larva y su picadura produce inflamación prurítica de la piel. La incidencia de picaduras de chinches es elevada en las regiones tropicales.

Tratamiento. Las garrapatas deben arrancarse una vez anestesiadas con una gota de benceno, éter de etilo o xileno. La prevención se basa en el uso de pesticidas organofosforados 0 repelentes.

\section{Ciempiés (Quilópodos)}

Los ciempiés se diferencian de los milpiés (Diplópodos) en que tienen sólo un par de patas por segmento corporal y en que los apéndices de su primer segmento son dientes venenosos. Las especies más peligrosas se encuentran en Filipinas. El veneno de los ciempiés tiene sólo un efecto localizado (edema doloroso).

Tratamiento. Las picaduras deben tratarse con aplicaciones tópicas de lociones de amoníaco diluido, permanganato o hipoclorito. También pueden administrarse antihistamínicos.

\section{Insectos (H exá podos)}

Los insectos pueden inyectar veneno a través de sus apéndices bucales (Simuliidos, moscas negras; Culicidos, mosquitos; P hlebotomo, moscas de la arena) 0 a través del aguijón (abejas, avispas, avispones, hormigas carnívoras). Pueden causar urticarias con sus pelos (orugas, mariposas) o producir ampollas con su hemolinfa (castaridae, mosca vesicante y Staphylinidae, escarabajo vagabundo). L as picaduras de las moscas negras producen lesiones necróticas, algunas veces con trastornos generales; las picaduras de mosquito producen lesiones pruriginosas difusas. Las picaduras de los himenópteros (abejas, etc.) producen intenso dolor local con eritema, edema y, en ocasiones, necrosis. Pueden producirse accidentes generales como consecuencia de la sensibilización o la multiplicidad de picaduras (escalofríos, náuseas, disnea, enfriamiento de las extremidades). Las picaduras en el rostro o en la lengua son particularmente graves y pueden producir la muerte por asfixia cuando se produce edema de glotis. Las orugas y las mariposas pueden causar lesiones pruriginosas generalizadas en la piel (edema de $\mathrm{Q}$ uincke), algunas veces acompañadas de conjuntivitis. No es raro que se produzca una infección 
superpuesta. EI veneno de las cantáridas produce lesiones vesiculares o bullosas en la piel (Poederus). Existe también el peligro de complicaciones viscerales (nefritis tóxica). Algunos insectos, como los himenópteros y las orugas se encuentran en todas las regiones del mundo, aunque otros subórdenes están más localizados. Las mariposas peligrosas se encuentran principalmente en Guyana y en la República Centroafricana; las cantáridas se encuentran en Japón, A mérica del Sur y K enia; las moscas negras viven en las regiones intertropicales y en Europa central; las moscas de la arena se encuentran en 0 riente Próximo.

Prevención. La primera medida de prevención es el uso de mosquiteras y la aplicación de repelentes e insecticidas. LoS trabajadores con un elevado riesgo de exposición a picaduras de insectos pueden ser desensibilizados en casos de alergia mediante la administración de dosis crecientes de extracto del cuerpo del insecto.

\section{- CARACTERISTICAS CLINICAS DE LA MORDEDURA DE SERPIENTE}

David A. Warrel**

\section{Características clínicas}

Dependiendo de las especies, una cierta proporción de los pacientes mordidos por serpientes venenosas (entre el $10 \%$ y el $60 \%$ ) no desarrollan síntomas tóxicos (envenenamiento) o estos son mínimos pese a presentar marcas que indican la penetración en la piel de los colmillos de la serpiente.

El miedo y los efectos del tratamiento, así como el veneno de la serpiente, contribuyen a producir los síntomas. Incluso pacientes que no están envenenados pueden sufrir sofocos, desvanecimiento y disnea, con constricción del tórax, palpitaciones, sudores y acroparestesia. Los torniquetes apretados pueden producir congestión e isquemia de las extremidades; las incisiones locales en el lugar de la mordedura originan hemorragia e insensibilización, y las medicinas de origen vegetal, vómitos.

Los primeros síntomas que pueden atribuirse directamente a la mordedura son dolor local y hemorragia en el lugar de penetración de los colmillos, seguidos por dolor, sensibilidad dolorosa, inflamación e hinchazón que asciende por el miembro, linfangitis y dilatación dolorosa de los ganglios linfáticos regionales. L os pacientes con mordeduras de víboras europeas, $D$ aboia russelii, especies de Bothrops, elápidos australianos y Atractaspis engaddensis pueden presentar síncope precoz, vómitos, cólico, diarrea, angioedema y respiración sibilante. Las náuseas y los vómitos son síntomas comunes de envenenamiento grave.

\section{Tipos de mordedura}

Colúbridos (serpientes con colmillos posteriores, como las del tipo Dispholidus y las especies de Thelotornis, Rhabdophis y Philodryas)

Se produce inflamación local, hemorragia en las marcas de los colmillos $y$, en ocasiones (R habophis tigrinus), desvanecimiento. Posteriormente pueden aparecer vómitos, dolor abdominal de tipo cólico y cefalea, así como hemorragia sistémica generalizada con hinchazón extensa (cardenales), coagulopatía, hemolisis intravascular e insuficiencia hepática. El envenenamiento puede desarrollarse lentamente durante varios días.

*Adaptado de The Oxford Textbook of M edicine, dirigido por DJ Weatherall, JG G Ledingham y DA Warrell (2ª edición, 1987), págs. 6.66-6.77. Con autorización de $\mathrm{O}$ xford U niversity Press.
Atractaspididae (víboras topo, serpiente negra de Natal) Los efectos locales incluyen dolor, inflamación, equimosis, necrosis y dilatación dolorosa de los ganglios linfáticos locales. En pacientes envenenados por $A$. engaddensis. se han descrito síntomas intestinales violentos (náuseas, vómitos y diarrea), anafilaxis (disnea, insuficiencia respiratoria, shock) y cambios ECG (bloque a-v, ST, onda T).

\section{Elápidos (cobras, búngaros, mambas, serpientes de coral y serpientes venenosas australianas)}

Las mordeduras de búngaros, mambas, serpientes de coral y algunas cobras (p. ej., Naja haje y N. nivea) producen efectos locales mínimos, mientras que las mordeduras de las cobras escupidoras africanas ( $N$. nigricollis, N. mossambica, etc.) y las cobras asiáticas (N. naja, N. kaouthia, N. sumatrana, etc.) causan inflamación local dolorosa que puede ser extensa, formar cardenales o producir necrosis superficial.

Entre los síntomas neurotóxicos iniciales, antes de que se presenten síntomas neurológicos objetivos, figuran: vómitos, "pesadez" de los párpados, visión borrosa, fasciculaciones, parestesia alrededor de la boca, hiperacusia, cefalea, desvanecimiento, vértigo, hipersalivación, congestión de la conjuntiva y "piel de gallina". La parálisis se inicia como ptosis y oftalmoplejia externa y aparece ya a los 15 minutos de la mordedura, aunque algunas veces tarda diez o más horas en presentarse. Posteriormente, el rostro, el paladar, las mandíbulas, la lengua, las cuerdas bucales, los músculos del cuello y los músculos de la deglución sufren parálisis progresiva. La obstrucción de las vías respiratorias puede originar una insuficiencia respiratoria en esta etapa, o posteriormente con parálisis de los músculos intercostales, el diafragma y los músculos accesorios de la respiración. Los efectos neurotóxicos son totalmente reversibles, ya sea de forma inmediata en respuesta a la administración de antídoto 0 de anticolinesterasas - (p. ej., tras la mordedura de cobras asiáticas, de algunas serpientes de coral de América Latina (M icrurus), y víboras de la muerte australianas (A canthophis)) - 0 por remisión espontánea en el plazo de entre uno y siete días.

El envenenamiento causado por serpientes australianas produce vómitos inmediatos, cefalea, síncope, neurotoxicidad, trastornos hemostáticos y, con algunas especies, cambios en el $E C G$, rabdomiólisis generalizada e insuficiencia renal. L a dilatación dolorosa de los ganglios linfáticos regionales indica que el envenenamiento sistémico es inminente, pero por lo común los síntomas locales no existen o son leves excepto tras la mordedura de las especies de P seudechis.

\section{Oftalmia venenosa causada por elápidos "escupidores"}

L os pacientes "escupidos" por este tipo de elápidos experimentan dolor intenso en los ojos, conjuntivitis, blefarospasmo, edema palpebral y leucorrea. En más de la mitad de los pacientes escupidos por $\mathrm{N}$. nigricollis se observan erosiones en la córnea. R ara vez, el veneno es absorbido en la cámara anterior, causando hipopión y uveitis anterior. La infección secundaria a las erosiones corneales puede producir opacidades permanentes que dificultan la visión o panoftalmitis.

\section{Vipéridos (víboras, culebras, serpientes de cascabel, víboras con cabeza de lanza, mocasines y crótalos)}

EI envenenamiento local es relativamente grave. La inflamación puede detectarse ya a los 15 minutos, aunque en ocasiones tarda horas en aparecer. Se extiende rápidamente y puede afectar a todo el miembro y al tronco adyacente. Se produce dolor asociado y sensibilidad dolorosa en los ganglios linfáticos locales. En los días siguientes pueden aparecer cardenales, equimosis y necrosis. La frecuencia y gravedad de esta última es notable tras la mordedura de algunas serpientes de cascabel, víboras con 
cabeza de lanza (género B othrops), crótalos asiáticos y víboras africanas (géneros $\mathrm{E}$ chis y $\mathrm{B}$ itis). C uando el tejido envenenado está contenido en una zona estrecha, como el espacio pulpar de los dedos en manos o pies o en la zona anterior de la tibia, puede producirse isquemia. Si no se observa inflamación durante las dos horas siguientes a la mordedura de una víbora, existe cierta seguridad de que no se ha producido envenenamiento. Sin embargo, con algunas especies se produce un envenenamiento mortal aun sin manifestación de síntomas locales (p. ej., Crotalus durissus terrificus, $C$. scutulatus y víbora birmana de Russell).

Las alteraciones de la presión arterial son un rasgo común del envenenamiento por vipéridos. La hemorragia persistente en las heridas producidas por colmillos, en los puntos de venopunción o inyección, en otras heridas nuevas o parcialmente cicatrizadas y durante el posparto, indica que la sangre no se coagula. La hemorragia sistémica espontánea suele detectarse en las encías, pero también puede presentarse como epistaxis, hematemesis, equimosis cutánea, hemoptisis o hemorragias subconjuntival, retroperitoneal o intracraneal. L os pacientes envenenados por la víbora birmana de Russell pueden presentar hemorragia en la glándula pituitaria anterior (síndrome de Sheehan).

La hipotensión y el shock son frecuentes en pacientes con mordeduras de algunas serpientes de cascabel de América del Norte (p. ej., C. adamanteus, C. atrox y C. scutulatus), B othrops, D aboia y especies de Vipera ( $p$. ej., $V$. palaestinae y $V$. berus). La presión venosa central suele ser baja y la velocidad del pulso rápida, lo que indica hipovolemia, causada habitualmente por la extravasación de líquido en la extremidad en la que se ha producido la mordedura. Los pacientes envenenados por las víboras birmanas de Russell suelen mostrar signos de un aumento de la permeabilidad vascular. La presencia de anomalías en el ECG 0 arritmia cardíaca indican afectación directa del músculo cardíaco. Los pacientes envenenados por algunas especies de los géneros $V$ ipera y Bothrops pueden experimentar desvanecimientos recurrentes transitorios, con signos de reacción autofarmacológica o anafiláctica, como vómitos, sudores, cólico, diarrea, shock o angioedema, que aparecen 0 apenas transcurridos cinco minutos 0 muchas horas después de la mordedura.

La insuficiencia renal es la principal causa de mortalidad en pacientes envenenados por víboras de Russell. En el plazo de unas horas pueden presentar oliguria y dolor en los riñones, que indica isquemia renal. La insuficiencia renal es también característica del envenenamiento por especies de B othrops y $C$. d. terrificus.

En los pacientes mordidos por $C$. d. ter rificus, Gloydius blomhoffii, $B$ itis atropos y $D$. russelii pulchella de Sri Lanka, se observa una neurotoxicidad similar a la provocada por los elápidos, en ocasiones con signos de rabdomiólosis generalizada. La progresión a parálisis respiratoria o generalizada es poco frecuente.

\section{Pruebas de laboratorio}

EI recuento de neutrófilos periféricos aumenta a 20.000 o más células por microlitro en pacientes con envenenamiento grave. $L a$ hemoconcentración inicial, resultante de la extravasación de plasma (especies de Crotalus y $D$. russelii de Birmania) va seguida de anemia causada por hemorragia 0 , rara vez, por hemólisis. La trombocitopenia es habitual tras la mordedura de crótalos (p. ej., C. rhodostoma, Crotalus viridis helleri) y algunos vipéridos (p. ej., Bitis arietans y $D$. russelii), pero es poco habitual tras la mordedura de especies $E$ chis. M uy útil para determinar la desfibrogenación inducida por el veneno es la sencilla prueba de coagulación sanguínea total. Se colocan unos cuantos mililitros de sangre venosa en un tubo de ensayo de vidrio nuevo, limpio y seco, se deja reposar durante 20 minutos a temperatura ambiente y se inclina para comprobar si la sangre se ha coagulado o no. La sangre no coagulada indica envenenamiento sistémico y puede servir para el diagnóstico de una especie en particular (por ejemplo, especies $E$ chis en Africa). Los pacientes con rabdomiólisis generalizada exhiben un marcado aumento de la concentración sérica de creatin-quinasa, mioglobina y potasio. La orina de color marrón 0 negra indica rabdomiólisis generalizada 0 hemólisis intravascular. L as concentraciones de enzimas séricas, como la creatin-fosfoquinasa y la aspartato aminotransferasa aumentan moderadamente en pacientes con envenenamiento local grave, probablemente debido a lesiones musculares en el lugar de la mordedura. La orina debe analizarse para determinar el contenido de sangre/ hemoglobina, mioglobina y proteínas, hematuria microscópica y recuento de hematíes.

\section{Tratamiento}

\section{Primeros auxilios}

Los pacientes deben ser trasladados al centro médico más cercano con la mayor rapidez y comodidad posible, evitando el movimiento de la extremidad en la que se ha producido la mordedura mediante el uso de una tablilla o cabestrillo.

Los métodos tradicionales de primeros auxilios pueden ser nocivos y no deben utilizarse. Las incisiones locales y la succión pueden introducir agentes infecciosos, dañar los tejidos y causar hemorragia persistente, además de que existen pocas probabilidades de extraer gran parte del veneno de la herida. L os posibles beneficios del método de extracción al vacío no se han demostrado en pacientes humanos y podría dañar los tejidos blandos. El permanganato de potasio y la crioterapia intensifican la necrosis local. Los electrochoques pueden ser peligrosos, y tampoco se han demostrado sus beneficios. Los torniquetes y los vendajes de comprensión pueden causar gangrena, fibrinolisis, parálisis de los nervios periféricos y aumento del envenenamiento local en la extremidad ocluida.

El método de inmovilización por presión consiste en aplicar un vendaje firme, aunque no apretado, en la extremidad en la que se ha producido la mordedura, con una venda de entre 4 y $5 \mathrm{~m}$ de largo y $10 \mathrm{~cm}$ de ancho, empezando en el lugar de la mordedura e incorporando una tablilla. En los animales éste es un método eficaz para prevenir la absorción sistémica en el caso de los elápidos australianos, y de otros venenos, pero en el ser humano no ha sido sometido todavía a ensayos clínicos. La inmovilización por presión está recomendada para mordeduras de serpientes con venenos neurotóxicos (p. ej., Elapidae, $H$ ydrophiidae), pero no cuando la inflamación y la necrosis local pueden constituir un problema (p. ej., Viperidae).

En ningún caso se recomienda la caza, captura o matanza de la serpiente, pero si ésta ya está muerta, debe llevarse junto con el paciente al hospital. No debe tocarse con las manos desnudas, ya que puede producir mordeduras reflejas a pesar de estar aparentemente muerta.

Los pacientes trasladados al hospital deben tumbarse de costado para evitar la aspiración de los vómitos. Los vómitos persistentes se tratan con clorpromazina intravenosa (25-50 mg en los adultos, $1 \mathrm{mg} / \mathrm{kg}$ de peso corporal en los niños). Si el paciente presenta síncope, shock, angioedema u otros síntomas anafilácticos (autofarmacológicos), se le administra adrenalina al $0,1 \%$ por vía subcutánea $(0,5 \mathrm{ml}$ a los adultos y $0,01 \mathrm{ml} / \mathrm{kg}$ de peso corporal a los niños) y un antihistamínico como la clorfeniramina mediante una inyección intravenosa lenta $(10 \mathrm{mg}$ a los adultos, $0,2 \mathrm{mg} / \mathrm{kg}$ de peso corporal a los niños). Los pacientes con coagulopatía desarrollan grandes hematomas tras las inyecciones intramusculares o subcutáneas, razón por la cual debe utilizarse la vía intravenosa siempre que sea posible. Los pacientes con insuficiencia respiratoria o cianosis se tratan estableciendo una vía respiratoria, administrándoles oxígeno y, en caso necesario, con respiración asistida. Si el paciente está 
inconsciente y no se detecta el pulso ni en la femoral ni en la carótida, deberá procederse inmediatamente a una reanimación cardiopulmonar (RCP).

\section{Tratamiento hospitalario}

\section{Evaluación clínica}

En la mayoría de los casos de mordedura de serpiente, no se sabe con seguridad cuál es la especie responsable ni la cantidad y composición del veneno inyectado. Lo ideal, por tanto, es que los pacientes sean hospitalizados para mantenerlos en observación durante al menos 24 horas. La inflamación local tras un envenenamiento grave por mordedura de crótalo suele detectarse ya a los 15 minutos, que se prolonga hasta 2 horas cuando el envenenamiento es por otras serpientes. Las mordeduras de búngaros (Bungarus), corales (M icrurus, $M$ icruroides), otros elápidos y serpientes marinas no siempre causan envenenamiento local. Las marcas de los colmillos son invisibles en algunos casos. El dolor y la dilatación dolorosa de los ganglios linfáticos que riegan la zona de la mordedura son un primer síntoma de envenenamiento por vipéridos y algunos elápidos, entre ellos los elápidos australianos y asiáticos. En todos los casos deben examinarse con detenimiento las marcas de los colmillos, ya que normalmente éste es el primer lugar en el que aparecen signos clínicos de una hemorragia espontánea; otros sitios habituales son la nariz, los ojos (conjuntiva), la piel y el tracto gastrointestinal. La hemorragia en puntos de venipunción y otras heridas indica que existe una coagulopatía. La hipotensión y el shock son síntomas importantes de hipovolemia o cardiotoxicidad, especialmente frecuentes en pacientes con mordeduras de serpientes de cascabel norteamericanas y algunos vipéridos ( $p$. ej., V. berus, $D$. russelii, V. palaestinae). El ptosis (p. ej., caída de los párpados) es uno de los primeros síntomas de envenenamiento neurotóxico. La fuerza de los músculos respiratorios debe evaluarse objetivamente: por ejemplo, midiendo la capacidad vital. La presencia de trismus, sensibilidad dolorosa muscular generalizada y orina de color marrón oscuro indica rabdomiólisis (hidrofidios). Si se sospecha un veneno procoagulante, deberá verificarse la coagulabilidad de la sangre en el lecho del paciente mediante la prueba de coagulación sanguínea total durante 20 minutos.

La presión arterial, la velocidad del pulso, la velocidad respiratoria, el nivel de consciencia, la presencia o ausencia de ptosis, la extensión de la inflamación local y cualquier otro nuevo síntoma deberán registrarse a intervalos frecuentes.

\section{Tratamiento contra el veneno}

La decisión más importante es si debe o no administrarse un antiveneno, ya que éste es el único antídoto específico. En la actualidad se ha demostrado claramente que, en pacientes con envenenamiento grave, los beneficios de este tratamiento compensan con creces el riesgo de reacción al antídoto (véase más adelante).

\section{Indicaciones generales para la administración de un antídoto}

La administración de un antídoto está indicada cuando existen síntomas de envenenamiento sistémico como los siguientes:

1. anomalías hemostáticas, como hemorragia sistémica espontánea, coagulopatía o trombocitopenia profunda; $\left(<50 / \mid \times 10^{-9}\right)$

2. neurotoxicidad;

3. hipotensión y shock, anomalías del ECG u otras evidencias de disfunción cardiovascular;

4. deterioro de la consciencia por cualquier causa;

5. rabdomiólisis generalizada.

Las evidencias que sugieren un envenenamiento grave son leucocitosis neutrofílica; aumento de enzimas séricas, como la creatin-quinasa y las aminotransferasas; hemoconcentración; anemia grave; mioglobinuria; metahemoglobinuria; hipoxemia y acidosis.

Si no hay envenenamiento sistémico se administrará un antídoto si la inflamación local afecta a más de la mitad del miembro que ha sufrido la mordedura, si se han formado ampoIlas o equimosis en una zona extensa, si hay mordeduras en los dedos o si la inflamación progresa con rapidez, especialmente en pacientes mordidos por especies cuyos venenos se sabe que producen necrosis local (p. ej., vipéridos, cobras asiáticas y cobras escupidoras africanas).

\section{Indicaciones especiales para la administración de antídoto} Algunos países desarrollados disponen de recursos económicos y técnicos para un número mayor de situaciones:

Estados Unidos y Canadá: tras la mordedura de las serpientes de cascabel más peligrosas (C. atrox, C. adamanteus, C. viridis, $C$. horridus y $C$. scutulatus), se recomienda la instauración inmediata de un tratamiento contra el veneno antes de que se haga evidente un envenenamiento sistémico. La rápida propagación de la inflamación local se considera una indicación para la administración de antídoto, como también lo es el dolor inmediato o cualquier otro síntoma de envenenamiento tras la mordedura de serpientes de coral (M icruroides euryxanthus y M icrurus fulvius).

Australia: la administración de antídoto está recomendada en pacientes con sospecha o confirmación de mordedura de serpiente si existe sensibilidad dolorosa de los ganglios linfáticos locales u otras evidencias de difusión sistémica del veneno, y en cualquier persona con mordedura confirmada de una especie identificada como altamente venenosa.

Europa: (víbora común: Vipera berus y otras víboras europeas): el antídoto está indicado para prevenir la morbilidad y acortar el período de convalecencia en pacientes con envenenamiento moderadamente grave, así como para salvar las vidas de pacientes con envenenamiento grave. Las indicaciones son:

1. descenso de la presión arterial (presión sistólica inferior a $80 \mathrm{mmH} \mathrm{g}$, 0 en más de $50 \mathrm{mmH} \mathrm{g}$ con respecto al valor normal o basal) con o sin síntomas de shock;

2. otros síntomas de envenenamiento sistémico (véase lo anteriormente expuesto), entre ellos hemorragia espontánea, coagulopatía, edema o hemorragia pulmonares (detectados mediante radiografía de tórax), anomalías ECG y leucocitosis periférica manifiesta (más de $15.000 / \mu \mathrm{l}$ ) y aumento de la concentración sérica de creatinin-quinasa;

3. envenenamiento local grave (inflamación en más de la mitad del miembro afectado por la mordedura en el plazo de 48 horas) incluso sin envenenamiento sistémico,

4. en adultos, inflamación que se extiende en un plazo de cuatro horas por encima de la muñeca tras la mordedura en una mano, o por encima del tobillo tras la mordedura en un pie.

Los pacientes mordidos por víboras europeas que muestren algún síntoma de envenenamiento deben ser hospitalizados para mantenerlos en observación durante al menos 24 horas. EI antídoto debe administrarse siempre que existan evidencias de envenenamiento sistémico (véanse los puntos 1 y 2 anteriores) aun si tardan varios días en manifestarse.

\section{Predicción de reacciones al antídoto}

Es importante saber que la mayoría de las reacciones a los antídotos no están causadas por hipersensibilidad adquirida de Tipo I, IgE mediadas, sino por la activación del complemento mediada por agregados de IgG o fragmentos FC. Las pruebas de 
piel y conjuntiva no predicen las reacciones inmediatas (anafilácticas) ni tardías (tipo enfermedad sérica) al antídoto; en cambio, retrasan la instauración del tratamiento y pueden sensibilizar al paciente. Por ello no deben utilizarse.

\section{Contraindicaciones del antídoto}

Los pacientes con antecedentes de reacción al antisuero equino sufren reacciones más frecuentes y graves cuando reciben antídoto equino. Las personas con atopia no presentan un mayor riesgo de reacción, pero cuando ésta se produce, suele revestir una mayor gravedad. En tal caso puede prevenirse o reducirse con un tratamiento previo de adrenalina, antihistamina e hidrocortisona por vía subcutánea, o infusión intravenosa continua de adrenalina durante la administración del antídoto. No se recomienda una rápida desensibilización.

\section{Selección y administración del antídoto}

El antídoto debe administrarse sólo si se sabe que su espectro de especificidad incluye a la especie responsable de la mordedura. L as soluciones opacas deben descartarse, ya que la precipitación de proteína indica pérdida de actividad y mayor riesgo de reacción. Los antídotos monoespecíficos (monovalentes) son ideales cuando se conoce la especie responsable de la mordedura. Los antídotos poliespecíficos (polivalentes) se utilizan en muchos países, ya que es difícil identificar a la serpiente responsable; pueden ser tan eficaces como los monoespecíficos, pero su actividad neutralizante del veneno es menos específica por unidad de peso de inmunoglobulina. A parte de los venenos utilizados para la inmunización de los animales de los que se obtiene el antídoto, otros venenos pueden contrarrestarse mediante neutralización paraespecífica [p. ej., los venenos de los $\mathrm{H}$ idrofidios se neutralizan con antídoto para la serpiente tigre (N otechis scutatus)].

El antídoto está indicado mientras persistan los síntomas de envenenamiento sistémico (es decir, durante varios días), pero lo ideal es administrarlo tan pronto como aparecen estos síntomas. La vía intravenosa es la más eficaz. La infusión de antídoto diluido en aproximadamente $5 \mathrm{ml}$ de líquido isotónico/ $\mathrm{kg}$ de peso corporal es más fácil de controlar que la inyección intravenosa "a presión" de antídoto sin diluir y administrado a una velocidad aproximada de $4 \mathrm{ml} / \mathrm{min}$, aunque no se han observado diferencias en la incidencia o gravedad de las reacciones al antídoto con estos dos métodos de administración.

\section{Dosis de antídoto}

Las recomendaciones de los fabricantes se basan en las pruebas de protección realizadas en ratones y pueden inducir a la confusión. Es preciso realizar ensayos clínicos para establecer las dosis iniciales adecuadas de los principales antídotos. En la mayoría de los casos, la dosis de antídoto es empírica. Los niños reciben la misma dosis que los adultos.

\section{Respuesta al antídoto}

Al poco tiempo de inyectar el antídoto puede producirse una considerable mejoría sintomática. En los pacientes en estado de shock, la presión arterial puede aumentar y es posible que recobren la consciencia ( $C$. rhodostoma, $V$. berus, Bitis arietans). LOS síntomas neurotóxicos pueden mejorar en el plazo de 30 minutos (especies de Acanthophis, N. kaouthia), aunque lo normal es que remitan al cabo de varias horas. La hemorragia sistémica espontánea suele interrumpirse al cabo de 15-30 minutos y la coagulabilidad de la sangre se recupera en las seis horas siguientes a la administración del antídoto siempre que se administre una dosis neutralizante. La dosis de antídoto debe aumentarse si los síntomas severos de envenenamiento persisten al cabo de una 0 dos horas o si no se restaura la coagulabilidad de la sangre en un plazo aproximado de seis horas. El envenenamiento sistémico puede reaparecer horas o días después de una respuesta inicialmente buena al antídoto y se explica por la absorción continua del veneno desde el lugar de su inyección y la eliminación del antídoto en la circulación sanguínea. Las vidas medias plasmáticas aparentes de los antídotos equinos $\mathrm{F}\left(\mathrm{ab}^{\prime}\right)_{2}$ en los pacientes envenenados oscilan entre 26 y 95 horas. Por consiguiente, estos pacientes deben someterse a una evaluación diaria durante al menos tres o cuatro días.

\section{Reacciones al antídoto}

- Las reacciones inmediatas (anafilácticas) aparecen entre 10 y 180 minutos después de administrar el antídoto en el 3-84 \% de los pacientes. La incidencia aumenta con la dosis y disminuye cuando se utiliza un antídoto altamente específico y la administración se realiza por vía intramuscular en lugar de intravenosa. Los síntomas consisten en picores, urticaria, tos, náuseas, vómitos, otras manifestaciones de estimulación del sistema nervioso autónomo, fiebre, taquicardia, broncoespasmo y shock. M uy pocas de estas reacciones pueden atribuirse a una hipersensibilidad adquirida de tipo I I gE mediada.

- Las reacciones pirogénicas se producen como consecuencia de la contaminación del antídoto con endotoxinas. U na o dos horas después del tratamiento aparecen fiebre, escalofríos, vasodilatación y descenso de la presión arterial. Los niños pueden sufrir convulsiones febriles.

- Las reacciones tardías de tipo enfermedad sérica (complejo inmune) pueden producirse a los 5-24 días (7 días como promedio) de la administración del antídoto. La incidencia de estas reacciones y la rapidez de su aparición aumentan con la dosis del antídoto. Las características clínicas son fiebre, prurito, urticaria, artralgia (que afecta también a la articulación temporomandibular), linfadenopatía, inflamación periarticular, mononeuritis múltiple, albuminuria y, rara vez, encefalopatía.

\section{Tratamiento de las reacciones al antídoto}

L a adrenalina (epinefrina) es un tratamiento eficaz para las reacciones inmediatas; a los adultos se les administra entre 0,5 y $1,0 \mathrm{ml}$ de adrenalina al $0,1 \%$ ( 1 en $1.000,1 \mathrm{mg} / \mathrm{ml}$ ) por vía subcutánea (en el caso de niños, $0,01 \mathrm{ml} / \mathrm{kg}$ ) en el momento en que aparecen los primeros signos de una reacción. La dosis puede repetirse si la reacción no se controla. Para combatir los efectos de la histamina liberada durante la reacción, debe administrarse un antagonista antihistamina $\mathrm{H}_{1}$, como maleato de clorfeniramina (10 mg en los adultos, 0,2 mg/ kg en los niños) por vía intravenosa. $L$ as reacciones pirogénicas se tratan enfriando al paciente y administrándole antipiréticos (paracetamol). Las reacciones tardías responden a un antihistamínico oral como clorfeniramina ( $2 \mathrm{mg}$ cada seis horas en los adultos, $0,25 \mathrm{mg} / \mathrm{kg} /$ día en dosis divididas en los niños) o prednisolona oral (5 mg cada seis horas durante cinco o siete días en los adultos, $0,7 \mathrm{mg} / \mathrm{kg} /$ día en dosis divididas en los niños).

\section{Tratamiento de apoyo}

\section{Envenenamiento neurotóxico}

La parálisis bulbar y respiratoria puede producir la muerte por aspiración, obstrucción de las vías respiratorias o insuficiencia respiratoria. Las vías respiratorias deben mantenerse despejadas y, si aparece insuficiencia respiratoria, tendrá que insertarse un tubo endotraqueal o realizarse una traqueotomía. Las anticolinesterasas tienen un efecto variable, pero potencialmente útil, en pacientes con envenenamiento neurotóxico, especialmente cuando se trata de neurotoxinas postsinápticas. La "prueba de Tensilon" debe realizarse en todos los casos de envenenamiento neurotóxico y ante la sospecha de miastenia grave. A estos 
pacientes se les administra sulfato de atropina $(0,6 \mathrm{mg}$ en los adultos, $50 \mu \mathrm{g} / \mathrm{kg}$ de peso corporal en los niños) por vía intravenosa (para bloquear los efectos muscarínicos de la acetilcolina) seguido por una inyección intravenosa de cloruro de edrofonio (10 mg en los adultos, 0,25 mg/ kg en los niños). Los pacientes que responden satisfactoriamente pueden mantenerse con metil sulfato de neostigmina (entre 50 y $100 \mu \mathrm{g} / \mathrm{kg}$ de peso corporal) y atropina, administrados cada cuatro horas 0 mediante administración continua.

\section{Hipotensión y shock \\ Si se produce un descenso de la presión venosa yugular o central, o si existen otras evidencias clínicas de hipovolemia o exsanguina- ción, debe realizarse una transfusión de plasma, preferiblemente de sangre reciente o plasma fresco congelado. Si se observa hipo- tensión persistente o profunda o evidencias de aumento de la permeabilidad capilar (p. ej., edema facial y conjuntival, derrames serosos, hemoconcentración, hipoalbuminemia), se administrará un vasoconstrictor selectivo como la dopamina (empezando con dosis de 2,5 hasta $5 \mu \mathrm{g} / \mathrm{kg}$ de peso corporal/ $\mathrm{min}$ mediante inyección en una vena central).}

\section{Oliguria e insuficiencia renal}

La producción de orina, la creatinina sérica, la urea y los electrolitos deben medirse todos los días en los pacientes con envenenamiento grave y en los que han recibido una mordedura de especies de las que se sabe que producen insuficiencia renal (p. ej., D. russelii, $C$. d. terrificus, especies de Bothrops, serpientes marinas). Si el volumen de orina disminuye por debajo de $400 \mathrm{ml}$ en 24 horas, deben insertarse catéteres uretrales y venosos centrales. Si el flujo de orina no aumenta tras la rehidratación y la administración de diuréticos al paciente (p. ej., frusemida hasta $1.000 \mathrm{mg}$ por infusión intravenosa), debe administrarse dopamina ( $2.5 \mu \mathrm{g} / \mathrm{kg}$ de peso corporal/ min por inyección intravenosa) y someter al paciente a un equilibrio estricto de líquidos. Si estas medidas no son eficaces, será preciso recurrir a diálisis peritoneal, hemodiálisis o hemofiltración.

\footnotetext{
Infección local en el lugar de la mordedura

Las mordeduras de algunas especies (p. ej., especies de Bothrops, C. rhodostoma) parecen ser particularmente propensas a complicarse con infecciones locales causadas por bacterias presentes en el veneno de la serpiente 0 en sus colmillos. Tales infecciones se previenen con penicilina, cloramfenicol o eritromicina y una dosis de vacuna de recuerdo de toxoide tetánico, especialmente si la herida es de tipo incisivo o si ha sufrido algún tipo de desgarro. Cuando existen indicios de necrosis local debe añadirse un aminoglucósido como la gentamicina o el metronidazol.
}

\section{Tratamiento del envenenamiento local}

L as ampollas pueden vaciarse con una aguja fina. La extremidad afectada por la mordedura debe colocarse en la posición más cómoda posible. U na vez que aparezcan signos claros de necrosis local (zona insensible y oscurecida con olor putrefacto o signos de descamación), deberá procederse a la limpieza quirúrgica, injerto cutáneo laminar inmediato y aplicación de una pomada antimicrobiana de amplio espectro. El aumento de la presión en el interior de compartimentos fasciales herméticos, como los espacios de pulpa digital y el compartimento anterior de la tibia puede causar lesiones isquémicas. Tal complicación es más frecuente tras la mordedura de serpientes de cascabel norteamericanas como C. adamanteus, Calloselasma rhodostoma, T rimeresurus flavoviridis, especies de Bothrops y Bitis arietans. Los síntomas son: dolor intenso, debilidad de los músculos compartimentales y dolor cuando se estiran pasivamente, hipestesia en las áreas de la piel enervadas por nervios que recorren esa áera. La detección del pulso arterial (p. ej., mediante ultrasonidos Doppler) no descarta isquemia dentro de la zona. L as presiones superiores a $45 \mathrm{~mm} \mathrm{Hg}$ dentro de la zona se asocian a un elevado riesgo de necrosis isquémica. En estas circunstancias, puede considerarse la posibilidad de una fasciotomía, aunque no debe intentarse hasta que se haya restaurado la coagulabilidad sanguínea y el recuento de plaquetas supere $50.000 / \mu \mathrm{l}$. Un tratamiento precoz adecuado con antídoto evitará el desarrollo de síndromes intracompartimentales en la mayoría de los casos.

\section{Trastornos hemostáticos}

U na vez que se administra un antídoto específico para neutralizar los efectos anticoagulantes del veneno, la restauración de la coagulabilidad y la función plaquetaria pueden acelerarse administrando sangre reciente, plasma fresco congelado, crioprecipitados (que contienen fibrinógeno, factor VIII, fibronectina y algunos factores $\mathrm{V}$ y X III) o concentrados de plaquetas. No debe utilizarse heparina. Los corticoides no están indicados para el tratamiento del envenenamiento.

\section{Tratamiento de la oftalmia producida por veneno de serpiente} Cuando el veneno escupido por una cobra se introduce en los ojos, los primeros auxilios consisten en el lavado con grandes volúmenes de agua o cualquier otro líquido inerte que se tenga a mano. El dolor puede aliviarse con colirio de adrenalina $(0,1 \%)$. Salvo que pueda descartarse una abrasión corneal mediante tinción fluorescente y examen a la luz de una lámpara de hendidura, el tratamiento debe ser el mismo que para una lesión córnea: un antibimicrobiano tópico, como tetraciclina o cloranfenicol. En la actualidad no se recomienda la instilación de antídoto diluido.

\section{Referencias}

Brock, T D, M T M adigan. 1988. Biology of M icroorganisms. L ondres: Prentice $\mathrm{H}$ all.

Burrell, R. 1991. Microbiological agents as health risks in indoor air. Environ $H$ ealth Persp 95:29-34.

Dahl, S, JT Mortensen, K Rasmussen. 1994 Cheese-packers' disease: R espiratory complaints at a cheese-packing dairy. U geskrift for Laeger 156(4):5862-5865.

Dutkiewicz, J, L Jablonski, S-A O lenchock. 1988. O ccupational biohazards. A review. Am J Ind $M$ ed 14:605-623.

Dutkiewicz, J.1994. Bacteria, fungi, and endotoxin as potential agents of occupational hazard in a potato processing plant. Am J Ind M ed 25(1):43-46.

Fox, JG, NS Lipman. 1991. Infections transmitted by large and small laboratory animals. D is Clin North Am 5:131-63.
Hewitt, JB, ST M isner, PF Levin. 1993. Health hazards of nursing; identifying work place hazards and reducing risks. H ealth Nurs 4(2):320-327.

Hoglund, S. 1990. Farmers' health and safety program in Sweden. Am J Ind M ed 18(4):371-378.

Jacjels, R . 1985. Health hazards of natural and introduced chemical components of boatbuilding woods. Am J Ind M ed 8(3):241-251.

Kolmodin Hedman, B, G Blomquist, E Sikstorm. 1986. Mould exposure in museum personnel. Int Arch $O$ ccup E nviron $\mathrm{H}$ ealth 57(4):321-323.

O lcerst, R B. 1987. M icroscopes and ocular infections. Am Ind H yg Assoc J 48(5):425-431.

O rganización Mundial de la Salud (OMS). 1995. WHO XVII O ccupational Health and Safety. En International Digest of $\mathrm{H}$ ealth Legislation Ginebra: OMS.
Pitlik, S, SA Berger, D Huminer. 1987. Nonenteric infections acquired through contact with water. $\mathrm{R}$ ev Infect $D$ is 9(1):54-63.

Rioux, AJ, B Juminer. 1983. Animales venenosos. En Enciclopedia de salud y seguridad en el trabajo (3a ed.), dirigido por L Parmeggiani. Ginebra: OIT.

Sterling, TD, C Collett, D Rumel. 1991. Epidemiología del edificio enfermo (en portugués). Rev Sauda Publica 25(1):56-63.

Van Eeden, PJ, JR Joubert, BW Van De Wal, JB K ing, A De K ock, JH Groenewald. 1985. A nosocomial outbreak of $C$ rimean-C ongo haemorrhagic fever at T yberg H ospital: Part 1, Clinical features. S Afr M ed J (SAM J ) 68(9):711-717.

Weatherall, DJ, JGG Ledingham, DA Warrell (dirs.). 1987. The $O$ xford Textbook of M edicine. $2^{a}$ edición. Oxford: OUP. 



\section{DESASTRES NATURALES Y TECNOLOGICOS}

Director del capítulo

Pier Alberto B ertazzi

\section{Sumario}

Catástrofes y accidentes mayores

Pier Alberto B ertazzi . . . . . . . . . . . . . . . . . . 39.2

Preparación para las catástrofes

Peter J. Baxter. . .

Actividades posteriores a las catástrofes

B enedetto Terracini y U rsula A ckermann-Liebrich. . . . . . . . . . . . . 39.20

Problemas relacionados con el clima

J ean French . . . . . . . . . . . . . . . . . . . . . . . 39.23

Avalanchas: riesgos y medidas de protección

Gustav Poinstingl .

Transporte de materiales peligrosos: sustancias químicas y radiactivas

D onald M . Campbell

Accidentes por radiación

Pierre Verger y D enis W inter

Salud en el trabajo y medidas de seguridad en áreas agrarias contaminadas por radionuclidos: la experiencia de Chernóbil

Yuri Kundiev, Leonard D obrovolsky y V. I. C hernyuk. .

Estudio de caso: el incendio de la fábrica de juguetes $\mathrm{K}$ ader

Casey Cavanaugh Grant

Consecuencias de las catástrofes: lecciones desde

una perspectiva médica

J osé L uis Z eballos 


\section{CATASTROFES Y ACCIDENTES} MAYORES

\section{Pier Alberto Bertazzi}

\section{Tipo y frecuencia de las catástrofes}

En 1990, la 44 Asamblea General de las Naciones Unidas consagró la década para la reducción de la frecuencia y el impacto de las catástrofes naturales (L ancet 1990). U na comisión de expertos aprobó la siguiente definición de catástrofe: "Trastorno del ecosistema humano que desborda la capacidad de la comunidad para continuar con su funcionamiento normal".

En las últimas décadas, los datos mundiales sobre catástrofes ponen claramente de manifiesto la existencia de una estructura común a todas ellas que se caracteriza por dos rasgos fundamentales: el aumento del número de personas afectadas y la presencia de una correlación geográfica (Federación Internacional de las Sociedades de la Cruz Roja y la Medialuna Roja (IFRCRCS) 1993). En la Figura 39.1, a pesar de la enorme variación existente entre unos años y otros, es clara la tendencia al alza. En la Figura 39.2 se muestran los países más afectados por catástrofes importantes en 1991. En todos los países del mundo se producen calamidades, pero en los más pobres es más frecuente la pérdida de vidas humanas.

Se han elaborado y revisado muchas definiciones y clasificaciones de las catástrofes (Grisham 1986; Lechat 1990; Logue, Melick y Hansen 1981; Weiss y Clarkson 1986). A título de ejemplo, mencionaremos tres de ellas: los Centros para el Control de Enfermedades [C enters for Disease Control (CDC 1989)] de Estados U nidos determinaron tres categorías principales de catástrofes: sucesos geológicos, como terremotos y erupciones volcánicas; trastornos climáticos, como huracanes, tornados, olas de calor, gotas frías o inundaciones; y, por último, problemas de origen humano, como hambrunas, contaminación atmosférica, catástrofes industriales, incendios e incidentes generados por reactores nucleares. 0 tra clasificación, basada en las causas (Parrish, Falk y M elius 1987), distingue entre catástrofes naturales, como los sucesos climáticos y geológicos, y las

Figura 39.1 • N úmero de personas afectadas anualmente por catástrofes en todo el mundo en el período de 1967 a 1991.

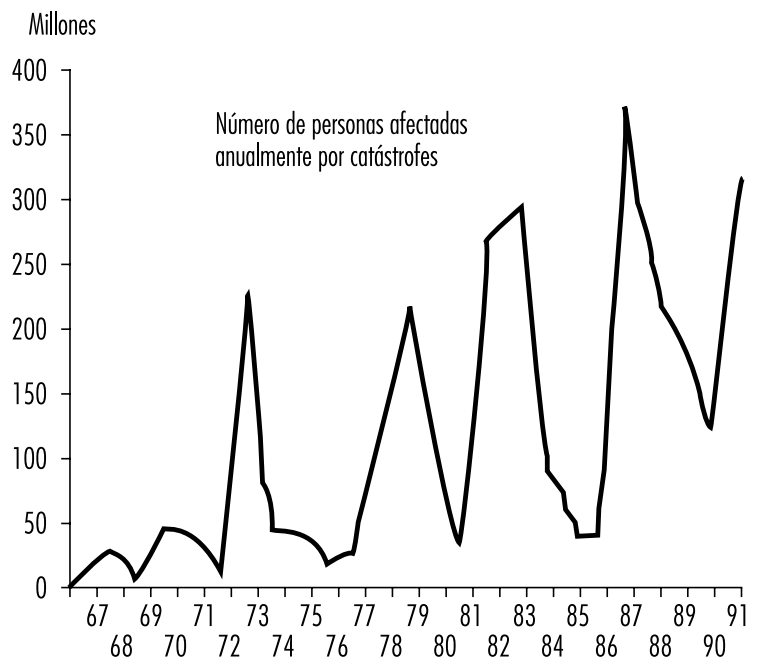

Fuente: IFRCRCS 1993
Figura 39.2 - N úmero de personas muertas a consecuencia de catástrofes en 1991: los 20 países con más víctimas mortales.

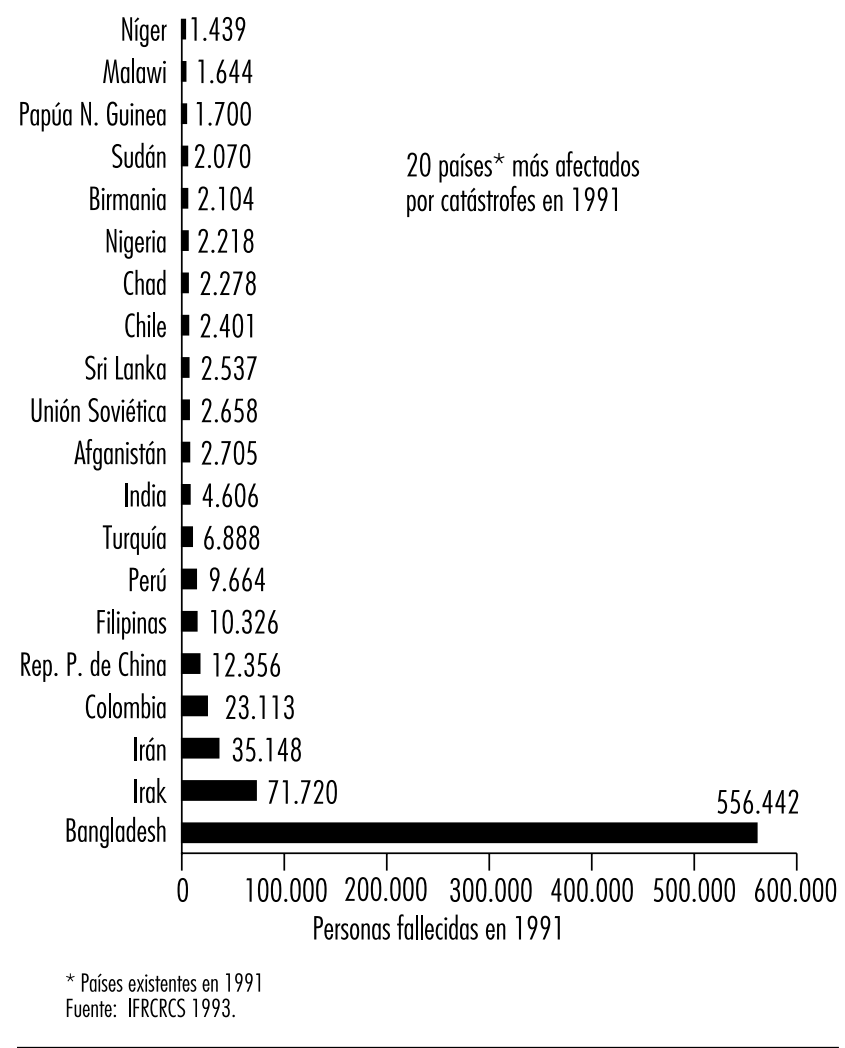

catástrofes de origen humano, que se definen como sucesos artificiales, tecnológicos e intencionados, perpetuados por las personas (como el transporte, los conflictos armados, los incendios y explosiones, y los escapes químicos y radiactivos). U na tercera clasificación (Tabla 39.1), elaborada por el Centro para la Investigación de la Epidemiología de Catástrofes de L ovaina, Bélgica, se basa en una estructura de investigación creada por la O ficina de Coordinación de las Naciones Unidas para el Socorro en Catástrofes en 1991 y fue publicada en W orld D isaster R eport 1993 (IFRCRCS 1993).

En la Figura 39.4 se ofrece el número de catástrofes para cada categoría. Bajo el epígrafe "Accidentes" se incluyen todas las incidencias repentinas de origen humano, y su frecuencia sólo se ve superada por la categoría "Inundaciones". En tercer lugar se encuentran las "Tormentas", seguidas de "Terremotos" e "Incendios".

Tomando como base los datos del IFRCRCS 1993, se puede obtener más información sobre el tipo, frecuencia y consecuencias de las catástrofes, naturales o no naturales, entre 1969 y 1993. A unque las agencias valoran la gravedad de las catástrofes atendiendo al número de víctimas mortales, cada vez es más importante observar también el número de afectados. En todo el mundo, el número de personas afectadas por las catástrofes es casi mil veces mayor que el de víctimas mortales; para muchas de estas personas, la supervivencia después de la catástrofe es cada vez es más difícil, lo que las hace más vulnerables a nuevas desgracias. Se trata de una cuestión importante no sólo en lo que se refiere a las catástrofes naturales (Tabla 39.2), sino también en las de origen humano (Tabla 39.3, página 39.5), especialmente tratándose de accidentes químicos, cuyos efectos sobre las víctimas pueden manifestarse años y hasta décadas 
Tabla 39.1 • Definición de los tipos de catástrofes.

\begin{tabular}{|c|c|c|c|}
\hline $\begin{array}{l}\text { Naturales } \\
\text { repentinas }\end{array}$ & $\begin{array}{l}\text { Naturales } \\
\text { prolongadas }\end{array}$ & $\begin{array}{l}\text { Repentinas } \\
\text { humanas }\end{array}$ & $\begin{array}{l}\text { Prolongadas } \\
\text { humanas }\end{array}$ \\
\hline Avalanchas & Epidemias & $\begin{array}{l}\text { Colapsos } \\
\text { estructurales }\end{array}$ & $\begin{array}{l}\text { Nacional } \\
\text { (conflictos } \\
\text { civiles, guerra } \\
\text { civil) }\end{array}$ \\
\hline Gota fría & Sequía & $\begin{array}{l}\text { Derrumbamiento de } \\
\text { edificios }\end{array}$ & $\begin{array}{l}\text { Internacional } \\
\text { (conflictos } \\
\text { armados) }\end{array}$ \\
\hline Seísmos & Desertización & $\begin{array}{l}\text { Derrumbamiento de } \\
\text { minas 0 } \\
\text { hundimientos }\end{array}$ & $\begin{array}{l}\text { Desplazamientos } \\
\text { de población }\end{array}$ \\
\hline $\begin{array}{l}\text { Seísmos poste- } \\
\text { riores al } \\
\text { terremoto }\end{array}$ & Hambruna & Catástrofe aérea & $\begin{array}{l}\text { Personas } \\
\text { desplazadas }\end{array}$ \\
\hline Inundaciones & $\begin{array}{l}\text { Escasez de } \\
\text { alimentos o } \\
\text { problemas de } \\
\text { cosecha }\end{array}$ & Catástrofe terrestre & Refugiados \\
\hline $\begin{array}{l}\text { Inundación } \\
\text { repentina }\end{array}$ & & Catástrofe marítima & \\
\hline Rotura de presa & & $\begin{array}{l}\text { Accidente indus- } \\
\text { trial/ tecnológico }\end{array}$ & \\
\hline Erupción volcánica & & Explosiones & \\
\hline $\begin{array}{l}\text { Avalancha de lava } \\
\text { ardiente }\end{array}$ & & Explosiones químicas & \\
\hline Ola de calor & & $\begin{array}{c}\text { Explosión nuclear } \\
0 \text { explosiones } \\
\text { termonucleares }\end{array}$ & \\
\hline Ciclón & & $\begin{array}{l}\text { Explosiones en } \\
\text { minería }\end{array}$ & \\
\hline Tormenta & & Contaminación & \\
\hline Granizo & & Lluvia ácida & \\
\hline Tormenta de arena & & $\begin{array}{l}\text { Contaminación } \\
\text { química }\end{array}$ & \\
\hline Oleaje tormentoso & & $\begin{array}{l}\text { Contaminación } \\
\text { atmosférica }\end{array}$ & \\
\hline Tormenta eléctrica & & $\begin{array}{l}\text { Clorofluorocarbo- } \\
\text { nados (CFC) }\end{array}$ & \\
\hline Tormenta tropical & & $\begin{array}{l}\text { Contaminación } \\
\text { petrolífera }\end{array}$ & \\
\hline Tornado & & Incendios & \\
\hline Plagas de insectos & & $\begin{array}{l}\text { Incendios forestales/ } \\
\text { de pastos }\end{array}$ & \\
\hline \multicolumn{4}{|l|}{$\begin{array}{l}\text { Corrimientos de } \\
\text { tierras }\end{array}$} \\
\hline \multicolumn{4}{|l|}{$\begin{array}{l}\text { Inundación de } \\
\text { tierras }\end{array}$} \\
\hline \multicolumn{4}{|l|}{ Escasez de energía } \\
\hline $\begin{array}{l}\text { Maremoto o } \\
\text { tsunami y oleaje } \\
\text { de marea }\end{array}$ & & & \\
\hline
\end{tabular}

después (Bertazzi 1989). El problema de la vulnerabilidad humana ante las catástrofes es crucial para las estrategias de prevención.

La sequía, las hambrunas y las inundaciones siguen afectando a muchas más personas que ningún otro tipo de catástrofe. Desde luego, los vientos fuertes (ciclones, huracanes y tifones) causan, proporcionalmente, más muertes que las hambrunas y las inundaciones con respecto al conjunto de la población afectada; por su parte, los terremotos, que son las catástrofes más repentinas, siguen mostrando el mayor índice de víctimas mortales entre la población afectada (Tabla 39.4, página 39.5). Los accidentes tecnológicos afectaron a más personas que los incendios (Tabla 39.5, página 39.6).

En las Tablas 39.6 y 39.7 pueden verse los tipos y el número de calamidades registradas en 25 años en cada continente. Los vientos fuertes, los accidentes (sobre todo de transporte) y las inundaciones concentran el mayor número de acontecimientos catastróficos, y en su mayoría se produjeron en Asia. A frica fue víctima, con mucho, del mayor número de sequías del mundo. Por otra parte, aunque en Europa las catástrofes arrojan relativamente pocas víctimas mortales, tienen lugar tantos sucesos catastróficos como en Asia o Africa; los índices de mortalidad, inferiores, reflejan una menor vulnerabilidad humana a las crisis. Se obtiene un claro ejemplo comparando las cifras de víctimas mortales de los accidentes químicos de Seveso (I talia) y Bhopal (India) (Bertazzi 1989).

Las cifras correspondientes a 1994 (Tablas 39.8 y 39.9, página 39.7) muestran que Asia sigue siendo la región más proclive a las catástrofes y que los tipos de sucesos más frecuentes son accidentes mayores, inundaciones y vientos fuertes. Aunque los terremotos arrojan unas elevadas tasas de mortalidad, no son más frecuentes que las catástrofes tecnológicas mayores. D ejando aparte los incendios, la media anual de sucesos no naturales es levemente inferior a la de los 25 años anteriores. En cambio, se ha elevado el promedio de catástrofes naturales, con excepción de las inundaciones y los volcanes. En 1994, Europa sufrió más catástrofes de origen humano que A sia (39 frente a 37).

\section{Accidentes químicos mayores}

En este siglo, las peores catástrofes no naturales con víctimas, tanto mortales como no mortales, han sido ocasionadas por los conflictos armados, los transportes y la actividad industrial. En un principio, las catástrofes industriales afectaban sobre todo a personas de determinadas profesiones, pero, más adelante, y especialmente a partir de la segunda Guerra M undial, el rápido crecimiento y expansión de la industria química y el uso de la energía nuclear dieron lugar a que esos sucesos representasen también un grave peligro para las personas situadas fuera del área de trabajo y para el medio ambiente en general. Nos concentraremos en los accidentes mayores relacionados con productos químicos.

La primera catástrofe química de origen industrial documentada data de 1600 y fue descrita por Bernardino Ramazzini (Bertazzi 1989). Las catástrofes químicas actuales difieren en la forma en que suceden y en el tipo de productos químicos involucrados (OIT 1988). Su potencial de riesgo depende tanto de la propia naturaleza del producto químico como de la cantidad de sustancia liberada. N ormalmente, se trata de sucesos incontrolados relacionados con incendios, explosiones o escapes tóxicos que se cobran gran cantidad de víctimas mortales y lesionados dentro y fuera de la central de energía, y ocasionan enormes daños a bienes humanos 0 al medio ambiente.

En la Tabla 39.10 (página 39.7) se ofrecen algunos ejemplos típicos de accidentes químicos mayores debidos a explosiones. En la Tabla 39.11 (página 39.8) se muestran algunas catástrofes mayores debidas a incendios. En la actividad industrial se producen más incendios que explosiones y escapes tóxicos, aunque en general con menos víctimas mortales. La explicación de este hecho podría encontrarse en una mejor prevención y preparación de las personas. En la Tabla 39.12 (página 39.8) se recogen algunos accidentes industriales mayores relacionados con escapes tóxicos de sustancias químicas varias. L os productos 
Tabla 39.2 - N úmero de víctimas de catástrofes debidas a fenómenos naturales de 1969 a 1993 : media correspondiente a 25 años por zona.

$\begin{array}{lrrrrrr} & \text { Africa } & \text { América } & \text { Asia } & \text { Europa } & \text { Oceanía } & \text { Total } \\ \text { Muertos } & 76.883 & 9.027 & 56.072 & 2.220 & 99 & 144.302 \\ \text { Heridos } & 1.013 & 14.944 & 27.023 & 3.521 & 100 & 46.601 \\ \text { Otros afectados } & 10.556 .984 & 4.400 .232 & 105.044 .476 & 563.542 & 95.128 & 120.660 .363 \\ \text { Personas que quedaron sin } & 172.812 & 360.964 & 3.980 .608 & 67.278 & 31.562 & 4.613 .224\end{array}$

Fuente: Walker 1995.

químicos tóxicos más frecuentemente utilizados en cantidades peligrosas son el cloro y el amoníaco, y ambos han ocasionado numerosos accidentes mayores. También el escape de materiales inflamables o tóxicos puede provocar incendios.

Basándonos en la bibliografía sobre catástrofes químicas importantes, podemos determinar otras características comunes a las catástrofes industriales de nuestro tiempo. Las revisaremos brevemente, no sólo para establecer una clasificación general, sino también para evaluar la naturaleza del problema y los desafíos que nos plantea.

\section{Catástrofes manifiestas}

Las catástrofes manifiestas consisten en emisiones hacia el medio ambiente cuyo origen y daño potencial no ofrecen ninguna duda; ejemplos claros son Seveso, Bhopal y Chernóbil.

Seveso representa el prototipo de catástrofe industrial química (H omberger y cols. 1979; Pocchiari y cols. 1983, 1986). El accidente se produjo el 10 de julio de 1976 en la región de Seveso, cerca de M ilán, Italia, en una fábrica de producción de triclorofenol, y contaminó con la potente sustancia tóxica 2,3,7,8-tetraclorodibenceno-para-dioxina (TCDD) varios kilómetros cuadrados de campo habitado. Hubo que evacuar a más de 700 personas y se establecieron restricciones para 30.000 habitantes más. El efecto más claro sobre la salud fue el acné clórico, pero aún no se ha terminado de establecer el cuadro de posibles consecuencias para la salud de este accidente (Bruzzi 1983; Pesatori 1995).

Bhopal representa, probablemente, la peor catástrofe industrial química de toda la H istoria (D as 1985a, 1985b; Friedrich Naumann Foundation 1987; Tachakra 1987). En la noche del 2 de diciembre de 1984, un escape de gas formó una nube letal sobre la ciudad de Bhopal, en la región central de la India, produciendo miles de víctimas mortales y cientos de miles de heridos en el breve espacio de unas horas. El accidente se produjo debido a una reacción fuera de control en uno de los tanques en que se almacenaba isocianato de metilo (MIC). El tanque de almacenaje era de hormigón y contenía unas 42 toneladas del compuesto, que se utilizaba para la fabricación de pesticidas; el tanque estalló, expulsando M IC y otras sustancias químicas disociadas hacia la atmósfera. Además de las evidentes consecuencias catastróficas del accidente, aún no se han determinado los posibles efectos a largo plazo sobre la salud de los afectados o expuestos (Andersson y cols. 1986; Sainani y cols. 1985).

\section{Catástrofes lentas}

Las catástrofes lentas sólo se manifiestan porque víctimas humanas se encuentren casualmente en la vía de escape 0 porque, con el tiempo, los datos ambientales revelen la existencia de un peligro derivado de materiales nocivos.

Figura 39.3 - N úmero total de acontecimientos por cada tipo de catástrofe.

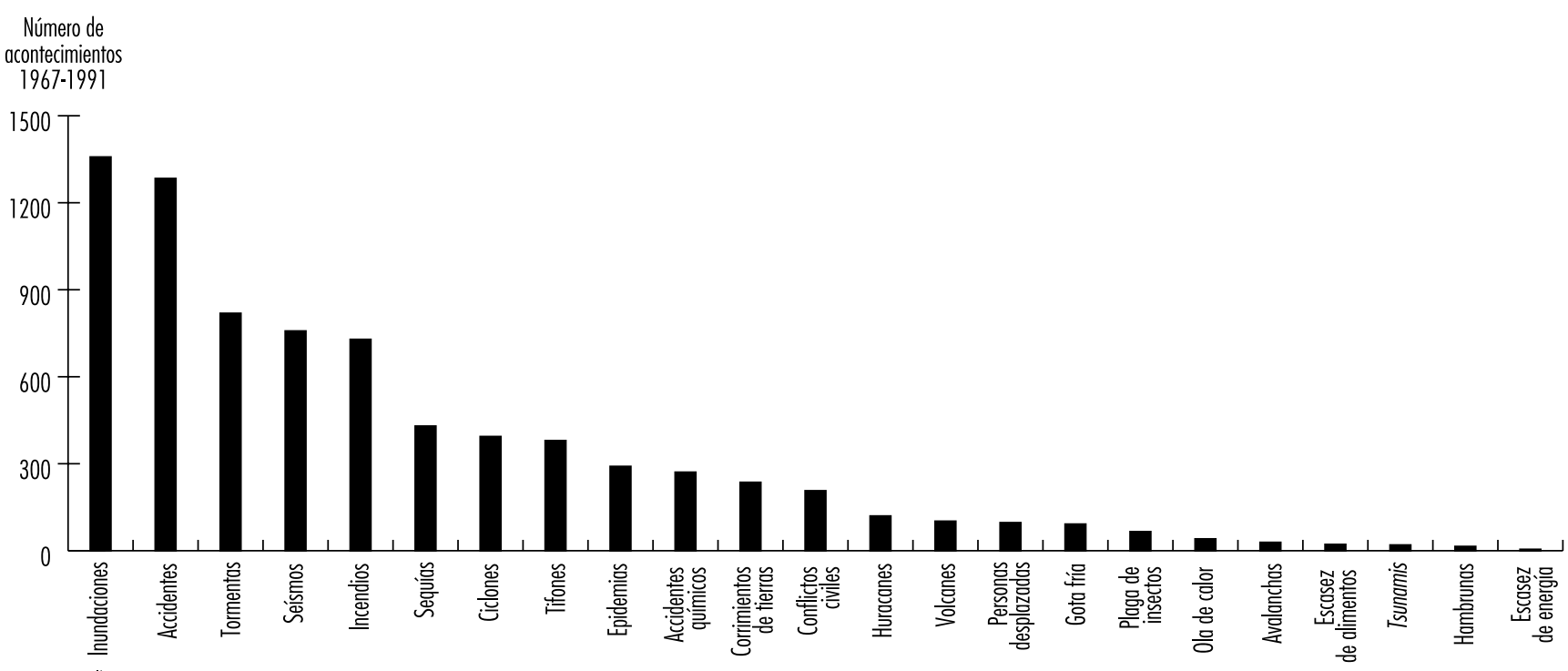

Fuente: Walker 1995. 
Tabla 39.3 - N úmero de víctimas de catástrofes no debidas a fenómenos naturales de 1969 a 1993 : media correspondiente a 25 años por zona.

$\begin{array}{lrrrrrr} & \text { Africa } & \text { América } & \text { Asia } & \text { Europa } & \text { Oceanía } & \text { Total } \\ \text { Muertos } & 16.172 & 3.765 & 2.204 & 739 & 18 & 22.898 \\ \text { Heridos } & 236 & 1.030 & 5.601 & 483 & 476 & 7.826 \\ \text { Afectados } & 3.694 & 48.825 & 41.630 & 7.870 & 610 & 102.62 \\ \text { Personas que quedaron sin hogar } & 2.384 & 1.722 & 6.275 & 7.664 & 24 & 18.069\end{array}$

Fuente: Walker 1995.

Uno de los ejemplos más impresionantes e ilustrativos del primer tipo es la "enfermedad de M inamata". En 1953, los habitantes de las aldeas pesqueras de la bahía de $M$ inamata, en Japón, comenzaron a sufrir unos trastornos neurológicos inhabituales. La enfermedad fue bautizada kibyo, "enfermedad misteriosa". Tras muchas investigaciones, la explicación más probable pareció ser la ingestión de pescado envenenado; en 1957, se consiguió provocar experimentalmente la enfermedad alimentando a gatos con pescado capturado en la bahía; al año siguiente, se sugirió que el cuadro clínico de kibyo, que incluía polineuritis, ataxia cerebelar y ceguera cortical, era similar al presentado por envenenamiento con compuestos de mercurio alquilo. Había que buscar una fuente de mercurio orgánico y finalmente se encontró en una fábrica que evacuaba sus residuos a la bahía de M inamata. En julio de 1961, la enfermedad había afectado a 88 personas, de las cuales 35 (40 \%) habían muerto (H unter 1978).

Un ejemplo del segundo tipo es L ove Canal, una excavación cercana a las cataratas del N iágara, en Estados U nidos. La zona se había utilizado como vertedero químico y municipal durante un período aproximado de 30 años, hasta 1953. Posteriormente, el terreno se rellenó y se construyeron casas en las inmediaciones. A finales del decenio de 1960, se presentaron denuncias por olores a productos químicos en los cimientos, y comenzaron a denunciarse cada vez con mayor frecuencia emisiones químicas en las cercanías del vertedero. En el decenio de 1970, los habitantes empezaron a temer que pudiera surgir algún peligro grave para su salud, y esta opinión común dio paso a investigaciones ambientales y sanitarias. $\mathrm{N}$ inguno de los estudios publicados logró demostrar de forma concluyente la existencia de un vínculo causal entre la exposición a productos químicos y al vertedero y efectos adversos sobre la salud de los habitantes. Con todo, no existe duda alguna de que esta comunidad ha sufrido consecuencias sociales y psicológicas graves, especialmente los habitantes que fueron evacuados (H olden 1980).

\section{Envenenamientos masivos por vía alimentaria}

LoS brotes de envenenamiento por vía alimentaria pueden deberse a la liberación de sustancias químicas tóxicas en el medio ambiente por la utilización de productos químicos en la manipulación y el procesamiento de los alimentos. U no de los episodios más graves de este tipo se produjo en España (Spurzem y Lockey 1984; O M S 1984; Lancet 1983). En mayo de 1981, en loS suburbios pobres de Madrid apareció un brote de un síndrome desconocido hasta la fecha. El fenómeno llegó a afectar a más de 20.000 personas.

En junio de 1982, 315 pacientes habían muerto (unas 16 muertes por cada 1.000 casos). Los síntomas clínicos iniciales incluían neumonía intersticial, diversas erupciones cutáneas, linfadenopatías, eosinofilia intensa y síntomas gastrointestinales. Prácticamente una cuarta parte de los supervivientes de la fase aguda requirieron hospitalización ulterior por alteraciones neuromusculares. Se observaron igualmente trastornos esclerodermáticos de la piel en esta fase tardía, junto con hipertensión pulmonar y fenómeno de R aynaud.

Un mes después de producirse los primeros casos, se descubrió que la enfermedad estaba asociada al consumo de aceite de colza desnaturalizado barato, vendido en recipientes de plástico sin etiqueta, y habitualmente adquirido a vendedores ambulantes. L as advertencias publicadas por las autoridades españolas contra el consumo del aceite sospechoso condujeron a un descenso radical del número de hospitalizaciones por neumonía tóxica (Gilsanz y cols. 1984; K ilbourne y cols. 1983).

0 tro envenenamiento accidental masivo por vía alimentaria que ha sido ampliamente descrito sucedió en Japón (M asuda y Yoshimura 1984) y Taiwan (Chen y cols. 1984), y se relacionó con bifenilos policlorados (PCB).

\section{Catástrofes transnacionales}

En la actualidad, las catástrofes de origen humano no respetan necesariamente las fronteras nacionales. Un ejemplo obvio es C hernóbil, cuyos efectos contaminantes se extendieron desde el océano Atlántico hasta la cordillera de los U rales (Agencia de la Energía Nuclear, 1987). O tro ejemplo lo tenemos en Suiza (Fundación Friedrich Naumann 1987; Salzman 1987). El 1 de noviembre de 1986, poco después de medianoche, se incendió un almacén de la multinacional farmacéutica Sandoz en

Tabla 39.4 - N úmero de víctimas de catástrofes debidas a fenómenos naturales de 1969 a 1993: media correspondiente a 25 años por tipo.

$\begin{array}{lrrrrrrr} & \text { Seísmos } & \begin{array}{c}\text { Sequías y } \\ \text { hambrunas }\end{array} & \text { Inundaciones } & \text { Vientos fuertes } & \begin{array}{l}\text { Corrimientos } \\ \text { de tierras }\end{array} & \text { Volcanes } & \text { Total } \\ \text { Muertos } & 21.668 & 73.606 & 12.097 & 28.555 & 1.550 & 1.009 & 138.486 \\ \text { Heridos } & 30.452 & 0 & 7.704 & 7.891 & 245 & 279 & 46.571 \\ \text { Afectados } & 1.764 .724 & 57.905 .676 & 47.849 .065 & 9.417 .442 & 131.807 & 94.665 & 117.163 .379 \\ \text { Personas que quedaron } & 224.186 & 22.720 & 3.178 .267 & 1.065 .928 & 106.889 & 12.513 & 4.610 .504\end{array}$

sin hogar

Fuente: Walker 1995. 
Tabla 39.5 • N úmero de víctimas de catástrofes no debidas a fenómenos naturales de 1969 a 1993: media correspondiente a 25 años por tipo.

\begin{tabular}{lrcrr} 
& Accidentes & $\begin{array}{l}\text { Accidentes } \\
\text { tecnológicos }\end{array}$ & Incendios & Total \\
Muertos & 3.419 & 603 & 3.300 & 7.321 \\
Heridos & 1.596 & 5.564 & 699 & 7.859 \\
Afectados & 17.153 & 52.704 & 32.771 & 102.629 \\
Personas que & 868 & 8.372 & 8.829 & 18.069 \\
$\quad$ quedaron sin & & & & \\
$\quad$ hogar & & & & \\
Fuente: Walker 1995. & & & & \\
\hline
\end{tabular}

Schweizerhalle, $10 \mathrm{~km}$ al sur de Basilea, y aproximadamente 30 toneladas de productos químicos almacenados fueron arrastradas por el agua utilizada para combatir el incendio hasta el cercano río $\mathrm{R}$ in. En una extensión de unos $250 \mathrm{~km}$, el medio ambiente resultó gravemente dañado. A parte de los síntomas de irritación notificados en las zonas de Basilea alcanzadas por los gases y vapores producidos por el incendio, no se comunicaron casos de enfermedad grave. No obstante, este accidente suscitó una gran preocupación en al menos cuatro países europeos (Suiza, Francia, A lemania y Países Bajos).

La dimensión transnacional no sólo es aplicable a las consecuencias y los daños ocasionados por las catástrofes, sino también a sus causas remotas. El caso de Bhopal puede servir de ejemplo. Al analizar las causas de la catástrofe, algunos investigadores llegaron a la conclusión de que "la catástrofe de Bhopal se produjo como resultado de actos y decisiones concretas tomadas en Danbury, Connecticut u otros lugares, en la superestructura de la empresa, pero no en Bhopal". (Friedrich Naumann Foundation 1987).

\section{Catástrofes "propias del desarrollo"}

Los modelos emergentes de industrialización, junto con la modernización de la agricultura en los países en desarrollo, requieren la aplicación y utilización de tecnología y productos importados o adoptados en contextos muy distintos de aquellos para los que se había previsto inicialmente su uso. Ante las estrictas normativas de los países industrializados, las empresas exportan las actividades peligrosas a zonas del mundo en que las medidas para la protección del medio ambiente y de la salud pública son menos rigurosas. Las actividades industriales se concentran en emplazamientos urbanos ya existentes, y contribuyen de forma significativa a la presión ocasionada por la superpoblación y la insuficiencia de servicios públicos. Estas actividades se distribuyen entre un sector pequeño, altamente organizado, y un sector grande y desorganizado; los controles obligatorios relativos a la seguridad de los trabajadores y del medio ambiente son menos estrictos en este último ( $\mathrm{K}$ rishna M urti 1987). Un ejemplo es el de Pakistán, país en que, de los 7.500 agricultores participantes en un programa de control de la malaria en 1976 hasta 2.800 experimentaban alguna forma de intoxicación (Baker y cols. 1978). Se ha estimado que se producen unos 500.000 envenenamientos agudos por pesticidas al año, que ocasionan unas 9.000 muertes, y que sólo en torno al $1 \%$ de los casos mortales se registran en países industrializados, a pesar de consumir el $80 \%$ de la producción agroquímica total del mundo (Jeyaratnam 1985).

Se argumenta también que las sociedades en desarrollo arrastran una doble carga, en vez de verse aliviadas del fardo del subdesarrollo. De hecho, es posible que a las consecuencias del subdesarrollo se estén sumando las de una industrialización incorrecta (K rishna M urti 1987). Así, parece apremiante reforzar la cooperación internacional en tres ámbitos: investigación científica, salud pública y políticas de emplazamiento y seguridad industriales.

\section{Lecciones para el futuro}

A pesar de la variedad de catástrofes industriales reseñadas, pueden extraerse algunas lecciones comunes sobre cómo prevenir su aparición y cómo mitigar los efectos de catástrofes químicas importantes sobre la población. En particular:

- Es conveniente que varios expertos trabajen en estrecha coordinación sobre el terreno; en general, deberían abarcar todos los ámbitos relacionados con las consecuencias ambientales del agente, sus propiedades tóxicas para los seres humanos y la flora y fauna, los métodos analíticos, la medicina clínica y patológica, la bioestadística y la epidemiología.

- Tomando como base datos preexistentes o los que puedan obtenerse en las fases iniciales, debe elaborarse lo antes posible un plan global, para determinar objetivos, problemas y recursos necesarios.

- Las actividades de las primeras fases influyen en toda la actuación posterior. Dado que cabe prever efectos a largo plazo en casi todos los tipos de catástrofes industriales, hay que prestar una gran atención a garantizar la disponibilidad de la información necesaria para estudios posteriores (por ejemplo, identificadores adecuados de las personas expuestas para su seguimiento).

- Al planificar investigaciones a largo plazo, debería concederse una importancia extrema a la viabilidad, para facilitar los

Tabla 39.6 • Catástrofes debidas a fenómenos naturales de 1969 a 1993: número de acontecimientos en 25 años.

$\begin{array}{lccrrrr} & \text { Africa } & \text { América } & \text { Asia } & \text { Europa } & \text { Oceanía } & \text { Total } \\ \text { Seísmos } & 40 & 125 & 225 & 167 & 83 & 640 \\ \text { Sequías y hambrunas } & 277 & 49 & 83 & 15 & 14 & 438 \\ \text { Inundaciones } & 149 & 357 & 599 & 123 & 138 & 1.366 \\ \text { Corrimientos de tierras } & 11 & 85 & 93 & 19 & 10 & 218 \\ \text { Vientos fuertes } & 75 & 426 & 637 & 210 & 203 & 1.551 \\ \text { Volcanes } & 8 & 27 & 43 & 16 & 4 & 98 \\ \text { Otros* } & 219 & 93 & 186 & 91 & 4 & 593\end{array}$

* El epígrafe "Otros" incluye los siguientes fenómenos: avalanchas, gotas frías, olas de calor, plagas de insectos, tsunamis.

Fuente: Walker 1995 
Tabla 39.7 - Catástrofes no debidas a fenómenos naturales de 1969 a 1993: número de a contecimientos en 25 años.

$\begin{array}{lrrrrrr} & \text { Africa } & \text { América } & \text { Asia } & \text { Europa } & \text { Oceanía } & \text { Total } \\ \text { Accidentes } & 213 & 321 & 676 & 274 & 18 & 1.502 \\ \text { Accidentes } & 24 & 97 & 97 & 88 & 4 & 310 \\ \begin{array}{l}\text { tecnológicos } \\ \text { Incendios }\end{array} & 37 & 115 & 236 & 166 & 29 & 583 \\ \begin{array}{l}\text { Fuente: Walker 1995. } \\ \text { Fun }\end{array} & & & & & \end{array}$

logros científicos y de salud pública y la claridad de la comunicación.

- Sobre todo, por razones de validez y efectividad/ coste, es aconsejable basarse en información "sólida", siempre que sea posible, a la hora de identificar y enumerar la población en estudio (por ejemplo, los residentes), estimar el grado de exposición (por ejemplo, medidas ambientales y biológicas) y elegir los criterios de valoración (por ejemplo, mortalidad).

\section{Control de instalaciones}

\section{para la prevención de accidentes mayores}

El objetivo de este artículo es servir de guía para el establecimiento de un sistema de control de instalaciones expuestas a riesgos de accidentes mayores. La primera parte del mismo se fundamenta en dos documentos de la OIT y en el Convenio más reciente de dicha organización (véase el recuadro de la página 39.9). La directiva europea ha servido de base de la segunda parte del artículo.

\section{Perspectiva de la OIT}

Gran parte de lo que sigue se ha extraído de dos documentos, Prevención de Accidentes Industriales M ayores (OIT 1991) y M anual Práctico de Control de Altos R iesgos (OIT 1988). El "Convenio sobre la Prevención de Accidentes Industriales M ayores" (OIT 1993) (véase el recuadro adjunto) complementa y actualiza el contenido de los dos documentos anteriores. En todos estos documentos se proponen medios de protección de los trabajadores, de la población y del medio ambiente contra el riesgo de accidentes mayores, mediante: 1) la prevención de accidentes mayores en las instalaciones, y 2) la minimización de las consecuencias de un accidente mayor, tanto en el emplazamiento como fuera de él, por ejemplo, a) estableciendo una separación adecuada entre las instalaciones expuestas a riesgos de accidentes mayores y las viviendas y otros focos de población cercanos, como hospitales, escuelas o tiendas, y b) una apropiada planificación de emergencia.

Para datos concretos, se remite al Convenio de la OIT de 1993; lo que sigue es más bien un resumen narrativo del documento citado.

Tabla 39.9 - Catástrofes no debidas a fenómenos naturales: número por región del mundo y por tipo en 1994.

\begin{tabular}{lcrrrrr} 
& Africa & América & Asia & Europa & Oceanía & Total \\
Accidentes & 8 & 12 & 25 & 23 & 2 & 70 \\
$\begin{array}{l}\text { Accidentes } \\
\text { tecnológicos }\end{array}$ & 1 & 5 & 7 & 7 & 0 & 20 \\
$\begin{array}{l}\text { Incendios } \\
\text { Fuente: Walker 1995. }\end{array}$ & 0 & 5 & 5 & 9 & 2 & 21 \\
\hline
\end{tabular}

Tabla 39.8 • Catástrofes debidas a fenómenos naturales: número por región del mundo y por tipo en 1994.

$\begin{array}{lcccccc} & \text { Africa } & \text { América } & \text { Asia } & \text { Europa } & \text { Oceanía } & \text { Total } \\ \text { Seísmos } & 3 & 3 & 12 & 1 & 1 & 20 \\ \begin{array}{c}\text { Sequías y } \\ \text { hambrunas }\end{array} & 0 & 2 & 1 & 0 & 1 & 4 \\ \begin{array}{l}\text { Inundaciones } \\ \text { Corrimientos }\end{array} & 15 & 13 & 27 & 13 & 0 & 68 \\ \quad \text { de tierras } & & 1 & 3 & 1 & 0 & 5 \\ \begin{array}{l}\text { Vientos } \\ \text { fuertes }\end{array} & 6 & 14 & 24 & 5 & 2 & 51 \\ \text { Volcanes } & 0 & 2 & 5 & 0 & 1 & 8 \\ \text { Otros* } & 2 & 3 & 1 & 2 & 0 & 8\end{array}$

* El epígrafe "Otros" incluye los siguientes fenómenos: avalanchas, gotas frías, olas de calor, plagas de insectos, tsunamis.

Fuente: Walker 1995

Por la naturaleza y la cantidad de sustancias peligrosas presentes, las instalaciones de alto riesgo pueden ocasionar accidentes mayores en una de las categorías generales siguientes:

- emisión de sustancias químicas tóxicas en cantidades (toneladas) letales o dañinas incluso a distancias considerables del punto de emisión debido a la contaminación del aire, el agua 0 el suelo;

- emisión de sustancias extremadamente tóxicas en cantidades (kilogramos) letales o dañinas incluso a distancias considerables del punto de emisión;

- escape de cantidades ingentes (toneladas) de líquidos inflamables o gases, que pueden quemarse y producir elevados niveles de radiación térmica o formar una nube de vapor explosiva,

- explosión de materiales inestables o reactivos.

Tabla 39.10 • Ejemplos de explosiones industriales.

\begin{tabular}{|c|c|c|c|}
\hline \multirow[t]{2}{*}{ Sustancia química } & \multicolumn{2}{|c|}{ Consecuencias } & \multirow[t]{2}{*}{ Lugar y fecha } \\
\hline & Muertos & Heridos & \\
\hline Eter dimetílico & 245 & 3.800 & $\begin{array}{l}\text { Ludwigshafen, } \\
\text { República Federal } \\
\text { de Alemania, } 1948\end{array}$ \\
\hline Queroseno & 32 & 16 & $\begin{array}{l}\text { Bitburg, República } \\
\text { Federal de Alemania, } 1948\end{array}$ \\
\hline Isobutano & 7 & 13 & $\begin{array}{l}\text { Lake Charles, } \\
\text { Louisiana, } \\
\text { Estados Unidos, } 1967\end{array}$ \\
\hline Residuos petrolíferos & 2 & 85 & Pernis, Países Bajos, 1968 \\
\hline Propileno & - & 230 & $\begin{array}{l}\text { East Saint Louis, } \\
\text { Illinois, } \\
\text { Estados Unidos, } 1972\end{array}$ \\
\hline Propano & 7 & 152 & $\begin{array}{l}\text { Decatur, Illinois, } \\
\quad \text { Estados Unidos, } 1974\end{array}$ \\
\hline Ciclohexano & 28 & 89 & $\begin{array}{l}\text { Flixborough, } \\
\text { Reino Unido, } 1974\end{array}$ \\
\hline Propileno & 14 & 107 & $\begin{array}{l}\text { Beek, } \\
\text { Países Bajos, } 1975\end{array}$ \\
\hline
\end{tabular}


Tabla 39.11 • Ejemplos de incendios graves.

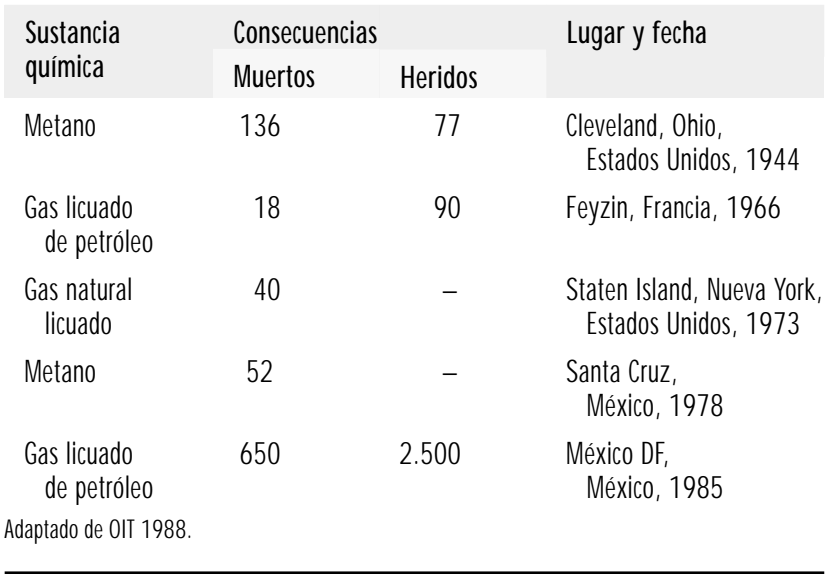

\section{Obligaciones de los E stados miembros}

El Convenio de 1993 obliga a los Estados miembros que no puedan poner inmediatamente en práctica el conjunto de medidas preventivas y de protección previstas en él a:

- elaborar planes, en consulta con las organizaciones más representativas de empresas y de trabajadores y con otras partes interesadas que pudieran verse afectadas, con miras a la aplicación por etapas de dichas medidas, dentro de un plazo fijo;

- adoptar y revisar periódicamente una política nacional coherente relativa a la protección de los trabajadores, la población y el medio ambiente contra los riesgos de accidentes mayores;

- aplicar dicha política mediante disposiciones preventivas y de protección para las instalaciones expuestas a riesgos de accidentes mayores y, cuando sea posible, promover la utilización de las mejores tecnologías de seguridad disponibles, y

- aplicar el Convenio de conformidad con la legislación y la práctica nacionales.

\section{Elementos del sistema de control de riesgos de accidentes mayores}

La diversidad de accidentes importantes ha dado origen al concepto de riesgo de accidente mayor, cuando una actividad industrial requiere controles superiores a los aplicados al funcionamiento de las fábricas normales para proteger tanto a los trabajadores como a las personas que viven y trabajan fuera. Dichos controles no sólo tienen por objetivo prevenir los accidentes, sino también mitigar las consecuencias de cualquier accidente que pueda producirse.

Los controles deben basarse en un enfoque sistemático, con los siguientes componentes básicos:
Tabla 39.12 • Ejemplos de escapes tóxicos graves.

\begin{tabular}{|c|c|c|c|}
\hline \multirow[t]{2}{*}{ Sustancia química } & \multicolumn{2}{|c|}{ Consecuencias } & \multirow[t]{2}{*}{ Lugar y fecha } \\
\hline & Muertos & Heridos & \\
\hline Fosgeno & 10 & - & $\begin{array}{l}\text { Poza Rica, } \\
\text { México, } 1950\end{array}$ \\
\hline Cloro & 7 & - & $\begin{array}{l}\text { Wilsum, República } \\
\text { Federal de } \\
\text { Alemania, } 1952\end{array}$ \\
\hline Dioxina/ TCDD & - & 193 & $\begin{array}{l}\text { Seveso, Italia, } \\
1976\end{array}$ \\
\hline Amoníaco & 30 & 25 & $\begin{array}{l}\text { Cartagena, Colombia, } \\
1977\end{array}$ \\
\hline Dióxido de azufre & - & 100 & $\begin{array}{l}\text { Baltimore, Maryland, } \\
\text { Estados Unidos, } 1978\end{array}$ \\
\hline Sulfuro de hidrógeno & 8 & 29 & $\begin{array}{l}\text { Chicago, Illinois, } \\
\text { Estados Unidos, } 1978\end{array}$ \\
\hline $\begin{array}{l}\text { Isocianato de metilo } \\
\text { idaptado de OIT } 1988 .\end{array}$ & 2.500 & 200.000 & Bhopal, India, 1984 \\
\hline
\end{tabular}

- Identificación de las instalaciones expuestas a riesgos de accidentes mayores, incluyendo sus cantidades umbrales respectivas y un inventario. Las autoridades públicas y las empresas deben velar por la identificación de las instalaciones expuestas a riesgos de accidentes mayores, y revisar y actualizar periódicamente la lista de las mismas.

- Información sobre la instalación. U na vez que se ha determinado cuáles son las instalaciones expuestas a riesgos de accidentes mayores, debe recogerse información adicional sobre su diseño y funcionamiento. Dicha información se compilará y organizará de forma sistemática, y estará disponible para todas las partes interesadas dentro y fuera del sector. Para conseguir una descripción completa de los riesgos, puede ser necesario llevar a cabo estudios de seguridad y evaluaciones de riesgos, al objeto de descubrir posibles fallos en los procesos y establecer prioridades durante el proceso de evaluación de riesgos.

- Disposiciones especiales para proteger la información confidencial.

- M edidas en el marco de la actividad industrial. Las empresas son las principales responsables de gestionar y mantener unas instalaciones seguras. Para ello se requiere una sólida política de seguridad. La inspección técnica, el mantenimiento, la modificación de las instalaciones, la formación y la selección de personal adecuado deben llevarse a cabo de acuerdo con procedimientos normalizados de control de calidad para instalaciones expuestas a riesgos de accidentes mayores. Además de la redacción del informe de seguridad, deben investigarse todo tipo de

Tabla 39.13 - Función de los responsables de la gestión de instalaciones con riesgos de accidentes mayores en sistemas de control de riesgos.

Medidas (en función de la legislación local)

Notificar a las autoridades Informar de modificaciones importantes

Elaborar y presentar el informe Suministrar otra información de seguridad previa solicitud
Medidas en caso de accidente mayor

Preparar un plan de emergencia interior (dentro de la instalación)

Suministrar a las autoridades locales información que les permita elaborar un plan de emergencia exterior (fuera de la instalación) 


\section{Convenio de la OIT sobre la prevención de accidentes industriales mayores, 1993 (No. 174)}

\section{OIT, 80ạ Sesión, 2 de junio de 1993}

\section{PARTE I. CAM PO DE APUCACION Y DEFIN IC IO N ES}

\section{Artículo 1}

1. El presente Convenio tiene por objeto la prevención de accidentes mayores que involucren sustancias peligrosas y la limitación de las consecuencias de dichos accidentes....

\section{Artículo 3}

\section{A los efectos del presente $C$ onvenio:}

a) la expresión "sustancia peligrosa" designa toda sustancia o mezcla que, en razón de propiedades químicas, físicas o toxicológicas, ya sea sola o en combinación con otras, entrañe un peligro;

b) la expresión "cantidad umbral" designa respecto de una sustancia o categoría de sustancias peligrosas la cantidad fijada por la legislación nacional con referencia a condiciones específicas que, si se sobrepasa, identifica una instalación expuesta a riesgos de accidentes mayores;

c) la expresión "instalación expuesta a riesgos de accidentes mayores" designa aquella que produzca, transforme, manipule, utilice, deseche, 0 almacene, de manera permanente 0 transitoria, una 0 varias sustancias o categorías de sustancias peligrosas, en cantidades que sobrepasen la cantidad umbral;

d) la expresión "accidente mayor" designa todo acontecimiento repentino, como una emisión, un incendio o una explosión de gran magnitud, en el curso de una actividad dentro de una instalación expuesta a riesgos de accidentes mayores, en el que estén implicadas una 0 varias sustancias peligrosas y que exponga a los trabajadores, a la población o al medio ambiente a un peligro grave, inmedia to o diferido;

e) la expresión "informe de seguridad" designa un documento escrito que contenga la información técnica, de gestión y de funcionamiento relativa a los peligros y los riesgos que comporta una instalación expuesta a riesgos de accidentes mayores y a su prevención, y que justifique las medidas adoptadas para la seguridad de la instalación,

f) el término "cuasiaccidente" designa cualquier acontecimiento repentino que implique la presencia de una 0 varias sustancias peligrosas y que, de no ser por efectos, acciones o sistemas atenuantes, podría haber derivado en un accidente mayor.

\section{PARTE II. PRIN C IPIOS G EN ERALES}

\section{Artículo 4}

1. Todo M iembro deberá formular, adoptar y revisar periódicamente, habida cuenta de la legislación, las condiciones y la práctica nacionales, y en consulta con las organizaciones más representativas de empleadores y de trabajadores y con otras partes interesadas que pudieran ser afectadas, una política nacional coherente relativa a la protección de los trabajadores, la población y el medio ambiente, contra los riesgos de accidentes mayores.

2. Esta política deberá ser aplicada mediante disposiciones preventivas y de protección para las instalaciones expuestas a riesgos de accidentes mayores y, cuando sea posible, deberá promover la utilización de las mejores tecnologías de seguridad disponibles.

\section{Artículo 5}

1. La autoridad competente 0 un organismo aprobado o reconocido por la autoridad competente deberá, previa consulta con las organizaciones más representativas de empleadores y de trabajadores y con otras partes interesadas que pudieran ser afectadas, establecer un sistema para la identificación de las instalaciones expuestas a riesgos de accidentes mayores según se definen en el artículo 3, c), basado en una lista de sustancias peligrosas o de categorías de sustancias peligrosas, o de ambas, que incluya sus cantidades umbrales respectivas, de conformidad con la legislación nacional o las normas internacionales.

2. El sistema de clasificación al que se hace referencia en el párrafo 1 anterior deberá ser revisado y a ctualizado regularmente.

\section{Artículo 6}

La autoridad competente, después de consultar a las organizaciones representativas de empleadores y de trabajadores interesadas, deberá tomar disposiciones especiales para proteger las informaciones confidenciales que le son transmitidas o puestas a su disposición de conformidad con cualquiera de los artículos 8, 12, 13014 , cuya revelación pudiera causar perjuicio a las actividades de un empleador, siempre y cuando dicha confidencialidad no implique un peligro grave para los trabajadores, la población 0 el medio ambiente.

PARTE III. RESPO N SABIUDADES DE LO S EM PLEADO RES

\section{IDEN TIFIC ACIO N}

Artículo 7

Los empleadores deberán identificar, de conformidad con el sistema mencionado en el artículo 5, toda instalación expuesta a riesgos de accidentes mayores sujeta a su control.

\section{N O TIFIC ACIO N}

\section{Artículo 8}

1. Los empleadores deberán notificar a la autoridad competente toda instalación expuesta a riesgos de accidentes mayores que hayan identificado:

a) dentro de un plazo fijo en el caso de una instalación ya existente;

b) antes de ponerla en funcionamiento en el caso de una nueva instalación.

2. Los empleadores deberán también notificar a la autoridad competente el cierre definitivo de una instalación expuesta a riesgos de accidentes mayores antes de que éste tenga lugar.

\section{Artículo 9}

Respecto a cada instalación expuesta a riesgos de accidentes mayores, los empleadores deberán establecer y mantener un sistema documentado de prevención de riesgos de accidentes mayores en el que se prevean:

a) la identificación y el estudio de los peligros y la evaluación de los riesgos, teniendo también en cuenta las posibles interacciones entre sustancias;

b) medidas técnicas que comprendan el diseño, los sistemas de seguridad, la construcción, la selección de sustancias químicas, el funcionamiento, el mantenimiento y la inspección sistemática de la instalación;

c) medidas de organización que comprendan la formación e instrucción del personal, el abastecimiento de equipos de protección destinados a garantizar su seguridad, una adecuada dotación de personal, los horarios de trabajo, la distribución de responsabilidades y el control sobre los contratistas externos y los trabajadores temporales que interveng an dentro de la instala ción;

d) planes y procedimientos de emergencia que comprendan:

i) la preparación de planes y procedimientos de emergencia eficaces, con inclusión de procedimientos médicos de emergencia, para su aplicación in situ en caso de accidente mayor 0 de peligro de accidente mayor, la verificación y evaluación periódica de su eficacia y su revisión cuando sea necesario; 
ii) el suministro de información sobre los accidentes posibles y sobre los planes de emergencia in situ a las autoridades y a los organismos encargados de establecer los planes y procedimientos de emergencia para proteger a la población y al medio ambiente en el exterior de la instalación;

iii) todas las consultas necesarias con dichas autoridades y organismos;

e) medidas destinadas a limitar las consecuencias de un accidente mayor;

f) la consulta con los trabajadores y sus representantes;

g) las disposiciones tendentes a mejorar el sistema, que comprendan medidas para la recopilación de información y para el análisis de accidentes y cuasiaccidentes. La experiencia así adquirida deberá ser discutida con los trabajadores y sus representantes y deberá ser registrada, de conformidad con la legislación y la práctica nacional...

\section{PARTE IV. RESPO N SABIUDADES DE LAS AUTO RIDADES CO M PETEN TES}

\section{PLAN ES PARA CASOS DE EM ERG EN CIA FUERA DE LA IN STALACIO N}

\section{Artículo 15}

Tomando en cuenta la información proporcionada por el empleador, la autoridad competente deberá velar por que se establezcan y actualicen a intervalos apropiados, y se coordinen con las autoridades y organismos interesados, los planes y procedimientos de emergencia que contengan disposiciones para proteger a la población y al medio ambiete fuera del emplazamiento en que se encuentre cada instalación expuesta a riesgos de accidentes mayores.

\section{Artículo 16}

La autoridad competente deberá velar por que:

a) se difunda entre los miembros de la población que estén expuestos a los efectos de un accidente mayor, sin que tengan que solicitarlo, la información sobre las medidas de seguridad que han de adoptarse y sobre la manera de comportarse en caso de accidente mayor, y por que se actualice y se difunda de nuevo dicha información a intervalos a propiados:

b) se dé la alarma cuanto antes al producirse un accidente mayor,

c) cuando las consecuencias de un accidente mayor puedan trascender las fronteras, se proporcione a los Estados afectados la información requerida en los apartados a) y b) con el fin de contribuir a las medidas de cooperación y coordinación.

\section{Artículo 17}

La autoridad competente deberá elaborar una política global de emplazamiento que prevea una separación adecuada entre las instalaciones en proyecto que estén expuestas a riesgos de accidentes mayores y las áreas de trabajo, las zonas residenciales y los servicios públicos, y deberá adoptar disposiciones apropiadas al respecto en lo que atañe a las instalaciones existentes. Dicha política deberá inspirarse en los principios generales enunciados en la parte II de este Convenio.

\section{IN SPEC C IO N}

\section{Artículo 18}

1. La autoridad competente deberá disponer de personal debidamente calificado que cuente con una formación y competencia adecuadas y con el apoyo técnico y profesional suficiente para desempeñar sus funciones de inspección, investigación, evaluación y asesoría sobre los temas especificados en este Convenio, así como para asegurar el cumplimiento de la legislación nacional.
2. Los representantes del empleador y los representantes de los trabajadores de la instalación expuesta a riesgos de accidentes mayores deberán tener la posibilidad de acompañar a los inspectores cuando controlen la aplicación de las medidas prescritas en virtud del presente Convenio, a menos que los inspectores estimen, a la luz de las directrices generales de la autoridad competente, que ello puede perjudicar el cumplimiento de sus funciones de control.

\section{Artículo 19}

La autoridad competente deberá tener derecho a suspender cualquier actividad que presente una amenaza inminente de accidente mayor.

\section{PARTE V. DERECHOS Y O BUG ACIO N ES DE LO S TRABAJADO RES} $Y$ DE SUS REPRESEN TAN TES

\section{Artículo 20}

En una instalación expuesta a riegos de accidentes mayores, los trabajadores y sus representantes deberán ser consultados mediante mecanismos apropiados de cooperación, con el fin de garantizar un sistema seguro de trabajo. En particular, los trabajadores y sus representantes deberán:

a) estar suficiente y adecuadamente informados de los riesgos que entraña dicha instalación y de sus posibles consecuencias;

b) estar informados acerca de cualquier instrucción o recomendación hecha por la autoridad competente;

c) ser consultados para la preparación de los siguientes documentos y tener acceso a los mismos:

i) el informe de seguridad;

ii) los planes y procedimientos de emergencia;

iii) los informes sobre los accidentes;

d) recibir periódicamente instrucciones y formación con respecto a los procedimientos y prácticas de prevención de accidentes mayores y de control de acontecimientos que puedan dar lugar a un accidente mayor y a los procedimientos de emergencia que han de aplicarse en tales casos;

e) dentro de sus atribuciones, y sin que en modo alguno ello pueda perjudicarles, tomar medidas correctivas y, en caso necesario, interrumpir la actividad cuando, basándose en su formación y experiencia, tengan razones válidas para creer que existe un peligro inminente de accidente mayor $y$, según corresponda, informar a su supervisor o dar la alarma antes o tan pronto como sea posible después de haber tomado las medidas correctivas;

f) discutir con el empleador cualquier peligro potencial que ellos consideren que puede causar un accidente mayor y tener derecho a informar a la autoridad competente acerca de dichos peligros.

\section{Artículo 21}

Los trabajadores empleados en el emplazamiento de una instalación expuesta a riesgos de accidentes mayores deberán:

a) observar todos los procedimientos y prácticas relativos a la prevención de accidentes mayores y al control de acontecimientos que puedan dar lugar a un accidente mayor en las instalaciones expuestas a dichos riesgos;

b) observar todos los procedimientos de emergencia en caso de producirse un accidente mayor.

\section{PARTE VI. RESPO N SABIUDAD DE LO S PAÍSES EXPO RTADO RES}

\section{A rtículo 22}

Cuando en un Estado M iembro exportador el uso de sustancias, tecnologías o procedimientos peligrosos haya sido prohibido por ser fuente potencial de un accidente mayor, dicho Estado deberá poner a disposición de todo país importador la información relativa a esta prohibición y a las razones que la motivan. 
accidentes y presentar a la autoridad competente copias de los informes.

- Medidas de la administración y de otras autoridades competentes. Se realizarán evaluaciones de riesgos a los fines de la concesión de permisos (en su caso), inspección y aplicación de la legislación vigente. La planificación de la ordenación del territorio puede reducir considerablemente el potencial catastrófico. La formación de inspectores de fábrica es también una función importante de la administración u otra autoridad competente.

- Planes para casos de emergencia. El objetivo es reducir las consecuencias de los accidentes importantes. A la hora de elaborar el plan de emergencia, hay que distinguir entre planificación interna y planificación externa.

\section{Responsabilidades de la empresa}

L as instalaciones expuestas a riesgos de accidentes mayores deben observar unas normas de seguridad muy estrictas. Además, la empresa desempeña un papel clave en la organización y aplicación de un sistema de control de riesgos de accidentes mayores. En particular, tal como se indica en la Tabla 39.13, es responsable de:

- comunicar la información necesaria para identificar las instalaciones expuestas a riesgos de accidentes mayores dentro de un plazo fijo;

- llevar a cabo una evaluación de los riesgos;

- notificar a la autoridad competente el resultado de dicha evaluación de riesgos;

- adoptar medidas técnicas que comprendan el diseño, los sistemas de seguridad, la construcción, la selección de sustancias químicas, el funcionamiento, el mantenimiento y la inspección sistemática de la instalación;

- implantar medidas de organización, incluidas, entre otras, la formación e instrucción del personal y una adecuada dotación de personal;

- elaborar un plan de emergencia;

- adoptar medidas destinadas a mejorar la seguridad de la fábrica y limitar las consecuencias de un posible accidente;

- consultar a los trabajadores y a sus representantes;

- mejorar el sistema, tomando como base los cuasiaccidentes y la información correspondiente;

- garantizar que los procedimientos de control de calidad son efectivos, y auditarlos periódicamente,

- notificar a la autoridad competente antes del cierre permanente de cualquier instalación expuesta a riesgos de accidentes mayores.

En primer lugar, y ante todo, las empresas con instalaciones que pueden ocasionar un accidente mayor tienen la obligación de controlar ese riesgo. Para ello, deben ser conscientes de la naturaleza del peligro, de los sucesos que provocan accidentes y de las posibles consecuencias de los mismos. Esto significa que, para controlar adecuadamente un riesgo elevado, las empresas deben conocer las respuestas a las siguientes preguntas:

- ¿Constituyen un alto riesgo las sustancias tóxicas, explosivas 0 inflamables existentes en la instalación?

- ¿Hay agentes o sustancias químicas que, al combinarse, puedan presentar riesgo de toxicidad?

- ¿Q ué fallos o errores pueden provocar condiciones anormales que generen un accidente mayor?

- Si se produce un accidente mayor, ¿cuáles serán las consecuencias de un incendio, una explosión o un escape tóxico para los trabajadores, los habitantes de las cercanías de la instalación, la fábrica o el medio ambiente?

- ¿Q ué puede hacer la empresa para impedir que se produzcan tales accidentes?
- ¿Qué puede hacerse para mitigar las consecuencias de un posible accidente?

\section{Evaluación de riesgos}

EI modo más adecuado de responder a estas preguntas es realizar una evaluación de riesgos, para comprender por qué se producen los accidentes y cómo pueden evitarse 0 , al menos, mitigarse. Los métodos que pueden utilizarse para esta evaluación se resumen en la Tabla 39.14.

\section{Funcionamiento seguro}

A continuación se pasa revista a los distintos aspectos que deben tenerse en cuenta para el control de los riesgos.

\section{Diseño de los componentes de la fábrica}

Un componente debe ser resistente a los siguientes fenómenos: carga estática, carga dinámica, presión interna y externa, corrosión, presiones derivadas de grandes diferencias de temperatura y presiones debidas a agentes externos (viento, nieve, seísmos,

Tabla 39.14 - Métodos de trabajo para la evaluación de riesgos.

\begin{tabular}{|c|c|c|c|}
\hline Método & Intención & Objetivo & $\begin{array}{l}\text { Principio de } \\
\text { trabajo }\end{array}$ \\
\hline $\begin{array}{l}\text { 1. Análisis } \\
\text { preliminar } \\
\text { del riesgo }\end{array}$ & $\begin{array}{l}\text { 1. Identificación } \\
\text { de riesgos }\end{array}$ & $\begin{array}{l}\text { 1. Adecuación } \\
\text { del concepto } \\
\text { de seguridad }\end{array}$ & $\begin{array}{l}\text { 1. Uso de } \\
\text { "herramient } \\
\text { de razona- } \\
\text { miento" }\end{array}$ \\
\hline
\end{tabular}

2. Diagramas matrices de las interacciones

3. Uso de listas de comprobación

4. Análisis de fallos y efectos

5. Estudio del peligro y de la viabilidad de la operación

6. Análisis de la secuencia de accidente (razonamiento inductivo)

2. Evaluación del peligro atendiendo a

2. Optimización de la fiabilidad y disponibilidad la frecuencia de los sistemas de aparición de seguridad

2. Uso de "herramientas de búsqueda" y documentación esquemática

7. Análisis del árbol de fallos (deductivo)

8. Análisis de las consecuencias del accidente

$\begin{array}{lll}\text { 3. Evaluación } & \text { 3. Paliación de las } & \text { 4. Elaboración } \\ \text { de las } & \text { consecuencias } & \text { de un modelo } \\ \text { consecuencias } & \text { y desarrollo } & \text { matemático de } \\ \text { del accidente } & \text { de los } & \text { los procesos } \\ & \text { planes de } & \text { físicos y } \\ & \text { emergencia } & \text { químicos } \\ & \text { óptimos }\end{array}$

Fuente: OIT 1988 
asentamientos). Normas de diseño son, por tanto, un requisito mínimo para las instalaciones expuestas a riesgos de accidentes mayores.

\section{Funcionamiento y control}

Cuando se diseña una instalación para resistir todas las presiones que pueden producirse en condiciones de funcionamiento normales o anormales pero previstas, el mantenimiento de la misma dentro de los límites de seguridad corresponde al sistema de control de procesos.

Para aplicar dicho sistema de control, es necesario supervisar las variables que intervienen en el proceso y las partes activas de la instalación. El personal operativo debe estar adecuadamente formado, y ser consciente de las modalidades operativas y de la importancia del sistema de control. Para asegurarse de que el personal operativo no tenga que confiar solamente en el funcionamiento de los sistemas automáticos, éstos deben combinarse con alarmas acústicas u ópticas.

Es de capital importancia comprender que cualquier sistema de control dará problemas en condiciones operativas inhabituales, como en las fases de puesta en marcha y parada. $H$ ay que prestar una atención especial a estas fases de funcionamiento. $L a$ empresa deberá auditar periódicamente los procedimientos de control de calidad.

\section{Sistemas de seguridad}

Toda instalación expuesta a riesgos de accidentes mayores debe estar dotada de algún tipo de sistema de seguridad. La forma y diseño de dicho sistema dependerá de los riesgos inherentes a la fábrica. A continuación enumeramos los sistemas de seguridad disponibles:

- sistemas que evitan los desvíos respecto de las condiciones de funcionamiento admisibles;

- sistemas que previenen fallos de los componentes relacionados con la seguridad;

- suministros de servicios (electricidad, gas, aire comprimido, etc.) relacionados con la seguridad;

- sistemas de alarma;

- medidas técnicas de protección,

- prevención de errores humanos o de organización.

\section{Mantenimiento y supervisión}

El nivel de seguridad de una fábrica y el buen funcionamiento de su sistema de seguridad dependerán directamente del correcto mantenimiento y supervisión de tales sistemas.

\section{Inspección y reparaciones}

Es necesario establecer un plan de inspecciones internas para el personal operativo, que incluya las instrucciones y las condiciones operativas que deben observarse durante las tareas de inspección. Se especificarán procedimientos estrictos de reparación.

\section{Formación}

Dado que las personas pueden influir tanto negativa como positivamente en la seguridad de una fábrica, es importante reducir las influencias negativas y fomentar las positivas. Ambos objetivos pueden conseguirse mediante una adecuada selección, formación y evaluación/ valoración periódica del personal.

\section{Mitigación de las consecuencias}

Aunque se haya realizado una evaluación de los riesgos, se hayan detectado estos últimos y se hayan adoptado medidas adecuadas para prevenir los accidentes, no queda totalmente suprimida la posibilidad de que se produzca alguno. Por esta razón, el concepto de seguridad debe incluir la planificación y adopción de medidas capaces de mitigar las consecuencias de un accidente.
Dichas medidas deben ser coherentes con los riesgos detectados en la evaluación. A demás, han de ir acompañadas de una formación adecuada del personal de fábrica, del personal de emergencia y del personal de los servicios públicos. Sólo la formación y la realización de simulacros de accidentes pueden hacer que los planes de emergencia sean lo bastante realistas para funcionar correctamente en caso de emergencia.

\section{Notificaciones en materia de seguridad a la autoridad competente}

En función de la reglamentación vigente en cada país, las empresas que cuenten con instalaciones expuestas a riesgos de accidentes mayores deberán notificar tal hecho a la autoridad correspondiente. Las notificaciones podrán realizarse en los tres pasos siguientes:

- identificación/notificación de instalaciones de alto riesgo (incluido cualquier cambio previsto en la instalación);

- elaboración de informes periódicos de seguridad (que serán revisados a la luz de las transformaciones introducidas en la instalación),

- notificación inmediata de cualquier tipo de accidente, seguida de un informe detallado.

\section{Derechos y obligaciones de los trabajadores y sus representantes}

Se consultará a los trabajadores y a sus representantes, mediante mecanismos apropiados de cooperación, con el fin de garantizar un sistema seguro de trabajo. Se les consultará sobre la elaboración de los informes de seguridad, de los planes y procedimientos de emergencia, y de los informes de accidentes, a todos los cuales tendrán acceso. Recibirán formación sobre la prevención de accidentes mayores y los procedimientos de emergencia aplicables en tal caso. Por último, los trabajadores y sus representantes deberán estar capacitados para aplicar las medidas correctivas necesarias, dentro de los límites de sus competencias, cuando crean que existe un peligro inminente de accidente mayor. También estarán facultados para notificar cualquier riesgo a las autoridades competentes. Los trabajadores deberán observar todos los procedimientos y prácticas relativos a la prevención de accidentes mayores y al control de acontecimientos que puedan dar lugar a un accidente mayor. Observarán todos los procedimientos de emergencia en caso de que producirse un accidente mayor.

\section{Aplicación de un sistema de prevención de riesgos mayores}

Aunque en la mayoría de los países del mundo están muy generalizados el almacenamiento y la utilización de grandes cantidades de materiales peligrosos, los sistemas actualmente empleados para su control varían mucho de unos países a otros. Esto significa que la velocidad de aplicación de un sistema de prevención de riesgos mayores dependerá de los recursos ya existentes en cada país, especialmente en términos de inspectores de instalación formados y experimentados, y de los recursos disponibles a escala local y nacional para los distintos elementos del sistema de control. A hora bien, en todos los países será necesario establecer prioridades en un programa por etapas.

\section{Identificación de riesgos mayores}

Este es el punto de partida básico de cualquier sistema de prevención: la definición de qué es, en la práctica, un riesgo mayor. Aunque existen definiciones en algunos países y en particular en la UE, la definición de riesgo mayor de cada país concreto refleja las prioridades y prácticas nacionales y, en especial, su modelo industrial.

Cualquier definición que se utilice para detectar riesgos mayores constará probablemente de una lista de sustancias peligrosas, junto con un inventario para cada una de ellas, de tal 
modo que cualquier instalación que almacene o utilice una de esas sustancias en cantidades excesivas será, por definición, una instalación expuesta a riesgos mayores. El siguiente paso es determinar dónde hay instalaciones expuestas a riesgos de accidentes mayores en una región o país concreto. Si un país desea saber cuáles son sus instalaciones de alto riesgo antes de que entre en vigor la legislación pertinente, puede avanzar mucho de manera informal, especialmente si cuenta con la colaboración de la industria. Las fuentes de información existentes, como informes de inspección de fábrica, datos sobre organismos industriales, etc., pueden dar lugar a una lista provisional que, además de posibilitar el establecimiento de prioridades de inspección en una fase temprana, permitirá evaluar los recursos necesarios para los distintos elementos del sistema de prevención.

\section{Creación de un grupo de expertos}

En los países que estén considerando por primera vez la posibilidad de implantar un sistema de prevención de riesgos mayores, un primer paso importante será crear un grupo de expertos en el seno de una unidad especial de la administración. Dicho grupo deberá establecer prioridades a la hora de decidir su programa inicial de actividad. Puede resultar necesario formar a los inspectores de fábrica en las técnicas de inspección de riesgos mayores, incluidas las normas de funcionamiento de este tipo de instalaciones. El grupo también puede asesorar sobre el emplazamiento de nuevos riesgos mayores y el uso de los terrenos circundantes. A demás, establecerá contactos en otros países, para mantenerse al día sobre los progresos realizados en este ámbito.

\section{Preparación para las emergencias dentro de la fábrica}

Los planes de emergencia requieren una evaluación del tipo de accidentes que pueden producirse en una instalación de alto riesgo y del modo en que pueden atacarse en la práctica. La gestión de los posibles accidentes exigirá tanto personal como equipo, y deberá comprobarse que ambos factores están presentes en cantidad suficiente. Los planes deben incluir los siguientes elementos:

- evaluación de la dimensión y naturaleza de los incidentes previstos y de su probabilidad de aparición;

- formulación del plan y relaciones con autoridades externas, incluidos los servicios de emergencia;

- procedimientos: a) dar la alarma; b) comunicaciones dentro y fuera de la fábrica;

- designación del personal clave, junto con sus obligaciones y responsabilidades;

- centro de control de emergencias,

- acción interna y externa.

\section{Preparación para las emergencias fuera de la fábrica}

A este ámbito se ha prestado menos atención que a la planificación interna de emergencias, y muchos países se enfrentan con este problema por primera vez. En el plan de emergencia externo deben tenerse en cuenta los posibles accidentes identificados por la instalación de alto riesgo, su probabilidad de aparición y la proximidad de personas que vivan o trabajen en las inmediaciones. Debe contemplar un modo rápido de dar la alarma y de evacuar a la población y forma de conseguirlo. Hay que tener presente que las viviendas convencionales de construcción sólida ofrecen una protección considerable contra las nubes de gases tóxicos, mientras que las chabolas o construcciones similares son vulnerables a tales accidentes.

En el plan de emergencia se indicarán las organizaciones a las que se debe acudir en caso de emergencia, y se comprobará que conocen la función que se espera de ellas: por ejemplo, los hospitales y el personal médico deberán decidir el modo de gestionar un número elevado de víctimas, y en particular qué tratamientos prescribir. EI plan externo de emergencia deberá ensayarse regularmente con la colaboración de la población.

Si un accidente importante puede tener efectos transfronterizos, deberá suministrarse plena información a las autoridades de los territorios correspondientes, así como asistencia en los mecanismos de cooperación y coordinación.

\section{Emplazamiento}

Es clara la necesidad de una política de emplazamientos de las instalaciones expuestas a riesgos mayores: dado que no se puede garantizar una seguridad absoluta, las instalaciones de este tipo deben situarse lejos de las personas que viven y trabajan fuera de la instalación. Como prioridad, puede ser adecuado concentrar los esfuerzos en las nuevas instalaciones, y tratar de impedir la acumulación de viviendas en su entorno, en particular chabolas, que son comunes en muchos países.

\section{Formación e inspectores de instalaciones}

Es probable que en muchos países los inspectores de instalaciones desempeñen una función crucial en la aplicación de un sistema de prevención de riesgos mayores. Dichos inspectores deberán estar cualificados para identificar en poco tiempo este tipo de riesgos. Si disponen de inspectores especializados a los que recurrir, los inspectores de fábrica contarán con ayuda para la inspección de los riesgos mayores, que suele presentar aspectos extremadamente técnicos.

Los inspectores necesitarán una formación y unas cualificaciones adecuadas para su trabajo. Es probable que, en muchos países, la propia industria sea la mejor fuente de conocimientos técnicos y pueda prestar ayuda para la formación de los inspectores de instalaciones.

La autoridad competente deberá estar facultada para suspender cualquier operación que plantee un riesgo inminente de accidente grave.

\section{Evaluación de riesgos mayores}

Esta tarea debe correr a cargo de especialistas, si es posible con arreglo a unas directrices formuladas, por ejemplo, por el grupo de expertos o por inspectores especializados, y quizá con la asistencia del equipo de gestión de la empresa poseedora de la instalación. La evaluación supone un estudio sistemático del riesgo potencial de accidentes mayores. El equipo de gestión deberá realizar un ejercicio similar - aunque mucho menos detalladoal llevado a cabo para elaborar el informe de seguridad para la inspección de la instalación y el plan interno de emergencia.

La evaluación comprenderá un estudio de todas las operaciones de manipulación de materiales peligrosos, incluido su transporte.

Se incluirá un análisis de las consecuencias de la inestabilidad del proceso o de cualquier transformación significativa de las variables que intervienen en el mismo.

D eberá contemplarse la ubicación relativa de los materiales peligrosos.

Se evaluarán también las consecuencias de fallos comunes.

Además, en la evaluación se identificarán las posibles consecuencias para la población externa de los accidentes mayores identificados, lo que determinará si puede ponerse en funcionamiento el proceso o la propia fábrica.

\section{Información a la población}

La experiencia en accidentes mayores, especialmente en escapes de gases tóxicos, ha demostrado la importancia de informar con antelación a la población situada en las inmediaciones sobre: a) cómo reconocer que se está produciendo una emergencia; 
b) qué hacer, y c) qué tratamiento médico es el apropiado para las personas afectadas por el gas.

En caso de emergencia, suele recomendarse a los habitantes de viviendas convencionales de construcción sólida que entren en su casa, cierren puertas y ventanas, apaguen la ventilación 0 el aire acondicionado y sintonicen la emisora local de radio para recibir nuevas instrucciones.

Si cerca de una instalación expuesta a riesgos mayores hay muchas personas viviendo en chabolas, estos consejos son inadecuados, y puede ser necesario proceder a una evacuación masiva.

\section{Requisitos previos de un sistema de prevención de riesgos mayores}

\section{Personal}

Un sistema de prevención de riesgos mayores plenamente desarrollado requiere una amplia variedad de personal especializado. Además del personal industrial que participe directa 0 indirectamente en la seguridad de funcionamiento de la instalación, hay que contar con inspectores generales de fábrica, inspectores especializados, evaluadores de riesgos, planificadores de emergencias, responsables del control de calidad, planificadores locales de ordenación del territorio, policía, servicios médicos, autoridades fluviales, etc., además de legisladores que promulguen nueva legislación y normativas para el control de los riesgos mayores.

En la mayoría de los países, los recursos humanos para estas tareas serán limitados, por lo que es esencial establecer unas prioridades realistas.

Tabla 39.15 - Directiva de la CE relativa a los riesgos de accidentes graves en instalaciones industriales.

Sustancias tóxicas (muy tóxicas y tóxicas):

Sustancias que presentan los siguientes valores de toxicidad aguda y que, por sus propiedades físicas y químicas, pueden dar lugar a riesgos de accidentes mayores:

$\begin{array}{llll} & L D_{50} \text { vía oral } & \mathrm{LD}_{50} \text { vía cutánea } & \\ \text { rata } \mathrm{mg} / \mathrm{kg} & \text { rata/ conejo mg/ kg } & \begin{array}{l}\mathrm{L} \mathrm{C}_{50} \text { inhalación } \\ (4 \text { horas }) \text { rata } \mathrm{mg} / 1\end{array} \\ \text { 1. } & \mathrm{LD}_{50}<5 & \mathrm{LD}<1 & \mathrm{LD}_{50}<0,10 \\ \text { 2. } & 5<\mathrm{LD}_{50}<25 & 10<\mathrm{LD}_{50}<50 & 0,1<L \mathrm{C}_{50}<0,5 \\ \text { 3. } & 25<\mathrm{L}_{50}<200 & 50<\mathrm{LD}_{50}<400 & 0,5<L \mathrm{C}_{50}<2\end{array}$

Sustancias inflamables:

1. Gases inflamables: sustancias que, en estado gaseoso a la presión normal y mezcladas con el aire, resultan inflamables y cuyo punto de ebullición es igual o inferior a $20 \stackrel{0}{C}$ a la presión normal.

2. Líquidos altamente inflamables: sustancias cuyo punto de inflamación es inferior a $21 \stackrel{\circ}{\circ}$ y cuyo punto de ebullición es superior a $20 \stackrel{\circ}{C}$ a la presión normal.

3. Líquidos inflamables: sustancias cuyo punto de inflamación es inferior a $55^{\circ}$ C y que permanecen en estado líquido bajo el efecto de una presión, en la medida en que determinadas formas de tratamiento, como presión y temperatura elevadas, puedan dar lugar a riesgos de accidentes mayores.

Sustancias explosivas:

Sustancias que pueden explotar bajo el efecto de la llama o que son más sensibles a los choques o los frotamientos que el dinitrobenceno.

\section{Equipos}

U na característica de los sistemas de control de riesgos mayores es que puede conseguirse mucho con muy poco equipamiento. Los inspectores de fábrica no precisan demasiado material adicional a sus equipos de seguridad habituales. Lo que sí es necesario es adquirir experiencia y conocimientos técnicos, así como medios para transmitirlos desde el grupo de expertos a, por ejemplo, el instituto laboral local, los inspectores de instalación y la industria. Puede ser igualmente necesario recurrir a ayudas e instalaciones adicionales para la formación.

\section{Información}

Un factor crucial a la hora de establecer un sistema de prevención de riesgos mayores es obtener información actualizada y transmitirla rápidamente a todas aquellas personas que puedan necesitarla para desempeñar sus tareas de seguridad.

Actualmente, el volumen de literatura especializada sobre los distintos aspectos del trabajo con riesgos graves es considerable $y$, si se utiliza de forma selectiva, puede constituir una importante fuente de información para un grupo de expertos.

\section{Responsabilidad de los países exportadores}

Cuando en un Estado miembro exportador el uso de sustancias, tecnologías o procesos peligrosos haya sido prohibido por ser fuente potencial de un accidente mayor, dicho Estado deberá poner a disposición de todo país importador la información relativa a esta prohibición y a las razones que la motivan.

Del Convenio han emanado varias recomendaciones no vinculantes. U na de ellas se refiere a la dimensión transfronteriza, y recomienda a las empresas nacionales o multinacionales con más de un establecimiento o instalación que establezcan medidas de seguridad para la prevención de accidentes mayores y el control de acontecimientos que puedan dar lugar a un accidente mayor, sin discriminación alguna entre los trabajadores de todos sus establecimientos, independientemente del lugar o país en que estén situados (véase igualmente la sección "C atástrofes transnacionales" de este artículo).

\section{Directiva europea relativa a los riesgos de accidentes graves en determinadas actividades industriales}

Tras los graves accidentes sucedidos en la industria química europea en las dos últimas décadas, varios países de la Europa occidental adoptaron una legislación específica para las actividades de alto riesgo. U na característica clave de esa legislación es la obligación de las empresas con actividades industriales de alto riesgo de proporcionar información sobre la actividad y sus riesgos basada en los resultados de estudios sistemáticos de seguridad. Después del accidente de Seveso (Italia) en 1976, las normativas en la materia de los distintos países se agruparon e integraron en una directiva de la CE. La Directiva, relativa a los riesgos de accidentes graves en determinadas actividades industriales, está en vigor desde 1984 y se denomina habitualmente Directiva Seveso (C onsejo de las Comunidades Europeas 1982, 1987).

Al objeto de determinar cuáles son las instalaciones expuestas a riesgos graves, la Directiva de la CE se basa en las características de toxicidad, inflamabilidad y explosión de las sustancias químicas (véase la Tabla 39.15).

En los anexos a la D irectiva se incluye una lista de sustancias y límites umbrales de las mismas para determinar las actividades industriales concretas de alto riesgo. L a actividad industrial se define como el conjunto de instalaciones del mismo fabricante distantes menos de 500 metros entre ellas y perteneciendo a la misma fábrica o planta industrial. C uando la cantidad de sustancias almacenadas supera el valor límite umbral de la lista, la 
Tabla 39.16 - Principales sustancias químicas utilizadas en la identificación de instalaciones con riesgos de accidentes mayores.

\begin{tabular}{lrr} 
Denominación de las sustancias & Cantidad (>) & no CEE \\
Sustancias inflamables en general: & $200 \mathrm{t}$ & 124 \\
Gases inflamables & $50.000 \mathrm{t}$ & 125 \\
Líquidos altamente inflamables & & \\
Sustancias inflamables en particular: & $50 \mathrm{t}$ & 24 \\
Higrógeno & $50 \mathrm{t}$ & 25 \\
Oxido de etileno & & \\
Explosivos en particular: & $2.500 \mathrm{t}$ & $146 \mathrm{~b}$ \\
Nitrato de amonio & $10 \mathrm{t}$ & 132 \\
Nitroglicerina & $50 \mathrm{t}$ & 145 \\
Trinitrotolueno & & \\
Sustancias tóxicas en particular: & $200 \mathrm{t}$ & 18 \\
Acrilonitrilo & $500 \mathrm{t}$ & 22 \\
Amoniaco & $25 \mathrm{t}$ & 16 \\
Cloro & $250 \mathrm{t}$ & 148 \\
Dióxido de azufre & $50 \mathrm{t}$ & 17 \\
Sulfuro de hidrógeno & $20 \mathrm{t}$ & 19 \\
Cianuro de hidrógeno & $200 \mathrm{t}$ & 20 \\
Disulfuro de carbono & $50 \mathrm{t}$ & 94 \\
Ácido fluorhídrico & $250 \mathrm{t}$ & 149 \\
Acido clorhídrico & $75 \mathrm{t}$ & 180 \\
Trióxido de azufre & & \\
Sustancias muy tóxicas en particular: & $150 \mathrm{~kg}$ & 36 \\
Isocianato de metilo & $750 \mathrm{~kg}$ & 15 \\
Fosgeno & & \\
\hline & & \\
\hline
\end{tabular}

actividad se denomina instalación de alto riesgo. La lista de sustancias consta de 180 productos químicos, cuyos límites umbrales varían desde $1 \mathrm{~kg}$ para sustancias extremadamente tóxicas a 50.000 t para líquidos altamente inflamables. Para el almacenaje aislado de sustancias, se ofrece una lista separada de unas cuantas sustancias.

A demás de los gases inflamables, líquidos y explosivos, la lista incluye sustancias químicas como amoníaco, cloro, dióxido de azufre y acrilonitrilo.

Para facilitar la aplicación de un sistema de control de riesgos graves y fomentar su aplicación por las autoridades y las empresas, deben definirse prioridades, prestando especial atención a las instalaciones más peligrosas. En la Tabla 39.16 se sugiere una lista de prioridades.

Tomando como guía las sustancias químicas que figuran en la tabla, puede elaborarse una lista de instalaciones. Si ésta sigue siendo demasiado larga para ser gestionada por las autoridades, pueden fijarse nuevas prioridades estableciendo nuevos límites de cantidades. También se puede recurrir al establecimiento de prioridades dentro de la fábrica para determinar sus partes más peligrosas. En vista de la diversidad y complejidad de la industria en general, no es posible restringir las instalaciones de alto riesgo a determinados sectores de la actividad industrial. A hora bien, la experiencia nos indica que las instalaciones de alto riesgo suelen concentrarse en las siguientes actividades:
- petroquímica y refinerías

- química y centrales químicas

- almacenaje y terminales de GLP (G ases licuados del petróleo)

- centros de almacenaje y distribución de sustancias químicas

- grandes almacenes de fertilizante

- fábricas de explosivos

- actividades que utilizan cloro en grandes cantidades.

\section{Preparacion para las catast Rofes}

Peter J. Baxter

En las dos últimas décadas, en materia de reducción de catástrofes se ha pasado de las medidas principalmente paliativas, improvisadas en la fase posterior al suceso, a la planificación anticipada o preparación para las catástrofes. En el caso de las catástrofes naturales, se ha adoptado este enfoque en la filosofía del programa D écada I nternacional de las $N$ aciones $U$ nidas para la reducción de las catástrofes naturales (IDNDR). Un plan completo de gestión de riesgos se compone de las cuatro fases siguientes, que pueden aplicarse a todo tipo de catástrofes naturales y tecnológicas:

- planificación previa a la catástrofe

- preparación para la emergencia

- respuesta a la emergencia

- recuperación y reconstrucción después del impacto.

El objetivo de la preparación para las catástrofes es implantar medidas de prevención y de reducción de riesgos a la vez que se desarrolla la preparación para emergencias y la capacidad de respuesta. En este proceso, los análisis de riesgo y vulnerabilidad son las actividades científicas que sirven de base a las tareas de reducción del riesgo y preparación para las emergencias, que siempre deberán emprenderse en colaboración con los planificadores y los servicios de emergencia.

En el marco de la preparación para las catástrofes, la mayor parte de los profesionales sanitarios considerarán que su función es planificar el tratamiento de emergencia de un gran número de víctimas. Desde luego, para reducir radicalmente las consecuencias de las catástrofes en el futuro, el sector sanitario debe participar en el desarrollo de las medidas de prevención y en todas las fases de la planificación de catástrofes, junto con científicos, ingenieros, planificadores de emergencias y responsables de toma de decisiones. Este enfoque interdisciplinario plantea un gran desafío al sector sanitario en las postrimerías del siglo $X X$, en tanto en cuanto las calamidades, naturales 0 humanas, son cada vez más destructivas y costosas en términos de vidas y bienes debido a la expansión de las poblaciones humanas por todo el planeta.

Entre las catástrofes naturales repentinas o de desencadenamiento rápido se encuentran las condiciones climáticas extremas (inundaciones y vientos fuertes), terremotos, seísmos, corrimientos de tierras, erupciones volcánicas, maremotos e incendios catastróficos, y sus efectos tienen muchos aspectos en común. Por otro lado, las hambrunas, las sequías y la desertización son resultado de procesos más largos, que hasta la fecha no se comprenden demasiado bien, y sus consecuencias no se prestan tanto a la aplicación de medidas de reducción. Actualmente, la causa más común del hambre es el conflicto armado o las denominadas catástrofes complejas (como en Sudán, Somalia o la antigua Yugoslavia).

Un rasgo común a las catástrofes naturales y a las complejas es el desplazamiento de grandes masas de personas, y sus necesidades alimentarias y de todo tipo requieren una gestión especializada. 
Por otra parte, en la civilización moderna son cada vez más frecuentes las catástrofes tecnológicas 0 de origen humano, como pueden ser los episodios de contaminación atmosférica aguda, los incendios y los accidentes químicos o nucleares; estas dos últimas categorías son las más importantes hoy en día. En este artículo nos ocuparemos de la planificación de las catástrofes químicas, pues los accidentes nucleares se abordan en otras secciones de la E nciclopedia.

\section{Catástrofes naturales repentinas}

En esta categoría, las calamidades más destructivas son las inundaciones, los huracanes, los terremotos y las erupciones volcánicas. Se han obtenido ya algunos éxitos en la reducción de catástrofes mediante sistemas de alarma anticipada, mapas de riesgos y medidas de ingeniería estructural en zonas sísmicas. Así, gracias a la vigilancia por satélite de las predicciones del clima mundial, a un sistema regional de recepción de avisos a su debido tiempo y a una eficaz planificación de las evacuaciones, la pérdida de vidas humanas ocasionada por el huracán Hugo, el más fuerte de toda la historia del Caribe, que se abatió sobre Jamaica y las Islas Caimán en 1988, fue comparativamente pequeña (sólo 14 muertes). En 1991, la alarma dada por los científicos filipinos que vigilaban de cerca el monte Pinatubo salvó miles de vidas, gracias a una evacuación correctamente programada, en una de las erupciones más grandes del siglo. En todo caso, el "ajuste tecnológico" es sólo uno de los aspectos de la mitigación de las catástrofes. L a magnitud de las pérdidas humanas y económicas ocasionadas por las catástrofes en los países en desarrollo subraya la gran importancia de los factores socioeconómicos - fundamentalmente la pobreza- en el aumento de la vulnerabilidad, así como la necesidad de tener en cuenta estos aspectos en las medidas de preparación para las catástrofes.

En todos los países, la reducción de las catástrofes naturales tiene que competir con otras prioridades. La reducción de las catástrofes puede fomentarse también a través de la legislación, la educación, la calidad de la construcción, etc., en el marco del programa general de reducción de riesgos de una sociedad o de su visión cultural de la seguridad, como parte integrante de las políticas de desarrollo sostenible y como medida de garantía de calidad para las estrategias de inversión (por ejemplo, al planificar nuevas ocupaciones del territorio).

\section{Catástrofes tecnológicas}

Es obvio que, en el caso de los riesgos naturales, es imposible impedir que se produzca el proceso geológico o meteorológico.

Pero no puede decirse lo mismo de los riesgos tecnológicos: es posible avanzar mucho en la prevención de catástrofes adoptando medidas de reducción de riesgos en el diseño de las fábricas, y los gobiernos pueden establecer la legislación necesaria para implantar un alto nivel de seguridad industrial. En los países de la CE, la Directiva Seveso es un ejemplo, e incluye requisitos para la planificación interna y externa en caso de emergencia.

En los accidentes químicos graves se producen grandes explosiones de vapores o gases inflamables, incendios y escapes tóxicos procedentes de instalaciones peligrosas fijas o del transporte y distribución de sustancias químicas. Se ha prestado especial atención al almacenaje de gases tóxicos en grandes cantidades; el más común es el cloro (que, si se produce un escape repentino por un fallo en un tanque de almacenaje 0 una grieta en una tubería, puede formar grandes nubes, más pesadas que el aire, que pueden ser arrastradas por el viento a gran distancia en concentraciones tóxicas). Se han elaborado modelos informáticos de dispersión de gases densos por escapes repen- tinos para el cloro y otros gases comunes, que los planificadores utilizan para elaborar medidas de respuesta a la emergencia. Dichos modelos pueden utilizarse también para determinar el número de víctimas de un escape accidental previsible, del mismo modo que se están elaborando modelos para predecir el número y tipo de víctimas de terremotos importantes.

\section{Prevención de catástrofes}

U na catástrofe es cualquier trastorno del ecosistema humano que desborda la capacidad de la comunidad para continuar con su funcionamiento normal. La situación no se limita a una diferencia cuantitativa en el funcionamiento de los servicios sanitarios o de emergencias (por ejemplo, la situación causada por un gran número de víctimas). Es diferente desde el punto de vista cualitativo, en el sentido de que las demandas no pueden ser adecuadamente satisfechas por una sociedad sin la ayuda de otras zonas no afectadas, del mismo país o de otro. La palabra catástrofe se utiliza a menudo de forma inadecuada para describir incidentes importantes muy divulgados o de naturaleza política; cuando realmente sucede una catástrofe, puede producirse una ruptura total en el funcionamiento normal de una localidad. El objetivo de la preparación para las catástrofes es capacitar a una comunidad y sus servicios clave para funcionar en esas caóticas circunstancias, a fin de reducir la morbilidad y mortalidad humanas y los daños económicos. La existencia de un gran número de víctimas graves no es una condición imprescindible de una catástrofe, como se demostró en la catástrofe química de Seveso de 1976 (se procedió a una evacuación masiva por temor a la existencia de riesgos a largo plazo para la salud a causa de la contaminación del suelo con dioxina). "C uasicatástrofes" puede ser una descripción mejor de determinados acontecimientos, y los brotes de reacciones psicológicas o de estrés pueden ser también la única manifestación en algunos casos (como en el accidente del reactor en Three $\mathrm{M}$ ile Island, EE.UU., en 1979). H asta que se adopte una terminología definitiva, deberíamos aceptar la descripción de Lechat de los objetivos sanitarios de la gestión de catástrofes, que son:

- la prevención o reducción de la mortalidad como resultado del impacto, de retrasos en el rescate y de la falta de una asistencia adecuada;

- la asistencia a las víctimas de traumatismos inmediatamente posteriores al impacto, quemaduras, problemas psicológicos, etc.;

- la gestión de condiciones climáticas y ambientales adversas (exposición, falta de comida y de agua potable);

- la prevención de la morbilidad a corto y a largo plazo como resultado de la catástrofe (brotes de enfermedades contagiosas debidos a un trastorno de la higiene, a la utilización de refugios temporales, a un número excesivo de personas 0 a la alimentación de socorro; epidemias como la malaria, a causa de la interrupción de las medidas de control; aumento de la morbilidad y mortalidad derivadas del trastorno del sistema de asistencia sanitaria; problemas mentales y emocionales),

- garantizar la recuperación de la salud normal mediante la prevención de una malnutrición prolongada debida a la interrupción del suministro de alimentos y de la agricultura.

La prevención de catástrofes no puede existir en el vacío; es esencial la existencia en cada país de una estructura de ámbito nacional (cuya organización variará de unos a otros), así como de otras de ámbito regional y municipal. En países con un alto nivel de riesgos naturales, pocos ministerios quedarán fuera. La responsabilidad de la planificación corresponderá a organismos tales como las fuerzas armadas o los servicios de protección civil en algunos países. 
Figura 39.4 - El riesgo es el producto de peligro por vulnerabilidad: curvas características.

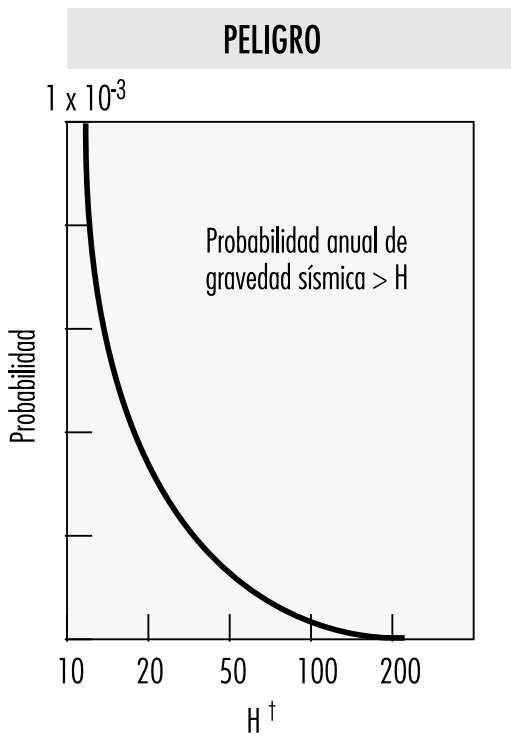

$X$

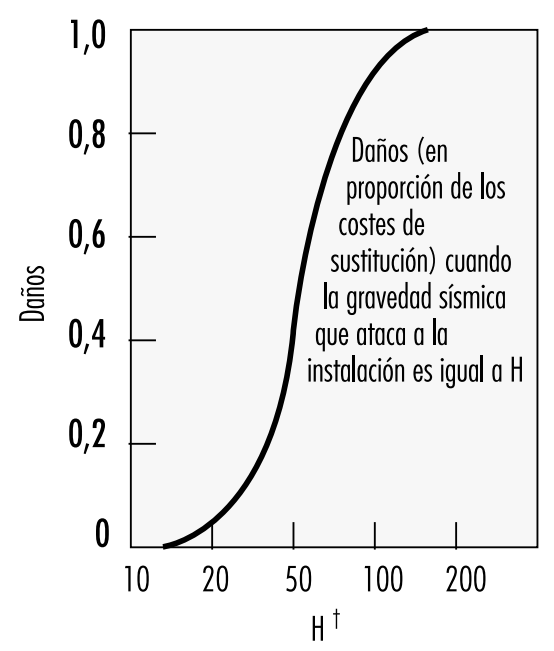

$=$

RIESGO

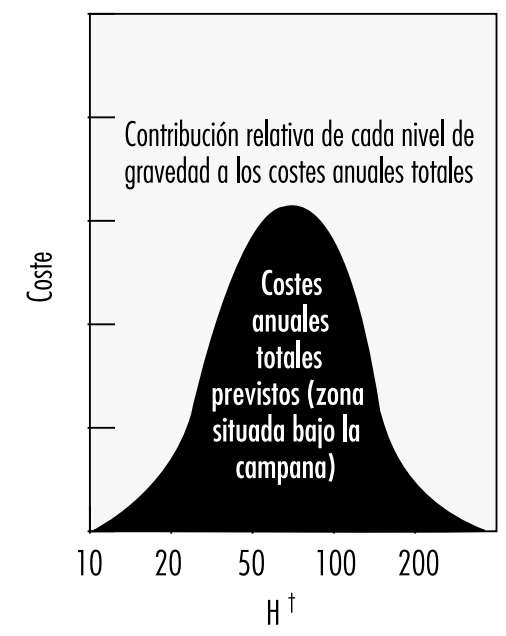

† Gravedad del movimiento sísmico, \% g a 0,2 s. de aceleración espectral Fuente: Coburn y Spence 1992.

Si existe un sistema nacional para la prevención de catástrofes naturales, sería conveniente construir sobre él un sistema de respuesta a catástrofes tecnológicas, en lugar de crear uno completamente nuevo. EI Centro de Actividad del Programa de Industria y Medio Ambiente del Programa de las Naciones Unidas para el Medio Ambiente ha desarrollado el programa Sensibilización y preparación ante emergencias a nivel local (APELL). Con la participación conjunta de la industria y la administración, el programa pretende prevenir los accidentes tecnológicos y reducir sus consecuencias en los países en desarrollo, sensibilizando a la comunidad sobre la presencia de instalaciones peligrosas y ofreciendo asistencia para desarrollar planes de respuesta a emergencias.

\section{Evaluación del peligro}

Los distintos tipos de catástrofes naturales y sus consecuencias deben evaluarse en términos de probabilidad de aparición en todos los países. Algunos países, como el Reino U nido, gozan de una situación de bajo riesgo - los principales peligros son tormentas de viento e inundaciones-, mientras que otros, como Filipinas, sufren con implacable regularidad una amplia gama de fenómenos naturales que pueden tener repercusiones importantes sobre la economía e incluso en la estabilidad política del país. Cada peligro requiere una evaluación independiente, teniendo en cuenta al menos los aspectos siguientes:

- causa o causas;

- distribución geográfica, magnitud o gravedad y probable frecuencia de aparición;

- mecanismos físicos de destrucción;

- elementos y actividades más vulnerables a la destrucción.

- posibles consecuencias sociales y económicas de una catástrofe.

En las zonas con alto riesgo de terremotos, erupciones volcánicas e inundaciones, los expertos deben elaborar mapas de riesgo al objeto de predecir la ubicación y la naturaleza de los efectos en caso de producirse un incidente grave. Después, los responsables de la ordenación del territorio pueden utilizar estas evaluaciones de peligro para reducir los riesgos a largo plazo, como también pueden servir a los planificadores de emergencia, que se encargan de la respuesta previa a la catástrofe. Ahora bien, la demarcación de zonas sísmicas y la elaboración de mapas de riesgo volcánico se encuentran aún en fase embrionaria en la mayoría de los países en desarrollo, y el IDNDR considera vital acelerar la elaboración de mapas de riesgos.

Para evaluar el peligro de riesgos naturales es necesario estudiar en detalle la información relativa a catástrofes ocurridas en siglos pasados, así como realizar un exhaustivo trabajo geológico de campo para localizar acontecimientos importantes, como terremotos y erupciones volcánicas, de tiempos pretéritos 0 prehistóricos. A prender del comportamiento de los principales fenómenos naturales del pasado es un enfoque útil, pero ni mucho menos infalible, para valorar el peligro de sucesos futuros. Existen métodos hidrológicos normalizados para la estimación de las inundaciones, y muchas zonas proclives a éstas pueden reconocerse fácilmente porque coinciden con llanuras pluviales naturales bien delimitadas. En el caso de los ciclones tropicales, los datos de impacto en líneas costeras pueden utilizarse para determinar la probabilidad de que un huracán afecte a cualquier punto de la costa en un año determinado, pero cada huracán debe ser urgentemente estudiado tan pronto se forma, para predecir su trayectoria real y su velocidad con una antelación mínima de 72 horas a su llegada. Los terremotos, volcanes y lluvias intensas desencadenan con frecuencia corrimientos de tierras. En la última década se han venido observando cada vez más casos de grandes volcanes cuyas laderas corren peligro de desmoronamiento debido a la inestabilidad de su masa, acumulada en períodos de actividad; como resultado, pueden producirse corrimientos de tierras devastadores.

Con respecto a las catástrofes tecnológicas, las comunidades locales deben hacer inventario de las actividades industriales peligrosas de su entorno. Actualmente, los graves accidentes ocurridos en el pasado aportan numerosos ejemplos de las consecuencias de estos riesgos si se produce un fallo en un proceso 0 en una contención. En muchos países desarrollados 
existen hoy día planes muy detallados para casos de accidentes químicos en torno a instalaciones peligrosas.

\section{Evaluación de los riesgos}

Tras evaluar un peligro y sus posibles consecuencias, el siguiente paso es llevar a cabo una estimación de los riesgos. El peligro puede definirse como la posibilidad de que ocurra algún daño, y el riesgo es la probabilidad de que se produzcan víctimas mortales, heridos o daños a bienes como consecuencia de un peligro natural de un tipo y magnitud determinados. EI riesgo puede definirse cuantitativamente como:

$$
\text { R iesgo }=\text { valor } \times \text { vulnerabilidad } \times \text { peligro }
$$

donde el valor puede representar un número potencial de vidas 0 bienes económicos (edificios, por ejemplo) que puede perderse en el suceso. Evaluar la vulnerabilidad es un aspecto clave de la estimación de los riesgos. En el caso de los edificios, se tratará de medir la susceptibilidad inherente a las estructuras expuestas a fenómenos naturales potencialmente dañinos. Por ejemplo, la probabilidad de que un edificio se venga abajo en un terremoto puede determinarse a partir de su ubicación con respecto a una línea de falla sísmica y de la resistencia sísmica de su estructura. En la ecuación anterior, el nivel de pérdida resultante de la aparición de un fenómeno natural de una magnitud determinada puede expresarse en una escala de 0 (sin daños) a 1 (pérdida total), mientras que el peligro es el riesgo concreto expresado como la probabilidad de pérdidas evitables por unidad de tiempo. Por tanto, la vulnerabilidad es la fracción de valor que probablemente se perderá como resultado de un suceso de este tipo. La información necesaria para un análisis de vulnerabilidad puede obtenerse, por ejemplo, mediante la realización de investigaciones por arquitectos e ingenieros en las viviendas situadas en áreas peligrosas. La Figura 39.4 muestra algunas curvas de riesgo típicas.

Actualmente, es mucho más difícil realizar evaluaciones de vulnerabilidad a partir de información sobre las distintas causas de muerte y lesiones para los diferentes tipos de impacto, pues los datos disponibles son muy toscos, incluso para los terremotos, no está normalizada la clasificación de heridas y se carece de un registro exacto del número de muertes - y mucho menos de sus causas. Estas graves limitaciones ilustran la necesidad de realizar un esfuerzo mucho mayor por reunir datos epidemiológicos en las catástrofes, a fin de poder desarrollar las medidas preventivas de un modo científico.

Actualmente, los cálculos matemáticos de riesgo de hundimiento de edificios en terremotos y de caída de cenizas en erupciones volcánicas pueden digitalizarse en mapas en forma de escalas de riesgos, para mostrar gráficamente las áreas de alto riesgo en un suceso previsible y saber dónde deben concentrarse las medidas de protección civil previas. Así, la estimación de los riesgos, combinada con el análisis económico y de coste/ efectividad, será valiosísima a la hora de decidir entre las distintas posibilidades de reducción de riesgos.

Además de las estructuras de edificios, otro aspecto importante de la vulnerabilidad son las infraestructuras (básicas), como:

- transportes

- telecomunicaciones

- suministro de agua

- sistemas de alcantarillado

- suministro de electricidad

- instalaciones de asistencia sanitaria.

En cualquier catástrofe natural, todas ellas pueden quedar destruidas o gravemente deterioradas; sin embargo, dado que el tipo de fuerza destructiva puede variar dependiendo del peligro natural o tecnológico, las medidas de protección deben diseñarse teniendo en cuenta la estimación de riesgos. Los sistemas geográficos de información son modernas técnicas informáticas que permiten elaborar mapas sobre diversos datos y sirven de ayuda en estas tareas.

Al planificar la reacción a una catástrofe química, la estimación cuantificada de riesgos (ECR) se utiliza para determinar la probabilidad de que se produzca una anomalía en la fábrica y como guía útil para los responsables, pues ofrece estimaciones numéricas del riesgo. Las técnicas de ingeniería para efectuar este tipo de análisis están muy avanzadas, al igual que los medios para elaborar mapas zonales de riesgo en torno a las instalaciones peligrosas. Existen métodos que predicen las ondas de presión y la concentración de la radiación térmica a distintas distancias de una explosión de vapor o gas inflamable. $\mathrm{H}$ ay modelos informáticos para predecir, en un recorrido de kilómetros, la concentración de gases más pesados que el aire que el viento arrastrará a partir de un escape accidental de una cantidad determinada en un recipiente o fábrica, en condiciones climáticas diversas. En este tipo de accidentes, la vulnerabilidad tiene que ver principalmente con la proximidad de viviendas, escuelas, hospitales y otros edificios públicos. $\mathrm{H}$ ay que tener en cuenta los riesgos individuales y colectivos para cada tipo de catástrofe y comunicar su significado a la población local en el marco de la planificación general en materia de catástrofes.

\section{Reducción de riesgos}

U na vez evaluada la vulnerabilidad, deben adoptarse las medidas pertinentes para reducirla, así como el riesgo general. Los edificios nuevos deben ser resistentes a los seísmos si se construyen en una zona sísmica y los antiguos pueden modernizarse para reducir las probabilidades de derrumbe. Puede ser necesario cambiar de sitio los hospitales o "reforzarlos" contra peligros como las tormentas de viento, por ejemplo. En la ordenación territorial de zonas con riesgo de tormentas o de erupción volcánica, no hay que olvidar nunca la necesidad de contar con unas buenas carreteras como vías de evacuación, y pueden adoptarse otras medidas de ingeniería civil en función de la situación. A largo plazo, la medida más importante es regular la utilización del territorio para evitar el desarrollo de asentamientos en zonas peligrosas, como llanuras pluviales, laderas de volcanes activos 0 inmediaciones de fábricas químicas importantes. Depender en exceso de la ingeniería puede generar una falsa seguridad en zonas peligrosas, o incluso ser contraproducente, pues aumenta el riesgo de sucesos catastróficos inusuales (como la construcción de diques en cursos de agua importantes proclives a inundaciones graves).

\section{Preparación para situaciones de emergencia}

La planificación y organización de posibles situaciones de emergencia debería correr a cargo de un equipo interdisciplinario de planificación que se ocupe de la comunidad local, y otro equipo encargado de la evaluación de peligros, reducción de riesgos y respuesta a emergencias. En materia de gestión de víctimas, es ampliamente conocido que, en un país en desarrollo, los equipos médicos del exterior pueden tardar al menos tres días en llegar al lugar de la catástrofe. Puesto que la mayoría de las muertes que podrían evitarse se producen en las primeras 24 a 48 horas, esa asistencia llegará demasiado tarde. Por ello, la preparación para emergencias debe afrontarse primariamente a escala local, de forma que la propia comunidad disponga de los medios para iniciar las medidas de rescate y auxilio inmediatamente después de una desgracia.

En consecuencia, una información adecuada a la población en la fase de planificación debería ser un aspecto clave de la preparación de emergencias. 


\section{Necesidades de información y comunicación}

A partir de los análisis de peligro y riesgo, es esencial disponer de medios para dar la alarma lo antes posible, así como de un sistema de evacuación de las zonas de alto riesgo en caso de emergencia. $\mathrm{H}$ ay que planificar los sistemas de comunicación entre los distintos servicios de emergencia de ámbito local y nacional, y, para la transmisión y divulgación efectiva de información en una catástrofe, habrá que establecer una cadena formal de comunicación. Pueden contemplarse también otras medidas, como el almacenamiento de provisiones alimentarias y agua en las viviendas.

U na comunidad cercana a una instalación peligrosa debe ser consciente de que puede oírse una alarma debido a una emergencia (por ejemplo, una sirena si hay un escape de gas) y conocer las medidas de protección que debe adoptar (como entrar inmediatamente en casa y cerrar las ventanas hasta que se les indique que salgan). Un factor esencial en una catástrofe química es la capacidad para definir rápidamente el peligro sanitario que plantea un escape tóxico, lo que significa identificar la sustancia o sustancias químicas emitidas, conocer sus efectos agudos o a largo plazo y determinar quiénes han estado expuestos a dichos efectos entre la población general. Establecer líneas de comunicación con fuentes de información sobre venenos y centros de emergencias químicas es una medida de planificación esencial. Por desgracia, puede ser difícil o imposible saber qué sustancias químicas están presentes en reacciones incontroladas o incendios químicos y, aun cuando fuera fácil identificar un producto químico, el conocimiento toxicológico sobre el ser humano, y en especial de sus efectos crónicos, puede ser escaso o no existir en absoluto, como se descubrió tras el escape de isocianato de metilo en Bhopal. Con todo, si se carece de información sobre el peligro, se dificultará seriamente la gestión médica de las víctimas y de la población expuesta, y también será más difícil tomar decisiones sobre la necesidad de evacuar la zona contaminada.

$\mathrm{H}$ ay que prever la constitución de un equipo interdisciplinario encargado de reunir información y emprender una evaluación rápida de los riesgos para la salud y para el medio ambiente, al objeto de excluir la contaminación de suelos, agua y cosechas, teniendo en cuenta que las bases de datos toxicológicos disponibles pueden ser inadecuadas para tomar decisiones en una catástrofe importante, o incluso en pequeños incidentes en los que una comunidad cree haber sufrido una exposición grave. Este equipo debería contar con la experiencia suficiente para confirmar la naturaleza del escape químico e investigar sus probables efectos sobre la salud y el medio ambiente.

En catástrofes naturales, la epidemiología es igualmente importante para valorar las necesidades de asistencia sanitaria en la fase posterior al impacto, así como para el seguimiento de enfermedades infecciosas. La recopilación de datos sobre los efectos de la catástrofe es un ejercicio científico que debería incluirse también en el plan de respuesta; un equipo designado a tal fin debería encargarse de esta tarea para suministrar información vital al equipo de coordinación de la catástrofe y contribuir a la modificación y perfeccionamiento del plan de emergencia.

\section{M ando y control, y comunicaciones de emergencia}

La designación del servicio de emergencia responsable, así como la creación de un equipo de coordinación de la catástrofe, variarán en función de los países y del tipo de catástrofe, pero debe planificarse con antelación. En el lugar de los hechos, puede designarse como mando y control o como centro de coordinación interno a un vehículo concreto. Por ejemplo, los servicios de emergencia no pueden confiar demasiado en las comunicaciones telefónicas, que pueden sobrecargarse, de forma que será necesario establecer conexiones por radio.

\section{Plan hospitalario en caso de accidente mayor}

H abrá que evaluar la capacidad de los hospitales para gestionar accidentes importantes en términos de personal, recursos materiales (quirófanos, camas, etc.) y tratamiento (medicamentos y equipos). L os hospitales deben contar con planes concretos para hacer frente a un repentino y masivo ingreso de víctimas; una unidad móvil del hospital deberá trasladarse al lugar de los hechos para trabajar con los equipos de búsqueda y rescate en la extracción de las personas atrapadas o en la clasificación in situ de un gran número de víctimas. Es posible que los hospitales importantes no puedan funcionar debido a los daños causados por la catástrofe, como ocurrió en el terremoto de Ciudad de M éxico en 1985. Puede ser necesario, por tanto, restaurar o reforzar unos servicios sanitarios destruidos. Para accidentes químicos, los hospitales deben establecer contactos con centros de información toxicológica. También debería contemplarse la capacidad de recurrir a gran número de profesionales de la asistencia sanitaria de dentro y fuera del área catastrófica para atender a los heridos, así como los medios para enviar rápidamente equipos médicos de emergencia y medicamentos.

\section{Equipos de emergencia}

En la fase de planificación deben identificarse los equipos de búsqueda y rescate necesarios para una catástrofe concreta y el lugar en que se almacenarán, pues habrá que emplearlos con rapidez en las primeras 24 horas, cuando se puede salvar el mayor número de vidas. Los medicamentos y equipos médicos clave tienen que estar disponibles para un traslado rápido, junto con equipos de protección para el personal de emergencia, incluidos los profesionales sanitarios en el lugar de la catástrofe. La presencia de ingenieros con la preparación necesaria para restaurar urgentemente el agua, la electricidad, las comunicaciones y las carreteras puede ser capital a la hora de mitigar los peores efectos de las catástrofes.

\section{Plan de respuesta a emergencias}

Los servicios independientes de emergencia y el sector sanitario - incluida la sanidad pública, los servicios de salud en el trabajo y los profesionales de la salud ambiental- deberían elaborar planes para afrontar posibles catástrofes, que podrían agruparse en un único plan principal. Además de los planes hospitalarios, la planificación de la salud debería incluir programas detallados de respuesta a los distintos tipos de catástrofes, diseñados a la luz de las evaluaciones de peligro y de riesgo realizadas en el marco de la preparación de la catástrofe. Deberían elaborarse protocolos de tratamiento para los tipos concretos de lesiones que puede ocasionar cada catástrofe. Así, para los casos de derrumbe de edificios por terremotos, podría anticiparse toda una gama de traumatismos, incluido el síndrome de aplastamiento, mientras que las quemaduras físicas y las lesiones derivadas de la inhalación tóxica son características de las erupciones volcánicas. En catástrofes químicas, debería planificarse la clasificación, los procedimientos de descontaminación, la administración de antídotos - en su caso- y el tratamiento de emergencia por afecciones pulmonares agudas ocasionadas por gases tóxicos irritantes. La planificación ulterior debe ser suficientemente flexible para hacer frente a emergencias de transporte con intervención de sustancias tóxicas, especialmente en zonas sin instalaciones fijas que normalmente exigirían a las autoridades elaborar planes intensivos de emergencia local. La gestión de emergencia de traumatismos físicos y químicos en catástrofes es un campo vital de la planificación de la asistencia sanitaria, y requiere la formación del personal del hospital en medicina de catástrofes. 
Debería incluirse la gestión de evacuados, el emplazamiento de centros de evacuación y las medidas sanitarias preventivas. $\mathrm{H}$ abría que considerar igualmente la necesidad de una gestión de urgencia del estrés para prevenir este tipo de trastornos en las víctimas y en el personal de emergencia. En ocasiones, los trastornos psicológicos pueden constituir el principal y hasta el único efecto sobre la salud, especialmente si la respuesta a un incidente ha sido inadecuada y ha generado una ansiedad indebida en la comunidad. Este es un problema específico de los incidentes químicos y de radiación, que puede reducirse a su mínima expresión con una adecuada planificación de emergencia.

\section{Formación y educación}

Es probable que el personal médico y otros profesionales sanitarios de los hospitales y de atención primaria no estén habituados a trabajar en catástrofes. Por tanto, la preparación para emergencias debe incluir ejercicios de formación con el sector sanitario y los servicios de emergencia. Los ejercicios simulados tienen también un valor incalculable, y deberían ser lo más realistas posible, dadas las pocas probabilidades existentes de realizar ejercicios físicos a gran escala en vista de su alto coste.

\section{Recuperación posterior}

Consiste en la recuperación del estado anterior a la catástrofe en el área afectada. La planificación previa debe contemplar la posterior atención social, económica y psicológica, así como la rehabilitación del medio ambiente. En el caso de accidentes químicos, este último punto comprende asimismo evaluaciones ambientales de contaminantes del agua y las cosechas y, en su caso, las medidas correctivas, como la descontaminación de suelos y edificios y la restauración del suministro de agua potable.

\section{Conclusión}

$\mathrm{H}$ asta ahora, el esfuerzo internacional para la preparación de las catástrofes ha sido relativamente pequeño en comparación con las medidas paliativas; sin embargo, aunque la inversión en protección contra catástrofes es costosa, existe un amplio corpus de conocimientos científicos y técnicos disponible que, correctamente aplicado, podría marcar una gran diferencia en las consecuencias de las catástrofes sobre la salud y la economía en todos los países.

\section{- ACTIVIDADES POSTERIORES A LAS CATASTROFES}

\section{Benedetto Terracini y U rsula Ackermann-Liebrich}

Los accidentes industriales pueden afectar a los trabajadores expuestos en el lugar de trabajo y a la población cercana a la fábrica en que se produce el accidente. Si el accidente es contaminante, es probable que la población afectada sea incomparablemente mayor que el número de trabajadores, lo que plantea complejos problemas logísticos. En este artículo se abordan dichos problemas, así como los ocasionados por los accidentes agrarios.

Entre los motivos para cuantificar los efectos de un accidente sobre la salud podemos citar los siguientes:

- la necesidad de garantizar que todas las personas expuestas han recibido atención médica (independientemente de que todas ellas requiriesen tratamiento). La atención médica puede consistir en la detección y mitigación de consecuencias adversas clínicamente reconocibles (si las hay), y en la aplicación de medios para prevenir posibles efectos y complicaciones posteriores. Es una tarea obligatoria cuando se produce un accidente en una fábrica, en cuyo caso se sabrá exactamente el número e identidad de las personas que trabajan en ella y se podrá efectuar un seguimiento completo;

- la necesidad de identificar a las personas con derecho a una compensación por los efectos del accidente. Es necesario clasificar a los pacientes en función de la gravedad de su enfermedad y de las probabilidades de que ésta haya sido causada por la catástrofe;

- la adquisición de conocimientos sobre la patogénesis de las enfermedades en el ser humano,

- el interés científico de descifrar los mecanismos de la toxicidad en el ser humano, incluidos aspectos que pueden contribuir a una reevaluación, para una exposición dada, de las dosis consideradas "seguras" en el ser humano.

\section{Clasificación de los accidentes atendiendo a sus consecuencias para la salud}

Los accidentes ambientales engloban una amplia gama de sucesos que se producen en las más variadas circunstancias. Se percibe o se sospecha su existencia en primer lugar por cambios ambientales o por la aparición de una enfermedad. En ambos casos, la evidencia (o sospecha) de que "algo puede haber salido mal" puede surgir repentinamente [como el incendio en el almacén de Sandoz en Schweizerhalle, Suiza, en 1986 o la epidemia de lo que luego se denominó "síndrome del aceite tóxico" (SAT) en España en 1981] o de forma soterrada (excesos de mesotelioma tras exposición ambiental - no en el trabajo- a amianto en Wittenoom, Australia). En todos los casos, hay algún momento en que no se halla respuesta a los dos interrogantes fundamentales: ¿Q ué consecuencias para la salud se han producido hasta ahora? y ¿qué es previsible que ocurra?

Al evaluar la repercusión de un accidente sobre la salud humana, pueden interactuar tres tipos de factores:

1. el agente 0 agentes liberados, sus propiedades peligrosas y el riesgo creado por su escape;

2. la experiencia personal de la catástrofe,

3. las medidas de respuesta (Bertazzi 1991).

Puede ser difícil determinar la naturaleza y magnitud del escape, así como la capacidad del material para entrar en los distintos componentes del entorno humano, como la cadena alimentaria o el suministro de agua. Veinte años después del accidente, la cantidad de 2,3,7,8-TCDD liberado en Seveso el 10 de julio de 1976 sigue siendo objeto de controversia. Además, dados los escasos conocimientos sobre la toxicidad de este compuesto, cualquier predicción de riesgo en los días que siguieron el accidente era necesariamente discutible.

La experiencia personal de la catástrofe consiste en el miedo, la ansiedad y el sufrimiento (U rsano, M cC aughey y Fullerton 1994) provocados por el accidente, independientemente de la naturaleza del peligro y del riesgo real. Se incluyen tanto cambios conscientes del comportamiento, no necesariamente justificados (como la disminución de la tasa de nacimientos en muchos países europeos occidentales en 1987, tras el accidente de Chernóbil), como condiciones psicogénicas (como síntomas de inquietud en los escolares y soldados israelíes tras el escape de sulfuro de hidrógeno de una letrina defectuosa en un colegio de la orilla occidental del Jordán en 1981). En la actitud ante el accidente influyen también factores subjetivos: en Love Canal, por ejemplo, los padres jóvenes, con poca experiencia de contacto con sustancias químicas en el lugar de trabajo, eran más favorables a evacuar la zona que los padres mayores con hijos ya crecidos. 
Por último, un accidente puede tener una repercusión indirecta sobre la salud de las personas expuestas, bien sea por crear peligros adicionales (la inquietud asociada a la evacuación) 0 , paradójicamente, por generar efectos potencialmente beneficiosos (como el abandono del hábito del tabaco a consecuencia del contacto con los profesionales de la salud).

\section{Medición de la repercusión de un accidente}

No hay duda de que cada accidente requiere una evaluación de sus consecuencias cuantificables o potenciales sobre la población humana expuesta (y sobre la animal, doméstica o salvaje), y puede ser necesario actualizar periódicamente dicha evaluación. Son muchos los factores que influyen en los detalles, extensión y naturaleza de los datos que pueden reunirse para la evaluación. Es fundamental la cantidad de recursos disponibles. A accidentes de la misma gravedad pueden concederse distintos grados de atención en países diferentes, dependiendo de su capacidad para desviar recursos de otros ámbitos sanitarios o sociales. La cooperación internacional puede mitigar parcialmente esta discrepancia: en la práctica, se limita a episodios particularmente dramáticos o que presentan un interés científico especial.

Las consecuencias generales de un accidente sobre la salud pueden ser desde desdeñables hasta graves. La gravedad depende de la naturaleza de las afecciones provocadas por el accidente (que pueden incluir la muerte), de la magnitud de la población expuesta y del porcentaje de población que desarrolla la enfermedad. Los efectos desdeñables son más difíciles de demostrar desde un punto de vista epidemiológico.

Entre las fuentes de datos que deben utilizarse para evaluar las consecuencias de un accidente sobre la salud se encuentran, en primer lugar, las estadísticas ya existentes (antes de plantearse la creación de nuevas bases de datos de población, siempre debería considerarse la posibilidad de utilizar los datos ya recogidos). Puede obtenerse información adicional de estudios epidemiológicos analíticos basados en hipótesis, para los cuales las estadísticas existentes pueden ser o no útiles. Si en un entorno laboral no existe una vigilancia sanitaria de los trabajadores, el accidente puede ofrecer la oportunidad de establecer un sistema de vigilancia que finalmente ayude a proteger a los trabajadores de otros peligros potenciales para la salud.

A efectos de la vigilancia clínica (a corto o largo plazo) y del pago de compensaciones, la enumeración exhaustiva de las personas expuestas es una condición sine qua non. Es algo relativamente sencillo de hacer en los accidentes ocurridos dentro de fábricas. Cuando la población afectada puede definirse atendiendo al lugar en que vive, la lista de habitantes de demarcaciones municipales (o de unidades menores, si es posible) puede ofrecer una aproximación aceptable. La elaboración de un registro puede ser más problemática en otras circunstancias, en particular cuando existe la necesidad de elaborar una lista de personas con síntomas posiblemente atribuibles al accidente. En el episodio de SAT en E spaña, para obtener el registro de las personas que debían incluirse en el seguimiento clínico a largo plazo se utilizó la lista de las 20.000 personas que solicitaban una compensación financiera, y se corrigió posteriormente revisando las historias clínicas. D ada la publicidad que se dio a este episodio, el registro se considera razonablemente completo.

Un segundo requisito es que las actividades encaminadas a medir la repercusión de un accidente sean racionales, estén claramente definidas y sean fáciles de explicar a la población afectada. El período de latencia puede variar de días a años. Si se dan determinadas condiciones, pueden formularse hipótesis a priori sobre la naturaleza de la enfermedad y la probabilidad de su aparición con precisión suficiente para diseñar un programa de vigilancia clínica adecuado y estudios centrados en uno 0 varios de los objetivos mencionados al principio de este artículo.
Dichas condiciones comprenden la rápida identificación del agente liberado en el accidente, la disponibilidad de un conocimiento adecuado sobre sus propiedades peligrosas a corto y largo plazo, la cuantificación del escape, y algunos datos sobre las diferencias de susceptibilidad a los efectos del agente entre individuos distintos. En la práctica, raras veces se dan estas condiciones; una consecuencia de la incertidumbre e ignorancia subyacentes es que es más difícil resistir la presión de la opinión pública y de los medios de comunicación para que se dispense una prevención o una intervención médica de dudosa utilidad.

Por último, lo antes posible tras la confirmación de un accidente, es necesario crear un equipo interdisciplinario (incluidos médicos, químicos, higienistas industriales, epidemiólogos, toxicólogos humanos y experimentales) que sea responsable ante la autoridad política y ante el público. En la selección de expertos, hay que tener presente que la gama de sustancias químicas y tecnológicas que pueden intervenir en un accidente es muy amplia, de forma que pueden presentarse varios tipos de toxicidad con diferentes sistemas bioquímicos y fisiológicos.

\section{Medición de la repercusión de un accidente a través de las estadísticas existentes}

Los actuales indicadores sanitarios (mortalidad, natalidad, ingresos hospitalarios, bajas laborales por enfermedad y visitas médicas) pueden proporcionar una visión inmediata de las consecuencias de un accidente, siempre que sean estratificables para la zona afectada, lo que no siempre será posible, pues a veces se trata de áreas pequeñas que no se corresponden necesariamente con unidades administrativas. Es probable que las asociaciones estadísticas entre el accidente y un exceso de sucesos inmediatos (que tienen lugar en días o semanas) detectados por medio de los indicadores sanitarios existentes sean causales, pero esto no significa necesariamente que se esté produciendo un efecto de toxicidad (por ejemplo, un exceso de visitas médicas puede estar ocasionado por el miedo y no por la aparición real de la enfermedad). Como siempre, hay que tener cuidado al interpretar cualquier cambio en los indicadores sanitarios.

Aunque no todos los accidentes producen víctimas mortales, la mortalidad es un criterio de valoración fácilmente cuantificable, ya sea mediante el recuento directo (como en Bhopal) o por comparación entre el número de sucesos observados y el previsto (episodios agudos de contaminación atmosférica en zonas urbanas). D eterminar que un accidente no está asociado a un exceso de mortalidad inmediata puede ayudar a la hora de evaluar la gravedad de su repercusión y dedicar atención a las consecuencias no mortales. Además, la mayoría de los países disponen de las estadísticas necesarias para calcular la previsión de fallecimientos, que permiten establecer estimaciones en zonas tan pequeñas como las que habitualmente se ven afectadas por un accidente. $L$ a evaluación de la mortalidad sobre la base de determinadas afecciones es más problemática, debido a una posible predisposición de los funcionarios sanitarios - conocedores de cuáles son las enfermedades que se espera que aumenten tras el accidente- al certificar las causas de los fallecimientos (predisposición de sospecha de diagnóstico).

En consecuencia, la interpretación de los indicadores sanitarios a partir de las fuentes de datos existentes requiere un cuidadoso plan de análisis específicos, que incluya la consideración detallada de posibles factores de confusión.

En ocasiones, poco después de un accidente, se plantea la conveniencia de crear un registro de cáncer convencional en la población, o un registro de malformaciones. Para estas afecciones concretas, los registros pueden proporcionar una información más fiable que otras estadísticas (como la mortalidad o los ingresos hospitalarios), especialmente si los registros de nueva creación se gestionan de acuerdo con normas internacionales 
aceptables. Ahora bien, su creación requiere la reasignación de recursos. Además, si tras un accidente se establece un registro completamente nuevo de malformaciones basado en la población, lo más probable es que en un plazo de nueve meses no genere datos comparables a los de otros registros, y se producirán una serie de problemas deductivos (en especial, error estadístico del segundo tipo). En última instancia, la decisión se basa en gran medida en la evidencia de carcinogenicidad, embriotoxicidad 0 teratogenicidad del peligro 0 peligros que se han producido, y en los posibles usos alternativos de los recursos disponibles.

\section{Estudios epidemiológicos específicos}

$\mathrm{Ni}$ siquiera en zonas cubiertas por precisos sistemas de vigilancia de los motivos de los ingresos hospitalarios y de las consultas médicas, los indicadores ofrecerán toda la información necesaria para evaluar la repercusión de un accidente sobre la salud ni la adecuación de la respuesta médica al mismo. Hay afecciones concretas o indicadores de respuesta individual que no requieren el contacto con los servicios médicos, o no se corresponden con las clasificaciones de enfermedad utilizadas habitualmente en las estadísticas (de forma que su aparición no sería detectable). Puede ser necesario considerar "víctimas" del accidente a personas en condiciones limítrofes entre la aparición y la no aparición de la enfermedad. Con frecuencia, es necesario investigar la gama de protocolos terapéuticos utilizada (y evaluar su eficacia). En este artículo se expone sólo una muestra de los problemas que pueden plantearse y hacer necesaria una investigación específica. En cualquier caso, deben establecerse procedimientos para recibir otras quejas.

La investigación difiere de la atención sanitaria en el sentido de que no está directamente relacionada con el interés de una persona en tanto que víctima de un accidente. U na investigación específica debe plantearse de forma que cumpla sus objetivos: ofrecer una información fiable y demostrar o rechazar una hipótesis. EI muestreo puede ser razonable a los efectos de una investigación (si es aceptada por la población afectada), pero no para la atención médica. Por ejemplo, en caso de derrame de un agente que se sospeche pueda dañar la médula ósea, hay dos escenarios totalmente diferentes a la hora de responder a las dos preguntas siguientes: a) si la sustancia química induce realmente la leucopenia, y b) si todas las personas expuestas han sido sometidas a una detección exhaustiva de leucopenia. En un marco laboral, puede darse respuesta a las dos preguntas. En una población, la decisión dependerá también de las posibilidades de una intervención útil para tratar a los afectados.

En principio, hay que contar con un nivel suficiente de capacidad epidemiológica local para decidir si deben realizarse estudios específicos y, en caso afirmativo, diseñarlos y supervisar su puesta en funcionamiento. Ahora bien, las autoridades sanitarias, los medios de comunicación o la población pueden no considerar neutrales a los epidemiólogos de la zona; así, puede ser necesario recurrir a ayuda externa, incluso en una fase muy temprana. Los mismos epidemiólogos deberían contribuir a la interpretación de los datos descriptivos basados en las estadísticas disponibles, y al desarrollo de hipótesis causales si es necesario. Si la zona no dispone de epidemiólogos, será necesaria la colaboración de otros organismos (normalmente los institutos nacionales de salud o la OM S). Son de lamentar los episodios debidos a la falta de capacidad epidemiológica.

En cualquier caso, si se considera necesario un estudio epidemiológico, hay que responder a algunas preguntas preliminares: ¿cómo se utilizarán los resultados previsibles? ¿Puede el deseo de una deducción más refinada retrasar indebidamente los procedimientos de limpieza u otras medidas preventivas? ¿Debe el equipo científico interdisciplinario (y tal vez otros epide- miólogos) documentar y evaluar previamente el programa de investigación propuesto? ¿Se dará a las personas que van a ser estudiadas una información detallada para garantizar su autorización plenamente informada, previa y voluntaria? Si se demuestra la existencia de un efecto sobre la salud, ¿qué tratamientos están disponibles y cómo se aplicarán?

Por último, si el accidente ha sido grave y hay razones para temer consecuencias posteriores, deberían llevarse a cabo estudios de cohortes de mortalidad prospectivos. La viabilidad de dichos estudios difiere de un país a otro. En Europa, varían entre la posibilidad de "señalizar" nominalmente a las personas (como en las poblaciones rurales de Shetland, Reino U nido, tras el derrame de Braer $\mathrm{O}$ il) y la necesidad de contactos sistemáticos con las familias de las víctimas para identificar a las personas moribundas (por ejemplo, el SAT, en España).

\section{Detección selectiva de afecciones prevalentes}

0 frecer atención médica a las personas afectadas es una reacción natural ante un accidente que puede haberlas dañado. El intento de identificar a todos aquellos individuos de una población expuesta que padezcan enfermedades relacionadas con el accidente (y ofrecerles atención médica, si la necesitan) responde al concepto convencional de detección selectiva. L os principios básicos, las posibilidades y las limitaciones de cualquier programa de detección selectiva (independientemente de la población a que se dirija, la enfermedad que haya que identificar o la herramienta utilizada como prueba diagnóstica) tienen tanta validez ante un accidente ambiental como en cualquier otra circunstancia (M orrison 1985).

Tan importante como estimar la participación y comprender las razones de la falta de respuesta es medir la sensibilidad, adecuación y valor predictivo de la prueba o pruebas diagnósticas, diseñar un protocolo para procedimientos diagnósticos posteriores (si es necesario) y administrar la terapia (en su caso). Si no concede suficiente importancia a estos principios, los programas de detección selectiva a corto o largo plazo pueden resultar más perjudiciales que beneficiosos. Efectuar análisis médicos o de laboratorio innecesarios es malgastar recursos y desviarlos del suministro de la asistencia necesaria al conjunto de la población. Hay que planificar y evaluar cuidadosamente los procedimientos para garantizar un alto nivel de atención a estos principios.

Las reacciones emocionales y las incertidumbres que rodean los accidentes ambientales pueden complicar aún más las cosas: los médicos tienden a la vaguedad en el diagnóstico de enfermedades limítrofes, y algunas "víctimas" pueden considerarse con derecho a tratamiento médico, independientemente de si lo necesitan o de si les es útil. A pesar del caos que suele seguir a un accidente ambiental, hay que tener presentes algunas condiciones sine qua non para cualquier programa de detección selectiva:

1. Ios procedimientos deben recogerse en un protocolo escrito (incluidas las pruebas diagnósticas de segundo grado y la terapia que se aplicará a las personas afectadas o enfermas);

2. debe designarse un responsable del programa;

3. debe hacerse una estimación preliminar de la adecuación y sensibilidad de la prueba diagnóstica;

4. debe existir coordinación entre los médicos que participen en el programa,

5. las tasas de participación deben cuantificarse y revisarse a intervalos regulares.

E fectuar algunas estimaciones previas de la eficacia del programa en su conjunto ayudaría también a decidir si merece o no la pena aplicarlo (por ejemplo, no es conveniente fomentar ningún programa de anticipación del diagnóstico del cáncer de pulmón). 
Asimismo, debe crearse un procedimiento encaminado a reconocer otras quejas.

En cualquier fase, los procedimientos de detección selectiva pueden tener otra utilidad: estimar la prevalencia de las enfermedades, como base para evaluar las consecuencias del accidente. U na fuente importante de sesgos en estas estimaciones (que se acentúa con el tiempo) es la representatividad de las personas expuestas que se someten a los procedimientos de diagnóstico. 0 tro problema es la identificación de grupos de control adecuados para comparar las estimaciones de prevalencia obtenidas. Los controles efectuados entre la población pueden estar sujetos a sesgos tanto en la selección como en la muestra de personas expuestas. Con todo, en algunas circunstancias, los estudios de prevalencia son de la mayor importancia (especialmente cuando no se conoce la historia natural de la enfermedad, como en el caso del SAT), y pueden utilizarse grupos de control exteriores al estudio, incluidos los reunidos en otros lugares para otros objetivos, cuando el problema es importante o grave.

\section{Empleo de sustancias biológicas con fines epidemiológicos}

A efectos descriptivos, la recogida de sustancias biológicas (orina, sangre, tejidos) de miembros de la población expuesta puede proporcionar indicadores de dosis internas, que por definición son más precisos - aunque no los sustituyen totalmente- que los que pueden obtenerse mediante estimaciones de la concentración del contaminante en los distintos componentes del medio ambiente o mediante cuestionarios individuales. En toda evaluación, deberían tenerse en cuenta los posibles sesgos derivados de la falta de representatividad de los miembros de la comunidad de los que se toman las muestras biológicas.

Almacenar muestras biológicas puede ser útil, en una fase posterior, para la realización de estudios epidemiológicos específicos que requieran estimaciones de la dosis interna (o de los efectos precoces) a escala individual. Es vital recoger (y conservar adecuadamente) muestras biológicas inmediatamente después del accidente, y esta práctica debe fomentarse aun en ausencia de hipótesis definidas para su uso. El proceso de autorización informada debe garantizar que el paciente comprende que su material biológico se almacenará para ser utilizado en análisis aún no determinados. A este respecto, es útil excluir determinados análisis (como la identificación de trastornos de la personalidad) del uso de las muestras, al objeto de ofrecer mayor protección al paciente.

\section{Conclusiones}

EI razonamiento subyacente a la intervención médica y a los estudios epidemiológicos sobre la población afectada por un accidente varía entre dos extremos: evaluar la repercusión de agentes que constituyen peligros potenciales demostrados, y a los que la población afectada está (o ha estado) claramente expuesta, y explorar los posibles efectos de agentes cuyo potencial de peligro se supone y cuya presencia en la zona se sospecha. Las diferencias entre los expertos (y entre las personas en general) en la percepción de la importancia de un problema son inherentes a la condición humana. Lo que importa es que cualquier decisión tenga una motivación clara y un plan de acción transparente, y cuente con el apoyo de la comunidad afectada.

\section{Problemas ReLACIONADOS CON EL CLIMA}

Jean French

D urante mucho tiempo se ha aceptado que los problemas relacionados con el clima son un fenómeno natural, y es inevitable que se produzcan muertes o lesiones a causa de este tipo de acontecimientos (véase la Tabla 39.17). H asta las dos últimas décadas no se empezaron a estudiar los factores que contribuyen a la muerte y las lesiones derivadas de fenómenos atmosféricos como un medio de prevención. Dado el poco tiempo transcurrido desde la adopción de este enfoque, los datos son limitados, especialmente los relativos al número y circunstancias de las muertes y lesiones de trabajadores derivadas de fenómenos atmosféricos. Lo que sigue es un panorama general de los hallazgos realizados hasta la fecha.

\section{Inundaciones y maremotos}

\section{Definiciones, fuentes y episodios}

Las inundaciones se producen como resultado de varias causas distintas. En una misma zona climática, se observan importantes variaciones en materia de inundaciones a causa de las

Tabla 39.17 • Riesgos profesionales asociados con fenómenos atmosféricos.

\begin{tabular}{|c|c|c|c|c|c|c|c|}
\hline $\begin{array}{l}\text { Fenómeno } \\
\text { atmosférico }\end{array}$ & Tipo de trabajador & $\begin{array}{l}\text { Agentes } \\
\text { bioquímicos }\end{array}$ & $\begin{array}{l}\text { Lesiones } \\
\text { traumáticas }\end{array}$ & Ahogados & $\begin{array}{l}\text { Quemaduras/golpes } \\
\text { de calor }\end{array}$ & $\begin{array}{l}\text { Accidentes de } \\
\text { automóvil }\end{array}$ & Estrés \\
\hline \multirow[t]{5}{*}{$\begin{array}{l}\text { Inundaciones } \\
\text { Huracanes }\end{array}$} & $\begin{array}{l}\text { Personal de policía, } \\
\text { incendios } \\
\text { y emergencias }\end{array}$ & $*$ & $*$ & $*$ & & & \\
\hline & Transporte & & $*$ & $* *$ & & & $*$ \\
\hline & Metro & & & $*$ & & & $*$ \\
\hline & Instalador de líneas & & $*$ & & $*$ & & $*$ \\
\hline & Limpieza & $* * *$ & & & & & $*$ \\
\hline \multirow[t]{3}{*}{ Tornados } & $\begin{array}{l}\text { Personal de policía, } \\
\text { incendios y } \\
\text { emergencias }\end{array}$ & $*$ & $*$ & & & & $*$ \\
\hline & Transporte & & $* * *$ & & & $*$ & $*$ \\
\hline & Limpieza & $* *$ & $*$ & & & & \\
\hline $\begin{array}{l}\text { Incendios } \\
\text { forestales leves }\end{array}$ & Bomberos & $* *$ & $* *$ & & $* *$ & $* * *$ & $*$ \\
\hline grado de riesgo. & & & & & & & \\
\hline
\end{tabular}


fluctuaciones del ciclo hidrológico y de otras condiciones naturales y artificiales (C hagnon, Schict y Semorin 1983). El Servicio Meteorológico Nacional de Estados Unidos (US N ational Weather Service) ha definido como inundaciones repentinas las que se producen unas horas después de precipitaciones intensas 0 excesivas, del fallo de presas o diques, o del escape repentino de agua embalsada por la obstrucción producida por el hielo o por troncos. Aunque la mayor parte de las inundaciones repentinas son consecuencia de una intensa actividad tormentosa local, algunas se producen en conjunción con ciclones tropicales. Las causas primeras de las inundaciones repentinas suelen ser unas condiciones atmosféricas que influyen en la continuidad e intensidad de las precipitaciones. Entre otros factores que contribuyen a las inundaciones repentinas se cuentan la inclinación de las laderas (terreno montañoso), la ausencia de vegetación, la falta de drenaje del suelo, las materias flotantes y los embalses de hielo, el deshielo rápido, los fallos de presas y diques, la ruptura de lagos glaciares y las anomalías volcánicas (M arrero 1979).

En las inundaciones fluviales pueden influir factores que generen inundaciones repentinas, pero se pueden producir inundaciones más lentas como resultado de las características del cauce, del tipo de suelo y de subsuelo y del grado de modificación artificial de sus vías de escape (Chagnon, Schict y Semorin 1983; $M$ arrero 1979). Las inundaciones costeras pueden ser consecuencia de temporales, resultado a su vez de tormentas o ciclones tropicales, o ser ocasionadas por vientos tormentosos que lleven las aguas del mar al interior. El tipo más devastador de inundación costera es el tsunami o maremoto generado por seísmos submarinos o erupciones volcánicas. La mayor parte de los tsunamis registrados se han producido en el Pacífico y sus zonas costeras. Las islas $\mathrm{H}$ awai son especialmente propensas a sufrir daños ocasionados por los tsunamis, pues se encuentran en medio del Pacífico (C hagnon, Schict y Semorin 1983; Whitlow 1979).

\section{Factores de morbilidad y mortalidad}

Se ha estimado que las inundaciones representan el $40 \%$ de las catástrofes mundiales y producen los daños más graves. La inundación más letal conocida en toda la $\mathrm{H}$ istoria se produjo en el río Amarillo en 1887, cuando el río desbordó diques de una altura de 70 pies, destruyendo once ciudades y trescientos pueblos. Se calcularon 900.000 víctimas mortales. En 1969, el número de muertos se situó en torno a los cientos de miles en la provincia de Shantung, en C hina, cuando todo el valle del río A marillo se vio inundado por oleajes tormentosos. En enero de 1967, una inundación repentina en Río de Janeiro causó la muerte a 1.500 personas. En 1974, lluvias intensas inundaron Bangladesh y ocasionaron 2.500 muertos. En 1963, lluvias intensas provocaron un enorme corrimiento de tierras que cayó sobre el lago situado detrás de la presa de Vaiont en el norte de I talia, empujando 100 millones de toneladas de agua sobre la presa y causando 2.075 muertes (Frazier 1979). En 1985, en Puerto R ico cayeron, en un espacio de diez horas, entre 7 y 15 pulgadas de lluvia, ocasionando la muerte a 180 personas (French y $\mathrm{H}$ olt 1989).

Las inundaciones fluviales se han controlado gracias a la ingeniería y a una mayor forestación de las vertientes (Frazier 1979). No obstante, en los últimos años se han incrementado las inundaciones repentinas, que constituyen la primera causa de muertes relacionadas con fenómenos atmosféricos en Estados Unidos. El aumento de las muertes debidas a inundaciones repentinas se atribuye al crecimiento de la población y a la mayor urbanización de zonas muy proclives a este tipo de inundaciones (M ogil, M onro y G roper 1978).

El paso rápido del agua, junto con materiales como rocas y árboles caídos, son la primera causa de morbilidad y mortalidad relacionada con inundaciones. Algunos estudios realizados en Estados Unidos han demostrado que en las inundaciones se registra una elevada proporción de ahogados en coches; se trata de personas que se desplazan en coche hacia zonas bajas o por puentes inundados; se quedan atascadas en zonas de aguas altas 0 se ven bloqueadas por materiales, quedando atrapadas dentro del coche mientras les alcanzan las corrientes de agua (French y cols. 1983). Algunos estudios de seguimiento de víctimas de inundaciones muestran una pauta consistente de problemas psicológicos hasta cinco años después de la inundación (M elick 1976; Logue 1972). O tros estudios ponen de manifiesto un aumento significativo de la incidencia de hipertensión, afecciones cardiovasculares, linfoma y leucemia en víctimas de inundaciones, que algunos investigadores atribuyen a factores de estrés (Logue y Hansen 1980; Janerich y cols. 1981; Greene 1954). Se produce un mayor potencial de exposición a agentes biológicos y químicos cuando las inundaciones averían los sistemas de depuración de aguas y de evacuación de residuos, rompen depósitos subterráneos, desbordan zonas de residuos tóxicos o favorecen la propagación y dispersión de sustancias químicas almacenadas sobre el nivel del suelo (French y Holt 1989).

Aunque, en general, los trabajadores están expuestos a los mismos riesgos de inundaciones que la población general, algunos grupos profesionales corren mayor peligro. Los trabajadores de la limpieza presentan un alto riesgo de exposición a agentes biológicos y químicos tras inundaciones. Los trabajadores subterráneos, en especial los que trabajan en espacios cerrados, pueden verse atrapados en inundaciones repentinas. Los conductores de camiones y otros trabajadores de transportes corren un alto riesgo de mortalidad en vehículos a consecuencia de inundaciones. Como en otras catástrofes relacionadas con el clima, los bomberos, la policía y el personal médico de emergencia se enfrentan también a situaciones de alto riesgo.

\section{M edidasde prevención y control, y necesidades de investigación}

La prevención de las muertes y lesiones causadas por las inundaciones puede adoptar muchas formas: identificación de las zonas proclives a inundaciones; advertencia al público de la existencia de dichas zonas y asesoramiento sobre las medidas de prevención adecuadas; inspección de presas y emisión de certificados de seguridad de las mismas; definición de las condiciones meteorológicas que provocan precipitaciones y escorrentías intensas, y alarma inmediata de inundación para una zona geográfica concreta en un espacio de tiempo determinado. La morbilidad y mortalidad derivadas de exposiciones secundarias pueden evitarse garantizando que los suministros de agua y de alimentos sean seguros y no estén contaminados con agentes biológicos y químicos, e implantando unas prácticas apropiadas de evacuación de los residuos humanos. El suelo que rodea los depósitos y las balsas de residuos tóxicos debería someterse a inspecciones para determinar si se ha producido contaminación debido al desbordamiento de zonas de almacenaje (French y Holt 1989). Aunque los programas de vacunación masiva son contraproducentes, los trabajadores sanitarios y de la limpieza deben ser convenientemente inmunizados e instruidos en unas prácticas higiénicas adecuadas.

Es necesario mejorar la tecnología para que las alarmas de inundación repentina puedan concretarse más en términos de tiempo y lugar. Deberían evaluarse las condiciones para determinar si la evacuación ha de realizarse en coche 0 a pie. Tras una inundación, es conveniente estudiar una cohorte de trabajadores de sectores relacionados con la inundación para evaluar el riesgo de efectos adversos sobre la salud física y mental. 


\section{Huracanes, ciclones y tormentas tropicales}

\section{Definiciones, fuentes y episodios}

Un huracán se define como un sistema de rotación de vientos que gira en sentido contrario a las agujas del reloj en el hemisferio norte, se forma con aguas tropicales y produce unos vientos de al menos $118,4 \mathrm{~km} / \mathrm{h}$. Esta acumulación giratoria de energía se forma cuando determinadas condiciones de calor y presión provocan y empujan vientos a través de una amplia zona de océano que acaban envolviéndose en un área de bajas presiones. Un tifón es comparable a un huracán, pero se forma en aguas del Pacífico. Ciclón tropical es el término utilizado para designar la circulación de viento en torno a un núcleo de bajas presiones atmosféricas en aguas tropicales. U na tormenta tropical se define como un ciclón con vientos de 62,4 a $117,8 \mathrm{~km} / \mathrm{h}$, y una depresión tropical es un ciclón con vientos inferiores a $62,4 \mathrm{~km} / \mathrm{h}$.

A ctualmente, se considera que muchos ciclones tropicales se generan en A frica, en la zona inmediatamente al sur del Sáhara. Se inician como una inestabilidad en una estrecha corriente de aire de Este a 0 este que se produce en la zona entre junio y diciembre debido a la gran diferencia de temperaturas existente entre el desierto cálido y la zona más fresca y húmeda situada al sur. Los estudios demuestran que los trastornos generados en Africa tienen largos ciclos de vida, y muchos de ellos cruzan el Atlántico (Herbert y Taylor 1979). A lo largo del siglo XX, vienen cruzando el Atlántico una media anual de diez ciclones tropicales, seis de los cuales se convierten en huracanes. Cuando el huracán (o tifón) alcanza su intensidad máxima, las corrientes de aire formadas en las zonas de altas presiones de las Bermudas o del Pacífico desvían su curso hacia el norte. Aquí, las aguas del océano son más frías, hay menos evaporación, menos vapor de agua y menos energía para alimentar la tormenta. Si la tormenta llega a tierra, el suministro de vapor de agua se corta por completo. Como el huracán o tifón sigue desplazándose hacia el norte, sus vientos comienzan a disminuir. D eterminadas características topográficas, como las montañas, pueden contribuir también a la disolución de la tormenta. Las zonas geográficas de mayor riesgo de huracanes son el Caribe, M éxico y los E stados de la Costa Este y la Costa del G olfo de Estados U nidos. Un típico tifón del Pacífico se forma en las aguas tropicales cálidas situadas al este de las islas Filipinas. Puede avanzar hacia el 0 este y alcanzar la costa china o girar hacia el norte, acercándose a Japón. La trayectoria de la tormenta se determina a medida que va desplazándose en torno al borde occidental del sistema de altas presiones del Pacífico (U nderstanding Science and N ature: W eather and Climate 1992).

La potencia destructiva de un huracán (tifón) viene determinada por la forma en que se combinan el temporal, el viento y otros factores. Los sistemas de predicción han desarrollado una escala de cinco categorías de potencial catastrófico para cuantificar el riesgo previsible de huracanes próximos. La categoría 1 es un huracán mínimo y la 5 un huracán máximo. En el período comprendido de 1900 a 1982, se abatieron directamente sobre Estados U nidos 136 huracanes, 55 de ellos de una intensidad mínima de 3. Florida sufrió los efectos del mayor número y de las más intensas de estas tormentas, junto con Texas, L ouisiana y Carolina del Norte, por este orden (H erbert y Taylor 1979).

\section{Factores de morbilidad y mortalidad}

Aunque los vientos ocasionan grandes daños a los bienes, no son la causa del mayor número de muertes en un huracán. La mayor parte de las víctimas mueren ahogadas. La inundación que acompaña a un huracán puede deberse a una lluvia intensa 0 al temporal. EI Servicio meteorológico nacional de Estados U nidos (US N ational Weather Service) estima que los temporales causan nueve de cada diez muertes asociadas a los huracanes (H erbert y
Taylor 1979). Los grupos profesionales a los que más intensamente afectan los huracanes (tifones) son los relacionados con el transporte marítimo (debido a la extrema agitación de los mares y a los grandes vientos); con el tendido eléctrico, a quienes se recurre para reparar líneas dañadas, con frecuencia en plena tormenta; bomberos y policías que intervienen en evacuaciones y en la protección de los bienes de los evacuados; y personal médico de emergencia. En la sección de inundaciones se contemplan otros grupos profesionales.

\section{Medidas de prevención y control, y necesidades de investigación}

EI número de muertos y heridos asociado con huracanes (tifones) ha descendido radicalmente en los últimos veinte años en las zonas en que se han implantado avanzados sistemas de alarma. Los pasos principales que hay que seguir para prevenir muertes y lesiones son los siguientes: identificar los datos meteorológicos previos que anuncian estas tormentas, y seguir su curso y su posible transformación en huracanes; dar la alarma con tiempo para permitir una evacuación inmediata, si es necesario; aplicar prácticas estrictas de ordenación del territorio y códigos rigurosos de construcción en zonas de alto riesgo, y elaborar planes de emergencia en este tipo de áreas para permitir una evacuación ordenada y disponer de refugios suficientes para los evacuados.

Dado que se han estudiado en profundidad los factores meteorológicos que contribuyen a los huracanes, contamos con gran cantidad de información al respecto. Ahora bien, hacen falta más datos sobre la variación en incidencia e intensidad de los huracanes a lo largo del tiempo. Después de cada huracán debería evaluarse la eficacia de los planes de emergencia existentes, y determinar si las construcciones protegidas contra la velocidad del viento están también protegidas contra los temporales.

\section{Tornados}

\section{Formación y pautas de incidencia}

L os tornados se forman cuando capas de aire de diferente temperatura, densidad y velocidad se combinan para producir poderosas corrientes ascendentes que forman inmensas nubes del tipo cúmulonimbos; éstas se transforman en apretadas espirales que giran sobre su eje al ser empujadas por fuertes vientos transversales. Este vórtice arrastra hacia el interior de la nube más aire caliente, que hace que el sistema rote con mayor rapidez, hasta que del cúmulonimbo sale una nube en forma de embudo que encierra una fuerza explosiva (U nderstanding Science and Nature: W eather and Climate 1992). Un tornado medio tiene una trayectoria aproximada de 2 millas de largo y 50 yardas de ancho, y afecta en torno a 0,06 millas cuadradas, con una velocidad del viento de hasta 300 millas por hora. Los tornados se producen en zonas en que pueden chocar frentes cálidos y fríos, lo que genera unas condiciones inestables. Aunque las probabilidades de que un tornado afecte a una localidad concreta son extremadamente pequeñas (probabilidad de 0,0363), algunas zonas, como el M edio $O$ este de Estados U nidos, son especialmente vulnerables.

\section{Factores de morbilidad y mortalidad}

Los estudios demuestran que las personas que ocupan viviendas móviles y coches ligeros están expuestas a un riesgo especialmente alto en caso de tornado. Según un estudio sobre tornados realizado en las cataratas de Wichita, Texas, los ocupantes de viviendas móviles tenían 40 veces más probabilidades de sufrir lesiones graves o fatales que los habitantes de viviendas fijas, y los ocupantes de automóviles corrían un riesgo aproximadamente cinco veces mayor (G lass, Craven y Bregman 1980). La principal 
causa de muerte es el traumatismo craneoencefálico, seguido de fracturas de cráneo y de tronco. Las fracturas son la forma más frecuente de lesiones no fatales ( $M$ andlebaum, $N$ ahrwold y Boyer 1966; H igh y cols. 1956). También los trabajadores que pasan la mayor parte de su tiempo de trabajo en automóviles ligeros o que tienen sus oficinas en viviendas móviles se encuentran en una situación de alto riesgo. Son aplicables asimismo las consideraciones sobre los trabajadores de la limpieza que se avanzaron en el capítulo de inundaciones.

\section{Prevención y control}

La emisión de alarmas adecuadas y la necesidad de que la población tome las medidas oportunas en respuesta a dichas alarmas son los factores más importantes para la prevención de muertes y lesiones relacionadas con tornados. En Estados Unidos, el Servicio meteorológico nacional ha adquirido avanzados equipos, como radares $\mathrm{D}$ oppler, para detectar las condiciones que llevan a la formación de un tornado, y dar la alarma. U n aviso de tornado significa que una zona determinada reúne condiciones que pueden desembocar en la formación de un tornado, y una alarma de tornado quiere decir que se ha avistado un tornado en una zona dada, cuyos habitantes deben refugiarse adecuadamente: es decir, bajar a los sótanos, si existen; meterse en una habitación o habitáculo interior 0 , si se encuentran en el exterior, refugiarse en una cuneta 0 en una hondonada (barranco).

$\mathrm{H}$ ay que avanzar más en la investigación para evaluar si las alarmas se divulgan de una forma eficaz, y qué grado de atención les presta la población. También está por determinar si las áreas de refugio prescritas ofrecen realmente una protección adecuada contra la muerte o lesiones. $\mathrm{H}$ ay que reunir información sobre el número de muertes y lesiones en los trabajadores de servicios relacionados con tornados.

\section{Rayos e incendios forestales}

\section{Definiciones, fuentes y episodios}

Cuando un cúmulonimbo se convierte en una tormenta, varias secciones de la nube acumulan cargas eléctricas positivas y negativas. U na vez creadas dichas cargas, las negativas fluyen hacia las positivas en un rayo que se desplaza por el interior de la nube 0 de la nube al suelo. La mayor parte de los rayos se dirigen de una nube a otra, pero el $20 \%$ lo hacen de la nube al suelo. U n rayo entre una nube y el suelo puede ser positivo o negativo. Un rayo positivo es más potente y tiene más probabilidades de desencadenar un incendio forestal. EI hecho de que caiga un rayo no provocará un incendio a menos que encuentre un material fácilmente inflamable, como agujas de pino, hierba o resina. Si el fuego se propaga a madera en descomposición, puede arder sin ser percibido durante un largo período de tiempo. Los rayos generan incendios con más frecuencia cuando la lluvia contenida en la nube de tormenta se evapora antes de llegar al suelo. Este fenómeno se denomina rayo seco (Fuller 1991). Se estima que, en zonas secas y rurales, como Australia y el oeste de Estados U nidos, el $60 \%$ de los incendios forestales son causados por el rayo.

\section{Factores de morbilidad y mortalidad}

La mayor parte de los bomberos que mueren en incendios fallecen en accidentes de camión o helicóptero, o bien al ser alcanzados por la caída de ramaje, más que por el propio incendio. C laro está que la lucha contra el fuego puede provocar golpes de calor, agotamiento por calor y deshidratación. EI golpe de calor consiste en que la temperatura del cuerpo supera los $39,4{ }^{\circ} \mathrm{C}$ y puede ocasionar la muerte 0 daños al cerebro. EI monóxido de carbono es otra amenaza, particularmente en fuegos sin llama. En un estudio sobre 293 bomberos, los investigadores descubrieron que la sangre de 62 de ellos contenía niveles de carboxihemoglobina superiores al máximo admisible, de un $5 \%$, tras ocho horas en el frente de incendio (Fuller 1991).

M edidas de prevención y control, ynecesidades de investigación Debido al peligro y al estrés físico y mental inherentes a la lucha contra el fuego, los bomberos no deben trabajar más de 21 días seguidos, con un día libre por cada 7 días trabajados. Además de llevar un equipo de protección adecuado, deben aprender los factores de seguridad, como planificar vías de escape, mantenerse en comunicación, estar alerta ante peligros, estar pendientes del clima, confirmar las instrucciones y actuar antes de que una situación se haga crítica. Entre las órdenes habituales de lucha contra el fuego destacan: saber cuál es el desarrollo del incendio, colocar torres de vigilancia y dar unas instrucciones claras y comprensibles (Fuller 1991).

Entre los factores relacionados con la prevención de incendios forestales provocados por rayos se incluye reducir la presencia de materiales combustibles, como maleza y leña seca o árboles fácilmente combustibles como los eucaliptos, impedir la construcción en zonas con alta probabilidad de incendios y procurar una detección precoz de los incendios forestales. La detección precoz se ha visto facilitada por el desarrollo de nuevas tecnologías, como un sistema de infrarrojos que se monta en helicópteros para vigilar si las caídas de rayos notificadas por la vigilancia aérea y por los sistemas de detección han provocado incendios, y para establecer puntos de actuación para los efectivos de tierra y para el lanzamiento de agua desde helicópteros (Fuller 1991).

Es necesario contar con más información sobre el número y circunstancias de las muertes y lesiones asociadas a los incendios forestales provocados por rayos.

\section{AVALANCHAS: RIESG OS Y MEDIDAS DE PROTECCION}

G ustav Poinstingl

Desde que los seres humanos comenzaron a asentarse en zonas montañosas, han estado expuestos a los riesgos inherentes a la vida en la montaña. Entre los peligros más traicioneros se encuentran las avalanchas y los corrimientos de tierras, que se han cobrado víctimas hasta nuestros días

Cuando las montañas quedan cubiertas por varios pies de nieve en invierno, y se dan determinadas condiciones, una masa de nieve que cubre las laderas empinadas o las cumbres como una espesa manta puede desprenderse del suelo y deslizarse hacia abajo por efecto de su propio peso. Así, inmensas cantidades de nieve caen estrepitosamente en la dirección más recta y se depositan en los valles. La energía cinética liberada produce peligrosas avalanchas, que barren, aplastan o entierran cuanto encuentran a su paso.

Las avalanchas se dividen en dos categorías en función del tipo y estado de la nieve: avalanchas de nieve seca o "polvo" y avalanchas de nieve húmeda o "papa". Las primeras son peligrosas por las olas de "choque" que desencadenan y las últimas debido a su enorme volumen, pues la mayor humedad de la nieve húmeda aplasta todo cuanto encuentra a su paso, frecuentemente a gran velocidad, llegando a arrastrar secciones del subsuelo.

Pueden surgir situaciones especialmente peligrosas cuando la nieve acumulada en grandes laderas descubiertas de vertientes expuestas al viento se ve compactada por éste. Entonces, suele 
formarse una cubierta que mantiene una cohesión exclusivamente superficial, como una cortina suspendida desde lo alto, y descansa sobre una base que puede producir un efecto de rodamiento de bolas. Si se hace un "corte" en esta cubierta (por ejemplo, si un esquiador deja un rastro transversal en la ladera) o si por cualquier razón esta delgada capa se rompe (por ejemplo por su propio peso), toda la carga de nieve puede deslizarse ladera abajo como una plancha, convirtiéndose normalmente en una avalancha a medida que avanza.

En el interior de la avalancha puede crearse una enorme presión, capaz de arrastrar, destruir o aplastar vehículos y construcciones enteras como si fueran juguetes. Q ue los seres humanos tienen muy pocas posibilidades de sobrevivir a un infierno semejante es evidente, pues si no se muere aplastado se tiene muchas probabilidades de morir de asfixia 0 de frío. Por tanto, no es sorprendente que alrededor del $20 \%$ de las personas atrapadas en avalanchas sean encontradas muertas, aunque se hallen inmediatamente.

La topografía y vegetación de la zona determina la trayectoria de las masas de nieve en su descenso hacia el valle. Los habitantes de la zona lo saben por observación y tradición, y en invierno se mantienen alejados de las zonas de peligro.

En otros tiempos, la única manera de escapar a estos peligros era no exponerse a ellos. Las granjas y asentamientos humanos se construían en lugares cuyas condiciones topográficas no permitían la aparición de avalanchas, o que tras años de experiencia se sabían alejados de las vías de avalancha conocidas. La gente llegaba a evitar totalmente las zonas montañosas durante el período de peligro.

Los bosques situados en las laderas superiores proporcionan una considerable protección contra estas catástrofes naturales, pues soportan las masas nieve en las zonas amenazadas y pueden restringir, detener o desviar avalanchas ya iniciadas, siempre que no hayan acumulado demasiado impulso.

Sea como fuere, la historia de los países montañosos está salpicada de catástrofes debidas a las avalanchas, que se han cobrado - y siguen haciéndolo- un gran tributo en vidas humanas y bienes. Por una parte, se suele subestimar la velocidad e impulso de las avalanchas. Por otra, éstas siguen en ocasiones trayectorias que, tras siglos de experiencia, no se habían considerado como vías de avalancha. Determinadas condiciones climáticas desfavorables, unidas a un determinado tipo de nieve y al estado del suelo (por ejemplo vegetación dañada, erosión o pérdidas de suelo como resultado de lluvias intensas) configuran unas circunstancias que pueden desembocar en una de esas "catástrofes del siglo".

Q ue una zona esté especialmente expuesta al peligro de avalanchas depende no sólo de las condiciones climáticas, sino - en mayor medida- de la estabilidad de la cubierta de nieve y de si la zona en cuestión está situada en una de las vías o trayectorias de avalancha habituales. $\mathrm{H}$ ay mapas especiales que muestran las zonas en que se sabe que se han producido avalanchas 0 es probable que ocurran como resultado de las características topográficas, especialmente las vías y trayectorias de avalanchas frecuentes. En zonas de alto riesgo está prohibida la construcción.

A hora bien, estas medidas de precaución han dejado de ser suficientes, ya que, a pesar de la prohibición de construir en determinadas zonas y de toda la información disponible sobre los riesgos, muchas personas se sienten atraídas por las pintorescas zonas de montaña y se construye cada vez más, incluso en zonas de reconocido peligro. Además de esta indiferencia 0 elusión de las prohibiciones de construcción, una de las manifestaciones de la moderna sociedad del ocio es que miles de turistas van a la montaña con fines deportivos o recreativos en invierno, a zonas en que las avalanchas están prácticamente programadas.
La ladera ideal para esquiar es empinada y libre de obstáculos, y debe contar con una alfombra de nieve lo bastante gruesa: condiciones ideales para el esquiador, pero también para que la nieve se deslice hacia el valle.

$\mathrm{Si}$, a pesar de todo, no se pueden evitar los riesgos o éstos se aceptan hasta cierto punto a modo de "efectos secundarios" e indeseables del placer que supone el deporte, es necesario desarrollar medios para hacer frente a estos peligros de otra manera.

Para mejorar las posibilidades de supervivencia de las personas enterradas por avalanchas, es esencial disponer de servicios de rescate bien organizados, teléfonos de emergencia cerca de las zonas de riesgo e información actualizada, tanto a las autoridades como a los turistas, sobre la situación en las zonas peligrosas. U nos sistemas de alarma precoz y una buena organización de los servicios de rescate, con el mejor equipo posible, pueden aumentar considerablemente las posibilidades de supervivencia de las personas enterradas por avalanchas, así como reducir la cuantía de los daños.

\section{Medidas de protección}

Se han desarrollado y probado en todo el mundo diversos métodos de protección contra las avalanchas, desde los servicios transfronterizos de alarma y las barreras hasta la provocación de las mismas mediante explosiones o disparando armas de fuego en la nieve.

La estabilidad de la cubierta de nieve está básicamente determinada por la relación entre tensión mecánica y densidad. Su estabilidad puede variar considerablemente dependiendo del tipo de tensión (por ejemplo presión, tensión, resistencia al corte) en una misma zona geográfica (en qué parte del terreno puede comenzar una avalancha). Los perfiles, el sol, los vientos, la temperatura y las pequeñas anomalías en la estructura de la cubierta de nieve - a causa de rocas, esquiadores, máquinas quitanieves u otros vehículos- pueden también afectar a su estabilidad. Por lo tanto, la estabilidad puede verse reducida por intervenciones locales deliberadas como voladuras o aumentada por la instalación de soportes o barreras adicionales. Estas medidas, que pueden ser de naturaleza permanente o temporal, son los dos principales métodos de protección contra avalanchas.

Las medidas permanentes incluyen estructuras eficaces y duraderas, barreras de apoyo en las zonas de inicio de avalanchas, barreras de desviación o frenado en la trayectoria de las mismas, y barreras de bloqueo en la zona de salida. El objetivo de las medidas temporales de protección es asegurar y estabilizar las áreas en que pueden iniciarse avalanchas, desencadenando deliberadamente avalanchas pequeñas y limitadas para eliminar cantidades peligrosas de nieve en algunas zonas.

L as barreras de apoyo aumentan artificialmente la estabilidad de la cubierta de nieve en zonas de avalancha potencial. Las barreras de arrastre, que impiden que el viento arrastre más nieve a la zona de avalancha, pueden reforzar el efecto de las barreras de apoyo. Las barreras de desviación y frenado en el camino de la avalancha y las de bloqueo en el área de salida pueden desviar o aminorar la velocidad de la masa descendente de nieve y acortar la distancia de derrame frente al área protegida. Las barreras de apoyo son estructuras fijadas al suelo, más o menos perpendiculares a la ladera, que oponen una resistencia suficiente a la masa de nieve descendente. Deben formar soportes que lleguen hasta la superficie de la nieve. L as barreras de apoyo suelen organizarse en varias filas y cubren toda la zona desde la cual, en determinadas condiciones climáticas, podrían formarse avalanchas que amenazasen la localidad protegida. Son necesarios años de observación y medición de la nieve en la zona para determinar correctamente la colocación, estructura y dimensiones de las barreras, que además deben contar con un 
determinado grado de permeabilidad, para permitir que las avalanchas menores y los corrimientos superficiales de tierras atraviesen varias filas de barreras sin causar daños. Si la permeabilidad no es suficiente, existe el peligro de que la nieve se apile tras las barreras y que posteriores avalanchas se deslicen sobre ellas sin impedimento alguno, arrastrando a su paso mayores masas de nieve.

A diferencia de las barreras, las medidas temporales reducen el peligro durante un período de tiempo. La idea es desencadenar avalanchas por medios artificiales. Las masas de nieve amenazadoras se eliminan de la zona potencial de avalanchas provocando artificialmente y bajo control, en momentos oportunos y predeterminados, varias avalanchas pequeñas. Así se aumenta considerablemente la estabilidad de la cubierta de nieve que queda en el lugar de la avalancha y se reduce el riesgo de avalanchas más peligrosas, al menos durante un período de tiempo limitado, cuando la amenaza de avalanchas es muy alta.

Ahora bien, la magnitud de las avalanchas artificiales no puede determinarse previamente con exactitud. Por tanto, para correr el menor riesgo posible de accidentes mientras se están llevando a cabo estas medidas temporales, es necesario evacuar, aislar y comprobar toda la zona que va a verse afectada por la avalancha artificial, desde su punto de partida hasta su detención final.

Las posibles aplicaciones de estos dos métodos de prevención del peligro son fundamentalmente diferentes. En general, es mejor utilizar métodos permanentes para proteger zonas imposibles 0 difíciles de evacuar 0 de aislar, o en las que los asentamientos o bosques podrían peligrar incluso con avalanchas controladas. Por otro lado, las carreteras, las pistas de esquí y las laderas de esquí, que son fáciles de aislar durante cortos espacios de tiempo, son típicos ejemplos de zonas en las que pueden aplicarse medidas de protección temporales.

Los distintos métodos de desencadenar avalanchas artificiales incluyen operaciones que a su vez plantean determinados riesgos y, sobre todo, requieren medidas de protección para las personas encargadas de esta tarea. Lo esencial es provocar rupturas iniciales mediante temblores artificiales (voladuras). Estos reducen la estabilidad de la cubierta de nieve lo suficiente para producir un deslizamiento de la misma.

Las voladuras son especialmente adecuadas para liberar avalanchas en laderas empinadas. Normalmente, es posible extraer pequeñas cantidades de nieve a intervalos y evitar así la producción de avalanchas graves, que se arrastran a gran distancia y pueden ser extremadamente destructivas. Con todo, es esencial que las operaciones de voladura sean llevadas a cabo en cualquier momento del día y en todo tipo de climas, y esto no es siempre posible. Los métodos para producir avalanchas por medio de voladuras varían considerablemente dependiendo del medio utilizado para llegar a la zona en que va a tener lugar la voladura.

Las zonas en que es probable que se inicien avalanchas pueden ser bombardeadas con granadas o cohetes desde posiciones de seguridad, pero este sistema sólo tiene éxito (es decir, produce la avalancha) entre el 20 y el $30 \%$ de los casos, pues resulta prácticamente imposible determinar y alcanzar con exactitud los objetivos más efectivos a cierta distancia, y también porque la cubierta de nieve absorbe el choque de la explosión. Además, puede ocurrir que las granadas no estallen.

Las voladuras con explosivos comerciales directamente en la zona en que es probable que se inicien avalanchas suelen tener más éxito. Los métodos más efectivos consisten en llevar el explosivo por medio de estacas o cables a la parte del terreno nevado en que va a desencadenarse la avalancha, y detonarlo a una altura de 1,5 a $3 \mathrm{~m}$ por encima de la cubierta de nieve.
A parte de detonar granadas en las laderas, se han desarrollado tres métodos diferentes para llevar el explosivo de producción artificial de avalanchas al punto real en que se quiere iniciar la avalancha:

- cable transportador de dinamita

- voladura manual

- arrojar o bajar la carga explosiva desde helicópteros.

El cable transportador es el método con más garantías de éxito, y al mismo tiempo el más seguro. Con la ayuda de un pequeño funicular especial, el cable transportador de dinamita, la carga explosiva se transporta en una cuerda enrollada hasta el punto de voladura en la zona cubierta de nieve donde quiere provocarse la avalancha. Con un adecuado control de la cuerda y con la ayuda de señales e indicadores, es posible conducir la carga con exactitud hasta los puntos que la experiencia señala como más eficaces y hacer que explote directamente sobre ellos. Los mejores resultados se consiguen cuando la carga se detona a la altura adecuada por encima de la cubierta de nieve. Dado que el cable transportador discurre a mayor altura sobre el nivel del suelo, es necesario utilizar mecanismos de descenso. La carga explosiva cuelga de una cuerda enrollada alrededor del mecanismo de descenso. La carga se baja hasta la altura adecuada sobre el punto elegido accionando un motor que desenrolla la cuerda. La utilización del cable transportador de dinamita permite llevar a cabo la voladura desde una posición segura, incluso con escasa visibilidad, de día o de noche.

Por los buenos resultados obtenidos y su coste relativamente bajo, este método de desencadenar avalanchas se utiliza mucho en toda la zona alpina; en la mayor parte de los países alpinos se requiere un permiso para el funcionamiento de los cables transportadores de dinamita. En 1988, tuvo lugar un intercambio intensivo de experiencias en este ámbito entre fabricantes, usuarios y representantes de la administración de las zonas al pinas de Austria, Baviera y Suiza. La información reunida se ha recogido, de forma abreviada, en publicaciones informativas y normativas vinculantes. Básicamente, se trata de normas técnicas de seguridad para equipos e instalaciones, e instrucciones para realizar con seguridad estas operaciones. Al preparar la carga explosiva y poner en funcionamiento el equipo, los trabajadores encargados de la voladura deben contar con la mayor libertad de movimientos posible en torno a los diversos controles y aparatos del cable transportador. D ebe haber vías de acceso a pie seguras y fácilmente accesibles, para que los trabajadores puedan abandonar el lugar con rapidez en caso de emergencia. También deben existir vías de acceso seguras hasta los soportes y estaciones del cable transportador. Para asegurar las explosiones, deben utilizarse dos mechas y dos detonadores por carga.

Un segundo método para la producción de avalanchas artificiales, utilizado con frecuencia en el pasado, es la voladura manual. En este caso, el técnico en explosivos tiene que trepar hasta la zona de la cubierta de nieve en que se va a desencadenar la avalancha. La carga explosiva puede colocarse en estacas clavadas en la nieve, pero por lo general se lanza ladera abajo hacia un punto señalado por experiencia como especialmente efectivo. Normalmente, es imperativo que los ayudantes aseguren al técnico mediante una cuerda durante toda la operación. Claro está que, por muy cuidadosamente que se proceda, no puede eliminarse del todo el peligro de caídas o de encontrar avalanchas en el camino al punto de voladura, dado que estas actividades suelen requerir largos ascensos, a veces en condiciones climáticas desfavorables. Debido a estos peligros, este método, que también debe cumplir unas normas de seguridad, raras veces se utiliza en nuestros días. 
Durante muchos años, en los Alpes y otras zonas se ha practicado un tercer método, el uso de helicópteros para desencadenar avalanchas. Por el peligro que corren los que van a bordo, en la mayoría de los países alpinos y otros países montañosos sólo se recurre a este procedimiento cuando es urgente para eliminar un peligro grave, cuando no pueden utilizarse otros procedimientos o cuando utilizarlos representaría un riesgo aún mayor. Debido a la particular situación legal que crea el uso de vehículos aéreos para tales propósitos y a los riesgos que ello implica, en los países alpinos se han elaborado directrices concretas sobre el desencadenamiento de avalanchas desde helicópteros con la colaboración de las autoridades de aviación, de las instituciones y autoridades responsables de la salud en el trabajo y de especialistas en este terreno. Dichas directrices contemplan no sólo las leyes y normativas sobre explosivos y las disposiciones de seguridad, sino también las cualificaciones físicas y técnicas de las personas encargadas de tales operaciones.

Las avalanchas se desencadenan desde helicópteros ya sea bajando la carga con una cuerda y detonándola sobre la cubierta de nieve o dejándola caer con la mecha ya encendida. Deben emplearse helicópteros especialmente adaptados y provistos de una autorización para realizar tales operaciones. Para proceder con seguridad, debe haber una estricta división de responsabilidades entre el piloto y el técnico de explosivos. La carga debe prepararse correctamente y la longitud de la mecha se seleccionará dependiendo de que ésta vaya a ser bajada 0 lanzada. Por seguridad, deben utilizarse dos detonadores y dos mechas, como en los otros métodos. Por regla general, cada carga contiene de 5 a $10 \mathrm{~kg}$ de explosivo. Pueden bajarse varias cargas o dejarse caer una tras otra en un solo vuelo. Las detonaciones deben observarse visualmente, para comprobar que ninguna de ellas ha fallado.

Todos estos procesos de voladura requieren el uso de explosivos especiales, eficaces en condiciones de frío e insensibles a influencias mecánicas. L as per sonas encargadas de llevar a cabo estas operaciones deben estar especialmente cualificadas para ello y contar con la experiencia necesaria.

Las medidas de protección temporales y permanentes contra avalanchas se diseñaron originalmente para zonas de aplicación claramente diferentes. Las costosas barreras permanentes se destinaban sobre todo a proteger pueblos y construcciones, en especial contra avalanchas graves. En un principio, las medidas de protección temporales se limitaban casi exclusivamente a proteger carreteras, estaciones de esquí e instalaciones que podían cerrarse con facilidad. En la actualidad, se tiende a aplicar una combinación de los dos métodos. Para elaborar un programa de seguridad eficaz para una zona determinada, es necesario analizar la situación en detalle y determinar qué método ofrece la mayor protección posible.

\section{- TRANSPORTE DE MATERIALES PELIG RO SO S: SUSTAN CIAS Q UIMICAS Y RADIACTIVAS}

\section{Donald M. Campbell}

La industria y la economía de los países dependen, en parte, del gran número de materiales peligrosos que se transportan desde el proveedor hasta el usuario y, en última instancia, hasta la planta de eliminación de residuos. Los materiales peligrosos se transportan por carretera, ferrocarril, vías navegables, aire, gasoductos y oleoductos, y en su gran mayoría llegan a destino con seguridad y sin incidentes. La magnitud y el alcance del problema pueden ilustrarse con la industria del petróleo. En el Reino U nido, se distribuyen anualmente unos 100 millones de toneladas de productos a través de tuberías, carretera, ferrocarril y vías navegables. A proximadamente un $10 \%$ de las personas que trabajan en la industria química británica están relacionadas con la distribución (es decir, con el transporte y el almacenamiento).

Un material peligroso puede definirse como "una sustancia o material cuyo transporte puede plantear un riesgo desproporcionado para la salud, la seguridad o los bienes". La expresión "riesgo desproporcionado" engloba un amplio espectro de consideraciones sanitarias, ambientales y en materia de incendios. Son materiales peligrosos los explosivos, los gases inflamables, los gases tóxicos, los líquidos altamente inflamables, los líquidos inflamables, los sólidos inflamables, las sustancias peligrosas en contacto con la humedad, las sustancias oxidantes y los líquidos tóxicos.

LoS riesgos consisten directamente en la posibilidad de escapes, combustiones y otros incidentes durante el transporte de la sustancia o sustancias. Los accidentes más graves se producen en el transporte por carretera y ferrocarril y "pueden afectar tanto a los trabajadores como a la población en general". EI peligro existe tanto cuando los materiales se están cargando o descargando, como en ruta. La población de riesgo comprende las personas que viven cerca de la carretera o del ferrocarril, y las que van en otros vehículos o trenes que se vean implicados en un accidente grave. Entre las zonas de riesgo se encuentran los puntos de detención temporal, como las zonas de maniobras del ferrocarril o las zonas de estacionamiento de camiones en las áreas de servicio de las carreteras. Los riesgos marítimos se concentran en la entrada y salida de puerto de los barcos, y en la carga y descarga en él; también presenta riesgos el tráfico costero y el tráfico angosto, así como por las vías de navegación interior.

El tipo de incidentes que pueden producirse en relación con el transporte, tanto en tránsito como en instalaciones fijas, incluye el sobrecalentamiento químico, los derrames, los escapes, las emisiones de vapor o gas, los incendios y las explosiones. D os de los sucesos fundamentales que ocasionan incidentes son las colisiones y los incendios. En los camiones cisterna, otras causas de escape pueden ser fugas en válvulas o un exceso de llenado. En general, tanto en carretera como en ferrocarril, los incendios no provocados por choques son mucho más frecuentes que los provocados por éstos. Los incidentes asociados al transporte pueden producirse en zonas rurales, industriales o residenciales, y pueden implicar a vehículos o trenes solos o vigilados. En muy pocos casos la causa principal del incidente es un accidente.

El personal de emergencia debe ser consciente de la posibilidad de exposición y contaminación de los seres humanos a sustancias peligrosas en los accidentes de ferrocarril, en carreteras y terminales de carga, en buques (tanto oceánicos como interiores) y sus correspondientes almacenes. L os gasoductos y oleoductos (tanto de larga distancia como de sistemas locales de distribución) pueden constituir un peligro si se producen daños o escapes, ya sea aisladamente 0 en asociación con otros incidentes. Los incidentes de transporte suelen ser más peligrosos que los que tienen lugar en instalaciones fijas. Puede ocurrir que los materiales implicados sean desconocidos, que las señales de aviso queden ocultas por un vuelco, humos o escombros, y que no haya especialistas o que éstos hayan sido víctimas del incidente. EI número de personas expuestas depende de la densidad de población, tanto de día como de noche, de la proporción de personas dentro y fuera de las casas y del sector de población que pueda considerarse particularmente vulnerable. Además de la población que normalmente se encuentra en la zona, corre también peligro el personal de los servicios de emergencia que acuden al accidente. No es raro que, en un incidente de 
transporte de sustancias peligrosas, una proporción significativa de las víctimas pertenezcan a dichos servicios.

En los veinte años transcurridos de 1971 a 1990, 15 personas perecieron en las carreteras del Reino Unido por causa de sustancias químicas peligrosas, frente a la media anual de 5.000 muertos en accidentes. Ahora bien, pequeñas cantidades de materiales peligrosos pueden ocasionar daños significativos. Entre los ejemplos en varios países pueden citarse los siguientes:

- un avión se estrelló cerca de Boston, EE.UU ., a causa de un escape de ácido nítrico;

- más de 200 personas murieron debido a la explosión de un camión cisterna que transportaba propileno cerca de un camping en España;

- en un accidente de tren en el que se vieron envueltos 22 vagones de sustancias químicas en $\mathrm{M}$ ississauga, $\mathrm{C}$ anadá, se rompió una cisterna que contenía 90 toneladas de cloro; se produjo una explosión y un gran incendio. No se produjeron víctimas mortales, pero hubo que evacuar a 250.000 personas;

- una colisión ferroviaria junto a la autopista en Eccles, Reino U nido, provocó tres muertos y 68 heridos y fue seguida de un grave incendio de los productos petrolíferos transportados que no ocasionó víctimas;

- un camión cisterna de gasolina quedó sin control en H errborn, Alemania, quemando gran parte de la ciudad;

- en Peterborough, Reino U nido, un vehículo que transportaba explosivos ocasionó la muerte a una persona y casi destruye un centro industrial,

- en Bangkok, T ailandia, explotó un camión cisterna de gasolina y produjo la muerte a gran número de personas.

La mayoría de los incidentes graves son provocados por gases o líquidos inflamables (en parte debido a los volúmenes transportados), con algunos incidentes causados por gases y emanaciones tóxicas (incluidos los productos de la combustión).

Los estudios realizados en el Reino U nido han arrojado los siguientes datos relativos al transporte por carretera:

- frecuencia de accidentes durante el transporte de materiales peligrosos: $0,12 \times 10^{-6} / \mathrm{km}$;

- frecuencia de escapes durante el transporte de materiales peligrosos: 0,027 × $10^{-6} / \mathrm{km}$,

- probabilidad de un escape tras un accidente de tráfico: 3,3\%.

Estas incidencias no son sinónimo de accidentes con materiales peligrosos en que intervienen vehículos, y pueden constituir sólo una pequeña proporción de éstos. Existe asimismo la categoría de accidentes relacionados con el transporte por carretera de materiales peligrosos.

Entre los acuerdos internacionales sobre transporte de sustancias potencialmente peligrosas hay que citar los siguientes:

R eglamento para el transporte seguro de materiales radiactivos, 1985 (modificado en 1990), Agencia Internacional de la Energía Atómica, V iena, 1990 (STI / PU B/ 866). Su objetivo es establecer normas de seguridad que ofrezcan un nivel aceptable de control del riesgo de radiación a personas, bienes y medio ambiente asociado al transporte de material radiactivo.

Convenio internacional para la seguridad de la vida humana en el mar, 1974 (SOLAS 74). En este Convenio se establecen normas básicas de seguridad para buques de transporte de pasajeros y de mercancías, incluidos los que transportan materiales peligrosos en grandes cantidades.

Convenio internacional para la prevención de la contaminación causada por buques, 1973, modificado por el Protocolo de 1978 (M ARPOL $73 / 78)$. En este documento se estipulan normas para la prevención de la contaminación por aceite, por líquidos nocivos a granel, por contaminantes envasados 0 en contenedores,

\section{Estudio de caso: transporte de materiales peligrosos}

Un camión cisterna articulado que transportaba unos 22.000 litros de tolueno circulaba por una carretera principal que atraviesa Cleveland, Reino Unido. Un coche se interpuso en su camino y, como consecuencia del volantazo del conductor, la cisterna volcó. Se abrieron las tapas de registro (bocas de hombre) de los cinco compartimientos y el tolueno se derramó por la carretera y entró en ignición, provocando una balsa de fuego. El incendio afectó a cinco coches que circulaban por el carril contrario, pudiendo escapar todos sus ocupantes.

Los bomberos llegaron a los cinco minutos de la llamada. El líquido en ignición había entrado en los sumideros y a unos $400 \mathrm{~m}$ del accidente podían verse los sumideros en llamas. Se activó el Plan de emergencia del condado; los servicios sociales y de transporte público fueron alertados de la posibilidad de una evacuación. En un principio, los bomberos se centraron en la extinción de los incendios de los automóviles y en la búsqueda de sus ocupantes. La siguiente tarea fue encontrar una fuente de agua adecuada. Acudió al lugar un miembro del equipo de seguridad de la empresa química para coordinar la acción con la policía y los bomberos. También acudió personal del servicio de ambulancias y de las autoridades sanitarias y del agua. Tras varias consultas, se decidió dejar que el tolueno se quemara, en lugar de extinguir el incendio y provocar con ello la emisión de vapores químicos. La policía emitió avisos durante un período de cuatro horas por la radio nacional y local aconsejando a la población que no saliera de casa y que cerrase las ventanas. La carretera se cerró durante ocho horas. Cuando el tolueno llegó a un nivel inferior a las tapas de registro, se apagó el fuego y se extrajo de la cisterna el resto del tolueno. El siniestro se dio por concluido unas 13 horas después del accidente.

La radiación térmica representaba un peligro potencial para los seres humanos; la contaminación del suelo, el aire, y el agua, para el medio ambiente; y la interrupción del tráfico, para la economía. El plan de la empresa para este tipo de accidentes de transporte se activó en 15 minutos, con la presencia de cinco personas en el lugar del siniestro. Existía un plan del condado de actuación exterior, que se siguió desde un centro de control en el que participaron la policía y los bomberos. Se tomaron mediciones de la concentración del contaminante, pero no se hicieron predicciones de su dispersión. La respuesta de la brigada de incendios movilizó a más de 50 personas y diez aparatos, cuyas funciones principales fueron la lucha contra el incendio, el lavado y la retención del derrame. Más de 40 oficiales de policía intervinieron en la dirección del tráfico, advertencia a la población, seguridad y control de la prensa. La respuesta del servicio sanitario se materializó en dos ambulancias y dos miembros del personal médico presentes en el lugar del accidente. La reacción de la autoridad local englobó a los servicios de medio ambiente, transporte y asistencia social. Se informó a la población del incidente por medio de altavoces, por la radio y haciendo correr la voz. La información se concentró en qué debía hacerse, en especial refugiarse en el interior de los edificios.

En términos de daños a seres humanos, el resultado del accidente fue de dos hospitalizaciones: un particular y un empleado de la empresa, que resultaron heridos en el choque. Se produjo una contaminación atmosférica visible, pero la contaminación del suelo y del agua fue leve. Desde el punto de vista económico, se ocasionó un daño importante a la carretera y grandes retrasos en el tráfico, pero no se perdieron cosechas, ganado o producción. Entre las conclusiones que se sacaron, hay que citar el valor de una rápida recuperación de información del sistema Chemdata y la presencia del experto técnico de la empresa, que inmediatamente dirigió la acción del modo más adecuado. Se destacó asimismo la importancia de la adopción de comunicados de prensa conjuntos para todos los servicios de respuesta al accidente. Hay que considerar la repercusión ambiental de la lucha contra el fuego. Si se hubiera combatido el incendio en las fases iniciales, una cantidad considerable de líquido contaminante (alcohol etílico y tolueno) podía haber entrado en los sumideros, en los suministros de agua y en el suelo. 
cisternas o vagones de carretera o ferrocarril, por aguas residuales y por basuras. Los requisitos establecidos en esta normativa se amplían en el Código marítimo internacional de sustancias peligrosas.

Existe un importante corpus de reglamentación internacional sobre el transporte de sustancias nocivas por aire, ferrocarril, carretera y vías navegables (en muchos países convertido en legislación nacional). En la mayoría de los casos se ha tomado como base normas impulsadas por Estados U nidos y se contemplan los principios de identificación, etiquetado, prevención y mitigación. El Comité de Expertos de las N aciones U nidas sobre el Transporte de M ateriales Peligrosos ha elaborado unas R ecomendaciones sobre el transporte de sustancias peligrosas. E sas normas van dirigidas a los Estados y las organizaciones internacionales interesadas en la reglamentación del transporte de sustancias peligrosas. Entre otros aspectos, las recomendaciones comprenden principios de clasificación y definición de categorías, enumeración de los componentes de las sustancias peligrosas, requisitos generales de embalaje, procedimientos de prueba, elaboración, etiquetado o rotulado, y documentos de transporte. Las recomendaciones ("Libro naranja") no tienen fuerza de ley, pero constituyen la base de todos los reglamentos internacionales adoptados por diversas organizaciones:

- O rganización Internacional de la Aviación Civil: Instrucciones técnicas para la seguridad del transporte aéreo de sustancias peligrosas (T is)

- Organización M arítima Internacional: Código marítimo internacional de sustancias peligrosas (C ódigo IM D G)

- Comunidad Económica Europea: Acuerdo europeo sobre el transporte internacional por carretera de sustancias peligrosas (ADR)

- O ficina de Transporte Ferroviario Internacional: Reglamento sobre el transporte internacional ferroviario de sustancias peligrosas (RID).

Es necesario elaborar planes de emergencia para reaccionar ante un accidente grave con sustancias peligrosas tanto durante el transporte como en instalaciones fijas. La tarea de planificación se ve dificultada por el hecho de que no se sabe de antemano dónde va a producirse un accidente, lo que exige una planificación flexible. No puede preverse qué sustancias intervendrán en un accidente de transporte. Por la naturaleza del incidente, pueden mezclarse varios productos en un mismo lugar y ocasionar considerables problemas a los servicios de emergencia. El incidente puede tener lugar en una zona altamente urbanizada, aislada o rural, muy industrializada o comercial. 0 tro factor es la población transeúnte que pueda verse envuelta sin saberlo, ya sea porque el accidente ocasione una caravana en la carretera o porque se detengan trenes de pasajeros debido a un accidente de ferrocarril.

Es necesario, por tanto, desarrollar planes locales y nacionales para reaccionar ante tales sucesos. Los planes deben ser sencillos, flexibles y fáciles de comprender. Dado que los accidentes graves de transporte pueden producirse en muchos lugares, el plan debe adecuarse a todas las localizaciones posibles. Para que el plan funcione eficazmente en todo momento y en localidades tanto rurales y aisladas como urbanas y superpobladas, todas las organizaciones que participen en la respuesta al accidente deben actuar con flexibilidad, sin dejar de respetar por ello los principios básicos de la estrategia general.

Los primeros en acudir deben recabar la mayor cantidad posible de información para determinar la índole del peligro. La reacción más adecuada vendrá determinada por la naturaleza del incidente: si se trata de un derrame, un incendio, un escape tóxico o una combinación de los anteriores. Los servicios de emergencia deben conocer los sistemas nacionales e internacionales de señalización de los vehículos que transportan sustancias y materiales peligrosos, y tener acceso a alguna de las bases de datos nacionales e internacionales que pueden ayudar a identificar el peligro y los problemas conexos.

Es vital controlar rápidamente el incidente. La cadena de mando debe estar claramente identificada, aunque puede cambiar en el curso del suceso, pasando de los servicios de emergencia a la policía o al gobierno civil de la localidad afectada. El plan debe permitir reconocer los efectos para la población, tanto para las personas que trabajen o residan en la zona potencialmente afectada como para las que pasen por allí. $H$ ay que recurrir a expertos en asuntos de salud pública para que asesoren tanto sobre la gestión inmediata del incidente como sobre los posibles efectos para la salud a largo plazo, directos e indirectos (a través de la cadena alimentaria). Deben determinarse puntos de contacto para obtener asesoramiento sobre la contaminación ambiental de cursos de agua y otros puntos, así como sobre la repercusión de las condiciones climáticas en el movimiento de nubes de gas. Entre las medidas de reacción, los planes deben contemplar la posibilidad de evacuación. No obstante, las propuestas deben ser flexibles, pues puede ocurrir que haya que considerar cuestiones en materia de costes y beneficios, tanto en la gestión del incidente como en términos de salud pública. Se debe definir con toda claridad la política a seguir para mantener a los medios de comunicación plenamente informados, así como las medidas que se adoptarán para mitigar los efectos del accidente. La información debe ser exacta y oportuna, y el portavoz debe conocer el plan de respuesta global y tener acceso a expertos para responder a preguntas especializadas. U nas relaciones inadecuadas con los medios de comunicación pueden trastornar la gestión del suceso y provocar comentarios desfavorables, y a veces injustificados, sobre la respuesta global al episodio. Todo plan debe incluir ejercicios adecuados de simulacros de catástrofes, que permiten a los distintos organismos participantes conocer los puntos fuertes y débiles en la organización de los demás. Son necesarios tanto los ejercicios con maquetas como los físicos.

Aunque la bibliografía especializada en derrames químicos es muy amplia, la parte dedicada a la descripción de sus consecuencias ecológicas es pequeña. En su mayoría se trata de estudios de casos. Las descripciones de derrames reales se centran en los problemas para la salud y la seguridad humanas, y se limitan a describir en términos generales las consecuencias ecológicas. Las sustancias químicas se integran en el medio ambiente fundamentalmente a través de la fase líquida. Sólo en pocos casos los accidentes que tuvieron consecuencias ecológicas afectaron inmediatamente a los seres humanos, y los efectos sobre el medio ambiente no fueron motivados por las mismas sustancias o por las mismas vías de escape.

L os controles realizados para prevenir los riesgos para la salud y la vida humana derivados del transporte de materiales peligrosos contemplan: las cantidades transportadas, la dirección y control de los medios de transporte, la trayectoria, la autoridad en los puntos de intercambio y de concentración, y los asentamientos cercanos a tales zonas. Es necesario seguir investigando cuestiones relacionadas con los criterios de riesgo, la cuantificación del riesgo y la equivalencia del riesgo. El Health and Safety Executive del Reino Unido ha desarrollado un servicio de datos denominado "Servicio de Datos del Major Incident Data Service" (MHIDAS), una base de datos de los incidentes químicos más graves de todo el mundo. Actualmente, esa base contiene información sobre más de 6.000 incidentes. 


\section{- ACCIDENTES POR RADIACION}

\section{Pierre Verger y Denis Winter}

\section{Descripción, fuentes y mecanismos}

A parte del transporte de materiales radiactivos, existen tres situaciones en las que pueden producirse accidentes por radiación:

- utilización de reacciones nucleares para producir energía o armas, o para la investigación;

- aplicaciones industriales de la radiación (gammagrafía, irradiación),

- medicina de investigación y medicina nuclear (diagnóstico o terapia).

Los accidentes por radiación pueden clasificarse en dos grupos, atendiendo a si se produce o no emisión o dispersión de radionúclidos en el medio ambiente; cada uno de ellos afecta a poblaciones diferentes.

La magnitud y duración del riesgo de exposición para la población en general depende de la cantidad y características (semivida, propiedades fisicoquímicas) de los radionúclidos liberados al medio ambiente (Tabla 39.18). Este tipo de contaminación se produce cuando, en centrales nucleares 0 industriales 0 en instalaciones médicas, se rompe alguna de las barreras de contención que separan los materiales radiactivos del medio ambiente. Si no tiene lugar una emisión al entorno, sólo resultarán expuestos a la radiación los trabajadores presentes en la instalación o los que manipulan los equipos o materiales radiactivos.

La exposición a la radiación ionizante puede producirse por tres vías, independientemente de que el grupo diana se componga de trabajadores o de población en general: irradiación externa, irradiación interna y contaminación de piel y heridas.

La irradiación externa tiene lugar cuando las personas se ven expuestas a una fuente de radiación exterior al cuerpo, ya sea concentrada (radioterapia, fuentes de radiación) o difusa (nubes radiactivas y lluvia radiactiva, Figura 39.5). La irradiación puede ser parcial y afectar sólo a una parte del cuerpo, o total y extenderse a todo él.

Se produce irradiación interna cuando se introducen sustancias radiactivas en el organismo (Figura 39.5), ya sea por inhalación de partículas radiactivas presentes en el aire (por ejemplo

Tabla 39.18 • Radionúclidos típicos y sus correspondientes semividas radiactivas.

\begin{tabular}{lrlrc} 
Radionúclido & Símbolo & $\begin{array}{l}\text { Radiación } \\
\text { emitida }\end{array}$ & $\begin{array}{l}\text { Semivida } \\
\text { física* }\end{array}$ & $\begin{array}{l}\text { Semivida } \\
\text { biológica } \\
\text { tras la } \\
\text { incorporación* }\end{array}$ \\
Bario 133 & Ba-133 & $\gamma$ & $10,7 \mathrm{a}$ & $65 \mathrm{~d}$ \\
Cerio 144 & Ce-144 & $\beta, \gamma$ & $284 \mathrm{~d}$ & $263 \mathrm{~d}$ \\
Cesio 137 & Cs-137 & $\beta, \gamma$ & $30 \mathrm{a}$ & $109 \mathrm{~d}$ \\
Cobalto 60 & C0-60 & $\beta, \gamma$ & $5,3 \mathrm{a}$ & $1,6 \mathrm{a}$ \\
Iodo 131 & I-131 & $\beta, \gamma$ & $8 \mathrm{~d}$ & $7,5 \mathrm{~d}$ \\
Plutonio 239 & Pu-239 & $\alpha, \gamma$ & $24.065 \mathrm{a}$ & $50 \mathrm{a}$ \\
Polonio 210 & P0-210 & $\alpha$ & $138 \mathrm{~d}$ & $27 \mathrm{~d}$ \\
Estroncio 90 & Sr-90 & $\beta$ & $29,1 \mathrm{a}$ & $18 \mathrm{a}$ \\
Tritio & $\mathrm{H}-3$ & $\beta$ & $12,3 \mathrm{a}$ & $10 \mathrm{~d}$ \\
* a = años; d = días. & & & & \\
\hline
\end{tabular}

cesio 137 o iodo 131, contenidos en la nube de Chernóbil), o por ingestión de materias radiactivas presentes en los alimentos (como iodo 131 en la leche). La irradiación interna puede afectar a todo el cuerpo o sólo a determinados órganos, dependiendo de la naturaleza de los radionúclidos: el cesio 137 se distribuye de forma homogénea por todo el cuerpo, en tanto que el iodo 131 y el estroncio 90 se concentran respectivamente en la glándula tiroides y en los huesos.

Por último, puede producirse también una exposición por contacto directo de las sustancias radiactivas con la piel y las heridas.

\section{Accidentes en centrales nucleares}

Entre las instalaciones pertenecientes a esta categoría se encuentran las centrales energéticas, los reactores experimentales, las plantas de fabricación y de tratamiento y retratamiento de combustible nuclear y los laboratorios de investigación. Los centros militares disponen de reactores de plutonio y de reactores situados en barcos y en submarinos.

\section{Centrales nucleares}

La transformación de la energía térmica emitida por la fisión atómica es la base de la producción de electricidad a partir de la energía nuclear. Esquemáticamente, puede considerarse que las centrales nucleares constan de: a) un núcleo que contiene el material fisionable (para reactores de agua a presión, de 80 a 120 toneladas de óxido de uranio); b) equipos intercambiadores de calor, que contienen fluidos refrigerantes; c) equipos de transformación de energía térmica en electricidad, similares a los utilizados en otros tipos de centrales energéticas.

Los principales riesgos de estas instalaciones son aumentos intensos y repentinos de energía, que funden el núcleo y emiten productos radiactivos. Se han producido dos accidentes con fusión del núcleo del reactor: en Three M ile Island (1979, Pensilvania, Estados U nidos) y en Chernóbil (1986, U crania).

El accidente de Chernóbil fue lo que se denomina un acontecimiento límite: es decir, un repentino (en el espacio de pocos segundos) aumento en la fisión que provoca la pérdida de control del proceso. En este caso, el núcleo del reactor resultó completamente destruido y se liberaron cantidades masivas de materiales radiactivos (Tabla 39.19). Las emisiones alcanzaron una altura de $2 \mathrm{~km}$, lo que favoreció su dispersión a gran distancia (a todos los efectos, todo el hemisferio norte).

Figura 39.5 - Trayectoria de la exposición a radiaciones ionizantes tras un escape accidental de radiactividad al medio ambiente.

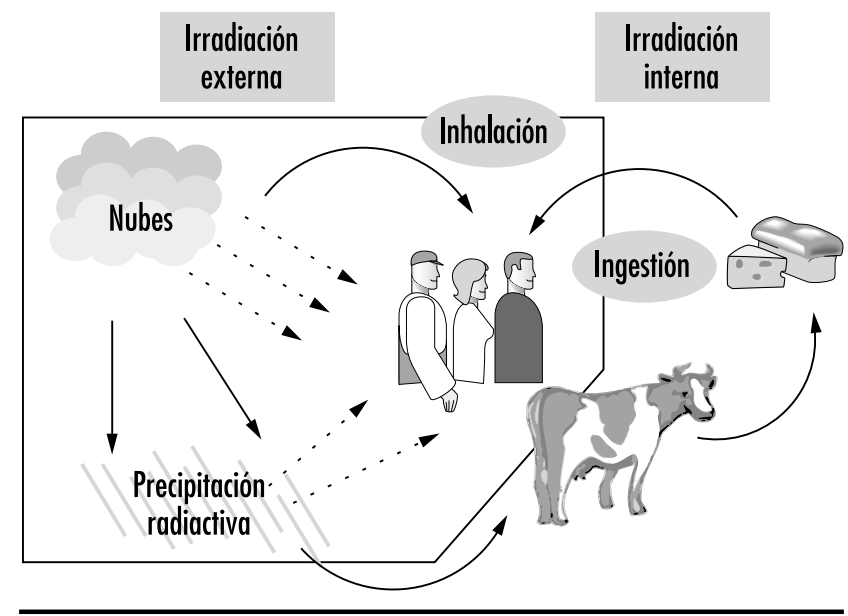


Tabla 39.19 • Comparación de distintos accidentes nucleares.

\begin{tabular}{|c|c|c|c|c|c|c|}
\hline Accidente & Tipo de instalación & $\begin{array}{l}\text { Mecanismo del } \\
\text { accidente }\end{array}$ & $\begin{array}{l}\text { Radiactividad total } \\
\text { emitida }(\mathrm{GBq})\end{array}$ & $\begin{array}{l}\text { Duración } \\
\text { de la emisión }\end{array}$ & $\begin{array}{l}\text { Principales radionúclidos } \\
\text { emitidos }\end{array}$ & $\begin{array}{l}\text { Dosis } \\
\text { colectiva (hSv) }\end{array}$ \\
\hline Khyshtym 1957 & $\begin{array}{l}\text { Almacenamiento de } \\
\text { productos de fisión } \\
\text { de alta actividad }\end{array}$ & Explosión química & $740 \times 10^{6}$ & $\begin{array}{l}\text { Casi } \\
\text { instantánea }\end{array}$ & Estroncio 90 & 2.500 \\
\hline Windscale 1957 & $\begin{array}{l}\text { Reactor de producción } \\
\text { de plutonio }\end{array}$ & Incendio & $7,4 \times 10^{6}$ & $\begin{array}{l}\text { Aproximadamente } \\
23 \text { horas }\end{array}$ & $\begin{array}{l}\text { Iodo } 131 \text {, polonio 210, } \\
\text { cesio } 137\end{array}$ & 2.000 \\
\hline $\begin{array}{l}\text { Three Mile Island } \\
1979\end{array}$ & Reactor industrial PWR & $\begin{array}{l}\text { Problema de } \\
\text { refrigerante }\end{array}$ & 555 & $?$ & lodo 131 & $16-50$ \\
\hline Chernóbil 1986 & $\begin{array}{l}\text { Reactor industrial } \\
\text { RBMK }\end{array}$ & Acontecimiento límite & $3.700 \times 10^{6}$ & $\begin{array}{l}\text { Más de } \\
10 \text { días }\end{array}$ & $\begin{array}{l}\text { Iodo } 131 \text {, iodo } 132, \\
\text { cesio } 137 \text {, cesio } 134, \\
\text { estroncio } 89 \text {, estroncio } 90\end{array}$ & 600.000 \\
\hline
\end{tabular}

Fuente: UNSCEAR 1993.

El comportamiento de la nube radiactiva resulta difícil de analizar debido a los cambios meteorológicos sucedidos durante el período de emisión (Figura 39.6) (O IEA 1991).

Se elaboraron mapas de contaminación a partir de la medición del cesio-137, uno de los principales productos de emisión radiactiva (Tablas 39.18 y 39.19), en diversos puntos de la atmósfera. Resultaron extremadamente contaminadas extensas zonas de U crania, Bielorrusia (Belarús) y Rusia; la repercusión sobre el resto de Europa fue menos significativa (Figuras 39.7 y 39.8 (UNSCEAR 1988). En la Tabla 39.20 se ofrecen datos sobre las superficies contaminadas, las características de la población expuesta y las vías de exposición.

EI accidente de Three M ile I sland se clasifica como accidente térmico sin escape del reactor principal, y se produjo por un

Figura 39.6 - Trayectoria de las emisiones del accidente de Chernóbil, 26 de abril - 6 de mayo de 1986.

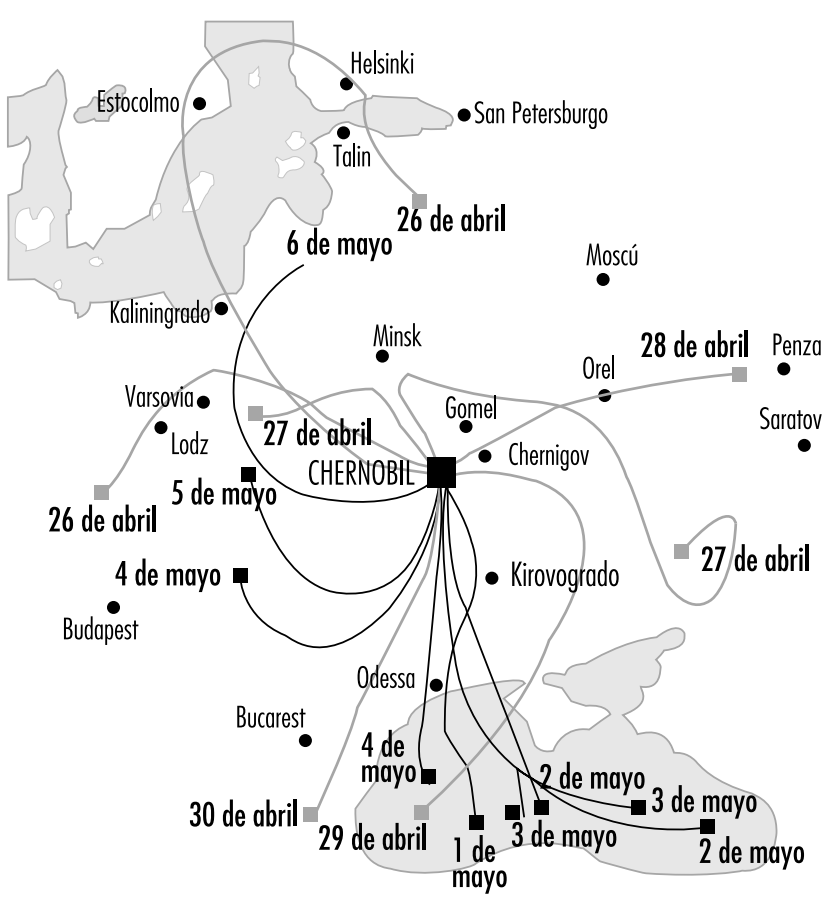

fallo en el refrigerante del núcleo del reactor durante varias horas. Gracias a la carcasa de contención, sólo escapó al medio ambiente una cantidad limitada de material radiactivo, y ello a pesar de la destrucción parcial del núcleo del reactor (Tabla 39.19). Aunque no se dio la orden de evacuar, 200.000 habitantes abandonaron voluntariamente la zona. Por último, en 1957, en la costa occidental de Inglaterra, tuvo lugar un accidente con un reactor de producción de plutonio (Windscale, Tabla 39.19). Este incidente se debió al incendio del núcleo del reactor, que provocó emisiones al medio ambiente por una chimenea de 120 metros de altura.

\section{Instalaciones de tratamiento de combustible}

Las instalaciones de producción de combustible se sitúan en un nivel industrial anterior a los reactores nucleares y se utilizan para la extracción de mena y la transformación fisicoquímica de uranio en material fisionable para su uso en reactores (Figura 39.9). Estas instalaciones presentan esencialmente riesgos de accidente químico, relacionados con la presencia de hexafluoruro de uranio $\left(U_{6}\right)$, un compuesto gaseoso del uranio que, en contacto con el aire, puede descomponerse y producir ácido fluorhídrico (HF), un gas muy corrosivo.

Entre las instalaciones situadas en un nivel industrial posterior a los reactores nucleares se encuentran los almacenes y centrales de reprocesamiento de combustible. El reprocesado químico del uranio enriquecido o de plutonio ha originado cuatro acontecimientos límite (R odrigues 1987). A diferencia de los accidentes en centrales nucleares, en éstos intervinieron cantidades pequeñas de material radiactivo - como mucho, decenas de kilogramos-, sus efectos mecánicos fueron desdeñables y no se produjo ninguna emisión ambiental de radiactividad. La exposición se limitó a una dosis muy alta en un período muy corto (del orden de minutos) de irradiación externa de los trabajadores por rayos gamma y neutrones.

En 1957, un tanque que contenía residuos altamente radiactivos explotó en la primera central militar de producción de plutonio de Rusia, situada en K hyshtym, al sur de los U rales. Se contaminaron más de $16.000 \mathrm{~km}^{2}$ y se emitieron $740 \mathrm{PBq}$ (20 M Ci) a la atmósfera (Tablas 39.19 y 39.21).

\section{Reactores de investigación}

En estas instalaciones, los riesgos son similares a los que plantean las centrales nucleares, pero menos graves, dada la menor generación de energía. Se han registrado diversos acontecimientos límite con irradiación significativa del personal (Rodrigues 1987). 
Figura 39.7 • Deposición de cesio-137 en Bielorrusia Rusia y Ucrania, tras el accidente de Chernóbil.

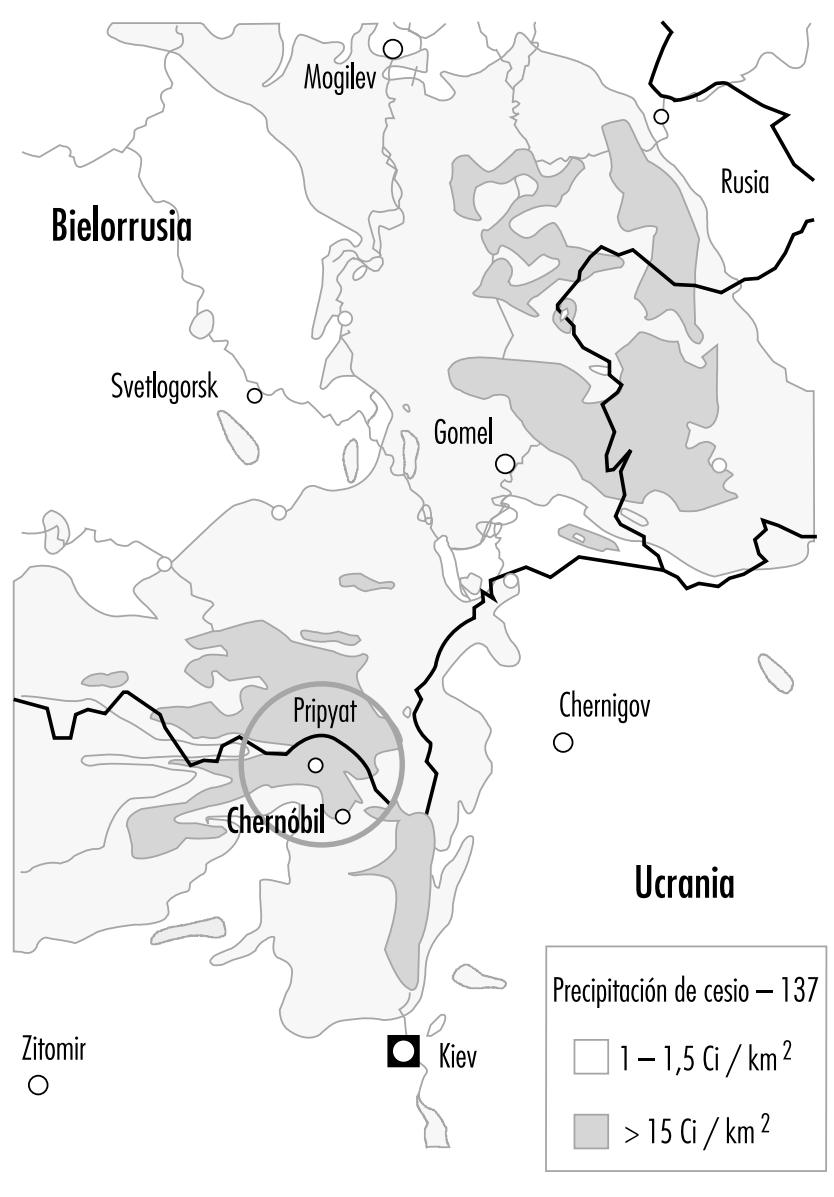

Accidentes relacionados con el empleo de fuentes de radiación en la industria y en la medicina (excluidas las centrales nucleares) (Zerbib 1993)

El accidente más común de este tipo son las pérdidas de fuentes de radiación para gammagrafías utilizadas en la industria (por ejemplo, para la inspección radiográfica de juntas y soldaduras). N o obstante, los usos médicos también pueden generar pérdidas de fuentes de radiación (Tabla 39.22). Pueden darse dos situaciones distintas: es posible que alguien recoja y conserve la fuente durante varias horas (por ejemplo en el bolsillo) y después notifique el hallazgo y la restituya; o puede recogerla y

Tabla 39.21 • Superficie de las zonas contaminadas y dimensión de las poblaciones expuestas a contaminación por estroncio-90 tras el accidente de Khyshtym (Urales, 1957).

$\begin{array}{crcr}\text { Contaminación }\left(\mathrm{kBq} / \mathrm{m}^{2}\right) & \left(\mathrm{Ci} / \mathrm{km}^{2}\right) & \text { Area }\left(\mathrm{km}^{2}\right) & \text { Población } \\ \geq 37.000 & \geq 1.000 & 20 & 1.240 \\ \geq 3.700 & \geq 100 & 120 & 1.500 \\ \geq 74 & \geq 2 & 1.000 & 10.000 \\ \geq 3,7 & \geq 0,1 & 15.000 & 270.000\end{array}$

Tabla 39.20 - Superficie de las zonas contaminadas, tipos de poblaciones expuestas y modalidades de exposición en Ucrania, Bielorrusia y Rusia tras el accidente de Chernóbil.

$\begin{array}{llll}\text { Tipo de población } & \text { Super- } & \text { Tamaño de la } & \text { Principales } \\ & \text { ficie } & \text { población } & \text { modalidades } \\ & \left(\mathrm{km}^{2}\right) & (000) & \text { de exposición }\end{array}$

Poblaciones expuestas por motivos profesionales:

Empleados presentes en la

$\approx 0,44$

instalación en el

momento del accidente

Bomberos

(primeros auxilios)

$\approx 0,12$

Irradiación externa, inhalación, contaminación de la piel por el reactor averiado, fragmentos

del reactor dispersos por la instalación vapores y polvos radiactivos

Trabajadores de la limpieza

$600-800$

Irradiación externa, $y$ de socorro*

inhalación, contaminación de la piel

Población general:

Evacuada de la zona

prohibida en los

primeros días

115 Irradiación externa por

la nube, inhalación

de elementos

radiactivos presentes en la nube

Habitantes de

zonas contaminadas**

$\left(\mathrm{MBq} / \mathrm{m}^{2}\right)\left(\mathrm{Ci} / \mathrm{km}^{2}\right)$

$\begin{array}{ccrr}>1,5 & (>40) & 3.100 & 33 \\ 0,6-1,5 & (15-40) & 7.200 & 216 \\ 0,2-0,6 & (5-15) & 17.600 & 584 \\ 0,04-0,2 & (1-5) & 103.000 & 3.100 \\ \text { Habitantes de otras áreas } & & 280.000 \\ <0.04 \mathrm{MBq} / \mathrm{m}^{2} & & \end{array}$

Radiación externa por precipitación de lluvia radiactiva, ingestión de productos contaminados

Irradiación externa por precipitación de lluvia radiactiva, ingestión de productos contaminados

* Personas que participan en la limpieza en un radio de $30 \mathrm{~km}$ de la instalación. Se trata, entre otros de bomberos, personal militar, técnicos e ingenieros que intervinieron en las primeras semanas, así como médicos e investigadores en fecha posterior.

** contaminación por cesio-137.

Fuente: UNSCEAR 1988; IAEA 1991.

Ilevársela a casa. M ientras que en el primer caso se producen quemaduras parciales, en el segundo puede tener lugar una irradiación fuerte de varias personas.

La recuperación de fuentes de radiación de los equipos de radioterapia ha provocado varios accidentes con exposición de trabajadores de la chatarra. En dos casos, los accidentes de Juárez y de Goiânia, la población en general también resultó expuesta (véase la Tabla 39.22 y el recuadro de la página 39.35).

El accidente de Juárez se descubrió de la forma más casual (OIEA 1989b). El 16 de enero de 1984, un camión de barras de acero que entró en el laboratorio científico de Los Alamos (Nuevo M éxico, Estados Unidos) activó un detector de radiaciones. Tras una investigación posterior, se descubrió la presencia de cobalto 60 en las barras y se siguió la pista de esta 
sustancia hasta una fundición mexicana. El 21 de enero, se determinó que la fuente de material radiactivo era una chatarrería de Juárez, altamente contaminada. Gracias a una vigilancia sistemática de las carreteras y autopistas con detectores, se identificó un camión altamente contaminado. Finalmente, se estableció que la primera fuente de radiación era un aparato de radioterapia que había estado en un centro médico hasta diciembre de 1983, momento en que se desmontó y se llevó a la chatarrería. En la chatarrería, la cápsula protectora del cobalto-60 se rompió, liberando los gránulos de cobalto. Algunos de ellos cayeron en el camión utilizado para transportar desechos y otros se dispersaron por la chatarrería en operaciones posteriores, mezclándose con los demás residuos.

Se han producido algunos accidentes relacionados con la entrada de trabajadores en zonas industriales de radiación (por ejemplo para la preservación de alimentos, esterilización de productos médicos o polimerización de sustancias químicas). En todos los casos, los accidentes se debieron a un inadecuado 0 nulo respeto de los procedimientos de seguridad, o a la desconexión o mal estado de los sistemas de seguridad y de alarma. En dichos accidentes, las dosis de irradiación externa a que se vieron expuestos los trabajadores fueron lo bastante altas para causar la muerte. Las dosis se recibieron en pocos segundos o minutos (Tabla 39.23).

Por último, el personal médico o científico que elabora 0 manipula fuentes de radiación puede verse expuesto a radiación por contaminación de la piel o heridas, o por inhalación o ingestión de materiales radiactivos. Este tipo de accidente también es posible en centrales nucleares.

\section{Aspectos del problema relacionados con la sanidad pública}

\section{Evolución en el tiempo}

EI Radiation Accident Registry de EE.UU. (O ak R idge, Estados U nidos) es un registro mundial de los accidentes por radiación con participación de personas que se han producido desde el

Tabla 39.22 - Accidentes por pérdida de fuentes de radiación, que provocaron la exposición de la población general.

\begin{tabular}{|c|c|c|c|c|}
\hline $\begin{array}{l}\text { País } \\
\text { (año) }\end{array}$ & $\begin{array}{l}\text { Número de } \\
\text { personas } \\
\text { expuestas }\end{array}$ & $\begin{array}{l}\text { Número de } \\
\text { personas } \\
\text { que reci- } \\
\text { bieron dosis } \\
\text { altas* }\end{array}$ & $\begin{array}{l}\text { Número de } \\
\text { fallecidos** }\end{array}$ & $\begin{array}{l}\text { Material } \\
\text { radiactivo }\end{array}$ \\
\hline México (1962) & $?$ & 5 & 4 & Cobalto 60 \\
\hline China (1963) & $?$ & 6 & 2 & Cobalto 60 \\
\hline Argelia (1978) & 22 & 5 & 1 & Iridio 192 \\
\hline Marruecos (1984) & $?$ & 11 & 8 & |ridio 192 \\
\hline $\begin{array}{l}\text { México (Juárez, } \\
\text { 1984) }\end{array}$ & $\approx 4.000$ & 5 & 0 & Cobalto 60 \\
\hline $\begin{array}{l}\text { Brasil (Goiânia, } \\
\text { 1987) }\end{array}$ & 249 & 50 & 4 & Cesio 137 \\
\hline $\begin{array}{l}\text { China (Xinhou, } \\
\text { 1992) }\end{array}$ & $\approx 90$ & 12 & 3 & Cobalto 60 \\
\hline $\begin{array}{l}\text { Estados Unidos } \\
\text { (Indiana, 1992) }\end{array}$ & $\approx 90$ & 1 & 1 & Iridio 192 \\
\hline
\end{tabular}

\section{El accidente de Goiânia, 1987}

Entre el 21 y el 28 de septiembre de 1987, fueron hospitalizadas varias personas con vómitos, diarrea, vértigo y lesiones cutáneas en varias partes del cuerpo en el centro especializado en enfermedades tropicales de Goiânia, una ciudad de un millón de habitantes situada en el Estado brasileño de G oias. Estos problemas se atribuyeron a una enfermedad parasitaria común en Brasil. El 28 de septiembre, el médico responsable de la supervisión sanitaria de la ciudad se reunió con una mujer que le entregó una bolsa con material de un aparato recogido de una clínica abandonada y polvo que, según la mujer, emitía "una luz azul". Pensando que el aparato era probablemente un equipo de rayos $X$, el médico llamó a sus colegas del hospital de enfermedades tropicales. Se informó al Departamento de Medio Ambiente de Goias y, al día siguiente, un médico tomó mediciones en la sala del departamento de higiene, lugar en que se dejó la bolsa durante la noche. Se encontraron niveles de radiactividad muy altos. En posteriores investigaciones, pudo determinarse que la fuente de la radiación era una fuente de cesio 137 [actividad total: aproximadamente $50 \mathrm{TBq}$ $(1.375 \mathrm{Ci})]$ que había pertenecido a un equipo de radioterapia de una clínica abandonada desde 1985. La cápsula protectora del cesio había sido desmontada el 10 de septiembre de 1987 por dos trabajadores de la chatarrería y la fuente de cesio, en polvo, había sido retirada. Tanto el cesio como los fragmentos de la cápsula contaminada se dispersaron con el tiempo por la ciudad. Muchas personas que habían transportado o manipulado el material, o que sencillamente lo habían visto (incluidos padres, amigos y vecinos) resultaron contaminadas. En total, se examinó a más de 100.000 personas, de las cuales 129 resultaron gravemente contaminadas, 50 tuvieron que ser hospitalizadas (14 por insuficiencia medular) y 4 murieron, entre ellas una niña de 6 años. El accidente tuvo gravísimas consecuencias económicas y sociales para toda la ciudad de Goiânia y el Estado de Goias: un $1 / 1000$ de la superficie de la ciudad quedó contaminada y el precio de los productos agrícolas, alquileres, sector inmobiliario y terrenos cayó. Los habitantes de todo el Estado sufrieron una auténtica discriminación.

Fuente: IAEA 1989 a.

año 1944. Para ser incluido en este registro, un accidente debe ser objeto de un informe publicado y haber generado una exposición total del cuerpo humano superior a 0,25 Sievert (Sv), una exposición cutánea superior a 6 Sv o una exposición de otros tejidos y órganos superior a 0,75 Sv (para la definición de dosis, véase el recuadro de la página 39.37). Así, quedan excluidos del registro accidentes interesantes para la sanidad pública, pero que dieron como resultado niveles inferiores de exposición (para la discusión sobre las consecuencias de la exposición, véase más adelante).

El análisis de los datos de 1944 a 1988 pone de manifiesto un claro aumento tanto en la frecuencia de los accidentes por radiación como en el número de individuos expuestos a partir de 1980 (Tabla 39.24). Es probable que el aumento del número de personas expuestas se deba al accidente de Chernóbil, y concretamente a los cerca de 135.000 habitantes iniciales de la zona prohibida, en un radio de $30 \mathrm{~km}$ del lugar del accidente. LoS accidentes de Goiânia (Brasil) y Juárez (M éxico) se produjeron también en este período y ocasionaron una exposición significativa de gran cantidad de personas (T abla 39.22).

\section{Poblaciones potencialmente expuestas}

Desde el punto de vista de la exposición a radiaciones ionizantes, hay dos poblaciones de interés: las poblaciones expuestas por motivos de trabajo y la población en general. El Comité Científico de las $\mathrm{N}$ aciones U nidas para el Estudio de los E fectos de las 
Figura 39.8 • Precipitación de cesio-137 (kBq/ km²) sobre Europa tras el accidente de Chernóbil.

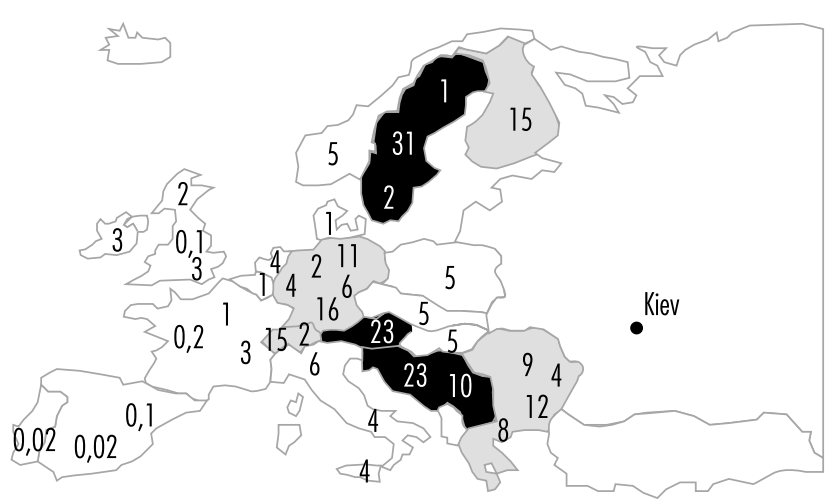

Fuente: UNSCEAR 1988

Radiaciones A tómicas (U NSCEAR 1993) estima que, en todo e mundo, 4 millones de trabajadores se vieron expuestos a radiaciones ionizantes en el trabajo durante el período comprendido entre 1985 y 1989; de ellos, aproximadamente el $20 \%$ trabajaban en la producción, utilización y procesamiento de combustible nuclear (Tabla 39.25). Se ha estimado que los Estados miembros del OIEA poseían 760 fuentes de radiación en 1992, de los cuales 600 eran aceleradores de electrones y 160 fuentes de radiación gamma.

EI número de instalaciones nucleares por país es un buen indicador del potencial de exposición de la población en general (Figura 39.10, página 39.38).

\section{Efectos sobre la salud}

Efectos directos de la radiación ionizante sobre la salud

En general, los efectos de la radiación ionizante sobre la salud son bien conocidos y dependen de la intensidad de la dosis recibida y
Figura 39.9 • Ciclo de tratamiento del combustible nuclear.

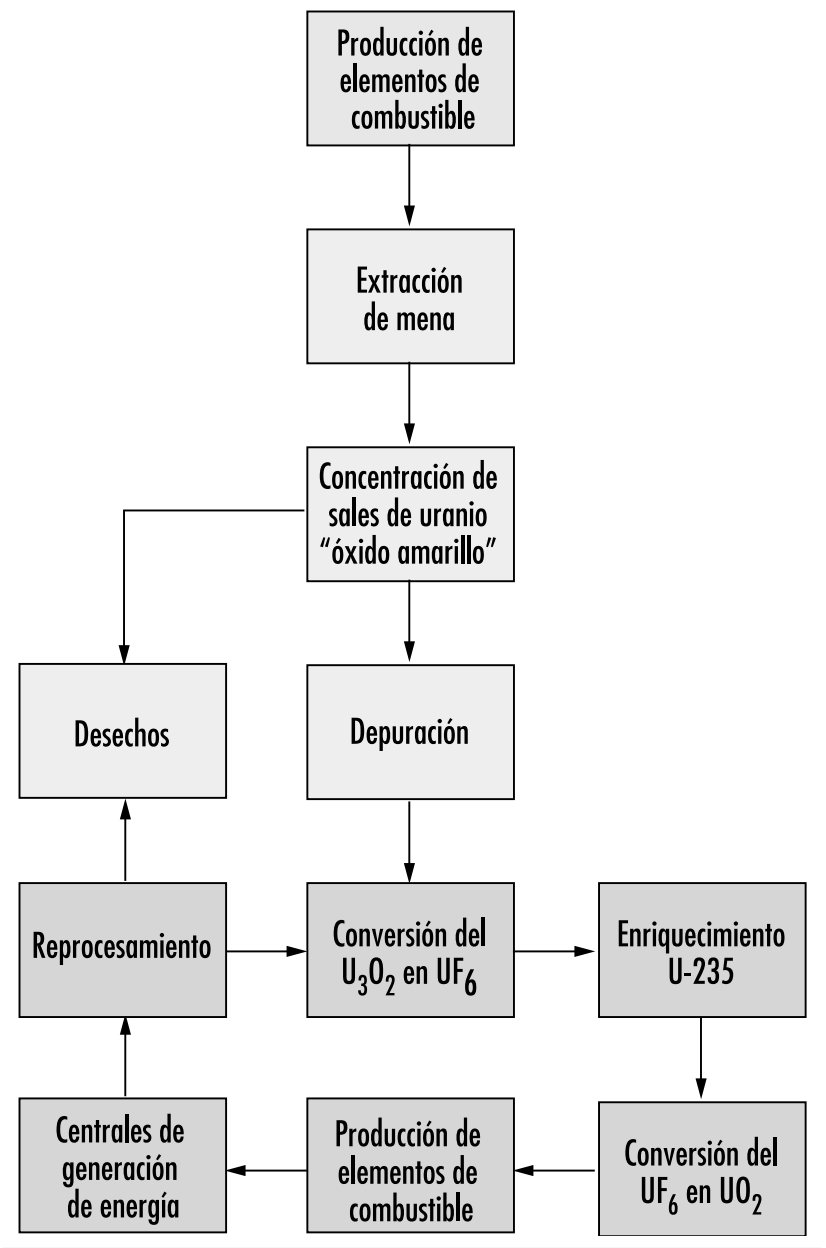

de la cuantía de la dosis (dosis recibida por unidad de tiempo; véase el recuadro de la página siguiente).

Tabla 39.23 • Principales accidentes con fuentes industriales de radiación.

\begin{tabular}{|c|c|c|c|c|c|c|}
\hline Fábrica, fecha & Equipos* & $\begin{array}{l}\text { Número de } \\
\text { víctimas }\end{array}$ & $\begin{array}{l}\text { Nivel y duración } \\
\text { de la exposición }\end{array}$ & $\begin{array}{l}\text { Organos y tejidos } \\
\text { afectados }\end{array}$ & $\begin{array}{l}\text { Dosis recibida (Gy), } \\
\text { fábrica }\end{array}$ & Efectos médicos \\
\hline Forbach, agosto de 1991 & $\mathrm{AE}$ & 2 & $\begin{array}{l}\text { varios decigyl } \\
\text { segundo }\end{array}$ & $\begin{array}{l}\text { Manos, cabeza, } \\
\text { tronco }\end{array}$ & 40, piel & $\begin{array}{l}\text { Quemaduras del } 25 \% \text { al } 60 \% \text { de la } \\
\text { superficie del cuerpo }\end{array}$ \\
\hline Maryland, diciembre de 1991 & AE & 1 & $?$ & Manos & 55, manos & Amputación digital bilateral \\
\hline Vietnam, noviembre de 1992 & AE & 1 & 1.000 Gy/ minuto & Manos & 1,5, cuerpo entero & $\begin{array}{l}\text { Amputación de la mano derecha y } \\
\text { de un dedo de la izquierda }\end{array}$ \\
\hline Italia, mayo de 1975 & IC & 1 & Varios minutos & $\begin{array}{l}\text { Cabeza, cuerpo } \\
\text { entero }\end{array}$ & 8, médula ósea & Muerte \\
\hline San Salvador, febrero de 1989 & IC & 3 & $?$ & $\begin{array}{l}\text { Cuerpo entero, } \\
\text { piernas, pies }\end{array}$ & 3- 8, cuerpo entero & Amputación de 2 piernas, 1 muerte \\
\hline Israel, junio de 1990 & IC & 1 & 1 minuto & $\begin{array}{l}\text { Cabeza, cuerpo } \\
\text { entero }\end{array}$ & $10-20$ & Muerte \\
\hline $\begin{array}{l}\text { Bielorrusia, octubre de } 1991 \\
\text { * AE: acelerador de electrones IC: irradiade } \\
\text { Fuente: Zerbib 1993; Nénot } 1993 .\end{array}$ & IC & 1 & Varios minutos & Cuerpo entero & 10 & Muerte \\
\hline
\end{tabular}


Tabla 39.24 • Accidentes de radiación incluidos en el registro (mundial, 1944-1988) de accidentes de 0 ak Ridge (Estados Unidos).

\begin{tabular}{lcrr} 
& $1944-79$ & $1980-88$ & $1944-88$ \\
Número total de accidentes & 98 & 198 & 296 \\
Número de personas afectadas & 562 & 136.053 & 136.615 \\
$\begin{array}{l}\text { Número de personas } \\
\text { expuestas a dosis superiores a } \\
\text { los límites de exposición* }\end{array}$ & 306 & 24.547 & 24.853 \\
$\begin{array}{l}\text { Número de muertes (efectos } \\
\text { agudos) }\end{array}$ & 16 & 53 & 69 \\
* 0,25 Sv para exposición total del cuerpo, 6 Sv para exposición de la piel, 0,75 Sv para otros tejidos \\
yórganos. \\
\hline
\end{tabular}

\section{Efectos deterministas}

Se producen efectos deterministas cuando la dosis supera cierto nivel y la cuantía de la dosis es alta. La gravedad de los efectos es proporcional a la dosis, aunque existe una dosis máxima para cada órgano (Tabla 39.26).

En accidentes del tipo de los comentados anteriormente, los efectos deterministas pueden ser generados por una irradiación parcial intensa, como la causada por la irradiación externa, por contacto directo con una fuente (como una fuente encontrada fuera de su sitio, recogida y guardada en el bolsillo) o por contaminación dérmica. Todo ello provoca quemaduras radiológicas. Si la dosis parcial es del orden de 20 a 25 Gy (Tabla 39.23, Recuadro 1), puede producirse necrosis del tejido. U na irradiación total del cuerpo humano en una dosis superior a 0,5 Gy puede generar un síndrome conocido como síndrome de radiación agudo, caracterizado por trastornos digestivos (náuseas, vómitos, diarrea) y aplasia medular de gravedad variable. $\mathrm{H}$ ay que tener en cuenta que puede darse simultáneamente una irradiación parcial y una irradiación total del cuerpo humano.

En acontecimientos límite, murieron nueve de los 60 trabajadores expuestos en centros de procesamiento de combustible nuclear o en reactores de investigación (Rodrigues 1987). Los fallecidos recibieron de 3 a $45 \mathrm{~Gy}$, en tanto que los supervivientes recibieron de 0,1 a $7 \mathrm{~Gy}$. Entre los supervivientes se observaron los efectos siguientes: síndrome de radiación agudo (efectos gastrointestinales y hematológicos), cataratas bilaterales y necrosis de miembros con amputación.

En Chernóbil, el personal de la central, así como el personal de emergencia que no llevaba equipos de protección especiales,

Tabla 39.25 • Evolución temporal de la exposición profesional a radiación ionizante artificial en todo el mundo (en miles).

$\begin{array}{lccc}\text { Actividad } & 1975-79 & 1980-84 & 1985-89 \\ \text { Tratamiento de combustible nuclear* } & 560 & 800 & 880 \\ \text { Aplicaciones militares** } & 310 & 350 & 380 \\ \text { Aplicaciones industriales } & 530 & 690 & 560 \\ \text { Aplicaciones médicas } & 1.280 & 1.890 & 2.220 \\ \text { Total } & 2.680 & 3.730 & 4.040 \\ \text { * Producción y reprocesamiento de combustible: } 40.000 \text {; funcionamiento del reactor: } 430.000 . \\ \text { ** incluidos } 190.000 \text { miembros del personal a bordo de buques. } \\ \text { Fuente: UNSCEAR 1993. }\end{array}$

\section{¿Qué quiere decir dosis?}

Hay muchas maneras de definir una dosis de radiación ionizante y cada una responde a objetivos diferentes.

\section{Dosis absorbida}

La dosis absorbida es la más parecida a la dosis farmacológica. M ientras que la dosis farmacológica es la cantidad de sustancia administrada a una persona por unidad de peso o de superficie, la dosis radiológica absorbida es la cantidad de energía transmitida por radiación ionizante por unidad de masa. La dosis absorbida se mide en $\mathrm{G}$ rays ( $1 \mathrm{G}$ ray $=1$ julio/ $\mathrm{kg}$ ).

Cuando las personas se ven expuestas de una forma homogénea - por ejemplo, por radiación externa de rayos cósmicos y terrestres o por radiación interna de potasio-40 presente en el interior del cuerpo-, todos los órganos y tejidos reciben la misma dosis. En tales circunstancias, puede hablarse de dosis total. Sin embargo, también es posible que la exposición no sea homogénea, en cuyo caso algunos órganos y tejidos recibirán dosis mucho mayores que otros. Entonces resulta más adecuado hablar de dosis en órgano. Por ejemplo, la inhalación de derivados del radón provoca principalmente una exposición de los pulmones, y la integración de iodo radiactivo provoca la irradiación de la glándula tiroides. En estos casos, podemos hablar de dosis pulmonar y dosis tiroidea.

No obstante, también se han desarrollado otras unidades de dosis, que tienen en cuenta las diferencias entre los efectos de los distintos tipos de radiación y los grados de sensibilidad a la radiación de los diversos tejidos y órganos.

\section{Dosis equivalente}

El desarrollo de efectos biológicos (como la inhibición del crecimiento celular, la necrosis de células, la azoospermia) depende no sólo de la dosis absorbida, sino también del tipo específico de radiación. La radiación alfa tiene mayor potencial ionizante que la radiación beta o gamma. El concepto de dosis equivalente tiene en cuenta esta diferencia, al aplicar factores de ponderación de la radiación. El factor de ponderación para la radiación beta y gamma (bajo potencial ionizante) es igual a 1 , mientras que el de las partículas alfa (alto potencial ionizante) es 20 (ICRP 60). La dosis equivalente se mide en Sieverts (Sv).

\section{Dosis efectiva}

En casos de irradiación heterogénea (como la exposición de varios órganos a radionúclidos diferentes), puede ser útil calcular una dosis total que englobe las dosis recibidas por todos los órganos y tejidos. Para ello, es necesario tener en cuenta la sensibilidad a la radiación de cada uno de los tejidos y órganos, calculada a partir de los resultados de estudios epidemiológicos sobre cánceres inducidos por radiación. La dosis efectiva se mide en Sieverts (Sv) (IC RP 1991). El concepto de dosis efectiva se desarrolló a los fines de la protección contra la radiación (por ejemplo, gestión del riesgo), y por tanto resulta inadecuada para su uso en estudios epidemiológicos.

\section{Dosis colectiva}

La dosis colectiva refleja la exposición de un grupo o una población y no de un individuo, y resulta útil para evaluar las consecuencias de la exposición a radiación ionizante a escala de población 0 de grupo. Se calcula sumando las dosis individuales recibidas, 0 bien multiplicando la dosis individual media por el número de individuos expuestos o de la población afectada. La dosis colectiva se mide en man-Sieverts (man Sv). 
Figura 39.10 • Distribución mundial de reactores de generación de energía y de centrales de reprocesamiento de combustible, 1989-1990.

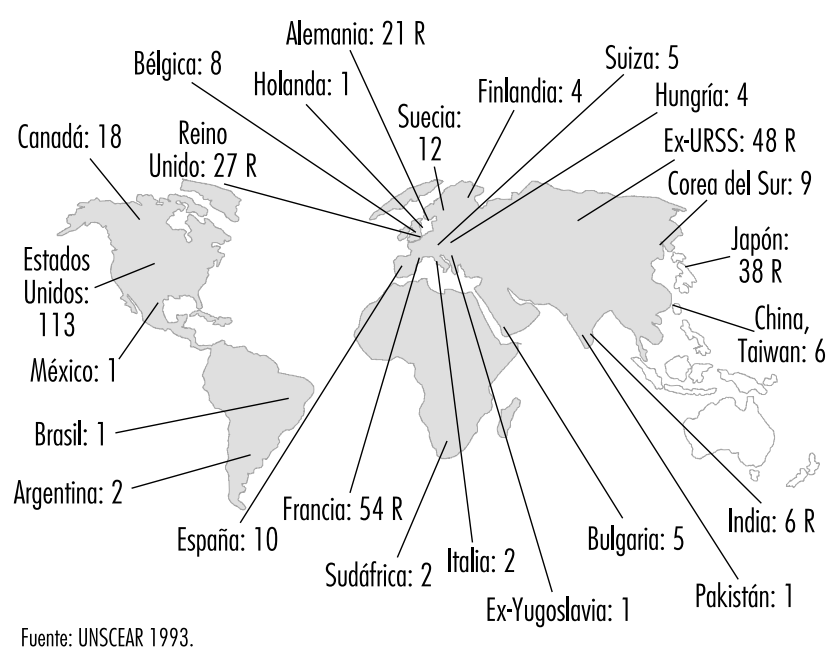

sufrió una alta exposición a radiación beta y gamma en las primeras horas o días después del accidente. $\mathrm{H}$ ubo que hospitalizar a 500 personas; 237 que recibieron irradiación total presentaron síndrome de radiación agudo y 28 murieron a pesar del tratamiento (Tabla 39.27) (U N SCEAR 1988). O tras recibieron irradiación parcial de miembros, que en algunos casos afectó a más del $50 \%$ de la superficie del cuerpo: muchos años después, siguen padeciendo trastornos dérmicos múltiples (Peter, BraunFalco y Birioukov 1994).

\section{Efectos estocásticos}

Son de tipo probabilístico (es decir, su frecuencia aumenta con la dosis recibida), pero su gravedad es independiente de la dosis. Los principales efectos estocásticos son los siguientes:

- M utación. Se ha observado en experimentos con animales, pero ha sido difícil de documentar en seres humanos.

- Cáncer. El efecto de la irradiación sobre el riesgo de desarrollar cáncer se ha estudiado en los pacientes de radioterapia y en los supervivientes de los bombardeos de Hiroshima y Nagasaki. EI UNSCEAR $(1988,1994)$ resume periódicamente los resultados de estos estudios epidemiológicos. La duración típica del período de latencia es de 5 a 15 años a partir de la fecha de exposición, en función del órgano y del tejido expuesto. En la Tabla 39.28 se indican los cánceres para los que se ha confirmado una asociación con radiación ionizante. Se ha demostrado una presencia excesiva de cáncer entre los supervivientes de los bombardeos de $\mathrm{H}$ iroshima y $\mathrm{N}$ agasaki, con exposiciones superiores a 0,2 Sv.

- T umores benignos sel eccionados. A denomas tiroideos benignos.

En torno a los efectos de la radiación ionizante, siguen siendo polémicos dos puntos importantes.

En primer lugar, ¿cuáles son los efectos de dosis bajas de radiación (por debajo de 0,2 Sv) y de cuantías bajas de dosis? La mayoría de los estudios epidemiológicos se han efectuado sobre los supervivientes de los bombardeos de $\mathrm{H}$ iroshima y $\mathrm{N}$ agasaki 0 pacientes de radioterapia, poblaciones expuestas a dosis relativamente altas en períodos muy cortos, y las estimaciones del riesgo de cáncer tras la exposición a dosis bajas y a cuantías bajas de dosis han sido esencialmente resultado de extrapolaciones de
Tabla 39.26 • Efectos deterministas: cantidades máximas en determinados órganos.

$\begin{array}{lr}\text { Tejido o efecto } & \begin{array}{r}\text { Dosis equivalente } \\ \text { recibida por el ó }\end{array} \\ \text { Testículos: } & 0,15 \\ \text { Esterilidad temporal } & 3,5-6,0 \\ \text { Esterilidad permanente } & \\ \text { Ovarios: } & \\ \quad \text { Esterilidad } & 2,5-6,0 \\ \text { Cristalino: } & \\ \text { Opacidades detectables } & \\ \quad \text { Visión deficiente (cataratas) } & 0,5-2,0 \\ \text { Médula ósea: } & 5,0 \\ \text { Disminución de la hematopoyesis } & 0,5\end{array}$

Fuente: ICRP 1991

dichas poblaciones. Algunos estudios sobre trabajadores de centrales nucleares expuestos a dosis bajas durante varios años han puesto de manifiesto que los riesgos de leucemia y otros cánceres son coherentes con las extrapolaciones de grupos de alta exposición, pero estos resultados no se han confirmado (U N SCEAR 1994; C ardis, G ilbert y Carpenter 1995).

En segundo lugar, ¿hay una dosis mínima? (es decir, una dosis por debajo de la cual no se producen efectos) La respuesta a esta pregunta sigue sin conocerse. Algunos estudios experimentales han demostrado que constantemente se están reparando daños en el material genético (ADN) provocados por errores espontáneos o por factores ambientales. Con todo, esta reparación no siempre es eficaz, y puede dar como resultado una transformación maligna de las células (U NSCEAR 1994).

\section{Otros efectos}

Por último, hay que mencionar la posibilidad de efectos teratogénicos debido a la irradiación durante el embarazo. Se ha observado microcefalia y retraso mental en niños nacidos de mujeres supervivientes a los bombardeos de Hiroshima y Nagasaki que recibieron una irradiación mínima de 0,1 Gy en el primer trimestre de gestación (O take, Schull y Yoshimura 1989; O take y Schull 1992). No se sabe si estos efectos son deterministas o estocásticos, pero los datos sí sugieren la existencia de un umbral mínimo.

\section{Efectos observados tras el accidente de Chernóbil}

El de Chernóbil es el accidente nuclear más grave acaecido hasta la fecha. Con todo, hasta ahora, diez años después, no se han

\begin{tabular}{|c|c|c|c|c|}
\hline $\begin{array}{l}\text { Gravedad } \\
\text { del SAG }\end{array}$ & $\begin{array}{l}\text { Dosis equiva- } \\
\text { lente (Gy) }\end{array}$ & $\begin{array}{l}\text { Número de } \\
\text { sujetos }\end{array}$ & $\begin{array}{l}\text { Número de } \\
\text { muertes (\%) }\end{array}$ & $\begin{array}{l}\text { Período medio de } \\
\text { supervivencia (días) }\end{array}$ \\
\hline I & $1-2$ & 140 & - & - \\
\hline$\|$ & $2-4$ & 55 & $1(1,8)$ & 96 \\
\hline |II & $4-6$ & 21 & $7(33,3)$ & 29,7 \\
\hline IV & $>6$ & 21 & $20(95,2)$ & 26,6 \\
\hline
\end{tabular}


Tabla 39.28 • Resultados de los estudios epidemiológicos del efecto de una alta cuantía de dosis de radiación externa sobre el cáncer.

\begin{tabular}{lccc} 
Localización del cáncer & \multicolumn{2}{c}{ Hiroshima/ Nagasaki } & Otros estudios \\
& Mortalidad & Incidencia & No positivol \\
& & & total Nol
\end{tabular}

evaluado con exactitud todos los efectos sobre la salud de la población más expuesta. Y ello por múltiples razones:

- algunos efectos no aparecen hasta muchos años después: por ejemplo, los tumores sólidos suelen tardar de 10 a 15 años en aparecer;

- como transcurrió algún tiempo entre el accidente y el inicio de los estudios epidemiológicos, pueden no haberse detectado algunos efectos surgidos en el período inmediatamente posterior al accidente;

- no siempre se recogieron adecuadamente datos útiles para la cuantificación del riesgo de cáncer. Así ocurre especialmente con los datos necesarios para estimar la exposición de la glándula tiroides a ioduros radiactivos emitidos en el incidente (telurio-132, iodo-133) (Williams y cols. 1993),

- por último, muchas personas inicialmente expuestas abandonaron las zonas contaminadas, y es probable que su seguimiento no se continuara.

Trabajadores. En la actualidad, no existen datos exhaustivos sobre todos los trabajadores que sufrieron una fuerte irradiación en los primeros días después del accidente. Se están realizando estudios sobre el riesgo de leucemia y tumores sólidos en los trabajadores de la limpieza y de socorro (véase la Tabla 39.20), pero existen muchas dificultades. El seguimiento periódico del estado de salud de los trabajadores de la limpieza y de socorro resulta obstaculizado en gran medida por el hecho de que muchos de ellos procedían de distintas zonas de la antigua U nión Soviética y volvieron a sus lugares de origen después de trabajar en la central de Chernóbil. A demás, la dosis recibida debe estimarse retrospectivamente, puesto que no hay datos fiables para este período.

Población en general. H asta la fecha, el único efecto verosímil asociado con la radiación ionizante es el aumento de la incidencia del cáncer de tiroides a partir de 1989 en los niños menores de 15 años. Este efecto se detectó en Bielorrusia (Belarús) en 1989, sólo tres años después del incidente, y ha sido confirmado por varios grupos de expertos (Williams y cols. 1993). El incremento ha sido especialmente visible en las zonas más contaminadas de Belarús, como la región de Gomel. El cáncer de tiroides, que suele ser raro en niños menores de 15 años (tasa anual de incidencia de 1 a 3 por millón), multiplicó su incidencia por diez a escala nacional y por veinte en la zona de Gomel (Tabla 39.29, Figura 39.11) (Stsjazhko y cols. 1995). Posteriormente, se notificó una incidencia de cáncer de tiroides diez veces mayor en las cinco zonas más contaminadas de U crania y también un aumento de este cáncer en la región de Bryansk (Rusia) (Tabla 39.29). Se sospecha igualmente que se haya producido un aumento del mismo entre los adultos, pero esta suposición no ha sido confirmada. Los programas sistemáticos de detección selectiva emprendidos en las zonas contaminadas permitieron observar los cánceres latentes antes del accidente; a este respecto, fue especialmente útil la utilización de ultrasonografías capaces de detectar cánceres de tiroides de pocos milímetros. La magnitud del aumento de la incidencia en los niños, junto con la agresividad de los tumores y la rapidez de su desarrollo, sugieren que el aumento observado en el cáncer de tiroides se debe parcialmente al accidente.

En las zonas más contaminadas (es decir, la región de $\mathrm{G}$ omel), las dosis tiroideas fueron altas, especialmente en los niños (Williams y cols. 1993). Este resultado es coherente, si tenemos en cuenta las significativas emisiones de iodo que provocó el accidente y el hecho de que el iodo radiactivo, en ausencia de medidas preventivas, tiende a concentrarse en la glándula tiroides. 
Tabla 39.29 • Evolución temporal de la incidencia* y número total de cánceres de tiroides en niños en Bielorrusia, Ucrania y Rusia, 1981-94.

\begin{tabular}{|c|c|c|c|c|}
\hline & \multicolumn{2}{|c|}{ Incidencia (/ 100.000) } & \multicolumn{2}{|c|}{ Número de casos } \\
\hline & $1981-85$ & 1991-94 & $1981-85$ & 1991- 94 \\
\hline \multicolumn{5}{|l|}{ Bielorrusia } \\
\hline Todo el país & 0,3 & 3,06 & 3 & 333 \\
\hline Región de Gomel & 0,5 & 9,64 & 1 & 164 \\
\hline \multicolumn{5}{|l|}{ Ucrania } \\
\hline Todo el país & 0,05 & 0,34 & 25 & 209 \\
\hline $\begin{array}{l}\text { Las cinco áreas más } \\
\text { contaminadas }\end{array}$ & 0,01 & 1,15 & 1 & 118 \\
\hline \multicolumn{5}{|l|}{ Rusia } \\
\hline Todo el país & $?$ & $?$ & $?$ & $?$ \\
\hline $\begin{array}{l}\text { Regiones de Bryansk } \\
\text { y Kaluga }\end{array}$ & 0 & 1,00 & 0 & 20 \\
\hline $\begin{array}{l}\text { Incidencia: proporción entre el } \\
\text { inado y la población total en es } \\
\text { lente: Stsjazhko y cols. } 1995 .\end{array}$ & $\begin{array}{l}\text { número de ca } \\
\text { studio durante }\end{array}$ & $\begin{array}{l}\text { luevos de un } \\
\text { ismo período }\end{array}$ & ermedad dura & un período dete \\
\hline
\end{tabular}

La exposición a la radiación es un factor de riesgo muy documentado para el desarrollo del cáncer de tiroides. En numerosos estudios sobre niños expuestos a radioterapia en zonas de la cabeza y cuello se ha observado un claro aumento de la incidencia del cáncer de tiroides. En la mayoría de los casos, el incremento se hizo patente de 10 a 15 años después de la exposición, pero en ocasiones fue detectable en un plazo de 3 a 7 años. Por otro lado, no están bien establecidos los efectos de la irradiación interna de iodo 131 y de isótopos de iodo de semivida corta en niños (Shore 1992).

$\mathrm{H}$ ay que estudiar la magnitud y las pautas exactas del aumento de la incidencia de cáncer de tiroides en las poblaciones más expuestas en los años venideros. C abe prever que los estudios epidemiológicos en curso ayuden a cuantificar la relación entre la dosis recibida por la glándula tiroides y el riesgo de desarrollar cáncer, y a identificar la función de otros factores genéticos y ambientales de riesgo. $\mathrm{H}$ ay que señalar que en las zonas afectadas se registra una insuficiencia de iodo generalizada.

En un plazo de cinco a diez años después del accidente, cabe esperar un aumento de la incidencia de la leucemia - y en especial de la leucemia juvenil, puesto que los niños son más sensibles a los efectos de la radiación ionizante- entre los miembros más expuestos de la población. Aunque aún no se ha observado un aumento de este tipo, las carencias metodológicas de los estudios realizados hasta la fecha no permiten sacar conclusiones definitivas.

\section{Efectos psicosociales}

La aparición de problemas psicológicos crónicos más o menos graves después de haber sufrido traumas está firmemente establecida y ha sido estudiada sobre todo en poblaciones sometidas a catástrofes ambientales como inundaciones, erupciones volcánicas y terremotos. El estrés postraumático es una afección grave, duradera e incapacitadora (APA 1994).

La mayoría de nuestros conocimientos sobre los problemas psicológicos y el estrés provocados por accidentes de radiación proceden de los estudios realizados tras el accidente de Three
Figura 39.11 • Incidencia* del cáncer de tiroides en niños menores de 15 años en Bielorrusia.

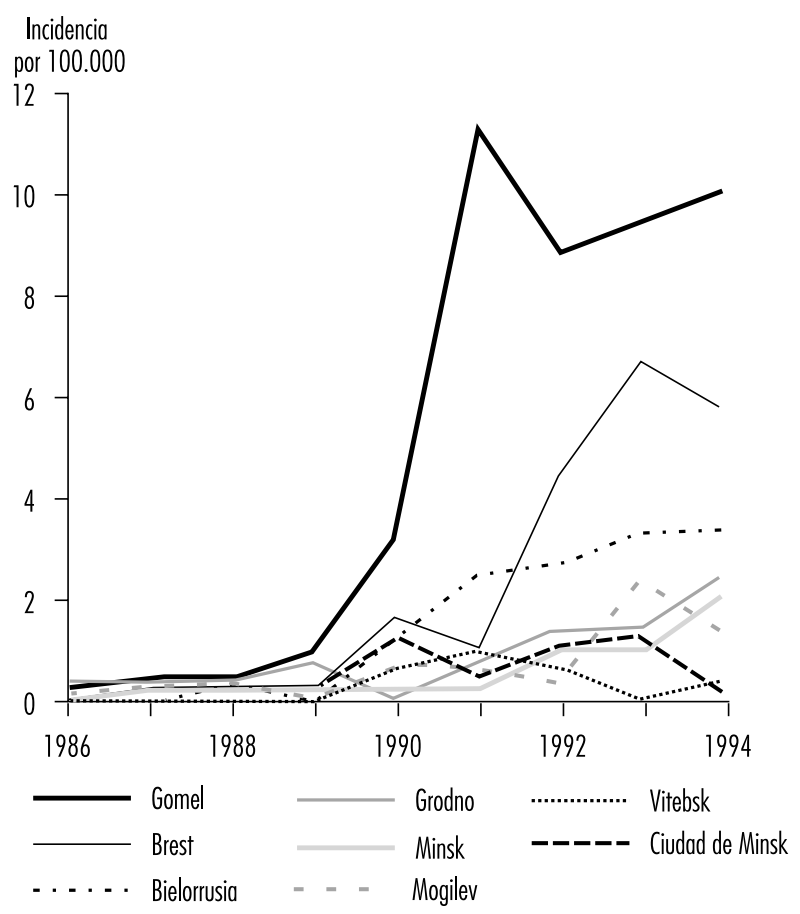

*Incidencia: número de casos nuevos de una enfermedad en un período dado, expresado en fracción de lo población expuesta.

M ile Island. En el año que siguió al accidente, se observaron efectos psicológicos inmediatos en la población expuesta, en particular las madres de niños pequeños mostraron mayor sensibilidad, ansiedad y depresión (Bromet y cols. 1982). A demás, se detectaron más problemas de depresión y ansiedad en los trabajadores de la central que en los de otra central de energía (Bromet y cols. 1982). En los años siguientes (es decir, tras la reapertura de la central), alrededor de una cuarta parte de la población estudiada presentó problemas psicológicos relativamente importantes. No se observaron diferencias en la frecuencia de los problemas psicológicos entre el resto de la población estudiada y las poblaciones de control (Dew y Bromet 1993). L os problemas psicológicos fueron más frecuentes en las personas que vivían cerca de la central y no disponían de una red de apoyo social, las que tenían un historial anterior de problemas psiquiátricos o las que habían desalojado sus casas en el momento del accidente (Baum, Cohen y H all 1993).

También se están realizando estudios sobre las poblaciones expuestas al accidente de Chernóbil: el estrés parece ser un aspecto importante de salud pública (por ejemplo, trabajadores de la limpieza y de socorro, y personas que viven en una zona contaminada). A hora bien, todavía no hay datos fiables sobre la naturaleza, la gravedad, la frecuencia y la distribución de los problemas psicológicos entre las poblaciones objetivo. Entre los factores que deben tenerse en cuenta al evaluar las consecuencias psicológicas y sociales del accidente sobre los habitantes de áreas contaminadas se encuentran las duras condiciones socioeconómicas existentes, la diversidad de los sistemas de compensación disponibles, los efectos de la evacuación y el reasentamiento (unas 100.000 personas se reinstalaron en los años posteriores al accidente) y los efectos del descenso de la calidad de vida (por ejemplo, modificación de la alimentación). 


\begin{tabular}{|c|c|c|c|}
\hline Tabla $39.30 \bullet$ & $\begin{array}{l}\text { Escala internaci } \\
\text { nucleares. }\end{array}$ & onal de incident & \\
\hline Nivel & $\begin{array}{l}\text { Fuera de la } \\
\text { instalación }\end{array}$ & $\begin{array}{l}\text { Dentro de la } \\
\text { instalación }\end{array}$ & $\begin{array}{l}\text { Estructura de } \\
\text { protección }\end{array}$ \\
\hline $\begin{array}{c}\text { 7- Accidente } \\
\text { mayor }\end{array}$ & $\begin{array}{l}\text { Emisión grave, } \\
\text { amplios efectos } \\
\text { sobre la salud y } \\
\text { sobre el medio } \\
\text { ambiente }\end{array}$ & & \\
\hline $\begin{array}{c}6 \text { - Accidente } \\
\text { grave }\end{array}$ & $\begin{array}{l}\text { Emisión significativa, } \\
\text { puede ser nece- } \\
\text { sario aplicar } \\
\text { todas las medidas } \\
\text { de reacción. }\end{array}$ & & \\
\hline 5- Accidente & $\begin{array}{l}\text { Emisión limitada, } \\
\text { puede ser nece- } \\
\text { sario aplicar } \\
\text { algunas medidas } \\
\text { de reacción. }\end{array}$ & $\begin{array}{l}\text { Daños graves en los } \\
\text { reactores y } \\
\text { estructuras de } \\
\text { protección }\end{array}$ & \\
\hline 4- Accidente & $\begin{array}{l}\text { Emisión baja, exposi- } \\
\text { ción de la pobla- } \\
\text { ción cercana a los } \\
\text { límites de } \\
\text { exposición }\end{array}$ & $\begin{array}{l}\text { Daños en los reac- } \\
\text { tores y estruc- } \\
\text { turas de } \\
\text { protección, expo- } \\
\text { sición mortal } \\
\text { de los } \\
\text { trabajadores }\end{array}$ & \\
\hline $\begin{array}{c}\text { 3- Incidente } \\
\text { grave }\end{array}$ & $\begin{array}{l}\text { Emisión muy baja, } \\
\text { exposición de la } \\
\text { población inferior a } \\
\text { los límites de } \\
\text { exposición }\end{array}$ & $\begin{array}{l}\text { Nivel grave de } \\
\text { contaminación, } \\
\text { efectos graves } \\
\text { sobre la salud de } \\
\text { los trabajadores }\end{array}$ & $\begin{array}{l}\text { Se ha evitado } \\
\text { por muy poco } \\
\text { el accidente }\end{array}$ \\
\hline 2- Incidente & & $\begin{array}{l}\text { Nivel grave de } \\
\text { contaminación, } \\
\text { sobreexposición } \\
\text { de los } \\
\text { trabajadores }\end{array}$ & $\begin{array}{l}\text { Deficiencias } \\
\text { graves } \\
\text { de las } \\
\text { medidas } \\
\text { de seguridad }\end{array}$ \\
\hline 1 - Anomalía & & & $\begin{array}{l}\text { Anomalía supe- } \\
\text { rior a los } \\
\text { límites } \\
\text { normales de } \\
\text { funciona- } \\
\text { miento }\end{array}$ \\
\hline 0 - Disparidad & $\begin{array}{l}\text { Sin importancia } \\
\text { desde el punto de } \\
\text { vista de la } \\
\text { seguridad }\end{array}$ & & \\
\hline
\end{tabular}

\section{Principios de prevención y directrices}

\section{Principios de seguridad y directrices}

\section{Uso industrial y médico de fuentes de radiación}

Aunque es cierto que todos los accidentes graves de radiación notificados se han producido en centrales nucleares, también el uso de fuentes de radiación en otros contextos ha provocado accidentes con consecuencias graves para los trabajadores o para la población en general. La prevención de este tipo de accidentes es esencial, en particular dado el desalentador pronóstico en caso de exposición a dosis elevadas. La prevención depende de una adecuada formación de los trabajadores y del mantenimiento de un exhaustivo inventario de los ciclos de vida de las fuentes de radiación, lo que incluye información tanto sobre su naturaleza como sobre su ubicación. La OIEA ha elaborado una serie de directrices y recomendaciones de seguridad para la utilización de fuentes de radiación en la industria, la medicina y la investigación (Safety Series no 102); se trata de aplicar principios similares a los que se exponen más adelante para las centrales nucleares.

\section{Seguridad en centrales nucleares (OIEA Safety Series no 75, INSAG -3)}

EI objetivo es proteger a los seres humanos y al medio ambiente de cualquier tipo de emisión de materiales radiactivos. A tal fin, es necesario aplicar una serie de medidas en las fases de diseño, construcción, funcionamiento y desmantelamiento de las centrales nucleares.

L a seguridad de las centrales nucleares depende fundamentalmente del principio de "defensa en profundidad": es decir, de la existencia simultánea de varios sistemas y mecanismos diferentes diseñados para compensar errores y deficiencias técnicas 0 humanas. En concreto, los materiales radiactivos están separados del medio ambiente por una serie de barreras sucesivas. En los reactores de producción de energía nuclear, la última de estas barreras es la estructura de contención (inexistente en la central de Chernóbil, pero presente en Three M ile I sland). Para evitar que se rompan estas barreras y limitar las consecuencias de posibles rupturas, deben aplicarse tres medidas de seguridad a lo largo de toda la vida operativa de la central: control de la reacción nuclear, refrigeración del combustible y contención del material radiactivo.

O tro principio esencial de la seguridad es el "análisis de la experiencia": es decir, la utilización de información resultante de todo tipo de sucesos ocurridos en otras centrales para aumentar la seguridad de la central. Así, el análisis de los accidentes de Three M ile Island y Chernóbil ha conducido a la introducción de modificaciones para garantizar que no se produzcan accidentes similares en otros lugares.

Por último, cabe señalar que se han realizado importantes esfuerzos para potenciar una cultura de la seguridad, es decir, una cultura que responda de forma continuada a las necesidades de la seguridad en la organización, la actividad y la práctica de la central, así como en los comportamientos personales. Para aumentar la visibilidad de los incidentes y accidentes en centrales nucleares, se ha desarrollado una escala internacional

Tabla 39.31 - Ejemplos de niveles generales de intervención en las medidas de protección de la población general.

$\begin{array}{ll}\text { Medidas de protección } & \text { Nivel de intervención (dosis preventiva) } \\ \begin{array}{l}\text { Emergencia } \\ \text { Contención }\end{array} & 10 \mathrm{mSv} \\ \text { Evacuación } & 50 \mathrm{mSv} \\ \text { Distribución de iodo estable } & 100 \mathrm{mGy} \\ \text { Posteriores } & \\ \text { Reasentamiento provisional } & 30 \mathrm{mSv} \text { en } 30 \text { días; } 10 \mathrm{mSv} \text { en los } 30 \\ \text { días siguientes } \\ \text { Reasentamiento permanente } & 1 \text { Sv el resto de la vida } \\ \text { Fuente: IAEA 19g4. } & \end{array}$


de accidentes nucleares (INES), idéntica en principio a las utilizadas para medir la gravedad de fenómenos naturales como terremotos y vientos (Tabla 39.30). A hora bien, dicha escala no permite evaluar la seguridad de una central o establecer comparaciones a escala internacional.

\section{Principios de protección de la población en general contra la exposición radiactiva}

En casos de posible exposición de la población en general, puede ser necesario aplicar medidas de protección diseñadas para impedir o limitar la exposición a la radiación ionizante, algo especialmente importante para evitar los efectos deterministas. Las primeras medidas que deben aplicarse en caso de emergencia son la evacuación, el refugio y la administración de la cantidad adecuada de iodo. D ebe distribuirse entre la población expuesta una cantidad adecuada de iodo estable, al objeto de saturar la tiroides e inhibir la absorción de iodo radiactivo. Ahora bien, para que sea eficaz, el bloqueo de la tiroides debe producirse antes o inmediatamente después del comienzo de la exposición. Por último, puede ser necesaria el reasentamiento temporal o permanente, la descontaminación y el control de la agricultura y de los alimentos.

Cada una de estas medidas de reacción tiene su propio "nivel de acción" (Tabla 39.31), que no debe confundirse con las dosis límite de CIPR para los trabajadores y para la población en general, desarrolladas para garantizar una adecuada protección en casos de exposición no accidental (CIPR 1991).

\section{Necesidades de investigación y tendencias futuras}

En la actualidad, la investigación sobre seguridad se centra en mejorar el diseño de los reactores de energía nuclear; más concretamente en reducir el riesgo y los efectos de una posible fusión del núcleo.

La experiencia adquirida en accidentes anteriores debe permitir mejorar el tratamiento

terapéutico de las víctimas de una irradiación grave. Se está investigando el uso de factores de crecimiento de las células de la médula ósea (factores de crecimiento hematopoyético) para el tratamiento de la aplasia medular inducida por la radiación (insuficiencia en el desarrollo) (T hierry y cols. 1995).

Aún no están claros los efectos que provocan unas dosis bajas de radiación ionizante ni los efectos según la frecuencia de las dosis; dichos efectos deben comprenderse, tanto desde un punto de vista estrictamente científico, como con vistas a establecer dosis límite para la población en general y para los trabajadores. Es necesario desarrollar más la investigación biológica para dilucidar los mecanismos carcinogénicos que tienen lugar. Los resultados de estudios epidemiológicos a gran escala, especialmente los que se están realizando sobre trabajadores de centrales nucleares, deben contribuir a mejorar la exactitud de las estimaciones de riesgo de cáncer en poblaciones expuestas a dosis bajas - cuantías bajas de dosis. Los estudios sobre poblaciones expuestas a radiación ionizante a causa de accidentes nos ayudarán a comprender mejor los efectos de dosis mayores, con frecuencia administradas en bajas cuantías de dosis.

La infraestructura necesaria (organización, equipo y material) para una recopilación de los datos a su debido tiempo, que es esencial para la evaluación de los efectos de los accidentes de radiación sobre la salud, debe estar implantada desde mucho antes del accidente.

Por último, es preciso realizar una amplia investigación para determinar con exactitud los efectos psicológicos y sociales de los accidentes de radiación (por ejemplo, la naturaleza, frecuencia y factores de riesgo de las reacciones psicológicas postraumáticas, patológicas o no). Esta investigación es esencial para mejorar la gestión de la población expuesta, tanto por el motivos profesionales como por otras razones

\section{SALUD EN EL TRABAJO Y MEDIDAS DE SEGURIDAD EN AREAS AG RARIAS CONTAMINADAS POR RADIONUCLIDOS: LA EXPERIENCIA DE CHERNOBIL}

\author{
Yuri Kundiev, Leonard Dobrovolsky \\ y V. I. Chernyuk
}

En general, la contaminación masiva de tierras agrícolas por radionúclidos se produce por accidentes graves en empresas pertenecientes a la industria nuclear 0 en centrales nucleares. Accidentes de este tipo se produjeron en Windscale (Inglaterra) y al sur de los U rales (Rusia). El accidente más grave tuvo lugar en abril de 1986, en la central nuclear de Chernóbil: provocó una intensa contaminación del suelo en varios miles de kilómetros cuadrados.

Los principales factores que influyen en los efectos de un accidente radiológico en zonas agrarias son los siguientes:

- el hecho de que la radiación se deba a una sola exposición o a una exposición prolongada;

- la cantidad total de sustancias radiactivas que se han incorporado al medio ambiente;

- el ratio o proporción de radionúclidos en la precipitación o Iluvia radiactiva caida a distancia;

- la distancia entre la fuente de radiación y las tierras y asentamientos agrarios;

- las características hidrogeológicas y edafológicas de las tierras agrícolas, y los fines a que se destinan;

- las características laborales de la población rural; dieta, suministro de agua,

- el tiempo transcurrido desde el accidente radiológico.

Como resultado del accidente de Chernóbil, se incorporaron al medio ambiente más de 50 millones de curios ( $\mathrm{Ci}$ ) de radionúclidos, en su mayoría volátiles. En la primera fase, que duró 2,5 meses (el período de semidesintegración

del iodo), el iodo 131 ocasionó el mayor peligro biológico, con dosis significativas de radiación gamma de alta energía.

Durante el período de semidesintegración del iodo debe regularse estrictamente el trabajo en las tierras agrícolas. El iodo-131 se acumula en la glándula tiroides, dañándola. Tras el accidente de Chernóbil, en un radio de $30 \mathrm{~km}$ de la central se definió una zona de elevadísima intensidad de radiación, en la que no estaba permitido vivir ni trabajar.

Fuera de la zona prohibida, se distinguieron cuatro áreas con distintas proporciones de radiación gamma en el suelo, en función de los tipos de tareas agrarias que podían llevarse a cabo; durante el período de semidesintegración del iodo, las cuatro zonas presentaban los siguientes niveles de radiación, medidos en roentgen $(R)$ :

- zona 1: menos de $0,1 \mathrm{mR} / \mathrm{h}$

- zona 2: 0,1 a $1 \mathrm{mR} / \mathrm{h}$

- zona 3: 1,0 a $5 \mathrm{mR} / \mathrm{h}$

- zona 4: $5 \mathrm{mR} / \mathrm{h}$ y más.

En realidad, debido a la contaminación "concentrada" de radionúclidos durante el período de semidesintegración del iodo, 
en estas zonas se llevaron a cabo las tareas agrarias con unos niveles de radiación gamma comprendidos entre 0,2 y $25 \mathrm{mR} / \mathrm{h}$. A parte de la desigual contaminación, la causa de la variación en los niveles de radiación gamma residió en las diferentes concentraciones de radionúclidos en los distintos cultivos. En particular, los cultivos forrajeros están expuestos a altos niveles de emisores de partículas gamma durante la cosecha, transporte, ensilaje y utilización como forraje.

Tras la desintegración espontánea del iodo 131, el mayor peligro para los trabajadores agrarios lo representan los núclidos de vida larga de cesio 137 y estroncio 90. El cesio 137, un emisor de partículas gamma, es un producto químico análogo al potasio; su ingesta por seres humanos o animales produce una distribución uniforme por todo el cuerpo y se expele con relativa rapidez con la orina y las heces. Así, en las zonas contaminadas, el estiércol representa una fuente adicional de radiación y debe eliminarse lo antes posible de las explotaciones ganaderas, almacenándolo en instalaciones especiales.

El estroncio 90, un emisor de partículas beta, es un producto químico análogo al calcio; se deposita en la médula ósea de los seres humanos y de los animales. El estroncio 90 y el cesio 137 pueden introducirse en el cuerpo humano a través de leche, carne 0 verduras contaminadas.

Tras la desintegración espontánea de los radionúclidos de vida corta, la división de las tierras agrícolas en zonas se lleva a cabo atendiendo a un principio diferente. En este caso, se tiene en cuenta no el nivel de radiación gamma, sino la medida de

Tabla 39.32 - Criterios para las zonas de contaminación.

\begin{tabular}{|c|c|c|c|}
\hline $\begin{array}{l}\text { Zonas de } \\
\text { contaminación }\end{array}$ & $\begin{array}{l}\text { Límites de contamina- } \\
\text { ción de suelos }\end{array}$ & $\begin{array}{l}\text { Límites de } \\
\text { dosis }\end{array}$ & Tipo de medida \\
\hline $\begin{array}{l}\text { 1. Radio de } \\
30 \mathrm{~km}\end{array}$ & - & - & $\begin{array}{l}\text { Están prohibidos } \\
\text { la residencia y } \\
\text { el trabajo agrí- } \\
\text { cola. }\end{array}$ \\
\hline $\begin{array}{l}\text { 2. Reasenta- } \\
\text { miento sin } \\
\text { condiciones }\end{array}$ & $\begin{array}{l}15(\mathrm{Ci}) / \mathrm{km}^{2} \\
\text { cesio- } 37 \\
3 \mathrm{Ci} / \mathrm{km}^{2} \\
\text { estroncio } 90 \\
0,1 \mathrm{Ci} / \mathrm{km}^{2} \text { plutonio }\end{array}$ & $\begin{array}{l}0,5 \\
c S v / a n ̃ o\end{array}$ & $\begin{array}{l}\text { El trabajo agrícola } \\
\text { se lleva a cabo } \\
\text { siguiendo una } \\
\text { rotación } \\
\text { quincenal y } \\
\text { bajo un riguroso } \\
\text { control } \\
\text { radiológico. }\end{array}$ \\
\hline $\begin{array}{l}\text { 3. Reasenta- } \\
\text { miento } \\
\text { voluntario }\end{array}$ & $\begin{array}{l}\text { 5- } 15 \mathrm{Ci} / \mathrm{km}^{2} \\
\text { cesio } 137 \\
0,15-3,0 \mathrm{Ci} / \mathrm{km}^{2} \\
\text { estroncio } 90 \\
0,01-0,1 \mathrm{Ci} / \mathrm{km}^{2} \\
\text { plutonio }\end{array}$ & $\begin{array}{l}0,01-0,5 \\
\text { cSv/ año }\end{array}$ & $\begin{array}{l}\text { Se toman } \\
\text { medidas } \\
\text { para reducir } \\
\text { la contaminación } \\
\text { de la primera } \\
\text { capa de suelo; } \\
\text { el trabajo agrícola } \\
\text { se lleva a cabo } \\
\text { bajo un riguroso } \\
\text { control } \\
\text { radiológico. }\end{array}$ \\
\hline $\begin{array}{l}\text { 4. Vigilancia } \\
\text { radiológica y } \\
\text { ecológica }\end{array}$ & $\begin{array}{l}\text { 1- } 5 \mathrm{Ci} / \mathrm{km}^{2} \\
\text { cesio } 137 \\
0,02-0,15 \mathrm{Ci} / \mathrm{km}^{2} \\
\text { estroncio } 90 \\
\text { 0,05- } 0,01 \mathrm{Ci} / \mathrm{km}^{2} \\
\text { plutonio }\end{array}$ & $\begin{array}{l}0,01 \\
\text { cSv/ año }\end{array}$ & $\begin{array}{l}\text { El trabajo agrícola } \\
\text { se lleva a cabo } \\
\text { de la forma habi- } \\
\text { tual pero bajo } \\
\text { control radiológico }\end{array}$ \\
\hline
\end{tabular}

la contaminación del suelo por cesio 137, estroncio 90 y plutonio 239.

Cuando se dan niveles de contaminación particularmente graves, la población es evacuada y el trabajo en las explotaciones agrícolas se realiza siguiendo una rotación quincenal. En la Tabla 39.32 se muestran los criterios de delimitación zonal en las áreas contaminadas.

Al trabajar en tierras agrícolas contaminadas por radionúclidos, puede producirse absorción física de radionúclidos por inhalación y contacto con el polvo del suelo y con los cultivos. A quí, son extremadamente peligrosos los emisores de partículas tanto beta (estroncio 90) como alfa.

Como resultado de los accidentes en centrales nucleares, parte de los materiales radiactivos que se incorporan al medio ambiente son partículas del combustible del reactor muy activas y de baja dispersión: "partículas calientes".

Durante las tareas agrarias y en períodos de viento, se generan grandes cantidades de polvo con partículas calientes. Esta circunstancia se ha visto confirmada por los resultados de las investigaciones realizadas sobre los filtros de aire de tractores que trabajaban en tierras contaminadas.

La evaluación de la dosis en los pulmones de los trabajadores agrarios expuestos a partículas calientes puso de manifiesto que, fuera de la zona de los $30 \mathrm{~km}$, ésta ascendía a varios milisieverts (Loshchilov y cols. 1993).

Según los datos de Bruk y cols. (1989), la actividad total de cesio 137 y cesio 134 en el polvo inhalado por personas que trabajaban con máquinas fue de entre 0,005 y $1,5 \mathrm{nCi} / \mathrm{m}^{3}$. De acuerdo con sus cálculos, la dosis efectiva en los pulmones variaba de 2 a 70 cSv en el período total de trabajo.

Se estableció una relación entre la cantidad de contaminación por cesio 137 del suelo y la radiactividad del aire en la zona de trabajo. Según los datos del Instituto de salud en el trabajo de $\mathrm{K}$ iev, cuando la contaminación del suelo por cesio 137 estaba comprendida entre 7,0 y $30,0 \mathrm{Ci} / \mathrm{km}^{2}$, la radiactividad del aire de la zona alcanzaba los $13,0 \mathrm{~Bq} / \mathrm{m}^{3}$. En las zonas de control, donde la densidad de la contaminación era de 0,23 a $0,61 \mathrm{Ci} / \mathrm{km}^{3}$, la radiactividad del aire en la zona de trabajo variaba entre $0,1 \mathrm{y}$ $1,0 \mathrm{~Bq} / \mathrm{m}^{3}$ (K rasnyuk, C hernyuk y Stezhka 1993).

Los análisis médicos de los operadores de máquinas agrícolas en las zonas "limpias" y en las contaminadas pusieron de manifiesto un aumento de las afecciones cardiovasculares en estos últimos, en forma de cardiopatía isquémica y de distonía neurocirculatoria. Entre otros trastornos, se registró una mayor frecuencia de displasia de la glándula tiroides y un mayor nivel de monocitos en sangre.

\section{Requisitos de higiene}

\section{Programas de trabajo}

Después de accidentes graves en centrales nucleares, suelen implantarse normativas temporales para la población. Tras el accidente de Chernóbil, se adoptaron normas para un período de un año, con el TLV de 10 cSv. Se considera que los trabajadores reciben el $50 \%$ de su dosis por radiación externa durante el trabajo. Aquí, la intensidad máxima de radiación en la jornada laboral de ocho horas no debe superar los $2,1 \mathrm{mR} / \mathrm{h}$.

En las faenas agrarias, los niveles de radiación en el lugar de trabajo pueden fluctuar mucho dependiendo de la concentración de sustancias radiactivas en el suelo y en las plantas; varían también durante su procesamiento tecnológico (ensilaje, elaboración de forraje seco, etc.). Para reducir las dosis soportadas por los trabajadores, se introducen reglamentos de limitación temporal de las tareas agrarias. En la Figura 39.12 se indican los reglamentos adoptados tras el accidente de Chernóbil. 
Figura 39.12 • Límites temporales del trabajo agrícola en función de la intensidad de la radiación gamma en los lugares de trabajo.

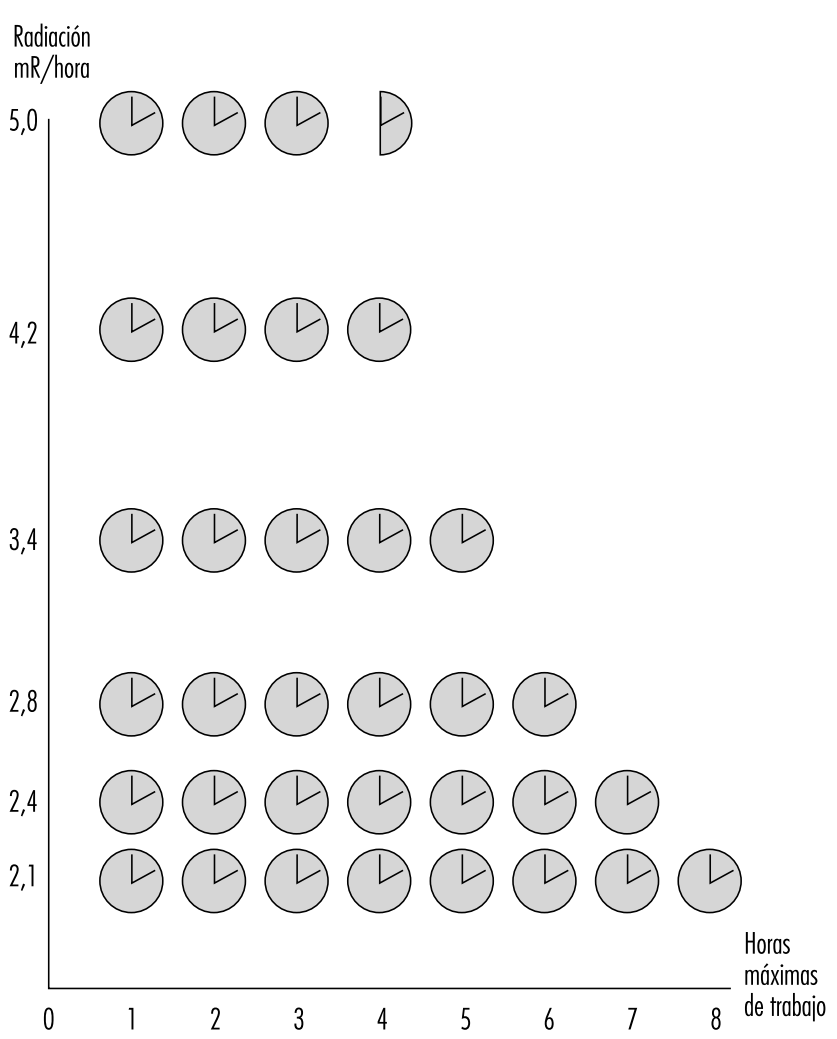

\section{Agrotecnología}

Al realizar tareas agrarias en condiciones de contaminación intensa de suelos y plantas, es necesario respetar estrictamente las medidas de prevención de la contaminación por polvo. La carga y descarga de sustancias secas y polvorientas debe mecanizarse, cubriendo con tela el cuello del tubo transportador. También deben adoptarse medidas para reducir la liberación de polvo en cualquier otra faena agrícola.

El trabajo con maquinaria agrícola debe efectuarse vigilando la presurización de la cabina y eligiendo la dirección adecuada para trabajar con el viento por el costado preferible. Si es posible, se recomienda regar primero las áreas de cultivo. Es aconsejable utilizar las tecnologías industriales para eliminar en la mayor medida posible el trabajo manual en el campo.

Conviene aplicar a los suelos sustancias capaces de potenciar la absorción y fijación de los radionúclidos, transformándolos en compuestos insolubles e impidiendo así su transmisión a las plantas.

\section{Maquinaria agrícola}

U no de los principales peligros para los trabajadores es la maquinaria agrícola contaminada por radionúclidos. El tiempo de trabajo admisible con máquinas depende de la intensidad de la radiación gamma emitida por las superficies de la cabina. No sólo es imperativa la total presurización de la misma, sino también un control adecuado de los sistemas de ventilación y de aire acondicionado. Concluido el trabajo, deben lavarse las cabinas y sustituirse los filtros.
Al mantener y reparar las máquinas tras los procedimientos de descontaminación, la intensidad de la radiación gamma en las superficies exteriores no debe superar $\operatorname{los} 0,3 \mathrm{mR} / \mathrm{h}$.

\section{Edificios}

$\mathrm{H}$ ay que lavar regularmente tanto el exterior como el interior de los edificios. Las construcciones deben estar provistas de duchas. Para la preparación de forraje que contenga componentes en polvo, es necesario respetar los procedimientos de prevención de la absorción de polvo por parte de los trabajadores, así como mantener libre de polvo los suelos, equipos, etc.

La presurización del equipo debe realizarse bajo control. Los lugares de trabajo deben dotarse de una ventilación general eficaz.

\section{U so de pesticidas y fertilizantes minerales}

D ebe limitarse la aplicación de pesticidas en polvo y en gránulos y de fertilizantes minerales, así como la aspersión desde aviones. Son preferibles la aspersión automática y la aplicación de sustancias químicas granuladas y fertilizantes líquidos mixtos. L os fertilizantes minerales en polvo deben almacenarse y transportarse en contenedores herméticamente cerrados.

El trabajo de carga y descarga, la preparación de soluciones pesticidas y otras actividades deben realizarse con el mejor equipo posible de protección personal (guardapolvos, cascos, gafas protectoras, respiradores, guantes de goma y botas).

\section{Suministro de agua y alimentación}

$H$ ay que disponer de un local especial cerrado, o de camionetas sin corrientes de aire, para que los trabajadores puedan comer. Antes de comer, deben limpiarse la ropa y lavarse completamente las manos y la cara con jabón y agua corriente. En verano, debe suministrarse agua potable a los trabajadores de campo. El agua ha de guardarse en contenedores cerrados, en los que no debe entrar polvo cuando se llenen de agua.

\section{Análisis médico preventivo de los trabajadores}

Un médico debe realizar análisis médicos periódicos; es obligatorio efectuar análisis de sangre, electrocardiogramas y pruebas de la función respiratoria. Si los niveles de radiación no rebasan los límites tolerables, la frecuencia de los análisis médicos no debe ser inferior a una vez cada 12 meses. Si se observan niveles mayores de radiación ionizante, los análisis deben realizarse con mayor frecuencia (después de la siembra, de la cosecha, etc.) teniendo debidamente en cuenta la intensidad de la radiación en los lugares de trabajo y la dosis total absorbida.

\section{Organización del control radiológico en zonas agrarias}

Los principales índices que caracterizan la situación radiológica tras la precipitación de lluvia radiactiva son los siguientes: intensidad de la radiación gamma en la zona, contaminación del terreno agrícola por los radionúclidos seleccionados y contenido en radionúclidos de los productos agrícolas.

La determinación de los niveles de radiación gamma permite trazar los límites geográficos de las zonas gravemente contaminadas, estimar las dosis de radiación externa de las personas que trabajan en tareas agrarias y elaborar los correspondientes programas de seguridad radiológica.

$\mathrm{H}$ abitualmente, las funciones de seguimiento radiológico en agricultura son responsabilidad de los laboratorios radiológicos del servicio de sanidad, así como de los laboratorios radiológicos veterinarios y agroquímicos. Estos laboratorios se encargan asimismo de la formación y educación del personal adscrito al control dosimétrico y a las consultas a la población rural. 


\section{ESTUdIO DE CASO: EL INCENDIO DE LA FABRICA DE JUGUETES KADER}

\section{Casey Cavanaugh Grant}

Un trágico incendio industrial acaecido en Tailandia llamó la atención del mundo entero sobre la necesidad de adoptar y aplicar códigos y normas actualizados a las instalaciones industriales.

El 10 de mayo de 1993, un gran incendio declarado en la fábrica K ader Industrial (Thailand) Co. Ltd., situada en la provincia de $\mathrm{N}$ akhon Pathom en Tailandia, ocasionó la muerte a 188 trabajadores (Grant y K lem 1994). Se trata del peor incendio accidental con pérdida de vidas humanas en un edificio industrial de toda la historia reciente, dudoso honor que durante 82 años correspondió al incendio de la fábrica Triangle Shirtwaist en la ciudad de Nueva York, en el que perecieron 146 trabajadores (Grant 1993). A pesar de los años que separan ambas calamidades, las dos presentan sorprendentes características comunes.

Varios organismos nacionales e internacionales prestaron atención a este incidente. Con respecto a la protección contra el fuego, la Asociación nacional de protección contra incendios (National Fire Protection Association, NFPA) cooperó con la O rganización Internacional del Trabajo (OIT) y el Cuerpo de bomberos de Bangkok para documentar este incendio.

\section{Cuestiones de economía mundial}

En Tailandia, el incendio de $\mathrm{K}$ ader despertó un gran interés por las medidas nacionales de seguridad contra incendios y, en particular, por los requisitos en materia de construcción y las políticas de aplicación. Chuan L eekpai, Primer M inistro de Tailandia, que se trasladó esa misma tarde al lugar del incendio, prometió que el Gobierno se ocuparía de los problemas de la seguridad contra incendios. Según el Wall Street J ournal (1993), Leekpai pidió la adopción de medidas rigurosas contra quienes infrinjan las normas de seguridad y Sanan K achornprasart, ministro de Industria, declaró que "las fábricas que no tengan sistemas de prevención de incendios recibirán la orden de instalarlos o serán cerradas".

Seguidamente, el W all Street I ournal afirma que, en opinión de líderes sindicales, expertos en seguridad y funcionarios, aunque el incendio de $\mathrm{K}$ ader puede contribuir a hacer más estrictos los códigos de construcción y los reglamentos de seguridad, es de temer que aún esté lejos un progreso duradero, pues las empresas ignoran las normas y los gobiernos consideran más importante el crecimiento económico que la seguridad de los trabajadores.

$\mathrm{D}$ ado que la mayor parte de las acciones de $\mathrm{K}$ ader Industrial (T hailand) Co. Ltd. estaban en manos extranjeras, el incendio impulsó también el debate internacional sobre la responsabilidad de los inversores internacionales en la seguridad de los trabajadores de los países en que invierten. El $20 \%$ de los accionistas de Kader son de Taiwan y el 79,96 \% de Hong Kong. Sólo el $0,04 \%$ de $\mathrm{K}$ ader es propiedad de tailandeses.

La mundialización de la economía significa que los productos se fabrican en un lugar y se utilizan en otros, a veces muy distantes. EI deseo de competitividad en este nuevo mercado no debe llevarnos a poner en peligro las normas básicas de seguridad contra incendios industriales. Tenemos la obligación moral de ofrecer a los trabajadores un nivel adecuado de protección contra incendios, estén donde estén.

\section{La fábrica}

$\mathrm{L}$ a fábrica $\mathrm{K}$ ader, que producía juguetes de trapo y muñecas de plástico fundamentalmente para su exportación a Estados U nidos y otros países desarrollados, estaba ubicada en la localidad de Sam Phran, en la provincia de Nakhon Pathom, prácticamente a medio camino entre Bangkok y la cercana ciudad de K anchanaburi, donde se encontraba el vergonzoso puente ferroviario sobre el río K wai de la segunda G uerra M undial.

Todas las estructuras destruidas en el incendio eran propiedad de $\mathrm{K}$ ader, dueño y gestor de la fábrica. Kader tiene dos empresas hermanas que también operan en este lugar en virtud de un acuerdo de arrendamiento.

La sociedad $K$ ader Industrial (T hailand) C o. L td. se registró por primera vez el 27 de enero de 1989, pero se suspendió el permiso a la empresa el 21 de noviembre del mismo año, tras un incendio acaecido el 16 de agosto de 1989, que destruyó la nueva fábrica. El incendio se atribuyó a la ignición de una tela de poliéster utilizada para la fabricación de muñecas en un hilador. Tras la reconstrucción de la fábrica, el M inisterio de Industria autorizó su reapertura el 4 de julio de 1990.

Entre la reapertura de la fábrica y el incendio de mayo de 1993, se produjeron numerosos incendios de menor importancia. U no de ellos, el acaecido en febrero de 1993, dañó considerablemente el edificio Tres, que aún se estaba reparando en el momento del incendio de mayo de 1993. El incendio de febrero se produjo por la noche, en una zona de almacenamiento, y afectó a materiales de poliéster y algodón. Varios días después, un inspector del trabajo visitó la instalación y emitió un informe en el que se indicaba la necesidad de introducir en la fábrica encargados de seguridad, equipos de seguridad y un plan de emergencia.

En los primeros informes del incendio de mayo de 1993 se señala que la fábrica $K$ ader constaba de cuatro edificios: tres de ellos destruidos por el fuego. En cierto sentido, es cierto; sin embargo, esos tres edificios formaban en realidad una sola estructura en forma de letra $E$ (véase la Figura 39.13), cuyas tres partes principales recibían el nombre de edificios U no, Dos y Tres. Cerca, había un taller de un piso de altura y otra estructura de cuatro pisos denominada edificio Cuatro.

La construcción en forma de $E$ era una estructura de cuatro alturas a base de bloques de hormigón sobre una estructura de acero. $\mathrm{H}$ abía ventanas en torno al perímetro de cada piso, y el tejado era levemente inclinado, rematado en pico. Cada parte del edificio contaba con un ascensor de mercancías y dos escaleras de 1,5 metros de ancho. L os ascensores de mercancías eran jaulas de barrotes.

Todos los edificios de la fábrica estaban equipados con sistemas de alarma contra incendios. Ninguno de ellos disponía de rociadores automáticos de agua, sino de extintores portátiles, y había mangueras contra incendios instaladas en los muros exteriores y en los huecos de las escaleras de cada edificio. $\mathrm{N}$ inguna parte de la estructura de acero del edificio estaba revestida contra incendios.

La información sobre el número total de trabajadores presentes en la fábrica es contradictoria. La Federación de industrias tailandesas se comprometió a ayudar a 2.500 trabajadores que quedaron sin empleo a causa del incendio, pero no está claro cuántos se encontraban allí en un momento dado. En el momento del incendio, se notificó que había 1.146 trabajadores en el edificio Uno: 36 en el primer piso, 10 en el segundo, 500 en el tercero y 600 en el cuarto. En el edificio D os había 405 trabajadores: 60 en el primer piso, 5 en el segundo, 300 en el tercero y 40 en el cuarto. No está claro cuántos trabajadores había en el edificio Tres, pues parte de él aún estaba en obras. La mayoría de los trabajadores de la fábrica eran mujeres. 
Figura 39.13 • Plano de la instalación de la fábrica de juguetes Kader

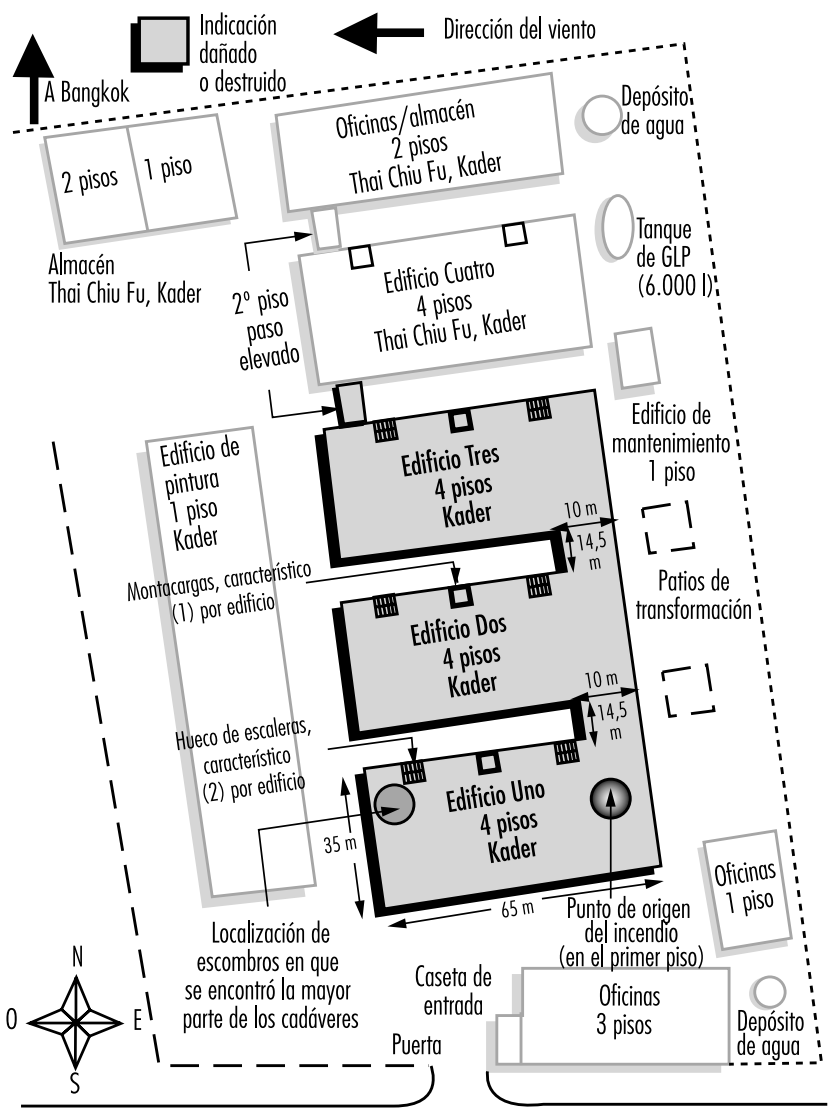

Calle Phutthamonthon 4

\section{El incendio}

El lunes 10 de mayo era un día normal de trabajo en la fábrica $\mathrm{K}$ ader. A proximadamente a las 4.00 p.m., cuando iba a terminar el turno de día, se descubrió un pequeño incendio en el primer piso, cerca del extremo sur del edificio U no. Esta zona se utilizaba para empaquetar y almacenar los productos acabados, de modo que contenía una considerable carga de combustible (véase la Figura 39.14). Todos los edificios de la fábrica contenían una carga combustible compuesta de telas, plásticos y materiales de relleno, así como de otros materiales normales de trabajo.

Los guardias de seguridad cercanos al incendio trataron de extinguir las llamas sin éxito; a las 4.21 p.m. llamaron a la brigada de bomberos de la policía local. Las autoridades recibieron dos llamadas más, a las 4.30 p.m. y a las 4.31 p.m. A pesar de que la fábrica $K$ ader se encuentra justo fuera del territorio jurisdiccional de Bangkok, respondieron a la llamada tanto los bomberos de Bangkok como los de la provincia de Nakhon Pathom.

$M$ ientras los trabajadores y los guardias de seguridad trataban en vano de extinguir el fuego, el edificio empezó a llenarse de humo y de productos de combustión. Los supervivientes contaron que en el edificio U no no llegó a sonar la alarma de incendio, pero que muchos trabajadores se alarmaron al ver humo en los pisos superiores. Parece ser que, a pesar del humo, los guardias de seguridad dijeron a algunos trabajadores que permanecieran en sus puestos de trabajo, ya que se trataba de un incendio menor que no tardarían en controlar.
El fuego se propagó rápidamente a todo el edificio U no y pronto resultó imposible permanecer en los pisos superiores. Las llamas bloquearon el hueco de la escalera del extremo sur del edificio, de modo que la mayor parte de los trabajadores acudieron rápidamente a la escalera norte. Esto quiere decir que había aproximadamente 1.100 personas tratando de abandonar los pisos tercero y cuarto por una sola escalera.

Los primeros bomberos llegaron a las 4.40 p.m.; habían tardado más de lo normal debido a la localización relativamente lejana de la instalación y a las condiciones del tráfico de Bangkok. Cuando llegaron, el edificio U no era ya pasto de las llamas y empezaba a derrumbarse, mientras la gente saltaba de los pisos tercero y cuarto.

A pesar de los esfuerzos de la brigada de incendios, el edificio Uno se vino completamente abajo hacia las 5.14 p.m. L os fuertes vientos que soplaban hacia el norte extendieron rápidamente las llamas a los edificios Dos y Tres antes de que los bomberos pudieran impedirlo. Según se notificó, el edificio D os se derrumbó a las 5.30 p.m. y el edificio Tres a las 6.05 p.m. La brigada de incendios logró evitar que el fuego entrara en el edificio Cuatro y en el pequeño taller situado allí cerca, y los

Figura 39.14 • Disposición interna de los edificios Uno, Dos y Tres.

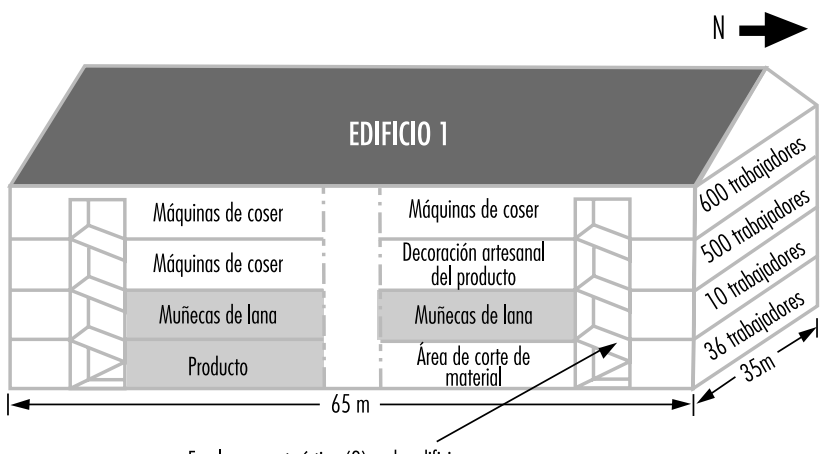

Escalera característica (2) cada edificio
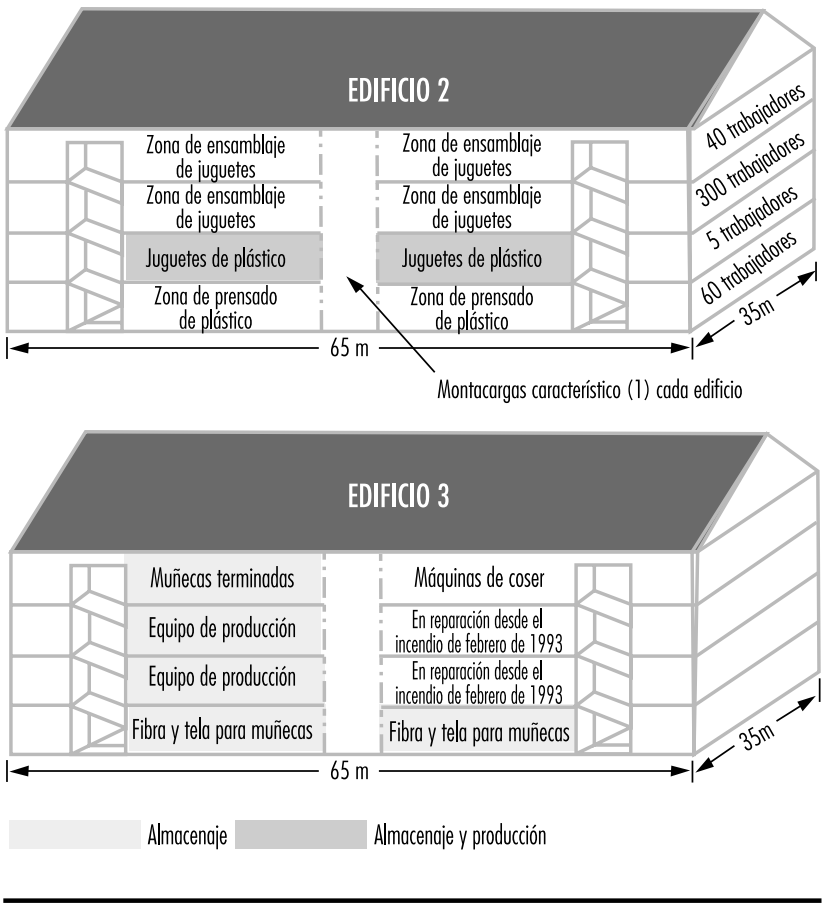
bomberos consiguieron controlar el incendio a las 7.45 p.m. En la batalla se emplearon aproximadamente 50 equipos de lucha contra el fuego.

Al parecer, las alarmas de incendios de los edificios D os y Tres funcionaron bien, y todos los trabajadores que se encontraban en ellos salieron con vida. Los trabajadores del edificio U no no tuvieron tanta suerte. M uchos de ellos saltaron desde los pisos superiores. En total, fueron trasladados al hospital 469 trabajadores, de los que murieron 20. L os demás muertos fueron encontrados en la búsqueda posterior al incendio en las ruinas de la escalera norte del edificio. Muchos de ellos habían fallecido a causa de productos de combustión letales, antes o durante el derrumbe del edificio. Según los últimos datos disponibles, 188 personas, en su mayoría mujeres, murieron como consecuencia de este incendio.

Aun empleando seis grandes grúas hidráulicas que se trasladaron al lugar para facilitar la búsqueda de las víctimas, pasaron varios días hasta que se recuperaron todos los cadáveres. No se registraron muertos entre los bomberos, aunque sí un herido.

EI tráfico circundante, que normalmente está congestionado, dificultó el traslado de las víctimas al hospital. Casi 300 trabajadores heridos fueron trasladados al cercano hospital Sriwichai II, pero muchos de ellos fueron enviados a otros centros médicos cuando el número de víctimas superó la capacidad del hospital.

Al día siguiente, el hospital Sriwichai II informó que había acogido a 111 víctimas del incendio. El hospital $\mathrm{K}$ asemrat ingresó a 120; Sriwichai Pattanana a 60; Sriwichai I a 50; R atanathibet I a 36; Siriraj a 22; y Bang Phai a 17. 0 tros 53 trabajadores heridos fueron llevados a otros centros médicos de la zona. En total, 22 hospitales de Bangkok y de la provincia de Nakhon Pathom participaron en el tratamiento de las víctimas del siniestro.

El hospital Sriwichai II notificó que el $80 \%$ de las 111 víctimas que había acogido sufría lesiones graves y el $30 \%$ precisaba intervención quirúrgica. La mitad de los pacientes adolecían únicamente de inhalación de humo, pero el resto sufrían también quemaduras y fracturas que iban desde tobillos rotos hasta fracturas de cráneo. Al menos el $10 \%$ de los trabajadores de $\mathrm{K}$ ader hospitalizados en el Sriwichai II corrían peligro de sufrir parálisis permanente.

Determinar el origen de este incendio fue todo un desafío, pues la parte de las instalaciones en que se inició el fuego quedó totalmente destruida y los supervivientes proporcionaron informaciones contradictorias. Dado que el incendio se declaró cerca de un gran cuadro de mandos eléctricos, los investigadores pensaron, en un principio, que la causa pudo haber sido algún problema en el sistema eléctrico. Se consideró también la posibilidad de un incendio provocado. Por lo demás, en la actualidad, las autoridades tailandesas opinan que la fuente de ignición pudo haber sido un cigarrillo arrojado descuidadamente.

\section{Análisis del incendio}

Durante 82 años, el incendio declarado en 1911 en la fábrica Triangle Shirtwaist, en la ciudad de Nueva York, fue el peor incendio industrial con pérdida de vidas humanas, en el que las víctimas se limitaron al edificio en que se originó el fuego. Con 188 fallecidos, la fábrica $\mathrm{K}$ ader ha sustituido al incendio de Triangle en los libros de marcas.

Al analizar el incendio de K ader, la comparación directa con el incendio de Triangle ofrece algunas referencias útiles. Ambos edificios se parecían en varias cosas. La situación de las salidas era incorrecta, los sistemas fijos de protección contra incendios fueron insuficientes 0 ineficaces, los materiales iniciales de combustión prendieron fácilmente y las separaciones o sectori- zaciones de incendios horizontales y verticales eran inadecuadas. A demás, ninguna de las dos empresas había ofrecido a sus trabajadores una formación adecuada de seguridad contra incendios. A hora bien, existe una clara diferencia entre estos dos incendios: el edificio de la fábrica Triangle Shirtwaist no se derrumbó, a diferencia del de K ader.

La situación inadecuada de los puntos de salida es, tal vez, el factor más significativo de la elevada mortalidad de los incendios de K ader y Triangle. Si las disposiciones en materia de salidas de la NFPA 101, el Código de salvamento, que se adoptaron como resultado directo del incendio de Triangle, se hubieran aplicado en el edificio $\mathrm{K}$ ader, se habrían perdido muchas menos vidas humanas (N FPA 101, 1994).

M uchos requisitos básicos del Código de salvamento se aplican directamente al incendio de $\mathrm{K}$ ader. Por ejemplo, dicho código exige que cualquier edificio o estructura se construya, organice y gestione de modo que sus ocupantes no corran ningún peligro indebido por fuego, humo, emanaciones o pánico que pueda surgir durante una evacuación o en el tiempo que se tarda en socorrerles.

También exige que todos los edificios cuenten con el suficiente número de salidas y otros medios de salvaguardia del tamaño suficiente y en los puntos adecuados para ofrecer una vía de escape a todos los ocupantes. Dichas salidas deben ser las adecuadas para la estructura o el edificio concreto, habida cuenta de su empleo, del número de ocupantes y la capacidad de los mismos, de la protección contra incendios disponible, de la altura y tipo de construcción y de cualquier otro factor necesario para ofrecer a todos los ocupantes un nivel razonable de seguridad. O bviamente, este no era el caso de la fábrica $K$ ader, donde las llamas bloquearon uno de los dos huecos de escaleras del edificio Uno, lo que obligó a unas 1.100 personas a huir de los pisos tercero y cuarto por la misma escalera.

A demás, las salidas deben organizarse y mantenerse de forma que ofrezcan una vía libre y sin obstáculos para salir de todas las partes del edificio, siempre que esté ocupado. L as salidas deben ser bien visibles y el camino que conduce a ellas ha de estar indicado de tal modo que todos los ocupantes del edificio física y mentalmente capacitados conozcan la dirección de escape desde cualquier punto.

Todas las salidas o aperturas verticales entre pisos de un edificio deben estar aisladas o protegidas del modo necesario para que los ocupantes estén razonablemente a salvo mientras salen y para impedir que el fuego, el humo o las emanaciones se propaguen de unos pisos a otros antes de que aquéllos hayan podido utilizar las salidas.

En el resultado de los incendios de Triangle y de Kader influyó significativamente la falta de unas separaciones o sectorizaciones horizontales y verticales adecuadas. Las dos fábricas se organizaron y construyeron de tal modo que un incendio en un piso inferior podía extenderse rápidamente a los superiores, atrapando a un gran número de trabajadores.

En las instalaciones industriales son característicos los espacios de trabajo grandes y abiertos; para frenar la propagación del fuego, deben instalarse y mantenerse suelos y muros revestidos resistentes contra incendios. También debe impedirse que el incendio se extienda por fuera, a través de las ventanas de un piso a las de otro piso, como ocurrió en el incendio de Triangle.

El modo más eficaz de limitar la propagación vertical del fuego es aislar las escaleras, los ascensores y otras aberturas verticales entre pisos. EI hecho de que la fábrica $\mathrm{K}$ ader dispusiera de unos montacargas de barrotes abre serias dudas sobre la capacidad de la protección pasiva contra incendios del edificio para impedir la propagación vertical del fuego y el humo. 


\section{Formación en seguridad contra incendios y otros factores}

Otro factor que contribuyó a la enorme pérdida de vidas humanas en los incendios de Triangle y $\mathrm{K}$ ader fue la falta de una formación adecuada en seguridad contra incendios y los rígidos procedimientos de seguridad de ambas empresas.

Tras el incendio en el edificio $\mathrm{K}$ ader, los supervivientes notificaron que los ejercicios de evacuación y la formación en seguridad contra incendios habían sido mínimos; los guardias de seguridad sí habían recibido, al parecer, una formación elemental. La fábrica de Triangle Shirtwaist no contaba con ningún plan de evacuación y no se llevaban a cabo ejercicios de evacuación. Es más, los supervivientes de Triangle informaron tras el incendio que, por motivos de seguridad, se les solía detener cuando salían del edificio al final del día. Según varias acusaciones de los supervivientes de $\mathrm{K}$ ader, también en este caso los mecanismos de seguridad entorpecieron la salida; estas acusaciones aún se están investigando. Sea como fuere, la falta de un plan de evacuación bien entendido parece haber sido un importante factor de la elevada mortalidad del incendio de $\mathrm{K}$ ader. En el capítulo 31 del Código de salvamento se contemplan los ejercicios de evacuación y la formación contra incendios.

La ausencia de sistemas fijos de protección automática contra incendios también influyó en el resultado de los incendios de Triangle y $\mathrm{K}$ ader. Ninguna de las dos instalaciones contaba con rociadores automáticos de agua, aunque los edificios de $\mathrm{K}$ ader sí disponían de un sistema de alarma de incendio. Según el Código de salvamento, deben instalarse alarmas de incendios en aquellos edificios cuyas dimensiones, organización u ocupación hacen improbable que los propios ocupantes adviertan inmediatamente un incendio. Por desgracia, según los informes, las alarmas no llegaron a funcionar en el edificio Uno, lo que provocó un considerable retraso en la evacuación. No se produjeron fallecimientos en los edificios Dos y Tres, en los que el sistema de alarma funcionó bien.

Los sistemas de alarma de incendios deben diseñarse, instalarse y mantenerse siguiendo las normas establecidas en documentos como NFPA 72, el Código nacional de alarma de incendio (NFPA 72, 1993). Los sistemas de rociado de agua deben diseñarse e instalarse con arreglo a documentos como NFPA 13, Installation of Sprinkler Systems y mantenerse de acuerdo con NFPA 25, Inspection, Testing, and $M$ aintenance of $W$ ater- $B$ ased Fire Protection Systems (NFPA 13, 1994; N FPA 25, 1995).

Los materiales iniciales de combustión en ambos incendios, Triangle y $\mathrm{K}$ ader, fueron similares. EI incendio de Triangle se inició en contenedores de restos textiles y se propagó rápidamente a telas y ropas combustibles, antes de prender en los muebles, algunos de los cuales estaban impregnados de aceite de máquinas. El material inicial de combustión de la fábrica $\mathrm{K}$ ader consistió en telas de poliéster y algodón, plásticos y otros materiales utilizados para la fabricación de juguetes de trapo, muñecas de plástico y productos similares. Son materiales que prenden con gran facilidad, que pueden contribuir a un rápido crecimiento del fuego y que tienen un alta tasa de liberación de calor.

Probablemente, la industria manipulará siempre materiales difíciles de proteger contra el fuego, pero los fabricantes deberían tener en cuenta estas características y tomar las precauciones necesarias para minimizar los riesgos que entrañan.

\section{Integridad estructural del edificio}

La diferencia más notable entre el incendio de Triangle y el de $K$ ader reside en el efecto del fuego sobre la integridad de la estructura. Aunque el incendio de Triangle destruyó los tres pisos superiores de un edificio de diez, su estructura permaneció intacta. En cambio, los edificios de K ader se derrumbaron con relativa facilidad, porque los soportes estructurales de acero no estaban revestidos contra incendios y no podían resistir altas temperaturas. En la inspección de los restos del incendio no se encontró evidencia alguna de que los elementos de acero pudieran haber estado revestidos contra el fuego.

O bviamente, el derrumbe de un edificio en un incendio representa una gran amenaza tanto para sus ocupantes como para los bomberos. Desde luego, no está claro que el colapso de los edificios de K ader incidiera directamente en el número de víctimas mortales, pues éstas posiblemente habían fallecido ya cuando el edificio se vino abajo. Si los trabajadores de los pisos superiores del edificio Uno hubieran tenido una protección contra los productos de la combustión y el calor cuando trataban de escapar, el derrumbe del edificio habría contribuido más directamente en la pérdida de vidas humanas.

\section{Principios de protección contra incendios}

Entre los principios de protección contra incendios que han sido objeto de una mayor atención a raíz del incendio de $\mathrm{K}$ ader se encuentran el diseño de las salidas, la formación de los ocupantes en seguridad contra incendios, los sistemas de detección automática y de supresión, las separaciones o sectorizaciones contra incendios y la integridad estructural. Estas enseñanzas no son nuevas. Se aprendieron hace más de 80 años con el incendio de Triangle Shirtwaist y, más recientemente, en otros incendios fatales de lugares de trabajo, como: la fábrica de procesamiento de pollos de $\mathrm{H}$ amlet, $\mathrm{C}$ arolina del $\mathrm{N}$ orte, EE.UU., en el que perecieron 25 trabajadores; la fábrica de muñecas en K uiyong, China, con 81 trabajadores muertos; y la central eléctrica de N ewark, New Jersey, EE.UU., donde fallecieron los 3 trabajadores de la central (G rant y K lem 1994; K lem 1992; K lem y G rant 1993).

En particular, los incendios de Carolina del Norte y $\mathrm{New}$ Jersey demuestran que la mera existencia de códigos y normas actualizados, como el Código de salvamento del NFPA, no impide la pérdida de vidas humanas. Para que surtan efecto, estos códigos y normas deben también adoptarse y aplicarse rigurosamente.

L as autoridades nacionales, estatales y locales deben analizar la aplicación de las normas en materia de construcción y de incendios para determinar si es necesario adoptar nuevos códigos o actualizar los existentes. Al llevar a cabo esta revisión, deberían comprobar también si se ha implantado un plan de revisión e inspección de edificios para garantizar el respeto de las normas. Por último, hay que proceder a una inspección periódica de seguimiento de los edificios existentes, para garantizar que se mantiene el más alto nivel de protección contra incendios a lo largo de toda la vida del edificio.

También los propietarios y gestores de edificios deben ser conscientes de su responsabilidad a la hora de garantizar un entorno laboral seguro para sus trabajadores. Como mínimo, deberían aplicarse los conocimientos actuales en protección contra incendios, tal como se reflejan en los códigos y normas, para minimizar la posibilidad de un incendio catastrófico.

$\mathrm{Si}$ los edificios de K ader hubiesen estado equipados con rociadores automáticos de agua y con alarmas de incendios en buen estado, la pérdida de vidas humanas podría no haber sido tan grande. Si las salidas del edificio U no hubieran estado mejor diseñadas, se podrían haber evitado cientos de heridos al saltar de los pisos tercero y cuarto. Si hubieran existido separaciones 0 sectorizaciones horizontales y verticales, el incendio podría no haberse propagado tan rápidamente a todo el edificio. Si los elementos de acero de la estructura hubieran estado revestidos, los edificios podrían no haberse derrumbado.

En palabras del filósofo George Santayana, "quienes olvidan el pasado están condenados a repetirlo". En muchos aspectos, el incendio de K ader de 1993 fue, lamentablemente, una repetición del incendio de Triangle Shirtwaist de 1911. Mirando al 
futuro, tenemos que hacer todo lo necesario, como sociedad global, para impedir que la historia vuelva a repetirse.

\section{CONSECUENCIAS DE LAS CATAST ROFES: LECCIO NES DESDE UNA PERSPECTIVA MEDICA}

José L uis Zeballos*

América L atina y el $C$ aribe no se han ahorrado su cuota de catástrofes naturales. Casi todos los años, sucesos catastróficos provocan muertos, heridos y un enorme perjuicio económico. Se estima que, en esta zona, las catástrofes naturales más graves de los dos últimos decenios ocasionaron pérdidas de bienes que afectaron a casi 8 millones de personas y provocaron unos 500.000 heridos y unos 150.000 muertos. Se trata de cifras basadas esencialmente en fuentes oficiales. (Es bastante difícil obtener información precisa sobre las catástrofes repentinas, pues existen múltiples fuentes pero no un sistema normalizado de información.) La Comisión E conómica para América Latina y el Caribe (CEPAL) estima que cada año, por término medio, las catástrofes en América Latina y el Caribe cuestan 1.500 millones de dólares de EE.UU. y se cobran 6.000 vidas humanas (Jovel 1991).

En la Tabla 39.33 se recogen las principales catástrofes naturales que se abatieron sobre países de esta región del mundo en el período de 1970 a 1993. H ay que señalar que no se incluyen las catástrofes lentas, como sequías e inundaciones.

\section{Repercusión económica}

En las últimas décadas, la CEPAL ha llevado a cabo un amplio trabajo de investigación sobre los efectos sociales y económicos de las catástrofes. Dicho trabajo ha demostrado claramente que las catástrofes tienen consecuencias negativas para el avance social y económico de los países en desarrollo. De hecho, las pérdidas monetarias causadas por una catástrofe grave superan con frecuencia los ingresos brutos anuales del país afectado. No es sorprendente que estos sucesos puedan paralizar países y potenciar las turbulencias generalizadas en los terrenos político y social.

En esencia, las catástrofes tienen tres tipos de efectos económicos:

- efectos directos sobre los bienes de la población afectada;

- efectos indirectos ocasionados por la pérdida de producción económica y de servicios,

- efectos secundarios que se hacen visibles tras la catástrofe: por ejemplo, reducción de la renta nacional, aumento de la inflación, problemas de comercio exterior, aumento del gasto financiero, déficit fiscal, reducción de las reservas monetarias, etc. (J ovel 1991).

En la Tabla 39.34 se ofrece una estimación de las pérdidas ocasionadas por seis graves catástrofes naturales. Aunque no parezcan especialmente devastadoras para países desarrollados con economías fuertes, pueden tener una repercusión importante y duradera sobre las frágiles y debilitadas economías de los países en desarrollo (O PS 1989).

\section{Infraestructura sanitaria}

En cualquier emergencia desencadenada por una catástrofe grave, la primera prioridad es salvar vidas y prestar inmediatamente asistencia de emergencia a los heridos. Entre los servicios

*Este artículo constituye una adaptación autorizada de Zeballos 1993b.
Tabla 39.33 • Principales catástrofes en América Latina y el Caribe, 1970-1993.

\begin{tabular}{|c|c|c|c|c|}
\hline Año & País & $\begin{array}{l}\text { Tipo de } \\
\text { catástrofe }\end{array}$ & $\begin{array}{l}\text { №de } \\
\text { muertes } \\
\text { notificadas }\end{array}$ & $\begin{array}{l}\text { Estimación } \\
\text { del } n \text {-de } \\
\text { personas } \\
\text { afectadas }\end{array}$ \\
\hline 1970 & Perú & Seísmo & 66.679 & 3.139 .000 \\
\hline 1972 & Nicaragua & Seísmo & 10.000 & 400.000 \\
\hline 1976 & Guatemala & Seísmo & 23.000 & 1.200 .000 \\
\hline 1980 & Haití & Huracán (Allen) & 220 & 330.000 \\
\hline 1982 & México & Erupción volcánica & 3.000 & 60.000 \\
\hline 1985 & México & Seísmo & 10.000 & 60.000 \\
\hline 1985 & Colombia & Erupción volcánica & 23.000 & 200.000 \\
\hline 1986 & El Salvador & Seísmo & 1.100 & 500.000 \\
\hline 1988 & Jamaica & Huracán (Gilbert) & 45 & 500.000 \\
\hline 1988 & México & Huracán (Gilbert) & 250 & 200.000 \\
\hline 1988 & Nicaragua & Huracán (Joan) & 116 & 185.000 \\
\hline 1989 & $\begin{array}{l}\text { Montserrat, } \\
\text { Dominica }\end{array}$ & Huracán (Hugo) & 56 & 220.000 \\
\hline 1990 & Perú & Seísmo & 21 & 130.000 \\
\hline 1991 & Costa Rica & Seísmo & 51 & 19.700 \\
\hline 1992 & Nicaragua & Tsunami & 116 & 13.500 \\
\hline 1993 & Honduras & Tormenta tropical & 103 & 11.000 \\
\hline
\end{tabular}

Fuente: OPS 1989; OFDA (USAID), 1989; UNDRO 1990

médicos de emergencia movilizados por estos motivos, los hospitales desempeñan una función esencial. De hecho, en países con un sistema normalizado de respuesta a emergencias (donde el concepto de "servicios médicos de emergencia" engloba la asistencia de emergencia por medio de la coordinación de subsistemas independientes entre los que se incluyen paramédicos, bomberos y equipos de rescate), los hospitales constituyen el componente principal de dicho sistema (OPS 1989).

Los hospitales y otras instalaciones de asistencia sanitaria presentan una alta densidad de ocupación. Alojan a pacientes, personal y visitas, y funcionan 24 horas al día. Los pacientes pueden estar rodeados de equipos especiales o conectados a sistemas de mantenimiento de la vida que dependen del

Tabla 39.34 • Pérdidas ocasionadas en seis catástrofes naturales.

\begin{tabular}{|c|c|c|c|}
\hline Catástrofe & Lugar & Año(s) & $\begin{array}{l}\text { Pérdidas totales } \\
\text { (en millones de } \\
\text { dólares de EE.UU.) }\end{array}$ \\
\hline Seísmo & México & 1985 & 4.337 \\
\hline Seísmo & El Salvador & 1986 & 937 \\
\hline Seísmo & Ecuador & 1987 & 1.001 \\
\hline $\begin{array}{l}\text { Erupción volcánica } \\
\text { (Nevado del Ruiz) }\end{array}$ & Colombia & 1985 & 224 \\
\hline $\begin{array}{l}\text { Inundaciones, sequía } \\
\text { ("El Niño") }\end{array}$ & $\begin{array}{l}\text { Perú, Ecuador, } \\
\text { Bolivia }\end{array}$ & 1982.83 & 3.970 \\
\hline Huracán (Joan) & Nicaragua & 1988 & 870 \\
\hline
\end{tabular}


Tabla 39.35 - N úmero de hospitales y de camas de hospital dañadas o destruidas en tres catástrofes naturales graves.

\begin{tabular}{lcc} 
Tipo de catástrofe & $\begin{array}{l}\text { № de hospitales } \\
\text { dañados o destruidos }\end{array}$ & $\begin{array}{c}\text { №de camas } \\
\text { perdidas }\end{array}$ \\
$\begin{array}{l}\text { Seísmo, México (Distrito Federal, } \\
\text { septiembre de 1985) }\end{array}$ & 13 & 4.387 \\
$\begin{array}{l}\text { Seísmo, El Salvador (San Salvador, } \\
\text { octubre de 1986) }\end{array}$ & 4 & 1.860 \\
$\begin{array}{l}\text { Huracán Gilbert (Jamaica, } \\
\text { septiembre de 1988) }\end{array}$ & 23 & 5.085 \\
$\begin{array}{l}\text { Total } \\
\text { Fuente: OPS 1989; OFDA(USAID) 1989; CEPAL. }\end{array}$ & 40 & 11.332 \\
\hline
\end{tabular}

suministro de energía. Según documentos en poder del Banco Interamericano de Desarrollo (BID) (comunicación personal, Tomas Engler, BID), el coste estimado de una cama en un hospital especializado varía de un país a otro, pero la media oscila entre 60.000 y 80.000 dólares de EE.UU., y es mayor para instalaciones altamente especializadas. En Estados U nidos, y especialmente en California, con su amplia experiencia en ingeniería de resistencia a seísmos, el coste de una cama de hospital puede superar los 110.000 dólares de EE.UU.. En suma, los hospitales modernos son instalaciones muy complejas que combinan la función de hoteles, oficinas, laboratorios y almacenes (Peisert y cols. 1984; FE M A 1990).

Estas instalaciones de asistencia sanitaria son muy vulnerables a huracanes y terremotos, lo que ha quedado sobradamente demostrado en experiencias anteriores en América L atina y el Caribe. Por ejemplo, como se muestra en la Tabla 39.35, sólo tres catástrofes del decenio de 1980 dañaron 39 hospitales y destruyeron unas 11.332 camas de hospital en El Salvador, Jamaica y M éxico. A demás de los daños físicos ocasionados a estas instalaciones en momentos críticos, hay que tener en cuenta la pérdida de vidas humanas (incluida la muerte de profesionales locales altamente cualificados con un futuro prometedor) (véanse las Tablas 39.36 y 39.37).

Actualmente, la capacidad de muchos hospitales de América Latina para resistir a catástrofes sísmicas es incierta. Son muy numerosos los instalados en estructuras antiguas, algunas ellas de la época colonial española; y aunque otros muchos ocupan

Tabla 39.37 - Camas de hospital perdidas a consecuencia del terremoto de Chile de marzo de 1985.

\begin{tabular}{lllcc} 
Zona & № de & № & \multicolumn{2}{c}{ Camas perdidas en la zona } \\
& hospitales & de camas & No. & $\%$ \\
$\begin{array}{l}\text { Area urbana } \\
\text { (Santiago) }\end{array}$ & 26 & 11.464 & 2.373 & 20,7 \\
$\begin{array}{l}\text { Zona 5 (Viña } \\
\text { del Mar, Valparaíso, } \\
\text { San Antonio) }\end{array}$ & 23 & 4.573 & 622 & 13,6 \\
$\begin{array}{l}\text { Zona 6 (Rancagua) } \\
\text { Zona 7 (Ralca, } \\
\text { Meula) }\end{array}$ & 15 & 1.413 & 212 & 15,0 \\
Total & 15 & 2.286 & 64 & 2,8 \\
Fuente: Wyllie y Durkin 1986. & & 19.736 & 3.271 & 16,6 \\
\hline
\end{tabular}

Tabla 39.36 • Víctimas del derrumbamientos de dos hospitales en el terremoto de M éxico de 1985.

\begin{tabular}{lcccc} 
& \multicolumn{4}{c}{ Hospitales derrumbados } \\
& Hospital general & Hospital de Juárez \\
& Número & $\%$ & Número & $\%$ \\
Fallecidos & 295 & 62,6 & 561 & 75,8 \\
Salvados & 129 & 27,4 & 179 & 24,2 \\
Desaparecidos & 47 & 10,0 & - & - \\
Total & 471 & 100,0 & 740 & 100,0 \\
Fuente: OPS 1987. & & & & \\
\hline
\end{tabular}

edificios contemporáneos de atractivo diseño arquitectónico, la laxa aplicación de las normas de construcción pone en duda su capacidad de resistencia a terremotos.

\section{Factores de riesgo en terremotos}

De los distintos tipos de catástrofes naturales repentinas, los terremotos son, con mucho, los más dañinos para los hospitales. Naturalmente, cada terremoto presenta sus propias características en cuanto a epicentro, tipo de ondas sísmicas, naturaleza geológica del suelo por el que se propagan las ondas, etc. No obstante, los estudios han puesto de manifiesto la existencia de una serie de factores comunes que tienden a ocasionar muertes y lesiones, y algunos otros que tienden a impedirlas. Entre ellos se encuentran las características estructurales relacionadas con el derrumbe de edificios, factores asociados al comportamiento humano y determinadas características de los equipos no estructurales, mobiliario y otros artículos, del interior de los edificios.

En los últimos años, estudiosos y planificadores han prestado especial atención a la identificación de los factores de riesgo en hospitales con la esperanza de elaborar mejores recomendaciones y normas para la construcción y organización de éstos en áreas muy vulnerables. Una breve enumeración de los factores de riesgo se muestra en la Tabla 39.38. Se ha observado que estos factores de riesgo, y especialmente los relacionados con los aspectos estructurales, influyeron en las pautas de destrucción de un terremoto ocurrido en Armenia en diciembre de 1988, que ocasionó la muerte a unas 25.000 personas, afectó a 1.100 .000 y destruyó 0 dañó gravemente 377 escuelas, 560 instalaciones sanitarias y 324 centros públicos y culturales (USAID 1989).

Tabla 39.38 - Factores de riesgo asociados con los daños sísmicos a la infraestructura hospitalaria.

\begin{tabular}{|c|c|c|}
\hline Estructural & No estructural & Del comportamiento \\
\hline Diseño & Equipo médico & $\begin{array}{l}\text { Información a la } \\
\text { población }\end{array}$ \\
\hline \multirow[t]{2}{*}{ Calidad de la construcción } & Equipo de laboratorio & Motivación \\
\hline & Equipo de oficina & Planes \\
\hline Materiales & Archivadores, estantes & Programas educativos \\
\hline Condiciones del suelo & $\begin{array}{l}\text { Hornos, refrigeradores, } \\
\text { calentadores }\end{array}$ & $\begin{array}{l}\text { Formación del personal de } \\
\text { asistencia sanitaria }\end{array}$ \\
\hline Características sísmicas & Aparatos de Rayos X & \\
\hline Hora del acontecimiento & Materiales reactivos & \\
\hline Densidad de población & & \\
\hline
\end{tabular}


En junio de 1990, un terremoto en Irán provocó daños de importancia similar, ocasionó la muerte a unas 40.000 personas, hirió a otras 60.000 , dejó sin hogar a 500.000 y derrumbó entre el $60 \%$ y el $90 \%$ de los edificios en las áreas afectadas (UNDRO 1990).

Para enfrentarse a este tipo de calamidades, se celebró en 1989 en Lima, Perú, un seminario internacional sobre la planificación, diseño, reparación y organización de hospitales en zonas propensas a los terremotos. Este seminario, patrocinado por la O PS, la U niversidad Nacional de Ingeniería de Perú y el Centro Peruano-Japonés de Investigación Sísmica (CISM ID), reunió a arquitectos, ingenieros y gestores hospitalarios para estudiar los diversos aspectos de las instalaciones sanitarias localizadas en dichas zonas. El seminario aprobó una serie de recomendaciones y requisitos técnicos para realizar los análisis de vulnerabilidad de las infraestructuras hospitalarias, mejorar el diseño de las nuevas instalaciones y establecer medidas de seguridad en los hospitales ya existentes, con especial atención a los situados en zonas de alto riesgo sísmico (CISM ID 1989)1

\section{Recomendaciones sobre la preparación de Hospitales}

Como sugiere lo anterior, la preparación de los hospitales para posibles catástrofes constituye un importante cometido de la O ficina para la preparación de emergencias y el socorro en catástrofes de la O PS. En los últimos diez años, ha animado a los Estados miembros a emprender actividades con este objetivo, entre las que se incluyen las siguientes:

- clasificación de los hospitales en función de sus factores de riesgo y puntos débiles;

- desarrollo de planes de respuesta internos y externos para hospitales y formación del personal;

- desarrollo de planes de emergencia y establecimiento de medidas de seguridad para el personal profesional y técnico,

- refuerzo de los sistemas de apoyo que ayudan a los hospitales a funcionar en situaciones de emergencia.

M ás en general, un objetivo capital de la actual D écada de las $\mathrm{N}$ aciones U nidas para la R educción de las $\mathrm{C}$ atástrofes $\mathrm{N}$ aturales (IDNDR) es atraer, motivar y comprometer a las autoridades sanitarias y políticas de todo el mundo para que refuercen los servicios sanitarios encargados de la asistencia en catástrofes y reduzcan su fragilidad en los países en desarrollo.

\section{Cuestiones relacionadas con los accidentes tecnológicos}

En las dos últimas décadas, los países en desarrollo han entablado una intensa competencia para conseguir el desarrollo industrial.

\section{Las principales razones de esa competencia son las siguientes:}

- atraer inversión de capital y generar puestos de trabajo;

- satisfacer la demanda interna de productos a menor coste y reducir la dependencia del mercado internacional;

- competir con mercados internacionales y subregionales,

- sentar las bases del desarrollo.

Por desgracia, los esfuerzos realizados no siempre han dado como resultado los objetivos apetecidos. En efecto, la flexibilidad para atraer la inversión de capital, la falta de una normativa sólida en materia de seguridad industrial y protección ambiental, la negligencia en el funcionamiento de las fábricas industriales, el uso de tecnologías obsoletas y otros factores han contribuido a aumentar el riesgo de accidentes tecnológicos en determinadas zonas.

Además, la falta de reglamentación sobre el establecimiento de asentamientos humanos en las inmediaciones de las industrias es un factor de riesgo adicional. En las principales ciudades latinoamericanas, es común ver asentamientos humanos prácticamente en torno a los complejos industriales, y los habitantes de esos asentamientos no están al corriente de los posibles riesgos (Zeballos 1993a).

Para evitar accidentes como el sucedido en Guadalajara (M éxico) en 1992, se sugieren las siguientes líneas directrices para el establecimiento de industrias químicas, al objeto de proteger a los trabajadores y a la población en general:

- elección de la tecnología adecuada y estudio de alternativas;

- localización apropiada de las plantas industriales;

- reglamentación de los asentamientos humanos en las inmediaciones de las industrias;

- consideraciones de seguridad para la transferencia de tecnología;

- inspección sistemática de las plantas por parte de las autoridades locales;

- conocimientos y experiencias aportados por agencias especializadas;

- papel de los trabajadores en la observancia de las normas de seguridad;

- legislación estricta;

- clasificación de materiales tóxicos y estricta supervisión de su utilización;

- educación de la población y formación de los trabajadores;

- establecimiento de mecanismos de reacción en caso de emergencia,

- formación de los trabajadores sanitarios en planes de emergencia para accidentes tecnológicos.

\section{Referencias}

Agencia de la OCDE para la Energía Nuclear. 1987. The Radiological Impact of the Chernobyl Accident in OECD Countries. París: Agencia de la OCDE para la Energía Nuclear.

American Psychiatric Association (APA). 1994. DSM IV Diagnostic and Statistical $M$ anual of $M$ ental $D$ isorders. Washington, DC: APA

Andersson, N, M Kerr Muir, MK Ajwani, S Mahashabde, A Salmon, K V aidyanathan. 1986. Persistent eye watering among Bhopal survivors. Lancet 2:1152.

Baker, EL, M Zack, JW M iles, L Alderman, M Warren, RD Dobbin, S Miller, WR T eeters. 1978. Epidemic malathion poisoning in Pakistan malaria working. Lancet 1:31-34.
Baum, A, L Cohen, M H all. 1993. Control and intrusive memories as possible determinants of chronic stress. Psychosom M ed 55:274-286.

Bertazzi, PA. 1989. Industrial disasters and epidemiology. A review of recent experiences. Scand I W ork Environ $\mathrm{H}$ ealth 15:85-100.

-. 1991. Long-term effects of chemical disasters. Lessons and result from Seveso. Sci T otal Environ 106:5-20.

Bromet, EJ, DK Parkinson, HC Schulberg, LO Dunn, PC Condek. 1982. M ental health of residents near the Three M ile Island reactor: A comparative study of selected groups. J Prev Psychiat 1(3):225-276

Bruk, GY, NG Kaduka, VI Parkhomenko. 1989. Contaminación atmosférica por radionúclidos como resultado del accidente de la central nuclear de Chernobyl y su contribución a la radiación de la población (en ruso). M ateriales del Primer Congreso R adiológico de la U nión celebrado los días 21-27 de agosto en M oscú. R esúmenes (en ruso). Puschkino, 1989, vol. II:414-416.

Bruzzi, P. 1983. Health impact of the accidental release of TCDD at Seveso. En Accidental Exposure to Dioxins. $\mathrm{H}$ uman $\mathrm{H}$ olth Aspects, dirigido por $\mathrm{F} C \mathrm{Cou}$ ston y F Pocchiari. N ueva Y ork: Academic Press.

Cardis, E, ES Gilbert, L Carpenter. 1995. Effects of low doses and low dose rates of external ionizing radiation: Cancer mortality among nuclear industry workersin three countries. R ad R es 142:117-132.

Centers for Disease Control (CDC). 1989. The Public $\mathrm{H}$ ealth $\mathrm{C}$ onsequences of $\mathrm{D}$ isasters. A tlanta: $C D C$. 
Centro Peruano-Japones de Investigaciones Sísmicas y M itigación de Desastres. U niversidad Nacional de Ingeniería (CISM ID). 1989. Seminario Internacional de Planeamiento, D iseño, R eparación y Administración de Hospitales en Zonas Sísmicas: Conclusiones y Recomendaciones. Lima: CISM ID/U niv N acional de Ingeniería.

Chagnon, SAJR, RJ Schicht, RJ Semorin. 1983. A Plan for Research on Floods and their M itigation in the U nited States. Champaign, Illinois: Illinois State W ater Survey.

Chen, PS, M L Luo, CK Wong, CJ Chen. 1984. Polychlorinated biphenyls, dibenzofurans, and quaterphenyls in toxic rice-bran oil and PCBs in the blood of patients with $P C B$ poisoning in Taiwan. Am J Ind M ed 5:133-145.

Coburn, A, R Spence. 1992. Earthquake Protection. Chichester: Wiley.

Comisión Internacional de Protección Radiológica (CIPR ). 1991. Annals of the ICR P. ICR P Publication N o. 60. Oxford: Pergamon Press.

Comité Científico de las Naciones U nidas para el Estudio de los efectos de las R adiaciones A tómicas (U N SCEAR ). 1988. Sources, E ffects and R isks of I onizing Radiation. N ueva Y ork: U NSCEAR .

- . 1993. Sources and $E$ ffects of I onizing R adiation. Nueva Y ork: UNSCEAR

- . 1994. Sources and E ffects of I onizing Radiation. Nueva Y ork: UNSCEAR

Consejo de la Comunidad Europea (CCE). 1982. Directiva del Consejo de 24 de junio relativa a los riesgos de accidentes graves en determinadas actividades industriales (82/501/ CEE). D iario 0 ficial de las Comunidades E uropeas L 230:1-17.

- . 1987. Directiva del Consejo de 19 de marzo, enmienda de la Directiva 82/501/ CEE relativa a los riesgos de accidentes graves en determinadas actividades industriales (87/216/ CEE). D iario 0 ficial de las Comunidades E uropeas L 85:36-39.

Das, JJ. 1985a. Aftermath of Bhopal tragedy. J Indian M ed Assoc 83:361-362.

-. 1985b. The Bhopal tragedy. J Indian M ed Assoc 83:72-75.

Dew, M A, EJ Bromet. 1993. Predictors of temporal patterns of psychiatric distress during ten years following the nuclear accident at Three M ile Island. Social Psych Psychiatric E pidemiol 28:49-55.

Federación Internacional de Sociedades de la Cruz Roja y de la M edialuna Roja (IFRCS). 1993. The W orld D isaster R eport. D ordrecht: M artinus N ijhoff.

Federal Emergency Management Agency (FEMA). 1990. Seismic considerations: H ealth care facilities Earthquake $\mathrm{H}$ azard Reduction Series, No. 35 Washington, DC: FEM A.

Frazier, K. 1979. The Violent Face of Nature: Severe Phe nomena and $\mathrm{N}$ atural $\mathrm{D}$ isasters. Floods. Nueva Y ork: William M orrow \& Co.

Freidrich Naumann Foundation. 1987. Industrial H azards in T ransnational W ork: Risk, Equity and $E$ mpowerment. Nueva Y ork: Council on International and Public Affairs.

French, J, K Holt. 1989. Floods: Public $\mathrm{H}$ ealth Conse quences of $D$ isasters. Centers for Disease Control M onograph. Atlanta: CDC

French, J, R Ing, S Von Allman, R Wood. 1983. $M$ ortality from flash floods: A review of National Weather Service reports, 1969-1981. Publ H ealth $\mathrm{R}$ ep 6(N oviembre/ Diciembre):584-588.

Fuller, M . 1991. Forest Fires. N ueva Y ork: J ohn Wiley.

Gilsanz, V, J Lopez Alverez, S Serrano, J Simon. 1984. Evolution of the alimentary toxic oil syndrome due to ingestion of denatured rapeseed oil. Arch Int M ed 144:254-256.

Glass, RI, RB Craven, DJ Bregman. 1980. Injuries from the Wichita Falls tornado: Implications for prevention. Science 207:734-738.
Grant, CC, TI K lem. 1994. T oy factory fire in Thailand kills 188 workers. N F PA J 88(1):42-49.

Grant, CC. 1993. Triangle fire stirs outrage and reform. NFPA 」 87(3):72-82.

Greene, WAJ. 1954. Psychological factors and reticuloendothelial disease: Preliminary observations on a group of males with lymphoma and leukemia. Psychosom M ed :16-20.

Grisham, JW. 1986. H ealth Aspects of the Disposal of $W$ aste Chemicals. N ueva Y ork: Pergamon Press.

H erbert, P, G Taylor. 1979. Everything you always wanted to know about hurricanes: Part 1. W eatherwise (A bril).

High, D, JT Blodgett, EJ Croce, EO Horne, JW M CK oan, CS Whelan 1956. M edical aspects of the Worcester tornado disaster. N ew Engl J M ed 254:267-271.

Holden, C. 1980. Love Canal residents under stress. Science 208:1242-1244.

H omberger, E, G R eggiani, J Sambeth, HK Wipf. 1979. The Seveso accident: Its nature, extent and consequences. Ann O ccup H yg 22:327-370.

H unter, D. 1978. The Diseases of O ccupations. Londres: H odder \& Stoughton.

Janerich, DT, AD Stark, P Greenwald, WS Bryant, HI Jacobson, J M cC usker. 1981. Increased leukemia, lymphoma and spontaneous abortion in W estern N ew Y ork following a disaster. Publ $\mathrm{H}$ ealth R ep 96:350-356.

Jeyaratnam, J. 1985. 1984 and occupational health in developing countries Scand I W ork Environ $\mathrm{H}$ ealth 11:229-234

Jovel, JR. 1991. Los efectos económicos y sociales de los desastres naturales en América Latina y el $C$ aribe. Santiago, Chile: Documento presentado en el Primer Programa Regional de Formación PNUD/UNDRO para la Gestión de Desastres celebrado en Bogotá, Colombia.

K ilbourne, EM, JG Rigau-Perez, J H eath CW, M M Zack, H Falk, M M artin-M arcos, A De Carlos, 1983. Clinical epidemiology of toxic-oil syndrome. N ew Engl J M ed 83:1408-1414.

K lem, TJ, CC G rant. 1993. T hree W orkers D ie in E lectrical Power Plant Fire. NFPA J 87(2):44-47.

K lem, TJ. 1992. 25 die in food plant fire. NFPA J 86(1):29-35

K rasnyuk, EP, VI Chernyuk, VA Stezhka. 1993. Condiciones de trabajo y estado de salud de los operadores de maquinaria agrícola en áreas controladas tras el accidente de Chernobyl (en ruso). En resúmenes del congreso sobre Chernobyl y salud humana celebrado los días 20-22 de abril.

K rishna M urti, CR. 1987. Prevention and control of chemical accidents: Problems of developing countries. En I stituto Superiore Sanita', W orld H ealth O rganization, International Programme On Chemical Safety. Edimburgo: CEP Consultants.

Lancet. 1983. T oxic oil syndrome. 1:1257-1258.

Lechat, M F. 1990. The epidemiology of health effects of disasters. E pidemiol R ev 12:192.

Logue, JN, H A H ansen. 1980. A case control study of hypertensive women in a post-disaster community: Wyoming Valley, Pensilvania. J H um Stress 2:2834.

Logue, JN, M E M elick, H H ansen. 1981. Research issues and directions in the epidemiology of health effects of disasters. E pidemiol Rev 3:140.

Logue, JN . 1972. L ong term effects of a major natural disaster: The Hurricane Agnes flood in the Wyoming V alley of Pennsylvania, June 1972. Tesis doctoral, C olumbia U niv. School of Public H ealth.

Loshchilov, NA, VA Kashparov, YB Yudin, VP Proshchak, VI Yushchenko. 1993. Inhalación de radionúclidos durante los trabajos agrícolas en zonas contaminadas por radionúclidos como conse- cuencia del accidente de Chernóbil (en ruso). Gigiena i sanitarija (M oscú) 7:115-117.

M andlebaum, I, D Nahrwold, DW Boyer. 1966. $M$ anagement of tornado casualties. I Trauma 6:353-361.

M arrero, J. 1979. Danger: Flash floods- the number one killer of the 70's. W eatherwise (Febrero):34-37.

Masuda, Y, H Yoshimura. 1984. Polychlorinated biphenyls and dibenzofurans in patients with $\mathrm{Yu}$ sho and their toxicological significance: A review. Am J Ind M ed 5:31-44.

M elick, M F. 1976. Social, psychological and medical aspects of stress related illness in the recovery period of a natural disaster. T esis, Albania, U niversidad Estatal de Nueva Y ork.

Mogil, M, J Monro, H Groper. 1978. NWS's flash flood warning and disaster preparedness programs. B Am M eteorol Soc :59-66.

Morrison, AS. 1985. Screening in Chronic Disease Oxford: OUP.

National Fire Protection Association (NFPA). 1993. National Fire Alarm Code. NFPA No. 72. Quincy, $M$ assachussetts: NFPA.

-. 1994. Standard for the Installation of Sprinkler Systems. NFPA N 0. 13. Q uincy, M assachussetts: NFPA

-. 1994. Life Safety Code. NFPA No. 101. Quincy, M assachussetts: NFPA.

- . 1995. Standard for the Inspection, T esting, and M ainte nance of $W$ ater- $B$ ased Fire Protection Systems. NFPA N o. 25. Q uincy, M assachussetts: NFPA.

Nénot, JC. 1993. Les surexpositions accidentelles CEA, Institut de Protection et de Sûreté Nucléaire R apport D PH D/ 93-04.a, 1993, 3-11.

O ficina del Coordinador de las $\mathrm{N}$ aciones U nidas para el Socorro en Caso de Desastres (UNDR O). 1990. I ran earthquake. U NDR 0 N ews 4 (Septiembre).

Organismo Internacional de Energía Atómica (OIEA). 1988. B asic Safety Principles for N uclear Powe Plants INSAG-3. Safety Series, No. 75. Viena: OIEA.

—. 1989a. L'accident radiologique de Goiânia. Viena: OIEA.

-. 1989b. A large-scale C 0-60 contamination case M éxico 1984. En E mergency Planning and P reparedness for Accidents Involving Radioactive $M$ aterials $U$ sed in M edicine, Industry, Research and T eaching. V iena: OIEA.

-. 1990. R ecommendations for the Safe U se and R egulation of Radiation Sources in Industry, M edicine, R easearch and T eaching. Safety Series, N o. 102. V iena: OIEA.

—. 1991. The International Chernobyl Project. T echnical report, assessment of radiological consequences and evaluation of protective measures, report by an International Advisory Committee. Viena: OIEA.

-. 1994. Intervention Criteria in a Nuclear or Radiation E mergency. Safety Series, N o. 109. Viena: O IEA.

O rganización Internacional del Trabajo (OIT). 1988. $\mathrm{M}$ ajor $\mathrm{H}$ azard Control. A Practical M anual. Ginebra: OIT

-. 1991. Prevention of M ajor Industrial Accidents. Ginebra: OIT

—. 1993. Convenio núm. 174 (1993): Prevención de accidentes industriales graves. Ginebra: O IT.

O rganización Mundial de la Salud (OM S). 1984. T oxic Oil Syndrome. M ass F ood Poisoning in Spain. Copenhague: O ficina Regional de la OMS para Europa.

O rganización Panamericana de la Salud (O PS). 1989. A nalysis of PAH O's E mergency Preparedness and Disaster Relief Program. Executive Committee document SPP12/ 7. Washington, DC: OPS.

- . 1987. Crónicas de desastre: terremoto en M éxico. Washington, DC: O PS. 
O take, M , WJ Schull, H Y oshimura. 1989. A R eview of Radiation-related Damage in the Prenatally Exposed A tomic B omb Survivors. Commentary R eview Series, RERF CR 4-89.

O take, M , WJ Schull. 1992. Radiation-related Small H ead Sizes among Prenatally Exposed Atomic B omb Survivors. Technical R eport Series, RER F 6-92.

Parrish, RG, H Falk, JM M elius. 1987. Industrial disasters: Classification, investigation, and prevention. En Recent Advances in 0 ccupational $\mathrm{H}$ ealth, dirigido por JM H arrington. Edimburgo: Churchill Livingstone.

Peisert, M, RE Cross, LM Riggs. 1984. The H ospital's R ole in E mergency M edical Services Systems. Chicago: American H ospital Publishing.

Pesatori, AC. 1995. Dioxin contamination in Seveso: The social tragedy and the scientific challenge. M ed Lavoro 86:111-124.

Peter, RU, O Braun-Falco, A Birioukov. 1994. Chronic cutaneous damage after accidental exposure to ionizing radiation: The Chernobyl experience. J Am Acad D ermatol 30:719-723.

Pocchiari, F, A DiDomenico, V Silano, G Zapponi. 1983. Environmental impact of the accidental re lease of tetrachlorodibenzo-p-dioxin(TCDD) at Seveso. En Accidental Exposure to Dioxins: H uman $\mathrm{H}$ ealth Aspects, dirigido por $\mathrm{F}$ Coulston y $\mathrm{F}$ Pocchiari. N ueva Y ork: Academic Press.

-. 1986. The Seveso accident and its aftermath. En Insuring and $M$ anaging $H$ azardous Risks: F rom Seveso to $B$ hopal and Beyond, dirigido por PR K leindorfer $y$ HC K unreuther. Berlín: Springer-V erlag.

R odrigues de O liveira, A. 1987. Un répertoire des accidents radiologiques 1945-1985. Radioprotection 22(2):89-135.

Sainani, GS, VR J oshi, PJ M ehta, P Abraham. 1985. Bhopal tragedy -A year later. J Assoc Phys India 33:755-756.

Salzmann, JJ. 1987. "Schweizerhalle" and Its Conse quences. Edimburgo: CEP C onsultants.

Shore, RE. 1992. Issues and epidemiological evidences regarding radiation-induced thyroid cancer. Rad R es 131:98-111.

Spurzem, JR, JE Lockey. 1984. T oxic oil syndrome. Arch Int M ed 144:249-250.

Stsjazhko, VA, AF Tsyb, ND Tronko, G Souchkevitch, KF Baverstock. 1995. Childhood thyroid cancer since accidents at Chernobyl. Brit $\mathrm{M}$ ed J 310:801.

T achakra, SS. 1987. T he Bhopal D isaster. Edimburgo: CEP Consultants.

Thierry, D, P Gourmelon, C Parmentier, JC Nenot. 1995. Hematopoietic growth factors in the treatment of therapeutic and accidental irradiationinduced aplasia. Int J Rad Biol (en imprenta).

Understanding Science and Nature: $W$ eather and Climate 1992. Alexandria, V irginia: T ime-Life.

U rsano, RJ, BG M cC aughey, CS Fullerton. 1994. Individual and Community $R$ esponses to $T$ rauma and $D$ isaster: The Structure of $\mathrm{H}$ uman Chaos. Cambridge: Cambridge U niv. Press.

US Agency for International Development, (USAID). 1989. Soviet U nion: Earthquake OFDA/AID Annual Report, FY 1989. Arlington, V irginia: USAID.
Walker, P. 1995. W orld Disaster Report. Ginebra: Federación Internacional de Sociedades de la Cruz R oja y de la M edialuna R oja.

W all Street ] . 1993 Thailand fire shows region cuts corners on safety to boost profits, $13 \mathrm{M}$ ay.

Weiss, B, TW Clarkson. 1986. Toxic chemical disaster and the implication of Bhopal for technology transfer. M ilbank Q 64:216.

Whitlow, J. 1979. Disasters: T he Anatomy of E nvironmental $\mathrm{H}$ azards. Athens, $\mathrm{G}$ eorgia: U niv. of $\mathrm{G}$ eorgia Press.

Williams, D, A Pinchera, A K araoglou, KH Chadwick. 1993. Thyroid Cancer in Children Living $\mathrm{Near}$ Chernobyl. Informe del grupo de expertos sobre las consecuencias del accidente de Chernóbil, EUR 15248 EN. Bruselas: Comisión de la Comunidad Europea (CCE).

Wyllie, L, M Durkin. 1986. The $C$ hile earthquake of $M$ arch 3, 1985: Casualties and effects on the health care system. E arthquake Spec 2(2):489-495.

Zeballos, JL. 1993a. Los desastres químicos, capacidad de respuesta de los países en vías de desarrollo. W ashington, DC: Organización Panamericana de la Salud (OPS).

$-.1993 b$. Effects of natural disasters on the health infrastructure: Lessons from a medical perspective. Bull Pan Am H ealth Organ 27: 389-396.

Zerbib, JC. 1993. Les accidents radiologiques survenus lors d'usages industriels de sources radioactives ou de générateurs électirques de rayonnement. En Sécurité des sources radioactives scellées et des générateurs dectriques de rayonnement. París: Société française de radioprotection.

\section{0 tras lecturas recomendadas}

Akleyev, AV, ER Lyubchansky. 1994. Environmental and medical effects of nuclear weapon production in the Southern U rals. Sci T otal E nviron 142:1-8.

Baxter, PJ, PC Davies, V M urray. 1989. M edical planning for toxic releases into the community: The example of chlorine gas. Brit । Ind $\mathrm{M} \mathrm{ed}$ 46:277-285.

Bertazzi, PA, A di Domenico. 1994. Chemical, environment, and health aspects of the Seveso, I taly accident. En Dioxins and $\mathrm{H}$ ealth, dirigido por $\mathrm{A}$ Schecter. N ueva Y ork: Plenum.

Bertazzi, PA, AC Pesatori, D Consonni, A Tironi, MT Landi, C Zocchetti. 1993. Cancer incidence in a population accidentally exposed to 2,3,7,8tetrachlorodibenzo-p-dioxin. E pidemiology 4:398406.

Bertazzi, PA, C Zocchetti, AC Pesatori, S Guercilena, M Sanarico, L Radice. 1989. Ten-year mortality study of population involved in the Seveso incident in 1976. Am J E pidemiol 129:1187-1200.

Bertazzi, PA. 1995. M an-made chemical disasters. En Environmental E pidemiology: Exposures and D isease dirigido por R Bertollini, MD Lebowitz, R Saracci y DA Savitz. Boca R aton: Lewis.

Castle, M. 1993. The T ransport of Dangerous Goods: A Short Guide to the International R egulations. Leatherhead: PIR A International.

Departamento Federal de la Aviación Civil. 1988. $W$ essungen $F$ ür Lawinensprengensätze $M$ it $H$ elikoptern. Suiza: D epartamento Federal de la A viación Civil.
Disaster epidemiology. 1990. L ancet 336:845.

D oll, R. 1985. Purpose of symposium. En Interpretation of Negative E pidemiological Evidence for Carcinogenicity, dirigido por NJ Wald y R Doll. Lyon: Agencia Internacional para la Investigación sobre el Cáncer (IARC).

Grupo de Trabajo O M S-ECEH . 1995. Assessment of $\mathrm{H}$ ealth Consequences of $\mathrm{M}$ ajor Chemical Incidents. Epidemiological A pproach. Bilthoven: Centro Europeo de M edio Ambiente y Salud.

Gubler, H. 1988a. T emporäre und permanente Lawinenschutzmaßnahmen für touristische Anglagen. Int Seilbahnrundschau 1:22-24.

-. 1988b. Temporäre und permanente Lawinenschutzmaßnahmen für touristische Anglagen. Int Seilbahnrundschau 2:18-20.

Health and Safety Commission, AC on DS. 1991. $M$ ajor $\mathrm{H}$ azard $\mathrm{Aspects}$ of the $\mathrm{T}$ ransport of $\mathrm{D}$ angerous Substances. L ondres: H M SO

Lechat, M F. 1991. The international decade for natural disaster reduction: Background and objectives. D isasters 14:1-6.

Meulenbelt, J, GI Noordergraaf, TJF Savelkould. 1994. H ealth Aspects Chemical Accident. Den $\mathrm{H}$ aag: CIP-G egevens K oninkluke Bibliotheek.

M inisterio Federal de Economía y T ransporte Públicos. 1990. Sicherheitstechnische Richtlinien für das künstliche Auslösen von Lawinen durch Sprengungen von $\mathrm{H}$ ubschraubern aus. Decreto del $\mathrm{M}$ inisterio Federal de Economía y Transporte Públicos, Austria, Zl. $431,000 / 31 / 90$, con fecha 27 de junio de 1990, versión actualmente operativa/ sin copyright.

— . 1993. Richtlinien für das künstliche Auslösen von L awinen durch Arbeitnehmer bei Seilbahnunternehmen. Decreto del M inisterio Federal de Economía y T ransporte Públicos, Austria,ZI. 443,017/ 1-IV/52/93, de enero de 1993.

M urray, V. 1990. M ajor Chemical Disasters. M edical Aspects of $M$ anagement. Londres: Royal Society of M edicine Services.

$\mathrm{O}$ ficina del $\mathrm{C}$ oordinador de las $\mathrm{N}$ aciones $\mathrm{U}$ nidas para el Socorro en Caso de Desastres (UNDR O ). 1991. $\mathrm{M}$ itigating $\mathrm{N}$ atural D isasters. Nueva Y ork: U NDR O.

O rganización para la Cooperación y el Desarrollo Económico (O CDE). 1991a. International Directory of Emergency Response Centres. OECD Environment M onographs, N 0. 43. París: OCDE.

-. 1991b. U sers Guide: Information Systems U seful to Emergency Planners and Responders Available. París: OCDE.

- . 1992. Guiding Principles for Chemical Accident Prevention, Preparedness and R esponse. París: O CDE.

-. 1994. H ealth Aspects of Chemical Accidents. París: OCDE.

Programa de las $\mathrm{N}$ aciones U nidas para el M edio Ambiente (PNU M A). N.d. A wareness and Preparedness for Emergencies At Local Level(APPELL) A Process for $R e$ sponding to T echnological Accidents. Nairobi: PNU M A.

R oyal Society of M edicine. 1990. M ajor Chemical D isasters: M edical Aspects of $M$ anagement, dirigido por $V$ $M$ urray. L ondres: R oyal Society of M edicine.

Technica. 1991. Lessons Learned from Emergencies After Accidents in the U nited Kingdom Involving $D$ angerous Chemical Substances. Londres: T echnica. 



\section{EIECTRICIDAD}

Directora del capítulo

Dominique Folliot

\section{Sumario}

Efectos fisiológicos de la electricidad

D ominique Folliot. ............................... 40.2

Electricidad estática

Claude $M$ enguy . . . . . . . . . . . . . . . . . . . 40.6

Prevención y normas

Renzo Comini . . . . . . . . . . . . . . . . . . . . . . . . . . . . . . 40.11 


\section{- EFECTOS FISIO LO GICOS DE LA ELECTRICIDAD}

\section{Dominique Folliot}

El estudio de los peligros, la electrofisiología y la prevención de accidentes eléctricos exige la comprensión de varios conceptos técnicos y médicos.

L as definiciones de los tér minos electrobiológicos que se dan a continuación están tomadas del capítulo 891 de International E lectrotechnical Vocabulary (Electrobiología) (Comisión Electrotécnica Internacional) (CEI) (1979).

Un choque eléctrico es el efecto fisiopatológico resultante del paso directo 0 indirecto de una corriente eléctrica externa a través del cuerpo. Comprende contactos directos e indirectos y corrientes unipolares y bipolares.

De los individuos (vivos o fallecidos) que han experimentado descargas eléctricas se dice que han sufrido electrización; el término electrocución debe reservarse para casos seguidos de muerte. Los alcances de rayos son sacudidas eléctricas mortales a consecuencia de los rayos (G ourbiere y cols. 1994).

La Oficina Internacional del Trabajo (OIT), la Unión Europea (UE), la U nion internationale des producteurs et distributeurs d'énergie électrique (UNIPEDE), la A sociación Internacional de la Seguridad Social (AISS) y el Comité TC 64 de la Comisión Electrotécnica Internacional han recopilado estadísticas internacionales sobre accidentes eléctricos. La interpretación de estas estadísticas se ve obstaculizada por las variaciones de unos países a otros en materia de técnicas de recogida de datos, de pólizas de seguro y de definiciones de accidentes mortales. Con todo, pueden considerarse posibles las estimaciones siguientes de la tasa de electrocución (Tabla 40.1).

El número de electrocuciones desciende poco a poco, en términos absolutos y, lo que resulta más llamativo, en función del consumo total de electricidad. A proximadamente la mitad de los accidentes eléctricos tiene un origen profesional, mientras que la otra mitad ocurre en casa y en actividades de ocio. En Francia, la media de fallecimientos entre 1968 y 1991 fue de 151 por año, según cifras del Institut national de la santé et de la recherche médicale (IN SER M ).

Tabla 40.1 • Estimaciones de la tasa de electrocución, 1988

$\begin{array}{lll} & \begin{array}{l}\text { Electrocuciones por } \\ \text { millón de habitantes }\end{array} & \begin{array}{l}\text { Total } \\ \text { muertes }\end{array} \\ \text { Estados Unidos } & & \\ \text { Francia } & 2,9 & 714 \\ \text { Alemania } & 2,0 & 115 \\ \text { Austria } & 1,6 & 99 \\ \text { Japón } & 0,9 & 11 \\ \text { Suecia } & 0,9 & 112 \\ \text { S } & 0,6 & 13\end{array}$

${ }^{1}$ Según la National Fire Protection Association (Massachusetts, EE UU), estas estadísticas son más representativas para una recopilación general de datos y de requisitos de informes legales que de un ambiente más peligroso. Las estadísticas de EE UU incluyen fallecimientos por exposición a sistemas de transporte de electricidad y electrocuciones originadas por productos de consumo. En 1988, los productos de consumo causaron 290 fallecimientos (1,2 muertes por millón de habitantes). En 1993, la tasa de fallecimientos por electrocución debida a todas las causas descendió a 550 (2,1 muertes por millón de habitantes); el 38 \% de ellas estuvo relacionada con productos de consumo (0,8 muertes por millón de habitantes).

\section{Base física y fisiopatológica de la electrización}

L os especialistas en electricidad dividen los contactos eléctricos en dos grupos: directos, que implican el contacto con componentes activos, e indirectos, en los que los contactos tienen derivación a tierra. C ada uno de estos grupos exige medidas preventivas totalmente diferentes.

Desde el punto de vista médico, el camino que recorre la corriente a través del cuerpo es el determinante clave del pronóstico y la terapéutica. Por ejemplo, el contacto bipolar de la boca de un niño con la clavija de un cordón de extensión origina quemaduras muy graves en la boca, pero no la muerte si el niño está bien aislado del suelo.

En espacios de trabajo, donde es corriente que existan altas tensiones, también es posible que salte un arco eléctrico entre un componente activo que se encuentre a alta tensión y los trabajadores que se acercan demasiado al componente. Las situaciones específicas del trabajo influyen también en las consecuencias de Ios accidentes eléctricos: por ejemplo, los trabajadores pueden caerse 0 no actuar como es debido al ser sorprendidos por una sacudida eléctrica, por lo demás relativamente inofensiva.

Todas las tensiones presentes en los lugares de trabajo son susceptibles de provocar accidentes. Cada sector industrial tiene su propio conjunto de condiciones capaz de originar contacto directo, indirecto, unipolar, bipolar, por arco o inducido y, en último término, accidentes. D esde luego, no es posible abarcar en este artículo todas las actividades humanas relacionadas con la electricidad, pero conviene recordar al lector los principales tipos de trabajo eléctrico que han recogido las directrices preventivas internacionales que se describen en el capítulo sobre prevención:

1. actividades que implican trabajar con cables activos (la aplicación de procedimientos extremadamente rigurosos ha conseguido reducir el número de electrizaciones durante este tipo de trabajo);

2. actividades que implican trabajar con cables desactivados,

3. actividades realizadas en la proximidad de cables activos (estas actividades exigen la máxima atención, puesto que a menudo son ejecutadas por personas que no son electricistas).

\section{Fisiopatología}

En la ley de Joule para corriente continua

$$
W=V \times I \times t=\left.R\right|^{2} t
$$

(el calor producido por una corriente eléctrica es proporcional a la resistencia y al cuadrado de la corriente) todas las variables guardan una estrecha relación entre sí. Si se trata de corriente alterna también es preciso tener en cuenta el efecto de la frecuencia (Folliot 1982).

L os organismos vivos son conductores eléctricos. La electrización tiene lugar cuando hay una diferencia de potencial entre dos puntos del organismo. Es importante subrayar que el peligro de accidentes eléctricos no surge del mero contacto con un conductor activo, sino del contacto simultáneo con un conductor activo y otro cuerpo a potencial diferente.

Los tejidos y órganos que recorre la corriente pueden experimentar una excitación funcional motora que en algunos casos es irreversible, o bien sufrir lesión temporal o permanente, en general a consecuencia de quemaduras. El grado de estas lesiones está en función de la energía liberada o de la cantidad de electricidad que atraviesa los tejidos. Así pues, el tiempo de paso de la corriente eléctrica es crítico para determinar la gravedad de la lesión. (Por ejemplo, las anguilas eléctricas y las rayas producen descargas muy desagradables, capaces de inducir pérdida del sentido. Pero aunque la tensión de la descarga sea de $600 \mathrm{~V}$, la corriente de alrededor de $1 \mathrm{~A}$ y la 
resistencia del sujeto de unos 600 ohms, estos peces son incapaces de inducir una sacudida mortal, porque la duración de la descarga es demasiado corta, de algunas decenas de microsegundos.) Así pues, a altas tensiones ( $>1.000 \mathrm{~V}$ ), la muerte se debe casi siempre a la extensión de las quemaduras. A tensiones más bajas, la muerte está en función de la cantidad de electricidad $(Q=\mid \times t)$, que llega al corazón, determinada por el tipo, el emplazamiento y el área de los puntos de contacto.

En las secciones siguientes se estudian el mecanismo de la muerte ocasionada por accidentes eléctricos, los tratamientos inmediatos más eficaces y los factores que determinan la gravedad de la lesión, que son la resistencia, intensidad, tensión, frecuencia y forma de onda.

\section{Causas de muerte en accidentes eléctricos en la industria}

En casos raros, la causa de la muerte es la asfixia, debida al tétanos prolongado del diafragma, a la inhibición de los centros respiratorios en casos de contacto con la cabeza o a densidades de corriente muy altas, por ejemplo, a consecuencia de alcances de rayo (Gourbiere y cols. 1994). Si se presta ayuda en los tres minutos siguientes, se puede reanimar a la víctima con unas bocanadas de respiración artificial boca a boca.

Por el contrario, la principal causa de muerte sigue siendo el colapso de la circulación periférica que sigue a la fibrilación ventricular. A parece siempre que no se aplica masaje cardíaco al mismo tiempo que la respiración boca a boca. Todos los electricistas deberían saber cómo hacerlo, y continuar haciéndolo hasta la llegada de la asistencia médica urgente, que casi siempre tarda más de tres minutos. M uchísimos electropatólogos e ingenieros de todo el mundo han estudiado las causas de la fibrilación ventricular, con objeto de idear mejores medidas protectoras, activas o pasivas (Comisión Electrotécnica Internacional 1987; 1994). La desincronización aleatoria del miocardio exige la persistencia de una corriente eléctrica de frecuencia, intensidad y tiempo de tránsito específicos. Y lo más importante es que la señal eléctrica llegue al miocardio durante la denominada fase vulnerable del ciclo cardíaco, correspondiente al comienzo de la onda $T$ del electrocardiograma.

La Comisión Electrotécnica Internacional $(1987 ; 1994)$ ha publicado curvas que describen el efecto de la intensidad de corriente y del tiempo de tránsito sobre la probabilidad (expresada en tanto por ciento) de fibrilación y el camino mano-pie de la corriente en un varón de $70 \mathrm{~kg}$ y buena salud. Son adecuadas para corrientes industriales en el margen de frecuencias de 15 a $100 \mathrm{~Hz}$, mientras que las frecuencias más altas se encuentran ahora en estudio. Cuando los tiempos de tránsito son inferiores a $10 \mathrm{~ms}$, el área situada debajo de la curva de la señal eléctrica es una aproximación razonable de la energía eléctrica.

\section{Papel de los diversos parámetros eléctricos}

Cada uno de los parámetros eléctricos (corriente, tensión, resistencia, tiempo, frecuencia) y la forma de onda son determinantes importantes de las posibles lesiones, por sí mismos y en virtud de su interacción.

Para la corriente alterna, así como para otras condiciones antes definidas, se han establecido umbrales de corriente. La intensidad de corriente durante la electrización se desconoce, puesto que está en función de la resistencia del tejido en el momento del contacto $(I=V / R)$, pero por lo general es perceptible a niveles que rondan $1 \mathrm{~mA}$. A corrientes relativamente bajas la persona puede sufrir contracciones musculares que le impidan apartarse de un objeto activado. El umbral de esta corriente está en función de la capacidad, del área de contacto, de la presión de contacto y de variaciones individuales. En la práctica, todos los hombres y casi todas las mujeres y niños pueden apartarse de corrientes de hasta de $6 \mathrm{~mA}$. Con $10 \mathrm{~mA}$, se ha observado que el $98,5 \%$ de los hombres, el $60 \%$ de mujeres y el 7,5\% de los niños se aparta. Con $20 \mathrm{~mA}$ sólo el $7,5 \%$ de los hombres y ninguna mujer o niño se sueltan. $Y$ la cifra se reduce a cero en todos los casos con $30 \mathrm{~mA}$ o más.

Corrientes de unos $25 \mathrm{~mA}$ pueden provocar la tetanización del diafragma, el músculo respiratorio más potente. Si el contacto se mantiene durante tres minutos, sobreviene también la parada cardíaca.

$\mathrm{H}$ ay peligro de fibrilación ventricular a niveles situados en torno a $45 \mathrm{~mA}$, con una probabilidad en adultos del $5 \%$ tras un contacto de 5 segundos. D urante la cirugía cardíaca, reconocida como una situación especial, una corriente de 20 a $100 \times 10^{-6} \mathrm{~A}$ aplicada directamente al miocardio, es suficiente para inducir fibrilación. A esta sensibilidad miocardial se debe la rigidez de las normas aplicadas a los aparatos de electromedicina.

Si todo lo demás es constante ( $V, R$, frecuencia), los umbrales de corriente dependen también de la forma de onda, de la especie animal, del peso de la dirección de la corriente en el corazón, de la relación entre el tiempo de tránsito de la corriente y el ciclo cardíaco, del punto del ciclo cardíaco en el cual llega la corriente, y de factores individuales.

En general se conoce la tensión que interviene en los accidentes. En casos de contacto directo, la fibrilación ventricular y la gravedad de las quemaduras son directamente proporcionales a la tensión, puesto que

$$
\mathrm{V}=\mathrm{R} \mid \text { y } W=\mathrm{V} \times \mathrm{I} \times \mathrm{t}
$$

Las quemaduras debidas a una sacudida eléctrica de alta tensión van asociadas a muchas complicaciones, que sólo son predecibles en algunos casos. Por consiguiente, las víctimas de estos accidentes han de ser atendidas por especialistas bien informados. La liberación de calor tiene lugar sobre todo en los músculos y en los haces neurovasculares. La pérdida de plasma que sigue al daño en el tejido origina shock, en algunos casos rápido e intenso. Para un área superficial dada, las quemaduras electrotérmicas (quemaduras provocadas por una corriente eléctrica) son siempre más graves que otros tipos de quemaduras. Las electrotérmicas son al mismo tiempo externas e internas y, aunque en un principio no parezca ser evidente, pueden inducir lesión vascular con efectos secundarios graves. Entre éstos se cuentan estenosis internas y trombos que, con frecuencia, por la necrosis que producen, exigen la amputación.

La destrucción de tejidos también es responsable de la liberación de cromoproteínas, como la mioglobina. La misma liberación se observa en víctimas de traumatismos por aplastamiento, aunque el grado de liberación es notable en víctimas de quemaduras de alta tensión. Se cree que la precipitación de mioglobina en los túbulos renales, resultante de la acidosis causada por anoxia e hipercaliemia, es la causa de la anuria. Confirmada experimentalmente pero no aceptada por todos, a esta teoría se debe que se recomiende un tratamiento inmediato de alcalinización. La alcalinización intravenosa, que corrige también la hipovolemia y las acidosis resultantes de muerte celular, es la conducta recomendada.

En el caso de contactos indirectos, también se han de tener en cuenta la tensión de contacto (V) y el límite de tensión convencional.

La tensión de contacto es la tensión a la cual una persona queda sometida cuando toca al mismo tiempo dos conductores entre los cuales existe una tensión diferencial debida a un aislamiento defectuoso. La intensidad de la corriente de paso resultante depende de las resistencias del cuerpo humano y del circuito exterior. No se debe permitir que esta corriente llegue a ser superior a los niveles de seguridad 0 , lo que es lo mismo, deberá permanecer dentro de las curvas de seguridad 
tiempo-corriente. La tensión de contacto máxima tolerable por tiempo indefinido sin que induzca efectos electropatológicos se denomina límite de tensión convencional 0 , con una expresión más intuitiva, tensión de seguridad.

Se desconoce el valor real de la resistencia durante los accidentes eléctricos. La variación de las resistencias en serie - por ejemplo, ropa y calzado- explica gran parte de la variación observada en los efectos de accidentes eléctricos de una clara similitud, pero ejerce poca influencia sobre el resultado de accidentes que impliquen contactos bipolares y electrizaciones de alta tensión. En casos que impliquen corriente alterna, al cálculo estándar basado en tensión y corriente $(R=V / I)$ es preciso añadir el efecto de fenómenos capacitivos e inductivos.

La resistencia del cuerpo humano es la suma de la resistencia de la piel (R) en los dos puntos de contacto y de la resistencia interna del cuerpo $(R)$. La resistencia de la piel varía con factores ambientales y, como mencionó Biegelmeir (Comisión Electrotécnica Internacional 1987; 1994), en parte depende de la tensión de contacto. 0 tros factores como la presión, el área de contacto, el estado de la piel en el punto de contacto, y factores individuales influyen también en la resistencia. Así pues, es poco realista el tratar de basar medidas preventivas en estimaciones de la resistencia de la piel. Por el contrario, la prevención debe basarse en la adaptación de equipo y procedimientos a las personas, no a la inversa. Con objeto de simplificar las cosas, la CEI ha definido cuatro tipos de ambiente: seco, húmedo, mojado e inmersión, y ha definido parámetros útiles para la planificación de las actividades de prevención en cada caso.

La frecuencia de la señal eléctrica responsable de los accidentes eléctricos es conocida de todos. En Europa, es casi siempre de $50 \mathrm{~Hz}$, y en las A méricas es por lo general de $60 \mathrm{~Hz}$. En casos raros relacionados con los ferrocarriles en países como Alemania, Austria y Suiza, es de $16 \% 3 \mathrm{~Hz}$, frecuencia que en teoría representa un riesgo mayor de tetanización y de fibrilación ventricular. Debe recordarse que la fibrilación no es una reacción muscular, sino que es provocada por estimulación repetitiva, con una sensibilidad máxima a la frecuencia aproximada de $10 \mathrm{~Hz}$. Por esto es por lo que, para una tensión dada, la corriente alterna de frecuencia extremadamente baja, se considera que es de tres a cinco veces más peligrosa que la corriente continua en relación con los efectos que no sean quemaduras.

L os umbrales antes descritos son directamente proporcionales a la frecuencia de la corriente. Así pues, a $10 \mathrm{kH} z$ el umbral de detección es diez veces superior. La CEI estudia ahora curvas revisadas del peligro de fibrilación para frecuencias superiores a $1.000 \mathrm{~Hz}$ (C omisión Electrotécnica Internacional 1994).

Por encima de una determinada frecuencia, las leyes físicas que rigen la penetración de corriente en el cuerpo cambian por completo. A medida que comienzan a predominar fenómenos capacitivos e inductivos, los efectos térmicos derivados de la cantidad de energía liberada se convierten en el efecto principal.

La forma de onda de la señal eléctrica responsable de un accidente eléctrico suele ser conocida. Puede ser un determinante importante de lesión en accidentes sobrevenidos por el contacto con condensadores o semiconductores.

\section{Estudio clínico de la descarga eléctrica}

Es clásica la división de las electrizaciones entre incidentes de baja tensión (de 50 a $1.000 \mathrm{~V}$ ) y de alta tensión (>1.000 V).

La baja tensión es un peligro cotidiano, desde luego omnipresente, y las descargas originadas por ella se encuentran en entornos domésticos, de ocio, agrícolas y hospitalarios, así como en los industriales.

Para pasar revista ordenadamente las descargas eléctricas de baja tensión, desde la más trivial a la más grave, debemos comenzar con las que no presentan complicaciones. Sus víctimas pueden apartarse por sí mismas del daño, conservan la conciencia y mantienen la ventilación normal. Los efectos sobre el corazón se limitan a una simple taquicardia sinusal con o sin anormalidades cardiográficas leves. A pesar de las consecuencias relativamente leves de estos accidentes, la electrocardiografía sigue siendo una precaución médica y médico-legal adecuada. Se aconseja la investigación técnica de estos incidentes, que pueden llegar a ser graves, como complemento del reconocimiento clínico (G ilet y C hoquet 1990).

Las víctimas de descargas algo más fuertes y duraderas debidas a contactos eléctricos experimentan perturbaciones 0 pérdida de conciencia, pero se recuperan por completo con más o menos rapidez, y el tratamiento acelera la recuperación. Un reconocimiento revela por lo general hipertonías neuromusculares, problemas de hiperventilación reflectiva y congestión, ésta última como efecto secundario frecuente de obstrucción orofaríngea. Los trastornos cardiovasculares son el resultado de hipoxia 0 anoxia, o bien pueden adoptar la forma de taquicardia, hipertensión y, en algunos casos, incluso aborto. Los pacientes en estas condiciones necesitan atención hospitalaria.

L as víctimas ocasionales que pierden la conciencia, al cabo de unos cuantos segundos de contacto aparecen pálidos o cianíticos, dejan de respirar, tienen un pulso apenas perceptible y presentan midriasis, indicativa de lesión cerebral aguda. Aunque por lo general se debe a la fibrilación ventricular, la patogénesis precisa de esta muerte aparente carece de importancia. Lo importante es iniciar con rapidez un tratamiento bien definido, puesto que se sabe desde hace algún tiempo que este estado clínico nunca conduce a muerte real. EI pronóstico en estos casos de descarga eléctrica (en los cuales es posible la recuperación total) depende de la rapidez y calidad de los primeros auxilios. La estadística demuestra que lo más probable es que éstos sean administrados por personal no médico y, por lo tanto, se recomienda proporcionar formación a todos los electricistas para que puedan realizar las acciones básicas que garanticen la supervivencia.

En casos de muerte aparente tiene que darse prioridad al tratamiento. Pero en otros casos hay que conceder atención a los traumas múltiples resultantes de tétanos violentos, de caídas o de la proyección de la víctima por el aire. Una vez resuelto el peligro inmediato de que la víctima pierda la vida, se debe atender al trauma y las quemaduras, incluidas las provocadas por contactos de baja tensión.

Los accidentes derivados de altas tensiones dan lugar a quemaduras importantes, aparte de los efectos descritos en los accidentes de baja tensión. La conversión de energía eléctrica en calor ocurre en los espacios internos y externos. En un estudio de accidentes eléctricos realizado en Francia por el departamento médico de la empresa suministradora de energía EDF-GDF, casi el $80 \%$ de las víctimas sufrieron quemaduras, que se clasifican en cuatro grupos:

1. quemaduras de arco, que suelen afectar a la piel expuesta y que en algunos casos se complican con quemaduras debidas a ropa ardiendo;

2. quemaduras electrotérmicas múltiples, extensas y profundas, originadas por contactos de alta tensión;

3. quemaduras clásicas, provocadas por ropa ardiendo y por la proyección de material en llamas,

4. quemaduras mixtas, provocadas por arcos, incendio y paso de corriente.

Se realizará un seguimiento y los reconocimientos complementarios que exijan las particularidades del accidente. La estrategia utilizada para establecer un pronóstico 0 con fines médico-legales está determinada, como es natural, por la naturaleza de las complicaciones observadas 0 esperadas. En 
electrizaciones de alta tensión (Folliot 1982) y en descargas atmosféricas (G ourbiere y cols. 1994), la enzimología y el análisis de cromoproteínas y de los parámetros de coagulación de la sangre son obligatorios.

Es fácil que el curso de la recuperación del trauma eléctrico se vea comprometido antes o después por complicaciones, en especial las que afectan a los sistemas cardiovascular, nervioso y renal. La envergadura de tales complicaciones es suficiente para hospitalizar a las víctimas de electrizaciones de alta tensión; algunas de ellas pueden dejar secuelas funcionales o que afecten al aspecto externo.

Si el camino de la corriente es tal que el corazón es atravesado por una corriente significativa, aparecerán complicaciones cardiovasculares. De éstas, las observadas con más frecuencia y las más benignas son los trastornos funcionales, con presencia 0 ausencia de correlatos clínicos. Las arritmias - taquicardia sinusal, extrasistolia, fluter y fibrilación atrial (en este orden)son las anormalidades electrocardiográficas más corrientes, cuyas secuelas pueden ser permanentes. Los trastornos de conducción son más raros, y además son difíciles de relacionar con accidentes eléctricos en ausencia de un electrocardiograma previo.

También se ha informado de trastornos más graves, como fallo cardíaco, lesión de válvulas y quemaduras miocardiales, pero son raros, aun en víctimas de accidentes de alta tensión. También se ha informado de casos claros de angina e incluso de infarto.

En la semana siguiente a la electrización de alta tensión aparece la lesión periférica vascular. Se han propuesto varios mecanismos patógenos: espasmo arterial, acción de la corriente eléctrica en las capas medias y musculares de los vasos y modificación de los parámetros de coagulación de la sangre.

$\mathrm{H}$ ay una amplia variedad de complicaciones neurológicas posibles. La más temprana en aparecer es el accidente cerebrovascular, con independencia de que la víctima experimente al principio pérdida de conciencia. La fisiopatología de estas complicaciones comprende trauma craneal (cuya presencia debe comprobarse), el efecto directo de la corriente sobre la cabeza o la modificación de la circulación sanguínea cerebral y la inducción de un edema cerebral retardado. Además, el trauma o la acción directa de la corriente eléctrica pueden provocar complicaciones medulares y periféricas secundarias.

L os trastornos sensoriales afectan el ojo y a los sistemas audiovestibular o coclear. Es importante examinar lo antes posible la córnea, el cristalino y el fondo del ojo, y seguir la evolución de las víctimas de arcos y de contacto directo en la cabeza por si hubiera efectos retardados. Pueden desarrollarse cataratas después de un período de varios meses sin síntomas. Los trastornos vestibulares y la pérdida de audición se deben sobre todo a efectos de estallido y, en víctimas de descargas atmosféricas transmitidas por líneas telefónicas, a trauma eléctrico (G ourbiere y cols. 1994).

Las mejoras en las prácticas de urgencia móvil han hecho disminuir en gran medida la frecuencia de complicaciones renales, en especial la oligoanuria, en víctimas de electrización de alta tensión. La rehidratación temprana y cuidadosa y la alcalinización intravenosa es el tratamiento preferente en víctimas de quemaduras graves. Se han comunicado algunos casos de albuminuria y de hematuria microscópica persistente.

\section{Cuadros clínicos y problemas diagnósticos}

El cuadro clínico de la descarga eléctrica es complicado por la variedad de aplicaciones industriales de la electricidad y por sus cada vez más frecuentes y variadas aplicaciones médicas. Ahora bien, durante mucho tiempo los únicos accidentes eléctricos fueron los provocados por descargas atmosféricas (Gourbiere y cols. 1994). Las descargas atmosféricas acumulan cantidades de electricidad muy notables: una de cada tres víctimas de descargas atmosféricas muere. Los efectos de una descarga atmosférica - quemaduras y muerte aparente- son comparables a los resultantes de la electricidad industrial y son atribuibles a descarga eléctrica, a transformación de energía eléctrica en calor, a efectos de estallido y a las propiedades eléctricas del rayo.

Las descargas atmosféricas son tres veces más frecuentes en hombres que en mujeres, lo cual refleja pautas de trabajo con distintos riesgos de exposición al rayo.

L os efectos más corrientes observados en víctimas de electrización yatrogénica son las quemaduras resultantes del contacto con superficies metálicas puestas a masa de escal pelos eléctricos. L a magnitud de las corrientes de fuga aceptables en dispositivos electromédicos varía de un dispositivo a otro. Lo mínimo que debe hacerse es observar las especificaciones de los fabricantes y las recomendaciones de empleo.

Para concluir esta sección nos gustaría debatir el caso especial de la descarga eléctrica en mujeres embarazadas, que puede provocar la muerte de la mujer, del feto o de ambos. En un caso célebre, un feto vivo fue liberado con éxito mediante un corte de cesárea 15 minutos después de que su madre hubiera muerto por electrocución a $220 \mathrm{~V}$ (Folliot 1982).

Los mecanismos patofisiológicos del aborto provocado por descarga eléctrica exige un estudio más detallado. ¿Es provocado por trastornos de conducción en el tubo cardíaco embrionario sometido a un gradiente de tensión, o por desgarro de la placenta resultante de vasoconstricción?

La aparición de accidentes eléctricos tan raros como éste son un motivo más para exigir notificación de todos los casos de lesiones ocasionadas por la electricidad.

\section{Diagnóstico positivo y médico-legal}

Las circunstancias en las cuales ocurre la descarga eléctrica son por lo general lo bastante claras para permitir un diagnóstico etiológico inequívoco. Pero no siempre es éste el caso, incluso en entornos industriales

El diagnóstico de fallo circulatorio tras la descarga eléctrica es de extraordinaria importancia, puesto que exige que haya personas en las cercanías que inicien los primeros auxilios inmediatos y básicos una vez que se haya cortado la corriente. La parada respiratoria en ausencia de pulso es una indicación absoluta para comenzar el masaje cardíaco y la respiración artificial boca a boca. Antes, estas medidas sólo se tomaban cuando aparecía midriasis (dilatación de las pupilas), signo diagnóstico de lesión cerebral aguda. Pero la práctica actual es intervenir tan pronto como el pulso deje de ser detectable.

Como la pérdida de conciencia debida a la fibrilación ventricular tarda varios segundos en presentarse, las víctimas tienen tiempo de apartarse del equipo que ha originado el accidente. Es un asunto con cierta importancia médico-legal: por ejemplo, cuando la víctima de un accidente se encuentra a varios metros de un armario eléctrico u otra fuente de tensión sin signos de lesión eléctrica.

No debe olvidarse que la ausencia de quemaduras eléctricas no excluye la posibilidad de electrocución. Si la autopsia de individuos hallados en ambientes eléctricos o cerca de un equipo capaz de generar tensiones peligrosas no revela lesiones de Jelinek visibles y ningún signo aparente de muerte, se debe considerar la posibilidad de electrocución.

$\mathrm{Si}$ el cuerpo se encuentra en el exterior, al diagnóstico de descarga atmosférica se llega por el proceso de eliminación. Se deben buscar signos de descarga atmosférica en un círculo de 50 metros de radio alrededor del cuerpo. EI museo de electropatología de Viena ofrece una exhibición impresionante de estos signos, entre los que se cuentan vegetación carbonizada y arena 
vitrificada. L os objetos metálicos que llevaba la víctima pueden aparecer fundidos.

Aunque por fortuna el suicidio por medios eléctricos es raro en la industria, las muertes en las que la negligencia es un factor propiciatorio siguen siendo una triste realidad. Suele suceder sobre todo en emplazamientos no normalizados, en especial los que incluyen la instalación y operación de suministros eléctricos provisionales en condiciones exigentes.

No hay motivo para que sigan ocurriendo accidentes eléctricos, puesto que se dispone de medidas preventivas eficaces, que se describen en el artículo "Prevención y N ormas".

\section{- ELECTRICIDAD ESTATICA}

\section{Claude M enguy}

Todos los materiales difieren en el grado en que permiten el paso de cargas eléctricas. L os materiales conductores permiten el paso de cargas, mientras que los aislantes obstaculizan su movimiento. La electrostática es el campo de la ciencia dedicado a estudiar las cargas o los cuerpos cargados en reposo. Se tiene electricidad estática cuando en los objetos se forman cargas eléctricas que no se desplazan. Si las cargas circulan, se establece una corriente y la electricidad ya no es estática. Los no profesionales dan el nombre de electricidad a la corriente resultante de las cargas en movimiento, fenómeno que se explica en otros artículos de este capítulo. electrización estática es el término utilizado para designar cualquier proceso que dé por resultado la separación de cargas eléctricas positivas y negativas. La conducción se mide con una propiedad denominada conductancia, mientras que un aislante se caracteriza por su resistividad. La separación de cargas que conduce a la electrización es resultado de procesos mecánicos: por ejemplo, el contacto entre objetos, la fricción o la colisión de dos superficies. Puede tratarse de dos superficies sólidas 0 una sólida y otra líquida. Es más raro que el proceso mecánico sea la ruptura o separación de superficies sólidas o líquidas. En este artículo nos ocupamos del contacto y de la fricción.

\section{Procesos de electrización}

El fenómeno de generación de electricidad estática por fricción (triboelectrización) se conoce desde hace miles de años. Para inducir electricidad basta con que haya contacto entre dos materiales. La fricción sólo es un tipo de interacción que aumenta el área de contacto y genera calor: fricción es el término general que describe el movimiento de dos objetos en contacto; la presión ejercida, su velocidad de deslizamiento y el calor generado son los determinantes principales de la carga generada por fricción. Algunas veces, la fricción originará también el arranque de partículas sólidas.

Cuando los dos sólidos en contacto son metales (contacto metal-metal), hay migración de electrones de uno al otro. Cada metal se caracteriza por un potencial inicial diferente (potencial de Fermi), y la naturaleza tiende siempre al equilibrio; es decir, los fenómenos naturales trabajan para eliminar las diferencias de potencial. Tal migración de electrones da lugar a la generación de un potencial de contacto. Como las cargas de un metal son muy móviles (los metales son conductores excelentes), las cargas se recombinarán incluso en el último punto de contacto antes de que los dos metales se separen. Por lo tanto, es imposible inducir electricidad por el hecho de poner en contacto dos metales y separarlos después; las cargas se desplazarán siempre para eliminar la diferencia de potencial.

Cuando un metal y un aislante entran en contacto casi sin fricción en el vacío, el nivel de energía de los electrones del metal se aproxima al del aislante. Impurezas superficiales o del volumen se encargan de que ocurra así e impiden también la formación de un arco (la descarga de electricidad entre los dos cuerpos cargados: los electrodos) en el momento de la separación. La carga transferida al aislante es proporcional a la afinidad electrónica del metal, y cada aislante tiene también una afinidad electrónica, 0 atracción de electrones, asociada con ella. Así pues, también es posible la transferencia de iones positivos o negativos del aislante al metal. La carga en la superficie después del contacto y separación se calcula por la ecuación 1 de la Tabla 40.2 .

Cuando dos aislantes entran en contacto, tiene lugar una transferencia de cargas a causa de los diferentes estados de su energía superficial (ecuación 2, Tabla 40.2). Las cargas transferidas a la superficie de un aislante pueden migrar hacia capas más profundas del material. La humedad y la contaminación superficial pueden modificar en gran medida el comportamiento de las cargas. L a humedad superficial en particular incrementa las densidades de estados de energía superficial al aumentar la conducción superficial, que favorece la recombinación de cargas, y facilita la movilidad iónica. La mayoría de las personas reconocerán este fenómeno por sus experiencias cotidianas, ya que saben que en tiempo seco están sujetos a electricidad estática. El contenido de agua de algunos polímeros (plásticos) cambiará cuando se cargan. El aumento o disminución del contenido de agua llega a invertir el sentido de la circulación de cargas (su polaridad).

La polaridad (positividad y negatividad relativas) mutua de dos aislantes en contacto depende de la afinidad electrónica de cada material. Los aislantes se clasifican por sus afinidades electrónicas, algunos de cuyos valores ilustrativos se recogen en la Tabla 40.3. La afinidad electrónica de un aislante es una consideración importante en los programas de prevención que se debaten más adelante en este artículo.

Aunque ha habido intentos de establecer una serie triboeléctrica que ordenaría los materiales de manera que los que adquieren carga positiva al ponerse en contacto con materiales aparecieran en la serie antes que los que adquieren carga negativa al ponerse en contacto con esos mismos materiales, no se ha llegado a establecer una serie reconocida en todo el mundo.

Cuando se juntan un sólido y un líquido (para formar una interfaz sólido-líquido), hay una transferencia de cargas por la migración de los iones existentes en el líquido. Tales iones surgen de la disociación de posibles impurezas o por reacciones electroquímicas de oxidación-reducción. Como en la práctica no existen líquidos perfectamente puros, siempre habrá en el líquido algunos iones positivos y negativos que puedan ligarse a la interfaz líquido-sólido. $\mathrm{H}$ ay muchos tipos de mecanismo mediante los cuales se pueda inducir esta ligadura (p. ej., adherencia electrostática a superficies metálicas, absorción química, inyección electrolítica, disociación de grupos polares y, si la pared de la vasija es aislante, reacciones líquido-sólido.)

Como las sustancias que disuelven (disocian) son eléctricamente neutras en principio, generarán igual número de cargas positivas y negativas. La electrización sólo ocurre si las cargas positivas o las negativas se adhieren con preferencia a la superficie del sólido. Si sucede esto, se forma una capa muy compacta conocida como la capa de Helmholtz. Como la capa de H elmholtz está cargada, atraerá hacia sí iones de la polaridad opuesta. Tales iones se agruparán en una capa más difusa, conocida como capa de G ouy, que se sitúa encima de la superficie de la capa compacta de $\mathrm{H}$ elmholtz. EI espesor de la capa de G ouy aumenta con la resistividad del líquido. Los líquidos conductores forman capas de $\mathrm{G}$ ouy muy delgadas.

La doble capa se separará si el líquido fluye y entonces la capa de H elmholtz permanecerá ligada a la interfaz y la capa de 
Tabla 40.2 - Relaciones básicas en electrostática: conjunto de ecuaciones.

Ecuación 1: Carga por contacto de un metal y un aislante

En general, la densidad superficial de carga $\left(\mathrm{s}_{\mathrm{s}}\right.$ ) que sigue al contacto y separación puede expresarse por:

donde

$$
\sigma_{s}=\mathrm{eN}_{\mathrm{E}}\left(\phi_{\mathrm{m}}-\phi_{i}\right)
$$

e es la carga de un electrón

$N_{E}$ es la densidad de estados de energía en la superficie del aislante

$\phi_{i}$ es la afinidad electrónica del aislante, y

$\phi_{m}$ es la afinidad electrónica del metal

Ecuación 2: Carga posterior al contacto entre dos aislantes

La forma general siguiente de la ecuación 1 se aplica a la transferencia de carga entre dos aislantes con estados energéticos diferentes (sólo con superficies perfectamente limpias):

$$
\sigma_{5}=e \frac{N_{E 1} \cdot N_{E 2}}{N_{E 1}-N_{E 2}}\left(\phi_{1}-\phi_{2}\right)
$$

donde $N_{E 1}$ y $N_{E 2}$ son las densidades de estados de energía en la superficie de los dos aislantes, y $\phi_{1}$ y $\phi_{2}$ son las afinidades electrónicas de los dos aislantes.

\section{Ecuación 3: Densidad superficial de carga máxima}

La rigidez dieléctrica $\left(E_{G}\right)$ del gas circundante impone un límite superior a la carga que es posible generar en una superficie aislante plana. En el aire $E_{G}$ es de unos 3 MV/ m. La densidad superficial de carga máxima viene dada por:

$$
\sigma_{\text {smax }}=e_{0} E_{G}=2,66 \times 10^{-5} \mathrm{C} / \mathrm{m}^{2}=2,660 \mathrm{pC} / \mathrm{cm}^{2}
$$

\section{Ecuación 4: Carga máxima en una partícula esférica}

Cuando partículas esféricas ideales se cargan por efecto corona, la carga máxima que cada partícula puede adquirir viene dada por el límite de Pauthenier:

$$
\begin{array}{ll}
\text { donde } & q_{\max }=4 \pi \varepsilon_{0} p E_{G} a^{2} \\
q_{\max } & \text { es la carga máxima } \\
a & \text { es el radio de la partícula } \\
e_{1} & \text { es la permitividad relativa y }
\end{array}
$$

$$
p=\frac{3 \varepsilon_{\mid}}{\varepsilon_{\mid}+2}
$$

Gouy será arrastrada por el líquido que se desplaza. EI movimiento de estas capas cargadas produce una diferencia de potencial (el potencial zeta), y la corriente inducida por las cargas móviles se conoce como la corriente de gasto. La cantidad de carga que se acumula en el líquido depende del ritmo al cual los iones se difunden hacia la interfaz y de la resistividad del líquido ( $r$ ). Ahora bien, la corriente de gasto es constante a lo largo del tiempo.

$\mathrm{Ni}$ los líquidos muy aislantes ni los conductores llegan a cargarse; los primeros porque hay muy pocos iones en presencia, y los segundos porque en líquidos que conducen muy bien la electricidad, los iones se recombinarán con gran rapidez. En la práctica, sólo habrá electrización en líquidos cuya resistividad sea mayor que $10^{7} \Omega$ mo menor que $10^{11} \Omega \mathrm{m}$. Los mayores valores observados son de $r=10^{9} \mathrm{a} 10^{11} \Omega \mathrm{m}$.

\section{Ecuación 5: Descargas de conductores}

El potencial de un conductor aislado portador de una carga $Q$ viene dado por $V=Q /$ C y la energía almacenada por:

$$
W=\frac{1}{2} \mathrm{CV}^{2}=\frac{1}{2} \frac{Q^{2}}{C}
$$

Ecuación 6: Evolución temporal del potencial de un conductor cargado

En un conductor cargado por una corriente constante $\left(I_{G}\right)$, la evolución temporal del potencial es:

$$
V=R_{f} I_{G}\left(1-e^{\frac{-t}{R_{f} c}}\right)
$$

donde

$R_{f}$ es la resistencia de pérdida de corriente del conductor

Ecuación 7: Potencial final de un conductor cargado

Si el tiempo transcurrido es largo, $t \gg R_{f} C$, la ecuación anterior se convierte en:

$$
V=R_{f} I_{G}
$$

y la energía almacenada viene dada por:

Ecuación 8: Energía almacenada de un conductor cargado

$$
W=\frac{1}{2} C R_{f}^{2} I_{G}^{2}
$$

Los líquidos en movimiento inducirán acumulación de carga en las superficies aislantes sobre las cuales discurren. La medida de la formación de densidad superficial de carga estará limitada (1) por la rapidez con que los iones del líquido se recombinen en la interfaz líquido-sólido, (2) por la velocidad con que los iones del líquido sean conducidos por el aislante, o (3) porque se originen arcos en la superficie 0 el volumen del aislante y por lo tanto se pierda la carga. El régimen turbulento y el movimiento sobre superficies rugosas favorecen la electrización.

$\mathrm{Si}$ a un cuerpo cargado (un electrodo) que tiene un radio pequeño ( $p$. ej., un alambre) se le aplica una tensión alta (de varios kilovoltios), el campo eléctrico en la proximidad inmediata del cuerpo cargado es elevado, pero disminuye en seguida con la distancia. Si hay descarga de las cargas almacenadas, dicha descarga estará limitada a la región en que el campo 
Tabla 40.3 • Afinidades electrónicas de determinados polímeros. $^{1}$

$\begin{array}{lll}\text { Carga } & \text { Material } & \text { Afinidad electrónica (EV) } \\ - & \text { PVC (cloruro de polivinilo) } & 4,85 \\ & \text { Poliamida } & 4,36 \\ & \text { Policarbonato } & 4,26 \\ \text { PTFE (politetrafluoretileno) } & 4,26 \\ \text { PETP (tereftalato de polietileno) } & 4,25 \\ \text { Poliestireno } & 4,22 \\ \text { Poliamida } & 4,08\end{array}$

1 Un material adquiere carga positiva cuando entra en contacto con un material que lo precede en la lista, y carga negativa cuando entra en contacto con un material que le sigue en la lista. No obstante, la afinidad electrónica de un aislante es multifactorial.

eléctrico es más intenso que la rigidez dieléctrica de la atmósfera circundante, fenómeno conocido como efecto corona, porque el arco también emite luz. (M uchas personas han visto las chispitas que se forman cuando han experimentado en su propia persona un shock de electricidad estática.)

La densidad de carga en una superficie aislante se modifica también por los electrones en movimiento generados por un campo eléctrico de gran intensidad. Tales electrones generarán iones a partir de las moléculas de gas existentes en la atmósfera con la cual entran en contacto. Cuando la carga eléctrica del cuerpo sea positiva, el cuerpo cargado repelerá los iones positivos que se hayan generado. Los electrones creados por objetos cargados negativamente perderán energía a medida que se retiran del electrodo, y se ligarán a moléculas gaseosas de la atmósfera para formar iones negativos que continuarán separándose de los puntos de carga. Los iones positivos y negativos quedan en reposo sobre cualquier superficie aislante y modifican la densidad de carga de la superficie. Es un tipo de carga mucho más fácil de controlar y más uniforme que las cargas generadas por fricción. Las cargas generadas de esta forma tienen un límite, que se describe matemáticamente en la ecuación 3 de la Tabla 40.2.

Para generar cargas más altas, es preciso incrementar la rigidez dieléctrica del ambiente, bien mediante la creación de un vacío, bien por metalización de la otra superficie de la película aislante. Por este último método se arrastra el campo eléctrico hacia dentro del aislante y por lo tanto se reduce la intensidad de campo en el gas circundante.

Cuando un conductor sumergido en un campo eléctrico (E) se pone a tierra (véase la Figura 40.1), pueden producirse cargas por inducción. En estas condiciones, el campo eléctrico induce polarización (separación de los centros de gravedad de los iones negativos y positivos del conductor). U n conductor que se ponga a tierra temporalmente en un solo punto adquirirá una carga neta cuando se desconecte de tierra, a causa de la migración de cargas en la proximidad del punto. De aquí que las partículas conductoras situadas en un campo uniforme oscilen entre electrodos y produzcan cargas y descargas en cada contacto.

\section{Peligros asociados a la electricidad estática}

Los efectos nocivos provocados por la acumulación de electricidad estática varían desde la incomodidad que se experimenta cuando al tocar un objeto cargado, como la manilla de una puerta, hasta las lesiones muy graves, incluso fallecimientos, provocadas por una explosión debida a la electricidad estática. El efecto fisiológico de las descargas electrostáticas en seres humanos varía desde una picazón incómoda hasta acciones reflejas violentas. Se trata de efectos producidos por la corriente de descarga y, en especial, por la densidad de corriente en la piel.

En este artículo describiremos algunas de las formas por las cuales las superficies y los objetos se cargan en la práctica (electrización). Cuando el campo eléctrico inducido supera la capacidad del ambiente circundante para resistir a la carga (es decir, supera a la rigidez dieléctrica del ambiente), tiene lugar una descarga. (En el aire, la rigidez dieléctrica viene descrita por la curva de Paschen, y depende del producto de la presión por la distancia entre los cuerpos cargados.)

L as descargas disruptivas adoptan las formas siguientes:

- chispas o arcos que puentean dos cuerpos cargados (dos electrodos metálicos);

- descargas parciales, o en escobilla, que puentean un electrodo metálico y un aislante, o incluso dos aislantes; estas descargas se denominan parciales porque el camino de conducción no pone en cortocircuito dos electrodos metálicos, sino que en general es múltiple y en forma de escobilla,

- descargas en corona, conocidas también como poder de las puntas, que surgen en el fuerte campo eléctrico formado alrededor de cuerpos cargados o electrodos de radio muy pequeño.

Los conductores aislados tienen una a capacidad neta $C$ con respecto a tierra. En la ecuación 5 de la Tabla 40.2 se expresa la relación entre carga y potencial.

U na persona que lleve calzado aislante es un ejemplo corriente de conductor aislado. El cuerpo humano es un conductor electrostático, con una capacidad típica respecto a tierra de unos $150 \mathrm{pF}$ y un potencial de hasta $30 \mathrm{kV}$. Como las personas son conductores aislados, pueden experimentar descargas electrostáticas, como la sensación (más o menos desagradable) que se nota cuando una mano se acerca a la manilla de una puerta 0 a otro objeto metálico. Cuando el potencial alcanza el valor aproximado de $2 \mathrm{kV}$, se experimentará el equivalente a una energía de 0,3 $\mathrm{mJ}$, aunque este umbral varía de una persona a otra. Si las descargas son más fuertes, los movimientos reflejos involuntarios pueden originar caídas. En el caso

Figura 40.1 - Mecanismo de carga de un conductor por inducción.

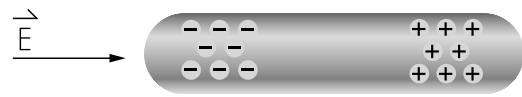

a. Polarización del conductor por efecto de un campo eléctrico

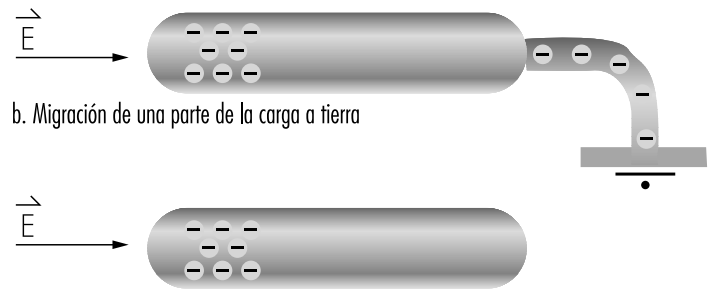

c. El conductor otra vez desconectado de tierra

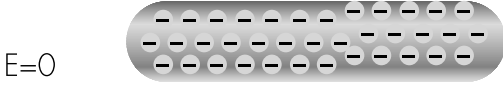

d. Retirada del campo eléctrico: el conductor conserva una carga neta 
de trabajadores que utilizan herramientas, ello puede dar lugar a lesiones en la víctima y en otras personas que se hallen trabajando cerca. Las ecuaciones 6 a 8 de la Tabla 40.2 describen la evolución temporal del potencial.

El arco real saltará cuando la fuerza del campo eléctrico inducido supere a la rigidez dieléctrica del aire. Debido a la rápida migración de las cargas en conductores, casi todas éstas confluyen en el punto de descarga y liberan toda la energía almacenada en forma de chispa. Las consecuencias son graves cuando se trabaja con sustancias inflamables o explosivas 0 en un ambiente inflamable.

La aproximación de un electrodo puesto a tierra a una superficie aislante cargada modifica el campo eléctrico e induce una carga en el electrodo. A medida que las superficies se acercan entre sí, la intensidad del campo aumenta y puede llegar a originar una descarga parcial desde la superficie aislante cargada. C omo las cargas de las superficies aislantes no son muy móviles, en la descarga sólo participa una pequeña proporción de la superficie, y por consiguiente la energía liberada en este tipo de descarga es mucho menor que en los arcos.

La carga y la energía transferida parecen ser directamente proporcionales al diámetro del electrodo metálico, hasta unos $20 \mathrm{~mm}$. La polaridad inicial del aislante también influye en la carga y en la energía transferida. Las descargas parciales de las superficies con carga positiva son menos energéticas que si las cargas son negativas. Es imposible determinar a priori la energía transferida por una descarga desde una superficie aislante, al contrario que ocurre en la situación que afecta a superficies conductoras. En realidad, como la superficie aislante no es equipotencial, ni siquiera es posible definir las capacidades que intervienen.

\section{Descarga disruptiva}

En la ecuación 3 (Tabla 40.2) vimos que la densidad superficial de carga de una superficie aislante en el aire no puede ser superior a $2.660 \mathrm{pC} / \mathrm{cm}^{2}$.

Si consideramos una placa aislante o una película de espesor a, que descansa en un electrodo metálico o que tenga una cara metálica, es fácil demostrar que el campo eléctrico es arrastrado hacia el interior del aislante por la carga inducida en el electrodo a medida que se depositan cargas en la cara no metálica. El resultado es que el campo eléctrico en el aire se debilita y se hace menor que si una de las caras no fuera metálica. En este caso, la rigidez dieléctrica del aire no limita la acumulación de carga en la superficie aislante y es posible alcanzar densidades de carga muy elevadas $\left(>2.660 \mathrm{pC} / \mathrm{cm}^{2}\right)$. L a acumulación de carga aumenta la conductividad superficial del aislante.

Cuando un electrodo se aproxima a una superficie aislante, tiene lugar una descarga disruptiva que afecta a una gran proporción de la superficie cargada, que se ha convertido en conductora. Debido a las grandes áreas superficiales que intervienen, este tipo de descarga libera grandes cantidades de energía. En el caso de películas, el campo en el aire es muy débil, y la distancia entre el electrodo y la película no puede ser mayor que el espesor de la película para que suceda la descarga. La descarga disruptiva se produce también cuando un aislante cargado se separa de su alma metálica. En tales circunstancias, el campo en el aire experimenta un aumento abrupto y toda la superficie del aislante se descarga para restablecer el equilibrio.

\section{Descargas electrostáticas y peligros de incendio y explosión}

En atmósferas explosivas pueden tener lugar violentas reacciones de oxidación exotérmicas, con transferencia energética a la atmósfera, provocadas por:
- llamas francas;

- chispas eléctricas;

- chispas de radiofrecuencia en las inmediaciones de una emisora de radio potente;

- chispas producidas por colisiones (p. ej., entre metal y hormigón),

- descargas electrostáticas.

Nos interesa únicamente este último caso. La temperatura de inflamabilidad (temperatura a la cual el líquido arde en contacto con una llama franca) de diversos líquidos, y la temperatura de ignición espontánea de diversos vapores se dan en la Sección de Q uímica de esta E nciclopedia. El peligro de incendio asociado a las descargas electrostáticas se calcula tomando como referencia el límite inferior de inflamabilidad de los gases, vapores y sólidos o de los aerosoles líquidos. El límite puede variar en términos considerables, como se ilustra en la Tabla 40.4.

U na mezcla de aire y de un gas o vapor inflamable sólo explosiona si la concentración de la sustancia inflamable está situada entre sus límites explosivos superior e inferior. Dentro de este intervalo, la energía mínima de ignición (EM I), o energía que ha de poseer una descarga electrostática para incendiar la mezcla, depende íntimamente de la concentración. Se ha demostrado de modo concluyente que la energía mínima de ignición depende de la velocidad de liberación de energía y, por extensión, de la duración de la descarga. El radio del electrodo es otro factor condicionante:

- Los electrodos de pequeño diámetro (del orden de varios milímetros) dan lugar a descargas en corona en vez de producir chispas.

- Con electrodos de diámetros mayores (del orden de varios centímetros), la masa del electrodo se basta para enfriar las chispas.

En general, las EMI más bajas se obtienen con electrodos que tienen el tamaño justo para impedir descargas en corona.

La EM I depende también de la distancia entre los electrodos, y es mínima a la distancia de amortiguación ("distance de pincement"), distancia a la cual la energía producida en la zona de reacción se hace superior a las pérdidas térmicas en los electrodos. Se ha demostrado experimentalmente que cada sustancia inflamable tiene una distancia de seguridad máxima, correspondiente a la distancia entre electrodos mínima a la cual ocurre una explosión. En los hidrocarburos, esta distancia es menor que $1 \mathrm{~mm}$.

La probabilidad de explosiones de polvo depende de su concentración. La probabilidad máxima va asociada a concentraciones del orden de 200 a $500 \mathrm{~g} / \mathrm{m}^{3}$. La EM I también depende del tamaño de las partículas, y las más finas son las que explosionan con más facilidad. Tanto en gases como en aerosoles, la EM I disminuye con la temperatura.

Tabla 40.4 • Límites inferiores típicos de inflamabilidad.

$\begin{array}{ll}\text { Descarga } & \text { Límite } \\ \text { Algunos polvos } & \text { Varios julios } \\ \text { Aerosoles muy finos de azufre y aluminio } & \text { Varios milijulios } \\ \text { Vapores de hidrocarburos y otros líquidos orgánicos } & 200 \text { microjulios } \\ \text { Hidrógeno y acetileno } & 20 \text { microjulios } \\ \text { Explosivos } & 1 \text { microjulio }\end{array}$




\begin{tabular}{ll}
\hline Tabla $40.5 \begin{array}{l}\text { Carga específica asociada a determinadas } \\
\text { operaciones industriales. }\end{array}$ & $\begin{array}{l}\text { Carga específica } \\
(\mathrm{q} / \mathrm{m})(\mathrm{C} / \mathrm{kg})\end{array}$ \\
Operación & $10^{-8}-10^{-11}$ \\
Cernido & $10^{-7}-10^{-9}$ \\
Llenado o vaciado de silos & $10^{-6}-10^{-8}$ \\
Transporte por tornillo sin fin & $10^{-6}-10^{-7}$ \\
Molienda & $10^{-4}-10^{-7}$ \\
Micronización & $10^{-4}-10^{-6}$ \\
Transporte neumático &
\end{tabular}

\section{Ejemplos de la industria}

M uchos procesos utilizados a diario para manipular y transportar sustancias químicas generan cargas electrostáticas. Entre ellas se cuentan:

- el vertido de polvos desde sacos;

- el cernido;

- el transporte por tuberías;

- la agitación de líquidos, sobre todo en presencia de varias fases, sólidos suspendidos o gotitas de líquidos no miscibles;

- el rociado o niebla de líquidos.

Las consecuencias de la generación de cargas electrostáticas comprenden problemas mecánicos, peligro de descarga electrostática en los operadores y, si se utilizan productos que contengan disolventes o vapores inflamables, incluso explosión (véase la Tabla 40.5).

Los hidrocarburos líquidos, como el petróleo, el queroseno y muchos disolventes corrientes, tienen dos características que les confieren una sensibilidad especial a los problemas de electricidad estática:

- resistividad alta, que les permite acumular elevados niveles de cargas,

- vapores inflamables, que aumentan el riesgo de descargas de baja energía que disparan incendios y explosiones.

Pueden generarse cargas durante el transporte ( $p$. ej., en la circulación por tuberías, bombas o válvulas). EI paso por filtros finos, como los utilizados durante el Ilenado de los depósitos de aviones, genera densidades de carga de varios centenares de microculombios por metro cúbico. La sedimentación de partículas y la generación de nieblas o espumas cargadas durante el llenado de depósitos también origina cargas.

Entre 1953 y 1971 la electricidad estática fue la responsable de 35 incendios y explosiones durante el llenado o a continuación del llenado de depósitos de queroseno, y durante el llenado de depósitos de camiones se produjeron aún más accidentes. La presencia de filtros o salpicaduras durante el llenado (que pueden generar espumas o nieblas) son los factores de riesgo que más veces fueron identificados. También hubo accidentes a bordo de barcos petroleros, sobre todo durante la limpieza de tanques.

\section{Principios de la prevención de electricidad estática}

Todos los problemas relativos a electricidad estática se derivan de:

- la generación de cargas eléctricas;

- la acumulación de estas cargas en aislantes o conductores aislados,
- el campo eléctrico producidos por estas cargas, que a su vez dan lugar a una fuerza o a una descarga disruptiva.

Las medidas preventivas tratan de evitar la acumulación de cargas electrostáticas, y la estrategia más recomendable es impedir que se generen las cargas eléctricas. Si esto no fuera posible, hay que aplicar medidas dirigidas a conectar las cargas a tierra. Por último, si la formación de descargas es inevitable, los objetos sensibles deberán protegerse contra los efectos de las descargas.

\section{Supresión o reducción de la generación de cargas electrostáticas}

Es la primera medida que debe emprenderse en la prevención electrostática, porque es la única medida preventiva que elimina el problema en su origen. Pero, como se ha descrito antes, las cargas se generan siempre que dos materiales, uno de los cuales como mínimo es aislante, entran en contacto y a continuación se separan. En la práctica, puede haber generación de carga incluso por contacto y separación de un material consigo mismo. En realidad, la generación de carga afecta a las capas superficiales de los materiales. Como la más ligera diferencia de humedad superficial o contaminación superficial da lugar a la generación de cargas estáticas, es imposible impedir por completo la generación de cargas.

Para reducir la cantidad de cargas generadas por superficies que entran en contacto, es preciso:

- Evitar que los materiales entren en contacto mutuo si tienen afinidades electrónicas muy diferentes; es decir, si están muy separados en la serie triboeléctrica. Por ejemplo, evitar el contacto entre vidrio y T eflon (PTFE), o entre PVC y poliamida (nailon) (véase la T abla 40.3).

- Reducir la tasa de flujo entre materiales, con lo cual disminuye la velocidad de deslizamiento entre materiales sólidos. Por ejemplo, puede reducirse el ritmo de extrusión de películas plásticas, del movimiento de materiales colocados en una cinta transportadora o el caudal de líquidos en una tubería.

No se han establecido límites definitivos de seguridad para medidas de caudal. La norma británica BS-5958Parte 2 Code of Practice for Control of U ndesirable Static Electricity recomienda que el producto de la velocidad (en metros per segundo) y el diámetro de la tubería (en metros) sea inferior a 0,38 para líquidos con conductividades menores que $5 \mathrm{pS} / \mathrm{m}$ (en picosiemens por metro) y menor que 0,5 para líquidos con conductividades superiores a $5 \mathrm{pS} / \mathrm{m}$. Tal criterio sólo es válido para líquidos de una sola fase transportados a velocidades no superiores a $7 \mathrm{~m} / \mathrm{s}$.

D ebe ponerse de relieve que al reducir la velocidad de deslizamiento o de flujo no sólo se disminuye la generación de cargas, sino que también se ayuda a disipar cargas que pudieran haberse generado. $Y$ es así porque al disminuir las velocidades de circulación resultan tiempos de permanencia mayores que los asociados a las zonas de relajación, donde los caudales se reducen por estrategias, como aumentar el diámetro de las tuberías, lo cual, a su vez, incrementa la puesta a tierra.

\section{Puesta a tierra de la electricidad estática}

La regla básica de la prevención electrostática es eliminar las diferencias de potencial entre objetos. Para conseguirlo, o bien se conectan entre sí, o se ponen a masa (toma de tierra). Con todo, los conductores aislados acumulan cargas y por lo tanto se cargan por inducción, fenómeno exclusivo de ellos. Las descargas de conductores pueden adoptar la forma de chispas de alta energía y son peligrosas. 
Tabla 40.6 Ejemplos de equipos sensibles a descargas electrostáticas.

\begin{tabular}{|c|c|}
\hline Elemento sensible & Ejemplos \\
\hline \multirow[t]{2}{*}{ Fuente } & $\begin{array}{l}\text { Un operador que toca la manilla de una puerta o el } \\
\text { chasis de un coche }\end{array}$ \\
\hline & $\begin{array}{l}\text { Componente con carga electrónica que entra en contacto } \\
\text { con un objeto puesto a tierra }\end{array}$ \\
\hline Blanco & $\begin{array}{l}\text { Componentes o materiales electrónicos que tocan a un } \\
\text { operador cargado }\end{array}$ \\
\hline Entorno & $\begin{array}{l}\text { Mezcla explosiva inflamada por una descarga } \\
\text { electrostática }\end{array}$ \\
\hline
\end{tabular}

Se trata de una regla que se atiene a las recomendaciones en materia de prevención de descargas eléctricas, que también exigen la puesta a tierra de todas las partes metálicas accesibles, como se especifica en la norma francesa Instalaciones eléctricas de baja tensión (NFC 15-100). Para conseguir la máxima seguridad electrostática, que es lo que aquí nos ocupa, esta regla debe generalizarse a todos los elementos conductores. Se incluyen aquí cercos metálicos de mesa, manillas de puertas, componentes electrónicos, depósitos utilizados en las empresas químicas y el chasis de los vehículos que transportan hidrocarburos.

Desde el punto de vista de seguridad electrostática, el ideal sería que todo fuera conductor y estuviera siempre puesto a tierra, a la que se transferirían en todo momento las cargas generadas. En estas circunstancias, todo tendría siempre el mismo potencial, y por lo tanto el campo eléctrico - y el riesgo de descarga- sería cero. Pero casi nunca es posible alcanzar esta situación ideal, por los motivos siguientes:

- No todos los productos que es necesario manipular son conductores, y muchos de ellos no pueden hacerse conductores mediante el uso de aditivos. Así sucede con numerosos productos agrícolas y farmacéuticos, así como con líquidos de gran pureza.

- Hay propiedades convenientes para el producto final, como por ejemplo la transparencia óptica o la baja conductividad térmica, que pueden excluir el empleo de materiales conductores.

- Es imposible disponer una puesta a tierra permanente en equipos móviles como carruajes metálicos, herramientas electrónicas sin cordón, vehículos e incluso operadores humanos.

\section{Protección contra las descargas electrostáticas}

Debe tenerse en cuenta que en esta sección únicamente se abordan la protección de equipo sensible a la electrostática contra descargas inevitables, la reducción de la generación de cargas y la eliminación de éstas. La capacidad de proteger el equipo no

Figura 40.2 - Dibujo esquemático del problema de la descarga electrostática.

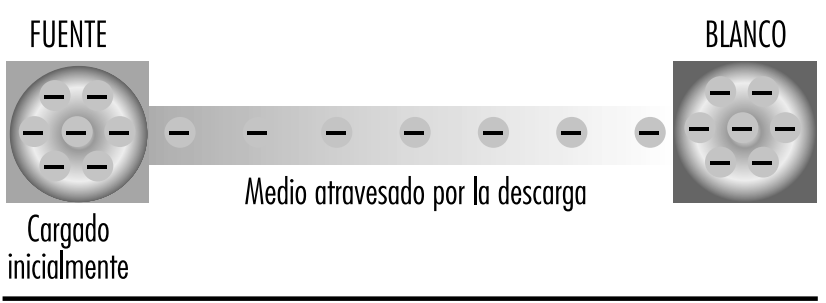

suprime la necesidad fundamental de prevenir ante todo la acumulación de carga electrostática.

Como se ilustra en la Figura 40.2 todos los problemas electrostáticos incluyen una fuente de descarga electrostática (el objeto cargado inicialmente), un blanco que recibe la descarga y el medio por el cual circula la descarga (descarga dieléctrica). Debe subrayarse que el blanco o el medio pueden ser sensibles a la electrostática. Algunos ejemplos de elementos sensibles se recogen en la Tabla 40.6.

\section{Protección de trabajadores}

Los trabajadores que tienen motivos para creer que se encuentran cargados eléctricamente (por ejemplo, cuando desmontan un vehículo en tiempo seco 0 andan con determinados tipos de calzado), pueden adoptar numerosas medidas protectoras, como las siguientes:

- Reducir la densidad de corriente en la piel, para lo cual basta con tocar un conductor puesto a tierra con un elemento metálico, como una llave o herramienta.

- Reducir el valor de cresta de la corriente mediante la descarga en un objeto disipador que se pueda tener a mano (un dispositivo de sobremesa o especial, como una muñequera protectora con resistencia en serie).

\section{Protección en atmósferas explosivas}

En atmósferas explosivas, es el propio ambiente el que resulta ser sensible a las descargas electrostáticas, que de ocurrir podrían dar lugar a ignición o explosión. En estos casos, la protección consiste en sustituir el aire, bien por una mezcla gaseosa cuyo contenido de oxígeno sea inferior a la concentración mínima para que la mezcla se inflame bien por un gas inerte, como el nitrógeno. Los gases inertes se han utilizado en silos y en vasijas de reacción de los sectores químico y farmacéutico. En este caso, es preciso tomar las precauciones debidas para garantizar que los trabajadores reciban un suministro de aire adecuado.

\section{PreVenCION Y NORMAS}

Renzo Comini

\section{Peligros y medidas preventivas en instalaciones eléctricas}

Los numerosos componentes que forman parte de las instalaciones eléctricas presentan diversos grados de robustez. Pero con independencia de su inherente fragilidad, todos tienen que funcionar con fiabilidad en condiciones inclementes. Por desgracia, aun en las mejores circunstancias, el equipo eléctrico está sujeto a fallos susceptibles de ocasionar lesiones a las personas o daños materiales.

El funcionamiento seguro de las instalaciones eléctricas es el resultado de un buen diseño inicial, no la mera actualización debida a los sistemas seguridad. Tal afirmación es un corolario del hecho de que mientras la corriente circula a la velocidad de la luz, todos los sistemas electromecánicos y electrónicos presentan retardos de reacción provocados sobre todo por la inercia térmica, la inercia mecánica y las condiciones de mantenimiento. Los retardos, cualesquiera que sean sus orígenes, son lo bastante duraderos para que las personas puedan sufrir lesiones, y el equipo, daños (Lee, Capelli-Schellpfeffer y K elly 1994; Lee, Cravalho y Burke 1992; K ane y Sternheim 1978.)

Es esencial que el equipo sea instalado y mantenido por personal cualificado. Se debe subrayar que es preciso establecer medidas técnicas que garanticen el funcionamiento 
seguro de las instalaciones y al mismo tiempo protejan al personal y al equipo.

\section{Introducción a los peligros eléctricos}

La operación adecuada de las instalaciones eléctricas exige que la maquinaria, el equipo y las líneas y circuitos eléctricos estén protegidos de los peligros causados tanto por factores internos (es decir, que surgen dentro de la instalación) como externos (Andreoni y Castagna 1983).

Las causas internas comprenden:

- tensiones excesivas;

- cortocircuitos;

- modificación de la forma de onda de la corriente;

- inducción;

- interferencia;

- corrientes excesivas;

- corrosión, que provoca fugas de corriente eléctrica a tierra;

- calentamiento de materiales conductores y aislantes, que pueden producir quemaduras en el operador, emisiones de gases tóxicos, incendio de componentes y, en atmósferas inflamables, explosiones;

- fugas de líquidos aislantes, como el aceite,

- generación de hidrógeno o de otros gases que favorezcan la formación de mezclas explosivas.

Cada combinación peligro-equipo exige medidas protectoras específicas, algunas de las cuales son obligatorias en virtud de leyes 0 de reglamentos técnicos internos. Los fabricantes tienen la responsabilidad de conocer las estrategias técnicas específicas capaces de reducir riesgos.

Entre las causas externas se cuentan:

- factores mecánicos (caídas, golpes, vibración);

- factores físicos y químicos (radiación natural o artificial, temperaturas extremas, aceites, líquidos corrosivos, humedad);

- viento, hielo, rayos;

- vegetación (árboles y raíces, secos y mojados);

- animales (en zonas urbanas y rurales), que pueden dañar el aislamiento de líneas de distribución de energía y, por lo tanto, provocar cortocircuitos o falsos contactos,

- y, no menos grave aunque se mencione en último lugar, algunos adultos 0 niños descuidados, imprudentes 0 inconscientes de los riesgos y de los procedimientos de funcionamiento.

0 tras causas externas son la interferencia electromagnética procedente de líneas de alta tensión, receptores de radio, máquinas de soldar (capaces de generar sobretensiones transitorias) y solenoides.

Las causas de los problemas más habituales proceden del mal funcionamiento o falta de normalización de elementos como:

- equipo protector mecánico, térmico o químico;

- sistemas de ventilación, sistemas de refrigeración de máquinas, equipo, líneas o circuitos,

- coordinación de aislantes empleados en partes diferentes de la planta

- coordinación de fusibles y disyuntores automáticos.

Un solo fusible o disyuntor automático es incapaz de proporcionar una protección adecuada frente a excesivas corrientes en dos circuitos diferentes. Los fusibles o disyuntores automáticos protegen contra fallos de fase-neutro, pero la protección contra fallos de fase-tierra exige disyuntores automáticos de corriente residual. Se recomiendan las medidas siguientes:

- utilización de relés de tensión y descargadores para coordinar los sistemas de protección;
- sensores y componentes mecánicos o eléctricos en los sistemas protectores de la instalación;

- separación de circuitos a tensiones diferentes (debe mantenerse una separación de aire adecuada entre conductores; las conexiones deben estar aisladas; los transformadores se deben equipar con pantallas conectadas a tierra y protección conveniente contra tensiones excesivas, y con bobinados de primario y secundario totalmente segregados);

- códigos de colores u otras precauciones útiles para evitar equivocaciones en la identificación de hilos;

- confundir el conductor de la fase activa con el neutro da lugar a la electrización de los componentes metálicos externos del equipo,

- equipo de protección contra interferencia electromagnética.

La importancia de estas medidas es especial en la instrumentación y las líneas utilizadas para la transmisión de datos o el intercambio de señales de protección y/o control. Se debe mantener la separación adecuada entre las líneas o los filtros y pantallas empleados. En los casos más críticos se utilizan a veces cables de fibra óptica.

El riesgo asociado a las instalaciones eléctricas aumenta cuando el equipo trabaja en condiciones extremas, las más corrientes de las cuales se derivan de peligros eléctricos en ambientes húmedos o mojados.

Las finas capas conductoras líquidas que se forman sobre las superficies metálicas y aislantes en ambientes húmedos 0 mojados crean caminos nuevos, irregulares y peligrosos para la corriente. La infiltración de agua reduce la eficacia del aislamiento y, si el agua llega a penetrar en el aislamiento, puede provocar fugas de corriente y cortocircuitos. Se trata de efectos que no sólo dañan las instalaciones eléctricas, sino que multiplican los riesgos para las personas. Así, este peligro justifica la necesidad de normas especiales para trabajar en ambientes duros, como emplazamientos a la intemperie, instalaciones agrícolas, edificios en construcción, cuartos de baño, minas, bodegas y algunos emplazamientos industriales.

Se dispone de equipo que suministra protección contra la lluvia, las salpicaduras laterales o la inmersión completa. El equipo ideal debe ser cerrado, aislado y anticorrosión. Los recintos metálicos han de estar puestos a tierra. EI mecanismo de fallo en estos ambientes mojados es el mismo que el observado en atmósferas húmedas, pero los efectos son más graves.

\section{Peligros eléctricos en atmósferas pulverulentas}

EI polvo fino que entra en las máquinas y en el equipo eléctrico produce abrasión, sobre todo de las piezas móviles. El polvo conductor puede provocar también cortocircuitos, mientras que el polvo aislante interrumpe el paso de corriente y aumenta la resistencia de contacto. Las acumulaciones de polvo fino o grueso alrededor de las cajas de equipo son depósitos potenciales de humedad y agua. El polvo seco es un aislante térmico, que reduce la dispersión del calor y aumenta la temperatura local; este aumento puede dañar los circuitos eléctricos y provocar incendios 0 explosiones.

Se deben instalar sistemas estancos al agua y a prueba de explosión en emplazamientos industriales o agrícolas donde se lleven a cabo procesos en que intervengan polvos.

\section{Peligros eléctricos en atmósferas explosivas o en} emplazamientos que alberguen materiales explosivos

Las explosiones, incluidas las de atmósferas que contengan gases y polvos explosivos, pueden dispararse por la apertura y cierre de circuitos eléctricos activos, o bien por cualquier otro proceso transitorio capaz de generar chispas de energía suficiente. 
He aquí los lugares en los que existe este peligro:

- minas y lugares subterráneos donde se puedan acumular gases, en especial metano;

- empresas químicas;

- salas de almacenamiento de baterías de plomo, en las que se puede acumular hidrógeno;

- el sector agroalimentario, en el que se pueden generar polvos orgánicos naturales;

- el sector de materiales sintéticos,

- la metalurgia, en especial la que utiliza aluminio y magnesio.

Allí donde exista este peligro, el número de circuitos y equipos eléctricos deberá ser el mínimo: por ejemplo, mediante la eliminación de motores y transformadores eléctricos o su sustitución por equipo neumático. El equipo eléctrico que no pueda eliminarse debe quedar encerrado, para evitar cualquier contacto de gases y polvos inflamables con chispas, y mantenido dentro del recinto cerrado en una atmósfera de gas inerte a presión positiva.. D onde haya posibilidad de explosión se utilizarán recintos a prueba de explosión y cables eléctricos a prueba de incendios. Se ha desarrollado un abanico completo de equipo a prueba de explosión para algunos sectores de alto riesgo (p. ej., el sector del petróleo y el químico).

Debido al elevado coste del equipo a prueba de explosión, las plantas se suelen dividir en zonas de distinto peligro eléctrico. Cuando se aplica este criterio, en las zonas de alto riesgo se emplea equipo especial, mientras que en las demás se acepta un cierto grado de riesgo. Se han desarrollado diversos criterios y soluciones técnicas específicas de sectores; éstas comprenden por lo general alguna combinación de puesta a tierra, segregación de componentes e instalación de barreras divisorias de zonas.

\section{Unión equipotencial}

Si todos los conductores que pudieran tocarse simultáneamente, incluso los de tierra, estuviesen al mismo potencial, no habría peligro para las personas. Los sistemas de unión equipotencial son un intento de lograr esta condición ideal (Andreoni y Castagna 1983; L ee, Cravalho y Burke 1992).

En la unión equipotencial, cada conductor expuesto del equipo eléctrico no dedicado a la transmisión y todo conductor accesible ajeno del mismo emplazamiento se conectan a un conductor de protección puesto a tierra. Debe recordarse que mientras los conductores de equipo no destinado a la transmisión están inactivos durante el funcionamiento normal, pueden activarse en caso de fallo de aislamiento. Al disminuir la tensión de contacto, la unión equipotencial impide que los componentes metálicos alcancen tensiones que lleguen a ser peligrosas para el personal y el equipo.

En la práctica, es necesario conectar la misma máquina a la malla de unión equipotencial en más de un punto. Deben identificarse con cuidado las zonas de contacto defectuoso debido, por ejemplo, al recubrimiento de aislantes como lubricantes y pintura. De modo similar, es conveniente conectar todas las tuberías de servicios locales y externos (p. ej., agua, gas y calefacción) a la rejilla de unión equipotencial.

\section{Puesta a tierra}

En la mayoría de los casos, es necesario minimizar la caída de tensión entre los conductores de la instalación y tierra. Para realizarlo, los conductores se conectan a un conductor de protección puesto a tierra.

$\mathrm{H}$ ay dos tipos de conexiones de tierra:

- tierras funcionales: por ejemplo, puesta a tierra del conductor neutro de un sistema trifásico, o del punto medio del devanado secundario de un transformador,
- tierras de protección: por ejemplo, puesta a tierra de todos los elementos conductores de equipo. El objeto de este tipo de puesta a tierra es minimizar tensiones en los elementos conductores, mediante la creación de un camino preferente para las corrientes de fuga, en especial las corrientes que pudieran afectar a las personas.

En condiciones de funcionamiento normal, por la conexiones de puesta a tierra no pasa ninguna corriente. Pero en caso de activación accidental del circuito, la baja resistencia de la conexión de puesta a tierra hace que el paso de corriente sea lo bastante elevado para fundir el fusible o los conductores no conectados a tierra.

La tensión de fuga máxima en mallas equipotenciales admitida en la mayoría de las normas es $50 \mathrm{~V}$ para ambientes secos, $25 \mathrm{~V}$ para ambientes mojados o húmedos y $12 \mathrm{~V}$ para laboratorios médicos y otros ambientes de alto riesgo. Aunque estos valores únicamente son indicativos, debe ponerse de relieve la necesidad de garantizar una toma de tierra adecuada en puestos de trabajo, espacios públicos y en residencias especiales.

La eficacia de la puesta a tierra depende sobre todo de la existencia de corrientes de fuga altas y estables a tierra, pero también de un acoplamiento galvánico adecuado de la malla equipotencial y del diámetro de los conductores de conexión a la malla. Debido a la importancia de las fugas a tierra, tiene que ser evaluada con gran exactitud.

Las conexiones a tierra tienen que ser tan fiables como las mallas equipotenciales, y es preciso verificar periódicamente su funcionamiento correcto.

A medida que la resistencia a tierra aumenta, el potencial del conductor de puesta a tierra y de la tierra en torno del conductor se aproxima a la del circuito eléctrico; en el caso de la tierra en torno del conductor, el potencial generado es inversamente proporcional a la distancia del conductor. Con objeto de evitar tensiones escalonadas peligrosas, los conductores de tierra han de estar apantallados como es debido y puestos a tierra a profundidades adecuadas.

Como alternativa a la puesta a tierra del equipo, las normas permiten emplear equipos con doble aislamiento. Su uso, recomendado en emplazamientos residenciales, minimiza la probabilidad de fallo del aislamiento al suministrar dos sistemas de aislamiento separados. No es aconsejable confiar en que el equipo con doble aislamiento proteja como es debido contra fallos de conexiones, como los asociados a las clavijas sueltas pero activadas, puesto que las normas de algunos países relativas a clavijas y enchufes murales no consideran el empleo de dichas clavijas.

\section{Disyuntores}

El método más seguro de reducir peligros eléctricos para personas y equipo es minimizar la duración de la corriente de fuga y el aumento de tensión, en el momento ideal antes de que la energía eléctrica haya empezado a aumentar. Los sistemas de protección en el equipo eléctrico suele incorporar tres relés: un relé de corriente de defecto para proteger contra las fugas hacia tierra, un relé magnético y un relé térmico para proteger contra sobrecargas y cortocircuitos.

En los disyuntores de corriente de defecto, los conductores del circuito se arrollan en torno a un anillo que detecta el vector suma de las corrientes entrantes y salientes del equipo a proteger. El vector suma es igual a cero durante el funcionamiento normal, pero es igual a la corriente de fuga en casos de fallo. Cuando esta corriente alcanza el umbral del disyuntor, éste se dispara. Los disyuntores de corriente de defecto se pueden disparar por corrientes tan bajas como $30 \mathrm{~mA}$ y con retardos tan breves como $30 \mathrm{~ms}$. 
La corriente máxima que transporta un conductor sin ningún peligro está en función del área de su sección transversal, su aislamiento y su instalación. Si se sobrepasa la carga segura máxima o si la disipación de calor está limitada, el conductor experimentará un calentamiento excesivo. Los dispositivos limitadores de corriente, como fusibles y disyuntores magnetotérmicos, cortan automáticamente el circuito si el paso de corriente es excesivo, o si aparecen corrientes a tierra, sobrecarga o cortocircuito. Los dispositivos limitadores de corriente deben interrumpir el paso de corriente cuando ésta es superior a la permitida por la capacidad del conductor.

La elección de equipo protector capaz de proteger personal y equipo es uno de los aspectos más importantes de la gestión de instalaciones eléctricas y ha de tener en cuenta no sólo la capacidad de transporte de corriente de los conductores, sino también las características de los circuitos y del equipo conectado a ellos.

En los circuitos que soporten cargas de corriente muy altas será preciso emplear fusibles o disyuntores especiales de gran capacidad.

\section{Fusibles}

Existen varios tipos de fusibles, cada uno de ellos diseñado para una aplicación específica. El empleo de un tipo de fusible equivocado 0 de un fusible de capacidad inadecuada puede provocar lesiones a personas y daños al equipo. Los fusibles de capacidad excesiva originan con frecuencia el calentamiento del cableado 0 equipo, con la consiguiente posibilidad de que se produzcan incendios.

Antes de sustituir fusibles, deje el circuito fuera de servicio, efectúe el enclavamiento de los aparatos de corte y compruebe que está inactivo. La comprobación puede salvar vidas. A continuación, identifique la causa del posible cortocircuito o sobrecarga y sustituya los fusibles fundidos por otros del mismo tipo y capacidad. No inserte nunca fusibles en un circuito activo.

\section{Disyuntores}

Si bien los disyuntores se emplean desde hace mucho tiempo en circuitos de alta tensión con grandes capacidades de corriente, ha venido aumentando su utilización en muchas otras clases de circuitos. Existen numerosos tipos, que ofrecen opciones de armado inmediato y retardado y operación manual o automática.

Los disyuntores se clasifican en dos categorías generales: térmicos y magnéticos.

Los disyuntores térmicos únicamente reaccionan frente a la subida de temperatura. Por lo tanto, las variaciones de la temperatura ambiente del disyuntores afectará al punto en que el disyuntor se dispare.

L os disyuntores magnéticos, por el contrario, sólo reaccionan ante la cantidad de corriente que pasa por el circuito. Es un tipo de disyuntor más adecuado para los casos en que existan fluctuaciones amplias de la temperatura que exigirían sobredimensionar el disyuntor, o cuando el disyuntor se dispara con frecuencia.

En el caso de contacto con líneas que transporten mucha corriente, los circuitos de protección no impiden lesiones personales ni daños al equipo, puesto que se diseñan para proteger únicamente líneas y sistemas de transporte de energía del paso excesivo de corriente provocado por fallos.

Debido a la resistencia del contacto con tierra, la corriente que atraviesa un objeto que está en contacto al mismo tiempo con la línea y tierra será en general menor que la corriente de disparo. Las corrientes de defecto atravesando el cuerpo humano deben reducirse en mayor grado por la resistencia del cuerpo mientras no llegue a disparar el disyuntor, por lo que son extremadamente peligrosas. En la práctica, es casi imposible diseñar un sistema de transporte de energía que impida lesiones corporales 0 daños a cualquier objeto que toque las líneas de transporte sin que éstas dejen de ser un sistema útil de transmisión de energía, puesto que los umbrales de disparo de los dispositivos de protección de los circuitos que interesan están muy por encima del nivel de peligro para el hombre.

\section{Normas y reglamentos}

El entramado de normas y reglamentos internacionales se ilustra en la Figura 40.3 (Winckler 1994). Las filas corresponden al ámbito geográfico de las normas, mundial (internacional), continental (regional) o nacional, mientras que las columnas corresponden a los campos de aplicación de las normas. La CEI y la O rganización Internacional de N ormalización (ISO ) comparten ambas una estructura superior, el Grupo Coordinador M ixto de Presidentes (JPCG); el equivalente europeo es el G rupo M ixto de Presidentes (JPG).

Cada organismo de normalización mantiene reuniones periódicas internacionales. La composición de los distintos organismos refleja el desarrollo de la normalización.

EI Comité E uropeo de Normalización E lectrotécnica (CENELEC) fue creado en 1957 por los comités de ingeniería eléctrica de los países firmantes del Tratado de Roma que estableció la Comunidad Económica Europea. A los seis miembros fundadores se sumaron después los miembros de la Asociación Europea de Libre Comercio (AELC), y CENELEC en su forma actual data del 13 de febrero de 1972.

En contraste con la Comisión Electrotécnica Internacional (CEI), el CENELEC se centra en la implantación de normas internacionales en los países miembros y no en la creación de nuevas normas. Tiene particular importancia recordar que mientras la adopción de normas de la CEI por los países miembros es voluntaria, la adopción de normas y reglamentos del CENELEC es obligatoria en la Unión Europea. Más del $90 \%$ de las normas del CENELEC han derivado de normas de la CEI, y más del $70 \%$ de ellas son idénticas. La influencia del CENELEC ha atraído también el interés de los países de Europa oriental, la mayoría de los cuales se convirtieron en miembros afiliados en 1991.

Figura 40.3 - Estructura de las normas y reglamentos internacionales.

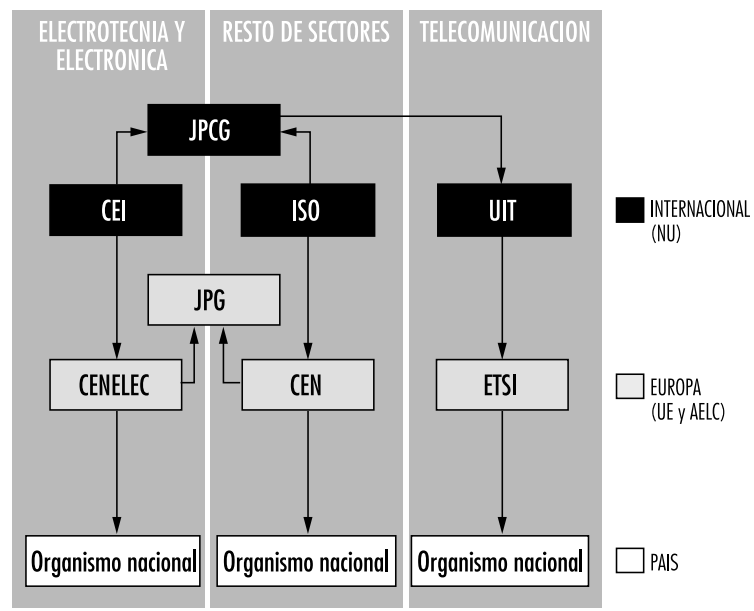

JPCG = Grupo Coordinador Mixto de Presidentes $\quad J P G=$ Grupo Mixto de Presidentes

CEI = Comisión Electrotécnica Internacional $\quad$ CENELEC $=$ Comité Europeo de Normalización Electrotécnica

ISO = Organización Internacional de Normalización $\quad$ CEN = Comité Europeo de Normalización

UIT = Unión Internacional de Telecomunicaciones ETSI = Instituto Europeo de Normas de Telecomunicaciones 
La A sociación Internacional de Ensayos y $M$ ateriales, precursora de la ISO, como se conoce en la actualidad, fue fundada en 1886 y mantuvo su actividad hasta la primera Guerra M undial, tras la cual dejó de funcionar como asociación internacional. Algunas organizaciones nacionales sobrevivieron, como la American Society for Testing and M aterials (AST M). En 1926 se fundó en Nueva York la Asociación Internacional de Normalización (ISA), que mantuvo actividad hasta la segunda Guerra M undial. La ISA fue reemplazada en 1946 por la ISO, que es responsable de todos los campos excepto los de ingeniería eléctrica y telecomunicaciones. El Comité Europeo de Normalización (CEN) es el equivalente europeo de la ISO y tiene la misma función que el CENELEC, aunque sólo el $40 \%$ de las normas CEN se derivan de normas ISO.

La cada vez mayor consolidación económica internacional crea la necesidad de bases de datos técnicos comunes en el campo de la normalización. Se trata de un proceso que está en curso en varias partes del mundo, y es probable que haga evolucionar nuevos organismos de normalización extraeuropeos. CANENA es un organismo regional de normalización creado por los países del Tratado de Libre Comercio de América del N orte (T LC) (C anadá, M éxico y Estados U nidos). El cableado de edificios en EE UU se rige por el National Electrical Code, ANSI/ NFPA 70-1996. Esta norma se aplica también en otros países de América del Norte y del Sur. D efine los requisitos de la instalación de cableados en locales desde el punto de conexión hasta el sistema de suministro eléctrico. A barca la instalación de conductores y equipo eléctrico dentro o sobre edificios públicos y privados, incluidas casas móviles, vehículos recreativos y edificios flotantes, parques de materiales, parques de atracciones, estacionamientos y otros solares, y subestaciones industriales. No ampara instalaciones en barcos ni embarcaciones que no sean edificios flotantes: material rodante, aviones o vehículos de automoción. El National Electric Code no es aplicable a otros campos que estén ya regulados por el $N$ ational Electrical Security Code, como las instalaciones de equipos del servicio público de comunicaciones y las instalaciones de suministro de electricidad.

\section{Normas europeas y americanas para la operación de instalaciones eléctricas}

La norma europea EN 50110-1, O peración de Instalaciones E léctricas (1994a), preparada por la Task Force 63-3 del CENELEC, es el documento básico que se aplica a la operación de instalaciones eléctricas y a las actividades de trabajo en ellas, con ellas o cerca de las mismas. La norma establece los requisitos mínimos para todos los países del CENELEC; las normas nacionales adicionales se describen en subpartes separadas de la norma (EN 50110-2).

La norma se aplica a instalaciones diseñadas para la generación, transmisión, conversión, distribución y utilización de energía eléctrica, y para la operación a los niveles de tensión habituales. Aunque las instalaciones típicas trabajan a tensiones bajas, la norma se aplica también a instalaciones de muy baja y de alta tensión. $L$ as instalaciones pueden ser permanentes y fijas (p. ej., instalaciones de distribución en fábricas o edificios de oficinas) o móviles.

En la norma se especifican los procedimientos de operación y mantenimiento seguros para el trabajo en instalaciones eléctricas o cerca de las mismas. Entre las actividades de trabajo aplicables se incluyen las de trabajo no eléctrico, como la construcción junto a líneas aéreas o cables subterráneos, además de todos los tipos de trabajo eléctrico. D eterminadas instalaciones eléctricas, como las existentes a bordo de aviones y barcos, no están sujetas a la norma.
La norma equivalente en Estados U nidos es el $\mathrm{N}$ ational Electrical Safety Code (NESC), del American National Standards Institute (1990). EI NESC se aplica a instalaciones y funciones de suministro de servicios públicos desde el punto de generación de electricidad y señales de comunicación, pasando por la malla de transmisión, hasta el punto de suministro a las instalaciones del cliente. Determinadas instalaciones, como las existentes en minas y barcos, no están sujetas al NESC. Las directrices del NESC se han ideado para garantizar la seguridad de los trabajadores dedicados a la instalación, el funcionamiento o el mantenimiento de líneas de suministro eléctrico y de comunicación y sus equipos asociados. Tales directrices constituyen la norma mínima aceptable de seguridad profesional y pública en las condiciones especificadas. La norma no pretende ser una especificación de diseño o un manual de instrucciones. En el aspecto formal, el NESC tiene que ser considerado una norma nacional de seguridad aplicable en $E$ stados $U$ nidos.

Las reglas extensivas de las normas europeas y americanas sustentan la realización segura de trabajos en instalaciones eléctricas.

\section{La norma europea (1994a)}

\section{Definiciones}

La norma sólo da definiciones de los términos más corrientes; en la Comisión Electrotécnica Internacional (1979) se dispone de más información. Para los fines de esta norma, la instalación eléctrica se refiere a todo el equipo empleado en la generación, transporte, conversión, distribución y utilización de energía eléctrica. Se incluyen todas las fuentes de energía, incluso baterías y condensadores (ENEL 1994; EDF-GDF 1991).

\section{Principios básicos}

Operación segura: EI principio básico de trabajo seguro en, con 0 cerca de una instalación eléctrica es la necesidad de evaluar el riesgo eléctrico antes de comenzar el trabajo.

Personal: Las mejores reglas y procedimientos de trabajo en, con o cerca de una instalación eléctrica carecen de valor si los trabajadores no están totalmente familiarizados con ellas y no las cumplen a rajatabla. Todo el personal que interviene en el trabajo en, con o cerca de una instalación eléctrica, deberá ser instruido en los requisitos de seguridad, las reglas de seguridad y las normas empresariales aplicables a su trabajo. Cuando el trabajo es largo o complejo, esta instrucción deberá repetirse. Se exigirá a los trabajadores que observen estos requisitos, reglas e instrucciones.

Organización: Cada instalación eléctrica se colocará bajo la responsabilidad de la persona nombrada para controlar la instalación eléctrica. En casos de empresas que comprendan más de una instalación, es esencial que las personas nombradas para controlar cada instalación cooperen entre sí.

Cada actividad de trabajo será responsabilidad de la persona nombrada para controlar el trabajo. Cuando el trabajo comprenda otras tareas, se nombrarán per sonas responsables de la seguridad de cada una de ellas, quienes informarán al coordinador. Puede nombrase a una misma persona para controlar el trabajo y para controlar la instalación eléctrica.

Comunicación: A quí se incluyen todos los medios de transmisión de información entre personas, es decir, palabra hablada (incluidos teléfono, radio y conversación), escrita (incluido el fax) y los medios visuales (incluidos los paneles de instrumentos, vídeo, señales y luces).

Deberá hacerse una notificación formal de toda la información necesaria para la operación segura de la instalación eléctrica, p. ej., disposición de las redes, estado de las de conmutaciones y posición de los dispositivos de seguridad. 
Lugar de trabajo: Deberá proporcionarse espacio de trabajo, acceso e iluminación adecuados en las instalaciones eléctricas en las cuales, con las cuales o cerca de las cuales se haya de realizar cualquier trabajo.

$H$ erramientas, equipo y procedimientos: Las herramientas, equipo y procedimientos cumplirán los requisitos de las normas europeas, nacionales e internacionales aplicables, cuando éstas existan.

Dibujos e informes: Los dibujos e informes de la instalación estarán actualizados y disponibles.

Señalización: Se dispondrán las señales adecuadas que llamen la atención sobre peligros específicos en los lugares necesarios cuando la instalación esté funcionando y durante cualquier trabajo.

\section{Procedimientos operativos estándar}

A ctividades operativas : Las actividades operativas están ideadas para cambiar el estado eléctrico de una instalación eléctrica. $\mathrm{H}$ ay dos tipos:

- operaciones encaminadas a modificar el estado eléctrico de una instalación eléctrica, p. ej., con objeto de utilizar equipo, conectar, desconectar, poner en marcha o parar una instalación o sección de una instalación para llevar a cabo un trabajo. Son actividades que pueden realizarse localmente 0 por control remoto,

- desconexión antes o reconexión después de un trabajo sin tensión, que será ejecutada por trabajadores cualificados 0 formados.

Pruebas funcionales: Incluyen los procedimientos de medición, prueba e inspección.

Se define por medición todo el conjunto de actividades utilizadas para recoger datos físicos en instalaciones eléctricas. La medición deberá ser ejecutada por profesionales cualificados.

La prueba comprende todas las actividades ideadas para verificar el funcionamiento o la condición eléctrica, mecánica o térmica de una instalación eléctrica. La prueba deberá ser ejecutada por trabajadores cualificados.

La inspección consiste en verificar que una instalación eléctrica cumple las especificaciones técnicas y los reglamentos de seguridad aplicables.

\section{Procedimientos de trabajo}

Generalidades: La persona nombrada para controlar la instalación eléctrica y la persona nombrada para controlar el trabajo deben cerciorarse ambas de que los trabajadores reciben instrucciones específicas y detalladas antes de iniciar el trabajo y a la terminación del mismo.

Antes de empezar el trabajo, la persona nombrada para controlarlo deberá informar a la encargada de controlar la instalación eléctrica sobre la naturaleza del trabajo que se pretende realizar, su emplazamiento y las consecuencias para la instalación eléctrica. La notificación se dará por escrito siempre que sea posible, en especial cuando el trabajo sea complejo.

Las actividades de trabajo se dividen en tres categorías: trabajo sin tensión, trabajo con tensión y trabajo en la proximidad de instalaciones con tensión. Para cada tipo de trabajo se han desarrollado medidas de protección contra descargas eléctricas, cortocircuitos y arcos.

Inducción: Cuando se ejecuten trabajos en líneas eléctricas sometidas a inducción de corriente, se deberá tomar las precauciones siguientes:

- puesta a tierra a intervalos adecuados; esto reduce el potencial entre conductores y tierra hasta el nivel de seguridad,
- unión equipotencial del lugar de trabajo; así se impide que los trabajadores formen parte de un circuito inductivo.

Condiciones atmosféricas: Cuando se vean relámpagos o se oigan truenos, no se deberán iniciar o continuar trabajos en instalaciones de exterior 0 en instalaciones de interior conectadas directamente a líneas aéreas.

\section{Trabajo sin tensión}

Las prácticas de trabajo siguientes garantizarán que las instalaciones eléctricas en el lugar de trabajo permanezcan sin tensión mientras dure la actividad laboral. A menos que haya contraindicaciones claras, las prácticas deberán aplicarse en el orden que se indica.

D esconexión completa: La sección de la instalación en la cual se haya de ejecutar el trabajo deberá ser aislada de todas las fuentes de suministro de corriente, y asegurada contra la reconexión.

Seguro contra reconexión: Todos los dispositivos cortacircuitos utilizados para aislar la instalación eléctrica durante el trabajo deberán ser desactivados, si es posible mediante el bloqueo del mecanismo de operación.

Verificación de que la instalación está inactiva: La ausencia de corriente deberá ser verificada en todos los polos de la instalación eléctrica del lugar de trabajo o lo más cerca del mismo que sea posible.

Puesta a tierra y en cortocircuito: En todos los lugares de trabajo de alta tensión y en algunos de baja tensión, todas las partes en que se vaya a trabajar deberán ser puestas a tierra y en cortocircuito después de haber sido desconectadas. Los equipos y dispositivos de puesta a tierra y en cortocircuito deben conectarse en primer lugar a la toma de tierra; sólo después de esta puesta a tierra se conectarán al sistema los componentes que se vayan a derivar a tierra. Siempre que sea posible en la práctica, los sistemas de puesta a tierra y en cortocircuito deberán ser visibles desde el lugar de trabajo. Las instalaciones de baja y alta tensión tienen sus propios requisitos específicos. En estos tipos de instalación, todos los lados de los lugares de trabajo y todos los conductores que entran al recinto deberán ser puestos a tierra y cortocircuitados.

Protección contra partes activas adyacentes: Cuando haya partes de una instalación eléctrica en la proximidad del lugar de trabajo que no sea posible desactivar, es preciso tomar medidas protectoras adicionales. L os trabajadores no comenzarán el trabajo sin haber recibido permiso de la persona nombrada para controlar el trabajo, quien a su vez deberá recibir autorización de la persona nombrada para controlar la instalación eléctrica. U na vez realizado el trabajo, los trabajadores abandonarán el lugar de trabajo, serán guardadas las herramientas y el equipo, y a continuación se quitarán los sistemas de puesta a tierra y en cortocircuito. La persona nombrada para controlar el trabajo notificará entonces a la persona nombrada para controlar la instalación eléctrica que la instalación está disponible para la reconexión.

\section{Trabajo con tensión}

Generalidades: El trabajo con tensión es el que se realiza dentro de una zona en que hay paso de corriente. La norma EN 50179 proporciona una guía sobre las dimensiones de la zona de trabajo con tensión. Se aplicarán medidas protectoras ideadas para prevenir descargas eléctricas, arcos y cortocircuitos.

Formación y calificación: Deberán aplicarse programas específicos de formación para desarrollar y mantener la capacidad de los trabajadores calificados o formados para desempeñar trabajo relacionados con la tensión. U na vez impartido el programa, los 
trabajadores recibirán una nota de calificación y autorización para realizar trabajos específicos con tensiones específicas.

M antenimiento de las calificaciones: La capacidad de realizar trabajos con tensión deberá ser mantenida mediante la práctica o nueva formación.

T écnicas de trabajo: En la actualidad, hay tres técnicas reconocidas, que se distinguen por su aplicabilidad a diferentes tipos de partes activas y por el equipo necesario para prevenir descargas eléctricas, arcos y cortocircuitos:

- trabajo con pértiga (trabajo a distancia);

- trabajo con guantes aislantes (trabajo en contacto),

- trabajo con manos desnudas (trabajo a potencial).

Cada técnica exige preparación, equipo y herramientas diferentes, y la elección de la técnica más adecuada dependerá de las características del trabajo en cuestión.

$H$ erramientas y equipo: D eberán especificarse las características, almacenamiento, mantenimiento, transporte e inspección de herramientas, equipo y sistemas.

Condiciones atmosféricas: Se aplican restricciones al trabajo con tensión en condiciones atmosféricas adversas, puesto que las propiedades de los aislantes, la visibilidad y la movilidad del trabajador quedan disminuidas.

Organización del trabajo: El trabajo deberá prepararse por adelantado; la preparación se presentará por escrito cuando el trabajo sea complejo. La instalación en general, y la sección donde se vaya a ejecutar el trabajo en particular, deberá mantenerse en el estado definido durante la preparación. La persona nombrada para controlar el trabajo informará a la que controla la instalación eléctrica sobre la naturaleza del trabajo, el lugar de la instalación donde será ejecutado el trabajo y la duración estimada del mismo. Antes de comenzar el trabajo, deberá explicarse a los trabajadores la naturaleza de éste, las medidas de seguridad importantes, el papel de cada trabajador, y las herramientas y equipos que se van a utilizar.

Existen procedimientos específicos para instalaciones de muy baja tensión, de baja tensión y de alta tensión.

\section{Trabajo en la proximidad de partes con tensión}

$G$ eneralidades: El trabajo en la proximidad de partes activas, con tensiones nominales superiores a 50 VCA ó 120 VCC sólo será realizado cuando se hayan adoptado medidas de seguridad que garanticen la imposibilidad de tocar las partes con tensión o de entrar en la zona activada. Para ello se pueden emplear pantallas, barreras, cerramientos o cubiertas aislantes.

Antes de comenzar el trabajo, la persona nombrada para controlar el trabajo instruirá a los trabajadores, en particular a los no familiarizados con el trabajo en la proximidad de partes con tensión, con las distancias de seguridad que deben observarse en el lugar de trabajo, las prácticas principales de seguridad y la necesidad de un comportamiento que garantice la seguridad de todo el equipo de trabajo. Los límites del lugar de trabajo estarán definidos con precisión, marcados y señalizados para atraer la atención sobre las condiciones de trabajo no habituales. La información se repetirá las veces que sea necesario, en particular cuando haya cambios en las condiciones de trabajo.

L os trabajadores deberán cerciorarse de que ninguna parte de su cuerpo ni ningún objeto invada la zona activada. Se adoptarán precauciones especiales cuando se manipulen objetos largos, por ejemplo, herramientas, puntas de cable, tuberías y escaleras.

Protección mediante pantallas, barreras, cerramientos o cubiertas aislantes: La selección e instalación de estos dispositivos protectores deberá suministrar protección suficiente contra ataques eléctricos y mecánicos predecibles. El equipo deberá estar mantenido a punto y protegido durante el trabajo.

\section{M antenimiento}

G eneralidades: Su finalidad es conservar la instalación eléctrica en la condición adecuada. El mantenimiento puede ser preventivo (es decir, periódico, para evitar paradas y mantener el equipo en condiciones de trabajo normal) o correctivo (es decir, el realizado para sustituir piezas defectuosas).

El trabajo de mantenimiento se clasifica en dos categorías de riesgo:

- trabajo que implica el riesgo de descarga eléctrica, en que deben observarse los procedimientos aplicables al trabajo con tensión y al trabajo en la proximidad de partes activas,

- trabajo en que el diseño del equipo permite realizar algunas operaciones de mantenimiento sin necesidad de aplicar procedimientos completos de trabajo con tensión.

Personal: EI personal que vaya a realizar el trabajo deberá tener la cualificación adecuada (o bien recibirá formación suficiente), y contará con las herramientas e instrumentos apropiados de medición y prueba.

Trabajo de reparación: El trabajo de reparación consta de las fases siguientes: localización del fallo; arreglo del fallo y/ o sustitución de componentes; nueva puesta en servicio de la sección reparada de la instalación. C ada una de estas fases exige procedimientos específicos.

Trabajo de sustitución: En general, la sustitución de fusibles en instalaciones de alta tensión deberá ser realizada sin tensión. La sustitución de fusibles será efectuada por trabajadores cualificados que observen los procedimientos de trabajo adecuados. La sustitución de lámparas y piezas desmontables, como motores de arranque, se llevará a cabo sin tensión. En instalaciones de alta tensión, el trabajo de sustitución se realizará también con procedimientos de reparación.

\section{Formación de personal en materia de riesgos eléctricos}

La organización eficaz del trabajo y la formación en seguridad son elementos clave para tener éxito en cualquier organización, programa de prevención y programa de salud y seguridad en el trabajo. Los trabajadores han de poseer la formación adecuada para hacer su trabajo con seguridad y eficacia.

La responsabilidad de implantar la formación de empleados pertenece a la dirección, que ha de reconocer la necesidad de que para que la organización pueda alcanzar sus objetivos los empleados han de rendir a un determinado nivel. La consecución de estos niveles de rendimiento exige el establecimiento de políticas de formación y, por extensión, de programas concretos de formación. En los programas se deben incluir fases de formación y de calificación.

Los programas de trabajo con tensión incluirán los elementos siguientes:

Formación: En algunos países, los programas y las instalaciones de formación han de contar con la aprobación formal de un comité de trabajo con tensión u organismo similar. LoS programas se basan ante todo en la experiencia práctica, complementada con formación técnica. La formación adopta la forma de trabajo práctico en instalaciones modelo, interiores 0 exteriores, semejantes a aquéllas en que se deberá realizar el trabajo real.

Calificaciones: Los procedimientos de trabajo con tensión son muy exigentes, e insisten en la necesidad de utilizar a la persona adecuada en el lugar correcto. La manera más fácil de lograrlo es disponer de personal cualificado con diferentes niveles de especialización. La persona nombrada para controlar el trabajo debe ser un trabajador cualificado. Cuando sea necesaria la supervisión, también ésta debe ser responsabilidad de una persona cualificada. Los trabajadores sólo deben 
trabajar en instalaciones cuya tensión y complejidad se correspondan con su nivel de cualificación o formación. En algunos países, la cualificación está regulada por normas nacionales.
Por último, los trabajadores deben recibir instrucciones y formación en técnicas esenciales de salvamento. Remitimos al lector que desee ampliar la información al capítulo relativo a primeros auxilios.

\section{Referencias}

American National Standards Institute (ANSI). 1990. National E lectrical Safety Code: ANSI C2. Nueva Y ork: ANSI.

Andreoni, D, R Castagna. 1983. L'Ingegnere e la Sicurezza. Vol. 2. R oma: Edizioni Scientifiche.

Comisión Electrotécnica Internacional (CEI). 1979. Electrobiologie. Capítulo 891 en G eneral Index of International E lectrotechnical Vocabulary. G inebra: CEI.

-. 1987. Effets du Courant Passant par le Corps humain: D euxième partie. ICE 479-2. Ginebra: CEI.

-. 1994. Effets du Courant Passant par le Corps humain: Première partie. Ginebra: CEI.

Comunidad Económica Europea (CEE). 1989. Directiva del Consejo de 12 de junio de 1989 sobre la adopción de medidas para promover mejoras en la seguridad y la salud de los trabajadores en el lugar de trabajo. D ocumento núm. 89/391/ CE E. Luxemburgo: CEE.

EDF-GDF. 1991. Carnet de Prescriptions au Personnel- P révention du $R$ isque electrique.

ENEL Spa. 1994. Disposizioni per la Prevenzione del R ischi E lettrici.

Folliot, D. 1982. Les accidents d'origine électrique, leur prévention. Collection monographie de médecine du travail. París: Editions M asson.

Gilet, JC, R Choquet. 1990. La Sécurité électrique: T echniques de prévention. Grenoble, Francia: Société alpine de publication.

Gourbiere, E, J Lambrozo, D Folliot, C Gary. 1994 Complications et séquelles des accidents dus à la foudre. Rev Gén E lectr 6 (4 de junio).

K ane, JW, MM Sternheim. 1980. Fisica Biomedica. R oma: EMSI.

Lee, RC, EG Cravalho, JF Burke. 1992. Electrical T rauma. Cambridge: $\mathrm{C}$ ambridge U niv. Press.

Lee, RC, M Capelli-Schellpfeffer, KM K elly. 1994. Electrical injury: A multidisciplinary approach to therapy, prevention and rehabilitation. Ann NY Acad Sci 720.
N orma Europea (1994a). O peration of E lectrical Installations. Versión definitiva EN 50110-1.

Norma Europea (1994b). O peration of Electrical Installations (Anexos Nacionales) Versión definitiva EN 50110-2.

Winckler, R. 1994. Electrotechnical Standardization in Europe: A Tool for the Internal M arket. Bruselas: CENELEC

\section{0 tras lecturas recomendadas}

Association Suisse des Electriciens. 1990. R equisitos básicos de seguridad para los equipos eléctricos de pequeño voltaje (Prescriptions de sécurité fondamentales pour matériels électriques à basse tension). Zurich: Association Suisse des Electriciens.

Casini, VJ. 1993. O ccupational electrocutions: Investigation and prevention. Prof Saf 38(1):34-39.

Comisión Electrotécnica Internacional (CEI). 1990a. Graphic Symbols for U se on E quipment. G inebra: CEI.

-. 1990b. Safety of T ransportable M otor-O perated E lectric T ools-Part 1: General R equirements. G inebra: CEI.

- . 1994. M arking of E lectrical E quipment with $R$ atings $R e$ lated to E lectrical Supply-Safety R equirements. Ginebra: CEI.

Donnachie, PE. 1994. Dangers of electricity- An introduction. $H$ ealth Safety D ata F C:1 (J unio):1-4.

Fraser, D. 1990. U nit: Safety technology-module: Electrical safety. En $O$ ccupational $H$ ealth and Safety. Portsmouth: Portsmouth Polytechnic.

Garside, R. 1990. E lectrical Apparatus and $\mathrm{H}$ azardous Areas. A ylesbury: $\mathrm{H}$ exagon T echnology.

Grube, BJ, DM H eimbach, LH Engrav, M K Copass. 1990. N eurologic consequences of electrical burns. T rauma 30(3):254-258.

H arvey-Sutton, PL, TR D riscoll, MS Frommer, JE $H$ arrison. 1992. W ork-related electrical fatalities in Australia, 1982-1984. Scand I W ork Environ H ealth 18(5):293-297.
$H$ auptverband der Gewerblichen Berufsgenossenschaften. 1989. Código de práctica para la prevención de riesgos de ignición por cargas electrostáticas: D irectrices sobre la electricidad estática (en alemán). Colonia: Carl H eymanns V erlag.

Health and Safety Executive. 1993. E lectricity at W ork: Safe W orking Practices. Londres: H er M ajesty's Stationery 0 ffice.

Institut national de Recherche et de Sécurité. 1993. Accidentes de origen eléctrico (A ccidents d'origine électrique). París: Institut national de recherche et de sécurité.

Jenkins, BD. 1993. T ouch Voltages in Electrical Installations. O xford: Blackwell Scientific Publications.

K inloch, CD. 1987. E lectrical Installation: Snags and Solutions: R eed Business Publishing.

O meish, TM, M Sebastian. 1991. O vercoming electrical risks in hazardous process areas. Fire Prev (245) (Diciembre):21-26.

Paureau, J, M Rollin. 1990. Calzado antiestático de seguridad: Evaluación de los principales métodos utilizados para determinar la resistencia del aislamiento (en francés). Cahiers de notes documentaires- Sécurité et hygiène du travail, $2^{\circ}$ - trimestre (139): 405-419.

Pineault, M , M R ossignol, R G Barr. 1994. Inter-rater analysis of a classification scheme of occupational fatalities by electrocution. J Saf Res 25(2):107-115.

Reilly, JP, H Antoni. 1992. Electrical Stimulation and Electropathology. Cambridge: Cambridge Univ. Press.

Suruda, A, L Smith. 1992. Work-related electrocutions involving portable power tools and appliances. J 0 ccup M ed 34(9):887-892.

Tilley, L. 1992. Electrocution-A shock to the system. Aust Safety N ews 63(11):58-59.

Walker, E. 1992. Safety M anagers Pocket Guide to E lectrical Inspection. R oterdam: Saxton Safety Services.

Yakuboff, K P, HE K leinert. 1991. Electrical injuries. En $O$ ccupational $\mathrm{H}$ and and $\mathrm{U}$ pper Extremity Injuries and $\mathrm{D}$ iseases, dirigido por $\mathrm{ML} \mathrm{K}$ asdan. Filadelfia: $\mathrm{H}$ anley $\&$ Belfus. 


\section{INCENDIOS}

Director del capítulo

Casey C. Grant

\section{Sumario}

Conceptos básicos

D ougal D rysdale . . . . . . . . . . . . . . . . . . . . . . . 41.2

Fuentes de peligro de incendio

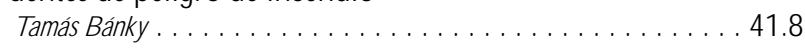

M edidas de prevención contra incendios

Peter F. J ohnson .

M edidas de protección pasiva contra incendios

Yngve Anderberg. .......................... 41.19

M edidas activas de protección contra incendios

Gary Taylor ........................... 41.23

O rganización de la lucha contra incendios

S. Dheri............................. 41.26 


\section{- CONCEPTOS BASICOS}

Dougal Drysdale

\section{La química y la física del fuego}

Un incendio es la manifestación de una combustión incontrolada. En ella intervienen materiales combustibles que forman parte de los edificios en que vivimos, trabajamos y jugamos o una amplia gama de gases, líquidos y sólidos que se utilizan en la industria y el comercio. Estos materiales, normalmente constituidos por carbono, se agruparán en el contexto de este estudio bajo la denominación de sustancias combustibles. Aunque estas sustancias presentan una gran variedad en cuanto a su estado químico y físico, cuando intervienen en un incendio responden a características comunes, si bien se diferencian en la facilidad con que se inicia éste (ignición), la velocidad con que se desarrolla (propagación de la llama) y la intensidad del mismo (velocidad de liberación de calor). A medida que profundizamos en la ciencia de los incendios, cada vez es posible cuantificar y predecir con mayor exactitud el comportamiento de un incendio, lo que nos permite aplicar nuestros conocimientos a la prevención de los incendios en general. El objetivo de esta sección es revisar algunos principios fundamentales y contribuir a la comprensión del desarrollo de los incendios.

\section{Conceptos básicos}

Estamos rodeados de materiales combustibles que, en determinadas condiciones, pueden entrar en combustión si se les aplica una fuente de ignición capaz de iniciar una reacción en cadena. En el marco de este proceso, la "sustancia combustible" reacciona con el oxígeno del aire liberando energía (calor) y generando productos de combustión, algunos de los cuales pueden ser tóxicos. Es necesario comprender con claridad los mecanismos de ignición y combustión.

Normalmente, la mayoría de los incendios se producen en materiales sólidos (p. ej. madera o sus derivados y polímeros sintéticos), pero también, en menor medida, en combustibles líquidos y gaseosos. Antes de estudiar algunos conceptos básicos, es conveniente revisar brevemente la combustión de gases y líquidos.

\section{Llamas de difusión y de premezclado}

Un gas inflamable ( $p$. ej., el propano, $\mathrm{C} 3 \mathrm{H} 8$ ) puede entrar en combustión de dos formas diferentes. U na corriente o chorro de gas de una tubería (un simple mechero Bunsen con la entrada de aire cerrada) puede entrar en ignición y arder como llama de difusión , produciéndose la combustión en aquellas zonas en que el combustible gaseoso y el aire se mezclan mediante un proceso de difusión. Este tipo de llama presenta una luminosidad amarilla característica que indica la presencia de partículas diminutas de hollín formadas como resultado de una combustión incompleta. Algunas de esas partículas arden en la llama, pero otras emergen por la punta de la misma para formar el humo.

0 tra forma de combustión tiene lugar cuando el gas y el aire se mezclan antes de la ignición y se produce una combustión de premezclado, siempre que el rango de concentración de la mezcla de gas y aire se encuentre entre los límites de inflamabilidad inferior y superior (véase la Tabla 41.1). Fuera de dichos límites la mezcla no resulta inflamable (recuerde que cuando se abre la entrada de aire de un mechero Bunsen, en la boca se estabiliza una llama de premezclado). Cuando una mezcla es inflamable, la ignición puede provocarse aplicando una fuente de ignición de pequeñas dimensiones (chispa eléctrica). La mezcla de tipo estequiométrico es la que arde con mayor facilidad, pues la proporción de oxígeno presente es la adecuada para quemar toda la sustancia combustible y transformarla en
Tabla 41.1 • Ĺmites inferior y superior de inflamabilidad en el aire.

\begin{tabular}{lll} 
& $\begin{array}{l}\text { Límite inferior de } \\
\text { inflamabilidad } \\
\text { (\% volumen) }\end{array}$ & $\begin{array}{l}\text { Límite superior de } \\
\text { inflamabilidad } \\
\text { (\% volumen) }\end{array}$ \\
Monóxido de carbono & 12,5 & 74 \\
Metano & 5,0 & 15 \\
Propano & 2,1 & 9,5 \\
n-Hexano & 1,2 & 7,4 \\
n-Decano & 0,75 & 5,6 \\
Metanol & 6,7 & 36 \\
Etanol & 3,3 & 19 \\
Acetona & 2,6 & 13 \\
Benceno & 1,3 & 7,9 \\
\hline
\end{tabular}

dióxido de carbono y agua (véase la ecuación siguiente, que demuestra que, aunque el nitrógeno está presente en la misma proporción que en el aire, no participa en la reacción). En esta reacción el material de combustión es el propano $(\mathrm{C} 3 \mathrm{H} 8)$ :

$$
\mathrm{C}_{3} \mathrm{H}_{8}+5 \mathrm{O}_{2}+18,8 \mathrm{~N}_{2}=3 \mathrm{CO}_{2}+4 \mathrm{H}_{2} \mathrm{O}+18,8 \mathrm{~N}_{2}
$$

En este caso, para que arda una mezcla estequiométrica de propano y aire basta una simple descarga eléctrica de $0,3 \mathrm{~mJ}$, es decir, una chispa estática casi imperceptible como la que puede provocar una persona al caminar por una alfombra sintética y tocar un objeto conectado a tierra. Para determinados gases reactivos como el hidrógeno, etileno o etino, bastarían cantidades aún menores de energía. En una atmósfera de oxígeno puro (como en la reacción anterior, pero sin nitrógeno como diluyente) la energía necesaria sería incluso menor.

La llama de difusión asociada a un flujo de combustible gaseoso ilustra la forma de combustión que se observa cuando un combustible líquido o sólido arde con llama. Pero, en este caso, la llama se alimenta de los vapores de la sustancia combustible generados en la superficie de la fase condensada. La velocidad de suministro de estos vapores depende de su velocidad de combustión en la llama de difusión. La energía se transfiere de la llama a la superficie, generando así la energía necesaria para producir los vapores. En los combustibles líquidos se trata de un simple proceso de evaporación, pero en los sólidos debe existir una cantidad suficiente de energía para lograr la descomposición química del combustible y romper las grandes moléculas de polímero en fragmentos más pequeños capaces de evaporarse y escapar de la superficie. Esta reacción térmica es indispensable para mantener el flujo de vapores y, con ello, la llama de difusión (Figura 41.1). Las llamas pueden extinguirse actuando sobre este proceso de diferentes formas (véase más adelante).

\section{Transferencia de calor}

La comprensión del proceso de transferencia del calor (o energía) es clave para estudiar el comportamiento y los procesos de los incendios, por lo que merece un análisis detenido. $\mathrm{H}$ ay muchos textos de consulta excelentes (Welty, Wilson y Wicks 1976; DiNenno 1988), pero para estos fines nos bastará estudiar los mecanismos de conducción, convección y radiación. Las ecuaciones básicas para la transferencia de calor en estado estacionario (og") son:

$$
\begin{aligned}
& \text { Conducción: } \quad \alpha k^{\prime \prime}=\frac{k}{\mid}\left(T_{1}-T_{2}\right) \mathrm{kW} / \mathrm{m}^{2} \\
& \text { Convección: } \quad q \mathrm{~s}^{\prime \prime}=h\left(\mathrm{~T}_{1}-\mathrm{T}_{2}\right) \mathrm{kW} / \mathrm{m}^{2} \\
& \text { Radiación: } \quad \text { q" }=\varepsilon \sigma\left(\mathrm{T}_{1}^{4}-\mathrm{T}_{2}^{4}\right) \mathrm{kW} / \mathrm{m}^{2}
\end{aligned}
$$


Figura 41.1 • Representación esquemática de una superficie en ignición y de los procesos de transferencia de calor y masa en la misma.

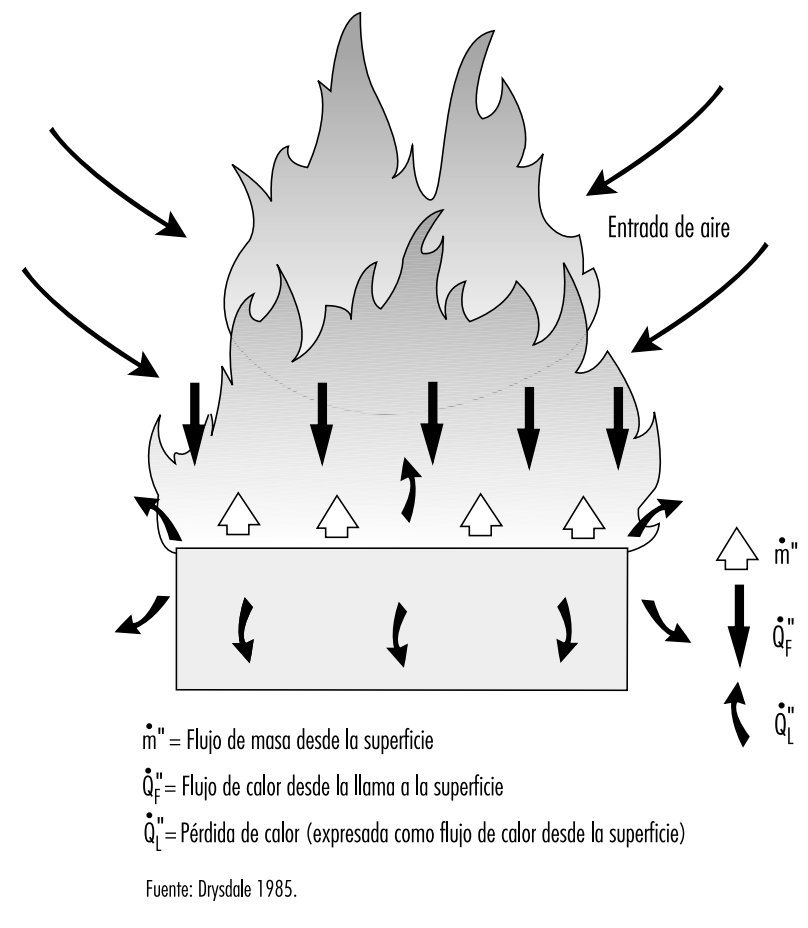

La conducción es fundamental en la transferencia de calor a través de sólidos (siendo k una propiedad del material conocida como conductividad térmica ( $\mathrm{kW} / \mathrm{mK}$ ) y l la distancia $(\mathrm{m})$ a lo largo de la cual la temperatura desciende de $\mathrm{T}_{1}$ a $\mathrm{T}_{2}$ (en grados K elvin). La convección en este contexto es la transferencia de calor de un fluido (en este caso, aire, llamas o productos de combustión) a una superficie (sólida o líquida), siendo h el coeficiente de transferencia de calor por convección (kW/ m2K ), que depende de la configuración de la superficie y de la naturaleza del flujo que pasa por ella. La radiación es similar a la luz visible (pero con una longitud de onda mayor) y no necesita un medio de propagación (puede ser el vacío), siendo $\varepsilon$ la emisividad (eficiencia de radiación de una superficie) y $\sigma$ la constante de Stefan-Boltzman $\left(56,7 \times 10^{-12} \mathrm{~kW} / \mathrm{m}^{2} \mathrm{~K}{ }^{4}\right)$. La radiación térmica viaja a la velocidad de la luz $\left(3 \times 10^{8} \mathrm{~m} / \mathrm{s}\right)$ y cualquier objeto sólido que se interponga en su camino proyectará una sombra.

\section{Velocidad de combustión y velocidad de liberación de calor}

En la transferencia de calor desde la llama a la superficie de las sustancias combustibles condensadas (líquidas y sólidas) se combinan la convección y la radiación, aunque esta última es la que domina cuando el diámetro efectivo del incendio supera $1 \mathrm{~m}$. La velocidad de combustión [ma $(\mathrm{g} / \mathrm{s})$ ] puede expresarse mediante la fórmula siguiente:

$$
m_{\alpha}=\frac{Q \alpha_{F}^{\prime \prime}-Q \alpha_{L}^{\prime \prime}}{L_{v}} \cdot A_{\text {combustible }} g / \mathrm{s}
$$

Q ¿" es el flujo de calor desde la llama a la superficie $\left(\mathrm{kW} / \mathrm{m}^{2}\right) ; Q_{F}^{\prime \prime}$ es la pérdida de calor de la superficie (p. ej., por radiación o por conducción a través del sólido) expresada como flujo ( $\left.\mathrm{kW} / \mathrm{m}^{2}\right)$; $A_{\text {combustible }}$ es el área superficial del combustible $\left(\mathrm{m}^{2}\right)$ y $\mathrm{L} v$ el calor de gasificación (equivalente al calor latente de evaporación de un líquido) $(\mathrm{kJ} / \mathrm{g})$. Cuando se produce un incendio en un espacio cerrado, los gases calientes que emergen del mismo (impulsados por la flotabilidad) se quedan debajo del techo, calentando las superficies superiores del recinto. La capa de humo resultante y las superficies calientes irradian calor hacia la parte inferior del recinto, especialmente hacia la superficie de combustible, y aumentan así la velocidad de combustión:

$$
m_{\alpha}=\frac{Q \alpha_{F}^{\prime \prime}+Q \alpha_{\text {ext }}^{\prime \prime}-Q \alpha_{L}^{\prime \prime}}{L_{v}} \cdot A_{\text {combustible }} g / s
$$

siendo Q\&" el calor adicional suministrado por radiación desde la parte superior del recinto $\left(\mathrm{kW} / \mathrm{m}^{2}\right)$. Esta reacción adicional provoca un aumento considerable de la velocidad de combustión, aśi como un fenómeno de descarga en los recintos cerrados en que existe un suministro adecuado de aire y una cantidad suficiente de combustible para mantener el incendio (D rysdale 1985).

La velocidad de combustión está moderada por la magnitud del valor de L v, calor de gasificación, que tiende a ser bajo en los líquidos y relativamente alto en los sólidos, es decir, los sólidos tienden a arder mucho más despacio que los líquidos.

Parece que el parámetro que más influye en el comportamiento de combustión de un material (o de un conjunto de materiales) es la velocidad de liberación de calor ( $\mathrm{RHR}$ ), que está ligada a la velocidad de combustión con arreglo a la ecuación siguiente:

$$
\mathrm{RHR}=m \Delta \mathrm{H}, \quad \mathrm{kW}
$$

siendo $\Delta \mathrm{H}_{\mathrm{c}}$ el calor efectivo de combustión de la sustancia combustible $(\mathrm{kJ} / \mathrm{g})$. Actualmente disponemos de nuevas técnicas para determinar el RHR de diferentes flujos de calor (p. ej., el Calorímetro de Cono) y medir el RHR de objetos voluminosos, como muebles tapizados y revestimientos de paredes, con calorímetros de gran capacidad basados en los valores de consumo de oxígeno para determinar la velocidad de liberación del calor (Babrauskas y Grayson, 1992).

No hay que olvidar que, a medida que aumentan las proporciones de un incendio, no sólo se incrementa la velocidad de liberación de calor, sino también la velocidad de aparición de los "productos de combustión", que contienen sustancias tóxicas y humo formado por partículas, cuyo volumen aumentará a medida que disminuye la ventilación en el recinto cerrado.

\section{Ignición}

La ignición de un líquido o de un sólido requiere el aumento de su temperatura superficial hasta que se desprenden vapores a una velocidad suficiente para, una vez iniciada la ignición de estos, mantener la llama. Los combustibles líquidos pueden clasificarse según su punto de inflamación o temperatura mínima a la que puede existir un vapor o una mezcla de aire inflamable en la superficie (es decir, la presión del vapor corresponde al límite inferior de inflamabilidad). En la Tabla 41.2 se incluyen algunos ejemplos típicos de estas temperaturas, que pueden determinarse con un aparato estándar. Para producir un flujo de vapores capaz de mantener una llama de difusión es necesaria una temperatura ligeramente superior, conocida como punto de ignición. Estos conceptos se aplican asimismo a los sólidos combustibles, aunque en éstos las temperaturas son más altas debido a las exigencias de la descomposición química. El punto de ignición se encuentra normalmente por encima de $300{ }^{\circ} \mathrm{C}$ dependiendo del combustible. Por lo general, los materiales ignífugos presentan puntos de ignición bastante más altos (véase la Tabla 41.2).

La facilidad de ignición de un material sólido depende, por tanto, de la facilidad con que se eleva su temperatura superficial hasta alcanzar el punto de ignición, por ejemplo, mediante la exposición a un calor radiante 0 a un flujo caliente de gases. Este 
Tabla 41.2 - Puntos de inflamación y de ignición de combustibles líquidos y sólidos.

\begin{tabular}{|c|c|c|}
\hline & $\begin{array}{l}\text { Punto de inflamación } \\
\text { en vaso cerrado }\left({ }^{\circ} \mathrm{C}\right)\end{array}$ & $\begin{array}{l}\text { Punto de } \\
\text { ignición }{ }^{2}\left({ }^{\circ} \mathrm{C}\right)\end{array}$ \\
\hline Gasolina (100 Octanos) (I) & -38 & - \\
\hline n-Decano (I) & 46 & 61,5 \\
\hline n-Dodecano (I) & 74 & 103 \\
\hline Polimetilmetacrilato (s) & - & $\approx 310$ \\
\hline Polimetilmetacrilato FR (s) & - & $\approx 377$ \\
\hline Polipropileno (s) & - & $\approx 330$ \\
\hline Polipropileno FR (s) & - & $\approx 397$ \\
\hline Poliestireno (s) & - & $\approx 367$ \\
\hline Poliestireno FR (s) & - & $\approx 445$ \\
\hline
\end{tabular}

proceso depende menos de las características de la descomposición química que del espesor y las propiedades físicas del sólido, como su conductividad térmica $(k)$, densidad $(\rho)$ y capacidad calorífica (c). Los sólidos de espesores finos, como las virutas de madera, arden con gran facilidad porque tienen una masa térmica baja, es decir, se necesita una cantidad relativamente reducida de calor para aumentar su temperatura hasta el punto de ignición. En cambio, cuando se aplica calor a la superficie de un sólido de gran espesor, parte del calor pasa de la superficie al interior, lo que reduce el aumento de la temperatura en su superficie. Puede demostrarse teóricamente que la velocidad de aumento de la temperatura en la superficie viene determinada por la inercia térmica del material, es decir, el valor k $\rho c$ del producto. La práctica nos lo confirma, pues los materiales gruesos con una inercia térmica alta ( $p$. ej., madera de roble, poliuretano sólido) necesitan un tiempo prolongado para entrar en ignición cuando se les aplica un flujo de calor determinado, mientras que, en idénticas condiciones, los materiales gruesos con una inercia térmica baja (p. ej., tableros de fibra aislante, espuma de poliuretano) arden muy rápidamente (Drysdale 1985).

\section{Fuentes de ignición}

En la Figura 41.2 (Ignición dirigida) se muestra de forma esquemática el proceso de ignición. Para que éste tenga lugar, la fuente de ignición no sólo debe ser capaz de elevar la temperatura de la superficie hasta el punto de ignición o por encima del mismo, sino también de conseguir que los vapores entren en combustión. La aplicación de una llama produce ambas cosas, pero un flujo de radiación desde una fuente remota provoca la aparición de vapores a una temperatura superior al punto de ignición sin que lleguen a arder. Ahora bien, si los vapores formados están suficientemente calientes (lo que supone que la temperatura de superficie sea muy superior al punto de ignición) pueden entrar en ignición de forma espontánea al mezclarse con el aire. Este proceso se denomina ignición espontánea.

Existe gran número de fuentes de ignición, que sólo tienen en común el hecho de ser resultado de alguna forma de descuido u omisión. En una lista típica podrían incluirse, por ejemplo, llamas desnudas, "objetos del fumador", calentamiento por
Figura 41.2 • Representación de una ignición dirigida.

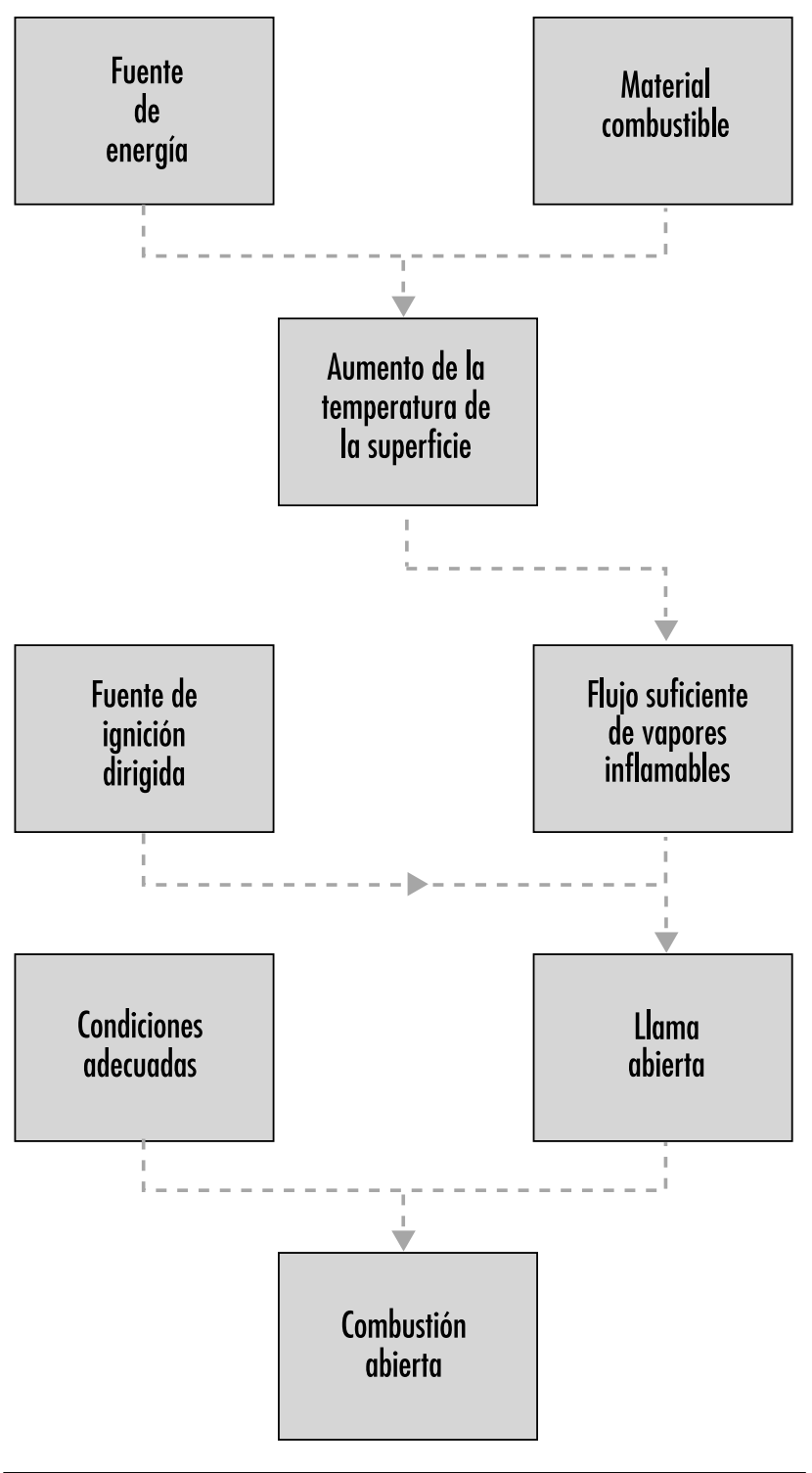

fricción o equipos eléctricos (calentadores, planchas, hornillos, etc.) (véase la Tabla 41.3). Cabe mencionar a este respecto el excelente estudio de Cote (1991).

$\mathrm{H}$ ay que tener en cuenta que los cigarrillos que arden sin llama no pueden provocar directamente una combustión con llama (ni siquiera en los combustibles gaseosos habituales), pero sí una combustión sin llama en materiales propensos a este tipo de combustión, que se carbonizan al calentarlos. En la combustión sin llama se oxida la superficie carbonizada, generando localmente el calor suficiente para producir una nueva carbonización del combustible adyacente aún sin quemar. Se trata de un proceso muy lento que, en algunos casos, puede llegar a producir llamas y provocar un incendio que se propagará a gran velocidad.

En los materiales propensos a la combustión sin llama puede darse también un fenómeno de autocalentamiento (Bowes 1984), que se produce cuando se guardan grandes cantidades de material, de forma que el calor generado por la lenta oxidación superficial no puede escapar y da lugar a un aumento 
Tabla 41.3 • Fuentes de ignición.

\begin{tabular}{|c|c|}
\hline & Ejemplos \\
\hline Equipos eléctricos & $\begin{array}{l}\text { Calentadores eléctricos, secadores de pelo, } \\
\text { mantas eléctricas, etc. }\end{array}$ \\
\hline Fuentes de llama abierta & Cerilla, mechero, equipos de soldadura, etc. \\
\hline Equipos con combustible gaseoso & Estufa de gas, calefactor, hornillo, etc. \\
\hline Otros equipos con combustible & Estufa de leña, etc. \\
\hline Material de fumador & Cigarrillo, pipa, etc. \\
\hline Objetos calientes & Tubos calientes, chispas mecánicas, etc. \\
\hline Exposición al calor & Fuego próximo, etc. \\
\hline Calentamiento espontáneo & $\begin{array}{l}\text { Trapos impregnados en aceite de linaza, } \\
\text { pila de carbón, etc. }\end{array}$ \\
\hline Reacción química & $\begin{array}{l}\text { Poco frecuente: p. ej., permanganato } \\
\text { potásico con glicerol }\end{array}$ \\
\hline
\end{tabular}

de la temperatura dentro de la masa. En determinadas condiciones se inicia un proceso incontrolado que puede conducir a una reacción de combustión sin llama en el interior del material.

\section{Propagación de la llama}

Un factor básico del aumento de dimensiones de un incendio es la velocidad de propagación de una llama por las superficies combustibles adyacentes. La propagación de la llama puede representarse como un frente de avance de la ignición en donde el extremo frontal de la llama actúa como fuente de ignición del combustible que todavía no está ardiendo. La velocidad de propagación viene determinada, por un lado, por las propiedades del material, de las que depende la facilidad de ignición y, por otro, por la interacción entre la llama existente y la superficie de avance del frente. $L a$ propagación vertical en sentido ascendente es la más rápida, pues la flotabilidad garantiza que las llamas se desplacen hacia arriba, y así la superficie superior al área de combustión queda expuesta a la transferencia directa del calor de las llamas. Compárese esta situación con la propagación en una superficie horizontal, en que las llamas del área de combustión se elevan verticalmente, lejos de la superficie. Realmente, la experiencia demuestra que la propagación vertical es la más peligrosa (p. ej., propagación de llamas en cortinas y sábanas o en ropas sueltas como camisones).

La velocidad de propagación también depende del flujo de calor radiante aplicado. EI volumen de un incendio en el interior de una habitación crecerá con mayor rapidez al aumentar el nivel de radiación generado a medida que se extiende el incendio, lo que contribuirá a acelerar su propagación.

\section{Teoría de la extinción de incendios}

La extinción y supresión de los incendios puede estudiarse a la luz de la exposición anterior sobre la teoría de los incendios. Los procesos de combustión de fase gaseosa (p. ej., reacciones de llama) son muy sensibles a los inhibidores químicos. Algunas de las sustancias ignífugas empleadas para mejorar el comportamiento ante el fuego de los materiales se basan en el hecho de que la liberación de pequeñas cantidades de un inhibidor entre los vapores del combustible impiden el mantenimiento de la Ilama. La presencia de una sustancia ignífuga no convierte un material combustible en incombustible, pero dificulta su ignición e incluso puede llegar a impedirla totalmente si la fuente de ignición es pequeña. En cambio, en un incendio ya activo, acabará ardiendo, pues el elevado flujo de calor anula el efecto ignífugo.

\section{Un incendio puede extinguirse de diferentes formas:}

1. cortando el suministro de vapores combustibles;

2. apagando la llama con extintores químicos (inhibición);

3. cortando el suministro de aire (oxígeno) del incendio (sofocación),

4. insuflando aire

\section{Control del flujo de vapores combustibles}

El primer método, cortar el suministro de vapores combustibles, es claramente aplicable a los casos de incendio de chorros de gas en que el suministro de combustible puede cortarse fácilmente, pero también es el método más común y seguro para extinguir incendios de combustibles condensados. En los incendios con materiales sólidos, es necesario enfriar la superficie del material combustible por debajo de la temperatura de ignición para reducir el flujo de vapores hasta que ya no pueda mantenerse la llama. La forma más eficaz de conseguirlo es aplicar agua, de forma manual o mediante un sistema automático (rociadores, pulverizadores, etc.). Por lo general, los incendios de materiales líquidos no pueden tratarse de esta forma: no es posible enfriar suficientemente los combustibles líquidos con bajas temperaturas de ignición y, en el caso de combustibles con altas temperaturas de ignición, al entrar en contacto la fuerte evaporación de agua con la superficie caliente del líquido, el combustible en ignición puede resultar expulsado fuera del depósito, lo que tendría consecuencias muy graves para el personal encargado de la extinción del incendio (existen, sin embargo, casos muy especiales en los que se ha diseñado un sistema automático de evaporación de agua a alta presión para este tipo de incendios).

Los incendios de materiales líquidos se extinguen normalmente utilizando espumas contra incendios (C ote, 1991). Se introduce un concentrado de espuma en un chorro de agua y, a continuación, se aplica al incendio a través de una boquilla especial que permite la entrada de aire en el flujo. Se produce así una espuma que flota sobre el líquido y reduce la velocidad de generación de los vapores combustibles mediante un efecto de bloqueo al tiempo que protege la superficie de la transferencia de calor de las llamas. La espuma se aplica con cuidado para que vaya formando una "masa flotante", que aumenta poco a poco de tamaño hasta que cubre toda la superficie del líquido. Por otro lado, el tamaño de las llamas se va reduciendo a medida que crece la masa flotante y, al mismo tiempo, la espuma se va descomponiendo y liberando agua que contribuye a enfriar la superficie. Con este complejo mecanismo se consigue finalmente controlar el flujo de vapores.

De los distintos concentrados de espuma disponibles en el mercado es importante elegir uno compatible con los líquidos que se pretende proteger. Las primeras "espumas de proteínas" se desarrollaron para incendios de hidrocarburos líquidos; su desventaja es que se deshacen rápidamente cuando entran en contacto con combustibles líquidos solubles en agua. Actualmente, se dispone de "espumas sintéticas" para tratar toda la gama posible de incendios con materiales líquidos. U na de ellas, la espuma formadora de película acuosa (AFFF), es una espuma universal que crea una película de agua sobre la superficie del combustible líquido, lo que aumenta su efectividad.

\section{Apagar la llama}

Este método consiste en utilizar supresores químicos para extinguir la llama. En las reacciones que se producen en la llama intervienen radicales libres de alta reactividad y existencia efímera pero que se regeneran continuamente a través de un proceso de ramificación de cadenas que conserva una concentración suficientemente alta para alimentar la reacción global (p. ej., una reacción del tipo $\mathrm{R} 1$ ) a alta velocidad. Los supresores químicos 
aplicados en cantidad suficiente provocan una fuerte reducción de la concentración de radicales y extinguen de forma eficaz las llamas. Los agentes más comunes de este tipo son los halones y los polvos secos.

Los halones reaccionan en la llama generando unas sustancias intermedias que a su vez reaccionan fácilmente con los radicales de la llama. Se necesitan cantidades relativamente pequeñas de halones para extinguir un incendio, por lo que siempre se les ha considerado muy adecuados. Las concentraciones de extinción son "respirables" (aunque los productos generados al pasar a través de la llama son nocivos). L os polvos secos actúan de forma similar, pero en determinadas circunstancias resultan mucho más efectivos. Las partículas finas se dispersan en la llama y anulan las cadenas de radicales. Es importante que las partículas sean pequeñas y numerosas. Los fabricantes de muchas marcas comerciales de polvos secos eligen para ello un polvo "decrepitante", cuyas partículas, al ser expuestas a las altas temperaturas de la llama, se fragmentan a su vez en partículas más pequeñas.

Cuando empiezan a arder las ropas de una persona, el mejor método para controlar las llamas y brindarle protección es un extintor de polvo seco. U na intervención rápida permite una rápida "extinción", minimizando los daños. A hora bien, el fuego debe extinguirse por completo, pues las partículas caen rápidamente al suelo y cualquier llama residual puede reavivarlo. De forma similar, los halones sólo son efectivos en tanto se mantiene la concentración local necesaria. Así, cuando se aplica fuera de un recinto cerrado, el vapor de halón se dispersa rápidamente y el incendio se reaviva de nuevo si queda alguna llama residual. Igualmente, la pérdida del supresor produce la reignición del material combustible si las temperaturas de la superficie son suficientemente altas. $\mathrm{Ni}$ los halones ni los polvos secos llegan a enfriar de forma efectiva la superficie del combustible.

\section{Cortar el suministro de aire}

La descripción que sigue representa una simplificación excesiva del proceso. Aunque al "suprimir el suministro de aire" lógicamente se extingue el incendio, en realidad sólo es necesario reducir la concentración de oxígeno por debajo de un nivel crítico. El "ensayo del índice de oxígeno" permite clasificar los materiales combustibles en función de la concentración mínima de oxígeno necesaria para mantener una llama en una mezcla de oxígeno/nitrógeno. Muchos materiales arden a temperatura ambiente $\left(20{ }^{\circ} \mathrm{C}\right.$ aprox.) a partir de concentraciones de oxígeno del $14 \%$ aproximadamente y en ausencia de fuentes de calor. $L a$ concentración crítica disminuye a medida que aumenta la temperatura. Así, en un incendio que lleve ardiendo cierto tiempo, la llama se mantendrá aún en concentraciones bajas, próximas al $7 \%$. Un incendio en una habitación puede ser controlado e incluso llegar a autoextinguirse si se limita el suministro de oxígeno manteniendo puertas y ventanas cerradas. Las llamas se apagarán, pero la combustión sin llama continuará con concentraciones de oxígeno mucho más bajas. Si se deja entrar aire al abrir una puerta o romper una ventana antes de que la habitación se haya enfriado lo suficiente, puede producirse un fuerte reavivamiento del incendio conocido.

La "supresión del aire" es difícil de conseguir. Sin embargo, una atmósfera puede "inertizarse" mediante inundación total con un gas que no favorezca la combustión, como nitrógeno, dióxido de carbono o gases de un proceso de combustión (p. ej., motores de un barco), bajos en oxígeno y altos en dióxido de carbono. Esta técnica sólo puede utilizarse en espacios cerrados, dado que es necesario mantener la concentración del "gas inerte" hasta que se haya extinguido el incendio o hasta que puedan iniciarse las operaciones de extinción del mismo. La inundación total se aplica especialmente en las bodegas de

\section{Tabla 41.4 • Comparación de las concentraciones de} inertización de diferentes gases.

$\begin{array}{lc}\text { Agente } & \text { Concentración mínima (\% volumen) } \\ \text { Halón } 1301 & 8,0 \\ \text { Halón } 1211 & 8,1 \\ \text { Nitrógeno } & \approx 58 \\ \text { Dióxido de carbono } & \approx 35\end{array}$

buques y en las bibliotecas de libros antiguos. Las concentraciones mínimas necesarias de gas inerte que se ofrecen en la Tabla 41.4 están basadas en el supuesto de que el incendio se detecta en su fase inicial y la inundación se realiza antes de que se haya acumulado un calor excesivo en el recinto.

La "supresión del aire" puede conseguirse en las proximidades de un incendio de pequeñas dimensiones aplicando localmente un supresor con un extintor. El dióxido de carbono es el único gas de este tipo utilizado. Sin embargo, dado que se dispersa rápidamente, es fundamental extinguir bien todas las llamas durante la operación, pues de lo contrario el incendio se reavivará. En la reignición influye también el hecho de que el dióxido de carbono tiene un efecto de enfriamiento prácticamente nulo. M erece la pena señalar que una fina pulverización de agua sobre la llama puede producir su extinción mediante el efecto combinado de la evaporación de las pequeñas gotas (que enfrían la zona de combustión) y la reducción de la concentración de oxígeno al diluirse con el vapor de agua (que actúa de la misma forma que el dióxido de carbono). Entre los posibles sustitutos de los halones se encuentran los pulverizadores finos de agua y los nebulizadores.

Cabe reseñar que no resulta aconsejable extinguir una llama de gas salvo que inmediatamente después pueda cortarse el flujo del mismo. De lo contrario, se formaría un volumen importante de gas inflamable que podría entrar en ignición y producir graves daños.

\section{Insuflar aire}

Incluimos este método en la presente enumeración para completar el estudio. Una llama de una cerilla puede apagarse fácilmente aumentando la velocidad del aire en la proximidad de la llama por encima de un valor crítico. El mecanismo funciona desestabilizando la llama en las proximidades del material combustible. En principio, pueden controlarse incendios de mayor volumen de esta misma forma, aunque normalmente se requieren cargas explosivas para generar velocidades suficientemente altas, como en los incendios en pozos de petróleo.

Por último, es importante resaltar que la facilidad de extinción de un incendio disminuye rápidamente a medida que éste progresa. Por tanto, una detección precoz permite su extinción con cantidades mínimas de supresor y limita las pérdidas. Al seleccionar un sistema de supresión hay que tener en cuenta la velocidad potencial de desarrollo del incendio y los sistemas de detección disponibles.

\section{Explosiones}

U na explosión se caracteriza por una liberación repentina de energía que produce una onda expansiva capaz de causar un daño remoto. Existen dos tipos de fuentes: la alta explosión y la explosión por presión. La primera fuente es típica de compuestos como el trinitrotolueno (TNT) y la ciclotrimetilentrinitramina (RDX). Se trata de sustancias altamente exotérmicas que se descomponen liberando grandes cantidades de energía. A pesar de que son térmicamente estables (algunos en menor medida, por 
lo que deben ser insensibilizados para poderlos manejar de forma segura), pueden llegar a detonar, descomponiéndose y propagándose a la velocidad del sonido a través de los sólidos. Si la cantidad de energía liberada es suficientemente alta, a partir de la fuente se propaga una onda expansiva de gran potencial de destrucción a distancia.

Para valorar el daño remoto, puede estimarse la magnitud de la explosión en términos de "equivalente TNT" (normalmente en toneladas métricas). Esta técnica, basada en los muy numerosos datos recogidos sobre el potencial de destrucción del TNT (en gran parte en tiempo de guerra), se basa en leyes empíricas de escalado desarrolladas a partir de estudios del daño ocasionado por cantidades conocidas de TNT. En tiempos de paz, los explosivos potentes se utilizan en actividades como la minería, las canteras y obras importantes de ingeniería civil. Su utilización representa un riesgo, por lo que requieren un manejo específico.

Sin embargo, la segunda fuente de explosión puede ser igualmente devastadora, especialmente si se desconocen sus riesgos. Las sobrepresiones que dan lugar a explosiones pueden deberse a procesos químicos en instalaciones 0 simplemente a efectos físicos, como cuando se calienta un recipiente externamente hasta que alcanza una sobrepresión. El término BLEVE (Boiling Liquid Expanding Vapour Explosion -explosión por vapor en expansión de un líquido hirviendo) tiene su origen aquí, en los problemas de las calderas de vapor. Actualmente, este término se emplea también cuando, en un depósito que contiene un gas licuado a presión, como el LPG (gas de petróleo licuado), se produce un incendio, que libera el contenido inflamable, y éste a su vez entra en combustión produciendo una "bola de fuego".

En otros casos, la sobrepresión se debe a un proceso químico interno. En las industrias de transformación, el autocalentamiento del material puede provocar una reacción incontrolada que genere altas temperaturas y presiones capaces de ocasionar una explosión por presión. Sin embargo, el tipo más común de explosión es el debido a la ignición de una mezcla de gas/ aire inflamable confinada en algún aparato de una instalación o en cualquier estructura cerrada. La condición previa es la formación de una mezcla inflamable, evitable con un diseño y una gestión adecuados. U na liberación accidental dará lugar a una atmósfera inflamable si la concentración de gas (o vapor) se encuentra entre los límites superior e inferior de inflamabilidad (Tabla 41.1). Si se introduce una fuente de ignición en una de estas zonas, una llama de premezclado se propagará rápidamente a partir de la misma, convirtiendo la mezcla de combustible/ aire en productos de combustión a una temperatura elevada; esta última puede llegar a ser de $2.100 \mathrm{~K}$, lo que demuestra que en un sistema completamente cerrado que se encuentre inicialmente a $300 \mathrm{~K}$, son posibles sobrepresiones de hasta 7 bar. Sólo los depósitos a presión de diseño especial son capaces de soportar estas sobrepresiones. Los edificios normales se derrumbarán, a no ser que estén protegidos por paneles de alivio de presión, discos de ruptura o sistemas de supresión de la explosión. Cuando se forma una mezcla inflamable dentro de un edificio, la explosión puede llegar a ocasionar daños estructurales importantes o incluso su destrucción total, si la explosión no se dirige hacia el exterior a través de aberturas originadas en las primeras fases de la explosión (p. ej. rotura de las ventanas).

Explosiones de este tipo se asocian también a la ignición de suspensiones de polvo en el aire (Palmer, 1973), como las producidas cuando se levanta una nube de polvo "explosivo" procedente de estanterías, vigas y cornisas de un edificio y dicha nube queda expuesta a continuación a una fuente de ignición (p. ej., en molinos de harina, elevadores de grano, etc.). El polvo debe ser combustible (obviamente), aunque no todos los polvos combustibles pueden explotar a temperatura ambiente.

Se han diseñado ensayos estándar para determinar cuándo es capaz un polvo de producir una explosión. Dichos ensayos se utilizan asimismo para estudiar los "límites de explosividad" de los polvos explosivos, similares conceptualmente a los "límites de inflamabilidad" de gases y vapores. Por lo general, una explosión de polvo ocasiona daños de gran magnitud, porque la primera explosión genera aún más polvo, dando lugar a una nube de polvo aún mayor que, a su vez, entra inevitablemente en ignición y produce una explosión aún mayor.

Los venteos o alivios de explosión sólo son eficaces si la velocidad de desarrollo de ésta es relativamente baja, como ocurre cuando se propaga una llama de premezclado en una mezcla inflamable estacionaria o en una nube de polvo explosivo. Las aberturas de explosión no tienen ninguna utilidad cuando se produce una detonación, ya que dichas aberturas deben originarse en la fase inicial del suceso, cuando la presión todavía es relativamente baja.

Al producirse una detonación, la presión se eleva demasiado rápidamente como para que los alivios sean efectivos, por lo que el recinto cerrado de una planta tendrá que soportar presiones internas tan altas que provocarán su destrucción total. Puede producirse una detonación de una mezcla de gas inflamable cuando está contenida en una tubería o un conducto largo. En determinadas condiciones, la propagación de la llama de premezclado empuja el gas sin arder por delante del frente de la llama a una velocidad que incrementa la turbulencia, lo que a su vez incrementa la velocidad de propagación. Se produce así una reacción recurrente que acelera la llama hasta que se forma una onda de choque.

Esto, combinado con el proceso de combustión, produce una onda de detonación que puede propagarse a velocidades muy por encima de los $1.000 \mathrm{~m} / \mathrm{s}$. Es posible comparar este fenómeno con la velocidad fundamental de combustión de una mezcla estequiométrica de propano/ aire de $0,45 \mathrm{~m} / \mathrm{s}$ [velocidad a la que se propaga la llama a través de una mezcla de propano/ aire en reposo (es decir, sin turbulencias)].

No debe subestimarse la importancia de la turbulencia en el desarrollo de este tipo de explosiones. Para el éxito de un sistema de seguridad antiexplosión es fundamental que se produzca el venteo rápido de los gases o el tratamiento por supresión en la fase inicial del proceso. Si la velocidad de desarrollo de la explosión es demasiado rápida, el sistema de seguridad no resultará eficaz, pudiendo producirse peligrosas sobrepresiones.

U na alternativa al venteo es la supresión de la explosión. Este tipo de protección requiere una detección de la explosión en su fase inicial, lo más próxima posible a la ignición. El detector se utiliza para activar la rápida liberación de un supresor en el trayecto de la llama de propagación, deteniendo la explosión de forma eficaz antes de que aumente la presión hasta un punto en que la integridad del recinto se vea amenazada. Los halones se han utilizado habitualmente para este fin, pero ahora se encuentran desfasados y se están estudiando sistemas de pulverización de agua a alta presión.

Este tipo de protección resulta muy caro y de aplicación limitada, pues sólo puede utilizarse en volúmenes relativamente reducidos, donde el supresor pueda distribuirse de forma rápida y uniforme ( $p$. ej., tuberías de transporte de vapor inflamable 0 polvos explosivos)

\section{Análisis de la información para la protección contra incendios}

En términos generales, puede decirse que hace poco que la ciencia de los incendios se ha desarrollado lo suficiente para aportar una base informativa que permita tomar decisiones 
racionales en materia de diseño industrial y de seguridad. Tradicionalmente, la seguridad contra incendios se desarrollaba sobre una base ad hoc, que respondía de forma eficaz a los accidentes mediante la imposición de normativas o restricciones que evitaran su repetición. Así, por ejemplo, el Gran Incendio de Londres de 1666 dio lugar al establecimiento de la primera normativa (o código) para edificios y al desarrollo de los seguros contra incendios. Accidentes más recientes, como los de bloques de oficinas de São Paulo, Brasil, en 1972 y 1974, han promovido modificaciones en la legislación de construcción para evitar en el futuro incendios múltiples de este tipo. Del mismo modo, en California (EE.UU.), al detectarse el riesgo asociado a determinados tipos de tapizados de mobiliario moderno (especialmente de espuma de poliuretano estándar), se impuso una estricta normativa para su control.

Son sólo algunos casos en los que el estudio de las consecuencias de un incendio llevaron a establecer normativas para mejorar la seguridad del individuo y de la comunidad en caso de incendio. La adopción de cualquier medida al respecto debe estar justificada por un análisis de la información disponible y, además, debe demostrarse que el problema es real. En algunos casos, como en los incendios de São Paulo, no es más que un ejercicio académico, pero en otros, como cuando se intenta "demostrar" que el mobiliario actual puede dar lugar a problemas, hay que asegurarse de que los costes resultantes se gastan de forma coherente. Para ello, es necesario disponer de una base de datos fiable sobre incendios que abarque un período significativo de tiempo y permita observar las tendencias en cuanto a número de incendios, número de víctimas, incidencia de un determinado tipo de ignición, etc. Después, podrán utilizarse las técnicas estadísticas para estudiar si una tendencia 0 cambio es suficientemente significativo como para tomar las medidas correspondientes.

En algunos países, el Cuerpo de Bomberos está obligado a presentar un informe sobre los incendios atendidos. En el R eino U nido y Estados U nidos, el oficial responsable rellena un formulario, que se remite a una organización central [el $\mathrm{H}$ ome $\mathrm{O}$ ffice en el Reino Unido y la National Fire Protection Association (NFPA) en Estados U nidos] en la que se codifican y procesan los datos. Estos últimos quedan a disposición de las entidades gubernamentales u otras instancias interesadas. Estas bases de datos son fundamentales para analizar (por ejemplo) las principales fuentes de ignición y los objetos con mayor facilidad de combustión. Así, por ejemplo, un análisis del número de víctimas en relación con la fuente de ignición ha demostrado que el número de personas que fallecen en los incendios iniciados por fumadores guarda una clara desproporción con el número de incendios originados de este modo.

La fiabilidad de estas bases de datos depende de la habilidad con que el personal del cuerpo de bomberos realice la investigación, tarea nada sencilla que requiere una gran habilidad y conocimientos, especialmente sobre la ciencia de los incendios. El Fire Service del Reino U nido está obligado estatutariamente a presentar un informe de cada incendio atendido bajo la responsabilidad del oficial encargado. El diseño del formulario es fundamental, y debe incluir la información necesaria con el nivel de detalle requerido. En el Fire Protection $\mathrm{H}$ andbook (Cote, 1991) se incluye el "Basic Incident Report Form" recomendado por el NFPA.

Los datos pueden utilizarse de dos formas, bien para identificar un problema de incendio, bien como argumento racional necesario para justificar unas determinadas medidas que requieran un gasto público o privado. Para demostrar el efecto de las medidas adoptadas puede utilizarse una base de datos de cierta antigüedad. De las estadísticas NFPA para el período comprendido entre 1980 y 1989 (C ote, 1991) se deducen los diez puntos siguientes:

1. Los detectores de humo para el hogar se utilizan mucho y resultan muy eficaces (aunque quedan importantes problemas por resolver en la estrategia de detección).

2. Los rociadores automáticos reducen considerablemente las pérdidas humanas y materiales. El aumento del uso de aparatos de calefacción portátiles ha disparado el número de incendios en el hogar originados por estos equipos.

3. Los incendios provocados siguen una línea descendente desde la punta del decenio de 1970, pero los daños materiales asociados no han disminuido.

4. Un gran porcentaje de las víctimas del cuerpo de bomberos se produce por ataques al corazón y actividades ajenas al trabajo.

5. Las áreas rurales presentan las tasas de mortalidad por incendio más altas.

6. Los objetos del fumador son causa de la máxima mortalidad en los accidentes en el hogar (incendios en tapicerías, colchones o ropa de cama).

7. Las tasas de mortalidad por incendio en EE.UU . y Canadá se encuentran entre las más altas de los países desarrollados.

8. Los Estados del sur de EE.UU. presentan las tasas de mortalidad por incendio más altas.

9. El máximo riesgo de fallecimiento en caso de incendio corresponde a las personas de mayor edad.

Aunque estas conclusiones son, lógicamente, específicas para Estados U nidos, algunas tendencias son comunes al resto de los países. La correcta utilización de estos datos puede aportar los medios necesarios para formular políticas coherentes de seguridad contra incendios. A hora bien, dichas medidas serán inevitablemente más "reactivas" que "proactivas", pues las últimas sólo pueden implantarse tras un estudio detallado de los riesgos de incendio. Esta metodología se ha ido imponiendo poco a poco, primero en la industria nuclear y después en la química, petroquímica y afines, donde los riesgos son más fácilmente identificables que en las demás industrias. Su aplicación a hoteles y edificios públicos en general suele ser mucho más compleja y requiere la aplicación de técnicas que reproducen en un modelo el incendio para predecir su posible desarrollo y la forma de propagación de los productos de combustión por el edificio, con el consiguiente riesgo para sus ocupantes. Con este tipo de modelos se han realizado grandes progresos, aunque todavía queda un largo camino por recorrer antes de que puedan utilizarse estas técnicas con total fiabilidad. En la ingeniería de seguridad contra incendios es necesario aún ampliar la investigación de base antes de poder comercializar herramientas fiables para el estudio de los peligros de incendio.

\section{Fuentes de PELIGRO DE INCENDIO}

\section{Tamás Bánky}

$\mathrm{H}$ ay varias definiciones para los términos incendio y combustión. Las definiciones del fenómeno de la combustión más interesantes a los fines del presente documento son las siguientes:

- La combustión es un proceso automantenido de reacciones en las que se producen transformaciones físicas y químicas.

- Los materiales que intervienen en la combustión reaccionan con un agente oxidante próximo, que, en la mayoría de los casos, es el oxígeno del aire. 
- Para una ignición se requieren unas condiciones favorables de partida, que, por lo general, suelen ser un calentamiento suficiente del sistema para cubrir la demanda inicial de energía de la reacción en cadena.

- Las reacciones suelen ser exotérmicas, es decir, durante la combustión se libera calor, fenómeno que a menudo va acompañado de una llama visible.

La ignición puede considerarse el primer paso del proceso automantenido de combustión, debiendo distinguir entre ignición dirigida (o forzada), si el fenómeno está causado por una fuente de ignición externa, o autoignición, si el fenómeno es resultado de reacciones que se producen en el propio material combustible con liberación de calor.

La facilidad de ignición viene definida por un parámetro empírico, la temperatura de ignición (es decir, la temperatura mínima, determinable mediante ensayo, a la que debe calentarse un material para que se inicie su ignición). Dependiendo de que la determinación de este parámetro (con métodos de ensayo especiales) se realice con o sin fuente de ignición, se distingue entre temperatura de ignición dirigida y temperatura de autoignición

En el caso de la ignición dirigida, la energía necesaria para activar los materiales que intervienen en la reacción de combustión es suministrada por una fuente de ignición. Ahora bien, no existe una relación directa entre la cantidad de energía necesaria para la ignición y la temperatura de ignición; en efecto, si bien la composición química de los elementos del sistema de combustión es un factor fundamental de la temperatura de ignición, en ella influyen también en gran medida el tamaño y la forma de los materiales, la presión ambiental, las condiciones del flujo de aire, los parámetros de la fuente de ignición, las características geométricas del equipo de ensayo, etc. Por esta razón, los valores de la temperatura de autoignición y de ignición dirigida publicados en la bibliografía pueden diferir considerablemente.

Para analizar el mecanismo de ignición de los materiales, hay que diferenciar entre materiales sólidos, líquidos y gaseosos.

La mayor parte de los sólidos toman la energía de una fuente de ignición externa por conducción, convección o radiación (en la mayoría de los casos por una combinación de todas ellas), o se calientan como resultado de procesos internos que inician la descomposición en sus superficies.

Para que se produzca la ignición en un líquido, es necesario que se forme un espacio de vapor capaz de arder sobre su superficie. Los vapores liberados y los productos gaseosos de descomposición se mezclan con el aire que se encuentra sobre la superficie del material líquido o sólido.

Las turbulencias que se producen en la mezcla y/ o en la difusión ayudan al oxígeno a alcanzar las moléculas, átomos y radicales libres dispuestos a reaccionar que se encuentran en y por encima de la superficie. Las partículas inducidas interaccionan y liberan calor. EI proceso se va acelerando progresivamente y, cuando se inicia la reacción en cadena, el material entra en ignición y arde.

La combustión en la capa inferior a la superficie de los materiales sólidos combustibles se denomina combustión sin llama y la reacción de combustión que tiene lugar en la interfaz entre el material sólido y el gas, calentamiento al rojo. La combustión con llama es el proceso en cuyo curso la reacción exotérmica de combustión entra en la fase gaseosa. Es típica de la combustión tanto de materiales líquidos como sólidos.

Los gases combustibles arden de forma natural en la fase gaseosa. Un principio empírico importante es que las mezclas de gas y aire sólo pueden entrar en ignición dentro de un determinado rango de concentración, lo que también es válido para los vapores de líquidos. Los límites inferior y superior de inflamabilidad de gases y vapores dependen de la temperatura y la presión de la mezcla, la fuente de ignición y la concentración de los gases inertes de la mezcla.

\section{Fuentes de ignición}

La energía calorífica puede clasificarse en cuatro categorías básicas según su origen (Sax, 1979):

1. energía calorífica generada por reacciones químicas (oxidación, combustión, disolución, calentamiento espontáneo, descomposición, etc.);

2. energía calorífica eléctrica (por resistencia, inducción, arco, chispas eléctricas, descargas electrostáticas, rayos, etc.);

3. energía calorífica mecánica (por fricción, chispas por fricción),

4. calor generado por descomposición nuclear.

A continuación se estudian las fuentes de ignición más frecuentes.

\section{Llama abierta}

La llama abierta es la fuente de ignición más sencilla y frecuente. $G$ ran cantidad de herramientas de uso generalizado y de equipos industriales funcionan con llamas desnudas o dan lugar a la formación de llamas desnudas. Encendedores, cerillas, hornos, aparatos de calefacción, equipos de soldadura, tuberías dañadas de gas y petróleo, etc. pueden considerarse fuentes potenciales de ignición. Dado que, en el caso de la llama abierta, la fuente de ignición primaria constituye en sí misma una combustión automantenida, el mecanismo de ignición significa básicamente la propagación de la combustión a otro sistema. La combustión se inicia cuando la fuente de ignición con llama abierta dispone de suficiente energía como para provocar la ignición.

\section{Ignición espontánea}

L as reacciones químicas que generan calor de forma espontánea, al ser "fuentes internas de ignición", conllevan un riesgo de ignición y combustión. Materiales propensos al calentamiento y la ignición espontáneos pueden convertirse en fuentes de ignición secundarias y provocar la ignición de materiales combustibles próximos.

Aunque algunos gases (p. ej., fosfuro de hidrógeno, hidruro de boro, hidruro de silicio) y líquidos (p. ej., carbonilos metálicos, composiciones organometálicas) son propensos a la ignición espontánea, en la mayoría de los casos ésta tiene lugar como reacción superficial en los materiales sólidos. La ignición espontánea, como todas las igniciones, depende de la estructura química del material, pero su aparición está determinada por el grado de dispersión. La extensa superficie específica permite la acumulación local de calor de reacción y contribuye a aumentar la temperatura del material por encima de la temperatura de ignición espontánea.

La ignición espontánea de líquidos también se ve favorecida cuando entran en contacto con aire o materiales sólidos de gran superficie específica. En condiciones atmosféricas normales, las grasas y los aceites especialmente insaturados con enlaces dobles, al ser absorbidos por materiales fibrosos o sus productos 0 al impregnarse en textiles de origen vegetal o animal, son propensos a la ignición espontánea en condiciones atmosféricas normales. La ignición espontánea de productos de lana de vidrio y de lana mineral fabricados con fibras no combustibles o materiales inorgánicos con una gran superficie específica y contaminados con grasa han dado origen a gran número de incendios graves.

La ignición espontánea se observa principalmente en polvo de materiales sólidos. En metales con una buena conductividad calorífica, para acumular el calor local necesario para la ignición es necesario que estén muy finamente fragmentados. A medida 
que disminuye el tamaño de partícula, aumenta la probabilidad de una ignición espontánea y en algunos polvos metálicos (p. ej., hierro) se produce piroforicidad. Cuando se almacena y maneja polvo de carbón, hollín fino o polvo de lacas y resinas sintéticas, así como durante su procesamiento, debe prestarse especial atención a las medidas preventivas contra incendios para reducir el peligro de una ignición espontánea.

Los materiales propensos a la descomposición espontánea presentan una especial capacidad para entrar en ignición de forma espontánea. Cuando se coloca hidracina sobre cualquier material de gran área superficial, inmediatamente arde con llama. Los peróxidos, muy utilizados en la industria plástica, se descomponen espontáneamente con gran facilidad, convirtiéndose en peligrosas fuentes de ignición y llegando a iniciar en algunos casos una combustión explosiva.

Un caso especial de ignición espontánea es la violenta reacción exotérmica que se produce cuando determinados productos químicos entran en contacto entre sí, como el ácido sulfúrico concentrado con todos los materiales combustibles orgánicos, los cloratos con sales sulfúricas o amónicas, los compuestos orgánicos halogenados con metales alcalinos, etc. La incompatibilidad de estos materiales (materiales incompatibles) exige una especial atención para su almacenamiento, especialmente cuando se hace conjunto, así como a la hora de elaborar la normativa de seguridad contra incendios.

Vale la pena mencionar que esta peligrosa forma de calentamiento altamente espontánea puede verse favorecida, en algunos casos, por unas condiciones técnicas incorrectas (ventilación insuficiente, baja capacidad de enfriamiento, fallos de mantenimiento y limpieza, sobrecalentamiento de la reacción, etc.) 0 incluso estar causada por ellas.

Algunos productos agrícolas, como piensos de fibra, semillas oleaginosas, cereales germinados, productos finales de la industria de transformación (tiras secas de remolacha, fertilizantes, etc.) son propensos a la ignición espontánea. El calentamiento espontáneo de estos materiales presenta una característica especial: las peligrosas condiciones de temperatura de los sistemas se ven favorecidas por algunos procesos biológicos exotérmicos de difícil control.

\section{Fuentes de ignición eléctrica}

La maquinaria mecánica, los instrumentos y equipos de calefacción alimentados con energía eléctrica, así como los equipos de transformación mecánica y de iluminación no suelen suponer un riesgo de incendio para su entorno siempre que se instalen de acuerdo con la correspondiente normativa en materia de seguridad y de instalación y se observen durante su funcionamiento las instrucciones necesarias. Un mantenimiento regular y una supervisión periódica disminuyen considerablemente la probabilidad de incendios y explosiones. Las causas más frecuentes de incendios en equipos eléctricos y cableados son la sobrecarga, los cortocircuitos, las chispas eléctricas y las resistencias de alto contacto.

Se produce una sobrecarga cuando el cableado y los aparatos eléctricos soportan una corriente superior a la fijada por diseño. La sobrecorriente, al pasar a través del cableado y del aparato, provoca un calentamiento excesivo que daña, rompe o carboniza los componentes del sistema eléctrico y funde el recubrimiento del cable; las partes metálicas entran en una combustión sin llama, las unidades estructurales combustibles entran en ignición y, si se dan ciertas condiciones, puede llegarse incluso a la propagación del incendio en el entorno. La causa más frecuente de sobrecarga suele ser la conexión de un número de aparatos superior al permitido 0 de capacidad superior al valor estipulado.
Desde el punto de vista de la seguridad laboral de los sistemas eléctricos, uno de los mayores peligros son los cortocircuitos. Siempre son consecuencia de un fallo y se producen cuando partes del cableado eléctrico o del equipo aisladas entre sí y a tierra, contactan entre sí o con tierra. Este contacto puede ser directo, como en el contacto metal-metal, o indirecto, a través de un arco eléctrico. Cuando se produce un cortocircuito porque algunas unidades del sistema eléctrico entran en contacto entre sí, la resistencia es mucho menor y, como consecuencia, la intensidad de la corriente es extremadamente alta. La energía calorífica liberada durante una sobrecarga originada por grandes cortocircuitos puede dar lugar a un incendio en el mecanismo afectado, entrando en ignición los materiales y equipos próximos y propagándose el fuego al edificio.

Aunque las chispas eléctricas son fuentes de energía calorífica de naturaleza reducida, en la práctica actúan con frecuencia como fuentes de ignición. En condiciones normales de trabajo, la mayoría de los dispositivos eléctricos no producen chispas, aun cuando el funcionamiento de algunos de ellos suela ir acompañado de ellas.

Las chispas son muy peligrosas cuando en la zona donde se generan existen concentraciones explosivas de gas, vapor o polvo. Por tanto, los equipos que normalmente producen chispas durante su funcionamiento sólo pueden instalarse en lugares en que éstas no puedan provocar un incendio. El contenido energético de las chispas es insuficiente por sí mismo para provocar la ignición de los materiales del entono o para iniciar una explosión.

Cuando en un sistema eléctrico no existe contacto metálico perfecto entre las unidades estructurales a través de las cuales fluye la corriente, en el punto de fallo aparecerá una resistencia de alto contacto. Este fenómeno se debe, en la mayoría de los casos, a un montaje incorrecto de las juntas o a instalaciones inadecuadas. La separación de las juntas durante el funcionamiento y el desgaste natural también pueden provocar resistencias de alto contacto. Gran parte de la corriente que fluye a través de los puntos con aumento de resistencia se transformará en energía calorífica. Si esa energía no se disipa suficientemente (y no se elimina la causa), se producirá un fuerte incremento de temperatura que puede provocar un peligroso incendio.

Si los mecanismos operan por inducción (motores, dínamos, transformadores, relés, etc.) y no están bien calculados, pueden surgir corrientes parásitas durante el funcionamiento que harán que se calienten las unidades estructurales (las bobinas y sus núcleos de hierro), provocando la ignición de los materiales aislantes y la combustión del equipo. Las corrientes parásitas también pueden surgir (con consecuencias desastrosas) en las unidades estructurales metálicas de equipos de alto voltaje.

\section{Chispas electrostáticas}

En el proceso de carga electrostática cualquier material, en principio eléctricamente neutro (y ajeno a cualquier circuito eléctrico), se carga positiva o negativamente. Existen tres tipos de cargas:

1. cargas separadas, cuando las cargas de polaridad sustractiva se acumulan en dos cuerpos simultáneamente;

2. cargas de paso, cuando las cargas al circular dejan cargas de polaridad opuesta,

3. cargas de recepción, cuando el cuerpo recibe las cargas del exterior.

Estos tres tipos de cargas pueden aparecer como consecuencia de diferentes procesos físicos, como la separación después de un contacto, la escisión, la pulverización, el desplazamiento, el frotamiento, el flujo de polvos o fluidos por un conducto, el golpeado, un cambio de presión, un cambio de estado, la 
fotoionización, la ionización térmica, la distribución electrostática o una descarga de alto voltaje.

L a carga electrostática puede aparecer en los cuerpos conductores y en los aislantes como resultado de cualquiera de los procesos anteriormente mencionados, aunque en la mayoría de los casos son los procesos mecánicos los responsables de la acumulación de estas cargas indeseadas.

De entre el gran número de efectos negativos y riesgos debidos a las cargas electrostáticas y a la consiguiente descarga por chispa, cabe destacar los efectos sobre los equipos electrónicos (p. ej., ordenadores de control de procesos) y los equipos contra incendios y explosiones.

Los equipos electrónicos corren peligro ante todo cuando la energía de la descarga es suficientemente alta para ocasionar la destrucción de la entrada de algún elemento semiconductor. En el último decenio, el desarrollo de las unidades electrónicas ha ido acompañado de un rápido incremento del riesgo asociado.

Para que exista riesgo de incendio o de explosión es necesario que coincidan en el espacio y en el tiempo dos condiciones: la presencia de un medio combustible y la descarga con capacidad de ignición. Este peligro se observa principalmente en la industria química, y puede estimarse tomando como base la denominada sensibilidad de chispa de los materiales peligrosos (energía mínima de ignición) y depende de la magnitud de la carga.

Es fundamental reducir estos riesgos y sus múltiples consecuencias, que pueden ir desde problemas operativos a catástrofes con víctimas mortales. Existen dos formas de protección frente a las cargas electrostáticas:

1. impedir que se inicie el proceso de carga (lógico, pero normalmente difícil de percibir),

2. limitar la acumulación de cargas para impedir las descargas peligrosas (o cualquier otro riesgo).

El rayo, fenómeno eléctrico atmosférico de la naturaleza, puede considerarse una fuente de ignición. Las cargas estáticas producidas en las nubes se compensan cayendo hacia la Tierra (rayo) y produciendo una descarga de alta energía. Los materiales combustibles que se encuentran en las proximidades del lugar de caída del rayo pueden llegar a entrar en ignición. En algunos casos, en la caída del rayo se generan impulsos muy fuertes y la energía se compensa en varias fases. En otros, se establece un flujo de corriente de larga duración que puede llegar a alcanzar órdenes de magnitud de $10 \mathrm{~A}$.

\section{Energía calorífica mecánica}

En la práctica industrial la fricción está siempre presente. En las operaciones mecánicas se desarrolla calor por fricción y, si la disipación de calor se ve obstaculizada y el calor se acumula en el sistema, la temperatura puede alcanzar valores peligrosos, llegando a originar un incendio.

Las chispas por fricción pueden producirse por la fricción de metales (pulido, troceado, desbastado, corte, golpeado), al caer objetos o herramientas metálicas a un suelo duro o durante las operaciones de pulido, cuando el material presenta contaminaciones metálicas. $L$ a temperatura de la chispa generada suele ser superior a la temperatura de ignición de los materiales combustibles convencionales (chispas en acero, $1.400-1.500{ }^{\circ} \mathrm{C}$ o chispas en aleaciones de cobre-níquel, $300-400{ }^{\circ} \mathrm{C}$ ); sin embargo, la capacidad de ignición depende de la cantidad total de calor producido y de la energía de ignición mínima del material. En la práctica, se ha demostrado que las chispas por fricción significan un riesgo real de incendio en espacios abiertos con gases, vapores y polvos combustibles en concentraciones peligrosas. En tales circunstancias debe evitarse la utilización de materiales que produzcan fácilmente chispas o procesos mecánicos con producción de chispas. Por ello y para mayor seguridad, se utilizarán herramientas de madera, piel o plástico, o de aleaciones de cobre y bronce, que producen chispas de baja energía.

\section{Superficies calientes}

En la práctica, las superficies de aparatos y mecanismos pueden calentarse, tanto en condiciones normales como por avería, hasta alcanzar temperaturas peligrosas. Así, hornos, estufas, secadores, salidas de gas residual, conductos de gas, etc., pueden originar incendios en espacios con aire explosivo. Además, las superficies calientes pueden provocar la combustión de materiales combustibles próximos 0 en contacto con ellas. Como medida preventiva debe mantenerse una distancia de seguridad y realizar una supervisión y un mantenimiento regulares para reducir la probabilidad de que se presente un sobrecalentamiento peligroso.

\section{Peligros de incendio en materiales y productos}

0 bviamente, para que un sistema sea combustible, es imprescindible la presencia en él de material combustible. Los fenómenos de combustión y las fases de la misma dependen básicamente de las propiedades físicas y químicas del material de que se trate. Parece razonable, por tanto, estudiar el carácter y las propiedades de inflamabilidad de los distintos materiales y productos. En la presente sección se han agrupado los materiales de acuerdo con sus características técnicas, en lugar de utilizar conceptos teóricos (NFPA, 1991).

\section{Productos de madera y derivados}

La madera es uno de los materiales más comunes del entorno humano. Casas, estructuras de edificios, muebles y bienes de consumo están fabricados en madera y este material también se utiliza mucho para la fabricación de productos como el papel y en la industria química.

La madera y sus derivados son fácilmente combustibles y, cuando entran en contacto con superficies a alta temperatura 0 quedan expuestos a una radiación de calor, llama abierta o cualquier otra fuente de ignición, se producen procesos de carbonización, calentamiento al rojo, ignición o combustión, dependiendo de las condiciones del proceso. Para ampliar su ámbito de aplicación, es necesario mejorar sus propiedades anticombustión. Las unidades estructurales fabricadas en madera suelen tratarse con agentes ignífugos (p. ej., mediante saturación, impregnación o recubrimiento superficial) para conseguir que sean menos combustibles.

La característica más importante de la combustibilidad de los distintos tipos de madera es la temperatura de ignición. Su valor depende principalmente de algunas propiedades de la madera y de las condiciones en que se realiza la prueba, como densidad, humedad, tamaño, y forma de la muestra de madera y de la fuente de ignición, tiempo e intensidad de exposición, y entorno del ensayo. Es interesante observar las diferencias en la temperatura de ignición obtenidas con los distintos métodos de ensayo. La práctica demuestra que los productos limpios y secos presentan una facilidad de ignición extremadamente baja, mientras que en madera polvorienta, impregnada de aceite y almacenada en recintos con una ventilación insuficiente, se han registrado incendios por ignición espontánea. Se ha demostrado empíricamente que un contenido mayor de humedad aumenta la temperatura de ignición y reduce la velocidad de combustión de la madera. La descomposición térmica de la madera es un proceso complejo que consta de las fases siguientes:

- La descomposición térmica con pérdida de masa se inicia ya entre 120 y $200{ }^{\circ} \mathrm{C}$; en esta fase se libera el contenido de humedad y se produce la degradación de los materiales no combustibles en el área de combustión. 
- Entre 200 y $280{ }^{\circ} \mathrm{C}$ se producen principalmente reacciones endotérmicas y se absorbe la energía calorífica de la fuente de ignición.

- Entre 280 y $500{ }^{\circ} \mathrm{C}$ las reacciones exotérmicas de los productos de descomposición se aceleran constantemente dando lugar al proceso primario y, al mismo tiempo, se desarrollan fenómenos de carbonización. En este rango de temperatura tiene lugar ya una combustión sostenida. Después de la ignición, la combustión no es constante debido a la capacidad de las capas carbonizadas para aislar el calor. Por tanto, el calentamiento de las capas más profundas es limitado y lento. Al aumentar la superficie de productos de descomposición combustibles, se completa la combustión.

- A temperaturas superiores a $500{ }^{\circ} \mathrm{C}$, la madera carbonizada forma residuos. Al calentarse al rojo, se producen cenizas que contienen materiales inorgánicos sólidos, y concluye el proceso.

\section{Fibras y textiles}

La mayoría de los textiles fabricados a base de fibras que se encuentran en el entorno humano son combustibles. La ropa, el mobiliario y el entorno habitable están constituidos en su totalidad 0 en parte por textiles, que representan un peligro tanto durante su producción, procesado y conservación como durante su utilización.

Las materias primas de los textiles pueden ser naturales 0 artificiales; las fibras sintéticas pueden utilizarse solas o mezcladas con fibras naturales. Químicamente, las fibras naturales de origen vegetal (algodón, cáñamo, yute, lino) están formadas por celulosa, que es combustible, y presentan una temperatura de ignición relativamente alta $\left(\approx 400{ }^{\circ} \mathrm{C}\right)$. U na característica positiva de su combustión es que, cuando se eleva su temperatura, se carbonizan pero no se funden. Esto resulta especialmente beneficioso para el tratamiento médico de las quemaduras.

L as características de riesgo de incendio de las fibras basadas en proteínas de origen animal (lana, seda, pelo) todavía son más positivas que las de las fibras vegetales, ya que presentan una temperatura más alta de ignición $\left(500-600^{\circ} \mathrm{C}\right)$ y, en las mismas condiciones, su combustión es menos intensa.

Cada vez adquieren mayor importancia las aplicaciones textiles de la industria de los plásticos, que aprovecha algunas propiedades mecánicas extremadamente positivas de los productos poliméricos. Entre las características de las fibras sintéticas acrílicas, de poliéster y termoplásticas (nylon, polipropileno, polietileno), las relativas a la combustión son las menos positivas. La mayoría de estas fibras, a pesar de su elevada temperatura de ignición $\left(\approx 400-600{ }^{\circ} \mathrm{C}\right)$, se funden cuando se exponen al calor, entran fácilmente en ignición, arden con intensidad, gotean 0 se funden durante la combustión y liberan una cantidad considerable de humo y gases tóxicos. Estas propiedades pueden mejorarse si se mezclan con fibras naturales, dando lugar a los denominados tejidos con mezcla de fibra. También pueden tratarse con agentes ignífugos. En la fabricación de textiles para la industria y de ropa ignífuga ya se están utilizando mucho productos inorgánicos de fibras no combustibles (fibras de vidrio y metálicas).

En los textiles, las propiedades de seguridad más importantes son las relacionadas con la capacidad de ignición, la propagación de la llama y la generación de calor y de productos de combustión tóxicos. Para su determinación, se han desarrollado métodos especiales de ensayo. Los resultados obtenidos se aplican en los lugares donde se utilizan estos productos (vivienda, mobiliario, tapizado de vehículos, ropa, alfombras, cortinas, ropa de protección contra el calor y las inclemencias) y sirven para elaborar la normativa de seguridad contra los riesgos derivados de su uso. Una tarea fundamental de los

investigadores industriales es desarrollar textiles que soporten altas temperaturas mediante un tratamiento ignífugo (difícilmente combustibles, con un tiempo de ignición prolongado, baja velocidad de propagación de la llama, baja velocidad de liberación de calor) y con una producción reducida de productos de combustión tóxicos, a fin de reducir los accidentes por incendio debidos a la combustión de este tipo de materiales.

\section{Líquidos combustibles e inflamables}

En presencia de una fuente de ignición, los líquidos combustibles e inflamables son fuentes potenciales de riesgo. En primer lugar, el espacio (cerrado o abierto) de vapor formado por encima de estos líquidos representa un peligro de incendio y de explosión y puede dar lugar a una combustión y, con mayor frecuencia, a una explosión, si el material está presente en la mezcla vaporaire en una determinada concentración. Por lo tanto, la combustión y la explosión de líquidos combustibles e inflamables puede evitarse si:

- se eliminan las fuentes de ignición, el aire y el oxígeno;

- en lugar de oxígeno está presente en el ambiente un gas inerte;

- el líquido se almacena en un depósito o sistema cerrado (véase la Figura 41.3),

- se impide que se alcance la concentración peligrosa de vapor mediante una ventilación adecuada.

En la práctica, se conocen muchas características relacionadas con la naturaleza peligrosa de los líquidos combustibles e inflamables, como puntos de inflamación en vaso cerrado y abierto, punto de ebullición, temperatura de ignición, velocidad de evaporación, límites superior e inferior de la concentración de combustibilidad (límites inflamables o explosivos), o la densidad relativa de vapor en relación con el aire y la energía necesarios para la ignición de vapores. Todos estas características

Figura 41.3 - Tipos más comunes de tanques para el almacenamiento de líquidos inflamables y combustibles.

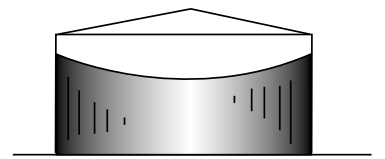

TANQUE NORMAL DE TECHO CONICO

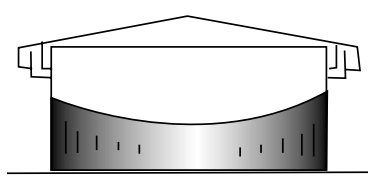

TANQUE DE TECHO DESPLAZANTE

El techo de sellado líquido se desplaza en sentido ascendente 0 descendente según el volumen de vapor

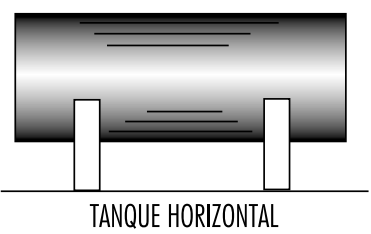

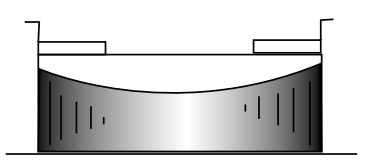

TANQUE DE TECHO FLOTANTE

El techo se apoya sobre el líquido, desplazándose en sentido ascendente 0 descendente según el nivel

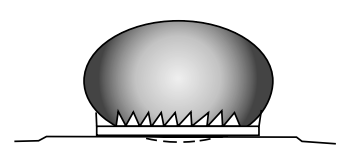

TANQUE ESFEROIDE

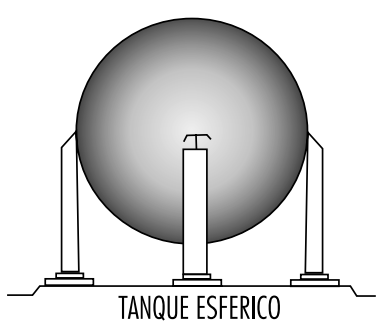


proporcionan una gran información sobre la facilidad de ignición de los distintos líquidos.

En casi todo el mundo se utiliza el punto de inflamación, parámetro determinado mediante un ensayo estándar en condiciones atmosféricas, como base para establecer las diferentes categorías de riesgo de los líquidos y las de los materiales que se comportan como líquidos a temperaturas relativamente bajas. Para cada categoría de inflamabilidad y combustibilidad, se fijan los correspondientes requisitos de seguridad en materia de conservación y manipulación, los procesos de operación y el equipo eléctrico que debe instalarse en la zona. También hay que identificar para cada categoría las zonas de riesgo que rodean a los equipos. La experiencia demuestra que se pueden producir incendios y explosiones - dependiendo de la temperatura y la presión del sistema- en un rango de concentración comprendido entre ambos límites de inflamabilidad.

\section{G ases}

A pesar de que todos los materiales - a determinada presión y temperatura - pueden pasar a estado gaseoso, los materiales que en la práctica se consideran gases son aquellos que se encuentran en dicho estado en condiciones normales de presión atmosférica $(\approx 100 \mathrm{kPa})$ y temperatura $\left(\approx 20^{\circ} \mathrm{C}\right)$.

Con respecto a los peligros de incendio y explosión, los gases pueden clasificarse en dos grandes grupos: gases combustibles y gases no combustibles. D e acuerdo con la definición aceptada en la práctica, los gases combustibles son aquellos que entran en combustión en el aire con una concentración normal de oxígeno, siempre que existan las condiciones adecuadas. La ignición sólo se produce por encima de una determinada temperatura, con la temperatura de ignición necesaria y dentro de un determinado rango de concentración.

Los gases no combustibles son aquellos que no entran en combustión ni en oxígeno ni en aire independientemente de su concentración. Algunos de estos gases favorecen la combustión (p. ej., el oxígeno), mientras que otros la inhiben. Los gases no combustibles y que no favorecen la combustión se denominan gases inertes (nitrógeno, gases nobles, dióxido de carbono, etc.).

Normalmente, y para una mayor eficiencia económica en la conservación y transporte de gases en depósitos o cisternas, éstos se comprimen, licúan o condensan en frío (estado criógeno). Básicamente, existen dos situaciones de peligro cuando se manipulan gases: durante el período de almacenaje y cuando se extraen de los depósitos.

En gases comprimidos en depósitos de almacenamiento, el calor externo puede aumentar considerablemente la presión interior del depósito y, si se alcanza una sobrepresión extrema, llega a producirse una explosión. Los depósitos de almacenamiento de gases incluyen normalmente una fase de vapor y otra líquida. Como resultado de los cambios de presión y temperatura, la extensión de la fase líquida aumenta la compresión del espacio de vapor, mientras que la presión de vapor del líquido aumenta proporcionalmente al aumento de la temperatura. Estos procesos pueden dar lugar a una presión crítica peligrosa. Los depósitos de almacenamiento deben incluir dispositivos de liberación de sobrepresión capaces de mitigar una situación de peligro ocasionada por altas temperaturas.

Si los depósitos de almacenamiento no están bien cerrados o están dañados, el gas saldrá a la atmósfera libre, se mezclará con el aire y, dependiendo de su cantidad y su flujo, puede provocar la formación de una gran atmósfera explosiva. El aire que se encuentra en las proximidades de un depósito con fugas puede ser nocivo para la respiración y para las personas que se encuentran cerca supone un peligro, en parte por el efecto tóxico de algunos gases y en parte por la dilución de la concentración de oxígeno.
L os gases representan un peligro de incendio potencial y hay que manipularlos de un modo seguro. Para ello, y especialmente en el entorno industrial, deben conocerse en detalle las siguientes características: propiedades químicas y físicas de los gases, temperatura de ignición, límites superior e inferior de concentración de inflamabilidad, parámetros peligrosos del gas en el depósito, riesgo ocasionado por la liberación de gases a la atmósfera, dimensiones de las zonas de seguridad necesarias y medidas especiales que deben tomarse en caso de emergencia por incendio.

\section{Productos químicos}

Para un trabajo seguro, es fundamental conocer los parámetros de riesgo de los productos químicos. Sólo pueden elaborarse medidas preventivas y normas de seguridad contra incendios si se tienen en cuenta las propiedades químicas y físicas que presentan en relación con el peligro de incendio. De entre esas propiedades las más importantes son: combustibilidad, capacidad de ignición, capacidad de reacción con otros materiales, agua 0 aire, propensión a la corrosión, toxicidad y radiactividad.

La información sobre estas propiedades de los productos químicos figura en las fichas técnicas elaboradas por los fabricantes y en los manuales sobre productos químicos peligrosos. Se trata no sólo de las características técnicas generales de los materiales, sino también de los valores reales de los parámetros de peligro (temperatura de descomposición, temperatura de ignición, concentraciones límite de combustión, etc.), su comportamiento especial, los requisitos de almacenamiento y de seguridad contra incendios, y recomendaciones de primeros auxilios y asistencia médica.

La toxicidad de los productos químicos puede dar lugar a dos situaciones de riesgo en un incendio potencial. Por un lado, la alta toxicidad de ciertos productos químicos puede resultar peligrosa en caso de incendio y, por otro, su presencia en el área de incendio puede dificultar las operaciones de extinción.

Los agentes oxidantes (nitratos, cloratos, peróxidos inorgánicos, permanganatos, etc.), aunque en sí no son combustibles, contribuyen en gran medida a la ignición de los materiales combustibles, así como a su combustión, que puede ser intensa y en ocasiones explosiva.

En el grupo de materiales inestables se encuentran los productos químicos (acetaldehídos, óxido de etileno, peróxidos orgánicos, cianuro de hidrógeno, cloruro de vinilo) que se polimerizan o se descomponen de forma espontánea o con mucha facilidad dando lugar a reacciones exotérmicas violentas.

Los materiales que reaccionan con el agua y el aire son extremadamente peligrosos. Estos materiales (óxidos, hidróxidos, hidruros, anhídridos, metales alcalinos, fósforo, etc.) interaccionan con el agua y el aire de la atmósfera e inician reacciones que van acompañadas de una liberación de calor muy alta. Los materiales combustibles entran en una ignición espontánea. A demás, los componentes combustibles que entran en combustión pueden explotar y propagarse a otros materiales combustibles que se encuentren en las proximidades.

La mayoría de los materiales corrosivos (los ácidos inorgánicos - sulfúrico, nítrico, perclórico, etc. - y los halógenos - flúor, cloro, bromo, yodo-) son agentes oxidantes fuertes y tienen efectos muy destructivos sobre los tejidos vivos, por lo que es necesario tomar las necesarias medidas de seguridad contra incendios.

Los elementos y compuestos radiactivos, además de los peligros derivados de la radiación, pueden presentar también un peligro de incendio. Cuando en un incendio resulta dañada la estructura de objetos radiactivos, pueden liberarse materiales que irradien rayosy con un efecto ionizador muy fuerte y provoquen la destrucción de los organismos vivos. Los accidentes 
nucleares pueden ir acompañados de incendios, cuyos productos de descomposición adsorben contaminantes radiactivos (radiación $\alpha$ y $\beta$ ). Estos últimos pueden producir daños permanentes en las personas que participan en las tareas de rescate si penetran en sus cuerpos. Algunos materiales son extremadamente peligrosos porque las personas afectadas no perciben a través de sus sentidos ninguna radiación, y su estado de salud general no parece quedar afectado. Si materiales radiactivos entran en combustión, deberá supervisarse constantemente la radiactividad del lugar, los productos de descomposición y el agua utilizada en la extinción del incendio con los dispositivos de medición adecuados. Estos factores deben tenerse en cuenta al diseñar la estrategia de intervención. Los edificios donde se manipulan, procesan y almacenan materiales radiactivos deben construirse con materiales no combustibles de alta resistencia al fuego. Es necesario también utilizar equipos automáticos de alta calidad para la detección, señalización y extinción de los incendios.

\section{Explosivos y agentes de voladura}

Los materiales explosivos se utilizan para fines militares e industriales. Se trata de productos químicos y mezclas de los mismos que, cuando se les aplica una fuerza mecánica intensa (golpe, choque, fricción) o cuando se inicia la ignición, se transforman súbitamente en gases de gran volumen mediante una reacción de oxidación extremadamente rápida (p. ej., 1.000-10.000 m/ s). EI volumen de estos gases es mucho mayor que el del material explosionado y ejerce una presión muy alta en sus proximidades. En una explosión pueden alcanzarse temperaturas elevadas (2.500-4.000 $\left.{ }^{\circ} \mathrm{C}\right)$ que provocan la ignición de los materiales combustibles en la zona de explosión.

La fabricación, el transporte y el almacenamiento de materiales explosivos debe cumplir unos requisitos estrictos, como el NFPA 495, Código de M ateriales Explosivos.

A demás de los materiales explosivos utilizados para fines militares e industriales, también se incluyen en la categoría de materiales peligrosos los materiales de voladura inductiva y los productos pirotécnicos. Las mezclas más utilizadas son las de materiales explosivos (ácido pícrico, nitroglicerina, hexógeno, etc.), aunque también se utilizan mezclas de materiales que pueden explosionar (polvo negro, dinamita, nitrato amónico, etc.). L os materiales plásticos, conocidos por su utilización en los actos terroristas, constan básicamente de mezclas de materiales de efecto rompedor y plastificante (ceras, vaselina, etc.).

En cuanto a los materiales explosivos, el método más eficaz de protección contra incendios es su alejamiento de las fuentes de ignición. Algunos materiales explosivos reaccionan con el agua 0 con diversos materiales orgánicos y se oxidan. Para el manejo de estos materiales deben tenerse muy en cuenta los requisitos y la normativa de almacenamiento con otros materiales.

\section{M etales}

La práctica nos enseña que casi todos los metales, en las condiciones adecuadas, pueden entrar en combustión en el aire. Por su comportamiento en caso de incendio, el acero y el aluminio de gran espesor estructural se consideran materiales no combustibles. Sin embargo, el polvo de aluminio y de hierro y los algodones metálicos de fibra de metal fina pueden entran fácilmente en ignición y, por tanto, arder de forma intensa. Los metales alcalinos (litio, sodio, potasio), los metales alcalinotérreos (calcio, magnesio, zinc), el circonio, el hafnio, el titanio, etc. entran en ignición con extrema facilidad cuando están en forma de polvo, limaduras o tiras finas. Algunos metales tienen tal capacidad de reacción que deben almacenarse fuera del contacto con el aire, en una atmósfera de gas inerte o bajo un líquido neutro a los metales.
Los metales combustibles y los propensos a la combustión producen reacciones de combustión extremadamente violentas, con procesos de oxidación de alta velocidad y liberación de cantidades de calor bastante mayores que las observadas en la combustión de líquidos combustibles e inflamables. Tras la fase preliminar de calentamiento e ignición al rojo, la combustión del polvo metálico sedimentado puede convertirse en una combustión rápida. El polvo en movimiento y las nubes de polvo resultantes de la combustión pueden dar lugar a graves explosiones. La capacidad de combustión y la afinidad con el oxígeno de algunos metales (como el magnesio) es tan alta que, después de entrar en ignición, continúan ardiendo en algunos de los medios (p. ej., nitrógeno, dióxido de carbono, atmósfera de vapor) utilizados para extinguir incendios producidos por materiales combustibles, sólidos y líquidos.

La extinción de los incendios de metales representa un desafío especial para los equipos de bomberos, resultando decisiva la elección de un agente extintor adecuado y del procedimiento empleado.

Los incendios de metales pueden controlarse mediante una detección precoz, una intervención rápida y adecuada del equipo de bomberos utilizando el método de extinción más efectivo y, si es posible, el alejamiento de la zona del incendio de metales y otros materiales combustibles 0 , al menos, la reducción de sus cantidades.

En una combustión con metales radiactivos (plutonio, uranio) debe prestarse especial atención a la protección contra las radiaciones y tomar las medidas preventivas oportunas para evitar la penetración de productos de descomposición tóxicos en los organismos vivos. Así, los metales alcalinos, por su capacidad para reaccionar violentamente con el agua, sólo pueden extinguirse con polvos secos. La combustión del magnesio no debe extinguirse con agua, dióxido de carbono, halones o nitrógeno, porque pueden agravar aún más la situación. Los únicos agentes que pueden aplicarse con éxito en este caso son los gases nobles 0 , en ocasiones, el trifluoruro de boro.

\section{Plásticos y cauchos}

Los plásticos son compuestos orgánicos macromoleculares fabricados sintéticamente 0 mediante la modificación de materiales naturales. La estructura y forma de estos materiales macromoleculares, que son el resultado de reacciones de polimerización, poliadición o policondensación, influye considerablemente en sus propiedades. Las cadenas moleculares de los termoplásticos (poliamidas, policarbonatos, poliésteres, poliestireno, cloruro de polivinilo, polimetil-metacrilato, etc.) son lineales o ramificadas, los elastómeros (neopreno, polisulfuros, isopreno, etc.) presentan ligeros enlaces cruzados, mientras que los plásticos termoendurecidos (duroplásticos: polialquilos, resinas epoxi, poliuretanos, etc.) presentan fuertes enlaces cruzados.

El caucho natural se utiliza en la industria del mismo nombre como materia prima, y se somete a un proceso de vulcanización. Los cauchos artificiales, cuya estructura es similar a la del caucho natural, son polímeros y copolímeros del butadieno.

El uso de los productos plásticos y del caucho es cada vez más frecuente en todos los campos de la vida cotidiana. La gran variedad y las excelentes propiedades técnicas de estos materiales permiten su aplicación a áreas tan diversas como estructuras de edificios, mobiliario, ropas, mercancías y piezas para vehículos y maquinaria.

N ormalmente, los plásticos y el caucho, al igual que los materiales orgánicos, se consideran materiales combustibles. Para analizar su comportamiento en un incendio se utilizan una serie de parámetros que pueden determinarse con métodos especiales. Teniendo en cuenta esos parámetros (combustibilidad, capacidad de ignición, capacidad de producción de humos, 
propensión a la producción de gases tóxicos y al goteo en la combustión), se definen sus ámbitos de aplicación y se establecen las condiciones de seguridad necesarias frente a incendios.

En muchos casos, la temperatura de ignición de los plásticos es superior a la de la madera u otros materiales, pero la mayoría de las veces éstos entran en ignición con mayor facilidad y su combustión se realiza con más rapidez e intensidad. Los incendios de materiales plásticos suelen ir acompañados de un desagradable fenómeno de liberación de grandes cantidades de un humo muy denso que puede limitar fuertemente la visibilidad y dar lugar a gases tóxicos (ácido clorhídrico, fosgeno, monóxido de carbono, cianuro de hidrógeno, gases nitrosos, etc.). Los materiales termoplásticos se funden durante la combustión, después se fluidifican y, según su ubicación, (p. ej., si se encuentran en o sobre un techo) producen goteo en la zona de combustión y pueden provocar la ignición de los materiales combustibles que se encuentran debajo de ellos.

La optimización de las características de combustión es un problema complejo y un "tema clave" de la química de los plásticos. Los agentes ignífugos inhiben la combustibilidad, la ignición es más lenta, la velocidad de combustión disminuye y la propagación de la llama se hace más lenta pero, por otro lado, aumentan la cantidad y densidad del humo y la mezcla de gas producida es más tóxica.

\section{Polvo}

Por su estado físico, el polvo se considera un material sólido, pero sus propiedades físicas y químicas difieren de las del mismo material en forma compacta. Es sabido que muchos accidentes industriales y catástrofes están provocados por explosiones de polvo. $M$ ateriales que no son combustibles en su estado normal, como los metales, pueden originar una explosión cuando se encuentran en forma de polvo mezclado con aire y se les aplica una fuente de ignición, incluso de baja energía. El peligro de una explosión existe igualmente en el caso de polvo de materiales combustibles.

EI polvo representa un peligro de explosión no sólo cuando flota en el aire, sino también cuando está sedimentado. Entre las capas de polvo puede acumularse el calor y desarrollarse una combustión lenta en su interior debido a un aumento de la capacidad de reacción de las partículas y a su menor conductividad térmica. Entonces, el polvo puede ser agitado por ráfagas, lo que aumenta las posibilidades de explosión.

Los partículas flotantes en una distribución fina suponen un riesgo aún más grave. Para los polvos, al igual que para los gases y los vapores combustibles, existe un rango especial de concentración aire-polvo en el que puede producirse una explosión. Los límites superior e inferior de la concentración explosiva y la amplitud del rango de concentración dependen del tamaño y la distribución de las partículas. Si la concentración de polvo es superior a la concentración máxima necesaria para producir una explosión, una parte del polvo no será destruida por el incendio y absorberá el calor; en consecuencia, la presión de explosión desarrollada se mantendrá por debajo del máximo. El contenido de humedad del aire también influye en las posibilidades de explosión, ya que la temperatura de ignición de la nube de polvo aumentará en función de la cantidad de calor necesaria para evaporar la humedad. Cuando se mezcla un polvo inerte extraño con una nube de polvo, se reduce la explosividad de la mezcla polvo-aire. El efecto es el mismo cuando se mezclan gases inertes con la mezcla de polvo-aire, pues se reduce la concentración de oxígeno necesaria para la combustión.

La experiencia demuestra que todas las fuentes de ignición, incluso las de energía mínima, pueden provocar la ignición de una nube de polvo (Ilama abierta, arco eléctrico, chispa mecánica o electrostática, superficie caliente, etc.). Según los resultados obtenidos en el laboratorio, los requisitos de energía para la ignición de nubes de polvo son entre 20 y 40 veces mayores que para las mezclas de vapor combustible y aire.

Los factores que influyen en el peligro de explosión de polvo sedimentado son las características físicas y térmicas de la capa de polvo, la temperatura de calentamiento al rojo del polvo y las propiedades de ignición de los productos de descomposición liberados por la capa de polvo.

\section{MEDIDAS DE PREVENCION CONTRA INCENDIOS}

\section{Peter F. Johnson}

L a H istoria habla del uso del fuego para calentar y cocinar, pero también de los importantes daños causados por el mismo en muchas ciudades. Casas, edificios y hasta ciudades enteras han quedado destruidas por incendios.

U na de las primeras medidas preventivas que se instauraron fue el decreto que obligaba a apagar todos los fuegos domésticos antes de la caída de la noche. Así, en 872 en 0 xford, Inglaterra, las autoridades ordenaron que se tocase una campana de toque de queda a la caída del día para recordar a los ciudadanos que apagasen todos los fuegos (Bugbee, 1978). R ealmente, la palabra inglesa curfew (toque de queda) se deriva de la francesa couvre feu, que significa literalmente "cubre fuego".

La causa de los incendios suele ser un error humano al poner en contacto un combustible con una fuente de ignición (p. ej., papel de desecho almacenado cerca de un calentador 0 líquidos inflamables que se utilizan cerca de una llama abierta).

Para que se produzca un incendio es necesario un combustible, una fuente de ignición y algún mecanismo que ponga en contacto el combustible con la fuente de ignición en presencia de aire o de otro oxidante. D esarrollando estrategias para reducir los riesgos del combustible, eliminar las fuentes de ignición o impedir la interacción entre combustible e ignición, se pueden reducir las pérdidas personales y materiales causadas por los incendios.

En los últimos años, cada vez es mayor la preocupación por la prevención de los incendios como una de las maneras más efectivas desde el punto de vista económico de tratar este tema. Suele resultar más fácil (y más económico) evitar que se produzca un incendio que controlarlo o extinguirlo una vez iniciado.

Así lo ilustra el Fire Safety Concepts Tree (NFPA 1991; 1995a) desarrollado por el NFPA en Estados Unidos. Este enfoque sistemático de la seguridad contra incendios demuestra que es posible reducir las víctimas mortales por incendio en el lugar de trabajo evitando la ignición de los mismos o controlando su repercusión.

La prevención de incendios exige modificar el comportamiento humano, y para ello es necesario impartir una formación de seguridad frente a incendios a cargo de la dirección, utilizando los últimos avances en materia de formación y normativa, así como otros materiales pedagógicos. En muchos países, estas estrategias son de obligado cumplimiento por ley y las empresas están obligadas a cumplir la normativa legal de prevención de incendios como parte de su compromiso de seguridad frente a los trabajadores.

La formación en prevención de incendios se analiza en la sección siguiente. A ctualmente, en los sectores comercial e industrial se reconoce la importancia de la prevención de incendios. A escala internacional se están utilizando mucho las siguientes publicaciones: L ees, L oss Prevention in the Process Industries, volúmenes 1 y 2 (1980); N FPA 1-Fire Prevention Code (1992); T he $M$ anagement of $\mathrm{H}$ ealth and Safety at Work Regulations (ECD, 1992) y Fire Protection $\mathrm{H}$ andbook del NFPA (C ote, 1991), a las 
que hay que añadir gran número de reglamentos y normativas, así como el material de formación desarrollado por gobiernos, empresas y compañías de seguros de distintos países con el fin de minimizar las pérdidas personales y materiales.

\section{Formación sobre seguridad contra incendios}

Para que un programa de seguridad contra incendios sea efectivo, debe existir un compromiso de política social en cuanto a la seguridad y poner en marcha un plan efectivo con las fases siguientes: a) planificación (establecimiento de metas y objetivos), b) diseño y aplicación y c) evaluación del programa (para supervisar su efectividad).

\section{M etas y objetivos}

Gratton (1991), en un interesante artículo sobre la formación en materia de seguridad contra incendios, definió la diferencia entre metas, objetivos y prácticas de aplicación o estrategias. Las metas son declaraciones generales de intenciones para "reducir el número de incendios y, con ello, el número de muertos y heridos entre los trabajadores, así como su repercusión económica para las empresas".

Los aspectos personales y económicos de la meta general no son incompatibles. Las prácticas modernas de gestión de riesgos demuestran que las mejoras en seguridad para los trabajadores a través de la implantación de prácticas efectivas de control de pérdidas pueden ser positivas desde el punto de vista económico para la empresa, al mismo tiempo que suponen un beneficio para la comunidad.

Estas metas deben traducirse a objetivos específicos de seguridad contra incendios en función de la empresa y de los trabajadores. Los objetivos, que deben ser cuantificables, suelen contemplar aspectos como:

- reducir los accidentes industriales y los incendios asociados;

- reducir el número de muertos y heridos,

- reducir el daño material a la empresa.

En muchas empresas pueden establecerse objetivos adicionales, como la reducción de los costes de interrupción de la actividad o la minimización del riesgo de responsabilidad legal.

Pero, en otras, el cumplimiento de los códigos y normas locales sobre edificios basta para garantizar el cumplimiento de sus objetivos de seguridad contra incendios. Sin embargo, dicha normativa tiende a limitarse a la seguridad personal, dando por hecho que los incendios se van a producir.

La gestión moderna de seguridad contra incendios entiende que, si bien la seguridad absoluta no es un objetivo realista, pueden establecerse objetivos cuantificables para:

- minimizar los accidentes de incendio mediante una prevención efectiva de los mismos;

- limitar el tamaño y las consecuencias de los incendios utilizando equipos y procedimientos de emergencia efectivos,

- utilizar los seguros como salvaguardia en caso de incendios graves e imprevistos, especialmente los provocados por catástrofes naturales como terremotos o incendios en bosques.

\section{Diseño y aplicación}

El diseño y la aplicación de los programas de formación en prevención de incendios dependen en gran medida del desarrollo de estrategias bien planificadas, de una gestión efectiva y de la motivación de los individuos. Para que un programa de seguridad contra incendios tenga éxito, debe existir un apoyo social fuerte y decidido a su aplicación.

Entre las estrategias posibles, estudiadas por Koffel (1993) $y$ en el Industrial Fire $\mathrm{H}$ azards $\mathrm{H}$ andbook del NFPA (Linville, 1990), cabe citar:
- la promoción de la política y de las estrategias corporativas sobre seguridad contra incendios entre el personal de la empresa;

- la identificación de todos los posibles escenarios de incendio y la aplicación de acciones adecuadas para reducir los riesgos;

- la supervisión de todos los códigos y normativas específicos que definen el nivel de cuidado en una industria concreta;

- la implantación de un programa de gestión de pérdidas para determinar las pérdidas en relación con los objetivos de rendimiento,

- la formación de todo el personal en técnicas adecuadas de prevención de incendios y respuesta a emergencias.

Entre las estrategias de aplicación existentes a escala internacional cabe destacar:

- los cursos de la Fire Protection Association (FPA) en el R eino U nido y su diploma de 'Fire Prevention' (W elch, 1993);

- la fundación SweR isk, compañía subsidiaria de la Swedish Fire Protection Association, que ayuda a las empresas a valorar los riesgos y desarrollar programas de prevención de incendios (Jernberg, 1993);

- la participación masiva en Japón de ciudadanos y trabajadores en la campaña de prevención de incendios desarrollada por la Agencia de L ucha contra Incendios de Japón (H unter, 1991),

- Ia formación en seguridad en Estados U nidos a través de la utilización del Firesafety E ducator's $\mathrm{H}$ andbook (N FPA, 1983) y del Public Fire E ducation M anual (O sterhoust, 1990).

Es de vital importancia determinar la efectividad de los programas formativos de seguridad contra incendios, lo que proporcionará la motivación necesaria para financiar, desarrollar o modificar nuevos programas.

El mejor ejemplo de supervisión de una formación de seguridad contra incendios puede encontrarse tal vez en Estados U nidos. EI programa Learn $\mathrm{N}$ ot to Burn ${ }^{\circledR}$, ideado para educar a la juventud norteamericana en los peligros de incendio, ha sido coordinado por la División de Educación Pública del NFPA. Según la supervisión y el análisis realizados en 1990, se consiguieron salvar 194 vidas gracias a la utilización de las medidas de seguridad impartidas en programas de seguridad contra incendios. El 30 \% de las mismas puede atribuirse directamente al programa Learn $\mathrm{N}$ ot to Burn ${ }^{\circledR}$.

En Estados U nidos, la instalación de detectores de humo en las viviendas y los programas formativos de seguridad contra incendios permitieron reducir el número de víctimas mortales producidas en incendios en los hogares, que pasaron de 6.015 muertos en 1978 a 4.050 en 1990 (NFPA 1991).

\section{Prácticas de mantenimiento industrial}

En el sector industrial, Lees (1980) está considerado una autoridad internacional. Este autor afirma que, en muchas industrias, el potencial de pérdida masiva de vidas, daños graves o materiales es ahora mucho mayor que en el pasado. Actualmente, y en especial en las industrias petroquímica y nuclear, existe un gran peligro de incendio, explosión y liberación de gases tóxicos.

Por esta razón, la prevención de incendios es la clave para minimizar su ignición. Las plantas industriales modernas pueden conseguir un buen nivel de seguridad contra incendios mediante una buena gestión de los programas de:

- inspección de mantenimiento y seguridad;

- formación del personal en prevención de incendios;

- mantenimiento y reparación de equipos,

- seguridad y prevención de incendios provocados (Blye y Bacon, 1991). 
La interesante guía de Higgins (1991) en el Fire Protection $\mathrm{H}$ andbook del NFPA analiza la importancia del mantenimiento en la prevención de incendios de instalaciones comerciales e industriales.

Las modernas herramientas informáticas de evaluación del riesgo de incendio en instalaciones industriales conceden gran importancia al mantenimiento para minimizar los riesgos del combustible y prevenir su contacto con fuentes de ignición. El software FREM (Fire Risk Evaluation M ethod) de Australia considera el mantenimiento como un factor clave en la seguridad contra incendios (K eith, 1994).

\section{Equipos de calefacción}

Entre los equipos de calefacción que se utilizan en el comercio y la industria se encuentran las estufas, los hornos convencionales, los hornos de madera, los deshidratadores, los secadores y los tanques de enfriamiento.

En el Industrial Fire $\mathrm{H}$ azards $\mathrm{H}$ andbook del NFPA, Simmons (1990) identifica los siguientes riesgos de incendio de los equipos de calefacción:

1. la probabilidad de provocar la ignición de los materiales combustibles almacenados en las proximidades;

2. el peligro derivado de la existencia de combustible sin quemar o de una combustión incompleta;

3. el sobrecalentamiento debido a un fallo del equipo,

4. la ignición de disolventes combustibles, materiales sólidos u otros productos en proceso.

Estos peligros pueden paliarse mediante la combinación, en el marco de un programa efectivo de prevención de incendios, de medidas de gestión y control adecuadas, de formación y prácticas para los trabajadores y de limpieza y mantenimiento.

EI Fire Protection $\mathrm{H}$ andbook del NFPA (Cote, 1991) incluye recomendaciones detalladas para los distintos tipos de calefacción, que resumimos a continuación.

\section{H or nos y estufas}

Los incendios y explosiones en hornos y estufas suelen deberse al combustible utilizado, a las sustancias volátiles generadas 0 a una combinación de ambos. Muchos hornos y estufas funcionan a temperaturas comprendidas entre 500 y $1.000^{\circ} \mathrm{C}$, que superan la temperatura de ignición de la mayoría de los materiales.

Los hornos y estufas requieren una serie de mandos y bloqueadores para evitar que los gases combustibles sin quemar - los productos de una combustión incompleta se acumulen y entren en ignición. Normalmente, este peligro es mayor al inicio de la combustión o durante las operaciones de apagado. Por tanto, los técnicos deben disponer de una formación especial que garantice una actuación acorde con la normativa de seguridad.

Entre los elementos básicos de un sistema de seguridad contra la propagación de incendios suelen encontrarse la construcción de edificios con materiales incombustibles, su aislamiento de otros equipos y materiales combustibles y un sistema de extinción automática de incendios.

\section{H or nos de madera}

Los hornos de madera se utilizan para secar este material (Lataille, 1990) y elaborar o cocer productos de arcilla (H rbacek, 1984).

Estos equipos de altas temperaturas representan también un peligro para su entorno. Para evitar incendios, es fundamental un diseño que tenga en cuenta su aislamiento y un mantenimiento adecuado.

L os hornos utilizados para secar madera son doblemente peligrosos, porque la madera representa en sí misma un alto riesgo de incendio y a menudo se calienta a temperaturas cercanas a su punto de ignición. Es fundamental limpiar regularmente las instalaciones para evitar que se acumulen pequeños trozos de madera y serrín que puedan entrar en contacto con el aparato de calefacción. Los mejores hornos de madera son los fabricados con un material resistente al fuego y equipados con rociadores automáticos y sistemas de ventilación/ circulación de aire de alta calidad.

\section{Deshidratadores y secadores}

Se utilizan para reducir el contenido de humedad de los productos agrícolas, como leche, huevos, granos, semillas y heno. L os secadores pueden ser de caldeo directo, en cuyo caso el material a secar entra en contacto con los mismos, o por caldeo indirecto. En ambos casos, es necesario efectuar controles para cerrar el suministro de calor en caso de que se alcancen temperaturas excesivas, incendio en el secador, en el sistema de escape o en el de transporte, o fallo en la ventilación. También es necesario realizar una limpieza adecuada para impedir la formación de productos que puedan provocar la ignición.

\section{Tanques de enfriamiento}

Los principios generales de la seguridad contra incendios en los tanques de enfriamiento han sido estudiados por 0 strowski (1991) y Watts (1990).

El proceso de enfriamiento controlado consiste en la introducción de un metal caliente en un tanque de aceite. La finalidad es endurecer 0 templar el material mediante un cambio metalúrgico.

La mayoría de los aceites de enfriamiento son minerales y combustibles y deben elegirse con cuidado para cada aplicación de forma que la temperatura de ignición del aceite sea superior a la temperatura de funcionamiento del tanque de inmersión.

Es fundamental que el aceite no rebose de la boca del tanque y se derrame por los laterales. Para ello se realizarán controles del nivel de líquido y drenajes adecuados.

La inmersión parcial de materiales calientes es la causa más común de incendio en los tanques de enfriamiento y puede evitarse controlando que la transferencia y el transporte del material sean los adecuados.

También deben realizarse controles para impedir que se alcancen temperaturas excesivas en el aceite y en la entrada de agua al tanque, que podrían provocar incendios graves por ebullición y derrames de líquido alrededor del tanque.

A menudo se utilizan sistemas de extinción con dióxido de carbono o productos químicos secos para proteger la superficie del tanque. Se recomienda asimismo proteger el edificio con rociadores automáticos de techo. En algunos casos puede ser necesario también disponer una protección especial para los técnicos que trabajen en las proximidades del tanque. A menudo se instalan sistemas de pulverización de agua para proteger a los trabajadores.

Pero, por encima de todo, es fundamental formar adecuadamente a los trabajadores para los casos de emergencia, incluyendo formación sobre el uso de los extintores portátiles.

\section{Equipos de procesos químicos}

Las operaciones que se realizan para modificar la naturaleza química de los materiales han sido causa frecuente de importantes catástrofes, ocasionando grandes daños y muertos y heridos entre los trabajadores y las comunidades vecinas. LoS peligros que presentan las plantas químicas son los incendios, las explosiones y la liberación de materiales tóxicos. Esta energía destructiva procede a menudo de una reacción química incontrolada en los materiales en proceso o de la combustión de 
materiales que producen ondas expansivas, altos niveles de radiación y proyectiles, que pueden causar víctimas a gran distancia.

\section{Operaciones y equipos de procesamiento}

La primera fase del diseño es analizar los procesos químicos implicados y su potencial de liberación de energía. Lees (1980), en su obra L oss P revention in the Process I ndustries, considera las fases siguientes:

- diseño adecuado de los procesos;

- estudio de los mecanismos de fallo y análisis de fiabilidad;

- identificación de los peligros y auditorías de seguridad,

- evaluación de riesgos-causas/ consecuencias.

Al estudiar los niveles de peligrosidad debe evaluarse:

- la emisión y dispersión potencial de productos químicos, especialmente de sustancias tóxicas y contaminantes;

- Ios efectos de la radiación en un incendio y la dispersión de productos combustibles,

- los productos de explosión, especialmente ondas de choque con capacidad para destruir fábricas y edificios.

Puede encontrarse más información sobre los riesgos y su control en Plant guidelines for technical management of chemical process safety (AIC hE , 1993); Sax's D angerous P roperties of Industrial M aterials (Lewis, 1979) e Industrial Fire $\mathrm{H}$ azards $\mathrm{H}$ andbook del NFPA (Linville, 1990).

\section{Localización y protección de las instalaciones}

Una vez identificados los peligros y las consecuencias en caso de incendio, explosión o liberación de productos tóxicos, puede estudiarse la localización de la planta química.

Lees (1980) y Bradford (1991) han elaborado unas directrices relativas a la localización de las plantas, que deben estar suficientemente alejadas de las comunidades vecinas para garantizar que no se vean afectadas en caso de accidente industrial. U na técnica ampliamente utilizada para determinar la distancia de separación de las plantas químicas es la Q R A, o valoración del riesgo cuantitativo.

En el desastre ocurrido en Bhopal, India, en 1984 se vieron las consecuencias de ubicar una planta química demasiado cerca de una comunidad: más de 1.000 personas resultaron muertas por productos químicos tóxicos en un accidente industrial.

El dejar una zona libre alrededor de la planta química permite un acceso rápido a la misma del equipo de bomberos desde cualquier punto, sea cual sea la dirección del viento.

Las plantas químicas deben disponer de cámaras de control antiexplosión, refugios para los trabajadores y equipos de extinción de incendios que garanticen la seguridad de los trabajadores y permitan una intervención efectiva del equipo de bomberos en caso de accidente

\section{Control de derrames}

Deben minimizarse los derrames de materiales inflamables o peligrosos mediante un adecuado diseño del proceso, con válvulas de seguridad y con equipos de detección/ control adecuados. Como medida preventiva de derrames de gran magnitud hay que construir áreas protegidas por muros, a veces de tierra, que eviten su propagación y donde puedan arder sin causar daños en caso de entrar en ignición.

Los incendios en los sistemas de drenaje son habituales, por lo que se les debe prestar especial atención.

\section{Peligros de la transferencia de calor}

En las plantas químicas, los equipos de transferencia de calor de un fluido caliente a otro más frío representan una fuente potencial de incendio. Temperaturas locales excesivas pueden ocasionar la descomposición y combustión de muchas sustancias, dando lugar en algunos casos al fallo del equipo de transferencia de calor de un fluido a otro y provocando una reacción violenta indeseada.

Para un funcionamiento seguro es fundamental establecer unos niveles de inspección y mantenimiento rigurosos, con una limpieza regular del equipo de transferencia de calor.

\section{Reactores}

Los reactores son depósitos en los que se realizan determinados procesos químicos. Pueden ser de tipo continuo o discontinuo y requieren un diseño especial para resistir las presiones resultantes de explosiones o reacciones incontroladas, así como disponer de mecanismos de desahogo de presión y aberturas de emergencia.

Entre las medidas de seguridad en los reactores químicos hay que citar:

- instrumentos y controles adecuados (incluida circuitería redundante) para detectar posibles accidentes;

- limpieza, inspección y mantenimiento de alta calidad del equipo y de los controles de seguridad;

- formación adecuada de los técnicos en materia de control y actuación en caso de emergencia,

- equipo adecuado de extinción de incendios y personal contra incendios.

\section{Procesos de soldadura y corte}

En las Fichas de previsión de pérdidas (1977) de la Factory M utual Engineering Corporation (FM) se asegura que cerca del $10 \%$ de las pérdidas de bienes industriales se deben a accidentes en los que intervienen procesos de soldadura y corte de materiales, por lo general metales. E stá claro que las elevadas temperaturas necesarias para fundir los metales pueden provocar un incendio, al igual que las chispas que generan muchos de estos procesos.

Las Fichas de la FM (1977) indican que los materiales que más veces se encuentran en los incendios causados por procesos de soldadura y corte son líquidos inflamables, depósitos de aceite, polvos combustibles y madera. L os entornos en que se producen este tipo de accidentes suelen ser instalaciones de almacenamiento, zonas en construcción de edificios, instalaciones en reparación y sistemas de tratamiento de residuos.

Las chispas generadas en procesos de soldadura y corte pueden saltar hasta distancias de $10 \mathrm{~m}$ y caer sobre materiales combustibles donde provocan una combustión sin llama y posteriormente un incendio con llama.

\section{Procesos eléctricos}

La soldadura y el corte por arco eléctrico son procesos en los que interviene la electricidad para generar el arco, que es la fuente de calor necesaria para fundir y unir metales. Los destellos de chispas son habituales, por lo que es necesario proteger a los trabajadores contra ellos, así como contra la electrocución y la intensa radiación por arco.

\section{Procesos con gas combustible-oxígeno}

El calor de combustión del gas y del oxígeno se utiliza para generar llamas de elevada temperatura y fundir metales que se van a unir o cortar. M anz (1991) indica que el acetileno es el gas combustible más utilizado por su elevada temperatura de llama, $3.000^{\circ} \mathrm{C}$ aproximadamente.

La presencia de un combustible y de oxígeno a alta presión presenta un peligro adicional: la fuga de estos gases de sus cilindros de almacenamiento. Es importante recordar que muchos materiales que no entran en combustión o lo hacen lentamente en el aire, sí arden violentamente en oxígeno puro. 
Medidas de protección y precaución

M anz (1991) en el Fire Protection H andbook del NFPA estudia las buenas prácticas de seguridad, entre las que cita:

- diseño, instalación y mantenimiento adecuado de los equipos de soldadura y corte, y en especial control del almacenamiento de los cilindros de combustible y oxígeno y de posibles fugas de los mismos;

- preparación adecuada de las áreas de trabajo para eliminar todos los peligros de ignición accidental de materiales combustibles próximos;

- riguroso control de todos los procesos de soldadura y corte;

- formación de todos los trabajadores en las prácticas de seguridad

- utilización de ropa ignífuga y protección facial de los trabajadores y las personas que trabajen en sus proximidades,

- ventilación adecuada para evitar que los trabajadores y las personas que trabajen en las proximidades estén expuestos a gases y humos nocivos.

Para soldar o cortar tanques u otros depósitos que han contenido materiales inflamables se requieren unas precauciones especiales. Cabe citar a este respecto la guía $R$ ecommended Safe Practices for the Preparation for W elding and Cutting of Containers that have held $\mathrm{H}$ azardous Substances (1988) de la A merican Welding Society.

Para las zonas de construcción puede resultar útil la guía inglesa Fire Prevention on Construction Sites (1992) del Loss Prevention Council, que contiene un modelo de autorización para controlar las operaciones de corte y soldadura aplicable a cualquier planta o instalación industrial. U n modelo de autorización similar se encuentra en las Fichas de la FM para procesos de corte y soldadura (1977).

\section{Protección contra rayos}

El rayo es una de las causas más frecuentes de incendios con víctimas mortales en muchos países del mundo. En Estados U nidos, fallecen cada año unas 240 personas al ser alcanzadas por un rayo.

El rayo es una forma de descarga eléctrica entre las nubes y la Tierra. En la Ficha publicada por la FM sobre este tema (1984) se indica que la intensidad del rayo puede oscilar entre 2.000 y $200.000 \mathrm{~A}$ y la diferencia de potencial que se establece entre las nubes y la T ierra puede ser de $5-50 \times 10^{6} \mathrm{~V}$.

La frecuencia de los rayos varía según los países y las zonas en función, esencialmente, del número de días de tormenta al año. La magnitud de los daños causados por los rayos depende en gran medida del tipo de suelo, y son mayores en zonas donde la tierra presenta una alta resistividad.

\section{Medidas de protección en edificios}

En la norma Standard for the Installation of L ightning P rotection Systems 780 del NFPA (1995b) se recogen los requisitos en materia de diseño para la protección de los edificios contra rayos. Aunque se sigue investigando la causa exacta de la descarga por rayo, la protección se basa en disponer de un medio para que la descarga del rayo pueda penetrar en la tierra o abandonarla sin dañar los edificios.

L os sistemas de pararrayos tienen pues dos funciones:

- interceptar la descarga del rayo antes de que alcance al edificio,

- proporcionar una vía inofensiva de descarga a tierra.

A tal fin, los edificios deben estar equipados con:

- pararrayos;

- conductores de bajada,

- buenas conexiones a tierra, de 10 ohm o inferiores.
Para más detalles sobre el diseño de protecciones antirrayo en edificios, consúltese el artículo de D avis (1991) en el Fire P rotection $\mathrm{H}$ andbook del NFPA (Cote, 1991) y el Code of Practice (1992) del British Standards Institute.

Las descargas directas de los rayos pueden dañar cables de transmisión aéreos, transformadores, subestaciones exteriores y otras instalaciones eléctricas. También los equipos de transmisión eléctrica pueden recibir voltajes inducidos y sobrevoltajes que, al penetrar en los edificios, den lugar a incendios, destrucción de instalaciones y graves interrupciones de funcionamiento. Para evitarlo, es necesario disponer de disipadores de sobrevoltajes que desvíen a tierra estos picos de voltaje a través de tomas de tierra efectivas.

L os sobrevoltajes transitorios inducidos en cables eléctricos y de comunicación de muchos edificios pueden causar daños en los equipos informáticos de gran sensibilidad, de creciente utilización en el comercio y en la industria. Por esta razón, hay que disponer de una protección transitoria como la descrita en la obra T he Protection of Structures Against Lightning del British Standards Institute BS 6651:1992.

\section{Mantenimiento}

Para una protección efectiva es esencial un mantenimiento adecuado de los sistemas de protección contra rayos. Especial atención merecen las tomas de tierra, elemento fundamental para la efectividad de los pararrayos.

\section{MEDIDAS DE PROTECCION PASIVA CONTRA INCENDIOS}

Yngve Anderberg

\section{Limitación de los incendios por compartimentación}

Planificación de la construcción y localización de los edificios EI trabajo de ingeniería en materia de seguridad debe comenzar en la fase de proyecto del edificio, pues los requisitos de seguridad contra incendios influyen en gran medida en la disposición y trazado del mismo. Así, el proyectista podrá incorporar las medidas de seguridad contra incendios con mayor facilidad y a menor coste. En el enfoque global deben tenerse en cuenta tanto el interior del edificio como la planificación de la zona exterior. Los requisitos normativos obligatorios están siendo sustituidos por requisitos funcionales, lo que se traduce en un aumento de la demanda de expertos en este campo. Desde un principio, el proyectista debe colaborar con expertos en incendios para:

- definir los riesgos específicos de incendio del edificio;

- definir las distintas alternativas para obtener el nivel de seguridad contra incendios más adecuado;

- analizar las alternativas pertinentes desde el punto de vista técnico y económico,

- establecer los criterios para elegir la mejor alternativa técnica.

Una vez determinado el emplazamiento, el arquitecto debe tener en cuenta las características técnicas y funcionales del mismo en el proyecto. Del mismo modo, ha de considerar las características de la ubicación antes de tomar decisiones sobre la protección contra incendios, pues ésta puede influir considerablemente en el tipo de protección activa y pasiva que aconsejen los asesores de incendios. Al elaborar el proyecto, hay que considerar los recursos locales disponibles para la lucha contra incendios y el tiempo que se puede tardar en llegar al edificio. No es posible ni debe esperarse que el cuerpo de bomberos se 
responsabilice totalmente de la protección de los ocupantes y los bienes del edificio; ha de contar con la ayuda de protecciones activas y pasivas contra incendios en el edificio capaces de proporcionarle una seguridad razonable en caso de incendio. En un incendio, las operaciones pueden ser de rescate, control del incendio y protección de los bienes, siendo la máxima prioridad en cualquier operación contra incendios la de garantizar la evacuación de todos los ocupantes del edificio antes de la aparición de situaciones críticas.

\section{Diseño estructural basado en clasificaciones y en cálculos}

Un buen método para normalizar la protección contra incendios y los requisitos de seguridad de un edificio es clasificar el tipo de construcción según los materiales utilizados en su estructura y el grado de resistencia al fuego de cada elemento. La clasificación puede basarse en ensayos en horno de acuerdo con ISO 834 (el riesgo de incendio viene definido por la curva estándar de temperatura/ tiempo), en una combinación de ensayos y cálculos, o sólo en cálculos. Estos procedimientos permiten identificar la resistencia estándar al fuego (capacidad para mantener las funciones necesarias durante 30, 60, 90 minutos, etc.) de un elemento estructural de carga o separación. La clasificación (especialmente si está basada en ensayos) es un método simplificado y conservador, y cada vez se va sustituyendo más por métodos de cálculo funcional que tienen en cuenta el efecto de incendios naturales totalmente desarrollados. Sin embargo, los ensayos de incendio siempre serán necesarios, aunque pueden optimizarse combinándolos con simulaciones por ordenador, lo que permite reducir considerablemente el número de ensayos. Normalmente, en los ensayos de incendios, la carga sobre los elementos estructurales es el $100 \%$ de la proyectada, pero en la realidad el factor de utilización de carga suele ser menor. Los criterios de aceptación son específicos para el conjunto o para el elemento analizado. La resistencia estándar contra incendios es el tiempo que un elemento puede resistir el fuego sin derrumbarse.

Los requisitos estructurales y de protección contra incendios incluidos en las normativas modernas basadas en el rendimiento tienen por objetivo conseguir un diseño de ingeniería óptimo y equilibrado en relación con la gravedad del incendio previsto. Estos estudios han abierto el camino a una ingeniería contra incendios basada en cálculos sobre la temperatura y los efectos estructurales en un proceso completo de incendio (con calentamiento y posterior enfriamiento) dentro de un compartimiento. En los cálculos relativos a incendios naturales se considera que los elementos estructurales (fundamentales para la estabilidad del edificio) y toda la estructura no deben derrumbarse durante todo el proceso de incendio ni durante su enfriamiento posterior.

En los últimos 30 años, se ha investigado mucho en este campo y se han desarrollado modelos informáticos que tienen en cuenta las propiedades mecánicas y térmicas de los materiales a elevadas temperaturas. Algunos de esos modelos se han validado con gran número de datos experimentales y se han obtenido estimaciones precisas del comportamiento estructural en caso de incendio.

\section{Compartimentación}

Un compartimiento contra incendios es un espacio dentro de un edificio que puede comprender uno o varios pisos y que está delimitado por elementos separadores, de forma que, en caso de incendio, éste no pueda propagarse fuera de él. La compartimentación es importante para evitar que el fuego se propague a espacios demasiado grandes 0 a todo el edificio. Las personas y los bienes materiales que se encuentren fuera del compartimiento quedan protegidos gracias a la extinción del incendio por el cuerpo de bomberos, a su extinción de forma espontánea 0 , al menos, a los elementos separadores, que retardan la propagación del incendio y del humo hasta que los ocupantes puedan ser rescatados.

La resistencia al fuego específica de un compartimiento depende de su finalidad y del tipo de incendio potencial. LoS elementos separadores que limitan el compartimiento deben resistir el máximo incendio posible o contener el fuego hasta que los ocupantes puedan ser evacuados. Los elementos de carga del compartimiento pueden estar diseñados para resistir todo el proceso de incendio o solamente presentar una determinada resistencia medida en períodos de tiempo iguales o superiores a los exigidos para los elementos separadores.

\section{Integridad estructural durante un incendio}

C on la exigencia de mantenimiento de la integridad estructural durante un incendio se trata de evitar el derrumbamiento de la estructura y garantizar la capacidad de los elementos separadores de evitar la ignición y la propagación de la llama a los espacios colindantes. Pueden adoptarse distintos enfoques para los diseños de resistencia contra incendios. Hay clasificaciones de ensayos estándar de resistencia a incendios según ISO 834, combinaciones de ensayos y cálculos o únicamente cálculos, así como una estimación informática sobre los riesgos de incendio.

\section{Acabado interior}

El acabado interior comprende los materiales de superficie de paredes, techos y suelo. Existen muchos tipos de acabado interior, como yeso, escayola, madera y plásticos. Entre sus múltiples funciones se encuentran las de aislamiento acústico y térmico o la protección contra el desgaste y la abrasión.

El acabado interior se relaciona con los incendios en cuatro aspectos: puede aumentar la velocidad del incendio hasta alcanzar condiciones de descarga, puede incrementar el incendio propagando la llama, puede aumentar la liberación de calor al añadir combustible y puede producir humo y gases tóxicos. Por lo tanto, deberán evitarse aquellos materiales que presentan altas velocidades de propagación de llama, proporcionen combustible al incendio o produzcan cantidades peligrosas de humo y gases tóxicos.

\section{Propagación del humo}

Cuando se declara un incendio en un edificio, el humo puede llegar a extenderse a lugares muy alejados. Los huecos de la escalera y de los ascensores pueden verse invadidos por el humo, bloqueando la evacuación y dificultando la extinción del incendio. Actualmente se considera que, en un incendio, el humo es el máximo factor de riesgo (véase la Figura 41.4).

Entre las fuerzas de desplazamiento del humo se incluyen el tiro natural, la flotabilidad de los gases de combustión, el efecto del viento, los sistemas de ventilación y el efecto de pistón de los ascensores.

Cuando en el exterior el ambiente es frío, se produce un movimiento ascendente de aire en las cajas de los ascensores. En el interior del edificio el aire tiende a flotar, al estar más caliente y ser menos denso que el aire exterior. La fuerza de flotabilidad hace que el aire ascienda por los huecos de los ascensores, fenómeno conocido como tiro natural. La diferencia de presión entre los huecos de los ascensores y el exterior, generadora del movimiento del aire, viene dada por la fórmula siguiente:

$$
\Delta P_{50}=\frac{g P_{\text {atm }}}{R}\left(\frac{1}{T_{0}}-\frac{1}{T_{S}}\right) Z
$$

siendo

$\Delta \mathrm{P}_{50}=$ diferencia de presión entre los huecos de los ascensores y el exterior

g = aceleración de la gravedad 
Figura 41.4 - Producción de humo en un incendio.

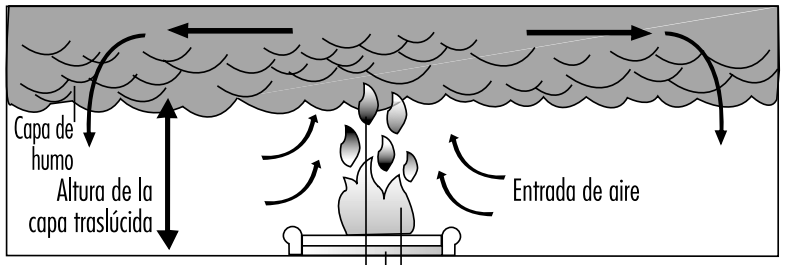

Llamas con humo en penacho

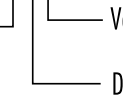

Vapores inflamables en combustión

Descomposición del combustible sólido con desprendimiento de vapores inflamables

$\mathrm{P}_{\text {atm }}=$ presión atmosférica absoluta

$R^{\text {atm }}=$ constante de gas del aire

$\mathrm{T}_{0}=$ temperatura absoluta del aire exterior

$\mathrm{T}_{\mathrm{s}}=$ temperatura absoluta del aire dentro de los huecos de los ascensores

$z \quad=$ elevación

En un incendio, el humo a elevada temperatura flota por su baja densidad. La ecuación de flotabilidad de los gases de combustión es similar a la ecuación del tiro natural.

A demás de la flotabilidad, la energía liberada en un incendio también puede producir movimientos de humo por expansión. El aire entrará en el compartimiento del incendio y el humo caliente se distribuirá por el mismo. Si despreciamos la masa del combustible, la relación de flujos volumétricos puede expresarse como una relación de temperaturas absolutas.

El viento afecta en gran medida al movimiento del humo. No debe olvidarse el efecto de pistón en los ascensores, pues cuando un ascensor se desplaza en su caja, se producen presiones transitorias

Durante la formación de un incendio, el sistema de calefacción, ventilación y aire acondicionado (HVAC) actúa como transportador del humo. Cuando se inicia un incendio en una zona desocupada de un edificio, este sistema HVAC puede transportar el humo a otro espacio habitado, por lo que debe diseñarse de forma que, en caso de incendio, la ventilación se apague 0 el sistema pase a un modo especial de control de humo.

El movimiento del humo puede controlarse mediante mecanismos de compartimentación, dilución, flujo de aire, presurización o flotabilidad.

\section{Evacuación de los ocupantes}

\section{Diseño de las vías de escape}

El diseño de las vías de escape debe basarse en una evaluación previa del sistema global de protección contra incendios (véase la Figura 41.5).

La evacuación de las personas que se encuentran en un edificio en llamas depende de sus reacciones durante la huida, pues deben tomar diferentes decisiones según la situación. Dichas reacciones varían mucho dependiendo de las capacidades físicas y mentales de cada cual.

El propio edificio influye en las decisiones tomadas por los ocupantes en su huida, a través de la señalización y de los sistemas de seguridad instalados. La propagación del incendio y del humo es el factor que más repercute en la toma de decisiones

de los ocupantes. El humo limita la visibilidad en el edificio y crea un ambiente irrespirable. La radiación del fuego y las llamas afectan a grandes espacios, que dejan de ser utilizables para la evacuación, lo que aumenta el riesgo.

Para diseñar las vías de escape de un edificio es necesario conocer primero la reacción de los ocupantes y sus patrones de movimiento en caso de incendio.

L as tres fases de una evacuación son: aviso, reacción y evacuación. La fase de aviso depende de si existe un sistema de alarma en el edificio, de si los ocupantes pueden comprender o no la situación o de la forma de compartimentación del edificio. La fase de reacción se relaciona con la capacidad de los ocupantes para tomar decisiones, de las características del incendio (como cantidad de calor y de humo) y del sistema de vías de escape del edificio. Por último, en la fase de evacuación influyen los puntos donde se pueden formar aglomeraciones y del comportamiento de los ocupantes en las distintas situaciones.

En edificios concretos donde es habitual la movilidad de sus ocupantes, por ejemplo, se han realizado estudios que muestran algunas características reproducibles de los flujos de personas saliendo de edificios, lo que ha permitido realizar simulaciones y modelizaciones informáticas para diseñar las vías de escape

Los recorridos de evacuación deben proyectarse en función del peligro del incendio, ya que cuanto mayor sea el peligro, menor debe ser la distancia hasta la salida de emergencia.

Una salida segura de un edificio exige unas vías de escape seguras entre el lugar del incendio y el exterior. Por lo tanto,

Figura 41.5 - Principios básicos de seguridad de escape.

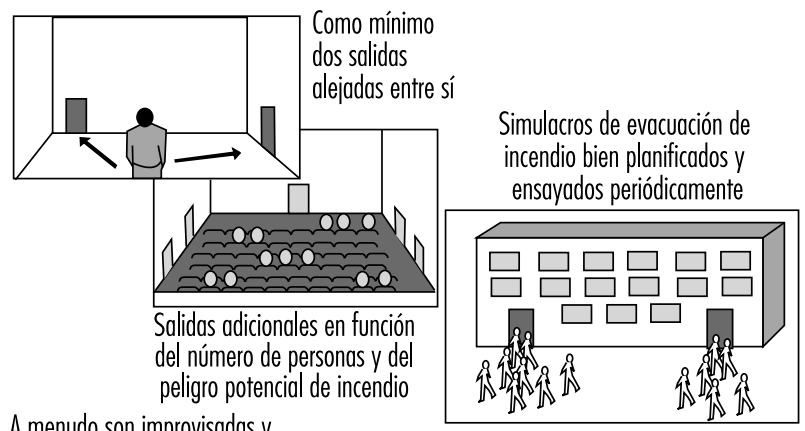

A menudo son improvisadas y pueden resultar peligrosas

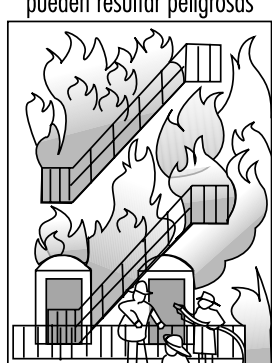

El incendio puede bloquear las salidas de emergencia, como se observa en este dibujo basado en una fotografía de un incendio real

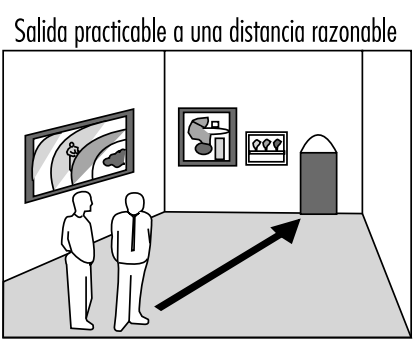

Salidas de emergencia señalizadas, libres y

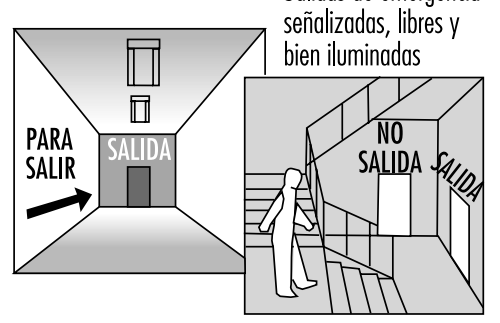


deben existir suficientes vías de escape, estar debidamente proyectadas y tener la capacidad adecuada. Debería haber, como mínimo, una vía de escape alternativa, dado que, por ejemplo, el incendio, el humo y las características de los ocupantes pueden llegar a impedir el uso de las vías de escape. Estas últimas han de estar protegidas del fuego, el calor y el humo durante el tiempo que dure la salida. Así, en los códigos de construcción debe considerarse la protección pasiva para la evacuación y, lógicamente, para la protección contra incendios. Un edificio debe responder a situaciones críticas, tal como se recogen en las normativas sobre evacuación. Por ejemplo, en Suecia, el Código de la construcción establece que la capa de humo no debe descender por debajo de $1,6+0,1 \mathrm{H}$ (siendo $\mathrm{H}$ la altura total del compartimiento), la radiación máxima ha de ser de $10 \mathrm{~kW} / \mathrm{m} 2$ y de corta duración y la temperatura ambiental no debe exceder los $80^{\circ} \mathrm{C}$.

La evacuación será efectiva si el incendio se detecta en su fase inicial y los ocupantes son avisados rápidamente a través de los sistemas de detección y alarma. U na señalización adecuada de las vías de escape facilita considerablemente la evacuación. Asimismo, es importante la organización y realización de simulacros de evacuación.

\section{Comportamiento humano en caso de incendio}

La forma en que una persona reacciona en caso de incendio depende del papel que asume, de la experiencia anterior, de la educación, la personalidad, la percepción de amenaza de la situación, las características físicas, las vías de escape disponibles y la actuación de las demás personas que comparten con ella esa experiencia. Entrevistas y estudios realizados a lo largo de 30 años han confirmado que los episodios de comportamiento desadaptado o de pánico se producen raras veces y en condiciones específicas. El comportamiento en caso de incendio suele estar determinado por el análisis de la información, que genera acciones de cooperación y altruistas.

El comportamiento humano pasa por varias fases, y hay varias alternativas para pasar de una a otra. D e forma resumida, un incendio presenta tres fases generales:

1. La persona percibe las señales iniciales y las investiga o malinterpreta.

2. Una vez que el incendio ya es visible, la persona intenta obtener más información, ponerse en contacto con otras personas 0 abandonar el lugar.

3. Después, la persona intenta luchar contra el incendio, interaccionar con otros o escapar.

La actividad previa a la declaración del incendio es un factor importante. Cuando una persona está realizando una actividad habitual, como comer en un restaurante, su comportamiento posterior estará considerablemente condicionado por ella.

La percepción de una señal puede depender de la actividad previa al incendio. Existen diferencias entre el hombre y la mujer, siendo la mujer más receptiva a ruidos y olores, aunque en pequeña medida. También existen diferencias de papel en las respuestas iniciales a la señal. En incendios en el hogar, si la mujer percibe la señal y la investiga, el hombre al ser informado posiblemente irá a "echar un vistazo" y postergará otras acciones. En locales de mayor tamaño, la señal puede ser un aviso de alarma. Se ha observado que, cuando la información llega de otras personas, no propicia la adopción de un comportamiento efectivo.

Las personas pueden percatarse o no de que se ha producido un incendio. Su comportamiento dependerá de que consigan definir su situación correctamente
U na vez detectado el incendio, se inicia la fase de "preparación". L as características de los ocupantes pueden influir mucho en la forma en que se desarrolla esta fase. La fase de "preparación" incluye, por orden cronológico, los siguientes pasos: "instruir", "explorar" y "abandonar el lugar".

La fase "actuar", que es la fase final, depende del papel, el tipo de ocupación, el comportamiento y la experiencia anterior de la persona y puede dar lugar a una evacuación precoz o a una extinción efectiva.

\section{Sistemas de transporte en edificios}

Los sistemas de transporte deben tenerse en cuenta en la fase de diseño e integrarse en el sistema de protección global del edificio. Los peligros asociados a dichos sistemas deben contemplarse en cualquier planificación o estudio contra incendios.

Los sistemas de transporte de los edificios, como los ascensores y escaleras mecánicas, hacen posible la vida en los edificios altos. L os huecos de los ascensores pueden contribuir a la propagación del humo y las llamas. Por otro lado, un ascensor es una herramienta necesaria en las operaciones de lucha contraincendios en los edificios altos.

Los sistemas de transporte pueden agravar los problemas de seguridad, ya que el hueco del ascensor actúa como una chimenea debido al tiro natural del humo caliente y los gases del incendio. Esto suele dar lugar a un ascenso del humo y de los productos de combustión desde los niveles inferiores del edificio a los superiores.

Los edificios con muchos pisos presentan nuevos y diferentes problemas a los equipos de protección contra incendios, como el uso del ascensor en las emergencias. En caso de incendio resulta peligroso utilizar los ascensores por varias razones:

1. L os ocupantes pueden estar pulsando el botón de un ascensor en un descansillo a la espera de que llegue un ascensor que puede no responder en absoluto y perder así un tiempo valioso para huir.

2. Los ascensores no dan prioridad a ninguna llamada, y una de ellas puede ser la del piso del incendio.

3. Los ascensores no pueden ponerse en marcha hasta que no se han cerrado sus puertas, y el pánico puede producir aglomeraciones en el ascensor y bloquear las puertas, impidiendo su cierre.

4. La electricidad puede fallar en cualquier momento durante el incendio, dejando a las personas atrapadas en el ascensor (véase la Figura 41.6.)

\section{Simulacros de incendio y formación de los ocupantes}

U na correcta señalización de las vías de escape facilita la evacuación pero no garantiza la seguridad durante un incendio. LoS simulacros, necesarios para asegurar una huida organizada, son especialmente importantes en la escuela y en los restaurantes, hospitales, hoteles y grandes empresas, así como en industrias de alto riesgo. Los simulacros de desalojo permiten evitar la confusión y contribuyen a una evacuación correcta de todos los ocupantes del edificio.

Todos los empleados deben ocuparse de comprobar los sistemas disponibles, contar a los ocupantes cuando estén fuera de la zona de incendio, buscar a los rezagados y controlar que no vuelvan a entrar. También deben conocer las señales de evacuación y las rutas de salida. En los simulacros, ha de establecerse una ruta principal y una alternativa, y todos los empleados deben saber utilizar ambas. Después de cada simulacro de evacuación, se celebrará una reunión de responsables para evaluar el éxito de la misma y resolver cualquier posible problema. 


\section{MEDIDAS ACTIVAS DE PROTECCION CONTRA INCENDIOS}

G ary Taylor

\section{Seguridad personal y material}

Dado que la máxima prioridad de cualquier política de protección contra incendios de un edificio es garantizar un nivel aceptable de seguridad a sus ocupantes, en la mayoría de los países la normativa legal de protección contra incendios se centra en los problemas de seguridad personal. En cuanto a la seguridad material, se intenta limitar los daños al inmueble. En muchos casos, son objetivos complementarios. Cuando existe una preocupación por la pérdida del inmueble, de su función o de su contenido, el propietario puede decidir implantar medidas por encima del mínimo necesario para garantizar la seguridad personal.

\section{Sistemas de detección de incendios y de alarma}

Un sistema de detección de incendios y de alarma permite detectar un incendio de forma automática y avisar a los ocupantes del edificio de la amenaza de incendio. La alarma sonora o visible de un sistema de detección de incendios es la primera señal que perciben los ocupantes de un edificio para iniciar la evacuación. Esto es especialmente importante en edificios grandes o de gran altura, donde es difícil para la mayoría de los ocupantes saber si se ha iniciado un incendio en la estructura, y es bastante improbable o imposible que un ocupante pueda avisar a todos los demás.

\section{E lementos básicos de un sistema de detección de incendios y de} alarma

Un sistema de detección de incendios y de alarma puede incluir todos 0 algunos de los elementos siguientes:

1. una unidad de control del sistema;

2. un suministro primario o principal de energía eléctrica;

3. un suministro secundario de energía (stand-by), normalmente alimentado por baterías o por un generador de emergencia;

4. dispositivos de activación de la alarma, como detectores automáticos de incendios, pulsadores manuales y/ o dispositivos de flujo de sistemas de rociadores, conectados a "circuitos de activación" de la unidad de control del sistema;

5. dispositivos de alarma, como timbos o luces, conectados a "circuitos indicadores" de la unidad de control del sistema;

6. controles auxiliares, como funciones de apagado de la ventilación, conectados a circuitos de salida de la unidad de control del sistema;

7. alarmas conectadas a un centro de emergencia externo, como el centro de bomberos,

8. circuitos de control para activar un sistema de protección contra incendios o un sistema de control de humos.

\section{Sistemas de control de humos}

Para reducir el peligro de que, en caso de incendio, el humo se introduzca en las vías de escape durante la evacuación, pueden utilizarse sistemas de control de humos. Por lo general, se utilizan sistemas mecánicos de ventilación para introducir aire fresco en las vías de escape. Este método suele utilizarse para presurizar los huecos de la escalera o edificios con patios, y mejorar así el nivel de seguridad personal.

\section{Extintores portátiles y mangueras}

Suele dotarse a los edificios de extintores portátiles y mangueras de agua para que los utilicen los ocupantes en la extinción de
Figura 41.6 • Ejemplo de señal pictográfica para ascensores.

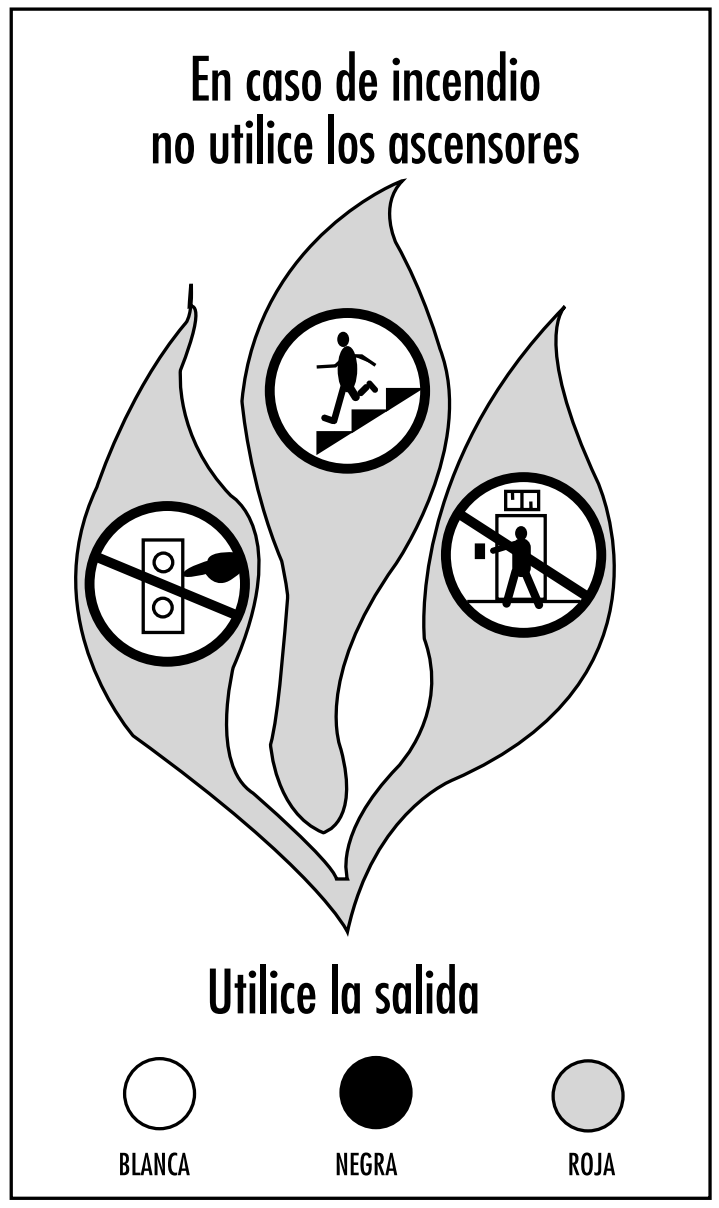

incendios de reducidas dimensiones (véase la Figura 41.7). LoS ocupantes de un edificio no deben utilizar los extintores portátiles ni las mangueras sin haber sido formados en su uso. En cualquier caso, al utilizarlos, deben tener mucho cuidado de no situarse de modo que bloqueen una vía de escape. En cualquier incendio, sea cual fuere su tamaño, la primera medida que hay que tomar es siempre avisar a los demás ocupantes del edificio y pedir ayuda a un centro de bomberos profesional.

\section{Sistemas de rociadores de agua}

Los sistemas de rociadores de agua constan de un suministro de agua, válvulas de distribución y tuberías conectadas a rociadores automáticos (véase la Figura 41.8). Aunque los sistemas actuales de rociadores están diseñados para controlar la propagación de incendios, en muchas ocasiones se ha logrado incluso extinguirlos totalmente.

Una idea errónea es que en caso de incendio se activan todos los rociadores automáticos. En realidad, cada uno está diseñado para abrirse solamente cuando detecta una cantidad de calor indicativa de incendio. Así pues, sólo fluye agua de los rociadores abiertos por haber detectado calor en sus proximidades. Este diseño garantiza un uso eficiente del agua en la lucha contraincendios y limita los daños por agua. 
Figura 41.7 - Extintores portátiles.

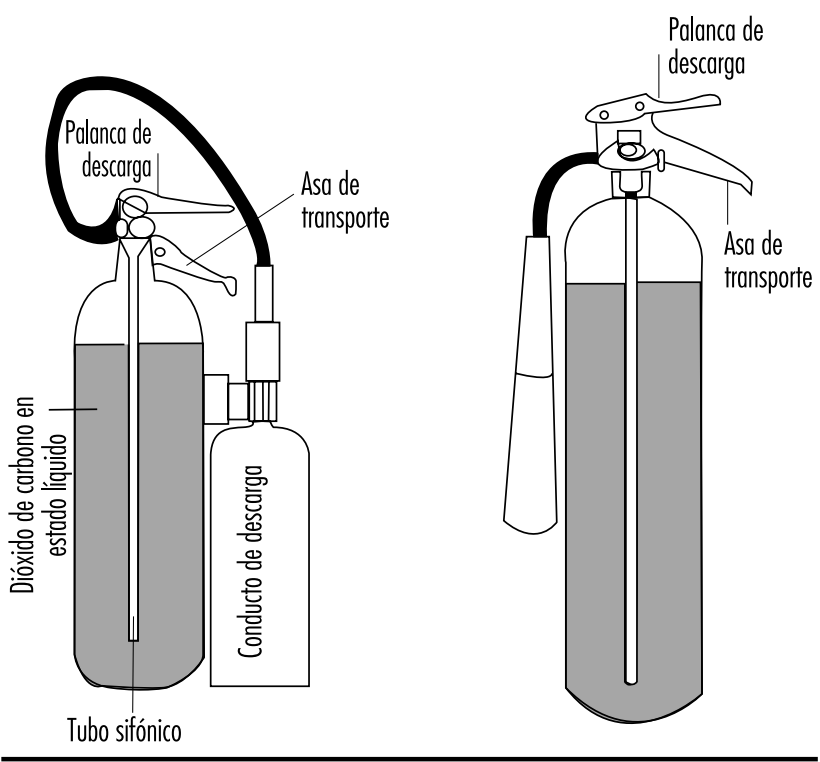

\section{Suministro de agua}

Un sistema automático de rociadores debe disponer de agua en cantidad, presión y volumen suficientes para garantizar un funcionamiento fiable en cualquier momento. Si el suministro municipal de agua no reúne estos requisitos, deberá instalarse un depósito o bomba que asegure el suministro.

\section{Válvulas de control}

Las válvulas de control deben mantenerse siempre en posición abierta. A menudo, la supervisión de las válvulas de control se realiza con un sistema automático de alarma, mediante dispositivos que, cuando detectan una válvula cerrada, activan una señal de aviso en el panel de control del sistema de alarma contra incendios. Si no es posible realizar este tipo de control, deben bloquearse las válvulas en la posición abierta.

\section{Tuberías}

El agua fluye a través de una red de tuberías, normalmente suspendidas del techo, dotadas de rociadores cada cierta distancia. Las tuberías de los sistemas de rociadores deben poder

Figura 41.8 - Instalación tipo de rociadores con entradas de agua, tomas de agua exteriores y canalizaciones subterráneas.

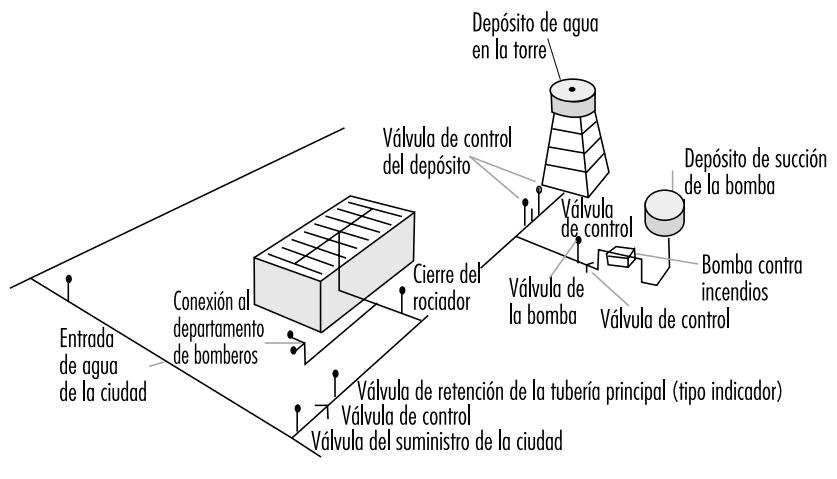

resistir una presión de trabajo no inferior a $1.200 \mathrm{kPa}$. En los sistemas de tuberías al aire, las fijaciones deben ser atornilladas, de pestaña, de junta mecánica o soldada.

\section{Rociadores}

Un rociador consta de un orificio, que normalmente se mantiene cerrado por un elemento liberador sensible a la temperatura, y un deflector de pulverización. EI diseño de la descarga de agua y los requisitos de espaciado de cada rociador garantizan una cobertura total del riesgo protegido.

\section{Sistemas especiales de extinción}

Los sistemas especiales de extinción se utilizan cuando los rociadores de agua no aportan una protección adecuada o cuando resulta inaceptable el riesgo de daño por agua. En muchos casos en que el daño por agua es problemático, pueden utilizarse sistemas especiales de extinción junto con sistemas de rociadores de agua, estando diseñados los primeros para activarse en la fase inicial del incendio.

\section{Sistemas especiales de extinción con agua y con aditivos en el agua}

\section{Sistemas de pulverización de agua}

L os sistemas de pulverización de agua aumentan la efectividad de ésta al dividirla en gotas pequeñas, lo que genera una mayor superficie de contacto con el fuego y un aumento relativo de la capacidad de absorción de calor. A menudo se opta por este sistema para mantener fríos grandes depósitos a presión, como las esferas de butano, cuando existe peligro de incendio en una zona adyacente. Es similar al sistema de rociadores, aunque aquí todos los rociadores están abiertos y para abrir las válvulas de control se utiliza un sistema independiente de detección o se realiza la operación de forma manual. Esto permite que el agua fluya a través de la red de canalización hasta llegar a todos los dispositivos de pulverización de salida del sistema de tuberías.

\section{Sistemas de espuma}

En un sistema de espuma se inyecta un concentrado líquido en el suministro de agua antes de la válvula de control. A continuación, se mezcla el concentrado de espuma con aire, bien mediante una descarga mecánica o aspirando aire en el dispositivo de descarga. El aire que entra en la solución de espuma produce una espuma expandida que, al ser menos densa que la mayoría de los hidrocarburos, forma una capa por encima del líquido inflamable. La capa de espuma reduce la propagación del vapor combustible. El agua, que representa casi el $97 \%$ de la solución de espuma, aporta un efecto de enfriamiento que reduce aún más la propagación del vapor y enfría los objetos calientes que podrían actuar como fuente de reignición.

\section{Sistemas de extinción a base de gases}

\section{Sistemas de dióxido de carbono}

Estos sistemas utilizan dióxido de carbono, almacenado como gas licuado comprimido en depósitos a presión (véanse las Figuras 41.9 y 41.10). Los depósitos disponen de una válvula automática que se abre en caso de incendio gracias a un sistema de detección independiente 0 mediante accionamiento manual. EI dióxido de carbono, una vez liberado, se aplica al incendio a través de un sistema de tuberías y boquillas de descarga. El gas actúa como extintor al desplazar el oxígeno del incendio. LoS sistemas de dióxido de carbono están indicados para su uso en espacios abiertos como imprentas, o recintos cerrados como salas de máquinas de barcos. En la concentración necesaria para la extinción de incendios es tóxico para las personas, por lo que 
Figura 41.9 - Esquema de un sistema de dióxido de carbono a alta presión para inundación total.

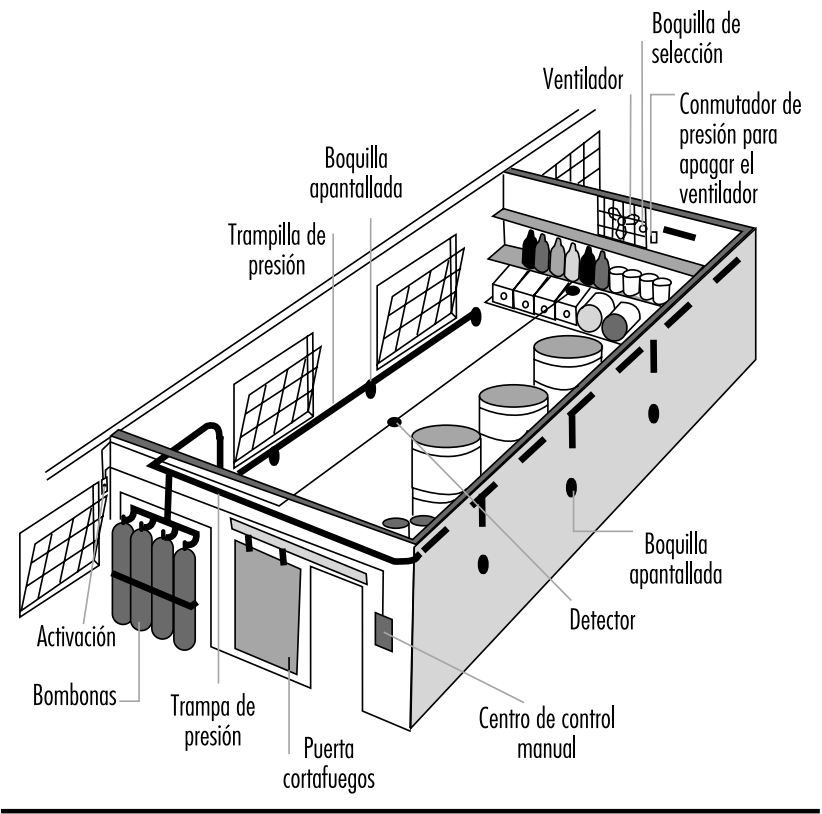

antes de aplicarlo es necesario tomar medidas especiales de evacuación de las personas que se encuentren en la zona protegida. Al diseño del sistema deben incorporarse medidas de seguridad especiales como una alarma predescarga que alerte a las personas que trabajan en la zona protegida. El dióxido de carbono está considerado un producto de extinción limpio porque no produce efectos secundarios y no es conductor de la electricidad.

\section{Sistemas de gas inerte}

Por lo general los sistemas de gas inerte utilizan una mezcla de nitrógeno y argón como medio de extinción. En algunos casos en la mezcla de gas también se incluye un reducido porcentaje de dióxido de carbono. Las mezclas de gas inerte extinguen el fuego al reducir la concentración de oxígeno dentro del volumen protegido y su uso está indicado solamente en espacios cerrados. La

Figura 41.10 - Sistema de inundación total instalado en una habitación con doble suelo.

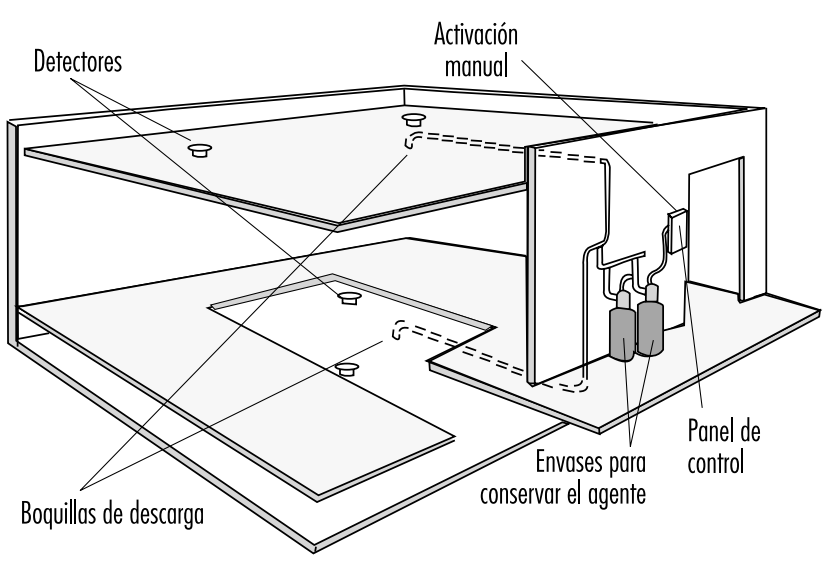

característica de las mezclas de gas inerte es que reducen el oxígeno a una concentración lo suficientemente baja como para extinguir muchos tipos de incendios pero sin llegar a niveles que puedan suponer una amenaza para los ocupantes de la zona protegida. L os gases inertes se comprimen y almacenan en depósitos a presión. La operación del sistema es similar a la del dióxido de carbono pero dado que los gases inertes no pueden ser licuados por compresión, el número de depósitos de almacenamiento necesarios para proteger un determinado recinto cerrado es mayor que en el caso del dióxido de carbono.

\section{Sistemas de halones}

L os halones 1301, 1211 y 2402 están clasificados como sustancias que destruyen la capa de ozono. En 1994 se ha abandonado la producción de estos agentes de extinción de acuerdo con lo estipulado en el Protocolo de M ontreal, acuerdo internacional para proteger la capa de ozono de la Tierra. EI halón 1301 se utilizaba principalmente en sistemas contra incendios fijos y se almacenaba como gas licuado y comprimido en depósitos a presión como los utilizados para el dióxido de carbono. La ventaja del halón 1301 era que sus presiones de almacenamiento eran inferiores y que una concentración muy baja proporcionaba una capacidad de extinción efectiva. Los sistemas de halón 1301 se utilizaban con éxito para incendios en recintos totalmente cerrados donde la concentración de extinción alcanzada puede mantenerse durante un período suficiente de tiempo como para extinguir el incendio. En la mayoría de los casos las concentraciones utilizadas no suponían una amenaza inmediata para los ocupantes. El halón 1301 se sigue utilizando en casos excepcionales para los que no existen alternativas aceptables como, por ejemplo, en incendios en aviones comerciales y militares y en algunos casos especiales en los que se necesitan concentraciones de inertización para evitar explosiones en zonas con ocupantes. El halón de los sistemas existentes ya sustituidos deberá utilizarse para aplicaciones críticas, evitando así tener que seguir produciendo estos productos de extinción que son nocivos para el medio ambiente y se ayudará a proteger la capa de ozono.

\section{Sistemas de hidrocarburos halogenados}

L os agentes de hidrocarburos halogenados se desarrollaron como consecuencia de la preocupación ambiental por sustituir a los halones. Estos agentes difieren ampliamente entre sí en cuanto a toxicidad, impacto ambiental, peso de almacenamiento, requisitos de volumen, coste y disponibilidad del equipo aprobado. Todos ellos pueden almacenarse como gases licuados en depósitos a presión. La configuración del sistema es similar a la del dióxido de carbono.

\section{Diseño, instalación y mantenimiento de sistemas activos contra incendio}

E ste tipo de equipos sólo debería ser diseñado, instalado y mantenido por expertos. Para poder realizar su trabajo con efectividad los encargados de la compra, instalación, inspección, pruebas, homologación y mantenimiento de estos equipos deberían consultar a un especialista competente y experimentado en la lucha contra incendios.

\section{Información adicional}

Esta sección de la Enciclopedia presenta una visión de conjunto resumida de los sistemas activos contra incendios existentes en la actualidad en el mercado. El lector podrá encontrar más información en su asociación nacional contra incendios, su agente asegurador o el departamento de prevención de incendios de su localidad. 


\section{- ORgANIZACION DE LA LUCHA CONTRA INCENDIOS}

S. Dheri

\section{Organización interna de emergencia}

Los beneficios son el objetivo principal de cualquier industria y, para alcanzarlo, son fundamentales una gestión eficiente y actualizada y una continuidad en la producción. C ualquier interrupción de la producción, sea cual fuere la razón, afectará de forma negativa a los beneficios. Si la interrupción es resultado de un incendio o una explosión, puede ser muy larga y paralizar la industria.

Con gran frecuencia, la propiedad está asegurada y las pérdidas ocasionadas por el incendio, si las hay, son indemnizadas por la compañía aseguradora. Pero los seguros son sólo una forma de extender el daño causado por un incendio o una explosión al mayor número posible de personas y, al final, la pérdida repercute a escala nacional. Además, el seguro no garantiza la continuidad de la producción ni elimina o minimiza las pérdidas resultantes.

Por lo tanto, la dirección de la empresa debe reunir una información completa sobre los peligros de incendio y explosión, evaluar el potencial de pérdidas e implantar las medidas oportunas para controlar el riesgo, a fin de eliminar o minimizar la incidencia de estas catástrofes y establecer una organización interna de emergencia.

\section{Planificación de emergencias}

En la medida de lo posible, la organización de emergencia debe contemplarse ya en la fase de planificación, e irse implantando de forma progresiva, desde la selección del emplazamiento para la empresa hasta el inicio de la producción.

El éxito de una organización de emergencia depende en gran medida de la participación generalizada tanto de los trabajadores como de la dirección, lo que debe tenerse en cuenta a la hora de planificarla.

Seguidamente estudiaremos los diferentes aspectos de una planificación de emergencia. Para más información, consúltese el Fire Protection $\mathrm{H}$ andbook del US National Fire Protection Association (NFPA) o cualquier otra publicación de referencia sobre el tema (C ote, 1991).

Fase 1

El plan de emergencia debe iniciarse con las actividades siguientes:

1. Identificar y evaluar los peligros de incendio y explosión asociados al transporte, manipulación y almacenamiento de cada materia prima, producto intermedio, producto terminado y proceso industrial, así como elaborar medidas preventivas detalladas para suprimir o minimizar los peligros.

2. Analizar los requisitos de las instalaciones y los equipos de protección contra incendios, y determinar las fases de actuación de cada uno de ellos.

3. Elaborar las especificaciones de las instalaciones y equipos de protección contra incendios.

Fase 2

Se comprobará:

1. La disponibilidad de un suministro de agua adecuado, que cubra las necesidades de la lucha contra incendios además de las de proceso y uso doméstico;

2. Los riesgos potenciales de catástrofe natural (inundaciones, terremotos, Iluvias torrenciales, etc.) en la zona de emplazamiento;
3. El entorno, es decir, naturaleza y extensión de los espacios circundantes, y posibles riesgos en caso de incendio 0 explosión;

4. La existencia de equipos de protección contra incendios internos o públicos, la distancia a que se encuentran, su idoneidad para proteger de los posibles riesgos y la capacidad de respuesta ante una llamada de emergencia;

5. La capacidad de respuesta del cuerpo de bomberos, teniendo en cuenta los obstáculos existentes, como cruces de vías de ferrocarril, transbordadores, resistencia y/ 0 anchura inadecuada de los puentes existentes para los equipos de protección contra incendios, atascos de tráfico, etc.;

6. El entorno sociopolítico, es decir, las tasas de delincuencia y las actividades políticas que puedan provocar desórdenes de orden público.

\section{Fase 3}

Se preparará el proyecto y los planos de edificación, así como las especificaciones del material de construcción. Se realizarán las tareas siguientes:

1. Delimitar el espacio de cada tienda, lugar de trabajo, etc. mediante muros contrafuegos, puertas cortafuegos, etc.

2. Especificar el uso de materiales ignífugos en la construcción del edificio o la estructura.

3. G arantizar la protección de las columnas de acero y de otros elementos estructurales.

4. A segurarse de que existe una separación adecuada entre los edificios, las estructuras y los equipos.

5. Planificar la instalación de bocas de incendios, rociadores, etc.

6. Incluir en el proyecto vías de acceso adecuadas para que los equipos de extinción puedan llegar a cualquier zona de las instalaciones y a todas las fuentes de agua para la extinción de incendios.

Fase 4

Durante la construcción, se deberá:

1. Comunicar al contratista y a sus empleados las políticas de gestión del riesgo de incendio, y asegurarse de que se cumplan.

2. Comprobar exhaustivamente todas las instalaciones y equipos de protección contra incendios antes de aceptar la obra.

Fase 5

Si por las dimensiones de la industria, los peligros asociados 0 una ubicación alejada se requiere la presencia continua de un cuerpo de bomberos, se deberá organizar, equipar y formar a personal con dedicación exclusiva y nombrar a un jefe de lucha contra incendios también con dedicación exclusiva.

\section{Fase 6}

Con el fin de garantizar la plena participación de todos los empleados, se deberá:

1. Formar a todo el personal en las medidas de prevención que deben tomar en su trabajo diario y en el papel que tengan asignado en caso de incendio o explosión. Dicha formación incluirá el manejo de los equipos de protección contra incendios.

2. Garantizar el estricto cumplimiento de las medidas de prevención por parte de todo el personal afectado mediante revisiones periódicas

3. Inspeccionar regularmente y asegurar un buen mantenimiento de todos los equipos y sistemas de protección contra incendios. Cualquier defecto observado deberá subsanarse lo antes posible. 


\section{Actuación en caso de emergencia}

Para evitar la confusión durante una emergencia, es fundamental que todas las personas conozcan su papel y el de los demás en caso de emergencia. Deberá elaborarse y divulgarse un plan de emergencia bien estudiado, con el que deberá familiarizarse todo el personal. En dicho plan se indicarán de forma concreta y clara las responsabilidades de cada persona y la correspondiente jerarquía de mando. Un plan de emergencia debe incluir como mínimo:

1. El nombre de la industria

2. La dirección de las instalaciones, con número de teléfono y plano de localización

3. El objetivo del plan de emergencia y la fecha efectiva de su entrada en vigor

4. El área cubierta y un plano de localización

5. La organización de emergencia, indicando la jerarquía de mando encabezada por su director

6. Los sistemas contra incendios y los equipos móviles y portátiles, detallados

7. D etalles de la disponibilidad de asistencia

8. Las alarmas contra incendios y los equipos de comunicación

9. La actuación en caso de emergencia, definiendo por separado y de forma concreta las acciones que debe emprender:

- la persona que detecta el incendio;

- el cuerpo de bomberos particular de la empresa;

- el jefe de la sección implicada en la emergencia;

- los jefes de otras secciones no implicadas en la emergencia;

- la organización de seguridad;

- el jefe de bomberos, en su caso;

- el director de la empresa,

- otros.

10. La jerarquía de mando en la escena del accidente. Se considerarán todas las situaciones posibles, indicando claramente la persona que debe asumir el mando en cada caso y las circunstancias en que debe solicitarse ayuda a otra organización.

11. Las medidas que deben tomarse después del incendio. Se indicarán las responsabilidades en materia de:

- reposición o rellenado de todos los sistemas, equipos y fuentes de agua de protección contra incendios;

- investigación de la causa del incendio o la explosión;

- preparación y presentación de los informes,

- adopción de medidas que eviten que vuelva a producirse una emergencia similar.

Cuando se dispone de un plan de asistencia mutua, debe enviarse a todas las unidades participantes una copia del plan de emergencia y recibir a cambio los planes de sus instalaciones respectivas.

\section{Protocolos de evacuación}

Como resultado de una explosión o un incendio pueden producirse situaciones que requieran la ejecución de un plan de emergencia.

Una explosión puede ir seguida o no de incendio, pero en la mayoría de los casos genera un efecto devastador que puede herir e incluso causar la muerte a las personas que se encuentren en sus proximidades y/ o causar daños materiales en las instalaciones, según el caso. U na explosión puede producir también una confusión generalizada, que provoque la parada inmediata de los procesos de fabricación o de parte de ellos y el desplazamiento simultáneo de gran cantidad de personas. Si no se consigue controlar y organizar inmediatamente la situación, se crean situaciones de pánico que pueden dar lugar a daños personales y materiales de mayor magnitud.
Cuando en un incendio exista la posibilidad de que el humo liberado por el material en combustión o el propio fuego alcance a otras partes del inmueble y/ o deje a personas atrapadas, será necesario realizar evacuaciones u operaciones de rescate masivas.

Siempre que se producen desplazamientos masivos de personas, surgen problemas de tráfico, especialmente si es necesario utilizar carreteras, calles o áreas públicas. Si no se ha previsto este problema y no se han planificado con antelación las medidas oportunas, se producirán cuellos de botella que obstaculizarán e impedirán la extinción del incendio y los trabajos de rescate.

La evacuación de un gran número de personas, especialmente en edificios altos, también puede plantear dificultades. Para una evacuación correcta, no sólo es necesario disponer de vías de escape adecuadas, sino también realizar la evacuación de forma ágil. A este respecto, hay que prestar especial atención a las necesidades de las personas discapacitadas

Así pues, los métodos de evacuación deben estar incluidos en el plan de emergencia y ser comprobados periódicamente mediante simulacros de incendios en los que también pueden simularse problemas de tráfico. En estos simulacros deberán intervenir todas las organizaciones participantes y afectadas, periódicamente. Después de cada ejercicio, se celebrará una reunión para comentar los fallos detectados y buscar la causa. $\mathrm{H}$ abrá que tomar también las medidas oportunas para evitar que los mismos fallos se repitan en ejercicios futuros, suprimiendo todas las dificultades y revisando, en caso necesario, el plan de emergencia.

D eberá guardarse la información pertinente de todos los ejercicios y simulacros de evacuación realizados.

\section{Servicios médicos de emergencia}

Los heridos en un incendio o explosión deben recibir ayuda médica inmediata o ser trasladados rápidamente a un hospital una vez suministrados los primeros auxilios.

Es fundamental disponer de uno o más puestos de primeros auxilios y, cuando las dimensiones o el carácter peligroso de la industria lo requieran, uno o más equipos móviles sanitarios, todos ellos dotados permanentemente de personal competente.

En función del tamaño de la industria y del número de trabajadores, habrá que disponer de una o más ambulancias con personal capaces de transportar a los heridos a hospitales. A demás, se tomarán las medidas oportunas para garantizar la disposición rápida de más ambulancias en caso necesario.

Cuando así lo requiera el tamaño de la industria o del lugar de trabajo, se contratará a un médico con dedicación exclusiva para cualquier situación de emergencia.

Se celebrarán los acuerdos necesarios con un hospital para dar prioridad al ingreso de los posibles heridos en caso de incendio o explosión. En el plan de emergencia se indicarán estos hospitales con su correspondiente número de teléfono, así como el nombre de la persona responsable de alertarles cuando, caso de producirse la emergencia, se vaya a enviar a heridos a los mismos.

\section{Recuperación de las instalaciones}

Es importante que todos los equipos de seguridad y emergencia vuelvan a estar dispuestos lo antes posible una vez pasada la emergencia. En el plan de emergencia se indicará la persona 0 sección responsable de esta tarea. También se implantará un sistema de control que garantice su realización.

\section{Relaciones con el departamento de bomberos}

La dirección de una empresa no puede prever ni hacer frente a todas las posibles contingencias, lo que tampoco resultaría 
rentable. Aun habiendo adoptado los métodos más modernos de gestión de incendios, siempre habrá ocasiones en que los equipos de protección contra incendios no cubran las necesidades reales. Para esas ocasiones es conveniente elaborar un programa de asistencia mutua con el departamento de bomberos. La dirección debe mantener una buena relación con el mismo y conocer la asistencia que puede proporcionarle en caso de emergencia en sus instalaciones. A su vez, el departamento de bomberos debe conocer el riesgo específico en caso de emergencia. Para ello es necesaria una relación fluida entre la dirección y el departamento de bomberos

\section{Manipulación de materiales peligrosos}

En un accidente, los bomberos pueden desconocer los peligros asociados a los materiales utilizados en la industria y una descarga accidental o una manipulación o un almacenamiento inadecuados de materiales peligrosos pueden provocar situaciones de riesgo que pongan seriamente en peligro su salud o provoquen un incendio o explosión. No es fácil recordar en esos momentos todos los peligros de cada material. Para ello se han desarrollado medios de identificación rápida de riesgos con etiquetas o marcas.

\section{Identificación de materiales peligrosos}

Cada país tiene su propia normativa de etiquetado para el almacenamiento, manipulación y transporte de materiales peligrosos, en la que pueden intervenir varios departamentos. El cumplimiento de la normativa local es esencial, pero también sería deseable utilizar un sistema de identificación de materiales peligrosos reconocido internacionalmente y de aplicación universal. En Estados U nidos, el NFPA ha desarrollado un sistema a tal fin. Estas etiquetas, que se adhieren a los depósitos de materiales peligrosos, incluyen información sobre la naturaleza y el grado de peligrosidad para la salud del material, su inflamabilidad y su reactividad. Además, en ellas pueden incluirse los peligros especiales que puedan presentar para el cuerpo de bomberos. Para más información sobre el grado de peligrosidad, consúltese el NFPA 704, Standard System for the Identification of the Fire $\mathrm{H}$ azards of $\mathrm{M}$ aterials (1990a), que clasifica los peligros en: peligros para la salud, peligros de inflamabilidad y peligros de reactividad (inestabilidad).

\section{Peligros para la salud}

Los peligros para la salud comprenden todos los daños posibles que un material puede ocasionar a una persona por contacto 0 absorción. $\mathrm{H}$ ay peligros para la salud debidos a las propiedades específicas del material o a los productos tóxicos producidos por la combustión o la descomposición del material. El nivel de peligro se asigna tomando como base al máximo peligro posible en caso de incendio o emergencia similar, e indica si los bomberos tienen que trabajar con ropa de protección especial o con equipos de respiración o simplemente con la ropa normal.

El grado de peligro para la salud de un material se determina en una escala de 4 a 0 , en donde 4 indica el máximo peligro y 0 un peligro mínimo o inexistente.

\section{Peligro de inflamabilidad}

Se trata de la facilidad de combustión del material. Un mismo material se comporta de forma diferente a este respecto según las circunstancias ( $p$. ej., materiales que pueden entran en combustión en unas determinadas condiciones pueden no hacerlo si éstas se modifican). La forma y características inherentes de los materiales influyen en el peligro de inflamabilidad, que se determina del mismo modo que en el caso anterior.

\section{Peligros de reactividad (inestabilidad)}

Los materiales capaces de liberar energía por sí mismos (p. ej., por autorreacción o polimerización) y las sustancias susceptibles de erupción violenta 0 reacciones explosivas presentan un peligro de reactividad al entrar en contacto con el agua, con otros agentes de extinción o con otros materiales.

La violencia de la reacción puede aumentar si se aplica calor o presión, si la sustancia entra en contacto con determinados materiales formando una combinación combustible-oxidante 0 si entra en contacto con sustancias incompatibles, contaminantes sensibilizantes o catalizadores.

EI peligro de reactividad viene determinado y expresado en términos de facilidad, velocidad y cantidad de energía liberada. Se puede dar una información adicional tal como el peligro de radiactividad o la prohibición del uso de agua u otro medio de extinción en la lucha contra incendios.

La etiqueta de material peligroso es un rombo dividido a su vez en cuatro rombos más pequeños (véase la Figura 41.11).

El rombo superior indica el peligro para la salud, el de la izquierda el peligro de inflamabilidad, el de la derecha el peligro de reactividad y el inferior otros peligros, como la radiactividad o la reactividad especial con el agua.

En esta señalización puede incluirse un código de color, bien para el fondo o para el número que indica el peligro. Los códigos de color son: azul para el peligro para la salud, rojo para el peligro de inflamabilidad, amarillo para el peligro de reactividad y fondo blanco para el peligro especial.

\section{G estión de materiales peligrosos}

En la industria, dependiendo de la naturaleza del material peligroso de que se trate, hay que disponer de equipo de protección y agentes especiales de extinción de incendios, así como del equipo de protección necesario para su aplicación.

Todos los trabajadores han de ser formados en las precauciones y procedimientos que deben adoptar en caso de accidente al manejar los distintos materiales peligrosos. También deben conocer el significado de las señales de identificación.

Todos los miembros del equipo contra incendios y los trabajadores deben saber utilizar correctamente la ropa de protección, los equipos de protección para la respiración y las técnicas especiales de lucha contra incendios. El personal debe estar preparado para afrontar cualquier situación de emergencia gracias a simulacros y ejercicios frecuentes, que serán debidamente grabados.

Para hacer frente a riesgos graves para la salud y a los efectos de esos riesgos en los bomberos, es necesaria la presencia de un jefe de servicio médico competente que tome medidas inmediatas cuando una persona resulte expuesta a una contaminación peligrosa. Todas las personas afectadas deben ser inmediatamente atendidas por el médico.

En caso necesario, se tomarán las medidas pertinentes para disponer un centro de descontaminación en las instalaciones y llevar a cabo procesos de descontaminación correctos bajo supervisión médica.

\section{Control de residuos}

La industria genera una gran cantidad de residuos que pueden dar lugar a accidentes durante su manipulación, transporte y almacenamiento. Dependiendo de la industria de la que procedan o de la naturaleza de los materiales implicados, pueden ser inflamables, tóxicos, corrosivos, pirofóricos, químicamente reactivos o radiactivos. En la mayoría de los casos, y salvo que se tomen las medidas pertinentes para eliminarlos de forma ecológica, representan un peligro para la vida de personas y animales, contaminan el entorno y ocasionan incendios o explosiones. Es 
Figura 41.11 El diamante N FPA 704.

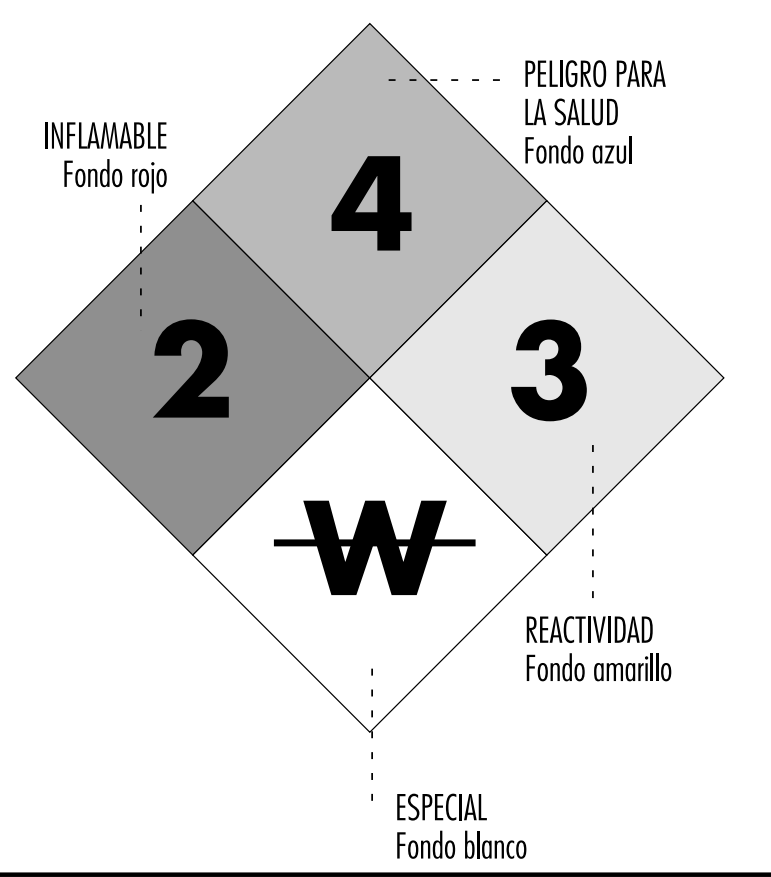

fundamental, por tanto, conocer en detalle las propiedades físicas y químicas de los materiales residuales y las limitaciones de los distintos métodos de eliminación para garantizar su eficacia económica y su seguridad.

A continuación se resumen las propiedades de los residuos industriales:

1. La mayoría de los residuos industriales son peligrosos y pueden tener efectos inesperados durante su eliminación e incluso posteriormente. En consecuencia, la naturaleza y características de comportamiento de todos los residuos deben examinarse cuidadosamente para evaluar su repercusión a corto y largo plazo y determinar el método de eliminación más adecuado.

2. La mezcla de dos residuos aparentemente inocuos en sí mismos puede suponer un peligro inesperado debido a su interacción química o física.

3. En el caso de líquidos inflamables, se deben evaluar los riesgos asociados, teniendo en cuenta su punto de inflamación, la temperatura de ignición, el límite de inflamabilidad y la energía de ignición necesaria para iniciar la combustión. En el caso de sólidos, también hay que considerar el tamaño de la partícula.

4. La mayoría de los vapores inflamables son más densos que el aire. Durante su recogida, eliminación, manipulación o transporte, pueden liberarse de forma accidental vapores y gases inflamables, y ser trasladados a considerable distancia por el viento. Al entrar en contacto con una fuente de ignición, retornan rápidamente a la fuente. Los derrames importantes de líquidos inflamables son especialmente peligrosos en este sentido y pueden requerir la evacuación de las personas.

5. Los materiales pirofóricos como los alquilos de aluminio, entran en ignición de forma espontánea cuando se les expone al aire. Por esta razón, hay que tener especial cuidado al manipular, transportar, almacenar y eliminar estos materiales, realizando estas operaciones preferiblemente en una atmósfera de nitrógeno.
6. Algunos materiales, como los hidróxidos de potasio, sodio y aluminio reaccionan de forma violenta con el agua o la humedad, y entran en combustión violenta. El polvo de bronce genera un calor considerable en presencia de humedad.

7. El contacto de oxidantes potentes con materiales orgánicos puede iniciar una rápida combustión e incluso una explosión. Los trapos y otros materiales impregnados en aceites vegetales o terpenos presentan un riesgo de combustión espontánea debido a la oxidación de los aceites y la posterior formación de calor hasta alcanzar la temperatura de ignición.

8. Algunas sustancias corrosivas pueden dañar gravemente la piel u otros tejidos vivos o causar la corrosión de materiales de construcción, especialmente metales, debilitando su estructura.

9. Algunas sustancias tóxicas pueden ocasionar el envenenamiento de personas o animales por contacto con la piel, inhalación o contaminación de los alimentos o el agua. LoS efectos pueden desarrollarse a corto o largo plazo. Estas sustancias, si se eliminan por vertido o combustión, pueden contaminar las fuentes de agua 0 alcanzar a trabajadores 0 animales.

10. Sustancias tóxicas derramadas durante las operaciones de proceso, transporte (incluidos accidentes), manipulación 0 almacenamiento y gases tóxicos liberados a la atmósfera pueden afectar al personal de emergencia e incluso a la población. Este peligro es máximo cuando las sustancias derramadas se evaporan a temperatura ambiente, porque los vapores pueden ser transportados por el viento a largas distancias.

11. Algunas sustancias pueden desprender un olor fuerte, picante o desagradable, bien por sí mismas o al entrar en combustión en el aire libre. En ambos casos, representan un peligro público aunque no sean tóxicas y, si no es posible su reciclaje, deben eliminarse por incineración. Las sustancias con olor no son necesariamente tóxicas; del mismo modo, sustancias sin olor y algunas sustancias con olor agradable pueden producir efectos fisiológicos negativos.

12. Algunas sustancias como los explosivos, los materiales pirotécnicos, los peróxidos orgánicos y otros productos químicos son sensibles al calor y al choque y pueden explotar con un efecto devastador si no se manipulan con cuidado o si se mezclan con otras sustancias. Por tanto, habrá que separar cuidadosamente estas sustancias y destruirlas con la debida supervisión.

13. Los materiales residuales contaminados con radiactividad pueden ser tan peligrosos como los propios materiales radiactivos. Su eliminación requiere un conocimiento especializado. Puede solicitarse información sobre la eliminación de este tipo de residuos a la organización de la energía nuclear de cada país.

Algunos de los métodos utilizados para eliminar residuos industriales y de emergencia son biodegradación, enterramiento, incineración, vertido controlado, capa de mantillo, combustión al aire libre, pirólisis y eliminación a través de un contratista. A continuación se analizan brevemente todos estos métodos.

\section{Biodegradación}

M uchos productos químicos se destruyen totalmente en períodos que oscilan entre 6 y 24 meses si se mezclan con unos $15 \mathrm{~cm}$ de la capa superior del suelo. Este fenómeno se conoce como biodegradación y se debe a la acción de las bacterias existentes en el suelo. Pero no todas las sustancias se comportan de esta forma.

\section{Enterramiento}

Los residuos, especialmente los químicos, se eliminan a menudo mediante enterramiento. Es una práctica peligrosa tratándose de 
productos químicos activos porque, pasado un tiempo, las sustancias enterradas pueden quedar al descubierto 0 ser desenterradas y arrastradas por la lluvia hasta los cursos de agua. La sustancia expuesta o el material contaminado pueden tener efectos fisiológicos negativos al entrar en contacto con el agua que ingieren personas o animales. Se han registrado casos de contaminación de agua a los 40 años de haber enterrado productos químicos peligrosos.

\section{Incineración}

Es uno de los métodos más seguros y satisfactorios de eliminación de residuos, siempre que se utilice un incinerador bien diseñado y bajo control. Ahora bien, hay que vigilar que las sustancias puedan incinerarse de forma segura y sin causar problemas o peligros especiales. Casi todos los incineradores industriales disponen de un equipo de control de la contaminación, que debe ser cuidadosamente elegido e instalado teniendo en cuenta la composición del efluente de carga registrado por el incinerador durante la combustión de los residuos industriales.

Durante el funcionamiento del incinerador, hay que evitar que su temperatura se eleve de forma excesiva debido a la producción de una gran cantidad de gases volátiles 0 a la naturaleza de los residuos incinerados. Puede producirse un fallo por una temperatura excesiva 0 , al cabo del tiempo, por corrosión. El depurador de gases también debe ser revisado periódicamente para comprobar si presenta signos de corrosión por el contacto con ácidos, y es necesario realizar un mantenimiento regular del sistema de depuración de gases para garantizar su correcto funcionamiento.

\section{Vertido controlado}

Las zonas bajas o depresiones suelen utilizarse como vertedero de materiales residuales hasta que se nivelan con las áreas colindantes. Entonces, se aplastan los residuos, se cubren con tierra y se pasa una apisonadora. A continuación, el terreno puede utilizarse para edificar o con otros fines.

Para que la operación de vertido controlado sea satisfactoria debe elegirse el lugar teniendo en cuenta la proximidad de tuberías, desagües, cables de energía, pozos de petróleo y gas, minas o cualquier otro peligro. Los residuos se mezclan con tierra y se distribuyen de forma homogénea en una depresión o una zanja amplia. Cada capa vertida debe compactarse mecánicamente antes de añadir la siguiente.

Normalmente, se añade una capa de $50 \mathrm{~cm}$ de tierra por encima de los residuos y se compacta, dejando suficientes respiraderos en el suelo para que pueda salir el gas producido por la actividad biológica. También debe procurarse un drenaje adecuado del área de vertido controlado.
A veces, los residuos, dependiendo de sus constituyentes, pueden entrar en ignición en el vertedero. Por esta razón, deben vallarse estas áreas adecuadamente y mantener una vigilancia permanente hasta que se considere que ha pasado el peligro de ignición. También hay que tomar las medidas necesarias para extinguir un posible incendio de los residuos en el vertedero.

\section{Acolchado}

Se han realizado pruebas con polímeros para reutilizarlos de forma similar al acolchado (material suelto con el que se protegen las raíces de las plantas), cortándolos en virutas o gránulos, pues de esta forma se degradan muy lentamente y su efecto sobre el suelo es puramente físico. Sin embargo, este método no se ha utilizado todavía de forma generalizada.

\section{Combustión al aire libre}

La combustión al aire libre de los residuos contamina la atmósfera y existe el peligro de que el fuego se descontrole y se propague a las propiedades o áreas colindantes, que exploten los contenedores o que se produzcan daños debido a los materiales radiactivos que pueden formar parte de los residuos. Este método de eliminación se ha prohibido en algunos países por no considerarse deseable.

\section{Pirólisis}

Es posible recuperar determinados compuestos mediante la destilación de los productos obtenidos durante la pirólisis (descomposición mediante calentamiento) de polímeros y sustancias orgánicas, aunque todavía no se ha implantado de forma generalizada.

\section{Eliminación de materiales a través de contratistas}

Tal vez sea el método más adecuado. Es importante que para esta tarea sólo se seleccionen contratistas fiables y reconocidos y con experiencia en la eliminación de residuos industriales y materiales peligrosos. Estos últimos deben separarse cuidadosamente para ser eliminados por separado.

\section{Clases específicas de materiales}

Entre los materiales peligrosos actualmente utilizados en la industria se encuentran: (1) los metales combustibles y los reactivos, como magnesio, potasio, litio, sodio, titanio y circonio; (2) los residuos combustibles: (3) los aceites de secado; (4) los líquidos inflamables y los disolventes residuales; (5) los materiales oxidantes (líquidos y sólidos); y (6) los materiales radiactivos. Todos estos materiales requieren una manipulación y unas precauciones especiales, que hay que estudiar cuidadosamente. Para más información sobre la identificación de materiales peligrosos y los riesgos asociados a los materiales industriales se remite a las publicaciones siguientes: Fire Protection H andbook (C ote, 1991) y Sax's D angerous Properties of Industrial M aterials (L ewis, 1979).

\section{Referencias}

American Institute of Chemical Engineers (AIChE). 1993. Plant Guidelines for T echnical M anagement of Chemical Process Safety. Nueva Y ork: Center for Chemical Process Safety.

American W elding Society (AWS). 1988. R ecommended Safe Practices for the Preparation for W elding and Cutting of Containers that have held $\mathrm{H}$ azardous Substances. $\mathrm{M} \mathrm{i}$ ami: AWS

Babrauskas, V, SJ Grayson. 1992. H eat R elease in Fires. Barking: Elsevier Science.

Blye, P, P Bacon. 1991. Fire prevention practices in commerce and industry. Capítulo 2, Sección 2 en
Fire Protection $\mathrm{H}$ andbook, $17^{\mathrm{a}}$ ed., dirigido por AE Cote. Q uincy, M assachussetts: NFPA.

Bowes, PC. 1984. Self-H eating: E valuating and Controlling the $\mathrm{H}$ azards. Londres: $\mathrm{H}$ er M ajesty's Stationary $\mathrm{O}$ fice.

Bradford, WJ. 1991. Chemical processing equipment. Capítulo 15, Sección 2 en Fire Protection $H$ andbook, 17 a ed., dirigido por AE Cote. Q uincy, $M$ assachussetts: NFPA.

British Standards Institute (BSI). 1992. T he Protection of Structures A gainst Lightning. British Standard C ode of Practice, BS6651. Londres: BSI.

Bugbee, P. 1978. Principles of Fire Protection. Q uincy, $M$ assachussetts: NFPA.
Cote, AE. 1991. Fire Protection $H$ andbook, 17ạ ed. Q uincy, M assachussetts: NFPA.

Davis, NH. 1991. Lightning protection systems. Capítulo 32, Sección 2 en Fire Protection $H$ andbook, $17^{a}$ ed., dirigido por AE Cote. Quincy, M assachussetts: NFPA.

DiNenno, PJ. 1988. $\mathrm{H}$ andbook of $\mathrm{F}$ ire P rotection $E$ ngineering. Boston: SFPE

Directiva de la Comisión Europea (DCE). 1992. The $\mathrm{M}$ anagement of $\mathrm{H}$ ealth and Safety at Work R egulations.

Drysdale, DD, HE Thomson. 1994. Fourth I nternational Symposium on Fire Safety Science. O ttawa: IAFSS. 
Drysdale, DD. 1985. Introduction to Fire Dynamics. Chichester: Wiley.

Factory M utual Engineering Corporation (FM ). 1977. Cutting and welding. L oss P revention D ata Sheets 10 . 15, junio 1977.

- . 1984. Lightning and surge protection for electrical systems. Loss Prevention Data Sheets 5-11/14-19, agosto 1984.

Gratton, J. 1991. Firesafety education. Capítulo 2, Sección 1 en Fire Protection $\mathrm{H}$ andbook, 17ª ed., dirigido por $A E$ Cote. Quincy, M assachussetts: NFPA.

H iggins, JT. 1991. H ousekeeping practices. Capítulo 34, Sección 2 en Fire Protection $H$ andbook, 17 a ed. dirigido por AE Cote. Quincy, M assachussetts: NFPA.

H rbacek, EM . 1984. Clay products plants. En Industrial Fire $\mathrm{H}$ azards $\mathrm{H}$ andbook, dirigido por J Linville. Q uincy, M assachussetts: NFPA.

H unter, K. 1991. Technology distinguishes Japan's fire service. Natl Fire Prev Agen J (Septiembre/ O ctubre)

Jernberg, LE. 1993. Improving risks in Sweden. Fire Prev 257 ( $M$ arzo).

K eith, R. 1994. FREM -Fire Risk Evaluation M ethod. $M$ elbourne: $R$. K eith \& Assoc.

K offel, WE. 1993. Establishing industrial fire safety programs. Natl Fire Prev Agen J (M arzo/ Abril).

Lataille, JJ. 1990. Lumber kilns and agricultural dehydrators and dryers. En Industrial Fire $\mathrm{H}$ azards $\mathrm{H}$ andbook, dirigido por J Linville. Quincy, M assachussetts: NFPA

Lees, FP. 1980. Loss Prevention in the Process Industries. V ol. 1, 2. Londres: Butterworths.

Lewis, R RJ. 1979. Sax's D angerous Properties of Industrial $M$ aterials. Nueva Y ork: $V$ an N ostrand R einhold.

Linville, J (dir.). 1990. Industrial Fire $\mathrm{H}$ azards $\mathrm{H}$ andbook. Q uincy, M assachussetts: NFPA.

Loss Prevention Council. 1992. Fire Prevention On Construction Sites. Londres: Loss Prevention Council.

M anz, A. 1991. Welding and cutting. Capítulo 14 Sección 2 en Fire Protection $\mathrm{H}$ andbook, 17ạ ed., dirigido por $A E$ Cote. Quincy, M assachussetts: NFPA.

National Fire Protection Association (NFPA). 1983 $F$ iresafety $E$ ducator's $H$ andbook: A Comprehensive $G$ uide to Planning, Designing, and Implementing Firesafety Programs. FSO -61. Q uincy, M assachussetts: NFPA.

- . 1990a. Standard System for the Identification of the Fire $\mathrm{H}$ azards of $\mathrm{M}$ aterials. NFPA N 0. 704. Q uincy, M assachussetts: NFPA.

- . 1995a. Guide to the Fire Safety Concepts T ree. NFPA N o. 550. Q uincy, M assachussetts: NFPA.

- . 1995b. Standard for the Installation of $L$ ighting P rotection Systems. NFPA N 0.780. Q uincy, M assachussetts: NFPA.

-. 1992. Fire Prevention Code NFPA No.1. Quincy, $M$ assachussetts: NFPA.

O sterhoust, C. 1990. Public Fire E ducation. IFST A No. 606. Stillwater, O klahoma: A sociación Internacional para la Formación del Servicio de Incendios (IFST A).

Ostrowski, R. 1991. Oil quenching. Fire Protection $\mathrm{H}$ andbook, 17a ed., dirigido por AE Cote. Quincy, $M$ assachussetts: NFPA.

Palmer, K N. 1973. Dust Explosion and Fires. Londres: Chapman \& $\mathrm{H}$ all.

Simmons, JM. 1990. H eat processing equipment. En Industrial $\mathrm{Fire} \mathrm{H}$ azards $\mathrm{H}$ andbook. $\mathrm{O}$ uincy, $\mathrm{M}$ assachussetts: NFPA.
Watts, KI. 1990. Oil quenching. En Industrial Fire $\mathrm{H}$ azards $\mathrm{H}$ andbook, dirigido por J Linville. Q uincy, M assachussetts: NFPA.

Welch, J. 1993. The changing face of FPA training: Fire prevention. Fire Prev (Julio/ Agosto): 261.

Welty, JR, RE Wilson, CE Wicks. 1976. Fundamentals of $M$ omentun, $H$ eat and $M$ ass T ransfer. N ueva $Y$ ork: John Wiley \& Sons

\section{0 tras lecturas recomendadas}

Barry, T J, B N ewman. 1976. Some problems of synthetic polymers at elevated temperatures. Fire $T$ echnol 12(3):186-192.

Berta, I, I Fodor. 1990. Electrostatical ignition sources. En Fire and Explosion Safety, dirigido por T K ompolthy. Budapest: M ûszaki K öyvkiadó.

Boddington, T, JF Griffiths, K H asegawa. 1984. Induction times to thermal ignition in systems with distributed temperatures: An experimental test of theoretical interpretations. Combust Flame 55(3):297.

Boyle, AR, FJ Llewellyn. 1950. The electrostatic ignitability of dust clouds and powders. J Appl Chem 69:173-181.

Bryan, JL. 1991a. Concept of egress design. En Fire Protection $\mathrm{H}$ andbook, dirigido por AE Cote. Q uincy, M assachussetts: NFPA.

- . 1991b. Human behaviour and fire. En Fire Protection $\mathrm{H}$ andbook, dirigido por $\mathrm{AE}$ Cote. $\mathrm{Q}$ uincy, $\mathrm{M}$ assachussetts: NFPA.

-. 1991c. Traffic and exit drill. En Fire Protection $\mathrm{H}$ andbook, dirigido por AE Cote. Q uincy, M assachussetts: NFPA.

Canter, D. 1985. Studies of H uman B ehaviour in Fire: E mpirical Results and Their Implications for Education and D esign. H erts: D epartment of Environment, Building Research Establishment, Fire Research Station

Chamberlain, DL. 1983. H eat R elease $R$ ate Properties of W ood-Based M aterials. NBSIR 82-2597. Washington, DC: N ational Bureau of Standards.

C offe, R D. 1971. Evaluation of chemical stability. Fire T echnol 7(1):37-45

Dean, JA. 1984. Lange's $H$ andbook of Chemistry. Sandusky, $\mathrm{O}$ hio: $\mathrm{H}$ andbook Publishers.

DeH aan, N. 1991. Interior finish. En Fire Protection $\mathrm{H}$ andbook, dirigido por AE Cote. Q uincy, M assachussetts: NFPA.

D onoghue, EA. 1991. Building transportation system. $\mathrm{En} F$ ire Protection $\mathrm{H}$ andbook, dirigido por $\mathrm{AE}$ Cote. $Q$ uincy, M assachussetts: NFPA.

Eggleston, LA, AJ Pryor. 1967. The limits of dust explosibility. Fire T echnol 3(2):77-89.

Eurocode 1: Basis of Design and Actions on Structures. Part 2.2: Actions on Structures Exposed to Fire (1991-2-2): CEN, EN V 1991-2-2.

Goodall, DG, R Ingle. 1967. The ignition of flammable liquids by hot surfaces. Fire T echnol 3(2):115128.

Gordon, BF. 1981. Flame retardants and textile material. Fire Safety J 4:109-123.

Griffith, JF, JR M ullins. 1984. I gnition, self-heating, and the effects of added gases during the thermal decomposition of di-t-butyl peroxide. Combust Flame 56(2):135.

$\mathrm{H}$ anson, RJ, A Thomas. 1984. Flame development in swirling flows in closed vessels. Combust Flame 55(3):255

$\mathrm{H}$ arley, CS. 1991. Building and site planning for firesafety. En Fire Protection $\mathrm{H}$ andbook, dirigido por AE Cote. Q uincy, M assachussetts: NFPA.
Hilado, CJ, HJ Cumming. 1977. The HC value: A method of estimating the flammability of mixtures of combustible gases. Fire T echnol 13(3):195.

Hilado, CJ. 1982. Flammability $\mathrm{H}$ andbook for Plastics. Lancaster, Pensilvania: T echnomic Publishing.

H irschler, M M. 1992. Smoke and heat release and ignitability as measures of fire hazard from burning of carpet tiles. Fire Safety J 18(4):305.

Hommel, G. 1987. H andbuch Der Gefährlichen Güter. Berlín: Springer Verlag.

Ihrig, AM, SL Smith. 1994. The role of alkali and alkaline earth metal ions in cellulosic smoldering. J Fire Sci 12(4):357.

Janssens, M . 1991. Piloted ignition of wood: A review. Fire M ater 15(4):151.

K arter, M JJ. 1991. Fire loss in the U nited States during 1990. NFPA I Septiembre/ O ctubre: 36.

K lote, JH. 1992. Design of Smoke M anagement Systems. Atlanta.

M artin, JT, B M iller. 1978. The thermal and flammability behaviour of polyester-wool blends. Textile Res) 48:97-103.

M izuno, T, K K awagoe. 1986. Burning behaviour of upholstered chairs: Part 3, Flame and plume characteristics in fire test. Fire Sci T echnol 6(12):29.

Nagy, J, H G D orset, M Jacobson. 1964. Preventing Ignition of D ust D ispersions By I nerting. Pittsburgh, Pensilvania: USDI, Bureau of M ines. (R I6543)

Nishimoto, T, M M orita, H Y ajima. 1986. Spontaneous combustion of coal (III) (I sothermal M ethod). Fire Sci T echnol 6(1 y 2):1.

O hlemiller, TJ, FE R ogers. 1978. A survey of several factors influencing smolder combustion in flexible and rigid polymer foams. J Fire Flamm 9:489-509.

O htani, H. 1990. Theoretical consideration on the ignition of hot iron in high pressure oxygen. Fire Sci T echnol 10(1 y 2):1.

Pál, K , H M acskásy. 1980. Plastics and their Combustibility. Budapest: M ûszaki K önyvkiadó

Perry, JH, CH Chilton. 1974. Chemical Engineers' $\mathrm{H}$ andbook. Nueva Y ork: $\mathrm{M} \mathrm{CG}$ raw-H ill.

Purser, DA, WD W oolley. 1983. Biological studies of combustion atmospheres. J Fire Sci 1(2):118.

R asbash, DJ. 1980. R eview of explosion and fire hazard of liquified petroleum gas. Fire Safety J 2(4):223-236.

SFPE y NFPA. 1988. The SFPA H andbook of Fire Protection E ngineering. Q uincy, $M$ assachussetts: SFPE.

Sharma, TP, S K umar. 1992. Products of combustion of the metal powders. Fire Sci T echnol 12(2):29.

Sugawa, O, H Yamamoto. 1989. Reduction of Smoke Particles from Fire R etarded W ood. Fire Sci T echnol 9(1):1.

Tewarson, A, DP M acaion. 1993. Polymers and composites- An examination of fire spread and generation of heat and fire products. I Fire Sci 11(5):421.

T ewarson, A. 1975. Flammability of Polymers and O rganic Liquids, Part I, Burning Intensity. Norwood, M assachussetts: Factory M utual R esearch Corp.

- . 1994. Flammability parameters of materials: I gnition, combustion, and fire propagation. Fire Safety J 12(4):329.

Thorne, PF. 1976. Flashpoints of mixtures of flammable and non-flammable liquids. Fire M ater 1:134140.

White, RH, EV N ordheim. 1992. Charring rate of wood for ASTM E 119 exposure. Fire Technol 28(1):5. 

Director del capítulo

J ean-J acques Vogt

\section{Sumario}

Respuestas fisiológicas a la temperatura ambiente

W. L arry Kenney . . . . . . . . . . . . . . . . . . 42.2

Efectos del estrés por calor y trabajo en ambientes calurosos

Bodil Nielsen. . . . . . . . . . . . . . . . . . . . . . . 42.5

Trastornos producidos por el calor

Tokuo 0 gawa $\ldots \ldots \ldots \ldots \ldots \ldots \ldots \ldots \ldots \ldots \ldots \ldots \ldots \ldots \ldots \ldots \ldots$

Prevención del estrés por calor

Sarah A. N unneley . . . . . . . . . . . . . . . . . . . . . 42.11

Fundamentos físicos del trabajo en condiciones de calor

J acques $M$ alchaire . . . . . . . . . . . . . . . . . . 42.15

Evaluación del estrés por calor e índices de estrés

por calor

Kenneth C. Parsons . . . . . . . . . . . . . . . . . . . . . . . 42.17

Intercambio de calor a través de la ropa

W outer A. Lotens . . . . . . . . . . . . . . . . . . 42.26

Ambientes fríos y trabajo con frío

Ingvar H olmér, Per-0 la G ranberg y Goran D ahlstrom . . . . . . . . . . . 42.32

Prevención del estrés por frío en condiciones extremas

al aire libre

J acques Bittel y Gustave Savourey

Indices de frío y normas sobre el frío

Ingvar H olmér. 


\section{- RESPUESTAS FISIO LO GICAS A LA TEMPERAT URA AMBIENTE}

\section{W. Larry Kenney}

Durante toda su vida, los seres humanos mantienen la temperatura corporal dentro de unos límites de variación muy estrechos y protegidos a toda costa. Los límites máximos de tolerancia para las células vivas corresponden a unos 0 으 (formación de cristales de hielo) y unos 45 으 (coagulación térmica de proteínas intracelulares); sin embargo, los seres humanos pueden soportar temperaturas internas inferiores a $35 \stackrel{\circ}{\circ}$ o superiores a $41 \stackrel{\circ}{\circ}$, aunque sólo durante períodos muy cortos de tiempo. Para mantener la temperatura interna dentro de esos límites, el ser humano ha desarrollado unas respuestas fisiológicas muy eficaces, y en algunos casos especializadas, al estrés térmico agudo. La finalidad de esas respuestas es facilitar la conservación, producción o eliminación del calor corporal, requieren la coordinación firmemente controlada de varios sistemas corporales.

\section{Equilibrio térmico del ser humano}

La principal fuente de calor para el organismo es, con diferencia, la producción de calor metabólico (M). Incluso con una eficiencia mecánica máxima, entre el 75 y el $80 \%$ de la energía implicada en el trabajo muscular se libera en forma de calor. En reposo, una tasa metabólica de $300 \mathrm{ml}$ de $\mathrm{O}_{2}$ por minuto crea una carga térmica de aproximadamente $100 \mathrm{~W}$. EI trabajo en estado estable con un consumo de oxígeno de $1 \mathrm{l} /$ min genera aproximadamente $350 \mathrm{~W}$ de calor, menos cualquier energía asociada al trabajo externo (W). Incluso con una intensidad de trabajo leve o moderada, la temperatura interna del organismo aumentará aproximadamente un grado centígrado cada 15 min si no existe un medio eficaz de disipar el calor. De hecho, las personas que están en muy buena forma física pueden producir más de $1.200 \mathrm{~W}$ de calor durante un período de 1 a 3 horas sin sufrir trastornos por calor (G isolfi y Wenger 1984).

El calor puede también absorberse del medio ambiente por radiación $(R)$ y convección $(C)$ si la temperatura de globo (una medida del calor radiante) y la temperatura del aire (bulbo seco) sobrepasan respectivamente la temperatura cutánea. Se trata de fuentes de calor pequeñas por lo común en comparación con M $y$, en realidad, se convierten en fuentes de pérdida de calor cuando se invierte el gradiente térmico de la piel al aire. El último proceso de termolisis, el de evaporación (E), suele ser también el más importante, puesto que el calor latente de la evaporación del sudor es bastante elevado, aproximadamente $680 \mathrm{~W}-\mathrm{h} / \mathrm{I}$ de sudor evaporado. Todas estas relaciones se describen en profundidad más adelante.

En ambientes fríos o térmicamente neutros, la termogénesis se equilibra con la termolisis, no se almacena calor y la temperatura corporal se equilibra; es decir:

$$
M-W \pm R \pm C-E=0
$$

Ahora bien, cuando la exposición al calor es más intensa:

$$
M-W \pm R \pm C>E
$$

y se almacena calor. En particular, los trabajos pesados (con un elevado gasto de energía que aumenta $M-W$ ), unas temperaturas ambientales demasiado altas (que aumentan $R+C$ ), una elevada humedad (que limita E) y el uso de prendas de vestir gruesas o relativamente impermeables (que crean una barrera para la evaporación del sudor), dan lugar a este tipo de escenario. Finalmente, si el esfuerzo es prolongado o la hidratación inadecuada, E puede verse superado por la capacidad limitada del organismo para secretar sudor (entre 1y $2 \mathrm{l} / \mathrm{h}$ durante cortos períodos de tiempo).

\section{La temperatura corporal y su control}

Para describir las respuestas fisiológicas al frío y al calor, el organismo puede dividirse en dos componentes: el "núcleo" y la "periferia". La temperatura del núcleo $(T$ ) representa la temperatura corporal interna o profunda y puede medirse en la boca, en el recto 0 , en contextos de laboratorio, en el esófago o la membrana timpánica (tímpano). La temperatura de la periferia está representada por la temperatura cutánea media $\left(T_{s k}\right)$. La temperatura corporal media $\left(T_{b}\right)$ es en todo momento un equilibrio ponderado de estas temperaturas, es decir

$$
\mathrm{T}_{\mathrm{b}}=\mathrm{k}_{\mathrm{c}}+(1-\mathrm{k}) \mathrm{T}_{\mathrm{sk}}
$$

en donde el factor de ponderación k varía entre aproximadamente 0,67 y 0,90 .

C uando el organismo se enfrenta a condiciones que se alejan de la neutralidad térmica (estrés por frío o calor), intenta controlar $T$ mediante ajustes fisiológicos, y $T$ constituye la principal fuente de retroinformación para que el cerebro coordine dicho control. Aunque la temperatura cutánea local y media es una importante fuente de información sensorial, $T_{\text {sk }}$ varía mucho con la temperatura ambiente, con un valor medio de $33 \stackrel{\circ}{\circ}$ en condiciones de termoneutralidad y alcanzando $36037 \stackrel{\circ}{\circ}$ en condiciones de trabajo pesado en ambientes calurosos. La exposición de todo el organismo o de una parte del mismo al frío puede hacer que esta temperatura descienda considerablemente. La sensibilidad táctil aparece entre los 15 y los $20^{\circ} \mathrm{C}$, mientras que la temperatura crítica para la destreza manual se sitúa entre los 12 y los $16^{\circ} \mathrm{C}$. L L os umbrales superior e inferior del dolor para los valores de $T_{s k}$ son aproximadamente de $43 \stackrel{\circ}{\circ}$ y $10 \stackrel{\circ}{\circ}$, respectivamente.

L os estudios de mapeo de alta precisión han localizado el lugar de mayor regulación térmica en la zona del cerebro conocida como centros supra y preópticos del hipotálamo anterior. En esta región existen células nerviosas que responden tanto al calentamiento (neuronas sensibles al calor) como al enfriamiento (neuronas sensibles al frío). Es una zona que domina el control de la temperatura corporal al recibir información sensorial aferente y enviar señales a la piel, los músculos y otros órganos implicados en la regulación térmica a través del sistema nervioso autónomo. 0 tras zonas del sistema nervioso central (hipotálamo posterior, formación reticular, puente, bulbo raquídeo y médula espinal) forman las conexiones ascendentes y descendentes con los centros supra y preópticos del hipotálamo anterior y realizan una serie de funciones facilitadoras.

El sistema de control del organismo es similar al control termostático de una vivienda con funciones tanto de calefacción como de refrigeración. Cuando la temperatura corporal sobrepasa una cierta temperatura teórica "de referencia", se activan las respuestas de los efectores asociadas a la termolisis (sudoración, aumento del flujo sanguíneo periférico). Cuando la temperatura corporal desciende por debajo del valor de referencia, se inician las respuestas de termogénesis (reducción del flujo sanguíneo periférico, escalofríos). Pero, al contrario que los sistemas de calefacción y refrigeración de las viviendas, el sistema de regulación térmica del ser humano no funciona como un sencillo sistema de encendido y apagado, sino que tiene también funciones de control gradual y control de la velocidad del cambio. Debe tenerse en cuenta que la "temperatura de referencia" existe sólo en teoría, pero es útil para comprender estos conceptos. No obstante, todavía queda mucho trabajo para comprender plenamente los mecanismos asociados a la temperatura termorreguladora de referencia. 
Cualquiera que sea su base, la temperatura de referencia es relativamente estable y no se ve afectada por el trabajo ni por la temperatura ambiente. De hecho, el único caso demostrado de alteración aguda de dicha temperatura es la provocada por el grupo de pirógenos endógenos implicados en la respuesta febril. Las respuestas de los efectores que el organismo utiliza para mantener el equilibrio térmico se inician y controlan en respuesta a un "error de carga", es decir, a una temperatura corporal que está momentáneamente por encima o por debajo de la temperatura de referencia (Figura 42.1). Cuando la temperatura interna desciende por debajo del valor de referencia, se crea un error de carga negativo que desencadena los procesos de termogénesis (escalofríos, vasoconstricción periférica). Cuando la temperatura interna sobrepasa el valor de referencia, se crea un error de carga positivo que activa a los efectores de la termolisis (vasodilatación periférica, sudoración). En ambos casos, la transferencia de calor resultante reduce el error de carga y ayuda a estabilizar la temperatura corporal.

\section{Regulación térmica en ambientes calurosos}

Como ya se ha dicho antes, el ser humano desprende calor al medio ambiente principalmente mediante una combinación de procesos secos (radiación y convección) y evaporación. Para facilitar este intercambio, se activan y regulan los dos principales sistemas efectores: vasodilatación periférica y sudoración. Aunque la vasodilatación periférica suele producir pequeños aumentos en la pérdida de calor seco (radiactivo y convectivo), su principal función es transferir calor del interior del cuerpo a la periferia (transferencia interna de calor), mientras que la evaporación de sudor constituye un medio extremadamente eficaz para enfriar la sangre antes de que regrese a los tejidos corporales profundos (transferencia externa de calor).

\section{Vasodilatación periférica}

La cantidad de calor transferido del núcleo a la periferia depende del flujo sanguíneo periférico (FSP), el gradiente de temperatura entre el centro y la periferia y el calor específico de la sangre (algo inferior a $4 \mathrm{~kJ} /{ }^{\circ} \mathrm{C}$ por litro de sangre). En reposo y en un ambiente térmicamente neutro, la piel recibe aproximadamente entre 200 y $500 \mathrm{ml} / \mathrm{min}$ de flujo sanguíneo, lo que representa sólo entre un 5 y un $10 \%$ de la sangre total bombeada por el corazón (gasto cardíaco). D ebido a la existencia de un gradiente

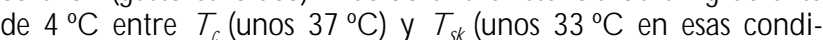
ciones), el calor metabólico producido por el organismo para soportar la vida es transmitido constantemente a la piel por convección para su disipación. Por el contrario, en condiciones de hipertermia severa, como cuando se realiza un trabajo pesado en condiciones de calor, el gradiente térmico del centro a la piel es menor y la transferencia de calor necesaria se consigue con un gran aumento del FSP. En condiciones de estrés máximo por calor, el FSP puede alcanzar entre 7 y $8 \mathrm{l} / \mathrm{min}$, casi la tercera parte del gasto cardíaco (R owell 1983). El elevado flujo sanguíneo se consigue gracias a lo que se conoce como el "sistema vasodilatador activo". En la vasodilatación activa intervienen las señales de los nervios simpáticos enviadas del hipotálamo a las arteriolas de la piel, aunque se desconoce cuál es el neurotransmisor que participa en este proceso.

Como ya se mencionó antes, el FSP es el principal responsable

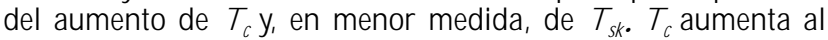
iniciarse el trabajo muscular y la producción de calor metabólico $y$, una vez que se alcanza un cierto umbral de $T_{c}$, FSP empieza también a aumentar rápidamente. Tal relación termorreguladora básica se ve influida por factores no térmicos que constituyen un segundo nivel de control crítico para modificar el FSP cuando la estabilidad cardiovascular global se ve amenazada. Las
Figura 42.1 - Modelo de regulación térmica del cuerpo humano.

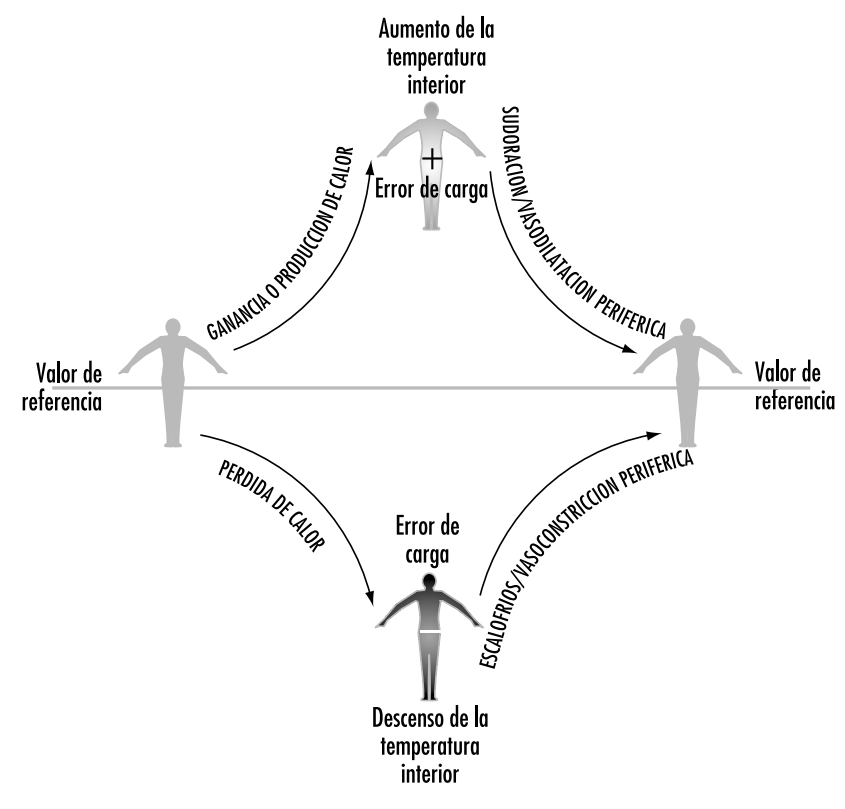

venas de la piel tienen una gran capacidad de distensión y una parte importante del volumen circulatorio se acumula en estos vasos. D e esta forma se facilita el intercambio de calor al hacerse más lenta la circulación por los capilares para aumentar el tiempo de tránsito; sin embargo, esta acumulación, sumada a la pérdida de líquidos producida por la sudoración, puede también reducir la velocidad del retorno de la sangre al corazón. Entre los factores no térmicos cuya influencia en el FSP ha sido demostrada figuran las posturas erguidas, la deshidratación y la respiración con presión positiva (uso de respirador). Actúan a través de los reflejos que se activan cuando la presión de llenado del corazón se reduce y los receptores de la distensión situados en las grandes venas y en la aurícula derecha dejan de ser estimulados; por consiguiente, su efecto es más evidente durante el trabajo aeróbico prolongado en postura erguida. Son reflejos que sirven para mantener la presión arterial y, cuando se realiza un trabajo, para mantener un flujo sanguíneo adecuado a los músculos activos. Por consiguiente, el FSP en un momento dado depende del efecto combinado de las respuestas reflejas termorreguladoras y de otro tipo.

La necesidad de aumentar el flujo sanguíneo periférico con el fin de ayudar a regular la temperatura tiene un gran impacto en la capacidad del sistema cardiovascular para regular la presión arterial. Por esta razón, se necesita una respuesta coordinada de todo el sistema cardiovascular al estrés por calor. ¿Q ué ajustes cardiovasculares tienen lugar para permitir el aumento del flujo y el volumen periféricos? Cuando se trabaja en ambientes fríos 0 térmicamente neutros, el aumento necesario del gasto cardíaco se ve facilitado por el aumento de la frecuencia cardíaca (FC), puesto que el volumen sistólico (VS) experimenta incrementos mínimos cuando la intensidad del esfuerzo supera el $40 \%$ del esfuerzo máximo. En ambientes calurosos, la FC es mayor con cualquier intensidad de trabajo, para compensar el menor volumen sanguíneo central (VSC) y el menor VS. Con niveles superiores de trabajo se alcanza la frecuencia cardíaca máxima y esta taquicardia es, por consiguiente, incapaz de mantener el gasto cardíaco necesario. La segunda manera de aumentar el 
FSP es reduciendo el flujo sanguíneo en zonas como el hígado, los riñones y los intestinos (Rowell 1983). El redireccionamiento del flujo puede conseguir un aumento adicional de 800 a $1.000 \mathrm{ml}$ en el flujo sanguíneo periférico y ayuda a compensar los efectos nocivos de la acumulación periférica de sangre.

\section{Sudoración}

En el ser humano, el sudor contribuye a la regulación térmica y es secretado por entre 2 y 4 millones de glándulas sudoríparas ecrinas repartidas de manera no uniforme por la superficie del cuerpo. Al contrario que las glándulas sudoríparas apocrinas, que tienden a aparecer agrupadas (en el rostro, las manos y las regiones axilar y genital) y que secretan sudor a los folículos pilosos, las glándulas ecrinas secretan sudor directamente a la superficie de la piel. Es un sudor inodoro, incoloro y relativamente diluido, puesto que se trata de un ultrafiltrado de plasma, motivo por el cual posee un elevado calor latente de evaporación y es ideal para los fines de la termolisis.

Como ejemplo de la eficacia de este sistema termolítico, un hombre que trabaje con un consumo de oxígeno de 2,3 I/ min producirá un calor metabólico neto $(M-W)$ de aproximadamente $640 \mathrm{~W}$. Sin sudoración, la temperatura corporal aumentaría a un ritmo aproximado de $1^{\circ} \mathrm{C}$ cada $607 \mathrm{~min}$. Con una evaporación eficiente de unos $16 \mathrm{~g}$ de sudor por minuto (una tasa razonable), la velocidad de la pérdida de calor puede igualar a la velocidad de acumulación de calor, de manera que la temperatura interna del organismo se mantiene estable; es decir,

$$
M-W \pm R \pm C-E=0
$$

Las glándulas ecrinas tienen una estructura sencilla constituida por una parte secretora en forma de espiral, un conducto y un poro cutáneo. EI volumen de sudor producido por cada glándula depende tanto de la estructura como de la función de la glándula y la tasa total de sudoración depende a su vez del número de glándulas (densidad de glándulas sudoríparas activas) y de la producción de cada una de esas glándulas. EI hecho de que algunas personas suden más que otras puede atribuirse principalmente a las diferencias en el tamaño de las glándulas sudoríparas (Sato y Sato 1983). La aclimatación al calor es otro factor importante que determina la producción de sudor. Con la edad, la disminución de la tasa de sudoración se debe no tanto a un menor número de glándulas ecrinas activas como a una menor producción de sudor por glándula (Kenney y Fowler 1988), probablemente como resultado de la combinación de alteraciones estructurales y funcionales que acompañan al proceso de envejecimiento.

Al igual que las señales vasomotoras, los impulsos nerviosos que reciben las glándulas sudoríparas se originan en los centros supra y preópticos de hipotálamo anterior y descienden a lo largo del tallo encefálico. Las glándulas están enervadas por fibras colinérgicas simpáticas, una rara combinación en el organismo humano. Aunque la acetilcolina es el principal neurotransmisor, los transmisores adrenérgicos (catecolaminas) también estimulan las glándulas ecrinas.

En muchos aspectos, el control de la sudoración es similar al control del flujo sanguíneo periférico. Ambos tienen características similares de activación (umbral) y una relación lineal con el aumento de $T$ L $L$ a sudoración suele iniciarse antes en la espalda y el pecho, y las curvas de la relación entre la tasa local de sudoración y $T$, tienen una mayor pendiente en estos lugares. Al igual que el FSP, la sudoración se ve modificada por factores no térmicos, como una hidratación insuficiente o la hiperosmolalidad. Conviene también recordar que existe un fenómeno llamado "hidromeiosis", que ocurre en ambientes muy húmedos o zonas de la piel cubiertas constantemente por prendas húmedas. En esas zonas siempre húmedas se reduce el flujo de sudor, lo que sirve como mecanismo de protección contra la deshidratación continua, puesto que el sudor que permanece en la piel en lugar de evaporarse no sirve para fines termolíticos.

Con una tasa de sudoración adecuada, la pérdida de calor por evaporación depende en definitiva del gradiente de la presión del vapor de agua entre la piel húmeda y el aire que la rodea. Así, una elevada humedad ambiental y el uso de prendas gruesas 0 impermeables limitan la pérdida de calor por evaporación, mientras que el aire seco, las corrientes de aire sobre el cuerpo y una prendas de vestir finas y porosas facilitan la evaporación. Por otra parte, cuando se realiza un trabajo intenso y se produce una sudoración abundante, la pérdida de calor por evaporación puede también verse limitada por la capacidad del organismo para producir sudor (como máximo entre 1 y $2 \mathrm{l} / \mathrm{h}$ ).

\section{Regulación térmica en ambientes fríos}

U na diferencia importante entre la respuesta del ser humano al frío y su respuesta al calor es que la conducta desempeña una función mucho más importante en la primera. Por ejemplo, el uso de prendas adecuadas y la adopción de posturas que reduzcan la superficie disponible para la pérdida de calor ("encogerse") son mucho más importantes en condiciones de frío que en condiciones de calor. U na segunda diferencia es la importancia que cobra la función de las hormonas durante el estrés por frío, así como la mayor secreción de catecolaminas (norepinefrina y epinefrina) y hormonas tiroideas.

\section{Vasoconstricción periférica}

Una estrategia eficaz contra la pérdida de calor corporal por radiación y convección consiste en aumentar el aislamiento efectivo proporcionado por la periferia. En el ser humano, esto se consigue reduciendo el flujo sanguíneo periférico, es decir, por vasoconstricción periférica. La constricción de los vasos cutáneos es más pronunciada en las extremidades que en el tronco. Al igual que la vasodilatación activa, la vasoconstricción periférica está también controlada por el sistema nervioso simpático y se ve afectada por $\mathrm{T}_{c}, \mathrm{~T}_{\mathrm{sk}} \mathrm{y}$ las temperaturas locales.

El efecto del enfriamiento de la piel en la respuesta de la frecuencia cardíaca y la presión arterial depende de la zona del cuerpo que se haya enfriado y de que el frío sea lo suficientemente intenso como para causar dolor. Por ejemplo, cuando las manos se sumergen en agua fría, aumentan la $\mathrm{FC}$, la presión arterial sistólica (PAS) y la presión arterial diastólica (PAD). Cuando el rostro se enfría, la PAS y la PAD aumentan como consecuencia de una respuesta simpática generalizada; sin embargo, la FC se reduce debido a un reflejo parasimpático (LeBlanc 1975). Para aumentar todavía más la complejidad de la respuesta global al frío, existe una gran variabilidad de una persona a otra. Si el estrés por frío es lo suficientemente intenso como para reducir la temperatura interna del organismo, la FC puede aumentar (por la activación simpática) o disminuir (por el mayor volumen sanguíneo central).

U n caso especialmente interesante es el de la vasodilatación inducida por frío. Cuando las manos se sumergen en agua fría, el FSP se reduce inicialmente para conservar el calor. A medida que desciende la temperatura de los tejidos, el FSP aumenta paradójicamente, vuelve a reducirse y repite esta pauta cíclica. Se ha sugerido que la vasodilatación inducida por frío sirve para prevenir lesiones en los tejidos por congelación, aunque esta afirmación no ha podido demostrarse todavía. Desde un punto de vista mecánico, la dilatación transitoria se produce probablemente cuando los efectos directos del frío tienen la gravedad suficiente como para reducir la transmisión nerviosa, anulando temporalmente la estimulación inducida por el frío de los receptores simpáticos situados en los vasos sanguíneos (mediadores del efecto constrictor). 


\section{E scalofríos}

A medida que el cuerpo se va enfriando, la segunda línea de defensa es el escalofrío, que consiste en una contracción aleatoria involuntaria de las fibras musculares superficiales, sin reducir la pérdida de calor pero aumentando su producción. Puesto que este tipo de contracciones no producen ningún trabajo, se libera calor. U na persona en reposo puede multiplicar por tres o cuatro su producción de calor metabólico con una tiritona intensa y aumentar así $T_{c}$ en $0,5 \stackrel{\circ}{ } \mathrm{C}$. L as señales para iniciar los escalofríos se originan principalmente en la piel y, además de los centros supra y preópticos de hipotálamo anterior, el hipotálamo posterior interviene también en cierta medida.

Aunque son muchos los factores que contribuyen a la aparición de escalofríos (y a la adaptación al frío en general), uno de los más importantes es la cantidad de grasa corporal. Un hombre con poca grasa subcutánea (entre 2 y $3 \mathrm{~mm}$ de espesor) comienza a sentir escalofríos al cabo de $40 \min$ a $15{ }^{\circ} \mathrm{C}$ y de 20 min a $10 \stackrel{\circ}{\circ}$, mientras que un hombre con mayor cantidad de grasa aislante $(11 \mathrm{~mm})$ posiblemente no experimente escalofríos a $15 \stackrel{\circ}{\circ}$ y sólo al cabo de 60 min a $10 \stackrel{\circ}{ } \mathrm{C}$ (LeBlanc 1975).

\section{- EFECT OS DEL ESTRES POR CALOR Y TRABAJO EN AMBIENTES CALUROSOS}

\section{Bodil Nielsen}

Cuando una persona se ve expuesta al calor, se activan los mecanismos fisiológicos de termolisis para mantener la temperatura normal del organismo. Los flujos de calor entre el organismo y el medio ambiente dependen de la diferencia de temperatura entre:

1. el aire circundante y objetos como paredes, ventanas, el cielo, etc.

2. la temperatura superficial de la persona

La temperatura superficial de la persona está regulada por mecanismos fisiológicos, como variaciones en el flujo sanguíneo periférico y la evaporación del sudor secretado por las glándulas sudoríparas. Además, la persona puede cambiarse de ropa para influir en el intercambio de calor con el medio ambiente. Cuanto más calurosas sean las condiciones ambientales, menor será la diferencia entre la temperatura ambiente y la temperatura superficial de la piel o de la ropa. Con ello, el "intercambio de calor seco" por convección y radiación se reduce en ambientes cálidos comparado con los ambientes fríos. Cuando la temperatura ambiente es superior a la temperatura corporal periférica, el cuerpo absorbe calor de su entorno. En este caso, el calor absorbido, sumado al calor liberado por los procesos metabólicos, debe perderse mediante evaporación del sudor para mantener la temperatura corporal. Así, la evaporación del sudor adquiere una importancia cada vez mayor al aumentar la temperatura ambiente. Por este motivo la velocidad del aire y la humedad ambiental (presión parcial del vapor de agua) son factores ambientales críticos en ambientes calurosos. C uando la humedad es alta, el cuerpo sigue produciendo sudor, pero la evaporación se reduce. El sudor que no puede evaporarse no tiene efecto de enfriamiento: resbala por el cuerpo y se desperdicia desde el punto de vista de la regulación tér mica.

El cuerpo humano contiene aproximadamente un $60 \%$ de agua, lo que supone entre 35 y 40 I en una persona adulta. Casi la tercera parte del agua corporal corresponde al líquido extracelular, que se distribuye entre las células y el sistema vascular (plasma sanguíneo). Los restantes dos tercios del agua corporal corresponden al líquido intracelular, que se encuentra en el interior de las células. La composición y el volumen de los compartimientos de agua corporal están sometidos a un estrecho control en el que intervienen mecanismos hormonales y neurológicos. El sudor es secretado por los millones de glándulas sudoríparas que se encuentran en la superficie de la piel cuando se activa el centro de la regulación térmica por un aumento de la temperatura corporal. El sudor contiene sal $(\mathrm{NaCl}$, cloruro sódico), aunque en menor medida que el líquido extracelular. Por consiguiente, con el sudor se pierden agua y sal, que deben reponerse.

\section{Efectos de la sudoración}

En ambientes térmicamente neutros y confortables se pierden pequeñas cantidades de agua por difusión a través de la piel. Con todo, cuando se realiza un trabajo intenso en condiciones de calor, las glándulas sudoríparas activas pueden excretar grandes cantidades de sudor, hasta más de $2 \mathrm{l} / \mathrm{h}$ durante varias horas. Incluso una pérdida de sudor de tan sólo el $1 \%$ del peso corporal $(\approx$ entre 600 y $700 \mathrm{ml}$ ) afecta considerablemente al rendimiento laboral, lo que se manifiesta en un aumento de la frecuencia cardíaca (FC) (la FC aumenta unos cinco latidos por minuto por cada $1 \%$ de pérdida de agua corporal) y de la temperatura interna del organismo. Si el trabajo es continuado, se produce un aumento gradual de la temperatura corporal, que puede alcanzar un valor cercano a $40 \stackrel{\circ}{ } \mathrm{C}$, una temperatura a la que probablemente se producirán trastornos por calor, debido en parte a la pérdida de líquido del sistema vascular (Figura 42.2). La pérdida de agua del plasma sanguíneo reduce la cantidad de sangre que llena las venas centrales y el corazón, de manera que, con cada latido, el corazón tiene que bombear un volumen sistólico más

Figura 42.2 - Distribuciones calculadas de agua en el compartimiento extracelular (CEC) y el compartimiento intracelular $(\mathrm{CIC})$ antes y 2 horas después de deshidratación por esfuerzo a una temperatura ambiente de $30^{\circ} \mathrm{C}$

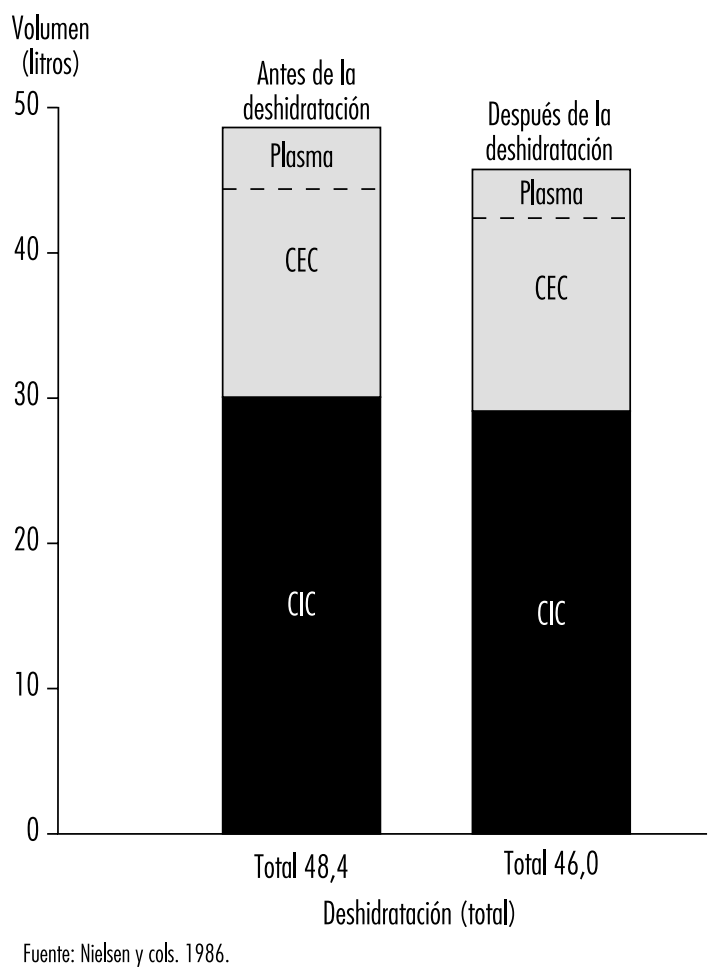


pequeño. Como consecuencia, el gasto cardíaco (la cantidad total de sangre que es expelida del corazón por minuto) tiende a reducirse y la frecuencia cardíaca tiene que aumentar para mantener la circulación y la presión arterial.

U n sistema de control fisiológico, llamado el sistema de reflejos de los barorreceptores, mantiene unos niveles normales del gasto cardíaco y la presión arterial en todas las condiciones. En estos reflejos participan receptores, sensores presentes en el corazón y el sistema arterial (aorta y arterias carótidas) que vigilan el grado de distensión del corazón y los vasos por la sangre que los llena. L os impulsos de estos sensores viajan a través de los nervios hasta el sistema nervioso central y desencadenan una serie de ajustes que, en caso de deshidratación, producen una constricción de los vasos sanguíneos y una reducción del flujo sanguíneo a las vísceras (hígado, intestino, riñones) y a la piel. De esa forma, el flujo sanguíneo disponible se redistribuye para favorecer la circulación hacia los músculos que están trabajando y el cerebro (R owell 1986).

Una deshidratación severa puede producir agotamiento por calor y colapso circulatorio; en estas circunstancias, la persona es incapaz de mantener la presión arterial y la consecuencia es que pierde el conocimiento. Los síntomas del agotamiento por calor son cansancio generalizado, habitualmente con cefalea, atontamiento y náuseas. La principal causa del agotamiento por calor es el estrés circulatorio provocado por la pérdida hídrica del sistema vascular. La reducción del volumen sanguíneo activa una serie de reflejos que reducen la circulación a los intestinos y la piel. La disminución del flujo sanguíneo periférico agrava la situación, puesto que se reduce la pérdida de calor en la superficie y aumenta todavía más la temperatura interna. El individuo puede desvanecerse por una caída de la presión arterial y la consiguiente disminución del riego cerebral. Cuando la persona se tumba, aumenta el aporte sanguíneo al corazón y al cerebro y, una vez que se enfría y bebe algo de agua, se recupera de forma casi inmediata.

Si los procesos que causan el agotamiento por calor se "descontrolan", la persona puede sufrir un golpe de calor. La reducción gradual de la circulación periférica hace que la temperatura aumente cada vez más y esto produce una reducción 0 incluso un bloqueo total de la sudoración y un aumento más rápido de la temperatura interna, que causa colapso circulatorio y puede provocar la muerte o lesiones cerebrales irreversibles. En los pacientes que han sufrido un golpe de calor se observan cambios en la sangre (como elevada osmolalidad, bajo $\mathrm{pH}$, hipoxia, adherencia celular de los hematíes, coagulación intravascular) y daños en el sistema nervioso. El reducido aporte sanguíneo al intestino puede causar daños en los tejidos y la liberación de sustancias (endotoxinas) que provocan fiebre (H ales y R ichards 1987). EI golpe de calor es una urgencia médica aguda de posibles consecuencias fatales que se describe con más detalle en la sección sobre "trastornos producidos por el calor".

Además de la pérdida hídrica, la sudoración produce una pérdida de electrolitos, principalmente sodio $\left(\mathrm{Na}^{+}\right)$y cloro $\left(\mathrm{Cl}^{-}\right)$, aunque en menor medida también magnesio $\left(\mathrm{M} \mathrm{g}^{++}\right)$, potasio $\left(\mathrm{K}^{+}\right)$y otros (véase la Tabla 42.1). El sudor contiene menos sal que los compartimientos de líquidos corporales, cuya concentración de sal aumenta con la excreción de sudor. A sí se produce un efecto específico en la circulación, al afectar a la musculatura vascular lisa que controla el grado de dilatación de los vasos. Ahora bien, algunos investigadores han demostrado que interfiere con la capacidad de sudoración, de tal manera que se requiere una mayor temperatura corporal para estimular las glándulas sudoríparas: se reduce la sensibilidad de éstas ( $N$ ielsen 1984). Si el sudor excretado se repone simplemente con agua, puede ocurrir que el contenido de cloruro sódico en el
Tabla 42.1 • Concentración de electrolitos en el plasma sanguíneo y en el sudor.

$\begin{array}{lll}\begin{array}{l}\text { Electrolitos y otras } \\ \text { Sustancias }\end{array} & \begin{array}{l}\text { Concentraciones } \\ \text { plasmáticas }(\mathrm{g} \text { por I) }\end{array} & \begin{array}{l}\text { Concentraciones en } \\ \text { el sudor }(\mathrm{g} \text { por } \mathrm{l})\end{array} \\ \begin{array}{l}\text { Sodio }\left(\mathrm{Na}^{+}\right) \\ \text {Potasio }\left(\mathrm{K}^{+}\right)\end{array} & 0,5 & 0,2-1,5 \\ \text { Calcio }\left(\mathrm{Ca}^{++}\right) & 0,1 & 0,15 \\ \text { Magnesio }\left(\mathrm{Mg}^{++}\right) & 0,02 & \text { pequeñas cantidades } \\ \text { Cloro }\left(\mathrm{Cl}^{-}\right) & 3,5 & \text { pequeñas cantidades } \\ \text { Bicarbonato }\left(\mathrm{HCO}_{3}{ }^{-}\right) & 1,5 & 0,2-1,5 \\ \text { Proteínas } & 70 & \text { pequeñas cantidades } \\ \text { Lípidos, glucosa, iones } & 15-20 & 0 \\ \text { pequeños } & & \text { pequeñas cantidades }\end{array}$

Adaptado de Vellar 1969.

organismo sea menor que en estado normal (hipoosmótico). El resultado es la aparición de calambres por una alteración del funcionamiento de los nervios y los músculos, un trastorno que antes se conocía como "calambres del minero" o "calambres del fogonero" y que puede prevenirse añadiendo sal a la dieta (en los años veinte en el Reino U nido se recomendaba beber cerveza como medida preventiva).

Tanto la menor circulación periférica como la actividad de las glándulas sudoríparas afectan a la regulación térmica y la pérdida de calor de tal manera que la temperatura interna del organismo aumenta más que en un estado de plena hidratación.

En muchas profesiones diferentes, los trabajadores están expuestos a estrés por calor externo; por ejemplo, trabajadores de las plantas siderúrgicas, industrias del vidrio, papeleras, panaderías, industrias mineras. También los deshollinadores y los bomberos están expuestos a calor externo. Las personas que trabajan en espacios confinados como vehículos, buques y aviones pueden sufrir asimismo los efectos del calor. Los trabajadores que utilizan prendas protectoras o que realizan trabajos pesados con prendas impermeables pueden ser víctimas de agotamiento por calor incluso con unas temperaturas ambientales moderadas o frescas. L os efectos nocivos del estrés por calor se manifiestan cuando aumenta la temperatura interna del organismo y se produce una intensa sudoración.

\section{Rehidratación}

Los efectos de la deshidratación por la pérdida de sudor pueden remediarse bebiendo la cantidad suficiente de líquidos para reponer el sudor. La rehidratación suele tener lugar durante la recuperación después del trabajo y el ejercicio. Con todo, cuando se realizan trabajos prolongados en ambientes calurosos, el rendimiento laboral mejora si el trabajador ingiere líquidos al mismo tiempo que realiza la actividad. El consejo habitual es, por tanto, beber cuando se tenga sed.

No obstante, existen algunos problemas importantes. Uno de ellos es que la sensación de sed no es lo suficientemente intensa para compensar la pérdida hídrica que se produce al mismo tiempo; en segundo lugar, el tiempo necesario para reponer un gran déficit hídrico es muy largo, más de 12 horas. Por último, existe un límite en la velocidad a la que el agua puede pasar del estómago (donde se almacena) al intestino, donde tiene lugar la absorción. La velocidad es menor que las tasas de sudoración observadas cuando se realizan esfuerzos en condiciones de calor. 
Se han efectuado numerosos estudios sobre distintas bebidas para reponer el agua, los electrolitos y los depósitos de hidratos de carbono que pierden los atletas cuando realizan esfuerzos prolongados. Los principales hallazgos han sido los siguientes:

- La cantidad de líquido que puede utilizarse (es decir, que puede transportarse del estómago al intestino) está limitada por la "velocidad de vaciado gástrico", cuyo máximo es de unos $1.000 \mathrm{ml} / \mathrm{h}$.

- Si el líquido es "hiperosmótico" (contiene iones/ moléculas en mayor concentración que la sangre), esta velocidad se reduce. Por el contrario, los "líquidos isoosmóticos" (que contienen agua e iones/ moléculas en la misma concentración y osmolalidad que la sangre) pasan a la misma velocidad que el agua pura.

- La adición de pequeñas cantidades de sal y azúcar aumenta la velocidad de absorción de agua en el intestino (M aughan 1991).

Teniendo lo anterior en cuenta, se pueden preparar "líquido de rehidratación" o elegir alguno de los muchos productos que se venden en el mercado. N ormalmente el equilibrio hídrico y electrolítico se restablece al beber durante las comidas. Los trabajadores 0 atletas que pierden grandes cantidades de sudor tienen que esforzarse en beber más de lo que les apetece. El sudor contiene entre 1 y $3 \mathrm{~g}$ de $\mathrm{NaCl}$ por litro, por lo que la pérdida de más de unos $5 \mathrm{I}$ al día puede causar una depleción salina a no ser que se añadan suplementos a la dieta.

A los trabajadores y atletas se les recomienda también que controlen su equilibrio hídrico pesándose con frecuencia - por ejemplo, por las mañanas (a la misma hora y en las mismas condiciones)- y que intenten mantener un peso constante. En cualquier casos, una variación del peso corporal no refleja necesariamente un cierto grado de deshidratación. El agua forma enlaces químicos con el glucógeno, un hidrato de carbono almacenado en los músculos, y se libera cuando el glucógeno se utiliza durante el ejercicio. D ependiendo del contenido de glucógeno en el organismo, pueden producirse cambios de peso de hasta $1 \mathrm{~kg}$. El peso corporal medido todas las mañanas refleja también los cambios producidos por las "variaciones biológicas" en el contenido de agua: por ejemplo, en relación con el ciclo menstrual, la mujer puede retener hasta $102 \mathrm{~kg}$ de agua durante la fase premenstrual ("tensión premenstrual").

\section{Control hídrico y electrolítico}

El volumen de los compartimientos de agua corporal (es decir, los volúmenes de líquidos extracelular e intracelular) y sus concentraciones de electrolitos se mantienen muy constantes gracias a un equilibrio regulado entre la absorción y la pérdida de líquidos y sustancias.

El agua se obtiene con la ingestión de alimentos y líquidos. Los procesos metabólicos, como la combustión de las grasas y los hidratos de carbono contenidos en los alimentos, liberan también una cierta cantidad de agua. La pérdida de agua se produce en los pulmones durante la respiración, cuando el aire inspirado absorbe el agua presente en las superficies húmedas de las vías respiratorias antes de ser exhalado. En ambientes térmicamente neutros y en reposo, se difundan pequeñas cantidades de agua a través de la piel. Ahora bien, con la sudoración la pérdida de agua puede llegar a más de 102 litros por hora durante varias horas. El contenido hídrico del organismo está controlado. El aumento de la pérdida de agua a través de la sudoración se compensa con la bebida y una menor excreción de orina, mientras que el exceso de agua se pierde mediante una mayor producción de orina.

Tal control de la absorción y la excreción de agua se ejerce a través del sistema nervioso autónomo y las hormonas. La sensación de sed aumenta la ingestión de agua y la excreción renal de agua está regulada. También el volumen y la composición de electrolitos de la orina están sujetos a control. LoS sensores que participan en este mecanismo de control se encuentran en el corazón y se activan con la "saturación" del sistema vascular. Cuando el Ilenado del corazón se reduce (por ejemplo, tras la pérdida de sudor), los receptores envían un mensaje a los centros del cerebro responsables de la sed y a las áreas que inducen la liberación de hormona antidiurética (HAD) en la pituitaria posterior que actúa reduciendo el volumen de orina.

Existen también mecanismos fisiológicos que controlan la composición electrolítica de los líquidos corporales a través de procesos que tienen lugar en los riñones. Losalimentos contienen nutrientes, minerales, vitaminas y electrolitos. En el presente contexto, lo más importante es la ingesta de cloruro sódico con la dieta, que varía según los hábitos alimenticios entre 10 y 20-30 g al día. Es una cantidad normalmente mucho mayor de la necesaria, de manera que el exceso se excreta a través de los riñones, un proceso controlado por múltiples mecanismos hormonales (angiotensina, aldosterona, AN F, etc.), a su vez controlados por los estímulos procedentes de los osmorreceptores del cerebro y los riñones en respuesta sobre todo a la osmolalidad del $\mathrm{Na}^{+}$y el $\mathrm{Cl}^{-}$en la sangre y en el líquido renal, respectivamente.

\section{Diferencias individuales y étnicas}

No es sorprendente que se observen diferencias en la reacción al calor de hombres y mujeres, así como de personas jóvenes y mayores, ya que difieren en ciertas características que pueden influir en la transferencia del calor, como la superficie, la relación entre peso y altura, el grosor de las capas aislantes de grasa cutánea y la capacidad física de producir trabajo y calor (capacidad aeróbica $\approx$ tasa máxima de consumo de oxigeno). Los datos disponibles sugieren que la tolerancia al calor se reduce en las personas de edad avanzada, quienes tardan más en sudar que las personas jóvenes y reaccionan con un mayor flujo sanguíneo periférico durante la exposición al calor.

Al comparar los sexos se ha observado que la mujer tolera mejor la humedad que el hombre. En ambientes húmedos, la evaporación del sudor se reduce, de manera que la proporción superficie/ masa ligeramente mayor en la mujer podría actuar en su favor. Con todo, la capacidad aeróbica es un importante factor que debe considerarse al comparar la respuesta de distintas personas expuestas al calor. En condiciones de laboratorio, las respuestas fisiológicas al calor son similares cuando se estudian grupos de personas con la misma capacidad física para el trabajo ("absorción máxima de oxígeno": $\mathrm{VO}_{2 \mathrm{max}}$ ): por ejemplo, hombres jóvenes y de edad avanzada, u hombres frente a mujeres (Pandolf y cols. 1988). En este caso, un cierto tipo de trabajo (pedaleo en una bicicleta con ergómetro) produce la misma carga en el sistema circulatorio (es decir, la misma frecuencia cardíaca y el mismo aumento de la temperatura interna) con independencia de la edad y el sexo.

Las mismas consideraciones son válidas para las comparaciones entre diferentes grupos étnicos. Cuando se tienen en cuenta las diferencias en dimensiones corporales y capacidad aeróbica, no se observan diferencias significativas que puedan atribuirse a la raza. C on todo, en la vida cotidiana en general, las personas de edad avanzada tienen, como promedio, un menor $\mathrm{VO}_{2 \max }$ que las jóvenes, y las mujeres, un menor $\mathrm{VO}_{2 \max }$ que los hombres en su mismo grupo de edad.

Por consiguiente, cuando se realiza una tarea específica con una cierta intensidad de trabajo absoluta (medida, por ejemplo, en vatios), la persona con menor capacidad aeróbica registrará un mayor aumento de la frecuencia cardíaca y la temperatura corporal y su capacidad de soportar un estrés adicional por calor externo será menor que las personas con un mayor $\mathrm{VO}_{2 \max }$. 
Para fines de salud y seguridad en el trabajo, se han desarrollado una serie de índices del estrés por calor, que tienen en cuenta la gran variación individual en la respuesta al calor y al trabajo, así como los ambientes calurosos específicos para los que se construye el índice. Los índices se describen con más detalle más adelante en este capítulo.

Las personas expuestas repetidamente al calor lo tolerarán mejor al cabo de tan solo unos días. Se aclimatan. La tasa de sudoración aumenta y el mayor enfriamiento de la piel reduce la temperatura interna y la frecuencia cardiaca durante el trabajo en las mismas condiciones.

Por consiguiente, la aclimatación artificial de los trabajadores cuando se prevé su exposición a elevadas temperaturas (brigadas contra incendios, personal de rescate, personal militar) tendrá probablemente un efecto beneficioso para reducir el estrés.

En resumen, cuanto más calor produce una persona, más calor tiene que disiparse. En un ambiente caluroso, la evaporación del sudor es el factor limitante de la termolisis. L as diferencias individuales en la capacidad de sudoración son considerables. M ientras que algunas personas no poseen glándulas sudoríparas, en la mayoría de los casos el entrenamiento físico y la exposición repetida al calor produce un aumento de la cantidad de sudor excretado durante una prueba normalizada de estrés por calor. El estrés por calor produce un aumento de la frecuencia cardíaca y la temperatura interna del organismo. La frecuencia cardíaca máxima y/ o una temperatura interna de unos $40 \stackrel{\circ}{\circ}$ establecen el límite fisiológico absoluto de la capacidad física para el trabajo en un ambiente caluroso ( $\mathrm{N}$ ielsen 1994).

\section{T TRAST ORNOS PRODUCIDOS POR EL CALOR}

Tokuo Ogawa

U na elevada temperatura ambiente, una elevada humedad, un esfuerzo extenuante o una disipación insuficiente del calor pueden causar una serie de trastornos provocados por el calor, entre ellos trastornos sistémicos como síncope, edema, calambres, agotamiento y golpe de calor, así como trastornos locales como afecciones cutáneas.

\section{Trastornos sistémicos}

Los calambres por calor, el agotamiento por calor y el golpe de calor tienen importancia clínica. Los mecanismos responsables de estos trastornos sistémicos son una insuficiencia circulatoria, un desequilibrio hídrico y electrolítico y/ o hipertermia (elevada temperatura corporal). El más grave de todos ellos es el golpe de calor, que puede provocar la muerte si no se trata rápida y correctamente.

Sin considerar la población infantil, existen dos poblaciones que presentan un mayor riesgo de sufrir trastornos por calor. $L a$ primera y más grande de ellas es la constituida por las personas de edad avanzada, especialmente cuando carecen de recursos económicos y sufren enfermedades crónicas como diabetes mellitus, obesidad, malnutrición, insuficiencia cardíaca congestiva, alcoholismo crónico y demencia, o necesitan medicamentos que interfieren con la regulación térmica. La segunda población con riesgo de sufrir trastornos por calor está formada por personas sanas que intentan realizar esfuerzos físicos prolongados o se exponen a un estrés excesivo por calor. Los factores que predisponen a las personas jóvenes a sufrir trastornos por calor, además de una disfunción congénita o adquirida de las glándulas sudoríparas, son una mala forma física, la falta de aclimatación, una baja eficiencia laboral y una menor relación entre superficie cutánea y masa corporal.

\section{Síncope por calor}

EI síncope es una pérdida de conocimiento temporal como resultado de la reducción del riego cerebral que suele ir precedido por palidez, visión borrosa, mareo y náuseas. Puede ocurrir en personas expuestas a estrés por calor. EI término colapso por calor se ha utilizado como sinónimo de síncope por calor. Los síntomas se atribuyen a vasodilatación cutánea, acumulación de sangre por la postura corporal con el resultado de un menor retorno venoso al corazón y un gasto cardíaco también reducido. La deshidratación leve que se produce en la mayoría de las personas expuestas al calor aumenta la probabilidad de sufrir un síncope por calor. Las personas con enfermedades cardiovasculares o que no están aclimatadas tienen más riesgo de sufrir un colapso por calor. Las víctimas suelen recuperar el conocimiento rápidamente una vez que se tumban en posición supina.

\section{E dema por calor}

En personas no aclimatadas expuestas a un ambiente caluroso puede aparecer edema leve dependiente, es decir, la hinchazón de manos y pies. Suele afectar a las mujeres y desaparece con la aclimatación. Remite al cabo de unas horas cuando el paciente se tumba en un lugar fresco.

\section{Calambres por calor}

Los calambres por calor pueden aparecer tras una intensa sudoración como consecuencia de un trabajo físico prolongado. A parecen espasmos dolorosos en las extremidades y en los músculos abdominales sometidos a un trabajo intenso y a la fatiga, aunque la temperatura corporal apenas aumenta. Esos calambres están causados por la depleción salina que se produce cuando la pérdida hídrica resultante de una sudoración profusa y prolongada se repone con agua no suplementada con sal y cuando los niveles circulantes de sodio descienden por debajo de un nivel crítico. Los calambres por calor son, en sí mismos, relativamente inocuos. Suelen afectar a personas en buena forma física que son capaces de realizar un esfuerzo físico prolongado y antiguamente se conocían como "calambres del minero" o "calambres del cortador de cañas" porque afectaban con frecuencia a estos trabajadores.

El tratamiento de los calambres por calor consiste en interrumpir la actividad, descansar en un lugar fresco y reponer los líquidos y electrolitos perdidos. La exposición al calor debe evitarse durante al menos 24048 horas.

\section{Agotamiento por calor}

El agotamiento por calor es el trastorno más común provocado por el calor que se observa en la práctica clínica. Se produce como resultado de una deshidratación severa tras perderse una gran cantidad de sudor. Es típico en personas jóvenes por lo demás sanas que realizan un esfuerzo físico prolongado (agotamiento por calor inducido por el esfuerzo), como corredores de maratón, personas que practican deportes al aire libre, reclutas militares y trabajadores de la construcción. La principal característica de este trastorno es una deficiencia circulatoria causada por depleción hídrica y/ o salina. Puede considerarse como un estadio incipiente del golpe de calor que, si no recibe tratamiento, puede progresar a éste último. Tradicionalmente se han distinguido dos tipos de agotamiento por calor: el provocado por depleción hídrica y el provocado por depleción salina, aunque con frecuencia se da una mezcla de ambos tipos.

El agotamiento por calor producido por depleción hídrica aparece como resultado de una intensa y prolongada sudoración y una ingesta insuficiente de agua. Puesto que el sudor contiene 
iones de sodio en una concentración que oscila entre 30 y 100 miliequivalentes por litro, menor que su concentración plasmática, la sudoración profusa causa déficit hídrico (reducción del contenido de agua corporal) e hipernatremia (aumento de la concentración plasmática de sodio). El agotamiento por calor se caracteriza por sed, debilidad, fatiga, atontamiento, ansiedad, oliguria (reducción de la excreción de orina), taquicardia (pulso

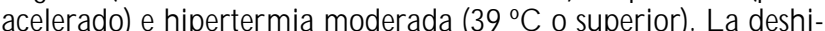
dratación produce también una reducción de la sudoración, un aumento de la temperatura cutánea y un aumento de las concentraciones plasmáticas de proteínas y sodio y del hematocrito (proporción entre el volumen de hematíes y el volumen de sangre).

El tratamiento consiste en trasladar a la víctima a un lugar fresco, permitir que descanse tumbada con las rodillas levantas, humedecer su cuerpo con una toalla o esponja fría y reponer los líquidos perdidos por vía oral 0 , si la ingestión oral es imposible, por infusión intravenosa. La cantidad de agua y sal repuesta debe vigilarse estrechamente, así como la temperatura y el peso corporales. La ingestión de agua no debe regularse según la sed que tenga la víctima, especialmente cuando los líquidos perdidos se reponen con agua del grifo, porque la dilución de la sangre apaga inmediatamente la sensación de sed, retrasando así la recuperación del equilibrio hídrico del organismo. El fenómeno de ingestión insuficiente de agua se llama deshidratación voluntaria. Además, el suministro de agua sin suplemento de sales puede complicar los trastornos por calor, según se describe más adelante. La deshidratación de más del $3 \%$ del peso corporal debe siempre tratarse con reposición de agua y electrolitos.

El agotamiento por calor como consecuencia de depleción salina se produce tras una intensa y prolongada sudoración y una reposición insuficiente de agua y sales. Su aparición se ve favorecida por una aclimatación incompleta, vómitos, diarrea, etc. Es un tipo de agotamiento por calor que suele aparecer unos días después de la depleción hídrica. Es más común en personas sedentarias de edad avanzada expuestas al calor que han bebido una gran cantidad de agua para calmar su sed. L os síntomas más frecuentes son cefalea, atontamiento, debilidad, fatiga, náuseas, vómitos, diarrea, anorexia, espasmos musculares y confusión mental. En los análisis de sangre se observa un menor volumen plasmático, un aumento del hematocrito y de los niveles plasmáticos de proteínas e hipercalcemia (exceso de calcio en sangre). En estos casos, la detección precoz y un tratamiento rápido son fundamentales, consistiendo este último en trasladar al paciente a un lugar fresco, permitir que descanse tumbado y reponer el agua y los electrolitos. Deben vigilarse la osmolaridad o la densidad específica de la orina, así como las concentraciones plasmáticas de urea, sodio y cloro, la temperatura corporal y la ingesta de agua y sales. Si la víctima recibe un tratamiento adecuado, normalmente se empieza a sentir mejor al cabo de unas horas y se recupera sin secuelas. De lo contrario, puede evolucionar en poco tiempo a un golpe de calor.

\section{G olpe de calor}

El golpe de calor es una urgencia médica grave que puede provocar la muerte. Es un cuadro clínico complejo caracterizado por una hipertemia incontrolada que causa lesiones en los tejidos. Semejante elevación de la temperatura corporal se produce inicialmente por una intensa congestión por calor debida a una carga térmica excesiva. La hipertermia resultante provoca una disfunción del sistema nervioso central y, entre otras cosas, un fallo en el mecanismo normal de regulación térmica, acelerando así el aumento de la temperatura corporal. Existen dos tipos principales de golpe de calor: golpe de calor clásico y golpe de calor inducido por el esfuerzo. El primero suele afectar a personas muy jóvenes, personas de edad avanzada, personas obesas o personas con escasa preparación física cuando realizan actividades normales con exposición prolongada a elevadas temperaturas, mientras que el segundo se produce en adultos jóvenes cuando realizan esfuerzos físicos. A demás, existe una modalidad mixta de golpe de calor que combina los rasgos de las dos formas anteriores.

Las personas de edad avanzada, sobre todo las que padecen un trastorno crónico, como enfermedad cardiovascular, diabetes mellitus o alcoholismo, o las que tienen que recibir ciertos medicamentos, especialmente fármacos psicotrópicos, presentan un elevado riesgo de sufrir un golpe de calor clásico. Por ejemplo, durante olas prolongadas de calor se ha observado que la tasa de mortalidad de la población mayor de 60 años es diez veces mayor que la de la población con 60 o menos años. También se ha observado un aumento similar de la mortalidad de la población musulmana mayor de 60 años durante el peregrinaje a la M eca, predominando en este caso el tipo mixto de golpe de calor. Los factores que predisponen a las personas de edad avanzada a un golpe de calor, excluidas las enfermedades crónicas mencionadas antes, son: percepción térmica reducida, inhibición de las respuestas vasomotoras y sudomotoras (reflejo de sudoración) a cambios en la carga térmica y menor capacidad de aclimatación al calor.

L as personas que trabajan o realizan esfuerzos físicos intensos en ambientes calurosos y húmedos corren un alto riesgo de sufrir un trastorno por calor inducido por el esfuerzo, ya sea agotamiento por calor o golpe de calor. Los atletas que se someten a un intenso esfuerzo físico pueden desarrollar hipertermia si producen calor metabólico a una gran velocidad, incluso aunque el ambiente no sea muy caluroso y, como resultado, desarrollan con frecuencia una patología asociada al estrés por calor. Las personas con peor preparación física corren menos riesgo en este sentido, ya que con más conscientes de su propia capacidad y no realizan esfuerzos tan grandes. Claro está que las personas que practican deportes por diversión y que se sienten altamente motivadas y eufóricas, intentan con frecuencia esforzarse más allá de su capacidad física y pueden sucumbir a un trastorno por calor (normalmente agotamiento por calor). U na mala aclimatación, una hidratación inadecuada, un atuendo poco apropiado, el consumo de alcohol y las enfermedades cutáneas que causan anhidrosis (reducción o ausencia de sudoración), principalmente sarpullidos (véase más adelante), agravan los síntomas.

Los niños son más propensos a sufrir agotamiento por calor 0 golpe de calor que los adultos. Producen más calor metabólico por unidad de masa y su capacidad de disipación del calor es menor por su capacidad relativamente pequeña de producir sudor.

\section{Características clínicas del golpe de calor}

EI golpe de calor se define por tres criterios:

1. hipertermia severa con una temperatura interna (corporal profunda) normalmente superior a $42{ }^{\circ} \mathrm{C}$;

2. alteraciones del sistema nervioso central,

3. piel caliente y seca con cese de la sudoración.

El diagnóstico de golpe de calor se establece fácilmente cuando se cumplen estos tres criterios. Desde luego, puede pasarse por alto cuando uno de esos criterios no se cumple, no está claro o se ignora. Por ejemplo, a no ser que la temperatura interna se mida correctamente y sin demora, es posible que no se detecte una hipertermia profunda; 0 en los estadios iniciales de un golpe de calor inducido por el esfuerzo puede persistir la sudoración 0 incluso ésta ser profusa, manteniendo la piel húmeda. 
El golpe de calor suele aparecer de manera brusca y sin síntomas precursores, aunque algunos pacientes con riesgo inminente de golpe de calor pueden presentar síntomas de alteraciones del sistema nervioso central, como cefalea, náuseas, atontamiento, debilidad, somnolencia, confusión, ansiedad, desorientación, apatía, conducta irracional, temblores, espasmos y convulsiones. U na vez que se produce el golpe de calor, las alteraciones del sistema nervioso central están presentes en todos los casos. El nivel de consciencia suele estar deprimido, siendo frecuente el coma profundo. Los temblores aparecen en la mayoría de los casos, especialmente en personas con buena preparación física. Los signos de disfunción del cerebelo son evidentes y pueden persistir como secuela. $L$ as pupilas dilatadas constituyen otra observación frecuente en estos pacientes. En las personas que sobreviven a un golpe de calor pueden quedar secuelas como ataxia cerebelosa (ausencia de coordinación muscular), hemiplejía (parálisis en un lado del cuerpo), afasia e inestabilidad emocional.

También son frecuentes los vómitos y la diarrea. La taquipnea (respiración acelerada) suele presentarse en los primeros estadios y el pulso puede ser débil y rápido. La hipotensión, una de las complicaciones más comunes, se produce como resultado de una marcada deshidratación, una vasodilatación periférica intensa y la depresión transitoria del músculo cardíaco. En algunos casos se observa insuficiencia renal aguda, especialmente cuando el golpe de calor está provocado por un esfuerzo.

En los casos graves se producen hemorragias en todos los órganos parenquimáticos, en la piel (petequia) y en el tracto gastrointestinal. Las manifestaciones hemorrágicas clínicas son melanorragia (heces de color oscuro), hematemesis (vómitos con sangre), hematuria (sangre en la orina), hemoptisis (sangre en los esputos), epistaxis (hemorragia nasal), púrpura (manchas moradas), equimosis (marcas negras y azules) y hemorragia conjuntival. C on frecuencia se produce coagulación intravascular. La diatesis hemorrágica (tendencia a sangrar) suele asociarse a coagulación intravascular diseminada (CID). La CID ocurre principalmente en las personas que sufren un golpe de calor inducido por el esfuerzo y en las que aumenta la actividad fibrinolítica (disolvente de coágulos) del plasma. Por otra parte, la hipertermia de todo el organismo reduce el recuento de plaquetas, prolonga el tiempo de protrombina, disminuye los factores de la coagulación y eleva la concentración de los productos de degradación de la fibrina (PDF). Los pacientes con signos de CID y hemorragia presentan una mayor temperatura interna, una menor presión arterial, un menor $\mathrm{pH}$, una menor $\mathrm{pO}_{2}$, en la sangre arterial y una mayor incidencia de oliguria, anuria y shock, así como una mayor tasa de mortalidad.

El shock es también una complicación frecuente. Se atribuye a una insuficiencia circulatoria periférica que se agrava con la CID, causando la diseminación de coágulos en el sistema microcirculatorio.

\section{Tratamiento del golpe de calor}

El golpe de calor es una urgencia médica que requiere un rápido diagnóstico y un tratamiento agresivo para salvar la vida del paciente. La medición correcta de la temperatura interna del organismo es fundamental: la temperatura rectal o esofágica debe medirse utilizando un termómetro que pueda leer hasta $45 \stackrel{\circ}{ } \mathrm{C}$. La temperatura no debe nunca medirse en la boca o la axila, ya que puede variar significativamente con respecto a la temperatura interna real.

El objetivo del tratamiento es reducir la temperatura corporal disminuyendo la exposición al calor y facilitando la disipación de calor desde la piel. El tratamiento consiste en trasladar al paciente a un lugar seguro, fresco, a la sombra y bien ventilado, despojarle de las prendas innecesarias y airearle. El enfriamiento del rostro y la cabeza puede ayudar a reducir la temperatura del cerebro.

Se ha puesto en duda la eficiencia de algunas técnicas de enfriamiento. Se aduce que la aplicación de compresas frías en los principales vasos sanguíneos del cuello, las ingles y las axilas, la inmersión del cuerpo en agua fría o la utilización de sábanas frías para envolver al paciente pueden desencadenar tiritonas y vasoconstricción periférica, impidiendo así un enfriamiento eficiente. EI tratamiento de elección recomendado tradicionalmente cuando el paciente llegaba al centro médico era su inmersión en un baño de agua fría, seguido por un masaje vigoroso de la piel para reducir al mínimo la vasoconstricción periférica. Es un método de enfriamiento que presenta varias desventajas: plantea dificultades al personal de enfermería por la necesidad de administrar al paciente oxígeno y líquidos y controlar continuamente la presión arterial y el electrocardiograma, así como problemas higiénicos del baño por los vómitos y diarreas que sufren los pacientes comatosos. Un método alternativo consiste en pulverizar un líquido frío sobre el cuerpo del paciente al mismo tiempo que se aplica una corriente de aire para promover la evaporación del líquido en la piel. Es un método de enfriamiento que puede reducir la temperatura corporal entre 0,03 y $0,06 \stackrel{\circ}{\circ} \mathrm{C} / \mathrm{min}$.

En cuanto el paciente llega al centro médico, deben adoptarse medidas para prevenir las convulsiones, temblores y tiritonas. La monitorización cardíaca continua, la determinación de las concentraciones plasmáticas de electrolitos y los análisis de gases sanguíneos venosos son esenciales. Debe iniciarse sin demora la infusión intravenosa de soluciones electrolíticas a una temperatura relativamente baja de unos $10 \stackrel{\circ}{ } \mathrm{C}$, junto con oxigenoterapia controlada. La entubación de la tráquea para proteger las vías aéreas, la inserción de un catéter cardíaco para estimar la presión venosa central, la colocación de un tubo gástrico y la inserción de un catéter urinario son otras de las medidas recomendadas.

\section{Prevención del golpe de calor}

Para prevenir un golpe de calor, deben tenerse en cuenta numerosos factores humanos, como la aclimatación, la edad, la anatomía, el estado de salud en general, la ingesta de agua y sales, la vestimenta, las peculiaridades de los cultos religiosos y la ignorancia o la propensión a ignorar las normas que tienen como finalidad promover la salud pública.

Antes de realizar un esfuerzo físico en un ambiente caluroso, los trabajadores, los atletas o los peregrinos deben ser informados de la carga de trabajo y el nivel de estrés por calor que tendrán que soportar, así como los riesgos de un golpe de calor. Antes de arriesgarse a realizar una actividad física intensa y/ 0 a exponerse a altas temperaturas, se recomienda un período de aclimatación. EI nivel de actividad debe corresponderse con la temperatura ambiente y el esfuerzo físico debe evitarse 0 al menos reducirse al mínimo durante las horas más calurosas del día. Cuando se realiza un esfuerzo físico, es esencial tener libre acceso a agua. Puesto que con el sudor se pierden electrolitos y la posibilidad de ingesta voluntaria de agua puede estar limitada, retrasando así la reposición de líquidos para evitar la deshidratación térmica, tras una intensa sudoración deben también reponerse los electrolitos. La utilización de un ropa adecuada es otra medida importante. Las prendas fabricadas con tejidos que absorben el agua y son permeables al aire y al vapor de agua facilitan la disipación del calor. 


\section{Alteraciones cutáneas}

La erupción por calor o miliaria es la alteración cutánea más común asociada a la exposición al calor. Se produce cuando la obstrucción de los conductos sudoríparos impide que el sudor alcance la superficie cutánea y se evapore. EI síndrome de retención del sudor aparece cuando la anhidrosis (imposibilidad de liberar sudor) afecta a toda la superficie corporal y predispone al paciente a un golpe de calor.

La miliaria suele estar provocada por un esfuerzo físico en un ambiente caluroso y húmedo, enfermedades febriles, aplicación de compresas húmedas, vendajes, escayolas o cintas adhesivas, o la utilización de prendas poco permeables. La miliaria se clasifica en tres tipos según el grado de retención de sudor: miliaria cristalina, miliaria rubra y miliaria profunda.

La miliaria cristalina está causada por una retención del sudor en o justo por debajo del estrato córneo de la piel, en donde se forman ampollas pequeñas, transparentes, sin inflamación. Suele aparecer en "grupos" tras sufrir quemaduras solares severas 0 durante una enfermedad febril. Por lo demás, este tipo de miliaria es asintomática y remite espontáneamente en unos días, cuando las ampollas se rompen y forman escamas.

La miliaria rubra aparece cuando la exposición intensa al calor produce una sudoración prolongada y profusa. Es el tipo más frecuente de miliaria, caracterizado por la acumulación de sudor en la epidermis. Se forman pápulas, vesículas o pústulas rojas, acompañadas por sensación de quemazón y picor (sarpullido). El conducto sudoríparo está obstruido en su parte terminal, lo que se atribuye a la acción de bacterias aeróbicas residentes, principalmente cocos, cuya población aumenta considerablemente en el estrato córneo cuando éste se hidrata con el sudor. Las bacterias secretan una toxina que daña las células epiteliales córneas del conducto sudoríparo y provoca una reacción inflamatoria que precipita la obstrucción de la luz del conducto. La infiltración de leucocitos provoca la completa obstrucción del conducto e imposibilita el flujo del sudor durante varias semanas.

En la miliaria profunda, el sudor queda retenido en la dermis y produce unas pápulas planas e inflamadas, nódulos y abcesos, con menos sensación de picor que en la miliaria rubra. Esun tipo de miliaria que se encuentra normalmente sólo en las zonas tropicales. Puede evolucionar en una secuencia progresiva a partir de una miliaria rubra tras episodios repetidos de sudoración intensa, cuando la reacción inflamatoria se extiende hacia abajo desde las capas superiores de la piel.

Astenia anhidrótica tropical. Es un término que se puso de moda durante la segunda Guerra M undial cuando las tropas desplegadas en zonas tropicales sufrieron erupciones por calor e intolerancia al calor. Es una modalidad del síndrome de retención del sudor que se encuentra en ambientes tropicales calurosos y húmedos. Se caracteriza por anhidrosis y erupciones tipo miliaria, acompañadas de síntomas de congestión por calor, como palpitaciones, pulso acelerado, hipertermia, cefalea y debilidad. Produce rápida y gradualmente intolerancia a la actividad física en ambientes calurosos. Suele ir precedida de una miliaria rubra generalizada.

Tratamiento. El tratamiento inicial y esencial de la miliaria y el síndrome de retención del sudor requiere el traslado de la persona afectada a un ambiente fresco. $L$ as duchas frescas, el secado suave de la piel y la aplicación de una loción de calamina puede atenuar las molestias del paciente. La aplicación de bacteriostatos químicos es una medida eficaz para prevenir la expansión de la microflora y preferible al uso de antibióticos, ya que éstos pueden hacer que los microorganismos desarrollen resistencia.

La obstrucción de los conductos sudoríparos suele remitir al cabo de unas 3 semanas, como resultado de la renovación de la epidermis.

\section{Prevencion del estres POR CALOR}

Sarah A. Nunneley

Aunque el ser humano tiene una capacidad considerable para compensar el estrés por calor que ocurre en condiciones naturales, muchos entornos profesionales y/ 0 actividades físicas exponen a los trabajadores a unas temperaturas demasiado elevadas que suponen un riesgo para su salud y productividad. En este artículo se describen las técnicas que pueden utilizarse para reducir la incidencia de los trastornos provocados por el calor y su gravedad. Las intervenciones se dividen en cinco categorías: aumentar la tolerancia al calor de las personas expuestas, aseguorar una reposición puntual de los líquidos y electrolitos perdidos, modificar las prácticas de trabajo para reducir la carga de calor por esfuerzo, controlar las condiciones climáticas y utilizar prendas protectoras.

Cuando se evalúa el nivel de exposición al calor y se preparan estrategias preventivas, no deben ignorarse los factores ajenos al lugar de trabajo que pueden influir en la tolerancia térmica. Por ejemplo, la carga fisiológica total y la susceptibilidad potencial a los trastornos por calor será mucho mayor si el estrés por calor continúa fuera de las horas de trabajo, ya sea por realizar un segundo trabajo, realizar actividades recreativas extenuantes 0 residir en barrios especialmente calurosos. Además, el estado nutricional y el grado de hidratación reflejan pautas de alimentación o ingestión de líquidos que también pueden variar según la estación o las prácticas religiosas.

\section{Aumento de la tolerancia al calor}

Los candidatos a puestos de trabajo expuestos al calor deben encontrarse en un buen estado de salud general y poseer unos atributos físicos adecuados para el trabajo que deben realizar. La obesidad 0 las enfermedades cardiovasculares contribuyen al riesgo y las personas con antecedentes de patologías previas inexplicadas o recurrentes asociadas al calor no deben ser asignadas a tareas que conlleven un gran estrés térmico. A continuación se comentan algunas de las características físicas y fisiológicas que pueden influir en la tolerancia al calor y que se dividen en dos grandes categorías: características intrínsecas fuera del control del individuo, como tamaño corporal, sexo, etnicidad y edad; y características adquiridas, que al menos en parte pueden ser controladas por la persona y que son aptitud física, aclimatación al calor, obesidad, trastornos de la salud y estrés autoinducido.

Los trabajadores deben ser informados de la naturaleza del estrés por calor y sus efectos nocivos, así como de las medidas protectoras ofrecidas en el lugar de trabajo. Deben saber que la tolerancia al calor depende en gran medida de la ingesta de suficiente cantidad de agua y de una dieta equilibrada. Además, los trabajadores deben conocer los síntomas de los trastornos producidos por el calor, entre ellos mareo, palidez, dificultades respiratorias, palpitaciones y sed extrema. D eben aprender también las técnicas fundamentales de primeros auxilios y saber cuándo deben solicitar ayuda si reconocen los síntomas en ellos mismos o en sus compañeros.

Las empresas deben implantar un sistema para notificar los incidentes relacionados con el calor en el lugar de trabajo. La aparición de trastornos por calor en más de una persona (o repetidamente en una misma persona) es con frecuencia una señal de advertencia de un problema grave inminente e indica la necesidad de realizar una evaluación inmediata del lugar de trabajo y revisar la idoneidad de las medidas preventivas. 
Características del ser humano que influyen en la adaptación Dimensiones corporales. Los niños y los adultos de muy pequeño tamaño presentan dos desventajas potenciales para el trabajo en ambientes calurosos. En primer lugar, el trabajo impuesto externamente representa un carga relativa mayor para un organismo con poca masa muscular, ya que provoca un mayor aumento de la temperatura interna del organismo y la aparición más rápida de fatiga. Además, la mayor proporción entre superficie y masa corporal de las personas de talla pequeña puede constituir una desventaja en condiciones de extremo calor. En conjunto, estos factores explican por qué los hombres que pesan menos de $50 \mathrm{~kg}$ corren un mayor riesgo de sufrir un trastorno por calor cuando realizan actividades mineras a grandes profundidades.

Sexo. Los primeros estudios de laboratorio realizados en mujeres parecieron demostrar que éstas eran relativamente intolerantes al calor en comparación con los hombres. Por lo demás, ahora sabemos que casi todas las diferencias pueden explicarse por las dimensiones corporales y los niveles adquiridos de capacidad física y aclimatación al calor. No obstante, existen algunas ligeras diferencias entre los dos sexos en cuanto a los mecanismos de disipación del calor: las tasas máximas de sudoración son más elevadas en el hombre y pueden aumentar su tolerancia en ambientes extremadamente calurosos y secos, mientras que las mujeres están mejor capacitadas para suprimir una sudoración excesiva y, por tanto, para conservar el agua corporal y el calor, en ambientes calurosos y húmedos. Aunque el ciclo menstrual se asocia a un cambio en la temperatura basal del organismo y altera ligeramente las respuestas termorreguladoras de la mujer, estos ajustes fisiológicos son demasiado pequeños para influir en la tolerancia al calor y en la eficiencia de la regulación térmica en situaciones laborales reales.

Cuando se tiene en cuenta el físico y la preparación física de la persona, hombres y mujeres son esencialmente similares en sus respuestas al estrés por calor y en su capacidad de aclimatación al trabajo en ambientes calurosos. Por este motivo, la selección de trabajadores para puestos de trabajo en ambientes calurosos debe basarse en la salud y la forma física de cada persona, no en el sexo. Las personas de talla muy pequeña y sedentarias, sea cual sea su sexo, tolerarán peor la exposición al calor en el trabajo.

El efecto del embarazo en la tolerancia al calor de la mujer no está claro, pero la alteración de los niveles hormonales y las mayores demandas circulatorias que el feto impone a la madre pueden aumentar su susceptibilidad al desmayo. La hipertermia maternal severa (sobrecalentamiento) causada por una enfermedad parece aumentar la incidencia de malformaciones fetales, pero no existen pruebas de un efecto similar causado por estrés térmico en el trabajo.

E tnicidad. Aunque los distintos grupos étnicos proceden de climas diferentes, existen pocas pruebas de diferencias intrínsecas o genéticas en la respuesta al estrés por calor. Todos los seres humanos parecen funcionar como animales tropicales; su capacidad de vivir y trabajar en un rango de condiciones térmicas refleja su adaptación mediante conductas complejas y el desarrollo de la tecnología. L as diferencias étnicas en las respuestas al estrés térmico están probablemente más relacionadas con las dimensiones corporales y el estado nutricional que con los rasgos intrínsecos de cada raza.

$\mathrm{E}$ dad. L as poblaciones industriales muestran generalmente un declive gradual en la tolerancia al calor a partir de los 50 años de edad. Existen algunas evidencias de una reducción con la edad de la vasodilatación periférica (ampliación de la cavidad de los vasos sanguíneos de la piel) y la tasa máxima de sudoración, pero estos cambios pueden atribuirse principalmente a una menor actividad física y a una mayor acumulación de grasa corporal. La edad no parece reducir la tolerancia al calor ni la capacidad de aclimatación si la persona mantiene un alto nivel de acondicionamiento aeróbico. Con todo, el envejecimiento de la población se asocia a una mayor incidencia de enfermedades cardiovasculares y otras patologías que pueden reducir la tolerancia individual al calor.

Capacidad física. La capacidad aeróbica máxima $\left(\mathrm{VO}_{2 \max }\right)$ es probablemente el principal determinante de la capacidad de una persona para realizar un trabajo físico prolongado en condiciones de calor. Como se comentaba antes, las diferencias observadas en un principio entre distintos grupos en cuanto a la tolerancia al calor y que se atribuyeron al sexo, la raza o la edad, se achacan ahora a diferencias en la capacidad aeróbica y la aclimatación al calor.

Para conseguir y mantener una buena capacidad física para el trabajo, el sistema de transporte de oxígeno tiene que desafiarse repetidamente mediante un esfuerzo intenso mantenido durante al menos 30 o 40 minutos, 3 o 4 días a la semana. En algunos casos, la actividad laboral proporciona la preparación física necesaria, pero la mayoría de los puestos de trabajo en la industria son menos extenuantes y deben complementarse con un programa de ejercicio regular para adquirir una forma física óptima.

La pérdida de capacidad aeróbica (pérdida de forma física) es relativamente lenta, de manera que la inactividad durante los fines de semanas o durante unas vacaciones de 102 semanas produce sólo cambios mínimos. Por el contrario, cuando la persona se ve obligada a cambiar su forma de vida durante semanas o meses por una lesión, una enfermedad crónica u otros factores de estrés, se produce una marcada reducción de la capacidad aeróbica en el plazo de semanas o meses.

Aclimatación al calor. La aclimatación al trabajo en ambientes calurosos puede aumentar considerablemente la tolerancia del ser humano a este factor de estrés, de manera que una tarea que en un principio la persona no aclimatada es incapaz de realizar, se convierte en un trabajo más fácil al cabo de un período de ajuste gradual. Las personas en muy buena forma física suelen aclimatarse al calor y ser capaces de completar el proceso en menos tiempo y con menos estrés que las personas sedentarias. La estación afecta también a la duración de este proceso; los trabajadores contratados en verano pueden estar ya parcialmente aclimatados al calor, mientras que los contratados en invierno necesitarán un período más largo de ajuste.

En la mayoría de las situaciones, la aclimatación puede conseguirse mediante la incorporación gradual del trabajador a la tarea expuesta al calor. Por ejemplo, el trabajador nuevo puede ser asignado al trabajo sólo por las mañanas y durante períodos de tiempos cada vez mayores durante los primeros días. Es un tipo de aclimatación en el puesto que debe realizarse bajo la estrecha supervisión de personal experimentado; el nuevo trabajador debe estar autorizado en todo momento a retirarse a ambientes más frescos en cuanto experimente síntomas de intolerancia. Las condiciones extremas pueden exigir un protocolo formal de exposición progresiva al calor, como el utilizado para los trabajadores de las minas de oro en Sudáfrica.

El mantenimiento de la plena aclimatación al calor en el trabajo exige la exposición al calor mientras se trabaja entre tres y cuatro veces a la semana; una menor frecuencia o una exposición pasiva al calor tendrá un efecto mucho más débil y puede reducir gradualmente la tolerancia al calor. En todo caso, el descanso laboral durante los fines de semana no parece tener un efecto apreciable en la aclimatación. La interrupción de la exposición durante 2 o 3 semanas hace que se pierda parte de la aclimatación, aunque algo permanecerá en las personas que habitan en zonas cálidas y/ o que realizan ejercicio aeróbico regular.

0 besidad. U $n$ alto contenido de grasa corporal tiene escaso efecto en la regulación térmica, ya que para la disipación de calor en la piel participan los capilares y la glándulas sudoríparas que se encuentran más cerca de la superficie de la piel que de la 
capa de grasa subcutánea. D esde luego, las personas obesas están en desventaja por su exceso de peso corporal, ya que todos los movimientos les exigen un mayor esfuerzo muscular y, por consiguiente, generan más calor que en las personas delgadas. Además, la obesidad suele reflejar un estilo de vida sedentario que reduce la capacidad aeróbica y dificulta la aclimatación al calor.

Trastornos de la salud y otros factores de estrés. La tolerancia al calor de un trabajador en un día cualquiera puede verse reducida por una serie de trastornos de la salud. Como ejemplos pueden citarse las enfermedades febriles (temperatura corporal mayor de la normal), vacunación reciente o gastroenteritis asociada a una alteración del equilibrio hídrico o electrolítico. Las afecciones cutáneas, como quemaduras solares y eritemas, pueden reducir la capacidad de sudoración. Además, el riesgo de sufrir un trastorno por calor aumenta en ocasiones con la prescripción de algunos medicamentos, entre ellos simpatomiméticos, anticolinérgicos, diuréticos, fenotiazinas, antidepresivos cíclicos e inhibidores de la monoaminooxidasa.

El consumo de alcohol es un problema frecuente y grave entre los trabajadores expuestos al calor. EI alcohol no sólo reduce la ingesta de alimentos y agua, sino que también actúa como un diurético (aumenta la cantidad de orina excretada) y altera la capacidad de razonamiento. Los efectos nocivos del alcohol persisten muchas horas después del momento de su consumo. L os alcohólicos que sufren un golpe de calor tienen una tasa de mortalidad mucho mayor que los no alcohólicos.

\section{Reposición oral de agua y electrolitos}

H idratación. La evaporación del sudor es la principal vía de disipación del calor corporal y se convierte en el único mecanismo posible de enfriamiento cuando la temperatura ambiente es mayor que la corporal. Los requisitos de agua no pueden reducirse con el entrenamiento físico, sino tan sólo reduciendo la exposición al calor del trabajador. La pérdida hídrica y la rehidratación en el ser humano han sido objeto de numerosos estudios en los últimos años y ahora se dispone de un mayor volumen de información.

U na persona de $70 \mathrm{~kg}$ puede tener una tasa de sudoración de entre 1,5 y $2,0 \mathrm{l} / \mathrm{h}$ indefinidamente, y un trabajador puede perder varios litros o hasta el $10 \%$ de su peso corporal a lo largo de una jornada de trabajo en un ambiente extremadamente caluroso. La pérdida será incapacitante a no ser que al menos parte del agua se reponga durante el turno de trabajo. Con todo, puesto que la absorción de agua en el intestino tiene un tope de unos $1,5 \mathrm{l} / \mathrm{h}$ durante el trabajo, unas tasas superiores de sudoración producirán una deshidratación progresiva a lo largo del día.

La ingestión de líquidos para saciar la sed no es suficiente para mantener a una persona bien hidratada. La mayoría de las personas no sienten la necesidad de beber hasta que han perdido entre 1 y 2 I de agua corporal, y si están muy motivadas para realizar un trabajo pesado, pueden sufrir pérdidas de hasta 3 y $4 \mathrm{I}$ antes de que una sed imperiosa les obligue a parar y beber. Paradójicamente, la deshidratación reduce la capacidad de absorción de agua en el intestino. Por consiguiente, los trabajadores expuestos al calor deben ser educados sobre la importancia de beber agua suficiente durante el trabajo y proseguir una rehidratación generosa al término de la jornada. Deben conocer también la importancia de la "prehidratación" (consumo de una gran cantidad de agua inmediatamente antes de la exposición a un gran estrés por calor) ya que el calor y el esfuerzo impiden que el organismo elimine el exceso de agua por la orina.

L as empresas deben facilitar el acceso a agua u otras bebidas adecuadas para fomentar la rehidratación. Cualquier obstáculo físico o práctico a la bebida fomentará una deshidratación "voluntaria" y aumentará el riesgo de sufrir un trastorno por calor. Las siguientes recomendaciones deben ser un componente esencial de cualquier programa para el mantenimiento de la hidratación:

- Todos los trabajadores deben tener libre acceso a agua potable fresca o recibir agua una vez cada hora, o con más frecuencia si las condiciones imponen un estrés mayor.

- Se proporcionará a los trabajadores vasos limpios, ya que es casi imposible que una persona se rehidrate bebiendo directamente de un grifo de agua.

- Los recipientes de agua deben mantenerse a la sombra o en un lugar fresco a 15 o 20 ㅇ (no se recomiendan las bebidas muy frías ya que tienden a inhibir la ingesta).

El agua puede mezclarse con aromatizantes para mejorar su aceptación. A hora bien, no se recomiendan las bebidas con fama de "calmar" la sed, porque inhiben la ingesta antes de que se produzca una rehidratación completa. Por este motivo, es mejor ofrecer agua o bebidas aromatizadas diluidas y evitar las bebidas carbónicas, con cafeína o con altas concentraciones de azúcar 0 sal.

Nutrición. Aunque el sudor es hipotónico (menor contenido de sal) con respecto al suero sanguíneo, una sudoración profusa produce una pérdida continua de cloruro sódico y pequeñas cantidades de potasio que deben reponerse todos los días. A demás, el trabajo en ambientes calurosos acelera el metabolismo de oligoelementos como el magnesio y el zinc. Todos estos elementos esenciales se obtienen normalmente a través de los alimentos, de ahí la importancia de insistir a los trabajadores en la necesidad de una dieta equilibrada y evitar el consumo excesivo de dulces y tentempiés, que carecen de componentes nutritivos importantes. Algunas dietas de los países industrializados contienen grandes cantidades de cloruro sódico y la probabilidad de que los trabajadores desarrollen déficits salinos es muy pequeña; pero otras dietas más tradicionales no contienen una cantidad suficiente de sal. En algunas condiciones, es posible que la empresa tenga que proporcionar alimentos salados 0 algunos suplementos dietéticos durante el turno de trabajo.

En los países industrializados ha aumentado la venta de "bebidas para deportistas" o "calmantes de la sed" que contienen cloruro sódico, potasio e hidratos de carbono. EI componente esencial de cualquier bebida es el agua, pero las bebidas suplementadas con electrolitos pueden ser útiles para las personas que ya han sufrido una importante deshidratación (pérdida hídrica) combinada con depleción electrolítica (pérdida de sal). Suelen tener estas bebidas un elevado contenido de sal y deben mezclarse con volúmenes iguales o mayores de agua antes de su consumo. También puede prepararse una mezcla mucho más económica para la rehidratación oral según la siguiente receta: a un litro de agua potable se le añade $40 \mathrm{~g}$ de azúcar (sacarosa) y $6 \mathrm{~g}$ de sal (cloruro sódico). L os trabajadores no deben recibir comprimidos de sal, ya que podrían abusar de ellos y una sobredosis les causaría problemas gastrointestinales, aumento de la producción de orina y mayor riesgo de sufrir un trastorno por calor.

\section{Modificación de las prácticas de trabajo}

El objetivo común de la modificación de las prácticas de trabajo es reducir la exposición ponderada en el tiempo al estrés por calor hasta unos límites aceptables. Para ello, debe reducirse la carga de trabajo físico impuesta al trabajador o programar unos descansos adecuados para que pueda recuperarse térmicamente. En la práctica, la producción máxima de calor metabólico ponderada en el tiempo se limita a $350 \mathrm{~W}$ (5 kcal/ $\mathrm{min})$, ya que un trabajo más duro produce cansancio físico y exige largos períodos de descanso. 
Los niveles de esfuerzo individual pueden reducirse limitando el trabajo externo, como la elevación de pesos, y reduciendo la tensión muscular motora y estática, como la asociada a una postura forzada. Son objetivos que pueden alcanzarse optimizando el diseño de las tareas de acuerdo con los principios ergonómicos, proporcionando ayudas mecánicas o dividiendo el esfuerzo físico entre un mayor número de trabajadores.

La forma más sencilla de modificar las prácticas de trabajo es permitir que cada persona trabaje a su propio ritmo. L os trabajadores que realizan una tarea con la que están familiarizados en un clima normal se regularán a sí mismos para trabajar a un ritmo que produzca una temperatura rectal de unos $38^{\circ} \mathrm{C}$. El estrés térmico hace que voluntariamente reduzcan el ritmo de trabajo o descansen cada cierto tiempo. Tal capacidad de adaptación voluntaria del ritmo de trabajo depende probablemente de la consciencia de fatiga y estrés cardiovascular. Los seres humanos no pueden detectar conscientemente las elevaciones en la temperatura corporal interna; por ello se basan en la temperatura y la humedad de la piel para evaluar el malestar térmico.

O tra alternativa para modificar las prácticas de trabajo consiste en imponer unos ciclos obligatorios de trabajo y descanso. La empresa especifica la duración de los períodos de trabajo, la duración de los períodos de descanso y el número de veces que este ciclo tiene que repetirse. La recuperación térmica requiere mucho más tiempo que el necesario para reducir la velocidad respiratoria y la frecuencia cardíaca aumentadas por el trabajo. La reducción de la temperatura interna a los mismos niveles que en reposo exige entre 30 y 40 minutos de descanso en un ambiente fresco y seco, o más tiempo si la persona debe descansar en un lugar caluroso o con las prendas protectoras puestas. Si la empresa necesita mantener un nivel constante de producción, tendrá que asignar varios equipos de trabajadores para que trabajen por turnos y puedan recuperarse, exigiendo dicha recuperación un descanso o la realización de tareas sedentarias en un lugar fresco.

\section{Control climático}

Si el coste no fuera un factor limitante, todos los problemas de estrés por calor se solucionarían mediante la aplicación de las técnicas de ingeniería para convertir los ambientes de trabajo hostiles en agradables. Existen multitud de técnicas que pueden utilizarse dependiendo de las condiciones específicas del lugar de trabajo y los recursos disponibles. Tradicionalmente, las industrias expuestas al calor pueden dividirse en dos categorías: procesos con calor seco y procesos con calor húmedo. Los procesos con calor seco, como la fundición de metales y la fabricación de vidrio, que exponen a los trabajadores a un aire muy caliente combinado con una intensa carga de calor radiante, pero que añaden poca humedad al ambiente. Por el contrario, las industrias expuestas a calor y humedad, como las fábricas textiles, las papeleras y la minería, exigen la exposición a un calor menos extremo, pero originan una elevada humedad ambiente como resultado de los procesos húmedos y el escape de vapor.

Las técnicas de control ambiental más económicas intentan reducir la transferencia de calor de la fuente al medio ambiente. El aire caliente puede extraerse al exterior de la zona de trabajo y sustituirse por aire fresco. Las superficies calientes pueden cubrirse con material aislante 0 revestimientos reflectantes que reduzcan la emisión de calor, al tiempo que conserven el calor necesario para el proceso industrial. Una segunda línea de defensa es la ventilación a gran escala del área de trabajo para crear un intenso influjo de aire exterior. La alternativa más costosa es el acondicionamiento del aire para enfriar y secar la atmósfera del lugar de trabajo. Aunque la reducción de la temperatura ambiente no afecta a la transmisión de calor radiante, ayuda a reducir la temperatura de las paredes y otras superficies que pueden actuar como fuentes secundarias de calor convectivo y radiante.

Cuando el control ambiental general es imposible o poco económico, es posible que puedan mejorarse las condiciones térmicas en las áreas de trabajo locales. Pueden construirse cabinas con aire acondicionado en el interior de un espacio de trabajo más grande, o dirigir un flujo de aire fresco a un puesto de trabajo específico ("refrigeración local" o "ducha de aire"). Pueden interponerse pantallas reflectantes locales 0 incluso portátiles entre el trabajador y la fuente de calor radiante. Las técnicas de ingeniería moderna permiten controlar con sistemas remotos los procesos en caliente, de tal forma que los trabajadores no tengan que verse expuestos todos los días a unos ambientes calurosos altamente estresantes.

Cuando el lugar de trabajo se ventila con aire exterior 0 cuando la capacidad de acondicionamiento del aire es limitada, las condiciones térmicas reflejarán los cambios climáticos. Los aumentos bruscos de la temperatura y la humedad exteriores pueden aumentar el estrés por calor a niveles que superen la tolerancia al calor de los trabajadores. Por ejemplo, una ola de calor en primavera puede precipitar una epidemia de trastornos por calor entre los trabajadores que todavía no están tan aclimatados al calor como lo estarían en verano. En estos casos, las empresas deben instalar un sistema que permita predecir las variaciones en el estrés térmico como consecuencia de los cambios climáticos, de manera que puedan adoptarse precauciones a tiempo.

\section{Prendas protectoras}

Algunos trabajos en condiciones térmicas extremas exigen la protección térmica de los trabajadores con prendas especializadas. La protección pasiva se consigue con prendas aislantes y reflectoras; el aislamiento por sí sólo protege a la piel de las variaciones térmicas. Asimismo, pueden utilizarse delantales reflectores para proteger al personal que trabaja delante de una fuente radiante. Las brigadas contra incendios que tienen que enfrentarse a llamas con una temperatura extremadamente elevada utilizan trajes llamados "bunkers", que combinan un gran aislamiento contra el aire caliente y una superficie aluminizada que refleja el calor radiante.

0 tra forma de protección pasiva es el traje de hielo, en cuyos bolsillos se introduce aguanieve o hielo (o hielo seco) y que se pone por encima de la ropa interior para evitar un enfriamiento molesto de la piel. El cambio de fase del hielo fundido absorbe parte de la carga de calor metabólico y ambiental de la superficie cubierta, pero el hielo debe sustituirse cada cierto tiempo; cuanto mayor sea la exposición al calor, mayor será la frecuencia con que tenga que cambiarse el hielo. Son trajes que resultan útiles para el trabajo en minas profundas, salas de calderas de los barcos y otros ambientes muy calurososy húmedos con acceso a un congelador.

La protección térmica activa se consigue mediante trajes refrigerados con aire o líquido que cubren todo el cuerpo o una parte del mismo, normalmente el torso y en ocasiones la cabeza.

R efrigeración con aire Los sistemas más sencillos se ventilan con el aire del ambiente circundante o con aire comprimido enfriado por expansión o durante su paso por un tubo vorticial. Tal refrigeración precisa unos grandes volúmenes de aire; la velocidad mínima de ventilación para un traje sellado es de unos $450 \mathrm{l} / \mathrm{min}$. El enfriamiento del aire puede teóricamente producirse por convección (cambio de temperatura) o evaporación del sudor (cambio de fase). Con todo, la eficacia de la convección se ve limitada por el escaso calor específico del aire y la dificultad de suministrarlo a bajas temperaturas en un ambiente caluroso. La mayoría de los trajes refrigerados con aire actúan, por consiguiente, por enfriamiento evaporativo. El trabajador experimenta un estrés térmico moderado y deshidratación, pero es capaz de regular su temperatura mediante el control natural del 
nivel de sudoración. El aire refrigerado aumenta también la sensación de bienestar por su tendencia a secar la ropa interior. Entre sus desventajas figuran: a) la necesidad de conectar a la persona a la fuente de aire, b) su excesivo volumen, y c) la dificultad de que el aire llegue a las extremidades.

R efrigeración con líquidos. Se basa en la circulación de una mezcla de agua y anticongelante a través de una red de canales 0 pequeños tubos, para luego devolver el líquido calentado a un disipador térmico, en dónde se elimina el calor añadido durante su paso por el cuerpo. Las velocidades de circulación del líquido suelen ser del orden de $1 \mathrm{l} / \mathrm{min}$. El disipador térmico libera energía térmica al ambiente por evaporación, fusión, refrigeración 0 proceso termoeléctricos. Los trajes refrigerados con líquidos ofrecen un potencial de refrigeración mucho mayor que los sistemas de aire. Si el traje cubre todo el cuerpo y está conectado a un disipador térmico adecuado, puede eliminar todo el calor metabólico y mantener el equilibrio térmico corporal sin necesidad de sudar; este tipo de sistema es el utilizado por los astronautas que trabajan en el exterior de sus naves. Por lo demás, un mecanismo de refrigeración tan potente como éste exige algún tipo de sistema de control de la temperatura, que suele consistir en el ajuste manual de una válvula que cierra la entrada de parte del líquido circulante una vez que ha pasado por el disipador térmico. Los sistemas de refrigeración con líquidos pueden diseñarse para colgarse a la espalda y proporcionar refrigeración continua durante el trabajo.

Cualquier dispositivo de refrigeración que añada peso y volumen al cuerpo humano puede, lógicamente, interferir con el trabajo. Por ejemplo, el peso de un traje de hielo aumenta considerablemente el coste metabólico de los movimientos y es, por tanto, más útil para trabajos físicos ligeros, como sería el caso de los trabajadores con labores exclusivas de vigilancia en un compartimiento caluroso. Los sistemas que exigen conectar al trabajador a un disipador térmico pueden ser imposibles de utilizar en muchos tipos de trabajo. L a refrigeración intermitente es útil cuando los trabajadores tienen que utilizar prendas protectoras pesadas (como los trajes protectores que se utilizan en la industria química) y no pueden transportar un disipador térmico ni conectarse al mismo mientras trabajan. La retirada del traje durante los períodos de descanso supone una pérdida de tiempo y conlleva el riesgo de exposición tóxica; en estas circunstancias, es más sencillo que los trabajadores utilicen un traje aclimatado que sólo se conecta al disipador térmico durante los períodos de descansos, permitiendo la recuperación térmica en unas condiciones de lo contrario insoportables.

\section{- FundaMENTOS FISICOS DEL TRABAJO EN CONDICIONES DE CALOR}

\section{Jacques M alchaire}

\section{Intercambios térmicos}

El cuerpo humano intercambia calor con su entorno por distintas vías: conducción a través de la superficies en contacto con él, convección y evaporación con el aire del ambiente y radiación con las superficies vecinas.

\section{Conducción}

La conducción es la transmisión de calor entre dos sólidos que están en contacto. Los intercambios se producen entre la piel y la ropa, el calzado, los puntos de presión (asiento, asas), herramientas, etc. En la práctica, para el cálculo matemático del equilibrio térmico, el flujo de calor por conducción se estima indirectamente como una cantidad igual al flujo de calor por convección y radiación que tendría lugar si esas superficies no estuvieran en contacto con otros materiales.

\section{Convección}

La convección consiste en la tranferencia de calor entre la piel y el aire circundante. Si la temperatura de la piel, $t_{s k}$ en grados C elsius $\left({ }^{\circ} \mathrm{C}\right)$, es mayor que la temperatura del aire $\left(t_{a}\right)$, el aire en contacto con la piel se calienta y, como consecuencia, se desplaza hacia arriba. Se establece así una circulación de aire, conocida como convección natural, en la superficie del cuerpo. El intercambio aumenta si el aire pasa sobre la piel a una cierta velocidad, ya que se fuerza la convección. El flujo de calor intercambiado por convección, $C$, en vatios por metro cuadrado $\left(\mathrm{W} / \mathrm{m}^{2}\right)$ puede estimarse con la siguiente ecuación:

$$
\mathrm{c}=\mathrm{h}_{\mathrm{c}} \mathrm{F}_{\mathrm{clC}}\left(\mathrm{t}_{\mathrm{sk}}-\mathrm{t}_{\mathrm{a}}\right)
$$

donde $h_{c}$ es el coeficiente de convección $\left(\mathrm{W} /{ }^{\circ} \mathrm{C} \mathrm{m}^{2}\right)$, que es una función de la diferencia entre $t_{s k} y t_{a}$ en el caso de la convección natural, y de la velocidad del aire $V_{a}$ (en $\mathrm{m} / \mathrm{s}$ ) en la convección forzada; $F_{c c}$ es el factor de reducción del intercambio de calor por convección debido a la ropa.

\section{Radiación}

Todos los cuerpos emiten radiación electromagnética cuya intensidad depende de su temperatura absoluta $T$ (en grados K elvin: K ) elevada a la cuarta potencia. La piel, con una temperatura que puede oscilar entre 30 y $35^{\circ} \mathrm{C}$ (303 y $308 \mathrm{~K}$ ), emite este tipo de radiación en la zona infrarroja. Además recibe la radiación emitida por las superficies vecinas. El flujo térmico intercambiado por radiación, $\mathrm{R}$ (in $\mathrm{W} / \mathrm{m}^{2}$ ), entre el cuerpo y su entorno puede describirse con la siguiente expresión:

donde:

$$
R=\varepsilon \sigma\left(\frac{A_{R}}{A_{D}}\right) F_{c l R}\left(T_{s k}^{4}-T_{r}^{4}\right)
$$

$\sigma$ es la constante universal de radiación $\left(5,67 \times 10-8 \mathrm{~W} / \mathrm{m}^{2} \mathrm{~K}^{4}\right)$

$\varepsilon$ es la emisividad de la piel que, para la radiación infrarroja, es igual a 0,97 e independiente de la longitud de onda, y para la radiación solar es aproximadamente igual a 0,5 en las personas de raza blanca y 0,85 en las personas de raza negra

$A_{R} / A_{D}$ es la fracción de la superficie corporal que participa en los intercambios, siendo del orden de 0,66, 0,70 o 0,77 , dependiendo de si la persona está en cuclillas, sentada o de pie

$\mathrm{F}_{\mathrm{clR}}$ es el factor de reducción de los intercambios de calor por radiación debido a la ropa

$\mathrm{T}_{\text {sk }}$ (en $\mathrm{K}$ ) es la temperatura media de la piel

$T_{r}$ (en K ) es la temperatura media radiante del ambiente; esto es, la temperatura uniforme de una esfera negra mate de gran diámetro que rodearía a la persona e intercambiaría con ella la misma cantidad de calor que con el entorno real.

La anterior expresión puede sustituirse por una ecuación simplificada similar a la de los intercambios por convección:

$$
R=h_{r}\left(A_{R} / A_{D}\right) F_{c I R}\left(t_{s k}-t_{r}\right)
$$

donde $h_{r}$ es el coeficiente de intercambio por radiación $\left(\mathrm{W} /{ }^{\circ} \mathrm{C} \mathrm{m}^{2}\right)$.

\section{Evaporación}

Sobre todas las superficies húmedas existe una capa de aire saturado con vapor de agua. Si la atmósfera no está saturada, el vapor se difunde desde esta capa a la atmósfera. La capa tiende a regenerarse absorbiendo el calor de evaporación (0,674 vatios hora por gramo de agua) de la superficie húmeda, que se enfría. Si toda la piel está cubierta de sudor, la evaporación es máxima $\left(E_{\text {max }}\right.$ ) y depende sólo de las condiciones ambientales, de acuerdo con la siguiente expresión:

$$
E_{\max }=h_{e} F_{p c l}\left(P_{s k, s}-P_{a}\right)
$$


donde:

$h_{e}$ es el coeficiente de intercambio por evaporación (W/ $\mathrm{m}^{2} \mathrm{kPa}$ )

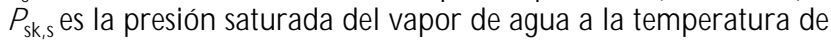
la piel (expresado en $\mathrm{kPa}$ )

$P_{a}$ es la presión parcial de vapor de agua en el ambiente (expresada en $\mathrm{kPa}$ )

$F_{\text {pcl }}$ es el factor de reducción del intercambio por evaporación debido a la ropa.

\section{Aislamiento térmico de la ropa}

En el cálculo del flujo de calor por convección, radiación y evaporación se aplica un factor de corrección para tener en cuenta la ropa utilizada. En el caso de prendas de algodón, los dos factores de reducción $\mathrm{F}_{\mathrm{cl}}$ y $\mathrm{F}_{\mathrm{cIR}}$ pueden calcularse como:

$$
F_{c l}=1 /\left(1+\left(h_{c}+h_{r}\right) I_{c l}\right)
$$

donde:

$h_{c}$ es el coeficiente de intercambio por convección

$h_{r}$ es el coeficiente de intercambio por radiación

$I_{c l}$ es el aislamiento térmico efectivo $\left(\mathrm{m}^{2} / \mathrm{W}\right)$ de la ropa.

Con respecto a la reducción de la transferencia de calor por evaporación, el factor de corrección $\mathrm{F}_{\text {pcl }}$ viene dado por la siguiente expresión:

$$
F_{p c l}=1 /\left(1+2,22 h_{c} l_{c l}\right)
$$

El aislamiento térmico de las prendas de vestir $\mathrm{I}_{\mathrm{cl}}$ se expresa en $\mathrm{m}^{2}$ / W 0 en clo. Un aislamiento de 1 clo corresponde a $0,155 \mathrm{~m}^{2} / \mathrm{W}$ y se consigue, por ejemplo, con un traje de calle normal (camisa, corbata, pantalones, chaqueta, etc.).

En la norma ISO 9920 (1994) se indica el aislamiento térmico proporcionado por diferentes combinaciones de prendas. En el caso de prendas protectoras especiales que reflejan el calor 0 limitan la permeabilidad al vapor en condiciones de calor, o absorben y aíslan en condiciones de estrés por calor, deben aplicarse factores de corrección individuales. En cualquier caso, hasta la fecha el problema sigue sin comprenderse bien y las predicciones matemáticas son muy aproximadas.

\section{Evaluación de los parámetros básicos del ambiente de trabajo}

Como ya se ha visto, los intercambios térmicos por convección, radiación y evaporación dependen de cuatro parámetros climáticos: la temperatura del aire $t_{a}$ en ${ }^{\circ} \mathrm{C}$, la humedad del aire expresada por su presión parcial de vapor $\mathrm{P}_{\mathrm{a}}$ en $\mathrm{kPa}$, la temperatura radiante media $t_{r}$ en ${ }^{\circ} \mathrm{C}$, y la velocidad del aire $V_{a}$ en $\mathrm{m} / \mathrm{s}$. Los instrumentos y métodos utilizados para medir estos parámetros físicos del medio ambiente están sujetos a la norma ISO 7726 (1985), en la que se describen los diferentes tipos de sensores que deben utilizarse, se especifican sus rangos de medición y su exactitud, y se recomiendan algunos procedimientos de medición. En la presente sección se resume parte del contenido de esa norma, con especial referencia a la condiciones de uso de los instrumentos y aparatos más comunes.

\section{Temperatura del aire}

La temperatura del aire $\left(t_{a}\right)$ tiene que medirse con independencia de cualquier radiación térmica y con una exactitud de $\pm 0,2{ }^{\circ} \mathrm{C}$ entre 10 y $30{ }^{\circ} \mathrm{C}$, y de $\pm 0,5{ }^{\circ} \mathrm{C}$ fuera de ese rango.

Existen muchos tipos de termómetros, aunque los de mercurio son los más comunes. Su ventaja está en la exactitud, siempre que se hayan calibrado correctamente en un principio, y como principales desventajas, su largo tiempo de respuesta y la imposibilidad de realizar registros automáticos. Los termómetros electrónicos, por su parte, tienen generalmente un tiempo de respuesta muy corto (entre 5 s y $1 \mathrm{~min}$ ), pero su calibración plantea numerosos problemas.
Cualquiera que sea el tipo de termómetro utilizado, su sensor debe protegerse contra la radiación. Por lo común, no hay más que rodear el sensor con un cilindro hueco de aluminio brillante. Tal protección está asegurada en el psicrómetro que se describe en la siguiente sección.

\section{Presión parcial del vapor de agua}

L a humedad del aire puede caracterizarse de cuatro formas:

1. Ia temperatura del punto de rocío: temperatura a la que debe enfriarse el aire para saturarse de humedad $\left(t_{d},{ }^{\circ} \mathrm{C}\right)$;

2. la presión parcial de vapor de agua: fracción de la presión del aire debida al vapor de agua $\left(\mathrm{P}_{\mathrm{a}}, \mathrm{KPa}\right)$;

3. la humedad relativa (HR), que viene dada por la expresión:

$$
H R=100 \cdot P_{a} / P_{S, t a}
$$

donde $P_{S, t a}$ es la presión del vapor saturado asociada a la temperatura del aire,

4. la temperatura de bulbo húmedo $\left(t_{w}\right)$, que es la temperatura mínima que alcanza un bulbo rodeado de una mecha húmeda protegido contra la radiación y ventilado a más de $2 \mathrm{~m} / \mathrm{s}$ por el aire ambiental.

Todos estos valores están matemáticamente relacionados.

La presión de saturación del vapor de agua $P_{S, t}$ a cualquier temperatura t viene dada por:

$$
P_{s, t}=0,6105 \cdot e^{\left(\frac{17,27 \cdot t}{t+237,3}\right)}
$$

mientras que la presión parcial del vapor de agua está relacionada con la temperatura por la expresión:

$$
P_{a}=P_{s, t w}-\left(t_{a}-t_{w}\right) / 15
$$

donde $P_{s, t w}$ es la presión de vapor saturado a la temperatura del bulbo húmedo.

El diagrama psicrométrico (Figura 42.3) permite combinar todos estos valores. En este diagrama se representa:

- en el eje de las y, la escala de la presión parcial del vapor de agua $\mathrm{P}_{\mathrm{a}}$, expresada en $\mathrm{kPa}$;

- en el eje de las $x$, la escala de la temperatura del aire;

- las curvas de la humedad relativa constante,

- Ias líneas rectas oblicuas de la temperatura constante de bulbo húmedo.

Figura 42.3 - Diagrama psicrométrico.

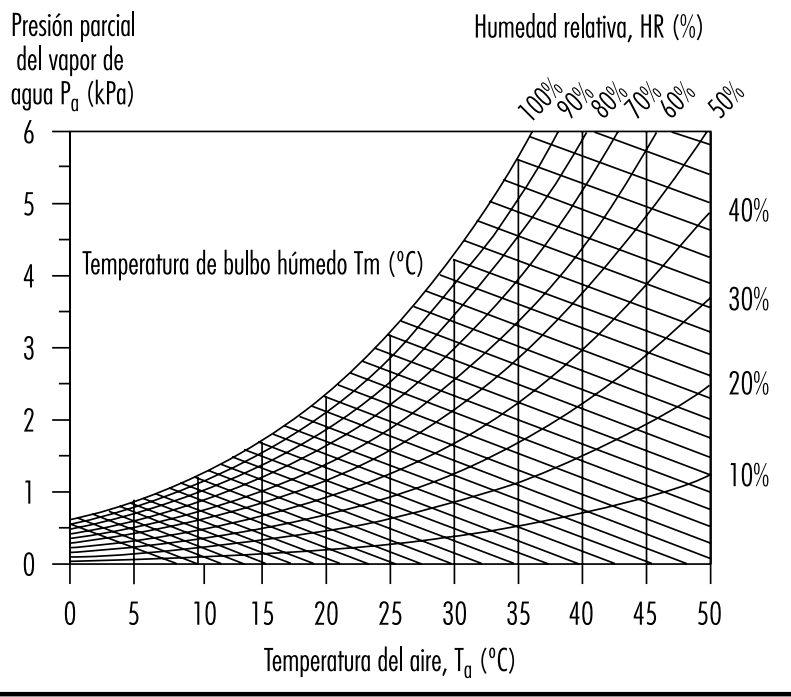


Los parámetros de la humedad utilizados con más frecuencia en la práctica son:

- la humedad relativa, medida con higrómetros y aparatos electrónicos más sofisticados,

- Ia temperatura del bulbo húmedo, medida con el psicrómetro; de ahí se deriva la presión parcial del vapor de agua, que es el parámetro más utilizado en el análisis del equilibrio térmico

EI rango de medición y la exactitud recomendada son de 0,5 a $6 \mathrm{kPa}$ y $\pm 0,15 \mathrm{kPa}$. Para la medición de la temperatura de bulbo húmedo, el rango se extiende de 0 a $36 \stackrel{\circ}{\circ}$, con una exactitud idéntica a la de la temperatura del aire. Con respecto a los higrómetros utilizados para medir la humedad relativa, el rango se extiende de 0 a $100 \%$, con una exactitud de $\pm 5 \%$.

\section{Temperatura radiante media}

La temperatura radiante media $\left(t_{r}\right)$, según se ha definido antes, puede estimarse de tres formas diferentes:

1. a partir de la temperatura medida por el termómetro de effera negra;

2. a partir de las temperaturas radiantes medidas a lo largo de tres ejes perpendiculares,

3. por cálculo, integrando los efectos de las diferentes fuentes de radiación.

A quí se describirá sólo la primera de estas técnicas.

El termómetro de esfera negra consiste en una sonda térmica, cuyo elemento sensible está situado en el centro de una esfera completamente cerrada, fabricada con un metal que sea un buen conductor del calor (cobre) y pintada de negro mate para que su coeficiente de absorción en la zona infrarroja se aproxime a 1,0. La esfera se coloca en el lugar de trabajo y se somete a intercambios por convección y radiación. La temperatura del globo $\left(t_{g}\right)$ depende así de la temperatura radiante media, la temperatura del aire y la velocidad del aire.

Para un globo negro estándar de $15 \mathrm{~cm}$ de diámetro, la temperatura media de radiación puede calcularse a partir de la temperatura del globo utilizando la siguiente ecuación:

$$
t_{r}=\sqrt[4]{\left(t_{g}+273\right)^{4}+2,5 \times 10^{8} \times v_{a}{ }^{0,6}\left(t_{g}-t_{a}\right)}-273
$$

En la práctica, es muy importante que la emisividad del globo se mantenga próxima a 1,0 volviéndola a pintar de negro mate siempre que sea necesario.

La principal limitación de este tipo de globo es su largo tiempo de respuesta (del orden de 20 a 30 minutos, dependiendo del tipo de globo utilizado y de las condiciones ambientales). La medición es válida sólo si las condiciones de la radiación se mantienen constantes durante ese período de tiempo, y eso no siempre es posible en los entornos industriales, en cuyo caso la medición no será exacta. Los anteriores tiempos de respuesta corresponden a globos de $15 \mathrm{~cm}$ de diámetro con termómetros de mercurio convencionales. Pueden acortarse utilizando sensores de menor capacidad térmica o reduciendo el diámetro del globo, en cuyo caso la ecuación anterior deberá modificarse para tener en cuenta esta diferencia en el diámetro.

Para el cálculo del índice WBGT se utiliza directamente la temperatura del globo negro. Es por tanto esencial utilizar un globo de $15 \mathrm{~cm}$ de diámetro. No obstante, pueden utilizarse otros índices basados en la temperatura radiante media, en cuyo caso podrá utilizarse un globo de menor tamaño para reducir el tiempo de respuesta, siempre que se modifique la anterior ecuación para tener este hecho en cuenta. La norma ISO 7726 (1985) permite una exactitud de $\pm 2{ }^{\circ} \mathrm{C}$ en la medición de $t_{r}$ entre 10 y $40 \stackrel{\circ}{\circ}, y \pm 5 \stackrel{\circ}{C}$ fuera de ese rango.

\section{Velocidad del aire}

$L$ a velocidad del aire debe medirse sin tener en cuenta la dirección del flujo de aire. De lo contrario, la medición tendrá que realizarse en tres ejes perpendiculares $(x, y$ y $z$ ) y calcular la velocidad global por la suma de vectores:

$$
\mathrm{V}_{\mathrm{a}}=\sqrt{\mathrm{V}_{\mathrm{x}}^{2}+\mathrm{V}_{\mathrm{y}}^{2}+\mathrm{V}_{z}^{2}}
$$

EI rango de medida recomendado por la norma ISO 7726 se extiende de 0,05 a $2 \mathrm{~m} / \mathrm{s}$. La exactitud exigida es del $5 \%$. Debe medirse como el valor medio de 103 minutos.

Existen dos tipos de instrumentos para medir la velocidad del aire: los anemómetros de aspas giratorias y los termoanemómetros.

\section{Anemómetros de aspas giratorias}

La medición se realiza contando el número de vueltas de las aspas durante un cierto período de tiempo. De esta forma, se obtiene la velocidad media del aire durante ese período de tiempo de una manera discontinua. Los anemómetros presentan dos principales desventajas:

1. Son muy sensibles a la dirección del aire y tienen que orientarse estrictamente en la dirección del flujo de aire Cuando la dirección del aire varía o se desconoce, tienen que realizarse mediciones en tres direcciones perpendiculares.

2. El rango de medición se extiende de unos $0,3 \mathrm{~m} / \mathrm{s}$ a $10 \mathrm{~m} / \mathrm{s}$. Las limitaciones de este instrumento con velocidades de aire bajas tienen importancia cuando, por ejemplo, se trata de analizar una situación de estrés térmico en la que no debe superarse una velocidad de $0,25 \mathrm{~m} / \mathrm{s}$. Aunque el rango de medición puede ampliarse más allá de $10 \mathrm{~m} / \mathrm{s}$, rara vez es inferior a 0,3 0 incluso a $0,5 \mathrm{~m} / \mathrm{s}$, lo que limita en gran medida las posibilidades de utilización de este aparato en ambientes próximos al bienestar, en donde las velocidades máximas permitidas son de 0,50 incluso de $0,25 \mathrm{~m} / \mathrm{s}$.

\section{Anemómetros de hilo caliente}

Son instrumentos complementarios a los anemómetros de aspas giratorias, ya que su rango dinámico se extiende básicamente de 0 a $1 \mathrm{~m} / \mathrm{s}$. Proporcionan una estimación instantánea de la velocidad en un punto del espacio; por consiguiente, es necesario utilizar valores medios en el tiempo y en el espacio. Son instrumentos muy sensibles también a la dirección del aire, de manera que los anteriores comentarios sirven igual en este caso. Finalmente, la medición es sólo correcta desde el momento en que la temperatura del instrumento alcanza la del ambiente que tiene que medirse.

\section{EVALUACION DEL ESTRES POR CALOR E INDICES DE ESTRES POR CALOR}

\section{Kenneth C. Parsons}

El estrés por calor se produce cuando el entorno de una persona (temperatura del aire, temperatura radiante, humedad y velocidad del aire), su ropa y su actividad interactúan para producir una tendencia a que la temperatura corporal aumente. EI sistema de regulación térmica del organismo responde para aumentar la pérdida de calor. Tal respuesta puede ser poderosa y eficaz, pero puede también producir un estrés en el organismo que origine molestias, enfermedades o incluso la muerte. Por tanto, es importante evaluar los ambientes calurosos para garantizar la salud y la seguridad de los trabajadores.

Los índices de estrés por calor proporcionan herramientas para evaluar ambientes calurosos y estimar el estrés térmico al 
Figura 42.4 - Variación de tres medidas de la carga térmica con niveles crecientes de estrés térmico a mbiental.

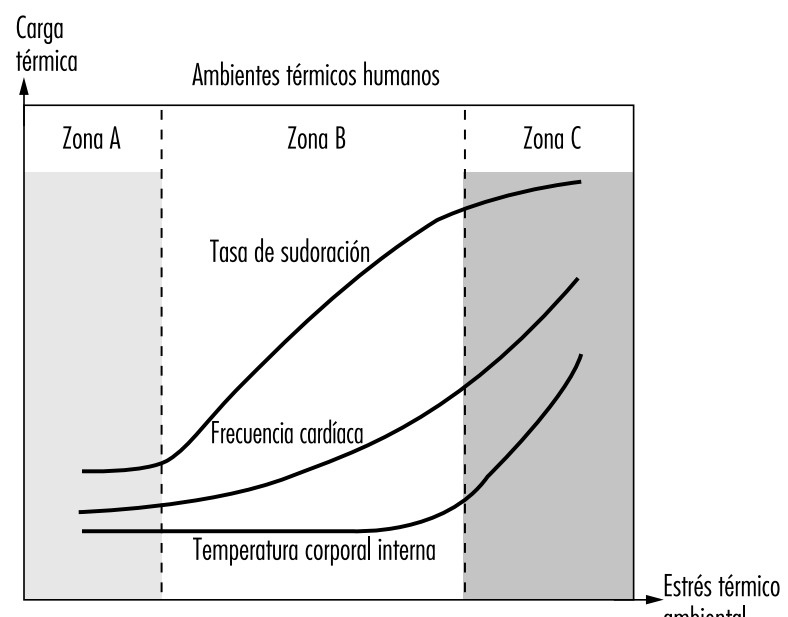

La variación de las tres medidas de la carga térmica con niveles crecientes de estrés térmico ambiental. En la zona B, la zona prescriptiva (ZP), la temperatura corporal interna se mantiene constante gracias a un aumento de la tasa de sudoración. En la zona C, la zona de urgencia ambiental (ZUA), la tasa de sudoración ya no puede aumentar más y la temperatura corporal se eleva. La transición se denomina límite superior de la zona prescriptiva (LSZP).

Fuente: OMS 1969.

que pueden verse expuestos los trabajadores. Los valores límite basados en los índices de estrés por calor indicarán cuando este estrés puede llegar a ser inaceptable.

En general, los mecanismos del estrés por calor se conocen bien y las prácticas de trabajo para ambientes cálidos están bien establecidas. Entre ellas se incluyen: conocimiento de los signos de advertencia de estrés por calor, programas de aclimatación y rehidratación. No obstante, el gran número de accidentes que siguen produciéndose sugiere la necesidad de repasar estos conocimientos

En 1964, Leithead y Lind realizaron una gran encuesta y concluyeron que los trastornos por calor se producen por una 0 más de las razones siguientes:

1. la existencia de factores como deshidratación o falta de aclimatación;

2. apreciación inadecuada de los peligros del calor, ya sea por parte de las autoridades supervisoras o por las personas en situación de riesgo,

3. circunstancias accidentales o imprevistas que causan la exposición a un gran estrés por calor.

Los autores concluyeron que muchas de las muertes podían atribuirse a negligencia o falta de consideración y que cuando llegan a producirse trastornos, es muy importante disponer de todo lo necesario para administrar un tratamiento correcto y rápido.

\section{Indices de estrés por calor}

Un índice de estrés por calor es un único número que integra los efectos de seis parámetros básicos en cualquier ambiente térmico al que puede verse expuesto un ser humano, de tal manera que su valor varía dependiendo del estrés térmico experimentado por la persona expuesta a un ambiente caluroso. El valor del índice (medido o calculado) puede utilizarse para diseñar puestos de trabajo o prácticas de trabajo y establecer unos límites de seguridad. Se han realizado numerosas investigaciones para determinar el índice definitivo de estrés por calor y no existe acuerdo sobre cuál es el mejor de todos ellos. Por ejemplo, Goldman (1988) presenta 32 índices de estrés por calor y es probable que en todo el mundo se utilicen como mínimo el doble de ese número. M uchos índices no consideran los seis parámetros básicos, aunque todos ellos tienen que tenerlos en cuenta a la hora de su aplicación.

La utilización de uno u otro índice dependerá de cada contexto y de ahí que existan tantos índices diferentes. Algunos índices son teóricamente inadecuados, aunque su uso puede estar justificado para aplicaciones específicas por la experiencia de una industria en particular.

Según Kerslake (1972), “Es evidente que la manera de combinar los factores ambientales tiene que depender de las propiedades de la persona expuesta a ellos, pero ninguno de los índices de estrés por calor que se utilizan en la actualidad tienen esto en cuenta". La reciente tendencia a la normalización [p. ej., ISO 7933 (1989b) e ISO 7243 (1989a)] ha creado presiones para que se adopten índices similares en todo el mundo. No obstante, será necesario adquirir experiencia con el uso de cualquier nuevo índice.

La mayoría de los índices de estrés por calor consideran, ya sea directa 0 indirectamente, que el principal factor de estrés para el organismo es el relacionado con la sudoración. Por ejemplo, cuanto más sudor tenga que perderse para mantener el equilibrio tér mico y la temperatura corporal interna, mayor será el estrés impuesto al organismo. Para que un índice del estrés por calor refleje el ambiente térmico humano y sirva para predecir el estrés por calor, se precisa un mecanismo que estime la capacidad de una persona para, a través de la sudoración, perder calor en un ambiente caluroso.

Los índices basados en la evaporación del sudor al ambiente son útiles cuando las personas mantienen la temperatura corporal interna principalmente a través de la sudoración. En general, se dice que estas condiciones están en la zona prescriptiva (O M S 1969). Así, la temperatura corporal interna permanece relativamente constante, mientras que la frecuencia cardíaca y el nivel de sudoración aumentan con el estrés por calor. En el límite superior de la zona prescriptiva (LSZP), la regulación térmica es insuficiente para mantener el equilibrio térmico y la temperatura corporal aumenta. Se denomina zona de urgencia ambiental (O M S 1969). En esta zona, el almacenamiento de calor está relacionado con la temperatura corporal interna y puede utilizarse como un índice para determinar los tiempos de exposición permisibles (p. ej., basados en un límite de seguridad establecido para mantener una temperatura "interior" de $38{ }^{\circ} \mathrm{C}$; véase la Figura 42.4).

Los índices de estrés por calor pueden clasificarse como racionales, empíricos o directos. Los índices racionales se basan en cálculos para los que se utiliza la ecuación del equilibrio térmico; losíndices empíricos se basan en el uso de ecuaciones obtenidas a partir de las respuestas fisiológicas de los seres humanos (p. ej., pérdida de sudor); y los índices directos se basan en la medición (normalmente de la temperatura) de instrumentos utilizados para simular la respuesta del cuerpo humano. A continuación se describen los índices más importantes y más utilizados.

\section{Indices racionales}

\section{Indice de Estres por Calor (Heat Stress Index, HSI)}

EI Indice de Estrés por Calor es la proporción entre la evaporación necesaria para mantener el equilibrio térmico $\left(E_{\text {req }}\right)$ y la evaporación máxima que podría conseguirse en ese ambiente $\left(E_{\max }\right)$, expresada como porcentaje (Belding y $\mathrm{H}$ atch 1955). En la Tabla 42.2 se indican las ecuaciones utilizadas. 
Tabla 42.2 - Ecuaciones utilizadas para calcular el índice de estrés por calor (HSI) y los tiempos de exposición permisibles (AET).

\begin{tabular}{|c|c|c|c|c|}
\hline & & & Con ropa & Sin ropa \\
\hline (1) Pérdida por radiación (R) & $R=k_{1}\left(35-t_{\Gamma}\right) W m^{-2}$ & para $k_{1}=$ & 4,4 & 7,3 \\
\hline (2) Pérdida por convección (C) & $C=k_{2} \cdot v^{0,6}\left(35-t_{a}\right) W m^{-2}$ & para $k_{2}=$ & 4,6 & 7,6 \\
\hline (3) Pérdida máxima por evaporación $\left(E_{\max }\right)$ & $E_{\max }=k_{3} \cdot V^{0,6}\left(56-P_{a}\right) W^{-2}$ (límite superior de $\left.390 \mathrm{Wm}^{-2}\right)$ & para $k_{3}=$ & 7,0 & 11,7 \\
\hline $\begin{array}{l}\text { (4) Pérdida requerida por evaporación }\left(E_{\text {req }}\right) \\
\text { (5) Indice de estrés por calor ( } H S I)\end{array}$ & $\begin{aligned} E_{\text {req }} & =M-R-C \\
H S I & =\frac{\left(E_{\text {req }}\right)}{\left(E_{\text {max }}\right)} \times 100\end{aligned}$ & & & \\
\hline (6) Tiempo de exposición permisible (AET) & AET $=\frac{2440}{\left(E_{\text {req }}-E_{\text {max }}\right)}$ mins & & & \\
\hline
\end{tabular}

donde: $M=$ calor metabólico; $t_{a}=$ temperatura del aire; $t_{r}=$ temperatura radiante; $P_{a}=$ presión parcial del vapor; $v=$ velocidad del aire.

EI HSI está pues relacionado con el estrés, fundamentalmente en términos de sudoración corporal, para valores de entre 0 y 100. Con un $\mathrm{HSI}=100$, la evaporación necesaria es la máxima posible y representa el límite superior de la zona prescriptiva. Con un $\mathrm{HSI}>100$, se almacena calor en el organismo y los tiempos de exposición permisibles se calculan en función de un aumento de $1,8 \stackrel{\circ}{\circ} \mathrm{C}$ de la temperatura interna del organismo (calor almacenado de $264 \mathrm{~kJ}$ ). Con un $\mathrm{H} \mathrm{SI}<0$ existe un ligero estrés por calor; por ejemplo, cuando los trabajadores se están recuperando de la exposición al calor (véase la Tabla 42.3).

Se asigna un límite superior de $390 \mathrm{~W} / \mathrm{m}^{2}$ a $\mathrm{E}_{\text {max }}$ (sudoración de 1 l/ h como la máxima tasa de sudoración mantenida durante 8 horas), se hacen supuestos sencillos sobre los efectos de la ropa (camisa de manga larga y pantalones) y se supone que la temperatura cutánea se mantiene constante a $35 \stackrel{\circ}{ } \mathrm{C}$.

\section{Indice de Estrés Térmico (Index of Thermal Stress, ITS)}

Givoni $(1963,1976)$ propuso el Indice de Estrés T érmico, que es una versión mejorada del Indice de Estrés por Calor. U na mejora importante es que se reconoce que no todo el sudor se evapora

Tabla 42.3 • Interpretación de los valores del índice de estrés por calor (HSI).

HSI Efecto de la exposición durante ocho horas

- 20 Estrés por calor leve ( $p$. ej., durante el período de recuperación de la exposición al calor).

$0 \quad$ No se produce estrés térmico

10-30 Estrés por calor leve o moderado. Ligero efecto en el trabajo físico, pero posible efecto en el trabajo cualificado

40-60 Estrés por calor intenso, que supone un riesgo para la salud a no ser que la persona esté en muy buena forma física. Necesidad de aclimatación

70-90 Estrés por calor muy intenso. El personal debe ser seleccionado mediante un examen médico. Asegurar un consumo adecuado de agua y sal

100 Estrés máximo tolerado diariamente por hombres jóvenes en buena forma física y aclimatados

Más de 100 Tiempo de exposición limitado por el aumento de la temperatura corporal interna (véase "I. Indice de estrés térmico" en el recuadro Indices de calor de la página 42.22.)

\section{Tasa de sudoración requerida}

O tra mejora teórica y práctica incorporada al H SI y al ITS fue la tasa de sudoración requerida (required sweat rate, SW req) (Vogt y cols. 1981). Es un índice que calcula la sudoración necesaria para conseguir el equilibrio térmico a partir de una ecuación perfeccionada del equilibrio térmico, pero lo más importante es que constituye un método práctico para interpretar los cálculos comparando lo que se necesita con lo que es fisiológicamente posible y aceptable en el ser humano.

L os extensos debates y las evaluaciones industriales y de laboratorio (CEC 1988) de este índice tuvieron como resultado su aceptación como Norma Internacional ISO 7933 (1989b). Las diferencias entre las respuestas observadas y esperadas de los trabajadores motivaron la inclusión de notas de advertencia con relación a los métodos de evaluación de la deshidratación y la transferencia de calor por evaporación a través de la ropa en la propuesta de su adopción como Norma Europea (prEN -12515). (V éase "II. Tasa de sudoración requerida" en el recuadro Indices de calor.)

\section{Interpretación de SW}

Para realizar una interpretación práctica de los valores calculados, se utilizan valores de referencia en términos de lo que es aceptable y factible (véase la Tabla 42.4).

En primer lugar se realiza una predicción de la humedad de la piel $\left(W_{p}\right)$, la tasa de evaporación $\left(E_{p}\right)$ y la tasa de sudoración $\left(S W_{p}\right)$. Básicamente, si los valores calculados como necesarios son factibles, se consideran valores previstos (p. ej., $S W_{p}=S W_{\text {req }}$ ). Si no son factibles, pueden tomarse como valores máximos (p. ej., SW $W_{p}=S W_{\max }$ ). En el diagrama de flujos de decisión se ofrecen más detalles (véase la Figura 42.5).

Si la tasa de sudoración requerida puede conseguirse sin que se produzca una pérdida inadmisible de agua, no existe ningún límite en la exposición al calor durante un turno de trabajo de 8 horas. De lo contrario, se calculan las exposiciones de duración limitada (EDL) a partir de:

Cuando $E_{p}=E_{\text {req }}$ y $S W_{p}=D_{\max } / 8$, entonces $E D L=$ 480 minutos y $S W_{\text {req }}$ puede utilizarse como índice de estrés por calor. Si lo anterior no se cumple, entonces:

$$
\begin{gathered}
E D L 1=600_{\max } /\left(E_{r e q}-E_{p}\right) \\
E D L 2=60 D_{\max } / S W_{p}
\end{gathered}
$$


Figura 42.5 - Diagrama de flujos de decisión para $S W_{p}$ (tasa de sudoración requerida).

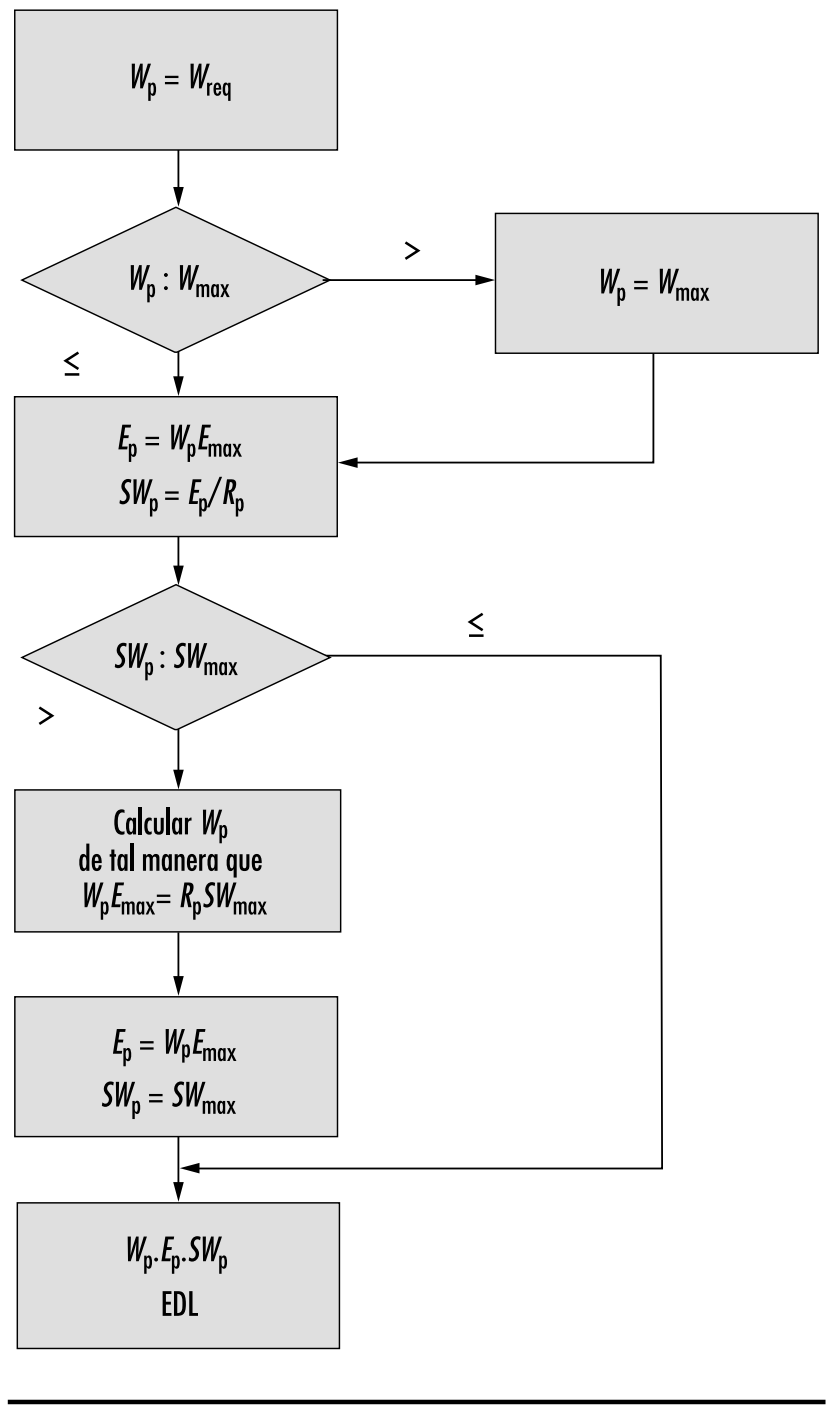

EDL es el menor de EDL 1 yEDL 2. En ISO 7933 (1985) se facilitan más detalles (1989b) al respecto.

\section{Otros índices racionales}

EI índice SW req y la norma ISO 7933 (1989) constituyen el método racional más sofisticado basado en la ecuación del equilibrio térmico y han supuesto un gran avance. Aunque puede mejorarse aún más, hay otro método alternativo que consiste en utilizar un modelo térmico. La nueva Temperatura Efectiva ( $\mathrm{E}^{*}$ ) y la Temperatura Efectiva Estándar (TEE) son índices basados en el modelo binodal de la regulación térmica en el ser humano (N ishi y Gagge 1977). Givoni y Goldman (1972, 1973) han propuesto también otros modelos empíricos de predicción para evaluar el estrés por calor.

\section{Indices empíricos}

\section{Temperatura efectiva y temperatura efectiva corregida}

El índice de Temperatura Efectiva (H oughton y Yaglou 1923) se creó inicialmente para proporcionar un método de determinación de los efectos relativos de la temperatura del aire y la humedad en la sensación de bienestar. Tres personas juzgaron cuál de dos cámaras climatizadas era más cálida caminando por ellas. Utilizando diferentes combinaciones de temperatura y humedad del aire (y después otros parámetros), se determinaron las líneas de bienestar equivalente. Las tres personas describieron sus impresiones inmediatas y se registraron sus respuestas transitorias. EI resultado fue que se sobrestimó el efecto de la humedad a temperaturas bajas y se subestimó a temperaturas altas (en comparación con las respuestas en estado estable). Aunque en un principio era un índice de bienestar, la sustitución de la temperatura de bulbo seco por la temperatura del globo negro en los nomogramas de la TE proporcionó la Temperatura Efectiva Corregida (TEC) (Bedford 1940). Los estudios publicados por M acpherson (1960) sugirieron que la TEC predecía los efectos fisiológicos de un aumento de la temperatura radiante media. En la actualidad, la TE y la TEC se utilizan rara vez como índices del bienestar, aunque se han utilizado como índices del estrés por calor. Bedford (1940) propuso la TEC como un índice de calor, con límites superiores de 34 ㄷ para una "eficiencia razonable" y de $38,6 \stackrel{\circ}{\circ}$ para la tolerancia. Ahora bien, otras investigaciones han demostrado que la TE presenta importantes desventajas cuando se utiliza como índice del estrés por calor, razón por la cual se empezó a utilizar el índice de la tasa de sudoración prevista durante cuatro horas (T SP4).

\section{Tasa de sudoración prevista durante cuatro horas}

El índice de la tasa de sudoración prevista durante cuatro horas (T SP4) fue propuesto en Londres por M cArdle y cols. (1947) y evaluado en Singapur durante 7 años de trabajo resumido por Macpherson (1960). Es la cantidad de sudor secretado por hombres jóvenes aclimatados y en buena forma física expuestos al ambiente durante 4 horas mientras cargan munición en cañones durante una batalla naval. EI número (valor de índice) que por sí sólo resume el efecto de los seis parámetros básicos es la cantidad de sudor producido por esa población específica, pero debe utilizarse como un valor de índice y no como una indicación de la cantidad de sudor en un determinado grupo de interés.

Con todo, fuera de la zona prescriptiva (p. ej., TSP4> $5 \mathrm{l}$ ), la tasa de sudoración no parecía ser un buen indicador del estrés.

Tabla 42.4 • Valores de referencia para los criterios de estrés y carga térmica (ISO 7933, 1989b).

\begin{tabular}{|c|c|c|c|c|c|}
\hline \multirow[t]{2}{*}{ Criterio } & & \multicolumn{2}{|c|}{$\begin{array}{l}\text { Personas no } \\
\text { aclimatadas }\end{array}$} & \multicolumn{2}{|c|}{$\begin{array}{l}\text { Personas } \\
\text { aclimatadas }\end{array}$} \\
\hline & & Alarma & Peligro & Alarma & Peligro \\
\hline \multicolumn{6}{|c|}{ Humedad máxima de la piel } \\
\hline$w_{\max }$ & & 0,85 & 0,85 & 1,0 & 1,0 \\
\hline \multicolumn{6}{|c|}{ Tasa de sudoración máxima } \\
\hline \multirow[t]{2}{*}{$\operatorname{Reposo}\left(M<65 \mathrm{Wm}^{-2}\right)$} & $S W_{\max } W m^{-2} g h^{-1}$ & 100 & 150 & 200 & 300 \\
\hline & & 260 & 390 & 520 & 780 \\
\hline \multirow[t]{2}{*}{ Trabajo $\left(M \geq 65 \mathrm{Wm}^{-2}\right)$} & $S W_{\max } W^{-2} g^{-1}$ & 200 & 250 & 300 & 400 \\
\hline & & 520 & 650 & 780 & 1.040 \\
\hline \multicolumn{6}{|c|}{ Acumulación máxima de calor } \\
\hline$Q_{\max }$ & $W_{h m^{-2}}$ & 50 & 60 & 50 & 60 \\
\hline \multicolumn{6}{|l|}{ Pérdida hídrica máxima } \\
\hline \multirow[t]{2}{*}{$D_{\max }$} & $\mathrm{Whm}^{-2} \mathrm{~g}$ & 1.000 & 1.250 & 1.500 & 2.000 \\
\hline & & 2.600 & 3.250 & 3.900 & 5.200 \\
\hline
\end{tabular}




\section{Figura 42.6 - Nomograma para la predicción de la "tasa de sudoración prevista durante 4 horas" (TSP4).}

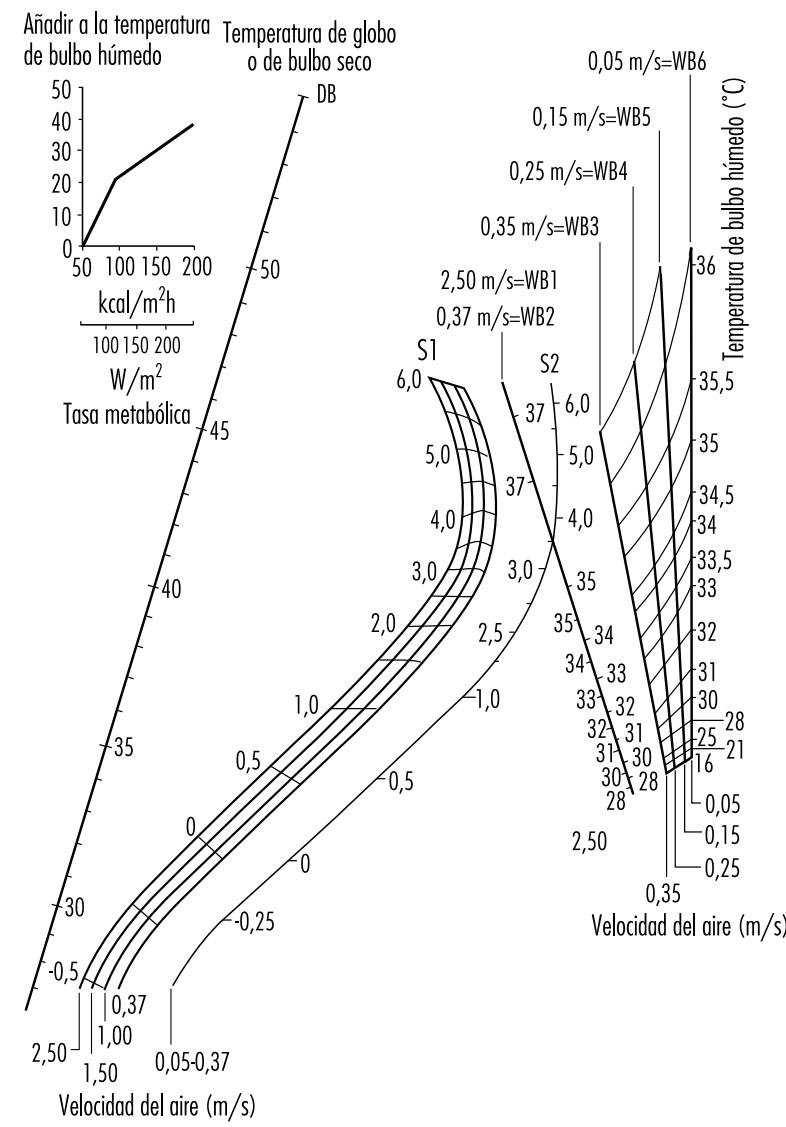

El nomograma se describe en el recuadro de la página 42.22 en "III. Tasa de sudoración prevista durante 4 horas".

LoS nomogramas de TSP4 (Figura 42.6) se ajustaron para intentar tener en cuenta este hecho. La T SP4 parece haber sido útil en las condiciones para las que se derivó; sin embargo, los efectos de la ropa se simplifican en exceso y es más útil como índice del calor almacenado. M cArdle y cols. (1947) propusieron una T SP 4 máxima de 4,5 I para que no se produjese la incapacitación de ningún hombre joven aclimatado y en buena forma física.

\section{Predicción de la frecuencia cardíaca como índice}

Fuller y Brouha (1966) propusieron un índice sencillo basado en la predicción de la frecuencia cardíaca (heart rate, HR) en latidos por minuto. La relación, tal como fue formulada con la tasa metabólica en BTU/h y la presión parcial de vapor en $\mathrm{mmHg}$ permitía realizar una predicción sencilla de la frecuencia cardíaca a partir de $(T+p)$, de ahí el índice $T+p$.

Givoni y Goldman (1973) propusieron también ecuaciones para la variación de la frecuencia cardíaca con el tiempo y correcciones para tener en cuenta el grado de aclimatación de las personas, según se indica en el recuadro de la página 42.22 con el título "IV. Frecuencia cardíaca".

N IOSH (1986) describe un método para predecir la frecuencia cardíaca durante el trabajo y la recuperación (obtenido de

Tabla 42.5 - Modelo de evaluación del estrés por calor basado en la frecuencia cardíaca.

$\begin{array}{ll}\text { Frecuencia cardíaca total } & \text { Nivel de actividad } \\ H R_{0} & \text { Reposo (neutralidad térmica) } \\ H R_{0}+H R_{M} & \text { Trabajo } \\ H R_{0}+H R_{S} & \text { Esfuerzo estático } \\ H R_{0}+H R_{t} & \text { Estrés térmico } \\ H R_{0}+H R_{N} & \text { Emoción (psicológica) } \\ H R_{0}+H R_{e} & \text { Residual } \\ \text { Basado en Vogt y cols. (1981) e IS0 9886 (1992). }\end{array}$

Brouha 1960 y Fuller y Smith 1980, 1981). La temperatura corporal y la frecuencia cardíaca se miden durante el período de recuperación después de un ciclo de trabajo o en determinados momentos durante la jornada de trabajo. Al final de un ciclo de trabajo, el trabajador se sienta en un taburete, se le toma la temperatura oral y se registran las siguientes tres frecuencias de pulso:

$P_{1}$ : frecuencia de pulso medida entre 30 segundos y 1 minuto

$P_{2}$ : frecuencia de pulso medida entre 1,5 y 2 minutos

$\mathrm{P}_{3}$ : frecuencia de pulso medida entre 2,5 y 3 minutos

El principal criterio de estrés por calor es una temperatura oral de $37,5^{\circ} \mathrm{C}$.

Si $\mathrm{P}_{3} \leq 90 \mathrm{lpm}$ y $\mathrm{P}_{3}-\mathrm{P}_{1}=10 \mathrm{lpm}$, indica una carga de trabajo grande, aunque con sólo un pequeño aumento de la temperatura corporal. Si $\mathrm{P}_{3}>90 \mathrm{Ipm}$ y $\mathrm{P}_{3}-\mathrm{P}_{1}<10 \mathrm{lpm}$, el estrés (calor + trabajo) es demasiado grande y se deben adoptar medidas para diseñar el trabajo.

Vogt y cols. (1981) e ISO 9886 (1992) propusieron un modelo (Tabla 42.5) que utiliza la frecuencia cardíaca para evaluar las condiciones térmicas:

El componente de carga térmica (posible índice de estrés por calor) puede calcularse a partir de:

$$
H R t=H R r-H R_{0}
$$

Tabla 42.6 - Valores de referencia del W BG T obtenidos de ISO 7243 (1989a).

Tasa metabólica M Valor de referencia de WBGT

$\left(\mathrm{Wm}^{-2}\right)$

Persona aclimatada al calor $\left({ }^{\circ} \mathrm{C}\right)$

0 . Reposo $M \leq 65 \quad 33$

1. $65<M \leq 130 \quad 30$

2. $130<M \leq 200$

2.

$\sin$ movimiento apreciable del aire

3. $200<M<260 \quad 25$

25

23

4. $M>260$

Nota: son valores estimados para una temperatura rectal máxima de $38^{\circ} \mathrm{C}$ 


\section{Indices de calor: fórmulas y definiciones}

\section{Indice de estrés térmico (ITS)}

La ecuación del equilibrio térmico perfeccionada es:

$$
E_{\text {req }}=H-(C+R)-R_{s}
$$

donde $E_{\text {req }}$ es la evaporación necesaria para mantener el equilibrio térmico, $R_{s}$ es la carga solar y $H$ es la producción de calor metabólico, que se utiliza en lugar de la tasa metabólica para tener en cuenta el trabajo externo. Una importante mejora introducida en esta nueva ecuación es el reconocimiento de que no todo el sudor se evapora (p. ej., una parte gotea), de manera que la tasa de sudoración requerida está relacionada con la tasa de evaporación según la expresión:

$$
S W=E_{r e} q / n s c
$$

donde nsc es la eficiencia de la sudoración.

Para ambientes interiores, la transferencia de calor se calcula a partir de:

$$
R+C=a V^{0,3}\left(35-T_{g}\right)
$$

Para ambientes exteriores con carga solar, $T_{g}$ se sustituye por $T_{a}$ y se tiene en cuenta la carga solar $\left(R_{S}\right)$ :

$$
R_{s}=E_{s} K_{p e} K_{c l}\left(1-a\left(v^{0,2}-0,88\right)\right)
$$

Estas ecuaciones se han obtenido a partir de datos experimentales y no son estrictamente racionales.

La pérdida máxima de calor por evaporación es:

$$
E_{\text {max }}=K_{p} v^{0,3}\left(56-P_{a}\right)
$$

y la eficiencia de la sudoración viene dada por

$$
n s c=\exp \left\{-0,6\left[\left(E_{\text {req }} / E_{\max }\right)-0,12\right]\right\}
$$

pero

$$
n s C=1 \text { si } E_{\text {req }} / E_{\max }<0,12
$$

$$
n s c=0,29 \text { si } E_{\text {req }} / E_{\max }>2,15
$$

El índice de estrés térmico (ITS) en $\mathrm{g} / \mathrm{h}$ viene dado por:

$$
\text { ITS }=\left(H-(R+C)-R_{S}\right) /(0,37 n s c)
$$

donde $\left(H-(R+C)-R_{s}\right)$ es la tasa de evaporación requerida $E_{r e} q, 0,37$ convierte $W / \mathrm{m}^{2}$ en $\mathrm{g} / \mathrm{h}$ y nsc es la eficiencia de la sudoración (M clntyre 1980).

\section{Tasa de sudoración requerida}

Al igual que los otros índices racionales, $S W_{\text {req }}$ se deriva de los seis parámetros básicos: temperatura del aire $\left(T_{a}\right)$, temperatura radiante $\left(T_{r}\right)$, velocidad del aire con esa humedad relativa $(V)$, aislamiento de la ropa $\left(I_{c}\right)$, tasa metabólica $(M)$ y trabajo externo $(W)$. Son necesarios también los valores de la superficie efectiva de radiación para distintas posturas (sentado $=0,72$, de pie $=0,77)$. A partir de estos valores, la evaporación necesaria se calcula como:

$$
E_{\text {req }}=M-W-C_{\text {res }}-E_{\text {res }}-C-R
$$

Existen ecuaciones para cada componente (véanse las Tablas 42.10 y 42.9 ). La temperatura cutánea media se calcula a partir de una ecuación de regresión lineal múltiple o se supone un valor de $36{ }^{\circ} \mathrm{C}$

A partir de la evaporación requerida $\left(E_{\text {req }}\right)$, la evaporación máxima $\left(E_{\max }\right)$ y la eficiencia de la sudoración $(r)$, se calcula lo siguiente:

$$
\begin{aligned}
& \text { Humedad cutánea requerida } W_{\text {req }}=E_{\text {req }} / E_{\max } \\
& \text { Tasa de sudoración requerida } S W_{\text {req }}=E_{\text {req }} / r
\end{aligned}
$$

III. Tasa de sudoración prevista durante 4 horas (TSP4) Los pasos necesarios para obtener el valor del índice TSP4 son resumidos por M clntyre (1980) así:

Si $T_{g} \neq T_{a}$, debe aumentarse la temperatura de bulbo húmedo en $0,4 \cdot\left(T_{g}-T_{a}\right){ }^{\circ} \mathrm{C}$

Si la tasa metabólica $M>63 \mathrm{~W} / \mathrm{m}^{2}$, debe aumentarse la temperatura de bulbo húmedo en la cantidad que se indica en el gráfico (véase la Figura 42.6).

Si la persona está vestida, debe aumentarse la temperatura del bulbo húmedo en $1,5 \mathrm{I}_{\text {clo }}\left({ }^{\circ} \mathrm{C}\right)$.

Estas modificaciones son aditivas.

La TSP4 se determina a partir de la Figura 42.6. La TSP4 es, por tanto

$$
T S P 4=T S B 4+0,37 I_{c 10}+\left(0,012+0,001 I_{c 10}\right)(M-63)
$$

\section{Frecuencia cardíaca}

$$
F C=22,4+0,18 M+0,25\left(5 T_{a}+2 P_{a}\right)
$$

donde $M$ es la tasa metabólica $W / \mathrm{m}^{2}, T_{2}$ es la temperatura del aire en ${ }^{\circ} \mathrm{C}$ y $P_{a}$ es la presión del vapor en $\mathrm{Mb}$.

Givoni y Goldman (1973) han propuesto ecuaciones para predecir la frecuencia cardíaca de personas (soldados) en a mbientes calurosos. Definen un índice de frecuencia cardíaca (IFC) según la variación de la temperatura rectal de equilibrio prevista.

IFC es pues:

$$
\begin{aligned}
T_{\text {ref }} & =36,75+0,004\left(M-W_{\text {ex }}\right) \\
& +(0,025 / \mathrm{clo})\left(T_{a}-36\right) \\
& +0,8 \mathrm{e}^{0,0047}\left(E_{\text {req }}-E_{\text {ma }} \mathrm{x}\right) .
\end{aligned}
$$

IFC $=0,4 M+(2,5 /$ clo $)\left(T_{a}-36\right)+80 e^{0,0047}\left(E_{\text {req }}-E_{\text {max }}\right)$ donde $M=$ tasa metabólica (vatios), $W_{\text {ex }}=$ trabajo mecánico (vatios), clo = aislamiento térmico de la ropa, $T_{a}=$ temperatura del aire $\left({ }^{\circ} \mathrm{C}\right), E_{\text {req }}=$ carga térmica metabólica y ambiental total (vatios), $E_{\max }=$ capacidad de enfriamiento por evaporación de la ropa y el ambiente (vatios).

La frecuencia cardíaca de equilibrio ( $F C_{f}$ en latidos por minutos) viene dada por:

$$
H R_{f}=65+0,35 \text { (IFC - 25) para IFC } \leq 225
$$

es decir, existe una relación lineal (entre la temperatura rectal y la frecuencia cardíaca) para frecuencias cardíacas de hasta unos 150 latidos por minuto. Para IFC $>225$ :

$$
F C_{f}=65+\left(F C_{f}-65\right)\left(1-\mathrm{e}^{-3 t}\right)
$$

es decir, existe una relación exponencial a medida que la frecuencia cardíaca se aproxima al máximo, donde:

$F C_{f}=$ frecuencia cardíaca de equilibrio (lpm),

65 = supuesta frecuencia cardíaca en reposo y en condiciones de bienestar (lpm), y $t=$ tiempo en horas.

\section{Indice de temperatura de globo de bulbo húmedo} (WBGT)

La temperatura de globo de bulbo húmedo viene dada por:

$$
\text { W BG T }=0,7 T_{n w b}+0,2 T_{g}+0,1 T_{a}
$$

para condiciones con radiación solar, y

$$
W B G T=0,7 T_{n w b}+0,3 T_{g}
$$

para interiores sin radiación solar, donde $T_{n w b}=$ temperatura de un termómetro de bulbo húmedo con ventilación natural, $T_{a}=$ temperatura del aire, y $T_{g}=$ temperatura de un termómetro de globo negro de $150 \mathrm{~mm}$ de diámetro. 
Tabla 42.7 • Prácticas de trabajo en ambientes calurosos.
A. Controles técnicos
1. Reducción de la fuente de calor
2. Control del calor convectivo
3. Control del calor radiante

4. Control del calor evaporativo

\author{
B. Prácticas de trabajo e higiene \\ y controles administrativos \\ 1. Limitar la duración y/ o la temperatura de exposición
}

2. Reducir la carga de calor metabólico

3. Aumentar la tolerancia

4. Educación en materia de salud y seguridad

5. Programas de detección de la intolerancia al calor

\section{Programa de alerta de calor}

1. En primavera, crear un comité de alerta de calor (médico o enfermero/ a de empresa, higienista industrial, experto técnico en seguridad, técnico de operaciones, alto directivo)

2. Declarar alerta de calor ante una ola de calor

Ejemplo

Alejarla de los trabajadores o reducir la temperatura. No siempre posible.

Modificar la temperatura del aire y los movimientos de aire. Los refrigeradores locales pueden ser útiles.

Reducir la temperatura de las superficies 0 instalar pantallas reflectoras entre la fuente radiante y los trabajadores. Modificar la emisividad de la superficie. Utilizar puertas que se abran sólo cuando sea necesario el acceso.

Aumentar el movimiento del aire, reducir la presión del vapor de agua. Utilizar ventiladores 0 aire acondicionado. Humedecer la ropa y dirigir un chorro de aire hacia la persona.

Ejemplo

Realizar los trabajos a las horas del día y las épocas del año con menos calor. Proporcionar áreas frescas para el descanso y la recuperación. Proporcionar personal adicional, dar al trabajador libertad para interrumpir el trabajo, aumentar el consumo de agua.

Mecanización. Rediseñar los puestos de trabajo. Reducir el tiempo de trabajo. Ampliar la plantilla.

Programa de aclimatación al calor. Mantener a los trabajadores en buena forma física. Asegurar la reposición del agua perdida y mantener el equilibrio electrolítico en caso necesario.

Supervisores que sepan reconocer los signos de un trastorno por calor y conozcan las técnicas de primeros auxilios. Instrucción básica de todo el personal sobre precauciones personales, uso de equipos protectores y efectos de factores ajenos al trabajo (p.ej., alcohol). Uso de un sistema basado en el "compañero". Existencia de planes de contingencia para tratamiento.

Antecedentes de trastornos por calor. Mala forma física.

\section{Ejemplo}

Organizar cursos de formación. Encomendar a los supervisores la comprobación de las fuentes de agua, etc. Comprobar las instalaciones, prácticas, disponibilidad, etc.

Posponer las tareas que no sean urgentes. Ampliar la plantilla, prolongar los períodos de descanso. Recordar a los trabajadores que tienen que beber. Mejorar las prácticas de trabajo.

\section{Enfriamiento adicional del cuerpo y uso de prendas protectoras}

Recurrir a ello si no son susceptibles de modificar el trabajador, el trabajo o el ambiente y si el estrés por calor sigue superando los límites permisibles. Los trabajadores deben estar plenamente aclimatados al calor y haber recibido una formación adecuada en el uso de prendas protectoras. Como ejemplos pueden citarse los trajes refrigerados con agua, los trajes refrigerados con aire, las chaquetas con hielo en los bolsillos y los trajes exteriores humedecidos.

\section{E. Deterioro del rendimiento laboral}

Debe recordarse que el uso de prendas protectoras contra agentes tóxicos aumenta el estrés por calor. Todas las prendas entorpecen las actividades y pueden reducir el rendimiento laboral ( $p$. ej., al reducir la capacidad de recibir información sensorial dificultando aśl la audición o la visión).

Fuente: NIOSH 1986.

donde $\mathrm{H}$ R es la frecuencia cardíaca después de la recuperación y $H R_{0}$ es la frecuencia cardíaca en reposo en un ambiente térmicamente neutro.

\section{Indices directos del estrés por calor}

\section{Indice de temperatura de globo de bulbo húmedo}

El índice de temperatura de globo de bulbo húmedo (W et $B$ ulb G lobe T emperature Index, WBG T) es, con diferencia, el más utilizado en todo el mundo. Fue desarrollado durante una investigación realizada por la M arina de Estados U nidos sobre los accidentes por calor que sufría el personal militar (Yaglou y M inard 1957) como una aproximación a la Temperatura Efectiva Corregida (TEC) más complicada de obtener, modificada para tener en cuenta la absorción solar de los uniformes militares de color verde.

L oS valores límites del WBGT se utilizaron para determinar cuándo los reclutas militares podían recibir instrucción. Se observó que los accidentes por calor y el tiempo perdido por interrupción de la instrucción se reducían cuando se utilizaba el índice WBGT en lugar de tan sólo la temperatura del aire. EI índice WBGT fue adoptado por NIOSH (1972), ACGIH (1990) e ISO 7243 (1989a) y su uso se sigue recomendando hoy en día. En la norma ISO 7243 (1989a), basada en el índice WBGT, se describe un método sencillo de utilizar en ambientes calurosos para establecer un diagnóstico "rápido". Dicha norma incluye también las especificaciones de los instrumentos de medida, como son los valores límite del WBGT para personas aclimatadas y no aclimatadas (véase la Tabla 42.6). Por ejemplo, 
Tabla 42.8 • Ecuaciones utilizadas para el cálculo del índice $S W$ y en el método de evaluación de ISO 7933 (1989b).

$$
\begin{aligned}
& S W_{\text {req }}=\frac{E_{\text {req }}}{r_{\text {req }}} \\
& E_{\text {req }}=M-W-C_{\text {res }}-E_{\text {res }}-C-R \\
& C_{\text {res }}=0,0014 M\left(35-t_{a}\right) \\
& E_{\text {res }}=0,0173 M\left(5,624-P_{a}\right) \\
& C=h_{c} \cdot F_{c l}\left(\bar{t}_{s k}-\bar{t}_{a}\right) \\
& R=h_{r} \cdot F_{c l}\left(\bar{t}_{s k}-\bar{t}_{r}\right) \\
& W=E / E_{\max } \\
& r=1-w^{2} / 2 \\
& h_{c}=2,38\left|\bar{t}_{s k}-t_{a}\right|^{0,25} \text { para la convección natural } \\
& =3,5+5,2 \mathrm{v}_{\mathrm{ar}} \text {, para } \mathrm{v}_{\mathrm{ar}}<1 \mathrm{~ms}^{-1} \\
& =8,7 \mathrm{v}_{\mathrm{ar}}{ }^{0,6}, \text { para } \mathrm{v}_{\mathrm{ar}}>1 \mathrm{~ms}^{-1}
\end{aligned}
$$$$
v_{a r}=v_{a}+0,0052(M-58)
$$$$
h_{r}=\left(\sigma E_{s k} \cdot A_{r} / A_{0}\right) \frac{\left[\left(\bar{t}_{s k}+273\right)^{4}-\left(\bar{t}_{r}+273\right)^{4}\right]}{\left(t_{s k}-\bar{t}_{r}\right)}
$$$$
F_{c l}=\frac{1}{\left[\left.\left(h_{c}+h_{r}\right)\right|_{c l}+\frac{1}{f_{c l}}\right]}
$$$$
f_{c l}=1+1,97 I_{c l}
$$$$
E_{\max }=\frac{\left(P_{s k, s}-P_{a}\right)}{R_{T}}
$$$$
R_{T}=\frac{1}{\left(h_{e}-F_{p d}\right)}
$$$$
h_{e}=16,7 h_{c}
$$

$$
F_{p d}=\left\{1+2,22 h_{c}\left[\frac{I_{c l}-\left(1+\frac{1}{f_{c l}}\right)}{h_{c}-h_{r}}\right]\right\}^{-1}
$$

$\bar{t}_{s k}=30,0+0,093 t_{a}+0,045 \bar{t}_{r}-0,571 v_{a}+0,254 P_{a}+0,00128 M-3,57 I_{c l}$ $0 \bar{t}_{s k}=36^{\circ} \mathrm{C}$, para una aproximación o cuando los valores superan los límites para los que se derivó la ecuación.
Tabla 42.9 • Descripción de los términos utilizados en ISO 7933 (1989b).

Símbolo Término

Unidades

$A_{r} / A_{d u} \quad$ fracción de la superficie cutánea implicada en el inter- $n d$ cambio de calor por radiación

C intercambio de calor a través de la piel por convección $\mathrm{Wm}^{-2}$

$C_{\text {res }} \quad$ pérdida de calor en la respiración por convección $\quad \mathrm{Wm}^{-2}$

E flujo de calor por evaporación en la superficie cutánea $\mathrm{Wm}^{-2}$

$E_{\max }$ tasa máxima de evaporación que puede conseguirse $\mathrm{Wm}^{-2}$ con la piel totalmente húmeda

$E_{\text {req }}$ evaporación necesaria para el equilibrio térmico $\quad \mathrm{Wm}^{-2}$

$E_{\text {res }} \quad$ pérdida de calor en la respiración por evaporación $\mathrm{Wm}^{-2}$

$E_{s k} \quad$ emisividad de la piel $(0,97) \quad n d$

$F_{c l} \quad$ factor de reducción por intercambio de calor sensible a nd través de la ropa

$F_{p c l} \quad$ factor de reducción por el intercambio de calor latente nd

$f_{c l} \quad$ relación entre la superficie de la persona vestida y $n d$ desvestida

$h_{c} \quad$ coeficiente de transferencia de calor por convección $\quad \mathrm{Wm}^{-2} \mathrm{~K}^{-1}$

$h_{e} \quad$ coeficiente de transferencia de calor por evaporación $\quad \mathrm{Wm}^{-2} \mathrm{KPa}^{-1}$

$h$ coeficiente de transferencia de calor radiante $\quad \mathrm{Wm}^{-2} \mathrm{~K}^{-1}$

$I_{c l}$ aislamiento térmico básico de la ropa seca $\mathrm{m}^{2} \mathrm{KW}^{-1}$

$K \quad$ intercambio de calor a través de la piel por conducción $\mathrm{Wm}^{-2}$

M tasa metabólica $\mathrm{Wm}^{-2}$

$P_{a} \quad$ presión parcial del vapor de agua $\quad \mathrm{kPa}$

$P_{s k, s} \quad$ presión de vapor saturado a la temperatura cutánea $\mathrm{kPa}$

$R \quad$ intercambio de calor a través de la piel por radiación $\mathrm{Wm}^{-2}$

$R_{T} \quad$ resistencia total a la evaporación de la capa de aire $\mathrm{m}^{2} \mathrm{kPaW}^{-1}$ limitante y la ropa

$r_{\text {req }}$ eficiencia evaporativa con la tasa de sudoración nd requerida tasa de sudoración requerida para el equilibrio térmico $\mathrm{Wm}^{-2}$

$\sigma \quad$ constante de Stefan-Boltzman, $5,67 \times 10^{-8} \quad \mathrm{Wm}^{-2} \mathrm{~K}^{-4}$

$t_{a}$ temperatura del aire $\quad{ }^{\circ} \mathrm{C}$

$\bar{t}_{\mathrm{r}} \quad$ temperatura radiante media $\quad{ }^{\circ} \mathrm{C}$

$\bar{t}_{\text {sk }}$ temperatura cutánea media ${ }^{\circ} \mathrm{C}$

$v_{a} \quad$ velocidad del aire para una persona estacionaria $\mathrm{ms}^{-1}$

$v_{\text {ar }} \quad$ velocidad relativa del aire $\mathrm{ms}^{-1}$

W trabajo mecánico $\mathrm{Wm}^{-2}$

W humedad de la piel nd

$W_{\text {req }} \quad$ humedad necesaria de la piel nd

$n d=$ no dimensional. 
Tabla 42.10 - Valores de W BG T $\left({ }^{\circ} \mathrm{C}\right)$ para cuatro fases de trabajo.

\begin{tabular}{lll}
$\begin{array}{l}\text { Fase del trabajo } \\
\text { (minutos) }\end{array}$ & $\begin{array}{l}\text { WBGT }= \\
\text { WBGT }_{\text {ank }}+2 \text { WBGT }_{\text {abd }}+\text { WBGT }_{\text {hd }}\end{array}$ & $\begin{array}{l}\text { WBGT de } \\
\text { referencia }\end{array}$ \\
$0-60$ & 25 & 30 \\
$60-90$ & 23 & 33 \\
$90-150$ & 23 & 30 \\
$150-180$ & 30 & 28 \\
\hline
\end{tabular}

para una persona aclimatada en reposo con una ropa de 0,6 clo, el valor límite del WBGT es de $33^{\circ} \mathrm{C}$. Los límites establecidos por ISO 7243 (1989a) y NIOSH 1972 son casi idénticos. LoS cálculos del índice WBGT se explican en la sección V del recuadro adjunto.

Gracias a la simplicidad de este índice y a su aplicación por organismos influyentes, se ha conseguido su aceptación generalizada. Al igual que todos los índices directos, presenta limitaciones cuando se utiliza para simular la respuesta humana y debe utilizarse con precaución en aplicaciones prácticas. En el mercado existen instrumentos portátiles que miden el índice WBG T (p. ej., O lesen 1985).

\section{Límite fisiológico de exposición al calor (LFEC)}

Dasler $(1974,1977)$ propone unos valores límites del WBGT basándose en la predicción de que se sobrepasen dos límites fisiológicos (a partir de datos experimentales) de estrés inadmisible. L os límites vienen dados por:

LFEC $=\left(17,25 \times 10^{8}-12,97 \mathrm{M} \times 10^{6}+18,61 M^{2} \times 10^{3}\right) \times$ W BG $^{-5,36}$

Por tanto, este índice utiliza el índice directo WBGT en la zona de urgencia ambiental (véase la Figura 42.4), donde puede producirse almacenamiento de calor.

\section{Indice de temperatura de globo húmedo (Wet Globe Tempera- ture, WG T)}

L a temperatura de un globo negro húmedo del tamaño adecuado puede utilizarse como índice del estrés por calor. Tal índice se basa en el principio de que dicha temperatura se ve afectada tanto por la transferencia de calor seco como por la evaporación, como sería el caso de un hombre que suda. Así, la temperatura puede utilizarse, basándose en la experiencia previa, como índice del estrés por calor. O lesen (1985) describe el WGT como la temperatura de un globo negro de $63,5 \mathrm{~mm}$ de diámetro cubierto por una tela negra humedecida. La temperatura se lee una vez alcanzado el equilibrio al cabo de unos 10 o 15 minutos de exposición. EI NIOSH (1986) describe el Botsball (Botsford 1971) como el instrumento más sencillo y fácil de leer. Se trata de una esfera de cobre de 3 pulgadas $(76,2 \mathrm{~mm})$ de diámetro cubierta por una tela negra que se mantiene con una humedad del $100 \%$ gracias a un recipiente de agua que empapa automáticamente la tela. El componente sensor del termómetro está situado en el centro de esfera y la temperatura se lee en un dial (codificado en colores).

Existe una sencilla ecuación que relaciona WG T y WBGT:

$$
W B G T=W G T+2 \stackrel{\circ}{C}
$$

para condiciones moderadas de calor radiante y humedad (N IOSH 1986), pero por supuesto esta relación se mantiene sólo en ciertas condiciones.

\section{Indice de 0 xford}

Lind (1957) propuso un índice sencillo y directo de la exposición al calor limitada por el almacenamiento y basada en una suma ponderada de la temperatura de bulbo húmedo aspirado $\left(T_{w b}\right)$ y la temperatura de bulbo seco $\left(\mathrm{T}_{\mathrm{db}}\right)$ :

$$
W D=0,85 T_{w b}+0,15 T_{d b}
$$

Los tiempos de exposición permisible establecidos para los equipos de rescate de las minas se basaron en este índice. Aunque tiene muchas aplicaciones, no es adecuado cuando existe una importante radiación térmica.

\section{Prácticas de trabajo en ambientes calurosos}

EI NIOSH (1986) proporciona una descripción detallada de las prácticas de trabajo en ambientes calurosos, incluidas las prácticas de medicina preventiva. En ISO CD 12894 (1993) se recomienda la vigilancia médica de las personas expuestas a ambientes calurosos o fríos. Debe siempre recordarse que un derecho humano básico, contemplado en la D eclaración de H esinki, es que, siempre que sea posible, las personas pueden retirarse de unas condiciones ambientales extremas sin necesidad de explicación. Cuando dicha exposición tiene lugar, los riesgos pueden reducirse considerablemente con unas prácticas de trabajo adecuadas.

Un principio razonable en la ergonomía ambiental y la higiene industrial es que los factores de estrés ambiental deben siempre intentar reducirse en su fuente. EI NIO SH (1986) clasifica los métodos de control en cinco tipos (véase la Tabla 42.7).

Se han realizado numerosas investigaciones militares sobre las Ilamadas prendas protectoras NBC (nucleares, biológicas y químicas). En ambientes calurosos, los trabajadores no se pueden quitar la ropa y las prácticas de trabajo son muy importantes. U n problema similar ocurre con los trabajadores de las centrales nucleares. Los métodos de enfriamiento rápido de los trabajadores para que puedan volver al trabajo consisten en humedecer la superficie exterior de las prendas de vestir con agua y la aplicación de un chorro de aire frío sobre dicha superficie. O tras técnicas consisten en utilizar dispositivos activos de refrigeración y métodos para refrigerar algunas partes del cuerpo. En la actualidad se está empezando a utilizar la tecnología de las prendas militares en contextos industriales, pero aún así unas prácticas adecuadas de trabajo pueden reducir considerablemente el riesgo.

\section{Evaluación de ambientes calurosos utilizando las normas ISO}

El siguiente ejemplo hipotético demuestra como pueden utilizarse las normas ISO para evaluar un ambiente caluroso

\begin{tabular}{|c|c|c|c|c|c|c|}
\hline $\begin{array}{l}\text { Fase del trabajo } \\
\text { (minutos) }\end{array}$ & $\begin{array}{l}t_{a} \\
\left({ }^{\circ} \mathrm{C}\right)\end{array}$ & $\begin{array}{l}t_{r} \\
\left({ }^{\circ} \mathrm{C}\right)\end{array}$ & $\begin{array}{l}P_{a} \\
\text { (Kpa) }\end{array}$ & $\begin{array}{l}\mathrm{V} \\
\left(\mathrm{ms}^{-1}\right)\end{array}$ & $\begin{array}{l}\mathrm{clo} \\
\text { (clo) }\end{array}$ & $\begin{array}{l}\text { Act } \\
\left(W^{-2}\right)\end{array}$ \\
\hline $0-60$ & 30 & 50 & 3 & 0,15 & 0,6 & 100 \\
\hline $60-90$ & 30 & 30 & 3 & 0,05 & 0,6 & 58 \\
\hline $90-150$ & 30 & 30 & 3 & 0,20 & 0,6 & 100 \\
\hline $150-180$ & 30 & 60 & 3 & 0,30 & 1,0 & 150 \\
\hline
\end{tabular}
(Parsons 1993). 
El trabajo en una fábrica siderúrgica se divide en cuatro fases. Los trabajadores se visten y realizan un trabajo ligero durante 1 hora en un ambiente expuesto a calor radiante. Descansan una hora y seguidamente realizan el mismo trabajo ligero durante otra hora protegidos del calor radiante. A continuación, realizan un trabajo que les exige un nivel moderado de actividad física en un ambiente con calor radiante durante 30 minutos.

ISO 7243 proporciona un método sencillo para vigilar el ambiente utilizando el índice W BG T. Si los niveles calculados de WBGT son inferiores a los valores WBGT de referencia indicados en esta norma, no es necesario tomar ninguna medida. Si los sobrepasan (Tabla 42.6), debe reducirse el estrés al que están sometidos los trabajadores mediante controles técnicos y unas prácticas de trabajo adecuadas. Una medida complementaria o alternativa consiste en realizar una evaluación analítica de acuerdo con ISO 7933.

Los valores WBGT para el trabajo que se presentan en la Tabla 42.10 se midieron conforme a las especificaciones indicadas en ISO 7243 e ISO 7726. Los factores ambientales y personales relacionados con las cuatro fases del trabajo se presentan en la Tabla 42.11.

Puede observarse que durante parte del trabajo, los valores WBGT sobrepasan los valores de referencia, por lo que se concluye que es necesario realizar un análisis más detallado.

El método analítico de evaluación que se describe en ISO 7933 se aplicó utilizando los datos que aparecen en la Tabla 42.11 y el programa informático citado en el anexo de la norma. En la Tabla 42.12 se muestran los resultados correspondientes a los trabajadores aclimatados en términos de nivel de alarma.

Por consiguiente, una evaluación global permite predecir que los trabajadores no aclimatados, pero con capacidad física para el trabajo, podrían realizar un turno de 8 horas sin sufrir un estrés fisiológico (térmico) inaceptable. Si se precisa una mayor exactitud, o si es necesario evaluar a trabajadores individuales, las normas ISO 8996 e ISO 9920 proporcionan información más detallada sobre la producción de calor metabólico y el aislamiento de la ropa.

La norma ISO 9886 describe métodos para medir el estrés fisiológico de los trabajadores y puede utilizarse para diseñar y evaluar ambientes de trabajadores específicos. La temperatura cutánea media, la temperatura interna del organismo, la frecuencia cardíaca y la pérdida de masa son relevantes en este ejemplo. ISO CD 12894 proporciona directrices para la supervisión médica de una investigación.

Tabla 42.12 • Evaluación analítica utilizando ISO 7933.

\begin{tabular}{|c|c|c|c|c|c|}
\hline \multirow{2}{*}{$\begin{array}{l}\text { Fase del } \\
\text { trabajo } \\
\text { (minutos) }\end{array}$} & \multicolumn{3}{|c|}{ Valores previstos } & \multirow{2}{*}{$\begin{array}{l}\text { Exposición } \\
\text { de duración } \\
\text { limitada } \\
\text { (minutos) }\end{array}$} & \multirow{2}{*}{$\begin{array}{l}\text { Razón del } \\
\text { límite }\end{array}$} \\
\hline & $\mathrm{t}_{s} \mathrm{k}\left({ }^{\circ} \mathrm{C}\right)$ & $w(n d)$ & $\begin{array}{l}S W \\
\left(g h^{-1}\right)\end{array}$ & & \\
\hline $0-60$ & 35,5 & 0,93 & 553 & 423 & Pérdida hídrica \\
\hline $60-90$ & 34,6 & 0,30 & 83 & 480 & Sin límite \\
\hline $90-150$ & 34,6 & 0,57 & 213 & 480 & Sin límite \\
\hline $150-180$ & 35,7 & 1,00 & 566 & 45 & $\begin{array}{l}\text { Temperatura } \\
\text { corporal }\end{array}$ \\
\hline Total & - & 0,82 & 382 & 480 & Sin límite \\
\hline
\end{tabular}

\section{INTERCAMBIO DE CALOR A TRAVES DE LA ROPA}

Wouter A. Lotens

Para poder sobrevivir y trabajar en condiciones más calurosas o más frías, debe crearse un clima cálido en la superficie de la piel por medio de la ropa y el calentamiento o enfriamiento artificial. Para poder diseñar las prendas más eficaces para el trabajo a temperaturas extremas, tienen que conocerse los mecanismos de intercambio de calor a través de la ropa.

\section{Mecanismos de transferencia de calor a través de la ropa}

\section{Naturaleza del aislamiento proporcionado por la ropa}

La transferencia de calor a través de la ropa 0 , al contrario, el aislamiento que proporcionan las prendas de vestir, depende en gran medida de que el aire quede atrapado en y sobre la ropa. La ropa consiste, como primera aproximación, en cualquier tipo de material que atrape capas de aire. Es una definición aproximada porque algunas de las propiedades de los materiales son importantes, como la construcción mecánica de los tejidos (por ejemplo, resistencia al viento y capacidad de las fibras para soportar tejidos gruesos) y las propiedades intrínsecas de las fibras (por ejemplo, absorción y reflexión de calor radiante, absorción de vapor de agua, transpiración del sudor). Para ambientes no demasiado extremos suelen sobrestimarse las ventajas de algunos tipos de fibras.

\section{Capas de aire y movimiento del aire}

La idea de que es el aire, y en particular el aire inmóvil, el que proporciona aislamiento, sugiere que las capas gruesas de aire aumentan el aislamiento. Y no deja de ser cierto, aunque el grosor de las capas de aire está físicamente limitado. Las capas se forman por adhesión de moléculas de gas a cualquier superficie, por cohesión de una segunda capa de moléculas a la primera, y así sucesivamente. $C$ on todo, las fuerzas que unen a las sucesivas capas son cada vez más débiles, de manera que las moléculas exteriores se mueven incluso con movimientos externos de aire muy pequeños. Cuando el aire está inmóvil, las capas de aire pueden tener un grosor de hasta $12 \mathrm{~mm}$, pero cuando el movimiento del aire aumenta, como en el caso de una tormenta, el grosor se reduce a menos de $1 \mathrm{~mm}$. En general, existe una relación de raíz cuadrada entre el grosor de las capas de aire y el movimiento del aire (véase el recuadro de "Fórmulas y Definiciones"). La función exacta depende del tamaño y la forma de la superficie.

\section{Conducción de calor del aire inmóvil y en movimiento}

El aire inmóvil actúa como una capa aislante que tiene una conductividad constante con independencia de la forma del material. Las alteraciones de las capas de aire produce una pérdida de grosor efectivo; estas alteraciones pueden estar causadas no sólo por el viento, sino también por el movimiento de la persona que lleva la ropa, desplazamiento de todo el cuerpo (un componente del viento) y movimiento de ciertas partes del cuerpo. A este efecto se suma la convección natural. En la Figura 42.7 se muestra un gráfico del efecto de la velocidad del aire en la capacidad aislante de una capa de aire.

\section{Transferencia de calor por radiación}

La radiación es otro importante mecanismo para la transferencia de calor. Todas las superficies irradian calor y absorben el calor irradiado por otras superficies. El flujo de calor radiante es aproximadamente proporcional a la diferencia de temperatura entre 


\section{Fórmulas y definiciones}

En general existe una relación de raíz cuadrada entre el grosor d de una capa de aire estático y la velocidad del aire $v$. La función exacta depende del tamaño y la forma de la superficie, pero para el cuerpo humano se puede realizar la siguiente aproximación:

$$
d=0,0031 / \sqrt{ } v
$$

El aire inmóvil actúa como una capa aislante con una conductividad $\lambda$ (constante del material, con independencia de su forma) de $0,026 \mathrm{~W} / \mathrm{mK}$, y un coeficiente de transferencia de calor $h$ (unidades de $\mathrm{W} / \mathrm{m}^{2} \mathrm{~K}$ ) (propiedad conductora del material) de:

$$
h=\lambda \cdot d=8,3 \sqrt{ } v \text { (Kerslake 1972). }
$$

El flujo de calor radiante $\left(f_{r}\right)$ entre dos superficies es aproximadamente proporcional a la diferencia de temperatura entre ambas:

$$
f_{r}=4 \cdot \varepsilon \cdot \sigma \cdot T^{3} \Delta T
$$

donde $T$ es la temperatura media absoluta (en grados Kelvin) de las dos superficies, $\varepsilon$ es el coeficiente de absorción y $\sigma$ es la constante de Stefan-Boltzmann $\left(5,67 \times 10^{-8} \mathrm{~W} / \mathrm{m}^{2} \mathrm{~K}^{4}\right)$. La magnitud del intercambio de radiación está inversamente relacionada con el número de capas interpuestas (n):

$$
f_{r}=f_{r 0} /(1+n)
$$

El aislamiento proporcionado por la ropa $\left(I_{c} \mid\right)$ viene dado por las siguientes ecuaciones:

$$
\begin{gathered}
I_{c l}=\left(T_{s k}-T_{c l}\right) / f_{d r y} \\
I_{a}=\left(T_{c l}-T_{a}\right) \cdot f_{c l} / f_{d r y} \\
I_{t}=I_{c l}+I_{a} / f_{c l}
\end{gathered}
$$

donde $\mathrm{I}_{\mathrm{cl}}$ es el aislamiento intrínseco, $\mathrm{I}_{\mathrm{a}}$ es el aislamiento del aire (adyacente), $I_{t}$ es el aislamiento total, $T_{s k}$ es la temperatura cutánea media, $T_{c l}$ es la temperatura media de la superficie exterior de la ropa, $T_{a}$ es la temperatura del aire, $f_{d r y}$ es el flujo de calor seco (calor convectivo y radiante) por unidad de superficie de la piel y $f_{c l}$ es el factor de la superficie de la ropa. Este coeficiente se subestimó en los primeros estudios, pero estudios más recientes coinciden en la expresión $f_{\mathrm{cl}}=1+1,9 \cdot I_{\mathrm{cl}}$

I suele expresarse en unidades clo; un clo equivale a $0,155 \mathrm{~m}^{2} \mathrm{~K} / \mathrm{W}$

M cC ullough y cols. (1985) derivaron una ecuación de regresión a partir de los datos sobre distintos conjuntos de prendas, utilizando el grosor del tejido $\left(d_{\text {fabr }}\right.$ en $\mathrm{mm}$ ) y el porcentaje de la superficie corporal cubierta $\left(p_{b c}\right)$ como determinantes. Su fórmula para calcular el aislamiento proporcionado por cada prenda de vestir $\left(l_{\text {cli }}\right)$ es:

$$
I_{c l i}=0,0012 \cdot p_{b c}+0,0002 \cdot p_{b c} \cdot d_{f a \% 4 b r}-0,012
$$

La resistencia evaporativa $R$ (unidades de $s / \mathrm{m}$ ) puede definirse como:

$$
\mathrm{R}_{\mathrm{cl}}=\left(C_{\mathrm{sk}}-C_{\mathrm{cl}}\right) / \dot{m}
$$

(o en ocasiones $R_{\mathrm{e}}=\left(P_{\mathrm{sk}}-P_{\mathrm{cl}}\right) / \mathrm{f}_{\mathrm{e}}$, en $\mathrm{m}^{2} \mathrm{~Pa} / \mathrm{W}$ )

$$
R_{c l}=\left(d_{e n s}+0,001 \cdot n+0,3 \cdot d_{c l}\right) / D
$$

Para las capas de tejido, el equivalente de aire $\left(d_{\text {eq }}\right)$ es el grosor del aire que ofrece la misma resistencia a la difusión del calor que el tejido. Los flujos a sociados de vapor $(m)$ y calor la tente $\left(f_{e}\right)$ son:

$$
\begin{gathered}
\dot{m}=\mathrm{D} \cdot \Delta \mathrm{C} / d_{\text {eq }} \text { (en unidades } \mathrm{g} / \mathrm{m}^{2} \mathrm{~s} \text { ) } \\
\mathrm{f}_{\mathrm{e}}=\mathrm{H}_{\mathrm{e}} \cdot \dot{\mathrm{m}} \text { (en unidades } \mathrm{W} / \mathrm{m}^{2} \text { ) }
\end{gathered}
$$

donde $D$ es el coeficiente de difusión $\left(\mathrm{m}^{2} / \mathrm{s}\right), C$ la concentración de vapor $\left(\mathrm{g} / \mathrm{m}^{3}\right)$ y $\mathrm{H}_{\mathrm{e}}$ el calor de evaporación $(2.430 \mathrm{~J} / \mathrm{g})$.

$$
d_{\text {eq }}=0,001+1,3 \cdot d_{\text {fabr }}
$$

(obtenido de Lotens 1993). $d_{\text {eq }}$ está relacionado con $R$ por:

donde:

$$
d_{\text {eq }}=R \cdot D
$$

$D$ es el coeficiente de difusión del vapor de agua en el aire, $2,5 \times 10^{-5} \mathrm{~m}^{2} / \mathrm{s}$.

\section{Resistencia al vapor del aire y los tejidos}

Las capas de aire ofrecen también resistencia a la difusión del sudor evaporado de la piel húmeda al ambiente. La resistencia es más o menos proporcional al grosor del conjunto de prendas. En el caso de los tejidos, la resistencia al vapor depende del aire atrapado y de la densidad de la construcción. En los tejidos naturales, una gran densidad no permite un gran grosor. Debido a esta limitación, se puede estimar el equivalente de aire de tejidos que no contienen películas ni revestimientos (véase la Figura 42.8). L os tejidos revestidos o los tejidos laminados en películas pueden ofrecer una resistencia imprevisible al vapor que debe determinarse por medición.

\section{De los tejidos y la capas de aire a las prendas de vestir}

\section{Capas múltiples de tejido}

Algunas conclusiones importantes que pueden extraerse de los mecanismos de transferencia del calor es que para que una prenda de vestir proporcione un gran aislamiento tiene que ser necesariamente gruesa, que se puede conseguir un gran aislamiento con conjuntos de prendas que consten de múltiples capas finas, que una prenda floja proporciona más aislamiento que una 


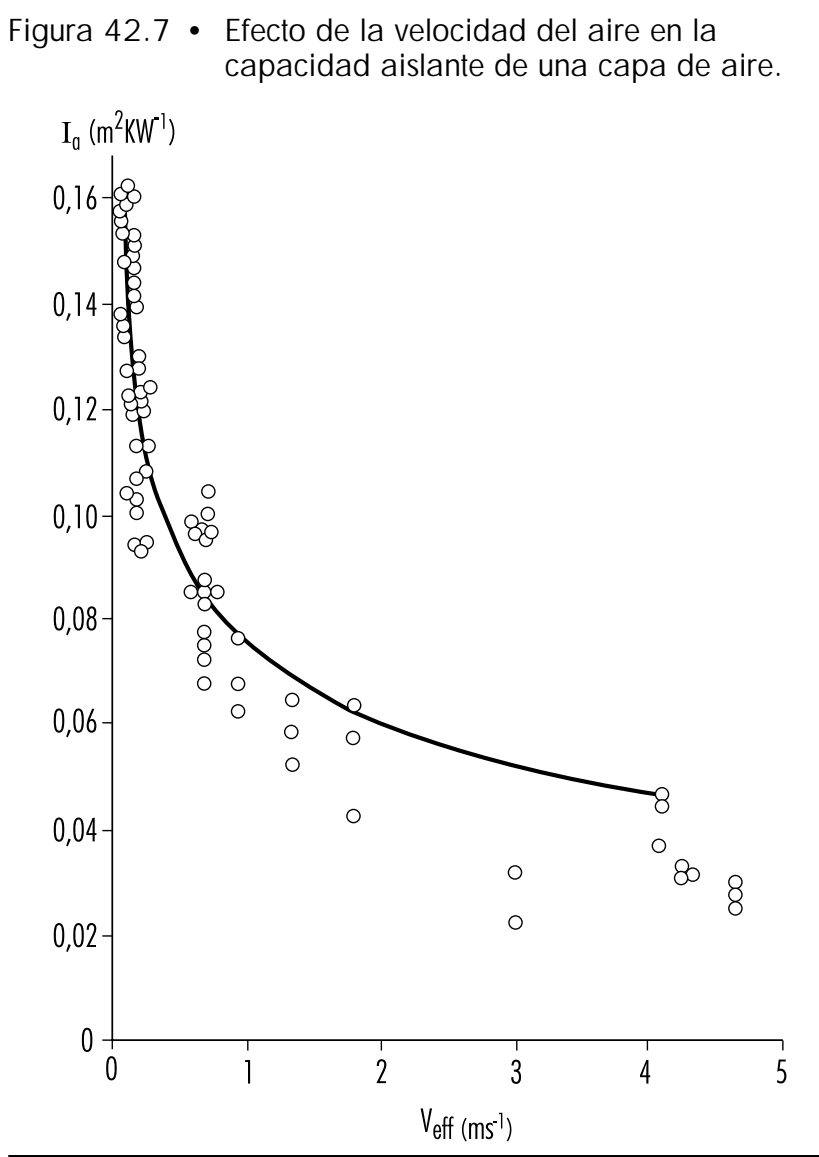

apretada y que el aislamiento tiene un límite inferior determinado por la capa de aire que se adhiere a la piel.

En el caso de las prendas de abrigo, es difícil conseguir el grosor necesario utilizando sólo tejidos finos. U na solución consiste en crear tejidos gruesos añadiendo dos tejidos interiores finos a una guata. La finalidad de la guata es crear una capa de aire y mantener el aire interno lo más quieto posible. Los tejidos gruesos ofrecen otra desventaja: cuantas más capas se superpongan, más se restringe la movilidad.

\section{Tipos de prendas de vestir}

El aislamiento que proporciona un conjunto de prendas de vestir depende en gran medida de su diseño. Los parámetros del diseño que influyen en el aislamiento son el número de capas, las aberturas, el ajuste, la distribución del aislamiento por el cuerpo y las zonas de piel al descubierto. Algunas propiedades de los materiales, como su permeabilidad al aire, su reflectancia y los revestimientos son también importantes. Además, el viento y la actividad alteran el aislamiento. ¿Se puede hacer una descripción adecuada de la ropa para poder predecir el bienestar y la tolerancia del que la usa? Se han hecho algunos intentos utilizando técnicas diferentes. La mayoría de las estimaciones del aislamiento total de la ropa se han realizado para condiciones estáticas (sin movimiento, sin aire) o en interiores, porque los datos disponibles se obtuvieron de maniquíes térmicos (M cCullough, Jones y H uck 1985). Las mediciones en seres humanos son laboriosas y los resultados varían ampliamente. D esde mediados del decenio de 1980 se han desarrollado y utilizado maniquíes móviles fiables (O lesen y cols. 1982; Nielsen, O lesen y Fanger 1985). Asimismo, la mejora de las técnicas de medición ha permitido realizar experimentos humanos más exactos. Un

\section{Figura 42.8 - Relación entre el grosor y la resistencia al vapor $\left(d_{\mathrm{eq}}\right)$ de tejidos sin revestimiento.}

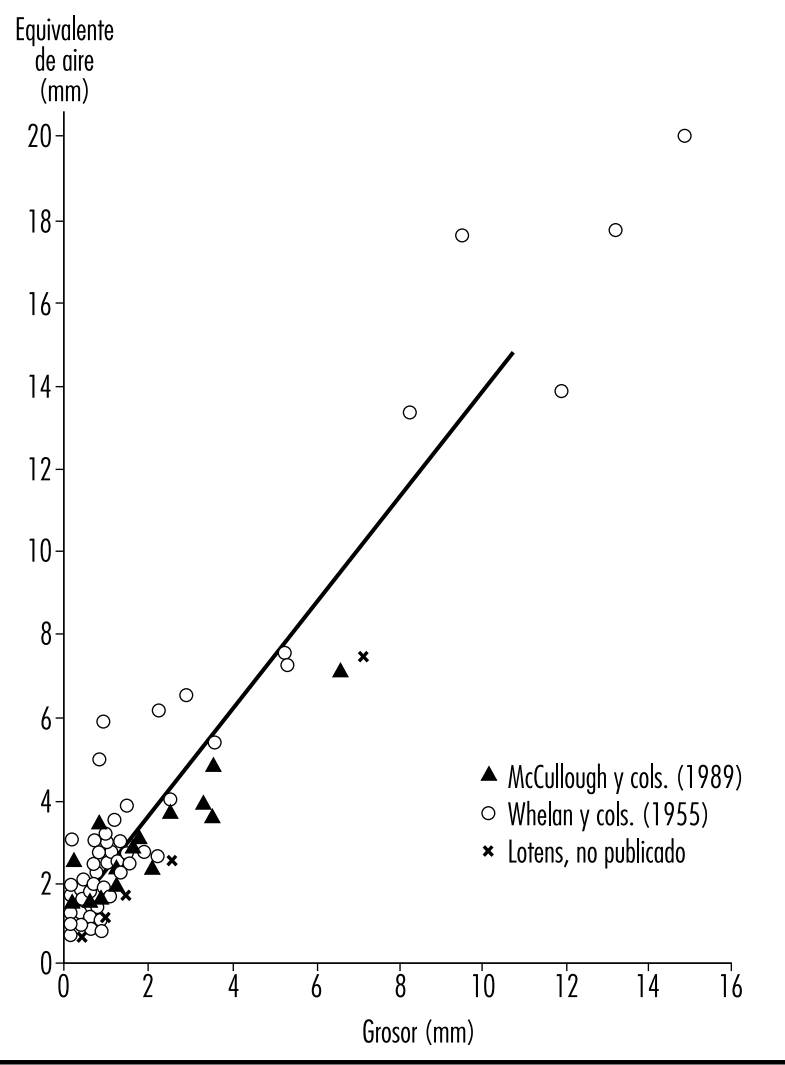

problema que todavía no se ha solucionado del todo es que en estas evaluaciones no se tiene debidamente en cuenta la evaporación del sudor. Casi nunca se utilizan maniquíes capaces de sudar y en ningún caso éstos permiten realizar una distribución realista de la tasa de sudoración en el cuerpo. Los seres humanos sudan, pero de una forma variable.

\section{Definición del aislamiento proporcionado por la ropa}

El aislamiento de la ropa $\left(I_{c l}\right.$ en unidades de $\left.\mathrm{m}^{2} \mathrm{~K} / \mathrm{W}\right)$ en condiciones estables, sin fuentes de radiación ni condensación sobre la ropa, se define en el recuadro. $I_{c l}$ suele expresarse en unidades clo (que no es una unidad internacional estándar). U n clo equivale a $0,155 \mathrm{~m}^{2} \mathrm{~K} / \mathrm{W}$. El uso de la unidad clo significa implícitamente que la medida hace referencia a todo el cuerpo y, por tanto, que incluye la tranfferencia de calor por las partes del cuerpo expuestas.

$I_{c \mid}$ se modifica por acción del movimiento y el viento, según se ha explicado antes, y una vez realizadas las correcciones oportunas, se obtiene el aislamiento resultante, un término utilizado con frecuencia, aunque no aceptado unánimemente.

\section{Distribución de la ropa por el cuerpo}

La transferencia total de calor corporal incluye el calor transferido por la piel expuesta (normalmente cabeza y manos) y el calor que atraviesa la ropa. El aislamiento intrínseco (véase el recuadro) se calcula para toda la superficie cutánea, no sólo para las partes protegidas. La piel expuesta transfiere más calor que la piel cubierta y, por tanto, tiene una gran influencia en el aislamiento intrínseco. Es un efecto que se potencia cuando aumenta la velocidad del aire. En la Figura 42.9 puede observarse que el aislamiento intrínseco se reduce sucesivamente debido a la curvatura 
Figura 42.9 - Aislamiento intrínseco e influencia de la curvatura del cuerpo, la piel desnuda y la velocidad del viento.

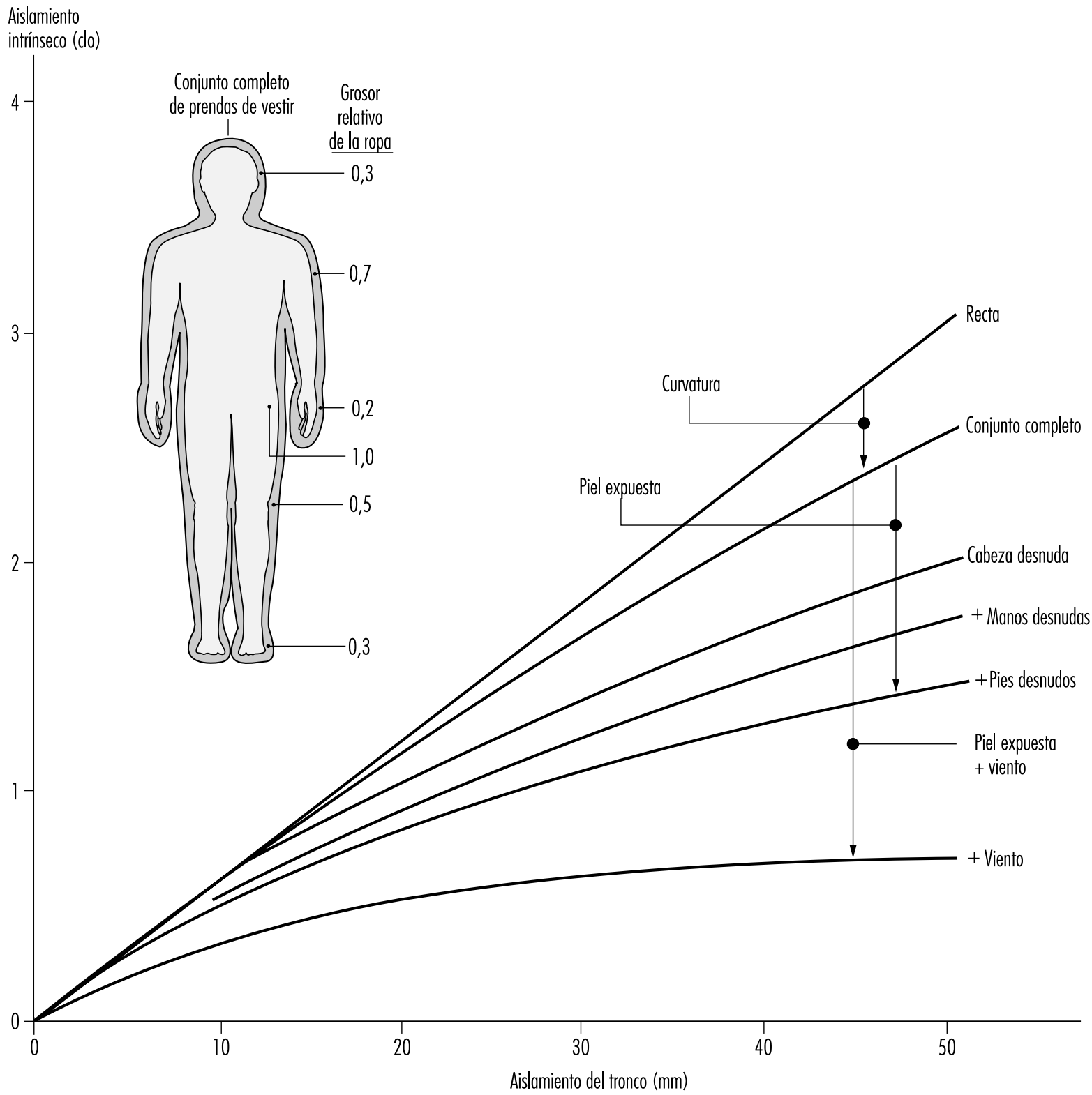

de la formas corporales (las capas exteriores son menos eficaces que las interiores), las partes del cuerpo expuestas (vías adicionales para la transferencia de calor) y la mayor velocidad del aire (menos aislamiento, sobre todo en la piel expuesta) (Lotens 1989). Cuando se utilizan trajes gruesos, la reducción del aislamiento es mucho más notable.

\section{G rosor y cobertura típica de la ropa}

A parentemente, tanto el grosor del aislamiento como la cobertura de la piel son determinantes de la pérdida de calor. En la vida real, estos dos factores están correlacionados en el sentido de que las prendas de abrigo no sólo son más gruesas, sino que también cubren una mayor proporción del cuerpo que las utilizadas en verano. En la Figura 42.10 se demuestra que estos efectos en conjunto producen una relación casi lineal entre el grosor de la prenda (expresado como volumen del material aislante por unidad de superficie de la prenda) y el aislamiento (Lotens 1989). El límite inferior viene dado por el aislamiento del aire adyacente y el límite superior, por la posibilidad de utilizar la prenda. La distribución uniforme proporciona el mejor aislamiento en climas fríos, pero las prendas que pesan y abultan mucho en las extremidades resultan poco prácticas. Por consiguiente, el grosor de la ropa suele ser mayor en el tronco y la sensibilidad de algunas zonas de piel al frío está adaptada a esta práctica. Las extremidades desempeñan una importante función en el control del equilibrio térmico del ser humano y un elevado aislamiento de las extremidades limita la eficacia de esa regulación.

\section{Ventilación de las prendas de vestir}

Las capas de aire atrapadas en la ropa están sujetas al movimiento del que la lleva y al viento, pero en un grado diferente a la 
Figura 42.10 - A islamiento total resultante del grosor de la ropa y su distribución sobre el cuerpo.

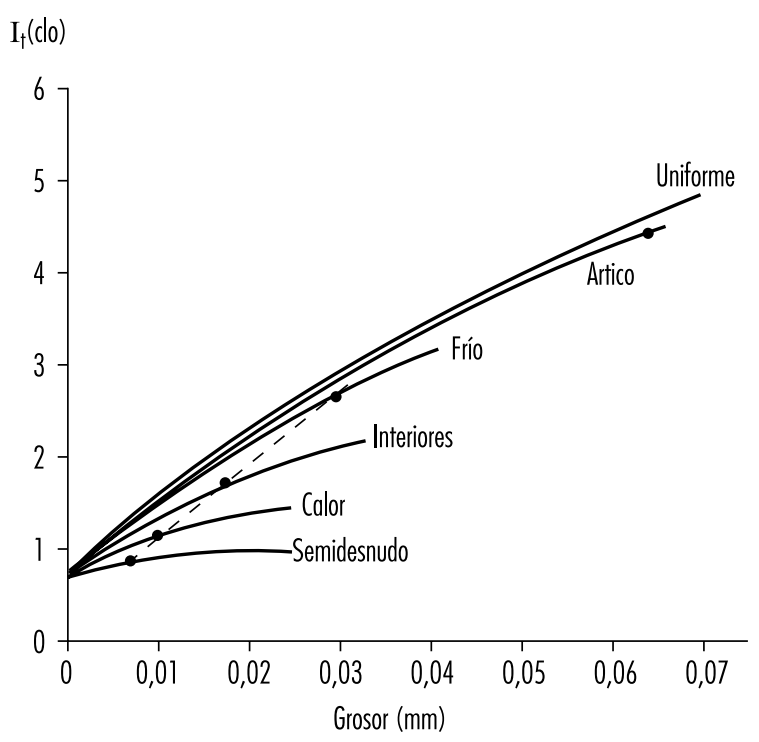

capa de aire adyacente. El viento produce ventilación en el interior de las prendas, tanto por el aire que penetra en los tejidos, como por el que se introduce por las aberturas, mientras que el movimiento de la persona aumenta la circulación interna. $H$ avenith, H eus y L otens (1990) observaron que el movimiento es un factor más importante en el interior de las prendas de vestir que en la capa de aire adyacente, en función de la permeabilidad al aire del tejido. En el caso de tejidos muy permeables al aire, el viento produce una ventilación considerable. Lotens (1993) demostró que la ventilación puede expresarse como una función de la velocidad efectiva del viento y la permeabilidad del tejido al aire.

\section{Estimación del aislamiento y la resistencia al vapor de las prendas de vestir}

Estimación física del aislamiento proporcionado por la ropa El grosor de un traje proporciona una primera estimación del aislamiento. La conductividad típica de un traje es de $0,08 \mathrm{~W} / \mathrm{mK}$. Con un grosor medio de $20 \mathrm{~mm}$, se obtiene un $\mathrm{I}_{\mathrm{cl}}$ de $0,25 \mathrm{~m}^{2} \mathrm{~K} / \mathrm{W}, 0$ 1,6 clo. En todo caso, las partes holgadas, como los pantalones o las mangas, tienen una conductividad mucho mayor, del orden de 0,15 , mientras que las partes ajustadas tienen una conductividad de 0,04, el famoso 4 clo por pulgada comunicado por Burton y Edholm (1955).

\section{Estimaciones obtenidas de ta blas}

O tros métodos utilizan valores obtenidos de tablas de prendas de vestir medidas previamente en maniquíes. Para investigar un conjunto de prendas de vestir, éste tiene que separarse en sus distintos componentes y buscar en la tabla el valor correspondiente a cada uno de ellos. Si se hace una elección incorrecta de la prenda más parecida que aparece en la tabla, pueden introducirse errores. Para estimar el aislamiento intrínseco de un conjunto de prendas, los valores del aislamiento proporcionado por cada prenda tienen que introducirse en una ecuación sumatoria (M cC ullough, Jones y H uck 1985).

\section{Factor de la superficie cubierta por la ropa}

Para calcular el aislamiento total tiene que estimarse $f_{c l}$ (véase el recuadro de la pág. 42.24). U na estimación experimental práctica consiste en medir la superficie cubierta por la ropa, introduciendo correcciones para tener en cuenta las prendas superpuestas, y dividir por la superficie cutánea total (DuBois y DuBois 1916). 0 tras estimaciones de distintos estudios demuestran que $f_{c l}$ aumenta linealmente con el aislamiento intrínseco.

\section{Estimación de la resistencia al vapor}

La resistencia al vapor de un conjunto de prendas de vestir es la suma de la resistencia de la capas de aire y las capas de ropa. Normalmente, el número de capas varía según la parte del cuerpo y la mejor estimación es la media ponderada de las distintas partes del cuerpo, incluida la piel expuesta a la intemperie.

\section{Resistencia relativa al vapor}

La resistencia a la evaporación se utiliza con menos frecuencia que $I_{c l}$, ya que se han realizado pocas mediciones de $C_{c l}\left(0 P_{c l}\right)$. Woodcock (1962) evitó este problema definiendo el índice de permeabilidad al vapor de agua $i_{m}$ como el cociente entre $I_{c l}$ y $R$, relacionado con el mismo cociente para una única capa de aire (este último cociente es casi constante y se conoce como constante psicrométrica $\mathrm{S}, 0,0165 \mathrm{~K} / \mathrm{Pa}, 2,34 \mathrm{~K} \mathrm{~m}^{3} / \mathrm{g} 0$ $2,2 \mathrm{~K} /$ torr); $\mathrm{i}_{\mathrm{m}}=\mathrm{I}_{\mathrm{cl}} \mathrm{l}\left(\mathrm{R} \cdot \mathrm{S}\right.$ ). L Los valores típicos de $\mathrm{i}_{\mathrm{m}}$ para prendas sin revestimientos, medidos en maniquíes, varían entre 0,3 y 0,4 (M cCullough, Jones y Tamura 1989). L os valores de $i_{m}$ para tejidos superpuestos y el aire adyacente pueden medirse con relativa facilidad utilizando un calentador húmedo, pero el valor depende en realidad del flujo de aire sobre el aparato y de la reflectancia de la cabina sobre la que se instala. Algunas veces se intenta extrapolar el cociente entre $R$ e $I_{c l}$ en personas vestidas obtenido de la medición de tejidos a conjuntos de prendas de vestir (DIN 7943-2 1992). Es un proceso que plantea dificultades técnicas, entre otras cosas porque $R$ es sólo proporcional al componente convectivo de $I_{c l}$, de manera que tienen que realizarse cuidadosas correcciones para tener en cuenta la

Figura 42.11 - Articulación del cuerpo humano en cilindros.

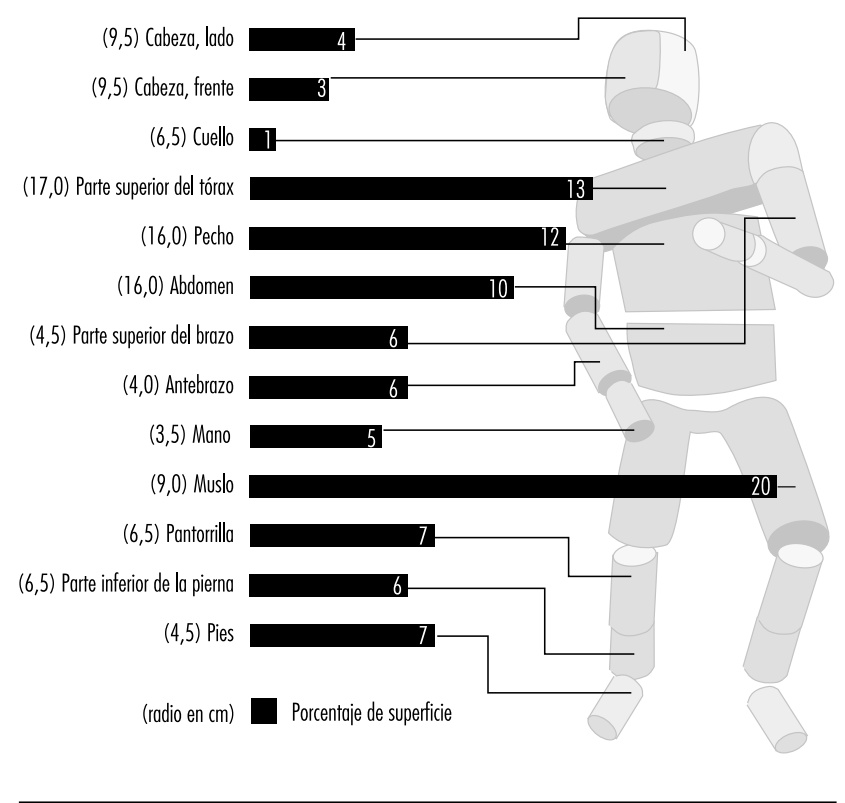


Figura 42.12 • Disminución de la resistencia al vapor de distintas prendas para la lluvia con el viento y la acción de caminar.

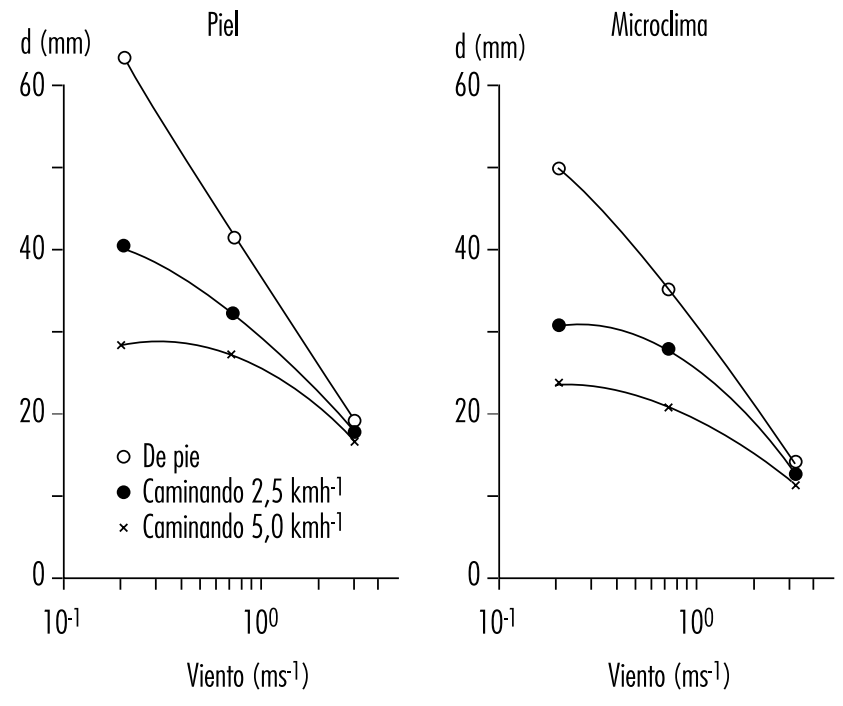

transferencia de calor radiante. 0 tra razón es que el aire atrapado entre capas superpuestas de distintas prendas de vestir y un único traje puede ser diferente. De hecho, la difusión de vapor y la transferencia de calor se tratan mejor por separado.

\section{E stimaciones con model os articulados}

Existen modelos más sofisticados para calcular el aislamiento y la resistencia al vapor de agua que los métodos antes explicados. Tales modelos calculan el aislamiento local aplicando las leyes físicas a distintas partes del cuerpo y sumando para obtener el aislamiento intrínseco de todo el cuerpo humano. Para ello, la forma del cuerpo humano se aproxima a un conjunto de cilindros articulados (Figura 42.11). El modelo de M cCullough, Jones y Tamura (1989) exige obtener datos sobre cada una de las capas que componen el conjunto de prendas, especificados por segmento del cuerpo. El modelo CLOMAN de Lotens y Havenith (1991) exige la entrada de un menor número de valores. Estos modelos tienen una exactitud similar y mejor que la de cualquiera de los otros métodos mencionados, con la excepción de la determinación experimental. N o obstante, son modelos más complejos de lo que sería deseable para que fueran ampliamente utilizados.

\section{E fecto de la actividad física y el viento}

Lotens y Havenith (1991) introdujeron también modificaciones, basadas en los datos publicados en la literatura, del aislamiento y la resistencia al vapor para tener en cuenta la actividad física y el viento. EI aislamiento se reduce cuando la persona está sentada 0 de pie y esta reducción es mayor cuando mayor es el aislamiento proporcionado por la ropa. En cualquier caso, la actividad física reduce el aislamiento más que la postura, dependiendo del vigor de los movimientos. Al caminar se mueven los dos brazos y las dos piernas y el aislamiento se reduce más que cuando se monta en bicicleta, actividad en la que sólo se mueven las piernas. También en este caso, la reducción es mayor cuanto más gruesas sean las prendas de vestir. Cuanto más ligera sea la prenda, mayor será la reducción del aislamiento provocada por el viento. Tal vez esté en relación con la permeabilidad al aire de los tejidos interiores, que suelen ser prendas menos apropiadas para climas fríos.

En la Figura 42.12 se muestran algunos efectos típicos del viento y el movimiento del cuerpo en la resistencia al vapor de la ropa para la lluvia. No existe consenso en la literatura sobre la magnitud de estos efectos. La importancia de esta cuestión se refleja en el hecho de que algunas normas, como la ISO 7730 (1994), exigen que se tenga en cuenta el aislamiento resultante cuando se aplican a personas activas 0 a personas expuestas a un movimiento importante del aire, un requisito ignorado con frecuencia.

\section{Control de la humedad}

\section{E fectos de la absorción de humedad}

C uando los tejidos pueden absorber vapor de agua, como es el caso de la mayoría de las fibras naturales, la ropa actúa como un regulador del vapor. Tal propiedad altera la transferencia de calor cuando se pasa de un ambiente a otro. Cuando una persona que lleva ropa no absorbente pasa de un ambiente seco a un ambiente húmedo, la evaporación de sudor se reduce bruscamente. Si utiliza ropa higroscópica, el tejido absorbe vapor y el cambio en la evaporación se produce de manera gradual. Al mismo tiempo, el proceso de absorción libera calor al tejido, aumentando su temperatura. De esta forma se reduce la transferencia de calor seco desde la piel. En una primera aproximación, ambos efectos se anulan entre sí, de manera que la transferencia

Figura 42.13 - Descripción general de un modelo térmico dinámico.

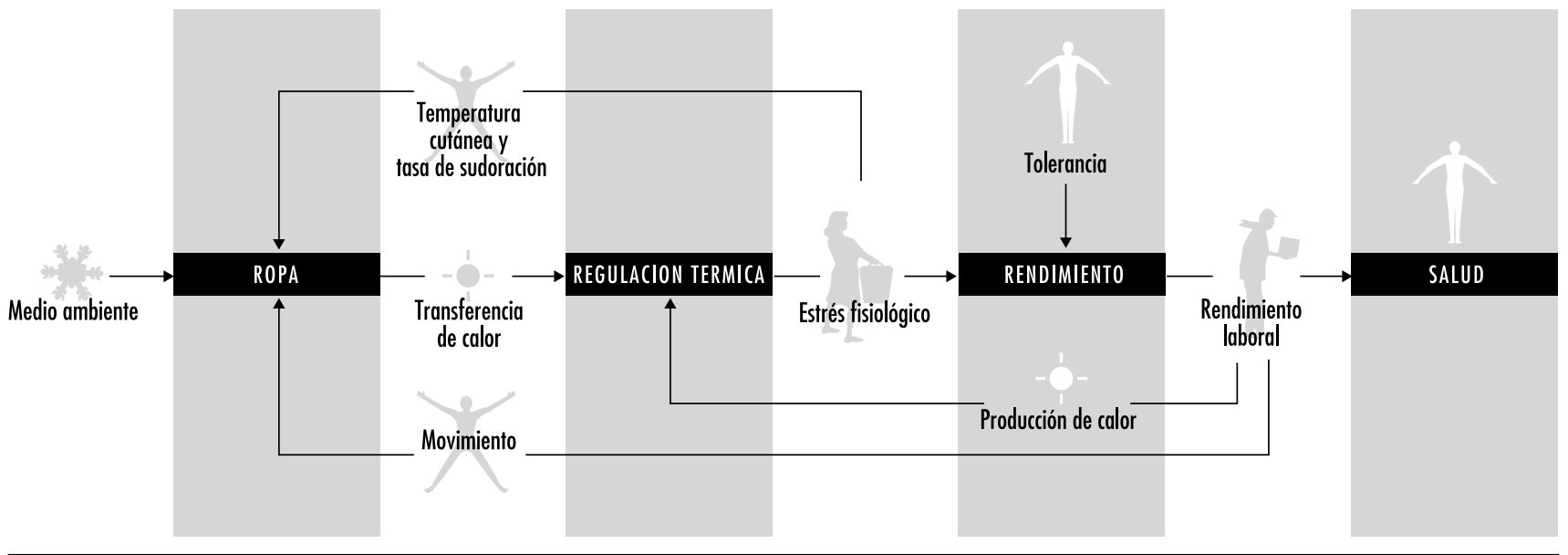


total de calor no experimenta cambios. La diferencia con los trajes no higroscópicos es el cambio más gradual en la evaporación del sudor en la piel y, por consiguiente, un menor riesgo de acumulación de sudor.

\section{Capacidad de absorción de vapor}

La capacidad de absorción de un tejido depende del tipo de fibra y de la masa de tejido. La masa absorbida es aproximadamente proporcional a la humedad relativa, aunque mayor por encima del 90 \%. La capacidad de absorción (Ilamada recuperación ) se expresa como la cantidad de vapor de agua que absorben $100 \mathrm{~g}$ de fibra seca con una humedad relativa del $65 \%$. Los tejidos pueden clasificarse de la siguiente manera:

- absorción pequeña: tejidos acrílicos, poliéster (entre 1 y 2 g por $100 \mathrm{~g})$

- absorción intermedia: nylon, algodón, acetato (entre 6 y 9 g por $100 \mathrm{~g}$ )

- absorción grande: seda, lino, cáñamo, rayón, yute, lana (entre 11 y $15 \mathrm{~g}$ por $100 \mathrm{~g}$ ).

\begin{abstract}
Absorción de agua
La retención de agua en los tejidos, muchas veces confundida con la absorción de vapor, obedece a reglas diferentes. El agua libre se une débilmente a los tejidos y se difunde en todas las direcciones a través de capilares. Es un proceso conocido como "mecha". La transferencia de líquido de una capa a otra tiene lugar sólo en tejidos húmedos y bajo presión. La ropa puede humedecerse por el sudor no evaporado (superfluo) que se absorbe de la piel. El contenido de líquido de un tejido puede ser elevado y su evaporación posterior pone en peligro el equilibrio térmico. Suele ocurrir durante los períodos de descanso después de un trabajo intenso y se conoce como enfriamiento tardío. La capacidad de retención de líquido de los tejidos depende más de la construcción del tejido que de la capacidad de absorción de la fibra, y en la práctica es normalmente suficiente con que absorba el sudor superfluo.
\end{abstract}

\section{Condensación}

La ropa puede humedecerse por condensación del sudor evaporado en una determinada capa. La condensación se produce cuando la humedad es mayor de lo que permite la temperatura local. En climas calurosos, esto ocurre generalmente en el interior del tejido exterior, mientras que en climas de frío extremo ocurre incluso en las capas más profundas. La condensación hace que se acumule humedad, pero también aumenta la temperatura, como ocurre con la absorción. No obstante, la diferencia entre condensación y absorción es que ésta es un proceso que dura poco, mientras que la condensación puede prolongarse mucho más tiempo. La transferencia de calor latente durante la condensación puede realizar una importante contribución a la termolisis, un efecto no siempre deseable. La acumulación de humedad es en la mayoría de los casos una desventaja, debido a las molestias que produce y al riesgo de un enfriamiento tardío. En caso de intensa condensación, el líquido puede alcanzar de nuevo la piel y evaporarse otra vez. Es un ciclo que funciona como un tubo isotérmico y puede reducir considerablemente el aislamiento proporcionado por la ropa interior.

\section{Simulación dinámica}

Desde principios de siglo se han desarrollado numerosas normas e índices para clasificar las prendas de vestir y los climas. Casi todos ellos se referían a estados estables, condiciones en las que el clima y el trabajo se mantienen el tiempo suficiente como para que la persona conserve una temperatura corporal constante.
H oy en día es raro que se produzca, como consecuencia de la mejora de las condiciones de trabajo y la medicina del trabajo. La atención se centra ahora en las exposiciones cortas a circunstancias extremas, casi siempre como consecuencia de una política calamitosa en materia de prendas protectoras.

Por ello son necesarias las simulaciones dinámicas de la transferencia de calor a través de la ropa y el estrés térmico del portador (Gagge, Fobelets y Berglund 1986). Pueden realizarse con modelos informáticos dinámicos en un escenario concreto. Entre los modelos más sofisticados que existen en la actualidad destaca el THDYN (L otens 1993), que permite una gran diversidad de especificaciones de prendas de vestir y que ha sido actualizado para considerar las características individuales de la persona simulada (Figura 42.13). En el futuro tendrán que proponerse nuevos modelos, pero lo que realmente se necesita es una evaluación experimental más amplia y la aplicación de esos modelos por parte de los expertos. Los modelos dinámicos basados en la termofísica y la transferencia de masas incorporan todos los mecanismos de transferencia de calor y sus interacciones (absorción de vapor, calor de fuentes radiantes, condensación, ventilación, acumulación de humedad, etc.) para una gran variedad de prendas de vestir, incluidas las de diario, de trabajo o protectoras.

\section{AMBIENTES FRIOS Y TRABAJO CON FRIO} Ingvar H olmér, Per-0 la G ranberg
y G oran D ahlstrom

Un ambiente frío se define por unas condiciones que causan pérdidas de calor corporal mayores de lo normal. En este contexto, "normal" se refiere a lo que una persona experimenta en la vida diaria en condiciones termoneutras, normalmente en interiores, aunque es un concepto que puede variar en función de factores sociales, económicos o climáticos. Para los fines de este artículo, se considerarán fríos los ambientes con una temperatura inferior a $18020^{\circ} \mathrm{C}$.

El trabajo en ambientes fríos engloba diversas actividades industriales y laborales en diferentes condiciones climáticas (véase la Tabla 42.23). En la mayoría de los países, el sector de la alimentación exige que el trabajo se realice en condiciones frías, normalmente entre 2 y $8 \stackrel{\circ}{\circ}$ para los alimentos frescos y por debajo de -25 o C para los alimentos congelados. En unos ambientes fríos artificiales como éstos, las condiciones están relativamente bien definidas y la exposición es más o menos la misma de una día para otro.

En muchos países, los cambios climáticos estacionales implican que el trabajo al aire libre o en interiores sin calefacción tiene que realizarse durante períodos más o menos largos en condiciones de frío. La exposición al frío puede variar considerablemente en diferentes lugares del planeta y según el tipo de trabajo (véase la Tabla 42.23). EI agua fría constituye otro peligro al que se enfrentan las personas que, por ejemplo, trabajan en alta mar. En este artículo se describen las respuestas al estrés por frío y las medidas preventivas. M ás adelante en este mismo capítulo se describen los métodos para evaluar el estrés por frío y los límites permisibles de temperatura según las normas internacionales recientemente adoptadas.

\section{Estrés por frío y trabajo en ambientes fríos}

El estrés por frío puede estar presente de muchas formas diferentes, afectando al equilibrio térmico de todo el cuerpo, así como al equilibrio térmico local de las extremidades, la piel y los 
pulmones. El tipo y la naturaleza del estrés por frío se describen con detalle más adelante. L os mecanismos naturales de respuesta al estrés por frío se basan en la adaptación de comportamiento, en particular, cambio y ajuste de la ropa. U na protección suficiente permite evitar el enfriamiento corporal. Sin embargo, la protección en sí misma puede ocasionar efectos adversos no deseados. El problema se ilustra en la Figura 42.14.

El enfriamiento de todo el cuerpo 0 de algunas partes del mismo origina molestias, insensibilidad, disfunción neuromuscular y, en última instancia, lesiones por frío. Las molestias causadas por el frío suelen ser un estímulo potente para una adaptación de la conducta que reduzca o limite su efecto. La prevención del enfriamiento mediante el uso de prendas de abrigo, calzado, guantes y gorros o cascos interfiere con la movilidad y la destreza del trabajador. Puede hablarse de un "coste de la protección" en términos de una mayor restricción del movimiento y un mayor agotamiento. La necesidad continua de ajustar los equipos para mantener un alto nivel de protección exige atención y capacidad de juicio y puede comprometer factores como la vigilancia y el tiempo de reacción. U no de los objetivos principales de la investigación ergonómica es mejorar la funcionalidad de las prendas de vestir manteniendo al mismo tiempo la protección contra el frío.

En consecuencia, los efectos del trabajo en ambientes fríos deben dividirse en:

- efectos del enfriamiento corporal,

- efectos de las medidas protectoras ("coste de la protección").

En ambientes fríos, la adaptación del comportamiento reduce el efecto del frío y, en definitiva, permite mantener el equilibrio térmico normal y la sensación de bienestar. Una adaptación inadecuada provocará reacciones termorreguladoras de compensación fisiológica (vasoconstricción y escalofríos). La acción combinada de la adaptación del comportamiento y fisiológica determina el efecto resultante del estrés por frío.

En las siguientes secciones se describen estos efectos, que pueden dividirse en efectos agudos (los que ocurren en el plazo

Figura 42.14 • Ejemplos de los efectos del frío.

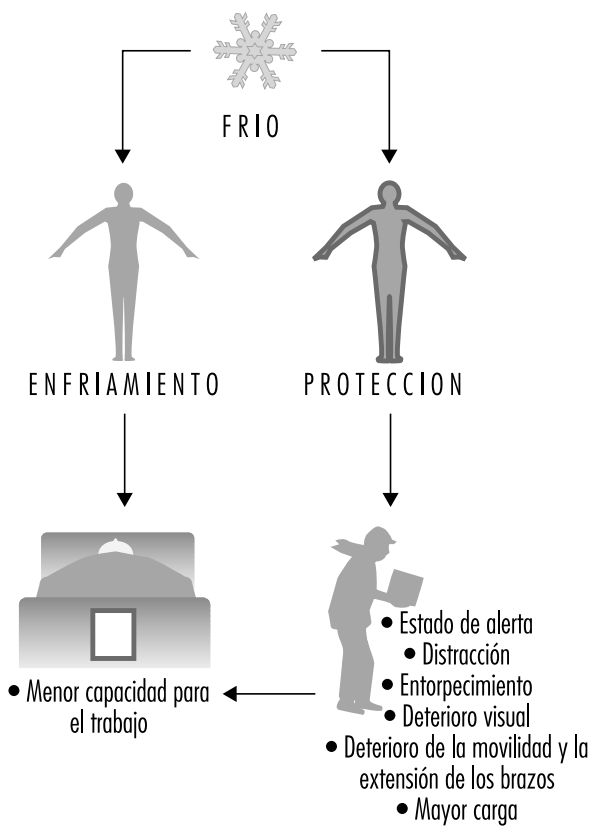

\section{Tabla 42.13 • Duración del estrés por frío descompensado y reacciones asociadas.}

$\begin{array}{cll}\text { Duración } & \text { Efectos fisiológicos } & \text { Efecto psicológico } \\ \text { Segundos } & \begin{array}{l}\text { Boqueo inspiratorio } \\ \text { Hiperventilación } \\ \text { Aumento de la frecuencia cardíaca } \\ \text { Vasoconstricción periférica } \\ \\ \text { Elevación de la presión arterial }\end{array} & \begin{array}{l}\text { Sensación cutánea, } \\ \text { malestar }\end{array} \\ \text { Minutos } & \begin{array}{l}\text { Enfriamiento de los tejidos } \\ \text { Enfriamiento de las extremidades }\end{array} & \begin{array}{l}\text { Reducción del rendi- } \\ \text { miento }\end{array} \\ & \begin{array}{l}\text { Deterioro neuromuscular } \\ \text { Tiritona }\end{array} & \begin{array}{l}\text { Dolor por enfriamiento } \\ \text { local }\end{array} \\ & \begin{array}{l}\text { Congelación por contacto y convección } \\ \text { Horas }\end{array} & \text { Menor capacidad para el trabajo físico } \\ & \text { Hipotermia } & \text { Deterioro de la función } \\ & \text { Lesiones por frío } & \text { mental } \\ \text { Días/ meses } & \text { Lesiones por frío sin congelación } & \text { Habituación } \\ & \text { Aclimatación } & \text { Menores molestias } \\ \text { Años } & \text { Efectos tisulares crónicos (?) } & \end{array}$

de minutos u horas), efectos de larga duración (que se prolongan durante días o incluso años) y otros efectos (no directamente relacionados con las reacciones al frío per se). En la Tabla 42.13 se ofrecen ejemplos de reacciones según la duración de la exposición al frío. Lógicamente, los tipos de respuestas y su magnitud dependen en gran medida del nivel de estrés. Con todo, las exposiciones de larga duración (durante días o más tiempo) rara vez alcanzan los mismos niveles que las exposiciones agudas.

\section{E fectos agudos del enfriamiento}

El efecto más evidente y directo del estrés por frío es el enfriamiento inmediato de la piel y las vías respiratorias superiores. $L$ a respuesta de los termorreceptores desencadena una secuencia de reacciones termorreguladoras. El tipo y la magnitud de la reacción depende sobre todo del tipo y el grado de enfriamiento. Como ya se ha mencionado, los principales mecanismos de defensa son la vasoconstricción periférica y los escalofríos. Ambos contribuyen a conservar el calor corporal y la temperatura interna del organismo, pero comprometen las funciones cardiovascular y neuromuscular.

Ahora bien, los efectos fisiológicos de la exposición al frío también modifican las reacciones fisiológicas a través de mecanismos complejos y en parte desconocidos. L os ambientes fríos causan distracción en el sentido de que se necesita un mayor esfuerzo mental para enfrentarse a los nuevos factores de estrés (evitar el enfriamiento, adoptar medidas de protección, etc.). Por otra parte, el frío causa también un estado de alerta, en el sentido de que aumentan los niveles de actividad nerviosa simpática y, por consiguiente, la preparación para la acción. En condiciones normales, las personas utilizan sólo una pequeña parte de su capacidad, reservando por tanto la mayor parte de la misma para hacer frente a condiciones inesperadas o extremas.

\section{Percepción del frío y bienestar térmico}

L a mayoría de los seres humanos experimentan una sensación de neutralidad térmica a una temperatura operativa de entre $20 \mathrm{y}$ 26 ㄷ cuando realizan un trabajo muy ligero o sedentario (trabajo de oficina a $70 \mathrm{~W} / \mathrm{m}^{2}$ ) con la ropa adecuada (valores de aislamiento entre 0,6 y 1,0 clo). En este estado y en ausencia de desequilibrios térmicos locales, como corrientes de aire, las 
Figura 42.15 - Temperatura óptima para el "bienestar" térmico dependiendo de la ropa y del nivel de actividad física (W/ $\mathrm{m}^{2}$ ).

Valor clo

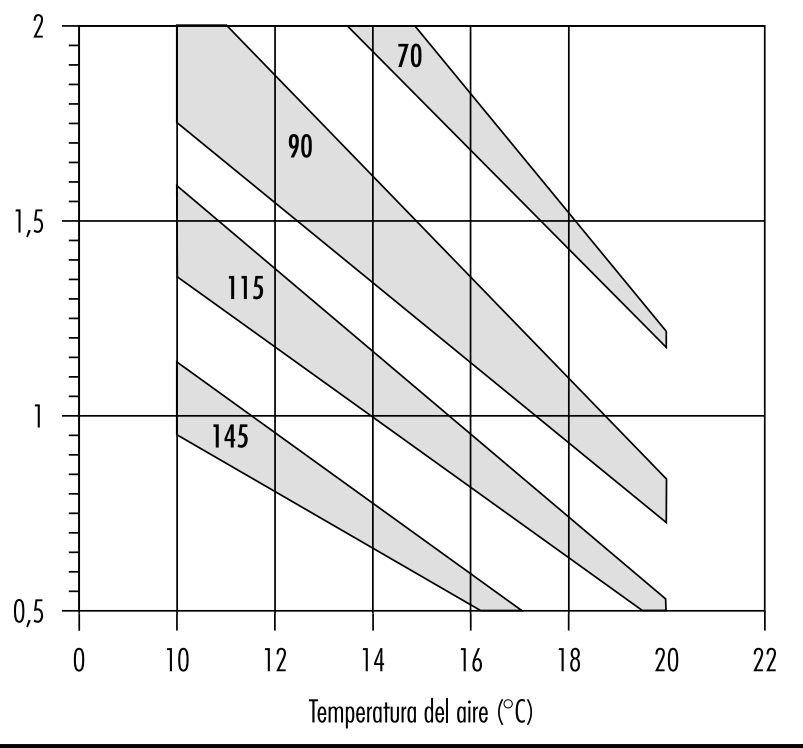

personas se encuentran en un estado de bienestar térmico. Son condiciones que se describen y especifican con detalle en normas como ISO 7730 (véase el capítulo Control ambiental de interiores en esta E nciclopedia ).

La percepción humana del frío está estrechamente relacionada con el equilibrio térmico de todo el cuerpo, así como con el equilibrio térmico local de los tejidos. La sensación de malestar por frío aparece cuando el equilibrio térmico del organismo no puede mantenerse como consecuencia de una ropa poco adecuada para el nivel de actividad física (producción de calor metabólico). Con temperaturas de entre +10 y $+30 \stackrel{\circ}{\circ}$, la magnitud del "malestar por frío" en una población puede predecirse utilizando la ecuación del bienestar de Fanger descrita en ISO 7730.

Una fórmula simplificada y razonablemente exacta para calcular la temperatura termoneutra (t) para una persona normal es:

$$
\mathrm{t}=33,5-3 \cdot \mathrm{l}_{\mathrm{cl}}-\left(0,08+0,05 \cdot \mathrm{c}_{\mathrm{cl}}\right) \cdot \mathrm{M}
$$

en donde $\mathrm{M}$ es el calor metabólico medido en $\mathrm{W} / \mathrm{m}^{2}$ e ${ }_{\mathrm{cl}}$ el valor del aislamiento proporcionado por la ropa medido en clo.

El aislamiento que debe proporcionar la ropa (valor clo) es mayor a $+10^{\circ} \mathrm{C}$ que el calculado con el método IREQ (valor calculado del aislamiento requerido) (ISO TR 11079, 1993). La razón de esta discrepancia es la aplicación de criterios diferentes de "bienestar" en los dos métodos. ISO 7730 se centra principalmente en el bienestar térmico y permite una sudoración considerable, mientras que ISO TR 11079 contempla sólo una sudoración de "control" a niveles mínimos, necesaria en ambientes fríos. En la Figura 42.15 se muestra la relación entre el aislamiento proporcionado por la ropa, el nivel de actividad física (producción de calor) y la temperatura ambiente según la ecuación anterior y el método IREQ. Las áreas sombreadas corresponden a la variación esperada en el aislamiento requerido de la ropa como resultado de niveles diferentes de "bienestar".

La información contenida en la Figura 42.15 sirve sólo como orientación para establecer las condiciones térmicas óptimas en ambientes interiores. Existe una variación considerable en la percepción que cada persona tiene del bienestar térmico y el malestar por frío. La variación se debe a diferencias en la ropa y el nivel de actividad física, aunque también contribuyen las preferencias subjetivas y la habituación.

En particular, las personas que realizan una actividad muy ligera o sedentaria se hacen cada vez más susceptibles al enfriamiento local cuando la temperatura ambiente desciende por debajo de 20 o $22 \stackrel{\circ}{\circ}$. En tales condiciones, la velocidad del aire debe mantenerse reducida (por debajo de $0,2 \mathrm{~m} / \mathrm{s}$ ) y tienen que utilizarse prendas aislantes adicionales para cubrir las partes más sensibles del cuerpo (como cabeza, cuello, espalda y tobillos). EI trabajo sentado con temperaturas inferiores a $20 \stackrel{\circ}{ } \mathrm{C}$ requiere un asiento y un respaldo aislantes para reducir el enfriamiento local causado por la compresión de las prendas de vestir.

Cuando la temperatura ambiente desciende por debajo de $10 \stackrel{\circ}{ } \mathrm{C}$, el concepto de bienestar es más difícil de aplicar. Las asimetrías térmicas se hacen "normales" (p. ej., rostro frío e inhalación de aire frío). Aunque exista un equilibrio térmico corporal óptimo, estas asimetrías pueden ocasionar molestias y exigir una fuente de calor adicional para eliminarlas. EI bienestar térmico en ambientes fríos, al contrario que en ambientes interiores térmicamente neutros, suele coincidir con una ligera sensación de calor, un hecho que debe recordarse a la hora de evaluar el estrés por frío utilizando el índice IREQ.

\section{Rendimiento}

La exposición al frío y las reacciones fisiológicas y de conducta asociadas influyen en el rendimiento humano a distintos niveles de complejidad. En la Tabla 42.14 se presenta un esquema de los diferentes tipos de efectos en el rendimiento que pueden preverse con una exposición leve o extrema al frío.

En este contexto, la exposición leve produce un enfriamiento nulo o despreciable del interior del cuerpo y un enfriamiento moderado de la piel y las extremidades. La exposición severa produce un equilibrio térmico negativo, un descenso de la temperatura interna y una marcada reducción de la temperatura de las extremidades.

Las características físicas de la exposición leve o intensa al frío dependen mucho del equilibrio entre la producción interna de calor corporal (como resultado del trabajo físico) y la pérdida de calor. Las prendas protectoras y las condiciones climáticas determinan la cantidad de calor perdido.

Como ya se ha mencionado antes, la exposición al frío causa distracción y enfriamiento (Figura 42.14). Ambos influyen en el rendimiento laboral, aunque la magnitud de efecto varía según el tipo de trabajo.

Tabla 42.14 • Efectos esperados de la exposición a frío leve e intenso.

$\begin{array}{lll}\text { Rendimiento } & \begin{array}{l}\text { Exposición leve } \\ \text { al frío }\end{array} & \begin{array}{l}\text { Exposición intensa } \\ \text { al frío }\end{array} \\ \text { Rendimiento manual } & 0- & -- \\ \text { Rendimiento muscular } & 0 & - \\ \text { Rendimiento aeróbico } & 0 & - \\ \text { Tiempo de reacción simple } & 0 & - \\ \text { Tiempo de reacción consciente } & - & - \\ \text { Seguimiento, vigilancia } & 0- & - \\ \text { Tareas cognitivas, mentales } & 0- & -\end{array}$

0 indica ningún efecto; - indica deterioro; - - indica deterioro grave; 0 - indica observaciones contradictorias 
Tabla 42.15 - Importancia de la temperatura de los tejidos corporales para el rendimiento físico del ser humano.

$\begin{array}{lllll}\text { Rendimiento } & \begin{array}{l}\text { Temperatura } \\ \text { cutánea de } \\ \text { manos/ dedos }\end{array} & \begin{array}{l}\text { Temperatura } \\ \text { cutánea } \\ \text { media }\end{array} & \begin{array}{l}\text { Temperatura } \\ \text { muscular }\end{array} & \begin{array}{l}\text { Temperatura } \\ \text { del núcleo } \\ \text { central }\end{array} \\ \begin{array}{l}\text { Tarea manual } \\ \text { sencilla }\end{array} & - & 0 & - & 0 \\ \begin{array}{l}\text { Tarea manual } \\ \text { compleja }\end{array} & -- & (-) & -- & - \\ \text { Muscular } & 0 & 0- & -- & 0- \\ \text { Aeróbico } & 0 & 0 & - & -\end{array}$

0 indica ningún efecto; - indica deterioro con descenso de la temperatura; - - indica deterioro grave; 0 - indica observaciones contradictorias; ( - ) indica posibilidad de un pequeño efecto.

La conducta y la función mental son más susceptibles al efecto de la distracción, mientras que el rendimiento físico se ve más afectado por el enfriamiento. La compleja interacción de las respuestas fisiológicas y psicológicas (distracción, estado de alerta) a la exposición al frío no se conoce bien y en el futuro tendrán que realizarse más investigaciones en este campo.

En la Tabla 42.15 se indican las relaciones observadas entre el rendimiento físico y las temperaturas del organismo. Se supone que el rendimiento físico depende en gran medida de la temperatura de los tejidos y disminuye cuando la temperatura de los tejidos y órganos vitales desciende. N ormalmente, la destreza manual depende críticamente de la temperatura de los dedos y las manos, así como del músculo del antebrazo. La locomotricidad gruesa se ve poco afectada por la temperatura superficial local, pero es muy sensible a la temperatura muscular. Puesto que algunas de estas temperaturas están relacionadas entre sí

Figura 42.16 Relación entre destreza manual y temperatura cutánea de los dedos.

Destreza manual (para utilizar un panel de clavijas)

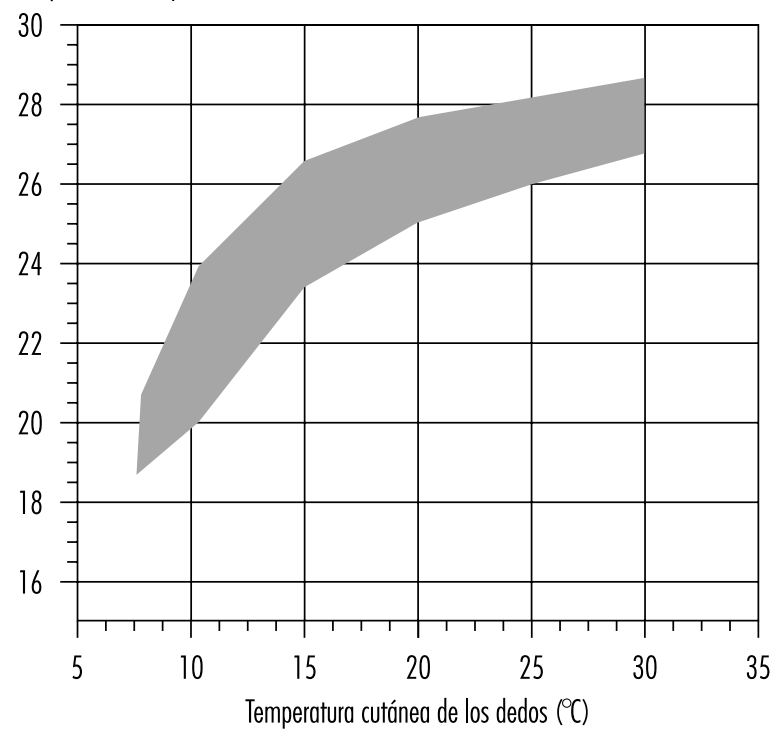

Fuente: Daanen 1993 (p. ej., la temperatura interna y muscular), es difícil establecer relaciones directas.

El resumen de los efectos en el rendimiento que se ofrecen en las Tablas 42.14 y 42.15 es necesariamente muy esquemático. Tal información debería servir como base para la acción, entendiendo por acción una evaluación detallada de las condiciones ambientales o la adopción de medidas preventivas.

Un importante factor que contribuye a reducir el rendimiento es la duración de la exposición. Cuando más dure la exposición al frío, mayor será el efecto en los tejidos profundos y en la función neuromuscular. Por otra parte, factores como la habituación y la experiencia modifican los efectos nocivos y permiten recuperar en parte el nivel de rendimiento.

\section{Rendimiento manual}

Las manos son muy sensibles a la exposición al frío. D ebido a su pequeña masa y a su gran superficie, las manos y los dedos pierden mucho calor a pesar de mantener unas temperaturas tisulares elevadas (entre 30 y 35 oC). En consecuencia, esas temperaturas elevadas sólo pueden mantenerse con un alto nivel de producción interna de calor que permita un flujo sanguíneo elevado y sostenido a las extremidades.

La pérdida de calor en las manos puede reducirse en ambientes fríos utilizando unos guantes apropiados. D esde luego, unos buenos guantes para proteger del frío tienen necesariamente grosor y volumen $y$, en consecuencia, deterioran la destreza manual. Por consiguiente, el rendimiento manual en ambientes fríos no puede conservarse con medidas pasivas. En el mejor de los casos, la reducción del rendimiento puede limitarse si se llega a un compromiso equilibrado entre la elección de unos guantes funcionales, la conducta en el trabajo y un régimen adecuado de exposición al frío.

El funcionamiento de las manos y los dedos depende de las temperaturas tisulares locales (Figura 42.16). Los movimientos finos, delicados y rápidos de los dedos se entorpecen cuando la temperatura de los tejidos desciende tan sólo unos grados. Con un enfriamiento más profundo y un descenso de la temperatura, la locomotricidad gruesa también se deteriora. La destreza manual se deteriora considerablemente con unas temperaturas cutáneas de unos 6 a $8 \stackrel{\circ}{\circ}$ como consecuencia del bloqueo de los receptores sensoriales y térmicos de la piel. Dependiendo de los requisitos del trabajo, es posible que tenga que medirse la temperatura cutánea en varios lugares de las manos y los dedos. La temperatura en la punta de los dedos puede descender más de diez grados comparada con la temperatura del dorso de la mano en ciertas condiciones de exposición. En la Figura 42.17 se indican las temperaturas críticas para diferentes tipos de efectos en la destreza manual.

\section{Rendimiento neuromuscular}

De las Figuras 42.16 y 42.17 se deduce que el frío tiene un efecto pronunciado en la función y el rendimiento muscular. El enfriamiento del tejido muscular reduce el flujo sanguíneo y hace más lentos algunos procesos neuronales, como la transmisión de señales nerviosas y la función sináptica. Además, aumenta la viscosidad de los tejidos y la fricción interna con el movimiento.

La producción de fuerza isométrica se reduce un $2 \%$ por cada ${ }^{\circ} \mathrm{C}$ que desciende la temperatura muscular. La producción de fuerza dinámica se reduce entre un 2 y un $4 \%$ por cada ${ }^{\circ} \mathrm{C}$ que desciende la temperatura muscular. En otras palabras, el enfriamiento reduce la fuerza muscular y tiene un efecto incluso mayor en las contracciones dinámicas.

\section{Capacidad física para el trabajo}

Como ya se ha mencionado antes, el rendimiento muscular disminuye con el frío. Cuando la función muscular se deteriora, 
Figura 42.17 - Efectos brutos estimados en la destreza manual con diferentes niveles de temperatura de manos y dedos.

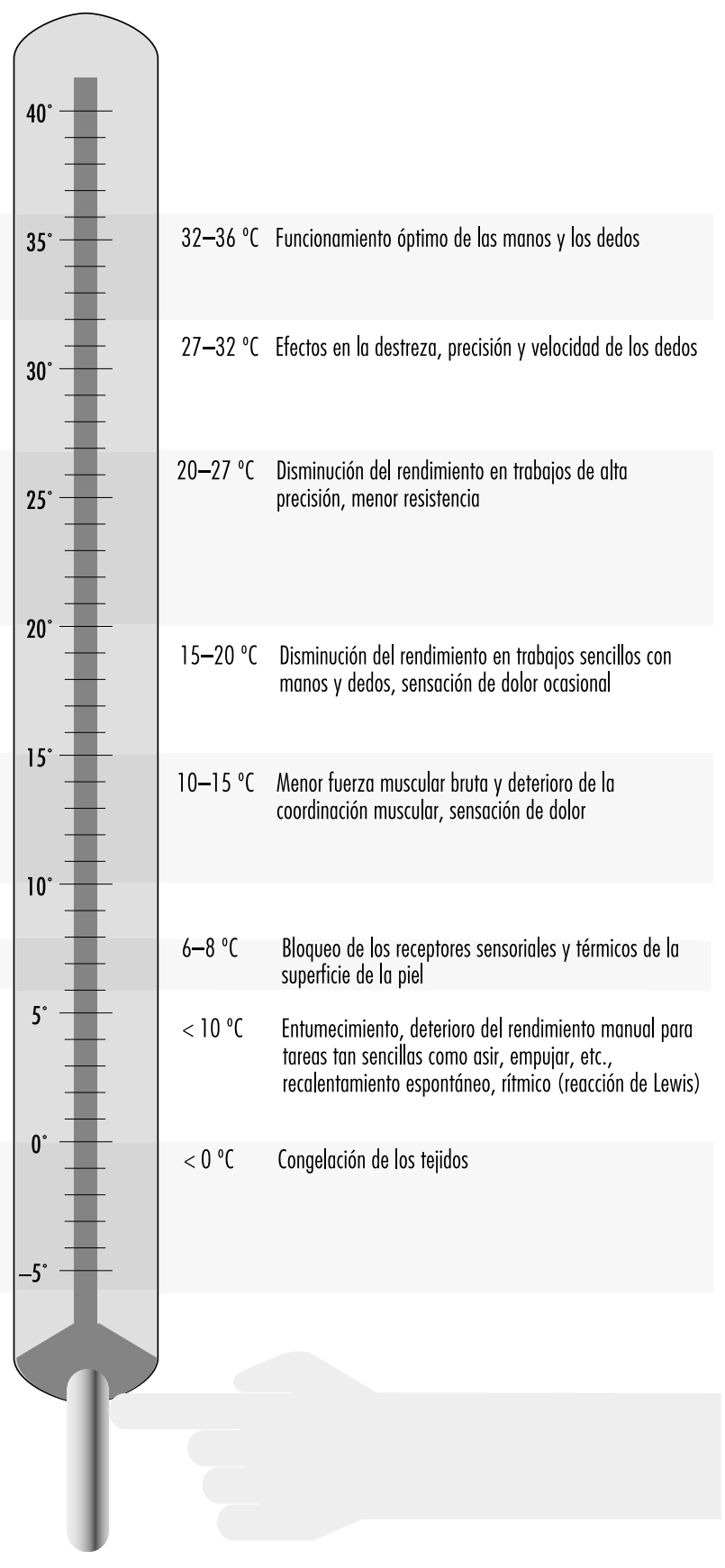

se produce también un deterioro general de la capacidad física para el trabajo. Un factor que contribuye a este deterioro de la capacidad para el trabajo aeróbico es la mayor resistencia periférica de la circulación sistémica. La vasoconstricción pronunciada aumenta la circulación central, pudiendo causar diuresis por frío y elevación de la presión arterial. El enfriamiento del interior del cuerpo puede también tener un efecto directo en la contractibilidad del músculo cardíaco.
La capacidad para el trabajo, medida por la capacidad aeróbica máxima, se reduce entre un 5 y un $6 \%$ por cada $\stackrel{\circ}{C}$ que desciende la temperatura interna. Así, la resistencia puede disminuir rápidamente como consecuencia de una menor capacidad máxima y los mayores requisitos energéticos del trabajo muscular.

\section{Otros efectos del frío}

\section{Temperaturas corporales}

Al descender la temperatura, la superficie del cuerpo es la que se ve más afectada (y también la más tolerante). La temperatura cutánea puede descender por debajo de $0 \stackrel{0}{ } \mathrm{C}$ durante unos segundos cuando la piel entra en contacto con superficies metálicas muy frías. I gualmente, la temperatura de las manos y los dedos puede descender varios grados por minuto en condiciones de vasoconstricción o con una mala protección. Con temperaturas cutáneas normales, las derivaciones arteriovenosas hacia la periferia hacen que aumente la irrigación de brazos y manos. De esta forma aumenta su temperatura y mejora la destreza manual. Cuando la piel se enfría, estas derivaciones se cierran y se reduce la perfusión de manos y pies a casi la décima parte. Las extremidades constituyen el $50 \%$ de la superficie corporal y el $30 \%$ de su volumen. EI retorno sanguíneo se produce por venas profundas que discurren paralelas a las arterias, de manera que la pérdida de calor se reduce por el principio de la contracorriente.

La vasoconstricción adrenérgica no afecta a la región de la cabeza y el cuello, un hecho que tiene que tenerse en cuenta en situaciones de emergencia para prevenir la hipotermia. U na persona con la cabeza al descubierto puede perder un $50 \%$ o más de su producción de calor en reposo a temperaturas por debajo de cero.

Para que se produzca hipotermia (descenso de la temperatura interna) tiene que existir un nivel elevado y sostenido de pérdida de calor de todo el cuerpo (M aclean y Emslie-Smith 1977). El equilibrio entre la producción y la pérdida de calor determina la velocidad del enfriamiento resultante, ya afecte a todo 0 a una parte del cuerpo. Las condiciones necesarias para alcanzar el equilibrio térmico pueden analizarse y evaluarse utilizando el índice IREQ. U na respuesta marcada al enfriamiento local de las partes que más sobresalen del cuerpo humano (p. ej., dedos de la mano, dedos del pie y orejas) es el llamado fenómeno de pendulación (reacción de Lewis). Tras un descenso inicial brusco, la temperatura de los dedos aumenta varios grados (Figura 42.18). Tal reacción se repite de manera cíclica. La respuesta es muy local, más pronunciada en la punta de los dedos que en su base e inexistente en la mano. La respuesta de la palma de la mano refleja mejor la variación de la temperatura del flujo sanguíneo en los dedos. La respuesta puede modificarse por exposición repetida (amplificada), pero prácticamente se suprime cuando se produce el enfriamiento de todo el cuerpo.

EI enfriamiento progresivo del cuerpo produce una serie de efectos fisiológicos y mentales. En la Tabla 42.16 se indican algunas de las respuestas típicas asociadas a diferentes niveles de temperatura interna.

\section{Corazón y circulación}

EI enfriamiento de la frente y la cabeza provoca una elevación brusca de la presión arterial sistólica y, en definitiva, un aumento de la frecuencia cardíaca. Una reacción similar se observa cuando se sumergen las manos desnudas en agua muy fría. La reacción es de corta duración y al cabo de unos segundos 0 minutos se recuperan unos valores normales o ligeramente elevados.

La pérdida excesiva de calor corporal produce vasoconstricción periférica. En particular, durante la fase transitoria, el 
Figura 42.18 • La vasodilatación inducida por el frío de los vasos sanguíneos de los dedos produce un a umento cíclico de la temperatura tisular.

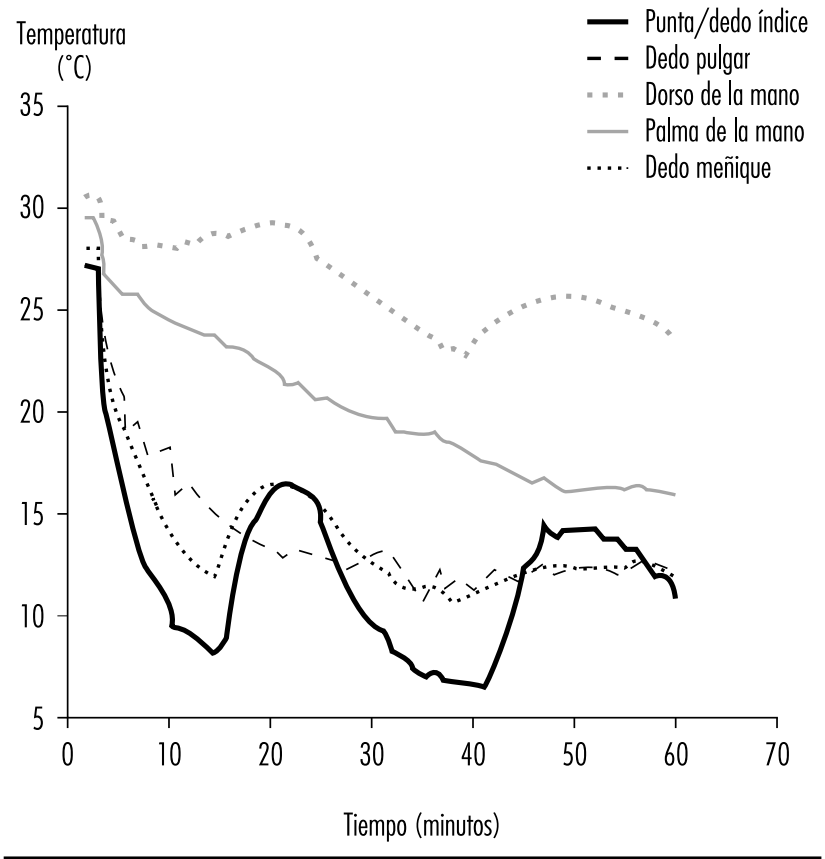

aumento de la resistencia periférica produce una elevación de la presión arterial sistólica y de la frecuencia cardíaca. El corazón tiene que trabajar más que para realizar actividades similares a temperaturas normales, un fenómeno que experimentan dolorosamente las personas con angina de pecho.

Como ya se ha mencionado antes, el enfriamiento de los tejidos profundos suele hacer más lentos los procesos fisiológicos de células y órganos. El enfriamiento debilita el proceso de inervación y suprime las contracciones del corazón. La fuerza de las contracciones se reduce y, además de aumentar la resistencia periférica de los vasos sanguíneos, el gasto cardíaco también se reduce. En cualquier caso, con una hipotermia moderada 0 severa, la función cardiovascular disminuye por la reducción general del metabolismo.

\section{Pulmones y vías aéreas}

La inhalación de volúmenes moderados de aire seco y frío no plantea grandes problemas a las personas sanas. El aire muy frío puede ocasionar molestias, sobre todo en la nariz. U nos elevados niveles de ventilación de aire muy frío pueden también causar microinflamación de la membrana mucosa de las vías respiratorias superiores.

A medida que progresa la hipotermia, se deprime la función pulmonar al mismo tiempo que se produce una reducción general del metabolismo.

\section{Aspectos funcionales (capacidad de trabajo)}

Un requisito fundamental para el funcionamiento en ambientes fríos es disponer de protección suficiente contra el frío. Ahora bien, la protección en sí misma puede interferir gravemente con las condiciones necesarias para un buen rendimiento. $L$ as prendas de abrigo tienen un efecto entorpecedor bien conocido. El uso de prendas protectoras para la cabeza interfiere con el habla y la visión y el uso de guantes deteriora la destreza manual. Aunque la protección es necesaria para mantener unas condiciones de trabajo saludables y confortables, las consecuencias en términos de disminución del rendimiento deben ser también tenidas en cuenta. Se precisa más tiempo para realizar las mismas tareas y éstas exigen un esfuerzo mayor.

L as prendas de abrigo fácilmente pueden pesar entre 3 y 6 kilos, incluido el calzado y las prendas para la cabeza. Es un peso que aumenta la carga de trabajo, en particular cuando el trabajo es deambulante. Asimismo, la fricción entre las distintas capas de ropa genera resistencia al movimiento. EI calzado no debe pesar en exceso, puesto que el peso añadido a las piernas tiene una mayor contribución relativamente mayor en la carga detrabajo.

La organización del trabajo, el lugar de trabajo y los equipos utilizados deben adaptarse a los requisitos específicos del trabajo en ambientes fríos. D ebe permitirse más tiempo para realizar las tareas y programar descansos frecuentes para que los trabajadores puedan recuperarse y calentarse. El lugar de trabajo debe permitir un movimiento fácil del trabajador, a pesar de que éste utilice prendas abultadas. I gualmente, los equipos deben estar diseñados para que puedan ser manejados con guantes o estar

Tabla 42.16 Respuestas del ser humano al enfriamiento: reacciones indicativas a diferentes niveles de hipotermia.

\begin{tabular}{|c|c|c|c|}
\hline Fase & $\begin{array}{l}\text { Tempera- } \\
\text { tura del } \\
\text { núcleo }\left({ }^{\circ} \mathrm{C}\right)\end{array}$ & $\begin{array}{l}\text { Reacciones } \\
\text { fisiológicas }\end{array}$ & $\begin{array}{l}\text { Reacciones } \\
\text { psicológicas }\end{array}$ \\
\hline \multirow[t]{2}{*}{ Normal } & 37 & Temperatura corporal normal & $\begin{array}{l}\text { Sensación de } \\
\text { neutralidad } \\
\text { térmica }\end{array}$ \\
\hline & 36 & $\begin{array}{l}\text { Vasoconstricción, enfriamiento } \\
\text { de manos y pies }\end{array}$ & Malestar \\
\hline \multirow[t]{3}{*}{$\begin{array}{l}\text { Hipotermia } \\
\text { leve }\end{array}$} & 35 & $\begin{array}{l}\text { tiritona intensa, menor capa- } \\
\text { cidad para el trabajo }\end{array}$ & $\begin{array}{l}\text { Deterioro de la } \\
\text { función mental, } \\
\text { desorientación, } \\
\text { apatía }\end{array}$ \\
\hline & 34 & Fatiga & $\begin{array}{l}\text { Consciencia } \\
\text { normal y capa- } \\
\text { cidad de } \\
\text { respuesta }\end{array}$ \\
\hline & 33 & Torpeza y balbuceos & \\
\hline \multirow[t]{4}{*}{$\begin{array}{l}\text { Hipotermia } \\
\text { moderada }\end{array}$} & 32 & Rigidez muscular & $\begin{array}{l}\text { Perdida progresiva } \\
\text { de la consciencia, } \\
\text { alucinaciones }\end{array}$ \\
\hline & 31 & Respiración débil & $\begin{array}{l}\text { Escasos } \\
\text { momentos de } \\
\text { consciencia }\end{array}$ \\
\hline & 30 & & Letargo \\
\hline & 29 & $\begin{array}{l}\text { Ausencia de reflejos nerviosos, } \\
\text { disminución de la frecuencia } \\
\text { cardíaca y dificultad para } \\
\text { detectar el pulso }\end{array}$ & \\
\hline \multirow[t]{3}{*}{$\begin{array}{l}\text { Hipotermia } \\
\text { severa }\end{array}$} & 28 & $\begin{array}{l}\text { Arritmias cardíacas (auriculares } \\
\text { y/ } 0 \text { ventriculares) }\end{array}$ & \\
\hline & 27 & $\begin{array}{l}\text { Ausencia de reacción de las } \\
\text { pupilas a la luz, ausencia de } \\
\text { reflejos tendinosos profundos y } \\
\text { superficiales }\end{array}$ & \\
\hline & 25 & $\begin{array}{l}\text { Muerte por fibrilación ventri- } \\
\text { cular o asistole }\end{array}$ & \\
\hline
\end{tabular}


provistos de algún tipo de aislamiento en el caso de que tengan que manejarse con las manos desnudas.

\section{Lesiones por frío}

Las graves lesiones producidas por el aire frío pueden prevenirse en la mayoría de los casos y sólo ocurren esporádicamente en la vida normal, aunque tienen una gran importancia en las guerras y cataclismos. Con todo, muchos trabajadores corren el riesgo de sufrir lesiones por frío en sus actividades rutinarias. Los trabajos realizados al aire libre en climas extremos (como en las regiones árticas o subárticas) - por ejemplo, pesca, agricultura, construcción, prospecciones de gas y petróleo o pastoreo de renos-, así como los trabajos realizados en interiores fríos (como en las industrias de la alimentación y el almacenaje) pueden exponer a los trabajadores al peligro de una lesión por frío.

Las lesiones por frío pueden ser sistémicas o localizadas. Las lesiones locales, que suelen preceder a la hipotermia sistémica, constituyen dos entidades clínicamente diferentes: lesiones por frío con congelación (LFCC) y lesiones por frío sin congelación (LFSC).

\section{Lesiones por frío con congelación}

\section{Fisiopatología}

Se trata de lesiones localizadas que se producen cuando la pérdida de calor es suficiente para ocasionar una verdadera congelación de los tejidos. Además del ataque criogénico directo a las células, el daño vascular causado por la menor perfusión y la hipoxia tisular son mecanismos patogénicosque contribuyen a la lesión.

La vasoconstricción de los vasos cutáneos tiene un gran importancia en el origen de una congelación. Como consecuencia de las grandes derivaciones arteriovenosas, la irrigación de las estructuras periféricas como las manos, los pies, la nariz y las orejas aumenta considerablemente en ambientes calurosos. Por ejemplo, sólo se necesita la décima parte del flujo sanguíneo en las manos para la oxigenación de los tejidos. El resto sirve para generar calor, facilitando así la destreza manual. Incluso aunque no se produzca un descenso de la temperatura interna, el enfriamiento local de la piel obstruye estas derivaciones arteriovenosas.

Para proteger la viabilidad de las partes periféricas de las extremidades durante la exposición al frío, se produce una vasodilatación intermitente inducida por el frío (VIIF) como resultado de la apertura de las anastomosis arteriovenosas y sucede cada 5 o 10 minutos. El fenómeno supone un compromiso en el plano fisiológico humano para conservar el calor y aún así preservar intermitentemente la función de las manos y los pies. La vasodilatación es percibida por la persona como sensación de comezón. La VIIF se hace menos pronunciada al descender la temperatura corporal. Las variaciones individuales en la VIIF podrían explicar la diferente susceptibilidad a las lesiones locales por frío. Las poblaciones indígenas de regiones frías presentan una VIIF más pronunciada.

En la criopreservación de tejidos vivos se produce la formación de cristales de hielo tanto en el espacio intracelular como extracelular; sin embargo, en las LFCC clínicas, con una velocidad de congelación mucho menor, sólo se forman cristales de hielo en el espacio extracelular. El proceso es exotérmico; es decir, libera calor. Por consiguiente, la temperatura del tejido se mantiene en el punto de congelación hasta que el proceso termina.

A medida que crecen los cristales de hielo en el espacio extracelular, el líquido extracelular se condensa, convirtiendo a este espacio en un medio hiperosmótico que provoca la difusión pasiva de agua desde el compartimiento intracelular, un agua que también se congela. El proceso continúa hasta que todo el agua "libre" (sin estar unida a proteínas, azúcares y otras moléculas) se ha cristalizado. La deshidratación de las células altera las estructuras proteicas, los lípidos de las membranas y el pH celular, provocando una destrucción incompatible con la supervivencia celular. La resistencia a las LFCC varía según el tejido. La piel, por ejemplo, es más resistente que los músculos y los nervios, un hecho que podría deberse al menor contenido de agua en el espacio intracelular y extracelular de la epidermis.

En un principio se pensó que los factores hemorreológicos indirectos desempeñaban la misma función que en las lesiones por frío sin congelación. No obstante, recientes estudios en animales han demostrado que la congelación causa lesiones en la estructura de las arteriolas, vénulas y capilares antes de que aparezcan evidencias de lesiones en otros elementos de la piel. Por consiguiente, es evidente que el componente reológico de la patogénesis de las LFCC es también un efecto criobiológico.

Cuando un tejido congelado se recalienta, el agua se difunde de nuevo a las células deshidratadas, provocando turgencia intracelular. La descongelación produce una dilatación vascular máxima, con edema y formación de ampollas como consecuencia del daño sufrido por las células endoteliales (capa interna de la piel). La destrucción de la capa de células endoteliales deja al descubierto la membrana basal, que inicia las adhesiones plaquetarias y desencadena la cascada de la coagulación. El estancamiento de sangre y la trombosis que se producen a continuación provocan anoxia.

Al ser la pérdida de calor de la zona expuesta la que determina el riesgo de congelación, el enfriamiento causado por el viento es un factor de riesgo importante y se debe, no sólo al viento que sopla, sino también a cualquier movimiento de aire sobre el cuerpo. Correr, esquiar, patinar o conducir vehículos abiertos provocan dicho movimiento. Sin embargo, la carne expuesta no se congelará mientras la temperatura ambiente se mantenga por encima del punto de congelación, incluso aunque la velocidad del viento sea muy grande.

EI consumo de alcohol y tabaco, así como la malnutrición y la fatiga, son factores que predisponen a una LFCC. Una lesión previa por frío aumenta el riesgo de LFCC posteriores, ya que se produce una respuesta simpática postraumática anormal.

L os metales fríos pueden causar rápidamente una congelación cuando se agarran con la mano desnuda. La mayoría de las personas son conscientes de este peligro, pero ignoran el riesgo que conlleva la manipulación de líquidos ultrafríos. La gasolina enfriada a - 30 o $C$ congela la carne expuesta casi al instante, ya que la pérdida de calor evaporativo se combina con la pérdida por conducción. $L a$ rápida congelación produce cristalización extra e intracelular con destrucción de las membranas celulares principalmente por causas mecánicas. U n tipo similar de LFCC ocurre cuando se derrama propano líquido directamente sobre la piel.

\section{Cuadro clínico}

Las lesiones por frío con congelación se subdividen en congelación superficial y profunda. La lesión superficial se limita a la piel y a los tejidos subcutáneos que se encuentran inmediatamente por debajo. En la mayoría de los casos, este tipo de lesión afecta a la nariz, los lóbulos de las orejas, los dedos de las manos y los dedos de los pies. El primer síntoma suele ser un dolor punzante y agudo. La parte afectada de la piel palidece o adquiere un color blanco ceroso. Se entumece y se hunde al aplicar presión, ya que los tejidos subyacentes siguen estando vivos y conservan su flexibilidad. Cuando la LFCC progresa a una lesión profunda, la piel adquiere color blanco y aspecto marmóreo, se endurece y se adhiere al tocarla.

\section{Tratamiento}

Una congelación debe recibir cuidados inmediatamente para evitar que una lesión superficial se convierta en una lesión 
profunda. La víctima debe ser trasladada a un refugio; si no existe ninguno en las proximidades, habrá que protegerla del viento con el cuerpo de los compañeros, un saco de dormir o algún otro medio similar. La zona congelada debe descongelarse por transmisión pasiva de calor de una parte más caliente del cuerpo. La mano calentada puede colocarse sobre el rostro y la mano fría en la axila o la ingle. Puesto que la persona congelada sufre estrés por frío con vasoconstricción periférica, el mejor tratamiento es el calor que pueda darle un compañero. El masaje y el frotamiento de la parte congelada con nieve o con una bufanda de lana está contraindicado. Son tratamientos mecánicos que sólo agravan la lesión, ya que el tejido está lleno de cristales de hielo. Tampoco debe intentarse la descongelación delante de un fuego de campamento 0 un hornillo de campo, ya que este tipo de calor no penetra en profundidad y al estar la zona parcialmente anestesiada, se puede producir una lesión por quemadura.

$L$ as señales de dolor en un pie congelado desaparecen antes de que se produzca la congelación, ya que la conductividad del nervio se suprime a una temperatura de unos $+8 \stackrel{\circ}{\circ}$. L a paradoja es que la última sensación que la víctima tiene es que jno siente nada en absoluto! En condiciones extremas, cuando la evacuación exige viajar a pie, la descongelación debe evitarse. Caminar con un pie congelado no parece aumentar el riesgo de destrucción tisular, mientras que la recongelación de un tejido congelado lo aumenta al máximo.

EI mejor tratamiento de una congelación es descongelarla en agua calentada a $40 \circ 42 \stackrel{\circ}{\circ}$. El procedimiento de descongelación debe continuar con agua a esa temperatura hasta que se recupere la sensibilidad, el color y la textura blanda del tejido. Es una forma de descongelación que suele producir un tinte más encarnado que rosa como consecuencia de la estasis venosa.

El tratamiento administrado sobre el terreno debe ir más allá de la descongelación local. Toda la persona debe recibir cuidados, ya que la congelación suele ser el primer síntoma de una hipotermia progresiva. $\mathrm{H}$ abrá que abrigarla y hacerle beber líquidos calientes y nutritivos. Es probable que la víctima se muestre apática y sin fuerzas para cooperar. Debe insistirse en que realice actividades musculares, como golpear los brazos contra los laterales del cuerpo: así se abren las derivaciones arteriovenosas periféricas de las extremidades.

La congelación profunda se produce cuando la descongelación por transferencia de calor pasivo durante 20030 minutos no tiene éxito. En ese caso, la víctima debe ser trasladada al hospital más cercano. No obstante, si dicho traslado puede durar varias horas, es preferible trasladar a la persona a la vivienda más cercana y descongelar sus lesiones con agua caliente. U na vez finalizada la descongelación, debe tumbarse al paciente con la zona lesionada elevada y organizar su traslado al hospital más cercano lo antes posible.

EI recalentamiento rápido produce un dolor moderado 0 intenso y es probable que el paciente necesite algún analgésico. Las lesiones capilares producen extravasación de suero con tumefacción local y formación de ampollas durante las primeras 6-18 horas. Las ampollas deben mantenerse intactas para prevenir infecciones.

\section{Lesiones por frío sin congelación}

\section{Fisiopatología}

Los requisitos previos para sufrir una LFSC son la exposición prolongada a ambientes fríos y húmedos, aunque por encima de la temperatura de congelación, e inmovilización con estancamiento venoso. La deshidratación, una alimentación inadecuada, el estrés, enfermedades o lesiones concomitantes o la fatiga son factores que aumentan el riesgo. Las LFSC afectan casi exclusivamente a las piernas y a los pies. En la vida diaria no suelen producirse lesiones graves de este tipo, pero en tiempos de guerra o cuando se producen catástrofes, son y siempre serán un grave problema, sobre todo por la dificultad de detectarlas como consecuencia de la aparición lenta de los síntomas, que al principio son poco específicos.

Las LFSC pueden aparecer cuando la temperatura ambiente es inferior a la corporal. Al igual que en las LFCC, las fibras contráctiles simpáticas y el frío en sí mismo producen una prolongada vasoconstricción. El proceso inicial es de naturaleza reológica y similar al observado en las lesiones por reperfusión isquémica. Además de la duración de la exposición a bajas temperaturas, la susceptibilidad de la víctima parece ser un factor importante.

El cambio patológico provocado por la lesión isquémica afecta a muchos tejidos. Los músculos se degeneran, sufriendo necrosis, fibrosis y atrofia; los huesos muestran una osteoporosis precoz. De especial interés son los efectos en los nervios, ya que las lesiones nerviosas producen dolor, disestesia prolongada e hiperhidrosis como secuelas frecuentes de estas lesiones.

\section{Cuadro clínico}

En una lesión por frío sin congelación, los síntomas iniciales son muy vagos y la víctima se da cuenta demasiado tarde del grave peligro que corre. Los pies se enfrían y se hinchan. La persona los siente pesados, acorchados y entumecidos. Le duelen y con frecuencia aparecen arrugas en la plantas. La primera fase isquémica dura entre unas horas y unos días. Va seguida por una fase hiperémica de entre 2 y 6 semanas, durante la cual los pies están calientes, con pulsos marcados y edema progresivo. No es raro que aparezcan ampollas, ulceraciones y, en algunos casos graves, gangrena.

\section{Tratamiento}

El tratamiento es sobre todo de apoyo. En el lugar de trabajo, los pies deben secarse con cuidado, pero manteniéndolos fríos. Por otra parte, todo el organismo debe calentarse. La persona debe recibir grandes cantidades de bebidas calientes. Al contrario que en el caso de las lesiones por frío con congelación, una LFSC nunca debe calentarse activamente. EI tratamiento con agua caliente para recalentar las lesiones locales por frío sólo está permitido cuando se han formado cristales de hielo en los tejidos. C ualquier otro tratamiento debe ser, por regla general, conservador. D esde luego, la fiebre, los signos de coagulación intravascular diseminada y la licuefacción de los tejidos afectados requieren intervención quirúrgica, algunas veces con amputación.

Las lesiones por frío sin congelación pueden prevenirse casi siempre reduciendo el tiempo de exposición al mínimo. Es importante prestar a los pies los cuidados adecuados, tomándose el tiempo necesario para secarlos y disponiendo de instalaciones para cambiarse los calcetines por otros secos. EI reposo con los pies levantados y la ingestión de bebidas calientes pueden parecer medidas ridículas, pero tienen una gran importancia.

\section{Hipotermia}

La hipotermia significa una temperatura corporal inferior a la normal. Ahora bien, desde el punto de vista térmico, el organismo consta de dos zonas: la periferia y el núcleo. La primera es superficial y su temperatura varía considerablemente según el ambiente externo. El núcleo consiste en los tejidos más profundos (p. ej., cerebro, corazón, pulmones y parte superior del abdomen), y el cuerpo intenta siempre mantener una temperatura interna de $37 \pm 2$ o C. Cuando la regulación térmica se deteriora y la temperatura interna empieza a descender, la persona sufre estrés por frío, pero hasta que la temperatura interna no alcanza $35 \stackrel{\circ}{\circ} \mathrm{C}$, no se considera que la víctima se encuentra en un estado de hipotermia. Entre los 35 y los $32 \stackrel{\circ}{\circ}$, la hipotermia se considera leve; 
entre 32 y $28 \stackrel{\circ}{ } \mathrm{C}$, moderada y por debajo de $28 \stackrel{\circ}{ } \mathrm{C}$, severa (Tabla 42.16).

\section{Efectos fisiológicos del descenso de la temperatura interna del organismo}

Cuando la temperatura interna empieza a descender, se produce una intensa vasoconstricción que redirige la sangre de la periferia al núcleo, evitando así la conducción de calor del interior del cuerpo a la piel. Para mantener la temperatura, se provocan escalofríos, con frecuencia precedidos por un aumento del tono muscular. U na tiritona de intensidad máxima puede aumentar la tasa metabólica entre cuatro y seis veces, pero puesto que las contracciones involuntarias son de carácter oscilante, dicha tasa metabólica no suele aumentar a más del doble. La frecuencia cardíaca, la presión arterial, el gasto cardíaco y la frecuencia respiratoria aumentan. La centralización del volumen sanguíneo produce una diuresis osmolal con sodio y cloro como los principales componentes.

La irritabilidad auricular en las primeras fases de la hipotermia suele provocar fibrilación auricular. A temperaturas más bajas, son frecuentes las extrasístoles ventriculares. La muerte se produce a o por debajo de $28 \stackrel{\circ}{\circ}$, casi siempre como resultado de la fibrilación ventricular, aunque también puede sobrevenir una asístole.

La hipotermia deprime el sistema nervioso central. La lasitud y la apatía son los primeros síntomas de un descenso de la temperatura interna. Dichos efectos deterioran la capacidad de juicio, producen una conducta extraña y ataxia y terminan en letargo y coma a una temperatura de entre 30 y $28 \stackrel{\circ}{\circ}$.

$L$ a velocidad de conducción nerviosa se reduce al descender la temperatura. Las manifestaciones clínicas de este fenómeno son disartria, torpeza y dificultad del habla. El frío afecta también a los músculos y las articulaciones, deteriorando la destreza manual. Reduce el tiempo de reacción y la coordinación y aumenta la frecuencia de los errores. Incluso en las personas con hipotermia leve se observa rigidez muscular. A una temperatura interna inferior a $30 \stackrel{\circ}{\circ}$, la actividad física es imposible.

La exposición a un ambiente extremadamente frío es un requisito previo básico para que se produzca hipotermia. Los extremos de edad son un factor de riesgo. Las personas de edad avanzada con deterioro de la función termorreguladora, o las personas cuya masa muscular o cuya capa de grasa aislante están reducidas, corren un mayor riesgo de sufrir hipotermia.

\section{Clasificación}

Desde un punto de vista práctico, la hipotermia puede subdividirse en (véase también la Tabla 42.16):

- hipotermia accidental

- hipotermia aguda por inmersión

- hipotermia subaguda por agotamiento

- hipotermia en traumatismos

- hipotermia crónica subclínica.

La hipotermia aguda por inmersión se produce cuando una persona se sumerge en agua fría. El agua tiene una conductividad térmica unas 25 veces mayor que el aire. El estrés por frío se hace tan grande que la temperatura interna se ve obligada a descender a pesar de una producción máxima de calor corporal. La hipotermia se desencadena antes de que la persona sea víctima del agotamiento.

La hipotermia aguda por agotamiento puede ocurrirle a cualquier trabajador expuesto al frío, así como a esquiadores, escaladores y montañeros. En esta forma de hipotermia, la actividad muscular mantiene la temperatura corporal siempre que se disponga de fuentes de energía. Con todo, la hipoglucemia indica que la persona está en situación de riesgo. Incluso una exposición relativamente leve al frío puede ser suficiente para que prosiga el enfriamiento y se produzca una situación peligrosa.

La hipotermia con traumatismo importante es un signo preocupante. La persona que ha sufrido el traumatismo es incapaz de mantener la temperatura interna y la pérdida de calor puede agravarse con la infusión de líquidos fríos y la retirada de las prendas de vestir. Los pacientes en situación de shock que desarrollan hipotermia tienen una mortalidad mucho mayor que las víctimas normotérmicas.

La hipotermia crónica subclínica afecta con frecuencia a personas de edad avanzada y suele asociarse a malnutrición, uso de ropa inadecuada y movilidad restringida. El alcoholismo, el abuso de drogas y las enfermedades metabólicas crónicas son factores que contribuyen a este tipo de hipotermia.

\section{Tratamiento prehospitalario}

El principio básico de la asistencia primaria que debe recibir un trabajador con hipotermia es evitar que pierda más calor. Si la víctima está consciente, debe ser trasladada a un refugio, 0 al menos a un lugar protegido. Se retirarán las prendas mojadas y se intentará proporcionarle el mayor aislamiento posible. Es fundamental mantener a la víctima en posición tumbada y con la cabeza cubierta.

Los pacientes con hipotermia aguda por inmersión requieren un tratamiento bastante diferente al de los pacientes con hipotermia subaguda por agotamiento. La víctima por inmersión suele encontrarse en una situación más favorable. EI descenso de la temperatura interna se produce mucho antes de que el cuerpo sufra agotamiento y, por consiguiente, la capacidad de generar calor está intacta. El equilibrio hídrico y electrolítico no está alterado. Por consiguiente, estas personas pueden ser tratadas con una rápida inmersión en un baño caliente. Si no se dispone de una bañera, el paciente deberá introducir los pies y las manos en agua caliente. EI calor local abre las derivaciones arteriovenosas, aumenta rápidamente la circulación sanguínea en la extremidades y acelera el proceso de calentamiento.

Por el contrario, en la hipotermia por agotamiento, la víctima se encuentra en una situación mucho más peligrosa. L as reservas calóricas se han consumido, el equilibrio electrolítico está alterado y, sobre todo, la persona está deshidratada. La diuresis por frío se inicia inmediatamente después de la exposición al frío; la lucha contra el frío y el viento aumenta la sudoración, aunque ésta no se percibe en un ambiente frío y seco; por último, la víctima no siente sed. El paciente con hipotermia por agotamiento no debe nunca ser recalentado rápidamente sobre el terreno o durante su traslado al hospital, debido al riesgo de que sufra un choque hipovolémico. Un estado prolongado de hipotermia estacionaria es preferible a los denodados esfuerzos por recalentar a la víctima en unas circunstancias que, de producirse complicaciones, éstas no podrán controlarse. Es fundamental mover al paciente con suavidad para reducir al mínimo el riesgo de una posible fibrilación ventricular.

Incluso al personal médico con la debida formación le resulta muchas veces difícil saber si una persona hipotérmica está viva o no. U n colapso cardiovascular aparente puede ser, en realidad, tan sólo una depresión del gasto cardíaco. En muchos casos es necesaria la palpación o auscultación durante al menos un minuto para detectar pulsos espontáneos.

La decisión de recurrir o no a la reanimación cardiopulmonar (RCP) es difícil de tomar sobre el terreno. Si existe algún signo de vida, la RCP está contraindicada. Las compresiones prematuras del tórax pueden provocar fibrilación ventricular. No obstante, la RCP debe iniciarse inmediatamente si se produce una parada cardíaca o cuando las circunstancias permiten realizar los procedimientos de una manera razonable y continua. 


\section{Salud y frío}

U na persona sana, con la ropa y los equipos adecuados, y con una organización adecuada del trabajo, no se encuentra en una situación que ponga en riesgo su salud, incluso aunque el frío sea extremo. Sigue existiendo controversia sobre si la exposición al frío durante largos períodos de tiempo de las personas que viven en regiones frías supone un riesgo para la salud. La situación es bastante diferente en el caso de las personas con problemas de salud, en cuyo caso la exposición al frío puede ser un problema. En algunas situaciones, la exposición al frío o a factores relacionados con el frío o el efecto combinado del frío y otros riesgos pueden poner en peligro la salud, especialmente si se produce una situación de emergencia o un accidente. En zonas remotas, en donde la comunicación con un supervisor es difícil o imposible, los propios trabajadores tienen que decidir si existe o no una situación que ponga en peligro su salud. En estos casos, deberán tomar las precauciones necesarias para hacer segura la situación o interrumpir el trabajo.

En las regiones árticas, el clima y otros factores pueden ser tan extremos que obliguen a tener en cuenta otras consideraciones.

E nfermedades infecciosas. Las enfermedades infecciosas no están relacionadas con el frío. En regiones árticas y subárticas se producen enfermedades endémicas. Las enfermedades agudas 0 crónicas obligan a la persona a interrumpir su exposición al frío y el trabajo pesado.

El catarro común, sin fiebre ni síntomas generales, no hace que el trabajo en ambientes fríos sea nocivo. Ahora bien, en personas con complicaciones como asma, bronquitis o problemas cardiovasculares, la situación es diferente y se recomienda que no trabajen al aire libre durante la estación fría. L o mismo puede decirse de las personas con catarro acompañado de fiebre, tos profunda, dolor muscular y deterioro general de su estado.

El asma y la bronquitis son frecuentes en las regiones frías. La exposición al frío suele agravar los síntomas. El cambio de medicación reduce en algunas ocasiones los síntomas durante la estación fría. Algunas personas mejoran con la administración de medicamentos inhalados.

L as personas con enfermedades asmáticas o cardiovasculares pueden responder a la inhalación de aire frío con broncoconstricción y vasoespasmo. Se han observado síntomas asmáticos en atletas que realizan intensos entrenamientos durante varias horas al día en climas fríos. No se sabe si el enfriamiento del tracto pulmonar es la principal causa de estos síntomas. Actualmente existen en el mercado máscaras ligeras que realizan una cierta función de intercambiador de calor, conservando así la energía y la humedad.

Un tipo endémico de enfermedad crónica es el "pulmón del esquimal", típica de los cazadores y tramperos esquimales que se ven expuestos a un frío extremo y a un trabajo pesado durante largos períodos de tiempo. L a hipertensión pulmonar progresiva suele causar con el tiempo una insuficiencia cardiaca que afecta a la parte derecha del corazón.

T rastornos cardiovasculares. La exposición al frío afecta considerablemente al sistema cardiovascular. La noradrenalina liberada por los terminales nerviosos simpáticos aumenta el gasto cardíaco y la frecuencia cardíaca. El dolor torácico provocado por una angina de pecho suele intensificarse en ambientes fríos. El riesgo de sufrir un infarto aumenta con la exposición al frío, especialmente cuando se combina con un trabajo pesado. El frío aumenta la presión arterial y, por consiguiente, el riesgo de hemorragia cerebral. Por consiguiente, las personas en situación de riesgo deben ser advertidas para que reduzcan su exposición a trabajos pesados en ambientes fríos.

En la estación invernal suele producirse una mayor mortalidad. U na explicación de esta observación podría ser el aumento ya mencionado del trabajo del corazón, que produce un mayor riesgo de arritmia en personas sensibles. 0 tra observación es un aumento del hematocrito durante la estación fría, que causa una mayor viscosidad de la sangre y una mayor resistencia al flujo. U na posible explicación es que el clima frío puede exponer a las personas a unas cargas de trabajo repentinas y muy pesadas, como retirar la nieve, caminar en nieve profunda, resbalar, etc.

Trastornos metabólicos. La diabetes mellitus es frecuente en las regiones más frías del mundo. La diabetes, aunque no presente complicaciones, puede hacer imposible el trabajo al aire libre en las regiones más remotas, sobre todo si la persona necesita tratamiento con insulina. La arteriosclerosis periférica precoz hace a estas personas más sensibles al frío y aumenta el riesgo de congelación local.

L as personas con deterioro de la función tiroidea pueden sufrir fácilmente hipotermia debido a la ausencia de la hormona termogénica, mientras que las personas hipertiroideas soportan el frío incluso con prendas ligeras.

Los pacientes con estos diagnósticos deben recibir una atención especial de los profesionales sanitarios y siempre se les debe informar de su problema.

Problemas musculosquel éticos. Se supone que el frío en sí mismo no causa enfermedades en el sistema musculosquelético, ni siquiera reumatismo. Por otra parte, el trabajo en ambientes fríos suele imponer una gran demanda a los músculos, tendones, articulaciones y columna vertebral, debido a la elevada carga que suelen conllevar este tipo de trabajos. La temperatura de las articulaciones se reduce más rápidamente que la de los músculos. Cuando se enfrían las articulaciones, aumenta la viscosidad del líquido sinovial y el consiguiente aumento de la resistencia al movimiento provoca rigidez. Cuando se combina con un trabajo pesado o una sobrecarga local, el riesgo de lesión aumenta. Además, el uso de prendas protectoras puede dificultar el movimiento de algunas partes del cuerpo, contribuyendo así al riesgo.

La artritis de las manos es un problema especial. Se sospecha que la exposición frecuente al frío puede causar artritis, pero por el momento existen pocas evidencias científicas al respecto. U na persona con artritis en las manos verá reducida su destreza manual en ambientes fríos y sentirá dolor y molestias.

Criopatías. Las criopatías son trastornos que aparecen cuando la persona es hipersensible al frío. Los síntomas son variables y pueden consistir en alteraciones del sistema vascular, de la sangre 0 del tejido conjuntivo, "alergia" y otros.

Algunas personas sufren lo que se conoce como dedos blancos. Cuando los dedos se exponen al frío, aparecen manchas blancas en la piel, sensación de frío, deterioro de la destreza manual y dolor. Son problemas más frecuentes en las mujeres, pero sobre todo afectan a fumadores y trabajadores que utilizan herramientas vibradoras 0 conducen trineos motorizados. LoS síntomas pueden ser tan molestos que lleguen a imposibilitar el trabajo incluso con exposiciones ligeras al frío. Ciertos tipos de medicación pueden agravar los síntomas.

La urticaria por frío, causada por una sensibilización de los mastocitos, se presenta como un eritema urticante en las partes de la piel expuestas al frío. Si se interrumpe la exposición, los síntomas suelen desaparecer en menos de una hora. R ara vez la enfermedad se complica con síntomas más generales y graves. En ese caso, o si la propia urticaria es muy molesta, la persona debe evitar la exposición a cualquier tipo de frío.

L a acrocianosis se manifiesta por cambios cianóticos en el color de la piel tras la exposición al frío. O tros síntomas pueden consistir en disfunción de la mano y los dedos en la zona acrocianótica. Los síntomas son muy comunes y con frecuencia se reducen a un nivel aceptable al disminuir la exposición al frío (por ejemplo, con unas prendas de abrigo adecuadas) 0 el consumo de nicotina. 
Estrés psicológico. La exposición al frío, sobre todo cuando se combina con factores relacionados con el frío y la vida en lugares muy apartados, impone a la persona un estrés no sólo fisiológico, sino también psicológico. Cuando se trabaja en ambientes fríos, con mal tiempo, en lugares apartados y quizás en situaciones potencialmente peligrosas, el estrés psicológico puede alterar o incluso deteriorar la función psicológica de la persona de tal manera que le impida realizar con seguridad gran parte del trabajo.

Tabaco y rapé. Los efectos nocivos a largo plazo del tabaco y, en cierta medida, del rapé, se conocen bien. La nicotina aumenta la vasoconstricción periférica, reduce la destreza manual y aumenta el riesgo de lesión por frío.

Alcohol. El consumo de alcohol produce una sensación agradable de calor y en general se piensa que inhibe la vasoconstricción inducida por el frío. Con todo, en estudios experimentales realizados en seres humanos durante exposiciones relativamente cortas al frío, se ha demostrado que el alcohol no interfiere con el equilibrio térmico de manera importante. No obstante, la capacidad de provocar escalofríos se reduce y, cuando se realiza un esfuerzo extenuante, la pérdida de calor aumenta. Se sabe que el alcohol es la principal causa de mortalidad por hipotermia en la zonas urbanas. Produce una sensación de euforia y altera el juicio, haciendo que se ignoren las medidas profilácticas.

E mbarazo. D urante el embarazo, las mujeres no son más sensibles al frío. Es más, pueden serlo menos debido a un aumento del metabolismo. Los factores de riesgo durante el embarazo se combinan con los factores relacionados con el frío, como riesgos de accidentes, torpeza por el uso de prendas de abrigo voluminosas, levantamiento de pesos pesados, peligro de resbalar y posiciones forzadas durante el trabajo. Por consiguiente, el sistema de asistencia sanitaria, la sociedad y las empresas deben prestar una atención especial a las mujeres embarazadas que trabajan en ambientes fríos.

\section{Farmacología y frío}

Los efectos secundarios negativos de los fármacos durante la exposición al frío pueden afectar a la regulación térmica (general o local) y, a su vez, la exposición al frío puede alterar el efecto de los fármacos. Siempre que el trabajador mantenga una temperatura corporal normal, la mayoría de los medicamentos prescritos no interfieren en el rendimiento. Ahora bien, los tranquilizantes (p. ej., barbitúricos, benzodiacepinas, fentotiazidas y antidepresivos cíclicos) pueden alterar la atención. En una situación peligrosa, los mecanismos de defensa contra la hipotermia se deterioran y la conciencia del peligro de una situación se reduce.

L os betabloqueadores provocan vasoconstricción periférica y reducen la tolerancia al frío. Si una persona necesita recibir algún tipo de medicación y su trabajo le obliga a exponerse al frío, deberán considerarse los efectos secundarios negativos de los fármacos que recibe.

Por otra parte, ningún fármaco ni nada que se beba, coma o administre por otras vías al organismo es capaz de aumentar la producción normal de calor, por ejemplo, en una situación de emergencia cuando existe peligro de hipotermia o lesión por frío.

\section{Programa de control de la salud}

Los riesgos para la salud relacionados con el estrés por frío, los factores relacionados con el frío y los accidentes o traumatismos se conocen sólo de forma limitada. Existe una gran variación individual, en cuanto a forma física y estado de salud, que debe tenerse en cuenta. Como ya se ha mencionado antes, algunas enfermedades, medicamentos y otros factores pueden hacer que una persona sea más susceptible a los efectos de la exposición al frío. Los programas de control de la salud deben formar parte de los procedimientos de contratación de nuevos trabajadores y constituir también una actividad rutinaria para todo el personal. En la Tabla 42.17 se indican los factores que se deben controlar para diferentes tipos de trabajo en ambientes fríos.

\section{Prevención del estrés por frío}

\section{Adaptación del ser humano}

Con la exposición repetida al frío, las personas sienten menos molestias y aprenden a adaptarse y a enfrentarse a las condiciones de una manera personalizada y más eficiente que al inicio de la exposición. La habituación reduce en cierta medida el efecto de alerta y distracción y mejora la capacidad de razonamiento y la precaución.

\section{Conducta}

La estrategia más lógica y natural para prevenir y controlar el estrés por frío es la precaución y una conducta intencionada. Las respuestas fisiológicas no son muy eficaces para prevenir la pérdida de calor. Por ello, los seres humanos dependen mucho de las medidas externas, como el uso de prendas de abrigo, el cobijo y el suministro externo de calor. La mejora y el perfeccionamiento de las prendas de abrigo y los equipos constituyen la base para aumentar la seguridad de la exposición al frío. Desde luego, es esencial que estas prendas y equipos superen las pruebas adecuadas para garantizar que cumplen las normas internacionales.

Las medidas para prevenir y controlar la exposición al frío suelen ser responsabilidad de la empresa o el supervisor. Sin embargo, la eficiencia de las medidas protectoras depende considerablemente de los conocimientos, la experiencia, la motivación y la capacidad de cada trabajador para realizar los ajustes necesarios según sus propios requisitos, necesidades y preferencias. Por tanto, la educación y formación son elementos importantes en cualquier programa de control de la salud.

\section{Aclimatación}

Se ha demostrado que existen diferentes tipos de aclimatación cuando la exposición al frío se prolonga durante largos períodos

Tabla 42.17 • Componentes recomendados de los programas de control de la salud para los trabajadores expuestos a estrés por frío y factores relacionados con el frío.

$\begin{array}{llll}\text { Componente } & \begin{array}{l}\text { Trabajo } \\ \text { al aire } \\ \text { libre }\end{array} & \begin{array}{l}\text { Trabajo en } \\ \text { cámaras } \\ \text { frigoríficas }\end{array} & \begin{array}{l}\text { Trabajo en } \\ \text { regiones }\end{array} \\ \text { Enticas y subárticas }\end{array}$

$*$ = control rutinario, $* *=$ factor importante que debe considerarse, $* * *=$ factor muy importante que debe considerarse. 
de tiempo. El aumento del flujo sanguíneo en las manos y los dedos permite mantener una temperatura tisular más elevada y produce una mayor vasodilatación inducida por el frío (véase la Figura 42.18). La destreza manual se mantiene más fácilmente tras la exposición repetida de las manos al frío.

El enfriamiento repetido de todo el cuerpo parece aumentar la vasoconstricción periférica, aumentando así el aislamiento del tejido superficial. Las pescadoras de perlas coreanas presentan un marcado aumento del aislamiento cutáneo durante la estación invernal. R ecientes investigaciones han revelado que la utilización de trajes de buceo reduce el estrés por frío tanto que el aislamiento de los tejidos no cambia.

Se han propuesto tres tipos de posibles adaptaciones:

- aumento del aislamiento de los tejidos (como ya se ha mencionado);

- reacción hipotérmica (descenso "controlado" de la temperatura interna),

- reacción metabólica (aumento de metabolismo).

Las adaptaciones más pronunciadas deberían encontrarse en las poblaciones nativas de regiones frías. En todo caso, la tecnología moderna y los hábitos de vida han reducido los tipos más extremos de exposición al frío. Las prendas de abrigo, las viviendas con calefacción y la conducta consciente permiten a la mayoría de las personas mantener un clima casi tropical en la superficie de la piel (microclima), reduciendo así el estrés por frío y debilitando el estímulo para la adaptación fisiológica.

Probablemente los grupos más expuestos al frío hoy en día son las expediciones polares y los trabajadores en industrias de las regiones árticas y subárticas. Parece ser que el tipo de adaptación que más se observa con la exposición a frío extremo (aire 0 agua fría) es el del aislamiento. En otras palabras, se pueden mantener temperaturas interiores más altas con la misma o menos pérdida de calor.

\section{Dieta y equilibrio hídrico}

En muchos casos, el trabajo en ambientes fríos se asocia a actividades que consumen mucha energía. Además, la protección contra el frío requiere el uso de prendas y equipos que pesan varios kilos. El efecto entorpecedor de la ropa aumenta el effuerzo muscular. Por consiguiente, algunos trabajos requieren más energía (y más tiempo) en ambientes fríos. El aporte de calorías a través de los alimentos debe compensar este consumo de energía. L as personas que trabajan al aire libre deben aumentar el porcentaje de calorías proporcionadas por alimentos grasos

La dieta de los trabajadores expuestos a ambientes fríos debe aportar la energía suficiente. D ebe incluir suficientes hidratos de carbono para asegurar unos niveles plasmáticos de azúcar suficientes y estables en los trabajadores que realizan trabajos pesados. Recientemente se han lanzado al mercado productos que supuestamente estimulan y aumentan la producción de calor corporal en ambientes fríos. En general, tales productos consisten simplemente en hidratos de carbono y por el momento no han dado mejores resultados que otros productos similares (chocolate) en las pruebas a las que se les ha sometido, ni tampoco mejores resultados a los esperados por su contenido energético.

La exposición al frío puede provocar una pérdida considerable de agua. En primer lugar, el enfriamiento de los tejidos produce una redistribución del volumen sanguíneo, provocando "diuresis por frío". El trabajo y la ropa no deben interferir en este proceso, que puede desarrollarse en poco tiempo y exigir medidas urgentes. El aire casi seco a temperaturas por debajo de cero permite una evaporación continua en la piel y el tracto respiratorio que no se percibe fácilmente. L a sudoración contribuye a la pérdida de agua y debe controlarse cuidadosamente, evitándola en la medida de lo posible por su efecto nocivo en el aislamiento cuando el sudor es absorbido por las prendas de vestir. En ambientes con temperaturas bajo cero, no siempre se tiene acceso a agua. Cuando se trabaja al aire libre, el agua tiene que ser suministrada o producida derritiendo nieve o hielo. Puesto que la sensación de sed se reduce, es fundamental que los trabajadores expuestos al frío beban agua con frecuencia para evitar una deshidratación progresiva. El déficit hídrico puede reducir la capacidad de trabajo y aumentar el riesgo de sufrir lesiones por frío.

\section{Acondicionamiento de los trabajadores para el trabajo en ambientes fríos}

Las medidas más eficaces y adecuadas para adaptar a los seres humanos al trabajo en ambientes fríos son, con diferencia, las que tienen como objetivo el acondicionamiento de los trabajadores: educación, formación y práctica. Como ya se ha dicho antes, gran parte del éxito de la adaptación al frío depende de la conducta de las personas. La experiencia y los conocimientos son elementos importantes en este comportamiento.

Las personas que trabajan en ambientes fríos deben recibir una introducción básica a los problemas específicos del frío. D eben ser informadas de las reacciones fisiológicas y subjetivas, los aspectos relacionados con la salud, el riesgo de accidentes y las medidas de protección, como el uso de prendas protectoras y las técnicas de primeros auxilios. D eben ser entrenadas gradualmente para las tareas que se les encomienda. Sólo después de un cierto tiempo (días o semanas) deberán trabajar toda la jornada en condiciones extremas. En la Tabla 42.18 se ofrecen recomendaciones sobre el contenido de los programas de acondicionamiento para distintos tipos de trabajo en ambientes fríos.

La introducción básica consiste en educación e información sobre los problemas específicos del frío. El registro y el análisis de accidentes y lesiones constituyen la mejor base para las medidas preventivas. La formación en primeros auxilios debe impartirse como un curso básico para todo el personal, aunque algunos grupos específicos deberán recibir un curso avanzado. Las medidas de protección son un componente esencial de cualquier programa de acondicionamiento y se describen con más detalle en la siguiente sección. La formación en técnicas de

Tabla 42.18 - Componentes de los programas de acondicionamiento para los trabajadores expuestos al frío.

$\begin{array}{llll}\text { Componente } & \begin{array}{l}\text { Trabajo al } \\ \text { aire libre }\end{array} & \begin{array}{l}\text { Trabajo en } \\ \text { cámaras } \\ \text { frigoríficas }\end{array} & \begin{array}{l}\text { Trabajo en } \\ \text { regiones } \\ \text { árticas y } \\ \text { subárticas }\end{array} \\ \begin{array}{l}\text { Control de la salud } \\ \text { Introducción básica }\end{array} & * * * & * * & * * * \\ \text { Prevención de accidentes } & * * * & * * & * * * \\ \begin{array}{l}\text { Formación básica en } \\ \text { primeros auxilios }\end{array} & * * * & * * * & * * * \\ \begin{array}{l}\text { Formación avanzada en } \\ \text { primeros auxilios }\end{array} & * * & * * * \\ \begin{array}{l}\text { Medidas de protección } \\ \text { Formación en técnicas de } \\ \text { supervivencia }\end{array} & * * * & * * & * * * \\ * \text { vivel rutinario, texto } & * * & * * \text { factor importante que debe considerarse, *** factor muy importante que } \\ \text { debe considerarse. }\end{array}$


supervivencia es importante para las personas que trabajan en regiones árticas y subárticas, así como para las que trabajan al aire libre en otras zonas remotas.

\section{Control técnico}

\section{Principios generales}

Debido a los muchos y complejos factores que influyen en el equilibrio térmico del ser humano y a las grandes variaciones individuales, es difícil definir la temperaturas críticas para trabajos prolongados. Las temperaturas que se indican en la Figura 42.19 deben interpretarse como valores que exigen la adopción de medidas para mejorar las condiciones. A temperaturas inferiores a las que aparecen en la Figura 42.19, deberán controlarse y evaluarse las exposiciones. Las técnicas para la evaluación del estrés por frío y las recomendaciones sobre las exposiciones de duración limitada se describen en otras secciones de este capítulo. Se supone que los trabajadores disponen de la mejor protección posible para manos, pies y cuerpo (prendas de vestir). Con una protección inadecuada, el enfriamiento puede producirse a temperaturas considerablemente mayores.

En las Tablas 42.19 y 42.20 se proponen diferentes medidas de prevención y protección que pueden aplicarse a casi todos los tipos de trabajo en ambientes fríos. Con una cuidadosa planificación y previsión puede ahorrarse mucho esfuerzo. Los ejemplos que se ofrecen son recomendaciones. Debe insistirse en que las adaptaciones finales de la ropa, los equipos y la conducta durante el trabajo deben delegarse en los trabajadores. Sólo con una adaptación prudente e inteligente de la conducta a los requisitos de las condiciones ambientales reales puede conseguirse una exposición segura y eficiente.

$\mathrm{L}$ a American Conference of $\mathrm{G}$ overnmental Industrial H ygienists, (ACGIH 1992) ha realizado algunas recomendaciones sobre las condiciones climáticas en las que deberían adoptarse ciertas medidas. L os requisitos fundamentales son los siguientes:

- deben proporcionarse a los trabajadores prendas protectoras suficientes y adecuadas,

- deben tomarse precauciones especiales con los trabajadores de edad avanzada o con los trabajadores que sufren problemas circulatorios

A continuación se ofrecen otras recomendaciones relacionadas con la protección de las manos, el diseño del lugar de trabajo y las prácticas de trabajo.

\section{Protección de las manos}

Con temperaturas inferiores a $16^{\circ} \mathrm{C}$, las operaciones manuales de alta precisión exigen el calentamiento de las manos. Los mangos metálicos de las herramientas y barras deben cubrirse con materiales aislantes cuando su temperatura sea inferiores $a-1 \stackrel{\circ}{-} \mathrm{C}$. El trabajador debe utilizar guantes anticontacto siempre que exista el riesgo de tocar superficies con temperaturas

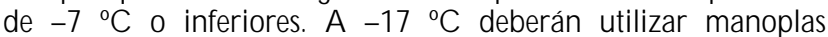
aislantes. Los líquidos evaporativos a temperaturas inferiores a $4{ }^{\circ} \mathrm{C}$ deberán manipularse con precaución para evitar que salpiquen zonas de la piel desnudas o mal protegidas.

\section{Prácticas de trabajo}

Por debajo de una temperatura equivalente de congelación de $-12 \stackrel{\circ}{\circ}$, los trabajadores deben someterse a una supervisión constante (vigilancia por un compañero). M uchas de las medidas que se sugieren en la Tabla 42.18 son aplicables. Con temperaturas más bajas, se hace cada vez más importante que los trabajadores reciban formación sobre los procedimientos de seguridad y salud.

\section{Diseño del lugar de trabajo}

El lugar de trabajo debe estar protegido del viento y las velocidades del aire deben mantenerse por debajo de $1 \mathrm{~m} / \mathrm{s}$. Siempre que sea necesario, los trabajadores deberán utilizar prendas de abrigo contra el viento. Asimismo, deberán utilizar protectores oculares en condiciones especiales de exposición al sol y a superficies cubiertas de nieve. Se recomienda que las personas que trabajan siempre a temperaturas inferiores a- $18 \stackrel{\circ}{\circ}$. sean sometidas a exámenes médicos. Entre las recomendaciones sobre la vigilancia del lugar de trabajo destacan las siguientes:

- Termometría adecuada cuando la temperatura sea inferior a $16 \stackrel{\circ}{\circ}$.

- Control de la velocidad del aire en interiores al menos cada 4 horas.

- Medición de la velocidad del viento en trabajos al aire libre y con temperaturas ambientales inferiores $\mathrm{a}-1$ O $\mathrm{C}$.

- Determinación de la Temperatura Equivalente de Congelación para distintas combinaciones de velocidad del aire y temperatura ambiente.

La mayoría de las recomendaciones que se ofrecen en las Tablas 42.19 y 42.20 son pragmáticas y sencillas.

El uso de prendas de abrigo es la medida más importante para el control individual. Las capas múltiples de ropa permiten soluciones más flexibles que el uso de un único traje que incorpora la función de capas múltiples. No obstante, las necesidades específicas del trabajo determinarán cuál es el sistema más funcional. La ropa protege contra el enfriamiento. Pero también el exceso de ropa en ambientes fríos es un problema frecuente para los miembros de las expediciones árticas que se ven expuestos a frío extremo. El exceso de ropa puede producir rápidamente una intensa sudoración, acumulándose el sudor en las capas de ropa. Durante los períodos de baja actividad, la ropa húmeda se seca

\section{Figura 42.19 - Temperaturas estimadas a las que pueden producirse ciertos desequilibrios térmicos del organismo*.}

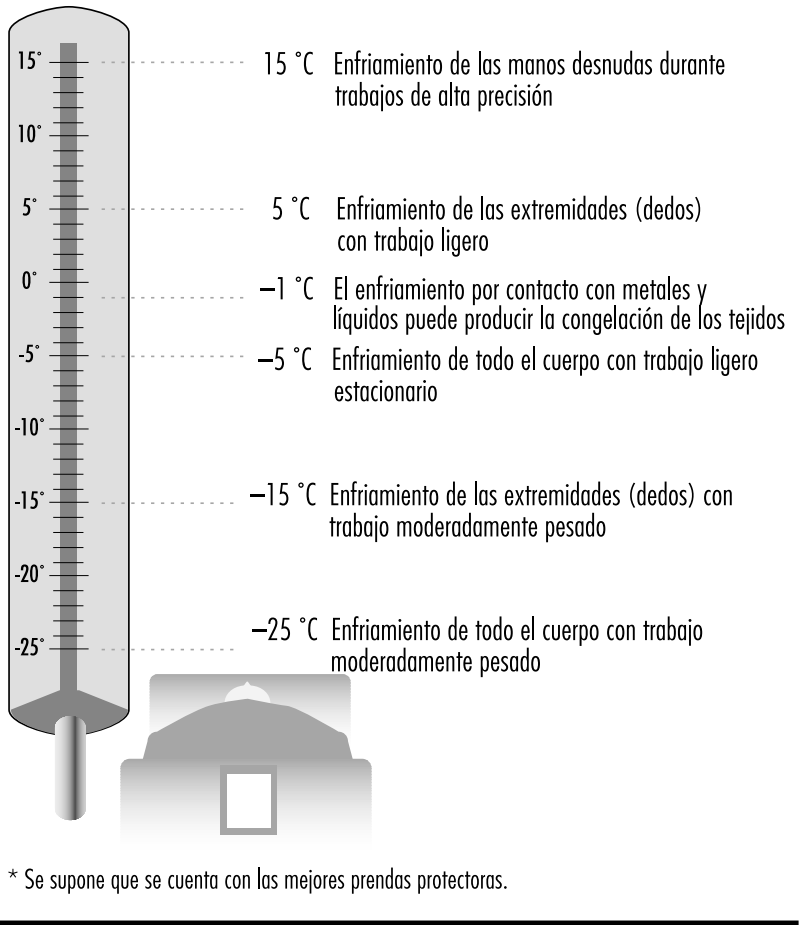


Tabla 42.19 Estrategias y medidas durante distintas fases del trabajo para prevenir y reducir el estrés por frío.

\section{Fase/ factor Medidas recomendadas}

Fase de Programar el trabajo para una estación más cálida ( para el trabajo al planificación aire libre)

Comprobar si el trabajo puede realizarse en interiores (para el trabajo al aire libre).

Reservar más tiempo para el trabajo en ambientes fríos y con prendas protectoras.

Analizar la idoneidad de las herramientas y los equipos utilizados.

Organizar el trabajo en períodos adecuados de trabajo-descanso, considerando las tareas, la carga de trabajo y el nivel de protección. Proporcionar un espacio o refugio con calefacción para la recuperación. Proporcionar formación para tareas complejas en condiciones normales. Comprobar las historias médicas de los trabajadores.

Comprobar que los trabajadores poseen los conocimientos y las destrezas adecuadas.

Facilitar información sobre riesgos, problemas, síntomas y medidas preventivas.

Separar la línea de producción del área de trabajo y mantener estas dos zonas a temperaturas diferentes.

Controlar a niveles bajos la velocidad, la humedad, y el nivel de ruido del sistema de acondicionamiento del aire.

Asignar personal adicional para acortar la exposición.

Seleccionar prendas protectoras adecuadas y otros equipos de protección.

Antes de Comprobar las condiciones ambientales al inicio del trabajo.

cada turno de Programar unos regímenes adecuados de trabajo-descanso.

trabajo Permitir el control individual de la intensidad del trabajo y de la ropa.

Seleccionar una ropa adecuada y otros equipos personales.

Comprobar el tiempo y las previsiones climáticas (para el trabajo al aire libre).

Preparar programas y controlar las estaciones (para el trabajo al aire libre).

Organizar un sistema de comunicación (para el trabajo al aire libre).

Durante el Permitir períodos de descanso en un refugio con calefacción.

turno de trabajo Permitir interrupciones frecuentes para tomar alimentos y bebidas calientes.

Permitir flexibilidad en términos de intensidad y duración del trabajo.

Proporcionar un lugar para cambiarse de ropa (calcetines, guantes, etc.). Proteger contra la pérdida de calor por contacto con superficies frías.

Reducir al mínimo la velocidad del aire en las zonas de trabajo.

Mantener el lugar de trabajo libre de agua, hielo y nieve.

Aislar el suelo de los lugares de trabajo estacionarios.

Permitir el acceso a ropa adicional para calentarse.

Vigilar las reacciones subjetivas (sistema basado en el compañero) (para el trabajo al aire libre).

Informar periódicamente al capataz 0 a la base (para el trabajo al aire libre).

Permitir un tiempo suficiente de recuperación después de exposiciones severas (para el trabajo al aire libre).

Proteger contra los efectos del viento y la lluvia (para el trabajo al aire libre).

Vigilar las condiciones climáticas y anticipar cambios climáticos (para el trabajo al aire libre).

Fuente: Adaptado de Holmér 1994.

aumentando la pérdida de calor corporal. L a medida preventiva obvia es reducir la sudoración mediante una selección adecuada de las prendas de vestir y realizar las adaptaciones necesarias a los cambios en la intensidad del trabajo y las condiciones climáticas. No existe ningún tejido que puede absorber grandes cantidades de sudor y al mismo tiempo conservar unas buenas propiedades de aislamiento y bienestar. La lana permanece esponjada y aparentemente seca aunque absorba cierta cantidad de agua (recuperación de humedad), pero si se producen grandes cantidades de sudor, éste se condensa y produce problemas similares a los observados con otros tejidos. La humedad permite cierta liberación de calor y contribuye a conservar el calor. A hora bien, cuando la prenda de lana se seca sobre el cuerpo, el proceso se invierte según se ha comentado antes y la persona se enfría inevitablemente.

La tecnología de las fibras modernas ha producido numerosos materiales y tejidos nuevos para la fabricación de prendas de vestir. Ahora existen trajes que combinan la impermeabilidad al agua con una buena permeabilidad al vapor de agua, 0 un elevado aislamiento con menos peso o grosor. Con todo, es esencial que se seleccionen prendas con propiedades y funciones garantizadas y demostradas. Existen muchos productos que intentan imitar a otros más costosos. Algunos de ellos son de tan mala calidad que su uso puede resultar peligroso.

La protección contra el frío depende principalmente del aislamiento térmico proporcionado por todo el conjunto de prendas de vestir (I clo). Claro está que propiedades como la permeabilidad al aire, al vapor de agua y al agua de la capa exterior en particular son esenciales para la protección contra el frío. Existen normas internacionales y métodos de ensayo para medir y clasificar estas propiedades. I gualmente, los guantes y el calzado pueden ser sometidosa pruebas para determinar sus propiedades protectoras utilizando normas como las normas europeas EN 511 y EN 344 (CEN 1992, 1993).

\section{Trabajo en exteriores fríos}

L os problemas específicos del trabajo en exteriores fríos se deben a la combinación de los factores climáticos que pueden ocasionar estrés por frío. La combinación del viento y una temperatura ambiente baja aumenta significativamente la capacidad de enfriamiento del ambiente, un hecho que tiene que tenerse en cuenta para la organización del trabajo, la protección del lugar de trabajo y la selección de las prendas de vestir. Las precipitaciones, ya sean en forma de nieve o lluvia, o acumuladas en el suelo, requieren algunos ajustes. La variación en las condiciones climáticas obliga a los trabajadores a planificar, llevar y utilizar prendas y equipos adicionales.

Gran parte de los problemas del trabajo al aire libre se deben a las variaciones, en ocasiones grandes, del nivel de actividad y las condiciones climática durante un mismo turno de trabajo. $\mathrm{N}$ o existe ninguna prenda de vestir que pueda adaptarse a unas variaciones tan grandes. En consecuencia, la ropa tiene que cambiarse y ajustarse con frecuencia. De lo contrario, se producirá enfriamiento por una protección insuficiente, o sudoración o sobrecalentamiento por un exceso de ropa. En este último caso, gran parte del sudor se condensa o es absorbido por la ropa. En períodos de descanso y baja actividad, la ropa sudada supone un riesgo potencial, puesto que al secarse reduce el calor corporal.

Las medidas de protección para el trabajo al aire libre incluyen unos regímenes adecuados de trabajo y descanso, éste último en refugios o cabinas con calefacción. Los puestos de trabajo estacionarios pueden protegerse del viento y de las precipitaciones con tiendas de campaña con o sin calefacción. En algunos casos será necesario utilizar calefactores de calor infrarrojo o de gas. La prefabricación de piezas o componentes se realiza a veces al aire libre. A temperaturas por debajo de cero, las condiciones del lugar de trabajo, incluidas las climáticas, deben ser controladas periódicamente. Deberán establecerse unas normas claras sobre los procedimientos aplicables cuando las condiciones empeoren. Asimismo, deberán acordarse los niveles de temperatura, corregidos en ocasiones para tener en cuenta el viento (índice de enfriamiento por el viento) y vinculados a un programa de acción. 
Tabla 42.20 - Estrategias y medidas relacionadas con factores y equipos específicos.

Conducta Permitir tiempo para ajustar la vestimenta.

Evitar la sudoración y el enfriamiento realizando a tiempo adaptaciones de la ropa en función de la carga de trabajo y/ o la exposición. Ajustar la carga de trabajo (para mantener la sudoración al mínimo). Evitar cambios rápidos en la intensidad del trabaio.

Permitir una ingesta adecuada de líquidos y comidas calientes. Permitir períodos de descanso en áreas protegidas (refugio, habitación caliente) ( para trabajos al aire libre).

Evitar que la ropa se moje con agua o nieve.

Permitir una recuperación suficiente en una zona protegida (para trabajos al aire libre).

Informar del progreso del trabajo al capataz o a la base (para trabajos al aire libre).

Notificar importantes desviaciones del plan y el programa de trabajo (para trabajos al aire libre).

Ropa Seleccionar prendas de vestir con las que se tenga experiencia previa.

En el caso de prendas nuevas, seleccionar aquéllas que hayan superado ciertas pruebas.

Seleccionar el nivel de aislamiento en función del clima y la actividad previstos.

Utilizar ropa flexible que permita ajustar el grado de aislamiento.

Las prendas de vestir deben ser fáciles de poner y quitar.

Reducir la fricción interna entre las capas de ropa mediante una selección adecuada de tejidos.

Seleccionar el tamaño de las prendas exteriores para que quepan las prendas interiores.

Utilizar un sistema de capas múltiples:

- la capa interna para el control microclimático

- la capa intermedia para el control del aislamiento

- la capa externa para la protección ambiental.

La capa interna no debe absorber agua en caso de que el sudor no pueda ser suficientemente controlado.

La capa interna debe ser absorbente si se prevé que no se producirá sudoración o ésta será escasa.

La capa interna puede consistir en tejidos de doble función, en el sentido de que la fibra en contacto con la piel no sea absorbente y las fibras próximas a la capa intermedia absorban agua o humedad.

La capa intermedia debe permitir que se estanquen capas de aire.

La capa intermedia debe tener forma estable y ser elástica.

La capa intermedia puede estar protegida por capas que actúen como barrera al vapor.

Las prendas de vestir deben solaparse lo suficiente en la zona de la cintura y la espalda.

La capa exterior debe seleccionarse en función de los requisitos de protección adicional contra el viento, el agua, el aceite, el fuego, el desgarro o la abrasión.

El diseño de la capa externa debe permitir un control fácil y amplio de las aperturas del cuello, las mangas, las muñecas, etc. para regular la ventilación del espacio interior.

Las cremalleras y otros cierres tienen que funcionar también en condiciones de nieve y viento.

Los botones deben evitarse.

La ropa debe poder abrocharse y desabrocharse incluso con dedos fríos y torpes.

El diseño debe permitir que se adopten posturas flexionadas sin que por ello se compriman las capas y se reduzca el aislamiento.

Evitar constricciones innecesarias.

Llevar siempre mantas de sobra a prueba de viento (NOTA: La "manta del astronauta" aluminizada no protege más de lo normal por ser a prueba de viento. Una gran bolsa de basura de polietileno produce el mismo efecto).

Educación y Proporcionar educación e información sobre los problemas especiales del frío. formación Proporcionar información y formación en primeros auxilios y tratamiento de las lesiones por frío.
Poner a prueba la maquinaria, las herramientas y los equipos en condiciones frías controladas.

Seleccionar equipos probadas siempre que sea posible.

Formar a los trabajadores para realizar operaciones complejas en condiciones de frío controladas.

Informar sobre accidentes y prevención de accidentes.

Protección de Las manoplas proporcionan el mejor aislamiento.

las manos Las manoplas deben permitir el uso de unos guantes interiores finos.

Las exposiciones prolongadas que exigen un trabajo manual de precisión deben interrumpirse con períodos frecuentes de recalentamiento.

Los calentadores de bolsillo y otras fuentes externas de calor pueden evitar o retrasar el enfriamiento de las manos.

Las mangas de las chaquetas deben acomodar fácilmente los puños de los

guantes 0 las manoplas, ya sea por debajo o por encima.

La ropa exterior debe permitir que los quantes puedan quardarse 0 engancharse fácilmente cuando el trabajador se los quite.

Calzado Las botas deben proporcionar un gran aislamiento del suelo (suela).

La suela debe estar fabricada con un material flexible y contar con un dibujo antideslizante.

Las botas deben tener el tamaño adecuado para que quepan varias capas de calcetines y una plantilla.

La ventilación de la mayor parte del calzado es mala, razón por la cual debe controlarse la humedad con el cambio frecuente de los calcetines y las plantillas.

Control de la humedad mediante una barrera al vapor entre la capa interior y exterior.

Las botas deben secarse completamente entre turno y turno. Las perneras deben ajustarse fácilmente a la botas, ya sea por debajo o por encima.

Prendas

para la

Una prenda flexible para la cabeza es un importante instrumento para el control del calor y las pérdidas de calor de todo el cuerpo.

Las prendas para la cabeza deben ser impermeables al viento.

El diseño debe proporcionar protección suficiente a las orejas y el cuello.

El diseño debe acomodar otros tipos de equipos protectores (p. ej., orejeras, gafas de seguridad).

Cara Las máscaras deben ser aislantes e impermeables al viento.

Ningún elemento metálico debe estar en contacto con la piel.

El uso de máscaras especiales de respiración o piezas bucales permite lograr un calentamiento y humidificación considerables del aire inspirado.

Utilizar gafas de seguridad para el trabajo al aire libre, especialmente en presencia de aguanieve y nieve.

Deben protegerse los ojos de la radiación ultravioleta y el deslumbramiento.

Equipos y Seleccionar herramientas y equipos diseñados y probados para

herramien- condiciones de frío.

tas Elegir un diseño que pueda manejarse con las manos enfundadas en guantes.

Precalentar las herramientas y los equipos.

Guardar las herramientas y los equipos en un lugar con calefacción.

Aislar los mangos de las herramientas y los equipos.

Maquinaria Seleccionar maquinaria diseñada para ambientes fríos.

Guardar la maquinaria en lugares protegidos.

Precalentar la maquinaria antes de utilizarla. Aislar los mangos y controles.

Diseñar los mangos y controles para que puedan manejarse con las manos enfundadas en guantes.

Prepararla para que su reparación y mantenimiento sean fáciles en condiciones adversas.

Lugar de Mantener la velocidad del aire lo más reducida posible.

trabajo Utilizar pantallas contra el viento o prendas impermeables al viento.

Aislar el suelo cuando el trabajo tenga que realizarse durante un perído de tiempo prolongado de pie, de rodillas o tumbado en el suelo. Proporcionar calor adicional cuando el trabajo sea ligero y estacionario. 


\section{Trabajo en cámaras frigoríficas}

L os alimentos congelados tienen que ser almacenados y transportados a temperaturas ambientales muy bajas $\left(<-20^{\circ} \mathrm{C}\right)$. El trabajo en cámaras frigoríficas existe en casi todas las partes del mundo. Es un tipo de exposición artificial al frío que se caracteriza por un clima constante y controlado. Los trabajadores pueden verse expuestos al frío de manera continua o, lo más frecuente, de manera intermitente, turnándose entre los ambientes fríos y los ambientes cálidos o calurosos fuera de la cámara.

Siempre que el trabajo exija un cierto esfuerzo físico, puede conseguirse un equilibrio térmico seleccionando las prendas protectoras adecuadas. Los problemas especiales de las manos y los pies suelen exigir descansos periódicos cada 1,5 o 2 horas. El período de descanso debe ser suficientemente largo para permitir el recalentamiento (20 minutos).

La manipulación manual de los productos congelados exige el uso de unos guantes protectores que proporcionen un aislamiento suficiente (sobre todo de la palma de la mano). Los requisitos y métodos de ensayo para los guantes de protección contra el frío se establecen en la norma europea EN 511, que se describe con más detalle en el artículo "Indices del frío y normas sobre el frío" en este mismo capítulo. La instalación de calefactores locales (p. ej., radiadores infrarrojos) en los puestos de trabajo estacionarios facilitan el equilibrio térmico.

Gran parte del trabajo en las cámaras frigoríficas se realiza con carretillas elevadoras. La mayoría de estos vehículos son descubiertos. La conducción crea una velocidad relativa del aire, que en combinación con las bajas temperaturas, aumenta el enfriamiento corporal. A demás, el trabajo en sí mismo es ligero y la producción asociada de calor metabólico es pequeña. En consecuencia, el aislamiento requerido de la ropa es bastante alto (alrededor de 4 clo) y no puede conseguirse con la mayoría de las prendas utilizadas. El conductor se queda frío, empezando por los pies y las manos, razón por la cual la exposición tiene que tener una duración limitada. Dependiendo de la disponibilidad de prendas protectoras, los regímenes de trabajo deberán organizarse con períodos de trabajo en ambientes fríos y ambientes cálidos y períodos de descanso en ambientes térmicamente neutros. U na medida sencilla para facilitar el equilibrio térmico consiste en instalar un asiento calefactado en la carretilla. De esta forma podrá prolongarse el tiempo de exposición al frío y prevenir el enfriamiento local del asiento y la espalda. 0 tras soluciones más sofisticadas y costosas consisten en el uso de cabinas con calefacción.

En los países cálidos existen problemas especiales cuando los trabajadores de las cámaras frigoríficas, normalmente los conductores de las carretillas, se ven expuestos intermitentemente a calor $\left(+30^{\circ} \mathrm{C}\right)$ y frío $(-30 \stackrel{\circ}{C})$. Las exposiciones breves (entre 1 y $5 \mathrm{~min}$ ) a estos ambientes extremos pueden dificultar el uso de una ropa adecuada, que será excesiva para el período de trabajo al aire libre e insuficiente para el trabajo en la cámara frigorífica. El uso de carretillas con cabinas climatizadas puede ser la única solución posible, una vez solucionado el problema de la condensación en los cristales. Para organizar unos regímenes de trabajo adecuados, tiene que considerarse siempre el tipo de trabajo realizado y la protección disponible.

L os lugares de trabajo frescos, como los que se encuentran por ejemplo en el sector de los alimentos frescos, presentan unas condiciones climáticas con unas temperaturas ambientales de entre $+2 \mathrm{y}+16 \stackrel{\circ}{\circ} \mathrm{C}$, dependiendo del tipo de alimento. Algunos de estos ambientes se caracterizan por una elevada humedad relativa que provoca la condensación de agua en las zonas frescas y la acumulación de humedad o agua en el suelo, a la vez que aumenta el riesgo de resbalones. Son problemas que pueden solucionarse con una buena higiene del lugar de trabajo y unas rutinas de limpieza que contribuyan a reducir la humedad relativa.

La velocidad local de aire en los puestos de trabajo es a veces demasiado alta, provocando quejas de los trabajadores por la existencia de corrientes de aire. L os problemas pueden resolverse cambiando o ajustando las salidas de aire frío o reconfigurando los puestos de trabajo. La acumulación de productos congelados o frescos cerca de los puestos de trabajo puede contribuir a la sensación de corriente debido a un mayor intercambio de calor por radiación. La ropa debe seleccionarse basándose en una evaluación de los requisitos y en el método IREQ. Además, la ropa debe diseñarse para proteger al trabajador contra las corrientes locales, la humedad y el agua. L os requisitos higiénicos especiales para la manipulación de los alimentos imponen ciertas restricciones en el diseño y el tipo de prendas de vestir (es decir, de la capa exterior). U na vestimenta adecuada debe constar de la ropa interior, una capa intermedia aislante, y la capa exterior, para formar un sistema protector suficiente y funcional. Las prendas para la cabeza suelen ser necesarias por motivos higiénicos. Con todo, las prendas que se utilizan en la actualidad suelen ser de papel y no ofrecen ninguna protección contra el frío. El calzado consiste en zuecos o zapatos ligeros, con malas propiedades aislantes. La selección de unas prendas más adecuadas para la cabeza y los pies puede ayudar a conservar el calor en estas partes del cuerpo y contribuir a mejorar el equilibrio térmico general.

Un problema especial en muchos lugares de trabajo es la conservación de la destreza manual. Las manos y los dedos se enfrían rápidamente cuando la actividad muscular es pequeña 0 moderada. EI uso de guantes aumenta la protección, pero reduce la destreza. T iene que lograrse un equilibrio delicado entre estas dos demandas. Para cortar carne se suelen utilizar guantes metálicos. El uso de unos guantes de tejido fino por debajo puede reducir el efecto de enfriamiento y aumentar la sensación de bienestar. L os guantes finos pueden ser suficientes para muchos fines. 0 tras medidas para evitar el enfriamiento de las manos consisten en utilizar, por ejemplo, radiadores infrarrojos. En el mercado existen guantes calentados eléctricamente, pero su ergonomía suele ser deficiente, así como su capacidad de calentamiento y la autonomía de su batería.

\section{Exposición al agua fría}

La inmersión del cuerpo en agua fría produce la pérdida de grandes cantidades de calor en períodos de tiempo muy cortos y conlleva un riesgo evidente. La conductividad del calor del agua es 25 veces mayor que la del aire y en muchas situaciones de exposición, la capacidad del agua circundante para absorber calor, es realmente infinita.

La temperatura termoneutra (sensación térmica neutra) del agua es de unos $32033^{\circ} \mathrm{C}$, y a temperaturas inferiores el cuerpo responde con vasoconstricción y escalofríos. U na larga exposición a agua con una temperatura de entre 25 y $30 \stackrel{\circ}{\circ}$ provoca el enfriamiento del cuerpo y un desarrollo progresivo de hipotermia. $\mathrm{N}$ aturalmente, esta respuesta es mayor y más grave cuanto menor sea la temperatura del agua.

La exposición al agua fría es frecuente en los accidentes marítimos y en algunos deportes acuáticos. En cualquier caso, incluso durante las actividades laborales, los trabajadores corren el riesgo de una hipotermia por inmersión (p. ej., buceo, pesca, navegación y operaciones en alta mar).

Las víctimas de naufragios pueden verse obligadas a sumergirse en agua fría con una protección que puede ir desde prendas finas hasta trajes de buceo. L os chalecos salvavidas forman parte de los equipos que los barcos deben llevar obligatoriamente a bordo. D eben ir provistos de un collar para reducir la pérdida de calor en la cabeza de las víctimas inconscientes. El equipo del 
barco, la eficacia de los procedimientos de emergencia y la conducta de la tripulación y los pasajeros son importantes factores que determinan el éxito de una operación de rescate y las posteriores condiciones de exposición.

L os buzos tienen que sumergirse con frecuencia en aguas frías. L a temperatura de la mayoría de las aguas en las que se practica el buceo profesional, sobre todo a cierta profundidad, es baja, normalmente inferior a $10 \stackrel{\circ}{ } \mathrm{C}$. C ualquier exposición prolongada a aguas así de frías exige el uso de ropa de buceo aislante.

Pérdida de calor. El intercambio de calor en el agua puede concebirse simplemente como un flujo de calor a través de dos gradientes de temperatura: uno interno, del núcleo a la periferia del cuerpo, y otro externo, de la superficie cutánea al agua circundante. La pérdida de calor en la superficie corporal puede describirse simplemente como:

$$
c_{w}=h_{c} \cdot\left(T_{s k}-T_{w}\right) \cdot A_{D}
$$

donde $C_{w}$ es la tasa de pérdida de calor de convección $(W), h{ }_{c}$ es el coeficiente de transferencia de calor de convección $\left(\mathrm{W} /{ }^{\circ} \mathrm{C} \mathrm{m}^{2}\right)$, $\mathrm{T}$ sk es la temperatura cutánea media $\left({ }^{\circ} \mathrm{C}\right), \mathrm{T}_{\text {w }}$ es la temperatura del agua $\left({ }^{\circ} \mathrm{C}\right)$ y $A$ es la superficie del cuerpo. Los pequeños componentes de la pérdida de calor por la respiración y las partes no sumergidas ( $p$. ej., la cabeza) se ignoran (véase la siguiente sección sobre el buceo).

El valor de h varía entre 100 y $600 \mathrm{~W} /{ }^{\circ} \mathrm{Cm}^{2}$. El valor mínimo corresponde al agua estacionaria. Las turbulencias, ya sean causadas por los movimientos al nadar o por las corrientes de agua, multiplican por dos o por tres el coeficiente de convección. Se comprende fácilmente que cualquier cuerpo sin protección sufra una pérdida considerable de calor cuando se sumerge en agua fría, en ocasiones superando el calor que es capaz de producir incluso con un esfuerzo intenso. D e hecho, una persona (vestida o desnuda) que se sumerja en agua fría ahorra en la mayoría de los casos más calor quedándose quieta que nadando.

La pérdida de calor al agua puede reducirse significativamente mediante el uso de prendas protectoras especiales.

B uceo. L os buzos que descienden varios cientos de metros por debajo del nivel del mar deben protegerse de los efectos de la presión (un ATA 0 0,1 M Pa/ $10 \mathrm{~m}$ ) y el frío. La inspiración de aire frío (o una mezcla de gas frío de helio y oxígeno) hace que el cuerpo pierda calor a través de los tejidos pulmonares. La pérdida directa de calor del interior del organismo es grande a presiones elevadas y puede alcanzar fácilmente valores mayores que la producción de calor metabólico en reposo. El organismo humano no percibe fácilmente esta pérdida de calor. La temperatura interna puede descender a niveles peligrosos sin que el cuerpo responda con escalofríos cuando la temperatura superficial del cuerpo todavía se mantiene. Las operaciones modernas en alta mar exigen que el buzo disponga de una fuente adicional de calor en el traje y en el respirador para compensar la gran pérdida de calor de convección. En el buceo a grandes profundidades marinas, la zona de confort es estrecha y exige unas temperaturas más altas que al nivel de la superficie del mar: entre $32 \stackrel{\circ}{\circ}$ cuando la presión es de 20 a 30 ATA (entre 2 y 3 M Pa) y aumentando a 32 o $34 \stackrel{\circ}{\circ}$ hasta 50 ATA (5 M Pa).

Factores fisiológicos: La inmersión en agua fría provoca una respuesta respiratoria aguda. La respuesta inicial consiste en "boqueada inspiratoria", hiperventilación, taquicardia, vasoconstricción periférica e hipertensión. La apnea inspiratoria dura varios segundos y va seguida por hiperventilación. La respuesta es casi imposible de controlar voluntariamente. Por consiguiente, la persona puede inhalar fácilmente agua si el mar está movido y su cuerpo se encuentra sumergido. Los primeros segundos de inmersión en agua muy fría son peligrosos y puede producirse el ahogamiento repentino de la persona. La inmersión lenta y con la protección adecuada del cuerpo reduce la reacción y permite un mejor control de la respiración. La reacción desaparece gradualmente y en general la respiración se normaliza al cabo de unos minutos

La rápida pérdida de calor en la superficie cutánea obliga a insistir en la importancia de los mecanismos internos (fisiológicos o constitucionales) para reducir el flujo de calor del interior del cuerpo a la piel. El ejercicio aumenta el flujo de sangre en las extremidades y, sumado a la mayor convección externa, puede de hecho acelerar la pérdida de calor a pesar de una mayor producción de calor.

Al cabo de 5010 minutos de inmersión en agua muy fría, la temperatura de las extremidades desciende rápidamente. La función neuromuscular se deteriora y la capacidad de coordinar y controlar el rendimiento muscular se degrada. La capacidad de nadar puede reducirse considerablemente y en poco tiempo pone en situación de riesgo a la persona.

Las dimensiones corporales es otro factor importante. U na persona alta tiene una mayor superficie corporal y pierde más calor que una persona pequeña en las mismas condiciones ambientales. Con todo, la masa corporal relativamente mayor compensa este hecho de dos formas. La producción de calor metabólico aumenta cuanto mayor es la superficie corporal y el contenido de calor es mayor con la misma temperatura corporal. Este último factor supone una mayor amortiguación de las pérdidas de calor y un descenso más lento de la temperatura interna. Los niños corren un mayor riesgo que los adultos.

El factor más importante con diferencia es el contenido de grasa corporal, en particular, el grosor de la capa de grasa subcutánea. El tejido adiposo es más aislante que otros tejidos y apenas está irrigado por la circulación periférica. Una vez que se produce la vasoconstricción, la capa de grasa subcutánea actúa como una capa aislante. Dicho efecto aislante está casi linealmente relacionado con el grosor de la capa. En consecuencia, las mujeres, que en general acumulan más grasa cutánea que los hombres, pierden menos calor en las mismas condiciones. I gualmente, las personas gruesas se encuentran en una mejor situación que las delgadas.

Protección personal. Como ya se ha mencionado antes, la inmersión prolongada en aguas frías y templadas exige un aislamiento externo adicional en forma de trajes de buceo, trajes de inmersión 0 un equipo similar. El traje húmedo de espuma de neopreno proporciona aislamiento por el grosor del material (células tupidas de espuma) y por la "entrada" relativamente controlada de agua al microclima de la piel. Este último fenómeno produce un calentamiento de dicha agua y el aumento de la temperatura cutánea. Existen trajes de distintos grosores que proporcionan más o menos aislamiento. Un traje húmedo se comprime con la profundidad y pierde, por tanto, gran parte de su capacidad de aislamiento.

EI traje seco se utiliza casi siempre con temperaturas inferiores a $10 \stackrel{\circ}{ } \mathrm{C}$. Permite el mantenimiento de una temperatura cutánea más elevada, dependiendo de la cantidad de aislamiento adicional que se lleve por debajo del traje. Un requisito fundamental es que el traje no deje pasar nada de agua, ya que pequeñas cantidades de agua (entre 0,5 y $1 \mathrm{I}$ ) reducen considerablemente su capacidad aislante. Aunque el traje seco también se comprime con la profundidad, se añade automática o manualmente aire seco a través de la bombona de oxígeno del buzo para compensar esa reducción del volumen. Por consiguiente, puede mantenerse una capa de aire con un microclima que proporciona un buen aislamiento.

Como ya se ha mencionado antes, el buceo a grandes profundidades requiere un calentamiento auxiliar. EI gas respirado se precalienta y el traje también se calienta inyectando agua caliente desde la superficie o desde el cinturón del buzo. Las técnicas más recientes de calentamiento se basan en ropa interior 
Figura 42.20 - Tiempos previstos de supervivencia para situaciones típicas de alta mar en el Mar del N orte.

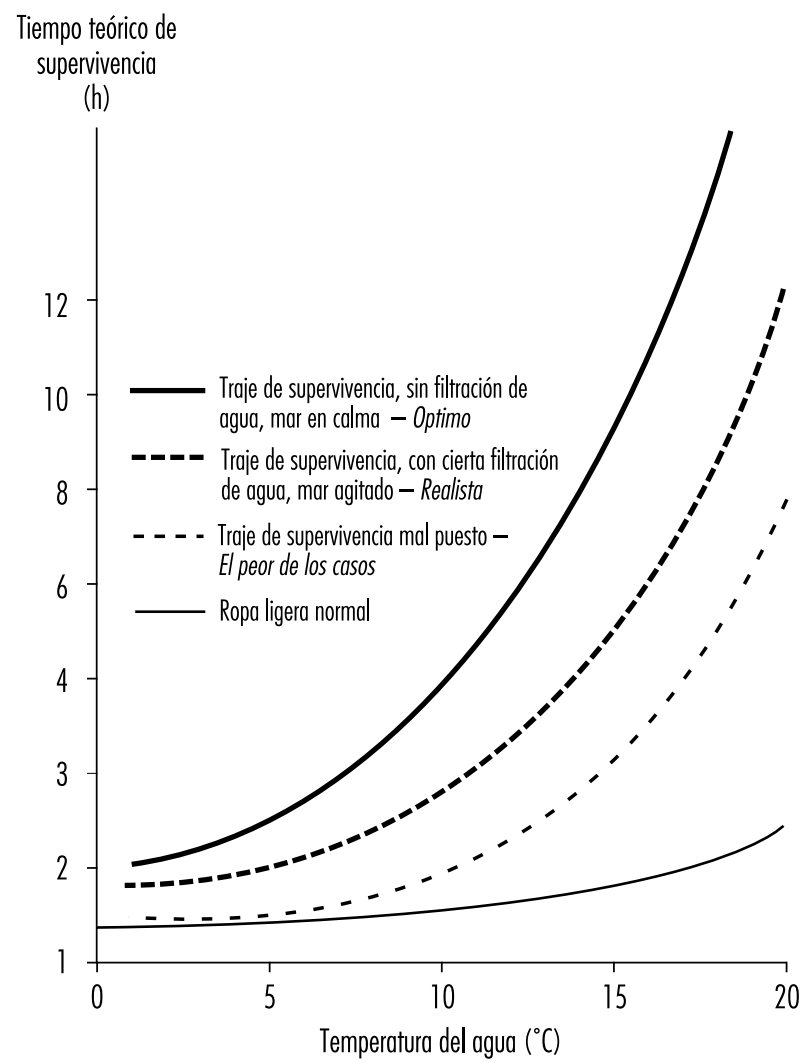

Fuente: Hayes 1988

calentada eléctricamente o circuitos cerrados de túbulos llenos de un líquido caliente.

Las manos son particularmente sensibles al enfriamiento y pueden exigir una protección adicional en forma de guantes aislantes o calentados.

Exposiciones seguras. El rápido desarrollo de la hipotermia y el peligro inminente de muerte por la exposición a aguas frías exige algún tipo de predicción de las condiciones de exposición seguras e inseguras. En la Figura 42.20 se muestran los tiempos de supervivencia teóricos para cuatro condiciones típicas de trabajo en alta mar en el $\mathrm{M}$ ar del $\mathrm{N}$ orte. EI criterio aplicado es un descenso de la temperatura interna a $34 \stackrel{\circ}{\circ}$ en el décimo percentil de la población. Se supone que ésta es la temperatura alcanzada por una persona consciente y con pleno dominio de sí misma. EI uso y funcionamiento correctos de un traje seco multiplica por dos el tiempo teórico de supervivencia. L a curva inferior corresponde a una persona sin protección sumergida con ropa normal. Cuando la ropa se empapa de agua, el aislamiento efectivo es muy pequeño y los tiempos de supervivencia muy cortos (adaptado de Wissler 1988).

\section{Trabajo en regiones árticas y subárticas}

Las regiones árticas y subárticas del mundo plantean problemas adicionales a los del trabajo normal en ambientes fríos. La estación fría coincide con la oscuridad. El número de horas de luz es pequeño. Tales regiones abarcan zonas muy grandes, despobladas o escasamente pobladas, como el norte de Canadá, Siberia y el norte de Escandinavia. Además, la naturaleza es hostil.
Tienen que recorrerse distancias muy grandes y se tarda mucho tiempo en ir de un lado a otro. La combinación de frío, oscuridad y aislamiento exigen consideraciones especiales en términos de organización del trabajo, preparación y equipos. En particular, los trabajadores deben aprender técnicas de supervivencia y primeros auxilios, recibir los equipos adecuados y tenerlos a su disposición mientras trabajan.

Como ya se ha visto, los trabajadores de las regiones árticas están expuestos a numerosos riesgos para su salud. EI riesgo de accidentes y lesiones es elevado, el abuso de drogas es frecuente, las pautas culturales plantean problemas y se producen confrontaciones entre la cultura local nativa y las demandas de la industria occidental moderna. La conducción de trineos motorizados es un ejemplo de la exposición a riesgos múltiples en las condiciones típicas de las regiones árticas (véase más adelante). Se cree que el estrés por frío es uno de los factores de riesgo que explica la mayor frecuencia de algunas enfermedades. El aislamiento geográfico es otro factor que produce ciertos tipos de defectos genéticos en algunas regiones nativas. Las enfermedades endémicas, por ejemplo, ciertas enfermedades infecciosas, tienen también importancia a escala local o regional. L os colonizadores o los trabajadores desplazados corren un mayor riesgo por los diferentes tipos de reacciones al estrés psicológico provocado por el nuevo entorno, las duras condiciones climáticas, el aislamiento y la preocupación.

En este contexto, debe considerarse la adopción de medidas específicas. EI trabajo siempre se realizará en grupos de tres, para que en caso de emergencia una persona pueda ir en busca de ayuda mientras que la otra se queda cuidando a la víctima de, por ejemplo, un accidente. La variación estacional de la luz diurna y del clima debe también tenerse en cuenta para planificar las actividades laborales. L os trabajadores deben someterse a reconocimientos médicos para detectar problemas de salud. En caso necesario, se dispondrá de equipos adicionales para situaciones de emergencia o supervivencia. Vehículos como coches, camiones o trineos motorizados deberán transportar equipos especiales para reparaciones y situaciones de emergencia.

Un problema específico del trabajo en estas regiones en el de los trineos motorizados. En los últimos treinta años, los trineos motorizados han evolucionado de unos vehículos primitivos con tecnología rudimentaria a unas máquinas veloces y tecnológicamente avanzadas. Se utilizan con frecuencia para actividades recreativas, pero también para el trabajo (entre el 10 y el $20 \%$ de su uso). Las profesiones típicas que utilizan trineos motorizados son la policía, el personal militar, los pastores de renos, los leñadores, los agricultores, el sector del turismo, los tramperos y los equipos de búsqueda y rescate.

La exposición a la vibración de estos trineos conlleva un mayor riesgo de lesiones inducidas por la vibración para el conductor. El conductor y los pasajeros están expuestos a gases de escape no purificados. El ruido producido por el motor puede ocasionar pérdida de audición. D ebido a la gran velocidad que alcanzan estos vehículos, las irregularidades del terreno y la escasa protección del conductor y los pasajeros, el riesgo de accidentes es grande.

El sistema musculosquelético está expuesto a vibraciones y a posiciones y cargas extremas durante el trabajo, especialmente cuando se conduce por terrenos abruptos o escarpados. Si el vehículo se atasca, la manipulación del pesado motor provoca sudoración y con frecuencia problemas musculosquéleticos (p. ej., lumbago).

Las lesiones por frío son comunes entre los conductores de trineos motorizados. La velocidad del vehículo agrava la exposición al frío. Las partes más lesionadas del cuerpo son la cara (en casos extremos con afectación de la córnea), las orejas, las manos y los pies. 
L os trineos motorizados se utilizan en zonas remotas en donde el clima, el terreno y otras condiciones contribuyen a los riesgos.

Los trabajadores que conducen trineos motorizados tienen que utilizar un casco diseñado para las condiciones de la conducción considerando los riesgos específicos de exposición producidos por el propio vehículo, las condiciones del terreno y el clima. La ropa debe ser caliente, impermeable al viento y flexible. Los diferentes tipos de actividad experimentadas durante la conducción de un trineo motorizado son difíciles de acomodar con tan sólo un sistema de vestimenta y requieren una consideración especial.

El tráfico de trineos motorizados en zonas remotas plantea también un problema de comunicación. La organización del trabajo y los equipos debe garantizar una comunicación segura con la base central. Deberán transportarse equipos especiales para hacer frente a situaciones de emergencia y proteger a la víctima durante el tiempo suficiente para que pueda llegar el equipo de rescate. Son equipos que incluyen, por ejemplo, un saco de dormir, ropa de repuesto, un maletín de primeros auxilios, una pala para quitar la nieve, un juego de herramientas y lo necesario para poder cocinar.

\section{- PreVencion del estres por FRIO EN CONDICIONES EXTREMAS AL AIRE LIBRE}

\section{Jacques Bittel y G ustave Savourey}

La prevención de los efectos fisiopatológicos de la exposición al frío debe considerarse desde dos puntos de vista; el primero de ellos se refiere a los efectos fisiopatológicos observados durante la exposición general al frío (es decir, de todo el cuerpo); el segundo se refiere a los efectos observados durante la exposición local al frío, que afecta principalmente a las extremidades (manos y pies). Las medidas preventivas en este sentido intentan reducir la incidencia de los dos principales tipos de estrés por frío-hipotermia accidental y congelación de las extremidades. Para ello se requiere una doble estrategia: métodos fisiológicos (p. ej., alimentación e hidratación adecuadas, desarrollo de mecanismos de adaptación) y medidas farmacológicas y tecnológicas (p. ej., cobijo, abrigo). En última instancia, todos estos métodos tienen como finalidad aumentar la tolerancia al frío de todo el cuerpo o de algunas partes del mismo. Además, para asegurar una prevención eficaz es esencial que los trabajadores expuestos al frío reciban información y tengan los conocimientos necesarios sobre este tipo de lesiones.

\section{Métodos fisiológicos para prevenir las lesiones por frío}

La exposición al frío del ser humano va acompañada de vasoconstricción periférica para reducir la pérdida de calor a través de la piel, y producción de calor metabólico (esencialmente por medio de los escalofríos) que implica la necesidad de ingerir alimentos. El gasto energético necesario para todo tipo de actividad física en ambientes fríos aumenta por la dificultad de caminar sobre la nieve o el hielo y la necesidad frecuente de transportar equipos pesados. Además, la pérdida hídrica puede llegar a ser considerable por la sudoración asociada a dicha actividad física. Si el agua no se repone, puede producirse deshidratación y una mayor susceptibilidad a la congelación. La deshidratación suele agravarse, no sólo por la restricción voluntaria de la ingesta de agua, sino también por la dificultad de ingerir un fluido adecuado (el agua disponible puede estar congelada, o es posible que tenga que obtenerse descongelando nieve), pero también por la tendencia a evitar una micción frecuente que exige abandonar el refugio. La necesidad de agua en ambientes fríos es difícil de estimar porque depende de la carga de trabajo de la persona y del aislamiento que proporcione la ropa. En cualquier caso, la ingesta de líquidos tiene que ser abundante y en forma de bebidas calientes (entre 5 y 6 I al día en caso de actividad física). La observación del color de la orina, que debe ser siempre clara, permite saber si se está ingiriendo una cantidad suficiente de líquidos.

Con respecto a la ingesta de calorías, puede suponerse que en ambientes fríos el aporte de calorías debe aumentar entre un 25 y un $50 \%$ comparado con los climas templados o cálidos. Existe una fórmula que permite calcular la ingesta de calorías (en kcal) necesaria para mantener el equilibrio energético en condiciones de frío por persona y por día: kcal/persona por día $=4.151-28,62 \mathrm{~T}_{\mathrm{a}}$, donde $\mathrm{T}_{\mathrm{a}}$ es la temperatura ambiente en ${ }^{\circ} \mathrm{C}$ ( $1 \mathrm{kcal}=4,18$ julios). Así, para una $\mathrm{T}$ a de $-20 \stackrel{\circ}{\circ} \mathrm{C}$, tiene que preverse una necesidad de unas $4.723 \mathrm{kcal}\left(2,0 \times 10^{4} \mathrm{~J}\right)$. La ingesta de alimentos no parece que tenga que modificarse cualitativamente para evitar problemas digestivos de tipo diarrea. Por ejemplo, la ración para climas fríos del Ejército de Estados U nidos consiste en $4.568 \mathrm{kcal}\left(1,9 \times 10^{4} \mathrm{~J}\right)$ en forma de alimentos deshidratados, por día y por persona, que se divide cualitativamente de la siguiente forma: $58 \%$ hidratos de carbono, $11 \%$ proteínas y $31 \%$ grasas (Edwards, Roberts y M utter 1992). L os alimentos deshidratados tienen la ventaja de ser ligeros y fáciles de preparar, aunque tienen que ser rehidratados antes de su consumo.

En la medida de lo posible, las comidas deben tomarse calientes y divididas entre el desayuno y la comida en cantidades normales. Puede complementarse la dieta con sopas calientes, galletas y barras de cereales tomadas a lo largo de todo el día, así como con un mayor aporte calórico en la cena, que aumenta la termogénesis inducida por la digestión y ayuda a que la persona se duerma. El consumo de alcohol es muy poco recomendable en climas fríos, porque el alcohol produce vasodilatación cutánea (fuente de pérdida de calor) y aumenta la diuresis (fuente de pérdida de agua), modificando también la sensibilidad de la piel y alterando la capacidad de razonamiento (que son los factores básicos para reconocer los primeros signos de una lesión por frío). El consumo excesivo de bebidas con cafeína es también

Tabla 42.21 • Mecanismos generales de adaptación al frío estudiados durante una prueba normal de exposición al frío realizada antes y después de un período de aclimatación.

\begin{tabular}{|c|c|c|c|}
\hline Medida & $\begin{array}{l}\text { Utilización de la medida como } \\
\text { indicador de } \\
\text { la adaptación }\end{array}$ & $\begin{array}{l}\text { Variación } \\
\text { del } \\
\text { indicador }\end{array}$ & $\begin{array}{l}\text { Tipo de } \\
\text { adaptación }\end{array}$ \\
\hline $\begin{array}{l}\text { Temperatura } \\
\text { rectal } t_{\text {re }}\left({ }^{\circ} \mathrm{C}\right)\end{array}$ & $\begin{array}{l}\text { Diferencia entre } t_{\mathrm{re}} \text { al término de } \\
\text { la prueba de frío y } t_{\mathrm{r}} \text { en condi- } \\
\text { ciones termoneutras tras la } \\
\text { aclimatación }\end{array}$ & $\begin{array}{l}+0= \\
-\end{array}$ & $\begin{array}{l}\text { termoneutra } \\
\text { hipotérmica }\end{array}$ \\
\hline $\begin{array}{l}\text { Temperatura } \\
\text { cutánea } \\
\text { media } \\
\bar{t}_{s k}\left({ }^{\circ} \mathrm{C}\right)\end{array}$ & $\begin{array}{l}t_{s k}{ }^{\circ} \mathrm{C} \text { después } / t_{s k}{ }^{\circ} \mathrm{C} \text { antes, } \\
\text { donde } t_{s k} \text { es el nivel de tempera- } \\
\text { tura al término de la prueba de } \\
\text { frío }\end{array}$ & $\begin{array}{l}<1 \\
=1 \\
>1\end{array}$ & $\begin{array}{l}\text { aislante } \\
\text { isoaislante } \\
\text { hipoaislante }\end{array}$ \\
\hline $\begin{array}{l}\text { Metabolismo } \\
\text { medio } \\
\bar{M}\left(W / m^{2}\right)\end{array}$ & $\begin{array}{l}\text { Cociente entre M después de la } \\
\text { aclimatación y M antes de la } \\
\text { aclimatación }\end{array}$ & $\begin{array}{l}<1 \\
= \\
>1\end{array}$ & $\begin{array}{l}\text { metabólica } \\
\text { isometabólica } \\
\text { hipometabólica }\end{array}$ \\
\hline
\end{tabular}


nocivo, puesto que esta sustancia tiene un efecto vasoconstrictor periférico (mayor riesgo de congelación) y un efecto diurético.

A demás de una alimentación adecuada, el desarrollo de mecanismos generales y locales de adaptación puede reducir la incidencia de lesiones por frío y mejorar el rendimiento psicológico y físico al reducir el estrés causado por el frío. Sin embargo, es necesario definir los conceptos de adaptación, aclimatación y habituación al frío, ya que estos tres términos tienen distintas implicaciones de acuerdo con el uso que hacen de ellos diferentes teóricos.

En opinión de Eagan (1963), el término adaptación al frío es de carácter genérico. El autor agrupa bajo el término adaptación los conceptos de adaptación genética, aclimatación y habituación. La adaptación genética se refiere a los cambios fisiológicos transmitidos genéticamente que favorecen la supervivencia en un medio hostil. Bligh y Johnson (1973) diferencian entre adaptación genética y adaptación fenotípica, definiendo el concepto de adaptación como "cambios que reducen la carga fisiológica producida por un factor de estrés en el entorno".

La aclimatación puede definirse como una compensación funcional que se establece a lo largo de un período de varios días o varias semanas en respuesta a factores complejos del entorno, como variaciones climáticas en el medio ambiente, o a un único factor en el entorno, como en el laboratorio (la "aclimatización artificial" o "aclimatación" según esos autores) (Eagan 1963).

La habituación es un cambio en las respuestas fisiológicas como resultado de la disminución de las respuestas del sistema nervioso central a ciertos estímulos (Eagan, 1963). Esa habituación puede ser específica o general. La habituación específica es el proceso que tiene lugar cuando una cierta parte del cuerpo se acostumbra a unos estímulos repetidos. La adaptación local o general al frío se adquiere generalmente por medio de la habituación.

Tanto en el laboratorio como en ambientes naturales se han observado diferentes tipos de adaptación general al frío. $\mathrm{H}$ ammel (1963) propuso una clasificación de estos diferentes tipos de adaptación. La adaptación de tipo metabólico se manifiesta por el mantenimiento de la temperatura interna y una mayor producción de calor metabólico, como se observa en los Alacalufs de la T ierra del Fuego o en la población nativa del Artico. La adaptación de tipo aislante se manifiesta por el mantenimiento de la temperatura interna, pero también por una disminución de la temperatura cutánea media (aborígenes de las costas tropicales de Australia). La adaptación de tipo hipotérmica se refleja en un descenso más o menos considerable de la temperatura interna (tribus del desierto de K alahari, indios quechua, indios del Perú). Finalmente, la adaptación puede ser de tipo aislante e hipotérmico mixto (aborígenes del centro de Australia, lapones, buzos Amas coreanos).

En realidad, esta clasificación es de carácter meramente cualitativo y no tiene en cuenta todos los componentes del equilibrio térmico. Por consiguiente, hemos propuesto recientemente una clasificación que no es sólo cualitativa, sino también cuantitativa (véase la Tabla 42.21). La modificación de la temperatura corporal por sí sola no indica necesariamente una adaptación general al frío. De hecho, un cambio en el retraso del inicio de los escal ofríos es una buena indicación de la sensibilidad del sistema de regulación térmica. Bittel (1987) ha propuesto también una reducción de la deuda térmica como un indicador de la adaptación al frío. Además, este autor demostró la importancia de la ingesta calórica para los mecanismos de adaptación. Nosotros hemos confirmado esta observación en nuestro laboratorio; las personas aclimatadas al frío en el laboratorio a $1{ }^{\circ} \mathrm{C}$ durante 1 mes de manera discontinua desarrollaron una adaptación de tipo hipotérmico (Savourey y cols. 1994, 1996). La hipotermia está directamente relacionada con la reducción del porcentaje de masa de grasa corporal. El nivel de capacidad física aeróbica $\left(\mathrm{VO}_{2 \text { max }}\right)$ no parece influir en el desarrollo de este tipo de adaptación al frío (Bittel y cols. 1988; Savourey, Vallerand y Bittel 1992). La adaptación de tipo hipotérmico parece ser la que más ventajas ofrece, puesto que mantiene las reservas de energía y retrasa la aparición de escalofríos sin que la hipotermia sea peligrosa (Bittel y cols. 1989). Trabajos recientes de laboratorio han demostrado que se puede inducir este tipo de adaptación sometiendo a las personas a inmersión intermitente de las extremidades inferiores en agua helada. Además, este tipo de aclimatación produce el "síndrome polar de la triyodotironina" descrito por Reed y sus colaboradores en 1990 en personas que habían pasado largos períodos de tiempo en la región polar. Se trata de un síndrome complejo que sigue sin comprenderse del todo y se manifiesta principalmente por una disminución de la triyodotironina en ambientes tér micamente neutros y durante la exposición aguda al frío. A hora bien, todavía no se ha definido la relación entre este síndrome y la adaptación de tipo hipotérmico (Savourey y cols. 1996).

La adaptación local de la extremidades ha sido ampliamente documentada (LeBlanc 1975). Se ha estudiado tanto en tribus nativas como en grupos profesionales expuestos naturalmente a frío en las extremidades (esquimales, lapones, pescadores de la isla de Gaspé, pescadores ingleses, carteros en Q uebec) y en personas adaptadas artificialmente en el laboratorio. Todos los estudios han demostrado que esta adaptación se manifiesta por un aumento de la temperatura cutánea, menor dolor y una vasodilatación paradójicamente más rápida que se produce con temperaturas cutáneas más altas, evitando así la congelación. L os cambios se deben principalmente a un aumento del flujo sanguíneo periférico y no a la producción local de calor en el músculo, como nosotros hemos demostrado recientemente (Savourey, Vallerand y Bittel 1992). La inmersión de las extremidades varias veces al día en agua fría $(5 \stackrel{\circ}{\circ})$ durante algunas semanas es suficiente para inducir estos mecanismos de adaptación locales. No obstante, existen pocos datos científicos sobre estos diferentes tipos de adaptación.

\section{Métodos farmacológicos para prevenir las lesiones por frío}

La administración de fármacos para aumentar la tolerancia al frío ha sido objeto de una serie de estudios. La tolerancia general al frío aumenta con fármacos que favorecen la termogénesis. De hecho, en el ser humano se ha demostrado que los escalofríos van acompañados por un aumento considerable de la oxidación de hidratos de carbono y un mayor consumo de glucógeno muscular (M artineau y Jacob 1988). Los compuestos metilxantínicos ejercen sus efectos estimulando el sistema simpático, exactamente igual que el frío, de manera que pueden aumentar la oxidación de hidratos de carbono. Sin embargo, Wang, M an y Bel Castro (1987) han demostrado que la teofilina no consigue evitar el descenso de la temperatura en personas mantenidas en reposo en condiciones de frío. La combinación de cafeína y efedrina logra un mejor mantenimiento de la temperatura corporal en las mismas condiciones (Vallerand, Jacob y K avanagh 1989), aunque la ingestión de cafeína sola no modifica ni la temperatura corporal ni la respuesta metabólica (Kenneth y cols. 1990). L a prevención farmacológica de los efectos del frío a nivel general sigue siendo objeto de investigación. A escala local, se han realizado estudios sobre la prevención farmacológica de la congelación. Se han estudiado algunos fármacos utilizando un modelo animal de congelación. Los antiagregantes plaquetarios, los corticoides y algunas otras sustancias tienen un efecto protector siempre que se administren antes del período de recalentamiento. $\mathrm{H}$ asta donde sabemos, no se ha realizado ningún estudio similar en seres humanos. 


\section{Métodos técnicos para prevenir las lesiones por frío}

Son un componente básico de la prevención de las lesiones por frío y, sin ellos, los seres humanos serían incapaces de vivir en las zonas climáticas frías. La construcción de refugios, el uso de una fuente de calor y las prendas de abrigo permiten crear un microclima favorable para que el ser humano pueda habitar en regiones muy frías. Ahora bien, no siempre se dispone de las ventajas aportadas por la civilización moderna (como en el caso de expediciones civiles o militares, víctimas de naufragios, personas lesionadas, vagabundos, víctimas de avalanchas, etc.). Tales grupos son, por tanto, especialmente vulnerables a las lesiones por frío.

\section{Precauciones para el trabajo en ambientes fríos}

El problema del acondicionamiento para el trabajo en ambientes fríos afecta principalmente a las personas que no están acostumbradas a trabajar en ambientes fríos y/ o que proceden de zonas climáticas templadas. Es muy importante que los trabajadores sean informados de las lesiones que puede causar el frío, pero también deben ser informados de una serie de conductas favorables. Todas las personas que trabajen en regiones frías deben conocer los primeros signos de lesión, especialmente de las lesiones locales (color de la piel, dolor). La conducta con respecto a la ropa es vital: el uso de varias capas de ropa permite a la persona ajustar el aislamiento proporcionado por la ropa a los niveles variables de gasto energético y estrés externo. Las prendas impermeables (Iluvia, sudor) deben mantenerse secas. D ebe prestarse una gran atención a la protección de las manos y los pies (no usar vendas apretadas, atención a una cobertura adecuada, cambio frecuente de calcetines - por ejemplo, dos o tres veces al día- debido a la sudoración). D ebe evitarse el contacto directo con todos los objetos metálicos fríos (riesgo de congelación inmediata). La ropa debe estar garantizada contra el frío y haber sido probada antes de la exposición al frío. D eben recordarse las recomendaciones dietéticas (con atención a la ingesta calórica y a las necesidades de hidratación). El abuso de alcohol, cafeína y nicotina debe estar prohibido. T iene que comprobarse el buen estado de los equipos accesorios (refugio, tiendas, sacos de dormir) y eliminar la condensación en las tiendas y en los sacos de dormir para evitar la formación de hielo. Los trabajadores no deben soplar en los guantes para calentarlos, ya que se puede formar hielo. Por último, los trabajadores deben recibir recomendaciones para mejorar su forma física. De hecho, un buen nivel de capacidad física aeróbica permite una mayor termogénesis en ambientes de frío extremo (Bittel y cols. 1988) y una mayor resistencia física, un factor favorable debido al mayor consumo de energía que conlleva la actividad física en ambientes fríos.

Las personas de mediana edad tienen que someterse a una estrecha vigilancia, ya que son más susceptibles a las lesiones por frío que las personas jóvenes por su respuesta vascular más limitada. Un cansancio excesivo y una profesión sedentaria aumentan el riesgo de lesión. L as personas con ciertos trastornos médicos (urticaria por frío, síndrome de R aynaud, angina de pecho, congelación previa) deben evitar su exposición a un frío intenso. O tros consejos que también pueden ser útiles son: proteger la piel expuesta contra la radiación solar, proteger los labios con cremas especiales y proteger los ojos de la radiación ultravioleta con gafas de sol.

Cuando surja un problema en una zona fría, los trabajadores deben mantener la calma, nunca deben separarse del grupo y deben intentar mantener su calor corporal cavando hoyos y apretándose unos contra otros. Debe prestarse una atención especial a la provisión de alimentos y a los medios para solicitar ayuda (radio, cohetes de socorro, espejos para enviar señales, etc.). Cuando exista el riesgo de inmersión en aguas frías, deberán suministrarse botes salvavidas, así como equipos impermeables al agua y que proporcionen un buen aislamiento térmico. En caso de que se produzca un naufragio y no se disponga de botes salvavidas, la persona debe intentar limitar la pérdida de calor al máximo agarrándose a los materiales flotantes, encogiéndose y nadando lentamente con el tórax fuera del agua, puesto que la convección creada al nadar aumenta considerablemente la pérdida de calor. El agua del mar no debe beberse por su alto contenido de sales.

\section{Modificación de las tareas en ambientes fríos}

En una zona fría, las tareas se modifican considerablemente. EI peso de la ropa, el transporte de cargas (tiendas, alimentos, etc.) y la necesidad de atravesar terrenos difíciles aumenta la energía consumida por la actividad física. Además, la coordinación de los movimientos y la destreza manual se ven dificultadas por la ropa. El campo visual se reduce con frecuencia por el uso de gafas de sol. Asimismo, la percepción del ambiente se altera y reduce a $6 \mathrm{~m}$ cuando la temperatura del aire seco es inferior $a-18 \stackrel{\circ}{\circ}$ o cuando sopla viento. La visibilidad puede ser nula en caso de nieve o niebla. El uso de guantes puede dificultar las tareas manuales de precisión. La condensación puede hacer que se forme una capa de hielo sobre las herramientas y si éstas se agarran con la mano desnuda, existe el riesgo de que produzcan una congelación. La estructura física de las prendas de vestir se altera en condiciones de frío extremo y el hielo que se forma como resultado de la congelación y la condensación suelen atascar las cremalleras. Finalmente, los combustibles deben protegerse contra la congelación mediante el uso de anticongelantes.

Por consiguiente, para conseguir un rendimiento óptimo de los trabajadores en ambientes fríos, éstos deben llevar varias capas de ropa, protegerse debidamente las extremidades, adoptar medidas para evitar la condensación en la ropa, las herramientas y las tiendas e interrumpir cada cierto tiempo el trabajo para recalentarse en un refugio con calefacción. El trabajo debe organizarse en una secuencia de tareas sencillas, de ser posible con dos equipos de trabajo, uno que trabaje mientras el otro se recalienta. Los trabajadores no deben mantenerse inactivos en los ambientes fríos, no deben trabajar en solitario ni deben apartarse de los caminos frecuentados. Debe designarse a una persona competente para que se haga responsable de la protección y la prevención de accidentes.

En conclusión, parece ser que un buen conocimiento de las lesiones por frío, el conocimiento del entorno, una buena preparación (aptitud física, alimentación, inducción de mecanismos de adaptación), una ropa apropiada y una distribución adecuada de las tareas puede evitar las lesiones por frío. C uando se produce una lesión, una rápida asistencia y un tratamiento inmediato pueden evitar lo peor.

\section{Prendas protectoras: trajes impermeables}

EI uso de trajes impermeables tiene como finalidad la protección contra las consecuencias de una inmersión accidental $y_{\text {, por }}$ consiguiente, afecta no sólo a todos los trabajadores que pueden sufrir este tipo de accidentes (marinos, pilotos de aire), sino también a los que trabajan en aguas frías (buzos profesionales). En la Tabla 42.22, extraída del 0 ceanographic Atlas of the $\mathrm{N}$ orth American 0 cean, se indica que incluso en el Mediterráneo occidental, la temperatura del agua rara vez sobrepasa los $15 \stackrel{\circ}{ } \mathrm{C}$. Cuando se produce una inmersión, el tiempo de supervivencia de una persona vestida con chaleco salvavidas pero sin equipo antiinmersión se ha estimado en 1,5 horas en el mar Báltico y de 6 horas en el M editerráneo en enero, mientras que en agosto es de 12 horas en el Báltico y limitado sólo por el agotamiento en el M editerráneo. El uso de equipos protectores es, por tanto, una necesidad para las personas que trabajan en el mar, 
Tabla 42.22 • N úmero medio de días al mes y al año con una temperatura inferior a $15 \stackrel{\circ}{\circ} \mathrm{C}$.

\begin{tabular}{lllll} 
Mes & $\begin{array}{l}\text { Báltico } \\
\text { occidental }\end{array}$ & $\begin{array}{l}\text { Golfo de } \\
\text { Alemania }\end{array}$ & $\begin{array}{l}\text { Oceano Atlán- } \\
\text { tico (a la altura } \\
\text { de Brest) }\end{array}$ & $\begin{array}{l}\text { Mediterráneo } \\
\text { occidental }\end{array}$ \\
Enero & 31 & 31 & 31 & 31 \\
Febrero & 28 & 28 & 28 & 28 \\
Marzo & 31 & 31 & 31 & 31 \\
Abril & 30 & 30 & 30 & 26 a 30 \\
Mayo & 31 & 31 & 31 & 8 \\
Junio & 25 & 25 & 25 & de vez en cuando \\
Julio & 4 & 6 & de vez en cuando & de vez en cuando \\
Agosto & 4 & de vez en cuando & de vez en cuando & 0 \\
Septiembre & 19 & 3 & de vez en cuando & de vez en cuando \\
Octubre & 31 & 22 & 20 & 2 \\
Noviembre & 30 & 30 & 30 & 30 \\
Diciembre & 31 & 31 & 31 & 31 \\
Total & 295 & 268 & 257 & 187 \\
\hline
\end{tabular}

especialmente cuando corren el riesgo de una inmersión sin poder recibir asistencia inmediata.

Las dificultades de fabricar este tipo de equipos son complejas, porque tienen que tenerse en cuenta requisitos múltiples y con frecuencia conflictivos. Las limitaciones son: a) la necesidad de una protección térmica eficaz tanto en el aire como en el agua, sin impedir la evaporación del sudor; b) la necesidad de mantener a la persona en la superficie del agua, y c) las tareas que deben realizarse. El equipo debe, por tanto, diseñarse de acuerdo con el riesgo implicado. Para ello tendrán que conocerse con detalle las condiciones anticipadas: la temperatura ambiente (temperatura del agua, aire, viento), el tiempo que transcurrirá hasta recibir ayuda, y la presencia 0 ausencia de un bote salvavidas, por ejemplo. Las características aislantes de las prendas de vestir dependen de los materiales utilizados, los contornos del cuerpo, la compresibilidad del tejido protector (que determina el grosor de la capa de aire aprisionada en la ropa dependiendo de la presión ejercida por el agua), y la humedad que puede acumularse en la ropa. La humedad de la ropa depende principalmente de su resistencia al agua. Para la evaluación de estos equipos tiene que tenerse en cuenta la eficacia de la protección térmica proporcionada, no sólo en el agua, sino también contra el aire frío. Tienen que estimarse los tiempos probables de supervivencia dependiendo de la temperatura del agua y del aire, así como del estrés térmico previsto y el posible estorbo mecánico de la ropa (Boutelier, 1979). Finalmente, las pruebas de impermeabilidad realizadas con personas en movimiento permitirán detectar posibles deficiencias en este sentido. En definitiva, el equipo antiinmersión debe cumplir tres requisitos:

- Debe proporcionar una protección térmica eficaz tanto en el agua como en el aire.

- Debe ser cómodo.

- No debe restringir demasiado los movimientos ni pesar mucho.

Para cumplir estos requisitos, se han adoptado dos principios: o bien utilizar un material que no sea impermeable, pero que mantenga sus propiedades aislantes en el agua (como es el caso del Ilamado traje "húmedo"), o bien garantizar la total impermeabilidad con materiales que además sean aislantes (traje "seco"). En la actualidad, el principio del traje húmedo se aplica cada vez menos, sobre todo en aviación. En la última década, la O rganización $\mathrm{M}$ arítima Internacional ha recomendado el uso de un traje antiinmersión o de supervivencia que cumpla los criterios del Convenio Internacional para la Seguridad de la Vida H umana en el Mar (SO LAS) adoptado en 1974. Son criterios que se refieren en particular al aislamiento, a la filtración mínima de agua al interior del traje, al tamaño del traje, a su ergonomía, a su compatibilidad con las ayudas para la flotación y a los procedimientos de prueba. A hora bien, la aplicación de estos criterios plantea una serie de problemas (especialmente, los relacionados con la definición de las pruebas que deben aplicarse).

Aunque los trajes antiinmersión se utilizan desde hace mucho tiempo (los esquimales han utilizado siempre pieles e intestinos de foca cosidos entre sí) estos trajes son difíciles de perfeccionar y es probable que los criterios de normalización se revisen en los próximos años.

\section{INDICES DE FRIO Y NORMAS SOBRE EL FRIO}

Ingvar H olmér

El estrés por frío se define como la carga térmica impuesta al organismo con la cual se pueden esperar pérdidas de calor mayores a las normales y acciones termorreguladores compensadoras para mantener la termoneutralidad del cuerpo. Las pérdidas normales de calor, por tanto, se refieren a las que experimentan normalmente las personas durante las condiciones de vida al aire libre (temperatura del aire de 20 a $25 \stackrel{\circ}{\circ}$ ).

Al contrario de lo que ocurre en condiciones de calor, la ropa y la actividad física son factores positivos, en el sentido de que cuanta más ropa se lleve, más se reduce la pérdida de calor y cuanta más actividad física se realice, mayor es la producción interna de calor y la posibilidad de compensar la pérdida de calor. En consecuencia, los métodos de evaluación centrados en la determinación de la protección necesaria (ropa) con unos ciertos niveles de actividad física, exige conocer los niveles de actividad física con unos ciertos valores de protección o "temperatura" o unas ciertas combinaciones de ambos (Burton y Edholm 1955; H olmér 1988; Parsons 1993).

No obstante, es importante reconocer que existen límites en la cantidad de ropa que puede utilizarse y en el alto nivel de actividad que puede mantenerse durante largos períodos de tiempo. Las prendas de abrigo suelen ser abultadas y entorpecen los movimientos. Se necesita más espacio para el desplazamiento y los movimientos. El nivel de actividad física puede estar determinado por el ritmo de trabajo impuesto, aunque es preferible que sea controlado por la persona. D ependiendo de su capacidad para el trabajo físico, todas las personas tienen una tasa máxima de producción de energía que pueden sostenerse durante largos períodos de tiempo. Por consiguiente, una mayor capacidad física para el trabajo supone una ventaja para exposiciones extremas prolongadas.

En este artículo se describen los métodos de evaluación y control del estrés por frío. Los problemas relacionados con los aspectos organizativos, psicológicos, médicos y ergonómicos se abordan en otras secciones.

\section{Trabajo en ambientes fríos}

El trabajo en ambientes fríos engloba una diversidad de condiciones naturales y artificiales. La exposición al frío más extremo 
Tabla 42.23 • Temperaturas del aire en distintos ambientes de trabajo expuestos al frío.

\begin{tabular}{|c|c|}
\hline$-120 \stackrel{\circ}{C}$ & Cámara climatizada para crioterapia humana \\
\hline$-90 \cong \mathrm{C}$ & Temperatura mínima en la base Vostock del Polo Sur \\
\hline$-55 \stackrel{\circ}{C}$ & $\begin{array}{l}\text { Cámara frigorífica para pescados y producción de productos } \\
\text { desecados y congelados }\end{array}$ \\
\hline$-40 \cong \mathrm{C}$ & Temperatura "normal" en una base polar \\
\hline$-28 \stackrel{\circ}{C}$ & Cámara frigorífica para productos congelados \\
\hline$+2 a+12 \stackrel{\circ}{\circ} \mathrm{C}$ & $\begin{array}{l}\text { Almacenamiento, preparación y transporte de alimentos } \\
\text { frescos }\end{array}$ \\
\hline
\end{tabular}

entre - 50 y - $20 \stackrel{\circ}{\mathrm{C}}$ Temperatura media en enero en el norte de Canadá y Siberia

entre - 20 y - $10 \stackrel{\circ}{\mathrm{C}}$ Temperatura media en enero en el sur de Canadá, norte de Escandinavia y centro de Rusia

entre - 10 y $0 \stackrel{\circ}{\mathrm{C}} \quad$ Temperatura media en enero en el norte de Estados Unidos, sur de Escandinavia, Europa central, algunas zonas de Oriente Medio y Extremo Oriente, centro y norte de Japón

Fuente: Adaptado de Holmér 1993

se produce en las misiones espaciales. Con todo, las condiciones de trabajo en ambientes fríos en la superficie de la tierra abarcan un rango de temperaturas de más de 100 ํ C (Tabla 42.23). Lógicamente, la magnitud y severidad del estrés por frío aumenta cuanto menor es la temperatura ambiente.

De la Tabla 42.23 se deduce claramente que grandes poblaciones de trabajadores al aire libre experimentan estrés por frío más o menos intenso en muchos países. Además, en todo el mundo se realizan trabajos en cámaras frigoríficas. L as encuestas realizadas en los países escandinavos revelan que aproximadamente el $10 \%$ de la población activa considera el frío como un importante factor negativo en el lugar de trabajo.

\section{Tipos de estrés por frío}

Pueden definirse los siguientes tipos de estrés por frío:

- enfriamiento de todo el cuerpo

- enfriamiento local, que puede ser enfriamiento de las extremidades, enfriamiento cutáneo por convección (enfriamiento por el viento), enfriamiento cutáneo por conducción (enfriamiento por contacto) y enfriamiento del tracto respiratorio.

Lo más probable es que varios, sino todos estos tipos, estén presentes al mismo tiempo.

La evaluación del estrés por frío exige determinar el riesgo de uno 0 más de los efectos mencionados. En general, para una primera clasificación general, se puede recurrir a la Tabla 42.24 . El estrés por frío aumenta cuanto menor sea el nivel de actividad física y la protección disponible.

La información que contiene esta Tabla debe interpretarse como una señal para la acción. En otras palabras, el tipo particular de estrés por frío debe evaluarse y controlarse cuando así sea necesario. A temperaturas moderadas predominan los problemas de malestar y pérdidas funcionales como consecuencia del enfriamiento local. A temperaturas más bajas, el factor más importante es el riesgo inminente de lesión por frío como secuela de los otros efectos. Muchos de los efectos no presentan una relación directa con el nivel de estrés y en ningún caso puede descartarse que un cierto problema causado por el frío persista también fuera del rango de temperaturas indicado en la Tabla.

\section{Métodos de evaluación}

Los métodos para evaluar el estrés por frío se describen en el Informe Técnico de ISO 11079 (ISO TR 11079, 1993). Otras normas referentes a la determinación de la producción de calor metabólico (ISO 8996, 1988), la estimación de las características térmicas de las prendas de vestir (ISO 9920, 1993) y las mediciones fisiológicas (ISO DIS 9886, 1989c) proporcionan información complementaria útil para la evaluación del estrés por frío.

En la Figura 42.21 se resumen las relaciones entre factores climáticos, efecto esperado de enfriamiento y método de evaluación recomendado. A continuación se describen los métodos y la recopilación de datos con más detalle.

\section{Enfriamiento de todo el cuerpo}

El riesgo de enfriamiento de todo el cuerpo se determina analizando las condiciones necesarias para mantener el equilibrio térmico del organismo. EI nivel de aislamiento de las prendas de vestir necesario para mantener el equilibrio térmico con ciertos niveles de carga fisiológica se calcula utilizando una ecuación matemática del equilibrio térmico. El aislamiento necesario así calculado, IREQ, puede considerarse como un índice del estrés por frío. Tal valor indica un nivel de protección (expresado en clo). Cuanto mayor sea dicho valor, mayor será el riesgo de un desequilibrio térmico corporal. Los dos niveles de carga fisiológica considerados son nivel bajo (neutral o sensación de "bienestar") y nivel alto (ligero frío o sensación de frío).

La utilización del IREQ requiere una evaluación en tres etapas:

- determinación del IREQ para unas ciertas condiciones de exposición;

- comparación del IREQ con el nivel de protección proporcionado por la ropa,

- determinación del tiempo de exposición si el nivel de protección es inferior al IREQ.

Tabla 42.24 • Clasificación esquemática del trabajo en a mbientes fríos.

$\begin{array}{lll}\text { Temperatura } & \text { Tipo de trabajo } & \text { Tipo de estrés por frío } \\ \text { entre } 10 \text { y } 20 \stackrel{\text { O C }}{ } & \begin{array}{c}\text { Trabajo sedentario, ligero, } \\ \text { trabajo manual de } \\ \text { precisión }\end{array} & \begin{array}{l}\text { Enfriamiento de todo el } \\ \text { cuerpo, enfriamiento de } \\ \text { las extremidades }\end{array}\end{array}$

entre 0 y $10 \stackrel{\circ}{C} \quad$ Trabajo sedentario y esta- Enfriamiento de todo el cionario, trabajo ligero cuerpo, enfriamiento de las extremidades

entre - 10 y $0 \stackrel{\circ}{\mathrm{C}}$ Trabajo físico ligero, mani- Enfriamiento de todo el pulación de herramientas cuerpo, enfriamiento de y materiales

las extremidades, enfriamiento por contacto

entre - 20 y-10 $\stackrel{\circ}{0}$ Actividad moderada, mani- Enfriamiento de todo el pulación de metales y cuerpo, enfriamiento de líquidos (gasolina, etc.), las extremidades, enfriacondiciones de viento miento por contacto, enfriamiento convectivo

por debajo de - $20 \stackrel{0}{0}$ Todo tipo de trabajos Todo tipo de estrés por frío 
Tabla 42.25 • Clasificación de los niveles de tasa metabólica.

\begin{tabular}{|c|c|c|c|c|c|}
\hline \multirow[t]{2}{*}{ Clase } & \multicolumn{2}{|c|}{ Rango de tasa metabólica, M } & \multicolumn{2}{|c|}{$\begin{array}{l}\text { Valor que debe } \\
\text { utilizarse para } \\
\text { calcular la tasa } \\
\text { metabólica media }\end{array}$} & \multirow[t]{2}{*}{ Ejemplos } \\
\hline & $\begin{array}{l}\text { Por unidad } \\
\text { de superficie } \\
\text { cutánea } \\
\left(\mathrm{W} / \mathrm{m}^{2}\right)\end{array}$ & $\begin{array}{l}\text { Para una superficie } \\
\text { cutánea media } \\
\text { de } 1,8 \mathrm{~m}^{2} \\
\text { (W) }\end{array}$ & $\left(W / m^{2}\right)$ & $(W)$ & \\
\hline $\begin{array}{l}0 \\
\text { Reposo }\end{array}$ & $M \leq 65$ & $M \leq 117$ & 65 & 117 & Reposo \\
\hline \multirow[t]{2}{*}{$\begin{array}{l}1 \\
\text { Tasa } \\
\text { metabólica baja }\end{array}$} & $65<M \leq 130$ & $117<M \leq 234$ & 100 & 180 & $\begin{array}{l}\text { Sentado cómodamente: trabajo manual ligero (escribir, mecanografiar, dibujar, coser, } \\
\text { contabilidad); trabajo con manos y brazos ( pequeñas herramientas manuales, inspección, } \\
\text { montaje o clasificación de materiales ligeros); trabajo con brazos y piernas (conducir un } \\
\text { vehículo en condiciones normales, manejar un conmutador de pedal o pedales). }\end{array}$ \\
\hline & & & & & $\begin{array}{l}\text { De pie: perforación ( piezas pequeñas); fresado ( piezas pequeñas); bobinado; devanado } \\
\text { de inducidos pequeños; maquinado con herramientas de poca potencia; caminar (velo- } \\
\text { cidad de hasta } 3,5 \mathrm{~km} / \mathrm{h} \text { ). }\end{array}$ \\
\hline $\begin{array}{l}2 \\
\text { Tasa metabólica } \\
\text { moderada }\end{array}$ & $130<M \leq 200$ & $234<M \leq 360$ & 165 & 297 & $\begin{array}{l}\text { Trabajo continuo de brazos y piernas (clavado con martillo, tareas de llenado); trabajo de } \\
\text { brazos y piernas (conducción campo a través de camiones, tractores o maquinaria de } \\
\text { construcción); trabajo de brazos y tronco (trabajo con martillo neumático, montaje de } \\
\text { tractores, enyesado, manipulación intermitente de materiales moderadamente pesados, } \\
\text { desherbado, cavado con azada, recolección de frutas o verduras); empujar o tirar de } \\
\text { vagones o carretillas de peso ligero; caminar a una velocidad de } 3,5 \mathrm{~km} / \mathrm{h} \text {; forjado. }\end{array}$ \\
\hline $\begin{array}{l}3 \\
\text { Tasa } \\
\text { metabólica } \\
\text { elevada }\end{array}$ & $200<M \leq 260$ & $360<M \leq 468$ & 230 & 414 & $\begin{array}{l}\text { Trabajo intenso de brazos y tronco: transportar materiales pesados; excavar; trabajo con } \\
\text { martillo de fragua; aserrado, cepillado o cincelado de maderas duras; segado manual; } \\
\text { cavar; caminar a una velocidad de entre } 5,5 \mathrm{~km} / \mathrm{h} \text { y } 7 \mathrm{~km} / \mathrm{h} \text {. } \\
\text { Empujar o tirar de vagones o carretillas con cargas pesadas; desbarbado de piezas } \\
\text { fundidas; colocación de bloques de hormigón. }\end{array}$ \\
\hline $\begin{array}{l}4 \\
\text { Tasa metabólica } \\
\text { muy alta }\end{array}$ & $M>260$ & $M>468$ & 290 & 522 & $\begin{array}{l}\text { Actividad muy intensa a un ritmo rápido o máximo; trabajar con un hacha; excavar o } \\
\text { cavar a un ritmo rápido; subir escaleras, trepar o escalar; caminar a paso rápido subiendo } \\
\text { pequeños escalones, correr, caminar a una velocidad superior a } 7 \mathrm{~km} / \mathrm{h} \text {. }\end{array}$ \\
\hline 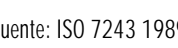 & & & & & \\
\hline
\end{tabular}

En la Figura 42.22 se indican los valores IREQ para un bajo nivel de carga fisiológica (sensación térmica neutral) y diferentes niveles de actividad física.

Los métodos para estimar los niveles de actividad física se describen en ISO 7243 (Tabla 42.25).

U na vez determinado el IREQ para unas ciertas condiciones, este valor se compara con el nivel de protección proporcionado por la ropa, que depende del valor del aislamiento resultante ("I I") y se mide de acuerdo con el proyecto de norma europea prEN-342 (1992). También puede derivarse de las tablas de los valores de aislamiento básico (ISO 9920).

En la Tabla 42.26 se indican los valores de aislamiento básico correspondientes a vestimentas típicas. Son valores que han de corregirse para tener en cuenta la reducción que supuestamente produce el movimiento del cuerpo y la ventilación. Normalmente no se realiza ninguna corrección para tener en cuenta el nivel de reposo, sino que los valores se reducen un $10 \%$ para el trabajo ligero y un $20 \%$ para niveles de actividad más altos.

EI nivel de protección proporcionado por las mejores prendas de vestir se sitúa entre 3 y 4 clo. Cuando la ropa disponible no proporciona un aislamiento suficiente, se calcula un límite de tiempo de exposición en las condiciones reales. El límite depende de la diferencia entre el aislamiento necesario de la ropa y el proporcionado por la ropa disponible. Puesto que ya no se consigue una protección completa contra el enfriamiento, el límite de tiempo se calcula en función de la reducción prevista de contenido de calor del cuerpo. I gualmente se puede calcular un tiempo de recuperación para reponer la misma cantidad de calor.

En la Figura 42.23 se indican los límites de tiempo para trabajos ligeros y moderados con dos niveles de aislamiento de la ropa. Los valores pueden extrapolarse para estimar los límites de tiempo con otras combinaciones de prendas de vestir. La Figura 42.24 puede utilizarse como directriz para evaluar el tiempo de exposición cuando se dispone de las mejores prendas protectoras.

Las exposiciones intermitentes suelen conllevar períodos de trabajo interrumpidos por descansos para recalentamiento o por períodos de trabajo en ambientes más cálidos. En la mayoría de los casos, los trabajadores no se cambian de ropa o sólo se cambian algunas prendas (principalmente por motivos prácticos). En consecuencia, el IREQ correspondiente a una exposición intermitente puede calcularse como una media ponderada en el tiempo. El período promediado no debe ser mayor de una 0 dos horas. En la Figura 42.24 se indican los valores IREQ ponderados en el tiempo para ciertos tipos de exposición intermitente. L os límites de tiempo son más orientativos que obligatorios y corresponden a una persona media. La variación individual en términos de características, requisitos y preferencias es muy grande y este hecho debe ser tenido en cuenta mediante la selección de unas prendas de vestir que permitan una gran flexibilidad para ajustar el nivel de protección. 
Tabla 42.26 - Ejemplos de valores del a islamiento básico $\left(I_{c l}\right)$ proporcionado por la ropa*.

Conjunto de prendas de vestir

Calzoncillos, camisa de manga corta, pantalones ajustados, medias, zapatos

$I_{c \mid}\left(m^{2} \stackrel{c o l}{W}\right) \quad I_{c \mid}(c l 0)$

Calzoncillos, camisa, pantalones ajustados, calcetines, zapatos

$0,08 \quad 0,5$

Calzoncillos, mono, calcetines, zapatos

$0,10 \quad 0.6$

$0,11 \quad 0,7$

Calzoncillos, camisa, mono, calcetines, zapatos

$0,13 \quad 0,8$

Calzoncillos, camisa, pantalones, bata corta, calcetines, zapatos

$0,14 \quad 0,9$

Calzoncillos, camiseta, calzoncillos, camisa, mono, medias, zapatos

Calzoncillos, camiseta, camisa, pantalones, chaqueta, chaleco, calcetines, zapatos

Calzoncillos, camisa, pantalones, chaqueta, mono, calcetines, zapatos

Camiseta, calzoncillos, pantalones aislantes, chaqueta aislante, calcetines, zapatos

$0,19 \quad 1,3$

Calzoncillos, camiseta, camisa, pantalones ajustados, mono aislante, medias, zapatos

$0,22 \quad 1,4$

$0,23 \quad 1,5$

Calzoncillos, camiseta, camisa, pantalones, chaqueta interior, chaqueta exterior, gorro, guantes, calcetines, zapatos

Calzoncillos, camiseta, camisa, pantalones interiores, chaqueta interior, chaqueta exterior, pantalones exteriores, calcetines, zapatos

Calzoncillos, camiseta, camisa, pantalones interiores, chaqueta interior, chaqueta exterior, pantalones exteriores, calcetines, zapatos, gorro, guantes

Camiseta, calzoncillos, pantalones interiores aislantes, chaqueta interior aislante, pantalones exteriores, chaqueta exterior, calcetines, zapatos

Camiseta, calzoncillos, pantalones interiores aislantes, chaqueta aislante, pantalones exteriores, calcetines, zapatos, gorro, guantes

Camiseta, calzoncillos, pantalones interiores aislantes, chaqueta interior aislante, pantalones exteriores y parka con forro, calcetines, zapatos, gorro, manoplas

Trajes árticos

Sacos de dormir

$0,31 \quad 2,0$

$0,34 \quad 2,2$

$0,40 \quad 2,6$

$0,40-0,52 \quad 2,6-3,4$

$0,46-0,70 \quad 3-4,5$

$0,46-1,1 \quad 3-8$

* El nivel teórico de protección se refiere exclusivamente a condiciones estáticas sin viento (en reposo). Los valores tendrán que reducirse con niveles de actividad mayores. Fuente: Adaptado de ISO/ TR-11079 1993.

Figura 42.21 • Evaluación del estrés por frío en relación con los factores climáticos y los efectos del enfriamiento.

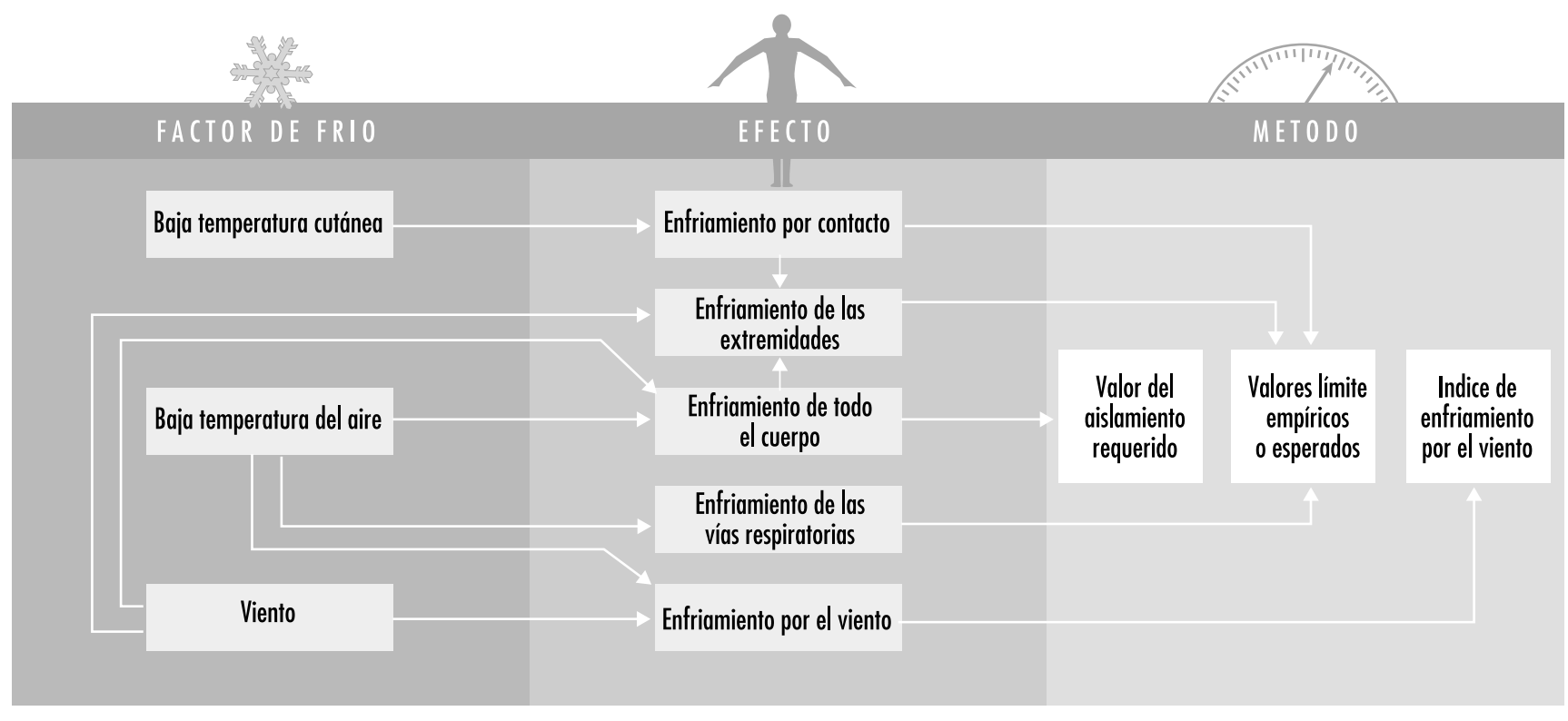


Figura 42.22 - Valores IREQ necesarios para mantener un bajo nivel de estrés fisiológico (sensación de neutralidad térmica) a distintas temperaturas.

IREQ (do)

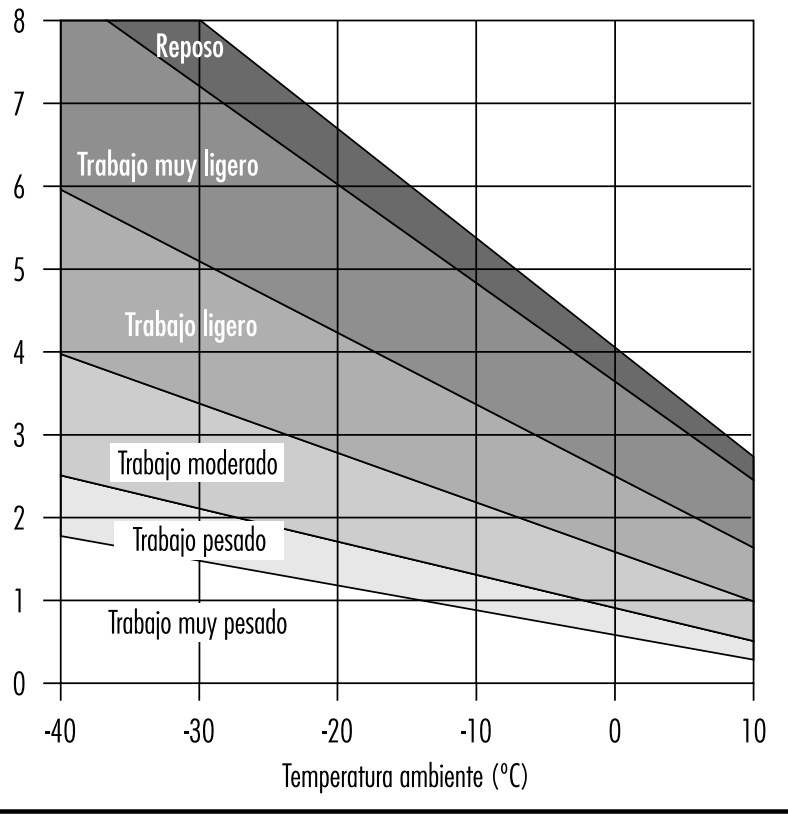

\section{Enfriamiento de las extremidades}

Las extremidades - en particular los dedos de las manos y los pies- son más propensas al enfriamiento. A no ser que la sangre caliente pueda aportar calor suficiente, la temperatura de los tejidos descenderá progresivamente. El flujo sanguíneo en las extremidades depende de las necesidades energéticas (para la actividad muscular) y las necesidades de regulación térmica.

\section{Figura 42.23 • Límites de tiempo para el trabajo ligero y moderado con dos niveles de aislamiento de la ropa.}

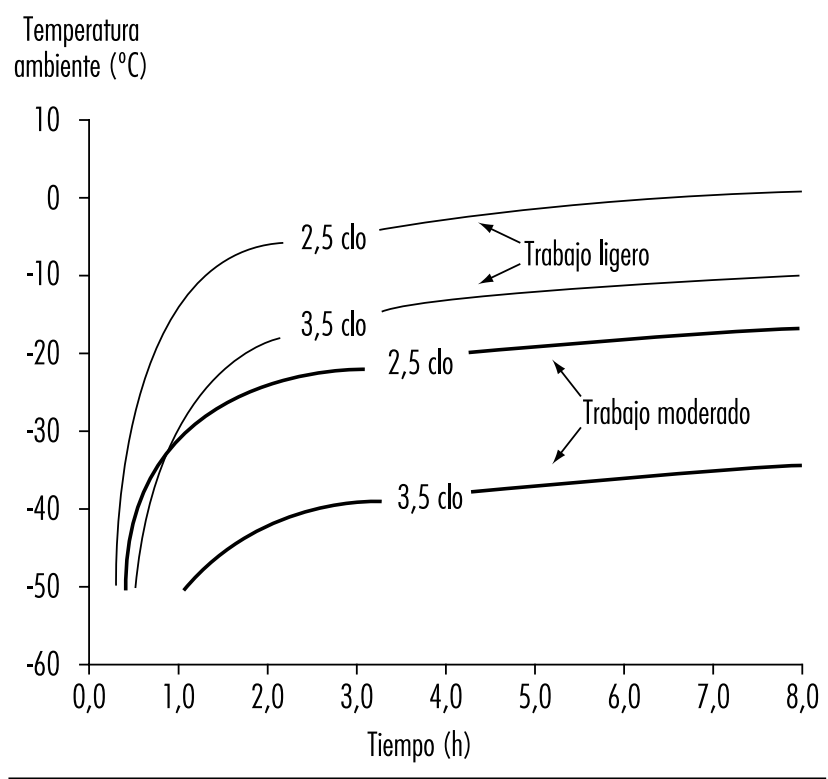

Figura 42.24 - Valores IREQ ponderados en el tiempo para la exposición intermitente y continua al frío.

IREQ ponderado

en el tiempo (clo)

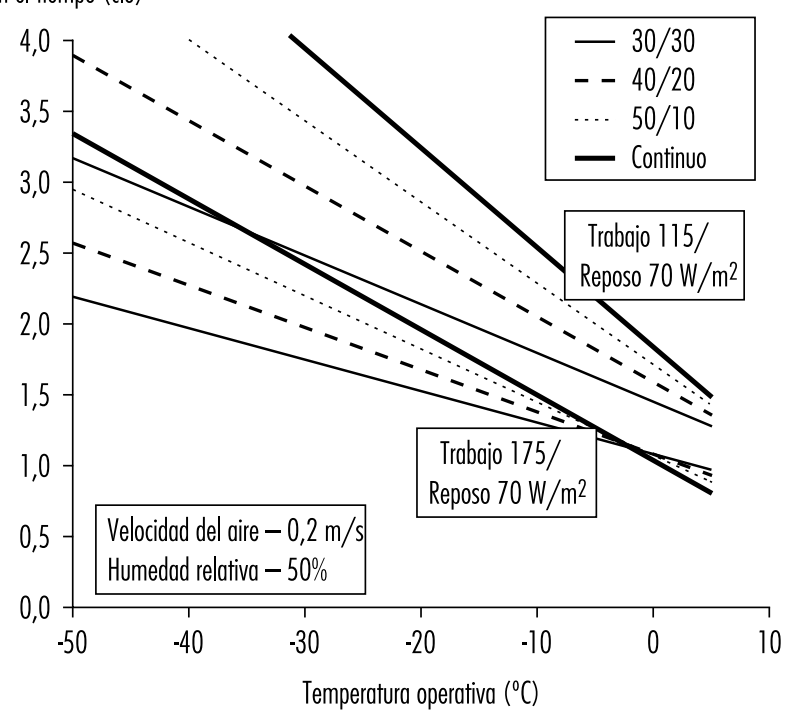

Cuando el equilibrio térmico de todo el cuerpo se ve amenazado, la vasoconstricción periférica ayuda a reducir las pérdidas de calor en el interior del cuerpo a expensas de los tejidos periféricos. Cuando se realiza una actividad física intensa, se produce una mayor cantidad de calor y el flujo sanguíneo en la extremidades puede mantenerse más fácilmente.

La protección proporcionada por los guantes y el calzado en términos de reducción de las pérdidas de calor es limitada. Cuando el aporte de calor a las extremidades es pequeño (p. ej., en reposo o con una actividad ligera), el aislamiento necesario para mantener las manos y los pies calientes es muy grande

Figura 42.25 - Protección de los dedos.

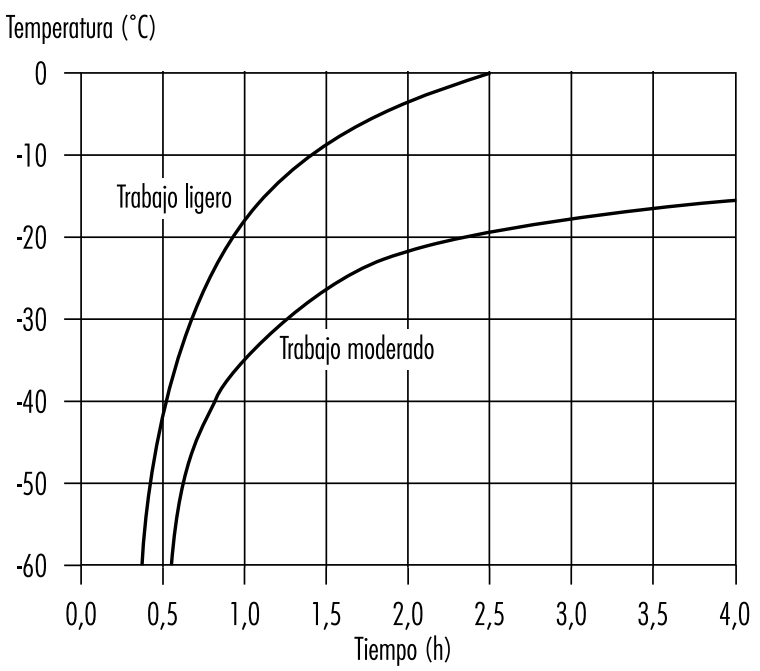

Las curvas indican los límites permisibles de tiempo y temperatura para la exposición de los dedos al frío en condiciones de trabajo ligero o moderado (datos basados en los cálculos del intercambio de calor de las manos y en una temperatura crítica en las puntas de los dedos de $5^{\circ} \mathrm{C}$ ). 
Tabla 42.27 • Clasificación de los guantes en función de su resistencia térmica (I) al enfriamiento convectivo.

$\begin{array}{ll}\text { Clase } & I\left(\mathrm{~m}^{2} \stackrel{\circ}{ } \mathrm{C} / W\right) \\ 1 & 0,10 \leq 1<0,15 \\ 2 & 0,15 \leq 1<0,22 \\ 3 & 0,22 \leq 1<0,30 \\ 4 & 1 \geq 0,30\end{array}$

Fuente: Basado en EN 511 (1993).

Tabla 42.28 • Clasificación de los guantes en función de su resistencia térmica al enfriamiento por contacto (I).

$\begin{array}{ll}\text { Clase } & I\left(\mathrm{~m}^{2} \mathrm{aC} / \mathrm{W}\right) \\ 1 & 0,025 \leq 1<0,05 \\ 2 & 0,05 \leq 1<0,10 \\ 3 & 0,10 \leq 1<0,15 \\ 4 & 1 \geq 0,15\end{array}$

Fuente: Basado en EN 511 (1993).

Tabla 42.29 • Indice de enfriamiento por el viento (W ind C hill Index, W C I), temperatura equivalente de enfriamiento $\left(T_{\text {eq }}\right)$ y tiempo de congelación de la carne al desnudo

\begin{tabular}{lll} 
WCl $\left(W / \mathrm{m}^{2}\right)$ & $T_{\text {eq }}($ C) & Efecto \\
1.200 & -14 & Mucho frío \\
1.400 & -22 & Frío glacial \\
1.600 & -30 & Congelación de la carne expuesta \\
1.800 & -38 & en menos de 1 hora \\
2.000 & -45 & Congelación de la carne expuesta \\
2.200 & -53 & en menos de 1 minuto \\
2.400 & -61 & Congelación de la carne expuesta \\
2.600 & -69 & en menos de 30 segundos \\
\hline
\end{tabular}

(Van Dilla, Day y Siple 1949). La protección proporcionada por guantes y manoplas consigue sólo retrasar la velocidad del enfriamiento $y$, en consecuencia, alarga el tiempo transcurrido hasta que la temperatura desciende a un nivel crítico. Con niveles de actividad mayores, una mejor protección permite mantener calientes los pies y las manos a temperaturas ambientales más bajas.

No se dispone de ningún método normalizado para la evaluación del enfriamiento de las extremidades. Por lo demás, en ISO TR 11079 se sugieren unas temperaturas críticas de 24 o $C$ y 15 o $C$ en las manos para niveles de estrés leve y grave, respectivamente. La temperatura en la punta de los dedos puede ser
Figura 42.26 - Relación entre el riesgo esperado de estrés por frío y los procedimientos de medición necesarios.

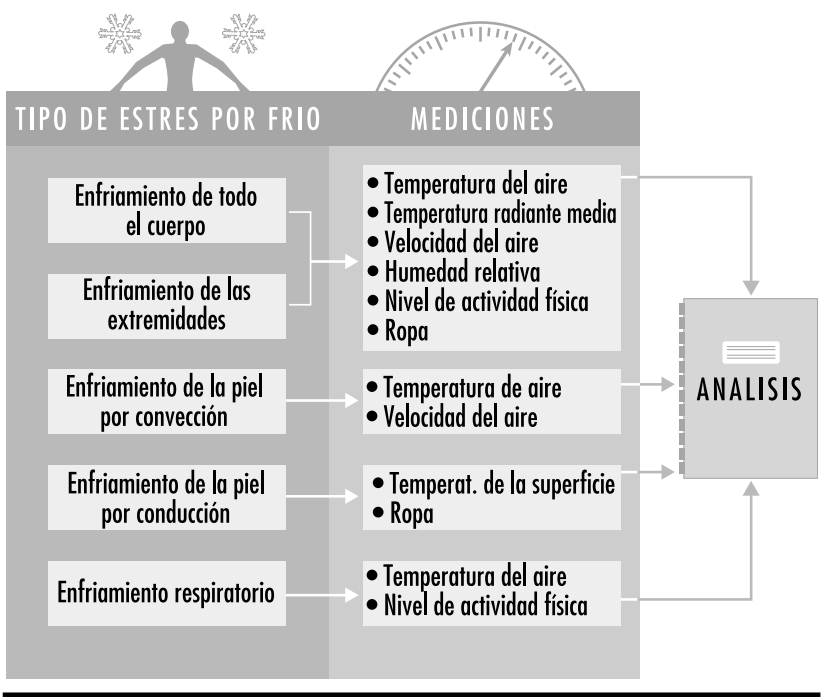

fácilmente entre 5 y $10^{\circ} \mathrm{C}$ más baja que la temperatura cutánea media de la mano o la temperatura del dorso de la mano.

La información que se ofrece en la Figura 42.25 es útil para determinar los tiempos de exposición permisibles y la protección necesaria. Las dos curvas se refieren a condiciones con y sin vasoconstricción (alto y bajo nivel de actividad). Además, se supone que el aislamiento de los dedos es alto (2 clo) y que se utiliza una ropa adecuada.

Para los dedos de los pies se pueden elaborar unas curvas similares. Con todo, es posible que el número de clo tenga que aumentar para conseguir una protección adecuada de los pies con tiempos de exposición más largos. No obstante, de las Figuras 42.23 y 42.25 se deduce que el enfriamiento de las extremidades suele ser un factor más crítico que el enfriamiento de todo el cuerpo en la determinación de los tiempos de exposición.

La protección proporcionada por los guantes se evalúa utilizando los métodos descritos en la norma europea E N-511 (1993). El aislamiento térmico de todo el guante se mide con un modelo de mano calentada eléctricamente. Se aplica una velocidad de viento de $4 \mathrm{~m} / \mathrm{s}$ para simular unas condiciones de uso realistas. En la Tabla 42.27 se indican los resultados para cuatro clases de guantes.

\section{Frío por contacto}

El contacto entre la mano desnuda y superficies frías puede reducir rápidamente la temperatura cutánea y causar lesiones por congelación. Pueden existir problemas incluso con superficies a 15 ㄷ. E n particular, las superficies metálicas tienen unas excelentes propiedades conductivas y pueden enfriar rápidamente las zonas de la piel que entren en contacto con ellas.

En la actualidad no existe ningún método normalizado para una evaluación general del enfriamiento por contacto, aunque pueden darse las siguientes recomendaciones (ACGIH 1990; Chen, N ilsson y H olmér 1994; Enander 1987):

- El contacto prolongado con superficies metálicas por debajo de 15 o C puede reducir la destreza manual.

- El contacto prolongado con superficies metálicas por debajo de 7 o $C$ puede provocar entumecimiento.

- El contacto prolongado con superficies metálicas por debajo de $0 \stackrel{\text { ㄷ }}{ }$ puede provocar congelación. 
Tabla 42.30 - Capacidad de enfriamiento del viento en la carne al desnudo expresada como temperatura equivalente de enfriamiento en condiciones de calma casi total (velocidad del viento $1,8 \mathrm{~m} / \mathrm{s}$ ).

\begin{tabular}{|c|c|c|c|c|c|c|c|c|c|c|c|}
\hline \multirow{3}{*}{$\begin{array}{l}\text { Velocidad del } \\
\text { viento }(\mathrm{m} / \mathrm{s})\end{array}$} & \multicolumn{11}{|c|}{ Lectura real del termómetro $(\stackrel{Q}{C})$} \\
\hline & 0 & -5 & -10 & -15 & -20 & -25 & -30 & -35 & -40 & -45 & -50 \\
\hline & \multicolumn{11}{|c|}{ Temperatura equivalente de enfriamiento $(\stackrel{C}{C})$} \\
\hline 1.8 & 0 & -5 & -10 & -15 & -20 & -25 & -30 & -35 & -40 & -45 & -50 \\
\hline 2 & -1 & -6 & -11 & -16 & -21 & -27 & -32 & -37 & -42 & -47 & -52 \\
\hline 3 & -4 & -10 & -15 & -21 & -27 & -32 & -38 & -44 & -49 & -55 & -60 \\
\hline 5 & -9 & -15 & -21 & -28 & -34 & -40 & -47 & -53 & -59 & -66 & -72 \\
\hline 8 & -13 & -20 & -27 & -34 & -41 & -48 & -55 & -62 & -69 & -76 & -83 \\
\hline 11 & -16 & -23 & -31 & -38 & -46 & -53 & -60 & -68 & -75 & -83 & -90 \\
\hline 15 & -18 & -26 & -34 & -42 & -49 & -57 & -65 & -73 & -80 & -88 & -96 \\
\hline 20 & -20 & -28 & -36 & -44 & -52 & -60 & -68 & -76 & -84 & -92 & -100 \\
\hline
\end{tabular}

Los valores sombreados representan riesgo de congelación.

- El contacto breve con superficies metálicas por debajo de $-7 \stackrel{\circ}{\circ}$ puede provocar congelación.

- Debe evitarse todo contacto con líquidos cuya temperatura esté por debajo de cero grados.

0 tros materiales presentan una secuencia similar de riesgos, aunque las temperaturas necesarias son menores con los materiales menos conductores (plásticos, lana, espuma).

La protección contra el enfriamiento proporcionada por los guantes puede determinarse utilizando la norma europea EN 511. En la Tabla 42.28 se indican los resultados para cuatro clases de guantes.

\section{Enfriamiento convectivo de la piel}

EI Indice de Enfriamiento por el Viento (W ind-Chill Index, WCI) constituye un método sencillo y empírico para evaluar el enfriamiento de la piel no protegida (rostro) (ISO TR 11079). El método predice la pérdida de calor de los tejidos según la temperatura del aire y la velocidad del viento.

En la Tabla 42.29 se indican las respuestas asociadas a diferentes valores de $\mathrm{WCl}$.

Una interpretación frecuentemente utilizada del $\mathrm{WCI}$ es la temperatura equivalente de enfriamiento que, en condiciones de calma $(1,8 \mathrm{~m} / \mathrm{s})$, representa el mismo valor $\mathrm{WCI}$ que la combinación real de temperatura y viento. En la Tabla 42.30 se indican las temperaturas equivalentes de enfriamiento para distintas combinaciones de temperatura del aire y velocidad del viento. Los valores corresponden a personas activas y bien vestidas. Puede considerarse que existe riesgo cuando la temperatura equivalente desciende por debajo de $-30 \stackrel{\circ}{ } \mathrm{C}$, y la piel puede congelarse en 102 minutos por debajo de $-60 \stackrel{\circ}{\circ}$.

\section{Enfriamiento del tracto respiratorio}

$L a$ inhalación de aire frío y seco puede causar problemas a personas sensibles con temperaturas de incluso +10 y $15^{\circ} \mathrm{C}$. L L as personas sanas que realizan un trabajo ligero o moderado no necesitan una protección especial del tracto respiratorio hasta que la temperatura no desciende $\mathrm{a}-30 \stackrel{\circ}{ } \mathrm{C}$. C on temperaturas inferiores a $-20 \stackrel{\circ}{C}$ no deben realizarse esfuerzos muy intensos durante tiempos prolongados de exposición (p. ej., carreras de resistencia en atletismo).

Las mismas recomendaciones se aplican al enfriamiento de los ojos. En la práctica, las intensas molestias y el deterioro visual que produce el enfriamiento de los ojos suele obligar a utilizar gafas protectoras u otro tipo de protección mucho antes de que la exposición se haga peligrosa.

\section{Mediciones}

Dependiendo del tipo de riesgo esperado, tendrán que realizarse diferentes series de mediciones (Figura 42.26). Los procedimientos para la recopilación de datos y el grado de precisión de las mediciones dependen de la finalidad de las mismas. Debe obtenerse información pertinente sobre la variación de los parámetros climáticos con el tiempo, así como del nivel de actividad física y/ o de la ropa. Para estas mediciones deberán adoptarse procedimientos simples de ponderación en el tiempo (ISO 7726).

\section{Medidas preventivas para reducir el estrés por \\ frío}

Las acciones y medidas para controlar y reducir el estrés por frío implican una serie de consideraciones durante las fases de planificación y preparación de los turnos de trabajo, así como durante el trabajo, que se tratan en otras secciones de este capítulo y esta Enciclopedia. 


\section{Referencias}

ACGIH (American Conference of Governmental Industrial $\mathrm{H}$ ygienists). 1990. Threshold L imit Values and Biological Exposure Indices for 1989-1990. Nueva York: ACGIH.

- 1992. Cold stress. En Threshold Limit Values for Physical Agents in the W ork E nvironment. N ueva Y ork: ACGIH.

Bedford, T. 1940. Environmental warmth and its measurement. M edical Research M emorandum N 0.17. Londres: $\mathrm{H}$ er M ajesty's Stationery $\mathrm{O}$ ffice.

Belding, HS, TF $\mathrm{H}$ atch. 1955. Index for evaluating heat stress in terms of resulting physiological strain. H eating Piping Air C ondit 27:129-136.

Bittel, JH M , C N onotte-V arly, GH Livecchi-G onnot, GLM Savourey, AM H anniquet. 1988. Physical fitness and thermoregulatory reactions in a cold environment in men. J A ppl Physiol 65:1984-1989.

Bittel, JH M, GH Livecchi-Gonnot, AM H anniquet, $J L$ Etienne. 1989. Thermal changes observed be fore and after J.L. Etienne's journey to the North Pole. Eur J Appl Physiol 58:646-651.

Bittel, JH M . 1987. Heat debt as an index for cold adaptation in men. J Appl Physiol 62(4):1627-1634.

Bligh, J, K G Johnson. 1973. Glossary of terms for thermal physiology. J Appl Physiol 35(6):941-961.

Botsford, JH. 1971. A wet globe thermometer for environmental heat measurement. Am Ind $\mathrm{H} y g$ I 32:1-10.

Boutelier, C. 1979. Survie et protection des équipages en cas d'immersion accidentelle en eau froide Neuilly-sur-Seine: AGARD A.G. 211.

Brouha, L. 1960. Physiology in Industry. Nueva Y ork: Pergamon Press.

Burton, AC, O E Edholm. 1955. M an in a Cold Environment. Londres: Edward Arnold.

Chen, F, H Nilsson, RI Holmér. 1994. Cooling re sponses of finger pad in contact with an aluminum surface. Am Ind H yg Assoc I 55(3):218-22.

Comité Europeo de Normalización (CEN). 1992. EN 344. Protective Clothing A gainst Cold . Bruselas: CEN .

-. 1993. EN 511. Protective Gloves Against Cold . Bruselas: CEN

Daanen, HAM . 1993. Deterioration of manual performance in cold and windy conditions. AGARD, OTAN, CP-540.

Dasler, AR, 1974. Ventilation and thermal stress, ashore and afloat. En Capítulo 3, M anual of $\mathrm{N}$ aval Preventive M edicine. Washington, DC: N avy Department, Bureau of M edicine and Surgery.

- . 1977. H eat stress, work functions and physiological heat exposure limits in man. En Thermal Analysis- H uman Comfort- Indoor Environments. NBS Special Publication 491. Washington, DC: US Department of C ommerce.

Deutsches Institut für Normierung (DIN) 7943-2. 1992. Schlafsacke, Thermophysiologische Prufung. Berlín: DIN.

Dubois, D, EF Dubois. 1916. Clinical calorimetry X: A formula to estimate the appropiate surface area if height and weight be known. Arch Int $\mathrm{Med}$ 17:863-871.

Eagan, CJ. 1963. Introduction and terminology. Fed Proc 22:930-933.

Edwards, JSA, DE Roberts, SH M utter. 1992. Relations for use in a cold environment. J W ildlife $\mathrm{M}$ ed 3:27-47.

Enander, A. 1987. Sensory reactions and performance in moderate cold. T esis doctoral. Solna: Instituto N acional de M edicina del T rabajo.

Fuller, FH, L Brouha. 1966. New engineering methods for evaluating the job environment ASH RAE | 8(1):39-52.
Fuller, FH, PE Smith 1980. The effectiveness of preventive work procedures in a hot workshop. En FN Dukes-D obos y A H enschel (dirs.). P roceedings of a NIOSH W orkshop on Recommended H eat Stress Standards. Washington DC: DHSS (NIOSH) publication N 0. 81-108.

- . 1981. Evaluation of heat stress in a hot workshop by physiological measurements. Am Ind H yg Assoc ] 42:32-37.

Gagge, AP, AP Fobelets, LG Berglund. 1986. A standard predictive index of human response to the thermal environment. ASH RAE T rans 92:709-731.

Gisolfi, CV , CB Wenger. 1984. T emperature regulation during exercise: $\mathrm{O}$ Id concepts, new ideas. Exercise Sport Sci R ev 12:339-372.

Givoni, B, RF Goldman. 1972. Predicting rectal temperature response to work, environment and clothing. J Appl Physiol 2(6):812-822.

-. 1973. Predicting heart rate response to work, environment and clothing. J Appl Physiol 34(2):201-204.

Givoni, B. 1963. A new method for evaluating industrial heat exposure and maximum permissible work load. Artículo presentando en el Congreso Internacional de Biometeorología celebrado en París (Francia) en septiembre de 1963.

—. 1976. M an, Climate and Architecture, 2nd ed. Londres: Applied Science.

Goldman, RF. 1988. Standards for human exposure to heat. En Environmental E rgonomics, dirigido por IB M ekjavic, EW Banister y JB M orrison. Londres: T aylor \& Francis.

$\mathrm{H}$ ales, JR S, DAB R ichards. 1987. H eat Stress. Amsterdam, N ueva Y ork: $O$ xford Excerpta M edica.

H ammel, HT. 1963. Summary of comparative thermal patterns in man. Fed Proc 22:846-847.

Havenith, G, R Heus, WA Lotens. 1990. Clothing ventilation, vapour resistance and permeability index: Changes due to posture, movement and wind. E rgonomics 33:989-1005

$H$ ayes. 1988. En E nvironmental Ergonomics, dirigido por IB M ekjavic, EW Banister, JB M orrison. Londres: T aylor \& Francis.

H olmér, I. 1988. Assessment of cold stress in terms of required clothing insulation-IREQ. Int I Ind E rg 3:159-166.

- . 1993. Work in the cold. R eview of methods for assessment of cold stress. Int Arch $\mathrm{Occ} E$ nv $H$ ealth 65:147-155

- 1994. Cold stress: Part 1-Guidelines for the practitioner. Int J Ind E rg 14:1-10.

-. 1994. Cold stress: Part 2-The scientific basis (knowledge base) for the guide. Int I Ind Erg $14: 1-9$

H oughton, FC, CP Y agoglou. 1923. Determining equal comfort lines. J ASH VE 29:165-176.

K enneth, W, P Sathasivam, AL Vallerand, T B G raham. 1990. Influence of caffeine on metabolic responses of men at rest in 28 and $5{ }^{\circ} \mathrm{C}$. I Appl Physiol 68(5):1889-1895.

Kenney, WL, SR Fowler. 1988. M ethylcholineactivated eccrine sweat gland density and output as a function of age. J A ppl Physiol 65:1082-1086.

K erslake, DM CK . 1972. The Stress of $H$ ot Environments. C ambridge: Cambridge U niversity Press.

LeBlanc, J. 1975. M an in the Cold. Springfield, Illinois, Estados U nidos: Charles $\mathrm{C}$ T homas Publ.

Leithead, CA, AR Lind. 1964. $H$ eat Stress and $H$ ead Disorders. Londres: Cassell.

Lind, AR. 1957. A physiological criterion for setting thermal environmental limits for everybody's work. J Appl Physiol 18:51-56.
Lotens WA G H avenith. 1991. Calculation of clothing insulation and vapour resistance. Ergonomics 34:233-254.

Lotens, WA. 1989. The actual insulation of multilayer clothing. Scand J W ork Environ $\mathrm{H}$ ealth 15 Supl. 1:66-75.

-. 1993. H eat transfer from humans wearing clothing. T esis, U niversidad T ecnológica. D elft, Países Bajos. (ISBN 90-6743-231-8).

M aclean, D, D Emslie-Smith. 1977. Accidental H ypothermia. Oxford, Londres, Edimburgo, M elbourne: Blackwell Scientific Publication.

Macpherson, RK. 1960. Physiological responses to hot environments. M edical Research Council Special Report Series N 0. 298. Londres: H M SO

M artineau, L, I Jacob. 1988. M uscle glycogen utilization during shivering thermogenesis in humans. J Appl Physiol 56:2046-2050.

M aughan, RJ. 1991. Fluid and electrolyte loss and replacement in exercise. J Sport Sci 9:117-142.

M cArdle, B, W Dunham, HE Halling, WSS Ladell, IW Scalt, ML Thomson, JS Weiner. 1947. The prediction of the physiological effects of warm and hot environments. M edical Research Council Rep 47/ 391 . Londres: R N P

McCullough, EA, BW Jones, PEJ Huck. 1985. A comprehensive database for estimating clothing insulation. ASH RAE T rans 91:29-47.

M cCullough, EA, BW Jones, T T amura. 1989. A database for determining the evaporative resistance of clothing. ASH RAE T rans 95:316-328.

M cIntyre, DA. 1980. Indoor Climate. Londres: Applied Science Publishers Ltd.

M ekjavic, IB, EW Banister, JB M orrison (dirs.). 1988. Environmental Ergonomics. Filadelfia: Taylor \& Francis.

$\mathrm{N}$ ational Institute for $\mathrm{O}$ ccupational Safety and $\mathrm{H}$ ealth (NIOSH ). 1972. O ccupational exposure to hot environments. HSM 72-10269. Washington, DC: US D epartment of $\mathrm{H}$ ealth Education and W elfare.

-. 1986. O ccupational exposure to hot environments. NIO SH Publication N 0. 86-113. Washington, DC: NIOSH.

$\mathrm{N}$ ielsen, B. 1984. Dehydration, rehydration and thermoregulation. En E Jokl y M H ebbelinck (dirs.). $M$ edicine and Sports Science. Basilea: S. K arger.

-. 1994. Heat stress and acclimation. E rgonomics 37(1):49-58.

Nielsen, R, BW O lesen, P-O Fanger. 1985. Effect of physical activity and air velocity on the thermal insulation of clothing. E rgonomics 28:1617-1632.

Nishi, Y, AP Gagge. 1977. Effective temperature scale used for hypo- and hyperbaric environments. Aviation Space and E nvir M ed 48:97-107.

O lesen, BW, E Sliwinska, TL M adsen, P-O Fanger. 1982. Effect of body posture and activity on the thermal insulation of clothing: $M$ easurements by a movable thermal manikin. ASHRAE Trans 88:791-805.

O lesen, BW. 1985. Heat stress. En Bruel and Kjaer T echnical Review No. 2. Dinamarca: Bruel and K jaer.

Organización Mundial de la Salud (OMS). 1969. $\mathrm{H}$ ealth factors involved in working under conditions of heat stress. T echnical Report 412 . Ginebra: OMS.

Pandolf, K B, BS Cadarette, M N Sawka, AJ Y oung, R P Francesconi, RR Gonzales. 1988. I A ppl Physiol 65(1):65-71.

Parsons, KC. 1993. H uman Thermal Environments. $H$ ampshire, R eino U nido: T aylor \& Francis.

Reed, HL, D Brice, K M M Shakir, KD Burman, M M D'Alesandro, JT O 'Brian. 1990. Decreased free 
fraction of thyroid hormones after prolonged Antarctic residence. J A ppl Physiol 69:1467-1472.

R owell, LB. 1983. Cardiovascular aspects of human thermoregulation. Circ R es 52:367-379.

- . 1986. H uman Circulation Regulation During Physical Stress. O xford: O U P

Sato, K, F Sato. 1983. Individual variations in structure and function of human eccrine sweat gland. Am J Physiol 245:R 203-R 208.

Savourey, G, AL Vallerand, J Bittel. 1992. General and local adaptation after a ski journey in a severe arctic environment. E ur J Appl Physiol 64:99-105.

Savourey, G, B Barnavol, JP Caravel, C Feuerstein, J Bittel. 1996. H ypothermic general cold adaptation induced by local cold acclimation. Eur J Appl Physiol 73:237-244.

Savourey, G, JP Caravel, B Barnavol, J Bittel. 1994. Thyroid hormone changes in a cold air environment after local cold acclimation. I Appl Physiol 76(5):1963-1967.

V allerand, AL, I Jacob, M F K avanagh. 1989. M echanism of enhanced cold tolerance by an ephedrine/ caffeine mixture in humans. J Appl Physiol 67:438-444.

V an Dilla, M A, R Day, PA Siple. 1949. Special problems of the hands. En Physiology of $H$ eat R egulation, dirigido por R N ewburgh. Filadelfia: Saunders.

V ellar, OD. 1969. N utrient L osses through Sweating. O slo: U niversitetsforlaget.

Vogt, JJ, V Candas, JP Libert, F Daull. 1981. Re quired sweat rate as an index of thermal strain in industry. En Bioengineering, Thermal Physiology and Comfort, dirigido por K Cena y JA Clark. Amsterdam: Elsevier. 99-110.

Wang, LCH, SFP M an, AN Bel Castro. 1987. M etabolic and hormonal responses in theophyllineincreased cold resistance in males. J Appl Physio 63:589-596.

Wissler, EH. 1988. A review of human thermal models. En Environmental Ergonomics, dirigido por IB M ekjavic, EW Banister y JB M orrison. Londres: T aylor \& Francis.

Woodcock, AH . 1962. M oisture transfer in textile systems. Part I. T extile R es J 32:628-633.

Yaglou, CP, D M inard. 1957. Control of heat casualties at military training centers. Am M ed Assoc Arch Ind $\mathrm{H}$ ealth 16:302-316 y 405.

Comisión Europea (CE). 1988. Actas del seminario sobre índices de estrés por calor. Luxemburgo: CE, Dirección de Salud y Seguridad.

O rganización Internacional de N ormalización (ISO). 1985. ISO 7726. Thermal Environments- Instruments and $M$ ethods for M easuring Physical Q uantities. Ginebra: ISO

-. 1989a. ISO 7243. H ot Environments- Estimation of the $H$ eat Stress on W orking $M$ an, Based on the W BGT Index (W et B ulb G lobe T emperature). G inebra: ISO .

-. 1989b. ISO 7933. H ot Environments-Analytical De termination and Interpretation of T hermal Stress using $\mathrm{Cal}$ culation of R equired Sweat R ate. Ginebra: ISO .

-. 1989c. ISO DIS 9886. E rgonomics- Evaluation of T hermal Strain by Physiological M easurements. Ginebra: ISO
- 1990. ISO 8996. E rgonomics- Determination of M etabolic $\mathrm{H}$ eat Production. G inebra: ISO.

—. 1992. ISO 9886. Evaluation of Thermal Strain by Physiological M easurements. Ginebra: ISO

- . 1993. Assessment of the Influence of the T hermal E nvironment using Subjective) udgement Scales. Ginebra: ISO .

— . 1993. ISO CD 12894. Ergonomics of the Thermal E nvironment- M edical Supervision of Individuals Exposed to $\mathrm{H}$ ot or Cold E nvironments. G inebra: ISO

-. 1993. ISO TR 11079 Evaluation of Cold Environments- Determination of Required Clothing Insulation, IRE Q. G inebra: ISO . (T echnical R eport)

- . 1994. ISO 9920. E rgonomics- E stimation of the T hermal Characteristics of a Clothing Ensemble Ginebra: ISO

- 1994. ISO 7730. M oderate Thermal Environments- Determination of the PM V and PPD Indices and Specification of the Conditions for Thermal Comfort. Ginebra: ISO .

-. 1995. ISO DIS 11933. E rgonomics of the Thermal Environment. Principles and Application of International Standards. Ginebra: ISO

\section{0 tras lecturas recomendadas}

Alm, NO. 1992. Strategies for accident prevention in circumpolar regions. Arctic M ed Res 50 Supl. 7:99101.

Anon. 1993. The support of air operations under extreme hot and cold weather conditions. Neuillysur-Seine, Francia: AG AR D/ OT AN , C 10-304.

Bennett, PB, DH Elliot. 1991. T he Physiology and M edicine of D iving. L ondres: Bailliere T indall.

Burton, AC, OG Edholm. 1969. M an in a Cold Environment. Nueva Y ork: $\mathrm{H}$ afner Publishing Company, Inc.

Clark, RP, OG Edholm. 1985. M an and his Thermal Environment. Londres: Edward Arnold.

Eiken, O, P K aiser, I H olmér, R Baer. 1989. Physiological effects of a mouth-borne heat exchanger during heavy exercise in a cold environment. E rgonomics 32(6):645-653.

Enander, AE. 1990. Working performance in the cold. Proceedings of W orking and Survival in the Cold. T rondheim, N oruega: Sintef U nimed, 69-92.

- . 1987. Effects of moderate cold on performance of psychomotor and cognitive tasks. Ergonomics 30(10):1431-1445.

Fanger, P-O. 1970. Thermal Comfort. Nueva York: $M$ CG raw-H ill Book Co.

Francis, TJR. 1985. Non-freezing cold injuries-T he pathogenesis. J R oyal $N$ avies M ed Serv 71:3-8.

Frimodt-M uller, B, H Bay-Nielsen. 1992. Classification of accidents in the Arctic. Arctic M ed Res 51 Supl. 7:15-21

Granberg, P-O , J H assi, I H olmér, T Larsen, H R efsum, K Y ttrehus, M K nip. 1991. Cold physiology and cold injuries. Arctic M ed Res 50: Supl. 6.

Granberg, PO . 1995. H uman endocrine responses to the cold. Arctic M ed R es 54:91-103.

H amlet, M P. 1988. H uman cold injuries. En H uman Performance Physiology and Environmental M edicine at T errestrial Extremes, dirigido por K B Pandolf, $M N$ Sawka y RR Gonzalez (dirs.). Alexandria, Vir- ginia: Army Research Institute of Environmental M edicine. 435-466.

Holmér, I (dir.). 1994. W ork in Cold Environments. Solna, Suecia: Instituto $\mathrm{N}$ acional de M edicina del Trabajo.

Ingall, TJ. 1993. H yperthermia and hypothermia. En Clinical Autonomic Disorders, dirigido por PA Low. Boston: Little Brown and Company.

K hogali, M , JR S H ales. 1983. H eat Stroke and T emperature R egulation. Sidney: A cademic Press.

Leppäluoto, J (dir.). 1995. Effects of cold on the human organism. Arctic M ed Res 54: Supl. 2.

Litchfield, P. M anual performance in the cold: A review of some of the critical factors. J R oy Nav M ed Serv 73:173-177.

Lloyd, EL. 1986. H ypothermia and Cold Stress. Londres y Sidney: Croom H elm

M ekjavic, I, J Bligh. 1987. The pathophysiology of hypothermia. En International R eviews of E rgonomics, dirigido por DJ Oborne. Nueva York:T aylor \& Francis. 201-218.

M iddaugh, J. 1992. Epidemiology of injuries in northern areas. Arctic M ed R es 51:5-14.

M ills, WJ. 1991. Cold injury. Alaska M ed 35:1.

M orton, WE, JWS H earle. 1975. Physical Properties of T extile F ibres. Londres: H einemann.

$\mathrm{N}$ ewburgh, LH (dir.). 1949. Physiology of $\mathrm{H}$ eat R egulation and the Science of Clothing. Nueva Y ork: $\mathrm{H}$ afner Publishing $\mathrm{C}$ o.

Nishi, Y, AP Gagge. 1970. M oisture permeation of clothing-A factor governing thermal equilibrium and comfort. ASH RAE T rans 76(1):137-145.

O rganización Internacional de N ormalización (ISO). 1984. Thermal Environments- Specifications Relating to Appliances and $M$ ethods for $M$ easuring Physical Characteristics of the E nvironment. G inebra: ISO

Pandolf, K B, M N Sawka, R R G onzales. 1988. H uman Performance Physiology and Environmental M edicine at T errestrial Extremes. Indianapolis: Benchmark Press.

Parsons, K C, JG Fox, B M etz. 1995. H eat stress indices (número especial). E rgonomics Vol. 38, N o. 1, enero 1995.

Savourey, G, B Barnavol, JP Caravel, G Barbe, J Bittel. 1993. Induction d'un syndrome polaire de la "tri-iodothyronine" en laboratoire chez l'homme. CR Acad Sci Paris 607-610.

Shitzer, A, A Stroschein, WE Santee, RR Gonzales, K B Pandolf. 1991. Q uantification of conservative endurance times in thermally insulated coldstressed digits. I Appl Physiol 71(6):2528-2535.

Toner, M M , WD M cArdle. 1988. Physiological adjustments of man to the cold. En $\mathrm{H}$ uman Performance Physiology and E nvironmental $M$ edicine at T errestrial EXtremes, dirigido por K B Pandolf, M N Sawka y RR Gonzalez. Alexandria, Virginia: US Army Research Institute of Environmental M edicine.

Whelan, ME, LE M acH attie, AC Goodings, LH T url. 1955. The diffusion of water vapour through luminae with particular reference to textile fabrics. T extile Res ) 25(3):197-223.

Young, AJ. 1988. Human adaptation to cold. En H uman Performance Physiology and Environmental M edicine at Terrestrial Extremes, dirigido por KB Pandolf, MN Sawka y RR Gonzalez (dirs.). Alexandria, V irginia: US Army R esearch Institute of Environmental M edicine. 



\section{HORAS DE TRABAJO}

Director del capítulo

Peter Knauth

\section{Sumario}

H oras de trabajo

Peter Knauth........................... 43.2 


\section{HORAS DE TRABAJO}

Peter Knauth

EI trabajo por turnos es el que se realiza permanente o frecuentemente fuera de las horas de trabajo regulares diurnas. En efecto, este tipo de trabajo se puede realizar permanentemente de noche permanentemente en horario de tarde 0 en horarios variables. Cada tipo de turnos tiene ventajas e inconvenientes y se asocia a diferentes efectos en el bienestar, la salud, la vida social y el rendimiento laboral.

En los sistemas tradicionales de turnos de rotación lenta, los turnos rotan semanalmente; esto es, a una semana de trabajo nocturno sigue un turno semanal de trabajo de tarde y, a continuación, un turno de mañana. En el sistema de rotación rápida, sólo se trabajan uno, dos o, como mucho, tres días consecutivos en cada turno. En algunos países, como Estados U nidos, se generalizan los turnos de duración superior a 8 horas, en especial los de 12 horas (Rosa y cols. 1990).

El ser humano es un ser básicamente diurno; esto es, su organismo está fundamentalmente "programado" para trabajar de día y solazarse y descansar de noche. Existen mecanismos internos (el denominado reloj biológico) que controlan la fisiología y la bioquímica del organismo para ajustarlo al ciclo de 24 horas. Estos ciclos se denominan ritmos circadianos. La perturbación de las variaciones circadianas del funcionamiento fisiológico producido por la necesidad de permanecer despiertos y trabajando en horas biológicamente anómalas, y de dormir durante el día, es uno de los rasgos más estresantes del trabajo por turnos.

A pesar de la suposición generalizada de que la perturbación del sistema circadiano puede tener efectos perjudiciales a largo plazo, no ha resultado fácil establecer una relación causa-efecto. A pesar de la ausencia de pruebas incontrovertibles, existe un amplio consenso en torno a la conveniencia de implantar en el lugar de trabajo unos turnos que eviten, en la medida de lo posible, una perturbación permanente de los ritmos circadianos.

\section{Efectos combinados de los factores relacionados con el lugar de trabajo}

Algunos trabajadores sometidos al sistema de turnos se encuentran además expuestos a otros riesgos en el lugar de trabajo, como los causados por agentes tóxicos o por trabajos que exigen un gran esfuerzo físico o mental. Sin embargo, se han dedicado muy escasos estudios a los problemas producidos por la conjunción del trabajo por turnos y la existencia de unas condiciones de organización, ambientales y de trabajo desfavorables, en las que
Ios efectos negativos del trabajo por turnos pueden deberse, no sólo al desfase entre los ritmos circadianos y las condiciones de vida, sino también a las condiciones de trabajo adversas que pueden asociarse al trabajo por turnos.

La presencia de uno o más factores de riesgo en el lugar de trabajo, como ruidos, condiciones climáticas desfavorables, iluminación deficiente, vibraciones, etc., es en ocasiones más frecuente en los sistemas de tres turnos de trabajo, los sistemas irregulares y los turnos de noche que en los sistemas de sólo dos turnos y en el horario de trabajo diurno.

\section{Variables intervinientes}

Según Härmä (1993), la tolerancia del trabajo por turnos varía sensiblemente de una persona a otra, lo que puede obedecer a la presencia de un gran número de posibles variables. Como se ilustra en la Figura 43.1, algunas diferencias individuales que pueden influir en la tensión que sufren quienes trabajan por turnos son las diferencias de fase y amplitud del ciclo circadiano, la edad, el sexo, la situación de embarazo, la aptitud física y la flexibilidad para conciliar el sueño, y la capacidad para superar la somnolencia.

M ientras que para algunos autores (Andlauer y cols. 1979; Reinberg y cols. 1988; Costa y cols. 1989; K nauth y H ärmä 1992) existe una correlación entre una mayor amplitud de los ciclos circadianos y una menor frecuencia de problemas de salud, otros investigadores aseguran que este factor no supone una mayor facilidad de ajuste al trabajo por turnos (Costa y cols. 1989, M inors y Waterhouse 1981), ni aun después de tres años de trabajo (V idacek y cols. 1987).

Existen dos importantes dimensiones de la personalidad que parecen estar asociadas a los ritmos circadianos: la inclinación "matutina" 0 "vespertina" y la introversión o extroversión (Kerkhof 1985). La inclinación "matutina" o "vespertina" se puede establecer mediante cuestionarios (H orne y Östberg 1976; Folkard y cols. 1979; Torval y Åkerstedt 1980; M oog 1981) o midiendo la temperatura corporal. Los individuos de condición matutina ("alondras"), caracterizados por una secuencia de fases adelantada de la temperatura corporal, se acuestan y despiertan antes que la mayoría de las personas, mientras que los individuos vespertinos ("búhos") presentan una secuencia de fases retrasada en el ritmo circadiano y suelen acostarse y despertarse más tarde. La condición de "alondra" sería más ventajosa para los turnos de mañana, y la pertenencia al grupo de los "búhos" lo sería para los turnos de noche. Sin embargo, algunos autores señalan que un porcentaje desproporcionadamente elevado de quienes abandonan el trabajo por turnos son del tipo matutino (Å kerstedt y Fröberg 1976; H auke y cols. 1979; Torsvall y Åkerstedt 1979). Tanto Bohle y

Figura 43.1 - Modelo de estrés y tensión de los trabajadores por turnos.

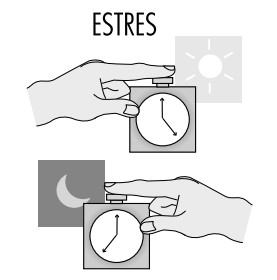

- Variación por fases de las horas de trabajo y de sueño

- Condiciones de trabajo, de organización y ambientales desfavorables
VARIABLES PRESENTES

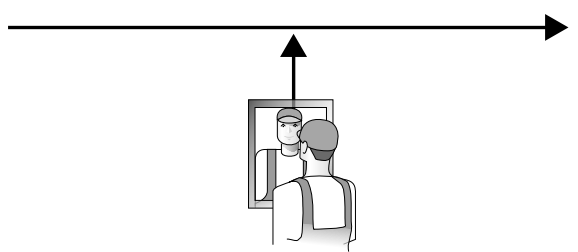

- Características individuales

- Factores relacionados con el trabajo

- Condiciones ambientales

- Circunstancias familiares

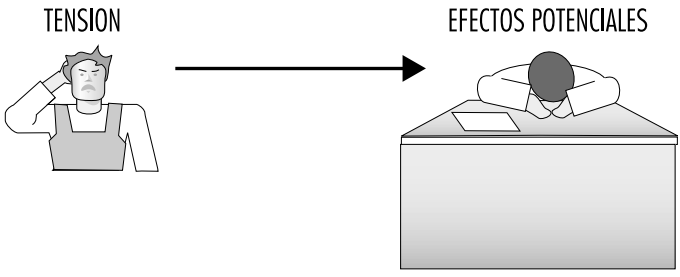

- Ineficiencia

- Menor bienestar

- Daño para la salud

- Problemas de relación 
Tilley (1989) como Vidacek y cols. (1987) han hallado una relación entre la condición matutina y la tolerancia decreciente del trabajo por turnos. En cambio, otros investigadores (Costa y cols. 1989) informan de hallazgos opuestos a éste. En este sentido, es de subrayar que la mayoría de los estudios se han centrado exclusivamente en "alondras" y "búhos" muy caracterizados, que, en total, constituyen únicamente el $5 \%$ de la población.

En numerosas investigaciones realizadas mediante cuestionarios se ha establecido que los efectos adversos del trabajo por turnos se incrementa con la edad y que el grupo crítico de edad es, en promedio, el comprendido entre los 40 y los 50 años (Foret y cols. 1981; Koller 1983; Âkerstedt y Torsvall 1981). Con los años, resulta cada vez más difícil dormir durante el día. Asimismo, existen indicios de que la adaptación de los ritmos circadianos a las exigencias del trabajo por turnos es más lenta en los trabajadores de edad madura que en los más jóvenes (H ärmä y cols. 1990; M atsumoto y M orita 1987).

El sexo y el embarazo son dos variables que, aunque debatidas frecuentemente, no han sido aún suficientemente investigadas en estudios longitudinales. Rutenfranz y cols. (1987) han estudiado la literatura existente y llegado a la conclusión de que los ritmos circadianos de hombres y mujeres reaccionan de la misma forma a la alternancia de las fases de trabajo y sueño en relación con el trabajo nocturno. N o obstante, es preciso tomar en consideración dos aspectos: el ciclo menstrual y la carga adicional del cuidado de los hijos y las labores domésticas.

Si bien algunos autores hablan de una mayor frecuencia de los trastornos menstruales en grupos de mujeres que realizan trabajos por turnos en comparación con las que trabajan de día (Tasto y cols. 1978; U chata y Sasakawa 1982), la homogeneidad de estos grupos de trabajadoras por turnos y con horario de día resultaba dudosa. Pokorski y cols. (1990) estudiaron la sensación de incomodidad experimentada por un grupo de mujeres que trabajaban en tres turnos durante las tres fases del ciclo menstrual: premenstrual, menstrual y posmenstrual. Las diferencias entre estas fases eran más significativas que las que se daban entre los turnos de mañana, tarde y noche.

EI cuidado de los hijos en el hogar reducía el tiempo dedicado al sueño y al ocio por las enfermeras que trabajaban por turnos. Un estudio realizado por Estryn-Behar en 120 mujeres empleadas permanentemente en el turno de noche reveló que el período medio de sueño al final de un turno de noche era de 6 horas 31 minutos en las mujeres sin hijos, de 5 horas y 30 minutos en las mujeres con hijos mayores, y de 4 horas y 55 minutos en las mujeres con hijos pequeños (Estryn-Behar y cols. 1978). Sin embargo, según un estudio realizado en un grupo de mujeres policías, las mujeres con hijos tenían una actitud más favorable hacia el trabajo por turno que las demás (Beermann y cols. 1990).

En un estudio realizado por Härmä y cols. (1988a, b), la aptitud física se reveló como un factor propicio a una mayor tolerancia del trabajo por turnos. Según un estudio de seguimiento realizado con un diseño de muestras apareadas, el grupo de participantes que intervino regularmente en un programa de cuatro meses informó de una reducción significativa de la sensación general de fatiga, sobre todo durante la permanencia en el turno de noche, así como de una disminución de los síntomas musculoesqueléticos y una prolongación de las horas de sueño.

En algunos estudios se ha establecido una relación entre la "flexibilidad de los hábitos de sueño" y la "capacidad para superar la somnolencia", evaluadas según el cuestionario desarrollado por Folkard y cols. (1979; 1982), y una mayor tolerancia del trabajo por turnos (Wynne y cols. 1986; Costa y cols. 1989; Vidacek y cols. 1987). Sin embargo, otros estudios (como el de Bohle y Tilley, 1989), no han confirmado esta relación.
O tras variables capaces de influir en la tolerancia del trabajo por turnos son el "compromiso con el trabajo por turnos", definido como el modo en que las personas programan su vida (Folkard y cols. 1979; M inors y Waterhouse 1981), y el "estilo de afrontamiento" de las personas que trabajan por turnos (0 Isson y cols. 1987; O Isson y K andolin 1990).

Además de las características individuales, los factores ambientales parecen ser determinantes de la magnitud de los problemas que presentan las personas que trabajan por turnos. Küper y cols. (1980) y K nauth (1983) hallaron que los trabajadores por turnos que veían frecuente o sistemáticamente frustrados sus intentos de dormir de día por causa del ruido se quejaban con mayor frecuencia de problemas nerviosos y gastrointestinales que los que experimentaban poca o ninguna perturbación del sueño.

\section{Efectos del trabajo por turnos sobre la salud}

La mayoría de los problemas de salud que aquejan a las personas que trabajan por turnos se asocian a la calidad del sueño de que disfrutan durante el día después de un turno de noche $y$, en menor medida, al descanso anterior al inicio del turno de mañana. Como el funcionamiento de los ritmos circadianos es tal que el organismo está preparado para la actividad diurna y el reposo nocturno, al finalizar un turno de noche, el cuerpo no se encuentra, en general, perfectamente predispuesto para el sueño. También pueden influir otros factores. En efecto, la luz natural puede perturbar el sueño, y el nivel de ruidos es mayor durante el día que por la noche. Así, la mayoría de los trabajadores del turno de noche se quejan del ruido de los niños y del tráfico. Además, algunos trabajadores nocturnos interrumpen su descanso diurno para comer en familia, y otros deben reducir las horas de sueño para realizar las labores domésticas y cuidar de los hijos. En un estudio de una muestra de trabajadores nocturnos (K nauth 1983) se halló que la duración del reposo nocturno se había reducido a seis horas. Aunque existen acentuadas variaciones de una a otra persona, seis o menos horas de sueño son insuficientes para muchos seres humanos (Williams y cols. 1974). Específicamente, al cabo de numerosas jornadas consecutivas de trabajo nocturno, se suele producir un déficit acumulado de sueño que tiene repercusiones tanto en la productividad como en la vida social (Naitoh y cols. 1974), así como en la posibilidad de un mayor riesgo de accidentes. Asimismo, diversos estudios electroencefalográficos han revelado que la calidad del sueño diurno también se resiente (K nauth 1983).

El déficit de sueño se puede producir al cabo de una semana de trabajo por turnos, tanto nocturno como matutino. La propensión a prolongar el sueño durante el fin de semana después de una semana de trabajo en el turno de mañana parece reflejar una mayor necesidad de reposo.

H ak y K ampmann (1981) estudiaron los fenómenos del sueño y la fatiga en los maquinistas ferroviarios. Cuanto antes empezaba el turno de mañana, más breve era el período de sueño del turno de noche precedente y más fatigados se sentían los maquinistas durante el turno matinal. Tanto Moors (1990) como Folkard y Barton (1993) confirmaron la disminución de las horas de sueño asociada al adelanto del comienzo del turno de mañana. Este fenómeno se puede explicar en parte por la presión del entorno familiar para retrasar la hora de retirarse a dormir y, en parte, por el "reloj biológico" que, en opinión de Lavie (1986), genera una "zona vedada" para el sueño, consistente en una franja de tiempo durante la cual la facilidad para conciliar el sueño se reduce drásticamente. Según esta última hipótesis, si el trabajador se acuesta antes porque el siguiente turno de mañana comienza más temprano, es posible que le cueste conciliar el sueño. 
Tabla 43.1 • Intervalos de tiempo entre el comienzo del trabajo por turnos y el momento en que se diagnosticaron las tres enfermedades (desviación media y típica en años).

$\begin{array}{lrrr}\begin{array}{l}\text { Horario de } \\ \text { trabajo }\end{array} & \text { Gastroduodenitis } & \text { Ulcera péptica } & \begin{array}{r}\text { Trastornos } \\ \text { neuróticos }\end{array} \\ \text { Trabajo diurno } & 12,6 \pm 10,9 & 12,2 \pm 9,9 & 9,7 \pm 6,8 \\ \text { Dos turnos } & 7,8 \pm 6,6 & 14,4 \pm 8,2 & 9,0 \pm 7,5 \\ \text { Tres turnos } & 7,4 \pm 6,5 & 5,0 \pm 3,9 & 6,8 \pm 5,2 \\ \text { Trabajo nocturno } & 4,7 \pm 4,3 & 5,6 \pm 2,8 & 3,6 \pm 3,3\end{array}$

Fuente: Costa y cols. 1981

Trastornos gastrointestinales. EI trabajo nocturno provoca alteraciones en el horario y la secuencia de las comidas. En efecto, durante la noche, el estómago no puede admitir, en cantidad ni calidad, una típica comida diurna. Por lo tanto, resulta comprensible que los trabajadores del turno de noche sufran inapetencia con mayor frecuencia que quienes trabajan de día y que los que no hacen turnos de noche, como afirman Rutenfranz y cols. (1981) sobre la base de un estudio de la literatura dedicada a la cuestión.

A largo plazo, los hábitos alimentarios irregulares pueden provocar molestias e incluso trastornos gastrointestinales. No obstante, es indudable que las causas de los síndromes gastrointestinales complejos son múltiples. No resulta fácil analizar estudios como el de Costa (1996), debido a las diferencias metodológicas. La mayoría de los hallazgos proceden de estudios transversales, es decir, de muestras de personas que actualmente trabajan por turnos. Por consiguiente, si algunos han abandonado el sistema de turnos por causa de problemas o enfermedades, la población restante está más o menos autoseleccionada (en lo que se denomina efecto del "trabajador saludable"). Esto hace que el estado de salud de un grupo de trabajadores por turnos pueda ser mejor que el de una muestra de trabajadores ubicados en el turno de día, sencillamente porque los problemas sociales y de salud han impulsado a algunos de los que antes trabajaban por turnos a pasarse al trabajo diurno y los que permanecen en los turnos son los más aptos para adaptarse.

En los estudios longitudinales, que son casi exclusivamente retrospectivos, los problemas de autoselección y de falta de seguimiento por exclusión son perfectamente conocidos. Por ejemplo, para la obtención de la muestra utilizada en el estudio de L euliet (1963), la población de la encuesta se redujo prácticamente a la mitad durante los doce años que duró el estudio. Al igual que ocurre con los estudios transversales, los efectos más serios se observan entre quienes, habiendo trabajado anteriormente por turnos, se han pasado al trabajo de día por sus problemas de salud. Según Thiis-Evensen (1958), la úlcera péptica era dos veces más frecuente entre las personas que habían trabajado por turnos que entre los trabajadores diurnos. Aanonsen (1964) y Angersbach y cols. (1980) observaron, respectivamente, que la frecuencia de úlcera péptica era dos y tres veces y media mayor entre quienes habían trabajado regularmente por turnos, así como una reducción significativa de la frecuencia de las enfermedades gastrointestinales después de abandonar dicha modalidad.

Costa y cols. (1981) calcularon el intervalo de tiempo entre el comienzo del trabajo por turnos y el diagnóstico de la enfermedad (Tabla 43.1). Al comparar grupos con diferentes horarios de trabajo, hallaron los menores intervalos medios $(4,7$ años) para la aparición de la gastroduodenitis entre los trabajadores adscritos permanentemente al turno de noche. Entre las personas que trabajaban de noche (esto es, los trabajadores que alternaban en los tres turnos y los dedicados exclusivamente al turno nocturno), la úlcera péptica se desarrollaba en intervalos de unos 5 años. En su revisión, Costa (1996) llega a la conclusión de que "existen elementos de juicio bastantes para afirmar que el trabajo por turnos es un factor de riesgo de trastornos y enfermedades gastrointestinales, en especial de úlcera péptica" (Tabla 43.1).

Trastornos cardiovasculares. Como se ilustra en la Tabla 43.2, K ristensen (1989) ha analizado los aspectos metodológicos y analíticos de los estudios de la frecuencia de los trastornos cardiovasculares. En la mayoría de los trabajos publicados a

Tabla 43.2 - Relación entre el trabajo por turnos y la frecuencia de trastornos cardiovasculares.

\begin{tabular}{|c|c|c|c|}
\hline Referencia & Año de publicación & Conclusiones & $\begin{array}{l}\text { Comentarios } \\
\text { metodológicos/clasificación }\end{array}$ \\
\hline Thiis-Evenson (1949); Aanonsen (1964) & $1949-1964$ & 0 & 2 \\
\hline Taylor y Pocock (1972) & 1972 & 0 & ? elección correcta de los controles \\
\hline Rutenfranz y cols. (1977); Carpentier y cols. (1977) & 1977 & 0 , artículos de revisión & \\
\hline Angersbach y cols. (1980); Koller y cols. (1983) & $1980-1983$ & $\begin{array}{l}+ \text {, especialmente las bajas; } \\
+, \text { con la edad }\end{array}$ & $2-3$ \\
\hline Michel-Briand y cols. (1981) & 1981 & t, en trabajadores jubilados & 1 \\
\hline $\begin{array}{l}\text { Alfredsson y cols. }(1982,1983,1985) ; \\
\text { Knutsson y cols. }(1986)\end{array}$ & $1982-1986$ & $\begin{array}{l}\text { t, en hombres y mujeres, } \\
\text { empeora con el número de años } \\
\text { en el trabajo por turnos }\end{array}$ & $3-4$ \\
\hline Akerstedt y cols. (1984) & 1984-1986 & t, artículos de revisión & \\
\hline Orth-Gomer (1985) & 1985 & t, artículos de revisión & \\
\hline Andersen (1985) & 1985 & $\begin{array}{l}+, \text { profesiones asociadas al trabajo } \\
\text { por turnos }\end{array}$ & \\
\hline Frese y Semmer (1986) & 1986 & $t$, en las bajas & \\
\hline
\end{tabular}

Fuente: Waterhouse y cols. 1992, basado en Kristensen 1989. Clasificación de las conclusiones utilizada por Kristensen: t, mayor frecuencia; 0, sin variación. Clasificación metodológica: 1-4, por orden creciente de calidad de la metodología. 
partir de 1978 se informa de un incremento de los trastornos cardiovasculares, sobre todo entre las personas que han abandonado el trabajo por turnos. Waterhouse y cols. (1992) descartan la posibilidad de negar absolutamente esta relación, según la opinión generalizada (H arrington 1978).

Trastornos neurológicos. Aunque los estudios de los trastornos neurológicos que afectan a quienes trabajan por turnos adolecen de falta de normalización de los síntomas y trastornos (Waterhouse y cols. 1991; Costa 1996), según Waterhouse (1992), "se evidencia actualmente una mayor tendencia al malestar general - incluidas la ansiedad y elementos depresivos- entre los trabajadores por turnos que entre sus compañeros que trabajan de día". C osta (1996) formula una conclusión similar, aunque más cauta: "Las pruebas disponibles permiten afirmar que el trabajo por turnos puede influir en la morbilidad de los trastornos psiconeuróticos en mayor o menor medida, en relación a otros factores individuales o sociales".

M ortalidad. Sólo existe un estudio epidemiológico concienzudo de la mortalidad de los trabajadores del sistema de turnos. Empleando una muestra de 8.000 personas, Taylor y Pocock (1972) compararon las tasas de mortalidad de las personas que trabajaban por turnos con las correspondientes a los que realizan trabajo diurno durante trece años. No se observaron variaciones entre las tasas respectivas correspondientes a los trabajadores diurnos y por turnos y en el momento del estudio. Sin embargo, la tasa de mortalidad normalizada correspondiente a las personas que anteriormente habían trabajado por turnos era de 118,9, en contraste con una tasa de 101,5 para los trabajadores que en aquel momento trabajaban en el sistema de turnos, lo que "puede ser un simple reflejo de la práctica de autoexclusión de los trabajadores menos aptos" (H arrington 1978).

\section{Problemas sociales de las personas que trabajan por turnos}

EI trabajo por turnos puede repercutir negativamente en la vida familiar, la participación en la actividad institucional y las relaciones sociales. La magnitud de los problemas que pueden producirse está en función de diversos factores, como la naturaleza del sistema de turnos, el sexo, edad, estado civil y estructura de la familia del trabajador, así como de la extensión del trabajo por turnos en la región.

Durante una semana de trabajo en el turno de tarde, el contacto regular del trabajador con sus hijos de edad escolar 0 con su cónyuge que trabaja de mañana o en turnos de día se reduce considerablemente. Este problema es serio sobre todo para las personas adscritas a los denominados turnos permanentes de tarde ( $M$ ott y cols. 1965). En el sistema tradicional de dos turnos discontinuos, se alternan una semana de trabajo en el turno de mañana y una semana en el turno de tarde, con lo que el contacto familiar se trastorna cada dos semanas. En el sistema tradicional de tres turnos rotativos se trabaja de tarde cada tres semanas. En los sistemas de turnos de rotación rápida, el contacto familiar nunca se quiebra durante una semana completa. Las investigaciones han dado resultados contradictorios. A sí, mientras que M ott y cols. (1965) indican que el trabajo prolongado en el turno de tarde o de noche puede perjudicar la vida conyugal, M aasen (1981) no llega a la misma conclusión. EI trabajo por turnos, sobre todo si ambos progenitores trabajan en este sistema, también puede afectar negativamente el rendimiento escolar de los hijos (Maasen 1981; Dickmann y cols. 1981).

En los estudios realizados sobre el valor percibido del tiempo libre disfrutado durante diferentes días y horas de la semana se ha puesto de relieve que el fin de semana se valoraba más que los días de semana, y que el tiempo libre en horas vespertinas y nocturnas era más apreciado que el disponible durante el día (Wedderburn 1981; H ornberger y K nauth 1993). El contacto con los familiares, amigos, clubes, partidos políticos, iglesias, etc. se resiente principalmente del trabajo en fin de semana y en los turnos de tarde y nocturnos (M ott y cols. 1965), como demuestran Bunnage (1981), Walker (1985) y Colligan y R osa (1990).

L os trabajadores por turnos sólo disfrutan de ventaja sobre las personas que trabajan de día en relación con las actividades más o menos solitarias, dado que actividades como la jardinería, el paseo, la pesca 0 el bricolaje son relativamente flexibles y se pueden realizar en cualquier momento distinto de los fines de semana y las horas vespertinas.

En algunos estudios (Banks 1956; U lich 1957; D ownie 1963; Sergean 1971) se han abordado los problemas del cónyuge del trabajador empleado por turnos, que se ve obligado a modificar su estilo de vida para adaptarlo al horario variable de éste. Por ejemplo, puede verse obligado a demorar la realización de los trabajos domésticos más ruidosos y a mantener a los niños callados mientras aquél descansa después de trabajar durante el turno de noche. Además, se queda solo durante los turnos de tarde, nocturnos y de fin de semana, aparte de soportar la irritabilidad del compañero. El $87 \%$ de los cónyuges de una muestra de trabajadores que habían abandonado el sistema de turnos semanales por un régimen de turnos de rotación rápida se manifestaron a favor de este último. Aducían que, en el sistema anterior, el cónyuge se encontraba muy fatigado al final de un período de trabajo en el turno de noche y precisaba varios días para recuperarse, por lo que no se encontraba de humor para compartir los momentos de ocio. En cambio, en el nuevo sistema de turnos de rotación rápida, en el que sólo se trabajan dos o tres noches seguidas, el cónyuge se mostraba menos fatigado y se mostraba más dispuesto a participar en distracciones.

Las mujeres que trabajan por turnos suelen tener más problemas con el sueño y las obligaciones domésticas, debido a que las responsabilidades familiares no se reparten equitativamente entre los cónyuges. No obstante, algunas enfermeras que trabajan permanentemente de noche han optado voluntariamente por ese horario por causas familiares (Barton y cols. 1993). En todo caso, como asegura Walker (1985) al resumir su análisis, "afirmar que el trabajo nocturno permanente para una madre es compatible con la educación de los hijos es hacer caso omiso de los 'costes' que implica". La fatiga permanente causada por la reducción del tiempo de sueño puede ser uno de estos "costes".

\section{Rendimiento en el trabajo}

A parte de los posibles efectos del trabajo por turnos sobre la salud del trabajador, el rendimiento laboral también puede verse afectado. H arrington (1978) formuló algunas conclusiones generales sobre el rendimiento en el trabajo sobre la base de un análisis de la productividad y los accidentes. Sus conclusiones, que siguen siendo válidas, han sido replanteadas por Waterhouse y cols. (1992):

Se observaron frecuentes variaciones en cuanto a los errores y al rendimiento general, correspondiendo los peores resultados al turno de noche:

- Es posible evitar o reducir la reducción del rendimiento en horas nocturnas si se hacen pausas en el trabajo, si éste es interesante y si se mantiene la motivación.

- El rendimiento baja (más durante el turno de noche, por regla general) si se realizan tareas aburridas o repetitivas, si hay falta de sueño o si el tiempo de trabajo efectivo se incrementa.

Las diferencias individuales se han revelado con frecuencia como la variable más influyente en el rendimiento. 
Se plantea una dificultad metodológica al comparar la productividad y los accidentes durante los turnos de mañana, de tarde y de noche. En efecto, las condiciones ambientales, organizativas y de trabajo durante el día y la noche no son perfectamente homologables (Colquhoun 1976; Carter y Corlett 1982; Waterhouse y cols. 1992). Esto hace que sea difícil controlar todas las variables. No resulta, por tanto, sorprendente que en un análisis de 24 estudios hubiera casi tantos en los que se observaba una mayor frecuencia de accidentes nocturnos que diurnos, como lo contrario (K nauth 1983). En algunos estudios la carga de trabajo diurno era comparable con la del turno de noche y se disponía de mediciones relativas a las 24 horas. Los autores de la mayoría de estos estudios (por ejemplo, Browne 1949; Bjerner y cols. 1955; H ildebrandt y cols. 1974; Harris 1977; H amelin 1981) apreciaron una cierta reducción del rendimiento durante el turno de noche. No obstante, como ha señalado M onk (1990), es posible que los efectos circadianos sólo se manifiesten cuando el trabajador se encuentra presionado. Si no hay presiones, el rendimiento diurno puede equipararse con el de noche, debido a que ambos se sitúan muy por debajo del nivel óptimo.

\section{Diseño de los sistemas de trabajo por turnos}

En la Figura 43.2 se ilustran las principales recomendaciones para el diseño de los sistemas de trabajo por turnos.

\section{Trabajo nocturno permanente}

El turno de noche es el más perturbador de todos por lo que respecta al ajuste psicológico, al sueño y al bienestar. En efecto, los ritmos psicológicos circadianos de la mayoría de las personas que trabajan por turnos suelen precisar más de una semana para ajustarse plenamente al trabajo nocturno, y todo ajuste parcial se pierde al cabo de algunos días de alejamiento del turno de noche. Esto hace que los ritmos biológicos de los trabajadores

Figura 43.2 - Recomendaciones para el diseño de sistemas de turnos.

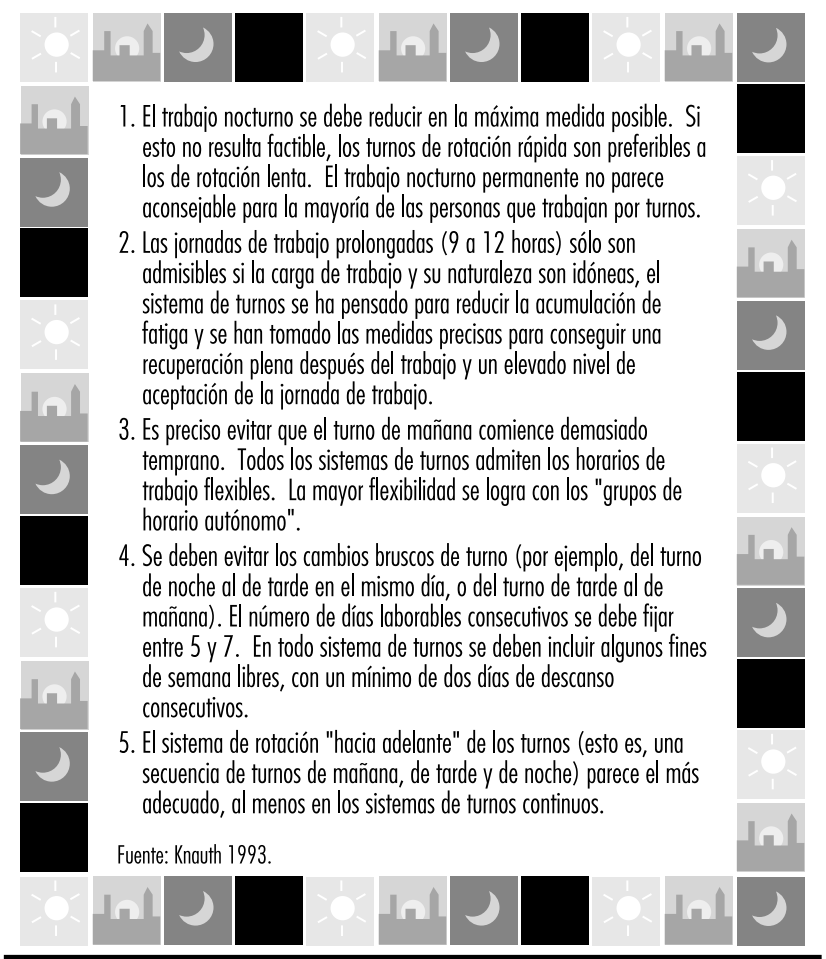

permanentemente empleados en el turno de noche se encuentren en un estado de perturbación permanente. En uno de los estudios (Alfredsson y cols. 1991), el aumento de la fatiga y de las perturbaciones del sueño eran entre dos y tres veces mayores entre los guardias de seguridad que trabajaban permanentemente de noche que en la muestra del conjunto de la población trabajadora del país.

A lgunos autores han sugerido diversos medios de combinar la tolerancia individual al trabajo por turnos y determinados estímulos externos a fin de facilitar la adaptación de los trabajadores. Según Hildebrandt y cols. (1987), las personas caracterizadas por una secuencia de fases retrasada en el ritmo circadiano (tipos vespertinos) son capaces de adaptarse al trabajo nocturno. Moog (1988) afirma que estas personas deben trabajar en el turno de noche durante períodos muy prolongados, esto es, mucho más de diez noches seguidas. Para aprovechar esta adaptación al trabajo de noche, Folkard (1990) ha llegado a proponer la creación de una "subcultura nocturna" en la que, además de trabajar regularmente de noche, el individuo haga vida nocturna y duerma de día, incluso en los festivos. Aunque este sistema permita, a largo plazo, incrementar el rendimiento en el trabajo nocturno (Wilkinson 1992) provocaría una acumulación del déficit de sueño y un aislamiento social que resultaría inaceptable para la mayoría de personas (Smith y Folkard 1993).

Existe un número cada vez mayor de estudios dedicados a los efectos de la luz artificial sobre la readaptación de los ritmos circadianos (entre ellos merecen citarse los de Wever y cols. 1983; la sesión especial del IX Simposio Internacional sobre el Trabajo Nocturno y por Turnos; Costa y cols. 1990a; Rosa y cols. 1990 y Czeisler y cols. 1990). Sin embargo, en opinión de Eastman (1990), "resulta sumamente laborioso determinar el equilibrio adecuado entre iluminación, trabajo y reposo para quienes trabajan por turnos, tanto por lo que respecta a su capacidad para adaptar los ritmos circadianos, mejorar el sueño o reducir la fatiga como desde la perspectiva de su integración social".

El turno fijo de noche es el que repercute de forma más negativa sobre los familiares que han de adaptar su estilo de vida a este horario, sobre la vida sexual y sobre la posibilidad de que los trabajadores desempeñen sus funciones familiares (Stein 1963; M ott y cols. 1965; Tasto y cols. 1978; Gadbois 1981). Sin embargo, según algunos estudios del turno nocturno permanente, las enfermeras de noche informaban de menos problemas que las integradas en turnos rotativos o en el turno de día (Verhaegen y cols. 1987; Barton y cols. 1993). Barton y cols. sugieren que una posible explicación de estos hallazgos es que la libre elección del turno de día o de noche puede influir en gran medida en la percepción de los problemas posteriores. Con todo, es discutible que esta elección sea realmente "libre", dado que muchas enfermeras optan por trabajar de noche porque es la única forma que tienen de compatibilizar satisfactoriamente las responsabilidades domésticas con el trabajo fuera del hogar (G adbois 1981).

El trabajo nocturno permanente también tiene alguna ventaja. En efecto, los trabajadores del turno de noche se sienten más independientes y menos vigilados durante el trabajo (Brown 1990; H off y Ebbing 1991). Además, como resulta más difícil sustraerse al trabajo durante la noche, parece desarrollarse entre los compañeros un mayor "espíritu de equipo", sprit de corps). Con todo, se suele optar por el trabajo nocturno principalmente por el incremento de ingresos que suponen los complementos por trabajo nocturno (H off y E bbing 1991).

A pesar de que se tiene poca información acerca de los efectos a largo plazo sobre la salud del trabajo nocturno permanente y del equilibrio óptimo entre trabajo-sueño con luz brillante, se 
sabe que el turno de noche es el que más perturba el ajuste psicológico, el sueño y el bienestar; por consiguiente, mientras no se conozcan los resultados de futuros estudios, asumiremos la hipótesis de que el trabajo nocturno permanente no es aconsejable para la mayoría de las personas que trabajan por turnos.

\section{Sistemas de tur nos de rotación rápida o de rotación lenta}

Los turnos de rotación más rápida son más ventajosos que los de rotación semanal. En efecto, una rotación rápida mantiene la orientación diurna del ritmo circadiano, y así evita un estado de perturbación permanente impuesto por el ajuste parcial a unas orientaciones diurnas y nocturnas alternantes. U na sucesión de jornadas de trabajo en el turno de noche puede producir una acumulación de falta de sueño, esto es, una falta de sueño crónica (Tebas y M ahan 1989; Folkard y cols. 1990). A largo plazo, esta situación podría tener un "coste" biológico 0, incluso, provocar problemas de salud. No obstante, no existe un estudio epidemiológico riguroso en el que se comparen los efectos respectivos del trabajo por turnos regulares de rotación rápida y lenta. Los grupos analizados en la mayoría de los estudios publicados no son comparables por lo que respecta a la pirámide de edades, el contenido del puesto de trabajo, el nivel de autoselección, etc. (por ejemplo, Tasto y cols. 1978; Costa y cols. 1981) y, en otros casos, los trabajadores adscritos a turnos fijos de mañana, tarde 0 noche aparecen agrupados en una sola categoría (Jamal y Jamal 1982). En algunos estudios de campo longitudinales (Williamson y Sanderson 1986; K nauth y K iesswetter 1987; K nauth y Schönfelder 1990; H ornberger 1995; K nauth 1996) se han analizado los efectos del paso de un turno semanal a un turno de rotación más rápida. En los 27 grupos de trabajadores por turnos estudiados, la mayoría de los encuestados se manifestaron a favor de los grupos de rotación más rápida al cabo de un período de prueba. En resumen, los turnos de rotación rápida son preferibles a los de rotación más lenta. En cambio, Å kerstedt (1988) discrepa de esta aserción, dado que la mayor somnolencia suele producirse durante la primera jornada de trabajo nocturno, por causa del intenso ajetreo anterior. EI autor recomienda la rotación lenta.

0 tro argumento a favor del sistema de turnos de rotación rápida es que los trabajadores tienen tardes libres todas las semanas y, por tanto, contactos más regulares con amigos y compañeros que en los turnos semanales. Sobre la base de un análisis de los elementos periódicos del tiempo de trabajo y de ocio, H edden y cols. (1990) postulan que los sistemas de rotación que facilitan una sincronización más breve y más frecuente de la vida laboral con la actividad social producen menos perturbación que los esquemas de rotación que inducen una sincronización más prolongada, pero menos frecuente.

\section{Duración de los turnos}

Los hallazgos contradictorios de los estudios del efecto de una jornada laboral extensa no permiten formular una recomendación general sobre las jornadas prolongadas (K elly y Schneider 1982; Tepas 1985). Una jornada prolongada, de entre 9 y 12 horas, sólo es aconsejable en los casos siguientes ( $K$ nauth y Rutenfranz 1982; Wallace 1989; Tsaneva y cols. 1990; O ng y Kogi 1990):

1. Si tanto la naturaleza como la carga de trabajo son adecuadas para una jornada laboral extensa.

2. Si el sistema de turnos se ha diseñado con la finalidad de reducir la fatiga acumulada.

3. Si funciona un sistema eficaz de cobertura del absentismo.

4. Si no se trabajan horas extraordinarias.

5. Si la exposición a los agentes tóxicos es limitada.

6. Si resulta factible una recuperación plena al cabo de la jornada de trabajo y un elevado nivel de aceptación del horario laboral (por ejemplo, vivienda, problemas familiares, desplazamientos hacia y desde el lugar de trabajo, clima, exclusión del pluriempleo, etc.).

Las exigencias fisiológicas se deben tomar en consideración. Según Bonjer (1971), la tasa aceptable de consumo de oxígeno durante una jornada de 8 horas se sitúa alrededor o por debajo del $30 \%$ del consumo máximo de oxígeno, y durante una jornada de 12 horas debe situarse aproximadamente en el $23 \%$ o menos del consumo máximo. Como el consumo de oxígeno se incrementa con las exigencias físicas del puesto de trabajo, parece inferirse de ello que la jornada de 12 horas sólo es aceptable para los trabajos que exijan esfuerzo físico ligero. Sin embargo, incluso en este supuesto, si el estrés psíquico o mental generado por el trabajo es demasiado intenso, las jornadas prolongadas no resultan aconsejables. El estrés y la tensión específicos de un determinado lugar de trabajo debe ser objeto de una evaluación precisa por personal experto antes de implantar una jornada de trabajo prolongada.

Uno de los posibles inconvenientes de los turnos de doce horas, especialmente si se trata de trabajar de noche, es el aumento de la fatiga. Por lo tanto, el sistema de turnos se debe diseñar de modo que se prevenga la acumulación de fatiga; esto es, hay que evitar toda sucesión prolongada de jornadas de 12 horas, y procurar que el turno de día no comience demasiado pronto. Koller y cols. (1991) recomiendan limitar a uno o dos el número de jornadas consecutivas de trabajo nocturno. Esta recomendación se apoya en los resultados positivos obtenidos en los estudios de los sistemas de turnos basados en jornadas discontinuas de 12 horas de trabajo nocturno (Nachreiner y cols. 1975; Nedeltcheva y cols. 1990). En la muestra de un estudio belga, la duración de la jornada se había aumentado a nueve horas comenzando el trabajo una hora antes por la mañana (M oors 1990). El turno de día se iniciaba a las 06:30 horas en lugar de una hora después y, en un sistema de dos turnos, el de mañana se adelantó una hora para comenzar a las 05:00 horas En una semana laboral de 5 días, estos regímenes llevan a una acumulación del déficit de sueño y a quejas de cansancio. El autor recomienda que los turnos empiecen como en los regímenes antiguos y que el turno correspondiente se alargue una hora por la tarde.

Nuestros conocimientos son muy limitados en lo que atañe al problema de la exposición y eliminación de las sustancias tóxicas durante el tiempo libre, y su relación con jornadas de trabajo prolongadas (Bolt y Rutenfranz 1988). Los límites a la exposición se suelen basar en una exposición de 8 horas y no se pueden extrapolar de forma lineal a una jornada de 12 horas. Aunque algunos autores (como Hickey y Reist 1997; OSH A 1978; Brief y Scala 1986; Koller y cols. 1991) han propuesto fórmulas matemáticas para adaptar estas exposiciones a los horarios de trabajo que se desvían de la jornada usual de 8 horas, ninguno de estos métodos ha sido aceptado generalmente.

Al diseñar los sistemas de turnos se deben tomar en consideración la carga de trabajo, el medio ambiente de trabajo y las condiciones imperantes fuera del lugar de trabajo. O ng y K ogi (1990) informan de que "el caluroso clima tropical y los ruidosos bloques de vivienda de Singapur no facilitaban el descanso de los trabajadores que tenían que dormir de día". Estas condiciones contribuían a incrementar la fatiga y a mermar la productividad durante la jornada de 12 horas del día siguiente. 0 tra fuente de preocupación por el bienestar de los trabajadores se refiere al empleo que hacen los que trabajan por turnos de sus largos períodos de tiempo libre. En algunos estudios se subraya la tendencia a ocupar este tiempo con el pluriempleo lo que aumenta su carga total de trabajo (Angersbach y cols. 1980; 
Wallace 1989; O ng y Kogi 1990). Al diseñar los sistemas de turnos de 12 horas es igualmente preciso tomar en consideración otros factores sociales, como el desplazamiento al lugar de trabajo, las circunstancias personales, el apoyo social y los acontecimientos cotidianos (T saneva y cols. 1990).

\section{H ora rios de los turnos}

Aunque no existe una solución óptima al problema del horario de los turnos de trabajo, los estudios publicados avalan la recomendación de no iniciar la jornada de mañana demasiado temprano. Un comienzo excesivamente adelantado tiende a reducir el tiempo total de descanso, dado que la mayoría de las personas que trabajan por turnos se acuestan a la hora habitual (K nauth y cols. 1980; Âkerstedt y cols. 1990; Costa y cols. 1990b; M oors 1990; Folkard y Barton 1993). También se ha observado un aumento de la fatiga durante el turno de mañana (Reinberg y cols. 1975; H ak y K ampman 1981; M oors 1990), así como un mayor riesgo de errores y de accidentes durante él (Wild y Theis 1967; H ildebrandt y cols. 1974; Pokorny y cols. 1981; Folkard y Totterdell 1991).

Partiendo de la base que los turnos de trabajo tienen una duración invariable de ocho horas, todo retraso del inicio del turno de mañana impone un retraso correlativo del turno de noche (esto es, en lugar de fijarse los cambios de turno a las 07:00, $15: 00$ y 23:00, se establecen a las 08:00, 16:00 y 24:00). Todo retraso en el inicio del turno de noche lleva, asimismo, aparejada una posposición equivalente del final del turno de tarde. En ambos casos, se pueden producir problemas con el transporte, al disminuir la frecuencia de los servicios de autobuses, trenes y tranvías.

La decisión de fijar el cambio de turnos para una hora determinada puede estar igualmente en función del contenido del puesto de trabajo. Así, en los hospitales, la tarea de despertar, lavar y preparar a los pacientes recae por lo general en el turno de noche (Gadbois 1991).

También se han expuesto diversas razones para iniciar antes la jornada laboral. En algunos estudios se ha subrayado que, cuanto más tarde se concilie el sueño de día al cabo de una jornada de trabajo nocturno, más breve será el reposo (Foret y Lantin 1972; Åkerstedt y Gillberg 1981; K nauth y Rutenfranz 1981). En efecto, el sueño diurno está expuesto a diversas perturbaciones $y$, cuanto antes se concilia el sueño tras un turno de noche, más fácil es evitarlas. D ebry y cols. (1967) recomiendan que los turnos finalicen a las 04:00, 12:00 y 20:00 horas, para que los trabajadores hagan tantas comidas con la familia como puedan. Para Gadbois (1991), un comienzo adelantado del turno de noche facilita el contacto del personal con los pacientes hospitalizados.

Incluso en los sistemas de tres turnos se pueden implantar horarios de trabajo flexibles en que los trabajadores puedan elegir libremente su horario laboral (M CE wan 1978; K nauth y cols. 1981b, 1984; K nauth y Schönfelder 1988). No obstante, a diferencia de lo que ocurre con los trabajadores de día, los que trabajan por turnos se ven en la necesidad de concertar el horario previamente con sus compañeros.

\section{Distribución del tiempo libre en el sistema de turnos}

La distribución del tiempo libre entre turnos consecutivos repercute considerablemente en aspectos como el sueño, la fatiga y el bienestar, así como en la vida familiar y social y la satisfacción general del trabajador con el sistema de turnos. Si median únicamente ocho horas entre el final de una jornada y el comienzo de la siguiente, se reducen las horas de sueño y la fatiga se incrementa en el turno siguiente (K nauth y Rutenfranz 1972; Saito y K ogi 1978; K nauth y cols. 1983; Totterdell y Folkard 1990).
Demasiadas jornadas laborales sucesivas pueden provocar una acumulación de fatiga y, en su caso, una sobreexposición a los efectos de sustancias tóxicas (Bolt y Rutenfranz 1988). No es fácil fijar un límite máximo al número de jornadas de trabajo consecutivas, debido a la variabilidad de la carga de trabajo, la planificación de las pausas y la exposición a condiciones ambientales desfavorables. Con todo, Koller y cols. (1991) recomiendan fijar el límite de jornadas de trabajo consecutivas entre 5 y 7.

El descanso de fin de semana reviste particular importancia. Pátkei y Dahlgren (1981) han estudiado el grado de satiffacción con diferentes sistemas de turnos de rotación rápida. Se halló que el nivel de satisfacción con un sistema de turnos de siete días con tres a cinco días de semana libres era sensiblemente mayor que con un sistema con sólo dos días libres. Los autores postulan que "la duración del tiempo libre puede constituir un factor determinante del atractivo de los turnos de rotación rápida". Por otra parte, los días de descanso del primer sistema de turnos se compensaban con períodos adicionales de vacaciones durante el año.

Sentido de la rotación. 0 tra cuestión importante es la relativa al sentido de la rotación (T saneva y cols. 1987; Totterdell y Folkard 1990). El sistema de turnos en el que se pasa del turno de mañana al turno de tarde y, a continuación, al turno de noche, rota hacia adelante (demora de fase, rotación en el sentido de las agujas del reloj). La rotación en sentido contrario a las agujas del reloj - 0 hacia atrás - se caracteriza por un adelanto de fase que se desplaza del turno de noche al de tarde y de éste al de mañana. La rotación hacia adelante parece corresponderse más con el ritmo circadiano endógeno, que tiene un período superior a 24 horas; sin embargo, sólo existen dos estudios de campo longitudinales de los efectos de los distintos sentidos de la rotación (Landen y cols. 1981; Czeisler y cols. 1982). La mayoría de los trabajadores por turnos estudiados en estos trabajos parecen preferir la rotación hacia adelante; no obstante, los resultados no son definitivos. Barton y Folkard (1993) hallaron que el sistema de rotación en sentido contrario a las agujas del reloj produce mayores niveles de fatiga y de perturbación del sueño entre turnos. Los sistemas "híbridos" no se mostraban más eficaces. Los sistemas de rotación en el sentido de las agujas del reloj estaban asociados a un menor número de problemas. En todo caso, Turck (1986) asegura que el nivel de perturbación del sueño de ambos sistemas es similar.

Se ha podido determinar que una muestra de personas que trabajaban en un sistema de turnos discontinuos con rotación hacia atrás se mostraban satisfechas con un período prolongado de descanso entre el final del último turno de mañana y el comienzo del primer turno de noche, en especial si en dicho período se incluye un fin de semana.

Aunque existen escasos elementos de juicio y se precisan más investigaciones, la rotación hacia adelante parece ser la más recomendable, al menos por lo que respecta a los sistemas de turnos continuos.

\section{Optimización del sistema de turnos}

No existe un sistema de turnos "óptimo" y los directivos y trabajadores de cada empresa deben buscar el mejor equilibrio posible entre las exigencias de la empresa y las necesidades de los trabajadores en la toma de una decisión que, además, debe fundarse en los principios científicos que informan el diseño de los sistemas de turnos. La estrategia de aplicación influye sensiblemente en la aceptación de un nuevo sistema de turnos. Se ha publicado un gran número de manuales y directrices para la implantación de nuevos horarios de trabajo (OIT 1990). O curre con demasiada frecuencia que los trabajadores integrados en los turnos no participan suficientemente en las fases de análisis, planificación y diseño de sus turnos. 
Figura 43.3 - Sistema de turnos continuos rotativos.

\begin{tabular}{|c|c|c|c|c|c|c|c|c|c|c|c|c|c|c|c|}
\hline SEMANA & $\mathrm{L}$ & M & $x$ & $\mathrm{~J}$ & V & S & D & $\mathrm{L}$ & M & $x$ & $\mathrm{~J}$ & V & S & D & Jornada laboral media semanal: \\
\hline 1 y 2 & & & & & ) & & & & & & & & n & m & \\
\hline 3 y 4 & 3 & $\zeta$ & & & & & & & & & & 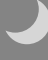 & & & 10 semanas \\
\hline 5 y 6 & & & & & & & & 2 & & & & & & & $\begin{array}{l}\text { cuatro turnos complemen- } \\
\text { tarios } / 10 \text { semanas }\end{array}$ \\
\hline 7 y 8 & - & 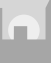 & ) & 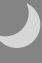 & & & & & & & & & $\mathcal{\gamma}$ & 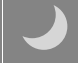 & \\
\hline 9 y 10 & & & & & & & & & 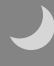 & & & & & & $\begin{array}{l}\text { turnos complementarios/ } \\
10 \text { semanas }\end{array}$ \\
\hline
\end{tabular}

La solución que se perfila como la más recomendable consiste en un sistema de turnos continuos con una rotación rápida hacia adelante, ocho horas de jornada laboral, algunos fines de semana libres, un mínimo de dos días consecutivos de descanso y evitando toda modificación brusca. Este esquema básico de turnos de trabajo tiene una duración media de 33,6 horas semanales, que quizás no pueda aceptarse universalmente. Si hay que hacer turnos complementarios, el grado de aceptación aumenta si se establece un calendario con una cierta antelación, por ejemplo, a comienzos de año, con objeto de que los trabajadores puedan planificar sus vacaciones. En algunas empresas no se obliga a los trabajadores de mayor edad a hacer turnos complementarios.

En las Figuras 43.3 y 43.4 se ilustran algunos sistemas de turnos continuos y discontinuos en los que se aplican estas reglas. En la Figura 43.5 se ilustra un sistema de turnos aplicable en un lugar de trabajo con menor flexibilidad. El esquema comprende un total de 128 horas semanales de actividad y una jornada de trabajo media de 37 horas. El sistema consta de un máximo de tres turnos de noche y dos fines de semana largos (la tercera semana, de jueves a domingo; y la quinta y sexta semanas, de sábado a lunes). Se trata de un esquema irregular en el que el sentido de la rotación no es hacia adelante, por lo que resulta menos óptimo. En los sistemas de turnos basados en un total de 120 horas semanales de actividad no se pueden

Figura 43.4 - Sistema de turnos discontinuos rotativos.

\begin{tabular}{|c|c|c|c|c|c|c|c|}
\hline SEMANA & $\mathrm{L}$ & $\mathrm{M}$ & $\mathrm{X}$ & $\mathrm{J}$ & $\mathrm{V}$ & $\mathrm{S}$ & $\mathrm{D}$ \\
\hline 1 & & & & & \\
\hline 2 & & & & & \\
\hline 3 & & & & & \\
\hline 4 & & & & \\
\hline
\end{tabular}

$=$ Turno de mañana $\mid \mathrm{In}=$ = Turno de tarde $\mathcal{J}=$ Turno de noche $=$ Día libre utilizar sistemas de turnos de rotación gradual, como sería el de trabajar desde las 06:00 horas del lunes hasta la misma hora del sábado, con una jornada semanal media de 40 horas.

El sistema de turnos que se ilustra en la Figura 43.6 resulta factible si el personal nocturno se puede reducir. De lunes a viernes trabajan dos equipos en el turno de mañana, dos en el de tarde y únicamente uno en el turno de noche. Esto permite reducir el número de jornadas nocturnas por trabajador en comparación con el sistema tradicional de tres turnos.

\section{Períodos de descanso}

En el contexto de la ordenación de la jornada de trabajo, la concesión de unos períodos de descanso suficientes - como las pausas durante la jornada laboral y para las comidas, el descanso diurno o nocturno y el descanso semanal- es igualmente importante para el bienestar y para la salud y seguridad de los trabajadores.

Figura 43.5 - Sistema de turnos discontinuos rotativos con siete equipos.

\begin{tabular}{|c|c|c|c|c|c|c|c|}
\hline SEMANA & $\mathrm{L}$ & $\mathrm{M}$ & $\mathrm{X}$ & $\mathrm{J}$ & $\mathrm{V}$ & $\mathrm{S}$ & $\mathrm{D}$ \\
\hline 1 & & & \\
\hline 2 & & & & \\
\hline 3 & & & \\
\hline 4 & & \\
\hline 5 &
\end{tabular}


Figura 43.6 - Sistema de turnos discontinuos con una reducción del personal del turno de noche del $50 \%$.

\begin{tabular}{|c|c|c|c|c|c|c|}
\hline SEMANA & $L$ & $\mathrm{M}$ & $X$ & $\mathrm{~J}$ & V & S \\
\hline 1 & & & & & & \\
\hline 2 & & & & $\mathrm{n}$ & & \\
\hline 3 & & & & & & \\
\hline 4 & & & & & & \\
\hline 5 & $\mathrm{n}$ & $\mathrm{n}$ & & $\mathrm{A}$ & $\mathrm{m}$ & \\
\hline 6 & & & & 2 & ) & \\
\hline
\end{tabular}

La aplicación de períodos de descanso está justificada por diversas causas.

\section{Recuperación}

Los trabajadores que realizan labores con elevada carga física tienden a fatigarse y se ven en la necesidad de interrumpir esporádicamente el trabajo para descansar. Estas pausas permiten la desaparición de los síntomas de cambios funcionales reversibles. Por ejemplo, si el esfuerzo físico provoca un aumento de la frecuencia cardíaca, ésta vuelve al valor anterior al inicio del trabajo al cabo de una pausa suficiente para descansar. La eficacia de la pausa se reduce en proporción exponencial inversa a la duración de la misma. La mayor eficacia de una pausa breve ha permitido fijar el principio de que muchas interrupciones cortas son preferibles a unas pocas pausas muy prolongadas.

\section{Prevención de la fatiga}

Como se ilustra en los estudios clásicos de K arrasch y M üller (1951), cuando se realiza un trabajo físico pesado, un mayor número de pausas para descansar puede servir, no sólo para reducir la fatiga, sino también, en determinadas circunstancias, para prevenirla. En el laboratorio, los sujetos hacían ejercicio en la bicicleta ergométrica (Figura 43.7). Este duro esfuerzo físico (10 mkp/seg) se estructuraba así: al final de cada período de trabajo $(100 \%)$ se concedía un período más prolongado de descanso (150 \%). C ada uno de los tres experimentos se caracterizaba por una duración distinta de los períodos de trabajo y de descanso. Así, en el primer experimento, el sujeto trabajaba 5 minutos, descansaba 7 minutos, volvía a trabajar 5 minutos y ponía fin a la experiencia cuando estaba agotado. La frecuencia cardíaca alcanzaba unas 140 pulsaciones por minuto durante el primer período de trabajo y más de 160 durante el segundo período. Transcurrida una hora desde el final del experimento, la frecuencia cardíaca no había alcanzado el valor que tenía antes de iniciarse la experiencia. EI segundo experimento descrito en la figura citada constaba de períodos de trabajo (2 minutos) y de descanso (3 minutos) más breves. Aunque la carga de trabajo era idéntica a la del primer experimento, el sujeto podía trabajar más tiempo antes de quedar totalmente agotado. En el tercer experimento se fijaron unos valores extremos de 0,5 minutos de trabajo y 0,75 minutos de descanso. El corazón latía a un ritmo regular y el experimento finalizaba, no por el agotamiento del sujeto, sino por razones técnicas. Aunque, evidentemente, esta alternancia extrema del trabajo y el descanso no es aplicable en la industria, la experiencia ilustra cómo puede prevenirse la fatiga extrema si se fraccionan las pausas.

Este fenómeno se ha contrastado igualmente en otros estudios realizados con diferentes indicadores, como el ácido láctico (Åstrand y Rodahl 1970).

En un estudio realizado en una muestra de trabajadores del metal, la comparación de un sistema de 20 minutos de trabajo seguidos invariablemente de una pausa de 10 minutos con un sistema de 10 minutos de trabajo y una pausa 5 minutos permitió establecer la superioridad del segundo esquema (Scholz 1963), debido a que, en él, la frecuencia cardíaca media a lo largo de 8 horas era más baja.

La prevención de la fatiga se ha evidenciado igualmente realizando determinaciones de la frecuencia cardíaca en experimentos de aprendizaje de los rendimientos sensoriomotores (Rutenfranz y cols. 1971). Además, el aprendizaje era claramente más rápido en los experimentos que comprendían períodos regulares de descanso que en aquellos otros en los que ese descanso estaba ausente, como se ilustra en la Figura 43.8.

\section{Aumento del rendimiento}

L as pausas para descansar se han considerado por regla general como interrupciones improductivas del tiempo de trabajo. Sin embargo, Graf (1922, 1927) demostró que los períodos de descanso podían considerarse, por así decirlo, como una "recompensa". La experiencia del deporte enseña que los velocistas inician la carrera de 100 metros a gran velocidad, mientras que los fondistas inician la carrera de 5.000 metros "al trote". G raf ha publicado resultados semejantes en relación con el trabajo mental (Figura 43.9). En un experimento, se pidió a tres grupos de personas que realizasen determinados cálculos, y los salarios se vincularon al rendimiento. D esconocedores de esta circunstancia, los miembros del grupo A (que disfrutaron de su primer descanso al cabo de tres horas) empezaron a trabajar a un ritmo más reducido que los integrantes del grupo B (que sabían que tendrían la primera pausa para descansar a los 45 minutos de trabajo). Tanto la mayor velocidad inicial como el máximo rendimiento posterior correspondieron al grupo C (con un período de descanso cada 15 minutos de trabajo).

\section{M antenimiento de un nivel de vigilancia adecuado}

En algunas tareas monótonas de supervisión o de control visual, así como en las tareas muy simples, con ciclos breves, resulta difícil mantener el nivel de alerta durante períodos de tiempo prolongados. Esta disminución del nivel de alerta se puede prevenir, introduciendo pausas en el trabajo, (o mediante la reestructuración del trabajo).

\section{Ingesta de alimentos}

El valor de recuperación de las pausas para comer suele ser limitado, particularmente si los trabajadores deben realizar un recorrido considerable hasta el comedor, hacer cola para servirse, comer con precipitación y regresar rápidamente al lugar de trabajo.

\section{Ejercicio físico compensatorio}

Se recomienda a los trabajadores que - como los operadores de pantallas de visualización de datos- deben realizar su labor adoptando posturas forzadas que realicen algún ejercicio físico compensatorio durante los períodos de descanso. O bviamente, la solución ideal consiste en modificar el diseño del lugar de trabajo según los principios ergonómicos. La realización de ejercicios 
Figura 43.7 - Frecuencia cardíaca durante y después de un trabajo físico pesado con diferentes duraciones de los períodos de trabajo y de descanso y una relación constante trabajo/ descanso de 2:3.
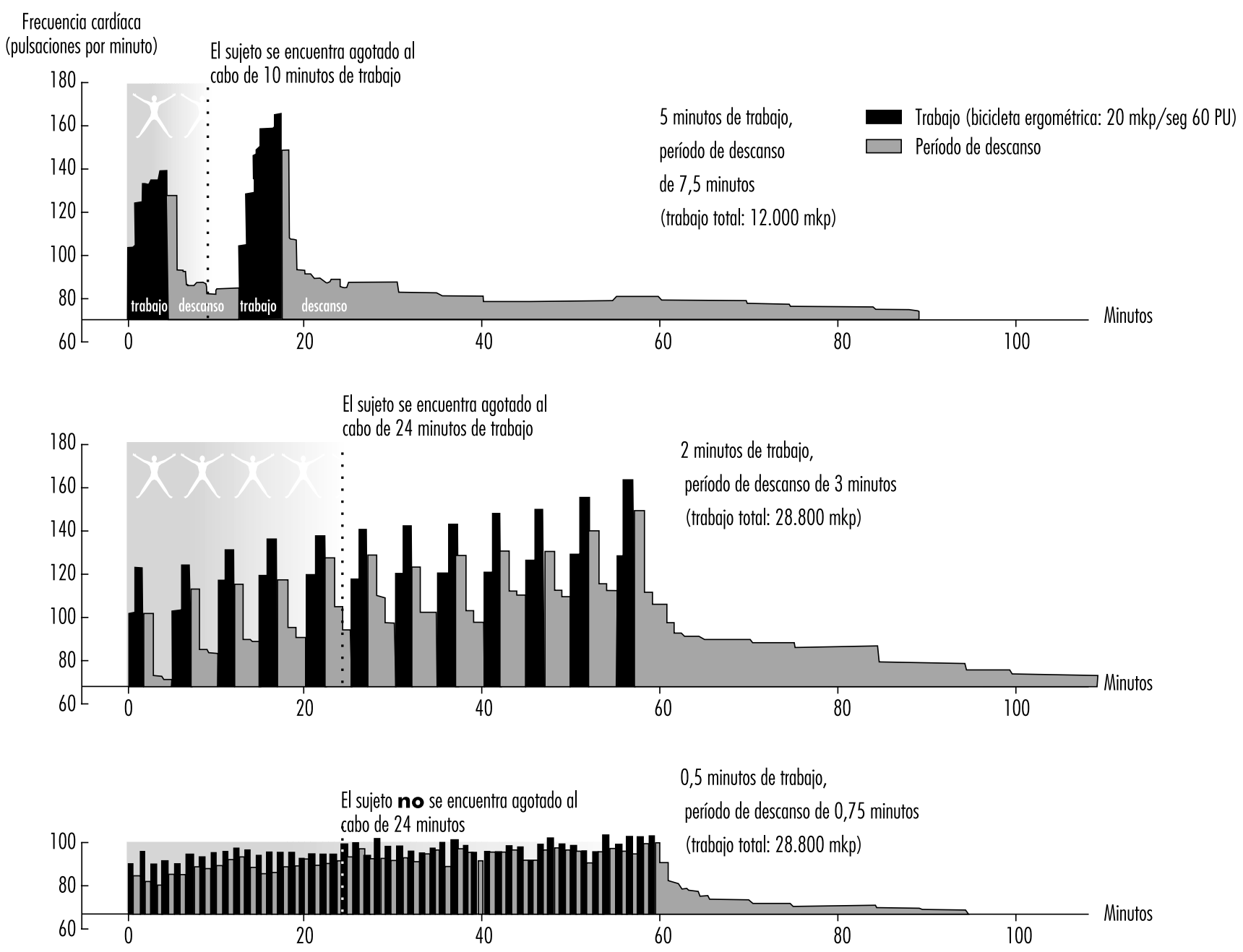

Fuente: Karrasch y Müeller 1951.

físicos en el lugar de trabajo parece tener más aceptación en los países asiáticos que en otras partes.

\section{Comunicación}

No hay que descuidar la dimensión social de las pausas para descansar por lo que respecta a la comunicación entre los trabajadores. Existe una contradicción entre la recomendación, fisiológicamente justificada, de observar pequeñas pausas en medio de un trabajo físico pesado, y el deseo de los trabajadores de reunirse con sus compañeros en áreas de descanso. Esto obliga a buscar un punto de equilibrio.

Hettinger (1993) ha postulado las reglas siguientes para mejorar la estructura de las pausas para descansar:

- La primera parte del período de descanso produce el mayor grado de recuperación, lo que explica la eficacia de las pausas breves, esto es, que muchas pausas breves sean más aconsejables para la recuperación que un menor número de pausas prolongadas.

- Hay algunas excepciones a la regla. En efecto, la pausa para refrescar que sigue a un período de trabajo en un ambiente caluroso debe producirse en un recinto con un ambiente neutro durante un mínimo de 10 minutos. EI período de calentamiento siguiente a un tiempo de trabajo en un ambiente frío (15 a $30 \stackrel{\circ}{\circ}$ ) se debe producir igualmente en un recinto con clima neutro durante no menos de 30 minutos. Por su parte, el período de descanso siguiente a un tiempo de trabajo en un medio sumamente ruidoso debe transcurrir durante un tiempo relativamente prolongado en un recinto con un nivel de ruido inferior a $70 \mathrm{~dB}(\mathrm{~A})$. Estos períodos de descanso son dudosos, si se tiene en cuenta que, si el tiempo de exposición se reduce a la mitad, el volumen de ruido sólo se reduce en unos $3 \mathrm{~dB}(\mathrm{~A})$.

- La frecuencia y duración de la pausa de descanso están en función del nivel de dificultad del esfuerzo físico o mental. Por lo que respecta al esfuerzo físico, cuando éste implica un consumo de energía superior al límite de resistencia aceptable, aunque inferior a $40 \mathrm{KJ} / \mathrm{min}$, el período de descanso puede programarse dentro del turno de trabajo. En cambio, cuando implica un consumo de energía superior a $40 \mathrm{KJ} / \mathrm{min}$, el período de descanso debe situarse inmediatamente después de realizar la tarea, dado el incremento exponencial de la fatiga. 
Figura 43.8 - Efecto de los períodos de descanso sobre el aprendizaje del rendimiento sensoriomotor.

Tiempo de

rendimiento correcto

(\% del tiempo máximo)

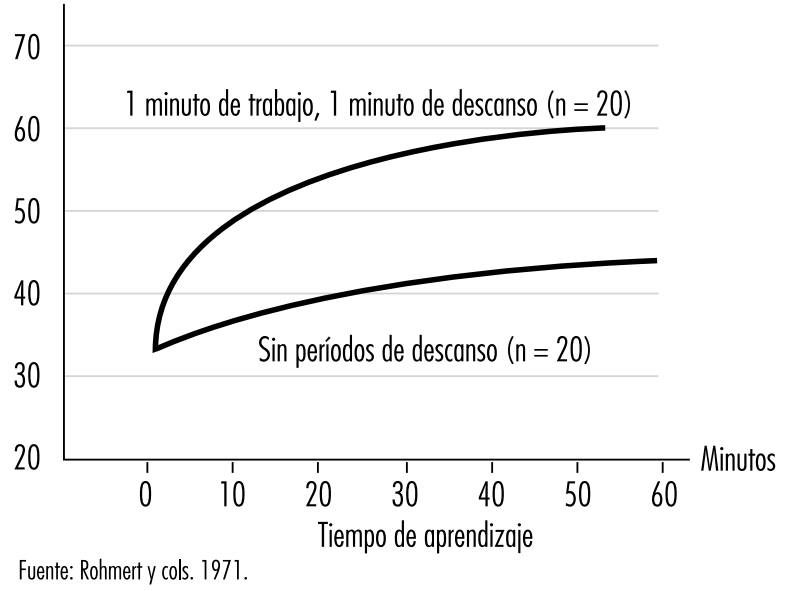

- Las "pseudoactividades" (pausas encubiertas) no deben reducir la eficacia de los períodos de descanso. Esto se debe poner en conocimiento de los trabajadores y sus superiores.

Las pausas para comidas deben tener una duración mínima de 15 minutos

Para más información sobre los períodos de descanso siguientes al esfuerzo muscular, véase L aurig (1981), y respecto a las pausas posteriores a un esfuerzo mental, véase L uczak (1982).

\section{Reducción de los problemas con el sueño}

No existen fórmulas mágicas para que las personas que trabajan por turnos concilien con rapidez el sueño y duerman profundamente. Lo que vale para una persona quizás no funcione con otra.

Con todo, pueden ofrecerse algunos consejos útiles, particularmente para dormir el día siguiente a una jornada de trabajo nocturna:

- Pedir a los miembros de la familia que utilicen auriculares para oír la radio o ver la televisión, e instalar un teléfono provisto de contestador automático silencioso. D esconectar el timbre de la puerta.

- Comunicar el horario laboral a los miembros de la familia y evitar la realización de las labores domésticas ruidosas durante el tiempo previsto para dormir.

- A mortiguar los efectos de la iluminación y los ruidos exteriores colocando cortinas gruesas de tonalidades oscuras, puertas insonorizadas y aire acondicionado.

- U tilizar tapones para los oídos y una mascarilla para dormir, y abstenerse de ingerir bebidas que contengan cafeína desde cinco horas antes de la hora de irse a dormir.

- Si el vecindario es ruidoso, habría que considerar la posibilidad de mudarse a un barrio más tranquilo.

El trabajador debe abstenerse de recurrir al alcohol para concitar el sueño, además de tomarse el tiempo preciso para relajarse al finalizar la jornada de trabajo (Community $\mathrm{H}$ ealth Network 1984; M onk 1984; Wedderburn 1991).

En los casos en que está en juego la seguridad, algunos autores recomiendan las "siestas reparadoras" durante el turno de noche para superar el nivel mínimo nocturno circadiano de atención (Andlauer y cols. 1982). M uchas empresas japonesas que trabajan ininterrumpidamente permiten estos descansos durante el turno de noche (K ogi 1981).

\section{Alimentación}

Aunque no existen pruebas de que la alimentación influya en la adaptación al trabajo nocturno (Rosa y cols. 1990), se han ofrecido algunos consejos prudentes:

- M ientras se trabaje en el turno de noche, la comida principal debe hacerse antes de las 01:00 horas y ser más rica en proteínas que en carbohidratos, además de baja en grasas.

- Se recomienda tomar un refrigerio consistente en fruta fresca 0 productos lácteos entre las 04:00 y las 04:15 horas.

- Es mejor hacer las comidas a horarios regulares.

- Deben evitarse las comidas copiosas justo antes de irse a la cama. El trabajador debe aprender a interpretar las señales de su organismo y a juzgar su bienestar digestivo y sus niveles energéticos (Community Health Network 1984; Wedderburn 1991; K nauth y cols. 1991).

\section{Medidas de salud en el trabajo}

Algunos autores (por ejemplo, Rutenfranz y cols. 1985; Scott y LaD ou 1990) recomiendan una exploración y supervisión médica del personal con anterioridad a su incorporación al trabajo por turnos. Se desaconseja el trabajo nocturno de los trabajadores que se encuentren en alguno de los casos siguientes:

- un historial de trastornos gastrointestinales, como úlcera péptica recurrente o síndrome de colon irritable, siempre que los síntomas sean graves;

- diabetes mellitus insulinodependiente;

- tirotoxicosis;

- enfermedad coronaria, en especial si existe angina inestable 0 antecedentes de infarto de miocardio;

- narcolepsia y otras afecciones que produzcan perturbaciones crónicas del sueño.

- epilepsia;

- trastornos psiquiátricos graves, especialmente depresión crónica;

- asma que precise medicación, en especial si el paciente depende de los esteroides;

Figura 43.9 - Efecto de los períodos breves de descanso sobre el rendimiento mental.

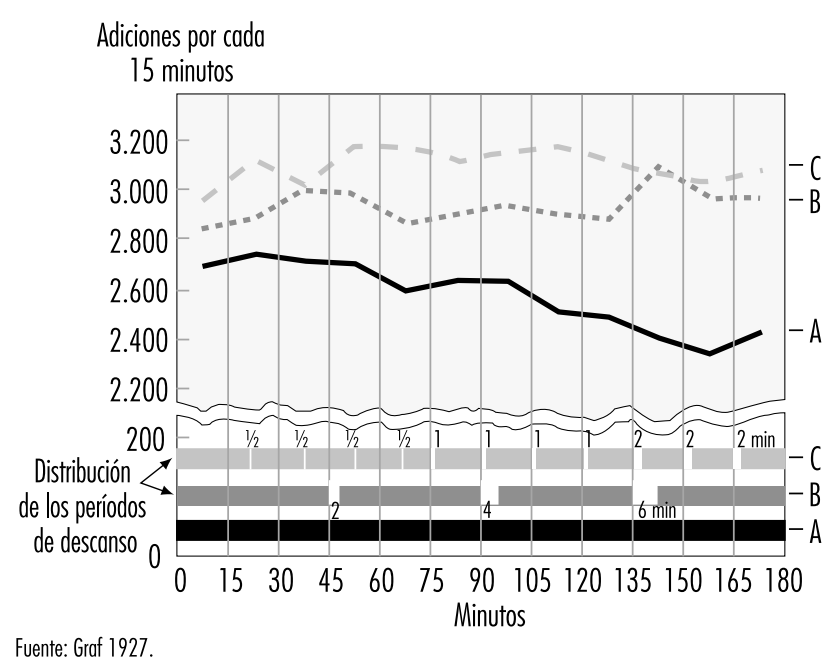


- tuberculosis activa y extendida;

- alcoholismo o drogadicción,

- deficiencia acusada de la visión o hemeralopia (ceguera diurna) demasiado grave para una corrección efectiva.

A demás, Scott y LaD ou (1990) mencionan algunas "contraindicaciones relativas" utilizables principalmente en el asesoramiento de los futuros empleados, como unos hábitos de sueño rígidos con acusada tendencia "matinal". Deberían tenerse en cuenta la edad y el alcance de las responsabilidades familiares.

Hermann (1982) propone un calendario para las exploraciones médicas periódicas. La segunda de ellas se debe realizar dentro de los doce meses siguientes al inicio del trabajo nocturno; posteriormente, los menores de 25 años se deben someter a exploración cada dos años como mínimo; los trabajadores de entre 25 y 50 años de edad, cada cinco años; los de 50 a 60 años de edad, cada dos o tres años; y con una frecuencia anual o bienal los que cuenten más de 60 años.

\section{Técnicas de comportamiento individual}

Se han realizado pocos estudios de la capacidad de las personas que trabajan por turnos para combatir el estrés (0 Isson y cols. 1987; O Isson y K andolin 1990; K andolin 1993; Spelten y cols. 1993). Las estrategias activas - consistentes, por ejemplo, en comentar los problemas con otras personas- parecen más idóneas para combatir el estrés que las pasivas, como el consumo de alcohol ( $K$ andolin 1993). No obstante, se echan en falta estudios longitudinales en los que se examine la relación entre las técnicas de comportamiento o la estrategia de afrontamiento y estrés.

\section{Remuneración económica}

Aunque existen numerosos planes de remuneración aplicables a las personas que trabajan por turnos (prima por turnos), las retribuciones en metálico no constituyen una compensación adecuada de los eventuales efectos negativos sobre la salud y la alteración de la vida social.
Es evidente que el mejor modo de solucionar un problema consiste en eliminar o mitigar sus causas. Sin embargo, como la eliminación total del trabajo por turnos es imposible, existen medidas alternativas que merecen tomarse en consideración, como la reducción de las horas de trabajo no usuales para las personas; la reducción del turno de noche; la eliminación de la parte no imprescindible del trabajo nocturno (a veces, la reorganización del trabajo permite transferir algunas actividades al turno de mañana o de tarde); la implantación de sistemas mixtos de trabajo en los que cada trabajador se libre del sistema de trabajo por turnos, como mínimo, un mes al año; la creación de nuevos equipos de trabajo por turnos, pasando, por ejemplo, de un sistema de tres turnos a otro de cuatro, o de un modelo de cuatro turnos a otro de cinco, o bien reduciendo el número de horas extraordinarias. 0 tra posibilidad consiste en reducir las horas de trabajo en el sistema de turnos, estableciendo una jornada semanal más corta para los trabajadores por turnos que para los trabajadores de día, además de pausas retribuidas y vacaciones más largas. 0 tras posibles soluciones consisten, bien en incrementar los días libres, bien en un sistema de jubilación anticipada o gradual.

Todas estas propuestas se han aplicado en algunas empresas industriales y de servicios (véase K nauth y cols. 1990).

\section{Otras medidas}

Se han formulado muchas otras propuestas para mejorar la situación de las personas que trabajan por turnos, como el ejercicio físico (Härmä y cols. 1988a, b), la ayuda farmacológica (R osa y cols. 1990), el consejo familiar (Rosa y cols. 1990), la mejora del medio ambiente de trabajo ( $K$ nauth y cols. 1989), la apertura de vías de comunicación entre las personas que trabajan por turnos y sus sindicatos o representantes parlamentarios (M onk 1988; K nauth y cols. 1989), o la implantación en la empresa de un "Programa de sensibilización respecto al trabajo por turnos" (M onk 1988). La ausencia de una solución ideal para los problemas del trabajo por turnos debe impulsar la búsqueda de soluciones creativas (C olquhoun y cols. 1996).

\section{Referencias}

Aanonsen, A. 1964. Shift W ork and H ealth. O slo: U niversitetsforlaget.

Åkerstedt, T, A K nutsson, L Alfredsson, T Theorell. 1984. Shiftwork and cardiovascular disease. Scand I W ork E nviron $\mathrm{H}$ ealth 10:409-14.

Åkerstedt, T , J Fröberg. 1976. Shift work and healthinterdisciplinary aspect. En Shift W ork and $\mathrm{H}$ ealth, dirigido por PG Rentos y RD Shepard. Washington, DC: Department of $\mathrm{H}$ ealth, Education and Welfare.

Åkerstedt, T, L T orsvall, G K ecklund, A K nutsson. 1990. The shift cycle and clinical indices of insomnia. En Shiftwork: $H$ ealth, Sleep and Performance, dirigido por G Costa, G Cesana, $K$ Kogi $y$ A W edderburn. Frankfurt: Peter Lang.

Åkerstedt, T , L T orsvall. 1981. Age, sleep and adjustment to shiftwork. En Sleep 1980, dirigido por WP K oella. Basilea: K arger.

Åkerstedt, T, M Gilberg. 1981. Sleep disturbances and shiftwork. En Night and Shiftwork: Biological and Social Aspects, dirigido por A Reinberg, N Vieux y $P$ Andlauer. 0 xford: Pergamon.

Åkerstedt, T. 1988. Sleepiness as a consequence of shift work. Sleep 11:17-34.

Alfredsson, L, C-L Spetz, T Theorell. 1985. Type of occupation and near-future hospitalization for myocardial infarction and some other diagnoses. Int J E pidemiol 14:378-88.
Alfredsson, L, R K arasek, T Theorell. 1982. M yocardial infarction risk and psychosocial work environment: An analysis of the male Swedish working force. Soc Sci M ed 16:463-7.

Alfredsson, L, T Åkerstedt, M M attson, B Wilborg. 1991. Self-reported health and well-being amongst night security guards: A comparison with the working population. E rgonomics 34:525-530.

Alfredsson, L, T T heorell. 1983. Job characteristics of occupations and myocardial infarction risk: Effect of possible confounding factors. Soc Sci M ed 17:1497-1503.

Andersen, 0. 1985. Dodelight og erhverv 1970-80 [M ortalidad y profesión 1970-80]. Statistike U ndersogelser nr 41. Copenhague: Danmarks Statistik.

Andlauer, P, A R einberg, L Fourré, W Battle, G Duverneuil. 1979. Amplitude of the oral temperature circadian rhythm and the tolerance to shift-work. J Physiol 75:507-512.

Andlauer, P, J Rutenfranz, K Kogi, H Thierry, N Vieux, G Duverneuil. 1982. Organization of night shifts in industries where public safety is at stake. Int A rch 0 ccup E nviron $H$ ealth 49:353-355.

Angersbach, D, P K nauth, H L oskant, M J K arvonen, K Undeutsch, J Rutenfranz. 1980. A retrospective cohort study comparing complaints and diseases in day and shift workers. Int Arch $\mathrm{O}$ ccup $\mathrm{E}$ nviron $\mathrm{H}$ ealth 45:127-140.

Åstrand, PO, K R odahl. 1970. T extbook of W ork Physiology. N ueva Y ork: M cG raw-H ill.
Banks, 0. 1956. Continuous shift work: The attitudes of wives. 0 ccup Psychol 30:69-84

Barton, J, L Smith, P T otterdell, E Spelten, S Folkard. 1993. D oes individual choice determine shift system acceptability? E rgonomics 36:93-99.

Barton, J, S Folkard. 1993. A dvancing versus delaying shift systems. E rgonomics 36:59-64.

Beermann, B, K -H Schmidt, J R utenfranz. 1990. Zur Wirkung verschiedener Schichttypen auf das gesundheitliche Befinden und das Schlaf- und Freizeitverhalten. Z Arb W iss 44:14-17.

Bjerner, B, A Holm, A Swensson. 1955. Diurnal variation in mental performances. $\mathrm{Br}$ J Ind $\mathrm{M}$ ed 12:103-110.

Bohle, P, AJ Tilley. 1989. The impact of night work on psychological well-being. E rgonomics 32:10891099.

Bolt, H M , J R utenfranz. 1988. The impact of aspects of time and duration of exposure on toxicokinetics and toxicodynamics of workplace chemicals. En $\mathrm{H}$ ealth Surveillance of Individual W orkers Exposed to Chemical Agents, dirigido por WRF Notten, RFM Herber, WJ Hunter, AC M onster y RL Zielhuis. Berlín: Springer Verlag.

Bonjer, FH . 1971. T emporal factors and physiological load. En $M$ easurement of $M$ an At $W$ ork dirigido por WJ Singleton, JG Fox y D Whitfield. Londres: T aylor \& Francis.

Breithaupt, H, G Hildebrandt, D Dohr, R Josch, U Sieber, M Werner. 1978. Tolerance to shift of 
sleep, as related to the individual circadian phase position. E rgonomics 21:767-774.

Brief, RS, RA Scala. 1986. O ccupational health aspects of unusual work schedules: A review of Exxon's experiences. Am Ind H yg Assoc f 47:199-202.

Brown, FM . 1990. Sleep-nap behaviors of three permanent shifts of hospital nurses. En Shiftwork: $H$ ealth, Sleep and Performance, dirigido por G Costa, G Cesana, K Kogi y A Wedderburn. Frankfurt: Peter Lang.

Browne, RC. 1949. The day and night performance of teleprinter switchboard operators. O ccup Psycho 23:121-126.

Bunnage, D. 1981. Study on the consequences of shiftwork on social and family life. En T he E ffects of Shiftwork On Health, Social and Family Life Dublín: Fundación Europea para la M ejora de las Condiciones de $V$ ida y de T rabajo.

Carpentier, J, P Cazamian. 1977. Night W ork: Its E ffects on the $\mathrm{H}$ ealth and W elfare of the W orker. Ginebra: OIT.

Carter, FA, EN Corlett. 1982. Accidents and Shiftwork Dublín: Fundación Europea para la M ejora de las Condiciones de $\mathrm{V}$ ida y de T rabajo.

Colligan, MJ, RR Rosa. 1990. Shiftwork effects on social and family life. En Shiftwork, dirigido por A) Scott. Filadelfia: $\mathrm{H}$ anley \& Belfus.

Colquhoun, WP, G Costa, S Folkard, P K nauth. 1996. Shiftwork: Problems and Solutions. Frankfurt: $\mathrm{Pe}$ ter Lang.

Colquhoun, WP. 1976. Accidents, injuries and shift work. En Shift W ork and $\mathrm{H}$ ealth. A Symposium, dirigido por PG R entos y RD Shepard. Washington, DC: Department of $\mathrm{H}$ ealth, Education and Welfare

Community $\mathrm{H}$ ealth N etwork. 1984. Shiftwork: $\mathrm{H}$ ow to Cope Part 1: Sleep. Part 2: Eating. Part 3: The Rest of Your Life. Claremont, $\mathrm{NH}$ : Community $\mathrm{H}$ ealth Network.

Costa, G, D O livato, E Peroni, E M ossini, G G onella 1990b. Problems connected to the introduction of night work in a group of female workers of a food industry. En Shiftwork: H ealth, Sleep and Performance, dirigido por G Costa, G Cesana, K Kogi y A W edderburn. Frankfurt: Peter Lang.

Costa, G, F Lievore, G Casaletti, E Gaffuri, S Folkard. 1989. Circadian characteristics influencing interindividual differences in tolerance and adjustment to shiftwork. E rgonomics 32:373-385.

Costa, G, G C esana, K K ogi, A Wedderburn. 1990a. Shiftwork: $\mathrm{H}$ ealth, Sleep and Performance. Frankfurt: $\mathrm{Pe}$ ter $L$ ang.

Costa, G, P Apostoli, F d'Andrea, E Gaffuri. 1981. $G$ astrointestinal and neurotic disorders in textile shift workers. En Night and Shift W ork: Biological and Social Aspects, dirigido por N Reinberg, N Vieux y $P$ Andlauer. $O$ xford: Pergamon Press.

Costa, G. 1996. Effects on health and well-being. En Shiftwork: Problems and Solutions, dirigido por WP Colquhoun, S Folkard, G Costa, P K nauth, y $P$ Lang. Frankfurt: Peter Lang.

Czeisler, CA, MC Moore-Ede, RM Coleman. 1982. $R$ otating shift work schedules that disrupt sleep are improved by applying circadian principles. Science 217:460-463.

Czeisler, CA, M P Johnson, JF Duffy, EN Brown, JM R onda, RE K ronauer. 1990. Exposure to bright light and darkness to treat physiologic maladaptation to night work. N ew Engl J M ed 322:1253-1259.

Debry, G, P G irault, J Lefort, J T hiébault. 1967. Enquête sur les habitudes alimentaires des travailleurs "à feux continus". B Instit Natl Santé R ech M éd 22:1169-1202.

Diekmann, A, G Ernst, F Nachreiner. 1981. Auswirkung der Schichtarbeit des $V$ aters auf die schulische Entwicklung der K inder. Z Arb W iss 35:174-178.
Downie JH 1963. Some Social and Industrial I mplications of Shift W ork. Industrial W elfare Society. Londres: $\mathrm{R}$ obert $\mathrm{H}$ yde $\mathrm{H}$ ouse.

Eastman, $\mathrm{Cl}$. 1990. A critical review of the circadian rhythm and bright light literature with recommendations for shift work. W ork Stress 4:245-260.

Estryn-Behar, M, C Gadbois, E V aichere. 1978. Effets du travail de nuit en équipes fixes sur une population féminine. Résultats d'une enquête dans le secteur hospitalier. Arch M al Prof 39:531-535.

Folkard, S, J Arendt, M Clark. 1990. Sleep and mood on a "weekly" rotating (7-7-7) shift system: Some preliminary results. En Shiftw ork: $\mathrm{H}$ ealth, Sleep and Performance, dirigido por G Costa, G Cesana, K K ogi y A W edderburn. Frankfurt: Peter L ang.

Folkard, S, J Barton. 1993. D oes the 'forbidden zone' for sleep onset influence morning shift sleep duration? E rgonomics 36: 85-91.

Folkard, S, P T otterdell. 1991. Circadian variations in performance. Implications for abnormal work hours. R esúmenes de las ponencias presentadas en el simposio internacional "Trabajo por turnos y demandas del puesto de trabajo". 11-12 de julio, París.

Folkard, S, TH Monk, EK Lewis, CP Whelpton 1982. Individual differences and adjustment to shiftwork. En Shiftwork-Q uantity and Quality of Sleep. Individual Differences. Dublín: Fundación Europea para la M ejora de las Condiciones de Vida y de Trabajo.

Folkard, S, TH M onk, M C Lobban. 1979. T owards a predictive test of adjustment to shift work. E rgonomics 22:79-91.

Folkard, S. 1990. Circadian performance rhythms Some practical and theoretical implications. Phi $T$ rans R oyal Soc L ondon 327:543-553.

Foret, J, G Bensimon, O Benoit, N Vieux. 1981. Quality of sleep as a function of age and shift work. En Aspects of $\mathrm{H}$ uman Efficiency, dirigido por A R einberg, N V ieux y P Andlauer. Londres: English U niversity Press.

Foret, J, G Lantin. 1972. The sleep of train drivers: An example of the effects of irregular work schedules on sleep. En T he Sleep of T rain D rivers: An Example of the $E$ ffects of Aspects of $H$ uman $E$ fficiency, dirigido por WP Colquhoun. Londres: English U niversity Press.

Frese, M, N Semmer. 1986. Shiftwork, stress, and psychosomatic complaints: A comparison between workers in different shiftwork schedules, nonshiftworkers, and former shiftworkers. Ergonomics 29:99-114.

Gadbois, C. 1981. Women on night shift: Interdependence of sleep and off-the-job-activities. En Night and Shiftwork: Biological and Social Aspects, dirigido por A R einberg, N V ieux y P Andlauer. Oxford: Pergamon Press.

- . 1991. Round the clock operations in hospitals Shift scheduling, task demands and work organisation. Resúmenes de las ponencias presentadas en el simposio internacional "T rabajo por turnos y demandas del puesto de trabajo". París 11-12 de julio.

Graf, 0. 1922. Über lohnendste Arbeitspausen be geistiger Arbeit. Psychol Arbeiten 7:548-611.

- 1927. Die Arbeitspausen in Theorie und Praxis. Psychol Arbeiten 9:563-681.

$\mathrm{H}$ ak, A, R Kampmann. 1981. Working irregular hours: Complaints and state of fitness of railway personnel. En Night and Shiftwork: Biological and Social Aspects, dirigido por A Reinberg, N Vieux y $P$ Andlauer. 0 xford: Pergamon.

$\mathrm{H}$ amelin, P. 1981. Les conditions temporelles de travail des conducteurs routiers et la sécurité routière. Travail $\mathrm{H}$ um 44:5-21.

Härmä, MI, J Ilmarinen, P K nauth, J Rutenfranz, 0 Hänninen. 1988a. Physical training intervention in female shift workers: I. T he effects of inter- vention on fitness, fatigue, sleep, and psychosomatic symptoms. E rgonomics 31:39-50.

-. 1988b. Physical training intervention in female shift workers: II. The effects of intervention on the circadian rythms, short-term memory, and body temperature. E rgonomics 31:51-63.

H ärmä, M I, P K nauth, J IImarinen, H O llila. 1990. The relation of age to the adjustment of the circadian rhythms of oral temperature and sleepiness to shift work. Chronobiol Int 7:227-233.

H ärmä, MI. 1993. Individual differences in tolerance to shiftwork: A review. E rgonomics 36:101-109.

H arrington, JM . 1978. Shift W ork and H ealth: A C ritical R eview of the Literature. Londres: $\mathrm{H}$ er M ajesty's Stationery 0 ffice.

H arris, W. 1977. Fatigue, circadian rhythm and truck accidents. En Vigilance, Theory, O perational Performance, and Physiological Correlates, dirigido por R R M ackie. N ueva Y ork: Plenum.

H auke, P, H K ittler, R M oog. 1979. Inter-individual differences in tolerance to shift-work related to morningness-eveningness. Chronobiologia 6:109.

Hedden, I, H Grzech-Sukalo, F Nachreiner. 1990. Classification of shift rotas on the basis of periodic components. En Shiftwork, H ealth, Sleep and Performance, dirigido por G Costa, G Cesana, K K ogi y A W edderburn. Frankfurt: Peter Lang.

Herrmann, H. 1982. Bedeutung und Bewertung der $N$ achtarbeit-G edanken zur Erstellung eines berufsgenossenschaftlichen Grundsatzes. En Kombinierte Belastungen Am Arbetsplatz, dirigido por T M Fliedner. Stuttgart: G enter V erlag.

H ettinger, T . 1993. Ermüdung und Pausen. En Kompendium $\mathrm{D}$ er Arbeitswissenschaft, dirigido por $\mathrm{T}$ H ettinger y $G$ W obbe. Ludwigshafen R hein: $K$ iehl.

H ickey, J, P R eist. 1977. A pplication of occupational exposure limits to unusual working schedules. Am Ind $H$ yg Assoc) 38:613.

Hildebrandt, G, P D eitmer, R M oog, L Poellmann. 1987. Physiological criteria for the optimization of shift work (relations to field studies). En Contemporary Advances in Shiftwork Research, dirigido por A O ginski, J Pokorski y J Rutenfranz. Cracovia: $M$ edical A cademy.

H ildebrandt, G, W R ohmert, J R utenfranz. 1974. 12 and 24 hour rhythms in error frequency of locomotive drivers and the influence of tiredness. Int J Chronobiol 2:175-180.

$\mathrm{H}$ off, A, U Ebbing. 1991. M enschengerechte U msetzung Von Arbeitszeitverkürzungen. D ortmund, Forschungsanwendung $\mathrm{Fa}$ 25: Bundesanstalt für Arbeitsschutz.

H ornberger, S, P K nauth. 1993. Interindividual differences on the subjective evaluation of leisure time utility. E rgonomics 36:255-264.

- . 1995. Effects of various types of change in shift schedules: A controlled longitudinal study. W ork Stress 9(213):124-133.

H orne, JA, O Ö stberg. 1976. A self-assessment questionnaire to determine morningness-eveningness in human circadian rhythms. Int J Chronobiol 4:97110.

Jamal, M, SM Jamal. 1982. Work and nonwork experiences of fixed and rotating shifts: An empirical assessment. J V ocat B ehav 20:282-293.

K andolin, I. 1993. Burnout of female and male nurses in shiftwork. E rgonomics 36:141-147.

K arrasch, K, EA M üller. 1951. Das V erhalten der Pulsfrequenz in der Erholungsperiode nach körperlicher Arbeit. Arbeitsphysiol 14:369-382.

K elly, RJ, M F Schneider. 1982. The twelve-hour shift revisited: $R$ ecent trends in the electric power industry. J H um E rgol 11:369-384.

K erkhof, A. 1985. Inter-individual differences in the human circadian system: A review. Biol Psychol 20:83-112.

K nauth, E, E Emde, J Rutenfranz, E K iesswetter, P Smith. 1981a. R e-entrainment of body tempera- 
ture in field studies of shiftwork. Int Arch 0 ccup E nviron $H$ ealth 49:137-149.

K nauth, P, E K iesswetter, P Schwarzenau. 1984. Er fahrungen mit einer flexiblen Arbeitszeitregelung bei D reischichtarbeitern. Z Arb W iss 38:96-99.

K nauth, P, E K iesswetter, W Ottmann, MJ K arvonen, J R utenfranz. 1983. Time-budget studies of policemen in weekly or swiftly rotating shift systems. A ppl E rgon 14:247-252.

$K$ nauth, $P, E$ K iesswetter. 1987. A change from weekly to quicker shift rotations. A field study of discontinuous three-shift workers. Ergonomics 30:1311-1321.

K nauth, P, E Schönfelder, S H ornberger. 1991. Compensation for Shiftwork. Bulletin for European Shiftwork Topics. Dublín: Fundación Europea para la M ejora de las $C$ ondiciones de $V$ ida y de T rabajo.

K nauth, $P, E$ Schönfelder. 1988. Systematische Darstellung innovativer. A rbeitszeitmod Pers 40:408-412.

- 1990. Effects of a new shift system on the social life of shiftworkers. En Shiftwork: $\mathrm{H}$ ealth, Sleep and Performance, dirigido por G Costa, G Cesana, $K$ K ogi y A Wedderburn. Frankfurt: Peter Lang.

Knauth, P, G Ernst, P Schwarzenau, J Rutenfranz. 1981b. M öglichkeiten der K ompensation negativer Auswirkungen der Schichtarbeit. Z Arb W iss $35: 1-7$.

K nauth, $P$, J R utenfranz. 1972. U ntersuchungen über die Beziehungen zwischen Schichtform und T agesaufteilung. Int Arch Arbeitsmed 30:173-191.

- . 1981. Duration of sleep related to the type of shift work. En Night and Shiftwork: Biological and Social Aspects, dirigido por $\mathrm{A}$ R einberg, $\mathrm{N}$ Vieux y $\mathrm{P}$ Andlauer. 0 xford: Pergamon Press.

-. 1982. Development of criteria for the design of shiftwork systems. I H um E rgol 11:337-367.

Knauth, $P, K$ Landau, C Dröge, M Schwitteck, M Widynski, J Rutenfranz. 1980. Duration of sleep depending on the type of shift work. Int Arch $O$ ccup E nviron $\mathrm{H}$ ealth 46:167-177.

K nauth, P, M H ärmä. 1992. The relation of shift work tolerance to the circadian adjustment. Chronobiol Int 9:46-54.

K nauth, P, S D ovalova, E Schönfelder. 1989. Guide lines for Shiftworkers. Bulletin for European Shiftwork T opics (B EST). Dublín: Fundación Europea para la $M$ ejora de las $C$ ondiciones de $V$ ida y de T rabajo.

K nauth, P. 1983. E rgonomische B eiträge Zu Sicherheitsaspekten Der Arbeitszeitorganisation. Düsseldorf: Fortschr.-Ber.

- 1993. The design of shift systems. E rgonomics 36:15-28.

—. 1996. Designing better shift systems. Appl Ergon 24(1):39-44

Knutsson, A, A A kerstedt, BG Jonsson, K O rthGomer. 1986. Increased risk of ischaemic heart disease in shift workers. L ancet 2:89-92.

K nutsson, A, K Z de Ancelar. 1982. Några medicinska och sociala aspekter pà skiftarbete vid Ortvikens Pappersbruk [Some medical and social aspects of shift work at 0 rtviken's Papermill]. Stressforskingsrapport Nr. 148 Estocolmo: Laboratoriet för klinisk stressforskning.

K ogi, K . 1981. Comparison of resting conditions be tween various shift rotation systems for industrial workers. En Night and Shift W ork: B iological and Social Aspects, dirigido por A R einberg, N V ieux y P Andlauer. O xford: Pergamon

K oller, M, M K undi, M H aider. 1991. N eue $H$ erausforderungen menschengerechter A rbeits-Z eitgestaltung. V iena: Ö sterreichischer A rbeiterkammertag

K oller, M. 1983. H ealth risks related to shift work. An example of time-contingent effects of long-term stress. Int Arch $\mathrm{O}$ ccup E nviron $\mathrm{H}$ ealth 53:59-75.

K ristensen, TS. 1989. Cardiovascular diseases and the work environment. A critical review of the epidemiologic literature on nonchemical factors. Scand J W ork Environ H ealth 15:165-179.
K üpper, R I Rutenfranz, P K nauth, R Romahn, K Undeutsch, I Löwenthal. 1980. Weschselwirkungen zwischen lärmbedingten Störungen des $T$ agschlafs und der $\mathrm{H}$ äufigkeit verschiedener Beschwerden bei Schichtarbeitern. En Arbeitsbedingte $G$ esundheitsschäden- Fiktion 0 der W irklichkeit?, dirigido por W Brenner, J Rutenfranz, E Baumgartner y M H aider. Stuttgart: G enter V erlag.

Landen, RO, AO Vikström, B Ö berg. 1981. Ordningspoliser I Stockholm: Delrapport III: I Intervention- Sociala 0 ch Psykologiska R eactioner På F örändrade Arbetstider. Estocolmo: Laboratoriet för $\mathrm{K}$ linisk Stressforskning $\mathrm{K}$ arolinska Institutet.

Laurig, W. 1981. Belastung, Beanspruchung und Erholungszeit bei energetisch-muskulärer ArbeitLiteraturexpertise. En Forschungsbericht Nr. $272 \mathrm{D} \mathrm{er}$ $B$ undesanstalt Für Arbeitsschutz Und U nfallforschung D ortmund. Bremerhaven: W irtschaftsverlag NW.

L avie, P. 1986. U Itrashort sleep-waking schedule, III. 'Gates' and 'forbidden zones' for sleep. Electroen Clin N euro 63:414-425.

Leuliet, S. 1963. D ouze années de travail posté $3 \times 8$. Arch M al Prof 24:164-171.

L uczak, H. 1982. B elastung, B eanspruchung Und E rholungszeit $B$ ei Informatorisch- $M$ entaler Arbeit- Literaturexpertise Forschungsbericht $D$ er B undesanstalt $F$ ür Arbeitsschutz Und U nfallforschung D ortmund. Bremerhaven: W irtschaftsverlag NW.

M aasen, A. 1981. The family life of shiftworkers and the school career of their children. En T he E ffects of Shiftwork On Health, Social and Family Life Dublín: Fundación Europea para la M ejora de las Condiciones de $V$ ida y de T rabajo.

M atsumoto, K, Y M orita. 1987. Effects of night-time nap and age on sleep patterns of shiftworkers. Sleep 10:580-589.

M CE wan, YW. 1978. Flexible working arrangements in continuous shift production. Pers R ev :12-19.

Michel-Briand, C, JL Chopard, A Guiot, M Paulmier, G Studer. 1981. The pathological consequences of shift work in retired workers. $A d v$ Biosci 30:399-407.

M inors, S, JM Waterhouse. 1981. Anchor sleep as a synchronizer of rhythms on abnormal routines. Int | Chronobiol 7:165-188.

M onk, TH. 1988. H ow to M ake Shift W ork Safe and Productive. Des Plaines, Illinois: American Society of Safety Engineers.

-. 1990. Shiftwork performance. En Shiftwork, dirigido por AJ Scott. Filadelfia: $\mathrm{H}$ anley \& Belfus.

M oog, R. 1981. Morning-evening types and shift work. A questionnaire study. Adv Biosci 30:481-488.

-. 1988. Die Individuelle Circadiane Phasenlage E in Prädiktor D er Nacht-U nd Schicht-Arbeitstoleranz. M arberg: T esis.

Moors, SH. 1990. Learning from a system of seasonally-determined flexibility: Beginning work earlier increases tiredness as much as working longer days. En Shiftwork: $\mathrm{H}$ ealth, Sleep and Performance, dirigido por G Costa, G Cesana, K K ogi y A Wedderburn. Frankfurt: Peter Lang.

$M$ ott, PE, FC M ann, Q M CL oughlin, DP Warwick. 1965. Shift W ork: The Social, P sychological and Physical Consequences. Ann Arbor, M ichigan: T he U niversity of $M$ ichigan Press.

Nachreiner, F, R Frielingsdorf, $R$ Romahn, $P$ K nauth, W K uhlmann, $F$ K limmer, J R utenfranz, E Werner. 1975. Schichtarbeit bei kontinuierlicher Produktion. Arbeitssoziologische, sozialpsychologische, arbeitspsychologische und arbeitsmedizinische Aspekte. Forschungsbericht der Bundesanstalt für Arbeitsschutz Und U nfallforschung D ortmund, Nr 141. O pladen: Westdeutscher V erlag

Naitoh, P, TL K elly, C Englund. 1990. H ealth effects of sleep deprivation. En Shiftw ork Filadelfia: $\mathrm{H}$ anley $\&$ Belfus.
Nedeltcheva, K, N Nilolova, A Stoynev, S H andjiev. 1990. Excretion of catecholamines and glucocorticoids in shift working railwaymen. En Shiftwork: $H$ ealth, Sleep and Performance, dirigido por G Costa, G Cesana, K K ogi y A Wedderburn. Frankfurt: Peter Lang.

O ccupational Safety and $\mathrm{H}$ ealth Administration OSHA). 1978. Modification on PELs for prolonged exposure periods. En Industrial $H$ ygiene $M$ anual. Washington, DC: OSH A.

O Isson, K, I K andolin, K K auppinen-T oropainen 1987. Shiftworkers' coping with stress. En Contemporary Advances in Shiftwork Research, dirigido por J O ginski, J Pokorski y J Rutenfranz. Cracovia: $M$ edical Academy.

O Isson, K, I K andolin. 1990. Strains and satisfaction of three-shift workers-an interview method for the occupational health care. En Shiftw ork: $\mathrm{H}$ ealth, Sleep and Performance, dirigido por $\mathrm{G}$ Costa, $\mathrm{G} \mathrm{Ce}$ sana, K K ogi y A Wedderburn. Frankfurt: Peter Lang.

Ong, CN, K K ogi. 1990. Shiftwork in developing countries: Current issues and trends. En Shiftwork, dirigido por AJ Scott. Filadelfia: $\mathrm{H}$ anley \& Belfus.

O rganización Internacional del Trabajo (O IT). 1990 The hours we work: N ew work schedules in policy and practice. Cond W ork Dig 9. Ginebra: OIT.

O rth-Gomer, K. 1985. Cardiovascular disease-factors of importance in shift workers. En Seventh Swedish-Yugoslavian Symposium on $\mathrm{O}$ ccupational $\mathrm{H}$ ealth, dirigido por B K omodin-H edman. Estocolmo: Arbetarskyddsverket 56-53. (Arbete och hälsa 198527.)

Pátkei, P, K Dahlgren. 1981. Satisfaction with different types of rapidly rotating shift systems. En Night and Shift W ork: Biological and Social Aspects, dirigido por A Reinberg, N V ieux y P Andlauer. O xford: Pergamon Press.

Pokorny, M LI, DHJ Blom, P Van Leeuwen. 1981. Analysis of traffic accident data (from busdrivers) an alternative approach (I). En Night and Shiftwork: Biological and Social Aspects. 0 xford: Pergamon.

Pokorski, J, I Iskra-Golec, AM Czekaj, C Noworal. 1990. M enstrual rhythm and shiftwork interference- a subjective retrospective study. En Shiftwork: $\mathrm{H}$ ealth, Sleep and Performance, dirigido por G Costa, G Cesana, K K ogi y A Wedderburn. Frankfurt: Peter Lang.

Reinberg, A, A-J Chaumont, A Laporte 1975. Circadian temporal structure of 20 shift workers (8-hour shift weekly rotation): An autometric field study. En Experimental Studies of Shiftwork, dirigido por P Colquhoun, S Folkard, P K nauth y I R utenfranz. O pladen: W estdeutscher $V$ erlag.

Reinberg, A, Y M otohaschi, P Bourdelean, $P$ Andlauer, F Levi, A Bicakova-R ocher. 1988. Alteration of period and amplitude of circadian rhythms in shiftworkers. Eur J Appl Physiol 57:15-25.

Rohmert, W, J Rutenfranz, E U lich. 1971. Das Anlernen sensumotorischer F ertigkeiten. W irtschaftliche und soziale Aspekte des technischen W andels in der B undesrepublik D eutschland. Bd. 7. Frankfurt a.M .: Europäische Verlagsanstalt.

Rosa, RR, MH Bonnet, RR Bootzin, CI Eastman, T M onk, PE Penn, DI T epas, JK Walsh. 1990. Intervention factors for promoting adjustment to nightwork and shiftwork. En Shiftwork, dirigido por A) Scott. Filadelfia: $\mathrm{H}$ anley \& Belfus.

Rutenfranz, J, B Beermann, I Löwenthal. 1987. Nachtarbeit für $\mathrm{F}$ rauen. Ü berlegungen aus chronophysiologischer und arbeitsmedizinischer Sicht. Schriftenreihe Arbeitsme dizin Sozial-M edizin Präventivmedizin. Stuttgart: G entner Verlag.

Rutenfranz, J, M H aider, M K oller. 1985. O ccupational health measures for nightworkers and shiftworkers. En Hours of W ork: Temporal Factors in W ork-Scheduling, dirigido por S Folkard y TH M onk. Chichester: Wiley. 
Rutenfranz, J, P K nauth, D Angersbach. 1981. Shift work research issues. En B iological R hythms, Sleep and Shift W ork, dirigido por LC Johnson, DI T epas, WP Colquhoun y M J Colligan. Nueva Y ork: Spectrum.

Rutenfranz, J, W R ohmert, A Iskander. 1971. Über das Verhalten der Pulsfrequenz während des Erlernens sensumotorischer Fertigkeiten unter be sonderer Berücksichtigung der Pausenwirkung. Int Z eitschr Angewandte Physiol einsch Arbeitphysiol 29:101118.

Rutenfranz, J, WP Colquhoun, P K nauth, JN G hata. 1977. Biomedical and psychosocial aaspects of shift work: A review. Scand J W ork Environ $\mathrm{H}$ ealth 3:165-82.

Saito, Y, K K ogi. 1978. Psychological conditions of working night and subsequent day shifts with short sleep hours between them. E rgonomics 21:871.

Scholz, H. 1963. Die Physische Arbeitsbelastung Der Giessereiarbeiter. Forschungsbericht $D$ es Landes N ordrhein-W estfalen Nr. 1185. O pladen: Westdeutscher Verlag.

Scott, AJ, J LaD ou. 1990. Shiftwork: Effects on sleep and health with recommendations for medical surveillance and screening. En Shiftwork, dirigido por A) Scott. Filadelfia: $\mathrm{H}$ anley $\&$ Belfus.

Seibt, A, G Friedrichsen, A Jakubowski, O Kaugmann, U Schurig. 1986. Investigations of the effect of work-dependent noise in combination with shift work. En Night and Shiftwork: Long-T erm E ffects and Their Prevention, dirigido por M $\mathrm{H}$ aider, M K oller, R C ervinka. Frankfurt: Peter Lang.

Sergean, R. 1971. M anaging Shiftwork. Londres: Gower Press.

Smith, L, S Folkard. 1993. Is a 'safer' permanent night shift practicable? E rgonomics 36:317-318.

Spelten, E, L Smith, P Totterdell, J Barton, S Folkard, P Bohle 1993. The relationship between coping strategies and G H Q -scores in nurses. E rgonomics 36:227-232.

Stein, A. 1963. Z ur F rage der B elastung berufstätiger F rauen durch $\mathrm{N}$ acht - U nd Schichtarbeit. M unich: T esis.

Tasto, DL, M J Colligan, EW Skjei, SJ Polly. 1978. $\mathrm{H}$ ealth Consequences of Shift W ork, Final Report, SR Project URU-4426. Cincinnati: T aft Laboratories $\mathrm{N}$ ational Institute for $\mathrm{O}$ ccupational Safety and $\mathrm{H}$ ealth, Behavioral and M otivational Factors Branch.

Taylor, PJ, SJ Pocock. 1972. M ortality of shift and day workers 1956-68. Br J Ind M ed 29:201-207.

T epas, DI, R P M ahan. 1989. The many meanings of sleep. W ork Stress 3:93-102.

Tepas, DI. 1985. Flexitime, compressed workweeks and other alternative work schedules. En $\mathrm{H}$ ours of W ork. T emporal Factors in W ork-Scheduling, dirigido por S Folkard y T M onk. C hichester: Wiley.

Thiis-Evensen, E. 1958. Shiftwork and health. Ind M ed Surgery 27:493-497. (1949. Publicado originalmente en noruego.)

Torsvall, L, T A kerstedt. 1979. Shift work and diurnal type: A questionnaire study. Chronobiologia 6:163-164.

-. 1980. A diurnal type scale: Construction, consistency and validation in shift work. Scand J W ork Environ $\mathrm{H}$ ealth 6:283-290.

T otterdell, P, S Folkard. 1990. The effects of changing from weekly rotating to a rapidly rotating shift schedule. En Shiftw ork: H ealth, Sleep, and Performance, dirigido por G Costa, G Cesana, K Kogi y A W edderburn. Frankfurt: Peter $L$ ang

T saneva, N, L M incheva, M Topalova, R Beraha. 1987. H olter ECG monitoring of shift workers in modern electronics. En Contemporary Advances in Shiftw ork Research, dirigido por A O ginski, J Pokorski y J Rutenfranz. C racovia: M edical Academy.
Tsaneva, N, R Nicolova, M Topalova, S Danev. 1990. Changes in the organism of shift workers operating a day and night 12 hour schedule in carbon disulfide production. En Shiftw ork: $H$ ealth, Sleep, and Performance, dirigido por G Costa, G Cesana, $K$ K ogi y A W edderburn. Frankfurt: Peter Lang.

T urek, FW. 1986. Circadian principles and design of rotating shift work schedules. Am । Physiol 251:R 636-R 638.

U ehata, T, N Sasakawa. 1982. The fatigue and maternity disturbances of night workwomen. I H um E rgol 11:465-474.

Ulich, E, M Rauterberg, T Moll, T Greutmann, O Strohm. 1991. Task orientation and useroriented dialogue design. Int J H um Comput Interact 3:117-144.

U lich, E. 1957. Zur Frage der Belastung des arbeitenden $M$ enschen durch Nacht- und Schichtarbeit. Psychol R undschau 8:42-61.

Verhaegen, P, R Cober, M De Smedt, J Dirkx, J Kerstens, D R yvers, P V an Daele. 1987. The adaptation of night nurses to different work schedules. E rgonomics 30:1301-1309.

Vidacek, S, LJ K aliterna, B Radosevic-Vidacek. 1987. Predictive validity of individual difference measures for health problems in shiftworkers: preliminary results. En Contemporary Advances in Shiftwork R esearch, dirigido por A 0 ginski, J. Pokorski y J. R utenfranz. Cracovia: M edical A cademy.

Walker, J. 1985. Social problems of shiftwork. En $\mathrm{H}$ ours of W ork. Temporal Factors in W ork-Scheduling, dirigido por S Folkard y T Monk. Chichester: Wiley.

Wallace, M . 1989. The 3 day week: 12 hour shifts. En $M$ anaging Shiftwork, dirigido por $M$ Wallace. Bundoora, Australia: La Trobe University, Department of Psychology, Brain-Behaviour R esearch Institute.

Waterhouse, JM, S Folkard, DS M inors. 1992. Shiftwork, $H$ ealth and Safety. An 0 verview of the Scientific Literature 1978-1990. Health and safety executive contract research report N O. 3l. Londres: H M SO.

Wedderburn, AAI 1981. Is there a pattern in the value of time off work? In Night and Shiftwork: Biological and Social Aspects, dirigido por N Reinberg, $\mathrm{N} V$ ieux y P Andlauer. O xford: Pergamon.

-. 1991. Guidelines for Shiftworkers. Bulletin of European Shiftwork T opics (BEST), no.3. Dublín: Fundación Europea para la $\mathrm{M}$ ejora de las $\mathrm{C}$ ondiciones de $V$ ida y de T rabajo.

Wever, RA, J Polasek, CM Wildgruber. 1983. Bright light effects on human circadian rhythms. Pflügers Arch 396:85-87.

Wild, HW, H Theis. 1967. Der Einfluss des Schichtbeginns auf die U nfallhäufigkeit. Glückauf, B ergmännische Z eitschrift 103:833-838.

Wilkinson, RT . 1992. H ow fast should the night shift rotate? E rgonomics 35:1425-1446.

Williams, RL, I K aracan, CI Hursch. 1974. EEG of $H$ uman Sleep: Clinical Application. Nueva Y ork: Wiley.

Williamson, AM , JW Sanderson. 1986. Changing the speed of shift rotation, a field study. E rgonomics 29:1085-1096.

Wynne, RF, GM Ryan, JH C ullen. 1986. Adjustment to shiftwork and its prediction: R esults from a longitudinal study. En Night and Shiftwork: Long-T erm $\mathrm{E}$ ffects and Their Prevention, dirigido por M Haider, M K oller y R Cervinka. Frankfurt: Peter Lang.

\section{O tras lecturas recomendadas}

Cesana, GC, M Ferrario, R Curti, R Zanettini, A G rieco, $R$ Sega, A Palermo, G M ara, A Libretti, $S$ Algeri. 1982. Work-stress and urinary catechola- mines excretion in shift workers exposed to noise. M edicina del Lavaro 2:99-109.

De Haan, EG. 1990. Improving shiftwork schedules in a bus company: T owards more autonomy. En Shiftwork: $H$ ealth, Sleep and Performance, dirigido por $G$ Costa, G Cesana, K K ogi y A Wedderburn. Frankfurt: Peter Lang.

Folkard, S, P T otterdell. 1993. Circadian variations in performance. Ergonomics.

Folkard, S, T Åkerstedt. 1992. A three-process model of the regulation of alertness sleepiness. En Sleep, A rousal and Performance dirigido por RJ Broughton y BD 0 gilvie. Boston: Birkhäuser.

Folkard, S, TH M onk. 1985. H ours of W ork: T emporal F actors in W ork Scheduling. Chichester: Wiley.

Irion, H, R R ossner, H Lazarus. 1983. Entwicklung des $\mathrm{H}$ örverlustes in A bhängigkeit von $\mathrm{L}$ ärm, Alter und anderen E inflüssen. B undesanstalt für Arbeitsschutz und U nfallforschung. D ortmund: Forschungsbericht.

K iesswetter, E. 1992. The impact of heat stress on adjustment to shift work. ACE S 4:23-24

Lehmann, G. 1962. Praktische Arbeitsphysiologie. Stuttgart: G eorg T hième V erlag.

Monk, TH. 1991. Sleep, Sleepiness and Performance. Chichester: Wiley.

O rganización Internacional del T rabajo (OIT). 1989. Part-time work. Cond W ork D ig 8(1).

Ottmann, W, R Flügge, P K nauth, T Gallwey, A C raig, J Rutenfranz. 1986. Combined effects of experimental nightwork and heat stress on cognitive performance tasks. En Night and Shiftwork: Long-T erm Effects and Their Prevention, dirigido por M H aider, M K oller y R Cervinka. Frankfurt: $\mathrm{Pe}-$ ter Lang.

Pokorski, J, A O ginski, P K nauth. 1986. Workphysiological field studies concerning effects of combined stress in morning, afternoon and nightshifts. En Night and Shiftwork: Long-T erm E ffects and Their Prevention, dirigido por M H aider, M K oller y $R$ Cervinka. Frankfurt: Peter Lang.

Reinberg, A, M Smolensky, G Labrecque, F Levi, J Cambar. 1986. Biological rhythms and exposure limits to potentially noxious agents. En Night and Shiftwork: Long-T erm E ffects and Their Prevention, dirigido por $\mathrm{M} H$ aider, $M$ Koller y $\mathrm{R}$ Cervinka. Frankfurt: Peter Lang.

Rutenfranz J W Ottmann, B Schmitz, R Flügge, P K nauth. 1986. Circadian rhythms of physiological functions during experimental shift work with additional heat stress. En Night and Shiftwork: Long$T$ erm $E$ ffects and Their Prevention, dirigido por $\mathrm{M} H$ aider, $\mathrm{M}$ K oller y $\mathrm{R}$ Cervinka. Frankfurt: $\mathrm{Pe}$ ter $L$ ang.

Seeber, AE, E K ieswetter, M Blaszkowicz. 1992. Exposure to mixtures of solvents and shift work: Interrelations concerning neurobehavioral effects. ACE S 4:20-21.

Seibt, A, C Hilpmann, G Friedrichsen. 1983. Zur auralen Wirkung des hörschädigenden Lärms bei Schichtarbeit. Z ges H yg 29:206-208.

Smith, A, C M ils. 1986. A cute effects of meals, noise and nightwork. B rit | Psychol 77:377-387.

Smith, AP. 1991. The combined effects of noise, nightwork and meals on mood. Int Arch 0 ccup E nviron $\mathrm{H}$ ealth 63:105-108.

Thierry, H, G H oolwerf, PJD Drenth. 1975. Attitudes of permanent day and shift workers towards shiftwork- a field study. En Experimental Studies of Shiftwork, dirigido por $\mathrm{P}$ Colquhoun, S Folkard, $P$ K nauth, J Rutenfranz. O pladen: Westdeutscher Verlag.

T orsvall, L, T Åkerstedt, M Gillberg. 1981. Age, sleep and irregular workhours: A field study with EEG recording, catecholamine excretion and selfratings. Scand J W ork E nviron H ealth 7:196-203. 
Director del capítulo

X avier Guardino Solá

\section{Sumario}

Calidad del aire interior: introducción

X avier Guardino Solá ........................ 44.2

$N$ aturaleza y fuentes de los contaminantes químicos

en el interior

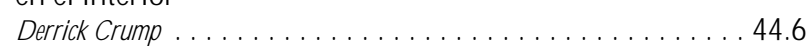

Radón

M aría J osé $B$ erenguer $\ldots \ldots \ldots \ldots \ldots \ldots \ldots \ldots \ldots \ldots \ldots \ldots \ldots \ldots \ldots$

H umo de tabaco

D ietrich $H$ offmann y E rnst L. W ynder . . . . . . . . . . . . 44.12

Regulación del consumo de tabaco

X avier Guardino Solá ........................ 44.16

D eterminación y valoración de los contaminantes químicos

M. Gracia R osell Farrás.

Contaminación biológica

Brian Flannigan. . . . . . . . . . . . . . . . . . . . . 44.22

Reglamentos, recomendaciones, normas y patrones

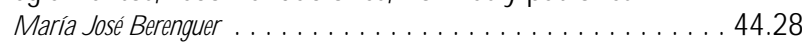




\section{- CALIDAD DEL AIRE INTERIOR: INTRODUCCION}

\section{Xavier G uardino Solá}

La conexión entre el uso de un edificio como lugar de trabajo o vivienda y la aparición, en algunos casos, de molestias y síntomas que responden a la definición de una enfermedad es un hecho que ya no puede cuestionarse. La principal responsable es la contaminación de diversos tipos presente en el edificio, que suele denominarse "mala calidad del aire en interiores". Los efectos adversos debidos a esa deficiente calidad del aire en espacios cerrados afecta a muchas personas, ya que se ha demostrado que los habitantes de las ciudades pasan entre el 58 y el $78 \%$ de su tiempo en un ambiente interior que se encuentra contaminado en mayor o menor grado. Es un problema que se ha visto agravado por la construcción de edificios diseñados para ser más herméticos y que reciclan el aire con una proporción menor de aire fresco procedente del exterior con el fin de aumentar su rentabilidad energética. Actualmente se acepta de forma general que los edificios que carecen de ventilación natural presentan riesgo de exposición a contaminantes.

El término aire interior suele aplicarse a ambientes de interior no industriales: edificios de oficinas, edificios públicos (colegios, hospitales, teatros, restaurantes, etc.) y viviendas particulares. L as concentraciones de contaminantes en el aire interior de estas estructuras suelen ser de la misma magnitud que las encontradas habitualmente al aire exterior, y mucho menores que las existentes en el medio ambiente industrial, donde se aplican normas relativamente bien conocidas con el fin de evaluar la calidad del aire. Aun así, muchos ocupantes de edificios se quejan de la calidad del aire que respiran, por lo que es necesario investigar esta situación. La calidad del aire interior comenzó a considerarse un problema a finales del decenio de 1960, aunque los primeros estudios no se llevaron a cabo hasta unos diez años después.

Aunque parecería lógico pensar que para que la calidad del aire sea buena, éste debe contener los componentes necesarios en proporciones apropiadas, en realidad es a través del usuario (de su respiración), cómo mejor puede valorarse su calidad. La razón está en que el aire inhalado se percibe perfectamente a través de los sentidos, ya que el ser humano es sensible a los efectos olfativos e irritantes de cerca de medio millón de compuestos químicos. Por consiguiente, si los ocupantes de un edificio están todos satisfechos con el aire, se dice que éste es de alta calidad, y de mala calidad si sucede lo contrario. ¿Significa esto que es posible predecir cómo se percibirá el aire a partir de su composición? Sí, pero sólo en parte. Es un método que puede aplicarse a ambientes industriales, donde los compuestos químicos específicos relacionados con la producción se conocen, se determinan sus concentraciones y se comparan con valores límite umbral. Pero en edificios no industriales donde puede haber millares de sustancias químicas en el aire pero en concentraciones tan bajas que, quizá, sean miles de veces menores que los límites establecidos para el medio ambiente industrial, la situación es diferente. En la mayoría de estos casos la información sobre la composición química del aire interior no nos permite predecir cómo se percibirá el aire, ya que el efecto conjunto de miles de estos contaminantes, junto con la temperatura y la humedad, pueden producir un aire que se percibe como irritante, viciado o enrarecido, es decir, de mala calidad. Algo parecido sucede con la composición detallada de un alimento y su sabor: el análisis químico es insuficiente para predecir si el alimento tendrá un sabor bueno o malo. Por este motivo, cuando se planifica un sistema de ventilación y su
Figura 44.1 - Síntomas y enfermedades relacionados con la calidad del aire interior.

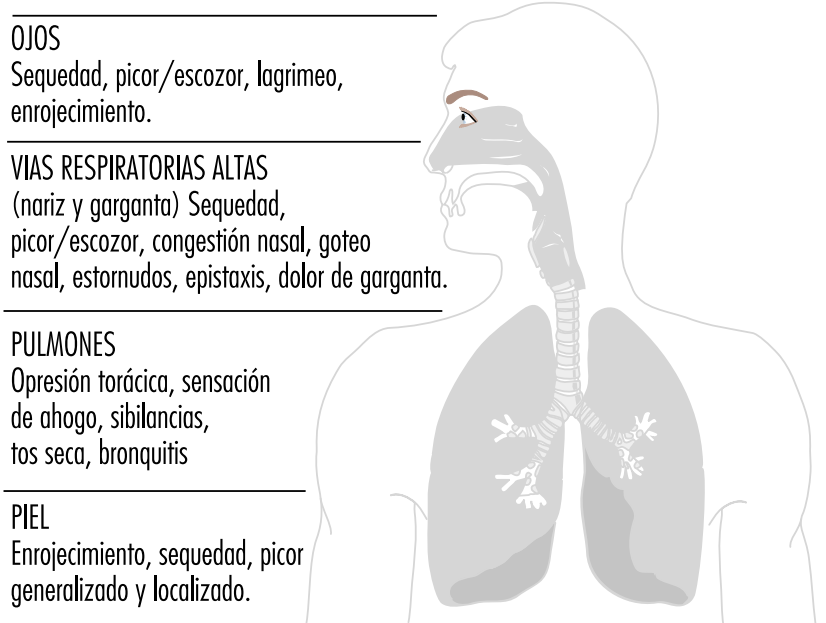

GENERAL

Cefalea, debilidad, somnolencia/letargo, dificultad para concentrarse, irritabilidad, ansiedad, náuseas, mareo.

\section{ENFERMEDADES MAS FRECUENTES:}

\section{HIPERSENSIBILIDAD}

Neumonitis por hipersensibilidad, fiebre por humidificadores, asma, rinitis, dermatitis. INFECCIONES

Legionelosis (enfermedad del legionario), fiebre de Pontiac, tuberculosis, resfriado común, gripe. De origen químico o físico desconocido, incluido el cáncer.

mantenimiento periódico, rara vez se requiere un análisis químico exhaustivo.

Existe otro punto de vista que considera a las personas como única fuente de contaminación del aire interior. Y no sería equivocado si estuviéramos tratando con materiales de construcción, muebles y sistemas de ventilación como los utilizados hace 50 años, cuando predominaban el ladrillo, la madera y el acero. Ahora bien, con los materiales modernos la situación ha cambiado. Todos los materiales generan contaminación, unos en pequeña y otros en gran cantidad, y juntos contribuyen al deterioro de la calidad del aire interior.

Los cambios en el estado de salud de una persona debidos a la mala calidad del aire interior pueden manifestarse en diversos síntomas agudos y crónicos así como en forma de diversas enfermedades específicas. Todos ellos se ilustran en la Figura 44.1. Aunque los casos en que la mala calidad del aire interior da lugar al desarrollo completo de una enfermedad son pocos, puede causar malestar, estrés, absentismo laboral y pérdida de productividad (con aumentos paralelos de los costes de producción); además, las acusaciones sobre problemas relacionados con los edificios pueden generar rápidamente un conflicto entre los ocupantes, sus empresas y los propietarios de los edificios.

Por lo común resulta difícil establecer con precisión en qué medida la mala calidad del aire interior puede afectar a la salud, ya que no se dispone de suficiente información con respecto a la relación entre la exposición y el efecto a las concentraciones a las que suelen estar presentes los contaminantes. Por tanto, es necesario obtener información en condiciones de dosis elevadas (como las de las exposiciones en el entorno industrial) y 
extrapolarla a dosis mucho más bajas con el margen de error correspondiente. Por otro lado, aunque se conocen bien los efectos de la exposición aguda a muchos contaminantes presentes en el aire, existen importantes lagunas en los datos relativos a las exposiciones a largo plazo a concentraciones bajas y a mezclas de diferentes contaminantes. Los conceptos de nivel sin efecto (NSE), efecto nocivo y efecto tolerable, confusos incluso en el ámbito de la toxicología industrial, son aquí aún más difíciles de definir. Se han realizado pocos estudios concluyentes sobre este tema, tanto relativos a edificios públicos y oficinas como a viviendas particulares.

Existen normas para la calidad del aire en el exterior establecidas con el fin de proteger a la población general. Se han obtenido determinando los efectos adversos sobre la salud debidos a la exposición a contaminantes en el medio ambiente. Son útiles como directrices generales para conseguir una calidad aceptable del aire interior; las propuestas por la Organización M undial de la Salud son un ejemplo de estas normas. Se han establecido criterios técnicos [como el valor límite umbral de la conferencia Americana de $\mathrm{H}$ igienistas Industriales del Gobierno (American Conference of Governmental Industrial $\mathrm{H}$ ygienists, $\mathrm{AC} \mathrm{GIH}$ ) de E stados U nidos y los valores límite legalmente establecidos para ambientes industriales en diferentes países, para los trabajadores adultos y para duraciones específicas de exposición que, por lo tanto, no pueden aplicarse directamente a la población general. La Sociedad Americana de Ingenieros de Calefacción, R efrigeración y Acondicionamiento del Aire (American Society of $\mathrm{H}$ eating, Refrigeration and Air Conditioning Engineers, ASHRAE) de Estados Unidos ha elaborado una serie de normas y recomendaciones, muy utilizadas para la valoración de la calidad del aire interior.

0 tro aspecto que debe considerarse como parte de la calidad del aire interior essu olor, ya que éste suele ser el parámetro definitorio. La combinación de un cierto olor con el leve efecto irritante de un compuesto en el aire de un interior puede conducirnos a definir su calidad como "fresca" y "limpia" o como "viciada" y "contaminada". Por consiguiente, el olor es muy importante al definir la calidad del aire interior. Aunque los olores dependen objetivamente de la presencia de compuestos en cantidades superiores a sus umbrales olfativos, a menudo se evalúan desde un punto de vista estrictamente subjetivo. Debe tenerse en cuenta que la percepción de un olor puede deberse a los olores de numerosos compuestos diferentes y que la temperatura y la humedad también pueden modificar sus características. D esde el punto de vista de la percepción, son cuatro las características que nos permiten definir y medir los olores: intensidad, calidad, tolerabilidad y umbral. Con todo, es muy difícil "medir" los olores desde un punto de vista químico en el aire interior. Por esa razón la tendencia es eliminar los olores "malos" y utilizar, en su lugar, los considerados buenos con el fin de dar al aire una calidad agradable. El enmascaramiento de los malos olores con otros agradables suele fracasar, ya que pueden reconocerse por separado olores de muy diferentes calidades, y el resultado es imprevisible.

Cuando más del $20 \%$ de los ocupantes de un edificio se quejan de la calidad del aire o presentan síntomas claros se puede afirmar que existe el fenómeno conocido como síndrome del edificio enfermo. Se manifiesta en diversos problemas físicos y ambientales asociados a interiores no industriales. L os casos de síndrome del edificio enfermo suelen ir acompañados de las características siguientes: las personas afectadas presentan síntomas indeterminados, similares a los del resfriado común o a los de las enfermedades respiratorias; los edificios son eficientes en ahorro de la energía y tienen un diseño y una construcción modernos 0 han sido remodelados recientemente con materiales nuevos, y los ocupantes no pueden controlar la temperatura, la humedad ni la iluminación de su lugar de trabajo. La distribución porcentual estimada de las causas más frecuentes de síndrome del edificio enfermo es: ventilación insuficiente debida a falta de mantenimiento, distribución deficiente y entrada insuficiente de aire fresco (50 a $52 \%$ ); contaminación generada en el interior, como la producida por las máquinas de oficina, el humo del tabaco y los productos de limpieza (17 a $19 \%$ ); contaminación procedente del exterior del edificio debida a una disposición inadecuada de las entradas de aire y de los respiraderos de aspiración (11\%); contaminación microbiológica del agua estancada en los conductos del sistema de ventilación, humidificadores y torres de refrigeración (5\%), y formaldehído y otros compuestos orgánicos emitidos por los materiales de construcción y decoración (3 a 4 \%). Por tanto, en la mayoría de los casos se cita la ventilación como importante causa originaria.

O tra cuestión de naturaleza diferente es la de las enfermedades relacionadas con los edificios, más graves aunque menos frecuentes, que van acompañadas de síntomas clínicos muy definidos y resultados de laboratorio claros. Algunos ejemplos de estas enfermedades son la neumonitis por hipersensibilidad, la fiebre del humidificador, la legionelosis y la fiebre de Pontiac. U na opinión bastante generalizada entre los investigadores es que estas enfermedades deben considerarse independientes del síndrome del edificio enfermo.

Se han llevado a cabo estudios para confirmar las causas de los problemas de calidad del aire y sus posibles soluciones. En los últimos años, el conocimiento de los contaminantes presentes en el aire interior y de los factores que contribuyen al deterioro de su calidad ha avanzado de forma considerable, aunque queda todavía mucho camino por recorrer. Los estudios realizados en los últimos 20 años han demostrado que la presencia de contaminantes en muchos ambientes de interior es superior a la prevista y, además, se han identificado contaminantes diferentes a los presentes en el aire exterior. Lo cual contradice la suposición de que los interiores sin actividad industrial carecen hasta cierto punto de contaminantes y que, en el peor de los casos, su composición podría ser equivalente a la del aire libre. Los contaminantes como el radón y el formaldehído se identifican casi exclusivamente en el medio ambiente interior.

La calidad del aire interior, incluida la de las viviendas, se ha convertido en un problema de salud ambiental, como el control de la calidad del aire en el exterior o la exposición en el trabajo. A hora bien, ya se ha comentado que una persona residente en un área urbana pasa entre el 58 y el $78 \%$ de su tiempo en un medio ambiente de interior, y las personas más susceptibles (esto es, los ancianos, los niños pequeños y los enfermos) son las que más tiempo están en esas condiciones. Es un asunto que comenzó a preocupar a partir de 1973 cuando, debido a la crisis energética, los esfuerzos dirigidos a la conservación de energía se concentraron en la reducción de la entrada del aire exterior a los espacios interiores en la mayor medida posible, con el fin de disminuir los costes de calefacción y refrigeración de los edificios. Aunque no todos los problemas relacionados con la calidad del aire interior son consecuencia de medidas en materia de ahorro de energía, es evidente que conforme fue generalizándose ese principio, comenzaron a aumentar las quejas sobre la calidad del aire interior y a surgir todos los problemas.

0 tro asunto digno de atención es la presencia de microorganismos en el aire interior, lo que puede causar problemas de carácter infeccioso y alérgico. No debe olvidarse que los microorganismos son un componente normal y esencial de los ecosistemas. Por ejemplo, en el suelo y en la atmósfera suelen hallarse diversos hongos y bacterias saprófitos que se nutren de materia orgánica muerta del medio ambiente, los cuales se han detectado también en el medio ambiente de interiores. L os problemas de contaminación biológica en interiores han sido objeto de interés en los últimos años. 
Figura 44.2 - Diagrama de un edificio que muestra diversas fuentes de contaminantes de interior y de exterior.

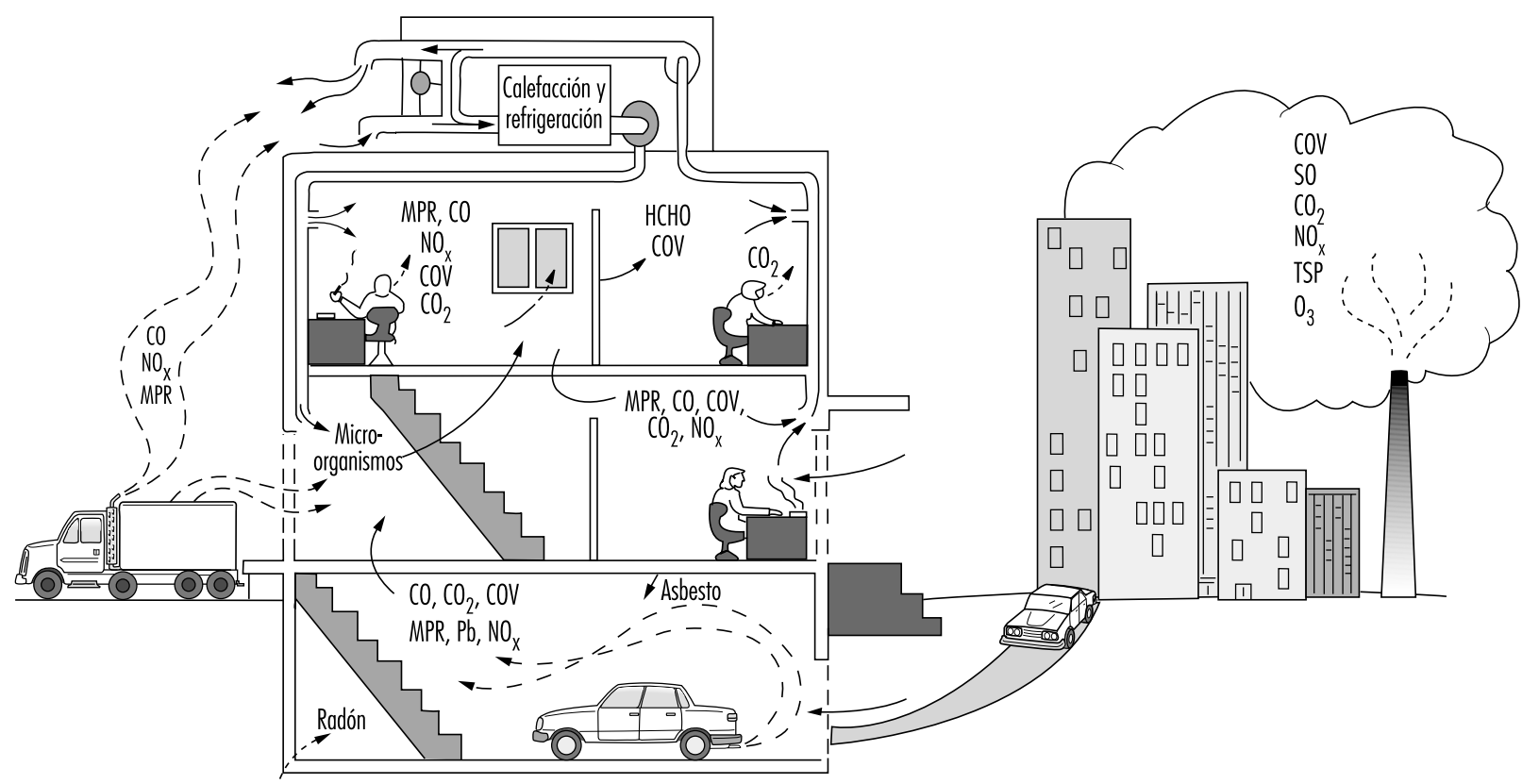

$\mathrm{CO}=$ monóxido de carbono; $\mathrm{CO2}$ = dióxido de carbono; $\mathrm{HCHO}=$ formaldehído; $\mathrm{NOx}=$ óxidos de nitrógeno; $\mathrm{Pb}=$ plomo; $M P R=$ materia particulada respirable; $\mathrm{COV}=$ compuestos orgánicos volátiles .

El brote de enfermedad del legionario de 1976 es el caso que más ha llamado la atención de una enfermedad causada por un microorganismo en el medio ambiente de interiores. O tros agentes infecciosos, como los virus que pueden causar enfermedades respiratorias agudas, también son detectables en interiores, especialmente si la densidad de ocupación es alta y existe una recirculación de aire importante. En realidad, no se conoce en qué medida los microorganismos o sus componentes están implicados en la aparición de enfermedades asociadas a los edificios. Se han desarrollado protocolos (sólo en cierta medida) para demostrar y analizar numerosos tipos de agentes microbianos, y aún así, la interpretación de los resultados es en ocasiones incoherente.

\section{Aspectos del sistema de ventilación}

La calidad del aire interior en un edificio depende de una serie de variables, como la calidad del aire del exterior, el diseño del sistema de ventilación y acondicionamiento del aire, las condiciones en que opera y se mantiene este sistema, la división en compartimentos del edificio y las fuentes interiores de contaminantes y su magnitud (véase la Figura 44.2). En suma, puede afirmarse que los defectos más frecuentes son consecuencia de una ventilación inadecuada, de la contaminación generada en el interior y de la procedente del exterior.

Con respecto al primero de estos problemas, las causas de ventilación inadecuada pueden ser: una entrada insuficiente de aire fresco debido a un nivel alto de recirculación del aire 0 a un bajo volumen de entrada; la colocación y orientación incorrectas en el edificio de los puntos de entrada del aire exterior; una distribución deficiente y, en consecuencia, una mezcla incompleta con el aire del edificio, lo que puede originar estratificación, zonas no ventiladas, diferencias de presión no previstas que originan corrientes de aire y cambios continuos en las características termohigrométricas (que advierte el ocupante al moverse por el edificio) y filtración incorrecta del aire debida a la falta de mantenimiento o a un diseño inadecuado del sistema de filtrado (una deficiencia particularmente grave cuando el aire exterior es de mala calidad o cuando el nivel de recirculación es elevado).

\section{Origen de los contaminantes}

La contaminación en el interior tiene diferentes orígenes: los propios ocupantes, los materiales inadecuados o con defectos técnicos utilizados en la construcción del edificio; el trabajo realizado en el interior; el uso excesivo o inadecuado de productos normales (plaguicidas, desinfectantes, productos de limpieza y encerado); los gases de combustión (procedentes del tabaco, de las cocinas, de las cafeterías y de los laboratorios); y la conjunción de contaminantes procedentes de otras zonas mal ventiladas que se difunde hacia áreas vecinas, afectándolas. T éngase en cuenta que las sustancias emitidas en el aire interior tienen muchas menos oportunidades de diluirse que las emitidas en el aire exterior debido a las diferencias de volumen de aire disponible. En lo que respecta a la contaminación biológica, su origen se debe fundamentalmente a la presencia de agua estancada, de materiales impregnados con agua, gases, etc., y a un mantenimiento incorrecto de los humidificadores y las torres de refrigeración.

Por último, debe considerarse también la contaminación procedente del exterior. Con respecto a la actividad humana, hay tres fuentes principales: la combustión en fuentes estacionarias (centrales energéticas), la combustión en fuentes móviles (vehículos) y los procesos industriales. Los cinco contaminantes más importantes emitidos por estas fuentes son: el monóxido de carbono, los óxidos de azufre, de nitrógeno, los compuestos orgánicos volátiles (incluidos los hidrocarburos), los hidrocarburos aromáticos policíclicos y las partículas. La combustión interna de los vehículos es la principal fuente de monóxido de carbono e hidrocarburos y una fuente importante de óxidos de nitrógeno. La combustión en fuentes estacionarias es el principal origen de los óxidos de azufre. Los procesos industriales y las fuentes estacionarias de combustión generan más de la mitad de 
las partículas emitidas al aire por la actividad humana, y los procesos industriales pueden ser fuente de compuestos orgánicos volátiles. También hay contaminantes generados de forma natural propulsados a través del aire, como las partículas de polvo volcánico, la sal de suelo y de mar, las esporas y los microorganismos. La composición del aire exterior varía de un lugar a otro, en función de la presencia y la naturaleza de las fuentes de contaminación circundantes y de la dirección del viento predominante. En el aire exterior "limpio" (sin fuentes de contaminación) suele hallarse la siguiente concentración de contaminantes: dióxido de carbono, 320 ppm; 0zono, 0,02 ppm; monóxido de carbono, 0,12 ppm; óxido nítrico, 0,003 ppm; y dióxido de nitrógeno, 0,001 ppm. Ahora bien, estos valores aumentan notablemente en el aire urbano.

Al margen de los contaminantes generados en el exterior, en ocasiones ocurre que el aire contaminado procedente del edificio sale al exterior y penetra de nuevo a través de las entradas del sistema de aire acondicionado. 0 bien se infiltra a través de los cimientos del edificio (p. ej., el radón, los gases de combustibles, los efluvios de las alcantarillas, los fertilizantes, los insecticidas y desinfectantes). Se ha observado que cuando aumenta la concentración de un contaminante en el aire exterior, lo hace también en el interior, aunque de forma más lenta (la relación es similar cuando la concentración disminuye); por consiguiente, puede afirmarse que los edificios ejercen un efecto de escudo frente a los contaminantes externos. Con todo, el medio ambiente del interior de un edificio no es, naturalmente, un reflejo exacto de las condiciones del exterior.

Los contaminantes presentes en el aire interior se diluyen en el aire exterior que entra en el edificio y lo acompañan al salir. Cuando la concentración de un contaminante es menor en el aire del exterior que en el del interior, el intercambio de ambos causará la reducción de la concentración del contaminante en el aire interior del edificio. Si un contaminante se origina en el exterior y no en el interior, ese intercambio producirá un aumento de su concentración en el interior, como se comentó anteriormente.

Los modelos para el equilibrio de las cantidades de contaminantes en el aire interior se basan en el cálculo de su acumulación, en unidades de masa con respecto al tiempo, a partir de la diferencia entre la cantidad que entra más la que se genera en el interior, y la que sale con el aire más la que se elimina por otros medios. Si se dispone de valores apropiados para cada uno de los factores de la ecuación, podrá estimarse la concentración en el interior para varias condiciones. El uso de esta técnica permite comparar las diferentes alternativas de control de la contaminación en interiores.

Los edificios con bajas tasas de intercambio con el aire exterior se clasifican como estancos o energéticamente eficaces. Y este último calificativo se debe a que en invierno entra en ellos menos aire frío, reduciendo la energía necesaria para calentar el aire hasta la temperatura ambiente, recortando aś los costes de calefacción. A la par, cuando hace calor, también se utiliza menos energía para enfriar el aire. Los edificios que no tienen estas características se ventilan abriendo puertas y ventanas por un proceso natural. A hora bien, aun estando cerradas, las diferencias de presión debidas al viento y al gradiente térmico existente entre el interior y el exterior, fuerzan la entrada del aire a través de las grietas y hendiduras, de las juntas de ventanas y puertas, de la chimeneas y de otras aberturas, lo que origina la denominada ventilación por infiltración.

La ventilación de un edificio se mide en renovaciones por hora. U na renovación por hora significa que cada hora entra desde el exterior un volumen de aire igual al volumen del edificio; de la misma forma, cada hora se expulsa al exterior un volumen similar de aire interior. Si no hay ventilación forzada (con un ventilador), este valor es difícil de determinar, aunque se considera que varía entre 0,2 y 2,0 renovaciones por hora. Si los otros parámetros no varían, la concentración de contaminantes generados en el interior será menor en edificios con valores elevados de renovación, aunque estos valores no son una garantía de calidad del aire interior. Salvo en áreas con una contaminación atmosférica considerable, los edificios más abiertos tienen una concentración de contaminantes menor en el aire interior que los construidos más herméticamente. Con todo, los edificios más abiertos tienen menor eficacia energética. EI dilema entre la eficacia energética y la calidad del aire tiene gran importancia.

M uchas de las medidas para reducir los costes de energía afectan a la calidad del aire interior en mayor o menor grado. A demás de reducir la velocidad con la que el aire circula dentro del edificio, los effuerzos para aumentar el aislamiento y la impermeabilidad de éste requieren la instalación de materiales que pueden ser fuentes de contaminación en el interior. 0 tra medida, como añadir a los viejos sistemas de calefacción central, a menudo ineficaces, fuentes secundarias que calientan 0 consumen el aire interior pueden elevar también los niveles de contaminación en el interior.

Entre los contaminantes más habituales en el aire interior se encuentran, aparte de los procedentes del exterior, los metales, el amianto y otros materiales fibrosos, el formaldehído, el ozono, los plaguicidas y los compuestos orgánicos en general, el radón, el polvo doméstico y los aerosoles biológicos. A ellos se añade una amplia variedad de microorganismos, como los hongos, las bacterias, los virus y los protozoos, de los cuales los hongos y las bacterias saprófitos son los que mejor se conocen, probablemente debido a que se dispone de la tecnología necesaria para medirlos en el aire. No puede decirse lo mismo de los virus, las rickettsias, las clamidias, los protozoos y muchos hongos y bacterias patógenos, para cuyo muestreo y recuento no se dispone todavía de la metodología apropiada. Entre los agentes infecciosos merecen especial mención los siguientes: Legionella pneumophila, M ycobacterium avium, virus, Coxiella burnetii e $\mathrm{H}$ istoplasma capsulatum; y entre los alergenos: Cladosporium, Penicillium y Cytophaga.

\section{Investigación de la calidad del aire interior}

La experiencia indica que las técnicas tradicionales utilizadas en la higiene industrial y en la calefacción, la ventilación y el acondicionamiento del aire no siempre proporcionan resultados satisfactorios para resolver los problemas actuales, ni aún los más comunes, en materia de calidad del aire interior, aunque el conocimiento básico de estas técnicas permite una buena aproximación para tratar o reducir los problemas de forma rápida y barata. La solución a los problemas de la calidad del aire interior requiere a menudo, además de uno o más expertos en calefacción, ventilación y acondicionamiento del aire e higiene industrial, de especialistas en el control de la calidad del aire interior, en química analítica, en toxicología, en medicina ambiental, en microbiología, en epidemiología y en psicología.

Cuando se realiza un estudio sobre la calidad del aire interior, los objetivos establecidos influirán profundamente en su diseño y en las actividades dirigidas a la toma de muestras y la evaluación, ya que en algunos casos se primarán los procedimientos que proporcionen una respuesta rápida, mientras que en otros serán los valores globales. La duración del programa estará dictada por el tiempo necesario para obtener muestras representativas, y dependerá también de la estación y de las condiciones meteorológicas. Si el objetivo es realizar un estudio de exposición y efecto, además de muestras a largo y corto plazo para evaluar picos, será necesario tomar muestras personales para confirmar la exposición directa de las personas. 
Para algunos contaminantes existen métodos validados y muy utilizados, pero sólo son unos pocos. Las técnicas para medir los niveles de muchos de los contaminantes presentes en interiores normalmente están basadas en aplicaciones de higiene industrial; pero dado que las concentraciones que nos interesan en el aire interior suelen ser mucho menores que las presentes en ambientes industriales, esos métodos suelen ser inadecuados. En los métodos de medición de la contaminación atmosférica se utilizan márgenes de concentraciones similares, pero son pocos los contaminantes a los que pueden aplicarse; además, el uso de estos métodos en el aire interior presenta dificultades: por ejemplo, un instrumento de muestreo de gran volumen para determinar partículas no sólo sería demasiado ruidosos, sino que podría modificar la propia calidad del aire interior.

En la determinación de contaminantes en el aire interior se utilizan diferentes procedimientos: monitores continuos e instrumentos de muestreo (activos de tiempo completo, pasivos de tiempo completo, directos y personales). Actualmente existen procedimientos adecuados para medir los niveles de formaldehído, de óxidos de carbono y nitrógeno, de compuestos orgánicos volátiles y de radón, entre otros. Los contaminantes biológicos se determinan mediante técnicas de sedimentación en placas de cultivo abiertas; actualmente se utilizan cada vez más los sistemas activos que hacen que el aire choque contra una placas con nutrientes que se cultivan posteriormente. La cantidad de microorganismos presentes se expresa en unidades de formación de colonias por metro cúbico.

Al investigar un problema de calidad del aire interior de un edificio suele elaborarse previamente una estrategia práctica que consiste en una aproximación en fases. La primera, la investigación inicial, puede realizarse utilizando técnicas de higiene industrial y debe estructurarse de forma que el investigador no necesite ser un especialista en el campo de la calidad del aire interior. Se lleva a cabo una inspección general del edificio y se comprueban sus instalaciones, en particular las que afectan a la regulación y al funcionamiento correcto del sistema de calefacción, ventilación y acondicionamiento del aire, de acuerdo con las normas establecidas en el momento de su instalación. Es importante a este respecto considerar si las personas afectadas son capaces de modificar las condiciones de su entorno. Si el edificio no tiene sistemas de ventilación forzada, debe estudiarse el grado de eficacia de la ventilación natural de la que dispone. Si después de su revisión (y ajuste en caso necesario), las condiciones de funcionamiento de los sistemas de ventilación cumplen las normas, y aun así continúan las quejas, deberá llevarse a cabo una investigación técnica de tipo general para determinar el grado y la naturaleza del problema. La investigación inicial también debe permitir una valoración de si los problemas han de considerarse únicamente desde el punto de vista del edificio, o si será necesaria la intervención de especialistas en higiene, psicología y otras disciplinas.

Si el problema no se identifica y resuelve en esta primera fase, hay otras posteriores en las que se realizan investigaciones más especializadas que se ocupan de los problemas potenciales identificados en la primera fase. Tales investigaciones pueden incluir un análisis más detallado del sistema de calefacción, ventilación y acondicionamiento del aire del edificio, una evaluación más amplia de los materiales de los que se sospecha que emiten gases y partículas, un análisis químico detallado del aire ambiente en el edificio y evaluaciones médicas o epidemiológicas para detectar síntomas de enfermedad.

En lo que respecta al sistema de calefacción, ventilación y acondicionamiento del aire, debe revisarse el equipo de refrigeración para comprobar la ausencia de crecimiento microbiano y de acumulación de agua en sus bandejas de goteo, deben comprobarse las unidades de ventilación para verificar que funcionan correctamente, deben examinarse los sistemas de entrada y retorno del aire en varios puntos para comprobar su hermeticidad, y debe comprobarse el interior de los conductos suficientemente como para confirmar que no hay microorganismos. La última consideración es fundamental cuando se utilizan humidificadores, aparatos que requieren programas de mantenimiento, funcionamiento e inspección especialmente meticulosos con el fin de prevenir el crecimiento de microorganismos, los cuales pueden propagarse a través del sistema de aire acondicionado.

Las medidas que suelen adoptarse por lo común para mejorar la calidad del aire interior de un edificio son: la eliminación de la fuente, su aislamiento o ventilación independiente, la separación entre la fuente y las personas a las que afecta, la limpieza general del edificio y un mayor nivel de comprobación y mejora del sistema de calefacción, ventilación y acondicionamiento del aire. Lo cual puede implicar desde modificaciones en puntos concretos hasta un nuevo diseño. El proceso suele ser repetitivo, por lo que el estudio debe reiniciarse varias veces, utilizando técnicas más avanzadas en cada ocasión. En el capítulo 45 de esta Enciclopedia se ofrece una descripción más detallada de las técnicas de control.

Por último, es de destacar que ni aun con las investigaciones más completas sobre la calidad del aire interior es posible establecer una relación clara entre las características y la composición del aire interior y la salud y el bienestar de sus ocupantes. Sólo la experiencia, por un lado, y el diseño racional de la ventilación, de la ocupación y de la división en compartimentos de los edificios, por el otro, son posibles garantías desde un principio de que la calidad del aire interior será adecuada para la mayoría de sus ocupantes.

\section{N ATURALEZA Y FUENTES DE LOS CONTAMINANTES QUIMICOSEN EL INTERIOR}

Derrick Crump

\section{Contaminantes químicos característicos}

Los contaminantes químicos del aire interior pueden tomar forma de gases y vapores (inorgánicos y orgánicos) y de partículas, y pueden haber penetrado al interior desde el ambiente exterior o bien haberse formado dentro del edificio. La importancia relativa del origen interior o exterior varía según los distintos contaminantes y en función del tiempo.

He aquí los contaminantes químicos principales y más comunes en el aire interior:

1. dióxido de carbono $\left(\mathrm{CO}_{2}\right)$, un producto metabólico que se utiliza a menudo como indicador del nivel general de contaminación del aire en relación con la presencia de seres humanos en el interior;

2. monóxido de carbono ( $\mathrm{CO}$ ), óxidos de nitrógeno $\left(\mathrm{NO}_{\mathrm{x}}\right)$ y dióxido de azufre $\left(\mathrm{SO}_{2}\right)$, gases de combustión inorgánicos formados fundamentalmente durante la combustión de combustibles y de ozono $\left(\mathrm{O}_{3}\right)$, producto de reacciones fotoquímicas en atmósferas contaminadas aunque también puede ser liberado por algunas fuentes de interiores;

3. compuestos orgánicos que se originan a partir de diversas fuentes interiores y del exterior. En el aire interior hay cientos de compuestos químicos orgánicos, aunque la mayoría están presentes a concentraciones muy bajas. T ales compuestos pueden agruparse en función de su punto de ebullición; en la Tabla 44.1 se muestra una clasificación muy 
Tabla 44.1 • Clasificación de los contaminantes orgánicos en interiores.

\begin{tabular}{|c|c|c|c|c|}
\hline Categoría & Descripción & Abreviatura & Rango de ebullición $(\stackrel{\circ}{C})$ & $\begin{array}{l}\text { Métodos de muestreo utilizados habitualmente } \\
\text { en estudios de campo }\end{array}$ \\
\hline 1 & Compuestos orgánicos muy volátiles (gaseosos) & COMV & $<0$ a $50-100$ & Muestreo de lotes; adsorción en carbón vegetal \\
\hline 2 & Compuestos orgánicos volátiles & $\mathrm{COV}$ & $50-100$ a $240-260$ & $\begin{array}{l}\text { Adsorción en Tenax, negro de humo molecular o } \\
\text { carbón vegetal }\end{array}$ \\
\hline 3 & Compuestos orgánicos semivolátiles & $\cos V$ & $240-260$ a $380-400$ & Adsorción en espuma de poliuretano o XAD-2 \\
\hline 4 & $\begin{array}{l}\text { Compuestos orgánicos asociados a partículas } \\
\text { o materia orgánica particulada }\end{array}$ & MOP & 380 & Filtros de recogida \\
\hline
\end{tabular}

utilizada que identifica cuatro grupos de compuestos orgánicos: a) compuestos orgánicos muy volátiles (CO M V); b) compuestos orgánicos volátiles (COV); c) compuestos orgánicos semivolátiles (COSV), y d) compuestos orgánicos asociados a partículas (CO AP). L os compuestos orgánicos de fase particulada se disuelven 0 adsorben en partículas. Pueden transformarse en vapor o en partículas, dependiendo de su volatilidad. Por ejemplo, los hidrocarburos poliaromáticos (H PA) constituidos por dos anillos de benceno fusionados ( $p$. ej., el naftaleno) se encuentran principalmente en la fase de vapor y los constituidos por cinco anillos (p. ej., el benz[a]pireno) predominantemente en la pase particulada.

U na característica importante de los contaminantes del aire interior es que sus concentraciones varían espacial y temporalmente más que las del exterior. Esto es debido a la gran variedad de fuentes, al funcionamiento intermitente de algunas de ellas y en los diversos desagües existentes.

Las concentraciones de contaminantes generados principalmente por fuentes de combustión están sometidas a grandes variaciones temporales y tienen un carácter intermitente. Las liberaciones esporádicas de compuestos orgánicos volátiles debidas a actividades humanas como la pintura, también varían enormemente con el tiempo. 0 tras emisiones, como la liberación de formaldehído a partir de productos con base de madera, varían con los cambios de temperatura y de humedad del edificio, pero tienen un carácter continuo. La emisión de compuestos químicos orgánicos a partir de otros materiales puede depender menos de las condiciones de temperatura y humedad, pero sus concentraciones en el aire interior dependerán en gran medida de las condiciones de ventilación.

L as variaciones espaciales dentro de una habitación suelen ser menos pronunciadas que las temporales. $D$ entro de un edificio puede haber grandes diferencias por lo que se refiere a fuentes localizadas: es el caso de las fotocopiadoras en una oficina central, los hornos de gas en la cocina de un restaurante y las zonas restringidas para el consumo de tabaco.

\section{Fuentes dentro del edificio}

Los niveles elevados de contaminantes generados por combustión, en particular de dióxido de nitrógeno y monóxido de carbono en espacios interiores, suelen proceder de aparatos de combustión mal ventilados o con un mantenimiento deficiente y del consumo de tabaco. Los calentadores de queroseno y de gas no ventilados emiten cantidades importantes de $\mathrm{CO}, \mathrm{CO}_{2}, \mathrm{NO}_{x}$ $\mathrm{SO}_{2}$, partículas y formaldehído. Las cocinas y hornos de gas también liberan estos productos directamente al aire interior. En condiciones de funcionamiento normales, los calentadores de aire a presión con calefacción por gas y los calentadores de agua no deben liberar productos de combustión al aire interior del edificio. Ahora bien, puede producirse un escape y reflujo de gases de combustión en aparatos defectuosos cuando la habitación está despresurizada debido a la confluencia de los sistemas de escape y a ciertas condiciones meteorológicas.

\section{H umo de tabaco ambiental}

La contaminación del aire interior por el humo de tabaco procede del flujo lateral y del flujo principal de humo exhalado, y generalmente recibe el nombre de humo de tabaco ambiental (HTA). Se han identificado varios millares de componentes diferentes del humo del tabaco, cuyas cantidades individuales varían en función del tipo de cigarrillo y de las condiciones de producción de humo. Los principales compuestos químicos asociados al HTA son: nicotina, nitrosaminas, HPA, $\mathrm{CO}, \mathrm{CO}_{2}, \mathrm{NO}_{x}$, acroleína, formaldehído y cianuro de hidrógeno.

\section{M ateriales y mobiliario de edificios}

Los materiales que más interés han despertado como fuentes de contaminación del aire interior han sido los tableros a base de madera que contienen resina de formaldehído ureico (FU) y los aislantes de paredes mediante una cámara de aire con FU. El formaldehído que emiten estos productos eleva los niveles del mismo en los edificios, fenómeno que se ha asociado a numerosos casos de mala calidad del aire interior en países desarrollados, en particular a finales del decenio de 1970 y principios del de 1980. En la Tabla 44.2 se presentan ejemplos de materiales que liberan formaldehído en los edificios, y se muestra que las tasas más elevadas de emisión pueden estar asociadas a los objetos con base de madera y los aislantes de paredes con FU, de uso muy común.

Tabla 44.2 - Tasas de emisión de formaldehído de diversos materiales de decoración y productos de consumo.

\begin{tabular}{lc} 
& $\begin{array}{c}\text { Rango de tasas de emisión de } \\
\text { formaldehído }\left(\mu \mathrm{g} / \mathrm{m}^{2} / \text { día }\right)\end{array}$ \\
Paneles de fibras de densidad media & $17.600-55.000$ \\
Paneles de pared de contrachapado & $1.500-34.000$ \\
$\quad$ de madera dura & \\
Aglomerado & $2.000-25.000$ \\
Aislamiento de espuma de & $1.200-19.200$ \\
$\quad$ urea-formaldehído & \\
Contrachapado de madera blanda & $240-720$ \\
Productos de papel & $260-680$ \\
Productos de fibra de vidrio & $400-470$ \\
Telas & $35-570$ \\
Suelo flexible & $<240$ \\
Alfombras & 0.65 \\
Tapicería & $0-7$ \\
\hline
\end{tabular}


El aglomerado se fabrica a partir de partículas finas de madera (aproximadamente de $1 \mathrm{~mm}$ ) que se mezclan con resinas de FU (entre 6 y $8 \%$ del peso) y se prensan en forma de paneles de madera. Se utiliza mucho para suelos, paneles de pared, estanterías y piezas de armarios y muebles. Las láminas de madera dura están unidas con resina de FU y se utilizan habitualmente para paneles de pared decorativos y piezas de muebles. Los paneles de fibra de densidad media (PFDM) tienen partículas de madera más finas que las utilizadas en los aglomerados, y también están unidas con resina de FU. Los PFDM se utilizan sobre todo en la fabricación de muebles. La fuente principal de formaldehído en todos estos productos es el que queda atrapado como residuo en el proceso de fabricación de la resina, en el que se requieren cantidades excesivas de formaldehído para que reaccione con la urea. Por consiguiente, cuanto más nuevo es el producto, mayor será la emisión, que irá disminuyendo en función del grosor del producto, de la fuerza de emisión inicial, de la presencia de otras fuentes de formaldehído, del clima local y del comportamiento de los ocupantes. La tasa de descenso inicial de las emisiones puede ser del $50 \%$ durante los primeros ocho o nueve meses, tras los cuales el proceso se va haciendo mucho más lento. Pueden producirse emisiones secundarias debidas a la hidrólisis de la resina de FU, por lo que las tasas de emisión aumentan durante períodos de temperatura y humedad elevadas. Tras grandes

\section{Tabla 44.3 - Concentraciones de compuestos orgánicos volátiles totales (COVT) y tasas de emisión asociadas a los diversos recubrimientos y revestimientos de suelos y paredes.}

\begin{tabular}{|c|c|c|}
\hline Tipo de material & $\begin{array}{l}\text { Concentraciones } \\
\left(\mathrm{mg} / \mathrm{m}^{3}\right)\end{array}$ & $\begin{array}{l}\text { Tasa de emisión } \\
\left(\mathrm{mg} / \mathrm{m}^{2} \mathrm{~h}\right)\end{array}$ \\
\hline \multicolumn{3}{|l|}{ Papel de pared } \\
\hline Vinilo y papel & 0,95 & 0,04 \\
\hline Vinilo y fibra de vidrio & 7,18 & 0,30 \\
\hline Papel pintado & 0,74 & 0,03 \\
\hline \multicolumn{3}{|c|}{ Recubrimiento de pared } \\
\hline Hessian & 0,09 & 0,005 \\
\hline PVCa & 2,43 & 0,10 \\
\hline Textil & 39,60 & 1,60 \\
\hline Textil & 1,98 & 0,08 \\
\hline \multicolumn{3}{|l|}{ Recubrimiento de suelo } \\
\hline Linóleo & 5,19 & 0,22 \\
\hline Fibras sintéticas & 1,62 & 0,12 \\
\hline Goma & 28,40 & 1,40 \\
\hline Plástico blando & 3,84 & 0,59 \\
\hline PVC homogéneo & 54,80 & 2,30 \\
\hline \multicolumn{3}{|l|}{ Revestimiento } \\
\hline Látex acrílico & 2,00 & 0,43 \\
\hline $\begin{array}{l}\text { Barniz, epoxi } \\
\text { transparente }\end{array}$ & 5,45 & 1,30 \\
\hline $\begin{array}{l}\text { Barniz, poliuretano, } \\
\text { dos componentes }\end{array}$ & 28,90 & 4,70 \\
\hline $\begin{array}{l}\text { Barniz, endurecido } \\
\text { con ácido }\end{array}$ & 3,50 & 0,83 \\
\hline PVC, polivinil cloruro. & & \\
\hline
\end{tabular}

esfuerzos por parte de los fabricantes, se han elaborado materiales de emisión reducida utilizando en la producción de resina una relación más baja (próxima a 1:1) de urea y formaldehído, además de eliminadores de formaldehído. Su regulación y la demanda por parte de los consumidores han dado lugar a un uso extendido de estos productos en algunos países.

Los materiales de construcción y los muebles liberan muchos otros C OV que han despertado cada vez más interés durante los decenios de 1980 y 1990. La emisión puede corresponder a una mezcla compleja de compuestos, aunque algunos de ellos pueden ser predominantes. En un estudio de 42 materiales de construcción se identificaron 62 especies químicas diferentes. L os COV eran principalmente hidrocarburos alifáticos y aromáticos, sus derivados de oxígeno y terpenos. Los compuestos con mayores concentraciones de emisión continuada, en orden decreciente, fueron: tolueno, m-xileno, terpeno, n-butilacetato, n-butanol, n-hexano, p-xileno, etoxietilacetato, n-heptano y o-xileno. La complejidad de la emisión hace que los informes sobre las emisiones y concentraciones en el aire se basen en la concentración o la liberación de los compuestos orgánicos volátiles totales (COVT). En la Tabla 44.3 se dan ejemplos de las tasas de emisión de COVT para varios materiales de construcción. En ellos se observa que existen diferencias importantes en las emisiones entre unos productos y otros, lo que significa que si se dispusiera de datos suficientes se podrían elegir los materiales adecuados en la fase de planificación para reducir al mínimo la liberación de COV en edificios de nueva construcción.

Se ha demostrado que los conservantes de la madera son una fuente de pentaclorofenol y lindano en el aire y en el polvo del interior de los edificios. Se utilizan fundamentalmente para la protección de la madera frente a la exposición atmosférica y también en biocidas aplicados para evitar la desecación de la madera y el control de los insectos.

\section{Productos de consumo y otras fuentes de contaminación interior}

La diversidad y número de productos de consumo y domésticos varía constantemente, y sus emisiones químicas dependen de cómo se utilizan. Entre los productos que pueden influir en los niveles de COV en el interior se encuentran los aerosoles, los artículos de higiene personal, los disolventes, los adhesivos y las pinturas. En la Tabla 44.4 se muestran los principales componentes químicos presentes en varios productos de consumo.

O tros C OV se han asociado a otras fuentes. El cloroformo se introduce en el aire interior principalmente a consecuencia de la dispensación o calentamiento de agua corriente. Las copiadoras de proceso líquido liberan isodecanos al aire. Está muy extendido el uso de insecticidas para combatir las cucarachas, las termitas, las pulgas, las moscas, las hormigas y los ácaros, y se encuentran en forma de pulverizadores, nebulizadores, polvos, tiras impregnadas, cebos y collares para animales. Algunos de los compuestos son diazinón, paradiclorobenceno, pentaclorofenol, clordano, malatión, naftaleno y aldrín. También son fuentes de contaminación los ocupantes de la oficina (dióxido de carbono y olores), los materiales de oficina (COV y ozono), los mohos (COV, amoníaco, dióxido de carbono), la tierra contaminada (metano, COV), los depuradores de aire eléctricos y los generadores de iones negativos (ozono).

\section{Inter vención del medio ambiente exterior}

En la Tabla 44.5 se muestran las relaciones interior-exterior típicas para los principales tipos de contaminantes presentes en el aire interior y las concentraciones medias observadas en el aire exterior de áreas urbanas en el R eino U nido. EI dióxido de azufre presente en el aire interior procede normalmente del exterior, tanto de fuentes naturales como antropogénicas. La combustión 
Tabla 44.4 • Componentes y emisiones de productos de consumo y otras fuentes de compuestos orgánicos volátiles (CO V).

\begin{tabular}{|c|c|c|}
\hline Fuente & Compuesto & Tasa de emisión \\
\hline $\begin{array}{l}\text { Agentes de limpieza } \\
\text { y plaguicidas }\end{array}$ & $\begin{array}{l}\text { Cloroformo } \\
\text { 1,2-Dicloroetano } \\
\text { 1,1,1-Tricloroetano } \\
\text { Tetracloruro de carbono } \\
\text { m-Diclorobenceno } \\
\text { p-Diclorobenceno } \\
\text { n-Decano } \\
\text { n-Undecano }\end{array}$ & $\begin{array}{l}15 \mu \mathrm{g} / \mathrm{m}^{2} . h \\
1,2 \mu \mathrm{g} / \mathrm{m}^{2} . h \\
37 \mu \mathrm{g} / \mathrm{m}^{2} . h \\
71 \mu \mathrm{g} / \mathrm{m}^{2} . h \\
0,6 \mu \mathrm{g} / \mathrm{m}^{2} . h \\
0,4 \mu \mathrm{g} / \mathrm{m}^{2} . h \\
0,2 \mu \mathrm{g} / \mathrm{m}^{2} . h \\
1,1 \mu \mathrm{g} / \mathrm{m}^{2} . h\end{array}$ \\
\hline Antipolilla & p-Diclorobenceno & $14.000 \mu \mathrm{g} / \mathrm{m}^{2} . \mathrm{h}$ \\
\hline $\begin{array}{l}\text { Ropas limpiadas en } \\
\text { seco }\end{array}$ & Tetracloroetileno & $0,5-1 \mathrm{mg} / \mathrm{m}^{2} . \mathrm{h}$ \\
\hline Cera de suelo líquida & $\begin{array}{l}\text { COVT (trimetilpenteno e } \\
\text { isómeros de dodecano) }\end{array}$ & $96 \mathrm{~g} / \mathrm{m}^{2} . \mathrm{h}$ \\
\hline Cera en pasta para piel & $\begin{array}{l}\text { COVT (pineno y 2-metil- } \\
\text { 1-propanol) }\end{array}$ & $3,3 \mathrm{~g} / \mathrm{m}^{2} . \mathrm{h}$ \\
\hline Detergente & $\begin{array}{l}\text { COVT (limoneno, pineno } \\
\text { y mirceno) }\end{array}$ & $240 \mathrm{mg} / \mathrm{m}^{2} . \mathrm{h}$ \\
\hline Emisiones humanas & $\begin{array}{l}\text { Acetona } \\
\text { Acetaldehído } \\
\text { Acido acético } \\
\text { Alcohol metílico }\end{array}$ & $\begin{array}{l}50,7 \mathrm{mg} / \text { día } \\
6,2 \mathrm{mg} / \text { día } \\
19,9 \mathrm{mg} / \text { día } \\
74,4 \mathrm{mg} / \text { día }\end{array}$ \\
\hline Papel de copia & Formaldehído & $0,4 \mu \mathrm{g} /$ hoja \\
\hline Humidificador de vapor & $\begin{array}{l}\text { Dietilaminoetanol, } \\
\text { ciclohexilamina }\end{array}$ & - \\
\hline Fotocopiadora húmeda & 2,2,4-Trimetilheptano & - \\
\hline Disolventes domésticos & Tolueno, etil benceno & - \\
\hline Quitapinturas & Diclorometano, metanol & - \\
\hline Quitapinturas & $\begin{array}{l}\text { Diclorometano, tolueno, } \\
\text { propano }\end{array}$ & - \\
\hline Protector de tela & $\begin{array}{l}\text { 1,1,1-Tricloroetano, } \\
\text { propano, destilados del } \\
\text { petróleo }\end{array}$ & - \\
\hline Pintura de látex & $\begin{array}{l}\text { 2-Propanol, butanona, } \\
\text { etilbenceno, tolueno }\end{array}$ & - \\
\hline $\begin{array}{l}\text { Refrescador de } \\
\text { habitación }\end{array}$ & $\begin{array}{l}\text { Nonano, decano, etil- } \\
\text { heptano, limoneno }\end{array}$ & - \\
\hline Agua de ducha & Cloroformo, tricloroetileno & - \\
\hline
\end{tabular}

de combustibles fósiles que contienen azufre y la fundición de minerales de azufre son fuentes importantes de dióxido de azufre en la troposfera. Los niveles de fondo son muy bajos (1 ppb), pero en áreas urbanas las concentraciones máximas por hora pueden ser de 0,1 a 0,5 ppm. El dióxido de azufre puede penetrar en un edificio a través del aire utilizado para la ventilación o infiltrarse a través de pequeñas grietas en la estructura del edificio, en función de la hermeticidad del edificio, de las condiciones meteorológicas y de las temperaturas internas. U na vez en el interior, se mezcla y se diluye con el aire interior. El dióxido de azufre que entra en contacto con los materiales del edificio y los muebles es adsorbido, lo cual puede reducir de forma importante la concentración en el interior con respecto a la existente en el exterior, en particular cuando los niveles de dióxido de azufre en el exterior son elevados.
Los óxidos de nitrógeno proceden de la combustión, y entre sus fuentes más importantes se encuentran los gases de escape de los automóviles, los generadores eléctricos calentados con combustibles fósiles y los calentadores domésticos. EI óxido nítrico (NO) es poco tóxico, pero puede oxidarse y producir dióxido de nitrógeno ( $\mathrm{NO}_{2}$ ), en particular en casos de contaminación fotoquímica. L as concentraciones de fondo de dióxido de nitrógeno son de aproximadamente $1 \mathrm{ppb}$, pero pueden alcanzar las 0,5 ppm en áreas urbanas. El exterior es la principal fuente de dióxido de nitrógeno en los edificios sin aparatos de combustible no ventilados. Como en el caso del dióxido de azufre, la adsorción por las superficies internas reduce la concentración en el interior con respecto a la existente en el exterior.

El ozono se produce en la troposfera por reacciones fotoquímicas en atmósferas contaminadas y su formación depende de la intensidad de la luz del sol y de la concentración de óxidos de nitrógeno, hidrocarburos reactivos y monóxido de carbono. En lugares remotos, las concentraciones de fondo de ozono son de 10 a 20 ppb y pueden superar las 120 ppb en áreas urbanas durante los meses de verano. Las concentraciones en el interior son significativamente más bajas debido a la reacción con las superficies del interior y a la falta de fuentes potentes.

Se estima que la liberación de monóxido de carbono como resultado de actividades antropogénicas origina el $30 \%$ de la concentración presente en la atmósfera del hemisferio norte. LoS niveles de fondo son de aproximadamente $0,19 \mathrm{ppm}$, y en las áreas urbanas existe un nivel diurno de concentraciones relacionado con el uso de vehículos de motor, con niveles máximos por hora que oscilan entre 3 ppm y 50 a 60 ppm. Es una sustancia relativamente no reactiva, por lo que no su concentración no disminuye por reacción o adsorción en las superficies de interiores. Por tanto, al nivel de fondo originado por el aire del exterior hay que añadir las fuentes de interior, como los aparatos de combustible no ventilados.

La relación entre interior y exterior en los compuestos inorgánicos depende del compuesto en cuestión y puede variar con el tiempo. Para los compuestos con fuentes importantes en el interior, como el formaldehído, suelen ser mayores las concentraciones en el interior. En el caso del formaldehído, las

Tabla 44.5 • Principales contaminantes químicos del aire interior y sus concentraciones en el medio urbano del Reino Unido.

\begin{tabular}{|c|c|c|}
\hline $\begin{array}{l}\text { Sustancia/ grupo } \\
\text { de sustancias }\end{array}$ & $\begin{array}{l}\text { Relación de concentraciones } \\
\text { interior/ exterior }\end{array}$ & $\begin{array}{l}\text { Concentraciones } \\
\text { típicas urbanas }\end{array}$ \\
\hline Dióxido de azufre & $\sim 0,5$ & $10-20 \mathrm{ppb}$ \\
\hline Dióxido de nitrógeno & $\leq 5-12$ (fuentes de interior) & $10-45 \mathrm{ppb}$ \\
\hline Ozono & $0,1-0,3$ & $15-60 \mathrm{ppb}$ \\
\hline Dióxido de carbono & $1-10$ & 350 ppm \\
\hline Monóxido de carbono & $\leq 5-11$ (fuente de interior) & $0,2-10 \mathrm{ppm}$ \\
\hline Formaldehído & $\leq 10$ & $0,003 \mathrm{mg} / \mathrm{m}^{3}$ \\
\hline $\begin{array}{l}\text { Otros compuestos } \\
\text { orgánicos } \\
\text { Tolueno } \\
\text { Benceno } \\
\text { m-y p-xilenos }\end{array}$ & $1-50$ & $\begin{array}{l}5,2 \mu \mathrm{g} / \mathrm{m}^{3} \\
6,3 \mu \mathrm{g} / \mathrm{m}^{3} \\
5,6 \mu \mathrm{g} / \mathrm{m}^{3}\end{array}$ \\
\hline Partículas en suspensión & $\begin{array}{l}\text { 0,5-1 (excluido el TAa) } \\
2-10 \text { (incluido el TA) }\end{array}$ & $50-150 \mu \mathrm{g} / \mathrm{m}^{3}$ \\
\hline
\end{tabular}

a TA, tabaquismo ambiental. 
concentraciones en el exterior suelen ser inferiores a los $0,005 \mathrm{mg} / \mathrm{m}^{3}$ y las concentraciones en el interior son diez veces mayores que las del exterior. 0 tros compuestos como el benceno tienen fuentes importantes en el exterior, particularmente los vehículos de motor de gasolina. Entre las fuentes de benceno en el interior está el HTA, que da lugar a concentraciones medias en los edificios del Reino Unido 1,3 veces mayores que las presentes en el exterior. El medio ambiente de interiores no parece ser un medio de eliminación importante de este compuesto, por lo que no protege frente al benceno procedente del exterior.

\section{Concentraciones típicas en edificios}

Las concentraciones de monóxido de carbono en interiores suelen variar entre 1 y 5 ppm. En la Tabla 44.6 se resumen los resultados de 25 estudios. Las concentraciones aumentan con el humo de tabaco ambiental, aunque es excepcional que superen las 15 ppm.

Las concentraciones de dióxido de nitrógeno en el interior suelen ser de 29 a 46 ppb. Si hay fuentes específicas, como estufas de gas, las concentraciones pueden aumentar significativamente, y el consumo de tabaco puede tener un efecto cuantificable (véase la Tabla 44.6).

Muchos COV están presentes en el medio ambiente de interior a concentraciones que varían entre aproximadamente 2 y $20 \mathrm{mg} / \mathrm{m}^{3}$. En la Figura 44.3 se resume una base de datos de Estados Unidos con 52.000 registros sobre 71 productos químicos en viviendas, edificios públicos y oficinas. En los ambientes en los que el consumo de tabaco es intenso o la ventilación deficiente se generan concentraciones de HTA elevadas, que pueden producir concentraciones de COV de entre 50 hasta $200 \mathrm{mg} / \mathrm{m}^{3}$. Los materiales de construcción contribuyen de forma importante a las concentraciones de contaminantes en el interior, y en las casas nuevas probablemente haya mayor número de compuestos que superen los $100 \mathrm{mg} / \mathrm{m}^{3}$. Las reformas y la pintura contribuyen a la producción de niveles

\begin{tabular}{|c|c|c|}
\hline Lugar & $\begin{array}{l}\text { Valores de } \mathrm{NO}_{\mathrm{x}} \\
(\mathrm{ppb})\end{array}$ & $\begin{array}{l}\text { Valores medios } \\
\text { de CO (ppm) }\end{array}$ \\
\hline \multicolumn{3}{|c|}{ Oficinas } \\
\hline $\begin{array}{l}\text { Tabaco } \\
\text { Control }\end{array}$ & $\begin{array}{c}42-51 \\
-\end{array}$ & $\begin{array}{l}1,0-2,8 \\
1,2-2,5\end{array}$ \\
\hline \multicolumn{3}{|c|}{ Otros lugares de trabajo } \\
\hline $\begin{array}{l}\text { Tabaco } \\
\text { Control }\end{array}$ & $\begin{array}{l}N D^{a}-82 \\
27\end{array}$ & $\begin{array}{l}1,4-4,2 \\
1,7-3,5\end{array}$ \\
\hline \multicolumn{3}{|c|}{ Transporte } \\
\hline $\begin{array}{l}\text { Tabaco } \\
\text { Control }\end{array}$ & $\begin{array}{c}150-330 \\
-\end{array}$ & $\begin{array}{l}1,6-33 \\
0-5,9\end{array}$ \\
\hline \multicolumn{3}{|c|}{ Restaurantes y cafeterías } \\
\hline $\begin{array}{l}\text { Tabaco } \\
\text { Control }\end{array}$ & $\begin{array}{l}5-120 \\
4-115\end{array}$ & $\begin{array}{l}1,2-9,9 \\
0,5-7,1\end{array}$ \\
\hline \multicolumn{3}{|c|}{ Bares y tabernas } \\
\hline $\begin{array}{l}\text { Tabaco } \\
\text { Control }\end{array}$ & $\begin{array}{l}195 \\
4-115\end{array}$ & $\begin{array}{l}\sim 3-17 \\
\sim 1-9,2\end{array}$ \\
\hline
\end{tabular}

Figura 44.3 - Concentraciones diarias de diversos compuestos en ambientes de interior.

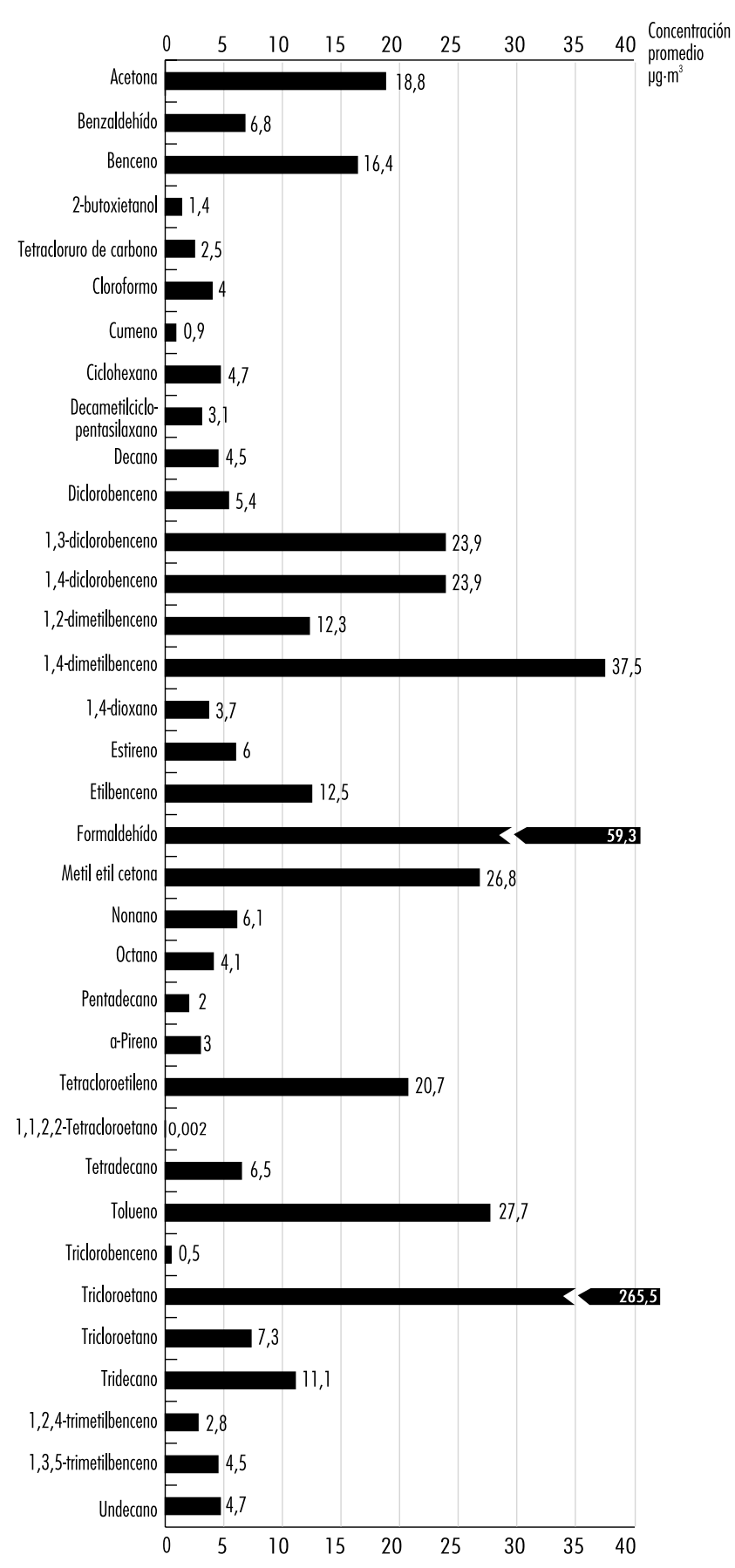

significativamente más altos de COV. Las concentraciones de compuestos, como el acetato etílico, el 1,1,1-tricloroetano y el limoneno, pueden superar los $20 \mathrm{mg} / \mathrm{m}^{3}$ en los períodos en que el edificio está ocupado, mientras que en ausencia de los residentes la concentración de diversos COV puede disminuir en cerca del $50 \%$. Se han descrito casos específicos de concentraciones elevadas de contaminantes debidas a los materiales y al 
mobiliario, a partir de las quejas de los ocupantes del edificio. Entre estos contaminantes se encuentran la trementina mineral resultante de la inyección de hiladas hidrófugas para aislamiento de muros, el naftaleno de productos que contienen alquitrán mineral, el etilhexanol procedente de suelos vinílicos y el formaldehído liberado en productos a base de madera.

EI gran número de COV presentes en los edificios dificulta detallar las concentraciones de algunos compuestos seleccionados. EI concepto de COVT se ha utilizado como medida de la mezcla de compuestos presentes. No existe ninguna definición de uso generalizado de los compuestos que representan los COVT, pero algunos investigadores han propuesto que la limitación de las concentraciones por debajo de $300 \mathrm{mg} / \mathrm{m}^{3}$ debería reducir las quejas de los ocupantes con respecto a la calidad del aire interior.

Los plaguicidas utilizados en el interior tienen una volatilidad relativamente baja y sus concentraciones se encuentran en un nivel bajo (microgramos por metro cúbico). Los compuestos volatilizados pueden contaminar el polvo y todas las superficies del interior debido a sus bajas presiones de vapor y a la tendencia a ser adsorbidos por los materiales del interior. Las concentraciones de HPA en el aire también dependen en gran medida de su distribución entre las fases de gas y de aerosol. El consuno de tabaco por los ocupantes puede tener un efecto importante sobre las concentraciones en el aire interior. Las concentraciones de HPA varían normalmente entre 0,1 y $99 \mathrm{ng} / \mathrm{m}^{3}$.

\section{RADON}

\section{M aría José Berenguer}

La mayor parte de la radiación a la que se expone un ser humano durante su vida procede de fuentes naturales del espacio exterior 0 de materiales presentes en la corteza de la Tierra. Los materiales radiactivos pueden afectar al organismo desde fuera 0 , si son inhalados 0 ingeridos con alimentos, desde dentro. La dosis recibida es muy variable, porque depende, por un lado, de la cantidad de minerales radiactivos presentes en el área del mundo en la que vive la persona - que está relacionada con la cantidad de radioisótopos presentes en el aire y con la cantidad existente en los alimentos y sobre todo en el agua potable- y, por el otro, del uso de ciertos materiale $s$ de construcción y de la utilización de gas o carbón como combustible, así como del tipo de construcción empleado y de los hábitos tradicionales de las personas de la localidad en cuestión.

En la actualidad, el radón se considera la fuente más frecuente de radiación natural. Junto con sus "hijos", los radioisótopos formados durante su desintegración, el radón constituye aproximadamente tres cuartas partes de la dosis eficaz equivalente a la que los seres humanos están expuestos debido a fuentes terrestres naturales. La presencia de radón se asocia a un aumento de la incidencia de cáncer de pulmón debido al depósito de sustancias radiactivas en la región bronquial.

El radón es un gas incoloro, inodoro e insípido con un peso siete veces superior al del aire. Existen normalmente dos isótopos. U no es el radón 222, un radioisótopo presente en la serie radiactiva relacionada con la desintegración del uranio 238; su fuente más importante en el medio ambiente son las rocas y la tierra, en las que se forma el elemento que le precede, el radio 226 . El otro es el radón 220 , perteneciente a la serie radiactiva del torio, y cuya incidencia es menor que la del radón 222
El uranio está muy extendido en la corteza terrestre. La concentración media del radio en el suelo es del orden de $25 \mathrm{~Bq} / \mathrm{kg}$. U n becquerel $(\mathrm{Bq})$ es la unidad del sistema internacional y representa una unidad de actividad radioisotópica equivalente a una desintegración por segundo. La concentración media de gas radón en la atmósfera en la superficie terrestre es de $3 \mathrm{~Bq} / \mathrm{m}^{3}$, con unos valores que oscilan entre 0,1 (sobre los océanos) y $10 \mathrm{~Bq} / \mathrm{m}^{3}$. El nivel depende de la porosidad del suelo, de la concentración local de radio 226 y de la presión atmosférica. Dado que la semivida del radón 222 es de 3.823 días, la mayor parte de la dosis no está causada por el gas, sino por sus "hijas".

El radón se encuentra en materiales existentes y fluye de la tierra en cualquier lugar. D ebido a sus características, se dispersa fácilmente en el exterior, pero tiene tendencia a concentrarse en espacios cerrados, sobre todo en fosos y edificios, y en especial en espacios mas pequeños en los que su eliminación es difícil sin una ventilación adecuada. En regiones cálidas se estima que las concentraciones de radón en interiores son ocho veces mayores que las concentraciones en el exterior.

Así pues, la exposición al radón para la mayor parte de la población tiene lugar principalmente en el interior de los edificios. La media de las concentraciones de radón depende, básicamente, de las características geológicas del terreno, de los materiales de construcción utilizados y de las características de ventilación del edificio.

La principal fuente de radón en los espacios interiores es el radio presente en el suelo sobre el que descansa el edificio o los materiales utilizados en su construcción. 0 tras fuentes importantes - aunque su influencia relativa es mucho menor- son el aire exterior, el agua y el gas natural. En la Figura 44.4 se muestra la aportación de cada fuente al total.

Los materiales de construcción más comunes, como la madera, los ladrillos y los bloques de hormigón de escoria, emiten relativamente poco radón, a diferencia del granito y de la piedra pómez. Con todo, los principales problemas están causados por el uso de materiales naturales, como la pizarra de

Figura 44.4 - Fuentes de radón en el medio ambiente de interior.

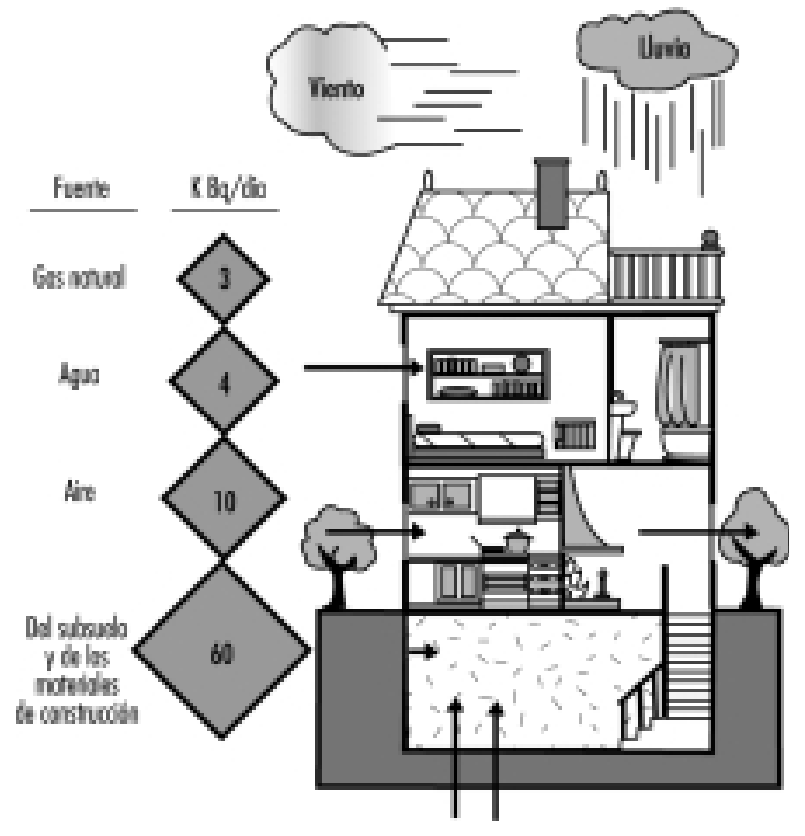


alumbre, en la producción de materiales de construcción. 0 tra fuente de problemas ha sido el uso de subproductos relacionados con el tratamiento de los minerales de fosfato y con la producción de aluminio, así como con el uso de la escoria resultante del tratamiento del mineral de hierro en altos hornos y de las cenizas originadas en la combustión del carbón. Además, en algunos casos también se utilizaron en la construcción residuos procedentes de la minería del uranio.

El radón puede penetrar en el agua y en el gas natural del subsuelo. El agua utilizada para abastecer un edificio, sobre todo si procede de pozos profundos, puede contener cantidades importantes de radón. Si esta agua se utiliza para cocinar, la cocción puede liberar gran parte del radón que contiene. Si el agua se consume fría, el cuerpo elimina el gas rápidamente, por lo que su ingestión no suele entrañar un riesgo importante. La combustión del gas natural en estufas sin chimenea, en calentadores o en otros aparatos puede causar también un aumento de radón en espacios interiores, especialmente en las viviendas. El problema se agrava a veces en los cuarto de baño, debido a que el radón contenido en el agua y en el gas natural utilizado para el calentador del agua se acumula si la ventilación no es suficiente.

Dado que los posibles efectos del radón sobre la población en general no se han conocido hasta hace pocos años, los datos disponibles sobre las concentraciones existentes en espacios interiores se limitan a los países que, debido a sus características o circunstancias especiales, están más sensibilizados con este problema. Lo que sí se sabe es que en una misma región es posible encontrar concentraciones en espacios interiores muy superiores a las concentraciones del exterior. En H elsinki (Finlandia), por ejemplo, se han encontrado concentraciones de radón en el aire interior 5.000 veces mayores que las concentraciones existentes normalmente en el exterior. En parte puede deberse a medidas de ahorro de energía que contribuyen notablemente a la concentración de radón en espacios interiores, en particular si el edificio está bien aislado. En los edificios estudiados hasta ahora en diferentes países y regiones se observa que las concentraciones de radón en su interior presentan una distribución que se aproxima a la log-normal. Es de destacar que un pequeño número de edificios de cada región muestran concentraciones diez veces superiores a la media. Los valores de referencia para el radón en espacios interiores y las recomendaciones de corrección de diversas organizaciones se muestran en el apartado "Reglamentos, recomendaciones, normas y patrones" de este capítulo.

Como conclusión, la principal forma de prevenir las exposiciones al radón es evitar la construcción en áreas que, por su naturaleza, emiten una gran cantidad de radón al aire. En los casos en que esto no sea posible, los suelos y las paredes deben aislarse de forma apropiada, y no deben utilizarse materiales de construcción que contengan elementos radiactivos. Los espacios interiores, especialmente los sótanos, deben tener una ventilación suficiente.

\section{- HuMO DE TABACO}

Dietrich H offmann y Ernst $L$. Wynder

En 1985, el inspector general de Sanidad del Public Health Service de Estados U nidos revisó las consecuencias sanitarias del consumo de tabaco en el lugar de trabajo con respecto al cáncer y a las enfermedades pulmonares crónicas. La conclusión a la que llegó fue que para la mayoría de los trabajadores de Estados U nidos, el consumo de cigarrillos representa una causa de muerte y discapacidad mayor que su entorno de trabajo. Con todo, el control del consumo de tabaco y la disminución de la exposición a agentes peligrosos en el lugar de trabajo son esenciales, ya que con frecuencia estos factores actúan de forma sinérgica con el consumo de tabaco en la inducción y en el desarrollo de enfermedades respiratorias. Se ha demostrado que algunas exposiciones profesionales inducen al desarrollo de bronquitis crónica en los trabajadores. Entre ellas se encuentran las exposiciones al polvo de carbón, cemento y grano, a los aerosoles de sílice, a los vapores producidos durante las soldaduras y al dióxido de azufre. La bronquitis crónica en los trabajadores de estas profesiones a menudo se agrava por el consumo de cigarrillos (inspector general de Sanidad de EE.UU. 1985).

Los datos epidemiológicos han demostrado claramente que los mineros del uranio y los trabajadores del amianto que fuman cigarrillos presentan un riesgo de padecer cáncer del aparato respiratorio significativamente mayor que los trabajadores de estas profesiones que no fuman. El efecto cancerígeno del uranio y del amianto y del consumo de cigarrillos no sólo es aditivo, sino también sinérgico en la inducción del carcinoma de células escamosas de pulmón (inspector general de Sanidad de EE.UU. 1985; H offmann y Wynder 1976; Saccomanno, H uth y A uerbach 1988; H ilt y cols. 1985). L os efectos cancerígenos de la exposición al níquel, al arsénico y sus compuestos, al cromato y a los éteres de clorometilo, y los del consumo de cigarrillos son aditivos (inspector general de Sanidad de EE.UU. 1985; Hoffmann y Wynder 1976; IARC 1987a; Pershagen y cols. 1981). Se podría aceptar que los trabajadores de los hornos de coque que fuman tienen un riesgo más elevado de padecer cáncer de pulmón y de riñón que los trabajadores de esta profesión no fumadores; sin embargo, carecemos de datos epidemiológicos que respalden esta hipótesis (I ARC 1987c).

El propósito de este artículo es evaluar los efectos tóxicos de la exposición de los varones y las mujeres al humo de tabaco ambiental (TA) y al humo de flujo central $(\mathrm{HC})$, en el lugar de trabajo. Por supuesto, el hecho de restringir el consumo de tabaco en el lugar de trabajo beneficiará a los fumadores activos al disminuir su consumo de cigarrillos durante la jornada laboral, aumentando de ese modo la posibilidad de que se conviertan en exfumadores; pero el cese del consumo de tabaco también será beneficioso para aquellos no fumadores alérgicos al humo de tabaco o que ya tienen enfermedades de pulmón o de corazón.

\section{Naturaleza fisicoquímica de humo de tabaco ambiental}

\section{H umo de flujo central y de flujo lateral}

EI HTA se define como el material presente en el aire interior procedente del humo de tabaco. En general, la fuente principal del HTA es el humo de los cigarrillos, aunque también contribuyen el humo de tabaco de pipa y de puros. EI HTA es un aerosol compuesto que emana principalmente del cono de combustión de un producto del tabaco entre las aspiraciones. La emanación se denomina humo de flujo lateral $(H \mathrm{~L})$. En menor proporción, el HTA también contiene componentes de humo de flujo central $(\mathrm{HC})$, es decir, aquellos que exhala el fumador. En la Tabla 44.7 se muestran las proporciones de los agentes tóxicos principales y de los agentes cancerígenos en el humo inhalado, en el humo de flujo central y en el humo de flujo lateral (Hoffmann y Hecht 1990; Brunnemann y Hoffmann 1991; Guerin y cols. 1992; Luceri y cols. 1993). La Agencia Internacional para la Investigación sobre el Cáncer (IARC) reconoce los componentes del humo marcados con $\mathrm{C}$ en su epígrafe "T ipo de toxicidad" como cancerígenos animales. Entre estos se encuentra el benceno, la $\beta$-naftilamina, el 4-aminobifenilo y el polonio-210, 
Tabla 44.7 - Algunos agentes tóxicos y tumorígenos en el humo de flujo lateral de los cigarrillos no diluido.

\begin{tabular}{|c|c|c|c|}
\hline Compuesto & $\begin{array}{l}\text { Tipo de } \\
\text { toxicidada }\end{array}$ & $\begin{array}{l}\text { Cantidad en el } \\
\text { humo de flujo } \\
\text { lateral por } \\
\text { cigarrillo }\end{array}$ & $\begin{array}{l}\text { Relación del } \\
\text { humo lateral } \\
\text { respecto al } \\
\text { humo central }\end{array}$ \\
\hline \multicolumn{4}{|l|}{ Fase de vapor } \\
\hline Monóxido de carbono & T & $26,80-61 \mathrm{mg}$ & $2,5-14,9$ \\
\hline Carbonil sulfuro & T & $2.3 \mu \mathrm{g}$ & $0,03-0,13$ \\
\hline 1,3-Butadieno & C & $200-250 \mu \mathrm{g}$ & $3,8-10,8$ \\
\hline Benceno & C & $240-490 \mu \mathrm{g}$ & $8-10$ \\
\hline Formaldehído & C & $300-1.500 \mu \mathrm{g}$ & $10-50$ \\
\hline Acroleína & T & $40-100 \mu \mathrm{g}$ & $8-22$ \\
\hline 3-Vinilpiridina & T & $330-450 \mu \mathrm{g}$ & $24-34$ \\
\hline Cianuro de hidrógeno & T & $14-110 \mu \mathrm{g}$ & $0,06-0,4$ \\
\hline Hidrazina & C & $90 \mathrm{ng}$ & 3 \\
\hline Oxidos de nitrógeno $\left(\mathrm{NO}_{\mathrm{x}}\right)$ & $T$ & $500-2.000 \mu \mathrm{g}$ & $3,7-12,8$ \\
\hline N-Nitrosodimetilamina & C & $200-1.040 \mathrm{ng}$ & $12-440$ \\
\hline N-Nitrosodietilamina & C & $N D^{b}-1.000 \mathrm{ng}$ & $<40$ \\
\hline N-Nitrosopirrolidina & C & $7-700 \mathrm{ng}$ & $4-120$ \\
\hline \multicolumn{4}{|l|}{ Fase particulada } \\
\hline Alquitrán & $C$ & $14-30 \mathrm{mg}$ & $1,1-15,7$ \\
\hline Nicotina & T & $2,1-46 \mathrm{mg}$ & $1,3-21$ \\
\hline Fenol & IT & $70-250 \mu \mathrm{g}$ & $1,3-3,0$ \\
\hline Catecol & $\mathrm{COC}$ & $58-290 \mu \mathrm{g}$ & $0,67-12,8$ \\
\hline 2-Toluidina & $C$ & $2,0-3,9 \mu \mathrm{g}$ & $18-70$ \\
\hline$\beta$-Naftilamina & C & $19-70 \mathrm{ng}$ & $8,0-39$ \\
\hline 4-Aminobifenilo & C & $3,5-6,9 \mathrm{ng}$ & $7,0-30$ \\
\hline Benz[ a] antraceno & C & $40-200 \mathrm{ng}$ & $2-4$ \\
\hline Benzo[a]pireno & C & $40-70 \mathrm{ng}$ & $2,5-20$ \\
\hline Quinolina & C & $15-20 \mu \mathrm{g}$ & $8-11$ \\
\hline NNNC & C & $0,15-1,7 \mu \mathrm{g}$ & $0,5-5,0$ \\
\hline$N_{N K}^{d}$ & c & $0,2-1,4 \mu \mathrm{g}$ & $1,0-22$ \\
\hline N-Nitrosodietanolamina & $c$ & $43 \mathrm{ng}$ & 1,2 \\
\hline Cadmio & C & $0,72 \mu \mathrm{g}$ & 7,2 \\
\hline Níquel & c & $0,2-2,5 \mu \mathrm{g}$ & $13-30$ \\
\hline Zinc & T & $6,0 \mathrm{ng}$ & 6,7 \\
\hline Polonio-210 & $c$ & $0,5-1,6 \mathrm{pCi}$ & $1,06-3,7$ \\
\hline
\end{tabular}

que también son cancerígenos humanos conocidos (IARC 1987a; IARC 1988). Cuando se fuman cigarrillos con filtro, algunos componentes volátiles y semivolátiles son eliminados de forma selectiva del HC por el filtro (H offmann y Hecht 1990). Ahora bien, estos compuestos aparecen en cantidades muy superiores en el $\mathrm{HL}$ no diluido en comparación con el HC. Además, los componentes del humo cuya formación se ve favorecida durante la incandescencia en la atmósfera reductora del cono de combustión, se liberan al $\mathrm{HL}$ en mayor grado que al $\mathrm{HC}$. Entre ellos se encuentran grupos de cancerígenos como las nitrosaminas volátiles, las nitrosaminas específicas del tabaco (NAET) y las aminas aromáticas.

\section{HTA en el aire interior}

Aunque el $\mathrm{HL}$ no diluido contiene cantidades más elevadas de componentes tóxicos y cancerígenos que el $\mathrm{HC}$, el $\mathrm{HL}$ inhalado por los no fumadores se encuentra muy diluido en el aire y sus propiedades están alteradas a causa de la degradación de algunas especies reactivas. En la Tabla 44.8 se exponen datos referidos a agentes tóxicos y cancerígenos presentes en muestras de aire interior con varios grados de contaminación por humo de tabaco (H offmann y Hecht 1990; Brunnemann y Hoffmann 1991; Luceri y cols. 1993). La dilución del $\mathrm{HL}$ en el aire tiene un impacto significativo sobre las características físicas de este aerosol. En general, la distribución de diversos agentes entre la fase de vapor y la fase particulada está alterada a favor de la primera. Las partículas en el H TA son más pequeñas $(<0,2 \mu)$ que en el $\mathrm{HC}(\sim 0,3 \mu)$ y los valores $\mathrm{pH}$ del $\mathrm{HL}(\mathrm{pH} 6,8-8,0)$ y del HTA son mayores que el $\mathrm{pH}$ del HC $(5,8-6,2$; Brunnemann y H offmann 1974). En consecuencia, entre el 90 y el $95 \%$ de la nicotina está presente en la fase de vapor del HTA (Eudy y cols. 1986). De forma similar, otros componentes básicos, como los alcaloides menores de la Nicotiana, así como las aminas y el amoníaco, están presentes sobre todo en la fase de vapor del HTA (H offmann y H echt 1990; Guerin y cols. 1992).

\section{Indicadores biológicos de la captación de HTA por las personas no fumadoras}

Aunque muchos trabajadores no fumadores están expuestos al HTA en el lugar de trabajo, en restaurantes, en sus propios domicilios 0 en otros espacios cerrados, es prácticamente imposible valorar la captación real de HTA por un individuo. La exposición al HTA puede determinarse de forma más exacta cuantificando los constituyentes específicos del humo de tabaco o sus metabolitos en los líquidos fisiológicos o en el aire exhalado. Si bien se han examinado varios parámetros, como el $\mathrm{CO}$ en el aire exhalado, la carboxihemoglobina en sangre, el tiocianato (un metabolito del cianuro de hidrógeno) en la saliva o en la orina, o la hidroxiprolina y la $\mathrm{N}$-nitrosoprolina en la orina, sólo tres determinaciones son en realidad útiles para evaluar la captación de HTA por las personas no fumadoras, las cuales nos permiten distinguir la exposición pasiva al humo de tabaco de la exposición de los fumadores activos y de los no fumadores no expuestos al humo de tabaco.

El indicador biológico más utilizado para la exposición al HTA de los no fumadores es la cotinina, un metabolito principal de la nicotina. Se determina mediante cromatografía de gases 0 por radioinmunoanálisis en sangre 0 , preferiblemente, en orina, y refleja la absorción de nicotina a través del pulmón y de la cavidad oral. U nos pocos mililitros de la orina de los fumadores pasivos son suficientes para determinar la cotinina mediante uno de los dos métodos. En general, un fumador pasivo presenta unos niveles de cotinina de 5 a $10 \mathrm{ng} / \mathrm{ml}$ de orina; no obstante, en ocasiones se han encontrado valores superiores en no fumadores que estuvieron expuestos a altas concentraciones de HTA durante un período de tiempo prolongado. Se ha establecido una respuesta a la dosis entre la duración de la exposición al HTA y la excreción urinaria de cotinina (Tabla 44.9, Wald y cols. 1984). En la mayoría de los estudios de campo, la cotinina urinaria de los fumadores pasivos alcanza niveles de entre el 0,1 y el $0,3 \%$ de las concentraciones medias encontradas en la orina de los fumadores; con todo, en exposiciones prolongadas a altas concentraciones de HTA, los niveles de cotinina han alcanzado valores de hasta el $1 \%$ de los niveles 
Tabla 44.8 A Algunos agentes tóxicos y tumorígenos en ambientes de interior contaminados con humo de tabaco.

\begin{tabular}{|c|c|c|}
\hline Contaminante & Lugar & Concentración/ $\mathrm{m}^{3}$ \\
\hline Oxido nítrico & $\begin{array}{l}\text { Salas de trabajo } \\
\text { Restaurantes } \\
\text { Bares } \\
\text { Cafeterías }\end{array}$ & $\begin{array}{l}50-440 \mu \mathrm{g} \\
17-240 \mu \mathrm{g} \\
80-250 \mu \mathrm{g} \\
2,5-48 \mu \mathrm{g}\end{array}$ \\
\hline Dióxido de nitrógeno & $\begin{array}{l}\text { Salas de trabajo } \\
\text { Restaurantes } \\
\text { Bares } \\
\text { Cafeterías }\end{array}$ & $\begin{array}{r}68-410 \mu \mathrm{g} \\
40-190 \mu \mathrm{g} \\
2-116 \mu \mathrm{g} \\
67-200 \mu \mathrm{g}\end{array}$ \\
\hline Cianuro de hidrógeno & Cuartos de estar & $8-122 \mu g$ \\
\hline 1,3-Butadieno & Bares & $2,7-4,5 \mu \mathrm{g}$ \\
\hline Benceno & Lugares públicos & $20-317 \mu \mathrm{g}$ \\
\hline Formaldehído & $\begin{array}{l}\text { Cuartos de estar } \\
\text { Tabernas }\end{array}$ & $\begin{array}{l}2,3-5,0 \mu g \\
89-104 \mu g\end{array}$ \\
\hline Acroleína & Lugares públicos & $30-120 \mu \mathrm{g}$ \\
\hline Acetona & Cafés & $910-1.400 \mu \mathrm{g}$ \\
\hline Fenoles (volátiles) & Cafés & 7,4-11,5 ng \\
\hline N-Nitrosodimetilamina & Bares, Restaurantes, oficinas & $<10-240 \mathrm{ng}$ \\
\hline N-Nitrosodietilamina & Restaurantes & $<10-30 \mathrm{ng}$ \\
\hline Nicotina & $\begin{array}{l}\text { Residencias } \\
\text { Oficinas } \\
\text { Edificios públicos }\end{array}$ & $\begin{array}{r}0,5-21 \mu g \\
1,1-36,6 \mu g \\
1,0-22 \mu g\end{array}$ \\
\hline 2-Toluidina & $\begin{array}{l}\text { Oficinas } \\
\text { Salón de cartas con fumadores }\end{array}$ & $\begin{array}{r}3,0-12,8 \mathrm{ng} \\
16,9 \mathrm{ng}\end{array}$ \\
\hline$\beta$-Naftilamina & $\begin{array}{l}\text { Oficinas } \\
\text { Salón de cartas con fumadores }\end{array}$ & $\begin{array}{r}0,27-0,34 \mathrm{ng} \\
0,47 \mathrm{ng}\end{array}$ \\
\hline 4-Aminobifenilo & $\begin{array}{l}\text { Oficinas } \\
\text { Salón de cartas con fumadores }\end{array}$ & $\begin{array}{l}0,1 \mathrm{ng} \\
0,11 \mathrm{ng}\end{array}$ \\
\hline Benz(a) antraceno & Restaurantes & $1,8-9,3 \mathrm{ng}$ \\
\hline Benzo(a)pireno & $\begin{array}{l}\text { Restaurantes } \\
\text { Salas de fumadores } \\
\text { Cuartos de estar }\end{array}$ & $\begin{array}{r}2,8-760 \mu g \\
88-214 \mu g \\
10-20 \mu g\end{array}$ \\
\hline$N_{N N}^{a}$ & $\begin{array}{l}\text { Bares } \\
\text { Restaurantes }\end{array}$ & $\begin{array}{r}4,3-22,8 \mathrm{ng} \\
N D^{D}-5,7 \mathrm{ng}\end{array}$ \\
\hline NNKC & $\begin{array}{l}\text { Bares } \\
\text { Restaurantes } \\
\text { Coches con fumadores }\end{array}$ & $\begin{array}{r}9,6-23,8 \mathrm{ng} \\
1,4-3,3 \mathrm{ng} \\
29,3 \mathrm{ng}\end{array}$ \\
\hline
\end{tabular}

a $N N N=N^{\prime}-$-nitrosonornicotina.

b $N D=n o$ detectado.

c NNK=4-(metilnitrosamino)-1-(3-piridil)-1-butanona

cuantificados en la orina de los fumadores activos (US N ational Research Council 1986; IARC 1987b; US Environmental Protection Agency 1992).

El cancerígeno de la vejiga urinaria 4-aminobifenilo, que se transfiere del humo del tabaco al HTA, ha sido identificado como un aducto de la hemoglobina en los fumadores pasivos en concentraciones de hasta el $10 \%$ del nivel medio de aductos hallado en los fumadores (H ammond y cols. 1993). En la orina de sujetos no fumadores que han estado expuestos en un laboratorio de ensayo a altas concentraciones de $\mathrm{HL}$ se han determinado valores de hasta el $1 \%$ de los niveles medios de un metabolito del cancerígeno derivado de la nicotina
Tabla 44.9 - Cotinina urinaria en no fumadores en función del número de horas notificadas de exposición al humo de tabaco de otras personas en los siete días previos.

Duración de la exposición

$\begin{array}{lccc}\text { Quintil } & \text { Límites (hs) } & \text { Número } & \begin{array}{l}\text { Cotinina urinaria (media } \pm \mathrm{DE} \text { ) } \\ (\mathrm{ng} / \mathrm{ml})^{\mathrm{a}}\end{array} \\ 10 & 0,0-1,5 & 43 & 2,8 \pm 3,0 \\ 20 & 1,5-4,5 & 47 & 3,4 \pm 2,7 \\ 30 & 4,5-8,6 & 43 & 5,3 \pm 4,3 \\ 4 \underline{0} & 8,6-20,0 & 43 & 14,7 \pm 19,5 \\ 50 & 20,0-80,0 & 45 & 29,6 \pm 73,7 \\ \text { Todos } & 0,0-80,0 & 221 & 11,2 \pm 35,6\end{array}$

a La tendencia al aumentar la exposición fue significativa $(p<0,001)$.

Fuente: Basado en Wald y cols. 1984

4-(metilnitrosamina)-1-(3-piridilo)-1-butanona (N NK), presente en la orina de los fumadores de cigarrillos (H echt y cols. 1993). Aunque el último método de indicadores biológicos no ha sido aplicado todavía en estudios de campo, se muestra prometedor como indicador apropiado de la exposición de los sujetos no fumadores a un cancerígeno pulmonar específico del tabaco.

\section{Humo de tabaco ambiental y salud humana}

\section{Otros trastornos además del cáncer}

La exposición prenatal al HC, al HTA, o a ambos, y la exposición posnatal precoz al HTA aumentan la probabilidad de que aparezcan complicaciones durante las infecciones respiratorias virales en los niños durante su primer año de vida.

En las publicaciones científicas se hallan varias docenas de informes clínicos procedentes de varios países, en los que se observa que los hijos de padres fumadores, sobre todo los menores de dos años de edad, presentan un aumento de la incidencia de enfermedades respiratorias agudas (US Environmental Protection Agency 1992; Inspector general de Sanidad de EE.UU. 1986; Medina y cols. 1988; Riedel y cols. 1989). En otros estudios también se describe un aumento de las infecciones del oído medio en niños expuestos al humo de los cigarrillos consumidos por los padres. La elevación de la prevalencia de derrame del oído medio atribuible al HTA causó un aumento de la hospitalización de niños pequeños para ser sometidos a intervención quirúrgica (US Environmental Protection A gency 1992; Inspector general de Sanidad de EE.UU. 1986).

En los últimos años, debido a la existencia de suficiente número de pruebas clínicas, se ha llegado a la conclusión de que el tabaquismo pasivo está asociado a un aumento de la gravedad del asma en los niños que ya padecen la enfermedad, y de que es más probable la aparición de nuevos casos de asma infantil (US Environmental Protection A gency 1992).

En 1992, la US Environmental Protection Agency (1992) revisó de forma exhaustiva los estudios sobre síntomas respiratorios y función pulmonar en adultos no fumadores expuestos a HTA y se llegó a la conclusión de que el tabaquismo pasivo tiene efectos sutiles pero estadísticamente significativos sobre la salud respiratoria de los adultos no fumadores.

L as publicacionesacerca del efecto del tabaquismo pasivo sobre las enfermedades respiratorias o coronarias en trabajadores son muy escasas. Los varones y las mujeres expuestos al H TA en el lugar de trabajo (oficinas, bancos, instituciones académicas, etc.) 
durante diez o más años presentaban un deterioro de la función pulmonar (W hitey Froeb 1980; M asi ycols. 1988).

\section{Cáncer de pulmón}

En 1985, la Agencia Internacional para la Investigación sobre el Cáncer (IARC) revisó la asociación entre la exposición pasiva al humo de tabaco y el cáncer de pulmón en las personas no fumadoras. Si bien en algunos estudios todos los no fumadores con cáncer de pulmón que habían comunicado exposición al HTA fueron entrevistados personalmente y habían proporcionado información detallada sobre la exposición (US National Research Council 1986; US EPA 1992; US Inspector general de Sanidad de EE. UU. 1986; K abat y Wynder 1984), la IARC llegó a la siguiente conclusión:

Las observaciones que se han hecho hasta ahora sobre las personas no fumadoras son compatibles con un aumento del riesgo por tabaquismo 'pasivo' o una ausencia de riesgo. Con todo, el conocimiento de la naturaleza del humo de flujo central y del humo de flujo lateral, de los materiales absorbidos durante el tabaquismo 'pasivo' y de la relación cuantitativa entre la dosis y el efecto que habitualmente se observa en la exposición a cancerígenos lleva a la conclusión de que el tabaquismo pasivo da lugar a un cierto riesgo de padecer cáncer (IARC 1986).

Por tanto, existe una dicotomía evidente entre los datos experimentales que respaldan la idea de que el HTA entraña un riesgo de padecer cáncer, y los datos epidemiológicos, que no son concluyentes en lo que se refiere a la exposición al HTA y el riesgo de cáncer. Los datos experimentales, incluidos los estudios con indicadores biológicos, han reforzado aún más la teoría de que el HTA es cancerígeno, como se comentó anteriormente. Analizaremos ahora hasta qué punto los estudios epidemiológicos que se han completado desde el citado informe de la IARC han contribuido a aclarar la cuestión del cáncer de pulmón y el HTA.

Basándose en los primeros estudios epidemiológicos y en unos 30 estudios publicados después de 1985, la exposición de los no fumadores al HTA constituyó un factor de riesgo de cáncer de pulmón inferior a 2,0, en relación con el riesgo de un no fumador sin exposición importante al H TA (US Environmental Protection Agency 1992; K abat y Wynder 1984; IARC 1986; Brownson y cols. 1992; Brownson y cols. 1993). Pocos o ninguno de estos estudios epidemiológicos cumplen los criterios de causalidad en la asociación entre un factor ambiental o profesional y el cáncer de pulmón. Los criterios que cumplen estos requisitos son:

1. un grado de asociación bien establecido (factor de riesgo $\geq 3$ );

2. capacidad de reproducción de la observación en una serie de estudios;

3. concordancia entre la duración de la exposición y el efecto,

4. verosimilitud biológica.

Una de las mayores dudas acerca de los datos epidemiológicos recae en la limitada fiabilidad de las respuestas obtenidas al preguntar sobre los hábitos fumadores a los sujetos objeto de estudio 0 a sus familiares. $\mathrm{H}$ abida cuenta de las historias de tabaquismo que proporcionan los casos y controles, parece existir una concordancia general entre las de los padres y las de los cónyuges; no obstante, las tasas de coincidencia con respecto a la duración y la intensidad del consumo de tabaco son bajas (Brownson y cols. 1993; M CL aughlin y cols. 1987; M CL aughlin y cols. 1990). Varios investigadores han desafiado la fiabilidad de la información proporcionada por los sujetos sobre su hábito de fumar. Como ejemplo de ello, cabe citar la investigación a gran escala realizada en el sur de Alemania. La población del estudio, seleccionada al azar, estaba formada por más de 3.000 mujeres y varones, de 25 a
64 años de edad, a quienes se preguntó sobre sus hábitos fumadores en tres ocasiones: en 1984-1985, en 1987-1988 y de nuevo en 1989-1990, recogiendo las tres veces una muestra de orina de cada probando y analizando los niveles de cotinina. Se consideró fumadores a los voluntarios con niveles de cotinina superiores a $20 \mathrm{ng}$ por $\mathrm{ml}$ de orina. Entre los 800 exfumadores que afirmaban ser no fumadores, el $6,3 \%$, el $6,5 \%$ y el $5,2 \%$ presentaban niveles de cotinina superiores a $20 \mathrm{ng} / \mathrm{ml}$ durante los tres períodos de tiempo ensayados. El porcentaje de sujetos que afirmaban no haber sido nunca fumadores y que fueron identificados como fumadores, de acuerdo con los análisis de cotinina, era del $0,5 \%, 1,0 \%$ y $0,9 \%$ respectivamente (H eller y cols. 1993).

$L$ a reducida fiabilidad de los datos obtenidos a través del cuestionario y el número relativamente limitado de no fumadores con cáncer de pulmón que no estuvieron expuestos a cancerígenos en sus lugares de trabajo indican que es necesario realizar un estudio epidemiológico prospectivo con valoración de indicadores biológicos ( $p$. ej., cotinina, metabolitos de hidrocarburos aromáticos polinucleares o metabolitos de la NNK en la orina) para llevar a cabo una evaluación concluyente de la cuestión de la causalidad entre el tabaquismo involuntario y el cáncer de pulmón. Aunque estos estudios prospectivos con indicadores biológicos suponen un esfuerzo importante, son fundamentales para responder los interrogantes en materia de exposición cuyas implicaciones sobre la salud pública son notables.

\section{Humo de tabaco ambiental y medio ambiente en el trabajo}

Aunque los estudios epidemiológicos no han demostrado hasta ahora una relación causal entre la exposición al H TA y el cáncer de pulmón, es conveniente proteger a los trabajadores de la exposición al humo de tabaco ambiental en el lugar de trabajo. Tal concepto se apoya en la observación de que la exposición prolongada de personas no fumadorasal H TA en el lugar de trabajo puede causar un deterioro de la función pulmonar. A demás, en ambientes profesionales con exposición a cancerígenos, el tabaquismo involuntario puede aumentar el riesgo de cáncer. En Estados U nidos, la Environmental Protection A gency ha clasificado el H TA como cancerígeno del grupo A (cancerígenos humanos conocidos); por consiguiente, en Estados U nidos la ley exige la protección de los trabajadores frente a la exposición al HTA.

Pueden adoptarse varias medidas para proteger a las personas no fumadoras de la exposición al HTA: prohibir el consumo de tabaco en el lugar de trabajo, 0 al menos separar a los fumadores de los no fumadores donde sea posible, y asegurarse de que las habitaciones para fumadores tengan un sistema de aspiración de humos independiente. El enfoque más gratificante $y$, con mucho, más prometedor es ayudar a los trabajadores que fumen cigarrillos a intentar que abandonen su hábito.

El lugar de trabajo proporciona una excelente oportunidad de aplicar programas para dejar de fumar; de hecho, en numerosos estudios se ha demostrado que los programas en lugares de trabajo tienen resultados más satisfactorios que los programas en clínicas, debido a que los programas patrocinados por el empresario son más intensos y ofrecen incentivos económicos o de otro tipo (I nspector general de Sanidad de EE. U U. 1985). También se ha afirmado que la eliminación de las enfermedades pulmonares crónicasy del cáncer profesionales exige un intento de convertir a los fumadores en no fumadores. A demás, las intervenciones en el lugar de trabajo, como los programas para dejar de fumar, pueden originar cambios duraderos en la reducción de algunosfactores de riesgo cardiovascular para los trabajadores (G omel y cols. 1993).

Agradecemos profundamente a Ilse H offmann su colaboración en el aspecto editorial, y a Jennifer Johnting por la preparación de este manuscrito. Son estudios financiados por las becas USPHS CA-29580 y CA-32617 del National C ancer Institute. 


\section{- REgulaCiOn DEL CONSUMO DE TABACO}

\section{Xavier G uardino Solá}

Por lo que se refiere a la adopción de medidas para disminuir el consumo de tabaco, los gobiernos deberían tener en consideración que aunque dejar de fumar es una decisión que las personas toman por sí mismas, es responsabilidad del gobierno adoptar todas las medidas necesarias para animarles a ello. Los legisladores y los gobiernos de muchos países han dado pasos dubitativos, debido a que aunque la disminución en el consumo de tabaco es una mejora indiscutible de la salud pública, con el consiguiente ahorro en el gasto sanitario público, habría una serie de pérdidas y trastornos económicos en muchos sectores, al menos de forma temporal. La presión que las organizaciones y agencias internacionales para la salud y el medio ambiente pueden ejercer en este sentido es muy importante, ya que muchos países podrían suavizar sus medidas en contra del consumo de tabaco debido a problemas económicos, especialmente si el tabaco es una fuente importante de ingresos.

En el presente artículo se describen de manera concisa las medidas reguladoras que pueden adoptarse para disminuir el consumo de tabaco en un país.

\section{Advertencias en los paquetes de cigarrillos}

U na de las primeras medidas adoptadas en muchos países es exigir que los paquetes de cigarrillos muestren de forma clara la advertencia de que el consumo de tabaco perjudica seriamente la salud del fumador. El objetivo no es ejercer un efecto inmediato sobre el fumador, sino más bien demostrar que el gobierno está preocupado por el problema y que está creando un ambiente psicológico que favorecerá la adopción de medidas posteriores con las que, de otra manera, podría sentirse agredida la población fumadora.

Algunos expertos defienden la inclusión de estas advertencias en los puros y en el tabaco de pipa. Pero la opinión más general es que tales medidas son innecesarias, ya que las personas que utilizan esta clase de tabaco no suelen inhalar el humo, y a lo que conduciría probablemente la ampliación de este tipo de advertencias es a un descuido de los mensajes en su conjunto. Por eso la opinión que prevalece es que las advertencias deben aplicarse sólo a los paquetes de cigarrillos. Por el momento, no se ha considerado la referencia al humo pasivo, pero es una opción que no debe descartarse.

\section{Restricciones del consumo de tabaco en lugares públicos}

La prohibición de fumar en los lugares públicos constituye uno de los instrumentos reguladores más eficaces. Las prohibiciones disminuyen de forma significativa el número de personas expuestas al humo pasivo y, además, pueden reducir el consumo diario de cigarrillos en los fumadores. L as quejas habituales de los propietarios de locales públicos, como hoteles, restaurantes, instalaciones recreativas, salones de baile y teatros, entre otros, se basan en el argumento de que estas medidas ocasionarán una pérdida de clientes. Ahora bien, si los gobiernos aplican estas medidas de forma global, el impacto negativo de la pérdida de clientes aparecerá sólo en la primera fase, ya que al final las personas se adaptarán a la nueva situación.

La creación de espacios para fumadores es otra posibilidad. La separación de los fumadores de los no fumadores debería ser eficaz para conseguir los efectos beneficiosos deseados, al crear barreras que evitan que los no fumadores inhalen el humo del tabaco. Por tanto, la separación debe ser física y, si el sistema de aire acondicionado utiliza aire reciclado, el aire procedente de las zonas de fumadores no deberá mezclarse con el de las zonas de no fumadores. Por consiguiente, la creación de espacios para fumadores implica gastos de construcción y división en compartimentos, pero podría ser una solución para aquellos que desean ofrecer sus servicios al público fumador.

A parte de los lugares en los que es obvio que el consumo de tabaco esté prohibido por razones de seguridad, debido a la posibilidad de que se produzca una explosión o un incendio, también deberían existir zonas en las que no se permita el consumo de tabaco aunque no exista esa clase de riesgos para la seguridad, como los centros de asistencia sanitaria, las instalaciones deportivas, los colegios y las guarderías.

\section{Restricción del consumo de tabaco en el trabajo}

Las restricciones del consumo de tabaco en el lugar de trabajo también podrían ser consideradas a la vista de lo citado anteriormente. L os gobiernos y los propietarios de negocios, junto con los sindicatos, pueden elaborar programas para reducir el consumo de tabaco en el trabajo cuyas campañas suelen tener éxito.

Siempre que sea posible, se recomienda crear zonas de no fumadores a fin de establecer una política contra el consumo de tabaco y apoyar a los que defienden el derecho a no ser fumadores pasivos. En caso de conflicto entre un fumador y un no fumador, las normativas siempre deben permitir que prevalezca el no fumador, y cuando no puedan estar separados se deberá exigir al fumador que se abstenga de fumar en el puesto de trabajo.

A demás de los lugares en los que debe prohibirse el consumo de tabaco por razones de salud o de seguridad, tampoco debe ignorarse en otras áreas la posible sinergia entre los efectos de la contaminación química en el lugar de trabajo y el humo del tabaco. EI peso de tales consideraciones dará lugar, sin duda, a una notable ampliación de las restricciones del consumo de tabaco, sobre todo en los lugares de trabajo industriales.

\section{Mayor presión económica contra el tabaco}

0 tro de los instrumentos reguladores en los que confían los gobiernos para frenar el consumo de tabaco es la elevación de los impuestos, sobre todo de los cigarrillos. Es una política encaminada a disminuir el consumo de tabaco, que justificaría la relación inversa entre el precio del tabaco y su consumo, y que puede determinarse comparando la situación en diferentes países. L a medida se considera eficaz cuando la población está advertida de los peligros del consumo de tabaco y aconsejada acerca de la necesidad de dejar de fumar. Un aumento en el precio del tabaco puede ser un motivo para dejar de fumar. Con todo, esta política tiene muchos detractores, cuyas críticas se basan en argumentos que se comentan brevemente a continuación.

En primer lugar, según muchos especialistas, el aumento del precio del tabaco por razones fiscales va seguido de una reducción temporal del consumo de tabaco, tras lo cual se produce una vuelta gradual a los niveles de consumo previos a medida que los fumadores se acostumbran al nuevo precio. En otras palabras, los fumadores asimilan un aumento en el precio del tabaco de la misma manera que la gente se acostumbra a otros impuestos 0 a la subida del coste de la vida.

En segundo lugar, también se ha observado un cambio en los hábitos de los fumadores, quienes, al subir los precios, tienden a buscar marcas más baratas de menor calidad que probablemente supongan también un riesgo mayor para su salud (porque carecen de filtro o porque tienen cantidades más elevadas de alquitrán y nicotina). Tal cambio podría llegar a inducir a los fumadores a hacerse sus propios cigarrillos, lo que eliminaría por completo cualquier posibilidad de controlar el problema. 
En tercer lugar, muchos expertos opinan que las medidas de este tipo tienden a afianzar la creencia de que el gobierno acepta el tabaco y su consumo como otra manera más de recaudar impuestos, lo que conduce a la idea contradictoria de que lo que el gobierno pretende en realidad es que la gente fume para poder recaudar más dinero con los impuestos especiales sobre el tabaco.

\section{Limitación de la publicidad}

0 tro instrumento utilizado por los gobiernos para reducir el consumo de tabaco es restringir 0 , simplemente, prohibir la publicidad del producto. L os gobiernos y muchas organizaciones internacionales tienen una política de prohibir la publicidad del tabaco en ciertas esferas, como los deportes (al menos algunos deportes), la asistencia sanitaria, el medio ambiente y la educación. L os efectos beneficiosos incuestionables de esta política son especialmente eficaces cuando se elimina la publicidad en entornos que influyen en las personas jóvenes en un momento en el que es probable que adopten el hábito de fumar.

\section{Programas públicos para animar a las personas a dejar de fumar}

La utilización de campañas antitabaco como práctica normal, adecuadamente establecida y organizada como norma de conducta en ciertas esferas, como el mundo del trabajo, ha demostrado ser muy eficaz.

\section{Campañas para educar a los fumadores}

Complementando lo anteriormente comentado, otro de los instrumentos de que disponen los gobiernos para reducir los efectos adversos del consumo de tabaco sobre la salud en la población es la educación de los fumadores con el fin de que fumen "mejor" y de que reduzcan su consumo de cigarrillos. Tales medidas deben ir encaminadas a disminuir el consumo diario de cigarrillos, a inhibir la inhalación de humo en la mayor medida posible, a no fumar las colillas de los cigarrillos (la toxicidad del tabaco aumenta hacia el final del cigarrillo), a no mantener el cigarrillo constantemente en los labios y a adoptar preferencias por marcas con menor contenido de alquitrán y nicotina.

Es un tipo de medidas que evidentemente no reducen el número de fumadores, pero sí el daño sufrido por éstos por su hábito. Se han propuesto argumentos en contra de esta clase de medidas debido a que pueden dar la impresión de que fumar no es un hábito intrínsecamente malo, ya que se dice a los fumadores cómo se fuma mejor.

\section{Consideraciones finales}

La acción normativa y legislativa de los diferentes gobiernos es lenta y no suficientemente eficaz, sobre todo en comparación con lo que sería necesario considerando los problemas causados por el tabaco. A menudo las causas son los obstáculos legales contra la aplicación de estas medidas, los argumentos contra la competencia desleal o incluso la protección de los derechos del individuo a fumar. Los progresos en la aplicación de leyes han sido lentos pero constantes. Por otro lado, debe tenerse en cuenta la diferencia entre los fumadores activos y los fumadores pasivos 0 "de segunda mano". Todas las medidas que ayudarían a alguien a dejar de fumar, o al menos a reducir su consumo diario, deben ir dirigidas al fumador; todo el peso de las normativas debe recaer en combatir este hábito. D eben proporcionarse al fumador pasivo todos los argumentos posibles para defender sus derechos a no inhalar humo de tabaco y a disfrutar del uso de entornos libres de tabaco en el hogar, en el trabajo y en el ocio.

\section{DETERMINACION Y VALORACION DE LOS CONTAMINANTES QUIMICOS}

\section{G racia Rosell Farrás}

Desde el punto de vista de la contaminación, el aire interior no industrial muestra varias características que lo diferencian del aire exterior, 0 aire atmosférico, y del aire del medio ambiente industrial. Además de los contaminantes presentes en el aire atmosférico, el aire interior también contiene contaminantes generados por los materiales de construcción y por las actividades que tienen lugar en el interior del edificio. Las concentraciones de contaminantes en el aire interior tienden a ser iguales o inferiores a las existentes en el aire atmosférico, dependiendo de la ventilación; los contaminantes generados por los materiales de construcción suelen ser diferentes de los presentes en el aire atmosférico y pueden encontrarse a concentraciones elevadas, mientras que los generados por las actividades desarrolladas en el interior del edificio dependen de la naturaleza de estas actividades y pueden tener concentraciones similares a las existentes en el aire atmosférico, como en el caso del $\mathrm{CO}$ y el $\mathrm{CO}_{2}$.

Por este motivo, el número de contaminantes presentes en el aire interior no industrial esamplio y variabley losnivelesde concentración son bajos (salvo en los casos en los que existe una importante fuente de producción); varían según las condiciones atmosféricas/ climatológicas, el tipo o las características del edificio, su ventilación y las actividades desarrolladas en su interior.

\section{Análisis}

Gran parte de la metodología utilizada para estimar la calidad del aire interior deriva de la higiene industrial y de determinaciones de inmisión del aire atmosférico. Existen pocos métodos analíticos específicamente validados para este tipo de análisis, aunque algunas organizaciones, como la O rganización M undial de la Salud y la Environmental Protection Agency de Estados Unidos están realizando investigaciones en este campo. 0 tro obstáculo es la escasez de información sobre la relación exposición-efecto con respecto a exposiciones prolongadas a concentraciones bajas de contaminantes.

Los métodos analíticos utilizados para la higiene industrial están diseñados para determinar concentraciones elevadas, y no se han definido para muchos contaminantes, mientras que el número de contaminantes en el aire interior puede ser elevado y variado y los niveles de concentración pueden ser bajos, salvo en ciertos casos. La mayoría de los métodos empleados en la higiene industrial se basan en la toma de muestras y sus análisis; muchos de estos métodos pueden aplicarse al aire interior si se consideran varios factores: ajustar los métodos a los niveles de concentración habituales en el aire interior, aumentar su sensibilidad sin reducir la precisión (por ejemplo, aumentando el volumen del aire ensayado) y validar su especificidad.

L os métodos analíticos utilizados para determinar las concentraciones de contaminantes en el aire atmosférico son similares a los empleados para el aire interior, de forma que algunos de ellos pueden utilizarse directamente para el aire interior mientras que otros pueden adaptarse fácilmente. Ahora bien, es importante tener en cuenta que algunos métodos están diseñados para una lectura directa de una muestra, mientras que otros requieren una instrumentación voluminosa $y$, en ocasiones, ruidosa y además utilizan grandes volúmenes de aire en la toma de muestra que pueden distorsionar la lectura.

\section{Planificación de las lecturas}

Para mejorar la calidad del aire interior puede utilizarse el procedimiento tradicional en el campo del control ambiental en el 
lugar de trabajo, que consiste en identificar y cuantificar un problema, proponer medidas correctoras, asegurarse de que se ponen en práctica estas medidas y valorar su eficacia después de un período de tiempo. Se trata de un procedimiento habitual que no siempre es el más adecuado, ya que a menudo no es necesaria una evaluación tan exhaustiva mediante la toma de numerosas muestras. Las medidas exploratorias, que pueden variar desde una inspección visual al análisis del aire ambiente por métodos de lectura directa, y que pueden proporcionar una concentración aproximada de contaminantes, son suficientes para resolver muchos de los problemas existentes. U na vez que se han tomado las medidas correctoras, pueden evaluarse los resultados con una segunda determinación, y sólo cuando no exista una clara evidencia de mejoría se realizará una inspección más exhaustiva (con determinaciones en profundidad) 0 un estudio analítico completo (Fondo Sueco para el Ambiente de Trabajo 1988).

Las principales ventajas de este procedimiento sobre el método más tradicional son el coste, la velocidad y la eficacia, pero requiere personal competente, con experiencia, y la utilización del equipo apropiado. En la Figura 44.5 se resumen los objetivos de las diferentes fases de este procedimiento.

\section{Estrategia de la toma de muestras}

El control analítico de la calidad del aire interior debe considerarse como un último recurso cuando la inspección previa de exploración no proporciona resultados positivos, o si son necesarios una evaluación o un control de los ensayos iniciales.

Suponiendo un cierto conocimiento previo de las fuentes de contaminación y de los tipos de contaminantes, las muestras, incluso cuando sea un número limitado, deben ser representativas de los diversos espacios estudiados. La toma de muestras debe planificarse para responder las preguntas ¿Q ué? ¿Cómo? ¿Dónde? y ¿Cuándo?

\section{Qué}

Los contaminantes en cuestión deben ser identificados de antemano y, considerando los diferentes tipos de información que pueden obtenerse, debe decidirse si realizar determinación de emisión o de inmisión.

Las determinaciones de la emisión para la calidad del aire interior permiten conocer la influencia de diferentes fuentes de

Figura 44.5 - Planificación de las determinaciones para una evaluación de exploración.

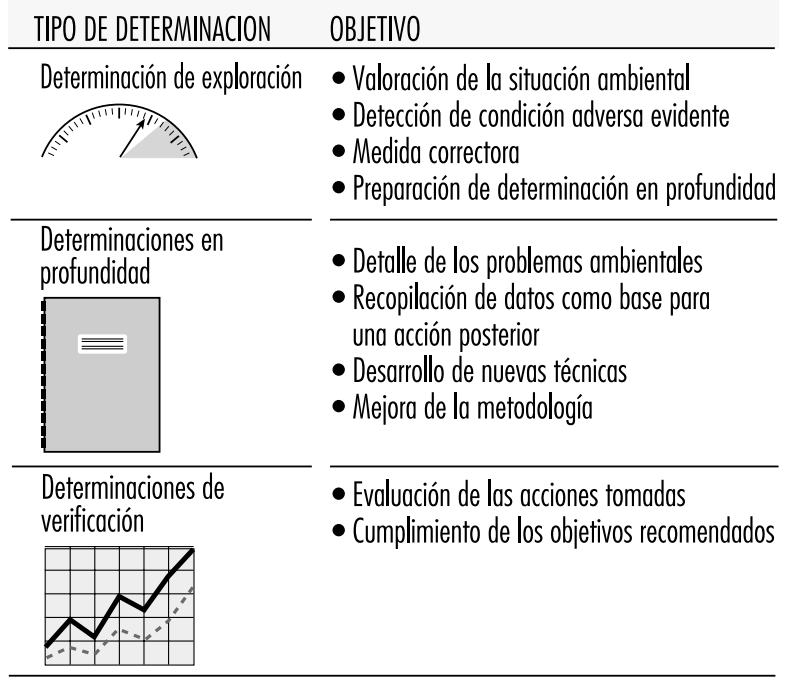

contaminación, de las condiciones climáticas, de las características del edificio y de la intervención humana, lo que nos permite controlar o reducir las fuentes de emisiones y mejorar la calidad del aire interior. Existen diferentes técnicas para realizar este tipo de determinación: colocar un sistema de captación junto a la fuente de emisión, definir un área de trabajo limitada y estudiar las emisiones como si representaran las condiciones reales de trabajo, o trabajar en condiciones forzadas aplicando sistemas de control que se basan en el espacio de la cabeza.

L as determinaciones de la inmisión nos permiten establecer el nivel de contaminación del aire interior en las diferentes áreas del edificio divididas en compartimentos, haciendo posible la creación de un mapa de la contaminación de toda la estructura. Utilizando estas determinaciones, identificando las diferentes áreas en las que las personas han realizado sus actividades y calculando el tiempo que han pasado realizando esa tarea, será posible establecer los niveles de exposición. O tra forma de llevarlo a cabo es hacer que los trabajadores lleven dispositivos de control durante el trabajo.

Si el número de contaminantes es amplio y variado puede ser más práctico seleccionar algunas sustancias indicativas de forma que la determinación sea representativa y no demasiado cara.

\section{Cómo}

La selección del tipo de determinación dependerá del método disponible (lectura directa o toma de muestras y análisis) y de la técnica de medición: emisión o inmisión.

\section{Dónde}

El lugar elegido debe ser el más apropiado y representativo para obtener muestras. Para ello debe conocerse el edificio que se está estudiando: su orientación con respecto al sol, el número de horas que recibe luz solar directa, el número de pisos, el tipo de división en compartimentos, si la ventilación es natural o artificial, si pueden abrirse las ventanas, etc. También es necesario conocer el origen de las quejas y los problemas; por ejemplo, si se producen en los pisos superiores 0 inferiores, 0 en las áreas próximas o distantes a las ventanas, o en las áreas con una ventilación 0 iluminación deficientes, entre otros. La selección de los mejores lugares para tomar las muestras se basará en toda la información disponible con respecto a los criterios anteriormente mencionados.

\section{Cuándo}

Decidir cuándo realizar las determinaciones dependerá de cómo cambien las concentraciones de contaminantes del aire en el tiempo. La contaminación puede detectarse inicialmente por la mañana, durante la jornada de trabajo o al final del día; puede detectarse al comienzo 0 al final de la semana; durante el invierno o el verano; cuando el aire acondicionado está conectado o desconectado; o bien en otros momentos.

Para abordar estos aspectos correctamente, debe conocerse la dinámica del ambiente interior en cuestión. También es necesario conocer el objetivo de las muestras, que se basará en los tipos de contaminantes que interese investigar. En la dinámica del ambiente interior influyen la diversidad y variabilidad de las fuentes de contaminación, las diferencias físicas de los espacios estudiados, el tipo de compartimentación, el tipo de ventilación y climatización utilizada, las condiciones atmosféricas exteriores (viento, temperatura, estación, etc.) y las características del edificio (número de ventanas, su orientación, etc.).

Los objetivos de las determinaciones definirán si la toma de muestras se llevará a cabo durante intervalos de tiempo cortos 0 largos. Si se cree que los efectos de los contaminantes en cuestión sobre la salud son prolongados, deberán determinarse las concentraciones promedio durante períodos largos de tiempo. 
Para las sustancias con efectos agudos pero no acumulativos, bastará realizar determinaciones durante períodos cortos de tiempo. Si se sospechan emisiones intensas de corta duración, se requerirán tomas de muestras frecuentes durante períodos cortos para detectar el tiempo de emisión. Con todo, no debe olvidarse que en muchos casos las opciones para utilizar uno u otro tipo de método de toma de muestras depende de los métodos analíticos disponibles o exigidos.

Si después de considerar todas estas cuestiones no está suficientemente claro cuál es el origen del problema, o cuándo tiene lugar con mayor frecuencia, la decisión con respecto a cuándo y dónde tomar muestras deberá realizarse al azar, calculando el número de muestras en función de la fiabilidad y los costes de las mismas.

\section{Técnicas de determinación}

Los métodos disponibles para tomar muestras del aire interior para su análisis pueden agruparse en dos tipos: métodos basados en una lectura directa y métodos en los que se toman muestras para un posterior análisis.

Los métodos basados en una lectura directa son aquellos en los que la toma de la muestra y la determinación de la concentración de contaminantes se realizan de forma simultánea; son rápidos y las determinaciones son instantáneas, por lo que proporcionan datos precisos a un coste relativamente bajo. Entre estos métodos se incluyen los tubos colorimétricos y los monitores específicos.

EI uso de tubos colorimétricos se basa en el cambio de color de un reactivo específico al entrar en contacto con un contaminante concreto. Los más utilizados son los tubos que contienen un reactivo sólido, por los que se hace pasar el aire mediante una bomba manual. La valoración de la calidad en el aire interior con tubos colorimétricos sólo es útil para determinaciones de exploración y para determinar emisiones esporádicas, ya que su sensibilidad suele ser baja, salvo para algunos contaminantes como el $\mathrm{CO}$ y el $\mathrm{CO}_{2}$, que pueden estar presentes a concentraciones elevadas en el aire interior. Es importante tener en cuenta que la precisión de este método es baja y que a menudo existen interferencias por contaminantes que no están siendo investigados.

En el caso de los monitores específicos, la detección de contaminantes se basa en principios físicos, eléctricos, térmicos, electromagnéticos y quimioelectromagnéticos. La mayoría de los monitores de este tipo pueden utilizarse para realizar determinaciones de corta o larga duración y obtener un perfil de contaminación en un lugar concreto. Su precisión viene determinada por sus respectivos fabricantes, y su uso correcto requiere calibraciones periódicas mediante atmósferas controladas o mezclas de gas certificadas. La precisión y la sensibilidad de los monitores es cada vez mayor. Muchos de ellos poseen memoria interna para almacenar las lecturas, que posteriormente pueden transferirse a ordenadores para la creación de bases de datos y para una organización y recuperación sencilla de los resultados.

Los métodos de toma de muestras y los análisis pueden clasificarse en activos (o dinámicos) y pasivos, dependiendo de la técnica.

Con los sistemas activos, los contaminantes pueden captarse haciendo pasar el aire a través de un soporte en los que se atrapa el contaminante, concentrando así la muestra. El proceso se lleva a cabo con filtros, sólidos adsorbentes y soluciones absorbentes o reactivas colocadas en borboteadores 0 impregnadas en material poroso, a través de los cuales se hace pasar el aire y se analizan los contaminantes o los productos de reacción. Para el análisis de las muestras de aire obtenidas por sistemas activos se requiere un captador, una bomba para mover el aire y un sistema para medir el volumen de aire muestreado, bien directamente o bien utilizando datos sobre el flujo y la duración.

El flujo y el volumen de aire muestreado se especifican en los manuales de referencia o deben determinarse mediante ensayos previos, y dependerán de la cantidad y del tipo de absorbente 0 adsorbente utilizado, de los contaminantes que se están midiendo, del tipo de determinación (emisión o inmisión) y del estado del aire ambiente durante la toma de la muestra (humedad, temperatura, presión). La eficacia de la recogida aumenta al disminuir el caudal de aire en la captación 0 al aumentar la cantidad de captador utilizado, bien directamente 0 colocando captadores en serie.

0 tro tipo de muestreo activo es la toma directa de aire en una bolsa u otro tipo de contenedor inerte, impermeable y hermético. Este tipo de toma de muestras se utiliza para algunos gases $\left(\mathrm{CO}, \mathrm{CO}_{2}, \mathrm{H}_{2} \mathrm{~S}, \mathrm{O}_{2}\right)$ y resulta útil como una medida de exploración cuando se desconoce el tipo de contaminante. El inconveniente es que al no concentrar la muestra la sensibilidad puede ser insuficiente, por lo que podría ser necesario un procesamiento más complejo en el laboratorio para aumentar la concentración.

Los sistemas pasivos capturan contaminantes por difusión 0 permeación sobre una base que puede ser un adsorbente sólido, bien solo o impregnado con un reactivo específico. Son sistemas más cómodos y fáciles de utilizar que los sistemas activos. No requieren bombas para tomar la muestra ni personal muy preparado. L os tiempos de toma de muestra pueden ser largos, y los resultados son concentraciones medias. Es un método que no puede utilizarse para medir concentraciones máximas; en estos casos deben utilizarse sistemas activos. Para emplear correctamente sistemas pasivos es importante conocer la velocidad a la que se capta cada contaminante, que dependerá del coeficiente de difusión del gas o vapor y del diseño del monitor.

En la Tabla 44.10 se muestran las características más importantes de cada método de muestreo y la Tabla 44.11 presenta los diversos métodos utilizados para obtener y analizar las muestras para los contaminantes del aire interior más importantes.

\section{Selección del método}

Para seleccionar el mejor método de muestreo, en primer lugar debe determinarse que existen métodos validados para los contaminantes en estudio y comprobarse que se dispone de los instrumentos y materiales apropiados para recoger y analizar el contaminante. G eneralmente es necesario saber cuál será el coste y la sensibilidad requerida para el trabajo, así como conocer los elementos que pueden interferir en la determinación, dependiendo del método escogido.

La estimación de las concentraciones mínimas de lo que se espera medir resulta muy útil al evaluar el método utilizado para analizar la muestra. La concentración mínima requerida está directamente relacionada con la cantidad de contaminante que puede recogerse considerando las condiciones especificadas por el método empleado (es decir, el tipo de sistema utilizado para tomar la muestra, o la duración de la toma de muestras y el volumen de aire muestreado). Tal cantidad mínima es la que determina la sensibilidad requerida del método utilizado para el análisis; puede calcularse a partir de datos de referencia publicados para un contaminante o grupo de contaminantes específico, siempre que estos datos se hayan obtenido mediante un método similar al que se va a utilizar. Por ejemplo, si en el área en estudio se encuentran generalmente concentraciones de hidrocarburos de $30\left(\mu \mathrm{g} / \mathrm{m}^{3}\right)$, el método analítico empleado debe permitir la determinación de estas concentraciones sin dificultad. Si la muestra se obtiene con un tubo de carbón activado durante cuatro horas y con un flujo de 0,5 litros por minuto, la cantidad de hidrocarburos recogida en la muestra se 
Tabla 44.10 - Metodología para la toma de muestras.

\begin{tabular}{|c|c|c|c|}
\hline Características & Activa & Pasiva & $\begin{array}{l}\text { Lectura } \\
\text { directa }\end{array}$ \\
\hline Determinaciones a intervalos de tiempo & + & & + \\
\hline Determinaciones a largo plazo & & + & + \\
\hline Monitorización & & & + \\
\hline Concentración de la muestra & + & + & \\
\hline Determinación de inmisión & + & + & + \\
\hline Determinación de emisión & + & + & + \\
\hline \multicolumn{2}{|l|}{ Respuesta inmediata } & & + \\
\hline
\end{tabular}

calcula multiplicando el flujo de la sustancia por el período de tiempo de monitorización. En el ejemplo anterior, esto equivale a:

$\mu \mathrm{g}$ de hidrocarburos $\geq \mu \mathrm{g} / \mathrm{m}^{3} / 10^{3} \times 4 \mathrm{~h} \times 60 \mathrm{~min} \times 0,5 \mathrm{l} / \mathrm{min} \geq 3,6 \mu \mathrm{g}$

Para esta aplicación puede utilizarse cualquier método para detectar hidrocarburos que requiera que la cantidad presente en la muestra sea inferior a 3,6 $\mu \mathrm{g}$

0 tra estimación podría calcularse a partir del límite máximo establecido como límite permisible para el aire interior con respecto al contaminante que se está determinando. Si no existen estas cifras y no se conocen las concentraciones habituales presentes en el aire interior ni la tasa a la que se está liberando el contaminante al espacio, pueden utilizarse aproximaciones basadas en los niveles potenciales del contaminante que pueden afectar de forma negativa a la salud. El método elegido debe ser capaz de medir el $10 \%$ del límite establecido o de la concentración mínima que puede afectar a la salud. Aún si el método de análisis elegido tiene un grado de sensibilidad aceptable, es posible encontrar concentraciones de contaminantes por debajo del límite inferior de detección del método elegido. Es algo que debe tenerse en cuenta al calcular las concentraciones promedio. Por ejemplo, si de diez determinaciones realizadas, tres se encuentran por debajo del límite de detección, deberán calcularse dos promedios: uno asignando un valor de 0 a estas tres determinaciones y otro asignándoles el límite de detección más bajo, lo cual proporciona un promedio mínimo y un promedio máximo. El promedio determinado real se encontrará entre estos dos valores.

\section{Procedimientos analíticos}

El número de contaminantes del aire interior es elevado y éstos se encuentran presentes en concentraciones bajas. La metodología disponible hasta ahora se basa en la adaptación de métodos utilizados para controlar la calidad del aire atmosférico o del exterior y la del aire del medio ambiente industrial. La adaptación de estos métodos para el análisis del aire interior implica cambiar el rango de la concentración buscada, cuando el método lo permite, utilizando tiempos de muestreo más largos y cantidades mayores de absorbentes 0 adsorbentes. Todos estos cambios son apropiados cuando no conllevan una pérdida de fiabilidad o precisión. La determinación de una mezcla de contaminantes suele ser

Tabla 44.11 - Métodos de detección de gases en el aire interior.

\begin{tabular}{|c|c|c|c|c|c|}
\hline \multirow[t]{2}{*}{ Contaminante } & \multirow[t]{2}{*}{ Lectura directa } & \multicolumn{3}{|c|}{ Métodos } & \multirow[t]{2}{*}{ Análisis } \\
\hline & & Captura por difusión & $\begin{array}{l}\text { Captura por } \\
\text { concentración }\end{array}$ & Captura directa & \\
\hline Monóxido de carbono & $\begin{array}{l}\text { Célula electroquímica } \\
\text { Espectroscopia de infrarrojos }\end{array}$ & & & Bolsa o contenedor inerte & $C G^{a}$ \\
\hline Ozono & Quimioluminiscencia & & Borboteador & & UV-Vis \\
\hline Dióxido de azufre & Célula electroquímica & & Borboteador & & UV-Vis \\
\hline Dióxido de nitrógeno & $\begin{array}{l}\text { Quimioluminiscencia } \\
\text { Célula electroquímica }\end{array}$ & $\begin{array}{l}\text { Filtro impregnado con un } \\
\text { reactivo }\end{array}$ & Borboteador & & UV-Vis \\
\hline Dióxido de carbono & Espectroscopia de infrarrojos & & & Bolsa o contenedor inerte & CG \\
\hline Formaldehído & - & $\begin{array}{l}\text { Filtro impregnado con un } \\
\text { reactivo }\end{array}$ & $\begin{array}{l}\text { Borboteador } \\
\text { Sólidos adsorbentes }\end{array}$ & & $\begin{array}{l}\text { CLARc } \\
\text { Polarografía } \\
\text { UV-Vis }\end{array}$ \\
\hline $\mathrm{COV}$ & CG portátil & Sólidos adsorbentes & Sólidos adsorbentes & Bolsa o contenedor inerte & $\begin{array}{l}\text { CG (DCEE-DILe-DNPf-DFFI9) } \\
\text { CG-EM }\end{array}$ \\
\hline Plaguicidas & - & & $\begin{array}{l}\text { Sólidos adsorbentes } \\
\text { Borboteador } \\
\text { Filtro } \\
\text { Combinaciones }\end{array}$ & & $\begin{array}{l}\text { CG (DCE-FPD-DNP) } \\
\text { CG-EM }\end{array}$ \\
\hline Partículas & - & Sensor óptico & Filtro & $\begin{array}{l}\text { Impactor } \\
\text { Ciclona }\end{array}$ & $\begin{array}{l}\text { Gravimetría } \\
\text { Microscopia }\end{array}$ \\
\hline
\end{tabular}




\begin{tabular}{|c|c|c|}
\hline Contaminante & Monitor de lectura directa ${ }^{a}$ & Muestreo y análisis \\
\hline Monóxido de carbono & + & + \\
\hline Dióxido de carbono & + & + \\
\hline Dióxido de nitrógeno & + & + \\
\hline Formaldehído & - & + \\
\hline Dióxido de azufre & + & + \\
\hline Ozono & + & + \\
\hline $\mathrm{COV}$ & + & + \\
\hline Plaguicidas & - & + \\
\hline Particulados & + & + \\
\hline
\end{tabular}

cara y los resultados obtenidos imprecisos. En muchos casos, lo único que se garantizará será la obtención de un perfil de contaminación que indicará el nivel de contaminación durante los intervalos de muestreo, en comparación con el aire limpio, con el aire atmosférico o con otros espacios de interior. Los monitores de lectura directa se utilizan para controlar el perfil de contaminación, pero pueden no ser adecuados si son demasiado ruidosos o grandes. Actualmente se están diseñando monitores más pequeños y más silenciosos con una mayor precisión y sensibilidad. En la Tabla 44.12 se muestra un esquema del estado actual de los métodos utilizados para medir los diferentes tipos de contaminantes.

\section{Análisis de gases}

Los métodos activos son los más utilizados para el análisis de gases, y se llevan a cabo utilizando soluciones absorbentes 0 sólidos adsorbentes, o tomando directamente una muestra de aire con una bolsa u otro contenedor inerte y hermético. Para prevenir la pérdida de parte de la muestra y aumentar la exactitud de la determinación, el volumen de la muestra debe ser menor y la cantidad de absorbente 0 adsorbente utilizado debe ser mayor que para otros tipos de contaminación. También debe tenerse cuidado al transportar y almacenar la muestra (conservándola a baja temperatura y reduciendo el tiempo transcurrido hasta su análisis). Los métodos de lectura directa se utilizan con gran frecuencia para medir gases, por la considerable mejora de las prestaciones de los monitores modernos, más sensibles y precisos que antes. Debido a su facilidad de uso y al nivel y el tipo de información que proporcionan, están sustituyendo de forma progresiva a los métodos tradicionales de análisis. En la Tabla 44.13 se muestran los niveles mínimos de detección para los diversos gases estudiados considerando el método de muestreo y el análisis utilizado.

M onóxido y dióxido de carbono, contaminantes habituales del aire interior, se determinan utilizando monitores que los detectan directamente por medios electroquímicos o infrarrojos, aunque los detectores por infrarrojos no son muy sensibles. También pueden determinarse tomando muestras de aire directamente con bolsas inertes y analizando la muestra mediante cromatografía de gases con un detector de ionización de llama, que transforma los gases a metano por medio de una reacción catalítica antes de su detección. Los detectores de conductividad térmica suelen ser suficientemente sensibles para determinar concentraciones habituales de $\mathrm{CO}_{2}$.

\section{Dióxido de nitrógeno}

Se han desarrollado diversos métodos para detectar el dióxido de nitrógeno, $\mathrm{NO}_{2}$, en el aire interior utilizando monitores pasivos y tomando muestras para un análisis posterior, pero estos métodos han mostrado problemas de sensibilidad que probablemente se resolverán en el futuro. El método más conocido es el tubo de Palmes, que tiene un límite de detección de 300 ppb. En el marco no industrial, se deberán tomar muestras durante un mínimo de cinco días para obtener un límite de detección de 1,5 ppb, tres veces superior al valor del blanco para una exposición de una semana. También se han desarrollado monitores portátiles con detección en tiempo real basados en la reacción quimicolumínica entre el $\mathrm{NO}_{2}$ y el reactivo luminol, pero los resultados obtenidos con este método pueden modificarse por la temperatura y su linealidad y sensibilidad dependen de las características de la solución de luminol utilizada. Los monitores con sensores electroquímicos poseen una sensibilidad mayor, pero pueden sufrir interferencias por los compuestos que contienen azufre (Freixa 1993).

\section{Dióxido de azufre}

Para determinar el dióxido de azufre, $\mathrm{SO}_{2}$, en un ambiente interior se utiliza un método espectrofotométrico. Se hace borbotear la muestra de aire a través de una solución de tetracloromercuriato para formar un complejo estable que, a su vez, se determina espectrofotométricamente después de reaccionar con pararosanilina. O tros métodos se basan en la fotometría de llama y en la fluorescencia ultravioleta pulsante, y también existen métodos basados en la derivación de la determinación antes del análisis espectroscópico. Es un tipo de detección utilizado para monitores de aire atmosférico, aunque no es adecuado para el análisis del aire interior debido a la falta de especificidad y a que muchos de estos monitores requieren un sistema de ventilación para eliminar los gases que generan. Dado que se han reducido enormemente las emisiones de $\mathrm{SO}_{2}$ y a que este compuesto no es considerado un contaminante importante del aire interior, el desarrollo de monitores para su detección no ha avanzado mucho. Ahora bien, existen instrumentos portátiles en el mercado que pueden detectar el $\mathrm{SO}_{2}$ basándose en la detección de pararosanilina (Freixa 1993).

\section{Ozono}

El ozono, $\mathrm{O}_{3}$, sólo puede encontrarse en ambientes de interior en situaciones especiales en las que se genera de forma continua, ya que se degrada rápidamente. Se determina mediante métodos de lectura directa, tubos colorimétricos y métodos de quimioluminiscencia. También puede detectarse por métodos utilizados en higiene industrial que pueden adaptarse fácilmente para el aire interior. La muestra se obtiene con una solución absorbente de yoduro potásico en un medio neutral y a continuación se somete a análisis espectrofotométrico.

Tabla 44.13 • Límites inferiores de detección para algunos gases por monitores utilizados para valorar la calidad del aire interior ${ }^{a}$.

$\begin{array}{lcl}\text { Contaminante } & \begin{array}{l}\text { Monitor de lectura } \\ \text { directa }\end{array} & \begin{array}{l}\text { Análisis de toma de } \\ \text { muestra y activo/ pasivo }\end{array} \\ \text { Monóxido de carbono } & 1,0 \mathrm{ppm} & 0,05 \mathrm{ppm} \\ \text { Dióxido de nitrógeno } & 2 \mathrm{ppb} & 1,5 \mathrm{ppb}(1 \text { semana })^{b} \\ \text { Ozono } & 4 \mathrm{ppb} & 5,0 \mathrm{ppb} \\ \text { Formaldehído } & & 5,0 \mathrm{ppb}(1 \text { semana })^{b}\end{array}$

a Los monitores de dióxido de carbono que usan espestroscopia de infrarrojos siempre son suficientemente sensibles. $\quad$ b Monitores pasivos (duración de la exposición). 


\section{Formaldehído}

El formaldehído es un contaminante importante del aire interior, y debido a sus propiedades químicas y tóxicas se recomienda una evaluación individualizada. Existen diferentes métodos para detectar el formaldehído en el aire, todos ellos basados en la toma de muestras para un análisis posterior, con fijación activa o por difusión. El método de captura más apropiado dependerá del tipo de muestra (emisión o inmisión) utilizado y de la sensibilidad del método analítico. Los métodos tradicionales se basan en la obtención de una muestra haciendo borbotear el aire a través de agua destilada o de una solución de bisulfato sódico al $1 \%$ a $5^{\circ} \mathrm{C}$, y a continuación analizándolo por métodos espectrofluorométricos. D urante su almacenamiento, también debe conservarse a $5{ }^{\circ} \mathrm{C}$. El $\mathrm{SO}_{2}$ y los componentes del humo del tabaco pueden interferir en el análisis. C ada vez se utilizan con mayor frecuencia en el análisis del aire interior sistemas o métodos activos que capturan contaminantes por difusión con adsorbentes sólidos; constan de una base que puede ser un filtro o un sólido saturado con un reactivo, como el bisulfato sódico o la 2,4-difenilhidrazina. Los métodos que toman el contaminante por difusión, además de las ventajas generales propias del método, son más sensibles que los métodos activos debido a que el tiempo necesario para obtener la muestra es mayor (Freixa 1993).

\section{Detección de compuestos orgánicos volátiles (COV)}

L os métodos utilizados para medir o monitorizar los vapores orgánicos en el aire interior deben cumplir una serie de criterios: tener una sensibilidad del orden de partes por billón (ppb) a partes por trillón (ppt), los instrumentos utilizados para tomar la muestra 0 realizar la lectura directa deben ser portátiles y fáciles de manejar, y los resultados obtenidos deben ser precisos y susceptibles de duplicación. Son muchos los métodos que cumplen estos criterios, pero los más utilizados para analizar el aire interior se basan en la toma de muestras y el análisis. Existen métodos de detección directa que consisten en cromatógrafos de gases portátiles con diferentes métodos de detección. Se trata de instrumentos caros, de manejo difícil y utilizables sólo por personal preparado. Para compuestos orgánicos polares y no polares con un punto de ebullición de entre $0{ }^{\circ} \mathrm{C}$ y $300^{\circ} \mathrm{C}$, el adsorbente más utilizado para sistemas de muestreo pasivos y activos ha sido el carbón activado. También se emplean polímeros porosos y resinas poliméricas, como Tenax GC, $X$ AD -2 y A mbersorb. El másutilizado de ellos esT enax. Las muestras obtenidas con carbón activado se extraen con disulfuro de carbono y se analizan por cromatografía de gases con ionización de llama, captura de electrones o detectores de espectrometría de masa, seguido de un análisis cualitativo y cuantitativo. L as muestras obtenidas con Tenax suelen extraerse por desorción térmica con helio y se condensan en una trampa de nitrógeno líquido antes de introducirlas en el cromatógrafo. 0 tro método común consiste en obtener muestras directamente, utilizando bolsas o contenedores inertes, introduciendo el aire directamente en el cromatógrafo de gases o concentrando primero la muestra con un adsorbente y una trampa fría. L os límites de detección de estos métodos dependen del compuesto analizado, del volumen de muestra tomado, de la contaminación basal y de los límites de detección del instrumento empleado. D ebido a que es imposible cuantificar todos y cada uno de los compuestos presentes, la cuantificación suele realizarse por familias, utilizando como referencia compuestos característicos de cada una de ellas. En la detección de C OV en el aire interior esmuy importante la pureza de los disolventes utilizados. Si se aplica desorción térmica, la pureza de los gasestambién esimportante.

\section{Detección de plaguicidas}

Los métodos empleados habitualmente para detectar plaguicidas en el aire interior consisten en la toma de muestras con adsorbentes sólidos, aunque no se descarta el uso de borboteadores y sistemas mixtos. EI adsorbente sólido más utilizado ha sido el polímero poroso Chromosorb 102, aunque cada vez es más frecuente el uso de espumas de poliuretano (EPU ) que pueden capturar un mayor número de plaguicidas. Los métodos de análisis varían de acuerdo con el método de muestreo y el plaguicida. Generalmente se analizan por cromatografía de gases con diferentes detectores específicos, desde captura de electrones hasta espectrometría de masa. La capacidad de este último método para identificar compuestos es considerable. EI análisis de estos compuestos presenta varios problemas, como la contaminación de las partes de vidrio de los sistemas de toma de muestras con cantidades mínimas de bifenilos policlorados (BPC), ftalatos 0 plaguicidas.

\section{Detección de polvo o partículas a mbientales}

Para la captura y análisis de partículas y fibras en el aire se dispone de una gran variedad de técnicas y equipos adecuados para la valoración de la calidad del aire interior. Los monitores que permiten una lectura directa de la concentración de partículas en el aire utilizan detectores de luz difusa, mientras que los métodos basados en la toma de muestras y análisis utilizan la pesada y el análisis con un microscopio. Es un tipo de análisis que requiere un separador, como un ciclón o un impactor, para eliminar las partículas de mayor tamaño antes de poder utilizar un filtro. Los métodos que emplean un ciclón son bastante precisos, pero requieren unos caudales de aire bajos, por lo que la toma de muestras requiere mucho tiempo. Los monitores pasivos ofrecen una precisión excelente, pero están influidos por la temperatura ambiente y tienden a dar valores más altos cuando las partículas son pequeñas.

\section{CONTAMINACION BIOLOGICA}

Brian Flannigan

\section{Características y orígenes de la contaminación biológica del aire interior}

Aunque existe una amplia variedad de partículas de origen biológico (biopartículas) en el aire interior, en la mayoría de los ambientes de trabajo de interior los microorganismos (microbios) tienen gran importancia para la salud. Además de microorganismos (como virus, bacterias, hongos y protozoos), el aire interior puede contener granos de polen, detritus animal y fragmentos de insectos y ácaros y sus productos de excreción (Wanner y cols. 1993). Además de los aerosoles biológicos de estas partículas, también puede haber compuestos orgánicos volátiles que emanan de organismos vivos, como las plantas y los microorganismos presentes en el interior.

\section{Polen}

Los granos de polen contienen sustancias (alergenos) que pueden causar respuestas alérgicas en personas susceptibles 0 atópicas, que se manifiestan generalmente como "fiebre del heno" o rinitis. La alergia se asocia principalmente al medio ambiente exterior; en el aire interior, las concentraciones de polen suelen ser considerablemente menores que en el aire atmosférico La diferencia en la concentración de polen entre el aire exterior y el interior es mayor en el caso de los edificios en los que los sistemas de calefacción, ventilación y aire acondicionado (CVAA) tienen una filtración eficaz en la entrada del aire externo. Las unidades de aire acondicionado de ventana también producen niveles de polen en el interior más bajos que los existentes en edificios con ventilación natural. El aire de algunos ambientes de trabajo de interior puede 
llegar a tener un contenido elevado de polen, como en el caso de que exista un gran número de plantas con flores por razones estéticas o en los invernaderos comerciales.

\section{Detritus}

El detritus está constituido por partículas finas de piel, pelo y plumas (y saliva y orina desecadas), y es una fuente de potentes alergenos que pueden causar ataques de rinitis o asma en personas susceptibles. Las principales fuentes de detritus en ambientes de interior suelen ser los gatos y los perros, pero también son fuentes potenciales las ratas y los ratones (como mascotas, animales de experimentación o vermes), hámsters, jerbos (una especie de rata del desierto), cobayas y pájaros de jaula. El detritus originado por éstos y otros animales de granja y de compañía (como los caballos) puede estar en la ropa, pero en los ambientes de trabajo la mayor exposición al detritus probablemente tenga lugar en instalaciones de cría de animales y laboratorios 0 en edificios infestados de vermes

\section{Insectos}

Aunque estos organismos y sus productos excretores pueden causar también alergias respiratorias y de otra naturaleza, no parecen contribuir de forma significativa a la carga biológica en suspensión en el aire en la mayoría de las situaciones. Las partículas de cucarachas (especialmente Blatella germanica y Periplaneta americana) pueden ser un componente importante en ambientes de trabajo insalubres, cálidos y húmedos. Las exposiciones a partículas de cucarachas y otros insectos, como langostas, gorgojos, escarabajos y moscas de la fruta, pueden ser causa de problemas de salud entre los trabajadores de instalaciones de cría de animales y laboratorios.

\section{Acaros}

Son arácnidos que se asocian en particular al polvo, pero puede haber fragmentos de estos parientes microscópicos de las arañas y de sus productos de excreción (heces) en el aire interior. El ácaro del polvo de casa, Dermatophagoides pteronyssinus, es la especie más importante. Junto a sus parientes cercanos, es una causa importante de alergia respiratoria. Se asocia principalmente a los hogares, donde abunda en las ropas de cama, pero también están presentes en los muebles tapizados. Existen algunas pruebas que indican que estos muebles pueden constituir nichos de ácaros en las oficinas. Los ácaros de almacén asociados a los alimentos y a los piensos para animales almacenados, como A carus, G lyciphagus y Tyrophagus, también pueden aportar fragmentos alergénicos al aire interior. Aunque es más probable que afecten a los granjeros y a trabajadores que manipulan género alimentario a granel, como D. pteronyssinus, puede haber ácaros de almacén en el polvo de los edificios, en particular en condiciones calurosas y húmedas.

\section{Virus}

Los virus son microorganismos muy importantes en términos del nivel total de problemas de salud que causan, pero no pueden vivir de forma independiente fuera de células y tejidos vivos. Aunque existen pruebas que indican que algunos de ellos se desplazan en el aire recirculante de los sistemas CVAA, el principal medio de transmisión es el contacto entre personas. La inhalación a corta distancia de aerosoles generados al toser 0 estornudar, como en el caso de los virus del resfriado y de la gripe, también es importante. Por consiguiente, es probable que las tasas de infección sean mayores en situaciones de aglomeración humana. No existen cambios evidentes en el diseño o gestión de los edificios que puedan modificar esta situación.

\section{Bacterias}

Son microorganismos que se dividen en dos categorías principales, dependiendo de su reacción a la tinción de G ram. L os tipos grampositivos más frecuentes se originan en la boca, la nariz, la nasofaringe y la piel, y son Staphylococcus epidermidis, S. aureus y especies de Aerococcus, M icrococcus y Streptococcus. Las bacterias gramnegativas no suelen ser abundantes, pero en ocasiones especies de Actinetobacter, A eromonas, F lavobacterium y especialmente $P$ seudomonas pueden ser importantes. El agente causal de la enfermedad del legionario, Legionella pneumophila, puede estar presente en suministros de agua caliente y en humidificadores de aire acondicionado, así como en equipos de terapia respiratoria, jacuzzis, saunas y duchas. Se propaga desde estas instalaciones en aerosoles acuosos, pero también puede entrar en los edificios en el aire procedente de torres de refrigeración próximas. EI tiempo de supervivencia para L. pneumophila en el aire interior parece no ser mayor de 15 minutos.

Además de las bacterias unicelulares anteriormente mencionadas, también existen tipos filamentosos que producen esporas dispersadas por el aire, los actinomicetos. Parecen estar asociados a materiales estructurales húmedos, y pueden producir un olor a tierra característico. D os de estas bacterias capaces de crecer a $60^{\circ} \mathrm{C}$, Faenia rectivirgula (antiguamente llamada M icropolyspora faeni) y $T$ hermoactinomyces vulgaris, pueden estar presentes en humidificadores y otros equipos de CVAA.

\section{H ongos}

Los hongos se dividen en dos grupos: el primero, las levaduras y mohos microscópicos conocidos como microhongos, y el segundo, los hongos del yeso y de la madera podrida, denominados macrohongos, ya que producen esporas macroscópicas apreciables a simple vista. Además de las levaduras unicelulares, los hongos colonizan sustratos formando redes (micelio) o filamentos (hifas). L os hongos filamentosos producen numerosas esporas que se dispersan por el aire a partir de estructuras microscópicas (productoras de esporas en los mohos) y de estructuras grandes (productoras de esporas en los macrohongos).

Existen esporas de muchos mohos diferentes en el aire de las casas y de los lugares de trabajo no industriales, pero probablemente los más frecuentes sean las especies de Cladosporium, PeniciIlium, Aspergillus y E urotium. Algunos mohos presentes en el aire interior, como las especies de Cladosporium, son abundantes en las superficies de las hojas y de otras partes de las plantas del exterior, en particular en verano. En cualquier caso, aunque las esporas presentes en el aire interior pueden originarse en el exterior, la Cladosporium también es capaz de crecer y producir esporas sobre superficies húmedas en el interior, contribuyendo así a la carga biológica del aire interior. Se considera que las diversas especies de Penicillium se originan generalmente en el interior, al igual que Aspergillus y E urotium. En la mayoría de las muestras de aire interior se encuentran levaduras, y en ocasiones pueden estar presentes a niveles elevados. Las levaduras rosas R hodotorula o Sporobolomyces son componentes destacados de la flora en suspensión en el aire y también pueden aislarse de superficies afectadas por mohos.

Los edificios proporcionan numerosos nichos o rincones que contienen el material orgánico muerto que sirve como nutriente a la mayoría de los hongos y bacterias para su crecimiento y producción de esporas. Los nutrientes están presentes en materiales como los siguientes: madera; papel, pintura y otros revestimientos de superficies; mobiliario como alfombras y muebles tapizados; tierra de macetas; polvo; escamas de piel y secreciones de seres humanos y de otros animales; y en alimentos cocinados y sus ingredientes crudos. EI hecho de que tenga lugar o no el crecimiento de estos microorganismos depende del nivel de humedad. Las bacterias sólo son capaces de crecer en 
superficies saturadas, o en el agua de las bandejas de drenaje, reservorios y similares de Ios equipos CVAA. Algunos mohos también requieren condiciones de casi saturación, pero otros son menos exigentes y pueden proliferar en materiales húmedos aunque no estén totalmente saturados. EI polvo puede ser un lugar de depósito y, si está suficientemente húmedo, un lugar de cultivo para los mohos. Por consiguiente, una cantidad importante de esporas entran en suspensión en el aire cuando se mueve el polvo.

\section{Protozoos}

Los protozoos, como A canthamoeba y $\mathrm{N}$ aegleri son animales unicelulares microscópicos que se alimentan de bacterias y otras partículas orgánicas presentes en humidificadores, reservorios y bandejas de drenaje de sistemas CVAA. Pueden formarse aerosoles de partículas de estos protozoos, que se han citado como causas posibles de fiebre por humidificadores.

\section{Compuestos orgánicos volátiles microbianos}

Los compuestos orgánicos volátiles microbianos varían considerablemente en su composición química y su olor. Algunos son producidos por una amplia variedad de microorganismos, pero otros están asociados a especies particulares. El denominado alcohol del champiñón, 1-octen-3-ol (que posee un olor a champiñones frescos) se encuentra entre los producidos por numerosos mohos diferentes. 0 tros compuestos volátiles menos frecuentes son la 3,5-dimetil-1,2,4-tritiolona (descrito como "fétido"); la geosmina, o 1,10-dimetil-trans-9-decalol ("terroso"); y la 6-pentil- $\alpha$-pirona ("coco", "mohoso"). Entre las bacterias, especies de Pseudomonas producen pirazinas con un olor a "patata mohosa". El olor de cualquier microorganismo es el producto de una mezcla compleja de COVM .

\section{Historia de los problemas microbiológicos de la calidad del aire interior}

Durante más de un siglo se han realizado investigaciones microbiológicas del aire en viviendas, colegios y otros edificios. Las primeras investigaciones estaban relacionadas a veces con la "pureza" microbiológica relativa del aire en diferentes tipos de edificios y con la posible relación que pudiera tener con la tasa de mortalidad entre los ocupantes. Junto con el prolongado interés por la diseminación de patógenos en los hospitales, el desarrollo de muestreadores volumétricos microbiológicos de aire en los decenios de 1940 y 1950 condujo a investigaciones sistemáticas de microorganismos transmitidos por el aire en los hospitales, y posteriormente de mohos alergénicos conocidos en el aire de viviendas y edificios públicos así como en el aire atmosférico. En los decenios de 1950 y 1960 se investigaron las enfermedades respiratorias profesionales, como el pulmón del granjero, el pulmón del trabajador de la malta y la bisinosis (entre los trabajadores del algodón). Aunque la fiebre seudogripal por humidificadores en un grupo de trabajadores se describió por primera vez en 1959, transcurrieron entre diez y quince años antes de que se comunicaran nuevos casos. Con todo, incluso ahora se desconoce la causa específica de esta enfermedad, aunque se ha implicado a los microorganismos en su patogenia. También se han sugerido como posible causa del "síndrome del edificio enfermo", pero las pruebas obtenidas hasta ahora sobre esta relación son muy escasas.

Aunque actualmente se conocen bien las propiedades alérgicas de los hongos, el primer informe acerca de problemas de salud debidos a la inhalación de toxinas micóticas en un lugar de trabajo no industrial, un hospital de Q uebec, no apareció hasta 1988 (M ainville y cols. 1988). Los síntomas de fatiga extrema entre el personal del hospital fueron atribuidos a micotoxinas de tricoteceno en esporas de Stachybotrys atra y Trichoderma viride, y desde entonces el "síndrome de fatiga crónica" causado por exposición a polvo micotóxico fue detectado entre profesores y otros trabajadores de un colegio. El primero ha sido causa de enfermedad en trabajadores de oficina, y mientras que algunos de los efectos sobre la salud eran de naturaleza alérgica, otros correspondían a un tipo asociado más a menudo a una toxicosis (Johanning y cols. 1993). En otros lugares, la investigación epidemiológica ha indicado que podría existir algún factor o factores no alérgicos asociados a hongos que afectan al estado de salud respiratorio. Las micotoxinas producidas por especies individuales de mohos podrían desempeñar un papel importante en este proceso, pero también es posible que otros atributos más generales de los hongos inhalados sean nocivos para el estado de salud del sistema respiratorio.

\section{Microorganismos asociados a la calidad del aire interior y sus efectos sobre la salud}

Aunque los patógenos son relativamente infrecuentes en el aire interior, existen numerosos informes que relacionan microorganismos de transmisión aérea con una serie de procesos alérgicos, entre los que se incluyen los siguientes: a) dermatitis alérgica atópica; b) rinitis; c) asma; d) fiebre por humidificadores, y e) alveolitis alérgica extrínseca ( $A A E$ ), también conocida como neumonitis por hipersensibilidad ( $\mathrm{NH}$ ).

L os hongos son considerados más importantes que las bacterias como componentes de los aerosoles biológicos presentes en el aire interior. D ebido a que crecen en superficies húmedas en forma de placas de moho, los hongos suelen poner en evidencia problemas de humedad y de riesgo potencial para la salud en un edificio. El crecimiento de moho contribuye tanto en número como en especies a la flora de moho del aire interior, que de lo contrario no estaría presente. Al igual que las bacterias gramnegativas y los actinomicetos, los hongos hidrófilos ("amantes de la humedad") son indicadores de lugares extremadamente húmedos de cultivos (visibles u ocultos) y, por consiguiente, de mala calidad del aire interior. Entre ellos se encuentran F usarium, Phoma, Stachybotrys, Trichoderma, U locladium, levaduras y, con menor frecuencia, los patógenos oportunistas Aspergillus fumigatus y Exophiala jeanselmei. Los niveles elevados de mohos que muestran grados variables de xerofilia ("amor por la sequedad"), al tener una necesidad menor de agua, pueden indicar la existencia de sitios de cultivo que son menos húmedos, pero aún así importantes para el crecimiento. Los mohos también son abundantes en el polvo de las casas, por lo que su presencia en número elevado también puede indicar que existe una atmósfera con polvo. Varían desde especies de Cladosporium ligeramente xerófilas (capaces de soportar condiciones de sequedad) a especies moderadamente xerófilas como A spergillus versicolor, Penicillium (por ejemplo, P. aurantiogriseum y P. chrysogenum) y las extremadamente xerófilas A spergill us penicillioides, E urotium y W allemia.

Los patógenos micóticos rara vez se encuentran presentes de forma abundante en el aire interior, pero A. fumigatus y algunos otros aspergillus oportunistas, que pueden invadir el tejido humano, crecen en la tierra de las plantas colocadas en macetas. Exophiala jeanselmei es capaz de crecer en desagües. Aunque no es probable que las esporas de éstos y de otros patógenos oportunistas, como Fusarium solani y Pseudallescheria boydii, sean peligrosas para la salud, sí pueden serlo para personas inmunodeprimidas.

L os hongos de transmisión aérea son mucho más importantes que las bacterias como causas de enfermedad alérgica, aunque parece que, al menos en Europa, los alergenos micóticos son menos importantes que los del polen, los ácaros del polvo de las casas y el detritus animal. M uchos tipos de hongos han demostrado ser alergénicos. En la Tabla 44.14 se muestran algunos de los hongos presentes en el aire interior citados con mayor 
Tabla 44.14 - Ejemplos de tipos de hongos en el aire interior que pueden causar rinitis o asma.

$\begin{array}{lll}\text { Alternaria } & \text { Geotrichum } & \text { Serpula } \\ \text { Aspergillus } & \text { Mucor } & \text { Stachybotrys } \\ \text { Cladosporium } & \text { Penicillium } & \text { Stemphylium/ Ulocladium } \\ \text { Eurotium } & \text { Rhizopus } & \text { Wallemia } \\ \text { Fusarium } & \text { Rhodotorula/ Sporobolomyces } & \\ \end{array}$

frecuencia como causa de rinitis y asma. Las especies de E urotium y otros mohos extremadamente xerófilos del polvo de casa probablemente sean más importantes como causas de rinitis y asma de lo que se había considerado anteriormente. La dermatitis alérgica debida a hongos es mucho menos frecuente que la rinitis/ asma, y en ella se ha implicado a organismos como Alternaria, A spergillus y Cladosporium. L os casos de $A A E$, relativamente raros, se han atribuido a diversos hongos, desde la levadura Sporobolomyces al macrohongo pudridor de la madera, Serpula (Tabla 44.15). Generalmente se considera que el desarrollo de síntomas de $A A E$ en una persona requiere una exposición a, como mínimo, un millón (probablemente, unos cien millones) de esporas con alergenos por metro cúbico de aire. Tales niveles de contaminación sólo es probable que existan en edificios en los que hay un crecimiento micótico intenso.

Como se comentó anteriormente, la inhalación de esporas de especies tóxicas supone un riesgo potencial (Sorenson 1989; M iller 1993). No son sólo las esporas de Stachybotrys las que contienen concentraciones elevadas de micotoxinas. También las esporas de este moho, que crece en el papel de pared y en otros sustratos de celulosa en edificios húmedos y que también es alergénico, contienen micotoxinas extremadamente potentes; otros mohos tóxicos que se encuentran presentes con mayor frecuencia en el aire interior son Aspergillus (especialmente A. versicolor), Penicillium (por ejemplo, P. aurantiogriseum y P. viridicatum) y Trichoderma. Los datos experimentales indican que diversas micotoxinas de las esporas de estos mohos son inmunosupresoras y que inhiben intensamente los procesos de depuración y otras funciones de los macrófagos pulmonares fundamentales para la salud del aparato respiratorio (Sorenson 1989).

Se conocen poco los efectos sobre la salud de los COVM producidos durante el crecimiento y la esporulación de los mohos, 0 de sus equivalentes bacterianos. Aunque muchos COVM parecen tener una toxicidad relativamente baja (Sorenson 1989), datos aislados indican que pueden provocar cefaleas, molestias y, quizá, respuestas respiratorias agudas en el ser humano.

Las bacterias presentes en el aire interior generalmente no representan un peligro para la salud, ya que en la flora predominan los microorganismos grampositivos de la piel y de las vías respiratorias altas. Sin embargo, los recuentos elevados de estas bacterias indican exceso de población y mala ventilación. La presencia de un gran número de tipos gramnegativos o de Actinomyctales en el aire indica que existen superficies o materiales húmedos, desagües 0 , en particular, humidificadores de sistemas CVAA en los que están proliferando. Se ha demostrado que algunas bacterias gramnegativas (o endotoxinas extraídas de sus paredes) provocan síntomas de fiebre por humidificadores. En ocasiones, el crecimiento en humidificadores ha sido suficientemente intenso para la producción de aerosoles que contenían una cantidad suficiente de células alergénicas, causando síntomas similares a los de la neumonía aguda de AAE (véase la Tabla 44.15).

En raras ocasiones, los sistemas de recirculación pueden dispersar bacterias patógenas como $M$ ycobacterium tuberculosis en los núcleos de gotitas procedentes de individuos infectados por un medio ambiente cerrado. A unque el patógeno L egionella pneumophila ha sido aislado de humidificadores y sistemas de aire acondicionado, la mayoría de los brotes de legionelosis se han asociado a aerosoles originados en torres de refrigeración 0 duchas.

\section{Influencia de los cambios en el diseño de los edificios}

Con el paso de los años, el aumento del tamaño de los edificios junto con el desarrollo de sistemas de tratamiento del aire que han culminado en los sistemas CVAA modernos, ha originado cambios cuantitativos y cualitativos en la carga biológica del aire en ambientes de trabajo de interior. En las dos últimas décadas, la tendencia al diseño de edificios con un uso mínimo de energía ha dado lugar al desarrollo de edificios con una infiltración y exfiltración de aire muy reducidas, lo que permite la concentración de microorganismos de transmisión aérea y de otros contaminantes. En este tipo de edificios "herméticos", el vapor de agua, que anteriormente habría sido ventilado hacia el exterior, se condensa sobre superficies frías, creando las condiciones adecuadas para el crecimiento de microbios. Además, los sistemas CVAA, diseñados únicamente para conseguir una eficacia económica máxima, a menudo favorecen el crecimiento microbiano y constituyen un riesgo para la salud de los ocupantes de edificios grandes. Por ejemplo, los humidificadores que utilizan agua recirculada se contaminan rápidamente y actúan como generadores de microorganismos; los pulverizadores de agua humidificadores aerosolizan microorganismos, y la colocación de filtros en localización retrógrada en lugar de anterógrada con respecto a estas áreas de producción y aerosolización de microbios permite la transmisión anterógrada de aerosoles microbianos al lugar de

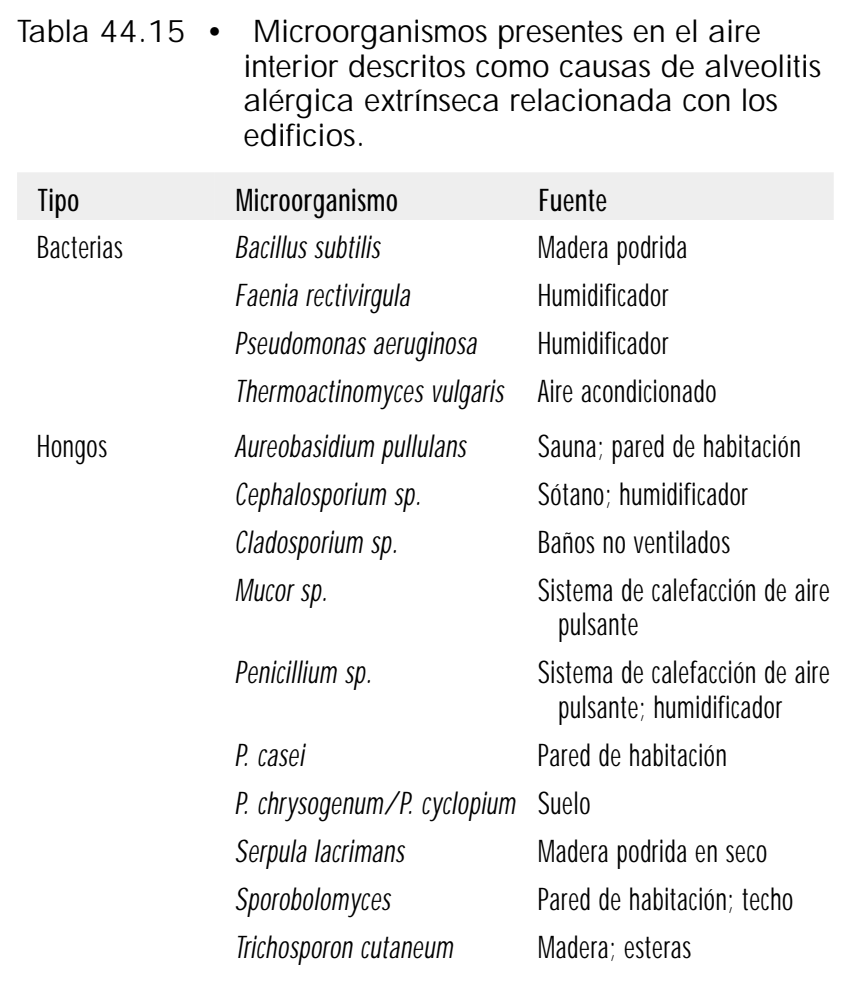


trabajo. La colocación de entradas de aire próximas a torres de refrigeración u otras fuentes de microorganismos, así como la dificultad de acceso al sistema CVAA para su mantenimiento y limpieza o desinfección, también son defectos de diseño, operación y mantenimiento que pueden poner en peligro la salud, ya que exponen a los ocupantes a cifras elevadas de microorganismos de transmisión aérea específicos, en lugar de las cifras bajas de una mezcla de especies representativa del aire del exterior que debería ser la norma.

\section{Métodos para evaluar la calidad del aire interior}

\section{Muestreo de microorganismos en el aire}

Al investigar la flora microbiana del aire en un edificio, por ejemplo, para intentar establecer la causa de problemas de salud entre sus ocupantes, es necesario obtener datos objetivos detallados y fiables. Dado que la idea más extendida considera que el estado microbiológico del aire interior debe reflejar el estado en el aire atmosférico (ACGIH 1989), deben identificarse de forma exacta los organismos y compararse con los existentes en el aire atmosférico en ese momento.

\section{M uestreadores de aire}

Los métodos de muestreo que permiten, bien de forma directa 0 bien de forma indirecta, el cultivo de bacterias y hongos de transmisión aérea viables en agar gel nutritivo proporcionan la mejor oportunidad de identificar las especies, motivo por el cual se utilizan con gran frecuencia. EI medio agar se incuba hasta que se desarrollan colonias a partir de las partículas biológicas atrapadas y se recuentan e identifican, o se subcultivan en otro medio para un nuevo examen. Los medios agar necesarios para bacterias son diferentes de los necesarios para hongos, y algunas bacterias, como Legionella pneumophila, sólo pueden aislarse en medios selectivos especiales. Para los hongos, se recomienda el uso de dos medios: un medio de objetivo general y un medio más selectivo para el aislamiento de hongos xerófilos. La identificación se basa en las características macroscópicas de las colonias y en sus características microscópicas o bioquímicas, y requiere unos conocimientos y una experiencia considerables.

Se ha revisado adecuadamente el rango de métodos de muestreo disponibles (p. ej., Flannigan 1992; Wanner y cols. 1993), y en este estudio sólo se mencionan los sistemas más utilizados. Es posible realizar una valoración provisional recogiendo de forma pasiva los microorganismos que gravitan fuera del aire en placas de Petri abiertas que contienen medio agar. Los resultados obtenidos utilizando estas placas de asentamiento no son volumétricos, están influidos intensamente por la turbulencia atmosférica y favorecen la recogida de esporas grandes (pesadas) o grupos de esporas o células. Por consiguiente, es preferible utilizar un muestreador de aire volumétrico. Un tipo muy utilizado es el muestreador por impacto, en el que las partículas de transmisión aérea impactan sobre una superficie de agar. Se hace pasar aire a través de una hendidura sobre una placa agar en rotación (muestreadores por impacto de tipo hendidura) 0 a través de un disco perforado sobre la placa agar (muestreador por impacto de tipo criba). Aunque a menudo se utiliza el muestreador de criba de una fase, algunos investigadores prefieren el muestreador Andersen de seis fases. A medida que el aire pasa en cascada a través de agujeros cada vez más pequeños en sus seis secciones apiladas de aluminio, las partículas se clasifican en diferentes placas agar de acuerdo con su tamaño aerodinámico. Por tanto, este muestreador revela el tamaño de las partículas a partir de las cuales se desarrollarán colonias cuando se incuben posteriormente las placas agar, e indica el lugar del sistema respiratorio en el que es más probable que se depositen los diferentes organismos. Un muestreador popular que funciona por un principio diferente es el muestreador centrífugo Reuter. La aceleración centrífuga del aire a través de un ventilador produce el impacto de las partículas a alta velocidad en un medio agar colocado en una tira de plástico que recubre el cilindro de muestreo.

0 tro enfoque para el muestreo es recoger microorganismos en un filtro de membrana colocado en una carcasa de filtro conectada a una bomba recargable de bajo volumen. EI dispositivo completo puede sujetarse a un cinturón 0 arnés para recoger una muestra personal durante un día normal de trabajo. Después del muestreo, pueden extenderse pequeñas porciones de lavados del filtro y de diluciones de los lavados en diversos medios agar, incubarse y hacer recuentos de microorganismos viables. Una alternativa al muestreador de filtro es el impactor líquido, en el que las partículas en suspensión en el aire (el cual se hace pasar a través de chorros capilares), impactan y se acumulan en el líquido. A continuación, se tratan porciones del líquido recogido y de las diluciones preparadas a partir de él de la misma forma que en el caso de los muestreadores de filtro.

U na deficiencia importante de estos métodos de muestreo "viable" es que sólo valoran organismos realmente cultivables, y éstos pueden representar sólo un $102 \%$ de las esporas totales presentes en el aire. Por lo demás, pueden realizarse recuentos totales (viables más no viables) utilizando muestreadores por impacto en los que las partículas se recogen en las superficies adherentes de varillas en rotación (muestreador por impacto de brazo rotatorio) o en la tapa de plástico o el porta de vidrio microscópico de diferentes modelos de muestreador por impacto de tipo hendidura. Los recuentos se realizan al microscopio, pero de esta forma sólo puede identificarse un número relativamente bajo de hongos, es decir, los que tienen esporas bien definidas. Se ha mencionado el muestreador de filtración en relación con la valoración de microorganismos viables, pero éste también es un medio de obtener un recuento total. U na parte de los mismos lavados que se colocan en placas en medio agar puede teñirse $y$, así, se pueden contar los microorganismos al microscopio. También pueden realizarse recuentos totales de la misma forma a partir del líquido recogido en impactores líquidos.

\section{Elección del muestreador de aire y estrategia de muestreo}

EI muestreador que se vaya a utilizar depende en gran medida de la experiencia del investigador, pero la elección es importante por motivos cuantitativos y cualitativos. Por ejemplo, las placas agar de los muestreadores por impacto de una fase se "sobrecargan" con esporas con mucha mayor facilidad durante el muestreo que las placas de un muestreador de seis fases, dando lugar a un crecimiento excesivo de las placas incubadas y a graves errores cuantitativos y cualitativos en la valoración de la población de transmisión aérea. La forma en que funcionan los diferentes muestreadores, sus tiempos de muestreo y la eficacia con la que eliminan tamaños diferentes de partículas del aire ambiente, las extraen del flujo de aire y las recogen en una superficie o en un líquido, difieren considerablemente. Debido a estas diferencias, no es posible realizar una comparación válida entre los datos obtenidos utilizando un tipo de muestreador en una investigación con los obtenidos con otro tipo de muestreador en una investigación diferente.

La estrategia de muestreo y la elección del muestreador son muy importantes. No puede recomendarse ninguna estrategia de muestreo general; cada caso requiere su propio enfoque (Wanner y cols. 1993). U n problema importante es que la distribución de microorganismos en el aire interior no es uniforme, ni en el espacio ni en el tiempo. Dependen profundamente del grado de actividad en una habitación, en particular, del trabajo 
Tabla 44.16 - N iveles observados de microorganismos en el aire y el polvo de ambientes de interior no industriales.

\begin{tabular}{lccc}
$\begin{array}{l}\text { Categoría de } \\
\text { contaminación }\end{array}$ & UFCa por metro de aire & $\begin{array}{l}\text { Hongos como } \\
\text { UFCl g de polvo }\end{array}$ \\
Muy baja & Bacterias & Hongos & \\
Baja & $<50$ & $<25$ & $<10.000$ \\
Intermedia & $<100$ & $<100$ & $<20.000$ \\
Alta & $<500$ & $<500$ & $<50.000$ \\
Muy alta & $<2.000$ & $<2.000$ & $<120.000$ \\
a UFC, unidades formadoras de colonias. & $>2.000$ & $>120.000$ \\
Fuente: Adaptado de Wanner y cols. 1993. & & \\
\hline
\end{tabular}

de limpieza o construcción que levanta el polvo asentado. En consecuencia, existen importantes fluctuaciones en el número de microorganismos en intervalos de tiempo relativamente cortos. Además de los muestreadores de filtro y de los impactores líquidos, que se utilizan durante varias horas, la mayoría de los muestreadores de aire se emplean para obtener una muestra "rápida" en sólo unos minutos. Por consiguiente, deberán tomarse muestras en todas las condiciones de ocupación y uso, incluido el muestreo con los sistemas CVAA encendidos y apagados. Aunque un muestreo extenso puede revelar el rango de concentraciones de esporas viables encontrado en un medio ambiente de interior, no es posible valorar de forma satisfactoria la exposición de las personas a microorganismos en el medio ambiente. $\mathrm{N}$ i siquiera las muestras tomadas durante un día de trabajo con un muestreador de filtro personal proporcionan un cuadro adecuado, sino sólo un valor promedio, pero no revelan los picos de exposición.

A demás de los efectos claramente demostrados de los alergenos particulados, la investigación epidemiológica indica que puede haber algunos factores no alergénicos asociados a hongos, que afectan al aparato respiratorio. Las micotoxinas producidas por especies individuales de mohos podrían desempeñar un papel importante, pero también es posible que intervengan factores más generales. En el futuro, el enfoque global para investigar la carga micótica en el aire interior probablemente será: a) valorar qué especies alergénicas y tóxicas están presentes mediante el muestreo de hongos viables, y b) obtener una medida de la cantidad total de material micótico al que las personas están expuestas en un medio ambiente de trabajo. Como se comentó anteriormente, para obtener esta última información podrían realizarse recuentos totales durante un día de trabajo. En cualquier caso, en el futuro próximo podrían adoptarse de forma más general métodos recientes desarrollados para el análisis del 1,3- $\beta$-glucano o ergosterol (M iller 1993). A mbas sustancias son componentes estructurales de los hongos, por lo que proporcionan una medida de la cantidad de material micótico (es decir, su biomasa). Se ha descrito una relación entre los niveles de 1,3- $\beta$-glucano en el aire interior y los síntomas del síndrome del edificio enfermo (M iller 1993).

\section{Normas y directrices}

Aunque algunas organizaciones han clasificado los niveles de contaminación del aire interior y del polvo (Tabla 44.16), debido a los problemas con los muestreadores de aire ha habido una resistencia justificable a definir patrones numéricos 0 valores normativos. Se ha observado que la carga microbiana de transmisión aérea en los edificios con sistemas de aire acondicionado deben ser claramente inferiores a las presentes en el aire atmosférico, mientras que las diferencias entre los edificios con ventilación natural y el aire atmosférico son menores. La ACGIH (1989) recomienda utilizar el orden de rango de las especies de hongos en el aire interior y atmosférico para interpretar los datos del muestreo del aire. La presencia o preponderancia de algunos mohos en el aire interior, pero no en el aire atmosférico, podría ser indicio de un problema en el interior de un edificio. Por ejemplo, la abundancia de mohos hidrófilos como Stachybotrys atra en el aire interior indica casi siempre un lugar muy húmedo de cultivo dentro de un edificio.

Aunque organismos influyentes, como el Comité de A erosoles Biológicos de la ACGIH, no han establecido directrices numéricas, una guía canadiense sobre los edificios de oficinas (Nathanson 1993), basado en unos cinco años de investigación de aproximadamente 50 edificios del gobierno federal con aire acondicionado, incluye algunas orientaciones sobre estos valores. Entre los principales puntos se encuentran los siguientes:

1. La flora del aire "normal" debe ser cuantitativamente inferior, pero cualitativamente similar, a la del aire atmosférico.

2. La presencia de una o más especies de hongos a niveles significativos en las muestras de aire interior pero no en las muestras del exterior indica la existencia de un cultivo en el interior.

3. Los hongos patógenos como Aspergillus fumigatus, H istoplasma y Cryptococcus no deben estar presentes en cantidades importantes.

4. La persistencia de los mohos tóxicos como Stachybotrys atra y A spergillus versicolor en una cantidad significativa requiere una investigación y emprender acciones.

5. Un valor superior a 50 unidades de formación de colonias por metro cúbico (UFC/ $\mathrm{m}^{3}$ ) puede ser preocupante si sólo existe una especie (diferente a los hongos comunes de exterior que habitan en las hojas); un valor de hasta $150 \mathrm{CFU} / \mathrm{m}^{3}$ es aceptable si las especies presentes reflejan la flora del exterior; un valor de hasta $500 \mathrm{CFU} / \mathrm{m}^{3}$ es aceptable en verano si los hongos de exterior que habitan en las hojas son el principal componente.

Tales valores numéricos se basan en muestras de aire de cuatro minutos recogidas con un muestreador centrífugo Reuter. D ebe destacarse el hecho de que estos valores no pueden trasladarse a otros procedimientos de muestreo, a otros tipos de edificios 0 a otras regiones climáticas o geográficas. La norma o lo que es aceptable sólo puede basarse en investigaciones extensas de un tipo de edificios en una región concreta utilizando procedimientos bien definidos. No se pueden establecer valores límite umbral para la exposición a los mohos en general ni a una especie en particular.

\section{Control de los microorganismos en ambientes de interior}

El determinante fundamental del crecimiento microbiano y la producción de células y esporas que pueden convertirse en aerosoles en ambientes de interior es el agua, y el control debe conseguirse reduciendo la posibilidad de humedad en lugar de utilizar biocidas. El control requiere un mantenimiento apropiado y una reparación adecuada del edificio, lo que incluye un secado rápido y la eliminación de las causas de escapes e inundaciones (M orey 1993a). A unque a menudo se cita el mantenimiento de la humedad relativa de las habitaciones a un nivel inferior al $70 \%$ como medida de control, ésta sólo es eficaz si la temperatura de las paredes y de otras superficies está próxima a la temperatura del aire. En la superficie de las paredes con escaso aislamiento, la temperatura puede estar por debajo del punto de condensación, 
por lo que se desarrolla condensación y crecen hongos hidrófilos e incluso bacterias (Flannigan 1993). U na situación similar puede producirse en climas tropicales o subtropicales húmedos en los que la humedad del aire que penetra la cubierta de un edificio con aire acondicionado se condensa en la superficie interna del refrigerador (M orey 1993b). En estos casos, el control depende del diseño y del uso correcto de las barreras de aislamiento y del vapor. Junto con rigurosas medidas de control de la humedad, los programas de mantenimiento y limpieza deben asegurar la eliminación del polvo y otros productos de desecho que proporcionan nutrientes para el crecimiento y que actúan como reservorios de microorganismos.

En los sistemas CVAA (Nathanson 1993), debe evitarse la acumulación de agua estancada, por ejemplo, en las bandejas de drenaje 0 debajo de los serpentines de refrigeración. En los casos en los que los sistemas CVAA contienen mechas o tanques de agua calentados para la humidificación, es necesario limpiarlos y desinfectarlos de forma periódica para limitar el crecimiento microbiano. La humidificación por vapor seco probablemente reduce en gran medida el riesgo de crecimiento microbiano. LoS filtros deben sustituirse periódicamente debido a que pueden acumular suciedad y humedad y, por tanto, proporcionar sitios de cultivo para el crecimiento microbiano. Los microorganismos también crecen en el aislamiento acústico poroso utilizado para revestir conductos, si éste se humedece. La solución es aplicar el aislamiento al exterior y no al interior; las superficies internas deben ser lisas y no deben proporcionar un medio ambiente que favorezca el crecimiento. Tales medidas de control generales controlarán el crecimiento de Legionella en sistemas CVAA, pero se han recomendado otras medidas, como la instalación de un filtro de aire particulado de alta eficacia (HEPA) en la entrada de aire (Feeley 1988). A demás, los sistemas de agua deben asegurar que el agua se caliente de manera uniforme a $60^{\circ} \mathrm{C}$, que no hay áreas en las que se estanque el agua y que ningún accesorio contiene materiales que favorezcan el crecimiento de $L$ egionella.

En los casos en los que las medidas de control han sido insuficientes y se ha producido el crecimiento de moho, es necesario tomar medidas de corrección. Es fundamental eliminar y desechar todos los materiales orgánicos porosos, como alfombras y otros elementos de decoración blandos, tejas y material de aislamiento, en los que exista crecimiento. Las superficies lisas deben lavarse con lejía de hipoclorito sódico o un desinfectante apropiado. No deben utilizarse biocidas que puedan convertirse en aerosoles en los sistemas CVAA.

Durante las medidas de corrección, debe tenerse cuidado siempre de no aerosolizar los microorganismos presentes sobre 0 en materiales contaminados. En los casos de grandes áreas de crecimiento de mohos (10 metros cuadrados o más) puede ser necesario contener el riesgo potencial, manteniendo una presión negativa en el área de contención durante la corrección y disponiendo áreas de bloqueo/descontaminación del aire entre el área de contención y el resto del edificio (M orey 1993a, 1993b; Departamento de Salud de la ciudad de Nueva York 1993). El polvo presente antes de la eliminación del material contaminado en contenedores herméticos o generados durante este procedimiento deben recogerse utilizando una aspiradora con un filtro APAE. Durante su trabajo, el personal especialista en corrección debe llevar protección respiratoria APAE facial total y ropa, calzas y guantes protectores desechables (D epartamento de Salud de la ciudad de Nueva York 1993). En los casos de áreas más pequeñas de crecimientos de mohos, puede utilizarse el personal de mantenimiento habitual después de una preparación adecuada. En tales casos, no se considera necesaria la contención, pero el personal debe llevar protección respiratoria completa y guantes. En todos los casos, deberá informarse del peligro a los ocupantes habituales y al personal que va a llevar a cabo la corrección. El personal no debe padecer asma, alergia ni trastornos inmunosupresores (D epartamento de Salud de la ciudad de N ueva York 1993).

\section{REgLAMENTOS, RECOMEN DACIONES, NORMAS Y PATRONES}

María José Berenguer

\section{Criterios de establecimiento}

La definición de normas y patrones específicos para el aire interior es producto de una política proactiva en este campo por parte de los organismos responsables de su establecimiento y del mantenimiento de la calidad del aire interior a niveles aceptables. En la práctica, las tareas se dividen y comparten entre numerosas entidades responsables de controlar la contaminación, mantener la salud, garantizar la seguridad de los productos, vigilar la higiene profesional y regular la edificación y la construcción.

El establecimiento de un reglamento está encaminado a limitar o reducir los niveles de contaminación en el aire interior. Tal objetivo puede alcanzarse controlando las fuentes de contaminación existentes, diluyendo el aire interior con aire exterior y comprobando la calidad del aire disponible. Se requiere para ello el establecimiento de límites máximos específicos para los contaminantes presentes en el aire interior.

La concentración de cualquier contaminante en el aire interior sigue un modelo de masa equilibrado expresado en la siguiente ecuación:

donde:

$$
\frac{d C i}{d t}=\frac{Q}{V}+n C_{0}-a C_{i}-n C_{i}
$$

$C_{i}=$ la concentración del contaminante en el aire interior $\left(\mathrm{mg} / \mathrm{m}^{3}\right)$;

$Q=$ la tasa de emisión ( $\mathrm{mg} / \mathrm{h}) ;$

$\mathrm{V}=$ el volumen de espacio interior $\left(\mathrm{m}^{3}\right)$;

$C_{0}=$ la concentración del contaminante en el aire atmosférico $\left(\mathrm{mg} / \mathrm{m}^{3}\right)$;

$\mathrm{n}=$ la tasa de ventilación por hora,

a = la tasa de degradación del contaminante por hora.

Generalmente se observa que, en condiciones estáticas, la concentración de los contaminantes presentes dependerá en parte de la cantidad del compuesto liberado al aire por la fuente de contaminación y su concentración en el aire atmosférico, y de los diferentes mecanismos por los que se elimina el contaminante. Los mecanismos de eliminación incluyen la dilución del contaminante y su "desaparición" con el tiempo. Todos los reglamentos, recomendaciones, normas y patrones que pueden establecerse para reducir la contaminación deben considerar estas posibilidades.

\section{Control de las fuentes de contaminación}

U na de las formas más eficaces de reducir los niveles de concentración de un contaminante en el aire interior es controlar las fuentes de contaminación del interior del edificio. Entre ellas, los materiales utilizados en la construcción y la decoración, las actividades que tienen lugar dentro del edificio y los propios ocupantes.

Si se juzga necesario regular las emisiones debidas a los materiales de construcción empleados, existen patrones que limitan directamente el contenido en estos materiales de compuestos para los que se han demostrado efectos nocivos para la salud. Algunos de estos compuestos se consideran cancerígenos, como el formaldehído, el benceno, algunos plaguicidas, el amianto, la 
fibra de vidrio y otros. 0 tro método es regular las emisiones estableciendo patrones de emisión.

Tal posibilidad presenta muchas dificultades prácticas, entre las que destacan la falta de acuerdo con respecto a cómo determinar estas emisiones, la falta de conocimiento acerca de sus efectos sobre la salud y el bienestar de los ocupantes del edificio, y las dificultades inherentes de la identificación y la cuantificación de los cientos de compuestos emitidos por los materiales en cuestión. Una forma de establecer patrones de emisión es a partir de un nivel aceptable de concentración del contaminante y calcular una tasa de emisión que tenga en cuenta las condiciones ambientales - temperatura, humedad relativa, tasa de intercambio de aire, factor de carga, etc.- representativas de la forma en que se utiliza realmente el producto. La principal crítica a este método es que más de un producto puede generar el mismo compuesto contaminante. Los patrones de emisión se obtienen a partir de determinaciones realizadas en atmósferas controladas en las que las conducciones estás perfectamente definidas. Se han publicado normas para Europa (COST 613 1989 y 1991) y para Estados U nidos (AST M 1989). Las críticas planteadas habitualmente contra estas normas se basan en los siguientes aspectos: a) la dificultad para obtener datos comparativos, y b) los problemas surgidos cuando un espacio de interior tiene fuentes intermitentes de contaminación.

Con respecto a las actividades que pueden tener lugar en un edificio, el principal foco de atención lo constituye el mantenimiento del edificio. En estas actividades, el control puede establecerse en forma de reglamentos sobre la realización de ciertas tareas, como recomendaciones relativas a la aplicación de plaguicidas o la reducción de exposición al plomo 0 al amianto durante la renovación o la demolición de un edificio.

Debido a que el humo del tabaco - generado por los ocupantes de un edificio- es muy a menudo causa de contaminación del aire interior, merece un tratamiento especial. M uchos países tienen leyes, a escala estatal, que prohíben fumar en ciertos lugares públicos, como restaurantes o teatros, pero son muy frecuentes otras disposiciones que permiten fumar en ciertas partes especialmente diseñadas de un edificio concreto.

Cuando se prohíbe el uso de ciertos productos o materiales, estas prohibiciones se basan en sus efectos nocivos sobre la salud declarados, que están relativamente documentados para los niveles presentes en el aire interior. O tra dificultad es que a menudo no se dispone de suficiente información o conocimiento acerca de las propiedades de los productos que pudieran utilizarse en su lugar.

\section{Eliminación del contaminante}

$\mathrm{H}$ ay veces en que no es posible evitar las emisiones de ciertas fuentes de contaminación, como en el caso de las emisiones debidas a los ocupantes del edificio. Entre ellas se incluyen el dióxido de carbono y los efluvios biológicos, la presencia de materiales con propiedades no controladas de ninguna manera o la realización de las tareas diarias. En estos casos, una forma de reducir los niveles de contaminación es a través de sistemas de ventilación y otros medios utilizados para limpiar el aire interior.

La ventilación es una de las opciones en las que más se confía para reducir la concentración de contaminantes en espacios interiores. Claro está que la necesidad de ahorrar energía también requiere que la entrada de aire exterior para renovar el aire interior sea lo menor posible. Existen patrones a este respecto que especifican tasas de ventilación mínima, basadas en la renovación del volumen de aire interior por hora con aire del exterior, o que establecen una contribución mínima de aire por ocupante o unidad de espacio, o que tienen en cuenta la concentración de dióxido de carbono considerando las diferencias entre los espacios con y sin fumadores. En el caso de los edificios con ventilación natural, también se han establecido los requisitos mínimos para las diferentes partes de un edificio, como las ventanas.

Entre las referencias citadas con mayor frecuencia por la mayoría de los patrones existentes, tanto nacionales como internacionales - aunque no sean legalmente vinculantes- se encuentran las normas publicadas por la Sociedad Americana de Ingenieros de Calefacción, Refrigeración y Acondicionamiento del Aire (A merican Society of $\mathrm{H}$ eating, Refrigerating and Air Conditioning Engineers, ASHRAE). Se formularon para ayudar a los profesionales del acondicionamiento del aire en el diseño de sus instalaciones. En la norma 62-1989 de la ASHRAE (ASHRAE 1989), se especifican las cantidades mínimas de aire necesarias para ventilar un edificio, así como la calidad del aire interior aceptable para sus ocupantes con el fin de prevenir efectos adversos sobre la salud. Para el dióxido de carbono (un compuesto que la mayoría de los autores no consideran un contaminante dado su origen humano, pero que se utiliza como indicador de la calidad del aire interior para establecer el correcto funcionamiento de los sistemas de ventilación), esta norma recomienda un límite de 1.000 ppm para cumplir los criterios de bienestar (olor). En esta norma también se especifica la calidad del aire atmosférico requerida para la renovación del aire interior.

En los casos en los que la fuente de contaminación - sea interior o exterior- no es fácil de controlar y en los que es necesario utilizar un equipo especial para eliminarlo del medio ambiente, existen patrones para garantizar su eficacia, como los que definen métodos específicos para comprobar el funcionamiento de un cierto tipo de filtro.

\section{Extrapolación de las normas en materia de higiene en el trabajo a las normas sobre calidad del aire en el interior}

Es posible establecer diferentes tipos de valores de referencia aplicables al aire interior en función del tipo de población a la que es necesario proteger. Los valores pueden basarse en normas de calidad para el aire ambiente, en valores específicos para contaminantes concretos (como dióxido de carbono, monóxido de carbono, formaldehído, compuestos orgánicos volátiles, radón, etc.), o pueden basarse en normas utilizadas generalmente en higiene del trabajo. L os últimos son valores formulados exclusivamente para su aplicación en el medio ambiente industrial. Están diseñados, sobre todo, para proteger a los trabajadores de los efectos agudos de los contaminantes (como irritación de las mucosas o de las vías respiratorias altas), o para prevenir la intoxicación con efectos sistémicos. D ebido a esta posibilidad, muchos autores, al tratar el tema del medio ambiente de interior, utilizan como referencia los valores límite de exposición para ambientes industriales establecidos por la Conferencia Americana de $\mathrm{H}$ igienistas Industriales del Gobierno (ACGIH) de Estados Unidos. Tales límites se denominan valores límite umbral (TLV), e incluyen valores límite para días de trabajo de ocho horas y semanas de trabajo de cuarenta horas.

Se aplican índices numéricos con el fin de adaptar los T LV a las condiciones del medio ambiente de interior de un edificio, y los valores se reducen habitualmente por un factor de 2,10 0 incluso 100, dependiendo de la clase de efectos sobre la salud involucrados y del tipo de población afectada. Entre las razones dadas para reducir los valores de T LV cuando se aplican a exposiciones de esta clase está el hecho de que en el medio ambiente no industrial el personal está expuesto de forma simultánea a concentraciones bajas de varias sustancias químicas, normalmente desconocidas, capaces de actuar de manera sinérgica de una forma que no puede controlarse con facilidad. Por otro lado, generalmente se acepta que en el medio ambiente 
industrial el número de sustancias peligrosas que deben controlarse es conocido, y a menudo limitado, aunque las concentraciones suelen ser mucho más altas.

Además, en muchos países las situaciones industriales se controlan para asegurar el cumplimiento de los valores de referencia establecidos, algo que no se realiza en ambientes no industriales. Por consiguiente, es posible que en este tipo de ambientes, el uso esporádico de algunos productos pueda producir concentraciones elevadas de uno o varios compuestos, sin ningún control ambiental y sin forma de detectar los niveles de exposición que se han producido. Por otro lado, se conocen 0 deben conocerse los riesgos inherentes a una actividad industrial, por lo que existen medidas para su reducción o control. Los trabajadores afectados están informados y disponen de los medios para reducir el riesgo y protegerse. Además, los trabajadores de la industria suelen ser adultos con un buen estado de salud y un estado físico aceptable, mientras que la población de los ambientes de interior presenta, en general, un rango más amplio de estados de salud. El trabajo normal en una oficina, por ejemplo, puede ser realizado por personas con limitaciones físicas o susceptibles a reacciones alergénicas que no podrían trabajar en ciertos ambientes industriales. Un caso extremo de esta línea de razonamiento se aplicaría al uso de un edificio como vivienda. Por último, como se comentó anteriormente, los $T L V$, al igual que otros patrones profesionales, se basan en exposiciones de 8 horas al día y 40 horas a la semana, lo cual representa menos de la cuarta parte del tiempo que una persona estaría expuesta si permaneciera continuamente en el mismo medio ambiente 0 si estuviera expuesta a alguna sustancia durante las 168 horas de una semana. Además, los valores de referencia se basan en estudios que incluyen exposiciones semanales y que tienen en cuenta tiempos sin exposición (entre exposiciones) de 16 horas al día y 64 horas a la semana, lo que dificulta enormemente las extrapolaciones basadas en estos datos.

La conclusión a la que llega la mayoría de los autores es que para usar las normas de higiene en el trabajo para el aire interior, los valores de referencia deben incluir un margen de error muy amplio. Por consiguiente, la norma 62-1989 de la ASHRAE sugiere una concentración de una décima parte del valor TLV recomendado por la ACGIH en ambientes industriales para los contaminantes químicos que no tienen sus propios valores de referencia establecidos.

Con respecto a los contaminantes biológicos, no existen criterios técnicos para su evaluación que puedan ser aplicables al ambiente industrial o a espacios de interior, como es el caso de los TLV de la ACGIH para contaminantes químicos. Podría deberse a la naturaleza de los contaminantes biológicos, que muestran una amplia variabilidad de características que dificultan el establecimiento de criterios para su evaluación generalizados y validados para una situación concreta. Entre las características se incluyen la capacidad reproductiva del organismo en cuestión, el hecho de que la misma especie microbiana puede presentar varios grados de patogenicidad o el hecho de que las alteraciones en factores ambientales como la temperatura y la humedad pueden influir en su presencia en un medio ambiente determinado. No obstante, a pesar de estas dificultades, el Comité de Aerosoles Biológicos de la ACGIH ha desarrollado normas para evaluar estos agentes biológicos en ambientes de interior: Guidelines for the Assessment of Bioaerosols in the Indoor E nvironment (1989). Los protocolos estándar recomendados en estas normas establecen sistemas y estrategias de muestreo, procedimientos analíticos, interpretación de datos y recomendaciones para las medidas de corrección. Pueden utilizarse cuando la información médica o clínica sugiere la existencia de enfermedades como la fiebre por humidificadores, la neumonitis por hipersensibilidad o alergias relacionadas con contaminantes biológicos. Las normas pueden aplicarse cuando sea necesario el muestreo para documentar la contribución relativa de fuentes de aerosoles biológicos ya identificadas o para validar una hipótesis médica. EI muestreo debe realizarse para confirmar fuentes potenciales, pero no se recomienda el muestreo sistemático del aire para detectar aerosoles biológicos.

\section{Normas y directrices existentes}

Diferentes organizaciones internacionales, como la O rganización M undial de la Salud (O M S) y el Consejo Internacional de Investigación de Edificios (International C ouncil of Building Research, (IBC), organizaciones privadas como la ASHRAE, países como Estados Unidos y Canadá, entre otros, están estableciendo normas y directrices de exposición. Por su parte, la Unión Europea (UE), a través del Parlamento Europeo, ha presentado una resolución sobre la calidad del aire en espacios de interior, donde se establece la necesidad de que la Comisión Europea proponga, lo antes posible, directivas específicas que incluyan:

1. una lista de sustancias que deben prohibirse o regularse, tanto en la construcción como en el mantenimiento de edificios;

2. normas de calidad aplicables a los diferentes tipos de ambientes de interior;

3. protocolos de procedimiento para la gestión y mantenimiento de las instalaciones de aire acondicionado y ventilación,

4. normas mínimas para el mantenimiento de edificios abiertos al público.

M uchos compuestos químicos tienen olores y cualidades irritantes a concentraciones que, de acuerdo con nuestros conocimientos, no son peligrosas para los ocupantes de un edificio pero que pueden ser percibidos por un gran número de personas, para las que, por tanto, pueden resultar molestas. L oS valores de referencia actualmente utilizados tienden a cubrir esta posibilidad.

Tabla 44.17 - Normas en materia de calidad del aire de la Environmental Protection Agency de Estados Unidos.

\begin{tabular}{|c|c|c|c|}
\hline \multicolumn{4}{|c|}{ Concentración promedio } \\
\hline Contaminante & $\mu \mathrm{g} / \mathrm{m}^{3}$ & ppm & $\begin{array}{l}\text { Intervalo de tiempo para } \\
\text { las exposiciones }\end{array}$ \\
\hline \multirow[t]{3}{*}{ Dióxido de azufre } & $80^{a}$ & 0,03 & 1 año (media aritmética) \\
\hline & $365^{a}$ & 0,14 & 24 horasc $^{\circ}$ \\
\hline & $1.300^{b}$ & 0,5 & 3 horasc $^{\circ}$ \\
\hline \multirow[t]{2}{*}{ Partículas } & $150^{a, b}$ & - & 24 horas $^{d}$ \\
\hline & $50^{a, b}$ & - & 1 añod (media aritmética) \\
\hline \multirow{2}{*}{$\begin{array}{l}\text { Monóxido de } \\
\text { carbono }\end{array}$} & $10.000^{\mathrm{a}}$ & 9,0 & 8 horasc $^{c}$ \\
\hline & $40.000^{\mathrm{a}}$ & 35,0 & 1 horac $^{c}$ \\
\hline Ozono & $235^{a, b}$ & 0,12 & 1 hora \\
\hline $\begin{array}{l}\text { Dióxido de } \\
\text { nitrógeno }\end{array}$ & $100^{a, b}$ & 0,053 & 1 año (media aritmética) \\
\hline Plomo & $1,5^{a, b}$ & - & 3 meses \\
\hline
\end{tabular}

a Norma primaria. $\quad{ }^{b}$ Norma secundaria. c Valor máximo que no debe superarse más de una vez en un año. d Determinada como partículas de diámetro $\leq 10 \mu \mathrm{m}$.

Fuente: US Environmental Protection Agency. National Primary and Secondary Ambient Air Quality Standards. Code of Federal Regulations, Título 40, Parte 50 (julio 1990). 


\begin{tabular}{|c|c|c|}
\hline Contaminante & $\begin{array}{l}\text { Valor de referencia } \\
\text { (media ponderada } \\
\text { en el tiempo) }\end{array}$ & $\begin{array}{l}\text { Duración de la } \\
\text { exposición }\end{array}$ \\
\hline \multicolumn{3}{|l|}{ Compuestos orgánicos } \\
\hline Disulfuro carbónico & $100 \mu \mathrm{g} / \mathrm{m}^{3}$ & 24 horas \\
\hline 1,2-Dicloroetano & $0,7 \mathrm{mg} / \mathrm{m}^{3}$ & 24 horas \\
\hline Formaldehído & $100 \mu \mathrm{g} / \mathrm{m}^{3}$ & 30 minutos \\
\hline Metilén cloruro & $3 \mathrm{mg} / \mathrm{m}^{3}$ & 24 horas \\
\hline Estireno & $800 \mu \mathrm{g} / \mathrm{m}^{3}$ & 24 horas \\
\hline Tetracloroetileno & $5 \mathrm{mg} / \mathrm{m}^{3}$ & 24 horas \\
\hline Tolueno & $8 \mathrm{mg} / \mathrm{m}^{3}$ & 24 horas \\
\hline Tricloroetileno & $1 \mathrm{mg} / \mathrm{m}^{3}$ & 24 horas \\
\hline \multicolumn{3}{|c|}{ Compuestos inorgánicos } \\
\hline Cadmio & $\begin{array}{r}1.5 \mathrm{ng} / \mathrm{m}^{3} \\
0.20 \mathrm{ng} / \mathrm{m}^{3}\end{array}$ & $\begin{array}{l}1 \text { año (áreas rurales) } \\
1 \text { año (áreas rurales) }\end{array}$ \\
\hline Monóxido de carbono & $\begin{array}{c}100 \mathrm{mg} / \mathrm{m}^{3 \mathrm{c}} \\
60 \mathrm{mg} / \mathrm{m}^{3 \mathrm{c}} \\
30 \mathrm{mg} / \mathrm{m}^{3 \mathrm{c}} \\
10 \mathrm{mg} / \mathrm{m}^{3}\end{array}$ & $\begin{array}{l}15 \text { minutos } \\
30 \text { minutos } \\
1 \text { hora } \\
8 \text { horas }\end{array}$ \\
\hline Sulfuro de hidrógeno & $150 \mu \mathrm{g} / \mathrm{m}^{3}$ & 24 horas \\
\hline Plomo & $0,5-1,0 \mu \mathrm{g} / \mathrm{m}^{3}$ & 1 año \\
\hline Manganeso & $1 \mu \mathrm{g} / \mathrm{m}^{3}$ & 1 hora \\
\hline Mercurio & $1 \mu \mathrm{g} / \mathrm{m}^{3 \mathrm{~b}}$ & 1 hora \\
\hline Dióxido de nitrógeno & $\begin{array}{l}400 \mu \mathrm{g} / \mathrm{m}^{3} \\
150 \mu \mathrm{g} / \mathrm{m}^{3}\end{array}$ & $\begin{array}{l}1 \text { hora } \\
24 \text { horas }\end{array}$ \\
\hline Ozono & $\begin{array}{r}150-200 \mu \mathrm{g} / \mathrm{m}^{3} \\
10-120 \mu \mathrm{g} / \mathrm{m}^{3}\end{array}$ & $\begin{array}{l}1 \text { hora } \\
8 \text { horas }\end{array}$ \\
\hline Dióxido de azufre & $\begin{array}{c}500 \mu \mathrm{g} / \mathrm{m}^{3} \\
350 \mu \mathrm{g} / \mathrm{m}^{3}\end{array}$ & $\begin{array}{l}10 \text { minutos } \\
1 \text { hora }\end{array}$ \\
\hline Vanadio & $1 \mu \mathrm{g} / \mathrm{m}^{3}$ & 24 horas \\
\hline
\end{tabular}

a La información contenida en esta tabla debe utilizarse conjuntamente con las explicaciones proporcionadas en la publicación original. $\quad{ }^{b}$ Este valor hace referencia únicamente al aire interior. ' La exposición a esta concentración no debe superar el tiempo indicado ni debe repetirse en un plazo de 8 horas.

Fuente: OMS 1987.

Considerando el hecho de que no se recomienda el uso de normas de higiene profesional para el control del aire interior a menos que se aplique un factor de corrección, en muchos casos es mejor consultar los valores de referencia empleados como normas o directrices para la calidad del aire ambiente. La Agencia de Protección Ambiental (Environmental Protection A gency, EPA) de Estados U nidos ha establecido normas para el aire ambiente con el fin de proteger, con un margen de seguridad apropiado, la salud de la población en general (normas primarias) e incluso su bienestar (normas secundarias) contra los efectos adversos que puedan preverse debido a un contaminante específico. Por consiguiente, estos valores de referencia son útiles como guía general para establecer un patrón aceptable de calidad del aire para un espacio de interior determinado, y algunas normas, como las de la ASH RAE-92, los utilizan como criterios de calidad para la renovación del aire en un edificio cerrado. En la Tabla 44.17 se muestran los valores de referencia para el dióxido de azufre, el monóxido de carbono, el dióxido de nitrógeno, el ozono, el plomo y la materia particulada.

Por su parte, la OMS ha establecido normas con el fin de proporcionar una base para proteger la salud pública de los efectos adversos debidos a la contaminación del aire y a eliminar o reducir hasta un nivel mínimo los contaminantes del aire que se ha demostrado o se sospecha que son peligrosos para la salud y el bienestar humanos (OMS 1987). En estas normas no se hacen distinciones con respecto al tipo de exposición en cuestión, por lo que cubren exposiciones debidas al aire atmosférico y a exposiciones que pueden ocurrir en espacios interiores. En las Tablas 44.18 y 44.19 se muestran los valores propuestos por la OMS (1987) para sustancias no cancerígenas, así como las diferencias entre las que causan efectos sobre la salud y las que causan molestias sensoriales.

Para las sustancias cancerígenas, la EPA ha establecido el concepto de unidades de riesgo. Representan un factor utilizado para calcular el aumento de la probabilidad de que un ser humano contraiga un cáncer debido a la exposición durante tosa su vida a una sustancia cancerígena en el aire a una concentración de $1 \mu \mathrm{g} / \mathrm{m}^{3}$. El concepto es aplicable a sustancias que pueden estar presentes en el aire interior (metales como el arsénico, el cromo VI y el níquel; compuestos orgánicos como el benceno, el acrilonitrilo y los hidrocarburos aromáticos policíclicos; o materia particulada, como el amianto).

En el caso concreto del radón, en la Tabla 44.20 se muestran los valores de referencia y las recomendaciones de diferentes organizaciones. Así, la EPA recomienda una serie de intervenciones progresivas cuando los niveles en el aire interior superan los $4 \mathrm{pCi} / \mathrm{l}\left(150 \mathrm{~Bq} / \mathrm{m}^{3}\right)$, estableciendo un esquema de tiempo para la reducción de estos niveles. La UE, basándose en un informe presentado en 1987 por un grupo de trabajo de la Comisión Internacional sobre Protección Radiológica (CIPR), recomienda una concentración anual promedio de gas radón, distinguiendo entre los edificios existentes y los de nueva construcción. Por su parte, la O M S hace sus recomendaciones considerando la exposición a los productos de degradación del radón, expresada como concentración de equivalentes de radón en equilibrio (EER) y teniendo en cuenta un aumento del riesgo de

Tabla 44.19 - Valores de referencia de la O MS para algunas sustancias no cancerígenas presentes en el aire, basados en los efectos sensoriales o reacciones de molestia durante un promedio de 30 minutos.

\begin{tabular}{|c|c|c|c|}
\hline \multirow[t]{2}{*}{ Contaminante } & \multicolumn{3}{|l|}{ Umbral de olor } \\
\hline & Detección & Reconocimiento & Valor de referencia \\
\hline $\begin{array}{l}\text { Disulfuro } \\
\text { carbónico }\end{array}$ & $200 \mu \mathrm{g} / \mathrm{m}^{3}$ & $-{ }^{a}$ & $20 \mu \mathrm{g} / \mathrm{m}^{3 \mathrm{~b}}$ \\
\hline $\begin{array}{l}\text { Sulfuro de } \\
\text { hidrógeno }\end{array}$ & $0,2-2,0 \mu \mathrm{g} / \mathrm{m}^{3}$ & $0,6-6,0 \mu \mathrm{g} / \mathrm{m}^{3}$ & $7 \mu \mathrm{g} / \mathrm{m}^{3}$ \\
\hline Estireno & $70 \mu \mathrm{g} / \mathrm{m}^{3}$ & $210-280 \mu \mathrm{g} / \mathrm{m}^{3}$ & $70 \mu \mathrm{g} / \mathrm{m}^{3}$ \\
\hline $\begin{array}{l}\text { Tetracloro- } \\
\text { etleno }\end{array}$ & $8 \mathrm{mg} / \mathrm{m}^{3}$ & $24-32 \mathrm{mg} / \mathrm{m}^{3}$ & $8 \mathrm{mg} / \mathrm{m}^{3}$ \\
\hline Tolueno & $1 \mathrm{mg} / \mathrm{m}^{3}$ & $10 \mathrm{mg} / \mathrm{m}^{3}$ & $1 \mathrm{mg} / \mathrm{m}^{3}$ \\
\hline
\end{tabular}

a Datos no proporcionados. ${ }^{b}$ En la fabricación de viscosa se acompaña de otras sustancias olorosas, como el sulfuro de hidrógeno y el carbonil sulfuro.

Fuente: OMS 1987. 
contraer cáncer de entre $0,7 \times 10^{-4}$ y $2,1 \times 10^{-4}$ para una exposición total durante la vida de $1 \mathrm{~Bq} / \mathrm{m}^{3} \mathrm{EER}$.

Por último, debe recordarse que los valores de referencia se establecen, en general, basándose en los efectos conocidos de las diferentes sustancias sobre la salud. Aunque esto puede representar a menudo una ardua tarea en el caso del análisis del aire interior, no tiene en cuenta los posibles efectos sinérgicos de ciertas sustancias. Entre éstas se encuentran, por ejemplo, los compuestos orgánicos volátiles (COV). Algunos autores han apuntado la posibilidad de definir los niveles totales de concentración de compuestos orgánicos volátiles (COVT) al que los ocupantes de un edificio pueden comenzar a reaccionar. U na de las principales dificultades estriba en que, desde el punto de vista del análisis, la definición de COVT todavía no se ha resuelto para satisfacción de todos.

En la práctica, el futuro establecimiento de valores de referencia en el relativamente nuevo campo de la calidad del aire interior estará determinado por el desarrollo de políticas ambientales. Ello dependerá de los avances del conocimiento en cuanto a los efectos de los contaminantes y de las mejorías en las técnicas analíticas que puedan ayudarnos a determinar estos valores.
Tabla 44.20 • Valores de referencia para el radón de tres organizaciones.

\begin{tabular}{|c|c|c|}
\hline Organización & Concentración & Recomendación \\
\hline $\begin{array}{l}\text { Environmental } \\
\text { Protection Agency }\end{array}$ & $\begin{array}{c}4-20 \mathrm{pCi} / \mathrm{I} \\
20-200 \mathrm{pCi} / \mathrm{I} \\
\geq 200 \mathrm{pCi} / \mathrm{I}\end{array}$ & $\begin{array}{l}\text { Reducir el nivel en años } \\
\text { Reducir el nivel en meses } \\
\text { Reducir el nivel en } \\
\text { semanas o evacuar } \\
\quad \text { a los ocupantes }\end{array}$ \\
\hline \multirow[t]{2}{*}{ Unión Europea } & $\begin{array}{l}>400 \mathrm{~Bq} / \mathrm{m}^{3} \mathrm{a}, \mathrm{b} \\
\quad \text { (edificios existentes) }\end{array}$ & Reducir el nivel \\
\hline & $\begin{array}{l}>400 \mathrm{~Bq} / \mathrm{m}^{3} \text { a } \\
\text { (nueva construcción) }\end{array}$ & Reducir el nivel \\
\hline $\begin{array}{l}\text { Organización Mundial } \\
\text { de la Salud }\end{array}$ & $\begin{array}{l}>100 \mathrm{~Bq} / \mathrm{m}^{3} \mathrm{EER}^{\mathrm{c}} \\
>400 \mathrm{~Bq} / \mathrm{m}^{3} \mathrm{EER}^{\mathrm{C}}\end{array}$ & $\begin{array}{l}\text { Reducir el nivel } \\
\text { Tomar una acción } \\
\text { inmediata }\end{array}$ \\
\hline
\end{tabular}

a Concentración promedio anual de gas radón. b Equivalente a una dosis de $20 \mathrm{mSv} /$ año c Promedio anual.

\section{Referencias}

Agencia Internacional para la Investigación sobre el Cáncer (IARC). 1986. Tobacco Smoking. Vol. 38. Lyon: IARC.

- . 1987a. Bis(Chloromethyl)E ther and Chloromethyl M ethyl E ther. V ol. 4 (1974), Supl. 7 (1987). Lyon: IAR C.

-. 1987b. Coke Production. Vol. 4 (1974), Supl. 7 (1987). Lyon: IAR C

-. 1987c. Environmental Carcinogens: M ethods of Analysis and Exposure. Vol. 9. Passive smoking. IARC Scientific Publications, no. 81. Lyon: IAR C.

- . 1987d. Nickel and Nickel Compounds. Vol. 11 (1976), Supl. 7 (1987). Lyon: IAR C.

- . 1988. Overall E valuation of C arcinogenicity: An U pdating of IARC M onographs 1 to 42. V ol. 43. Lyon: IARC.

American Conference of Governmental Industrial $\mathrm{H}$ ygienists (ACGIH). 1989. Guidelines for the Assessment of Bioaerosols in the Indoor Environment. Cincinnati, O hio: ACGIH.

American Society for Testing $M$ aterials (ASTM). 1989. Standard Guide for Small-Scale E nvironmental De terminations of Organic Emissions from Indoor M aterials/ Products. Atlanta: AST M.

American Society of $\mathrm{H}$ eating R efrigerating and Air Conditioning Engineers (ASH RAE). 1989. Ventilation for Acceptable Indoor Air Quality. Atlanta: ASH RAE.

Brownson, RC, MCR Alavanja, ET Hock, TS Loy. 1992. Passive smoking and lung cancer in nonsmoking women. Am J Public H ealth 82:1525-1530.

Brownson, RC, M CR Alavanja, ET Hock. 1993. Reliability of passive smoke exposure histories in a case-control study of lung cancer. Int J E pidemiol 22:804-808

Brunnemann, KD D H offmann. 1974. The $\mathrm{pH}$ of tobacco smoke. F ood Cosmet T oxicol 12:115-124.

- . 1991. Analytical studies on $\mathrm{N}$-nitrosamines in tobacco and tobacco smoke. Rec Adv Tobacco Sci 17:71-112.

COST 613. 1989. Formaldehyde emissions from wood based materials: Guideline for the determination of steady state concentrations in test chambers. En Indoor Air Quality \& Its Impact On M an. Luxemburgo: CE.

- . 1991. Guideline for the characterization of volatile organic compounds emitted from indoor mate- rials and products using small test chambers. En Indoor Air Quality \& Its Impact On M an. Luxemburgo: CE.

Eudy, LW, FW Thome, DK Heavner, CR Green, BJ Ingebrethsen. 1986. Studies on the vapourparticulate phase distribution of environmental nicotine by selective trapping and detection methods. En Proceedings of the Seventy-Ninth Annual M eeting of the Air Pollution Control Association, J une 20-27.

Feeley, JC. 1988. Legionellosis: Risk associated with building design. En Architectural Design and Indoor $M$ icrobial Pollution, dirigido por RB K undsin. Oxford: O U P.

Flannigan, B. 1992. Indoor microbiological pollutants- sources, species, characterisation: An evaluation. En Chemical, M icrobiological, $H$ ealth and Comfort A spects of Indoor Air Quality - State of the Art in SBS, dirigido por H K nöppel y $P$ Wolkoff. Dordrecht: K luwer.

-. 1993. Approaches to the assessment of microbial flora of buildings. Environments for People: IAQ '92. Atlanta: ASH RAE.

Fondo Sueco para el Ambiente de Trabajo. 1988. To $M$ easure or to $T$ ake $D$ irect $R$ emedial Action? Investigation and $M$ easurement Strategies in the $W$ orking E nvironment. Estocolmo: Arbetsmiljöfonden [Fondo Sueco para el Ambiente de T rabajo].

Freixa, A. 1993. Calidad del aire: gases presentes a bajas concentraciones en ambientes cerrados. M adrid: Instituto $\mathrm{N}$ acional de Seguridad e H igiene en el T rabajo.

Gomel, M, B Oldenburg, JM Simpson, N O wen. 1993. Work-site cardiovascular risk reduction: A randomized trial of health risk assessment, education, counselling and incentives. Am J Public $\mathrm{H}$ ealth 83:1231-1238

Guerin, MR, RA Jenkins, BA Tomkins. 1992. The Chemistry of Environmental Tobacco Smoke. Chelsea, $M$ ich: Lewis.

Hammond, SK, J Coghlin, PH Gann, M Paul, K Taghizadek, PL Skipper, SR T annenbaum. 1993. Relationship between environmental tobacco smoke and carcinogen-hemoglobin adduct levels in non-smokers. J $\mathrm{N}$ atl Cancer Inst 85:474-478.

Hecht, SS, SG Carmella, SE M urphy, S Akerkar, K D Brunnemann, D Hoffmann. 1993. A tobaccospecific lung carcinogen in men exposed to cigarette smoke. N ew E ngl J M ed 329:1543-1546.
Heller, W-D, E Sennewald, J-G Gostomzyk, G Scherer, F Adlkofer. 1993. Validation of ETSexposure in a representative population in Southern G ermany. Indoor Air Publ Conf 3:361-366.

Hilt, B, S Langard, A Anderson, J R osenberg. 1985. A sbestos exposure, smoking habits and cancer incidence among production and maintenance workers in an electrical plant. Am J Ind M ed 8:565-577.

H offmann, D, EL Wynder. 1976. Smoking and occupational cancer. Prevent M ed 5:245-261.

H offmann, D, SS H echt. 1990. Advances in tobacco carcinogenesis. En $\mathrm{H}$ andbook of Experimental Pharmacology, dirigido por CS Cooper y PL Grover. N ueva Y ork: Springer.

Johanning, E, PR M orey, BB Jarvis. 1993. Clinicalepidemiological investigation of health effects caused by Stachybotrys atra building contamination. En P roceedings of Sixth International C onference $0 \mathrm{n}$ Indoor Air Q uality and Climate, $\mathrm{H}$ elsinki.

K abat, GC, EL Wynder. 1984. Lung cancer incidence in non-smokers. Cancer 53:1214-1221.

Luceri, G, G Peiraccini, G M oneti, P Dolara. 1993. Primary aromatic amines from sidestream cigarette smoke are common contaminants of indoor air. T oxicol Ind $\mathrm{H}$ ealth 9:405-413.

M ainville, C, PL Auger, W Smorgawiewicz, D N eculcea, J N eculcea, M Lévesque. 1988. M ycotoxines et syndrome d'extrême fatigue dans un hôpital. En $\mathrm{H}$ ealthy Buildings, dirigido por B Petterson y $\mathrm{T}$ Lindvall. Estocolmo: Consejo Sueco para la Investigación de Edificios.

Masi, M A y cols. 1988. Environmental exposure to tobacco smoke and lung function in young adults. Am R ev R espir D is 138:296-299.

MCLaughlin, JK, JS M andel, ES Mehl, WJ Blot. 1990. Comparison of next of kin with selfrespondents regarding question on cigarette, coffee and alcohol consumption. Epidemiology 1(5):408412.

M CL aughlin, JK, M S Dietz, ES M ehl, WJ Blot. 1987. Reliability of surrogate information on cigarette smoking by type of informant. Am J E pidemiol 126:144-146.

M edina, E, R M edina, AM K aempffer. 1988. Effects of domestic smoking on the frequency of infantile respiratory diseases. R ev Chilena P ediatrica 59:60-64. 
Miller, JD. 1993. Fungi and the building engineer. E nvironments for People: IAQ '92. A tlanta: ASH R AE.

M orey, PR . 1993a. M icrobiological events after a fire in a high-rise building. En Indoor Air ' 93 . H elsinki: Indoor Air '93.

-. 1993b. U se of hazard communication standard and general duty clause during remediation of fungal contamination. En Indoor Air '93. H elsinki: Indoor Air '93.

Nathanson, T. 1993. Indoor Air Quality in Office Buildings: A T echnical Guide O ttawa: H ealth C anada.

New Y ork City Department of $\mathrm{H}$ ealth. 1993. Guide lines $0 \mathrm{n}$ Assessment and R emediation of Stachybotrys A tra in Indoor E nvironments. N ueva Y ork: N ew Y ork City D epartment of $\mathrm{H}$ ealth.

O rganización M undial de la Salud (O M S). 1987. Air Quality Guidelines for Europe. European Series, no. 23. Copenhague: Publicaciones Regionales de la OMS.

Pershagen, G, S Wall, A T aube, I Linnman. 1981 $\mathrm{O} n$ the interaction between occupational arsenic exposure and smoking and its relationship to lung cancer. Scand J W ork E nviron H ealth 7:302-309.

Riedel, F, C Bretthauer, CHL Rieger. 1989. Einfluss von paasivem $\mathrm{R}$ auchen auf die bronchiale Reaktivitact bei Schulkindern. Prax Pneumol 43:164-168.

Saccomanno, G, GC H uth, O Auerbach. 1988. Relationship of radioactive radon daughters and cigarette smoking in genesis of lung cancer in uranium miners. Cancer 62:402-408.

Sorenson, W G. 1989. Health impact of mycotoxins in the home and workplace: An overview. En Biodete rioration Research 2, dirigido por CE 0 'Rear y GC Llewellyn. Nueva Y ork: Plenum.

US Environmental Protection Agency (US EPA) 1992. Respiratory $H$ ealth $E$ ffects of Passive Smoking: Lung Cancer and 0 ther Disorders. Washington, DC USEPA

US National Research Council. 1986. Environmental Tobacco Smoke: M easuring Exposures and Assessing $\mathrm{H}$ ealth Effect. Washington, DC: National Academy of Sciences.

US Surgeon General. 1985. The H ealth Consequences of Smoking: Cancer and Chronic Lung D isease in the W orkplace. Washington, DC: DH H S (PHS).

- . 1986. The $H$ ealth Consequences of I nvoluntary Smoking. Washington, DC: DHHS (CDC).
Wald, NJ, I Borcham, C Bailey, C Ritchie, JE Haddow, J K night. 1984. U rinary cotinine as marker of breathing other people's tobacco smoke. Lancet 1:230-231.

Wanner, H-U, AP Verhoeff, A Colombi, B Flannigan, S Gravesen, A M ouilleseux, A N evalainen, Papadakis, K Seidel. 1993. Biological Particles in Indoor E nvironments. Indoor Air $\mathrm{Q}$ uality and I ts I mpact On $M$ an. Bruselas: Comisión Europea.

White, JR, H F Froeb. 1980. Small airway dysfunction in non-smokers chronically exposed to tobacco smoke. N ew Engl J M ed 302:720-723.

\section{O tras lecturas recomendadas}

Agencia Internacional para la Investigación sobre el Cáncer (IARC). 1993. Indoor Air, E nvironmental Carcinogens. $M$ ethods of Analysis and $E$ xposure $M$ easurement Vol. 12. Lyon: IARC.

Berenguer, MJ, X Guardino, A Hernández, MC M artí, C N ogareda, M D Solé. 1994. El síndrome de edificio enfermo. Guía para su evaluación. M adrid: Instituto $\mathrm{N}$ acional de Seguridad e $\mathrm{H}$ igiene en el Trabajo.

Berenguer, M J. 1991. Síndrome de edificio enfermo: F actores de riesgo. M adrid: Instituto $N$ acional de Seguridad e $\mathrm{H}$ igiene en el T rabajo.

Department of the Environment. 1993. U rban Air Quality in the U nited Kingdom. Londres: Department of the Environment.

Dudney, CS, ED Copenhaver. 1983. The elements of indoor air quality. En Indoor Air Quality, dirigido por PJ Walsh, CS Dudney, ED Copenhaver. Boca R aton: CRC Press.

Fanger, PO. 1990. Indoor air quality perceived by human beings. En T he Practitioner's Approach to Indoor Air Q uality Investigations: Proceedings, Indoor Air Quality International Symposium, dirigido por DM Weekes y R B Gammage. Akron, O hio: American Industrial $\mathrm{H}$ ygiene Association (AIH A).

Godish, T. 1989. Indoor Air Pollution Control. Chelsea, M ich: Lewis.

— . 1991. Air Quality. Chelsea, M ich: Lewis.

Guardino, X. 1984. T oma de muestra de gases y vapores con bolsa. Norma general. Madrid: Instituto Nacional de Seguridad e H igiene en el Trabajo.

K noppel, H , P W olkoff. 1992. Chemical, M icrobiological, $\mathrm{H}$ ealth and Comfort Aspects of Indoor Air Quality- State of the Art in SBS. D ordrecht: K luwer A cademic.
Lewis, RG, L Wallace. 1989. Workshop: Instrumentation and methods for measurement of indoor air quality and related factors. En D esign and Protocol for $M$ onitoring Indoor Air Quality, dirigido por NL Nageda y JP H arper. Filadelfia: American Society for T esting $M$ aterials (AST M ).

M orey, PR, JC Feeley. 1990. The landlord, tenant, and investigator: Their needs, concerns, and viewpoints. En Biological Contaminants in Indoor Environments, dirigido por JC Feeley y JA 0 tten. Filadelfia: A merican Society for T esting $M$ aterials.

Naciones U nidas. 1985. R adiation D oses, E ffects, Risks. Nairobi, K enya: PNU M A.

Nageda, NL, HE Rector, MD K oontz. 1987. Guide lines for M onitoring Indoor Air Quality. Washington, DC: $\mathrm{H}$ emisphere.

Namiesnik, J, T G orecki, B K osdron-Zabiegala, J Lukasiak. 1992. Indoor air quality, pollutants, their sources and concentration levels. Build Environ 27(3):339-356.

O rganización M undial de la Salud (O M S) 1989. Indoor Air Quality: Organic Pollutants. Copenhague: O ficina R egional de la O M S para Europa.

O tson, R, P Fellin. 1992. V olatile organics in the indoor environment: Sources and occurrence. En Gaseous Pollutants: Characterisation and Cycling, dirigido por J N riagu. Nueva Y ork: Wiley.

Rafferty, PJ, PJ Quinlan. 1990. The practitioner's guide to indoor air quality. En The Practitioner's Approach to Indoor Air Quality Investigations, dirigido por DM Weekes y RB Gammage. Akron, O hio: A merican Industrial $\mathrm{H}$ ygiene Association (AIH A).

Scheff, PA, RA Wadden, BA Bates. 1990. Indoor air pollution. En $\mathrm{H}$ ealth and Safety Beyond the W orkplace, dirigido por LV Cralley, LJ Cralley y WC Cooper. N ueva Y ork: Willey.

Seifert, J. 1992. R egulating I ndoor Air: Chemical, M icrobiological, $\mathrm{H}$ ealth and Comfort Aspects of Indoor Air Quality-State of the Art in SBS. Bruselas: Kluwer Academic.

Turiel, I. 1986. Indoor Air Quality and $\mathrm{H}$ uman $\mathrm{H}$ ealth. Palo Alto, C alif: Stanford U niv. Press.

Wadden, RA, PA Scheff. 1983. Indoor Air Pollution. Characterization, Prediction and Control. Nueva Y ork: Wiley.

Wolkoff, P. 1992. Chemical, M icrobiological, H ealth and Comfort Aspects of Indoor Air Quality-State of the Art in SBS. Bruselas: ECSC.

Y ocom, JE, SM M CC arthy. 1991. M easuring Indoor Air Q uality: A Practical Guide. Chichester: Wiley. 

Director del capítulo

J uan Guasch F arrás

\section{Sumario}

Control ambiental en interiores: principios generales

A. $H$ ernández Calleja . . . . . . . . . . . . . . . . . . 45.2

El aire en interiores: métodos de control y depuración

E. A dán Liébana y A. H ernández Calleja . . .

O bjetivos y principios de la ventilación general y de la ventilación de dilución

E milio Castejón .

Criterios de ventilación para edificios no industriales

A. H ernández Calleja

Sistemas de calefacción y aire acondicionado

F. R amos Pérez y J. Guasch Farrás. .

El aire en interiores: ionización

E. A dán Liébana y J. G uasch Farrás. 


\section{CONTROL AMBIENTAL EN} INTERIORES: PRINCIPIOS GENERALES

\section{A. Hernández Calleja}

Las personas que viven en áreas urbanas pasan entre el 80 y el $90 \%$ de su tiempo realizando actividades sedentarias en espacios interiores, tanto durante el trabajo como durante el tiempo de ocio (véase la Figura 45.1).

Este hecho ha llevado a la creación de ambientes interiores más confortables y homogéneos que los exteriores, sujetos a condiciones climáticas variables. Para ello, ha sido necesario acondicionar el aire de estos espacios, calentándolo en invierno y enfriándolo en verano.

Para que el sistema de acondicionamiento fuera eficaz y rentable, había que controlar el aire que entraba en los edificios desde el exterior, cuyas características térmicas eran contrarias a las deseadas. Ello se tradujo en edificios cada vez más herméticos y en un control más riguroso de la cantidad de aire exteriior utilizada para renovar las atmósferas interiores más viciadas.

Con la crisis energética de principios del decenio de 1970 - y la consiguiente necesidad de ahorrar energía- cambió la situación, se redujo drásticamente el volumen de aire exterior utilizado para ventilación. Lo que se hacía entonces era reciclar muchas veces el aire del edificio. Por supuesto, el objetivo era reducir el coste del acondicionamiento del aire. Pero comenzó a ocurrir otra cosa: aumentó considerablemente el número de quejas, molestias y problemas de salud de los ocupantes de los edificios. Lo cual, a su vez, repercutió en los costes sociales y financieros debidos al absentismo y llevó a los especialistas a estudiar el origen de las quejas que, hasta entonces, se pensaban ajenas a la contaminación.

No es difícil explicar qué fue lo que provocó las quejas: se construyen edificios cada vez más herméticos, se reduce el volumen de aire de ventilación, se utilizan más productos y materiales para aislar los edificios térmicamente, se multiplica y diversifica el número de productos químicos y materiales

Figura 45.1 - Los habitantes de las ciudades pasan entre un 80 y un $90 \%$ de su tiempo en interiores.

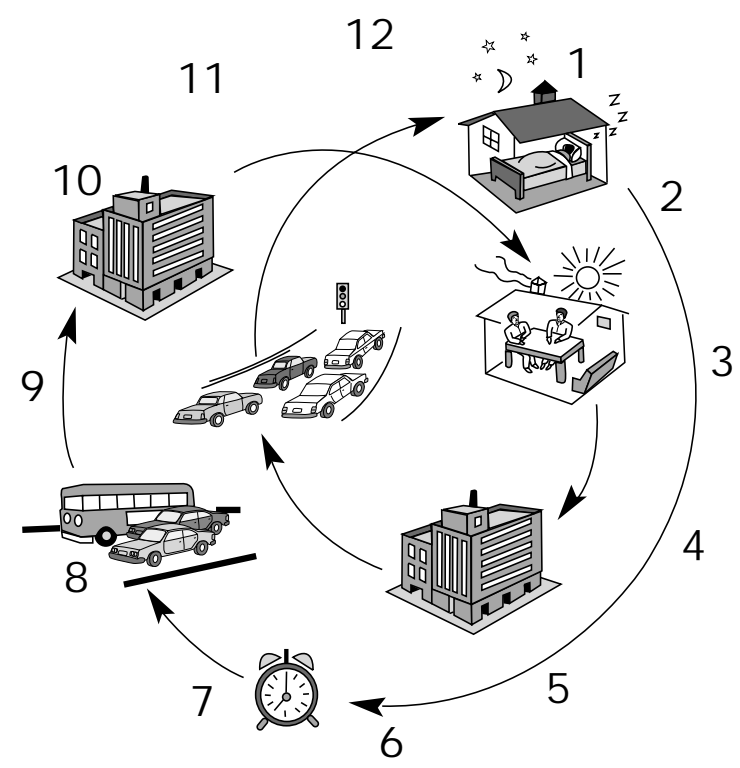

sintéticos utilizados y gradualmente se pierde el control individual del ambiente. Todo ello se traduce en un ambiente interior cada vez más contaminado.

Es entonces cuando los ocupantes de los edificios cuyo ambiente se ha degradado reaccionan, en su mayor parte, quejándose del ambiente en el que viven y presentando síntomas clínicos. Los síntomas más frecuentes son la irritación de las membranas mucosas (ojos, nariz y garganta), dolores de cabeza, insuficiencias respiratorias y una mayor incidencia de resfriados, alergias y demás.

A la hora de definir las posibles causas de tales quejas, la aparente sencillez de esta tarea se convierte en complejidad cuando se intenta establecer una relación causa-efecto. En este caso, es preciso considerar todos los factores (ya sean ambientales o de otro tipo) y su relación con las quejas o los problemas de salud que han aparecido.

La conclusión (después de muchos años de estudiar la cuestión) es que estos problemas tienen muy diversas causas. Son excepciones aquellos casos en los que se ha establecido Tabla 45.1 - Los contaminantes de interiores más comunes
y sus fuentes.

\begin{tabular}{|c|c|c|}
\hline Situación & Fuentes de emisión & Contaminante \\
\hline \multirow[t]{4}{*}{ Exterior } & Fuentes fijas & \\
\hline & $\begin{array}{l}\text { Establecimientos industriales, } \\
\text { producción de energía }\end{array}$ & $\begin{array}{l}\text { Dióxido de azufre, óxidos de } \\
\text { nitrógeno, ozono, material en } \\
\text { partículas, monóxido de } \\
\text { carbono, compuestos orgánicos }\end{array}$ \\
\hline & Automóviles & $\begin{array}{l}\text { Monóxido de carbono, plomo, } \\
\text { óxidos de nitrógeno }\end{array}$ \\
\hline & Suelo & Radón, microorganismos \\
\hline \multirow[t]{18}{*}{ Interior } & Materiales de construcción & \\
\hline & Piedra, hormigón & Radón \\
\hline & $\begin{array}{l}\text { Compuestos de madera, } \\
\text { chapeado }\end{array}$ & $\begin{array}{l}\text { Formaldehído, compuestos } \\
\text { orgánicos }\end{array}$ \\
\hline & Aislamiento & Formaldehído, fibra de vidrio \\
\hline & Ignífugos & Asbesto \\
\hline & Pintura & Compuestos orgánicos, plomo \\
\hline & Equipos e instalaciones & \\
\hline & Sistemas de calefacción, cocinas & $\begin{array}{l}\text { Monóxido y dióxido de carbono, } \\
\text { óxidos de nitrógeno, com- } \\
\text { puestos orgánicos, material en } \\
\text { partículas }\end{array}$ \\
\hline & Fotocopiadoras & Ozono \\
\hline & Sistemas de ventilación & Fibras, microorganismos \\
\hline & Ocupantes & \\
\hline & Actividad metabólica & $\begin{array}{l}\text { Dióxido de carbono, vapor de } \\
\text { agua, olores }\end{array}$ \\
\hline & Actividad biológica & Microorganismos \\
\hline & Actividad humana & \\
\hline & Hábito de fumar & $\begin{array}{l}\text { Monóxido de carbono, otros com- } \\
\text { puestos, material en partículas }\end{array}$ \\
\hline & Ambientadores & Fluorocarburos, olores \\
\hline & Limpieza & Compuestos orgánicos, olores \\
\hline & Ocio, actividades artísticas & Compuestos orgánicos, olores \\
\hline
\end{tabular}
partículas, monóxido de compuestos orgánicos óxidos de nitrógeno

Radón, microorganismos

Materiales de construcción

Compuestos de madera chapeado

Aislamiento

Ignífugos

Pintura

Asbesto

Equipos e instalaciones

Ocio, actividades artísticas 
claramente la relación causa-efecto, como en el caso del brote de legionelosis, por ejemplo, o los problemas de irritación o de incremento de la sensibilidad debidos a la exposición al formaldehído.

El fenómeno recibe el nombre de síndrome del edificio enfermo y se define como los síntomas que afectan a los ocupantes de un edificio en el que las quejas derivadas de malestares físicos son más frecuentes de lo que podría esperarse razonablemente.

En la Tabla 45.1 se presentan algunos ejemplos de contaminantes y las fuentes de emisiones más comunes que pueden asociarse con una disminución de la calidad del aire en interiores.

Además de la calidad del aire interior, que resulta afectada por contaminantes químicos y biológicos, el síndrome del edificio enfermo se atribuye a muchos otros factores. Algunos son físicos, como el calor, el ruido y la iluminación; otros son psicosociales, entre los cuales destacan la organización del trabajo, las relaciones laborales, el ritmo de trabajo y la carga de trabajo.

El aire interior desempeña un papel muy importante en el síndrome del edificio enfermo y, por consiguiente, controlar su calidad puede contribuir, en la mayoría de los casos, a rectificar - mejorar las condiciones que dan lugar a la aparición del síndrome. Con todo, conviene recordar que la calidad del aire no es el único factor que hay que considerar a la hora de evaluar ambientes interiores

\section{Medidas de control ambiental en interiores}

La experiencia demuestra que la mayoría de los problemas de los ambientes interiores son consecuencia de decisiones tomadas durante el diseño y la construcción del edificio. Aunque estos problemas pueden resolverse más adelante tomando medidas correctivas, hay que señalar que es más eficaz y rentable prevenir y corregir las deficiencias durante el diseño del edificio.

La gran variedad de las posibles fuentes de contaminación determina la multiplicidad de las medidas correctivas que pueden tomarse para mantenerlas bajo control. En el diseño de un edificio intervienen profesionales de diversos campos, como arquitectos, ingenieros, interioristas y otros. Por consiguiente, en esta fase es importante tener en cuenta los diferentes factores que contribuyen a eliminar o minimizar los problemas que pueden surgir en el futuro a causa de la mala calidad del aire. L os factores que es preciso considerar son:

- la elección del solar;

- el diseño arquitectónico;

- la elección de los materiales,

- Ios sistemas de ventilación y aire acondicionado utilizados para controlar la calidad del aire en interiores.

\section{Elección del solar de construcción}

La contaminación del aire puede proceder de fuentes que se encuentren cerca o lejos del solar elegido. Es un tipo de contaminación que incluye, principalmente, gases orgánicos e inorgánicos derivados de la combustión - ya sea de automóviles, fábricas o centrales eléctricas próximas al solar- y partículas suspendidas en el aire de origen diverso.

La contaminación del suelo incluye compuestos gaseosos procedentes de materias orgánicas enterradas y de las emanaciones de radón. Tales contaminantes pueden penetrar en el edificio a través de grietas de los materiales de construcción que estén en contacto con el suelo o por migración a través de materiales semipermeables.

La evaluación de los diferentes solares posibles deberá realizarse durante las fases de planificación de la construcción del edificio. Para que la elección del solar sea la más acertada deberán tenerse en cuenta los datos y circunstancias siguientes:

1. Datos que demuestren los niveles de contaminación ambiental en la zona, para evitar fuentes de contaminación alejadas.

2. A nálisis de fuentes de contaminación adyacentes o próximas, teniendo en cuenta factores como la cantidad de tráfico rodado y las posibles fuentes de contaminación industrial, comercial o agrícola.

3. Niveles de contaminación en el suelo y en el agua, entre ellos los compuestos orgánicos volátiles o semivolátiles, el gas radón y otros compuestos radiactivos derivados de la desintegración del radón. Es una información de gran utilidad si hay que decidir sobre un cambio de solar o si hay que tomar medidas para mitigar la presencia de estos contaminantes en el futuro edificio. Entre las medidas que pueden tomarse cabe citar el sellado eficaz de los canales de penetración o el diseño de sistemas de ventilación general que aseguren la creación de presión positiva en el futuro edificio.

4. Información sobre el clima y la dirección predominante del viento en la zona, así como sobre las variaciones diarias y estacionales. Son aspectos importantes para decidir la orientación más adecuada del edificio.

Por otra parte, es preciso controlar las fuentes locales de contaminación utilizando diversas técnicas específicas, como el drenaje o limpieza del suelo, su despresurización o la utilización de pantallas arquitectónicas o paisajísticas.

\section{Diseño arquitectónico}

La integridad del edificio ha sido, durante siglos, un requisito fundamental a la hora de planificar y diseñar un nuevo edificio. A estos efectos, tanto en la actualidad como en el pasado se han tenido en cuenta la capacidad de los materiales para resistir la degradación producida por la humedad, los cambios de temperatura, la circulación del aire, la radiación, el ataque de agentes químicos y biológicos o los desastres naturales.

Ello no supone un problema en el contexto actual; es más, en el proyecto deben tomarse las decisiones adecuadas en relación con la integridad y el bienestar de los ocupantes. Durante esta fase del proyecto es preciso tomar decisiones acerca de cuestiones como el diseño de interiores, la elección de los materiales, la ubicación de las actividades que con posibilidad de convertirse en fuentes de contaminación, las aberturas del edificio al exterior, las ventanas y el sistema de ventilación.

\section{Aberturas del edificio}

La planificación del lugar que van a ocupar esas aberturas y su orientación son medidas de control eficaces durante el diseño del edificio, a fin de minimizar la cantidad de contaminación que penetre en él procedente de fuentes de contaminación previamente detectadas. Es conveniente tener en cuenta lo siguiente:

- Las aberturas deben quedar alejadas de las fuentes de contaminación y no encontrarse en la dirección predominante del viento. Si las aberturas están próximas a salidas de humos 0 escapes, será preciso planificar el sistema de ventilación de modo que se produzca una presión de aire positiva en esa zona, a fin de evitar el retorno del aire evacuado, tal como puede verse en la Figura 45.2.

- Es preciso tener especial cuidado de asegurar el drenaje y evitar las filtraciones en los puntos de contacto del edificio con el suelo, en los cimientos, en las superficies embaldosadas, en los lugares donde estén ubicados los conductos y el sistema de desagüe y en otros puntos. 
Figura 45.2 • Penetración de la contaminación del exterior.

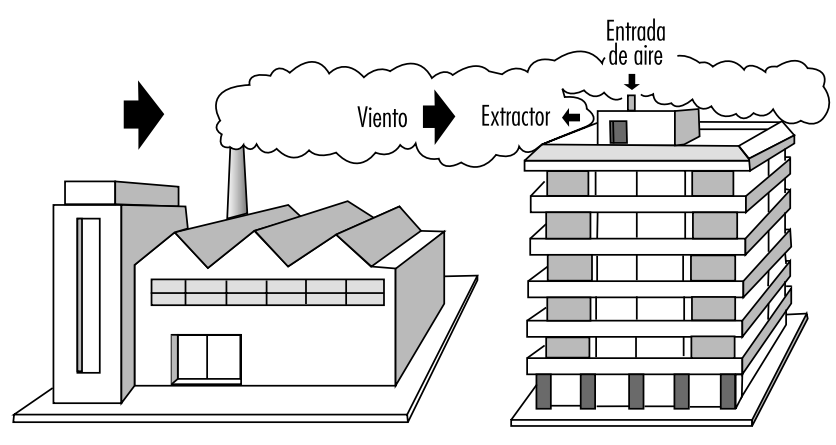

- Los accesos a muelles de carga y garajes deben construirse lejos de los puntos normales de entrada de aire al edificio así como de las entradas principales.

\section{Ventanas}

Durante los últimos años se ha invertido la tendencia observada en los decenios de 1970 y 1980, y actualmente existe propensión a incluir ventanas practicables en los nuevos proyectos arquitectónicos. Lo cual comporta varias ventajas. U na de ellas es la posibilidad de obtener ventilación suplementaria en las zonas que lo necesiten (se supone que son pocas), siempre y cuando el sistema de ventilación disponga de sensores para prevenir desequilibrios en dichas áreas. $\mathrm{H}$ ay que tener en cuenta que la posibilidad de abrir una ventana no siempre garantiza la entrada de aire fresco en el edificio; si el sistema de ventilación está presurizado, no se conseguirá más ventilación por abrir una ventana. 0 tras ventajas son de carácter meramente psicosocial, ya que permiten que los ocupantes tengan un cierto grado de control individual sobre su entorno y acceso visual directo al exterior.

\section{Protección contra la humedad}

El principal medio de control consiste en reducir la humedad de los cimientos del edificio, donde es frecuente que se desarrollen y propaguen microorganismos, especialmente hongos.

La deshumidificación de la zona y la presurización del suelo pueden evitar la aparición de agentes biológicos, así como la penetración de los contaminantes químicos que pueda haber en el suelo.

0 tra medida que hay que considerar es el sellado y control de las áreas cerradas del edificio más susceptibles a la humedad del aire, ya que la humedad puede dañar los materiales utilizados en los revestimientos del edificio, con lo que dichos materiales pueden convertirse en una fuente de contaminación microbiológica.

\section{Planificación de espacios interiores}

Es importante conocer, durante las fases de planificación, el uso que se dará al edificio o las actividades que en él se desarrollarán. Sobre todo, es importante conocer qué actividades pueden constituir una fuente de contaminación, lo que permitirá posteriormente limitarlas y controlarlas. Algunos ejemplos de dichas actividades dentro de un edificio son la preparación de alimentos, los trabajos de imprenta y artes gráficas, el hábito de fumar y el uso de máquinas fotocopiadoras.

La ubicación de estas actividades en recintos específicos, separados y aislados de otras actividades, debe decidirse de tal manera que los ocupantes del edificio se vean afectados lo menos posible.
Es aconsejable que estos procesos estén provistos de un sistema de extracción localizado y de sistemas de ventilación general con características especiales. La primera de estas medidas tiene por objeto controlar los contaminantes en la fuente de emisión. La segunda, aplicable cuando existen numerosas fuentes, cuando éstas están dispersas en un espacio determinado o cuando el contaminante no sea excesivamente peligroso, debe cumplir los requisitos siguientes: debe ser capaz de proporcionar volúmenes de aire fresco adecuados en función de los niveles establecidos para la actividad en cuestión, no debe utilizar de nuevo parte alguna del aire del local ni mezclarlo con el flujo general de ventilación del edificio y debe incluir extracción forzada suplementaria si es necesario. En estos casos es preciso planificar cuidadosamente la circulación del aire en los recintos para evitar la transmisión de contaminantes entre espacios contiguos (puede crearse, por ejemplo, una presión negativa en un espacio determinado).

A veces se logra el control mediante la eliminación o la reducción de contaminantes en el aire al filtrar o depurar éste químicamente. Para utilizar estas técnicas de control hay que tener en cuenta las características físicas y químicas de los contaminantes. Por ejemplo, los sistemas de filtración son adecuados para eliminar partículas del aire - en tanto que la eficacia del filtro se corresponda con el tamaño de las partículas filtradas-, pero permiten el paso de gases y vapores.

En espacios interiores, la eliminación de la fuente de contaminación es el método más eficaz de controlar ésta. Un buen ejemplo son las restricciones y prohibiciones del hábito de fumar en el lugar de trabajo. Si se permite fumar, generalmente es en zonas restringidas equipadas con sistemas de ventilación especiales.

\section{Elección de los materiales}

Para intentar evitar posibles problemas de contaminación en un edificio, es conveniente prestar atención a las características de los materiales de construcción y decoración, al mobiliario, a las actividades de trabajo que se realizarán normalmente y a los métodos que se utilizarán para limpiar y desinfectar el edificio y para el control de insectos y plagas. También es posible reducir los niveles de compuestos orgánicos volátiles (COV), por ejemplo, si se emplean únicamente materiales y equipamientos cuyos índices de emisión de estos compuestos sean conocidos y si se seleccionan aquellos que tengan los niveles más bajos.

$\mathrm{H}$ oy en día, aunque algunos laboratorios e instituciones han realizado estudios sobre emisiones de este tipo, la información sobre los índices de emisión de contaminantes de los materiales de construcción es más bien escasa, y ello se agrava por la gran cantidad de productos existentes y la variabilidad que presentan a lo largo del tiempo.

A pesar de esta dificultad, algunos productores han comenzado a estudiar sus productos y a incluir, habitualmente a petición del consumidor o del profesional de la construcción, información sobre las investigaciones realizadas. Cada vez son más los productos calificados como "respetuosos con el medio ambiente", "no tóxicos", etcétera.

Ahora bien, todavía hay muchos problemas que resolver. Entre ellos cabe citar el alto coste de los análisis necesarios, en lo que atañe al tiempo tanto como al dinero; la falta de normas que regulen los métodos de ensayo de muestras; la complicada interpretación de los resultados obtenidos debido al desconocimiento de los efectos de algunos contaminantes para la salud, y la falta de acuerdo entre los investigadores respecto a si es preferible utilizar materiales con alto nivel de emisión durante un período breve en lugar de materiales con un nivel bajo durante períodos de tiempo más largos. 
Lo cierto es que en los próximos años el mercado de los materiales de construcción y decoración será más competitivo y sufrirá una mayor presión legislativa. Con ello se eliminarán algunos productos 0 a se sustituirán por otros que tengan menores índices de emisión. Ya se están tomando medidas de este tipo con los adhesivos utilizados en la producción de moquetas, a lo que se añade, en la producción de pinturas, la eliminación de compuestos peligrosos, como el mercurio y el pentaclorofenol.

$\mathrm{H}$ asta que se tenga más información y madure la reglamentación legislativa en este campo, los encargados de elegir los materiales y productos más apropiados para la construcción de edificios nuevos serán los profesionales. $\mathrm{He}$ aquí algunas consideraciones que pueden ayudarles a tomar una decisión:

- Es preciso disponer de información sobre la composición química del producto y los índices de emisión de contaminantes, así como sobre cualquier aspecto concerniente a la salud, la seguridad y el confort de los ocupantes expuestos a los mismos. Esta información deberá facilitarla el fabricante del producto.

- Es preciso elegir los productos que tengan los índices de emisión de contaminantes más bajos posibles, atendiendo en especial a la presencia de compuestos carcinógenos y teratógenos, irritantes, toxinas sistémicas, compuestos odoríferos y demás.

- D eberán especificarse los adhesivos o materiales que presenten grandes superficies de emisión o absorción, como los materiales porosos, los textiles, las fibras sin revestimiento y similares, y restringirse su uso.

- Será necesario implantar procedimientos preventivos para la manipulación e instalación de estos materiales y productos. Durante y después de su instalación, se ventilará el recinto exhaustivamente y se utilizará el proceso de horneado (véase más adelante) para acelerar el curado de ciertos productos. También deberán aplicarse las medidas higiénicas recomendadas en cada caso.

- Uno de los procedimientos recomendados para minimizar la exposición a las emisiones de nuevos materiales durante las fases de instalación y acabado, así como durante la ocupación inicial del edificio, es ventilar el mismo durante 24 horas con un 100 por cien de aire exterior. La eliminación de compuestos orgánicos por medio de esta técnica evita su retención en los materiales porosos, que pueden actuar como depósitos y después como fuentes de contaminación al liberar los compuestos almacenados al medio ambiente.

- Otra medida es incrementar la ventilación al máximo nivel posible antes de volver a ocupar un edificio que haya quedado cerrado durante un cierto tiempo: durante las primeras horas del día, los fines de semana o las vacaciones.

- En algunos edificios se ha utilizado un procedimiento especial para acelerar el "curado" de nuevos materiales, conocido como horneado, por el cual la temperatura del edificio se eleva durante 48 horas o más, manteniendo la circulación del aire al mínimo. Las altas temperaturas favorecen la emisión de compuestos orgánicos volátiles. Después se ventila el edificio y se reduce así su carga contaminante. Los resultados obtenidos hasta la fecha demuestran que este procedimiento puede ser eficaz en algunas situaciones.

\section{L os sistemas de ventilación y el control de los climas \\ en interiores}

La ventilación es uno de los métodos más importantes para controlar la calidad del aire en los espacios cerrados. $\mathrm{H}$ ay en ellos tantas y tan diversas fuentes de contaminación que resulta casi imposible controlarlos por completo en la fase de diseño. Como ejemplo citaremos la contaminación generada por los propios ocupantes del edificio, a partir de las actividades que desarrollan y de los productos que utilizan para su higiene personal; en general, el diseñador no controla esas fuentes de contaminación.

Por consiguiente, el método de control normalmente utilizado para diluir y eliminar los contaminantes de los espacios interiores contaminados es la ventilación; puede realizarse con aire exterior limpio o con aire reciclado y convenientemente depurado.

Es necesario considerar muchas cuestiones diferentes a la hora de diseñar un sistema de ventilación que haya de servir adecuadamente como método de control de contaminación. Entre ellas cabe citar la calidad del aire exterior que se vaya a utilizar; los requisitos especiales de ciertos contaminantes o de la fuente que los genera; el mantenimiento preventivo del propio sistema de ventilación, que también debe tenerse en cuenta como posible fuente de contaminación, y la distribución del aire dentro del edificio.

En la Tabla 45.2 se resumen las cuestiones principales en el diseño de un sistema de ventilación necesarias para mantener ambientes interiores de calidad.

En un sistema típico de ventilación/ aire acondicionado, el aire que se toma del exterior y que se mezcla con una proporción variable de aire reciclado pasa a través de diferentes sistemas de acondicionamiento del aire, suele filtrarse, calentarse o enfriarse según la estación y se humidifica o deshumidifica en función de las necesidades.

Una vez tratado, el aire se distribuye por conductos a cada una de las áreas del edificio y se reparte a través de rejillas de dispersión. Después se mezcla en todos los espacios ocupados, provocando un intercambio térmico y renovando la atmósfera interior hasta que finalmente se extrae de cada recinto por conducciones de retorno.

La cantidad de aire exterior que debe utilizarse para diluir y eliminar contaminantes es objeto de debate y de él se han ocupado muchos estudios. En los últimos años han cambiado las recomendaciones relativas a los niveles de aire exterior y se han publicado nuevas normas de ventilación, en la mayoría de los casos para aumentar los volúmenes de aire exterior utilizados. Aun así, estas recomendaciones son insuficientes para controlar eficazmente todas las fuentes de contaminación, y la razón está en que las normas establecidas se basan en la ocupación y no tienen en cuenta otras fuentes de contaminación importantes, como los materiales empleados en la construcción, el mobiliario y la calidad del aire procedente del exterior.

Así pues, la cantidad de ventilación necesaria debe basarse en tres aspectos fundamentales: la calidad del aire que se desee obtener, la calidad del aire exterior disponible y la carga total de contaminación del espacio que se intenta ventilar. De aquí parten los estudios realizados por el profesor P. O. Fanger y su equipo (Fanger 1988, 1989). Su objeto es establecer nuevas normas de ventilación que satisfagan las necesidades de calidad del aire y que proporcionen un nivel de confort aceptable desde el punto de vista de sus ocupantes.

Uno de los factores que afectan a la calidad del aire en espacios interiores es la calidad del aire exterior. L as características de las fuentes de contaminación exteriores, como el tráfico rodado y las actividades industriales o agrícolas, las hacen incontrolables para los diseñadores, los propietarios y los ocupantes de los edificios. Es en casos de este tipo cuando las autoridades responsables en materia de medio ambiente deben asumir la responsabilidad de elaborar directrices de protección medioambiental y de asegurar su cumplimiento. Sin embargo, existen muchas medidas de control aplicables y útiles para reducir y eliminar la contaminación ambiental.

- eiminar la contaminación ambiental. 
Tabla 45.2 • Requisitos básicos de un sistema de ventilación por dilución.

Componente o función
del sistema
Dilución por aire exterior
Ubicación de las
entradas de aire

tores de aire

Filtración y depuración

Control microbiológico

Distribución del aire

Debe garantizarse un volumen mínimo de aire por ocupante y por hora.

El objetivo debe ser renovar el volumen de aire interior un número mínimo de veces por hora. contaminación.

Debe garantizarse la extracción directa al exterior en espacios en los que vayan a realizarse actividades que generen contaminación.

Debe evitarse situar las entradas de aire cerca de fuentes de contaminación conocidas.

Deben evitarse zonas próximas a aguas estancadas y ración

Debe evitarse que entren animales y que las aves se posen o hagan sus nidos cerca de las entradas de aire.

Los extractores deben colocarse lo más lejos posible de las entradas de aire y deberá aumentarse la altura de las salidas de evacuación.

Las salidas de evacuación deben orientarse en dirección opuesta a las campanas de entrada de aire.

Deberán utilizarse filtros de partículas mecánicos y eléctricos.

Es preciso instalar un sistema de eliminación química de contaminantes.

Debe evitarse poner materiales porosos en contacto de distribución.

Debe evitarse la acumulación de agua estancada acondicionado.

Deberá establecerse un programa de mantenimiento preventivo, y planificarse la limpieza periódica de los humidificadores y las torres de refrigeración.

Es preciso eliminar y evitar la formación de zonas
El volumen de aire exterior suministrado debe aumentarse en función de la intensidad de las fuentes de a los aerosoles que emanan de las torres de refrigecon corrientes de aire, incluidos los de los conductos cuando se forme condensación en aparatos de aire muertas (donde no hay ventilación) y la estratificación del aire.

Es preferible mezclar el aire allí donde los ocupantes lo respiran.

Es preciso mantener presiones adecuadas en todos los recintos en función de las actividades que se realicen en ellos.

Es preciso controlar los sistemas de propulsión y extracción del aire para mantener el equilibrio entre ellos.

Como ya se ha mencionado, es preciso prestar especial atención a la ubicación y orientación de las conducciones de entrada y salida de aire, para evitar la reabsorción de la contaminación del propio edificio o de sus instalaciones (torres de refrigeración, respiraderos de cocinas y baños, etc.), así como de los edificios de las proximidades.
Si resulta que el aire exterior o reciclado está contaminado, las medidas de control que se recomiendan son el filtrado y la depuración. EI método más eficaz para eliminar las partículas es utilizar precipitadores electrostáticos y filtros mecánicos de retención (la eficacia de éstos últimos será mayor cuanto más precisa sea su calibración conforme al tamaño de las partículas que se desea eliminar).

La utilización de sistemas capaces de eliminar gases y vapores por absorción y adsorción químicas es una técnica raramente utilizada fuera del sector industrial; con todo, es habitual hallar sistemas que enmascaran el problema de la contaminación, especialmente los olores, por ejemplo, utilizando ambientadores.

0 tras técnicas para depurar y mejorar la calidad del aire utilizan ionizadores y ozonadores. El mejor principio en la utilización de estos sistemas para mejorar la calidad del aire, hasta que se conozcan sus verdaderas propiedades y sus posibles efectos perjudiciales para la salud es la prudencia.

U na vez que el aire ha sido tratado y enfriado o calentado, se reparte por los espacios interiores. Q ue la distribución del aire sea o no aceptable dependerá, en gran medida, de la elección, el número y la colocación de las rejillas difusoras.

Dadas las diferencias de opinión existentes sobre la eficacia de los distintos procedimientos para mezclar el aire, algunos diseñadores han comenzado a utilizar, en algunas situaciones, sistemas distribuidores de aire que lo reparten a nivel del suelo o desde las paredes, en lugar de las rejillas de difusión colocadas en el techo. En cualquier caso, es preciso planificar cuidadosamente la ubicación de los registros de retorno para evitar cortocircuitar la entrada y salida de aire, lo cual impediría que se mezclase por completo, tal como puede verse en la Figura 45.3.

Según el grado de compartimentación de los espacios de trabajo, la distribución del aire puede presentar diversos problemas. Por ejemplo, es posible que en los espacios abiertos provistos de rejillas de difusión en el techo el aire de la habitación no se mezcle por completo. Y el problema se agrava cuando el sistema de ventilación suministra volúmenes variables de aire. Los conductos de distribución de estos sistemas están provistos de terminales que modifican la cantidad de aire suministrado a dichos conductos en función de los datos recibidos de los termostatos de zona.

Figura 45.3 • Ejemplo de cómo puede cortocircuitarse la distribución del aire en espacios interiores.

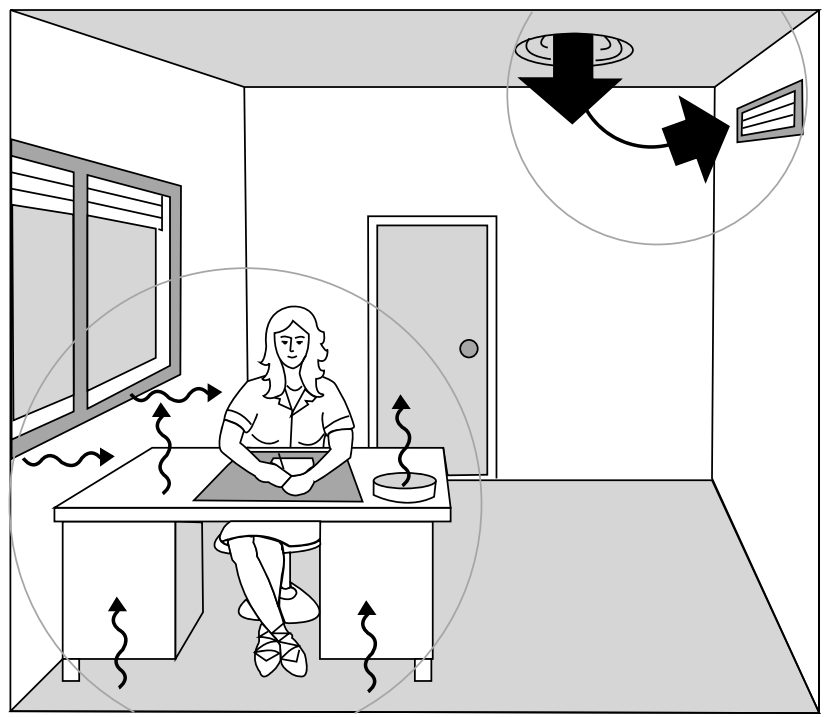


Tabla 45.3 • Medidas de control de la calidad del aire en interiores y sus efectos en los ambientes interiores.

\begin{tabular}{|c|c|}
\hline Acción & Efecto \\
\hline \multicolumn{2}{|c|}{ Ambiente térmico } \\
\hline Aumento del volumen de aire fresco & Aumento de las corrientes \\
\hline $\begin{array}{l}\text { Reducción de la humedad relativa para } \\
\text { evitar el desarrollo de microorganismos de } \\
\text { agentes microbiológicos }\end{array}$ & $\begin{array}{l}\text { Humedad relativa } \\
\text { insuficiente }\end{array}$ \\
\hline \multicolumn{2}{|c|}{ Ambiente acústico } \\
\hline $\begin{array}{l}\text { Suministro intermitente de aire exterior para } \\
\text { conservar la energía }\end{array}$ & $\begin{array}{l}\text { Exposición intermitente al } \\
\text { ruido }\end{array}$ \\
\hline \multicolumn{2}{|c|}{ Ambiente visual } \\
\hline $\begin{array}{l}\text { Reducción en el uso de luces fluorescentes para } \\
\text { reducir la contaminación fotoquímica }\end{array}$ & $\begin{array}{l}\text { Reducción de la eficacia } \\
\text { de la iluminación }\end{array}$ \\
\hline \multicolumn{2}{|c|}{ Ambiente psicosocial } \\
\hline Oficinas diáfanas & $\begin{array}{l}\text { Pérdida de intimidad y de } \\
\text { un espacio de trabajo } \\
\text { definido }\end{array}$ \\
\hline
\end{tabular}

Si el aire fluye a velocidad reducida a través de un número significativo de estos terminales (sucede cuando los termostatos de diferentes zonas alcanzan la temperatura deseada) y se reduce automáticamente la potencia de los ventiladores que impulsan el aire, pueden surgir dificultades. Por ejemplo, que el flujo total de aire que circula por el sistema sea menor, en algunos casos mucho menor, o incluso que se interrumpa totalmente la "entrada" de aire fresco del exterior. La colocación de sensores que controlen el flujo de aire exterior en el punto de entrada del sistema puede asegurar el mantenimiento de un flujo mínimo de aire fresco en todo momento.

0 tro problema habitual es el bloqueo del flujo de aire debido a la colocación de divisiones totales o parciales en el espacio de trabajo. $\mathrm{H}$ ay muchos medios de corregir esta situación. U no de ellos es dejar un espacio abierto en el borde inferior de los

Tabla 45.4 • Ajustes del medio ambiente de trabajo y sus efectos sobre la calidad del aire en interiores.

Acción

Ambiente térmico

Cálculo del suministro de aire exterior basado en cuestiones térmicas

El uso de humidificadores

Ambiente acústico

Aumento en el uso de materiales aislantes

\section{Ambiente visual}

Sistemas basados exclusivamente en la iluminación artificial

Ambiente psicosocial

Utilización de equipos en el espacio de trabajo, tales como fotocopiadoras e impresoras
Efecto

Volúmenes insuficientes de aire fresco

Peligro microbiológico potencial

Posible liberación de contaminantes

Insatisfacción, mortalidad de las plantas, desarrollo de agentes microbiológicos

Aumento del nivel de contaminación tabiques que dividen los cubículos. 0 tros son la instalación de ventiladores suplementarios y la colocación de rejillas difusoras en el suelo. El uso de ventiloconvectores de inducción ayuda a mezclar el aire y permite el control individualizado de las condiciones térmicas de un espacio determinado. Sin restar importancia a la calidad del aire per se ni a los medios de controlarla, hay que tener en cuenta que para conseguir un ambiente interior confortable debe existir un equilibrio entre los diferentes elementos que afectan al mismo. Cualquier medida que se tome - aunque sea positiva - que afecte sólo a uno de los elementos, sin tener en cuenta el resto, puede romper el equilibrio y dar lugar a nuevas quejas por parte de los ocupantes del edificio. En las Tablas 45.3 y 45.4 se ilustra cómo algunas de estas medidas, cuya finalidad es mejorar la calidad del aire interior, provocan el fallo de otros elementos de la ecuación, de modo que la regulación del ambiente de trabajo puede afectar a la calidad del aire interior.

La calidad del ambiente general de un edificio que se encuentra en la fase de diseño dependerá, en gran medida, de las personas encargadas de su gestión, pero sobre todo de que se adopte una actitud positiva con respecto a los ocupantes del edificio. Para los propietarios del mismo, los ocupantes son los sensores más fiables para calibrar el correcto funcionamiento de las instalaciones destinadas a crear un ambiente interior de calidad.

Los sistemas de control basados en un concepción "paternalista", encargados de tomar todas las decisiones que regulan los ambientes interiores, como la iluminación, la temperatura, la ventilación, etcétera, tienden a perjudicar el bienestar psicológico y sociológico de sus ocupantes, quienes ven así disminuida 0 bloqueada su capacidad para crear condiciones ambientales que se ajusten a sus necesidades. A demás, los sistemas de control de este tipo son a veces incapaces de cambiar para adaptarse a las diferentes exigencias ambientales que pueden surgir a consecuencia de cambios en las actividades realizadas en un espacio determinado, en el número de personas que trabajen en el mismo o cambios en el reparto del espacio.

La solución podría consistir en instalar un sistema de control centralizado para el ambiente interior, con controles localizados regulados por los ocupantes. Es una idea muy utilizada en el ámbito de lo visual, donde la iluminación general se complementa con iluminación más localizada, que debería ampliarse a otros sistemas: calefacción y aire acondicionado generales y localizados, suministros de aire fresco generales y localizados, etcétera.

En resumen, puede decirse que, en cada caso deberá optimizarse una parte de las condiciones ambientales por medio de un control centralizado basado en aspectos de seguridad, salud y economía, mientras que las diferentes condiciones ambientales locales deberán ser optimizadas por el usuario del recinto. Cada usuario tiene necesidades diferentes y reacciona de manera distinta a determinadas condiciones. Es indudable que un compromiso de este tipo entre las diferentes partes aumentará la satisfacción, el bienestar y la productividad.

\section{EL AIRE EN INTERIORES: METODOS DE CONTROL Y DEPURACION}

\section{E. Adán Liébana y A. Hernández Calleja}

La calidad del aire dentro de un edificio depende de una serie de factores entre los que cabe citar la calidad del aire exterior, el diseño del sistema de ventilación y de aire acondicionado, el funcionamiento y mantenimiento del sistema y las fuentes de 
contaminación interior. En términos generales, el nivel de concentración de un contaminante en un espacio interior vendrá determinado por el equilibrio existente entre la generación del contaminante y su velocidad de eliminación.

En cuanto a la generación de contaminantes, las fuentes de contaminación también pueden ser internas o externas. Entre las fuentes externas cabe citar la contaminación atmosférica producida por procesos industriales de combustión, el tráfico rodado, las centrales eléctricas y demás; la contaminación emitida cerca de las galerías de entrada de aire al edificio, como la procedente de torres de refrigeración o salidas de escape de otros edificios; y las emanaciones de suelos contaminados, como el gas radón, las fugas de depósitos de gasolina o los pesticidas.

Entre las fuentes de contaminación interna, merece la pena mencionar las asociadas con los propios sistemas de ventilación y aire acondicionado (principalmente la contaminación microbiológica de cualquier parte de dichos sistemas), los materiales utilizados en la construcción y la decoración del edificio y los ocupantes del edificio. Fuentes específicas de contaminación interior son el humo del tabaco, las fotocopiadoras, los laboratorios en general, los fotográficos en particular, las prensas de imprenta, los gimnasios, los salones de belleza, las cocinas y cafeterías, los cuartos de baño, los aparcamientos y las salas de calderas. Todas deben tener un sistema de ventilación general y el aire extraído de estas zonas no debe volver a utilizarse en el edificio. Cuando la situación lo exija, también deberán tener un sistema de extracción localizada.

La evaluación de la calidad del aire interior supone, entre otras tareas, la medición y evaluación de los contaminantes que pueda haber en el edificio. Se utilizan varios indicadores para averiguar la calidad del aire en el interior. Entre ellos cabe citar las concentraciones de monóxido de carbono y dióxido de carbono, la cantidad total de compuestos orgánicos volátiles (T C OV), la cantidad total de partículas en suspensión (T SP) y la velocidad de ventilación. Existen varios criterios o valores diana recomendados para la evaluación de algunas de las sustancias presentes en los espacios interiores, que vienen enumerados en diferentes normas o directrices, como las directrices para la calidad del aire en interiores adoptadas por la O rganización M undial de la Salud (O M S), o las normas de la Sociedad A mericana de Ingenieros de Calefacción, R efrigeración y Acondicionamiento del Aire (American Society of $\mathrm{H}$ eating, R efrigerating and Air Conditioning Engineers, ASH RAE).

Ahora bien, no hay normas definidas para muchas de estas sustancias. Por ahora, la línea de acción recomendada es aplicar los valores y normas para ambientes industriales indicados por la Conferencia Americana de Higienistas Industriales del Gobierno (American Conference of Governmental Industrial Hygienists, ACGIH), (ACGIH 1992). Después se aplican factores de seguridad o de corrección del orden de la mitad, la décima o la centésima parte de los valores especificados.

Los métodos de control del aire interior pueden dividirse en dos grupos principales: el control de la fuente de contaminación y el control del ambiente mediante estrategias de ventilación y depuración del aire.

\section{Control de la fuente de contaminación}

La fuente de contaminación puede controlarse por varios medios, entre los que cabe citar:

1. E liminación. Eliminar la fuente de contaminación es el método ideal para controlar la calidad del aire en interiores. Se trata de una medida permanente que no requiere operaciones de mantenimiento posteriores. Se aplica cuando se conoce la fuente de la contaminación, como en el caso del humo del tabaco, y no precisa la sustitución del agente en cuestión.
2. Sustitución. En algunos casos hay que sustituir el producto que origina la contaminación. A veces es posible cambiar los productos utilizados (para limpieza, decoración, etc.) por otros que presten el mismo servicio pero que sean menos tóxicos o presenten un riesgo menor para las personas que los utilizan.

3. Aislamiento o confinamiento espacial. El objeto de estas medidas es reducir la exposición limitando el acceso a la fuente. Es un método por el que se interponen barreras (parciales o totales) o medidas de contención alrededor de la fuente de contaminación para minimizar las emisiones al aire circundante y limitar el acceso de personas a la zona próxima a la fuente de contaminación. Los recintos deben estar equipados con sistemas de ventilación suplementarios que puedan extraer aire y suministrar un flujo de aire dirigido adonde sea necesario. Ejemplos de este enfoque son los hornos cerrados, las salas de calderas y las salas de fotocopiadoras.

4. Sellado de la fuente. En este método se utilizan materiales y/o productos que eviten o minimicen la emisión de contaminación. Se ha propuesto como medio para evitar la dispersión de fibras de amianto sueltas de antiguos aislantes, así como para reducir la emisión de formaldehído de las paredes tratadas con resinas. En edificios contaminados por gas radón, esta técnica se utiliza para sellar bloques de hormigón y fisuras en paredes de sótanos, utilizándose polímeros para evitar la inmisión de radón del suelo. Las paredes de sótanos también pueden tratarse con pintura epoxídica y un sellador polimérico de polietileno o poliamida para evitar contaminación que pueda filtrarse a través de las paredes o por el suelo.

5. Ventilación por extracción localizada. Los sistemas de ventilación localizados funcionan capturando el contaminante en la propia fuente, o lo más cerca posible de ella. La captura se realiza con una campana concebida para atrapar el contaminante en una corriente de aire que fluye entonces a través de conductos hacia el sistema de depuración con ayuda de un ventilador. Si no es posible depurar o filtrar el aire extraído, deberá evacuarse al exterior y no volverá a utilizarse en el edificio.

\section{Control del ambiente}

Los ambientes interiores de edificios no industriales suelen tener muchas fuentes de contaminación que, además, tienden a estar dispersas. El sistema más empleado para corregir o prevenir los problemas de contaminación en interiores es, por consiguiente, la ventilación, ya sea general o de dilución. L o que se hace es mover y dirigir el flujo de aire para capturar, retener y transportar los contaminantes desde su fuente hasta el sistema de ventilación. Por añadidura, la ventilación general también permite el control de las características térmicas del ambiente interior acondicionando y recirculando el aire (véase más adelante, en este mismo capítulo, la sección "O bjetivos y principios de la ventilación general y de la ventilación de dilución").

A fin de diluir la contaminación interna, sólo es aconsejable aumentar el volumen de aire exterior si el sistema es de tamaño apropiado y no se provoca falta de ventilación en otras zonas ni se impide el correcto acondicionamiento del aire. Para que un sistema de ventilación sea lo más eficaz posible, es conveniente instalar extractores localizados en las fuentes de contaminación; el aire mezclado con contaminación no deberá volver a utilizarse; los ocupantes deberán situarse junto a los difusores de aire y las fuentes de contaminación junto a los extractores; los contaminantes deberán expulsarse por la vía más corta posible, y los recintos que tengan fuentes de contaminación localizadas deberán mantenerse a presión negativa en relación con la presión atmosférica exterior. 
La mayoría de las deficiencias de ventilación parecen ir ligadas a una cantidad inadecuada de aire exterior. Con todo, una distribución inadecuada del aire de renovación también puede dar lugar a problemas de calidad del aire. Por ejemplo, en habitaciones con techos muy altos, que reciban aire caliente (menos denso) desde arriba, pueden ocurrir problemas de estratificación y entonces la ventilación no podrá diluir la contaminación presente en la habitación. La ubicación y colocación de los difusores y retornos de aire en relación con los ocupantes y las fuentes de contaminación es una cuestión que requiere especial atención a la hora de diseñar el sistema de ventilación.

\section{Técnicas de depuración del aire}

Es conveniente elegir y diseñar con precisión los métodos de depuración del aire para cada tipo concreto de contaminante. Una vez instalado, el mantenimiento periódico evitará que el propio sistema se convierta en una nueva fuente de contaminación. A continuación se describen seis métodos empleados para eliminar contaminantes del aire.

\section{Filtración de partículas}

L a filtración es un método útil para eliminar líquidos o sólidos en suspensión, pero hay que tener en cuenta que no elimina gases ni vapores. Los filtros pueden capturar partículas por obstrucción, impacto, intercepción, difusión y atracción electrostática. La filtración en un sistema de aire acondicionado es necesaria por muchas razones. Una de ellas es evitar la acumulación de suciedad que pueda reducir la eficacia del intercambio de calor. El sistema también puede sufrir corrosión a causa de ciertas partículas (ácido sulfúrico y cloruros). También se necesita filtración para evitar desequilibrios en el sistema de ventilación debidos a la formación de depósitos en las palas de los ventiladores y al envío de información falsa a los controles por obstrucción de los sensores.

L os sistemas de filtración de aire interior se sirven de al menos dos filtros colocados en serie. El primero, un prefiltro o filtro primario, retiene sólo las partículas más grandes. Debe cambiarse a menudo para que el filtro siguiente dure más tiempo. El filtro secundario es más eficaz que el primero y puede filtrar esporas fúngicas, fibras sintéticas y, en general, polvo más fino que el recogido por el filtro primario. Los filtros deben ser suficientemente eficaces para eliminar partículas irritantes y tóxicas.

La elección de un filtro se basa en su eficacia, en su capacidad para acumular polvo, en su pérdida de carga y en el nivel exigido de pureza del aire. La eficacia de un filtro se mide por las normas ASHRAE 52-76 y Eurovent 4/ 5 (ASHRAE 1992; CEN 1979). Su capacidad de retención se define como la masa del polvo que retiene por el volumen del aire filtrado y se utiliza para filtros que sólo retienen partículas grandes (filtros de eficacia media y baja). Para medir su capacidad de retención, se hace pasar a través del filtro polvo aerosol sintético, de concentración y granulometría conocidas. La parte retenida en el filtro se calcula por gravimetría.

La eficacia de un filtro expresa el número de partículas retenidas por el volumen de aire filtrado. Es el mismo valor que se utiliza para caracterizar filtros que también retienen partículas más finas. En este caso, se hace pasar a través del mismo una corriente de aerosol atmosférico compuesto de partículas de entre 0,5 y $1 \mu \mathrm{m}$ de diámetro. La cantidad de partículas capturadas se mide con un opacímetro, aparato que mide la opacidad provocada por el sedimento. El ensayo con Dioctilftalato (DOP) es utilizado para clasificar los filtros de aire particulado de alta eficacia (H EPA). La prueba se realiza con un aerosol fabricado por evaporación y condensación de dioctilftalato, que produce
Tabla 45.5 - Eficacia de los filtros (conforme a la norma ASHRAE 52-76) para partículas de $3 \mu \mathrm{m}$ de diámetro.

\begin{tabular}{llllll}
$\begin{array}{l}\text { Descripción } \\
\text { del filtro }\end{array}$ & \multicolumn{3}{c}{ ASHRAE 52-76 } & \multicolumn{3}{c}{ Eficacia (\%) } \\
& $\begin{array}{l}\text { Mancha } \\
\text { de polvo (\%) }\end{array}$ & $\begin{array}{l}\text { Retención } \\
(\%)\end{array}$ & Inicial & Final & Promedio \\
Medio & $25-30$ & 92 & 1 & 25 & 15 \\
Medio & $40-45$ & 96 & 5 & 55 & 34 \\
Alto & $60-65$ & 97 & 19 & 70 & 50 \\
Alto & $80-85$ & 98 & 50 & 86 & 68 \\
Alto & $90-95$ & 99 & 75 & 99 & 87 \\
$95 \%$ HEPA & - & - & 95 & 99,5 & 99,1 \\
$99,97 \%$ HEPA & - & - & 99,97 & 99,7 & 99,97
\end{tabular}

partículas de 0,3 $\mu \mathrm{m}$ de diámetro. El método se basa en la propiedad fotodispersora de las gotas de dioctilftalato: si sometemos el filtro a esta prueba, la intensidad de la luz dispersada será proporcional a la concentración superficial de este material y podrá medirse la penetración del filtro por la intensidad relativa de la luz dispersada antes y después de filtrar el aerosol. Para que un filtro obtenga la denominación HEPA, debe demostrar una eficacia superior al $99,97 \%$ en esta prueba.

Aunque existe una relación directa entre ellos, los resultados de los tres métodos no son directamente comparables. La eficacia de todos los filtros disminuye a medida que se van obstruyendo y entonces pueden convertirse en fuente de olores y contaminación. La vida útil de un filtro de alta eficacia puede alargarse en gran medida colocando uno o varios filtros de menor rango delante del filtro de alta eficacia. En la Tabla 45.5 se presentan los valores de rendimiento inicial, final y promedio de diferentes filtros, conforme a los criterios establecidos por la norma ASH R AE 52-76 para partículas de 0,3 $\mu$ m de diámetro.

\section{Precipitación electrostática}

Se trata de un método útil para controlar partículas. Los equipos de esta clase funcionan ionizando las partículas y eliminándolas después de la corriente de aire por medio de un electrodo acumulador que las atrae y captura. La ionización se produce cuando el efluente contaminado pasa por el campo eléctrico generado por una alta tensión aplicada entre los electrodos de acumulación y descarga. La tensión se obtiene por medio de un generador de corriente continua. El electrodo acumulador cuenta con una superficie grande y suele tener una carga positiva, mientras que el electrodo de descarga es un cable con carga negativa.

L os factores más importantes que afectan a la ionización de partículas son el estado del efluente, su descarga y las características de las partículas (tamaño, concentración, resistividad, etc.). La efectividad de la captura aumenta con la humedad y con el tamaño y la densidad de las partículas, y disminuye al aumentar la viscosidad del efluente.

La principal ventaja de estos dispositivos es que son muy eficaces para recoger sólidos y líquidos, incluso cuando las partículas son muy finas. Además, estos sistemas pueden utilizarse con grandes volúmenes y a altas temperaturas. La pérdida de presión es mínima. Los inconvenientes son su alto coste inicial, sus necesidades de espacio y los riesgos de seguridad que plantean por las altas tensiones que requieren, especialmente si se utilizan en aplicaciones industriales. 
Los precipitadores electrostáticos tienen toda una gama de aplicaciones, desde la reducción de las emisiones de partículas en ámbitos industriales, hasta la mejora de la calidad del aire en el interior de domicilios privados. En este último caso se trata de dispositivos más pequeños, que funcionan con tensiones de entre 10.000 y 15.000 voltios. Normalmente disponen de sistemas equipados con reguladores automáticos de tensión que permiten aplicar siempre la tensión suficiente para producir la ionización sin provocar descargas entre ambos electrodos.

\section{Generación de iones negativos}

Es un método utilizado para eliminar partículas suspendidas en el aire y, en opinión de algunos autores, para crear ambientes más saludables. Todavía se está estudiando la eficacia de este método como medio para reducir malestares o enfermedades.

\section{Adsorción de gases}

Es un método utilizado para eliminar gases y vapores contaminantes, como el formaldehído, el dióxido de azufre, el ozono, los óxidos de nitrógeno y los vapores orgánicos. La adsorción es un fenómeno físico por el que las moléculas de gas quedan atrapadas en un material adsorbente sólido y poroso, de superficie muy extensa. Para eliminar este tipo de contaminante se hace pasar el aire a través de un cartucho lleno del material adsorbente. EI material más utilizado es el carbono activado, que atrapa una gran variedad de gases inorgánicos y compuestos orgánicos. C abe citar como ejemplos los hidrocarburos alifáticos, clorados y aromáticos, las cetonas, los alcoholes y los ésteres.

El gel de sílice es asimismo un adsorbente inorgánico y se utiliza para atrapar compuestos más polares, como los compuestos aminados y el agua. También existen otros adsorbentes de tipo orgánico compuestos de polímeros porosos. Conviene recordar que todos los sólidos adsorbentes sólo atrapan una cierta cantidad de contaminante y después, una vez saturados, tienen que ser regenerados 0 reemplazados. 0 tro método de captura a través de sólidos adsorbentes es utilizar una mezcla activa de alúmina y carbono impregnada con unos reactivos específicos. Por ejemplo, algunos óxidos metálicos capturan vapor de mercurio, sulfuro de hidrógeno y etileno. Hay que tener en cuenta que no es posible retener el dióxido de carbono por adsorción.

\section{Absorción de gases}

Para eliminar gases y vapores por absorción se utiliza un sistema que fija las moléculas haciéndolas pasar a través de una solución absorbente con la que reaccionan químicamente. Es un método muy selectivo y utiliza reactivos específicos para el contaminante que se quiere capturar.

También debe reemplazarse o regenerarse antes de que se agote. Como el sistema se basa en que el contaminante pase del estado gaseoso al líquido, las propiedades físicas y químicas del mismo son muy importantes: su solubilidad y reactividad, el $\mathrm{pH}$, la temperatura y la superficie de contacto entre el gas y el líquido. Si el contaminante es muy soluble, será suficiente con hacerlo borbotear a través de la solución para fijarlo al reactivo. Si el contaminante no es tan soluble, el sistema que se emplee deberá asegurar una mayor superficie de contacto entre el gas y el líquido. En la Tabla 45.6 se muestran algunos ejemplos de absorbentes y los contaminantes para los que son especialmente adecuados.

\section{Ozonización}

Es un método de mejora de la calidad del aire en interiores que se basa en el uso del gas ozono. El ozono se genera a partir del
Tabla 45.6 - Reactivos utilizados como absorbentes para varios contaminantes.

\begin{tabular}{ll} 
Absorbente & Contaminante \\
Dietillhidroxamina & Sulfuro de hidrógeno \\
Permanganato potásico & Gases odoríferos \\
Ácidos clorhídrico y sulfúrico & Aminas \\
Sulfuro sódico & Aldehídos \\
Hidróxido sódico & Formaldehído \\
\hline
\end{tabular}

oxígeno por radiación ultravioleta o descarga eléctrica y se emplea para eliminar contaminantes dispersos en el aire. El gran poder oxidante de este gas lo hace adecuado como agente antimicrobiano, desodorante y desinfectante y apto para eliminar gases y vapores nocivos. También se emplea para purificar espacios con altas concentraciones de monóxido de carbono. En ámbitos industriales se utiliza para tratar el aire de cocinas, cafeterías, plantas de elaboración de alimentos y pescado, plantas químicas, plantas de tratamiento de aguas residuales, plantas de transformación del caucho, plantas de refrigeración, etcétera. En oficinas, se utiliza con instalaciones de aire acondicionado para mejorar la calidad del aire.

El ozono es un gas azulado con un penetrante olor característico. En altas concentraciones es tóxico e incluso mortal para el hombre. Es preciso diferenciar la producción de ozono intencionada, accidental y natural. El ozono es un gas sumamente tóxico e irritante ya sea en exposiciones de larga o corta duración. Debido al modo en que reacciona en el cuerpo, no se conocen niveles que no tengan efectos biológicos. En la sección de productos químicos de la Enciclopedia se trata más detalladamente esta cuestión.

Los procesos que emplean ozono deben llevarse a cabo en espacios cerrados o tener un sistema de extracción localizado para capturar cualquier liberación de gas en su origen. Los cilindros de ozono deben almacenarse en áreas refrigeradas, lejos de agentes reductores, materiales inflamables 0 productos que puedan catalizar su disgregación. Hay que tener en cuenta que si los ozonadores funcionan a presiones negativas y tienen dispositivos de paro automático en caso de avería, se minimiza la posibilidad de que se produzcan fugas.

Los equipos eléctricos utilizados en procesos que empleen ozono deben estar perfectamente aislados y su mantenimiento debe estar a cargo de personal experimentado. Si se utilizan ozonadores, los conductos y equipos accesorios deberán tener dispositivos que cierren inmediatamente los ozonadores en los casos siguientes: si se detecta una fuga; cuando se produce una pérdida de eficacia en las funciones de ventilación, deshumidificación o refrigeración; si se produce un exceso de presión o un vacío (según el sistema); 0 si la potencia del sistema es excesiva o insuficiente.

Cuando se instalen ozonadores, deberán ir provistos de detectores específicos para ozono. No puede confiarse en el sentido del olfato porque puede saturarse. Las fugas de ozono se detectan con tiras reactivas de yoduro de potasio que se vuelven azules, pero no es un método específico, ya que la prueba da positivo con la mayoría de los oxidantes. Es mejor realizar un control de fugas continuado por medio de acumuladores electroquímicos, fotometría de ultravioletas o quimioluminiscencia, conectando el dispositivo de detección elegido a un sistema de alarma que actúe cuando se alcancen ciertas concentraciones. 


\section{- O BJETIVOS Y PRINCIPIOS DE LA VENTILACION GENERAL Y DE LA VENTILACION DE DILUCION}

\section{E milio Castejón}

Si los contaminantes generados en un lugar de trabajo han de ser controlados ventilando todo el recinto, hablamos de ventilación general. Su utilización implica la aceptación de que el contaminante se distribuya en cierta medida por todo el lugar de trabajo y pueda por tanto afectar a los trabajadores que estén lejos de la fuente de contaminación. Por consiguiente, la ventilación general es la estrategia opuesta a la extracción localizada, que pretende eliminar el contaminante interceptándolo lo más cerca posible de la fuente (véase "El aire en interiores: métodos de control y depuración", en este mismo capítulo).

U no de los objetivos básicos de cualquier sistema de ventilación general es el control de los olores corporales, y es posible lograrlo suministrando no menos de 0,45 metros cúbicos por minuto de aire fresco por ocupante. Si se fuma con frecuencia o el trabajo requiere un intenso esfuerzo físico, será preciso aumentar la ventilación, hasta superar los $0,9 \mathrm{~m}^{3} / \mathrm{min}$ por persona.

Si los únicos problemas ambientales que debe resolver el sistema de ventilación son los que acabamos de describir, es conveniente tener en cuenta que cada recinto tiene cierto nivel de renovación de aire "natural" por medio de la llamada "infiltración", que se produce a través de puertas y ventanas, incluso estando cerradas, y a través de otros puntos de penetración de las paredes. Los manuales de los sistemas de aire acondicionado suelen contener amplia información a este respecto, pero puede decirse que, como mínimo, el nivel de ventilación debido a la infiltración alcanza entre las 0,25 y 0,5 renovaciones por hora. Un recinto industrial experimentará normalmente entre 0,5 y 3 renovaciones de aire por hora.

Si se utiliza para controlar contaminantes químicos, la ventilación general deberá limitarse exclusivamente a aquellas situaciones en las que no se generen grandes cantidades de contaminantes y sean de toxicidad relativamente moderada, y en las que los trabajadores no realicen sus tareas muy cerca de la fuente de contaminación. Si no se respetan estas condiciones, será difícil conseguir un control adecuado del ambiente de trabajo ya que las tasas de renovación de aire tendrán que ser tan altas que la velocidad del aire creará malestar, además de que mantener unas tasas de renovación tan altas resulta caro. Por consiguiente, no suele recomendarse la ventilación general para el control de sustancias químicas, excepto en el caso de los disolventes que tengan concentraciones admisibles de más de 100 partes por millón.

Por otra parte, si el objetivo de la ventilación general es mantener las características térmicas del ambiente de trabajo con vistas a cumplir límites legalmente aceptables o recomendaciones técnicas, como las directrices de la 0 rganización Internacional de Normalización (International O rganization for Standardization, ISO), este método tiene menos limitaciones. Por consiguiente, la ventilación general se utiliza más que para controlar el ambiente térmico, para limitar la contaminación química, pero es obligado reconocer su utilidad como complemento de las técnicas de extracción localizada.

Aunque las expresiones ventilación general y ventilación por dilución se han considerado sinónimas durante muchos años, en la actualidad ya no es así, debido a una nueva estrategia de ventilación general: la ventilación por desplazamiento. Aunque la ventilación por dilución tanto como la ventilación por desplazamiento encajan en la definición de ventilación general anteriormente descrita, sus estrategias para controlar la contaminación son muy diferentes.

La ventilación por dilución tiene por objeto mezclar al máximo el aire que se introduce mecánicamente con todo el aire ya existente, de modo que la concentración de un determinado contaminante sea lo más uniforme posible en todo el espacio (o de modo que la temperatura sea lo más uniforme posible, si lo que se pretende conseguir es el control térmico). Para conseguir la uniformidad, se inyectan corrientes de aire desde el techo a velocidad relativamente alta, para generar una fuerte circulación del aire. El resultado es un alto grado de mezcla del aire fresco con el aire ya presente en el espacio en cuestión.

La ventilación por desplazamiento, debería ser, en teoría, la inyección de aire en un recinto de manera que el aire fresco desplace el aire anteriormente existente sin mezclarse con él. La ventilación por desplazamiento se consigue inyectando aire fresco lentamente y cerca del suelo y realizando la extracción de aire cerca del techo. El uso de este tipo de ventilación para controlar el ambiente térmico tiene la ventaja de que aprovecha el movimiento natural del aire generado por variaciones de densidad provocadas, a su vez, por diferencias de temperatura. Aunque la ventilación por desplazamiento ya se utiliza mucho en situaciones industriales, la bibliografía sobre este tema es todavía bastante limitada, por lo que sigue siendo difícil evaluar su eficacia.

\section{La ventilación por dilución}

El diseño de un sistema de ventilación por dilución se basa en la hipótesis de que la concentración del contaminante es la misma en todo el espacio. Los ingenieros químicos suelen referirse a este modelo como el "tanque agitado".

Si se asume que el aire inyectado en el espacio en cuestión está exento del contaminante y que en el momento inicial su concentración en dicho espacio es cero, será necesario conocer dos hechos a fin de calcular la velocidad de ventilación necesaria: la cantidad de contaminante que se genera y el nivel de concentración ambiental que se busca (que hipotéticamente será el mismo en todo el recinto).

En estas condiciones, los cálculos correspondientes dan lugar a la siguiente ecuación:

$$
c(t)=\frac{a}{Q}\left(1-\exp \left(-\frac{Q t}{V}\right)\right)
$$

donde

$c(t)=$ Concentración del contaminante en el espacio en cuestión, en el tiempot.

a $=$ C antidad de contaminante que se genera (masa por unidad de tiempo).

Q = Velocidad de alimentación de aire fresco (volumen por unidad de tiempo).

$\mathrm{V}=$ Volumen del espacio en cuestión.

La ecuación anterior demuestra que la concentración tenderá a ser constante en el valor a/ $Q$, y que lo hará más rápidamente cuanto menor sea el valor de $Q / V$, al que suele denominarse "número de renovaciones por unidad de tiempo". Aunque ocasionalmente el índice de calidad de la ventilación se considere prácticamente equivalente a ese valor, la ecuación citada demuestra claramente que su influencia se limita a controlar la velocidad de estabilización de las condiciones ambientales, no el nivel de concentración en el que se producirá la estabilidad. Eso dependerá exclusivamente de la cantidad de contaminante que se genere (a) y de la velocidad de ventilación (Q). 
Si el aire de un espacio determinado está contaminado pero no se generan nuevas cantidades de contaminante, la velocidad de disminución de la concentración a lo largo de un período de tiempo vendrá dada por la siguiente expresión:

$$
c_{2}=c_{1} \exp \left(-\frac{Q\left(t_{2}-t_{1}\right)}{V}\right)
$$

donde $Q$ y $V$ tienen el significado indicado anteriormente, $t_{1}$ y $t_{2}$ son los tiempos inicial y final respectivamente, y $c_{1}$ y $c_{2}$ son las concentraciones inicial y final.

Es posible hallar expresiones de cálculo en casos en los que la concentración inicial no sea cero (Constance 1983; ACGIH 1992), en los que el aire de ventilación inyectado en el recinto no esté totalmente exento de contaminante (por ejemplo, porque se recicla parte del aire a fin de reducir costes de calefacción en invierno), o en los que las cantidades de contaminante generadas varíen en función del tiempo.

Si hacemos caso omiso de la etapa de transición y asumimos que se ha logrado la estabilidad, la ecuación indica que la velocidad de ventilación es equivalente a a/ $c_{\text {lim }}$, donde $c_{\text {lim }}$ es el valor de la concentración que debe mantenerse en el espacio dado. Tal valor queda recogido en disposiciones o bien, como norma auxiliar, en recomendaciones técnicas, como los Valores Límite U mbral (TLV) de la Conferencia Americana de Higienistas Industriales del Gobierno (ACGIH), que recomienda que la velocidad de ventilación se calcule con la fórmula:

$$
Q=\frac{a}{c_{\lim }} K
$$

donde a y $c_{\text {lim }}$ tienen el significado ya descrito y $\mathrm{K}$ es un factor de seguridad. $\mathrm{H}$ ay que elegir un valor de $\mathrm{K}$ entre 1 y 10 en función de la eficacia de la mezcla de aire en el espacio dado, de la toxicidad del disolvente (cuanto menor sea clim, mayor será el valor de K), y de cualquier otra circunstancia que el higienista industrial considere pertinente. $\mathrm{La} A C G I H$ cita como criterios determinantes, entre otros, la duración del proceso, el ciclo de operaciones y la ubicación habitual de los trabajadores con respecto a las fuentes de emisión del contaminante, el número de dichas fuentes y su ubicación, los cambios en la cantidad de ventilación natural achacables a causas estacionales y la reducción prevista de la eficacia funcional de los equipos de ventilación.

En cualquier caso, para utilizar la fórmula anterior se requiere un conocimiento bastante exacto de los valores de a y $\mathrm{K}$ que deberán utilizarse, por lo que aquí se ofrecen algunas sugerencias al respecto.

Por lo común es posible calcular la cantidad de contaminante generada a partir de la cantidad de determinados materiales consumidos en el proceso generador del contaminante. De modo que, en el caso de un disolvente, la cantidad utilizada será una buena indicación de la cantidad máxima que pueda existir en el ambiente.

Como ya se ha indicado, el valor de K deberá determinarse en función de la eficacia de la mezcla de aire. Por consiguiente, ese valor será menor cuanto más uniforme sea la distribución de la concentración del contaminante existente en cualquier punto del espacio en cuestión. Ello, a su vez, dependerá de cómo se distribuya el aire dentro del espacio ventilado.

De acuerdo con estos criterios, deberán utilizarse valores mínimos de $\mathrm{K}$ cuando se inyecte aire de manera que éste se reparta uniformemente, por ejemplo, utilizando una cámara de sobrepresión) y cuando la inyección y extracción del aire se realicen en extremos opuestos del espacio dado. Por otra parte, deberán utilizarse mayores valores de $\mathrm{K}$ cuando el aire se suministre de manera puntual y se extraiga en puntos cercanos a la entrada de aire fresco (véase la Figura 45.4).
Figura 45.4 • Esquema de circulación del aire en una habitación con dos aberturas de suministro.

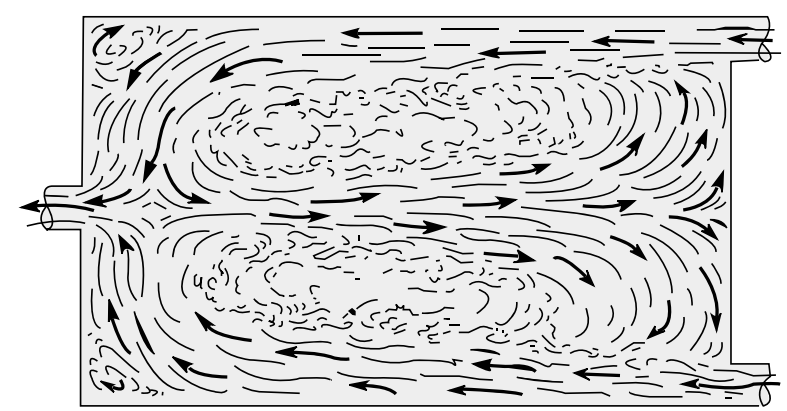

Fuente: Baturin 1972.

$\mathrm{H}$ ay que subrayar que cuando se inyecta aire en un espacio determinado (especialmente si se hace a alta velocidad), la corriente de aire así creada ejerce una fuerza considerable sobre el aire circundante. A continuación, el aire se mezcla con la corriente y reduce su velocidad, creando además una turbulencia cuantificable. En consecuencia, este proceso hace que el aire ya presente en el recinto se mezcle impetuosamente con el aire fresco inyectado, generando corrientes de aire internas. Predecir estas corrientes, incluso en términos generales, requiere una gran dosis de experiencia (véase la Figura 45.5).

A fin de evitar los problemas que provocaría que los trabajadores se vieran sometidos a corrientes de aire a velocidades relativamente altas, el aire suele inyectarse por medio de rejillas difusoras diseñadas para facilitar la rápida mezcla del aire fresco con el aire ya presente en el recinto. Así se consigue que las zonas en las que el aire se mueve a alta velocidad tengan la menor extensión posible.

Tales corrientes no se producen en las proximidades de los puntos de evacuación o extracción del aire a través de puertas, ventanas, extractores $u$ otras aberturas. EI aire llega a las rejillas de extracción desde todas las direcciones, de modo que, incluso a una distancia relativamente corta de las mismas, el movimiento del aire no se percibe fácilmente como corriente de aire.

En cualquier caso, cuando de lo que se trata es de la distribución del aire, es importante situar los puestos de trabajo, en la medida de lo posible, de manera que el aire fresco llegue a los trabajadores antes que a las fuentes de contaminación.

Si existen fuentes importantes de calor en el recinto, el movimiento de aire vendrá condicionado en gran medida por las corrientes de convección provocadas por las diferencias de densidad entre el aire frío, más denso, y el aire caliente, más ligero. En espacios de este tipo, el diseñador de la distribución del aire ha de tener presente la existencia de tales fuentes de calor, o el movimiento de aire podría ser muy diferente del previsto.

Por otra parte, la presencia de contaminación química no altera la densidad del aire de manera cuantificable. Aunque los contaminantes en su estado puro pueden tener una densidad muy diferente de la del aire (normalmente mucho mayor), dadas las concentraciones reales en el lugar de trabajo, la mezcla de aire y contaminante no tiene una densidad significativamente diferente a la del aire puro.

A demás, es preciso señalar que uno de los errores más habituales que se cometen al aplicar este tipo de ventilación es instalar sólo extractores de aire en el recinto, sin prever entradas de aire adecuadas. Así se disminuye la eficacia de los ventiladores de extracción y, por consiguiente, las velocidades reales de 
Figura 45.5 - Factores K recomendados para ubicar entradas y salidas de aire.

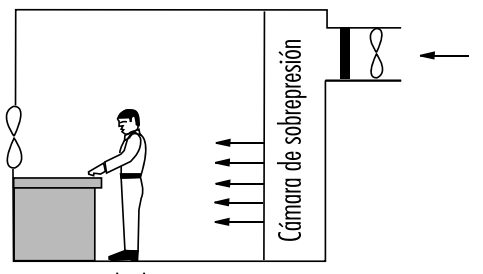

Entrada de aire óptima

Salida de aire óptima

$K=1,0$ mínimo

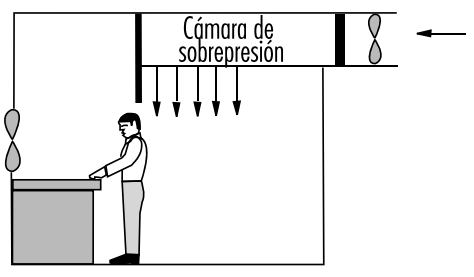

Entrada de aire óptima Salida de aire óptima $K=1,0$ mínimo

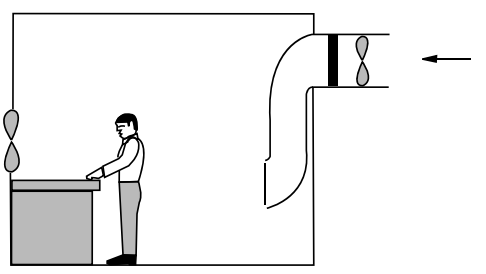

Entrada de aire óptima Salida de aire óptima $\mathrm{K}=1,5$ mínimo
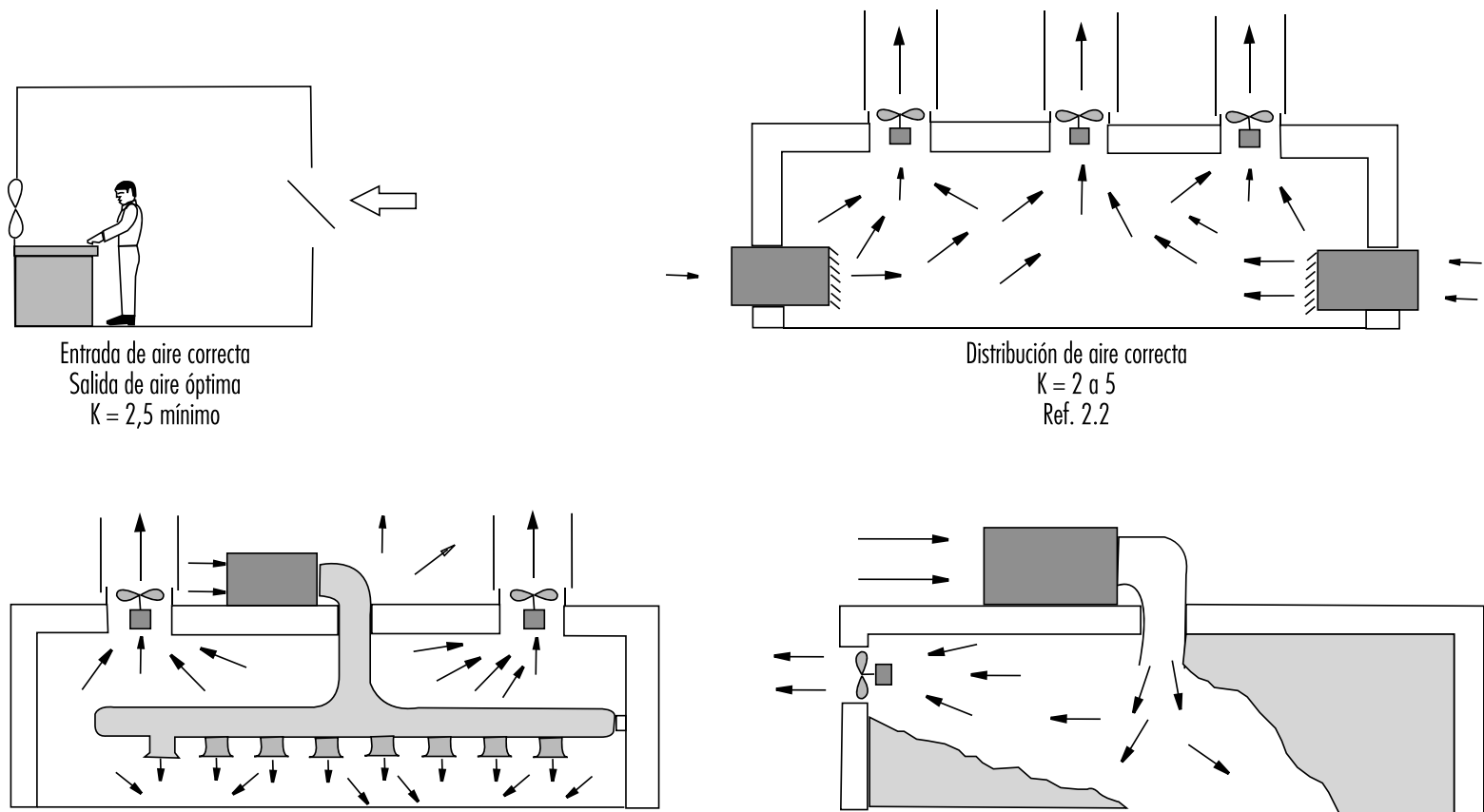

Distribución de aire bueno

$K=1,5$ a 2

Ref. 2.2

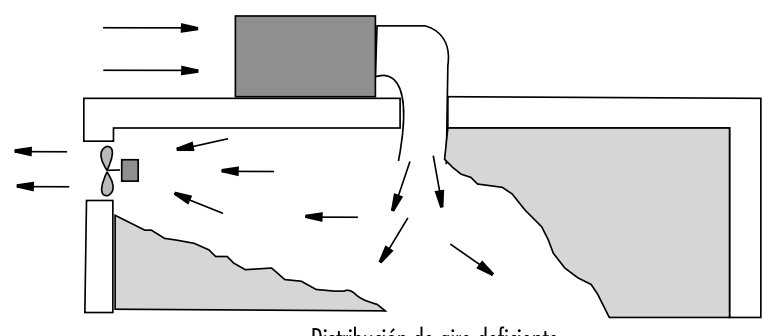

Distribución de aire deficiente

$\mathrm{K}=5$ a 10

Ref. 2.2

Los valores de K (factor de seguridad aquí utilizado) únicamente tienen en cuenta las entradas y salidas de extracción de aire, y son sólo orientativos. En la ecuación debe emplearse el valor correcto de K, el cual se determinará teniendo en cuenta lo siguiente: a) el número y la situación de los trabajadores, b) las fuentes de contaminación y c) la toxicidad de los contaminantes. Ref. Z.Z: Norma AFOSH 161.2 de las Fuerzas Aéreas.

Fuente: ACGIH 1992.

extracción de aire son muy inferiores a las previstas. En consecuencia, el contaminante se encuentra en concentraciones ambientales superiores a las calculadas inicialmente.

Para evitar este problema, es preciso estudiar de qué modo se introducirá el aire en el espacio en cuestión. L o recomendable es utilizar ventiladores de introducción además de ventiladores de extracción. Normalmente, la velocidad de extracción debe ser superior a la de introducción a fin de tener en cuenta la infiltración por ventanas y otras aberturas. A demás, conviene mantener dicho espacio bajo una presión ligeramente negativa para evitar el arrastre de contaminantes a zonas no contaminadas.

\section{La ventilación por desplazamiento}

Como ya se ha mencionado, lo que se pretende con la ventilación por desplazamiento es minimizar la mezcla de aire fresco con el aire ya existente en el recinto así como ajustar el sistema al modelo conocido como "flujo pistón", lo que suele hacerse introduciendo aire lentamente y a poca altura y extrayéndolo cerca del techo. Tiene dos ventajas en comparación con la ventilación por dilución.

En primer lugar, permite reducir la velocidad de renovación del aire, porque la contaminación se concentra cerca del techo, donde no hay trabajadores que lo respiren. La concentración media será entonces superior al valor $c_{\text {lim }}$ antes mencionado, pero eso no implica un mayor riesgo para los trabajadores, porque en la zona ocupada del espacio en cuestión, la concentración del contaminante será igual o menor que $c_{\text {lim. }}$.

Además, cuando el objetivo de la ventilación es el control del ambiente térmico, la ventilación por desplazamiento permite introducir aire más caliente de lo que sería necesario en un sistema de ventilación por dilución. La razón está en que el aire caliente se extrae a una temperatura superior en varios grados a 
la temperatura existente en la zona ocupada del espacio en cuestión.

Los principios fundamentales de la ventilación por desplazamiento se deben a Sandberg, quien a principios del decenio de 1980 elaboró su teoría general para el análisis de las situaciones en las que haya concentraciones desiguales de contaminantes en espacios cerrados. A sí se superaron las limitaciones teóricas de la ventilación por dilución (que presupone una concentración uniforme en todo el espacio dado) y se abrió el camino a las aplicaciones prácticas (Sandberg 1981).

Aunque la ventilación por desplazamiento se utiliza mucho en algunos países, especialmente en Escandinavia, se han publicado muy pocos estudios que comparen la eficacia de los diferentes métodos en instalaciones reales. Ello se debe, sin duda, a las dificultades prácticas que presenta la instalación de dos sistemas de ventilación diferentes en una fábrica y a que el análisis experimental de estos tipos de sistemas requiere el uso de localizadores. La localización se realiza agregando un gas localizador a la corriente de aire de ventilación y cuantificando después las concentraciones del gas en diferentes puntos del recinto y en el aire extraído. A partir de esta clase de examen puede deducirse cómo se distribuye el aire en el interior del recinto y comparar después la eficacia de los diferentes sistemas de ventilación.

Los pocos estudios disponibles que se han realizado en instalaciones reales no son concluyentes, excepto por lo que respecta al hecho de que los sistemas que emplean ventilación por desplazamiento renuevan mejor el aire. Sin embargo, en estos estudios suelen expresarse reservas acerca de los resultados en cuanto que no han sido confirmados por mediciones del nivel de contaminación ambiental en los puestos de trabajo.

\section{- CRITERIOS DE VENTILACION PARA EDIFICIOS NO INDUSTRIALES}

\section{A. Hernández Calleja}

Una de las funciones principales de un edificio en el que se realizan actividades no industriales (oficinas, colegios, viviendas, etc.) es proporcionar a los ocupantes un ambiente saludable y confortable para trabajar. La calidad de este ambiente depende, en gran medida, del correcto diseño, mantenimiento y funcionamiento de los sistemas de ventilación y climatización del edificio.

Por consiguiente, estos sistemas deben crear condiciones térmicas aceptables (temperatura y humedad) y una calidad del aire interior también aceptable. En otras palabras: conseguir una mezcla adecuada de aire exterior con aire interior y emplear sistemas de filtrado y depuración capaces de eliminar los contaminantes del ambiente interior.

$\mathrm{L} a$ idea de que el bienestar en espacios interiores requiere el uso de aire limpio del exterior se ha venido expresando desde el siglo X VIII. Benjamin Franklin reconoció que el aire de una habitación es más sano si se puede ventilar de manera natural, abriendo ventanas. $L$ a idea de que suministrando grandes cantidades de aire exterior contribuía a reducir el riesgo de contagio de enfermedades como la tuberculosis ganó credibilidad en el siglo XIX.

Los estudios realizados durante el decenio de 1930 demostraron que, a fin de diluir los efluvios biológicos humanos en concentraciones que no causaran malestar a causa de los olores, el volumen de aire fresco exterior necesario en una habitación varía entre 17 y 30 metros cúbicos por hora y por ocupante.

La Sociedad Americana de Ingenieros de Calefacción, Refrigeración y Acondicionamiento del Aire (ASHRAE) recomendaba, en su norma no 62 del año 1973, un flujo mínimo de
34 metros cúbicos de aire exterior por hora y por ocupante para controlar los olores. Se recomendaba un mínimo absoluto de $8,5 \mathrm{~m}^{3} /$ hora/ ocupante para evitar que el dióxido de carbono supere las 2.500 ppm, que es la mitad del límite de exposición establecido para ambientes industriales.

En el año 1975 esta misma organización adoptó el citado mínimo absoluto en su norma no 90 - en mitad de una crisis energética-, dejando temporalmente a un lado la necesidad de mayores flujos de ventilación para diluir contaminantes, como el humo del tabaco, los efluvios biológicos, etcétera.

En su norma no 62 (1981), ASHRAE rectificó esta omisión y estableció su recomendación en $34 \mathrm{~m}^{3} /$ hora/ ocupante para zonas de fumadores y en $8,5 \mathrm{~m}^{3} /$ hora/ ocupante para zonas de no fumadores.

La última norma publicada por ASHRAE, también con el no 62 (1989), establece un mínimo de $25,5 \mathrm{~m}^{3} /$ hora/ ocupante para espacios interiores ocupados, con independencia de si se permite fumar o no. También recomienda aumentar este valor si el aire introducido en el edificio no se mezcla adecuadamente en la zona de respiración o si existen fuentes de contaminación inusuales en el edificio.

En 1992, la Comisión de las Comunidades Europeas editó la publicación Guidelines for Ventilation R equirements in B uildings (D irectrices para calcular las necesidades de ventilación en edificios). En contraste con las recomendaciones existentes para normas de ventilación, esta guía no especifica volúmenes de ventilación previstos para un espacio determinado; en su lugar, da recomendaciones de cálculo en función de la calidad deseada del aire interior.

Las normas existentes prescriben unos volúmenes de ventilación predeterminados que deberán suministrarse por ocupante. Las tendencias que evidencian las nuevas directrices demuestran que los cálculos de volúmenes no garantizan por sí solos una buena calidad del aire interior en todos los ámbitos. Hay tres razones fundamentales.

En primer lugar, presuponen que los ocupantes son las únicas fuentes de contaminación. En estudios recientes se ha demostrado que es preciso tener en cuenta otras fuentes de contaminación, como el mobiliario, las tapicerías y el propio sistema de ventilación. La segunda razón es que estas normas recomiendan la misma cantidad de aire exterior con independencia de la calidad del aire que se introduce en el edificio. Y la tercera razón es que no definen claramente la calidad que debe tener el aire en el interior del recinto. Por consiguiente, lo que se propone es que en el futuro las normas de ventilación se basen en las tres premisas siguientes: la elección de una categoría definida de calidad del aire para el espacio que se va a ventilar, la carga total de contaminantes en el espacio ocupado y la calidad del aire exterior disponible.

\section{La calidad percibida del aire}

La calidad del aire interior puede definirse como el grado de satisfacción de las exigencias y necesidades del ser humano. Básicamente, los ocupantes de un espacio exigen dos cosas con respecto al aire que respiran: percibirlo como aire fresco y no viciado, estancado o irritante; y saber que los efectos perjudiciales para la salud que pueden derivarse de respirar ese aire son despreciables.

Es habitual pensar que el grado de calidad del aire en un espacio determinado depende más de los componentes de ese aire que de la repercusión que tiene en los ocupantes. Por tanto, parece fácil evaluar la calidad del aire, ya que se asume que a partir de su composición es posible conocer su calidad. Es un método de evaluación de la calidad del aire que funciona bien en ámbitos industriales, donde hallamos compuestos químicos que se utilizan en el proceso de producción o se derivan del 
mismo y donde existen aparatos de medición y criterios de referencia para valorar las concentraciones. Ahora bien, no sirve para ambientes no industriales, que son lugares donde puede haber miles de sustancias químicas, pero a concentraciones muy bajas, quizá mil veces inferiores a los límites de exposición recomendados; la evaluación de estas sustancias una por una daría lugar a una falsa valoración de la calidad de ese aire y probablemente se juzgaría alta. Pero falta aún un aspecto, y es que no se conoce el efecto conjunto de esos miles de sustancias en los seres humanos, razón por la que se percibe el aire como viciado, estancado o irritante.

La conclusión a la que se ha llegado es que los métodos tradicionales utilizados en la higiene industrial no están bien adaptados para definir el grado de calidad que percibirán los seres humanos que hayan de respirar el aire evaluado. La alternativa a los análisis químicos es utilizar personas como dispositivos de medición para cuantificar la contaminación del aire, empleando jurados para realizar las evaluaciones.

Los seres humanos perciben la calidad del aire con dos sentidos: el olfativo, situado en la cavidad nasal y sensible a cientos de miles de sustancias olorosas, y el químico, situado en las membranas mucosas de la nariz y los ojos, que es sensible a un número parecido de sustancias irritantes presentes en el aire. Es la respuesta conjunta de ambos sentidos la que determina cómo se percibe el aire y la que permite que el sujeto juzgue si su calidad es aceptable.

\section{La unidad olf}

Un olf (del latín = olfactus) es la tasa de contaminantes al aire (bioefluentes) que emite una persona normal, entendiendo por persona normal un adulto de edad media que trabaja en una oficina 0 en un lugar de trabajo no industrial similar, de forma sedentaria y térmicamente confortable con un nivel de higiene personal de 0,7 baños/ día. Se eligió la contaminación de un ser humano para definir el término olf por dos razones: la primera es que los efluvios biológicos emitidos por una persona son bien conocidos, y la segunda es que existía mucha información sobre la insatisfacción provocada por tales efluvios.

Cualquier otra fuente de contaminación puede expresarse como el número de personas normales (unidades olf) necesarias para provocar la misma cantidad de insatisfacción que la fuente de contaminación evaluada.

En la Figura 45.6 se representa una curva que define un olf. La curva muestra cómo se percibe la contaminación producida

Figura 45.6 • Curva de definición de la unidad olf.

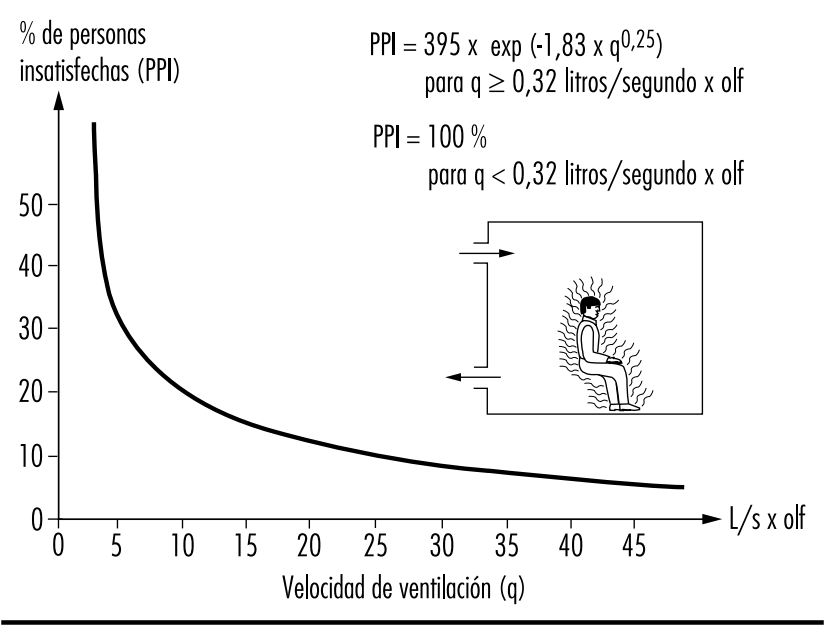

Figura 45.7 - Relación entre la calidad percibida del aire expresada en porcentaje de personas insatisfechas y en decipoles.

Calidad percibida del aire/

$\%$ de personas

insatisfechas (PPI)

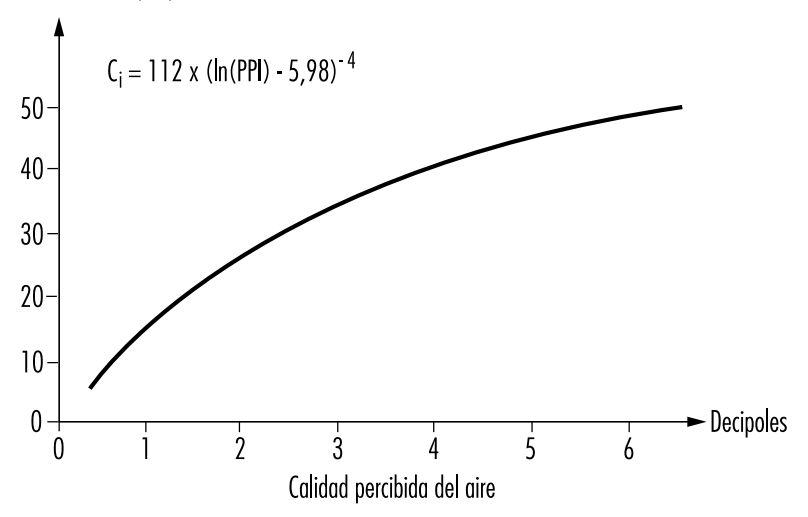

por una persona normal (1 olf) a diferentes velocidades de ventilación, y permite calcular el porcentaje de individuos insatisfechos - en otras palabras, los que percibirán que la calidad del aire es inaceptable nada más entrar en la habitación-. La curva se basa en diferentes estudios europeos en los que 168 personas juzgaron la calidad del aire contaminado por más de un millar de personas, tanto hombres como mujeres, consideradas normales. Estudios parecidos realizados en Norteamérica y Japón presentan un alto grado de correlación con los datos europeos.

\section{La unidad decipol}

La concentración de contaminación en el aire depende de la fuente de contaminación y de su dilución a consecuencia de la ventilación. La contaminación percibida en el aire se define como la concentración de efluvios biológicos humanos que provocarían la misma incomodidad o insatisfacción que la concentración de aire contaminado que se está evaluando. Un decipol (del latín pollutio) es la contaminación provocada por una persona normal (1 olf) cuando la velocidad de ventilación es de 10 litros de aire no contaminado por segundo, de modo que podemos decir que:

1 decipol $=0,1$ olf $/$ (litro/ segundo)

En la Figura 45.7, obtenida a partir de los mismos datos que la figura anterior, se presenta la relación entre la calidad percibida del aire expresada en porcentaje de individuos insatisfechos y en decipoles.

Tabla 45.7 • N iveles de calidad del aire en interiores.

\begin{tabular}{|c|c|c|c|}
\hline \multicolumn{4}{|c|}{ Calidad percibida del aire } \\
\hline $\begin{array}{l}\text { Categoría } \\
\text { (nivel de } \\
\text { calidad) }\end{array}$ & $\begin{array}{l}\text { Porcentaje de } \\
\text { individuos } \\
\text { insatisfechos }\end{array}$ & Decipoles & $\begin{array}{l}\text { Velocidad de ventilación } \\
\text { requerida } 1 \\
\text { litros/ segundo } \times \text { olf }\end{array}$ \\
\hline A & 10 & 0,6 & 16 \\
\hline B & 20 & 1,4 & 7 \\
\hline C & 30 & 2,5 & 4 \\
\hline
\end{tabular}

1 Se supone que el aire exterior está limpio y que la eficacia del sistema de ventilación es igual a uno. Fuente: CCE 1992 
Para determinar la velocidad de ventilación necesaria desde el punto de vista del confort, es esencial elegir la calidad del aire que se desea tener en el recinto. En la Tabla 45.7 se proponen tres categorías o niveles de calidad, que se obtienen a partir de las Figuras 45.6 y 45.7. Cada nivel se corresponde con un determinado porcentaje de personas insatisfechas. $L$ a elección de uno u otro nivel dependerá, sobre todo, de la utilización del espacio y de cuestiones económicas.

Como ya se ha indicado, los datos son resultado de experimentos realizados con jurados, pero es importante tener en cuenta que algunas de las sustancias presentes en el aire que pueden ser peligrosas (compuestos cancerígenos, microorganismos y sustancias radiactivas, por ejemplo) no son reconocidas por los sentidos, y que los efectos sensoriales de otros contaminantes no guardan relación cuantitativa con su toxicidad.

\section{Fuentes de contaminación}

Como ya se ha dicho, uno de los puntos débiles de las normas de ventilación actuales es que sólo tienen en cuenta a los ocupantes como fuentes de contaminación, mientras que está reconocido que las futuras normas deberán tener en cuenta todas las fuentes de contaminación posibles. A parte de los ocupantes y sus actividades, incluida la posibilidad de que fumen, existen otras fuentes que contribuyen significativamente a la contaminación del aire, como el mobiliario, las tapicerías y alfombras, los materiales de construcción, los productos utilizados en decoración, los productos de limpieza y el propio sistema de ventilación.

Lo que determina la carga de contaminación del aire en un espacio determinado es la combinación de todas estas fuentes de contaminación. Tal carga puede expresarse como contaminación química o como contaminación sensorial en unidades olf.

Tabla 45.8 • Contaminación originada por los ocupantes de un edificio.

$\begin{array}{llll}\text { Carga } & \mathrm{CO}_{2} & \mathrm{CO}^{3} & \text { Vapor } \\ \text { sensorial } & {[\mathrm{I} /(\mathrm{h} \times} & {[\mathrm{II}(\mathrm{h} \times} & \text { de agua } \\ \text { olf/ ocupante } & \text { ocupante) }] & \text { ocupante) }] & {[\mathrm{g} /(\mathrm{h} \times} \\ & & \text { ocupante) }]\end{array}$

Sedentarios, 1-1,2 met $^{1}$

\begin{tabular}{|c|c|c|c|c|}
\hline $0 \%$ de fumadores & 1 & 19 & & 50 \\
\hline $20 \%$ de fumadores ${ }^{2}$ & 2 & 19 & $11 \times 10^{-3}$ & 50 \\
\hline $40 \%$ de fumadores ${ }^{2}$ & 3 & 19 & $21 \times 10^{-3}$ & 50 \\
\hline $100 \%$ de fumadores ${ }^{2}$ & 6 & 19 & $53 \times 10^{-3}$ & 50 \\
\hline \multicolumn{5}{|l|}{ Ejercicio físico } \\
\hline Bajo, 3 met & 4 & 50 & & 200 \\
\hline Medio, 6 met & 10 & 100 & & 430 \\
\hline $\begin{array}{l}\text { Alto (atlético), } \\
10 \text { met }\end{array}$ & 20 & 170 & & 750 \\
\hline \multicolumn{5}{|l|}{ Niños } \\
\hline $\begin{array}{l}\text { Centro de atención } \\
\text { infantil } \\
\text { ( } 3-6 \text { años), } \\
2,7 \text { met }\end{array}$ & 1,2 & 18 & & 90 \\
\hline $\begin{array}{l}\text { Colegio } \\
\text { (14-16 años), } \\
1,2 \text { met }\end{array}$ & 1,3 & 19 & & 50 \\
\hline
\end{tabular}

11 met es la tasa metabólica de una persona sedentaria en reposo ( 1 met $=58 \mathrm{~W} / \mathrm{m}^{2}$ de superficie cutánea). ${ }^{2}$ Consumo medio de 1,2 cigarrillos/ hora por fumador. Tasa de emisión media, $44 \mathrm{ml}$ de CO por cigarrillo. ${ }^{3}$ Del humo del tabaco. ${ }^{4}$ Aplicable a personas cercanas a la neutralidad térmica. Fuente: CCE 1992.
Tabla 45.9 • Ejemplos del grado de ocupación de diferentes edificios.

$\begin{array}{ll}\text { Edificio } & \text { Ocupantes } / \mathrm{m}^{2} \\ \text { Oficinas } & 0,07 \\ \text { Salas de conferencias } & 0,5 \\ \text { Teatros, otros grandes espacios de reuniones } & 1,5 \\ \text { Colegios (aulas) } & 0,5 \\ \text { Centros de atención infantil } & 0,5 \\ \text { Viviendas } & 0,05\end{array}$

Fuente: CCE 1992.

En este último tipo se incluye el efecto de varias sustancias químicas tal como las perciben los seres humanos.

\section{La carga química}

La contaminación que emana de un material determinado puede expresarse como la tasa de emisión de cada sustancia química. La carga total de contaminación química se calcula sumando todas las fuentes y se expresa en microgramos por segundo ( $\mu \mathrm{g} / \mathrm{s})$.

En realidad, es difícil calcular la carga de contaminación porque es común disponer de pocos datos sobre las tasas de emisión de muchos materiales habitualmente utilizados.

\section{La carga sensorial}

La carga de contaminación que perciben los sentidos surge de las fuentes de contaminación que afectan a la calidad percibida del aire. El valor dado de esta carga sensorial puede calcularse sumando todos los olf de las diferentes fuentes de contaminación existentes en un espacio determinado. Como en el caso anterior, todavía no se dispone de mucha información sobre los olf por metro cuadrado (olf/ $\mathrm{m}^{2}$ ) de muchos materiales. Por esa razón resulta más práctico calcular la carga sensorial de todo el edificio, incluidos los ocupantes, el mobiliario y el sistema de ventilación.

En la Tabla 45.8 se presenta la carga de contaminación en unidades olf creada por los ocupantes del edificio a medida que realizan diferentes tipos de actividades, en función de quienes fuman y quienes no fuman, así como la producción de varios compuestos como el dióxido de carbono $\left(\mathrm{CO}_{2}\right)$, el monóxido de carbono (C O ) y el vapor de agua. En la Tabla 45.9 se presentan varios ejemplos de porcentajes de ocupación típicos en diferentes tipos de espacios. Y por último, en la Tabla 45.10 se exponen los resultados de la carga sensorial - medida en olf por metro cuadrado- presente en diferentes edificios.

Tabla 45.10 • Contaminación debida al edificio.

\begin{tabular}{lll} 
& \multicolumn{2}{l}{ Carga sensorial: olf/ $\mathrm{m}^{2}$} \\
& Promedio & Intervalo \\
Oficinas & 0,3 & $0,02-0,95$ \\
Colegios (aulas) $^{2}$ & 0,3 & $0,12-0,54$ \\
Instalaciones de atención infanti| $^{3}$ & 0,4 & $0,20-0,74$ \\
Teatros $^{4}$ & 0,5 & $0,13-1,32$ \\
Edificios de baja contaminación $^{5}$ & & $0,05-0,1$
\end{tabular}

1 Datos obtenidos en 24 oficinas ventiladas mecánicamente. 2 Datos obtenidos en 6 colegios ventilados mecánicamente. ${ }^{3}$ Datos obtenidos en 9 centros de atención infantil ventilados mecánicamente. ${ }^{4}$ Datos obtenidos en 5 teatros ventilados mecánicamente. ${ }^{5}$ Objetivo que deberán alcanzar los edificios nuevos

Fuente: CCE 1992 
Tabla 45.11 • N iveles de calidad del aire exterior.

\begin{tabular}{|c|c|c|c|c|c|}
\hline & \multirow{2}{*}{$\begin{array}{l}\text { Calidad } \\
\text { percibida } \\
\text { del aire } \\
\text { Decipol }\end{array}$} & \multicolumn{4}{|c|}{ Contaminantes ambientales ${ }^{2}$} \\
\hline & & $\begin{array}{l}\mathrm{CO}_{2} \\
\left(\mathrm{mg} / \mathrm{m}^{3}\right)\end{array}$ & $\begin{array}{l}\mathrm{CO} \\
\left(\mathrm{mg} / \mathrm{m}^{3}\right)\end{array}$ & $\begin{array}{l}\mathrm{NO}_{2} \\
\left(\mu \mathrm{g} / \mathrm{m}^{3}\right)\end{array}$ & $\begin{array}{l}\mathrm{SO}_{2} \\
\left(\mu \mathrm{g} / \mathrm{m}^{3}\right)\end{array}$ \\
\hline $\begin{array}{l}\text { Junto al mar, } \\
\text { en las } \\
\text { montañas }\end{array}$ & 0 & 680 & $0-0,2$ & 2 & 1 \\
\hline $\begin{array}{l}\text { En ciudad, alta } \\
\text { calidad }\end{array}$ & $<0,1$ & 700 & $1-2$ & $5-20$ & $5-20$ \\
\hline $\begin{array}{l}\text { En ciudad, baja } \\
\text { calidad }\end{array}$ & $>0,5$ & $700-800$ & $4-6$ & $50-80$ & $50-100$ \\
\hline
\end{tabular}

1 Los valores de calidad percibida del aire son valores medios diarios. ${ }^{2}$ Los valores de contaminantes corresponden a concentraciones medias anuales.

Fuente: CCE 1992.

\section{Calidad del aire exterior}

0 tra premisa, que ultima los datos necesarios para la creación de normas de ventilación en el futuro, es la calidad del aire exterior. La publicación Air Quality Guidelines for Europe (Directrices de calidad del aire para Europa), editada por la O M S (1987), recoge los valores recomendados de exposición a ciertas sustancias, tanto en espacios interiores como en exteriores

En la Tabla 45.11 se indican los niveles de calidad percibida del aire exterior, así como las concentraciones de varios contaminantes químicos típicos presentes en exteriores.

Es conveniente tener en cuenta que, en muchos casos, la calidad del aire exterior puede ser peor que los niveles indicados en la tabla o en las directrices de la O M S. Entonces será preciso depurar el aire antes de introducirlo en los espacios ocupados.

\section{Eficacia de los sistemas de ventilación}

O tro factor importante, que afectará al cálculo de las necesidades de ventilación de un espacio determinado, es la eficacia de la ventilación $\left(E_{v}\right)$, que se define como la relación entre la concentración de contaminantes en el aire extraído y $\left(C_{e}\right)$ y la concentración en la zona de respiración $\left(C_{b}\right)$.

$$
E_{v}=C_{e} C_{b}
$$

La eficacia de la ventilación depende de la distribución del aire y de la ubicación de las fuentes de contaminación en el espacio en cuestión. Si la mezcla de los contaminantes con el aire es completa, la eficacia de la ventilación será igual a uno; si la calidad del aire en la zona de respiración es mejor que la del aire extraído, entonces la eficacia será mayor que uno y se podrá conseguir la calidad deseada del aire con menores velocidades de ventilación. Por otra parte, será necesario aumentar la ventilación si su eficacia es menor que uno, o para decirlo de otro modo, si la calidad del aire en la zona de respiración es inferior a la calidad del aire extraído.

Para calcular la eficacia de la ventilación, resulta útil dividir los espacios en dos zonas: por una de ellas entra el aire y la otra comprende el resto de la habitación. En los sistemas basados en el principio de mezcla, la zona por la que entra el aire suele estar por encima de la zona de respiración y se alcanzan las mejores condiciones cuando la mezcla es tan completa que ambas zonas se convierten en una. En los sistemas de ventilación basados en el principio de desplazamiento, el aire entra en la zona ocupada por las personas y la zona de extracción suele quedar por encima de las cabezas; en este caso, las mejores condiciones se alcanzan cuando la mezcla entra ambas zonas es mínima.

Por consiguiente, la eficacia de la ventilación depende de la ubicación y las características de los elementos que suministran y extraen el aire y de la ubicación y las características de las fuentes de contaminación. Además, depende también de la temperatura y de los volúmenes de aire suministrados. Es posible calcular la eficacia de un sistema de ventilación por simulación numérica o realizando mediciones. Si no se dispone de datos, pueden utilizarse los valores de la Figura 45.8 para diferentes sistemas de ventilación. Son valores de referencia que tienen en cuenta la repercusión de la distribución del aire, pero no la ubicación de las fuentes de contaminación, ya que suponen que están uniformemente distribuidas por todo el espacio ventilado.

\section{Cálculo de las necesidades de ventilación}

En la Figura 45.9 se presentan las ecuaciones utilizadas para calcular las necesidades de ventilación desde el punto de vista del confort y de la protección de la salud.

\section{Necesidades de ventilación a efectos de confort}

L os primeros pasos para el cálculo de las necesidades a efectos de confort consisten en decidir el nivel de calidad que se desea que tenga el aire en el interior del espacio ventilado (véase la Tabla 45.7), y en calcular la calidad del aire exterior disponible (véase la Tabla 45.11).

El siguiente paso es calcular la carga sensorial, utilizando las Tablas 45.8, 45.9 y 45.10 para seleccionar las cargas en función de los ocupantes y sus actividades, del tipo del edificio y del nivel de ocupación por metro cuadrado de superficie. El valor total se obtiene sumando todos los datos.

En función del principio de funcionamiento del sistema de ventilación y utilizando la Figura 45.8, es posible calcular la eficacia de la ventilación. Aplicando la ecuación (1) de la Figura 45.8 se obtendrá el valor de la cantidad de ventilación necesaria.

Figura 45.8 - Eficacia de la ventilación en la zona de respiración de acuerdo con diferentes principios de ventilación.

\begin{tabular}{|c|c|c|c|}
\hline Principio de ventilación & $\begin{array}{c}\text { Diferencias de temperatura } \\
\text { entre el suministro de } \\
\text { aire y la zona de } \\
\text { respiración }\left(t_{s}-t_{i}\right) \text { en }{ }^{\circ}\end{array}$ & $\begin{array}{c}<0 \\
\text { Eficacia del sistema } \\
\text { de ventilación }\end{array}$ \\
\hline Ventilación \\
por mezcla
\end{tabular}


Figura 45.9 - Ecuaciones para el cálculo de las necesidades de ventilación.

\begin{tabular}{|c|c|}
\hline Confort & Salud \\
\hline$Q_{c}=10 \times \frac{G}{C_{i}-C_{0}} \times \frac{1}{E_{v}}$ & $Q_{H}=\frac{G}{C_{v}-C_{0}} \times \frac{1}{E_{v}}$ \\
\hline $\begin{array}{l}Q_{c}=\text { Corriente de aire necesaria para el } \\
\quad \text { confort (litros/segundo) } \\
G=\text { Carga sensorial total (olf) } \\
C_{i}=\text { Calidad idónea del aire interior (decipoles) } \\
C_{C}=\text { Calidad del aire exterior (entrada) (decipoles) }\end{array}$ & 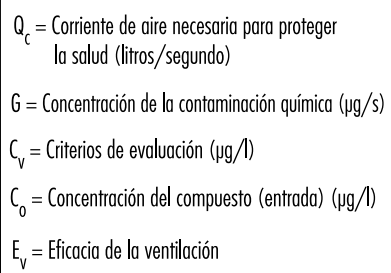 \\
\hline
\end{tabular}

Necesidades de ventilación a efectos de protección de la salud Con un procedimiento similar al descrito en el apartado anterior, pero utilizando la ecuación (2) de la Figura 45.8, se obtendrá el valor de la corriente de ventilación necesaria para prevenir problemas de salud. Para calcular este valor es necesario identificar la sustancia o el grupo de sustancias químicas críticas que nos propongamos controlar y calcular sus concentraciones en el aire; también es necesario considerar diferentes criterios de evaluación, teniendo en cuenta los efectos del contaminante y la sensibilidad de los ocupantes a los que deseamos proteger -niños o ancianos, por ejemplo-.

L amentablemente, sigue siendo difícil calcular las necesidades de ventilación a efectos de protección de la salud, debido a la falta de información sobre algunas de las variables que forman parte de los cálculos, como las emisiones de contaminantes $(G)$, los criterios de evaluación para espacios interiores $\left(C_{v}\right)$ y otras.

Los estudios realizados en este campo demuestran que en los espacios que precisan ventilación para conseguir condiciones confortables, las concentraciones de sustancias químicas son bajas. Ahora bien, esos espacios pueden contener fuentes de contaminación peligrosas. Lo mejor en estos casos es eliminar, sustituir o controlar las fuentes de contaminación en lugar de diluir los contaminantes mediante la ventilación general.

\section{- SISTEMAS DE CALEFACCION Y AIRE ACONDICIONADO}

\section{F. Ramos Pérez y J. G uasch Farrás}

Las necesidades de una persona determinada en relación con la calefacción dependerán de muchos factores, que pueden clasificarse en dos grupos principales: los relacionados con el entorno y los relacionados con factores humanos. Entre los primeros podríamos citar la geografía (altitud y latitud), el clima, el tipo de exposición que conlleva el espacio en el que se encuentra la persona, o las barreras que protegen a dicho espacio del ambiente exterior, etc. Entre los segundos se encuentran el consumo de energía por parte del trabajador, el ritmo de trabajo - la cantidad de effuerzo necesario para realizarlo, la ropa o las prendas utilizadas contra el frío y los gustos o preferencias personales.
La necesidad de calefacción es estacional en muchas regiones, pero esto no significa que pueda prescindirse de la calefacción durante la estación fría. El frío afecta a la salud, al rendimiento físico y mental, a la precisión y, ocasionalmente, puede aumentar el riesgo de accidentes. El objetivo de un sistema de calefacción es mantener condiciones térmicas agradables que eviten o minimicen los efectos perjudiciales para la salud.

L as características fisiológicas del cuerpo humano le permiten soportar grandes variaciones de las condiciones térmicas. LoS seres humanos mantienen su equilibrio térmico por medio del hipotálamo, a través de los receptores térmicos de la piel; así la temperatura del cuerpo se mantiene entre 36 y $38{ }^{\circ} \mathrm{C}$, como puede verse en la Figura 45.10.

L os sistemas de calefacción requieren mecanismos de control muy precisos, especialmente en aquellos casos en los que los trabajadores realizan sus tareas sentados 0 en una posición fija que no estimula la circulación de la sangre hasta sus extremidades. Si el trabajo realizado permite una cierta movilidad, el control del sistema puede ser algo menos preciso. Finalmente, si el trabajo se realiza en condiciones anormalmente adversas, como en cámaras frigoríficas o en condiciones climáticas muy frías, pueden tomarse medidas complementarias de protección, tejidos especiales, regular el tiempo que se pasa en tales condiciones o suministrar calor por medio de sistemas eléctricos incorporados en el atuendo del trabajador.

\section{Definición y descripción del ambiente térmico}

Un requisito exigible a cualquier sistema de calefacción 0 aire acondicionado que funcione correctamente es que tenga en cuenta el control de las variables que definen el ambiente térmico dentro de límites especificados en cada estación del año. He aquí las variables:

1. la temperatura del aire;

2. la temperatura media de las superficies interiores que delimitan el recinto;

3. la humedad del aire,

4. las velocidades y la uniformidad de las velocidades del aire dentro del recinto

Se ha demostrado que, en recintos en los que la temperatura del aire y la de las paredes coincide, existe una relación muy simple entre la temperatura equivalente para una determinada sensación térmica y las temperaturas del aire y de las superficies de las paredes de un recinto, que proporcionan la misma sensación térmica en una habitación diferente. La relación puede expresarse de la forma siguiente:

donde

$$
T_{\text {et }}=\frac{T_{\mathrm{dbt}}+\mathrm{T}_{\mathrm{ast}}}{2}
$$

$\mathrm{T}_{\text {œt }}=$ temperatura equivalente del aire para una sensación térmica dada.

$T_{\mathrm{dbt}}=$ temperatura del aire medida con un termómetro seco.

$T_{\text {ast }}=$ temperatura media medida en la superficie de las paredes

Por ejemplo, si el aire y las paredes de un espacio determinado están a $20^{\circ} \mathrm{C}$, la temperatura equivalente será de $20^{\circ} \mathrm{C}, \mathrm{y}$ la sensación de calor será la misma que en una habitación cuyas paredes estén a una temperatura de $15{ }^{\circ} \mathrm{C}$ y el aire a $25^{\circ} \mathrm{C}$, porque esa habitación tendría la misma temperatura equivalente. D esde el punto de vista de la temperatura, la sensación de confort térmico sería la misma.

\section{Propiedades del aire húmedo}

A la hora de planificar un sistema de aire acondicionado, es preciso tener en cuenta tres elementos: el estado termodinámico 
Figura 45.10 - Mecanismos termorreguladores en los seres humanos.

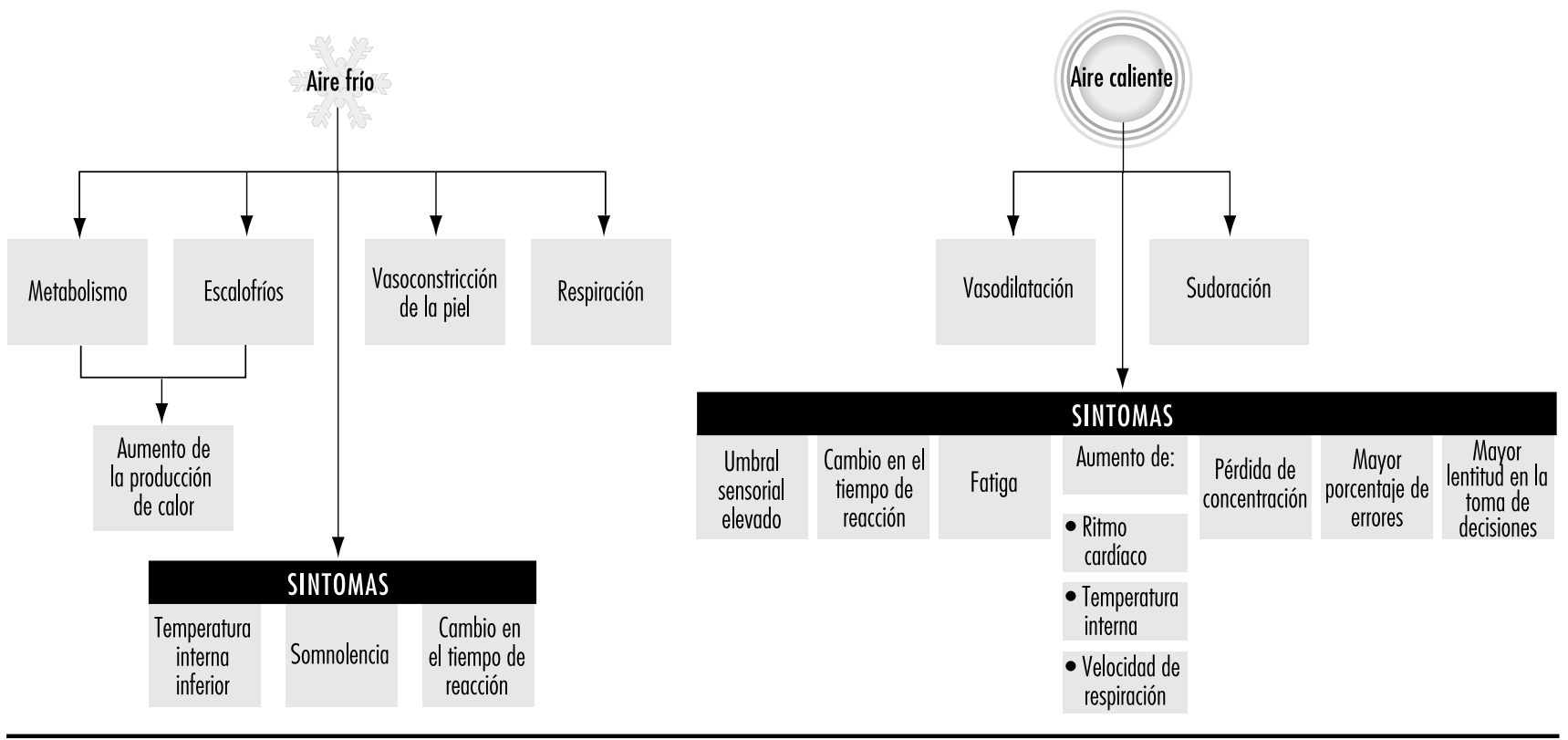

del aire en el recinto, del aire exterior y del aire que se suministrará a la habitación. La elección de un sistema capaz de transformar las propiedades termodinámicas del aire suministrado al recinto se basará en las cargas térmicas de cada componente. A sí pues, necesitamos conocer las propiedades termodinámicas del aire húmedo, que son las siguientes:

$\mathrm{T}_{\mathrm{dbt}}=$ temperatura del bulbo seco, medida con un termómetro aislado de radiaciones de calor.

$T_{\text {dpt }}=$ temperatura del punto de rocío, o temperatura a la que el aire seco no saturado alcanza el punto de saturación.

$W=$ relación de humedad que varía desde cero, para el aire seco, hasta $W_{s}$, para el aire saturado, expresado en $\mathrm{kg}$ de vapor de agua por $\mathrm{kg}$ de aire seco.

$H R=$ humedad relativa .

t* $^{*}$ = temperatura termodinámica del bulbo húmedo.

$\mathrm{v} \quad=$ volumen específico del aire $\mathrm{y}$ del vapor de agua (expresado en unidades de $\mathrm{m}^{3} / \mathrm{kg}$ ). Es el valor recíproco de la densidad.

$\mathrm{H}$ = entalpía, $\mathrm{kcal} / \mathrm{kg}$ de aire seco con el vapor de agua asociado.

De las variables citadas, sólo tres son directamente cuantificables: la temperatura del bulbo seco, la temperatura del punto de rocío y la humedad relativa. Existe una cuarta variable que puede cuantificarse experimentalmente, y se define como la temperatura del bulbo húmedo. Se obtiene humedeciendo el bulbo de un termómetro y moviéndolo, normalmente con ayuda de una cuerda, a través de aire húmedo no saturado a velocidad moderada. La diferencia entre esta variable y la temperatura termodinámica del bulbo seco es insignificante (un 3 por ciento), de modo que ambas pueden utilizarse para el cálculo sin dar lugar a un error excesivo.

\section{Diagrama psicrométrico}

L as propiedades definidas en la sección anterior tienen una relación funcional y pueden representarse de forma gráfica en un diagrama psicrométrico, que es un gráfico simplificado obtenido a partir de las tablas de la Sociedad A mericana de Ingenieros de Calefacción, Refrigeración y Acondicionamiento del Aire (ASHRAE). Las coordenadas del diagrama representan la entalpía y el grado de humedad; las líneas dibujadas representan las temperaturas de termómetro seco y húmedo, la humedad relativa y el volumen específico. Conociendo dos de las variables antes citadas es posible obtener todas las propiedades del aire húmedo a partir de este diagrama.

\section{Condiciones de confort térmico}

El confort térmico se define como un estado mental que expresa satiffacción con el ambiente térmico y en él influyen factores físicos y fisiológicos.

Resulta difícil prescribir condiciones generales que deban cumplirse para proporcionar confort térmico, porque las condiciones son diferentes según la situación de trabajo; incluso podrían ser necesarias diferentes condiciones para un mismo puesto de trabajo ocupado por diferentes personas. No es posible aplicar una norma técnica de condiciones térmicas necesarias para el confort en todos los países, debido a las diferentes condiciones climáticas y a las diferentes costumbres que rigen la forma de vestir.

Se han llevado a cabo estudios con trabajadores que realizan trabajos manuales ligeros, estableciendo una serie de criterios de temperatura, velocidad y humedad, presentados en la Tabla 45.12 (Bedford y Chrenko 1974).

Los factores citados están interrelacionados, por lo que se precisa una temperatura del aire inferior si existe una alta radiación térmica, y una temperatura superior si la velocidad del aire también es más alta.

\begin{tabular}{|c|c|}
\hline Factor ambiental & Norma propuesta \\
\hline Temperatura del aire & $21^{\circ} \mathrm{C}$ \\
\hline Temperatura radiante media & $\geq 21^{\circ} \mathrm{C}$ \\
\hline Humedad relativa & $30-70 \%$ \\
\hline Velocidad del aire & $0,05-0,1$ metros/ segundo \\
\hline Gradiente de temperatura (de la cabeza a los pies) & $\leq 2,5^{\circ} \mathrm{C}$ \\
\hline
\end{tabular}


Figura 45.11 - Zonas de confort basadas en mediciones limitadas a la temperatura global y a la velocidad de las corrientes de aire.
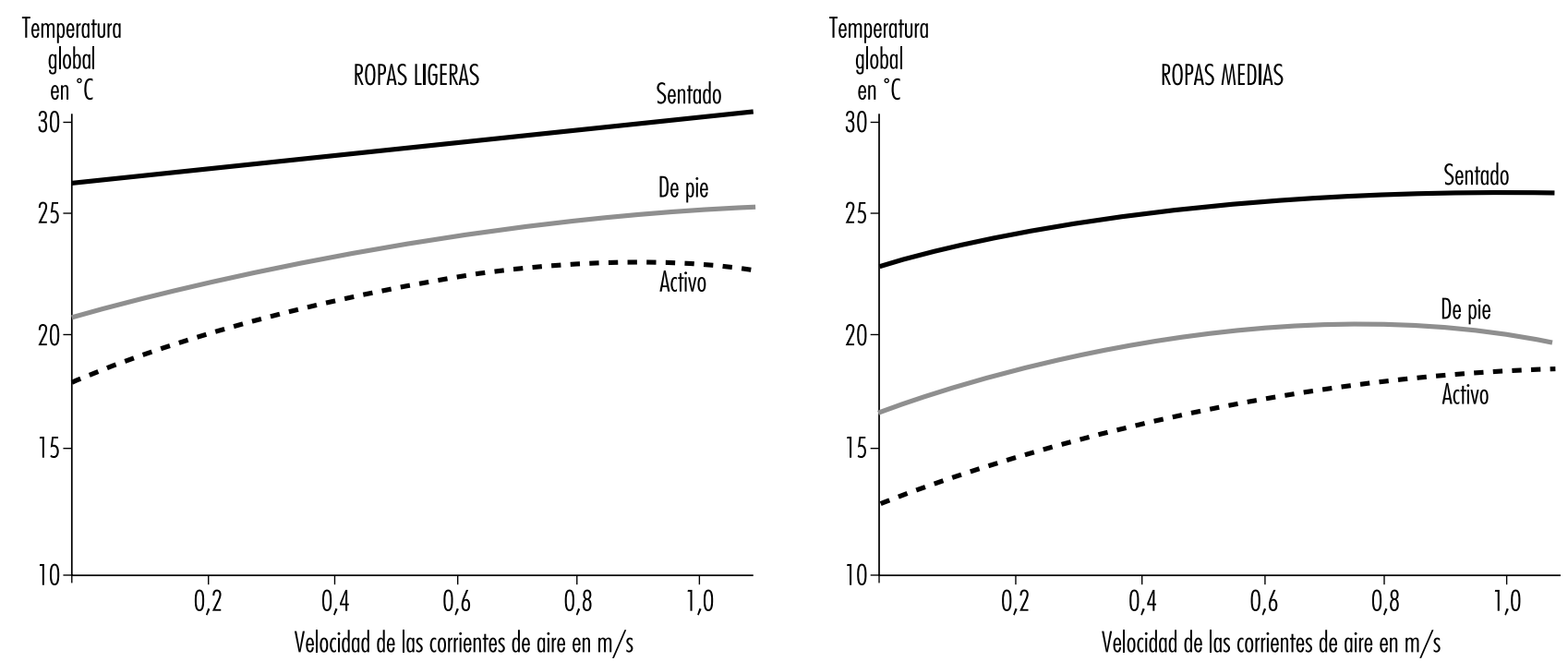

Fuente: 0 OIT 1983

Por lo común, será preciso realizar las correcciones siguientes: Se aumentará la temperatura del aire:

- si el aire fluye a alta velocidad;

- en situaciones de trabajo sedentario;

- si la ropa utilizada es ligera,

- cuando las personas deban aclimatarse a altas temperaturas interiores.

\section{Se disminuirá la temperatura del aire:}

- si se realizan trabajos manuales pesados,

- cuando se utilice ropa de abrigo.

Para conseguir una sensación de confort térmico, la situación más aconsejable será aquella en la que la temperatura ambiental sea ligeramente superior a la del aire, y en la que el flujo de energía térmica radiante sea el mismo en todas las direcciones y no sea excesivo por encima de la cabeza. D eberá minimizarse el aumento de la temperatura en altura, manteniendo los pies calientes sin crear una carga térmica excesiva por encima de la cabeza. Un factor importante que afecta a la sensación de confort térmico es la velocidad del aire. Existen diagramas que ofrecen velocidades recomendadas del aire en función de la actividad realizada y del tipo de ropa utilizado (véase la Figura 45.11).

En algunos países existen normas que especifican las temperaturas ambientales mínimas, pero todavía no se han establecido valores óptimos. Normalmente, el máximo valor indicado de temperatura del aire es de $20^{\circ} \mathrm{C}$. Con las recientes mejoras técnicas, ha aumentado la complejidad de la valoración del confort térmico. $\mathrm{H}$ an aparecido muchos índices, incluido el de temperatura efectiva (ET, Effective Temperature) y el índice de temperatura efectiva corregida (CET, Corrected Effective Temperature); el índice de sobrecarga calórica; el índice de estrés por calor ( $\mathrm{HSI}, \mathrm{H}$ eat Stress Index); la temperatura del globo del bulbo húmedo (WBGT, Wet Bulb Globe Temperature); y el índice Fanger de valores medios (IM V, Index of M edian Values), entre otros. EI índice WBGT nos permite determinar los intervalos de descanso necesarios en función de la intensidad del trabajo realizado para evitar el estrés térmico en las condiciones de trabajo. De ello se trata con más detalle en el capítulo 42, Calor y frío.

\section{Zona de confort térmico en un diagrama psicrométrico}

La zona del diagrama psicrométrico correspondiente a las condiciones en las que un adulto percibe el confort térmico ha sido estudiado atentamente y definido en la norma de la ASHRAE a partir de la temperatura efectiva o temperatura medida con un termómetro seco en un recinto uniforme con un 50 por ciento de humedad relativa. En este recinto las personas tendrían el mismo intercambio de calor por energía radiante, convección y evaporación que tendrían con el nivel de humedad en el ambiente local dado. La ASHRAE define la escala de temperatura efectiva para un nivel de ropa de 0,6 clo (unidad de aislamiento; 1 clo corresponde al aislamiento que proporciona un conjunto de prendas normal), lo que supone un nivel de aislamiento térmico de $0,155 \mathrm{~K} \mathrm{~m}^{2} \mathrm{~W}^{-1}$, donde $\mathrm{K}$ es el intercambio de calor por conducción medido en vatios por metro cuadrado $\left(\mathrm{W} \mathrm{m}^{-2}\right)$ para un movimiento de aire de $0,2 \mathrm{~m} \mathrm{~s}^{-1}$ (en reposo), para un tiempo de exposición de una hora, en una actividad sedentaria elegida de 1 met (unidad metabólica $=50 \mathrm{~K} \mathrm{cal} / \mathrm{m}^{2} \mathrm{~h}$ ). En la Figura 45.11 puede verse esta zona de confort y utilizarse en ambientes térmicos donde la temperatura del calor radiante sea aproximadamente igual a la temperatura medida con un termómetro seco y donde la velocidad del aire sea inferior a $0,2 \mathrm{~m} \mathrm{~s}^{1}$ para personas vestidas con ropa ligera y que realicen actividades sedentarias.

\section{Fórmula de confort: el método de Fanger}

EI método desarrollado por $P$. 0 . Fanger se basa en una fórmula que relaciona variables de temperatura ambiente, temperatura radiante media, velocidad relativa del aire, presión del vapor de agua en el aire ambiental, nivel de actividad y resistencia térmica de la ropa. En la Tabla 45.13 se presenta un ejemplo obtenido con la fórmula del confort que puede utilizarse en aplicaciones prácticas para obtener una temperatura confortable en función de la ropa, de la tasa metabólica de la actividad realizada y de la velocidad del aire. 
Tabla 45.13 • Temperaturas de confort térmico $\left({ }^{\circ} \mathrm{C}\right)$ con una humedad relativa del $50 \%$ (a partir de la fórmula de P. 0 . Fanger).

\begin{tabular}{|c|c|c|c|c|}
\hline Metabolismo (vatios) & 105 & & & \\
\hline Temperatura radiante & do & $20^{\circ} \mathrm{C}$ & $25^{\circ} \mathrm{C}$ & $30^{\circ} \mathrm{C}$ \\
\hline \multirow[t]{3}{*}{$\begin{array}{l}\text { Ropa (clo) } \\
\quad 0,5 \mathrm{~V}_{\mathrm{a}} /\left(\mathrm{m}_{\mathrm{sg}} \mathrm{g}^{-1}\right)\end{array}$} & 0,2 & 30,7 & 27,5 & 24,3 \\
\hline & 0,5 & 30,5 & 29,0 & 27,0 \\
\hline & 1,5 & 30,6 & 29,5 & 28,3 \\
\hline \multirow{4}{*}{$\begin{array}{l}\operatorname{Ropa}(\mathrm{clo}) \\
0,5 \mathrm{~V}_{\mathrm{a}} /\left(\mathrm{m} \cdot \mathrm{sg}^{-1}\right)\end{array}$} & & & & \\
\hline & 0,2 & 26,0 & 23,0 & 20,0 \\
\hline & 0,5 & 26,7 & 24,3 & 22,7 \\
\hline & 1,5 & 27,0 & 25,7 & 24,5 \\
\hline Metabolismo (vatios) & 157 & & & \\
\hline Temperatura radiante & do & $20^{\circ} \mathrm{C}$ & $25^{\circ} \mathrm{C}$ & $30^{\circ} \mathrm{C}$ \\
\hline \multirow{4}{*}{$\begin{array}{l}\text { Ropa (clo) } \\
\quad 0,5 \mathrm{~V}_{\mathrm{a}} /\left(\mathrm{m}_{\mathrm{sg}} \mathrm{sg}^{-1}\right)\end{array}$} & & & & \\
\hline & 0,2 & 21,0 & 17,1 & 14,0 \\
\hline & 0,5 & 23,0 & 20,7 & 18,3 \\
\hline & 1,5 & 23,5 & 23,3 & 22,0 \\
\hline \multirow{4}{*}{$\begin{array}{l}\operatorname{Ropa}(\mathrm{clo}) \\
0,5 \mathrm{~V}_{\mathrm{a}} /\left(\mathrm{m}_{\mathrm{sg}} \mathrm{gg}^{-1}\right)\end{array}$} & & & & \\
\hline & 0,2 & 13,3 & 10,0 & 6,5 \\
\hline & 0,5 & 16,0 & 14,0 & 11,5 \\
\hline & 1,5 & 18,3 & 17,0 & 15,7 \\
\hline Metabolismo (vatios) & 210 & & & \\
\hline Temperatura radiante & do & $20^{\circ} \mathrm{C}$ & $25^{\circ} \mathrm{C}$ & $30^{\circ} \mathrm{C}$ \\
\hline \multirow{4}{*}{$\begin{array}{l}\operatorname{Ropa}(\mathrm{clo}) \\
\quad 0,5 \mathrm{~V}_{\mathrm{a}} /\left(\mathrm{m}_{\mathrm{sg}} \mathrm{sg}^{-1}\right)\end{array}$} & & & & \\
\hline & 0,2 & 11,0 & 8,0 & 4,0 \\
\hline & 0,5 & 15,0 & 13,0 & 7,4 \\
\hline & 1,5 & 18,3 & 17,0 & 16,0 \\
\hline \multirow{4}{*}{$\begin{array}{l}\operatorname{Ropa}(\mathrm{clo}) \\
\quad 0,5 \mathrm{~V}_{\mathrm{a}} /\left(\mathrm{m}_{\mathrm{sg}} \mathrm{sg}^{-1}\right)\end{array}$} & & & & \\
\hline & 0,2 & $-7,0$ & 1 & 1 \\
\hline & 0,5 & $-1,5$ & $-3,0$ & 1 \\
\hline & 1,5 & $-5,0$ & 2,0 & 1,0 \\
\hline
\end{tabular}

\section{Sistemas de calefacción}

El diseño de cualquier sistema de calefacción debe estar directamente relacionado con el trabajo que se va a realizar y con las características del edificio en el que se instalará. En los edificios industriales es difícil encontrar proyectos en los que se tengan en cuenta las necesidades de calefacción de los trabajadores, a menudo porque aún están sin definir los procesos y los puestos de trabajo. N ormalmente, los sistemas se diseñan con un criterio muy abierto, contemplando sólo las cargas térmicas que existirán en el edificio y la cantidad de calor que es preciso suministrar para mantener una temperatura determinada en el edificio, sin tener en cuenta la distribución del calor, la situación de los puestos de trabajo ni otros factores parecidos de carácter menos general. Tales deficiencias en el diseño de ciertos edificios se traducen en carencias, como puntos fríos, corrientes de aire, un número insuficiente de elementos de calefacción y otros problemas.
Para conseguir un buen sistema de calefacción en la planificación de un edificio, se indican a continuación algunas de las cosas que será preciso tener en cuenta:

- La correcta colocación del aislamiento para ahorrar energía y para minimizar los gradientes de temperatura en el edificio.

- La máxima reducción de la infiltración de aire frío en el edificio para minimizar las variaciones de temperatura en las áreas de trabajo.

- El control de la contaminación del aire por medio de sistemas de extracción localizada y de ventilación por desplazamiento 0 difusión.

- El control de las emisiones de calor procedentes de los procesos utilizados en el edificio y su distribución en las áreas ocupadas del edificio.

Si la calefacción se suministra por medio de quemadores sin chimeneas de escape, será preciso prestar especial atención a la inhalación de los productos de la combustión. Por lo común, cuando los materiales combustibles son petróleo, gas o carbón de calefacción, producen dióxido de azufre, óxidos de nitrógeno, monóxido de carbono y otros productos de combustión. Existen límites a la exposición del ser humano a estos compuestos que es preciso controlar, en particular en espacios cerrados donde puede aumentar rápidamente la concentración de esos gases cuando disminuye la eficacia de la reacción de combustión.

Planificar un sistema de calefacción supone siempre conseguir el equilibrio entre varias cuestiones, como un bajo coste inicial, la flexibilidad del servicio, la eficacia energética y la aplicabilidad. Por consiguiente, el consumo de electricidad durante las horas en que sea más económico, por ejemplo, podría rentabilizar el uso de calefactores eléctricos. 0 tra opción sería utilizar sistemas químicos de almacenamiento de calor que puedan utilizarse después durante las horas punta de demanda (utilizando sulfato sódico, por ejemplo). A simismo es posible estudiar la instalación conjunta de varios sistemas diferentes que funcionen de modo que se optimicen los costes.

La instalación de calefactores capaces de utilizar gas o petróleo de calefacción es especialmente interesante. El uso directo de electricidad implica un consumo de energía de primera clase que puede resultar cara en muchos casos, pero que puede aportar la flexibilidad necesaria en ciertas circunstancias. Las bombas de calor y otros sistemas de cogeneración que aprovechan el calor residual, pueden aportar soluciones muy ventajosas desde el punto de vista financiero. El problema de estos sistemas es su alto coste inicial.

H oy en día la tendencia en el ámbito de los sistemas de calefacción y aire acondicionado es conseguir un funcionamiento óptimo ahorrando energía. Por consiguiente, los nuevos sistemas tienen sensores y controles distribuidos por los espacios que se van a calentar, con lo que se suministra calor sólo durante los tiempos necesarios para lograr confort térmico. Tales sistemas pueden ahorrar hasta un $30 \%$ de los costes energéticos de la calefacción. En la Figura 45.12 se ilustran algunos sistemas de calefacción, con sus ventajas y sus inconvenientes.

\section{Sistemas de aire acondicionado}

La experiencia demuestra que los ambientes industriales próximos a la zona de confort durante los meses de verano aumentan la productividad, tienden a registrar un menor número de accidentes, tienen un menor índice de absentismo $y$, en general, contribuyen a mejorar las relaciones humanas. En el caso de los establecimientos de venta al por menor, los hospitales y los edificios con grandes superficies, la finalidad del aire acondicionado suele ser proporcionar confort térmico cuando las condiciones exteriores así lo requieren. 
Figura 45.12 • Características de los sistemas de calefacción más utilizados en los lugares de trabajo.

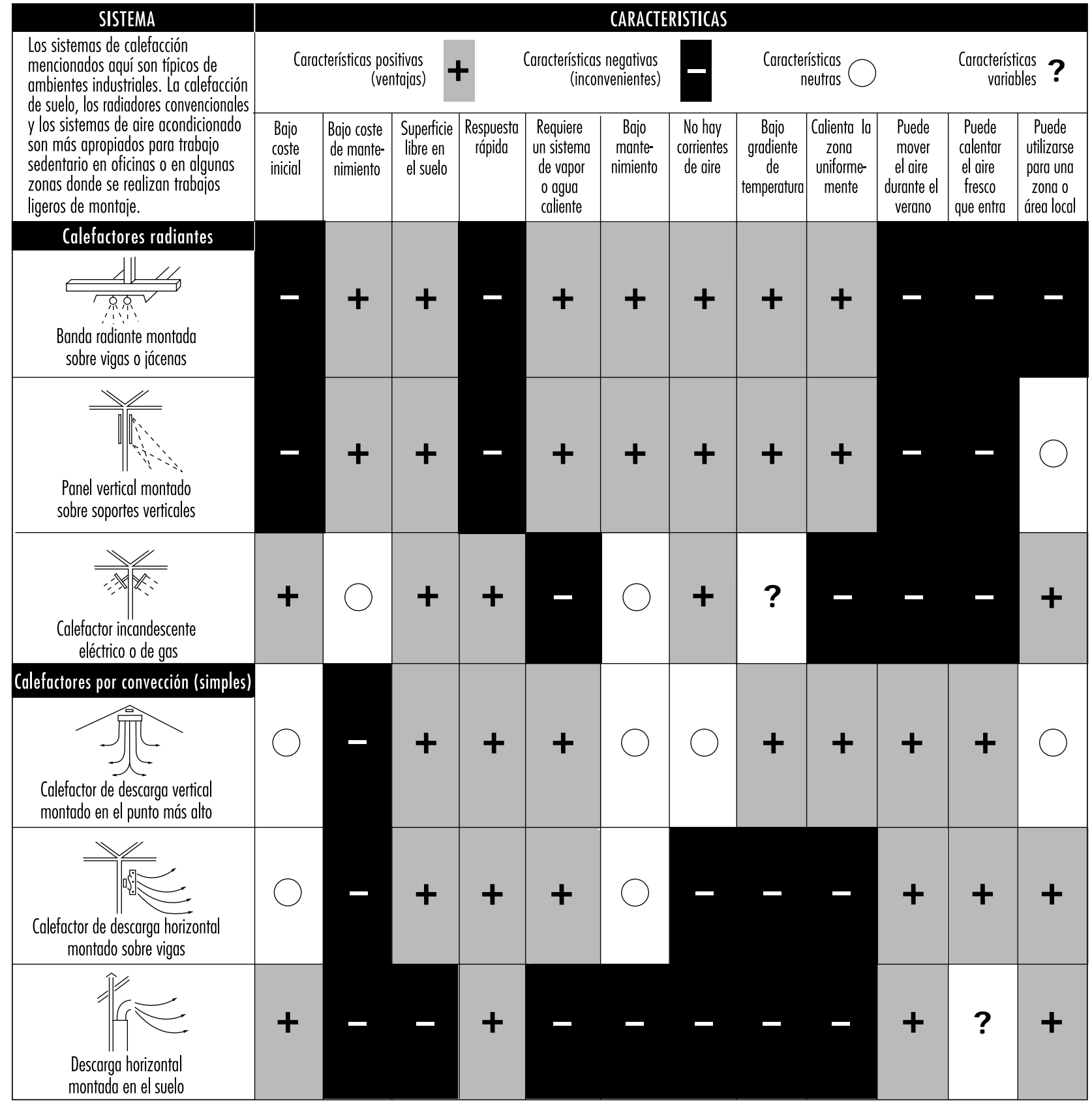

Fuente: OIT 1983

En ciertos ambientes industriales cuyas condiciones externas son muy duras, el objetivo de los sistemas de calefacción es proporcionar calor suficiente para evitar posibles efectos perjudiciales para la salud, más que para conseguir un ambiente térmico confortable. Factores que requieren una atención especial son el mantenimiento y el uso apropiados del equipo de aire acondicionado, en particular si está provisto de humidificadores, ya que pueden convertirse en fuentes de contaminación microbiana, con los riesgos que estos contaminantes tienen para la salud del ser humano.

Actualmente, los sistemas de ventilación y climatización tienden a cubrir, conjuntamente y a menudo utilizando la misma instalación, las necesidades de calefacción, refrigeración y acondicionamiento del aire de un edificio. Para los sistemas de refrigeración pueden utilizarse múltiples clasificaciones.

Según la configuración del sistema, pueden clasificarse de la manera siguiente:

- Unidades herméticamente selladas, con fluido refrigerante instalado en fábrica, que pueden abrirse y recargarse en un taller de reparación. Son las unidades de aire acondicionado utilizadas normalmente en oficinas, viviendas y similares.

- U nidades semiherméticas de tamaño medio, hechas en fábrica, de mayor tamaño que las unidades domésticas y que pueden repararse a través de aberturas diseñadas a tal efecto. 
Figura 45.13 • Esquema simplificado de un sistema de aire acondicionado.

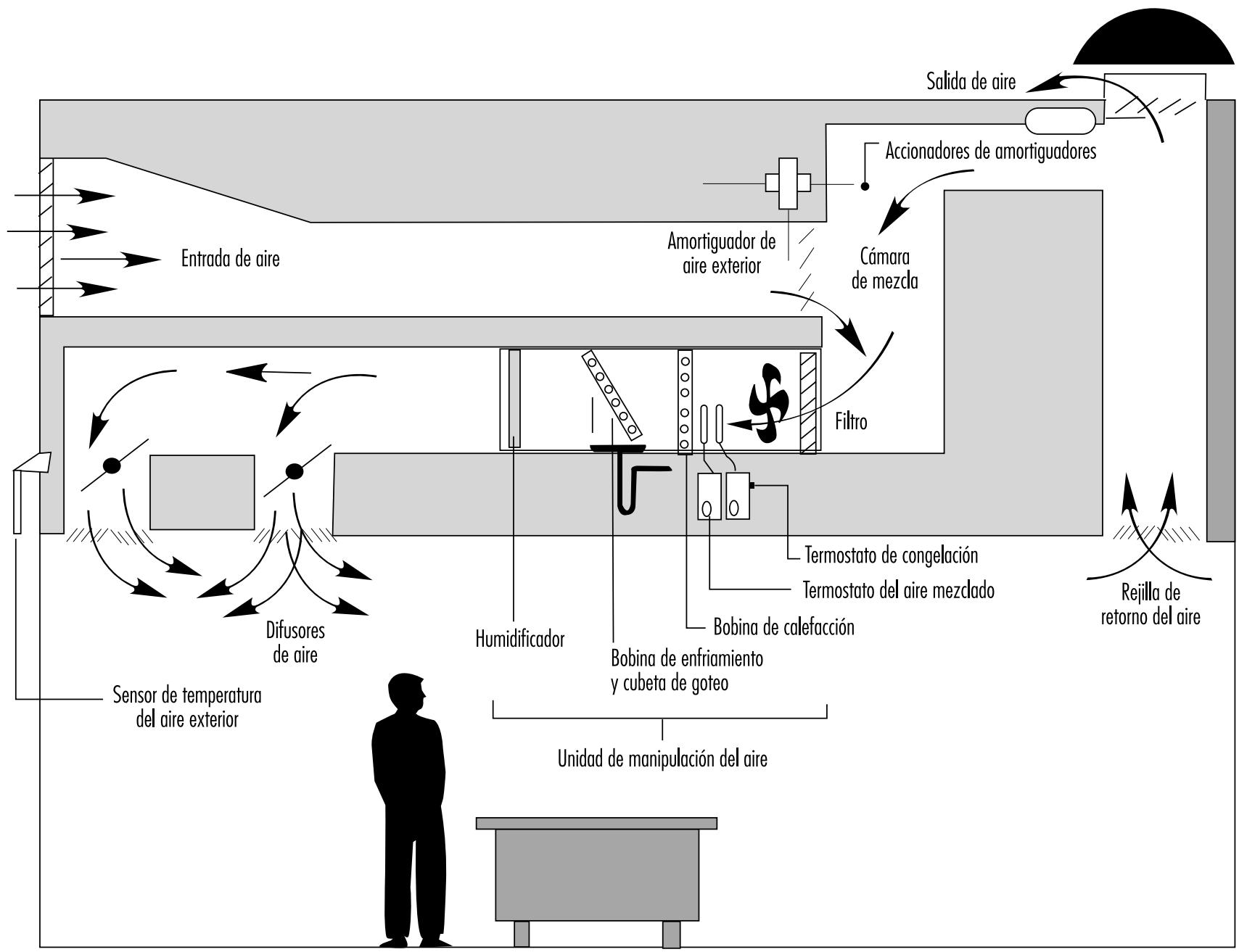

Fuente: NIOSH 1991.

- Sistemas segmentados para almacenes y grandes superficies, que constan de piezas y componentes claramente diferenciados y físicamente separados (el compresor y el condensador están físicamente separados del evaporador y de la válvula de expansión). Se utilizan en grandes edificios de oficinas, hoteles, hospitales, grandes fábricas y edificios industriales.

En función de su cobertura, pueden clasificarse del modo siguiente:

- Sistemas para una sola zona: una unidad de tratamiento del aire sirve a varias habitaciones del mismo edificio, que tienen parecidas necesidades de calefacción, refrigeración y ventilación y que se regulan con un mando común (un termostato o dispositivo similar). Los sistemas de este tipo pueden acabar siendo inadecuados para proporcionar un nivel de confort adecuado para cada habitación si en el plan de diseño no se han tenido en cuenta las diferentes cargas térmicas de las habitaciones de la misma zona. Por ejemplo, si aumenta la ocupación de una habitación o si se añade iluminación u otras fuentes de calor, como ordenadores o máquinas fotocopiadoras, no previstas durante el diseño original del sistema. También puede sentirse incomodidad por los cambios estacionales de la cantidad de radiación solar recibida por una habitación o incluso por los cambios de una habitación a otra durante la jornada.

- Sistemas para zonas múltiples: los sistemas de este tipo pueden suministrar aire a diferente temperatura y humedad a diferentes zonas, calentando, enfriando, humidificando o deshumidificando el aire de cada zona y variando el flujo de aire. Son sistemas que, aunque tengan en general una unidad de enfriamiento común y centralizada (compresor, evaporador, etc.), están equipados con diversos elementos, como dispositivos de control del flujo de aire, bobinas de calefacción y humidificadores. Son capaces de regular las condiciones de una habitación a partir de cargas térmicas específicas, que detectan por medio de sensores distribuidos en las habitaciones por toda su área de influencia.

En función del flujo de aire que estos sistemas bombean al interior del edificio, se clasifican de la manera siguiente:

- Volumen constante (CV, Constant V olume): estos sistemas bombean un flujo constante de aire a cada habitación. Los cambios de temperatura se efectúan calentando o enfriando el aire. Con frecuencia, estos sistemas mezclan un porcentaje de aire exterior con aire interior reciclado. 
- V olumen variable (V AV , V ariable Air V olume): estos sistemas mantienen el confort térmico variando la cantidad de aire calentado o enfriado que suministran a cada recinto. Aunque funcionen principalmente por el principio de mezcla, también pueden combinarse con sistemas que cambien la temperatura del aire que introducen en la habitación.

Los problemas más frecuentes de estos tipos de sistemas son el exceso de calor o frío si el sistema no se regula para que responda a las variaciones de las cargas térmicas, 0 una falta de ventilación si el sistema no introduce una cantidad mínima de aire exterior para renovar el aire interior circulante. Con ello se crean ambientes interiores estancados en los que se deteriora la calidad del aire.

L os elementos básicos de todos los sistemas de aire acondicionado son (véase también la Figura 45.13):

- U nidades que retienen la materia sólida, habitualmente bolsas filtrantes o precipitadores electrostáticos.

- U nidades de calentamiento o enfriamiento del aire: en ellas se intercambia calor por intercambio térmico con agua fría o líquidos refrigerantes, por ventilación forzada en verano y por calefacción con bobinas eléctricas o por combustión en invierno.

- U nidades para controlar la humedad: en invierno, es posible añadir humedad inyectando directamente vapor de agua o por la evaporación directa del agua; en verano puede eliminarse por medio de bobinas refrigeradas que condensan el exceso de humedad del aire, o por medio de un sistema de agua refrigerada por el que el aire húmedo fluye a través de una cortina de agua de gotas más frías que el punto de rocío del aire húmedo.

\section{- El aire EN INTERIORES: IONIZACION}

\section{E. Adán Liébana y J. G uasch Farrás}

La ionización es una de las técnicas utilizadas para eliminar partículas del aire. Los iones actúan como núcleos de condensación para partículas pequeñas que, al aglutinarse, crecen y se precipitan.

La concentración de iones en espacios interiores cerrados es, como norma general y si no hay fuentes de iones adicionales, inferior a la existente en espacios abiertos. De ahí la creencia de que una mayor concentración de iones negativos mejora la calidad del aire en interiores.

Algunos estudios basados en datos epidemiológicos y en investigaciones experimentales planificadas afirman que el aumento de la concentración de iones negativos en ambientes de trabajo mejora la eficacia del trabajador y el ánimo de los empleados, mientras que los iones positivos tienen un efecto perjudicial. Con todo, se han hecho estudios paralelos donde se demuestra que los datos sobre los efectos de la ionización negativa en la productividad de los trabajadores son incoherentes y contradictorios. Por consiguiente, parece que todavía no es posible afirmar inequívocamente que la generación de iones negativos es realmente beneficiosa.

\section{Ionización natural}

Las moléculas individuales de gas en la atmósfera pueden ionizarse negativa o positivamente ganando o perdiendo respectivamente un electrón. Para que esto ocurra, primero es necesario que una molécula determinada adquiera energía suficiente - que habitualmente recibe el nombre de energía de ionización de esa molécula en particular-. En la naturaleza existen muchas fuentes de energía, de origen tanto cósmico como terrestre, capaces de producir este fenómeno: la radiación de fondo en la atmósfera; las ondas solares electromagnéticas (especialmente las ultravioletas), los rayos cósmicos, la atomización de líquidos - como la producida por los saltos de agua - , el movimiento de grandes masas de aire sobre la superficie de la tierra, fenómenos eléctricos como los rayos y las tormentas, el proceso de combustión y las sustancias radiactivas.

Las configuraciones eléctricas de los iones así formados, aunque todavía no se conocen por completo, parecen incluir los iones de la carbonatación y $\mathrm{H}^{+}, \mathrm{H}_{3} \mathrm{O}^{+}, \mathrm{O}^{+}, \mathrm{N}^{+}, \mathrm{OH}^{-}, \mathrm{H}_{2} \mathrm{O}^{-}$y $\mathrm{O}_{2}^{-}$. Tales moléculas ionizadas pueden agregarse por adsorción a partículas suspendidas (niebla, ślice y otros contaminantes). L os iones se clasifican por su tamaño y movilidad. Esta última se define como la velocidad en un campo eléctrico y se expresa en centímetros por segundo por tensión por centímetro $(\mathrm{cm} / \mathrm{s} / \mathrm{V} / \mathrm{cm})$, también expresado:

$$
\frac{\mathrm{cm}^{2}}{\mathrm{Vs}}
$$

Los iones atmosféricos tienden a desaparecer por recombinación. Su vida media depende de su tamaño y es inversamente proporcional a su movilidad. Los iones negativos son estadísticamente más pequeños y su vida media es de varios minutos, mientras que los iones positivos son más grandes y su vida media es de aproximadamente media hora. La carga espacial es el cociente de la concentración de iones positivos y de la concentración de iones negativos. El valor de esta relación es mayor que uno y depende de factores como el clima, la ubicación y la estación del año. En los espacios donde vive el ser humano, este coeficiente puede tener valores menores que uno. En la Tabla 45.14 se muestran las características.

\section{Ionización artificial}

La actividad humana modifica la ionización natural del aire. LoS procesos industriales y nucleares y los incendios pueden provocar ionización artificial. Las partículas suspendidas en el aire favorecen la formación de iones de Langevin (iones agregados en partículas). Los radiadores eléctricos aumentan considerablemente la concentración de iones positivos. Los aparatos de aire acondicionado también aumentan la carga espacial del aire interior.

Los lugares de trabajo tienen maquinaria que produce iones positivos y negativos al mismo tiempo, como en el caso de las máquinas que son importantes fuentes locales de energía mecánica (prensas, máquinas hiladoras y tejedoras), energía eléctrica (motores, impresoras electrónicas, fotocopiadoras, instalaciones y líneas de alta tensión), energía electromagnética (pantallas de rayos catódicos, televisores, monitores de ordenador) o energía radiactiva (terapia con cobalto-42). Son equipos que crean ambientes con mayores concentraciones de iones positivos

Tabla 45.14 • Características de los iones en función de la movilidad y el diámetro.

\begin{tabular}{lll} 
Movilidad $\left(\mathrm{cm}^{2} / \mathrm{Vs}\right)$ & Diámetro $(\mu \mathrm{m})$ & $\begin{array}{l}\text { Características } \\
\text { 3,0-0,1 }\end{array}$ \\
$0,001-0,003$ & $\begin{array}{l}\text { Pequeños, alta movilidad, } \\
\text { vida corta }\end{array}$ \\
$0,1-0,005$ & $0,003-0,03$ & $\begin{array}{l}\text { Tamaño intermedio, más } \\
\text { lentos que los iones } \\
\text { pequeños }\end{array}$ \\
$\begin{array}{l}\text { lones lentos, agregados a } \\
\text { partículas (iones de } \\
\text { Langevin) }\end{array}$ \\
\hline
\end{tabular}


debido a la mayor vida media de estos últimos en comparación con los iones negativos.

\section{Concentraciones de iones en el ambiente}

Las concentraciones de iones varían según las condiciones ambientales y meteorológicas. En zonas con poca contaminación, como bosques y montañas, o en lugares situados a gran altitud, aumenta la concentración de iones pequeños; en zonas próximas a fuentes radiactivas, saltos de agua o rápidos fluviales, las concentraciones pueden alcanzar miles de iones pequeños por centímetro cúbico. Por otra parte, en las proximidades del mar y cuando los niveles de humedad son altos, existe un exceso de iones grandes. En general, la concentración media de iones negativos y positivos en aire limpio es de 500 y 600 iones por centímetro cúbico respectivamente.

Algunos vientos pueden transportar grandes concentraciones de iones positivos: el föehn en Suiza, el Santa Ana en Estados Unidos, el siroco en Africa del Norte, el chinook en las $M$ ontañas R ocosas y el sharav en 0 riente M edio.

En lugares de trabajo donde no hay factores de ionización significativos suele haber una acumulación de iones grandes. En especial, por ejemplo, en lugares herméticamente cerrados y en minas. La concentración de iones negativos disminuye bastante en espacios cerrados y en áreas contaminadas o polvorientas. Existen muchas razones por las que también se reduce la concentración de iones negativos en espacios interiores con sistemas de aire acondicionado. U na de ellas es que los iones negativos permanecen atrapados en conducciones y filtros de aire o son atraídos a superficies con carga positiva. Así, las pantallas de rayos catódicos y los monitores de ordenador tienen una carga positiva que crea en sus proximidades un microclima deficiente en iones negativos. L os sistemas de filtración de aire diseñados para "salas blancas", que requieren que los niveles de contaminación con partículas se mantengan al mínimo, también parecen eliminar los iones negativos.

Por otra parte, un exceso de humedad condensa los iones, mientras que una falta de ella crea ambientes secos con grandes cargas electrostáticas. Tales cargas se acumulan en plásticos y fibras sintéticas, tanto en la habitación como en las personas.

\section{Generadores de iones}

Los generadores ionizan el aire, con lo que suministran una gran cantidad de energía que puede proceder de una fuente de radiación alfa (como el tritio) o de una fuente de electricidad por aplicación de una alta tensión a un electrodo de punta afilada. Las fuentes radiactivas están prohibidas en la mayoría de los países debido a sus problemas secundarios de radiactividad.

Los generadores eléctricos consisten en un electrodo aguzado rodeado por una corona; el electrodo recibe una tensión negativa de miles de voltios y la corona se pone a masa. Los iones negativos son expulsados mientras que los positivos son atraídos hacia el generador. La cantidad de iones negativos generados aumenta en proporción a la tensión aplicada y al número de electrodos que contiene. Los generadores con mayor número de electrodos y que utilizan una tensión más baja son más seguros, porque cuando la tensión excede de 8.000 a 10.000 voltios, el generador no sólo produce iones, sino también ozono y algunos óxidos nitrosos. La diseminación de iones se consigue por repulsión electrostática.

La migración de iones dependerá de la alineación del campo magnético generado entre el punto de emisión y los objetos que lo rodean. $L$ a concentración de los iones que rodean a los generadores no es homogénea y disminuye significativamente cuanto más lejos están de ellos. La instalación de ventiladores en estos equipos aumentará la zona de dispersión iónica. Conviene recordar que es preciso limpiar periódicamente los elementos activos de los generadores para asegurar su correcto funcionamiento.

Los generadores también pueden funcionar por atomización de agua, efectos termoeléctricos o rayos ultravioleta. Existen generadores de muchos tipos y tamaños. Pueden instalarse en techos y paredes o colocarse en cualquier sitio si son pequeños y portátiles.

\section{Medición de iones}

Los dispositivos medidores de iones se fabrican colocando dos placas conductivas con una separación entre ellas de $0,75 \mathrm{~cm}$ y aplicando una tensión variable. Los iones recogidos se miden con un picoamperímetro y se registra la intensidad de la corriente. $L$ as tensiones variables permiten la medición de concentraciones de iones de diferente movilidad. La concentración de iones (N) se calcula a partir de la intensidad de la corriente eléctrica generada utilizando la fórmula siguiente:

$$
N=\frac{1}{V q A}
$$

donde I es la corriente en amperios, $V$ es la velocidad del aire, $q$ es la carga de un ion univalente $\left(1,6 \times 10^{-19}\right)$ en culombios y A es el área efectiva de las placas colectoras. Se presupone que todos los iones tienen una carga simple y que todos ellos quedan retenidos en el colector. $\mathrm{H}$ ay que tener en cuenta que este método tiene sus limitaciones debido a la corriente de fondo y a la influencia de otros factores, como la humedad y los campos de electricidad estática.

\section{Los efectos de los iones en el cuerpo}

Los iones negativos pequeños son los que supuestamente tienen el mayor efecto biológico debido a su mayor movilidad. Las altas concentraciones de iones negativos pueden matar o bloquear el crecimiento de microorganismos patógenos, pero no se han descrito efectos perjudiciales para los seres humanos.

Algunos estudios indican que la exposición a altas concentraciones de iones negativos produce en algunas personas cambios bioquímicos y fisiológicos que tienen un efecto relajante, reducen la tensión y los dolores de cabeza, mejoran la atención y reducen el tiempo de reacción. Tales efectos podrían deberse a la supresión de la hormona neuronal serotonina $(5-\mathrm{HT})$ y de la histamina en ambientes cargados con iones negativos; estos factores podrían afectar a un segmento hipersensible de la población. A hora bien, otros estudios han llegado a conclusiones diferentes sobre los efectos de los iones negativos para el cuerpo. Por consiguiente, sigue abierto el debate en cuanto a los beneficios de la ionización negativa y serán precisas más investigaciones antes de adoptar una posición. 


\section{Referencias}

American Conference of Governmental Industria $H$ ygienists (ACGIH). 1992. Industrial Ventilation- A $M$ anual of Recommended Practice. 21a ed. Cincinnati, O hio: ACGIH

American Society of $\mathrm{H}$ eating, R efrigerating, and AirConditioning Engineers (ASHRAE). 1992. M thod of T esting Air Cleaner D evices U sed in General Ventilation for R emoving Particulate M atter. Atlanta: ASH RAE.

Baturin, VV. 1972. F undamentals of Industrial Ventilation. Nueva Y ork: Pergamon.

Bedford, T , FA Chrenko. 1974. Basic Principles of Ventilation and $\mathrm{H}$ eating. Londres: $\mathrm{HK}$ Lewis.

Centre Europeo de Normalización (CEN). 1979. $M$ ethod of T esting Air Filters $U$ sed in $G$ eneral Ventilation. Eurovent 4/ 5. Antwerp: Comité Europeo de Normalización.

Chartered Institution of Building Services. 1978. E nvironmental C riteria for D esign. : C hartered Institution of Building Services.

Consejo de la Comunidad Europea (CCE). 1992 Guidelines for Ventilation Requirements in Buildings. Luxemburgo: CE.

Constance, JD. 1983. Controlling In-Plant A riborne Contaminants. System D esign and Calculations. N ueva Y ork: M ercel D ekker.

Fanger, PO . 1988. Introduction of the olf and the decipol units to quantify air pollution perceived by humans indoors and outdoors. Energy Build 12:7-19.

-. 1989. The new comfort equation for indoor air quality. ASH RAE J ournal 10:33-38.

O rganización Internacional del Trabajo (OIT). 1983. Enciclopedia de salud y seguridad en el trabajo, dirigido por L Parmeggiani. 3aed. Ginebra: O IT.

$N$ ational Institute for $\mathrm{O}$ ccupational Safety and $\mathrm{H}$ ealth (NIO SH ). 1991. Building Air Q uality: A Guide for Building $O$ wners and Facility $M$ anagers. Cincinnati, $\mathrm{O}$ hio: NIOSH.
Sandberg, M. 1981. What is ventilation efficiency? Build E nviron 16:123-135.

O rganización M undial de la Salud (O M S). 1987. Air Quality Guidelines for Europe. European Series, No. 23. Copenhague: Publicaciones Regionales de la OMS.

\section{0 tras lecturas recomendadas}

Air filters- how effective are they? 1991. Indoor Air Q uality U pdate 4(8):1-7.

American Society of $\mathrm{H}$ eating, R efrigerating, and AirConditioning Engineers (ASHRAE). 1977. H andbook and Product Directory: Fundamentals. Atlanta: ASHRAE.

-. 1978. H andbook and Product Directory: Applications. Atlanta: ASHRAE.

Berg-M unch, B, G Clausen, PO Fanger. 1986. Ventilation requirements for the control of body odor in spaces occupied by women. E nviron Int 12:195-199.

Bethe, RM. 1978. Air Pollution Control Technology. Nueva Y ork: $V$ an N ostrand R einhold.

Billings, CE. 1982. Methods for indoor air quality. E nviron Int 8:497-504.

Breum, N O . 1991. High versus low momentum ventilation in a machine workshop. Staub-R einhaltung der L uft 51:91-96.

Brunet, R. 1976. Ventilation et chauffage des locaux de travail associés á l'économie et á la récupération d'energie. Institut National de Recherche et de Securité 532.

Cain, WS et al. 1983. Ventilation requirements in buildings: Control of occupancy odor and tobacco smoke odor. A tmos E nviron 17(6):1187-1197.

Central cooling air conditioners: Standard for safety. 1978. IIlinois: U nderwriters L aboratories, Inc.

Cone, J, MJ Hodgson. 1989. Building-associated illness and problem buildings. State Art R ev 0 ccup $M$ ed 4(4).
Fanger, PO . 1973. Assessment of man's thermal comfort in practice. $\mathrm{Br}$ J Ind $\mathrm{M}$ ed 30:313-324.

Gilet, JC, JC Laforest, P M éreau, B Vandevyver. 1992. I onization négative de l'air. Cahiers De Notes D ocumentaires.

Hamilton, M. 1984. Air I on Balance in the W orkplace Vol. 2. Industrial Safety Data File, No. 65. Londres: U nited Trade Press.

H awkins, LH. 1982. Air ions and office health. O ccup $H$ ealth 34(3):116-124.

H awkinson, TE, DE Barber. 1982. The industrial hygiene significance of small air ions. Am Ind $\mathrm{H}$ yg AsSoc) 42:759-762.

$\mathrm{H}$ ealth and Safety Executive. 1983. O zone: $\mathrm{H}$ ealth $\mathrm{H}$ azards and Precautionary $M$ easures. : H ealth and Safety Executive.

Hedge, A, M D Collis. 1987. Do negative air ions affect human mood and performance? Occup $\mathrm{H}$ yg 31(3):285-290.

Hedge, A, A Eleftherakis. 1982. Air ionization: An evaluation of its physiological and psychological effects. $O$ ccup $H$ yg 25(4):409-419.

Heinsohn, RJ. 1991. Industrial Ventilation. Engineering Principles. Nueva Y ork: Wiley.

Liu, RT, RR Raber, HHS Yu. 1991. Filter selection on an engineering basis. H eating/ Piping/ AirConditioning 63(5):37-44.

$\mathrm{N}$ ational Institute for $\mathrm{O}$ ccupational Safety and $\mathrm{H}$ ealth (NIO SH ). 1978. Symposium Proceedings: T he R ecirculation of Industrial Exhaust Air. Cincinnati, O hio: NIOSH.

Rolloos, M. 1993. HVAC systems and indoor air quality. Indoor E nviron 2:204-212.

Thermal,visual, and acoustic requirements of buildings. 1979. B uilding R esearch E stablishment D igest 226.

Turiel, I. 1986. Indoor Air Quality and $\mathrm{H}$ uman $\mathrm{H}$ ealth. Palo Alto, California: Stanford U niv. Press.

Weekes, DM , RB Gammage. 1990. The Practitioner's Approach to Indoor Air Quality Investigations. Akron,O hio: American Industrial Hygiene Association. 


\section{ILUMINACION}

Director del capítulo

J uan Guasch F arrás

\section{Sumario}

Tipos de lamparas e iluminación

Richard Forster .......................... 46.2

Condiciones necesarias para el confort visual

Fernando R amos Pérez y A na H ernández Calleja. . .

Condiciones de la iluminación general

N. Alan Smith. 


\section{- TIPOS DE LAMPARAS E ILUMINACION}

\section{Richard Forster}

Una lámpara es un convertidor de energía. Aunque pueda realizar funciones secundarias, su principal propósito es la transformación de energía eléctrica en radiación electromagnética visible. $\mathrm{H}$ ay muchas maneras de crear luz, pero el método normalmente utilizado en la iluminación general es la conversión de energía eléctrica en luz.

\section{Tipos de luz}

\section{Incandescencia}

Los materiales sólidos y líquidos, al calentarse, emiten radiación visible a temperaturas superiores a $1.000 \mathrm{~K}$; este fenómeno recibe el nombre de incandescencia.

Las lámparas de filamentos se basan en este calentamiento para generar luz: una corriente eléctrica pasa a través de un fino hilo de tungsteno, cuya temperatura se eleva hasta alcanzar entre 2.500 y $3.200 \mathrm{~K}$, en función del tipo de lámpara y su aplicación.

Existe un límite para este método, que viene descrito por la Ley de Planck para el comportamiento de un radiador de cuerpo negro, de acuerdo con la cual, la distribución espectral de la energía radiada aumenta con la temperatura. A unos $3.600 \mathrm{~K}$ o más, se produce un marcado aumento en la emisión de radiación visible y la longitud de onda de la máxima energía se desplaza hacia la banda visible. Es una temperatura cercana al punto de fusión del tungsteno, que es el material utilizado como filamento, de modo que, en la práctica, el límite de temperatura es de unos $2.700 \mathrm{~K}$, por encima del cual la evaporación del filamento resulta excesiva. Una consecuencia de estos desplazamientos espectrales es que una gran parte de la radiación desprendida no se emite en forma de luz, sino en forma de calor en la región de infrarrojos. Por consiguiente, las bombillas de filamentos pueden ser dispositivos de calefacción eficaces y se utilizan en lámparas diseñadas para secar materiales impresos, preparar alimentos y criar animales.

\section{Descarga eléctrica}

La descarga eléctrica es una técnica utilizada en las modernas fuentes de luz para el comercio y la industria, debido a que la producción de luz es más eficaz. Algunos tipos de lámparas combinan la descarga eléctrica con la fotoluminiscencia.

U na corriente eléctrica que pasa a través de un gas excita los átomos y moléculas para emitir radiación con un espectro característico de los elementos presentes. N ormalmente se utilizan dos metales, sodio y mercurio, porque sus características dan lugar a radiaciones útiles en el espectro visible. $\mathrm{N}$ inguno de estos metales emite un espectro continuo y las lámparas de descarga tienen espectros selectivos. La reproducción del color nunca será idéntica a la obtenida con espectros continuos. Las lámparas de descarga suelen dividirse en las categorías de baja o alta presión, aunque estos términos sólo son relativos, y una lámpara de sodio de alta presión funciona a menos de una atmósfera.

\section{Tipos de luminiscencia}

La fotoluminiscencia se produce cuando la radiación es absorbida por un sólido y reemitida en una longitud de onda diferente. Cuando la radiación reemitida está dentro del espectro visible, el proceso se denomina fluorescencia o fosforescencia.

La electrol uminiscencia se produce cuando la luz es generada por una corriente eléctrica que pasa a través de ciertos sólidos, como los materiales fosfóricos. Se utiliza en cuadros de instrumentos y
Tabla 46.1 • Mejora de los requisitos de rendimiento lumínico y vataje de algunas lámparas de tubo fluorescente de $1.500 \mathrm{~mm}$.

$\begin{array}{llll}\begin{array}{l}\text { Potencia } \\ \text { (W) }\end{array} & \begin{array}{l}\text { Diámetro } \\ (\mathrm{mm})\end{array} & \text { Gas interior } & \begin{array}{l}\text { Eficiencia lumínica } \\ \text { (lúmenes) }\end{array} \\ 80 & 38 & \text { argón } & 4.800 \\ 65 & 38 & \text { argón } & 4.900 \\ 58 & 25 & \text { criptón } & 5.100 \\ 50 & 25 & \text { argón } & 5.100\end{array}$

letreros luminosos, pero no ha demostrado ser una fuente de luz práctica para la iluminación de edificios o exteriores.

\section{Evolución de las lámparas eléctricas}

Aunque el progreso tecnológico ha permitido producir diferentes lámparas, los principales factores que han influido en su desarrollo han sido fuerzas externas al mercado. Por ejemplo, la producción de las lámparas de filamentos que se utilizaban a principios de siglo sólo fue posible cuando se dispuso de buenas bombas de vacío y del proceso de trefilado del tungsteno. Con todo, fue la generación y distribución de electricidad a gran escala, para satisfacer la demanda de iluminación eléctrica, la que determinó el crecimiento del mercado. La iluminación eléctrica ofrecía muchas ventajas en comparación con la luz generada por gas o aceite, como la estabilidad de la luz, el escaso mantenimiento, la mayor seguridad que supone no tener una llama desnuda y la ausencia de subproductos locales de combustión.

Durante el período de recuperación que siguió a la segunda Guerra Mundial, lo importante era la productividad. La lámpara fluorescente tubular se convirtió en la fuente de luz dominante porque con ella era posible iluminar fábricas y oficinas sin sombras y comparativamente sin calor, aprovechando al máximo el espacio disponible. En la Tabla 46.1 se indican los requisitos de vataje y rendimiento lumínico de una lámpara fluorescente tubular típica de $1.500 \mathrm{~mm}$.

En el decenio de 1970 aumentó el precio del petróleo y los costes energéticos se convirtieron en una parte importante de los costes de explotación. El mercado demandaba lámparas fluorescentes que produjesen la misma cantidad de luz con un menor consumo eléctrico, por lo que se perfeccionó el diseño de la lámpara de varias maneras. A medida que se aproxima el fin de siglo, aumenta la conciencia de los problemas ambientales globales. Factores como el mejor aprovechamiento de las materias primas escasas, el reciclaje o la seguridad en el vertido de los productos y la continua preocupación por el consumo de energía (sobre todo de la generada a partir de combustibles fósiles) influyen en el diseño de las lámparas actuales.

\section{Criterios de rendimiento}

Los criterios de rendimiento varían según la aplicación. En general, no existe una jerarquía concreta de importancia de estos criterios.

Rendimiento lumínico: la emisión de lúmenes de una lámpara determinará su idoneidad en relación con la escala de la instalación y la cantidad de iluminación necesaria.

Coloración y reproducción del color: se aplican escalas y valores numéricos independientes a la coloración y a la reproducción del color. Es importante recordar que las cifras sólo son orientativas y que algunas sólo son aproximaciones. Siempre que sea posible, deberán realizarse valoraciones de idoneidad con 
lámparas reales y con los colores o materiales aplicables a la situación.

Vida útil de la lámpara: la mayoría de las lámparas tienen que ser reemplazadas varias veces durante la pervivencia de la instalación de alumbrado y los diseñadores deben reducir al mínimo los inconvenientes para los ocupantes como consecuencia de las averías esporádicas y del mantenimiento. Las lámparas tienen muy diversas aplicaciones. La previsión de vida útil media suele ser un compromiso entre coste y rendimiento. Por ejemplo, la lámpara de un proyector de diapositivas durará unos cuantos cientos de horas, porque es importante que alcance el máximo rendimiento lumínico para conseguir una imagen de buena calidad. Por el contrario, algunas lámparas de alumbrado de carreteras pueden durar hasta dos años, lo que representa unas 8.000 horas de encendido.

A demás, la vida útil de la lámpara se ve afectada por las condiciones de trabajo, por lo que no existe una cifra válida para todas las situaciones. D e igual manera, la duración efectiva de la lámpara puede venir determinada por diferentes formas de deterioro. El fallo físico, como la rotura del filamento o de la propia lámpara, puede venir precedido de una reducción del rendimiento lumínico o de cambios en la coloración. La duración de la lámpara resulta afectada por condiciones ambientales externas como la temperatura, la vibración, la frecuencia de encendido, las fluctuaciones de la tensión de alimentación, la orientación, etcétera.

Es preciso observar que la vida media establecida para un tipo de lámpara es el tiempo que tardan en fallar el $50 \%$ de las lámparas de una partida de pruebas. No es probable que esta definición de vida útil sea aplicable a muchas instalaciones comerciales o industriales, por lo que la duración de una lámpara suele ser inferior en la práctica a los valores publicados, que sólo deberán utilizarse a efectos de comparación.

E ficiencia: como norma general, la eficiencia de un tipo determinado de lámpara será mejor cuanto mayor sea el régimen de potencia, porque la mayoría de las lámparas tienen cierta pérdida fija. A hora bien, comparando diferentes tipos de lámparas se observan marcadas variaciones de eficiencia. Es conveniente utilizar las lámparas de mayor eficiencia, siempre que se cumplan al mismo tiempo los criterios de tamaño, color y vida útil. No debe ahorrarse energía a expensas del confort visual 0 del rendimiento de los
Tabla 46.2 • Rendimientos típicos de las lámparas.

\section{Eficiencia de las lámparas}

Lámpara de filamento de $100 \mathrm{~W}$

14 lúmenes/ vatio

Tubo fluorescente de $58 \mathrm{~W}$

89 lúmenes/ vatio

Lámpara de sodio de alta presión de $400 \mathrm{~W}$

125 lúmenes/ vatio

Lámpara de sodio de baja presión de $131 \mathrm{~W}$

198 lúmenes/ vatio

ocupantes. En la Tabla 46.2 se ofrecen algunos valores típicos de eficiencia.

\section{Principales tipos de lámparas}

A lo largo de los años, se han ido desarrollando varios sistemas de nomenclatura en los registros y normas nacionales e internacionales.

En 1993, la Comisión Electrotécnica Internacional (CEI) publicó un nuevo Sistema Internacional de Codificación de Lámparas (SICL) pensado para sustituir a los sistemas de codificación nacionales y regionales ya existentes. En la Tabla 46.3 figuran algunos códigos SICL en formato abreviado para diversas lámparas.

\section{Lámparas incandescentes}

Utilizan un filamento de tungsteno dentro de un globo de vidrio al vacío o lleno de un gas inerte que evite la evaporación del tungsteno y reduzca el ennegrecimiento del globo. Existen lámparas de muy diversas formas, que pueden resultar muy decorativas. En la Figura 46.1 se muestran los componentes de una lámpara típica de iluminación general (G eneral Lighting Service, GLS).

Las lámparas incandescentes también se presentan en una amplia gama de colores y acabados. En la Tabla 46.4 aparecen algunas formas típicas y los códigos SICL.

Se trata de unas lámparas que siguen teniendo aceptación en la iluminación doméstica debido a su bajo coste y pequeño tamaño. Con todo, su baja eficiencia genera costes de explotación muy altos en la iluminación comercial e industrial, por lo que normalmente se prefieren las lámparas de descarga. U na lámpara de $100 \mathrm{~W}$ tiene una eficiencia típica de 14 lúmenes/ vatio en comparación con los 96 lúmenes/ vatio de una lámpara fluorescente de $36 \mathrm{~W}$.

Las lámparas incandescentes todavía se utilizan cuando la atenuación de la luz es una característica de control conveniente, ya que resulta fácil atenuarlas reduciendo la tensión de alimentación.

Tabla 46.3 - Sistema Internacional de Codificación de Lámparas (SIC L), sistema de codificación en formato abreviado para algunos tipos de lámparas.

\begin{tabular}{|c|c|c|c|c|}
\hline Tipo (código) & $\begin{array}{l}\text { Potencia normal } \\
\text { (vatios) }\end{array}$ & $\begin{array}{l}\text { Reproducción del } \\
\text { color }\end{array}$ & $\begin{array}{l}\text { Temperatura } \\
\text { colorimétrica (K) }\end{array}$ & $\begin{array}{l}\text { Vida útil } \\
\text { (horas) }\end{array}$ \\
\hline Lámparas fluorescentes de tamaño reducido (FS) & $5-55$ & buena & $2.700-5.000$ & $5.000-10.000$ \\
\hline Lámparas de mercurio de alta presión (QE) & $80-750$ & correcta & $3.300-3.800$ & 20.000 \\
\hline Lámparas de sodio de alta presión (S-) & $50-1.000$ & de incorrecta a buena & $2.000-2.500$ & $6.000-24.000$ \\
\hline Lámparas incandescentes (I) & $5-500$ & buena & 2.700 & $1.000-3.000$ \\
\hline Lámparas de inducción (XF) & $23-85$ & buena & $3.000-4.000$ & $10.000-60.000$ \\
\hline Lámparas de sodio de baja presión (LS) & $26-180$ & color amarillo monocromático & 1.800 & 16.000 \\
\hline Lámparas halógenas de tungsteno de baja tensión (HS) & $12-100$ & buena & 3.000 & $2.000-5.000$ \\
\hline Lámparas de haluro metálico (M-) & $35-2.000$ & de buena a excelente & $3.000-5.000$ & $6.000-20.000$ \\
\hline Lámparas fluorescentes tubulares (FD) & $4-100$ & de correcta a buena & $2.700-6.500$ & $10.000-15.000$ \\
\hline Lámparas halógenas de tungsteno (HS) & $100-2.000$ & buena & 3.000 & $2.000-4.000$ \\
\hline
\end{tabular}


Figura 46.1 • Construcción de una lámpara GLS.

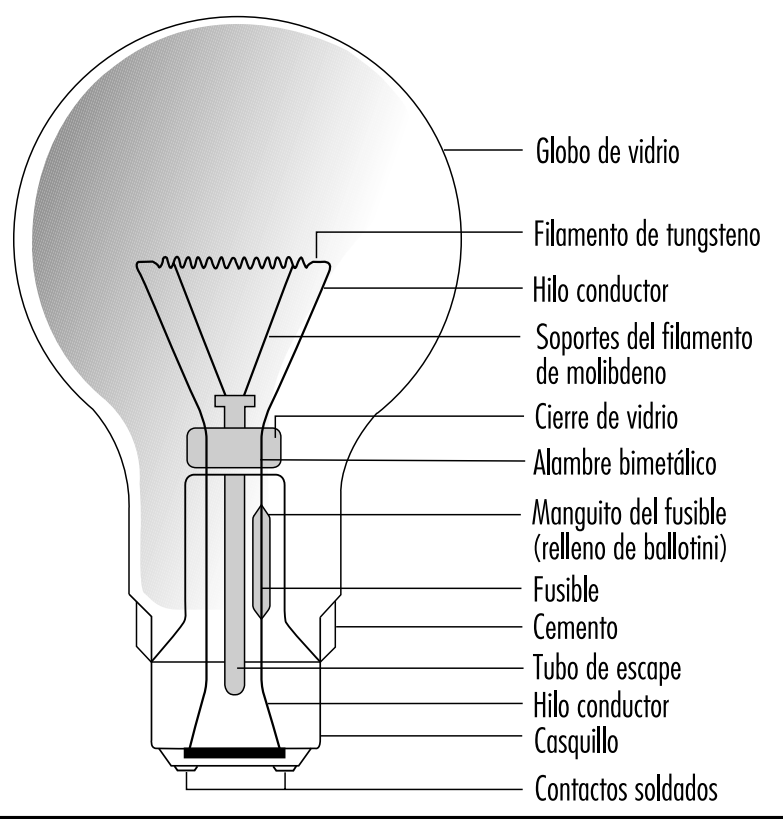

El filamento de tungsteno es una fuente de luz de tamaño reducido, que puede enfocarse fácilmente con reflectores 0 lentes. Las lámparas incandescentes son útiles en la iluminación de expositores, donde se requiere control direccional.

\section{Lámparas halógenas de tungsteno}

Son parecidas a las lámparas incandescentes y producen luz de la misma manera, a partir de un filamento de tungsteno. Ahora bien, el globo contiene gas halógeno (bromo o yodo) que actúa controlando la evaporación del tungsteno (véase la Figura 46.2).

Es fundamental para el ciclo del halógeno que la bombilla se mantenga a una temperatura mínima de $250{ }^{\circ} \mathrm{C}$ para que el haluro de tungsteno permanezca en estado gaseoso y no se condense sobre la superficie del globo. Tal temperatura da lugar a que las bombillas se fabriquen con cuarzo en lugar de vidrio. El cuarzo permite reducir el tamaño de la bombilla.

La mayoría de las lámparas halógenas de tungsteno duran más tiempo que sus equivalentes incandescentes y el filamento alcanza una temperatura más alta, creando más luz y un color más blanco.

Figura 46.2 • El ciclo halógeno.

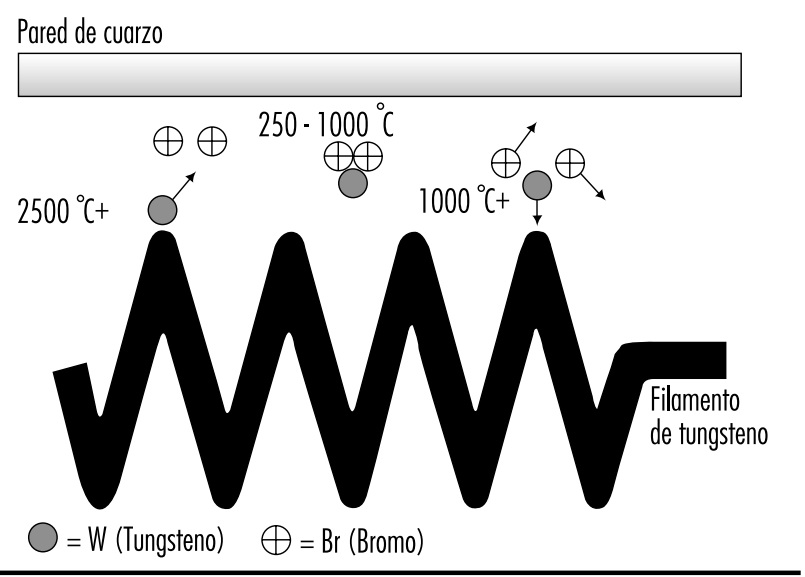

Tabla 46.4 • Colores y formas comunes a las lámparas incandescentes, con sus códigos del SICL.

\begin{tabular}{|c|c|}
\hline Color/ Forma & Código \\
\hline Transparente & IC \\
\hline Esmerilado & $/ F$ \\
\hline Blanco & I W \\
\hline Rojo & $/ R$ \\
\hline Azul & / B \\
\hline Verde & $1 G$ \\
\hline Amarillo & IY \\
\hline Forma de pera (GLS) & IA \\
\hline Forma cilíndrica & IB \\
\hline Forma cónica & IC \\
\hline Forma de globo & IG \\
\hline Forma de seta & IM \\
\hline
\end{tabular}

Las lámparas halógenas de tungsteno han encontrado aceptación en situaciones cuyos principales requisitos son un tamaño reducido y un alto rendimiento. Como ejemplo típico cabe citar la iluminación de escenarios, incluyendo el cine y la televisión, donde el control direccional y la atenuación son requisitos habituales.

\section{Lámparas halógenas de tungsteno de baja tensión}

Fueron diseñadas originalmente para proyectores de diapositivas y películas. A $12 \mathrm{~V}$, un filamento diseñado para los mismos vatios que en el caso de una corriente de $230 \mathrm{~V}$ se hace más pequeño y grueso. Puede enfocarse más eficazmente, y la mayor masa del filamento permite una temperatura de trabajo más alta, aumentando el rendimiento lumínico. El filamento grueso es más robusto. Son características que se han considerado ventajosas en el mercado de los expositores comerciales y, aunque es necesario incorporar un transformador reductor, estas lámparas dominan actualmente la iluminación de escaparates (véase la Figura 46.3).

Aunque los usuarios de proyectores cinematográficos desean el máximo de luz posible, un exceso de calor deteriora el medio

Figura 46.3 • Lámpara reflectora dicroica de baja tensión.

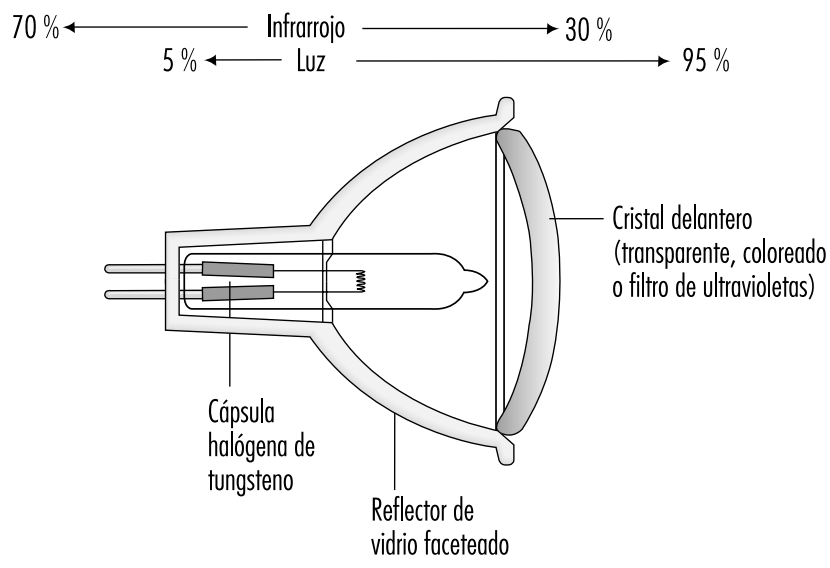


Figura 46.4 • Lámparas de filamento G LS y tensión de alimentación.

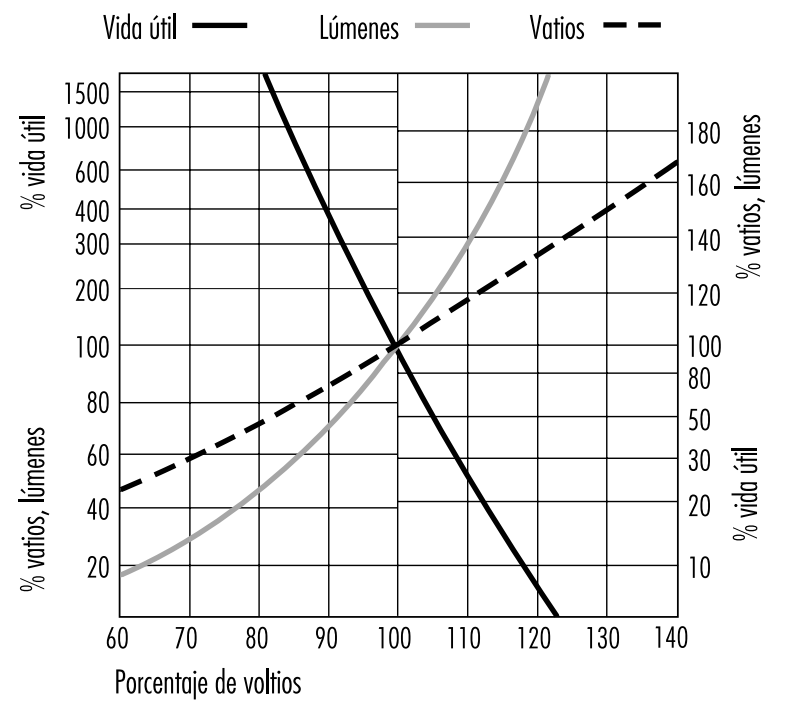

de la transparencia. Se ha desarrollado un tipo especial de reflector que sólo refleja la radiación visible, permitiendo que la radiación de infrarrojos (calor) pase a través de la parte trasera de la lámpara. En la actualidad, esta característica está incorporada en muchas lámparas de reflectores de baja tensión para la iluminación de expositores, así como en equipos de proyección.

Sensibilidad a la tensión: todas las lámparas de filamentos son sensibles a las variaciones de tensión, viéndose afectadas en términos de rendimiento lumínico y vida útil. Se está consiguiendo "armonizar" la tensión de alimentación a $230 \mathrm{~V}$ en toda Europa ampliando las tolerancias de trabajo de las autoridades que regulan la generación de electricidad. Se tiende a un $\pm 10 \%$, que es una gama de tensiones de 207 a $253 \mathrm{~V}$. En esta gama no es razonable trabajar con lámparas incandescentes ni con lámparas halógenas de tungsteno, por lo que será necesario adaptar la tensión de alimentación efectiva a la potencia de las lámparas (véase la Figura 46.4).

Las lámparas de descarga también se verán afectadas por tan grandes variaciones de tensión, de modo que será importante la correcta especificación del equipo de control.

\section{Lámparas fluorescentes tubulares}

Son lámparas de mercurio de baja presión que están disponibles en versiones de "cátodo caliente" y "cátodo frío". La primera versión es el tubo fluorescente convencional para fábricas y oficinas; "cátodo caliente" se refiere al cebado de la lámpara por precalentamiento de los electrodos para que la ionización del gas y del vapor de mercurio sea suficiente para realizar la descarga.

Las lámparas de cátodo frío se utilizan principalmente en letreros y anuncios publicitarios (véase la Figura 46.5).

Las lámparas fluorescentes necesitan equipo de control externo para efectuar el cebado y para regular la corriente de la lámpara. A demás de la pequeña cantidad de vapor de mercurio, hay un gas de cebado (argón o criptón).

La baja presión del mercurio genera una descarga de luz de color azul pálido. La mayor parte de la radiación está en la región ultravioleta a $254 \mathrm{~nm}$, una frecuencia de radiación característica del mercurio. En el interior de la pared del tubo hay un fino revestimiento fosfórico, que absorbe los rayos ultravioleta e irradia la energía en forma de luz visible. EI color de la luz viene
Figura 46.5 - Principio de la lámpara fluorescente.

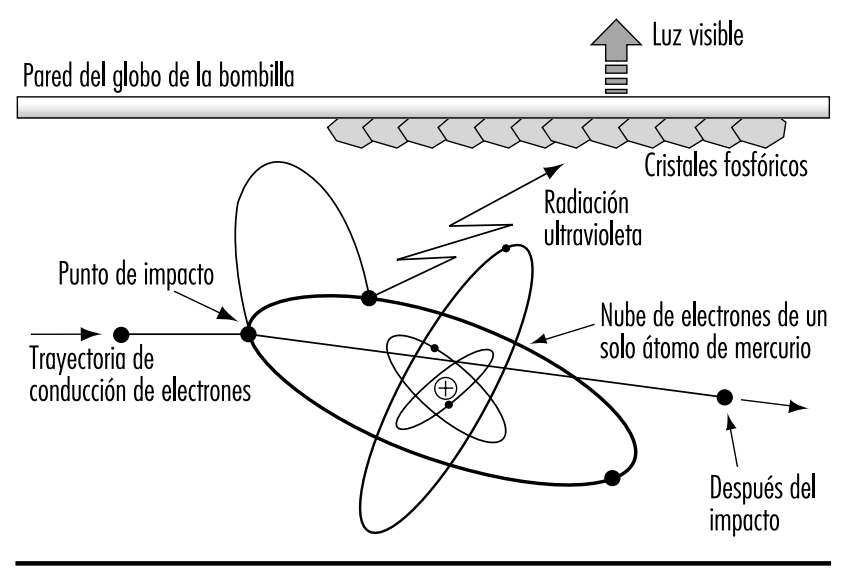

determinado por el revestimiento fosfórico. Existe toda una gama de materiales fosfóricos con diversas características de coloración y reproducción del color.

Durante el decenio de 1950 los materiales fosfóricos disponibles ofrecían la posibilidad de elegir entre una eficiencia razonable (60 lúmenes/vatio) con una luz deficiente en rojos y azules, o una mejor reproducción del color a partir de materiales fosfóricos "de lujo" pero de menor eficiencia (40 lúmenes/ vatio).

En el decenio de 1970 ya se habían desarrollado nuevos materiales fosfóricos de banda estrecha que irradiaban luz roja, azul y verde por separado, pero que, en combinación, producían luz blanca. El ajuste de las proporciones dio lugar a toda una gama de coloraciones diferentes, todas ellas con similares y excelentes propiedades de reproducción del color. Se trata de materiales trifosfóricos más eficaces que los primeros tipos y representan la solución de iluminación más económica, aunque las lámparas sean más caras. La mayor eficiencia reduce los costes de explotación e instalación.

El principio del material trifosfórico ha venido a ampliarse con las lámparas multifosfóricas en situaciones donde la reproducción del color es esencial, como en galerías de arte y en la comparación de colores en la industria.

Los modernos materiales fosfóricos de banda estrecha son más duraderos, mejoran la constancia del flujo luminoso y aumentan la vida útil de la lámpara.

\section{Lámparas fluorescentes de tamaño reducido}

El tubo fluorescente no es un sustituto práctico para la lámpara incandescente debido a su forma alargada. Pueden hacerse tubos cortos y estrechos de aproximadamente el mismo tamaño que la lámpara incandescente, pero esto impone una carga eléctrica muy superior al material fosfórico. Para que la lámpara tenga una vida útil aceptable es esencial utilizar trifosfóricos (véase la Figura 46.6).

En todas las lámparas fluorescentes de tamaño reducido se utilizan trifosfóricos, de modo que, si se utilizan junto con las alargadas, también deberán utilizarse en estas últimas, para mantener la coherencia de los colores. Algunas lámparas de tamaño reducido incluyen el equipo de control necesario para crear dispositivos de conversión para lámparas incandescentes. La gama va en aumento y permite actualizar fácilmente las instalaciones de alumbrado ya existentes para utilizar más eficazmente la energía. En el caso de que los controles originales lo permitieran, estas unidades integradas no serían adecuadas para el efecto de atenuación. 
Figura 46.6 • Fluorescente de tamaño reducido de cuatro patas.

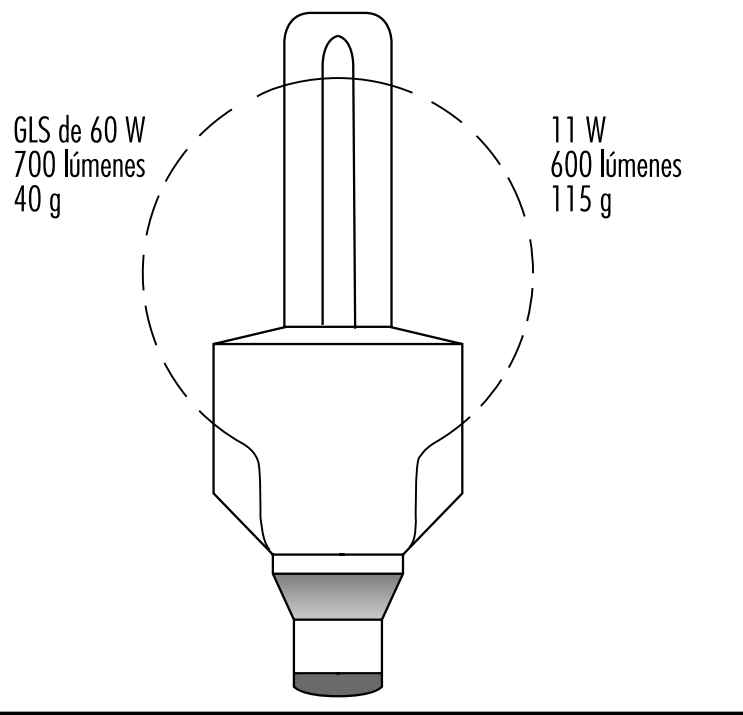

Equipo electrónico de control de alta frecuencia: si la frecuencia normal de alimentación de 50 o $60 \mathrm{~Hz}$ aumenta a $30 \mathrm{kHz}$, se produce un $10 \%$ de aumento en la eficiencia de los tubos fluorescentes. LOS circuitos electrónicos pueden manejar las lámparas individualmente a tales frecuencias. El circuito electrónico está diseñado para proporcionar el mismo rendimiento lumínico que el equipo de control de hilo bobinado, con menor potencia en la lámpara. Con ello es posible compatibilizar el paquete luménico, con la ventaja de que la menor carga en la lámpara aumentará notablemente la vida útil de ésta. El equipo de control electrónico puede trabajar en toda una gama de tensiones de alimentación.

No existe una norma común para el equipo de control electrónico y el rendimiento de las lámparas puede diferir de la información publicada por los fabricantes.

El uso de equipo electrónico de alta frecuencia elimina el problema normal de parpadeo de la luz, al que algunos ocupantes pueden ser sensibles.

\section{Lámparas de inducción}

Recientemente han aparecido en el mercado lámparas que utilizan el principio de inducción. Son lámparas de mercurio de baja presión con revestimientos trifosfóricos y cuya producción de luz es similar a la de las lámparas fluorescentes. La energía se transmite a la lámpara por radiación de alta frecuencia, aproximadamente a 2,5 M Hz, desde una antena situada en el centro de la lámpara. No existe conexión física entre la bombilla y la bobina. Sin electrodos u otras conexiones alámbricas, la construcción del recipiente de descarga es más sencilla y duradera. La vida útil de la lámpara se determina principalmente por la fiabilidad de los componentes electrónicos y la constancia del flujo luminoso del revestimiento fosfórico.

\section{Lámparas de mercurio de alta presión}

Las descargas de alta presión son más compactas y tienen mayores cargas eléctricas; por consiguiente, requieren tubos de descarga de arco hechos de cuarzo para soportar la presión y la temperatura. El tubo de descarga de arco va dentro de una envoltura exterior de vidrio con una atmósfera de nitrógeno o argónnitrógeno para reducir la oxidación y el chisporroteo. La bombilla filtra eficazmente la radiación ultravioleta del tubo de descarga de arco (véase la Figura 46.7).
Figura 46.7 • Componentes de una lámpara de mercurio.

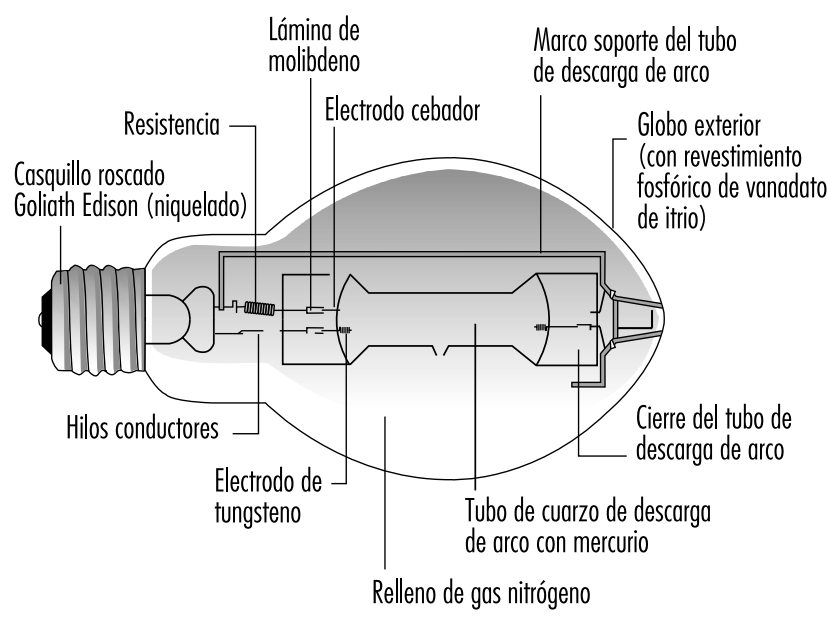

A alta presión, la descarga de mercurio es principalmente radiación azul y verde. Para mejorar el color, un revestimiento fosfórico aplicado a la bombilla añade luz roja. Existen versiones de lujo con mayor contenido de rojo, que proporcionan un mayor rendimiento lumínico y reproducen mejor el color.

A todas las lámparas de descarga de alta presión les cuesta alcanzar su pleno rendimiento. La descarga inicial se realiza a través del gas conductor interior y el metal se evapora a medida que aumenta la temperatura de la lámpara. A presión estable, la lámpara no se vuelve a cebar inmediatamente sin un equipo de control especial. Se produce una demora mientras la lámpara se enfría suficientemente y se reduce la presión, de modo que basta la tensión de alimentación normal o el circuito de ignición para restablecer el arco.

Las lámparas de descarga tienen una característica de resistencia negativa, por lo que es necesario el equipo de control externo para regular la corriente. Existen pérdidas debidas a los componentes del estos equipos de control, de modo que el usuario deberá tener en cuenta el vataje total al estudiar los costes de explotación y la instalación eléctrica. Las lámparas de mercurio de alta presión constituyen una excepción, y uno de sus tipos contiene un filamento de tungsteno que actúa como dispositivo limitador de corriente y además agrega colores cálidos a la descarga verde/ azul. Con lo cual, las lámparas incandescentes pueden reemplazarse directamente.

Aunque las lámparas de mercurio tienen una larga vida útil, de alrededor de 20.000 horas, su rendimiento lumínico disminuye hasta aproximadamente el $55 \%$ del inicial al final de este período y, por consiguiente, su vida económica puede ser menor.

\section{Lámparas de haluro metálico}

Es posible mejorar el color y el rendimiento lumínico de las lámparas de descarga de mercurio añadiendo diferentes metales al arco de mercurio. La dosis es pequeña en cada lámpara y, a efectos de precisión en la aplicación, es más conveniente manejar los metales en polvo, en forma de haluros, que se disgrega cuando la lámpara se calienta y libera el metal.

U na lámpara de haluro metálico puede utilizar varios metales diferentes, cada uno de los cuales emite un color característico específico. Entre ellos cabe citar:

- disprosio - verde-azul de banda ancha

- indio - azul de banda estrecha

- litio - rojo de banda estrecha 
- escandio - verde-azul de banda ancha

- sodio - amarillo de banda estrecha

- talio - verde de banda estrecha

- estaño - rojo-naranja de banda ancha

No existe una mezcla estándar de metales, por lo que puede ser que las lámparas de haluro metálico de diferentes fabricantes no sean compatibles en aspecto o funcionamiento. En las lámparas de menor vataje, de 35 a $150 \mathrm{~W}$, existe una compatibilidad física y eléctrica más próxima a una norma común.

L as lámparas de haluro metálico necesitan equipo de control, pero la falta de compatibilidad significa que es necesario combinar bien cada lámpara con su equipo para que las condiciones de cebado y funcionamiento sean correctas.

\section{Lámparas de sodio de baja presión}

El tubo de descarga de arco tiene un tamaño similar al tubo fluorescente, pero está hecho de un vidrio contrachapado especial con una capa interior resistente al sodio. El tubo de descarga de arco tiene forma de " $U$ " estrecha y va dentro de una envoltura exterior al vacío para asegurar la estabilidad térmica. Durante el cebado, el gas neón del interior de la lámpara produce un intenso resplandor rojo.

La radiación característica del vapor de sodio a baja presión es de un amarillo monocromático. Es un color próximo a la sensibilidad máxima del ojo humano y las lámparas de sodio de baja presión son las más eficaces que existen, a casi 200 lúmenes/ vatio. A hora bien, su aplicación viene limitada por la condición de que la discriminación de los colores no tenga importancia visual, como en el caso de las carreteras principales, los pasos subterráneos y las calles residenciales.

En muchas situaciones estas lámparas están siendo reemplazadas por lámparas de sodio de alta presión. Su menor tamaño ofrece mejor control óptico, particularmente en el alumbrado de carreteras, donde existe cada vez mayor preocupación por el excesivo resplandor del cielo.

\section{Lámparas de sodio de alta presión}

Son parecidas a las de mercurio de alta presión, pero ofrecen mejor eficiencia (más de 100 lúmenes/ vatio) y una excelente constancia del flujo luminoso. La naturaleza reactiva del sodio requiere que el tubo de descarga de arco se fabrique con alúmina policristalina translúcida, ya que el vidrio o el cuarzo son inadecuados. El globo de vidrio exterior contiene un vacío para evitar el chisporroteo y la oxidación. La descarga de sodio no emite radiación ultravioleta, por lo que los revestimientos fosfóricos no tienen ninguna utilidad. Algunas bombillas son esmeriladas 0 revestidas para difuminar la fuente de luz (véase la Figura 46.8).

Figura 46.8 - Componentes de una lámpara de sodio de alta presión.

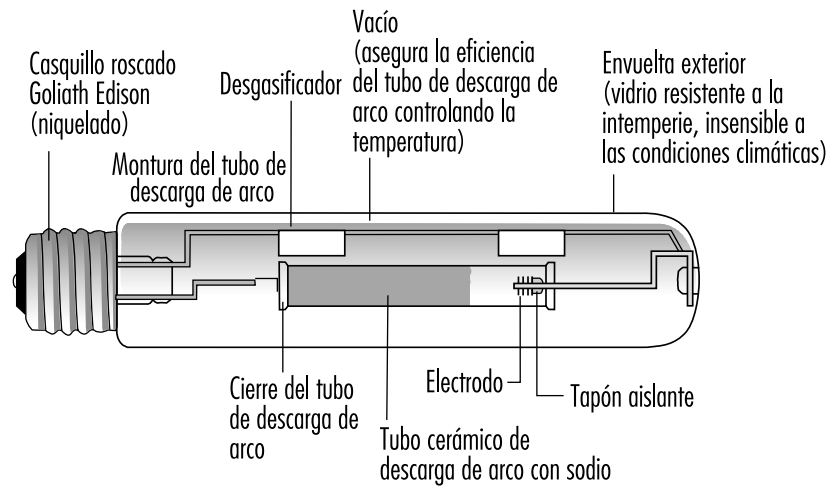

Tabla 46.5 • Tipos de lámparas de sodio de alta presión.

\begin{tabular}{llll}
$\begin{array}{l}\text { Tipo de lámpara } \\
\text { (Código) }\end{array}$ & Color (K) & $\begin{array}{l}\text { Rendimiento } \\
\text { (lúmenes/ vatio) }\end{array}$ & $\begin{array}{l}\text { Vida útil } \\
\text { (horas) }\end{array}$ \\
Normal & 2.000 & 110 & 24.000 \\
De lujo & 2.200 & 80 & 14.000 \\
Blanca (SON) & 2.500 & 50 & \\
\hline
\end{tabular}

Al aumentar la presión del sodio, la radiación se convierte en una banda ancha alrededor del pico amarillo y su coloración es de un blanco dorado. A hora bien, al aumentar la presión, disminuye la eficiencia. A ctualmente existen tres tipos independientes de lámparas de sodio de alta presión, como se ilustra en la Tabla 46.5 .

Generalmente, se utilizan las lámparas normales para el alumbrado exterior, las lámparas de lujo para los interiores industriales y las blancas son para aplicaciones comerciales y de exposición.

\section{Atenuación de las lámparas de descarga}

Las lámparas de alta presión no pueden atenuarse satisfactoriamente, ya que al cambiar la potencia de la lámpara cambia la presión y, por consiguiente, las características fundamentales de la lámpara.

L as lámparas fluorescentes pueden atenuarse utilizando suministros eléctricos de alta frecuencia generados normalmente con el equipo de control electrónico. La coloración permanece muy constante. Además, el rendimiento lumínico es aproximadamente proporcional a la potencia de la lámpara, con el consiguiente ahorro de energía eléctrica cuando se reduce dicho rendimiento. La integración del rendimiento lumínico de la lámpara con el nivel predominante de luz natural puede dar lugar a un nivel de iluminancia casi constante en un interior.

\section{CONDICIONES NECESARIAS PARA EL CONFORT VISUAL}

\section{Fernando Ramos Pérez y Ana Hernández Calleja}

Los seres humanos poseen una capacidad extraordinaria para adaptarse a su ambiente y a su entorno inmediato. De todos los tipos de energía que pueden utilizar los humanos, la luz es la más importante. La luz es un elemento esencial de nuestra capacidad de ver y necesaria para apreciar la forma, el color y la perspectiva de los objetos que nos rodean en nuestra vida diaria. La mayor parte de la información que obtenemos a través de nuestros sentidos la obtenemos por la vista (cerca del $80 \%$ ). Y al estar tan acostumbrados a disponer de ella, damos por supuesta su labor. Ahora bien, no debemos olvidar que ciertos aspectos del bienestar humano, como nuestro estado mental o nuestro nivel de fatiga, se ven afectados por la iluminación y por el color de las cosas que nos rodean. D esde el punto de vista de la seguridad en el trabajo, la capacidad y el confort visuales son extraordinariamente importantes, ya que muchos accidentes se deben, entre otras razones, a deficiencias en la iluminación o a errores cometidos por el trabajador, a quien le resulta difícil identificar objetos o los riesgos asociados con la maquinaria, los transportes, los recipientes peligrosos, etcétera.

L os trastornos visuales asociados con deficiencias del sistema de iluminación son habituales en los lugares de trabajo. Dado que la vista es capaz de adaptarse a situaciones de iluminación 
deficiente, a veces no se tienen estos aspectos en cuenta con la seriedad que se debería.

El correcto diseño de un sistema de iluminación debe ofrecer las condiciones óptimas para el confort visual. Para conseguir este objetivo, debe establecerse una primera línea de colaboración entre arquitectos, diseñadores de iluminación y los responsables de higiene en el trabajo, que debe ser anterior al inicio del proyecto, con el fin de evitar errores que pueda ser difícil corregir una vez terminado. Entre los aspectos más importantes que es preciso tener en cuenta cabe citar el tipo de lámpara y el sistema de alumbrado que se va a instalar, la distribución de la luminancia, la eficiencia de la iluminación y la composición espectral de la luz.

El hecho de que la luz y el color afectan a la productividad y al bienestar psicofisiológico del trabajador debe animar a los técnicos en iluminación, fisiólogos y ergonomistas a tomar iniciativas destinadas a estudiar y determinar las condiciones más favorables de luz y color en cada puesto de trabajo. La combinación de iluminación, el contraste de luminancias, el color de la luz, la reproducción del color o la elección de los colores son los elementos que determinan el clima del colorido y el confort visual.

\section{Factores que determinan el confort visual}

Los requisitos que un sistema de iluminación debe cumplir para proporcionar las condiciones necesarias para el confort visual son los siguientes:
- iluminación uniforme;

- luminancia óptima;

- ausencia de brillos deslumbrantes;

- condiciones de contraste adecuadas;

- colores correctos,

- ausencia de luces intermitentes o efectos estroboscópicos.

Es importante examinar la luz en el lugar de trabajo no sólo con criterios cuantitativos, sino también cualitativos. El primer paso es estudiar el puesto de trabajo, la precisión que requieren las tareas realizadas, la cantidad de trabajo, la movilidad del trabajador, etcétera. La luz debe incluir componentes de radiación difusa y directa. El resultado de la combinación de ambos producirá sombras de mayor o menor intensidad, que permitirán al trabajador percibir la forma y posición de los objetos situados en el puesto de trabajo. Deben eliminarse los reflejos molestos, que dificultan la percepción de los detalles, así como los brillos excesivos o las sombras oscuras.

El mantenimiento periódico de la instalación de alumbrado es muy importante. El objetivo es prevenir el envejecimiento de las lámparas y la acumulación de polvo en las luminarias, cuya consecuencia será una pérdida constante de luz. Por esta razón, es importante elegir lámparas y sistemas fáciles de mantener. Una bombilla incandescente mantiene su eficiencia hasta los momentos previos al fallo, pero no ocurre lo mismo con los tubos fluorescentes, cuyo rendimiento puede sufrir una reducción del $75 \%$ después de mil horas de uso.

Figura 46.9 • N iveles de iluminación en función de las tareas realizadas.

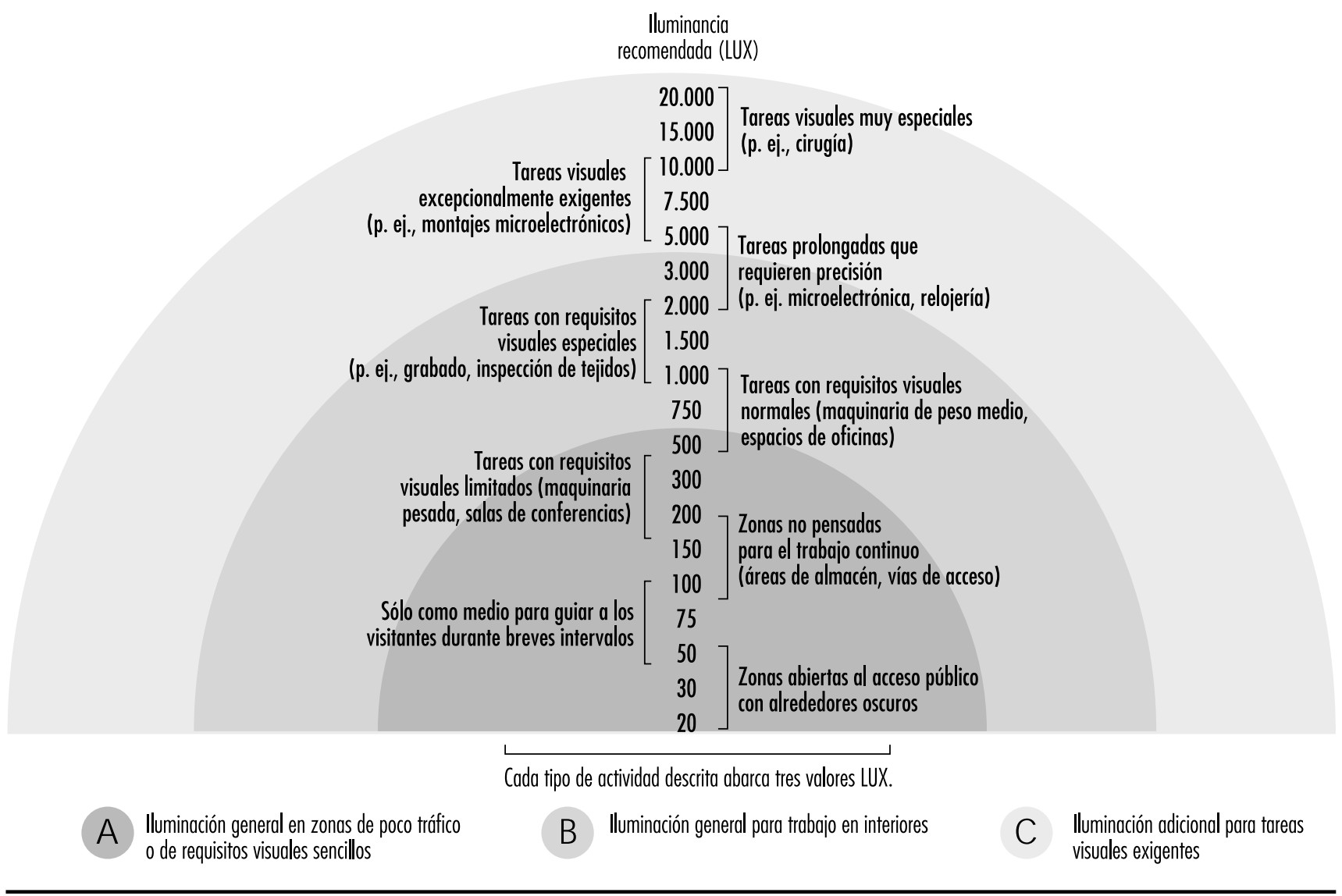




\section{Niveles de iluminación}

Cada actividad requiere un nivel específico de iluminación en el área donde se realiza. En general, cuanto mayor sea la dificultad de percepción visual, mayor deberá ser el nivel medio de la iluminación. En varias publicaciones se ofrecen directrices de niveles mínimos de iluminación asociados a diferentes tareas. En concreto, los recogidos en la Figura 46.9 se han tomado de las normas europeas CENTC 169 y se basan más en la experiencia que en el conocimiento científico.

El nivel de iluminación se mide con un luxómetro que convierte la energía luminosa en una señal eléctrica, que posteriormente se amplifica y permite una fácil lectura en una escala de lux calibrada. Al elegir un cierto nivel de iluminación para un puesto de trabajo determinado, deberán estudiarse los siguientes puntos:

- la naturaleza del trabajo

- la reflectancia del objeto y de su entorno inmediato;

- las diferencias con la luz natural y la necesidad de iluminación diurna,

- la edad del trabajador.

\section{Unidades y magnitudes de iluminación}

En el campo de la iluminación se utilizan habitualmente varias magnitudes. Las más básicas son las siguientes:

Flujo luminoso: energía luminosa emitida por una fuente de luz durante una unidad de tiempo. U nidad: Iumen (Im).

Intensidad luminosa: flujo luminoso emitido en una dirección determinada por una luz que no tiene una distribución uniforme. U nidad: candela (cd).

Nivel de iluminación: nivel de iluminación de una superficie de un metro cuadrado que recibe un flujo luminoso de un lumen. Unidad: $\mathrm{lux}=\mathrm{Im} / \mathrm{m}^{2}$.

Luminancia o brillo fotométrico: se define para una superficie en una dirección determinada, y es la relación entre la intensidad luminosa y la superficie vista por un observador situado en la misma dirección (superficie aparente). U nidad: $\mathrm{cd} / \mathrm{m}^{2}$.

Contraste: diferencia de luminancia entre un objeto y su entorno 0 entre diferentes partes de un objeto.

R eflectancia: proporción de la luz que es reflejada por una superficie. Es una cantidad no dimensional. Su valor varía entre 0 y 1

\section{Factores que afectan a la visibilidad de los objetos}

El grado de seguridad con que se ejecuta una tarea depende, en gran parte, de la calidad de la iluminación y de las capacidades

Tabla 46.6 • Contrastes de color

$\begin{array}{ll}\text { Contrastes de color por } & \text { orden descendente } \\ \text { Color del objeto } & \text { Color del fondo } \\ \text { Negro } & \text { Amarillo } \\ \text { Verde } & \text { Blanco } \\ \text { Rojo } & \text { Blanco } \\ \text { Azul } & \text { Blanco } \\ \text { Blanco } & \text { Azul } \\ \text { Negro } & \text { Blanco } \\ \text { Amarillo } & \text { Negro } \\ \text { Blanco } & \text { Rojo } \\ \text { Blanco } & \text { Verde } \\ \text { Blanco } & \text { Negro }\end{array}$

visuales. La visibilidad de un objeto puede resultar alterada de muchas maneras. U na de las más importantes es el contraste de luminancias debido a factores de reflexión, a sombras, o a los colores del propio objeto y a los factores de reflexión del color. Lo que el ojo realmente percibe son las diferencias de luminancia entre un objeto y su entorno o entre diferentes partes del mismo objeto. En la Tabla 46.6 se muestran los contrastes entre colores por orden descendente.

La luminancia de un objeto, de su entorno y del área de trabajo influyen en la facilidad con que puede verse un objeto. Por consiguiente, es de suma importancia analizar minuciosamente el área donde se realiza la tarea visual y sus alrededores.

0 tro factor es el tamaño del objeto a observar, que puede ser adecuado o no, en función de la distancia y del ángulo de visión del observador. Los dos últimos factores determinan la disposición del puesto de trabajo, clasificando las diferentes zonas de acuerdo con su facilidad de visión. Podemos establecer cinco zonas en el área de trabajo (véase la Figura 46.10).

Un factor adicional es el intervalo de tiempo durante el que se produce la visión. El tiempo de exposición será mayor o menor en función de si el objeto y el observador están estáticos, o de si uno de ellos o ambos se están moviendo. La capacidad del ojo para adaptarse automáticamente a las diferentes iluminaciones de los objetos también puede influir considerablemente en la visibilidad.

Figura 46.10 • Distribución de las zonas visuales en el puesto de trabajo.

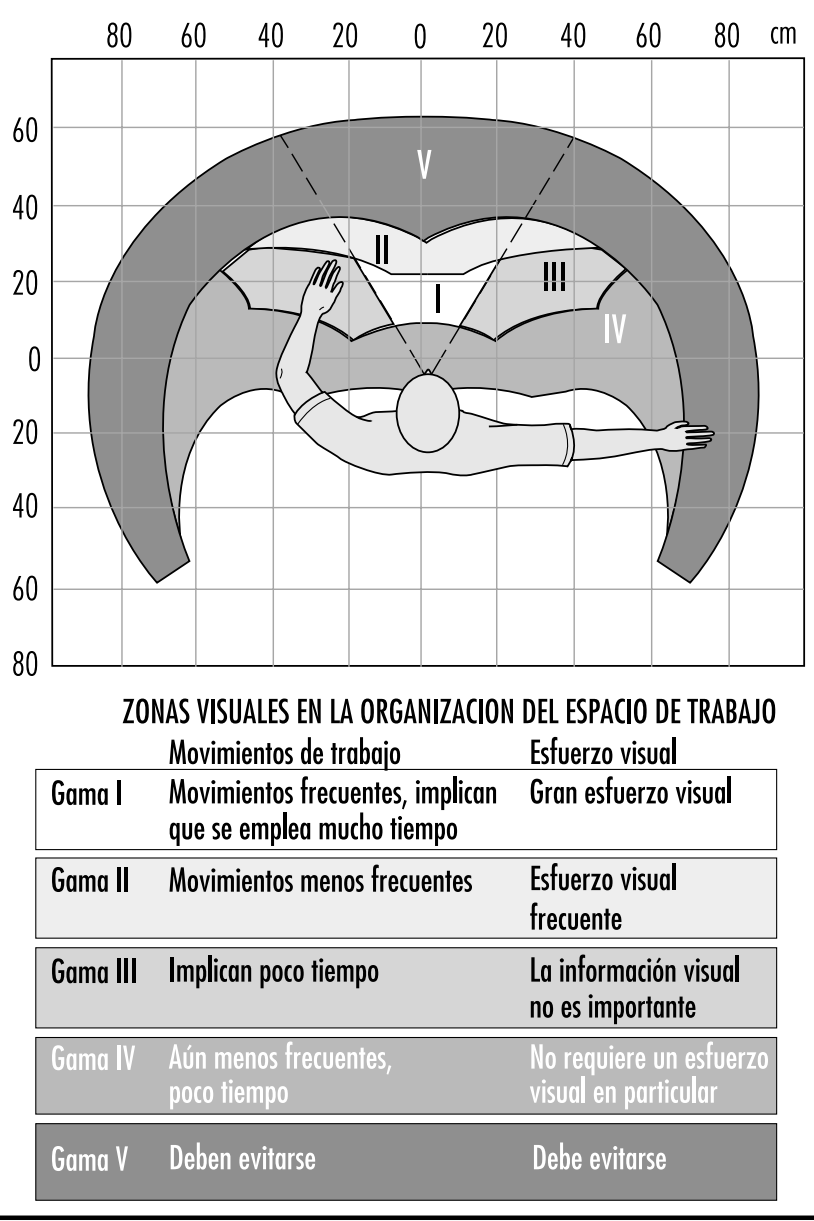




\section{Distribución de la luz; deslumbramiento}

Los factores esenciales en las condiciones que afectan a la visión son la distribución de la luz y el contraste de luminancias. Por lo que se refiere a la distribución de la luz, es preferible tener una buena iluminación general en lugar de una iluminación localizada, con el fin de evitar deslumbramientos. Por esta razón, los accesorios eléctricos deberán distribuirse lo más uniformemente posible con el fin de evitar diferencias de intensidad luminosa. EI constante ir y venir por zonas sin una iluminación uniforme causa fatiga ocular y, con el tiempo, esto puede dar lugar a una reducción de la capacidad visual.

Cuando existe una fuente de luz brillante en el campo visual se producen brillos deslumbrantes; el resultado es una disminución de la capacidad de distinguir objetos. Los trabajadores que sufren los efectos del deslumbramiento constante y sucesivamente pueden sufrir fatiga ocular, así como trastornos funcionales, aunque en muchos casos ni siquiera sean conscientes de ello.

El deslumbramiento puede ser directo (cuando su origen está en fuentes de luz brillante situadas directamente en la línea de visión) o reflejado (cuando la luz se refleja en superficies de alta reflectancia). En el deslumbramiento participan los factores siguientes:

1. Luminancia de la fuente de luz: la máxima luminancia tolerable por observación directa es de $7.500 \mathrm{~cd} / \mathrm{m}^{2}$. En la Figura 46.11 se recogen algunos de los valores aproximados de luminancia para varias fuentes de luz.

2. U bicación de la fuente de luz: el deslumbramiento se produce cuando la fuente de luz se encuentra en un ángulo de 45 grados con respecto a la línea de visión del observador. L as figuras siguientes ilustran maneras y métodos de evitar el deslumbramiento directo y reflejado (véase la Figura 46.12).

En general, se produce más deslumbramiento cuando las fuentes de luz están montadas a poca altura 0 en grandes habitaciones, porque las fuentes de luz así ubicadas pueden entrar fácilmente en el ángulo de visión que provoca deslumbramiento.

3. Distribución de luminancias entre diferentes objetos y superficies: cuanto mayores sean las diferencias de luminancia entre los objetos situados en el campo de visión, más brillos se crearán y mayor será el deterioro de la capacidad de ver provocado por los efectos ocasionados en los procesos de adaptación de la visión. L os valores máximos recomendados de disparidad de luminancias son:

- Tarea visual: superficie de trabajo = 3:1

- Tarea visual: alrededores = 10:1.

4. T iempo de exposición: incluso las fuentes de luz de baja luminancia pueden provocar deslumbramiento si se prolonga demasiado la exposición.

Figura 46.11 • Valores aproximados de luminancia.

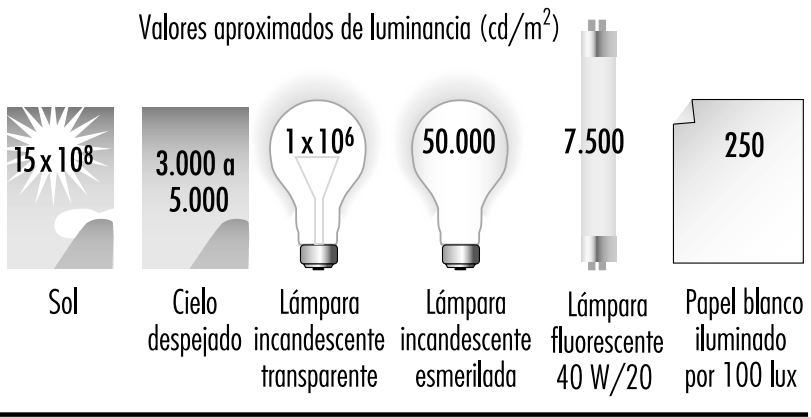

Evitar el deslumbramiento es un propósito relativamente sencillo y puede conseguirse de diferentes maneras. U na de ellas, por ejemplo, es colocar rejillas bajo las fuentes de iluminación, 0 utilizar difusores o reflectores parabólicos que puedan enfocar la luz apropiadamente, o instalar las fuentes de luz de modo que no interfieran con el ángulo de visión. A la hora de diseñar el ambiente de trabajo, la correcta distribución de la luminancia es tan importante como la propia iluminación, pero también es importante considerar que una distribución de luminancias excesivamente uniforme dificulta la percepción espacial y tridimensional de los objetos.

\section{Sistemas de iluminación}

El interés por la iluminación natural ha aumentado recientemente. $Y$ no se debe tanto a la calidad de este tipo de iluminación como al bienestar que proporciona. Pero como el nivel de iluminación de las fuentes naturales no es uniforme, se necesita un sistema de iluminación artificial. Los sistemas de iluminación más utilizados son los siguientes:

\section{Iluminación general uniforme}

En este sistema, las fuentes de luz se distribuyen uniformemente sin tener en cuenta la ubicación de los puestos de trabajo. EI nivel medio de iluminación debe ser igual al nivel de iluminación necesario para la tarea que se va a realizar. Son sistemas utilizados principalmente en lugares de trabajo donde no existen puestos fijos.

D ebe tener tres características fundamentales: primero, estar equipado con dispositivos antibrillos (rejillas, difusores, reflectores, etcétera); segundo, debe distribuir una fracción de la luz

Figura 46.12 • Factores que afectan al deslumbramiento.

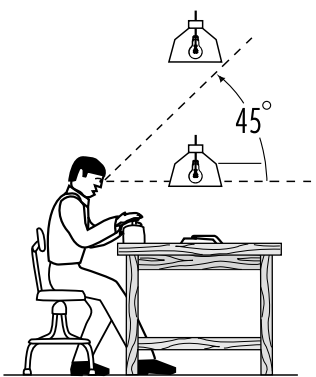

1. Altura de la instalación de alumbrado

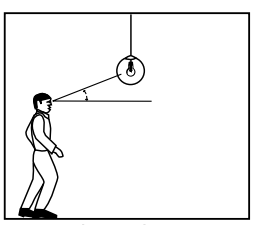

Más deslumbramiento

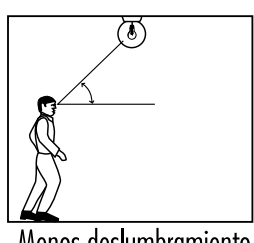

Menos deslumbramiento

\section{Tamaño de la habitación}

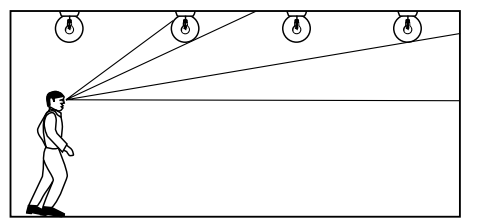

Más deslumbramiento

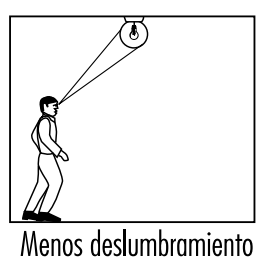


Figura 46.13 • Sistemas de iluminación.
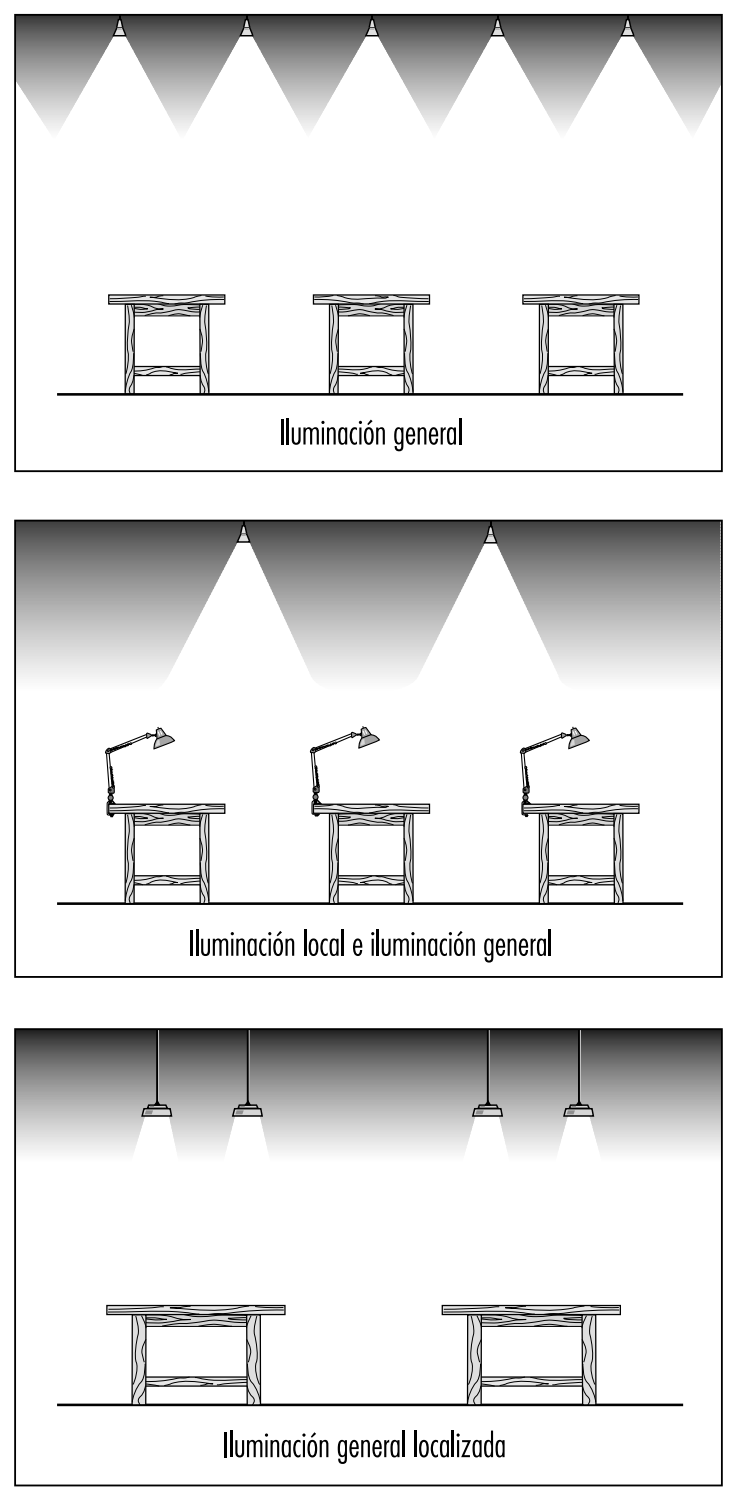

hacia el techo y la parte superior de las paredes, y tercero, las fuentes de luz deben instalarse a la mayor altura posible, para minimizar los brillos y conseguir una iluminación lo más homogénea posible (véase la Figura 46.13).

\section{Iluminación general e iluminación localizada de apoyo}

Se trata de un sistema que intenta reforzar el esquema de la iluminación general situando lámparas junto a las superficies de trabajo. Las lámparas suelen producir deslumbramiento y los reflectores deberán situarse de modo que impidan que la fuente de luz quede en la línea directa de visión del trabajador. Se recomienda utilizar iluminación localizada cuando las exigencias visuales sean cruciales, como en el caso de los niveles de iluminación de 1.000 lux o más. Generalmente, la capacidad visual del trabajador se deteriora con la edad, lo que obliga a aumentar el nivel de iluminación general o a complementarlo con iluminación localizada. En la Figura 46.14 se aprecia claramente este fenómeno.
Figura 46.14 • Pérdida de la agudeza visual con la edad.

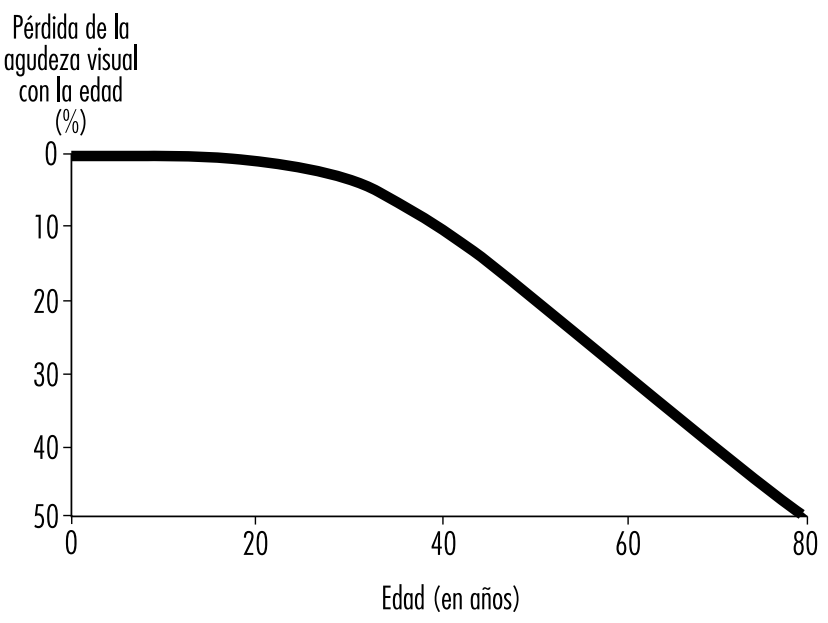

\section{Iluminación general localizada}

Es un tipo de iluminación con fuentes de luz instaladas en el techo y distribuidas teniendo en cuenta dos aspectos: las características de iluminación del equipo y las necesidades de iluminación de cada puesto de trabajo. Está indicado para aquellos espacios o áreas de trabajo que necesitan un alto nivel de iluminación y requiere conocer la ubicación futura de cada puesto de trabajo con antelación a la fase de diseño.

\section{Color: conceptos básicos}

Elegir el color adecuado para un lugar de trabajo contribuye en gran medida a la eficiencia, la seguridad y el bienestar general de los empleados. Del mismo modo, el acabado de las superficies y de los equipos que se encuentran en el ambiente de trabajo contribuye a crear condiciones visuales agradables y un ambiente de trabajo agradable.

La luz ordinaria consiste en radiaciones electromagnéticas de diferentes longitudes de onda que corresponden a cada una de las bandas del espectro visible. M ezclando luz roja, amarilla y azul, podemos obtener la mayoría de los colores visibles, incluyendo el blanco. Nuestra percepción del color de un objeto depende del color de la luz con la que se ilumina y de la manera en que el propio objeto refleja la luz.

Las lámparas pueden clasificarse en tres categorías, en función de la coloración de la luz que emiten:

- color cálido: para usos residenciales se recomienda una luz blanca de tono rojizo;

- color intermedio: para ambientes de trabajo se recomienda una luz blanca,

- color frío: para tareas que requieren un alto nivel de iluminación o para climas calientes, se recomienda una luz blanca de tono azulado.

Los colores también pueden clasificarse en calientes o fríos según su tonalidad (véase la Figura 46.15).

\section{Contraste y temperatura de diferentes colores}

L os contrastes de color resultan afectados por el color de la luz elegida y, por esa razón, de ello dependerá la calidad de la iluminación en una aplicación concreta. El color de la luz que se va a utilizar deberá decidirse en función de la tarea que se deba realizar bajo ella. Si el color es próximo al blanco, la 
Figura 46.15 • Tonalidades de colores "cálidos" y "fríos".

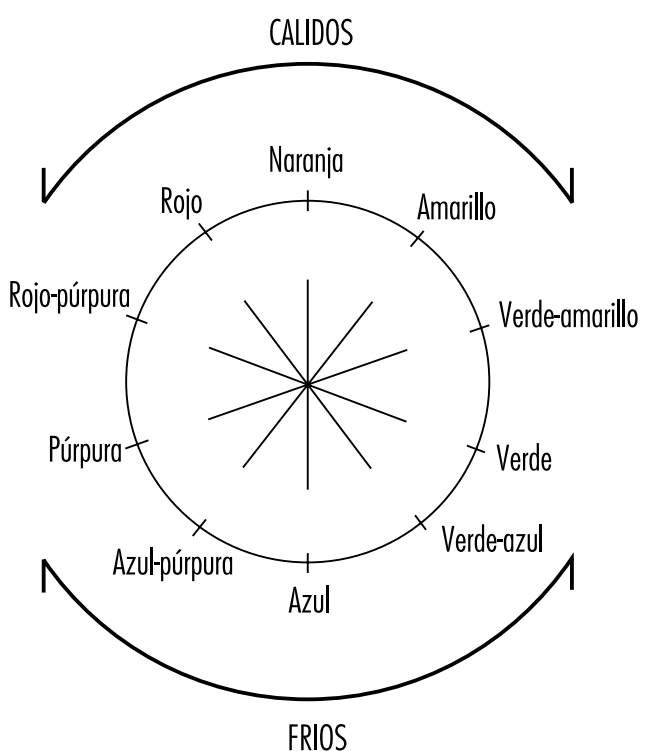

reproducción del color y la difusión de la luz serán mejores. Cuanta más luz se aproxime al extremo rojo del espectro, peor será la reproducción del color, pero el ambiente será más cálido y atractivo.

La coloración de la iluminación no sólo depende del color de la luz, sino también de la intensidad luminosa. La temperatura colorimétrica está relacionada con las diferentes formas de iluminación. La sensación de satiffacción con la iluminación de un ambiente determinado depende de esta temperatura. D e este modo, por ejemplo, la temperatura colorimétrica de una bombilla de filamento incandescente de $100 \mathrm{~W}$ es de $2.800 \mathrm{~K}$, la de un tubo fluorescente es de $4.000 \mathrm{~K}$ y la de un cielo encapotado es de $10.000 \mathrm{~K}$.

K ruithof definió, a través de observaciones empíricas, un diagrama de bienestar para diferentes niveles de iluminación y temperaturas colorimétricas en un ambiente determinado (véase la Figura 46.16). De este modo, demostró que es posible sentirse cómodo en ciertos ambientes con bajos niveles de iluminación si la temperatura colorimétrica también es baja (si el nivel de iluminación es de una candela, por ejemplo, con una temperatura colorimétrica de $1.750 \mathrm{~K}$ ).

L os colores de las lámparas eléctricas pueden subdividirse en tres grupos en relación con sus temperaturas colorimétricas:

- blanco de luz diurna: alrededor de $6.000 \mathrm{~K}$;

- blanco neutro: alrededor de $4.000 \mathrm{~K}$,

- blanco cálido: alrededor de $3.000 \mathrm{~K}$.

\section{Combinación y elección de los colores}

La elección de los colores es muy relevante si la estudiamos conjuntamente con aquellas funciones en las que es importante identificar los objetos que se han de manipular. También es relevante a la hora de delimitar vías de comunicación y en aquellas tareas que requieren un contraste nítido.

La elección de la tonalidad no es una cuestión tan importante como la elección de las cualidades reflectantes apropiadas de una superficie. Existen varias recomendaciones que pueden aplicarse a este aspecto de las superficies de trabajo:

Techos: la superficie de un techo debe ser lo más blanca posible (con un factor de reflexión del $75 \%$ ), porque entonces reflejará la luz de manera difusa, disipando la oscuridad y reduciendo los brillos de otras superficies. A ello se añade el ahorro en iluminación artificial.

Paredes y suelos: las superficies de las paredes situadas a nivel de los ojos pueden provocar deslumbramiento. Los colores pálidos con factores de reflexión del 50 al $75 \%$ suelen ser adecuados para las paredes. Aunque las pinturas brillantes tienden a durar más tiempo que los colores mate, son más reflectantes. Por consiguiente, las paredes deberán tener un acabado mate 0 semibrillante.

L os acabados de los suelos deberán ser de colores ligeramente más oscuros que las paredes y los techos para evitar brillos. EI factor de reflexión de los suelos debe oscilar entre el 20 y el $25 \%$.

E quipo: las superficies de trabajo, mesas y maquinaria deberán tener factores de reflexión de entre un 20 y un $40 \%$. Los equipos deberán tener un acabado duradero de un color puro - grises o marrones claros- y el material no deberá ser brillante.

El uso apropiado de los colores en el ambiente de trabajo contribuye al bienestar, aumenta la productividad y puede tener efectos positivos para la calidad. También puede contribuir a mejorar la organización y a prevenir accidentes.

Existe la creencia generalizada de que blanquear paredes y techos y suministrar niveles adecuados de iluminación es todo lo que puede hacerse por lo que se refiere al confort visual de los empleados. Pero estos factores de confort pueden mejorarse combinando el blanco con otros colores, evitando así la fatiga y el aburrimiento que caracterizan a los ambientes monocromáticos. Los colores también afectan al nivel de estímulo de una persona: los colores cálidos tienden a activar y relajar, mientras los colores fríos se utilizan para inducir al individuo a liberar su energía.

El color de la luz, su distribución y los colores utilizados en un espacio determinado son, entre otros, los principales factores que influyen en las sensaciones que tienen las personas. Dados los muchos colores y factores de confort existentes, es imposible establecer directrices precisas, especialmente teniendo en cuenta

Figura 46.16 • Diagrama de confort en función de la iluminación y las temperaturas colorimétricas.

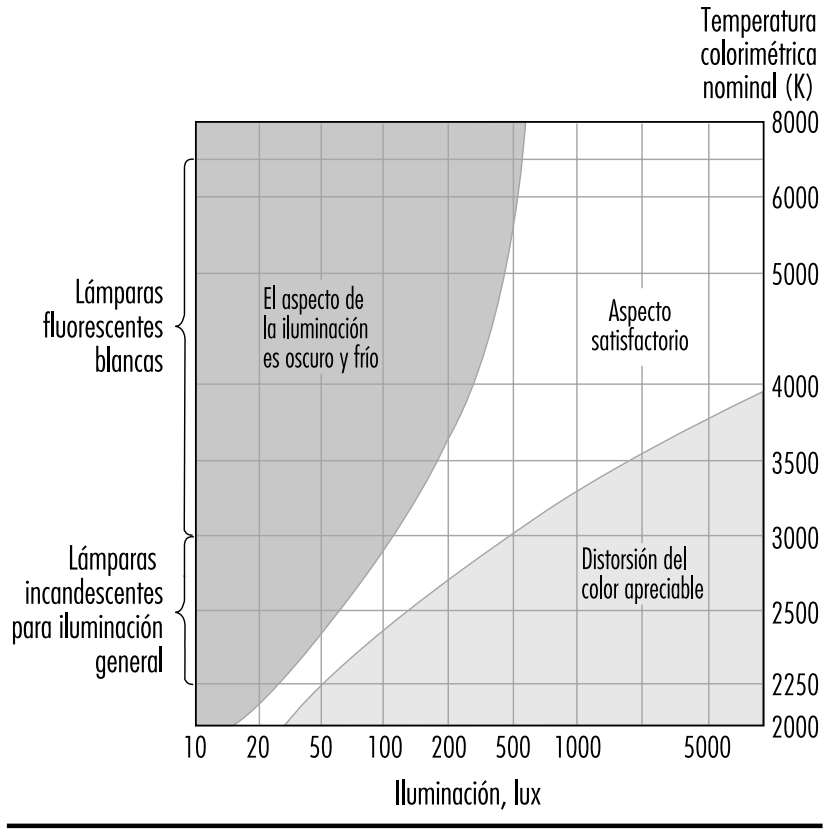


que todos estos factores deben combinarse de acuerdo con las características y necesidades de un determinado puesto de trabajo. Por lo demás, es posible citar varias normas prácticas básicas y generales que pueden contribuir a crear un ambiente habitable.

- Los colores brillantes provocan sentimientos de confort, estímulo y serenidad, mientras los colores oscuros tienden a tener un efecto deprimente.

- Las fuentes de luz de colores cálidos ayudan a reproducir bien los colores cálidos. L os objetos de colores cálidos son más agradables a la vista con luz cálida que con luz fría.

- Los colores claros y apagados (como los pasteles) son muy apropiados como colores de fondo, mientras que los objetos deben tener colores ricos y saturados.

- Los colores cálidos excitan el sistema nervioso y transmiten la sensación de que aumenta la temperatura.

- Los colores fríos son preferibles para objetos. T ienen un efecto calmante y pueden utilizarse para producir el efecto de curvatura. Los colores fríos contribuyen a crear una sensación de descenso de la temperatura.

- La sensación de color de un objeto depende del color de fondo y del efecto de la fuente de luz sobre su superficie.

- Los ambientes físicamente fríos o calientes pueden atemperarse utilizando iluminación cálida o fría, respectivamente.

- La intensidad de un color será inversamente proporcional a la parte del campo visual normal que ocupe.

- El color puede influir en la apariencia espacial de una habitación. El techo de la habitación parecerá ser más bajo si sus paredes se pintan de un color claro y el techo y el suelo de color más oscuro, y parecerá tener un techo más alto si las paredes son más oscuras y el techo claro.

\section{Identificación de los objetos por el color}

La elección de los colores puede afectar a la eficacia de los sistemas de iluminación al influir en la fracción de luz que se refleja. Pero el color también desempeña un papel importante a la hora de identificar objetos. Podemos utilizar colores brillantes y atractivos o contrastes de color para destacar situaciones u objetos que requieran especial atención. En la Tabla 46.7 figuran algunos de los factores de reflexión para diferentes colores y materiales.

En cualquier caso, la identificación por colores sólo deberá emplearse cuando sea verdaderamente necesario, ya que sólo funcionará correctamente si no hay demasiados objetos

Tabla 46.7 • Factores de reflexión de diferentes colores y materiales iluminados con luz blanca.

$\begin{array}{lc}\text { Color/ material } & \text { Factor de reflexión (\%) } \\ \text { Blanco } & 100 \\ \text { Papel blanco } & 80-85 \\ \text { Marfil, amarillo lima } & 70-75 \\ \text { Amarillo brillante, ocre claro, verde claro, azul pastel, } & 60-65 \\ \quad \text { rosa claro, crema } & \\ \text { Verde lima, gris pálido, rosa, naranja, gris azulado } & 50-55 \\ \text { Madera clara, azul celeste } & 40-45 \\ \text { Roble, hormigón seco } & 30-35 \\ \text { Rojo oscuro, verde árbol, verde oliva, verde hierba } & 20-25 \\ \text { Azul oscuro, púrpura } & 10-15 \\ \text { Negro } & 0\end{array}$

destacados por su color. A continuación se indican algunas recomendaciones para identificar diferentes elementos por su color:

- E quipos de incendios y de seguridad: es aconsejable identificar estos equipos colocando un gráfico reconocible en la pared más próxima, de modo que puedan localizarse rápidamente.

- M aquinaria: es crucial que los dispositivos de parada o de emergencia de todas las máquinas sean de colores brillantes. También es aconsejable marcar con colores las áreas que requieran lubricación o mantenimiento periódico, lo cual puede facilitar y añadir funcionalidad a estos procedimientos.

- Tuberías y canalizaciones: si son importantes o transportan sustancias peligrosas, lo mejor es colorearlas por completo. En algunos casos puede ser suficiente colorear solamente una línea en toda su longitud.

- Escaleras: con el fin de facilitar el descenso, es preferible que cada escalón tenga una sola franja coloreada y no varias.

- R iesgos: sólo debe utilizarse el color para identificar un riesgo cuando éste no pueda eliminarse. La identificación será mucho más eficaz si se realiza de conformidad con un código de colores predeterminado.

\section{CONDICIONES DE LA ILUMINACION GENERAL}

\section{N. Alan Smith}

La iluminación de los ambientes interiores tiene por objeto satisfacer las siguientes necesidades:

- contribuir a crear un ambiente de trabajo seguro;

- ayudar a realizar tareas visuales,

- crear un ambiente visual apropiado.

La creación de un ambiente de trabajo seguro tiene que estar en el primer lugar de la lista de prioridades y, en general, se aumenta la seguridad haciendo que los peligros sean claramente visibles. El orden de prioridad de las otras dos necesidades dependerá en gran medida del uso dado al ambiente interior. La realización de la tarea puede mejorarse haciendo que sea más fácil ver todos sus detalles, mientras que se crean ambientes visuales apropiados variando el énfasis de iluminación dado a los objetos y superficies existentes dentro del ambiente interior.

La luz y el color influyen en nuestra sensación general de bienestar, incluyendo la moral y la fatiga. Con bajos niveles de iluminación, los objetos tienen poco o ningún color o forma y se produce una pérdida de perspectiva. A la inversa, el exceso de luz puede ser tan incómodo como su escasez.

En general, la gente prefiere una habitación con luz diurna a una habitación sin ventanas. Además, se considera que el contacto con el mundo exterior contribuye a la sensación de bienestar. La introducción de controles de iluminación automáticos, junto con la atenuación de altas frecuencias en las lámparas fluorescentes, ha permitido proporcionar a los ambientes interiores una combinación controlada de luz natural y luz artificial. A ello se añade la reducción de los costes energéticos.

En la percepción del carácter de un ambiente interior influyen el brillo y el color de sus superficies visibles, tanto interiores como exteriores. $L$ as condiciones de iluminación general de un ambiente interior pueden conseguirse utilizando luz 
Figura 46.17 • Sistemas de iluminación.

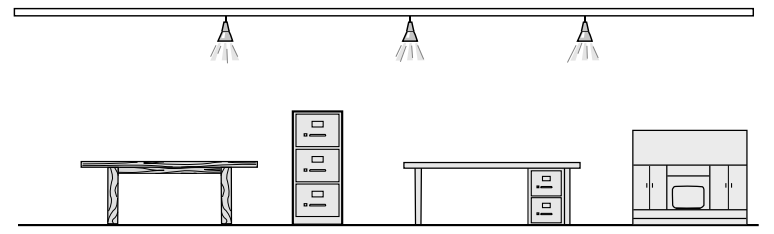

A. General

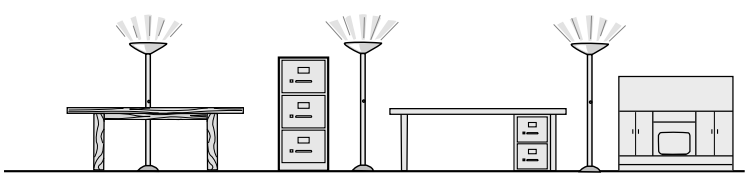

B. Localizada

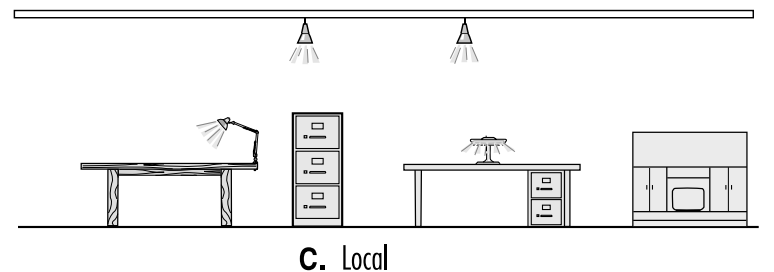

natural o iluminación artificial, o lo que es más probable, con una combinación de ambas.

\section{Evaluación de la iluminación}

\section{Requisitos generales}

Los sistemas de iluminación utilizados en interiores comerciales pueden subdividirse en tres categorías principales: iluminación general, iluminación localizada e iluminación local.

Normalmente, las instalaciones de iluminación general proporcionan una iluminancia aproximadamente uniforme en todo el plano de trabajo. Son sistemas que suelen estar basados en el método luménico de diseño, donde una iluminancia media es:

Iluminancia media (lux) =

Flujo luminoso (lumenes) $x$ factor de utilizacion $x$ factor de mantenimiento Area $\left(\mathrm{m}^{2}\right)$

Los sistemas de iluminación localizada proporcionan iluminancia en áreas de trabajo generales con un nivel reducido de iluminancia simultáneo en áreas adyacentes.

Los sistemas de iluminación locales proporcionan iluminancia para áreas relativamente pequeñas que incorporan tareas visuales. Normalmente, estos sistemas se complementan con un nivel especificado de iluminación general. En la Figura 46.17 se recogen las diferencias típicas entre los sistemas descritos.

$C$ uando hay que realizar tareas visuales, es esencial alcanzar el nivel exigido de iluminancia y estudiar las circunstancias que afectan a su calidad.

El uso de luz natural para iluminar tareas tiene tanto ventajas como limitaciones. Las ventanas por las que entra la luz natural a un ambiente interior favorecen la realización de tareas de modelado tridimensional y, aunque la distribución espectral de la luz natural varía a lo largo del día, se considera que, en general, su reproducción del color es excelente.
Con todo, no es posible proporcionar una iluminancia constante para una tarea utilizando sólo la luz natural, debido a su gran variabilidad, y si la tarea está dentro del mismo campo de visión que un cielo brillante, es probable que se produzcan brillos deslumbrantes que entorpecen la realización de la tarea. La utilidad de la luz natural para iluminar tareas es sólo parcial, por lo que la iluminación artificial, sobre la que puede ejercerse un mayor control, tiene un papel importante que desempeñar.

Como el ojo humano sólo percibe superficies y objetos a través de la luz que reflejan, de ello se deduce que el aspecto del ambiente se verá afectado por las características de la superficie y los valores de reflectancia, junto con la cantidad y calidad de la luz.

A la hora de estudiar la iluminación de un ambiente interior, es esencial determinar el nivel de iluminancia y compararlo con los niveles recomendados para diferentes tareas (véase la Tabla 46.8).

\section{Iluminación para tareas visuales}

En la capacidad del ojo humano para distinguir los detalles - agudeza visual- influyen significativamente el tamaño de la tarea, el contraste y el rendimiento visual del observador. El aumento de la cantidad y calidad de la iluminación también mejorará significativamente el rendimiento visual. Los detalles cruciales de la tarea y el contraste entre ésta y su entorno circundante influyen en cómo afecta la iluminación a su realización. En la Figura 46.18 se muestran los efectos de la iluminancia sobre la agudeza visual. A la hora de estudiar la iluminación de las tareas visuales, es importante tener en cuenta la capacidad del ojo humano para realizar la tarea con rapidez y precisión, lo que se conoce como rendimiento visual. En la Figura 46.19 se muestran los efectos típicos de la iluminancia sobre el rendimiento visual de una tarea determinada.

La predicción de la iluminancia que alcanzará una superficie de trabajo es de suma importancia para el diseño de la iluminación. A hora bien, el sistema visual humano responde a la distribución de la luminancia dentro del campo de visión. La escena existente dentro de un campo visual se interpreta diferenciando entre el color superficial, la reflectancia y la iluminación. La luminancia depende tanto de la iluminancia sobre una superficie como de la reflectancia de la misma. Tanto la luminancia como la iluminancia son cantidades objetivas. Sin embargo, la respuesta al brillo es subjetiva.

Tabla 46.8 - N iveles típicos recomendados de iluminancia mantenida para diferentes ubicaciones 0 tareas visuales.
Ubicación/ Tarea

Oficinas generales

Puestos de trabajo informatizados

Áreas de montaje en fábrica

Trabajo de poca precisión

Trabajo medio

Trabajo de precisión

Trabajo de alta precisión

Montaje de instrumentos

Montaje/ reparaciones de joyería

Quirófanos de hospital
Valor típico recomendado de iluminancia mantenida (lux) 500 500 300 500 750

1.000

1.500

50.000 
Figura 46.18 • Relación típica entre la agudeza visual y la iluminancia.

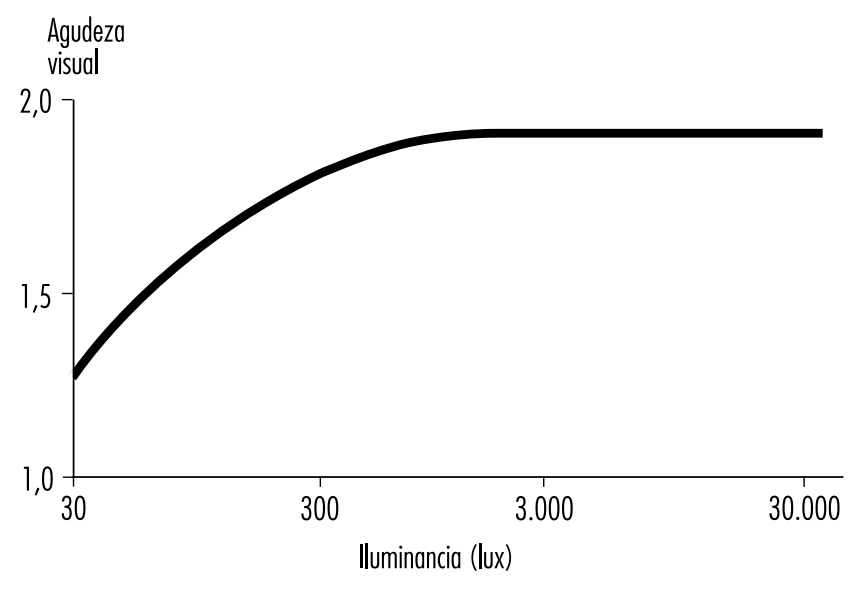

Con el fin de producir un ambiente que proporcione satisfacción, confort y rendimiento visual, es preciso equilibrar las luminancias existentes dentro del campo de visión. Lo ideal es que las luminancias existentes alrededor de una tarea disminuyan gradualmente, evitándose así fuertes contrastes. La Figura 46.20 ilustra la variación de luminancia recomendada en los alrededores de una tarea.

EI método luménico de diseño de la iluminación da lugar a una iluminancia media en el plano horizontal de trabajo y es posible utilizar un método de establecer valores de iluminancia media en los techos y paredes de un interior, que pueden convertirse en valores de luminancia media a partir de los detalles del valor de reflectancia media de las superficies de la habitación.

La ecuación que relaciona la luminancia y la iluminancia es la siguiente:

$$
\text { Luminancia }\left(\mathrm{cd} \cdot \mathrm{m}^{-2}\right)=\frac{\text { Iluminancia (lux) } \times \text { R eflectancia }}{\pi}
$$

En la Figura 46.21 se ilustra una oficina típica con valores relativos de iluminancia (de un sistema de iluminación general de techo) sobre las superficies principales de la habitación, junto con recomendaciones de reflectancia. El ojo humano tiende a ser atraído a la parte más brillante de la escena visual. De ello se deduce que habitualmente se producen valores superiores de luminancia en las áreas de realización de tareas visuales. EI ojo

Figura 46.20 • Variación de la luminancia a lo largo de una tarea.

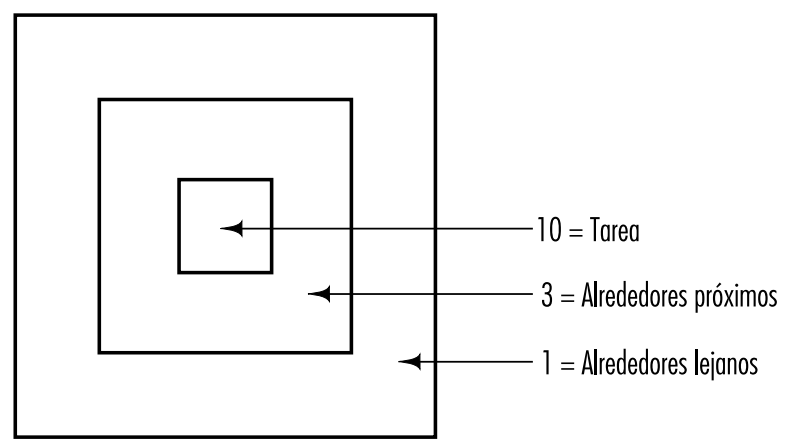

Variación de luminancia en los alrededores de una tarea
Figura 46.19 • Relación típica entre el rendimiento visual y la iluminancia.

Rendimiento

visual relativo

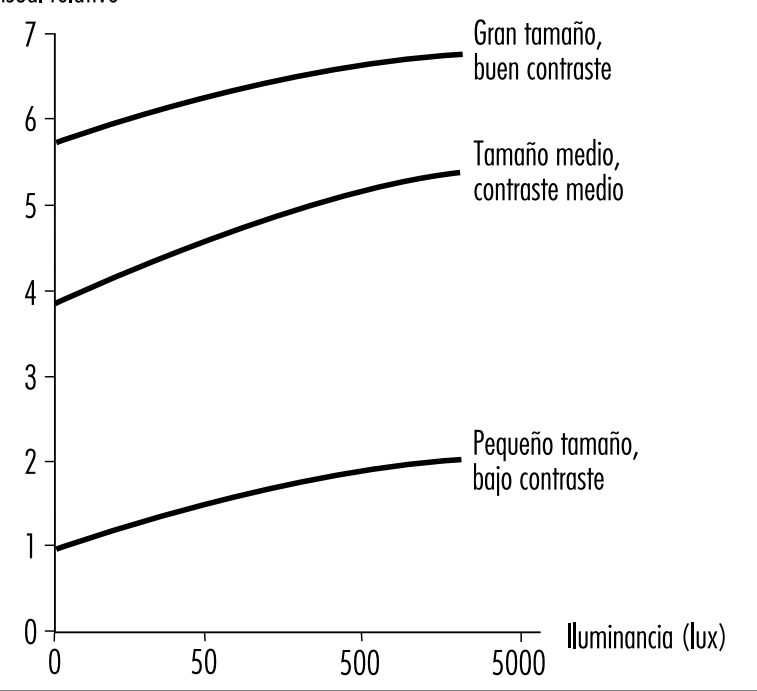

humano reconoce los detalles de una tarea visual distinguiendo entre las partes más claras y más oscuras de la misma. La variación en el brillo de una tarea visual se determina calculando el contraste de luminancias:

$$
\text { Contraste de luminancias }(C)=\frac{\left|L_{t}-L_{b}\right|}{\left|L_{b}\right|}
$$

donde

$\mathrm{L}_{\mathrm{t}}=$ luminancia de la tarea;

$\mathrm{L}_{b}=$ luminancia del fondo;

y ambas luminancias se miden en $\mathrm{cd} \cdot \mathrm{m}^{-2}$

Las líneas verticales de esta ecuación significan que todos los valores de contraste de luminancias han de considerarse positivos.

En el contraste de una tarea visual influyen las propiedades de reflectancia de la propia tarea (véase la Figura 46.21).

Figura 46.21 • Valores típicos de iluminancia relativa junto con valores recomendados de reflectancia.

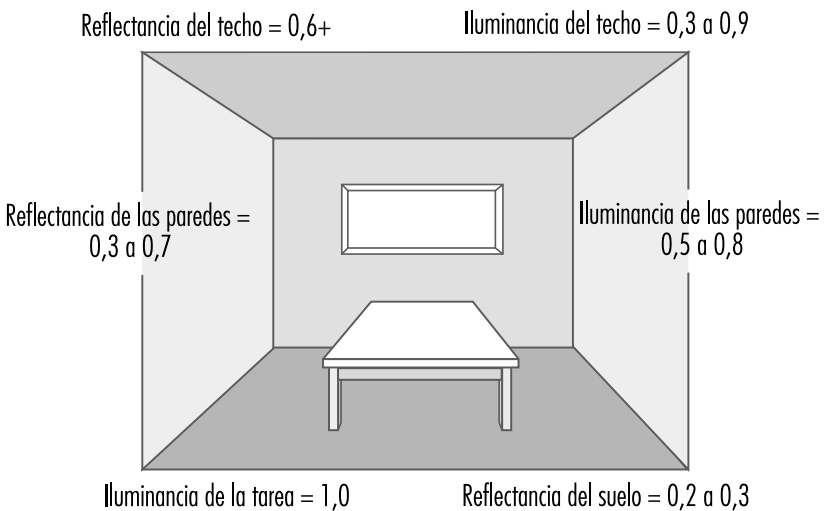


Figura 46.22 • Control del flujo luminoso por obstrucción.

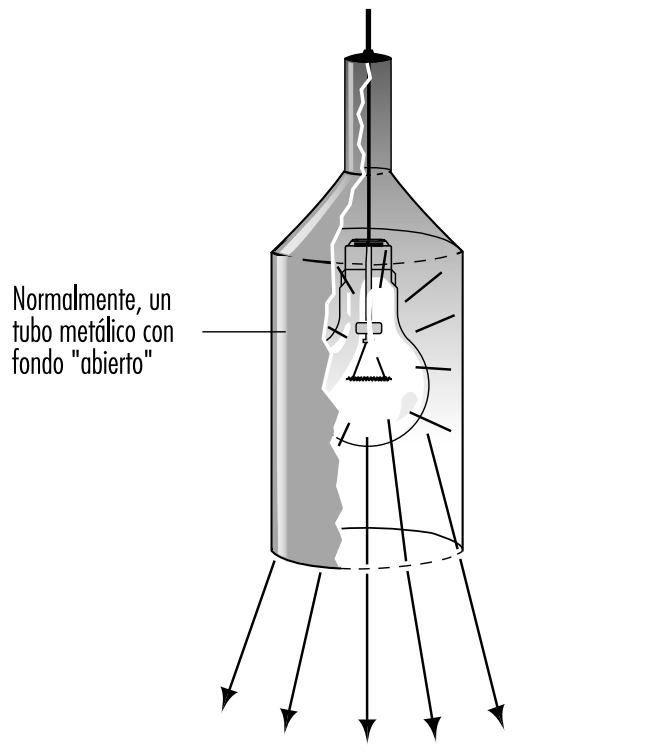

\section{Control óptico de la iluminación}

Si se utiliza una lámpara desnuda en una luminaria, es improbable que la distribución de la luz sea aceptable y, casi con toda seguridad, el sistema no será práctico desde el punto de vista económico. En estas situaciones, es probable que la lámpara desnuda se convierta en una fuente de deslumbramiento para los ocupantes de la habitación y, aunque eventualmente pueda llegar algo de luz al plano de trabajo, es probable que la eficacia de la instalación se vea seriamente reducida a consecuencia del brillo.

Será evidente la necesidad de alguna forma de control de luz, detallándose a continuación los métodos más empleados.

\section{Obstrucción}

Si se instala una lámpara en una caja opaca, con una sola abertura para que salga la luz, la distribución de la luz será muy limitada, como puede verse en la Figura 46.22.

\section{Reflexión}

En este método se utilizan superficies reflectantes, que pueden variar desde un acabado mate hasta un acabado de tipo especular. Es un método de control más eficaz que la obstrucción, ya que se recoge la luz dispersa y se vuelve a enfocar hacia el punto donde es necesaria. El principio de reflexión se ilustra en la Figura 46.23.

Figura 46.24 • Control del flujo luminoso por difusión.

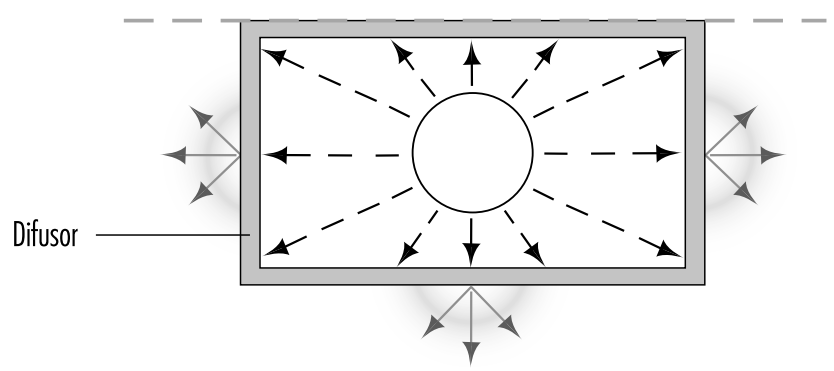

Figura 46.23 • Control del flujo luminoso por reflexión.

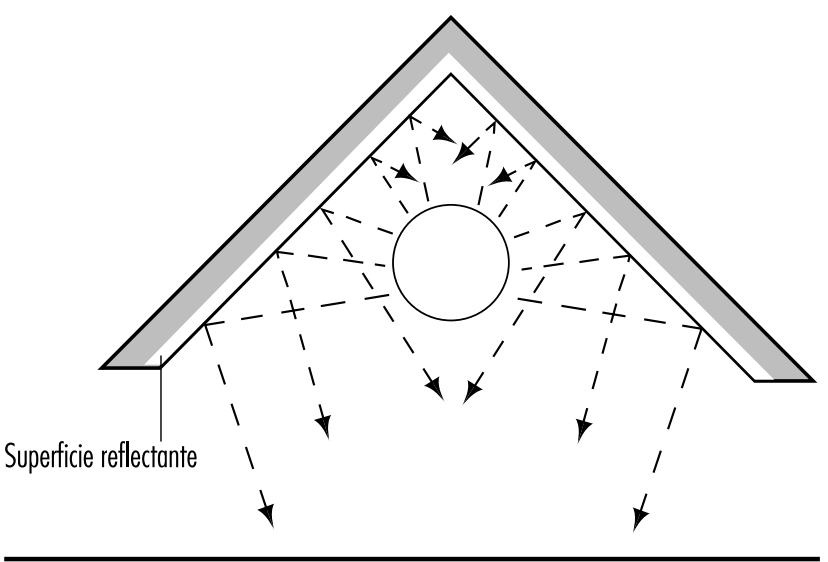

\section{Difusión}

Si se instala una lámpara dentro de un material translúcido, aumenta el tamaño aparente de la fuente de luz y se obtiene al mismo tiempo una reducción de brillo. Lamentablemente, los difusores prácticos absorben parte de la luz emitida, reduciendo en consecuencia la eficiencia global de la luminaria. El principio de difusión se recoge en la Figura 46.24.

\section{Refracción}

En este método se utiliza el efecto "prisma", por el que un material prismático de vidrio o plástico "curva" los rayos luminosos y, al hacerlo, enfoca la luz de nuevo hacia el punto donde es necesaria. Es un método muy apropiado para la iluminación general de interiores. Tiene la ventaja de combinar un buen control del brillo con una eficacia aceptable. En la Figura 46.25 se muestra la influencia de la refracción en control óptico.

En muchos casos, se utilizará en la luminaria una combinación de los métodos de control óptico aquí descritos.

\section{Distribución de luminancias}

La distribución del flujo luminoso de una luminaria es importante para determinar las condiciones visuales que se experimentarán en consecuencia. Cada uno de los cuatro métodos de control óptico antes descritos proporcionará a la luminaria diferentes propiedades de distribución del flujo luminoso.

En las áreas donde hay instaladas PV D (pantallas de visualización de datos) suelen producirse reflejos cegadores. Los síntomas que se suelen experimentar en tales situaciones son una

Figura 46.25 • Control del flujo luminoso por refracción.

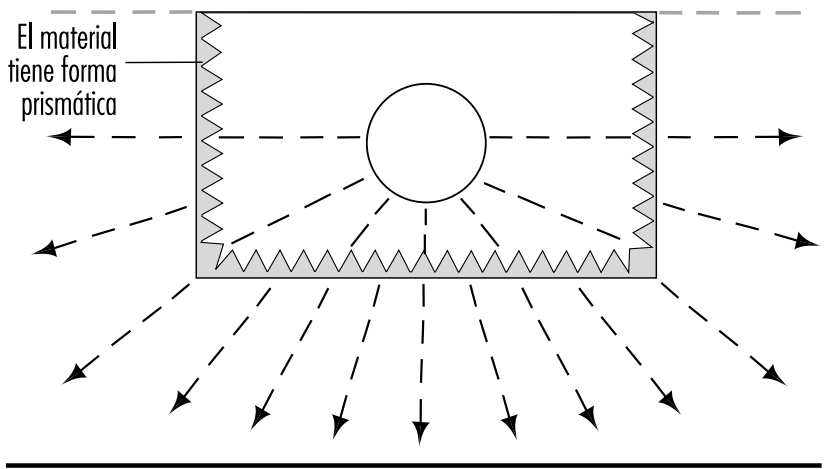


Figura 46.26 • Reflejos cegadores.
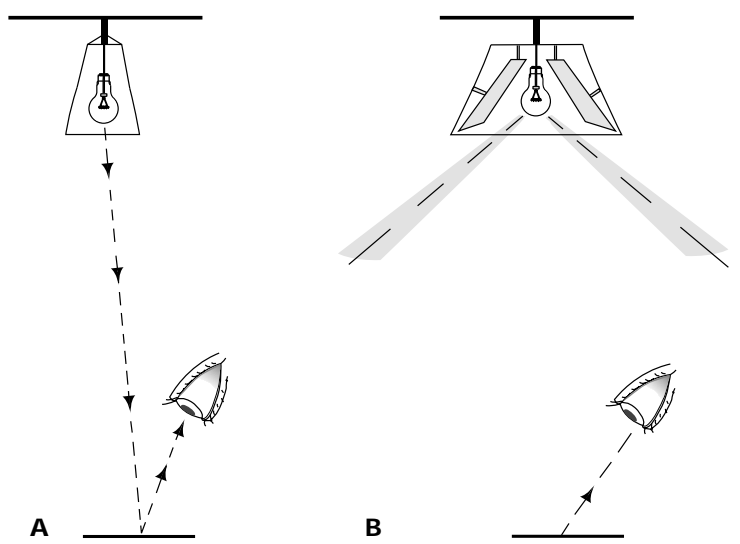

(a) Reflejos cegadores causados por apliques con un fuerte componente descendente de flujo luminoso;

(b) Luminarias con distribución de "ola de murciélago" para eliminar los reflejos cegadores sobre una superficie de trabajo horizontal.

reducción de la capacidad para leer correctamente el texto de una pantalla, provocada por la aparición de imágenes de alta luminancia no deseadas en la propia pantalla, normalmente procedentes de luminarias instaladas en el techo. Puede crearse una situación en la que estos reflejos también aparezcan en papel sobre un escritorio o mesa de trabajo.

Si las luminarias de un ambiente interior tienen un fuerte componente de flujo luminoso descendente en vertical, cualquier papel sobre una mesa situada debajo de una de estas luminarias reflejará la fuente de luz hacia los ojos de un observador que esté leyendo el papel o trabajando con él. Si el papel tiene un acabado satinado, la situación se agrava.

La solución del problema es disponer que la distribución del flujo luminoso de las luminarias utilizadas se realice predominantemente en ángulo con respecto a la vertical descendente, de modo que, siguiendo las leyes fundamentales de la física (ángulo de incidencia = ángulo de reflexión), se minimice el brillo reflejado. En la Figura 46.26 se muestra un ejemplo típico del problema y de su solución. La distribución del flujo luminoso que realiza la luminaria utilizada para resolver el problema se conoce con el nombre de distribución de "ala de murciélago".

La distribución de la luz de las luminarias también puede provocar un deslumbramiento directo y, en un intento por resolver este problema, es conveniente instalar unidades de iluminación local fuera del "ángulo prohibido" de 45 grados, como puede verse en la Figura 46.27.

\section{Condiciones óptimas de iluminación para el confort y el rendimiento visual}

Al investigar las condiciones de iluminación adecuadas para el confort y el rendimiento visual, es apropiado estudiar los factores que afectan a la capacidad de ver los detalles. Pueden subdividirse en dos categorías: las características del observador y las características de la tarea.

\section{Características del observador. Entre ellas cabe citar:}

- Ia sensibilidad del sistema visual de la persona al tamaño, el contraste y el tiempo de exposición;

- las características de adaptación transitoria;

- la susceptibilidad al deslumbramiento;

- la edad,

- Ias características psicológicas y de motivación.
Características dela tarea. Entre ellas cabe citar:

- la configuración de los detalles;

- contraste del detalle con el fondo;

- luminancia del fondo,

- la especularidad del detalle.

Por lo que respecta a tareas específicas, es preciso responder a las siguientes preguntas:

- ¿R esulta fácil ver los detalles de la tarea?

- ¿Es probable que la tarea se realice durante períodos prolongados?

- Si se cometen errores al realizar la tarea, ¿serán graves sus consecuencias?

A fin de crear condiciones óptimas de iluminación en el lugar de trabajo, es importante analizar lo que se exige de la instalación de alumbrado. Lo ideal sería que la iluminación de tareas revelase las características de color, tamaño, relieve y superficie de una tarea, evitando al mismo tiempo la creación de sombras posiblemente peligrosas, brillos deslumbrantes y un entorno "difícil" para la propia tarea.

Deslumbramiento. Cuando existe exceso de luminancia en el campo de visión se producen brillos y sus efectos en la visión pueden dividirse en dos grupos, denominados deslumbramiento incapacitante y deslumbramiento molesto.

Consideremos el ejemplo del deslumbramiento provocado por los faros de un vehículo que se nos aproxima en la oscuridad. Los ojos no pueden adaptarse al mismo tiempo a los faros del vehículo y al brillo de la carretera, muy inferior. Se trata de un ejemplo de deslumbramiento incapacitante, ya que la alta luminancia de las fuentes de luz produce un efecto incapacitante debido a la dispersión de la luz en el medio óptico. El deslumbramiento incapacitante es proporcional a la intensidad de la fuente de luz perjudicial.

El deslumbramiento molesto, que es más probable que se produzca en interiores, puede reducirse 0 incluso eliminarse por completo reduciendo el contraste entre la tarea y su entorno. Es preferible que las superficies de trabajo tengan acabados mate, de reflexión difusa, en lugar de acabados de reflexión especular, y la posición de cualquier fuente de luz perjudicial deberá

Figura 46.27 • Representación esquemática del ángulo prohibido.

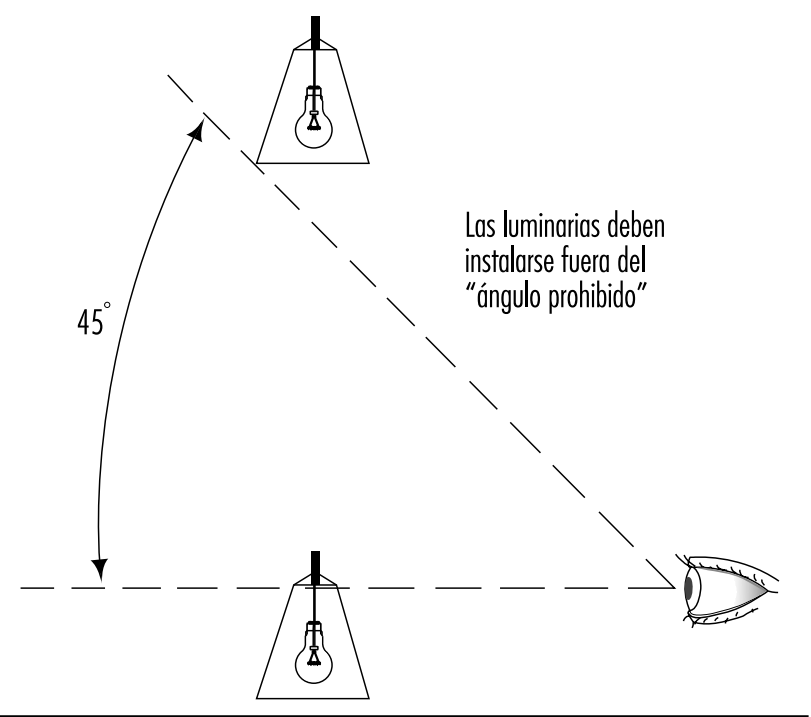


quedar fuera del campo normal de visión. En general, se consigue un rendimiento visual correcto cuando la propia tarea es más brillante que su entorno inmediato, pero no demasiado.

A la magnitud de deslumbramiento molesto se le da un valor numérico y se compara con valores de referencia a fin de predecir si será aceptable. En el apartado de "Medición" se analiza el método de cálculo de los índices de deslumbramiento que se utiliza en el Reino U nido y en otros lugares.

\section{Medición}

\section{Estudios de iluminación}

Frecuentemente se utiliza una técnica de estudio fundamentada en una cuadrícula de puntos de medición que cubre toda la zona analizada. La base de esta técnica es la división del interior en varias áreas iguales, cada una de ellas idealmente cuadrada. Se mide la iluminancia existente en el centro de cada área a la altura del tablero de una mesa (típicamente a 0,85 metros sobre el nivel del suelo) y se calcula un valor medio de iluminancia. En la precisión del valor de iluminancia media influye el número de puntos de medición utilizados.

Existe una relación que permite calcular el número mínimo de puntos de medición a partir del valor del índice de local (Room Index, RI) aplicable al interior analizado.

$$
\text { Indice de local }(R I)=\frac{\text { Longitud } x \text { Anchura }}{\text { Altura de montaje } x(\text { L ongitud }+ \text { Anchura })}
$$

Aquí, la longitud y la anchura son las dimensiones del recinto y la altura de montaje es la distancia vertical entre el centro de la fuente de luz y el plano de trabajo.

Figura 46.28 - Alzado y planta de un interior típico (utilizado como ejemplo).

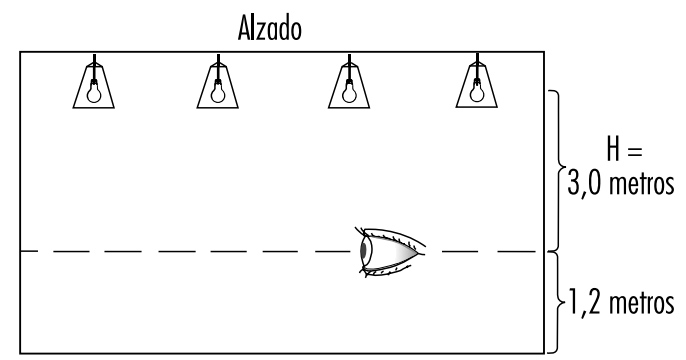

Planta

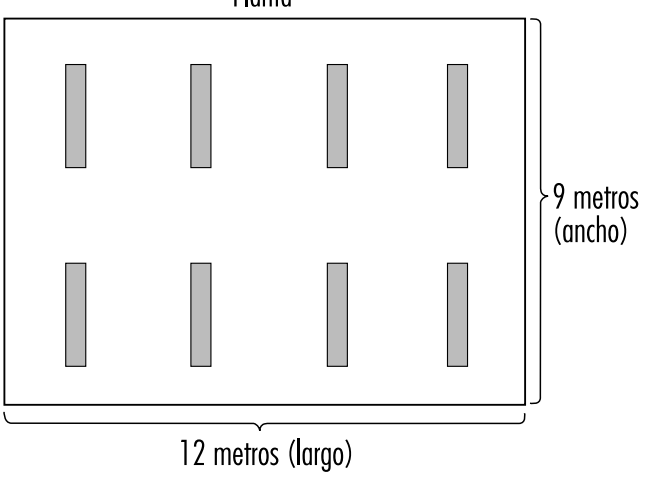

La relación mencionada se expresa de la forma siguiente:

$\mathrm{N}$ úmero mínimo de puntos de medición $=(x+2)^{2}$

donde " $x$ " es el valor del índice de local redondeado al entero superior, excepto que para todos los valores de RI iguales 0 mayores que 3, el valor de $x$ es 4 . A partir de la ecuación se obtiene el número mínimo de puntos de medición, pero las condiciones suelen requerir la utilización de un número de puntos superior a este mínimo.

Figura 46.29 • Posibles combinaciones de orientación de las luminarias y la dirección de la visión dentro del interior analizado como ejemplo.

$\rightarrow=$ dirección de la visión
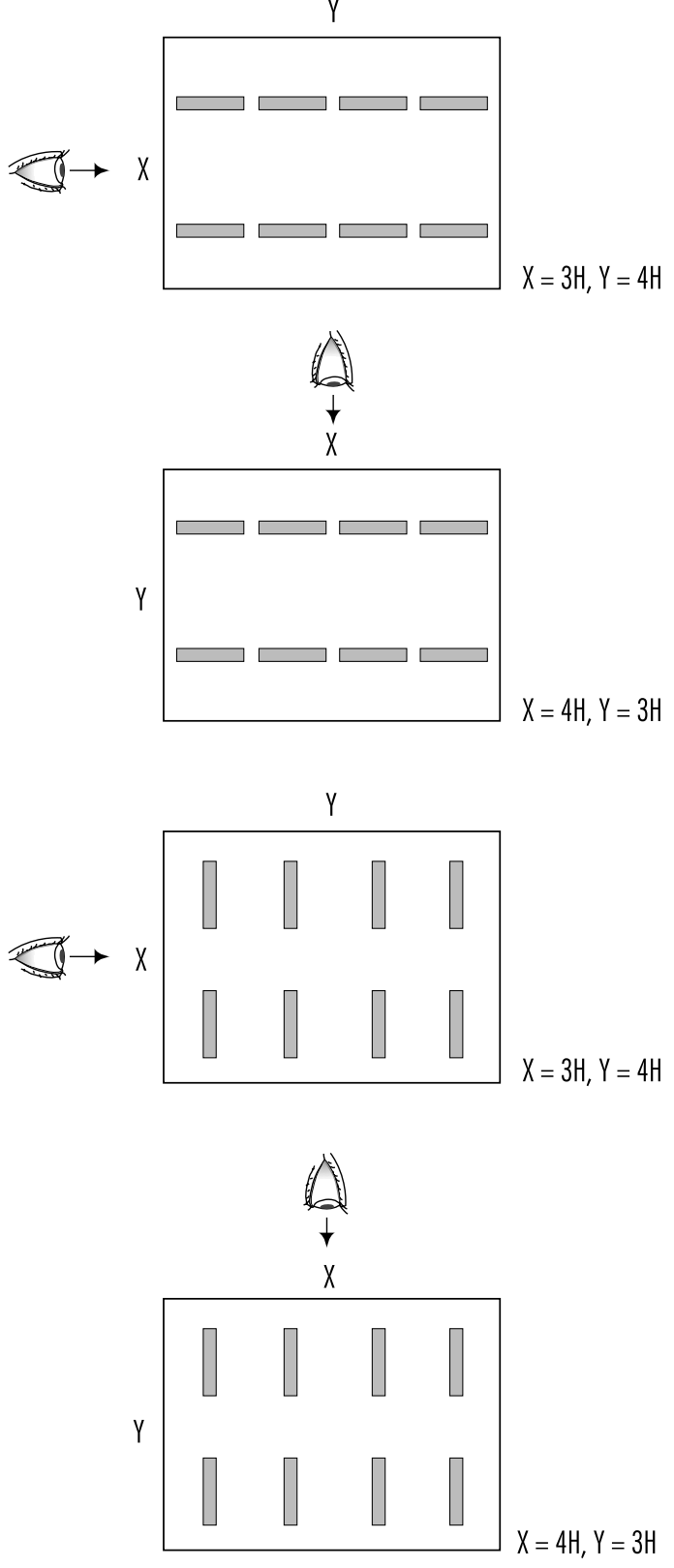

ENCICLOPEDIA DE SALUD Y SEGURIDAD EN EL TRABAJO 
Al analizar la iluminación de un área de trabajo y su entorno inmediato, es preciso tener en cuenta la variancia de la iluminancia o uniformidad de la iluminancia.

$$
\text { U niformidad de la iluminancia }=\frac{\text { Iluminancia mínima }}{\text { Iluminancia media }}
$$

Sobre cualquier área de trabajo y su entorno inmediato, la uniformidad no deberá ser inferior a 0,8. En muchos lugares de trabajo, es innecesario proporcionar el mismo nivel de iluminación a todas las áreas. Con la iluminación localizada o local puede ahorrarse algo de energía, pero cualquiera que sea el sistema utilizado, la variancia de la iluminancia no debe ser excesiva en un ambiente interior.

La diversidad de la iluminancia se expresa de la forma siguiente:

$$
\text { Diversidad de la iluminancia }=\frac{\text { Iluminancia máxima }}{\text { Iluminancia mínima }}
$$

La diversidad de la iluminancia no deberá exceder de 5:1 en ningún punto del área principal del ambiente interior.

Los instrumentos utilizados para medir la luminancia y la iluminancia suelen tener respuestas espectrales que varían con respecto a la respuesta del sistema visual humano. $L$ as respuestas se corrigen, normalmente utilizando filtros. Cuando los instrumentos incorporan filtros, se dice que disponen de corrección de color.

Los medidores de iluminancia tienen una corrección adicional que compensa la dirección de la luz que incide sobre la célula detectora. Cuando los instrumentos son capaces de medir la iluminancia con precisión desde direcciones variables de luz incidente, se dice que disponen de corrección cosenoidal.

\section{M edición del índice de deslumbramiento}

El sistema que se utiliza con frecuencia en el Reino U nido, con variaciones en otros lugares, es en esencia un proceso de dos fases. En la primera fase, se determina el valor del índice de deslumbramiento sin corrección (U ncorrected Glare Index, U GI). En la Figura 46.28 se presenta un ejemplo.

$\mathrm{La}$ altura $\mathrm{H}$ es la distancia vertical entre el centro de la fuente de luz y el nivel de los ojos de un observador sentado, normalmente aceptado como 1,2 metros sobre el nivel del suelo. Las principales dimensiones de la habitación se convierten entonces en múltiplos de $\mathrm{H}$. De este modo, como $\mathrm{H}=3,0$ metros, la longitud $=4 \mathrm{H}$ y la anchura $=3 \mathrm{H}$. Es preciso realizar cuatro cálculos independientes del índice U GI con el fin de determinar el peor escenario posible de acuerdo con las disposiciones representadas en la Figura 46.29.

Los fabricantes de equipos de iluminación preparan tablas que especifican, para valores determinados de reflectancia de tejidos en una habitación, valores del índice de deslumbramiento sin corrección para cada combinación de valores de $X$ e $Y$.

La segunda fase del proceso es aplicar factores de corrección a los valores UGI en función de los valores de flujo luminoso de las lámparas y de la desviación del valor de altura $(H)$.

Después se compara el valor del índice de deslumbramiento definitivo con el valor del índice de deslumbramiento límite (Limiting Glare Index, LGI), indicado en referencias tales como el Código CIBSE de Iluminación de Interiores (CIBSE Code for Interior Lighting, 1994)

\section{Referencias}

Chartered Institution of Building Services Engineers (CIBSE). 1993. Lighting G uide. Londres: CIBSE.

— . 1994. Code for Interior Lighting. Londres: CIBSE.

Comisión Electrotécnica Internacional (CEI). 1993. International Lamp Coding System. IEC document no. 123-93. Londres: CEI.

Comisión Internacional de Iluminación (CIE). 1992. $M$ aintenance of Indoor Electric Lighting Systems. CIE T echnical R eport N 0. 97. Austria: CIE.

Lighting Industry Federation. 1994. Lighting Industry Federation Lamp Guide. Londres: Lighting Industry Federation.

\section{O tras lecturas recomendadas}

Department of Productivity. 1979. Artificial Light at W ork. O ccupational Safety and $\mathrm{H}$ ealth Working Environment, No. 6. Canberra: Australian Government Publishing Service.
-. 1980. Colour at work. O ccupational Safety and Health Working Environment, No. 8. Canberra: Australian G overnment Publishing Service.

Association française de normalisation. 1975. Couleurs d'ambiance pour les lieux de travail. Norme française enregistrée NF X 08-004. Documento del CIS Núm. 76-1288. París: Tour Europe.

Bestratén, M, R Chavarria, A Hernandez, P Luna, C Nogareda, S Nogareda, M Oncins, M G Solé. 1994. Ergonomía. Centro Nacional De Condiciones De Trabajo. Barcelona: Instituto Nacional de Seguridad e $\mathrm{H}$ igiene en el T rabajo.

Cayless, M A, AM M arsden. 1983. Lamps and Lighting. Londres: E Arnold.

Comisión Europea (CE). 1989. Directiva marco. Directiva de la CE núm. 89/391/EEC. Bruselas: CE.

De Boer, JB, D Fischer. 1981. Interior Lighting. Antwerp: Philips T echnical Library.
Gardiner, K, JM Harrington. 1995. Occupational $H$ ygiene. O xford: Blackwell Science.

Grandjean, E. 1988. Fitting the Task to the $M$ an. Londres: T aylor \& Francis.

Greene, TC, PA Bell. 1980. Additional Considerations Concerning the $E$ ffect of ' $W$ arm' and 'C ool' $W$ all Colours On E nergy Conservation. Londres: Ergonomics.

Illuminating Engineers Society of North America. 1979. A merican National Standard. Practice of Industrial Lighting. ANSI/IES RP-7-1979. Nueva York: Illuminating Engineers Society of N orth America.

- . 1981. Lighting $\mathrm{H}$ andbook. N ueva Y ork: Illuminating Engineers Society of $\mathrm{N}$ orth America.

M andelo, P. 1994. Fundamentos de Ergonomía. Barcelona: U niversidad Politécnica de Barcelona.

M oon, P. 1961. Scientific B asis of Illuminating E ngineering. Londres: Dover Publications.

Organización Internacional del Trabajo (OIT). N.d. Artificial Lighting in Factory and Office. CIS Information Sheet N 0. 11. G inebra: OIT .

Walsh, JWT. N.d. T extbook of Illuminating Engineering. Londres: Pitman. 



\section{RUIDO}

Directora del capítulo

Alice H. Suter

\section{Sumario}

$\mathrm{N}$ aturaleza y efectos del ruido

Alice H. Suter ............................... 47.2

M edición del ruido y evaluación de la exposición

E duard I. D enisov y G erman A. Suvorov . . . . . . . . . . . . . . . 47.6

T écnicas de control del ruido

Dennis P. D riscoll. . . . . . . . . . . . . . . . . . . . . . . . . . . . . . 47.8

Programas de conservación de la audición

L arry H . R oyster y J ulia D oswell Royster . . . . . . . . . . . . . 47.12

Normas y reglamentaciones

Alice H. Suter . . . . . . . . . . . . . . . . . . . 47.16 


\section{- NATURALEZA Y EFECTOS DEL RUIDO}

Alice H. Suter

\section{La omnipresencia del ruido en el trabajo}

El ruido es uno de los peligros laborales más comunes. En Estados U nidos, por ejemplo, más de 9 millones de trabajadores se ven expuestos diariamente a niveles de ruido medios de 85 decibelios ponderados $\mathrm{A}$ (en adelante, dBA). Estos niveles de ruido son potencialmente peligrosos para su audición y pueden producir además otros efectos perjudiciales. Existen aproximadamente 5,2 millones de trabajadores expuestos a niveles de ruido aún mayores en entornos de fabricación y empresas de agua, gas y electricidad, lo cual representa alrededor del $35 \%$ del número total de personas que trabajan en el sector de fabricación en Estados U nidos.

Los niveles de ruido peligrosos se identifican fácilmente y en la gran mayoría de los casos es técnicamente viable controlar el exceso de ruido aplicando tecnología comercial, remodelando el equipo o proceso o transformando las máquinas ruidosas. Pero con demasiada frecuencia, no se hace nada. $\mathrm{H}$ ay varias razones para ello. En primer lugar, aunque muchas soluciones de control del ruido son notablemente económicas, otras son muy caras, en particular cuando hay que conseguir reducciones a niveles de 85 u 80 dBA.

U na razón muy importante de la ausencia de programas de conservación de la audición y de control del ruido es que, lamentablemente, el ruido suele aceptarse como un "mal necesario", una parte del negocio, un aspecto inevitable del trabajo industrial. El ruido peligroso no derrama sangre, no rompe huesos, no da mal aspecto a los tejidos y, si los trabajadores pueden aguantar los primeros días o semanas de exposición, suelen tener la sensación de "haberse acostumbrado" al ruido. Sin embargo, lo más probable es que hayan comenzado a sufrir una pérdida temporal de la audición, que disminuye su sensibilidad auditiva durante la jornada laboral y que a menudo persiste durante la noche. Esa pérdida auditiva avanza luego de manera insidiosa, ya que aumenta gradualmente a lo largo de meses y años, y pasa en gran medida inadvertida hasta alcanzar proporciones discapacitantes.

O tra razón importante de la falta de reconocimiento de los peligros del ruido es que el deterioro auditivo resultante implica un estigma. Como Raymond $\mathrm{H}$ étu ha demostrado tan claramente en su artículo sobre rehabilitación de la pérdida auditiva inducida por ruido en esta misma Enciclopedia, la opinión que suele tenerse de las personas que sufren deterioros auditivos es que están avejentadas y son mentalmente lentas e incompetentes en términos generales, y quienes corren el riesgo de sufrir este tipo de deterioro son reacios a reconocer ni su deficiencia ni el riesgo por miedo a ser estigmatizados. Esto es muy de lamentar, porque la pérdida auditiva inducida por ruido llega a ser permanente y, sumada a la que se produce a consecuencia de la edad, puede dar lugar a cuadros de depresión y aislamiento en personas de mediana edad y mayores. Las medidas preventivas deben tomarse antes de que comience la pérdida auditiva.

\section{Alcance de la exposición al ruido}

Como ya se ha mencionado, el ruido es especialmente imperante en las industrias de fabricación. EI D epartamento de Trabajo de Estados U nidos ha calculado que el $19,3 \%$ de las personas que trabajan en entornos de fabricación y empresas de agua, gas y electricidad se ven expuestas diariamente a niveles medios de ruido de $90 \mathrm{dBA}$ o más, el 34,4\% a niveles superiores a $85 \mathrm{dBA}$, y el $53,1 \%$ a niveles superiores a $80 \mathrm{dBA}$. Estas estimaciones deben ser bastante típicas del porcentaje de trabajadores expuestos a niveles peligrosos de ruido en otras naciones. Es probable que los niveles sean algo mayores en los países menos desarrollados, donde no se utilizan tanto los controles técnicos, y

Figura 47.1 • Exposición al ruido en el trabajo: la experiencia de Estados Unidos.

TOTAL- 9.031.000 TRABAJADORES EXPUESTOS A NIVELES DE RUIDO SUPERIORES A $85 \mathrm{dBA}$

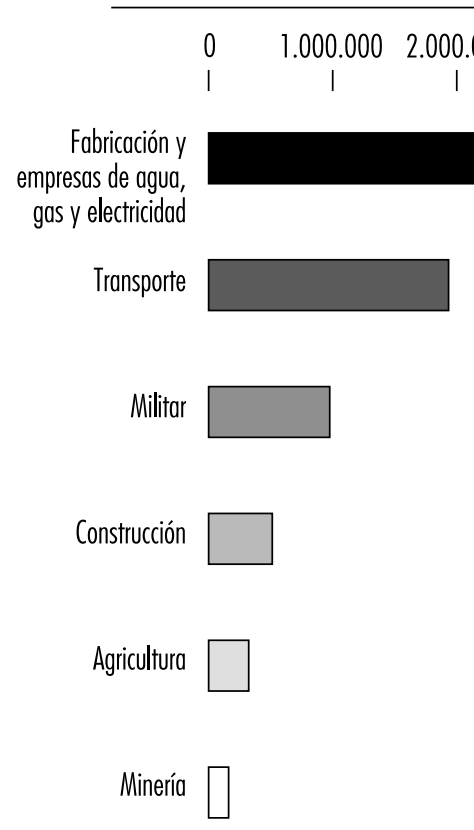

INDUSTRIAS DE FABRICACION MAS RUIDOSAS, POR ORDEN DECRECIENTE, EN FUNCION DEL PORCENTAJE DE TRABAJADORES EXPUESTOS A NIVELES DE RUIDO SUPERIORES A $90 \mathrm{dBA}$

1 
algo inferiores en países con programas de control del ruido más rigurosos, como los países escandinavos y Alemania.

M uchos trabajadores de todo el mundo experimentan exposiciones muy peligrosas, muy por encima de los $85090 \mathrm{dBA}$. Por ejemplo, el Departamento de Trabajo de Estados U nidos ha calculado que, sólo en las industrias de fabricación, casi medio millón de trabajadores se ven expuestos diariamente a niveles medios de ruido de $100 \mathrm{dBA}$ o más, y más de 800.000 a niveles de entre 95 y $100 \mathrm{dBA}$.

En la Figura 47.1 se enumeran las industrias de fabricación más ruidosas de Estados U nidos por orden decreciente, de acuerdo con el porcentaje de trabajadores expuestos a más de $90 \mathrm{dBA}$, y se indican estimaciones de exposición por sectores industriales

\section{Necesidades de investigación}

En los artículos siguientes del presente capítulo se intenta dejar claro que los efectos de la mayoría de los tipos de ruido sobre la audición son perfectamente conocidos. $\mathrm{H}$ ace ya unos 30 años que se elaboraron criterios relativos a los efectos del ruido continuo, variable e intermitente, que en lo esencial permanecen inalterados. En cambio, la situación no es la misma para el ruido de impulso. Para una misma energía sonora y a niveles relativamente bajos, el ruido de impulso parece no ser más perjudicial - y quizá lo sea menos- que el ruido continuo. Pero a niveles altos parece ser más perjudicial, sobre todo si se sobrepasa un nivel crítico (o, dicho más propiamente, una exposición crítica). Es necesario continuar investigando para definir con más exactitud la forma de la curva de daño/ riesgo.

0 tro punto que es necesario aclarar es el referente al efecto perjudicial del ruido, tanto para la audición como para la salud en general, combinado con otros agentes. Aunque los efectos combinados del ruido y de los fármacos ototóxicos se conocen bastante bien, crece la preocupación por la combinación del ruido con los productos químicos industriales. L os disolventes y otros agentes parecen aumentar su carácter neurotóxico cuando la exposición a ellos se combina con altos niveles de ruido.

L os trabajadores expuestos al ruido en el sector de fabricación y en las fuerzas armadas reciben en todo el mundo la mayor atención. En cambio, son muchos los trabajadores de la minería, la construcción, la agricultura y el transporte que están también expuestos a niveles peligrosos de ruido, como se señala en la Figura 47.1. Hay que evaluar las necesidades singulares asociadas a estos puestos de trabajo y que extender a ellas las medidas de control del ruido y otros aspectos de los programas de conservación de la audición. Por desgracia, facilitando estos programas a los trabajadores expuestos al ruido no se garantiza la prevención de la pérdida auditiva ni de sus otros efectos perjudiciales. Aunque existen métodos normalizados de evaluación de la eficacia de dichos programas, pueden ser muy complicados y no se utilizan mucho. Es preciso elaborar métodos de evaluación sencillos al alcance de empresas grandes o pequeñas, o que dispongan de recursos mínimos.

Como ya se ha mencionado, aunque existe la tecnología necesaria para eliminar la mayoría de los problemas de ruido, se observan grandes lagunas en su aplicación. Es necesario desarrollar métodos para suministrar información sobre cualesquiera soluciones de control del ruido a todos los que la necesiten. Es preciso informatizar los datos sobre control del ruido y ponerlos a disposición no sólo de los usuarios de los países en desarrollo, sino también de las naciones industrializadas.

\section{Tendencias futuras}

En algunos países se tiende a poner más énfasis en la exposición al ruido de carácter no laboral y en la parte de responsabilidad que incumbe a éste en la pérdida auditiva. Entre las actividades y fuentes de ruido de este tipo se incluyen la caza, el tiro al blanco, los juguetes ruidosos y la música a alto volumen. Este enfoque es beneficioso por cuanto que destaca algunas causas de deterioro auditivo potencialmente importantes, pero de hecho puede ser perjudicial si desvía la atención de los problemas graves de ruido en el trabajo.

Entre los países de la Unión Europea se evidencia una tendencia muy acentuada a la normalización de la cuestión del ruido. Este proceso incluye la elaboración de normas relativas a las emisiones de ruido de productos y a la exposición al ruido.

El proceso de elaboración de normas no es, en cambio, rápido en Norteamérica, sobre todo en Estados U nidos, donde el trabajo normativo está paralizado y existe la posibilidad de ir a la desregulación. Los esfuerzos por regular el ruido de nuevos productos se abandonaron en 1982, año en que se cerró la O ficina del Ruido de la Agencia de Protección Ambiental, y puede que las normas en materia de ruido no sobrevivan al clima desregulador actualmente existente en el Congreso.

Los países en desarrollo parecen encontrarse en vías de adoptar y revisar normas en materia de ruido. Estas normas tienden al conservadurismo, ya que apuntan a un límite de exposición permisible de $85 \mathrm{dBA}$, y un factor de acumulación (relación de interdependencia tiempo/intensidad) de $3 \mathrm{~dB}$. Q ueda abierta la cuestión de hasta qué punto se aplicarán estas normas, sobre todo en economías incipientes.

Algunos países en desarrollo tienden a concentrarse en el control del ruido por métodos técnicos, en lugar de abordar las complejidades de las pruebas audiométricas, los protectores auditivos, la formación y el mantenimiento de registros. Este enfoque parece muy sensato siempre que sea factible. En ocasiones habrá que complementarlo con la utilización de protectores auditivos para reducir la exposición a niveles seguros.

\section{Los efectos del ruido*}

La pérdida de la capacidad auditiva es el efecto perjudicial del ruido más conocido y probablemente el más grave, pero no el único. Otros efectos nocivos son los acufenos (sensación de zumbido en los oídos), la interferencia en la comunicación hablada y en la percepción de las señales de alarma, las alteraciones del rendimiento laboral, las molestias y los efectos extraauditivos. En la mayoría de las circunstancias, la protección de la audición de los trabajadores debe servir de protección contra la mayoría de estos otros efectos. Esta consideración debería alentar a las empresas a implantar programas adecuados de control del ruido y de conservación de la audición.

\section{Deterioro auditivo}

El deterioro auditivo inducido por ruido es muy común, pero a menudo se subestima porque no provoca efectos visibles ni, en la mayoría de los casos, dolor alguno. Sólo se produce una pérdida de comunicación gradual y progresiva con familiares y amigos y una pérdida de sensibilidad a los sonidos del entorno, como el canto de los pájaros o la música. Por desgracia, la capacidad de oír correctamente suele darse por supuesta hasta que se pierde.

Estas pérdidas pueden ser tan graduales que pasan inadvertidas hasta que el deterioro resulta discapacitante. La primera señal suele ser que los demás parecen no hablar tan claramente como solían. La persona afectada tiene que pedir a los demás que le repitan y a menudo observa cómo éstas se molestan por su aparente falta de consideración. Con frecuencia tiene que

* Parte de la información de este apartado es una adaptación de Suter, $\mathrm{AH}$, "N oise and the conservation of hearing", capítulo 2 del H earing Conservation $\mathrm{M}$ anual ( 3 a ed.), Council for Accreditation in $\mathrm{O}$ ccupational Hearing Conservation, M ilwaukee, Wisconsin, EE.UU. (1993) 
decir a su familia y amigos cosas como: "No me grites. Te oigo, pero es que no entiendo lo que dices."

A medida que aumenta la pérdida auditiva, el afectado comienza a retraerse de las relaciones sociales. Los actos religiosos, las reuniones cívicas, las reuniones sociales o los espectáculos comienzan a perder su atractivo y la persona prefiere quedarse en casa. El volumen de la televisión se convierte en motivo de conflicto $y$, a veces, obliga a otros miembros de la familia a salir de la habitación.

Con el tiempo, la presbiacusia, o pérdida de capacidad auditiva que acompaña de manera natural al proceso de envejecimiento, se suma a la deficiencia auditiva. Finalmente, la situación puede llegar a tal punto que el afectado sólo se comunique con sus familiares o amigos con grandes dificultades, y es entonces cuando se encuentra realmente aislado. Un audífono puede ayudar en algunos casos, pero nunca se restaura la claridad de la audición natural del mismo modo que se consigue en el caso de la visión con el uso de gafas graduadas.

\section{Deterioro auditivo de origen laboral}

El deterioro auditivo inducido por ruido suele considerarse enfermedad laboral, no lesión, porque su progresión es gradual. Es muy raro que se produzca una pérdida auditiva inmediata y permanente por efecto de un incidente ensordecedor, como una explosión, o un proceso muy ruidoso, como el remachado en acero. En tales casos, se entiende que se trata de una lesión y se habla de "traumatismo acústico". Lo habitual, como ya se ha señalado, es que se produzca una lenta disminución de la capacidad auditiva a lo largo de muchos años. El grado de deterioro dependerá del nivel del ruido, de la duración de la exposición y de la sensibilidad del trabajador en cuestión. Lamentablemente, no existe tratamiento médico para el deterioro auditivo de carácter laboral; sólo existe la prevención.

Los efectos del ruido sobre la audición están bien documentados y no hay mucho lugar a la controversia en lo que respecta al nivel de ruido continuado que provoca diversos grados de pérdida auditiva (ISO 1990). Es también indiscutible que el ruido intermitente produce pérdida auditiva. No obstante, los períodos de ruido que son interrumpidos por períodos de silencio pueden ofrecer al oído interno una oportunidad de recuperarse de una pérdida auditiva temporal y, por consiguiente, son algo menos peligrosos que el ruido continuado. Tal situación, es aplicable principalmente a los trabajos que se desarrollan en exteriores, pero no a ambientes interiores como las fábricas, donde son raros los necesarios intervalos de silencio (Suter 1993).

El ruido de impulso, como el producido por las armas de fuego o la estampación de metal, también perjudica la audición. Existen incluso pruebas de que entraña más peligro que otros tipos de ruido (Dunn y cols. 1991; Thiery y M eyer-Bisch 1988), aunque no siempre es aś. El grado de daño dependerá principalmente del nivel y la duración del impulso, y puede empeorar si existe un ruido continuado de fondo. También hay pruebas de que las fuentes de ruido de impulso de alta frecuencia son más perjudiciales que las de baja frecuencia ( $\mathrm{H}$ amernik, Ahroon y H sueh 1991; Price 1983).

La pérdida auditiva provocada por ruido suele ser, al principio, temporal. En el curso de una jornada ruidosa, el oído se fatiga y el trabajador experimenta una reducción de su capacidad auditiva conocida como desviación temporal del umbral (Temporary Threshold Shift, TTS). Entre el final de un turno de trabajo y el principio del siguiente, el oído suele recuperarse de gran parte de esta TTS, pero a menudo parte de la pérdida persiste. Tras días, meses y años de exposición, la T T S da lugar a efectos permanentes y comienzan a acumularse nuevas carencias por TTS sobre las pérdidas ya permanentes. U n buen programa de pruebas audiométricas permitirá identificar estas pérdidas auditivas temporales y proponer medidas preventivas antes de que se conviertan en permanentes.

Existen pruebas experimentales de que varios agentes industriales son tóxicos para el sistema nervioso y producen pérdidas auditivas en animales de laboratorio, especialmente si se presentan en combinación con ruido (Fechter 1989). Entre estos agentes cabe citar a) metales pesados peligrosos, como los compuestos de plomo y trimetiltina; b) disolventes orgánicos, como el tolueno, el sileno y el disulfuro de carbono, y c) un asfixiante, el monóxido de carbono. Las investigaciones realizadas recientemente con trabajadores industriales (M orata 1989; M orata y cols. 1991) sugieren que algunas de estas sustancias (el disulfuro de carbono y el tolueno) pueden incrementar el potencial nocivo del ruido. También existen pruebas de que ciertos fármacos que ya son tóxicos para el oído pueden incrementar los efectos perjudiciales del ruido (Boettcher y cols. 1987). C abe citar ciertos antibióticos y agentes quimioterápicos. Los responsables de los programas de conservación de la capacidad auditiva deben saber que los trabajadores expuestos a los productos químicos o fármacos mencionados pueden ser más sensibles a las pérdidas auditivas, tanto más si ya están expuestos a ruido.

\section{Deterioro auditivo de origen no laboral}

Es importante comprender que el ruido en el trabajo no es la única causa de pérdida auditiva inducida por ruido entre los trabajadores. $\mathrm{H}$ ay también fuentes de ruido extralaborales que producen lo que a veces se llama "socioacusia" y cuyos efectos sobre la audición son imposibles de diferenciar de aquellos otros. Tan sólo cabe establecer suposiciones, planteando preguntas detalladas acerca de las actividades recreativas y otras actividades ruidosas desarrolladas por el trabajador. Como ejemplos de fuentes socioacúsicas cabría citar las herramientas para el trabajo de la madera, las sierras de cadena, las motocicletas sin silenciador, la música a gran volumen y las armas de fuego. Disparar frecuentemente con armas de gran calibre (sin protección auditiva) puede contribuir de manera significativa a la pérdida auditiva inducida por ruido, mientras que cazar ocasionalmente con armas de menor calibre tiene menos probabilidades de causar daños.

La exposición a ruidos no laborales y la socioacusia resultante tienen importancia porque esta pérdida auditiva se suma a la que puede sufrirse por la exposición a fuentes de ruido de carácter laboral. En beneficio de la salud auditiva general de los trabajadores, sería conveniente aconsejarles que lleven protectores auditivos adecuados si desarrollan actividades recreativas ruidosas.

\section{Acufenos}

L os acufenos son un proceso que acompaña frecuentemente a las pérdidas auditivas temporales o permanentes inducidas por ruido, así como a otros tipos de pérdidas auditivas sensitivo-neuronales. A menudo descrito como "sensación de zumbido en los oídos", puede ser suave en algunos casos y severo en otros. Algunas personas dicen sentir más molestias por este zumbido que por el deterioro auditivo.

Es probable que las personas que sufren de acufenos noten éstos más en un ambiente silencioso, por ejemplo al intentar dormir por la noche 0 al sentarse en una cabina insonorizada para someterse a una prueba audiométrica. Es una señal de que se han irritado las células sensoriales del oído interno. Suele preceder a una pérdida auditiva inducida por ruido $y$, por consiguiente, es una importante señal de aviso. 


\section{La interferencia con la comunicación y la seguridad}

Es indudable que el ruido puede entorpecer o "enmascarar" la comunicación hablada y las señales de alarma. Ciertamente, muchos procesos industriales pueden llevarse a cabo sin problemas con un mínimo de comunicación entre los trabajadores. Sin embargo, otros trabajos, como los realizados por pilotos de compañías aéreas, ingenieros ferroviarios, comandantes de carros blindados y muchos otros, dependen en gran medida de la comunicación hablada. Algunas de estas personas utilizan sistemas electrónicos que suprimen el ruido y amplifican la voz. $\mathrm{H}$ oy en día, existen avanzados sistemas de comunicaciones, algunos de ellos con dispositivos que anulan las señales acústicas no deseadas, para facilitar la comunicación.

En muchos casos, los trabajadores no pueden hacer nada más que arreglárselas, esforzándose por comprender y comunicarse por encima del ruido, con gritos o señales. A veces, desarrollan afonías 0 incluso padecen nódulos u otras anomalías en las cuerdas vocales por forzar la voz en exceso. Es posible que requieran por ello atención médica.

La experiencia demuestra que con niveles de ruido superiores a $80 \mathrm{dBA}$ es preciso hablar muy alto y por encima de $85 \mathrm{dBA}$ hay que gritar. $C$ on niveles muy superiores a $95 \mathrm{dBA}$, hay que acercarse al interlocutor para poder comunicarse. Los especialistas en acústica han desarrollado métodos para predecir el grado de comunicación que puede darse en situaciones industriales. Las predicciones resultantes dependen de las características acústicas tanto del ruido como del habla (u otra señal que se desee), así como de la distancia entre los interlocutores.

Es bien sabido que el ruido puede entorpecer la seguridad, pero este problema sólo ha sido documentado por un número muy limitado de estudios ( $p$. ej., M oll van Charante y $M$ ulder 1990; Wilkins y Acton 1982). Sin embargo, se han recibido numerosos informes que muestran que la ropa y las manos de los trabajadores han quedado atrapadas en máquinas y éstos han sufrido graves lesiones mientras sus compañeros de trabajo eran ajenos a sus gritos de auxilio. Para evitar los fallos de comunicación en ambientes ruidosos, algunas empresas han instalado dispositivos visuales de aviso.

O tro problema, más reconocido por los propios trabajadores expuestos al ruido que por los profesionales de la conservación de la audición y de la salud en el trabajo, es que los protectores auditivos entorpecen a veces la percepción de las palabras y de las señales de alarma, sobre todo cuando ya se padece una pérdida auditiva y los niveles de ruido son inferiores a $90 \mathrm{dBA}$ (Suter 1992). En estos casos, es muy legítimo que los trabajadores se preocupen por llevar estos protectores. Es importante prestar atención a sus inquietudes e implantar controles técnicos del ruido o mejorar el tipo de protección que se ofrece, como los protectores incorporados en un sistema electrónico de comunicación. Además, ya existen protectores auditivos con una respuesta en frecuencia más plana, de más "alta fidelidad", que pueden mejorar la capacidad para comprender las palabras y las señales de aviso.

\section{E fectos sobre el rendimiento laboral}

Los efectos del ruido sobre el rendimiento laboral se han estudiado tanto en laboratorio como en condiciones reales de trabajo. Los resultados han demostrado que el ruido suele tener escasos efectos sobre el rendimiento de trabajos repetitivos y monótonos e incluso lo mejora en algunos casos si es de nivel bajo o moderado. En cambio, los niveles de ruido altos pueden degradar el rendimiento laboral, sobre todo si la tarea es complicada o requiere hacer varias cosas a la vez. EI ruido intermitente tiende a ser más perjudicial que el ruido continuo, sobre todo cuando los períodos de ruido son impredecibles e incontrolables. Algunas investigaciones indican que en los ambientes ruidosos es menos probable que las personas se ayuden unas a otras y más probable que presenten comportamientos antisociales. (Ver estudio detallado de los efectos del ruido sobre el rendimiento laboral en Suter 1992.)

\section{Molestias}

Aunque el término "molestias" suele relacionarse más con los problemas de ruido de carácter comunitario, como los que se plantean en aeropuertos o pistas de carreras automovilísticas, también los trabajadores industriales pueden sentirse molestos 0 irritados por el ruido de su lugar de trabajo. Estas molestias pueden estar relacionadas con el entorpecimiento de la comunicación hablada y del rendimiento laboral anteriormente descrito, pero también deberse a una auténtica aversión al ruido. A veces, esta aversión es tan fuerte que impulsa a algunos trabajadores a buscar empleo en otra parte, si bien no siempre se presenta esa oportunidad. Después de un período de adaptación, la mayoría de ellos no parecerán sentirse tan molestos, pero posiblemente sigan quejándose de fatiga, irritabilidad e insomnio. (Esa adaptación será mucho mejor si se equipa a los trabajadores jóvenes con protectores adecuados desde el principio, antes de que sufran pérdida auditiva alguna.) Es interesante observar que este tipo de información sale a veces a la superficie después de que una empresa inicia un programa de control del ruido y de conservación de la audición, una vez que los trabajadores se dan cuenta del contraste entre las condiciones previas y la mejora posterior.

\section{E fectos extraauditivos}

Como factor de estrés biológico, el ruido puede afectar a todo el sistema fisiológico. Actúa de la misma manera que otros factores de estrés, haciendo que el cuerpo responda de un modo que puede ser perjudicial a largo plazo. En los tiempos primitivos, cuando llegaba el momento de afrontar un peligro, el cuerpo pasaba por una serie de cambios biológicos, preparándose para pelear o salir corriendo (la clásica respuesta de "Iuchar 0 escapar"). Existen pruebas de que estos cambios aún persisten con la exposición a un nivel de ruido alto, aunque la persona se crea "adaptada" al ruido.

La mayoría de estos efectos parecen transitorios, pero con la exposición continuada algunos han demostrado ser crónicos en animales de laboratorio. Varios estudios de trabajadores industriales apuntan en la misma dirección, mientras que otros estudios no muestran efectos significativos (Rehm 1983; van Dijk 1990). Las pruebas son probablemente más claras en el caso de los efectos cardiovasculares, como el aumento de la presión arterial o los cambios en la química sanguínea. U na importante serie de estudios de laboratorio demostró la existencia de niveles crónicos de hipertensión arterial en animales a consecuencia de la exposición a un nivel de ruido de 85 a $90 \mathrm{dBA}$, que no volvieron a la normalidad al cesar la exposición (Peterson y cols. 1978, 1981 y 1983).

Los estudios de química sanguínea muestran aumentos de los niveles de las catecolaminas adrenalina y noradrenalina debidos a la exposición al ruido (Rehm 1983) y en una serie de experimentos realizados por investigadores alemanes se halló una conexión entre la exposición al ruido y el metabolismo del magnesio en seres humanos y animales (I sing y K ruppa 1993). El razonamiento actual sostiene que es muy probable que la aversión al ruido sirva de mediación psicológica para los efectos extraauditivos del ruido, por lo que resulta muy difícil obtener relaciones de respuesta a dosis. (Ver una descripción completa de este problema en Ising y K ruppa 1993.)

Como los efectos extraauditivos del ruido tienen la mediación del sistema auditivo, lo que significa que es necesario oír el ruido para que se produzcan efectos perjudiciales, un protector auditivo correctamente colocado debe reducir la probabilidad de 
que se produzcan estos efectos del mismo modo que lo hace con la pérdida auditiva.

\section{- MEDICION DEL RUIDO YEVALUACION DE LAEXPOSICION}

Eduard I. Denisov y G erman A. Suvorov

Para prevenir los efectos perjudiciales del ruido para los trabajadores, es preciso elegir con cuidado instrumentos, métodos de medición y procedimientos que permitan evaluar el ruido al que se ven expuestos aquéllos. Es importante evaluar correctamente los diferentes tipos de ruido (continuo, intermitente o de impulso), distinguir los ambientes ruidosos con diferentes espectros de frecuencias, y considerar asimismo las diversas situaciones laborales, tales como talleres de forja, salas de compresores de aire, procesos de soldadura por ultrasonidos, etc. Los principales objetivos de la medición del ruido en ambientes laborales son a) identificar a los trabajadores sometidos a exposiciones excesivas y cuantificar éstas y b) valorar la necesidad de implantar controles técnicos del ruido y demás tipos de control indicados. 0 tras aplicaciones de la medición del ruido son la evaluación de la eficacia de determinados controles del ruido y la determinación de los niveles de ruido de fondo en las cabinas audiométricas.

\section{Instrumentos de medida}

Entre los instrumentos de medida del ruido cabe citar los sonómetros, los dosímetros y los equipos auxiliares. El instrumento básico es el sonómetro, un instrumento electrónico que consta de un micrófono, un amplificador, varios filtros, un circuito de elevación al cuadrado, un promediador exponencial y un medidor calibrado en decibelios (dB). Los sonómetros se clasifican por su precisión, desde el más preciso (tipo 0) hasta el más impreciso (tipo 3). El tipo 0 suele utilizarse en laboratorios, el

Figura 47.2 - Sonómetro: control de calibración. Cortesía de Larson Davis.

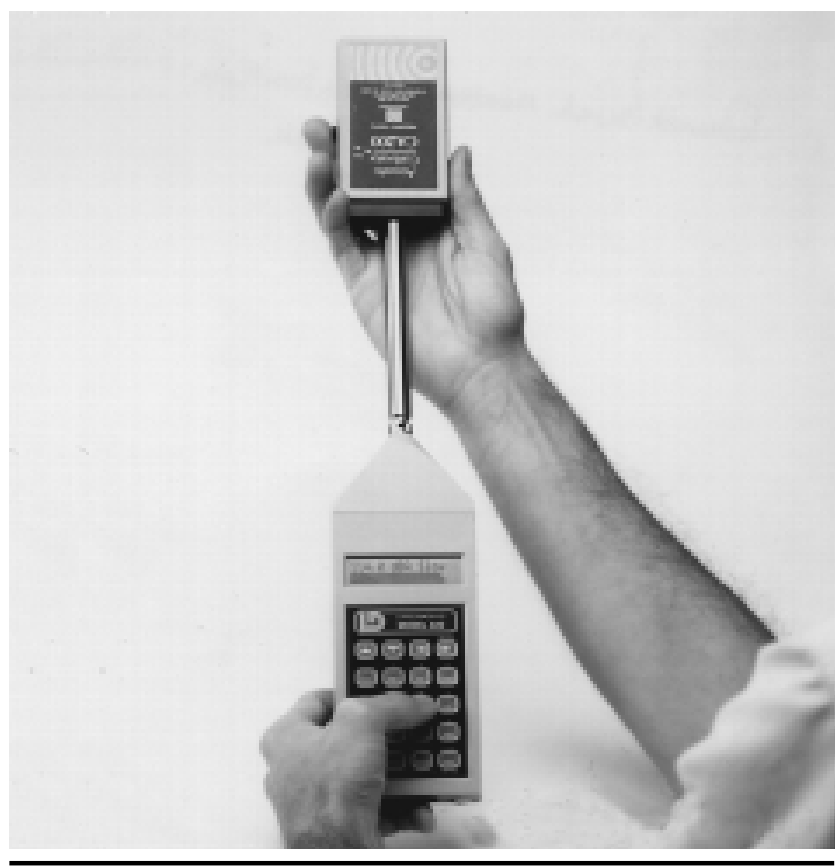

tipo 1 se emplea para realizar otras mediciones de precisión del nivel sonoro, el tipo 2 es el medidor de uso general, y el tipo 3, el medidor de inspección, no está recomendado para uso industrial. Las Figuras 47.2 y 47.3 ilustran un sonómetro.

Los sonómetros también incluyen dispositivos de ponderación de frecuencias, que son filtros que permiten el paso de la mayoría de las frecuencias pero que discriminan otras. El filtro más utilizado es la red de ponderación $A$, desarrollada para simular la curva de respuesta del oído humano a niveles de escucha moderados. Los sonómetros ofrecen asimismo diversas respuestas de medición: la respuesta "Ienta", con una constante de tiempo de 1 segundo; la respuesta "rápida" con una constante de tiempo de 0,125 segundos; y la respuesta "impulsivo" que tiene una respuesta de $35 \mathrm{~ms}$ para la parte creciente de la señal y una constante de tiempo de $1.500 \mathrm{~ms}$ para la parte decreciente de la señal.

Pueden encontrarse especificaciones de sonómetros en normas nacionales e internacionales, como la Organización Internacional de Normalización (ISO), la Comisión Electrotécnica Internacional (CEI) y el American National Standards Institute (ANSI). Las publicaciones de la CEI 651 (1979) y 804 (1985) se refieren a sonómetros de los tipos 0, 1 y 2, con ponderación de frecuencias $A, B$ y $C$, y constantes de tiempo de respuesta "Ienta", "rápida" e "impulsivo". La norma ANSI S1.4-1983, con su enmienda ANSI S1.4A-1985, también contiene especificaciones de sonómetros.

Para facilitar un análisis acústico más detallado, en los sonómetros modernos es posible conectar o incluir filtros de banda octava y de tercio de banda octava. L os sonómetros actuales son cada vez más pequeños y fáciles de manejar, al tiempo que aumentan sus posibilidades de medición.

Para medir exposiciones a ruido variable, como las que se producen en ambientes de ruido intermitente o de impulso, es más conveniente utilizar un sonómetro integrado. Estos equipos pueden medir simultáneamente los niveles de ruido equivalente, pico y máximo, y calcular, registrar y almacenar varios valores

\section{Cortesía de Larson Davis.}

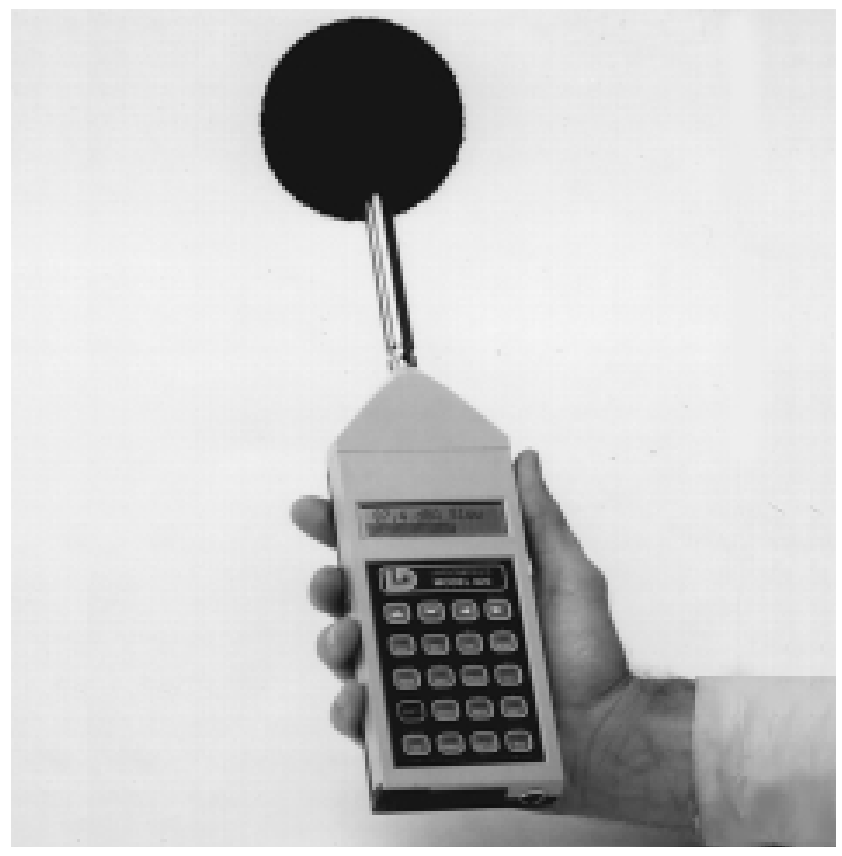


automáticamente. El medidor de dosis de ruido o "dosímetro" es una modalidad de sonómetro integrado que puede llevarse en el bolsillo de la camisa o sujeto a la ropa del trabajador. Sus datos pueden informatizarse e imprimirse.

Es importante asegurarse de que los instrumentos de medida del ruido estén siempre correctamente calibrados. Para ello hay que comprobar su calibración acústica antes y después de cada uso, además de realizar calibraciones electrónicas a intervalos apropiados.

\section{Métodos de medida}

Los métodos de medida del ruido dependen de los objetivos perseguidos. D e hecho, pueden valorarse:

- el riesgo de deterioro auditivo;

- los tipos de controles técnicos apropiados y su necesidad;

- la compatibilidad de la "carga de ruido" con el tipo de trabajo a realizar,

- el nivel de ruido de fondo necesario para no perjudicar la comunicación ni la seguridad.

La norma internacional ISO 2204 especifica tres tipos de métodos de medida de ruido: a) el método de control, b) el método de ingeniería y c) el método de precisión.

\section{El método de control}

Este es el método que menos tiempo y equipo necesita. Se miden los niveles de ruido de una zona de trabajo con un sonómetro, utilizando un número limitado de puntos de medida. Aunque no se realiza un análisis detallado del ambiente acústico, es preciso observar los factores temporales, como por ejemplo si el ruido es constante 0 intermitente y cuánto tiempo están expuestos los trabajadores. Suele utilizarse la red de ponderación A, pero si existe un componente predominante de baja frecuencia puede ser apropiado utilizar la red de ponderación C o la respuesta lineal.

\section{El método de ingeniería}

Con este método, las mediciones del nivel sonoro con factor de ponderación A o las que utilizan otras redes de ponderación se complementan con mediciones que utilizan filtros de banda de octava o de tercio de banda octava. El número de puntos de medición y las gamas de frecuencias se deciden en función de los objetivos de medición. También es preciso registrar factores temporales. Este método es útil para evaluar la interferencia con la comunicación hablada calculando los niveles de interferencia conversacional (Speech Interference Levels, SIL), así como para implantar programas de control técnico del ruido y realizar estimaciones de los efectos auditivos y no auditivos del ruido.

\section{El método de precisión}

Este método es necesario en situaciones complejas, en las que se requiere la descripción más minuciosa del problema de ruido. Las mediciones globales del nivel sonoro se complementan con mediciones en banda de octava o de tercio de octava y se registran historiales de intervalos de tiempo apropiados en función de la duración y las fluctuaciones del ruido. Por ejemplo, puede ser necesario medir los niveles pico de los impulsos utilizando el dispositivo de "captación de pico" del instrumento, o medir niveles de infrasonidos o ultrasonidos, lo que requiere capacidades de medición de frecuencias especiales, la directividad del micrófono, etc.

Q uienes utilicen el método de precisión deben asegurarse de que el margen dinámico del instrumento es suficiente para evitar sobrecargas al medir impulsos y de que la respuesta en frecuencia es suficientemente amplia si se van a medir infrasonidos o ultrasonidos. El instrumento debe ser capaz de medir frecuencias de hasta $2 \mathrm{~Hz}$ en infrasonidos y de hasta $16 \mathrm{kHz}$ como mínimo en ultrasonidos, con micrófonos que sean suficientemente pequeños.

Si la persona encargada de realizar las mediciones de ruido es inexperta, puede serle de utilidad dar los siguientes pasos de "sentido común":

1. Escuchar las principales características del ruido que se vaya a medir (características temporales, como por ejemplo si es constante, intermitente 0 impulsivo; características de frecuencia, como las del ruido de banda ancha, tonos predominantes, infrasonidos, ultrasonidos, etc.). $\mathrm{H}$ ay que anotar las características más destacadas.

2. Elegir los instrumentos más adecuados (tipo de sonómetro, dosímetro, filtros, registrador de cinta, etc.).

3. Comprobar la calibración y el funcionamiento del instrumento (baterías, datos de calibrado, correcciones del micrófono, etc.).

4. Anotar o realizar un esquema (si se utiliza un sistema) de los instrumentos, indicando el modelo y el número de serie.

5. Realizar un esquema del entorno de ruido que se vaya a medir, indicando las principales fuentes de ruido y las dimensiones y características importantes del recinto 0 ambiente exterior.

6. M edir el ruido y anotar el nivel medido para cada red de ponderación o para cada banda de frecuencias. Anotar también la respuesta del medidor ("Ienta", "rápida", "impulsivo", etc.), y la incertidumbre del medidor ( $p$. ej., más 0 menos $2 \mathrm{~dB}$ ).

Si las mediciones se realizan al aire libre, deberán anotarse si se consideran importantes los datos meteorológicos pertinentes, como el viento, la temperatura y la humedad. En las mediciones al aire libre, e incluso en algunas mediciones en recintos cerrados, deberá utilizarse siempre un guardaviento. $\mathrm{H}$ an de seguirse siempre las instrucciones del fabricante para evitar la influencia de factores tales como el viento, la humedad, el polvo y los campos eléctricos y magnéticos, que pueden afectar a las mediciones.

\section{Procedimientos de medición}

Existen dos criterios básicos de la medición del ruido en el trabajo:

- Puede medirse la exposición de cada trabajador, de un trabajador tipo o de un trabajador representativo. El dosímetro de ruido es el instrumento preferible a estos efectos.

- Pueden medirse niveles de ruido en varias áreas, creándose un mapa de ruido para la determinación de áreas de riesgo. En este caso, se utilizaría un sonómetro para tomar mediciones en puntos regulares de una red de coordenadas.

\section{Evaluación de la exposición del trabajador}

Para evaluar el riesgo de pérdida auditiva debido a la exposición a ruidos específicos, el lector deberá consultar la norma internacional ISO 1999 (1990). Esta norma contiene un ejemplo de esta evaluación de riesgos en su anexo $D$.

La exposición al ruido debe medirse cerca del oído del trabajador y, para evaluar el riesgo derivado de la exposición del trabajador, no han de realizarse restas que tengan en cuenta la atenuación proporcionada por los protectores auditivos. Si se adopta esta cautela es porque existen sólidas pruebas de que la atenuación proporcionada por los protectores auditivos, tal como se llevan en el trabajo, suele ser inferior a la mitad de la calculada por el fabricante. De hecho, los datos del fabricante se obtienen en condiciones de laboratorio y estos dispositivos no se suelen colocar ni llevar de modo tan eficaz en la práctica. Por el 
momento, no existe ninguna norma internacional que realice una estimación de la atenuación que ofrecen los protectores auditivos tal como se llevan en la práctica, pero una buena norma empírica sería dividir los valores de laboratorio por la mitad.

En algunas circunstancias, sobre todo en tareas difíciles 0 trabajos que exigen concentración, puede ser importante minimizar los efectos del estrés o la fatiga relacionados con la exposición al ruido, adoptando medidas de control del ruido. Esta regla puede ser aplicable incluso con niveles de ruido moderados (por debajo de $85 \mathrm{dBA}$ ), cuando haya poco riesgo de deterioro auditivo pero el ruido sea molesto 0 agobiante. En estos casos, es útil realizar evaluaciones de sonoridad aplicando la norma ISO 532 (1975), "M étodo de cálculo del nivel de sonoridad".

Puede realizarse una estimación de la interferencia con comunicación hablada de acuerdo con la norma ISO 2204 (1979), aplicando el "índice de articulación", o más sencillamente, midiendo los niveles de ruido de las bandas de octava de 500, 1.000 y $2.000 \mathrm{~Hz}$, para obtener el "nivel de interferencia conversacional".

\section{Criterios de exposición}

La elección de los criterios de exposición al ruido dependerá del objetivo a conseguir; por ejemplo, la prevención de la pérdida auditiva o la prevención del estrés y la fatiga. La exposición máxima permisible, en términos de niveles medios de ruido diario, pueden variar, según el país, de 80 a 85 ó 90 dBA, con factores de acumulación de 3, 4 o $5 \mathrm{dBA}$. En algunos países, como Rusia, los niveles de ruido permisibles se establecen entre 50 y $80 \mathrm{dBA}$, en función del tipo de trabajo realizado y teniendo en cuenta la carga de trabajo física y mental. Por ejemplo, los niveles admisibles para trabajar con ordenadores o para realizar trabajos administrativos exigentes van de 50 a 60 dBA. (Para más información sobre criterios de exposición, ver el artículo "Normas y reglamentaciones" en este mismo capítulo.)

\section{- TECNICAS DE CONTROL DEL RUIDO}

Dennis P. D riscoll

Idealmente, el medio más eficaz de control del ruido es evitar desde el principio que la fuente de ruido entre en la fábrica, implantando un programa eficaz de "adquisición de productos sin ruido" para introducir en el lugar de trabajo bienes de equipo diseñados para producir un bajo nivel de ruido. Para llevar a cabo un programa de este tipo, es preciso elaborar unas normas claras y bien redactadas que limiten las características de emisión de ruido de los nuevos equipos, instalaciones y procesos de fabricación. Un buen programa también incluye la vigilancia y el mantenimiento.

Una vez instalados los equipos e identificado el exceso de ruido por mediciones del nivel sonoro, el problema del control del ruido presenta matices más complejos. Sin embargo, existen soluciones técnicas que pueden aplicarse a los equipos existentes. Además, suele haber más de una opción de control del ruido para cada problema. Por consiguiente, para el responsable del programa de control es importante determinar los medios de reducción del ruido más viables y económicos en cada situación concreta.

\section{El control del ruido en el diseño de fábricas y productos}

El uso de normas escritas para definir los requisitos de los bienes de equipo, su instalación y aceptación es una práctica normal en la actualidad. U na de las principales oportunidades que tiene el proyectista de fábrica en materia de control del ruido es influir en la elección, compra y distribución en la planta de nuevos equipos. Si se redacta y administra correctamente, la implantación de un programa de "adquisición de productos sin ruido" puede resultar ser un medio eficaz de control del ruido.

El enfoque más proactivo del control del ruido en la fase de diseño de las instalaciones y la compra de bienes de equipo es el existente en Europa. En 1985, los doce Estados miembros de la Comunidad Europea (CE) - actualmente U nión Europea (UE - - promulgaron una serie de directivas "de nuevo enfoque" que contemplan una amplia gama de bienes de equipo o maquinaria, en lugar de establecer normas individuales para cada tipo de equipo. A finales de 1994 se habían publicado tres directivas de "nuevo enfoque" en las que se especifican requisitos sobre el ruido. Son las siguientes:

\section{89/392/ CEE, modificada por 91/368/ CEE y 93/44/ CEE 2. $89 / 106 / C E E, y$ \\ 3. $89 / 686 / C E E$, modificada por 93/95/ CEE.}

La primera de ellas (89/392/ CEE) se conoce comúnmente como "D irectiva sobre máquinas". O bliga a los fabricantes de bienes de equipo a incluir el control del ruido como parte esencial de la seguridad de las máquinas. Lo que se pretende en esencia es exigir que, para que un equipo o máquina pueda venderse dentro de la UE, ha de cumplir los requisitos esenciales relativos al ruido. En consecuencia, desde finales del decenio de 1980, los fabricantes interesados en vender en la UE han dado gran importancia al diseño de equipos con bajo nivel de ruido.

El grado de éxito que puedan conseguir las empresas no europeas que intenten implantar un programa voluntario de "adquisición de productos sin ruido" dependerá en gran medida de la oportunidad y el compromiso de la dirección. El primer paso del programa es establecer criterios de ruido aceptables para la construcción de una nueva fábrica, la ampliación de las instalaciones existentes y la compra de nuevos equipos. Para que el programa sea eficaz, tanto el comprador como el vendedor deben considerar los límites de ruido especificados como un requisito absoluto. Si un producto no cumple otros parámetros de diseño, como el tamaño, el caudal, la presión, el aumento de temperatura admisible, etc., la dirección de la empresa lo considera inaceptable. Este mismo compromiso debe asumirse en relación con los niveles de ruido para que un programa de este tipo tenga éxito.

Por lo que se refiere al elemento de oportunidad ya mencionado, cuanto antes se tengan en cuenta los aspectos relativos al ruido en el proceso de diseño de un proyecto o en la compra de un equipo, mayores serán las probabilidades de éxito. En muchas situaciones, el proyectista de fábrica o el comprador pueden elegir entre varios tipos de equipos. El conocimiento de sus respectivas características de ruido le permitirá especificar los más silenciosos.

Además de la elección de los bienes de equipo, es esencial participar desde el principio en la distribución de éstos en la planta de fábrica. Reubicar equipos sobre el papel durante la fase de diseño de un proyecto es evidentemente mucho más fácil que moverlos después físicamente, sobre todo una vez que están en funcionamiento. Una norma sencilla que debe cumplirse es mantener juntas las máquinas, los procesos y las áreas de trabajo que tengan un nivel de ruido aproximadamente igual; y separar las áreas más ruidosas de las más silenciosas por medio de zonas de interposición que tengan niveles de ruido intermedios.

La validación de los criterios de ruido como requisito absoluto exige un esfuerzo de cooperación entre el personal de departamentos de la empresa tales como ingeniería, jurídico, compras, higiene industrial y medio ambiente. Por ejemplo, los departamentos de higiene industrial, seguridad y/ o personal pueden 
determinar los niveles aconsejables de ruido de los equipos, así como realizar estudios de control de ruido para calificar los equipos. D espués, los ingenieros de la empresa pueden redactar la especificación de compra y elegir equipos silenciosos. El personal de compras probablemente administrará el contrato y contará con la ayuda de los representantes de la asesoría jurídica para hacerlo cumplir. Todas las partes deben comenzar a implicarse en el momento de la concepción del proyecto y continuar con las solicitudes de financiación, planificación, diseño, oferta, instalación y puesta en servicio.

$\mathrm{Ni}$ el documento de especificaciones más minucioso y conciso tiene gran valor si el proveedor o fabricante no asume la responsabilidad de su cumplimiento. Es preciso utilizar un lenguaje contractual claro para definir los medios de determinar el cumplimiento. Deben consultarse y cumplirse los procedimientos de la empresa concebidos para imponer garantías. Puede ser aconsejable incluir cláusulas de penalización por incumplimiento. Lo más importante de la estrategia de aplicación del contrato es que el comprador se comprometa a asegurarse del cumplimiento de los requisitos. $L$ a transigencia en los criterios de ruido a cambio de concesiones de coste, plazos de entrega, rendimiento 0 de otro tipo debe ser la excepción y no la norma.

En Estados Unidos, el ANSI ha publicado la norma ANSI S12.16, titulada "Directrices para la especificación del ruido en maquinaria nueva" (Guidelines for the Specification of $\mathrm{N}$ oise of $\mathrm{N}$ ew M achinery, 1992). Se trata de una guía útil para redactar una especificación interna de una empresa en materia de ruido. Además, contiene directrices para obtener datos de nivel sonoro de los fabricantes de los equipos. U na vez obtenidos estos datos, pueden ser utilizados por los proyectistas para planificar la distribución en planta de los equipos. D ebido a los diversos tipos de equipos y herramientas distintos para los que se ha preparado esta norma, no existe un único protocolo de inspección apropiado para la medida del nivel sonoro. En consecuencia, esta norma contiene información de referencia sobre el procedimiento apropiado de medición de ruido para ensayar diversos equipos estacionarios. Estos procedimientos de control han sido preparados por la asociación o la organización profesional pertinente y responsable en Estados U nidos para un determinado tipo o clase de bienes de equipo.

Figura 47.4 • Comparación entre datos de octavas y tercios de octava.

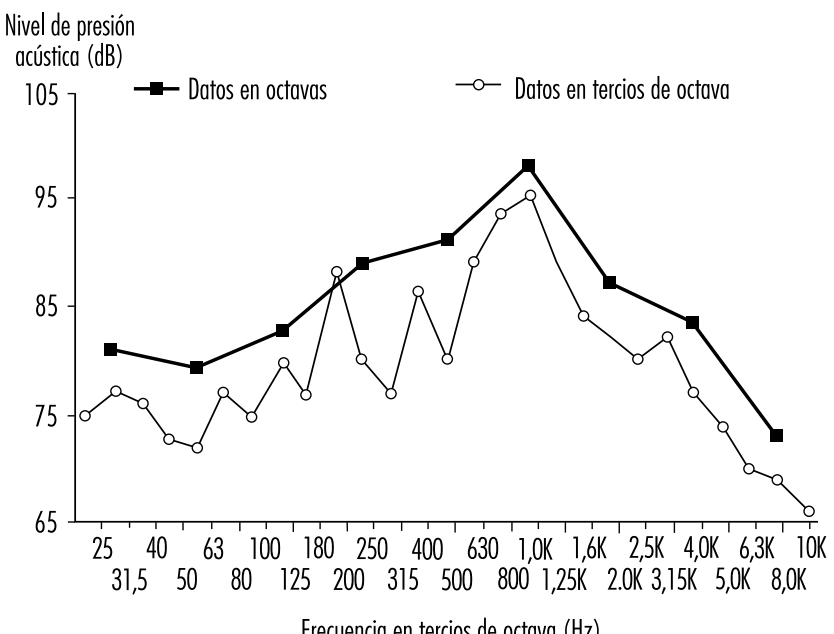

Todos los datos en banda de octava están trazados en la frecuencia central de la banda.

\section{Conversión de los equipos existentes}

Antes de decidir lo que es preciso hacer, hay que identificar la causa origen del ruido. Para ello, es útil comprender cómo se genera éste. El ruido es creado en su mayor parte por impactos mecánicos, por la circulación de aire a gran velocidad, por la circulación de líquidos a gran velocidad, por las superficies vibratorias de una máquina y, con bastante frecuencia, por el producto que se fabrica. Esto último es lo que suele ocurrir en industrias de fabricación y transformación como la metálica, la fabricación de vidrio, la elaboración de alimentos, la minería, etc., en las que la interacción entre el producto y las máquinas produce la energía que crea el ruido.

\section{Identificación de la fuente de ruido}

U no de los aspectos más difíciles del control del ruido es la identificación de la fuente. En un ambiente industrial típico suele haber varias máquinas en funcionamiento al mismo tiempo, con lo cual resulta difícil identificar la causa origen del ruido, sobre todo si se utiliza un sonómetro estándar. Este indica un nivel de presión acústica (Sound Pressure Level, SPL) en un punto específico, que muy probablemente es el resultado de más de una fuente de ruido. Por consiguiente, el inspector tiene que emplear un enfoque sistemático que permita separar cada fuente de las demás y conocer su aportación relativa al SPL total. Las técnicas siguientes pueden contribuir a identificar el origen o la fuente del ruido:

- Medir el espectro de frecuencias y representar los datos gráficamente.

- Medir el nivel sonoro, en dBA, en función del tiempo.

- Comparar los datos de frecuencias con equipos o líneas de producción similares.

- Aislar componentes con controles temporales o conectar y desconectar un equipo tras otro, siempre que sea posible.

U no de los métodos más eficaces para localizar la fuente del ruido consiste en medir su espectro de frecuencias. U na vez medidos los datos, es muy útil representar gráficamente los resultados de modo que puedan visualizarse las características de dicha fuente. En la mayoría de los problemas de supresión del ruido, las mediciones pueden realizarse utilizando filtros de octava o de tercio de octava con el sonómetro. La ventaja de la

Figura 47.5 • Comparación entre la tubería de unión y el nivel de fondo.

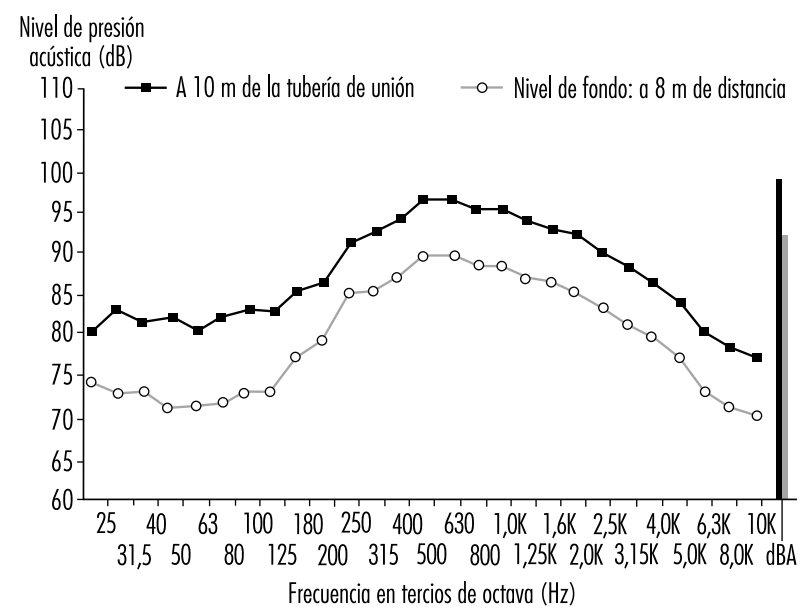

A efectos de presentación se representan en el lado derecho, en forma de barras, los niveles de ruido ponderados A para cada medición. 
medición a un tercios de octava es que proporciona información más detallada acerca de lo que emite un equipo concreto. La Figura 47.4 presenta una comparación entre mediciones en octavas y tercios de octava realizadas cerca de una bomba de nueve pistones. Tal como se observa, los datos en tercios de octava identifican claramente la frecuencia de bombeo y muchos de sus armónicos. Si sólo se utilizan datos en octavas, representados por la línea más densa y trazados para la frecuencia central de cada banda en la Figura 47.4, resulta más difícil diagnosticar lo que ocurre dentro de la bomba. Con datos en octavas hay un total de nueve puntos de datos entre 25 hertzios $(\mathrm{Hz})$ y $10.000 \mathrm{~Hz}$, como ilustra esta figura. Sin embargo, hay un total de 27 puntos de datos en esta gama de frecuencias con la utilización de las medidas en tercios de octava. Evidentemente, los datos en tercios de octava proporcionarán más datos útiles para identificar la causa de un ruido. Esta información es decisiva si el objetivo es controlar el ruido en origen. Si lo único que interesa es tratar la vía por la que se transmiten las ondas sonoras, entonces serán suficientes los datos en octavas a los efectos de elegir productos o materiales acústicamente apropiados.

La Figura 47.5 presenta una comparación entre el espectro en tercios de octava medido a $1 \mathrm{~m}$ de la tubería de unión de un compresor refrigerador de líquido y el nivel de fondo medido aproximadamente a $8 \mathrm{~m}$ de distancia (ver aproximaciones dadas en la nota al pie). Esta última posición representa el área general por la que circulan los empleados a través del recinto. El cuarto de compresores no está ocupado habitualmente por trabajadores, salvo cuando hay operarios de mantenimiento reparando 0 revisando otros equipos en él. A demás del compresor, hay otras máquinas grandes trabajando en esta zona. Para ayudar en la identificación de las fuentes de ruido primarias, se midieron varios espectros de frecuencias cerca de cada uno de los equipos. Al comparar cada espectro con los datos del ruido en el pasillo, sólo la tubería de unión del compresor presentó un espectro de forma similar. En consecuencia, puede llegarse a la conclusión de que ésta es la fuente de ruido principal que controla el nivel de ruido medido en el pasillo de los empleados. De modo que, tal como representa la Figura 47.5, utilizando datos de frecuencias medidos cerca del equipo y comparando gráficamente cada fuente con los datos registrados en los puestos de trabajo de los empleados u otras áreas de interés, a menudo es posible identificar claramente las fuentes de ruido dominantes.

Figura 47.6 - Puesto de trabajo del operario de embalajes.

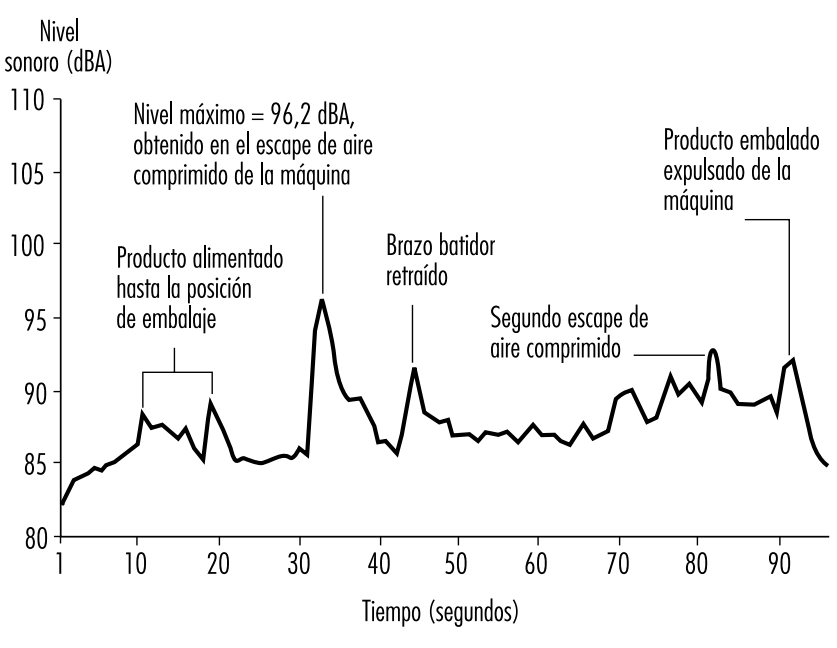

Cuando el nivel sonoro fluctúa, como ocurre con los equipos cíclicos, resulta útil medir la variación en el tiempo del nivel total de ruido con factor de ponderación $\mathrm{A}$. Con este procedimiento es importante observar y documentar los eventos que se suceden a lo largo del tiempo. La Figura 47.6 presenta el nivel de ruido medido en el puesto de trabajo del operario durante un ciclo completo de la máquina. El proceso ilustrado en la Figura 47.6 representa el de una máquina de embalaje que tiene una duración aproximada del ciclo de 95 segundos. Tal como puede observarse, el nivel de ruido máximo de 96,2 dBA se produce durante el escape de aire comprimido a los 33 segundos del ciclo de máquina. Los demás sucesos importantes también están indicados en la figura, que permite identificar la fuente de ruido y la contribución relativa de cada actividad durante todo el ciclo de embalaje.

En ambientes industriales donde hay varias líneas de proceso con los mismos equipos, merece la pena tomarse la molestia de comparar los datos de frecuencias de equipos similares. La Figura 47.7 ilustra esta comparación para dos líneas de proceso similares, que fabrican ambas el mismo producto y trabajan a la misma velocidad. Parte del proceso supone el uso de un dispositivo accionado neumáticamente que perfora un orificio de media pulgada en el producto como fase final de su producción. Un examen de esta figura revela claramente que la línea $n-1$ tiene un nivel sonoro total $5 \mathrm{dBA}$ superior al de la línea $n-2$. Además, el espectro de la línea no 1 contiene una frecuencia fundamental y muchos armónicos que no aparecen en el espectro de la línea no 2. En consecuencia, es necesario investigar la causa de estas diferencias. Si son significativas, suele ser una indicación de la necesidad de realizar tareas de mantenimiento, como ocurría con el mecanismo final de perforación de la línea $\mathrm{n}$ - 2. Sin embargo, este problema de ruido en particular necesitará medidas de control adicional, ya que el nivel total de la línea $n-1$ es relativamente alto. No obstante, el objetivo de esta técnica de inspección es identificar los diferentes problemas de ruido que pueden existir entre equipos y procesos similares que puedan solucionarse fácilmente con un mantenimiento eficaz u otros ajustes.

Tal como ya se ha dicho, un sonómetro estándar indica un nivel sonoro que comprende la energía acústica de una o más fuentes de ruido. En condiciones óptimas de medición, lo mejor sería medir cada equipo con todos los demás fuera de servicio.

\section{Figura 47.7 • O peración de perforación final para líneas de proceso idénticas.}

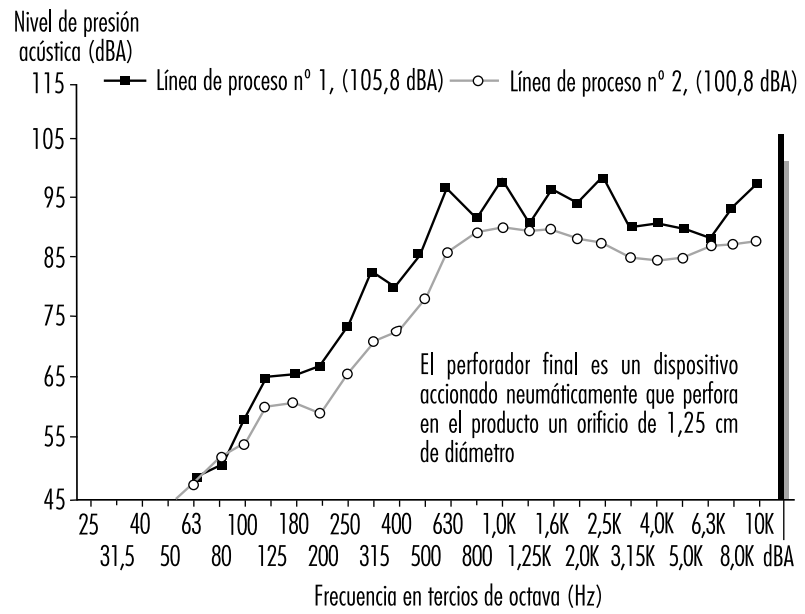

Todos los datos son ponderados $A$ 
Aunque esta situación es la ideal, en raras ocasiones resulta posible interrumpir la fabricación para poder aislar una fuente de ruido. Para obviar esta limitación, suele ser eficaz utilizar medidas de control temporal con ciertas fuentes de ruido que permitan reducirlo en cierta medida a corto plazo para poder medir otra fuente. Entre los materiales que pueden proporcionar una reducción temporal cabe citar los cerramientos de contrachapado, las mantas acústicas, los silenciadores y las barreras. A menudo, la aplicación permanente de estos materiales crea problemas a largo plazo, como pueden ser la intensificación del calor, dificultades de acceso para el operario o de circulación del producto, o costosas caídas de presión asociadas a unos silenciadores mal elegidos. Con todo, estos materiales pueden ser eficaces a corto plazo para aislar componentes individuales.

0 tro método para aislar una máquina o componente concreto consiste en conectar y desconectar diferentes equipos 0 secciones de una línea de producción. Para realizar eficazmente este tipo de análisis de diagnóstico, el proceso debe poder funcionar con el equipo desconectado. Además, el proceso de fabricación no puede resultar afectado en modo alguno. En otro caso, la medición podría no ser representativa del nivel de ruido en condiciones normales. Finalmente, todos los datos válidos pueden clasificarse por la magnitud del valor total en dBA a fin de establecer las prioridades de control técnico del ruido de los equipos.

\section{Selección de las opciones apropiadas de control del ruido}

U na vez identificada la causa o fuente del ruido y conocido cómo se radica a las áreas de trabajo, el paso siguiente consiste en elegir entre las opciones disponibles de control del ruido. El modelo estándar utilizado para el control de casi todos los riesgos para la salud consiste en examinar las diversas opciones de control aplicadas en la fuente, en la vía de transmisión y en el receptor. En algunas situaciones, bastará con controlar uno de estos elementos. Sin embargo, en otras circunstancias puede ser necesario tratar más de un elemento para obtener un ambiente de ruido aceptable.

El primer paso del proceso de control del ruido debe ser intentar alguna forma de tratamiento la fuente. En efecto, la modificación de la fuente aborda la causa originaria de un problema de ruido, mientras que el control de la vía de transmisión del sonido con barreras y cerramientos sólo trata los síntomas del ruido. Cuando existen varias fuentes de ruido en una máquina y el objetivo es el tratamiento en la fuente, será necesario estudiar todos los mecanismos generadores de ruido componente por componente.

En el caso del exceso de ruido generado por impactos mecánicos, entre las opciones de control a investigar cabría citar la adopción de métodos para reducir la fuerza impulsora, reducir la distancia entre componentes, equilibrar los equipos giratorios e instalar aisladores de vibraciones. Por lo que se refiere al ruido producido por la circulación de aire o líquidos a gran velocidad, la principal modificación consiste en reducir la velocidad del medio, suponiendo que esta opción sea factible. A veces, esa reducción se consigue aumentando la sección transversal de la tubería en cuestión. Es preciso eliminar toda obstrucción de la tubería para conseguir un flujo aerodinámico, que a su vez reducirá las variaciones de presión y la turbulencia del medio transportado. Finalmente, con la instalación de un silenciador puede conseguirse una reducción significativa del ruido total. Deberá consultarse con el fabricante del silenciador para elegir el dispositivo apropiado, en función de los parámetros de trabajo y de las restricciones establecidas por el comprador.

Si las superficies vibratorias de una máquina actúan como generadores de ruido aéreo, las opciones de control implican la reducción de la fuerza impulsora asociada al ruido, la creación de secciones de menor tamaño a partir de grandes superficies, la perforación de la superficie, el aumento de la masa o la rigidez del sustrato, y la aplicación de material amortiguador 0 dispositivos antivibratorios. Por lo que se refiere al de aisladores y dispositivos antivibratorios deberá consultarse con el fabricante del producto para elegir tanto los materiales como los procedimientos de instalación apropiados. Por último, en muchas industrias el propio producto fabricado suele ser eficaz radiador de ruido aéreo. En estas situaciones, es importante evaluar formas de fijar o sujetar mejor el producto durante la fabricación. 0 tra medida de control del ruido a investigar sería la reducción de la fuerza de impacto entre la máquina y el producto, entre piezas del propio producto o entre productos distintos.

A menudo, no es viable remodelar procesos o equipos ni modificar las fuentes de ruido. Además, hay situaciones en las que es prácticamente imposible identificar la causa del ruido. En tales casos, la adopción de medidas de control para el tratamiento de la vía de transmisión del sonido sería un medio eficaz de reducción del nivel sonoro total. Las dos medidas principales de supresión para los tratamientos de las vías de transmisión son los cerramientos acústicos y las barreras.

EI desarrollo de cerramientos acústicos ha progresado mucho en el mercado actual. Varios fabricantes ofrecen recintos comerciales y especiales. Para conseguir el sistema apropiado, el comprador tiene que facultar información relativa al nivel de ruido total (y posiblemente datos de frecuencias), las dimensiones del equipo, el objetivo de reducción de ruido, las necesidades de circulación del producto y de acceso de los empleados y cualquier otra restricción de trabajo. El proveedor podrá entonces utilizar dicha información para elegir un artículo de su almacén o fabricar un cerramiento a medida que satisfaga las necesidades existentes.

En muchos casos será más económico diseñar y construir un cerramiento que comprar uno comercial. Habrá que tener en cuenta muchos factores en el diseño del recinto si se quiere que sea satisfactorio tanto desde un punto de vista acústico como de producción. He aquí algunas directrices específicas para el diseño de cerramientos:

Dimensiones del cerramiento. No existe una directriz crítica sobre el tamaño o las dimensiones de un cerramiento. El mejor criterio a seguir es cuanto mayor, mejor. Lo importante es que haya suficiente holgura para que el equipo pueda realizar todos los movimientos previstos sin tocar el cerramiento.

Paredes del cerramiento. La reducción de ruido que se obtenga con un cerramiento dependerá de los materiales utilizados para construirlo y de lo hermético que sea. Para elegir los materiales apropiados para las paredes del recinto es conveniente atenerse a las siguientes normas empíricas (M oreland 1979):

- para un cerramiento sin absorción interna:

$$
T L_{\text {reqd }}=N R+20 \mathrm{dBA}
$$

- con aproximadamente un $50 \%$ de absorción interna:

$$
T L_{\text {reqd }}=N R+15 d B A
$$

- con un $100 \%$ de absorción interna:

$$
T L_{\text {reqd }}=N R+10 \mathrm{dBA} \text {. }
$$

En estas expresiones, $T L_{\text {reqd }}$ es la pérdida por transmisión exigible al panel o pared del cerramiento, y NR es la reducción de ruido que se pretende conseguir para cumplir el objetivo de supresión.

J untas. Para obtener la máxima eficiencia, todas las juntas de las paredes deben ser herméticas. Las aberturas alrededor de entradas de tubos, conexiones eléctricas, etc., deben quedar selladas con mastique no endurecible, como el sellador de silicona. 
Absorción interna. Para absorber y disipar la energía acústica, es conveniente forrar la superficie interna del recinto con un material acústicamente absorbente. Debe elegirse el material apropiado en función del espectro de frecuencias de la fuente de ruido. Los datos de absorción facilitados por el fabricante permiten elegir el material adecuado a dicha fuente. Es importante que los factores de absorción máximos se adapten a las frecuencias de la fuente cuyos niveles de presión acústica sean más altos. El fabricante o vendedor del producto también puede colaborar en la elección del material más eficaz en función del espectro de frecuencias de la fuente.

Aislamiento del cerramiento. Es importante que la estructura del cerramiento esté separada o aislada del equipo a fin de evitar que se transmitan vibraciones mecánicas al propio cerramiento. Si alguna pieza de la máquina, como las entradas de tuberías, llega a entrar en contacto con el cerramiento, es importante incluir dispositivos aislantes antivibratorios en el punto de contacto para cortocircuitar cualquier posible vía de transmisión. Finalmente, si la máquina hace que el suelo vibre, también deberá tratarse la base del cerramiento con material antivibratorio.

Previsión para la circulación del producto. Al igual que ocurre con la mayoría de los equipos de producción, será necesario que el producto entre y salga del recinto. El uso de canales o túneles acústicamente tratados puede permitir la circulación del producto y proporcionar además absorción acústica. Para minimizar la fuga de ruido, se recomienda que todas las vías de paso tengan el triple de longitud que el ancho interior de la mayor dimensión de la abertura del canal o túnel.

Previsión para el acceso de los trabajadores. Pueden instalarse puertas y ventanas para dar acceso físico y visual al equipo. Es fundamental que todas las ventanas tengan al menos las mismas pérdidas por transmisión que las paredes del recinto. Además, las puertas de acceso deben cerrar herméticamente por todos sus lados. Para impedir que el equipo funcione con las puertas abiertas, se recomienda incluir un sistema de enclavamiento que sólo permita el funcionamiento con las puertas totalmente cerradas.

Ventilación del cerramiento. En muchos de estos cerramientos, el calor puede resultar excesivo. Para introducir aire fresco en el recinto, deberá instalarse un ventilador con una capacidad de 650 a 750 pies cúbicos/metro en el conducto de salida 0 descarga. Por último, los conductos de admisión y descarga deben tratarse acústicamente con material absorbente

Protección del material absorbente. Para evitar la contaminación del material absorbente, deberá aplicarse una barrera antisalpicaduras sobre el forro insonorizante, que deberá estar hecho de un material muy ligero, como una película de una milipulgada. $L a$ capa absorbente deberá fijarse con metal expandido, chapa metálica perforada o tela metálica. EI material de recubrimiento deberá tener al menos un $25 \%$ de superficie abierta.

Un tratamiento alternativo de las vías de transmisión del sonido consiste en utilizar una barrera acústica que bloquee 0 proteja al receptor (el trabajador expuesto al ruido peligroso) de la vía sonora directa. U na barrera acústica es un material con alta pérdida por transmisión, como un muro o tabique macizo, interpuesta entre la fuente de ruido y el receptor. Al bloquear la vía directa de la línea de visión de la fuente, la barrera hace que las ondas acústicas alcancen al receptor tras reflejarse en varias superficies de la sala y por difracción en los bordes de la barrera. De este modo, se reduce el nivel de ruido total en el lugar ocupado por el receptor.

La eficacia de una barrera depende de su ubicación con respecto a la fuente de ruido 0 a los receptores y de sus dimensiones totales. Para reducir el ruido al mínimo posible, es preciso situar la barrera lo más cerca posible de la fuente o del receptor.
Además, debe ser lo más alta y ancha posible. Para bloquear eficazmente la vía de transmisión del sonido, es conveniente utilizar un material de alta densidad, del orden de 4 a $6 \mathrm{lb} / \mathrm{ft}^{3}$. Por último, la barrera no debe tener aberturas ni resquicios que puedan reducir su eficacia de manera significativa. Si es necesario incluir una ventanilla para obtener acceso visual al equipo, es importante que su coeficiente de transmisión del sonido sea al menos equivalente a la del material de la propia barrera.

La última opción para reducir la exposición de los trabajadores al ruido consiste en tratar el espacio o área en el que trabaje el empleado. Esta opción es la más práctica para aquellas actividades laborales, como la inspección de productos o los puestos de vigilancia de equipos, en las que limitan los movimientos del empleado estás limitados a una zona relativamente pequeña. En tales casos, se puede instalar una garita o cabina insonorizada para aislar al empleado y protegerle de los niveles de ruido excesivos. La exposición diaria al ruido se reducirá en tanto en cuanto se pase una parte importante del turno laboral dentro de la cabina. Para construir una cabina de este tipo, es conveniente consultar las directrices anteriormente descritas referentes al diseño de cerramientos.

Como conclusión, la implantación de un programa eficaz de "adquisición de productos sin ruido" debe ser el paso inicial de un proceso total de control del ruido. Este enfoque está concebido para evitar la compra o instalación de equipos que puedan presentar problemas de ruido. Sin embargo, en los casos en los que ya existen niveles de ruido excesivos, será necesario evaluar la opción más práctica de control técnico para cada fuente de ruido. Al determinar la prioridad relativa y la urgencia de la implantación de medidas de control del ruido, será preciso considerar la exposición de los trabajadores, la ocupación del espacio y los niveles de ruido de toda la zona. O bviamente, un aspecto importante del resultado deseado es que se consiga reducir al máximo la exposición del trabajador al ruido para la inversión económica realizada y que al mismo tiempo se ofrezca al trabajador el máximo grado de protección.

\section{Prog RAMAS DE CONSERVACION DE LA AUDICION}

\section{Larry H . Royster y Julia D oswell Royster*}

EI principal objetivo de los programas de conservación de la audición en el trabajo (PCA) es evitar las pérdidas auditivas provocadas por la exposición peligrosa al ruido en el lugar de trabajo (R oyster y Royster, 1989 y 1990). Sin embargo, la persona responsable - a quien nos referiremos en adelante como la "persona clave" - de asegurar la eficacia del PCA deberá utilizar su sentido común para modificar estas prácticas y adaptarlas a la situación local para conseguir el objetivo deseado: proteger a los trabajadores de los perjuicios derivados de la exposición al ruido en el trabajo. Un objetivo secundario de estos programas debe ser educar y motivar a las personas para que también ellas decidan protegerse de las exposiciones peligrosas a ruidos no laborales y transmitir sus conocimientos sobre la conservación de la audición a sus familiares y amigos.

La Figura 47.8 presenta las distribuciones de más de 10.000 muestras de exposición al ruido procedentes de cuatro fuentes de dos países, incluyendo diversos ambientes de trabajo industriales, mineros y militares. Las muestras son valores medios ponderados en períodos de 8 horas sobre la base de factores de

* Los autores agradecen al Departamento de Trabajo de Carolina del Norte su permiso para reutilizar materiales elaborados durante la redacción de una guía industrial NCDOL sobre conservación de la audición. 
Figura 47.8 • Estimación del peligro derivado de la exposición al ruido en diferentes poblaciones.

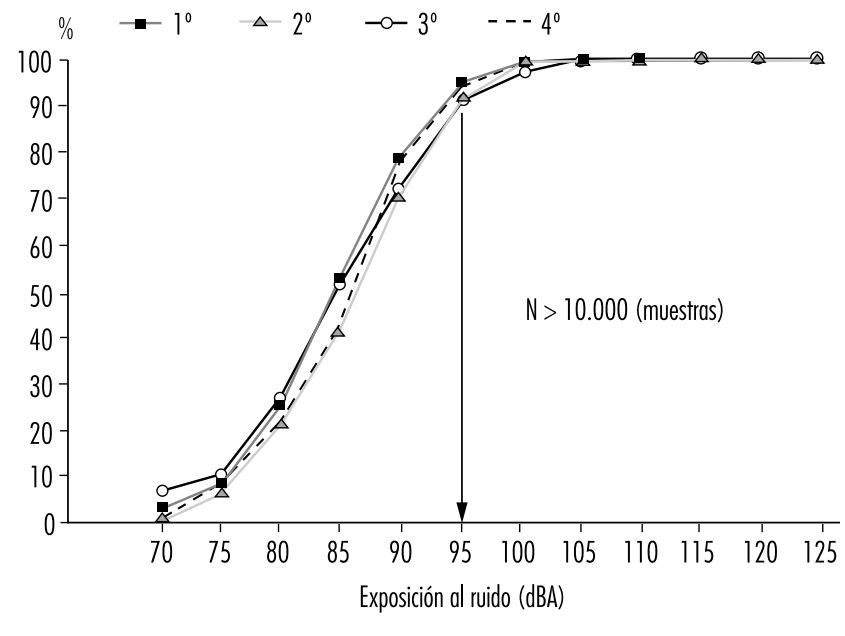

acumulación de 3, 4 y 5 dB. Estos datos indican que aproximadamente el $90 \%$ de las exposiciones diarias de ruido equivalente son de $95 \mathrm{dBA}$ o menos, y sólo el $10 \%$ superan los $95 \mathrm{dBA}$.

La importancia de los datos de la Figura 47.8, suponiendo que sean aplicables a la mayoría de los países y poblaciones, radica simplemente en que una gran mayoría de los empleados expuestos al ruido sólo tienen que conseguir protegerse de $10 \mathrm{dBA}$ de ruido para eliminar el peligro. En el caso de que se lleven protectores auditivos (PA), los responsables de la salud de los trabajadores deberán tomarse el tiempo necesario para equipar a cada persona con un protector que sea cómodo y práctico para su ambiente, que tenga en cuenta sus necesidades auditivas (capacidad para oír señales de aviso, conversaciones, etc.), y que sean herméticos al ruido cuando se lleven día tras día en entornos reales.

Este artículo presenta en forma condensada una serie de prácticas adecuadas de conservación de la audición, resumidas en la lista de control que contiene la Figura 47.9.

\section{Beneficios de la conservación de la audición}

La prevención de las pérdidas auditivas en el trabajo beneficia al trabajador porque preserva las capacidades auditivas que son cruciales para disfrutar de una buena calidad de vida: comunicación interpersonal, disfrute de la música, detección de sonidos de alarma y muchas más. EI PCA proporciona un beneficio en términos de chequeo sanitario, ya que las pérdidas auditivas de carácter no laboral y las enfermedades auditivas con posible tratamiento suelen detectarse por medio de audiometrías anuales. La reducción de la exposición al ruido también reduce el estrés y la fatiga relacionados con el ruido.

El empresario se beneficia directamente de la implantación de un PCA eficaz que mantenga a sus trabajadores en buenas condiciones de audición, ya que éstos serán más productivos y versátiles si no se deterioran sus capacidades de comunicación. L os PCA eficaces pueden reducir los porcentajes de accidentes y promover la eficiencia en el trabajo.

\section{Fases de un PCA}

La lista de control de la Figura 47.9 da detalles de cada fase. Diferentes personas pueden ser responsables de diferentes fases, y estas personas componen el equipo del PCA.

\section{Determinación de la exposición al ruido}

Los sonómetros o los dosímetros de ruido personales se utilizan para medir los niveles de ruido en el lugar de trabajo y calcular la exposición de los trabajadores al ruido para determinar si se necesita un PCA; en tal caso, los datos así recogidos permiten establecer políticas apropiadas para proteger a los trabajadores (R oyster, Berger y R oyster 1986). Los resultados de la evaluación identifican qué trabajadores (por departamento o puesto de trabajo) serán incluidos en el PCA, en qué áreas deberá exigirse el uso de protectores auditivos y qué protectores auditivos se considerarán adecuados. Es necesario tomar muestras en condiciones de producción representativas para clasificar las exposiciones en rangos (menos de 85 dBA, 85-89, 90-94, 95-99 dBA, etc.). La medición de niveles de ruido con factor de ponderación A durante la evaluación general suele identificar las fuentes de ruido dominantes en áreas de la fábrica donde posteriores estudios de control técnico del ruido pueden reducir significativamente la exposición de los trabajadores.

\section{Controles técnicos y administrativos del ruido}

Los controles de ruido pueden reducir la exposición de los empleados hasta un nivel seguro, eliminando la necesidad de un programa de conservación de la audición. Los controles técnicos (ver artículo "T écnicas de control del ruido" en este mismo capítulo) implican modificar la fuente de ruido (como incorporar silenciadores en toberas de salida de aire), la vía de transmisión (como encerrar el equipo en un recinto insonorizante) 0 el receptor (como instalar un cerramiento alrededor del puesto del empleado). $\mathrm{N}$ ormalmente es necesario que el trabajador participe en el diseño de tales modificaciones para que sean prácticas y no dificulten su trabajo. Obviamente, siempre que sea práctico y factible deberá reducirse o eliminarse la exposición del empleado a ruidos peligrosos por medio de controles técnicos.

Entre los controles administrativos del ruido cabe citar la sustitución de equipos anticuados por nuevos modelos más silenciosos, el cumplimiento de los programas de mantenimiento de equipos relativos al control del ruido, y la realización de cambios en los planes de trabajo de los empleados para reducir las dosis de ruido limitando el tiempo de exposición cuando resulte práctico y técnicamente aconsejable. El trabajo de planificación y diseño para reducir el ruido a niveles no peligrosos a la hora de poner en línea nuevas instalaciones de producción es un control administrativo que también puede eliminar la necesidad de un PCA.

\section{Formación y motivación}

$\mathrm{Ni}$ los miembros del equipo PCA ni los trabajadores participarán en la conservación de la audición hasta que comprendan su objetivo, cómo se beneficiarán directamente del programa y que el cumplimiento de los requisitos de seguridad e higiene de la empresa es una condición del empleo. Sin una adecuada formación que motive las acciones individuales, el PCA fracasará (Royster y Royster 1986). Entre otros, deberán tratarse los siguientes temas: la finalidad y los beneficios del PCA, los métodos y los resultados de la evaluación de ruido, el uso y mantenimiento de los tratamientos técnicos de control del ruido para reducir la exposición al mismo, exposiciones a ruidos peligrosos fuera del trabajo, de qué modo daña el ruido al oído, las consecuencias de la pérdida auditiva en la vida diaria, la elección y adaptación de protectores auditivos y la importancia de llevarlos con coherencia, de qué modo se identifican los cambios en la capacidad auditiva por medio de pruebas audiométricas para indicar la necesidad de aumentar la protección y las políticas PCA del empresario. Lo ideal es que se expliquen estos temas a pequeños grupos de trabajadores en reuniones de seguridad, disponiendo de tiempo suficiente para que planteen 
Figura 47.9 • Lista de control de prácticas adecuadas del PCA.

\section{DETERMINACION DE LA EXPOSICION AL RUIDO}

- Se han determinado exposiciones diarias individuales representativas para todas los puestos de trabajo expuestas a ruido.

- Se ha presentado un mapa de ruido de la fábrica que ilustra:

1. áreas en las que los trabajadores están incluidos en el PCA

2. áreas en las que es obligada la utilización de PA

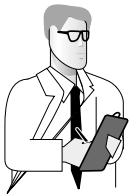

- Se ha informado a los trabajadores de las exposiciones diarias típicas de sus departamentos.

- Los miembros del equipo del PCA y los supervisores departamentales disponen de resúmenes de los resultados de las evaluaciones de ruido.

CONTROLES TECNICOS Y ADMINISTRATIVOS DE RUIDO

- Se ha realizado un estudio de control técnico del ruido para todas las áreas en las que es preciso llevar protectores auditivos.

- Se han identificado las fuentes de ruido dominantes en los recintos de producción.

- Se han identificado fuentes de ruido de los equipos que contribuyen a cada fuente de ruido dominante.

- Existen especificaciones de compra de equipos en materia de ruido y se utilizan a la hora de comprar nuevos equipos que puedan contribuir 0 aumentar significativamente las exposiciones.

- Existe un programa de mantenimiento de controles de ruido y su implantación continuada es la práctica normal.

- La fase de formación del PCA incluye información relativa al programa y las actividades de control del ruido y se presta la atención apropiada a los comentarios de las personas afectadas.

- La planificación de nuevas instalaciones incluye opciones de control del ruido. Las soluciones aplicadas en el pasado a los problemas de control del ruido están documentadas y se discuten durante los programas formativos.

FORMACION Y MOTIVACION

- Los miembros del equipo reciben formación acerca de las pérdidas auditivas y de la conservación de lo audición que les permite comprender los objetivos y políticas del PCA.

- Los miembros del equipo del PCA reciben formación respecto al modo de cumplir con sus obligaciones (especialmente en lo referente a la adaptación y utilización de protectores auditivos).

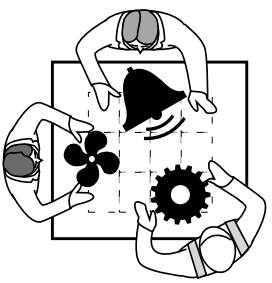

- Los trabaiadores asisten cada año a programas educativos actualizados que se concentran en por qué y cómo proteger su propia capacidad auditiva dentro y fuera del trabajo.

- El personal del PCA mantiene el programa en la mente de los empleados por medio de recordatorios informales con periodicidad al menos trimestral.

- La dirección respalda el PCA con su ejemplo personal (llevando protectores auditivos), haciendo cumplir las políticas y participando en los programas formativos.

- Se evalúa la participación del personal en el PCA durante su reunión anual.

PROTECCION AUDITIVA

- Se impone estricta y coherentemente la utilización de PA en las áreas necesarias.

- La comodidad, la practicidad y el nivel alcanzable de atenuación en el mundo real son los principales criterios para elegir los protectores auditivos que se mantendrán en almacén.

- A cada empleado se le adaptan PA individualmente y se le enseña cómo utilizarlos y cuidarlos apropiadamente.

- Se comprueba la adaptación de todos los tipos de protectores, incluyendo orejeras y tapones de tamaño único.

- Existe un mínimo de dos tapones (uno de ellos en varias medidas) y una orejera para elegir. Es preferible disponer de tres tapones y dos orejeras (una de ellas semiaural).

- Se reemplazan los protectores periódicamente.

- Los repartidores de protectores auditivos sólo distribuyen el tipo y tamaño de protección inicialmente adaptado a cada trabajador; para cambiar de tipo o tamaño, el trabajador debe volver al encargado de la adaptación.

- Se vuelve a comprobar el estado, la adaptación y la correcta colocación del protector auditivo de cada trabajador durante la evaluación audiométrica.

- Los empleados reciben protectores auditivos que pueden llevarse a casa para utilizarlas durante las exposiciones a ruidos fuera del trabajo.

\section{EVALUACIONES AUDIOMETRICAS}

- Los audiómetros están en buenas condiciones de funcionamiento.

- La calibración del audiómetro no se ajusta hasta que se sale de tolerancias y se registran permanentemente tanto las lecturas de preajuste como de ajuste posterior.

- Los técnicos audiometristas emplean métodos de pruebas coherentes bajo supervisión profesional.

- Se utiliza una cabina audiométrica.

- Los técnicos instruyen a los trabajadores para que escuchen atentamente y respondan a los tonos más débiles que puedan detectar.

- La historia auditiva del empleado se actualiza cada año y se entrega al revisor de audiometrías

- Los empleados reciben información inmediata del técnico audiometrista acerca de los resultados de la audiometría en relación con el uso apropiado del PA.

- Los empleados reciben información escrita del revisor de audiometrías acerca de

1. su estado auditivo en comparación con lo normal para su edad

2. cualquier cambio auditivo registrado a lo largo del tiempo

3. recomendaciones para mejorar la protección tanto dentro como fuera del trabajo, o para someterse a examen 0 tratamiento médico, en su caso.

- El revisor de audiometrías busca desviaciones significativas a cualquier frecuencia de pruebas audiométricas, no sólo criterios de desviación especificados en reglamentaciones.

- Los revisores de audiometrías revisan los umbrales mínimos de referencia de los trabajadores en busca de mejoras del umbral, así como de un empeoramiento persistente.

- El personal del PCA continúa asesorando y formando en materia de protección auditiva a los empleados que presentan cambios significativos de audición.

EVALUACION DEL PROGRAMA

- Existe una persona clave que supervisa las cinco fases del PCA.

- Los miembros del equipo del PCA comprueban que se cumplen y se documentan todas las tareas.

- Los PA son potencialmente eficaces en su uso real.

- Se impone la utilización de PA.

- Se mantiene una comunicación activa entre los miembros del equipo del PCA y con el personal de todos los niveles jerárquicos de la empresa.

- Los directivos se responsabilizan de su comportamiento en el PCA tanto a sí mismos como al personal de la empresa.

- Se analizan bases de datos audiométricas para evaluar la eficacia global del PCA a fin de prevenir las pérdidas auditivas inducidas por ruido en el trabajo.

MANTENIMIENTO DE REGISTROS

- Se asigna un solo responsable, como persona clave, para el mantenimiento/supervisión de todos los expedientes relativos a actividades del PCA.

- Los informes de las evaluaciones de ruido pasadas y presentes están en orden y disponibles para su revisión por todas las partes implicadas en el PCA (incluyendo a los trabajadores)

- La exposición diaria representativa está indicada en las audiometrías o disponible para las personas que los realizan y revisan, así como para las encargadas de adaptar y repartir los protectores auditivos.

- Se documentan los contenidos de los programas formativos y se mantienen registros de asistencia.

- Se mantiene un resumen de las actividades de control del ruido y se utiliza su valor formativo durante los programas de formación y motivación.

- Se documentan los procedimientos de adaptación y reparto de protectores auditivos.

- Se mantienen y están disponibles para su revisión todos los expedientes relacionados con evaluaciones audiométricas, como calibración de audiómetros, niveles de ruido de fondo en ambientes de pruebas, certificación y reciclaje de formación de técnicos y directrices de procedimiento generales. 
preguntas. En los PCA eficaces, la fase formativa es un proceso continuo - no sólo una presentación anual- ya que el personal del PCA aprovecha cada día las oportunidades de recordar a los demás cómo conservar su capacidad auditiva.

\section{Protección auditiva}

El empresario proporciona a los empleados protectores auditivos (tapones, orejeras y dispositivos semiinsertados) para que los lleven mientras existan niveles de ruido peligrosos en el lugar de trabajo. Como no se han desarrollado controles técnicos del ruido viables para muchos tipos de equipos industriales, los protectores auditivos son actualmente la mejor opción para prevenir la pérdida auditiva inducida por el ruido en estas situaciones. Como ya se ha indicado anteriormente, la mayoría de los trabajadores expuestos al ruido sólo tienen que conseguir una atenuación de $10 \mathrm{~dB}$ para quedar adecuadamente protegidos del ruido. Con la amplia selección de protectores auditivos disponibles hoy en día, es muy fácil conseguir una protección adecuada (R oyster 1985; Royster y Royster 1986) si se adaptan los protectores individualmente a cada trabajador para conseguir un sellado acústico con una comodidad aceptable y si se enseña al trabajador cómo llevar el protector correctamente para mantener dicho sellado, pero coherentemente siempre que exista un ruido peligroso.

\section{Evaluaciones audiométricas}

Cada persona expuesta debe someterse a un primer chequeo auditivo seguido de chequeos anuales para vigilar su estado auditivo y detectar cualquier cambio. Se utiliza una cabina audiométrica para definir los umbrales auditivos del trabajador a $0,5,1,2,3,4,6$ y $8 \mathrm{kHz}$. Si el PCA es eficaz, los resultados audiométricos de los empleados no mostrarán cambios significativos asociados con daños auditivos inducidos por el ruido en el trabajo. Si se hallan cambios auditivos sospechosos, el técnico audiometrista y el audiólogo o médico que revise el expediente podrán aconsejar al empleado que lleve los PA más cuidadosamente, valorar si se necesitan PA mejor adaptados y motivar a la persona para que sea más diligente en la protección de su oído tanto dentro como fuera del trabajo. A veces pueden identificarse cambios auditivos provocados por causas no laborales, como la exposición a ruidos de aficiones 0 armas de fuego, o problemas médicos del oído. El control audiométrico sólo es útil si se mantiene un control de calidad de los procedimientos de pruebas y si se utilizan los resultados para poner en marcha el seguimiento de las personas que presenten cambios auditivos significativos (R oyster 1985).

\section{Mantenimiento de registros}

Los requisitos relativos a tipos de registros y tiempo de conservación varían según los países. En los países donde las cuestiones relativas a litigios y compensaciones a los trabajadores son importantes, es preciso mantener los expedientes durante más tiempo del que exigen las reglamentaciones laborales, ya que suelen ser útiles a efectos legales. El objetivo del mantenimiento de los registros es documentar de qué modo se ha protegido a los trabajadores del ruido (R oyster y Royster 1989 y 1990). Entre los expedientes especialmente importantes cabe citar los procedimientos de evaluación de ruido y sus resultados, la calibración audiométrica y sus resultados, las actuaciones de seguimiento en respuesta a los cambios auditivos de los trabajadores y la documentación de adaptación de protectores auditivos y formación al respecto. Los registros deben citar los nombres de las personas que se ocuparon de las tareas del PCA así como de sus resultados.

\section{Evaluación del programa}

\section{Características de los programas eficaces}

Los PCA eficaces comparten las siguientes características y promueven una "cultura de seguridad" con respecto a todos los programas de seguridad (gafas de seguridad, cascos, comportamientos seguros en la elevación de cargas, etc.).

\section{La "persona clave"}

La estrategia más importante para que las cinco fases del PCA funcionen eficazmente en conjunto es unirlas bajo la supervisión de una persona de máxima responsabilidad (R oyster y Royster, 1989 y 1990). En las empresas más pequeñas, donde una persona puede ocuparse de todas las facetas del PCA, la falta de coordinación no suele ser un problema. Sin embargo, a medida que aumenta el tamaño de la organización, participan en el PCA personas de diferentes departamentos: personal de seguridad, personal médico, ingenieros, higienistas industriales, supervisores del almacén de utillajes, supervisores de producción, etc. Cuando personas de diversas disciplinas se ocupan de diferentes aspectos del programa, resulta muy difícil coordinar sus esfuerzos a menos que una "persona clave" pueda supervisar todo el PCA. La elección de esta persona es crucial para el éxito del programa. U na de las principales cualificaciones que debe tener la persona clave es un interés auténtico en el PCA de la empresa.

La persona clave está siempre accesible y sinceramente interesada en los comentarios o quejas que puedan contribuir a mejorar el PCA. No adopta una actitud distante ni permanece en su despacho, dirigiendo el PCA mediante órdenes escritas, sino que pasa tiempo en los talleres de producción o en cualquier parte donde haya trabajadores trabajando, a fin de relacionarse con ellos y observar de qué modo pueden evitarse 0 resolverse los problemas.

\section{Funciones y comunicaciones activas}

Los principales miembros del equipo PCA deben reunirse regularmente para examinar los progresos del programa y asegurarse de que todos cumplen sus obligaciones. U na vez que las personas encargadas de diferentes tareas comprenden de qué modo contribuyen sus propias funciones al resultado global del programa, cooperan mejor para prevenir las pérdidas auditivas. La persona clave puede lograr esta comunicación y cooperación activa si la dirección le otorga la autoridad necesaria para tomar decisiones en materia del PCA y le facilita los recursos necesarios para llevar a la práctica las decisiones tomadas. EI éxito del PCA depende de todas, desde el jefe máximo hasta el contratado más reciente; todos tienen un papel importante. El papel de la dirección es principalmente respaldar el PCA y aplicar sus políticas como una de las facetas del programa global de seguridad e higiene de la empresa. El papel de los mandos intermedios y de los supervisores es más directo: contribuyen a ejecutar las cinco fases. EI papel de los trabajadores es participar activamente en el programa y ser agresivos a la hora de realizar sugerencias para mejorar el funcionamiento del PCA. Sin embargo, para lograr la participación de los trabajadores, la dirección y el equipo PCA deben ser receptivos a sus comentarios y darles respuesta.

\section{Los protectores auditivos: eficaces y de obligada utilización}

La importancia de las políticas de protección auditiva para el éxito del PCA viene subrayada por dos características que debe tener un PCA eficaz: la estricta imposición de la utilización de los protectores auditivos (debe existir una obligación real, no sólo una política en papel) y la disponibilidad de protectores que puedan ser eficaces para quienes los lleven en el entorno de trabajo. Los protectores potencialmente eficaces son prácticos y lo bastante cómodos para que los empleados los lleven de manera 
coherente y proporcionan una atenuación acústica adecuada sin entorpecer la comunicación por un exceso de protección.

\section{Limitación de las influencias externas sobree PCA}

Si las decisiones tomadas a nivel local en relación con el PCA se ven limitadas por políticas impuestas por las oficinas centrales de la empresa, puede que la persona clave necesite la ayuda de la alta dirección para obtener excepciones a las normas corporativas o externas a fin de satisfacer las necesidades locales. La persona clave también debe mantener un control estricto sobre todo servicio prestado por asesores externos, contratistas o funcionarios públicos (como evaluaciones de ruido o audiometrías). Cuando se utilizan contratistas, resulta más difícil integrar sus servicios de manera cohesionada en el PCA global, pero es crucial conseguirlo. Si el personal de planta no se atiene a la información proporcionada por los contratistas, los elementos contratados del programa pierden efectividad. La experiencia indica claramente que es muy difícil establecer y mantener un PCA eficaz que dependa principalmente de contratistas externos.

En contraste con las características anteriores, a continuación se enumeran algunas causas comunes de ineficacia del PCA.

- comunicación y coordinación inadecuadas entre el personal del PCA:

- utilización de información insuficiente o errónea para tomar decisiones;

- formación inadecuada para los distribuidores y adaptadores de protectores auditivos;

- surtido inadecuado de protectores en almacén;

- exceso de confianza en las cifras a la hora de elegir dispositivos;

- no equipar y formar a cada usuario de PA individualmente;

- exceso de dependencia de fuentes externas (gobierno o contratistas) para la prestación de servicios PCA;

- no utilizar los resultados del control audiométrico para formar y motivar a los trabajadores,

- no utilizar datos audiométricos para evaluar la eficacia del PCA.

\section{Evaluación objetiva de los datos audiométricos}

Los datos audiométricos de la población expuesta al ruido proporcionan evidencias de si el PCA está previniendo las pérdidas auditivas en el trabajo. A lo largo del tiempo, los cambios auditivos de los trabajadores expuestos al ruido no deben ser mayores que los de los trabajadores de control equiparables sin trabajos ruidosos. Para obtener una primera indicación de eficacia del PCA, se han desarrollado procedimientos para el análisis de bases de datos audiométricos utilizando la variabilidad anual en los valores umbrales de la audición (Royster y Royster 1986a; ANSI 1991).

\section{- NORMAS Y REgLAMENTACIONES}

\section{Alice H. Suter}

\section{Terminología}

En materia de ruido en el trabajo, los términos reglamentación, norma y legislación se utilizan a menudo de manera indistinta, aunque técnicamente pueden tener significados ligeramente diferentes. U na norma es un conjunto de reglas o directrices codificadas, muy similar a una reglamentación, pero que puede elaborarse bajo los auspicios de un grupo de consenso, como la O rganización Internacional de N ormalización (ISO ). U na legislación consta de leyes prescritas por autoridades legislativas o gobiernos locales.
M uchas normas nacionales reciben el nombre de legislación. Algunos organismos oficiales utilizan también los términos "normas" y "reglamentaciones". El Consejo de las Comunidades Europeas (C CE) adopta directivas. Todos los miembros de la Comunidad E uropea tuvieron que "armonizar", alrededor del año 1990, sus normas (legales o reglamentarias) en materia de ruido con la directiva 1986 CEE sobre exposición al ruido en el trabajo (C CE 1986). Esto significa que las normas y reglamentaciones de los estados miembros en materia de ruido tuvieron que incorporar al menos el mismo nivel de protección que la directiva comunitaria. En Estados U nidos, una reglamentación es una norma u orden prescrita por una autoridad gubernativa y suele tener más carácter de formalidad que de norma propiamente dicha.

Algunas naciones tienen un código de práctica, que es algo menos formal. Por ejemplo, la norma nacional australiana de exposición al ruido en el trabajo consta de dos breves párrafos que establecen normas obligatorias, seguidas de un código de práctica de 35 páginas que da orientaciones prácticas respecto al modo de implantar la norma. Los códigos de práctica no suelen tener la fuerza legal de las reglamentaciones o legislaciones.

0 tro término que se utiliza ocasionalmente es recomendación, que es más parecida una directriz que a una norma obligatoria y no puede exigirse su cumplimiento. En este artículo, el término norma se utilizará genéricamente para aludir a normas de ruido de todos los grados de formalidad.

\section{Normas de consenso}

Una de las normas más utilizadas en materia de ruido es la ISO 1999, titulada "Acústica: determinación de la exposición al ruido en el trabajo y estimación del deterioro auditivo inducido por ruido (A coustics: $D$ etermination of $O$ ccupational $N$ oise Exposure and E stimate of N oise I nduced $\mathrm{H}$ earing I mpairment, ISO 1990). Esta norma de consenso internacional es una revisión de una versión anterior, menos detallada, y puede utilizarse para predecir el grado de pérdida auditiva esperado en varios centiles de la población expuesta a diversas frecuencias audiométricas en función del nivel de la exposición y su duración, de la edad y del sexo.

La ISO es normalmente muy activa en el campo de la normalización en materia de ruido. Su comité técnico TC 43, bajo el epígrafe "Acústica", está trabajando en una norma para evaluar la eficacia de los programas de conservación de la capacidad auditiva. Según von Gierke (1993), el subcomité 1o del TC43 (SC 1) tiene 21 grupos de trabajo, algunos de los cuales tienen cada uno más de tres normas en estudio. EI TC43/SC 1 ha publicado 58 normas en materia de ruido y 63 normas adicionales se encuentran en fase de revisión o preparación (von G ierke 1993).

\section{Criterios de riesgo-daño}

El término criterios de riesgo-daño se refiere al riesgo de deterioro auditivo derivado de diversos niveles de ruido. Son muchos los factores que influyen en la elaboración de estos criterios y normas además de los datos que describen el grado de pérdida auditiva derivado de un cierto grado de exposición al ruido. Las consideraciones son tanto técnicas como políticas.

Las siguientes cuestiones son buenos ejemplos de consideraciones políticas: ¿Qué proporción de la población expuesta al ruido debe ser protegida y qué pérdida auditiva constituye un riesgo aceptable? ¿D ebemos proteger de todo grado de pérdida auditiva incluso a los miembros más sensible de la población expuesta? ¿O sólo debemos protegerles de una deficiencia auditiva compensable? Esto viene a ser una cuestión de qué fórmula de pérdida auditiva debe utilizarse y las decisiones tomadas por diferentes organismos gubernativos han sido muy variadas. 
En los primeros años, se tomaron decisiones normativas que permitían grados de pérdida auditiva importantes como riesgo aceptable. La definición más común solía ser un umbral auditivo medio (o "barrera inferior") de $25 \mathrm{~dB}$ o más, a frecuencias audiométricas de $500,1.000$ y $2.000 \mathrm{~Hz}$. Desde entonces, las definiciones de "deterioro auditivo" o "deficiencia auditiva" han sido más restrictivas, con diferentes países o grupos de consenso abogando por diferentes definiciones. Por ejemplo, ciertas agencias gubernativas estadounidenses utilizan ahora $25 \mathrm{~dB}$ a $1.000,2.000$ y $3.000 \mathrm{~Hz}$. O tras definiciones pueden incorporar una barrera inferior de $20025 \mathrm{~dB}$ a $1.000,2.000$ y $4.000 \mathrm{~Hz}, \mathrm{y}$ pueden incluir una gama de frecuencias más amplia.

En general, a medida que las definiciones incluyen frecuencias más altas y "barreras" o umbrales auditivos más bajos, se reduce el riesgo aceptable y es más alto el porcentaje de población expuesta que parece encontrarse en situación de riesgo a causa

Tabla 47.1 • Límites de exposición permisibles (PEL), factores de acumulación y otros requisitos de la exposición al ruido según el país.

\begin{tabular}{|c|c|c|c|c|c|}
\hline País, fecha & PEL $\mathrm{L}_{a v .}, 8$ horas, dBA & $\begin{array}{l}\text { Factor de acumulación, } \\
\mathrm{dBA}^{\mathrm{b}}\end{array}$ & $\begin{array}{l}L_{\text {max }} r m s \\
L_{\text {pico }} S P L\end{array}$ & $\begin{array}{l}\text { Nivel para control } \\
\text { técnico dBAc }\end{array}$ & $\begin{array}{l}\text { Nivel para } \\
\text { audiometría dBAc }\end{array}$ \\
\hline Alemania, ${ }^{3,6} 1990$ & $\begin{array}{l}85 \\
55,70\end{array}$ & 3 & $140 \mathrm{~dB}$ pico & 90 & 85 \\
\hline Argentina & 90 & 3 & $110 \mathrm{dBA}$ & & \\
\hline Australia, ${ }^{1} 1993$ & 85 & 3 & $140 \mathrm{~dB}$ pico & 85 & 85 \\
\hline Brasil, 1992 & 85 & 5 & $\begin{array}{l}115 \mathrm{dBA} \\
140 \mathrm{~dB} \text { pico }\end{array}$ & 85 & \\
\hline Canadá, ${ }^{2} 1990$ & 87 & 3 & & 87 & 84 \\
\hline CCE, 3,41986 & 85 & 3 & $140 \mathrm{~dB}$ pico & 90 & 85 \\
\hline Chile & 85 & 5 & $\begin{array}{l}115 \mathrm{dBA} \\
140 \mathrm{~dB}\end{array}$ & & \\
\hline China, ${ }^{5} 1985$ & $70-90$ & 3 & $115 \mathrm{dBA}$ & & \\
\hline España, 1989 & 85 & 3 & $140 \mathrm{~dB}$ pico & 90 & 80 \\
\hline Estados Unidos, ${ }^{11} 1983$ & 90 & 5 & $\begin{array}{l}115 \mathrm{dBA} \\
140 \mathrm{~dB} \text { pico }\end{array}$ & 90 & 85 \\
\hline Finlandia, 1982 & 85 & 3 & & 85 & \\
\hline Francia, 1990 & 85 & 3 & $135 \mathrm{~dB}$ pico & & 85 \\
\hline Hungría & 85 & 3 & $\begin{array}{l}125 \mathrm{dBA} \\
140 \mathrm{~dB} \text { pico }\end{array}$ & 90 & \\
\hline India, 1989 & 90 & & $\begin{array}{l}115 \mathrm{dBA} \\
140 \mathrm{dBA}\end{array}$ & & \\
\hline Israel, 1984 & 85 & 5 & $\begin{array}{l}115 \mathrm{dBA} \\
140 \mathrm{~dB} \text { pico }\end{array}$ & & \\
\hline Italia, 1990 & 85 & 3 & $140 \mathrm{~dB}$ pico & 90 & 85 \\
\hline Noruega, ${ }^{10} 1982$ & $\begin{array}{l}85 \\
55,70\end{array}$ & 3 & $110 \mathrm{dBA}$ & & 80 \\
\hline Nueva Zelanda, ${ }^{9} 1981$ & 85 & 3 & $\begin{array}{l}115 \mathrm{dBA} \\
140 \mathrm{~dB} \text { pico }\end{array}$ & & \\
\hline Países Bajos, ${ }^{8} 1987$ & 80 & 3 & $140 \mathrm{~dB}$ pico & 85 & \\
\hline Reino Unido, 1989 & 85 & 3 & $140 \mathrm{~dB}$ pico & 90 & 85 \\
\hline Suecia, 1992 & 85 & 3 & $\begin{array}{l}115 \mathrm{dBA} \\
140 \mathrm{~dB} C\end{array}$ & 85 & 85 \\
\hline Uruguay & 90 & 3 & $110 \mathrm{dBA}$ & & \\
\hline
\end{tabular}

a PEL = Límites de exposición permisibles. b Factor de acumulación. A veces llamado factor de duplicación o relación de interdependencia tiempo/ intensidad, es la variación del nivel de ruido (en dB) permitido para cada división por dos o duplicación de la duración de la exposición. c c Al igual que los PEL, los niveles para controles técnicos y pruebas audiométricas son también, presumiblemente, niveles medios.

Fuentes: Arenas 1995; Gunn; Embleton 1994; OIT 1994. Se han consultado además las normas publicadas por varios países. 


\section{Notas a la tabla 47.1.}

${ }^{1}$ Los niveles para controles técnicos, las pruebas de audición y otros elementos del programa de conservación de la audición se definen en un código de Recomendaciones prácticas.

${ }^{2}$ Existen ciertas variaciones entre las distintas provincias canadienses: 0 ntario, $Q$ uebec y N ueva Brunswick utilizan 90 dBA con un factor de acumulación de $5 \mathrm{~dB}$; Alberta, $N$ ueva Escocia y Terranova utilizan $85 \mathrm{dBA}$ con un factor de acumulación de $5 \mathrm{~dB}$; y la Columbia Británica utiliza $90 \mathrm{dBA}$ con un factor de acumulación de $3 \mathrm{~dB}$. Todas ellas exigen controles técnicos a nivel del PEL M anitoba exige ciertas prácticas de conservación de la audición por encima de $80 \mathrm{dBA}$, protectores auditivos y formación según demanda por encima de 85 dBA, y controles técnicos por encima de $90 \mathrm{dBA}$.

${ }^{3}$ El Consejo de las Comunidades Europeas (86/188/CEE) y Alemania (UVV Larm-1990) establecen que no es posible indicar un límite preciso para la eliminación de riesgos para la audición y del riesgo de sufrir otros deterioros de la salud a causa del ruido. Por consiguiente, el empresario viene obligado a reducir el nivel de ruido al máximo posible, teniendo en cuenta los avances técnicos y la disponibilidad de medidas de control. Puede que otros estados comunitarios hayan adoptado también este enfoque.

${ }^{4}$ Los países integrantes de la Comunidad Europea se vieron obligados como mínimo a armonizar sus normas con la directiva comunitaria el 1 de enero de 1990.

${ }^{5}$ China exige diferentes niveles para diferentes actividades: p. ej., $70 \mathrm{dBA}$ para líneas de montaje de precisión, talleres de transformación y salas de ordenadores; $75 \mathrm{dBA}$ para salas de servicio, observación y descanso; $85 \mathrm{dBA}$ para talleres nuevos, y 90 dBA para talleres existentes.

${ }^{6}$ Alemania también tiene normas de ruido de $55 \mathrm{dBA}$ para tareas intelectualmente estresantes y de $70 \mathrm{dBA}$ para trabajos administrativos mecanizados.

${ }^{7}$ Recomendación.

${ }^{8}$ La legislación holandesa en materia de ruido requiere el control técnico del ruido a $85 \mathrm{dBA}$ "a menos que esto no pueda exigirse razonablemente". Deben facilitarse protectores auditivos por encima de 80 dBA y los trabajadores están obligados a llevarlos a niveles superiores a $90 \mathrm{dBA}$.

${ }^{9} \mathrm{~N}$ ueva Zelanda exige un máximo de 82 dBA para una exposición de 16 horas. Deberán llevarse orejeras con niveles de ruido superiores a $115 \mathrm{dBA}$.

${ }^{10} \mathrm{~N}$ oruega exige un PEL de $55 \mathrm{dBA}$ para trabajos que requieran un alto grado de concentración mental, 85 dBA para trabajos que requieran comunicación verbal o gran precisión y atención, y 85 dBA para otros ambientes de trabajo ruidosos. Los límites recomendados son $10 \mathrm{~dB}$ inferiores. Los trabajadores expuestos a niveles de ruido superiores a 85 dBA deberán llevar protectores auditivos.

${ }^{11}$ Estos niveles son aplicables a la norma OSHA en materia de ruido, que comprende a los trabajadores de la industria en general y de los gremios marítimos. Los servicios militares de Estados Unidos imponen normas algo más exigentes. El ejército y las fuerzas aéreas estadounidenses utilizan un PEL de 85 dBA y un factor de acumulación de 3 dB.

de niveles determinados de ruido. Si la intención fuera que no existiera ningún riesgo de pérdida auditiva a causa de la exposición al ruido, ni siquiera en los miembros más sensibles de la población expuesta, el límite de exposición permisible tendría que ser de $75 \mathrm{dBA}$. De hecho, la directiva comunitaria ha establecido que el nivel al que el riesgo es despreciable es un nivel equivalente $\left(\mathrm{L}_{e q}\right)$ de $75 \mathrm{dBA}$, nivel que también ha sido propuesto como objetivo para las instalaciones de producción de Suecia (K ihlman 1992).

Por lo general, la idea preponderante en este tema es que resulta aceptable que un grupo de trabajo expuesto a ruido pierda capacidad auditiva hasta cierto punto, pero no en exceso. No existe consenso por el momento sobre lo que se considera excesivo. Lo más probable es que la mayoría de los países adopten normas y reglamentaciones en un intento de mantener el riesgo al mínimo teniendo en cuenta la viabilidad técnica y económica al mismo tiempo, pero sin alcanzar un consenso sobre cuestiones tales como las frecuencias, la barrera 0 el porcentaje de población a proteger.

\section{Presentación de los criterios de riesgo-daño}

Los criterios de pérdida auditiva inducida por ruido pueden presentarse de dos maneras: desviación permanente del umbral inducida por ruido (Noise-Induced Permanent Threshold Shift, NIPT S) o riesgo porcentual. El criterio NIPTS es el grado de desviación permanente del umbral que persiste en una población después de restar la desviación del umbral que se produciría "normalmente" por causas distintas del ruido en el trabajo. El riesgo porcentual es el porcentaje de una población con un cierto grado de deterioro auditivo inducido por ruido después de restar el porcentaje de una población similar no expuesta a ruido en el trabajo. Este concepto se denomina a veces exceso de riesgo. Lamentablemente, ninguno de los dos métodos carece de problemas.

EI problema que presenta utilizar sólo el NIPT S es que resulta difícil resumir los efectos del ruido sobre la audición. Los datos suelen exponerse en una gran tabla que presenta la desviación del umbral inducida por ruido para cada frecuencia audiométrica en función del nivel de ruido, los años de exposición y el centil de población. El concepto de riesgo porcentual es más atractivo porque utiliza simples números y parece fácil de comprender. Pero el problema del riesgo porcentual es que puede variar enormemente en función de diversos factores, en especial la altura de la barrera del umbral auditivo y las frecuencias utilizadas para definir el deterioro auditivo (o deficiencia auditiva).

Con ambos métodos, el usuario necesita estar seguro de que las poblaciones expuestas y no expuestas están cuidadosamente equiparadas en lo referente a factores tales como la edad y la exposición a ruidos de carácter no laboral.

\section{Normas nacionales en materia de ruido}

La Tabla 47.1 indica algunas de las principales características de las normas de exposición al ruido de varios países. La mayoría de la información es actual al día de la fecha de esta publicación, pero algunas normas pueden haber sido revisadas recientemente. Se recomienda a los lectores que consulten las últimas versiones de las normas nacionales.

La Tabla 47.1 muestra claramente la tendencia de la mayoría de los países a utilizar un límite de exposición permisible (Permissible Exposure Limit, PEL) de $85 \mathrm{dBA}$, mientras que aproximadamente la mitad de las normas siguen utilizando 90 dBA para cumplir los requisitos de control técnico, tal como 
permite la directiva comunitaria. La gran mayoría de los países indicados han adoptado el factor de acumulación de $3 \mathrm{~dB}$, excepto Israel, Brasil y Chile, que utilizan de $5 \mathrm{~dB}$ con un criterio de nivel de $85 \mathrm{dBA}$. La otra excepción notable la constituye Estados U nidos (en el sector civil), aunque tanto el Ejército como la Aviación han adoptado $3 \mathrm{~dB}$.

Además de sus requisitos para proteger a los trabajadores de las pérdidas auditivas, varios países incluyen disposiciones para prevenir otros efectos perjudiciales del ruido. Algunos países establecen en sus reglamentaciones la necesidad de protección frente a los efectos extra-auditivos del ruido. Tanto la directiva comunitaria como la norma alemana reconocen que el ruido en el lugar de trabajo presenta un riesgo para la seguridad y la salud de los trabajadores más allá de la pérdida auditiva, pero que los conocimientos científicos actuales sobre efectos extra-auditivos no permiten establecer niveles de seguridad precisos.

La norma noruega especifica que los niveles de ruido no deben sobrepasar los $70 \mathrm{dBA}$ en los ambientes de trabajo donde es necesaria la comunicación hablada. La norma alemana aboga por la reducción del ruido para la prevención de riesgos de accidente, y tanto N oruega como A lemania exigen un nivel de ruido máximo de 55 dBA para mejorar la concentración y prevenir el estrés durante la realización de tareas intelectuales.

Algunos países tienen normas especiales en materia de ruido para diferentes tipos de ambientes laborales. Por ejemplo, Finlandia y Estados Unidos tienen normas de ruido para cabinas de vehículos automóviles, Alemania y Japón especifican niveles de ruido para oficinas. 0 tros incluyen el ruido como uno de los muchos riesgos regulados en un proceso determinado. 0 tras normas son aplicables a tipos específicos de equipos 0 máquinas, como compresores de aire, sierras mecánicas y equipos de construcción.

Además, algunos países han promulgado normas específicas para regular los protectores auditivos (como la directiva comunitaria, Países Bajos y N oruega) y los programas de conservación de la audición (como Francia, Noruega, España, Suecia y Estados U nidos).

Algunos estados utilizan enfoques innovadores para abordar el problema del ruido en el trabajo. Por ejemplo, Países Bajos tienen una norma específica para lugares de trabajo de nueva construcción, y Australia y Noruega ofrecen información a los empresarios destinada a que éstos den instrucciones a los fabricantes para que suministren equipos más silenciosos.

Existe poca información acerca del grado de cumplimiento de estas normas y reglamentaciones. Algunas especifican que los empresarios "deberían" tomar ciertas medidas (como en los códigos de práctica o directrices), mientras que la mayoría señalan que los empresarios "deberán". Las normas imperativas son más susceptibles de ser obligatorias, pero varía mucho la capacidad e inclinación de cada país para obligar al cumplimiento. Incluso dentro del mismo país, la aplicación de las normas laborales en materia de ruido pueden variar considerablemente según el gobierno del momento.

\section{Referencias}

American National Standards Institute (ANSI). 1985. ANSI SI.4-1983, As Amended By ANSI SI.4-1985. Nueva Y ork: ANSI

-. 1991. ANSI SI2.13. Evaluation of $H$ earing Conservation Programmes. Nueva Y ork: ANSI.

-. 1992. ANSI S12.16. Guidelines for the Specification of N oise of N ew M achinery. Nueva Y ork: ANSI.

Arenas, JP. 1995. Instituto de Acústica, U niversidad Austral de Chile. Trabajo presentado en el CXXIX Congreso de la Sociedad Acústica de América, $V$ aldivia, Chile.

Boettcher FA, D H enderson, M A Gratton, RW Danielson, CD Byrne. 1987. Synergistic interactions of noise and other ototraumatic agents. $\mathrm{Ear} H$ ear. 8(4):192-212.

Comisión Electrotécnica Internacional (CEI). 1979. Documento CEI Núm. 651

- . 1985. Documento CEI N úm. 804

Consejo de la Comunidad Europea (CCE). 1986. Directiva de 12 de mayo relativa a la protection de los trabajadores contra los riesgos debidos a la exposición al ruido durante el trabajo (86/ 188/ CEE)

- 1989a. Directiva 89/106/CEE de 21 de diciembre 1988 relativa a la aproximación de las disposiciones legales, reglamentarias y administrativas de los Estados M iembros sobre los productos de construcción, DO Núm. L40, 11 de febrero.

-. 1989b. Directiva 89/392/ CEE de 14 de junio de 1989 relativa a la aproximación de las legislaciones de los Estados Miembros sobre máquinas, DO Núm. L 183,29.6.1989.

-. 1989c. Directiva 89/686/ CEE de 21 de diciembre de 1989 sobre la aproximación de las disposiciones legales y reglamentarias en materia de equipos de protección individual, DO N úm. L 399, 30.12.1989.

- . 1991. Directiva 91/368/ CEE de 20 de junio de 1991, enmienda de la Directiva 89/392/ CEE relativa a la aproximación de las legislaciones de los
Estados M iembros sobre máquinas, DO Núm. L 198, 22.7.91.

-. 1993a. Directiva 93/44/CEE de 14 de junio de 1993, enmienda de la Directiva 89/392/ CEE relativa a la aproximación de las legislaciones de los Estados miembros sobre máquinas, DO Núm. L 175, 19.7.92.

- . 1993b. Directiva 93/ 95/ CEE de 29 de octubre de 1993, enmienda de la Directiva 89/686/ CEE sobre la aproximación de las disposiciones legales y reglamentarias de los Estados miembros en materia de equipos de protección individual, DO Núm. L 276, 9.11.93.

Dunn, DE, RR Davis, CJ Merry, JR Franks. 1991. $H$ earing loss in the chinchilla from impact and continuous noise exposure. I Acoust SoC Am 90:1975-1985.

Embleton, TFW. 1994. Technical assessment of upper limits on noise in the workplace. Noise/ N ews Intl. Poughkeepsie, NuevaY ork: I-INCE.

Fechter, LD. 1989. A mechanistic basis for interactions between noise and chemical exposure. ACES 1:23-28.

Gunn, P. N.d. Department of O ccupational $\mathrm{H}$ ealth Safety and Welfare, Perth, Australia O ccidental. Comunicación Personal.

Hamernik, RP, WA Ahroon, KD H sueh. 1991. The energy spectrum of an impulse: Its relation to hearing loss. I A coust Soc Am 90:197-204.

Ising, H, B K ruppa. 1993. L arm und Krankheit [N oise and D isease ]. Stuttgart: Gustav Fischer V erlag.

K ihlman, T. 1992. Sweden's action plan against noise. Noisel N ews Intl 1(4):194-208.

M oll van Charante, AW, PGH Mulder. 1990. Perceptual acuity and the risk of industrial accidents. Am I E pidemiol 131:652-663.

M orata, TC, DE D unn, LW K retchmer, GK Lemasters, U P Santos. 1991. Effects of simultaneous exposure to noise and toluene on workers' hearing and balance. En Proceedings of the F ourth International Conference $0 \mathrm{n}$ the Combined Environmental Factors, diri- gido por LD F echter. Baltimore: U niversidad I ohns $\mathrm{H}$ op-

M orata, T C. 1989. Study of the effects of simultaneous exposure to noise and carbon disulfide on workers' hearing. Scand Audiol 18:53-58.

M oreland, JB. 1979. Noise Control T echniques. En $\mathrm{H}$ andbook of $\mathrm{Noise}$ Control, dirigido por $\mathrm{CM} \mathrm{H}$ arris. $\mathrm{N}$ ueva Y ork: $\mathrm{M}$ CG raw-H ill

O rganización Internacional de N ormalización. (ISO ). 1975. M ethod for Calculating Loudness Level. ISO D ocument N 0. 532. G inebra:ISO

- . 1990. A coustics: D etermination of 0 ccupational $N$ oise $E$ Xposure and $\mathrm{E}$ stimate of $\mathrm{N}$ oise I nduced $\mathrm{H}$ earing I mpairment. ISO Document N 0. 1999. Ginebra: ISO .

O rganización Internacional del Trabajo (OIT ). 1994. N oise R egulations and Standards (Summaries). G inebra: OIT.

Peterson, EA, JS Augenstein, D T anis, DG Augenstein. 1981. Noise raises blood pressure without impairing auditory sensitivity. Science 211:14501452

Peterson, EA, JS Augenstein, DC Tanis, R Warner, A Heal. 1983. Proceedings of the Fourth International Congress On Noise As a Public $\mathrm{H}$ ealth Problem, dirigido por G R ossi. M ilán: Centro Richerche eStudi Amplifon.

Peterson, EA, IS Augenstein, DC T anis. 1978. Continuing studies of noise and cardiovascular function. J Sound Vibrat 59:123.

Price, GR. 1983. Relative hazard of weapons impulses. J A coust Soc Am 73:556-566.

Rehm, S. 1983. Research on extraaural effects of noise since 1978. En Proceedings of the F ourth International Congress On Noise As a Public $\mathrm{H}$ ealth Problem, dirigido por G R ossi. M ilán: Centro Richerche e Studi Amplifon.

Royster, JD, LH Royster. 1986. Audiometric data base analysis. En $\mathrm{N}$ oise and $\mathrm{H}$ earing $\mathrm{Conservation} \mathrm{M}$ anual, dirigido por E H B erger, W D W ard, I C M orrill y LH Royster. A kron, Ohio: American Industrial H ygiene Association (AIHA). 
- . 1989. H earing Conservation. NC-OSH A Industry Guide N o. 15. Raleigh, Carolina del Norte: N orth Carolina D epartment of $L$ abor.

-. 1990. H earing Conservation Programs: Practical Guide lines for Success. Chelsea, M ichigan: L ewis.

R oyster, JD. 1985. Audiometric evaluations for industrial hearing conservation. I Sound Vibrat 19(5):2429.

Royster, LH, EH Berger, JD Royster. 1986. Noise surveys and data analysis. En Noise and $\mathrm{H}$ earing $\mathrm{Con}$ servation $\mathrm{M}$ anual, dirigido por E H B erger, W H W ard, J C M orill y LH Royster. Akron, Ohio: American Industrial $\mathrm{H}$ ygiene Association (AIH A).

R oyster, LH, JD R oyster. 1986. Education and motivation. En N oise \& $H$ earing Conservation $M$ anual, dirigido por E H B erger, W H W ard, J C M orill y LH Royster. Akron, Ohio: American Industrial $\mathrm{H}$ ygiene Association (AIH A).

Suter, AH. 1992. Communication and J ob Performance in $\mathrm{N}$ oise: A R eview. A merican Speech-L anguage $\mathrm{H}$ ear- ing Association M onographs, N o.28. Washington, DC: ASH A.

- 1993. Noise and the conservation of hearing Chap. 2 in $H$ earing Conservation M anual M ilwaukee, Wisconsin: Council for Accreditation in O ccupational $\mathrm{H}$ earing $\mathrm{C}$ onservation.

Thiery, L, C M eyer-Bisch. 1988. H earing loss due to partly impulsive industrial noise exposure at levels between 87 and $90 \mathrm{dBA}$.) A coustSocA m 84:651-659.

Van Dijk, FJH. 1990. Epidemiological research on non-auditory effects of occupational noise exposure since 1983. En Noise As a Public $\mathrm{H}$ ealth Problem, dirigido por B B erglund y $T$ Lindvall. Estocolmo: Consejo Sueco para la Investigación de los E dificios.

V on Gierke, HE. 1993. Noise regulations and standards: Progress, experiences, and challenges. En $\mathrm{N}$ oise As a Public $\mathrm{H}$ ealth Problem, dirigido por M Vallet. $F$ rancia: Institut $\mathrm{N}$ ational de $\mathrm{R}$ echerche sur les $\mathrm{T}$ ransports et leur Securite.
Wilkins, PA, WI Acton, 1982. Noise and accidents: A review. Ann $\mathrm{O}$ ccup H yg 2:249-260.

\section{0 tras lecturas recomendadas}

Berger, EH. 1986. Hearing protection devices. En $\mathrm{N}$ oise and $\mathrm{H}$ earing Conservation $\mathrm{M}$ anual, dirigido por EH Berger, WH Ward, JC M orill y LH Royster. Akron, O hio: American Industrial $\mathrm{H}$ ygiene Association (AIHA).

H assall, A, K Zaveru. 1979. A coustic N oise M easurements N aerum, Dinamarca: Bruel \& K jaer.

Royster, LH, JD Royster. 1985. H earing protection devices. En $\mathrm{H}$ earing Conservation in Industry, dirigido por AS Feldman y CT Grimes. Baltimore: Williams \& Wilkins.

Suvorov, GA, LN Shkarinov, El Denisov. 1984. H ygienic Assessment of Occupational Noises and Vibration. M oscú: M editsina. 


\section{RADIACIONES IONIZANTES}

Director del capítulo

R obert N. Cherry, J r.

\section{Sumario}

Introducción

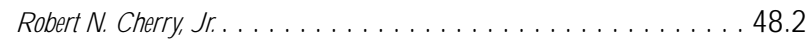

Biología radiológica y efectos biológicos

Arthur C. U pton .............................. 48.4

Fuentes de radiación ionizante

Robert N. Cherry, J r. . . . . . . . . . . . . . . . . . . . . . 48.11

D iseño de puestos de trabajo para seguridad radiológica

Gordon M. Lodde. . . . . . . . . . . . . . . . . . . . . . . . 48.18

Seguridad radiológica

Robert N. Cherry, J

Planificación de medidas y gestión de accidentes

radiológicos

Sydney W. Porter, J r. . . . . . . . . . . . . . . . . 48.34 


\section{INTRODUCCION}

Robert N. Cherry, Jr.

La radiación ionizante está en todas partes. Llega desde el espacio exterior en forma de rayos cósmicos. Está en el aire en forma de emisiones del radón radiactivo y su progenie. Los isótopos radiactivos que se originan de forma natural entran y permanecen en todos los seres vivos. Es inevitable. De hecho, todas las especies de este planeta han evolucionado en presencia de la radiación ionizante. Aunque los seres humanos expuestos a dosis pequeñas de radiación pueden no presentar de inmediato ningún efecto biológico aparente, no hay duda de que la radiación ionizante, cuando se administra en cantidades suficientes, puede causar daños. El tipo y el grado de estos efectos son bien conocidos.

Si bien la radiación ionizante puede ser perjudicial, también tiene muchas aplicaciones beneficiosas. El uranio radiactivo genera electricidad en centrales nucleares instaladas en muchos países. En medicina, los rayos $X$ permiten obtener radiografías para el diagnóstico de lesiones y enfermedades internas. Los médicos especializados en medicina nuclear utilizan material radiactivo como trazadores para formar imágenes detalladas de estructuras internas y estudiar el metabolismo. En la actualidad se dispone de radiofármacos terapéuticos para tratar trastornos como el hipertiroidismo y el cáncer. Los médicos utilizan en radioterapia rayos gamma, haces de piones, haces de electrones, neutrones y otros tipos de radiación para tratar el cáncer. Los ingenieros emplean material radiactivo en la operaciones de registro de pozos petrolíferos y para medir la densidad de la humedad en los suelos. Los radiólogos industriales se valen de rayos $X$ en el control de calidad para observar las estructuras internas de aparatos fabricados. Las señales de las salidas de edificios y aviones contienen tritio radiactivo para que brillen en la oscuridad en caso de fallo de la energía eléctrica. Muchos detectores de humos en viviendas y edificios comerciales contienen americio radiactivo.

Estos numerosos usos de la radiación ionizante y de los materiales radiactivos mejoran la calidad de vida y ayudan a la sociedad de muchas maneras. Pero siempre se deben sopesar los beneficios de cada uso con sus riesgos. Estos pueden afectar a los trabajadores que intervienen directamente en la aplicación de la radiación 0 el material radiactivo, a la población en general, a las generaciones futuras y al medio ambiente, 0 a cualquier combinación de los grupos enumerados. M ás allá de consideraciones políticas y económicas, los beneficios siempre deben superar a los riesgos cuando se trate de utilizar la radiación ionizante.

\section{Radiación ionizante}

La radiación ionizante consiste en partículas, incluidos los fotones, que causan la separación de electrones de átomos y moléculas. Pero algunos tipos de radiación de energía relativamente baja, como la luz ultravioleta, sólo puede originar ionización en determinadas circunstancias. Para distinguir estos tipos de radiación de la radiación que siempre causa ionización, se establece un límite energético inferior arbitrario para la radiación ionizante, que se suele situar en torno a 10 kiloelectronvoltios (keV).

La radiación ionizante directa consta de partículas cargadas, que son los electrones energéticos (llamados a veces negatrones), los positrones, los protones, las partículas alfa, los mesones cargados, los muones y los iones pesados (átomos ionizados). Este tipo de radiación ionizante interactúa con la materia sobre todo mediante la fuerza de Coulomb, que les hace repeler 0 atraer electrones de átomos y moléculas en función de sus cargas.
La radiación ionizante indirecta es producida por partículas sin carga. Los tipos más comunes de radiación ionizante indirecta son los generados por fotones con energía superior a $10 \mathrm{keV}$ (rayos $X$ y rayos gamma) y todos los neutrones.

Los fotones de los rayos $X$ y gamma interactúan con la materia y causan ionización de tres maneras diferentes como mínimo:

1. Los fotones de energía más baja interactúan sobre todo mediante el efecto fotoeléctrico, por el que el fotón cede toda su energía a un electrón, que entonces abandona el átomo 0 molécula. El fotón desaparece.

2. Los fotones de energía intermedia interactúan fundamentalmente mediante el efecto Compton, en virtud del cual el fotón y un electrón colisionan esencialmente como partículas. El fotón continúa su trayectoria en una nueva dirección con su energía disminuida, mientras que el electrón liberado parte con el resto de la energía entrante (menos la energía de unión del electrón al átomo o a la molécula).

3. La producción de pares sólo es posible con fotones cuya energía sea superior a 1,02 M eV. (Sin embargo, cerca de $1,02 \mathrm{MeV}$, el efecto Compton predomina todavía. La producción de pares predomina con energías más altas.) El fotón desaparece, y en su lugar aparece una pareja electrón-positrón (este fenómeno sólo ocurre en la proximidad de un núcleo, por consideraciones de conservación del momento cinético y de la energía). La energía cinética total del par electrón-positrón es igual a la energía del fotón menos la suma de las energías de la masa residual de electrón y positrón $(1,02 \mathrm{M} \mathrm{eV})$. Estos electrones y positrones energéticos se comportan entonces como radiación ionizante directa. A medida que pierde energía cinética, un positrón puede llegar a encontrarse con un electrón, y las partículas se aniquilarán entre sí. Entonces se emiten dos fotones de $0,511 \mathrm{M} \mathrm{eV}$ (por lo general) desde el punto de aniquilación, a 180 grados uno de otro.

Con un fotón dado puede ocurrir cualquiera de estos supuestos, salvo que la producción de pares sólo es posible con fotones de energía superior a 1,022 M eV. La energía del fotón y el material con el que interactúa determinan qué interacción es la más probable.

La Figura 48.1 muestra las regiones en las que predomina cada tipo de interacción en función de la energía del fotón y del número atómico del absorbente.

Figura 48.1 - Importancia relativa de las tres interacciones principales de los fotones con la materia.

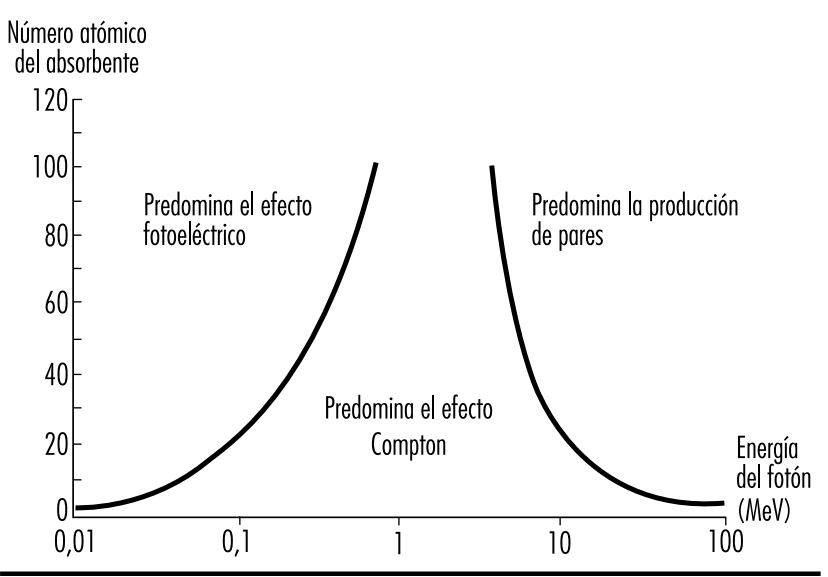


Las interacciones más comunes del neutrón con la materia son colisiones inelásticas, captura (o activación) de neutrón y fisión. Todas ellas son interacciones con núcleos. Un núcleo que colisiona inelásticamente con un neutrón queda en un nivel de energía más alto. Entonces puede liberar esta energía en forma de un rayo gamma, mediante la emisión de una partícula beta 0 de ambas formas. En la captura de neutrones, un núcleo afectado puede absorber el neutrón y expulsar energía en forma de rayos gamma $0 \mathrm{X}$ o partículas beta, 0 ambas cosas. Las partículas secundarias causan después ionización, como se ha visto antes. En la fisión, un núcleo pesado puede absorber al neutrón y se desdobla en dos núcleos más ligeros, que casi siempre son radiactivos.

\section{Cantidades, unidades y definiciones}

La Comisión Internacional de U nidades y M edidas de R adiación (ICRU ) desarrolla definiciones formales de cantidades y unidades de radiación y radiactividad que tienen aceptación internacional. La Comisión Internacional de Protección Radiológica (CIPR) también establece normas para la definición y utilización de diversas cantidades y unidades empleadas en seguridad radiológica. A continuación se da la descripción de algunas cantidades, unidades y definiciones que se suelen emplear en seguridad radiológica.

D osis absorbida. Es la cantidad dosimétrica fundamental de la radiación ionizante. En esencia, es la energía que la radiación ionizante imparte a la materia por unidad de masa. Se expresa por,

$$
D=\frac{d \varepsilon}{d m}
$$

donde $D$ es la dosis absorbida, de es la energía media impartida a la materia de masa dm. La unidad de dosis absorbida es el julio por kilogramo $\left(\mathrm{kg}^{-1}\right)$. El nombre especial de la unidad de dosis absorbida es el gray (Gy).

Actividad. Esta cantidad representa el número de transformaciones nucleares desde un estado energético nuclear dado por unidad de tiempo. Se expresa con:

$$
A=\frac{d N}{d t}
$$

donde $\mathrm{A}$ es la actividad, dN es el valor esperado del número de transiciones nucleares espontáneas desde el estado de energía dado durante el intervalo de tiempo dt. Está relacionada con el número de núcleos radiactivos $\mathrm{N}$ mediante:

$$
A=\lambda N
$$

donde $\lambda$ es la constante de desintegración. La actividad se expresa por segundo. El nombre especial de la unidad de actividad es el bequerelio $(\mathrm{Bq})$.

Constante de desintegración ( $\lambda$ ). Esta cantidad representa la probabilidad por unidad de tiempo de que ocurra una transformación nuclear para un radionucleido dado. La constante de desintegración se mide por segundo. Está relacionada con el período de semidesintegración $t_{1 / 2}$ de un radionucleido por:

$$
\lambda=\frac{\ln 2}{t_{1 / 2}} \approx \frac{0,693}{t_{1 / 2}}
$$

La constante de desintegración $\lambda$ está relacionada con la vida media, $\tau$, de un radionucleido por:

$$
\lambda=\frac{1}{\tau}
$$

La dependencia del tiempo de la actividad $A(t)$ y del número de núcleos radiactivos $N(t)$ se puede expresar por $A(0) e^{-\lambda t}$ y $N(0) e^{-\lambda t}$ respectivamente.
Efecto biológico determinista. Se trata de un efecto biológico causado por la radiación ionizante y cuya probabilidad de aparición es cero con dosis absorbidas pequeñas, pero que aumentará aceleradamente hasta uno (probabilidad $100 \%$ ) cuando la dosis absorbida supere un nivel determinado (el umbral). La inducción de cataratas es un ejemplo de efecto biológico estocástico.

$D$ osis efectiva. La dosis efectiva $E$ es la suma de las dosis equivalentes ponderadas en todos los tejidos y órganos del cuerpo. Es una magnitud utilizada en seguridad radiológica, de manera que su empleo no es adecuado para medir grandes dosis absorbidas suministradas en un período de tiempo relativamente corto. Viene dada por:

$$
E=\sum_{T} w_{T} H_{T}
$$

donde $w_{T}$ es la factor de ponderación tisular y $\mathrm{H}_{\mathrm{T}}$ es la dosis equivalente del tejido $\mathrm{T}$. La dosis efectiva se mide en $\mathrm{J} \mathrm{kg}^{-1}$. El nombre especial de la unidad de dosis efectiva es el sievert (Sv).

D osis equivalente. $L$ a dosis equivalente $H_{T}$ es la dosis absorbida promediada para un tejido u órgano (y no en un punto) y ponderada respecto de la cualidad de la radiación que interese. Es una magnitud utilizada en seguridad radiológica, de manera que su empleo no es adecuado para medir grandes dosis absorbidas grandes suministradas en un período de tiempo relativamente corto. Viene dada por:

$$
H_{T}=\sum_{R} W_{R} D_{T, R}
$$

donde $D_{T, R}$ es la dosis absorbida promediada para todo el tejido $u$ órgano $T$ debida a la radiación $R$ y $w_{R}$ es el factor de ponderación radiológica. La dosis equivalente tiene las unidades de $\mathrm{kg}^{-1}$. El nombre especial de la unidad de dosis equivalente es el sievert (Sv).

Período de semidesintegración. Esta magnitud es la cantidad de tiempo necesario para que la actividad de una muestra de radionucleido se reduzca a la mitad. Equivale al tiempo necesario para que un número dado de núcleos en un estado radiactivo dado se vea reducido a la mitad. Su unidad fundamental es el segundo (s), pero se suele expresar en horas, días y años. Para un radionucleido dado, el período de semidesintegración $t_{1 / 2}$ está relacionado con la constante de desintegración $\lambda$ por:

$$
\mathrm{t}_{1 / 2}=\frac{\ln 2}{\lambda} \approx \frac{0,693}{\lambda}
$$

Transferencia lineal de energía. Esta cantidad es la energía que una partícula cargada imparte a la materia por unidad de longitud a medida que la atraviesa. Se expresa por,

$$
L=\frac{d \varepsilon}{d l}
$$

donde $L$ es la transferencia lineal de energía (Ilamada también poder de parada lineal de la colisión) y de es la energía media perdida por la partícula al atravesar una distancia dl. La transferencia

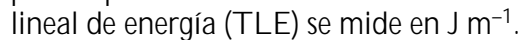

Vida media. Esta cantidad es el tiempo medio que un estado nuclear sobrevivirá antes de experimentar una transformación hasta un estado de energía más baja mediante la emisión de radiación ionizante. Su unidad fundamental es el segundo (s), pero también puede expresarse en horas, días o años. Está relacionada con la constante de desintegración por:

$$
\tau=\frac{1}{\lambda}
$$

donde $\tau$ es la vida media y $\lambda$ es la constante de desintegración de un nucleido dado en un estado energético dado. 
Tabla 48.1 • Factores de ponderación de la radiación $\mathrm{w}_{\mathrm{R}}{ }^{1}$.

Tipo y rango de la energía
Fotones, todas las energías
Electrones y muones, todas las energías²
Neutrones, energía <10 keV
$10 \mathrm{keV}$ a $100 \mathrm{keV}$
$>100 \mathrm{keV}$ a $2 \mathrm{MeV}$
$>2 \mathrm{MeV}$ a $20 \mathrm{MeV}$
$>20 \mathrm{MeV}$
Protones, distintos de los protones de retroceso, energía $>2 \mathrm{MeV}$
Partículas alfa, fragmentos de fisión, núcleos pesados

1 Todos los valores se refieren a la radiación incidente en el cuerpo 0 , si las fuentes son internas, a la emitida desde la fuente.

2 Excluidos los electrones Auger emitidos desde núcleos unidos a DNA.

Factor de ponderación radiológica. Se trata de un número $W_{R}$ que, para un tipo y una energía de radiación $\mathrm{R}$ dados, es representativo de los valores de la eficacia biológica relativa de dicha radiación para inducir efectos estocásticos en dosis bajas. Los valores de $W_{R}$ están relacionados con la transferencia lineal de energía (T LE) y se dan en la Tabla 48.1. La Figura 48.2 muestra la relación entre $W_{R}$ y $T L E$ para neutrones.

E ficacia biológica relativa (EBR ). La EBR de un tipo de radiación comparado con otro es la inversa de la relación de dosis absorbidas que producen el mismo grado de un punto final biológico definido.

E fecto biológico estocástico. Es un efecto biológico causado por la radiación ionizante cuya probabilidad de aparición aumenta al aumentar la dosis absorbida, probablemente sin ningún umbral, pero cuya gravedad es independiente de la dosis absorbida. E cáncer es un ejemplo de efecto biológico estocástico.

Factor de ponderación tisular $\mathrm{W}_{\mathrm{T}}$. Representa la contribución del tejido u órgano $\mathrm{T}$ al efecto lesivo total debido a todos los efectos estocásticos resultantes de la irradiación uniforme de todo el cuerpo. Se utiliza porque la probabilidad de efectos estocásticos debidos a una dosis equivalente depende del tejido u órgano irradiado. U na dosis equivalente uniforme por todo el cuerpo

Figura 48.2 • Factores de ponderación de la radiación para neutrones (la curva suave debe considerarse una aproximación).

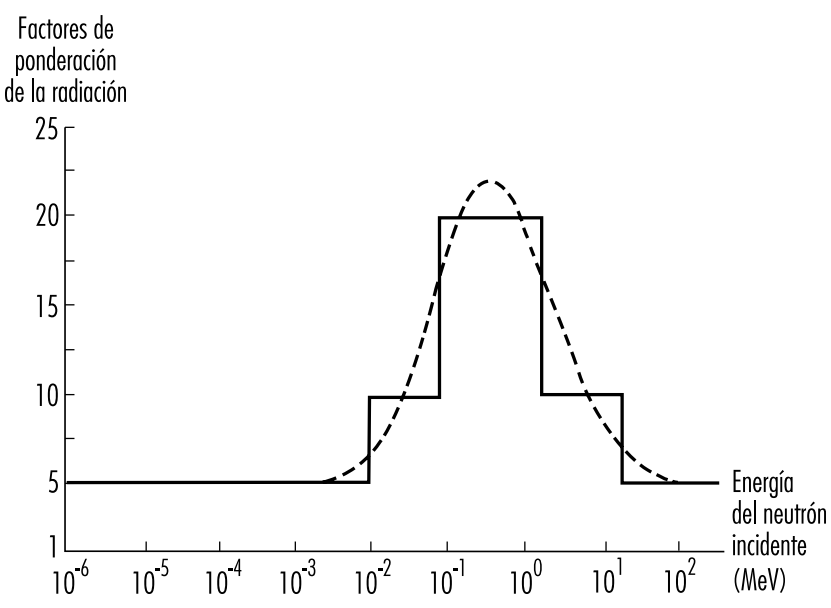

Tabla 48.2 - Factores de ponderación de tejidos $\mathrm{w}_{T}{ }^{1}$.

$\begin{array}{ll}\text { Tejido u órgano } & W_{T} \\ \text { Gónadas } & 0,20 \\ \text { Médula ósea (roja) } & 0,12 \\ \text { Colon } & 0,12 \\ \text { Pulmón } & 0,12 \\ \text { Estómago } & 0,12 \\ \text { Vejiga } & 0,05 \\ \text { Mama } & 0,05 \\ \text { Hígado } & 0,05 \\ \text { Esófago } & 0,05 \\ \text { Tiroides } & 0,05 \\ \text { Piel } & 0,01 \\ \text { Superficie ósea } & 0,01 \\ \text { Resto } & 0,052,3\end{array}$

1 Los valores se han deducido de una población de referencia con igual número de personas de ambos sexos y una amplia gama de edades. En la definición de dosis efectiva, los valores se aplican a trabajadores, a toda la población y a cualquier sexo.

2 A efectos de cálculo, el resto se compone de los tejidos y órganos adicionales siguientes: glándulas suprarrenales, cerebro, intestino grueso superior, intestino delgado, riñones, tejido muscular, páncreas, bazo, timo y útero. La lista incluye órganos que es probable que se irradien selectivamente. Se sabe que algunos órganos de la lista son susceptibles a la inducción de cáncer.

3 En los casos excepcionales en que uno de los teijdos u órganos restantes recibe una dosis equivaente superior a la dosis máxima en cualquiera de los doce órganos para los cuales se especifica un factor de ponderación, se debe aplicar un factor de ponderación de 0,025 a ese tejido u órgano y un factor de ponderación de 0,025 a la dosis media de los demás órganos del resto antes definido.

debe originar una dosis efectiva numéricamente igual a la suma de las dosis eficaces de todos los tejidos y órganos del cuerpo. Por lo tanto, la suma de todos los factores de ponderación tisulares se iguala a la unidad. En la Tabla 48.2 se ofrecen los valores de los factores de ponderación tisular.

\section{BIOLOGIA RADIOLOGICA YEFECTOS BIOLOGICOS}

\section{Arthur C. Upton}

Tras su descubrimiento por Roentgen en 1895, los rayos $X$ fueron introducidos con tanta rapidez para el diagnóstico y tratamiento de las enfermedades que casi en seguida comenzaron a encontrarse lesiones debidas a exposición excesiva a la radiación entre los primeros radiólogos, que todavía no eran conscientes de sus riesgos (Brown 1933). Las primeras lesiones fueron sobre todo reacciones cutáneas en las manos de quienes trabajaban con los primeros equipos de radiología, pero ya en el primer decenio se habían comunicado otros tipos de lesión, incluidos los primeros cánceres atribuidos a la radiación (Stone 1959).

En el curso del siglo transcurrido desde estos primeros hallazgos, el estudio de los efectos biológicos de la radiación onizante ha recibido un impulso permanente como consecuencia del uso cada vez mayor de la radiación en medicina, ciencia e industria, así como de las aplicaciones pacíficas y militares de la energía atómica. El resultado es que los efectos biológicos de la radiación se han investigados más a fondo que los de prácticamente cualquier otro agente ambiental. EI desarrollo de los conocimientos sobre los efectos de la radiación ha 
Figura 48.3 • Diferencias entre el poder penetrante en los tejidos de distintos tipos de radiación ionizante.

\begin{tabular}{|c|c|c|}
\hline $\begin{array}{l}\text { Tipo de } \\
\text { radiación }\end{array}$ & Fuente & Alcance en el tejido \\
\hline Alfa & $\begin{array}{l}{ }^{210} \mathrm{p}_{0} \\
5,3 \mathrm{MeV}\end{array}$ & Alcance $0.037 \mathrm{~mm}$ \\
\hline Beta & $\begin{array}{l}{ }^{14} \mathrm{C} \\
0,154 \mathrm{MeV} \\
\text { energía máxima }\end{array}$ & Älcance máximo 0,29 mm (en general menos) \\
\hline Beta & $\begin{array}{l}{ }^{32} \mathrm{p} \\
1,71 \mathrm{MeV} \\
\text { energía máxima }\end{array}$ & Alcance máximo 8 mm (en general menos) \\
\hline Gamma & $\begin{array}{l}125 \\
0,035 \mathrm{MeV}\end{array}$ & Distancia media a la colisión \\
\hline Gamma & $\begin{array}{l}{ }^{60} \mathrm{Co} \\
1,33 \mathrm{MeV}\end{array}$ & $\begin{array}{l}\text { Distancia media a la colisión } \\
164 \mathrm{~mm}\end{array}$ \\
\hline
\end{tabular}

Fuente: Shapiro 1972.

determinado el perfeccionamiento de medidas para proteger la salud humana contra muchos otros peligros medioambientales, además de la radiación.

\section{Naturaleza y mecanismos de los efectos biológicos de la radiación}

D eposición de energía. A diferencia de otras formas de radiación, la radiación ionizante es capaz de depositar suficiente energía localizada para arrancar electrones de los átomos con los que interactúa. Así, cuando la radiación colisiona al azar con átomos y moléculas al atravesar células vivas, da lugar a iones y radicales libres que rompen los enlaces químicos y provoca otros cambios moleculares que dañan las células afectadas. La distribución espacial de los fenómenos ionizantes depende del factor de ponderación radiológica, $w_{R}$ de la radiación (véanse la Tabla 48.1 y la Figura 48.3).

E fectos sobre el ADN. C ualquier molécula de la célula puede ser alterada por la radiación, pero el ADN es el blanco biológico más crítico, debido a la redundancia limitada de la información genética que contiene. U na dosis absorbida de radiación lo bastante grande para matar la célula media en división -2 gray (G y) - basta para originar centenares de lesiones en sus moléculas de ADN (Ward 1988). La mayoría de estas lesiones son reparables, pero las producidas por una radiación ionizante concentrada (por ejemplo, un protón o una partícula alfa) son en general menos reparables que las generadas por una radiación ionizante dispersada (por ejemplo, un rayo $X 0$ un rayo gamma) (Goodhead 1988). Por lo tanto, las radiaciones ionizantes concentradas (alta TLE) tienen por lo común un mayor efecto biológico relativo (EBR) que las radiaciones ionizantes dispersadas (baja T LE) en casi todas las formas de lesión (CIPR 1991).

E fectos sobre los genes. EI daño del ADN que queda sin reparar o es mal reparado puede manifestarse en forma de mutaciones, cuya frecuencia parece aumentar como una función lineal de la dosis, sin umbral, en alrededor de $10^{-5}$ a $10^{-6}$ por locus y por $\mathrm{G}$ y (NAS 1990). EI hecho de que la tasa de mutaciones parezca ser proporcional a la dosis se considera indicativo de que una sola partícula ionizante que atraviese el ADN es suficiente, en principio, para causar una mutación (NAS 1990). En las víctimas del
Figura 48.4 • Frecuencia de aberraciones cromosómicas dicéntricas en linfocitos humanos en relación con la dosis, la tasa de dosis y la calidad de la irradiación in vitro.

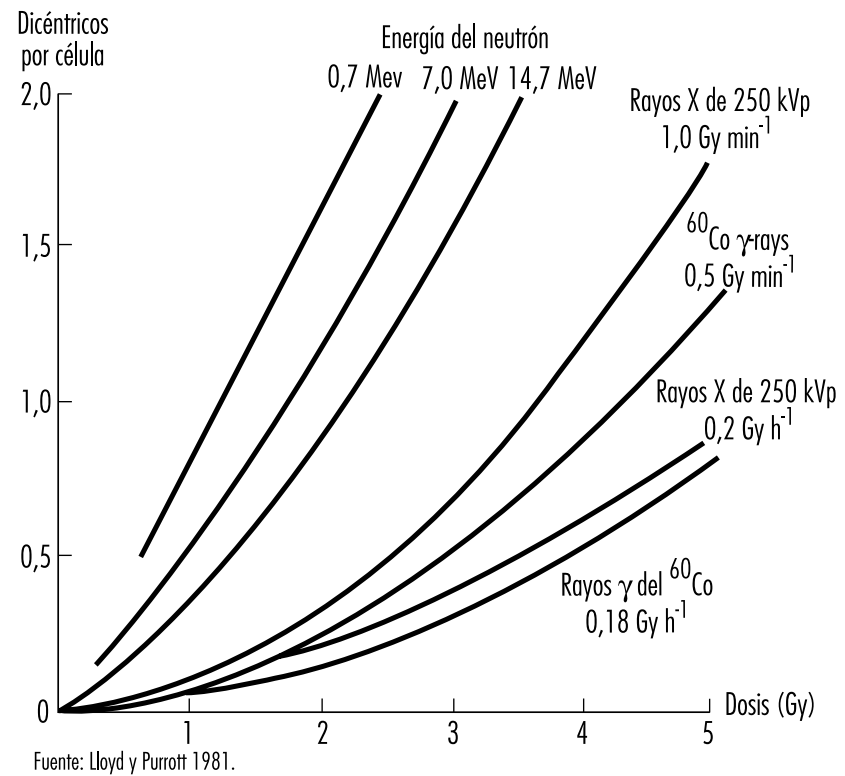

accidente de Chernóbil, la relación dosis-respuesta de las mutaciones de la glicoforina de células de la médula ósea es muy similar a la observada en supervivientes de la bomba atómica (Jensen, L anglois y Bigbee 1995).

E fectos sobre los cromosomas. Las lesiones por radiación del aparato genético pueden causar también cambios en el número y la estructura de los cromosomas, modificaciones cuya frecuencia se ha observado que aumenta con la dosis en trabajadores expuestos, en supervivientes de la bomba atómica y en otras personas expuestas a la radiación ionizante. La relación dosis-respuesta para las aberraciones cromosómicas en linfocitos

Figura 48.5 - Inhibición mitótica inducida por rayos $X$ en células del epitelio corneal de ratas.

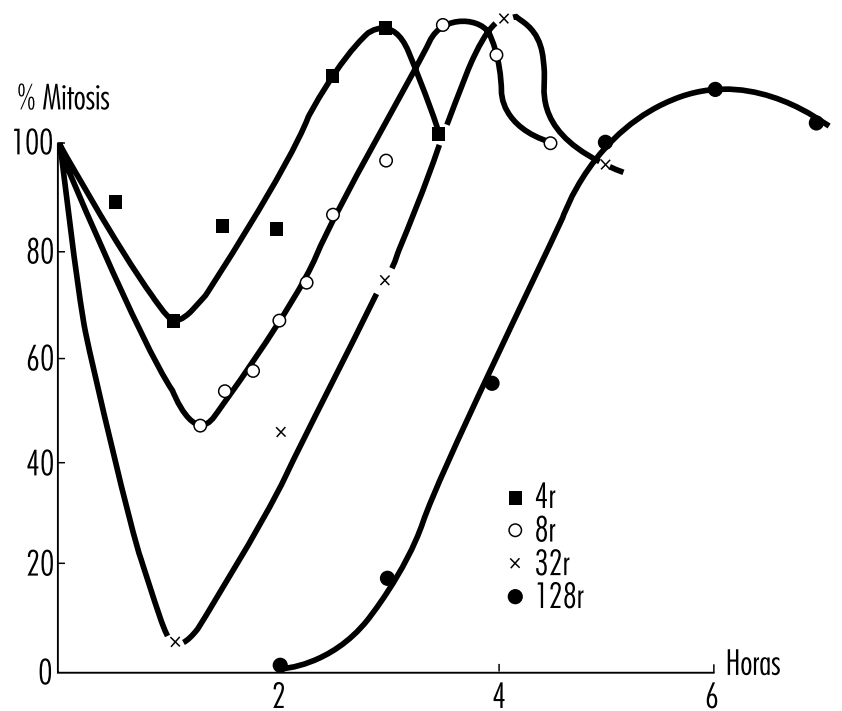

Fuente: Friedenwald y Sigelmen 1953 
Figura 48.6 • Curvas típicas dosis-supervivencia de células de mamíferos expuestas a rayos $X$ y neutrones rápidos.

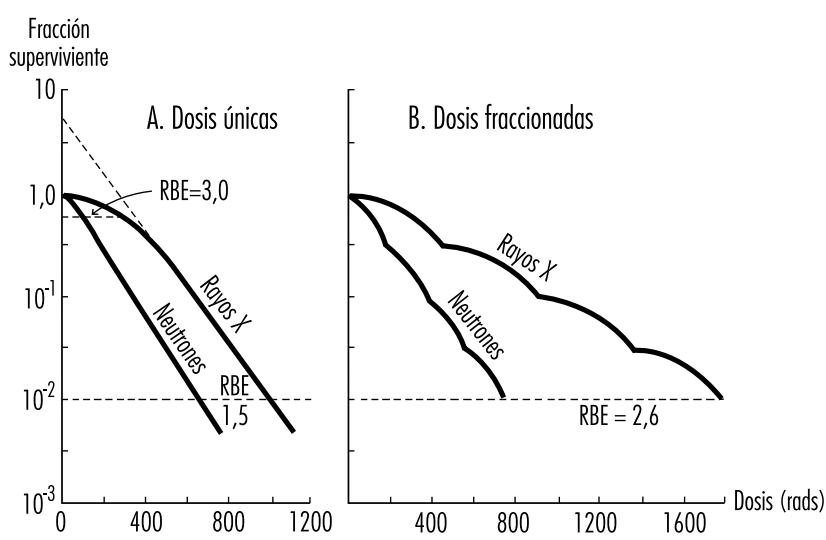

Fuente: Hall 1994.

de sangre humana (Figura 48.4) se ha determinado con bastante exactitud, de manera que la frecuencia de aberraciones en esas células puede servir de dosímetro biológico útil (O IEA 1986).

E fectos sobre la supervivencia celular. Entre las reacciones más tempranas a la irradiación figura la inhibición de la división celular, que aparece en seguida tras la exposición, aunque su grado y duración varían con la dosis (Figura 48.5). Si bien la inhibición de la mitosis es característicamente pasajera, la lesión radiológica de genes y cromosomas puede ser letal para las células en división, que en conjunto son muy sensibles a la radiación (CIPR 1984). M edida en términos de capacidad proliferativa, la supervivencia de las células en división tiende a disminuir exponencialmente con el aumento de la dosis, de manera que 1-2 G y bastan por lo general para reducir la población superviviente en alrededor del 50 \% (Figura 48.6).

E fectos sobre los tejidos. Las células maduras que no están en división son relativamente radiorresistentes, pero las que se dividen dentro de un tejido son radiosensibles, por lo que la irradiación intensiva puede matar un número suficiente para que el tejido se atrofie (Figura 48.7). La rapidez de esta atrofia depende de la dinámica de la población celular dentro del tejido afectado; es decir, en órganos caracterizados por un recambio celular lento, como el hígado y el endotelio vascular, el proceso es típicamente mucho más lento que en órganos caracterizados por un recambio celular rápido, como la médula ósea, la epidermis y la mucosa intestinal (CIPR 1984). Por otra parte, conviene subrayar que si el volumen de tejido irradiado es lo bastante pequeño, o si la dosis se acumula con la lentitud suficiente, la gravedad de la lesión puede reducirse notablemente por la proliferación compensatoria de las células supervivientes.

Figura 48.7 - Secuencia característica de acontecimientos en la patogenia de efectos no estocásticos de la radiación ionizante.

\begin{tabular}{|c|c|c|c|c|}
\hline MINUTOS & DE HORAS A DIAS & DE DIAS A SEMANAS & DE SEMANAS A MESES & DE MESES A AÑNOS \\
\hline $\begin{array}{c}\text { Daño } \\
\text { en células } \\
\text { germinales } \\
\text { en curso } \\
\text { de división }\end{array}$ & $\begin{array}{l}\text { Interferencia } \\
\text { en la } \\
\text { sustifución } \\
\text { de células } \\
\text { maduras }\end{array}$ & $\begin{array}{l}\text { Despoblación, } \\
\text { atrofia, } \\
\text { deterioro } \\
\text { de la función } \\
\text { del tejido }\end{array}$ & $\begin{array}{l}\text { Regeneración, } \\
\text { repoblación, } \\
\text { restauración } \\
\text { de la función } \\
\text { del tejido }\end{array}$ & $\begin{array}{l}\text { Fibrosis, } \\
\text { arteriosclerosis, } \\
\text { deterioro } \\
\text { de la función } \\
\text { del tejido }\end{array}$ \\
\hline
\end{tabular}

Fuente: Upton 1996.
Tabla 48.3 - Dosis umbral aproximadas de radiación $X$ terapéutica en fracciones convencionales que originan efectos clínicos no estocásticos perjudiciales en diversos tejidos.

$\begin{array}{llcc}\text { Organo } & \text { Lesión a los 5 años } & \begin{array}{c}\text { Dosis } \\ \text { umbral }\end{array} & \begin{array}{l}\text { Campo de } \\ \text { irradiación } \\ \text { (Gy)* }\end{array} \\ \text { (área) }\end{array}$




\section{Manifestaciones clínicas de la lesión}

T ipos de efectos. Los efectos de la radiación abarcan una amplia variedad de reacciones, que varían de modo notable en sus relaciones dosis-respuesta, manifestaciones clínicas, cronología y pronóstico (M ettler y U pton 1995). Los efectos suelen subdividirse por comodidad en dos amplios grupos: (1) efectos heredables, que se manifiestan en los descendientes de los individuos expuestos, y (2) efectos somáticos, que se manifiestan en los propios individuos expuestos. En estos últimos se incluyen los efectos agudos, que aparecen relativamente pronto después de la irradiación, así como los efectos tardíos (o crónicos), como el cáncer, que puede no aparecer hasta que han transcurrido meses, años 0 decenios.

E fectos agudos. Los efectos agudos de la radiación se deben sobre todo a la depleción de células progenitoras en los tejidos afectados (Figura 48.7), y sólo pueden inducirse por dosis lo bastante grandes para matar muchas de estas células (por ejemplo, Tabla 48.3). Por este motivo, tales efectos se consideran de naturaleza no estocástica, o determinista (CIPR 1984 y 1991), en contraste con los efectos mutágenos y cancerígenos de la radiación, que se consideran fenómenos estocásticos resultantes de alteraciones moleculares aleatorias en células individuales que aumentan como funciones lineales, sin umbral, de la dosis (NAS 1990; CIPR 1991).

Las lesiones agudas de los tipos que predominaban en los primeros trabajadores expuestos y en los pacientes tratados inicialmente con radioterapia han desaparecido prácticamente gracias a las mejoras introducidas en las precauciones de seguridad y en los métodos de tratamiento. Sin embargo, la mayoría de los pacientes tratados con radiación en la actualidad experimentan también alguna lesión del tejido normal irradiado. Además, siguen ocurriendo accidentes radiológicos graves. Por ejemplo, entre 1945 y 1987 se informó de unos 285 accidentes en reactores nucleares (excluido el de Chernóbil) ocurridos en diversos países, en los que resultaron irradiadas más de 1.350 personas, 33 de ellas con resultado mortal (L ushbaugh, Fry y R icks 1987). El accidente de C hernóbil, por sí solo, liberó material radiactivo suficiente para exigir la evacuación de decenas de millares de personas y animales domésticos del área circundante, y originó enfermedades radiológicas y quemaduras en más de 200 personas entre componentes de equipos de emergencia y bomberos, de las que 31 fallecieron (U N SCEAR 1988). Los efectos a largo plazo del material radiactivo liberado sobre la salud no pueden predecirse con certeza, pero las estimaciones de los riesgos resultantes de efectos cancerígenos, basadas en modelos de incidencia de dosis sin umbral (comentados a continuación), suponen que pueden producirse hasta 30.000 muertes adicionales por cáncer en la población del hemisferio norte durante los 70 próximos años a consecuencia del accidente, aunque es probable que los casos adicionales de cáncer en cualquier país sean demasiado escasos para permitir su detección epidemiológica (U SD O E 1987).

M enos catastróficos, pero mucho más numerosos que los accidentes de reactores, han sido los accidentes en que han intervenido fuentes de rayo gamma médicas e industriales, que también han sido causa de lesiones y pérdida de vidas. Por ejemplo, la eliminación inadecuada de una fuente de radioterapia de cesio 137 en Goiânia, Brasil, en 1987 originó la irradiación de docenas de víctimas confiadas, cuatro de las cuales murieron (UNSCEAR 1993).

Una exposición amplia de las lesiones por radiación escapa al ámbito de esta revisión, pero las reacciones agudas de los tejidos más radiosensibles son de interés general, por lo que se describen brevemente en las secciones siguientes.

Piel. Las células de la capa germinal de la epidermis son muy sensibles a la radiación. En consecuencia, la rápida exposición de la piel a una dosis de 6 Sv o más provoca eritema (enrojecimiento) de la zona expuesta, que aparece dentro del primer día, suele durar unas cuantas horas y va seguido al cabo de dos a cuatro semanas de una o más oleadas de un eritema más profundo y prolongado, así como de depilación (pérdida de pelo). Si la dosis supera los 10 a $20 \mathrm{~Sv}$, en dos o cuatro semanas pueden surgir ampollas, necrosis y ulceración, seguidas de fibrosis de la dermis y los vasos subyacentes, que pueden desembocar en atrofia y una segunda oleada de ulceración meses 0 años después (CIPR 1984).

M édula ósea y tejido linfoide. Los linfocitos también son muy radiosensibles; una dosis de 2 a 3 Sv irradiada en poco tiempo a todo el cuerpo puede destruir un número suficiente de ellos para que disminuya el recuento de linfocitos periféricos y la respuesta inmunitaria se deteriore en pocas horas (UN SCEAR 1988). Las células hematopoyéticas de la médula ósea tienen una sensibilidad similar a la radiación y su depleción con una dosis comparable es suficiente para causar granulocitopenia y trombocitopenia en las tres a cinco semanas siguientes. Si la dosis es mayor, estas disminuciones del recuento de granulocitos y plaquetas pueden ser lo bastante graves para originar hemorragia o una infección mortal (Tabla 48.4).

Intestino. Las células progenitoras del epitelio que reviste el intestino delgado también tienen extraordinaria sensibilidad a la

Tabla 48.4 • Formas y características principales del síndrome de radiación agudo.

\begin{tabular}{|c|c|c|c|c|}
\hline $\begin{array}{l}\text { Tiempo desde la } \\
\text { irradiación }\end{array}$ & $\begin{array}{l}\text { Forma } \\
\text { cerebral } \\
\text { (>50 Gy) }\end{array}$ & $\begin{array}{l}\text { Forma } \\
\text { gastro- } \\
\text { intestinal } \\
\text { (10-20 Gy) }\end{array}$ & $\begin{array}{l}\text { Forma hemato- } \\
\text { poyética } \\
\text { (2-10 Gy) }\end{array}$ & $\begin{array}{l}\text { Forma } \\
\text { pulmonar } \\
\text { ( }>6 \text { Gy a } \\
\text { pulmones) }\end{array}$ \\
\hline Primer día & náuseas & náuseas & náuseas & náuseas \\
\hline & $\begin{array}{l}\text { vómitos } \\
\text { diarrea } \\
\text { cefalea } \\
\text { desorien- } \\
\text { tación } \\
\text { ataxia } \\
\text { coma } \\
\text { convulsiones } \\
\text { muerte }\end{array}$ & $\begin{array}{l}\text { vómitos } \\
\text { diarrea }\end{array}$ & $\begin{array}{l}\text { vómitos } \\
\text { diarrea }\end{array}$ & vómitos \\
\hline Segunda semana & & $\begin{array}{l}\text { náuseas } \\
\text { vómitos } \\
\text { diarrea } \\
\text { fiebre } \\
\text { eritema } \\
\text { postración } \\
\text { muerte }\end{array}$ & & \\
\hline $\begin{array}{l}\text { Tercera a sexta } \\
\text { semanas }\end{array}$ & & & $\begin{array}{l}\text { debilidad } \\
\text { fatiga } \\
\text { anorexia } \\
\text { fiebre } \\
\text { hemorragia } \\
\text { epilación } \\
\text { recuperación (?) } \\
\text { muerte (?) }\end{array}$ & \\
\hline $\begin{array}{l}\text { Segundo a octavo } \\
\text { meses }\end{array}$ & & & & $\begin{array}{l}\text { tos } \\
\text { disnea } \\
\text { fiebre } \\
\text { dolor } \\
\text { torácico } \\
\text { fallo } \\
\text { respira- } \\
\text { torio (?) }\end{array}$ \\
\hline
\end{tabular}

Fuente: UNSCEAR 1988 
radiación. La exposición aguda a 10 Sv disminuye su número en grado suficiente para causar la denudación de las vellosidades intestinales suprayacentes en unos días (CIPR 1984; UNSCEAR 1988). La denudación de una superficie grande de la mucosa puede dar lugar a un síndrome fulminante similar a la disentería que causa rápidamente la muerte (Tabla 48.4).

Gónadas. Los espermatozoides maduros pueden sobrevivir a dosis grandes (100 Sv), pero los espermatogonios son tan radiosensibles que una dosis de sólo 0,15 Sv aplicada rápidamente a ambos testículos basta para causar oligospermia, y una dosis de 2 a 4 Sv puede provocar esterilidad permanente. También los oocitos son radiosensibles. U na dosis rápida de 1,5 a 2,0 Sv aplicada a ambos ovarios origina esterilidad temporal, y una dosis mayor, esterilidad permanente, en función de la edad de la mujer en el momento de la exposición (CIPR 1984).

A parato respiratorio. El pulmón no es muy radiosensible, pero la exposición rápida a una dosis de 6 a 10 Sv puede hacer que en la zona expuesta se desarrolle neumonía aguda en el plazo de uno a tres meses. Si se afecta un volumen grande de tejido pulmonar, el proceso puede originar insuficiencia respiratoria al cabo de unas semanas, o conducir a fibrosis pulmonar y cor pulmonale meses o años después (CIPR 1984; UNSCEAR 1988).

Cristalino del ojo. Las células del epitelio anterior del cristalino, que continúan dividiéndose toda la vida, son relativamente radiosensibles. El resultado es que una exposición rápida del cristalino a una dosis superior a 1 Sv puede generar en unos meses la formación de una opacidad polar posterior microscópica; y 2 a 3 Sv recibidos en una sola exposición breve (o la exposición a 5,5 a 14 Sv acumulada a lo largo de meses) pueden producir cataratas que dificulten la visión (CIPR 1984).

0 tros tẹidos. En comparación con los tejidos ya mencionados, la sensibilidad de otros tejidos del cuerpo a la radiación es en general bastante inferior (por ejemplo, Tabla 48.4); pero, como se verá a continuación, el embrión constituye una notable excepción. También conviene destacar que la radiosensibilidad de cualquier tejido aumenta cuando se encuentra en estado de crecimiento rápido (CIPR 1984).

Lesión radiológica de todo el cuerpo. La exposición rápida de una parte importante del cuerpo a una dosis superior a $1 \mathrm{G}$ y puede producir el síndrome de radiación agudo, que comprende: (1) una fase inicial prodrómica, caracterizada por malestar general, anorexia, náuseas y vómitos, (2) seguida de un período latente, (3) una segunda fase (principal) de enfermedad y (4) por último, la recuperación o la muerte (Tabla 48.4). L a fase principal de la enfermedad adopta por lo general una de las formas siguientes, según la localización predominante de la lesión radiológica: (1) hematológica, (2) gastrointestinal, (3) cerebral o (4) pulmonar (Tabla 48.4).

Lesión radiológica localizada. A diferencia de las manifestaciones clínicas de la lesión radiológica aguda de todo el cuerpo, que suelen ser dramáticas e inmediatas, la reacción a la irradiación muy localizada, tanto si procede de una fuente de radiación externa como de un radionucleido depositado en el interior del cuerpo, tiende a evolucionar con lentitud y a producir pocos síntomas o signos a menos que el volumen de tejido irradiado y/o la dosis sean relativamente grandes (por ejemplo, Tabla 48.4).

Efectos de los radionucleidos. Algunos radionucleidos-por ejemplo, el tritio $\left({ }^{3} \mathrm{H}\right)$, el carbono $14\left({ }^{14} \mathrm{C}\right)$ y el cesio 137 $\left({ }^{137} \mathrm{Cs}\right)$ - tienden a distribuirse sistémicamente y a irradiar la totalidad del cuerpo, mientras que lo característico de otros radionucleidos es que sean captados por y se concentren en órganos específicos, donde producen lesiones localizadas. Por ejemplo, el radio y estroncio $90\left({ }^{90} \mathrm{Sr}\right)$ se depositan sobre todo en los huesos, por lo que lesionan primordialmente los tejidos del esqueleto, mientras que el yodo radiactivo se concentra en la glándula tiroides, localización principal de cualquier lesión resultante (Stannard 1988: M ettler y U pton 1995).

\section{Efectos cancerígenos}

Características generales. La carcinogenicidad de la radiación ionizante, que se manifestó por primera vez a principios de este siglo cuando aparecieron cánceres de la piel y leucemias en las primeras personas que trabajaron con la radiación (U pton 1986), ha sido documentada desde entonces sin lugar a dudas por los excesos proporcionales a las dosis de numersosos tipos de neoplasias en pintores de esferas con radio, en mineros de galerías de roca viva, en supervivientes de la bomba atómica, en pacientes sometidos a radioterapia y en animales irradiados en experimentos de laboratorio (U pton 1986; NAS 1990).

L os tumores benignos y malignos inducidos por la irradiación se caracterizan porque tardan años o decenios en manifestarse y no presentan ningún rasgo conocido que permita distinguirlos de los producidos por otras causas. Es más, con pocas excepciones, su inducción sólo ha podido detectarse después de dosis equivalentes relativamente grandes $(0,5 \mathrm{~Sv})$, y ha variado con el tipo de neoplasia, así como con la edad y sexo de las personas expuestas (NAS 1990).

M ecanismos. Los mecanismos moleculares de la cancernogénesis radiológica todavía no se han determinado con todo detalle, pero en animales de laboratorio y en células cultivadas se ha observado que los efectos cancerígenos de la radiación incluyen efectos iniciadores, efectos promotores y efectos sobre la progresión de la neoplasia, que dependen de las condiciones experimentales en cuestión (NAS 1990). Los efectos parecen incluir también la activación de oncogenes y/ o la inactivación 0 pérdida de genes supresores de tumores en muchas ocasiones, por no decir en todas ellas. Además, los efectos cancerígenos de la radiación se parecen a los de los cancerígenos químicos en que también son modificables por hormonas, variables nutricionales y otros factores modificadores (NAS 1990). Por otra parte, hay que destacar que los efectos de la radiación pueden ser aditivos, sinérgicos 0 antagonistas con los de los agentes cancerígenos químicos, y que dependen de las sustancias químicas específicas y de las condiciones de exposición en cuestión (UNSCEAR 1982 y 1986).

Relación dosis-efecto. Los datos existentes no bastan para describir de modo inequívoco la relación dosis-incidencia de cualquier tipo de neoplasia o para definir durante cuánto tiempo tras la irradiación continuará siendo elevado el riesgo de un tumor en una población expuesta. Por lo tanto, los riesgos atribuibles a una irradiación de bajo nivel sólo pueden estimarse por extrapolaciones, basadas en modelos que incorporan hipótesis sobre dichos parámetros (NAS 1990). De los diversos modelos de dosis-efecto que se han utilizado para estimar los riesgos de la irradiación de bajo nivel, el que se ha considerado que se ajusta mejor a los datos disponibles es de la forma:

$$
R(D)=R_{0}[1+f(D) \cdot g(b)]
$$

donde $R_{0}$ denota el riesgo básico en función de la edad de fallecimiento por un determinado tipo de cáncer, $\mathrm{D}$ la dosis de radiación, $f(D)$ una función de la dosis que es cuadrático-lineal para la leucemia y lineal para algunos otros tipos de cáncer y $g(b)$ es una función de riesgo dependiente de otros parámetros, como el sexo, la edad en el momento de la exposición y el tiempo transcurrido desde ésta (NAS 1990). 
Tabla 48.5 - Riesgos estimados de contraer cáncer durante la vida atribuibles a una irradiación rápida de $0,1 \mathrm{~Sv}$.

\begin{tabular}{lcc} 
Tipo o lugar del cáncer & \multicolumn{2}{c}{ Exceso de muertes por cáncer por 100.000} \\
& $\left(n^{0}\right)$ & $(\%)^{*}$ \\
Estómago & 110 & 18 \\
Pulmón & 85 & 3 \\
Colon & 85 & 5 \\
Leucemia (excluida LLC) & 50 & 10 \\
Vejiga urinaria & 30 & 5 \\
Esófago & 30 & 10 \\
Mama & 20 & 1 \\
Hígado & 15 & 8 \\
Gónadas & 10 & 2 \\
Tiroides & 8 & 8 \\
Osteosarcoma & 5 & 5 \\
Piel & 2 & 2 \\
Resto & 50 & 1 \\
Total & 500 & 2 \\
* Aumento porcentual de la expectativa "de fondo" en una población no irradiada. \\
Fuente: ClPR 1991.
\end{tabular}

Modelos sin umbral de este tipo se han aplicado a datos epidemiológicos de los supervivientes japoneses de la bomba atómica y a otras poblaciones irradiadas para deducir estimaciones de los riesgos de por vida de diferentes formas de cáncer inducido por radiación (por ejemplo, Tabla 48.5). Pero estas estimaciones han de interpretarse con precaución cuando se intenta predecir los riesgos de cáncer atribuibles a dosis pequeñas o que se acumulan a lo largo de semanas, meses 0 años, puesto que los experimentos con animales de laboratorio han demostrado que la potencia cancerígena de los rayos $X$ y gamma disminuye hasta en un orden de magnitud cuando la exposición es muy prolongada. En realidad, como se ha subrayado en otro lugar (NAS 1990), los datos disponibles no excluyen la posibilidad de que haya un umbral en el rango de los milisievert (mSv) de dosis equivalente, por debajo del cual la radiación carecería de carcinogenicidad.

También conviene mencionar que las estimaciones tabuladas se basan en promedios de población y no son aplicables necesariamente a cualquier individuo; es decir, la susceptibilidad a determinados tipos de cáncer (por ejemplo, cánceres de tiroides y mama) es mucho mayor en niños que en adultos, y la susceptibilidad a determinados cánceres aumenta también en asociación con algunas alteraciones hereditarias, como el retinoblastoma y el síndrome de carcinoma de células nevoides basales (UNSCEAR 1988, 1994; NAS 1990). A pesar de estas diferencias de susceptibilidad, se han propuesto estimaciones basadas en poblaciones para usarlas en casos de indemnización como base para calibrar la probabilidad de que un cáncer que aparezca en una persona irradiada con anterioridad pueda haber sido causado por la exposición en cuestión (NIH 1985).

E valuación del riesgo con dosis bajas. H asta ahora, los estudios epidemiológicos para determinar si los riesgos de cáncer derivados de exposiciones a radiación de bajo nivel varían realmente en función de la dosis del modo pronosticado por las estimaciones anteriores no han llegado a conclusiones definitivas. Las poblaciones de zonas en las que existen niveles elevados de radiación de fondo natural no presentan aumentos de las tasas de cáncer atribuibles a ella de modo definitivo (NAS 1990; UNSCEAR 1994); por el contrario, algunos estudios han sugerido incluso una relación inversa entre niveles de radiación de fondo y tasas de cáncer, lo que algunos observadores interpretan como demostración de la existencia de efectos beneficiosos (u horméticos) de la irradiación de bajo nivel, acordes con las respuestas adaptativas de determinados sistemas celulares (UNSCEAR 1994). Ahora bien, la importancia de la relación inversa es cuestionable, puesto que no ha persistido tras controlar los efectos de variables que pudieran inducir a confusión (NAS 1990). De manera similar, en los trabajadores expuestos actualmente a la ración - salvo determinados grupos de mineros en galerías de roca viva (NAS 1994; Lubin, Boice y Edling 1994) - ya no se detectan aumentos de las tasas de cánceres distintos de la leucemia (UNSCEAR 1994), gracias a los avances en protección radiológica; por lo demás, las tasas de leucemia en estos trabajadores son coherentes con las estimaciones antes tabuladas (IARC 1994). En resumen, podemos concluir que los datos disponibles en la actualidad son coherentes con las estimaciones tabuladas (Tabla 48.5), que indican que menos del $3 \%$ de los casos de cáncer en la población general son atribuibles a radiación natural de fondo (NAS 1990; IARC 1994), aunque hasta el $10 \%$ de los cánceres de pulmón pueden atribuirse al radón de los recintos cerrados (NAS 1990; Lubin, Boice y Edling 1994).

Se ha observado que los elevados niveles de lluvia radiactiva procedente de una prueba de armas termonucleares realizada en Bikini en 1954 produjeron un aumento de la frecuencia de cáncer de tiroides en los habitantes de las I slas M arshall proporcional a la dosis que recibieron en la glándula tiroides cuando eran niños (Robbins y Adams 1989). De modo similar, se ha informado de que entre los niños que vivían en zonas de Bielorrusia y U crania contaminadas por los radionucleidos liberados en el accidente de Chernóbil se ha manifestado un aumento de incidencia del cáncer de tiroides (Prisyazhuik, Pjatak y Buzanov 1991; K asakov, D emidchik y Astakhova 1992), pero los hallazgos están en desacuerdo con los del Proyecto Internacional Chernóbil, que no encontró un exceso de nódulos tiroideos benignos o malignos en los niños que vivían en las zonas más contaminadas en torno a Chernóbil (M ettler, Williamson y R oyal 1992). Falta por determinar la base de la discrepancia, y si el exceso detectado puede ser únicamente resultado del aumento de la vigilancia. A este respecto, hay que resaltar que los niños del suroeste de U tah y Nevada que estuvieron expuestos a la lluvia radiactiva de las pruebas de armas nucleares en N evada durante el decenio de 1950 han presentado aumento en la frecuencia de todo tipo de cáncer de tiroides (K erber y cols. 1993), y la incidencia de la leucemia aguda parece haberse elevado en los niños que fallecieron entre 1952 y 1957, el período de máxima exposición a la lluvia radiactiva (Stevens y cols. 1990).

También se ha sugerido la posibilidad de que el exceso de leucemia entre los niños que vivían en la proximidad de centrales nucleares del Reino U nido pueda haber sido provocado por la radiactividad liberada por las centrales. No obstante, se estima que el incremento de la dosis total de radiación recibida por esos niños ha sido inferior al $2 \%$, de donde se infiere que hay otras explicaciones más probables (Doll, Evans y Darby 1994). La existencia de excesos comparables de leucemia infantil en lugares del R eino U nido que carecen de instalaciones nucleares, pero que por lo demás se parecen a los emplazamientos nucleares en que también han experimentado grandes influjos de población en los últimos tiempos, denota una etiología ineficaz de las agrupaciones de casos de leucemia observadas (K inlen 1988; D oll, Evans y Darby 1994). También se ha 
sugerido otra hipótesis (a saber, que las leucemias en cuestión pueden haber sido causadas por la irradiación profesional recibida por los padres de los niños afectados) basada en los resultados de un estudio de casos y controles (Gardner y cols. 1990), pero esta hipótesis se desecha en general por motivos que se explican en la sección siguiente.

\section{Efectos hereditarios}

Los efectos hereditarios de la irradiación, aunque bien documentados en otros organismos, no se han observado todavía en seres humanos. Por ejemplo, el estudio intensivo de más de 76.000 hijos de supervivientes japoneses de la bomba atómica, llevado a cabo a lo largo de cuatro decenios, no ha logrado desvelar efectos hereditarios de la radiación en esta población, medidos por desenlaces indeseados de la gestación, muertes neonatales, procesos malignos, reordenaciones cromosómicas equilibradas, aneuploidia de los cromosomas sexuales, alteraciones de los fenotipos de proteínas del suero o eritrocitos, cambios en la relación de sexos 0 alteraciones del crecimiento y del desarrollo ( $\mathrm{N}$ eel, Schull y Awa 1990). Por lo tanto, las estimaciones de los riesgos de efectos hereditarios de la radiación deben basarse en gran medida en la extrapolación a partir de hallazgos en ratones de laboratorio y otros animales de experimentación (NAS 1990; UNSCEAR 1993).

De los datos experimentales y epidemiológicos disponibles se deduce que la dosis necesaria para doblar la tasa de mutaciones hereditarias en células embrionarias humanas debe ser de 1,0 Sv como mínimo (NAS 1990; U NSCEAR 1993). En consecuencia, se estima que menos del $1 \%$ de las enfermedades determinadas genéticamente en la población humana pueden atribuirse a la irradiación de fondo natural (Tabla 48.6).

Tabla 48.6 - Frecuencias estimadas de trastornos heredables que pueden atribuirse a la irradiación ionizante natural de fondo.

\begin{tabular}{|c|c|c|c|}
\hline \multirow[t]{2}{*}{ Tipo de trastorno } & \multirow[t]{2}{*}{$\begin{array}{l}\text { Prevalencia } \\
\text { natural } \\
\text { (por millón } \\
\text { de nacidos vivos) }\end{array}$} & \multicolumn{2}{|c|}{$\begin{array}{l}\text { Contribución de la radiación de } \\
\text { fondo natural }{ }^{1} \\
\text { (por millón de nacidos vivos) })^{2}\end{array}$} \\
\hline & & $\begin{array}{l}\text { Primera } \\
\text { generación }\end{array}$ & $\begin{array}{l}\text { Generaciones } \\
\text { hasta } \\
\text { el equilibrio }\end{array}$ \\
\hline $\begin{array}{l}\text { Dominante } \\
\quad \text { autosómico }\end{array}$ & 180.000 & $20-100$ & 300 \\
\hline Ligado a X & 400 & $<1$ & $<15$ \\
\hline Recesivo & 2.500 & $<1$ & aumento muy lento \\
\hline Cromosómico & 4.400 & $<20$ & aumento muy lento \\
\hline Defectos congénitos & $20.000-30.000$ & 30 & $30-300$ \\
\hline \multicolumn{4}{|c|}{ Otros trastornos de etiología compleja: } \\
\hline Cardiopatía & 600.000 & no estimado 4 & no estimado 4 \\
\hline Cáncer & 300.000 & no estimado ${ }^{4}$ & no estimado ${ }^{4}$ \\
\hline Otros seleccionados & 300.000 & no estimado 4 & no estimado 4 \\
\hline \multicolumn{4}{|c|}{ 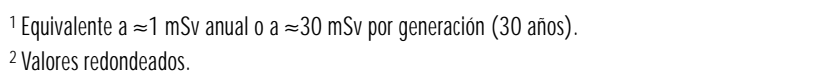 } \\
\hline \multicolumn{4}{|c|}{$\begin{array}{l}3 \text { Tras cientos de generaciones, la adición de mutaciones desfavorables inducidas por la radiación se ve } \\
\text { compensada con el tiempo por su pérdida en la población, de donde resultará un "equilibrio" genético. } \\
{ }^{4} \text { Faltan estimaciones cuantitativas de riesgo, a causa de la incertidumbre sobre el componente muta- } \\
\text { cional de la(s) enfermedad(es) indicada(s). } \\
\text { Fuente: National Research Council } 1990 \text {. }\end{array}$} \\
\hline
\end{tabular}

Como se ha mencionado antes, los resultados de un estudio de casos y controles han sugerido la hipótesis de que el exceso de leucemia y del linfoma no H odgkin en jóvenes residentes en la localidad de Seascale fue resultado de los efectos oncogénicos hereditables causados por la irradiación profesional de sus padres en la instalación nuclear de Sellafield (Gardner y cols. 1990). Sin embargo, contradicen esta hipótesis los argumentos siguientes:

1. La ausencia de cualquier exceso comparable en gran número de niños nacidos fuera de Seascale de padres que habían recibido dosis profesionales similares, o incluso mayores, en la misma central nuclear (W akeford y cols. 1994a)

2. La falta de excesos similares en niños franceses $(\mathrm{Hill}$ y LaPlanche 1990), canadienses (M CLaughlin y cols. 1993) 0 escoceses (K inlen, Clarke y Balkwill 1993) nacidos de padres con exposiciones profesionales comparables

3. La falta de excesos en los hijos de supervivientes de la bomba atómica (Y oshimoto y cols. 1990)

4. La falta de excesos en condados de EE.UU. donde hay centrales nucleares instaladas (J ablon, $\mathrm{H}$ rubec y Boice 1991)

5. El hecho de que la frecuencia de mutaciones inducidas por radiación que implica la interpretación sea mucho más elevada que las tasas observadas (W akeford y cols. 1994b).

Por lo tanto, los datos de conjunto disponibles no respaldan la hipótesis de la irradiación de gónadas paternas (Doll, Evans y D arby 1994; Little, C harles y Wakeford 1995).

\section{Efectos de la irradiación prenatal}

La radiosensibilidad es relativamente alta en toda la vida prenatal, pero los efectos de una dosis determinada varían de modo notable y dependen de la fase evolutiva del embrión o feto en el momento de la exposición (UNSCEAR 1986). Durante el período anterior a la implantación, el embrión es especialmente sensible a la muerte por irradiación, mientras que durante las fases críticas de la organogénesis es sensible a la inducción de malformaciones y otras alteraciones del desarrollo (Tabla 48.7). Estos últimos efectos se demuestran de modo dramático por el aumento proporcional a la dosis de la frecuencia de retraso mental grave (Figura 48.8) y el descenso proporcional a la dosis

\section{Figura 48.8 • Frecuencia del retraso mental grave en relación con la dosis de radiación en supervivientes de la bomba atómica que recibieron irradiación prenatal.}

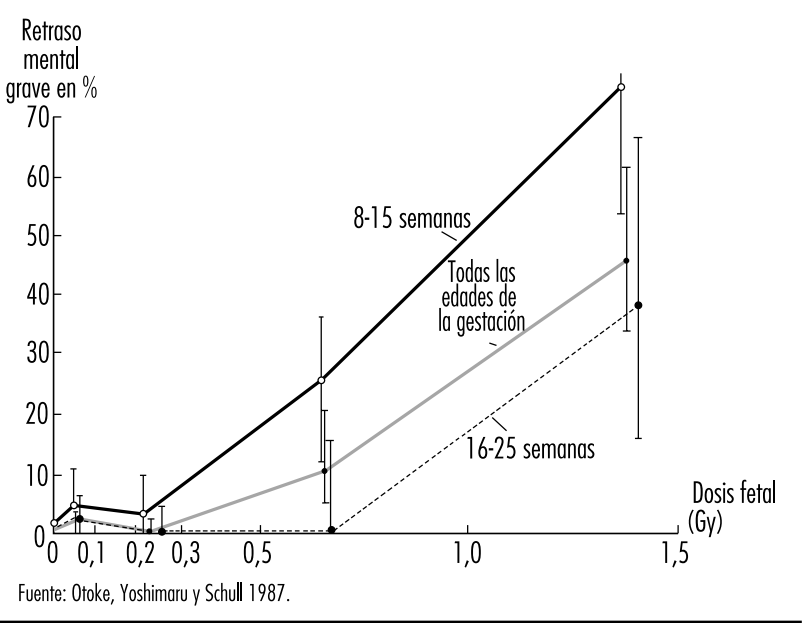


Tabla 48.7 - Principales anomalías del desarrollo producidas por irradiación prenatal.

\begin{tabular}{|c|c|c|}
\hline \multicolumn{3}{|l|}{ Cerebro } \\
\hline Anencefalia & Porencefalia & Microcefalia* \\
\hline Encefalocele & Mongolismo* & Bulbo reducido \\
\hline Atrofia cerebral & Retraso mental* & Neuroblastoma \\
\hline Acueducto estrecho & Hidrocefalia* & Dilatación de ventrículos* \\
\hline $\begin{array}{l}\text { Anomalías de médula } \\
\text { espinal* }\end{array}$ & $\begin{array}{l}\text { Anomalías de pares } \\
\text { craneales }\end{array}$ & \\
\hline \multicolumn{3}{|l|}{ Ojos } \\
\hline Anoftalmía & Microftalmía* & Microcórnea* \\
\hline Coloboma* & Iris deformado & Ausencia de cristalino \\
\hline Ausencia de retina & Párpados abiertos & Estrabismo* \\
\hline Nistagmo* & Retinoblastoma & Hipermetropía \\
\hline Glaucoma & Cataratas* & Ceguera \\
\hline Coriorretinitis* & Albinismo parcial & Anquilobléfaron \\
\hline \multicolumn{3}{|l|}{ Esqueleto } \\
\hline Atrofia general & Cráneo de tamaño reducido & Deformidades craneales* \\
\hline $\begin{array}{l}\text { Defectos de osificación } \\
\text { de la cabeza* }\end{array}$ & Cráneo abovedado & Cabeza estrecha \\
\hline Burbujas craneales & Fisura palatina* & Tórax en embudo \\
\hline Luxación de cadera & Espina bífida & Coxis deforme \\
\hline Pies deformes & Pie zambo* & Anomalías digitales* \\
\hline Calcáneo en valgo & Odontogénesis imperfecta* & Exostosis tibial \\
\hline Amelanogénesis* & Necrosis esclerotómica & \\
\hline \multicolumn{3}{|l|}{ Varios } \\
\hline Situs inversus & Hidronefrosis & Hidrouréter \\
\hline Hidrocele & Ausencia de riñón & Gónadas anormales* \\
\hline $\begin{array}{l}\text { Cardiopatía } \\
\text { congénita }\end{array}$ & Deformidades faciales & Alteraciones hipofisarias \\
\hline Deformidades de orejas & Alteraciones motoras & Necrosis dermatómicas \\
\hline Necrosis miotómicas & $\begin{array}{l}\text { Anormalidades de } \\
\text { pigmentación de la } \\
\text { piel }\end{array}$ & \\
\hline
\end{tabular}

* Estas anomalías se han observado en seres humanos expuestos a grandes dosis de radiación en el período prenatal y, por lo tanto, se han atribuido hipotéticamente a la irradiación.

Fuente: Brill and Forgotson 1964.

de las puntuaciones en la prueba del $\mathrm{Cl}$ en supervivientes de la bomba atómica que estuvieron expuestos entre las semanas octava y décimoquinta ( $y$, en menor medida, entre las semanas décimosexta y vigésimoquinta) (U N SCEAR 1986 y 1993).

La sensibilidad a los efectos cancerígenos de la radiación también parece ser relativamente alta en todo el período prenatal, a juzgar por la asociación entre cáncer infantil (incluida la leucemia) y exposición prenatal a rayos $X$ diagnósticos comunicada en estudios de casos y controles (NAS 1990). De los resultados de estos estudios se deduce que la irradiación prenatal puede originar un incremento del $4.000 \%$ por Sv del riesgo de leucemia y otros cánceres infantiles (U N SCEAR 1986; NAS 1990), lo que es un aumento bastante mayor que el atribuible a la irradiación posnatal (UNSCEAR 1988; NAS 1990). Aunque, paradójicamente, no se registrase ningún exceso de cáncer infantil en supervivientes de la bomba atómica irradiados en el período prenatal (Yoshimoto y cols. 1990), como se ha mencionado antes, fueron demasiado pocos estos supervivientes para excluir un exceso de la magnitud en cuestión.

\section{Resumen y conclusiones}

Los efectos perjudiciales de la radiación ionizante sobre la salud humana son de una gran diversidad, y abarcan desde lesiones con resultado fatal rápido a cánceres, defectos de nacimiento y trastornos hereditarios que aparecen meses, años o decenios después. La naturaleza, frecuencia y gravedad de los efectos dependen de la radiación en cuestión, así como de la dosis y las condiciones de exposición. La mayoría de esos efectos exigen niveles relativamente altos de exposición y sólo se encuentran, por lo tanto, en víctimas de accidentes, pacientes sometidos a radioterapia u otras personas que recibieron irradiaciones intensas. En cambio, se supone que los efectos genotóxicos y cancerígenos de la radiación ionizante aumentan en frecuencia como funciones lineales, sin umbral, de la dosis; por consiguiente, si bien no puede excluirse la existencia de umbrales para estos efectos, se supone que su frecuencia aumenta con cualquier nivel de exposición. Para la mayoría de los efectos de la radiación, la sensibilidad de las células expuestas varía según su tasa de proliferación y en relación inversa con su grado de diferenciación, por lo que el embrión y el niño en crecimiento son los más vulnerables.

\section{FUENTES DE RADIACION IONIZANTE}

Robert N. Cherry, Jr.

\section{Tipos de radiación ionizante}

\section{Partículas alfa}

Una partícula alfa es un conjunto de dos protones y dos neutrones estrechamente unidos. Es idéntica a un núcleo de helio $4\left({ }^{4} \mathrm{H}\right.$ e). De hecho, su destino último después de haber perdido la mayoría de su energía cinética es capturar dos electrones y convertirse en un átomo de helio.

L os radionucleidos emisores de partículas alfa son en general núcleos relativamente pesados. Casi todos los emisores alfa tienen números atómicos iguales o superiores al del plomo $\left({ }^{82} \mathrm{~Pb}\right)$. Cuando un núcleo se desintegra y emite una partícula alfa, su número atómico (el número de protones) y su número de neutrones disminuyen en dos, mientras que su número másico se reduce en cuatro. Por ejemplo, la desintegración alfa del uranio $238\left({ }^{238} \mathrm{U}\right)$ a torio $234\left({ }^{234} \mathrm{~T} \mathrm{~h}\right)$ se representa por:

$$
\begin{gathered}
{ }_{92}^{238} \mathrm{U}_{126} \rightarrow{ }_{90}^{234} \mathrm{Th}_{124}+\alpha \\
\alpha={ }_{2}^{4} \mathrm{He}_{2}
\end{gathered}
$$

El superíndice de la izquierda es el número másico (número de protones más neutrones), el subíndice de la izquierda es el número atómico (número de protones) y el subíndice de la derecha es el número de neutrones.

Los emisores alfa corrientes emiten partículas alfa con energías cinéticas entre unos 4 y 5,5 M eV. El alcance de estas partículas alfa en el aire no sobrepasa los $5 \mathrm{~cm}$ (véase la Figura 48.9). Se necesitan partículas alfa con una energía de $7,5 \mathrm{M} \mathrm{eV}$ para penetrar la epidermis (capa protectora de la piel, de 0,07 $\mathrm{mm}$ de espesor). Los emisores alfa no plantean por lo general ningún peligro de radiación externa. Sólo son peligrosos si se captan al interior del cuerpo. Como depositan su energía a corta 
Figura 48.9 • Relación entre alcance y energía de partículas alfa lentas en el aire a 15 y $760 \mathrm{~mm}$.

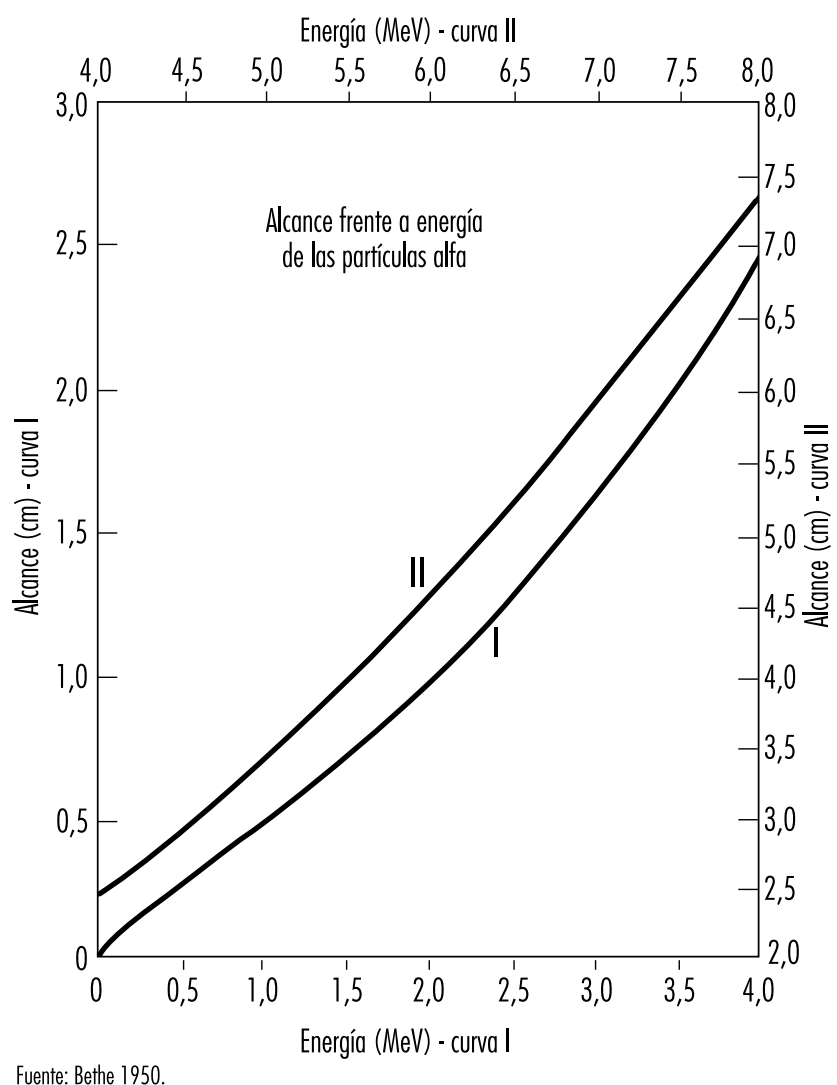

Fuente: Bethe 1950

distancia, las partículas alfa constituyen una radiación de alta transferencia lineal de energía (TLE) y tienen un factor de ponderación radiológica elevado, cuyo valor típico es $\mathrm{w}_{\mathrm{R}}=20$.

\section{Partículas beta}

Una partícula beta es un electrón o positrón muy energético. (El positrón es la antipartícula del electrón. Tiene la misma masa y la mayoría de las demás propiedades del electrón, salvo su carga, cuya magnitud es exactamente la misma que la del electrón, pero de signo positivo.) Los radionucleidos emisores beta pueden ser de peso atómico alto o bajo.

Los radionucleidos que tienen exceso de protones en comparación con nucleidos estables de número másico similar al suyo pueden desintegrarse cuando un protón del núcleo se convierte en neutrón. Cuando así sucede, el núcleo emite un positrón y una partícula extraordinariamente ligera y que muy rara vez interactúa llamada neutrino. (EI neutrino y su antipartícula carecen de interés en protección radiológica.) Cuando ha cedido la mayoría de su energía cinética, el positrón termina por colisionar con un electrón, con lo que se aniquilan ambos. La radiación de aniquilación producida es casi siempre la de dos fotones de 0,511 keV (kiloelectronvoltios) que se desplazan en sentidos separados por 180 grados. La desintegración típica con emisión de un positrón se representa por:

$$
{ }_{11}^{22} \mathrm{Na}_{11} \rightarrow{ }_{10}^{22} \mathrm{Ne}_{12}+\beta^{+}+\mathrm{v}
$$

donde el positrón está representado por $\beta^{+}$y el neutrino por v. Obsérvese que el nucleido resultante tiene el mismo número másico que el nucleido padre y un número atómico (de protones) menor en una unidad y un número de neutrones mayor en una unidad que los del nucleido original.

En la desintegración, la captura de un electrón compite con la pérdida de un positrón. En la desintegración con captura de electrón, el núcleo absorbe un electrón orbital y emite un neutrino. U na desintegración típica con captura de electrón viene dada por:

$$
{ }_{27}^{57} \mathrm{CO}_{30}+{ }_{-1}^{0} \mathrm{e}_{0} \rightarrow{ }_{26}^{57} \mathrm{Fe}_{31}+\mathrm{v}
$$

La captura de un electrón es posible siempre que el núcleo resultante tenga una energía total menor que la del núcleo inicial. En cambio, la desintegración con positrón exige que la energía total del átomo inicial sea mayor que la del átomo resultante en más de 1,02 M eV (dos veces la energía másica residual del positrón).

De manera similar a la desintegración con positrón y con captura de electrón, la desintegración con negatrón $\left(\beta^{-}\right)$ocurre en núcleos que tengan exceso de neutrones en comparación con núcleos estables del mismo número másico. En este caso, el núcleo emite un negatrón (electrón energético) y un antineutrino. U na desintegración típica con negatrón se representa por:

$$
{ }_{27}^{60} \mathrm{CO}_{33} \rightarrow{ }_{28}^{60} \mathrm{Ni}_{32}+\beta^{-}+\overline{\mathrm{V}}
$$

donde el negatrón se representa por $\beta^{-}$y el antineutrino por $\bar{v}$. Aquí, el núcleo resultante gana un protón a expensas de un neutrón, pero tampoco cambia su número másico.

La desintegración alfa es una reacción de dos cuerpos, de manera que las partículas se emiten con energías cinéticas discretas. En cambio, la desintegración beta es una reacción de tres cuerpos, de forma que las partículas beta se emiten en un espectro de energías. La energía máxima del espectro depende del radionucleido que se desintegra. La energía beta media del espectro es de alrededor de un tercio de la energía máxima (véase la Figura 48.10).

Las energías beta máximas típicas oscilan desde 18,6 keV para el tritio $\left({ }^{3} \mathrm{H}\right)$ a 1,71 M eV para el fósforo $32\left({ }^{32} \mathrm{P}\right)$.

El alcance de las partículas beta en el aire es de unos 3,65 m por $\mathrm{MeV}$ de energía cinética. Se necesitan partículas beta de $70 \mathrm{keV}$ de energía como mínimo para atravesar la epidermis. L as partículas beta son radiación de baja T LE.

\section{Radiación gamma}

La radiación gamma es radiación electromagnética emitida por un núcleo cuando experimenta una transición de un estado de energía más alta a un estado energético más bajo. El número de protones y neutrones del núcleo no varía en estas transiciones. EI

\section{Figura 48.10 • Espectro de energía de negatrones emitidos} por el ${ }^{32} \mathrm{P}$

Número relativo de

negatrones por unidad

de intervalo de energía

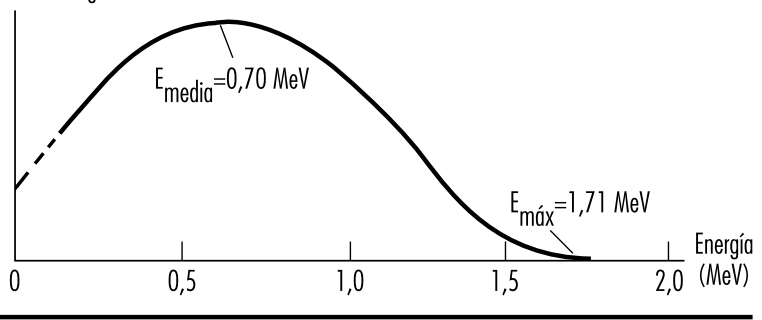


Figura 48.11 • Esquema de desintegración radiactiva del ${ }^{60} \mathrm{Co}$.

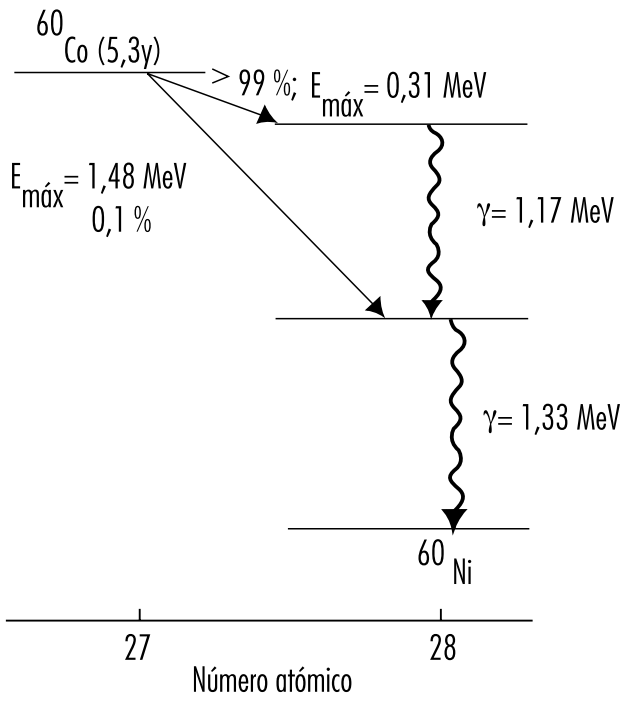

núcleo puede haber quedado en el estado de más energía después de una desintegración alfa o beta anterior. Es decir, los rayos gamma se emiten a menudo inmediatamente después de una desintegración alfa o beta. Los rayos gamma también pueden ser el resultado de la captura de un neutrón y de la dispersión inelástica de partículas subatómicas por núcleos. L os rayos gamma más energéticos se han observado en los rayos cósmicos.

En la Figura 48.11 se representa el esquema de desintegración del cobalto $60\left({ }^{60} \mathrm{Co}\right)$. M uestra una cascada de dos rayos gamma emitidos para transformarse en níquel $60\left({ }^{60} \mathrm{Ni}\right)$, con energías de 1,17 MeV y 1,33 M eV, después de la desintegración beta del ${ }^{60} \mathrm{C}$.

La Figura 48.12 ilustra el esquema de desintegración del molibdeno 99 ( ${ }^{99} \mathrm{M}$ o). O bsérvese que el núcleo de tecnecio 99 resultante $\left({ }^{99} \mathrm{Tc}\right)$ tiene un estado excitado que dura un tiempo excepcionalmente prolongado ( $t_{1 / 2}=6 \mathrm{~h}$ ). Un núcleo excitado de este tipo se denomina isómero. La mayoría de los estados nucleares excitados tienen períodos de semidesintegración comprendidos entre algunos picosegundos (ps) y 1 microsegundo $(\mu \mathrm{s})$.

La Figura 48.13 ilustra el esquema de desintegración del arsénico $74\left({ }^{74} \mathrm{As}\right)$, que demuestra que algunos radionucleidos se desintegran en más de una forma.

$M$ ientras que las partículas alfa y beta tienen alcances definidos en la materia, los rayos gamma experimentan una atenuación exponencial (si se pasa por alto la acumulación que resulta de la dispersión dentro de un material) a medida que atraviesan la materia. Cuando puede prescindirse de la acumulación, la atenuación de los rayos gamma viene dada por:

$$
I(x)=I(0) \cdot e^{-\mu x}
$$

donde I $(x)$ es la intensidad de los rayos gamma en función de la distancia $x$ en el material y $\mu$ es el coeficiente másico de atenuación. El coeficiente másico de atenuación depende de la energía de los rayos gamma y del material con el que interactúan los rayos gamma. Los valores del coeficiente másico de atenuación están tabulados en numerosos documentos de referencia. La Figura 48.14 muestra la absorción de rayos gamma en la materia en condiciones de buena geometría (puede ignorarse la acumulación)
Figura 48.12 • Esquema de desintegración radiactiva del ${ }^{99} \mathrm{Mo}$.

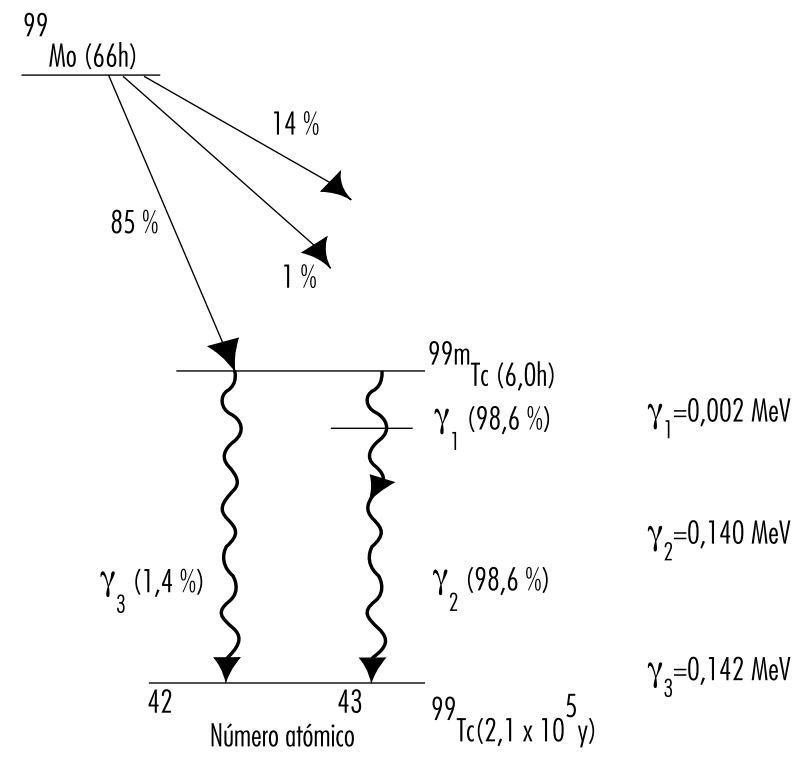

La acumulación tiene lugar cuando un haz ancho de rayos gamma interactúa con la materia. La intensidad medida en puntos dentro del material aumenta en relación con el valor esperado en "buena geometría" (haz estrecho) a causa de los rayos gamma que se dispersan por los lados del haz directo en el interior del dispositivo de medición. El grado de acumulación depende de la geometría del haz, del material y de la energía de los rayos gamma.

La conversión interna compite con la emisión gamma cuando un núcleo se transforma de un estado de más energía a otro de energía menor. En la conversión interna, en lugar de emitirse un rayo gamma desde el núcleo, se expulsa un electrón de una órbita interior del átomo. El electrón expulsado es ionizante

Figura 48.13 • Esquema de desintegración radiactiva del ${ }^{74} \mathrm{As}$, que ilustra los procesos competidores de emisión de negatrones, emisión de positrones y captura de electrones $\left(m_{0}\right.$ es la masa residual del electrón).

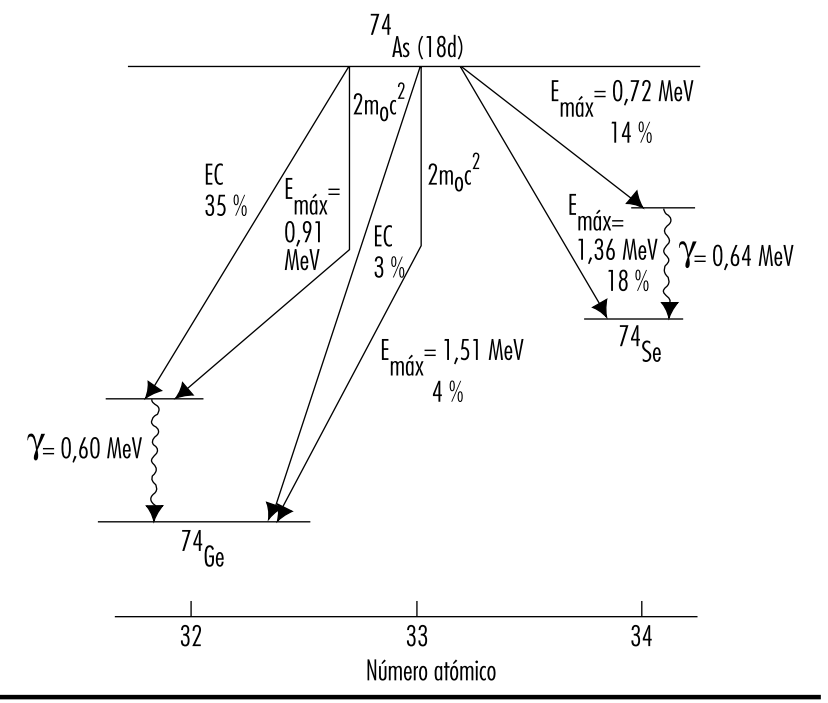


Figura 48.14 • Atenuación de rayos gamma de $667 \mathrm{keV}$ en $\mathrm{Al}$ y $\mathrm{Pb}$ en condiciones de buena geometría (la línea discontinua representa la atenuación de un haz polienergético de fotones).

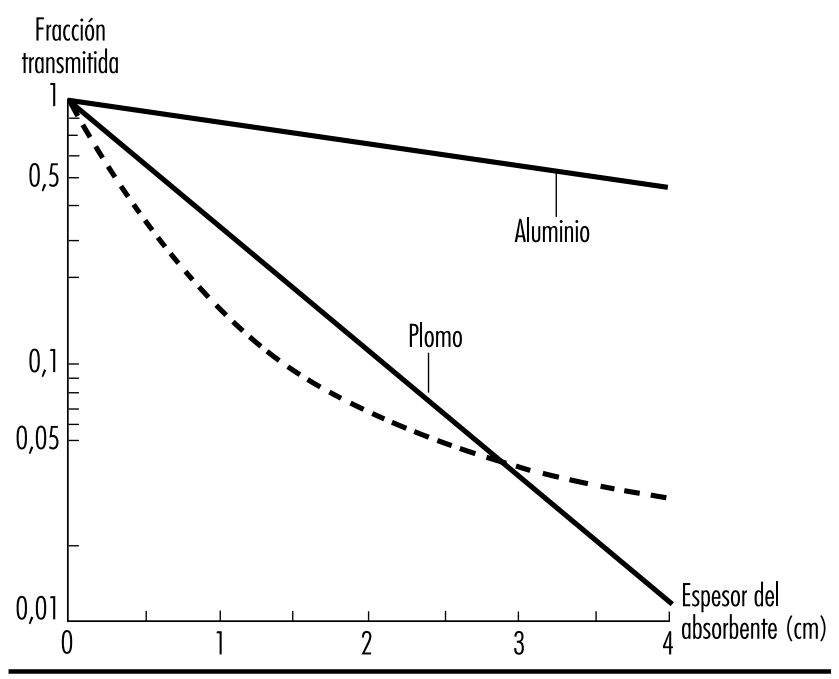

directamente. A medida que los electrones de las órbitas exteriores caen a niveles de energía más bajos para llenar el hueco dejado por el electrón expulsado, el átomo emite rayos $X$. La probabilidad de conversión interna frente a la probabilidad de emisión gamma aumenta con el número atómico.

\section{Rayos X}

Los rayos $X$ son una radiación electromagnética $y$, en ese sentido, son idénticos a los rayos gamma. La distinción entre rayos $X$ y rayos gamma radica en su origen. $M$ ientras que los rayos gamma se originan en el núcleo atómico, los rayos $X$ resultan de interacciones entre electrones. Aunque a menudo los rayos $X$ tienen energía inferior a la de los rayos gamma, éste no es el criterio que los diferencia. Se pueden producir rayos $X$ con energías mucho más elevadas que las de los rayos gamma procedentes de la desintegración radiactiva.

La conversión interna antes explicada es uno de los métodos de producción de rayos $X$. En este caso, los rayos $X$ resultantes tienen energías discretas iguales a la diferencia de los niveles de energía entre los que saltan los electrones orbitales.

Las partículas cargadas emiten radiación electromagnética siempre que son aceleradas o frenadas. La cantidad de radiación emitida es inversamente proporcional a la cuarta potencia de la masa de la partícula. Por consiguiente, los electrones emiten mucha más radiación $X$ que partículas más pesadas, como los protones, si todas las demás condiciones son iguales. LoS sistemas de rayos $X$ producen rayos $X$ mediante la aceleración de electrones que circulan a través de una gran diferencia de potencial eléctrico, de muchos $\mathrm{kV}$ o M V. Los electrones son después frenados rápidamente en un material denso y resistente al calor, como el tungsteno (W).

Los rayos $X$ emitidos desde estos sistemas tienen energías que se extienden en un espectro que va desde alrededor de cero hasta la energía cinética máxima adquirida por los electrones antes de la deceleración. A menudo, a este espectro continuo se superponen rayos $X$ de energía discreta, que se producen cuando los electrones frenados ionizan el material del blanco 0 anticátodo. Como otros electrones orbitales saltan para llenar los huecos dejados tras la ionización, emiten rayos $X$ de energías discretas similares a los rayos $X$ que se emiten después de la
Figura 48.15 - Espectro de rayos $X$ que ilustra la contribución de los rayos $X$ característicos producidos a medida que los electrones llenan los huecos de la capa K de W (la longitud de onda de los rayos $X$ es inversamente proporcional a su energía).

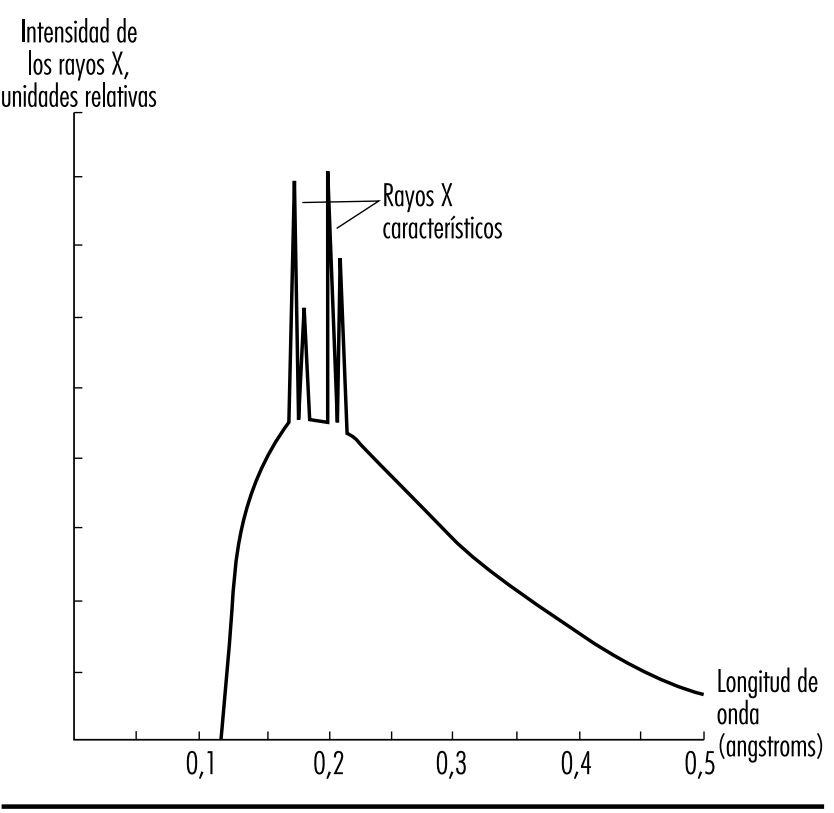

conversión interna. Reciben el nombre de rayos $X$ característicos porque son característicos del material del blanco (anticátodo). $\checkmark$ éase en la Figura 48.15 un espectro típico de rayos $X$. En la Figura 48.16 se ofrece un esquema de un tubo de rayos $X$ típico.

L os rayos $X$ interactúan con la materia de igual manera que los rayos gamma, pero una simple ecuación de atenuación exponencial no describe con precisión la atenuación de rayos $X$ con una gama continua de energías (véase la Figura 48.14). Sin embargo, como los rayos $X$ de energía más baja son eliminados del haz a medida que atraviesan el material con más rapidez que los de mayor energía, la descripción de la atenuación se aproxima a una función exponencial.

Figura 48.16 - Dibujo simplificado de un tubo de rayos $X$ con un ánodo estacionario y un filamento calentado.

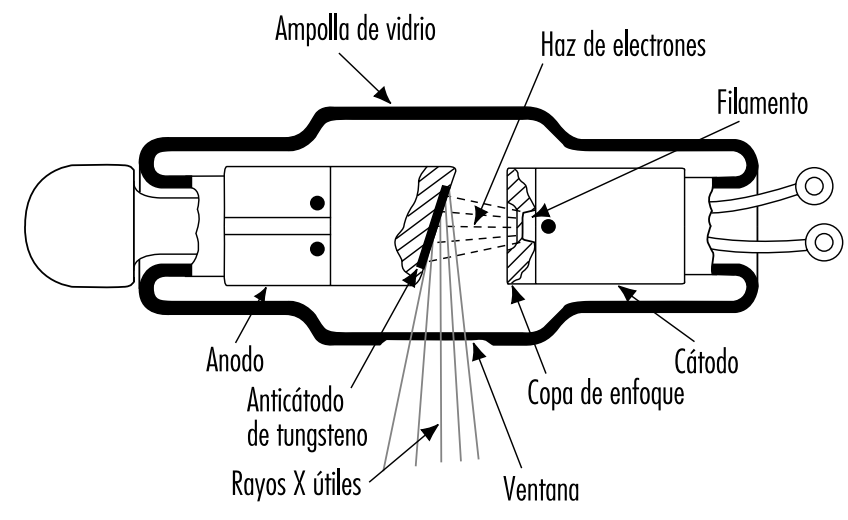




\section{Neutrones}

Por lo general, los neutrones no son emitidos como resultado directo de la desintegración radiactiva natural, sino que se producen durante reacciones nucleares. Los reactores nucleares son los que generan neutrones con mayor abundancia, pero los aceleradores de partículas y las fuentes especiales de neutrones, denominadas fuentes $(\alpha, n)$, también pueden producir neutrones.

Los reactores nucleares producen neutrones cuando los núcleos del uranio (U) que constituye el combustible nuclear se desdoblan o fisionan. De hecho, la producción de neutrones es esencial para mantener la fisión nuclear en un reactor.

Los aceleradores de partículas producen neutrones mediante la aceleración de partículas cargadas, como protones o electrones, hasta que alcanzan altas energías, para bombardear con ellas los núcleos estables de un blanco. Las partículas que pueden resultar de estas reacciones nucleares no son únicamente neutrones. Por ejemplo, la siguiente reacción produce neutrones en un ciclotrón que acelera iones deuterio para bombardear un blanco de berilio:

$$
{ }_{4}^{9} \mathrm{Be}+{ }_{1}^{2} \mathrm{H} \rightarrow{ }_{5}^{10} \mathrm{~B}+{ }_{0}^{1} \mathrm{n}
$$

Los emisores alfa mezclados con berilio son fuentes de neutrones portátiles. Estas fuentes $(\alpha, n)$ producen neutrones mediante la reacción:

$$
{ }_{4}^{9} \mathrm{Be}+{ }_{2}^{4} \alpha \rightarrow{ }_{6}^{12} \mathrm{C}+{ }_{0}^{1} \mathrm{n}
$$

La fuente de las partículas alfa puede ser de isótopos como el polonio $210\left({ }^{210} \mathrm{Po}\right)$, el plutonio $239\left({ }^{239} \mathrm{Pu}\right)$ y el americio 241 (241Am).

L os neutrones se clasifican en general por su energía, como se ilustra en la Tabla 48.8. Esta clasificación es un tanto arbitraria y puede variar en contextos diferentes.

Existen varios modos posibles de interacción del neutrón con la materia, pero las dos formas principales a efectos de seguridad radiológica son la dispersión elástica y la captura de neutrones.

La dispersión elástica es el medio por el que los neutrones de mayor energía son reducidos para producir energía térmica. L os neutrones de mayor energía interactúan sobre todo por dispersión elástica y en general no causan fisión ni producen material radiactivo por captura de neutrones. Los neutrones térmicos son los principales responsables de los últimos tipos de interacción.

La dispersión elástica se produce cuando un neutrón interactúa con un núcleo y rebota con menos energía. EI núcleo con el que ha chocado capta la energía cinética que el neutrón pierde. Después de ser excitado de este modo, el núcleo libera pronto esta energía en forma de radiación gamma.

Si el neutrón llega a alcanzar energías térmicas (llamadas así porque el neutrón está en equilibrio térmico con su entorno), es capturado fácilmente por la mayoría de los núcleos. Al no tener carga, los neutrones no son repelidos por los núcleos con cargas

Tabla 48.8 • Clasificación de los neutrones por su energía cinética.

$\begin{array}{lc}\text { Tipo } & \text { Escala energética } \\ \text { Lentos o térmicos } & 0-0,1 \mathrm{keV} \\ \text { Intermedios } & 0,1-20 \mathrm{keV} \\ \text { Rápidos } & 20 \mathrm{keV}-10 \mathrm{MeV} \\ \text { De alta energía } & >10 \mathrm{MeV}\end{array}$

positivas, como les ocurre a los protones. Cuando un neutrón térmico se aproxima a un núcleo y se sitúa dentro del radio de acción de la fuerza nuclear potente, del orden de algunos fm (1 fm $=10^{-15}$ metros), el núcleo captura el neutrón. EI producto resultante puede ser un núcleo radiactivo que emite un fotón u otra partícula o bien, en el caso de núcleos fisionables como ${ }^{235} \mathrm{U}$ y ${ }^{239} \mathrm{Pu}$, el núcleo captador puede fisionarse en dos núcleos más pequeños y más neutrones.

Las leyes de la cinemática indican que los neutrones alcanzarán energías térmicas con mayor rapidez si en el medio de dispersión elástica existe un gran número de núcleos ligeros. Un neutrón que rebota en un núcleo ligero pierde un porcentaje mucho mayor de su energía cinética que si rebota en un núcleo pesado. Por este motivo, el agua y los materiales hidrogenados son el mejor material de blindaje para frenar neutrones.

Un haz de neutrones monoenergético experimentará una atenuación exponencial en el material según una ecuación similar a la indicada antes para los fotones. La probabilidad de que un neutrón interactúe con un núcleo dado se describe en función del valor de la sección eficaz. La sección eficaz se mide en unidades de superficie. La unidad especial utilizada para la sección eficaz es el barn (b), definido por:

$$
1 b=10^{-24} \mathrm{~cm}^{2}
$$

Es extremadamente difícil producir neutrones sin acompañamiento de rayos gamma y rayos $X$. En general, cabe suponer que, si hay presentes neutrones, también hay fotones de alta energía.

\section{Fuentes de radiación ionizante}

\section{Radionucleidos primordiales}

En la naturaleza se encuentran radionucleidos primordiales porque sus períodos de semidesintegración son comparables con la edad de la Tierra. En la Tabla 48.9 se recogen los radionucleidos primordiales más importantes

Los isótopos del uranio y del torio encabezan una larga cadena de radioisótopos descendientes que están presentes también en la naturaleza. La Figura 48.17, A-C, ilustra las cadenas de desintegración de ${ }^{232} \mathrm{~T} h,{ }^{238} \mathrm{U}$ y ${ }^{235} \mathrm{U}$, respectivamente. Como la desintegración alfa es común para números másicos superiores a 205 y el número másico de la partícula alfa es 4, hay cuatro cadenas de desintegración distintas de los núcleos pesados. U na de estas cadenas (véase la Figura 48.17, D), la del ${ }^{237} \mathrm{~Np}$, no ocurre en la naturaleza, debido a que no contiene un radionucleido primordial (es decir, ningún radionucleido de esta cadena tiene un período de semidesintegración comparable con la edad de la T ierra).

Tabla $48.9 \cdot$ Radionucleidos primordiales.

$\begin{array}{llc}\text { Radioisótopo } & \begin{array}{l}\text { Período de semidesinte- } \\ \text { gración }\left(10^{9} \mathrm{Y}\right)\end{array} & \text { Abundancia (\%) } \\ { }^{238} \mathrm{U} & 4,47 & 99,3 \\ { }^{232} \mathrm{Th} & 14,0 & 100 \\ { }^{235} \mathrm{U} & 0,704 & 0,720 \\ { }^{40} \mathrm{~K} & 1,25 & 0,0117 \\ { }^{87} \mathrm{Rb} & 48,9 & 27,9\end{array}$


Figura 48.17 • Series de desintegración ( $\mathrm{Z}$ = número atómico; $\mathrm{N}$ = número másico).
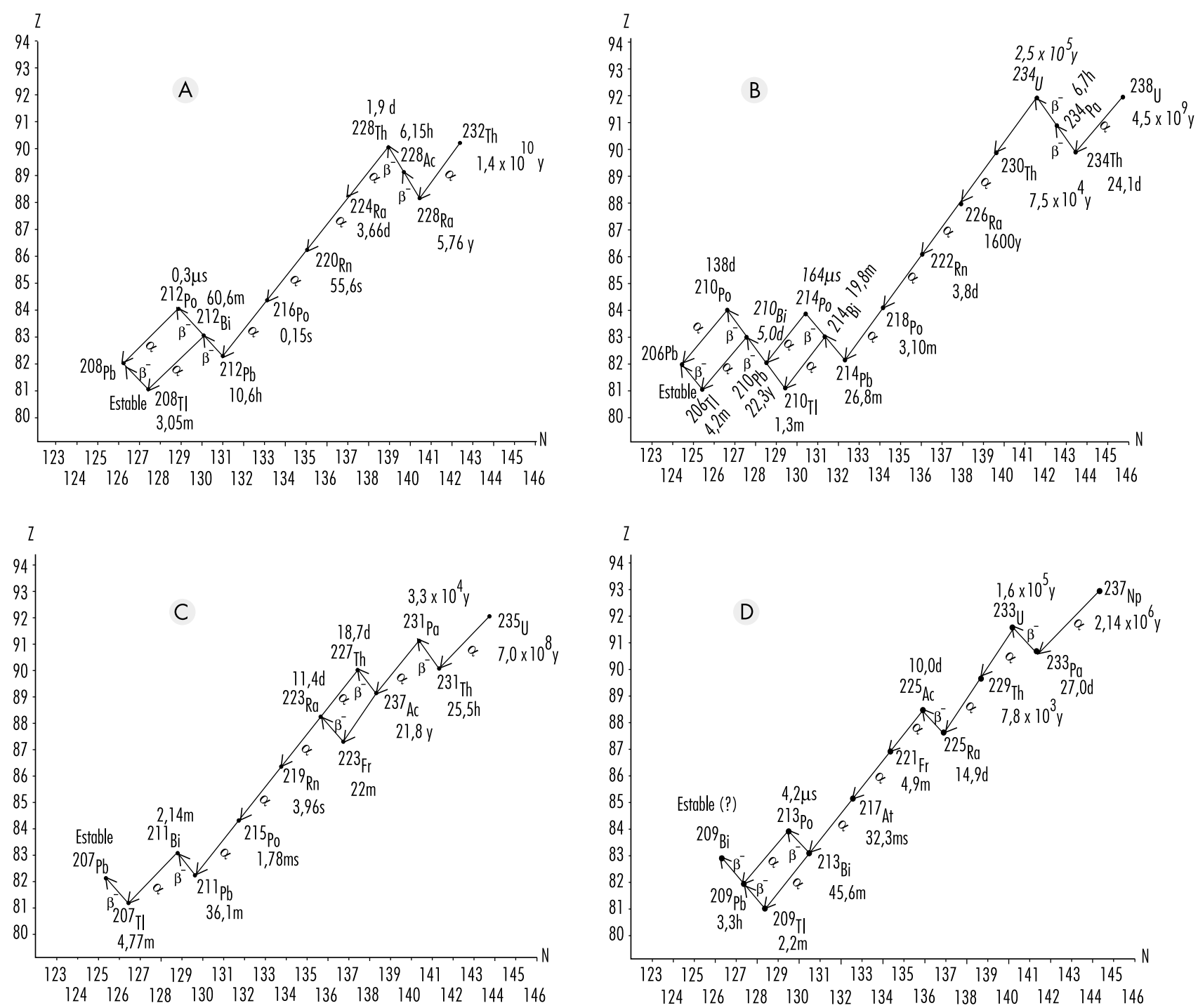

(A): Serie de desintegración del 232Th; (B): Serie de desintegración del 238U; (C): Serie de desintegración del 235U; (D): Serie de desintegración del ${ }^{237} \mathrm{~Np}$.

O bsérvese que en todas las cadenas hay isótopos del radón $(R n){ }^{219} R n,{ }^{220} R n$ y $\left.{ }^{222} R n\right)$. Como el $R n$ es un gas, una vez que se produce $\mathrm{R} n$ éste tiene la oportunidad de escapar a la atmósfera desde la matriz donde se formó. Ahora bien, el período de semidesintegración del ${ }^{219} \mathrm{Rn}$ es demasiado corto para que lleguen cantidades significativas del mismo a una zona donde se le puede respirar. El relativamente corto período de semidesintegración del ${ }^{220} \mathrm{R} n$ lo suele convertir en un peligro para la salud menor que el representado por el ${ }^{222} \mathrm{R} n$.

Sin contar el $\mathrm{R} n$, los radionucleidos primordiales externos al cuerpo humano entregan una dosis efectiva media de unos $0,3 \mathrm{mSv}$ anuales a la población humana. La dosis efectiva real anual varía entre límites amplios y está determinada sobre todo por la concentración de uranio y torio en el suelo local. En algunas partes del mundo en que son corrientes las arenas de monacita, la dosis efectiva anual recibida por un miembro de la población es de hasta unos $20 \mathrm{mSv}$. En otros lugares, como en atolones de coral y cerca de la orilla del mar, este valor puede bajar hasta 0,03 mSv (véase la Figura 48.17).

El radón suele considerarse por separado de otros radionucleidos terrestres presentes en la naturaleza. Aflora al aire desde el suelo. Una vez en el aire, el $\mathrm{Rn}$ se desintegra aún más a isótopos radiactivos de $\mathrm{Po}$, bismuto $(\mathrm{Bi})$ y $\mathrm{Pb}$. Esta progenie de radionucleidos se une a partículas de polvo que pueden ser respiradas y quedar atrapadas en los pulmones. Como son emisores alfa, ceden casi toda su energía de radiación a los pulmones.

Se estima que la dosis equivalente media anual recibida por los pulmones debida a esta exposición se sitúa en torno a $20 \mathrm{mSv}$. Esta dosis equivalente en los pulmones es comparable con una dosis efectiva de unos $2 \mathrm{mSv}$ en todo el cuerpo. Es evidente que el $\mathrm{Rn}$ y su progenie de radionucleidos son los contribuyentes más importantes a la dosis efectiva de radiación de fondo (véase la Figura 48.17). 


\section{Rayos cósmicos}

La radiación cósmica se compone de partículas energéticas de origen extraterrestre que inciden en la atmósfera de la Tierra (fundamentalmente partículas y en su mayor parte protones). También incluye partículas secundarias, casi todas fotones, neutrones y muones generados por las interacciones de las partículas primarias con gases de la atmósfera.

En virtud de estas interacciones, la atmósfera sirve de escudo contra la radiación cósmica, y cuanto más delgado sea este escudo, mayor será la tasa de dosis efectiva. Es decir, la tasa de dosis efectiva de rayos cósmicos aumenta con la altitud. Por ejemplo, la tasa de dosis a 1.800 metros de altura es alrededor del doble que al nivel del mar.

Como la radiación cósmica primaria consta esencialmente de partículas cargadas, recibe la influencia del campo magnético terrestre. Así, los habitantes de latitudes altas reciben dosis eficaces de radiación cósmica mayores que los que se encuentran más cerca del Ecuador. La variación debida a este efecto es del orden del $10 \%$.

Por último, la tasa de dosis efectiva de rayos cósmicos varía con la modulación de la salida de rayos cósmicos desde el Sol. En promedio, los rayos cósmicos contribuyen en alrededor de $0,3 \mathrm{mSv}$ a la dosis efectiva de radiación de fondo en todo el cuerpo.

\section{Radionucleidos cosmógenos}

Los rayos cósmicos producen radionucleidos cosmógenos en la atmósfera. L os más destacados de éstos son el tritio $\left({ }^{3} \mathrm{H}\right)$, el berilio $7\left({ }^{7} \mathrm{Be}\right)$, el carbono $14\left({ }^{14} \mathrm{C}\right)$ y el sodio $22\left({ }^{22} \mathrm{Na}\right)$. Son producidos por rayos cósmicos que interactúan con gases atmosféricos. Los

Tabla 48.10 • Fuentes y estimaciones de las dosis efectivas asociadas a la población debidas a materiales y a productos de consumo de tecnología avanzada.

Grupo I-Comprende un gran número de personas y la dosis efectiva individual es muy amplia

$\begin{array}{ll}\text { Productos del tabaco } & \text { Combustibles } \\ \text { Suministro doméstico de agua } & \text { Vidrio y cerámica } \\ \text { Materiales de construcción } & \text { Vidrio oftálmico }\end{array}$

Minería y productos agrícolas

Grupo II-Comprende un gran número de personas pero la dosis efectiva es relativamente pequeña o está limitada a una pequeña parte del cuerpo

Receptores de televisión

Materiales de construcción de carreteras y autopistas

Productos radioluminosos

Transporte aéreo de materiales radiactivos

Sistemas de inspección de aeropuertos Irradiadores de chispas y tubos electrónicos

Detectores de gases y aerosoles (humos)

Productos de torio-cebadores de lámparas fluorescentes y camisas de lámparas de gas

Grupo III-Comprende relativamente pocas personas y la dosis efectiva colectiva es pequeña

Productos de torio-varillas para soldar de tungsteno

Fuente: NCRP 1987 radionucleidos cosmógenos entregan una dosis efectiva anual de unos $0,01 \mathrm{mSv}$, que en su mayor parte procede del ${ }^{14} \mathrm{C}$.

\section{Lluvia radiactiva}

Desde el decenio de 1940 hasta el de 1960, se realizaron numerosas pruebas de armas nucleares sobre la superficie terrestre. Estas pruebas produjeron grandes cantidades de materiales radiactivos y los distribuyeron al medio ambiente de todo el mundo en forma de lluvia radiactiva. Aunque muchos de estos desechos se han transformado desde entonces en isótopos estables, las pequeñas cantidades que permanecen serán todavía una fuente de exposición durante muchos años. Además, las naciones que siguen realizando pruebas ocasionales de armas nucleares en la atmósfera añaden radiactividad a las existencias mundiales.

L os contribuyentes principales de la lluvia radiactiva a la dosis efectiva son en la actualidad el estroncio $90\left({ }^{90} \mathrm{Sr}\right)$ y el cesio 137 $\left({ }^{137} \mathrm{Cs}\right)$, los dos con períodos de semidesintegración de alrededor de 30 años. La dosis efectiva media anual debida a la lluvia radiactiva es de unos 0,05 $\mathrm{mSv}$.

\section{Material radiactivo en el organismo}

La acumulación de radionucleidos naturales en el cuerpo humano es sobre todo resultado de la inhalación e ingestión de estos materiales del aire, los alimentos y el agua. Entre estos nucleidos se encuentran radioisótopos de $\mathrm{Pb}, \mathrm{Po}, \mathrm{Bi}, \mathrm{Ra}, \mathrm{K}$ (potasio), C, H, U y Th. De ellos, el ${ }^{40} \mathrm{~K}$ es el contribuyente máximo. Los radionucleidos naturales depositados en el cuerpo contribuyen en unos 0,3 mSv a la dosis efectiva anual.

\section{Radiación producida por máquinas}

La utilización de rayos $X$ en las artes curativas es la mayor fuente de exposición a la radiación producida por máquinas. M illones de sistemas de rayos $X$ médicos están en uso en todo el mundo. $L a$ exposición media a estos sistemas de rayos $X$ médicos depende en gran medida del acceso de una población a los servicios sanitarios. En los países desarrollados, la dosis efectiva media anual debida a radiación de rayos $X$ por prescripción médica y a material radiactivo para diagnóstico y tratamiento es del orden de $1 \mathrm{mSv}$.

Los rayos $X$ son un subproducto de la mayoría de los aceleradores de partículas en la física de altas energías, sobre todo los que aceleran electrones y positrones. Sin embargo, un blindaje y unas medidas de seguridad adecuadas, más la escasa población en riesgo, convierten a esta fuente de exposición a la radiación en menos importante que las fuentes anteriores.

\section{Radionucleidos producidos por máquinas}

Los aceleradores de partículas pueden producir una gran variedad de radionucleidos en cantidades variables mediante reacciones nucleares. Las partículas aceleradas son protones, deuterones (núcleos de ${ }^{2} \mathrm{H}$ ), partículas alfa, mesones cargados, iones pesados y otros. Los materiales que hacen de blanco pueden ser de casi cualquier isótopo.

Los aceleradores de partículas son prácticamente la única fuente de radioisótopos emisores de positrones. ( $L$ os reactores nucleares tienden a producir radioisótopos ricos en neutrones que se desintegran por emisión de negatrones.) También se utilizan cada vez más para producir isótopos de vida corta destinados a aplicaciones médicas, en especial para tomografía por emisión de positrones (TEP).

\section{M ateriales y productos de consumo de tecnología avanzada} En gran número de actividades de la vida moderna aparecen rayos $X$ y materiales radiactivos, unos deseados y otros indeseables. En la Tabla 48.10 se enumeran estas fuentes de radiación. 


\section{- Diseño de PUESTOS DE tRABAJO PARA SEGURIDAD RADIO LOGICA}

Gordon M . Lodde

\section{Características básicas del diseño de las instalaciones radiológicas}

Los peligros que entrañan la manipulación y el uso de fuentes de radiación exigen características especiales de diseño y construcción de estas instalaciones que no se requieren en laboratorios 0 áreas de trabajo normales. Estas características especiales de diseño se incorporan de tal forma que los trabajadores no soporten incomodidades pero tengan la seguridad de que no están expuestos a peligros radiológicos externos 0 internos excesivos.

EI acceso a todas las zonas en las que pueda producirse exposición a fuentes de radiación o a materiales radiactivos deberá estar controlado, y no sólo en relación con los trabajadores de la instalación a quienes se puede permitir la entrada en dichas áreas de trabajo, sino también con respecto al tipo de ropa o equipo protector que deben llevar y a las precauciones que deben adoptar en las zonas controladas. En la administración de estas medidas de control, sirve de gran ayuda clasificar las zonas de trabajo en función de que exista o no radiación ionizante, contaminación radiactiva o ambas. La introducción de estos conceptos clasificatorios de las zonas de trabajo en las primeras fases de la planificación permitirá que la instalación posea después todas las características necesarias para hacer menos peligrosas las operaciones con fuentes de radiación.

Clasificación de las zonas de trabajo y los tipos de laboratorio

La base de la clasificación de la zona de trabajo es la agrupación de los radionucleidos según sus radiotoxicidades relativas por unidad de actividad. En el grupo I deben entrar los radionucleidos de toxicidad muy alta, en el grupo II los de toxicidad moderada a alta, en el grupo III los radionucleidos de toxicidad moderada y en el grupo IV los de toxicidad baja. La Tabla 48.11 muestra la clasificación de numerosos radionucleidos por grupos de toxicidad.

Tabla 48.11 • Clasificación de los radionucleidos por la radiotoxicidad relativa de una unidad de actividad.

\begin{tabular}{|c|c|c|c|c|c|c|c|c|c|}
\hline \multicolumn{10}{|c|}{ Grupo I: Toxicidad muy alta } \\
\hline $210 \mathrm{pb}$ & $210 \mathrm{po}_{0}$ & ${ }^{223} \mathrm{Ra}$ & ${ }^{226} \mathrm{Ra}$ & ${ }^{228} \mathrm{Ra}$ & ${ }^{227} \mathrm{AC}$ & ${ }^{227} \mathrm{Th}$ & ${ }^{228} \mathrm{Th}$ & ${ }^{230} \mathrm{Th}$ & ${ }^{231} \mathrm{~Pa}$ \\
\hline $230 \mathrm{U}$ & $232 U$ & $233 \mathrm{U}$ & $234 \mathrm{U}$ & ${ }^{237} \mathrm{~Np}$ & ${ }^{238} \mathrm{Pu}$ & ${ }^{239} \mathrm{Pu}$ & 240 pu & ${ }^{241} \mathrm{Pu}$ & ${ }^{242} \mathrm{Pu}$ \\
\hline${ }^{241} \mathrm{Am}$ & ${ }^{243} \mathrm{Am}$ & ${ }^{242} \mathrm{Cm}$ & ${ }^{243} \mathrm{Cm}$ & ${ }^{244} \mathrm{Cm}$ & ${ }^{245} \mathrm{Cm}$ & ${ }^{246} \mathrm{Cm}$ & ${ }^{249} \mathrm{Cm}$ & ${ }^{250} \mathrm{Cf}$ & ${ }^{252} \mathrm{Cf}$ \\
\hline \multicolumn{10}{|c|}{ Grupo II: Toxicidad alta } \\
\hline${ }^{22} \mathrm{Na}$ & ${ }^{36} \mathrm{Cl}$ & ${ }^{45} \mathrm{Ca}$ & ${ }^{46} \mathrm{SC}$ & ${ }^{54} \mathrm{Mn}$ & ${ }^{56} \mathrm{CO}$ & ${ }^{60} \mathrm{CO}$ & ${ }^{89} \mathrm{Sr}$ & ${ }^{90} \mathrm{Sr}$ & ${ }^{91}$ \\
\hline${ }^{95} \mathrm{Zr}$ & ${ }^{106} \mathrm{Ru}$ & ${ }^{110} \mathrm{Ag}^{\mathrm{m}}$ & ${ }^{115} \mathrm{Cd}^{\mathrm{m}}$ & $\left.{ }^{114}\right|^{n^{m}}$ & ${ }^{124} \mathrm{Sb}$ & ${ }^{125} \mathrm{Sb}$ & ${ }^{127} \mathrm{Te}^{\mathrm{m}}$ & ${ }^{129} \mathrm{Te}^{\mathrm{m}}$ & 124 \\
\hline 126 & 131 & $133 \mid$ & ${ }^{134} \mathrm{CS}$ & ${ }^{137} \mathrm{Cs}$ & ${ }^{140} \mathrm{Ba}$ & ${ }^{144} \mathrm{Ce}$ & ${ }^{152} \mathrm{Eu}(13$ a) & ${ }^{154} \mathrm{EU}$ & ${ }^{160} \mathrm{~Tb}$ \\
\hline${ }^{170} \mathrm{Tm}$ & ${ }^{181} \mathrm{Hf}$ & ${ }^{210} \mathrm{Bi}$ & ${ }^{182} \mathrm{Ta}$ & $192 / r$ & ${ }^{204} \mathrm{Tl}$ & ${ }^{207} \mathrm{Bi}$ & ${ }^{230} \mathrm{~Pa}$ & ${ }^{211}$ At & $212 \mathrm{pb}$ \\
\hline${ }^{224} \mathrm{Ra}$ & ${ }^{228} \mathrm{AC}$ & ${ }^{234} \mathrm{Th}$ & ${ }^{236} \mathrm{U}$ & ${ }^{249} B k$ & & & & & \\
\hline \multicolumn{10}{|c|}{ Grupo III: Toxicidad moderada } \\
\hline${ }^{7} \mathrm{Be}$ & ${ }^{14} \mathrm{C}$ & ${ }^{18} \mathrm{~F}$ & ${ }^{24} \mathrm{Na}$ & ${ }^{38} \mathrm{Cl}$ & ${ }^{31} \mathrm{Si}$ & $32 p$ & ${ }^{35} \mathrm{~S}$ & ${ }^{41} \mathrm{~A}$ & ${ }^{42} \mathrm{~K}$ \\
\hline${ }^{43} \mathrm{~K}$ & ${ }^{47} \mathrm{SC}$ & ${ }^{48} \mathrm{SC}$ & ${ }^{48} \mathrm{~V}$ & ${ }^{51} \mathrm{Cr}$ & ${ }^{52} \mathrm{Mn}$ & ${ }^{56} \mathrm{Mn}$ & ${ }^{52} \mathrm{Fe}$ & ${ }^{55} \mathrm{Fe}$ & ${ }^{59} \mathrm{Fe}$ \\
\hline${ }^{57} \mathrm{CO}$ & ${ }^{53} \mathrm{Ni}$ & ${ }^{65} \mathrm{Ni}$ & ${ }^{64} \mathrm{Cu}$ & ${ }^{65} \mathrm{Zn}$ & ${ }^{69} \mathrm{Zn}^{m}$ & ${ }^{72} \mathrm{Ga}$ & ${ }^{73} \mathrm{As}$ & ${ }^{74}$ As & ${ }^{76}$ As \\
\hline${ }^{77}$ As & ${ }^{82} \mathrm{Br}$ & ${ }^{85} \mathrm{Kr}^{\mathrm{m}}$ & ${ }^{87} \mathrm{Kr}$ & ${ }^{86} \mathrm{Rb}$ & ${ }^{85} \mathrm{Sr}$ & ${ }^{91} \mathrm{Sr}$ & ${ }^{90 y}$ & $92 y$ & $93 y$ \\
\hline${ }^{97} \mathrm{Zr}$ & ${ }^{95} \mathrm{Nb}$ & ${ }^{99} \mathrm{Mo}$ & ${ }^{96} \mathrm{TC}$ & ${ }^{97} \mathrm{TC}^{\mathrm{m}}$ & ${ }^{97} \mathrm{TC}$ & ${ }^{99} \mathrm{TC}$ & ${ }^{97} \mathrm{Ru}$ & ${ }^{103} \mathrm{Ru}$ & ${ }^{105} \mathrm{Ru}$ \\
\hline${ }^{105} \mathrm{Rh}$ & ${ }^{109} \mathrm{Pd}$ & ${ }^{105} \mathrm{Ag}$ & ${ }^{111} \mathrm{Ag}$ & ${ }^{109} \mathrm{Cd}$ & ${ }^{115} \mathrm{Cd}$ & $115 / n^{m}$ & ${ }^{113} \mathrm{Sn}$ & ${ }^{125} \mathrm{Sn}$ & $122 \mathrm{Sb}$ \\
\hline${ }^{125} \mathrm{Te}^{\mathrm{m}}$ & ${ }^{129} \mathrm{Te}$ & ${ }^{131} \mathrm{Te}^{\mathrm{m}}$ & ${ }^{132} \mathrm{Te}$ & $130 \mid$ & 132 & $134 \mid$ & 135 & ${ }^{135} \mathrm{Xe}$ & ${ }^{131} \mathrm{Cs}$ \\
\hline${ }^{136} \mathrm{Cs}$ & ${ }^{140} \mathrm{La}$ & ${ }^{141} \mathrm{Ce}$ & ${ }^{143} \mathrm{Ce}$ & ${ }^{142} \mathrm{Pr}$ & ${ }^{143} \mathrm{Pr}$ & ${ }^{147} \mathrm{Nd}$ & ${ }^{149} \mathrm{Nd}$ & ${ }^{147} \mathrm{Pm}$ & ${ }^{149} \mathrm{Pm}$ \\
\hline${ }^{151} \mathrm{Sm}$ & ${ }^{152} \mathrm{Eu}(9,2 \mathrm{~h})$ & ${ }^{155} \mathrm{Eu}$ & ${ }^{153} \mathrm{Gd}$ & ${ }^{159} \mathrm{Gd}$ & ${ }^{165} \mathrm{Dy}$ & ${ }^{166} \mathrm{Dy}$ & ${ }^{166} \mathrm{Ho}$ & ${ }^{169} \mathrm{Er}$ & ${ }^{171} \mathrm{Er}$ \\
\hline${ }^{171} \mathrm{Tm}$ & ${ }^{177} \mathrm{Lu}$ & ${ }^{181} \mathrm{~W}$ & ${ }^{185} \mathrm{~W}$ & ${ }^{187} \mathrm{~W}$ & ${ }^{183} \mathrm{Re}$ & ${ }^{186} \mathrm{Re}$ & ${ }^{188} \mathrm{Re}$ & ${ }^{185} \mathrm{Os}$ & ${ }^{191} \mathrm{Os}$ \\
\hline${ }^{193} \mathrm{Os}$ & $190 \mathrm{r} r$ & $195 / r$ & ${ }^{191} \mathrm{pt}$ & ${ }^{193} \mathrm{Pt}$ & ${ }^{197} \mathrm{Pt}$ & ${ }^{196} \mathrm{Au}$ & ${ }^{198} \mathrm{Au}$ & ${ }^{199} \mathrm{Au}$ & ${ }^{197} \mathrm{Hg}$ \\
\hline${ }^{197} \mathrm{Hg}^{\mathrm{m}}$ & ${ }^{203} \mathrm{Hg}$ & $200 \mathrm{Tl}$ & ${ }^{201} \mathrm{Tl}$ & $202 \mathrm{Tl}$ & ${ }^{203} \mathrm{~Pb}$ & ${ }^{206} \mathrm{Bi}$ & ${ }^{212} \mathrm{Bi}$ & ${ }^{220} \mathrm{Rn}$ & ${ }^{222} \mathrm{Rn}$ \\
\hline 231Th & ${ }^{233} \mathrm{~Pa}$ & ${ }^{239} \mathrm{~Np}$ & & & & & & & \\
\hline \multicolumn{10}{|c|}{ Grupo IV: Toxicidad baja } \\
\hline${ }^{3} \mathrm{H}$ & ${ }^{15} \mathrm{O}$ & ${ }^{37} \mathrm{~A}$ & ${ }^{58} \mathrm{CO}^{\mathrm{m}}$ & ${ }^{59} \mathrm{Ni}$ & ${ }^{69} \mathrm{Zn}$ & ${ }^{71} \mathrm{Ge}$ & ${ }^{85} \mathrm{Kr}$ & ${ }^{85} \mathrm{Sr}^{\mathrm{m}}$ & ${ }^{87} \mathrm{Rb}$ \\
\hline 91Ym & ${ }^{93} \mathrm{Zr}$ & ${ }^{97} \mathrm{Nb}$ & ${ }^{96} \mathrm{TC}^{\mathrm{m}}$ & ${ }^{99} \mathrm{TC}^{\mathrm{m}}$ & ${ }^{103} \mathrm{Rh}^{\mathrm{m}}$ & ${ }^{133} \mathrm{ln}^{\mathrm{m}}$ & 129 & ${ }^{131} \mathrm{Xe}^{\mathrm{m}}$ & ${ }^{133} \mathrm{Xe}_{\mathrm{e}}$ \\
\hline${ }^{134} \mathrm{Cs}^{\mathrm{m}}$ & ${ }^{135} \mathrm{Cs}$ & ${ }^{147} \mathrm{Sm}$ & ${ }^{187} \operatorname{Re}$ & ${ }^{191} O s^{m}$ & ${ }^{193} \mathrm{ptm}$ & $197 \mathrm{Pt}^{\mathrm{m}}$ & natTh & 232Th & $235 \mathrm{U}$ \\
\hline $238 \mathrm{U}$ & natU & & & & & & & & \\
\hline
\end{tabular}


Tabla 48.12 • Clasificación de zonas de trabajo.

Tipo Definición

1 Zonas en las que los niveles de dosis absorbida de radiación externa o los de contaminación radiactiva pueden ser altos

2 Zonas en las que pueden existir niveles de radiación externa y la posibilidad de contaminación exige instrucciones de operación

3 Zonas en las que el nivel medio de radiación externa

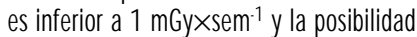
de contaminación radiactiva exige instrucciones de operación especiales

4 Zonas dentro de los confines de una instalación de irradiación donde los niveles de radiación externos son inferiores a 0,1 mGyxsem-1 y no existe contaminación radiactiva

\section{Control de acceso}

Acceso controlado sólo para trabajadores expuestos, en condiciones de trabajo con controles estrictos y equipo protector adecuado

Acceso limitado a trabajadores expuestos con ropa y calzado protectores adecuados

Acceso limitado a trabajadores expuestos, no es precisa ropa protectora

Acceso no controlado
Operaciones típicas

Laboratorios de fuentes radiactivas, zonas muy contaminadas

Fábricas de luminización y otras instalaciones equivalentes

Zonas de trabajo en la vecindad inmediata de operación radiológica; por ejemplo, salas de control

Zonas de administración y de espera de los pacientes
L os laboratorios pueden dividirse en tres tipos amplios basándose en consideraciones relativas a la radiotoxicidad, en las cantidades de materiales radiactivos que se manipularán en la zona de trabajo y en el tipo de operaciones que se realizan.

Tabla 48.13 • Clasificación de los laboratorios de manipulación de materiales radiactivos.

$\begin{array}{lccc}\begin{array}{l}\text { Grupo de } \\ \text { radio- } \\ \text { nucleidos }\end{array} & \text { Tipo de laboratorio necesario para cada actividad } \\ & \text { Tipo 1 } & \text { Tipo 2 } & \text { Tipo } 3 \\ \text { I } & <370 \mathrm{kBq} & 70 \mathrm{kBq} \text { a } & >37 \mathrm{MBq} \\ & & 37 \mathrm{MBq} & \\ \text { II } & <37 \mathrm{MBq} & 37 \mathrm{MBq} \text { a } & >37 \mathrm{GBq} \\ & & 37 \mathrm{GBq} & \\ \text { III } & <37 \mathrm{GBq} & 37 \mathrm{GBq} \text { a } & >370 \mathrm{GBq} \\ & & 370 \mathrm{GBq} & \\ \text { IV } & <370 \mathrm{GBq} & 370 \mathrm{GBq} a & >37 \mathrm{Tbq} \\ & & 37 \mathrm{TBq} & \end{array}$

Factores operativos para uso de material radiactivo en laboratorio

Factores de multiplicación de los niveles de actividad

Almacenamiento simple $\times 100$

Operaciones simples en húmedo (por ejemplo, preparación de alícuotas de solución madre)

Operaciones químicas normales (por ejemplo, preparación y análisis químicos simples)

Operaciones complejas en húmedo (por ejemplo, operaciones múltiples u operaciones con cristalería compleja)

Operaciones simples en seco (por ejemplo, manipulaciones de polvos de compuestos radiactivos volátiles)

Operaciones en seco y con polvo (por ejemplo, trituración)
La Tabla 48.12 describe los laboratorios por su tipo y pone ejemplos de cada uno de ellos. En la Tabla 48.13 se muestran los tipos de laboratorios junto con la clasificación de las zonas de trabajo y del control del acceso (O IEA 1973).

L os peligros que se derivan del trabajo con material radiactivo no sólo dependen del nivel de radiotoxicidad o de toxicidad química y de la actividad de los radionucleidos, sino también de la forma física y química del material radiactivo y de la naturaleza y complejidad de la operación o de los procedimientos que se realizan.

E mplazamiento de una instalación radiológica en un edificio Cuando una instalación radiológica forma parte de un edificio grande, se deben aplicar los criterios siguientes en el momento de decidir su emplazamiento:

- La instalación radiológica debe situarse en una parte poco frecuentada del edificio, de manera que el acceso a la zona pueda controlarse con facilidad.

- El riesgo de incendio debe ser mínimo en la zona elegida.

- El emplazamiento de la instalación radiológica y de la calefacción y ventilación deben ser tales que sean mínimas las posibilidades de difusión superficial y aérea de la contaminación radiactiva.

- El emplazamiento de la instalación radiológica debe elegirse con buen juicio, de manera que con un gasto mínimo en blindaje, los niveles de radiación puedan mantenerse dentro de los límites establecidos en la proximidad inmediata.

\section{Planificación de instalaciones radiológicas}

C uando se prevea una gradación de niveles de actividad, el laboratorio deberá estar situado de manera que el acceso a las zonas donde existan niveles elevados de radiación o de contaminación radiactiva tenga que ser gradual; es decir, que se entre primero a una zona sin radiación, después a otra de baja actividad, a continuación a otra de actividad media, etc.

Puede evitarse la necesidad de controles de ventilación complejos en laboratorios pequeños si se utilizan campanas 0 cajas con guantes para manipular fuentes no selladas de material radiactivo. Pero el sistema de ventilación debe diseñarse de manera que facilite la circulación del aire en una dirección, de forma que el material radiactivo que pueda quedar suspendido en el aire se aleje del trabajador expuesto. La circulación del aire 
debe ser siempre desde una zona no contaminada hacia otra contaminada o que pueda estarlo.

Para la manipulación de fuentes no selladas de radiactividad baja o media, la velocidad media del aire por la abertura de la campana deberá ser de unos $0,5 \mathrm{~ms}^{-1}$. Si la radiotoxicidad es elevada 0 el nivel de radiactividad alto, la velocidad del aire por la abertura deberá aumentarse hasta una media de 0,6 a $1,0 \mathrm{~ms}^{-1}$. Ahora bien, se tendrá en cuenta que una velocidad excesiva del aire puede extraer materiales radiactivos de contenedores abiertos y contaminar toda la zona de la campana.

La colocación de la campana en relación con las corrientes de aire que crucen el laboratorio es importante. En general, una campana debe situarse lejos de los pasos por donde entra el suministro o la renovación del aire. Si se emplean ventiladores de dos velocidades podrán funcionar a velocidad más alta mientras la campana se utilice y a menor velocidad cuando esté cerrada.

La finalidad de todo sistema de ventilación debe ser:

- proporcionar condiciones de trabajo confortables;

- proporcionar renovaciones continuas de aire (de tres a cinco renovaciones por hora) para eliminar y diluir los contaminantes indeseables del aire,

- reducir al mínimo la contaminación de otras zonas del edificio y del entorno.

En el diseño de instalaciones radiológicas, los requisitos de blindaje grueso pueden reducirse al mínimo mediante la adopción de ciertas medidas sencillas. Por ejemplo, en al caso de instalaciones de radioterapia, aceleradores, generadores de neutrones o fuentes de radiación panorámicas, un laberinto puede reducir la necesidad de montar una puerta con capa gruesa de plomo. El adelgazamiento gradual de la barrera protectora primaria en áreas que no se encuentran en el camino del haz útil o el enterramiento total o parcial de la instalación pueden reducir bastante la cantidad de blindaje necesario.

Es preciso conceder la máxima atención a la colocación adecuada de las ventanas de observación, de los cables de los conductos subterráneos y de los deflectores del sistema de ventilación. La ventana de observación sólo debe interceptar la radiación dispersada. M ejor aún es un circuito cerrado de televisión, que además puede mejorar la eficiencia.

\section{Acabados superficiales dentro de una zona de trabajo}

Todas las superficies rugosas, como las de yeso, hormigón, madera, etc., se deben sellar con un material adecuado. La elección del material debe hacerse teniendo en cuenta las consideraciones siguientes:

- conseguir una superficie lisa y químicamente inerte;

- las condiciones ambientales de temperatura, humedad y desgaste mecánico a las que pueden estar expuestas las superficies:

- compatibilidad con los campos de radiación a los que se expone la superficie,

- la necesidad de una reparación fácil en caso de deterioro.

No se recomiendan pinturas, barnices y lacas corrientes para recubrir superficies de desgaste. La aplicación de una material de revestimiento que se pueda eliminar con facilidad puede ser de ayuda si se produce contaminación y se precisa descontaminación. Sin embargo, la eliminación de esos materiales puede ser a veces difícil y engorrosa.

\section{Fontanería}

Los desagües, pilas de lavar y sumideros del suelo deben estar marcados. Las pilas donde puedan lavarse las manos contaminadas deben tener grifos accionados con la rodilla o el pie. Puede ser económico reducir el mantenimiento instalando tuberías que se descontaminen o sustituyan con facilidad si es preciso. En algunos casos es recomendable instalar depósitos subterráneos donde guardar o almacenar materiales radiactivos líquidos para controlar su eliminación posterior.

\section{Diseño de blindajes contra la radiación}

El blindaje es importante para disminuir la exposición radiológica de los trabajadores de la instalación y del público en general. Los requisitos del blindaje dependen de varios factores, incluidos el tiempo que los trabajadores de la instalación radiológica 0 el público en general están expuestos a las fuentes de radiación y el tipo y la energía de la fuentes de radiación y sus campos radiológicos.

En el diseño de blindajes radiológicos, el material absorbente debe colocarse lo más cerca posible de la fuente de radiación. Para cada tipo de radiación es preciso considerar por separado el blindaje que será necesario aplicar.

El diseño del blindaje puede ser una tarea compleja. Por ejemplo, el empleo de ordenadores para encontrar el modelo de blindaje de aceleradores, reactores y otras fuentes de radiación de alta energía escapa al ámbito de este artículo. En el diseño de blindajes complejos se debe consultar siempre a expertos calificados.

\section{Blindaje de fuentes gamma}

La atenuación de la radiación gamma difiere cualitativamente de la de las radiaciones alfa o beta. Estos dos tipos de radiación tienen un alcance definido en la materia y son absorbidos por completo, mientras que es posible reducir la intensidad de la radiación gamma mediante material absorbente cada vez más grueso, pero no puede absorberse por completo. Si la atenuación de los rayos gamma monoenergéticos se mide en condiciones de buena geometría (es decir, si la radiación está bien colimada en un haz estrecho), los datos de la intensidad, cuando se registran en papel semilogarítmico frente al espesor del absorbente, se encontrarán en una recta cuya pendiente será igual al coeficiente de atenuación, $\mu$.

La intensidad, o tasa de dosis absorbida transmitida a través de un absorbente, puede calcularse del modo siguiente:

$$
I_{(t)}=I_{(0)} e^{-\mu t}
$$

donde I (t) es la intensidad de los rayos gamma o la tasa de dosis absorbida transmitida por un absorbente de espesor t.

Las unidades de $\mu$ y t son recíprocas entre sí. Si el espesor del absorbente $t$ se mide en $\mathrm{cm}$, entonces $\mu$ es el coeficiente de atenuación lineal y se mide en $\mathrm{cm}^{-1}$. Si t tiene unidades de densidad superficial $\left(\mathrm{g} / \mathrm{cm}^{2}\right)$, entonces $\mu$ es el coeficiente de atenuación por unidad de masa $\mu_{\mathrm{m}} \mathrm{y}$ se mide en $\mathrm{cm}^{2} / \mathrm{g}$.

Como aproximación de primer orden basada en la densidad superficial, todos los materiales tienen aproximadamente las mismas propiedades de atenuación para fotones con energías entre alrededor de 0,75 y 5,0 MeV (megaelectronvoltios). Dentro de este intervalo de energías, las propiedades del blindaje contra rayos gamma son aproximadamente proporcionales a la densidad del material de blindaje. Si las energías de los fotones son menores o mayores, los materiales absorbentes de número atómico más alto suministran un blindaje más eficaz que los de número atómico más bajo para una densidad superficial dada.

En condiciones de geometría imperfecta (por ejemplo, si el haz es ancho o el blindaje grueso), la ecuación anterior subestimará en grado notable el espesor de blindaje necesario, porque supone que todo fotón que interactúa con el blindaje será 
eliminado del haz y no será detectado. Un número importante de fotones pueden ser dispersados por el blindaje hacia el detector, 0 fotones que se hayan dispersado del haz pueden volver dispersados hacia él tras una segunda interacción.

El espesor del blindaje para condiciones de geometría imperfecta puede estimarse mediante el factor de acumulación B , cuyo valor puede calcularse del modo siguiente:

$$
I_{(t)}=I_{(0)} B e^{-\mu t}
$$

El factor de acumulación es siempre mayor que uno, y puede definirse como la relación entre la intensidad de la radiación fotónica en cualquier punto del haz, incluidas la radiación primaria y la dispersada, y la intensidad del haz primario únicamente en ese punto. El factor de acumulación puede aplicarse al flujo de radiación o a la tasa de dosis absorbida.

Se han calculado factores de acumulación para distintas energías de fotones y diversos absorbentes. M uchas de las gráficas 0 tablas indican el espesor del blindaje en longitudes de relajación. Una longitud de relajación es el espesor de un blindaje que atenúa un haz estrecho hasta 1/ e (en torno al $37 \%$ ) de su intensidad original. Por consiguiente, una longitud de relajación viene dada por el valor numérico recíproco del coeficiente de atenuación lineal (es decir, $1 / \mu$ ).

El espesor de un absorbente que, cuando se introduce en el haz de fotones primarios, reduce a la mitad la tasa de dosis absorbida se llamada capa de hemirreducción (HVL) o espesor de hemirreducción (HVT). La HVL puede calcularse como sigue:

$$
H V L=\frac{\ln 2}{\mu}
$$

El espesor necesario de un blindaje antifotónico puede estimarse suponiendo una geometría de haz estrecho o satisfactoria al calcular el blindaje preciso, para luego aumentar el valor hallado en una HVL en consideración a la acumulación.

El espesor de un absorbente que, cuando se introduce en el haz de fotones primarios, reduce al décimo la tasa de dosis absorbida se llama capa del valor un décimo (TVL). U na TV L es igual a unas $3,32 \mathrm{HVL}$, puesto que:

$$
\frac{\ln 10}{\ln 2} \approx 3,32
$$

Los valores de TVL y HVL han sido tabulados para diversas energías de fotón y varios materiales corrientes de blindaje (p.ej., plomo, acero y hormigón) (Schaefer 1973).

La intensidad o tasa de dosis absorbida para una fuente puntual sigue la ley del inverso de la distancia al cuadrado y puede calcularse del modo siguiente:

$$
\frac{I_{1}}{I_{2}}=\left(\frac{d_{2}}{d_{1}}\right)^{2}
$$

donde $I_{i}$ es la intensidad de los fotones o tasa de dosis absorbida a la distancia $\mathrm{d}_{\mathrm{i}}$ de la fuente.

\section{Blindaje de aparatos de rayos $X$ médicos y no médicos}

$E I$ blindaje de aparatos de rayos $X$ se considera bajo dos aspectos diferentes, blindaje de la fuente y blindaje estructural. EI blindaje de la fuente suele ser efectuado por el fabricante o proveedor de la carcasa del tubo de rayos $X$.
Los reglamentos de seguridad especifican un tipo de carcasa protectora del tubo en las instalaciones de rayos $X$ para diagnostico médico, y otro para las instalaciones de rayos $X$ terapéuticos. Para aparatos de rayos $X$ no médicos, la carcasa del tubo y otras partes del aparato de rayos $X$, como el transformador, se blindan para reducir la fuga de la radiación $X$ a niveles aceptables.

Todas las máquinas de rayos $X$, médicas y no médicas, tienen carcasas protectoras del tubo diseñadas para limitar la radiación de fuga. La radiación de fuga, tal como se utiliza en estas especificaciones de carcasas para tubos, significa toda la radiación procedente de la carcasa del tubo menos la del haz útil.

$E$ El blindaje estructural de una instalación de rayos $X$ proporciona protección contra el haz de rayos $X$ útil o primario, la radiación de fuga y la radiación dispersada. Abarca tanto el aparato de rayos $X$ como el objeto que se irradia.

$L$ a cantidad de radiación dispersada depende del tamaño del campo de rayos $X$, de la energía del haz útil, del número atómico efectivo del medio de dispersión y del ángulo que forman el haz útil entrante y la dirección de dispersión.

Un parámetro clave del diseño es la carga de trabajo de la instalación (W ):

$$
W=E N_{v} N_{p} k
$$

donde W es la carga de trabajo semanal, que por lo general se da en $\mathrm{mA}$-min por semana; $\mathrm{E}$ es la corriente del tubo multiplicada por el tiempo de exposición por proyección, que se suele dar en $\mathrm{mA} \mathrm{s} ; \mathrm{N}_{v}$ es el número de proyecciones por paciente u objeto irradiado; $N_{p}$ es el número de pacientes $u$ objetos por semana y $k$ es un factor de conversión (1 min dividido por $60 \mathrm{~s}$ ).

0 tro parámetro clave del diseño es el factor de uso $U_{n}$ de una pared (o suelo o techo) $n$. La pared puede proteger cualquier zona ocupada, como una sala de control, oficina o sala de espera. El factor de uso viene dado por:

$$
U_{n}=\frac{N_{v, n}}{N_{v}}
$$

donde, $N_{v, n}$ es el número de proyecciones para las que el haz de rayos $X$ primario es dirigido hacia la pared $n$.

Las necesidades de blindaje estructural de una instalación dada de rayos $X$ se determinan teniendo en cuenta los datos siguientes:

- el potencial máximo del tubo, en kilovoltios-pico (kV p), al que funciona el tubo de rayos $X$;

- la corriente máxima del haz, en mA, con que funciona el sistema de rayos $X$;

- la carga de trabajo (W), que mide en unidades adecuadas (por lo general, mA-min por semana) la cantidad de uso del sistema de rayos $X$;

- el factor de uso (U ), que es la fracción de la carga de trabajo durante la cual el haz útil está dirigido en la dirección de interés;

- el factor de ocupación (T ), o factor por el que se debe multiplicar la carga de trabajo para introducir la corrección por el grado o tipo de ocupación de la zona a proteger;

- la tasa de dosis equivalente máxima permisible $(P)$ para una persona en zonas controladas y no controladas (los límites de dosis absorbida típicos son de $1 \mathrm{mG}$ y para una zona controlada en una semana y $0,1 \mathrm{mG}$ y para una zona no controlada en una semana),

- tipo del material de blindaje (por ejemplo, plomo u hormigón),

- la distancia (d) desde la fuente hasta el emplazamiento protegido. 
Incluidas estas consideraciones, el valor de la relación del haz primario o factor de transmisión $\mathrm{K}$ en $\mathrm{mG}$ y por $\mathrm{mA}$-min a la distancia de un metro viene dado por:

$$
K=\frac{P d^{2}}{W U T}
$$

El blindaje de la instalación de rayos $X$ tiene que construirse de manera que la protección no se vea mermada por juntas, por aberturas para conducciones, tuberías etc., que atraviesen las barreras, ni por conductos, registros de servicio y similares empotrados en las barreras. El blindaje no sólo debe cubrir la parte posterior de los registros de servicio, sino también los lados, o extenderse lo suficiente para ofrecer una protección equivalente. Los conductos que atraviesen barreras deben poseer las curvas suficientes para reducir la radiación al nivel exigido. Las ventanas de observación deberán tener un blindaje equivalente al exigido para la partición (barrera) o puerta en la que están practicadas.

Las instalaciones de radioterapia pueden necesitar cerrojos de puertas, luces de aviso, circuito cerrado de televisión o medios de comunicación audibles (p.ej., voz o timbre) y comunicación visual entre quien pueda estar en la instalación y el operador.

$\mathrm{H}$ ay barreras protectoras de dos tipos:

1. barreras protectoras primarias, que son suficientes para atenuar el haz primario (útil) hasta el nivel admisible

2. barreras protectoras secundarias, que son suficientes para atenuar la radiación de fuga, la dispersada y la difundida al nivel requerido.

Para diseñar la barrera protectora secundaria, se calcula por separado el espesor necesario para brindar protección contra cada componente. Si los espesores necesarios son aproximadamente iguales, se suma una H V L extra al espesor máximo calculado. Si la diferencia máxima entre los espesores calculados es de una T V L o más, bastará el valor más grueso de los calculados.

La intensidad de la radiación dispersada depende del ángulo de dispersión, de la energía del haz útil, del tamaño del campo o área de dispersión y de la composición del sujeto.

Al diseñar barreras protectoras secundarias, los cálculos se simplifican con las siguientes hipótesis conservadoras:

1. Cuando los rayos $X$ se producen a $500 \mathrm{kV}$ o menos, la energía de la radiación dispersada es igual a la energía del haz útil.

2. Después de ser dispersado, el espectro de energía de los haces de rayos $X$ generados a tensiones superiores a $500 \mathrm{kV}$ se degrada hasta el de un haz de $500 \mathrm{kV}$, y la tasa de dosis absorbida a $1 \mathrm{~m}$ y 90 grados del dispersor es el 0,1\% de la existente en el haz útil en el punto de dispersión.

La relación de transmisión de la radiación dispersada se expresa en función del factor de transmisión de la dispersión $\left(K_{u x}\right)$ con unidades de $\mathrm{mG} \cdot \mathrm{m}^{2}(\mathrm{~mA}-\mathrm{min})^{-1}$ :

$$
K_{\mu x}=\frac{400 \mathrm{Pd}_{\mathrm{scat}}{ }^{2} \mathrm{~d}_{\mathrm{sec}}{ }^{2}}{\mathrm{aWTFf}}
$$

donde $P$ es la tasa de dosis absorbida máxima semanal (en $m G y$ ), $d_{\text {scat }}$ es la distancia desde el anticátodo del tubo de rayos $X$ hasta el objeto (paciente), $d_{\text {sec }}$ es la distancia desde el dispersor (objeto) hasta el punto de interés que se pretende blindar con las barreras secundarias, a es la relación entre la radiación dispersada y la radiación incidente, $f$ es el tamaño real del campo de dispersión $\left(e n \mathrm{~cm}^{2}\right.$ ) y $\mathrm{F}$ es un factor que tiene en cuenta el hecho de que la salida de rayos $X$ aumenta con la tensión. Al disminuir el valor de $K_{\mu x}$ es preciso aumentar el espesor del blindaje.

EI factor de atenuación de fuga $B_{L X}$ para sistemas de diagnóstico de rayos $X$ se calcula del modo siguiente:

$$
B_{L x}=\frac{600 \mathrm{Pd}^{2}{ }^{2}}{W T} \text { (diagnóstico) }
$$

donde d es la distancia desde el anticátodo del tubo hasta el punto de interés e I es la corriente del tubo en $\mathrm{mA}$.

La relación de atenuación de la barrera para sistemas terapéuticos de rayos $X$ que funcionen a $500 \mathrm{kV}$ o menos viene dada por:

$$
B_{L x}=\frac{600 \mathrm{Pd}^{2} \mathrm{I}}{W T} \text { (terapéutico } \mathrm{V} \leq 500 \mathrm{keV} \text { ) }
$$

Para tubos de rayos $X$ terapéuticos que funcionen a potenciales superiores a $500 \mathrm{kV}$, la fuga suele estar limitada al 0,1\% de la intensidad del haz útil a $1 \mathrm{~m}$. El factor de atenuación en este caso es:

$$
B_{L X}=\frac{1.000 P d^{2}}{W T} \cdot \frac{1}{X_{n}}
$$

donde $X_{n}$ es la tasa de dosis absorbida (en $m G y / h$ ) a $1 \mathrm{~m}$ de un tubo de rayos $X$ terapéuticos que funcione con una corriente de $1 \mathrm{~mA}$ en el tubo.

EI número $n$ de $H V L$ necesarias para obtener la atenuación deseada $B_{L X}$ se obtiene de la relación:

$$
\begin{aligned}
& B_{L X}=\left(\frac{1}{2}\right)^{n} \\
& n=-\frac{\ln B_{L X}}{\ln 2}
\end{aligned}
$$

\section{Blindaje de partículas beta}

C uando se diseña un blindaje para un emisor beta de alta energía hay que tener en cuenta dos factores: las propias partículas beta y la bremsstrahlung (radiación de frenado) producida por partículas beta absorbidas por la fuente y el blindaje. La bremsstrahlung consta de fotones de rayos $X$ producidos cuando partículas cargadas a gran velocidad experimentan una deceleración rápida.

Por lo tanto, un blindaje beta se compone a menudo de una sustancia de número atómico bajo (para reducir al mínimo la producción de bremsstrahlung) que tenga el espesor suficiente para detener todas las la partículas beta, seguida de un material de número atómico alto que tenga el espesor suficiente para atenuar la bremsstrahlung hasta un nivel aceptable. (Si se invierte el orden de los blindajes aumenta la producción de bremsstrahlung en el primer blindaje hasta un nivel tan elevado que el segundo blindaje puede no proporcionar la protección adecuada.)

A efectos de estimar el peligro de bremsstrahlung, puede utilizarse la relación siguiente:

$$
f \approx \frac{6 \times 10^{-4} Z E_{\beta}}{1+6 \times 10^{-4} Z E_{\beta}}
$$

donde f es la fracción de la energía beta incidente convertida en fotones, $Z$ es el número atómico del absorbente y $\mathrm{E}_{\beta}$ es la energía máxima del espectro de partículas betas en $\mathrm{M}$ eV. Para garantizar una protección adecuada, se suele suponer que todos los fotones de la bremsstrahlung son de energía máxima. 
EI flujo $\phi$ de bremsstrahlung a una distancia d de la fuente beta se puede estimar por la ecuación:

$$
\phi \approx \frac{f \overline{E_{\beta}}}{4 p d^{2} E_{\beta}}
$$

$\overline{E_{\beta}}$ es la energía media de las partículas beta, que puede estimarse mediante:

$$
\overline{E_{\beta}} \approx \frac{E_{\beta}}{3}
$$

El alcance $R_{\beta}$ de las partículas beta en unidades de densidad superficial $\left(\mathrm{mg} / \mathrm{cm}^{2}\right)$ puede estimarse por la igualdad siguiente para partículas beta con energías entre 0,01 y $2,5 \mathrm{M} \mathrm{eV}$ :

$$
\mathrm{R}_{\beta} \approx 412 \cdot \mathrm{E}_{\beta}^{1,265-0,0954 \ln \mathrm{E}_{\beta}}
$$

donde $R_{\beta}$ está en $\mathrm{mg} / \mathrm{cm}^{2}$ y $E_{\beta}$ en $\mathrm{M} \mathrm{eV}$.

Para $\mathrm{E}_{\beta}>2,5 \mathrm{M} \mathrm{eV}$, el alcance de la partícula beta $R_{\beta}$ puede estimarse como sigue:

$$
\mathrm{R}_{\beta} \approx 530 \mathrm{E}_{\beta}-106
$$

donde $\mathrm{R}_{\beta}$ está en $\mathrm{mg} / \mathrm{cm}^{2}$ y $\mathrm{E}_{\beta}$ en $\mathrm{M} \mathrm{eV}$.

\section{Blindaje de partículas alfa}

Las partículas alfa son el tipo menos penetrante de radiación ionizante. Dada la naturaleza aleatoria de sus interacciones, el alcance de una partícula alfa individual varía entre los valores nominales que se indican en la Figura 48.18. En el caso de las partículas alfa, el alcance puede expresarse de diferentes formas: alcance mínimo, medio, extrapolado o máximo. El alcance medio es el que puede determinarse con más exactitud, corresponde al alcance de la partícula alfa "media" y es el más utilizado.

El aire es el medio absorbente utilizado con más frecuencia para especificar la relación alcance-energía de las partículas alfa. Para una energía alfa $\mathrm{E}_{\alpha}$ menor que unos $4 \mathrm{M} \mathrm{eV}, \mathrm{R}_{\alpha}$ en el aire viene dado aproximadamente por:

$$
\mathrm{R}_{\alpha} \approx 0,56 \cdot \mathrm{E}_{\alpha}
$$

donde $\mathrm{R}_{\alpha}$ está en $\mathrm{cm}$ y $\mathrm{E}_{\alpha}$ en $\mathrm{M} \mathrm{eV}$.

Para $\mathrm{E}_{\alpha}$ entre 4 y $8 \mathrm{M} \mathrm{eV}, \mathrm{R}_{\alpha}$ en el aire se expresa por la igualdad aproximada:

$$
\mathrm{R}_{\alpha} \approx 1,24 \cdot \mathrm{E}_{\alpha}-2,62
$$

donde $\mathrm{R}_{\alpha}$ está en $\mathrm{cm}$ y $\mathrm{E}_{\alpha}$ en $\mathrm{M} \mathrm{eV}$.

EI alcance de las partículas alfa en cualquier otro medio puede estimarse por la relación siguiente:

$\mathrm{R}_{\alpha}$ (en otro medio; $\mathrm{mg} / \mathrm{cm}^{2}$ ) $\approx 0,56 \mathrm{~A}^{1 / 3} \mathrm{R}_{\alpha}$ (en el aire; $\mathrm{cm}$ ) donde $\mathrm{A}$ es el número atómico del medio.

\section{Blindaje de neutrones}

La regla práctica general que se debe tener en cuenta para el blindaje de neutrones es que el equilibrio de la energía de neutrones se consigue y permanece constante después de una 0 dos longitudes de relajación del material de blindaje. Por lo tanto, para espesores de blindaje superiores a varias longitudes de relajación, la dosis equivalente fuera del blindaje de hormigón o hierro será atenuada con longitudes de relajación de $120 \mathrm{~g} / \mathrm{cm}^{2}$ $0145 \mathrm{~g} / \mathrm{cm}^{2}$, respectivamente.
Figura 48.18 • Distribución típica de alcances de partículas alfa.

Tasa de

conteo relativo

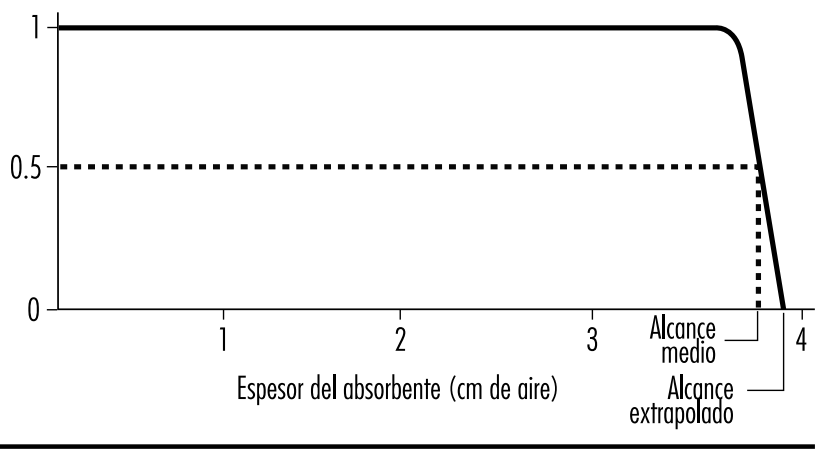

La pérdida de energía de los neutrones por dispersión elástica exige un blindaje hidrogenado para optimizar la transferencia de energía a medida que los neutrones son moderados 0 frenados. Para energías de neutrones superiores a $10 \mathrm{M} \mathrm{eV}$, los procesos inelásticos son eficaces en la atenuación de neutrones.

I gual que los reactores de las centrales nucleares, los aceleradores de alta energía exigen blindajes pesados para proteger a los trabajadores. La mayoría de las dosis equivalentes impartidas a los trabajadores proceden de la exposición a material radiactivo activado durante operaciones de mantenimiento. LoS productos de la activación se generan en los componentes y en los sistemas de apoyo del acelerador.

\section{Vigilancia del entorno del lugar de trabajo}

En la vigilancia del entorno del lugar de trabajo, es necesario estudiar por separado el diseño de los programas rutinarios y el de los operacionales. Cuando se persigan objetivos específicos se diseñarán programas de vigilancia especiales. No es aconsejable diseñar programas en líneas generales.

\section{Vigilancia rutinaria de la radiación externa}

U na medida importante que se debe tomar en la preparación de un programa de vigilancia rutinaria de la radiación externa en el lugar de trabajo es llevar a cabo un estudio exhaustivo cuando se ponga en servicio una nueva fuente de radiación o una nueva instalación, o cuando se hayan efectuado o vayan a efectuarse cambios sustanciales en una instalación existente.

La frecuencia de la vigilancia rutinaria está determinada por la consideración de los cambios esperados en el entorno radiológico. Si los cambios de los elementos protectores o las alteraciones de los procesos realizados en el lugar de trabajo son mínimos o no sustanciales, raras veces será preciso recurrir a la vigilancia rutinaria de la radiación en el lugar de trabajo. Pero si los campos de radiación pueden llegar a aumentar con rapidez y de manera imprevisible a niveles que puedan resultar peligrosos, hará falta establecer un sistema de vigilancia y alarma de radiación en la zona.

\section{Vigilancia operacional de la radiación externa}

EI diseño de un programa de vigilancia operacional depende en gran medida de si las operaciones a realizar influyen en los campos de radiación o si éstos permanecerán casi constantes durante todas las operaciones normales. El diseño detallado de este estudio depende sobre todo de la forma de la operación y de las condiciones en las que tiene lugar. 
Vigilancia rutinaria de la contaminación superficial

EI método tradicional de vigilancia rutinaria de la contaminación superficial consiste en vigilar una fracción representativa de las superficies de una zona con una frecuencia dictada por la experiencia. Si la naturaleza de las operaciones es tal que sea probable una contaminación superficial considerable y que los trabajadores pudieran transportar cantidades significativas de material radiactivo fuera de la zona de trabajo en un suceso único, la vigilancia rutinaria debe ser suplementada con el uso de monitores de contaminación de portal.

\section{Vigilancia operacional de la contaminación superficial}

U na de las formas de vigilancia operacional es el control de la posible contaminación de elementos a su salida de una zona sometida a control radiológico. Esta vigilancia debe incluir las manos y pies de los trabajadores.

Los objetivos principales de un programa de vigilancia de contaminación superficial son:

- ayudar a prevenir la difusión de la contaminación radiactiva;

- detectar fallos de contención o desviaciones de los procedimientos operativos correctos;

- limitar la contaminación superficial a niveles a los que las normas generales de limpieza sean suficientes para mantener las exposiciones radiológicas tan bajas como sea razonable alcanzar y evitar las exposiciones excesivas ocasionadas por la contaminación de ropa y piel,

- suministrar información que permita planificar programas optimizados para individuos, para la vigilancia del aire y para definir procedimientos operacionales.

\section{Vigilancia de la contaminación aérea}

La vigilancia de los materiales radiactivos transportados por el aire es importante porque la inhalación suele ser la principal vía de captación de este material por los trabajadores expuestos.

Será necesario establecer una vigilancia rutinaria del puesto de trabajo en relación con la contaminación aérea en las circunstancias siguientes:

- cuando se manipulen en grandes cantidades materiales gaseosos o volátiles;

- cuando la manipulación de cualquier material radiactivo en estas operaciones dé lugar a contaminación frecuente y sustancial del lugar de trabajo;

- durante el procesamiento de materiales radiactivos de toxicidad moderada a alta;

- durante la manipulación de radionucleidos terapéuticos no sellados en hospitales,

- durante el uso de celdas activadas, reactores y conjuntos críticos.

\section{Cuando se necesite un programa de vigilancia del aire, debe:}

- permitir valorar el límite superior probable de la inhalación de material radiactivo por los trabajadores expuestos;

- ser capaz de alertar de una contaminación aérea inesperada, de manera que los trabajadores expuestos puedan ser protegidos y se establezcan las medidas correctivas,

- suministrar información para planificar programas de vigilancia de la contaminación interna individual.

La forma más corriente de vigilancia de la contaminación del aire es utilizar muestreadores de aire en un número de lugares seleccionados que representen en grado razonable las zonas donde respiran los trabajadores expuestos. A veces es preciso tomar muestras que representen con más precisión las zonas de respiración mediante el uso de muestreadores de aire personales o de solapa.

\section{Detección y medición de la radiación} y de la contaminación radiactiva

La vigilancia o supervisión mediante instrumentos de barrido y detección en superficies de trabajo, suelo, ropa, piel y otras superficies son procedimientos meramente cualitativos. Es difícil convertirlos en cuantitativos. Los instrumentos empleados suelen ser dispositivos detectores, no medidores. Como la cantidad de radiactividad que interviene es a menudo pequeña, la sensibilidad de los instrumentos deberá ser alta.

El requisito de transportabilidad de los detectores de contaminación depende de los usos previstos. Si el instrumento está destinado a vigilancia general de superficies del laboratorio, es recomendable emplear un instrumento portátil. En cambio, si el instrumento es para una aplicación específica y el elemento a supervisar se puede llevar hasta el instrumento, la transportabilidad no es necesaria. Los monitores de ropa, manos y calzado no son portátiles en general.

Los instrumentos y monitores contadores suelen incorporar lecturas en medidores y salidas aurales o conectores para auriculares. En la Tabla 48.14 se identifican los instrumentos que pueden emplearse para la detección de contaminación radiactiva.

\section{Detectores de conta minación alfa}

La sensibilidad de un detector alfa está determinada por el área y el espesor de su ventana. Por lo general, el área de la ventana es de $50 \mathrm{~cm}^{2}$ o mayor, y la densidad superficial de la ventana es de $1 \mathrm{mg} / \mathrm{cm}^{2}$ o menor. Los monitores de contaminación alfa deben ser insensibles a la radiación beta y gamma para reducir al mínimo la interferencia de fondo. Esto se consigue por lo general mediante la discriminación de la altura de impulsos en el circuito contador.

Los monitores portátiles alfa pueden ser contadores proporcionales de gas o contadores de centelleo de sulfuro de zinc.

\section{D etectores de conta minación beta}

Pueden utilizarse monitores beta portátiles de varios tipos para la detección de contaminación por partículas beta. Los contadores Geiger-M ueller ( $G-M$ ) exigen en general una ventana delgada (de densidad superficial entre 1 y $40 \mathrm{mg} / \mathrm{cm}^{2}$ ). L os contadores de centelleo (de antraceno o plástico) son muy sensibles a las partículas beta y relativamente insensibles a los fotones. L os contadores beta portátiles no se pueden usar en general para vigilar la contaminación por tritio $\left({ }^{3} \mathrm{H}\right)$, porque la energía de las partículas beta del tritio es muy baja.

Todos los instrumentos empleados para detectar la contaminación beta responden también a la radiación de fondo,lo que debe tenerse en cuenta al interpretar las lecturas del instrumento.

Cuando existe una radiación de fondo de alto nivel, los contadores portátiles detectores de contaminación tienen un valor limitado, puesto que no indican aumentos pequeños de tasas de recuento iniciales elevadas. En estas condiciones, se recomiendan ensayos de barrido o de impregnación.

\section{Detectores de conta minación gamma}

Como la mayoría de los emisores gamma emiten también partículas beta, casi todos los monitores de contaminación detectarán radiación beta y gamma. La práctica habitual es emplear un detector que sea sensible a los dos tipos de radiación con el fin de incrementar la sensibilidad, puesto que la eficiencia de la detección suele ser mayor para partículas beta que para rayos gamma. L os contadores de centelleo de plástico o de cristales de yoduro de sodio ( $\mathrm{N}$ al) son más sensibles a los fotones que los contadores $\mathrm{G}-\mathrm{M}$, por lo que se recomiendan para detectar rayos gamma. 
Tabla 48.14 • Instrumentos detectores de contaminación.

\begin{tabular}{|c|c|c|c|}
\hline Instrumento & $\begin{array}{l}\text { Escala de la tasa de recuento y otras } \\
\text { características }^{1}\end{array}$ & Usos típicos & Observaciones \\
\hline \multicolumn{4}{|l|}{ Monitores $\beta \gamma$ de superficies ${ }^{2}$} \\
\hline \multicolumn{4}{|l|}{ Generales } \\
\hline $\begin{array}{l}\text { Contador portátil ( contador G-M³ de } \\
\text { pared delgada } 0 \text { de ventana delgada) }\end{array}$ & $\begin{array}{l}0-1.000 \mathrm{cpm} \\
0-10.000 \mathrm{cpm}\end{array}$ & Superficies, manos, ropa & Sencillo, fiable, alimentado por batería \\
\hline $\begin{array}{l}\text { Monitor G-M de laboratorio } \\
\text { de ventana terminal delgada }\end{array}$ & $\begin{array}{r}0-1.000 \mathrm{cpm} \\
0.10 .000 \mathrm{cpm} \\
0.100 .000 \mathrm{cpm}\end{array}$ & Superficies, manos, ropa & Alimentación a red \\
\hline \multicolumn{4}{|l|}{ Personales } \\
\hline $\begin{array}{l}\text { Monitor de manos y calzado, contador } \\
\text { G-M o del tipo de centelleo }\end{array}$ & $\begin{array}{l}\text { Entre } 1 \frac{1}{1} 2 \text { y } 2 \text { veces el fondo } \\
\text { natural }\end{array}$ & Vigilancia rápida de la contaminación & Funcionamiento automático \\
\hline \multicolumn{4}{|l|}{ Especiales } \\
\hline $\begin{array}{l}\text { Monitores de lavandería, de suelo, } \\
\text { de portal, de vehículo }\end{array}$ & $\begin{array}{l}\text { Entre } 1 \frac{1}{2} \text { y } 2 \text { veces el fondo } \\
\text { natural }\end{array}$ & Vigilancia de la contaminación & Cómodo y rápido \\
\hline \multicolumn{4}{|l|}{ Monitores alfa de superficies } \\
\hline \multicolumn{4}{|l|}{ Generales } \\
\hline $\begin{array}{l}\text { Contador portátil proporcional de aire con } \\
\text { sonda }\end{array}$ & $0-100.000 \mathrm{cpm}$ sobre $100 \mathrm{~cm}^{2}$ & Superficies, manos, ropa & $\begin{array}{l}\text { No utilizar en ambientes muy húmedos, } \\
\text { alimentado por batería, ventana frágil }\end{array}$ \\
\hline $\begin{array}{l}\text { Contador portátil de flujo de gas con } \\
\text { sonda }\end{array}$ & $0-100.000 \mathrm{cpm}$ sobre $100 \mathrm{~cm}^{2}$ & Superficies, manos, ropa & Alimentado por batería, ventana frágil \\
\hline Contador portátil de centelleo con sonda & $0.100 .000 \mathrm{cpm}$ sobre $100 \mathrm{~cm}^{2}$ & Superficies, manos, ropa & Alimentado por batería, ventana frágil \\
\hline \multicolumn{4}{|l|}{ Personales } \\
\hline $\begin{array}{l}\text { Monitor de tipo contador proporcional } \\
\text { para manos y calzado }\end{array}$ & $0-2.000 \mathrm{cpm}$ sobre unos $300 \mathrm{~cm}^{2}$ & $\begin{array}{l}\text { Vigilancia rápida de contaminación en } \\
\text { manos y calzado }\end{array}$ & Funcionamiento automático \\
\hline $\begin{array}{l}\text { Monitor de tipo contador de centelleo } \\
\text { para manos y calzado }\end{array}$ & $0-4.000 \mathrm{cpm}$ sobre unos $300 \mathrm{~cm}^{2}$ & $\begin{array}{l}\text { Vigilancia rápida de contaminación en } \\
\text { manos y calzado }\end{array}$ & Aspero \\
\hline Monitores de heridas & Detección de fotones de baja energía & Vigilancia de plutonio & Diseño especial \\
\hline \multicolumn{4}{|l|}{ Monitores de aire } \\
\hline \multicolumn{4}{|l|}{ Muestreadores de partículas } \\
\hline Papel de filtro, gran volumen & $1,1 \mathrm{~m}^{3} / \mathrm{min}$ & Muestras al azar rápidas & $\begin{array}{l}\text { Uso intermitente, exige contador } \\
\text { separado }\end{array}$ \\
\hline Papel de filtro, pequeño volumen & $0,2-20 \mathrm{~m}^{3} / \mathrm{h}$ & Vigilancia permanente del aire de recintos & Uso continuo, exige contador separado \\
\hline De solapa & $0,03 \mathrm{~m}^{3} / \mathrm{min}$ & $\begin{array}{l}\text { Vigilancia permanente del aire que se } \\
\text { respira }\end{array}$ & Uso continuo, exige contador separado \\
\hline Precipitador electrostático & $0,09 \mathrm{~m}^{3} / \mathrm{min}$ & Vigilancia permanente & $\begin{array}{l}\text { Muestra depositada en cápsula cilíndrica, } \\
\text { exige contador separado }\end{array}$ \\
\hline De impacto & $0,6-1,1 \mathrm{~m}^{3} / \mathrm{min}$ & Contamination alfa & Usos especiales, exige contador separado \\
\hline \multicolumn{4}{|l|}{ Monitores de tritio en el aire } \\
\hline Cámaras de ionización de caudales & $0.370 \mathrm{kBq} / \mathrm{m}^{3} \mathrm{~min}$ & Vigilancia permanente & $\begin{array}{l}\text { Pueden ser sensibles a otras fuentes de } \\
\text { ionización }\end{array}$ \\
\hline Sistemas de vigilancia completa del aire & \multicolumn{3}{|l|}{ Actividad mínima detectable } \\
\hline Papel de filtro fijo & \multicolumn{2}{|l|}{$\alpha \gg>0,04 \mathrm{~Bq} / \mathrm{m}^{3} ; \beta \gamma>>0,04 \mathrm{~Bq} / \mathrm{m}^{3}$} & $\begin{array}{l}\text { La acumulación de fondo puede } \\
\text { enmascarar la actividad de bajo } \\
\text { nivel, contador incluido }\end{array}$ \\
\hline Papel de filtro recambiable & \multicolumn{2}{|l|}{$\alpha \gg>0,04 \mathrm{~Bq} / \mathrm{m}^{3} ; \beta \gamma>>0,04 \mathrm{~Bq} / \mathrm{m}^{3}$} & $\begin{array}{l}\text { Registro permanente de la actividad en } \\
\text { el aire, la hora de medición puede } \\
\text { ajustarse desde la hora de recogida } \\
\text { hasta cualquier hora posterior. }\end{array}$ \\
\hline \multicolumn{4}{|c|}{$\begin{array}{l}1 \mathrm{cpm}=\text { cuentas por minuto. } \\
\left.2 \text { Pocos monitores de superficies son útiles para detectar tritio ( }{ }^{3} \mathrm{H}\right) \text {. Las pruebas de barrido con recuento por dispositivos de centelleo en líquidos son adecuadas para detectar contaminación por tritio. } \\
3 \mathrm{G}-\mathrm{M}=\text { contador de Geiger-Muller. }\end{array}$} \\
\hline
\end{tabular}




\section{M uestreadores y monitores de aire}

Pueden tomarse muestras de las partículas sólidas del aire por los métodos siguientes: sedimentación, filtración, impactación y precipitación electrostática o térmica. En general, el más utilizado para detectar la contaminación por partículas en el aire es el de filtración (bombeo de aire a través de un medio filtrante y medición de la radiactividad del filtro). Los caudales de muestreo son en general superiores a $0,03 \mathrm{~m}^{3} / \mathrm{min}$. Pero la mayoría de los caudales de muestreo en laboratorios no superan la cifra de $0,3 \mathrm{~m}^{3} / \mathrm{min}$. Entre los tipos específicos de muestreadores de aire se cuentan los que obtienen muestras al azar y los monitores continuos de aire (MCA). Existen MCA con papel de filtro fijo 0 recambiable. Un MCA debe incluir una alarma, puesto que el principio de funcionamiento que inspira su diseño es avisar de las variaciones en la contaminación transportada por el aire.

Como las partículas alfa tienen un alcance muy corto, es preciso utilizar filtros de carga superficial (por ejemplo, filtros de membrana) para la medición de contaminación por partículas alfa. La muestra recogida deberá ser delgada. EI tiempo entre la recogida y la medición tiene que elegirse de manera que permita la desintegración de la progenie del radón $(\mathrm{R} n)$.

Con el papel de filtro pueden detectarse isótopos radiactivo del yodo como ${ }^{123}$ |, ${ }^{125}$ | y ${ }^{131}$ | (sobre todo si el papel se carga con carbón activado o nitrato de plata), ya que parte del yodo se depositará en el papel de filtro. Pero en las mediciones cuantitativas se precisan trampas o cajas de carbón activado o zeolita de plata para que la absorción sea eficiente.

El agua tritiada y el gas de tritio son las formas principales de la contaminación por tritio. Aunque el agua tritiada tiene cierta afinidad por la mayoría de los papeles de filtro, las técnicas con papel de filtro no son muy eficaces para el muestreo de agua tritiada. Los métodos de medición más sensibles y exactos son los que recurren a la absorción del condensado de vapor de agua tritiada. La medición del tritio del aire (por ejemplo, en forma de hidrógeno, hidrocarburos o vapor de agua) puede ser eficaz si se hace con cámaras de $K$ anne (cámaras de ionización por flujo). La absorción del vapor de agua tritiada de una muestra de aire puede lograrse haciendo pasar la muestra por una trampa que contenga un tamiz molecular de gel de ślice o por burbujeo de la muestra en agua destilada.

La operación o proceso que se realice puede hacer necesaria la vigilancia de gases radiactivos, que puede lograrse con cámaras de $\mathrm{K}$ anne. Los dispositivos empleados con más frecuencia en el muestreo por absorción son depuradores y golpeadores preparados para el gas. M uchos gases pueden recogerse también mediante enfriamiento del aire por debajo del punto de congelación del gas y recogida del condensado. Este método de recogida se utiliza casi siempre para óxido de tritio y gases nobles.

$\mathrm{H}$ ay varias maneras de obtener muestras al azar. El método elegido debe ser el adecuado para el gas que se muestrea y para el procedimiento de análisis o medición correspondiente.

\section{Vigilancia del efluente}

Se entiende por vigilancia del efluente la medición de la radiactividad en su punto de descarga al medio ambiente. Se consigue con relativa facilidad porque las condiciones del lugar de muestreo están controladas. Las muestras se suelen tomar en una corriente de desechos que se descargan por una tubería de escape o de salida de líquidos.

$H$ ay casos en que es necesaria la vigilancia permanente de la radiactividad contenida en el aire. Además del dispositivo de recogida de muestras, que suele ser un filtro, una disposición típica de muestreo de partículas en el aire comprende un elemento agitador del aire, un fluxímetro y las tuberías asociadas. El agitador de aire se sitúa corriente abajo del colector de muestras; es decir, el aire se hace pasar primero por el colector de muestras y después por el resto del sistema de muestreo. Las tuberías de muestreo, en particular las previas al sistema colector de muestras, deben ser lo más cortas posible y sin curvas cerradas, áreas de turbulencia o resistencia a la circulación del aire. Para el muestreo del aire debe utilizarse una gama adecuada de caídas de presión a volumen constante. EI muestreo continuo en busca de isótopos radiactivos de xenón (X e) o criptón ( $\mathrm{K} r$ ) se consigue por adsorción a carbón activado o por métodos criogénicos. La celda de Lucas es una de las técnicas más antiguas y sigue siendo el método más extendido para medir concentraciones de $\mathrm{R} n$.

A veces es necesaria la vigilancia continua de tuberías de líquidos y de desechos para detectar materiales radiactivos, por ejemplo los desagües de laboratorios con fuentes radiactivas, laboratorios de medicina nuclear y tuberías de refrigerantes de reactores. Pero la vigilancia continua puede efectuarse mediante el análisis rutinario en laboratorio de una muestra pequeña proporcional al caudal del efluente. Existen muestreadores para la toma periódica de partes alícuotas o para la extracción continua de una cantidad pequeña de líquido.

El muestreo aleatorio es el método usual de determinar la concentración de material radiactivo en un depósito de retención. La muestra debe tomarse después de una recirculación, con el fin de comparar el resultado de la medición con los límites de descarga permitidos.

Lo ideal es que exista una buena concordancia entre los resultados de la vigilancia de efluentes y los de la vigilancia medioambiental, siendo los segundos calculables a partir de los primeros con ayuda de diversos modelos de conversión. Pero es preciso reconocer y subrayar que la vigilancia de efluentes, por buena o extensa que sea, no puede sustituir a la medición real de las condiciones radiológicas del medio ambiente.

\section{SEGURIDAD RADIOLOGICA}

Robert N. Cherry, Jr.

En este artículo se describen aspectos de los programas de seguridad radiológica. El objetivo de la seguridad radiológica es eliminar o limitar al mínimo los efectos nocivos de la radiación ionizante y del material radiactivo en los trabajadores, el público y el medio ambiente sin obstaculizar su empleo en actividades beneficiosas.

Casi ningún programa de seguridad radiológica tendrá que implantar todos y cada uno de los elementos que se describen a continuación. El diseño de un programa de seguridad radiológica depende de los tipos de fuentes de radiación ionizante que intervengan y de la forma en que se utilicen.

\section{Principios de la seguridad radiológica}

$\mathrm{L}$ a Comisión Internacional de Protección contra las R adiaciones (CIPR) ha propuesto los principios siguientes, que deben informar la utilización de la radiación ionizante y la aplicación de las normas de seguridad radiológica:

1. No debe adoptarse ninguna práctica que implique exposiciones a la radiación a menos que produzca un beneficio a los individuos expuestos o a la sociedad suficiente para compensar el perjuicio que ocasiona la radiación (la justificación de una práctica).

2. En relación con cualquier fuente particular dentro de una práctica, la magnitud de las dosis individuales, el número de personas expuestas y la probabilidad de incurrir en exposiciones cuando no exista seguridad de que vayan a recibirse 
deben mantenerse todas tan bajas como razonablemente se pueda (ALARA), teniendo en cuenta factores económicos y sociales. Este procedimiento debe estar limitado por restricciones sobre la dosis a individuos (restricciones de dosis), de manera que se limite la desigualdad que pueda resultar de los juicios económicos y sociales inherentes (la optimización de la protección).

3. La exposición de individuos resultante de la combinación de todas las prácticas pertinentes debe someterse a límites de dosis, o a algún control del riesgo en el caso de exposiciones potenciales, con el fin de garantizar que nadie se exponga por causa de estas prácticas a riesgos radiológicos que se consideren inaceptables en circunstancias normales. No todas las fuentes son susceptibles de control mediante acción en la misma fuente, y es necesario especificar las fuentes que se incluirán como pertinentes antes de seleccionar un límite de dosis (límites de dosis y de riesgo individuales ).

\section{Normas de seguridad radiológica}

Existen normas sobre exposición radiológica de los trabajadores y del público en general y sobre límites anuales de incorporación ( $L A I)$ de radionucleidos. De los $L A I$ pueden deducirse normas que regulen las concentraciones de radionucleidos en el aire y en el agua.

La CIPR ha publicado numerosas tabulaciones de los LAI y de las concentraciones correspondientes en el aire y en el agua. En la Tabla 48.15 ofrece un resumen de los límites de dosis recomendados.

\section{Dosimetría}

La dosimetría se utiliza para indicar los equivalentes de dosis que los trabajadores reciben de los campos de radiación externos a los que puedan estar expuestos. Los dosímetros se caracterizan por el tipo de dispositivo, por el tipo de radiación que miden y por la parte del cuerpo para la que se indicará la dosis absorbida.

Tabla 48.15 • Límites de dosis recomendados por la Comisión Internacional de Protección Radiológica ${ }^{1}$

\begin{tabular}{|c|c|c|}
\hline \multirow{2}{*}{ Aplicación } & \multicolumn{2}{|l|}{ Límite de dosis } \\
\hline & Profesional & Pública \\
\hline Dosis efectiva & $\begin{array}{l}20 \mathrm{mSv} \text { anuales } \\
\text { de media en } \\
\text { períodos definidos } \\
\text { de } 5 \text { años }\end{array}$ & $1 \mathrm{mSve}$ \\
\hline \multicolumn{3}{|c|}{ Dosis anual equivalente en: } \\
\hline Cristalino del ojo & $150 \mathrm{mSv}$ & $15 \mathrm{mSv}$ \\
\hline Piel $\left.\right|^{4}$ & $500 \mathrm{mSv}$ & $50 \mathrm{mSv}$ \\
\hline Manos y pies & $500 \mathrm{mSv}$ & _- \\
\hline
\end{tabular}

${ }^{1}$ Los límites se aplican a la suma de las dosis pertinentes de exposición externa en el período especificado y el compromiso de dosis durante 50 años (hasta la edad de 70 años para niños) por incorporaciones en el mismo período.

2 Con la condición adicional de que la dosis efectiva no sea superior a $50 \mathrm{mSv}$ en un solo año. A la exposición profesional de las mujeres embarazadas se aplican además otras restricciones.

3 En circunstancias especiales se podría permitir una dosis efectiva más alta en un solo año, siempre que la media de 5 años no fuera superior a $1 \mathrm{mSv}$ anual.

${ }^{4}$ La limitación de la dosis efectiva proporciona protección suficiente para la piel contra efectos estocásticos. Es preciso establecer un límite adicional de exposiciones localizadas para prevenir efectos deterministas.
Tres son los tipos principales de dosímetros de uso más corriente. Se trata de los dosímetros termoluminiscentes, dosímetros de película y cámaras de ionización. 0 tros tipos de dosímetros (no tratados aquí) son las láminas de fisión, los dispositivos de registro de huellas y los dosímetros de "burbuja" de plástico.

Los dosímetros termoluminiscentes son los dosímetros personales más utilizados. A plican el principio de que algunos materiales, cuando absorben energía de la radiación ionizante, la van almacenando, de modo que puede recuperarse después en forma de luz cuando los materiales se calientan. La cantidad de luz liberada es directamente proporcional, con bastante exactitud, a la energía absorbida de la radiación ionizante y, por lo tanto, a la dosis absorbida que ha recibido el material. Esta proporcionalidad es válida en un intervalo muy amplio de la energía de la radiación ionizante y de las tasas de dosis absorbida.

Para el procesamiento exacto de los dosímetros termoluminiscentes es preciso disponer de un equipo especial. La lectura del dosímetro termoluminiscente destruye la información de dosis que contiene. Pero si se les somete al procesamiento adecuado, los dosímetros termoluminiscentes son reutilizables.

El material empleado en dosímetros termoluminiscentes ha de ser transparente a la luz que emite. Los materiales más empleados en la fabricación de dosímetros termoluminiscentes son el fluoruro de litio (LiF) y el fluoruro de calcio $\left(\mathrm{CaF}_{2}\right)$. Los materiales pueden doparse con otros o prepararse en una composición isotópica específica para aplicaciones especializadas, como la dosimetría de neutrones.

M uchos dosímetros contienen varias pastillas termoluminiscentes con diferentes filtros delante de ellas para distinguir entre energías y tipos de radiación.

L a película fotográfica fue el material más corriente empleado en dosimetría personal antes de generalizarse la dosimetría termoluminiscente. EI grado de ennegrecimiento de la película depende de la energía absorbida de la radiación ionizante, pero la relación no es lineal. La dependencia de la respuesta de la película respecto de la dosis absorbida total, de la tasa de dosis absorbida y de la energía de la radiación es mayor que en los dosímetros termoluminiscentes y puede limitar el margen de aplicabilidad de la película. Pero ésta tiene la ventaja de suministrar un registro permanente de la dosis absorbida a que ha estado expuesta.

Pueden emplearse películas de diversas formulaciones y filtros en disposiciones diferentes para fines especiales, como dosimetría de neutrones. I gual que en los dosímetros termoluminiscentes, para el análisis correcto se necesita un equipo especial.

La película es en general mucho más sensible a la humedad y a la temperatura ambientes que los materiales termoluminiscentes, y puede dar lecturas elevadas falsas en condiciones adversas. Por el contrario, en los equivalentes de dosis indicados por los dosímetros termoluminiscentes puede influir el golpe originado por su caída sobre una superficie dura.

Unicamente las organizaciones muy grandes tienen servicios propios de dosimetría. La mayoría de ellas obtienen dichos servicios de empresas especializadas en estas tareas. Es importante que estas empresas tengan los permisos adecuados o estén certificadas por organismos independientes para que pueda confiarse en que los resultados de la dosimetría serán exactos.

Para obtener información dosimétrica inmediata se emplean pequeñas cámaras de ionización, de lectura directa, también denominadas cámaras de bolsillo. Es muy frecuente su uso cuando tiene que entrar personal en zonas de alta o muy alta radiación, donde se podría recibir una dosis absorbida grande en muy poco tiempo. Las cámaras de bolsillo se suelen calibrar en la propia instalación y son muy sensibles al choque. Por consiguiente, 
tienen que ser suplementadas siempre con dosímetros termoluminiscentes 0 de película, que son más exactos y fiables, pero que no dan resultados inmediatos.

Un trabajador necesita dosimetría cuando tiene una probabilidad razonable de acumular un determinado porcentaje, por lo general del 5 ó $10 \%$, del equivalente de dosis máximo permisible en todo el cuerpo o en ciertas partes de él.

El dosímetro de cuerpo entero debe llevarse a una altura comprendida entre los hombros y la cintura, en un punto donde se prevea la exposición máxima. Cuando las condiciones de exposición lo justifiquen, pueden llevarse otros dosímetros en dedos o muñecas, en el abdomen, en una cinta o sombrero en la frente, o en un collar, para evaluar la exposición localizada de las extremidades, de un feto o embrión, el tiroides o el cristalino de los ojos. Se recomienda consultar las directrices reglamentarias adecuadas sobre si se deben llevar dosímetros dentro o fuera de prendas protectoras, como delantales de plomo, guantes y collares.

Los dosímetros personales indican únicamente la radiación a la que ha estado expuesto el dosímetro. A signar el equivalente de dosis del dosímetro a la persona u órganos de la persona es aceptable si la dosis es pequeña, trivial, pero si el dosímetro indica dosis grandes, en especial si superan en mucho las definidas en las normas reguladoras, se deben analizar con cuidado la colocación del dosímetro y los campos de radiación reales a los cuales ha estado expuesto el trabajador para estimar la dosis que el trabajador recibió en realidad. Se debe obtener del trabajador una declaración, que formará parte de la investigación y será incluida en el informe. Pero la mayoría de las veces, las dosis muy grandes recibidas por el dosímetro se deben a la exposición radiológica deliberada del dosímetro mientras nadie lo llevaba puesto.

\section{Bioensayo}

Bioensayo (también llamado radiobioensayo) significa la determinación de los tipos, las cantidades o las concentraciones y, en algunos casos, los emplazamientos de material radiactivo en el cuerpo humano, ya sea por medición directa (recuento in vivo) 0 por análisis y evaluación de materiales excretados o eliminados del cuerpo humano.

EI bioensayo se suele utilizar para evaluar el equivalente de dosis del trabajador debido al material radiactivo incorporado al cuerpo. También puede dar una indicación de la eficacia de las medidas activas tomadas para evitar la incorporación. Raras veces se usa para estimar la dosis recibida por un trabajador en una exposición radiológica externa masiva (por ejemplo, mediante el recuento de leucocitos o defectos cromosómicos).

El bioensayo tiene que efectuarse cuando exista una posibilidad razonable de que un trabajador pueda incorporar o haya incorporado en su cuerpo más de un porcentaje determinado (por lo general el 5 ó $10 \%$ ) del LIA de un radionucleido. La forma química y física del radionucleido buscado en el cuerpo determina el tipo de bioensayo necesario para detectarlo.

El bioensayo puede consistir en analizar muestras tomadas del cuerpo (por ejemplo, orina, heces, sangre o cabellos) en busca de isótopos radiactivos. En este caso, la cantidad de radiactividad en la muestra puede relacionarse con la radiactividad en el cuerpo de la persona, y posteriormente con la dosis de radiación que el cuerpo de la persona o determinados órganos han recibido 0 está previsto que reciban. El bioensayo de orina para detección de tritio es un ejemplo de este tipo de bioensayo.

La exploración total o parcial del cuerpo con un escáner puede utilizarse para detectar fuera del cuerpo radionucleidos que emitan rayos $X$ o gamma de una energía medible. $E I$ bioensayo del tiroides para detección de yodo 131 (131) ) es un ejemplo de este tipo de bioensayo.
El bioensayo se puede efectuar sobre el terreno, o pueden remitirse muestras o enviarse al mismo personal a una instalación u organización especializada en bioensayos. En cualquier caso, la calibración adecuada de los instrumentos y la certificación de los procedimientos de laboratorio son esenciales para garantizar unos resultados exactos, precisos y defendibles.

\section{Ropa protectora}

La ropa protectora es suministrada por la empresa al trabajador para reducir la posibilidad de contaminación radiactiva del trabajador o de su ropa o para el blindaje parcial del trabajador contra la radiación beta, $X$ o gamma. Ejemplos de lo primero son la ropa, guantes, campanas y botas anticontaminación. Ejemplos de lo último son los delantales de plomo, guantes y gafas.

\section{Protección respiratoria}

Un dispositivo de protección respiratoria es un aparato, como por ejemplo un respirador, empleado para reducir la incorporación de materiales radiactivos aerotransportados al trabajador.

Los empleadores deben utilizar, en la medida que sea factible, controles de procesos u otros medios técnicos (por ejemplo, contención o ventilación) para limitar las concentraciones de materiales radiactivos en el aire. Cuando no sea posible aplicar estas medidas hasta rebajar las concentraciones de material radiactivo en el aire hasta valores inferiores a los que definen una zona con radiactividad en el aire, la empresa, coherente con mantener el equivalente de dosis efectiva total ALARA, incrementará la vigilancia y limitará las incorporaciones por uno 0 más de los medios siguientes:

- control de acceso;

- limitación de tiempos de exposición;

- empleo de equipo de protección respiratoria,

- otros controles

El equipo de protección respiratoria que se entregue a los trabajadores deberá cumplir las normas nacionales aplicables.

La empresa deberá implantar y mantener un programa de protección respiratoria que abarque:

- un muestreo del aire suficiente para identificar el peligro potencial, permitir la selección del equipo adecuado y estimar las exposiciones;

- las inspecciones y bioensayos necesarios para evaluar las incorporaciones reales;

- prueba de funcionamiento de los respiradores inmediatamente antes de cada uso;

- procedimientos escritos relativos a la selección, ajuste, entrega, mantenimiento y prueba de respiradores, incluida la comprobación de funcionamiento inmediatamente antes de cada uso; supervisión y formación de personal; vigilancia, incluidos muestreo del aire y bioensayos, y registro de resultados,

- determinación por un médico, antes del ajuste inicial de respiradores, y después con una periodicidad especificada por un médico, de que el usuario individual tiene las condiciones médicas para utilizar el equipo de protección respiratoria.

La empresa deberá advertir a cada usuario de respirador de que le está permitido abandonar la zona de trabajo en cualquier momento para descansar del uso del respirador en caso de mal funcionamiento del equipo, angustia física o psicológica, fallo de procedimiento 0 de comunicación, deterioro significativo de las condiciones operativas o cualesquiera otras condiciones que pudieran exigir este descanso.

Aunque las circunstancias puedan no exigir el empleo rutinario de respiradores, unas condiciones creíbles de emergencia pueden imponer su disponibilidad. En esos casos, los respiradores también deberán estar certificados para tal uso por una 
organización autorizada y mantenidos en perfecto orden de funcionamiento.

\section{Vigilancia de la salud en el trabajo}

Los trabajadores expuestos a la radiación ionizante deben contar con servicios de salud en el trabajo en el mismo grado que los expuestos a otros peligros profesionales.

Reconocimientos generales previos a la contratación evaluarán la salud general de los candidatos y establecerán datos de referencia. D ebe obtenerse siempre el historial médico y de exposición. La naturaleza de la exposición radiológica esperable puede recomendar la ejecución de reconocimientos especializados, como el del cristalino del ojo y el recuento de células de la sangre, lo que debe dejarse a la discreción del médico responsable.

\section{Inspecciones de contaminación}

Una inspección de contaminación es una evaluación de las condiciones radiológicas acompañantes a la producción, uso, liberación, eliminación o presencia de materiales radiactivos u otras fuentes de radiación. Cuando sea oportuno, esta evaluación incluirá un estudio del emplazamiento físico del material radiactivo y mediciones o cálculos de niveles de radiación o de concentraciones o cantidades del material radiactivo existente.

Las inspecciones de contaminación se realizan para poner de relieve el cumplimiento de los reglamentos nacionales y para evaluar los niveles de radiación, las concentraciones o cantidades de material radiactivo, así como los peligros radiológicos potenciales que pudieran existir.

La frecuencia de las inspecciones de contaminación estará determinada por el grado de peligro potencial existente. Se realizarán inspecciones semanales en las áreas de almacenamiento de residuos radiactivos y en laboratorios y clínicas donde se utilicen cantidades relativamente grandes de fuentes radiactivas no selladas. Será suficiente una inspección mensual en laboratorios que trabajan con fuentes radiactivas pequeñas, como en los laboratorios que realizan ensayos in vitro con ayuda de isótopos como tritio, carbono $14\left({ }^{14} \mathrm{C}\right)$ y yodo $125(1251)$ con actividades inferiores a unos pocos $\mathrm{kBq}$.

El equipo de seguridad radiológica y los medidores de inspección deberán ser los adecuados para los tipos de material radiactivo y radiaciones que se inspeccionan, y ha de estar perfectamente calibrado.

Las inspecciones de contaminación consisten en mediciones de los niveles de radiación ambiental con un contador GeigerM ueller (G-M), cámara de ionización o contador de centelleo; en mediciones de posible contaminación superficial $\alpha$ o $\beta \gamma$ con contadores $\mathrm{G}-\mathrm{M}$ de ventana delgada o contadores de centelleo de sulfuro de zinc ( $\mathrm{ZnS}$ ); y en pruebas de barrido de superficies que después serán contadas en un contador de centelleo de pozo (yoduro de sodio ( $\mathrm{Nal})$ ), un contador de germanio (Ge) 0 un contador de centelleo de líquido, como el caso requiera.

Se establecerán medidas de acción a distintos niveles en función de los resultados que se midan de radiación y contaminación ambiente. Cuando se sobrepase un nivel de acción, se tomarán de inmediato medidas para mitigar los niveles detectados, restablecer las condiciones aceptables e impedir una exposición innecesaria del personal a la radiación y la captación y difusión de material radiactivo.

\section{Vigilancia medioambiental}

La vigilancia medioambiental consiste en la recogida y medición de muestras del medio ambiente en busca de materiales radiactivos y en vigilar los niveles de radiación en áreas exteriores a los límites del lugar de trabajo. Los fines de la vigilancia medioambiental son: estimar las consecuencias sobre los seres humanos de la liberación de radionucleidos a la biosfera, detectar escapes de material radiactivo al medio ambiente antes de que lleguen a ser graves y poner de relieve el cumplimiento de los reglamentos.

La descripción completa de las técnicas de vigilancia medioambiental trasciende el ámbito de este artículo. Pero ello no impide pasar revista a los principios generales que inspiran dicha vigilancia.

Deberán tomarse muestras de los distintos escalones que permitan seguir el camino más probable de los radionucleidos desde el medio ambiente hasta el hombre. Por ejemplo, se tomarán muestras periódicas de suelo, agua, hierba y leche en regiones agrícolas alrededor de una central nuclear y se analizará su contenido de yodo 131 (131) y estroncio $90\left({ }^{90} \mathrm{Sr}\right)$.

La vigilancia medioambiental puede incluir la toma de muestras de aire, aguas subterráneas, aguas superficiales, suelo, follaje, pescado, leche, animales de caza, etc. La elección de las muestras a tomar y de la frecuencia del muestreo deberá basarse en los fines de la vigilancia, aunque a veces un número pequeño de muestras al azar puede desvelar un problema desconocido con anterioridad.

El primer paso en el diseño de un programa de vigilancia medioambiental es caracterizar el tipo, la cantidad y la forma física y química de los radionucleidos que se liberan o que pudieran liberarse por causa de un accidente.

La consideración siguiente es la posibilidad de transporte de estos radionucleidos por el aire, las aguas subterráneas y las aguas superficiales. El fin perseguido es predecir las concentraciones de radionucleidos que llegarán a los seres humanos directamente por el aire y el agua o indirectamente por los alimentos.

El siguiente aspecto objeto de preocupación es la bioacumulación de radionucleidos resultante de la deposición en medios acuáticos y terrestres. Su objetivo es predecir la concentración de radionucleidos después de haber entrado en la cadena alimentaria.

Por último, se estudian la tasa de consumo humano de los alimentos que pudieran estar contaminados y la contribución de este consumo a las dosis radiactivas en las personas y a los riesgos para la salud de los seres humanos. L os resultados de este análisis se utilizan para determinar el mejor método de muestreo medioambiental y para garantizar que se cumplen los objetivos del programa de vigilancia medioambiental.

\section{Ensayos de fuga de fuentes sel ladas}

U na fuente sellada significa que el material radiactivo está encerrado en una cápsula diseñada para impedir la fuga o escape del material. Estas fuentes tienen que ser sometidas a comprobaciones periódicas para verificar que no existen fugas de material radiactivo.

Toda fuente sellada será sometida a ensayo de fuga antes de su primera puesta en servicio a menos que el proveedor presente un certificado de que la fuente ha sido comprobada en los seis últimos meses (tres meses para emisores $\alpha$ ) antes de su transferencia al propietario actual. Toda fuente sellada será sometida a ensayo periódico de fuga cada seis meses (tres meses para emisores $\alpha$ ) o con una periodicidad especificada por el organismo competente.

En general, el ensayo de fuga no necesita aplicarse a las fuentes siguientes:

- fuentes que sólo contengan material radiactivo con un período de semidesintegración inferior a 30 días;

- fuentes que sólo contengan material radiactivo en forma de gas; 
- fuentes que contengan $4 \mathrm{M} \mathrm{Bq}$ o menos de material emisor $\beta \gamma$ o 0,4 M Bq o menos de material emisor $\alpha$;

- fuentes almacenadas y no utilizadas; no obstante, cada una de ellas deberá ser sometida a ensayo de fuga antes de ser utilizada o transferida, a menos que haya superado el ensayo de fuga en los seis meses anteriores a la fecha de utilización o transferencia,

- perlas de iridio $192(192 / r)$ encerradas en cinta de nylon.

Para realizar un ensayo de fuga se toma una muestra por barrido de la fuente sellada o de las superficies del dispositivo en que la fuente sellada está montada 0 almacenada en las que cabría esperar la acumulación de contaminación radiactiva, o mediante el lavado de la fuente en un volumen pequeño de solución detergente y el tratamiento de todo el volumen como la muestra.

La muestra debe medirse de manera que el ensayo de fuga pueda detectar la presencia de al menos $200 \mathrm{~Bq}$ de material radiactivo en la muestra.

El ensayo de fuga de las fuentes selladas de radio exige aplicar procedimientos especiales que detecten la fuga de gas radón $(\mathrm{Rn})$. Por ejemplo, uno de los procedimiento consiste en mantener la fuente sellada en un tarro con fibras de algodón durante un tiempo mínimo de 24 horas. Al día siguiente, se analizan las fibras de algodón para averiguar la presencia de progenie del $\mathrm{R} n$.

Una fuente sellada con fugas que superen los límites admisibles debe ser retirada del servicio. Si la fuente no tiene reparación, será tratada como los residuos radiactivos. El organismo competente puede exigir información de las fuentes con fugas si se sospecha que la fuga es resultado de un defecto de fabricación que merezca la pena investigar.

Figura 48.19 • Símbolo de radiación.

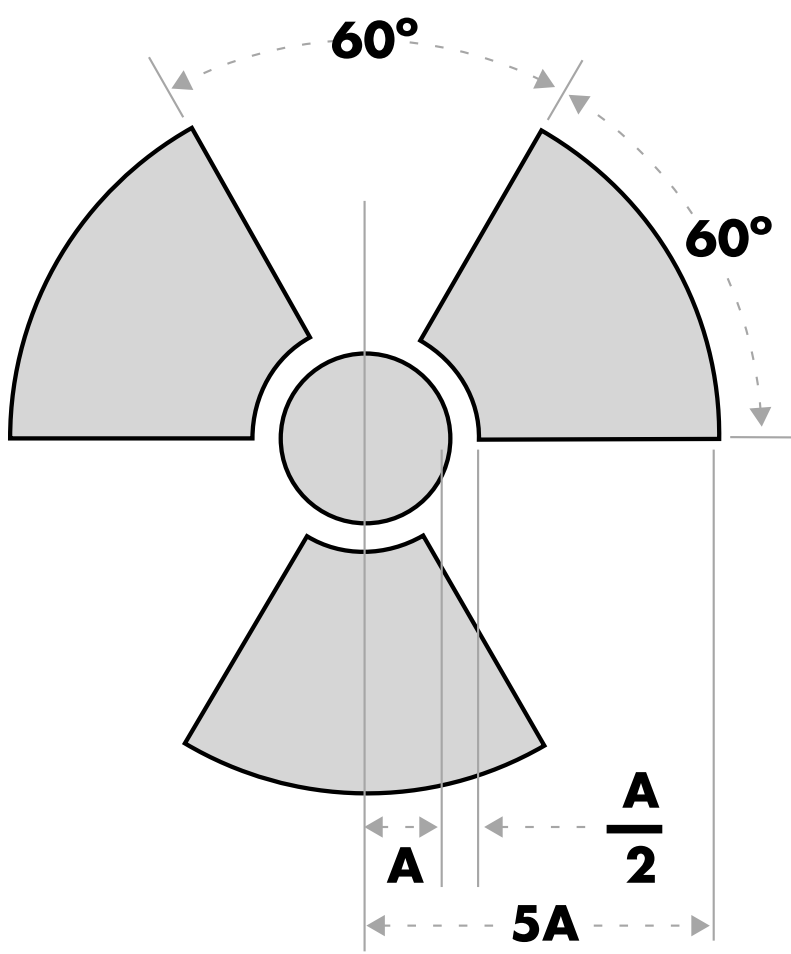

El área sombreada tiene que ser de color magenta o púrpura. El fondo deberá ser amarillo.

\section{Inventario}

EI personal de seguridad radiológica deberá mantener un inventario actualizado del material radiactivo y de otras fuentes de radiación ionizante que sea responsabilidad de la empresa. Los procedimientos de la organización garantizarán que el personal de seguridad radiológica tenga conocimiento de la recepción, uso, transferencia y eliminación del material y las fuentes, de manera que el inventario corresponda a las existencias actuales. Al menos cada tres meses, deberá efectuarse un inventario físico de todas las fuentes selladas. El inventario completo de fuentes de radiación ionizante debe verificarse durante la auditoría anual del programa de seguridad radiológica.

\section{Letreros de zonas}

La Figura 48.19 muestra el símbolo estándar internacional de radiación, que es obligatorio que destaque en todas las señales que identifiquen zonas controladas a efectos de seguridad radiológica y en las etiquetas de contenedores que indiquen la presencia de materiales radiactivos.

Las áreas controladas a efectos de seguridad radiológica se designan a menudo según el orden creciente de las tasas de dosis. Dichas áreas deberán ser identificadas con anuncios llamativos donde figure el símbolo de radiación y el letrero "PRECAUCION, ZONA DE RADIACION," "PRECAUCION [O PELIGRO], ZONA DE ALTA RADIACION," 0 "GRAVE PELIGRO, ZONA DE MUY ALTA RADIACION," según el caso.

4. U na zona de radiación es un área, accesible al personal, en la que existen niveles de radiación que pueden hacer que un individuo reciba un equivalente de dosis superior a 0,05 mSv en $1 \mathrm{~h}$ a $30 \mathrm{~cm}$ de la fuente de radiación o de cualquier superficie en la que penetre la radiación.

5. U na zona de alta radiación es un área, accesible al personal, en la que existen niveles de radiación que pueden hacer que un individuo reciba un equivalente de dosis superior a $1 \mathrm{mSv}$ en $1 \mathrm{~h}$ a $30 \mathrm{~cm}$ de la fuente de radiación 0 de cualquier superficie en la que penetre la radiación.

6. U na zona de muy alta radiación es un área, accesible al personal, en la que existen niveles de radiación que pueden hacer que un individuo reciba un equivalente de dosis superior a $5 \mathrm{G}$ y en $1 \mathrm{~h}$ a $1 \mathrm{~m}$ de la fuente de radiación o de cualquier superficie en la que penetre la radiación.

Si una zona o recinto contiene una cantidad importante de material radiactivo (definida por el organismo competente), la entrada a dicha área o recinto deberá estar señalada con un aviso llamativo que lleve el símbolo de radiación y el letrero "PRECAUCION [O PELIGRO], MATERIALES RADIACTIVOS".

U na zona con radiactividad aerotransportada es un recinto 0 área en la que la radiactividad del aire supera determinados niveles definidos por el organismo competente. Toda zona con radiactividad en el aire estará señalada con un aviso que lleve un símbolo 0 varios símbolos de radiación y el letrero "PRECAUCION, ZONA DE RADIACTIVIDAD EN EL AIRE" O "PELIGRO, ZONA DE RADIACTIVIDAD EN EL AIRE".

Pueden ser excepciones a estos requisitos de señalización las habitaciones de pacientes en hospitales donde esas habitaciones tienen ya establecido un control adecuado. Tampoco es preciso poner avisos en zonas o habitaciones en las que se colocarán fuentes de radiación durante períodos de ocho horas o menos y que tienen ya establecido un control adecuado permanente por personal calificado. 


\section{Control de acceso}

El grado en que deba estar controlado el acceso a una zona estará determinado por la gravedad del peligro potencial de radiación en esa zona.

\section{Control de acceso a zonas de alta radiación}

Cada punto de entrada o acceso a una zona de alta radiación deberá tener una o más de las características siguientes:

- un dispositivo de control que, al entrar en la zona, haga disminuir el nivel de radiación hasta otro inferior al que podría hacer recibir a un individuo una dosis de $1 \mathrm{mSv}$ en $1 \mathrm{~h}$ a $30 \mathrm{~cm}$ de la fuente de radiación o de cualquier superficie que penetre la radiación;

- un dispositivo de control que active una señal de alarma llamativa, visible 0 audible, que alerte a cualquier persona que entre en la zona de alta radiación y al supervisor de la actividad,

- entradas cerradas con llave, salvo durante horarios en que sea necesario el acceso a la zona, con control positivo en cada entrada individual.

Los controles exigidos en una zona de alta radiación pueden ser sustituidos por una vigilancia permanente, directa o electrónica, es decir, capaz de impedir la entrada no autorizada.

Los controles se establecerán de manera que no se impida a las personas abandonar el área de alta radiación.

\section{Control de acceso a zonas de muy alta radiación}

Además de los requisitos propios de una zona de alta radiación, se establecerán medidas adicionales para garantizar que nadie pueda tener acceso no autorizado o inadvertido a zonas en que los niveles de radiación podrían situarse en $5 \mathrm{G}$ y o más en $1 \mathrm{~h}$ a $1 \mathrm{~m}$ de una fuente de radiación o de cualquier superficie que sea penetrada por la radiación.

\section{Marcas en contenedores y equipo}

Todo recipiente que contenga material radiactivo por encima de una cantidad determinada por el organismo competente deberá llevar una etiqueta duradera y bien visible con el símbolo de

Figura 48.20 - Categoría I - etiqueta BLANCA.

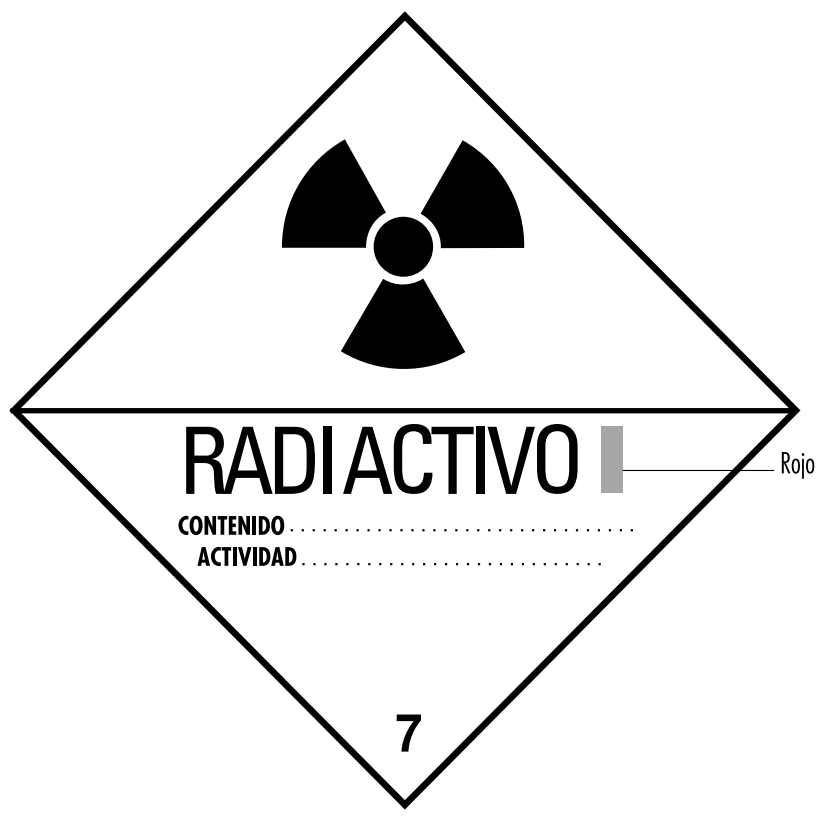

La etiqueta tendrá forma de diamante y $10 \mathrm{~cm}$ de lado. radiación y las palabras "PRECAUCION, MATERIAL RADIACTIVO" O "PELIGRO, MATERIAL RADIACTIVO". La etiqueta deberá contener también información suficiente como el radionucleido o radionucleidos del contenedor, una estimación de la cantidad de radiactividad, la fecha hasta la cual se estima que durará la actividad, niveles de radiación, clases de materiales y enriquecimiento másico) para que las personas que vayan a manipular o utilizar los contenedores, o a trabajar en su proximidad, tomen precauciones que eviten 0 reduzcan las exposiciones.

Antes de eliminar o desechar contenedores vacíos no contaminados hacia zonas no restringidas, es preciso quitar o borrar la etiqueta de material radiactivo, o bien se indicará con claridad que el contenedor no tiene ya materiales radiactivos.

No es obligatorio rotular los contenedores si:

1. los contenedores son atendidos por una persona que adopta las precauciones necesarias para impedir la exposición de individuos más allá de los límites reglamentarios;

2. Ios contenedores, cuando son transportados, se embalan y rotulan de acuerdo con las disposiciones para transporte adecuadas;

3. los contenedores sólo son accesibles a personas autorizadas para manipularlos o utilizarlos, o para trabajar en la proximidad de los contenedores, si su contenido está identificado para estos individuos mediante un registro escrito fácilmente asequible (ejemplos de contenedores de este tipo son los situados en lugares como canales llenos de agua, bóvedas de almacenamiento o celdas radiactivas). El registro deberá mantenerse todo el tiempo que los contenedores estén en uso para el fin indicado en el registro,

4. los contenedores están instalados en equipo de fabricación o de proceso, como componentes de reactor, tuberías y depósitos.

\section{Dispositivos de aviso y alarmas}

Las zonas de alta radiación y de muy alta radiación tienen que estar equipadas con dispositivos de aviso y alarmas como los ya

Figura 48.21 • Categoría II - etiqueta AMARILLA.

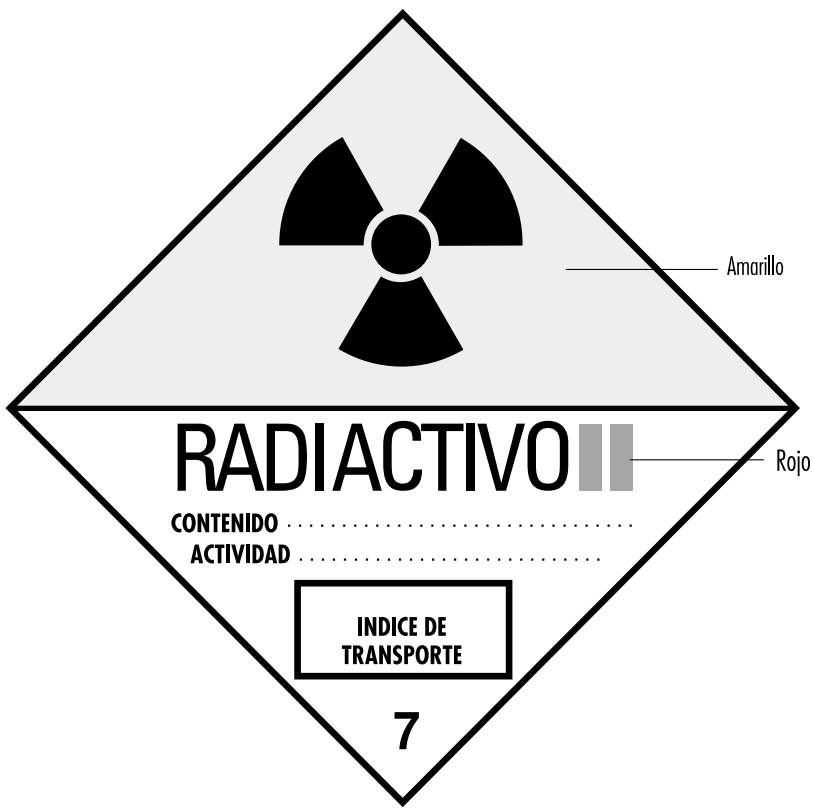

La etiqueta tendrá forma de diamante y $10 \mathrm{~cm}$ de lado. 

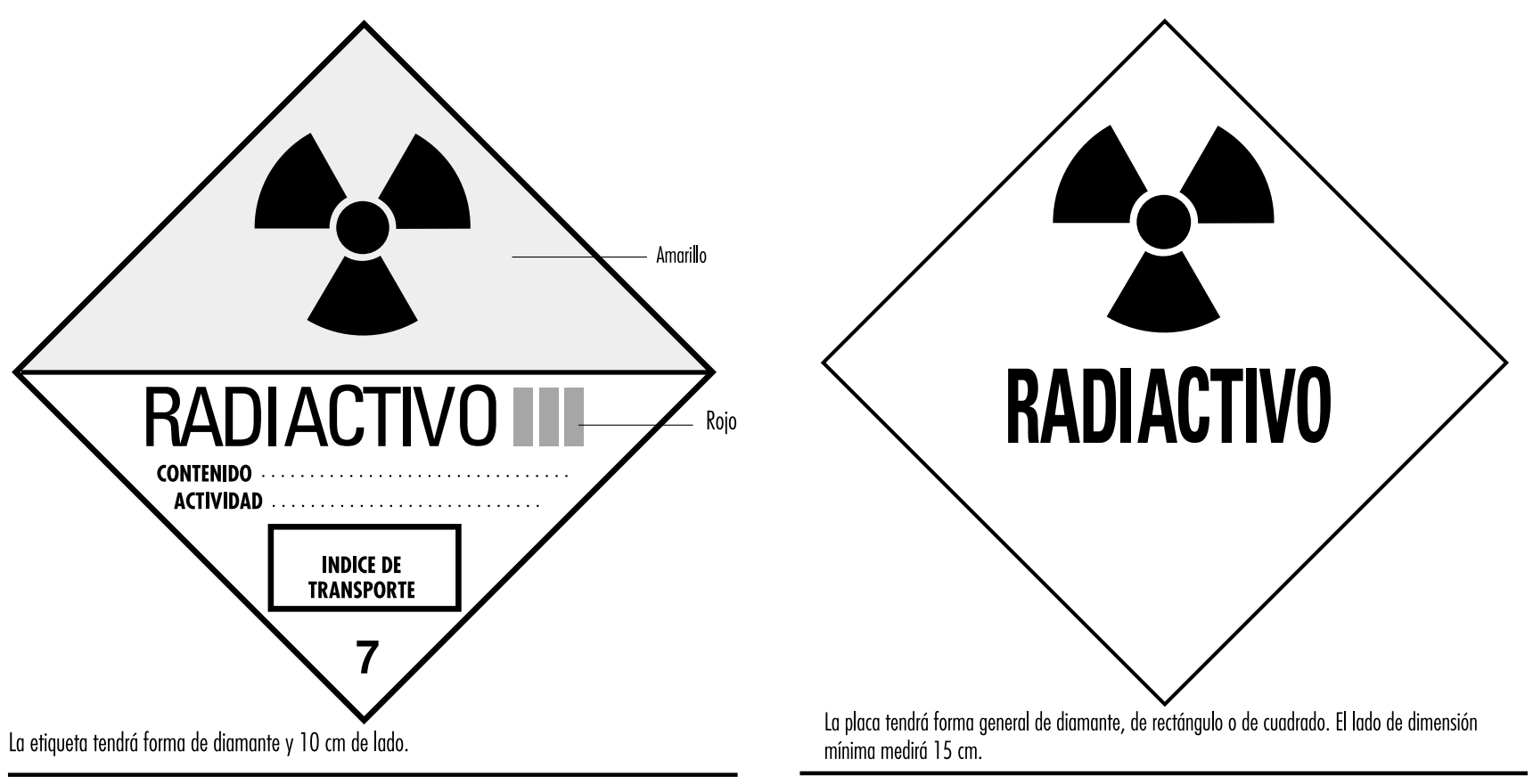
eliminación de estos residuos están controladas por los organismos competentes nacionales e internacionales.

Es frecuente que los residuos radiactivos tengan alguna propiedad distinta de la radiactividad que por sí misma convierta a estos desechos en peligrosos. Estos residuos se denominan residuos mixtos. Son ejemplos de ellos los residuos radiactivos que entrañan también peligro biológico o son tóxicos. LoS residuos mixtos requieren una manipulación especial. Antes de eliminarlos es preciso consultar a los organismos competentes en la materia.

\section{Retención para desintegración radiactiva}

Si el período de semidesintegración del material radiactivo es corto (en general, inferior a 65 días) y si la organización tiene espacio de almacenamiento suficiente, los residuos radiactivos pueden retenerse hasta su desintegración y la posterior eliminación sin preocuparse de su radiactividad. Un plazo de retención de al menos diez períodos de semidesintegración es suficiente para que los niveles de radiación sean indistinguibles del fondo natural.

Los residuos tienen que ser inspeccionados antes de su eliminación. En la inspección debe emplearse la instrumentación adecuada para detectar la radiación y demostrar que los niveles de radiación son indistinguibles del fondo.

\section{Incineración}

Si el organismo competente permite la incineración de los desechos, en general hay que demostrar que al incinerarlos no se origina concentración de radionucleidos en el aire hasta niveles no admisibles. Las cenizas deberán someterse a inspección periódica para verificar que no son radiactivas. En algunas circunstancias, puede ser necesario vigilar el escape de gases para cerciorarse de que no se rebasan las concentraciones admisibles en el aire.

\section{Eliminación por el sistema de desagüe sanitario}

Si el organismo competente permite este método de eliminación, por lo general hay que demostrar que este vertido no origina concentración de radionucleidos en el agua hasta niveles no admisibles. El material a eliminar ha de ser soluble 0 , en caso contrario, dispersable en el agua. El organismo competente suele establecer límites anuales específicos a esta eliminación por clases de radionucleido.

\section{Enterramiento}

Los residuos radiactivos no eliminables por ningún otro medio serán eliminados por enterramiento en lugares autorizados por los organismos competentes nacionales o locales, que son muy rigurosos en el control de este tipo de eliminación. No se suele permitir a los generadores de residuos eliminar éstos en sus propios terrenos. LoS costes asociados al enterramiento comprenden los gastos de embalado, transporte y almacenamiento. A estos costes se suma el del espacio necesario para el enterramiento, que puede reducirse si se compactan los desechos. Los costes de enterramiento de residuos radiactivos aumentan a ritmo creciente.

\section{Auditorías de programas}

Los programas de seguridad radiológica deben ser sometidos a una auditoría periódica que ponga de manifiesto su eficacia, integridad y conformidad con las disposiciones de los organismos competentes. La auditoría debe realizarse una vez al año como mínimo y abarcar todos los aspectos. Se admiten también auditorías internas, pero son preferibles las realizadas por organismos exteriores independientes. E stos suelen ser más objetivos y tienen un punto de vista más global que los auditores locales. Un organismo auditor no implicado en las operaciones diarias de un programa de seguridad radiológica está más preparado para identificar problemas que no detectan los operadores locales, acostumbrados a pasarlos por alto.

\section{Formación}

L os empleadores son responsables de que todos los trabajadores expuestos o que pudieran estar expuestos a radiación ionizante 0 a materiales radiactivos reciban formación en seguridad radiológica. Tienen que proporcionar formación inicial antes de que el trabajador comience a trabajar y renovar cada año la formación. Además, todas las mujeres trabajadoras en edad fértil deberán recibir formación e información especial sobre los efectos de la radiación ionizante en los niños no nacidos y sobre las precauciones que deben adoptar. Esta formación especial debe facilitarse a la mujer trabajadora cuando se la contrate, cada año posterior y si notifica a su empleador que está embarazada.

Todo el personal que trabaje en cualquier parte de una zona a la que esté restringido el acceso por causas de seguridad radiológica o que la frecuente:

- será informado del almacenamiento, transferencia o uso de materiales radiactivos o de radiación en esas partes de la zona restringida;

- recibirá formación sobre los problemas de protección de la salud relacionados con la exposición a esa clase de materiales radiactivos o de radiación, sobre precauciones o procedimientos para reducir la exposición y sobre los fines y funciones de los dispositivos protectores empleados;

- recibirá formación e instrucciones para observar, en la medida de sus atribuciones, las disposiciones aplicables de los reglamentos nacionales y de la empresa relativos a la protección de personal frente a exposiciones a la radiación o a materiales radiactivos existentes en esas zonas;

- será informado de sus responsabilidad de informar con diligencia al empleador de cualquier situación que pudiera entrañar la violación de reglamentos nacionales o de la empresa o una exposición innecesaria a radiación o a material radiactivo;

- será informado de la respuesta adecuada a los avisos que se emitan en caso de cualquier emergencia o fallo de funcionamiento que pueda implicar exposición a radiación o a material radiactivo,

- será asesorado en relación con los informes de exposición radiológica que los trabajadores puedan solicitar.

El alcance de las instrucciones de seguridad radiológica deberá ser acorde con los problemas potenciales de protección radiológica de la salud en la zona controlada. Las instrucciones deberán extenderse según proceda al personal auxiliar, como las enfermeras que atienden a pacientes sometidos a tratamientos radiactivos en hospitales y los bomberos y agentes de policía que pudieran responder a emergencias.

\section{Cualificaciones de los trabajadores}

Los empleadores deberán garantizar que los trabajadores que utilicen radiación ionizante estén cualificados para realizar el trabajo para el que han sido contratados. La trabajadores deberán tener la formación básica y la experiencia necesarias para desempeñar sus trabajos con seguridad, sobre todo en relación con la exposición a la radiación ionizante y a materiales radiactivos y con su utilización.

El personal de seguridad radiológica tendrá los conocimientos y calificaciones adecuados para poner en práctica y operar un programa de seguridad radiológica satisfactorio. Sus conocimientos y calificaciones estarán a la altura, como mínimo, de los problemas potenciales de protección radiológica de la salud que 
ellos y los trabajadores tengan probabilidades razonables de encontrar.

\section{Planificación de emergencias}

Todas las operaciones que utilicen radiación ionizante o materiales radiactivos, salvo las de menor cuantía, deberán contar con planes de emergencia. Estos planes deberán estar al día y se pondrán a prueba en simulaciones periódicas.

En los planes de emergencia deben considerarse todas las situaciones de emergencia verosímiles. Los planes de una gran central nuclear serán mucho más amplios, abarcarán una zona mucho mayor e implicarán a más personas que los planes de un pequeño laboratorio de radioisótopos.

Todos los hospitales, en especial los situados en grandes áreas metropolitanas, deben poseer planes para la recepción y asistencia de pacientes contaminados por radiactividad. L as organizaciones de policía y bomberos deben tener planes para hacer frente a accidentes de transporte de material radiactivo.

\section{Mantenimiento de registros}

Las actividades de seguridad radiológica de una organización exigen una documentación rigurosa, que se archivará en los soportes adecuados. E stos registros son esenciales si surge la necesidad de conocer exposiciones a la radiación o escapes de radiactividad anteriores y para demostrar el cumplimiento de lo dispuesto por los organismos competentes. Se dará una alta prioridad al mantenimiento coherente, exacto y completo de estos registros.

\section{Consideraciones organizativas}

El puesto del responsable principal de la seguridad radiológica se colocará en un nivel de la organización que le permita el acceso inmediato a todos los escalones de trabajadores y dirección. Esta persona deberá tener acceso libre a zonas cuyo acceso esté restringido por motivos de seguridad radiológica, y autoridad para detener inmediatamente las prácticas inseguras o ilegales.

\section{- Planificacion de medidas Y GESTION DE ACCIDENTES RADIOLOGICOS}

Sydney W. Porter, Jr.

En este artículo se describen varios accidentes por radiación importantes, sus causas y las respuestas a ellos. Un repaso de los acontecimientos que condujeron a estos accidentes y de los ocurridos durante y después de ellos puede dar a los planificadores información para evitar que sucedan accidentes similares en el futuro y, si volvieran a producirse, mejorar y acelerar la respuesta correspondiente.

\section{Muerte por radiación aguda resultante de una emisión accidental nuclear crítica el 30 de diciembre de 1958}

Este informe merece ser reseñado porque da cuenta de la mayor dosis accidental de radiación recibida por seres humanos (hasta la fecha) y por el tratamiento extraordinariamente profesional y meticuloso del caso. Representa una de las mejores descripciones documentadas que existen, si no la mejor, del síndrome de radiación agudo (IOM 1961).

A las 4.35 de la tarde del 30 de diciembre de 1958, en la planta de recuperación de plutonio del Laboratorio Nacional de Los Alamos (Nuevo M éxico, Estados U nidos) tuvo lugar una emisión accidental crítica que originó una lesión radiológica mortal a un empleado (K).

La hora del accidente es importante porque otros seis trabajadores habían estado en la misma sala con $\mathrm{K}$ treinta minutos antes. La fecha del accidente es importante porque el flujo normal de material fisionable había sido interrumpido en el sistema con motivo del inventario físico de fin de año. Esta interrupción provocó que un procedimiento rutinario se convirtiera en no rutinario y condujera a un "punto crítico" accidental de los sólidos ricos en plutonio introducidos por accidente en el sistema.

\section{Resumen de estimaciones de la exposición radiológica de $\mathbf{K}$} La mejor estimación de la exposición corporal total media de $\mathrm{K}$ la cifró entre 39 y $49 \mathrm{G}$ y, de los que unos $9 \mathrm{G}$ y fueron debidos a neutrones de fisión. La mitad superior del cuerpo recibió una porción de la dosis bastante mayor que la mitad inferior. La Tabla 48.16 muestra la estimación de la exposición radiológica de $K$.

\section{Evolución clínica del paciente}

En retrospectiva, la evolución clínica del paciente K puede dividirse en cuatro períodos distintos. Estos períodos difieren en duración, síntomas y respuesta a la terapéutica de apoyo.

El primer período, que duró de 20 a 30 minutos, se caracterizó por su inmediato colapso físico e incapacitación mental. Su estado evolucionó a la semiinconsciencia y la prostración grave.

El segundo período duró en torno a 1,5 horas y comenzó con su llegada en camilla a la sala de urgencias del hospital y terminó con su traslado desde la sala de urgencias a la planta para tratamiento de apoyo ulterior. Este intervalo se caracterizó por un shock cardiovascular tan grave que la muerte parecía inminente en todo momento. Parecía sufrir dolores abdominales intensos.

El tercer período, de unas 28 horas, se caracterizó por una mejoría subjetiva suficiente para alentar los intentos continuos de aliviar su anoxia, hipotensión y fallo circulatorio.

El cuarto período comenzó con la aparición no anunciada de irritabilidad y antagonismo rápidamente crecientes hasta bordear la manía, seguidos de coma y muerte en alrededor de 2 horas. La evolución clínica completa duró 35 horas desde el momento de exposición radiológica hasta el fallecimiento.

L os cambios clinico-patológicos más dramáticos se observaron en los sistemas hematopoyético y urinario. A las ocho horas no se encontraron linfocitos en la sangre circulante, y hubo una parada urinaria prácticamente completa a pesar de la administración de grandes cantidades de líquidos.

$\mathrm{L}$ a temperatura rectal de $\mathrm{K}$ varió entre 39,4 y $39,7{ }^{\circ} \mathrm{C}$ durante las 6 primeras horas y luego cayó de repente al valor normal, donde permaneció mientras estuvo vivo. Esta alta temperatura inicial y su mantenimiento durante 6 horas se

Tabla 48.16 • Estimaciones de la exposición de K a la radiación.

\begin{tabular}{llll} 
Región y condiciones & $\begin{array}{l}\text { Dosis } \\
\text { absorbida, } \\
\text { neutrones } \\
\text { rápidos (Gy) }\end{array}$ & $\begin{array}{l}\text { Dosis } \\
\text { absorbida, } \\
\text { gamma } \\
\text { (Gy) }\end{array}$ & $\begin{array}{l}\text { Dosis } \\
\text { absorbida } \\
\text { total } \\
\text { (Gy) }\end{array}$ \\
$\begin{array}{c}\text { Cabeza (incidente) } \\
\begin{array}{c}\text { Abdomen superior } \\
\text { (incidente) }\end{array}\end{array}$ & 30 & 78 & 104 \\
Total cuerpo (media) & 9 & 90 & 124 \\
\hline
\end{tabular}


consideraron acordes con su supuesta dosis masiva de radiación. Su pronóstico era grave.

De las diversas determinaciones efectuadas durante la evolución de la enfermedad, los cambios del recuento de leucocitos resultaron ser el indicador pronóstico más sencillo y mejor de la irradiación grave. La práctica desaparición de los linfocitos de la circulación periférica dentro de las 6 horas posteriores a la exposición se consideró una señal grave.

En el tratamiento sintomático de $\mathrm{K}$ se emplearon dieciséis agentes terapéuticos diferentes en un período aproximado de 30 horas. A pesar de ello y de la administración permanente de oxígeno, sus tonos cardíacos se hicieron muy distantes, lentos e irregulares unas 32 horas después de la irradiación. Su corazón experimentó una debilitación progresiva y de repente se paró a las 34 horas y 45 minutos de la irradiación.

\section{Accidente del reactor $\mathrm{n} 01$ de Windscale de 9 al 12 de octubre de 1957}

El reactor $n .01$ de Windscale era un reactor productor de plutonio con combustible de uranio, moderado con grafito y refrigerado por aire. EI núcleo fue destruido en parte por el fuego el 15 de octubre de 1957, lo que provocó la liberación aproximada de $0,74 \mathrm{PBq}\left(10^{+15} \mathrm{~Bq}\right)$ de yodo $131\left({ }^{131}\right)$ al entorno hacia el que soplaba el viento.

Según un informe de la Atomic Energy Commission de EE.UU. sobre el incidente de Windscale, el accidente fue provocado por errores de juicio del operador acerca de datos de termopares y empeoró por una manipulación defectuosa del reactor que permitió que aumentara con excesiva rapidez la temperatura del grafito. También contribuyó el hecho de que los termopares detectores de la temperatura del combustible estaban situados en la parte más caliente del reactor (es decir, donde se producían las tasas de dosis más altas) durante el funcionamiento normal, en lugar de en las partes del reactor que estuvieran más calientes durante una liberación anormal. 0 tra deficiencia del equipo era el medidor de potencia del reactor, que estaba calibrado para funcionamiento normal y daba lecturas bajas durante las temperaturas de cristalización. A consecuencia del segundo ciclo de calentamiento, la temperatura del grafito aumentó el 9 de octubre, sobre todo en la zona frontal inferior del reactor, donde parte de la vaina había fallado por el rápido aumento anterior de la temperatura. Aunque el 9 de octubre hubo varios escapes pequeños de yodo, no fueron reconocidos hasta el 10 de octubre, cuando el medidor de actividad del escape indicó un aumento significativo (que no se consideró demasiado importante). Por último, en la tarde del 10 de octubre, otros monitores (planta Calder) indicaron la liberación de radiactividad. Los esfuerzos por refrigerar el reactor mediante circulación de aire a presión no sólo fracasaron, sino que en realidad aumentaron la magnitud de la radiactividad liberada.

Los escapes estimados en el accidente de Windscale fueron de $0,74 \mathrm{PBq}$ de ${ }^{131} \mathrm{I}, 0,22 \mathrm{PBq}$ de cesio $137\left({ }^{137} \mathrm{Cs}\right), 3,0 \mathrm{~T} \mathrm{~Bq}$

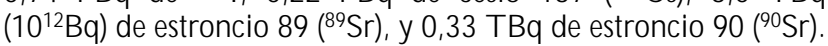
La máxima tasa de dosis absorbida gamma fuera de la instalación fue de unos $35 \mu \mathrm{G} y / \mathrm{h}$ debida a la actividad contenida en el aire. Las lecturas de actividad en el aire alrededor de las centrales de Windscale y Calder eran con frecuencia de 5 a 10 veces los niveles máximos admisibles, con picos ocasionales de 150 veces los niveles admisibles. Se prohibió beber leche procedente de una zona de $420 \mathrm{~km}$ de radio aproximadamente.

Durante las operaciones que se realizaron para recuperar el control del reactor, 14 trabajadores recibieron equivalentes de dosis superiores a $30 \mathrm{mSv}$ por trimestre natural, con el equivalente de dosis máximo en 46 mSv por trimestre natural.

\section{Lecciones aprendidas}

Se aprendieron muchas cosas en relación con el diseño y operación de reactores de uranio natural. Las insuficiencias en cuanto a la instrumentación del reactor y a la formación de operadores de reactores revelan también aspectos análogos a los del accidente de Three M ile Island (véase más adelante).

No existían directrices para la exposición admisible a corto plazo a yodo radiactivo en alimentos. EI M edical Research Council británico llevó a cabo una investigación y análisis inmediatos y exhaustivos. Se derrochó ingenio para deducir en seguida las concentraciones máximas admisibles de ${ }^{131}$ | en los alimentos. El estudio de Niveles de referencia en emergencias que resultó de este accidente es la base de las guías de planificación de emergencias que ahora se usan en todo el mundo (Bryant 1969).

Se dedujo una correlación útil para predecir la contaminación significativa de la leche por yodo radiactivo. Se descubrió que los pastos con niveles de radiación gamma superiores a $0,3 \mu \mathrm{G} / \mathrm{h}$ producían leche que superaba los $3,7 \mathrm{M} \mathrm{Bq} / \mathrm{m}^{3}$.

$L$ a dosis absorbida por inhalación de yodo radiactivo en exposición es despreciable en comparación con la ingerida al beber leche o comer derivados lácteos. En una emergencia, la espectroscopia gamma rápida es preferible a procedimientos de laboratorio más lentos.

Quince equipos de dos personas realizaron inspecciones de radiación y obtuvieron muestras. Veinte personas se ocuparon de coordinar los muestreos e informar de los datos. Alrededor de 150 radioquímicos participaron en el análisis de las muestras.

L os filtros de escape de lana de vidrio no son satisfactorios en caso de accidente.

\section{Accidente del acelerador de Gulf Oil del $\mathbf{4}$ de octubre de 1967}

Los técnicos de Gulf O il Company utilizaban un acelerador de Van de Graaf de $3 \mathrm{M} \mathrm{eV}$ para la activación de muestras de suelo el 4 de octubre 1967. La combinación de un fallo del corte de alimentación en la llave de la consola del acelerador y el encintado de varios de los cortacircuitos en la puerta del túnel de seguridad y en la puerta interior de la sala del blanco produjo exposiciones accidentales graves de tres personas. U na de ellas recibió en torno a $1 \mathrm{G}$ y de equivalente de dosis en todo el cuerpo, la segunda recibió cerca de $3 \mathrm{G}$ y de equivalente de dosis en todo el cuerpo y la tercera unos $6 \mathrm{G}$ y de equivalente de dosis en todo el cuerpo, además de alrededor de $60 \mathrm{G}$ y en las manos y $30 \mathrm{G}$ y en los pies

U na de las víctimas del accidente acudió al servicio médico, aquejada de náuseas, vómitos y dolores musculares generalizados. Sus síntomas se confundieron al principio con los de la gripe. Pero cuando el segundo paciente llegó con aproximadamente los mismos síntomas, se decidió que quizás hubieran recibido exposiciones significativas de radiación. Placas de película lo demostraron. EI Dr. Niel Wald, de la división de salud radiológica de la U niversidad de Pittsburgh, supervisó las pruebas de dosimetría y actuó también como coordinador médico en la investigación clínica y tratamiento de los pacientes.

EI Dr. Wald hizo llevar en seguida por avión unidades de filtros absolutos al hospital de Pittsburgh, Pensilvania, donde habían sido ingresados los tres pacientes. Hizo instalar estos filtros absolutos de flujo laminar para limpiar el entorno de los pacientes de todos los contaminantes biológicos. Estas unidades de "aislamiento inverso" se utilizaron en el paciente de $1 \mathrm{G}$ y de exposición durante unos 16 días, y en los pacientes de 3 y 6 G y de exposición durante mes y medio.

EI Dr. E. Donnal T homas, de la U niversidad de Washington, llegó para realizar un transplante de médula ósea al paciente de 6 Gy al octavo día de la exposición. El hermano gemelo del 
paciente fue el donante de médula ósea. Aunque este heroico tratamiento médico salvó la vida del paciente de $6 \mathrm{G}$ y, no pudo hacerse nada para salvar sus brazos y piernas, cada uno de los cuales recibió decenas de gray de dosis absorbida.

\section{Lecciones aprendidas}

Si se hubiera seguido el sencillo procedimiento operativo de utilizar siempre un detector cuando se entra a la sala de exposición, este trágico accidente podría haberse evitado.

Dos cortacircuitos como mínimo se habían bloqueado con cinta desde bastante tiempo antes de ocurrir este accidente. Anular los cortacircuitos protectores es intolerable.

Deberían haberse realizado verificaciones periódicas de mantenimiento en los cortacircuitos de potencia operados por llave del acelerador.

La celeridad de la atención médica salvó la vida de la persona con mayor exposición. El heroico procedimiento de realizar un transplante completo de médula ósea, junto con el empleo del aislamiento inverso y la calidad de la asistencia médica fueron factores esenciales para salvar la vida de esta persona.

Los filtros de aislamiento inverso pueden obtenerse en cuestión de horas e instalarse en cualquier hospital para la asistencia de pacientes muy expuestos.

En retrospectiva, las autoridades médicas que se ocuparon de estos pacientes habrían recomendado la amputación más temprana, y luego a la altura definitiva en los dos o tres meses siguientes a la exposición. La amputación temprana hace disminuir la probabilidad de infección, acorta el período de dolores agudos, reduce la medicación analgésica necesaria, es posible que reduzca la estancia del paciente en el hospital y quizás contribuya a adelantar la rehabilitación. D esde luego, la amputación temprana debe hacerse mientras se relaciona la información dosimétrica con las observaciones clínicas.

\section{Accidente del prototipo de reactor SL-1 (Idaho, EE.UU., 3 de enero de 1961)}

Este es el primer accidente mortal (y el único hasta la fecha) en la historia de las operaciones de reactores norteamericanos. EI reactor. SL-1 es un prototipo de pequeño reactor compacto del ejército (Army Package Power Reactor, APPR ) diseñado para su transporte por aire a zonas distantes para la producción de energía eléctrica. Este reactor se utilizaba para la prueba del combustible y para formar al personal del reactor. Era operado en el remoto emplazamiento desértico de la Estación $\mathrm{N}$ acional de Prueba de Reactores de Idaho Falls, Idaho, por la empresa Combustion Engineering para el ejército de EE.UU. EI SL-1 no era una central nuclear comercial (AEC 1961; American N uclear Society 1961).

En el momento del accidente, el $\mathrm{SL}-1$ estaba cargado con 40 elementos de combustible y 5 bandejas de barras de control. Podía producir del orden de $3 \mathrm{MW}$ (térmicos) y era un reactor de agua en ebullición refrigerado y moderado por agua.

El accidente ocasionó la muerte de tres militares, y se originó por la retirada de una sola barra de control en una distancia de más de $1 \mathrm{~m}$. Esto provocó que el reactor llegase a un inmediato punto crítico. Se desconoce el motivo por el cual un operador de reactores especializado y con licencia, con mucha experiencia en operaciones de renovación del combustible, retiró la barra de control más allá de su tope normal.

Una de las tres víctimas del accidente estaba viva todavía cuando el personal de respuesta inicial llegó por primera vez a la escena del accidente. Productos de fisión de alta actividad cubrían su cuerpo y estaban incrustados en su piel. En partes de la piel de la víctima se registraron más de $5,4 \mathrm{~Gy} / \mathrm{h}$ a $15 \mathrm{~cm}$, lo que obstaculizó el rescate y el tratamiento médico.

\section{Lecciones aprendidas}

Ningún reactor diseñado desde el accidente del SL-1 ha podido ser llevado a un estado "inmediato al crítico" con una sola barra de control.

Todos los reactores tienen que disponer de dosímetros portátiles locales que posean escalas superiores a $20 \mathrm{mG} / \mathrm{h}$. Se recomiendan dosímetros con escala máxima de $10 \mathrm{~Gy} / \mathrm{h}$.

Nota: El accidente de Three Mile Island demostró que $100 \mathrm{G}$ y/ h es la escala necesaria para mediciones gamma y beta.

Se necesitan instalaciones de tratamiento en las que un paciente muy contaminado pueda recibir tratamiento médico definitivo con medidas de protección razonables para el personal asistencial. Como la mayoría de estas instalaciones estarán en clínicas con otras funciones simultáneas, el control de contaminantes radiactivos contenidos en el aire y en el agua puede necesitar disposiciones especiales.

\section{Máquinas de rayos $X$ industriales $y$ analíticas}

$L$ as exposiciones accidentales a sistemas de rayos $X$ son numerosas y a menudo implican irradiaciones sumamente altas a pequeñas partes del cuerpo. No es inhabitual que los sistemas de difracción de rayos $X$ produzcan tasas de dosis absorbidas de $5 \mathrm{~Gy} / \mathrm{s}$ a $10 \mathrm{~cm}$ del foco del tubo. A distancias más cortas, se han medido con frecuencia tasas de $100 \mathrm{~Gy} / \mathrm{s}$. El haz suele ser estrecho, pero incluso una exposición de pocos segundos puede originar lesiones locales graves (Lubenau y cols. 1967; Lindell 1968; H aynie y O Isher 1981; ANSI 1977).

Como estos sistemas se utilizan a menudo en circunstancias "no rutinarias", tienen tendencia a producir exposiciones accidentales. Los sistemas de rayos $X$ de uso común en operaciones normales parecen ofrecer una seguridad razonable. EI fallo del equipo no ha ocasionado exposiciones graves.

\section{Lecciones aprendidas de las exposiciones accidentales a rayos $X$}

La mayoría de las exposiciones accidentales han tenido lugar en usos no rutinarios, cuando el equipo estaba semidesmontado o se habían quitado las cubiertas de blindaje.

En exposiciones más graves, no se habían dado instrucciones adecuadas a los operadores y al personal de mantenimiento.

Si se hubieran aplicado métodos sencillos y seguros contra fallos para garantizar que los tubos de rayos $X$ estuvieran apagados durante las intervenciones de reparación y mantenimiento, podrían haberse evitado muchas exposiciones accidentales.

Los operadores y el personal de mantenimiento que trabajan con estas máquinas deben utilizar dosímetros personales de dedo 0 de muñeca.

Si se hubieran exigido cortacorrientes se podrían haber evitado muchas exposiciones accidentales.

El error humano del operador fue una causa que contribuyó a desencadenar la mayoría de los accidentes. La falta de recintos adecuados 0 el diseño defectuoso del blindaje empeoraron a menudo la situación.

\section{Accidentes de radiografía industrial}

D esde el decenio de 1950 hasta el de 1970, la mayor tasa de accidentes radiológicos en una sola actividad ha correspondido siempre a las operaciones de radiografía industrial (OIEA 1969, 1977). Los órganos reguladores nacionales continúan la lucha para reducir esta frecuencia mediante la combinación de acciones como la mejora de reglamentos, exigencias estrictas de formación y políticas cada vez más rigurosas de inspección y cumplimiento (USCFR 1990). Estos esfuerzos normativos han tenido éxito en general, pero siguen ocurriendo muchos accidentes asociados a la radiología industrial. La legislación que 
impone fuertes multas puede ser la herramienta más eficaz para que la seguridad radiológica sea tenida en cuenta por los gestores de la radiología industrial ( $y$, en consecuencia, también por los trabajadores).

\section{Causas de los accidentes de radiografía industrial}

Formación de los trabajadores. En la radiografía industrial quizá sea donde los requisitos de educación y formación son menos exigentes que en ningún otro puesto de trabajo relacionado con la radiación. Por lo tanto, el cumplimiento de los requisitos de formación existentes debe ser obligado y riguroso.

Incentivo a la producción de los trabajadores. Durante años, el aspecto en que más se ha insistido a los radiólogos industriales ha sido el de la cantidad de radiografías satisfactorias producidas por día. Esta práctica puede conducir a que cometan actos inseguros y omitan el uso de la dosimetría personal, de manera que no se detectaría si se traspasan los límites del equivalente de dosis.

Falta de inspecciones adecuadas. Es de máxima importancia inspeccionar los contenedores de las fuentes (contenedores de almacenamiento) (Figura 48.24) después de cada exposición. La omisión de estas inspecciones es la causa más probable de exposiciones innecesarias, muchas de las cuales no se registran, puesto que los radiólogos industriales raras veces utilizan dosímetros de mano o dedo (Figura 48.24).

Problemas del equipo. D ebido a la intensa carga de trabajo de las cámaras de radiografía industrial, los mecanismos retráctiles de la fuente pueden aflojarse y provocar que la fuente no se retraiga por completo a su posición de almacenamiento seguro (punto $\mathrm{A}$ de la Figura 48.24). También hay muchas ocasiones en que los fallos de cortacircuitos de fuentes en armarios pueden causar exposiciones accidentales del personal.

\section{Diseño de planes de emergencia}

Para el diseño de planes de emergencia existen muchas directrices excelentes, tanto generales como específicas. Algunas referencias pueden ser de gran ayuda, y pueden consultarse en la bibliografía del final de este capítulo.

\section{Bosquejo inicial del plan y los procedimientos de emergencia} $\mathrm{H}$ ay que empezar por evaluar el inventario total de material radiactivo de la instalación en cuestión. Después es preciso

Figura 48.24 • Cámara de radiografías industriales.

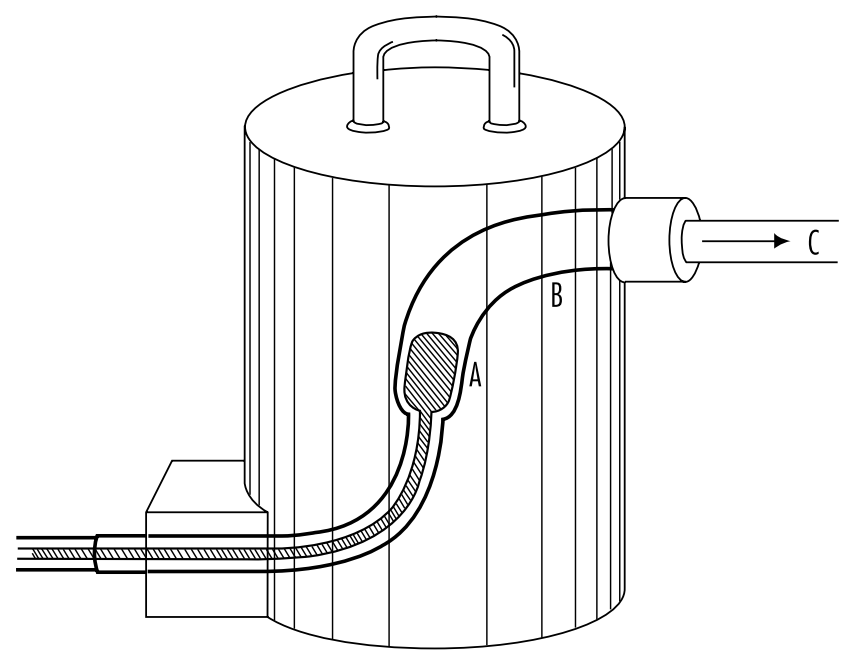

analizar los accidentes verosímiles, de manera que se puedan determinar los límites máximos probables de los escapes desde la fuente. A continuación, el plan y sus procedimientos deberán permitir a los operadores de la instalación:

1. reconocer una situación de accidente;

2. clasificar el accidente por su gravedad;

3. tomar medidas para mitigar el accidente:

4. cursar las notificaciones oportunas;

5. pedir ayuda de forma eficaz y rápida;

6. cuantificar los escapes;

7. vigilar las exposiciones dentro y fuera de la instalación, así como mantener las exposiciones de emergencia ALARA;

8. recuperar la instalación lo antes que las circunstancias permitan,

9. mantener registros exactos y detallados.

\section{Tipos de accidentes a sociados a reactores nucleares}

A continuación se da una lista de accidentes asociados a reactores nucleares, ordenados desde el más probable al menos probable. (Son mucho más probables, con gran diferencia, los accidentes del tipo industrial general, ajenos a los reactores nucleares.)

1. Escapes inesperados de material radiactivo de bajo nivel con exposición radiológica externa del personal escasa o nula. Suelen ocurrir durante reacondicionamientos importantes 0 en expediciones de resina o combustible agotado. Fugas del sistema de refrigeración y vertidos de muestras de refrigerante en sumideros son causa frecuente de difusión de contaminación radiactiva.

2. Exposición inesperada externa del personal. Suele suceder durante reacondicionamientos importantes 0 intervenciones normales de mantenimiento.

3. Una combinación de difusión de contaminación, contaminación de personal y exposición radiológica externa de bajo nivel del personal es el accidente que le sigue en probabilidad. Estos accidentes ocurren en las mismas condiciones que los de 1 y 2.

4. Contaminación de grandes superficies por causa de una fuga importante del sistema de refrigeración del reactor o una fuga de refrigerante del combustible agotado.

5. Pastillas o partículas grandes de CRUD activado (véase la definición más adelante) dentro o sobre la piel, oídos u ojos.

6. Exposición radiológica de alto nivel del personal de la central. Su causa suele ser el descuido.

7. Liberación de cantidades pequeñas, pero superiores a las admisibles, de residuos radiactivos fuera de los límites de la central. Suele ir asociada a fallos humanos.

8. Fusión del reactor. Es probable que produzca gran contaminación fuera de la central, además de alta exposición del personal.

9. Emisión accidental del reactor (accidente del tipo $\mathrm{SL}-1$ ).

\section{Radionucleidos esperados en accidentes de reactores refrigerados con agua:}

- productos de corrosión y erosión activados (comúnmente denominados (RUD) en el refrigerante; como cobalto 60 ó 58 $\left({ }^{60} \mathrm{Co},{ }^{58} \mathrm{Co}\right)$, hierro $59\left({ }^{59} \mathrm{Fe}\right)$, manganeso $58\left({ }^{58} \mathrm{M} \mathrm{n}\right)$ y tantalio $183\left({ }^{183} \mathrm{~T} \mathrm{a}\right)$;

- productos de fisión de bajo nivel radiactivo que suelen estar presentes en el refrigerante; como yodo 131 (131) y cesio $137\left({ }^{137} \mathrm{Cs}\right)$;

- en reactores de agua en ebullición, los puntos 1 y 2 anteriores más salida continua de gases de tritio $\left({ }^{3} \mathrm{H}\right)$ de bajo nivel y de 
Figura 48.25 • Ejemplo de plan de emergencia de central nuclear, índice de materias.

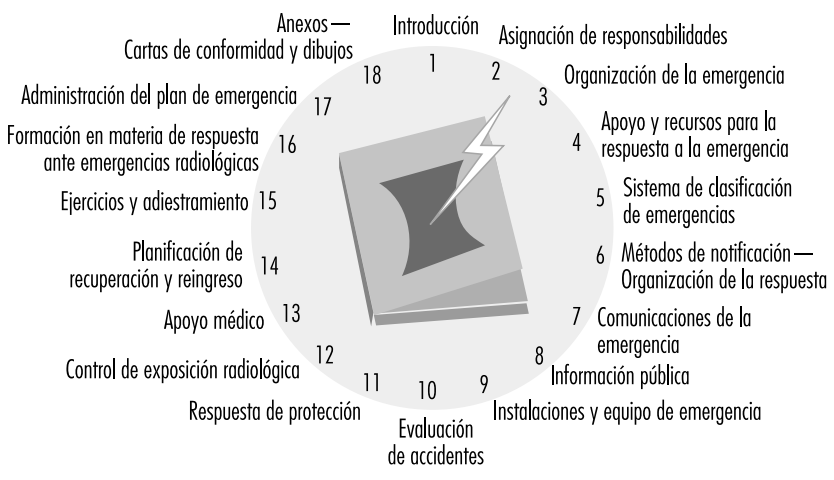

gases nobles radiactivos, como xenón 133 y $135\left({ }^{133} \mathrm{X} \mathrm{e},{ }^{135} \mathrm{X}\right.$ e), argón $41\left({ }^{41} \mathrm{Ar}\right)$, y criptón $85\left({ }^{85} \mathrm{~K} r\right)$,

- tritio $\left({ }^{3} \mathrm{H}\right)$ fabricado dentro del núcleo a la tasa de $1,3 \times 10^{-4}$ átomos de ${ }^{3} \mathrm{H}$ por fisión (sólo una fracción de este tritio abandona el combustible).

\section{Plan de emergencia típico de una central nuclear, índice}

En la Figura 48.28 se ofrece un ejemplo de índice de un plan de emergencia de una central nuclear. El plan deberá incluir todos

Figura 48.26 • Procedimientos típicos de implantación de un reactor nuclear.

1. SUPERVISOR ENCARGADO DEL TURNO NUCLEAR/ALTO EMPLEADO A CARGO DE EMERGENCIAS (SNSS/EDO):

a. Acciones necesarias durante una emergencia en la estación no afectada

b. Alerta - SNSS/EDO

c. Emergencia en zona del emplazamiento SNSS/EDO

d. Recomendación de medidas de protección

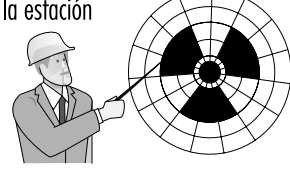

2. RESPUESTA DE LA ASISTENCIA:

a. Centro de asistencia técnica - Respuesta del equipo de ingeniería integrado

b. Activación y operación del centro de apoyo operativo

c. Centro de asistencia técnica - Soporte administrativo/respuesta de comunicadores

d. Convocatoria en respuesta a la emergencia/llamada al persona

\section{RESPUESTA DE LA PROTECCION RADIOLOGICA:}

a. Respuesta del técnico de protección radiológica presente en el turno

b. Centro de asistencia técnica - Respuesta de la protección radiológica

c. Punto de control - Respuesta de la protección radiológica/química

d. Centro de apoyo operativo - Respuesta de la protección radiológica

e. Bloqueo del tiroides con yodo estable

f. Muestreo del aire con sondas de emergencia

g. Muestreo de corrientes (ventilación de la planta/descarga de líquidos)

h. Vigilancia y descontaminación de personal/vehículos

i. Evaluación de dosis los apartados que se indican y adaptarse a las necesidades locales. La lista de los procedimientos de ejecución típicos de un reactor nuclear de potencia se recoge en la Figura 48.26.

\section{Vigilancia radiológica medioambiental \\ durante accidentes}

Esta tarea se denomina por lo general ER EM P (iniciales en inglés de "programa de vigilancia radiológica medioambiental para casos de emergencia" ) en las instalaciones grandes.

U na de las lecciones más importantes extraídas por la N uclear Regulatory Commission y otros organismos de Estados U nidos del accidente de Three $M$ ile Island fue que no se puede implantar con éxito un EREM P en uno o dos días sin una planificación cuidadosa previa. Aunque la administración norteamericana gastó muchos millones de dólares en vigilar el entorno de la central nuclear de Three M ile Island durante el accidente, se midieron menos del $5 \%$ de los vertidos por haberse efectuado una planificación previa defectuosa e inadecuada.

\section{Diseño de programas de vigilancia radiológica medioambiental para casos de emergencia}

L a experiencia ha demostrado que el único ER EM P útil es el que se integra en el programa de vigilancia radiológica medioambiental habitual. Durante los primeros días del accidente de Three Mile Island, se aprendió que un EREMP eficaz no se puede improvisar en un día o dos, por mucho personal y dinero que se dediquen al programa.

Figura 48.27 • Designación de sectores y zonas para muestreo radiológico y puntos de vigilancia dentro de las zonas de planificación de emergencias.

Los sectores $N$, NNE, EN, etc., representan secciones direccionales de la planta en incrementos de $22 \frac{1}{2^{\circ}}$.

Las zonas (1) a 10 representan la distancia desde la planta en incrementos de 1 milla Las zonas situadas más allá de la 10 se incrementan en 5 millas, y se denominan zonas 15, 20, 25, etc. hasta 50 .

Por ejemplo, el segmento en negro entre las millas $7^{a}$ y $8^{a}$ en dirección Noroeste desde la planta, se designará con NW8.

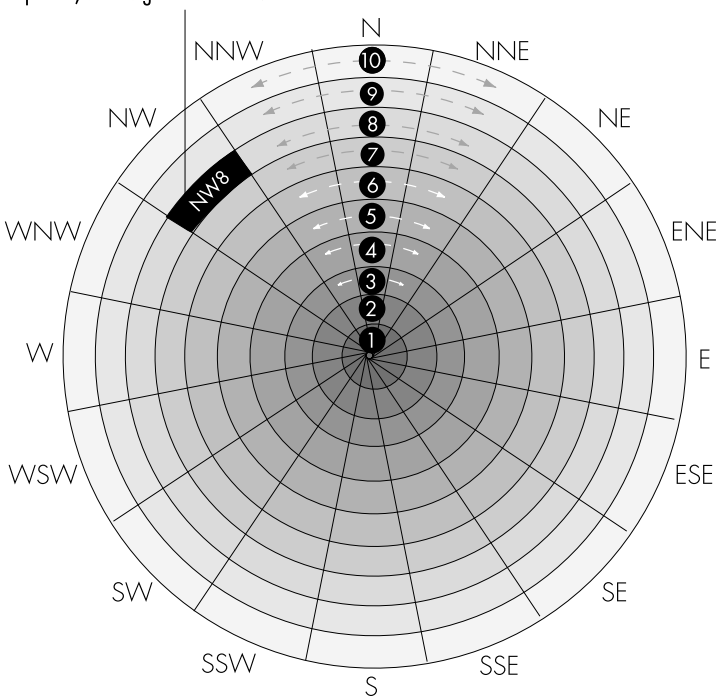

Fuente: Nuclear Regulatory Commission 1980 


\section{Puntos de muestreo}

Durante el seguimiento a largo plazo de un accidente se utilizarán todos los emplazamientos del programa de vigilancia radiológica medioambiental rutinaria. Se establecerán además otros nuevos de manera que a cada equipo motorizado de inspección se le asignen determinados emplazamientos en cada porción de cada sector de $22^{1 / 2^{\circ}}$ (véase la Figura 48.27). En general, los lugares de muestreo estarán en las zonas con carreteras. Pero será preciso establecer excepciones en sitios normalmente inaccesibles pero que puedan estar ocupados, como lugares de acampada 0 senderos de excursionistas que se encuentren en un radio aproximado de $16 \mathrm{~km}$ del accidente a favor del viento.

La Figura 48.27 muestra la designación de sectores y zonas de los puntos de vigilancia de la radiación y del medio ambiente. Se pueden designar los sectores de $2212^{\circ}$ mediante direcciones referidas a los puntos cardinales (por ejemplo, N, N NE, y NE ) o con simples letras (por ejemplo, de A a R). Pero no es recomendable utilizar letras porque es fácil confundirlas con la notación direccional. Por ejemplo, induce menos a error utilizar $\mathrm{S}$ para indicar el sur que la letra $\mathrm{l}$.

Cada emplazamiento designado para tomar muestras deberá ser visitado durante un ejercicio de simulación para que el personal responsable de la vigilancia y muestreo se familiarice con su situación y conozca los "espacios muertos" de la radio, las carreteras en mal estado, los problemas de encontrar los emplazamientos en la oscuridad y otros inconvenientes. Como ningún ejercicio abarcará todos los emplazamientos predesignados dentro de la zona de protección de emergencia del6 km, las simulaciones se proyectarán de manera que con el tiempo acaben por visitarse todos los puntos de muestreo. Suele merecer la pena determinar de antemano las posibilidades que tienen los vehículos de los equipos de inspección para comunicarse con los puntos predesignados. Los emplazamientos reales de los puntos de toma de muestras se eligen en virtud de los mismos criterios que en el REM P (NRC 1980); por ejemplo, línea del lugar, zona de exclusión mínima, individuo más cercano, comunidad más próxima, escuela más próxima, hospital, residencia de ancianos, rebaño de animales de leche, zona cultivada, granja, etc.

\section{Equipo de inspección radiológica}

En caso de accidente durante el que se hayan liberado materiales radiactivos en cantidad significativa, deberá haber grupos de inspección radiológica que establezcan una vigilancia permanente en la zona exterior. La vigilancia permanente deberá extenderse al interior de la instalación si las condiciones lo permiten. Lo normal es que estos equipos vigilen la radiación gamma y beta ambiental y tomen muestras del aire para detectar la presencia de partículas y halógenos radiactivos.

Estos equipos deben tener formación adecuada en todos los procedimientos de vigilancia, incluida la de sus propias exposiciones, y en la transmisión de los datos que obtengan a la estación base. Detalles como el tipo de detector, número de serie y estado de ventana abierta o cerrada se deberán comunicar en hojas de registro bien diseñadas.

Al comienzo de una emergencia, puede ser que un equipo de inspección de emergencia tenga que trabajar sin interrupción durante 12 horas. Pero después del período inicial, la jornada del grupo de inspección debe disminuir a ocho horas con un descanso de 30 minutos como mínimo.

Como puede ser necesario que la vigilancia sea continua, será preciso establecer procedimientos para suministrar al equipo de inspección comida y bebida, instrumentos y baterías de repuesto y transporte de ida y vuelta para los filtros de aire.

Aunque es probable que cada equipo de inspección trabaje 12 horas por turno, serán precisos tres turnos diarios para garantizar una vigilancia permanente. En el accidente de Three
M ile Island, durante las dos primeras semanas hubo en todo momento un mínimo de cinco equipos de vigilancia en acción. La logística de apoyo para un esfuerzo de esta índole tiene que responder a una planificación previa cuidadosa.

\section{Equipo de muestreo radiológico ambiental}

L os tipos de muestras ambientales tomadas durante un accidente dependen del tipo de vertido (en el aire o en el agua), de la dirección del viento y de la época del año. Deberán tomarse muestras del suelo y del agua potable, incluso en invierno. Aunque no se detecte liberación de halógenos radiactivos, deben tomarse muestras de leche, por su enorme factor de bioacumulación.

Se tomarán numerosas muestras alimentarias y ambientales para tranquilizar al público aunque haya razones técnicas que no justifiquen el esfuerzo. Además, estos datos pueden tener un valor incalculable en actuaciones legales posteriores.

En la toma de muestras ambientales es esencial emplear hojas de registro preparadas de antemano para recoger datos exteriores según procedimientos bien elaborados. Todas las personas que tomen muestras ambientales deben haber demostrado una clara comprensión de los procedimientos y tener una formación práctica documentada.

$\mathrm{Si}$ es posible, la recogida de muestras ambientales exteriores debe realizarla un equipo exterior independiente. También es preferible que las muestras ambientales habituales las obtenga el mismo equipo exterior, de manera que el valioso grupo interior pueda ser empleado en otras recogidas de datos durante un accidente.

$\mathrm{H}$ ay que destacar que durante el accidente de Three Mile I sland se recogieron todas las muestras ambientales que en teoría debían registrarse y que no se perdió ninguna muestra ambiental, y ello a pesar de que la tasa de muestreo fue diez veces mayor que las tasas de muestreo previas al accidente.

\section{Equipo de detección de emergencia}

La cantidad del equipo de detección de emergencia debe ser el doble como mínimo que el necesario en cualquier otro momento. D eben disponerse armarios en distintos lugares alrededor de los complejos nucleares de manera que ningún accidente impida el acceso a todos estos armarios. Para garantizar la disponibilidad del equipo, deben realizarse un inventario y una calibración del mismo cada semestre y después de cada ejercicio. Las instalaciones nucleares grandes deben disponer de furgones y camiones totalmente equipados para vigilancia de emergencia tanto interior como exterior

Durante un emergencia, puede ocurrir que los laboratorios de recuento queden inutilizados. Por lo tanto, se tomarán medidas preventivas para disponer de un laboratorio de recuento alternativo o móvil. Esta medida es ahora obligatoria en las centrales nucleares de EE.UU. (USNRC 1983).

El tipo y sofisticación del equipo de vigilancia medioambiental debe cumplir los requisitos de hacer frente al peor accidente verosímil de la instalación nuclear. A continuación se da una lista del equipo de vigilancia medioambiental típico que se necesita en centrales nucleares:

1. El equipo de muestreo del aire debe incluir unidades que funcionen con batería para el muestreo a corto plazo y que puedan funcionar con corriente alterna, dotadas de cintas registradoras y dispositivos de alarma para la vigilancia a más largo plazo.

2. El equipo de muestreo de líquidos debe contener muestreadores continuos, que deberán poder funcionar en el ambiente local con independencia de lo adverso que pueda ser.

3. Los detectores gamma portátiles para trabajo de implante deben tener una escala máxima de $100 \mathrm{G}$ y/ h, y el equipo de 
Figura 48.28 • Radiólogo industrial con dosímetros termoluminiscentes (DTL): uno en el bolsillo superior y otro de anillo (opcional en EE.UU.).

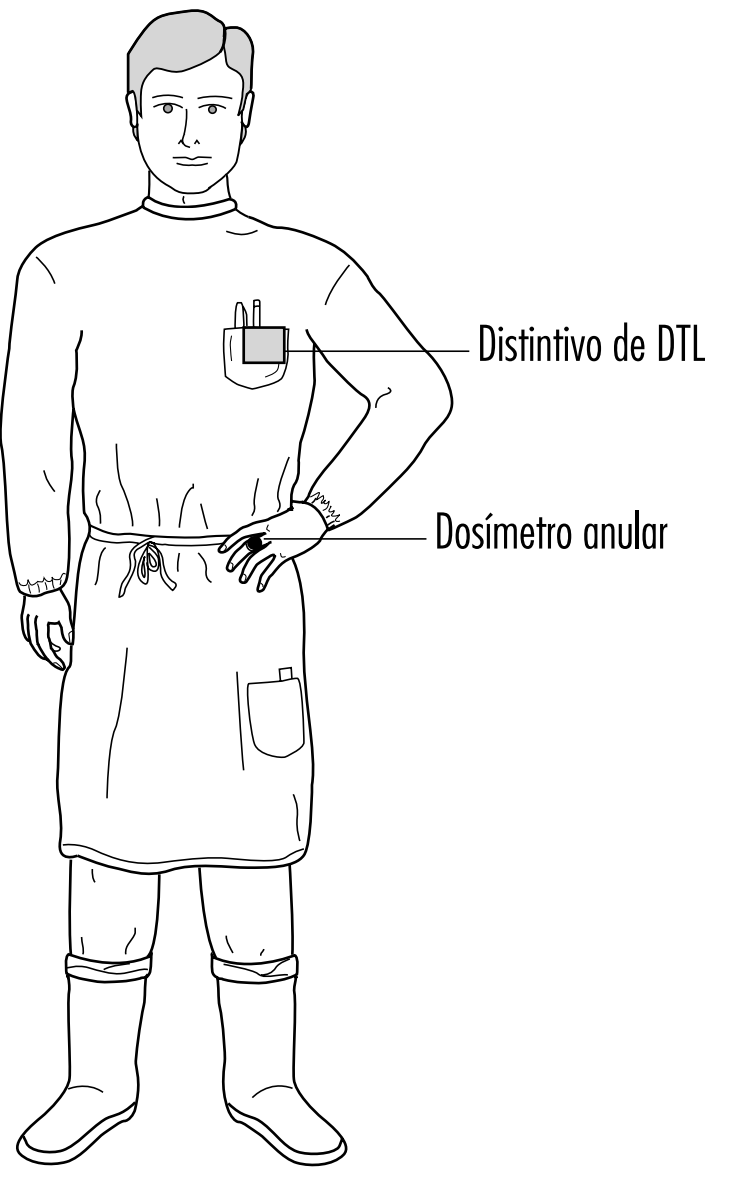

detección independiente debe poder medir radiación beta de hasta $100 \mathrm{~Gy} / \mathrm{h}$.

4. Dentro de la instalación, la dosimetría personal debe incluir equipo con capacidad de medición beta, así como dosímetros termoluminiscentes (DTL) anulares (Figura 48.28). A veces se necesita también otra dosimetría de extremidades. En las emergencias siempre es preciso disponer de juegos extra de dosímetros de control. Puede necesitarse un lector portátil de DTL que se conecte con el ordenador de la central por módem telefónico en emplazamientos de emergencia. Los grupos de inspección locales, como los de rescate y reparación, deben llevar dosímetros de bolsillo de pequeño y largo alcance, así como dosímetros preajustados para dar alarma. Será preciso conceder una atención cuidadosa a los niveles de dosis establecidas para los grupos de personas que puedan estar en zonas con altas radiaciones.

5. En los emplazamientos de emergencia y los vehículos de emergencia deben disponerse ropas de protección. Debe existir ropa protectora extra por si se producen accidentes de larga duración.

6. En todos los armarios y vehículos de emergencia debe haber equipo de protección respiratoria. Deben existir listas actualizadas de personal formado en técnicas respiratorias en cada una de las zonas principales de almacenamiento de equipo de emergencia.
7. Es esencial que los grupos de inspección que realicen vigilancia en caso de emergencia radiológica dispongan de vehículos dotados con radio. Deberá ser conocido el emplazamiento y disponibilidad de los vehículos de apoyo.

8. El equipo de los grupos de inspección ambiental debe almacenarse en un lugar conveniente, con preferencia en el exterior, donde pueda estar siempre disponible.

9. En el Centro de asistencia técnica y en la Instalación exterior para emergencias deben depositarse juegos de emergencia con el fin de que los grupos de inspección de relevo no tengan que entrar en el interior de la planta para recibir equipo y desplegarse.

10. En caso de accidente grave con liberación de materiales radiactivos en el aire, deben existir previsiones para el uso de helicópteros y avionetas para vigilancia aérea.

\section{Análisis de datos}

EI análisis de datos ambientales durante un accidente grave debe trasladarse lo antes posible a un emplazamiento exterior, como por ejemplo la Instalación exterior para emergencias.

D eben existir directrices preestablecidas sobre el momento en que han de comunicarse los datos de muestras ambientales a la dirección. El método y la frecuencia de la transferencia de los datos sobre muestras ambientales a los organismos gubernamentales deberán acordarse en los primeros momentos del accidente

\section{Lecciones sobre física de la salud y radioquímica extraídas del accidente de Three Mile Island}

Durante las primeras horas del accidente de Three M ile I sland de 28 de marzo de 1979, fue preciso recurrir a asesores externos para ejecutar las actividades siguientes, dado que los físicos sanitarios estaban totalmente ocupados en otras tareas:

- valoración de la liberación de efluentes radiactivos (gaseosos y líquidos), incluidos la recogida de muestras, la coordinación de laboratorios para recuento de muestras, el control de calidad de los laboratorios, la recogida de datos, el análisis de datos, la elaboración de informes, la distribución de datos a organismos gubernamentales y propietarios de la central;

- valoración de dosis, incluida la investigación de exposiciones excesivas supuestas y reales, investigaciones de contaminación cutánea y deposición interna, simulaciones de exposición significativa y cálculos de dosis;

- programa de vigilancia radiológica medioambiental, incluida la coordinación completa de la toma de muestras, el análisis de datos, la generación y distribución de informes, las notificaciones de puntos de acción, la expansión del programa para la situación de accidente y la contracción posterior del programa durante hasta un año después del accidente,

- estudios especiales de dosimetría beta, como estudios de los avances en la detección beta personal, confección de modelos de la dosis beta en la piel debida a contaminantes radiactivos, comparación mutua de todos los sistemas de dosímetros personales DT L beta-gamma disponibles comercialmente.

En la lista anterior se incluyen ejemplos de actividades que el personal físico-sanitario típico de una central no puede llevar a cabo adecuadamente durante un accidente grave. EI personal físico-sanitario de Three Mile Island tenía gran experiencia, conocimientos y competencia. Trabajaron de 15 a 20 horas diarias durante las dos primeras semanas del accidente sin un solo descanso. Ahora bien, las necesidades adicionales derivadas del accidente eran tan numerosas que se veían incapaces de ejecutar muchas tareas rutinarias importantes que en condiciones normales hubieran efectuado con comodidad. 
Entre las lecciones aprendidas del accidente de Three M ile Island se cuentan:

\section{Entrada al edificio auxiliar durante el accidente}

1. Todas las entradas han de reflejarse en un nuevo pase de trabajo radiológico revisado por el jefe de física sanitaria de la instalación y firmado por el superintendente de la unidad 0 sustituto designado.

2. U na sala de control adecuada debe tener el control absoluto de todas las entradas al edificio auxiliar y al de manipulación de combustible. No se permitirá la entrada a nadie sin que esté presente un físico sanitario en el punto de control durante la entrada.

3. No se permitirán entradas sin un detector en perfecto funcionamiento y de la escala adecuada. Inmediatamente antes de la entrada se realizará una comprobación de respuesta del medidor.

4. Se obtendrá la historia de exposición de todas las personas que vayan a entrar en una zona de alta radiación.

5. Se designará la exposición admisible durante la entrada, con independencia de la importancia de la tarea.

\section{M uestreo del refrigerante primario durante el accidente}

1. Todas las muestras que vayan a obtenerse en virtud de un nuevo permiso de trabajo expuesto deberán ser revisadas por el jefe de física sanitaria de la instalación y firmadas por el superintendente de la unidad o equivalente.

2. No se tomará ninguna muestra del refrigerante si no se lleva puesto un dosímetro de extremidad.

3. No se tomará ninguna muestra del refrigerante si no se dispone de guantes blindados y tenazas de $60 \mathrm{~cm}$ de longitud como mínimo cuando una muestra sea más radiactiva de lo esperado.

4. No se tomará ninguna muestra del refrigerante sin colocar antes un blindaje personal de vidrio plomado cuando una muestra sea más radiactiva de lo esperado.

5. La toma de muestras deberá interrumpirse si es probable que la exposición de una extremidad o la de todo el cuerpo supere los niveles prefijados que figuran en el permiso de trabajo expuesto.

6. Las exposiciones significativas se distribuirán entre varios trabajadores si es posible.

7. Todos los casos de contaminación cutánea superiores a niveles de actuación dentro de 24 horas deberán ser revisados.

\section{Entrada a la sala de válvulas de compensación}

1. Se realizarán inspecciones de zonas con radiación beta y gamma con detectores remotos que posean la escala máxima adecuada.

2. La entrada inicial en una zona con una tasa de dosis absorbida superior a $20 \mathrm{mG}$ y/h deberá ser revisada de antemano para verificar que la exposición a la radiación se mantendrá lo más baja que sea razonable lograr.

3. Cuando se sospechen fugas de agua, se medirá la posible contaminación del suelo.

4. Debe ponerse en marcha un programa coherente de tipo y colocación de dosímetros personales.

5. Cuando hayan entrado personas en una zona con una tasa de dosis absorbida superior a $20 \mathrm{mG}$ / h, los DTL deberán ser evaluados inmediatamente después de la salida.

6. Debe comprobarse que se observan todos los requisitos reflejados en el permiso de trabajo expuesto antes de entrar en una zona con una tasa de dosis absorbida superior a $20 \mathrm{mG} / \mathrm{h}$.

7. Las entradas por tiempo controlado en zonas peligrosas deben ser cronometradas por un físico sanitario.

\section{M edidas protectoras y vigilancia medioa mbiental exterior desde la perspectiva de la administración local}

1. Antes de comenzar un procedimiento de muestreo, se establecerán criterios para detenerlo.

2. No se permitirán interferencias exteriores.

3. Debe haber instaladas varias líneas telefónicas confidenciales. L os números se cambiarán después de cada crisis.

4. La capacidad de los sistemas de medición aéreos es mejor de lo que piensa la mayoría de la gente.

5. Se tendrá a mano una grabadora de cinta para registrar datos a intervalos regulares.

6. Durante el transcurso del episodio agudo, se dejará de leer periódicos, ver televisión y escuchar la radio, puesto que estas actividades lo único que hacen es añadir tensiones a las ya existentes

7. Se planificarán el suministro de alimentos y otras comodidades, como instalaciones para dormir, puesto que será imposible ir a casa en ningún momento.

8. Deberán planificarse posibilidades analíticas alternativas. Incluso un accidente pequeño puede alterar en grado significativo los niveles de radiación de fondo del laboratorio.

9. H ay que señalar que se gastará más energía en hacer frente a decisiones erróneas que a los verdaderos problemas.

10. Debe partirse de la idea de que las emergencias no pueden afrontarse desde lugares distantes.

11. H ay que señalar que las recomendaciones de medidas protectoras no están sujetas a votos en comités.

12. T odas las llamadas no esenciales se dejarán en espera, y se colgará el teléfono a quienes causen pérdidas de tiempo.

\section{El accidente radiológico de Goiânia de 1985}

En torno al 13 de septiembre 1985 se robó una unidad de teleterapia de $51 \mathrm{TBq}{ }^{137} \mathrm{C}$ s en una clínica abandonada de Goiânia, Brasil. D os personas que buscaban chatarra se llevaron a casa el conjunto de la fuente de la unidad de teleterapia e intentaron desarmarla. La tasa de dosis absorbida del conjunto de la fuente fue de unos $46 \mathrm{~Gy} / \mathrm{h}$ a $1 \mathrm{~m}$. No conocían el significado del símbolo de tres hojas indicador de radiación que figuraba en la cápsula de la fuente.

La cápsula de la fuente se rompió durante el desmontaje. Por una parte de esta ciudad de 1.000.000 de habitantes se difundió polvo de cloruro de cesio $137\left({ }^{137} \mathrm{C} \mathrm{sCl}\right)$ muy soluble, que originó uno de los accidentes más graves que una fuente sellada ha producido en la historia.

D espués del desmontaje, las piezas del conjunto de la fuente se vendieron a un chatarrero, que descubrió que el polvo de ${ }^{137} \mathrm{C} \mathrm{sCl}$ brillaba en la oscuridad con un color azulado (es de suponer que se tratase de radiación de Cerenkov). Pensó que el polvo pudiera ser de una piedra preciosa e incluso sobrenatural. Muchos amigos y familiares acudieron a ver el brillo "maravilloso". Se entregaron porciones de la fuente a varias familias. Este proceso continuó durante unos cinco días. Para entonces, numerosas personas habían desarrollado síntomas gastrointestinales del síndrome de exposición radiológica.

A los pacientes que fueron al hospital con trastornos gastrointestinales graves se les diagnosticó erróneamente reacciones alérgicas a algo que habían comido. L os efectos cutáneos graves por haber manipulado la fuente que presentaba un paciente se interpretaron como síntomas de alguna enfermedad tropical de la 
piel y el paciente fue enviado al hospital de enfermedades tropicales.

Esta trágica secuencia de acontecimientos continuó sin ser reconocida por personal especializado durante unas dos semanas. M ucha gente se frotó la piel con el polvo de ${ }^{137} \mathrm{CsCl}$ para que adquiriese brillo azul. La secuencia podría haber continuado mucho más si una de las personas irradiadas no hubiera acabado por relacionar la enfermedad con la cápsula de la fuente. Llevó lo que quedaba de la fuente de ${ }^{137} \mathrm{CsCl}$ en un autobús al departamento de sanidad pública de $\mathrm{G}$ oiânia, donde lo dejó. Un físico médico visitante inspeccionó la fuente al día siguiente. Tomó medidas por propia iniciativa para evacuar dos chatarrerías e informar a las autoridades. La rapidez y el grado global de la respuesta de la administración brasileña cuando tuvo conocimiento del accidente fueron impresionantes.

Alrededor de 249 personas sufrieron contaminación. Cincuenta y cuatro fueron hospitalizadas. Cuatro personas murieron, una de ellas una niña de seis años que recibió una dosis interna de unos $4 \mathrm{~Gy}$ por haber ingerido $1 \mathrm{GBq}\left(10^{9} \mathrm{~Bq}\right)$ de ${ }^{137} \mathrm{Cs}$.

\section{Respuesta al accidente}

Los objetivos de la respuesta inicial fueron:

- identificar los puntos principales contaminados;

- evacuar las residencias donde los niveles de radiactividad eran superiores a los niveles de intervención adoptados;

- establecer controles físico-sanitarios alrededor de estas áreas, e impedir el acceso cuando era necesario,

- identificar a las personas que habían recibido dosis significativas o estaban contaminadas.

Al principio, el equipo médico:

- nada más llegar a Goiânia, obtuvo las historias clínicas y las clasificó en relación con los síntomas del síndrome de radiación agudo;

- envió a todos los pacientes con radiación aguda al hospital de Goiânia (que fue preparado de antemano para el control de contaminación y exposición);

- al día siguiente, trasladó a los seis pacientes más críticos por avión al centro asistencial terciario de un hospital naval en R io de Janeiro (después se trasladaron a este mismo hospital ocho pacientes más);

- hizo preparativos para realizar dosimetría radiológica citogenética;

- basó el tratamiento médico de cada paciente en su evolución clínica,

- impartió formación informal al personal del laboratorio clínico para disminuir sus temores (la comunidad médica de Goiânia se resistía a prestar ayuda).

Los físicos sanitarios:

- asistieron a los médicos en dosimetría de radiación, bioensayo y descontaminación de la piel ;

- coordinaron e interpretaron el análisis de 4.000 muestras de orina y heces en un período de cuatro meses;

- realizaron recuentos corporales totales a 600 personas;

- coordinaron la vigilancia de contaminación radiológica de 112.000 personas (249 resultaron contaminadas);

- realizaron inspección aérea de toda la ciudad y sus suburbios con detectores de $\mathrm{Nal}$ montados a toda prisa ;

- realizaron inspecciones de más de $2.000 \mathrm{~km}$ de carreteras con detectores de $\mathrm{N}$ al montados en automóviles;

- establecieron niveles de actuación para descontaminar personas, edificios, automóviles, suelo, etc.;
- coordinaron a 550 trabajadores empleados en esfuerzos de descontaminación ;

- coordinaron la demolición de siete casas y la descontaminación de otras 85;

- coordinaron el transporte de 275 cargas de residuos radiactivos con camiones

- coordinaron la descontaminación de 50 vehículos;

- coordinaron el embalado de 3.500 metros cúbicos de residuos contaminados,

- utilizaron 55 dosímetros, 23 monitores de contaminación y 450 dosímetros de lectura automática.

\section{Resultados}

\section{Pacientes con síndrome de radiación agudo}

Cuatro pacientes murieron a consecuencia de dosis absorbidas de entre 4 y 6 Gy. Dos pacientes presentaron depresión medular grave, pero sobrevivieron a pesar de dosis absorbidas de 6,2 y 7,1 Gy (estimación citogenética). C uatro pacientes sobrevivieron con dosis absorbidas estimadas de 2,5 a $4 \mathrm{~Gy}$.

\section{Lesiones de la piel inducidas por la radiación}

Diecinueve de veinte pacientes hospitalizados tuvieron lesiones cutáneas inducidas por la radiación, que empezaron con hinchazón y ampollas. Estas lesiones se rompieron después y secretaron líquido. Diez de las diecinueve personas con lesiones cutáneas desarrollaron lesiones profundas en las cuatro o cinco semanas siguientes a la irradiación. Estas lesiones profundas indicaban una exposición gamma significativa de tejidos más profundos.

Todas las lesiones de la piel estaban contaminadas con ${ }^{137} \mathrm{C}$, con tasas de dosis absorbidas de hasta $15 \mathrm{mG} y / \mathrm{h}$.

La niña de seis años que ingirió $1 \mathrm{TBq}$ de ${ }^{137} \mathrm{Cs}$ (y que murió un mes después) tenía contaminación cutánea generalizada que dio una media de $3 \mathrm{mG} / \mathrm{h}$.

Un paciente necesitó una amputación un mes después de la exposición. Las imágenes de angiografía radioisotópica fueron útiles para determinar la demarcación entre arteriolas dañadas y normales.

\section{Resultados de contaminación interna}

Las pruebas estadísticas no demostraron diferencias importantes entre las cargas corporales determinadas por recuento corporal total y las determinadas por datos de excreción urinaria.

Se validaron los modelos que relacionaban datos de bioensayos con incorporaciones y carga corporal. Estos modelos fueron aplicables también a grupos de edad diferente.

El azul de Prusia fue útil para promover la eliminación del ${ }^{137} \mathrm{C} \mathrm{SCl}$ del cuerpo (si la dosificación era superior a $3 \mathrm{G}$ y/ d).

D iecisiete pacientes recibieron diuréticos para la eliminación de cargas corporales de ${ }^{137} \mathrm{CsCl}$. Estos diuréticos fueron ineficaces para desincorporar el ${ }^{137} \mathrm{C}$, por lo que su uso fue abandonado.

\section{Descontaminación de la piel}

En todos los pacientes se realizó descontaminación cutánea con agua y jabón, ácido acético y dióxido de titanio $\left(\mathrm{TiO}_{2}\right)$. Esta descontaminación sólo tuvo éxito en parte. Se supuso que el sudor originaba recontaminación de la piel a partir de la carga corporal de ${ }^{137} \mathrm{Cs}$.

Las lesiones de piel contaminada son muy difíciles de descontaminar. El desprendimiento de la piel necrótica redujo en grado notable los niveles de contaminación. 
Estudio de seguimiento sobre evaluación de dosis por análisis citogenético

$\mathrm{L}$ a frecuencia de aberraciones de los linfocitos en momentos diferentes tras el accidente siguieron tres pautas principales:

En dos casos, la frecuencia de la incidencia de aberraciones permaneció constante hasta un mes después del accidente y bajó al $30 \%$ de la frecuencia inicial tres meses después.

En dos casos se encontró una disminución gradual de alrededor del $20 \%$ cada tres meses.

En dos de los casos de contaminación interna más alta, hubo aumentos de la frecuencia de incidencia de aberraciones (en alrededor del 50 y $100 \%$ ) a lo largo de un período de tres meses.

\section{Estudios de seguimiento de las cargas corporales de ${ }^{137}$ Cs}

- Las dosis entregadas reales de los pacientes fueron controladas por bioensayo.

- Se siguieron los efectos de la administración de azul de Prusia.

- Se efectuaron mediciones in vivo en muestras de sangre, heridas y órganos de 20 personas para investigar la distribución no homogénea de ${ }^{137}$ C s y su retención en tejidos del cuerpo.

- Se estudiaron una mujer y su hijo recién nacido para investigar la retención y transferencia por alimentación materna.

\section{Niveles de actuación para intervención}

Se recomendó la evacuación de las viviendas cuando las tasas de dosis absorbidas eran superiores a $10 \mu \mathrm{Gy} / \mathrm{h}$ a $1 \mathrm{~m}$ de altura dentro de la casa.

La descontaminación reparadora de propiedades, ropa, suelo y alimentos se basó en que una persona no llegase a superar $5 \mathrm{mG}$ y en un año. La aplicación de este criterio por diferentes caminos dio por resultado la descontaminación del interior de una casa si la dosis absorbida pudiera superar $1 \mathrm{mG}$ y en un año y la descontaminación del suelo si la tasa de dosis absorbida pudiera rebasar $4 \mathrm{mG}$ y en un año (3 mG y de radiación externa y $1 \mathrm{mG}$ y de radiación interna).

\section{El accidente de la unidad 4 de la central nuclear de Chernóbil de 1986}

\section{Descripción general del accidente}

El peor accidente de una central nuclear de todo el mundo sucedió el 26 de abril de 1986 durante un ensayo de ingeniería eléctrica a muy baja potencia. C on el fin de realizar esta prueba, varios sistemas de seguridad se desconectaron o bloquearon.

Esta unidad era del modelo RBM K-1000, el tipo de reactor que producía en torno al $65 \%$ de toda la energía nuclear generada en la URRS. Era un reactor de agua en ebullición moderado por grafito que generaba $1.000 \mathrm{MW}$ de electricidad (M We). La RBM K-1000 no tiene un edificio de contención a prueba de presión y no se construye en la mayoría de los países.

EI reactor llegó pronto a la situación crítica y produjo una serie de explosiones de vapor. Las explosiones volaron toda la parte superior del reactor, destruyeron la delgada estructura que lo cubría e iniciaron una serie de incendios en los gruesos techos de asfalto de las unidades 3 y 4. L os escapes radiactivos duraron diez días, y 31 personas murieron. La delegación de la U R SS en el Organismo Internacional de la Energía A tómica estudió el accidente. Constataron que los experimentos en la unidad 4 del RBM K de Chernóbil que provocaron el accidente no habían obtenido la autorización necesaria y que las reglas escritas sobre medidas de seguridad en reactores eran inadecuadas. L a delegación afirmó además: "el personal que intervino carecía de la preparación adecuada para ejecutar los ensayos y no era consciente de los posibles peligros". Esta serie de ensayos crearon las condiciones que desencadenaron la situación de emergencia y condujeron a un accidente de reactor que casi nadie pensaba que pudiera ocurrir.

\section{Liberación de productos de fisión en el accidente de la unidad 4 de Chernóbil}

\section{Actividad total liberada}

U nos 1.900 PBq de productos de fisión y combustible (lo que en conjunto fue denominado corio por el grupo de recuperación del accidente de Three M ile I sland) fueron liberados a lo largo de los diez días que se emplearon en apagar todos los incendios y en sellar la unidad 4 con un material de blindaje absorbente de neutrones. La unidad 4 es ahora un sarcófago con un sellado permanente de acero y hormigón que encierra el corio residual y los restos del núcleo destruido del reactor.

El $25 \%$ de los 1.900 PBq fue liberado el primer día del accidente. EI resto lo fue durante los nueve días siguientes.

L os escapes radiológicos más importantes fueron $270 \mathrm{PBq}$ de ${ }^{131}$, $8,1 \mathrm{PBq}$ de ${ }^{90} \mathrm{Sr}$ y $37 \mathrm{PBq}$ de ${ }^{137} \mathrm{Cs}$. Pueden compararse estas cifras con las del accidente de Three Mile Island, que liberó 7,4 T Bq de ${ }^{131}$ y cantidades no medibles de ${ }^{90} \mathrm{Sr} 0{ }^{137} \mathrm{C} \mathrm{S}$.

Dispersión de los materiales radiactivos en el medio ambiente Los primeros escapes tomaron la dirección norte, pero los siguientes fueron en dirección oeste y suroeste. La primera pluma llegó a Suecia y Finlandia el 27 de abril. Los programas de vigilancia radiológica de centrales nucleares descubrieron inmediatamente el escape y alertaron al mundo sobre el accidente. Parte de esta primera pluma giró hacia Polonia y Alemania O riental. Las plumas siguientes barrieron la Europa del este y central los días 29 y 30 de abril. A continuación, en el Reino Unido se vieron productos de Chernóbil el 2 de mayo, después en Japón y China el 4 de mayo, en India el 5 de mayo y en Canadá y EE.UU. Ios días 5 y 6 de mayo. El hemisferio sur no informó de haber detectado esta pluma.

La deposición de la pluma estuvo gobernada en su mayor parte por la precipitación. La composición de la lluvia radiactiva en relación con los radionucleidos principales $\left({ }^{131} 1,{ }^{137} \mathrm{Cs},{ }^{134} \mathrm{C} s\right.$, y ${ }^{90} \mathrm{Sr}$ ) fue muy variable, incluso en la URSS. EI riesgo mayor consistió en la irradiación externa debida a la deposición superficial, así como el derivado de la ingestión de alimentos contaminados.

\section{Consecuencias radiológicas del accidente de la unidad 4 de Chernóbil}

\section{Consecuencias sanitarias generales agudas}

Dos personas murieron inmediatamente, una durante el hundimiento del edificio y otra 5,5 horas después por quemaduras térmicas. 0 tras 28, del personal del reactor y del cuerpo de bomberos, murieron por lesiones radiológicas. La dosis de radiación recibida por la población exterior a la central estuvo por debajo de los niveles que pueden provocar efectos radiológicos inmediatos.

El accidente de Chernóbil casi duplicó el número total de fallecimientos en todo el mundo debidos a accidentes radiológicos hasta 1986 (de 32 a 61). (Es interesante subrayar que la causa de las tres muertes del accidente del reactor SL-1 en EE.UU. aparece en las listas como explosión de vapor y que los dos primeros casos de Chernóbil tampoco se incluyen en las listas de muertes por accidente radiológico.)

\section{Factores que influyeron en las consecuencias sanitarias} del accidente en el interior

No se dispuso de la dosimetría individual de las personas de la instalación que estuvieron en mayor riesgo. La ausencia de náuseas 0 vómitos en las seis primeras horas siguientes a la 


\section{Organizaciones internacionales}

O rganismo Internacional de Energía A tómica

P. 0 . Box 100

A-1400 Viena

AUSTRIA

Comisión Internacional de Unidades y Medidas Radiológicas (International Commission on Radiation Units and M easurements)

7910 W oodmont Avenue

Bethesda, M aryland 20814

ESTADOS UN IDOS

Comisión Internacional de Protección Radiológica (C IPR)

P.O. Box N 0. 35

Didcot, 0 xfordshire

$0 \times 110 R J$

REIN $O$ UN IDO

Asociación Internacional de Protección Radiológica (International Radiation Protection Association)

Eindhoven University of Technology

P.0. Box 662

5600 AR Eindhoven

PAISES BAJOS

Comité de las $\mathrm{N}$ aciones Unidas sobre los Efectos de la Radiación Atómica (United $\mathrm{N}$ ations Committee on the Effects of A tomic Radiation)

BERN AM ASSO CIATES

4611 -F Assembly Drive

Lanham, Maryland 20706-4391

ESTADOS UN IDOS

exposición señaló sin lugar a dudas a los pacientes que habían recibido dosis absorbidas inferiores a las mortales, al mismo tiempo que era una buena indicación de los pacientes que no necesitaban atención médica inmediata por exposición radiológica. Esta información, junto con datos de la sangre (disminución del recuento de linfocitos) fue más útil que los datos de dosimetría personal.

Las pesadas prendas protectoras de los bomberos (una Iona porosa) permitieron que productos de fisión de alta actividad específica entraran en contacto con la piel. Estas dosis beta causaron quemaduras graves en la piel y constituyeron un factor determinante en muchas de las muertes. Cincuenta y seis trabajadores recibieron quemaduras graves en la piel. Estas quemaduras fueron muy difíciles de tratar y complicaron extremadamente la situación. H icieron imposible descontaminar a los pacientes antes de transportarlos a los hospitales.
Durante ese tiempo no hubo cargas corporales de material radiactivo interno que fueran significativas desde el punto de vista clínico. Sólo dos personas tuvieron cargas corporales elevadas (aunque no significativas desde el punto de vista clínico).

De las cerca de 1.000 personas observadas, 115 fueron hospitalizadas con síndrome de radiación agudo. 0 cho auxiliares médicos que trabajaron en el interior sufrieron el síndrome de radiación agudo.

Como se esperaba, no hubo pruebas de exposición a neutrones. (L a prueba buscaba sodio $24\left({ }^{24} \mathrm{~N}\right.$ a) en la sangre.)

Factores que influyeron en las consecuencias sanitarias del accidente en el exterior

Las medidas protectoras del público en general pueden dividirse en cuatro períodos distintos.

1. Las primeras $24 \mathrm{~h}$ : El público que recibía el viento de la central permaneció dentro de casa, con puertas y ventanas cerradas. Comenzó la distribución de yoduro de potasio $(\mathrm{KI})$ con el fin de bloquear la incorporación de ${ }^{131} \mid$ al tiroides.

2. U no a siete días: Pripyat fue evacuada una vez establecidas rutas de evacuación seguras. Se montaron estaciones de descontaminación. La región de Kiev fue evacuada. El número total de personas evacuadas fue superior a 88.000.

3. U na a sés semanas: El número total de personas evacuadas ascendió a 115.000. T odas ellas fueron sometidas a reconocimiento médico y realojadas. Se administró yoduro de potasio a 5,4 millones de rusos, entre ellos a 1,7 millones de niños. Las dosis de tiroides se redujeron en torno al 80-90\%. D ecenas de miles de cabezas de ganado vacuno fueron trasladadas de las áreas contaminadas. Se prohibieron la leche y los alimentos locales en una extensa zona (en función de lo exigido por los niveles de intervención).

4. D espués de 6 semanas: El círculo de evacuación de $30 \mathrm{~km}$ de radio se dividió en tres subzonas: (a) una zona de 4 a $5 \mathrm{~km}$ donde no se espera que vuelva a entrar público en el futuro previsible, (b) una zona de 5 a $10 \mathrm{~km}$ a la que se permitirá la vuelta de la población de forma limitada después de transcurrido cierto tiempo y (c) una zona de 10 a $30 \mathrm{~km}$ donde se prevé permitir el retorno de la población.

Se ha realizado un gran esfuerzo para descontaminar las zonas exteriores

La dosis radiológica total recibida por la población de la URSS que figura en un informe del Comité Científico de las Naciones Unidas para el Estudio de los Efectos de las R adiaciones Atómicas (U N SCEAR) es de 226.000 Sv-persona (72.000 Sv-persona comprometidos durante el primer año). El equivalente de dosis colectiva mundial estimado es del orden de 600.000 Sv-persona. El tiempo y estudios más detallados afinarán esta estimación (UNSCEAR 1988).

\section{Referencias}

Agencia Internacional para la Investigación sobre el Cáncer (IARC). 1994. IAR C study group on cancer risk among nuclear industry workers, new estimates of cancer risk due to low doses of ionizing radiation: An international study. Lance 344:1039-1043.

American National Standards Institute (ANSI). 1977. Radiation Safety for X-R ay, Diffraction and Fluorescence Analysis E quipment. $V$ ol. 43.2. N ueva Y ork: ANSI.

American Nuclear Society. 1961. Special report on SL-1 Accident. Nuclear News.
Bethe, H A. 1950. R evs. M od. Phys., 22, 213.

Brill, AB, EH Forgotson. 1964. Radiation and congenital malformations. Am J Obstet Gynecol 90:1149-1168.

Brown, P. 1933. American M artyrs to Science through the R oentgen Rays. Springfield, Illinois: Charles C Thomas.

Bryant, PM . 1969. Data assessments concerning controlled and accidental releases of I-131 and C S-137 to the atmosphere. $H$ ealth P hys 17(1).

Comisión Internacional para la Protección Radiológica (CIPR). 1984. Nonstochastic effects of ionizing radiation. Ann ICR P 14(3):1-33.
- . 1991. R ecomendaciones de la Comisión Internacional para la Protección R adiológica. Ann ICRP . 21:1-3.

Comité Científico de las Naciones Unidas para el Estudio de los Efectos de las R adiaciones A tómicas (U NSCEAR). 1982. I onizing Radiation: Sources and Biological Effects. Informe remitido a la Asamblea G eneral, con Anexos. Nueva Y ork: Naciones Unidas.

- . 1986. Genetic and Somatic E ffects of I onizing R adiation. Informe remitido a la Asamblea General, con Anexos. Nueva Y ork: N aciones U nidas. 
-. 1988. Sources, E ffects, and Risks of I onizing Radiation. Informe remitido a la A samblea General, con Anexos. Nue va Y ork: N aciones U nidas.

-. 1993. Sources and E ffects of I onizing R adiation. Informe remitido a la Asamblea General, con Anexos. Nueva Y ork: N aciones U nidas.

- . 1994. Sources and E ffects of I onizing R adiation. Informe remitido a la Asamblea General, con Anexos. Nueva Y ork: Naciones U nidas

Doll, R, NJ Evans, SC Darby. 1994. Paternal exposure not to blame. Nature 367:678-680.

Friedenwald, JS, S Sigelmen. 1953. The influence of ionizing radiation on mitotic activity in the rat corneal epithelium. Exp Cell Res 4:1-31.

Gardner, M J, A H all, M P Snee, S D ownes, CA Powell, JD T erell. 1990. Results of case-control study of leukaemia and lymphoma among young people near Sellafield nuclear plant in W est C umbria. B rit $M$ ed I 300:423-429.

Goodhead, DJ. 1988. Spatial and temporal distribution of energy. $\mathrm{H}$ ealth Phys 55:231-240.

H all, EJ. 1994. Radiobiology for the R adiologist. Filadelfia: JB Lippincott.

H aynie, JS, RH Olsher. 1981. A summary of x-ray machine exposure accidents at the Los Alamos $\mathrm{N}$ ational Laboratory. LAU P

Hill, C, A Laplanche. 1990. O verall mortality and cancer mortality around French nuclear sites. $\mathrm{Na}$ ture 347:755-757.

Jablon, S, Z H rubec, JDJ Boice. 1991. Cancer in populations living near nuclear facilities. A survey of mortality nationwide and incidence in two areas. J AM A 265:1403-1408.

Jensen, RH, RG Langlois, WL Bigbee. 1995. Elevated frequency of glycophorin $A$ mutations in erythrocytes from $C$ hernobyl accident victims. $R$ ad Res 141:129-135.

Journal of O ccupational M edicine (JOM). 1961. Suplemento especial. I O ccup M ed 3(3).

K asakov, VS, EP Demidchik, LN Astakhova. 1992. Thyroid cancer after Chernobyl. Nature 359:21.

K erber, RA, JE Till, SL Simon, JL Lyon, DC Thomas, S Preston-M artin, ML Rallison, RD Lloyd, WS Stevens. 1993. A cohort study of thyroid disease in relation to fallout from nuclear weapons testing. I AM A 270:2076-2082.

K inlen, LJ, K Clarke, A Balkwill. 1993. Paternal preconceptional radiation exposure in the nuclear industry and leukaemia and non-Hodgkin's lymphoma in young people in Scotland. Brit M ed 306:1153-1158.

K inlen, LJ. 1988. Evidence for an infective cause of childhood leukaemia: Comparison of a Scottish $\mathrm{N}$ ew T own with nuclear reprocessing sites in Britain. Lancet II:1323-1327.

Lindell, B. 1968. O ccupational hazards in x-ray anaIytical work. $\mathrm{H}$ ealth Phys 15:481-486.

Little, M P, M W Charles, R Wakeford. 1995. A review of the risks of leukemia in relation to parental pre-conception exposure to radiation. $\mathrm{H}$ ealth Phys 68:299-310.

Lloyd, DC, RJ Purrott. 1981. Chromosome aberration analysis in radiological protection dosimetry. Rad P rot D osimetry 1:19-28.

Lubenau, JO, J Davis, D McDonald, T Gerusky. 1967. Analytical X-R ay H azards: A Continuing Problem. Trabajo presentado en el XII Congreso anual de la $\mathrm{H}$ ealth Physics Society. Washington, DC: $\mathrm{H}$ ealth Physics Society.

Lubin, JH, JDJ Boice, C Edling. 1994. Radon and L ung Cancer R isk: A J oint A nalysis of $11 \mathrm{U}$ nderground $M$ iners Studies. NIH Publication No. 94-3644. Rockville, $\mathrm{M}$ aryland: $\mathrm{N}$ ational Institutes of $\mathrm{H}$ ealth $(\mathrm{N} I \mathrm{H})$.

Lushbaugh, CC, SA Fry, RC Ricks. 1987. Nuclear reactor accidents: Preparedness and consequences. B rit J Radiol 60:1159-1183.
MCLaughlin, JR, EA Clarke, D Bishri, TW Anderson. 1993. Childhood leukemia in the vicinity of $C$ anadian nuclear facilities. Cancer Causes and Control 4:51-58.

M ettler, FA, AC U pton. 1995. M edical E ffects of I onizing Radiation. N ueva Y ork: G rune \& Stratton.

M ettler, FA, M R Williamson, HD R oyal. 1992. Thyroid nodules in the population living around $C$ hernobyl. J AM A 268:616-619.

National A cademy of Sciences (NAS) y National Re search Council (NRC). 1990. H ealth E ffects of Exposure to Low Levels of I onizing Radiation. Washington DC : N ational A cademy Press.

- . 1994. H ealth $E$ ffects of Exposure to R adon. T ime for $R e$ assessment? Washington, DC: National Academy Press.

National Council on Radiation Protection and $M$ easurements (NCRP). 1987. Radiation Exposure of the U.S. Population from Consumer Products and $M$ iscellane ous Sources. Report No. 95, Bethesda, M aryland: NCRP.

National Institutes of $\mathrm{H}$ ealth (NIH). 1985. R eport of the $\mathrm{N}$ ational Institutes of $\mathrm{H}$ ealth $\mathrm{Ad} \mathrm{H}$ oc W orking Group to Develop Radioepidemiological T ables. NIH publication No. 85-2748. Washington, DC: US Government Printing 0 ffice

Neel, JV, W Schull, A Awa. 1990. The children of parents exposed to atomic bombs: Estimates of the genetic doubling dose of radiation for humans. Am H um G enet 46:1053-1072.

Nuclear Regulatory Commission (NUREG). 1980. Criteria for Preparation and $E$ valuation of Radiological E mergency Response Plans and Preparedness in Support of Nuclear Power Plants. Document No. NUREG 0654/ FEM A-REP-1, Rev. 1. Washington, DC NUREG.

O rganismo Internacional de la Energía Atómica (O IEA). 1969. Symposium on the $H$ andling of Radiation Accidents. Viena: OIEA.

-. 1973. Radiation Protection Procedure. International Atomic Energy Agency Safety Series, No. 38 Viena: OIEA.

- . 1977. Symposium on the $H$ andling of Radiation Acci dents. Viena: OIEA.

-. 1986. Biological Dosimetry: Chromosomal Aberration Analysis for Dose Assessment. Technical report No. 260. Viena: OIEA.

O take, M, H Y oshimaru, WJ Schull. 1987. Severe mental retardation among the prenatally exposed survivors of the atomic bombing of $\mathrm{H}$ iroshima and Nagasaki: A comparison of the old and new dosimetry systems. En RERF Technical Report. $\mathrm{Hi}$ roshima: Fundación para la Investigación de los Efectos de las $R$ adiaciones.

Prisyazhiuk, A, O A Pjatak, VA Buzanov. 1991. Cancer in the Ukraine, post-Chernobyl. Lancet 338:1334-1335.

R obbins, J, W Adams. 1989. R adiation effects in the $M$ arshall Islands. En Radiation and the Thyroid, diri gido por $S$ N agataki. T okio: Exerpta M edica.

Rubin, P, GW Casarett. 1972. A direction for clinical radiation pathology: the tolerance dose. En Frontiers of Radiation Therapy and Oncology, dirigido por J.M.V aeth. Basilea: Karger, y Baltimore: U niv. Park Press.

Schaeffer, NM . 1973. Reactor Shielding for Nuclear E ngineers, Report No. TID-25951. Springfield, Virginia: N ational T echnical Information Services.

Shapiro, J. 1972. Radiation Protection: A Guide for Scientists and Physicians. Cambridge, $M$ assachussetts $\mathrm{H}$ arvard U niv. Press.

Stannard, JN. 1988. Radioactivity and H ealth: A H istory. U.S. Dept. of Energy Report, DOE/RL/01830 T59. W ashington, DC: N ational T echnical Information Services, US. D ept. of Energy.
Stevens, W, JE Till, L Lyon y cols. 1990. Leukemia in $\mathrm{U}$ tah and radioactive fallout from the $\mathrm{N}$ evada test site. J AM A. 264: 585-591.

Stone, RS. 1959. M aximum permissable exposure standards. En Protection in Diagnostic Radiology, dirigido por BP Sonnenblick. New B runswick: Rutgers U niv. Press.

U pton, AC. 1986. Historical perspectives on radiation carcinogenesis. En Radiation Carcinogenesis, dirigido por AC Upton, RE Albert, FJ Burns y RE Shore, Nueva Y ork: Elsevier.

U pton, AC. 1996 Radiologic Sciences. En T he 0 xford T extbook of Public $\mathrm{H}$ ealth, dirigido por $\mathrm{R} \mathrm{D}$ etels, $\mathrm{W} \mathrm{H}$ olland, J M CE wen y GS O menn. Nueva York: Oxford U niversity Press.

US Atomic Energy Commission (AEC). 1957. The windscale reactor incident. En Accident Information Bulletin N 0.73 . Washington, DC: AEC.

-. 1961. Investigation B oard Report on the SI-1 Accident. Washington, DC : US NRC.

US C ode of Federal R egulations (USCFR). 1990. Licenses for Radiography and Radiation Safety R equirements for Radiographic O perations. Washington, DC: US Government.

US Department of Energy (USDOE). 1987. H ealth and $E$ nvironmental Consequences of the Chernobyl Nuclear Power Plant Accident. DOE/ER-0332.W ashington, DC: USDOE.

US Nuclear Regulatory Commission (NRC) 1983. Instrumentation for light-water-cooled nuclear power plants to assess plant and environs conditions during and after an accident. En NRC R egulatory Guide 1.97 . R ev. 3. W ashington, DC: NRC.

Wakeford, R, EJ Tawn, DM M cElvenny, LE Scott, $\mathrm{K}$ Binks, L Parker, $\mathrm{H}$ Dickinson, $\mathrm{H}$, J Smith. 1994a. The descriptive statistics and health implications of occupational radiation doses received by men at the Sellafield nuclear installation before the conception of their children. J. Radiol. Protect. 14 3-16.

Wakeford, R., EJ Tawn, DM M cElvenny, K Binks, LE Scott, L Parker. 1994b. The Seascale childhood leukaemia cases - the mutation rates implied by paternal preconceptional radiation doses. . R adiol. Protect. 14: 17-24.

Ward, JF. 1988. DNA damage produced by ionizing radiation in mammalian cells identities, mechanisms of formation, and repairability. Prog. Nucleic Acid Res. M ol. Biol. 35: 96-128.

Yoshimoto, Y, JV Neel, WJ Schull, H K ato, M Soda, $\mathrm{R}$ Eto, $\mathrm{K}$ M abuchi. 1990. M alignant tumors during the first two decades of life in the offspring of atomic bomb survivors. Am. J. H um. G enet. 46: 1041-1052.

\section{0 tras lecturas recomendadas}

- 1980. Guidance on Off-site E mergency Radiation M easurement Systems. Phase 1: Airborne Releases. Document No. FEMA-REP-2. Washington, DC: NUREG.

- 1980a. Emergency Planning. Document No. 45FR 55402. W ashington, DC: NUREG.

-. 1980b. National Radiological Emergency Preparedness/ Response Plan for Commercial Nuclear Power Plant Accident (M aster Plan). Document N o. 45FR 84910. Washington, DC: NUREG.

- . 1980C. N uclear R egulatory Commission Incident R esponse Plan. Document No. NUREG-0728. Washington, DC: NUREG.

-. 1981. E mergency Planning for Nuclear Power Reactors. Reg. guide 1.101. Washington, DC: NUREG

- . 1983a. E mergency Planning for R esearch and T est R eactors. R eg. guide 2.6. Washington, DC: NUREG.

-. 1983b. Instrumentation for Light-W ater-Cooled Nuclear Power Plants to Assess Plant and Environs Conditions 
D uring and After Accident. R eg. guide 1.97. Washington, DC: NUREG.

American N ational Standards Institute (ANSI). 1993. American $N$ ational Standards for $G$ eneral Radiation Safety - Installations U sing Non-M edical X-R ay and Sealed Gamma-Ray Sources, Energies U p to $10 \mathrm{M} \mathrm{eV}$. Nueva York: ANSI.

Cember, H. 1996. Introduction to $\mathrm{H}$ ealth Physics. Nueva Y ork: $\mathrm{M} \mathrm{CG}$ raw Hill.

Code of Federal R egulations. 1988. E mergency Planning and Preparedness for Production and $U$ tilization Facilities. Título 10, Parte 50, Apéndice $E$. Washington, DC: U S G overnment.

Comisión Internacional de Protección Radiológica (CIPR ). 1982. Protection against ionizing radiation from external sources used in medicine. Ann ICR P 9(1).

- . 1987. Data for use in protection against external radiation. Ann ICRP 17(2/3).

Comisión Internacional de Unidades y Medidas de Radiación (ICRUM). 1971. Radiation protection instrumentation and its application. Report No. 20. Viena: ICRUM

Eisenbud, M. 1987. Environmental Radioactivity. Nueva York: Academic Press.

Environmental Protection Agency (EPA). 1978. Protective Action Evaluation, Part 1: The Effectiveness of Sheltering as a Protective Action Against Nuclear Accidents I nvolving $G$ aseous R eleases. W ashington, DC: EPA.
-. 1991. M anual of Protective Action Guide and Protective Actions for Nuclear Incidents. Document No. EPA400-R-92.001. Washington, DC: EPA.

Goldbud and Jones. 1965. Radiological M onitoring in the E nvironment. N ueva Y ork: Pergamon.

Lubin, JH. 1994. Invited commentary: Lung cancer and exposure to residential radon. Am J E pidemiol 140:323-332.

$\mathrm{N}$ ational Council on R adiation Protection and M easurements (NCRP). 1964. Safe handling of radioactive materials. Report No. 30. Bethesda, M aryland: NCRP.

-. 1976. Structural Shielding Design and Evaluation for $M$ edical $U$ se of $X$ R ays and Gamma Rays U $p$ to $10 \mathrm{M} \mathrm{eV}$. R eport N 0. 49. Bethesda, M aryland: N CR P.

—. 1978. Instrumentation and monitoring methods for radiation protection. R eport N o. 57. Bethesda, M aryland: NCRP.

-. 1984. A handbook of radioactivity measurements proce dures. Report N 0. 58. 2a ed. Bethesda, M aryland: NCRP

Nuclear Regulatory Commission (NUREG). 1970. Analysis of $T$ echniques for $E$ stimating $E$ vacuation $T$ imes for Emergency Planning Zones. Document $\mathrm{No}$. NUREG / CR -1745. Washington, DC: NUREG.

- . 1978. Planning Basis for the Development of State and Local Government Radiological E mergency R esponse Plans in Support of Light W ater Nuclear Power Plants. D ocument No. 43FR 58668. Washington, DC: NUREG.
- . 1978. Potassium I odine as a T hyroid-B locking A gent in a Radiation Emergency. Document No. 43FR 58789. Washington, DC: NUREG.

—. 1979. Development Plan-Insurance of Protective Action Guides for Airborne Releases of Radioactivity as F ederal Guidance. D ocument N 0. 44FR 75344. W ashington, DC: NUREG

- . 1979. Radiological E mergency R esponse P lanning, $\mathrm{H}$ andbook for $F$ ederal Assistance to State and L ocal Government . Document N O. NUREG-0092. Washington, DC: NUREG.

O rganismo Internacional de Energía Atómica (OIEA). 1963. A B asic T oxicity Classification of Radionuclides. Technical Report Series, No.15. Viena: OIEA.

- . 1965. Personnel Dosimetry for Radiation Accidents. International A tomic E nergy Agency Symposium. Viena: OIEA.

-. 1973. Radioactive Contaminants of the Environment. Viena: OIEA.

-. 1979. Radiological Surveillance of Airborne Contaminants in the Working Environment. International Atomic Energy Agency Safety Series, No. 49. Viena: OIEA.

-. 1986. Principles for Limiting Releases of Radioactive $\mathrm{E}$ ffluent into the Environment. International Atomic Energy Agency Safety Series, No. 77. Viena: OIEA.

Reinig, WC. 1970. Environmental Surveillance in the Vicinity of Nuclear Facilities. H P Symposium Proceedings. Springfield, Illinois: Charles C Thomas. 
Director del capítulo

$B$ engt $K$ nave

\section{Sumario}

Campos eléctricos y magnéticos y consecuencias para

la salud

B engt Knave . . . . . . . . . . . . . . . . . . . . . 49.2

El espectro electromagnético: características físicas básicas

Kjell $\mathrm{H}$ ansson $\mathrm{M}$ ild $\ldots \ldots \ldots \ldots \ldots \ldots \ldots \ldots \ldots \ldots . \ldots . \ldots . \ldots$

R adiación ultravioleta

$D$ avid $H$. Sliney. . . . . . . . . . . . . . . . . . . 49.6

R adiación infrarroja

R. M atthes. . . . . . . . . . . . . . . . . . . . . . . . . . . 49.10

Luz y radiación infrarroja

D avid $H$. Sliney. . . . . . . . . . . . . . . . . . . . . . 49.14

Láseres

D avid $H$. Sliney. . . . . . . . . . . . . . . . . . . 49.18

Campos de radiofrecuencia y microondas

Kjell $H$ ansson $M$ ild . . . . . . . . . . . . . . . . . . . . . . 49.20

Campos eléctricos y magnéticos de VLF y ELF

M ichael H. Repacholi . . . . . . . . . . . . . . . . . . . 49.23

Campos eléctricos y magnéticos estáticos

$M$ artino $G$ randolfo . . . . . . . . . . . . . . . . . 49.28 


\section{- CAMPOS ELECTRICOS Y MAG NETICOS Y CONSECUENCIAS PARA LA SALUD}

\section{Bengt Knave}

En los últimos años se ha acrecentado el interés por los efectos biológicos y posibles consecuencias para la salud de los campos eléctricos y magnéticos débiles de baja intensidad. Se han presentado estudios sobre los campos magnéticos y el cáncer, sobre la reproducción y sobre las reacciones neurológicas y de comportamiento. Seguidamente se facilita un resumen de lo que sabemos, lo que aún requiere ser investigado y, en particular, sobre qué política es la apropiada, es decir, si ésta no debe implicar ningún tipo de restricciones de la exposición, si se debería evitar prudentemente, o si son necesarias costosas intervenciones.

\section{Lo que sabemos}

\section{Cáncer}

Estudios epidemiológicos sobre leucemia infantil y exposición residencial a líneas aéreas de tendido eléctrico parecen indicar un ligero aumento del riesgo, y se han notificado riesgos excesivos de leucemia y tumores cerebrales en profesiones "eléctricas". Recientes estudios con métodos de valoración de la exposición mejorados han reforzado en general la evidencia de una relación. No obstante, aún no están claras las características de la exposición - por ejemplo, en lo referente a la frecuencia de los campos magnéticos y la intermitencia de la exposición- y no se sabe mucho acerca de posibles factores de confusión o de modificación de los efectos. Además, la mayoría de los estudios sobre riesgo profesional apuntan a una forma especial de leucemia, la leucemia mieloide aguda, mientras que otros encuentran una mayor incidencia de otra forma, la leucemia linfática crónica. Los escasos estudios notificados sobre cáncer en animales no han sido de mucha ayuda para la valoración del riesgo y, a pesar de los numerosos estudios celulares experimentales realizados, no se ha presentado ningún mecanismo plausible y comprensible que permita explicar un efecto carcinogénico.

\section{Reproducción, con especial referencia a las consecuencias para el embarazo}

En estudios epidemiológicos se han notificado consecuencias adversas y cáncer infantil tras exposición materna y también paterna a campos magnéticos, indicándose en el caso de la exposición paterna un efecto genotóxico. Los esfuerzos realizados por otros equipos de investigación para reproducir los resultados positivos no han tenido éxito. Los estudios epidemiológicos con operadores de pantallas de visualización de datos (PVD), expuestos a los campos eléctricos y magnéticos emitidos por éstas han dado en su mayor parte resultados negativos, y los estudios teratogénicos realizados en animales utilizando campos como los de las PVD han arrojado resultados demasiado contradictorios para apoyar conclusiones fiables.

\section{Reacciones neurológicas y de comportamiento}

Estudios de provocación con voluntarios jóvenes parecen indicar alteraciones fisiológicas tales como disminución de la frecuencia cardiaca y alteraciones del electroencefalograma (EEG) tras la exposición a campos eléctricos y magnéticos relativamente débiles. El reciente fenómeno de la hipersensibilidad a la electricidad parece ser de origen multifactorial, y no está claro si los campos tienen que ver o no con él. Se ha notificado una gran variedad de síntomas y molestias, principalmente de la piel y el sistema nervioso. La mayoría de los pacientes tienen molestias cutáneas difusas en la cara, como enrojecimiento, rubefacción, rubicundez, calor, pinchazos, dolor y tirantez. También se describen síntomas asociados con el sistema nervioso, como cefalea, mareos, fatiga y debilidad, hormigueo y pinchazos en las extremidades, falta de aliento, palpitaciones, transpiración abundante, depresiones y fallos de memoria. No se han presentado síntomas característicos de enfermedad neurológica orgánica.

\section{Exposición}

La exposición a campos se produce en todos los ámbitos de la sociedad: en el hogar, en el trabajo, en las escuelas y por el funcionamiento de medios de transporte de propulsión eléctrica. Allí donde hay conductores eléctricos, motores eléctricos y equipo electrónico, se crean campos eléctricos y magnéticos. Intensidades de campo medias de 0,2 a 0,4 $\mu \mathrm{T}$ (microtesla) por jornada de trabajo parecen ser el nivel por encima del cual podría haber un aumento del riesgo, y se han calculado niveles similares para las medias anuales en relación con sujetos que viven debajo de líneas de alta tensión o en sus proximidades.

Muchas personas se hallan expuestas a niveles superiores a éstos, aunque durante períodos más breves, en sus hogares (debido a radiadores, afeitadoras, secadores de pelo y otros aparatos electrodomésticos, o a corrientes parásitas a causa de desequilibrios en el sistema de puesta a tierra eléctrica de los edificios), en el trabajo (en determinadas industrias y oficinas que implican proximidad a equipos eléctricos y electrónicos) 0 mientras viajan en trenes y otros medios de transporte de propulsión eléctrica. Se desconoce la importancia que reviste esta exposición intermitente. Existen asimismo otras incertidumbres en lo que respecta a la exposición (que implican interrogantes sobre la importancia de la frecuencia de los campos, sobre otros factores de modificación o de confusión, o sobre el conocimiento de la exposición total diurna y nocturna) y a su efecto (dada la consistencia de los hallazgos en cuanto a tipo de cáncer), así como a los estudios epidemiológicos, que aconsejan evaluar con gran cautela todas las valoraciones de riesgo.

\section{Valoraciones de riesgo}

Los resultados de estudios residenciales realizados en Escandinavia indican que el riesgo de leucemia se duplica a partir de $0,2 \mu \mathrm{T}$, es decir, los niveles de exposición que se dan normalmente a distancias de 50 o 100 metros de una línea de alta tensión. No obstante, el número de casos de leucemia infantil bajo cables de tendido aéreo es reducido, y por lo tanto el riesgo es bajo en comparación con otros riesgos ambientales que se dan en la sociedad. Se calcula que cada año se producen en Suecia dos casos de leucemia infantil debajo o cerca de líneas de alta tensión. De estos casos, uno podría atribuirse al riesgo de los campos magnéticos, si existe realmente.

Los niveles de exposición laboral a los campos magnéticos suelen ser mayores que en la exposición residencial, y los cálculos sobre riesgos de leucemia y tumores cerebrales de los trabajadores expuestos dan valores más altos que para los niños que viven cerca de líneas eléctricas aéreas. Según estimaciones basadas en el riesgo atribuible descubierto en un estudio realizado en Suecia, cada año podrían atribuirse a campos magnéticos unos 20 casos de leucemia y 20 de tumores cerebrales. Estas cifras deben compararse con el número total de casos anuales de cáncer que se dan en Suecia, y que es de 40.000, de los cuales se calcula que 800 son de origen profesional.

\section{Lo que queda por investigar}

Es evidente que se requieren más investigaciones para lograr una comprensión satiffactoria de los resultados de los estudios epidemiológicos realizados hasta ahora. $\mathrm{H}$ ay varios estudios epidemiológicos en curso en distintos países de todo el mundo, pero la pregunta es si ampliarán los conocimientos que ya tenemos. En 
realidad, se ignora qué características de los campos son las causantes de los efectos, si es que existe alguna. Por lo tanto, decididamente necesitamos más estudios sobre posibles mecanismos que expliquen los hallazgos que hemos reunido.

En cambio, existe en la literatura un gran número de estudios in vitro dedicados a la búsqueda de posibles mecanismos. Se han presentado varios modelos de favorecimiento del cáncer, basados en cambios de la superficie celular y del transporte de iones de calcio en la membrana celular, en trastornos de la comunicación celular, en la modulación del crecimiento celular, en la activación de secuencias de genes específicos por transcripción modulada de ácido ribonucleico (ARN), en la depresión de la producción de melatonina pineal, en la modulación de la actividad de la ornitina descarboxilasa y en posibles trastornos de los mecanismos de control antitumoral de los sistemas hormonal e inmunológico. Cada uno de estos mecanismos posee características que podrían explicar los efectos cancerígenos de los campos magnéticos notificados; no obstante, ninguno está exento de problemas y objeciones esenciales.

\section{Melatonina y magnetita}

Hay dos mecanismos posibles que podrían ser importantes en orden al favorecimiento del cáncer y que, por lo tanto, merecen especial atención. U no de ellos tiene que ver con la reducción de los niveles nocturnos de melatonina inducida por los campos magnéticos y el otro está relacionado con el descubrimiento de cristales de magnetita en los tejidos humanos.

Se sabe por estudios realizados con animales que la melatonina, debido a un efecto sobre los niveles de hormonas sexuales en circulación, tiene un efecto oncoestático indirecto. Algunos estudios con animales indican asimismo que los campos magnéticos suprimen la producción de melatonina pineal, hallazgo que sugiere un mecanismo teórico para el aumento notificado (por ejemplo) del cáncer de mama posiblemente provocado por la exposición a tales campos. Recientemente se ha propuesto una explicación alternativa al aumento del riesgo de cáncer. Se ha descubierto que la melatonina es un eliminador muy potente de radicales hidroxilo y que, por lo tanto, inhibe considerablemente el daño que los radicales libres podrían causar al ADN. Si se suprimen los niveles de melatonina, por efecto por ejemplo por campos magnéticos, el ADN es más vulnerable al ataque por oxidación. Esta teoría explica porqué la depresión de la melatonina por campos magnéticos podría provocar una mayor incidencia de cáncer en cualquier tejido.

A hora bien, ¿disminuyen realmente los niveles de melatonina en la sangre cuando los individuos están expuestos a campos magnéticos débiles? Existen indicios de que puede ser así, pero es necesario seguir investigando. Desde hace algunos años se sabe que la capacidad de las aves para orientarse durante las migraciones estacionales está relacionada con la presencia en las células de cristales de magnetita que responden al campo magnético terrestre. Ahora, como se ha expuesto, se ha demostrado también que en sus células humanas hay cristales de magnetita en una concentración teóricamente lo bastante elevada para responder a campos magnéticos débiles. Así pues, el papel de estos cristales de magnetita debería tenerse en cuenta en cualquier debate sobre los posibles mecanismos que pueden proponerse como relacionados con los efectos potencialmente perjudiciales de los campos eléctricos y magnéticos.

\section{Necesidad de conocer los mecanismos}

Resumiendo, existe una clara necesidad de proseguir los estudios acerca de esos posibles mecanismos. Los epidemiólogos necesitan información acerca de las características de los campos eléctricos y magnéticos en las que deberían centrarse en sus valoraciones de la exposición. En la mayoría de estudios epidemiológicos se han utilizado intensidades de campo de valor medio (con frecuencias de 50 a $60 \mathrm{~Hz}$ ); en otros se han estudiado mediciones de exposición acumulativas. En un estudio reciente se descubrió que los campos de frecuencia alta están relacionados con el riesgo. Por último, en algunos estudios con animales se ha encontrado que son importantes los transitorios de campo. Para los epidemiólogos, el problema no reside en los efectos; actualmente existen registros de enfermedades en numerosos países. El problema es que los epidemiólogos ignoran cuáles son las características relevantes de la exposición que deben tener en cuenta en sus estudios

\section{Política apropiada}

\section{Sistemas de protección}

En general, son varios los sistemas de protección que han de tenerse en cuenta en las normas, directrices y políticas. El más común es el sistema centrado en la salud, que trata de detectar un efecto específico perjudicial para la salud a un determinado nivel de exposición, independientemente del tipo de exposición, sea éste físico o químico. Un segundo sistema sería el de optimización de un peligro conocido y aceptado, sin necesidad de ningún umbral por debajo del cual sea inexistente el riesgo. En este sistema encajaría la radiación ionizante. Un tercer sistema contempla los peligros o riesgos en los que no se han demostrado con certeza razonable las relaciones causales entre exposición y consecuencias, pero en relación con los cuales existe una preocupación general por los posibles riesgos. Este último es el que inspira el denominado principio de precaución, o más recientemente, de evitación prudente, que puede resumirse como evitar en el futuro, con bajo coste, la exposición innecesaria en ausencia de certeza científica. Al abordar la exposición a los campos eléctricos y magnéticos desde esta perspectiva, se han presentado estrategias sistemáticas, por ejemplo, sobre el modo de tender las futuras líneas de alta tensión, de configurar los lugares de trabajo o de diseñar los aparatos electrodomésticos para reducir al mínimo la exposición.

Evidentemente, el segundo de los sistemas mencionados, el de optimización, no es aplicable en lo que atañe a las restricciones de los campos eléctricos y magnéticos, sencillamente porque no se conocen ni están aceptados como riesgos. En cambio, los otros dos sistemas son en la actualidad objeto de consideración.

\section{Normas y directrices para la restricción de la exposición de acuerdo con el sistema centrado en la salud}

En las guías internacionales, los límites para las restricciones de exposición a los campos están varios órdenes de magnitud por encima de los valores que puede medirse en las líneas eléctricas del tendido aéreo y los que se dan en las profesiones eléctricas. En 1990, la Asociación Internacional de Protección contra la Radiación (International Radiation Protection Association, IR PA) emitió unas G uías sobre límites de exposición a campos eléctricos y magnéticos de $50 / 60 \mathrm{~Hz}$, que han sido adoptadas como base de muchas normas nacionales. $D$ ado que desde entonces se han publicado nuevos e importantes estudios, y en 1993 la Comisión Internacional de Protección contra la R adiación no Ionizante (International Commission on Non-Ionizing Radiation Protection, ICNIR P), emitió un anexo. En 1993 se realizaron también en el Reino U nido valoraciones de riesgos en concordancia con las de la IR PA.

Estos documentos ponen de relieve que el estado actual de los conocimientos científicos no garantiza la limitación de los niveles de exposición para el público y la población laboral al nivel de $\mu \mathrm{T}$, y que se necesitan más datos para confirmar si existen o no riesgos para la salud. Las directrices de la IR PA y la ICNIRP se basan en los efectos de las corrientes inducidas por 
campos en el cuerpo, y que corresponden a las que normalmente se miden en éste (hasta $10 \mathrm{~mA} / \mathrm{m}^{2}$ aproximadamente). Se recomienda limitar la exposición de origen profesional a los campos magnéticos de $50 / 60 \mathrm{~Hz}$ a $0,5 \mathrm{mT}$ en el caso de exposición durante toda la jornada y a $5 \mathrm{mT}$ en el caso de exposiciones cortas de hasta dos horas. A simismo, se recomienda limitar la exposición a los campos eléctricos a 10 y $30 \mathrm{kV} / \mathrm{m}$. El límite de 24 horas para el público se fija en $5 \mathrm{kV} / \mathrm{m}$ y 0,1 mT.

Estas consideraciones sobre la reglamentación de la exposición se basan exclusivamente en informes sobre el cáncer. En los estudios de otros posibles efectos relacionados con los campos eléctricos y magnéticos (por ejemplo, trastornos de la reproducción y trastornos neurológicos y del comportamiento), los resultados no se consideran en general lo bastante claros y consistentes como para servir de base científica a la restricción de la exposición.

\section{El principio de precaución o de evitación prudente}

Aunque no existe ninguna diferencia real entre estos dos términos, en los debates sobre los campos eléctricos y magnéticos se suele utilizar el de la evitación prudente. Según se ha señalado, puede definirse ésta como la evitación futura, con bajo coste, de la exposición innecesaria mientras exista incertidumbre científica sobre los efectos para la salud. Se ha adoptado en Suecia, pero no en otros países.

En Suecia, cinco organismos gubernamentales (el Instituto de Protección contra la R adiación, la Junta N acional de Seguridad de la Electricidad, la Junta $\mathrm{N}$ acional de Salud y Bienestar, la Junta $\mathrm{N}$ acional de $\mathrm{H}$ igiene y Seguridad en el Trabajo y la Junta Nacional de la Vivienda, Construcción y Planificación) han declarado conjuntamente que "el conocimiento total acumulado hasta ahora justifica la adopción de medidas para reducir la energía de los campos". Siempre que el coste sea razonable, la política es proteger a las personas de la exposición de larga duración a campos magnéticos de alta intensidad. D urante la instalación de nuevos equipos o de nuevas líneas de alta tensión que puedan provocar exposiciones a campos magnéticos intensos, han de elegirse soluciones que determinen exposiciones de menor intensidad, siempre que no impliquen costes elevados 0 grandes inconvenientes. Según el Instituto de Protección contra la Radiación, por lo general es posible adoptar medidas para reducir el campo magnético cuando los niveles de exposición exceden de los habituales en un factor superior a diez, siempre que tales reducciones puedan hacerse con un coste razonable. En las situaciones en que los niveles de exposición derivados de las instalaciones existentes no sobrepasan los niveles habituales en un factor de diez, debe evitarse realizar una costosa reforma. $\mathrm{Ni}$ que decir tiene que este concepto de prevención ha sido criticado por muchos expertos de diferentes países, por ejemplo, por expertos de la industria de suministro eléctrico.

\section{Conclusiones}

En el presente artículo se ha resumido lo que sabemos acerca de los posibles efectos para la salud de los campos eléctricos y magnéticos, y de lo que aún requiere ser investigado. No se ha dado ninguna respuesta a la pregunta de la política que deba adoptarse, si bien se han presentado sistemas de protección opcionales. A este respecto, parece claro que la base de datos científica disponible es insuficiente para desarrollar límites de exposición en el nivel de $\mu T$, lo que a su vez significa que no hay motivos para efectuar costosas intervenciones con estos niveles de exposición. La cuestión de si debería adoptarse o no alguna forma de estrategia precautoria (por ej., la evitación prudente) es algo que deben decidir las autoridades responsables de la salud pública y la salud en el trabajo de los distintos países. Si no se adopta tal estrategia, normalmente no se impondrá ninguna restricción de la exposición, porque los límites umbrales basados en la salud están muy por encima de la exposición pública y profesional. Así pues, si bien es cierto que en la actualidad hay diferentes opiniones en lo que se refiere a normas, guías y políticas, existe un consenso general en cuanto a la necesidad de seguir investigando para conseguir una base sólida de cara a futuras acciones.

\section{EL ESPECTRO ELECTROMAGNETICO: CARACTERISTICAS FISICAS BASICAS}

Kjell Hansson Mild

La forma más conocida de energía electromagnética es la luz del sol. La frecuencia de la luz solar (luz visible) es la línea divisoria entre la radiación ionizante (rayos $x$, rayos cósmicos), más potente y de frecuencias más altas, y la radiación no ionizante, más benigna y de frecuencias más bajas. $\mathrm{H}$ ay un espectro de radiación no ionizante. A los efectos de este capítulo, en el extremo superior, justo por debajo de la luz visible, está la radiación infrarroja. M ás abajo se encuentra la amplia gama de radiofrecuencias, que incluye (en orden descendente) las microondas, la radio celular, la televisión, la radio FM y AM , las ondas cortas utilizadas en calentadores dieléctricos y de inducción y, en el extremo inferior, los campos con frecuencia de red eléctrica. El espectro electromagnético se representa en la Figura 49.1.

Del mismo modo que la luz visible o el sonido impregnan nuestro entorno, el espacio en que vivimos y trabajamos, también lo hace la energía de los campos electromagnéticos. A nálogamente, igual que la mayor parte de la energía acústica a la que estamos expuestos la crea la actividad humana, lo mismo ocurre con la energía electromagnética: desde los débiles niveles emitidos por los electrodomésticos que usamos a diario (los que permiten que funcionen nuestros aparatos de radio y televisión) hasta los elevados niveles que aplican los médicos con fines beneficiosos: por ejemplo, en la diatermia (tratamientos por calor). En general, la intensidad de tal energía disminuye rápidamente con la distancia a la fuente. Los niveles naturales de estos campos en el entorno son bajos.

La radiación no ionizante ( $\mathrm{N} N \mathrm{I})$ engloba toda la radiación y los campos del espectro electromagnético que no tienen suficiente energía para ionizar la materia. Es decir, la RNI es incapaz de impartir suficiente energía a una molécula 0 un átomo para alterar su estructura quitándole uno o más electrones. La división entre la $\mathrm{RNI}$ y la radiación ionizante suele establecerse en una longitud de onda de 100 nanómetros aproximadamente

Al igual que cualquier forma de energía, la energía R N I tiene el potencial necesario para interactuar con los sistemas biológicos, y las consecuencias pueden ser irrelevantes, perjudiciales en diferentes grados o beneficiosas. En el caso de la radiofrecuencia (R F) y la radiación de microondas, el principal mecanismo de interacción es el calentamiento, pero en la región de baja frecuencia del espectro, los campos de alta intensidad pueden inducir corrientes en el cuerpo y por ello resultar peligrosos. No obstante, se desconocen los mecanismos de interacción de las intensidades de los campos de bajo nivel.

\section{Cantidades y unidades}

A frecuencias inferiores a $300 \mathrm{MHz}$ aproximadamente, los campos se cuantifican en términos de intensidad de campo eléctrico $(E)$ e intensidad de campo magnético $(H)$. E se expresa en voltios por metro $(\mathrm{V} / \mathrm{m})$ y $\mathrm{H}$ en amperios por metro $(\mathrm{A} / \mathrm{m})$. 
Figura 49.1 - Espectro electromagnético.

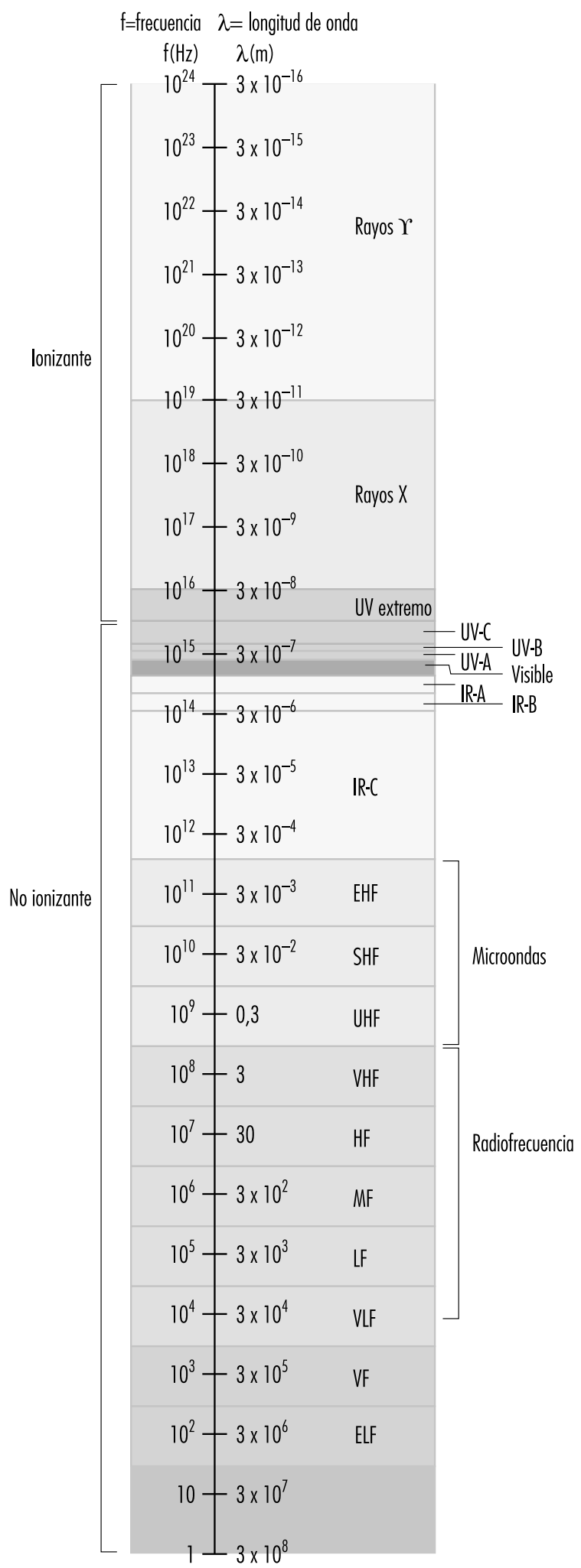

El espectro electromagnético se divide en dos regiones principales: la ionizante y la no ionizante, con las subdivisiones indicadas. Toda radiación puede expresarse por su longitud de onda y su frecuencia. La radiación no ionizante es la de longitud de onda superior a $100 \mathrm{~nm}$ aproximadamente, cuya energía es demasiado baja para ionizar la materia.
Ambos son campos vectoriales: se caracterizan por la magnitud y dirección en cada punto. En el intervalo de baja frecuencia, el campo magnético suele expresarse en términos de densidad de flujo, B, por medio de la unidad SI denominada tesla $(T)$. Al hablar de los campos de nuestro entorno diario, suele preferirse como unidad el submúltiplo microtesla $(\mu T)$. En algunos extos, la densidad de flujo se expresa en gauss (G), y la conversión entre estas unidades es (para campos en el aire): $1 \mathrm{~T}=10^{4} \mathrm{G} \circ 0,1 \mu \mathrm{T}=1 \mathrm{mG}$ y $1 \mathrm{~A} / \mathrm{m}=1,26 \mu \mathrm{T}$.

Existen diversas revisiones de los conceptos, cantidades, unidades y terminología utilizados en la protección contra la radiación no ionizante, incluyendo la radiación de radiofrecuencia (N CR P 1981; Polk y Postow 1986; O M S 1993).

El término radiación significa simplemente energía transmitida por ondas. Las ondas electromagnéticas son ondas de fuerzas eléctricas y magnéticas, cuyo movimiento ondulatorio se define como propagación de perturbaciones en un sistema físico. Todo cambio en el campo eléctrico va acompañado de un cambio en el campo magnético y viceversa. Estos fenómenos fueron descritos en 1865 por J.C. M axwell en cuatro ecuaciones que ahora se conocen como ecuaciones de M axwell.

Las ondas electromagnéticas se caracterizan por un conjunto de parámetros, que incluyen la frecuencia ( $f$ ), la longitud de onda $(\lambda)$, la intensidad del campo eléctrico, la intensidad del campo magnético, la polarización eléctrica $(P)$ (dirección del campo E ), la velocidad de propagación (c) y el vector de Poynting (S). La Figura 49.2 representa la propagación de una onda electromagnética en el espacio. La frecuencia se define como el número de cambios completos por segundo del campo eléctrico 0 magnético en un punto dado, y se expresa en hertzios $(\mathrm{Hz})$. La longitud de onda es la distancia entre dos crestas o dos valles consecutivos de la onda (máximos o mínimos). La frecuencia, la longitud de onda y la velocidad de la onda (v) están en la siguiente relación:

$$
v=f \lambda
$$

La velocidad de una onda electromagnética en el espacio es igual a la velocidad de la luz, pero la velocidad en los materiales depende de las propiedades eléctricas de éstos, es decir, de su permitividad $(\varepsilon)$ y permeabilidad $(\mu)$. La permitividad está relacionada con las interacciones del material con el campo eléctrico, en tanto que la permeabilidad expresa las interacciones con el campo magnético. Las permitividades de las sustancias biológicas difieren considerablemente de las que se dan en el espacio, pues dependen de la longitud de onda (especialmente en el intervalo de RF) y del tipo de tejido. En cambio, la permeabilidad de las sustancias biológicas es igual a la que se registra en el espacio.

En una onda plana, como la representada en la Figura 49.2, el campo eléctrico es perpendicular al campo magnético y la dirección de propagación es perpendicular a ambos campos, eléctrico y magnético.

En una onda plana, la relación entre el valor de la intensidad del campo eléctrico y el de la intensidad del campo magnético, que es constante, se denomina impedancia característica $(Z)$ :

$$
Z=E / H
$$

En el espacio, $Z=120 \pi \approx 377 \Omega$ pero en los restantes casos $Z$ depende de la permitividad y permeabilidad del material a través del cual viaja la onda.

La transferencia de energía se describe por el vector de Poynting, que representa la magnitud y dirección de la densidad del flujo electromagnético.

$$
\mathrm{S}=\mathrm{E} \times \mathrm{H}
$$


Figura 49.2 - O nda plana propagándose a la velocidad de la luz en dirección a $X$.

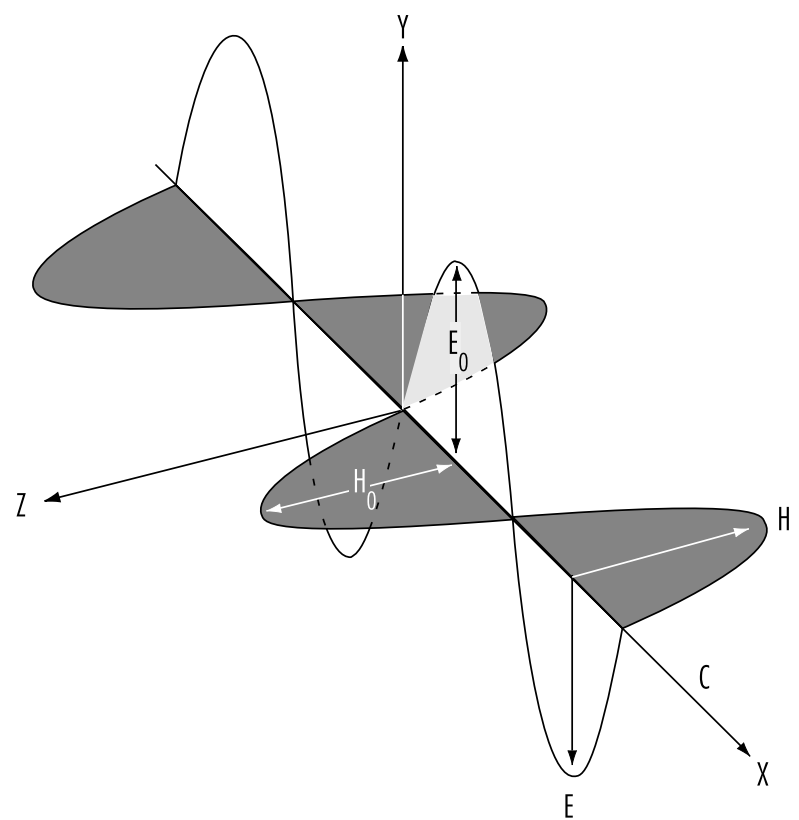

Una onda electromagnética tiene una componente eléctrica y otra magnética. En una onda plana, los campos E y B son perpendiculares entre sí y también perpendiculares a la dirección de propagación. Los campos $E$ y $B$ están en la relación $E=377 \mathrm{H}$. En la exposición de origen profesional a frecuencias inferiores a $300 \mathrm{MHz}$ nos encontramos en el llamado "campo próximo" y ambas componentes han de considerarse por separado.

En una onda en propagación, la integral de $S$ sobre cualquier superficie representa la potencia instantánea transmitida a través de su superficie (densidad de potencia). La magnitud del vector de Poynting se expresa en vatios por metro cuadrado $\left(\mathrm{W} / \mathrm{m}^{2}\right)$ (en algunos textos se emplea la unidad $\mathrm{mW} / \mathrm{cm}^{2}$, cuya equivalencia en unidades SI es $1 \mathrm{~mW} / \mathrm{cm}^{2}=10 \mathrm{~W} / \mathrm{m}^{2}$ ) y para las ondas planas está en relación con los valores de las intensidades de campo eléctrico y magnético:

$$
\mathrm{S}=\mathrm{E} 2 / 120 \pi=\mathrm{E} / 2 / 377
$$

y

$$
S=120 \pi H^{2}=377 H^{2}
$$

No todas las condiciones de exposición que se dan en la práctica pueden representarse por ondas planas. A distancias próximas a las fuentes de radiación de radiofrecuencia, las relaciones características de las ondas planas no se satisfacen. El campo electromagnético radiado por una antena puede dividirse en dos regiones: la zona de campo próximo y la zona de campo lejano. Normalmente, el límite entre estas zonas viene dado por:

$$
r=2 a^{2} / \lambda
$$

donde a es la dimensión máxima de la antena.

En la zona de campo próximo, la exposición ha de caracterizarse por los campos eléctrico y magnético. En la de campo lejano, es suficiente con uno de ellos, ya que ambos están relacionados entre sí por las anteriores ecuaciones, en las que intervienen $\mathrm{E}$ y $\mathrm{H}$. En la práctica, la situación de campo próximo suele darse a frecuencias inferiores a $300 \mathrm{M} \mathrm{Hz}$.
La exposición a los campos de R F se complica aún más por las interacciones de las ondas electromagnéticas con objetos. En general, cuando las ondas electromagnéticas encuentran un objeto, una parte de la energía incidente se refleja, otra parte es absorbida y el resto se transmite. L as proporciones de energía transmitida, absorbida o reflejada por el objeto dependen de la frecuencia y polarización del campo y de las propiedades eléctricas y la forma del objeto. La superposición de las ondas incidente y reflejada produce ondas estacionarias y una distribución de campos espacialmente no uniforme. Como las ondas se reflejan totalmente en los objetos metálicos, cerca de estos objetos se forman ondas estacionarias.

D ado que la interacción de los campos de R F con los sistemas biológicos depende de numerosas características de los campos y éstos son en la práctica complejos, al describir exposiciones a campos de R F deberían tenerse en cuenta los siguientes factores:

- si la exposición se produce en la zona de campo próximo o en la de campo lejano;

- si se produce en la de campo próximo, es necesario conocer los valores de $\mathrm{E}$ y de $\mathrm{H}$; si se da en la de campo lejano, se necesita $\mathrm{EOH}$;

- la variación espacial de la magnitud del campo o campos,

- la polarización de campo, es decir, la dirección del campo eléctrico con respecto a la dirección de propagación de la onda.

En lo que se refiere a la exposición a campos magnéticos de baja frecuencia, aún no está claro si la única consideración importante es la intensidad de campo o la densidad de flujo. Acaso sean importantes también otros factores, como el tiempo de exposición o la rapidez de las variaciones del campo.

El término campo electromagnético (EM F), tal como se utiliza en los medios informativos y en la prensa, se refiere generalmente a los campos eléctricos y magnéticos de baja frecuencia del espectro, pero también puede utilizarse en un sentido mucho más amplio y englobar el espectro completo de la radiación electromagnética. Téngase en cuenta que, en el intervalo de baja frecuencia, los campos E y B no están acoplados ni interrelacionados igual que a altas frecuencias, y que por lo tanto es más preciso denominarlos "campos eléctricos y magnéticos" que EM F.

\section{RADIACION ULTRAVIOLETA}

David H. Sliney

Al igual que la luz, que es visible, la radiación ultravioleta (RUV) es una forma de radiación óptica de longitudes de onda más cortas y fotones (partículas de radiación) más energéticos que los de la luz visible. La mayoría de las fuentes de luz emiten también algo de RUV. La RUV está presente en la luz del sol y también es emitida por un gran número de fuentes ultravioleta utilizadas en la industria, la ciencia y la medicina. Los trabajadores pueden encontrarse con la RUV en una gran variedad de puestos de trabajo. En algunos casos, con niveles bajos de luz ambiente pueden verse fuentes muy intensas de ultravioleta próximo ("Iuz negra"), pero normalmente la RUV es invisible y solo se detecta por el resplandor de materiales que producen fluorescencia al ser iluminados con RUV.

Del mismo modo que la luz se divide en colores que pueden verse en un arco iris, la RUV se subdivide en componentes comúnmente denominados UVA, U VB y UVC. Las longitudes de onda de la luz y la RUV suelen expresarse en nanómetros ( $\mathrm{nm})$; $1 \mathrm{~nm}$ es la milmillonésima parte $\left(10^{-9}\right)$ del metro. La UVC (RUV de muy corta longitud de onda) de la luz solar es absorbida por 
la atmósfera y no llega a la superficie terrestre. La UVC solo se obtiene de fuentes artificiales, tales como lámparas germicidas, que emiten la mayor parte de su energía a una sola longitud de onda $(254 \mathrm{~nm})$ que es muy eficaz para matar bacterias y virus sobre una superficie 0 en el aire.

La UVB es la RUV biológicamente más perjudicial para la piel y los ojos, y aunque la mayor parte de esta energía (que es un componente de la luz solar) es absorbida por la atmósfera, produce quemaduras solares y otros efectos biológicos. La RU V de larga longitud de onda, la UVA, se encuentra normalmente en la mayoría de las lámparas y es también la RUV más intensa que llega a la T ierra. Aunque la UVA puede penetrar profundamente en el tejido, no es tan perjudicial biológicamente como la UVB, ya que la energía individual de los fotones es menor que en la UVB o la UVC.

\section{Fuentes de radiación ultravioleta}

\section{Luz solar}

La mayor exposición de origen profesional a la RUV la experimentan quienes trabajan al aire libre, bajo la luz del sol. L a energía de la radiación solar está muy atenuada por la capa de ozono de la T ierra, que limita la RUV terrestre a longitudes de onda superiores a 290-295 nm. La energía de los rayos de corta longitud de onda (UVB), más peligrosos, de la luz solar depende considerablemente de su trayectoria oblicua en la atmósfera, y varía con la estación y la hora del día (Sliney 1986 y 1987; O M S 1994).

\section{Fuentes artificiales}

Entre las fuentes artificiales más importantes de exposición humana están las siguientes:

Soldadura al arco industrial. La principal fuente de exposición potencial a la RUV es la energía radiante de los equipos de soldadura al arco. Los niveles de RUV en torno al equipo de soldadura al arco son muy altos y pueden producirse lesiones oculares y cutáneas graves en un tiempo de tres a diez minutos de exposición a distancias visuales cortas, de unos pocos metros. La protección de los ojos y la piel es obligatoria.

Lámparas de RUV industriales/ en el lugar de trabajo. Muchos procesos industriales y comerciales, tales como el curado fotoquímico de tintas, pinturas y plásticos, requieren la utilización de lámparas que emiten una radiación intensa en la región del U V. Aunque la probabilidad de exposición perjudicial es baja gracias al empleo de blindajes, en algunos casos puede producirse exposición accidental.

"Lámparas de luz negra". Las lámparas de luz negra son lámparas especializadas que emiten predominantemente en la región del UV, y por lo general se utilizan para pruebas no destructivas con polvos fluorescentes, para la autentificación de billetes de banco y documentos, y para efectos especiales en publicidad y discotecas. No plantean ningún riesgo de exposición considerable para los humanos (excepto en ciertos casos para la piel fotosensibilizada).

Tratamiento médico. Las lámparas de RUV se utilizan en medicina para diversos fines de diagnóstico y terapéuticos. Normalmente, las fuentes de UVA se utilizan en aplicaciones de diagnóstico. Los niveles de exposición del paciente varían considerablemente según el tipo de tratamiento, y las lámparas UV empleadas en dermatología requieren una utilización cuidadosa por parte del personal.

Lámparas RUV germicidas. La RUV con longitudes de onda en el intervalo de 250-265 nm es la más eficaz para esterilización y desinfección dado que corresponde a un nivel máximo en el espectro de absorción del ADN. C omo fuente UV se utilizan con frecuencia tubos de descarga de mercurio de baja presión, ya que más del $90 \%$ de la energía radiada se emite en la línea de $254 \mathrm{~nm}$. Estas fuentes suelen denominarse "lámparas germicidas", "lámparas bactericidas" o simplemente "lámparas UVC". Se utilizan en hospitales para combatir la infección por tuberculosis, y también en el interior de cabinas microbiológicas de seguridad para inactivar los microorganismos del aire y de las superficies. E s esencial una instalación adecuada de las mismas y el uso de protección ocular.

B ronceado cosmético. En ciertas empresas hay camas solares en las que los clientes pueden broncearse por medio de lámparas especiales que emiten principalmente en la región del UVA, aunque también algo en la del UVB. EI uso habitual de una cama solar puede contribuir considerablemente a la exposición cutánea anual de una persona al UV; asimismo, el personal que trabaja en salones de bronceado puede resultar expuesto a bajos niveles. EI uso de medios de protección ocular tales como gafas de seguridad o gafas de sol debería ser obligatorio para el cliente, y dependiendo de la disposición del establecimiento incluso el personal puede necesitar protectores oculares.

Alumbrado general. L as lámparas fluorescentes son de uso habitual en el lugar de trabajo y también hace tiempo que se utilizan en el entorno doméstico. Estas lámparas emiten pequeñas cantidades de RUV y solo contribuyen en un pequeño porcentaje a la exposición anual de una persona a la radiación UV. L as lámparas de tungsteno halógenas cada vez se utilizan más en el hogar y en el lugar de trabajo para diversos fines de alumbrado y exhibición. Las lámparas halógenas sin apantallar pueden emitir niveles de RUV suficientes para causar graves lesiones a cortas distancias. Colocando sobre ellas filtros de vidrio se eliminaría este riesgo.

\section{Efectos biológicos}

\section{La piel}

\section{Eritema}

El eritema, o "quemadura solar", es un enrojecimiento de la piel que normalmente aparece de cuatro a ocho horas después de la exposición a la RU V y desaparece gradualmente al cabo de unos días. Las quemaduras solares intensas provocan formación de ampollas y desprendimiento de la piel. La UVB y la UVC son unas 1.000 veces más eficaces que la UVA como agentes causantes de eritema (Parrish, Jaenicke y Anderson 1982), pero el eritema producido por la UVB, de mayor longitud de onda (295 a $315 \mathrm{~nm}$ ) es más intenso y persiste durante más tiempo (H ausser 1928). Esta mayor intensidad y duración se deben a que la penetración de esta radiación de mayor longitud de onda en la epidermis es más profunda. La piel parece presentar la máxima sensibilidad a $295 \mathrm{~nm}$ aproximadamente (Luckiesh, Holladay y Taylor 1930; Coblentz, Stair y H ogue 1931), siendo esta sensibilidad mucho menor (aproximadamente 0,07 ) a longitudes de onda de $315 \mathrm{~nm}$ y superiores (M CK inlay y Diffey 1987).

La dosis eritémica mínima (DEM) para $295 \mathrm{~nm}$ notificada en estudios más recientes para piel sin broncear, ligeramente pigmentada, varía entre 6 y $30 \mathrm{~mJ} / \mathrm{cm}^{2}$ (Everett, 0 Isen y Sayer 1965; Freeman y cols. 1966; Berger, U rbach y Davies 1968). La DEM a $254 \mathrm{~nm}$ varía considerablemente dependiendo del tiempo transcurrido desde la exposición y de si la piel ha estado expuesta mucho tiempo a la luz solar en el exterior, pero suele ser del orden de $20 \mathrm{~mJ} / \mathrm{cm}^{2}$, pudiendo llegar a $0,1 \mathrm{~J} / \mathrm{cm}^{2}$. La pigmentación y el bronceado de la piel y, lo que es más importante, el engrosamiento del estrato córneo, pueden aumentar esta DEM en un orden de magnitud como mínimo. 


\section{Fotosensibilización}

Los especialistas de la salud en el trabajo encuentran con frecuencia efectos adversos por exposición de origen profesional a la RUV en trabajadores fotosensibilizados. EI tratamiento con ciertos medicamentos puede producir un efecto sensibilizante en la exposición a la UVA, lo mismo que la aplicación tópica de determinados productos, como algunos perfumes, lociones corporales, etc. Las reacciones a los agentes sensibilizantes pueden implicar, fotoalergia (reacción alérgica de la piel) y fototoxicidad (irritación de la piel) tras la exposición a la RUV de la luz solar o de fuentes industriales de RUV (también son frecuentes las reacciones de fotosensibilidad durante el empleo de aparatos de bronceado). Esta fotosensibilización cutánea puede estar producida por cremas o pomadas aplicadas a la piel, por medicamentos ingeridos por vía oral o inyectados, o por el uso de inhaladores bajo prescripción médica (véase Figura 49.3). EI médico que prescribe un fármaco potencialmente fotosensibilizante debería advertir siempre al paciente que adopte medidas apropiadas para protegerse de los efectos adversos, pero con frecuencia a éste se le dice únicamente que evite la luz solar y no las fuentes de RUV (dado que no es frecuente su uso por la población en general).

\section{Efectos retardados}

La exposición crónica a la luz solar - en especial, al componente UVB - acelera el envejecimiento de la piel e incrementa el riesgo de cáncer de piel (Fitzpatrick y cols. 1974; Forbes y Davies 1982; U rbach 1969; Passchier y Bosnjakovic 1987). Varios estudios epidemiológicos han mostrado que la incidencia de cáncer de piel está estrechamente relacionada con la latitud, la altitud y las condiciones atmosféricas, lo cual se relaciona a su vez con la exposición a la RUV (Scotto, Fears y G ori 1980; O M S 1993).

Aún no se han establecido con exactitud las relaciones cuantitativas entre dosis y respuesta para la carcinogénesis de la piel humana, aunque los individuos de piel blanca, en particular los de origen celta, son mucho más propensos a contraer cáncer de piel. No obstante, hay que señalar que las exposiciones a la RUV necesarias para provocar tumores de piel en modelos animales pueden tener lugar con lentitud suficiente para que no se produzca eritema, y que la efectividad relativa (relativa al pico a $302 \mathrm{~nm}$ ) notificada en esos estudios varía en la misma forma que las quemaduras solares (C ole, Forbes y D avies 1986; Sterenborg y Van der Leun 1987).

\section{El ojo}

\section{Fotoqueratitis y fotoconjuntivitis}

Son reacciones inflamatorias agudas como consecuencia de la exposición a radiación UVB y UVC, que aparecen pocas horas después de una exposición excesiva y normalmente remiten al cabo de uno o dos días.

\section{Lesión retiniana por luz brillante}

Aunque la lesión térmica de la retina por fuentes de luz es improbable, pueden producirse daños fotoquímicos por exposición a fuentes con una fuerte componente de luz azul, con reducción temporal o permanente de la visión. No obstante, la respuesta normal de aversión a la luz intensa evitará este riesgo a menos que se haga un esfuerzo consciente por mirar a las fuentes de luz brillante. La contribución de la RUV a la lesión de retina es generalmente muy pequeña, debido a que la absorción por el cristalino limita la exposición retiniana.

\section{Efectos crónicos}

La exposición laboral de larga duración a la RUV durante varios decenios puede contribuir a la formación de cataratas y a efectos degenerativos no relacionados con el ojo, tales como envejeFigura $49.3 \cdot \begin{aligned} & \text { Algunas de las sustancias } \\ & \text { foto sensibilizantes. }\end{aligned}$

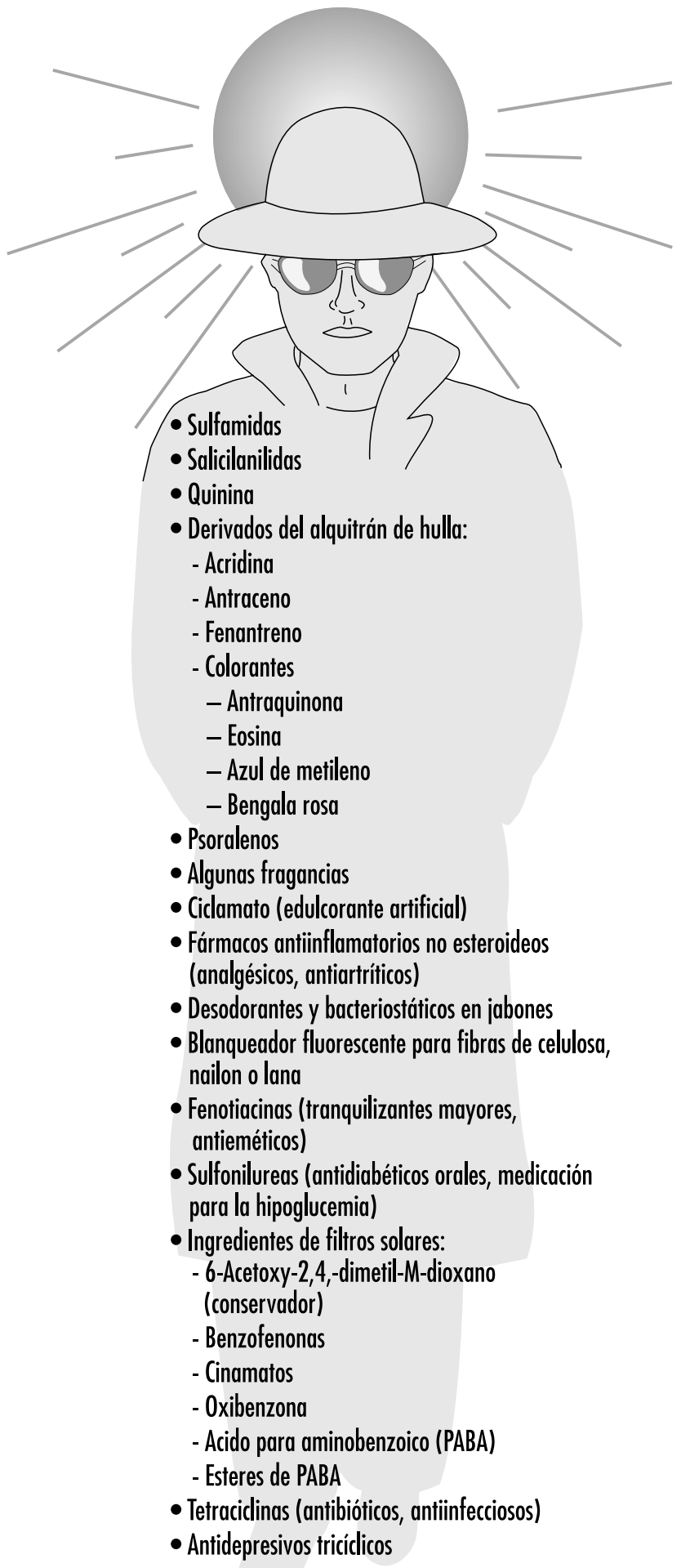

cimiento cutáneo y cáncer de piel relacionados con la exposición. También la exposición crónica a la radiación infrarroja puede elevar el riesgo de cataratas, aunque esto es muy improbable si se dispone de protección ocular. 
La radiación ultravioleta actínica (UVB y UVC) es fuertemente absorbida por la córnea y la conjuntiva. La sobreexposición de estos tejidos provoca queratoconjuntivitis, conocida comúnmente como "golpe de arco" o "ceguera producida por la nieve". Pitts ha comunicado el espectro de acción y la evolución temporal de la fotoqueratitis en la córnea del hombre, el conejo y el mono (Pitts 1974). El periodo de latencia varía en razón inversa de la intensidad de la exposición, desde 1,5 a 24 horas, pero normalmente es de 6 a 12 hours; el malestar suele desaparecer en 48 horas como máximo. A continuación aparece una conjuntivitis que puede ir acompañada de eritema de la piel alrededor de los párpados. D esde luego, la exposición a la RUV rara vez produce lesiones oculares permanentes. Pitts y Tredici (1971) notificaron datos de los umbrales de fotoqueratitis en humanos para bandas de longitudes de onda de $10 \mathrm{~nm}$ de ancho, desde 220 a $310 \mathrm{~nm}$. Se observó que la máxima sensibilidad de la córnea se produce a $270 \mathrm{~nm}$, valor que difiere sensiblemente del máximo para la piel. Presumiblemente, la radiación de $270 \mathrm{~nm}$ es biológicamente más activa debido a la falta de un estrato corneal que atenúe la dosis aplicada al tejido epitelial de la córnea a longitudes de onda de RUV más cortas. La respuesta a la longitud de onda, o espectro de acción, no varió tanto como los espectros de acción del eritema, cuyos umbrales varían entre 4 y $14 \mathrm{~mJ} / \mathrm{cm}^{2}$ a $270 \mathrm{~nm}$. El umbral notificado a $308 \mathrm{~nm}$ fue de $100 \mathrm{~mJ} / \mathrm{cm}^{2}$ aproximadamente.

Al contrario de lo que sucede en la exposición de la piel, la exposición repetida del ojo a niveles de RU V potencialmente peligrosos no incrementa la capacidad protectora del tejido afectado (la córnea), lo que conduce a la pigmentación y al engrosamiento del estrato corneal. Ringvold y cols. estudiaron las propiedades de absorción de RUV de la córnea (R ingvold 1980a) y del humor acuoso (Ringvold 1980b), así como los efectos de la radiación UVB sobre el epitelio córneo (Ringvold 1983), el estroma de la córnea (R ingvold y Davanger 1985) y el endotelio córneo (Ringvold, Davanger y O Isen 1982; O Isen y R ingvold 1982). Sus estudios con el microscopio electrónico mostraron que el tejido corneal posee notables propiedades de reparación y recuperación. Aunque podían apreciarse daños considerables en todas estas capas, que al parecer aparecían inicialmente en las membranas celulares, al cabo de una semana la recuperación morfológica era completa. La destrucción de queratocitos en la capa de estroma resultaba evidente y la recuperación endotelial era marcada a pesar de que en esta capa la renovación celular no es habitual. Cullen y cols. (1984) estudiaron el daño endotelial que era persistente si persistía la exposición a la RU V. Riley y cols. (1987) estudiaron también el endotelio córneo tras la exposición a la UVB y concluyeron que no era probable que agresiones graves aisladas tuvieran efectos retardados; no obstante, llegaron también a la conclusión de que la exposición crónica podría acelerar cambios del endotelio relacionados con el envejecimiento de la córnea.

L as longitudes de onda superiores a $295 \mathrm{~nm}$ pueden transmitirse a través de la córnea y son absorbidas casi totalmente por el cristalino. Pitts, Cullen y Hacker (1977b) demostraron que pueden producirse cataratas en conejos con longitudes de onda en la banda de 295-320 nm. Los umbrales para opacidades transitorias oscilaban entre 0,15 y $12,6 \mathrm{~J} / \mathrm{cm}^{2}$, dependiendo de la longitud de onda, con un umbral mínimo a $300 \mathrm{~nm}$. Para que se produjesen opacidades permanentes se requerían mayores exposiciones radiantes. No se observaron efectos en el cristalino en el intervalo de longitudes de onda de 325 a $395 \mathrm{~nm}$, ni siquiera con exposiciones radiantes muy superiores, de 28 a $162 \mathrm{~J} / \mathrm{cm}^{2}$ (Pitts, Cullen y Hacker 1977a; Zuclich y Connolly 1976). Estos estudios ilustran claramente el riesgo especial que presenta la banda espectral de $300-315 \mathrm{~nm}$, como era de esperar dado que los fotones de estas longitudes de onda penetran eficazmente y tienen suficiente energía para producir daños fotoquímicos.

Taylor y cols. (1988) aportaron pruebas epidemiológicas de que la U V B de la luz solar era un factor etiológico en la catarata senil, pero no mostraron ninguna correlación entre la catarata y la exposición a la UVA. Aunque en tiempos fue una creencia popular debido a la fuerte absorción de UVA por el cristalino, la hipótesis de que la UVA puede causar cataratas no ha sido avalada por estudios experimentales de laboratorio ni por estudios epidemiológicos. D e los datos experimentales de laboratorio que evidenciaron que los umbrales eran más bajos para la fotoqueratitis que para la cataratogénesis, hay que concluir que niveles inferiores a los necesarios para producir fotoqueratitis con exposición diaria, deberían considerarse peligrosos para el tejido del cristalino. Aun suponiendo que la córnea estuviese expuesta a un nivel prácticamente equivalente al del umbral para la fotoqueratitis, un cálculo estimativo indica que la dosis diaria de RUV para el cristalino a $308 \mathrm{~nm}$ sería inferior a $120 \mathrm{~mJ} / \mathrm{cm}^{2}$ con 12 horas de exposición al aire libre (Sliney 1987). En realidad, una exposición diaria media más realista sería inferior a la mitad de ese valor.

$\mathrm{H}$ am y cols. (1982) determinaron que el espectro de acción para la fotorretinitis producida por RUV se encuentra en la banda de 320-400 nm. Demostraron que los umbrales en la banda espectral visible, que eran de 20 a $30 \mathrm{~J} / \mathrm{cm}^{2}$ a $440 \mathrm{~nm}$, se reducían aproximadamente a $5 \mathrm{~J} / \mathrm{cm}^{2}$ para una banda de $10 \mathrm{~nm}$ centrada en $325 \mathrm{~nm}$. El espectro de acción aumentaba monotónicamente al disminuir la longitud de onda. D eberíamos concluir, por tanto, que niveles muy por debajo de $5 \mathrm{~J} / \mathrm{cm}^{2}$ a $308 \mathrm{~nm}$ producirían lesiones de retina, aunque estas lesiones no se manifestarían en las primeras 24 a 48 horas siguientes a la exposición.

No existen datos publicados sobre umbrales de daño en la retina inferiores a $325 \mathrm{~nm}$, por lo que cabe esperar que el patrón del espectro de acción para lesiones fotoquímicas en los tejidos de la córnea y el cristalino sea aplicable también a la retina, lo que supondría un umbral de daño del orden de $0,1 \mathrm{~J} / \mathrm{cm}^{2}$.

Aunque se ha demostrado claramente que la radiación UVB es mutágena y carcinógena para la piel, llama la atención la extrema infrecuencia de carcinogénesis en la córnea y la conjuntiva. No parece haber evidencia científica que relacione la exposición a la RUV con ningún tipo de cáncer de la córnea o la conjuntiva en humanos, aunque no sucede lo mismo con los animales. Esto sugiere que en el ojo humano actúa un sistema inmunológico muy eficaz, puesto que hay trabajadores que realizan su labor al aire libre y reciben una exposición a la RUV comparable a la que recibe el ganado. Esta conclusión está apoyada además por el hecho de que individuos con una respuesta inmunológica deficiente, como los que padecen xeroderma pigmentario, desarrollan con frecuencia neoplasias de la córnea y la conjuntiva (Stenson 1982).

\section{Normas de seguridad}

Se han establecido límites de exposición profesional LE a RUV que incluyen una curva de espectro de acción que engloba los datos umbral correspondientes a los efectos agudos determinados en estudios sobre dosis mínima de eritema y queratoconjuntivitis (Sliney 1972; IRPA 1989). Esta curva no difiere sensiblemente de los datos umbral colectivos, aun teniendo en cuenta los errores de medida y las variaciones de respuesta individual, y está muy por debajo de los umbrales cataratogénicos de la UVB.

El límite de exposición a la RUV es mínimo a $270 \mathrm{~nm}$ $\left(0,003 \mathrm{~J} / \mathrm{cm}^{2}\right.$ a $\left.270 \mathrm{~nm}\right)$ y, por ejemplo, a $308 \mathrm{~nm}$ es de $0,12 \mathrm{~J} / \mathrm{cm}^{2}$ (ACGIH 1995, IR PA 1988). El riesgo biológico es el mismo tanto si la exposición consiste en unas cuantas exposiciones en forma de impulsos a lo largo del día como en una 
exposición única de muy corta duración o en 8 horas de exposición a algunos microvatios por $\mathrm{cm}^{2}$, y los límites antes indicados se aplican a la jornada de trabajo completa.

\section{Protección en el trabajo}

La exposición laboral a la RUV debe minimizarse en la medida de lo posible. En lo referente a las fuentes artificiales deberá darse prioridad en lo posible a medidas técnicas tales como filtrado, blindaje y confinamiento. Los controles administrativos, tales como la limitación de acceso, pueden reducir los requisitos de protección individual.

L os trabajadores que actúan a la intemperie, como los obreros agrícolas, peones, trabajadores de la construcción, pescadores, etc. pueden reducir al mínimo su riesgo de exposición a la radiación UV solar utilizando ropa apropiada de tejido tupido y, lo que es más importante, un sombrero con ala para reducir la exposición de la cara y el cuello. Para reducir aún más la exposición pueden aplicarse filtros solares a la piel expuesta. Deben disponer de sombra y se les debe proporcionar todas las medidas protectoras necesarias antes indicadas.

En la industria existen numerosas fuentes que pueden producir lesiones oculares agudas con una exposición breve. $\mathrm{H}$ ay diversos protectores oculares con distintos grados de protección apropiados para cada uso. Entre los de uso industrial se encuentran los cascos para soldadura (que además ofrecen protección frente a la radiación intensa visible e infrarroja y protegen la cara), las caretas, las gafas de seguridad y las gafas con absorción UV. En general, los protectores oculares para uso industrial deben ajustarse perfectamente a la cara de manera que no haya intersticios por los que la RUV pueda llegar directamente al ojo y deben estar bien construidos para evitar lesiones físicas.

La idoneidad y selección de los medios de protección ocular dependen de los siguientes puntos:

- la intensidad y las características de la emisión espectral de la fuente de RUV;

- los patrones de comportamiento de las personas situadas cerca de fuentes de RUV (son importantes la distancia y el tiempo de exposición);

- las propiedades de transmisión del material de las gafas protectoras,

- el diseño de la montura de las gafas, para evitar la exposición periférica del ojo a RUV directa no absorbida.

En las situaciones de exposición industrial se puede valorar el riesgo ocular midiendo y comparando los niveles de exposición con los límites recomendados (Duchene, Lakey y Repacholi 1991).

\section{Medición}

Dada la estrecha dependencia entre los efectos biológicos y la longitud de onda, la medida principal de cualquier fuente de RUV es su potencia espectral o la distribución de su irradiancia espectral. E sta debe medirse con un espectrorradiómetro, constituido por un sistema óptico de entrada adecuado, un monocromador y un detector e indicador de RUV. Este tipo de instrumento no es de uso frecuente en higiene industrial.

En muchas situaciones prácticas se utiliza un medidor de RUV de banda ancha para determinar las duraciones de exposición seguras. A efectos de seguridad se puede configurar la respuesta espectral con arreglo a la función espectral utilizada para las directrices de exposición de la ACGIH y de la IR PA. Si no se utilizan instrumentos adecuados, se producirán graves errores en la valoración del riesgo. También existen dosímetros personales de RUV (por ejemplo, película de polisulfona), pero su aplicación se ha limitado en gran parte a la investigación de la seguridad en el trabajo en lugar de a estudios de evaluación de riesgos.

\section{Conclusiones}

Constantemente se producen daños moleculares de los principales componentes celulares debidos a la exposición a la RUV pero existen mecanismos de reparación para contrarrestar la exposición de la piel y los tejidos oculares a la radiación ultravioleta. Sólo cuando estos mecanismos de reparación se ven desbordados se producen lesiones biológicas agudas (Smith 1988). Por estas razones reducir la exposición a la RUV de origen profesional sigue siendo una importante preocupación para el personal de seguridad y salud en el trabajo.

\section{RADIACION INFRARROJA}

\section{R. M atthes}

La radiación infrarroja es la parte del espectro de radiación no ionizante comprendida entre las microondas y la luz visible. Es parte natural del entorno humano y por lo tanto las personas están expuestas a ella en pequeñas cantidades en todas las situaciones de la vida diaria, por ejemplo en el hogar o durante las actividades recreativas realizadas al sol. No obstante, puede producirse una exposición muy intensa debido a ciertos procesos técnicos en el lugar de trabajo.

M uchos procesos industriales implican el curado térmico de distintos tipos de materiales. N ormalmente, las fuentes de calor utilizadas o el propio material calentado emiten niveles tan altos de radiación infrarroja que un gran número de trabajadores corren el riesgo de resultar expuestos.

\section{Conceptos y magnitudes}

Las longitudes de onda de la radiación infrarroja (IR) están comprendidas entre $780 \mathrm{~nm}$ y $1 \mathrm{~mm}$. Según la clasificación de la Comisión Internacional de lluminación (CIE), esta banda se subdivide en IR A (de $780 \mathrm{~nm}$ a 1,4 $\mu \mathrm{m}$ ), IR B (de 1,4 $\mu \mathrm{m}$ a $3 \mu \mathrm{m}$ ) e IRC (de $3 \mu \mathrm{m}$ a $1 \mathrm{~mm}$ ). Tal subdivisión se ajusta de manera aproximada a las características de absorción dependiente de la longitud de onda de la IR en el tejido y a los diferentes efectos biológicos resultantes.

La cantidad y la distribución temporal y espacial de la radiación infrarroja se expresan mediante diferentes magnitudes y unidades radiométricas. D ebido a las propiedades ópticas y fisiológicas, especialmente del ojo, normalmente se hace una distinción entre fuentes "puntuales", es decir, pequeñas, y fuentes "extendidas". El criterio para esta distinción es el valor en radianes del ángulo $(\alpha)$ medido en el ojo, subtendido por la fuente. Este ángulo puede calcularse como un cociente, dividiendo la dimensión $\mathrm{D}_{1}$ de la fuente luminosa por la distancia de visión $r$. L as fuentes extendidas son aquéllas que subtienden un ángulo de visión en el ojo mayor que $\alpha_{\min }$, cuyo valor es normalmente de 11 milirradianes. Para todas las fuentes extendidas hay una distancia de visión en que $\alpha$ es igual a $\alpha_{\min }$; a distancias de visión mayores se puede tratar la fuente como puntual. En lo que a protección contra la radiación óptica se refiere, las magnitudes más importantes relativas a las fuentes extensas son la radiancia $\left(L\right.$, expresada en $\left.W \mathrm{~m}^{-2} \mathrm{sr}^{-1}\right)$ y la radiancia integrada en $\mathrm{e}$ tiempo ( $L_{p}$ en J $\mathrm{m}^{-2} \mathrm{sr}^{-1}$ ), que expresan el "brillo" de la fuente. A efectos de valorar el riesgo para la salud, las magnitudes más importantes relativas a las fuentes puntuales o extensas, a distancias de la fuente tales que $\alpha<\alpha_{\min }$, son la irradiancia ( $E$, expresada en $\mathrm{W} \mathrm{m}^{-2}$ ), que es equivalente al concepto de tasa de dosis de exposición, y la exposición radiante $\left(H\right.$, en $\left.\mathrm{J} \mathrm{m}^{-2}\right)$, que equivale al concepto de dosis de exposición. 
Figura 49.4 - Radiancia espectral $L_{\lambda}$ de un cuerpo negro radiante a la temperatura absoluta indicada en grados Kelvin en cada curva.

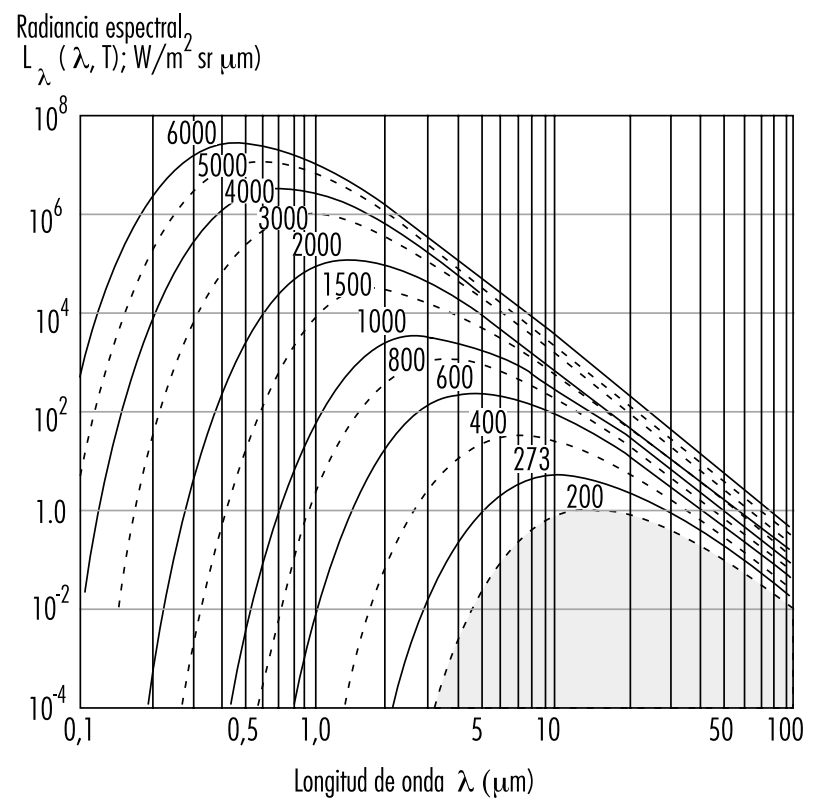

En algunas bandas del espectro, los efectos biológicos debidos a la exposición dependen mucho de la longitud de onda. Por lo tanto, es preciso utilizar magnitudes espectrorradiométricas adicionales (por ejemplo, la radiancia espectral, $L_{\lambda}$, expresada en $W \mathrm{~m}^{-2} \mathrm{sr}^{-1} \mathrm{~nm}^{-1}$ ) para ponderar los valores físicos de la emisión de la fuente con el espectro de acción aplicable relacionado con el efecto biológico.

\section{Fuentes y exposición profesional}

$L$ a exposición a la IR se debe a diversas fuentes naturales y artificiales. La emisión espectral de estas fuentes puede limitarse a una sola longitud de onda (como en el láser) o distribuirse sobre una amplia banda de longitudes de onda.
En general, los diferentes mecanismos que intervienen en la generación de radiación óptica son los siguientes:

- excitación térmica (radiación del cuerpo negro);

- descarga gaseosa,

- amplificación de la luz por emisión estimulada de radiación (láser), siendo el mecanismo de descarga gaseosa menos importante en la banda de IR .

La emisión de las fuentes más importantes utilizadas en numerosos procesos industriales se debe a excitación térmica y puede determinarse de modo aproximado utilizando las leyes físicas de la radiación del cuerpo negro si se conoce la temperatura absoluta de la fuente. $\mathrm{L}$ a emisión total $\left(\mathrm{M}\right.$, en $\left.\mathrm{V} \mathrm{m}^{-2}\right)$ de un cuerpo negro radiante (Figura 49.4) se expresa mediante la ley de Stefan-Boltzmann:

$$
M(T)=5,67 \times 10^{-8} T^{4}
$$

y depende de la cuarta potencia de la temperatura ( $T$, en $K$ ) del cuerpo radiante. La distribución espectral de la radiancia se expresa mediante la ley de radiación de Planck:

$$
\begin{gathered}
L_{\lambda}=\frac{2 c^{2} h}{\lambda^{5}\left(c \frac{h c}{|k T|}-1\right)} \\
c=\text { velocidad de la luz } \\
h=\text { constante de Planck } \\
k=\text { constante de Boltzmann }
\end{gathered}
$$

y la longitud de onda de la emisión máxima $\left(\lambda_{\max }\right)$ se expresa según la ley de Wien, por medio de la siguiente ecuación:

$$
\lambda_{\max }=\frac{2,898 \times 10^{-3}}{\mathrm{~T}}
$$

M uchos de los láseres utilizados en procesos médicos e industriales emiten niveles muy altos de IR. En general, comparada con otras fuentes de radiación, la radiación láser posee algunas

\begin{tabular}{|c|c|c|}
\hline Fuente & Aplicación o población expuesta & Exposición \\
\hline Luz solar & $\begin{array}{l}\text { Trabajadores a la intemperie, agricultores, trabajadores de la construcción, marineros, público } \\
\text { en general }\end{array}$ & $500 \mathrm{Wm}^{-2}$ \\
\hline Lámparas de filamento de tungsteno & $\begin{array}{l}\text { Población y trabajadores en general } \\
\text { Alumbrado general, secado de tintas y pinturas }\end{array}$ & $10^{5}-10^{6} \mathrm{Wm}^{-2} \mathrm{sr}^{-1}$ \\
\hline $\begin{array}{l}\text { Lámparas de filamento de tungsteno } \\
\text { halogenado }\end{array}$ & $\begin{array}{l}\text { (Véase lámparas de filamento de tungsteno) } \\
\text { Sistemas de copia (fijación), procesos generales (secado, cocción, retracción, reblandecimiento) }\end{array}$ & $50-200 \mathrm{Wm}^{-2}$ (a $\left.50 \mathrm{~cm}\right)$ \\
\hline Diodos fotoemisores (p. ej., diodo de GaAs) & Juguetes, electrónica de consumo, tecnología de transmisión de datos, etc. & $10^{5} \mathrm{Wm}^{-2} \mathrm{sr}^{-1}$ \\
\hline Lámparas de arco de xenón & $\begin{array}{l}\text { Proyectores, simuladores solares, luces de exploración } \\
\text { Operadores de cámaras de imprentas, trabajadores de laboratorios ópticos, artistas de } \\
\text { variedades }\end{array}$ & $10^{7} \mathrm{Wm}^{-2} \mathrm{sr}^{-1}$ \\
\hline Hierro en fusión & Horno de acero, trabajadores de acerías & $10^{5} \mathrm{Wm}^{-2} \mathrm{sr}^{-1}$ \\
\hline Baterías de lámparas de infrarrojos & Calentamiento y secado industriales & $10^{3}$ a $8-10^{3} \mathrm{Wm}^{-2}$ \\
\hline Lámparas de infrarrojos en hospitales & Incubadoras & $100-300 \mathrm{Wm}^{-2}$ \\
\hline
\end{tabular}
características inusuales que pueden influir en el riesgo consecutivo a una exposición, tales como los impulsos de muy corta duración o una irradiancia extremadamente alta. Por lo tanto, la radiación láser se trata con detalle más adelante en este capítulo.

Tabla 49.1 - Diferentes fuentes de IR, población expuesta y niveles de exposición aproximados. 
Numerosos procesos industriales requieren el empleo de fuentes que emiten altos niveles de radiación visible e infrarroja, por lo que un gran número de trabajadores, como panaderos, sopladores de vidrio, operarios de hornos de cocción, trabajadores de fundiciones, herreros, trabajadores metalúrgicos y bomberos, tienen potencial riesgo de exposición. Además de las lámparas hay que tener en cuenta otras fuentes, como llamas, sopletes de gas, sopletes de acetileno, baños de metal fundido y barras metálicas incandescentes. Estas fuentes se encuentran en fundiciones, acerías y muchas otras plantas de industria pesada. La Tabla 49.1 resume algunos ejemplos de fuentes de IR y sus aplicaciones.

\section{Efectos biológicos}

Por regla general, la radiación óptica no penetra a mucha profundidad en el tejido biológico. Por lo tanto, los principales objetivos de una exposición a IR son la piel y los ojos. En la mayoría de condiciones de exposición el principal mecanismo de interacción de la IR es térmico. Sólo los impulsos de muy corta duración que pueden producir los láseres, aunque no se tratan aquí, pueden originar también efectos termomecánicos. Con la radiación IR no son de prever efectos debidos a ionización o a la rotura de enlaces químicos, dado que la energía de las partículas, al ser inferior a 1,6 eV aproximadamente, es demasiado baja para causar tales efectos. Por la misma razón, las reacciones fotoquímicas sólo revisten importancia a longitudes de onda cortas en las regiones visible y ultravioleta del espectro. L os distintos efectos de la IR para la salud, dependientes de la longitud de onda, se deben principalmente a las propiedades ópticas de los tejidos, dependientes también de la longitud de onda que presenta el tejido: por ejemplo, la absorción espectral de los medios oculares (Figura 49.5).

\section{E fectos sobre el ojo}

En términos generales, el ojo está bien adaptado para autoprotegerse frente a la radiación óptica del entorno natural. Además, está protegido fisiológicamente contra lesiones por fuentes de luz intensa, como el sol o las lámparas de alta intensidad, mediante una respuesta de aversión que limita la duración de la exposición a una fracción de segundo (0,25 segundos aproximadamente).

La IR A afecta principalmente a la retina, debido a la transparencia de los medios oculares. Además, cuando se mira directamente a una fuente puntual 0 a un haz láser, la capacidad de enfocar en la región de la IR A hace la retina mucho más susceptible de sufrir daños que ninguna otra parte del cuerpo. Se considera que, con períodos de exposición cortos, el calentamiento del iris por absorción de radiación visible o IR próxima conduce a la formación de opacidades en el cristalino.

Al aumentar la longitud de onda, a partir de $1 \mu \mathrm{m}$ aproximadamente, aumenta también la absorción por los medios oculares. Por lo tanto, se considera que la absorción de radiación IR A por el cristalino y el iris pigmentado influye en la formación de opacidades de cristalino. Las lesiones del cristalino se atribuyen a longitudes de onda inferiores a $3 \mu \mathrm{m}$ (IRA e IRB). El humor acuoso y el cristalino presentan una absorción especialmente elevada de la radiación infrarroja de longitud de onda superior a $1,4 \mu \mathrm{m}$.

En la región IR B e IRC del espectro, los medios oculares se vuelven opacos a causa de la elevada absorción por el agua que contienen. En esta región, la absorción se produce principalmente en la córnea y el humor acuoso. Por encima de 1,9 $\mu \mathrm{m}$, el único medio realmente absorbente es la córnea. $L$ a absorción de radiación infrarroja de larga longitud de onda por la córnea puede elevar la temperatura del interior del ojo debido a la conducción térmica. Gracias a la rápida renovación de las
Figura 49.5 • Absorción espectral de los medios oculares.

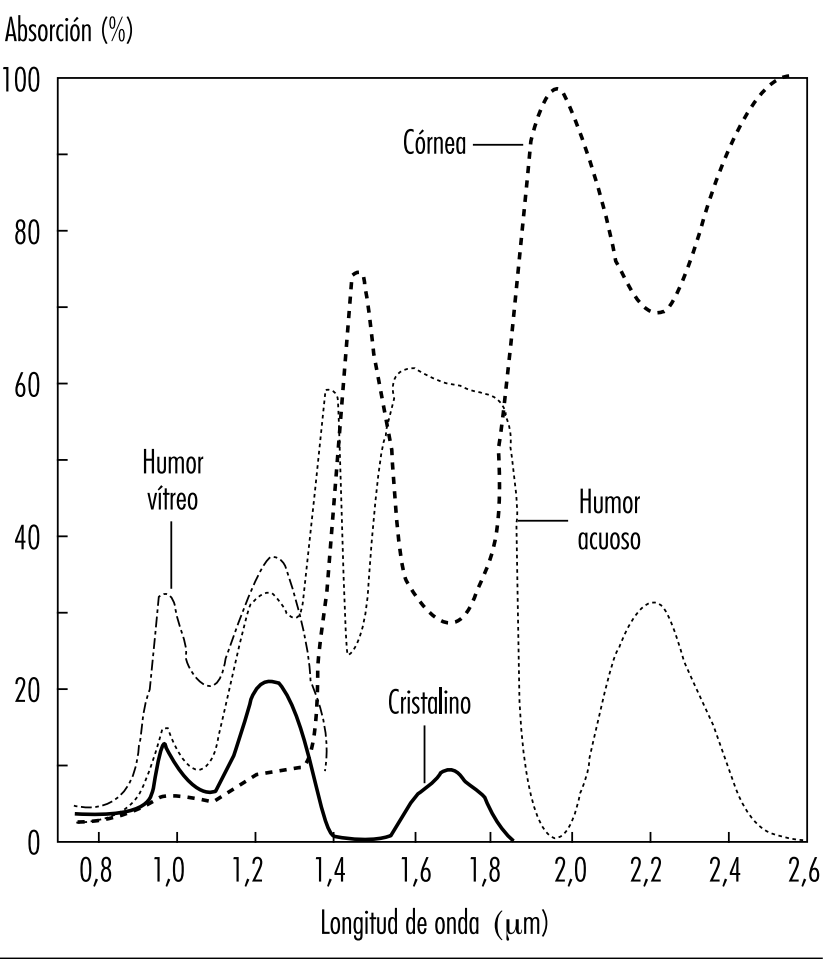

células superficiales de la córnea cabe esperar que cualquier daño que se limite a la capa externa de esta última sea temporal. En la banda de IRC, la exposición puede provocar en la córnea quemaduras similares a las de la piel. No obstante, las quemaduras de la córnea no son muy probables dada la reacción de aversión que desencadena la sensación dolorosa provocada por una exposición intensa.

\section{E fectos sobre la piel}

La radiación infrarroja no penetra en la piel a mucha profundidad, por lo que la exposición de la piel a una IR muy intensa puede producir efectos térmicos de distinta intensidad e incluso quemaduras graves. Los efectos sobre la piel dependen de las propiedades ópticas de ésta, tales como la profundidad de penetración en función de la longitud de onda (Figura 49.6). Particularmente, a longitudes de onda más largas, una exposición extensa puede provocar un gran aumento de temperatura local y quemaduras. D ebido a las propiedades físicas de los procesos de transporte térmico en la piel, los valores umbral para estos efectos dependen del tiempo. Por ejemplo, una irradiación de $10 \mathrm{~kW} \mathrm{~m}^{-2}$ puede causar una sensación dolorosa al cabo de 5 segundos, mientras que una exposición de $2 \mathrm{~kW} \mathrm{~m}^{-2}$ no producirá la misma reacción en períodos de duración inferior a 50 segundos aproximadamente.

Si la exposición se prolonga durante períodos muy largos, incluso con valores muy inferiores al umbral de dolor, el cuerpo humano puede sufrir una elevada carga térmica, en especial si la exposición abarca la totalidad del cuerpo como por ejemplo delante de acero fundido. Esto puede provocar un desequilibrio del sistema de termorregulación, en otro caso fisiológicamente bien equilibrado. El umbral de tolerancia de tales exposiciones depende de las diferentes condiciones individuales y ambientales, tales como la capacidad individual del sistema de termorregulación, el metabolismo del cuerpo durante la 
Figura 49.6 • Profundidad de penetración en la piel a diferentes longitudes de onda.

Longitud de onda $\mathrm{nm}$ )

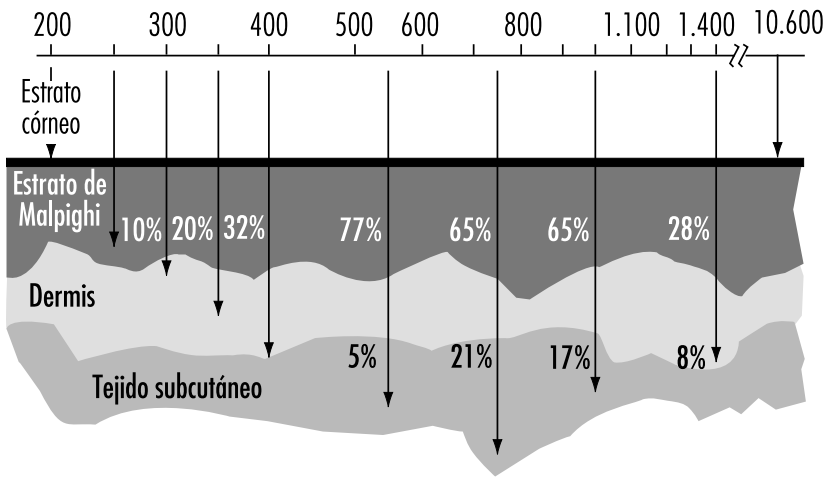

Los valores son porcentajes de radiación incidente que alcanza una determinada capa de la piel. Fuente: OMS 1982.

exposición o la temperatura ambiente, la humedad y el movimiento del aire (velocidad del viento). En ausencia de trabajo físico puede tolerarse una exposición de $300 \mathrm{Wm}^{-2}$ como máximo durante ocho horas en determinadas condiciones ambientales, pero este valor disminuye a $140 \mathrm{~W} \mathrm{~m}^{-2}$ aproximadamente durante el trabajo físico pesado.

\section{Normas de exposición}

Los efectos biológicos de la exposición a la IR que dependen de la longitud de onda y de la duración de la exposición, sólo son intolerables si se sobrepasan ciertos valores umbral de intensidad 0 de dosis. Como protección frente a tales condiciones de exposición intolerables, organizaciones internacionales como la 0 rganización M undial de la Salud (O M S), la O ficina Internacional del Trabajo (OIT), el Comité Internacional de Radiación no Ionizante de la Asociación Internacional de Protección contra la Radiación (INIRC/IRPA) y su sucesora la Comisión Internacional de Protección contra la R adiación no I onizante (IC NIR P), así como la Conferencia Americana de $\mathrm{H}$ igienistas Industriales del Gobierno (ACGIH), han propuesto límites de exposición a la radiación infrarroja de fuentes ópticas tanto coherentes como incoherentes. La mayoría de las propuestas nacionales e internacionales sobre guías para limitar la exposición humana a la radiación infrarroja se basan en los valores límites umbral (TLV) publicados por la AC GIH (1993/ 1994) o coinciden exactamente con ellos. Dichos límites están ampliamente aceptados y se aplican con frecuencia en situaciones profesionales. Se basan en el estado actual del conocimiento científico y están destinados a prevenir lesiones térmicas de la retina y de la córnea y a evitar posibles efectos retardados en el cristalino.

La revisión de 1994 de los límites de exposición de la ACGIH se expresa así:

1. Para la protección de la retina contra lesiones térmicas en caso de exposición a luz visible (por ejemplo, en el caso de fuentes luminosas potentes, la radiancia espectral $L_{\lambda}$ en $\mathrm{W} /\left(\mathrm{m}^{2} \mathrm{sr} \mathrm{nm}\right)$ ponderada con respecto a la función de riesgo térmico para la retina $R_{\lambda}$ (véase la T abla 49.2) sobre el intervalo de longitudes de onda $\Delta_{\lambda}$ y sumada sobre la gama de longitudes de onda de 400 a 1.400 nm, no deberá exceder de:

$$
\sum_{400}^{1400} \mathrm{~L}_{\lambda} \mathrm{R}_{\lambda} \Delta_{\lambda} \leq \frac{5 \times 10^{4}}{\alpha \cdot \mathrm{t}^{1 / 4}}
$$

siendo t la duración de visión limitada a intervalos de $10^{-3}$ a 10 segundos (es decir, en condiciones de visión accidentales, no de visión fija) y $\alpha$ el ángulo subtendido para la fuente en radianes calculado para $\alpha=$ máxima extensión de la fuente/ distancia a la fuente $\mathrm{R}_{\lambda}$ (Tabla 49.2).

2. Para proteger la retina de los riesgos de exposición de las lámparas de calor por infrarrojos o de cualquier fuente del IR próximo en ausencia de un fuerte estímulo visual, la radiancia infrarroja en el intervalo de longitudes de onda de 770 a $1.400 \mathrm{~nm}$ tal como es observada por el ojo (sobre la base de un diámetro de pupila de $7 \mathrm{~mm}$ ) en condiciones de visión de duración prolongada deberá limitarse a:

$$
\sum_{770}^{1400} \mathrm{~L}_{\lambda} \Delta_{\lambda} \leq \frac{6 \times 10^{3}}{\alpha}
$$

Este límite se basa en un diámetro de pupila de $7 \mathrm{~mm}$, ya que en este caso la respuesta de aversión (por ejemplo, cerrar los ojos) puede no existir debido a la ausencia de luz visible.

3. Para evitar posibles efectos retardados sobre el cristalino, tales como formación retardada de cataratas, y proteger la córnea de una sobreexposición, la radiación infrarroja a longitudes de onda superiores a $770 \mathrm{~nm}$ deberá limitarse a $100 \mathrm{~W} / \mathrm{m}^{2}$ para períodos superiores a $1.000 \mathrm{~s}$, y a:

$$
\sum_{770}^{3000} \mathrm{E}_{\lambda} \Delta_{\lambda} \leq 1,8 \times 10^{4} \mathrm{t}^{-3 / 4}
$$

para períodos más cortos.

4. Para pacientes afáquicos se indican funciones de ponderación separadas y los TLV resultantes para el intervalo de longitudes de onda del ultravioleta y la luz visible (305-700 nm).

\section{Medición}

Existen técnicas e instrumentos radiométricos que permiten analizar el riesgo para la piel y los ojos derivado de la exposición a fuentes de radiación óptica. Para caracterizar una fuente de luz convencional suele ser muy útil medir la radiancia. Para definir condiciones de exposición peligrosa a fuentes ópticas, son más importantes la irradiancia y la exposición radiante. La evaluación

Tabla 49.2 - Función de riesgo térmico para la retina.

$\begin{array}{llll}\begin{array}{l}\text { Longitud de onda } \\ (\mathrm{nm})\end{array} & \mathrm{R}_{\lambda} & \begin{array}{l}\text { Longitud de onda } \\ (\mathrm{nm})\end{array} & R_{\lambda} \\ 400 & 1,0 & 460 & 8,0 \\ 405 & 2,0 & 465 & 7,0 \\ 410 & 4,0 & 470 & 6,2 \\ 415 & 8,0 & 475 & 5,5 \\ 420 & 9,0 & 480 & 4,5 \\ 425 & 9,5 & 485 & 4,0 \\ 430 & 9,8 & 490 & 2,2 \\ 435 & 10,0 & 495 & 1,6 \\ 440 & 10,0 & 500-700 & 1,0 \\ 445 & 9,7 & 700-1.050 & 10((700-\lambda) / 500) \\ 450 & 9,4 & 1.050-1.400 & 0,2 \\ 455 & 9,0 & & \end{array}$

Fuente: ACGIH 1996 
de fuentes de banda ancha es más compleja que la de fuentes que emiten en una sola longitud de onda o en bandas muy estrechas, ya que han de tenerse en cuenta las características espectrales y el tamaño de la fuente. EI espectro de ciertas lámparas consiste en una emisión continua en una amplia banda de longitudes de onda, simultánea a la emisión en ciertas longitudes de onda individuales (líneas). Si no se suma debidamente la fracción de energía de cada línea a la emisión continua, pueden introducirse considerables errores en la representación de esos espectros.

Para la evaluación del riesgo para la salud, los valores de exposición han de medirse sobre una abertura límite está debidamente especificada en las normas de exposición. Normalmente se considera que la abertura más pequeña posible en la práctica es de $1 \mathrm{~mm}$. Las longitudes de onda superiores a $0,1 \mathrm{~mm}$ plantean dificultades debido a los considerables efectos de difracción que crea una abertura de $1 \mathrm{~mm}$. Para esta banda de longitudes de onda se ha aceptado una abertura de $1 \mathrm{~cm}^{2}$ (11 mm de diámetro), ya que los puntos calientes en esta banda son mayores que en longitudes de onda más cortas. Para la evaluación de los riesgos retinianos, el tamaño de la abertura se determinó por el tamaño de una pupila media y de acuerdo con ello se eligió una abertura de $7 \mathrm{~mm}$.

Por lo general, las mediciones en la región óptica son muy complejas. Las medidas tomadas por personal no formado pueden conducir a conclusiones carentes de validez. En Sliney y Wolbarsht (1980) puede verse un compendio detallado de procedimientos de medida.

\section{Medidas de protección}

La protección normal más eficaz frente a la exposición a la radiación óptica es el confinamiento total de la fuente y de todas las vías de radiación que puedan partir de ella. En la mayoría de los casos, tales medidas permiten cumplir fácilmente los límites de exposición. D e no ser así, deberá recurrirse a la protección individual. Por ejemplo, se utilizará protección ocular en forma de gafas o pantallas adecuadas, o bien ropa protectora. Si las condiciones de trabajo no permiten adoptar tales medidas, puede ser necesario ejercer un control administrativo y restringir el acceso a las fuentes muy intensas. En algunos casos, una medida para proteger al trabajador puede ser reducir la potencia de la fuente 0 bien el tiempo de trabajo (mediante pausas que le permitan recuperarse del estrés por calor).

\section{Conclusión}

Por lo general, la radiación infrarroja de las fuentes más comunes, tales como lámparas, o de la mayoría de las aplicaciones industriales, no supone ningún riesgo para los trabajadores. No obstante, en algunos lugares de trabajo puede entrañar un riesgo para la salud del trabajador. Además están aumentando rápidamente la aplicación y utilización de lámparas con fines especiales y en procesos a alta temperatura en la industria, la ciencia y la medicina. Si la exposición a tales aplicaciones es lo bastante elevada, no pueden excluirse ciertos efectos perjudiciales (principalmente en los ojos pero también en la piel). Se espera que aumente la importancia de las normas sobre exposición a la radiación óptica internacionalmente reconocidas. Para proteger al trabajador de una exposición excesiva deberían ser obligatorias ciertas medidas como el apantallamiento (pantallas oculares) o la ropa protectora.

Los principales efectos biológicos adversos atribuidos a la radiación infrarroja son las cataratas, conocidas como cataratas de los sopladores de vidrio o de los operarios de hornos. La exposición de larga duración incluso a niveles relativamente bajos produce estrés por calor en el cuerpo humano. En tales condiciones de exposición deben tenerse en cuenta factores adicionales, como la temperatura corporal y la pérdida de calor por evaporación, así como determinados factores ambientales.

En los países industrializados se han confeccionado algunas guías prácticas para informar e instruir a los trabajadores. Puede verse un compendio completo de las mismas en Sliney y Wolbarsht (1980).

\section{LUZ Y RADIACION INFRARROJA}

David H. Sliney

La luz y la energía radiante infrarroja (IR) son dos formas de radiación óptica que, junto a la radiación ultravioleta, constituyen el espectro óptico. D entro de este espectro, las distintas longitudes de onda tienen potenciales considerablemente diferentes para ocasionar efectos biológicos, por lo cual el espectro óptico puede subdividirse aún más.

El término luz debería reservarse para las longitudes de onda de energía radiante comprendidas entre 400 y $760 \mathrm{~nm}$, que provocan una respuesta visual en la retina (CIE 1987). La luz es el componente esencial de la emisión de las lámparas de iluminación, las pantallas de visualización y una gran variedad de dispositivos de alumbrado. A pesar de la importancia de la iluminación para la visión, algunas fuentes de luz pueden producir reacciones fisiológicas indeseadas, tales como discapacidad y molestias por deslumbramiento, parpadeo y otras formas de estrés ocular debido a un diseño ergonómico deficiente de las tareas del lugar de trabajo. La emisión de luz intensa es también un efecto secundario potencialmente peligroso de algunos procesos industriales, como la soldadura al arco.

La radiación infrarroja ( $R I R$, longitudes de onda de $760 \mathrm{~nm}$ a $1 \mathrm{~mm})$ se denomina también comúnmente radiación térmica (o calor radiante), y es emitida por todos los objetos calientes (motores calientes, metales en fusión y otras fuentes de calor en fundiciones, superficies termotratadas, lámparas eléctricas incandescentes, sistemas de calefacción radiantes, etc). Es emitida asimismo por una gran variedad de equipos eléctricos, como motores, generadores y transformadores eléctricos y diversos equipos electrónicos.

La radiación infrarroja es uno de los factores que contribuyen al estrés por calor. Niveles elevados de temperatura y humedad ambientales y un bajo grado de circulación del aire pueden combinarse con el calor radiante y producir estrés por calor con el potencial riesgo de lesiones por calor. En ambientes más frescos, las fuentes de calor radiante molestas o mal diseñadas también pueden producir malestar, siendo ésta una consideración ergonómica a tener en cuenta.

\section{Efectos biológicos}

Los riesgos profesionales que entrañan las formas de radiación visible e infrarroja para los ojos y la piel están limitados por la aversión de los ojos a la luz brillante y la sensación de dolor en la piel producida por un calentamiento radiante intenso. El ojo está bien adaptado para autoprotegerse contra lesiones por radiación óptica intensa (debidas a energía radiante ultravioleta, visible 0 infrarroja) procedente de la luz solar ambiental. Está protegido por una respuesta de aversión natural a la observación de fuentes de luz brillante que normalmente lo protege de lesiones por exposición a fuentes tales como el sol, las lámparas de arco y los arcos de soldadura, dado que esa aversión limita la duración de la exposición a una fracción de segundo (dos décimas aproximadamente). No obstante, las fuentes con fuerte emisión IR sin un estímulo visual intenso pueden ser peligrosas para el cristalino en 
caso de exposición crónica. U no también puede obligarse a mirar al sol, a un arco de soldadura o a un campo nevado y sufrir por ello una pérdida temporal (y a veces permanente) de visión. En una instalación industrial en la que hay luces brillantes a baja altura en el campo de visión, los mecanismos protectores del ojo son menos eficaces, por lo que es especialmente importante adoptar precauciones contra el riesgo.

Existen al menos cinco tipos distintos de riesgos para el ojo y la piel debidos a fuentes de luz intensa y radiación IR, y es preciso comprender cada uno de ellos para elegir las medidas protectoras. Además de los riesgos potenciales que presenta la radiación ultravioleta (RU V) de algunas fuentes de luz intensa, hay que tener en cuenta los siguientes: (Sliney y Wolbarsht 1980; O M S 1982):

1. Lesión térmica de la retina, que puede producirse a longitudes de onda de $400 \mathrm{~nm}$ a $1400 \mathrm{~nm}$. Normalmente el peligro de este tipo de lesión solo lo plantean los láseres, una fuente de arco de xenón muy intensa o un hongo nuclear. La quemadura local de la retina produce un punto ciego (escotoma).

2. Lesión fotoquímica de la retina por luz azul (riesgo asociado principalmente con la luz azul de $400 \mathrm{~nm}$ a $550 \mathrm{~nm}$ de longitud de onda) (Ham 1989). Esta lesión se denomina comúnmente fotorretinitis por "luz azul" y una forma especial de ella recibe el nombre de retinitis solar debido a la fuente que la produce. La retinitis solar recibió en tiempos la denominación de "ceguera de los eclipses" con la correspondiente "quemadura retiniana". Sólo en los últimos años se ha descubierto que la fotorretinitis obedece a un mecanismo de lesión fotoquímico consecutivo a la exposición de la retina a longitudes de onda cortas del espectro visible, concretamente la luz violeta y azul. Hasta el decenio de 1970 se creía que obedecía a un mecanismo de lesión térmico. E n contraste con la luz azul, la radiación IRA es muy poco eficaz como productora de lesiones retinianas ( $\mathrm{Ham}$ 1989; Sliney y Wolbarsht 1980).

3. Riesgos térmicos para el cristalino en la región del infrarrojo próximo (asociados con longitudes de onda de $800 \mathrm{~nm}$ a $3.000 \mathrm{~nm}$ aproximadamente) con potencial formación de catarata por calor industrial. La exposición media de la córnea a la radiación infrarroja de la luz solar es del orden de $10 \mathrm{~W} / \mathrm{m}^{2}$. En comparación con esto se ha notificado que trabajadores del vidrio y el acero expuestos a irradiancias infrarrojas del orden de 0,8 a $4 \mathrm{~kW} / \mathrm{m}^{2}$ diariamente durante 10 a 15 años han desarrollado opacidades lenticulares (Sliney y Wolbarsht 1980). Estas bandas espectrales contienen IR A e IR B (véase la Figura 49.1). La guía de la Conferencia Americana de $\mathrm{H}$ igienistas Industriales del G obierno (ACG IH ) sobre exposición a la IRA de la parte anterior del ojo es una irradiancia total ponderada en función del tiempo de $100 \mathrm{~W} / \mathrm{m}^{2}$ para duraciones de exposición superiores a $1.000 \mathrm{~s}(16,7 \mathrm{~min})$ (ACGIH 1992 y 1995).

4. Lesión térmica de la córnea y la conjuntiva (a longitudes de onda de $1.400 \mathrm{~nm}$ a $1 \mathrm{~mm}$ aproximadamente). Este tipo de lesión se limita casi exclusivamente a la exposición a radiación láser.

5. Lesión térmica de la piel. A unque rara vez se debe a fuentes convencionales, puede producirse en todo el espectro óptico.

\section{Importancia de la longitud de onda y del tiempo de exposición} Las lesiones térmicas (1) y (4) anteriores se limitan por lo general a duraciones de exposición muy breves y existen protecciones oculares diseñadas para prevenir estas lesiones agudas. No obstante, pueden producirse lesiones fotoquímicas como las mencionadas anteriormente en el punto (2), con dosis bajas repartidas a lo largo de la jornada de trabajo. El producto de la tasa de dosis por la duración de la exposición es siempre la dosis (de esta última es de la que depende el grado de riesgo fotoquímico). Al igual que con cualquier mecanismo de lesión fotoquímico, hay que tener en cuenta el espectro de acción que determina la eficacia relativa de las diferentes longitudes de onda en cuanto a la producción de un efecto fotobiológico. Por ejemplo, el espectro de acción correspondiente a la lesión retiniana fotoquímica tiene su máximo valor en $440 \mathrm{~nm}$ aproximadamente ( $\mathrm{H}$ am 1989). La mayoría de los efectos fotoquímicos se limitan a un intervalo de longitudes de onda muy estrecho, mientras que un efecto térmico puede producirse a cualquier longitud de onda del espectro. Por ello, la protección ocular para estos efectos específicos solo necesita bloquear una banda espectral relativamente estrecha para ser eficaz. Normalmente en la protección ocular frente a una fuente de banda ancha es preciso filtrar más de una banda espectral.

\section{Fuentes de radiación óptica}

\section{Luz solar}

La mayor exposición laboral a la radiación óptica se debe a la exposición a los rayos del sol de los trabajadores que realizan su actividad al aire libre. El espectro solar abarca desde la región de corte de la capa de ozono estratosférica, alrededor de los 290-295 nm en la banda del ultravioleta, hasta unos $5.000 \mathrm{~nm}$ $(5 \mu \mathrm{m})$ en la banda del infrarrojo. La radiación solar puede alcanzar un nivel de hasta $1 \mathrm{~kW} / \mathrm{m}^{2}$ durante los meses de verano y puede provocar estrés por calor, dependiendo de la temperatura ambiente y de la humedad.

\section{Fuentes artificiales}

Las principales fuentes artificiales de exposición humana a la radiación óptica son las siguientes:

1. Soldadura y corte. Normalmente los soldadores y sus compañeros están expuestos no solo a una intensa radiación UV, sino también a intensa radiación visible e IR emitida por el arco. En casos aislados estas fuentes han producido lesiones agudas en la retina. En estos entornos es obligatoria la protección ocular.

2. Industrias del metal y fundiciones. La fuente más importante de exposición visible e infrarroja son las superficies de metal fundido y de metal caliente en las industrias del acero y el aluminio y en las fundiciones. La exposición de los trabajadores varía normalmente entre 0,5 y $1,2 \mathrm{~kW} / \mathrm{m}^{2}$.

3. Lámparas de arco. Muchos procesos industriales y comerciales, por ejemplo aquellos en que se utilizan lámparas de curado fotoquímico, emiten intensa luz visible de onda corta (azul) así como radiación UV e IR. Aunque la probabilidad de exposición perjudicial es baja debido al apantallado, en algunos casos puede producirse exposición accidental.

4. Lámparas infrarrojas. Estas lámparas emiten predominantemente en el intervalo del IRA y suelen utilizarse para tratamiento por calor, secado de pintura y otras aplicaciones afines. No suponen ningún riesgo de exposición significativo para los humanos, ya que el malestar producido por la exposición limita ésta a un nivel seguro.

5. T ratamiento médico. En medicina se utilizan lámparas de infrarrojos para diversos fines diagnósticos y terapéuticos. Las exposiciones del paciente varían considerablemente según el tipo de tratamiento y las lámparas de IR requieren una utilización cuidadosa por parte del personal.

6. Alumbrado general. Las lámparas fluorescentes emiten muy poca radiación infrarroja y generalmente no son lo suficientemente brillantes para entrañar un riesgo potencial para los 
ojos. Las lámparas incandescentes de tungsteno y de tungsteno-halogeno emiten una fracción considerable de su energía radiante en la región del infrarrojo. Además, la luz azul emitida por las lámparas de tungsteno-halogeno puede entrañar un riesgo para la retina si una persona mira al filamento. A fortunadamente la respuesta de aversión del ojo a la luz brillante previene lesiones agudas incluso a cortas distancias. Este riesgo debería minimizarse o eliminarse colocando filtros "de calor" de vidrio sobre estas lámparas.

7. Proyectores y otros dispositivos ópticos. En los proyectores de exploración, proyectores cinematográficos y otros dispositivos colimadores de haces luminosos se utilizan fuentes de luz intensa que pueden entrañar un riesgo para la retina con el haz directo a distancias muy cortas.

\section{Medición de las propiedades de las fuentes}

La característica más importante de cualquier fuente óptica es la distribución de su potencia espectral. Esta se mide utilizando un espectrorradiómetro, constituido por un sistema óptico de entrada adecuado, un monocromador y un fotodetector.

En muchas situaciones prácticas se utiliza un radiómetro óptico de banda ancha para seleccionar una región espectral determinada. Por razones de iluminación visible y de seguridad se configura la respuesta espectral del instrumento para adaptarla a una respuesta espectral biológica; por ejemplo, los luxómetros se adaptan a la respuesta fotópica (visual) del ojo. Normalmente, si se exceptúan los medidores de riesgo de RUV, la medición y el análisis de riesgos de las fuentes de luz intensa y de las fuentes infrarrojas son demasiado complejos para los especialistas en salud y seguridad en el trabajo que realizan tareas de rutina. Se está trabajando en la normalización de las categorías de seguridad para las lámparas con el fin de que el usuario no necesite realizar mediciones para determinar los riesgos potenciales.

\section{Límites de exposición humanos}

Conociendo los parámetros ópticos del ojo humano y la radiancia de una fuente luminosa se pueden calcular las irradiancias (tasas de dosis) en la retina. También la exposición de las estructuras anteriores del ojo humano a la radiación infrarroja puede revestir interés y además debe tenerse en cuenta que la posición relativa de la fuente de luz y el grado de cierre de los párpados puede afectar considerablemente al cálculo correcto de una dosis de exposición ocular. En el caso de las exposiciones a ultravioleta y a luz visible de corta longitud de onda también es importante la distribución espectral de la fuente luminosa.

Varios grupos nacionales e internacionales han recomendado límites de exposición laboral (LE) para la radiación óptica (ACGIH 1992 y 1994; Sliney 1992). Aunque la mayoría de estos grupos han recomendado límites de exposición para la radiación UV y láser, solo uno de ellos ha recomendado LE para la radiación visible (es decir, la luz), concretamente la ACGIH, un organismo de gran prestigio en el campo de la salud en el trabajo. $L a$ ACGIH denomina a sus LE valores límite umbral, o TLV, y como éstos se publican una vez al año existe la oportunidad de efectuar una revisión anual (AC GIH 1992 y 1995). Estos valores se basan en gran parte en datos sobre lesiones oculares procedentes de estudios con animales y de datos de lesiones de retina en humanos producidas por observación del sol y por arcos de soldadura. Se basan asimismo en la hipótesis implícita de que las exposiciones medioambientales a energía radiante visible no suelen ser peligrosas para el ojo salvo en entornos muy poco usuales tales como campos nevados y desiertos o cuando se mira fijamente al sol.

\section{Evaluación de la seguridad de las radiaciones ópticas}

Debido a que una evaluación exhaustiva del riesgo requiere complejas mediciones de irradiancia y radiancia espectral de la fuente y a veces también instrumentos y cálculos muy especializados, rara vez se lleva a cabo in situ por higienistas industriales y técnicos en seguridad. En lugar de ello, la normativa sobre seguridad obliga a utilizar equipo de protección ocular en los entornos peligrosos. M ediante estudios de investigación se han evaluado una gran variedad de arcos, láseres y fuentes térmicas a fin de desarrollar recomendaciones generales para el establecimiento de normas de seguridad más fáciles de aplicar en la práctica.

\section{Medidas de protección}

La exposición laboral a la radiación visible e IR rara vez entraña riesgos y por lo general es beneficiosa. No obstante, algunas fuentes emiten una cantidad considerable de radiación visible provocando con ello la respuesta de aversión natural, por lo que hay pocas probabilidades de sobreexposición accidental de los ojos. En cambio, es muy probable que se produzca exposición accidental en el caso de fuentes artificiales que sólo emiten radiación en el infrarrojo próximo. Entre las medidas que pueden adoptarse para reducir al mínimo la exposición innecesaria del personal a la radiación IR están un diseño técnico adecuado del sistema óptico que se utilice, el uso de gafas o pantallas adecuadas, la limitación del acceso a las personas directamente relacionadas con el trabajo y la comprobación de que los trabajadores son conscientes de los riesgos potenciales que entraña la exposición a fuentes de radiación intensa visible e infrarroja. El personal de mantenimiento que sustituya lámparas de arco deberá poseer una formación adecuada para evitar cualquier exposición peligrosa. Es inadmisible que los trabajadores padezcan eritema cutáneo o fotoqueratitis. Si se produjesen estos procesos, deberán examinarse los métodos de trabajo y adoptarse medidas que garanticen la improbabilidad de sobreexposición en el futuro. Las operarias gestantes no corren riesgos específicos de radiación óptica por lo que respecta a la integridad de su embarazo.

\section{Diseño y normas en relación con los protectores oculares}

El diseño de protectores oculares para soldadura y otras operaciones que presentan fuentes de radiación óptica industrial (por ejemplo, trabajos de fundición, fabricación de vidrio y acero) se inició al comienzo del presente siglo con el desarrollo del vidrio de $C$ rooke. Las normas sobre protectores oculares que se desarroIlaron posteriormente se atenían al principio general de que puesto que la radiación infrarroja y ultravioleta no es necesaria para la visión, esas bandas espectrales deberían bloquearse del mejor modo posible con los materiales de vidrio existentes.

En el decenio de 1970 se probaron las normas empíricas sobre equipos de protección ocular y se comprobó que contenían amplios factores de seguridad frente a la radiación infrarroja y ultravioleta cuando se comparaban los factores de transmisión con los límites de exposición profesional vigentes, mientras que los factores de protección frente a la luz azul tan solo eran suficientes. En vista de ello, se ajustaron algunos requisitos de las normas.

\section{Protección frente a la radiación ultravioleta e infrarroja}

En la industria se utilizan diversas lámparas UV especializadas para detección por fluorescencia y para fotocurado o fotoendurecimiento de tintas, resinas plásticas, polímeros dentales, etc. Aunque normalmente las fuentes de UVA entrañan poco riesgo, pueden contener cantidades mínimas de radiación UVB peligrosa 0 presentar un problema de deslumbramiento 
discapacitante (debido a la fluorescencia del cristalino). Existe una amplia disponibilidad de lentes filtrantes de la radiación UV, de vidrio o de plástico, con factores de atenuación muy elevados, que protegen contra la totalidad del espectro UV. Cuando estos filtros ofrecen protección hasta $400 \mathrm{~nm}$, pueden presentar una coloración ligeramente amarillenta. Es muy importante que este tipo de protectores oculares (así como las gafas de sol industriales) ofrezcan protección para el campo de visión periférico. LoS protectores laterales y los de diseño envolvente son importantes como protección frente a la incidencia temporal de rayos oblicuos en la zona nasal de la lente, que suelen originar cataratas corticales.

Casi todos los materiales de las lentes de vidrio y de plástico bloquean la radiación ultravioleta de menos de $300 \mathrm{~nm}$ y la radiación infrarroja de longitud de onda superior a $3.000 \mathrm{~nm}$ (3 $\mu \mathrm{m})$ y para algunos láseres y fuentes ópticas ofrecen buena protección las gafas de seguridad transparentes ordinarias, con resistencia al impacto (por ejemplo las lentes de policarbonato transparentes bloquean eficazmente las longitudes de onda superiores a $3 \mu \mathrm{m})$. No obstante, es preciso añadir absorbentes tales como óxidos metálicos al vidrio o colorantes orgánicos a los plásticos para eliminar la radiación UV de hasta 380-400 nm aproximadamente y la infrarroja desde $780 \mathrm{~nm}$ hasta $3 \mu \mathrm{m}$. Esto puede resultar fácil o muy caro y difícil dependiendo del material, y la estabilidad del absorbente puede variar un poco. Los filtros según normas ANSI Z87.1 del American National Standards Institute deberán poseer los factores de atenuación apropiados en cada banda crítica del espectro.

\section{Protección en diversos sectores}

\section{Extinción de incendios}

Los bomberos pueden estar expuestos a radiación intensa en el infrarrojo próximo por lo que además de la vital protección de la cara y la cabeza suelen prescribirse filtros atenuadores de la radiación IR. En este caso también es importante la protección frente a los impactos.

\section{Protección ocular en los sectores de la fundición y el vidrio}

Las gafas y anteojos diseñados para protección ocular frente a la radiación infrarroja suelen tener un ligero tinte verdoso, aunque éste puede ser más oscuro si se desea proporcionar algo de confort frente a la radiación visible. $\mathrm{N}$ o hay que confundir estos protectores oculares con las lentes azules que se utilizan en las operaciones de fabricación de acero y de fundición, y cuya finalidad consiste en comprobar visualmente la temperatura de la masa fundida. Estas gafas azules no ofrecen protección y sólo deben usarse brevemente.

\section{Soldadura}

Se pueden conferir fácilmente propiedades de filtrado del infrarrojo y el ultravioleta a los filtros de vidrio por medio de aditivos tales como óxido de hierro pero el grado de atenuación estrictamente visible determina el grado de protección, que es una expresión logarítmica de la atenuación. N ormalmente se utiliza un grado de protección de 3 o 4 para la soldadura con gas (que exige utilizar gafas) y de 10 a 14 para la soldadura con arco eléctrico 0 de plasma (para las que se requiere un casco de protección). La regla práctica es que la atenuación frente a los riesgos oculares es adecuada si el soldador considera que puede observar el arco cómodamente. Los supervisores, ayudantes de los soldadores y demás personas presentes en la zona de trabajo pueden requerir filtros con un grado de protección relativamente bajo (por ejemplo 304 ) como protección frente a la fotoqueratitis ("golpe de arco" o "ceguera del soldador"). En los últimos años ha hecho su aparición un nuevo tipo de filtro de soldadura, el filtro autooscurecible. Cualquiera que sea el tipo de filtro, éste deberá cumplir las normas ANSI Z87.1 y Z49.1 en cuanto a los filtros de soldadura fijos especificados para tinte oscuro (Buhr y Sutter 1989; CIE 1987).

\section{Filtros de soldadura autooscurecibles}

El filtro de soldadura autooscurecible, cuyo número de tinte aumenta con la intensidad de la radiación óptica que incide en él, representa un importante avance en la capacidad de los soldadores para realizar soldaduras con un nivel uniforme de alta calidad, de un modo más eficaz y ergonómico. Antes, el soldador tenía que bajar y subir el casco o el filtro cada vez que encendía y apagaba el arco, y justo antes de encender éste tenía que trabajar a ciegas. Además, normalmente el casco se baja y se sube con un rápido movimiento del cuello y la cabeza, lo que puede provocar tensión de cuello o lesiones más graves. Debido a la incomodidad de este engorroso procedimiento, algunos soldadores suelen encender o "cebar" el arco con el casco convencional en posición elevada, lo que produce fotoqueratitis. En condiciones normales de iluminación ambiente, un soldador provisto de un casco con filtro autooscurecible puede ver suficientemente bien con la protección ocular colocada para realizar tareas tales como la alineación de las piezas a soldar, la colocación del equipo de soldadura en la posición precisa y el cebado del arco. En los cascos de diseños más comunes, unos sensores de luz detectan entonces el destello del arco prácticamente en cuanto se produce y activan una unidad de control electrónica para que conmute un filtro de cristal líquido de un grado de protección en estado claro a un grado de protección en estado oscuro preseleccionado, eliminando así la necesidad de realizar las maniobras, difíciles y peligrosas, que requieren los filtros de grado de protección fijo.

Con frecuencia se ha suscitado la cuestión de si los filtros autooscurecibles pueden entrañar problemas de seguridad ocultos. Por ejemplo ipueden las imágenes persistentes ("ceguera por arco") producidas en el lugar de trabajo conducir a un deterioro permanente de la visión? ¿O frecen realmente los nuevos tipos de filtro un grado de protección equivalente o mejor que el que pueden proporcionar los filtros fijos convencionales? Aunque se puede responder afirmativamente a esta segunda pregunta, hay que entender que no todos los filtros autooscurecibles son equivalentes. Las velocidades de reacción de los filtros, los valores de los grados de protección claros y oscuros obtenidos bajo una determinada intensidad de iluminación y el peso de cada unidad pueden variar de unos equipos a otros. La dependencia del rendimiento de la unidad respecto de la temperatura, la variación del grado de protección en función de la degradación de la batería eléctrica, el "grado de protección en estado de reposo" y otros factores técnicos varían según el diseño de cada fabricante. Estas consideraciones se están teniendo en cuenta en las nuevas normas.

Puesto que todos los sistemas proporcionan una atenuación adecuada con sus filtros, el atributo individual más importante que especifican los fabricantes de filtros autooscurecibles es la velocidad de cambio de filtro. En los filtros autooscurecibles actuales esta velocidad varía desde una décima de segundo a una velocidad superior a una diezmilésima de segundo. Buhr y Sutter (1989) han indicado un medio de especificar el tiempo máximo de conmutación pero su fórmula depende de la variación en el tiempo de la conmutación. La velocidad de conmutación es crucial, porque proporciona la mejor pauta para la importantísima (pero no especificada) medida de la cantidad de luz que entrará en el ojo al encender el arco, en comparación con la que deja pasar un filtro fijo que trabaja con el mismo grado de protección. Si entra en el ojo demasiada luz por cada conmutación durante la jornada, la dosis acumulada de energía 
luminosa produce "adaptación transitoria" y molestias de "tensión ocular" y otros problemas (la adaptación transitoria es la experiencia visual causada por cambios repentinos en nuestro entorno luminoso y puede caracterizarse con malestar, sensación de haber estado expuesto a deslumbramiento y pérdida temporal de agudeza visual). Los productos actuales con velocidades de conmutación del orden de 10 milisegundos ofrecen una protección más adecuada contra la fotorretinitis, si bien el tiempo de conmutación más corto, del orden de $0,1 \mathrm{~ms}$, tiene la ventaja de reducir los efectos de adaptación transitoria (Eriksen 1985; Sliney 1992).

A falta de pruebas exhaustivas de laboratorio, el soldador puede realizar unas sencillas comprobaciones. Se le puede sugerir simplemente que observe una página de texto impreso en letra menuda a través de varios filtros autooscurecibles. Así se tendrá una indicación de la calidad óptica de cada filtro. D espués se le puede pedir que intente cebar un arco mientras lo observa a través de cada uno de los filtros cuya compra se está considerando. Por suerte se puede confiar en el hecho de que los niveles de luz que resultan cómodos para ver, no son peligrosos. Se deberá comprobar la eficacia de filtración del UV y el IR en la ficha técnica del fabricante para asegurarse de que se eliminan las bandas innecesarias. U nos cuantos cebados de arco repetidos deberían ser suficientes para que el soldador perciba si experimentará malestar por adaptación transitoria, aunque lo mejor sería que la prueba durase toda una jornada.

El estado de reposo o fallo del grado de protección de un filtro autooscurecible (se produce cuando falla la batería) debería ofrecer el $100 \%$ de protección a los ojos del soldador durante uno o varios segundos como mínimo. Algunos fabricantes utilizan un estado oscuro como posición de desconexión y otros un grado de protección intermedio entre los estados oscuro y claro del filtro. En uno u otro caso, la transmitancia del filtro en estado de reposo debería ser sensiblemente inferior a la transmitancia del estado claro con el fin de excluir un riesgo para la retina. En cualquier caso, el dispositivo deberá proporcionar al usuario una indicación clara y evidente de cuándo está desconectado el filtro o cuándo se produce un fallo del sistema. De este modo se asegurará que el soldador sea alertado con antelación en caso de que el filtro no esté conectado o no funcione correctamente antes de que se inicie la soldadura. 0 tras características, tales como la duración de la carga de la batería o el rendimiento en condiciones extremas de temperatura, pueden ser importantes para ciertos usuarios.

\section{Conclusiones}

Aunque las especificaciones técnicas de los dispositivos que protegen los ojos de las fuentes de radiación óptica pueden parecer algo complicadas, existen normas de seguridad que especifican los grados de protección adecuados y estas normas ofrecen un factor de seguridad conservador para el usuario.

\section{- LASERES}

David H. Sliney

Un láser es un dispositivo que produce energía radiante electromagnética coherente dentro del espectro óptico comprendido entre la zona final del ultravioleta y el infrarrojo lejano (submilimétrico). El término láser es en realidad un acrónimo de light amplification by stimulated emission of radiation (amplificación de la luz por emisión estimulada de radiación). Aunque el proceso láser fue predicho teóricamente por Albert Einstein en 1916, la primera demostración de un láser conseguido con éxito no tuvo lugar hasta 1960. En los últimos años, los láseres han encontrado múltiples aplicaciones, desde el laboratorio de investigación hasta el entorno industrial, médico y de oficinas, así como en obras de construcción e incluso en el ámbito doméstico. En numerosas aplicaciones, tales como reproductores de videodiscos y sistemas de comunicación por fibra óptica, la salida de energía radiante del láser está confinada, no existe ningún riesgo para la salud del usuario y éste puede no advertir siquiera la presencia de un láser incorporado en el producto. Sin embargo, en algunas aplicaciones médicas, industriales o en investigación la energía radiante emitida por el láser es accesible y puede suponer un riesgo potencial para los ojos y la piel.

Puesto que el proceso láser (denominado a veces "laseo") puede producir un haz de radiación óptica (es decir energía radiante ultravioleta, visible o infrarroja) fuertemente colimado un láser, al contrario que en la mayoría de los riesgos que se presentan en el lugar de trabajo, puede suponer un riesgo a considerable distancia. Q uizás sea esta característica más que ninguna otra la que ha suscitado las especiales preocupaciones manifestadas por trabajadores y expertos en salud y seguridad en el trabajo. No obstante, los láseres pueden utilizarse sin peligro si se adoptan medidas apropiadas para controlar el riesgo. Existen normas de ámbito mundial para la utilización segura de los láseres, la mayoría de ellas "armonizadas" entre sí (ANSI 1993; CEI 1993). En todas estas normas se utiliza un sistema de clasificación de riesgos que agrupa los productos láser en cuatro amplias categorías según la potencia o energía de salida del láser y su capacidad para producir daño. Después se aplican medidas de seguridad acordes con la clasificación de riesgo (Cleuet y Mayer 1980; Duchene, Lakey y Repacholi 1991).

Los láseres operan a longitudes de onda discretas y aunque la mayoría son monocromáticos (es decir, emiten una sola longitud de onda 0 un solo color) no es infrecuente que un láser emita varias longitudes de onda discretas. Por ejemplo, el láser de argón emite varias líneas diferentes en la región del ultravioleta próximo y en la región visible del espectro, a pesar de estar diseñado en general para emitir solamente una línea verde (una sola longitud de onda) de 514,5 nm y/ o una línea azul de $488 \mathrm{~nm}$. Al considerar los riesgos potenciales para la salud, siempre es esencial establecer la longitud o longitudes de onda de salida.

Todos los láseres tienen tres componentes fundamentales:

1. un medio activo (un sólido, líquido o gas) que define las longitudes de onda de emisión posibles;

2. una fuente de energía (por ejemplo, corriente eléctrica, lámpara de bombeo o reacción química),

3. una cavidad resonante con acoplador de salida (generalmente dos espejos).

La mayoría de los sistemas láser utilizados en la práctica fuera del laboratorio de investigación tienen también un sistema de transmisión del haz, por ejemplo una fibra óptica o un brazo articulado con espejos para dirigir el haz hacia una estación de trabajo, y lentes focalizadoras para concentrarlo sobre un material a soldar, etc. En un láser, átomos o moléculas idénticos se llevan a un estado excitado mediante la energía suministrada por la lámpara de bombeo. Cuando los átomos o moléculas se encuentran en un estado excitado, un fotón ("partícula" de energía luminosa) puede estimular a un átomo o molécula excitados para que emitan un segundo fotón de la misma energía (longitud de onda) que viaja en fase (radiación coherente) en la misma dirección que el fotón estimulante. Con ello se ha amplificado al doble la luz emitida. Este mismo proceso repetido en cascada hace que se forme un haz luminoso que se refleja hacia delante y hacia atrás entre los espejos de la cavidad resonante. Al ser uno de estos espejos parcialmente transparente, una parte 
de la energía luminosa abandona la cavidad resonante y dando lugar a la emisión del haz láser. Aunque en la práctica los dos espejos paralelos suelen estar curvados para producir una situación de resonancia más estable, el principio básico es el mismo para todos los láseres.

A pesar de que en el laboratorio de física se han hecho demostraciones con varios miles de líneas láser diferentes (es decir, longitudes de onda láser discretas características de diferentes medios activos), tan solo unas veinte de ellas se han desarrollado comercialmente hasta ser de uso común en la tecnología cotidiana. Se han desarrollado y publicado guías y normas de seguridad en relación con los láseres, que abarcan básicamente todas las longitudes de onda del espectro óptico a fin de incluir tanto las líneas láser actualmente conocidas como los futuros láseres.

\section{Clasificación de los riesgos de los láseres}

Las normas actuales sobre seguridad de los láseres vigentes en todo el mundo siguen el método de agrupar los productos láser en clases de riesgo. En general, el esquema se basa en la agrupación en cuatro grandes clases de riesgo, de la 1 a la 4 . L os láseres de clase 1 no pueden emitir radiación láser potencialmente peligrosa y no suponen ningún riesgo para la salud. Las clases 2 a 4 entrañan un riesgo creciente para los ojos y la piel. Este sistema de clasificación es útil porque se prescriben medidas de seguridad para cada clase de láser. Las clases superiores requieren medidas de seguridad más estrictas.

La clase 1 se considera un grupo sin riesgo, "seguro para la vista". La mayoría de los láseres totalmente confinados (por ejemplo, los registradores láser de discos compactos) son de clase 1 . Un láser de clase 1 no requiere ninguna medida de seguridad.

La clase 2 corresponde a los láseres visibles que emiten una potencia muy baja, la cual no sería peligrosa ni siquiera aunque el haz penetrase en el ojo humano con toda su potencia y se enfocase sobre la retina. La respuesta de aversión natural del ojo a la contemplación de fuentes de luz muy brillante lo protege contra lesiones de retina si la energía que entra en él es insuficiente para dañar la retina dentro del tiempo de respuesta de aversión. Dicha respuesta consiste en el reflejo de parpadeo (de 0,16 a 0,18 segundos aproximadamente), la rotación del ojo y el movimiento de la cabeza cuando se produce la exposición a esa luz tan brillante. Las normas de seguridad actuales definen de modo conservador una duración de la respuesta de aversión de 0,25 segundos. Por lo tanto, los láseres de clase 2 tienen una potencia de salida igual 0 inferior a 1 miliwatio $(\mathrm{mW})$, que corresponde al límite de exposición admisible para 0,25 segundos. Son ejemplos de esta clase 2 los punteros láser y algunos láseres de alineación.

Algunas normas de seguridad contemplan también una subcategoría de la clase 2 denominada "clase $2 A$ ". La contemplación de los láseres de clase $2 \mathrm{~A}$ no es peligrosa durante un tiempo máximo de $1.000 \mathrm{~s}(16,7$ minutos). La mayoría de los lectores láser utilizados en puntos de venta (cajas de supermercados) y de los lectores de inventario son de la clase $2 \mathrm{~A}$.

Los láseres de la clase 3 presentan un riesgo para la vista, dado que la respuesta de aversión no es lo bastante rápida para limitar la exposición de la retina a un nivel momentáneamente seguro y también pueden producirse daños en otras estructuras del ojo (por ejemplo, la córnea y el cristalino). Normalmente la exposición accidental no entraña riesgos para la piel: son ejemplos de láseres de clase 3 numerosos láseres de investigación y telémetros láser militares.

La clase 3 tiene una subcategoría especial, denominada "clase 3A" (el resto de los láseres de clase 3 se denominan "clase 3B"). Los láseres de la clase 3A tienen una potencia de salida comprendida entre una y cinco veces los límites de emisión accesible (AEL) para la clase 1 o la clase 2, pero con una irradiancia de salida no superior al límite de exposición profesional correspondiente a la clase inferior. Son ejemplos de esta clase numerosos instrumentos láser de alineación y topografía.

Los láseres de clase 4 pueden entrañar riesgo de incendio, riesgo considerable para la piel o riesgo de reflexión difusa. Casi todos los láseres quirúrgicos y los de procesado de materiales utilizados para soldadura y corte son de clase 4 si no están confinados. Todos los láseres con una potencia de salida media superior a 0,5 W son de clase 4. Si un láser de alta potencia de clase 3 o clase 4 está totalmente confinado de manera que la energía radiante peligrosa no sea accesible, el sistema láser total podría ser de clase 1. El láser más peligroso, situado dentro de una carcasa se denomina láser interno o encapsulado.

\section{Límites de exposición profesional}

La Comisión Internacional de Protección contra la R adiación No Ionizante (ICNIRP 1995) ha publicado guías sobre límites de exposición humana a la radiación láser los cuales se actualizan periódicamente. En la Tabla 49.3 se indican los límites de exposición (LE) representativos de varios láseres usuales. Casi todos los haces láser sobrepasan los límites de exposición admisibles. Por lo tanto, en la práctica no suelen utilizarse los límites de exposición para determinar medidas de seguridad. En lugar de ello se aplica con este fin el esquema de clasificación láser que se basa en la aplicación de los LE en condiciones realistas.

\section{Normas de seguridad sobre láseres}

Muchas naciones han publicado normas de seguridad sobre láseres y la mayoría de ellas están armonizadas con la norma internacional de la Comisión Electrotécnica Internacional (CEI). La norma CEI 825-1 (1993) rige para los fabricantes; no obstante, también ofrece algunas orientaciones limitadas sobre seguridad para los usuarios. Todos los productos láser comerciales

Tabla 49.3 • Límites de exposición para láseres usuales.

$\begin{array}{lll}\text { Tipo de láser } & \begin{array}{l}\text { Principales } \\ \text { longitudes } \\ \text { de onda }\end{array} & \text { Límite de exposición } \\ \text { Fluoruro de argón } & 193 \mathrm{~nm} & 3,0 \mathrm{~mJ} / \mathrm{cm}^{2} \text { durante más de } 8 \mathrm{~h} \\ \text { Cloruro de xenón } & 308 \mathrm{~nm} & 40 \mathrm{~m} / \mathrm{cm}^{2} \text { durante más de } 8 \mathrm{~h} \\ \text { Argón ionizado } & 488.514,5 \mathrm{~nm} & 3,2 \mathrm{~mW} / \mathrm{cm}^{2} \text { durante más de } 0,1 \mathrm{~s} \\ \text { Vapor de cobre } & 510.578 \mathrm{~nm} & 2,5 \mathrm{~mW} / \mathrm{cm}^{2} \text { durante más de } 0,25 \mathrm{~s} \\ \text { Helio, neón } & 632,8 \mathrm{~nm} & 1,8 \mathrm{~mW} / \mathrm{cm}^{2} \text { durante más de } 10 \mathrm{~s} \\ \text { Vapor de oro } & 628 \mathrm{~nm} & 1,0 \mathrm{~mW} / \mathrm{cm}^{2} \text { durante más de } 10 \mathrm{~s} \\ \text { Criptón ionizado } & 568.647 \mathrm{~nm} & 1,0 \mathrm{~mW} / \mathrm{cm}^{2} \text { durante más de } 10 \mathrm{~s} \\ \text { Neodimio-YAG } & 1.064 \mathrm{~nm} & 5,0 \mu / \mathrm{cm}^{2} \text { durante } 1 \text { ns a } 50 \mu \mathrm{s} \\ & 1.334 \mathrm{~nm} & \text { No MPE para t <1 ns, } \\ 5 \mathrm{~mW} / \mathrm{cm}^{2} \text { durante } 10 \mathrm{~s} \\ \text { Dióxido de carbono } & 10-6 \mu \mathrm{m} & 100 \mathrm{~mW} / \mathrm{cm}^{2} \text { durante } 10 \mathrm{~s} \\ \text { Monóxido de } & \approx 5 \mu \mathrm{m} & \text { Hasta } 8 \mathrm{~h} \text {, superficie limitada } \\ \text { carbono } & & 10 \mathrm{~mW} / \mathrm{cm}^{2} \text { durante }>10 \mathrm{~s} \text { para } \\ & & \text { la mayor parte del cuerpo }\end{array}$

Todas las normas/ directrices contienen valores EMP a otras longitudes de onda y duraciones de exposición.

Nota: Para convertir EMP en $\mathrm{mW} / \mathrm{cm}^{2}$ a $\mathrm{m} / / \mathrm{cm}^{2}$, multiplicar por el tiempo de exposición t en segundos. Por ejemplo, el MPE para He-Ne 0 argón a $0,1 \mathrm{~s}$ es de $0,32 \mathrm{~mJ} / \mathrm{cm}^{2}$.

Fuente: Norma ANSI Z-136.1 (1993); valores TLV de la ACGIH (1995) y Duchene, Lakey y Repacholi (1991). 
deben exhibir la clasificación de riesgos indicada. En todos los productos de las clases 2 a 4 debe aparecer una etiqueta de advertencia apropiada según la clase correspondiente.

\section{Medidas de seguridad}

El sistema de clasificación de riesgos de los láseres facilita considerablemente la determinación de las medidas de seguridad adecuadas. Las normas de seguridad sobre láseres y las reglas prácticas requieren por sistema la adopción de medidas de control tanto más restrictivas cuanto más alta es la clasificación.

En la práctica siempre es preferible confinar totalmente el láser y la trayectoria del haz de manera que no sea accesible ninguna radiación láser potencialmente peligrosa. En otras palabras, si sólo se utilizan productos láser de clase 1 en el lugar de trabajo, la seguridad de uso está garantizada. Sin embargo, en muchas situaciones esto sencillamente no es viable, por lo que se requiere la oportuna formación de los trabajadores en la utilización segura del producto y en las medidas de control del riesgo.

A parte de la regla evidente de no apuntar con un láser a los ojos de una persona, no se exige ninguna medida de control para un producto láser de clase 2 . Para los láseres de clases superiores se requieren obviamente medidas de seguridad.

Si no es factible el confinamiento total de un láser de clase 304 , el uso de carcasas que cubran el haz (por ejemplo tubos), pantallas deflectoras y cubiertas ópticas puede eliminar casi totalmente el riesgo de exposición ocular peligrosa en la mayoría de los casos.

Cuando no sea posible encerrar láseres de las clases 3 y 4 , deberá establecerse una zona con entrada controlada para el láser y generalmente dentro de la zona de riesgo nominal (ZR N) del haz láser es obligatorio el uso de protectores oculares contra el láser. Aunque en la mayoría de laboratorios de investigación en los que se utilizan haces láser colimados la ZR N abarca la totalidad de la zona controlada del laboratorio, en aplicaciones de haz focalizado la ZR N puede ser sorprendentemente limitada y no abarcar toda la sala.

Como garantía contra el uso inadecuado y posibles acciones peligrosas por parte de usuarios del láser no autorizados debe utilizarse la llave de control que traen todos los productos láser fabricados comercialmente.

Dicha llave deberá guardarse en lugar seguro cuando no se utilice el láser si éste es accesible a las personas.

Durante la alineación y la puesta a punto inicial del láser es preciso adoptar precauciones especiales, ya que la probabilidad de sufrir lesiones oculares graves es muy elevada en tales circunstancias. Los operarios que trabajen con láseres deberán estar instruidos en los métodos de seguridad antes de realizar la puesta a punto y alineación del láser.

Después de establecerse los límites de exposición profesional se desarrollaron medios de protección ocular contra el láser y se definieron especificaciones para determinar las densidades ópticas (OD, una medida logarítmica del factor de atenuación) que serían necesarias para láseres específicos en función de la longitud de onda y de la duración de la exposición. Aunque existen en Europa normas específicas de protección ocular contra el láser, en Estados U nidos el American National Standards Institute facilita otras guías bajo las designaciones ANSI Z136.1 y ANSI Z136.3.

\section{Formación}

En la investigación de los accidentes con láseres tanto en situaciones de laboratorio como industriales surge un elemento común: la falta de una formación adecuada. La formación sobre seguridad de los láseres debe ser adecuada y suficiente para las operaciones con láser en las que intervendrá cada trabajador.
$\mathrm{H}$ a de ser específica para el tipo de láser y la tarea que el trabajador tenga encomendada.

\section{Vigilancia médica}

Los requisitos sobre vigilancia médica de los trabajadores que utilizan láseres varían de unos países a otros, en función de la normativa local sobre medicina en el trabajo. $\mathrm{H}$ ubo un tiempo, cuando el uso de los láseres estaba restringido a los laboratorios de investigación y era poco lo que se sabía sobre sus efectos biológicos, en que era completamente normal que todos los trabajadores que utilizaban láseres se sometieran periódicamente a un reconocimiento oftalmológico general completo, con fotografía del fondo de ojo (retina). No obstante, al principio del decenio de 1970 se cuestionó la validez de esta práctica, ya que los hallazgos clínicos eran casi siempre negativos y se advirtió claramente que tales exploraciones solo servían para descubrir lesiones agudas detectables subjetivamente. Esto indujo al grupo de trabajo sobre láseres de la OMS, reunido en Don Leaghreigh, Irlanda, en 1975 , a pronunciarse en contra de tales programas de vigilancia y a promover la comprobación de la función visual. A partir de entonces, la mayoría de los grupos nacionales de la salud en el trabajo ha rebajado continuamente las exigencias de reconocimiento médico. Hoy día los reconocimientos oftalmológicos completos sólo se exigen con carácter universal en caso de lesión ocular por láser o de sospecha de sobreexposición y generalmente se requiere una exploración de la función visual antes de desempeñar un puesto de trabajo. En algunos países se requieren exploraciones adicionales.

\section{Mediciones de los láseres}

A diferencia de lo que ocurre con algunos riesgos en el lugar de trabajo, en general no es necesario realizar mediciones para la vigilancia de niveles peligrosos de radiación láser en los lugares de trabajo. Dadas las dimensiones de los láseres confinados y de la mayoría de los haces láser, la probabilidad de alterar las trayectorias de los haces y la dificultad y el coste de los radiómetros láser, las normas actuales sobre seguridad preconizan medidas de control basadas en la clase de riesgo y no en la medición en el lugar de trabajo (vigilancia). El fabricante debe realizar mediciones para asegurarse del cumplimiento de las normas de seguridad sobre láseres y de la adecuada clasificación del riesgo. De hecho una de las primeras justificaciones para la clasificación del riesgo de los láseres fue la gran dificultad que entraña realizar medidas apropiadas para la evaluación del riesgo.

\section{Conclusiones}

Aunque el láser es algo relativamente nuevo en el lugar de trabajo, está difundiéndose rápidamente y lo mismo sucede con los programas relacionados con su seguridad. Las claves para el uso seguro de los láseres son, en primer término, confinar si es posible la energía radiante del láser y, si no lo es, adoptar medidas de control adecuadas e instruir a todo el personal que trabaje con láseres.

\section{CAMPOS DE RADIOFRECUENCIAY MICROONDAS}

Kjell Hansson Mild

La radiación de radiofrecuencia $(R F)$, energía electromagnética y microondas se utiliza en diversas aplicaciones en la industria, comercio, medicina e investigación, así como en el hogar. En la gama de frecuencia de 3 a $3 \times 10^{8} \mathrm{kHz}$ (es decir, $300 \mathrm{GHz}$ ) 
encontramos aplicaciones muy conocidas tales como las emisiones de radio y televisión, comunicaciones (telefonía de larga distancia, telefonía móvil, radiocomunicación), radar, calentadores dieléctricos, calentadores de inducción, fuentes de alimentación conmutadas y monitores de ordenador.

$L a$ radiación $R F$ de alta potencia es una fuente de energía térmica que comporta todas las implicaciones conocidas del calentamiento para los sistemas biológicos, incluyendo quemaduras, cambios temporales y permanentes en la reproducción, cataratas y muertes. En la amplia gama de las radiofrecuencias, la percepción cutánea del calor y el dolor térmico no son indicadores de detección fiables, ya que los receptores térmicos están situados en la piel y no perciben fácilmente el calentamiento profundo del cuerpo originado por estos campos. Es necesario establecer límites de exposición como protección contra estos efectos adversos para la salud de la exposición a los campos de radiofrecuencia.

\section{Exposición profesional}

\section{Calentamiento por inducción}

A plicando un campo magnético alterno intenso se puede calentar un material conductor por medio de las corrientes parásitas inducidas. Este calentamiento se utiliza para realizar procesos de forja, recocido y soldadura fuerte y blanda. Las frecuencias de trabajo varían entre 50/60 y varios millones de $\mathrm{Hz}$. Puesto que las bobinas que producen los campos magnéticos suelen ser de pequeñas dimensiones, el riesgo de alto nivel de exposición de todo el cuerpo es pequeño, no obstante, el nivel de exposición de las manos puede ser elevado.

\section{Calentamiento dieléctrico}

En la industria se utiliza energía de radiofrecuencia de 3 a $50 \mathrm{MHz}$ (principalmente a frecuencias de 13,56, 27,12 y $40,68 \mathrm{M} \mathrm{Hz}$ ) para diversos procesos de calentamiento. Entre las aplicaciones se incluyen el sellado y estampación de plásticos, secado de colas y pegamentos, tratamiento de tejidos y fibras textiles, carpintería y la fabricación de productos tan diversos como lonas, piscinas, forros de camas de agua, calzado, carteras de cheques de viaje, etc.

Las medidas notificadas en la literatura ( $\mathrm{H}$ ansson M ild 1980; IEEE COMAR 1990a, 1990b, 1991) indican que en muchos casos los campos de fuga eléctricos y magnéticos son muy intensos cerca de estos dispositivos de RF. A menudo los operarios son mujeres en edad fértil (es decir, de 18 a 40 años). En algunas situaciones de trabajo, los campos de fuga suelen ser extensivos, lo que provoca la exposición de todo el cuerpo de los operarios. En muchos dispositivos los niveles de exposición a campos eléctricos y magnéticos sobrepasan todas las guías de seguridad existentes en materia de R F.

Dado que estos dispositivos pueden originar una absorción muy elevada de energía de R $F$, interesa controlar los campos de fuga que emanan de los mismos. Por ello, la vigilancia periódica de la RF es esencial para determinar si existe un problema de exposición.

\section{Sistemas de comunicación}

Los trabajadores de los campos de la comunicación y el radar sólo están expuestos en la mayoría de las situaciones a campos de baja intensidad. No obstante, la exposición de los trabajadores que tienen que trepar a torres de FM / TV puede ser intensa, por lo que se requieren precauciones de seguridad. La exposición también puede ser considerable cerca de armarios de transmisión que tienen los enclavamientos anulados y las puertas abiertas

\section{Exposición médica}

U na de las aplicaciones más tempranas de la energía de R F fue la diatermia de onda corta. Para ésta suelen utilizarse electrodos sin blindaje, con el consiguiente riesgo de formación de campos de dispersión intensos.

Recientemente han empezado a utilizarse campos de RF en unión de campos magnéticos estáticos en la resonancia magnética (R M ). Puesto que la energía de RF utilizada es de baja intensidad y el campo casi siempre está totalmente confinado en la cámara de alojamiento del paciente, los niveles de exposición para los operarios son despreciables.

\section{Efectos biológicos}

Como magnitud dosimétrica se utiliza ampliamente la tasa de absorción específica (SAR, medida en watios por kilogramo), de la cual pueden derivarse los límites de exposición. La SAR de un organismo biológico depende de parámetros de exposición tales como la frecuencia de la radiación, la intensidad, la polarización, la configuración de la fuente radiante y del cuerpo, las superficies de reflexión y tamaño y la forma y propiedades eléctricas del cuerpo. Además, la distribución espacial de la SAR en el interior del cuerpo presenta una marcada falta de uniformidad. Esta distribución no uniforme de la energía provoca un calentamiento no uniforme de las partes profundas del cuerpo y puede producir gradientes de temperatura internos. A frecuencia superiores a $10 \mathrm{GHz}$, la energía se deposita cerca de la superficie corporal. EI máximo valor de SAR se da a aproximadamente $70 \mathrm{M} \mathrm{Hz}$ en el sujeto estándar y a unos $30 \mathrm{MHz}$ cuando la persona se encuentra de pie y en contacto con tierra de RF. En condiciones extremas de humedad y temperatura, valores de SAR de 1 a $4 \mathrm{~W} / \mathrm{kg}$ a $70 \mathrm{MHz}$ en todo el cuerpo suelen originar un aumento de temperatura interno de $2 \stackrel{\circ}{\circ} \mathrm{C}$ aproximadamente en seres humanos sanos, en una hora.

El calentamiento por R F es un mecanismo de interacción que ha sido estudiado en profundidad. Se han observado efectos térmicos a menos de $1 \mathrm{~W} / \mathrm{kg}$, pero en general no se han determinado umbrales de temperatura para estos efectos. Al evaluar efectos biológicos debe tenerse en cuenta el perfil tiempo-temperatura.

También se producen efectos biológicos cuando el calentamiento por RF no es un mecanismo adecuado ni posible. Estos efectos suelen estar relacionados con campos de R $F$ modulada y longitudes de onda milimétricas. Se han propuesto diversas hipótesis, pero aún no han aportado información útil para establecer límites de exposición en humanos. Es necesario entender los mecanismos de interacción fundamentales ya que no es factible explorar cada uno de los campos de R F para determinar sus interacciones biofísicas y biológicas características.

Los estudios en humanos y en animales indican que los campos de R F pueden causar efectos biológicos nocivos debido al calentamiento excesivo de los tejidos internos. Los sensores térmicos corporales están situados en la piel y no detectan fácilmente el calentamiento de zonas profundas del cuerpo. Por lo tanto, los trabajadores pueden absorber cantidades significativas de energía de R F sin percatarse inmediatamente de la presencia de campos de fuga. Existen notificaciones de que personal expuesto a campos de RF producidos por equipos de radar, calentadores y selladores de R F y torres de emisoras de radio y televisión ha experimentado una sensación de calentamiento algún tiempo después de haber estado expuesto. 
Figura 49.7 • Ĺmites de exposición según la IRPA (1988) para la intensidad de campo eléctrico $E$, la intensidad de campo magnético $H$ y la densidad de potencia.

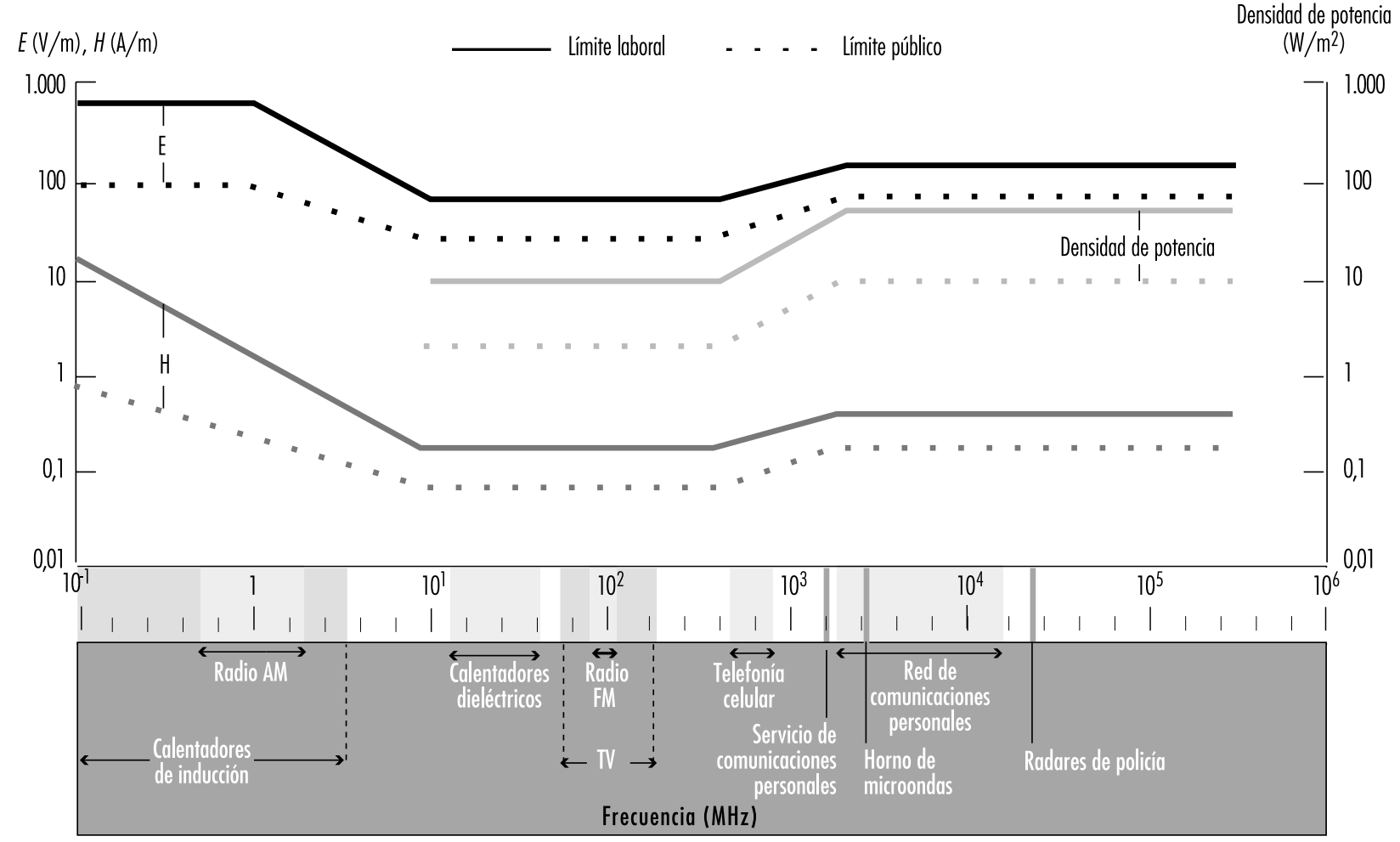

Apenas existen pruebas de que la radiación de R F pueda desencadenar cáncer en humanos. No obstante, en un estudio se sugiere que puede actuar como promotor del cáncer en animales (Szmigielski y cols. 1988). Los estudios epidemiológicos de personal expuesto a campos de R $\mathrm{F}$ son escasos y por lo general de ámbito limitado (Silverman 1990; N CR P 1986; O M S 1981). En la antigua Unión Soviética y en países del Este de Europa se han realizado varios estudios de trabajadores expuestos en el lugar de trabajo (Roberts y Michaelson 1985), sin bien estos estudios no son concluyentes en cuanto a los efectos para la salud.

Evaluaciones y estudios epidemiológicos en operarios de equipos de sellado por RF en Europa (Kolmodin-Hedman y cols. 1988; Bini y cols. 1986) han dado como resultado la posible presentación de los siguientes problemas específicos:

- quemaduras por R F o por contacto con superficies calientes;

- entumecimiento (es decir, parestesia) de manosy dedos; perturbación 0 alteración de la sensibilidad táctil;

- irritación ocular (posiblemente a causa de vapores emanados de material que contenía vinilo),

- calentamiento y malestar significativos en las piernas (debido quizá al flujo de corriente a tierra a través de las piernas).

\section{Teléfonos móviles}

El uso de radioteléfonos personales está aumentando rápidamente, con el aumento consiguiente del número de estaciones base, a menudo situadas en zonas públicas. No obstante, la exposición del público a estas estaciones es baja. Normalmente los sistemas funcionan a frecuencias cercanas a los $900 \mathrm{M} \mathrm{Hz} 0$ $1,8 \mathrm{G} \mathrm{H}$ z y utilizan tecnología analógica o digital. Los terminales son radiotransmisores pequeños de baja potencia que se sostienen muy cerca de la cabeza cuando se utilizan. Parte de la energía radiada por la antena es absorbida por la cabeza. Cálculos numéricos y mediciones realizados en cabezas simuladas indican que los valores de SAR pueden ser del orden de algunos W/ kg (véase también la declaración de la ICNIRP de 1996). Actualmente ha aumentado la preocupación pública por el riesgo que puedan suponer los campos electromagnéticos para la salud y se han dedicado varios programas de investigación a estudiar esta posibilidad (M cK inley y cols., informe no publicado). Están en curso varios estudios epidemiológicos en relación con el uso de teléfonos móviles y el cáncer cerebral. $\mathrm{H}$ asta ahora solo se han publicado los resultados de un estudio con animales (Repacholi y cols. 1997), concretamente ratones transgénicos expuestos una hora diaria durante 18 meses a una señal similar a la que se utiliza en la comunicación móvil digital. Al finalizar los experimentos, 43 de 101 animales expuestos presentaban linfomas, frente a 22 de 100 en el grupo de control de exposición simulada. EI incremento era estadísticamente significativo $(p>0,001)$. No es fácil interpretar estos resultados como relevantes para la salud humana, por lo que será necesario seguir investigando.

\section{Normas y directrices}

Varias organizaciones y servicios públicos han publicado normas y directrices de protección frente a la exposición excesiva a campos de R F. Grandolfo y $\mathrm{H}$ ansson M ild (1989) facilitaron un análisis de las normas de seguridad de ámbito mundial; en este artículo solo se comentan las directrices publicadas por la IR PA (1988) y la norma IEEE C 95.1 de 1991.

La IR PA (1988) facilita la explicación razonada y completa de los límites de exposición a R F. En síntesis, las directrices IR PA han adoptado un valor límite básico de SAR de $4 \mathrm{~W} / \mathrm{kg}$, por 
Figura 49.8 • Ĺmites de exposición según el IEEE (1991) para la intensidad de campo eléctrico E, la intensidad de campo magnético $H$ y la densidad de potencia.

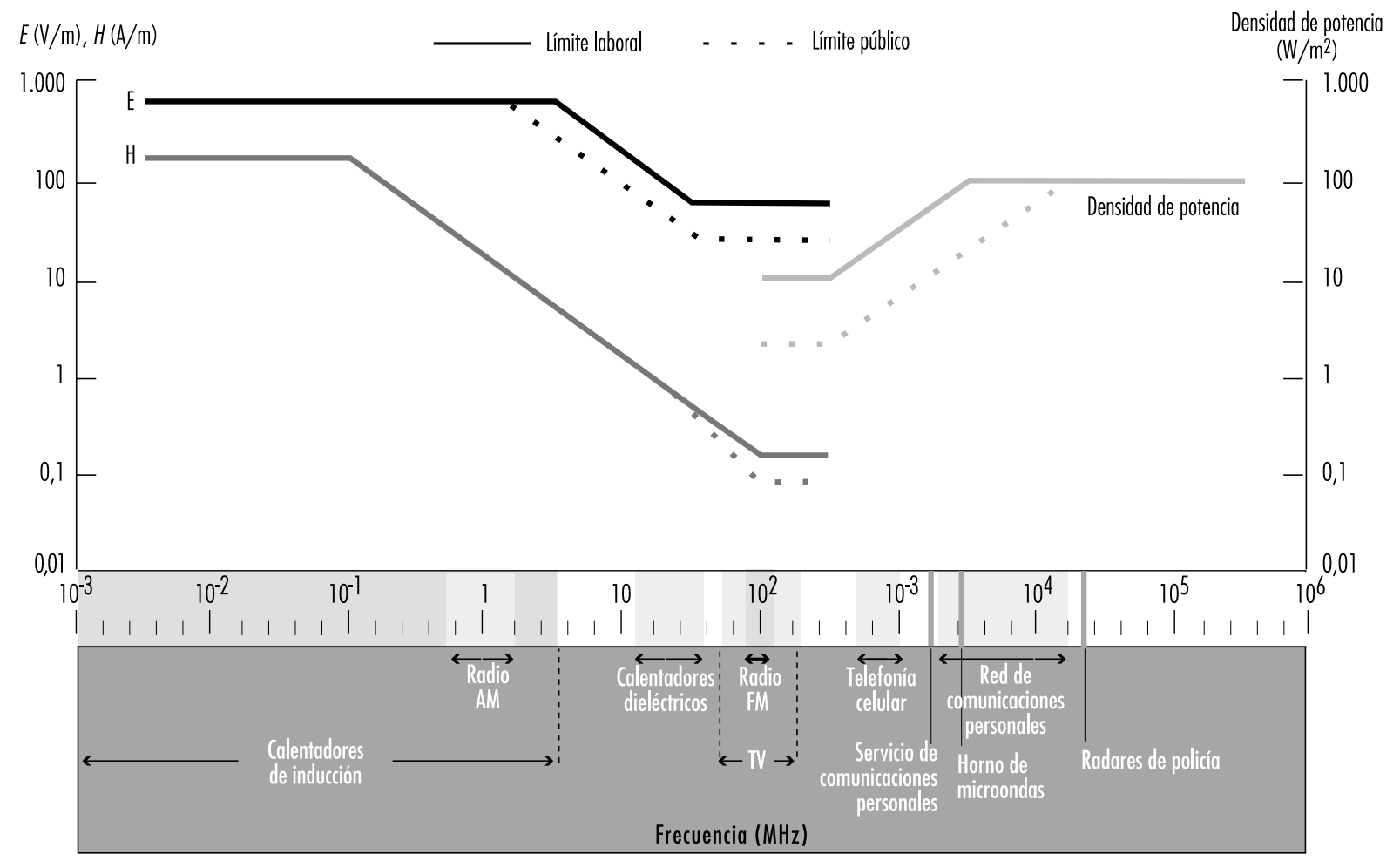

encima del cual se considera que existe una probabilidad creciente de que se produzcan consecuencias adversas para la salud debido a la absorción de energía de R F. No se han observado efectos perjudiciales para la salud tras exposiciones intensas por debajo de este nivel. Incorporando un factor de seguridad de diez para cubrir las posibles consecuencias de la exposición de larga duración, se utiliza $0,4 \mathrm{~W} / \mathrm{kg}$ como límite básico del que derivar los límites de exposición profesional. Para obtener los límites para el público en general se incorpora un factor de seguridad adicional de cinco.

Los límites de exposición derivados para la intensidad de campo eléctrico $(E)$, la intensidad de campo magnético $(H)$ y la densidad de potencia, expresados en $\mathrm{V} / \mathrm{m}, \mathrm{A} / \mathrm{m}$ y $\mathrm{W} / \mathrm{m}^{2}$, se indican en la Figura 49.7. Los cuadrados de los campos $\mathrm{E}$ y $\mathrm{H}$ están promediados sobre seis minutos; se recomienda que la exposición instantánea no exceda de los valores promediados en tiempo en un factor superior a 100. Asimismo, la corriente del cuerpo a tierra no deberá exceder de $200 \mathrm{~mA}$.

La norma C 95.1 establecida en 1991 por la IEEE especifica unos valores límite de exposición laboral (en ambiente controlado) de 0,4 W/ kg para la SAR media sobre la totalidad del cuerpo de una persona y de $8 \mathrm{~W} / \mathrm{kg}$ para la SAR máxima administrada a cada gramo de tejido durante 6 minutos o más. Los valores de exposición correspondientes para el público en general (en ambiente no controlado) son de 0,08 W/ kg para la SAR sobre todo el cuerpo y de 1,6 W/ kg para la SAR máxima. La corriente del cuerpo a tierra no deberá exceder de $100 \mathrm{~mA}$ en un ambiente controlado ni de $45 \mathrm{~mA}$ en un ambiente no controlado (para más detalles véase IEEE 1991). Los límites derivados se indican en la Figura 49.8.

Puede verse más información sobre campos de radiofrecuencia y microondas, por ejemplo, en Elder y cols. 1989, G reene 1992 y Polk y Postow 1986.

\section{CAMPOS ELECTRICOS Y MAGNETICOS DE VLF Y ELF}

Michael H. Repacholi

Los campos eléctricos y magnéticos de frecuencia extremadamente baja (ELF) y de muy baja frecuencia (VLF) abarcan el intervalo de frecuencia por encima de los campos estáticos $(>0 \mathrm{~Hz}$ ) hasta los $30 \mathrm{kHz}$. A los efectos de este artículo, la ELF se considera comprendida en el intervalo de frecuencia de 0 a $300 \mathrm{~Hz}$ y la V LF en el intervalo de $300 \mathrm{~Hz}$ a $30 \mathrm{kHz}$. En el intervalo de frecuencia $>0$ a $30 \mathrm{kHz}$, las longitudes de onda varían entre $\infty$ (infinito) y $10 \mathrm{~km}$, por lo que los campos eléctricos y magnéticos actúan de forma esencialmente independiente entre sí y deben tratarse por separado. La intensidad de campo eléctrico $(E)$ se mide en voltios por metro $(V / m)$, la intensidad de campo magnético $(H)$ en amperios por metro $(A / m)$ y la densidad de flujo magnético ( $B$ ) en tesla $(T)$.

Se ha suscitado un considerable debate sobre los posibles efectos adversos para la salud entre los trabajadores que utilizan equipos que funcionan en este intervalo de frecuencias. $L a$ frecuencia más común es con mucho la de $50 / 60 \mathrm{~Hz}$, utilizada para la generación, distribución y uso de energía eléctrica. LoS medios de información, la distribución de información inexacta y el debate científico en curso han alimentado la preocupación por la posibilidad de que la exposición a campos magnéticos de 50/ $60 \mathrm{~Hz}$ pueda estar relacionada con un aumento de la incidencia de cáncer (Repacholi 1990; N RC 1996).

El objeto de este artículo es facilitar una visión general de las siguientes cuestiones:

- fuentes, ocupaciones y aplicaciones;

- dosimetría y medición; 
- mecanismo de interacción y efectos biológicos;

- estudios en humanos y efectos para la salud;

- medidas de protección,

- normas sobre exposición laboral.

Se facilitan descripciones resumidas para informar a los trabajadores sobre los tipos e intensidades de los campos generados por las principales fuentes de ELF y VLF, efectos biológicos, posibles consecuencias para la salud y límites de exposición vigentes. También se ofrece un compendio de precauciones de seguridad y medidas de protección. Aunque muchos trabajadores utilizan pantallas de visualización de datos (PVD), en este artículo solo se facilitan breves indicaciones al respecto, ya que las mismas se tratan con mayor detalle en otro capítulo de la Enciclopedia.

Gran parte del material aquí contenido figura expuesto con mayor detalle en varias publicaciones recientes (O M S 1984, 1987, 1989, 1993; IRPA 1990; OIT 1993; NRPB 1992, 1993; IEEE 1991; G reene 1992; NRC 1996).

\section{Fuentes de exposición profesional}

Los niveles de exposición profesional varían considerablemente y dependen en gran medida del tipo de aplicación. La Tabla 49.4 ofrece un resumen de aplicaciones comunes de las frecuencias comprendidas en el intervalo de 0 a $30 \mathrm{kHz}$.

\section{Generación y distribución de energía eléctrica}

Las fuentes artificiales más importantes de campos eléctricos y magnéticos a $50 / 60 \mathrm{~Hz}$ son las que intervienen en la generación y distribución de energía eléctrica así como cualquier equipo que utilice corriente eléctrica. Casi todos estos equipos funcionan a frecuencias de alimentación de $50 \mathrm{~Hz}$ en la mayoría de los países y a $60 \mathrm{~Hz}$ en N orteamérica. Algunos sistemas de trenes eléctricos funcionan a $16,67 \mathrm{~Hz}$.

Las líneas de transmisión de alta tensión (AT) y las subestaciones producen los campos eléctricos más intensos a que pueden estar expuestos los trabajadores de forma habitual. Los factores más importantes a tener en cuenta en relación con la máxima intensidad de campo eléctrico a nivel del suelo son principalmente la altura de los conductores, la configuración geométrica, la distancia lateral a la línea de transmisión y el voltaje de ésta. A distancias laterales del doble de la altura de la línea, la

Tabla 49.4 - Aplicaciones de los equipos que trabajan dentro de la gama de 0 a $30 \mathrm{kHz}$.

Frecuencia Longitud de onda Aplicaciones típicas
$(\mathrm{Km})$

16,67; 18.000-5.000 Generación, transmisiones y uso de potencia,

$50 ; 60 \mathrm{~Hz} \quad$ procesos electrolíticos, calentamiento por inducción, hornos de arco y de colada, soldadura, transporte, etc., cualquier uso industrial, comercial, médico o en investigación de la energía eléctrica

0,3-3 kHz $\quad 1.000-100 \quad$ Modulación de emisiones radiadas, aplicaciones médicas, hornos eléctricos, calentamiento por inducción, temple, soldadura, fusión, afino de metales

3- $30 \mathrm{kHz} \quad 100-10 \quad$ Comunicaciones de muy largo alcance, radionavegación, modulación de emisiones radiadas, aplicaciones médicas, calentamiento por inducción, temple, soldadura, fusión, afino, PVD intensidad del campo eléctrico disminuye con la distancia aproximadamente de forma lineal (Zaffanella y Deno 1978). En el interior de los edificios próximos a líneas de transmisión de AT, las intensidades de los campos eléctricos suelen ser inferiores al campo no perturbado en un factor de aproximadamente 100.000 , dependiendo de la configuración del edificio y de los materiales de su estructura.

Por lo general, las intensidades de los campos magnéticos producidos por las líneas aéreas de transmisión de energía eléctrica son relativamente bajos en comparación con las aplicaciones industriales en las que intervienen corrientes de alta intensidad. Los empleados de compañías de suministro eléctrico que trabajan en subestaciones o en el mantenimiento de líneas de transmisión activas constituyen un grupo especial expuesto a campos intensos (de $5 \mathrm{mT}$ incluso más en algunos casos). En ausencia de materiales ferromagnéticos, las líneas del campo magnético forman círculos concéntricos alrededor del conductor. A parte de la geometría del conductor de energía eléctrica, lo único que determina la densidad del flujo magnético es la magnitud de la corriente. La dirección del campo magnético debajo de las líneas de transmisión de AT es principalmente transversal al eje longitudinal de la línea. La máxima densidad de flujo a nivel del suelo puede estar debajo del centro de la línea o de los conductores exteriores, dependiendo de la relación de fase entre conductores. La máxima densidad de flujo magnético a nivel del suelo en un sistema normal de líneas de transmisión aérea de $500 \mathrm{kV}$ de doble circuito es de aproximadamente $35 \mu \mathrm{T}$ por kiloamperio de corriente transmitida (Bernhardt y $M$ atthes 1992). La densidad de flujo magnético alcanza normalmente valores de hasta 0,05 mT en los lugares de trabajo situados cerca de líneas aéreas, en subestaciones y en centrales eléctricas que trabajan a frecuencias de $162 / 3,50$ ó $60 \mathrm{~Hz}$ (K rause 1986).

\section{Procesos industriales}

La exposición laboral a campos magnéticos se produce principalmente por trabajar cerca de equipos industriales que utilizan corrientes elevadas. Entre tales dispositivos se incluyen los que se emplean en soldadura, afino con electroescoria, calentamiento (hornos, calentadores de inducción) y agitación.

Estudios sobre calentadores de inducción utilizados en la industria, llevados a cabo en Canadá (Stuchly y Lecuyer 1985), Polonia (Aniolczyk 1981), Australia (Repacholi, datos no publicados) y Suecia (Lövsund, O berg y Nilsson 1982), indican que las densidades de flujo magnético en los puestos de trabajo de los operarios varían entre $0,7 \mu \mathrm{T}$ y $6 \mathrm{mT}$ dependiendo de la frecuencia utilizada y de la distancia a la máquina. En su estudio de los campos magnéticos producidos por equipos eléctricos industriales de producción de acero y de soldadura, Lövsund, O berg y Nilsson (1982) descubrieron que las máquinas de soldadura por puntos (50 Hz, 15 a $106 \mathrm{kA}$ ) y los hornos de colada ( $50 \mathrm{~Hz}, 13$ a $15 \mathrm{kA}$ ) producían campos de hasta $10 \mathrm{mT}$ a distancia de hasta $1 \mathrm{~m}$. En Australia se comprobó que una planta de calentamiento por inducción que funcionaba a frecuencias comprendidas entre $50 \mathrm{~Hz}$ y $10 \mathrm{kHz}$ producía campos de máxima intensidad de hasta 2,5 mT (hornos de inducción de $50 \mathrm{~Hz}$ ) en posiciones que podían ocupar los operarios. A demás, los campos máximos alrededor de los calentadores de inducción que funcionaban a otras frecuencias eran de $130 \mu \mathrm{T}$ a $1,8 \mathrm{kHz}, 25 \mu \mathrm{T}$ a $2,8 \mathrm{kHz}$ y superiores a $130 \mu \mathrm{T}$ a $9,8 \mathrm{kHz}$.

Como las bobinas que generan los campos magnéticos suelen ser de pequeñas dimensiones, rara vez se produce exposición de todo el cuerpo; la exposición suele ser local y afecta principalmente a las manos. La densidad de flujo magnético a que están expuestas las manos del operario puede alcanzar valores de 
hasta $25 \mathrm{mT}$ (Lövsund y M ild 1978; Stuchly y Lecuyer 1985). En la mayoría de los casos, la densidad de flujo es inferior a $1 \mathrm{mT}$. La intensidad del campo eléctrico en las proximidades del calentador de inducción suele ser baja.

Los trabajadores de la industria electroquímica pueden estar expuestos a altas intensidades de campo eléctrico y magnético producidas por hornos eléctricos y otros dispositivos que utilizan altas corrientes. Por ejemplo, cerca de hornos de inducción y de pilas electrolíticas industriales se miden a veces densidades de flujo magnético de hasta $50 \mathrm{mT}$.

\section{Pantallas de visualización de datos}

EI uso de pantallas de visualización de datos (PVD), o terminales de visualización como también se las denomina, aumenta a ritmo creciente. Los operadores de PVD se muestran preocupados por los posibles efectos de las emisiones de radiaciones de bajo nivel. En los casos más desfavorables se han llegado a medir campos magnéticos (a frecuencias de 15 a $125 \mathrm{kHz}$ ) de hasta 0,69 A/ m $(0,9 \mu \mathrm{T})$ cerca de la superficie de la pantalla (Bureau of Radiological $\mathrm{H}$ ealth 1981). Este resultado ha sido confirmado por numerosos estudios (R oy y cols. 1984; Repacholi 1985; IR PA 1988). Análisis exhaustivos de las mediciones y estudios de las pantallas realizados por organismos nacionales y expertos particulares han dado como resultado que las PV D no producen ninguna emisión de radiaciones que puedan tener consecuencias para la salud (Repacholi 1985; IR PA 1988; OIT 1993a). No es necesario efectuar medidas de radiación periódicas, ya que incluso en el caso más desfavorable o en situaciones de avería los niveles de emisión están muy por debajo de los límites de cualquier norma internacional o nacional (IR PA 1988).

En el documento (O IT 1993a) se ofrece un completo análisis de las emisiones, así como un compendio de la literatura científica, normas y guías pertinentes.

\section{Aplicaciones médicas}

Pacientes con fracturas óseas que no cicatrizan o no sueldan bien han sido tratados con campos magnéticos de impulsos (Bassett, $M$ ilchell y Gaston 1982; M itbreit y M anyachin 1984). A simismo se están realizando estudios sobre el uso de los campos magnéticos de impulsos para mejorar la cicatrización de heridas y la regeneración tisular.

Para la estimulación del crecimiento óseo se utilizan diversos dispositivos que generan impulsos de campos magnéticos. Un ejemplo característico es el del dispositivo que genera una densidad de flujo magnético media de 0,3 mT aproximadamente, una intensidad pico del orden de $2,5 \mathrm{mT}$ y que induce en el hueso intensidades de campo eléctrico pico en el intervalo de 0,075 a 0,175 V/m (Bassett, Pawluk y Pilla 1974). Cerca de la superficie del miembro expuesto, el dispositivo produce una densidad de flujo magnético pico del orden de 1,0 mT que origina densidades de corriente iónica pico de aproximadamente 10 a $100 \mathrm{~mA} / \mathrm{m}^{2}\left(1\right.$ a $\left.10 \mu \mathrm{A} / \mathrm{cm}^{2}\right)$ en el tejido.

\section{Medición}

Antes de iniciar las mediciones de campos de ELF o VLF, es importante obtener la máxima información posible sobre las características de la fuente y la situación de exposición. Esta información es necesaria para el cálculo estimativo de las intensidades de campo esperadas y para la selección de la instrumentación de medida más adecuada (Tell 1983).

La información acerca de la fuente debe incluir los siguientes datos:

- frecuencias presentes, incluyendo armónicos;

- potencia transmitida;

- polarización (orientación del campo E);
Tabla 49.5 - Fuentes de exposición laboral a campos magnéticos.

\begin{tabular}{|c|c|c|}
\hline Fuente & $\begin{array}{l}\text { Densidades de flujo } \\
\text { magnético (mT) }\end{array}$ & Distancia (m) \\
\hline PVD & Hasta $2,8 \times 10^{-4}$ & 0,3 \\
\hline Líneas de alta tensión & Hasta 0,4 & $\begin{array}{l}\text { Debajo de la } \\
\text { línea }\end{array}$ \\
\hline Centrales eléctricas & Hasta 0,27 & 1 \\
\hline Arcos de soldadura ( 0 - $50 \mathrm{~Hz}$ ) & $0,1-5,8$ & $0-0,8$ \\
\hline Calentadores de inducción (50- $10 \mathrm{kHz}$ ) & $0,9-65$ & $0,1-1$ \\
\hline Horno de colada de $50 \mathrm{~Hz}$ & $0,2-8$ & $0,5-1$ \\
\hline Horno de arco de $50 \mathrm{~Hz}$ & Hasta 1 & 2 \\
\hline Agitador de inducción de $10 \mathrm{~Hz}$ & $0,2-0,3$ & 2 \\
\hline Soldadura con electroescoria a $50 \mathrm{~Hz}$ & $0,5-1,7$ & $0,2-0,9$ \\
\hline Equipo terapéutico & $1-16$ & 1 \\
\hline
\end{tabular}

Fuente: Allen 1991; Bernhardt 1988; Krause 1986; Lövsund, Oberg y Nilsson 1982; Repacholi, datos no publicados; Stuchly 1986, Stuchly y Lecuyer 1985, 1989.

- características de modulación (valores pico y medio);

- ciclo de trabajo, anchura de impulso y frecuencia de repetición de impulsos,

- características de la antena, como tipo, ganancia, anchura de haz y velocidad de barrido.

La información sobre la situación de exposición deberá incluir lo siguiente:

- distancia a la fuente,

- existencia de objetos dispersantes de cualquier tipo. La dispersión en superficies planas puede incrementar el campo $E$ en un factor de 2. Las superficies curvas, como las de los reflectores de cónicos, pueden producir incrementos aún mayores.

Los resultados de los estudios realizados en centros de trabajo se resumen en la Tabla 49.5.

\section{Instr umentación}

Un instrumento de medida de campos eléctricos o magnéticos consta de tres partes básicas: la sonda, los cables y el monitor. Para garantizar unas mediciones adecuadas se requiere 0 es conveniente que la instrumentación reúna las siguientes características:

- La sonda debe responder solo al campo E o solo al campo H pero no a ambos simultáneamente.

- La sonda no debe producir perturbación significativa del campo.

- Los cables que unen la sonda al monitor no deben perturbar el campo en la sonda de modo significativo ni acoplar energía del campo.

- La respuesta en frecuencia de la sonda debe cubrir el intervalo de frecuencias que se necesita medir.

- Si se utiliza en campo próximo reactivo, conviene que las dimensiones del sensor de la sonda sean inferiores a la cuarta parte de una longitud de onda a la frecuencia más alta presente.

- El instrumento deberá indicar el valor medio cuadrático o valor eficaz (rms) del parámetro del campo medido.

- Se deberá conocer el tiempo de respuesta del instrumento. Es conveniente que tenga un tiempo de respuesta de 
aproximadamente 1 segundo como máximo, para que puedan detectarse con facilidad campos intermitentes.

- La sonda deberá responder a todos los componentes de polarización del campo. Esto puede conseguirse por respuesta isotrópica inherente o mediante la rotación física de la sonda en tres direcciones ortogonales

- 0 tras características deseables son una buena protección frente a sobrecargas, el funcionamiento con batería, la portabilidad y la construcción robusta.

- Los instrumentos ofrecen una indicación de uno o más de los siguientes parámetros: campo $\mathrm{E}$ medio $(\mathrm{V} / \mathrm{m}) \mathrm{o}$ valor medio cuadrático del campo $\mathrm{E}\left(\mathrm{N}^{2} / \mathrm{m}^{2}\right)$; campo $\mathrm{H}$ medio $(\mathrm{A} / \mathrm{m}) \mathrm{O}$ valor medio cuadrático del campo $\mathrm{H}\left(\mathrm{A}^{2} / \mathrm{m}^{2}\right)$.

\section{Estudios de exposición}

A menudo se realizan este tipo de estudios para determinar si los campos existentes en el lugar de trabajo están por debajo de los límites prescritos por las normas nacionales. Por lo tanto, la persona que efectúe las mediciones deberá conocer perfectamente dichas normas.

Se comprobarán todas las posiciones ocupadas y accesibles. El operador del equipo que se comprueba y el investigador que realiza el estudio deberán situarse lo más lejos posible de la zona de la verificación. Todos los objetos normalmente presentes que puedan reflejar o absorber energía deberán estar en su posición habitual. El investigador tomará precauciones contra las quemaduras por radiofrecuencia (RF) y shock, en particular cerca de sistemas de alta potencia y baja frecuencia.

\section{Mecanismos de interacción y efectos biológicos}

\section{M ecanismos de interacción}

Los únicos mecanismos por los que se ha comprobado que los campos de ELF y VLF interactúan con los sistemas biológicos son los siguientes:

- Campos eléctricos que inducen una carga superficial en un cuerpo expuesto, la cual induce en el interior del cuerpo corrientes (medidas en $\mathrm{mA} / \mathrm{m}^{2}$ ) cuya magnitud está en relación con la densidad de carga superficial. Dicha densidad de carga superficial puede variar considerablemente, dependiendo de las condiciones de exposición y del tamaño, forma y posición

Tabla 49.6 • Efectos del paso de corrientes por el cuerpo humano.

\begin{tabular}{|c|c|c|c|c|c|c|}
\hline \multirow[t]{2}{*}{ Efecto } & \multirow[t]{2}{*}{ Sujeto } & \multicolumn{5}{|c|}{ Corriente umbral en mA } \\
\hline & & $\begin{array}{l}50 \mathrm{y} \\
60 \mathrm{~Hz}\end{array}$ & $300 \mathrm{~Hz}$ & $\begin{array}{l}1000 \\
\mathrm{~Hz}\end{array}$ & $10 \mathrm{kHz}$ & $30 \mathrm{kHz}$ \\
\hline \multirow[t]{3}{*}{ Percepción } & Varones & 1,1 & 1,3 & 2,2 & 15 & 50 \\
\hline & Mujeres & 0,7 & 0,9 & 1,5 & 10 & 35 \\
\hline & Niños & 0,55 & 0,65 & 1,1 & 9 & 30 \\
\hline \multirow{3}{*}{$\begin{array}{l}\text { Umbral de no } \\
\text { soltar }\end{array}$} & Varones & 9 & 11,7 & 16,2 & 55 & 126 \\
\hline & Mujeres & 6 & 7,8 & 10,8 & 37 & 84 \\
\hline & Niños & 4,5 & 5,9 & 8,1 & 27 & 63 \\
\hline \multirow{3}{*}{$\begin{array}{l}\text { Tetanización } \\
\text { torácica; } \\
\text { fuerte sacudida }\end{array}$} & Varones & 23 & 30 & 41 & 94 & 320 \\
\hline & Mujeres & 15 & 20 & 27 & 63 & 214 \\
\hline & Niños & 12 & 15 & 20,5 & 47 & 160 \\
\hline
\end{tabular}

del cuerpo expuesto en el campo, lo que determina una distribución variable y no uniforme de corrientes en el interior del cuerpo.

- Los campos magnéticos también actúan sobre los humanos induciendo campos y corrientes eléctricos en el interior del cuerpo.

- Las cargas eléctricas inducidas en un objeto conductor (p. ej., un automóvil) expuesto a campos eléctricos de ELF o VLF pueden hacer que la corriente pase a través de una persona que esté en contacto con él.

- El acoplamiento del campo magnético a un conductor (por ejemplo una alambrada) hace que circulen corrientes eléctricas (de la misma frecuencia que el campo que produce la exposición) por el cuerpo de una persona en contacto con él.

- Cuando las personas se acercan lo suficiente a objetos metálicos expuestos a un campo eléctrico intenso, pueden producirse descargas transitorias (chispas).

- Los campos eléctricos o magnéticos pueden interferir en dispositivos médicos implantados (por ejemplo marcapasos cardíacos unipolares) y causar mal funcionamiento del dispositivo.

Las dos primeras interacciones indicadas son ejemplos de acoplamiento directo entre personas y campos de ELF O VLF. Las cuatro últimas son ejemplos de mecanismos de acoplamiento indirecto, ya que solo pueden producirse cuando el organismo expuesto se encuentra cerca de otros cuerpos. Estos pueden ser otros humanos o bien animales y objetos tales como automóviles, alambradas o dispositivos implantados.

Aunque se han postulado otros mecanismos de interacción entre tejidos biológicos y campos de ELF O VLF, o hay algún indicio de su existencia (O M S 1993; NRPB 1993; NRC 1996), no se ha demostrado que ninguno de ellos tenga consecuencias adversas para la salud.

\section{E fectos para la salud}

Las pruebas existentes indican que la mayoría de los efectos comprobados de la exposición a campos eléctricos y magnéticos en la gama de frecuencias de 0 a $30 \mathrm{kHz}$ se deben a respuestas agudas a la carga superficial y a la densidad de corriente inducida. Las personas pueden percibir los efectos de la carga superficial oscilante inducida en sus cuerpos por los campos eléctricos de ELF (pero no por los campos magnéticos); estos efectos se vuelven molestos si son lo bastante intensos. La Tabla 49.6 ofrece un resumen de los efectos de las corrientes que atraviesan el cuerpo humano (umbrales de percepción, y de no soltar o tetanización).

Células nerviosas y musculares humanas han sido estimuladas por las corrientes inducidas por exposición a campos magnéticos de varios $\mathrm{mT}$ y de 1 a $1,5 \mathrm{kHz}$; se cree que los umbrales de densidad de corriente son superiores a $1 \mathrm{~A} / \mathrm{m}^{2}$. Se pueden inducir en el ojo humano sensaciones visuales de destellos por exposición a campos magnéticos incluso de sólo 5 a $10 \mathrm{mT}$ (a $20 \mathrm{~Hz}$ ) aproximadamente 0 mediante corrientes eléctricas aplicadas directamente a la cabeza. La consideración de estas respuestas y de los resultados de los estudios neurofisiológicos señala que densidades de corriente superiores a $10 \mathrm{~mA} / \mathrm{m}^{2}$ pueden afectar a delicadas funciones del sistema nervioso central, tales como el razonamiento o la memoria (NR PB 1993). L os valores umbral suelen mantenerse constantes hasta $1 \mathrm{kH} \mathrm{z}$ aproximadamente pero a partir de ahí aumentan cuando lo hace la frecuencia.

Los resultados notificados de varios estudios in vitro (OM S 1993; NRPB 1993) indican cambios metabólicos, tales como alteraciones de la actividad enzimática y el metabolismo proteico, y disminución de la citotoxicidad linfocítica en diversas cepas de células expuestas a campos eléctricos y corrientes de 


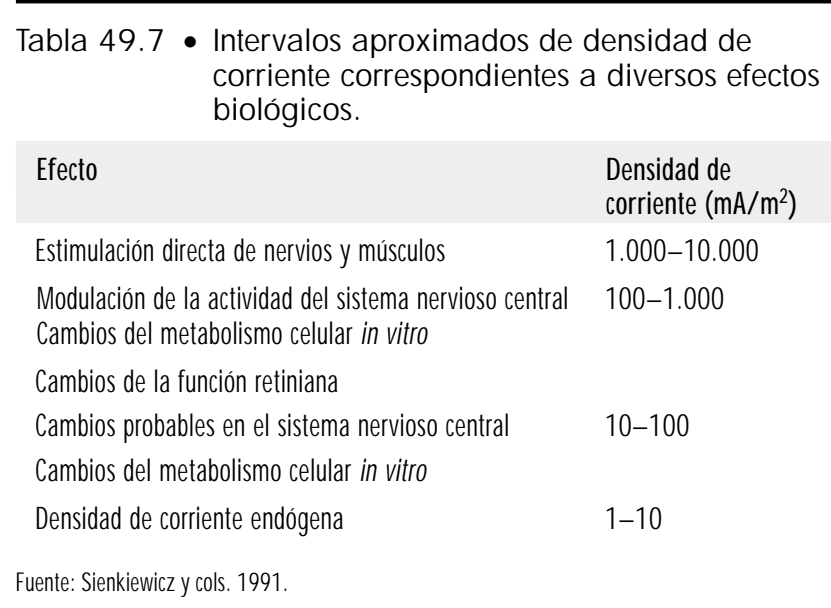

ELF y VLF aplicados directamente al cultivo celular. La mayoría de los efectos se notificaron a densidades de corriente comprendidas entre aproximadamente 10 y $1.000 \mathrm{~mA} / \mathrm{m}^{2}$, aunque estas respuestas no están tan claramente definidas (Sienkiewicz, Saunder y Kowalczuk 1991). En todo caso, merece la pena señalar que las densidades de corriente endógena generada por la actividad eléctrica de los nervios y músculos alcanzan normalmente valores tan elevados como $1 \mathrm{~mA} / \mathrm{m}^{2}$ y pueden llegar hasta $10 \mathrm{~mA} / \mathrm{m}^{2}$ en el corazón. Estas densidades de corriente no afectan de modo adverso a los nervios, músculos y otros tejidos. Tales efectos biológicos se evitarán restringiendo la densidad de corriente inducida a menos de $10 \mathrm{~mA} / \mathrm{m}^{2}$ a frecuencias de hasta $1 \mathrm{kHz}$ aproximadamente.

Entre las posibles áreas de interacción biológica que presentan numerosas implicaciones para la salud y acerca de las cuales tenemos un conocimiento limitado están las siguientes: posibles cambios en los niveles nocturnos de melatonina en la glándula pineal y alteraciones de los ritmos circadianos inducidos en animales por exposición a campos eléctricos o magnéticos de ELF, y posibles efectos de los campos magnéticos de ELF sobre los procesos de desarrollo y carcinogénesis. Existe además alguna evidencia de respuestas biológicas a campos eléctricos y magnéticos muy débiles, entre ellas la alteración de la movilidad de los iones de calcio en el tejido cerebral, los cambios en los patrones de activación neuronal y la alteración del comportamiento de los operandos. Se han notificado "ventanas" de amplitud y frecuencia que ponen en duda la hipótesis convencional de que la magnitud de una respuesta aumenta con la dosis. Estos efectos no están bien comprobados y no sirven de base para establecer restricciones a la exposición humana, aun cuando están previstas nuevas investigaciones (Sienkievicz, Saunder y K owalczuk 1991; O M S 1993; N RC 1996).

La Tabla 49.7 recoge los intervalos aproximados de densidades de corriente inducida correspondientes a diversos efectos biológicos en humanos.

\section{Normas sobre exposición laboral}

Casi todas las normas con límites comprendidos en la gama de $>0-30 \mathrm{kHz}$ se basan en la necesidad de mantener los campos y corrientes eléctricos inducidos dentro de niveles seguros. N ormalmente las densidades de corriente inducidas están restringidas a menos de $10 \mathrm{~mA} / \mathrm{m}^{2}$. La Tabla 49.8 ofrece un resumen de algunos límites de exposición profesional vigentes.

\section{Medidas de protección}

Las exposiciones de origen laboral que se producen cerca de líneas de transmisión de alta tensión dependen de la posición del
Tabla 49.8 • Límites de exposición laboral a campos eléctricos y magnéticos en el intervalo de frecuencias $>0$ a $30 \mathrm{kHz}$ ( $f$ se indica en $\mathrm{Hz}$ ).

\begin{tabular}{llll}
$\begin{array}{l}\text { País/ } \\
\text { Referencia }\end{array}$ & $\begin{array}{l}\text { Gama de } \\
\text { frecuencia }\end{array}$ & $\begin{array}{l}\text { Campo eléctrico } \\
(\mathrm{V} / \mathrm{m})\end{array}$ & $\begin{array}{l}\text { Campo magnético } \\
\text { (A/ m) }\end{array}$ \\
$\begin{array}{l}\text { Internacional } \\
\text { (IRPA 1990) }\end{array}$ & $50 / 60 \mathrm{~Hz}$ & 10.000 & 398 \\
$\begin{array}{l}\text { EE.UU. } \\
\text { (IEEE 1991) }\end{array}$ & $3-30 \mathrm{kHz}$ & 614 & 163 \\
$\begin{array}{l}\text { EE.UU. } \\
\text { (ACGIH 1993) }\end{array}$ & $1-100 \mathrm{~Hz}$ & 25.000 & $60 / \mathrm{f}$ \\
& $100-4.000 \mathrm{~Hz}$ & $2,5 \times 10^{6} / \mathrm{f}$ & $60 / \mathrm{f}$ \\
& $4-30 \mathrm{kHz}$ & 625 & $60 / \mathrm{f}$ \\
& $50 / 60 \mathrm{~Hz}$ & 10.000 & 1.600 \\
$\begin{array}{l}\text { Alemania (1996) } \\
\text { Reino Unido }\end{array}$ & $1-24 \mathrm{~Hz}$ & 25.000 & $64.000 / \mathrm{f}$ \\
(NRPB 1993) & $24-600 \mathrm{~Hz}$ & $6 \times 10^{5} / \mathrm{f}$ & $64.000 / \mathrm{f}$ \\
& $600-1.000 \mathrm{~Hz}$ & 1.000 & $64.000 / \mathrm{f}$ \\
& $1-30 \mathrm{kHz}$ & 1.000 & 64 \\
\hline
\end{tabular}

trabajador en el suelo o junto al conductor durante el trabajo con la línea activa a elevado potencial. Cuando se trabaja con la línea activa, puede utilizarse ropa protectora para reducir la intensidad de campo eléctrico y la densidad de corriente en el cuerpo a valores similares a los que se producirían si se trabajase en el suelo. La ropa protectora no aminora la influencia del campo magnético.

Las responsabilidades en cuanto a la protección de los trabajadores y del público en general contra los efectos potencialmente adversos de la exposición a campos eléctricos y magnéticos de ELF o VLF deben estar claramente delimitadas. Se recomienda que las autoridades competentes tomen en consideración los siguientes pasos:

- desarrollo y adopción de límites de exposición e implantación de un programa de cumplimiento;

- desarrollo de normas técnicas para reducir la susceptibilidad a la interferencia electromagnética, por ejemplo de los marcapasos;

- desarrollo de normas que definan zonas de acceso limitado alrededor de las fuentes productoras de campos eléctricos y magnéticos intensos como protección frente a la interferencia electromagnética (por ejemplo para marcapasos y otros dispositivos implantados). Debería estudiarse la utilización de señales de advertencia adecuadas;

- establecimiento del requisito de designar específicamente una persona responsable de la seguridad de los trabajadores y el público en cada lugar de trabajo con altos potenciales de exposición;

- desarrollo de procedimientos de medida y métodos de estudio normalizados;

- establecimiento de requisitos para la instrucción de los trabajadores en relación con los efectos de la exposición a campos eléctricos y magnéticos de ELF o VLF y las medidas y reglas destinadas a protegerlos,

- elaboración de guías o códigos de prácticas para la seguridad de los trabajadores expuestos a campos eléctricos y magnéticos de ELF o VLF. La OIT (1993) ofrece excelentes orientaciones para la confección de este tipo de códigos. 


\section{- CAMPOS ELECTRICOS Y MAG NETICOS ESTATICOS}

\section{M artino G randolfo}

Nuestros entornos, tanto el natural como el artificial, generan fuerzas eléctricas y magnéticas de diversas magnitudes, en exteriores, oficinas, viviendas particulares y lugares de trabajo industriales. Esto suscita dos importantes cuestiones: a) isuponen estas exposiciones efectos adversos para la salud humana?, y b) ¿qué límites pueden establecerse en un intento de definir límites "seguros" de tales exposiciones?

Este artículo se refiere específicamente a los campos estáticos eléctricos y magnéticos. Se describen estudios realizados con trabajadores de diversos sectores y con animales, los cuales no han revelado de modo concluyente ningún efecto biológico adverso a los niveles de exposición a campos eléctricos y magnéticos que se dan habitualmente. No obstante, se comentan los esfuerzos de varias organizaciones internacionales por establecer directrices guías para proteger a los trabajadores y a otras personas de cualquier posible nivel de exposición peligroso.

\section{Definiciones}

Cuando se aplica una tensión o una corriente eléctrica a un objeto tal como un conductor eléctrico, el conductor se carga y empiezan a actuar fuerzas en otras cargas cercanas. Pueden diferenciarse dos tipos de fuerzas: las producidas por cargas eléctricas estacionarias, denominadas fuerza electrostática, y las que solo aparecen cuando las cargas están en movimiento (como en el caso de la corriente eléctrica que circula por un conductor), conocidas como fuerza magnética. Para describir la existencia y distribución espacial de estas fuerzas, físicos y matemáticos han creado el concepto de campo. Así, hablamos de un campo de fuerza 0 , simplemente, de campos eléctricos y magnéticos.

El término estático describe una situación en que todas las cargas están inmóviles en el espacio o se desplazan con un movimiento uniforme. Como consecuencia de ello, tanto las cargas como las densidades de corriente son constantes en el tiempo. En el caso de las cargas inmóviles, tenemos un campo eléctrico cuya intensidad en cualquier punto del espacio depende del valor y la geometría de todas las cargas. En el caso de un circuito de corriente continua, tenemos un campo eléctrico y un campo magnético constantes en el tiempo (campos estáticos) dado que la densidad de carga en cualquier punto del circuito no varía.

La electricidad y el magnetismo son fenómenos claramente diferenciados cuando las cargas y la corriente son estáticas; en esta situación estática desaparece cualquier interconexión entre los campos eléctrico y magnético, de modo que éstos pueden tratarse por separado (a diferencia de lo que ocurre cuando los campos son variables en el tiempo). L os campos electrostáticos y magnéticos están claramente caracterizados por intensidades uniformes, independientes del tiempo y corresponden al límite de frecuencia cero de la banda de frecuencias extremadamente bajas (ELF).

\section{Campos eléctricos estáticos}

\section{Exposición natural y profesional}

Los campos eléctricos estáticos son producidos por cuerpos cargados eléctricamente cuando se induce una carga eléctrica en la superficie de un objeto dentro de un campo eléctrico estático. A consecuencia de ello, el campo eléctrico de la superficie de un objeto, sobre todo si el radio de curvatura es pequeño, como en el caso de un punto, puede ser mayor que el campo eléctrico no perturbado (es decir, el campo sin la presencia del objeto). EI campo en el interior del objeto puede ser muy pequeño o nulo. Los campos eléctricos actúan como una fuerza sobre los objetos cargados eléctricamente; por ejemplo, ejercen una fuerza en el vello corporal que puede ser percibida por el individuo.

G eneralmente, la carga superficial terrestre es negativa mientras que en las capas superiores de la atmósfera existe una carga positiva. El campo electrostático resultante cerca de la superficie terrestre tiene una intensidad de $130 \mathrm{~V} / \mathrm{m}$ aproximadamente. Esta densidad disminuye con la altitud y presenta un valor de aproximadamente $100 \mathrm{~V} / \mathrm{m}$ a una altitud de $100 \mathrm{~m}, 45 \mathrm{~V} / \mathrm{m}$ a $1 \mathrm{~km}$ y menos de $1 \mathrm{~V} / \mathrm{m}$ a $20 \mathrm{~km}$. Los valores reales varían ampliamente dependiendo del perfil local de temperatura y humedad y de la presencia de contaminantes ionizados. D ebajo de las nubes de tormenta, por ejemplo, e incluso al aproximarse éstas, se producen grandes variaciones de campo a nivel del suelo, dado que, por lo general, la parte inferior de una nube está cargada negativamente, mientras que la parte superior contiene una carga positiva. Además, existe una carga en el espacio entre la nube y el suelo. Según se aproxima la nube, el campo a nivel del suelo puede aumentar primero de valor y después invertirse, volviéndose positiva la carga del suelo. Durante este proceso pueden observarse campos de $100 \mathrm{~V} / \mathrm{m}$ a $3 \mathrm{kV} / \mathrm{m}$ incluso en ausencia de relámpagos locales; las inversiones de campo pueden producirse con gran rapidez, en menos de 1 minuto, y mientras dura la tormenta pueden persistir altas intensidades de campo. Tanto las nubes ordinarias como las de tormenta contienen cargas eléctricas, y por lo tanto, afectan profundamente al campo eléctrico a nivel del suelo. Asimismo, en presencia de niebla, lluvia e iones grandes y pequeños de aparición natural, son previsibles grandes desviaciones, de hasta el $200 \%$, respecto del campo existente con buen tiempo. I gualmente pueden producirse cambios en el campo eléctrico durante el ciclo diario con un tiempo espléndido: es probable que las causas de estas variaciones diurnas sean cambios sensiblemente regulares en la ionización, temperatura o humedad locales, con las consiguientes variaciones de la conductividad eléctrica atmosférica cerca del suelo, así como la transferencia de cargas mecánicas producida por movimientos locales del aire.

Los niveles típicos de los campos electrostáticos artificiales en oficinas y viviendas particulares están comprendidos entre 1 y $20 \mathrm{kV} / \mathrm{m}$; normalmente estos campos se generan alrededor de equipos de alta tensión, como televisores y pantallas de visualización de datos (PVD), o por rozamiento. Las líneas de transmisión de corriente continua (CC) generan campos estáticos eléctricos y magnéticos y son un medio económico de distribución de energía cuando hay que salvar largas distancias.

Los campos electrostáticos son muy utilizados en industrias como las de productos químicos, textiles, aviación, papel y caucho, así como en el transporte.

\section{E fectos biológicos}

Los estudios experimentales aportan pocas pruebas biológicas de un posible efecto adverso de los campos electrostáticos para la salud humana. Tampoco los escasos estudios realizados con animales parecen haber aportado datos que confirmen efectos perjudiciales genéticos, de crecimiento de tumores o sobre los sistemas endocrino o cardiovascular (la Tabla 49.9 ofrece un resumen de estos estudios con animales).

$\mathrm{N}$ o se han realizado estudios in vitro para evaluar el efecto de la exposición de células a campos eléctricos estáticos.

L os cálculos teóricos señalan que un campo eléctrico estático induce una carga en la superficie de las personas expuestas, la cual puede percibirse si se descarga en un objeto conectado a tierra. Si la tensión es suficientemente alta, el aire se ioniza y es capaz de producir una corriente eléctrica entre por ejemplo un 
Tabla 49.9 - Estudios en animales expuestos a campos electrostáticos.

\begin{tabular}{|c|c|c|}
\hline Objetivos biológicos & Efectos notificados & Condiciones de exposición \\
\hline \multirow[t]{3}{*}{ Hematología e inmunología } & $\begin{array}{l}\text { Cambios en las fracciones de albúmina y globulina de las proteínas } \\
\text { séricas en ratas }\end{array}$ & $\begin{array}{l}\text { Exposición continua a campos de entre } 2,8 \text { y 19,7 kV/ m desde los } \\
22 \text { a los } 52 \text { días de edad }\end{array}$ \\
\hline & Respuestas inconsistentes & \\
\hline & $\begin{array}{l}\text { Ausencia de diferencias significativas en los recuentos de hematíes, } \\
\text { proteínas de la sangre o química sanguínea en ratones }\end{array}$ & Exposición a $340 \mathrm{kV} / \mathrm{m} 22 \mathrm{~h}$ al día durante un total de $5.000 \mathrm{~h}$ \\
\hline \multirow[t]{2}{*}{ Sistema nervioso } & $\begin{array}{l}\text { Inducción de cambios significativos observada en los EEG de ratas, } \\
\text { pero sin ninguna indicación clara de respuesta consistente }\end{array}$ & Exposición a campos eléctricos de hasta $10 \mathrm{kV} / \mathrm{m}$ de intensidad \\
\hline & $\begin{array}{l}\text { Ausencia de cambios significativos en las concentraciones y tasas de } \\
\text { utilización de diversos neurotransmisores en el cerebro de ratas } \\
\text { macho }\end{array}$ & Exposición a un campo de $3 \mathrm{kV} / \mathrm{m}$ durante hasta $66 \mathrm{~h}$ \\
\hline \multirow[t]{2}{*}{ Comportamiento } & $\begin{array}{l}\text { Recientes estudios bien realizados sugieren ausencia de efectos en el } \\
\text { comportamiento de roedores }\end{array}$ & Exposición a campos de hasta $12 \mathrm{kV} / \mathrm{m}$ de intensidad \\
\hline & $\begin{array}{l}\text { Comportamiento de evitación en ratas macho, sin influencia de iones } \\
\text { aéreos }\end{array}$ & $\begin{array}{l}\text { Exposición a campos eléctricos de dispositivos de alta tensión } \\
\text { comprendidos entre } 55 \text { y } 80 \mathrm{kV} / \mathrm{m}\end{array}$ \\
\hline Reproducción y desarrollo & $\begin{array}{l}\text { Ausencia de diferencias significativas en el número total de crías y en } \\
\text { el porcentaje de crías supervivientes en ratones }\end{array}$ & $\begin{array}{l}\text { Exposición a } 340 \mathrm{kV} / \mathrm{m} 22 \mathrm{~h} \text { al día antes, durante y después de la } \\
\text { gestación }\end{array}$ \\
\hline
\end{tabular}

objeto cargado y una persona conectada a tierra. La descarga disruptiva depende de varios factores, tales como la forma del objeto cargado y las condiciones atmosféricas. Los valores típicos de las intensidades de campo eléctrico correspondientes varían entre 500 y $1.200 \mathrm{kV} / \mathrm{m}$.

Informes procedentes de algunos países indican que varios operadores de PVD han experimentado trastornos de la piel, pero no está clara la relación exacta entre estos trastornos y su trabajo. Se han señalado los campos eléctricos estáticos en los lugares de trabajo con PVD como posible causa de estos trastornos de la piel y acaso la carga electrostática del operador sea un factor relevante. No obstante, de acuerdo con las pruebas aportadas hasta ahora por la investigación, cualquier relación entre los campos eléctricos estáticos y los trastornos de la piel deberá seguir considerándose como hipotética.

\section{Normas sobre mediciones, prevención y exposición}

Las medidas de intensidad de los campos eléctricos estáticos pueden reducirse a medidas de voltajes 0 de cargas eléctricas. Existen en el comercio varios voltímetros electrostáticos que permiten medir con precisión fuentes electrostáticas u otras fuentes de alta impedancia sin necesidad de contacto físico. Algunos utilizan un troceador electrostático con baja deriva y realimentación negativa para conseguir precisión y baja sensibilidad en la separación entre sonda y superficie. En algunos casos, el electrodo electrostático "observa" la superficie que se mide a través de un pequeño orificio existente en la base de la sonda. La señal de corriente alterna troceada inducida en este electrodo es proporcional al voltaje diferencial entre la superficie que se mide y la sonda. También se utilizan como accesorios de los voltímetros electrostáticos adaptadores de gradiente que permiten usarlos como medidores de intensidad de campo electrostático; es posible la lectura directa en voltios por metro de la separación entre la superficie medida y la placa puesta a tierra del adaptador.

No existen datos fidedignos que puedan servir como guías para establecer límites básicos de exposición humana a campos eléctricos estáticos. En principio, podría determinarse un límite de exposición a partir de la descarga disruptiva mínima en el aire, pero la intensidad de campo que experimenta una persona situada dentro de un campo eléctrico estático varía según la orientación y la forma del cuerpo y esto debe tenerse en cuenta al intentar establecer un límite adecuado.

La Conferencia Americana de Higienistas Industriales del Gobierno (ACGIH 1995) ha recomendado valores límite umbral (T LV). Estos T LV se refieren a la máxima intensidad de campo eléctrico estático sin protección en el lugar de trabajo, y representa las condiciones a las que casi todos los trabajadores pueden estar expuestos repetidamente sin sufrir efectos adversos para la salud. Según la ACGIH, los niveles de exposición profesional no deberían exceder de una intensidad de campo electrostático de $25 \mathrm{kV} / \mathrm{m}$. Este valor debe utilizarse únicamente con carácter orientativo en el control de la exposición y debido a la susceptibilidad individual no debe considerarse como una línea divisoria clara entre los niveles seguros y peligrosos (este límite corresponde a la intensidad de campo presente en el aire, lejos de las superficies de conductores, donde las descargas con chispas y las corrientes de contacto pueden suponer riesgos significativos, y es aplicable tanto a exposiciones parciales del cuerpo como a exposiciones de cuerpo completo). Se deberán eliminar los objetos no conectados a tierra, o ponerlos a tierra, utilizando guantes aislantes para manipular los objetos no conectados a tierra. La prudencia aconseja utilizar dispositivos protectores (por ejemplo, trajes, guantes y aislamiento) en todos los campos que excedan de $15 \mathrm{kV} / \mathrm{m}$.

Según la ACGIH, la información actualmente disponible sobre respuestas humanas y posibles efectos de los campos eléctricos estáticos para la salud es insuficiente para establecer un TLV fiable para exposiciones promedio ponderadas en el tiempo. Cuando no se disponga de información específica del fabricante sobre interferencia electromagnética, se recomienda mantener los niveles de exposición de los portadores de marcapasos y otros dispositivos electrónicos médicos en un valor no superior a $1 \mathrm{kV} / \mathrm{m}$.

En Alemania, según una norma DIN, los niveles de exposición profesional no deben sobrepasar una intensidad de campo eléctrico estático de $40 \mathrm{kV} / \mathrm{m}$. Para exposiciones de corta duración (hasta 2 horas diarias) se permite un límite más alto, de $60 \mathrm{kV} / \mathrm{m}$.

En 1993, la National Radiological Protection Board (NRPB 1993) editó una recomendación sobre las restricciones 
adecuadas de la exposición de personas a campos electromagnéticos y radiación. Se incluyen aquí los campos estáticos tanto eléctricos como magnéticos. En el documento de la NRPB se proporcionan niveles de investigación con objeto de permitir la comparación de los valores de las magnitudes de campo medidas a fin de determinar si se cumplen o no las restricciones básicas. Si el campo al que está expuesto una persona excede del nivel de investigación correspondiente, deberá comprobarse el cumplimiento de las restricciones básicas. Entre los factores que podrían tenerse en cuenta en tal evaluación se incluyen por ejemplo la eficacia del acoplamiento de la persona al campo, la distribución espacial del campo en el volumen ocupado por la persona y la duración de la exposición.

Según la NRPB, no es posible recomendar restricciones básicas para evitar efectos directos de la exposición humana a campos eléctricos estáticos; se ofrecen orientaciones para evitar efectos molestos de la percepción directa de la carga eléctrica superficial y efectos indirectos tales como el shock eléctrico. Para la mayoría de las personas, la percepción molesta de carga eléctrica superficial actuando directamente sobre el cuerpo no se produce durante la exposición a intensidades de campo eléctrico estático inferiores a $25 \mathrm{kV} / \mathrm{m}$ aproximadamente, es decir, la misma intensidad de campo recomendada por la ACGIH. Para evitar que las descargas con chispa (efectos indirectos) causen molestias, la NRPB recomienda restringir las corrientes de contacto continuas a menos de $2 \mathrm{~mA}$. El shock eléctrico provocado por fuentes de baja impedancia puede evitarse siguiendo los procedimientos de seguridad eléctrica establecidos para tales equipos.

\section{Campos magnéticos estáticos}

\section{Exposición natural y profesional}

El cuerpo es relativamente transparente a los campos magnéticos estáticos; tales campos interactúan directamente con los materiales magnéticamente anisótropos (cuyas propiedades presentan valores distintos cuando se miden a lo largo de ejes en direcciones diferentes) y con las cargas en movimiento.

El campo magnético natural es la suma de un campo interno debido a la acción de la tierra como un imán permanente y un campo externo generado en el medioambiente por factores tales como la actividad solar o los de tipo atmosférico. El campo magnético interno de la tierra tiene su origen en la corriente eléctrica que circula por la capa superior del núcleo terrestre. Existen diferencias locales significativas en la intensidad de este campo, cuya magnitud media varía desde aproximadamente $28 \mathrm{~A} / \mathrm{m}$ en el ecuador (lo que corresponde a una densidad de flujo magnético de alrededor de $35 \mathrm{mT}$ en un material no magnético tal como el aire) hasta aproximadamente $56 \mathrm{~A} / \mathrm{m}$ sobre los polos geomagnéticos (valor correspondiente a unos $70 \mathrm{mT}$ en el aire).

Los campos artificiales superan en intensidad a los de origen natural en muchos órdenes de magnitud. Entre las fuentes

Tabla 49.10 • Principales tecnologías en las que se utilizan grandes campos magnéticos estáticos y niveles de exposición correspondientes.

Procedimientos

Tecnologías energéticas

Reactores de fusión termonuclear

Sistemas magnetohidrodinámicos

Sistemas de almacenamiento de energía con imanes superconductores

Generadores y líneas de transmisión superconductores

Instalaciones de investigación

Cámaras de burbujas

Espectrómetros superconductores

Aceleradores de partículas

Unidades de separación de isótopos

\section{Industria}

Producción de aluminio

Procesos electrolíticos

Fabricación de imanes
Niveles de exposición

Campos dispersos de hasta $50 \mathrm{mT}$ en zonas accesibles al personal.

Menos de 0,1 mT fuera del recinto del reactor

Aproximadamente $10 \mathrm{mT}$ a unos $50 \mathrm{~m}$;

$100 \mathrm{mT}$ únicamente a distancias superiores a $250 \mathrm{~m}$

Campos dispersos de hasta $50 \mathrm{mT}$ en lugares accesibles a los operarios

Campos dispersos con una intensidad inferior a 100 mT según proyecto

Durante los cambios de cassettes de película, el campo es de aproximadamente 0,4 - 0,5 T al nivel de los pies y de alrededor de $50 \mathrm{mT}$ a la altura de la cabeza

Aproximadamente $1 \mathrm{~T}$ en lugares accesibles a los operarios

El personal rara vez queda expuesto debido a su exclusión de la zona de alta radiación. Sólo se producen excepciones durante el mantenimiento

Breves exposiciones a campos de hasta $50 \mathrm{mT}$

Normalmente los niveles de los campos son inferiores a $1 \mathrm{mT}$

Niveles de hasta $100 \mathrm{mT}$ en lugares accesibles a los operarios

Niveles de campo medios y máximos de alrededor de 10 y $50 \mathrm{mT}$ respectivamente

De 2 a 5 mT en las manos de los trabajadores; en el intervalo de 300 a 500 mT al nivel del tórax y la cabeza

\section{Medicina}

Resonancia magnética nuclear de imagen y espectroscopia de RMN

Un imán de $1 \mathrm{~T}$ sin blindaje produce aproximadamente $0,5 \mathrm{mT}$ a $10 \mathrm{~m}$ y un imán de $2 \mathrm{~T}$ asimismo sin blindaje produce el mismo nivel de exposición a 13 m aproximadamente 
artificiales de campos magnéticos estáticos se encuentran todos los dispositivos que contienen hilos conductores de corriente continua, entre ellos numerosos aparatos y equipos industriales.

En las líneas de transmisión de energía de corriente continua, los campos magnéticos estáticos se producen por cargas en movimiento (una corriente eléctrica) en una línea bifásica. En las líneas de tendido aéreo, la densidad de flujo magnético a nivel del suelo es de aproximadamente $20 \mathrm{mT}$ para una línea de \pm 500 kV. En una línea de transmisión subterránea, enterrada a $1,4 \mathrm{~m}$ y que transporta una corriente máxima de alrededor de $1 \mathrm{kA}$, la densidad de flujo magnético máxima es inferior a $10 \mathrm{mT}$ a nivel del suelo.

La Tabla 49.10 ofrece una relación de las principales tecnologías en las que se utilizan campos magnéticos estáticos de alta intensidad, y de los niveles de exposición correspondientes.

\section{E fectos biológicos}

Las pruebas aportadas por experimentos de laboratorio con animales indican ausencia de efectos significativos en los numerosos factores de desarrollo, de comportamiento y fisiológicos evaluados a densidades de flujo magnético estático de hasta $2 \mathrm{~T}$. Tampoco los estudios en ratones han mostrado ningún daño del feto por exposición a campos magnéticos de hasta $1 \mathrm{~T}$.

Teóricamente, los efectos magnéticos podrían reducir la velocidad de la sangre que circula en un campo magnético intenso y producir un aumento de la presión arterial. Podría esperarse una reducción de flujo de unos cuantos puntos porcentuales como máximo a $5 \mathrm{~T}$, pero no se observó ninguno en sujetos humanos sometidos a 1,5 T cuando se investigaron.

Los resultados de algunos estudios con trabajadores que intervienen en la fabricación de imanes permanentes indican diversos síntomas subjetivos y alteraciones funcionales: irritabilidad, fatiga, dolor de cabeza, pérdida del apetito, bradicardia (frecuencia cardíaca lenta), taquicardia (frecuencia cardíaca rápida), disminución de la presión arterial, alteración del EEG, picores, quemazón y entumecimiento. No obstante, la ausencia de cualquier análisis estadístico o evaluación del impacto de riesgos físicos o químicos en el entorno de trabajo reduce de modo significativo la validez de estos informes y dificulta su valoración. Aunque los estudios no son concluyentes sugieren que si en realidad se producen efectos a largo plazo, éstos son muy ligeros; no se han notificado efectos acumulativos intensos. Se ha informado de que individuos expuestos a una densidad de flujo magnético de $4 \mathrm{~T}$ han experimentado efectos sensoriales asociados con el movimiento dentro del campo tales como vértigo, náuseas, sabor metálico y sensaciones magnéticas al mover los ojos o la cabeza. No obstante, dos estudios epidemiológicos de datos sobre la salud general de trabajadores crónicamente expuestos a campos magnéticos estáticos no revelaron ningún efecto significativo para la salud. Se obtuvieron datos sobre la salud de 320 trabajadores en plantas que utilizan grandes pilas electrolíticas para procesos de separación química, en las que el nivel de campo estático medio en el entorno de trabajo era de 7,6 mT y el campo máximo de 14,6 mT. En el grupo expuesto se detectaron ligeros cambios en el recuento leucocitario, aunque dentro del intervalo normal, en comparación con el grupo de control de 186 trabajadores. Ninguno de los cambios transitorios observados en la presión arterial y otras medidas sanguíneas se consideró indicativo de un efecto adverso significativo asociado con exposición a campos magnéticos. En otro estudio se evaluó la prevalencia de enfermedad en 792 trabajadores expuestos profesionalmente a campos magnéticos estáticos. El grupo de control estaba formado por 792 trabajadores no expuestos, de edad, raza y situación socioeconómica equivalentes. El intervalo de intensidades de exposición a campos magnéticos varió entre 0,5 mT para exposiciones de larga duración y 2 T para períodos de varias horas. No se observó ninguna variación estadísticamente significativa en la incidencia de 19 clases de enfermedad en el grupo expuesto en comparación con el de control. Tampoco se observó ninguna diferencia en cuanto a prevalencia de enfermedad entre un subgrupo de 198 trabajadores que habían experimentado exposiciones de 0,3 T o superiores durante períodos de una hora o más en comparación con el resto de la población expuesta 0 del grupo de control correspondiente.

Un estudio con trabajadores de la industria del aluminio reveló una elevada tasa de mortalidad por leucemia. Aunque este estudio epidemiológico indicaba un mayor riesgo de cáncer para las personas que intervienen directamente en la producción de aluminio, en la que los trabajadores están expuestos a grandes campos magnéticos estáticos, actualmente no existe ninguna prueba clara que indique con exactitud cuáles son los factores carcinogénicos causantes en el entorno de trabajo. En el proceso utilizado para la reducción del aluminio se crean alquitrán de hulla, componentes volátiles de la brea, emanaciones de fluoruros, óxidos de azufre y dióxido de carbono, y algunas de estas sustancias son candidatos más probables como causantes de cáncer que la exposición a campos magnéticos.

En un estudio con trabajadores franceses del aluminio se descubrió que la mortalidad por cáncer y otras causas no difería significativamente de la observada en la población masculina general de Francia (M ur y cols. 1987).

O tro hallazgo negativo en cuanto a la posible relación de las exposiciones a campos magnéticos con la aparición de cáncer procede de un estudio realizado en un grupo de trabajadores de una planta de cloroálcalis en la que las corrientes continuas de 100 kA utilizadas para la producción electrolítica de cloro producían, en los lugares ocupados por los trabajadores, densidades de flujo magnético estático comprendidas entre 4 y $29 \mathrm{mT}$. No se apreciaron diferencias significativas entre la incidencia de cáncer observada y esperada en estos trabajadores, en un período de 25 años.

\section{M ediciones, prevención y normas sobre exposición}

Durante los últimos treinta años, la medición de campos magnéticos ha experimentado un considerable desarrollo. EI progreso de las técnicas ha permitido desarrollar nuevos métodos de medida y mejorar los antiguos.

Los dos tipos más conocidos de sondas de campos magnéticos son una bobina blindada y una sonda de efecto $\mathrm{H}$ all. La mayoría de los medidores de campos magnéticos disponibles en el comercio utilizan uno u otro de ellos. Recientemente se han propuesto como sensores de campos magnéticos otros dispositivos de semiconductores, concretamente transistores bipolares y transistores de efecto de campo (FET), que ofrecen algunas ventajas sobre las sondas de efecto $\mathrm{H}$ all, tales como una mayor sensibilidad, una mayor resolución espacial y una respuesta en frecuencia más amplia.

El principio de la técnica de medida denominada resonancia magnética nuclear (R M N) consiste en determinar la frecuencia resonante de la muestra analizada, dentro del campo magnético a medir. Se trata de una medida absoluta que puede realizarse con gran precisión. El campo de medida de este método abarca desde aproximadamente $10 \mathrm{mT}$ hasta $10 \mathrm{~T}$, sin límites definidos. En mediciones de campo utilizando el método de resonancia magnética de protón se obtiene fácilmente una precisión de $10^{-4}$ con aparatos sencillos y puede alcanzarse una precisión de $10^{-6}$ adoptando amplias precauciones y utilizando mejores equipos. EI defecto inherente al método de la R M N es su limitación a un 
campo de bajo gradiente y la falta de información acerca de la dirección del campo.

Recientemente se han desarrollado también varios dosímetros personales adecuados para vigilar exposiciones a campos magnéticos estáticos.

Las medidas de protección para el uso industrial y científico de campos magnéticos pueden clasificarse en las siguientes categorías: medidas de diseño técnico, uso de la distancia de separación y controles administrativos. O tra categoría general de medidas de control del riesgo, que incluye el equipo de protección individual (por ejemplo, prendas y máscaras especiales), no existe para los campos magnéticos. N o obstante, un área especial de preocupación son las medidas protectoras contra riesgos potenciales por interferencia magnética con equipos electrónicos de emergencia o médicos y para implantes quirúrgicos y dentales. Las fuerzas mecánicas aplicadas a los implantes ferromagnéticos y objetos sin amarrar en instalaciones con campos de alta intensidad requieren tomar precauciones frente a los riesgos para la salud y la seguridad.

Las técnicas destinadas a minimizar la exposición indebida a campos magnéticos de alta intensidad en grandes instalaciones industriales y de investigación suelen pertenecer a uno de estos cuatro tipos:
1. distancia y tiempo
2. blindaje magnético
3. interferencia (EMI) y compatibilidad electromagnéticas
4. medidas administrativas.

El uso de señales de advertencia y zonas de acceso especial para limitar la exposición del personal cerca de instalaciones de grandes imanes ha sido de máxima utilidad para controlar la exposición. Este tipo de controles administrativos suelen ser preferibles al blindaje magnético, que puede resultar extremadamente caro. Los objetos ferromagnéticos y paramagnéticos (cualquier sustancia magnetizante) sueltos pueden convertirse en proyectiles peligrosos cuando están sujetos a gradientes de campo magnético intensos. Este riesgo solo puede evitarse retirando los objetos metálicos sueltos de la zona y los que lleve el personal. Deberá prohibirse la presencia de objetos tales como tijeras, limas de uñas, destornilladores y bisturíes en las proximidades.

Las primeras directrices sobre campos magnéticos estáticos se desarrollaron como recomendación no oficial en la antigua Unión Soviética. Esta norma estaba basada en investigaciones clínicas y sugería que la intensidad del campo magnético estático en el lugar de trabajo no debería sobrepasar los $8 \mathrm{kA} / \mathrm{m}$ (10 mT).

La Conferencia Americana de $\mathrm{H}$ igienistas Industriales del Gobierno publicó valores T LV de densidades de flujo magnético estático a los que la mayoría de los trabajadores podían estar expuestos repetidamente, día tras día, sin efectos nocivos para la salud. Al igual que en los campos eléctricos, estos valores deben utilizarse como orientación para el control de la exposición a campos magnéticos estáticos, pero no deben considerarse como una clara línea divisoria entre los niveles seguros y peligrosos. Según la ACGIH, las exposiciones laborales de rutina no debieran exceder de $60 \mathrm{mT}$, promediadas sobre la totalidad del cuerpo o de $600 \mathrm{mT}$ en las extremidades, sobre una base diaria, ponderada en el tiempo. Como valor techo se recomienda una densidad de flujo de $2 \mathrm{~T}$. Pueden existir riesgos para la salud debido a las fuerzas mecánicas ejercidas por el campo magnético sobre las herramientas e implantes médicos ferromagnéticos.

En 1994, la Comisión Internacional de Protección contra la Radiación no Ionizante (ICNIRP 1994) concluyó y publicó guías sobre los límites de exposición a campos magnéticos
Tabla 49.11 • Límites de exposición a campos magnéticos estáticos recomendados por la Comisión Internacional de Protección contra la Radiación no lonizante (ICN IRP).
Características de la exposición

\section{Laboral}

Toda la jornada (media ponderada en el tiempo)

Valor techo

Extremidades

Público en general

Exposición continua
Densidad de flujo magnético

$200 \mathrm{mT}$

$2 \mathrm{~T}$

$5 \mathrm{~T}$

$40 \mathrm{mT}$ estáticos. En estas guías se hace una distinción entre el límite de exposición para los trabajadores y para el público en general. Los límites recomendados por la ICNIRP para exposiciones profesionales y de público en general a campos magnéticos estáticos se resumen en la Tabla 49.11. Cuando las densidades de flujo magnético exceden de $3 \mathrm{mT}$ deben tomarse precauciones para prevenir riesgos por objetos metálicos volantes. Los relojes analógicos, tarjetas de crédito, cintas magnéticas y discos de ordenador pueden resultar afectados negativamente por la exposición a $1 \mathrm{mT}$, pero esto no se considera preocupante en relación con la seguridad de las personas.

Se podrá utilizar el acceso esporádico del público a instalaciones especiales en las que las densidades de flujo magnético excedan de $40 \mathrm{mT}$ en condiciones debidamente controladas, siempre que no se rebase el límite de exposición profesional correspondiente.

Los límites de exposición de la ICNIRP se han establecido para un campo homogéneo. Para campos no homogéneos (variaciones dentro del campo) la densidad de flujo magnético media deberá medirse sobre una superficie de $100 \mathrm{~cm}^{2}$.

Según un reciente documento de la N R PB, la restricción de la exposición aguda a menos de $2 \mathrm{~T}$ evitará respuestas agudas tales como mareos o náuseas y efectos nocivos para la salud como consecuencia de arritmia cardíaca (frecuencia cardíaca irregular) 0 alteración de la función mental. A pesar de la relativa falta de pruebas como resultado de los estudios de poblaciones expuestas en relación con posibles efectos a largo plazo de los campos de alta intensidad, la NRPB considera aconsejable restringir la exposición a largo plazo ponderada en el tiempo sobre 24 horas a menos de $200 \mathrm{mT}$ (una décima parte de la prevista para prevenir respuestas agudas). Estos niveles son muy similares a los recomendados por la ICNIRP; los TLV de la ACGIH son ligeramente inferiores.

Las personas con marcapasos cardíacos y otros dispositivos de activación eléctrica implantados, o con implantes ferromagnéticos, pueden no estar debidamente protegidos por los límites aquí indicados. La mayoría de los marcapasos cardíacos es improbable que resulten afectados por la exposición a campos de intensidad inferior a 0,5 $\mathrm{mT}$. Las personas portadoras de algunos implantes ferromagnéticos 0 de dispositivos de activación eléctrica (distintos de los marcapasos cardíacos) pueden ser afectadas por campos de nivel superior a algunos mT.

Existen otros conjuntos de guías que recomiendan límites de exposición laboral: tres de ellos están implantados en laboratorios de física de alta energía (Centro del Acelerador Lineal de Stanford y Laboratorio Nacional Lawrence Livermore en 
California, Laboratorio del A celerador del CERN en Ginebra), y una guía provisional del Departamento de Energía (DOE) de Estados U nidos.

En A lemania, según una norma DIN, las exposiciones profesionales no deben exceder de una intensidad de campo magnético estático de $60 \mathrm{kA} / \mathrm{m}$ (75 mT aproximadamente). C uando sólo están expuestas las extremidades, este límite se fija en $600 \mathrm{kA} / \mathrm{m}$, para exposiciones del cuerpo completo de corta duración están permitidos límites de intensidad de campo de hasta $150 \mathrm{kA} / \mathrm{m}$ (hasta 5 minutos por hora).

\section{Referencias}

Allen, SG. 1991. R adiofrequency field measurements and hazard assessment. J R adiol Protect 11:49-62.

American Conference of Governmental Industrial $\mathrm{H}$ ygienists (ACGIH). 1992. Documentation for the T hreshold Limit V alues. Cincinnati, O hio: ACGIH .

- . 1993. Threshold Limit Values for Chemical Substances and Physical Agents and B iological Exposure Indices. Cincinnati, O hio: ACGIH.

-. 1994a. Annual Report of ACGIH Physical Agents Threshold Limit Values Committee. Cincinnati, O hio: ACGIH.

- . 1994b. TLV's, Threshold Limit Values and Biological Exposure Indices for 1994-1995. Cincinnati, O hio: ACGIH.

- . 1995. 1995-1996 Threshhold Limit Values for Chemical Substances and Physical Agents and Biological Exposure Indices. Cincinnati, O hio: ACGIH.

- . 1996. $\mathrm{TLVS}^{\circledR}$ and BEIS ${ }^{\circledR}$. Threshold Limit Values for Chemical Substances and Physical Agents; Biological Exposure Indices. Cincinnati, O hio: ACGIH.

A merican National Standards Institute (ANSI). 1993. Safe U se of L asers. Standard N 0. Z-136.1. N ueva Y ork: ANSI.

Aniolczyk, R. 1981. Measurements of hygienic evaluation of electromagnetic fields in the environment of diathermy, welders, and induction heaters. M edycina Pracy 32:119-128.

A sociación Internacional para la Protección contra las Radiaciones (IR PA). 1985. Guidelines for limits of human exposure to laser radiation. H ealth Phys 48(2):341-359

- . 1988a. Change: R ecommendations for minor updates to the IR PA 1985 guidelines on limits of exposure to laser radiation. $\mathrm{H}$ ealth Phys 54(5):573-573

-. 1988b. Guidelines on limits of exposure to radiofrequency electromagnetic fields in the fre quency range from $100 \mathrm{kHz}$ to $300 \mathrm{GHz}$. H ealth Phys 54:115-123.

-. 1989. Proposed change to the IR PA 1985 guidelines limits of exposure to ultraviolet radiation. H ealth P hys 56(6):971-972.

A sociación Internacional para la Protección contra las Radiaciones (IRPA) y Comité Internacional de Radiaciones No I onizantes. 1990. Interim guidelines on limits of exposure to $50 / 60 \mathrm{~Hz}$ electric and magnetic fields. H ealth Phys 58(1):113-122.

Bassett, CAL, RJ Pawluk, AA Pilla. 1974. Augmentation of bone repair by inductively coupled electromagnetic fields. Science 184:575-577.

Bassett, CAL, SN M itchell, SR G aston. 1982. Pulsing electromagnetic field treatment in ununited fractures and failed artrodeses. I Am M ed Assoc 247:623-628.

Berger, D, F U rbach, RE Davies. 1968. The action spectrum of erythema induced by ultraviolet radiation. En Preliminary R eport XIII. Congressus Internationalis Dermatologiae, $M$ unchen, dirigido por $W$ Jadassohn y CG Schirren. Nueva Y ork: SpringerVerlag.

Bernhardt, JH, R M atthes. 1992. ELF and RF electromagnetic sources. En N on- I onizing Radiation Protection, dirigido por M W Greene. V ancouver: UBC Press.

Bernhardt, JH. 1988a. The establishment of frequency dependent limits for electric and magnetic fields and evaluation of indirect effects. Rad E nvir Biophys 27:1.

Bini, M , A Checcucci, A I gnesti, L M illanta, R O Imi, N R ubino, R V anni. 1986. Exposure of workers to intense RF electric fields that leak from plastic sealers. J M icrowave Power 21:33-40.

Buhr, E, E Sutter y Consejo Holandés de Salud. 1989. Dynamic filters for protective devices. En D osimetry of Laser Radiation in M edicine and Biology, dirigido por GJ M ueller y DH Sliney. Bellingham, Wash: SPIE.

Bureau of R adiological Health. 1981. An E valuation of Radiation Emission from Video Display Terminals. Rockville, M aryland: Bureau of Radiological $\mathrm{H}$ ealth.

Cleuet, A, A M ayer. 1980. R isques liés à l'utilisation industrielle des lasers. En Institut National de Recherche et de Sécurité, Cahiers de N otes D ocumentaires, N 0. 99 París: Institut National de Recherche et de Sécurité.

Coblentz, WR, R Stair, JM Hogue. 1931. The spectral erythemic relation of the skin to ultraviolet radiation. En Proceedings of the National Academy of Sciences of the U nited States of America Washington, $D C:$ N ational A cademy of Sciences.

Cole, CA, DF Forbes, PD Davies. 1986. An action spectrum for UV photocarcinogenesis. Photochem Photobiol 43(3):275-284

Comisión Electrotécnica Internacional (CEI). 1993. IEC Standard N 0. 825-1. Ginebra: CEI.

Comisión Internacional de Iluminación (CIE). 1987. International Lighting Vocabulary. V iena: CIE.

Comisión Internacional de Protección contra las Radiaciones No Ionizantes (ICNIR P). 1994. Guidelines on Limits of Exposure to Static Magnetic Fields. H ealth Phys 66:100-106.

—. 1995. Guidelines for $H$ uman Exposure Limits for Laser Radiation.

Cullen, AP, BR Chou, MG Hall, SE Jany. 1984. U Itraviolet-B damages corneal endothelium. Am J 0 ptom Phys 0 pt 61(7):473-478.

Declaración de la ICNIRP. 1996. Health issues related to the use of hand-held radiotelephones and base transmitters. H ealth Physics, 70:587-593.

Duchene, A, J Lakey, M Repacholi. 1991. IRPA Guidelines On Protection Against N on-I onizing Radiation. N ueva Y ork: Pergamon.

Elder, JA, PA Czerki, K Stuchly, K Hansson Mild, AR Sheppard. 1989. R adiofrequency radiation. En Nonionizing Radiation Protection, dirigido por MJ Suess y D A Benwell-M orison. G inebra: O M S.

Eriksen, P. 1985. Time resolved optical spectra from MIG welding arc ignition. Am Ind $\mathrm{H}$ yg Assoc J 46:101-104.

Everett, M A, RL O Isen, R M Sayer. 1965. U Itraviolet erythema. Arch D ermatol 92:713-719.

Fitzpatrick, TB, M A Pathak, LC Harber, M Seiji, A K ukita. 1974. Sunlight and $M$ an, $N$ ormal and A bnormal Photobiologic Responses. T okio: U niv. of T okyo Press.

Forbes, PD, PD Davies. 1982. Factors that influence photocarcinogenesis. Capítulo 7 de Photoimmunology, dirigido por JAM Parrish, L K ripke y WL M orison. Nueva Y ork: Plenum.

Freeman, RS, DW O wens, JM K nox, HT Hudson. 1966. R elative energy requirements for an erythemal response of skin to monochromatic wave- lengths of ultraviolet present in the solar spectrum. J Invest D ermatol 47:586-592.

Grandolfo, M, K H ansson Mild. 1989. Worldwide public and occupational radiofrequency and microwave protection. En E lectromagnetic B iointeraction. $M$ echanisms, Safety Standards, Protection Guides, dirigido por G Franceschetti, OP Gandhi y M Grandolfo. Nueva Y ork: Plenum.

Greene, MW. 1992. Non Ionizing Radiation. II Seminario internacional sobre radiaciones no ionizantes, 10-14 de mayo, V ancouver.

Ham, WT, HA M ueller, JJ Ruffolo, D Guerry III, RK Guerry. 1982. Action spectrum for retinal injury from near ultraviolet radiation in the aphakic monkey. Am J O phthalmol 93(3):299-306.

$\mathrm{H}$ am, WTJ. 1989. The photopathology and nature of the blue-light and near-UV retinal lesion produced by lasers and other optic sources. En Laser Applications in M edicine and Biology, dirigido por M L Wolbarsht. N ueva Y ork: Plenum.

$\mathrm{H}$ ansson Mild, K. 1980. O ccupational exposure to radio-frequency electromagnetic fields. Proc IEEE 68:12-17.

$\mathrm{H}$ ausser, K W. 1928. Influence of wavelength in radiation biology. Strahlentherapie 28:25-44.

Institute of Electrical and Electronic Engineers (IEEE). 1990a. IEEE COM AR Position of RF and M icrowaves. Nueva Y ork: IEEE.

-. 1990b. IEEE COMAR Position Statement On H ealth Aspects of $E$ xposure to $E$ lectric and $M$ agnetic $F$ ields from RF Sealers and D ielectric $H$ eaters. N ueva Y ork: IEEE.

-. 1991. IEEE Standard for Safety Levels W ith Respect to $H$ uman $E$ xposure to R adiofrequency E lectromagnetic $F$ ields $3 \mathrm{KH}$ z to $300 \mathrm{GH}$ z. Nueva Y ork: IEEE.

K olmodin-Hedman, $B, K$ H ansson M ild, E Jönsson, M C Anderson, A Eriksson. 1988. Health problems among operations of plastic welding machines and exposure to radiofrequency electromagnetic fields. Int A rch 0 ccup E nviron $\mathrm{H}$ ealth 60:243-247.

K rause, N. 1986. Exposure of people to static and time variable magnetic fields in technology, medicine, research and public life: Dosimetric aspects. En B iological Effects of Static and ELF-M agnetic Fiedds, dirigido por JH Bernhardt. M unchen: M M V M edizin V erlag.

Lövsund, P, K H M ild. 1978. Low F requency E lectromagnetic Field $\mathrm{N}$ ear Some Induction $\mathrm{H}$ eaters. Estocolmo: Consejo de Salud y Seguridad en el Trabajo de Estocolmo.

Lövsund, P, PA O berg, SEG Nilsson. 1982. ELF magnetic fields in electrosteel and welding industries. Radio Sci 17(5S):355-385.

Luckiesh, M L, L H olladay, AH T aylor. 1930. Reaction of untanned human skin to ultraviolet radiation. J O ptic Soc Am 20:423-432.

M CK inlay, A, JB Andersen, JH Bernhardt, M Grandolfo, $\mathrm{K}$-A H ossmann, FE van Leeuwen, $\mathrm{K}$ Hansson M ild, AJ Swerdlow, L V erschaeve, B V eyret. Proposal for a research programme by a European Commission Expert Group. Possible health effects related to the use of radiotelephones. Informe no publicado.

M CK inlay, AF, B Diffey. 1987. A reference action spectrum for ultraviolet induced erythema in human skin. En $H$ uman Exposure to U Itraviolet Radiation: Risks and Regulations, dirigido por WF Passchier y BFM Bosnjakovic. Nueva Y ork: Excerpta M edica Division, Elsevier Science Publishers. 
M itbriet, IM , VD M anyachin. 1984. Influence of magnetic fields on the repair of bone. Moscú, N auka, 292-296.

$N$ ational $C$ ouncil on $R$ adiation Protection and $M$ eas urements (NCR P). 1981. Radiofrequency E lectromagnetic Fields. Properties, Q uantities and U nits, Biophysical Interaction, and $M$ easurements. Bethesda, M aryland: NCRP.

- 1986. Biological Effects and Exposure Criteria for Radiofrequency E lectromagnetic Fields. R eport N o. 86. Bethesda, M aryland: NCR P.

National Radiological Protection Board (NRPB). 1992. E lectromagnetic $F$ ields and the $R$ isk of $C$ ancer. $V$ ol. 3(1). Chilton, R eino U nido: NR PB

-. 1993. Restrictions On H uman Exposure to Static and $T$ ime Varying Electromagnetic Fields and Radiations. Didcot, R eino U nido: NR PB.

National Research Council (NRC). 1996. Possible health effects of exposure to residential electric and magnetic fields. W ashington: NAS Press. 314

O ficina Internacional del Trabajo (OIT ). 1993a. Protection from Power F requency $E$ lectric and $M$ agnetic $F$ ields. $\mathrm{O}$ ccupational Safety and Health Series, No. 69. Ginebra: OIT

O Isen, EG, A R ingvold. 1982. H uman corneal endothelium and ultraviolet radiation. Acta 0 phthalmol 60:54-56

O rganización M undial de la Salud (O M S), Programa de las Naciones Unidas para el M edio Ambiente (PNUM A) y A sociación Internacional para la Protección contra las R adiaciones (IRPA). 1984. EXtremely Low F requency (ELF). Environmental $\mathrm{H}$ ealth Criteria, N o. 35. Ginebra: O M S.

O rganización M undial de la Salud (O M S). 1981. Radiofrequency and microwaves Environmental $\mathrm{H}$ ealth Criteria, N 0.16. G inebra: O M S.

-. 1982. Lasers and Optical Radiation. Environmental $\mathrm{H}$ ealth C riteria, N o. 23. Ginebra: O M S.

-. 1989. Non-Ionization Radiation Protection. Copenhague: $O$ ficina R egional de la O M S para Europa.

- 1994. U Itraviolet Radiation. Environmental Health Criteria, N o. 160. G inebra: O M S.

- . 1987. M agnetic Fields. Environmental $\mathrm{H}$ ealth Criteria, N 0.69. Ginebra: O M S.

- . 1993. E lectromagnetic Fields $300 \mathrm{~Hz}$ to $300 \mathrm{GH}$ z. Environmental $\mathrm{H}$ ealth Criteria, No. 137. Ginebra: OMS

Parrish, JA, K F Jaenicke, RR Anderson. 1982. Erythema and melanogenesis: Action spectra of normal human skin. Photochem Photobiol 36(2):187-191.

Passchier, WF, BFM Bosnjakovic. 1987. H uman Exposure to $U$ ltraviolet Radiation: Risks and Regulations. Nueva York: Excerpta M edica Division, Elsevier Science Publishers

Pitts, DG, AP Cullen, PD H acker. 1977a. O cular effects of ultraviolet radiation from 295 to $365 \mathrm{~nm}$. Invest O phthalmol V is Sci 16(10):932-939.

-. 1977b. U Itraviolet E ffects from 295 to $400 \mathrm{~nm}$ in the Rabbit Eye Cincinnati, $\mathrm{O}$ hio: National Institute for $\mathrm{O}$ ccupational Safety and $\mathrm{H}$ ealth (NIOSH).

Pitts, DG , TJ Tredici. 1971. The effects of ultraviolet on the eye. Am Ind H yg Assoc I 32(4):235-246.

Pitts, DG. 1974. The human ultraviolet action spectrum. Am J O ptom Phys 0 pt 51(12):946-960.

Polk, C, E Postow. 1986. CRC H andbook of Biological Effects of Electromagnetic Fields. Boca Raton: CRC Press.

Repacholi, M , A Basten, V Gebski, D N oonan, J Finnic, AW Harris. (1997). Lymphomas in E-Piml transgenic mice exposed to pulsed $900 \mathrm{M} \mathrm{Hz}$ elec tromagnetic fields. R adiation research, 147:631-640.

Repacholi, MH. 1985. Video display terminals -should operators be concerned? Austalas Phys Eng Sci M ed 8(2):51-61.
- . 1990. Cancer from exposure to $50760 \mathrm{~Hz}$ electric and magnetic fields: A major scientific debate. Austalas Phys Eng Sci M ed 13(1):4-17.

Riley, M V, S Susan, MI Peters, CA Schwartz. 1987. The effects of UVB irradiation on the corneal endothelium. Curr E ye Res 6(8):1021-1033.

Ringvold, A, M Davanger, EG O Isen. 1982. Changes of the corneal endothelium after ultraviolet radiation. A cta O phthalmol 60:41-53.

Ringvold, A, M Davanger. 1985. Changes in the rabbit corneal stroma caused by UV radiation. Acta O phthalmol 63:601-606.

Ringvold, A. 1980b. Aqueous humour and ultraviolet radiation. Acta 0 phthalmol 58:69-82.

—. 1980a. Cornea and ultraviolet radiation. Acta O phthalmol 58:63-68.

-. 1983. Damage of the corneal epithelium caused by ultraviolet radiation. Acta O phthalmol 61:898907.

Roberts, NJ, SM M ichaelson. 1985. Epidemiological studies of human exposure to radiofrequency radiation: A critical review. Int Arch Occup Environ $H$ ealth 56:169-178.

Roy, CR, KH Joyner, HP Gies, MJ Bangay. 1984. $M$ easurement of electromagnetic radiation emitted from visual display terminals (VDTs). Rad Prot Austral 2(1):26-30.

Scotto, J, TR Fears, GB Gori. 1980. M easurements of $U$ Itraviolet Radiations in the U nited States and Comparisons W ith Skin Cancer Data. Washington, DC: US G overnment Printing $O$ ffice.

Sienkiewicz, ZJ, RD Saunder, CI K owalczuk. 1991. $B$ iological $E$ ffects of $E$ xposure to $N$ on-I onizing E lectromagnetic Fields and Radiation. 11 Extremely L ow F requency E lectric and $M$ agnetic Fields. Didcot, Reino U nido: $\mathrm{N}$ ational R adiation Protection Board.

Silverman, C. 1990. Epidemiological studies of cancer and electromagnetic fields. En el Capítulo 17 de $B$ iological $E$ ffects and $M$ edical Applications of E lectromagnetic Energy, dirigido por OP Gandhi. Engelwood Cliffs, N ueva Jersey: Prentice $\mathrm{H}$ all.

Sliney, DH, ML Wolbarsht. 1980. Safety W ith Lasers and 0 ther 0 ptical Sources. N ueva Y ork: Plenum.

Sliney, DH. 1972. The merits of an envelope action spectrum for ultraviolet radiation exposure criteria. Am Ind H yg Assoc J 33:644-653.

—. 1986. Physical factors in cataractogenesis: Ambient ultraviolet radiation and temperature. Invest O phthalmol Vis Sci 27(5):781-790.

— . 1987. Estimating the solar ultraviolet radiation exposure to an intraocular lens implant. I Cataract R efract Surg 13(5):296-301.

- . 1992. A safety manager's guide to the new welding filters. W elding] 71(9):45-47.

Stenson, S. 1982. O cular findings in xeroderma pigmentosum: Report of two cases. Ann Ophthalmol 14(6):580-585

Sterenborg, HJCM , JC van der Leun. 1987. Action spectra for tumourigenesis by ultraviolet radiation. En $H$ uman Exposure to U Itraviolet Radiation: Risks and Regulations, dirigido por WF Passchier y BFM Bosnjakovic. Nueva York: Excerpta M edica Division, Elsevier Science Publishers.

Stuchly, M A, DW Lecuyer. 1985. Induction heating and operator exposure to electromagnetiic fields. $H$ ealth Phys 49:693-700.

-. 1989. Exposure to electromagnetic fields in arc welding. $\mathrm{H}$ ealth Phys 56:297-302.

Stuchly, MA. 1986. Human exposure to static and time-varying magnetic fields. $H$ ealth Phys 51(2):215-225

Szmigielski, S, M Bielec, S Lipski, G Sokolska. 1988. Immunologic and cancer related aspects of exposure to low-level microwave and radiofrequency fields. En M odern Bioelectricity, dirigido por AA $M$ ario. Nueva Y ork: $M$ arcel D ekker.
Taylor, HR, SK West, FS Rosenthal, B M unoz, HS N ewland, $H$ Abbey, EA Emmett. 1988. Effect of ultraviolet radiation on cataract formation. $\mathrm{New}$ Engl J M ed 319:1429-1433.

T ell, RA. 1983. Instrumentation for measurement of electromagnetic fields: Equipment, calibrations, and selected applications. En Biological E ffects and Dosimetry of Nonionizing Radiation, Radiofrequency and $M$ icrowave Energies, dirigido por M Grandolfo, SM $M$ ichaelson y A R indi. Nueva Y ork: Plenum.

U rbach, F. 1969. T he B iologic $E$ ffects of $U$ Itraviolet $R$ adiation. N ueva Y ork: Pergamon.

Zaffanella, LE, DW DeN 0. 1978. E lectrostatic and E lectromagnetic Effects of U Itra-H igh-Voltage T ransmission Lines. Palo Alto, California: Electric Power Research Institute.

Zuclich, JA, JS Connolly. 1976. O cular damage induced by near-ultraviolet laser radiation. I nvest Ophthalmol Vis Sci 15(9):760-764.

\section{0 tras lecturas recomendadas}

American Conference of Governmental Industrial $H$ ygienists (ACGIH ). 1990. A Guide for Control of Laser $\mathrm{H}$ azards. Cincinnati, $\mathrm{O}$ hio: $\mathrm{ACGIH}$.

-. 1991. Threshold Limit Values for Chemical Substances and Physical Agents and Biological Exposure Indices, 1990-1991. Cincinnati, O hio: ACGIH.

A sociación Internacional para la Protección contra las Radiaciones (IR PA) y Comisión Internacional de Protección contra las Radiaciones no Ionizantes (ICNIR P). 1993a. Alleged radiation risks from visual display units. H ealth Phys 54:231-232.

Avdeev, PS, YD Berezin, YP Gudakovskii, VR M uratov, AG M urzin, VA Fromzel. 1978. Experimental determination of maximum permissible exposure to laser radiation of $1.54 \mathrm{p}$ wavelength. Soviet I Q uant E lectr 8:137-141.

Bargeron, CB, OJ Deters, RA Farrell, RL M cCally. 1989. Epithelial damage in rabbit corneas exposed to $\mathrm{CO}_{2}$ laser radiation. $\mathrm{H}$ ealth $\mathrm{P}$ hys 56:85-95.

Bernhardt, JH. 1988b. Extremely low frequency (ELF) electric fields. En Non-lonizing Radiation: Physical Characteristics, Biological Effects and $\mathrm{H}$ ealth $\mathrm{H}$ azard Assessment, dirigido por $\mathrm{MH}$ Repacholi. Melbourne: Seminario Internacional sobre las Radiaciones No Ionizantes.

British Standards O rganisation (BSO). 1984. Radiation Safety of L aser Products and Systems. L ondres: BSO

D eutsche Electrotechische K ommission. 1996. E lectromagnetic Field Limit. Berlín: Deutsche Elektrotechische K ommission.

D eutsche Institut für N ormung (DIN). 1984. Radiation Safety of Laser Products. Berlín: DIN.

Duchene, AR, M A Repacholi, J Lakey. 1991. Guide lines for $L$ imits of $H$ uman $E$ xposure to $\mathrm{N}$ on- I onizing

Fankhauser, F. 1977. Physical and biological effects of laser radiation. Klinische $M$ onatsblatter fur Augenhiekunde 170(2):219.

Gabel, VP, R Birngruber. 1981. A comparative study of threshold lesions in the retinae of human volunteers and rabbits. $\mathrm{H}$ ealth Phys 40(2):238-240.

Geeraets, WJ, ER Berry. 1968. O cular spectral characteristics as related to hazards from lasers and other light sources. Am J O phthalmol 66:15-20.

Gezonheidsraad (Consejo de Salud de los Países Bajos). 1979. R ecommendations C oncerning A cceptable L evels of $E$ lectromagnetic $R$ adiation in the $W$ avelength $R$ ange from $100 \mathrm{~nm}$ and 0 ther 0 ptical Radiation Sources. Nueva York: Plenum.

Grandolfo, M, SM Michaelson, A Rindi. 1985. Biological Effects and Dosimetry of Static and ELF E lectromagnetic F ields. Nueva Y ork: Plenum Press.

Grossweiner, LI. 1984. Photochemistry of proteins: A review. Curr E ye Res 3(1):137-144. 
Harding, IJ, KJ Dilley. 1976. Structural proteins of the mammalian lens: A review with emphasis on changes in development, aging and cataract. Exp E ye Res 22(1):1-73.

K owalczuk, CI, ZJ Sienkiewicz, RD Saunder. 1991. Biological E ffect of Exposure to $\mathrm{N}$ on-I onizing E lectromagnetic Fields and Radiation. I-Static E lectric and M agnetic Fields. Chilton, Reino U nido: NR PB.

M inisterio de Sanidad de la UR SS. 1982. N ormas sanitarias para el diseño y el uso del láser (en ruso). M oscú: M inisterio de Sanidad de la U R SS

National Radiological Protection Board (NRPB). 1993. D ocuments of the National Radiological Protection B oard. B oard Statement On R estrictions On H uman Exposure to Static and T ime $V$ arying E lectromagnetic $F$ ields and Radiation. V ol. 4, number 5. Chilton, R eino U nido: NRPB.

O ficina Internacional del Trabajo (OIT). 1993b. Visual $D$ isplay U nits - R adiation Protection Guidance. O ccu- pational Safety and Health Series, No, 70. Ginebra: OIT.

Parrish, JA, RR Anderson, F U rbach, D Pitts 1978. UVA, Biological Effects of U ltraviolet Radiation W ith E mphasis On $H$ uman Responses to $L$ ongwave Radiation. Nueva Y ork: Plenum.

Pitts, DG, AP Cullen. 1981. Determination of infrared radiation levels for acute ocular cataractogenesis. Arch Klin O phthalmol 217:285-297.

Sliney, DH, S Trokel. 1992. M edical Lasers and Their Safe U se. N ueva Y ork: Springer-V erlag.

Sliney, DH . 1987. U nintentional exposure to ultraviolet radiation: $\mathrm{R}$ isk reduction and exposure limits. En $H$ uman Exposure to $U$ Itraviolet $R$ adiation: $R$ isks and Regulations, dirigido por WF Passchier y BFM Bosnjakovic. Nueva Y ork: Excerpta M edica Division, Elsevier Science Publishers.

Smith, K C. 1988. The Science of Photobiology. Nueva York: Plenum.
Stuck, BE, DJ Lund, ES Beatrice. 1981. O cular effects of holmium (2.06 um) and erbium (1054 gm) laser radiation. $H$ ealth P hys 40:835-846.

Suess, MJ, DA Benwell-M orison. 1989. Non-ionizing protection. OMS Regional Publications European Series, No. 25. Copenhague: O ficina R egional de la OMS para Europa.

Tung, WH, LTJ Chylack, UP Andley. 1988. Lens hexokinase deactivation by near-UV irradiation. Curr E ye Res 7(3):257-263.

Urbach, F, RW Gange. 1986. The Biological Effects of U VA Radiation. W estport, Connecticut: Praeger.

Willis, I, A K ligman, J Epstein. 1972. Effects of long ultraviolet rays on human skin: Photoprotective or photoaugmentative. I I nvest D ermatol 59:416-420.

Yanuzzi, LA, YL Fisher, A K rueger, J Slater. 1987. Solar retinopathy, a photobiological and geophysical analysis. T rans Am 0 phthalmol Soc 85:120-158.

Zuclich, JA. 1989. U Itraviolet-induced photochemical damage in ocular tissues. $H$ ealth P hys 56(5):671-682. 

Director del capítulo

M ichael J. Griffin

\section{Sumario}

\section{Vibraciones}

M ichad J. Griffin. ......................... 50.2

Vibraciones de cuerpo completo

$H$ elmut Seidel y M ichael J. Griffin . . . . . . . . . . . . . . . . . 50.3

Vibraciones transmitidas a las manos

M assimo B ovenzi . . . . . . . . . . . . . . . . . . . . . . . . . . 50.8

$M$ areo inducido por el movimiento

Alan J. Benson ............................. 50.14 


\section{- VIBRACIONES}

Michael J. Griffin

La vibración es un movimiento oscilatorio. Este capítulo resume las respuestas humanas a las vibraciones de cuerpo completo, las transmitidas a las manos y las causas del mareo, incluido por el movimiento.

Las vibraciones del cuerpo completo ocurren cuando el cuerpo está apoyado en una superficie vibrante (por ejemplo, cuando se está sentado en un asiento que vibra, de pie sobre un suelo vibrante 0 recostado sobre una superficie vibrante). Las vibraciones de cuerpo completo se presentan en todas las formas de transporte y cuando se trabaja cerca de maquinaria industrial.

Las vibraciones transmitidas a las manos son las vibraciones que entran en el cuerpo a través de las manos. Están causadas por distintos procesos de la industria, la agricultura, la minería y la construcción, en los que se agarran o empujan herramientas o piezas vibrantes con las manos o los dedos. La exposición a las vibraciones transmitidas a las manos puede provocar diversos trastornos.

EI mareo inducido por el movimiento puede ser producido por oscilaciones del cuerpo de bajas frecuencias, por algunos tipos de rotación del cuerpo y por el movimiento de señales luminosas con respecto al cuerpo.

\section{Magnitud}

Los desplazamientos oscilatorios de un objeto implican, alternativamente, una velocidad en una dirección y después una velocidad en dirección opuesta. Este cambio de velocidad significa que el objeto experimenta una aceleración constante, primero en una dirección y después en dirección opuesta. La magnitud de una vibración puede cuantificarse en función de su desplazamiento, su velocidad o su aceleración. A efectos prácticos, la aceleración suele medirse con acelerómetros. La unidad de aceleración es el metro por segundo al cuadrado $\left(\mathrm{m} / \mathrm{s}^{2}\right)$. La aceleración debida a la gravedad terrestre es, aproximadamente, de $9,81 \mathrm{~m} / \mathrm{s}^{2}$.

La magnitud de una oscilación puede expresarse como la distancia entre los extremos alcanzados por el movimiento (valor pico-pico) o como la distancia desde algún punto central hasta la desviación máxima (valor pico). Con frecuencia, la magnitud de la vibración se expresa como el valor promedio de la aceleración del movimiento oscilatorio, normalmente el valor cuadrático medio o valor eficaz ( $\mathrm{m} / \mathrm{s}^{2}$ r.m.s.). Para un movimiento de una sola frecuencia (senoidal), el valor eficaz es el valor pico dividido por $\sqrt{2}$.

Para un movimiento senoidal, la aceleración, a (en $\mathrm{m} / \mathrm{s}^{2}$ ), puede calcularse a partir de la frecuencia, $f$ (en ciclos por segundo), y el desplazamiento, $d$ (en metros):

$$
a=(2 \pi f)^{2} d
$$

Puede usarse esta expresión para convertir medidas de aceleración en desplazamientos, pero solo tiene precisión cuando el movimiento se produce a una sola frecuencia.

A veces se utilizan escalas logarítmicas para cuantificar magnitudes de vibración en decibelios. Cuando se utiliza el nivel de referencia de la Norma Internacional 1683, el nivel de aceleración, $L_{a}$, viene dado por la expresión $L_{a}=20 \log _{10}\left(a / a_{0}\right)$, en donde a es la aceleración medida (en $\mathrm{m} / \mathrm{s}^{2}$ r.m.s.) y $\mathrm{a}_{0}$ el nivel de referencia de $10^{-6} \mathrm{~m} / \mathrm{s}^{2}$. En algunos países se utilizan otros niveles de referencia.

\section{Frecuencia}

La frecuencia de vibración, que se expresa en ciclos por segundo (hertzios, Hz), afecta a la extensión con que se transmiten las vibraciones al cuerpo (p. ej., a la superficie de un asiento 0 a la empuñadura de una herramienta vibrante), a la extensión con que se transmiten a través del cuerpo ( $p$. ej., desde el asiento a la cabeza) y al efecto de las vibraciones en el cuerpo. La relación entre el desplazamiento y la aceleración de un movimiento depende también de la frecuencia de oscilación: un desplazamiento de un milímetro corresponde a una aceleración muy pequeña a bajas frecuencias, pero a una aceleración muy grande a frecuencias altas; el desplazamiento de la vibración visible al ojo humano no proporciona una buena indicación de la aceleración de las vibraciones.

Los efectos de las vibraciones de cuerpo completo suelen ser máximos en el límite inferior del intervalo de frecuencias, de 0,5 a $100 \mathrm{~Hz}$. En el caso de las vibraciones transmitidas a las manos, las frecuencias del orden de $1.000 \mathrm{~Hz} \mathrm{o}$ superiores pueden tener efectos perjudiciales. $L$ as frecuencias inferiores a unos $0,5 \mathrm{~Hz}$ pueden causar mareo inducido por el movimiento.

El contenido de frecuencia de la vibración puede verse en los espectros. En muchos tipos de vibraciones de cuerpo completo y de vibraciones transmitidas a las manos, los espectros son complejos, produciéndose algo de movimiento a todas las frecuencias. Sin embargo, suele haber picos a las frecuencias que se presentan en la mayor parte de las vibraciones.

Dado que la respuesta humana a las vibraciones varía según la frecuencia de vibración, es necesario ponderar la vibración medida en función de cuánta vibración se produce a cada una de las frecuencias. $L$ as ponderaciones en frecuencia reflejan la medida en que las vibraciones causan el efecto indeseado a cada frecuencia. Es necesario realizar ponderaciones para cada eje de vibración. Se requieren ponderaciones en frecuencia diferentes para las vibraciones de cuerpo completo, las vibraciones transmitidas a las manos y el mareo inducido por el movimiento.

\section{Dirección}

Las vibraciones pueden producirse en tres direcciones lineales y tres rotacionales. En el caso de personas sentadas, los ejes lineales se designan como eje $x$ (longitudinal), eje y (lateral) y eje $z$ (vertical). Las rotaciones alrededor de los ejes $x$, y y $z$ se designan como $r_{x}$ (balanceo), $r_{y}$ (cabeceo) y $r_{z}$ (deriva), respectivamente. Las vibraciones suelen medirse en la interfase entre el cuerpo y las vibraciones. Los sistemas principales de coordenadas para medir las vibraciones de cuerpo completo y las vibraciones transmitidas a las manos se exponen en los dos artículos siguientes del capítulo.

\section{Duración}

La respuesta humanas a las vibraciones depende de la duración total de la exposición a las vibraciones. Si las características de la vibración no varían en el tiempo, el valor eficaz de la vibración proporciona una medida adecuada de su magnitud promedio. En tal caso un cronómetro puede ser suficiente para evaluar la duración de la exposición. La intensidad de la magnitud promedio y la duración total pueden evaluarse según las normas expuestas en los siguientes artículos.

Si varían las características de la vibración, la vibración promedio medida dependerá del período durante el que se mida. Además, se cree que la aceleración eficaz infravalora la intensidad de los movimientos que contienen choques o son marcadamente intermitentes.

M uchas exposiciones profesionales son intermitentes, tienen una magnitud variable en cada momento o contienen choques esporádicos. La intensidad de tales movimientos complejos pueden acumularse de manera que dé un peso apropiado a, por ejemplo, períodos cortos de vibración de alta magnitud y períodos largos de vibración de baja magnitud. Para el cálculo de las dosis se utilizan diferentes métodos (véase "V ibraciones de 
cuerpo completo"; "Vibraciones transmitidas a las manos", y "M areo inducido por el movimiento" en este capítulo).

\section{- VibRaCiO NeS de CUERPO COMPLETO}

\author{
H elmut Seidel y M ichael J. Griffin
}

\section{Exposición profesional}

Las exposiciones profesionales a las vibraciones de cuerpo completo se dan, principalmente, en el transporte, pero también en algunos procesos industriales. EI transporte terrestre, marítimo y aéreo puede producir vibraciones que pueden causar malestar, interferir con las actividades u ocasionar lesiones. En la Tabla 50.1 se ofrece una relación de algunos ambientes que pueden entrañar gran probabilidad de riesgo para la salud.

La exposición más común a vibraciones y choques fuertes suele darse en vehículos todo terreno, incluyendo maquinaria de movimiento de tierras, camiones industriales y tractores agrícolas.

\section{Biodinámica}

Como todas las estructuras mecánicas, el cuerpo humano tiene frecuencias de resonancia a las que presenta una respuesta mecánica máxima. La explicación de las respuestas humanas a las vibraciones no puede basarse exclusivamente en una sola frecuencia de resonancia. $\mathrm{H}$ ay muchas resonancias en el cuerpo, y las frecuencias de resonancia varían de unas personas a otras y en función de la postura. Para describir el modo en que la vibración produce movimiento en el cuerpo suelen utilizarse dos respuestas mecánicas: transmisibilidad e impedancia.

\section{Tabla 50.1 - Actividades para las que puede ser conveniente alertar sobre los efectos desfavorables de la vibración de cuerpo completo.}

\section{Conducción de tractores}

Vehículos de combate blindados (p. ej., tanques) y otros similares

Otros vehículos todoterreno:

- Maquinaria de movimiento de tierras: cargadoras, excavadoras, bulldozers, motoniveladoras, cucharas de arrastre, volquetes, rodillos compactadores

- Máquinas forestales

- Maquinaria de minas y canteras

- Carretillas elevadoras

Conducción de algunos camiones (articulados y no articulados)

Conducción de algunos autobuses y tranvías

Vuelo en algunos helicópteros y aeronaves de alas rígidas

Algunos trabajadores que utilizan maquinaria de fabricación de hormigón

Algunos conductores ferroviarios

Uso de algunas embarcaciones de alta velocidad

Conducción de algunos ciclomotores

Conducción de algunos turismos y furgonetas

Algunas actividades deportivas

Algunos otros tipos de maquinaria industrial

Fuente: Adaptado de Griffin 1990.
La transmisibilidad indica qué fracción de la vibración se transmite, por ejemplo, desde el asiento a la cabeza. La transmisibilidad del cuerpo depende en gran medida de la frecuencia de vibración, el eje de vibración y la postura del cuerpo. La vibración vertical de un asiento causa vibraciones en varios ejes en la cabeza; en el caso del movimiento vertical de la cabeza, la transmisibilidad suele alcanzar su máximo valor en el intervalo de 3 a $10 \mathrm{~Hz}$.

La impedancia mecánica del cuerpo indica la fuerza que se requiere para que el cuerpo se mueva a cada frecuencia. Aunque la impedancia depende de la masa corporal, la impedancia vertical del cuerpo humano suele presentar resonancia en torno a los $5 \mathrm{~Hz}$. La impedancia mecánica del cuerpo, incluyendo esta resonancia, incide considerablemente en la forma en que se transmite la vibración a través de los asientos.

\section{Efectos agudos}

\section{Malestar}

El malestar causado por la aceleración de la vibración depende de la frecuencia de vibración, la dirección de la vibración, el punto de contacto con el cuerpo y la duración de la exposición a la vibración. En la vibración vertical de personas sentadas, el malestar causado por la vibración vertical a cualquier frecuencia aumenta en proporción a la magnitud de la vibración: si se reduce ésta a la mitad, el malestar tenderá a reducirse a la mitad.

Puede predecirse el malestar que producirá las vibraciones utilizando ponderaciones en frecuencia adecuadas (véase abajo) y describirse mediante una escala semántica de malestar. No existen límites prácticos en cuanto al malestar causado por las vibraciones: el malestar tolerable varía de unos ambientes a otros.

Las magnitudes tolerables de vibraciones en edificios están próximas a los umbrales de percepción de la vibración. Se supone que los efectos de las vibraciones en edificios sobre los humanos dependen del uso del edificio, además de la frecuencia, dirección y duración de las vibraciones. Directrices para la evaluación de las vibraciones en edificios se dan en diversas normas, tales como la N orma Británica 6472 (1992), que define un procedimiento para la evaluación de las vibraciones y los choques en los edificios.

\section{Interferencia con la actividad}

Las vibraciones pueden deteriorar la adquisición de información (p. ej., por los ojos), la salida de información (p. ej., mediante movimientos de las manos o de los pies) o los procesos centrales complejos que relacionan la entrada con la salida (p. ej., aprendizaje, memoria, toma de decisiones). Los mayores efectos de las vibraciones de cuerpo completo se producen en los procesos de entrada (principalmente la visión) y en los de salida (principalmente el control continuo de las manos).

Los efectos de las vibraciones sobre la visión y el control manual están causados principalmente por el movimiento de la parte del cuerpo afectada (es decir, el ojo o la mano). Dichos efectos pueden aminorarse reduciendo la transmisión de vibraciones al ojo o a la mano, o haciendo que la tarea esté menos sujeta a alteraciones ( $p$. ej., aumentando el tamaño de una pantalla o reduciendo la sensibilidad de un mando). Con frecuencia, los efectos de las vibraciones sobre la visión y el control manual pueden reducirse considerablemente diseñando de nuevo la tarea.

Según parece, a las tareas cognitivas simples (p. ej., el tiempo de reacción simple) no les afectan las vibraciones, a diferencia de lo que ocurre con los cambios de excitación o motivación o con los efectos directos en los procesos de entrada y salida de información. Lo mismo puede ocurrir con algunas tareas cognitivas 
complejas. Sin embargo, la escasez y diversidad de los estudios experimentales no excluye la posibilidad de efectos cognitivos reales y significativos de las vibraciones. L as vibraciones pueden influir en la fatiga, pero hay poca evidencia científica relevante y ninguna que apoye la forma compleja del "límite de la capacidad reducida por fatiga" propuesto en la Norma Internacional 2631 (ISO 1974, 1985).

\section{Alteraciones de las funciones fisiológicas}

Las alteraciones en las funciones fisiológicas se producen cuando los sujetos están expuestos a un ambiente de vibraciones de cuerpo completo en condiciones de laboratorio. Las alteraciones típicas de una "respuesta de sobresalto" (p. ej., aumento de la frecuencia cardíaca) se normalizan rápidamente con la exposición continuada, mientras que otras reacciones continúan o se desarrollan de modo gradual. EI último aspecto puede depender de todas las características de las vibraciones, incluyendo el eje, la magnitud de la aceleración y la clase de vibración (senoidal 0 aleatoria), así como de otras variables tales como el ritmo circadiano y las características de los sujetos (véase H asan 1970; Seidel 1975; D upuis y Zerlett 1986). C on frecuencia no es posible relacionar directamente las alteraciones de las funciones fisiológicas en condiciones de campo con las vibraciones, dado que ésta suele actuar conjuntamente con otros factores significativos, como la elevada tensión mental, el ruido y las sustancias tóxicas. Las alteraciones fisiológicas son frecuentemente menos sensibles que las reacciones psicológicas ( $p$. ej., el malestar). Si todos los datos disponibles sobre las alteraciones fisiológicas persistentes se resumen respecto a su primera aparición significativa, dependiendo de la magnitud y frecuencia de las vibraciones de cuerpo completo, hay un umbral con un límite inferior en torno a un valor eficaz de $0,7 \mathrm{~m} / \mathrm{s}^{2}$ entre 1 y $10 \mathrm{~Hz}$, que aumenta hasta un valor eficaz de $30 \mathrm{~m} / \mathrm{s}^{2}$ a $100 \mathrm{~Hz}$. Se han realizado numerosos estudios con animales, pero su relevancia para los humanos es dudosa.

\section{Alteraciones neuromusculares}

Durante el movimiento natural activo, los mecanismos de control motor actúan como un control de información de ida constantemente ajustado por la retroinformación adicional procedente de los sensores situados en los músculos, tendones y articulaciones. Las vibraciones de cuerpo completo producen un movimiento artificial pasivo del cuerpo humano, condición que difiere esencialmente de las vibraciones autoinducidas por la locomoción. La ausencia de control de información durante las vibraciones de cuerpo completo es la alteración más clara de la función fisiológica normal del sistema neuromuscular. La gama de frecuencias más amplia asociada con las vibraciones de cuerpo completo (entre 0,5 y $100 \mathrm{~Hz}$ ), comparada con la del movimiento natural (entre 2 y $8 \mathrm{~Hz}$ para los movimientos voluntarios, e inferior a $4 \mathrm{~Hz}$ para la locomoción) es otra diferencia más que ayuda a explicar las reacciones de los mecanismos de control neuromuscular a frecuencias muy bajas y a altas frecuencias.

Las vibraciones de cuerpo completo y la aceleración transitoria determinan una actividad alternante relacionada con la aceleración en el electromiograma (EMG) de los músculos superficiales de la espalda de personas sentadas que obliga a mantener una contracción tónica. Se supone que esta actividad es de naturaleza refleja. N ormalmente, desaparece por completo si los sujetos sometidos a vibraciones permanecen sentados y relajados en posición encorvada. La temporización de la actividad muscular depende de la frecuencia y magnitud de la aceleración. Los datos electromiográficos sugieren que la columna puede verse sometida a una carga mayor debido a la reducción de la estabilización muscular de la misma a frecuencias de 6,5 a $8 \mathrm{~Hz}$ y durante la fase inicial a un desplazamiento brusco hacia arriba. A pesar de la débil actividad EMG causada por las vibraciones de cuerpo completo, la fatiga de los músculos de la espalda durante la exposición a las vibraciones puede ser superior a la que se observa en posturas sentadas normales sin vibraciones de cuerpo completo.

Los reflejos de los tendones pueden disminuir o desaparecer temporalmente durante la exposición a las vibraciones de cuerpo completo a frecuencias superiores a $10 \mathrm{~Hz}$. L as pequeñas alteraciones del control postural tras la exposición a las vibraciones de cuerpo completo son muy variables, y sus mecanismos e importancia práctica no son bien conocidos.

\section{Alteraciones cardiovasculares, respiratorias, endocrinas y metabólicas}

Se han comparado las alteraciones observadas que persisten durante la exposición a las vibraciones con las que se producen durante el trabajo físico moderado (es decir, aumentos de la frecuencia cardíaca, presión arterial y consumo de oxígeno), incluso a una magnitud de vibración cercana al límite de tolerancia voluntaria. El aumento de ventilación obedece en parte a oscilaciones del aire en el sistema respiratorio. Las alteraciones respiratorias y metabólicas pueden no corresponderse, lo que posiblemente sugiere una perturbación de los mecanismos de control de la respiración. Se han comunicado diversos hallazgos, en parte contradictorios, sobre alteraciones de las hormonas adrenocorticotrópicas (ACTH) y las catecolaminas.

\section{Alteraciones sensoriales y del sistema nervioso central}

Se ha sostenido la existencia de alteraciones de la función vestibular debidas a las vibraciones de cuerpo completo sobre la base de una afectación de la regulación de la postura, a pesar de que ésta es controlada por un sistema muy complejo donde la perturbación de la función vestibular puede ser compensada ampliamente por otros mecanismos. Las alteraciones de la función vestibular parecen revestir mayor entidad en las exposiciones a frecuencias muy bajas o próximas a la resonancia de cuerpo completo. Se supone que una discordancia sensorial entre la información vestibular, visual y propioceptiva (estímulos recibidos en el interior de los tejidos) es un mecanismo importante que explica las respuestas fisiológicas a algunos entornos de movimiento artificial.

Los experimentos con exposición combinada, a corto plazo y prolongada, a ruido y vibraciones de cuerpo completo, parecen sugerir que las vibraciones tienen un pequeño efecto sinérgico sobre la audición. Como tendencia, se observaba que altas intensidades de vibraciones de cuerpo completo a 4 o $5 \mathrm{~Hz}$ se asociaban a mayores desplazamientos temporales del umbral (TTS) adicionales. No hubo ninguna relación evidente entre los TTS adicionales y el tiempo de exposición. LoS T TS adicionales parecían aumentar al aplicar dosis mayores de vibraciones de cuerpo completo.

Las vibraciones verticales y horizontales impulsivas evocan potenciales cerebrales. También se han detectado alteraciones de la función del sistema nervioso central humano al utilizar potenciales cerebrales evocados por el sistema auditivo (Seidel y cols. 1992). En los efectos influían otros factores ambientales (p. ej., el ruido), la dificultad de la tarea y el estado interno del sujeto (p. ej., activación, grado de atención hacia el estímulo).

\section{Efectos a largo plazo}

\section{Riesgo para la salud de la columna vertebral}

Los estudios epidemiológicos indican con frecuencia que existe un riesgo elevado para la salud en la columna vertebral de los trabajadores expuestos durante muchos años a intensas 
vibraciones de cuerpo completo (p. ej., trabajo en tractores 0 máquinas de movimiento de tierras). Seidel y Heide (1986), Dupuis y Zerlett (1986) y Bongers y Boshuizen (1990) han realizado minuciosos estudios de la literatura. En estas revisiones se llega a la conclusión de que intensas vibraciones de cuerpo completo de larga duración puede afectar negativamente a la columna e incrementar el riesgo de molestias lumbares. Tales molestias pueden ser consecuencia secundaria de una alteración degenerativa primaria de las vértebras y discos intervertebrales. Se descubrió que la parte afectada con más frecuencia es la región lumbar de la columna vertebral, seguida de la región torácica. Una elevada proporción de los deterioros de la región cervical, comunicados por varios autores, parecen estar causados por una postura fija desfavorable y no por la vibración, aunque no existe ninguna evidencia concluyente de la validez de esta hipótesis. Solo en unos pocos estudios se ha considerado la función de los músculos de la espalda y se ha encontrado una insuficiencia muscular. Algunos informes señalan un riesgo sensiblemente mayor de dislocación de los discos lumbares. En varios estudios de muestras representativas, Bongers y Boshuizen (1990) encontraron más casos de molestias lumbares en conductores de vehículos terrestres y en pilotos de helicópteros que en trabajadores de referencia comparables. Finalmente llegaron a la conclusión de que la conducción profesional de vehículos y el pilotaje de helicópteros son factores de riesgo importantes para las molestias lumbares y los trastornos de la espalda. Se observó un aumento del número de pensiones por discapacidad y de las bajas laborales de larga duración debido a trastornos relacionados con los discos intervertebrales entre los operadores de grúas y conductores de tractores.

Debido a la falta de datos o a la existencia de datos incompletos sobre las condiciones de exposición en los estudios epidemiológicos, no se pudieron obtener relaciones exactas entre exposición y efecto. Los datos existentes no permiten establecer un nivel sin efectos adversos (es decir, un límite de seguridad) que posibilite prevenir de modo fiable las enfermedades de la columna. Muchos años de exposición por debajo o cerca del límite de exposición contemplado en la versión actual de la Norma Internacional 2631 (ISO 1985) no excluyen el riesgo. Algunos hallazgos indican un aumento del riesgo para la salud cuando aumenta la duración de la exposición, si bien los procesos de selección han hecho que resulte difícil detectar una relación en la mayoría de los estudios. Por lo tanto, las investigaciones epidemiológicas no permiten establecer actualmente una relación entre dosis y efecto. Consideraciones teóricas sugieren efectos marcadamente perjudiciales de las cargas pico elevadas que actúan sobre la columna durante las exposiciones con altos valores transitorios. Por lo tanto, el uso de un método de "energía equivalente" para calcular la dosis de vibración (como el de la Norma Internacional 2631 (ISO 1985)) es cuestionable para exposiciones a vibraciones de cuerpo completo que contienen altas aceleraciones pico. L os efectos a largo plazo por las vibraciones de cuerpo completo dependiendo de la frecuencia de vibración no se han deducido de los estudios epidemiológicos. Las vibraciones de cuerpo completo a frecuencias de 40 a $50 \mathrm{~Hz}$ aplicada a través de los pies a operarios en posición de pie, fue seguida de cambios degenerativos de los huesos de los pies.

Por lo general, las diferencias entre sujetos se han pasado por alto en gran medida, aunque los fenómenos de la selección sugieren que pueden tener gran importancia. No hay datos claros que indiquen si los efectos de las vibraciones de cuerpo completo sobre la columna dependen del sexo.

La aceptación general de los trastornos degenerativos de la columna como enfermedad de origen profesional es objeto de debate. No se conocen elementos de diagnóstico específicos que permitan una diagnosis fiable del trastorno como consecuencia de la exposición a las vibraciones de cuerpo completo. Una elevada prevalencia de trastornos de columna degenerativos en poblaciones no expuestas impide confirmar la suposición de una etiología predominantemente profesional en individuos expuestos a vibraciones de cuerpo completo. No se conocen factores de riesgo individuales de tipo constitucional que pudieran modificar la tensión inducida por la vibración. La referencia a una intensidad mínima y/ o una duración mínima de las vibraciones de cuerpo completo como requisito previo para el reconocimiento del origen profesional de una enfermedad no tendría en cuenta la considerable variabilidad que cabe esperar en cuanto a susceptibilidad individual.

\section{Otros riesgos para la salud}

Estudios epidemiológicos sugieren que las vibraciones de cuerpo completo es solo uno entre un grupo de factores causales que contribuyen a otros riesgos para la salud. El ruido, la elevada tensión mental y el trabajo por turnos son ejemplos de factores concomitantes importantes que se sabe están relacionados con trastornos de la salud. Con frecuencia, las investigaciones de los trastornos de otros sistemas corporales han dado resultados divergentes 0 que indican una dependencia paradójica de la prevalencia de la patología respecto de la magnitud de las vibraciones de cuerpo completo (es decir, mayor prevalencia de efectos adversos a menor intensidad). Se ha observado un complejo característico de síntomas y alteraciones patológicas del sistema nervioso central, el sistema musculosquelético y el sistema circulatorio en operarios que trabajan de pie en máquinas utilizadas para la vibrocompactación de hormigón y están expuestos a niveles de vibraciones de cuerpo completo por encima del límite de exposición especificado en la Norma ISO 2631 con frequencias superiores a $40 \mathrm{~Hz}$ (Rumjancev 1966). Se ha denominado a este complejo "enfermedad de las vibraciones". La misma expresión, aunque con el rechazo de muchos especialistas, se ha utilizado a veces para describir un vago cuadro clínico causado por exposición de larga duración a vibraciones de cuerpo completo a baja frecuencia que, al parecer, se manifiesta inicialmente en forma de trastornos vegetativo-vasculares periféricos y cerebrales de carácter funcional inespecífico. De acuerdo con los datos disponibles se puede extraer la conclusión de que diferentes sistemas fisiológicos reaccionan independientemente unos de otros y que no existen síntomas que puedan servir como indicador de patología inducida por vibraciones de cuerpo completo.

Sistema nervioso, órgano vestibular y audición. Las vibraciones de cuerpo completo intensas a frequencias superiores a $40 \mathrm{~Hz}$ puede causar daños y alteraciones del sistema nervioso central. Se han comunicado datos contradictorios sobre los efectos de la vibración de cuerpo completo a frecuencias inferiores a $20 \mathrm{~Hz}$. Solo en algunos estudios se ha encontrado un aumento de molestias inespecíficas, tales como dolor de cabeza y aumento de la irritabilidad. Un autor ha afirmado la aparición de alteraciones del electroencefalograma (EEG) tras la exposición de larga duración a vibraciones de cuerpo completo y otros las han negado. A lgunos de los resultados publicados apuntan hacia una menor excitabilidad vestibular y una mayor incidencia de otras alteraciones vestibulares, entre las que se incluye el vértigo. Ahora bien, se mantiene la incertidumbre respecto a la existencia de relaciones causales entre vibraciones de cuerpo completo y alteraciones del sistema nervioso central o el sistema vestibular, al haberse detectado relaciones paradójicas entre intensidad y efecto.

En algunos estudios, se ha observado un aumento adicional de los desplazamientos permanentes del umbral (PTS) de audición tras una exposición combinada de larga duración a las vibraciones de cuerpo completo y al ruido. Schmidt (1987) 
Figura 50.1 • Dependencias de la frecuencia en cuanto a la respuesta humana a la vibración de cuerpo completo.

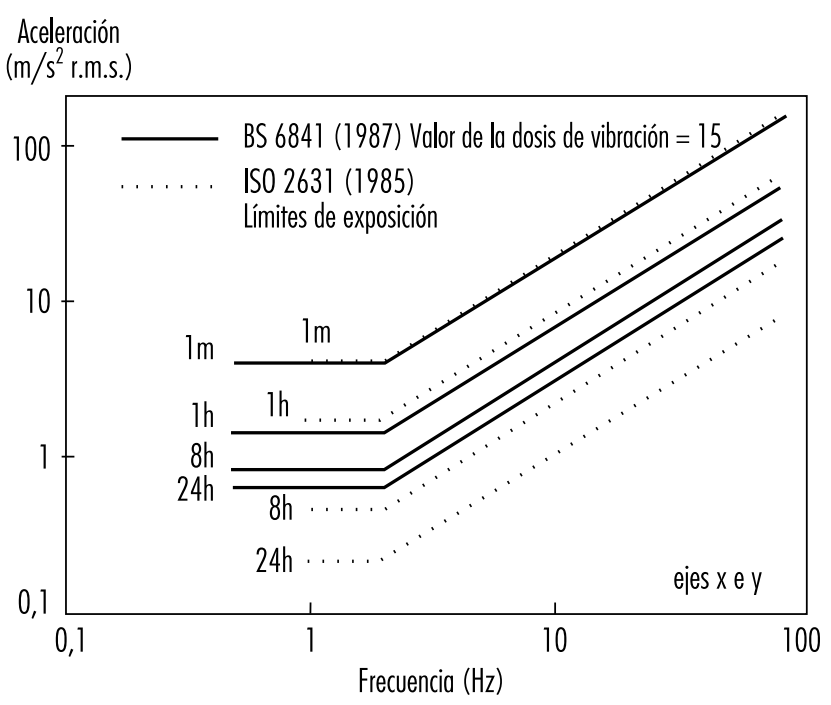

estudió a conductores y técnicos en el campo de la agricultura y comparó los desplazamientos permanentes del umbral después de 3 y 25 años de trabajo. Llegó a la conclusión de que las vibraciones de cuerpo completo puede inducir un desplazamiento adicional significativo del umbral a 3, 4,6 y $8 \mathrm{kHz}$, si la aceleración ponderada según la N orma Internacional 2631 (ISO 1985) supera un valor eficaz de $1,2 \mathrm{~m} / \mathrm{s}^{2}$ con exposición simultánea al ruido a un nivel equivalente de más de 80 decibelios (dBA).

Sistemas circulatorio y digestivo. Se han detectado cuatro grupos principales de alteraciones circulatorias con mayor incidencia entre trabajadores expuestos a vibraciones de cuerpo completo:

1. T rastornos periféricos, tales como el síndrome de R aynaud, cerca del punto de aplicación de la vibración de cuerpo completo (es decir, los pies de los operarios en posición de pie 0 , en menor grado, las manos de los conductores).

2. V enas varicosas de las piernas, hemorroides y varicocele.

3. Cardiopatía isquémica e hipertensión.

4. Alteraciones neurovasculares.

No siempre existe correlación entre la morbilidad de estas alteraciones circulatorias y la magnitud o duración de la exposición a la vibración. Aunque frecuentemente se ha observado una elevada prevalencia de diversos trastornos del sistema digestivo, casi todos los autores coinciden en que las vibraciones de cuerpo completo es solo una de las causas y quizá no la más importante.

Organos reproductores femeninos, embarazo y sistema genitourinario masculino. Se cree que el aumento del riesgo de aborto, alteraciones menstruales y anomalías posicionales ( $p$. ej., desprendimiento de útero) puede estar relacionado con la exposición de larga duración a las vibraciones de cuerpo completo (véase Seidel y H eide 1986). No se puede deducir de la literatura un umbral de exposición seguro que evite un aumento de estos riesgos para la salud. La susceptibilidad individual y sus variaciones temporales probablemente codeterminan estos efectos biológicos. En la literatura disponible no se ha comunicado un efecto perjudicial directo de la vibración de cuerpo completo sobre el feto humano, aunque algunos estudios en animales sugieren que la vibración de cuerpo completo puede afectar al feto. El desconocimiento del valor umbral para los efectos adversos sobre el embarazo sugiere la conveniencia
Aceleración

(m/s $/ \mathrm{s}^{2}$ r.m.s.)

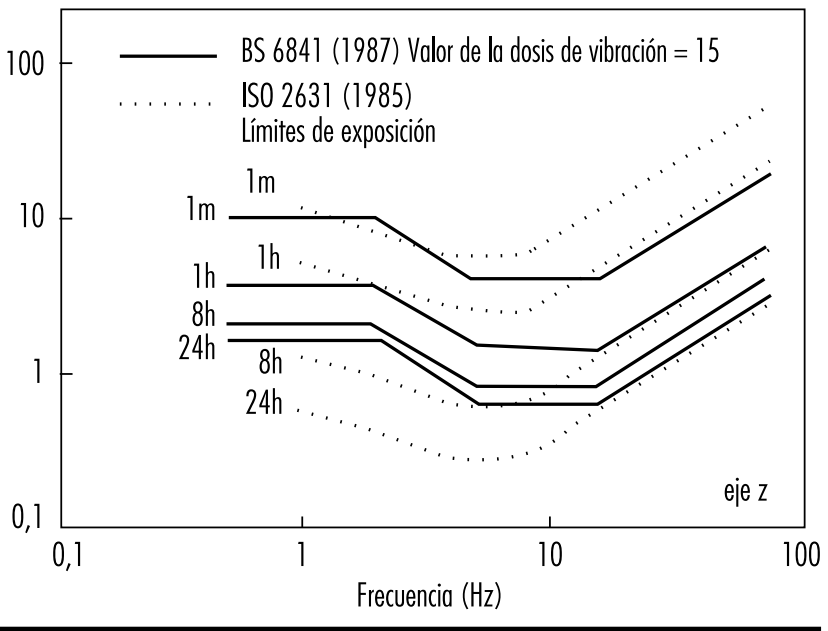

de limitar la exposición de origen profesional al mínimo razonable.

Se han publicado resultados divergentes sobre la aparición de enfermedades del sistema genitourinario masculino. En algunos estudios, se ha observado una mayor incidencia de prostatitis. $O$ tros estudios no han podido confirmar estos hallazgos.

\section{Normas}

Aunque no puede ofrecerse ningún límite preciso para prevenir los trastornos causados por las vibraciones de cuerpo completo, las normas definen métodos útiles para cuantificar la intensidad de las vibraciones. La Norma Internacional 2631 (ISO 1974, 1985) definió límites de exposición (véase la Figura 50.1) “establecidos aproximadamente en la mitad del nivel considerado como umbral del dolor (o límite de tolerancia voluntaria) para sujetos humanos sanos". En la Figura 50.1 se muestra también un nivel de acción del valor de la dosis de vibración para vibración vertical, derivado de la N orma Británica 6841 (BSI 1987b); esta norma es similar, en parte, a un proyecto revisado de la Norma Internacional.

El valor de la dosis de vibración puede considerarse como la magnitud de la vibración de un segundo de duración que sea de igual intensidad que la vibración medida. En el valor de la dosis de vibración se utiliza una dependencia temporal elevada a la cuarta potencia para calcular la intensidad de vibración acumulada durante el período de exposición, desde el choque más corto posible hasta una jornada completa de vibración (p. ej., BSI 6841):

$$
\text { Valor de la dosis de vibracion }=\left[\int_{t=0}^{\mathrm{t}=\infty} \mathrm{a}(\mathrm{t})^{4} \mathrm{dt}\right]^{\frac{1}{4}}
$$

El procedimiento del valor de la dosis de vibración puede utilizarse para valorar la intensidad de la vibración y de los choques repetitivos. Esta dependencia temporal elevada a la cuarta potencia es más fácil de usar que la dependencia temporal contemplada en la Norma ISO 2631 (véase la Figura 50.2).

\section{La N orma Británica 6841 ofrece la siguiente orientación.}

Valores altos de la dosis de vibración causan malestar intenso, dolor y lesiones. Los valores de la dosis de vibración 
Figura 50.2 - Dependencias del tiempo en cuanto a la respuesta humana a la vibración de cuerpo completo.

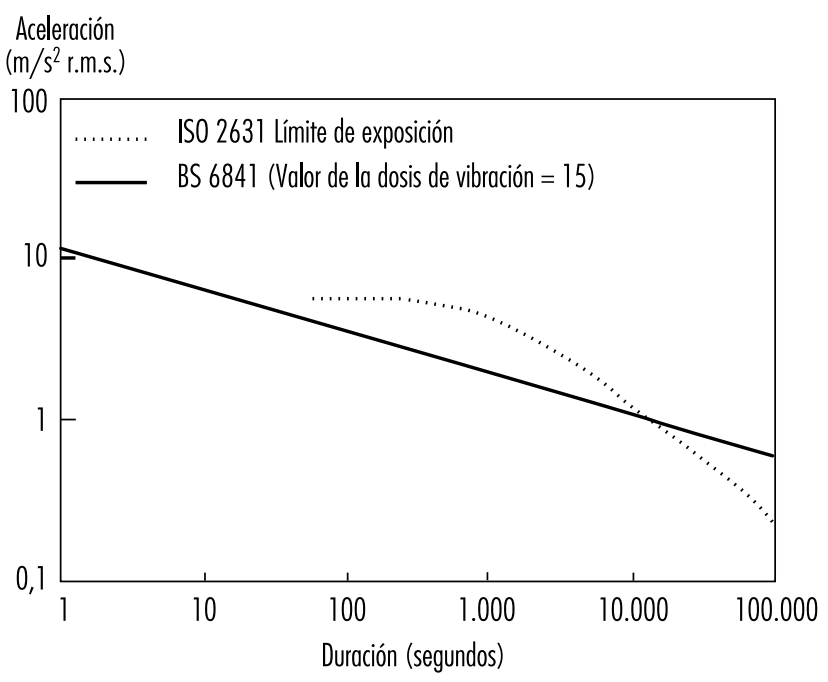

indican también, de modo general, la intensidad de las exposiciones a las vibraciones que los han producido. Con todo, actualmente no existe una opinión unánime sobre la relación precisa entre valores de dosis de vibración y riesgo de lesión. Se sabe que las magnitudes y duraciones de las vibraciones que producen valores de dosis de vibración en la región de $15 \mathrm{~m} / \mathrm{s}^{1,75}$ causan generalmente malestar intenso. Es razonable suponer que un aumento de la exposición a las vibraciones irá acompañado de un mayor riesgo de lesión (BSI 1987b).

Con valores altos de la dosis de vibración, puede ser necesario considerar previamente la capacidad física de las personas expuestas y diseñar precauciones de seguridad adecuadas. Puede tomarse también en consideración la necesidad de revisiones periódicas del estado de salud de las personas habitualmente expuestas.

El valor de la dosis de vibración proporciona una medida que permite comparar exposiciones muy variables y complejas. Las organizaciones pueden especificar límites o niveles de acción utilizando el valor de la dosis de vibración. Por ejemplo, en algunos países, se ha utilizado un valor de la dosis de vibración de $15 \mathrm{~m} / \mathrm{s}^{1,75}$ como nivel de acción provisional, pero puede ser conveniente limitar las exposiciones a las vibraciones 0 a choques repetidos a valores más altos o más bajos dependiendo de la situación. Con lo que sabemos actualmente, un nivel de acción solo sirve para indicar los valores aproximados que podrían ser excesivos. En la Figura 50.2 se indican las aceleraciones eficaces correspondientes a un valor de la dosis de vibración de $15 \mathrm{~m} / \mathrm{s}^{1,75}$ para exposiciones comprendidas entre un segundo y 24 horas. Cualquier exposición a vibraciones continuas, vibraciones intermitentes o choques repetidos pueden compararse con el nivel de acción calculando el valor de la dosis de vibración. No sería prudente rebasar un nivel de acción apropiado (o el límite de exposición según la Norma ISO 2631) sin tener en cuenta los posibles efectos para la salud de una exposición a la vibración o al choque.

La Directiva sobre seguridad de las máquinas de la Comunidad E conómica Europea establece que la máquina deberá diseñarse y construirse de manera que los riesgos resultantes de las vibraciones producidas por la misma se reduzcan al mínimo nivel posible, teniendo en cuenta el progreso tecnológico y los medios disponibles para reducir la vibración. La Directiva sobre seguridad de las máquinas (C onsejo de las Comunidades Europeas 1989) recomienda reducir las vibraciones por medios adicionales a la reducción en la fuente (p. ej., un buen asiento).

\section{Medida y valoración de la exposición}

Las vibraciones de cuerpo completo debe medirse en las interfases entre el cuerpo y la fuente de vibración. En el caso de personas sentadas esto implica la colocación de acelerómetros en la superficie del asiento, debajo de las tuberosidades isquiáticas de los sujetos. A veces las vibraciones se miden también en el respaldo del asiento (entre el respaldo y la espalda) así como en los pies y las manos (véase la Figura 50.3).

L os datos epidemiológicos por sí solos no son suficientes para definir cómo valorar las vibraciones de cuerpo completo de un modo que permita predecir los riesgos para la salud derivados de los diferentes tipos de exposición a las vibraciones. En estos momentos, la comprensión de las respuestas biodinámicas y de las respuestas subjetivas tomando en consideración los datos epidemiológicos, proporciona orientación al respecto. Actualmente, se supone que la forma en que los efectos para la salud derivados de los movimientos dependen de la frecuencia, dirección y duración del movimiento es igual o parecida a la del malestar por vibración. Ahora bien, se considera que lo importante es la exposición total, no la exposición promedio, y que por lo tanto es adecuado medir la dosis.

A demás de valorar las vibraciones medidas de acuerdo con las normas actuales, es aconsejable informar de los espectros de frecuencia, las magnitudes de los diferentes ejes y otras características de la exposición, incluyendo las duraciones de la exposición diaria y la de toda la vida. También debería tenerse en

Figura 50.3 - Ejes para medir exposiciones a la vibración en personas sentadas.

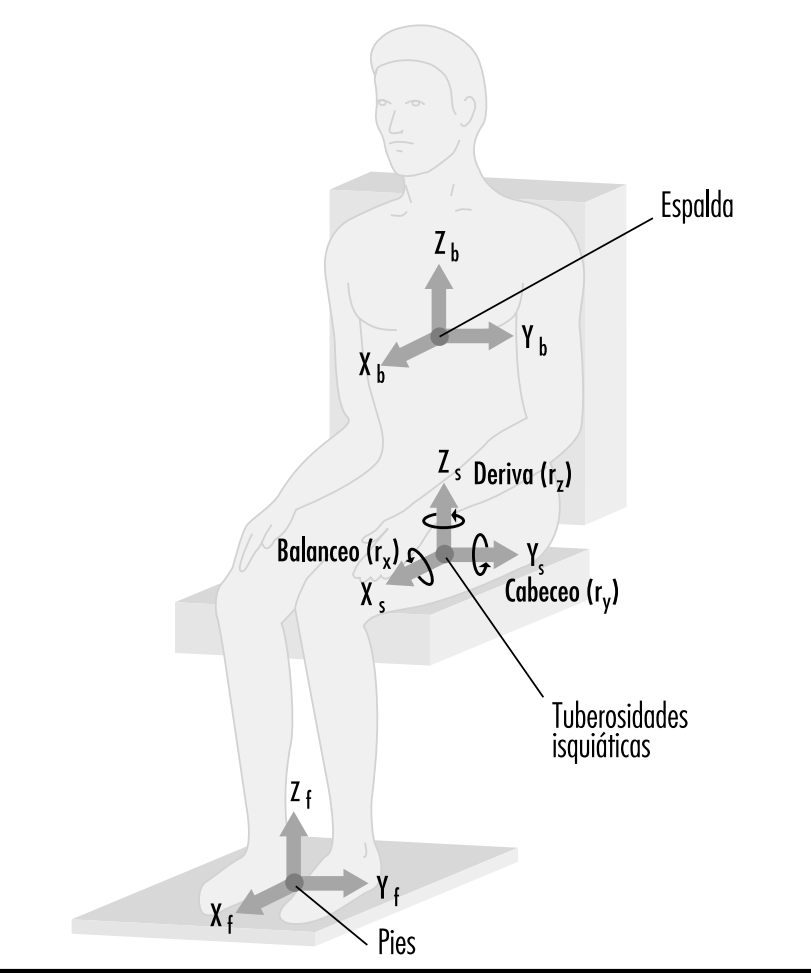


cuenta la presencia de otros factores ambientales adversos, en especial la postura sentada.

\section{Prevención}

Cuando sea posible se dará preferencia a la reducción de las vibraciones en la fuente. Para ello puede ser necesario reducir las ondulaciones del terreno o la velocidad de desplazamiento de los vehículos. 0 tros métodos para reducir la transmisión de vibraciones a los operarios exigen comprender las características del entorno de las vibraciones y la ruta de transmisión de las vibraciones al cuerpo. Por ejemplo, a menudo la magnitud de la vibración depende de la ubicación: en algunas zonas se experimentan magnitudes menores. En la Tabla 50.2 se ofrece una lista de algunas medidas preventivas que pueden tenerse en cuenta.

Tabla 50.2 - Resumen de medidas preventivas que han de considerarse cuando las personas están expuestas a vibración global de todo el cuerpo.

\begin{tabular}{|c|c|}
\hline Grupo & Acción \\
\hline Dirección & $\begin{array}{l}\text { Obtener asesoramiento técnico } \\
\text { Obtener asesoramiento médico } \\
\text { Prevenir a las personas expuestas } \\
\text { Formar a las personas expuestas } \\
\text { Analizar los tiempos de exposición } \\
\text { Adoptar medidas para retirar a los afectados de } \\
\quad \text { la exposición }\end{array}$ \\
\hline Fabricantes de máquinas & $\begin{array}{l}\text { Medir la vibración } \\
\text { Diseño que minimice las vibraciones de cuerpo } \\
\text { completo } \\
\text { Optimizar el diseño de la suspensión } \\
\text { Optimizar la dinámica de los asientos } \\
\text { Utilizar un diseño ergonómico para permitir una } \\
\quad \text { postura correcta, etc. } \\
\text { Asesorar en el mantenimiento de la máquina } \\
\text { Asesorar en el mantenimiento de los asientos } \\
\text { Alertar sobre las vibraciones peligrosas }\end{array}$ \\
\hline $\begin{array}{l}\text { Técnicos: en el lugar de } \\
\text { trabajo }\end{array}$ & $\begin{array}{l}\text { Medir la exposición a las vibraciones } \\
\text { Proveer máquinas adecuadas } \\
\text { Seleccionar asientos con buena atenuación } \\
\text { Mantener las máquinas } \\
\text { Informar a la dirección }\end{array}$ \\
\hline Médicos & $\begin{array}{l}\text { Reconocimiento selectivo antes de la contratación } \\
\text { Revisiones médicas periódicas } \\
\text { Anotar todos los síntomas comunicados } \\
\text { Advertir a los trabajadores con predisposición } \\
\quad \text { evidente } \\
\text { Asesorar sobre las consecuencias de la exposición } \\
\text { Informar a la dirección }\end{array}$ \\
\hline Personas expuestas & $\begin{array}{l}\text { Utilizar la máquina correctamente } \\
\text { Evitar la exposición innecesaria a las vibraciones } \\
\text { Comprobar que el asiento está bien ajustado } \\
\text { Adoptar una postura sentada correcta } \\
\text { Comprobar el estado de la máquina } \\
\text { Informar al supervisor de los problemas de } \\
\text { vibraciones } \\
\text { Obtener asesoramiento médico si aparecen } \\
\text { síntomas } \\
\text { Informar a la empresa de los trastornos } \\
\text { correspondientes }\end{array}$ \\
\hline
\end{tabular}

Fuente: Adaptado de Griffin 1990
Se pueden diseñar los asientos de manera que atenúen las vibraciones. La mayoría de los asientos presentan resonancia a bajas frecuencias, lo que hace que se produzcan mayores magnitudes de vibración vertical en el asiento que en el piso. A altas frecuencias suele producirse una atenuación de las vibraciones. En la práctica, las frecuencias de resonancia de los asientos habituales están en la región de los $4 \mathrm{~Hz}$. La amplificación en resonancia viene determinada en parte por la amortiguación del asiento. Un aumento de la capacidad de amortiguación del relleno del asiento tiende a reducir la amplificación en resonancia pero aumenta la transmisibilidad a altas frecuencias. $\mathrm{H}$ ay grandes variaciones de transmisibilidad entre asientos, las cuales se traducen en considerables diferencias en cuanto a la vibración que experimentan las personas.

U na indicación numérica simple de la eficacia de aislamiento de un asiento para una aplicación específica, es la que proporciona la transmisibilidad de la amplitud eficaz del asiento (SEAT) (véase Griffin 1990). Un valor de SEAT superior al $100 \%$ indica que, globalmente, las vibraciones en el asiento son peores que las vibraciones en el piso. Valores inferiores al $100 \%$ indican que el asiento ha proporcionado algo de atenuación útil. Los asientos deberían diseñarse de manera que tuviesen el valor SEAT más bajo que sea compatible con otras limitaciones.

Los asientos con suspensión llevan un mecanismo de suspensión separado debajo del panel del asiento. Se utilizan en algunos vehículos todo terreno, así como en camiones y autocares, y sus frecuencias de resonancia son bajas (en torno a $2 \mathrm{~Hz}$ ) y por lo tanto pueden atenuar las vibraciones a frecuencias superiores a unos $3 \mathrm{~Hz}$. Los valores de transmisibilidad de estos asientos los determina normalmente el fabricante del asiento, pero sus eficacias de aislamiento varían según las condiciones de trabajo.

\section{VIBRACIONES TRAN SMITIDAS A LAS MANOS}

M assimo Bovenzi

\section{Exposición de origen profesional}

Las vibraciones mecánicas producida por procesos o herramientas a motor y que penetran en el cuerpo por los dedos o la palma de las manos se denominan vibraciones transmitidas a las manos. Como sinónimos de vibraciones transmitidas a las manos se utilizan con frecuencia las expresiones vibraciones mano-brazo y vibraciones locales 0 segmentarias. En varias actividades industriales se encuentran muy extendidos los procesos y herramientas a motor que exponen las manos del operario a vibraciones. $L a$ exposición de origen profesional a las vibraciones transmitidas a las manos proviene de las herramientas a motor que se utilizan en fabricación ( $p$. ej., herramientas de percusión para trabajo de metales, amoladoras y otras herramientas rotativas, llaves de impacto), explotación de canteras, minería y construcción (p. ej., martillos perforadores de roca, martillos rompedores de piedra, martillos picadores, compactadores vibrantes), agricultura y trabajos forestales (p. ej., sierras de cadena, sierras de recortar, descortezadoras) y servicios públicos (p. ej., martillos rompedores de asfalto y hormigón, martillos perforadores, amoladoras de mano). También puede producirse exposición a vibraciones transmitidas a las manos por piezas vibrantes sostenidas con las manos del operario, como en el amolado de columna, y por controles manuales vibrantes, como al utilizar cortacéspedes 0 controlar rodillos vibrantes para compactación de carreteras. Se ha comunicado que el número de personas expuestas a vibraciones transmitidas a las manos en el trabajo excede de 
150.000 en los Países Bajos, de 0,5 millones en Gran Bretaña y de 145 millones en Estados Unidos. La exposición excesiva a las vibraciones transmitidas a las manos puede causar trastornos en los vasos sanguíneos, nervios, músculos, huesos y articulaciones de las extremidades superiores. Se calcula que del 1,7 al 3,6 \% de los trabajadores de los países europeos y de Estados U nidos están expuestos a vibraciones transmitidas a las manos potencialmente peligrosa (AISSA Sección Internacional de Investigación 1989). La expresión síndrome de vibraciones mano-brazo (HAV) se utiliza comúnmente en referencia a los síntomas asociados con exposición a vibraciones transmitidas a las manos, a saber:

- trastornos vasculares;

- trastornos neurológicos periféricos;

- trastornos de los huesos y articulaciones

- trastornos musculares,

- otros trastornos (todo el cuerpo, sistema nervioso central).

Actividades tales como la conducción de motocicletas o el uso de herramientas vibrantes domésticas pueden exponer las manos esporádicamente a vibraciones de gran amplitud, pero solo las largas exposiciones diarias pueden provocar problemas de salud (G riffin 1990).

La relación entre exposición a vibraciones transmitidas a las manos de origen profesional y efectos adversos para la salud dista de ser sencilla. En la Tabla 50.3 se proporciona una lista de algunos de los factores más importantes que contribuyen a causar lesiones en las extremidades superiores de los trabajadores expuestos a vibración.

\section{Biodinámica}

Cabe suponer que los factores que influyen en la transmisión de vibraciones al sistema de los dedos, la mano y el brazo desempeñan un papel importante en la génesis de lesiones por vibraciones. La transmisión de vibraciones depende de las características físicas de la vibración (magnitud, frecuencia, dirección) y de la respuesta dinámica de la mano (Griffin 1990).

\section{Transmisibilidad e impedancia}

Los resultados experimentales indican que el comportamiento mecánico de la extremidad superior humana es complejo, dado que la impedancia del sistema de la mano y el brazo-es decir, la resistencia a vibrar-presenta marcadas variaciones en función de los cambios de amplitud de vibración, frecuencia y dirección, fuerzas aplicadas y orientación de la mano y el brazo con respecto al eje del estímulo. En la impedancia influye también la constitución corporal y las diferencias estructurales de las diversas partes de la extremidad superior ( $p$. ej., la impedancia mecánica de los dedos es muy inferior a la de la palma de la mano). En general, a mayores niveles de vibración y a mayores presiones de agarre de la mano, mayor impedancia. C on todo, se ha descubierto que las variaciones de impedancia dependen considerablemente de la frecuencia y dirección del estímulo de la vibración y de las diversas fuentes de intravariabilidad e intervariabilidad del sujeto. En varios estudios se ha comunicado la existencia de una región de resonancia para el sistema de los dedos, la mano y el brazo en la gama de frecuencia comprendida entre 80 y $300 \mathrm{~Hz}$

M edidas de la transmisión de vibraciones a través del brazo humano han mostrado que las vibraciones de baja frecuencia $(<50 \mathrm{~Hz})$ se transmiten con poca atenuación a lo largo de la mano y el antebrazo. La atenuación en el codo depende de la postura del brazo, dado que la transmisión de vibraciones tiende a disminuir a medida que aumenta el ángulo de flexión en la articulación del codo. A frecuencias altas $(>50 \mathrm{~Hz})$, la transmisión de vibraciones disminuye progresivamente a medida que
Tabla 50.3 - Algunos factores potencialmente relacionados con efectos lesivos durante las exposiciones a las vibraciones transmitidas a las manos.

Características de la vibración

- Magnitud (eficaz, pico, ponderada/ no ponderada)

- Frecuencia (espectros, frecuencias dominantes)

- Dirección (ejes $x, y, z$ )

Herramientas o procesos

- Diseño de herramientas (portátiles, fijas)

- Tipo de herramienta (de percusión, rotativa, rotopercutante)

- Condición

- Operación

- Material que se trabaja

Condiciones de exposición

- Duración (exposiciones diarias, anuales)

- Modelo de exposición (continua, intermitente, períodos de descanso)

- Duración de la exposición acumulada

Condiciones ambientales

- Temperatura ambiente

- Flujo de aire

- Humedad

- Ruido

- Respuesta dinámica del sistema dedo-mano-brazo

- Impedancia mecánica

- Transmisibilidad de la vibración

- Energía absorbida

Características individuales

- Método de trabajo (fuerza de agarre, fuerza de empuje, postura de manobrazo, posición del cuerpo)

- Salud

- Formación

- Destreza

- Uso de guantes

- Susceptibilidad individual a la lesión

aumenta la frecuencia, y por encima de 150 a $200 \mathrm{~Hz}$ la mayor parte de la energía de vibración se disipa en los tejidos de la mano y los dedos. De las medidas de transmisibilidad se infiere que en la región de alta frecuencia, las vibraciones pueden ser responsable de daños a las estructuras blandas de los dedos y manos, mientras que las vibraciones de baja frecuencia y gran amplitud (p. ej., producida por herramientas de percusión) podría estar relacionada con lesiones de muñeca, codo y hombro.

\section{Factores que influyen en la dinámica de los dedos y la mano}

Cabe suponer que los efectos adversos de la exposición a las vibraciones están relacionados con la energía disipada en las extremidades superiores. La absorción de energía depende en gran medida de factores que afectan al acoplamiento del sistema dedos-mano a la fuente de vibraciones. Variaciones de la presión de agarre, fuerza estática y postura, modifican la respuesta dinámica del dedo, la mano y el brazo y, por consiguiente, la cantidad de energía transmitida y absorbida. Por 
ejemplo, la presión de agarre influye considerablemente en la absorción de energía y, en general, cuanto mayor es esta presión mayor es la fuerza transmitida al sistema de la mano y el brazo. Los datos de respuesta dinámica pueden suministrar información importante para valorar el potencial de las vibraciones de la herramienta para producir lesiones y para facilitar el desarrollo de dispositivos antivibración tales como empuñaduras y guantes.

\section{Efectos agudos}

\section{Malestar subjetivo}

La vibración es detectada por diversos mecanorreceptores de la piel, situados en los tejidos (epi)dérmicos y subcutáneos de la piel lisa y desnuda (glabra) de los dedos y manos. Tales receptores se clasifican en dos categorías - de adaptación lenta y rápidasegún sus propiedades de adaptación y su campo receptor. En las unidades mecanorreceptoras de adaptación lenta se encuentran los discos de Merkel y las terminaciones de Ruffini, que responden a la presión estática y a pequeñas variaciones de presión y son excitados a baja frecuencia $(<16 \mathrm{~Hz}$ ). Las unidades de adaptación rápida tienen los corpúsculos de M eissner y de Pacinian, que responden a variaciones rápidas de los estímulos y se encargan de producir la sensación de vibración en la gama de frecuencia entre 8 y $400 \mathrm{~Hz}$. La respuesta subjetiva a las vibraciones transmitidas a las manos se ha utilizado en varios estudios para obtener valores umbral, contornos de sensación equivalente y límites de sensación desagradable o de tolerancia a los estímulos vibratorios a diferentes frecuencias (G riffin 1990). Los resultados experimentales indican que la sensibilidad humana a la vibración disminuye a medida que aumenta la frecuencia, tanto en lo que se refiere a los niveles de vibración confortables como molestos. La vibración vertical parece causar mayor malestar que la vibración en otras direcciones. Se ha observado también que el malestar subjetivo está en función de la composición espectral de la vibración y de la fuerza de agarre ejercida sobre la empuñadura que vibra.

\section{Perturbación de la actividad}

La exposición aguda a vibraciones transmitidas a las manos puede causar un aumento temporal de los umbrales vibrotáctiles debido a una depresión de la excitabilidad de los mecanorreceptores de la piel. La magnitud de la variación temporal de estos umbrales, así como el tiempo de recuperación están sujetos a la influencia de distintas variables, tales como las características del estímulo (frecuencia, amplitud, duración), la temperatura y la edad y exposición anterior a la vibración del trabajador. La exposición al frío agrava la depresión táctil inducida por las vibraciones, debido a que la baja temperatura tiene un efecto vasoconstrictor en la circulación digital y reduce la temperatura de la piel de los dedos. En trabajadores expuestos a vibraciones que trabajan habitualmente en ambientes fríos, los episodios repetidos de deterioro agudo de la sensibilidad táctil puede conducir a una reducción permanente de la percepción sensorial y a la pérdida de destreza de manipulación lo que, a su vez, puede interferir en la actividad laboral y elevar el riesgo de lesiones graves por accidentes.

\section{Efectos no vasculares}

\section{Esqueléticos}

Las lesiones óseas y articulares inducidas por las vibraciones son objeto de controvertida. Diversos autores consideran que los trastornos de huesos y articulaciones en trabajadores que utilizan herramientas vibrantes de mano, no tienen carácter específico ni son similares a los originados por el proceso de envejecimiento y por el trabajo manual pesado. Por otra parte, algunos investigadores han comunicado que la exposición prolongada a vibraciones transmitidas a las manos puede producir alteraciones esqueléticas características en las manos, muñecas y codos. Estudios radiológicos realizados en un primer momento revelaron una alta prevalencia de vacuolas y quistes óseos en las manos y muñecas de trabajadores expuestos a vibraciones, pero otros estudios más recientes no han mostrado ningún aumento significativo con respecto a grupos de control integrados por trabajadores manuales. Se ha comunicado una prevalencia elevada de osteoartrosis de muñeca y artrosis y osteofitosis de codo en mineros del carbón, trabajadores de la construcción de carreteras y trabajadores del metal expuestos a choques y a vibración de baja frecuencia y gran amplitud producida por herramientas neumáticas de percusión. Por el contrario, hay poca evidencia de aumento de la prevalencia de trastornos óseos y articulares degenerativos en las extremidades superiores de los trabajadores expuestos a vibraciones de mediana 0 alta frecuencia procedentes de sierras de cadena o amoladoras. El esfuerzo físico intenso, un agarre con fuerza y otros factores biomecánicos pueden ser la causa de la mayor aparición de lesiones esqueléticas encontrada en trabajadores que utilizan herramientas de percusión. El dolor localizado, la hinchazón y la rigidez y deformidades de las articulaciones pueden estar relacionados con hallazgos radiológicos de degeneración ósea y articular. En unos cuantos países (Francia, Alemania e Italia entre ellos), se considera que los trastornos óseos y articulares que aparecen en trabajadores que utilizan herramientas de mano vibrantes, son una enfermedad de origen profesional, y los trabajadores afectados son indemnizados.

\section{Neurológicos}

Los trabajadores que manejan herramientas vibrantes pueden sufrir hormigueo y adormecimiento de dedos y manos. Si la exposición a las vibraciones continúa, estos síntomas tienden a empeorar y pueden interferir con la capacidad de trabajo y las actividades de su vida diaria. Los trabajadores expuestos a vibraciones pueden presentar umbrales vibratorios, térmicos y táctiles más elevados en los reconocimientos clínicos. Se ha sugerido que la exposición continua a las vibraciones no solo puede deprimir la excitabilidad de los receptores de la piel sino también inducir alteraciones patológicas en los nervios de los dedos, tales como edema perineural, seguido de fibrosis y pérdida de fibra nerviosa. Estudios epidemiológicos de trabajadores expuestos a vibraciones señalan que la prevalencia de trastornos neurológicos periféricos varía desde un pequeño porcentaje hasta más del 80 por ciento, y que la pérdida de sensibilidad afecta a usuarios de una amplia variedad de tipos de herramientas. Parece ser que la neuropatía por vibración se desarrolla con independencia de otros trastornos inducidos por las vibraciones. En el Taller de Estocolmo (Stockholm Workshop) 86 (1987) se propuso una

Tabla 50.4 - Fases neurosensoriales de la escala del Taller de Estocolmo para el síndrome de vibraciones mano-brazo.

$\begin{array}{ll}\text { Fase } & \text { Síntomas } \\ \text { OSN } & \text { Expuesto a vibración pero sin síntomas } \\ \text { ISN } & \text { Adormecimiento intermitente, con o sin hormigueo } \\ \text { 2SN } & \text { Adormecimiento intermitente o persistente, percepción sensorial reducida } \\ 3 \text { 3N } & \text { Adormecimiento intermitente o persistente, discriminación táctil y/ o } \\ & \text { destreza de manipulación reducidas }\end{array}$

Fuente: Stockholm Workshop 861987. 
escala del componente neurológico de síndrome de H AV, consistente en tres fases según los síntomas y los resultados del reconocimiento clínico y las pruebas objetivas (Tabla 50.4). Se requiere un diagnóstico diferencial cuidadoso para distinguir la neuropatía por vibraciones de neuropatías por compresión, tales como el síndrome del túnel carpiano (CTS), un trastorno debido a compresión del nervio mediano a su paso por un túnel anatómico de la muñeca. EI CTS parece ser un trastorno común en algunos grupos profesionales que utilizan herramientas vibrantes, tales como los perforadores, los chapistas y los trabajadores forestales. Se cree que los factores de estrés ergonómicos que actúan sobre la mano y la muñeca (movimientos repetitivos, agarre con fuerza, malas posturas), unidos a las vibraciones, pueden causar CT S en trabajadores que manejan herramientas vibrantes. La electroneuromiografía, que mide las velocidades de los nervios sensoriales y motores, ha demostrado ser útil para diferenciar el CTS de otros trastornos neurológicos.

\section{Musculares}

Los trabajadores expuestos a vibraciones pueden quejarse de debilidad muscular y dolor en las manos y brazos. En algunos individuos la fatiga muscular puede causar discapacidad. En algunos estudios de seguimiento de leñadores se ha comunicado una disminución de la fuerza de agarre de la mano. Se han sugerido lesión mecánica directa o daño del nervio periférico como posibles factores etiológicos de los síntomas musculares. También se han comunicado otros trastornos relacionados con el trabajo en trabajadores expuestos a vibraciones, como tendinitis y tenosinovitis en las extremidades superiores, y contractura de Dupuytren, una enfermedad del tejido fascial de la palma de la mano. Tales trastornos parecen tener relación con factores de estrés ergonómicos derivados del trabajo manual pesado, y la asociación con vibración transmitida a las manos no es concluyente.

\section{Trastornos vasculares}

\section{Fenómeno de Raynaud}

Giovanni Loriga, médico italiano, comunicó por primera vez en 1911 que los cortadores de piedra que utilizan martillos neumáticos en bloques de mármol y piedra en algunas serrerías de Roma, sufrían ataques de blanqueado de los dedos, semejantes a la respuesta vasospástica digital al frío o al estrés emocional descrita por $M$ aurice $R$ aynaud en 1862 . O bservaciones similares fueron realizadas por Alice $\mathrm{H}$ amilton (1918) en cortadores de piedra en Estados U nidos, y más tarde por varios otros investigadores. En la literatura se han utilizado diversos sinónimos para describir trastornos vasculares inducidos por vibraciones: dedo muerto o blanco, fenómeno de Raynaud de origen profesional, enfermedad vasospástica traumática y, más recientemente, dedo blanco inducido por vibración (VWF). Clínicamente, el VWF se caracteriza por episodios de dedos blancos o pálidos causados por oclusión espástica de las arterias digitales. Los ataques suelen desencadenarse por el frío y duran de 5 a 30040 minutos. Durante un ataque puede experimentarse pérdida completa de sensibilidad táctil. En la fase de recuperación, normalmente acelerada por calor o masaje local, puede aparecer enrojecimiento de los dedos afectados a causa de un aumento reactivo del flujo sanguíneo en los vasos cutáneos. En los pocos casos avanzados, los ataques vasospásticos digitales graves y repetidos pueden conducir a alteraciones tróficas (ulceración o gangrena) en la piel de las puntas de los dedos. Para explicar el fenómeno de R aynaud inducido por el frío en trabajadores expuestos a vibraciones, algunos investigadores invocan un reflejo vasoconstrictor simpático central exagerado causado por exposición prolongada a vibraciones perjudiciales, mientras que otros tienden a enfatizar el papel de las alteraciones locales inducidas por las vibraciones en los vasos digitales (p. ej., engrosamiento de la pared muscular, daño endotelial, alteraciones del receptor funcional). En el Taller de Estocolmo 86 (1987), se propuso una escala de gradación para la clasificación del VWF, (Tabla 50.5). También se dispone de un sistema numérico para los síntomas de VWF desarrollado por $G$ riffin y basado en puntuaciones para el blanqueado de las diferentes falanges (G riffin 1990). Para diagnosticar objetivamente el VWF se utilizan varias pruebas de laboratorio. La mayoría de ellas se basan en la provocación de frío y en la medida de la temperatura de la piel del dedo o del flujo y la presión de la sangre digital antes y después de enfriar los dedos y las manos. Estudios epidemiológicos han demostrado que la prevalencia de VWF varía ampliamente desde 1 a 100 por cien. Se ha descubierto que el VWF está relacionado con el uso de herramientas de percusión para el trabajo de metales, amoladoras y otras herramientas rotativas, martillos percusores y perforadores utilizados en excavación, maquinaria vibrante empleada en el trabajo forestal y otras herramientas y procesos motorizados. EI VWF está reconocido como enfermedad de origen profesional en muchos países. Desde 1975-80 se comunicó un descenso de la incidencia de nuevos casos de VWF entre trabajadores forestales tanto en Europa como en Japón, tras la introducción de sierras de cadena con sistemas antivibración y la aplicación de medidas administrativas que reducen el tiempo de utilización de las sierras. No se dispone aún de hallazgos similares para otros tipos de herramientas.

\section{Otros trastornos}

Algunos estudios indican que en los trabajadores afectados de VWF la pérdida de audición es mayor de lo esperado en función del envejecimiento y de la exposición al ruido por el uso de herramientas vibrantes. Se ha sugerido que los sujetos con VWF pueden presentar un riesgo adicional de deterioro auditivo debido a vasoconstricción simpática refleja, inducida por vibración, de los vasos sanguíneos que irrigan el oído interno. A demás de trastornos periféricos, algunas escuelas rusas y japonesas de medicina del trabajo han comunicado otros efectos adversos para la salud que afectan al sistema endocrino y al sistema nervioso central de trabajadores expuestos a vibración (Griffin 1990). El cuadro clínico denominado "enfermedad de las vibraciones", incluye signos y síntomas relacionados con la disfunción de los centros autónomos del cerebro (p. ej., fatiga persistente, dolor de cabeza, irritabilidad, perturbaciones del sueño, impotencia, anomalías electroencefalográficas). Se trata de hallazgos que han

Tabla 50.5 Escala del Taller de Estocolmo para las fases del fenómeno de Raynaud inducido por el frío en el síndrome de vibraciones mano-brazo.

$\begin{array}{lll}\text { Fase } & \text { Grado } & \text { Síntomas } \\ 0 & - & \text { Ningún ataque } \\ 1 & \text { Leve } & \begin{array}{l}\text { Ataques esporádicos que sólo afectan a las puntas de } \\ \text { uno } 0 \text { más dedos }\end{array} \\ 2 & \text { Moderado } & \begin{array}{l}\text { Ataques esporádicos que afectan a las falanges distal y } \\ \text { media ( rara vez también a la proximal) de uno o más } \\ \text { dedos }\end{array} \\ 3 & \text { Grave } & \begin{array}{l}\text { Ataques frecuentes que afectan a todas las falanges de } \\ \text { la mayoría de los dedos } \\ \text { Como en la fase 3, con alteraciones tróficas de la piel } \\ \text { en las puntas de los dedos }\end{array}\end{array}$

Fuente: Stockholm Workshop 861987. 
Figura 50.4 - Sistema de coordenadas basicéntrico para la medición de las vibraciones transmitidas a las manos.
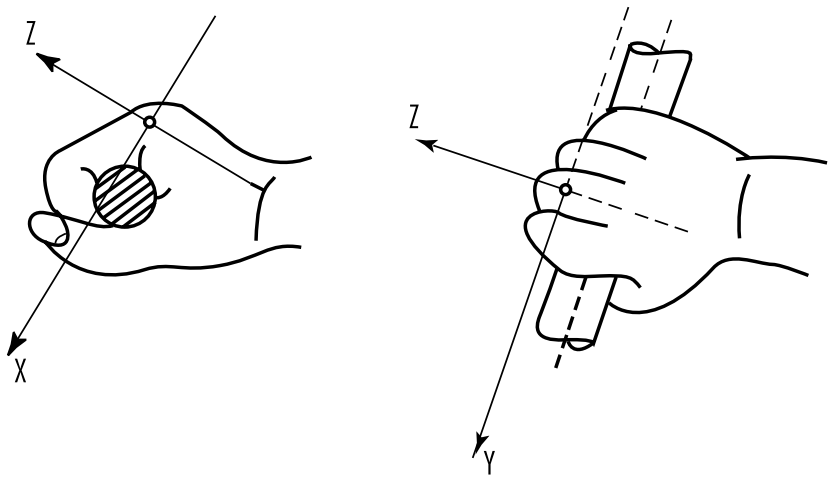

Fuente: ISO 53491986

de interpretarse con cautela; hacen falta más trabajos de investigación epidemiológica y clínica cuidadosamente diseñados para confirmar la hipótesis de una asociación entre trastornos del sistema nervioso central y la exposición a vibraciones transmitidas a las manos.

\section{Normas}

Varios países han adoptado normas o directrices sobre exposición a vibraciones transmitidas a las manos. La mayoría de ellas están basadas en la Norma Internacional 5349 (ISO 1986). Para medir las vibraciones transmitidas a las manos, la Norma ISO 5349 recomienda el empleo de una curva de ponderación de frecuencia que proporcione un valor aproximado de la sensibilidad de la mano a los estímulos de vibración dependiente de la frecuencia. La aceleración de la vibración ponderada en frecuencia $\left(a_{h, w}\right)$ se obtiene con un filtro de ponderación adecuado o sumando los valores de aceleración ponderada medidos en bandas de octava y de tercio de octava a lo largo de un sistema de coordenadas ortogonales $\left(x_{h}, y_{h}, z_{h}\right)$, (véase la Figura 50.4). En la Norma ISO 5349 la exposición diaria a la vibración se expresa en términos de aceleración continua equivalente ponderada en frecuencia para un período de cuatro horas $\left[\left(a_{h, w}\right)_{\text {eq(4) }}\right.$ en $\mathrm{m} / \mathrm{s}^{2}$ r.m.s], de acuerdo con la siguiente ecuación:

$$
\left(a_{h, w}\right)_{\text {eq }(4)}=(T / 4)^{1 / 2}\left(a_{h, w}\right)_{\text {eq }(T)}
$$

Tabla 50.6 • Valores límite umbral para vibraciones transmitidas a las manos.

$\begin{array}{llc}\begin{array}{l}\text { Exposición } \\ \text { diaria total }\end{array} & \begin{array}{l}\text { Aceleración eficaz ponderada en frecuencia en la } \\ \text { (horas) }\end{array} & \begin{array}{l}\text { dirección dominante que no debe sobrepasarse } \\ \mathrm{s}^{2}\end{array} \\ 4-8 & 4 & 0,40 \\ 2-4 & 6 & 0,61 \\ 1-2 & 8 & 0,81 \\ 1 & 12 & 1,22 \\ * 1 \mathrm{~g}=9,81 \mathrm{~m} / \mathrm{s}^{2} \text {. } & \\ \begin{array}{l}\text { Fuente: Según la American Conference of Governmental Industrial Hygienists (Conferencia Americana } \\ \text { de Higienistas Industriales del Gobierno) 1992. }\end{array}\end{array}$

Tabla 50.7 • Propuesta del Consejo de la Unión Europea para una Directiva del Consejo sobre agentes físicos: A nexo II A. Vibraciones transmitidas a la mano (1994).

\begin{tabular}{|c|c|c|}
\hline $\begin{array}{l}\text { Niveles } \\
\left(\mathrm{ms}^{-2}\right)\end{array}$ & $A(8)^{*}$ & Definiciones \\
\hline Umbral & 1 & $\begin{array}{l}\text { El valor de exposición por debajo del cual la } \\
\text { exposición continua o repetitiva no tiene ningún } \\
\text { efecto adverso sobre la salud y la seguridad de los } \\
\text { trabajadores }\end{array}$ \\
\hline Acción & 2,5 & $\begin{array}{l}\text { El valor por encima del cual deben adoptarse una } 0 \\
\text { más de las medidas** especificadas en los } \\
\text { correspondientes Anexos }\end{array}$ \\
\hline $\begin{array}{l}\text { Valor límite } \\
\text { de expo- } \\
\text { sición }\end{array}$ & 5 & $\begin{array}{l}\text { El valor de exposición por encima del cual una } \\
\text { persona no protegida está expuesta a riesgos } \\
\text { inaceptables. Está prohibido rebasar este nivel y } \\
\text { deberá evitarse implantado las medidas previstas en } \\
\text { la Directiva*** }\end{array}$ \\
\hline
\end{tabular}

${ }^{*} A(8)=8 \mathrm{~h}$ de aceleración equivalente ponderada en frecuencia.

** Información, formación, medidas técnicas, vigilancia de la salud.

*** Medidas apropiadas para la protección de la salud y la seguridad.

en donde T es el tiempo de exposición diario expresado en horas y $\left(a_{h, w}\right)_{\text {eq( }}(T)$ la aceleración continua equivalente ponderada en frecuencia para el tiempo de exposición diario T. La norma proporciona modificaciones para el cálculo de $\left(a_{n, w}\right)_{\text {eq(T) }}$ si una jornada de trabajo típica se caracteriza por varias exposiciones de diferente magnitud y duración. El Anexo A de la Norma ISO 5349 (que no forma parte de la norma) propone una relación dosis-efecto entre $\left(a_{n, w}\right)_{\text {eq (4) }}$ y VWF, que puede calcularse de forma aproximada por medio de la ecuación:

$$
C=\left[\left(a_{h, w}\right)_{e q(4)} T_{F} / 95\right]^{2} \times 100
$$

en donde $C$ es el percentil de trabajadores expuestos susceptibles de desarrollar VWF (en el rango del 10 al $50 \%$ ), y $T_{F}$ el tiempo de exposición que transcurre hasta que aparece el amoratamiento de los dedos entre los trabajadores afectados (en el rango de 1 a 25 años). Se utiliza la componente dominante, en un solo eje, de vibración dirigida a la mano para calcular $\left(a_{h, w}\right)_{\text {eq(4) }}$, que no deberá exceder de $50 \mathrm{~m} / \mathrm{s}^{2}$. De acuerdo con la relación entre dosis y efecto según ISO, puede esperarse que el VWF aparezca aproximadamente en el $10 \%$ de los trabajadores con exposición diaria a vibración a $3 \mathrm{~m} / \mathrm{s}^{2}$ durante diez años.

Para minimizar el riesgo de efectos adversos para la salud inducidos por vibración, otros comités y organizaciones han propuesto niveles de acción y valores límite umbral (TLV) de exposición a la vibración. La American Conference of Government Industrial Hygienists (ACGIH) ha publicado valores T LV de vibración transmitida a las manos medida por el procedimiento de ponderación de frecuencia según la Norma ISO (American C onference of Governmental Industrial H ygienists 1992), (véase la Tabla 50.6). Según la ACGIH, los TLV propuestos se refieren a la exposición a vibraciones a la que "casi todos los trabajadores pueden estar expuestos repetidamente sin pasar de la fase 1 del sistema de clasificación de VWF del Taller de Estocolmo. M ás recientemente, la Comisión de las Comunidades Europeas ha presentado niveles de exposición para vibración transmitida a las manos en el marco de una propuesta de Directiva para la protección de los trabajadores contra los riesgos derivados de agentes físicos (Consejo de la Unión Europea 1994), (véase la Tabla 50.7). En la Directiva propuesta, la cantidad utilizada para valorar el riesgo de vibración se 
Tabla 50.8 • Magnitudes de aceleración de vibración ponderada en frecuencia $\left(\mathrm{m} / \mathrm{s}^{2}\right.$ r.m.s.) que es de prever que produzcan dedo blanco por vibración en el $10 \%$ de las personas expuestas*.

\begin{tabular}{lrrrrrr}
$\begin{array}{l}\text { Exposición } \\
\text { diaria } \\
\text { (horas) }\end{array}$ & \multicolumn{6}{c}{ Exposición durante toda la vida (años) } \\
0,5 & 1 & 2 & 4 & 8 & 16 \\
0,25 & 256,0 & 128,0 & 64,0 & 32,0 & 16,0 & 8,0 \\
0,5 & 179,2 & 89,6 & 44,8 & 22,4 & 11,2 & 5,6 \\
1 & 128,0 & 64,0 & 32,0 & 16,0 & 8,0 & 4,0 \\
2 & 89,6 & 44,8 & 22,4 & 11,2 & 5,6 & 2,8 \\
4 & 64,0 & 32,0 & 16,0 & 8,0 & 4,0 & 2,0 \\
8 & 44,8 & 22,4 & 11,2 & 5,6 & 2,8 & 1,4
\end{tabular}

* Con exposición de corta duración, las magnitudes son elevadas y los trastornos vasculares pueden no ser el primer síntoma adverso en aparecer.

Fuente: Según British Standard 6842. 1987, BSI 1987 a.

expresa en términos de aceleración equivalente ponderada en frecuencia para un período de ocho horas, $A(8)=(T / 8)^{1 / 2}$ $\left(a_{h, w}\right)_{\text {eq }(T)}$, utilizando la suma vectorial de las aceleraciones ponderadas en frecuencia determinadas en las coordenadas ortogonales $a_{\text {sum }}=\left(a_{x, h, w}{ }^{2}+a_{y, h, w}{ }^{2}+a_{z, h, w}{ }^{2}\right)^{1 / 2}$ en la empuñadura de la herramienta o en la pieza vibrantes. Los métodos de medida y evaluación de la exposición a las vibraciones señalados en la Directiva se deriva básicamente de la Norma Británica (BS) 6842 (BSI 1987a). A hora bien, la N orma BS no recomienda límites de exposición, sino que facilita un apéndice informativo sobre el estado del conocimiento de la relación entre dosis y efecto para las vibraciones transmitidas a las manos. Las magnitudes estimadas de aceleración ponderada en frecuencia que pueden causar VWF en el $10 \%$ de los trabajadores expuestos a vibración según la Norma BS se indican en la Tabla 50.8.

\section{Medida y evaluación de la exposición}

Las medidas de vibración se llevan a cabo para contribuir al desarrollo de nuevas herramientas, comprobar la vibración de las herramientas en el momento de su adquisición, verificar las condiciones de mantenimiento y valorar la exposición humana a la vibración en el lugar de trabajo. El equipo de medida de la vibración consiste generalmente en un transductor (casi siempre un acelerómetro), un dispositivo amplificador, filtro (filtro de paso de banda y/ o red de ponderación en frecuencia) e indicador 0 registrador de amplitud o nivel. Las medidas de vibración deberían realizarse en la empuñadura de la herramienta o en la pieza, cerca de la superficie de la(s) mano(s), donde la vibración penetra en el cuerpo. Para obtener resultados precisos se requiere una cuidadosa selección de los acelerómetros (p. ej., tipo, masa, sensibilidad) y métodos apropiados de montaje del acelerómetro en la superficie vibrante. Las vibraciones transmitidas a las manos deberían medirse y registrarse en las direcciones adecuadas de un sistema de coordenadas ortogonales (véase la Figura 50.4). La medición debería efectuarse sobre un rando de frecuencia de 5 a $1.500 \mathrm{~Hz}$ como mínimo, y el contenido de frecuencia de aceleración de la vibración en uno o más ejes puede presentarse en bandas de octava con frecuencias centrales de 8 a $1.000 \mathrm{~Hz} 0$ en bandas de tercio de octava con frecuencias centrales de 6,3 a $1.250 \mathrm{~Hz}$. También puede expresarse la aceleración como aceleración ponderada en frecuencia utilizando una red de
Figura 50.5 - Valores medios y rango de distribución de la aceleración eficaz ponderada en frecuencia en el eje dominante medida en la(s) empuñadura(s) de algunas herramientas a motor utilizadas en trabajos forestales y en la industria.

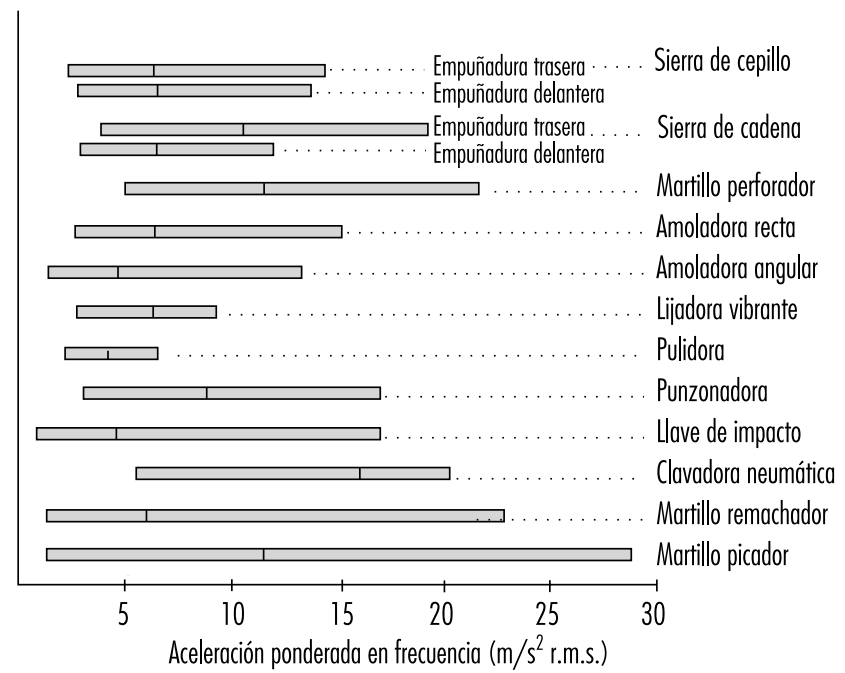

Fuente: Asociación Internacional de la Seguridad Social (AISA), Sección Internacional para la Investigación 1989

ponderación que reúna las características especificadas en las N ormas ISO 5349 o BS 6842.

Las medidas en el lugar de trabajo indican que pueden darse magnitudes de vibración y espectros de frecuencia diferentes en herramientas del mismo tipo o cuando se utiliza una misma herramienta de diferente forma. En la Figura 50.5 se refleja el valor medio y el rango de distribución de aceleraciones ponderadas medidas en el eje dominante de herramientas a motor utilizadas en trabajos forestales y en la industria (AISS, Sección Internacional de Investigación 1989). En varias normas la exposición a las vibraciones transmitidas a las manos se valora en términos de cuatro u ocho horas de aceleración equivalente ponderada en frecuencia calculada mediante las ecuaciones anteriores. En el método de obtención de la aceleración equivalente se supone que el tiempo de exposición diaria necesario para producir efectos adversos sobre la salud es inversamente proporcional al cuadrado de la aceleración ponderada en frecuencia ( $p$. ej., si se divide por dos la magnitud de la vibración, el tiempo de exposición puede multiplicarse por cuatro). Tal dependencia temporal se considera razonable a efectos de normalización y es adecuada para la instrumentación, pero hay que señalar que no está totalmente respaldada por datos epidemiológicos (Griffin 1990).

\section{Prevención}

La prevención de lesiones o trastornos causados por vibraciones transmitidas a las manos exige la implantación de procedimientos técnicos, médicos y administrativos (ISO 1986; BSI 1987a). También debería facilitarse asesoramiento adecuado a los fabricantes y usuarios de herramientas vibrantes. Las medidas administrativas deberían incluir una información y formación adecuadas para enseñar a los operarios que trabajan con maquinaria vibrante a adoptar métodos de trabajo correctos y seguros. Dado que se cree que la exposición continua a las vibraciones aumenta el riesgo por vibración, los horarios de trabajo deberían 
establecerse incluyendo períodos de descanso. Las medidas técnicas deberían incluir la elección de herramientas con la mínima vibración y con un diseño ergonómico apropiado. Según la Directiva CE para la seguridad de las máquinas (C onsejo de las Comunidades Europeas 1989), el fabricante deberá declarar si la aceleración ponderada en frecuencia de la vibración transmitida a las manos excede de $2,5 \mathrm{~m} / \mathrm{s}^{2}$, mediante la oportuna determinación por medio de los códigos de ensayo adecuados tal como se indica en la Norma Internacional ISO 8662/ 1 y los correspondientes documentos para las herramientas específicas (ISO 1988). Las condiciones de mantenimiento de las herramientas deberían comprobarse cuidadosamente mediante medidas periódicas de vibración. D eberían realizarse reconocimientos médicos previos a la realización del trabajo y exámenes clínicos periódicos subsiguientes de los trabajadores expuestos a vibraciones. Los objetivos de la vigilancia médica son informar al trabajador del riesgo potencial asociado con la exposición a las vibraciónes, evaluar el estado de salud y diagnosticar precozmente los trastornos inducidos por las vibraciones. En el primer reconocimiento debería prestarse especial atención a cualquier proceso que pueda agravarse por exposición a las vibraciones (p. ej., tendencia constitucional a enfermedad del dedo blanco, algunas formas del fenómeno secundario de Raynaud, daños anteriores en los miembros superiores, trastornos neurológicos). Después de considerar la severidad de los síntomas y las características del proceso de trabajo en su totalidad, debería decidirse entre evitar o reducir la exposición a las vibraciones del trabajador afectado. El trabajador debería ser informado sobre el uso de ropa adecuada para mantener caliente todo el cuerpo y debería evitar o minimizar el consumo de tabaco y el uso de algunos fármacos que pueden afectar la circulación periférica. Los guantes pueden ser útiles para proteger los dedos y las manos de traumatismos y para mantenerlos calientes. Los llamados guantes antivibración pueden proporcionar algo de aislamiento frente a las componentes de alta frecuencia de la vibración producida por algunas herramientas.

\section{- MAREO INDUCIDO POR EL MOVIMIENTO}

Alan J. Benson

El mareo inducido por el movimiento, o cinetosis, no es un proceso patológico, sino una respuesta normal a ciertos estímulos de movimiento con los que el individuo no está familiarizado y a los que, por lo tanto, no se encuentra adaptado; solo son verdaderamente inmunes quienes carecen de aparato vestibular funcional del oído interno.

\section{Movimientos que producen el mareo inducido por el movimiento}

$\mathrm{H}$ ay muchos tipos diferentes de movimiento que provocan el síndrome denominado mareo inducido por el movimiento. La mayoría de ellos están relacionados con medios de locomoción-en particular, barcos, aerodeslizadores, aviones, automóviles y trenes, y con menor frecuencia, elefantes y camellos. Las complejas aceleraciones generadas por atracciones mecánicas de feria tales como columpios, tiovivos, montañas rusas, etc., pueden provocar intenso mareo. Además, muchos astronautas/ cosmonautas padecen mareo (mareo espacial) cuando efectúan movimientos con la cabeza por primera vez en el entorno, sometido a fuerzas anormales (ingravidez) del vuelo orbital. También producen el síndrome del mareo ciertos estímulos visuales en movimiento, sin ningún movimiento físico del observador; son ejemplos de ello la visualización del mundo visual externo de los simuladores de base fija (mareo en simulador) o la proyección en pantalla gigante de escenas filmadas de un vehículo en movimiento (mareo en Cinerama o en IM AX).

\section{Etiología}

La característica esencial de los estímulos que producen mareo inducido por el movimiento es que éstos generan información discordante en los sistemas sensoriales que suministran al cerebro información acerca de la orientación espacial y el movimiento del cuerpo. El aspecto principal de esta discordancia es una desadaptación entre las señales suministradas, principalmente, por los ojos y el oído interno, y las que el sistema nervioso central "espera" recibir y que estén correlacionadas.

Pueden distinguirse varias categorías de desadaptación. La desadaptación más importante es la de las señales procedentes del aparato vestibular (laberinto) del oído interno, en el que los canales semicirculares (los receptores especializados de las aceleraciones angulares) y los otolitos (los receptores especializados de las aceleraciones lineales) no suministran información concordante. Por ejemplo, cuando se efectúa un movimiento de cabeza en un coche 0 un avión que está girando, los canales semicirculares y los otolitos son estimulados de manera atípica y suministran información errónea e incompatible, que difiere sustancialmente de la generada por ese mismo movimiento de cabeza en un entorno estable, de gravedad 1-G. De igual modo, las aceleraciones lineales de baja frecuencia (inferior a $0,5 \mathrm{~Hz}$ ), como las que se producen a bordo e un barco en aguas agitadas 0 en un avión que atraviesa una turbulencia, generan también señales vestibulares contradictorias y, por lo tanto, son una causa potencial de mareo.

También puede ser un factor contribuyente importante el desacuerdo de la información visual y vestibular. Es más probable que se maree el ocupante de un vehículo en movimiento que no puede ver el exterior que uno que dispone de una buena referencia visual externa. El pasajero que viaja bajo cubierta 0 en la cabina de un avión percibe el movimiento del vehículo mediante claves vestibulares, pero solo recibe información visual de su movimiento relativo dentro del vehículo. También la ausencia de una señal "esperada" y concordante en una modalidad sensorial determinada se considera la característica esencial del mareo inducido visualmente, dado que las claves visuales de movimiento no van acompañadas de las señales vestibulares que el individuo "espera" que se produzcan cuando está sometido al movimiento indicado por la presentación visual.

\section{Síntomas}

Ante la exposición al movimiento provocador, los signos y síntomas de mareo evolucionan en una secuencia determinada, en la que la escala temporal depende de la intensidad de los estímulos de movimiento y de la susceptibilidad del individuo. $\mathrm{H}$ ay, desde luego, considerables diferencias entre unos y otros individuos, no solo de susceptibilidad sino también en el orden de aparición de determinados signos y síntomas, 0 en la total ausencia de éstos. Normalmente, el primer síntoma es malestar epigástrico, seguido de náuseas, palidez y transpiración, y suele ir acompañado de una sensación de calor corporal, aumento de la secreción de saliva y eructos (flato). $\mathrm{N}$ ormalmente estos síntomas evolucionan con relativa lentitud, pero si continúa la exposición al movimiento se produce un rápido deterioro del bienestar y aumenta la intensidad de las náuseas, que finalmente desembocan en vómito 0 arcadas. El vómito puede proporcionar alivio pero lo más probable es que éste dure poco a menos que cese el movimiento. 
El síndrome de mareo tiene también otras características más variables. U n síntoma de temprana aparición puede ser la alteración del ritmo respiratorio, con suspiros y bostezos, y también puede producirse hiperventilación, sobre todo en personas a quienes la causa o consecuencia de su discapacidad les provoca ansiedad. Se comunican casos de dolor de cabeza, tinnitus (campanilleo) y vértigo, mientras que la apatía y la depresión son frecuentes en quienes padecen malestar agudo, y pueden ser de tal intensidad que lleguen a descuidarse la seguridad personal y la supervivencia. Tras el cese del movimiento provocador de mareo puede imponerse una sensación de letargo y somnolencia, siendo éstos a veces los únicos síntomas en situaciones en las que la adaptación al movimiento inhabitual se produce sin malestar.

\section{Adaptación}

Con la exposición continuada o repetida a un determinado movimiento provocador de mareo, la mayoría de los individuos experimentan una reducción de la severidad de los síntomas; normalmente después de tres o cuatro días de exposición continua (por ejemplo a bordo de un barco o en un vehículo espacial) se han adaptado al movimiento y pueden realizar sus tareas habituales sin discapacidad. En relación con el modelo de "discordancia", esta adaptación o habituación representa el establecimiento de una nueva serie de "expectativas" en el sistema nervioso central. Ahora bien, al regresar a un entorno familiar, estas expectativas dejarán de ser adecuadas y puede que se repitan los síntomas de mareo (mareo del desembarque) hasta que se produzca la readaptación. Los individuos difieren considerablemente en su velocidad de adaptación, en la forma de mantener ésta y en el grado en que pueden generalizar la adaptación protectora de un entorno de movimiento a otro. Lamentablemente, una pequeña proporción de la población (probablemente alrededor del $5 \%$ ) no consigue adaptarse o lo hace con tal lentitud que continúa experimentando síntomas durante todo el período de exposición al movimiento provocador de mareo.

\section{Incidencia}

La incidencia de mareo en un determinado entorno de movimiento depende de varios factores, en particular

- las características físicas del movimiento (su intensidad, frecuencia y dirección de actuación)

- la duración de la exposición;

- la susceptibilidad intrínseca del individuo;

- la tarea que se realiza,

- otros factores ambientales (p. ej., el olor).

No es de extrañar, por lo tanto, que la incidencia de mareo varíe ampliamente entre los diferentes entornos de movimiento. Por ejemplo: casi todos los ocupantes de lanchas salvavidas en mar agitado vomitan; el $60 \%$ de los alumnos que se preparan para tripular aviones sufren mareo en algún momento durante su entrenamiento, mareo que en el $15 \%$ de los casos es lo bastante intenso para perturbar su proceso de formación; en contraste, menos del $0,5 \%$ de los pasajeros de aviones de transporte civiles resultan afectados, aunque la incidencia es mayor al volar a baja altitud y con turbulencia en aviones pequeños de itinerario pendular.

Estudios de laboratorio y de campo han evidenciado que en el caso del movimiento oscilatorio lineal vertical (o elevación vertical rápida), la oscilación a una frecuencia de aproximadamente $0,2 \mathrm{~Hz}$ es la más provocadora de mareo (véase la Figura 50.6). Con una intensidad de oscilación (aceleración pico) dada, la incidencia de mareo disminuye con gran rapidez al aumentar la frecuencia por encima de $0,2 \mathrm{~Hz}$; el potencial provocador de mareo del movimiento a $1 \mathrm{~Hz}$ es menos de la décima parte que a $0,2 \mathrm{~Hz}$. Lo mismo sucede con el movimiento a frecuencias inferiores a $0,2 \mathrm{~Hz}$, aunque la relación entre incidencia y frecuencia no está bien definida debido a la falta de datos experimentales; desde luego, un entorno estable de 1-G y frecuencia cero no provoca mareo.

L as relaciones establecidas entre la incidencia de los síntomas de mareo y la frecuencia, magnitud y duración del movimiento de elevación vertical rápida (eje z ) han conducido al desarrollo de fórmulas sencillas que permiten predecir la incidencia cuando se conocen los parámetros físicos del movimiento. EI concepto, plasmado en la N orma Británica 6841 (BSI 1987b) y en el proyecto de Norma Internacional ISO 2631-1, es que la incidencia de los síntomas es proporcional al Valor de la Dosis de $M$ areo $\left(M S^{2} V_{z}\right.$ ). EI M SDV (en $\mathrm{m} / \mathrm{s}^{1.5}$ ) se define como sigue:

$$
\mathrm{MSDV}_{z}=\left(\mathrm{a}^{2} \mathrm{t}\right)^{1 / 2}
$$

en donde a es el valor medio cuadrático o valor eficaz (r.m.s.), de la aceleración ponderada en frecuencia (en $\mathrm{m} / \mathrm{s}^{2}$ ) determinada por integración lineal sobre la duración, $t$ (en segundos), de la exposición al movimiento.

La ponderación de frecuencia que debe aplicarse a la aceleración del estímulo es un filtro con una frecuencia central y características de atenuación similares a las representadas en la Figura 50.6. La función de ponderación está definida con exactitud en las normas.

El porcentaje de una población adulta inadaptada (P) con probabilidad de sufrir vómito viene dada por:

$$
\mathrm{P}=1 / \mathrm{MSDV}_{\mathrm{z}}
$$

EI MSDV $V_{z}$ puede utilizarse asimismo para predecir el nivel de malestar. En una escala de cuatro puntos, de cero (me siento perfectamente) a tres (me siento fatal) la "clasificación de enfermedad" (I) viene dada por:

$$
\mathrm{I}=0,02 \mathrm{M} \mathrm{SDV}_{\mathrm{z}}
$$

Teniendo en cuenta las grandes diferencias entre individuos en cuanto a su susceptibilidad al mareo, la relación entre $\mathrm{MSDV}_{\mathrm{z}}$ y la producción de vómito en experimentos de laboratorio y en pruebas en el mar (véase la Figura 50.7) es aceptable. $H$ ay que señalar que las fórmulas se desarrollaron a partir de datos adquiridos en exposiciones de duración comprendida entre unos 20 minutos y seis horas, habiéndose producido el

Figura 50.6 • Incidencia de cinetosis en función de la frecuencia de onda y la aceleración para 2 horas de exposición a movimiento senoidal vertical.

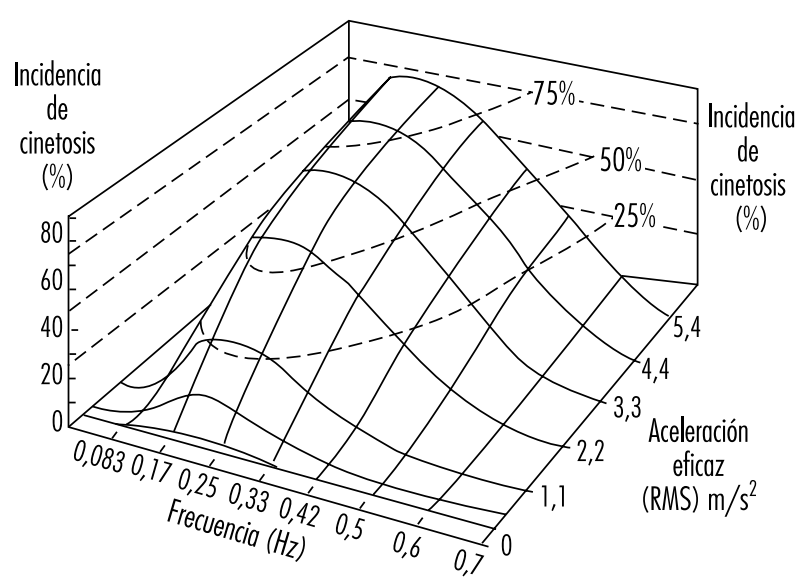

Fuente: McCauley y cols. 1976. 


\section{Figura 50.7 • Relación entre incidencia de vómito y dosis de estímulo (M SDV z $^{\text {) calculada }}$ por el procedimiento descrito en el texto. Datos procedentes de experimentos de laboratorio con oscilación vertical $(x-)$ y pruebas en el mar (+).}

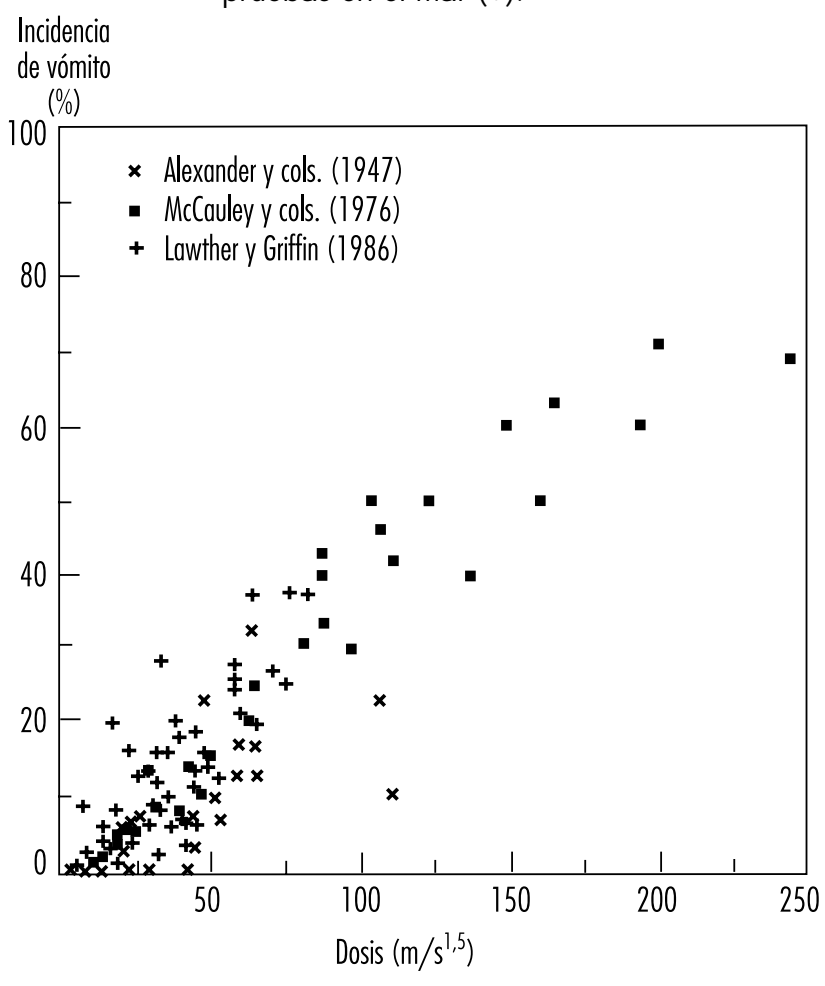

vómito hasta en el $70 \%$ de individuos(la mayoría sentados) expuestos a movimiento de elevación rápida vertical.

El conocimiento que se posee de la efectividad de la oscilación lineal que actúa en otros ejes corporales y en direcciones distintas de la vertical, es relativo. $\mathrm{H}$ ay alguna evidencia, obtenida en experimentos de laboratorio con grupos pequeños de sujetos, de que la oscilación lineal en un plano horizontal provoca más mareo, aproximadamente el doble, que la oscilación vertical de igual intensidad y frecuencia en sujetos sentados, pero menos, en la misma proporción, cuando el sujeto está en posición supina y el estímulo actúa en el eje longitudinal (z) del cuerpo. Por lo tanto, la aplicación de fórmulas y características de ponderación plasmadas en las normas respecto a la predicción de la incidencia de mareo, deberá realizarse con precaución y teniendo debidamente en cuenta las limitaciones antes señaladas.

La considerable variabilidad entre individuos en cuanto a su respuesta al movimiento provocador, es una característica importante del mareo. Las diferencias de susceptibilidad pueden estar relacionadas, en parte, con factores constitucionales. Los niños de edad muy inferior a unos dos años rara vez resultan afectados, pero con el crecimiento, la susceptibilidad aumenta rápidamente hasta alcanzar un valor máximo entre los cuatro y los diez años. A partir de entonces la susceptibilidad disminuye progresivamente, por lo que los mayores son menos propensos a verse afectados, aunque no son inmunes. Cualquiera que sea el grupo de edad, las mujeres son más sensibles que los hombres; los datos de incidencia sugieren una relación aproximada de 1,7:1. Se ha demostrado también que ciertas dimensiones de la personalidad, tales como la neurosis, la introversión y el estilo perceptual están correlacionadas, aunque débilmente, con la susceptibilidad. El mareo puede ser también una respuesta condicionada y una manifestación de ansiedad fóbica.

\section{Medidas preventivas}

Existen procedimientos que reducen al mínimo el estímulo provocador de mareo o aumentan la tolerancia. Pueden prevenir el mareo en una determinada proporción de la población, pero ninguno, exceptuando la retirada del entorno de movimiento, es eficaz al $100 \%$. Al diseñar un vehículo, es beneficioso tener en cuenta los factores que elevan la frecuencia y reducen la magnitud de las oscilaciones (véase la Figura 50.6) que experimentan los ocupantes durante el funcionamiento normal. La provisión de apoyo para la cabeza y sujeción corporal para minimizar los movimientos de cabeza innecesarios es ventajosa, y se ve reforzada si el ocupante puede adoptar una posición reclinada o de supinación. EI mareo es menos intenso si el ocupante puede ver el horizonte; para quienes carecen de una referencia visual externa, cerrar los ojos reduce la discordancia visual/ vestibular. También ayuda concentrarse en una tarea, especialmente el control del vehículo. Aunque estas medidas pueden aportar ventajas inmediatas, a la larga lo más beneficioso es desarrollar una adaptación protectora. Se consigue mediante una exposición continuada y repetida al entorno de movimiento, aunque puede facilitarse con ejercicios en tierra, en los que los estímulos provocadores de mareo se generan realizando movimientos con la cabeza mientras se gira en una mesa rotativa (tratamiento de desensibilización).

$\mathrm{H}$ ay varios fármacos que aumentan la tolerancia, aunque todos tienen efectos secundarios (en particular, sedación), por lo que no deben usarse cuando se ha de controlar un vehículo o es indispensable actuar con un rendimiento óptimo. Para una profilaxis a corto plazo (menos de cuatro horas), se recomienda de 0,3 a 0,6 mg de bromhidrato de hioscina (escopolamina); los antihistamínicos, clorhidrato de prometacina $(25 \mathrm{mg})$, clorhidrato de meclocina $(50 \mathrm{mg})$, dimenhidrinato $(50 \mathrm{mg})$ y cinaricina (30 mg) tienen una acción más duradera. La combinación de hioscina o prometacina con $25 \mathrm{mg}$ de sulfato de efedrina aumenta el poder profiláctico al tiempo que reduce algo los efectos secundarios. Se puede conseguir un efecto profiláctico de hasta 48 horas utilizando un parche de escopolamina, que permite absorber lentamente el fármaco a través de la piel a una velocidad controlada. $\mathrm{N}$ o se consiguen concentraciones efectivas del fármaco en el organismo hasta después de seis a ocho horas de la aplicación del parche, por lo que es preciso prever por anticipado la necesidad de este tipo de tratamiento.

\section{Tratamiento}

A quienes padezcan de mareo crónico con vómitos debe colocárseles, a ser posible, en una posición en que el estímulo de movimiento se reduzca al mínimo, y administrárseles un fármaco contra el mareo, preferiblemente prometacina inyectada. En caso de vómitos prolongados y repetidos, puede ser necesaria la reposición de líquido y electrolitos por vía intravenosa. 


\section{Referencias}

Alexander, SJ, M Cotzin, JB K lee, GR Wendt. 1947. Studies of motion sickness XVI: The effects upon sickness rates of waves and various frequencies but identical acceleration. J Exp Psy 37:440-447.

American Conference of Governmental Industrial $\mathrm{H}$ ygienists (ACGIH) . 1992. H and-arm (segmental) vibration. En Threshold Limit Values and Biological Exposures Indices for 1992-1993. Cincinnati, O hio: ACGIH.

Bongers, PM , HC Boshuizen. 1990. Back D isorders and W hole B ody Vibration at W ork. Tesis. Amsterdam: U niversidad de A msterdam.

British Standards Institution (BSI). 1987a. M easurement and $E$ valuation of $H$ uman Exposure to Vibration $T$ ransmitted to the $H$ and. BS 6842. Londres: BSI.

$-.1987 \mathrm{~b} . \mathrm{M}$ easurement and $\mathrm{E}$ valuation of $H$ uman $E$ xposure to W hole B ody M echanical Vibration and R epeated Shock. BS 6841. Londres: BSI.

Consejo de la Comunidad Europea (CCE). 1989. Directiva del Consejo de 14 de junio de 1989 relativa a la aproximación de las legislaciones de los Estados Miembros sobre máquinas. Diario O ficial de las Comunidades E uropeas L 183:9-32.

Consejo de la Unión Europea. 1994. Propuesta modificada de una Directiva del Consejo relativa a los requisitos mínimos de salud y seguridad con respecto a la exposición de los trabajadores a riesgos derivados de agentes físicos. Diario 0 ficial de las Comunidades E uropeas C 230 (19 de agosto):3-29.

Dupuis, H, G Zerlett. 1986. The E ffects of W hole B ody Vibration. Berlín: Springer-Verlag.
Griffin, MJ. 1990. Handbook of Human Vibration. Londres: A cademic Press.

Hamilton, A. 1918. A Study of Spastic Anemia in the $\mathrm{H}$ ands of Stonecutters. Industrial Accidents and $H$ ygiene Series no. 19. Bulletin No. 236. W ashington, DC: D epartment of Labor Statistics.

H asan, J. 1970. Biomedical aspects of low-frequency vibration. W ork E nviron $\mathrm{H}$ ealth 6(1):19-45.

Lawther, A, MJ Griffin. 1986. Prediction of the incidence of motion sickness from the magnitude, frequency and duration of vertical oscillation. J Acoust Soc Am 82:957-966.

M CC auley, ME, JW R oyal, CD Wilie, JF O 'Hanlon, RR M ackie. 1976. M otion Sickness Incidence: Exploratory Studies of $\mathrm{H}$ abituation Pitch and R oll, and the $R$ efinement of a $M$ athematical $M$ odel. T echnical R eport No. 1732-2. Golets, California: Human Factors R esearch.

O rganización Internacional de N ormalización (ISO). 1974. Guide for the Evaluation of $H$ uman Exposure to W hole B ody Vibration. G inebra: ISO.

-. 1985. Evaluation of $H$ uman Exposure to $W$ hole $B$ ody Vibration. Part 1: G eneral Requirements. ISO 2631/ 1. Ginebra: ISO .

- 1986. M echanical Vibration-Guidelines for the $M$ easurement and the Assessment of $H$ uman Exposure to $H$ and-T ransmitted Vibration. ISO 5349. Ginebra: ISO.

-. 1988. $\mathrm{H}$ and- $\mathrm{H}$ eld Portable Power T ools - M easurement of Vibrations at the $\mathrm{H}$ andle. Part $1:$ General. ISO 8662/ 1. Ginebra: ISO

Rumjancev, GI. 1966. Gigiena truda v proizvodstve sbornogo shelezobetona [H igiene industrial en la producción de hormigón armado]. M edicina (M oscú):1-128.

Schmidt, M. 1987. Die gemensame E inwirkung von $L$ ärm und $G$ anzkörpervibration und deren Auswirkungen auf den $H$ överlust be Agrotechnikern. Dissertation A. Halle, Alemania: Landwirtschaftliche Fakultät der $M$ artin-L uther-U niversität.

Sección Internacional de Investigación de la AISS. 1989. Vibration At W ork. París: INRS

Seidel, H, R Blüthner, J M artin, G M enzel, R Panuska, P U llsperger. 1992. Effects of isolated and combined exposures to whole-body vibration and noise on auditory-event related brain potentials and psychophysical assessment. Eur J Appl Physiol 0 ccup Phys 65:376-382.

Seidel, H, R H eide. 1986. Long-term effects of whole-body vibration: A critical survey of the literature. Int Arch O ccup E nviron $\mathrm{H}$ ealth 58:1-26.

Seidel, H. 1975. Systematische Darstellung physiologischer Reaktionen auf Ganzkörperschwingungen in vertikaler Richtung (Z-Achse) zur Ermittlung von biologischen Bewertungsparametern. E rgonom B erichte 15:18-39.

Seminario de Estocolmo 86. 1987. Symptomatology and diagnostic methods in the hand-arm vibration syndrome. Scand I W ork E nviron H ealth 13:271-388.

\section{0 tras lecturas recomendadas}

Benson, AJ. 1988. Motion sickness. En Aviation $\mathrm{M}$ edicine, dirigido por $\mathrm{J}$ Ernsting y $\mathrm{P} \mathrm{K}$ ing. Londres: Butterworths.

Reason, JT , JJ Brand. 1975. M otion Sickness. Londres: Academic Press. 



\section{VIOLENCIA}

Director del capítulo

Leon J. W arshaw

\section{Sumario}

La violencia en el lugar de trabajo

L eon J. W arshaw ............................. 51.2 


\section{- La Violencia en el LUgar De TRABAJO}

\section{Leon J. Warshaw}

La violencia está muy extendida en la sociedad moderna, y parece que va en aumento. A demás de las situaciones de represión, guerra o terrorismo, los medios de comunicación informan a diario en titulares sensacionalistas de las barbaridades a las que someten entre sí los seres humanos tanto en sociedades "civilizadas" como en otras más atrasadas. Cabe preguntarse si el aumento de este fenómeno ha sido real o si se trata sencillamente de que la información sobre el mismo es más exhaustiva. Al fin y al cabo, la violencia ha caracterizado las relaciones entre los seres humanos desde los tiempos prehistóricos. En las sociedades industriales actuales se ha convertido en una de las principales causas de muerte - en algunos sectores es la principal- y se considera cada vez más como un problema de salud pública.

Es inevitable, pues, encontrarla también en el lugar de trabajo. Entre 1980 y 1989, el homicidio fue la tercera causa más importante de muerte por lesiones en los lugares de trabajo norteamericanos, de acuerdo con los datos recogidos por el National Traumatic O ccupational Facilities Surveillance System (N IO SH 1993a). Los homicidios representaron un $12 \%$ de las muertes por lesiones en el lugar de trabajo durante ese período, sólo superadas las causas por vehículos de motor y maquinaria. En 1993 la cifra aumentó hasta el 17 \% lo que representa una tasa de 0,9 por cada 100.000 trabajadores, en este caso por detrás sólo de las muertes provocadas por los vehículos (Toscano y Windau 1994). En cuanto a las mujeres trabajadoras, fue la principal causa de muerte relacionada con el trabajo, aunque con una tasa $(0,4$ muertes por 100.000) inferior a la de los hombres (1,2 muertes por 100.000 trabajadores) (Jenkins 1995).

Con todo, esas muertes representan sólo la "punta del iceberg". Por ejemplo, cerca de 22.400 trabajadores de Estados U nidos resultaron heridos de gravedad como consecuencia de agresiones no mortales sufridas en el lugar de trabajo, que les obligaron a faltar algunos días para recuperarse (Toscano y Windau, 1994). Si bien no se dispone de datos fiables y precisos, se estima que por cada caso de muerte se han producido miles - quizás cientos de miles- de casos de violencia en el lugar de trabajo.

En el boletín que publica U nison, el gran sindicato británico que agrupa a los trabajadores de la asistencia sanitaria y los de la administración pública, se califica la violencia como "el principal riesgo a que se enfrentan sus afiliados en el trabajo. Se trata del riesgo que provoca lesiones con mayor frecuencia. Puede ser causa de niveles de estrés en el trabajo difíciles de controlar, que menoscaban la estima personal y ponen en peligro la capacidad de las personas de continuar en sus puestos de trabajo" (U nison 1992).

En el presente artículo se resumen las características de la violencia en el lugar de trabajo, el tipo de personas implicadas en este fenómeno, sus efectos en las mismas y en las empresas, y las medidas que se pueden adoptar para evitar o controlar esos efectos.

\section{Definición de violencia}

No existe acuerdo con respecto a la definición de la violencia generalmente aceptada. Por ejemplo, Rosenberg y M ercy (1991) incluyen en su definición todos los casos de violencia interpersonal mortal o no, en los que una persona hace uso de la fuerza física o de otros medios con la intención de causar daños, lesiones - la muerte a otra persona. La Comisión para el Conocimiento y el Control de los Comportamientos Violentos elegida por la
National Academy of Sciences de Estados Unidos adoptó la siguiente definición de violencia: Comportamientos de individuos que amenazan, intentan infligir o infligen un daño físico a otros de forma intencionada (Reiss y R oth 1993).

A mbas definiciones se ocupan sobre todo de la amenaza o del daño físico causado. Sin embargo, excluyen los casos en los que el insulto, el acoso y la humillación verbales, u otras formas de trauma psicológico, son el único daño infligido a la víctima, aunque no por ello menos demoledor. Tampoco contemplan el acoso sexual, que puede ser físico, aunque no es lo más habitual. Los investigadores encargados de la realización de la encuesta nacional sobre los trabajadores estadounidenses llevado a cabo por Northwestern National Life Insurance Company, dividieron los actos violentos en: acoso (acto de crear un ambiente hostil mediante palabras, acciones o contactos físicos molestos que no tengan como consecuencia un daño físico; amenazas (manifestaciones de la intención de causar un daño físico), y agresiones físicas (ataques violentos, con o sin uso de armas) (Lawless 1993).

En el Reino U nido, la definición de violencia en el lugar de trabajo por la que se rige el $\mathrm{H}$ ealth and Safety Executive es "todo incidente en el que un trabajador sea insultado, amenazado o agredido por otra persona en circunstancias surgidas durante el desempeño de su trabajo. Los agresores pueden ser pacientes, clientes o compañeros de trabajo" (M SF, 1993).

El término violencia se emplea en este artículo en su sentido más amplio, de forma que abarca cualquier tipo de comportamiento agresivo o insultante susceptible de causar un daño o molestias físicas o psicológicas a sus víctimas, ya sean estos objetivos intencionados o testigos inocentes involucrados de forma no personal 0 accidental en los incidentes. Si bien los lugares de trabajo pueden ser objeto de atentados terroristas 0 pueden verse envueltos en revueltas y tumultos, no se tratarán esas circunstancias.

\section{Alcance de la violencia en el lugar de trabajo}

No se dispone de información precisa sobre el alcance de la violencia en el lugar de trabajo. La mayor parte de la documentación existente se limita a los casos que se han denunciado formalmente: homicidios incluidos en las actas de defunción del registro de civil obligatorios, casos que entran a formar parte del sistema penal 0 aquellos que implican períodos de baja laboral y dan lugar a la reclamación de indemnizaciones. No obstante, por cada uno de esos casos existen muchos otros que no se denuncian, en los que los trabajadores son víctimas de comportamientos agresivos $u$ ofensivos. Por ejemplo, de acuerdo con un estudio realizado por el Bureau of Justice Statistics del Departamento de Justicia de Estados U nidos, más de la mitad de los casos de agresión en el trabajo no se denunciaron a la policía. Cerca del $40 \%$ de los encuestados respondieron que no denunciaron el incidente por considerarlo una cuestión de escasa importancia o personal, mientras que otro $27 \%$ declararon haber informado al respecto a un directivo de la empresa 0 al responsable de seguridad, pero, aparentemente, esas circunstancias no fueron comunicadas a la policía (Bachman 1994). Además de la falta de consenso en cuanto a la clasificación de la violencia, hay otras razones que explican el escaso nivel de denuncias:

- A ceptación cultural de la violencia. En muchas sociedades existe una tolerancia generalizada de la violencia entre o contra ciertos grupos (R osenberg y M ercy 1991). Aunque muchas personas la desaprueben, se suele justificar y tolerar como respuesta "normal" ante una situación de rivalidad. La violencia entre minorías y grupos étnicos se suele consentir, al considerarla una reacción justa ante la discriminación, la pobreza y la imposibilidad de lograr una mayor justicia social o económica, lo que redunda en una escasa autoestima y en el bajo valor que 
se atribuye a la vida humana. Por consiguiente, la agresión se considera una consecuencia de vivir en una sociedad violenta, más que de trabajar en un lugar inseguro. Por último, existe también el "síndrome del puesto de trabajo", en virtud del cual se presupone que los trabajadores de determinados puestos deben soportar ofensas verbales, amenazas e, incluso, agresiones físicas (SEIU 1995; U nison 1992).

- Ausencia de un procedimiento de denuncias. Sólo un reducido número de organizaciones han definido políticas concretas en materia de violencia o han establecido procedimientos de denuncia e investigación de casos de presunta violencia en el lugar de trabajo. Incluso en los casos en que se han implantado esos sistemas, el esfuerzo de obtener, cumplimentar y presentar el impreso en cuestión es un disuasivo, y no se denuncian sino los incidentes más graves

- Temor a la culpabilización o a las represalias. Los trabajadores pueden temer que se les haga responsables de las agresiones recibidas de un cliente o paciente. El miedo a las represalias del agresor es asimismo un poderoso disuasivo de la denuncia, sobre todo si se trata de un superior del trabajador que puede influir en la situación de su puesto de trabajo.

- Falta de interés por parte de la empresa. La falta de interés de la empresa en investigar y reaccionar ante incidentes anteriores desalentará sin duda la presentación de denuncias. Además, los supervisores, preocupados por que la violencia en el lugar de trabajo repercuta negativamente en su capacidad directiva, pueden disuadir e incluso impedir la presentación de las denuncias de los trabajadores de sus respectivas unidades.

Para determinar el alcance de la violencia en el lugar de trabajo, ante la ausencia de datos fiables, se ha tratado de efectuar extrapolaciones tanto de los datos estadísticos disponibles (por ejemplo, certificados de fallecimiento, denuncias penales y sistemas de indemnización de los trabajadores), como de encuestas elaboradas con ese fin. De este modo, de acuerdo con la National Crime Victimization Survey de Estados Unidos, cerca de un millón de trabajadores estadounidenses (la población activa total es de 110 millones) son objeto de agresiones en el lugar de trabajo cada año (Bachman 1994). En una encuesta telefónica realizada en 1993 entre 600 trabajadores estadounidenses a tiempo completo (excluidos los trabajadores autónomos y el personal militar), uno de cada cuatro encuestados afirmó haber sido víctima de algún tipo de violencia en el lugar de trabajo durante el año en cuestión: un $19 \%$ habían sido objeto de acoso, un $7 \%$ habían recibido amenazas y el $3 \%$ habían sido objeto de agresiones físicas. L os responsables del estudio constataron además que el $68 \%$ de las víctimas de acoso, el $43 \%$ de las amenazadas y el $24 \%$ de las agredidas no habían denunciado los incidentes (Lawless 1993)

Una encuesta parecida realizada entre trabajadores del $\mathrm{N}$ ational $\mathrm{H}$ ealth Service del Reino U nido reveló que, durante el año anterior, el 0,5\% tuvieron que recibir tratamiento médico tras sufrir una agresión física durante el desempeño del trabajo; el $11 \%$ sufrieron lesiones leves que requirieron sólo primeros auxilios; entre un $4 \%$ y un $6 \%$ fueron amenazados por personas que empuñaban un arma mortal, y un $17 \%$ recibieron amenazas verbales. $L$ a violencia fue un problema especialmente importante para el personal de urgencias de ambulancias y departamentos de accidentes, para el personal de enfermería y los trabajadores a cargo de pacientes con trastornos psicológicos (H ealth Services Advisory Committee 1987). El riesgo de que los trabajadores sanitarios se enfrenten a situaciones de violencia se ha convertido en una característica del trabajo diario de los servicios de asistencia sanitaria primaria y de los departamentos de accidentes y de urgencias (Shepherd, 1994).
Tabla 51.1 - Lugares de trabajo con las mayores tasas de homicidios laborales en Estados Unidos, 1980-1989.

\begin{tabular}{|c|c|c|}
\hline Lugares de trabajo & № de homicidios & Tasa $^{1}$ \\
\hline Servicio de taxi & 287 & 26,9 \\
\hline Tiendas de bebidas alcohólicas & 115 & 8,0 \\
\hline Gasolineras & 304 & 5,6 \\
\hline $\begin{array}{l}\text { Servicios privados de investigación o } \\
\text { de seguridad }\end{array}$ & 152 & 5,0 \\
\hline $\begin{array}{l}\text { Organismos judiciales o de orden } \\
\text { público }\end{array}$ & 640 & 3,4 \\
\hline Tiendas de alimentación & 806 & 3,2 \\
\hline Joyerías & 56 & 3,2 \\
\hline Hoteles y moteles & 153 & 3,2 \\
\hline Establecimientos donde se sirven & 754 & 1,5 \\
\hline
\end{tabular}

1 Número por cada 100.000 trabajadores al año. Fuente: NIOSH 1993b.

\section{EI homicidio en el lugar de trabajo}

A pesar de que los homicidios en el lugar de trabajo representan sólo una pequeña proporción de la totalidad de los homicidios, su alta incidencia en las muertes relacionadas con el trabajo, al menos en Estados U nidos, sus singulares características y la posibilidad de que las empresas adopten medidas preventivas, les confieren un interés especial. Por ejemplo, mientras que en la mayoría de los casos de homicidio ocurridos en la sociedad el homicida y su víctima se conocen entre sí (en muchas ocasiones son familiares cercanos), y sólo el $13 \%$ de ellos estaban ligados a otro delito, esas proporciones se invierten en el lugar de trabajo, escenario en el que más de las tres cuartas partes de los homicidios se cometieron en el transcurso de un robo (NIOSH 1992). Además, mientras que las personas mayores de 65 años presentan las tasas más bajas - dentro de la población total- en cuanto a probabilidad de ser víctimas de un homicidio en el lugar de trabajo presentan las tasas más altas (Castillo y Jenkins 1994).

En la Tabla 51.1 figuran los lugares de trabajo con mayores tasas de homicidios en Estados U nidos. M ás del $50 \%$ de ellos tiene lugar en dos sectores: el comercio al por menor y los servicios. En este último se incluye el servicio de taxis, que registra una tasa de homicidios casi 40 veces superior a la media, seguido por los establecimientos de venta de bebidas alcohólicas y productos de gran consumo, las gasolineras - objetivo principal de los robos- y los servicios privados de investigación y de seguridad (C astillo y Jenkins 1994).

En la Tabla 51.2 se recogen las profesiones que presentan las mayores tasas de homicidios en el lugar de trabajo. De nuevo, los taxistas encabezan la clasificación, lo que refleja su probabilidad de verse involucrados en intentos de delito, seguidos de los agentes de la ley, los recepcionistas de hotel y los trabajadores de diversos tipos de establecimientos de venta al por menor. A propósito de unos datos similares relativos al Reino Unido, Drever (1995) comprobó que la mayor parte de las profesiones con una elevada mortalidad por homicidios presentaban altas tasas de drogodependencia (montadores de andamios, profesiones literarias y artísticas, pintores y decoradores) o de abuso de alcohol (cocineros y pinches de cocina, encargados de bar, camareros y trabajadores de servicios de comidas). 
Tabla 51.2 - Profesiones con las mayores tasas de homicidios laborales en Estados Unidos, 1980-1989.

$\begin{array}{lcc}\text { Profesiones } & \text { №de homicidios } & \text { Tasa }^{1} \\ \text { Taxistas y chóferes } & 289 & 15,1 \\ \text { Agentes de la ley } & 520 & 9,3 \\ \text { Recepcionistas de hotel } & 40 & 5,1 \\ \text { Empleados de gasolineras } & 164 & 4,5 \\ \text { Guardias de seguridad } & 253 & 3,6 \\ \text { Manejo y embalaje de valores } & 260 & 3,1 \\ \text { Propietarios/ encargados de tiendas } & 1.065 & 2,8 \\ \text { Camareros } & 84 & 2,1\end{array}$

1 Número por cada 100.000 trabajadores al año. Fuente: NIOSH 1993b.

Como ya se ha indicado, la gran mayoría de los homicidios relacionados con el trabajo se producen durante el transcurso de un robo $u$ otro delito cometidos por personas normalmente desconocidas para la víctima. Los factores de riesgo que entrañan esos incidentes figuran en la Tabla 51.3.

Cerca del $4 \%$ de los homicidios en el lugar de trabajo se producen durante el enfrentamiento de la víctima con un familiar o conocido que le ha seguido hasta su lugar de trabajo. Alrededor del $21 \%$ están originados por un enfrentamiento relacionado con el lugar de trabajo: las dos terceras partes de éstos son cometidos por trabajadores o antiguos empleados que guardan rencor a algún directivo o compañero, y el resto, por clientes descontentos (Toscano y Windau 1994). En estos casos, el objetivo puede ser el directivo o compañero cuyas acciones provocaron la agresión o, en caso de que el rencor se dirija contra la organización, el propio lugar de trabajo y cualquier trabajador 0 visitante que se encuentre en ese lugar en ese preciso momento. En algunos casos, los agresores pueden sufrir trastornos emocionales, como Joseph T. Weisbecker, un trabajador con una discapacidad de larga duración de Louisville (K entucky) por enfermedad mental, que mató a ocho compañeros e hirió a otros doce antes de quitarse la vida (K uzmits 1990).

\section{Causas de la violencia}

El conocimiento actual de las causas y factores de riesgo de las agresiones violentas es muy rudimentario (Rosenberg y Mercy 1991). Naturalmente, son muchos los factores que

Tabla 51.3 • Factores de riesgo de los homicidios en el lugar de trabajo.

Trabajo en solitario 0 en grupos reducidos

Intercambio de dinero con el público

Trabajo a últimas horas de la noche o primeras de la mañana

Trabajo en zonas de alta criminalidad

Custodia de bienes o posesiones de valor

Trabajo en la calle ( por ejemplo, taxistas o policías)

Fuente: NIOSH 1993b. intervienen en el problema, en el que la configuración de cada incidente depende de las características del agresor, de la víctima 0 víctimas y de la naturaleza de la interacción entre ambos. D ebido a su complejidad, se han desarrollado varias teorías de la causalidad. Las teorías biológicas, por ejemplo, se ocupan sobre todo de factores como el sexo (la mayoría de los agresores son varones), la edad (la posibilidad de ser víctima de actos violentos en la sociedad disminuye con la edad, aunque, como ya se ha indicado, no sucede así en el lugar de trabajo) y la influencia de hormonas como la testosterona, de neurotransmisores como la serotonina y de otros agentes biológicos. La teoría psicológica dirige su atención a la personalidad y sostiene que la falta de afecto y los malos tratos durante la infancia engendran violencia, que se aprende por imitación de modelos y se refuerza mediante recompensas y castigos en los primeros años de vida (R osenberg y M ercy 1991). L os factores que se describen a continuación se han relacionado con la violencia.

\section{Enfermedad mental}

$\mathrm{Ni}$ la gran mayoría de las personas violentas son enfermos mentales, ni la gran mayoría de los enfermos mentales son violentos (American Psychiatric Association 1994). Sin embargo, las personas con trastornos mentales son a veces asustadizas, irritables, recelosas, nerviosas, airadas o varias cosas a la vez (Bullard 1994). D e ello se deriva un comportamiento que entraña cierto riesgo de violencia para los médicos, enfermeros y trabajadores que se ocupan de atenderlos en ambulancias, departamentos de urgencias y establecimientos psiquiátricos, tanto hospitalarios como ambulatorios.

Ciertos tipos de enfermedad mental están relacionados con una mayor propensión a la violencia. Los individuos con personalidades psicopáticas suelen tener un bajo umbral de rabia y frustración, lo que suele desencadenar comportamientos violentos ( $M$ arks 1992), mientras que los enfermos de paranoia son recelosos y propensos a las agresiones contra las personas $u$ organizaciones a quienes culpan cuando las cosas no les van como desean. Sin embargo, hay personas con otras formas de enfermedad mental que muestran comportamientos violentos. Además, algunos enfermos mentales son propensos a sufrir episodios de demencia aguda, en los que la violencia se vuelve contra sí mismos o contra quienes traten de contenerlos.

\section{Abuso de alcohol y drogas}

El abuso de alcohol está estrechamente ligado a los comportamientos agresivos y violentos. Si bien la embriaguez por parte de agresores o víctimas, o de ambos, suele desembocar en violencia, no existe acuerdo en cuanto a si el alcohol es la causa de la violencia o sólo uno de los factores que la causan (Pernanen 1993). Fagan (1993) insistía en que, si bien el alcohol afecta a las funciones neurobiológicas, de percepción y cognoscitivas, el entorno inmediato en que tiene lugar el acto de beber es el que canaliza las respuestas desinhibidoras al alcohol. Un estudio realizado en el condado de Los Angeles confirmó esta aseveración, ya que reveló que los incidentes violentos se producían con mucha más frecuencia en ciertos bares, mientras que eran relativamente raros en otros en los que se bebía tanto como en los primeros. La conclusión del estudio era que los comportamientos violentos no dependen de la cantidad de alcohol consumida sino, más bien, del tipo de personas atraídas por un determinado bar y de las reglas no escritas que rigen en esos lugares (Scribner, M acK innon y D wyer 1995).

Algo similar puede decirse del abuso de drogas ilegales. Salvo quizás en el caso del crack y las anfetaminas, el consumo de drogas suele asociarse con la sedación y el síndrome de abstinencia antes que con comportamientos agresivos y violentos. $L a$ mayor parte de la violencia relacionada con las drogas ilegales 
no parece residir en las drogas, sino en los esfuerzos para obtenerlas o para conseguir el dinero necesario para adquirirlas, así como en el tráfico ilegal de drogas.

\section{La violencia en la sociedad}

La violencia social no sólo se infiltra en los lugares de trabajo, sino que es un factor de riesgo especialmente importante para trabajadores como los policías y los bomberos, así como para los empleados de Correos y otros trabajadores del sector público, para el personal de reparaciones y de prestación de servicios, para los trabajadores sociales y para otros cuyos puestos de trabajo les lleven a barrios en los que la violencia y los delitos tienen un carácter endémico. La posesión generalizada de armas de fuego y, en particular en el caso de los jóvenes, el grado de violencia que se muestra en el cine y la televisión, son factores importantes que determinan la frecuencia de los actos violentos, sobre todo en Estados U nidos.

\section{Factores relacionados con el trabajo que se asocian a la violencia}

En cualquier lugar de trabajo pueden darse casos de violencia. Ahora bien, hay ciertos tipos de trabajo y de circunstancias relacionadas con el trabajo que se asocian de forma especial al riesgo de generar o de ser objeto de violencia, como las que se citan a continuación.

\section{Actividades delictivas}

Q uizá los menos complejos entre los episodios de violencia relacionados con el trabajo son los relacionados con la violencia criminal, principal causa de los homicidios en el lugar de trabajo. Se pueden distinguir dos categorías: los relacionados con intentos de robo u otros delitos y los vinculados al tráfico ilegal de drogas. La policía, los guardias de seguridad y otros trabajadores encargados de velar por el cumplimiento de la ley y el orden se enfrentan constantemente al riesgo de ser agredidos por criminales que intentan entrar en el lugar de trabajo o que se resisten a ser identificados y detenidos. Los que trabajan en solitario y los trabajadores de campo, cuyas obligaciones les llevan a barrios con altas tasas de criminalidad suelen ser objeto de intentos de robo. Los profesionales de la salud que hacen visitas a domicilio en esas zonas están expuestos a un riesgo especialmente alto porque suelen llevar consigo fármacos e instrumental para su administración, como jeringuillas y agujas hipodérmicas.

\section{Trato con el público}

Los trabajadores de servicios comunitarios en organismos públicos y agencias privadas, los de los bancos y otras entidades que prestan servicios de cara al público, suelen enfrentarse a agresiones por parte de individuos a quienes se ha hecho esperar sin razón, a quienes se ha recibido con desinterés e indiferencia (ya sea real o percibida) 0 a quienes la complicación de los procedimientos burocráticos y los tecnicismos han hecho fracasar en su intento de obtener información o servicios. Los empleados de establecimientos de venta al por menor que reciben artículos devueltos, los trabajadores que atienden los mostradores de despacho de billetes cuando hay overbooking en los vuelos, retrasos o cancelaciones, los conductores y revisores de autobuses o tranvías urbanos y otras personas encargadas de la atención a clientes cuyos deseos no pueden satisfacerse de forma inmediata, suelen ser objeto de agresiones verbales y, en ocasiones, incluso físicas. Además, hay que citar a quienes han de enfrentarse a multitudes impacientes y agitadas, como los agentes de policía, los guardias de seguridad, los porteros y acomodadores en acontecimientos deportivos y otros espectáculos.
Los trabajadores del sector público, sobre todo los uniformados, y los edificios y las oficinas oficiales donde trabajadores y visitantes pueden resultar heridos o muertos de forma indiscriminada, pueden ser objeto de violentas agresiones causadas por el resentimiento y la rabia contra leyes y políticas oficiales que sus autores no aceptan.

\section{Estrés laboral}

Los niveles elevados de estrés laboral pueden precipitar comportamientos violentos y, a su vez, la violencia en el lugar de trabajo puede ser un importante factor de estrés. Los determinantes del estrés laboral son bien conocidos (véase el capítulo 34, Factores psicosociales y de organización). EI denominador común es la devaluación del individuo o del trabajo que desempeña, lo que provoca fatiga, frustración y rabia hacia los directivos y compañeros, a quienes se estima desconsiderados, injustos e insultantes. Varios estudios de población recientes han demostrado la existencia de una relación entre violencia y pérdida del puesto de trabajo, uno de los factores de estrés relacionado con el trabajo más importantes (C atalano y cols. 1993; Yancey y cols. 1994).

\section{Ambiente interpersonal en el lugar de trabajo}

El ambiente interpersonal en el lugar de trabajo puede ser un caldo de cultivo para la violencia. La discriminación y el acoso, formas de violencia en sí mismas según se define en este artículo, pueden provocar una violenta reacción de venganza. Por ejemplo, MSF, el sindicato británico que agrupa a trabajadores de los ámbitos de la gestión empresarial, científico y financiero, subraya que una de las características del estilo directivo de algunas organizaciones es la intimidación en el lugar de trabajo (definida como comportamiento ofensivo, injurioso, intimidatorio, malicioso o insultante de carácter persistente; abuso de poder o imposición injusta de sanciones penales) (M FS 1995).

El acoso sexual se ha consolidado como una forma de agresión en el trabajo (SEIU 1995). Puede tratarse de tocamientos o caricias indeseadas, agresión física, insinuaciones u otras ofensas verbales, miradas insistentes o lascivas, solicitud de favores sexuales, invitaciones comprometedoras o de un ambiente de trabajo ofensivo a causa de la pornografía. L as situaciones en las que el trabajador considere que las condiciones de su puesto de trabajo dependen de su tolerancia ante las proposiciones o en las que el acoso cree un ambiente de trabajo intimidatorio, hostil u ofensivo son ilegales en Estados U nidos y se definen como una forma de discriminación sexual de acuerdo con lo dispuesto en el Título VII de la Ley de derechos civiles de 1964.

$\mathrm{Si}$ bien las mujeres son los objetivos más habituales, los varones son también objeto de acoso sexual, aunque con mucha menor frecuencia. Según una encuesta realizada entre trabajadores de la administración federal en Estados U nidos, un $42 \%$ de las mujeres encuestadas y un $15 \%$ de los varones declararon haber sido acosados sexualmente en el trabajo, y una encuesta de seguimiento realizada en 1987 reveló unos resultados similares (SEUI 1995). En Estados U nidos, la amplia cobertura que los medios de comunicación han dado a los casos de acoso a mujeres que se han "entrometido" en puestos y en lugares de trabajo ocupados tradicionalmente por varones, así como la notoriedad adquirida por destacadas figuras de la vida política y pública, que se han visto envueltos en presuntos casos de acoso, han provocado un aumento de las quejas presentadas ante los organismos estatales y las agencias federales que luchan contra la discriminación así como del número de demandas civiles presentadas.

El trabajo en la asistencia sanitaria y en los servicios sociales Además de los intentos de robo, como ya se ha indicado, el personal de asistencia sanitaria suele ser objeto de actos violentos 
por parte de pacientes en estado de ansiedad y con trastornos, sobre todo en departamentos de urgencias y ambulatorios, donde son frecuentes las largas esperas y el trato impersonal y donde la ansiedad y la rabia pueden desembocar en agresiones verbales 0 físicas. Pueden ser, asimismo, víctimas de las agresiones de familiares 0 amigos de pacientes que han sufrido un desenlace adverso que aquéllos, con razón o sin ella, atribuyen a negaciones, retrasos o errores en los tratamientos. En esos casos, pueden agredir al trabajador o trabajadores sanitarios que consideran responsable en particular, o bien pueden ejercer esa violencia de forma aleatoria contra cualquier miembro del personal del servicio médico.

\section{Efectos de la violencia en la víctima}

El trauma resultante de la agresión física depende de la naturaleza del ataque y de las armas empleadas. Las víctimas suelen presentar magulladuras y cortes en las manos y en los antebrazos si han intentado defenderse. Puesto que el rostro y la cabeza son objetivos habituales, las magulladuras y las fracturas de los huesos faciales son frecuentes y pueden causar traumas psicológicos, ya que la hinchazón y la equimosis resultan muy llamativas y tardan semanas en desaparecer (M ezey y Shepherd 1994).

Los efectos psicológicos causan más problemas que los traumatismos, sobre todo si un trabajador sanitario ha sido agredido por un paciente. Las víctimas experimentan una pérdida de serenidad y de autoconfianza en su competencia profesional, a lo que se añade un sentimiento de culpa por haber provocado la agresión o por no haberla previsto. Persiste en ellas una cierta rabia, indiscriminada o personalizada, ante el aparente rechazo de sus bienintencionados esfuerzos profesionales y una pérdida de confianza en sí mismos, así como una desconfianza hacia sus compañeros y supervisores, que puede afectar a su rendimiento en el trabajo. Todo ello va acompañado de insomnio, pesadillas, aumento o disminución del apetito, mayor consumo de tabaco, alcohol o drogas, retraimiento social y absentismo laboral (M ezey y Shepherd 1994).

EI trastorno por estrés postraumático (TEPT) es un síndrome psicológico concreto que puede desarrollarse después de grandes catástrofes y de casos de agresiones violentas, no sólo en las personas directamente implicadas en el incidente, sino en los testigos presenciales. Aunque suele estar relacionado con amenazas de muerte o accidentes mortales, el TEPT puede desencadenarse después de sufrir una agresión relativamente trivial, que se perciba como una amenaza de muerte (Foa y Rothbaum 1992). Los síntomas son: aparición de recuerdos y pesadillas recurrentes e intrusivos (escenas retrospectivas 0 flashbacks), que hacen revivir el incidente, sentimiento permanente de sobresalto y ansiedad, con tensión muscular, hiperactividad autonómica, pérdida de concentración y reactividad exacerbada. Se suelen evitar consciente 0 inconscientemente las circunstancias que recuerdan el incidente. Aunque el período de discapacidad puede ser largo, los síntomas suelen responder a una psicoterapia de apoyo. Es posible evitarlos mediante un parte realizado lo antes posible tras el incidente, seguido de consejo psicológico a corto plazo, si es preciso (Foa y Rothbaum 1992).

\section{Después del incidente}

Algunas de las medidas de intervención que se han de adoptar inmediatamente después del incidente son:

\section{Asistencia a la víctima}

Se deben facilitar los primeros auxilios y la asistencia médica que sean precisos a todos los heridos tan rápidamente como sea posible. Con eventuales fines forenses (por ejemplo, presentación de demandas penales o civiles contra el agresor), se deben describir con detalle las lesiones y, si es posible, fotografiarlas.

\section{Limpieza del lugar de trabajo}

Debe repararse todo daño causado en el lugar de trabajo y eliminar los escombros; deberán revisarse los equipos afectados para garantizar la completa recuperación de la seguridad y la limpieza en el lugar de trabajo (SEUI, 1995).

\section{Parte posterior al incidente}

Todas las personas implicadas o que hayan sido testigos del incidente deben participar en la elaboración de un parte tan pronto como sea posible, o en una sesión de "apoyo en casos de traumacrisis" impartida por un profesional cualificado del personal propio o por un consultor externo. Ello no sólo facilita apoyo emocional y permite identificar a aquellas personas que necesitan apoyo individual, sino que proporciona detalles más precisos sobre lo ocurrido. Si fuera necesario, además de la sesión de apoyo se creará un grupo de ayuda mutua (CAL/ O SH A 1995).

\section{Elaboración de un informe}

Se debe cumplimentar un impreso normalizado que se presenta a la persona adecuada dentro de la organización y, en su caso, a la policía local. Se han elaborado y publicado varias muestras de impresos que se pueden adaptar a las necesidades de una organización (U nison 1991; M SF 1993; SEU I 1995). La agregación y el análisis de los informes de incidentes presta información epidemiológica que permite identificar los factores de riesgo de violencia en el lugar de trabajo concreto y señalar la dirección que deberán tomar las acciones preventivas oportunas.

\section{Investigación del incidente}

Todo incidente de presunta violencia denunciado, por trivial que parezca, debe ser investigado por una persona con la formación precisa nombrada a tales efectos. (El nombramiento de la persona encargada de esas investigaciones podrá ser competencia del comité paritario de salud y seguridad, cuando exista). Las investigaciones estarán encaminadas a identificar las causas del incidente, las personas implicadas, qué medidas disciplinarias se deberían aplicar, en su caso, y qué se puede hacer para evitar que se repita. Si no se lleva a cabo una investigación imparcial y eficaz es síntoma de la falta de interés por parte de la dirección y de la despreocupación por la salud y el bienestar de los trabajadores.

\section{Apoyo por parte de la empresa}

Se deberá garantizar a las víctimas y testigos del incidente que no serán objeto de discriminación ni sufrirán cualquier otro tipo de represalia por haber informado del mismo. Se trata de una situación de especial importancia cuando el presunto agresor es el superior del trabajador.

De acuerdo con la legislación vigente en cada jurisdicción, con la naturaleza y el alcance de las lesiones y con la duración de la baja laboral, el trabajador podrá reclamar prestaciones de indemnización. En esos casos, se deberán cumplimentar los impresos de reclamación pertinentes.

Cuando proceda, se presentará un informe ante las autoridades locales encargadas del cumplimiento de la ley y se facilitará a la víctima asesoramiento jurídico sobre la presentación de cargos contra el agresor y ayuda para tratar con los medios de comunicación.

\section{Participación de los sindicatos}

Algunos sindicatos han desempeñado un importante papel en la lucha contra la violencia en el lugar de trabajo, sobre todo los que agrupan a trabajadores de los sectores de asistencia sanitaria y de 
servicios, como el Sindicato Internacional de Trabajadores del Sector Servicios (SEUI) en Estados U nidos, y Gestión Empresarial, Ciencia y Finanzas (MSF) y Unison en el Reino Unido. M ediante la elaboración de directrices y la publicación de hojas, boletines y folletos de hechos, se han ocupado de la formación de los trabajadores, sus representantes y sus empresas en cuanto a la importancia de la violencia en el lugar de trabajo, cómo afrontarla y cómo prevenirla. $\mathrm{H}$ an actuado como abogados de los afiliados que han sido víctimas para garantizarles que sus quejas y denuncias de violencia reciben la consideración que se merecen sin amenazas ni represalias y de que reciben todas las prestaciones a que tienen derecho. Junto con las asociaciones de empresa y gremiales y organismos públicos, los sindicatos reivindican políticas, reglas y reglamentos encaminadas a reducir el alcance de la violencia en el lugar de trabajo.

\section{Amenazas de violencia}

Todas las amenazas de violencia deben ser tomadas en serio, ya se dirijan a individuos concretos 0 a toda la organización. En primer lugar, se deben adoptar las medidas oportunas para proteger a las personas elegidas como objetivo. A continuación, si es posible, se debe identificar al agresor. Si esa persona no pertenece a la plantilla, se debe informar a las autoridades encargadas de la ley. Si pertenece a la organización, es aconsejable consultar con un profesional de salud mental cualificado para que asesore sobre la forma de afrontar la situación o para que trate directamente con el agresor.

\section{Estrategias preventivas}

Prevenir la violencia en el lugar de trabajo es, principalmente, responsabilidad de la empresa. Lo ideal sería desarrollar e implantar una política y un plan de actuación formales antes de que algún trabajador sea víctima de ella. Se trata de un proceso en el que no sólo deben intervenir los departamentos de recursos humanos, seguridad, asuntos legales y de salud y seguridad de los trabajadores, sino también los directivos de línea y otros representantes de los trabajadores. Para ello, se han publicado unas guías (véase la Tabla 51.4), de carácter genérico, cuyo objetivo es que se adapten a las circunstancias de cada lugar de trabajo o sector. Los denominadores comunes son:

\section{Definición de una política}

Se debe formular y publicar una política que proscriba de forma explícita los comportamientos discriminatorios y ofensivos, así como el uso de la violencia para la resolución de disputas, que debe estar acompañada por medidas disciplinarias concretas en los casos de infracción (incluso el despido).

\section{Evaluación de riesgos}

Una inspección del lugar de trabajo, complementado por el análisis de incidentes previos o de información recogida en encuestas realizadas a los trabajadores permitirá que un experto evalúe los factores de riesgo de violencia y sugiera intervenciones preventivas oportunas. El análisis del estilo directivo y de supervisión imperante, así como de la organización del trabajo, revela si existen altos niveles de estrés laboral que puedan provocar violencia. EI análisis de las interacciones con los clientes 0 pacientes pone de manifiesto características que pueden generar ansiedad, frustración o rabia innecesarias y provocar reacciones violentas.

\section{M odificaciones del lugar de trabajo para reducir los delitos}

Las orientaciones dadas por la policía o por expertos en seguridad privada pueden sugerir cambios en los procedimientos de trabajo y en el diseño y acondicionamiento del lugar de trabajo

que lo hagan menos atractivo como objeto de intentos de robo. EI Departamento de Justicia Penal de Virginia, en Estados U nidos, ha recurrido al modelo Prevención de delitos mediante el diseño medioambiental (CPTED), desarrollado por un consorcio de las escuelas de arquitectura del Estado, que propone: modificar la iluminación y la decoración interior y exterior, con especial atención a las zonas de aparcamiento, huecos de escaleras y servicios; situar las zonas de venta y salas de espera de forma que sean visibles desde la calle; utilizar cajas de seguridad con buzón o cajas fuertes con sistema de apertura retardada para guardar el dinero; instalar sistemas de alarma, monitores de televisión y otros equipos de seguridad (M alcan 1993). EI modelo CPTED se ha aplicado con éxito en establecimientos de productos de gran consumo, en bancos (sobre todo en cajeros automáticos en funcionamiento las 24 horas del día), en colegios y universidades, así como en el metropolitano de Washington, DC.

En la ciudad de Nueva York, donde los robos y asesinatos de taxistas son relativamente frecuentes en comparación con otras grandes ciudades, la Taxi and Limousine Commission elaboró un reglamento que obligaba a instalar una mampara transparente antibalas entre el conductor y los pasajeros del asiento trasero, una plancha antibalas en el respaldo del asiento del conductor y una luz exterior de socorro que el conductor puede encender pero no es visible desde el interior del vehículo (N YC / TCL 1994). (Se ha disparado la cifra de lesiones en la cabeza y en el rostro de los pasajeros de los asientos traseros que, al no haberse abrochado el cinturón de seguridad, salían despedidos hacia adelante cuando el taxi paraba bruscamente).

En caso de que el trabajo implique interacción con clientes 0 pacientes, se puede mejorar la seguridad de los trabajadores

Tabla 51.4 • Guías para la implantación de programas de prevención de la violencia en el lugar de trabajo.

Fecha Título

1991 Violence in the Workplace: NUPE Guidelines

1993 CAL/ OSHA Guidelines for Security and Safety of Health Care and Community Service Workers

1993 Prevention of Violence at Work: An MSF Guide with Model Agreement and Violence at Work Questionnaire (MSF Health and Safety Information No. 37)

1995 Assault on the Job: We Can Do Something About Workplace Violence (2nd Edition)

1995 CAL/ OSHA: Model Injury and Illness Prevention Program for Workplace Security

1996 Guidelines for Preventing Workplace Violence for Health Care and Social Service Workers (OSHA 3148)
Fuente

Unison Health Care 1 Marbledon Place Londres WC1H 9AJ, Reino Unido

Division of Occupational Safety and Health

Department of Industrial Relations 45 Fremont Street San Francisco, CA 94105, EE.UU.

MSF Health and Safety Office Dane O'Coys Road

Bishops Stortford Herts, CM23 2JN, Reino Unido

Service Employees International Union

1313 L Street, NW Washington, DC 20005, EE.UU.

Division of Occupational Safety and Health

Department of Industrial Relations

45 Fremont Street San Francisco, CA 94105, EE.UU.

OSHA Publications Office

P.O. Box 37535 Washington, DC 20013-7535 EE.UU. 
mediante barreras (ventanillas, mostradores o mesas, mamparas transparentes a prueba de golpes) y puertas con cerraduras a prueba de golpes (CAL/OSHA, 1993). El mobiliario y los equipos se dispondrán de forma que se evite que los trabajadores puedan quedar atrapados $y$, si es preciso mantener un cierto grado de intimidad, ello no se hará a expensas de que el trabajador quede a solas con una persona potencialmente agresiva o violenta en una zona cerrada y aislada.

\section{Sistemas de seguridad}

Todos los lugares de trabajo deben estar dotados de un sistema de seguridad adecuadamente diseñado. La entrada de intrusos puede reducirse limitando el acceso a través de una zona de recepción en la que se compruebe la identidad de los visitantes y se les entreguen tarjetas identificativas que indiquen las zonas que se visitarán. En determinadas circunstancias, es aconsejable emplear detectores de metales que delaten a los visitantes que escondan armas.

Los sistemas de alarma activados por "botones de emergencia" estratégicamente situados emiten señales auditivas 0 visuales que alertan a otros compañeros de la existencia de un peligro y de forma que permitan reclamar socorro a un puesto de seguridad cercano. Estos sistemas de alarma pueden conectarse también a la policía local. Sin embargo, pueden ser de poca utilidad si los guardias y los compañeros de trabajo no han recibido una formación adecuada para reaccionar con prontitud y precisión. Los monitores de televisión no sólo facilitan la vigilancia de protección, sino que graban los incidentes cuando ocurren y pueden ayudar en la identificación del causante. H uelga decir que esos sistemas electrónicos resultan de escasa utilidad si no cuentan con un mantenimiento adecuado y se prueban con una cierta regularidad para asegurarse de que funcionan correctamente.

L os radiotransmisores y teléfonos móviles pueden ser medidas de seguridad para el personal de campo y quienes trabajen en solitario. Son asimismo un medio para informar de su situación y, en su caso, para pedir atención médica o de otro tipo.

\section{Controles de las prácticas de trabajo}

Se deben revisar las prácticas de trabajo con regularidad y modificarlas para reducir al mínimo la acumulación de estrés laboral. Ello implica vigilar los horarios y la carga de trabajo, el contenido del puesto y efectuar un seguimiento del rendimiento laboral. Se debe mantener un nivel de dotación de personal adecuado en las zonas de trabajo de alto riesgo, tanto para evitar los comportamientos violentos como para afrontarlos en caso de que ocurran. Adaptar la dotación de personal para atender a clientes o pacientes en los momentos de máximo flujo ayudará a reducir las molestas esperas y la acumulación de personas en las zonas de trabajo.

\section{Formación del personal}

Trabajadores y supervisores deben estar preparados para detectar el aumento de la tensión y la inquietud y para devolver la calma con métodos no violentos. Los ejercicios de rol pueden ayudar a los trabajadores a tratar con individuos excesivamente agresivos u ofensivos evitando la provocación. En ciertas situaciones, es aconsejable formar a los trabajadores en materia de defensa personal, auque se corre el peligro de que fomente en ellos un grado de autoconfianza que les lleve a retrasar la petición de socorro 0 incluso a no hacerlo en absoluto

L os guardias de seguridad, el personal de instituciones psiquiátricas 0 penitenciarias y otras personas con una gran proba- bilidad de tratar con individuos físicamente violentos, deben estar preparados para calmarlos y contenerlos con un riesgo mínimo de lesiones a terceros o a ellos mismos (SEU I 1995). Sin embargo, de acuerdo con U nison (1991), la formación nunca puede sustituir a una adecuada organización del trabajo y a una seguridad correcta.

\section{Programas de asistencia a los empleados}

Los Programas de asistencia a los empleados (PAE, también conocidos como Programas de Ayuda a los Afiliados o PAA, si su responsable es un sindicato) pueden ser muy eficaces en situaciones de crisis, ya que a través de ellos se presta consejo y apoyo a las víctimas y a los testigos de incidentes violentos, se les remite a profesionales de salud mental externos en los casos en los que es necesario, se vigila su evolución y se supervisan las medidas de protección que faciliten su reincorporación al trabajo.

También pueden buscar apoyo en los PAE los trabajadores cuya frustración y rabia es posible que culmine en un comportamiento violento por estar sobrecargados de problemas relacionados con el trabajo, la familia o la comunidad. Si se dan varios casos así en una determinada zona del lugar de trabajo, Ios PAE pueden (respetando la confidencialidad de la información personal, que es fundamental para su desarrollo) servir de orientación a los directivos para que efectúen las modificaciones laborales oportunas que inutilicen el "polvorín" antes de que estalle la violencia.

\section{Investigación}

Dada la gravedad y la complejidad del problema y la escasez de información fiable, es preciso realizar más investigaciones epidemiológica, de causalidad, prevención y control de la violencia en la sociedad en general y en el lugar de trabajo. Ello requiere un esfuerzo interdisciplinar por parte (además de expertos en salud y seguridad en el trabajo), de profesionales de salud mental, trabajadores sociales, arquitectos e ingenieros, expertos en ciencias de la dirección, abogados, jueces y expertos en el sistema penal, autoridades en políticas públicas y otros. Se necesitan con urgencia sistemas de recopilación y análisis de datos mejores y más exhaustivos, y es preciso asimismo llegar a un acuerdo para definir una clasificación de la violencia que facilite la transmisión de informaciones e ideas entre distintas disciplinas.

\section{Conclusión}

La violencia es endémica en el lugar de trabajo. Los homicidios son una de las principales causas de muertes relacionadas con el trabajo, pero su impacto y su coste se ven considerablemente superados por los intentos fallidos, las agresiones físicas no mortales, las amenazas, el acoso, los comportamientos agresivos y las ofensas, de los que, en gran medida, se sigue careciendo de documentación y no se denuncian. Aunque la mayor parte de los homicidios están relacionados con actividades delictivas, la violencia en el lugar de trabajo no es sólo un problema de la justicia penal. Tampoco es sólo un problema de los profesionales en salud mental y los especialistas en adicciones, aunque está relacionado en gran medida con enfermedades mentales, alcoholismo y abuso de drogas. Requiere un esfuerzo coordinado de expertos en una gran variedad de disciplinas, encabezados por los profesionales en salud y seguridad en el trabajo, encaminado a desarrollar, validar y aplicar un conjunto de estrategias coherentes en materia de intervención y de prevención, sin olvidar que la diversidad de trabajadores, puestos de trabajo y sectores impone la necesidad de adaptarlas a las peculiaridades de la plantilla y la organización concreta que lo adopte. 


\section{Referencias}

American Psychiatric Association (APA). 1994. APA Fact Sheet: Violence and M ental IIIness. Washington, DC: APA.

Bachman, R. 1994. Crime Victimization Survey: Violence and Theft in the Workplace Washington, DC: US D epartment of Justice.

Bullard, H. 1994. M anagement of violent patients. En Violence in $\mathrm{H}$ ealth Care: A Practical Guide to Coping $\mathrm{W}$ ith Violence and Caring for Victims, dirigido por J Shepherd. O xford: OUP.

CAL/ O SH A Consultation Service. 1995. M odel Injury and Illness Prevention Program for W orkplace Security. Los Angeles: California Department of Industrial Relations.

CAL/OSHA. 1993. Guidelines for the Security and Safety of $\mathrm{H}$ ealth Care and Community Service W orkers. Los Angeles: California Department of Industrial Relations.

Castillo, DN, EL Jenkins, 1994. Industries and occupations at high risk for work-related homicide. J 0 ccup M ed 36: 125-132.

Catalano, R, D Dooley, RW Novaco, G Wilson, $\mathrm{R} H$ ough. 1993. Using ECA survey data to examine the effect of job layoffs on violent behaviour. H ospital and Community P sychiatry 44: 874-879.

Drever, F. 1995. Occupational $H$ ealth Decennial Supple ment: Office of Population Censuses and Survey. $\mathrm{H}$ ealth and Safety Executive Series D5, № 10. Londres: HMSO.

Fagan, J. 1993. Set and setting revisited: Influences of alcohol and illicit drugs on the social context of violent events. En Alcohol and Interpersonal Violence: Fostering M ultidisciplinary Perspectives, dirigido por SF $M$ artin. R ockville, M aryland: $N$ ational Institute of Alcohol A buse and Alcoholism.

Foa, EB, BO Rothbaum. 1992. Post-traumatic stress disorder: Clinical features and treatment. En Aggression and Violence T hroughout the L ifespan, dirigido por RD Peters, RJ McMahon y VI Quinsey. Newbury Park, California: Sage.
H ealth Services Advisory Committee. 1987. Violence to Staff in the Health Services. Londres: $\mathrm{H}$ ealth and Safety Commission, H M SO.

K uzmits, FE. 1990. When employees kill other employees: The case of Joseph T. Weisbecker. J 0 ccup M ed 32: 1014-1020.

Lawless, P. 1993. Fear and Violence in the W orkplace A Survey Documenting the Experience of American W orkers. M inneapolis, M innesota: N orthwestern N ational Life Insurance.

Malcan, JW. 1993. Report of Virginia Crime Prevention Center on Violent Crimes in Convenience Stores: Analysis of Crimes, Criminals and Costs. House doc. No. 30. Richmond, Virginia; Virginia Department of Criminal Justice.

M arks, B. 1992. Psychopathic and violent patients. Practitioner 236: 715-719.

M ezey, G, J Shepherd. 1994. Effects of assault on health-care professionals. En Violence in $\mathrm{H}$ ealth Care: Practical Guide to Coping W ith Violence and Caring for Victims, dirigido por J Shepherd. O xford: O U P

M SF (M anagement, Science and Finance). 1993. Prevention of Violence At W ork, and M SF Guide W ith $M$ odel Agreement and Violence At W ork Questionnaire M SF H ealth and Safety Information, no 37. H erts, R eino U nido: M SF H ealth and Safety $O$ ffice.

- 1995. Bullying At W ork and $H$ ow to T ackle It: A Guide for M SF M embers and Representatives. Herts, Reino U nido: M SF H ealth and Safety $O$ ffice.

$\mathrm{N}$ ational Institute of $\mathrm{O}$ ccupational Safety and $\mathrm{H}$ ealth (NIOSH). 1992. Homicide in US Workplaces: A Strategy for Prevention and Research. Cincinnati, $O$ hio: US Department of $\mathrm{Health}$ and Human Resources, NIOSH .

- . 1993a. Alert: R equest for Assistance in Preventing $\mathrm{H}$ omicide in the W orkplace. Cincinnati, O hio: NIOSH.

- . 1993b. Fatal Injuries to W orkers in the U nited States, 1980-1989: A Decade of Surveillance: National Profile. Cincinnati, O hio: US Department of $\mathrm{H}$ ealth and H uman R esources, NIOSH.

-. 1993c. NIOSH Alert: Request. Cincinnati, O hio: $\mathrm{NIOSH}$.
N ew Y ork City and T axi and Limousine Commission (T LC). 1994. N otice R egarding M andatory Installation of Partition and Trouble Lights. Industry Notice $94-2$.

Pernanen, K. 1993. Alcohol-related violence: Conceptual models and methodological issues. En Alcohol and Interpersonal Violence: F ostering M ultidisciplinary Perspectives, dirigido por SE M artin. R ockville, $M$ aryland: National Institute of Alcohol Abuse and Alcoholism.

Reiss, AJ, JA Roth. 1993. U nderstanding and Preventing Violence. Washington, DC: National Academy Press.

R osenberg, M I, JA M ercy. 1991. Assaultive violence. En Violence in America: A Public $\mathrm{H}$ ealth Approach, dirigido por MI Rosenberg y MA Fenley. Nueva Y ork: 0 xford U niv. Press.

Scribner, RA, DP M acK innon, JH D wyer. 1995. The risk of assaultive violence and alcohol availability in Los Angeles County. Am J Public Health 85(3): 335-340.

Shepherd, J. 1994. Violence in H ealth Care: A Practical Guide to Coping W ith Violence and Caring for Victims. Oxford: OUP.

T oscano, G, J W indau. 1994. The changing character of fatal work injuries. M onthly Labor R eview 117(10): 17-28.

Unión Internacional de Empleados de Servicios (SEIU ), AFL-CIO, y CLC. 1995. Assault On the ob: W e Can D o Something A bout W orkplace V iolence. W ashington, DC: SEIU.

Unison. 1991. Violence in the NHS: NUPE Guidelines. Londres: Unison.

-. 1992. Violence at work: A preventative strategy. U nison W ork H ealth Safe (Julio): 1 .

Y ancey, AH , K S G abel-H ughes, S Ezell, DL Zalkind. 1994. The relationship between violent trauma and nonemployment. J $\mathrm{N}$ atl M ed Assoc 86: 661-666.

\section{0 tras lecturas recomendadas}

MSF. W orking Alone: Guidance for M SF M embers and Safety R epresentatives. 



\section{PANTAUAS DE \\ VISUAUZACION DE DATOS}

Directora del capítulo

Diane B erthelette

\section{Sumario}

\section{Visión general}

Diane $B$ erthelette . . . . . . . . . . . . . . . . . . . . 52.2

Características de los puestos de trabajo con pantallas de visualización de datos

A hmet Çakir . . .

Problemas oculares y visuales

Paule R ey y I ean-J acques $M$ eyer.

R iesgos para la reproducción: datos experimentales U If B ergquist

Efectos en la reproducción: evidencias en humanos

Claire Infante Rivard

Trastornos musculosqueléticos

Gabrile B ammer .

Problemas de la piel

M ats $B$ erg y Sture Lidén. . . . . . . . . . . . . . . . . . 52.26

Aspectos psicosociales del trabajo con PVD

M ichael J. Smith y Pascale C arayon. . . . . . . . . . . . . . . . 52.26

Aspectos ergonómicos de la interacción ordenador/ hombre

$J$ ean-M arc Robert

Normas ergonómicas

Tom F. M. Stewart. . . . . . . . . . . . . . . . . . . . . 52.35 


\section{- VISION GENERAL}

Diane Berthelette

Las nuevas tecnologías de la información se están introduciendo, en distintos grados, en todos los sectores industriales. En algunos casos, el coste de informatizar los procesos de producción puede suponer una traba para la innovación, especialmente en las empresas pequeñas o de tamaño medio, 0 en los países en desarrollo. L os ordenadores permiten recopilar, almacenar, procesar y distribuir rápidamente grandes cantidades de información. Además, al conectarlos en red sus capacidades aumentan notablemente, ya que es posible compartir los recursos (Young 1993).

La influencia de la informatización sobre la naturaleza del empleo y las condiciones de trabajo es notable. D esde mediados del decenio de 1980, resultó evidente que la informatización del lugar de trabajo produciría cambios en la estructura de las tareas y en la organización del trabajo y, por extensión, en los requisitos del trabajo, en la planificación de las oportunidades de trabajo y en el estrés que padece el personal de producción y de gestión. La informatización puede beneficiar o perjudicar la salud y la seguridad en el trabajo. En algunos casos, la introducción de los ordenadores ha hecho más interesante el trabajo y ha producido mejoras en el medio ambiente de trabajo, al mismo tiempo que ha reducido la carga de trabajo. Ahora bien, en otros, la innovación tecnológica ha originado un aumento de la repetitividad e intensidad de las tareas, una reducción del margen de iniciativa individual y el aislamiento del trabajador. Además, se sabe que varias empresas han aumentado el número de turnos para así obtener el máximo beneficio económico de su inversión financiera (OIT 1984).

$\mathrm{H}$ asta donde sabemos, en 1994 sólo existía una fuente de estadísticas sobre el uso de los ordenadores en todo el mundo: T he Computer Industry Almanac (Juliussen y Petska-Juliussen 1994). Es una publicación donde, además de datos estadísticos sobre la distribución internacional actual del uso de los ordenadores, se encuentran los resultados de análisis prospectivos y retrospectivos. Las cifras que se muestran en la última edición indican que el número de ordenadores aumenta de forma exponencial, con un aumento especialmente importante a principios de decenio de 1980, cuando comenzó a popularizarse el uso de los ordenadores personales. Desde 1987 la capacidad total de procesamiento informático, cuantificada en millones de instrucciones por segundo (M IPS), ha aumentado 14 veces, gracias al desarrollo de nuevos microprocesadores (componentes transistores de los microordenadores que realizan cálculos aritméticos y lógicos). A finales de 1993, la capacidad informática total alcanzaba los 357 millones de M IPS.

Por desgracia, las estadísticas disponibles no permiten distinguir entre los ordenadores utilizados para trabajar y los utilizados para fines personales. Además, algunos sectores industriales carecen de datos estadísticos, lo cual se debe probablemente a problemas metodológicos para la obtención de información válida y fiable. Ahora bien, los informes de los comités sectoriales tripartitos de la Organización Internacional del Trabajo ofrecen información completa y relevante sobre la naturaleza y el nivel de implantación de las nuevas tecnologías en diversos sectores industriales.

En 1986 el número de ordenadores en uso en todo el mundo ascendía a 66 millones. Tres años más tarde superaba los 100 millones, y en 1997 se calcula que la cifra oscilaba entre 275 y 300 millones, que para el año 2000 alcanzará los 400 millones. Son predicciones basadas en un uso cada vez más amplio de las capacidades multimedia, las autopistas de la información y las tecnologías de reconocimiento de voz y de realidad virtual. Los autores del Almanac estiman que en un plazo de diez años a partir de la publicación del artículo, la mayoría de los televisores estarán equipados con ordenadores personales con el fin de simplificar el acceso a las autopistas de la información.

Según el Almanac, la relación entre ordenadores totales y población en 43 países de los cinco continentes era, en 1993, del $3,1 \%$. Cabe señalar, sin embargo, que el único país africano incluido en este cálculo fue Sudáfrica y el único país latinoamericano de Norte y Centroamérica, M éxico. Como indican las estadísticas, existe una gran variación a nivel internacional en el grado de informatización, y la relación ordenadores:población va desde el $0,07 \%$ al $28,7 \%$.

La relación entre ordenadores y población en los países en desarrollo, que no supera el $1 \%$, da idea del bajo nivel general de informatización existente en estos países (Tabla 52.1) (Juliussen y Petska-Juliussen 1994). En ellos, no sólo se producen pocos equipos y poco software, sino que la falta de recursos económicos les impide, en muchos casos, importar estos productos. Además, sus rudimentarios servicios telefónicos y eléctricos representan, a menudo, una barrera para un uso más extendido de los medios informáticos. Por último, la falta de un software lingüística y culturalmente adecuado y la falta de oportunidades de formación en los campos relacionados con la informática representan, por lo general, un problema adicional (Young 1993).

La informatización ha aumentado significativamente en los países de la antigua U nión Soviética desde el final de la Guerra Fría. Se calcula, por ejemplo, que la Federación Rusa ha aumentado su reserva de ordenadores de 0,3 millones en 1989 a 1,2 millones en 1993.

La mayor concentración de ordenadores se encuentra en los países industrializados, especialmente en N orteamérica, Australia, los países Escandinavos y Gran Bretaña (Juliussen y PetskaJuliussen 1994) y ha sido principalmente en estos países donde han surgido los primeros informes relacionados con la preocupación de los operadores de las pantallas de visualización de datos (PVD) por los riesgos para la salud detectados, y en donde se han realizado los primeros estudios para determinar la prevalencia de los efectos sobre la salud e identificar los factores de riesgo. Los problemas de salud estudiados se hallaban en las siguientes categorías: problemas visuales y oculares, problemas musculosqueléticos, problemas de la piel, problemas reproductivos y estrés.

Pronto se hizo evidente que los efectos sobre la salud observados en los operadores de PVD dependían, no sólo de las características de la pantalla y del diseño del puesto de trabajo, sino también de la naturaleza y estructura de las tareas, de la organización del trabajo y de la forma en que se había introducido la tecnología (OIT 1989). Varios estudios han mostrado una mayor prevalencia de síntomas entre las mujeres operadoras de PVD que entre los varones. Según estudios recientes, esta diferencia, más que a una diferencia biológica real, se debe principalmente a que las mujeres suelen tener menos control sobre su trabajo que los operadores varones. Se piensa que esta falta de control puede producir niveles de estrés más elevados, que producen, a su vez, una mayor prevalencia de síntomas en las mujeres operadoras de PV D.

El uso generalizado de las PVD comenzó en el sector terciario, fundamentalmente en el trabajo de oficina y, más específicamente, en la entrada de datos y en el tratamiento de textos. No es de extrañar, por tanto, que la mayor parte de los estudios sobre PVD se hayan centrado en los trabajadores de oficinas. En los países industrializados el uso de los equipos informáticos se ha extendido, con todo, a los sectores primario y secundario. Además, aunque inicialmente eran los trabajadores del área de producción quienes utilizaban casi exclusivamente las PVD, actualmente su uso se ha extendido a todos los niveles 
Tabla 52.1 • Distribución de los ordenadores en distintas regiones del mundo.

\begin{tabular}{|c|c|c|c|c|c|}
\hline Región & \multicolumn{2}{|c|}{ Ordenadores por cada 100 personas } & Región & \multicolumn{2}{|c|}{ Ordenadores por cada 100 personas } \\
\hline NORTEAM ERICA & & & EUROPA ORIENTAL & & \\
\hline Estados Unidos & & 28,7 & República Checa & & 2,2 \\
\hline Canadá & & 8,8 & Hungría & & 2,7 \\
\hline México & & 1,7 & Polonia & & 1,7 \\
\hline SUDAM ERICA & & & Federación Rusa & & 0,78 \\
\hline Argentina & & 1,3 & Ucrania & & 0,2 \\
\hline Brasil & & 0,6 & & & \\
\hline Chile & & 2,6 & OCEANIA & & \\
\hline Venezuela & & 1,9 & Australia & & 19,2 \\
\hline EUROPA OCCIDENTAL & & & Nueva Zelanda & & 14,7 \\
\hline Austria & & 9,5 & AFRICA & & \\
\hline Bélgica & & 11,7 & Sudáfrica & & 1 \\
\hline Dinamarca & & 16,8 & ASIA & & \\
\hline Finlandia & & 16,7 & China & & 0,09 \\
\hline Francia & & 12,9 & India & & 0,07 \\
\hline Alemania & & 12,8 & Indonesia & & 0,17 \\
\hline Grecia & & 2,3 & Israel & & 8,3 \\
\hline Irlanda & & 13,8 & Japan & & 9,7 \\
\hline Italia & & 7,4 & República de Corea & & 3,7 \\
\hline Países Bajos & & 13,6 & Filipinas & & 0,4 \\
\hline Noruega & & 17,3 & Arabia Saudí & & 2,4 \\
\hline Portugal & & 4,4 & Singapur & & 12,5 \\
\hline España & & 7,9 & Taiwán & & 7,4 \\
\hline Suecia & & 15 & Tailandia & & 0,9 \\
\hline Suiza & & 14 & Turquía & & 0,8 \\
\hline Reino Unido & & 16,2 & & & \\
\hline Menos que 1 & 1.5 & $6-10$ & $11-15$ & $16-20$ & $21-30$ \\
\hline
\end{tabular}

organizativos. En los últimos años, por lo tanto, los investigadores han comenzado a estudiar una mayor diversidad de usuarios de PVD, en un intento por suplir la falta de información científica adecuada para estas situaciones.

La mayoría de los puestos de trabajo informatizados están equipados con una PVD y un teclado o ratón que permite transmitir la información y las instrucciones al ordenador. El software media el intercambio de información entre el operador y el equipo y define el formato en el que se presenta la información en la pantalla. Con el fin de determinar los posibles riesgos asociados con el uso de las PVD, es necesario conocer, en primer lugar, no sólo las características de la PVD, sino también de los demás componentes del entorno de trabajo. En 1979, Çakir, $\mathrm{H}$ art y Stewart publicaron el primer análisis completo en este campo.

Resulta útil considerar el hardware utilizado por los operadores de PVD como un conjunto de componentes que interactúan entre sí (IRSST 1984). Los componentes son el propio terminal, el puesto de trabajo (incluidas las herramientas de trabajo y el mobiliario), la sala en la que se desarrolla la actividad y la iluminación. El segundo apartado de este capítulo trata sobre las características principales de los puestos de trabajo y su iluminación y ofrece una serie de recomendaciones que tienen como objetivo optimizar las condiciones de trabajo, considerando tanto las variaciones individuales, como la diversidad de tareas y organizaciones del trabajo. Se hace énfasis en la importancia de elegir un equipo y un mobiliario adecuado que permita una disposición flexible. Esta flexibilidad es esencial si se tiene en cuenta que los niveles de competitividad internacionales y la rápida evolución del desarrollo tecnológico obligan a las empresas a realizar continuas innovaciones y a adaptarse a los cambios que éstas conllevan.

L os siguientes seis apartados tratan sobre los problemas de salud estudiados en respuesta a las preocupaciones manifestadas por lo operadores de PVD. Se hace una revisión de la literatura científica relevante y se resalta la importancia y las limitaciones 
de los resultados obtenidos. La investigación en este campo abarca varias disciplinas, como la epidemiología, la ergonomía, la medicina, la ingeniería, la psicología, la física y la sociología. Debido a la complejidad de los problemas y en particular, a su naturaleza multifactorial, con frecuencia han sido equipos multidisciplinarios quienes han llevado a cabo las investigaciones. Desde el decenio de 1980, estos trabajos de investigación se han complementado con la organización regular de congresos internacionales, como H uman-Computer Interaction y Work with D isplay U nits, que proporcionan una oportunidad para el intercambio de información y para difundir los resultados de los estudios entre los investigadores y diseñadores, productores e usuarios de PV D.

El octavo apartado trata específicamente de la interacción ordenador/hombre y presenta los principios y los métodos subyacentes al desarrollo y la evaluación de las herramientas de interfaz. Este artículo resultará útil no sólo para el personal de producción, sino también para aquellos que estén interesados en los criterios utilizados para seleccionar las herramientas de interfaz.

Por último, en el noveno apartado se revisan las normas internacionales en materia de ergonomía hasta 1995, en relación con el diseño y la disposición de los puestos de trabajo informatizados. El objetivo de la elaboración de estas normas es reducir los riesgos a los que están expuestos los operadores de PVD durante el ejercicio de su trabajo. Las normas proporcionan directrices para las empresas que producen los componentes de las PVD, para los empresarios responsables de la compra y el diseño de los puestos de trabajo y para los empleados con responsabilidades en la toma de decisiones. Además, pueden resultar herramientas útiles para evaluar los puestos de trabajo existentes e identificar las modificaciones necesarias para optimizar las condiciones de trabajo de los operadores.

\section{- CARACTERISTICAS DE LOS PUESTOS DE TRABAJO CON PANTALLAS DE VISU ALIZACION DE DATOS}

Ahmet Çakir

\section{Diseño de los puestos de trabajo}

\section{Puestos de trabajo con pantallas de visualización de datos}

Las pantallas con imágenes generadas electrónicamente (pantallas de visualización de datos o PVD) representan el elemento más característico del equipo de trabajo informatizado, tanto en el lugar de trabajo como en la vida privada. Un puesto de trabajo puede estar diseñado para incluir, como mínimo, una PVD y un dispositivo de entrada de datos (por lo general un teclado), también es posible que incluya el espacio necesario para un equipo técnico adicional, como varias pantallas y dispositivos de entrada y salida de datos, etc. $\mathrm{H}$ ace pocos años, a principios del decenio de 1980, la entrada de datos era la tarea más habitual de los usuarios de ordenadores. Sin embargo, en muchos países industrializados, sólo un número relativamente pequeño de usuarios realiza actualmente este tipo de trabajo. Cada vez más, periodistas, directivos e incluso ejecutivos se convierten en "usuarios de PVD".

La mayor parte de los puestos de trabajo con PVD están diseñados para un trabajo sedentario; pero, el trabajar de pie podría ofrecer ciertas ventajas a los usuarios. Por ello, es necesario contar con directrices de diseño generales que puedan aplicarse a los puestos de trabajo sencillos y complejos, empleados tanto en posición sentada como de pie. A continuación se exponen tales directrices y su aplicación a algunos puestos de trabajo típicos.

\section{Directrices de diseño}

EI diseño del puesto de trabajo y la selección del equipo debería considerar no sólo las necesidades del usuario para una tarea determinada y la diversidad de tareas que el usuario deberá realizar durante la vida relativamente larga del equipo (unos 15 años o más), sino también los factores relativos al mantenimiento o al cambio de equipo. La norma ISO 9241, en su parte 5, introduce cuatro principios generales de aplicación al diseño del puesto de trabajo:

Directriz 1: Versatilidad y flexibilidad. El puesto de trabajo debería permitir al usuario realizar distintas tareas de forma cómoda y eficiente. En esta directriz se tiene en cuenta el hecho de que las tareas de los usuarios suelen variar, lo que reduce las posibilidades de aplicar de forma generalizada las directrices al lugar de trabajo.

Directriz 2: Adaptabilidad. El diseño de un puesto de trabajo y de sus componentes debe garantizar su "adaptabilidad" a distintos usuarios y a diversos requisitos de las tareas. EI concepto de adaptabilidad se refiere al grado en que el mobiliario y el equipo se ajustan a las diferentes necesidades de un usuario individual, es decir, si siguen siendo confortables y no producen molestias visuales o tensión postural. Si no se trata de un puesto de trabajo diseñado para una población específica de usuarios, por ejemplo, operadores de salas de control varones europeos menores de 40 años, el concepto de puesto de trabajo debería poderse adaptar a toda la población trabajadora, incluidos los usuarios con necesidades especiales, como por ejemplo, personas discapacitadas. La mayoría de las normas existentes para el mobiliario o para el diseño de los puestos de trabajo sólo tienen en consideración a una fracción de la población trabajadora (por ejemplo, a trabajadores "sanos" entre los percentiles 5 y 95 , entre 16 y 60 años de edad, considerados en la norma alemana DIN 33 402), y se olvidan de aquellas personas que necesitan una mayor atención. Además, aunque algunas prácticas de diseño aún se basen en la idea del usuario "medio", es necesario poner un mayor énfasis en la adaptabilidad individual. En relación con el mobiliario del puesto de trabajo, la adaptabilidad necesaria puede lograrse mediante un mobiliario regulable, diseñando distintos tamaños, o incluso mediante un equipo hecho a la medida del usuario. Garantizar una buena adaptabilidad es esencial para la salud y la seguridad de cada uno de los usuarios, ya que los problemas musculosqueléticos asociados con el uso de PVD son frecuentes e importantes.

Directriz 3: Cambio de postura. El diseño del puesto de trabajo debería favorecer el movimiento, ya que la carga muscular estática produce fatiga e incomodidad y puede llegar a producir problemas musculosqueléticos crónicos. U na silla que permita mover fácilmente la parte superior del cuerpo, contar con espacio suficiente para colocar y utilizar los documentos en papel, así como para colocar el teclado en distintas posiciones durante el día, son estrategias típicas para favorecer el movimiento del cuerpo cuando se trabaja con una PVD.

Directriz 4: Mantenimiento- adaptabilidad. El diseño del puesto de trabajo debería tener en cuenta factores como el mantenimiento, la accesibilidad y la capacidad del puesto de trabajo para ajustarse al cambio en las necesidades, como por ejemplo, la posibilidad de desplazar el equipo de trabajo si es necesario realizar una tarea distinta. Las publicaciones ergonómicas no han prestado mucha atención a los objetivos de esta 
Figura 52.1 • Disposición de un puesto de trabajo flexible que pueda adaptarse a las necesidades de los usuarios para distintas tareas.

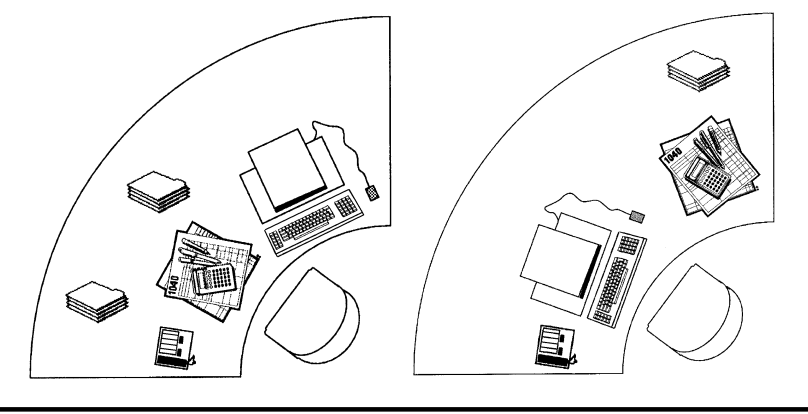

recomendación, debido a que se considera que los problemas relacionados con dichos factores han sido resueltos antes de que los usuarios comiencen a trabajar en el puesto de trabajo. En la realidad, sin embargo, ocurre que el puesto de trabajo cambia constantemente y en general, los espacios abarrotados, parcial o totalmente inadecuados para las tareas que hay que realizar, no suelen ser el resultado del proceso de diseño inicial, sino el resultado de cambios posteriores.

\section{Aplicación de las directrices}

Análisis dela tarea. El diseño del puesto de trabajo debería ir precedido por un análisis de la tarea que proporcione información sobre las principales tareas que se llevarán a cabo en el puesto de trabajo y el equipo necesario para ello. En este análisis, debería determinarse la prioridad dada a las fuentes de información (como los documentos en papel, las PVD o los dispositivos de entrada de datos), la frecuencia con la que se utilizarán y las posibles restricciones (por ej., limitaciones de espacio). El análisis debería incluir las tareas principales y sus relaciones en el espacio y en el tiempo, las áreas de atención visual (¿cuántos objetos visuales se utilizarán?) y la posición y el uso de las manos (¿escribir, teclear, señalar?).

\section{Recomendaciones generales de diseño}

Atura de las superficies de trabajo. Si se utilizan superficies de trabajo con una altura fija, el espacio mínimo libre entre el suelo y el plano de trabajo debería ser superior a la suma de la altura poplítea (la distancia del suelo a la parte posterior de la rodilla) y la altura a los muslos (en posición sentada), más una cierta altura para el calzado (25 mm para los varones y $45 \mathrm{~mm}$ para las mujeres). Si el puesto de trabajo se diseña para un uso general, la altura poplítea y la altura a los muslos deberá seleccionarse para el percentil 95 de la población masculina. La altura resultante bajo la superficie será entonces de $690 \mathrm{~mm}$ para la población del norte de Europa y para la población norteamericana de origen europeo. Para otras poblaciones, la altura mínima deberá determinarse de acuerdo con las características antropométricas específicas de cada población.

Si se selecciona la altura del espacio para las piernas de esta manera, la superficie de trabajo resultará demasiado alta para una gran proporción de los posibles usuarios, y al menos un $30 \%$ de estos usuarios necesitarán utilizar un reposapiés.

Si la altura de la superficie de trabajo es ajustable, el rango del ajuste puede calcularse a partir de las medidas antropométricas de las usuarias mujeres (percentil 2,5 ó 5 para la altura
Figura 52.2 • Disposición de un puesto de trabajo flexible.

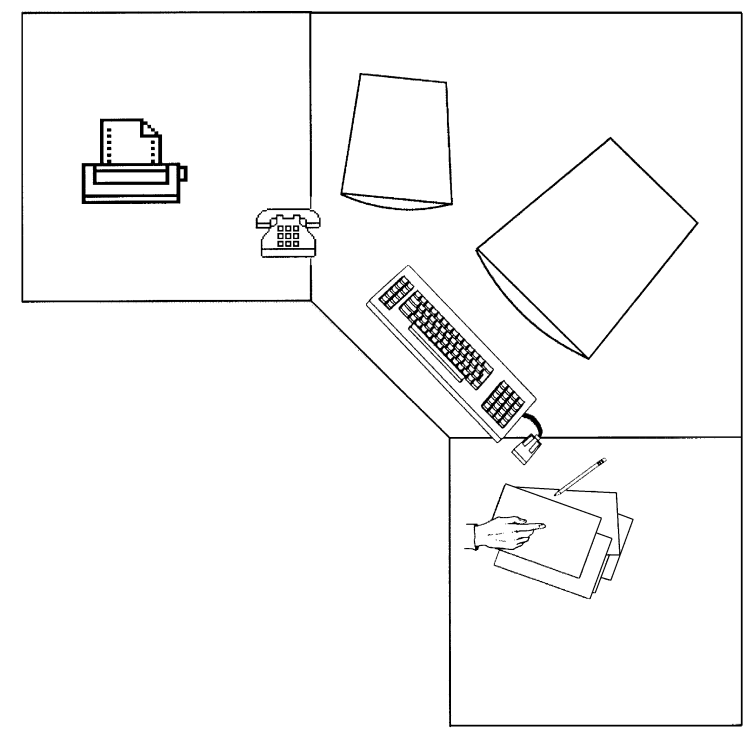

mínima) y de los usuarios varones (percentil 95 ó 97,5 para la altura máxima). Por lo general, un puesto de trabajo con estas dimensiones se ajustará a una gran proporción de personas sin apenas cambios. EI resultado de este cálculo es un rango de alturas entre $600 \mathrm{~mm}$ y $800 \mathrm{~mm}$ en países con una población de usuarios de una gran diversidad étnica. Debido a que pueden existir limitaciones técnicas y mecánicas para obtener un rango tan amplio, es posible obtener un buen ajuste combinando, por ejemplo, la regulación con equipos de distintos tamaños.

El grosor mínimo aceptable para la superficie de trabajo dependerá de las propiedades mecánicas del material. Desde el punto de vista técnico, es posible conseguir un grosor entre $14 \mathrm{~mm}$ (plástico resistente o metal) y $30 \mathrm{~mm}$ (madera).

Tamaño y forma de la superficiede trabajo. El tamaño y la forma de la superficie de trabajo están principalmente determinados por las tareas que se deben realizar y por el equipo necesario para ellas.

Para las tareas de entrada de datos, una superficie rectangular de $800 \mathrm{~mm}$ por $1200 \mathrm{~mm}$ proporciona suficiente espacio para colocar adecuadamente el equipo (PVD, teclado, documentos y atril) y para modificar su disposición de acuerdo con las necesidades personales. Tareas más complejas pueden requerir un espacio adicional. Así, el tamaño de la superficie de trabajo debería ser superior a $800 \mathrm{~mm}$ por $1.600 \mathrm{~mm}$. La profundidad de la superficie debería permitir la colocación de la PV D, lo que significa que en el caso de una PVD con un tubo de rayos catódicos, por ejemplo, se necesitará una profundidad de hasta $1.000 \mathrm{~mm}$.

En principio, el diseño propuesto en la Figura 52.1 proporciona la mayor flexibilidad para organizar el espacio de trabajo de diversas tareas. Con todo, no es fácil construir puestos de trabajo con este diseño; el que más se aproxima al diseño ideal es el que se muestra en la Figura 52.2. Tal diseño permite colocar una o dos PVD, dispositivos adicionales de entrada de datos, etc. El área mínima de la superficie de trabajo debería ser superior a $1,3 \mathrm{~m}^{2}$. 
Tabla 52.2 • Frecuencia e importancia de los elementos del equipo para una tarea determinada.

\begin{tabular}{|r|c|c|c|c|}
\hline \multirow{2}{*}{ ELEMENTO } & \multicolumn{4}{|c|}{ USO } \\
\cline { 2 - 5 } & \multicolumn{2}{|c|}{ TOCAR } & \multicolumn{2}{c|}{ VER } \\
\cline { 2 - 5 } & Frecuencia & Importancia & Frecuencia & Importancia \\
\hline TECLADO & - & 0 & 0 & $\bullet$ \\
\hline PVD & $\bullet$ & & & \\
\hline RATON & - & 0 & & \\
\hline DOCUMENTOS & $\bullet$ & & & \\
\hline
\end{tabular}

Mayor grado de importancia o frecuencia - Menor grado de importancia o frecuencia

Grado intermedio de importancia o frecuencia

Distribución del espacio detrabajo. La distribución espacial del equipo en el puesto de trabajo debería planificarse después de un análisis de la tarea que determine la importancia y la frecuencia de uso de cada elemento (Tabla 52.2). La pantalla de visualización que se utilice con más frecuencia debería situarse en el campo central de visión, es decir, en el área que aparece sombreada en la Figura 52.3, mientras que los controles más importantes y utilizados con más frecuencia, como el teclado, deberían situarse en la zona de alcance óptimo. En el lugar de trabajo representado mediante el análisis de la tarea (Tabla 52.2), el teclado y el ratón son, con gran diferencia, las piezas de equipo manejadas con más frecuencia y debe dárseles, por lo tanto, la mayor prioridad en el área de alcance. Los documentos que se consultan con frecuencia, pero que no requieren mucha manipulación, deben tener asignada una prioridad acorde con su importancia (por ejemplo, para realizar correcciones a mano). Si se colocan a la derecha del teclado, podría solucionarse el problema, pero también podría crear un conflicto con el uso frecuente del ratón, situado también a la derecha del teclado. Puesto que la PVD no requiere una regulación frecuente, puede situarse a la derecha 0 a la izquierda del campo central de visión, lo que permite colocar los documentos en un soporte plano detrás del teclado. Se trata de una posible solución "optimizada", aunque no perfecta.

Puesto que las dimensiones de muchos elementos del equipo son similares a las partes correspondientes del cuerpo humano, el uso de varios elementos para una sola tarea conllevará siempre algunos problemas. Tal vez también requieran algunos movimientos entre distintas zonas del puesto de trabajo, de ahí que un diseño como el que se muestra en la Figura 52.1 es importante para varios tipos de tareas.

En las últimas dos décadas, la capacidad informática, que inicialmente requería un espacio equivalente a un salón de baile, se ha logrado miniaturizar y condensar en una simple caja. Aún aś, a pesar de las expectativas de que la miniaturización del equipo pudiese resolver la mayoría de los problemas asociados con el diseño del lugar de trabajo, el tamaño de las PVD ha ido aumentando: en 1975, el tamaño de pantalla más utilizado era el de 15"; en 1995 la mayoría de la gente adquirió un monitor de 17" a 21" y el tamaño de los teclados tampoco ha disminuido en comparación con los que se utilizaban en 1973. U n análisis de la tarea cuidadoso sigue siendo sumamente importante para diseñar puestos de trabajo complejos. A demás, a pesar de que
Figura 52.3 • Campo visual en el espacio de trabajo.
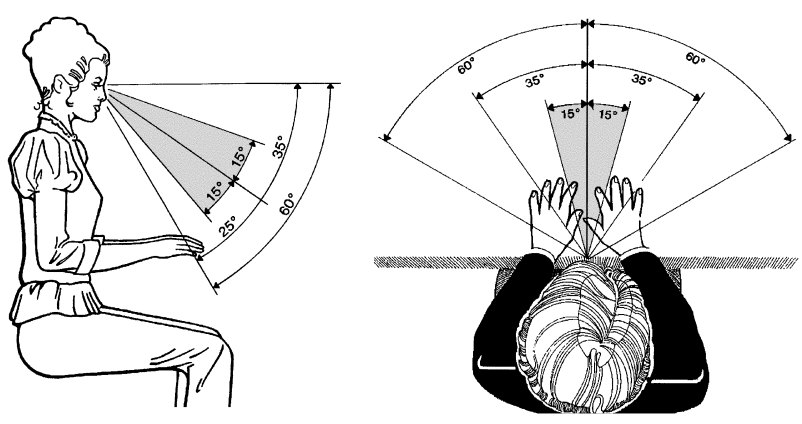

han aparecido nuevos dispositivos de entrada de datos, no han llegado a sustituir al teclado y requieren aún un mayor espacio en la superficie de trabajo, a veces de considerables dimensiones como por ejemplo, las tarjetas gráficas en formato A 3 .

U na ordenación eficiente del espacio dentro del puesto de trabajo, al igual que en los locales de trabajo puede ayudar a desarrollar puestos de trabajo aceptables desde el punto de vista ergonómico, evitando que se presenten problemas de salud y seguridad.

U na ordenación eficiente del espacio no significa ahorrar espacio a costa de la usabilidad de los dispositivos de entrada y, en especial, de los dispositivos de visualización. El uso de mobiliario adicional, como una mesa giratoria o un soporte especial para el monitor, sujeto a la mesa, parece una buena forma de ganar espacio en la mesa; ahora bien, puede ser contraproducente para la postura (al obligar a levantar los brazos) o la visión (al elevar la línea de visión a una altura menos relajada). Las estrategias de ahorro de espacio deberían garantizar que se mantiene una distancia visual adecuada (aproximadamente $600 \mathrm{~mm}$ a $800 \mathrm{~mm}$ ), así como una línea de visión óptima, que se obtiene con una inclinación de aproximadamente 35 ㅇ en relación con el plano horizontal (20ำ para la cabeza y 15으 para los ojos).

Nuevos conceptos de mobiliario. Tradicionalmente, el mobiliario de oficina se ha adaptado a las necesidades de las empresas, reflejando la jerarquía de tales organizaciones: grandes mesas en "lujosas" oficinas para los ejecutivos, en un extremo de la escala, y un mobiliario pequeño para las mecanógrafas y oficinas "funcionales" en el extremo opuesto. El diseño básico del mobiliario de oficina permaneció invariable durante décadas. La situación cambió radicalmente con la introducción de la tecnología de la información y dio lugar a un concepto de mobiliario totalmente nuevo: el del mobiliario de sistemas.

El mobiliario de sistemas se desarrolló cuando las personas comenzaron a darse cuenta de que el cambio en el equipo y en la organización del trabajo no podía hacerse por las limitadas capacidades del mobiliario existente para adaptarse a las nuevas necesidades. El mobiliario actual ofrece una caja de herramientas que permite a las organizaciones de usuarios crear el espacio de trabajo que necesitan, desde el mínimo indispensable para una sola PVD y un teclado, hasta puestos de trabajo complejos que permitan acomodar varios elementos del equipo, y posiblemente también, grupos de usuarios. Tal mobiliario está diseñado para el cambio e incorpora dispositivos de ordenación del cableado eficientes y flexibles. M ientras que la primera generación del mobiliario de sistemas no hizo más que añadir a una mesa existente una mesa auxiliar para la PV D, la tercera generación ha cortado completamente todos sus vínculos con la oficina 
tradicional. Este nuevo enfoque ofrece una gran flexibilidad en el diseño de los espacios de trabajo, limitada únicamente por el espacio disponible y por la capacidad de las organizaciones para utilizar esta flexibilidad.

\section{Radiación}

\section{La radiación en el contexto de las aplicaciones en las PVD}

$L$ a radiación es la emisión o transferencia de energía radiante. $L a$ emisión de energía radiante en forma de luz, según el objetivo previsto en el uso de las PVD, puede ir acompañada por la emisión de varios productos secundarios como calor, sonido, radiación infrarroja y ultravioleta, ondas de radio 0 rayos $X$, entre otros. $M$ ientras que algunas de estas formas de radiación, como la luz visible, afectan a los humanos de forma positiva, algunas emisiones de energía pueden tener efectos negativos, 0 incluso efectos biológicos destructivos, en especial cuando la intensidad es elevada y la duración de la exposición prolongada. $\mathrm{H}$ ace algunas décadas, se introdujeron límites de exposición para diferentes formas de radiación, con el fin de proteger a la gente. No obstante, actualmente se cuestionan algunos de estos límites y para campos magnéticos de baja frecuencia, no es posible establecer límites de exposición basados en los niveles de radiación natural de fondo.

\section{Radiación de radiofrecuencia y microonda emitida por las PVD}

Las PVD pueden emitir radiación electromagnética en un rango de frecuencias desde algunos $\mathrm{kHz}$ hasta $109 \mathrm{H}$ ertz (las Ilamadas radiofrecuencias $0 \mathrm{RF}$, con longitudes de onda que van desde algunos km hasta $30 \mathrm{~cm}$ ); no obstante, la energía total emitida depende de las características del circuito. En la práctica, sin embargo, la intensidad de campo de este tipo de radiación suele ser baja y está limitada a la proximidad inmediata de la fuente. Una comparación de la intensidad de los campos eléctricos alternos en el rango de $20 \mathrm{~Hz}$ a $400 \mathrm{kHz}$ indica que las PV D que utilizan tecnología de tubos de rayos catódicos (T RC) emiten, en general, niveles más elevados que otro tipo de pantallas.

La radiación de "microondas" abarca el rango desde $3 \times 10^{8} \mathrm{~Hz}$ hasta $3 \times 10^{11} \mathrm{~Hz}$ (longitudes de onda de $100 \mathrm{~cm}$ a $1 \mathrm{~mm}$ ). Las PVD no tienen fuentes de radiación de microondas que emitan una cantidad detectable de energía en esta banda.

Figura 52.4 • Criterios para la evaluación de la imagen.

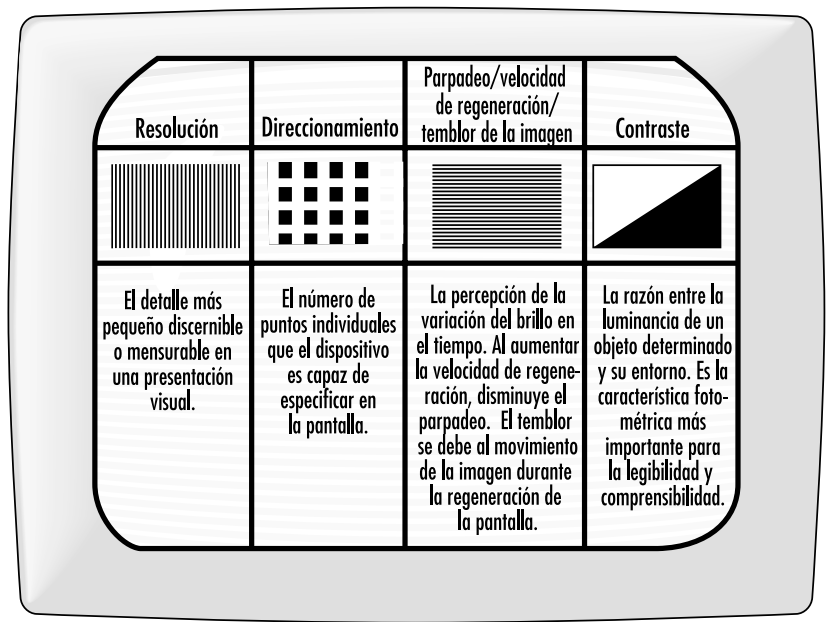

\section{Campos magnéticos}

Los campos magnéticos derivados de las PVD proceden de las mismas fuentes que los campos eléctricos alternos. A pesar de que los campos magnéticos no son "radiaciones", en la práctica es imposible separar los campos magnéticos y los campos eléctricos alternos, ya que unos inducen a los otros. U no de los motivos que hace que los campos magnéticos se traten en un capítulo aparte es que se sospecha que tengan efectos teratogénicos (más adelante en este capítulo se trata de esta cuestión).

A pesar de que los campos inducidos por las PVD son más débiles que los producidos por otras fuentes, como las líneas de alta tensión, las centrales eléctricas, las locomotoras eléctricas, los altos hornos o los equipos de soldadura, la exposición total producida por las PVD puede ser similar, ya que muchas personas trabajan ocho horas o más cerca de una PVD, mientras que su exposición a las líneas de alta tensión o a los motores eléctricos es mucho menos frecuente. Ahora bien, la relación entre los campos electromagnéticos y el cáncer sigue siendo un tema controvertido.

\section{Radiación óptica}

La radiación "óptica" abarca la radiación visible (la luz) con longitudes de onda entre los $380 \mathrm{~nm}$ (azul) y los $780 \mathrm{~nm}$ (rojo) y las bandas adyacentes del espectro electromagnético: el infrarrojo, de $3 \times 10^{11} \mathrm{~Hz}$ a $4 \times 10^{14} \mathrm{~Hz}$ (longitudes de onda de $780 \mathrm{~nm}$ a $1 \mathrm{~mm}$ ) y el ultravioleta, de $8 \times 10^{14} \mathrm{~Hz}$ a $3 \times 10^{17} \mathrm{~Hz}$ ). La radiación visible se emite a niveles de intensidad moderados, similares a los que emiten las superficies de la habitación $\left(\approx 100 \mathrm{~cd} / \mathrm{m}^{2}\right)$. Con todo, la radiación ultravioleta puede ser absorbida por el cristal del tubo (T RC) o no emitirse (todos los demás tipos de pantallas). Los niveles de radiación ultravioleta, en caso de ser detectables, son muy inferiores a los niveles de exposición laboral, y lo mismo sucede en el caso de la radiación infrarroja.

\section{Rayos X}

LOS TRC son fuentes conocidas de rayos $X$, mientras que otro tipo de tecnologías, como las pantallas de cristal líquido (LCD) no los emiten. El proceso físico que origina este tipo de emisiones también es bien conocido y los tubos y los circuitos se diseñan de forma que los niveles emitidos sean muy inferiores a los límites de exposición profesional y en muchos casos, incluso inferiores a los niveles de detección. La radiación emitida por una fuente sólo se detecta si su nivel es superior al nivel del fondo. En el caso de los rayos $X$, al igual que sucede con otros tipos de radiación ionizante, el nivel de fondo se debe a la radiación cósmica y a la radiación procedente de los materiales radiactivos del suelo y de los edificios. Durante su uso normal, la PVD no emiten rayos $X$ que superen los niveles de radiación de fondo ( $50 \mathrm{nG} y / \mathrm{h}$ ).

\section{Recomendaciones en relación con la radiación}

En Suecia, el antiguo M PR (Statens M ät och Provråd o Consejo $\mathrm{N}$ acional de M etrología y Pruebas), actualmente el SWEDAC, ha publicado una serie de recomendaciones para evaluar las PVD. Uno de los principales objetivos era limitar cualquier subproducto no deseado a niveles que pueden alcanzarse utilizando los medios técnicos razonables. Se trata de un enfoque que trasciende la perspectiva clásica de limitar la exposición peligrosa a niveles en los que la probabilidad de afectar negativamente la salud o la seguridad parecieran aceptablemente bajos.

Inicialmente, las recomendaciones del MPR produjeron el efecto indeseable de reducir la calidad óptica de las pantallas de TRC. Actualmente, sin embargo, sólo algunos productos que tienen una resolución excepcionalmente alta pueden perder calidad si el fabricante cumple las recomendaciones del MPR (ahora M PR-II). En ellas se incluyen límites para electricidad estática, campos eléctricos y magnéticos, parámetros visuales, etc. 


\section{Calidad de la imagen}

\section{Definiciones de la calidad de la imagen}

El término calidad describe la capacidad de distinguir los atributos de un objeto para un fin determinado. Así, la calidad de la imagen de una pantalla incluye todas las propiedades de la representación óptica en relación a la perceptibilidad de los símbolos en general, y a la legibilidad de los símbolos alfanuméricos. En este sentido, los términos ópticos utilizados por los fabricantes de los tubos, como resolución o tamaño mínimo de punto, describen criterios de calidad básicos relativos a la capacidad de un dispositivo dado para mostrar líneas finas o caracteres pequeños. Tales criterios son equiparables al grosor necesario de un lápiz o de un pincel para una tarea concreta de escritura o dibujo.

Algunos de los criterios de calidad utilizados por los ergónomos describen las propiedades ópticas relevantes para la legibilidad, como el contraste, mientras que otras propiedades, como el tamaño o el ancho de los caracteres, se relacionan más con las características tipográficas. En ergonomía se consideran, además, ciertas características que dependen de la tecnología, como el parpadeo de las imágenes, su persistencia o la uniformidad del contraste en un tipo determinado de pantallas (véase la Figura 52.4).

La tipografía es el arte de componer los "tipos", que no se refiere únicamente a la forma de las fuentes, sino también a la selección y definición de los tipos. Aquí se utilizará el término tipografía en el primer sentido.

\section{Características básicas}

Resolución. La resolución se define como el detalle más pequeño discernible o mensurable en una presentación visual. Por ejemplo, la resolución de una pantalla de TRC se expresa como el número máximo de líneas que pueden mostrarse en un espacio determinado, al igual que se hace habitualmente con la resolución de las películas fotográficas. También es posible describir el tamaño mínimo de punto que un dispositivo puede mostrar con una determinada luminancia (brillo). Cuanto más pequeño sea el punto mínimo, mejor será el dispositivo. Así, el número de puntos de tamaño mínimo (elementos de la imagen, también conocidos como pixeles) por pulgada (ppp) representa la calidad del dispositivo. Así, por ejemplo, un dispositivo de $72 \mathrm{ppp}$ es inferior a una pantalla de 200 ppp.

En general, la resolución de la mayoría de las pantallas de ordenador es bastante inferior a los 100 ppp; algunas pantallas gráficas alcanzan hasta 150 ppp, pero a costa del brillo, de manera que si se requiere un alto contraste, la resolución será menor. En comparación con la resolución de un documento impreso (entre 300 y 600 ppp en el caso de las impresoras láser), la calidad de una PVD es inferior (una imagen con 300 ppp tiene 9 veces más elementos en el mismo espacio que otra con $100 \mathrm{ppp})$.

Direccionamiento. El direccionamiento describe el número de puntos individuales que el dispositivo es capaz de especificar en el campo. El direccionamiento, que con frecuencia se confunde con la resolución (a veces deliberadamente), es una especificación de los dispositivos: " 800 x 600" significa que la tarjeta gráfica puede direccionar 800 puntos por cada una de las 600 líneas horizontales. Puesto que son necesarios al menos 15 elementos en sentido vertical para escribir números, letras y otros caracteres con rasgos ascendentes y descendentes, esta pantalla mostraría un máximo de 40 líneas de texto. En la actualidad, las mejores pantallas pueden direccionar $1.600 \times 1.200$ puntos; sin embargo, la mayoría de las pantallas utilizadas en la Industria direccionan $800 \times 600$ puntos e incluso menos.
Figura 52.5 - Aspecto de una letra con distintas resoluciones de pantalla, y a la derecha, tal como aparece en papel.

\section{MMMM}

En las pantallas "orientadas hacia caracteres", el direccionamiento no se hace mediante los puntos de la pantalla, sino a través de la llamada matriz de caracteres. La mayor parte de los dispositivos de este tipo cuentan con 25 líneas por pantalla, con 80 posiciones de caracteres en cada una de las líneas. En este tipo de pantallas, cada símbolo ocupa el mismo espacio, independientemente de su ancho. En la industria, el número más bajo de pixeles en la matriz es de 5 de ancho por 7 de alto. Esta matriz permite representar tanto mayúsculas como minúsculas, pero no muestran los rasgos descendentes de la " $p$ ", " $q$ " y " $g$ " ni los rasgos ascendentes de las mayúsculas: "Ä" o "Á". La matriz de $7 \times 9$, que ha sido "norma" desde mediados del decenio de 1980 , proporciona una calidad considerablemente mejor. Para conseguir una buena legibilidad y una forma razonablemente buena de los caracteres, el tamaño de la matriz de caracteres debe ser de al menos $12 \times 16$.

Parpadeo y frecuencia de regeneración. L as imágenes de las PVD de TRC y de otro tipo no son imágenes persistentes, a diferencia de las imágenes impresas. La apariencia de estabilidad se logra gracias a un mecanismo del ojo. En cualquier caso, esto no se logra sin molestias, ya que la imagen tiende a parpadear si no se regenera constantemente. El parpadeo puede afectar al rendimiento tanto como al confort del usuario y debería evitarse siempre.

El parpadeo es la percepción de la variación del brillo en el tiempo. La intensidad del parpadeo depende de varios factores, tales como las características del fósforo, el tamaño y brillo de la imagen parpadeante, etc. Estudios recientes muestran que se necesita una frecuencia de regeneración superior a $90 \mathrm{~Hz}$ para satisfacer al $99 \%$ de los usuarios, mientras que en estudios anteriores, frecuencias de regeneración tan bajas como los $50 \mathrm{~Hz}$ se consideraban satisfactorias. Dependiendo de las diversas características de la pantalla, es posible lograr una imagen sin parpadeo con frecuencias de regeneración entre $70 \mathrm{~Hz}$ y $90 \mathrm{~Hz}$; las pantallas con un fondo claro (polaridad positiva) requieren un mínimo de $80 \mathrm{~Hz}$ para no percibir el parpadeo.

Algunos dispositivos modernos ofrecen una frecuencia de regeneración ajustable; lamentablemente, las frecuencias de regeneración más elevadas están asociadas con una menor resolución o un menor direccionamiento. La capacidad de un dispositivo para mostrar imágenes de alta "resolución" con frecuencias de regeneración elevadas puede evaluarse por el ancho de banda de vídeo. En el caso de las pantallas de alta calidad, el ancho de banda máximo es superior a $150 \mathrm{M} \mathrm{Hz}$, mientras que algunos tipos de pantallas tienen menos de $40 \mathrm{M} \mathrm{Hz}$.

Para obtener una imagen sin parpadeo y una alta resolución en dispositivos con un ancho de banda menor, los fabricantes aplican un truco que deriva de los televisores comerciales: la exploración entrelazada. En este caso, las líneas de la imagen se regeneran en forma alternada, una sí y una no, con una frecuencia determinada. Aún así, el resultado no es satisfactorio 
si las imágenes son estáticas, como texto y gráficos, y la velocidad de regeneración es inferior a 2 x $45 \mathrm{~Hz}$. Por desgracia, el intento de eliminar el molesto efecto del parpadeo puede inducir otros efectos negativos.

Temblor dela imagen. El temblor es el resultado de la inestabilidad espacial de la imagen; se refiere a un elemento determinado de la imagen que no aparece en la misma posición en la pantalla después de cada proceso de regeneración. N o se puede separar la percepción de temblor de la percepción de parpadeo.

Es posible que el temblor se deba a la propia PVD, aunque también puede ser inducido por otro tipo de equipo del lugar de trabajo, como una impresora u otras PVD o dispositivos que generen campos magnéticos.

Contraste EI contraste de brillo, la relación entre la luminancia de un objeto determinado y su fondo, es la característica fotométrica más importante para la comprensibilidad y legibilidad. Aunque la mayoría de las normas indican una relación mínima de 3:1 (caracteres brillantes sobre fondo oscuro) o 1:3 (caracteres oscuros sobre fondo brillante), el contraste óptimo es en realidad de aproximadamente 10:1, y los dispositivos de buena calidad alcanzan valores superiores incluso en entornos brillantes.

EI contraste de las pantallas "activas" disminuye cuando aumenta la luz ambiente, mientras que las pantallas "pasivas" (como las LCD) pierden contraste en ambientes oscuros. Las pantallas pasivas con luz de fondo incorporada proporcionan una buena visibilidad en todos los ambientes en los que puede trabajar una persona.

Nitidez. La nitidez de una imagen es una característica bien conocida, aunque su definición no es muy precisa. De aquí que no exista un método universalmente reconocido para medir la nitidez como característica relevante para una buena legibilidad.

\section{Características tipográficas}

Legibilidad y comprensibilidad. La comprensibilidad se refiere a la capacidad de entender un texto como una serie de imágenes interconectadas, mientras que la legibilidad se refiere a la percepción de caracteres únicos o agrupados. Así, una buena legibilidad es, en general, un requisito previo para la comprensibilidad.

$L$ a legibilidad de un texto depende de varios factores, algunos de los cuales se han investigado exhaustivamente, mientras que otros igualmente importantes, como la forma de los caracteres, aún no han sido clasificados. Ello se debe en parte a que el ojo humano es un instrumento muy potente y los métodos de medición que se utilizan para el rendimiento y las frecuencias de error por lo general no son útiles para distinguir entre distintas fuentes. A sí, hasta cierto punto, la tipografía sigue siendo un arte más que una ciencia.

Las fuentes y la comprensibilidad. U na fuente es una familia de caracteres diseñados, bien para proporcionar una comprensibilidad óptima en un medio determinado (como por ejemplo, papel, pantallas electrónicas o pantallas de proyección), bien para proporcionar algún tipo de calidad estética o ambos. A pesar de que el número de fuentes disponibles supera las 10.000, sólo unas cuantas, quizá algunas decenas, se consideran "comprensibles". Debido a que la legibilidad y la comprensibilidad de una fuente también dependen de la experiencia del lector (se piensa, por ejemplo, que algunas fuentes "legibles" se consideran como tales únicamente porque se han utilizado prácticamente sin cambios durante décadas o incluso siglos), una misma fuente puede resultar menos legible en una pantalla que en papel, sencillamente porque los caracteres tienen un aspecto "nuevo". Con todo, ésta no es la causa principal de la mala legibilidad de las pantallas

En general, el diseño de las fuentes está restringido por problemas tecnológicos. Algunas tecnologías imponen límites muy estrechos para el diseño de caracteres, por ejemplo, las pantallas de cristal líquido (LED) o de trama, con un número limitado de puntos por pantalla. $\mathrm{Ni}$ siquiera las mejores pantallas de TRC pueden competir en muchos casos con las impresiones en papel (Figura 52.5). En los últimos años, las investigaciones han demostrado que la velocidad y la precisión de la lectura en pantalla es aproximadamente un $30 \%$ menor a la que se logra en papel; ahora bien, se desconoce aún si esto se debe a las características de la pantalla 0 a otros factores.

Características con efectos mensurables. Es posible medir los efectos de algunas características de las representaciones alfanuméricas, como por ejemplo, el tamaño aparente de los caracteres, la relación altura/ancho, la relación ancho del trazo/ tamaño, o el espaciado entre líneas, palabras y caracteres.

El tamaño aparente de los caracteres se mide en minutos de arco y su valor óptimo es de 20' a 22'; esto se corresponde con una altura de $3 \mathrm{~mm}$ a $3,3 \mathrm{~mm}$, en condiciones normales de visualización en oficinas. Un menor tamaño de los caracteres puede originar un mayor número de errores, tensión visual y también mayor tensión postural, debido a la restricción en la distancia de visión. Así, el texto no debería representarse con un tamaño aparente inferior a 16'.

No obstante, las representaciones gráficas pueden requerir un texto de menor tamaño. Para evitar errores, por una parte, y una carga visual excesiva para el usuario, por otra, las partes del texto que es necesario editar deberían mostrarse en un ventana separada para garantizar una buena comprensibilidad. Los caracteres con un tamaño aparente inferior a $12^{\prime}$ no deberían mostrarse como texto legible, sino sustituirse por un bloque rectangular sombreado. Los buenos programas permiten al usuario seleccionar el tamaño real mínimo de los caracteres que se desea mostrar como caracteres alfanuméricos.

La relación óptima altura/ ancho de los caracteres es de aproximadamente 1:0,8; la legibilidad disminuye notablemente si la relación es superior a 1:0,5. Para obtener una impresión con una buena legibilidad y también para las pantallas de TRC, la relación entre la altura de los caracteres y el grosor del trazo es de aproximadamente 10:1. A hora bien, esto ha de considerarse sólo una regla general, ya que los caracteres legibles más estéticos suelen mostrar varios grosores de trazo (véase la Figura 52.5).

El espaciado óptimo entre líneas también es muy importante no sólo para la comprensibilidad, sino también para ahorrar espacio cuando es necesario mostrar una cantidad determinada de texto en un espacio limitado. EI mejor ejemplo lo tenemos en los periódicos, en los que una gran cantidad de información es mostrada en una sola página, pero sin perder la comprensibilidad. El espaciado óptimo entre líneas es de aproximadamente un $20 \%$ de la altura de los caracteres entre los rasgos descendentes de una línea y los ascendentes de la siguiente; esta distancia equivale aproximadamente al $100 \%$ de la altura de los caracteres entre la base de una línea de texto y los trazos ascendentes de la siguiente. Si se reduce la longitud de la línea, también es posible reducir el espaciado entre las líneas sin perder comprensibilidad.

El espaciado entre los caracteres es invariable en las pantallas orientadas hacia caracteres, y ello reduce su comprensibilidad y su calidad estética en comparación con las pantallas con espacios variables. Es preferible un espaciado proporcional, que dependa de la forma y el ancho de los caracteres. C on todo, sólo en ciertas pantallas y cuando se usan programas específicos es 
posible lograr una calidad tipográfica similar a la de las fuentes impresas bien diseñadas.

\section{Iluminación ambiental}

\section{Problemas específicos de los puestos de trabajo con PVD}

Durante los últimos 90 años de desarrollo industrial, las teorías sobre la iluminación de nuevos lugares de trabajo se han regido por la idea de que una mayor cantidad de luz mejora la visión, reduce el estrés y la fatiga, y aumenta el rendimiento. "M ás luz", o más correctamente, "más luz solar", era el eslogan de la gente de $\mathrm{H}$ amburgo, en Alemania, hace más de 60 años, cuando se lanzaron a la calle para pedir hogares mejores y más sanos. En algunos países, como Dinamarca o Alemania, los trabajadores tienen hoy derecho a pedir luz solar en sus lugares de trabajo. La introducción de la tecnología de la información y las primeras PVD en áreas de trabajo, fue probablemente el primer suceso que hizo que trabajadores y científicos comenzaran a quejarse de demasiada luz en las áreas de trabajo. La discusión se avivó por el hecho fácilmente detectable de que la mayoría de las PVD estaban equipadas con TRC, que tienen superficies curvas de cristal con una gran tendencia a mostrar reflejos. Tales dispositivos, a veces conocidos como "pantallas activas", que pierden contraste cuando aumenta el nivel de iluminación ambiental. Ahora bien, no es fácil rediseñar la iluminación para reducir los problemas visuales causados por estos efectos, ya que la mayoría de los usuarios también utilizan fuentes de información en papel, que por lo general requieren un mayor nivel de iluminación ambiental para una buena visibilidad.

\section{El papel de la luz ambiente}

La luz ambiente en las proximidades de los puestos de trabajo con PVD tiene dos fines distintos. Por una parte, ilumina el espacio y los materiales de trabajo como los documentos, los teléfonos, etc. (efecto primario) y por otra, ilumina la habitación, haciendo visible su forma y proporcionando a los usuarios la impresión de un entorno luminoso (efecto secundario). Puesto que la mayoría de las instalaciones de iluminación se diseñan siguiendo el concepto de una iluminación general, las mismas fuentes de luz se utilizan para ambos fines. El efecto primario, la iluminación de los objetos para hacerlos visibles o legibles, se hizo cuestionable cuando la gente comenzó a utilizar pantallas activas que no necesitan de la luz ambiente para ser visibles. Así, el beneficio de la luz ambiente se ha reducido a su efecto secundario en los casos en los que la PVD es la principal fuente de información.

La luz ambiente afecta negativamente la función de las PVD, tanto de las de TRC (pantallas activas) como de las de LCD (pantallas pasivas), de forma específica:

\section{Pantallas deTRC:}

- La superficie curva de cristal refleja los objetos brillantes del entorno, generando una especie de "perturbación" visual.

- Dependiendo de la intensidad de la iluminación ambiental, se reduce el contraste de los objetos que aparecen en la pantalla hasta el punto de interferir con su comprensibilidad o su legibilidad.

- Las imágenes de las pantallas de TRC en color sufren una doble degradación: en primer lugar, se reduce el contraste de brillo de todos los objetos mostrados, al igual que en una pantalla de TRC monocroma y en segundo lugar, se modifican los colores, de forma que el contraste de color también disminuye. Además, se reduce el número de colores que pueden distinguirse.

\section{Pantallas de LCD y otros tipos de pantallas pasivas:}

- Los reflejos en las pantallas LCD tienen menor importancia que en las de TR C, ya que estas pantallas tienen una superficie plana.

- A diferencia de las pantallas activas, las de LCD (sin luz de fondo) pierden contraste con bajos niveles de iluminación ambiental.

- Debido a las características de pobre direccionalidad de la tecnología de algunas pantallas, la visibilidad o legibilidad de los objetos mostrados se reduce de forma significativa si la dirección principal de la luz incidente no es favorable.

Es muy variable el grado en que este efecto produce estrés a los usuarios o reduce la visibilidad, comprensibilidad o legibilidad de los objetos visuales en los distintos ambientes de trabajo. Por ejemplo, el contraste de los caracteres alfanuméricos en las pantallas monocromas (T RC) se reduce, pero si la iluminación de la pantalla es diez veces superior a la de un ambiente de trabajo normal, muchas pantallas seguirán mostrando suficiente contraste para permitir la lectura de estos caracteres. En cambio, la visibilidad de las pantallas en color de los sistemas de diseño asistido por ordenador (CAD) se reduce de forma importante, por lo que la mayoría de los usuarios prefieren atenuar la luz artificial o incluso apagarla y, además, evitar la entrada de luz solar al área de trabajo.

\section{Posibles soluciones}

Cambio en los niveles deiluminación. Desde 1974, se han realizado numerosos estudios que han dado origen a una serie de recomendaciones para reducir la iluminación de los lugares de trabajo. Se han basado principalmente en estudios con pantallas poco satisfactorias. Los niveles recomendados estaban entre 100 lux y 1.000 lux, y en general, se han propuesto niveles muy inferiores a las normas existentes para la iluminación de las oficinas (por ejemplo, 200 lux ó 300 a 500 lux).

Cuando se utilizan pantallas de polaridad positivas con una luminancia de aproximadamente $100 \mathrm{~cd} / \mathrm{m}^{2}$ y algún tipo de tratamiento antirreflejo eficaz, el uso de las PVD no limita el nivel aceptable de iluminación y los usuarios aceptan niveles de hasta 1.500 lux , un valor poco frecuente en un área de trabajo.

$\mathrm{Si}$ las principales características de las PVD no permiten trabajar cómodamente con la iluminación normal de la oficina, como ocurre cuando se trabaja con tubos electrónicos memorizadores, lectores de microimágenes, pantallas en color, etc., es posible mejorar notablemente las condiciones visuales si se introduce una iluminación con dos componentes. El sistema es una combinación de iluminación indirecta de la sala (efecto secundario) y de iluminación directa de la tarea. Los usuarios deben poder controlar ambos componentes.

Control de los refiejos dela pantalla. Controlar los reflejos de la pantalla es una tarea difícil, ya que casi todas las soluciones que mejoran las condiciones visuales afectan otras características importantes de la pantalla. Algunas soluciones propuestas durante muchos años, como los filtros de malla, eliminan los reflejos pero reducen de forma importante la legibilidad de la pantalla. Las fuentes de luz de baja luminancia producen menos reflejos en las pantallas, pero los usuarios generalmente consideran que la calidad de la iluminación es peor que con cualquier otro tipo de iluminación.

Por lo anterior, es necesario aplicar todas estas soluciones (véase la Figura 52.6) con precaución, y sólo después de un análisis de las causas reales de las molestias o problemas. Las tres formas posibles de controlar el reflejo en las pantallas son: la selección de la posición correcta de la pantalla con relación a las 
Figura 52.6 - Estrategias para reducir los reflejos en las pantallas.

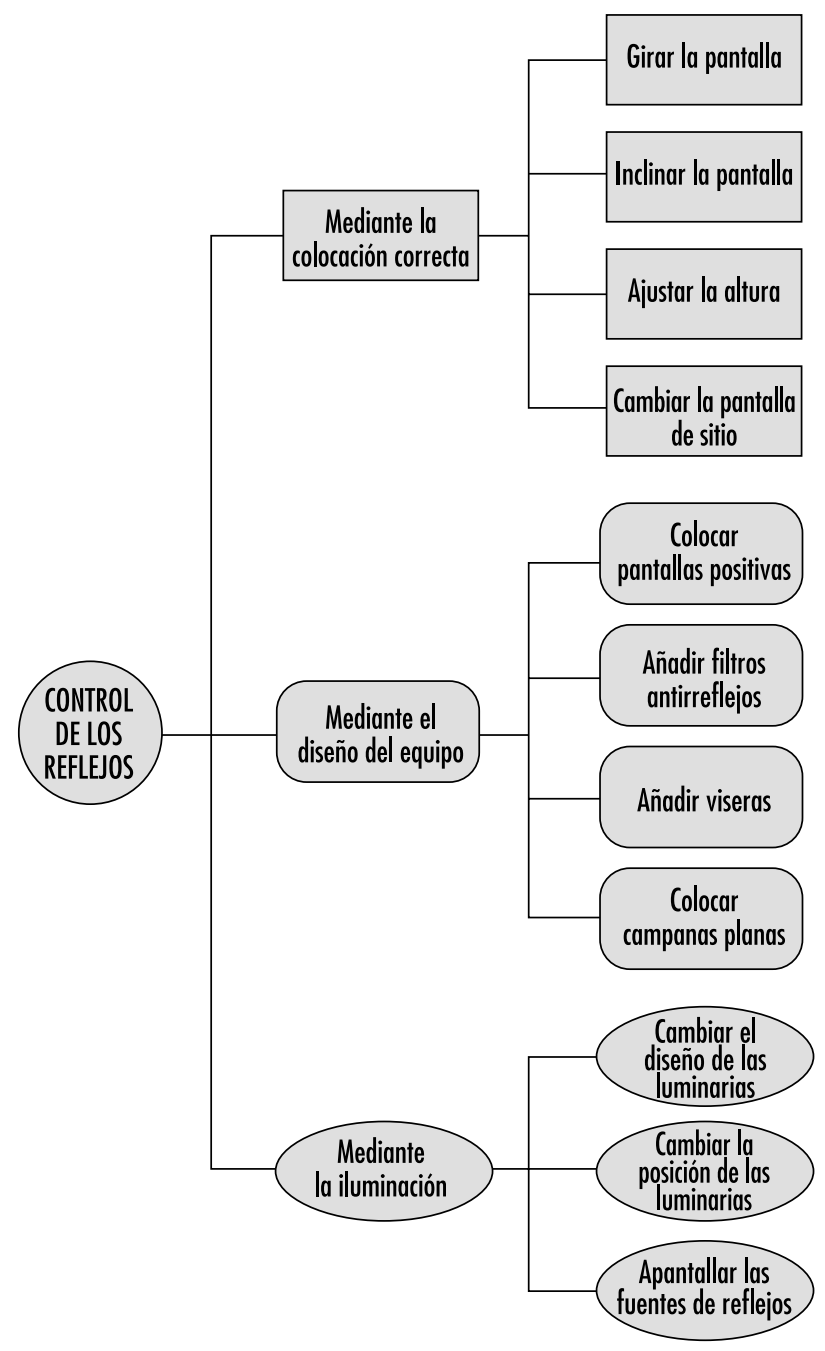

fuentes de reflejos; la selección del equipo adecuado o la adición de elementos al mismo; el uso de la iluminación. El coste de estas medidas es similar: no cuesta casi nada colocar las pantallas de forma que se eliminen los reflejos. No obstante, no siempre es posible; de manera que, en algunos ambientes de trabajo habrá que utilizar medidas relativas con el equipo, aunque sean más costosas. Los especialistas en iluminación suelen recomendar el control de los reflejos mediante el control de la iluminación; sin embargo, éste es el método más caro y no necesariamente el más eficaz para reducir los reflejos.

La medida más prometedora que existe actualmente es la introducción de las pantallas de polaridad positiva (pantallas con un fondo brillante) que incluyen un tratamiento antirreflejo adicional en la superficie de vidrio. U na solución aún mejor será la introducción de pantallas planas con una superficie prácticamente mate y un fondo brillante, aunque aún no están disponibles para el uso general.

A ñadir viseras a las pantallas es el último recurso de los ergónomos en ambientes de trabajo difíciles como las áreas de producción, las torres de control de los aeropuertos, las cabinas de los operadores de grúas, etc. Si el uso de viseras fuera realmente necesario, es probable que haya problemas más importantes con la iluminación que los meramente debidos a reflejos en las pantallas de visualización.

El cambio del diseño de las luminarias se logra principalmente de dos formas: una consiste en reducir la luminancia (el brillo aparente) de partes de las fuentes de luz (la llamada "iluminación para PVD") y la otra, en introducir luz indirecta en lugar de luz directa. Los resultados de los últimos estudios muestran que la introducción de luz indirecta proporciona una mejoría importante para los usuarios, reduce la carga visual y es bien aceptada por los usuarios.

\section{Pro blemas O CULARES Y VISUALES}

\section{Paule Rey y Jean-Jacques M eyer}

Existen numerosos estudios dedicados a las molestias visuales de los trabajadores que utilizan pantallas de visualización de datos (PVD), muchos de los cuales muestran resultados contradictorios. Existen discrepancias entre los estudios en relación con la prevalencia de los trastornos, que varía desde prácticamente $0 \%$ hasta el $80 \%$ o más (Dainoff 1982). No nos deben sorprender estas diferencias, ya que reflejan el gran número de variables que influyen en el grado de molestia o discapacidad del ojo.

Un estudio epidemiológico adecuado de las molestias visuales debería tener en cuenta las distintas variables de la población, como el sexo, la edad, las deficiencias de visión o el uso de gafas, así como el nivel socioeconómico. La naturaleza del trabajo que se desarrollará con la PVD y las características del diseño del puesto de trabajo y de la organización del trabajo también son importantes y muchas de estas variables están interrelacionadas.

Con frecuencia se han utilizado cuestionarios para evaluar las molestias visuales de los operadores de PVD. En estos casos, la prevalencia de las molestias visuales varía en función del contenido de los cuestionarios y de su análisis estadístico. Las preguntas adecuadas para este tipo de estudios refieren el grado de los síntomas de astenopía que presentan los operadores de PVD. Estos síntomas son bien conocidos e incluyen picor, enrojecimiento, escozor y lagrimeo. Están relacionados con la fatiga de la función de acomodación del ojo. En ocasiones, van acompañados de cefaleas, con el dolor localizado en la región frontal de la cabeza. También pueden ocurrir alteraciones de la función visual, con síntomas tales como visión doble o disminución de la capacidad de acomodación. La agudeza visual, con todo, no suele verse afectada, siempre que la medición se realice con un tamaño constante de la pupila.

$\mathrm{Si}$ el cuestionario incluye preguntas generales del tipo: "¿Se siente bien al final de la jornada laboral?" O “ ¿H a tenido alguna vez problemas visuales al trabajar con PVD?", la prevalencia de respuestas positivas es mayor que cuando se evalúan síntomas únicos relacionados con la astenopía.

$\mathrm{H}$ ay otros síntomas muy asociados a la astenopía. Con frecuencia se describe dolor en el cuello, hombros y brazos. Existen dos motivos principales por los que estos síntomas se presentan junto a los síntomas oculares. L os músculos del cuello participan en mantener una distancia estable entre los ojos y la pantalla cuando se trabaja con PVD, y este trabajo tiene dos componentes principales: la pantalla y el teclado, lo que significa que los hombros, los brazos y los ojos están trabajando al mismo tiempo y por lo tanto, están sujetos a tensiones similares relacionadas con el trabajo. 


\section{Variables del usuario relacionadas con el confort visual}

\section{Sexo y edad}

En la mayoría de las encuestas, las mujeres describen un mayor grado de molestias visuales que los varones. En un estudio realizado en Francia, por ejemplo, el 35,6 \% de las mujeres se quejaron de molestias visuales, frente al $21,8 \%$ de los varones (nivel de significación estadística $p \leq 0,5$ ) (D orard 1988). En otro estudio (Sjödren y Elfstrom 1990), se observó que aunque la diferencia en el grado de molestias entre las mujeres (41\%) y los hombres $(24 \%)$ era importante, era "más pronunciada para las personas que trabajaban entre 5 y 8 horas al día que para las que trabajaban de 1 a 4 horas". Tales diferencias no están necesariamente relacionadas con el sexo, ya que las mujeres y los hombres no suelen realizar el mismo tipo de tareas. Por ejemplo, en una planta informática estudiada, cuando tanto las mujeres como los hombres se dedicaban a una tarea tradicionalmente "femenina", ambos sexos presentaban la misma cantidad de molestias visuales. Por otra parte, cuando las mujeres realizaban tareas tradicionalmente "masculinas", no mostraban más molestias que los varones. En general, independientemente del sexo, el número de trastornos visuales entre los trabajadores cualificados que utilizan PVD para su trabajo es mucho menor que entre los trabajadores menos cualificados que realizan tareas más agotadoras, como la introducción de datos o el tratamiento de textos (Rey y Bousquet 1989). A lgunos de estos datos se muestran en la Tabla 52.3.

La mayor proporción de molestias visuales se encuentra generalmente en el grupo de edad de 40 a 50 años, probablemente debido a que en esta etapa los cambios en la capacidad de acomodación de los ojos ocurren rápidamente. Aunque se ha observado que los operadores de mayor edad presentan más molestias visuales que los más jóvenes y, como consecuencia, la presbiopía (deficiencias de visión debidas al envejecimiento) suele citarse como el trastorno visual más importante asociado con la incomodidad visual en los puestos de trabajo con PVD, también es importante considerar que existe una fuerte asociación entre la adquisición de habilidades en el uso de las PVD y la edad. G eneralmente hoy una mayor proporción de mujeres de más edad entre las operadoras de PVD poco cualificadas, y los varones jóvenes son, a menudo, más empleados en puestos más especializados. Es por esto que, antes de hacer una generalización sobre la edad y los problemas visuales asociados con el uso de las PVD, sería necesario corregir las cifras considerando la naturaleza del trabajo realizado con la PVD y el nivel de habilidad necesarios.

\section{D efectos visuales y lentes correctoras}

En general, aproximadamente la mitad de los operadores de PVD muestran algún tipo de deficiencia visual y muchas de estas personas utilizan lentes correctoras de algún tipo. Las

\section{Tabla 52.3 • Prevalencia de los síntomas oculares en 196 operadores de PVD, clasificados en cuatro categorías.}

$$
\text { Categorías }
$$

Mujeres en tareas "femeninas" Porcentaje de síntomas (\%)

Varones en tareas "femeninas" 81 75 68

Varones en tareas "masculinas" poblaciones de usuarios de PVD no difiere de la población de trabajadores en lo que se refiere a defectos oculares y uso de lentes correctoras. Por ejemplo, en un estudio (Rubino 1990) realizado con operadores de PV D italianos se observó que aproximadamente el $46 \%$ tenía una visión normal y un $38 \%$ presentaba miopía, lo que coincide con las cifras observadas entre los operadores de PVD suizos o franceses (M eyer y Bousquet 1990). La estimación de la prevalencia de los defectos oculares variará dependiendo de la técnica de valoración utilizada (Çakir 1981).

L a mayoría de los expertos creen que la presbiopía, per se, no tiene un efecto significativo sobre la incidencia de astenopía (cansancio ocular persistente). Es más bien el uso de lentes inadecuadas lo que parece inducir con mayor frecuencia la fatiga y las molestias oculares. Existen ciertas discrepancias sobre el efecto de la miopía en las personas jóvenes. Rubino no observó ningún efecto, mientras que, según M eyer y Bousquet (1990), los operadores miopes se quejan en seguida de tener sus gafas escasamente corregidas para la distancia entre los ojos y la pantalla (generalmente unos $70 \mathrm{~cm}$ ). Rubino ha propuesto que tal vez las personas que padecen deficiencias en la coordinación ocular sean más susceptibles a los trastornos visuales relacionados con el uso de las PVD.

U na observación importante realizada en un estudio francés, en el que un grupo de oftalmólogos examinó a 275 operadores de PVD y a 65 controles, fue que el $32 \%$ de las personas examinadas podían mejorar su visión con una buena corrección. En este estudio, el $68 \%$ de los participantes tenía una visión normal, el $24 \%$ presentaba miopía y el $8 \%$ hipermetropía (Boissin y cols. 1991). Así, a pesar de que los países industrializados se encuentran por lo general bien equipados para proporcionar un cuidado visual excelente, la corrección ocular se descuida completamente o resulta inadecuada para las personas que trabajan con PVD. Un resultado interesante de este estudio fue que se detectó un mayor número de casos de conjuntivitis en los operadores de PVD (48 \%) que en los controles. Puesto que la conjuntivitis se correlaciona con las deficiencias visuales, se confirma que es necesaria una mejor corrección ocular.

\section{Factores físicos y organizativos relacionados con el confort visual}

Es evidente que para poder evaluar, corregir y prevenir las molestias visuales en el trabajo con PVD, es esencial adoptar un modelo que considere los distintos factores mencionados anteriormente y en otras secciones de este capítulo. La fatiga y las molestias oculares pueden ser el resultado de las dificultades fisiológicas individuales para una acomodación y convergencia normales de los ojos, debidos a conjuntivitis o al uso de gafas mal corregidas para la distancia. Es posible que las molestias visuales estén relacionadas con el propio puesto de trabajo o con factores de la organización del trabajo, como la monotonía o el tiempo dedicado al trabajo, ya sea ininterrumpidamente o con pausas. Una iluminación inadecuada, los reflejos en la pantalla, el parpadeo de la imagen 0 una luminancia excesiva de los caracteres pueden también aumentar el riesgo de molestias oculares. En la Figura 52.7 se ilustran algunos de estos aspectos.

M uchas de las características adecuadas del diseño del puesto de trabajo se describen más detalladamente en la primera parte de este capítulo.

La distancia óptima para el confort visual, que al mismo tiempo deja suficiente espacio para el teclado, parece ser de unos $65 \mathrm{~cm}$. A hora bien, en opinión de muchos expertos, como A kabri y Konz (1991), idealmente "sería mejor determinar el enfoque en la oscuridad individual, así los puestos de trabajo podrían ajustarse a individuos concretos en lugar de a la media de la población". En cuanto al tamaño de los caracteres, una regla general válida es "cuanto más grandes mejor". 
Figura 52.7 • Factores que aumentan el riesgo de fatiga del ojo en los trabajadores que utilizan PVD.

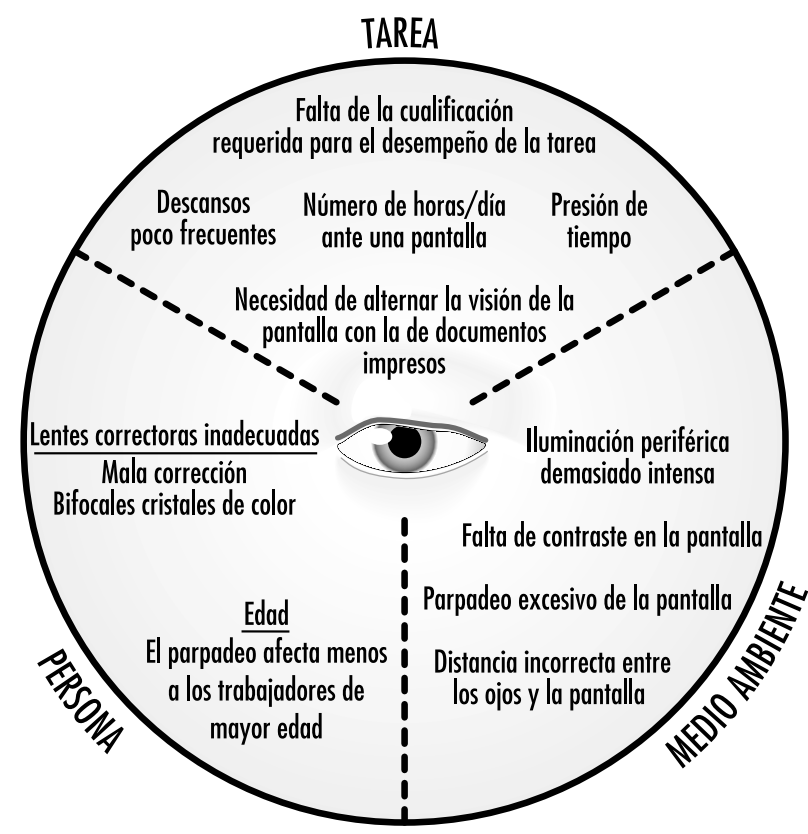

Generalmente, el tamaño de las letras aumenta al aumentar el tamaño de la pantalla y siempre es preciso llegar a un compromiso entre la comprensibilidad de las letras y el número de palabras y frases que pueden mostrarse en la pantalla al tiempo. Debería seleccionarse la propia PVD de acuerdo con los requisitos e intentar maximizar la comodidad del usuario.

Al diseño del puesto de trabajo y de la propia PVD se añade la necesidad de descanso de los ojos, fundamental en los trabajos menos cualificados, en los que la libertad para "moverse" es generalmente muy inferior a la de los trabajadores cualificados. L as tareas de entrada de datos y otras actividades del mismo tipo se realizan generalmente bajo una presión de tiempo y en ocasiones, incluso bajo control electrónico, que mide la productividad del operador de forma muy precisa. En otros trabajos interactivos con PVD, que conllevan el uso de bases de datos, los operadores se ven obligados a esperar la respuesta del ordenador y por lo tanto, a permanecer en su sitio.

\section{Parpadeo y molestias oculares}

El parpadeo es el cambio en el brillo de los caracteres de la pantalla en el tiempo y se describe detalladamente en la sección anterior. Cuando los caracteres no se regeneran con suficiente frecuencia, algunos operadores son capaces de percibir el parpadeo. Los trabajadores más jóvenes resultan más afectados puesto que su frecuencia de fusión del parpadeo es más alta que la de las personas de mayor edad (Grandjean 1987). L a frecuencia del parpadeo aumenta al aumentar el brillo y este es uno de los motivos por los que muchos operadores de PV D no utilizan habitualmente todo el rango de brillo disponible de la pantalla. En general, una PVD con una frecuencia de regeneración de al menos 70 Hz se "ajusta" a las necesidades visuales de gran parte de los operadores de PVD.

La sensibilidad de los ojos al parpadeo aumenta con el incremento del brillo y del contraste entre el área fluctuante y el entorno. EI tamaño del área fluctuante también afecta a la sensibilidad debido a que cuanto mayor sea el área a visualizar, mayor será el área de la retina que es estimulada. El ángulo con el que incide la luz del área fluctuante sobre el ojo y la amplitud de la modulación del área fluctuante también son variables importantes.

Cuanto mayor sea el usuario de la PVD, menos sensible serán los ojos, ya que con la edad disminuye la transparencia del cristalino y la excitabilidad de la retina. Lo mismo sucede en el caso de personas enfermas. $\mathrm{H}$ allazgos de laboratorio como estos han ayudado a entender las observaciones realizadas en campo. Por ejemplo, se ha observado que el parpadeo de la pantalla molesta a los operadores cuando necesitan leer documentos impresos (I sensee y Bennett, citado en G randjean 1987), y que la combinación de la fluctuación de la pantalla y de la luz fluorescente resulta particularmente molesta.

\section{Iluminación}

Los ojos funcionan mejor cuando el contraste entre el objetivo a visualizar y el fondo es máximo, como por ejemplo, letras negras sobre papel blanco. La eficiencia aumenta aún más cuando el borde exterior del campo visual está expuesto a niveles de brillo ligeramente menores. Por desgracia, en el caso de las PVD la situación es precisamente la inversa y este es uno de los motivos por los que muchos operadores de PVD intentan protegerse los ojos contra el exceso de luz.

Un contraste inadecuado del brillo y los reflejos molestos producidos por la luz fluorescente, por ejemplo, pueden producir, trastornos visuales en los operadores de PVD. En un estudio, el $40 \%$ de 409 operadores de PVD se quejaron de este tipo de trastornos (Läubli y cols. 1989).

Con el fin de minimizar los problemas debidos a la iluminación, al igual que en el caso de la distancia de visión, la flexibilidad es importante. Debería ser posible adaptar las fuentes de luz a la sensibilidad visual de los individuos. Los lugares de trabajo deberían ofrecer a los individuos la oportunidad de ajustar su iluminación.

\section{Características del trabajo}

Los trabajos que se realizan bajo presión de tiempo, especialmente si son poco cualificados y monótonos, van acompañados por una sensación de fatiga general que, a su vez, puede originar quejas de molestias visuales. En el laboratorio del autor, se observó que las molestias visuales aumentaban en función del número de cambios de acomodación que los ojos necesitaban realizar para el desempeño de la tarea. Esto era más frecuente en las tareas de entrada de datos o tratamiento de textos que en las tareas que involucraban un diálogo con el ordenador. Las tareas sedentarias que son y proporcionan pocas oportunidades para el desplazamiento también proporcionan menos oportunidades para la recuperación muscular y aumentan, por lo tanto, las molestias visuales.

\section{Organización del trabajo}

Las molestias oculares son sólo un aspecto de los problemas físicos y mentales asociados con muchos trabajos, como se describe más detalladamente en otras secciones de este capítulo. No es sorprendente, por lo tanto, encontrar una correlación elevada entre el nivel de molestias oculares y la satisfacción con el trabajo. A unque el trabajo nocturno no es habitual en el trabajo de oficina, sus efectos sobre las molestias visuales en el trabajo con PVD podrían ser inesperados. A pesar de que existen pocos datos disponibles para confirmarlo, esto puede deberse, por una parte, a que durante el turno de noche la capacidad visual podría ser ligeramente menor y por lo tanto, podría ser más vulnerable a los efectos de la PVD, mientras que por otra parte, la iluminación 
del ambiente puede ajustarse más fácilmente sin la interferencia de la luz natural, siempre que se eliminen los reflejos de las lámparas fluorescentes sobre las ventanas oscuras.

Las personas que utilizan PV D para trabajar en casa deberían asegurarse de que cuentan con el equipo y las condiciones de iluminación adecuadas para evitar los factores adversos del medio ambiente que se encuentran en muchos de los lugares de trabajo convencionales.

\section{Vigilancia médica}

No se ha identificado ningún agente particularmente peligroso, que suponga un riesgo para la visión. La astenopía entre los operadores de PVD parece ser más bien un fenómeno agudo, aunque se piensa que puede existir una tensión persistente de la acomodación. A diferencia de muchas enfermedades crónicas, el trabajador percibe muy pronto una mala adaptación al trabajo con una PVD, y esto hace que pueda buscar ayuda médica mucho antes que los trabajadores en otras situaciones laborales. Como resultado de estas consultas, con frecuencia se prescriben gafas, pero lamentablemente, éstas no siempre están bien adaptadas a las necesidades del lugar de trabajo aquí descritas. Es indispensable que los médicos tengan la formación específica para tratar a personas que trabajan con PV D. En el Swiss Federal Institute of Technology de Zurich, por ejemplo, se ha creado un curso especial exclusivamente con este fin.

En el caso de los trabajadores que utilizan PVD, deben tenerse en cuenta los siguientes factores. A diferencia del trabajo tradicional de oficina, la distancia entre los ojos y el objetivo a visualizar, la pantalla, es habitualmente de 50 a $70 \mathrm{~cm}$ y no puede modificarse. Así, sería necesario prescribir las lentes teniendo en cuenta esta distancia de visión fija. $L$ as lentes bifocales no son apropiadas porque requieren una extensión dolorosa del cuello para que el usuario pueda leer la pantalla. Las lentes multifocales son mejores, pero dado que limitan los movimientos oculares rápidos, pueden dar lugar a más movimientos de cabeza produciendo una tensión añadida.

La corrección ocular debería ser lo más precisa posible, teniendo en cuenta los menores defectos visuales (como el astigmatismo), así como la distancia de visión a la PVD. No deberían prescribirse cristales de color, que reducen el nivel de iluminación en el centro del campo visual. Las gafas parcialmente coloridas no son útiles, ya que en el lugar de trabajo, los ojos siempre se mueven en todas direcciones. El ofrecer unas gafas especiales a los empleados, desde luego, no significa que dejen de atenderse otras molestias visuales, ya que podrían reflejar deficiencias en el diseño ergonómico del puesto y del equipo de trabajo.

Por último, es necesario mencionar que los operadores que sienten más molestias son quienes necesitan mayores niveles de iluminación para realizar un trabajo detallado y, al mismo tiempo, quienes tienen una mayor sensibilidad a los reflejos. Los operadores con la vista corregida tenderán a aproximarse más a la pantalla para ver mejor y, por lo tanto, estarán más expuestos al parpadeo.

\section{La exploración selectiva y la prevención secundaria}

Los principios habituales de la prevención secundaria en salud pública son aplicables al ambiente de trabajo. La exploración selectiva debería estar dirigida hacia los riesgos conocidos y resulta más útil para las enfermedades con períodos de latencia prolongados. La exploración debería realizarse antes de que exista ningún indicio de la enfermedad a prevenir y sólo son útiles los ensayos con alta sensibilidad, alta especificidad y alto poder predictivo. Los resultados de la exploración selectiva pueden utilizarse para evaluar el grado de exposición tanto de los individuos como de los grupos.
Puesto que, en el trabajo con PVD, no se han identificado efectos adversos graves sobre los ojos y no se ha detectado un nivel peligroso de radiaciones asociado con los problemas visuales, se ha acordado que no existen indicios de que el trabajo con PVD "cause enfermedad o lesión ocular" (OMS 1987). La fatiga y las molestias oculares descritas entre los operadores de PVD no forman parte del tipo de efectos sobre la salud que constituyen la base de la vigilancia médica en un programa de prevención secundaria.

Con todo, en la mayoría de los países miembros de la O rganización Internacional del Trabajo, son comunes los reconocimientos médicos y visuales a los operadores de PVD previos al empleo, un requisito que apoyan tanto los sindicatos como los empresarios (OIT 1986). En muchos países europeos (entre ellos Francia, los Países Bajos y el R eino Unido), la vigilancia médica de los operadores de PVD, incluidas las pruebas oculares, se han instituido a raíz de la publicación de la Directiva 90/ 270/ CEE sobre el trabajo con equipos que incluyen pantallas de visualización.

Si se desea establecer un programa para la vigilancia médica de los operadores de PVD, es necesario considerar los siguientes aspectos para decidir el contenido del programa de exploración selectiva y los procedimientos de análisis adecuados:

- ¿Q ué se pretende con la vigilancia y cómo deben interpretarse los resultados?

- ¿N ecesitan la vigilancia todos los operadores de PV D?

- ¿Existe algún efecto ocular que se considere apropiado para un programa de prevención secundaria?

La mayor parte de las pruebas de exploración visual de rutina, al alcance de los médicos del trabajo, tienen una baja sensibilidad y un bajo poder predictivo para las molestias oculares asociadas con el trabajo con PVD (Rey y Bousquet 1990). Las tablas de Snellen para pruebas visuales son especialmente inadecuadas para medir la agudeza visual de los operadores de PVD y para predecir sus molestias oculares. En estas tablas, los objetivos a visualizar son letras oscuras y precisas en un fondo claro y bien iluminado, que no se parece en nada a las condiciones de visión típicas de las PV D. De hecho, debido a falta de métodos adecuados, los autores han desarrollado un procedimiento de análisis (el dispositivo (45) que simula la lectura y las condiciones de iluminación de un puesto de trabajo con una PVD. Lamentablemente, por el momento esto no es más que un dispositivo de laboratorio. Es importante reconocer, sin embargo, que la exploración no sustituye a un buen diseño del puesto de trabajo y a una buena organización del trabajo.

\section{Estrategias ergonómicas para reducir las molestias visuales}

A pesar de que no se ha demostrado que la exploración ocular y las visitas sistemáticas al especialista sean eficaces para reducir la sintomatología visual, se han incorporado en muchos programas de salud laboral para trabajadores que utilizan PVD. U na estrategia con una mejor relación coste-eficacia podría incluir un análisis ergonómico intensivo tanto del trabajo como del lugar de trabajo. Los trabajadores con enfermedades oculares conocidas deberían evitar el trabajo intensivo con PVD tanto como sea posible. La mala corrección de la visión es otra causa potencial de las quejas de los operadores y debe investigarse en tal caso de que ocurran. Las mejoras ergonómicas del lugar de trabajo podrían incluir estrategias para proporcionar un menor ángulo de lectura, con el fin de evitar la disminución de la frecuencia del parpadeo y la extensión del cuello, así como proporcionar la oportunidad de descansar y desplazarse por el área de trabajo. Los nuevos dispositivos, con teclados independientes, permiten ajustar las distancias. También se puede hacer que las PVD sean desplazables, por 
ejemplo, colocándolas en un brazo móvil. De esta forma se podría reducir la tensión ocular al permitir cambios en la distancia de visión para ajustarla a las correcciones oculares. Con frecuencia, las medidas adoptadas para reducir el dolor muscular de los brazos, hombros y espalda permiten al ergónomo reducir al mismo tiempo la tensión visual. Además del diseño del equipo, la calidad del aire puede afectar a los ojos. Un ambiente seco puede producir sequedad ocular, por lo que es necesaria una humidificación adecuada.

En general, deben tenerse en cuenta las siguientes variables físicas:

- Ia distancia entre la pantalla y los ojos;

- el ángulo de lectura, que determina la posición de la cabeza y del cuello;

- la distancia a las paredes y ventanas;

- la calidad de los documentos impresos (con frecuencia muy mala);

- la luminancia de la pantalla y del entorno (para la luz natural y artificial);

- los efectos de parpadeo;

- las fuentes de reflejos y deslumbramientos,

- el nivel de humedad.

Entre las variables de la organización que deben tenerse en cuenta para mejorar las condiciones visuales de trabajo están:

- el contenido de la tarea y el nivel de responsabilidad;

- los horarios de trabajo, el trabajo nocturno y la duración del trabajo;

- la libertad para "desplazarse",

- los trabajos a tiempo parcial o tiempo completo, etcétera.

\section{- RIESg O S PARA LA REPRO DUCCION: DATOS EXPERIMENTALES}

\section{UIf Bergqvist}

El objetivo de los estudios experimentales con modelos animales que se describen aquí es, en parte, responder a la pregunta de si la exposición a campos magnéticos de extremadamente baja frecuencia (EBF), a niveles similares a los detectados en puestos de trabajo con PVD, puede afectar a la función reproductora de los animales de forma que pueda significar un riesgo para la salud humana.

Los estudios que se consideran aquí se limitan a los estudios in vivo (es decir, realizados en animales vivos) de la reproducción en mamíferos expuestos a campos magnéticos de muy baja frecuencia (MBF), utilizando frecuencias apropiadas, y excluyendo, por lo tanto, los estudios sobre los efectos biológicos de los campos magnéticos M BF o EBF en general. Tales estudios en animales de experimentación no lograron demostrar de forma inequívoca que los campos magnéticos, como los que se encuentran en las proximidades de una PVD, afecten la reproducción. Además, como puede verse si se consideran los datos de los estudios experimentales descritos a continuación, los datos obtenidos en animales no proporcionan una información clara sobre los posibles mecanismos de los efectos por el uso de PVD en la reproducción humana. Estos datos complementan la relativa ausencia de indicios de un efecto mensurable del uso de las PVD en los estudios reproductores en poblaciones humanas.
Figura 52.8 • Porcentaje de ratones hembras con reabsorciones placentarias en relación con la exposición.

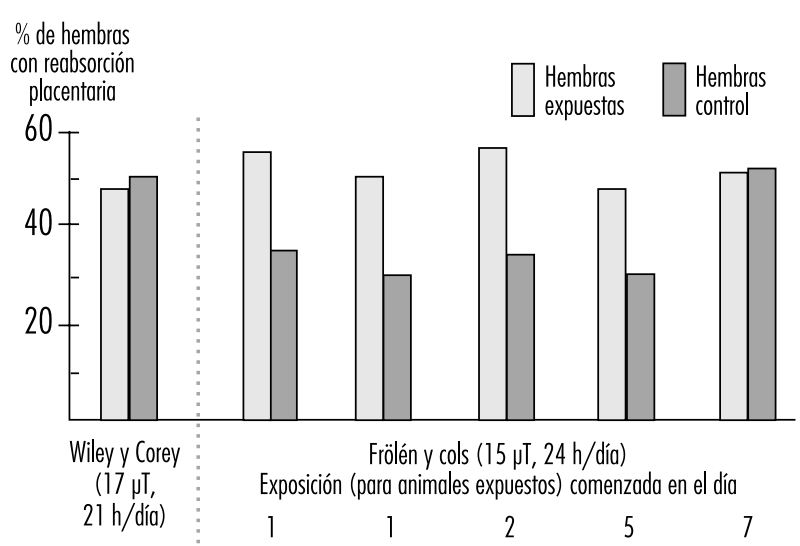

En el estudio de Wiley y Corey (1992), la exposición comenzó en el día l; en el de Frölén y Svedenstäl (1993), comenzó el día 1 en dos series experimentales, y en días variables en las tres series siguientes.

\section{Estudios sobre los efectos en la reproducción de los campos magnéticos MBF en roedores}

En cinco estudios teratológicos, tres con ratones y dos con ratas, se utilizaron campos magnéticos M BF similares a los que se detectan en las proximidades de las PVD. Los resultados de estos estudios se resumen en la Tabla 52.4. Sólo uno de los estudios (Tribukait y Cekan 1987) mostró un mayor número de fetos con malformaciones externas. Stuchly y cols. (1988) y Huuskonen, y Juutilainen y K omulainen (1993) describieron un aumento significativo en el número de fetos con malformaciones esqueléticas, pero sólo cuando el análisis se basó en el feto como una unidad. El estudio de Wiley y Corey (1992) no mostró ningún efecto de la exposición al campo magnético sobre la reabsorción placentaria ni otras consecuencias sobre la gestación. Las reabsorciones placentarias fueron equivalentes, en términos generales, a los abortos espontáneos en humanos. Por último, Frölén y Svedenstål (1993) realizaron una serie de cinco experimentos. En cada experimento, la exposición se producía en un día distinto. Entre los primeros cuatro subgrupos experimentales (día de inicio 1- día de inicio 5), se observaron aumentos significativos en el número de reabsorciones placentarias entre las hembras expuestas. A hora bien, no se observaron estos efectos en el experimento en el que la exposición comenzó el día 7, como se muestra en la Figura 52.8.

L as interpretaciones que los investigadores hacen de sus resultados son: Stuchly y colaboradores han señalado que las anormalidades observadas no son inusuales y han atribuido sus resultados a la "variación habitual intrínseca a cualquier evaluación teratológica". Huuskonen y cols., cuyos resultados fueron similares a los de Stuchly y cols., fueron menos negativos en su valoración y consideraron que sus resultados podrían indicar un efecto real, aunque también señalaron que las anormalidades eran "sutiles y probablemente no afectarían el desarrollo posterior de los fetos". En la discusión de sus resultados, en los que se observaron efectos en las primeras fases de la exposición, pero en las posteriores, Frölén y Svedenstål sugieren que los efectos observados podrían estar relacionados con efectos precoces sobre la reproducción, antes de la implantación en el útero del óvulo fecundado.

Además de los efectos sobre la reproducción, en el estudio de Stuchly y cols. se observó una disminución de las células rojas y 
Tabla 52.4 - Estudios teratológicos con ratas o ratones expuestos a campos magnéticos en dientes de sierra de $18-20 \mathrm{kHz}$.

$\begin{array}{lllll}\text { Estudio } & \text { Sujetos }^{\mathrm{a}} & \text { Frecuencia } & \text { Amplitud }^{\mathrm{b}} & \text { Duraciónc } \\ \text { Tribukait y Cekan (1987) } & \begin{array}{l}76 \text { camadas de }^{\mathrm{r}} \\ \text { ratones (C3H) }\end{array} & 20 \mathrm{kHz} & 1 \mu \mathrm{T}, 15 \mu \mathrm{T} & \begin{array}{l}\text { Expuestos en el día } 14 \text { de } \\ \text { la gestación }\end{array}\end{array}$

Resultados ${ }^{d}$

Aumento significativo de las malformaciones externas; sólo si se utiliza el feto como unidad de observación y sólo durante la primera mitad del experimento; sin diferencias en la reabsorción 0 en las muertes fetales.

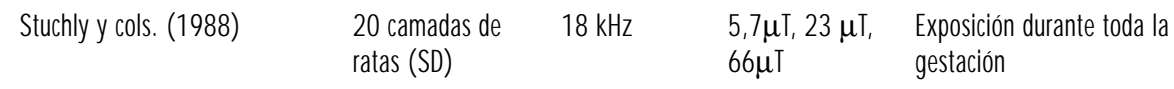

Aumento significativo de las malformaciones ratas (SD) $66 \mu \mathrm{T} \quad$ gestación esqueléticas menores; sólo si se utiliza el feto como unidad de observación; ligera disminución en la concentración de células sanguíneas; sin diferencias en la reabsorción ni en otro tipo de malformaciones

\begin{tabular}{|c|c|c|c|c|}
\hline Wiley y Corey (1992) & $\begin{array}{l}144 \text { camadas de } \\
\text { ratones (CD-1) }\end{array}$ & $20 \mathrm{kHz}$ & $\begin{array}{l}3,6 \mu \mathrm{T}, 17 \mu \mathrm{T}, \\
200 \mu \mathrm{T}\end{array}$ & $\begin{array}{l}\text { Exposición durante toda la } \\
\text { gestación }\end{array}$ \\
\hline Frölén y Svedenstål (1993) & $\begin{array}{l}707 \text { camadas de } \\
\text { ratones (CBA/ S) } \\
\text { en total }\end{array}$ & $20 \mathrm{kHz}$ & $15 \mu \top$ & $\begin{array}{l}\text { Comenzando en distintos } \\
\text { días de gestación en los } \\
\text { diferentes subexperimentos }\end{array}$ \\
\hline $\begin{array}{l}\text { Huuskonen, Juutilainen y } \\
\text { Komulainen (1993) }\end{array}$ & $\begin{array}{l}72 \text { camadas de } \\
\text { ratas (Wistar) }\end{array}$ & $20 \mathrm{kHz}$ & $15 \mu \top$ & $\begin{array}{l}\text { Exposición en el día } 12 \text { de } \\
\text { la gestación }\end{array}$ \\
\hline
\end{tabular}

Sin diferencias en ninguno de los resultados (malformaciones, reabsorción, etc.).

Aumento significativo en la reabsorción; sólo si la exposición se inicia del día 1 al 5; sin diferencias en cuanto a las malformaciones

Aumento significativo de las malformaciones esqueléticas menores; sólo si se utiliza el feto como unidad de observación; sin diferencias en la reabsorción ni en otro tipo de malformaciones.

\footnotetext{
a Número total de camadas en la categoría de máxima exposición.

b Amplitud de pico a pico.

c La exposición varió entre 7 y 24 horas/ día en los distintos experimentos.

¿ Por 'diferencias' se entienden las comparaciones estadísticas entre los animales expuestos y los no expuestos; por 'aumento', la comparación entre el grupo con mayor exposición y el grupo no expuesto.
}

blancas de la sangre en el grupo con un nivel de exposición mayor (en otros estudios no se realizaron recuentos de células sanguíneas). Aunque los autores, sugerían que podría ser indicio de un efecto leve de los campos magnéticos, también señalaban que las variaciones en el recuento de células sanguíneas estaban "dentro de los límites normales". La falta de datos histológicos y la ausencia de efectos sobre las células de la médula ósea hacen que sea difícil evaluar estos resultados.

\section{Interpretación y comparación de los estudios}

Pocos de los resultados aquí descritos son coherentes entre sí. Como señalan Frölén y Svedenstål, "no es posible dar conclusiones cualitativas con respecto a los efectos correspondientes en los seres humanos y en los animales de experimentación". Examinemos algunos de los argumentos que pudieron llevarles a esta conclusión.

Los resultados obtenidos por Tribukait no se consideraron concluyentes, en general, por dos razones. En primer lugar, sólo se obtuvieron efectos positivos cuando se utilizó el feto como unidad de observación para el análisis estadístico, mientras que los propios datos realmente indicaron un efecto específico en la camada. En segundo lugar, existe una discrepancia en este estudio entre los resultados de la primera y la segunda parte, lo que implica que los resultados positivos pueden ser el resultado de variaciones aleatorias 0 factores no controlados en el experimento.

Los estudios epidemiológicos en los que se han investigado malformaciones específicas no han demostrado un aumento de malformaciones esqueléticas en los hijos de madres que trabajan con PVD y que, por lo tanto, están expuestas a campos magnéticos de MBF. Por los motivos antes expuestos (análisis estadístico basado en el feto, anormalidades probablemente no relacionadas con la salud, y falta de concordancia con lo hallado en estudios epidemiológicos), los resultados obtenidos de malformaciones esqueléticas menores no proporcionan una indicación clara de que exista un riesgo para la salud humana.

Wiley y Corey (1992) no observaron un efecto de reabsorción placentaria similar al descrito por Frölén y Svedenstål. U na de las causas de esta discrepancia podría ser que utilizaron cepas distintas de ratones, y el efecto podría ser específico para la cepa utilizada por Frölén y Svedenstål. A parte de este posible efecto de la especie, es también notable que tanto las hembras

\section{Información técnica}

\section{Unidades de observación}

Durante la evaluación estadística de los estudios con mamíferos, debe considerarse al menos un aspecto del mecanismo, con frecuencia desconocido. Si la exposición afecta a la madre y, como consecuencia, a los fetos de la camada, debería utilizarse como unidad de observación (el efecto que está observándose y midiéndose) el estado de la camada en su conjunto, ya que los resultados individuales en los integrantes de la camada no son independientes. Por otra parte, si la hipótesis es que la exposición actua directa e independientemente sobre los fetos individuales de la camada, entonces es apropiado utilizar el feto como una unidad para la evaluación estadística. La práctica habitual consiste en utilizar la camada como unidad de observación, a menos que existan evidencias de que el efecto de la exposición sobre un feto es independiente del efecto sobre los demás fetos de la camada. 
expuestas a campos de $17 \mu \mathrm{T}$ como las hembras control en el estudio de Wiley mostraron frecuencias de reabsorción similares a las de las hembras expuestas de las series correspondientes en el estudio de Frölén, mientras que los grupos no expuestos en este último estudio mostraron frecuencias mucho menores (véase la Figura 52.8). U na explicación hipotética podría ser que la manipulación de los animales durante el período de tres horas sin exposición produjese un nivel de estrés más alto en los ratones del estudio de Wiley. En este caso, el efecto del campo magnético podría haber quedado "enmascarado" por el efecto del estrés. Aunque es difícil descartar definitivamente esta teoría a partir de los datos proporcionados, parece poco probable. Además, si existiese un efecto "real" atribuible al campo magnético, se esperaría que fuera evidente por encima del efecto constante del estrés a medida que aumentase la exposición al campo magnético. En los datos del estudio de Wiley, en cualquier caso, no se observó esta tendencia.

El estudio de Wiley describe el control del ambiente y la rotación de las jaulas para eliminar el efecto de factores no controlados que podrían variar entre distintos puntos de la habitación, al igual que los campos magnéticos; el estudio de Frölén, en cambio. no lo describe. Así, el control de "otros factores" está mejor documentado en el estudio de Wiley. $H$ ipotéticamente, los factores no controlados que no hayan sido aleatorizados podrían posiblemente proporcionar algunas explicaciones. También es interesante observar que la falta de efecto descrita en la serie de los 7 días en el estudio de Frölén no parece deberse a una disminución en los grupos expuestos, sino a un aumento en el grupo control. Lo cual indica que las variaciones en el grupo control son probablemente importantes de considerar cuando se comparan los resultados dispares de los dos estudios.

\section{Estudios de los efectos reproductores de los campos magnéticos EBF en roedores}

Se han realizado varios estudios, la mayoría en roedores, con campos de $50-80 \mathrm{~Hz}$. En la Tabla 52.5 se muestran los detalles de seis de estos estudios. A unque también se han llevado a cabo otros estudios de EBF, sus resultados no aparecen publicados en la literatura científica y generalmente sólo están disponibles como resúmenes de ponencias o comunicaciones. En general, los resultados son "efectos aleatorios", "ninguna diferencia observada", etc. No obstante, en un estudio se describió un número reducido de malformaciones externas en ratones CD-1 expuestos a $20 \mathrm{mT}$ en campos de $50 \mathrm{~Hz}$; pero los autores indicaron que estos resultados podrían reflejar un problema de selección. También se han realizado estudios en otras especies, (monos rhesus y vacas) y tampoco se han observado efectos adversos de la exposición.

Como puede observarse en la Tabla 52.5, los resultados obtenidos fueron muy variables. Resulta más difícil resumir estos estudios, ya que existen muchas variaciones en el régimen de exposición, en los criterios de valoración y en otros factores. El feto (o la cría "seleccionada" superviviente) fue la unidad utilizada en la mayoría de los estudios. En general, es evidente que estos estudios no muestran un efecto teratogénico importante debido a la exposición al campo magnético durante la gestación. Como se señaló anteriormente, las "malformaciones esqueléticas menores" no parecen ser importantes para evaluar el riesgo en humanos. Los resultados de los estudios conductuales de Salzinger y Freimark (1990) y M cGivern y Sokol (1990)

Tabla 52.5 - Estudios teratológicos con ratas o ratones expuestos a campos magnéticos de $15-60 \mathrm{kHz}$ sinusoidales o de impulsos cuadrados.

\begin{tabular}{|c|c|c|c|c|c|c|}
\hline \multirow[b]{2}{*}{ Estudio } & \multirow[b]{2}{*}{ Sujetos ${ }^{\mathrm{a}}$} & \multicolumn{4}{|c|}{ Exposición al campo magnético } & \multirow[b]{2}{*}{ Resultados } \\
\hline & & Frecuencia & Amplitud & Descripción & $\begin{array}{l}\text { Duración de la } \\
\text { exposición }\end{array}$ & \\
\hline Rivas y Rius (1985) & 25 ratones Swiss & $50 \mathrm{~Hz}$ & $83 \mu \mathrm{T}, 2,3 \mathrm{mT}$ & $\begin{array}{l}\text { Impulsos, de } \\
5 \text { ms de } \\
\text { duración }\end{array}$ & $\begin{array}{l}\text { Antes y durante la } \\
\text { gestación y el } \\
\text { crecimiento de las crías; } \\
\text { total } 120 \text { días }\end{array}$ & $\begin{array}{l}\text { Sin diferencias significativas al } \\
\text { nacimiento ni en ninguno de los } \\
\text { parámetros medidos; menor peso } \\
\text { corporal en los machos adultos }\end{array}$ \\
\hline Zecca y cols. (1985) & 10 ratas SD & $50 \mathrm{~Hz}$ & $5,8 \mathrm{mT}$ & & $\begin{array}{l}\text { Día } 6-15 \text { de la gestación, } \\
3 \mathrm{~h} / \text { día }\end{array}$ & Sin diferencias significativas \\
\hline $\begin{array}{l}\text { Tribukait y Cekan } \\
\text { (1987) }\end{array}$ & 35 ratones $\mathrm{C} 3 \mathrm{H}$ & $50 \mathrm{~Hz}$ & $\begin{array}{l}1 \mu \mathrm{T}, 15 \mu \mathrm{T} \\
\text { (pico) }\end{array}$ & $\begin{array}{l}\text { Formas de onda } \\
\text { cuadrada de } \\
0,5 \text { ms de } \\
\text { duración }\end{array}$ & $\begin{array}{l}\text { Día 0-14 de la gestación, } \\
24 \mathrm{~h} / \text { día }\end{array}$ & Sin diferencias significativas \\
\hline $\begin{array}{l}\text { Salzinger y Freimark } \\
(1990)\end{array}$ & $\begin{array}{l}41 \text { crías de ratas SD. } \\
\text { Sólo crías macho }\end{array}$ & $60 \mathrm{~Hz}$ & $\begin{array}{l}100 \mu \mathrm{T} \text { (rms). } \\
\text { También } \\
\text { exposición a } \\
\text { campos eléctricos. }\end{array}$ & $\begin{array}{l}\text { Polarización } \\
\text { circular uniforme }\end{array}$ & $\begin{array}{l}\text { Día } 0-22 \text { de la gestación } \\
\text { y } 8 \text { días después del } \\
\text { nacimiento, } 20 \mathrm{~h} / \text { día }\end{array}$ & $\begin{array}{l}\text { Menor aumento en la respuesta } \\
\text { cuando el entrenamiento comenzó } \\
\text { a los } 90 \text { días de edad }\end{array}$ \\
\hline $\begin{array}{l}\text { McGivern y Sokol } \\
(1990)\end{array}$ & $\begin{array}{l}11 \text { crías de ratas SD. } \\
\text { Sólo crías macho. }\end{array}$ & $15 \mathrm{~Hz}$ & $800 \mu \mathrm{T}$ (pico) & $\begin{array}{l}\text { Formas de onda } \\
\text { cuadrada de } \\
0,3 \text { ms de } \\
\text { duración }\end{array}$ & $\begin{array}{l}\text { Día } 15-20 \text { de la gesta- } \\
\text { ción, } 2 \times 15 \mathrm{~min} / \text { día }\end{array}$ & $\begin{array}{l}\text { Disminución de la conducta de } \\
\text { delimitación territorial por olor } \\
\text { a los } 120 \text { días de edad. } \\
\text { Ligero aumento en el peso de } \\
\text { los órganos. }\end{array}$ \\
\hline $\begin{array}{l}\text { Huuskonen y cols. } \\
\text { (1993) }\end{array}$ & 72 ratas Wistar & $50 \mathrm{~Hz}$ & $12,6 \mu \mathrm{T}$ (rms) & Sinusoidal & $\begin{array}{l}\text { Día 0-12 de la gestación, } \\
24 \mathrm{~h} / \text { día }\end{array}$ & $\begin{array}{l}\text { Más fetos/ camada. Malformaciones } \\
\text { esqueléticas menores }\end{array}$ \\
\hline
\end{tabular}

a A menos que se indique otra cosa, las cifras representan el número de animales (madres) en la categoría de mayor exposición. 
son interesantes, pero no constituyen indicios de los riesgos para la salud humana en los puestos de trabajo con PVD, ni desde el punto de vista de los procedimientos (uso de fetos y, en el caso de M cG ivern, una frecuencia distinta) ni de los efectos.

\section{Resumen de los estudios específicos}

Salzinger y M CG ivern observaron un retardo en el desarrollo conductual 3 - 4 meses después del nacimiento, en las crías de hembras expuestas. En estos estudios se utilizó aparentemente a crías individuales como unidad estadística, por lo que puede cuestionarse si el efecto descrito se debe a un efecto sobre la madre. En el estudio de Salzinger, también se expuso a las crías durante los primeros 8 días de vida, lo que significa que este estudio abarcó más que los riesgos reproductores. En ambos estudios se utilizó un número de camadas limitado. Además, los resultados de estos estudios no se corroboran entre sí, ya que hubo importantes variaciones en la exposición entre uno y otro, como puede observarse en la Tabla 52.5.

Además del cambio conductual en los animales expuestos, en el estudio de M cGivern se observó un aumento del peso de los órganos sexuales masculinos: la próstata, las vesículas seminales y el epidídimo (todas las partes del sistema reproductor masculino). Los autores especulan sobre si este hecho podría estar relacionado con la estimulación de los niveles enzimáticos de la próstata, ya que se ha observado cierto efecto de los campos magnéticos sobre algunas de las enzimas presentes en la próstata con campos de $60 \mathrm{~Hz}$.

Huuskonen y cols. (1993) observaron un aumento en el número de fetos por camada (10,4 fetos/ camada en el grupo expuesto a $50 \mathrm{~Hz}$ frente a 9 fetos/ camada en el grupo control). Los autores, al no observar una tendencia similar en otros estudios, quitaron importancia a este resultado señalando que "podría tratarse de un efecto incidental, más que real, del campo magnético". En 1985, Rivas y Rius describieron un resultado distinto, con un número ligeramente menor de nacimientos de crías vivas por camada en los grupos expuestos frente a los no expuestos. La diferencia no fue estadísticamente significativa. Los autores utilizaron tanto una base "por feto" como "por camada" para otros aspectos del análisis. EI aumento en las malformaciones esqueléticas menores sólo se observó cuando el análisis se basó en el feto como unidad de observación.

\section{Recomendaciones y resumen}

A pesar de la falta relativa de datos consistentes y positivos que demuestren efectos reproductivos en humanos o en animales, aún están justificados los intentos por reproducir los resultados de algunos de los estudios. Estos estudios deberían intentar reducir las variaciones en las exposiciones, métodos de análisis y cepas de animales utilizadas.

En general, los estudios experimentales realizados con campos magnéticos de $20 \mathrm{kHz}$ han producido resultados ligeramente variables. Si se considera estrictamente el procedimiento de análisis de las camadas y las pruebas de hipótesis estadísticas, no se ha demostrado ningún efecto en ratas (a pesar de que en ambos estudios se obtuvieron resultados no significativos similares). En ratones, los resultados han sido variables y no parece posible, por el momento, realizar ni una sola interpretación coherente de ellos. En el caso de los campos magnéticos de $50 \mathrm{~Hz}$, la situación varía ligeramente. Existen muy pocos estudios epidemiológicos sobre esta frecuencia y uno de los estudios indicó un posible riesgo de aborto. En cambio, en los estudios experimentales con animales no se han obtenido resultados similares. Globalmente, los resultados no demuestran un efecto en la gestación de los campos magnéticos de extremadamente baja frecuencia generados en las PVD. En conjunto, por lo tanto, los resultados no indican un efecto de los campos magnéticos M BF 0 EBF de las PVD sobre la reproducción.

\section{EFECTOSEN LA REPRODUCCION: EVIDENCIAS EN HUMANOS}

\section{Claire Infante-Rivard}

La seguridad de las pantallas de visualización de datos (PVD), en términos de consecuencias para la reproducción, se ha cuestionado desde la introducción generalizada de las PVD en el ambiente de trabajo durante el decenio de 1970. La preocupación por los efectos adversos en el embarazo surgió inicialmente como resultado de numerosos informes de aparentes "clusters" de abortos espontáneos o malformaciones congénitas entre las operadoras de PVD embarazadas (Blackwell y Chang 1988). A pesar de que se determinó que estos "clusters" no eran más de los esperados debidos al azar, ante el uso extendido de las PVD en los lugares de trabajo modernos (Bergqvist 1986), se iniciaron estudios para explorar esta posibilidad más detalladamente.

De los estudios publicados, que se revisan aquí, se podría concluir que, en general, el trabajo con las PV D no parece estar asociado con un mayor riesgo de consecuencias adversas en el embarazo. No obstante, esta conclusión generalizada es aplicable a las PVD tal como habitualmente se encuentran y se utilizan en las oficinas por trabajadores del sexo femenino. Con todo, si por alguna razón técnica existiese una pequeña proporción de PVD que indujesen realmente un campo magnético intenso, esta conclusión general de seguridad no podría aplicarse a esa situación especial, ya que no es probable que los estudios publicados hayan tenido la capacidad estadística para detectar este tipo de efectos. Si se desea obtener conclusiones generalizables sobre la seguridad, es indispensable que los estudios futuros, sobre el riesgo de efectos adversos sobre el embarazo asociado al uso de PVD, empleen mediciones de la exposición más refinadas.

Los efectos sobre la reproducción estudiados con más frecuencia han sido:

- Abortos espontáneos (10 estudios): definidos generalmente como la interrupción no intencionada del embarazo con hospitalización antes de la semana 20 de gestación.

- Malformaciones congénitas (8 estudios): se evaluaron muchos tipos distintos, pero en general, fueron diagnosticadas en el momento del nacimiento.

- 0 tras consecuencias (8 estudios): tales como, bajo peso al nacer (inferior a $2.500 \mathrm{~g}$ ), muy bajo peso al nacer (inferior a $1.500 \mathrm{~g}$ ) y fecundabilidad (tiempo desde la interrupción del método anticonceptivo hasta el embarazo). V éase la T abla 52.6.

\section{Discusión}

Al evaluar los "clusters" descritos entre consecuencias adversas en el embarazo y uso de PVD, se llegó a la conclusión de que había grandes probabilidades de que estos "clusters" se debieran al azar (Bergqvist 1986). Además, los resultados de los escasos estudios epidemiológicos que han evaluado la relación entre el uso de PVD y las consecuencias adversas en el embarazo no demuestran, en general un aumento del riesgo estadísticamente significativo.

En esta revisión, sólo dos de los diez estudios sobre abortos espontáneos determinaron un aumento estadísticamente significativo del riesgo con la exposición a las PVD (G oldhaber, Polen 


\section{Resumen de los estudios sobre las consecuencias en la reproducción}

En un estudio de casos-control sobre la relación entre los factores ambientales y profesionales y las malformaciones congénitas (Kurppa y cols. 1986) se identificaron 1.475 casos en el Registro Finlandés de Malformaciones Congénitas durante el período entre 1976 y 1982 (véase la Tabla 52.6). En uno de los casos de malformaciones, el control se hizo en una mujer del mismo distrito, cuyo parto tuvo lugar inmediatamente antes. La exposición a las pantallas de visualización de datos (PVD) durante el primer trimestre del embarazo fue evaluada directamente mediante entrevistas personales realizadas tanto en la clínica durante una visita postparto, como en el domicilio. La clasificación del uso de las PVD como probable 0 evidente la hicieron higienistas industriales (que no conocían el resultado del embarazo) a partir de la denominación del trabajo y las respuestas a las preguntas abiertas en las que se pedía a las mujeres que describieran una jornada laboral normal. $\mathrm{N}$ o hubo evidencias de un mayor riesgo ni entre las mujeres que dijeron estar expuestas a las PVD (O R 0,9; IC $95 \% 0,6-1,2)$ ni entre las mujeres cuya denominación del trabajo indicaba una posible exposición a las PVD (235 casos/ 255 controles).

Se identificó una cohorte de mujeres suecas pertenecientes a tres grupos profesionales estableciendo un vínculo entre el censo profesional y el Registro Médico de $\mathrm{N}$ acimientos durante 1980-1981 (Ericson y Källén 1986). Se realizó un estudio de casos en esta cohorte; los casos fueron: 412 mujeres hospitalizadas por abortos espontáneos y 110 mujeres más con otras consecuencias (muerte perinatal, malformaciones congénitas o peso al nacer inferior a $1.500 \mathrm{~g}$ ). Los controles se hicieron en 1.032 mujeres de edad similar, con hijos sin ninguna de estas características, elegidas del mismo registro. De acuerdo con los índices de probabilidades no ajustados, se observó una relación exposición-respuesta entre la exposición a las PVD estimada en horas por semana (divididas en categorías de cinco horas), y las consecuencias en el embarazo (excluidos los abortos espontáneos). Después de considerar factores como el consumo de tabaco y el estrés, no fue significativo el efecto del uso de las PVD sobre todas las consecuencias adversas para el embarazo.

Se realizó un estudio de cohortes con 4.117 embarazos en empleadas de la seguridad social de Suecia (W esterholm y Ericson 1986), seleccionando para ello uno de los tres grupos profesionales identificados por Ericson en un estudio anterior. Se compararon las tasas de abortos espontáneos con hospitalización, bajo peso al nacer, mortalidad perinatal y malformaciones congénitas en esta cohorte con las tasas en la población general. La cohorte fue dividida en cinco grupos de exposición, definidos por el sindicato y los representantes patronales. No se halló una mayor tasa en ninguna de las consecuencias estudiadas. El riesgo global relativo de abortos espontáneos, estandarizado por la edad de la madre, fue de 1,1 (IC $95 \% 0,8-1,4$ ).

Se realizó un estudio de cohortes de 1.820 nacimientos en mujeres que trabajaron en alguna ocasión en el centro de servicio postal noruego entre 1967-1984 (Bjerkedal y Egenaes 1986).Se calcularon las tasas de niños nacidos muertos, muertos durante la primera semana después del parto, muerte perinatal, peso bajo 0 muy bajo al nacer, nacimientos pretérmino, partos múltiples y malformaciones congénitas en los embarazos ocurridos durante el período de trabajo en el centro (990 embarazos) y los ocurridos antes o después del trabajo en el centro (830 embarazos). Las tasas de consecuencias adversas en el embarazo se estimaron para tres períodos de seis años, 1967-1972, 1973-1978 y 1979-1984. La introducción de las PVD comenzó en 1972, y en 1980 su uso estaba generalizado. El estudio concluyó que no había indicios de que la introducción de las PVD en el centro hubiese producido un aumento en la tasa de consecuencias adversas en el embarazo.

Se identificó una cohorte de 9.564 embarazos a través de los registros de pruebas de embarazo en orina de tres clínicas de California en 1981-1982 (Goldhaber, Polen y Hiatt 1988). Un requisito para participar en este estudio era tener un seguro médico del norte de $\mathrm{C}$ alifornia.
Se obtuvieron las consecuencias en el embarazo en todos los casos excepto en 391 embarazos. De esta cohorte, 460 de 556 casos de abortos espontáneos (<28 semanas), 137 de 156 casos de malformaciones congénitas y 986 de 1.123 controles (correspondientes a uno de cada cinco nacimientos normales en la cohorte original), respondieron a un cuestionario postal retrospectivo sobre exposiciones químico-ambientales, incluidos pesticidas y el uso de PVD durante el embarazo. El índice de probabilidades para las mujeres que utilizaron PVD durante más de 20 horas por semana en el primer trimestre del embarazo, ajustado por 11 variables incluidas la edad, los abortos o las malformaciones previas, el consumo de tabaco y de alcohol, fue de 1,8 (IC $95 \% 1,2-2,8$ ) para los abortos espontáneos y de 1,4 (IC $95 \% 0,7-2,9$ ) para los defectos de nacimiento, en comparación con las mujeres que no utilizaron PVD.

En un estudio realizado en la unidad de maternidad de 11 hospitales del área de Montreal durante un período de dos años (1982-1984), se entrevistó a 56.012 mujeres sobre factores laborales, personales y sociales después del parto (51.855) o del tratamiento por aborto espontáneo (4.127) (M cDonald y cols. 1988). Las mujeres también proporcionaron información sobre 48.637 embarazos previos. Se registraron las consecuencias adversas en el embarazo (abortos espontáneos, niños nacidos muertos, malformaciones congénitas y bajo peso al nacer) tanto para el embarazo en curso como para los anteriores. La razón entre las tasas observadas y las esperadas se calculó por grupo profesional para los embarazos actuales y anteriores. Las tasas esperadas para cada grupo profesional fueron halladas de las consecuencias en el total de la muestra, y ajustadas por ocho variables, incluidas la edad, el consumo de tabaco y de alcohol. $\mathrm{N}$ o se encontró un mayor riesgo en las mujeres expuestas a las PVD.

Se realizó un estudio de cohortes en 1.475 mujeres, comparando las tasas de amenazas de aborto, duración de la gestación, peso al nacer peso de la placenta e hipertensión inducida por el embarazo entre las mujeres que utilizaban PVD y las que no (N urminen y Kurppa 1988). La cohorte se definió como todos los casos negativos de un estudio previo de casos-control sobre malformaciones congénitas. La información acerca de los factores de riesgo se obtuvo de entrevistas personales. Las razones de las tasas ajustadas y no ajustadas para las consecuencias estudiadas no mostraron un efecto estadísticamente significativo del uso de las PVD.

Se realizó un estudio de casos-control de 344 abortos espontáneos tratados en tres hospitales de Calgary, Canadá, entre 1984 y 1985 (Bryant y Love 1989). Se eligieron dos grupos de controles (314 prenatales y 333 posparto) entre mujeres que habían dado a luz o que previsiblemente lo harían en los hospitales del estudio. Se emparejaron los controles con cada caso basándose en la edad que contaban cuando tuvieron el último período menstrual, el número de partos y el hospital en el que se llevaría a cabo el parto. El uso de PVD en el hogar y en el trabajo, antes y durante el embarazo, se determinó mediante entrevista en el hospital, en el caso de los controles postparto y de los abortos espontáneos, y en el domicilio, trabajo o centro de estudio, en el caso de los controles prenatales. Se controlaron las variables socioeconómicas y obstétricas. El uso de PVD fue similar entre los casos y los controles prenatales $(0 R=1,14 ; p=0,47)$ y postnatales $(0 R=0,80$; $p=0,2)$.

En un condado de California se realizó un estudio de casos-control en 628 mujeres con abortos espontáneos, identificadas a través de muestras enviadas a patología, cuyo último período menstrual tuvo lugar en 1986, y 1.308 controles con nacimientos vivos (W indham y cols. 1990). Los controles se seleccionaron aleatoriamente, en una proporción de dos a uno, entre mujeres emparejadas por la fecha del último período menstrual y por el hospital. Las actividades durante las primeras 20 semanas de embarazo se identificaron a través de entrevistas telefónicas. También se preguntó a las participantes sobre el uso de PVD durante su trabajo en este período. Los índices de probabilidades no ajustados entre los abortos espontáneos con un uso de PVD 
inferior a 20 horas por semana $(1,2$; IC $95 \% 0,88-1,6)$ e igual 0 superior a 20 horas por semana (1,3; IC $95 \% 0,87-1,5)$, no mostraron diferencias importantes cuando se ajustaron por variables como el grupo profesional, la edad de la madre, la pérdida fetal previa, el consumo de alcohol y de tabaco. En un análisis posterior de las mujeres del grupo control, no se observó un riesgo significativamente mayor de bajo peso al nacer o de retardo del crecimiento intrauterino.

Se realizó un estudio de casos-control en 24.352 embarazos ocurridos entre 214.108 empleadas de comercios y oficinas en Dinamarca, entre 1982 y 1985 (Brandt y $N$ ielsen 1990). Los casos, 421 mujeres que respondieron a las preguntas de las 661 mujeres que tuvieron hijos con malformaciones congénitas y que trabajaron durante el embarazo, fueron comparadas con 1.365 mujeres que respondieron a las preguntas de 2.252 trabajadoras embarazadas seleccionadas aleatoriamente. Los embarazos, su resultado y el tipo de empleo se determinaron mediante el cruce de tres bases de datos. La información sobre el uso de la PVD (sí/ no/ horas por semana) y otros factores personales y relacionados con el trabajo, como estrés, exposición a disolventes, forma de vida y factores ergonómicos, se determinaron mediante una encuesta por correo. En este estudio el uso de las PVD durante el embarazo no estuvo asociado a un mayor riesgo de malformaciones congénitas.

Utilizando la misma base del estudio anterior sobre las malformaciones congénitas (Brandt y $N$ ielsen 1990), 1.371 mujeres de las 2.248 cuyos embarazos terminaron en abortos espontáneos con hospitalización, se compararon con 1.699 embarazos seleccionados aleatoriamente ( $\mathrm{N}$ ielsen y Brandt 1990 ). A pesar de que el estudio se realizó en trabajadoras de comercios y oficinas, no todos los embarazos ocurrieron durante el período en que las mujeres estaban empleadas. La medida de la asociación utilizada en este estudio fue la razón entre la tasa de uso de la PVD en las mujeres con abortos espontáneos y la tasa de uso en la población de la muestra (formada por todos los embarazos, incluidos los que terminaron en abortos espontáneos). La razón de la tasa ajustada de la exposición a la PVD y el aborto espontáneo fue de 0,94 (IC $95 \% 0,77-1,14$ ).

Se realizó un estudio de casos-control entre 573 mujeres que tuvieron hijos con malformaciones cardiovasculares entre 1982 y 1984 (Tikkanen y Heinonen 1991). Los casos se identificaron a través del Registro Finlandés de $M$ alformaciones Congénitas. El grupo control fue de 1.055 mujeres seleccionadas aleatoriamente entre todos los partos hospitalarios en el mismo período de tiempo. El uso de PVD, clasificado como nunca, regular u ocasional, fue evaluado mediante una entrevista realizada 3 meses después del parto. No se encontró una asociación estadísticamente significativa entre el uso de PVD, en el hogar o en el trabajo, y las malforma ciones cardiovasculares.

Se realizó un estudio de cohortes con 730 mujeres casadas, con embarazos entre 1983 y 1986 (Schnorr y cols. 1991). Las mujeres trabajaban como operadoras telefónicas u operadoras de información telefónica para dos compañías telefónicas en ocho estados del sureste de Estados Unidos. Sólo las operadoras de información telefónica utilizaban PVD en su trabajo. El uso de PVD se determinó a través de los registros de la empresa. Los casos de abortos espontáneos (pérdida fetal antes de la semana 28 de gestación) se identificaron mediante entrevistas telefónicas; posteriormente, se utilizaron los certificados de nacimiento para contrastar la información de las mujeres con las consecuencias en el embarazo y, siempre que fue posible, se consultó a los médicos. Se midió la intensidad de los campos eléctricos y magnéticos de muy bajas o extremadamente bajas frecuencias en una muestra de los puestos de trabajo. Los puestos con PVD mostraron intensidades de campo más elevadas que los que no tenían PVD. No se observó un mayor riesgo para las mujeres que utilizaron PVD durante el primer trimestre del embarazo (0 R 0,93; IC $95 \% 0,63$ - 1,38) semanal, y no parecía haber una relación exposición-respuesta cuando se consideró el tiempo de uso de la PVD

Se utilizó una cohorte de 1.365 empleadas danesas de comercios y oficinas, que trabajaban en la época en que quedaron embarazadas, identificadas mediante un estudio previo (Brandt y N ielsen 1990; $\mathrm{N}$ ielsen y Brandt 1990), para estudiar la fecundabilidad en relación con el uso de PVD (Brandt y Nielsen 1992). La fecundabilidad se definió como el tiempo entre la interrupción del uso de anticonceptivos y la concepción, y se determinó a través de una encuesta por correo. El estudio mostró un riesgo relativo, de espera prolongada hasta el embarazo, superior en el subgrupo con al menos 21 horas semanales de uso de la PVD. (RR 1,61; IC $95 \% 1,09$ - 2,38).

Se utilizó una cohorte de 1.699 empleadas danesas de comercios y oficinas, formada por mujeres empleadas y no empleadas en la época en que quedaron embarazadas, identificadas del estudio descrito en el párrafo anterior, para estudiar el bajo peso al nacer (434 casos), los nacimientos pretérmino (443 casos), fetos pequeños para la edad gestacional (749 casos) y mortalidad infantil (160 casos) en relación con las pautas de uso de las PVD ( $N$ ielsen y Brandt 1992). El estudio no pudo mostrar un mayor riesgo de estos resultados adversos del embarazo en las mujeres que utilizaban PVD.

En un estudio de casos-control se encuestó a 150 mujeres nulíparas con abortos espontáneos diagnosticados clínicamente y a 297 mujeres nulíparas trabajadoras, que acudían a un hospital de Reading, Inglaterra, para recibir asistencia prenatal entre 1987 y 1989 (Roman y cols. 1992). Las entrevistas personales se realizaron durante la primera visita prenatal, en los controles, y tres semanas después del aborto, en las mujeres con abortos espontáneos. Para mujeres que indicaron que utilizaban PVD, se evaluó el tiempo de exposición estimado en horas por semana y la fecha de la primera exposición. También se evaluaron otros factores como las horas extra, la actividad física en el trabajo, el estrés y el confortfísico en el trabajo, la edad, el consumo de alcohol y el número de abortos previos. El índice de probabilidades de aborto espontáneo en las mujeres que trabajaban con PVD fue 0,9 (IC $95 \% 0,6-1,4$ ), y no hubo relación con el tiempo de uso de la PVD. Los resultados no variaron cuando se ajustaron por otros factores como la edad de la madre, consumo de tabaco, alcohol y los abortos espontáneos previos.

A partir de una población de empleados bancarios y de oficina de tres empresas finlandesas, se identificaron 191 casos de abortos espontáneos con hospitalización y 394 controles (nacimientos vivos) utilizando los registros médicos finlandeses de 1975 a 1985 (Lindbohm y cols. 1992). El uso de PVD se definió utilizando las informaciones de los trabajadores y de las empresas. La intensidad de los campos magnéticos se evaluó de forma retrospectiva en un laboratorio, con una muestra de las PVD utilizadas en las empresas. El índice de probabilidades de aborto espontáneo y uso de PVD fue de 1,1 (IC $95 \% 0,7$ $1,6)$. Cuando se agrupó a las usuarias de PVD según la intensidad de los campos de las PVD utilizadas, el índice de probabilidades fue de 3,4 (IC $95 \% 1,4-8,6$ ) para las trabajadoras que utilizaron PVD con un campo magnético más intenso, en la banda de las extremadamente bajas frecuencias $(0,9 \mu \mathrm{T})$, comparadas con las que utilizaron PVD con niveles de intensidad de campo inferiores a los límites de detección $(0,4 \mu \mathrm{T})$. Tal índice de probabilidades varió muy poco cuando se ajustó por factores ergonómicos y de carga mental de trabajo. Cuando se comparó a las trabajadoras expuestas a una intensidad mayor de los campos magnéticos con trabajadoras no expuestas a las PVD, el índice de probabilidades dejó de ser significativo.

Se realizó un estudio sobre consecuencias adversas en el embarazo y fertilidad en funcionarias de la hacienda británica (Bramwell y Davidson 1994). De los 7.819 cuestionarios enviados por correo en la primera etapa del estudio, se recogieron 3.711. El uso de las PVD se determinó con este primer cuestionario. La exposición se evaluó como horas de uso de PVD por semana durante el embarazo. Un año más tarde, se envió un segundo cuestionario para evaluar la incidencia de consecuencias adversas en el embarazo entre estas mujeres. Se obtuvieron 2.022 respuestas de las participantes originales. Como posibles factores de confusión se incluyeron el historial del embarazo, factores ergonómicos, factores de estrés laboral y consumo de cafeína, alcohol, tabaco y tranquilizantes. $\mathrm{N}$ o hubo relación entre el nivel de exposición determinado un año antes y la incidencia de consecuencias adversas en el embarazo. 
Tabla 52.6 • Utilización de PVD como un factor de las consecuencias adversas en el embarazo.

\begin{tabular}{|c|c|c|c|c|c|c|c|}
\hline \multicolumn{2}{|l|}{ Objetivos } & \multicolumn{4}{|c|}{ Métodos } & \multicolumn{2}{|r|}{ Resultados } \\
\hline Estudio & Consecuencia & Diseño & Casos & Controles & Exposición & OR/RR (IC $95 \%)$ & Conclusión \\
\hline $\begin{array}{l}\text { Kurppa y cols. } \\
(1986)\end{array}$ & $\begin{array}{l}\text { Malformaciones } \\
\text { congénitas }\end{array}$ & $\begin{array}{l}\text { Casos y } \\
\text { controles }\end{array}$ & 1.475 & $\begin{array}{l}1.475 \text { misma } \\
\text { edad, misma } \\
\text { fecha de parto }\end{array}$ & $\begin{array}{l}\text { Por la de } \\
\text { nominación } \\
\text { del puesto, } \\
\text { entrevistas } \\
\text { personales }\end{array}$ & $\begin{array}{l}235 \text { casos, } \\
255 \text { controles, } \\
0,9(0,6-1,2)\end{array}$ & $\begin{array}{l}\text { Sin indicios de mayor riesgo } \\
\text { para las mujeres expuestas a } \\
\text { las PVD o para las mujeres cuya } \\
\text { denominación del puesto indi- } \\
\text { caba una posible exposición }\end{array}$ \\
\hline $\begin{array}{l}\text { Ericson y } \\
\text { Källen } \\
(1986)\end{array}$ & $\begin{array}{l}\text { Abortos espontáneos, } \\
\text { muerte neonatal, } \\
\text { malformaciones, } \\
\text { peso muy bajo al nacer }\end{array}$ & De casos & $\begin{array}{r}412 \\
22 \\
62 \\
26\end{array}$ & $\begin{array}{l}1.032 \text { de edad } \\
\text { similar y del } \\
\text { mismo registro }\end{array}$ & $\begin{array}{l}\text { Por la de } \\
\text { nominación } \\
\text { del puesto }\end{array}$ & $\begin{array}{l}1,2(0,6-2,3) \\
\text { (consecuencias combinadas) }\end{array}$ & $\begin{array}{l}\text { El efecto del uso de PVD no fue } \\
\text { estadísticamente significativo }\end{array}$ \\
\hline $\begin{array}{l}\text { Westerholm } \\
\text { y Ericson } \\
(1986)\end{array}$ & $\begin{array}{l}\text { Muerte fetal, } \\
\text { bajo peso al nacer, } \\
\text { mortalidad prenatal, } \\
\text { malformaciones }\end{array}$ & Cohorte & $\begin{array}{c}7 \\
- \\
13 \\
43\end{array}$ & 4.117 & $\begin{array}{l}\text { Por la de } \\
\text { nominación } \\
\text { del puesto }\end{array}$ & $\begin{array}{l}1,1(0,8-1,4) \\
N D(\text { NS) } \\
\text { ND(NS) } \\
1,9(0,9-3,8)\end{array}$ & $\begin{array}{l}\text { Sin diferencias en ninguno de } \\
\text { los resultados estudiados. }\end{array}$ \\
\hline $\begin{array}{l}\text { Bjerkedal y } \\
\text { Egenaes } \\
(1986)\end{array}$ & $\begin{array}{l}\text { Muerte fetal, } \\
\text { muerte durante la } \\
\text { primera semana de } \\
\text { vida, muerte prenatal, } \\
\text { bajo peso al nacer, } \\
\text { peso muy bajo al } \\
\text { nacer, pretérmino, } \\
\text { parto múltiple, } \\
\text { malformaciones }\end{array}$ & Cohorte & $\begin{array}{r}17 \\
8 \\
25 \\
46 \\
10 \\
97 \\
16 \\
71\end{array}$ & 1.820 & $\begin{array}{l}\text { Registros de } \\
\text { empleo }\end{array}$ & $\begin{array}{l}\text { ND(NS) } \\
\text { ND(NS) } \\
\text { ND(NS) } \\
\text { ND(NS) } \\
\text { ND(NS) } \\
\text { ND(NS) } \\
\text { ND(NS) } \\
\text { ND(NS) }\end{array}$ & $\begin{array}{l}\text { Se concluyó que no había indi- } \\
\text { cios de que la introducción de } \\
\text { las PVD en el centro hubiese } \\
\text { aumentado la tasa de conse- } \\
\text { cuencias adversas en el emba- } \\
\text { razo. }\end{array}$ \\
\hline $\begin{array}{l}\text { Goldhaber, } \\
\text { Polen y Hiat } \\
(1988)\end{array}$ & $\begin{array}{l}\text { Abortos espontáneos, } \\
\text { malformaciones }\end{array}$ & $\begin{array}{l}\text { Casos y } \\
\text { controles }\end{array}$ & $\begin{array}{l}460 \\
137\end{array}$ & $\begin{array}{l}1.12320 \% \text { de } \\
\text { todos los naci- } \\
\text { mientos } \\
\text { normales, } \\
\text { misma región, } \\
\text { mismo tiempo }\end{array}$ & $\begin{array}{l}\text { Cuestionario } \\
\text { por correo }\end{array}$ & $\begin{array}{l}1,8(1,2-2,8) \\
1,4(0,7-2,9)\end{array}$ & $\begin{array}{l}\text { Riesgo estadísticamente mayor } \\
\text { de abortos espontáneos con la } \\
\text { exposición a la PVD. Sin un } \\
\text { mayor riesgo de malforma- } \\
\text { ciones congénitas asociado con } \\
\text { la exposición a las PVD. }\end{array}$ \\
\hline $\begin{array}{l}\text { McDonald y } \\
\text { cols. (1988) }\end{array}$ & $\begin{array}{l}\text { Abortos espontáneos, } \\
\text { muerte fetal, } \\
\text { malformaciones, } \\
\text { bajo peso al nacer }\end{array}$ & Cohorte & $\begin{array}{r}776 \\
25 \\
158 \\
228\end{array}$ & & $\begin{array}{l}\text { Entrevistas } \\
\text { personales }\end{array}$ & $\begin{array}{l}1,19(1,09-1,38) \\
\text { actual/ 0,97 previa } \\
0,82 \text { actual/ } 0,71 \text { previa } \\
0,94 \text { actual/ } 1,12 \\
(89-1,43) \text { previa } \\
1,10\end{array}$ & $\begin{array}{l}\text { No se detectó un mayor riesgo } \\
\text { en las mujeres expuestas a las } \\
\text { PVD. }\end{array}$ \\
\hline $\begin{array}{l}\text { Nurminen y } \\
\text { Kurppa } \\
(1988)\end{array}$ & $\begin{array}{l}\text { Amenaza de aborto, } \\
\text { gestación < } 40 \\
\text { semanas, bajo peso al } \\
\text { nacer, peso de la } \\
\text { placenta, hipertensión }\end{array}$ & Cohorte & $\begin{array}{r}239 \\
96 \\
57 \\
\text { ND } \\
\text { ND }\end{array}$ & & $\begin{array}{l}\text { Entrevistas } \\
\text { personales }\end{array}$ & $\begin{array}{l}0,9 \\
\text { PVD: } 30,5 \%, \text { no: } 43,8 \% \\
\text { PVD: } 25,4 \%, \text { no: } 23,6 \% \\
\text { otras comparaciones (ND) }\end{array}$ & $\begin{array}{l}\text { Las razones de las tasas crudas } \\
\text { y ajustadas no mostraron } \\
\text { efectos estadísticamente signifi- } \\
\text { cativos del trabajo con PVD. }\end{array}$ \\
\hline $\begin{array}{l}\text { Bryant y Love } \\
\text { (1989) }\end{array}$ & Abortos espontáneos & $\begin{array}{l}\text { Casos y } \\
\text { controles }\end{array}$ & 344 & $\begin{array}{l}647 \\
\text { Mismo hospital, } \\
\text { edad, último } \\
\text { período mens- } \\
\text { trual, número } \\
\text { de partos }\end{array}$ & $\begin{array}{l}\text { Entrevistas } \\
\text { personales }\end{array}$ & $\begin{array}{l}1,14(p=0,47) \text { prenatal } \\
0,80(p=0,2) \text { postnatal }\end{array}$ & $\begin{array}{l}\text { El uso de PVD fue similar entre } \\
\text { los casos y los controles prena- } \\
\text { tales y postnatales. }\end{array}$ \\
\hline $\begin{array}{l}\text { Windham y } \\
\text { cols. (1990) }\end{array}$ & $\begin{array}{l}\text { Abortos espontáneos, } \\
\text { bajo peso al nacer, } \\
\text { retardo del crecimiento } \\
\text { intrauterino }\end{array}$ & $\begin{array}{l}\text { Casos y } \\
\text { controles }\end{array}$ & $\begin{array}{r}626 \\
64 \\
68\end{array}$ & $\begin{array}{l}1.308 \text { misma } \\
\text { edad y último } \\
\text { período } \\
\text { menstrual }\end{array}$ & $\begin{array}{l}\text { Entrevistas } \\
\text { telefónicas }\end{array}$ & $\begin{array}{l}1,2(0,88-1,6) \\
1,4(0,75-2,5) \\
1,6(0,92-2,9)\end{array}$ & $\begin{array}{l}\text { Las odds-ratio crudas de los } \\
\text { abortos espontáneos y el uso de } \\
\text { PVD menor a } 20 \text { horas por } \\
\text { semana fueron de } 1,2 ; \text { IC } 95 \% \\
0,88-1,6 \text { y de } 1,3 ; \text { IC } 95 \% \\
0,87-1,5 \text { para } 20 \text { o más horas } \\
\text { por semana. El riesgo de bajo } \\
\text { peso al nacer y retardo del } \\
\text { crecimiento intrauterino no fue } \\
\text { significativamente mas elevado. }\end{array}$ \\
\hline
\end{tabular}


Tabla 52.6 • Utilización de PVD como un factor de las consecuencias adversas en el embarazo.

Continuación

\begin{tabular}{|c|c|c|c|c|c|c|c|}
\hline \multicolumn{2}{|l|}{ Objetivos } & \multicolumn{4}{|c|}{ Métodos } & & Resultados \\
\hline Estudio & Consecuencia & Diseño & Casos & Controles & Exposición & OR/ RR (IC $95 \%)$ & Conclusión \\
\hline $\begin{array}{l}\text { Brandt y } \\
\text { Nielsen } \\
(1990)\end{array}$ & $\begin{array}{l}\text { Malformaciones } \\
\text { congénitas }\end{array}$ & $\begin{array}{l}\text { Casos y } \\
\text { controles }\end{array}$ & 421 & $\begin{array}{l}1.365 ; 9,2 \% \\
\text { de todos los } \\
\text { embarazos, } \\
\text { mismo registro }\end{array}$ & $\begin{array}{l}\text { Cuestionario } \\
\text { por correo }\end{array}$ & $0,96(0,76-1,20)$ & $\begin{array}{l}\text { El uso de PVD durante el emba- } \\
\text { razo no se asoció con un mayor } \\
\text { riesgo de malformaciones } \\
\text { congénitas. }\end{array}$ \\
\hline $\begin{array}{l}\text { Nielsen y } \\
\text { Brandt } \\
\text { (1990) }\end{array}$ & Abortos espontáneos & $\begin{array}{l}\text { Casos y } \\
\text { controles }\end{array}$ & 1.371 & $\begin{array}{l}1.699 ; 9,2 \% \\
\text { de todos los } \\
\text { embarazos, } \\
\text { mismo registro }\end{array}$ & $\begin{array}{l}\text { Cuestionario } \\
\text { por correo }\end{array}$ & $0,94(0,77-1,14)$ & $\begin{array}{l}\text { No hubo riesgo estadística- } \\
\text { mente significativo de abortos } \\
\text { espontáneos con la exposición a } \\
\text { las PVD. }\end{array}$ \\
\hline $\begin{array}{l}\text { Tikkanen y } \\
\text { Heinonen } \\
\text { (1991) }\end{array}$ & $\begin{array}{l}\text { Malformaciones } \\
\text { cardiovasculares }\end{array}$ & $\begin{array}{l}\text { Casos y } \\
\text { controles }\end{array}$ & 573 & $\begin{array}{l}1.055 \text { mismo } \\
\text { tiempo, parto } \\
\text { hospitalario }\end{array}$ & $\begin{array}{l}\text { Entrevistas } \\
\text { personales }\end{array}$ & Casos $6,0 \%$, controles $5,0 \%$ & $\begin{array}{l}\text { No hubo asociación estadística- } \\
\text { mente significativa entre el uso } \\
\text { de PVD y las malformaciones } \\
\text { cardiovasculares }\end{array}$ \\
\hline $\begin{array}{l}\text { Schnorr } \\
\text { y cols. } \\
(1991)\end{array}$ & Abortos espontáneos & Cohorte & 136 & 746 & $\begin{array}{l}\text { Registros de } \\
\text { empresa de las } \\
\text { mediciones de } \\
\text { los campos } \\
\text { magnéticos }\end{array}$ & $0,93(0,63-1,38)$ & $\begin{array}{l}\text { No hubo un mayor riesgo para } \\
\text { las mujeres que utilizaron PVD } \\
\text { durante el primer trimestre de } \\
\text { embarazo ni tampoco, una rela- } \\
\text { ción exposición- respuesta } \\
\text { aparente para el tiempo de uso } \\
\text { de la PVD por semana. }\end{array}$ \\
\hline $\begin{array}{l}\text { Brandt y } \\
\text { Nielsen } \\
\text { (1992) }\end{array}$ & $\begin{array}{l}\text { Tiempo hasta el } \\
\text { embarazo }\end{array}$ & Cohorte & & & $\begin{array}{l}\text { Cuestionario } \\
\text { por correo }\end{array}$ & $1,61(1,09-2,38)$ & $\begin{array}{l}\text { Para un tiempo hasta el } \\
\text { embarazo superior a } 13 \text { meses, } \\
\text { se observó un riesgo relativo } \\
\text { mayor en el grupo con al menos } \\
21 \text { horas de uso de PVD por } \\
\text { semana. }\end{array}$ \\
\hline $\begin{array}{l}\text { Nielsen y } \\
\text { Brandt } \\
\text { (1992) }\end{array}$ & $\begin{array}{l}\text { Bajo peso al nacer, } \\
\text { nacimientos pretér- } \\
\text { mino, tamaño pequeño } \\
\text { para la edad gesta- } \\
\text { tional, mortalidad } \\
\text { infantil }\end{array}$ & Cohorte & $\begin{array}{l}434 \\
443 \\
749 \\
160\end{array}$ & & $\begin{array}{l}\text { Cuestionario } \\
\text { por correo }\end{array}$ & $\begin{array}{l}0,88(0,67-1,66) \\
1,11(0,87-1,47) \\
0,99(0,62-1,94) \\
\text { ND(NS) }\end{array}$ & $\begin{array}{l}\text { No se observó un riesgo mayor } \\
\text { en las mujeres expuestas a las } \\
\text { PVD. }\end{array}$ \\
\hline $\begin{array}{l}\text { Roman y cols. } \\
\text { (1992) }\end{array}$ & Abortos espontáneos & $\begin{array}{l}\text { Casos y } \\
\text { controles }\end{array}$ & 150 & $\begin{array}{l}297 \text { nulíparas } \\
\text { hospitalizadas }\end{array}$ & $\begin{array}{l}\text { Entrevistas } \\
\text { personales }\end{array}$ & $0,9(0,6-1,4)$ & $\begin{array}{l}\text { No hubo relación con el tiempo } \\
\text { de uso de las PVD. }\end{array}$ \\
\hline $\begin{array}{l}\text { Lindbohm } \\
\text { y cols. } \\
\text { (1992) }\end{array}$ & Abortos espontáneos & $\begin{array}{l}\text { Casos y } \\
\text { controles }\end{array}$ & 191 & $\begin{array}{l}394 \text { registros } \\
\text { médicos }\end{array}$ & $\begin{array}{l}\text { Registros labo- } \\
\text { rales de las } \\
\text { mediciones de } \\
\text { campo }\end{array}$ & $\begin{array}{l}1,1(0,7-1,6) \\
3,4(1,4-8,6)\end{array}$ & $\begin{array}{l}\text { La razón entre las trabajadoras } \\
\text { expuestas a intensidades } \\
\text { elevadas de campos magnéticos } \\
\text { y las expuestas a niveles no } \\
\text { detectables fue de } 3,4 \text { (IC } 95 \% \\
1,4-8,6 \text { ) }\end{array}$ \\
\hline $\begin{array}{l}\text { Bramwell y } \\
\text { Davidson } \\
\text { (1994) }\end{array}$ & $\begin{array}{l}\text { Abortos espontáneos, } \\
\text { fecundabilidad }\end{array}$ & Cohorte & 26 & - & $\begin{array}{l}\text { Cuestionario } \\
\text { por correo }\end{array}$ & $\mathrm{ND}(\mathrm{NS})$ & $\begin{array}{l}\text { No hubo relación entre el uso } \\
\text { de PVD y las consecuencias } \\
\text { adversas en el embarazo. }\end{array}$ \\
\hline
\end{tabular}

y Hiatt 1988; Lindbohm y cols. 1992). Ninguno de los ocho estudios sobre malformaciones congénitas mostró un mayor riesgo asociado con la exposición a las PVD. De los ocho estudios que consideraron otras consecuencias adversas en el embarazo, uno describe una asociación estadísticamente significativa entre el tiempo de embarazo y el uso de las PVD (Brandt y Nielsen 1992).

A pesar de que no existen diferencias importantes entre los tres estudios con resultados positivos y los que muestran resultados negativos, los avances en la evaluación de la exposición pueden haber aumentado las posibilidades de detectar un riesgo significativo. Si bien no fue exclusivo de los estudios positivos, estos tres estudios intentaron dividir a las trabajadoras en distintos niveles de exposición. Si existe un factor inherente al uso de las PVD que predisponga a una consecuencia adversa en el embarazo, la dosis recibida por la trabajadora podría influir sobre este resultado. A demás, los resultados de los estudios realizados por Lindbohm y cols. (1992) y Schnorr y cols. (1991) sugieren que sólo una pequeña proporción de las PVD podrían ser responsables del aumento del riesgo de abortos espontáneos entre las usuarias. Si esto es cierto, la incapacidad para identificar estas PVD podría introducir un sesgo y una subestimación del riesgo de abortos espontáneos entre las usuarias de PVD. 
O tros factores asociados con el trabajo con PVD, como el estrés y las restricciones ergonómicas, se han propuesto también como posibles factores de riesgo de consecuencias adversas en el embarazo (M cD onald y cols. 1988; Brandt y Nielsen 1992). EI hecho de que muchos de estos estudios no hayan controlado estos posibles factores de confusión puede haber producido resultados poco fiables.

Aunque puede ser biológicamente plausible que la exposición a niveles elevados de campos magnéticos de extremadamente bajas frecuencias, causados por algunas PVD, conlleve un mayor riesgo de efectos negativos en el embarazo (Bergqvist 1986), sólo se han intentado medir en dos estudios (Schnorr y cols. 1991; Lindbohm y cols. 1992). Los campos magnéticos de frecuencias extremadamente bajas están presentes en cualquier ambiente en el que se utilice electricidad. La contribución de estos campos a los efectos adversos sólo podría detectarse si hubiera una variación, en tiempo o en espacio, de estos campos. Si bien las PVD contribuyen a los niveles totales de los campos magnéticos en el lugar de trabajo, se piensa que sólo un pequeño porcentaje de las PV D tienen una influencia importante en los campos magnéticos medidos en el ambiente de trabajo (L indbohm y cols. 1992). Se piensa que sólo una fracción de las mujeres que trabajan con PVD puede estar expuesta a niveles de radiación magnética superiores a las normalmente encontradas en el ambiente de trabajo (Lindbohm y cols. 1992). L a falta de precisión en la evaluación de la exposición cuando se considera a todos los usuarios de PVD como "expuestos" reduce la capacidad de un estudio para detectar la influencia de los campos magnéticos derivados de las PV D sobre los efectos adversos en el embarazo.

En algunos estudios, mujeres sin trabajos retribuidos representaban una gran proporción de los grupos de comparación en las mujeres expuestas a PVD. En estas comparaciones, ciertos procedimientos de selección pueden haber afectado a los resultados (Infante-Rivard y cols. 1993); por ejemplo, se ha descartado automáticamente de la selección a las mujeres con enfermedades graves, dejando a mujeres sanas con más probabilidades para hallar efectos en la reproducción favorables en la población. Por otra parte, existe también la posibilidad de un "efecto de embarazo no sano en la trabajadora", ya que, las mujeres que tienen hijos pueden dejar de trabajar, mientras que las que no tienen hijos y quienes sufren abortos, pueden continuar trabajando. U na estrategia propuesta para calcular la magnitud de este sesgo es realizar un análisis independiente de las mujeres empleadas y no empleadas.

\section{TRAST ORNOS MUSCULOSQ UELETICOS}

Gabriele Bammer

\begin{abstract}
Introducción
Los operadores de PVD describen con frecuencia problemas musculosqueléticos en el cuello, los hombros y las extremidades superiores. No se trata de problemas exclusivos de los operadores de PVD, sino que también los refieren otros trabajadores que realizan tareas repetitivas o que requieren mantener el cuerpo en una postura fija (carga estática). Las tareas que conllevan el uso de fuerza también se asocian frecuentemente con problemas musculosqueléticos, pero estas tareas no son generalmente un problema de salud y seguridad importante en el caso de los operadores de PVD.

Entre los trabajadores de oficina, cuyo trabajo es por lo general sedentario y no suele estar asociado con un estrés físico,
\end{abstract}

la introducción de las PVD en los lugares de trabajo hizo que los problemas musculosqueléticos relacionados con el trabajo adquiriesen mayor relevancia. Un aumento de tipo epidémico de los problemas registrados a mediados del decenio de 1980 en Australia $y$, en menor grado, en Estados U nidos y el Reino Unido a principios del decenio de 1990, ha dado lugar a un debate sobre si estos síntomas tienen una base fisiológica y si están o no relacionados con el trabajo.

Quienes cuestionan que los problemas musculosqueléticos asociados con el trabajo con PVD (y de otro tipo) tengan una base fisiológica, generalmente defienden uno de los siguientes puntos de vista: los trabajadores fingen que están enfermos; los trabajadores se sienten motivados inconscientemente por las diversas ventajas secundarias, como las pagas compensatorias 0 los beneficios psicológicos de estar enfermo, conocidos como neurosis compensatoria; los trabajadores están convirtiendo un conflicto psicológico no resuelto 0 un trastorno emocional en síntomas físicos, es decir, trastornos de conversión y por último, que la fatiga normal se está exagerando desproporcionadamente por un proceso social que cataloga tal fatiga como un problema, conocido como iatrogénesis social. Un análisis riguroso de las evidencias para estas explicaciones alternativas muestra que no están tan bien fundamentadas como las que plantean una base fisiológica para estos trastornos (Bammer y Martin 1988). A pesar de que cada vez hay más indicios de que los trastornos musculosqueléticos tienen una base fisiológica, se desconoce la naturaleza exacta de estos problemas (Q uintner y Elvey 1990; Cohen y cols. 1992; Fry 1992; Helme, LeVasseur y Gibson 1992).

\section{Prevalencia de los síntomas}

Numerosos estudios han documentado la prevalencia de los problemas musculosqueléticos entre los operadores de PVD. Se han llevado a cabo principalmente en los países occidentales industrializados, aunque el interés por estos problemas es cada vez mayor en los países asiáticos y latinoamericanos, inmersos en un proceso rápido de industrialización. Existe una variación considerable de un país a otro en la forma en que se describen los trastornos musculosqueléticos y en el tipo de estudios realizados. L a mayoría de los estudios se basan en los síntomas referidos por los trabajadores, más que en los resultados de reconocimientos médicos. En general, los estudios pueden dividirse en tres grupos: los que han examinado lo que puede denominarse problemas compuestos, los que se han centrado en trastornos específicos y los que se han centrado en los problemas en una zona concreta 0 en un pequeño grupo de zonas.

\section{Problemas compuestos}

El término se refiere a una mezcla de problemas, que puede incluir dolor, pérdida de fuerza y trastornos sensoriales en diversas partes de la mitad superior del cuerpo. Los problemas compuestos se tratan como una sola entidad, conocida en Australia y el Reino U nido como lesiones por esfuerzos repetitivos (LER), en Estados Unidos como trastornos por traumas acumulativos (TTA) y en Japón como trastornos cervicobraquiales profesionales (TCP). En una revisión realizada en 1990 (Bammer 1990) sobre estos problemas en los trabajadores de oficinas (el $75 \%$ de los estudios se realizó con trabajadores que utilizaban PVD), se encontró que 70 estudios habían investigado los problemas compuestos y 25 de ellos habían descrito que ocurrían en un rango de frecuencias de entre el 10 y el $29 \%$ de los trabajadores estudiados. En los extremos, tres estudios no habían encontrado problemas, mientras que otros tres habían determinado que el $80 \%$ de los trabajadores padecían trastornos musculosqueléticos. La mitad de los estudios describían también problemas graves 0 frecuentes y 19 de ellos indicaban una 
Tabla 52.7 • Resumen de los estudios de campo empíricos que han utilizado un análisis multivariante para estudiar las causas de los problemas musculosqueléticos entre los trabajadores de oficina.

\begin{tabular}{|c|c|c|c|c|}
\hline \multirow[b]{2}{*}{ Referencia } & \multirow[b]{2}{*}{$\begin{array}{l}\text { № \% \% usua- } \\
\text { rios de PVD }\end{array}$} & \multicolumn{3}{|c|}{ Factores } \\
\hline & & $\begin{array}{l}\text { Ajenos al } \\
\text { trabajo }\end{array}$ & $\begin{array}{l}\text { Bio- } \\
\text { mecánicos }\end{array}$ & $\begin{array}{l}\text { Organización } \\
\text { del trabajo }\end{array}$ \\
\hline Blignault (1985) & $146 / 90 \%$ & 0 & 0 & • \\
\hline $\begin{array}{l}\text { División de epidemio- } \\
\text { logía de la South } \\
\text { Australian Health } \\
\text { Commission (1984) }\end{array}$ & $456 / 81 \%$ & $\bullet$ & $\bullet$ & $\bullet$ \\
\hline $\begin{array}{l}\text { Ryan, Mullerworth y } \\
\text { Pimble (1984) }\end{array}$ & $52 / 100 \%$ & $\bullet$ & • & $\bullet$ \\
\hline $\begin{array}{l}\text { Ryan y } \\
\text { Bampton (1988) }\end{array}$ & 143 & & & \\
\hline $\begin{array}{l}\text { Ellinger y cols. } \\
\text { (1982) }\end{array}$ & 280 & $\bullet$ & • & $\bullet$ \\
\hline $\begin{array}{l}\text { Pot, Padmos y } \\
\text { Bowers (1987) }\end{array}$ & $222 / 100 \%$ & $\begin{array}{l}\text { no } \\
\text { estudiados }\end{array}$ & $\bullet$ & $\bullet$ \\
\hline $\begin{array}{l}\text { Sauter y cols. } \\
\text { (1983b) }\end{array}$ & $251 / 74 \%$ & 0 & • & $\bullet$ \\
\hline $\begin{array}{l}\text { Stellman y cols. } \\
\text { (1987a) }\end{array}$ & $\begin{array}{l}1.0321 \\
42 \%\end{array}$ & $\begin{array}{l}\text { no } \\
\text { estudiados }\end{array}$ & • & $\bullet$ \\
\hline \multicolumn{5}{|c|}{$\begin{array}{l}\mathbf{O}=\text { no factor } \quad \bullet=\text { factor } \\
\text { Fuente: Adaptado de Bammer } 1990 .\end{array}$} \\
\hline
\end{tabular}

prevalencia de entre un 10 y un $19 \%$. En un estudio no se describieron problemas, mientras que en otro, se describieron en el $59 \%$ de los trabajadores. Las prevalencias más elevadas se encontraron en Australia y Japón.

\section{Trastornos específicos}

Los trastornos específicos incluyen problemas relativamente bien definidos, como la epicondilitis o el síndrome del túnel carpiano. Son trastornos menos frecuentemente estudiados y que ocurren con menor frecuencia. De 43 estudios realizados sobre este tema, 20 hallaron estos trastornos en un 0,2 a un $4 \%$ de los trabajadores. En cinco estudios no se encontraron indicios de trastornos específicos y en un estudio se observaron en el $40-49 \%$ de los trabajadores.

\section{Partes específicas del cuerpo}

0 tros estudios se han centrado en zonas concretas del cuerpo, como el cuello o las muñecas. Los problemas cervicales son los más frecuentes y se han investigado en 72 estudios, 15 de los cuáles han demostrado que ocurren en un 40 a un $49 \%$ de los trabajadores. Tres estudios hallaron estos problemas en el 5 - $9 \%$ de los trabajadores y un estudio, en más del $80 \%$. M enos de la mitad de estos estudios investigaron problemas graves, y generalmente los observaron con una frecuencia de entre un $5 \%$ y un $39 \%$. Tales niveles elevados de problemas cervicales se han encontrado en distintas partes del mundo, como Australia, Finlandia, Francia, Alemania, Japón, N oruega, Singapur, Suecia, Suiza, el Reino U nido y Estados U nidos. En cambio, sólo en 18 estudios se investigaron los problemas de las muñecas; de éstos, siete observaron este tipo de problemas en un $10 \%$ a un $19 \%$ de los trabajadores. Un estudio los describió en un 0,5 a un $4 \%$ de los trabajadores y otro, entre un 40 - $49 \%$.

\section{Causas}

En general, todo el mundo coincide en que la introducción de las PVD está asociada con un aumento de los movimientos repetitivos y un aumento de la carga estática debido al aumento de la velocidad de pulsación, y de la reducción (en comparación con las máquinas de escribir) de las tareas no relacionadas con el teclado, como cambiar de hoja, esperar los retornos del carro o el uso de cinta o líquido corrector. L a necesidad de mirar la pantalla también puede producir un aumento de la carga estática y la colocación inadecuada de la pantalla, del teclado o de las teclas de función puede dar lugar a posturas que pueden favorecer la aparición de problemas. También existen indicios de que la introducción de las PVD pueden asociarse con una reducción del personal y un aumento de la carga de trabajo. Asimismo, puede producir cambios en los aspectos psicosociales del trabajo, incluidas las relaciones sociales y jerárquicas, las responsabilidades de los trabajadores, las perspectivas profesionales y la carga mental de trabajo. En algunos lugares de trabajo, estos cambios han seguido una dirección favorable para los trabajadores, mientras que en otros, han producido un menor control del trabajador sobre su trabajo, falta de apoyo social para el trabajo, "descualificación", falta de oportunidades de promoción, ambigüedad en las funciones, estrés mental y vigilancia electrónica (ver revisión de Bammer 1987b y el informe de la OMS 1989 sobre una reunión de la O rganización M undial de la Salud). La asociación entre algunos de estos cambios psicosociales y los problemas musculosqueléticos se comenta a continuación. También parece que la introducción de las PVD ha contribuido a estimular un movimiento social en Australia que tuvo como consecuencia el reconocimiento de la existencia y relevancia de estos problemas (Bammer y M artin 1992).

Las causas pueden analizarse, por lo tanto, a nivel individual, social o del lugar de trabajo. A nivel individual, las causas posibles de estos trastornos pueden dividirse en tres categorías: trastornos no relacionados con el trabajo, factores biomecánicos y factores de la organización del trabajo (véase la Tabla 52.7). Se han utilizado varios enfoques para el estudio de las causas, pero los resultados obtenidos en conjunto han sido similares a los de estudios de campo empíricos en los que se ha utilizado el análisis multivariable (Bammer 1990). L os resultados de estos estudios se resumen en las Tablas 52.7 y 52.8. Estudios más recientes corroboran estos resultados generales.

\section{Factores no relacionados con el trabajo}

Existen pocos indicios de que factores no relacionados con el trabajo sean causas importantes de estos trastornos, aunque existen algunos indicios de que las personas con una lesión previa en la zona correspondiente o con problemas en otras partes del cuerpo pueden tener una mayor probabilidad de desarrollar problemas. No existe una relación clara con la edad y en un estudio en el que se examinó la relación con la neurosis no se encontró ninguna.

\section{Factores biomecánicos}

Se ha hallado que trabajar con determinadas articulaciones en ángulos extremos está asociado con problemas musculosqueléticos. Los efectos debidos a otros factores biomecánicos están menos definidos y algunos estudios han hallado que son importantes, mientras otros no. Estos factores son: la evaluación de la adecuación del mobiliario y del equipo por los investigadores, la evaluación de la adecuación del mobiliario y/ o del equipo por los trabajadores; los factores visuales en el lugar de trabajo, como reflejos; los factores visuales personales, como el uso de gafas; y la antigüedad en el puesto 0 como trabajador de oficina (Tabla 52.8). 
Tabla 52.8 • Resumen de estudios que muestran la implicación de ciertos factores considerados causa de problemas musculosqueléticos en los trabajadores de oficina.

\begin{tabular}{|c|c|c|c|c|c|c|c|c|c|c|c|c|c|c|c|}
\hline \multirow[b]{2}{*}{ País ${ }^{1}$} & \multirow[b]{2}{*}{$\begin{array}{l}\text { Noy } \% \\
\text { usuarios } \\
\text { de PVD }\end{array}$} & \multicolumn{3}{|c|}{$\begin{array}{c}\text { No relacionados con el } \\
\text { trabajo }\end{array}$} & \multicolumn{6}{|c|}{ Biomecánicos } & \multicolumn{5}{|c|}{ Organización del trabajo } \\
\hline & & Edad & $\begin{array}{l}\text { Predisp. } \\
\text { biológica }\end{array}$ & $\begin{array}{l}\text { Neuro- } \\
\text { ticismo }\end{array}$ & $\begin{array}{l}\text { Angulos } \\
\text { articu- } \\
\text { lares }\end{array}$ & $\begin{array}{l}\text { Eval. } \\
\text { Obj. } \\
\text { Mobil. } \\
\text { Equip. }\end{array}$ & $\begin{array}{l}\text { Eval. } \\
\text { Subj. } \\
\text { Mobil. } \\
\text { Equip. }\end{array}$ & $\begin{array}{l}\text { Trabajo } \\
\text { visual }\end{array}$ & $\begin{array}{l}\text { Visión } \\
\text { individuo }\end{array}$ & $\begin{array}{l}\text { Anti- } \\
\text { güedad } \\
\text { en el } \\
\text { puesto }\end{array}$ & Presión & $\begin{array}{l}\text { Auto- } \\
\text { nomía }\end{array}$ & $\begin{array}{l}\text { Cohesión } \\
\text { entre } \\
\text { compa- } \\
\text { ñeros }\end{array}$ & Variedad & $\begin{array}{l}\text { Uso del } \\
\text { teclado } \\
\text { (h) }\end{array}$ \\
\hline Australia & $\begin{array}{l}146 / \\
90 \%\end{array}$ & $\varnothing$ & & $\varnothing$ & & $\varnothing$ & & & & $\varnothing$ & $\mathrm{O}$ & $\bullet$ & $\bullet$ & $\bullet$ & $\varnothing$ \\
\hline Australia & $\begin{array}{l}456 / \\
81 \%\end{array}$ & $\bullet$ & $\mathrm{O}$ & & & $\boldsymbol{\square}$ & & & & $\varnothing$ & $\mathrm{O}$ & & & $\bullet$ & 0 \\
\hline Australia & $\begin{array}{l}52 / 143 / \\
100 \%\end{array}$ & $\boldsymbol{\Delta}$ & & & $\mathbf{\square}$ & $\mathbf{\square}$ & & & & 0 & $\mathrm{O}$ & & $\bullet$ & & 0 \\
\hline Alemania & 280 & O & $\mathrm{O}$ & & & $\mathbf{\square}$ & $\varnothing$ & $\mathbf{\square}$ & & 0 & 0 & $\bullet$ & & & 0 \\
\hline $\begin{array}{l}\text { Países } \\
\text { Bajos }\end{array}$ & $\begin{array}{l}2221 \\
100 \%\end{array}$ & & & & $\boldsymbol{\square}$ & $\mathbf{\square}$ & & $\varnothing$ & $\varnothing$ & & $\mathrm{O}$ & & $\bullet$ & $(\varnothing)$ & O \\
\hline $\begin{array}{l}\text { Estados } \\
\text { Unidos }\end{array}$ & $\begin{array}{l}251 / \\
74 \%\end{array}$ & $\varnothing$ & & & & $\varnothing$ & $\boldsymbol{\square}$ & & $\mathbf{\square}$ & & $\mathrm{O}$ & $\bullet$ & & $(\varnothing)$ & $\bullet$ \\
\hline $\begin{array}{l}\text { Estados } \\
\text { Unidos }\end{array}$ & $\begin{array}{l}1.0321 \\
42 \%\end{array}$ & & & & & $\varnothing$ & $\mathbf{\square}$ & & & & $\mathrm{O}$ & - & & $\bullet$ & \\
\hline
\end{tabular}

$\mathrm{O}=$ asociación positiva, estadísticamente significativa. $\quad \bullet=$ asociación negativa, estadísticamente significativa. $\quad \boldsymbol{a}=$ asociación estadísticamente significativa no direccional. $\varnothing=$ asociación no estadísticamente significativa. $(\varnothing)=$ no variabilidad del factor en este estudio. $\boldsymbol{\Delta}=$ el número de síntomas fue mayor en los más jóvenes y en los de mayor edad. 1El recuadro vacío significa que el factor no se incluyó en este estudio.

Fuente: Adaptado de Bammer 1990

\section{Factores relacionados con la organización}

Existen varios factores de la organización del trabajo claramente asociados con los problemas musculosqueléticos. Se describen con más detalle en otras secciones de este capítulo. Entre ellos están: la elevada presión de trabajo, la baja autonomía (es decir, poco nivel de control sobre el trabajo), la poca cohesión entre compañeros (es decir, poco apoyo de otros compañeros de trabajo), lo que significa que los trabajadores no reciben ayuda de los demás en los momentos de mayor presión y poca diversidad del trabajo.

El único factor estudiado, y con el que se obtuvieron resultados muy variados, fue el número de horas de trabajo con un teclado (Tabla 52.8). En general, se observa que las causas de los problemas musculosqueléticos a nivel individual son multifactoriales. Los factores relacionados con el trabajo, en especial la organización del trabajo, pero también los factores biomecánicos, tienen un papel claro. L os factores específicos más importantes pueden variar de un lugar de trabajo a otro y entre una persona y otra, dependiendo de las circunstancias individuales. Por ejemplo, el uso generalizado de apoyos para las muñecas en un lugar de trabajo en el que los problemas principales son un nivel de presión muy elevado y poca variedad de tareas no es probable que sea una estrategia eficaz. Por otra parte, un trabajador con una carga de trabajo satisfactoria y una diversidad de tareas podría, a pesar de todo, presentar problemas si la PV D está colocada en un ángulo inadecuado.

La experiencia australiana, en donde la prevalencia de los problemas musculosqueléticos disminuyó a finales del decenio de 1980, puede resultar útil para indicar cómo pueden abordarse las causas de estos problemas. Aunque este proceso no se ha documentado ni se ha investigado detalladamente, es probable que hayan existido varios factores asociados con esta disminución de la prevalencia. U no de ellos ha sido la introducción generalizada de mobiliario y equipos de diseño "ergonómico" en los lugares de trabajo. También se han mejorado las prácticas de trabajo a través de una multiplicidad de tareas y una reestructuración para reducir la presión y aumentar la autonomía y la variedad. Tales cambios estuvieron acompañados a menudo con la aplicación de una mayor igualdad de oportunidades de empleo y con estrategias de democracia industrial. A simismo, se llevaron a cabo estrategias generalizadas de prevención y de intervención precoz. De una forma menos positiva, algunos lugares de trabajo parecen haber aumentado su dependencia en los trabajadores temporales para realizar los trabajos repetitivos de teclado. Ello significa que los problemas no estarían relacionados con la empresa, sino que serían responsabilidad exclusiva del trabajador. Además, la importante controversia originada alrededor de estos problemas ha ocasionado que se estigmaticen, de forma que muchos trabajadores son ahora más renuentes a quejarse 0 a reclamar indemnizaciones cuando desarrollan algún síntoma. El problema se agudizó cuando algunos trabajadores comenzaron a perder los juicios entablados contra las empresas, rodeados de una gran publicidad. La reducción de los fondos para la investigación, la suspensión de publicaciones sobre la incidencia y prevalencia estadísticas y de publicaciones científicas sobre estos trastornos, así como la pérdida de interés de los medios de comunicación por estos problemas han hecho que parezca que el problema ha desaparecido.

\section{Conclusión}

Los problemas musculosqueléticos relacionados con el trabajo son un problema importante en todo el mundo. Significan un coste enorme tanto para el individuo como para la sociedad. $\mathrm{N}$ o existen criterios aceptados internacionalmente para estos trastornos y es necesario un sistema internacional de clasificación. D ebe hacerse énfasis en la prevención y en la intervención precoz, que debe ser multifactorial. Es necesario enseñar los principios ergonómicos a todos los niveles, desde la educación básica hasta la universitaria y deben existir directrices y 
normas basadas en los requisitos mínimos. Su puesta en práctica requiere tanto el compromiso de la empresa como la participación activa de los empleados (H agberg y cols. 1993).

A pesar de los numerosos casos registrados de personas con problemas graves y crónicos, existen pocas evidencias de tratamientos eficaces o de la mejor forma de rehabilitar a estos trabajadores para que puedan reintegrarse a la población activa. Lo cual demuestra que la prevención y la intervención precoz son las estrategias más importantes para controlar los problemas musculosqueléticos relacionados con el trabajo.

\section{Problemas de LA PIEL}

Los primeros informes de problemas de la piel entre las personas que trabajaban cerca de una PVD proceden de Noruega, en 1981. En el Reino U nido, Estados U nidos y Japón también se han descrito algunos casos. En Suecia, sin embargo, se han publicado numerosos casos, y los debates sobre los efectos del uso de las PVD sobre la salud se intensificaron cuando el Consejo Nacional de Aseguradoras sueco reconoció en 1985 un caso de enfermedad dérmica en un operador de PVD como una enfermedad profesional. La aceptación de la indemnización en este caso coincidió con un aumento notable del número de casos de

\section{Estudios de casos: las PVD y los problemas de piel}

Suecia: 450 pacientes fueron identificados y examinados por problemas de piel que atribuían al trabajo con PVD. Sólo se detectaron dermatosis faciales comunes y ninguno de los pacientes presentó dermatosis específicas que pudieran estar relacionadas con el uso de las PVD. A pesar de que muchos pacientes consideraban que sus síntomas eran importantes, las lesiones visibles de la piel eran, en realidad, leves de acuerdo con las definiciones médicas habituales, y la mayoría de los pacientes observaron una mejoría sin necesidad de tratamiento farmacológico a pesar de que continuaron utilizando PVD. Muchos de estos pacientes padecían alergias de contacto identificables, lo que explicaba sus síntomas de piel. Los estudios epidemiológicos en los que se comparó a pacientes que trabajaban con PVD con una población control no expuesta con un estado de piel similar no mostró ninguna relación entre el estado de la piel y el uso de las PVD. Por último, en un estudio de provocación tampoco se demostró ninguna relación entre los síntomas de los pacientes y los campos electrostáticos o magnéticos producidos por las PVD (W ahlberg y Lidén 1988; Berg 1988; Ldén 1990; Berg, Hedblad y Erhardt 1990; Swanbeck y Bleeker 1989). En cambio, a diferencia de los resultados obtenidos en los escasos estudios epidemiológicos iniciales (M urray y cols. 1981; Frank 1983; Lidén y W ahlberg 1985), en un estudio epidemiológico a gran escala (Berg, Lidén y Axelson 1990; Berg 1989) de 3.745 trabajadores administrativos seleccionados aleatoriamente, de los cuales 809 se sometieron a un examen médico, se mostró que, a pesar de que los empleados expuestos a las PVD presentaban significativamente más problemas de piel que la población control no expuesta, la exploración médica no reveló síntomas de piel más visibles o más enfermedades de la piel.

Gales [RU]: en un estudio mediante cuestionario no se hallaron diferencias entre los problemas de piel manifestados por trabajadores que utilizaban PVD y una población control (C armichael y Roberts 1992).

Singapur: una población control de profesores presentó significativamente más problemas de piel que los usuarios de PVD (Koh y cols. 1991). enfermedades dérmicas que se sospechaba que estuvieran relacionados con el uso de las PV D. En el departamento de dermatología laboral del $\mathrm{H}$ ospital $\mathrm{K}$ arolinska de Estocolmo, el número de casos aumentó de siete entre 1979 y 1985 a 100, entre noviembre de 1985 y mayo de 1986.

A pesar del número relativamente grande de personas que acudieron en busca de un tratamiento médico, por lo que ellos creían que eran problemas de piel relacionados con el uso de las PVD, no existen pruebas concluyentes de que las PVD, por sí mismas, causen enfermedades dérmicas de origen profesional. $L a$ frecuencia de enfermedades dérmicas en personas expuestas a las PVD parece tratarse de una coincidencia o podría estar relacionada con otros factores del lugar de trabajo. La observación de que el aumento en la incidencia de quejas por problemas de piel entre los operadores de PVD suecos no se haya observado en otros países en los que el debate en los medios de comunicación no ha sido tan intenso, corrobora esta conclusión. Además, los datos científicos obtenidos en estudios de provocación, en los que se ha expuesto intencionalmente a pacientes a campos electromagnéticos relacionados con las PV D para determinar si podía inducirse un efecto en la piel, no muestran datos significativos que permitan demostrar un posible mecanismo para el desarrollo de estos problemas que pudiera estar relacionado con los campos derivados de las PVD.

Con todo, es posible que el estrés relacionado con el trabajo sea un factor importante para explicar las molestias dérmicas asociadas con el uso de las PVD. Por ejemplo, en estudios de seguimiento de subgrupo de empleados de oficina expuestos a las PVC que estaban siendo estudiados por problemas de piel, se comprobó que el número de empleados del grupo con síntomas dérmicos que experimentaban estrés laboral era significativamente mayor que en el grupo sin síntomas de piel. Se observó una correlación entre los niveles de las hormonas sensibles al estrés, (testosterona, prolactina y tiroxina) y los síntomas de piel durante los días que trabajaban, pero no en sus días libres. Así, una posible explicación de las molestias faciales asociadas con el uso de PVD podría ser por los efectos de la tiroxina, que produce una dilatación de los vasos sanguíneos (Berg y cols. 1992).

\section{ASPECTOS PSICOSO CIALES DEL TRABAJO CON PVD}

M ichael J. Smith y Pascale Carayon

\section{Introducción}

L os ordenadores proporcionan eficiencia, ventajas competitivas y la capacidad de desarrollar procesos que no serían posibles de otra forma. Algunas áreas, como el control de procesos de fabricación, la gestión de inventarios, la gestión de registros, el control de sistemas complejos o la automatización de las oficinas se han beneficiado del uso de la informática. La informatización requiere una infraestructura considerable para que funcione adecuadamente. A demás de los cambios arquitectónicos y eléctricos necesarios para el uso de las máquinas, la introducción de los equipos informáticos requiere cambios en conocimiento y preparación de los empleados y la aplicación de nuevos métodos de gestión del trabajo. Las demandas de los trabajos que utilizan equipos informáticos pueden ser muy distintas de las de trabajos tradicionales. Con frecuencia, los trabajos informatizados son más sedentarios y pueden requerir más actividad mental y atención en las tareas y, al mismo tiempo, un menor consumo físico de energía. Las demandas de producción pueden ser elevadas, 
con una presión de trabajo constante y pocas posibilidades para la toma de decisiones.

Las ventajas económicas del uso de ordenadores en el trabajo han restado importancia a los posibles problemas sociales, de salud y seguridad para los trabajadores, como la pérdida de trabajo, los trastornos por traumas acumulativos y el mayor estrés mental. En muchos lugares de trabajo, la transición de formas tradicionales de trabajo a la informatización ha sido difícil y ha producido problemas psicosociales y sociotécnicos importantes para los trabajadores.

\section{Problemas psicosociales específicos de las PVD}

L as investigaciones realizadas (por ejemplo, Bradley 1983 y 1989; Bikson 1987; Westlander 1989; Westlander y Aberg 1992; Johansson y Aronsson 1984; Stellman y cols. 1987b; Smith y cols. 1981 y 1992a) han documentado cómo la introducción de los ordenadores en el lugar de trabajo han producido cambios importantes en el proceso del trabajo, las relaciones sociales, el estilo de gestión y en la naturaleza y contenido de las tareas. En el decenio de 1980, la ejecución del cambio tecnológico en la informatización era por lo general un proceso "de arriba a abajo", en el que los trabajadores no tenían derecho a participar en las decisiones relacionadas con la nueva tecnología o las nuevas estructuras de trabajo. Como resultado, surgieron gran cantidad de problemas físicos, de salud mental y de relaciones en las empresas.

Existe cierta controversia entre los expertos sobre los logros de los cambios que se están produciendo en las oficinas. M ientras que algunos opinan que la tecnología informática aumenta la calidad del trabajo y la productividad (Strassmann 1985), otros comparan los ordenadores con formas anteriores de tecnología, como las líneas de montaje de producción, y consideran que empeoran las condiciones de trabajo y aumentan el estrés laboral (M oshowitz 1986; Zuboff 1988). Nosotros consideramos que la tecnología de las pantallas de visualización de datos (PVD) afecta realmente al trabajo de distintas formas, pero que la tecnología es sólo un elemento de un sistema de trabajo mucho más amplio, que incluye factores relacionados con el individuo, las tareas, el entorno y la organización.

\section{Conceptualización del diseño del trabajo informatizado}

M uchas condiciones de trabajo afectan conjuntamente al usuario de PVD. Los autores proponen un modelo de diseño integral del trabajo que ilustra los distintos aspectos de las condiciones de

Figura 52.9 - Modelo de las condiciones de trabajo y su impacto sobre el individuo.

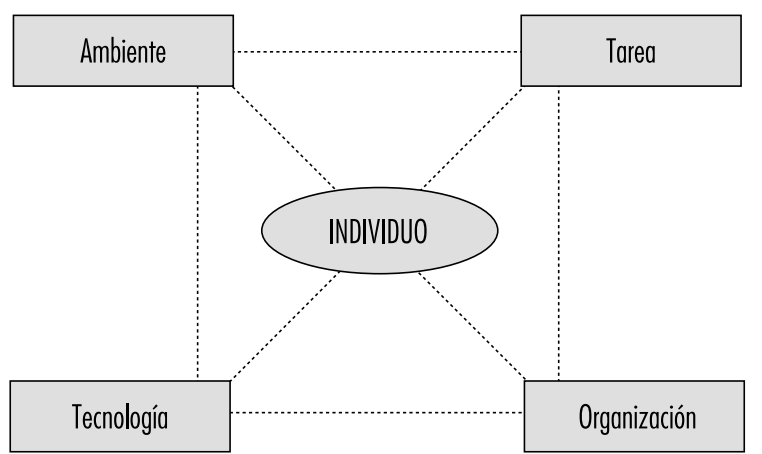

Fuente: Smith y Carayon-Sainfort 1989 trabajo que pueden interactuar y acumularse para producir estrés (Smith y Carayon-Sainfort 1989). En la Figura 52.9 se muestra este modelo conceptual para los distintos elementos de un sistema de trabajo que pueden ejercer cargas sobre los trabajadores y producir estrés. En el centro de este modelo está el individuo, con sus características físicas, percepción, personalidad y comportamiento distintivos. El individuo utiliza la tecnología para realizar tareas específicas de su trabajo. La naturaleza de la tecnología determina, en gran medida, el rendimiento y las habilidades y conocimientos necesarios para que el trabajador pueda utilizarla de forma eficaz. L os requisitos de la tarea también influyen sobre los niveles de conocimientos y cualificación necesarios. Tanto las tareas como las tecnologías afectan el contenido del trabajo y las exigencias mentales y físicas. El modelo también muestra que las tareas y las tecnologías están dentro de un contexto de trabajo que incluye el ambiente físico y social. El propio ambiente global también puede afectar a la comodidad, los estados psicológicos y las actitudes. Por último, la estructura organizativa define la naturaleza y el nivel de participación individual, las relaciones entre los trabajadores y los niveles control. La naturaleza de la organización afecta a la supervisión y a las normas de rendimiento.

Este modelo ayuda a explicar las relaciones entre los requisitos del trabajo, las cargas físicas y psicológicas y las tensiones resultantes. Representa un concepto de sistema en el que cualquiera de los elementos puede influir sobre todos los demás, y en el que todos los elementos interactúan para determinar la forma en que se lleva a cabo el trabajo y la eficiencia de éste para satisfacer las necesidades y objetivos individuales y de la empresa. La aplicación de este modelo al lugar de trabajo con PVD se describe a continuación.

\section{M edio ambiente}

Los factores del ambiente físico se consideran estresores, en la oficina y en cualquier otro lugar. La calidad del aire general y su limpieza contribuyen, por ejemplo, al síndrome del edificio enfermo y a otras respuestas de estrés (Stellman y cols. 1985; Hedge, Erickson y Rubin 1992.) El ruido es un estresor bien conocido que puede causar el aumento del "arousal", de la presión sanguínea y un estado psicológico negativo (Cohen y Weinstein 1981). 0 tros ejemplos podrían ser aquellas condiciones ambientales que producen alteraciones sensoriales y dificultan el desempeño de las tareas, aumentando el estrés y la irritabilidad emocional de los trabajadores (Smith y cols. 1981; Sauter y cols. 1983b).

\section{Tarea}

Con la introducción de la tecnología informática, aumentan las expectativas de rendimiento, lo cual crea una presión adicional sobre los trabajadores, ya que se espera que su rendimiento sea siempre el más alto. U na carga de trabajo excesiva y la presión en el trabajo son estresores significativos para los usuarios de ordenadores (Smith y cols. 1981; Piotrkowski, Cohen y Coray 1992; Sainfort 1990). Están apareciendo nuevos tipos de exigencias de trabajo al aumentar el uso de los ordenadores. Las exigencias cognitivas, por ejemplo, pueden convertirse en fuentes de un mayor estrés para los usuarios de las PVD (Frese 1987). Todos estos son aspectos de las exigencias del trabajo.

También existen aspectos positivos, ya que los ordenadores son capaces de realizar muchas de las tareas sencillas y repetitivas que antes se realizaban manualmente, con lo cual se reduce la repetitividad del trabajo, se enriquece su contenido y se amplía su significado. Ahora bien, esto no puede generalizarse, ya que muchos de los nuevos trabajos con ordenador, como la entrada de datos, siguen siendo repetitivos y aburridos. LoS ordenadores también proporcionan retroalimentación sobre el 


\section{Control electrónico del rendimiento de los empleados}

El uso de métodos electrónicos para registrar el rendimiento del trabajo de los empleados ha aumentado notablemente con la generalización del uso de los ordenadores personales, que convierten tal registro en un proceso sencillo y rápido. Las empresas pueden utilizar esa información para gestionar mejor los recursos tecnológicos y humanos. El control electrónico permite detectar cuellos de botella, retrasos en la producción y un rendimiento de los empleados inferior a la media (o al estándar) en tiempo real. Las nuevas tecnologías de comunicación electrónica tienen la capacidad de realizar un seguimiento del rendimiento de elementos individuales del sistema de comunicación y de señalar las aportaciones de trabajadores concretos. A través de la vigilancia electrónica es posible examinar elementos de trabajo, tales como la entrada de datos en los terminales del ordenador, las conversaciones telefónicas y los mensajes de correo electrónico.

El control electrónico aumenta el control directivo sobre los trabajadores y puede dar lugar a la adopción de estrategias directivas de organización que produzcan estrés. Esto genera interrogantes importantes acerca de la precisión del sistema de control y se refleja bien la contribución del trabajador al éxito de la empresa, la invasión de la privacidad del trabajador, trabajador frente a la tecnología en el control de las tareas y las repercusiones de los estilos de dirección que utilizan la información electrónica para dirigir la conducta de los trabajadores (Smith y Amick 1989; Amick y Smith 1992; Carayon 1993b). Es posible que el control aumente la producción, pero también puede producir estrés laboral, absentismo, rotación del personal y sabotaje. Cuando al control electrónico se añade el uso de incentivos para aumentar la producción, también puede aumentar el estrés relacionado con el trabajo (O TA 1987; Smith y cols. 1992a). Además, este tipo de control electrónico del rendimiento crea problemas relacionados con la privacidad de los trabajadores (0 IT 1991): en muchos países se ha prohibido su utilización.

Un requisito básico del control electrónico es que las tareas puedan dividirse en actividades fácilmente medibles y cuantificables, lo que suele implicar una concepción del trabajo que reduce el contenido de las tareas, ya que elimina la complejidad y la necesidad de pensar, que se ven sustituidas por acciones repetitivas. La filosofía subyacente es similar al principio básico de "O rganización cient́fica" (Taylor 1911), que recomienda la "simplificación" del trabajo.

rendimiento, lo que no es posible con otras tecnologías ( $\mathrm{K}$ alimo y Leppanen 1985), lo cual permite reducir la ambigüedad.

Algunos aspectos del trabajo informatizado han sido relacionados con un menor control, el cual se ha identificado como una fuente importante de estrés para los usuarios de ordenadores en oficinas. La incertidumbre relacionada con la duración de los problemas en los ordenadores, como las caídas y el tiempo de inactividad del sistema, pueden ser una fuente de estrés (Johansson y Aronsson 1984; Carayon-Sainfort 1992). LoS problemas en los ordenadores pueden ser especialmente estresantes si los trabajadores dependen de forma importante de la tecnología para realizar su trabajo, como es el caso de los empleados encargados de la reserva de billetes en las compañías aéreas.

\section{Tecnología}

El tipo de tecnología utilizada por el trabajador define con frecuencia su cualificación para realizar las tareas y el grado de carga fisiológica y psicológica. Si la tecnología produce una carga de trabajo excesiva o insuficiente, puede producir más estrés y efectos adversos para la salud física (Smith y cols. 1981; Johansson y Aronsson 1984; O stberg y N ilsson 1985). La tecnología cambia rápidamente, obligando a los trabajadores a adaptar continuamente sus conocimientos y cualificación para mantenerse al día. Además, la especialización actual puede quedarse obsoleta rápidamente. Tal "obsolescencia" tecnológica puede
En una empresa, por ejemplo, se introdujo un dispositivo de control telefónico en el nuevo sistema telefónico para los operadores de servicio al cliente. Tal sistema distribuía las llamadas telefónicas entrantes de los clientes, calculaba el tiempo de cada llamada y permitía al supervisor escuchar las conversaciones telefónicas del empleado. Fue instituido como una herramienta de ordenación del flujo de trabajo para determinar los períodos de máxima entrada de llamadas, con el fin de saber cuando era necesario un operador extra. En lugar de utilizar el sistema de control sólo con este fin, la dirección de la empresa utilizó también los datos para establecer patrones de rendimiento del trabajo (segundos por transacción) y para iniciar acciones disciplinarias contra los empleados con un "rendimiento inferior a la media". Este sistema de control electrónico presionaba a trabajar con un rendimiento superior a la media por temor a represalias. Los estudios han mostrado que tales presiones de trabajo no contribuyen a un buen rendimiento, sino que producen consecuencias adversas sobre la salud (Cooper y Marshall 1976; Smith 1987). De hecho, en este caso se demostró que el sistema de control aumentó el estrés de los empleados y disminuyó la calidad de la producción (Smith y cols. 1992a).

El control electrónico puede influir en la imagen que los empleados tienen de sí mismos y en los sentimientos sobre su valía personal. En algunos casos, el control puede aumentar la autoestima si el trabajador recibe información sobre los resultados positivos de su actuación. El hecho de que la dirección se interese por el trabajador como un recurso valioso es otro resultado positivo. Con todo, los trabajadores perciben estos efectos de distinta forma, en especial si el bajo rendimiento conlleva sanciones o reprimendas. El temor a una evaluación negativa produce ansiedad y daña la autoestima y la imagen que los trabajadores tienen de sí mismos. El control electrónico puede originar condiciones adversas de trabajo, como el trabajo con un ritmo impuesto, falta de participación de los trabajadores, reducción de la variedad y definición de las tareas, disminución del apoyo social entre compañeros y por parte de los supervisores, temor a perder el empleo, monotonía de las actividades y falta de control sobre las tareas (A mick y Smith 1992; Carayon 1993).

Michael J. Smith

deberse a la descualificación del trabajo y al empobrecimiento de su contenido, así como a una formación y especialización inadecuadas. Los trabajadores que no cuentan con el tiempo o los recursos necesarios para mantenerse al día en la tecnología pueden sentirse amenazados por ésta y sentir temor ante la posibilidad de perder su empleo. Así, los temores de los trabajadores de que su cualificación sea inadecuada para utilizar las nuevas tecnologías son una de las principales influencias adversas de la tecnología, que puede compensarse, evidentemente, con la formación adecuada. 0 tro efecto de la introducción de la tecnología es el temor a perder el empleo debido a la mayor eficiencia de aquella (O stberg y Nilsson 1985; Smith, Carayon y M iezio 1987).

Las sesiones intensas, repetitivas y prolongadas con las PVD también pueden contribuir a aumentar la tensión y el estrés ergonómicos (Stammerjohn, Smith y Cohen 1981; Sauter y cols. 1983b; Smith y cols. 1992b) y pueden causar molestias o trastornos visuales y musculosqueléticos, como se describe en otras secciones de este capítulo.

\section{Factores relacionados con la organización}

El contexto organizativo del trabajo puede influir sobre el estrés y la salud del trabajador. Cuando la tecnología requiere nuevas cualificaciones, la forma en que se presentan las nuevas tecnologías a los trabajadores y el apoyo que reciben de la organización, como la formación adecuada y el tiempo necesario para 
adaptarse, se ha relacionado con los niveles de estrés y las alteraciones emocionales experimentadas (Smith, Carayon y Miezio 1987). La oportunidad para desarrollarse y promocionar en un trabajo (carrera profesional) también está relacionado con el estrés (Smith y cols. 1981). La incertidumbre con relación al futuro laboral es una fuente importante de estrés entre los usuarios de ordenadores (Sauter y cols. 1983b; Carayon 1993a) y la posibilidad de perder el empleo también genera estrés (Smith y cols. 1981; K asl 1978).

Se ha indicado que la programación del trabajo, como los turnos de trabajo y las horas extra, repercuten negativamente sobre la salud física y mental (M onk y Tepas 1985; Breslow y Buell 1960). Las empresas que desean mantener los equipos en funcionamiento continuo, utilizan cada vez más el trabajo a turnos. Con frecuencia es necesario que los empleados hagan horas extra para poder cumplir con la carga de trabajo, especialmente cuando se producen retrasos debido a la caída o al mal funcionamiento del sistema.

L os ordenadores proporcionan a los directivos la capacidad de controlar electrónicamente el rendimiento de los trabajadores continuamente; esto puede crear condiciones de trabajo estresantes, por ejemplo, al aumentar la presión en el trabajo (véase el cuadro "Control electrónico"). Las relaciones personales negativas entre el empleado y el supervisor y la sensación de falta de control pueden aumentar en los lugares de trabajo supervisados electrónicamente.

La introducción de la tecnología de las PVD ha afectado a las relaciones sociales en el trabajo. El aislamiento social se ha identificado como una fuente importante de estrés para los usuarios de ordenadores (Lindström 1991; Yang y Carayon 1993), ya que el aumento del tiempo que el trabajador dedica al ordenador reduce el tiempo disponible para relacionarse con otros trabajadores y recibir o dar apoyo social. La necesidad del apoyo de los supervisores y compañeros está bien documentada (H ouse 1981), y se ha comprobado que puede reducir el impacto de otros factores de estrés sobre el estrés del trabajador. El apoyo de los compañeros, el supervisor o el personal técnico es importante para el trabajador que tiene problemas con su equipo; ahora bien, el ambiente de trabajo informático puede, irónicamente, reducir el nivel de tal apoyo social.

\section{El individuo}

Existen varios factores personales, como la personalidad, el estado de salud física, las habilidades y capacidades, el acondicionamiento físico, la experiencia y el aprendizaje previo, los motivos, objetivos y necesidades que determinan los efectos físicos y psicológicos antes descritos (Levi 1972).

\section{Mejora de las características psicosociales del trabajo con PVD}

El primer paso para reducir el estrés del trabajo con las PVD es identificar las características de la organización y del diseño del trabajo que pueden causar problemas psicosociales, a fin de poder modificarlas, sin perder de vista que los problemas de las PVD que pueden producir estrés laboral generalmente no son el resultado de aspectos aislados de la organización o del diseño del trabajo, sino más bien una combinación de varios aspectos de un diseño inadecuado del trabajo. Por lo tanto, las soluciones para reducir o eliminar el estrés laboral deben ser globales y considerar simultáneamente los numerosos factores de un diseño inadecuado del trabajo. Las soluciones que se centran únicamente en uno o dos factores no suelen tener éxito (véase la Figura 52.10.)

Las mejoras en el diseño del trabajo deberían comenzar por la organización del trabajo, brindando a los trabajadores un
Figura $52.10 \bullet$ Claves para reducir el aislamiento y el estrés.

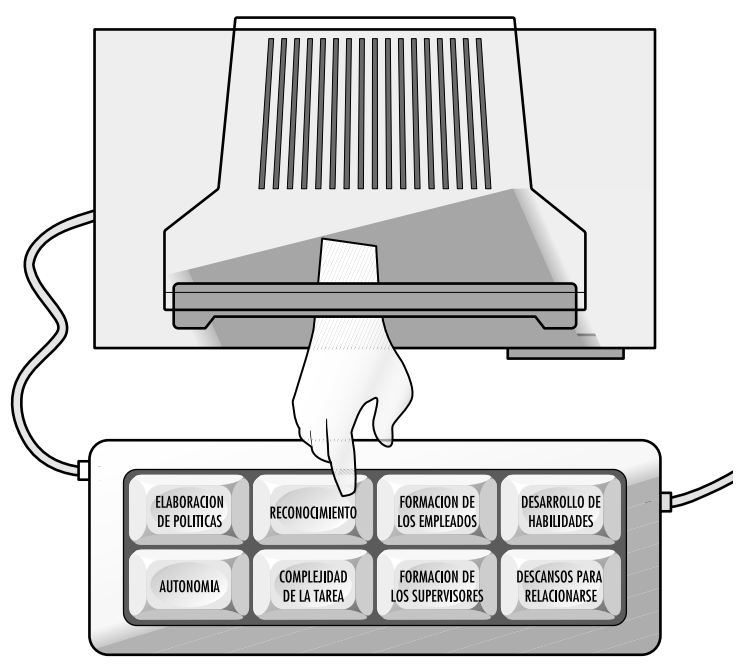

ambiente de apoyo. Así se aumenta la motivación por el trabajo y la sensación de seguridad del trabajador, al mismo tiempo que se reduce el sentimiento de estrés (House 1981). U na política que defina la importancia de los empleados dentro de la organización y señale explícitamente la forma en la que la organización proporcionará un ambiente de apoyo es un buen comienzo. U na forma muy efectiva de proporcionar apoyo a los empleados es proveerse de supervisores y directivos con una formación específica sobre los métodos de brindar apoyo. Los supervisores que respaldan a sus empleados pueden actuar como "amortiguadores" previniendo un estrés organizativo 0 tecnológico innecesario.

El contenido de las tareas se ha reconocido desde hace mucho tiempo como un elemento importante para la motivación y la productividad de los empleados (H erzberg 1974; Hackman y O Idham 1976). M ás recientemente, se ha esclarecido la relación entre el contenido del trabajo y las reacciones de estrés (Cooper y M arshall 1976; Smith 1987). $\mathrm{H}$ ay tres aspectos principales del contenido del trabajo que son específicamente importantes para el trabajo con PVD; estos son: la complejidad de la tarea, la cualificación del empleado y las oportunidades de desarrollo profesional. En cierto sentido, todos estos aspectos están relacionados con el fomento del clima motivacional que genere en el empleado satisfacción con el trabajo y desarrollo psicológico, (el cual se refiere al perfeccionamiento de las habilidades y capacidades intelectuales de los empleados), favorezca el aumento de la autoestima o imagen de sí mismo y aumente el reconocimiento social de los logros individuales.

El principal medio para aumentar el contenido del trabajo es incrementar el nivel de cualificación necesario para desarrollar las tareas, lo que significa generalmente ampliar el alcance de las tareas, así como enriquecer los elementos de cada tarea concreta (H erzberg 1974). Al ampliar el número de tareas se aumenta el repertorio de cualificaciones necesarias para realizar la tarea con éxito, así como la cantidad de decisiones que el empleado debe tomar para definir la secuencia de las tareas y actividades. El aumento en el nivel de especialización del contenido del trabajo favorece la imagen que el empleado se crea de su valía personal y de su importancia para la organización. A simismo, favorece la imagen positiva del individuo en su grupo social de trabajo dentro de la organización.

Aumentar la complejidad de las tareas, es decir, la cantidad de trabajo intelectual y la toma de decisiones que conlleva, es el 
siguiente paso lógico que se puede conseguir asociando tareas simples en grupos de actividades relacionadas que hay que coordinar, 0 añadiendo tareas mentales que requieran un conocimiento adicional y especialización informática. Especialmente durante la introducción de la tecnología informática, los requisitos de las nuevas tareas generalmente superan los conocimientos y cualificación actuales de los empleados que deben desempeñarlas. Por ello es necesario formar a los empleados en los nuevos aspectos de las tareas a fin de que adquieran la cualificación necesaria para llevarlas a cabo de forma adecuada. Tal formación no sólo mejorará los conocimientos y cualificación del empleado (con el correspondiente aumento de su rendimiento), sino que éste ganará también en autoestima y confianza en sí mismo. Al proporcionarle formación también se le indicará que la empresa desea invertir en el desarrollo de su preparación y, por lo tanto, le aportará confianza sobre la estabilidad y futuro de su empleo.

El control que el empleado puede tener sobre su trabajo tiene una influencia psicosocial muy importante ( $K$ arasek y cols. 1981; Sauter, Cooper y H urrell 1989). Es posible definir aspectos importantes del control respondiendo a las preguntas "quién, cómo y cuándo". La naturaleza de las tareas que deben llevarse a cabo, la necesidad de coordinación entre los empleados, los métodos que hay que utilizar para realizar las tareas y la programación de éstas pueden definirse respondiendo a estas preguntas. EI control del trabajo puede diseñarse a nivel de las tareas, de la unidad de trabajo y de la organización (Sainfort 1991; G ardell 1971). A nivel de la tarea, el empleado puede tener suficiente autonomía en cuanto a los métodos y procedimientos utilizados para realizarla. A nivel de la unidad de trabajo, los grupos de empleados pueden gestionar por sí mismos varias tareas interrelacionadas y el propio grupo puede decidir quién realizará determinadas tareas, el orden de las mismas, su coordinación y las normas de producción necesarias para cumplir con los objetivos de la organización. A nivel de la organización, los empleados pueden participar en actividades estructuradas que aportan información a los directivos sobre la opinión de los empleados o las sugerencias para mejorar la calidad. Cuando los niveles de control disponibles son limitados, es preferible introducir la autonomía a nivel de la tarea y crear después la estructura organizacional, tanto como sea posible (G ardell 1971).

Una de las consecuencias naturales de la automatización informática parece ser el aumento de la carga de trabajo, ya que el objetivo de la automatización es aumentar la cantidad y la calidad del trabajo producido. Muchas organizaciones consideran que tal aumento es necesario para costear la inversión en automatización. A hora bien, no es fácil establecer la carga de trabajo adecuada. Los ingenieros industriales han desarrollado métodos científicos para determinar los sistemas y cargas de trabajo adecuados (los requisitos de realización de un trabajo). Tales métodos se han utilizado con éxito en las industrias manufactureras durante décadas, pero han tenido poca aplicación al trabajo de oficina, ni siquiera después de la informatización que han experimentado. El uso de métodos científicos, como los descritos por K anawaty (1979) y Salvendy (1992), para establecer la carga de trabajo de los operadores de PV D debería ser una de las primeras prioridades en todas las organizaciones, ya que estos métodos establecen normas o requisitos de producción adecuados, contribuyen a proteger a los empleados de una carga de trabajo excesiva y ayudan a garantizar la calidad de los productos.

Las exigencias asociadas con niveles altos de concentración requeridos por las tareas informatizadas pueden reducir la cantidad de interacción social durante el trabajo, produciendo el aislamiento social de los empleados. Para compensar este efecto, deberían brindarse oportunidades de relacionarse a los empleados no ocupados en tareas informatizadas y a los que están en las pausas de descanso. Las tareas no informatizadas, que no requieran una concentración excesiva, podrían organizarse de forma que los empleados puedan trabajar próximos entre sí y tener así la oportunidad de hablar entre ellos. Tales relaciones proporcionan apoyo social, que es un factor modificador esencial en la reducción de los efectos adversos sobre la salud mental y los trastornos físicos, como las enfermedades cardiovasculares (H ouse 1981). Las relaciones sociales naturalmente también reducen el aislamiento y promueven una mayor salud mental.

Debido a que las condiciones poco ergonómicas también pueden producir problemas psicosociales para los usuarios de PVD, el establecimiento de las condiciones ergonómicas adecuadas es un elemento esencial del diseño integral del trabajo. De este tema se trata con más detalle en otras secciones de este capítulo y en otros capítulos de la E nciclopedia.

\section{La búsqueda del equilibrio}

Debido a que no existen trabajos ni lugares de trabajo "perfectos", libres de todos los estresores psicosociales y ergonómicos, con frecuencia es preciso llegar a un compromiso cuando se intenta mejorar el lugar de trabajo. Los procesos de rediseño implican generalmente un "compromiso" entre unas condiciones excelentes de trabajo y la necesidad de tener una productividad aceptable. Ello requiere tiempo para pensar cómo conseguir el mejor "equilibrio" entre los beneficios positivos para la salud de los empleados y la productividad. Lamentablemente, puesto que existen tantos factores que pueden producir condiciones psicosociales adversas generadoras de estrés, y puesto que estos factores están interrelacionados, las modificaciones de uno de los factores no necesariamente producen beneficios si no se realizan cambios concomitantes en los demás factores relacionados. En general, deberían considerarse dos aspectos del equilibrio: el equilibrio del sistema en su totalidad y el equilibrio compensatorio.

El equilibrio del sistema se basa en la idea de que el lugar de trabajo, los procesos o el trabajo es más que la suma de los componentes individuales del sistema. La interacción entre los diversos componentes produce resultados que son mayores (o menores) a la suma de las partes individuales y determina el potencial del sistema para producir resultados positivos. Por ello, las mejoras en el trabajo deben tenerlo en cuenta y adaptar el sistema de trabajo en su conjunto. Si una organización se centra exclusivamente en el componente tecnológico del sistema, se producirá un desequilibrio, ya que se habrán descuidado factores personales y psicosociales. El modelo del sistema de trabajo que se muestra en la Figura 52.9 puede utilizarse para identificar y entender las relaciones entre las exigencias del trabajo, los factores de diseño y el estrés, que deben estar equilibradas.

Debido a que pocas veces es posible eliminar todos los factores psicosociales que producen estrés, ya sea por motivos económicos o porque es imposible modificar aspectos inherentes a las tareas del trabajo, se utilizan técnicas de equilibrio compensatorio. El equilibrio compensatorio intenta reducir el estrés psicológico modificando aspectos del trabajo que pueden ser alterados en una dirección positiva para compensar otros aspectos que no pueden ser modificados. Existen cinco elementos del sistema de trabajo: la carga física, los ciclos de trabajo, el contenido del trabajo, el control y las relaciones entre los trabajadores, que actúan en conjunto para proporcionar los recursos necesarios para alcanzar los objetivos individuales y de la organización a través del equilibrio compensatorio. Aunque hemos descrito algunos de los atributos potencialmente negativos de estos elementos en términos de estrés laboral, cada uno 
de ellos tiene también aspectos positivos que pueden neutralizar las influencias negativas. Por ejemplo, la falta de preparación para utilizar la nueva tecnología puede compensarse mediante la formación de los empleados. EI bajo contenido del trabajo, que genera repetitividad y monotonía puede ser equilibrado con una estructura jerárquica que promueva la participación del empleado y el control sobre las tareas, y con la ampliación del trabajo que introduzca mayor diversidad de tareas. Las condiciones sociales del trabajo con PVD podrían mejorarse equilibrando las cargas que pueden producir estrés y considerando todos los elementos del trabajo y su potencial para causar o reducir estrés. La propia estructura de la organización podría ser adaptada para proporcionar trabajos enriquecidos que proporcionen apoyo al individuo. El aumento de los niveles de la plantilla, incrementando los niveles de responsabilidad compartida o los recursos financieros destinados al bienestar de los trabajadores son otras posibles soluciones.

\section{- ASPECTOSERG O NOMICOS DE LA INTERACCION ORDENADOR/HOMBRE}

Jean-M arc Robert

\section{Introducción}

EI desarrollo de interfaces eficaces para los sistemas informáticos es el objetivo fundamental de las investigaciones sobre las interacciones ordenador/ hombre.

Una interfaz puede definirse como la suma de los componentes del hardware y del software a través de los cuales se acciona el sistema y se informa a los usuarios de su estado. Los componentes del hardware incluyen los dispositivos de entrada de datos y los dispositivos señaladores (por ejemplo, el teclado 0 el ratón), los dispositivos de presentación de la información (como pantallas y altavoces), y los manuales del usuario y la documentación. Los componentes del software incluyen los comandos de menú, los iconos, las ventanas, la retroinformación, los sistemas de navegación y los mensajes, etc. Los componentes de hardware y de software de la interfaz pueden estar tan relacionados entre sí que pueden considerarse inseparables (por ejemplo, las teclas de función del teclado). La interfaz incluye todo lo que el usuario percibe, entiende y manipula cuando interactúa con el ordenador (M oran 1981). Es, por lo tanto, un determinante crucial de la relación persona-máquina.

La investigación sobre las interfaces tiene como objetivo mejorar la utilidad, accesibilidad, rendimiento, seguridad y usabilidad. Por este motivo, la utilidad se define en relación a la tarea que se desea realizar. Un sistema útil contiene las funciones necesarias para que el usuario realice las tareas que se le han encomendado (escritura, diseño, cálculo o programación). L a accesibilidad es una medida de la capacidad de una interfaz para permitir que varias categorías de usuarios, (en especial, los individuos discapacitados y los que trabajan en áreas geográficamente aisladas, que se desplazan continuamente o que tienen las dos manos ocupadas), utilicen el sistema para realizar sus actividades. EI rendimiento, considerado aquí desde un punto de vista humano más que técnico, es una medida del grado en el que un sistema mejora la eficiencia con la que los usuarios realizan su trabajo. C on ello nos referimos a las macros, las teclas de acceso rápido a los menús y los asistentes de software. La seguridad de un sistema se define por el grado en que una interfaz permite a los usuarios realizar su trabajo sin riesgo de accidentes 0 pérdidas de personas, de equipos, de datos o medio ambientales. Por último, la usabilidad se define como la facilidad con que puede aprenderse el uso de un sistema y utilizarse. Por extensión, este término incluye también a la utilidad y al rendimiento del sistema, antes definidos.

\section{Elementos del diseño de la interfaz}

Desde la invención de los sistemas operativos de tiempo compartido en 1963 y especialmente desde la introducción de los microordenadores en 1978, el desarrollo de las interfaces persona-ordenador ha sido vertiginoso (véase historia en $\mathrm{G}$ aines y Shaw 1986). El estímulo para este desarrollo se encuentra principalmente en tres factores simultáneos:

En primer lugar, la rápida evolución de la tecnología informática como resultado de los avances de la ingeniería eléctrica, de las ciencias, físicas e informáticas, ha sido uno de los determinantes principales del desarrollo de la interfaz de usuario. A ello se debe la aparición de ordenadores cada vez más potentes y rápidos, con gran capacidad de memoria, pantallas gráficas de alta resolución, y dispositivos señaladores más naturales que permiten la manipulación directa (ratones, "trackballs"). Estas tecnologías también fueron las responsables de la aparición de los microordenadores y que constituyeron la base para las interfaces basadas en caracteres de los decenios de 1960 y1970, para las interfaces gráficas de finales del decenio de 1970 y las interfaces multimedia e hipermedia aparecidas a mediados del decenio de 1980, basadas en entornos virtuales o en el uso de tecnologías de reconocimiento de entrada alternativa (por ejemplo, detección de voz, de escritura y del movimiento). En los últimos años, se ha realizado una investigación y un desarrollo considerables en estas áreas (Waterworth y Chignel 1989; $R$ heingold 1991). A compañando a estos avances, se han desarroIlado herramientas de software cada vez más avanzadas para el diseño de interfaces (por ejemplo, los sistemas de división en ventanas, las bibliotecas de objetos gráficos o los sistemas de desarrollo de prototipos) que reducen de forma importante el tiempo necesario para desarrollar las interfaces.

En segundo lugar, los usuarios de los sistemas informáticos han tenido un papel muy importante en el desarrollo de interfaces eficaces por tres motivos: el primero, porque los usuarios actuales no son ingenieros ni investigadores, a diferencia de los usuarios de los primeros ordenadores. Es por esto que piden sistemas que sean fáciles de aprender y de utilizar. El segundo motivo, la edad, el sexo, el idioma, el nivel cultural, la formación, la experiencia, las habilidades, la motivación y el interés de los usuarios individuales es muy variable. Por esto, las interfaces deben ser más flexibles y capaces de adaptarse mejor a una amplia gama de necesidades y expectativas; y tercero, los usuarios trabajan en sectores económicos diversos y realizan una variedad de tareas muy amplia. Por ello, los desarrolladores de interfaces deben reevaluar constantemente la calidad de sus interfaces.

En último lugar, la gran competitividad del mercado y las expectativas cada vez mayores en cuanto a la seguridad favorecen el desarrollo de mejores interfaces. Dos grupos de aliados son responsables de estos aspectos: por una parte, los productores de software, que luchan por reducir los costes sin perder las características distintivas de sus productos, que les permiten alcanzar sus objetivos comerciales y, por otra, los usuarios para quienes el software es un medio para ofrecer productos y servicios más competitivos a sus clientes. Para ambos grupos, una interfaz eficaz ofrece una serie de ventajas:

\section{Para los productores de software:}

- mejor imagen del producto

- mayor demanda de productos

- menor tiempo de formación 
- menor necesidad de servicio posventa

- una base sólida para desarrollar una línea de productos

- reducción del riesgo de errores y accidentes

- reducción de la documentación.

\section{Para los usuarios:}

- fase de aprendizaje más corta

- mayores posibilidades de aplicación general de las habilidades

- mejor uso del sistema

- mayor autonomía en el uso del sistema

- reducción del tiempo necesario para realizar una tarea

- menor número de errores

- mayor satisfacción.

Las interfaces eficaces pueden mejorar significativamente la salud y la productividad de los usuarios al tiempo que mejoran la calidad y reducen los costes de su formación. Para ello es necesario basar el diseño y la evaluación de las interfaces en principios ergonómicos y en normas prácticas, ya sean directrices, normas de empresa de los principales fabricantes de sistemas o normas internacionales. En el curso de los años, se ha acumulado una gran cantidad de principios ergonómicos y directrices relativas al diseño de interfaces (Scapin 1986; Smith y M osier 1986; M arshall, Nelson y Gardiner 1987; Brown 1988). Este bloque multidisciplinario abarca todos los aspectos de las interfaces modalidad carácter y gráficas, así como los criterios de evaluación de las interfaces. A pesar de que su aplicación concreta ocasionalmente supone algún problema (por ejemplo, terminología imprecisa, información inadecuada sobre las condiciones de uso, presentación inadecuada, etc.), sigue siendo un recurso valioso para el diseño y la evaluación de las interfaces.

Además, los principales fabricantes de software han desarrollado sus propias directrices y normas internas para el diseño de interfaces. He aquí los documentos que recogen dichas directrices:

- A pple H uman I nterface Guidelines (1987)

- O pen L ook (Sun 1990)

- OSF / M otif Style Guide (1990)

- IBM Common U ser A ccess guide to user interface design (1991)

- IB M A dvanced Interface D esign R eference (1991)

- The W indows interface: An application design guide (M icrosoft 1992)

Estas directrices tienen como objetivo simplificar el desarrollo de interfaces indicando un nivel mínimo de uniformidad y coherencia entre las interfaces utilizadas en la misma plataforma informática. Son precisas, detalladas y bastante completas en varios aspectos y tienen la ventaja adicional de ser bien conocidas, accesibles y ampliamente utilizadas. Son las normas de diseño "de facto" que utilizan los que desarrollan los sistemas y son, por lo mismo, indispensables.

Además, las normas de la Organización Internacional de Normalización (ISO) son también valiosas fuentes de información sobre el diseño y la evaluación de las interfaces. Estas normas se refieren principalmente a la uniformidad entre las interfaces, independientemente de las plataformas y aplicaciones. Se han elaborado en colaboración con las asociaciones nacionales de normalización, después de discutirlas ampliamente con los investigadores, diseñadores y fabricantes. La norma ISO más importante sobre el diseño de interfaces es la ISO 9241, que describe los requisitos ergonómicos para las pantallas de visualización de datos y consta de 17 partes. Por ejemplo, las partes 14, 15, 16 y 17 se refieren a cuatro tipos de diálogo persona-ordenador: los menús, los lenguajes de comandos, la manipulación directa y los formularios. Las normas ISO deberán tener prioridad sobre otros principios y directrices de diseño. Las siguientes secciones tratan sobre los principios que deben condicionar el diseño de las interfaces.

\section{Una filosofía de diseño centrada en el usuario}

Gould y Lewis (1983) han propuesto una filosofía de diseño centrada en el usuario de las pantallas de visualización. Los cuatro principios propuestos son:

1. A tención inmediata y continua a los usuarios. Se mantiene un contacto directo con los usuarios, con el fin de comprender mejor sus características y tareas.

2. Diseño integrado. Todos los aspectos de la usabilidad (por ejemplo, interfaz, manuales, sistemas de ayuda) se desarrollan en paralelo y se colocan bajo un control centralizado.

3. Evaluación inmediata y continua por parte de los usuarios. Los usuarios prueban las interfaces 0 prototipos en las primeras fases de diseño, en condiciones de trabajo simuladas. El rendimiento y las reacciones se miden cuantitativa y cualitativamente.

4. Diseño iterativo. El sistema es modificado dependiendo de los resultados de la evaluación, y vuelve a comenzar el ciclo de evaluación.

En Gould (1988) se explican con detalle estos principios. M uy relevantes cuando se publicaron, en 1985 , siguen siéndolo casi quince años después, debido a la imposibilidad de predecir la efectividad de las interfaces sin las pruebas de los usuarios. Tales principios constituyen la base de los ciclos de desarrollo basados en el usuario, propuestos por varios autores en los últimos años (Gould 1988; M antei y Teorey 1989; M ayhew 1992; $\mathrm{N}$ ielsen 1992; Robert y Fiset 1992).

En la última parte de este artículo analizaremos cinco etapas del ciclo de desarrollo que parecen determinar la efectividad de la interfaz final.

\section{Análisis de la tarea}

El análisis ergonómico de la tarea es uno de los pilares del diseño de interfaces. Esencialmente se trata del proceso por el que se definen las responsabilidades y actividades de los usuarios, lo que, a su vez, permite diseñar interfaces compatibles con las características de las tareas de los usuarios. Todas las tareas tienen dos facetas:

1. La tarea nominal, que corresponde a la definición formal de tarea hecha por la organización. Incluye los objetivos, los procedimientos, el control de calidad, las normas y las herramientas.

2. La tarea real, que corresponde a las decisiones de los usuarios y a los comportamientos necesarios para la ejecución de la tarea nominal.

EI corte entre la tarea nominal y la real es inevitable y deriva de la incapacidad de la tarea nominal de tener en cuenta las variaciones y las circunstancias imprevisibles del flujo de trabajo, así como de las diferencias en la representación mental que los usuarios hacen de su trabajo. EI análisis de la tarea nominal no basta para entender completamente las actividades de los usuarios.

El análisis de la actividad examina elementos como los objetivos de trabajo, el tipo de operaciones realizadas, su organización temporal (secuencial, en paralelo) y frecuencia, los modos operativos en que se basa, las decisiones, las fuentes de dificultades, los errores y los modos de recuperación. También muestra este análisis las distintas operaciones realizadas para llevar a cabo la tarea (detección, búsqueda, lectura, comparación, evaluación, decisión, estimación, anticipación), las entidades 
manipuladas (por ejemplo, en el control de procesos, la temperatura, presión, velocidad de flujo, el volumen) y la relación entre los operadores y las entidades. El contexto en el que es ejecutada la tarea condiciona estas relaciones. Tales datos son indispensables para definir y organizar las características futuras del sistema.

A nivel más básico, el análisis de la tarea está compuesto por la obtención de datos, su recopilación y análisis. Puede realizarse antes, durante o después de la informatización de la tarea. En todos los casos, proporciona directrices esenciales para el diseño y la evaluación de la interfaz. EI análisis de la tarea siempre está relacionado con la tarea real, aunque también puede estudiar tareas futuras a través de su simulación o la prueba de prototipos. Cuando se realiza antes de la informatización, estudia las "tareas externas" (es decir, las tareas que se realizan sin el ordenador), que se llevan a cabo con las herramientas de trabajo existentes (M oran 1983). Es un tipo de análisis útil incluso si se espera que la informatización modifique la tarea de forma importante, ya que permite definir la naturaleza y lógica de la tarea, los procedimientos de trabajo, la terminología, los operadores y tareas, las herramientas de trabajo y fuentes de dificultades. Al hacer esto, se obtienen los datos necesarios para la optimización de la tarea y la informatización.

EI análisis de la tarea realizado durante la informatización de la tarea se centra en "tareas internas", es decir, las realizadas y representadas por el sistema informático. En esta etapa se utilizan prototipos del sistema para la obtención de datos. El proceso se ocupa de los mismos puntos examinados en la etapa anterior, pero desde el punto de vista del proceso de informatización.

Después de la informatización de la tarea, el análisis de la tarea también estudia las tareas internas, pero el análisis ahora se centra en el sistema informático final. Este tipo de análisis se realiza con frecuencia para evaluar las interfaces existentes 0 como parte del diseño de interfaces nuevas.

El análisis jerárquico de la tarea es un método utilizado frecuentemente en ergonomía cognitiva que ha resultado muy útil en diversos campos, incluido el diseño de interfaces (Shepherd 1989). Consiste en la división de las tareas (u objetivos principales) en subtareas, cada una de las cuales puede subdividirse hasta conseguir el nivel de detalle deseado. Si los datos se obtienen directamente de los usuarios (por ejemplo, a través de entrevistas, comentarios, etc.), la división jerárquica puede dar una imagen de la ordenación mental que los usuarios hacen de la tarea. Los resultados del análisis pueden representarse mediante una tabla o un diagrama de árbol. Cada una de estos formatos tienen ventajas e inconvenientes.

\section{Análisis del usuario}

El otro pilar del diseño de interfaces es el análisis de las características del usuario. Las características relevantes pueden estar relacionadas con la edad, sexo, idioma, nivel cultural, formación, conocimientos técnicos o de informática, cualificación o motivación del usuario. Las variaciones en estos factores individuales son las responsables de las diferencias en y entre grupos de usuarios. U no de los principios básicos del diseño de interfaces es, por lo tanto, que no existe un usuario medio. Es necesario, por lo tanto, identificar distintos grupos de usuarios y sus características. Se debe impulsar a los representantes de cada grupo a que participen en el en los procesos de diseño y evaluación de las interfaces.

Por otra parte, se pueden utilizar técnicas psicológicas, ergonómicas y de ingeniería cognitiva para obtener información sobre las características de los usuarios relativas a la percepción, memoria, representación cognitiva, toma de decisiones y aprendizaje (Wickens 1992). Es evidente que la única manera de desarrollar interfaces que sean realmente compatibles con los usuarios es tener en cuenta el efecto de las diferencias en estos factores sobre las capacidades, límites y forma de trabajar de los usuarios.

L os estudios ergonómicos sobre las interfaces se han centrado casi exclusivamente en las habilidades perceptivas, cognitivas y motoras de los usuarios, más que en los factores afectivos, sociales o de actitud, aunque en los últimos años, el trabajo en estos campos ha adquirido mayor popularidad. (Para una visión integral de las personas como sistemas de procesamiento de la información, consultar Rasmussen 1986; para una revisión de los factores relacionados con el usuario que hay que considerar para el diseño de interfaces, consultar Thimbleby 1990 y M ayhew 1992). Los siguientes párrafos tratan sobre las cuatro características principales relacionadas con el usuario que deberían tenerse en cuenta durante el diseño de interfaces.

\section{Representación mental}

L os modelos mentales que los usuarios construyen de los sistemas que utilizan reflejan la forma en que reciben y entienden estos sistemas. Es por esto que los modelos pueden variar dependiendo de los conocimientos y experiencia de los usuarios (H utchins 1989). Con el fin de minimizar la curva de aprendizaje y facilitar el uso del sistema, el modelo conceptual en el que se basa un sistema debería ser similar a la representación mental que tiene el usuario de dicho sistema. Es necesario reconocer, sin embargo, que estos dos modelos nunca son idénticos. EI modelo mental se caracteriza por el hecho de que es personal (R ich 1983), incompleto, variable entre distintas partes del sistema, posiblemente equivocado en algunos puntos y en constante evolución. Su papel en las tareas rutinarias es secundario, pero resulta esencial en las tareas no rutinarias y durante el diagnóstico de problemas (Young 1981). En estos últimos casos, los usuarios no pueden trabajar correctamente si no cuentan con un modelo mental adecuado. El reto para los diseñadores de interfaces es diseñar sistemas cuya interacción con los usuarios induzcan a estos últimos a formar modelos mentales similares al modelo conceptual del sistema.

\section{Aprendizaje}

La analogía tiene un papel muy importante en el aprendizaje del usuario (Rumelhart y N orman 1983). Por esto, el uso de analogías o metáforas adecuadas en la interfaz facilita el aprendizaje, al maximizar la transferencia de conocimientos procedentes de situaciones o sistemas conocidos. Las analogías y metáforas intervienen en muchas partes de la interfaz, como los nombres de comandos y menús, los símbolos, iconos, códigos (por ejemplo, la forma y el color) y los mensajes. Cuando son pertinentes, contribuyen de forma muy importante a hacer que la interfaz resulte natural y más transparente a los usuarios. En cambio, cuando son irrelevantes, pueden entorpecer al usuario ( $\mathrm{H}$ alasz y M oran 1982). A ctualmente, las dos metáforas utilizadas en las interfaces gráficas son el escritorio y, en menor grado, la habitación.

Los usuarios generalmente prefieren aprender un nuevo programa utilizándolo inmediatamente y no leyendo un manual o siguiendo un curso; prefieren un aprendizaje basado en la acción que les permite estar activos cognitivamente. Este tipo de aprendizaje, sin embargo, causa algunos problemas a los usuarios (C arroll y R osson 1988; R obert 1989). R equiere una estructura de interfaz que sea compatible, transparente, coherente, flexible, de aspecto natural y que tolere errores, así como un conjunto de características que garanticen usabilidad, retroalimentación, sistemas de ayuda, ayudas para la navegación y manejo de errores (en este contexto, "errores" se refiere a las acciones que los usuarios desean deshacer). Las interfaces 
eficaces proporcionan a los usuarios una cierta autonomía durante la exploración.

\section{Desarrollo de conocimientos}

El conocimiento de los usuarios se desarrolla al aumentar la experiencia, pero tiende a llegar rápidamente a una meseta. Ello significa que las interfaces deben ser flexibles y capaces de responder simultáneamente a las necesidades de usuarios con distintos niveles de conocimientos. En el caso ideal, deberían ser sensibles al contexto y proporcionar una ayuda personalizada. El sistema EdC oach, desarrollado por Desmarais, G iroux y Larochelle (1993) es una interfaz de este tipo. La clasificación de los usuarios en principiantes, intermedios y avanzados no es adecuada para los fines del diseño de interfaces, ya que estas definiciones son demasiado estáticas y no tienen en cuenta las variaciones individuales. A ctualmente existe tecnología de la información capaz de responder a las necesidades de distintos tipos de usuarios, aunque más a un nivel de investigación que comercial (Egan 1988). El interés actual por sistemas de soporte del rendimiento sugiere que estos sistemas se desarrollarán intensamente en los próximos años.

\section{Errores inevitables}

Por último, es necesario reconocer que los usuarios cometen errores cuando utilizan los sistemas, independientemente de su nivel de preparación o de la calidad del sistema. Un estudio reciente realizado en Alemania por Broadbeck y cols. (1993) muestra que al menos el $10 \%$ del tiempo que invierten los trabajadores de oficina en los ordenadores está relacionado con la gestión de errores. U na de las causas de los errores es que los usuarios confían más en las estrategias de corrección que en las de prevención (Reed 1982). Los usuarios prefieren actuar rápidamente y cometer errores que después deben corregir, a trabajar más lentamente y evitar los errores. Es esencial tener en cuenta este aspecto cuando se diseñan las interfaces persona-ordenador. Además, los sistemas deberían ser tolerantes a los errores e incorporar un sistema de gestión de errores efectivo (Lewis y Norman 1986)

\section{Análisis de necesidades}

El análisis de necesidades es una parte explícita del ciclo de desarrollo de Robert y Fiset (1992), corresponde al análisis funcional de N ielsen y está integrado en otras etapas (análisis de la tarea, del usuario o de las necesidades) descritas por otros autores. Consiste en identificar, analizar y organizar todas las necesidades que el sistema informático puede satiffacer. Durante este proceso se identifican las características que es necesario añadir al sistema. El análisis de la tarea y del usuario, descrito anteriormente, debería ayudar a definir muchas de las necesidades, pero puede resultar inadecuado para definir las nuevas necesidades derivadas de la introducción de nuevas tecnologías o nuevas normativas (por ejemplo, sobre seguridad). El análisis de necesidades llena este vacío.

El análisis de las necesidades se lleva a cabo de la misma forma que el análisis funcional de los productos. Requiere la participación de un grupo de personas interesadas en el producto, que posea una formación, ocupación o experiencia en el trabajo complementarias. En este grupo puede haber futuros usuarios del sistema, supervisores, expertos en la materia y, si es necesario, especialistas en formación, organización del trabajo y seguridad. Asimismo, debe llevarse a cabo una revisión de la literatura científica y técnica en el campo de aplicación correspondiente, con el fin de establecer el estado actual de los conocimientos. También pueden estudiarse los sistemas competitivos usados en campos similares o relacionados. Posteriormente, se clasifican las distintas necesidades identificadas en este análisis, se valoran y presentan en un formato adecuado para utilizarlas durante todo el ciclo de desarrollo.

\section{Desarrollo de prototipos}

EI desarrollo de prototipos forma parte del ciclo de desarrollo de la mayoría de las interfaces y consiste en obtener un modelo preliminar en papel o electrónico (un prototipo) de la interfaz. Existen varios libros disponibles sobre el papel del desarrollo de prototipos en la interacción persona-ordenador (Wilson y Rosenberg 1988; H artson y Smith 1991; Preece y cols. 1994).

El desarrollo de prototipos es prácticamente indispensable debido a que:

1. Los usuarios tienen dificultades para evaluar las interfaces basándose sólo en sus especificaciones funcionales; la descripción de la interfaz está demasiado alejada de la interfaz real y la evaluación es demasiado abstracta. Los prototipos son útiles ya que permiten a los usuarios ver y utilizar la interfaz y evaluar directamente su utilidad y usabilidad.

2. Es prácticamente imposible construir una interfaz adecuada al primer intento. La interfaz debe ser probada por el usuario y modificada a menudo. Para evitar este problema, se desarrollan prototipos interactivos 0 en papel, que puedan probarse, modificarse 0 rechazarse, y se mejoran hasta obtener una versión satisfactoria. Es un proceso considerablemente más barato que trabajar con la interfaz real.

Desde el punto de vista del equipo de desarrollo, la producción de prototipos tiene varias ventajas. Los prototipos permiten integrar y visualizar los elementos de la interfaz desde las primeras etapas del ciclo de diseño, identificar rápidamente los problemas detallados, producir un objeto concreto y común de discusión para el equipo de desarrollo y durante las discusiones con los clientes, e ilustrar de forma sencilla las soluciones alternativas con fines de comparación y de evaluación interna de la interfaz. La ventaja más importante es, sin embargo, la posibilidad de tener prototipos evaluados por los usuarios.

Existen herramientas de software, económicas y muy potentes, disponibles comercialmente para el desarrollo de prototipos en distintas plataformas, incluidos los microordenadores [por ejemplo, Visual Basic and Visual $\mathrm{C}++\left(^{\mathrm{TM}} \mathrm{M}\right.$ icrosoft Corp.), UIM/X ('M Visual Edge Software), H yperC ard ( ${ }^{\mathrm{TM}}$ A pple Computer), SV T ( ${ }^{\mathrm{TM}}$ SVT Soft Inc.)]. El uso de estas herramientas, fáciles de obtener y relativamente fáciles de usar, se está generalizando entre los diseñadores y evaluadores de sistemas.

La inclusión de los prototipos ha cambiado completamente el proceso de desarrollo de la interfaz. Considerando la rapidez y flexibilidad con que es posible producir los prototipos, las encargados de desarrollarlos tienden actualmente a reducir el análisis inicial de la tarea, de los usuarios y de las necesidades y compensan estas deficiencias analíticas adoptando ciclos de evaluación más largos. Ello supone asumir que las pruebas de usabilidad identificarán los problemas y que es más rentable prolongar la evaluación que invertir tiempo en el análisis preliminar.

\section{Evaluación de las interfaces}

La evaluación de las interfaces por los usuarios es una forma indispensable y eficaz de mejorar la utilidad y usabilidad de la interfaz ( $\mathrm{N}$ ielsen 1993). La interfaz se evalúa casi siempre en formato electrónico, aunque también es posible probar prototipos en papel. La evaluación es un proceso iterativo y forma parte del ciclo de evaluación-modificación del prototipo, que continúa hasta que la interfaz se considera aceptable. Pueden ser necesarios varios ciclos de evaluación. La evaluación puede llevarse a cabo en el lugar de trabajo o en laboratorios de usabilidad (ver la 
edición especial de B ehaviour and Information Technology (1994) para obtener una descripción de varios laboratorios de usabilidad).

En algunos métodos de evaluación de la interfaz no participan los usuarios y pueden utilizarse como un complemento para la evaluación de éstos (K arat 1988; Nielsen 1993; Nielsen y Mack 1994). Un ejemplo relativamente frecuente de estos métodos consiste en utilizar criterios como la compatibilidad, la coherencia, la claridad visual, el control explícito, la flexibilidad, la carga de trabajo mental, la calidad de la retroalimentación, la calidad de la ayuda y los sistemas de manejo de errores. Para obtener una definición detallada de estos criterios, consultar Bastien y Scapin (1993); estos criterios constituyen también la base de un cuestionario ergonómico sobre las interfaces (Shneiderman 1987; R avden y Johnson 1989).

Después de la evaluación, es necesario encontrar soluciones para los problemas identificados, comentar y aplicar las modificaciones y tomar decisiones sobre si es necesario desarrollar un nuevo prototipo.

\section{Conclusión}

En esta discusión del desarrollo de las interfaces se han resaltado los objetivos principales y las tendencias generales en el campo de la interacción persona-ordenador. En resumen, a) el análisis de la tarea, del usuario y de las necesidades juega un papel primordial para entender los requisitos del sistema y, por extensión, las características necesarias en la interfaz, y b) el desarrollo de prototipos y la evaluación por los usuarios son indispensables para determinar la usabilidad de la interfaz. Existe un gran bagaje de conocimientos, formado por principios, directrices y normas de diseño, sobre las interacciones persona-ordenador. Con todo, actualmente es imposible producir una interfaz adecuada al primer intento. Constituye el reto más importante para los próximos años. Es necesario establecer vínculos más explícitos, directos y formales entre el análisis (de la tarea, usuarios, necesidades, contexto) y el diseño de la interfaz. También es necesario desarrollar métodos para aplicar los conocimientos ergonómicos actuales de forma más directa y más sencilla al diseño de las interfaces.

\section{- NORMAS ERGONOMICAS}

Tom F. M. Stewart

\section{Introducción}

Las normas ergonómicas pueden tener distintos formatos, como reglamentos promulgados a nivel nacional, o directrices y normas instituidas por organizaciones internacionales. Se trata de normas fundamentales en la mejora de la usabilidad de los sistemas. Las normas de diseño y rendimiento proporcionan confianza a los directivos de que podrán utilizar de forma productiva, eficaz, segura y cómoda los sistemas que adquieran. También proporcionan a los usuarios una referencia para juzgar sus propias condiciones de trabajo. En este artículo nos centraremos en la norma ergonómica 9241 (ISO 1992) de la O rganización Internacional de Normalización (ISO ), debido a que proporciona criterios importantes y reconocidos internacionalmente para seleccionar o diseñar equipos y sistemas con PVD. La ISO desarrolla su trabajo a través de varios comités técnicos, uno de los cuales es el Comité T écnico sobre la Ergonomía de la Interacción Persona-Sistema o ISO TC 159 SC 4, responsable de las normas ergonómicas para las situaciones en las que los seres humanos interactúan con los sistemas tecnológicos. Sus miembros son representantes de los organismos nacionales de normalización de los países miembros y en las reuniones participan delegaciones

\section{Estudio de caso: Directiva sobre equipos que} incluyen pantallas de visualización

\section{(90/270/EEC)}

Forma parte de una serie de directivas referentes a aspectos espe cíficos de salud y seguridad. Las directivas forman parte del programa de la Unión Europea para promover la salud y la seguridad en el mercado único. La directiva "madre" de esta serie o Directiva Marco ( $89 / 391 /$ CEE) establece los principios generales de la Comunidad con respecto a la salud y la seguridad. Entre estos principios comunes están la prevención de riesgos, siempre que sea posible, por eliminación de la fuente que los produce y el fomento de medidas de protección colectivas en lugar de individuales.

En los casos en los que el riesgo es inevitable, debe ser evaluado adecuadamente por personas con la debida cualificación y han de tomarse las medidas oportunas en función del nivel de riesgo. Así, si la evaluación muestra que el nivel de riesgo es leve, la adopción de medidas informales podría ser perfectamente adecuada. Pero, si se identifica un riesgo importante, es necesario adoptar medidas estrictas. La Directiva sólo impone obligaciones a los Estados miembros de la UE, no a empresas o fabricantes particulares. Los Estados miembros están obligados a transponer las disposiciones de la Direc tiva a las correspondientes leyes, normativas y disposiciones administrativas nacionales. A su vez, éstas obligan a los empresarios a garantizar un nivel mínimo de salud y seguridad para los usuarios de pantallas de visualización.

Las principales obligaciones para los empresarios son:

- Evaluar los riesgos producidos por el uso de las pantallas de visualización en los puestos de trabajo y adoptar las medidas oportunas para reducirlos.

- Garantizar que los nuevos puestos de trabajo ("puestos en servicio porvez primera después del 31 de diciembre de 1992") cumplan las disposiciones ergonómicas mínimas que figuran en el Anexo de la Directiva. Los puestos de trabajo que estuvieran en servicio en esa fecha tienen un plazo máximo de cuatro años para cumplir las disposiciones mínimas, con tal que no estén suponiendo un riesgo para los usuarios.

- Informar a los usuarios sobre el resultado de la evaluación, las medidas adopta das por el emp resa rio y sus derechos en virtud de esta Directiva.

- O rganizar la actividad de forma que el trabajo diario con la pantalla se interrumpa por medio de pausas regulares o cambios de actividad.

- O frecer un reconocimiento adecuado de los ojos y de la vista antes de comenzar a trabajar con una pantalla de visualización, de forma periódica con posterioridad y si experimentan problemas visuales. Asimismo proporciona rá dispositivos correcto res especiales, si los resultados del reconocimiento demuestran que son necesa rios y no pueden utilizarse dispositivos correctores normales.

- Proporcionar a los usuarios una formación en salud y seguridad adecuada antes de comenzar a usar la pantalla y cada vez que la organización del puesto de trabajo se modifique "sustancialmente".

La intención de esta Directiva es especificar más la forma en que deberían utilizarse los puestos de trabajo, que la forma en que deberían diseñarse los productos. Las obligaciones, por lo tanto, recaen sobre los empresarios y no sobre los fabricantes de los puestos de trabajo. Sin embargo, muchos empresarios pedirán a los provee dores que sus productos sean "conformes" con las especificaciones. En la práctica, esto no significa mucho, ya que la Directiva sólo contiene algunos requisitos de diseño, relativamente simples. Tales requisitos se incluyen en el Anexo [no ofrecido aquí] y se refieren a tamaño y reflectancia de la superficie de trabajo, la regulación del asiento, la independencia del teclado y la claridad de la imagen visualizada. 
nacionales para discutir y votar las resoluciones y los documentos técnicos. El trabajo técnico más importante del comité tiene lugar en ocho Grupos de trabajo (GT), cada uno de los cuales es responsable de los distintos elementos de trabajo indicados en la Figura 52.11. E ste subcomité desarrolló la ISO 9241.

EI trabajo de ISO es muy importante a nivel internacional. Los principales fabricantes prestan gran atención a las especificaciones ISO. La mayoría de los productores de PVD son sociedades internacionales. Es evidente que es necesario llegar internacionalmente a un consenso sobre las soluciones mejores y más eficaces a los problemas de diseño del lugar de trabajo, desde el punto de vista de los fabricantes internacionales. Muchas autoridades regionales, como el Comité Europeo de Normalización (CEN), han adoptado las normas de ISO que han considerado adecuadas. El Acuerdo de Viena, firmado por ISO y por CEN, es el instrumento oficial que garantiza una colaboración eficaz entre ambas organizaciones. A medida que se aprueban y publican las distintas partes de la ISO 9241 como normas internacionales, son adoptadas como normas europeas y pasan a formar parte de la EN 29241. Puesto que las normas del CEN sustituyen a las nacionales en la U nión Europea (UE) y en los países miembros del Acuerdo Europeo de Libre Comercio (EFTA), la importancia de las normas de ISO en Europa ha aumentado, y con ello la presión sobre ISO para producir normas y directrices eficientes en relación con las PVD.

\section{Normas de rendimiento del usuario}

Una alternativa a las normas del producto es desarrollar otras basadas en el rendimiento del usuario. Así, en lugar de especificar una característica del producto, como la altura de los caracteres que se piensa producirá una imagen legible, los responsables de las normas desarrollan procedimientos para probar directamente características tales como la legibilidad. La norma se formula entonces en términos del rendimiento del usuario precisado por el equipo y no en términos de cómo se logra. La medida del rendimiento es un parámetro compuesto que incluye la velocidad y la precisión y la ausencia de molestias.

Las normas basadas en el rendimiento del usuario tienen las siguientes ventajas:

- son relevantes para los problemas reales que experimentan los usuarios;

- admiten los desarrollos tecnológicos,

- son suficientemente flexibles para permitir la interacción entre los factores.

Con todo, las normas basadas en el rendimiento de los usuarios también tienen varios inconvenientes. No pueden ser total y científicamente válidas en todos los casos y representan compromisos razonables, que requieren que se invierta una cantidad de tiempo considerable para alcanzar un acuerdo entre todas las partes involucradas en el establecimiento de las normas.

\section{Cobertura y uso de la norma ISO 9241}

La norma referente a los requisitos ergonómicos de las PVD, ISO 9241, detalla los aspectos ergonómicos de los productos y la evaluación de las propiedades ergonómicas de un sistema. Todas las referencias a la ISO 9241 también se aplican a la EN 29241. Algunas partes proporcionan directrices generales para el diseño del equipo, del software y de las tareas, mientras que otras incluyen directrices y requisitos de diseño más específicos, relevantes para la tecnología actual, ya que resultan útiles a los diseñadores. Además de las especificaciones de los productos, la ISO 9241 resalta la necesidad de especificar los factores que afectan al rendimiento del usuario, incluida la forma de evaluar

Figura 52.11 • G rupos de trabajo del Comité Técnico sobre la ergonomía de la interacción persona/ sistema (ISO TC 159 SC 4). ISO 9241: cinco grupos de trabajo han desglosado las "partes" de la norma, que se indican a continuación. Se muestra la correspondencia entre las partes de la norma y los distintos aspectos del puesto de trabajo con los que se relacionan.

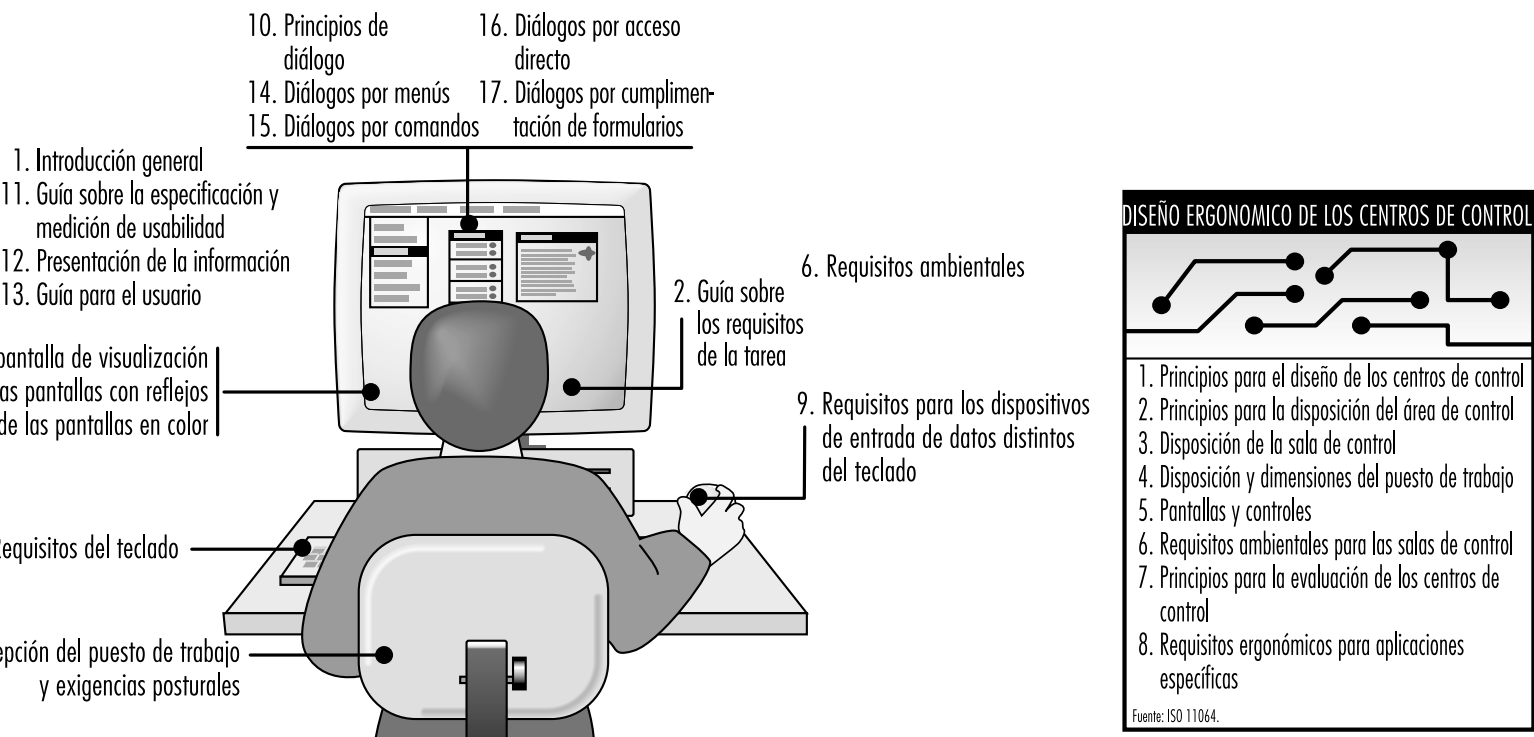


el rendimiento del usuario con el fin de determinar si un sistema es adecuado en el contexto en el que se va a utilizar.

La ISO 9241 se ha elaborado pensando en las tareas y ambientes de oficina, lo cual significa que en otros ambientes puede ser necesaria alguna desviación aceptable de esta norma. En muchos casos, esta adaptación de la norma de oficina podrá producir resultados mucho más satisfactorios que las especificaciones "a ciegas" o las pruebas de una norma específica aislada para una situación concreta. De hecho, uno de los problemas de las normas ergonómicas para las PVD es que la tecnología se desarrolla más rápidamente de lo que los responsables de la formulación de normas pueden trabajar. Así, es posible que un nuevo dispositivo no cumpla estrictamente los requisitos de una norma existente debido a que aborde las necesidades en cuestión de una forma radicalmente distinta a la que estaba prevista cuando se formuló la norma original. Por ejemplo, las primeras normas para la calidad de los caracteres en la pantalla partían de la construcción de una matriz simple de puntos. Las nuevas fuentes, más legibles, no habrían cumplido el requisito original porque no tienen el número especificado de puntos de separación entre ellos, un parámetro incoherente con su diseño.

A menos que las normas se especifiquen en términos del rendimiento que se desea obtener, los usuarios de las normas ergonómicas deben permitir que los proveedores cumplan con los requisitos demostrando que su solución proporciona un rendimiento equivalente o superior para lograr el mismo objetivo.

EI uso de la norma ISO 9241 en el proceso de especificación y adquisición coloca los aspectos ergonómicos de la pantalla de visualización como una prioridad para los directivos y ayuda a garantizar que tanto el comprador como el proveedor les den la importancia adecuada. La norma, pues, es una parte útil de la estrategia de la empresa para proteger la salud, la seguridad y la productividad de los usuarios de las pantallas.

\section{Aspectos generales}

ISO 9241 Parte 1 Introducción general explica los principios fundamentales de las diversas partes de la norma. D escribe el enfoque de rendimiento del usuario y proporciona una guía para utilizar la norma y sobre cómo estar en conformidad con las partes de la ISO 9241

ISO 9241 Parte 2 Guía para los requisitos de la tarea proporciona una guía para el diseño del trabajo y de la tarea dirigida a los responsables de la planificación del trabajo con PVD, con el fin

Figura 52.12 • Directrices y requisitos de la tarea.

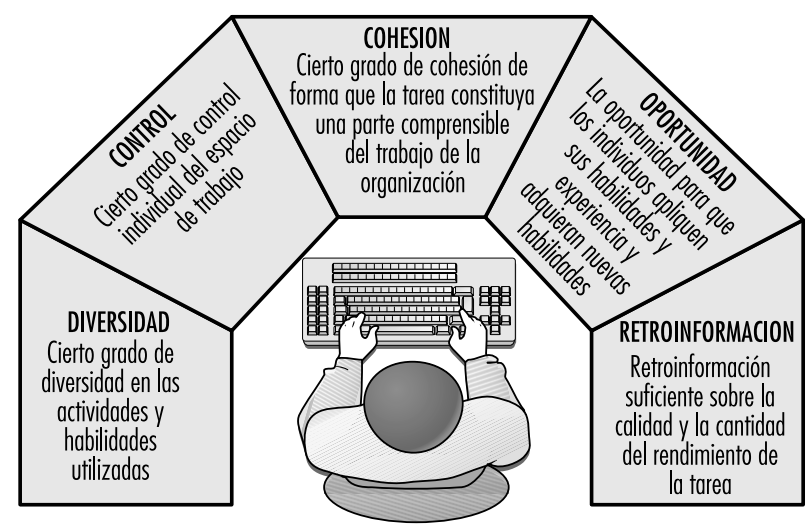

de aumentar la eficiencia y el bienestar de los usuarios individuales mediante la aplicación práctica del conocimiento ergonómico al diseño de las tareas de oficina con PVD. También comenta los objetivos y las características del diseño de las tareas (véase la Figura 52.12) y describe cómo se pueden identificar y especificar los requisitos de la tarea en organizaciones concretas y ser incorporados al diseño del sistema de organización y al proceso de aplicación.

\section{Aspectos ergonómicos del hardware y del entorno}

\section{Pantallas de visualización}

ISO 9241 (E N 29241) Parte 3 R equisitos para las pantallas de visualización de datos especifica los requisitos ergonómicos de las pantallas de visualización que garantizan una lectura cómoda, segura y eficiente para desempeñar las tareas de oficina. A pesar de que trata específicamente sobre las pantallas utilizadas en oficinas, sus recomendaciones son adecuadas para la especificación de la mayoría de las aplicaciones que utilizan pantallas con fines generales. Se propone una prueba de rendimiento del usuario que, una vez aprobada, puede servir de base para las pruebas de rendimiento y convertirse en una forma alternativa de cumplimiento con la norma para PVD.

ISO 9241 Parte 7 R equisitos de las pantallas con reflejos. EI objetivo de esta parte es especificar los métodos de medición de los brillos y reflejos en la superficie de las pantallas de visualización, incluidas aquellas con tratamientos superficiales. Está dirigida a los fabricantes de pantallas que desean garantizar que los tratamientos antirreflejos no reducen la calidad de la imagen.

ISO 9241 Parte 8 R equisitos para las pantallas en color. EI objetivo de esta parte es tratar sobre los requisitos de las pantallas en color, que consisten básicamente en una ampliación de los requisitos para las pantallas monocromas indicados en la Parte 3 , requisitos de las pantallas de visualización en general.

\section{Teclado y otros dispositivos de entrada de datos}

ISO 9241 Parte 4 Requisitos del teclado es importante que el teclado sea inclinable, independiente de la pantalla y fácil de utilizar, sin producir fatiga de los brazos o de las manos. Asimismo, la norma especifica las características de diseño ergonómico de un teclado alfanumérico para que pueda utilizarse de forma cómoda, segura y eficiente para realizar tareas de oficina. N uevamente, aunque la Parte 4 es una norma a utilizar para tareas de oficina, es adecuada para la mayoría de las aplicaciones en las que se utilizan teclados alfanuméricos con fines generales. Se incluyen especificaciones de diseño y un método alternativo de cumplir con las especificaciones mediante una prueba de rendimiento.

ISO 9241 Parte 9 R equisitos para los dispositivos de entrada diferentes al teclado especifica los requisitos ergonómicos de los dispositivos como el ratón y otros dispositivos de señalización que pueden utilizarse en combinación con una pantalla de visualización. También incluye una prueba de rendimiento.

\section{Puestos de trabajo}

ISO 9241 Parte 5 Concepción del puesto de trabajo y exigencias posturales facilita el manejo eficiente de las PVD y fomenta la adopción por el usuario de una postura de trabajo confortable y saludable. Se comentan los requisitos para una postura confortable y saludable, que incluyen:

- la colocación de los controles de los equipos usados más frecuentemente, de las pantallas y de las superficies de trabajo a una buena distancia de alcance;

- la oportunidad de cambiar de posición con frecuencia;

- el evitar los movimientos excesivos, frecuentes y repetitivos, que impliquen una extensión o rotación extremas de las extremidades o del tronco, 
- un respaldo que permita un ángulo de entre 90 y 110 grados entre la espalda y los muslos.

También se identifican las características del lugar de trabajo que favorecen una postura confortable y saludable y se proporcionan directrices para el diseño.

\section{Entorno de trabajo}

ISO 9241 Parte 6 R equisitos ambientales especifica los requisitos ergonómicos para el ambiente de trabajo con pantallas de visualización que proporcionan al usuario condiciones de trabajo confortables, seguras y productivas. A barca los aspectos visuales, acústicos y tér micos del ambiente. Su objetivo es proporcionar un entorno de trabajo que facilite el uso eficiente de las PVD y proporcione al usuario condiciones de trabajo confortables.

Identifica las características del ambiente de trabajo que influyen sobre una actividad eficiente y la comodidad del usuario, y proporciona directrices de diseño. Incluso cuando es posible controlar el ambiente de trabajo dentro de límites estrictos, la opinión de los individuos sobre su aceptabilidad varía, en parte debido a las preferencias individuales y en parte a que las distintas tareas pueden requerir entornos diferentes. Por ejemplo, los usuarios sentados ante una PVD durante períodos prolongados son más sensibles a sufrir las consecuencias que los usuarios cuyo trabajo les permite desplazarse por la oficina y trabajan frente a la PVD de forma intermitente.

EI trabajo con PVD restringe con frecuencia las posibilidades que las personas tienen para desplazarse por la oficina, por lo que un cierto grado de control individual sobre el entorno es muy recomendable. En las áreas de trabajo común, debe tenerse cuidado de no exponer a la mayoría de los usuarios a condiciones extremas que pueden ser las preferidas por algunas personas.

\section{Ergonomía del software y diseño del diálogo}

ISO 9241 Parte 10 Principios de diálogo presenta los principios ergonómicos aplicables al diseño de diálogo entre las personas y los sistemas de información, a saber:

- adecuados para la tarea

- autodescriptivos

- controlables

- conformes con las expectativas del usuario

- que toleren errores

- adecuados para la individualización

- adecuados para el aprendizaje.

Estos principios están apoyados con varios ejemplos que indican las prioridades relativas y la importancia de los distintos principios en aplicaciones prácticas. El punto de partida para este trabajo fue la norma alemana DIN 66234 Parte 8 Principios de diseño del diálogo ergonómico para lugares de trabajo con pantallas de visualización.

ISO 9241 Parte 11 Guía para la especificación y medición de la usabilidad ayuda a los responsables de especificar o medir la usabilidad proporcionándoles un cuadro general coherente y consensuado de los aspectos clave y los parámetros involucrados.
Puede utilizarse este cuadro como una parte de la especificación de los requisitos ergonómicos e incluye descripciones del contexto de uso, de los procedimientos de evaluación que deben llevarse a cabo, y de los criterios de medida que deben satisfacerse al evaluar la usabilidad del sistema.

ISO 9241 Parte 12 Presentación de la información proporciona orientaciones sobre los aspectos ergonómicos específicos relacionados con la representación y la presentación de la información de manera visual. Incluye recomendaciones sobre la forma de representar la información compleja, la disposición en pantalla y el diseño y uso de las ventanas. C onstituye un resumen útil de los materiales relevantes disponibles entre la gran cantidad de directrices y recomendaciones existentes. La información se presenta como orientaciones, sin necesidad de una prueba formal de conformidad.

ISO 9241 Parte 13 Guía para el usuario proporciona a los fabricantes directrices eficaces para que ellos proporcionen, a su vez, directrices a los usuarios. Entre estas últimas están la documentación, las pantallas de ayuda, los sistemas de gestión de errores y otro tipo de ayudas frecuentes en muchos sistemas de software. Al evaluar la usabilidad de un producto en la práctica, los usuarios reales deberían tener en cuenta la documentación y las instrucciones proporcionadas por el proveedor en forma de manuales, formación, etc., así como las características específicas del propio producto.

ISO 9241 Parte 14 D iálogos por menús proporciona orientaciones sobre el diseño de los sistemas basados en menús. Se aplica tanto a los menús de texto, como a los menús desplegables o emergentes en los sistemas gráficos. La norma contiene una gran cantidad de directrices desarrolladas a partir de publicaciones y estudios relevantes. Con el fin de abarcar la gran diversidad y complejidad de los sistemas basados en el uso de menús, la norma utiliza una forma de "cumplimiento condicional". Para cada directriz, se proporcionan criterios que ayudan a establecer si es o no aplicable al sistema en cuestión. Para los casos en que se determine que las directrices son aplicables, se proporcionan criterios para establecer si el sistema cumple o no con los requisitos.

ISO 9241 Parte 15 Diálogos por comandos proporciona orientaciones para el diseño de diálogos por comandos de texto. LoS diálogos son los recuadros habituales que aparecen en la pantalla y preguntan al usuario de la PVD, por ejemplo en los comandos de búsqueda. El software crea un "diálogo" en el que el usuario debe proporcionar el término que desea buscar, así como cualquier otra especificación importante del término, como el formato o el uso de mayúsculas y minúsculas.

ISO 9241 Parte 16 Diálogos por acceso directo trata sobre el diseño de los diálogos por acceso directo y las técnicas de diálogo WYSIWYG (W hat You See Is W hat You G et: lo que ve es lo que obtiene), tanto si se proporcionan como único medio de diálogo, como si se combinan con alguna otra técnica de diálogo. Se considera que el cumplimiento condicional desarrollado para la Parte 14 también puede ser válido para este modo de interacción.

ISO 9241 Parte 17 Diálogos por cumplimentación de formularios está en las primeras etapas de desarrollo. 


\section{Referencias}

A kabri, M, S K onz. 1991. V iewing distance for VDT work. En Designing For Everyone, dirigido por Y Q ueinnec y F Daniellou. Londres: Taylor \& Francis.

Amick, BC, MJ Smith. 1992. Stress, computer-based work monitoring and measuring systems: A conceptual overview. Appl E rgon 23(1):6-16.

Apple Computer Co. 1987. Apple Human Interface Guidelines. The Apple Desktop Interface. Waltham, $M$ assachussetts: Addison-W esley.

Bammer, G, B M artin. 1988. The arguments about $\mathrm{RSI}$ : An examination. Community $\mathrm{H}$ ealth Stud 12:348-358.

- . 1992. R epetition strain injury in Australia: M edical knowledge, social movement and de facto partisanship. Social Prob 39:301-319.

Bammer, G. 1987. How technologic change can increase the risk of repetitive motions injuries Seminars 0 ccup $M$ ed 2:25-30.

- . 1990. R eview of current knowledge -M usculoskeletal problems. En W ork W ith D isplay U nits 89: Selected Papers from the W ork with D isplay U nits Conference, September 1989, M ontreal, dirigido por L Berlinguet y $D$ Berthelette. Amsterdam: North $\mathrm{H}$ olland.

Bastien, JM C, DL Scapin. 1993. Ergonomic criteria for the evaluation of human-computer interfaces. Technical Report no. 156, Programme 3 Artificial Intelligence, cognitive systems, and man-machine interaction. Francia: IN RIA.

Berg, M, BB Arnetz, S Lidén, P Eneroth, A K allner. 1992. Techno-stress, a psychophysiological study of employees with VDU-associated skin complaints. J O ccup M ed 34:698-701.

Berg, M , M A H edblad, K Erkhardt. 1990. Facial skin complaints and work at visual display units: A histopathological study. Acta D erm-Venereol 70:216-220.

Berg, M, S Lidén, O Axelson. 1990. Skin complaints and work at visual display units: An epidemiological study of office employees. I Am Acad D ermatol 22:621-625

Berg, M. 1988. Skin problems in workers using visual display terminals: A study of 201 patients. Contact D ermat 19:335-341.

-. 1989. Facial skin complaints and work at visual display units. Epidemiological, clinical and histopathological studies. Acta Derm-Venereol Supl. 150:1-40.

Bergqvist, U 1986. Pregnancy and VDT work -An evaluation of the state of the art. En W ork W ith D isplay U nits 86: Selected Papers from the International Scientific Conference $O n$ W ork W ith Display U nits, M ay 1986, Stockholm, dirigido por B K nave y PG W idebäck. Amsterdam: N orth $\mathrm{H}$ olland.

Bikson, TK. 1987. Understanding the implementation of office technology. En Technology and the T ransformation of W hite Collar W ork, dirigido por RE K raut. Hillsdale, Nueva Jersey: Erlbaum Associates.

Bjerkedal, T, J Egenaes. 1986. Video display terminals and birth defects. A study of pregnancy outcomes of employees of the Postal-Giro-Center, 0 slo, Norway. En W ork W ith Display U nits 86 : Selected Papers from the Interantional Scientific Conference On W ork W ith Display U nits, M ay 1986, Stockholm, dirigido por B K nave y PG Widebäck. Amsterdam: N orth H olland.

Blackwell, R, A Chang. 1988. Video display terminals and pregnancy. A review. Brit J Obstet Gynaec 95:446-453

Blignault, I. 1985. Psychosocial aspects of occupational overuse disorders. Tesis del M aster de Psicología Clínica, Departamento de Psicología,
Universidad Nacional Australiana, Canberra ACT.

Boissin, JP, J M ur, JL Richard, J T anguy. 1991. Study of fatigue factors when working on a VDU. En $D$ esigning for E veryone, dirigido por $Y$ Q ueinnec y F D aniellou. Londres: T aylor \& Francis.

Bradley, G. 1983. Effects of computerization on work environment and health: From a perspective of equality between sexes. 0 ccup $\mathrm{H}$ ealth $\mathrm{N}$ ursing :35-39.

-. 1989. Computers and the Psychological Environment. Londres: T aylor \& Francis.

Bramwell, RS, MJ Davidson. 1994. Visual display units and pregnancy outcome: A prospective study. J Psychosom O bstet Gynecol 14(3):197-210.

Brandt, LPA, CV Nielsen. 1990. Congenital malformations among children of women working with video display terminals. Scand J W ork E nviron $\mathrm{H}$ ealth 16:329-333.

- . 1992. Fecundity and the use of video display terminals. Scand J W ork E nviron $\mathrm{H}$ ealth 18:298-301.

Breslow, L, P Buell. 1960. M ortality and coronary heart disease and physical activity on work in California. J Chron D is 11:615-626.

Broadbeck, FC, D Zapf, J Prumper, M Frese. 1993. Error handling in office work with computers: A field study. J O ccup O rgan Psychol 66:303-317.

Brown, CM L. 1988. H uman-Computer Interface Guide lines. N orwood, N ueva J ersey: Ablex.

Bryant, HE, EJ Love. 1989. Video display terminal use and spontaneous abortion risk. Int ] E pidemiol 18:132-138.

Çakir, A, D H art, TFM Stewart. 1979. T heVDT M anual. D armstadt: Inca-Fiej R esearch Association.

Çakir, A. 1981. Belastung und Beanspruching bei Biuldschirmtätigkeiten. En Schriften zur Arbeitspychologie, dirigido por M Frese. Berna: H uber.

Carayon, P. 1993a. Job design and job stress in office workers. E rgonomics 36:463-477.

- . 1993b. Effect of electronic performance monitoring on job design and worker stress: A review of the literature and conceptual model. $\mathrm{H}$ um Factors 35(3):385-396.

Carayon-Sainfort, P. 1992. The use of computers in offices: Impact on task characteristics and worker stress. Int J H um Comput Interact 4:245-261.

Carmichael, AJ, DL Roberts. 1992. Visual display units and facial rashes. Contact $D$ ermat 26:63-64.

Carroll, JM , M B R osson. 1988. Paradox of the active user. En Interfacing Thought. Cognitive Aspects of H uman-Computer Interaction, dirigido por J M Carroll. Cambridge: Bradford.

Cohen, M L, JF Arroyo, GD Champion, CD Browne. 1992. En search of the pathogenesis of refractory cervicobrachial pain syndrome. A deconstruction of the RSI phenomenon. M ed J Austral 156:432436 .

Cohen, S, N W einstein. 1981. N onauditory effects of noise on behavior and health. I Soc I ssues 37:36-70.

Cooper, CL, J M arshall. 1976. O ccupational sources of stress: A review of the literature relating to coronary heart disease and mental ill health. J 0 ccup Psychol 49:11-28.

Dainoff, M G. 1982. O ccupational Stress Factors in VDT $O$ peration: A Review of Empirical Research in Behavior and Information T echnology. Londres: T aylor \& Francis.

Desmarais, MC, L Giroux, L Larochelle. 1993. An advice-giving interface based on plan-recognition and user-knowledge assessment. Int I $M$ an $M$ ach Stud 39:901-924.

Dorard, G. 1988. Place et validité des tests ophthalmologiques dans l'étude de la fatigue visuelle engendrée par le travail sur écran. Grenoble: Facultad de Medicina, Universidad de Grenoble.
Egan, DE. 1988. Individual differences in humancomputer interaction. $\mathrm{En} \mathrm{H}$ andbook of $\mathrm{H}$ umanComputer Interaction, dirigido por M Helander. Amsterdam: Elsevier.

Ellinger, $S, W$ Karmaus, $H$ Kaupen- $H$ aas, KH Schäfer, G Schienstock, E Sonn. 1982. 1982 Arbeitsbedingungen, gesundheitsverhalten und rheumatische E rkrankungen. $\mathrm{H}$ amburgo: M edizinische Soziologie, Universidad de $\mathrm{H}$ amburgo.

Ericson, A, B K ällén. 1986. An epidemiological study of work with video screens and pregnancy outcome: II. A case-control study. Am J Ind M ed 9:459-475.

Frank, AL. 1983. E ffects of $H$ ealth F ollowing 0 ccupational Exposure to Video D isplay T erminals. Lexington, $\mathrm{K}$ entucky: Department of Preventive Medicine and Environmental $\mathrm{H}$ ealth.

Frese, M. 1987. Human-computer interaction in the office. En International R eview of Industrial and O rganizational Psychology, dirigido por CL Cooper. Nueva York: Wiley.

Frölén, H, N-M Svedenstål. 1993. Effects of pulsed magnetic fields on the developing mouse embryo. B iolelectromagnetics 14:197-204.

Fry, HJH. 1992. O veruse syndrome and the O veruse concept. Discussion Papers On the Pathology of W orkRelated N eck and U pper Limb Disorders and the I mplications for T reatment, dirigido por $\mathrm{G}$ Bammer. Working paper No. 32. Canberra: NCEPH, U niversidad N acional Australiana.

Gaines, BR, M LG Shaw. 1986. From timesharing to the sixth generation: The development of humancomputer interaction. Part I. Int I M an M ach Stud 24:1-27.

Gardell, B. 1971. Alienation and mental health in the modern industrial environment. En Society, Stress, and $D$ isease, dirigido por L L evi. O xford: O UP.

Goldhaber, MK, MR Polen, RA Hiatt. 1988. The risk of miscarriage and birth defects among women who use visual display terminals during pregnancy. Am J Ind M ed 13:695-706.

Gould, JD, C Lewis. 1983. Designing for usability- K ey principles and what designers think. En P roceedings of the $1983 \mathrm{CH}$ I Conference $\mathrm{O} n \mathrm{H}$ uman $\mathrm{Fac}$ tors in Computing Systems, 12 D ecember, B oston. Nueva York: ACM

Gould, JD. 1988. How to design usable systems. En $\mathrm{H}$ andbook of $\mathrm{H}$ uman $\mathrm{C}$ omputer Interaction, dirigido por M H elander. A msterdam: Elsevier.

Grandjean, E. 1987. E rgonomics in Computerized Offices. Londres: T aylor \& Francis.

Hackman, JR, GR Oldham. 1976. M otivation through the design of work: T est of a theory. O rgan $B$ ehav $H$ um Perform 16:250-279.

Hagberg, M, \& K ilbom, P Buckle, L Fine, T Itani, T Laubli, H Riihimaki, B Silverstein, G Sjøgaard, S Snook, E Viikari-Juntura. 1993. Strategies for prevention of work-related musculo-skeletal disorders. Appl Ergon 24:64-67.

Halasz, F, TP M oran. 1982. Analogy considered harmful. En Proceedings of the Conference On H uman Factors in Computing Systems. Gaithersburg, M aryland: ACM Press.

H artson, HR, EC Smith. 1991. R apid prototyping in human-computer interface development. Interact Comput 3(1):51-91.

Hedge, A, WA Erickson, G Rubin. 1992. Effects of personal and occupational factors on sick building syndrome reports in air-conditioned offices. En Stress and W ell-Being At W ork-Assessments and Interventions for Occcupational $M$ ental $H$ ealth, dirigido por JC Q uick, LR M urphy y JJ Hurrell Jr. Washington, DC: American Psychological Association.

Helme, RD, SA LeV asseur, SI Gibson. 1992. RSI revisited: Evidence for psychological and physio- 
logical differences from an age, sex and occupation matched control group. Aust NZ J M ed 22:23-29.

Herzberg, F. 1974. The wise old T urk. H arvard Bus R ev (Sept./ 0 ct.): $70-80$

H ouse, J. 1981. W ork Stress and Social Support. R eading, M assachussetts: Addison-W esley.

Hutchins, EL. 1989. M etaphors for interactive systems. En The Structure of Multimodal Dialogue, dirigido por DG Bouwhuis, MM Taylor y F N éel. Amsterdam: N orth $\mathrm{H}$ olland

H uuskonen, $\mathrm{H}$, J Juutilainen, $\mathrm{H}$ K omulainen. 1993. Effects of low-frequency magnetic fields on fetal development in rats. Bioledectromagnetics 14(3):205213.

Infante-R ivard, C, M David, R G authier, GE Rivard. 1993. Pregnancy loss and work schedule during pregnancy. E pidemiology 4:73-75.

Institut de recherche en santé et en sécurité du travail (IR SST ). 1984. Rapport du groupe de travail sur les terminaux è écran de visualisation. M ontreal: IR SST

International Business M achines Corp. (IBM ). 1991a. Systems Application Architecture. Common U ser Access GuideAdvanced Interface Design Reference. White Plains, N uevaY ork: IBM

-. 1991b. Systems Application Architecture. Common U ser Access Guide to U ser Interface Design. White Plains, Nueva Y ork: IBM.

Johansson, G, G Aronsson. 1984. Stress reactions in computerized administrative work. I O ccup B ehav 5:159-181.

Juliussen, E, K Petska-Juliussen. 1994. The Seventh Annual Computer Industry 1994-1995 Almanac. Dallas: Computer Industry Almanac.

K alimo, R, A Leppanen. 1985. Feedback from video display terminals, performance control and stress in text preparation in the printing industry. I 0 ccup Psychol 58:27-38.

K anawaty, G. 1979. Introduction to W ork Study. Gine bra: OIT.

Karasek, RA, D Baker, F M arxer, A Ahlbom, $\mathrm{R}$ Theorell. 1981. Job decision latitude, job demands, and cardiovascular disease. En M achine Pacing and 0 ccupational Stress, dirigido por G Salvendy y MJ Smith. Londres: T aylor \& Francis.

Karat, J. 1988. Software evaluation methodologies $\mathrm{En} \mathrm{H}$ andbook of $\mathrm{H}$ uman-Computer Interaction, dirigido por M H elander. Amsterdam: Elsevier.

K asl, SV . 1978. Epidemiological contributions to the study of work stress. En Stress At W ork, dirigido por CL Cooper y R Payne. Nueva Y ork: Wiley.

$\mathrm{K}$ oh, D, CL Goh, J Jeyaratnam, WC K ee, CN Ong. 1991. Dermatologic complaints among visual display unit operators and office workers. Am J Contac Dermatol 2:136-137.

K urppa, K, PC H olmberg, K R antala, T N urminen, L Saxén, S H ernberg. 1986. Birth defects, course of pregnancy, and work with video display units. A Finnish case-referent study. En W ork W ith D isplay U nits 86: Selected Papers from the International Scientific Conference $O n$ W ork W ith Display U nits, M ay 1986. Stockholm, dirigido por B K nave y PG Widebäck. Amsterdam: N orth $\mathrm{H}$ olland.

Läubli, T, H Nibel, C Thomas, U Schwanninger, H K rueger. 1989. M erits of periodic visual screening tests in VDU operators. En W ork W ith Computers, dirigido por MJ Smith y G Salvendy. Amsterdam: Elsevier Science.

Levi, L. 1972. Stress and Distress in Response to Psychosocial Stimuli. N ueva Y ork: Pergamon Press.

Lewis, C, DA N orman. 1986. Designing for error. En U ser Centered System: New Perspectives On H umanComputer Interation, dirigido por DA Norman y SW Draper. Hillsdale, Nueva Jersey: Erlbaum Associates.
Lidén, C, JE Wahlberg. 1985. Work with video display terminals among office employees. Scand W ork E nviron $\mathrm{H}$ ealth 11:489-493.

Lidén, C. 1990. C ontact allergy: A cause of facial dermatitis among visual display unit operators. Am I Contact D ermatol 1:171-176.

Lindbohm, M - L, M H ietanen, $P$ K ygornen, $M$ Sallmen, $P$ von N andelstadh, $H$ T askinen, $M$ Pekkarinen, M Ylikoski, K Hemminki. 1992. Magnetic fields of video display terminals and spontaneous abortion. Am J E pidemiol 136:1041-1051.

Lindström, K. 1991. Well-being and computermediated work of various occupational groups in banking and insurance. Int J H um Comput Interact 3:339-361.

M antei, M M , TJ T eorey. 1989. Incorporating behavioral techniques into the systems development life cycle. M IS Q Septiembre: 257-274.

M arshall, C, C N elson, M M Gardiner. 1987. Design guidelines. En Applying Cognitive Psychology to U serInterface Design, dirigido por MM Gardiner y B Christie. Chichester, R eino U nido: W iley.

Mayhew, DJ. 1992. Principles and Guidelines in Software U ser Interface Design. Englewood Cliffs, Nueva Jersey: Prentice $\mathrm{H}$ all.

$M C D$ onald, AD, JC MCDonald, B Armstrong, N Cherry, AD Nolin, D R obert. 1988. Work with visual display units in pregnancy. Brit J Ind M ed 45:509-515.

M cGivern, RF, RZ Sokol. 1990. Prenatal exposure to a low-frequency electromagnetic field demasculinizes adult scent marking behavior and increases accessory sex organ weights in rats. Teratology 41:1-8.

M eyer, J-J, A Bousquet. 1990. Discomfort and disability glare in VDT operators. En W ork W ith Display $U$ nits 89, dirigido por $L$ Berlinguet y D Berthelette. Amsterdam: Elsevier Science.

M icrosoft Corp. 1992. T he W indows Interface: An Application D esign Guide. Redmond, Washington: M icrosoft Corp.

M onk, TH, DI T epas. 1985. Shift work. En I ob Stress and Blue Collar W ork, dirigido por CL Cooper y MJ Smith. Nueva Y ork: Wiley.

M oran, T P. 1981. T he command language grammar: $A$ representation for the user interface of interaction computer systems. Int J $\mathrm{M}$ an $\mathrm{M}$ ach Stud 15:3-50.

- . 1983. G etting into a system: External-internal task mapping analysis. En Proceedings of the $1983 \mathrm{CH} \mathrm{I}$ Conference On H uman Factors in Computing Systems, 12-15 D ecember, B oston. N ueva Y ork: ACM

M oshowitz, A. 1986. Social dimensions of office automation. Adv Comput 25:335-404.

M urray, WE, CE M oss, WH Parr, C Cox, M J Smith, BFG Cohen, LW Stammerjohn, A Happ. 1981. Potential $\mathrm{H}$ ealth $\mathrm{H}$ azards of Video Display Terminals. NIOSH Research Report 81-129. Cincinnati, O hio: National Institute for 0 ccupational Safety and $\mathrm{H}$ ealth $(\mathrm{N} I \mathrm{OSH})$

Nielsen, CV, LPA Brandt. 1990. Spontaneous abortion among women using video display terminals. Scand I W ork E nviron $\mathrm{H}$ ealth 16:323-328.

- . 1992. Fetal growth, preterm birth and infant mortality in relation to work with video display terminals during pregnancy. Scand I W ork Environ $\mathrm{H}$ ealth 18:346-350.

Nielsen, J, RL M ack. 1994. U sability Inspection M ethods. Nueva Y ork: Wiley.

Nielsen, J. 1992. The usability engineering life cycle. Computer (M ar.):12-22.

-. 1993. Iterative user-interface design. Computer (N ov.):32-41.

Numéro spécial sur les laboratoires d'utilisabilité. 1994. B ehav Inf T echnol.

Nurminen, $T$ and $K$ K urppa. 1988. O ffice employment, work with video display terminals, and course of pregnancy. Reference mothers' experience from a Finnish case-referent study of birth defects. Scand J W ork E nviron $H$ ealth 14:293-298.

O ffice of Technology Assessment (OTA). 1987. The Electronic Supervisor: New T echnology, New Tensions. Washington, DC: US Government Printing 0 ffice.

O pen Software Foundation. 1990. OSF/M otif Style Guide. Englewood Cliffs, Nueva Jersey: Prentice $\mathrm{H}$ all.

O rganización Internacional de N ormalización (ISO). 1992. E rgonomic R equirements for O ffice W ork W ith Visual Display Terminals (VDTS). Norma ISO 9241.Ginebra: ISO

O rganización Internacional del Trabajo (O IT ). 1984. Automation, W ork Organisation and 0 ccupational Stress. Ginebra: OIT.

-. 1986. Special issue on visual display units. Cond W ork Dig.

-. 1989. W orking with Visual Display U nits. O ccupational Safety and Health Series, N 0. 61. Ginebra: OIT

-. 1991. W orker's privacy. Part I: Protection of personal data. C ond W ork Dig 10:2.

O rganización M undial de la Salud (O M S). 1987. Visual Display Terminals and W orkers' $H$ ealth. Ginebra: OMS.

-. 1989. Work with visual display terminals: Psychosocial aspects and health. J 0 ccup M ed 31:957-968.

O stberg, O, C Nilsson. 1985. Emerging technology and stress. En I ob Stress and Blue Collar W ork, dirigido por CL Cooper y MJ Smith. Nueva York: Wiley.

Piotrkowski, CS, BFG Cohen, KE Coray 1992. W orking conditions and well-being among women office workers. Int J H um Comput Interact 4:263-282.

Pot, F, P Padmos, A Brouwers. 1987. Determinants of the VDU operator's well-being. En W ork W ith D isplay U nits 86. Selected Papers from the International Scientific Conference $O \mathrm{n}$ W ork W ith Display U nits, $M$ ay 1986, Stockholm, dirigido por B K nave y PG W idebäck. Amsterdam: $\mathrm{N}$ orth $\mathrm{H}$ olland.

Preece, J, Y R ogers, H Sharp, D Benyon, S H olland, T Carey. 1994. H uman Computer Interaction. Reading, $M$ assachussetts: Addison-W esley.

Q uinter, J, R Elvey. 1990. The neurogenic hypothesis of RSI. Discussion Papers On the Pathology of W orkRelated N eck and U pper Limb Disorders and the I mplications for T reatment, dirigido por G Bammer. Working paper No. 24. Canberra: NCEPH, U niversidad N acional Australiana.

Rasmussen, J. 1986. Information Processing and $M$ an$\mathrm{M}$ achine Interaction. An Approach to Cognitive E ngineering. N ueva Y ork: N orth H olland.

Ravden, SJ, GI Johnson. 1989. Evaluating U sability of $H$ uman-Computer Interfaces: A Practical A pproach. West Sussex, R eino U nido: $E$ H orwood.

-. 1992. Systems Application Architecture: Common Communications Support. Englewood C liffs, Nueva Jersey: Prentice $\mathrm{H}$ all.

Reed, AV. 1982. Error correcting strategies and human interaction with computer systems. En Proceedings of the Conference $\mathrm{O} \mathrm{H}$ uman $\mathrm{F}$ actors in $\mathrm{C}$ omputing Systems $G$ aithersburg, M aryland: ACM .

Rey, P, A Bousquet. 1989. Visual strain of VDT operators: The right and the wrong. En W ork W ith Computers, dirigido por G Salvendy y MJ Smith. Amsterdam: Elsevier Science.

-. 1990. Medical eye examination strategies for VDT operators. En W ork W ith Display U nits 89 , dirigido por $L$ Berlinguet y $D$ Berthelette. Amsterdam: Elsevier Science.

Rheingold, HR. 1991. Virtual Reality. Nueva Y ork: T ouchstone.

Rich, E. 1983. U sers are individuals: Individualizing user models. Int J M an M ach Stud 18:199-214. 
Rivas, L, C R ius. 1985. Effects of chronic exposure to weak electromagnetic fields in mice. IRCS M ed Sci 13:661-662.

Robert, J-M, J-Y Fiset. 1992. Conception et évaluation ergonomiques d'une interface pour un logiciel d'aide au diagnostic: Une étude de cas. ICO primavera-verano:1-7.

Robert, J-M. 1989. Learning a computer system by unassisted exploration. An example: The Macintosh. En MACINTER \|M M n-Computer Interaction Research, dirigido por F K lix, N Streitz, Y Warren y $\mathrm{H}$ Wandke. Amsterdam: Elsevier.

Roman, E, V Beral, M Pelerin, C Hermon. 1992. Spontaneous abortion and work with visual display units. B rit J Ind M ed 49:507-512.

Rubino, GF. 1990. Epidemiologic survey of ocular disorders: The Italian multicentric research. En W ork W ith Display U nits 89 , dirigido por L Berlinguet y $D$ Berthelette. Amsterdam: Elsevier Science.

Rumelhart, DE, DA Norman. 1983. Analogical processes in learning. En Cognitive Skills and The Acquisition, dirigido por JR Anderson. Hillsdale, Nueva Jersey: Lawrence Erlbaum.

Ryan, GA, JH Mullerworth, J Pimble. 1984. The prevalence of repetition strain injury in data process operators. En Proceedings of the 21st Annual Conference of the E rgonomics Society of Australia and N ew Zealand. Sidney.

Ryan, GA, M Bampton. 1988. Comparison of data process operators with and without upper limb symptoms. Community $\mathrm{H}$ ealth Stud 12:63-68.

Sainfort, PC. 1990. Job design predictors of stress in automated offices. B ehav Inf T echnol 9:3-16.

- . 1991. Stress, job control and other job elements: A study of office workers. Int J Ind E rg 7:11-23.

Salvendy, G. 1992. H andbook of Industrial Engineering. Nueva Y ork: Wiley.

Salzinger, K, S Freimark. 1990. Altered operant behavior of adult rats after perinatal exposure to a $60-\mathrm{Hz}$ electromagnetic field. Biolelectromagnetics 11:105-116.

Sauter, SL, CL Cooper, JJ H urrell. 1989. J ob Control and $\mathrm{W}$ orker $\mathrm{H}$ ealth. N ueva $\mathrm{Y}$ ork: Wiley.

Sauter, SL, MS Gottlieb, KC Jones, NV Dodson, K M R ohrer. 1983a. Job and health implications of VDT use: Initial results of the Wisconsin-NIOSH study. Commun ACM 26:284-294.

Sauter, SL, M S Gottlieb, K M Rohrer, NV Dodson. 1983b. TheW ell-B eing of Video D isplay T erminal U sers. An Exploratory Study. Cincinnati, O hio: NIOSH.

Scapin, DL. 1986. Guide ergonomique de conception des interfaces hommemachine Rapport de recherche no. 77. Le Chesnay, Francia: INRIA.

Schnorr, TM, BA Grajewski, RW Hornung, MJ Thun, GM Egeland, WE M urray, DL Conover, WE Halperin. 1991. Video display terminals and the risk of spontaneous abortion. N ew Engl J $\mathrm{M}$ ed 324:727-733.

Shepherd, A. 1989. Analysis and training in information technology tasks. En T ask Analysis for H umanComputer Interaction, dirigido por D Diaper. Chichester: $\mathrm{E} H$ orwood.

Shneiderman, B. 1987. Designing the U ser Interface Strategies for Effective $H$ uman-Computer Interaction. R eading, M assachussetts: Addison-W esley.

Sjödren, S, A Elfstrom. 1990. Eye discomfort among 4000 VDU users. En W ork W ith Display U nits 89 , dirigido por $L$ Berlinguet y $D$ Berthelette. Amsterdam: Elsevier Science.

Smith, MJ, BC Amick. 1989. Electronic monitoring at the workplace: Implications for employee control and job stress. En I ob Control and W orker H ealth, dirigido por S Sauter, J H urrel y C Cooper. Nueva Y ork: Wiley.

Smith, MJ, BFG Cohen, LW Stammerjohn, A H app. 1981. An investigation of health complaints and job stress in video display operations. H um F actors 23:387-400.

Smith, M J, G Salvendy, P Carayon-Sainfort, R Eberts. 1992b. Human-computer interaction. En $\mathrm{H}$ andbook of Industrial Engineering, dirigido por G Salvendy. Nueva Y ork: Wiley.

Smith, MJ, P Carayon, K M iezio. 1987. VDT technology: Psychosocial and stress concerns. En W ork $W$ ith Display U nits, dirigido por B K nave y PG Widebäck. Amsterdam: Elsevier Science.

Smith, MJ, P Carayon, KH Sanders, S-Y Lim, D LeGrande. 1992a. Electronic performance monitoring, job design and worker stress. Appl Ergon 23:17-27.

Smith, M , P Carayon-Sainfort. 1989. A balance theory of job design for stress reduction. Int I Ind $\mathrm{E}$ rg 4:67-79.

Smith, MJ. 1987. O ccupational stress. En $\mathrm{H}$ andbook of E rgonomics/ H uman Factors, dirigido por $\mathrm{G}$ Salvendy. Nueva Y ork: Wiley.

Smith, SL, SL Mosier. 1986. Guidelines for Designing U ser Interface Software. Report ESD-TR-278. Bedford, M assachussetts: M ITRE.

South Australian $\mathrm{H}$ ealth Commission Epidemiology Branch. 1984. Repetition Strain Symptoms and W orking Conditions Among Keyboard W orkers Engaged in D ata Entry or W ord Processing in the South Australian Public Service Adelaide: South Australian $\mathrm{H}$ ealth $\mathrm{Com}$ mission.

Stammerjohn, LW, MJ Smith, BFG Cohen. 1981. Evaluation of work station design factors in VDT operations. $\mathrm{H}$ um F actors 23:401-412.

Stellman, JM, S K litzman, GC Gordon, BR Snow. 1985. Air quality and ergonomics in the office: Survey results and methodologic issues. Am Ind $\mathrm{H}$ yg Assoc) 46:286-293.

- 1987a. Comparison of well-being among nonmachine interactive clerical workers and full-time and part-time VDT users and typists. En W ork $W$ ith Display U nits 86 . Selected Papers from the International Scientific Conference On W ork W ith Display U nits, $M$ ay 1986, Stockholm, dirigido por B K nave y PG W idebäck. Amsterdam: N orth $\mathrm{H}$ olland.

-. 1987b. Work environment and the well-being of clerical and VDT workers. J O ccup B ehav 8:95-114.

Strassman, PA. 1985. Information Payoff: The T ransformation of $W$ ork in the $E$ lectronic Age. N ueva $Y$ ork: Free Press.

Stuchly, M , AJ Ruddick, y cols. 1988. Teratological assessment of exposure to time-varying magnetic fields. T eratology 38:461-466.

Sun M icrosystems Inc. 1990. O pen L ook. Graphical U ser Interface Application Style Guidelines. R eading, M assachussetts: Addison-W esley.

Swanbeck, G, T Bleeker. 1989. Skin problems from visual display units: Provocation of skin symptoms under experimental conditions. Acta D erm-Venereol 69:46-51.

T aylor, FW. 1911. T he Principles of Scientific M anagement. Nueva Y ork: N orton \& C 0 .

Thimbleby, H. 1990. U ser Interface D esign. Chichester: ACM.

Tikkanen, J, O P H einonen. 1991. M aternal exposure to chemical and physical factors during pregnancy and cardiovascular malformations in the offspring. T eratology 43:591-600

Tribukait, B, E Cekan. 1987. Effects of pulsed magnetic fields on embryonic development in mice. En W ork W ith Display U nits 86: Selected Papers from the International Scientific Conference On W ork W ith Display U nits, M ay 1986, Stockholm, dirigido por B K nave y PG Widebäck. Amsterdam: N orth H olland.

Wahlberg, JE, C Lidén. 1988. Is the skin affected by work at visual display terminals? Dermatol Clin 6:81-85.
Waterworth, JA, M H C hignell. 1989. A manifesto for hypermedia usability research. H ypermedia 1:205234.

W esterholm, P, A Ericson. 1986. Pregnancy outcome and VDU work in a cohort of insurance clerks. En W ork W ith Display U nits 86 . Selected Papers from the International Scientific Conference On W ork W ith D isplay $U$ nits, M ay 1986, Stockholm, dirigido por B K nave y PG W idebäck. Amsterdam: N orth H olland.

Westlander, G, E Aberg. 1992. Variety in VDT work: An issue for assessment in work environment research. Int J H um Comput I nteract 4:283-302.

Westlander, G. 1989. U se and non-use of VDT s-O rganization of terminal work. En W ork $W$ ith Computers: Organizational, M anagement, Stress and $\mathrm{H}$ ealth Aspects, dirigido por M J Smith y G Salvendy. Amsterdam: Elsevier Science.

W ickens, C. 1992. E nginering P sychology and $\mathrm{H}$ uman Performance. Nueva $Y$ ork: $\mathrm{H}$ arper Collins.

Wiley, M J, P Corey. 1992. The effects of continuous exposure to 20-khz sawtooth magnetic fields on the litters of CD-1 mice. T eratology 46:391-398.

Wilson, J, D R osenberg. 1988. R apid prototyping for user interface design. En $H$ andbook of $H$ umanComputer Interaction, dirigido por M Helander. Amsterdam: Elsevier.

Windham, GC, L Fenster, SH Swan, RR Neutra. 1990. U se of video display terminals during pregnancy and the risk of spontaneous abortion, low birthweight, or intrauterine growth retardation. Am J Ind M ed 18:675-688.

Y ang, C-L, P C arayon. 1993. Effects of job demands and job support on worker stress: A study of VDT users. B ehav Inf T echnol.

Young, JE. 1993. Global N etwork. Computers in a Sustainable Society. Washington, DC: Worldwatch Paper 115.

Y oung, R M . 1981. The machine inside the machine: U sers' models of pocket calculators. Int I $M$ an $M$ ach Stud 15:51-85.

Zecca, L, P Ferrario, G Dal Conte. 1985. Toxicological and teratological studies in rats after exposure to pulsed magnetic fields. Biodectrochem Bioenerget 14:63-69.

Zuboff, S. 1988. In the Age of the Smart M achine: The F uture of W ork and Power. Nueva Y ork: Basic Books.

\section{O tras lecturas recomendadas}

Berlinguet, L, D Berthelette. 1990. W ork W ith Display $U$ nits 89. Amsterdam: Elsevier Science.

Berthelette, D. 1995. Les changements technologiques et la gestion de la santé et de la sécurité du travail. En Changement technologique et gestion des ressources humaines: $F$ ondement et pratiques, dirigido por I R éal y J Ducharme. M ontreal: G aëtan M orin.

Card, SK, T P M oran, A N ewell. 1983. T he Psychology of $\mathrm{H}$ uman-C omputer Interactions. H illsdale, N ueva Jersey: Lawrence Erlbaum.

Cordingley, ES. 1989. K nowledge elicitation techniques for knowledge-based systems. En Knowledge Elicitation. Principles, T echniques and Applications, dirigido por D Diaper. Chichester: E H orwood.

Diaper, D. 1989. Task Analysis for H uman-Computer interaction. Chichester: $\mathrm{E}$ H orwood.

DiT ecco, D, G C witco, A Arsenault, M Andre. 1992. 0 perator stress and monitoring practices. Appl E rgon 23(1):29-34.

$\mathrm{H}$ andcock, PA, MH Chignell. 1989. Intelligent Interfaces. Theory, Research and Design. Amsterdam: Elsevier.

H ocking, B. 1987. Epidemiological aspects of "repetition strain injury". M ed J Austral 147:218-222.

Johnson, P, H Johnson. 1989. Integrating task analysis into system design: Surveying designers' needs. E rgonomics 32(11):1451-1467. 
Johnson, P, S Wilson, P M arkopoulos, J Pycock. 1993. Adept-Advanced Design Environment for Prototyping With Task Models. En Proceedings of INT ERCH I'93: Conference On H uman Factors in Computing Systems, 24-29 April, Amsterdam R eading, M assachussetts: Addison-W esley.

Johnson, P. 1985. Towards a task model of messaging: an example of the application of T.A.K.D. to user interface design. En People and Computers: Designing the Interface, dirigido por $\mathrm{P}$ Johnson $\mathrm{y}$ S Cook. Cambridge: CUP.

K nave, B, PG Widebäck. 1987. W ork W ith Display $U$ nits 86. Amsterdam: Elsevier Science.
K rueger, H. 1992. Exigences visuelles au poste $d$ tavail: Diagnostic et traitement Cahiers médicosociaux 36:171-181.

M ayer, RE. 1988. From novice to expert. En $\mathrm{H}$ andbook of $\mathrm{H}$ uman-Computer Interaction, dirigido por M H elander. Amsterdam: Elsevier.

M eyer, J J, D Francioli, P R ey. 1993. O bserved variations of lighting conditions versus feelings of visual discomfort in VDT operators: Application of a new model. In L ux E uropa 1993. E dimburgo: U niversidad $\mathrm{H}$ eriot-W att.

Rey, P. 1991. Précis de médecine du travail. Ginebra: $M$ edicine et $H$ ygiène.

Robert, J-M. 1993. Interfaces personne-système et élaboration de normes internationales. En Fran- cophonie et génie linquistique Grands enjeux et solutions à Privilégier. M ontreal: UREF.

Scalet, EA, TFM Stewart, KP M cGee. 1987. VDT $H$ ealth and Safety. Issues and Solution. Lawrence, $\mathrm{K}$ ansas: Ergosyst.

Scapin, DL, C Pierret-Golbreich. 1989. M ad: M éthode analytique de description des tâches. Antipolis: Sophia.

Sébillotte, S, DL Scapin. 1992. From U ser's Task K nowledge to $\mathrm{H}$ igh Level Interface Specification. encia Internacional de WWDU, 1-4 de septiembre, Berlín, Alemania.

Wilson, MD, PJ Barnard, A M acL ean. 1986. T ask Analyses in $\mathrm{H}$ uman-Computer Interaction. Hursley H uman Factors Laboratory HF122. 


\section{RIESGOS AMBIENTALES PARA LA SALUD}

Directores del capítulo

Annalee Yassi yT ord Kjellström

\section{Sumario}

Conexiones entre la salud ambiental y la salud en el trabajo

Annalee Yassi y Tord Kjellström.

La alimentación y la agricultura

La contaminación industrial en los países en desarrollo

Niu Shiru. . . .

Los países en desarrollo y la contaminación

Tee L. Guidotti

La contaminación del aire

I sabelle R omieu

La contaminación del suelo

TeL L. Guidotti y Chen W eiping.

La contaminación del agua

I vanildo $\mathrm{H}$ espanhol y R ichard $\mathrm{H}$ elmer

La energía y la salud

L. D. H amilton ...

La urbanización

E dmundo $W$ erna . . . . . . . . . . . . . . . . . . . . . . . . . . . 53.25

El cambio climático mundial y el agotamiento del ozono

J onathan A. Patz . . . . . . . . . . . . . . . . . . . . 53.27

L a extinción de especies, la pérdida de diversidad biológica y la salud humana

E ric Chivian........................... 53.32 


\section{- CONEXIONESENTRE LA SALUd AMBIENTAL Y LA SALUD EN EL TRABAJO}

\section{Annalee Yassi y Tord Kjellström}

EI desarrollo, y en particular la industrialización, han contribuido de forma extremadamente positiva a la salud, así como a una mayor prosperidad personal y social, y a una enorme mejora de los servicios de salud y educación, los transportes y las comunicaciones. Es indudable que, a escala mundial, la gente vive más y tiene un estado de salud mejor que hace siglos o incluso decenios. A hora bien, la industrialización ha tenido también consecuencias negativas para la salud, y no sólo para los trabajadores, sino para la población en general. E sos efectos se derivan directamente de la exposición a peligros para la seguridad y a agentes perjudiciales, o indirectamente del deterioro del medio ambiente local y mundial (véase en este capítulo "La contaminación industrial en los países en desarrollo").

En el presente artículo se esboza la naturaleza de los peligros para la salud de origen ambiental y las razones que justifican el establecimiento de una relación entre salud ambiental y salud en el trabajo.

Del mismo modo que los peligros derivados del trabajo, los peligros para la salud de origen ambiental pueden ser de carácter biológico, físico, biomecánico o psicosocial. Entre ellos se incluyen factores tradicionales como las deficiencias de saneamiento y vivienda, y la contaminación agrícola e industrial del aire, del agua, de los alimentos y del suelo. Estos peligros tienen gran cantidad de efectos sobre la salud, que pueden ser directos y catastróficos (por ejemplo, la reciente epidemia de cólera en América Latina y el episodio de intoxicación química en Bhopal, India), crónicos (por ejemplo, en M inamata, Japón) o sutiles e indirectos, discutidos incluso (por ejemplo, en Love Canal,
Estados U nidos). En la Tabla 53.1 se resumen algunas de las catástrofes más célebres de los últimos 50 años que han provocado episodios de "enfermedad de origen ambiental", pero es innegable que hay muchísimos otros ejemplos de este tipo, algunos de ellos no fácilmente detectables a nivel macroestadístico. Entre tanto, más de 1.000 millones de personas en el mundo carecen de acceso al agua potable (O M S 1992b), y más de 600 millones están expuestas a niveles ambientales de dióxido de azufre que superan en mucho los límites recomendados. Además, la presión sobre la agricultura y la producción de alimentos derivadas del incremento de la población y de la demanda "per cápita" conducirán probablemente a una mayor carga sobre el medio ambiente (véase en este capítulo "La alimentación y la agricultura"). Así pues, los efectos sobre la salud de origen ambiental comprenden los efectos nocivos indirectos de la industria sobre una alimentación y vivienda adecuadas y el deterioro de los sistemas mundiales de que depende la salud del planeta.

En muchos países, la agricultura a gran escala y el correspondiente uso intensivo de plaguicidas tóxicos representa un importante peligro para la salud tanto de los trabajadores como de sus familias. La contaminación por fertilizantes o desechos biológicos procedentes de la industria alimentaria, la industria del papel y otros sectores industriales puede tener también efectos perjudiciales sobre los cursos de agua, con la consiguiente reducción de la pesca y del suministro de alimentos. Es posible quienes se dedican a la pesca y a la recolección de otros productos marinos tengan que desplazarse largas distancias para obtener su captura diaria, con el incremento del riesgo de naufragio y de otras desgracias. 0 tro tipo de riesgo para la salud de origen ambiental es la difusión de enfermedades tropicales por los cambios ambientales asociados a avances como la construcción de presas, carreteras y otras infraestructuras. Una nueva presa puede crear un terreno abonado para la esquistosomiasis, enfermedad debilitadora que afecta a los cultivadores de

Tabla 53.1 - Algunos episodios importantes de "enfermedad de origen ambiental".

\begin{tabular}{|c|c|c|c|}
\hline Lugar y año & Peligro ambiental & Tipo de enfermedad & Número de afectados \\
\hline Londres, RU 1952 & $\begin{array}{l}\text { Grave contaminación del aire por dióxido de } \\
\text { azufre y partículas en suspensión }\end{array}$ & $\begin{array}{l}\text { Más manifestaciones de enfermedades } \\
\text { cardíacas y pulmonares }\end{array}$ & 3.000 muertos y muchos enfermos \\
\hline Toyama, Japón déc. 1950 & Cadmio en el arroz & Renal y ósea ("enfermedad de Itai-itai") & 200 graves, muchos más leves \\
\hline Sudeste de Turquía 1955-61 & Hexaclorobenceno en cereales & Porfiria; neurológica & 3.000 \\
\hline Minamata, Japón 1956 & Metilmercurio en el pescado & Neurológica ("enfermedad de Minamata") & 200 graves, 2.000 posibles afectados \\
\hline Ciudades EE.UU $1960-80$ & Plomo en pinturas & $\begin{array}{l}\text { Anemia, efectos en la mente y en el } \\
\text { comportamiento }\end{array}$ & Muchos miles \\
\hline Fukuoka, Japón 1968 & $\begin{array}{l}\text { Bifenilos policlorados (PCB) en aceite } \\
\text { comestible }\end{array}$ & Cutánea, debilidad general & Varios miles \\
\hline Irak 1972 & Metilmercurio en cereales & Neurológica & 500 muertos, 6.500 hospitalizados \\
\hline Madrid, España 1981 & Anilina u otra toxina en aceite comestible & Síntomas varios & 340 muertos, 20.000 afectados \\
\hline Bhopal, India 1985 & Isocianato de metilo & Pulmonar aguda & 2.000 muertos, 200.000 intoxicados \\
\hline California, EE.UU. 1985 & Plaguicida con carbamato en sandías & $\begin{array}{l}\text { Efectos sobre los sistemas gastrointestinal, } \\
\text { óseo, muscular y nervioso autónomo y } \\
\text { central (enfermedad del carbamato) }\end{array}$ & $\begin{array}{l}1.376 \text { casos notificados por consumo, } \\
17 \text { graves }\end{array}$ \\
\hline Chernóbil, URSS 1986 & $\begin{array}{l}\text { Yodo-134, Cesio-134 y -137 por explosión } \\
\text { de un reactor }\end{array}$ & $\begin{array}{l}\text { Radiación (incluidos incrementos del cáncer } \\
\text { y las enfermedades tiroideas en los niños) }\end{array}$ & $\begin{array}{l}300 \text { heridos, } 28 \text { muertos en tres meses, } \\
\text { más de } 600 \text { casos de cáncer de tiroides }\end{array}$ \\
\hline Goiánia, Brasil 1987 & $\begin{array}{l}\text { Cesio-137 de un aparato (abandonado) para } \\
\text { radiar a enfermos de cáncer }\end{array}$ & $\begin{array}{l}\text { Radiación (continúa el seguimiento de las } \\
\text { exposiciones in utero) }\end{array}$ & $\begin{array}{l}\text { Alrededor de } 240 \text { contaminados y dos } \\
\text { muertos }\end{array}$ \\
\hline Perú 1991 & Epidemia de cólera & Cólera & 139 muertos, muchos miles de afectados \\
\hline
\end{tabular}


arroz, que han de andar por el agua. U na nueva carretera puede facilitar la rápida comunicación entre una zona con malaria endémica y otra que hasta ese momento se había visto libre de la enfermedad.

$H$ ay que señalar que el factor más importante para un medio ambiente nocivo, ya sea en el lugar de trabajo o en general, es la pobreza. Entre las amenazas para la salud tradicionales de los países en desarrollo o de los sectores pobres de cualquier país figuran la escasez de saneamiento, de suministro de agua y de alimentos, que contribuyen a la propagación de enfermedades transmisibles, y la mala calidad de la vivienda, con una elevada exposición al humo de cocinar y un elevado riesgo de incendios, así como el alto riesgo de accidentes en la agricultura a pequeña escala 0 en las pequeñas industrias rurales. La reducción de la pobreza y la mejora de las condiciones de vida y de trabajo constituyen una prioridad fundamental a la hora de mejorar la salud en el trabajo y la salud ambiental de miles de millones de personas. A pesar de los effuerzos realizados en materia de conservación de la energía y desarrollo sostenible, la falta de tratamiento de las desigualdades subyacentes en la distribución de la riqueza representa una amenaza para el ecosistema mundial. Los bosques, por ejemplo, que constituyen la culminación de sucesivos procesos ecológicos, se están destruyendo a un ritmo alarmante debido a la tala comercial y al desmonte por poblaciones empobrecidas que buscan suelo para la agricultura y leña. Entre los efectos de la despoblación forestal cabe destacar la erosión de los suelos, que en su versión extrema puede llevar a la desertización. U na consecuencia importante de este proceso es la pérdida de diversidad biológica (véase en este capítulo " $L a$ extinción de especies, la pérdida de diversidad biológica y la salud humana"). Se estima que una tercera parte de las emisiones totales de dióxido de carbono procede de la quema de bosques tropicales (la importancia del dióxido de carbono como factor de calentamiento de la T ierra se examina en otra parte de este capítulo, "El cambio climático mundial y el agotamiento del ozono"). Resulta, pues, imprescindible abordar el problema de la pobreza al tratar de la salud ambiental mundial y del bienestar de los individuos, las comunidades y las regiones.

\section{Razones para vincular la salud ambiental y la salud en el trabajo}

La principal conexión existente entre el lugar de trabajo y el medio ambiente general es que la fuente de peligro suele ser la misma, ya se trate de una actividad agrícola o industrial. Para controlar el peligro sobre la salud, puede resultar eficaz en ambos casos un enfoque común. Así ocurre especialmente a la hora de elegir tecnologías químicas para la producción. Si se puede obtener un resultado o un producto aceptable con una sustancia química menos tóxica, la elección de dicha sustancia química puede reducir o incluso eliminar el riesgo para la salud. Un ejemplo es la utilización de pinturas al agua, más seguras, en vez de las que contienen disolventes orgánicos tóxicos. 0 tro es elegir, cuando es posible, métodos no químicos de lucha contra las plagas. De hecho, en muchos casos, sobre todo en el mundo en desarrollo, no hay separación entre el hogar y el lugar de trabajo, de modo que el entorno es en realidad el mismo.

Está ampliamente aceptado que los conocimientos científicos y la capacitación que se requieren para evaluar y controlar los peligros para la salud de origen ambiental son en su mayoría los mismos que se precisan para abordar los peligros para la salud en el lugar de trabajo. La toxicología, la epidemiología, la higiene en el trabajo, la ergonomía, la ingeniería de la seguridad - que son de hecho las disciplinas que se incluyen en la presente Enciclopedia- son los instrumentos básicos de la ciencia del medio ambiente. El proceso de evaluación y gestión de riesgos es también el mismo: identificación de los peligros, clasificación de los riesgos, evaluación de la exposición y estimación del riesgo. Los pasos siguientes son evaluar las opciones de control, controlar la exposición, dar a conocer el riesgo al público y establecer un programa continuo de vigilancia de la exposición y el riesgo. Así pues, la salud en el trabajo y la salud ambiental están estrechamente ligadas por metodologías comunes, especialmente en materia de evaluación de la salud y control de la exposición.

En muchas ocasiones se han identificado peligros para la salud de origen ambiental a partir de observaciones de consecuencias adversas sobre la salud de los trabajadores, y es indudable que en el lugar de trabajo es donde mejor se comprende el efecto de las exposiciones industriales. La documentación de los efectos sobre la salud se realiza generalmente por una de las tres vías siguientes: experimentos con animales u otros experimentos de laboratorio (tanto sin seres humanos como con seres humanos bajo control), exposiciones accidentales de alto nivel 0 estudios epidemiológicos realizados tras dichas exposiciones. Para llevar a cabo un estudio epidemiológico es necesario poder determinar tanto la población expuesta como la naturaleza y el nivel de la exposición, así como comprobar el efecto perjudicial sobre la salud. Suele ser más fácil definir los miembros de una población laboral que los componentes de una comunidad, especialmente en una comunidad muy cambiante; la naturaleza y el nivel de la exposición a que están sometidos los distintos miembros de la cohorte suelen estar más claros en una población laboral que en una comunidad; y los resultados de altos niveles de exposición son casi siempre más fáciles de delimitar que cambios más sutiles atribuibles a un bajo nivel de exposición. Aunque hay algunos ejemplos de exposición "fuera de fábrica" cercanos a las peores exposiciones en el lugar de trabajo (por ejemplo, la exposición al cadmio por la minería en China y Japón; las emisiones de plomo y cadmio procedentes de fundiciones en la Silesia superior, Polonia), la población laboral suele estar sometida a niveles de exposición mucho más altos que la comunidad de su entorno (O M S 1992).

Dado que los resultados negativos para la salud son más evidentes en los trabajadores, se ha utilizado la información sobre los efectos de la exposición en el trabajo a sustancias tóxicas (por ejemplo, a metales pesados como el plomo, el mercurio, el arsénico y el níquel, así como a carcinógenos muy conocidos como el amianto) para calcular el riesgo que presentan esos factores para la salud de la comunidad en general. En el caso del cadmio, por ejemplo, ya en 1942 empezaron a notificarse casos de osteomalacia con fracturas múltiples en trabajadores de una fábrica francesa que producía pilas alcalinas. Durante los decenios de 1950 y 1960, la intoxicación por cadmio se consideró una enfermedad estrictamente laboral. Sin embargo, los conocimientos obtenidos en el lugar de trabajo contribuyeron a que se reconociera que la osteomalacia y la enfermedad renal que se estaba observando en Japón por aquella época, la enfermedad de "Itai-itai", se debían en realidad a la contaminación del arroz por regar los cultivos con agua contaminada por cadmio procedente de fuentes industriales (K jellström 1986). A sí pues, la epidemiología en el trabajo ha contribuido en gran medida al conocimiento de los efectos de la exposición ambiental, lo que constituye una razón más para vincular estos dos ámbitos.

A escala individual, la enfermedad profesional afecta al bienestar en el hogar y en la comunidad y, en general, una persona que tiene problemas de salud por insuficiencias en el hogar y en la comunidad no puede ser productiva en el lugar de trabajo. Desde un punto de vista estrictamente científico, para realizar una auténtica evaluación de efectos sobre la salud y establecer las relaciones dosis-respuesta es necesario tener en cuenta las exposiciones totales (ambientales más profesionales). U n ejemplo clásico es la exposición a plaguicidas: la exposición 
en el lugar de trabajo puede verse considerablemente incrementada por la exposición en el medio ambiente, a través de la contaminación de los alimentos y las fuentes de agua, y de la exposición no profesional transmitida por el aire. Tomando únicamente los episodios de más de 100 intoxicados por alimentos contaminados, la O M S (1990c) ha documentado más de 15.000 casos de afectados y 1.500 fallecidos debido a una intoxicación por plaguicidas. En un estudio realizado sobre cultivadores de algodón de Centroamérica que utilizaban plaguicidas, no sólo muy pocos de los trabajadores tenían acceso a ropa protectora, sino que prácticamente todos vivían en un radio de 100 metros de los campos de algodón, muchos en viviendas temporales sin paredes que les protegieran de la vaporización aérea de los plaguicidas. Además, los trabajadores solían lavarse en canales de regadío que contenían residuos de plaguicidas, lo que incrementaba aún más la exposición (M ichaels, Barrera y Gacharna 1985). Para comprender la relación existente entre la exposición a plaguicidas y cualquiera de los efectos sobre la salud notificados se han de tener en cuenta todas las fuentes de exposición. En consecuencia, la evaluación simultánea de la exposición en el lugar de trabajo y la exposición ambiental mejora la precisión de la misma en los dos ámbitos.

Los problemas de salud derivados de los riesgos profesionales y ambientales son especialmente graves en los países en desarrollo, donde es menos probable que se apliquen métodos ya consolidados de control de los peligros a causa del limitado conocimiento de su existencia, la poca prioridad política concedida a las cuestiones de salud y medio ambiente, la escasez de recursos o la falta de sistemas adecuados de gestión de la salud ambiental y en el lugar de trabajo. En muchos lugares del mundo, la falta de recursos humanos con una formación adecuada representa un importante obstáculo para el control de los peligros de origen ambiental. Se ha documentado que los países en desarrollo padecen una grave escasez de expertos en salud en el trabajo (Noweir 1986). En 1985 un comité de expertos de la O M S llegó también a la conclusión de que había una necesidad urgente de personal capacitado en cuestiones de salud ambiental; y en el Programa 21, la estrategia internacionalmente acordada que adoptó la Conferencia de las Naciones Unidas sobre el Medio Ambiente y el Desarrollo (Naciones Unidas 1993), se identifica la capacitación ("creación de capacidad" nacional) como un elemento clave para la promoción de la salud humana por medio del desarrollo sostenible. Cuando los recursos son limitados, no es viable capacitar a un grupo de personas para que se ocupe de las cuestiones de salud en el lugar de trabajo y a otro grupo distinto para que aborde los peligros existentes más allá de las puertas de la fábrica.

Incluso en los países desarrollados se observa una tendencia clara a una utilización más eficiente de los recursos formando y empleando a profesionales en "salud en el trabajo y salud ambiental". En la actualidad, las empresas deben buscar el modo de gestionar su actividad con lógica y eficiencia dentro de su marco empresarial de obligaciones, legislación y política financiera. U na forma de conseguir ese objetivo es combinar en un mismo ámbito la salud en el trabajo y la salud ambiental.

Al diseñar los lugares de trabajo y decidir la estrategias de control en materia de higiene industrial se han de tener en cuenta cuestiones ambientales de carácter general. Sustituir una sustancia por otra que no sea tan tóxica puede tener sentido desde el punto de vista de la salud en el trabajo, pero si esa nueva sustancia no es biodegradable o daña la capa de ozono no será una solución adecuada para controlar la exposición - lo único que se haría es trasladar el problema a otro sitio. El empleo de los clorofluorocarbonos, que hoy se utilizan mucho como refrigerantes en lugar del amoníaco, sustancia más peligrosa, es el ejemplo clásico de lo que hoy sabemos que fue una sustitución inadecuada desde el punto de vista ambiental. Así pues, al vincular la salud en el trabajo y la salud ambiental se reduce el riesgo de adoptar decisiones erróneas en materia de control de las exposiciones.

Del mismo modo que la comprensión de los efectos sobre la salud de diversas exposiciones perjudiciales ha partido muchas veces del lugar de trabajo, el efecto sobre la salud pública de las exposiciones ambientales a esos mismos agentes ha constituido un importante factor de estímulo para la limpieza tanto en el lugar de trabajo como en la comunidad de su entorno. Por ejemplo, el descubrimiento de elevados niveles de plomo en la sangre de los trabajadores por un higienista industrial en una fundición de plomo en Bahía, Brasil, llevó a que se investigara la presencia de plomo en la sangre de los niños de zonas residenciales próximas. La comprobación de que los niños también presentaban elevados niveles de plomo contribuyó considerablemente a que la empresa adoptara medidas para reducir las exposiciones en el lugar de trabajo así como las emisiones de plomo de la fábrica (N ogueira 1987), aunque las exposiciones profesionales siguen siendo notablemente más altas de lo que toleraría la comunidad general.

De hecho, las normas de salud ambiental suelen ser mucho más estrictas que las de salud en el trabajo. Tenemos un ejemplo de ello en los valores de referencia recomendados por la OM S para determinadas sustancias químicas. L a diferencia suele justificarse con el argumento de que la comunidad comprende poblaciones sensibles, como personas de edad avanzada, enfermos, niños pequeños y mujeres embarazadas, mientras que la población laboral goza al menos de una salud suficientemente buena para trabajar. También suele aducirse que el riesgo es más "aceptable" para una población laboral, pues son personas que se benefician de tener un empleo, y por consiguiente están más dispuestas a aceptar el riesgo. La cuestión de las normas 0 criterios suscita vivos debates de carácter político, ético y científico. Vincular la salud en el trabajo y la salud ambiental puede contribuir de forma positiva a resolver esas controversias. A este respecto, estrechar la relación entre los dos ámbitos puede redundar en una mayor coherencia a la hora de establecer las normas.

Probablemente inspiradas, al menos en parte, por el activo debate sobre medio ambiente y desarrollo sostenible propuesto por el Programa 21, muchas organizaciones de profesionales de la salud en el trabajo han cambiado su denominación por la de organizaciones de "salud en el trabajo y salud ambiental" como una forma de reconocer que sus miembros dedican cada vez más atención a los peligros para la salud de origen ambiental tanto dentro como fuera del lugar de trabajo. Además, como se señala en el capítulo dedicado a la ética, en el Código internacional de ética para los profesionales de salud en el trabajo se afirma que proteger el medio ambiente es una de las obligaciones éticas de dichos profesionales.

En resumen, la salud en el trabajo y la salud ambiental están estrechamente ligadas por:

- el hecho de que la fuente de la amenaza para la salud suele ser la misma.

- sus metodologías comunes, especialmente en materia de evaluación de la salud y control de las exposiciones;

- la contribución aportada por la epidemiología del trabajo al conocimiento de los efectos de las exposiciones ambientales;

- los efectos de las enfermedades profesionales sobre el bienestar en el hogar y la comunidad, y, a la inversa, los efectos de las patologías ambientales sobre la productividad de los trabajadores;

- la necesidad científica de tener en cuenta las exposiciones totales para determinar las relaciones dosis-respuesta; 
- la eficiencia en el perfeccionamiento y aprovechamiento de los recursos humanos resultante de dicha vinculación;

- la mejora en las decisiones sobre control de las exposiciones derivada de esta visión más amplia;

- mayor coherencia a la hora de establecer las normas,

- el hecho de que vincular la salud ambiental y la salud en el trabajo es un incentivo más para rectificar los peligros a que están expuestas tanto la población laboral como la comunidad.

Aunque es deseable unir la salud en el trabajo y la salud ambiental, cada una de ellas tiene una orientación propia y específica que no debe perderse. La salud en el trabajo debe seguir centrándose en la salud de los trabajadores, y la salud ambiental atender a la salud del público general. Ahora bien, aunque es conveniente que los profesionales actúen estrictamente en sólo uno de estos dos campos, comprender bien el otro incrementa la credibilidad, la base de conocimientos y la eficacia del empeño global. Este es el espíritu que anima la presentación del presente capítulo.

\section{- La alimentacion y La AGRICULTURA ${ }^{1}$}

Friedrich K. Käferstein

\section{Las necesidades de producción frente a la presión demográfica y otras fuerzas}

En algunas regiones del mundo la población sigue creciendo con rapidez. Con respecto a la situación de 1990, en el año 2010 habrá 1.900 millones de personas más que alimentar, lo que supone un incremento del $36 \%$ (de 5.300 a 7.200 millones de habitantes).

Se estima que el $90 \%$ del crecimiento total previsto para los próximos 20 años se va a producir en países que actualmente se clasifican de naciones en desarrollo. Se asiste a una urbanización progresiva de la sociedad. La población urbana del mundo llegará a los 3.600 millones personas, lo que representa un incremento del $62 \%$ con respecto a los 2.200 millones de habitantes urbanos que había en 1990. A demás, la población urbana de los países en desarrollo se incrementará en un $92 \%$ (de 1.400 a 2.600 millones) en 20 años a partir de 1990, lo que significa que se habrá multiplicado por cuatro desde 1970. Aunque la planificación familiar reciba la urgente atención que requiere en todas las poblaciones en rápido crecimiento, el aumento demográfico y la urbanización seguirán dominando el panorama durante al menos dos decenios.

En los próximos 20 años será necesario incrementar en un $36 \%$ la cantidad de alimentos, otros productos agrícolas y agua potable simplemente para seguir el ritmo de ese aumento de la población; la necesidad de alimentar adecuadamente a 500 millones de personas para que no sigan estando malnutridas, y el aumento de la demanda procedente de poblaciones con ingresos cada vez mayores, son factores que conducirán a un enorme incremento de la producción total de alimentos. En los grupos de ingresos más altos, la población seguirá caracterizándose por una demanda excesiva de alimentos de origen animal, lo que provocará un aumento de la producción de piensos.

1 Este artículo ha sido elaborado por el Dr. F. K äferstein, Jefe de Seguridad Alimentaria de la O rganización M undial de la Salud. Se basa en su integridad en el informe de un grupo de trabajo de la O M S sobre alimentación y agricultura que prestó apoyo a la Comisión de Salud y M edio Ambiente de la OM S en su tarea de preparar un informe para la Conferencia de las Naciones Unidas sobre el M edio Ambiente y el Desarrollo (CNUMAD), celebrada en $\mathrm{R}$ ío de Janeiro en 1992. Ambos informes pueden solicitarse a la O M S. Figura 53.1 - Enfermedades transmitidas por los alimentos
en Venezuela.

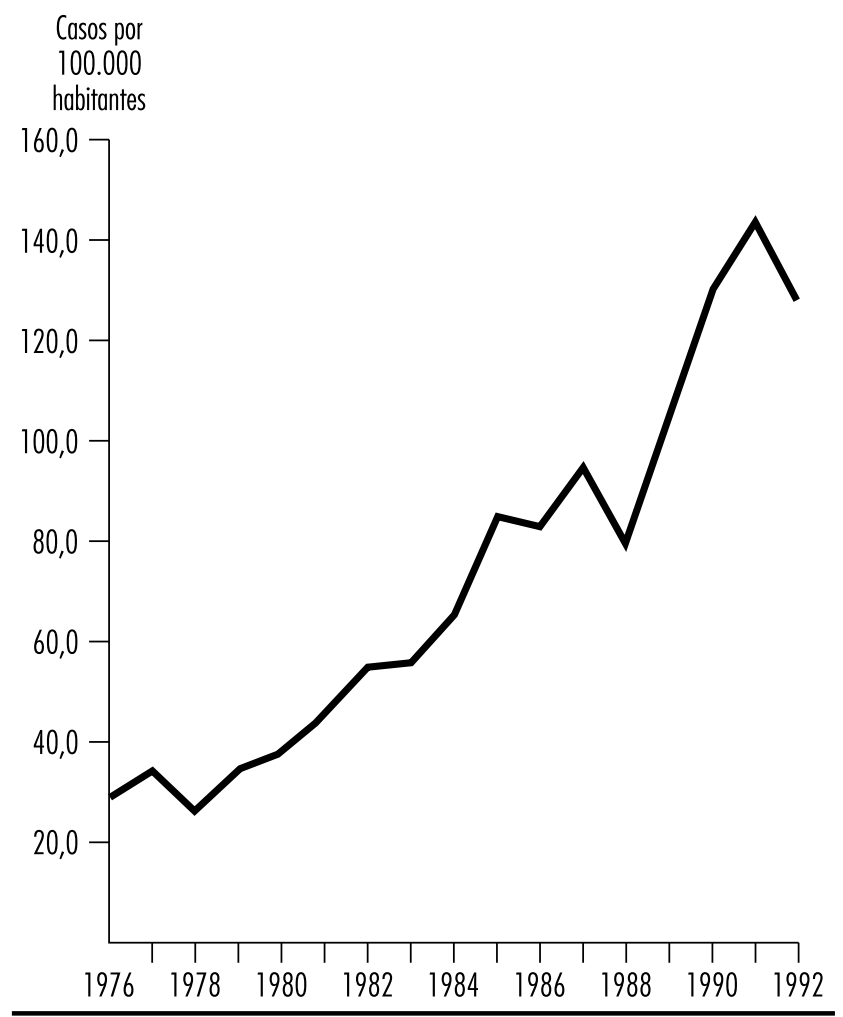

La presión sobre la agricultura y la producción de alimentos, así como el crecimiento demográfico y el incremento de la demanda "per cápita" harán recaer sobre el medio ambiente una carga mayor. Dicha carga se generará de manera desigual y tendrá efectos ambientales desiguales, pero en términos mundiales sus efectos serán negativos y exigirán una acción concertada.

Este incremento de la demanda se hará notar sobre unos recursos en tierra y agua que son finitos, teniendo en cuenta además que las zonas más productivas ya se han utilizado y que el coste de poner en producción tierras marginales y utilizar agua no fácilmente disponible será elevado. Es posible que gran parte de esas tierras marginales sean fértiles sólo temporalmente, a menos que se adopten medidas específicas para evitarlo, y la productividad de las pesquerías naturales está también sumamente limitada. La superficie de tierra cultivable descenderá debido a la erosión de los suelos por el exceso de pastoreo, el arrastre de tierras en zonas taladas, la salinización de los suelos y otros tipos de degradación de la tierra, así como por la expansión del desarrollo urbano, industrial y de otros tipos.

La disponibilidad de agua y su calidad, que son ya totalmente insuficientes en gran parte del mundo, seguirán constituyendo un problema importante en las zonas rurales de los países en desarrollo y también en muchas poblaciones urbanas, que pueden enfrentarse al problema adicional de tener que pagar elevadas tarifas por su utilización. L as necesidades de agua registrarán un importante incremento, y en algunas grandes ciudades satisfacer la demanda será cada vez más caro, pues habrá que traer el agua de zonas distantes. La reutilización del agua exige unas normas más estrictas en materia de tratamiento. La creciente producción de aguas residuales y de desecho obligará a ampliar las instalaciones de tratamiento, así como a realizar grandes desembolsos de capital. 


\begin{tabular}{|c|c|c|c|c|c|c|}
\hline \multirow[t]{2}{*}{ Agentes } & \multirow{2}{*}{$\begin{array}{l}\text { Reservorio/ portador } \\
\text { importante }\end{array}$} & \multicolumn{3}{|c|}{ Transmisióna por } & \multirow{2}{*}{$\begin{array}{l}\text { Multiplicación } \\
\text { en el alimento }\end{array}$} & \multirow[t]{2}{*}{ Ejemplos de alimentos que intervienen } \\
\hline & & Agua & Comida & $\begin{array}{l}\text { Persona a } \\
\text { persona }\end{array}$ & & \\
\hline \multicolumn{7}{|l|}{ Bacterias } \\
\hline Baccillus cereus & Suelo & - & + & - & + & $\begin{array}{l}\text { Arroz cocido, carnes cocidas, verduras, budines } \\
\text { con fécula }\end{array}$ \\
\hline Especies de Brucella & Ganado bovino, caprino y ovino & - & + & - & + & Leche cruda, productos lácteos \\
\hline Campylobacter jejuni & $\begin{array}{l}\text { Pollos, perros, gatos, ganado } \\
\text { bovino, cerdos, aves } \\
\text { silvestres }\end{array}$ & + & + & + & $-b$ & Leche cruda, aves de corral \\
\hline Clostridium botulinum & $\begin{array}{l}\text { Suelo, mamíferos, aves, } \\
\text { pescado }\end{array}$ & - & + & - & + & $\begin{array}{l}\text { Pescado, carne, verduras (conservas caseras), } \\
\text { miel }\end{array}$ \\
\hline \multicolumn{7}{|l|}{ Escherichia coli } \\
\hline Enterotoxigénicos & Humanos & + & + & + & + & Ensalada, verduras crudas \\
\hline Enteropatogénicos & Humanos & + & + & + & + & Leche \\
\hline Enteroinvasivos & Humanos & + & + & 0 & + & Queso \\
\hline Enterohemorrágicos & $\begin{array}{l}\text { Ganado bovino, aves de corral, } \\
\text { ovejas }\end{array}$ & + & + & + & + & Carne poco cocinada, leche cruda, queso \\
\hline Listeria monocytogenes & Medio ambiente & + & + & $-c$ & + & Queso, leche cruda, col cruda \\
\hline Mycobacterium bovis & Ganado bovino & - & + & - & - & Leche cruda \\
\hline Salmonella typhi y paratyphi & Humanos & + & + & \pm & + & $\begin{array}{l}\text { Productos lácteos y cárnicos, mariscos, verduras } \\
\text { crudas }\end{array}$ \\
\hline Salmonella (no typhi) & Humanos y animales & \pm & + & \pm & + & $\begin{array}{l}\text { Carnes, aves de corral, huevos, productos } \\
\text { lácteos, chocolate }\end{array}$ \\
\hline Shigella spp. & Humanos & + & + & + & + & Ensaladas de patata/ huevos \\
\hline $\begin{array}{l}\text { Staphylococcus aureus } \\
\text { (enterotoxinas) }\end{array}$ & & - & + & - & + & $\begin{array}{l}\text { Jamón, ensaladas de aves de corral y huevos, } \\
\text { productos de repostería con relleno de crema, } \\
\text { helados, queso }\end{array}$ \\
\hline Vibrio cholerae, 01 & Humanos, especies marinas & + & + & \pm & + & Ensaladas, mariscos \\
\hline Vibrio cholerae, no 01 & Humanos, especies marinas & + & + & \pm & + & Mariscos \\
\hline Vibrio parahaemolyticus & Agua marina, especies marinas & - & + & - & + & Pescado, cangrejos y otros mariscos crudos \\
\hline Vibrio vulnificus & Agua marina, especies marinas & + & + & - & + & Mariscos \\
\hline Yersinia enterocolitica & $\begin{array}{l}\text { Agua, animales salvajes, } \\
\text { cerdos, perros, aves de corral }\end{array}$ & + & + & - & + & Leche, carne de cerdo y aves de corral \\
\hline \multicolumn{7}{|l|}{ Virus } \\
\hline Virus de la hepatitis A & Humanos & + & + & + & - & Mariscos, frutas y verduras crudas \\
\hline Agentes de Norwalk & Humanos & + & + & - & - & Mariscos, ensaladas \\
\hline Rotavirus & Humanos & + & + & + & - & 0 \\
\hline Protozoos & & + & + & + & + & \\
\hline Cryptosporidium parvum & Humanos, animales & + & + & + & - & Leche cruda, salchichas crudas (no fermentadas) \\
\hline Entamoeba histolytica & Humanos & + & + & + & - & Verduras y frutas \\
\hline Giardia lamblia & Humanos, animales & + & \pm & + & - & Verduras y frutas \\
\hline $\begin{array}{l}\text { Toxoplasma gondii } \\
\text { Helmintos }\end{array}$ & Gatos, cerdos & 0 & + & - & - & Carnes poco cocinadas, verduras crudas \\
\hline Ascaris lumbricoides & Humanos & + & + & - & - & Alimentos contaminados por el suelo \\
\hline Clonorchis sinensis & Pescados de agua dulce & - & + & - & - & Pescados poco cocidos/ crudos \\
\hline Fasciola hepatica & Ganado bovino y caprino & \pm & + & - & - & Berros \\
\hline Opisthorclis viverrini/ felinus & Pescados de agua dulce & - & + & - & - & Pescados poco cocinados/ crudos \\
\hline Paragonimus sp. & Cangrejos de río & - & + & - & - & Cangrejos poco cocinados/ crudos \\
\hline Taenia saginata y T. solium & Ganado bovino y porcino & - & + & - & - & Carne poco cocinada \\
\hline Trichinella spiralis & Cerdos, carnívoros & - & + & - & - & Carne poco cocinada \\
\hline Trichuris trichiura & Humanos & 0 & + & - & - & Alimentos contaminados por el suelo \\
\hline
\end{tabular}

- Casi todas las infecciones entéricas agudas se transmiten con más facilidad durante el verano y en los meses húmedos, excepto las infecciones debidas a rotavirus y Yersinia enterocolitica, cuya transmisión es mayor en los meses más frescos. b En determinadas circunstancias se ha observado una multiplicación, pero está clara la importancia epidemiológica de esta observación. c Es frecuente la transmisión vertical de la madre embarazada al feto.

$+=$ Sí; $\pm=$ Raro; - = No; 0 = Sin información.

Adaptado de OMS/ FAO 1984. 
La permanente necesidad de desarrollo industrial a largo plazo para producir bienes, servicios y puestos de trabajo llevará a una producción de alimentos más intensiva, que a su vez estará más industrializada. En consecuencia, y especialmente debido al proceso de urbanización, aumentará en volumen e importancia la demanda de servicios de envasado, elaboración, almacenamiento y distribución de alimentos, y se incrementarán también los recursos dedicados a estas actividades.

El público se está sensibilizando mucho con respecto a la necesidad de producir, proteger y comercializar los alimentos de forma que se reduzcan al mínimo los cambios ambientales negativos, y es más exigente a ese respecto. La aparición de instrumentos científicos revolucionarios (por ejemplo, los avances de la biotecnología) ofrece la posibilidad de incrementar notablemente la producción alimentaria reduciendo los desechos y mejorando la seguridad.

El reto más importante es afrontar la creciente demanda de alimentos, otros productos agrícolas y agua de un modo que contribuya a mejorar la salud a largo plazo y que sea también sostenible, económico y competitivo.

Aunque a escala mundial hay actualmente alimentos suficientes para todos, se han de superar grandes dificultades para garantizar la disponibilidad y distribución equitativa de alimentos seguros, nutritivos y asequibles con los que satisfacer las necesidades de salud en muchas partes del mundo, y sobre todo en las zonas de rápido crecimiento demográfico.

$M$ uchas veces no se tienen plenamente en cuenta las posibles consecuencias sobre la salud a la hora de diseñar y aplicar políticas y programas agrícolas y pesqueros. Un ejemplo es la producción de tabaco, que tiene consecuencias muy graves y negativas sobre la salud humana y los escasos recursos en tierras y leña. Además, la falta de un enfoque de desarrollo integrado para los sectores agrícola y forestal conduce a que no se reconozca la importante relación existente entre esos sectores y la protección de los hábitat de especies silvestres, la diversidad biológica y los recursos genéticos

Si no se adoptan medidas oportunas y adecuadas para mitigar las repercusiones ambientales de la agricultura, la pesca, la producción de alimentos y el uso del agua, se producirán las situaciones siguientes:

- Con el incremento de la población urbana aumentará también la dificultad para mantener y desarrollar un sistema eficiente de distribución de alimentos. Ello puede agravar el problema de la inseguridad alimentaria en los hogares, la malnutrición a ella asociada y los consiguientes riesgos para la salud entre las crecientes masas de pobres urbanos.

- Las enfermedades microbianas, víricas y parasitarias debidas a alimentos y agua contaminados seguirán constituyendo graves problemas de salud. Seguirán apareciendo nuevos agentes de importancia para la salud pública. Se incrementarán las enfermedades diarreicas relacionadas con los alimentos y el agua, que producirán una elevada mortalidad infantil y una morbilidad generalizada.

- Se incrementarán notablemente las enfermedades transmitidas por vectores derivadas del riego, de otras formas de aprovechar los recursos hídricos y de la falta de control de las aguas residuales. La malaria, la esquistosomiasis, la filariasis y las fiebres arbovíricas seguirán constituyendo problemas de primera magnitud.

- Los problemas que hemos esbozado se reflejarán en la estabilización o el aumento de los niveles de malnutrición y mortalidad neonatal y de niños de corta edad, así como de los niveles de morbilidad a todas las edades, aunque predominantemente entre los pobres, las personas muy jóvenes o muy ancianas y los enfermos.
- Las enfermedades crónicas asociadas a formas de vida inade cuadas, al hábito de fumar y a la dieta (por ejemplo, la obesidad, la diabetes o la enfermedad coronaria), que son características de los países más prósperos, están apareciendo ya y convirtiéndose en problemas importantes también para los países en desarrollo. La creciente urbanización acelerará esa tendencia.

- A medida que la producción de alimentos vaya haciéndose más intensiva, se incrementará notablemente el riesgo de enfermedades y accidentes profesionales para los que trabajen en ese sector y sectores conexos, a menos que se realicen esfuerzos suficientes en materia de seguridad y prevención.

\section{Consecuencias para la salud de la contaminación biológica y de la presencia de sustancias químicas en los alimentos}

A pesar de los avances de la ciencia y la tecnología, la contaminación de los alimentos y del agua sigue siendo hoy un importante problema de salud pública. Las enfermedades transmitidas por los alimentos son quizás el problema sanitario más extendido del mundo contemporáneo y una causa importante de la reducción de la productividad económica (O M S/FAO 1984). Se deben a muy diversos agentes y abarcan todos los grados de gravedad, desde indisposiciones leves a enfermedades que pueden ser mortales. Ahora bien, sólo una pequeña proporción de los casos llega a conocimiento de los servicios de salud, y los que se investigan son aún menos. Así, se estima que en los países industrializados se notifican únicamente alrededor del $10 \%$ de los casos, mientras que en los países en desarrollo los casos notificados probablemente no van más allá del $1 \%$ del total.

Pese a estas limitaciones, los datos de que disponemos indican que las enfermedades transmitidas por alimentos van en aumento en todo el mundo, tanto en los países en desarrollo como en los países industrializados. Como ejemplo de esta tendencia puede citarse el caso de Venezuela (O PS/ O M S 1989) (Figura 53.1).

\section{Contaminación biológica}

\section{Países en desarrollo}

Según la información disponible está claro que los contaminantes biológicos (bacterias, virus y parásitos) constituyen las causas principales de las enfermedades transmitidas por alimentos (Tabla 53.2).

En los países en desarrollo son responsables de muy diversas enfermedades de este tipo (por ejemplo, cólera, salmonelosis, shigellosis, fiebres tifoideas y paratifoideas, brucelosis, poliomielitis y amebiasis). Las enfermedades diarreicas, en especial la diarrea infantil, representan el problema más importante, y se trata verdaderamente de un problema de enormes proporciones. C ada año padecen diarrea alrededor de 1.500 millones de niños menores de cinco años, y mueren por causa de la enfermedad más de tres millones. A ntes se pensaba que el agua contaminada era la fuente principal de patógenos que provocan la diarrea, pero hoy está demostrado que hasta el $70 \%$ de los episodios de diarrea pueden deberse a patógenos transmitidos por los alimentos (O M S 1990c). No obstante, la contaminación de los alimentos tiene su origen en muchos casos en el agua contaminada que se utiliza para regar y otros fines similares.

\section{Países industrializados}

Aunque la situación en materia de enfermedades transmitidas por los alimentos es muy grave en los países en desarrollo, el problema no se limita a ellos, y en los últimos años los países industrializados han sufrido una serie de epidemias importantes. En Estados U nidos se estima que se producen alrededor 
de 6,5 millones de casos al año, con 9.000 fallecimientos, pero según la Food and Drug Administration de ese país esta cifra está subestimada y la realidad puede llegar hasta 80 millones de casos (Cohen 1987; Archer y Kvenberg 1985; Young 1987). En la antigua Alemania occidental la estimación era de un millón de casos en 1989 (G rossklaus 1990). En un estudio realizado en los Países Bajos se comprobó que hasta el $10 \%$ de la población podía verse afectada por enfermedades transmitidas por los alimentos o por el agua (H oogenboom-Vergedaal y cols. 1990).

Con las actuales mejoras en los niveles de higiene personal, desarrollo del saneamiento básico, suministro de agua potable, infraestructuras eficaces y creciente aplicación de tecnologías como la pasteurización, muchas de estas enfermedades se han eliminado 0 reducido considerablemente en algunos países industrializados (como la salmonelosis transmitida por la leche). Sin embargo, en la mayoría de los países están aumentando de modo importante otras enfermedades transmitidas por los alimentos. Como ejemplo de este fenómeno puede citarse el caso de la antigua Alemania occidental (1946-1991) (Figura 53.2) (Statistisches Bundesamt 1994).

$M$ as en concreto, la salmonelosis se ha incrementado enormemente a ambos lados del Atlántico en los últimos años (Rodrigue 1990). En muchos casos se debe a la Salmonella enteritidis. En la Figura 53.3 se muestra el incremento de este microorganismo con respecto a otras cepas de Salmonella en Suiza. En muchos países se han identificado como fuentes principales de este patógeno la carne de aves de corral, los huevos y los alimentos que contienen huevos. En algunos países está contaminada con Salmonella spp. del $60 \%$ al $100 \%$ de la carne de aves de corral, y se ha citado también la participación de la carne, las ancas de rana, el chocolate y la leche (N otermans 1984; Roberts 1990). En 1985 de 170.000 a 200.000 personas se vieron afectadas en $\mathrm{C}$ hicago por un brote de salmonelosis provocado por leche pasteurizada contaminada (Ryzan 1987).

\section{Sustancias químicas y tóxicas en los alimentos}

A escala nacional e internacional se han realizado considerables esfuerzos para garantizar la seguridad química de los alimentos. A lo largo de un período de tres decenios dos comisiones conjuntas de la FAO y la OMS han evaluado gran número de sustancias químicas alimentarias. EI Comité M ixto FAO / O M S de Expertos en Aditivos A limentarios (JECFA) evalúa los aditivos, contaminantes y residuos de medicamentos veterinarios en los alimentos, y la Reunión Conjunta FAO / O M S sobre R esiduos de plaguicidas (JMPR) evalúa los residuos de plaguicidas. Se formulan recomendaciones sobre la ingesta diaria aceptable y sobre los niveles máximos de residuos y otros niveles máximos. Tomando como base esas recomendaciones, la Comisión del Codex Alimentarius y los gobiernos establecen las normas y los niveles de seguridad relativos a esas sustancias en los productos alimentarios. Además, el Programa mixto PNUM A/FAO / O M S sobre vigilancia de la contaminación de los alimentos (SIM UVIMA/A limentos) proporciona información sobre los niveles de contaminantes en los alimentos y sobre las tendencias cronológicas de la contaminación, lo que permite adoptar medidas preventivas y de control.

Aunque la información sobre la mayoría de los países en desarrollo es escasa, estudios realizados en los países industrializados sugieren que el abastecimiento alimentario es en gran parte seguro desde el punto de vista químico gracias a la amplia infraestructura existente a este respecto (es decir, legislación, mecanismos para imponer su cumplimiento, sistemas de supervisión y vigilancia) y al nivel general de responsabilidad de la industria alimentaria. No obstante, sí se producen situaciones de contaminación o adulteración accidentales, casos en los que las consecuencias sobre la salud pueden ser graves. Por ejemplo, en
Figura 53.2 - Enteritis infecciosa y fiebres tifoideas y paratifoideas ( $A, B$ y $C$ ) en Alemania.

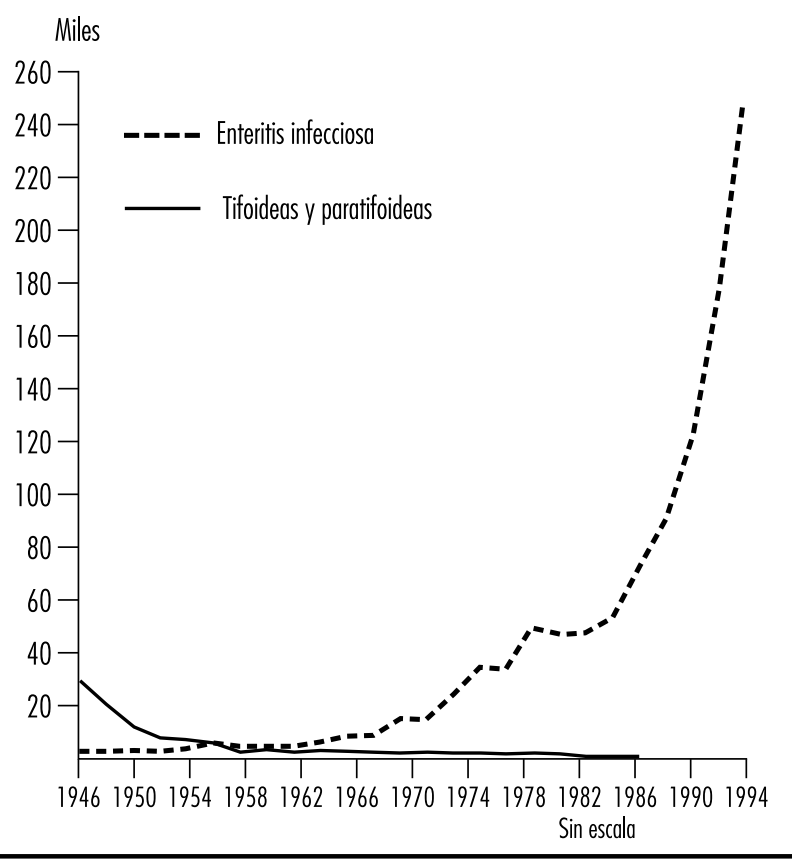

España aceite de cocinar adulterado acabó en 1981-1982 con la vida de unas 600 personas y ocasionó minusvalías - temporales o permanentes- a otras 20.000 (O M S 1984). A pesar de las intensas investigaciones aún no se ha determinado cuál fue el agente responsable de esta intoxicación masiva.

\section{Sustancias químicas de origen a mbiental}

$\mathrm{H}$ ay algunas sustancias químicas que pueden estar presentes en los alimentos como resultado de la contaminación ambiental. Sus efectos sobre la salud pueden ser sumamente graves, y en los últimos años han motivado una gran preocupación.

Figura 53.3 • Serotipos de Salmonella en Suiza.

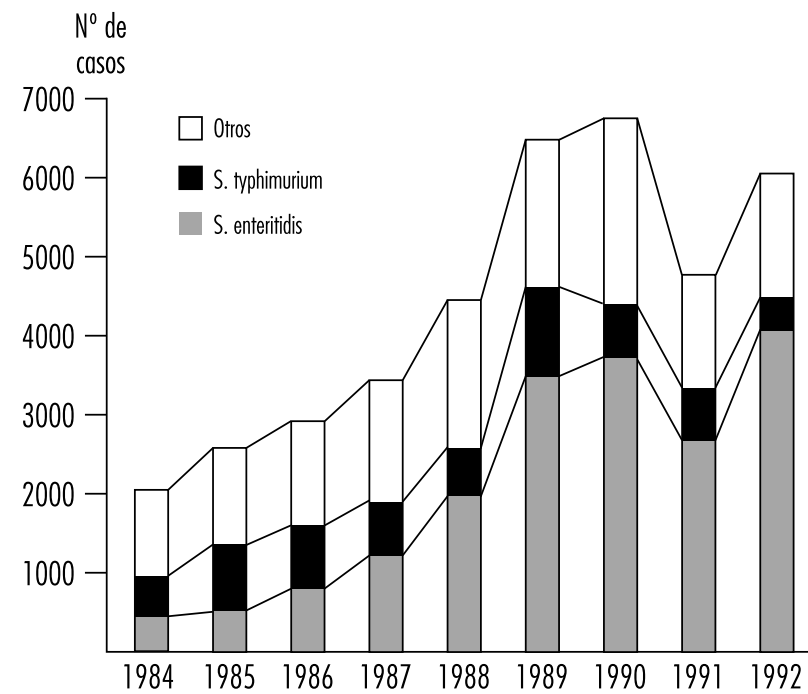

Fuente: Oficina Federal de Salud. 
Se han notificado consecuencias de gravedad tras la ingestión a lo largo de un tiempo prolongado de alimentos contaminados con metales pesados como el plomo, el cadmio o el mercurio.

EI accidente de Chernóbil dio lugar a una gran preocupación en cuanto a los riesgos para la salud de las personas expuestas a emisiones accidentales de radionucleidos. La gente que vivía en las cercanías del lugar donde se produjo el accidente estuvo expuesta, y esa exposición incluía la presencia de contaminantes radiactivos en los alimentos y el agua. En otros lugares de Europa y en otros continentes, a cierta distancia del accidente, esa preocupación se centró en los alimentos contaminados como fuente de exposición. En la mayoría de los países, la dosis media estimada derivada de la ingestión de alimentos contaminados representaba sólo una fracción muy pequeña de la dosis recibida normalmente por la radiación de fondo (O IEA 1991).

$O$ tras sustancias químicas ambientales de interés son los bifenilos policlorados (PCB). L os PCB se utilizan en diversas aplicaciones industriales. Se empezó a facilitar información sobre los efectos de los PCB sobre la salud humana a raíz de dos accidentes a gran escala que se produjeron en Japón (1968) y en Taiwán, China (1979). La experiencia adquirida en esos episodios demostró que, además de efectos agudos, los PCB pueden tener también efectos carcinogénicos.

EI DDT se utilizó mucho entre 1940 y 1960 como insecticida para aplicaciones agrícolas y para la lucha contra enfermedades transmitidas por vectores. En la actualidad está prohibido o restringido en muchos países por el riesgo potencial que presenta para el medio ambiente. En muchos países tropicales, el DDT sigue siendo una sustancia química importante que se utiliza para luchar contra la malaria. No se han notificado efectos nocivos debidos a los residuos de DDT en los alimentos (PNUM A 1988).

\section{Micotoxinas}

Las micotoxinas, que son los metabolitos tóxicos de algunos hongos microscópicos (mohos), pueden tener graves efectos perjudiciales para los humanos y también para los animales. Estudios con animales demuestran que, además de la intoxicación aguda, las micotoxinas pueden tener efectos carcinogénicos, mutagénicos y teratogénicos.

\section{Biotoxinas}

También es motivo de preocupación la intoxicación por biotoxinas marinas (lo que se conoce como "intoxicación por pescado"). Son ejemplos de ello la ciguatera y diversos tipos de intoxicación por consumo de mariscos.

\section{Sustancias tóxicas vegetales}

Las sustancias tóxicas presentes en las plantas comestibles y las plantas venenosas que se parecen a las comestibles (setas, algunas plantas silvestres de hoja verde) son causas importantes de trastornos de la salud en muchas zonas del mundo y plantean un difícil problema en materia de seguridad de los alimentos (O M S 1990b).

\section{- LA CONTAMINACION INDUSTRIAL EN LOS PAISES EN DESARROLLO}

Niu Shiru

Aunque la industrialización es un elemento esencial del crecimiento económico en los países en desarrollo, la actividad industrial puede tener también consecuencias negativas sobre la salud ambiental como resultado de la liberación de contaminantes en el aire y el agua y de la eliminación de residuos peligrosos. Es algo que sucede con frecuencia en los países en desarrollo, donde se presta menos atención a la protección del medio ambiente, las normas ambientales suelen ser inadecuadas o no se aplican eficazmente y aún no están plenamente desarrolladas las técnicas de lucha contra la contaminación. Con el rápido desarrollo económico, muchos países en desarrollo, como China y otros países asiáticos, se enfrentan a nuevos problemas ambientales. U no de ellos es la contaminación del medio ambiente procedente de industrias o tecnologías peligrosas transferidas por los países desarrollados, industrias y tecnologías que ya no son aceptables en esos países por razones de salud en el trabajo y salud ambiental, pero que pueden seguir utilizándose en los países en desarrollo porque su legislación ambiental es menos estricta. 0 tro problema es la rápida proliferación de empresas no estructuradas a pequeña escala en aldeas o zonas rurales, que muchas veces producen una importante contaminación del aire y el agua por carecer de los conocimientos necesarios o de medios financieros suficientes

\section{Contaminación del aire}

En los países en desarrollo, la contaminación del aire se deriva no sólo de la emisión de contaminantes por industrias relativamente grandes, como la siderúrgica, la de metales no ferrosos o la de productos del petróleo, sino también de la emisión esporádica de contaminantes por fábricas de pequeñas dimensiones, como cementeras, refinerías de plomo, fábricas de fertilizantes y plaguicidas químicos y otras similares, donde no se toman medidas suficientes de lucha contra la contaminación y se permite que los contaminantes escapen a la atmósfera.

Como las actividades industriales comportan siempre una generación de energía, la combustión de combustibles fósiles es una de las principales fuentes de contaminación del aire en los países en desarrollo, donde se utiliza mucho el carbón, no sólo para el consumo industrial sino también para el doméstico. En China, por ejemplo, más del $70 \%$ del consumo total de energía se basa en la combustión directa de carbón, que genera grandes cantidades de contaminantes (partículas en suspensión, dióxido de azufre, etc.) en condiciones de combustión incompleta e insuficiente control.

La naturaleza de los contaminantes del aire varía según la industria de que se trate. También la concentración de los distintos contaminantes en la atmósfera varía mucho dependiendo del proceso y el lugar en que se produzca, por las diversas condiciones geográficas y climáticas. Al igual que en otros lugares, en los países en desarrollo es difícil estimar los niveles concretos de exposición de la población general a los diversos contaminantes procedentes de las distintas industrias. En términos generales, los niveles de exposición en el lugar de trabajo son mucho más elevados que los que sufre la población general, pues en el ambiente general las emisiones se diluyen con rapidez y son dispersadas por el viento. Sin embargo, la duración de la exposición es mucho mayor para la población general que para los trabajadores.

Los niveles de exposición de la población general en los países en desarrollo suelen ser más altos que en los países desarrollados, donde la contaminación del aire se controla con más rigor y las zonas residenciales suelen estar alejadas de las industrias. Como se trata con más detalle en este mismo capítulo, muchos estudios epidemiológicos han puesto ya de manifiesto una estrecha asociación entre la reducción de la función pulmonar y la mayor incidencia de enfermedades respiratorias crónicas entre personas que por el lugar en el que viven están expuestas a largo plazo a los contaminantes atmosféricos comunes. 
Un estudio de caso relativo a los efectos de la contaminación atmosférica sobre la salud de 480 alumnos de primaria en Cubatao, Brasil, donde 23 industrias (siderurgia, industrias químicas, cementera, fábricas de fertilizantes, etc.) emitían gran cantidad de contaminantes combinados, demostró que el 55,3\% de los niños presentaban una reducción de la función pulmonar. 0 tro ejemplo de los efectos de la contaminación atmosférica sobre la salud se comprobó en la zona industrial especial de U Isan/ O nsan, en la República de Corea, donde se concentran muchas fábricas de gran tamaño (sobre todo petroquímicas y de refino de metales). La gente que vivía en la zona se quejaba de diversos problemas de salud, sobre todo del trastorno del sistema nervioso denominado "enfermedad de O nsan".

L as liberaciones accidentales de sustancias tóxicas a la atmósfera con graves riesgos para la salud suelen ser más frecuentes en los países en desarrollo. Ello puede deberse entre otras razones a una planificación insuficiente en materia de seguridad, a la falta de personal técnico cualificado para el mantenimiento de instalaciones adecuadas, a las dificultades para obtener piezas de repuesto, etc. U no de los peores de accidentes de este tipo fue el que se produjo en Bhopal, India, en 1984, donde los escapes de isocianuro de metilo causaron la muerte a 2.000 personas.

\section{Contaminación del agua y el suelo}

La eliminación inadecuada y a menudo negligente de los residuos industriales - el vertido incontrolado a los cursos de agua y a la tierra, contaminando agua y suelo- constituye otro grave problema de salud ambiental, aparte de la contaminación del aire de origen industrial, en los países en desarrollo, especialmente aquellos que poseen muchas empresas de aldea de pequeñas dimensiones como las de China. Algunas fábricas a pequeña escala, como las de teñido de textiles, pasta de papel y papel, curtiduría de cuero, galvanoplastia, lámparas fluorescentes, baterías de plomo y fundición de metales, producen siempre gran cantidad de residuos, que contienen sustancias tóxicas o peligrosas como cromo, mercurio, plomo, cianuro, etc., que cuando no son tratadas pueden contaminar ríos, arroyos y lagos, y también el suelo. A su vez, la contaminación del suelo puede contaminar los recursos de aguas subterráneas.

En Karachi, el río Lyan, que atraviesa la ciudad, se ha convertido en un desaguadero al aire libre de aguas residuales y efluentes industriales no tratados procedentes de unas 300 industrias de diversos tamaños Algo similar ocurre en Shanghai. Alrededor de 3,4 millones de metros cúbicos de residuos industriales y domésticos afluyen al arroyo Suzhou y al río $\mathrm{H}$ uangpu, que atraviesan el centro de la ciudad. Como resultado de esta grave contaminación, el río y el arroyo han perdido prácticamente todos los seres vivos, y por su olor y aspecto resultan desagradables y ofensivos para la población que vive en las zonas circundantes.

0 tro problema en materia de contaminación del agua y el suelo en los países en desarrollo lo plantea la transferencia de desechos tóxicos o peligrosos desde los países desarrollados a estos últimos. El coste de transportar estos desechos a sencillos lugares de almacenamiento situados en los países en desarrollo es muy inferior al que exige almacenarlos con seguridad o incinerarlos en sus países de origen de conformidad con las normativas oficiales aplicables. Así ha ocurrido en Tailandia, Nigeria, Guinea Bissau y otros países. En el transporte suelen producirse escapes que contaminan el aire, el agua y el suelo, lo que representa un riesgo potencial para la salud de las personas que viven en las proximidades.

Así pues, los problemas de salud de origen ambiental que se examinan en el presente capítulo tienden a afectar en una medida aún mayor a los países en desarrollo.

\section{LOS PAISES EN DESARROLLO Y LA CONTAMINACION}

Tee L. G uidotti

La contaminación industrial es un problema más complejo en los países en desarrollo que en las economías desarrolladas. LoS obstáculos estructurales que dificultan la prevención y limpieza de la contaminación son mayores. Esos obstáculos son en gran parte económicos, pues los países en desarrollo no poseen los recursos necesarios para controlar la contaminación en la misma medida en que lo hacen los países desarrollados. Por otra parte, los efectos de la contaminación pueden ser muy costosos para una sociedad en desarrollo en términos de salud, residuos, degradación del medio ambiente, reducción de la calidad de vida y coste de limpieza en el futuro. Un ejemplo extremo es la preocupación por el futuro de los niños expuestos al plomo en algunas megaciudades de países donde aún se utiliza la gasolina con plomo, o que viven en las proximidades de fundiciones. Se ha comprobado que algunos niños tienen niveles de plomo en sangre lo suficientemente elevados para afectar a su inteligencia y sus facultades cognitivas.

En los países en desarrollo, la industria suele funcionar con poco capital en comparación con los países desarrollados, y los fondos de inversión de que dispone se dedican en primer lugar a la adquisición del equipo y los recursos necesarios para la producción. Los economistas consideran "improductivo" el capital destinado a la lucha contra la contaminación, pues no genera un incremento de la producción ni de los rendimientos financieros. Pero la realidad es más compleja. Es posible que invertir en la lucha contra la contaminación no produzca un rendimiento directo evidente para la empresa o el sector, pero ello no significa que sea una inversión no rentable. En muchos casos, como por ejemplo, en el refino del petróleo, la lucha contra la contaminación reduce también la cantidad de residuos e incrementa la eficiencia de la explotación, de modo que la empresa sí obtiene un beneficio directo. Allí donde la opinión pública tiene peso y a una empresa le interesa mantener buenas relaciones públicas, la industria debe hacer un esfuerzo por controlar la contaminación en su propio interés. Por desgracia, en muchos países en desarrollo la estructura social no propicia esta situación, ya que la gente más duramente afectada por la contaminación tiende a pertenecer a las capas más empobrecidas y marginadas de la sociedad.

La contaminación puede causar daños al medio ambiente y a la sociedad en general, pero se trata de "deseconomías externas" que no afectan sustancialmente a la empresa misma, o al menos no la afectan desde el punto de vista económico. Lo que ocurre más bien es que los costes de la contaminación tienden a ser soportados por la sociedad en su conjunto, y la empresa se libera de ellos. Así sucede especialmente cuando la industria de que se trate es crítica para la economía local o las prioridades nacionales, lo que propicia una gran tolerancia hacia los daños que causa. U na solución sería "internalizar" esas deseconomías externas incorporando a los costes de explotación de la empresa los costes de limpieza o los costes estimados del daño ambiental bajo la forma de impuestos. La empresa tendría así un incentivo financiero para controlar la contaminación. Pero prácticamente ningún gobierno de países en desarrollo está en condiciones de establecer este impuesto.

En la práctica, raras veces se dispone de capital para invertir en equipos de control de la contaminación, a menos que la normativa oficial presione en ese sentido. Sin embargo, es muy infrecuente que los gobiernos se sientan motivados a regular la industria si no tienen razones apremiantes para ello y se ven 
presionados por sus ciudadanos. En la mayoría de los países desarrollados, la población tiene una razonable seguridad en materia de salud y de vida, y esperan mejorar su calidad de vida, algo que asocian con un entorno más limpio. Como hay más seguridad económica, esos ciudadanos están más dispuestos a aceptar un aparente sacrificio económico para conseguir un medio ambiente más limpio. En cambio, y para ser competitivos en los mercados mundiales, muchos países en desarrollo se muestran reacios a imponer normas a sus industrias. Al contrario, esperan que el crecimiento industrial de hoy conduzca a una sociedad del mañana suficientemente rica para corregir la contaminación. Por desgracia, el coste de la limpieza se incrementa al mismo ritmo o a un ritmo superior que los costes asociados al desarrollo industrial. En una fase temprana del desarrollo industrial, a un país en desarrollo le costaría en teoría muy poco prevenir la contaminación, pero esos países casi nunca poseen los recursos de capital necesarios para hacerlo. Posteriormente, cuando el país sí posee los recursos necesarios, los costes suelen ser increíblemente altos y el daño ya se ha producido.

En los países en desarrollo, la industria tiende a ser menos eficiente que en los desarrollados. Esa falta de eficiencia es un problema crónico de las economías en desarrollo, que refleja la falta de capacitación de los recursos humanos, el coste de la importación del equipo y la tecnología y el inevitable despilfarro que se produce cuando algunas partes de la economía están más desarrolladas que otras.

Esa ineficacia se debe también en parte a la necesidad de recurrir a tecnologías anticuadas que pueden obtenerse con facilidad, que no requieren una licencia muy cara o que no tienen un coste de utilización alto. Esas tecnologías suelen ser más contaminantes que las tecnologías de punta de que dispone la industria de los países desarrollados. Un ejemplo es la industria de la refrigeración, en que se utilizan clorofluorocarbonos (CFC) como refrigerantes químicos por ser mucho más baratos que las demás opciones, a pesar de que estas sustancias contribuyen en gran medida a agotar el ozono de la parte alta de la atmósfera y con ello a reducir la protección de la tierra frente a la radiación ultravioleta; algunos países eran muy reacios a aceptar la prohibición del uso de los CFC porque les resultaría económicamente imposible fabricar y adquirir frigoríficos. La solución evidente es la transferencia de tecnología, pero las empresas de los países más adelantados que han desarrollado esa tecnología o que poseen su licencia son lógicamente reacias a compartirla. $Y$ son reacias porque se han gastado sus propios recursos en desarrollar la tecnología, porque desean conservar la ventaja adquirida en sus mercados y porque sólo pueden obtener un rendimiento utilizando o vendiendo la tecnología durante el tiempo limitado de la patente.

0 tro problema al que se enfrentan los países en desarrollo es la falta de conocimientos especializados sobre los efectos de la contaminación, los métodos de vigilancia y la tecnología de control de la misma, así como la escasa sensibilización al respecto. En los países en desarrollo hay relativamente pocos expertos de campo, en parte porque, aunque las necesidades son en realidad mayores, hay menos puestos de trabajo y un mercado más restringido para sus servicios. Como el mercado para los equipos y servicios de control de la contaminación puede ser reducido, es posible que haya que importar conocimientos especializados y tecnología, con el consiguiente incremento de costes. Es posible también que los directivos y supervisores de la industria no sean conscientes del problema 0 lo sean en muy pequeña medida. Aun cuando un ingeniero, un directivo 0 un supervisor de la industria sea consciente de que una operación es contaminante, le puede resultar difícil convencer a otras personas de la empresa, a sus jefes 0 a los propietarios de que existe un problema que ha de resolverse.
En la mayoría de los países en desarrollo, la industria está compitiendo en el extremo inferior de los mercados internacionales, lo que significa que sus productos son competitivos por su precio y no por su calidad o por sus características especiales. Por ejemplo, son muy pocos los países en desarrollo que están especializados en la producción de acero de muy alta calidad para instrumentos quirúrgicos o maquinaria de precisión. Fabrican acero de calidades inferiores para la construcción y la industria manufacturera porque el mercado es mucho mayor, porque necesitan muchos menos conocimientos técnicos especializados para producirlo y porque pueden competir en precio siempre que la calidad sea aceptable. El control de la contaminación reduce la ventaja de precio incrementando los costes aparentes de la producción sin mejorar el producto o las ventas. El problema básico que se plantea en los países en desarrollo es cómo equilibrar esa realidad económica con la necesidad de proteger a sus ciudadanos, la integridad de su medio ambiente y su futuro, en el entendimiento de que una vez alcanzado el desarrollo los costes serán aún más elevados y el daño puede ser permanente.

\section{LA CONTAMINACION DEL AIRE}

Isabelle Romieu

EI problema de la contaminación del aire se ha ido agravando sin cesar desde que se inició hace 300 años la R evolución Industrial. Ello se ha debido a cuatro factores principales: una mayor industrialización, el incremento del tráfico, el rápido desarrollo económico y unos niveles más altos de consumo de energía. La información disponible nos indica que en muchos grandes centros urbanos se superan habitualmente las recomendaciones de la OMS respecto de los principales contaminantes de la atmósfera. A unque en los dos últimos decenios se ha avanzado en muchos países industrializados en el control de los problemas de la contaminación del aire, la calidad de éste - especialmente en las grandes ciudades del mundo en desarrollo- es cada vez peor. Especial preocupación despiertan los efectos negativos sobre la salud de los contaminantes del aire en muchas zonas urbanas, donde los niveles son suficientemente altos para incrementar la mortalidad y la morbilidad, la insuficiencia pulmonar y los efectos cardiovasculares y neuroconductuales (Romieu, Weizenfeld y Finkelman 1990; O M S/ PNU M A 1992). La contaminación del aire interior como resultado de la combustión doméstica es también un problema de importancia en los países en desarrollo (O M S 1992b), pero no lo abordaremos en este estudio, pues sólo consideraremos las fuentes, la dispersión y los efectos sobre la salud de la contaminación del aire exterior, incluido un estudio de caso de la situación en M éxico.

\section{Origen de los contaminantes del aire}

Entre los contaminantes del aire más habituales en el medio urbano figuran el dióxido de azufre $\left(\mathrm{SO}_{2}\right)$, las partículas en suspensión (PES), los óxidos de nitrógeno ( $\mathrm{NO} \mathrm{y} \mathrm{NO}_{2}$, denominados conjuntamente $\left.\mathrm{NO}_{x}\right)$, el ozono $\left(\mathrm{O}_{3}\right)$, el monóxido de carbono ( $\mathrm{CO}$ ) y el plomo ( $\mathrm{Pb}$ ). La combustión de combustibles fósiles en fuentes estacionarias produce $\mathrm{SO}_{2}, \mathrm{NO}_{x}$ y partículas, entre ellas aerosoles de sulfatos y nitratos que se forman en la atmósfera tras la conversión de los gases en partículas. L os vehículos a motor de gasolina son las principales fuentes de $\mathrm{NO}_{x}$, $\mathrm{CO}$ y $\mathrm{Pb}$, mientras que los motores diesel emiten cantidades significativas de partículas, $\mathrm{SO}_{2}$ y N $\mathrm{N}_{x}$. El ozono, oxidante fotoquímico y componente principal de la bruma fotoquímica, no se desprende directamente de las fuentes de combustión, sino que se 

Tabla 53.3 - Principales fuentes de contaminantes del
aire exterior.

\begin{tabular}{|c|c|}
\hline Contaminantes & Fuentes \\
\hline Oxidos de azufre & $\begin{array}{l}\text { Combustión de carbón y petróleo, } \\
\text { fundiciones }\end{array}$ \\
\hline Partículas en suspensión & $\begin{array}{l}\text { Productos de la combustión } \\
\text { (combustibles, biomasa), } \\
\text { humo del tabaco }\end{array}$ \\
\hline Oxidos de nitrógeno & Combustión de fuel y gas \\
\hline Monóxido de carbono & $\begin{array}{l}\text { Combustión incompleta de gasolina } \\
\text { y gas }\end{array}$ \\
\hline Ozono & Reacción fotoquímica \\
\hline Plomo & $\begin{array}{l}\text { Combustión de gasolina y carbón, } \\
\text { baterías, cables, soldadura, pintura }\end{array}$ \\
\hline Sustancias orgánicas & $\begin{array}{l}\text { Disolventes petroquímicos, vaporización } \\
\text { de combustibles sin quemar }\end{array}$ \\
\hline
\end{tabular}

Fuente: Adaptado de PNUMA 1991b.

forma en la parte baja de la atmósfera a partir de los $\mathrm{NO}_{x}$ y de compuestos orgánicos volátiles (C OV) en presencia de la luz solar (PNU M A 1991b). En la Tabla 53.3 se presentan las principales fuentes de contaminantes del aire exterior.

\section{Dispersión y transporte de los contaminantes del aire}

Los dos factores que más influyen en la dispersión y el transporte de las emisiones de contaminantes del aire son la meteorología (incluidos efectos de microclima como los "islotes de calor") y la topografía en relación con la distribución de la población. M uchas ciudades están rodeadas por colinas que pueden actuar como barrera para los vientos, de tal modo que la contaminación queda atrapada en ellas. Las inversiones térmicas pueden dar lugar a un problema similar en los climas templados y fríos. En condiciones de dispersión normales, los gases de contaminantes

Tabla 53.4 • Resumen de la relación entre exposición de corta duración y respuesta a las PM $_{10}$, con diversos indicadores de efectos sobre la salud.

\begin{tabular}{|c|c|c|}
\hline \multirow[t]{2}{*}{ Efectos sobre la salud } & \multicolumn{2}{|c|}{$\begin{array}{l}\text { Cambios porcentuales por cada } \\
\text { incremento de } 10 \mu \mathrm{g} / \mathrm{m}^{3} \text { en } \mathrm{PM}_{10}\end{array}$} \\
\hline & Media & Intervalo \\
\hline \multicolumn{3}{|l|}{ Mortalidad } \\
\hline Total & 1,0 & $0,5-1,5$ \\
\hline Cardiovascular & 1,4 & $0,8-1,8$ \\
\hline Respiratoria & 3,4 & $1,5-3,7$ \\
\hline \multicolumn{3}{|l|}{ Morbilidad } \\
\hline $\begin{array}{l}\text { Ingresos hospitalarios por afecciones } \\
\text { respiratorias }\end{array}$ & 1,1 & $0,8-3,4$ \\
\hline $\begin{array}{l}\text { Visitas a urgencias por afecciones } \\
\text { respiratorias }\end{array}$ & 1,0 & $0,5-4$ \\
\hline $\begin{array}{l}\text { Agravamiento de síntomas en } \\
\text { asmáticos }\end{array}$ & 3,0 & $1,1-11,5$ \\
\hline Cambios en el flujo expiratorio máximo & 0,08 & $0,04-0,25$ \\
\hline
\end{tabular}

Tabla 53.5 - Consecuencias para la salud a sociadas a cambios en la concentración máxima diaria del ozono ambiental en estudios epidemiológicos.

$\begin{array}{lll}\text { Consecuencias para la salud } & \begin{array}{l}\text { Cambios en } \\ 1-\mathrm{h}_{3}\left(\mu \mathrm{g} / \mathrm{m}^{3}\right)\end{array} & \begin{array}{l}\text { Cambios en } \\ 8-\mathrm{h} \mathrm{O}_{3}\left(\mu \mathrm{g} / \mathrm{m}^{3}\right)\end{array} \\ \begin{array}{l}\text { Agravamiento de síntomas en niños } \\ \text { y adultos sanos 0 }\end{array} & \\ \begin{array}{l}\text { asmáticos-actividad normal } \\ 25 \% \text { más }\end{array} & 200 & 100 \\ 50 \% \text { más } & 400 & 200 \\ 100 \% \text { más } & 800 & 300 \\ \text { Ingresos hospitalarios por afecciones } & & \\ \text { respiratoriasa } & & \\ 5 \% & 30 & 25 \\ 10 \% & 60 & 50 \\ 20 \% & 120 & 100\end{array}$

a Habida cuenta del alto grado de correlación que se ha observado entre las concentraciones 1 -h y 8 -h $\mathrm{O}_{3}$ en estudios sobre el terreno, la mejora del riesgo para la salud asociada a un descenso de los niveles de 1- 0 8-h 0 , debe ser casi idéntica.

Fuente: OMS 1995.

calientes ascienden al entrar en contacto con masas de aire más frías a medida que aumenta la altura. Sin embargo, en determinadas circunstancias la temperatura puede aumentar con la altura, y se forma una capa de inversión que impide que los contaminantes se alejen de su fuente de emisión y que retrasa su difusión. El transporte de la contaminación del aire a largas distancias desde las grandes zonas urbanas puede tener repercusiones a escala nacional y regional. Los óxidos de nitrógeno y azufre pueden contribuir a que se depositen ácidos en zonas muy alejadas de la fuente de emisión. Las concentraciones de ozono suelen ser altas a sotavento de las zonas urbanas debido al desfase de tiempo que se produce en los procesos fotoquímicos (PNUM A 1991b).

\section{Efectos de los contaminantes del aire sobre la salud}

L os contaminantes y sus derivados pueden tener efectos negativos al interactuar con moléculas que son decisivas para los procesos bioquímicos o fisiológicos del cuerpo humano 0 al dificultar su acción. $\mathrm{H}$ ay tres factores que influyen en el riesgo de daño tóxico derivado de esas sustancias: sus propiedades químicas y físicas, la dosis que llega a los lugares críticos de los tejidos y la capacidad de respuesta a la sustancia que tengan esos lugares. Los efectos negativos de los contaminantes del aire sobre la salud pueden diferir también en función del grupo de población de que se trate; en particular, las personas más jóvenes y las de edad avanzada pueden ser especialmente sensibles a los efectos nocivos y las que previamente padecen asma $u$ otras enfermedades respiratorias 0 cardíacas pueden sufrir un agravamiento de los síntomas por la exposición (O M S 1987).

\section{Dióxido de azufre y partículas}

Durante la primera mitad del siglo $X X$, episodios de notable estancamiento del aire tuvieron como resultado un incremento de la mortalidad en zonas donde la combustión de combustibles fósiles producía niveles muy altos de $\mathrm{SO}_{2}$ y PES. Al estudiar sus efectos sobre la salud a largo plazo se han relacionado también con la mortalidad y la morbilidad las concentraciones medias anuales de $\mathrm{SO}_{2}$ y PES. En estudios epidemiológicos recientes se 


\section{Estudio de caso: La contaminación del aire en Ciudad de México}

La zona metropolitana de Ciudad de México (ZMCM) está situada en la cuenca mexicana, a una altitud media de 2.240 metros. La cuenca consta de 2.500 kilómetros cuadrados y está rodeada de montañas, dos de las cuales tienen más de 5.000 metros de altura. Su población total se estimó en 17 millones en 1990. Por estas peculiares características geográficas y dada la escasez de vientos, hay poca ventilación, con una elevada frecuencia de inversiones térmicas, especialmente en invierno. Las más de 30.000 industrias existentes en la ZMCM y los tres millones de vehículos de motor que circulan cada día por ella son responsables del $44 \%$ del consumo total de energía. La contaminación del aire se vigila desde 1986, midiéndose el $\mathrm{SO}_{2}$, los $\mathrm{NO}_{x}$, el $\mathrm{CO}$, el $\mathrm{O}_{3}$, las partículas y los hidrocarburos que no contienen metano. Los principales problemas en este ámbito se relacionan con el ozono, sobre todo en la parte suroccidental de la ciudad (Romieu y cols. 1991). En 1992 el límite establecido en el país a este respecto (110 ppmm de máximo en una hora) se superó en la zona durante más de 1.000 horas y alcanzó un máximo de 400 ppmm. En la parte nororiental de la ciudad, cerca del parque industrial, se registran niveles elevados de partículas. En 1992, el promedio anual de partículas inhalables $\left(\mathrm{PM}_{10}\right)$ fue de $140 \mu \mathrm{g} / \mathrm{m}^{3}$. Desde 1990, el Gobierno viene adoptando importantes medidas de control para reducir la contaminación del aire, entre ellas un programa que prohíbe el uso del automóvil un día a la semana (conforme al último número de la matrícula), el cierre de una de las refinerías más contaminantes de las situadas en Ciudad de México y la introducción de la gasolina sin plomo. Con estas medidas se ha conseguido reducir la presencia de varios contaminantes, sobre todo el $\mathrm{SO}_{2}$, las partículas, el $\mathrm{NO}_{2}$, el $\mathrm{CO}$ y el plomo, pero el nivel de ozono sigue constituyendo un problema de gran importancia (véanse las Figuras $53.4,53.5$ y 53.6 ).

ha sugerido un efecto perjudicial de las partículas inhalables $\left(\mathrm{PM}_{10}\right)$ a concentraciones relativamente bajas (inferiores a las recomendaciones habituales) y se ha demostrado que existe una relación dosis-respuesta entre la exposición a $\mathrm{PM}_{10}$ y la mortalidad y morbilidad respiratorias (Dockery y Pope 1994; Pope, Bates y Razienne 1995; Bascom y cols. 1996), como se indica en la Tabla 53.4.

\section{Oxidos de nitrógeno}

En algunos estudios epidemiológicos se notifican efectos nocivos sobre la salud del $\mathrm{NO}_{2}$, entre ellos un aumento de la incidencia y la gravedad de las infecciones respiratorias y un incremento de los síntomas respiratorios, especialmente en exposiciones de larga duración. Se ha descrito también un empeoramiento de la situación clínica de las personas que padecen asma, enfermedad pulmonar obstructiva crónica y otros trastornos respiratorios crónicos. N o obstante, en otros estudios los investigadores no han observado efectos adversos del $\mathrm{NO}_{2}$ sobre las funciones respiratorias (O M S/ ECOT OX 1992; Bascom y cols. 1996).

\section{Oxidantes fotoquímicos y ozono}

Los efectos sobre la salud de la exposición a oxidantes fotoquímicos no pueden atribuirse únicamente a los oxidantes, pues la bruma fotoquímica está compuesta típicamente de $\mathrm{O}_{3}, \mathrm{NO}_{2}$, ácido y sulfato y otros agentes reactivos. Estos contaminantes pueden tener efectos aditivos o sinérgicos sobre la salud humana, pero parece que el $\mathrm{O}_{3}$ es el de mayor actividad biológica. Entre los efectos que tiene sobre la salud la exposición al ozono figuran
Figura 53.4 - N iveles de ozono en dos zonas de Ciudad de México. Máximo diario en una hora, por meses, 1994.
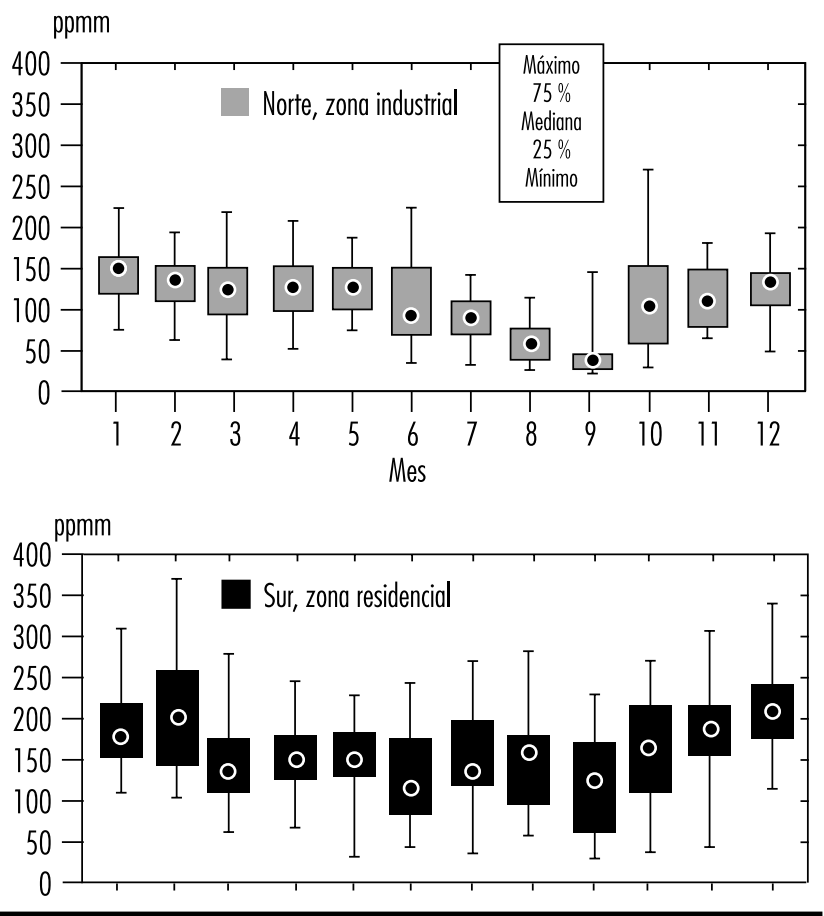

el descenso de la función pulmonar (con una mayor resistencia de las vías respiratorias, reducción del flujo de aire y reducción del volumen pulmonar) debido a la constricción de las vías, síntomas respiratorios (tos, silbido, falta de aire, dolores torácicos), irritación de los ojos, nariz y garganta y perturbación de determinadas actividades (como el rendimiento atlético) por la menor disponibilidad de oxígeno (O M S/ ECOTOX 1992). En la Tabla 53.5 se resumen los principales efectos agudos del ozono sobre la salud (O M S 1990a, 1995). Los estudios epidemiológicos sugieren una relación dosis-respuesta entre la exposición a niveles crecientes de ozono y la gravedad de los síntomas respiratorios y la disminución de las funciones respiratorias (Bascom y cols. 1996).

Figura 53.5 - Partículas $\left(\mathrm{PM}_{10}\right)$ en dos zonas de Ciudad de M éxico, 1988-1993.

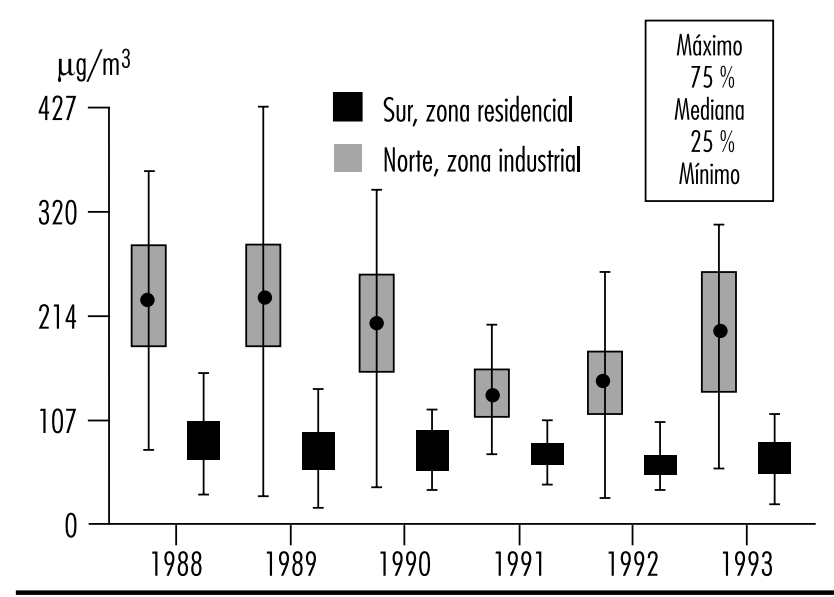


Figura 53.6 - N iveles de plomo en el aire en dos zonas de Ciudad de M éxico, 1988-1994.

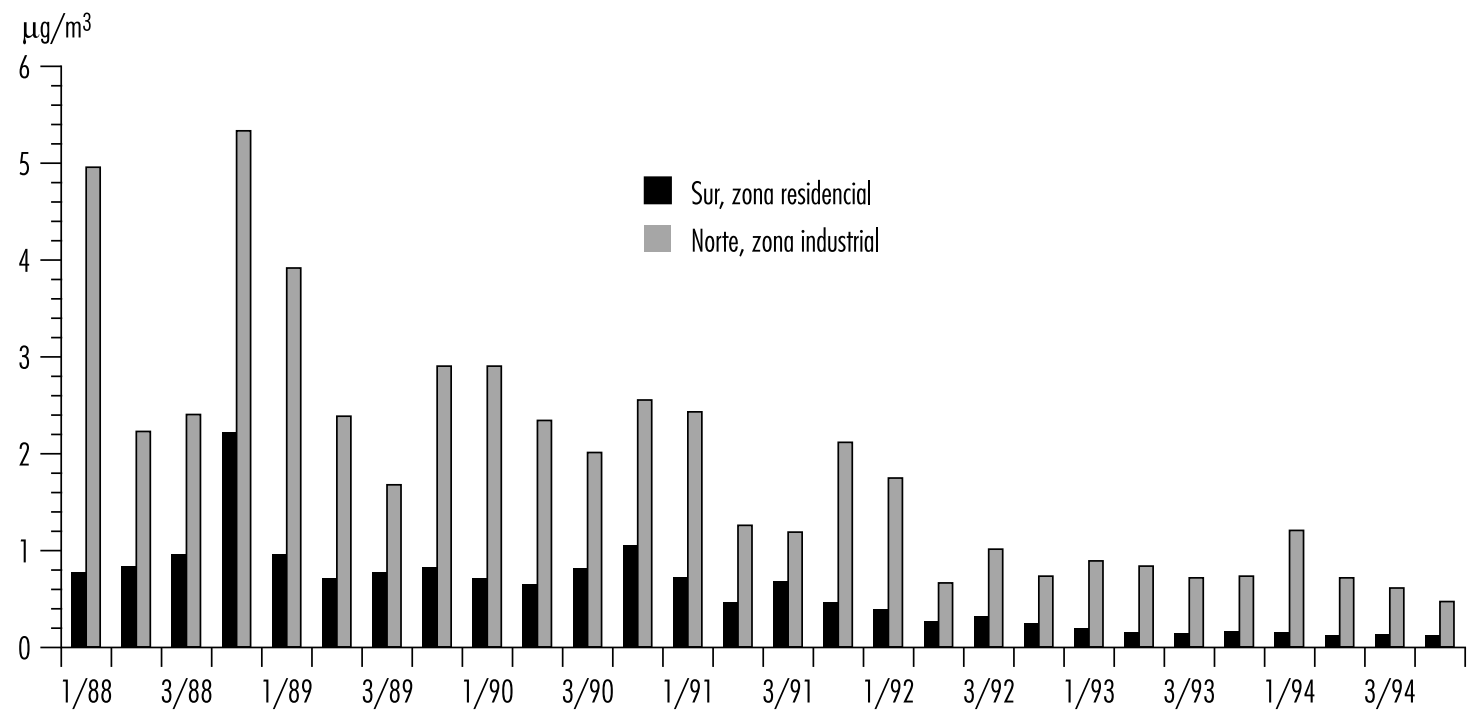

\section{Monóxido de carbono}

El principal efecto del $\mathrm{CO}$ es que se reduce el transporte de oxígeno a los tejidos mediante la formación de carboxihemoglobina $(\mathrm{COHb})$. Al aumentar los niveles de $\mathrm{COHb}$ en la sangre pueden observarse los siguientes efectos: efectos cardiovasculares en personas con angina de pecho previa (3\% a $5 \%$ ); deterioro de las tareas de vigilancia $(>5 \%)$; cefalea y vértigo $(\geq 10 \%)$; fibrinolisis y muerte (O M S 1987).

\section{Plomo}

La exposición al plomo afecta principalmente a la biosíntesis del hemo, pero puede actuar también sobre el sistema nervioso y otros sistemas, como el cardiovascular (presión sanguínea). Los niños recién nacidos y menores de cinco años son especialmente sensibles a la exposición al plomo por sus efectos sobre el desarrollo neurológico a niveles en sangre próximos a $10 \mu \mathrm{g} / \mathrm{dl}$ (CDC 1991).

En varios estudios epidemiológicos se ha investigado el efecto de la contaminación del aire, especialmente de la exposición al ozono, sobre la salud de la población de Ciudad de México. Estudios ecológicos han puesto de manifiesto el incremento de la mortalidad asociado a la exposición a partículas finas (Borja-Arburto y cols. 1995) y un incremento de las visitas a urgencias por asma infantil (Romieu y cols. 1994). Estudios sobre los efectos perjudiciales de la exposición al ozono realizados en niños sanos han demostrado un incremento del absentismo escolar por enfermedades respiratorias (Romieu y cols. 1992), así como un descenso de la función pulmonar tras exposiciones tanto agudas como subagudas (C astillejos y cols. 1992, 1995). Estudios realizados entre niños asmáticos han puesto de manifiesto un incremento de los síntomas respiratorios y un descenso de la tasa de expiración máxima tras la exposición al ozono (Romieu y cols. 1994) y a partículas finas (Romieu y cols. en prensa). Aunque parece clara la asociación entre la exposición aguda al ozono y los efectos nocivos sobre la salud de la población de Ciudad de M éxico, es necesario evaluar el efecto crónico de dicha exposición, en particular dados los elevados niveles de fotooxidantes observados en esa ciudad y la ineficacia de las medidas de control.

\section{LA CONTAMINACION DEL SUELO}

Tee L. G uidotti y Chen Weiping

La sociedad humana produce cada vez más desechos. Los desechos sólidos comerciales y domésticos representan un gran problema práctico para muchas autoridades locales. Por su parte, los residuos industriales suelen tener un volumen mucho menor, pero pueden contener materiales peligrosos, como sustancias químicas tóxicas, líquidos inflamables y amianto. Aunque la cantidad total es menor, la eliminación de los residuos industriales peligrosos ha generado una preocupación mayor que los desechos domésticos, pues se entiende que suponen un peligro para la salud y constituyen un riesgo de contaminación ambiental.

La generación de residuos peligrosos se ha convertido en un gran problema mundial, cuyo origen se encuentra en la producción y la distribución industrial. H ay contaminación cuando los residuos peligrosos llegan al suelo y a las aguas subterráneas como resultado de la inadeacuación o la irresponsabilidad en las medidas de eliminación. Los vertederos abandonados o mal atendidos plantean a la sociedad un problema especialmente difícil y costoso. En ocasiones, los residuos peligrosos se eliminan ilegalmente y con métodos aún más peligrosos porque el propietario no encuentra una forma asequible de deshacerse de ellos. Una de las grandes cuestiones sin resolver en cuanto al tratamiento de los residuos peligrosos es encontrar métodos de eliminación que sean a un tiempo seguros y baratos. La preocupación pública a este respecto se centra en los efectos que puede tener sobre la salud la exposición a sustancias químicas tóxicas, y en particular el riesgo de cáncer.

El Convenio de Basilea es un acuerdo internacional adoptado en 1989 para controlar el movimiento transfronterizo de residuos peligrosos y evitar que puedan enviarse para su eliminación a países que no posean las instalaciones necesarias para tratarlos de forma segura. EI Convenio exige que la generación de residuos peligrosos y su movimiento transfronterizo se mantengan a un nivel mínimo. El tráfico está sujeto a la autorización informada del país receptor y a su legislación. El movimiento transfronterizo debe responder a buenas prácticas ambientales y a la garantía de que el país receptor tiene capacidad para tratarlos de modo seguro. Todas las demás formas de tráfico se 
consideran ilegales y por tanto de intención delictiva, y están sujetas a las legislaciones y códigos penales de los respectivos países. El Convenio constituye un marco esencial para el control del problema a escala internacional.

\section{Propiedades peligrosas de las sustancias químicas}

Las sustancias peligrosas son compuestos y mezclas de los mismos que representan una amenaza para la salud y los bienes por su toxicidad, inflamabilidad, potencial explosivo, radiación u otras propiedades peligrosas. La atención pública se ha centrado mayormente en los peligros de los carcinógenos, los residuos industriales, los plaguicidas y la radiación. Sin embargo, son innumerables los compuestos no incluidos en esas categorías que pueden suponer una amenaza para la salud y la seguridad públicas.

L as sustancias químicas peligrosas pueden constituir un riesgo físico, como en los casos de accidentes industriales y de transporte. L os hidrocarburos pueden incendiarse e incluso explotar, y los incendios y explosiones pueden generar sus propios peligros tóxicos dependiendo de las sustancias químicas inicialmente presentes en ellos. Los incendios en lugares de almacenamiento de plaguicidas constituyen una situación especialmente peligrosa, pues estos últimos pueden convertirse en productos de combustión aún más tóxicos (como los paraoxones en el caso de los órganofosfatos) y, cuando la combustión se produce en presencia de compuestos de cloro, pueden generarse cantidades significativas de dioxinas y furanos, que son nocivos para el medio ambiente.

No obstante, lo que más preocupa a la mayoría de la gente con respecto a los residuos peligrosos es su toxicidad. L as sustancias químicas pueden ser tóxicas para los seres humanos y ser nocivas también para el medio ambiente a través de su toxicidad para las especies animales y vegetales. Son motivo de especial preocupación las que no se degradan fácilmente en el medio ambiente (característica que se denomina biopersistencia) o que se acumulan en él (característica que se denomina bioacumulación).

EI número de sustancias químicas de uso común y su peligrosidad se han modificado radicalmente. En la última generación, la investigación y desarrollo en química orgánica e ingeniería química han introducido miles de nuevos compuestos destinados a un amplio uso comercial, incluidos compuestos persistentes como los bifenilos policlorados (PCB), plaguicidas más potentes, aceleradores y sustancias para dar plasticidad, de efectos inusuales y aún mal conocidos. La producción de sustancias químicas se ha elevado enormemente. Por ejemplo, en 1941 la producción total de compuestos orgánicos sintéticos en Estados U nidos no llegaba a los 1.000 millones de $\mathrm{kg}$. H oy supera con mucho los 80.000 millones. M uchos compuestos que son hoy de uso común no fueron suficientemente ensayados y no los conocemos bien.

Las sustancias químicas tóxicas han entrado en nuestra vida diaria mucho más que en el pasado. Son muchas las fábricas 0 los vertederos de sustancias químicas que antes estaban aisladas 0 en los lindes de las poblaciones y que hoy se han incorporado a las zonas urbanas por el crecimiento de los alrededores de las grandes ciudades. Las poblaciones están hoy más cerca del problema que antes. Algunas comunidades se han construido directamente encima de antiguos vertederos. Aunque los accidentes con sustancias peligrosas pueden adoptar muchas formas y ser sumamente singulares, parece que en la gran mayoría interviene un grupo relativamente reducido de sustancias: disolventes, pinturas y revestimientos, soluciones metálicas, bifenilos policlorados (PCB), plaguicidas y ácidos y álcalis. En estudios realizados en Estados U nidos, las diez sustancias peligrosas que se encontraban con más frecuencia en los vertederos que exigían

Figura 53.7 • Sección transversal de un hipotético vertedero de desechos peligrosos.

Las precipitaciones pueden provocar escorrentías en la superficie

Las características de las capas sucesivas se determinan realizando perforaciones y examinando las muestras así obtenidas

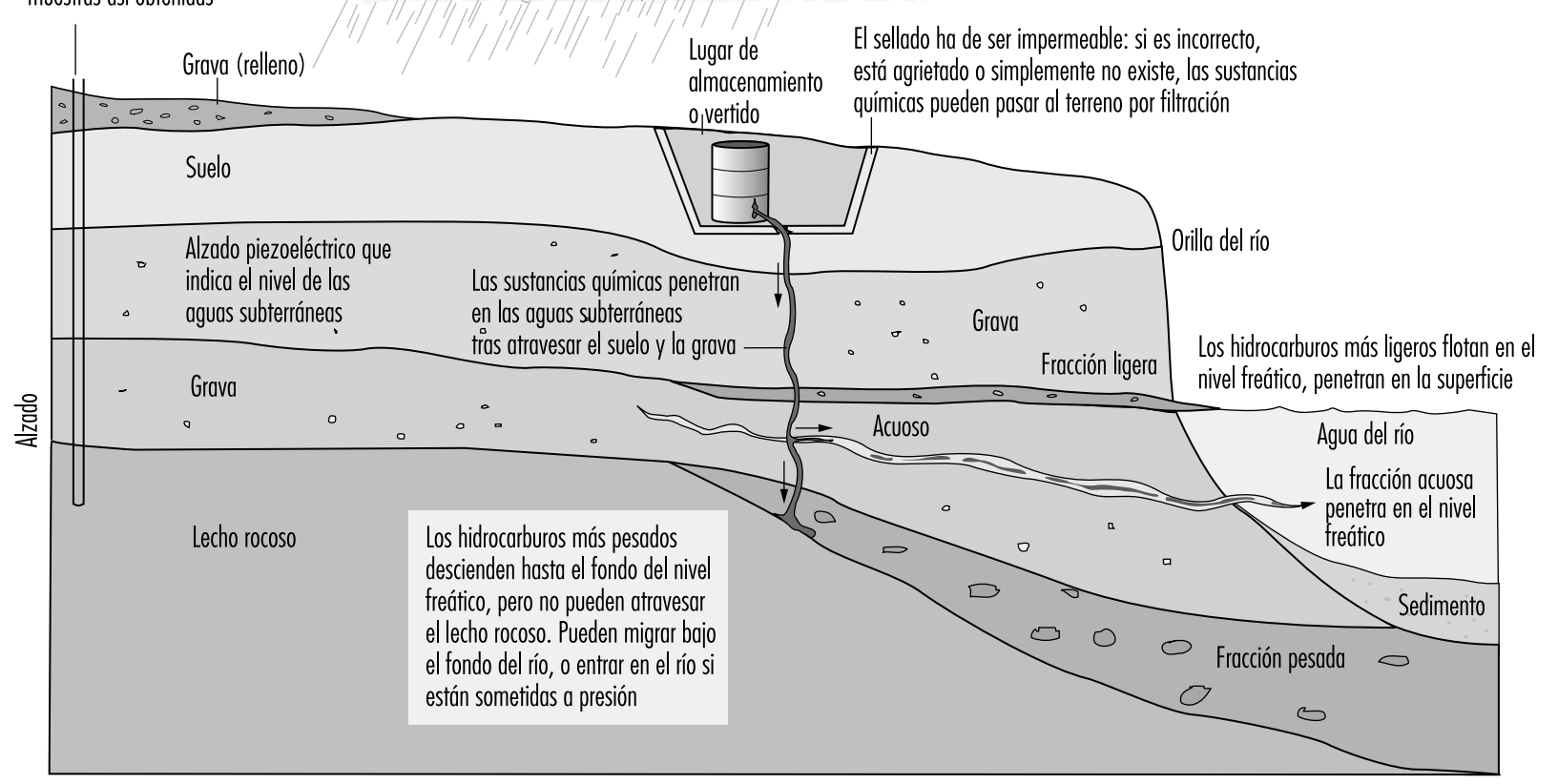


una intervención oficial eran el plomo, el arsenio, el mercurio, el cloruro de vinilo, el benceno, el cadmio, los PCB, el cloroformo, el benzo(a)pireno y el tricloroetileno. No obstante, el cromo, el tetracloroetileno, el tolueno y el di-2-etilhexilftalato también ocupaban un lugar destacado entre las sustancias que podían migrar o provocar una exposición humana. El origen de estos residuos químicos varía considerablemente y depende de la situación local, pero fuentes características de ese flujo de residuos son las soluciones para galvanoplastia, las sustancias químicas desechadas, los productos secundarios de procesos de fabricación y los disolventes desechados.

\section{Contaminación de las aguas subterráneas}

En la Figura 53.7 se presenta una sección transversal de un hipotético vertedero de residuos peligrosos para ilustrar los problemas que pueden surgir. (En la práctica, un vertedero de ese tipo no se situaría nunca junto a una masa de agua ni sobre un lecho de grava.) L as instalaciones de eliminación (contención) de residuos peligrosos bien diseñadas poseen un cerramiento sellado impermeable que impide que las sustancias peligrosas escapen y penetren en el terreno subyacente. Cuentan también con medios para tratar las sustancias químicas que pueden neutralizarse 0 transformarse y reducir así el volumen de residuos depositados en el vertedero; las sustancias químicas que no pueden tratarse se encierran en contenedores impermeables. (N o obstante, y como se verá más adelante, la permeabilidad es relativa.)

Las sustancias químicas pueden escapar por filtración cuando el contenedor se encuentra en mal estado, por lixiviación si entra agua en su interior o por derramamiento durante su manipulación o cuando el vertedero se ve alterado por alguna causa. U na vez que atraviesan el revestimiento interior del vertedero, o si ese revestimiento está roto o no existe, penetran en el suelo y migran hacia abajo por efecto de la gravedad. La migración es mucho más rápida en los suelos porosos, y más lenta cuando tiene que atravesar arcilla o un lecho rocoso. Aun bajo tierra, el agua fluye cuesta abajo y sigue el camino de menor resistencia, por lo que el nivel de las aguas subterráneas se inclina ligeramente en la dirección de la corriente, y ésta es mucho más rápida cuando atraviesa arena o grava. Si hay una capa freática bajo el suelo, las sustancias químicas acabarán por llegar a ella. Las sustancias más ligeras tienden a flotar en el agua y formar en ella una capa superior. Las más pesadas y los compuestos hidrosolubles tienden a disolverse o ser transportados por las aguas subterráneas en su lento desplazamiento a través de rocas porosas o grava. La región contaminada, que es lo que se llama penacho, , puede determinarse cartográficamente efectuando perforaciones o pozos de sondeo. El penacho se va extendiendo lentamente, avanzando en la misma dirección que las aguas subterráneas.

La contaminación de las aguas superficiales puede producirse por escorrentía desde el vertedero, cuando la capa superior de suelo está contaminada, o por las aguas subterráneas. Cuando las aguas subterráneas desembocan en una masa de agua local, como un río o un lago, la contaminación pasa a esa masa de agua. Algunas sustancias químicas tienden a depositarse en el sedimento del fondo, mientras que otras son transportadas por la corriente.

La contaminación de las aguas subterráneas puede tardar siglos en desaparecer. Si la población que vive en la zona utiliza como fuente de agua pozos superficiales, existe la posibilidad de exposición por ingestión y por contacto cutáneo.

\section{Problemas para la salud humana}

Las personas entran en contacto con las sustancias tóxicas de muchas maneras y la exposición puede producirse en distintos momentos de su vida útil. Puede ocurrir que personas que trabajan en una fábrica cuyo proceso industrial produce como residuos esas sustancias no se cambien de ropa ni se laven antes de ir a casa. 0 tras pueden vivir cerca de vertederos de residuos peligrosos ilegales o mal diseñados o dirigidos, produciéndose exposiciones como resultado de accidentes, de una manipulación negligente 0 de la falta de contención de la sustancia, o porque la zona no está suficientemente cerrada para impedir la entrada de los niños. La exposición puede producirse también en el hogar, como resultado de productos de consumo que están mal etiquetados, que han sido mal almacenados o que no contienen advertencias sobre su consumo por los niños.

$\mathrm{H}$ ay tres vías de exposición que son, con mucho, las más importantes a la hora de examinar la toxicidad de los residuos peligrosos: la inhalación, la ingestión y la absorción por la piel. U na vez absorbidas, y dependiendo de la ruta de exposición, las sustancias tóxicas pueden afectar a las personas de muchos modos. Evidentemente, la lista de posibles efectos tóxicos asociados a los residuos peligrosos es muy larga, pero la preocupación pública y los estudios científicos han tendido a centrarse en el riesgo de cáncer y en los efectos sobre el sistema reproductivo. En general, ello refleja el perfil de los peligros químicos presentes en los vertederos.

Se han efectuado numerosos estudios sobre personas que viven alrededor o cerca de esos lugares. Con escasas excepciones, los estudios demuestran más bien poco en cuanto a problemas de salud verificables y clínicamente importantes. Las excepciones suelen referirse a casos de contaminación excepcionalmente grave y cuando existe una ruta de exposición clara de personas que viven inmediatamente al lado del vertedero o han bebido agua procedente de aguas subterráneas contaminadas por el vertedero. Esta sorprendente ausencia de efectos documentados sobre la salud se explica probablemente por varias razones. Una de ellas es que, a diferencia de la contaminación del aire y de las aguas superficiales, la gente no tiene fácil acceso a los contaminantes químicos del suelo. Es posible vivir en zonas muy contaminadas por sustancias químicas, pero a menos que se entre realmente en contacto con ellas por una de las vías de exposición antes mencionadas no se producirá toxicidad. 0 tra razón es que los efectos crónicos de la exposición a esas sustancias químicas tóxicas tardan mucho en desarrollarse y son muy difíciles de estudiar. O tra razón, por último, puede ser que esas sustancias sean menos potentes como causantes de efectos crónicos sobre la salud de lo que generalmente se supone.

Dejando al margen los efectos sobre la salud humana, la contaminación del suelo puede ocasionar graves daños a los ecosistemas. Especies vegetales y animales, bacterias del suelo (que contribuyen a la productividad agrícola) y otros componentes de los ecosistemas pueden verse irreversiblemente dañados por unos niveles de contaminación que no vayan asociados a ningún efecto visible sobre la salud humana.

\section{Control del problema}

D ebido a las formas de distribución de la población, a las restricciones sobre el uso de la tierra, a los costes de transporte y a la preocupación social por los efectos ambientales, existe una gran presión para que se halle una solución al problema de la eliminación económica de los residuos peligrosos. Ello ha incrementado el interés por métodos como la reducción en la fuente, el reciclado, la neutralización química y los vertederos de eliminación (contención) segura de los residuos peligrosos. Los dos primeros reducen la cantidad de residuos producida y la neutralización química su toxicidad, convirtiéndolos a veces en un sólido de más fácil manejo. Siempre que es posible, se prefiere realizar esta operación en el lugar de producción de los residuos, para reducir 
el volumen que se ha de trasladar. Para los desechos residuales se necesitan instalaciones de eliminación bien diseñadas, dotadas de las mejores tecnologías de transformación química y contención disponibles.

La construcción de vertederos de contención seguros es relativamente costosa. $\mathrm{H}$ ay seleccionar cuidadosamente el lugar para garantizar que no se producirá rápidamente una contaminación de las aguas superficiales y de los principales acuíferos (aguas subterráneas). El vertedero ha de diseñarse y construirse con barreras impermeables para impedir la contaminación del suelo y de las aguas subterráneas. Dichas barreras suelen consistir en gruesos revestimientos de plástico y capas de relleno a base de arcilla prensada bajo las zonas de contención. En realidad, la barrera actúa para retrasar el inicio de la filtración, que acaba produciéndose, y para hacerla más lenta, reduciéndola a un ritmo aceptable que no produzca acumulación o contaminación significativa de las aguas subterráneas. La permeabilidad es una propiedad de los materiales que se define como su resistencia a ser penetrados por un líquido o gas en determinadas condiciones de presión y temperatura. Hasta la barrera menos permeable, como los revestimientos plásticos o la arcilla prensada, acabarán permitiendo el paso de alguna sustancia química líquida a través de la barrera, lo que puede tardar años o incluso siglos en producirse, y una vez iniciada la salida el flujo se mantendrá continuo, aunque puede ser que a una velocidad muy baja. Esto significa que las aguas subterráneas que se hallen inmediatamente debajo de un vertedero de residuos peligrosos corren siempre un determinado riesgo de contaminación, por pequeño que sea. U na vez contaminadas las aguas subterráneas, la descontaminación es muy difícil y con frecuencia imposible.

M uchos vertederos de residuos peligrosos se vigilan regularmente mediante sistemas de recogida de muestras y a través de pruebas en pozos cercanos para comprobar que la contaminación no se esté extendiendo. Los más avanzados se construyen con instalaciones de reciclado y transformación "in situ" o en las proximidades para reducir aún más los residuos que finalmente se depositan en el contenedor.

Los contenedores de residuos peligrosos no constituyen una solución perfecta al problema de la contaminación del suelo. En su diseño intervienen costosos conocimientos especializados, su construcción es cara y pueden exigir una vigilancia que represente un coste permanente. No garantizan que no se vaya a producir en el futuro una contaminación de las aguas subterráneas, aunque pueden reducir al mínimo esa posibilidad. Un importante inconveniente es que es inevitable que alguien viva en sus cercanías. L as comunidades en que se sitúan o se proyecta situar vertederos de residuos peligrosos suelen oponerse a ellos con energía, lo que dificulta a los gobiernos la concesión de la autorización. Es lo que se denomina el síndrome de "no en mi patio", y es una respuesta habitual al emplazamiento de instalaciones que se consideran indeseables. En el caso de los vertederos de residuos peligrosos, este síndrome tiende a ser especialmente acentuado.

Por desgracia, sin vertederos de contención de los residuos peligrosos, la sociedad puede perder por completo el control de la situación. Cuando no se dispone de un vertedero o cuando es demasiado caro utilizarlo, los residuos peligrosos suelen eliminarse ilegalmente. Entre las prácticas ilegales figuran el vertido de residuos líquidos al suelo en lugares distantes o en desagües que desembocan en los cursos de agua locales y su traslado a jurisdicciones que tienen una legislación más laxa en materia de manipulación de sustancias peligrosas. Ello puede provocar una situación más peligrosa aún de la que se derivaría de la existencia de un vertedero mal gestionado.

Puden utilizarse varias tecnologías para eliminar los residuos restantes. U na de las más limpias y eficaces es la incineración a altas temperaturas, pero el coste de las instalaciones es muy elevado. Uno de los enfoques más prometedores consiste en la incineración de residuos tóxicos líquidos en hornos de cemento, que funcionan a las altas temperaturas necesarias y existen tanto en el mundo en desarrollo como en el mundo desarrollado. $\mathrm{La}$ inyección en pozos profundos, por debajo del nivel freático, es una posibilidad para las sustancias químicas que no pueden eliminarse de otro modo. No obstante, la migración a las aguas subterráneas es una cuestión delicada, y a veces unas condiciones inusuales de presión bajo tierra o filtraciones en los pozos llevan a su contaminación. La deshalogenación es una tecnología química que despoja a los hidrocarburos halogenados, como los PCB, de los átomos de cloro y bromo, de manera que luego pueden eliminarse fácilmente por incineración.

Una importante cuestión sin resolver en el ámbito de la manipulación municipal de los desechos sólidos es la contaminación por residuos peligrosos vertidos de forma accidental o voluntaria. Este riesgo puede reducirse al mínimo desviando esos materiales por una vía distinta. En su mayoría, los sistemas municipales de manipulación de desechos sólidos desvían los residuos químicos y peligrosos de modo que no contaminen el flujo de desechos sólidos. Lo ideal es que ese nuevo flujo de desechos se desvíe a un vertedero seguro.

Existe una necesidad apremiante de instalaciones para recoger y eliminar adecuadamente pequeñas cantidades de residuos peligrosos con un coste mínimo. Una persona que tiene en su poder una botella o una lata de disolvente, plaguicida o algún polvo o líquido desconocido por lo general no puede permitirse el elevado coste de una eliminación adecuada, y no es consciente del riesgo. Se necesita algún sistema para recoger esos residuos peligrosos a los consumidores antes de que los viertan en el suelo, los tiren por el inodoro o los quemen y liberen en la atmósfera. $\mathrm{H}$ ay ayuntamientos que patrocinan los denominados "días de recogida de tóxicos", en los que los vecinos llevan pequeñas cantidades de materiales tóxicos a un lugar central para una eliminación segura de los mismos. En algunas zonas urbanas se han introducido sistemas descentralizados, que incluyen la recogida domiciliaria o local de pequeñas cantidades de sustancias tóxicas para su eliminación. En Estados U nidos, la experiencia ha demostrado que la gente está dispuesta a recorrer diez kilómetros para eliminar en condiciones de seguridad los desechos tóxicos domésticos. Es urgente educar a los consumidores y promover la conciencia de la toxicidad potencial de los productos habituales. Los plaguicidas en aerosol, las lejías, los productos de limpieza para el hogar y los líquidos limpiadores son potencialmente peligrosos, sobre todo para los niños.

\section{Vertederos de residuos peligrosos abandonados}

Los vertederos de residuos peligrosos que están abandonados 0 carecen de seguridad constituyen un problema común en todo el mundo. Los vertederos necesitados de una limpieza representan una gran carga para la sociedad. La capacidad de los países y las jurisdicciones locales para limpiar los grandes vertederos de residuos peligrosos es muy variable. Idealmente, el propietario del vertedero o la persona que lo creó debería hacerse cargo de su limpieza. En la práctica, los vertederos cambian muchas veces de manos, y los propietarios anteriores con frecuencia ya no trabajan en el sector mientras que los actuales pueden no tener los recursos financieros necesarios para la limpieza, con lo que ésta tiende a retrasarse durante largo tiempo entre costosos estudios técnicos y batallas legales. L os países más pequeños y menos ricos tienen pocas ventajas comparativas a la hora de negociar las limpiezas con los propietarios actuales o con las partes responsables, y carecen de recursos para ocuparse ellos mismos de la operación. 
Los enfoques tradicionales en materia de limpieza de vertederos son muy lentos y costosos, y requieren conocimientos técnicos sumamente especializados que suelen escasear. En primer lugar se evalúa el vertedero para determinar la gravedad de la contaminación del suelo y si están contaminadas o no las aguas subterráneas. Se estudia asimismo la probabilidad de que las personas que viven en las cercanías hayan entrado en contacto con sustancias peligrosas, y en algunos casos se estima el consiguiente riesgo para la salud. Se han de tomar decisiones sobre los niveles de limpieza aceptables, de forma que en última instancia la exposición se reduzca a esos niveles para proteger la salud humana y el medio ambiente. En su mayoría, los gobiernos adoptan decisiones sobre los niveles de limpieza aplicando las leyes ambientales pertinentes y las normas sobre contaminación del aire y el agua potable, y sobre la base de una evaluación de los riesgos que para la salud supone ese vertedero en concreto. Por consiguiente, los niveles de limpieza reflejan tanto las preocupaciones sanitarias como las ambientales. Se ha de decidir la forma de poner remedio a la situación del vertedero o el mejor método para conseguir esa reducción de la exposición. Se plantea así el problema técnico de conseguir esos niveles de limpieza mediante métodos de ingeniería y de otro tipo. Entre otras técnicas se utilizan las de incineración, solidificación, tratamiento químico, evaporación, inundación reiterada del terreno, biodegradación, contención, transporte de suelo a otros lugares y extracción por bombeo de agua subterránea. Estas opciones técnicas son demasiado complejas y variables en función de las circunstancias para describirlas aquí en detalle. Las soluciones deben adaptarse a cada situación particular y a los fondos de que se dispone para conseguir el control. En algunos casos no es posible corregir la situación y entonces se ha de decidir qué usos de la tierra se van a autorizar en ese lugar.

\section{- LA CONTAMINACION DEL AgUA}

\section{Ivanildo H espanhol y Richard H elmer}

Desde hace al menos dos milenios se ha venido deteriorando la calidad del agua natural hasta llegar a niveles de contaminación que limitan estrictamente los usos del agua o la hacen perjudicial para los humanos. Este deterioro se ha relacionado con el desarrollo socioeconómico en las cuencas fluviales, pero en la actualidad el transporte atmosférico de contaminantes a largas distancias ha modificado el panorama: hasta zonas muy alejadas pueden verse indirectamente contaminadas (M eybeck y H elmer 1989).

Las primeras manifestaciones de contaminación de las aguas urbanas las encontramos en la Edad Media, con noticias y quejas sobre la insuficiencia de los sistemas de eliminación de los excrementos, los cursos de agua sucia y hedionda en las ciudades superpobladas y otros problemas similares. La primera vez que se estableció una vinculación causal clara entre la mala calidad del agua y los efectos sobre la salud humana se remonta a 1854, año en que John Snow atribuyó el brote de una epidemia de cólera en $L$ ondres a una determinada fuente de agua potable.

D esde mediados del siglo $X X, y$ coincidiendo con el inicio de un crecimiento industrial acelerado, se han venido produciendo en rápida sucesión diversos tipos de problemas de contaminación del agua. En la Figura 53.8 se indican esos problemas y el momento de su aparición en los recursos europeos de agua dulce.

Como resumen de la situación europea cabe afirmar que: a) se han determinado y estudiado los problemas del pasado (patógenos, balance de oxígeno, eutroficación, metales pesados) y se han identificado y aplicado en mayor o menor medida los controles necesarios, y b) los problemas de hoy son de otro tipo: por una parte, fuentes puntuales y difusas de contaminación "tradicionales" (nitratos) y problemas de contaminación ambiental generalizada (compuestos orgánicos sintéticos), y, por otra, problemas "de tercera generación" que interfieren los ciclos globales (acidificación, cambio climático).

En el pasado, la contaminación del agua en los países en desarrollo se debía principalmente a los vertidos de aguas residuales sin tratar. La situación es hoy más compleja debido a la producción industrial de residuos peligrosos y a la utilización en rápido aumento de plaguicidas en la agricultura. De hecho, en algunos países en desarrollo, al menos en los países de industrialización reciente, el problema de la contaminación del agua es más grave que en los países industrializados (Arceivala 1989). Por desgracia, los países en desarrollo en su conjunto están muy atrasados en materia de control de las principales fuentes de contaminación. En consecuencia, la calidad del medio ambiente sufre un deterioro progresivo (O M S/ PN U M A 1991).

Figura 53.8 - Tipos de problemas de contaminación del agua.

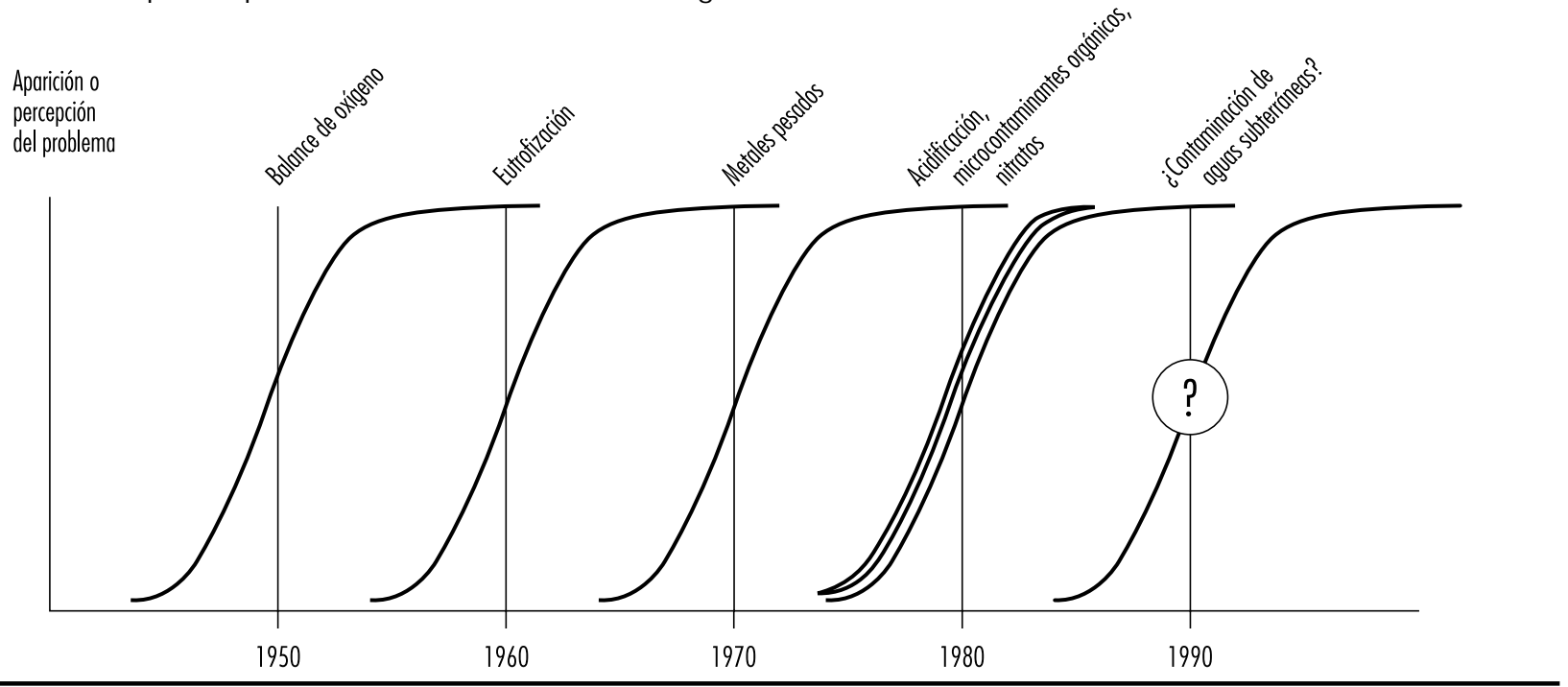




\section{Tipos y fuentes de contaminación}

$\mathrm{H}$ ay numerosos agentes microbianos, elementos y compuestos que pueden contaminar el agua. Pueden clasificarse de la siguiente manera: organismos microbiológicos, compuestos orgánicos biodegradables, materiales en suspensión, nitratos, sales, metales pesados, nutrientes y microcontaminantes orgánicos.

\section{Organismos microbiológicos}

Los organismos microbiológicos son habituales en las masas de agua dulce contaminadas por vertidos de aguas residuales domésticas sin tratar. Entre esos agentes microbianos figuran bacterias patogénicas, virus, helmintos, protozoos y otros organismos pluricelulares complejos que pueden producir enfermedades gastrointestinales. 0 tros organismos tienen un carácter más oportunista e infectan a individuos vulnerables a través del contacto corporal con agua contaminada o mediante la inhalación de gotitas de agua de mala calidad en aerosoles de diversos orígenes.

\section{Compuestos orgánicos biodegradables}

Sustancias orgánicas de origen natural (detritus terrestres alóctonos 0 residuos autóctonos de plantas acuáticas) o de fuentes antropogénicas (desechos domésticos, agrícolas y algunos industriales) son descompuestas por microbios aeróbicos a lo largo del curso del río. La consecuencia es un descenso del nivel de oxígeno del río a partir del punto en que se vierten las aguas residuales, lo que reduce la calidad del agua y pone en peligro la supervivencia de la biota acuática, especialmente de los peces de alta calidad.

\section{Partículas}

Las partículas son un importante medio de transporte de contaminantes orgánicos e inorgánicos. En los materiales en suspensión encontramos la mayoría de los metales pesados tóxicos, contaminantes orgánicos, patógenos y nutrientes como el fósforo. También está presente una cantidad apreciable de material orgánico biodegradable, que es responsable del consumo del oxígeno en disolución de los ríos. Las partículas proceden de la urbanización y de la construcción de carreteras, la despoblación forestal, las operaciones mineras, las operaciones de dragado de los ríos, fuentes naturales relacionadas con la erosión continental o catástrofes naturales. Las partículas más gruesas se depositan en el lecho de los ríos, los embalses, las Ilanuras aluviales y las marismas y lagos.

\section{Nitratos}

La concentración de nitratos en las aguas superficiales no contaminadas oscila entre menos de 0,1 y 1 miligramo por litro (expresado como nitrógeno), de manera que niveles de nitratos superiores a $1 \mathrm{mg} / \mathrm{I}$ indican influencias antropogénicas, como el vertido de residuos municipales y las escorrentías urbanas y agrícolas. La precipitación atmosférica es también una fuente importante de nitratos y amoníaco en las cuencas fluviales, sobre todo en zonas no afectadas por fuentes de contaminación directas, por ejemplo, algunas regiones tropicales. Elevadas concentraciones de nitratos en el agua potable pueden resultar altamente tóxicas para los recién nacidos que no reciben lactancia natural durante los primeros meses de vida o para las personas de edad avanzada, fenómeno que se denomina metahemoglobinemia.

\section{Sales}

La salinización del agua puede deberse a factores naturales, como la interacción geoquímica del agua con suelos salinos, 0 a actividades antropogénicas, como la agricultura de regadío, la entrada de agua marina a causa de un bombeo excesivo de aguas subterráneas en islas y zonas costeras o la eliminación de desechos industriales y salmueras de campos petrolíferos.

\section{Ejemplos de contaminación del agua en determinadas ciudades}

\section{Karachi (Pakistán)}

El río Lyari, que atraviesa Karachi, la mayor ciudad industrial del Pakistán, es un desaguadero abierto tanto desde el punto de vista químico como desde el microbiológico, una combinación de aguas residuales en bruto y de efluentes industriales sin tratar. Estos proceden en su mayoría de un polígono industrial en el que hay 300 grandes instalaciones industriales y casi tres veces más de instalaciones más pequeñas. Tres quintas partes de ellas son talleres textiles. La mayoría de las demás industrias de Karachi también vierten efluentes sin tratar en el curso de agua más próximo.

\section{Alejandría (Egipto)}

Las industrias de Alejandría representan alrededor del $40 \%$ del producto industrial total del país, y la mayoría vierte desechos líquidos sin tratar en el mar o en el lago Maryut. En el pasado decenio la producción pesquera en el lago Maryut descendió en más o menos un $80 \%$ debido a los vertidos directos de efluentes industriales y domésticos. El lago ha dejado de ser asimismo, por su deficiente estado, el importante enclave turístico que era. Se está produciendo un deterioro ambiental similar en la costa marina como resultado de los vertidos de aguas de desecho sin tratar procedentes de emisarios mal situados.

\section{Shanghai (China)}

Alrededor de 3,4 millones de metros cúbicos de desechos industriales y domésticos se vierten sobre todo en el arroyo Suzhou y en el río Huangpu, que pasan por el centro de la ciudad. Se han convertido en las principales alcantarillas (abiertas) de la urbe. Los desechos son en su mayor parte industriales, pues son pocas las casas que poseen inodoros conectados con la red de alcantarillado. El Huangpu está básicamente muerto desde 1980. En total, se tratan menos del $5 \%$ de las aguas de desecho de la ciudad. El nivel de la capa freática, normalmente alto, supone asimismo que diversas toxinas de las plantas industriales y los ríos locales llegan a las aguas subterráneas y a los ríos locales y contaminan los pozos, con los que también se abastece de agua la ciudad.

\section{Sao Paulo (Brasil)}

Cuando pasa por el Gran Sao Paulo, una de las mayores aglomeraciones urbanas del mundo, el río Tiete recibe diariamente 300 toneladas de efluentes de 1.200 industrias situadas en la zona. Entre los principales contaminantes figuran el plomo, el cadmio y otros metales pesados. Recibe asimismo 900 toneladas de aguas residuales cada día, de las que sólo se trata un $12,5 \%$ en las cinco estaciones depuradoras que hay en la zona.

Fuente: Basado en Hardoy y Satterthwaite 1989.

Aunque puede ser un inconveniente para el aprovechamiento del agua, sobre todo para regar cultivos sensibles o para beber, en sí misma la salinidad puede no ser directamente perjudicial para la salud, incluso a niveles bastante altos; sus efectos indirectos pueden ser sin embargo muy graves. La pérdida de tierra agrícola fértil y la reducción de los rendimientos de los cultivos por anegamiento y salinización del suelo en las zonas regadas acaban con el medio de vida de comunidades enteras y provocan graves situaciones de escasez de alimentos. 


\section{M etales pesados}

Los metales pesados como el plomo, el cadmio y el mercurio son microcontaminantes de especial interés, pues tienen importancia para la salud y el medio ambiente a causa de sus características de persistencia, elevada toxicidad y bioacumulación.

L os metales pesados que contribuyen a la contaminación del agua proceden básicamente de cinco fuentes: desgaste geológico, que es responsable del nivel de fondo; transformación industrial de menas y metales; utilización de metales y compuestos de metales, como las sales de cromo en las curtidurías, los compuestos de cobre en la agricultura y el tetraetilo de plomo como agente antidetonante en la gasolina; la lixiviación de metales pesados a partir de desechos domésticos y vertidos de residuos sólidos, y la presencia de metales pesados en los excrementos humanos y animales, sobre todo zinc. Los metales que se liberan en el aire procedentes de las emisiones de los automóviles, la combustión de combustibles y los procesos industriales pueden depositarse en el suelo y llegar a incorporarse a las aguas superficiales.

\section{Nutrientes}

La eutrofización se define como el enriquecimiento de las aguas con nutrientes de origen vegetal, sobre todo fósforo y nitrógeno, que generan un mayor crecimiento de las plantas (tanto algas como macrófitos) y se traducen en floraciones de algas visibles, marañas flotantes de algas o macrófitos, algas bentónicas y aglomeraciones sumergidas de macrófitos. Al descomponerse, ese material vegetal conduce al agotamiento de las reservas de oxígeno de las masas de agua, lo que a su vez provoca una serie de problemas secundarios como la mortalidad de los peces y la liberación de gases corrosivos y otras sustancias indeseables, como gas carbónico, metano, sulfuro de hidrógeno, sustancias organolépticas (que dan sabor y olor), toxinas y similares.

L os compuestos de fósforo y nitrógeno proceden básicamente de las aguas residuales domésticas no tratadas, pero hay también otras fuentes, como el drenaje de tierra agrícola con fertilizantes artificiales, las escorrentías superficiales de la ganadería intensiva y algunas aguas residuales industriales, que también pueden incrementar sustancialmente el nivel trófico de lagos y embalses, sobre todo en los países tropicales en desarrollo.

Los principales problemas relacionados con la eutrofización de lagos, embalses y depósitos de agua son los siguientes: agotamiento del oxígeno en la capa superior; menor calidad del agua, lo que dificulta el tratamiento, sobre todo para eliminar las sustancias que dan sabor y olor; disminución del valor de esas masas de agua con fines recreativos, con un mayor riesgo para la salud de los bañistas y un aspecto desagradable; inconvenientes para la pesca, debido a la mortalidad de peces y a la aparición de poblaciones de peces de baja calidad y escaso atractivo; envejecimiento y reducción de la capacidad de lagos y embalses por sedimentación; e incremento de los problemas de corrosión en conducciones y otras estructuras.

\section{M icrocontaminantes orgánicos}

Los microcontaminantes orgánicos pueden clasificarse en grupos de productos químicos en función de su utilización y, por tanto, de la forma en que se dispersan en el medio ambiente:

- Los plaguicidas son sustancias, por lo general sintéticas, que se introducen deliberadamente en el medio ambiente para proteger los cultivos o luchar contra vectores de enfermedades. Constituyen varias familias claramente diferenciadas, como los insecticidas organoclorados, los insecticidas organofosfatos, los herbicidas del tipo hormonal vegetal, las triacinas, los sustitutivos de urea y otros.
- Entre los materiales de uso doméstico e industrial común se encuentran las sustancias orgánicas volátiles que se utilizan como disolventes de extracción, los disolventes para desengrasar metales y limpiar ropa en seco, y los propulsores que se utilizan en aerosoles. Este grupo comprende también los derivados halogenados del metano, el etano y el etileno. Como su empleo está muy extendido, las tasas de dispersión en el medio ambiente en relación con las cantidades producidas son por lo general elevadas. Este grupo comprende también los hidrocarburos aromáticos policíclicos, cuya presencia en el medio ambiente se debe a la extracción, transporte y refino de productos del petróleo y a la dispersión de productos de combustión derivados de su uso (gasolina y fuel para calefacción).

- Entre los materiales de uso esencialmente industrial figuran sustancias que son agentes directos e intermedios de síntesis químicas, como el tetracloruro de carbono para sintetizar freones, el cloruro de vinilo para polimerizar PV C y derivados clorados del benceno, el naftaleno, el fenol y la anilina para fabricar tintes. T ambién se incluyen en este grupo productos acabados que se utilizan en sistemas cerrados, como fluidos para el intercambio de calor y dieléctricos.

Los microcontaminantes orgánicos proceden de fuentes puntuales y difusas, tanto urbanas como rurales. La mayoría tienen su origen en importantes actividades industriales, como el refino de petróleo, la minería del carbón, la síntesis orgánica y la fabricación de productos sintéticos, las industrias siderúrgicas, la industria textil y la industria de la madera y la pasta de papel. L os efluentes de fábricas de plaguicidas pueden contener importantes cantidades de esos productos manufacturados. U na proporción significativa de los contaminantes orgánicos se vierte al medio acuático a través de las escorrentías de superficies urbanas; y en las zonas agrícolas los plaguicidas con que se tratan los cultivos pueden llegar a las aguas superficiales a través de las escorrentías de agua de lluvia y del drenaje artificial 0 natural. También vertidos accidentales han ocasionado graves daños ecológicos y cierres temporales del suministro de agua.

\section{Contaminación urbana}

A causa de la contaminación urbana, multiforme, agresiva y en continuo crecimiento, la necesidad de mantener la calidad de los recursos hídricos se ha convertido en un problema grave, sobre todo en las zonas más urbanizadas del mundo en desarrollo. EI mantenimiento de la calidad del agua se ve obstaculizado por dos factores: el hecho de que no se imponga un control de la contaminación en las fuentes principales, sobre todo las industrias, y la insuficiencia de los sistemas de saneamiento y de recogida y eliminación de basuras (O M S 1992b). En un recuadro se ofrecen algunos ejemplos de contaminación del agua en varias ciudades de países en desarrollo.

\section{Efectos de la contaminación microbiana sobre la salud}

Las enfermedades ocasionadas por la ingestión de patógenos en el agua contaminada tienen una enorme importancia en todo el mundo. "Se estima que en los países en desarrollo el $80 \%$ del total de enfermedades, y más de una tercera parte de las muertes, están originadas por el consumo de agua contaminada, y por término medio cada persona pierde hasta una décima parte de su tiempo productivo a causa de enfermedades relacionadas con el agua" (CNUMAD 1992). Las enfermedades transmitidas por el agua representan la principal categoría de enfermedades transmisibles que intervienen en la mortalidad infantil en los países en desarrollo y la segunda - por detrás sólo de la tuberculosis- de las que intervienen en la mortalidad de adultos, con un millón de muertes al año. 
La cifra total anual de casos de cólera notificada a la OM S por sus Estados miembros alcanzó niveles sin precedentes durante la séptima pandemia, con un máximo de 595.000 casos en 1991 (OMS 1993). En la Tabla 53.6 se indican las tasas mundiales de morbilidad y mortalidad de las principales enfermedades relacionadas con el agua. Se trata de cifras muy subestimadas, pues muchos países notifican los casos de enfermedad de una manera bastante errática.

\section{Efectos de la contaminación química sobre la salud}

Los problemas de salud asociados a las sustancias químicas disueltas en el agua se derivan básicamente de la capacidad de esas sustancias para provocar efectos adversos tras largos períodos de exposición; son motivo de especial preocupación los contaminantes con propiedades tóxicas acumulativas, como los metales pesados y algunos microcontaminantes orgánicos, sustancias que son carcinogénicas y sustancias que pueden afectar al sistema reproductivo y al desarrollo. Otras sustancias que se hallan disueltas en el agua constituyen ingredientes esenciales de la ingesta alimentaria, y aún hay otras que tienen un carácter neutro con respecto a las necesidades humanas. Las sustancias químicas presentes en el agua, sobre todo en el agua potable, pueden clasificarse en tres categorías típicas desde el punto de vista de su repercusión sobre la salud (G alal-G orchev 1986):

- Sustancias que tienen un efecto tóxico agudo o crónico al consumirse. La gravedad del problema para la salud aumenta cuanto más alta es su concentración en el agua potable. Por otra parte, por debajo de un determinado umbral de concentración no se observan efectos sobre la salud, es decir, el metabolismo humano puede hacer frente a esa exposición sin que se detecten efectos mensurables a largo plazo. A esta categoría pertenecen diversos metales, nitratos, cianuros y otras sustancias.

- Sustancias genotóxicas, cuyos efectos sobre la salud comprenden problemas como la carcinogenicidad, la mutagenicidad y los defectos de nacimiento. Según las teorías científicas actuales no existe un umbral que pueda considerarse seguro, pues la ingestión de cualquier cantidad de la sustancia contribuye a incrementar los riesgos de cáncer y otros riesgos similares. Para determinar estos riesgos se utilizan complejos modelos de extrapolación matemática, pues se dispone de muy pocas pruebas epidemiológicas. Pertenecen a esta categoría las sustancias orgánicas sintéticas, muchos microcontaminantes orgánicos clorados, algunos plaguicidas y el arsénico.

Tabla 53.6 - Tasas mundiales de morbilidad y mortalidad de las principales enfermedades relacionadas con el agua.

\begin{tabular}{lll} 
& \multicolumn{2}{l}{ Número/ Año o período de notificación } \\
Enfermedad & Casos & Fallecimientos \\
Cólera-1993 & 297.000 & 4.971 \\
Tifoideas & 500.000 & 25.000 \\
Giardiasis & 500.000 & Escasos \\
Amebiasis & 48.000 .000 & 110.000 \\
Enfermedades diarreicas (menores de & 1.600 .000 .000 & 3.200 .000 \\
$\quad 5$ años) & & \\
Dracunculosis ("gusano de Guinea") & 2.600 .000 & - \\
Esquistosomiasis & 200.000 .000 & 200.000 \\
Fuente: Galal-Gorchev 1994. & & \\
\hline
\end{tabular}

- En el caso de algunos elementos como el flúor, el yodo y el selenio es decisiva la contribución del agua potable, y las deficiencias de ésta tienen efectos más o menos graves sobre la salud. Con todo, concentraciones altas esas sustancias tienen efectos igualmente graves, aunque de carácter distinto.

\section{Repercusiones ambientales}

L as repercusiones de la contaminación ambiental sobre la calidad del agua dulce son numerosas y se han venido produciendo desde hace mucho tiempo. El desarrollo industrial, la aparición de la agricultura intensiva, el crecimiento exponencial de la población humana y la producción y uso de decenas de miles de sustancias químicas sintéticas están entre las principales causas del deterioro de la calidad del agua a escala local, nacional y mundial. La cuestión más importante que plantea la contaminación del agua es la interferencia con los usos del agua tanto efectivos como proyectados.

Una de las causas más graves y extendidas de la degradación del medio ambiente es el vertido de desechos orgánicos a los cursos de agua (véase "C ompuestos orgánicos biodegradables"). Se trata de una contaminación preocupante sobre todo para el medio acuático, donde hay muchos organismos, como los peces, que necesitan altos niveles de oxígeno. Un grave efecto secundario de la anoxia del agua es la liberación de sustancias tóxicas por parte de las partículas y los sedimentos de fondo de los ríos y lagos. 0 tros efectos de la contaminación procedente de vertidos de aguas residuales domésticas a los cursos de agua y los acuíferos son la acumulación de nitratos en los ríos y aguas subterráneas y la eutrofización de lagos y embalses (véase " $N$ itratos" y "Sales"). En ambos casos la contaminación es un efecto sinérgico de los efluentes de aguas residuales y de las escorrentías o infiltraciones agrícolas.

\section{Repercusiones económicas}

Las consecuencias económicas de la contaminación del agua pueden ser bastante graves, dados sus efectos perjudiciales sobre la salud humana y el medio ambiente. La mala salud limita la productividad de los seres humanos, y la degradación ambiental reduce la productividad de los recursos hídricos que utiliza directamente la gente.

Esta carga de patología económica puede expresarse no sólo en costes de tratamiento, sino también cuantificando la pérdida de productividad. Así ocurre especialmente con las enfermedades que son sobre todo invalidantes, como la diarrea 0 el "gusano de G uinea". En la I ndia, por ejemplo, se ha estimado que cada año se pierden alrededor de 73 millones de jornadas de trabajo por enfermedades relacionadas con el agua (Arceivala 1989).

Las deficiencias de saneamiento y las epidemias resultantes tienen también un coste económico muy alto, como ha quedado patente en la reciente epidemia de cólera de América Latina. Se ha estimado que la epidemia tuvo en Perú un coste de 1.000 millones de dólares debido a la caída de las exportaciones agrícolas y del turismo. Esa cantidad es más del triple de lo que había invertido el país en servicios de abastecimiento de agua y saneamiento durante el decenio de 1980 (Banco M undial 1992).

Los recursos hídricos afectados por la contaminación no resultan ya adecuados como fuentes de agua para el abastecimiento municipal. En consecuencia, es necesario instalar costosas depuradoras o traer el agua limpia desde muy lejos, lo que ocasiona unos costes mucho más elevados.

En los países en desarrollo de Asia y el Pacífico, la Comisión E conómica y Social para A sia y el Pacífico (CESPAP) estimó que 
Figura 53.9 • Sistema energético de referencia, 1979.

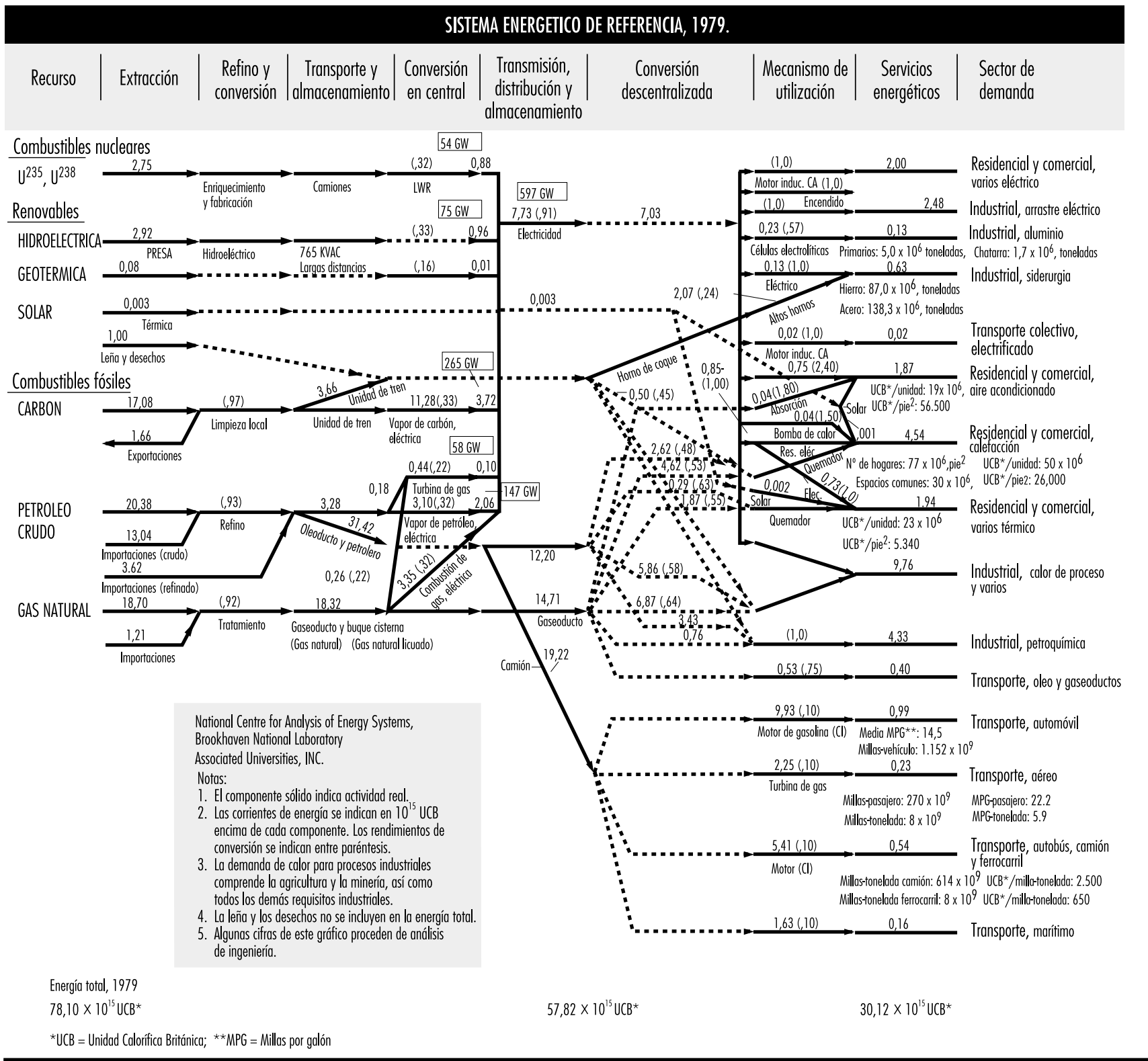

el daño ambiental en 1985 tuvo un coste más o menos equivalente al $3 \%$ del PNB, unos 250.000 millones de dólares, mientras que el coste de corregir esos daños sería de alrededor del $1 \%$.

\section{LA ENERGIA Y LA SALUD}

\section{D. H amilton}

El grupo de trabajo sobre energía de la Comisión de Salud y M edio Ambiente de la OM S (1992a) considera que, en materia de peligros para la salud de origen ambiental, hay cuatro problemas relacionados con la energía que merecen la mayor atención inmediata y/ o futura:
1. la exposición a agentes nocivos durante la utilización doméstica de biomasa y carbón;

2. la exposición derivada de la contaminación del aire urbano en muchas grandes ciudades del mundo;

3. Ios posibles efectos del cambio climático sobre la salud,

4. Ios accidentes graves, cuyos daños ambientales afectan a la salud de la población general.

Para realizar una estimación cuantitativa de los riesgos para la salud derivados de los distintos sistemas energéticos es necesario evaluar en todo el sistema todos los pasos de un ciclo de combustible, desde la extracción de la materia prima hasta el consumo final de la energía. Para que se puedan efectuar comparaciones válidas entre unas tecnologías y otras, los métodos, los datos y las necesidades de uso final han de ser similares y estar especificados. Al cuantificar los efectos de las necesidades de uso final deben evaluarse las diferencias de eficiencia de los distintos 
mecanismos de conversión en energía utilizable, mecanismos que son específicos para cada tipo de energía y cada combustible.

La evaluación comparativa se basa en la idea de un sistema de energía de referencia (SER), que describe los ciclos de cada combustible paso a paso, desde la extracción hasta la combustión y eliminación última de los residuos, pasando por la transformación. EI SER es un marco habitual y sencillo para definir los flujos de energía y otros datos conexos que se emplean en la evaluación de los riesgos. Un SER (Figura 53.9) es una representación en red de los principales componentes de un sistema energético en un año determinado, y especifica el consumo de recursos, el transporte de combustible, los procesos de conversión y los usos finales. Se presentan así de un modo compacto las principales características del sistema energético y a la vez se obtiene un marco para evaluar los principales efectos sobre los recursos, el medio ambiente, la salud y la economía que pueden derivarse de nuevas tecnologías o políticas.

En función de los riesgos que presentan para la salud, las tecnologías de la energía pueden clasificarse en tres grupos:

1. El grupo de combustibles se caracteriza por el empleo de grandes cantidades de combustibles fósiles o biomasa, carbón, petróleo, gas natural, madera, etc. Su obtención,

Tabla 53.7 • Principales efectos de las tecnologías de generación de electricidad sobre la salud (grupo de combustibles).

\begin{tabular}{|c|c|c|}
\hline Tecnología & Salud en el trabajo & Salud pública \\
\hline Carbón & $\begin{array}{l}\text { "Pulmón negro" } \\
\text { Traumas por accidentes } \\
\text { en minería } \\
\text { Traumas por accidentes } \\
\text { de transporte }\end{array}$ & $\begin{array}{l}\text { Efectos de la } \\
\text { contaminación del aire } \\
\text { Traumas por accidentes } \\
\text { de transporte }\end{array}$ \\
\hline Petróleo & $\begin{array}{l}\text { Traumas por accidentes } \\
\text { en perforaciones } \\
\text { Cáncer por exposición } \\
\text { a sustancias orgánicas } \\
\text { del refino }\end{array}$ & $\begin{array}{l}\text { Efectos de la } \\
\text { contaminación del aire } \\
\text { Traumas por explosiones } \\
\text { e incendios }\end{array}$ \\
\hline Esquisto bituminoso & $\begin{array}{l}\text { "Pulmón marrón" } \\
\text { Cáncer por exposición } \\
\text { a emisiones de la } \\
\text { destilación } \\
\text { Traumas por accidentes } \\
\text { de minería }\end{array}$ & $\begin{array}{l}\text { Cáncer por exposición } \\
\text { a emisiones de la } \\
\text { destilación } \\
\text { Efectos de la } \\
\text { contaminación del aire }\end{array}$ \\
\hline Gas natural & $\begin{array}{l}\text { Traumas por accidentes } \\
\text { en perforaciones } \\
\text { Cáncer por exposición a } \\
\text { emisiones del refino }\end{array}$ & $\begin{array}{l}\text { Efectos de la } \\
\text { contaminación del aire } \\
\text { Traumas por explosiones } \\
\text { e incendios }\end{array}$ \\
\hline Arenas alquitranadas & $\begin{array}{l}\text { Traumas por accidentes } \\
\text { de minería }\end{array}$ & $\begin{array}{l}\text { Efectos de la } \\
\text { contaminación del aire } \\
\text { Traumas por explosiones } \\
\text { e incendios }\end{array}$ \\
\hline Biomasa* & $\begin{array}{l}\text { Traumas por accidentes en } \\
\text { la recogida y la } \\
\text { transformación } \\
\text { Exposición a agentes } \\
\text { químicos y biológicos } \\
\text { peligrosos de la } \\
\text { transformación y } \\
\text { conversión }\end{array}$ & $\begin{array}{l}\text { Efectos de la } \\
\text { contaminación del aire } \\
\text { Enfermedades por } \\
\text { exposición a patógenos } \\
\text { Traumas por incendios } \\
\text { domésticos }\end{array}$ \\
\hline
\end{tabular}

* Como fuente de energía, considerada generalmente como renovable.
Tabla 53.8 • Principales efectos de las tecnologías de generación de electricidad sobre la salud (grupo de energías renovables).

\begin{tabular}{|c|c|c|}
\hline Tecnología & Salud en el trabajo & Salud pública \\
\hline Geotérmica & $\begin{array}{l}\text { Exposición a gases tóxicos: } \\
\text { rutinaria y accidental } \\
\text { Estrés por ruido } \\
\text { Traumas por accidentes en } \\
\text { perforaciones }\end{array}$ & $\begin{array}{l}\text { Enfermedad por exposición a } \\
\text { salmueras tóxicas y sulfuro } \\
\text { de hidrógeno } \\
\text { Cáncer por exposición a radón }\end{array}$ \\
\hline $\begin{array}{l}\text { Hidroeléctrica, } \\
\text { convencional } \\
\text { y de poca } \\
\text { caída }\end{array}$ & $\begin{array}{l}\text { Traumas por accidentes de } \\
\text { construcción }\end{array}$ & $\begin{array}{l}\text { Traumas por fallos en la presa } \\
\text { Enfermedad por exposición a } \\
\text { patógenos }\end{array}$ \\
\hline Fotovoltaica & $\begin{array}{l}\text { Exposición a materiales tóxicos } \\
\text { durante la fabricación: } \\
\text { rutinaria y accidental }\end{array}$ & $\begin{array}{l}\text { Exposición a materiales tóxicos } \\
\text { durante la fabricación y elimi- } \\
\text { nación: rutinaria y accidental }\end{array}$ \\
\hline Eólica & $\begin{array}{l}\text { Traumas por accidentes durante } \\
\text { la construcción y explotación }\end{array}$ & \\
\hline Térmica solar & $\begin{array}{l}\text { Traumas por accidentes durante } \\
\text { la fabricación } \\
\text { Exposición a sustancias } \\
\text { químicas tóxicas } \\
\text { durante la explotación }\end{array}$ & \\
\hline
\end{tabular}

transformación y transporte presentan altas tasas de accidentes, que constituyen los principales riesgos para la salud en el trabajo, y su combustión produce grandes cantidades de contaminantes del aire y residuos sólidos, que representan la principal amenaza para la salud pública.

2. El grupo de recursos renovables se caracteriza por la utilización de recursos renovables y difusos que poseen escasa densidad energética - el sol, el viento, el agua- y de los que se dispone en enormes cantidades sin coste alguno, pero cuya captación exige grandes superficies y la construcción de costosas instalaciones capaces de "concentrarlos" en formas utilizables. Los riesgos para la salud en el trabajo son elevados y se derivan sobre todo de la construcción de las instalaciones. Los riesgos para la salud pública son escasos y se limitan principalmente a accidentes de escasa probabilidad, como roturas de presas, fallos en equipos e incendios.

3. El grupo nuclear comprende las tecnologías de la fisión nuclear, que se caracterizan por una densidad de energía sumamente alta en el combustible transformado y, por tanto, por la necesidad de una cantidad pequeña de combustible y la generación de pocos residuos que transformar. Ahora bien, su concentración en la corteza terrestre es baja, por lo que su extracción y obtención requieren un considerable esfuerzo. L os riesgos para la salud en el trabajo son relativamente altos y consisten sobre todo en accidentes en la minería y en el proceso de transformación. Los riesgos para la salud pública son reducidos y radican sobre todo en las operaciones rutinarias de los reactores. Se ha de prestar especial atención a los temores de la población por los riesgos de exposición a la radiación - temores que son relativamente grandes por unidad de riesgo para la salud.

En las Tablas $53.7,53.8$ y 53.9 se indican los principales efectos sobre la salud de las tecnologías de generación de energía eléctrica.

Los estudios sobre las consecuencias para la salud de la combustión de leña en Estados U nidos, al igual que los análisis de otras fuentes de energía, se han basado en los efectos del suministro de una unidad de energía, a saber, la necesaria para 
Tabla 53.9 - Principales efectos de las tecnologías de generación de electricidad sobre la salud (grupo nuclear).

$\begin{array}{cc}\text { Tecnología } & \text { Salud en el trabajo } \\ \text { Fisión } & \text { Cáncer por exposición a } \\ & \text { radiación durante la } \\ & \text { extracción del uranio, } \\ & \text { transformación de } \\ \text { menas/ combustible, } & \text { funcionamiento de las } \\ \text { plantas de energía y } \\ \text { gestión de los desechos } \\ \text { Traumas por accidentes } \\ \text { durante la extracción, } \\ \text { la transformación, } \\ \text { la construcción y el } \\ \text { funcionamiento de } \\ \text { las plantas, y la gestión } \\ \text { de los desechos }\end{array}$

calentar un millón de viviendas/ año. Esa unidad era $6 \times 10^{7} \mathrm{G}$ ] de calor u $8,8 \times 10^{7} \mathrm{G}$ J de insumo de madera con una eficiencia del $69 \%$. Los efectos sobre la salud se estimaron en las fases de obtención, transporte y combustión. Las alternativas del petróleo y el carbón se dedujeron de trabajos anteriores (véase la Figura 53.10). Las incertidumbres de la obtención son \pm un factor de -2, las de los incendios domésticos \pm un factor de $-3, y$ las de la contaminación del aire \pm un factor superior a 10. Si los peligros de la energía eléctrica nuclear se calcularan a la misma

Figura 53.10 - Efectos sobre la salud por unidad de cantidad de energía.

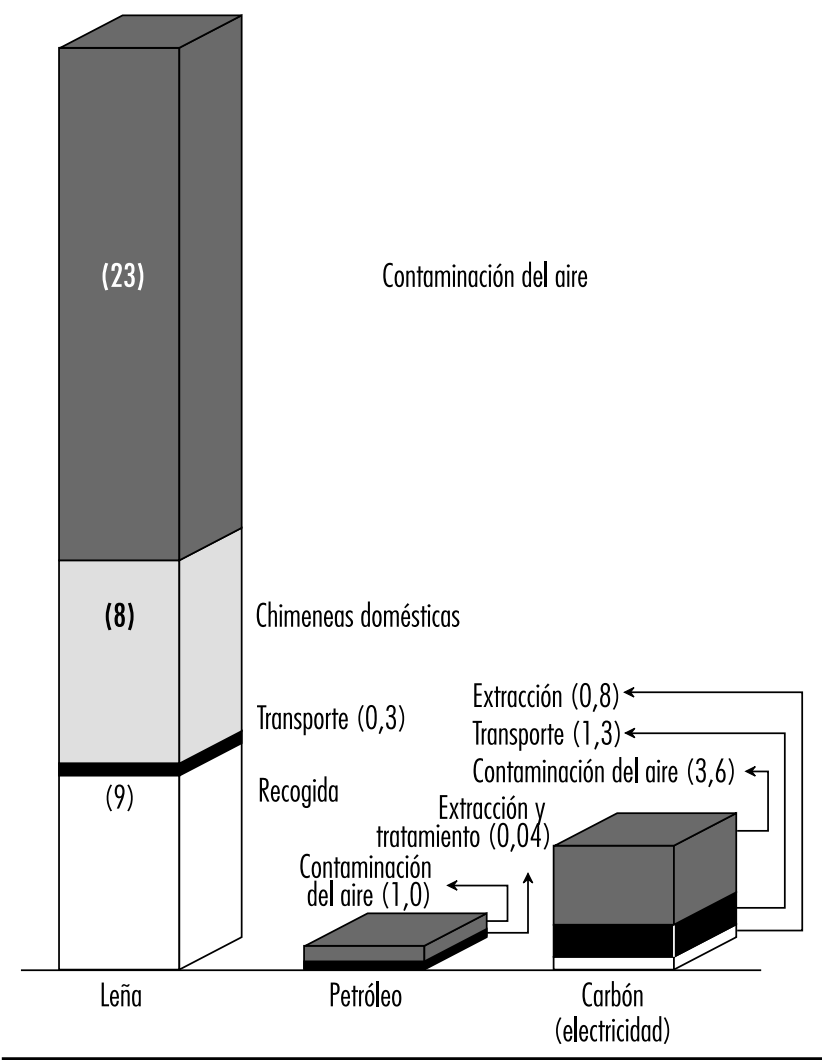

Figura 53.11 - Riesgo de muerte para una persona, debido a la utilización de leña como combustible doméstico durante 40 años.

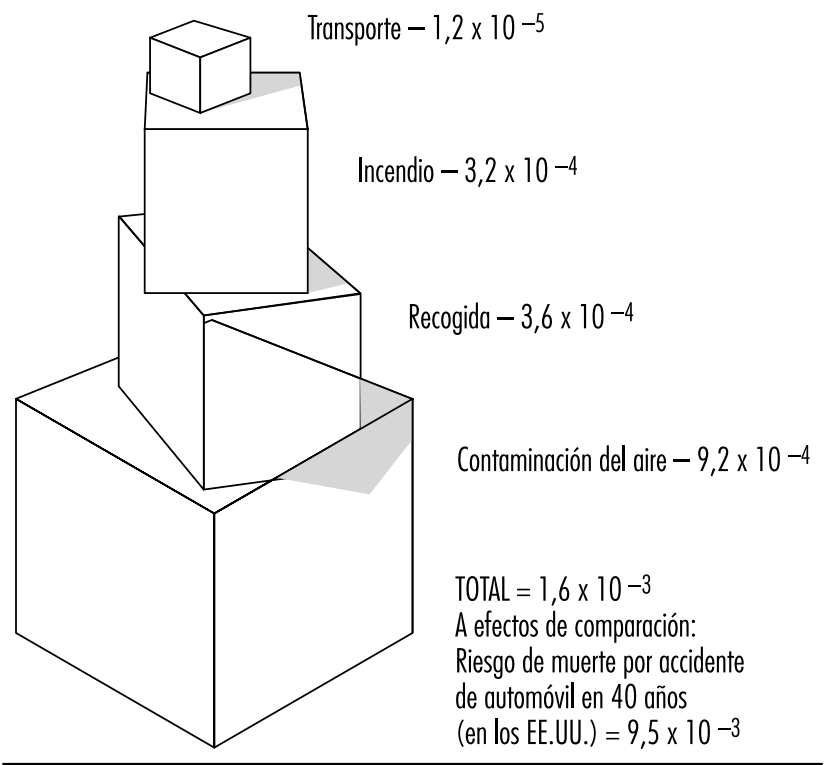

escala, el riesgo total sería de aproximadamente la mitad que el de la minería del carbón.

Un método que ayuda a comprender el riesgo es referirlo a una única persona que durante más de 40 años utiliza la leña como combustible para su vivienda (Figura 53.11). De ello se deriva un riesgo total de muerte de $-1,6 \times 10^{-3}$ (es decir, $-0,2 \%$ ). Esta cifra puede compararse con el riesgo de muerte por accidente de carretera en Estados Unidos durante ese mismo período de tiempo, que es $-9,3 \times 10^{-3}$ (es decir, un $-1 \%$ ), cinco veces mayor. La combustión de leña presenta riesgos del mismo orden que otras tecnologías de calefacción más convencionales. En ambos casos estamos por debajo del riesgo total de otras actividades habituales, y muchos aspectos del riesgo se prestan claramente a la adopción de medidas preventivas.

Pueden establecerse las siguientes comparaciones con respecto a los riesgos para la salud:

- R iesgo agudo para la salud en el trabajo. En el ciclo del carbón, el riesgo para la salud en el trabajo es claramente superior al asociado al petróleo y al gas; equivale más o menos al imputable a los sistemas de energía renovables cuando se incluye la construcción en la evaluación, y es entre 8 y 10 veces mayor que los riesgos inherentes a la energía nuclear. Los futuros avances tecnológicos en las fuentes de energía renovables solar y eólica pueden traducirse en una reducción significativa del riesgo agudo asociado a esos sistemas. La generación de energía hidroeléctrica entraña un riesgo agudo más o menos equivalente para la salud en el trabajo.

R iesgo a largo plazo para la salud en el trabajo. El riesgo de muerte a largo plazo se registra principalmente en la minería del carbón y el uranio, con una magnitud similar en una y otra. Con todo, la minería subterránea del carbón parece más peligrosa que la minería subterránea del uranio (calculando el riesgo sobre la base de una unidad normalizada de electricidad generada). En la minería del carbón en superficie, en cambio, el número total de fallecimientos a largo plazo es inferior al correspondiente a la energía nuclear.

- Riesgo agudo para la salud pública. Estos riesgos, resultantes sobre todo de accidentes de transporte, dependen en gran medida de 
la distancia recorrida y la modalidad de transporte. EI riesgo de la energía nuclear es entre 10 y 100 veces inferior al de todas las demás opciones, debido principalmente a que la cantidad de materiales que se transportan es relativamente baja. El ciclo del carbón presenta el mayor riesgo agudo para la salud pública, pues, utilizando el mismo razonamiento, es necesario transportar gran cantidad de material.

- R iesgo a largo plazo para la salud pública. H ay grandes incertidumbres en lo que se refiere a los riesgos a largo plazo para la salud pública asociados a todas las fuentes de energía. Son más 0 menos iguales en el caso de la energía nuclear y el gas natural, y al menos 10 veces inferiores a los asociados al carbón y el petróleo. Se espera que futuras innovaciones consigan reducir de forma significativa los riesgos derivados de las energías renovables.

Está claro que los efectos sobre la salud de las distintas fuentes de energía dependen de la cantidad y el tipo de uso de la energía. Esos factores varían considerablemente según las zonas geográficas. La leña es el cuarto combustible en importancia en el suministro mundial de energía, después del petróleo, el carbón y el gas natural. Cerca de la mitad de la población mundial, especialmente la que vive en zonas rurales y urbanas de los países en desarrollo, depende de la leña para cocinar y calentarse (ya sea de la leña misma o de su derivado, el carbón de leña, o, cuando no hay ni una cosa ni otra, de los residuos agrícolas 0 el estiércol). La leña representa más de la mitad del consumo mundial de madera, porcentaje que se eleva al $86 \%$ en los países en desarrollo y al $91 \%$ en Africa.

Al considerar las formas de energía nuevas y renovables, como la energía solar, la energía eólica y los combustibles de alcohol, la idea de un "ciclo de combustible" debe abarcar sectores como el de la energía fotovoltaica solar, en que el

Tabla 53.10 - Vivienda y salud.

\begin{tabular}{|c|c|}
\hline Problemas de vivienda & Peligros para la salud \\
\hline Escaso control de la temperatura & Estrés por calor, hipotermia \\
\hline $\begin{array}{l}\text { Escaso control de la ventilación (cuando } \\
\text { hay humo por fuego en el interior) }\end{array}$ & $\begin{array}{l}\text { Enfermedades respiratorias agudas } \\
\text { y crónicas }\end{array}$ \\
\hline Escaso control del polvo & Asma \\
\hline Hacinamiento & $\begin{array}{l}\text { Accidentes domésticos, más facilidad } \\
\text { de contagio de enfermedades ( } p . \text { ej. } \\
\text { tuberculosis, gripe, meningitis) }\end{array}$ \\
\hline $\begin{array}{l}\text { Escaso control de fuegos abiertos, } \\
\text { escasa protección contra el queroseno } \\
\text { o gas envasado }\end{array}$ & Quemaduras \\
\hline $\begin{array}{l}\text { Deficiente acabado de paredes, suelos } \\
\text { o techos (que permite la entrada de } \\
\text { vectores) }\end{array}$ & $\begin{array}{l}\text { Enfermedad de Chagas, peste, tifus, } \\
\text { shigellosis, hepatitis, poliomielitis, } \\
\text { enfermedad del legionario, fiebre } \\
\text { recurrente, alergia al polvo } \\
\text { doméstico }\end{array}$ \\
\hline $\begin{array}{l}\text { Ubicación de la casa (cerca de zonas } \\
\text { de cría de vectores) }\end{array}$ & $\begin{array}{l}\text { Malaria, esquistosomiasis, filariasis, } \\
\text { tripanosomiasis }\end{array}$ \\
\hline $\begin{array}{l}\text { Ubicación de la casa (en zonas proclives } \\
\text { a desastres como corrimientos de } \\
\text { tierras o inundaciones) }\end{array}$ & Accidentes \\
\hline Defectos de construcción & Accidentes \\
\hline
\end{tabular}

Fuente: Hardoy y cols. 1990; Harpham y cols. 1988; OMS, Comisión de Salud y Medio Ambiente $1992 \mathrm{~b}$ funcionamiento del mecanismo prácticamente no comporta riesgo alguno, si bien puede haber un riesgo considerable - muchas veces ignorado- en su fabricación.

Se ha intentado resolver esta dificultad ampliando el concepto de ciclo de combustible para incluir todas las fases de desarrollo de un sistema de energía - con inclusión por ejemplo, del hormigón que interviene en la planta que fabrica el vidrio para el colector solar. Con respecto a esta cuestión de la integridad, se ha señalando que el análisis "hacia atrás" de las etapas de fabricación equivale a una serie de ecuaciones simultáneas cuya solución - si es lineal- se puede expresar como una matriz de valores. Es un enfoque habitual entre los economistas, que lo formulan como análisis de insumo-producto, y ya se han obtenido las cifras correspondientes, que indican hasta qué punto cada actividad económica depende de las demás - aunque con respecto a categorías agregadas que posiblemente no se corresponden de manera exacta con las etapas de fabricación que sería deseable examinar para medir el daño a la salud.

No hay ningún método de análisis comparado del riesgo en la industria de la energía que sea plenamente satisfactorio por sí solo. Cada uno tiene sus ventajas y sus inconvenientes, y ofrece un tipo de información diferente. Dado el nivel de incertidumbre existente en los análisis del riesgo para la salud, es necesario examinar los resultados obtenidos por todos los métodos para trazar un panorama lo más detallado posible y comprender mejor la magnitud de las incertidumbres conexas.

\section{LA URBANIZACION}

\section{Edmundo Werna}

La urbanización es una de las principales características del mundo contemporáneo. A comienzos del siglo XIX, alrededor de 50 millones de personas vivían en zonas urbanas. En 1975 eran 1.600 millones y en el año 2000 serán 3.100 millones (H arpham, Lusty y Vaugham 1988). Estas cifras superan en mucho el crecimiento de la población rural.

Ahora bien, el proceso de urbanización tiene en muchas ocasiones repercusiones peligrosas para la salud de quienes trabajan y viven en ciudades y pueblos. En mayor o menor medida, la construcción de viviendas suficientes, la dotación en infraestructuras urbanas y el control del tráfico no han avanzado al mismo ritmo que el crecimiento de la población. Y ello ha generado una enorme cantidad de problemas para la salud.

\section{Vivienda}

A escala mundial, las condiciones de vivienda distan mucho de ser suficientes. Por ejemplo, a mediados del decenio de 1980, del $40 \%$ al $50 \%$ de la población de muchas ciudades de los países en desarrollo vivía en alojamientos por debajo del mínimo exigible (OMS, Comisión de Salud y M edio Ambiente 1992b). D esde entonces, esas cifras se han incrementado. Aunque en los países industrializados la situación es menos crítica, son frecuentes problemas como el deterioro de las viviendas, el hacinamiento e incluso la falta de vivienda.

En la Tabla 53.10 se presentan los principales aspectos del entorno de la vivienda que influyen en la salud, y los peligros a ellos asociados. Es probable que la salud de un trabajador se vea afectada si su lugar de residencia es deficiente en uno o varios de esos aspectos. En los países en desarrollo, por ejemplo, alrededor de 600 millones de habitantes viven en casas y barrios que comportan amenazas para su salud y su vida ( $\mathrm{H}$ ardoy, Cairncross y Satterthwaite 1990; O M S 1992b). 
Los problemas de vivienda pueden tener también un efecto directo sobre la salud en el trabajo de quienes trabajan en entornos residenciales. Entre esas personas cabe citar las que se dedican al servicio doméstico y un número cada vez mayor de pequeños productores de diversos tipos de industrias rurales. Dichos productores pueden verse afectados también por procesos de producción contaminantes. En algunos estudios sobre este tipo de industrias se han detectado residuos peligrosos, con consecuencias como enfermedades cardiovasculares, cáncer de piel, trastornos neurológicos, cáncer de bronquios, fotofobia y metahemoglobinemia infantil (H amza 1991).

Para prevenir los problemas relacionados con la vivienda pueden adoptarse medidas en distintas fases del proceso:

1. ubicación (por ejemplo, lugares seguros y libres de vectores);

2. diseño de la casa (por ejemplo, espacios suficientemente amplios y protección climática, utilización de materiales de construcción no perecederos, protección suficiente para el equipamiento);

3. construcción (prevención de los defectos constructivos),

4. mantenimiento (por ejemplo, control adecuado del equipamiento y detección adecuada).

La inserción de actividades industriales en el entorno residencial puede exigir medidas especiales de protección, dependiendo del proceso productivo de que se trate.

Las soluciones concretas pueden variar mucho de un lugar a otro, en función de las circunstancias sociales, económicas, técnicas y culturales. Son muchas las ciudades y los pueblos que cuentan con una legislación local en materia de urbanismo y construcción que incluye medidas para prevenir los peligros para la salud. Sin embargo, la legislación no suele aplicarse por ignorancia, falta de control legal o, en la mayoría de los casos, por falta de recursos financieros para construir viviendas adecuadas. Por consiguiente, es importante no sólo elaborar códigos adecuados (y actualizarlos), sino también crear las condiciones necesarias para su aplicación.

\section{Infraestructuras urbanas: prestación de servicios de salud ambiental}

0 tros problemas de salud pueden deberse a la falta de una atención adecuada a la vivienda, con servicios de salud ambiental como recogida de basuras, abastecimiento de agua, saneamiento y desagüe. Ahora bien, una prestación insuficiente de estos servicios tiene repercusiones más allá del ámbito de la vivienda y puede provocar peligros para la ciudad o el pueblo en su conjunto. Los niveles de prestación de esos servicios siguen siendo críticos en muchos lugares. Por ejemplo, del $30 \%$ al $50 \%$ de los residuos sólidos generados en los centros urbanos quedan sin recoger. En 1985 había 100 millones de personas más sin suministro de agua que en 1975. Todavía más de 2.000 millones de personas carecen de sistemas de saneamiento para eliminar los residuos humanos (Hardoy, Cairncross y Sattewrthwaite 1990; OM S, Comisión de Salud y M edio Ambiente 1992b). Y en los medios de comunicación suelen aparecer casos de inundaciones y otros accidentes que están relacionados con la insuficiencia de los desagües urbanos.

En la Tabla 53.11 figuran los peligros derivados de una prestación deficiente de servicios de salud ambiental. También son habituales los peligros que afectan a determinados tipos de servicios, por ejemplo, contaminación del abastecimiento de agua por la falta de saneamiento o la diseminación de los residuos a través del agua no desaguada. Para dar un sólo ejemplo entre muchos de la gravedad de estos problemas de infraestructura podemos decir que cada 20 segundos muere en el mundo un niño de diarrea, que es una de las principales consecuencias de la deficiencia de servicios de salud ambiental.
Tabla 53.11 • Infraestructuras urbanas y salud.

\begin{tabular}{|c|c|}
\hline $\begin{array}{l}\text { Problemas en la prestación de } \\
\text { servicios de higiene ambiental }\end{array}$ & Peligros para la salud \\
\hline Basura sin recoger & $\begin{array}{l}\text { Patógenos en los residuos, vectores de enfer- } \\
\text { medades ( sobre todo moscas y ratas) que } \\
\text { se alimentan o crían en los residuos, riesgo } \\
\text { de incendios, contaminación de los cursos } \\
\text { de agua }\end{array}$ \\
\hline $\begin{array}{l}\text { Deficiencias en la cantidad y/ } 0 \\
\text { calidad del agua }\end{array}$ & $\begin{array}{l}\text { Diarrea, tracoma, infecciones cutáneas, } \\
\text { infecciones por piojos, otras enfermedades } \\
\text { por consumo de alimentos sin lavar }\end{array}$ \\
\hline Falta de saneamiento & $\begin{array}{l}\text { Infecciones feco-orales (p. ej., diarrea, } \\
\text { cólera, fiebres tifoideas), parásitos } \\
\text { intestinales, filariasis }\end{array}$ \\
\hline Falta de desagüe & $\begin{array}{l}\text { Accidentes (por inundaciones, corrimientos } \\
\text { de tierras, hundimientos de casas), } \\
\text { infecciones feco-orales, esquistosomiasis, } \\
\text { enfermedades transmitidas por mosquitos } \\
\text { (p. ej., malaria, dengue, fiebre amarilla), } \\
\text { Filariasis de Bancroft }\end{array}$ \\
\hline
\end{tabular}

Fuente: Hardoy y cols. 1990; OMS, Comisión de Salud y Medio Ambiente 1992b.

Los trabajadores en cuyo entorno de trabajo inmediato 0 general no existen suficientes servicios de este tipo están expuestos a muchos riesgos para su salud. Aún más expuestos se encuentran quienes trabajan en la prestación o mantenimiento de esos servicios, como basureros, barrenderos y traperos.

$\mathrm{H}$ ay sin duda soluciones técnicas que pueden mejorar la prestación de los servicios de salud ambiental, entre las que se incluyen los métodos de reciclado de basuras (incluido el apoyo a los traperos), el empleo de diferentes tipos de vehículos de recogida de basuras para acceder a los distintos tipos de vías urbanas (incluidos los asentamientos no estructurados), mecanismos para ahorrar agua, un mayor control de las pérdidas de agua y métodos de saneamiento de bajo coste como las letrinas de pozo ventilado, las fosas sépticas o las alcantarillas de escasa perforación.

No obstante, el éxito de cada solución dependerá de su adecuación a las circunstancias locales y de los recursos y capacidades locales para aplicarla. La voluntad política es fundamental, pero no suficiente. En muchas ocasiones, los gobiernos han tenido dificultades para prestar servicios urbanos exclusivamente por sí mismos. En las experiencias satisfactorias suele producirse una cooperación entre el sector público, el sector privado y/ 0 el sector voluntario. Es importante la plena intervención y apoyo de las comunidades locales. Ello suele obligar al reconocimiento oficial de gran número de asentamientos ilegales y semilegales (especialmente en los países en desarrollo, pero no sólo en ellos), que soportan una parte importante de los problemas de salud ambiental. Los trabajadores que intervienen directamente en servicios como la recogida o reciclado de basuras y el mantenimiento de la red de alcantarillado necesitan un equipo de protección especial, como guantes, monos y máscaras.

\section{Tráfico}

Las ciudades y los pueblos dependen en gran medida del transporte de superficie para el traslado de personas y mercancías. A sí, el incremento de la urbanización en todo el mundo se ha visto acompañado de un enorme crecimiento del tráfico urbano. $Y$ esta situación ha generado gran número de accidentes. Alrededor 
de 500.000 personas mueren en accidentes de tráfico cada año, y dos tercios de esa cifra se producen en zonas urbanas o periurbanas. Además, según numerosos estudios realizados en diferentes países, por cada persona fallecida se producen de 10 a 20 heridos. En muchos casos las víctimas padecen una pérdida permanente o prolongada de productividad (U rban Edge 1990a; O M S, Comisión de Salud y M edio Ambiente 1992a). Gran parte de esos datos se refiere a personas que iban o venían del trabajo - y ese tipo de accidentes de tráfico se consideran desde hace poco un riesgo profesional.

Según estudios del Banco M undial, las principales causas de los accidentes de tráfico urbano son el mal estado de los vehículos, el mal estado de las vías, la confluencia de distintos tipos de tráfico - desde peatones y animales a camiones - en las mismas calles o vías, la inexistencia de aceras y el nerviosismo en el comportamiento viario (tanto entre conductores como entre peatones) (U rban Edge 1990a, 1990b).

0 tro peligro derivado de la expansión del tráfico urbano es la contaminación del aire y la contaminación por ruido. Entre los problemas para la salud figuran las enfermedades respiratorias agudas y crónicas, los tumores malignos y las deficiencias de audición (la contaminación se aborda también en otros artículos de la presente E nciclopedia).

Existen muchas soluciones técnicas para mejorar la seguridad viaria y de los vehículos (así como la contaminación). Pero, al parecer, el reto más importante es modificar las actitudes de conductores, peatones y funcionarios públicos. Se ha recomendado muchas veces la educación vial - desde la escuela elemental hasta campañas en los medios de comunicacióncomo política dirigida a los conductores y/ o peatones (y esos programas, cuando se han aplicado, han alcanzado por lo general cierto grado de éxito). Los funcionarios públicos son responsables de elaborar la legislación de tráfico y obligar a su cumplimiento, inspeccionar los vehículos y concebir y aplicar medidas técnicas de seguridad. Sin embargo, según los estudios antes mencionados, los funcionarios rara vez consideran los accidentes de tráfico (o la contaminación) un problema de la máxima prioridad, o rara vez cuentan con los medios necesarios para actuar en consecuencia (U rban Edge 1990a, 1990b). Por consiguiente, han de ser objeto de campañas educativas y se les ha de apoyar en su labor.

\section{El tejido urbano}

A demás de las cuestiones concretas ya señaladas (vivienda, servicios, tráfico), también el crecimiento global del tejido urbano tiene repercusiones sobre la salud. En primer lugar, las zonas urbanas suelen registrar una gran densidad de población, lo que facilita la difusión de enfermedades transmisibles. En segundo lugar, en esas zonas se concentran gran número de industrias, y la contaminación consiguiente. En tercer lugar, a través del proceso de crecimiento urbano, focos naturales de vectores de enfermedades pueden quedar atrapados en las nuevas áreas urbanas, y pueden crearse nuevos nichos para vectores de enfermedades. Los vectores pueden adaptarse a los nuevos hábitats (urbanos), por ejemplo, los responsables de la malaria urbana, el dengue y la fiebre amarilla. En cuarto lugar, la urbanización ha tenido muchas veces consecuencias psicosociales como el estrés, la alienación, la inestabilidad y la inseguridad, que a su vez han provocado problemas como la depresión y el uso indebido del alcohol y las drogas (H arpham, Lusty y Vaugham 1988; O M S, Comisión de Salud y M edio A mbiente 1992a).

Las experiencias del pasado han demostrado la posibilidad (y la necesidad) de abordar los problemas de salud con mejoras en la urbanización. Por ejemplo, "el notable descenso de las tasas de mortalidad y las mejoras en materia de salud que se consiguieron en Europa y Norteamérica a comienzos del presente siglo no debieron tanto a los establecimientos médicos como a la mejora de la nutrición y del abastecimiento de agua, del saneamiento y de otros aspectos de las condiciones de vivienda y de vida" (H ardoy, C airncross y Satterthwaite 1990).

La solución a los crecientes problemas planteados por la urbanización pasa por una sólida integración entre urbanismo y gestión de las ciudades (aspectos que suelen estar separados), así como por la participación de los distintos agentes públicos, privados y voluntarios que operan en el escenario urbano. La urbanización afecta a una gran variedad de trabajadores. A diferencia de otras fuentes o tipos de problemas de salud (que podrían afectar a categorías específicas de trabajadores), los riesgos profesionales derivados de la urbanización no pueden abordarse únicamente mediante la acción o presión sindical. Exigen una acción interprofesional 0 , de un modo aún más amplio, una acción de la comunidad urbana en general.

\section{EL CAMBIO CLIMATICO MUNDIAL Y EL AGOTAMIENTO DEL OZONO}

Jonathan A. Patz

\section{Cambio climático}

Los principales gases de efecto invernadero son el dióxido de carbono, el metano, el óxido nitroso, el vapor de agua y los clorofluorocarbonos (CFC). Estos gases dejan que la luz solar penetre hasta la superficie de la tierra, pero impiden que escape el calor radiante infrarrojo. El Grupo Intergubernamental de Expertos sobre Cambios Climáticos (IPCC) de las Naciones U nidas ha llegado a la conclusión de que las emisiones, básicamente procedentes de la industria, y la destrucción de "sumideros" de gases de efecto invernadero por una deficiente ordenación del uso de la tierra, especialmente por la despoblación forestal, han incrementado la concentración de gases muy por encima de los procesos naturales. De no producirse importantes cambios de política, se espera que los niveles de dióxido de carbono preindustrial aumenten hasta generar un incremento de $1,0-3,5{ }^{\circ} \mathrm{C}$ de la temperatura media mundial en el año 2100 (IPCC en prensa).

Los dos componentes básicos del cambio climático son: a) la elevación de la temperatura, con la inestabilidad y los extremos climáticos de ella derivados, y b) la elevación del nivel del mar por termoexpansión. Estos cambios pueden incrementar la frecuencia de las olas de calor y los episodios peligrosos de contaminación del aire, reducción de la humedad del suelo, mayor incidencia de fenómenos climáticos perturbadores e inundación de las costas (I PCC 1992). Entre los efectos para la salud pueden citarse un incremento de: a) la mortalidad y morbilidad relacionadas con el calor; b) las enfermedades infecciosas, en particular las transmitidas por insectos; c) la malnutrición por escasez de alimentos, y d) las crisis de las infraestructuras de salud pública a causa de los desastres climáticos y la elevación del nivel del mar, junto con las migraciones humanas relacionadas con el clima (véase la Figura 53.12).

Los humanos tienen una enorme capacidad para adaptarse a las condiciones climáticas y ambientales. No obstante, la tasa de cambio climático y potencialmente ecológico que se predice es motivo de gran preocupación tanto para los expertos en medicina como en ciencias de la Tierra. M uchos de los efectos sobre la salud se derivarán de las respuestas ecológicas a unas condiciones climáticas alteradas. Por ejemplo, la extensión de las enfermedades transmitidas por vectores dependerá de cambios en la vegetación y de la disponibilidad de reservorios o huéspedes intermedios, junto con los efectos directos de la temperatura y la humedad sobre los parásitos y sus vectores (Patz y 
Figura 53.12 - Efectos sobre la salud pública de los principales componentes del cambio climático mundial.

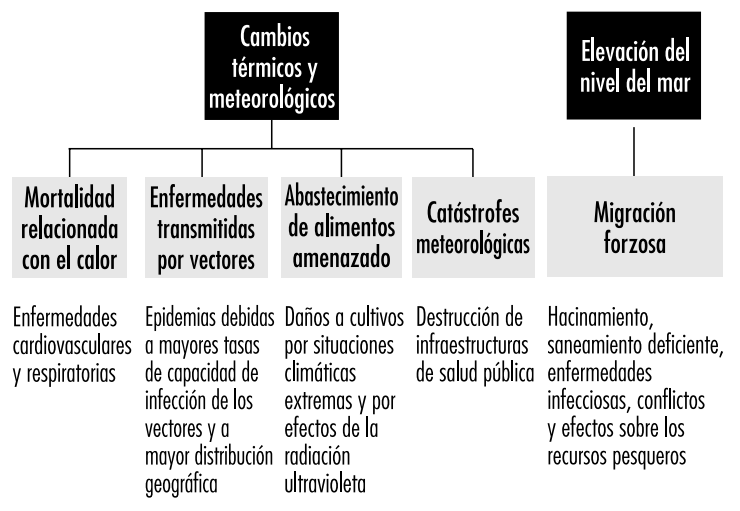

cols. 1996). Por consiguiente, para entender los peligros del cambio climático es necesario evaluar de un modo integrado el riesgo ecológico, para lo que se necesitan nuevos enfoques, más complejos que los análisis tradicionales del riesgo, basados en datos empíricos y en la relación causal entre un agente único y un efecto (M cM ichael 1993).

\section{Agotamiento del ozono estratosférico}

El ozono estratosférico se está agotando debido básicamente a las reacciones con radicales libres de halógenos procedentes de clorofluorocarbonos (CFC), junto con otros halocarbonos y bromuro de metilo (M olina y Rowland 1974). El ozono bloquea la penetración de la radiación ultravioleta B (UVB), que contiene las longitudes de onda biológicamente más destructivas (290-320 nanómetros). Se prevé que los niveles de UV B se eleven de forma desproporcionada en las zonas templadas y árticas, pues se ha establecido una clara relación entre las latitudes más altas y el grado de adelgazamiento de la capa de ozono (Stolarski y cols. 1992).

Se estima que durante el período de 1979 a 1991 la pérdida media de ozono, ajustada por el ciclo solar y otros factores, fue de un 2,7 \% por decenio (Gleason y cols. 1993). En 1993, investigadores que utilizaban un nuevo y sensible espectrorradiómetro en Toronto, C anadá, descubrieron que el agotamiento del ozono ha provocado hasta ahora incrementos locales de la radiación UVB ambiental de un $35 \%$ en el invierno y un $7 \%$ en el verano en relación con los niveles de 1989 (Kerr y M CEIroy 1993). En estimaciones anteriores del Programa de las $N$ aciones U nidas para el M edio Ambiente (PNU M A) se predijo un incremento del $1,4 \%$ de la UVB por cada $1 \%$ de reducción del ozono estratosférico (PNU M A 1991a).

Entre las repercusiones directas sobre la salud del agotamiento del ozono estratosférico, que produce un incremento de la radiación UVB ambiental, figuran: a) cáncer de piel, b) enfermedades oculares, y c) inmunosupresión. La radiación ultravioleta puede producir también efectos indirectos sobre la salud al ocasionar daños a los cultivos.

\section{Efectos del cambio en la temperatura y las precipitaciones sobre la salud}

M orbilidad y mortalidad relacionadas con el calor

Fisiológicamente, los humanos poseen una gran capacidad de termorregulación hasta determinado umbral de temperatura.
U nas condiciones climáticas que comprendan temperaturas superiores a dicho umbral mantenidas durante varios días consecutivos incrementan la mortalidad en la población. En las grandes ciudades, las deficiencias en la vivienda combinadas con el efecto urbano denominado "islote de calor" agravan aún más esas condiciones. En Shanghai, por ejemplo, ese efecto puede llegar a ser de hasta $6,5^{\circ} \mathrm{C}$ en una tarde de invierno sin viento (IPCC 1990). Los fallecimientos relacionados con el calor se producen sobre todo en la población de edad avanzada y se atribuyen a trastornos cardiovasculares y respiratorios (K ilbourne 1989). Algunas variables meteorológicas clave contribuyen a la mortalidad relacionada con el calor, y la más importante de ellas es una elevada temperatura durante la noche; se prevé que el efecto invernadero eleve especialmente estas temperaturas mínimas (K alkstein y Smoyer 1993).

Se espera que las regiones templadas y polares se calienten de un modo desproporcionadamente mayor que las zonas tropicales y subtropicales (I PCC 1990). Sobre la base de las predicciones de la Administración Nacional de Aeronáutica y del Espacio de Estados U nidos (NASA), las temperaturas estivales medias en N ueva York y San Luis, por ejemplo, ascenderían en 3,1 y $3,9{ }^{\circ} \mathrm{C}$ respectivamente si se duplicara el $\mathrm{CO}_{2}$ ambiental. Aun ajustando esas cifras para tener en cuenta la aclimatación fisiológica, la mortalidad estival anual en ciudades templadas como las citadas podría multiplicarse por más de cuatro (K alkstein y Smoyer 1993).

La química atmosférica es un factor importante de la formación de la bruma fotoquímica urbana, en virtud de la cual la fotodescomposición del $\mathrm{NO}_{2}$ en presencia de compuestos orgánicos volátiles tiene como consecuencia la producción de ozono troposférico (a nivel del suelo). Tanto la mayor radiación UV ambiental como unas temperaturas más altas propiciarían aún más esas reacciones. Son bien conocidas las perjudiciales consecuencias para la salud de la contaminación del aire y, si se siguen utilizando combustibles fósiles, aumentarán los efectos agudos y crónicos sobre la salud (véase en este capítulo "La contaminación del aire").

\section{E nfermedades infecciosas y cambio del clima/ ecosistema}

Los modelos de circulación general que combinan la atmósfera y los océanos predicen que las latitudes altas del hemisferio norte experimentarán una mayor elevación de la temperatura superficial según las actuales hipótesis del IPCC (IPCC 1992). Se espera que las temperaturas invernales mínimas resulten más afectadas, lo que permitirá que determinados virus y parásitos se extiendan a regiones en las que antes no podían vivir. Además de los efectos del clima sobre los vectores, la transformación de los ecosistemas podría tener importantes repercusiones para enfermedades en que la zona de distribución de los vectores y/ o huéspedes de reservorio está determinada por dichos ecosistemas.

Es posible que enfermedades transmitidas por vectores se extiendan a regiones templadas de ambos hemisferios y se intensifiquen en las zonas endémicas. La temperatura determina la capacidad de infección del vector pues afecta a la replicación de los patógenos, a su maduración y al período en que posee capacidad de infectar (Longstreth y Wiseman 1989). EI alto nivel de la temperatura y la humedad intensifican también el hábito de picar de varias especies de mosquito. El calor extremo, en cambio, puede abreviar el tiempo de supervivencia del insecto.

Las enfermedades infecciosas sobre las que es más probable que repercutan sutiles variaciones climáticas son aquellas en cuyo ciclo vital interviene una especie de sangre fría (invertebrado) (Sharp 1994). Entre las enfermedades cuyos agentes infecciosos, vectores o huéspedes se ven afectados por el cambio climático figuran la malaria, la esquistosomiasis, la filariasis, la 
Tabla 53.12 - Situación mundial de las principales enfermedades transmitidas por vectores.

\begin{tabular}{|c|c|c|c|c|c|}
\hline № a & Enfermedad & $\begin{array}{l}\text { Población en riesgo } \\
\text { (millones) }^{b}\end{array}$ & $\begin{array}{l}\text { Infección } \\
\text { (millones) }\end{array}$ & Distribución actual & $\begin{array}{l}\text { Posible cambio de distri- } \\
\text { bución como resultado } \\
\text { del cambio climático }\end{array}$ \\
\hline 1. & Malaria & 2.100 & 270 & Trópicos/ subtrópicos & ++ \\
\hline 2. & Filariasis linfáticas & 900 & 90,2 & Trópicos/ subtrópicos & + \\
\hline 3. & Oncocercosis & 90 & 17,8 & Africa/ América Latina & + \\
\hline 4. & Esquistosomiasis & 600 & 200 & Trópicos/ subtrópicos & ++ \\
\hline 5. & Tripanosomiasis africana & 50 & (25.000 casos nuevos/ año) & Africa tropical & + \\
\hline 6. & Leishmaniasis & 350 & $\begin{array}{l}12 \text { millones de infectados+ } \\
400.000 \text { casos nuevos/ año }\end{array}$ & $\begin{array}{l}\text { Asia/ Europa meridional/ } \\
\text { Africa/ Sudámerica }\end{array}$ & $?$ \\
\hline 7. & Dracunculosis & 63 & 1 & Trópicos (Africal Asia) & 0 \\
\hline \multicolumn{6}{|c|}{ Enfermedades arbovíricas } \\
\hline 8. & Dengue & 1.500 & & Trópicos/ subtrópicos & ++ \\
\hline 9. & Fiebre amarilla & +++ & & Africa/ América Latina & + \\
\hline 10. & Encefalitis japonesa & +++ & & Asia oriental y sudoriental & + \\
\hline 11. & Otras enfermedades & +++ & & & + \\
\hline
\end{tabular}

a Los números remiten a explicaciones en el texto. $\quad b$ Basado en una población mundial estimada en 4.800 millones de personas $(1989) . \quad 0=$ poco probable; $+=$ probable; $++=$ muy probable; $+++=$ no se dispone de estimación; ? = se desconoce.

leishmaniasis, la oncocercosis (ceguera del río), la tripanosomiasis (enfermedad de Chagas y enfermedad del sueño africana), el dengue, la fiebre amarilla y la encefalitis arbovírica. En la Tabla 53.12 figuran las cifras actuales del número de personas con riesgo de contraer esas enfermedades (O M S 1990d).

A escala mundial, la malaria es la más extendida de las enfermedades transmitidas por vectores y causa de uno a dos millones de muertos cada año. Según M artens y cols. (1995), a mediados del siglo próximo esa cifra puede incrementarse con otro millón más de muertes anuales debido al cambio climático. EI mosquito anófeles, que es el portador de la malaria, puede extenderse a la isoterma de invierno de $16{ }^{\circ} \mathrm{C}$, pues el parásito no se desarrolla por debajo de esa temperatura (Gilles y Warrell 1993). Las epidemias que se producen a altitudes superiores suelen coincidir con temperaturas por encima de la media (Loevinsohn 1994). También afecta a la malaria la despoblación forestal, pues en las zonas taladas se crean abundantes charcas de agua dulce en las que pueden desarrollarse las larvas del anófeles (véase en este capítulo "La extinción de especies, la pérdida de diversidad biológica y la salud humana").

En los dos últimos decenios los intentos por controlar la malaria han dado escaso fruto. El tratamiento no ha mejorado, pues la resistencia a los medicamentos se ha convertido en un problema importante en el caso de la cepa más virulenta, Plasmodium falciparum, y las vacunas antimalaria tienen una eficacia limitada (Institute of Medicine 1991). H asta ahora la gran capacidad de variación antigénica de los protozoos ha impedido la obtención de vacunas eficaces para la malaria y la enfermedad del sueño, lo que no nos permite albergar muchas esperanzas de encontrar nuevos agentes farmacéuticos de fácil obtención contra esas enfermedades. Las enfermedades en que intervienen huéspedes de reservorio intermedios (por ejemplo, ciervos y roedores en la enfermedad de Lyme) hacen básicamente inalcanzable la inmunidad humana con programas de vacunación, lo que representa otro obstáculo para la intervención médica preventiva.
A medida que el cambio climático vaya modificando el hábitat, con una reducción potencial de la diversidad biológica, los insectos vectores se verán obligados a buscar nuevos huéspedes (véase "La extinción de especies, la pérdida de diversidad biológica y la salud humana"). En Honduras, por ejemplo, insectos que buscan sangre, como el escarabajo asesino, que transmite la incurable enfermedad de C hagas (o tripanosomiasis americana), se han visto obligados a buscar huéspedes humanos al ver reducida la diversidad biológica por causa de la despoblación forestal. De 10.601 hondureños estudiados en regiones endémicas, el $23,5 \%$ son hoy seropositivos a esa enfermedad (Sharp 1994). L as enfermedades zoonóticas son con frecuencia fuente de infecciones humanas y generalmente afectan al hombre tras un cambio ambiental 0 una alteración en la actividad humana (Institute of M edicine 1992). M uchas enfermedades "incipientes" de los humanos son en realidad antiguas zoonosis de especies huéspedes animales. Por ejemplo, el $\mathrm{H}$ antavirus, que se ha demostrado recientemente que causa la muerte de seres humanos en el suroeste de Estados U nidos, está establecido desde hace mucho tiempo en los roedores y se considera que el reciente brote está relacionado con las condiciones climáticas/ ecológicas (Wenzel 1994).

\section{E fectos marinos}

El cambio climático puede afectar también a la salud pública a través de sus efectos sobre las floraciones nocivas de fitoplancton marino (o algas). El aumento de fitoplancton a escala mundial ha sido consecuencia del escaso control de la erosión, de la generosa aplicación de fertilizantes en la agricultura y de la liberación de aguas residuales en las costas, factores todos ellos que tienen como resultado unos efluentes ricos en nutrientes que fomentan el crecimiento de las algas. Las condiciones que favorecen este crecimiento podrían verse incrementadas con la prevista elevación de las temperaturas de la superficie del mar por el calentamiento de la Tierra. La sobreexplotación de peces y mariscos (consumidores de algas) y el extendido uso de plaguicidas tóxicos 
para esas especies contribuyen también al crecimiento excesivo del plancton (Epstein 1995).

Los principales ejemplos de enfermedades derivadas de un crecimiento excesivo de las algas son las mareas rojas, que provocan enfermedades diarreicas y de parálisis e intoxicaciones amnésicas por marisco. Se ha comprobado que el Vibrio cholerae se aloja en el fitoplancton marino; así pues, esas floraciones podrían constituir un reservorio ampliado que dé origen a epidemias de cólera (H uq y cols. 1990).

\section{Abastecimiento de alimentos y nutrición humana}

La malnutrición es una importante causa de mortalidad en la primera infancia y de morbilidad infantil debido a la inmunosupresión (véase "La alimentación y la agricultura"). El cambio climático podría afectar negativamente a la agricultura introduciendo cambios de largo plazo, como la reducción de la humedad del suelo por evapotranspiración y, de manera más inmediata, con fenómenos climáticos extremos como las sequías, las inundaciones (y erosión) y las tormentas tropicales. Las plantas pueden beneficiarse inicialmente de la "fertilización con $\mathrm{CO}_{2}$ ", que puede incrementar la fotosíntesis (IPCC 1990). Pero aun teniendo en cuenta ese fenómeno, la agricultura de los países en desarrollo se verá muy afectada: se estima que en esos países se encontrarán en una situación de riesgo de hambre de 40 a 300 millones de personas más debido al cambio climático (Sharp 1994).

$\mathrm{H}$ ay que tener en cuenta también los cambios ecológicos indirectos que afectan a los cultivos, pues puede modificarse la distribución de las plagas agrícolas (IPCC 1992) (véase "La alimentación y la agricultura"). Teniendo en cuenta la compleja dinámica de los ecosistemas, habrá que efectuar una evaluación completa, que vaya más allá de los efectos directos del cambio en las condiciones atmosféricas y/ o en los suelos.

\section{Efectos de los desastres climáticos y de la elevación del nivel del mar sobre la salud}

La expansión térmica de los océanos puede provocar una elevación del nivel del mar a un ritmo relativamente rápido, de dos a cuatro centímetros por decenio, y se espera que los extremos previstos del ciclo hidrológico ocasionen pautas climatológicas más duras y tormentas. Estos fenómenos afectarían directamente a las viviendas y a las infraestructuras de salud pública, como los sistemas de saneamiento y desagüe del agua de tormentas (I PCC 1992). Poblaciones vulnerables que viven en zonas costeras de baja altura y en pequeñas islas se verían obligadas a migrar a lugares más seguros. El hacinamiento y las deficientes condiciones de saneamiento de los refugiados ambientales podrían incrementar la difusión de enfermedades infecciosas como el cólera, y las tasas de transmisión de enfermedades transmitidas por vectores se elevarían considerablemente debido al hacinamiento y a la influencia potencial de los individuos infectados (O M S 1990d). La inundación de los sistemas de desagüe podría agravar aún más la situación, y también hay que tener en cuenta las repercusiones psicológicas derivadas del síndrome de estrés postraumático que sigue a las grandes tormentas.

El abastecimiento de agua dulce se reduciría debido a la intrusión salina en los acuíferos costeros y se perdería tierra agrícola costera debido a la salinización o directamente a la inundación. Por ejemplo, una elevación del nivel del mar de un metro destruiría el $15 \%$ y el $20 \%$ de la agricultura en Egipto y Bangladesh respectivamente (IPCC 1990). En cuanto a las sequías, la adaptación de los métodos de riego podría repercutir en los lugares de cría de artrópodos e invertebrados que son vectores (algo similar por ejemplo, a la esquistosomiasis en Egipto), pero no será fácil efectuar una evaluación costes/ beneficios de esas repercusiones.

\section{Efectos del agotamiento del ozono estratosférico sobre la salud}

E fectos directos de la radiación ultravioleta $B$ sobre la salud El ozono bloquea la penetración de la radiación ultravioleta $B$, que tiene longitudes de onda de 290-320 nanómetros, las más destructivas desde el punto de vista biológico. La UVB induce la formación de dímeros de pirimidina en las moléculas de ADN, lesión que, si no se repara, puede degenerar en cáncer (OIIC 1992). El cáncer de piel no melanoma (carcinoma escamoso y de células basales) y el melanoma de extensión superficial están relacionados con la exposición a la luz solar. En las poblaciones occidentales, la incidencia del melanoma se ha incrementado entre un $20 \%$ y un $50 \%$ cada cinco años en los dos últimos decenios (C oleman y cols. 1993). C uando no existe una relación directa entre la exposición acumulada a la radiación ultravioleta y el melanoma, se asocia a una exposición excesiva a la radiación ultravioleta durante la infancia. Con una reducción sostenida del $10 \%$ de la capa de ozono estratosférica, los casos de cáncer de piel no melanoma podrían incrementarse en un $26 \%$, lo que equivale a 300.000 casos más al año a escala mundial; el melanoma podría incrementarse en un $20 \%$, lo que equivale a 4.500 casos más al año (PNU M A 1991a).

La formación de cataratas es la causa de la mitad de los casos de ceguera en el mundo (17 millones cada año) y va asociada a la radiación UVB en una relación dosis-respuesta (Taylor 1990). Los aminoácidos y los sistemas de transporte de membrana en el cristalino del ojo son especialmente proclives a la fotooxidación por los radicales de oxígeno que genera la irradiación UVB (O IIC 1992). Una duplicación de la exposición a la radicación UVB podría provocar un incremento del $60 \%$ con respecto a los niveles actuales de cataratas corticales (Taylor y cols. 1988). EI PNU M A estima que una pérdida sostenida de ozono estratosférico del $10 \%$ tendría como resultado cerca de 1,75 millones de casos más de cataratas cada año (PNUMA 1991a). Entre otros efectos oculares de la exposición a la radiación UVB figuran la fotoqueratitis, la fotoquerato-conjuntivitis, la pinguécula y el pterigión (o crecimiento excesivo del epitelio conjuntivo) y la queratopatía climática de gotitas (O IIC 1992).

La capacidad del sistema inmune para funcionar eficazmente depende del procesamiento "local" de antígenos y su presentación a las células T, así como de un incremento de la respuesta "sistémica" a través de la producción de linfocinas (mensajeros bioquímicos) y de los coeficientes resultantes entre las células $T$ colaboradoras y las células T supresoras. La UVB produce inmunosupresión a ambos niveles. En estudios con animales se ha demostrado que la UVB puede afectar al curso de enfermedades cutáneas infecciosas, como la oncocercosis, la leishmaniasis y la dermatofitosis, y deteriorar la inmunovigilancia de las células transformadas precancerosas de la epidermis. Estudios preliminares indican además una influencia sobre la eficacia de las vacunas (K ripke y M orison 1986; O IIC 1992).

\section{E fectos indirectos de la UVB sobre la salud pública}

$\mathrm{H}$ istóricamente, las plantas terrestres no pudieron establecerse hasta que se formó la capa protectora de ozono, pues la UVB inhibe la fotosíntesis (PNUMA 1991a). EI debilitamiento de los cultivos alimentarios que pueden resultar dañados por la UVB podría incrementar aún más las repercusiones sobre la agricultura debidas al cambio climático y la elevación del nivel del mar.

El fitoplancton está en la base de la cadena alimentaria marina y actúa también como importante "sumidero" de dióxido de carbono. EI daño de la UV a esas algas en las regiones polares afectaría negativamente a la cadena alimentaria marina y agravaría el efecto invernadero. EI PNUMA 
estima que una pérdida de fitoplancton marino del $10 \%$ limitaría la absorción anual de $\mathrm{CO}_{2}$ por los océanos en cinco gigatoneladas, lo que equivale a las emisiones antropogénicas anuales derivadas de la combustión de combustibles fósiles (PNUM A 1991a).

\section{Peligros para la salud en el trabajo y estrategias de control}

\section{Peligros para la salud en el trabajo}

Para reducir las emisiones de gases de efecto invernadero procedentes de los combustibles fósiles, es necesario potenciar otras fuentes renovables de energía. Son muy conocidos los peligros que presenta la energía nuclear para la salud pública y la salud en el trabajo, y será necesario proteger las instalaciones, los trabajadores y el combustible consumido. El metanol puede sustituir en gran parte el uso de la gasolina; ahora bien, estas fuentes emiten formaldehídos, lo que supondrá un nuevo peligro para el medio ambiente. Los materiales superconductores para la transferencia de electricidad con eficiencia energética son en su mayoría materiales cerámicos compuestos de calcio, estroncio, bario, bismuto, talio e itrio (O M S en prensa).

$M$ enos se sabe sobre la seguridad en el trabajo en las unidades manufactureras de captación de la energía solar. Los principales elementos utilizados para construir las células fotovoltaicas son la sílice, el galio, el indio, el talio, el arsénico y el antimonio (O M S en prensa). La ślice y el arsénico afectan negativamente a los pulmones; el galio se concentra en el riñón, el hígado y los huesos, y las formas iónicas de indio son nefrotóxicas.

Los efectos destructivos de los CFC sobre la capa de ozono estratosférico ya se advirtieron en el decenio de 1970, y en 1978 la EPA de Estados U nidos prohibió la inclusión de esos propulsores inertes en los aerosoles. En 1985 se despertó una preocupación generalizada cuando un equipo británico que trabajaba en la Antártida descubrió el "agujero" en la capa de ozono (Farman, Gardiner y Shanklin 1985). La posterior aprobación del Protocolo de Montreal en 1987, con modificaciones en 1990 y 1992, ha obligado ya a fuertes reducciones en la producción de CFC.

Las sustancias químicas que pueden sustituir a los CFC son los hidroclorofluorocarbonos (H CFC) y los hidrofluorocarbonos (HFC). La presencia del átomo de hidrógeno puede facilitar la degradación de esos compuestos por los radicales hidróxilos $\left(\mathrm{OH}^{-}\right)$en la troposfera, con lo que se reduce el potencial de agotamiento del ozono estratosférico. Esas sustancias químicas sustitutivas de los CFC son sin embargo más reactivas biológicamente que aquéllos. $\mathrm{L}$ a naturaleza de un enlace $\mathrm{C}-\mathrm{H}$ hace que estas sustancias sean proclives a la oxidación a través del sistema del citocromo P-450 (O M S en prensa).

\section{M itigación y adaptación}

Para afrontar los retos que para la salud pública presenta el cambio climático mundial será necesario: a) un enfoque ecológico integrado; b) la reducción de los gases de efecto invernadero mediante el control de las emisiones industriales, políticas de uso de la tierra para elevar al máximo la extensión de los "sumideros" de $\mathrm{CO}_{2}$ y políticas demográficas para conseguir ambas cosas; c) la vigilancia de los indicadores biológicos tanto a escala regional como mundial; d) la adaptación de las estrategias de salud pública para reducir al mínimo los efectos del cambio climático inevitable, y e) la cooperación entre los países desarrollados y los países en desarrollo. En resumen, debe promoverse una mayor integración de las políticas ambientales y de salud pública.

\section{Estudio de caso: Virus transmitidos por mosquitos}

La encefalitis y el dengue transmitidos por mosquitos constituyen destacados ejemplos de enfermedades de vectores cuya distribución está limitada por el clima. Las epidemias de encefalitis de San Luis (SLE), que es la encefalitis arbovírica más frecuente en Estados Unidos, suelen producirse al sur de la isoterma de $22{ }^{\circ} \mathrm{C}$ en el mes de junio, a unque en años de calor fuera de temporada se han registrado brotes más al norte. Los brotes de la enfermedad en los humanos están estrechamente relacionados con períodos de varios días en que la temperatura supera los $27^{\circ} \mathrm{C}$ (Shope 1990).

Estudios sobre el terreno acerca de la SLE indican que un incremento de la temperatura en $1{ }^{\circ} \mathrm{C}$ acorta notablemente el tiempo transcurrido entre la absorción de sangre por el mosquito y la replicación vírica suficiente para crear en el vector la capacidad de infectar, que es lo que se denomina período de incubación extrínseca. Si a esto se suma el hecho de que la supervivencia del mosquito adulto se reduce a altas temperaturas, se estima que un incremento de la temperatura de 3 a $5{ }^{\circ} \mathrm{C}$ provocaría un notable desplazamiento hacia el norte de los brotes de SE (Reeves y cols. 1994).

La zona de distribución del mosquito que es vector primario del dengue (y la fiebre amarilla), el Aedes aegypti, se extiende hasta la latitud de $35^{\circ}$, pues a temperaturas muy frías mueren tanto las larvas como los adultos. El dengue está muy extendido en el $C$ aribe, América tropical, 0 ceanía, Asia, Africa y Australia. En los últimos 15 años las epidemias de dengue se han incrementado tanto en número de afectados como en gravedad, especialmente en los centros urbanos de los trópicos. El dengue hemorrágico es hoy una de las principales causas de hospitalización y mortalidad infantil en Asia suroriental (Institute of $\mathrm{M}$ edicine 1992). La misma pauta de ascenso de la enfermedad que se observó en Asia hace 20 años se está produciendo hoy en América.

El cambio climático podría modificar la transmisión del dengue. En 1986 se comprobó en México que el factor que mejor predice la transmisión del dengue es la temperatura media durante la temporada de lluvias, cuadriplicándose el riesgo ajustado entre los $17{ }^{\circ} \mathrm{C}$ y los $30^{\circ} \mathrm{C}$ (Koopman y cols. 1991). Estudios de laboratorio apoyan los datos obtenidos sobre el terreno. In vitro, el período de incubación extrínseca del virus del dengue de tipo 2 es de 12 días a $30^{\circ} \mathrm{C}$ y sólo de siete días entre 32 y $35{ }^{\circ} \mathrm{C}$ (W atts y cols. 1987). El hecho de que la temperatura acorte el período de incubación en cinco días hace posible que la tasa de transmisión de la enfermedad se multiplique por tres (Koopman y cols. 1991). Por último, el aumento de la temperatura provoca la eclosión de adultos más pequeños, que han de picar con más frecuencia para desarrollar una puesta de huevos. En resumen, la ascenso de las temperaturas puede hacer que haya más mosquitos infecciosos y que piquen con más frecuencia (Focks y cols. 1995).

El cambio climático y el agotamiento de la capa de ozono plantean un enorme número de riesgos para la salud a múltiples niveles, lo que destaca la importante relación existente entre la dinámica de los ecosistemas y el mantenimiento de la salud humana. Por tanto, las medidas preventivas han de basarse en esos sistemas, previendo las respuestas ecológicas principales al cambio climático así como los peligros físicos directos.

Algunos de los elementos clave que hay que tener en cuenta al evaluar el riesgo ecológico son las variaciones espaciales y 
temporales, los mecanismos de retroalimentación y el empleo de organismos de nivel inferior como indicadores biológicos tempranos.

La reducción de los gases de efecto invernadero mediante la sustitución de los combustibles fósiles por recursos energéticos renovables es la forma primaria de prevenir el cambio climático. Del mismo modo, la planificación estratégica del uso de la tierra y la estabilización de la presión demográfica sobre el medio ambiente permitirán conservar importantes "sumideros" naturales de gases de efecto invernadero.

Como es posible que cierto cambio climático se produzca inevitablemente, una prevención secundaria mediante la detección temprana basada en la vigilancia de los parámetros de salud obligará a establecer una coordinación sin precedentes. Por primera vez en la historia se intenta vigilar el sistema terrestre en su totalidad.

El Sistema M undial de O bservación del Clima integra Vigilancia Meteorológica M undial y Vigilancia Atmosférica $M$ undial, programas ambos de la O rganización M eteorológica $M$ undial (OM M ), con partes del Sistema M undial de Vigilancia del Medio Ambiente, del PNUMA. El Sistema Mundial de O bservación de los $O$ céanos es una nueva iniciativa conjunta de la Comisión O ceanográfica Intergubernamental de la O rganización de las Naciones U nidas para la Educación, la Ciencia y la Cultura (UNESCO), la OMS y el Consejo Internacional de U niones Científicas (CIUC). Para vigilar los cambios que se produzcan en los sistemas marinos se recurrirá a mediciones por satélite y submarinas.

El Sistema $M$ undial de O bservación Terrestre es un nuevo sistema patrocinado por el PNUMA, la UNESCO, la OMM, el CIU C y la O rganización de las $\mathrm{N}$ aciones U nidas para la A gricultura y la Alimentación (FAO) y aportará el componente terrestre del Sistema Mundial de Observación del Clima (O M M 1992).

Entre las medidas para reducir las inevitables consecuencias sobre la salud se encuentran: programas de preparación en caso de desastre; medidas urbanísticas para reducir el efecto de "islote de calor" y mejorar la vivienda; la planificación del uso de la tierra para reducir al mínimo la erosión, las inundaciones repentinas y la despoblación forestal innecesaria (por ejemplo, deteniendo la creación de pastizales para la exportación de carne); la adaptación de los comportamientos personales, como evitar la exposición al sol, y esfuerzos encaminados a luchar contra los vectores y extender la vacunación. $\mathrm{H}$ abrá que tener en cuenta los costes no pretendidos de las medidas de adaptación, como un mayor uso de plaguicidas.

La excesiva dependencia de los plaguicidas no sólo conduce a la resistencia de los insectos, sino que también elimina los organismos predadores naturales que son beneficiosos. EI efecto perjudicial sobre la salud pública y el medio ambiente derivado del uso actual de plaguicidas se ha estimado entre 100.000 y 200.000 millones de dólares al año (Institute of M edicine 1991).

Los países en desarrollo padecerán en una medida mayor y desproporcionada las consecuencias del cambio climático, aunque en la actualidad las naciones industrializadas son más responsables de la presencia de gases de efecto invernadero en la atmósfera.

En el futuro, los países más pobres influirán de un modo más significativo en la evolución del calentamiento de la Tierra, tanto por las tecnologías que decidan adoptar a medida que se acelere su desarrollo como por sus prácticas de uso de la tierra. Las naciones desarrolladas tendrán que adoptar políticas energéticas más racionales desde el punto de vista ambiental y transferir sin demora tecnologías nuevas (y asequibles) a los países en desarrollo.

\section{LA EXTINCION DE ESPECIES, LA PERDIDA DE DIVERSIDAD BIOLOGICA Y LA SALUD HUMANA ${ }^{1}$}

\section{Eric Chivian}

La actividad humana está provocando la extinción de especies animales, vegetales y microbianas a unas tasas que son varios miles de veces más altas que las producidas de manera natural (Wilson 1992) y que se aproximan a las mayores extinciones de la historia geológica. Cuando apareció el homo sapiens, hace unos 100.000 años, el número de especies existentes era el mayor que había habitado nunca la Tierra (Wilson 1989). Las actuales tasas de pérdida de especies están reduciendo ese número al más bajo desde el final de la era de los dinosaurios, hace 65 millones de años, y se estima que una cuarta parte del total de especies se extinguirá en los próximos 50 años (Ehrlich y Wilson 1991).

A demás de las cuestiones éticas que se plantean - como que no tenemos derecho a eliminar una enorme cantidad de otros organismos, muchos de los cuales aparecieron decenas de millones de años antes de nuestra llegada-, este comportamiento es en última instancia autodestructivo, pues altera el delicado equilibrio ecológico del que depende toda forma de vida, incluida la nuestra, y destruye la diversidad biológica que da fertilidad a los suelos, crea el aire que respiramos y aporta alimentos y otros productos naturales necesarios para la vida, la mayor parte de los cuales están aún por descubrir.

El crecimiento exponencial de la población humana y el aumento aún mayor del consumo de recursos y de la producción de residuos son los principales factores que ponen en peligro la supervivencia de otras especies. EI calentamiento de la Tierra, la Iluvia ácida, el agotamiento del ozono estratosférico y el vertido de sustancias químicas tóxicas en los ecosistemas del aire, el suelo y el agua dulce y salada llevan en última instancia a una pérdida de diversidad biológica. Pero el factor que más daño causa es la destrucción del hábitat a causa de actividades humanas, sobre todo la despoblación forestal.

A sí ocurre especialmente en el caso de los bosques higrofíticos tropicales. Q ueda menos del $50 \%$ de la superficie cubierta de bosques higrofíticos tropicales en la prehistoria, pero siguen talándose y quemándose a un ritmo de aproximadamente 142.000 kilómetros cuadrados cada año, superficie equivalente a la de Suiza y los Países Bajos juntos; es decir, cada segundo se pierde una superficie de manto forestal equivalente a un campo de fútbol (Wilson 1992). Esta destrucción es la principal responsable de la extinción masiva de especies del mundo.

Se ha estimado que en la T ierra hay entre 10 y 100 millones de especies distintas. Aun siendo conservadores y estimando en 20 millones el número total de especies en el mundo, 10 millones de especies se encontrarían en los bosques higrofíticos tropicales y, dadas las actuales tasas de despoblación forestal tropical, sólo en dichos bosques se perderían cada año 27.000 especies, más de 74 al día, tres cada hora (Wilson 1992).

En el presente artículo se examinan las consecuencias para la salud humana de esta pérdida generalizada de diversidad biológica. El autor está convencido de que, si la gente comprendiera plenamente el efecto que van a tener estas extinciones masivas - pérdida de la posibilidad de comprender y tratar muchas

1Este artículo es una adaptación, autorizada, de Chivian, E. 1993. Species Extinction and Biodiversity Loss: The Implications for $\mathrm{H}$ uman $\mathrm{H}$ ealth. En Critical Condition: $H$ uman $H$ ealth and the Environment, comp. $E$. Chivian, M. M cCally, H. Hu y A. H aines. Cambridge, M ass. y Londres, Inglaterra: M IT Press. N uestro agradecimiento a E.O. Wilson, R ichard Schultes, Stephen M orse, Andrew Spielman, Paul Epstein, David Potter, Nan Vance, Rodney Fujita, M ichael Balick, Suzan Strobel y Edson Albuquerque. 
enfermedades incurables y, en última instancia, quizás una amenaza para la supervivencia humana-, reconocería que las tasas actuales de pérdida de diversidad biológica representan nada menos que una emergencia médica de evolución lenta y pediría que se diera la máxima prioridad a los esfuerzos encaminados a conservar las especies y los ecosistemas.

\section{La pérdida de modelos para la medicina}

$\mathrm{H}$ ay tres grupos de especies animales en peligro, muy distantes entre sí en el reino animal - las ranas venenosas, los osos y los tiburones-, que constituyen un llamativo ejemplo de cómo importantes modelos para la ciencia biomédica pueden resultar eliminados por los seres humanos

\section{Ranas venenosas}

Toda la familia de las ranas venenosas, las $D$ endrobatidae, que se encuentran en los trópicos americanos, está amenazada por la destrucción de su hábitat - los bosques higrofíticos tropicales de tierras bajas de Centroamérica y Sudamérica (Brody 1990). Estas ranas de vivo colorido, en número de más de 100 especies, son especialmente sensibles a la despoblación forestal, pues viven únicamente en zonas muy concretas del bosque y no pueden hacerlo de forma natural en ningún otro sitio. Los científicos han descubierto que las toxinas que producen, utilizadas durante siglos por los indios centro y sudamericanos para envenenar las flechas y los dardos de las cerbatanas, se hallan entre las sustancias naturales más mortíferas que se conocen. Pero son también de enorme utilidad para la medicina. Los ingredientes activos de las toxinas son alcaloides, compuestos de anillo con nitrógeno que se encuentran casi exclusivamente en las plantas (son ejemplos la morfina, la cafeína, la nicotina y la cocaína). Los alcaloides se unen selectivamente a determinados canales y bombas de iones en las membranas nerviosa y muscular. Sin ellos, el conocimiento de esas unidades básicas de la función de la membrana, presentes en todo el reino animal, sería muy incompleto.

Además de su valor para la investigación neurofisiológica básica, las ranas venenosas ofrecen también valiosas claves bioquímicas para la producción de nuevos y potentes analgésicos con un mecanismo de acción distinto del de la morfina, de nuevos medicamentos para las arritmias cardiacas y de nuevos tratamientos para aliviar algunas enfermedades neurológicas como la enfermedad de Alzheimer, la miastenia grave y la esclerosis lateral amiotrófica (Brody 1990). Si se siguen destruyendo al ritmo actual los bosques higrofíticos de Centroamérica y Sudamérica, estas ranas de enorme valor se perderán.

\section{Osos}

El auge del mercado negro asiático de partes de osos, con la venta de vesículas biliares por su supuesto valor medicinal (a un precio 18 veces superior a su peso en oro) y de garras como exquisitez gastronómica (M ontgomery 1992), más la persistencia de la caza y la destrucción de sus hábitat han puesto en peligro las poblaciones de osos en muchas partes del mundo. Si llegan a extinguirse algunas especies, todos seremos más pobres, no sólo porque son criaturas bellas y fascinantes que ocupan importantes nichos ecológicos, sino también porque algunas especies poseen varios procesos fisiológicos únicos que pueden darnos importantes claves para tratar diversas dolencias humanas. Los osos negros que hibernan, por ejemplo, están inmóviles durante un período de hasta cinco meses en el invierno, y pese a ello no pierden masa ósea (Rosenthal 1993). (Los animales que verdaderamente hibernan, como las marmotas y la ardilla terrestre, muestran un marcado descenso de la temperatura corporal durante la hibernación y no se despiertan fácilmente. Los osos negros, en cambio, "hibernan" a temperaturas corporales casi normales y mantienen plenamente la capacidad de respuesta para defenderse al instante.) A diferencia de los humanos, que durante un período similar de inmovilidad (o sin sostener el peso corporal) perderían casi una cuarta parte de su masa ósea, los osos siguen fabricando hueso nuevo, para lo que utilizan el calcio que circula por su sangre (Floyd, Nelson y Wynne 1990). Comprender los mecanismos de cómo logran esa hazaña puede conducirnos a formas eficaces de prevención y tratamiento de la osteoporosis en las personas de edad avanzada (enorme problema que provoca fracturas, dolores e incapacidad), en las personas obligadas a guardar cama durante mucho tiempo y en los astronautas sometidos a prolongados períodos sin gravedad.

Además, los osos que "hibernan" no orinan durante meses. LoS humanos que no pueden excretar sus productos de desecho a través de la orina durante varios días acumulan un elevado nivel de urea en la sangre y mueren por su toxicidad. L os osos reciclan de algún modo la urea para fabricar nuevas proteínas, incluidas las musculares (Nelson 1973). Si pudiéramos determinar qué mecanismo rige este proceso quizás podríamos obtener tratamientos satisfactorios a largo plazo para las personas que padecen insuficiencia renal, que hoy dependen de la desintoxicación periódica en las máquinas de diálisis o de los trasplantes.

\section{Tiburones}

Al igual que los osos, muchas especies de tiburones se están viendo diezmadas debido a la demanda de su carne, especialmente en Asia, donde las aletas de tiburón para hacer sopa alcanzan precios que llegan hasta los 200 dólares el kilo (Stevens 1992). Como los tiburones tienen pocas crías, su crecimiento es lento y tardan años en madurar, son muy vulnerables a la sobreexplotación pesquera.

H ace casi 400 millones de años que los tiburones están en la Tierra, y han desarrollado órganos y funciones fisiológicas sumamente especializados que les han protegido de prácticamente todo tipo de amenazas, excepto del exterminio por parte de los humanos. La aniquilación de las poblaciones y la extinción de algunas de las 350 especies existentes pueden representar una gran catástrofe para la humanidad.

Los sistemas inmunes de los tiburones (y de sus parientes, las distintas especies de rayas) parecen haber evolucionado de tal manera que son casi invulnerables a la aparición de enfermedades cancerígenas e infecciones. Así como en otros peces y moluscos suelen verse tumores (Tucker 1985), son raros en los tiburones. Las primeras investigaciones van en apoyo de esta observación. Por ejemplo, no se ha podido provocar un crecimiento de tumores en tiburones a pesar de la inyección reiterada de sustancias conocidas por su potente carcinogenicidad (Stevens 1992). Investigadores del Massachusetts Institute of Technology han aislado una sustancia, que está presente en grandes cantidades en el cartílago del tiburón de Basking (Lee y Langer 1983), que inhibe considerablemente el crecimiento de nuevos vasos sanguíneos hacia los tumores sólidos, y con ello impide su crecimiento.

Los tiburones pueden ofrecernos también valiosos modelos para desarrollar nuevos tipos de medicamentos con que tratar las infecciones, aspecto especialmente importante en un momento en que los agentes infecciosos están adquiriendo una mayor resistencia a los antibióticos de los que disponemos actualmente.

\section{Otros modelos}

Podríamos mencionar otros muchos ejemplos de plantas, animales y microorganismos singulares que poseen el secreto de miles de millones de experimentos evolutivos y que están cada vez más amenazados por la actividad humana, con peligro de perderse para siempre para la ciencia médica. 


\section{La pérdida de nuevos medicamentos}

Las especies vegetales, animales y microbianas son en sí mismas las fuentes de algunos de los medicamentos más importantes de la actualidad y representan una proporción significativa de la farmacopea total. Farnsworth (1990) ha comprobado por ejemplo, que el $25 \%$ del total de recetas dispensadas en farmacias de la comunidad en Estados U nidos de 1959 a 1980 contenían ingredientes activos extraídos de plantas superiores. En el mundo en desarrollo este porcentaje es mucho más alto. $\mathrm{N}$ ada menos que el $80 \%$ de la población total de los países en desarrollo, lo que equivale a más o menos dos terceras partes de la población mundial, recurren casi exclusivamente a medicamentos tradicionales en los que se utilizan sustancias naturales, en su mayoría de origen vegetal.

Los conocimientos que poseen los curanderos tradicionales, que se han transmitido oralmente durante siglos, han permitido descubrir muchos medicamentos que son de amplio uso en la actualidad, la quinina, la fisostigmina, la d-tubocurarina, la pilocarpina y la efedrina, por citar sólo algunos (Farnsworth y cols. 1985). Pero esos conocimientos están desapareciendo con rapidez, sobre todo en el Amazonas, al desaparecer los curanderos nativos y ser sustituidos por médicos más modernos. Los botánicos y farmacólogos están tratando de aprender a toda prisa esas prácticas antiguas, que, al igual que las plantas forestales de que se sirven, están también en peligro (Farnsworth 1990; Schultes 199|; Balick 1990).

En busca de sustancias biológicamente activas los científicos han analizado la composición química de menos del $1 \%$ de las plantas conocidas de los bosques higrofíticos (Gottlieb y M ors 1980), una proporción similar de las plantas de zonas templadas (Schultes 1992) y porcentajes aún menores de los animales, hongos y microbios conocidos. Pero es posible que en los bosques, los suelos y los lagos y océanos haya aún decenas de millones de especies que no hemos descubierto. Con las extinciones masivas que se están produciendo en la actualidad, es posible que estemos destruyendo nuevos remedios para formas incurables de cáncer, para el SIDA, para la enfermedad cardíaca arterioesclerótica y para otras enfermedades que provocan un enorme padecimiento humano.

\section{Alteración del equilibrio entre ecosistemas}

Por último, la pérdida de especies y la destrucción de hábitats pueden trastornar el delicado equilibrio entre ecosistemas del que dependen todas las formas de vida, incluida la nuestra.

\section{Suministro de alimentos}

El suministro de alimentos podría verse gravemente amenazado. La despoblación forestal, por ejemplo, puede tener como consecuencia una notable reducción de las precipitaciones en las zonas agrícolas contiguas e incluso en regiones situadas a cierta distancia (Wilson 1988; Shulka, Nobre y Sellers 1990), lo que pondría en peligro la productividad de los cultivos. La pérdida de la cubierta del suelo por la erosión, que es otra consecuencia de la despoblación forestal, puede tener un efecto negativo irreversible sobre los cultivos de las regiones boscosas, especialmente en zonas de terreno montañoso, como ocurre en regiones de $\mathrm{N}$ epal, $\mathrm{M}$ adagascar y Filipinas.

Se están perdiendo también a un ritmo muy rápido murciélagos y aves, que se encuentran entre los principales predadores de los insectos que infestan o comen los cultivos (Brody 199|; Terborgh 1980), con innumerables consecuencias para la agricultura.

\section{Enfermedades infecciosas}

En Brasil, la malaria ha alcanzado recientemente proporciones epidémicas como consecuencia de los asentamientos masivos y la perturbación ambiental de la cuenca del Amazonas. En gran parte controlada durante el decenio de 1960, la malaria explotó 20 años después, con 560.000 casos notificados en 1988, de los cuales 500.000 sólo en el Amazonas (K ingman 1989). La epidemia fue consecuencia en gran parte de la afluencia de muchas personas poco o nada inmunizadas contra la malaria, que vivían en improvisados refugios y llevaban poca ropa protectora. Pero fue también resultado de su acción perturbadora sobre el medio ambiente del bosque higrofítico, al dejar por donde pasaban charcas de agua estancada - derivadas de la construcción de carreteras, de las escorrentías con sedimentos producto del desmonte de tierras y de la minería de superficie- en las que el Anopheles darlingi, que es el principal vector de la malaria en la zona, podía multiplicarse sin control (K ingman 1989).

La historia de las "nuevas" enfermedades víricas puede contener valiosas claves para comprender los efectos de la destrucción del hábitat sobre los seres humanos. L a fiebre hemorrágica argentina, por ejemplo, que es una dolorosa enfermedad vírica que tiene una mortalidad de entre el $3 \%$ y el $15 \%$ (Sanford 1991), viene produciéndose con proporciones de epidemia desde 1958 como resultado del desmonte generalizado de las pampas del centro del país y de la plantación de maíz (K ingman 1989).

De estas nuevas enfermedades víricas, la que ha tenido mayor repercusión sobre la salud humana y que puede ser un presagio de futuros brotes víricos es el SIDA, producido por el virus de inmunodeficiencia humana, en sus dos tipos, el VIH-1 y el VIH -2. Se está de acuerdo en general en que la actual epidemia de SIDA tuvo su origen en primates no humanos de Africa, que han actuado como huéspedes y reservorios naturales y asintomáticos para una familia de virus que producen inmunodeficiencia (Allan 1992). Existen suficientes pruebas genéticas de la existencia de vinculaciones entre el $\mathrm{VIH}-1$ y un virus que produce inmunodeficiencia en chimpancés africanos ( $H$ uet y Cheynier 1990) y entre el VIH -2 y otro virus de unos monos africanos del género Cercocebus ( $H$ irsch y O Imsted 1989; Gao y Yue 1992). ¿Son esas transmisiones víricas entre especies, de los primates a los humanos, el resultado de la invasión humana de entornos forestales degradados? Si así fuera, podríamos estar asistiendo con el SIDA al inicio de una serie de epidemias víricas originadas en los bosques higrofíticos tropicales, en los que puede haber miles de virus capaces de infectar a los humanos, algunos de los cuales podrían ser tan mortales como el SIDA (mortalidad de alrededor del $100 \%$ ), pero extenderse con más facilidad, por ejemplo, a través de las gotitas de agua transportadas por el aire. E sas enfermedades víricas potenciales podrían convertirse en la más grave consecuencia sobre la salud pública de la perturbación ambiental de los bosques higrofíticos.

\section{Otros efectos}

Pero lo que puede resultar más catastrófico para el conjunto de los seres humanos es la perturbación de otras interrelaciones entre organismos, ecosistemas y medio ambiente mundial, sobre las que no sabemos apenas nada. ¿Qué sucederá con el clima mundial y la concentración de gases en la atmósfera, por ejemplo, cuando se llegue a un umbral crítico de despoblación forestal? Los bosques desempeñan funciones decisivas para el mantenimiento de las pautas mundiales de precipitación y la estabilidad de los gases atmosféricos.

¿Cuáles serán los efectos sobre la vida marina si una mayor cantidad de radiación ultravioleta provoca la muerte masiva del fitoplancton oceánico, especialmente en los ricos mares situados debajo del "agujero" de ozono antártico? Esos organismos, que están en la base de toda la cadena alimentaria marina y que producen una parte significativa del oxígeno mundial y consumen una parte significativa de su dióxido de carbono, son 
sumamente vulnerables al daño producido por la radiación ultravioleta (Schneider 1991; Roberts 1989; B ridigare 1989).

¿Cuáles serán las consecuencias para el crecimiento de las plantas si la lluvia ácida y las sustancias químicas tóxicas envenenan los hongos y bacterias del suelo esenciales para su fertilidad? En los últimos 60 años se ha producido ya una pérdida del $40-50 \%$ de las especies de hongos de Europa occidental, entre ellos muchos hongos que establecen micorrizas simbióticas (Wilson 1992), que son cruciales para la absorción de los nutrientes por las plantas. Nadie sabe qué efectos tendrá esa pérdida.

Los científicos desconocen las respuestas a estas y otras preguntas de importancia crítica. Pero hay algunas señales biológicas preocupantes que sugieren que ya se ha producido un daño importante a los ecosistemas mundiales. $L$ a caída rápida y simultánea de las poblaciones de muchas especies de ranas en todo el mundo, incluso en medios limpios y alejados de poblaciones humanas, indica que pueden estar muriendo como consecuencia de algún cambio ambiental mundial (Blakeslee 1990). Estudios recientes (Blaustein 1994) sugieren que en algunos de esos casos la causa puede ser el incremento de la radiación ultravioleta $B$ debido al adelgazamiento de la capa de ozono.

$M$ ás cerca de los seres humanos, los mamíferos marinos como los delfines listados del M editerráneo, las focas moteadas europeas que viven frente a las costas de Escandinavia y de Irlanda del Norte y las belugas del río San Lorenzo están muriendo también en un número sin precedentes. En el caso de los delfines y las focas, algunas de las muertes parecen deberse a infecciones por virus morbilli (la familia de virus a la que pertenecen el del sarampión y el del moquillo de los perros), que producen neumonías y encefalitis (Domingo y Ferrer 1990; K ennedy y Smyth 1988), y que quizás son también consecuencia del deterioro de los sistemas inmunes. En el caso de las ballenas parecen intervenir contaminantes químicos como el DDT, el insecticida $M$ irex, los PCB, el plomo y el mercurio, que tienen un efecto de supresión de la fecundidad de las belugas y en última instancia provocan su muerte a causa de diversos tumores y neumonías (D old 1992). Las osamentas de las belugas estaban en muchas ocasiones tan repletas de contaminantes que podrían clasificarse como residuos peligrosos.

Cabe preguntarse si entre esas "especies indicadoras", como los canarios que mueren en las minas de carbón que contienen gases venenosos, en un aviso de que estamos perturbando el frágil equilibrio entre ecosistemas en que se apoyan todas las formas de vida, si entre esas especies figura la nuestra. La reducción del $50 \%$ en los recuentos de espermatozoides de hombres sanos de todo el mundo durante el período 1938-1990 (C arlsen y cols. 1992), el notable incremento de la tasa de malformaciones congénitas de los genitales externos masculinos en Inglaterra y Gales entre 1964 y 1983 (M atlai y Beral 1985), la muy importante elevación de las tasas de incidencia de algunos tipos de cáncer en niños blancos entre 1973 y 1988 (Angier 199l) y en adultos blancos entre 1973 y 1987 (Davis, Dinse y H oel 1994) en Estados Unidos, y el constante crecimiento de las tasas de mortalidad por varios tipos de cáncer en todo el mundo en los últimos 30 o 40 años (K urihara, A oki y Tominaga 1984; D avis y $\mathrm{H}$ oel 1990a, 1990b; H oel 1992) son elementos que sugieren que el deterioro del medio ambiente puede estar empezando a poner en peligro no sólo la supervivencia de ranas, mamíferos marinos y otras especies animales, vegetales y microbianas, sino también la de la especie humana.

\section{Resumen}

La actividad humana está provocando la extinción de organismos animales, vegetales y microbianos a un ritmo que bien puede traducirse en la eliminación de una cuarta parte de todas las especies que hay sobre la T ierra en los próximos 50 años. De esa destrucción se derivan incalculables consecuencias para la salud humana:

- la pérdida de modelos médicos para comprender la fisiología y las enfermedades humanas;

- la pérdida de nuevos medicamentos con los que podríamos conseguir tratar formas incurables de cáncer, el SIDA, la arterioesclerosis y otras enfermedades que provocan gran padecimiento humano.

\section{Referencias}

Agencia Internacional para la Investigación sobre el Cáncer (IARC). 1992. Solar and U Itraviolet R adiation. IARC M onographs $0 n$ the Evaluation of $C$ arcinogenic R isks to H umans L yon: IARC.

Allan, JS. 1992. V iral evolution and AIDS. J Natl Inst $H$ ealth R es 4:51-54.

Angier, N. 1991. Study finds mysterious rise in childhood cancer rate. New York Times (26 de junio):D 22.

Arceivala, SJ. 1989. Water quality and pollution control: Planning and management. En Criteria for and Approaches for $W$ ater $Q$ uality $M$ anagement in D eveloping Countries. Nueva Y ork: N aciones U nidas.

Archer, DL, JE K venberg. 1985. Incidence and cost of foodborne diarrhoea disease in the United States. J F ood Prod 48(10):887-894.

Balick, M J. 1990. Ethnobotany and the identification of therapeutic agents from the rainforest. CIBA F Symp 154:22-39.

Bascom, R y cols. 1996. H ealth effects of outdoor air pollution. State of the Art. Am J Resp Crit Care M ed 153:3-50.

Blakeslee, S. 1990. Scientists confront an alarming mystery: T he vanishing frog. N ew Y ork T imes. 20 de febrero: B7.
Blaustein, AR.1994. UL repair and resistance to solar UV-B in amphibian eggs: A link to population declines. Proc Natl Acad Sci U SA 91:1791-1795.

Borja-Arburto, VH, DP Loomis, C Shy, S Bangdiwala. 1995. Air pollution and daily mortality in M exico C ity. E pidemiology S64:231.

Bridigare, R R. 1989. Potential effects of UVB on marine organisms of the Southern $O$ cean: Distribution of phytoplankton and krill during Austral Spring. Photochem Photobiol 50:469-478

Brody, JE. 1990. U sing the toxin from tiny frogs, researchers seek clues to disease. New York Times. 23 de enero.

Brody, JE. 1991. Far from fearsome, bats lose ground to ignorance and greed. New York T imes. 29 de octubre: $\mathrm{Cl}, \mathrm{C} 10$.

Carlsen, E, A Gimmercman. 1992. Evidence for decreasing quality of semen during the past 50 years. B r M ed J 305:609-613.

Castillejos, M, D Gold, A Damokosh, P Serrano, G Allen, WF MCDonnell, D Dockery, S RuizV elasco, M Hernández, C H ayes. 1995. Acute effects of ozone on the pulmonary function of exercising schoolchildren from M exico City. Am | Resp Crit Care M ed 152:1501-1507.

Castillejos, M, D Gold, D Dockery, T Tosteson, T Baum, FE Speizer. 1992. Effects of ambient ozone on respiratory functions and symptoms in school children in Mexico City. Am Rev Respir Dis 145:276-282.

Centers for Disease Control (CDC). 1991. Preventing Lead Poisoning in Young Children. Washington, DC: US D epartment of $\mathrm{H}$ ealth and $\mathrm{H}$ uman Services.

Cohen, ML. 1987. Prepared statement in "H earing before the Committee of Agriculture, Nutrition and Forestry". Senado de Estados Unidos, 100ㅇ Congreso, Primera Sesión. (US Government Printing $O$ ffice, Washington, DC).

Coleman, M P, J Esteve, P Damiecki, A Arslan, H Renard. 1993. T rends in Cancer Incidence and M ortality. IARC Scientific Publications, No.121. Lyon: IARC.

Comisión sobre Salud y Medio Ambiente de la O rganización M undial de la Salud (O M S). 1992a. Report of the Panel On U rbanization. Ginebra: OMS.

-. 1992b. Report of the Pand On Energy. Ginebra: OMS.

Conferencia de las Naciones U nidas sobre el M edio Ambiente y el Desarrollo (CNU M AD). 1992. Protection for the quality and supply of freshwater resources. En Capítulo 18 de Application of Integrated Approaches to the D evelopment, $M$ anagement and $U$ se of $W$ ater R esources. Río de Janeiro: CNU M AD.

Davis, DL, D Hoel. 1990a. International trends in cancer mortality in France, W est Germany, Italy, 
Japan, England and Wales and the USA. Lancet 336 (25 de agosto):474-481.

- . 1990b. T rends in Cancer M ortality in Industrial Coun tries. Annals of the $\mathrm{New}$ York Academy of Sciences, N 0. 609.

Davis, DL, GE Dinse, DG Hoel. 1994. Decreasing cardiovascular disease and increasing cancer among whites in the U nited States from 19731987. J AM A 271(6):431-437.

Dockery, DW, CA Pope. 1994. Acute respiratory effects of particulate air pollution. Ann Rev Publ $H$ ealth 15:107-132.

Dold, C. 1992. Toxic agents found to be killing off whales. $N$ ew Y ork T imes. 16 de junio: C 4.

Domingo, M, L Ferrer. 1990. M orbillivirus in dolphins. Nature 348:21.

Ehrlich, PR, EO Wilson. 1991. Biodiversity studies: Science and policy. Science 253(5021):758-762.

Epstein, PR. 1995. Emerging diseases and ecosystem instability. Am J Public H ealth 85:168-172.

Farman, JC, H Gardiner, JD Shanklin. 1985. Large losses of total ozone in Antarctica reveal seasonal C IO x/ N O x interaction. N ature 315:207-211.

Farnsworth, NR, O Akerele, y cols. 1985. M edicinal plants in therapy. Bull W H $O$ 63(6):965-981.

Farnsworth, NR. 1990. The role of ethnopharmacology in drug development. CIBA F Symp 154:2-21.

Floyd, T, RA N elson, GF Wynne. 1990. Calcium and bone metabolic homeostasis in active and denning black bears. Clin Orthop Relat R 255 (Junio):301309

Focks, DA, E Daniels, DG H aile, JE K eesling. 1995. A simulation model of the epidemiology of urban dengue fever: literature analysis, model development, preliminary validation, and samples of simulation results. Am J T rop M ed $\mathrm{H}$ yg 53:489-506.

Galal-Gorchev, H. 1986. D rinking-W ater Quality and $H$ ealth. Ginebra: OMS, no publicado.

- . 1994. W H O Guidelines for D rinking W ater Q uality. Ginebra: 0 M S, no publicado.

Gao, F, L Y ue. 1992. H uman infection by genetically diverse SIV sm-related HIV -2 in W est Africa. $\mathrm{Na}$ ture 358:495.

Gilles, H M , DA Warrell. 1993. B ruce Chwatt's E ssential $M$ alaniology. Londres: Edward Arnold Press.

Gleason, JF, PK Bhartia, JR H erman, R M cPeters, y cols. 1993. Record low global ozone in 1992. Science 260:523-526.

G ottlieb, O R, W B M ors. 1980. Potential utilization of Brazilian wood extractives. J Agricul Food Chem 28(2): 196-215.

Grossklaus, D. 1990. Gesundheitliche Fragen im EG-Binnemarkt. Arch L ebensmittelhyg 41(5):99-102.

Hamza, A. 1991. I mpacts of Industrial and Small-Scale $M$ anufacturing $W$ astes 0 n U rban Environment in D eveloping Countries. Nairobi: Centro de las Naciones U nidas para los $\mathrm{A}$ sentamientos $\mathrm{H}$ umanos

H ardoy, JE, F Satterthwaite. 1989. Squatter Citizen: Life in the U rban Third W orld. Londres: Earthscan Publications.

H ardoy, JE, S Cairncross, D Satterthwaite. 1990. T he Poor Die Young: $\mathrm{H}$ ousing and $\mathrm{H}$ ealth in T hird W orld Cities. Londres: Earthscan Publications.

Harpham, T, T Lusty, P Vaugham. 1988. In the Shadow of the City- Community $\mathrm{H}$ ealth and the $\mathrm{U}$ rban Poor. O xford: OUP.

$\mathrm{H}$ irsch, VM, M Olmsted. 1989. An African primate lentivirus (SIV sm) closely related to HIV -S. Nature 339:389.

H oel, D G. 1992. T rends in cancer mortality in 15 industrialized countries, 1969-1986. J N atl Cancer Inst 84(5):313-320.

H oogenboom-V ergedaal, AM M y cols. 1990. E pdemiologisch E n M icrobiologisch Onderzoek M et B etrekking T ot $G$ astro-E nteritis Bij D eM ens in D e R egio's Amsterdam E n
H elmond in 1987 En 1988. Países Bajos: Instituto Nacional de Salud Pública y Protección del M edio Ambiente.

H uet, T, A C heynier. 1990. G enetic organization of a chimpanzee lentivirus related to HIV-1. Nature 345:356.

H uq, A, RR Colwell, R Rahman, A Ali, M A Chowdhury, S Parveen, DA Sack, E Russek-Cohen. 1990. Detection of Vibrio cholerae 01 in the aquatic environment by fluorescent-monoclonal antibody and culture methods. Appl Environ M icrobiol 56:2370-2373.

Institute of M edicine. 1991. M alaria: Obstacles and $0 \mathrm{p}$ portunities. Washington, DC: National Academy Press.

- . 1992. E merging Infections: M icrobial Threats to $\mathrm{H}$ ealth in the U nited States. Washington, DC: National Academy Press.

Intergovernmental Panel on Climate $C$ hange (IPCC). 1990. Climate Change: The IPCC I mpacts Assessment. Canberra: Australian Government Publishing Service.

- 1992. Climate Change 1992: The Supplementary R eport to the IPCC I mpacts Assessment. C anberra: Australian Government Publishing Service.

K alkstein, LS, KE Smoyer. 1993. The impact of climate change on human health: Some international implications. Experiencia 49:469-479.

K ennedy, S, JA Smyth. 1988. Confirmation of cause of recent seal deaths. N ature 335:404.

K err, JB, CT M cElroy. 1993. Evidence for large upward trends of ultraviolet-B radiation linked to ozone depletion. Science 262 (N oviembre):1032 1034.

K ilbourne EM . 1989. H eat waves. En T he public health consequences of disasters. 1989, dirigido por M B Gregg. Atlanta: Centers for Disease C ontrol.

K ingman, S. 1989. M alaria runs riot on Brazil's wild frontier. N ew Scientist 123:24-25.

K jellström, T. 1986. Itai-itai disease. En Cadmium and $H$ ealth, dirigido por L Friberg y cols. Boca R aton: CRC Press.

Koopman, JS, DR Prevots, MA Vaca-M arin, H Gomez-D antes, M L Zarate-Aquino, IM Longini $\mathrm{r}$, I Sepulveda-Amor. 1991. Determinants and predictors of dengue infection in M exico. Am E pidemiol 133:1168-1178.

K ripke, ML, WL M orison. 1986. Studies on the mechanism of systemic suppression of contact hypersensitivity by UV B radiation. II: Differences in the suppression of delayed and contact hypersensitivity in mice. I Invest D ermatol 86:543-549.

K urihara, M, K A oki, S T ominaga. 1984. Cancer M ortality Statistics in the W orld. Nagoya, Japón: The U niversity of Nagoya Press.

Lee, A, R Langer. 1983. Shark cartilage contains inhibitors of tumor angiogenesis. Science 221:11851187.

Loevinsohn, M. 1994. Climatic warming and increased malaria incidence in $\mathrm{R}$ wanda. Lancet 343:714-718.

Longstreth, J J Wiseman. 1989. The potential impact of climate change on patterns of infectious disease in the United States. En The Potential Effects of Global Climate C hange in the U nited States, dirigido por J Smith y DA T irpak. Washington, DC: US Environmental Protection Agency.

M artens, WM , LW Niessen, J Rotmans, TH Jetten, AJ M cM ichael. 1995. Potential impact of global climate change on malaria risk. E nviron $\mathrm{H}$ ealth Persp 103:458-464.

$M$ atlai, $P, V$ Beral. 1985. Trends in congenital malformations of external genitalia. Lancet 1 (12 de enero):108.
M CM ichael, AJ. 1993. Planetary Overload: Global E nvironmental Change and the $\mathrm{H}$ ealth of the $\mathrm{H}$ uman Species. Londres: C ambridge $U$ niversity Press.

M eybeck, M, D Chapman, R H elmer. 1989. Global Freshwater Q uality: A First Assessment. Ginebra: Sistema M undial de Vigilancia del M edio Ambiente (SIM UVIMA/ -AGUA)

M eybeck, M, R H elmer. 1989. The quality of rivers: From pristine stage to global pollution. Paleogeogr Paleoclimatol Paleoecol 75:283-309.

M ichaels, D, C Barrera, M G Gacharna. 1985. Economic development and occupational health in atin America: $N$ ew directions for public health in less developed countries. Am I Public $\mathrm{H}$ ealth 75(5):536-542.

M olina, MJ, FS Rowland. 1974. Stratospheric sink for chloro-fluoro-methanes: Chlorine atomcatalyzed destruction of ozone. Nature 249:810814.

M ontgomery, S. 1992. G risly trade imperils world's bears. T he B oston Globe. M arzo 2:23-24.

N aciones U nidas (NU ). 1993. A genda 21. N ueva Y ork: NU.

Nelson, RA. 1973. Winter sleep in the black bear. $M$ ayo $C$ lin Proc 48:733-737.

Nimmannitya, S. 1996. Dengue and dengue haemorrhagic fever. En M anson's T ropical Diseases, dirigido por GC C ook. Londres: WB Saunders.

Nogueira, DP. 1987. Prevention of accidents and injuries in Brazil. E rgonomics 30(2):387-393.

Notermans, S. 1984. Beurteilung des bakteriologischen Status frischen $G$ eflügels in Läden und auf M ärkten. F leischwirtschaft 61(1):131-134.

Noweir, M H. 1986. O ccupational health in developing countries, with special reference to Egypt. Am I Ind M ed 9:125-141.

O ficina Federal de la Salud (Suiza). 1990. Boletín de la 0 ficina Federal de la Salud. 29 de octubre.

Organismo Internacional de la Energía Atómica (OIEA). 1991. International Chernobyl Project Assessment of Radiological Consequences and $\mathrm{E}$ valuation of Protective M easures. V iena: OIEA.

O rganización M eteorológica M undial (O M M ). 1992. GCOS: Responding to the Need for Climate $O$ bservations. Ginebra: O M M .

Organización M undial de la Salud (OMS) y ECOT OX. 1992. M otor Vehicle Air Pollution. Public $\mathrm{H}$ ealth I mpact and $C$ ontrol M easures. Ginebra: OM S.

Organización Mundial de la Salud (OMS) y FAO. 1984. The R ole of Food Safety in $\mathrm{H}$ ealth and Development. WHO Technical Report Series, N 0. 705. Ginebra: OM S.

Organización Mundial de la Salud (OMS) y PNUM A. 1991. Progress in the Implementation of the M ar D el Plata Action Plan and a Strategy for the $1990 \mathrm{~s}$. Ginebra: OMS.

-. 1992. U rban Air Pollution in M egacities of the W orld. Blackwells, R eino U nido: O M S.

Organización Mundial de la Salud (WHO). 1984. T oxic Oil Syndrome: $M$ ass F ood Poisoning in Spain. Copenhague: O ficina R egional de la OM S para Europa.

- . 1987. Air Q uality Guidelines for E urope. European Series, No. 23. Copenhague: O ficina R egional de la OM S para Europa.

-. 1990a. Acute Effects On H ealth of Smog E pisodes. WHO Regional Publications European Series, No. 3. Copenhague: O ficina R egional de la OMS para Europa.

-. 1990b. Diet, Nutrition and Prevention of Chronic Diseases. WHO Technical Report Series, No. 797. Copenhague: O ficina Regional de la OMS para Europa.

-. 1990c. Global E stimates for $\mathrm{H}$ ealth Situation, Assessment and Projections. WHO Technical Report Series, N o. 797. G inebra: OM S. 
-. 1990d. Potential H ealth $\mathrm{E}$ ffects of Climatic Change Ginebra: OM S.

- . 1990e. Public health impact of pesticides used in agriculture. W orld $\mathrm{H}$ ealth Statistics Q uarterly 43:118187.

-. 1992a. Indoor Air Pollution from Biomass Fuel. Ginebra: OMS.

-. 1992b. O ur Planet, O ur H ealth. Ginebra: O M S.

- . 1993. W ekly E pidemiol Rec 3(69):13-20.

—. 1994. U Itraviolet Radiation. Environmental Health Criteria, N o. 160. Ginebra: O M S.

- . 1995. U pdate and R evision of the Air Q uality Guidelines for Europe. Copenhague: O ficina Regional de la O M S para Europa.

-. en imprenta. Potential $\mathrm{H}$ ealth $\mathrm{E}$ ffects of $\mathrm{G}$ lobal Climate Change: U pdate. G inebra: O M S

Organización Panamericana de la Salud (OPS) y O rganización M undial de la Salud (O M S. 1989. Informe final del Grupo de Trabajo sobre Vigilancia Epidemiológica y Enfermedades de Origen Alimentario. Documento no publicado HPV/ FOS/ 89-005.

Patz, JA, PR Epstein, TA Burke, JM Balbus. 1996. Global climate change and emerging infections diseases. J AM A 275:217-223.

Pope, CA, DV Bates, ME R azienne. 1995. Health effects of particulate air pollution: $T$ ime for reassessment? E nviron $\mathrm{H}$ ealth Persp 103:472-480.

Programa de las $\mathrm{N}$ aciones $\mathrm{U}$ nidas para el $\mathrm{M}$ edio Ambiente (PNU M A). 1988. Assessment of Chemical Contaminants in Food. Nairobi: PNU M A/ FAO / O M S.

—. 1991a. Environmental E ffects of O zone D epletion: 1991 U pdate. Nairobi: PNUM A.

-. 1991b. U rban Air Pollution. Environment Library, No. 4. Nairobi: PNUMA.

Reeves, WC, JL Hardy, WK Reisen, MM Milky. 1994. The potential effect of global warming on mosquitoborne arboviruses. I M ed Entomol 31(3):323-332.

Roberts, D. 1990. Sources of infection: Food. Lancet 336:859-861.

R oberts, L. 1989. Does the ozone hole threaten antarctic life. Science 244:288-289.

Rodrigue, DG. 1990. International increase in Salmonella enteritidis. A new pandemic? E pidemiol Inf 105:21-21.

Romieu, I, F M eneses, I Sienra, I Huerta, S R uiz, M White, R Etzel, M H ernandez-Avila. 1994. Effects of ambient air pollution on respiratory health of M exican children with mild asthma. Am J Resp Crit Care M ed 129:A659.

Romieu, I, F M eneses, S Ruiz, J Sienra, J Huerta, $M$ White, R Etzel. 1996. Effects of air pollution on respiratory health of children with mild asthma living in Mexico City. Am J Resp Crit Care Med 154:300-307.

Romieu, I, F M eneses, S Ruíz, J Sierra, J Huerta, M White, R Etzel, M Hernández. 1995. Effects of urban air pollution on emergency visits for childhood asthma in Mexico City. Am J Epidemiol 141(6):546-553.

R omieu, I, H W eizenfeld, I Finkelman. 1990. U rban air pollution in Latin America and the Caribbean: $\mathrm{H}$ ealth perspectives. W orld $\mathrm{H}$ ealth Stat Q 43:153167.

-. 1991. U rban air pollution in Latin America and the Caribbean. J Air W aste M anage Assoc 41:11661170 .

Romieu, I, M Cortés, S R uíz, S Sánchez, F M eneses, M Hernándes-A vila. 1992. Air pollution and school absenteeism among children in Mexico City. Am J E pidemiol 136:1524-1531.

Rosenthal, E. 1993. Hibernating bears emerge with hints about human ills. N ew York T imes 21 Abril: C $1, C 9$.

Ryzan, CA. 1987. Massive outbreak of antimicrobial-resistant salmonellosis traced to pasteurized milk. J AM A 258(22):3269-3274.

Sanford, JP. 1991. A renavirus infections. En el Capítulo 149 de $H$ arrison's Principles of Internal M edicine, dirigido por JD Wilson, E Braunwald, KJ Isselbacher, RG Petersdorf, JB M artin, AS Fauci y RK Root.

Schneider, K. 1991. O zone depletion harming sea life. $N$ ew Y ork T imes 16 de noviembre: 6 .

Schultes, RE 1992: Comunicación personal. 24 de enero de 1992.

-.1991 . Dwindling forest medicinal plants of the A mazon. $\mathrm{H}$ arvard M ed Alum B ull (V erano): 32-36.

Sharp, D. (dir.). 1994. H ealth and Climate Change. Londres: The Lancet Ltd.

Shope, RE. 1990. Infectious diseases and atmospheric change. En Global Atmospheric Change and Public $H$ ealth: Proceedings of the Center for E nvironmental Information, dirigido por JC White. Nueva York: Elsevier.

Shulka, J, C N obre, P Sellers. 1990. Amazon deforestation and climate change. Science 247:1325.

Statistisches Bundesamt. 1994. Gesundheitswersen: M eldepflichtige Krankheiten. Wiesbaden: Statistisches Bundesamt.

Stevens, WK . 1992. Terror of the deep faces harsher predator. N ew Y ork T imes. 8 de diciembre: $\mathrm{Cl}, \mathrm{C} 12$.

Stolarski, R, R Bojkov, L Bishop, C Zerefos, y cols. 1992. M easured trends in stratospheric ozone. Science 256:342-349.

Taylor, HR, SK West, FS Rosenthal, B M unoz, HS N ewland, H Abbey, EA Emmett. 1988. Effects of ultraviolet radiation on cataract formation. N Engl J M ed 319:1429-33.

T aylor, H R . 1990. Cataracts and ultraviolet light. En Global A tmospheric C hange and Public $\mathrm{H}$ ealth: P roceedings of the $C$ enter for $E$ nvironmental Information, dirigido por IC W hite. N ueva Y ork: Elsevier.

Terborgh, J. 1980. Where $\mathrm{H}$ ave All the Birds Gone? Princeton, Nueva Jersey: Princeton University Press.
T ucker, JB. 1985. D rugs from the sea spark renewed interest. B ioscience 35(9):541-545.

U rban Edge. 1990a. Reducing accidents: Lessons learned. U rban E dge 14(5):4-6.

-. 1990b. Road safety a lethal problem in third world. U rban E dge 14(5):1-3.

Watts, DM , DS Burke, BA H arrison, RE Whitmire, A Nisalak. 1987. Effect of temperature on the vector efficiency of Aedes aegypti for dengue 2 virus. Am J T rop M ed H yg 36:143-152.

Wenzel, RP. 1994. A new hantavirus infection in North America. New Engl J M ed 330(14):10041005.

Wilson, EO . 1988. The current state of biological diversity. En Biodiversity, dirigido por EO Wilson. Washington, DC: N ational Academy Press.

- . 1989. Threats to biodiversity. Sci Am 261:108-116.

- . 1992. The Diversity of Life. Cambridge, M assachussetts: $\mathrm{H}$ arvard U niversity Press.

World Bank. 1992. D evelopment and the E nvironment. OXford: OUP.

Young, FE. 1987. Food safety and FDA's action plan phase II. F ood T echnol 41:116-123.

\section{0 tras lecturas recomendadas}

Andrews, JSJ, H Frumkin, BL Johnson, MA M ehlman, C X intaras, HA Bucsela. 1994. H azardous $W$ aste and Public $H$ ealth: International Congress $O n$ the $\mathrm{H}$ ealth $\mathrm{E}$ ffects of $\mathrm{H}$ azardous $\mathrm{W}$ aste. Princeton, Nueva Jersey: Princeton Scientific Publishing.

Batstone, $R$ y cols. 1989. The Safe D isposal of $H$ azardous $W$ astes. The Special Needs and Problems of D eveloping Countries. W orld Bank T echnical Paper N 0. 93. Vol. IIII. Washington, DC: Banco $M$ undial.

Gentner, NE, P U nrau. 1979. Proceedings of the First International Conference $\mathrm{O} \mathrm{n} \mathrm{H}$ ealth $\mathrm{E}$ ffects of $\mathrm{E}$ nergy Production. Chalk River, O ntario, Canadá: Atomic Energy of $C$ anada.

K jellstrom, T. 1988. Health hazards of the environment. M easuring the harm. W orld $\mathrm{H}$ ealth : 2-5.

National R esearch Council. 1991. Public Health and $\mathrm{H}$ azardous Wastes. Environmental E pidemiology, No. V 1. Washington, DC: N ational A cademy Press.

Organismo Internacional de la Energía Atómica (OIEA). 1982. Proceedings of International Symposium, $H$ ealth Impacts of Different Sources of E nergy. Viena: OIEA.

-. 1984. Proceedings of Symposium Risks and B enefits of E nergy Systems. V iena: O IEA.

-. 1991. Senior Expert Symposium On Electricity and the Environment. Viena: OIEA.

Societé française d'énergie nucléaire. 1980. Colloquium On the Risks of Different Energy Sources, Paris, 24-26 J an. 1980. París: Gedim.

U pton, AC, T K neip, P T oniolo. 1989. Public health aspects of toxic chemical disposal sites. Ann Rev Publ $H$ ealth 10:1-25. 

Director del capítulo

Larry R. Kohler

\section{Sumario}

Panorama: la salud y la seguridad en el trabajo y el medio ambiente: dos caras de la misma moneda

Larry R. Kohler.

El medio ambiente y el mundo del trabajo: un concepto integral del desarrollo sostenible, el medio ambiente y el medio ambiente de trabajo

Larry R. Kohler . . . . . . . . . . . . . . . . . . . . . . . . . . . . . . 54.2

Leyes y reglamentos

F rançoise B urhenne Guilmin . . . . . . . . . . . . . . . . 54.7

Convenios internacionales sobre el medio ambiente

D avid F reestone........................... 54.10

Evaluaciones de impacto ambiental

Ron $B$ isset . . . . . . . . . . . . . . . . . . . . . . . . 54.15

Evaluación del ciclo vital (de la cuna a la tumba)

Sven-0 lof Ryding............................. 54.18

Evaluación y comunicación de riesgos

Adrian V. G heorghe y $\mathrm{H}$ ansjörg Seiler. .

Auditoría ambiental: definición y metodología

Robert Coyle.

Estrategias de gestión del medio ambiente y protección de los trabajadores

Cecilia B righi

Control de la contaminación ambiental: la prevención de la contaminación como objetivo prioritario de la empresa

R obert P. B ringer y Tom Z osel 


\section{Pan ORAMA: LA SALUd Y LA SEgURIDAD EN EL TRABAJO YEL MEDIO AMBIENTE: DOS CARAS DE LA MISMA MONEDA}

Larry R. Kohler

La presente es la primera edición de la Enciclopedia de la salud y seguridad en el trabajo en la que se ha querido expresamente abarcar las cuestiones ambientales que afectan a esta materia. En el presente capítulo se ponen de relieve diversos aspectos fundamentales de la política ambiental que se asocian crecientemente a la salud y seguridad en el trabajo. 0 tros capítulos dedicados a los problemas del medio ambiente son R iesgos ambientales para la salud y Control de la contaminación ambiental. Además, se ha tenido un especial cuidado en dedicar algunas secciones al medio ambiente en cada uno de los capítulos consagrados a los principales sectores industriales. Al considerar inicialmente la pertinencia de integrar las cuestiones ambientales en el contenido de la Enciclopedia, existía el objetivo, muy limitado, de incluir un único capítulo que fuese de utilidad como fuente de "remisión y consulta" y mostrase la creciente asociación de los problemas ambientales con el medio ambiente de trabajo y la salud y seguridad en el trabajo. Como la OIT ha venido repitiendo desde hace más de veinte años, el medio ambiente de trabajo y el entorno general constituyen las "dos caras de la misma moneda".

Sin embargo, no es menos evidente que la dimensión e importancia de las dificultades que esta "moneda de dos caras" plantea a los trabajadores de todo el mundo se han infravalorado y han recibido escasa atención en los planes de actuación. Existe el riesgo de que los éxitos descollantes que han atraído la atención y merecido elogios en esta Enciclopedia produzcan una falsa sensación de seguridad y confianza respecto a los conocimientos actuales sobre la salud y seguridad en el trabajo y el medio ambiente. Es cierto que las mejores tecnologías, políticas de gestión y herramientas existentes han permitido hacer progresos impresionantes en la prevención y subsanación de los problemas en diversos sectores fundamentales, sobre todo en los países industrializados. No es menos cierto, sin embargo que el ámbito de aplicación mundial de estas tecnologías, políticas de gestión y herramientas es claramente insuficiente y limitado, especialmente en los países en desarrollo y en las economías en transición.

En el presente capítulo se describen algunas de las políticas y herramientas más eficaces en la solución de los problemas y dificultades ambientales y de salud y seguridad en el trabajo, aunque no sería exacto afirmar que la aplicación de estas políticas y técnicas está universalmente extendida. Es importante, sin embargo, que los profesionales de la salud y seguridad en el trabajo de todo el mundo enriquezcan sus conocimientos de estas políticas y herramientas como requisito de la generalización de su aplicación y su adaptación práctica a distintas condiciones económicas y sociales.

En el primer artículo del presente capítulo se examinan someramente las relaciones entre la salud y seguridad en el trabajo y el medio ambiente, las políticas y los problemas laborales asociados al medio ambiente general y al concepto de "desarrollo sostenible". Este concepto se convirtió en el principio rector de la Agenda $X X I$, esto es, el plan de actuación para el siglo XXI aprobado en la Conferencia de las Naciones U nidas para el M edio Ambiente y el Desarrollo (CNU M AD) celebrada en Río de Janeiro en junio de 1992. La vieja concepción simplista - y absolutamente errónea- de que no sólo era posible, sino también imprescindible, separar los problemas - y las respuestas - que se producen en el lugar de trabajo de los que se plantean fuera de los límites de la empresa se ha difuminado bastante. De hecho, hoy en día, tanto los trabajadores como las empresas y sus organizaciones representativas han empezado a reconocer expresamente que los muros de la empresa son todo menos impermeables a los efectos de las políticas que se aplican y los problemas que se producen a ambos lados de esos muros.

En vista del reconocimiento generalizado de que los problemas de salud y seguridad en el trabajo se han abordado en el pasado de forma excesivamente aislada, en el presente capítulo se exponen de forma sucinta diversas cuestiones de política ambiental que pueden clarificar las ideas y facilitar la actividad de los profesionales de la salud y seguridad en el trabajo. Dos de los artículos del capítulo están dedicados al ordenamiento legal del medio ambiente y en ellos se describe su situación actual por lo que respecta a la rápida expansión de la respuesta legislativa en los ámbitos nacional e internacional a los actuales problemas y cuestiones ambientales.

En cuatro de los artículos del capítulo se examinan algunas de las principales herramientas de política ambiental que actualmente se utilizan para mejorar los resultados de la actuación ambiental, no sólo en la industria, sino en la totalidad de los sectores económicos y en todas las sociedades. En estos artículos se examinan la evaluación de impacto ambiental, el análisis de los ciclos vitales, la evaluación y comunicación de riesgos y la auditoría ambiental. En la última sección del presente capítulo se ofrecen dos dimensiones de la prevención y el control de la contaminación: una de ellas tiende a convertir la prevención de la contaminación en una de las prioridades de la empresa; la otra consiste en la perspectiva sindical de la prevención de la contaminación y en el desarrollo de técnicas productivas limpias.

El objetivo general del presente capítulo es brindar al lector una perspectiva y una percepción más amplias de la creciente relación entre la salud y seguridad en el trabajo y el medio ambiente de trabajo, de una parte, y los problemas ambientales que trascienden el lugar de trabajo, de otra. Es previsible que una mayor conciencia de esta vinculación produzca un intercambio de experiencia e información más amplio y efectivo entre los profesionales en la salud y seguridad en el trabajo y los expertos en el medio ambiente, con objeto de acrecentar nuestra capacidad de responder a los retos que se plantean en el lugar de trabajo y más allá.

\section{EL MEDIO AMBIENTE YEL MUNDO DEL TRABAJO: UN CONCEPTO INTEGRAL DEL DESARROLLO SO STENIBLE, EL MEDIO AMBIENTE Y EL MEDIO AMBIENTE DE TRABAJO}

Larry R. Kohler

Los profesionales de la salud y seguridad en el trabajo saben mejor que nadie que, si investigamos el origen de la mayor parte de los principales problemas que afectan a nuestro medio ambiente, llegamos al lugar de trabajo. De modo similar, las graves consecuencias de algunos productos y sustancias químicas para la salud y seguridad actúan como un sistema de alerta precoz de las posibles consecuencias para la salud ambiental más allá del lugar de trabajo.

A pesar de la evidente asociación entre el medio ambiente de trabajo y el medio ambiente general, muchos gobiernos, empresas y trabajadores continúan reaccionando a las causas y consecuencias de los problemas del medio ambiente laboral y general de forma acusadamente aislada y desigual. (Dada la 
importancia de distinguir entre el medio ambiente de trabajo y la dimensión ambientalmente más amplia que se expresa mediante adjetivos como físico, general 0 externo, en el presente artículo se empleará la expresión medio ambiente de trabajo para identificar globalmente a los problemas ambientales y de salud y seguridad que se suscitan en el lugar de trabajo, y la denominación medio ambiente para designar los problemas ambientales que se producen más allá del lugar de trabajo). El objetivo del artículo es llamar la atención del lector hacia las importantes ventajas que pueden derivarse de reaccionar ante los problemas ambientales - dentro y fuera del lugar de trabajo- con criterios más integrales y estratégicos. Esto no sólo vale para los países industrializados - que han realizado progresos considerables en relación, tanto con la salud y seguridad en el trabajo, como con el medio ambiente-, sino también para los países en desarrollo y las economías en transición, que tienen todavía por delante un problema mucho más vasto y agobiante.

Como el presente artículo se ha destinado específicamente a esta edición de la Enciclopedia de la salud y seguridad en el trabajo, no se ha concebido como un estudio exhaustivo de los problemas de salud y seguridad industrial asociados al medio ambiente, muchos de los cuales se tratan en otros capítulos de la Enciclopedia. De hecho, la salud y seguridad en el trabajo forma parte integrante de la actividad "ambiental" de toda empresa. Esto no implica que la protección del medio ambiente y la salud y seguridad en el trabajo sean perfectamente compatibles y mutuamente condicionantes en todos los casos; a veces, incluso, pueden resultar antagónicas. No obstante, el objetivo debe ser siempre encontrar los medios de proteger simultáneamente la salud y seguridad de los trabajadores y el medio ambiente general y evitar soluciones que impliquen la necesidad de optar por una u otro. La determinación de los problemas ambientales y las medidas de respuesta ha llevado con demasiada frecuencia a la formulación de falsas dicotomías: protección del medio ambiente 0 seguridad de los trabajadores, o seguridad ambiental contra seguridad en el puesto de trabajo. Si bien es cierto que tales contradicciones se pueden suscitar en casos muy específicos y atípicos, en la mayoría de los casos se hace imprescindible encontrar un equilibrio y diseñar una serie de estrategias a largo plazo para satisfacer ambos objetivos. Se infiere de esto que la colaboración entre la empresa y los trabajadores es una condición imprescindible para mejorar los resultados de la política ambiental y de salud y seguridad en el trabajo.

Esta percepción del medio ambiente y del mundo del trabajo se expone especialmente de relieve si se considera que la actuación en materia de salud y seguridad en el trabajo debe orientarse más a la prevención que a una simple política de control y corrección. La prevención es un concepto fundamental para la futura mejora de la salud y seguridad en el trabajo y el medio ambiente. En los inicios del siglo XX, la política de salud y seguridad en el trabajo de los países industrializados solía inspirarse en una preocupación simplista por el control, esto es, por la protección de los trabajadores contra los riesgos para la salud y la seguridad. Se hacía hincapié en diseñar soluciones que limitasen los accidentes introduciendo en la maquinaria mejoras como, por ejemplo, la colocación de dispositivos de protección. A medida que aumentaban nuestros conocimientos de los efectos para la salud de la exposición de los trabajadores a determinados productos y sustancias químicas, la reacción "lógica" solía consistir, primero, en proteger al trabajador contra la exposición a esos agentes mejorando los sistemas de ventilación o colocando dispositivos de protección. Si bien se produjeron desde un principio importantes excepciones, particularmente en los países industrializados, sólo en los últimos decenios se ha observado un incremento notable del interés de diversos sectores industriales clave por eliminar o reemplazar los productos y sustancias químicas tóxicas o peligrosas por otros que sean sensiblemente menos perjudiciales. Es de destacar que este hincapié en la prevención de las emisiones o en el empleo de determinados productos químicos ha crecido de forma paralela a la conciencia y la participación del público en la solución de los problemas ambientales. En el marco de esta nueva conciencia ambiental se han puesto de relieve las consecuencias, tanto inmediatas como mediatas, de la degradación del medio ambiente para nuestras economías y nuestras sociedades. Esta mayor sensibilización del público respecto al medio ambiente parece haber contribuido también a vigorizar el actual interés de los trabajadores por colaborar con las empresas en la mejora de la salud y seguridad en el trabajo. N o obstante, es absolutamente evidente - sobre todo en los países en desarrollo y en las economías en transición- que el trabajo más riguroso realizado hasta la fecha en relación con el medio ambiente y la salud y seguridad en el trabajo constituyen únicamente la punta del iceberg de los problemas ambientales y de higiene y seguridad industrial existentes en el planeta.

Las prioridades de la política ambiental aplicada en los países industrializados han seguido una evolución muy semejante, desde las medidas de control hasta las estrategias de prevención, si bien esta transición se ha realizado en un período mucho más breve que en el caso de la salud y seguridad en el trabajo. En un principio, la conciencia ambiental se limitaba a la preocupación por la "contaminación" La atención se centraba principalmente en las emisiones a la atmósfera, al suelo y al agua generadas por los procesos productivos. Por consiguiente, las medidas de respuesta solían basarse en unas estrategias centradas en "el último eslabón de la cadena", en las que se abordaba el problema de las emisiones locales. Por citar sólo un ejemplo, esta estrecha visión del problema inspiró soluciones como la construcción de chimeneas más altas que, en lugar de eliminar la contaminación, la diseminaban a mucha mayor distancia de la planta emisora y de la comunidad local. Aunque estas soluciones resultasen satisfactorias para la comunidad local y los trabajadores que vivían y trabajaban en ella, se provocaban nuevos problemas ambientales, como el de la contaminación a larga distancia e, incluso, internacional, que en algunos casos provoca la denominada "lluvia ácida". C uando los efectos secundarios de las estrategias centradas en el "ultimo eslabón de la cadena" se hicieron patentes, pasó bastante tiempo antes de que algunos responsables aceptasen que la solución de elevar la altura de las chimeneas tenía otras consecuencias gravemente negativas. El siguiente paso de este proceso de innovación consistió en instalar un complejo sistema de filtrado que bloquease las emisiones nocivas antes de que abandonasen la chimenea. Como se evidencia en este ejemplo, el interés de los responsables de la formulación de políticas se centraba más en la adopción de medidas de control de las emisiones que en la prevención de éstas. $\mathrm{H}$ oy, en cambio, se asiste a un esfuerzo creciente por prevenir las emisiones a través del empleo de nuevos combustibles y de la mejora de las tecnologías de combustión, así como de la modificación de los propios procesos productivos mediante la implantación de las denominadas tecnologías productivas "limpias".

Esta filosofía de prevención - que precisa, asimismo, un enfoque más global- tiene, al menos, cuatro ventajas sustanciales para el mundo del trabajo y el medio ambiente.

- A diferencia de las tecnologías que actúan en el "ultimo eslabón de la cadena", que incrementan los costes de producción sin aportar por regla general incrementos de la productividad ni rendimientos económicos, las tecnologías productivas limpias suelen generar mayor productividad y beneficios económicos tangibles. Dicho de otro modo, las tecnologías que 
actúan sobre "el último eslabón de la cadena" suelen ser beneficiosas para el medio ambiente, pero no para la cuenta de resultados. En cambio, las tecnologías productivas "limpias" no sólo previenen la degradación del medio, sino que también generan beneficios económicos efectivos.

- Las tecnologías productivas limpias no sólo suelen redundar en un uso más eficiente de los recursos naturales y la energía (por ejemplo, consumiendo menos recursos naturales para obtener similares volúmenes de producción), sino también en una reducción de las cantidades y la toxicidad de los residuos generados.

- Las políticas de implantación de las tecnologías productivas limpias pueden y deben comprender la adopción de medidas diseñadas para mejorar la situación de la salud y seguridad dentro de la empresa.

- La participación de los trabajadores en la protección de la salud, la seguridad y el medio ambiente en el marco de los procesos tecnológicos limpios vigorizará la moral y el nivel de comprensión y de rendimiento laboral de los trabajadores, cuya importancia para el logro de una producción de calidad es bien conocida.

Los reglamentos, leyes y políticas de gestión del medio ambiente han evolucionado y, bien coadyuvan al proceso de transición desde los métodos de control hacia las estrategias basadas en la prevención, bien se procura que evolucionen al ritmo de esta transición.

No obstante, tanto los métodos que actúan en el "último eslabón de la cadena" como las tecnologías productivas limpias repercuten directamente en la protección y creación de empleo. Es evidente que, en muchas regiones del mundo, especialmente en los países industrializados y las economías en transición, las operaciones de limpieza y subsanación abren importantes posibilidades de creación de puestos de trabajo. Al mismo tiempo, las tecnologías productivas limpias constituyen una nueva y prometedora industria que permitirá la creación de puestos de trabajo y que, por supuesto, precisará recursos adicionales para satisfacer las necesidades de formación y cualificación. Esto se pone especialmente de manifiesto en la urgente necesidad de que los trabajadores activos en la solución de los problemas planteados por la regeneración del medio ambiente reciben una formación efectiva en la salud y seguridad en el trabajo y el medio ambiente. A pesar de la considerable preocupación producida por los posibles efectos negativos sobre el empleo del creciente control y reglamentación en materia ambiental, si los controles y reglamentos se diseñan correctamente pueden contribuir a la creación de puestos de trabajo, mejorar la calidad del medio ambiente y fomentar los resultados de la política de salud y seguridad en el trabajo.

Desde el decenio de 1960 se ha venido produciendo otro cambio sustantivo en la concepción del medio ambiente, consistente en la evolución desde un interés exclusivo por los procesos productivos hacia una mayor atención a los efectos ambientales de los propios productos. El ejemplo más descollante de esta evolución es el automóvil, que ha inspirado ingentes esfuerzos por mejorar su "eficiencia" ambiental, aunque sigue abierta la debatida cuestión de si se debe complementar su mayor eficiencia ambiental con un sistema de transporte público igualmente eficiente. Es evidente, sin embargo, que todos los productos repercuten en el medio ambiente, si no en su producción y utilización, casi seguramente en su eliminación. Este cambio ha inspirado la promulgación de un cuerpo creciente de leyes y reglamentos reguladores del uso y eliminación de los productos y, en algunos casos, se ha llegado a la restricción o prohibición del uso de determinados productos. El proceso ha impulsado asimismo la aparición de nuevas técnicas de análisis, como la evaluación de impacto ambiental, el análisis de los ciclos vitales, la evaluación de riesgos y la auditoría ambiental (véanse los artículos dedicados a estas cuestiones más adelante, en este mismo capítulo). Esta nueva y más amplia perspectiva del medio ambiente no deja de tener implicaciones para el mundo del trabajo, en lo que atañe, por ejemplo, a las condiciones de trabajo de las personas empleadas en la eliminación de los productos y a las perspectivas de empleo de los trabajadores empleados en la producción, venta y prestación de servicios a los productos de uso prohibido o restringido.

0 tro elemento impulsor de la política ambiental ha sido el número y la trascendencia relativamente importantes de los accidentes de trabajo graves, especialmente desde la tragedia de Bophal, ocurrida en 1984. Bohpal y otros graves siniestros, como el de Chernóbil y el Exxon Valdez, mostraron al mundo - políticos, público, empresas y trabajadores- la falsedad de la idea tradicional de que lo que acontecía dentro de los límites de una planta no afecta al medio exterior, al público en general ni a las condiciones de vida de las comunidades vecinas. Aunque antes se habían producido graves catástrofes, la cobertura mundial que estos siniestros recibió en los medios audiovisuales conmocionó a vastos sectores del público, tanto de los países industrializados como de las naciones en desarrollo y de las economías en transición, y despertó una nueva conciencia y un sentimiento de apoyo a una política de protección ambiental que, al mismo tiempo, proteja a los trabajadores y al público. Es de destacar en este sentido el paralelismo entre este proceso y la historia de las movilizaciones en favor de la modernización de la legislación protectora de la salud y seguridad en el trabajo, que también estuvieron influidas en gran medida por graves incendios en fábricas y accidentes en la minería.

U no de los ejemplos más evidentes de la influencia de estos factores ambientales, en especial de la repercusión de las graves catástrofes ambientales ocurridas en épocas recientes, se pueden apreciar en la propia OIT, como se refleja en los acuerdos últimamente adoptados por sus organismos tripartitos. Por ejemplo, la OIT ha impulsado recientemente su actividad en el campo del medio ambiente y el mundo del trabajo. Destaca sobre todo la adopción, a partir de 1990, de tres grandes series de convenios y recomendaciones de la OIT enfocados en el medio ambiente de trabajo:

- Convenio y Recomendación sobre la seguridad en el uso de sustancias químicas en el trabajo, 1990 (170 y 177)

- Convenio y Recomendación sobre la prevención de graves accidentes de trabajo, 1992 (174 y 181)

- Convenio y Recomendación sobre salud y seguridad en las minas, 1995 (176 y 183).

Estas normas reflejan la tácita expansión del ámbito de los instrumentos de la OIT desde el tradicional enfoque exclusivo en la protección del trabajador hacia una concepción más global de estas cuestiones, caracterizada por las referencias efectuadas, tanto en los expositivos como en las disposiciones sustantivas, a los aspectos pertinentes de la protección del público y del medio ambiente. En el artículo 3 del Convenio no 174 se define el "accidente mayor" como "todo acontecimiento repentino (...) que exponga a los trabajadores, a la población o al medio ambiente a un peligro grave, inmediato o diferido"; y en el artículo 4 se dispone que "Todo M iembro deberá formular, adoptar y revisar periódicamente (...) una política nacional coherente relativa a la protección de los trabajadores, el público y el medio ambiente, contra el riesgo de accidentes graves". El amplio espectro de convenios y recomendaciones de la OIT dedicados al medio ambiente de trabajo constituye una valiosa fuente de inspiración para los países que se esfuerzan por mejorar los resultados de su política ambiental y de salud y seguridad en el trabajo. A este 
respecto, es de destacar que la OIT brinda apoyo y asesoramiento a los tres estamentos que la integran, con objeto de coadyuvar a la ratificación y aplicación por los mismos de las normas pertinentes de la OIT.

No obstante, al margen de las citados factores impulsores, existe una amplio espectro de otros factores que influyen de modo significativo en la relación entre el medio ambiente de trabajo y el general. Está claro que uno de los factores más evidentes es que, a pesar de los muchos problemas y aspectos comunes (como sustancias químicas, salud y accidentes), las cuestiones ambientales y las de salud y seguridad en el trabajo suelen corresponder a la competencia de diferentes ministerios y organismos oficiales, distintas leyes, reglamentos y normas y diferentes órganos de inspección y ejecución. Estas diferencias producen considerable confusión, posiblemente mayores costes ocasionados por la duplicación de funciones y, lo que resulta más desconcertante, la posible existencia de lagunas reguladoras que causan graves omisiones en la protección del público, los trabajadores y el medio ambiente. Por ejemplo, en un reciente estudio de varios organismos de inspección nacionales se han puesto de manifiesto diversos problemas de duplicación, lagunas e incongruencias en las competencias asignadas a los organismos de inspección industrial, laboral y del medio ambiente. En este estudio se han descrito casos de atribución de nuevas competencias de inspección ambiental sin la asignación del personal ni de los recursos económicos adecuados, ni una formación especializada. Esto ha inducido al personal antiguo a hacer dejación progresiva de sus obligaciones de inspección de la salud y seguridad en el trabajo. Además, en muchos países, estas funciones legislativas y de inspección conservan un ámbito sumamente reducido y no reciben un apoyo político y financiero adecuado. $\mathrm{H}$ abrá que insistir en la necesidad del desarrollo de una concepción más global de los mecanismos de supervisión, ejecución y solución de disputas que impregne a los reglamentos y normas de salud y la seguridad en el trabajo y gestión del medio ambiente.

Aunque las inspecciones constituyen un elemento esencial de todo sistema de protección del medio ambiente y de la salud y seguridad en el trabajo, por sí sólo nunca son suficientes. La responsabilidad de la salud y seguridad en el lugar de trabajo y de la relación entre el medio ambiente y el mundo del trabajo ha de permanecer en el nivel de la empresa. El mejor modo de conseguir unos resultados óptimos consiste en aumentar la confianza y la colaboración entre la dirección y el personal, apoyada por una formación eficaz de los trabajadores y por unos mecanismos conjuntos eficaces que canalicen esa colaboración. Estos esfuerzos conjuntos en el ámbito de la empresa serán más eficaces si se apoyan en unas relaciones fluidas y positivas con una inspección independiente, adecuadamente financiada y bien cualificada.

Si se planifica y se ejecuta correctamente, el actual proceso de liberalización y ajustes estructurales, sobre todo en el sector público, puede dar lugar a una gestión más eficaz de los mecanismos de protección ambiental y de seguridad e higiene en el trabajo. Sin embargo, existen síntomas preocupantes de que el proceso puede también producir un deterioro de los resultados de la política ambiental y de salud y seguridad en el trabajo si gobiernos, empresarios, trabajadores y opinión pública no conceden la prioridad necesaria a estas cuestiones. Con demasiada frecuencia, la salud y seguridad en el trabajo y el medio ambiente se consideran cuestiones que pueden abordarse "más tarde", una vez resueltos los problemas económicos más inmediatos. Sin embargo, la experiencia demuestra que los ahorros a corto plazo pueden generar en el futuro costosas actividades de solución de problemas que habrían podido evitarse hoy con un coste menor. Lejos de considerarse gastos improductivos en el "último eslabón de la cadena", los gastos en salud y seguridad en el trabajo y en medio ambiente se deben enfocar como inversiones esenciales y productivas desde las perspectivas social, ambiental y económica.

La colaboración entre empresarios y trabajadores en la solución de los problemas de salud y seguridad en el lugar de trabajo tiene una larga tradición y ha demostrado sobradamente su valor. Es de destacar que, en un principio, estas cuestiones se consideraban de la exclusiva competencia de las empresas. A ctualmente, en cambio, como resultado de los ingentes esfuerzos de los agentes sociales, los problemas de salud y seguridad en el trabajo se valoran en la mayoría de los países del mundo como objeto de colaboración bipartita o tripartita. Incluso, en muchos casos se han promulgado medidas legislativas en las que se exige la creación de comités paritarios en este ámbito.

También en este campo se ponen de manifiesto procesos de desarrollo similares entre la salud y seguridad en el trabajo y la gestión del medio ambiente. Cuando los trabajadores y sus organizaciones sindicales empezaron a plantear los problemas de salud y seguridad en el trabajo como cuestiones que les afectaban directamente, solían ser objeto de descalificación por su presunta falta de conocimientos y de formación técnica para comprender y abordar esas cuestiones. Se han necesitado decenios de intensos esfuerzos de los trabajadores y sus sindicatos para que se reconozca su contribución fundamental al conocimiento y la solución efectiva de estos problemas en el ámbito de la empresa. Los trabajadores tuvieron que insistir en que se trataba de su salud y seguridad y en que tenían derecho a participar en el proceso de toma de decisiones, además de contribuir con una importante aportación. De modo similar, muchas empresas y organizaciones empresariales han terminado por comprender los beneficios que pueden derivarse de esta colaboración. En la actualidad, muchos trabajadores y organizaciones sindicales deben hacer frente a descalificaciones similares de parte de empresas que niegan su capacidad para contribuir a la protección del medio ambiente. Con todo, es preciso reconocer que, también en este campo, un grupo de empresas responsables y previsoras, pertenecientes a un número limitado de sectores de vanguardia, han sido las primeras en reconocer las capacidades, la experiencia y el enfoque pragmático que los trabajadores pueden aportar al esfuerzo por mejorar el medio ambiente, y en tratar de crear una plantilla cualificada, plenamente motivada, bien informada y comprometida.

En todo caso, algunas empresas insisten en que el medio ambiente constituye una responsabilidad exclusiva de la dirección y se oponen a la creación tanto de comités paritarios de salud, seguridad y medio ambiente, como de unos comités conjuntos para el medio ambiente. Por el contrario, en otras empresas se ha reconocido la importancia práctica que la actuación conjunta de empresarios y trabajadores puede tener para la fijación y satisfacción de unos objetivos adecuados de actuación ambiental. Lejos de limitarse a la observancia de los mandatos legales, en estos objetivos se incluye también la actuación voluntaria para satisfacer las necesidades de las comunidades locales, la competitividad mundial, el marketing ecológico, etc. En los programas y planes voluntarios de actuación ambiental, desarrollados, dentro de cada empresa o a través de asociaciones sectoriales (como el programa de Atención Responsable de las industrias químicas) se suelen integran expresamente los aspectos ambientales con los de salud y seguridad en el trabajo. A nálogamente, las normas específicas y a menudo voluntarias elaboradas por entidades como la O rganización Internacional de N ormalización (ISO ) también han influido cada vez más en la protección del medio ambiente y de la salud y seguridad en el trabajo.

Los resultados positivos de la colaboración entre las organizaciones sindicales y empresariales ha inspirado asimismo diversas 
asociaciones y alianzas que rebasan los límites del lugar de trabajo en el interés de lograr que todos los interesados en la salud y seguridad y en el medio ambiente participen constructivamente en el proceso. En la OIT, este nuevo effuerzo por extender las relaciones de colaboración más allá de los límites del lugar de trabajo, hacia los grupos activos en las comunidades locales, las O N G interesadas en el medio ambiente y otras instituciones dedicadas a trabajar por la mejora del lugar de trabajo, se ha denominado "colaboración plustripartita".

Se perfilan en el horizonte nuevos problemas que pueden plantear retos y oportunidades específicos para el establecimiento de unos vínculos más efectivos entre la salud y seguridad en el trabajo y el medio ambiente. La pequeña y mediana empresa y el sector urbano informal se han mostrado especialmente impermeables a las políticas ambientales y de salud y seguridad en el trabajo. Esto reviste especial significación en relación con las extraordinarias implicaciones de uno de los mayores desafíos que el siglo XXI supondrá para el medio ambiente y el desarrollo: la calidad del agua. A hora bien, será preciso desarrollar planes de actuación conjunta que permitan comunicar de forma más eficaz los graves riesgos que algunas de las actividades actuales entrañan para los trabajadores y el medio ambiente. N o obstante, más allá de estos riesgos, se abren nuevas posibilidades de incrementar la productividad y aumentar los ingresos generados por las actividades tradicionales, así como perspectivas de creación de nuevas actividades lucrativas directamente asociadas al medio ambiente. Dados los numerosos vínculos, tanto directos como indirectos, existentes entre el sector estructurado y de la pequeña y mediana empresa y el sector urbano no estructurado, será preciso diseñar políticas innovadoras que canalicen el intercambio de experiencia de forma que contribuya a mejorar la política ambiental y de salud y seguridad en el trabajo. Las organizaciones sindicales y empresariales pueden brindar aportaciones prácticas y positivas a este proceso.

0 tra fuente emergente de complicaciones es la contaminación atmosférica en interiores. En otro tiempo solía considerarse que las grandes plantas industriales constituían el objetivo prioritario del esfuerzo de superación de las condiciones de trabajo insalubres. $\mathrm{H}$ oy en día, por el contrario, se observa un reconocimiento creciente de que en muchos locales comerciales y oficinas se pueden suscitar problemas de salud debidos a la contaminación en interiores. Esta contaminación se asocia al uso creciente de equipo electrónico y sustancias químicas, a la entrada del aire ambiental contaminado, al uso de sistemas cerrados de aire acondicionado y de recirculación del aire y, posiblemente, a una mayor conciencia de los trabajadores producida por la evolución de la realidad sanitaria, caracterizada, por ejemplo, por una mayor frecuencia del asma y las alergias. Es previsible que el esfuerzo por resolver los problemas de la contaminación atmosférica en interiores se base en una mayor integración de los aspectos ambientales y de salud y seguridad en el trabajo que la existente en el pasado.

\section{Vínculos con el desarrollo sostenible}

$\mathrm{H}$ asta ahora, se han destacado en este artículo breve y superficialmente algunas de las relaciones pasadas y, en su caso, futuras entre el medio ambiente y la salud y seguridad en el trabajo. No obstante, esta perspectiva puede catalogarse como excesivamente limitada en contraste con el enfoque más global e integral representado por el concepto de desarrollo sostenible. Este es el concepto clave - aunque no una "fórmula mágica" - subyacente en el proceso preparatorio de negociación y adopción de la denominada Agenda XXI, el plan de actuación para el siglo XXI aprobado en la Conferencia de las Naciones U nidas sobre el medio ambiente y el desarrollo (CNUMAD), celebrada en Río de Janeiro en junio de 1992 (véase Robinson 1993). El concepto de desarrollo sostenible ha sido y continuará siendo materia de arduos debates y conflictos, que en parte se han centrado en el aspecto semántico. En el presente artículo, el término desarrollo sostenible se entiende, a la vez, como un objetivo y como un proceso. Como objetivo, el desarrollo sostenible es el que satisface las necesidades de las generaciones presentes y futuras. Como proceso, implica la adopción de políticas en las que se tomen en consideración no sólo los factores económicos, sino también los aspectos sociales y ambientales.

Para que este concepto global funcione correctamente, los factores y aspectos citados se deben abordar sobre la base de análisis y respuestas nuevos. Es preciso que las cuestiones de salud y seguridad en el trabajo se conviertan en un elemento fundamental de la evaluación de las futuras decisiones sobre inversión y desarrollo, desde el lugar de trabajo hasta la negociación de los acuerdos internacionales. Lejos de considerarse un simple coste de explotación adicional, la protección de los trabajadores debe valorarse como un elemento imprescindible para el logro de unos objetivos económicos, sociales y ambientales que se integran en el desarrollo sostenible. Esto implica la necesidad de valorar y estimar la protección del trabajador como una inversión con una tasa de rendimiento potencialmente positiva en el marco de unos proyectos orientados a la satisfacción de unos objetivos económicos, sociales y ambientales. Tampoco la protección de los trabajadores se debe limitar a la protección de las personas en el lugar de trabajo, sino extenderse a las relaciones del trabajo con la salud en general, las condiciones de vida (agua, saneamiento, vivienda, etc.), el transporte, la cultura, etcétera. También implica que el esfuerzo por mejorar la salud y seguridad en el trabajo, lejos de ser un lujo reservado a los países ricos, constituye una condición previa del logro de los objetivos básicos de desarrollo económico y social de las naciones en desarrollo.

Como manifestó $\mathrm{M}$ ichel $\mathrm{H}$ ansenne, Director $\mathrm{G}$ eneral de la OIT, en su memoria para la Conferencia Internacional del Trabajo de 1990:

Ante todo, debe subrayarse la existencia de un problema fundamental que condiciona prácticamente todas las discusiones sobre la política ambiental: el de cómo compartir equitativamente los costos y beneficios de la política ambiental. "¿Quién ha de costear la mejora del medio ambiente?" Es un asunto que ha de discutirse y resolverse a todos los niveles, desde los puntos de vista del consumidor, los trabajadores y los empleadores, y desde la perspectiva de las instituciones locales, nacionales, regionales e internacionales.

Para la OIT, las repercusiones sociales y humanas de cómo se compartirán los costos y beneficios de la política ambiental en cada país y entre los diferentes países pueden ser tan importantes como la misma política ambiental. U na injusta distribución de los costos y beneficios socioeconómicos y ambientales del desarrollo, dentro de cada país y entre los diferentes países, no puede llevar a un desarrollo duradero general. Por el contrario, acentuaría la pobreza, la injusticia y la división.

En el pasado y, aún con demasiada frecuencia en nuestros días, los trabajadores se han visto obligados a soportar una parte desproporcionada de los costes sociales del desarrollo económico en forma de condiciones deplorables de salud y seguridad (como el trágico incendio de $\mathrm{K}$ ader Industrial Toy Company en Tailandia, que se cobró la vida de 188 trabajadores), unos salarios inadecuados (que suponen unos ingresos insuficientes para satiffacer las necesidades familiares básicas de alimentación, vivienda y educación), la denegación de la libertad de asociación e, incluso, la pérdida de la dignidad humana (tipificada en el recurso del trabajo forzado infantil). Del mismo modo, los trabajadores y sus comunidades locales han tenido que soportar 
buena parte de los costes, tanto de la degradación progresiva del medio ambiente, como del cierre de fábricas por consideraciones ambientales. Tampoco hay que perder de vista que, mientras que la atención de los países industrializados ha estado centrada en evitar que la promulgación de leyes y reglamentos de protección ambiental provoque la destrucción de puestos de trabajo, millones de personas han perdido o han experimentado un grave quebranto de su medio de vida como consecuencia de la rampante desertización y deforestación, las inundaciones y la erosión del suelo.

El desarrollo sostenible supone que estos costes ambientales y sociales, que en el pasado han sido "externalizados" por la industria y la sociedad en general, se "internalicen" en lo sucesivo y se reflejen en los costes de mercado de los bienes y servicios. Este proceso de internalización está siendo impulsado por los agentes del mercado y los grupos de consumidores, por la nueva regulación legal -incluidos los denominados instrumentos económicos- y por las propias empresas. Sin embargo, las posibilidades de éxito de este proceso de integración de los costes sociales y ambientales reales de la producción y el consumo estarán en función de la aplicación de nuevos esquemas de colaboración, comunicación y participación en el proceso de toma de decisiones. Las organizaciones sindicales y empresariales tienen una función vital que desempeñar en este proceso, concretamente, en las fases de diseño, aplicación y supervisión.

En este contexto, puede ser de utilidad Ilamar la atención del lector hacia las ingentes gestiones diplomáticas que se realizan en el marco del seguimiento de la CNUMAD con objeto de hacer posible el examen de los actuales desequilibrios en los esquemas mundiales de producción y consumo. En el capítulo 4 de la Agenda XXI, titulada "Esquemas de consumo cambiantes" se propugna la adopción de medidas tendentes al logro de los objetivos siguientes:

(a) Promover unos esquemas de producción y consumo que tiendan a reducir la presión sobre el medio ambiente y satisfaga las necesidades básicas de la humanidad.

(b) M ejorar el conocimiento de la función del consumo y del modo de crear unos hábitos de consumo sostenibles.

En el capítulo se reconoce asimismo abiertamente la necesidad de incrementar sustancialmente el consumo de productos básicos de millones de personas que viven en muchas regiones del mundo actualmente sumidas en la pobreza y estrechez más absolutas. Es previsible que los contactos y negociaciones que actualmente tienen lugar en el marco de la Comisión para el Desarrollo Sostenible sean lentos y laboriosos; sin embargo, podrían producir algunos cambios significativos en los actuales esquemas de producción y consumo, sobre todo en algunos de los sectores más críticos de la economía, como la química, la energía y el transporte. Estos contactos y negociaciones también repercutirán significativamente en los intercambios internacionales. Sin duda, todos estos cambios influirán de forma sustancial en la política ambiental y de salud y seguridad en el trabajo aplicada en los países industrializados y en las naciones en desarrollo, así como en otras áreas del mundo del trabajo, sobre todo en materia de empleo, ingresos y formación.

Aunque todas estas cuestiones se examinan actualmente en el ámbito mundial, es evidente que habrán de aplicarse en cada lugar de trabajo. Es, por lo tanto, imprescindible que este proceso de negociación a escala mundial sea un reflejo de la realidad, esto es, de las posibilidades y limitaciones existentes en el ámbito del lugar de trabajo en todo el mundo. En vista de la globalización de la economía y de la rápida transformación que experimentan la organización y las estructuras de nuestros lugares de trabajo (por ejemplo, la subcontratación, el trabajo a tiempo parcial y a domicilio y el teletrabajo), y de los cambios que previsiblemente traerá el siglo XXI a nuestra percepción del trabajo, nuestro estilo de vida y el empleo mismo, la tarea no será fácil. Sin embargo, las perspectivas de éxito de este proceso dependerán del apoyo, en todas sus etapas, de un esquema de colaboración tripartita entre los gobiernos y las organizaciones sindicales y empresariales.

\section{Conclusiones}

Los artículos de este capítulo se centran en la actuación a escala nacional e internacional, así como en las medidas concretas destinadas a mejorar los resultados de la política ambiental. Es evidente, sin embargo, que las principales políticas ambientales del futuro no se implantarán a escala nacional ni internacional, ni aun local, si bien cada una de estas dimensiones está llamada a desempeñar una función esencial. Los cambios reales se producirán a escala de la empresa y del lugar de trabajo. Los directivos de las grandes sociedades multinacionales, los gerentes de las pequeñas empresas familiares, los agricultores y los trabajadores por cuenta propia del sector no estructurado serán la verdadera fuerza motriz y los mentores del desarrollo sostenible. El cambio sólo será posible gracias a la sensibilización creciente y a la actuación coordinada de empresarios y trabajadores en el seno de la empresa y de otros agentes sociales (comunidades locales, organizaciones no gubernamentales, etc.) para integrar los objetivos ambientales y de salud y seguridad en el trabajo en los objetivos y prioridades de la empresa. A pesar de la magnitud del desafío, es previsible que todo el espectro de políticas formales e informales de salud y seguridad en el trabajo y protección ambiental a escala de la empresa se desarrolle, aplique y supervise en el marco de un proceso de colaboración entre la dirección, los trabajadores y otros agentes sociales

La salud y seguridad en el trabajo tiene una clara influencia en el logro de nuestros objetivos económicos, globales y ambientales globales; por consiguiente, esta actividad debe constituir un elemento esencial del proceso complejo de integración necesario para lograr el desarrollo sostenible. Como consecuencia de la conferencia de la CNU M AD, se ha instado a todos los gobiernos nacionales a que elaboren sus propios planes y programas nacionales inspirados en la Agenda XXI para un desarrollo sostenible. Los objetivos ambientales ya se han integrado en ese proceso. Sin embargo, queda mucho por hacer antes de que los objetivos sociales, de empleo y de salud y seguridad en el trabajo se integren expresamente en el proceso como parte inseparable del mismo, y de que se alcance el apoyo económico y político necesario para el logro de dichos objetivos.

La elaboración de este artículo ha sido posible gracias a la asistencia técnica, los útiles consejos y comentarios y el aliento constante ofrecidos por compañeros, gobiernos, empresas y trabajadores de todo el mundo, interesados en este campo y de reconocida competencia en el mismo, especialmente, por representantes cualificados de la Federación Internacional de Trabajadores de la Q uímica, Energía e Industrias Diversas (ICEF); Canadian Labour Congress; Communications, Energy and Paper Worker's U nions of Canada; $y$ L abourers' International U nion of N orth A merica, que han hecho hincapié en la urgente necesidad de actuar en este campo.

\section{LEYES Y REGLAMENTOS}

\section{Françoise Burhenne-G uilmin}

La relación entre la salud humana y el entorno del hombre se ha reconocido desde tiempo inmemorial. Este apotegma médico se remonta a $\mathrm{H}$ ipócrates, que enseñaba a sus discípulos a "prestar atención a los aires, las aguas y los lugares" para comprender las fuentes de la salud y la enfermedad de sus pacientes (L loyd 1983). 
Esta vieja concepción de la relación entre la salud humana y el medio ambiente ha perdurado. Tres factores han influido en el nivel de aceptación social de esa relación: el enriquecimiento de los conocimientos científicos del cuerpo humano, la mayor capacidad de curación de las distintas enfermedades, y la evolución paralela de los conceptos científicos, religiosos y culturales.

La Revolución Industrial suscitó un mayor interés por los factores ambientales como causa de la salud y enfermedad de sectores completos de la población. Esta tendencia se ha mantenido hasta nuestros días, fomentada por el desarrollo de las ciencias del medio ambiente y de las técnicas de determinación de las relaciones de causalidad y de evaluación de los riesgos.

La asociación de la salud con el medio ambiente se estableció claramente por vez primera en el lugar de trabajo, donde también se experimentaron por primera vez los efectos del incremento de la cantidad y variedad de agentes contaminantes como consecuencia de la diversificación de los procesos industriales. Sin embargo, estos agentes contaminantes no se encuentran confinados al medio ambiente de trabajo. En efecto, una vez emitidos, resulta difícil seguir la pista de la dispersión de estos agentes, aunque a final terminan depositándose en el medio natural. C iertamente, los agentes tóxicos ambientales se encuentran presentes en el suelo, el agua y el aire de los entornos naturales más remotos. A su vez, la salud humana se ve afectada por la contaminación del medio ambiente natural, con independencia de su origen local, nacional o internacional. Junto con otras clases de degradación del medio ambiente, que provocan un agotamiento de los recursos naturales a escala mundial, este fenómeno confiere una dimensión planetaria a la correlación entre las condiciones ambientales y la salud pública.

Se sigue la conclusión ineludible de que la calidad del medio ambiente de trabajo y la del medio natural se encuentran inextricablemente asociadas. Ninguno de estos problemas se puede resolver definitivamente a menos que ambos se aborden de modo simultáneo.

\section{Legislación ambiental: un medio para un fin}

La formulación de políticas diseñadas para conservar y mejorar el medio ambiente de trabajo y el entorno general constituye una condición previa del éxito de la gestión del medio ambiente. Sin embargo, un documento de política es un papel mojado a menos que se aplique, y su aplicación sólo es posible mediante la traducción de los principios políticos en normas legales. Desde esta perspectiva, el derecho está al servicio de la política, a la que aporta concreción y una cierta permanencia a través de una normativa adecuada.

Por su parte, la legislación es un simple marco que sólo resulta útil se si cumple y ejecuta. A su vez, el cumplimiento y ejecución de la ley son una función del contexto sociopolítico en que se producen. Sin el apoyo del público, las leyes se convierten por regla general en letra muerta.

Por consiguiente, la promulgación, observancia y ejecución de la legislación ambiental es, en gran medida, una función del grado de conocimiento y aceptación de las normas por aquéllos a quienes van destinadas, de lo que se infiere la importancia de difundir los conocimientos y la información ambiental, tanto entre los estamentos a los que van dirigidos, como entre el público en general.

\section{Función de la legislación ambiental: prevención y subsanación}

La función de la ley en el campo ambiental, como en muchos otros ámbitos, es doble. En primer lugar, consiste en dictar unas normas y crear unas condiciones favorables al control o la prevención de los daños al medio ambiente o la salud humana; y en segundo lugar, en posibilitar la reparación de los daños que se produzcan a pesar de la existencia de tales reglas y condiciones.

\section{Prevención por vía de regulación}

\section{Control del uso del suelo}

La regulación del uso del suelo constituye un elemento central de la legislación ambiental y una condición previa del control y orientación de la explotación del suelo y la utilización de los recursos naturales. El problema suele consistir en determinar si un determinado medio se puede destinar a otro uso, bien entendido de que la ausencia de utilización constituye una forma de usar el suelo.

El control del uso del suelo permite una ubicación óptima (o menos nociva) de las actividades humanas, además de imponer restricciones a las actividades previstas. Estos dos objetivos se suelen alcanzar mediante el requisito de la autorización previa.

\section{Autorización previa}

Se denomina genéricamente sistema de autorización previa el que impone ciertos permisos y licencias que preceptivamente deben solicitarse de las autoridades administrativas antes de iniciar determinadas actividades.

El primer paso consiste en definir legalmente las actividades de los sectores público y privado que se encuentran sujetas a autorización previa. Existen varios sistemas posibles que no se excluyen entre sí:

Control de las fuentes: Si una fuente de daños para el medio ambiente es claramente identificable, se suele someter ella misma al sistema de autorización previa (por ejemplo, todo tipo de instalaciones industriales y de vehículos de motor, etc.).

Control de sustancias: Si una determinada sustancia o clase de sustancia se considera potencialmente dañina para el medio ambiente, se suele someter a autorización previa su uso o diseminación.

Controles centrados en los medios y control integral de la contaminación: Se denominan controles centrados en los medios los dirigidos a proteger un determinado componente del medio ambiente (aire, agua, suelo). La aplicación de estos controles puede inducir un desplazamiento del daño ambiental de uno a otro medio, con lo que el deterioro global del medio ambiente no se reduce e incluso puede incrementarse. Esta circunstancia ha motivado la creación de los sistemas coordinados de autorización previa, en los que se evalúa la contaminación total procedente de una misma fuente que sufren todos los medios receptores antes de concederse una única autorización global.

\section{Normas ambientales}

Las normas ambientales constituyen límites máximos permitidos por imperativo legal directo 0 de manera indirecta, en forma de condiciones previas para la obtención de una autorización. Estos límites pueden referirse a los efectos o las causas del deterioro del medio ambiente:

- Normas referidas a los efectos son las que tienen el objetivo como punto de referencia. Pueden ser biológicas, de exposición y de calidad ambiental.

- Normas referidas a las causas son las que tienen la fuente del deterioro ambiental como punto de referencia. Pueden versar sobre emisiones, sobre productos o sobre procesos.

El tipo de norma más adecuado es una función de factores como la naturaleza del agente contaminante 0 del medio destinatario y el estado de la tecnología. También se tienen en cuenta otras consideraciones. En efecto, la adopción de normas constituye un medio de lograr un punto de equilibrio entre lo que es 
ambientalmente deseable en un momento dado en un determinado lugar y la viabilidad socioeconómica del logro de un determinado objetivo ambiental.

O bviamente, cuanto más estrictas son las normas, más aumentan los costes de producción. Por lo tanto, la existencia de normas distintas en diversos puntos de un mismo Estado o en varios Estados contribuye considerablemente a crear ventajas y desventajas competitivas en los mercados y pueden constituir barreras no arancelarias al comercio, de lo que se infiere la conveniencia de la armonización normativa en los ámbitos regional o mundial.

\section{Prevención mediante incentivos y desincentivos}

Los controles voluntarios se suelen utilizar como medidas complementarias o alternativas a los sistemas reglamentados. Esta modalidad de prevención suele consistir en la recomendación (en contraste con la imposición) de determinados límites y en la aplicación de incentivos y desincentivos económicos al cumplimiento o incumplimiento de los mismos.

La finalidad de los incentivos (por ejemplo, deducciones fiscales por amortización acelerada, desgravaciones fiscales, subvenciones) consiste en remunerar y, por ende, incitar una determinada conducta 0 actividad ambientalmente positiva. De este modo, en lugar de emplear el palo para imponer un determinado límite al nivel de las emisiones, se utiliza la zanahoria del beneficio económico.

L a finalidad de los desincentivos (como el cobro de impuestos o tasas por los residuos y emisiones) consiste en inducir un comportamiento ambientalmente positivo para evitar el pago del cargo en cuestión.

Existen otros medios de fomentar la observancia de los límites recomendados, como los programas de concesión de etiquetas ecológicas y la aportación de ventajas competitivas en los casos en que el consumidor es sensible a los problemas del medio ambiente.

Estos métodos, denominados voluntarios, se suelen valorar como alternativas a los controles "legales". ¡Al hacerlo se olvida que los incentivos y desincentivos se tienen que establecer en las leyes!

\section{Subsanación mediante sanciones penales 0 acciones civiles}

\section{Sanciones impuestas por el organismo regulador}

En los casos en que el organismo regulador está facultado para adoptar medidas de ordenación ambiental (por ejemplo, mediante un sistema de autorización previa), en el ordenamiento legal también se suelen conferir a dicho organismo facultades ejecutivas. Existen diversos medios que van desde la imposición de sanciones monetarias (por ejemplo, multa por cada día de incumplimiento) hasta la adopción de las medidas exigidas (por ejemplo, la colocación de filtros) a expensas de la entidad requerida, al cierre de la instalación por incumplimiento de los mandatos administrativos, etc.

En todos los ordenamientos jurídicos se establecen vías de impugnación de estos mandatos por parte de los obligados a cumplirlos. I gualmente importante es prever la posibilidad de que otros interesados (como las O NG representativas del interés público) impugnen las decisiones del organismo regulador. En este último caso, no sólo las acciones, sino también las omisiones de la Administración resultan impugnables.

\section{Sanciones penales}

En las normas legales en que se prescribe un determinado comportamiento ambiental se suele tipificar como delito el incumplimiento, intencional o no, de la norma establecida, y se fija el tipo de sanción imponible en cada caso. Las sanciones penales pueden ser monetarias (multas) 0 , en los casos graves, consistir en penas de prisión. Dependen de la legislación penal vigente en cada país. Por consiguiente, suelen estar previstas en la normativa penal sustantiva (por ejemplo, el código penal), en la que en ocasiones se incluye algún capítulo dedicado a los delitos contra el medio ambiente. La acción penal puede ser ejercitada por la A dministración pública o por la parte perjudicada.

Se ha criticado que en el ordenamiento jurídico de muchos países no se tipifiquen como delitos determinadas conductas contra el medio ambiente o se establezcan sanciones excesivamente leves para las infracciones de las normas de protección ambiental. Se insiste en que, si la cuantía de la sanción es inferior al coste de internalizar las medidas de gestión ambiental, es probable que los infractores opten deliberadamente por arrostrar las sanciones penales, especialmente si consisten en una simple multa. Tanto más cuando existe un déficit de aplicación ejecutiva de las leyes, esto es, si la aplicación ejecutiva de las normas legales es laxa o insuficiente, como suele ocurrir.

\section{Responsabilidad por daños}

L as normas de todo ordenamiento jurídico aplicables a la responsabilidad por daños también se aplican, lógicamente, a los daños a la salud y el medio ambiente. Esto implica en general que sólo se exige la reparación en metálico o en especie si se puede establecer la relación causal entre el daño y la acción culpable del causante o causante.

En el campo ambiental existen muchas dificultades para aplicar estos principios, lo cual ha dado lugar a la promulgación de leyes sui generis de responsabilidad por daños ambientales en un número creciente de países. Esta circunstancia ha permitido el reconocimiento de la responsabilidad objetiva y de la obligación de indemnizar con independencia de las circunstancias en que se haya producido el daño. En tales casos, sin embargo, se suele fijar un determinado límite monetario con objeto de hacer posible la contratación de una cobertura de seguro, que a veces es legalmente obligatoria.

O tra finalidad de esta legislación especial es facilitar la reparación de los daños causados al medio ambiente como tal (esto es, daños ecológicos, en contraposición a los perjuicios económicos), exigiendo por regla general la restitución del entorno a su estado anterior, siempre que la naturaleza del daño lo permita. En estos supuestos, el resarcimiento sólo procede si la restitución es imposible.

\section{Legitimación activa}

No todos están procesalmente legitimados para instar la imposición de sanciones ni para la obtención de un resarcimiento. La iniciativa suele estar limitada a la administración pública y a las personas físicas o jurídicas directamente afectadas por una situación determinada. Si el perjudicado es el medio ambiente, esta solución suele ser insuficiente, puesto que normalmente no es posible establecer una relación causal directa entre el daño ambiental y los intereses personales. Por lo tanto, es esencial que en el ordenamiento jurídico se legitime a los "representantes" del interés del público para demandar a la administración pública en los casos de omisión o falta de celo en el desempeño de sus funciones, así como para demandar a las empresas y personas físicas que violen la ley u ocasionen daños ambientales. Esto se puede lograr de varios modos. U no de ellos consiste en legitimar procesalmente a determinadas organizaciones no gubernamentales; asimismo, se puede prever en la normativa legal el ejercicio de la acción popular, la acción colectiva, etc. Esta legitimación activa para litigar en defensa del interés público y no únicamente 
para tutelar intereses particulares es una de las innovaciones más notables de la moderna legislación ambiental.

\section{Conclusiones}

Una legislación ambiental adecuada constituye una condición previa para alcanzar y mantener los niveles de calidad deseados en el medio ambiente, tanto natural, como de trabajo.

No es fácil definir el concepto de legislación ambiental "adecuada". Algunos propugnan una reducción del uso de los instrumentos reguladores y su reemplazo por un sistema de incentivos menos riguroso. En la práctica, empero, no existe una fórmula exacta para decidir cuáles deben ser los componentes de la ley. Lo importante, en todo caso, es ajustar la legislación a la situación concreta de cada país, adaptando los principios, métodos y técnicas conocidos a la necesidad, la capacidad y la tradición jurídica de cada país.

Tanto más en un momento en que un gran número de países en desarrollo y de economías en transición tratan de dotarse de una legislación ambiental "adecuada" o por modernizar su ordenamiento jurídico en la materia. Lamentablemente, en el curso de este esfuerzo, es bastante común que unos modelos legislativos válidos en un determinado contexto jurídico, económico y social - por lo general, de países industrializados- se apliquen en otros países y ordenamientos jurídicos para los que resultan totalmente inadecuados.

Por consiguiente, es posible que la "individualización" de la legislación constituya el principal requisito para lograr una legislación ambiental eficaz.

\section{- CONVENIOS INTERNACIONALES SOBRE EL MEDIO AMBIENTE}

\section{David Freestone}

La publicidad que acompañó a la Conferencia de las Naciones U nidas sobre el Medio Ambiente y el Desarrollo (CNUMAD) celebrada en R ío de Janeiro en junio de 1992 puso de relieve el destacado papel que el interés mundial por cuestiones como el recalentamiento de la Tierra y la pérdida de biodiversidad ocupan en la agenda política mundial. Ciertamente, en los veinte años transcurridos entre la Conferencia de Estocolmo sobre el M edio A mbiente H umano y la CNUM AD de 1992 no sólo se ha producido un importante incremento de la conciencia de la amenaza para el medio ambiente generada por las actividades humanas, sino también un crecimiento sustancial del número de acuerdos internacionales dedicados a los problemas ambientales. En efecto, se ha promulgado un gran número de tratados sobre el medio ambiente (véanse, por ejemplo, Burhenne 1974a, 1974b, 1974c; Hohmann 1992; M olitor 1991. Véase en Sand 1992 un análisis cualitativo contemporáneo de la cuestión).

Cabe recordar que, según el Estatuto, de 1945, del Tribunal Internacional de Justicia, las dos principales fuentes del derecho internacional son los convenios internacionales y la costumbre internacional (artículo 38(1) del Estatuto). La costumbre internacional está constituida por la práctica consuetudinariamente aplicada por los Estados con la intención de generar obligaciones jurídicas entre ellos. Si bien es posible que las costumbres internacionales se enraícen con relativa rapidez, la prontitud con que la conciencia de los problemas ambientales mundiales ha accedido a la agenda política internacional ha relegado a la costumbre a un segundo plano respecto al derecho escrito de los tratados y convenios en la evolución del ordenamiento jurídico. Si bien algunos principios fundamentales, como el de utilización equitativa de los recursos compartidos (Arbitraje de Lac
Lanoux, 1957) o la obligación de prohibir las actividades que deterioren el medio ambiente de los Estados vecinos (A rbitraje de Trail Smelter 1939, 1941) han surgido de decisiones judiciales fundadas en el derecho consuetudinario, los tratados han constituido, sin duda, el principal instrumento utilizado por la comunidad internacional para regular las actividades que amenazan el medio ambiente. 0 tro aspecto interesante de la regulación internacional del medio ambiente es el desarrollo del denominado "derecho no vinculante", constituido por documentos en los que los Estados, bien fijan pautas o manifiestan intenciones de actuación futura, bien se comprometen políticamente a perseguir determinados objetivos. Estos documentos pueden transformarse en instrumentos jurídicos formalmente vinculantes, por ejemplo, por decisión de las partes otorgantes de un convenio (véase en Freestone 1994 la importancia del derecho blando en el derecho ambiental internacional). LoS documentos de "derecho no vinculante" se han incorporado a numerosas compilaciones de derecho ambiental internacional.

En el presente artículo se ofrece un examen somero de los principales convenios internacionales sobre el medio ambiente. Si bien este tipo de examen se centra necesariamente en los principales convenios de ámbito mundial, no se puede despreciar el importante y creciente cuerpo de acuerdos regionales y bilaterales. (V éase en K iss y Shelton 1991, y en Birnic y Boyle 1992, un análisis sistemático del ordenamiento jurídico internacional del medio ambiente. V éase, asimismo, Churchill y Freestone 1991).

\section{Antes de Estocolmo}

La mayoría de los convenios internacionales ambientales anteriores a la conferencia de Estocolmo de 1972 se centraban en la conservación de la fauna y flora. Los primeros convenios de protección de las aves (como el Convenio de 1902 sobre protección de las aves útiles a la agricultura; véase, además, Lyster 1985) tienen un interés meramente histórico. M ayor transcendencia a largo plazo revisten los convenios generales de conservación de la naturaleza, si bien el Convenio de Washington de 1946 para la regulación de la caza de la ballena (y su protocolo de 1956) es particularmente notable en este período, si bien, como es natural, su objetivo se ha desplazado con el tiempo de la explotación a la conservación. Uno de los primeros convenios inspirados en la conservación fue el Convenio africano para la conservación de la naturaleza y los recursos naturales, suscrito en Argel en 1968, en el que, a pesar de su amplitud y de su carácter innovador, se cometió el error - reiterado en muchos otros convenios- de no crear una estructura administrativa que supervisase su aplicación. I gualmente notable - y mucho más fructífero- fue el Convenio R amsar de 1971 sobre las zonas húmedas de importancia internacional, especialmente como hábitat de aves acuáticas, en el que se estableció una serie de zonas húmedas protegidas en el territorio de los Estados signatarios.

0 tros documentos significativos de este período son los convenios mundiales sobre contaminación por hidrocarburos. Aunque el Convenio internacional de 1954 para la prevención de la contaminación del mar por hidrocarburos (OILPOL), modificado en 1962 y 1969, desbrozó el camino de la creación de un marco regulador del transporte marítimo de petróleo, los primeros convenios en los que se estipularon la adopción de medidas de urgencia y la obligación de reparar los daños provocados por la contaminación por hidrocarburos se concertaron en respuesta directa al primer siniestro sufrido por un gran buque cisterna: el naufragio del petrolero liberiano Torrey Canyon frente a las costas del sureste de Inglaterra, en 1969. En el Convenio internacional de 1969 sobre intervención en alta mar en caso de daños producidos por la contaminación por hidrocarburos se autorizaba a los Estados ribereños a intervenir fuera de sus 
aguas jurisdiccionales. En otros dos convenios afines al anterior: el Convenio internacional sobre responsabilidad civil por daños causados por la contaminación por hidrocarburos, de 1969, y el Convenio internacional para la creación de un fondo internacional de indemnización por los daños producidos por la contaminación por hidrocarburos, firmado en Bruselas en 1971, se autorizaba la reclamación de indemnizaciones a los armadores y operadores de los buques cisterna y se establecía la garantía de un fondo internacional de indemnización. (Es de destacar igualmente la importancia de los sistemas de indemnización voluntaria gestionados por el sector, como TOVALOP y CRISTAL. V éase al efecto A becassis y Jarashou 1985).

\section{De Estocolmo a Río}

En los años 1972 a 1992 se produjo un inusitado crecimiento del número y variedad de las normas de derecho ambiental internacional. Buena parte de este esfuerzo legislativo es directamente imputable a la Conferencia de Estocolmo. En la importante Declaración de la Conferencia de las Naciones U nidas sobre el Medio Ambiente Humano de 1972 no sólo se formularon diversos principios, la mayoría de los cuales eran de lege ferenda (esto es, que enunciaban cómo debía ser el derecho y no como era en realidad), sino que también se adoptaron un Plan de actuación ambiental de 109 puntos y una Resolución en los que se recababa el apoyo institucional y financiero de la O NU para su aplicación. El resultado de esta invocación fue la creación, con sede en $\mathrm{N}$ airobi, del Programa de las $\mathrm{N}$ aciones U nidas para el M edio Ambiente (PNUMA) en virtud de una Resolución de la Asamblea General de las Naciones Unidas (UNGA 1972). EI PNUMA ha patrocinado directamente la negociación de una serie de tratados de ámbito mundial sobre el medio ambiente, así como el desarrollo del importante Programa de M ares Regionales, que se ha traducido en la aprobación de una serie de ocho convenios marco regionales para la protección del medio ambiente marino, a cada uno de los cuales se ha unido un protocolo ajustado a las características específicas de la región. Varios programas regionales se encuentran aún en proceso de gestación.

Con objeto de facilitar el análisis del gran volumen de convenios ambientales elaborados durante este período, aquéllos se han agrupado en varias categorías: conservación de la naturaleza, protección del medio ambiente marino y regulación de los impactos ambientales internacionales.

\section{Conservación de la naturaleza y los recursos naturales}

Durante este período se celebraron diversos tratados para la conservación de la naturaleza, tanto de ámbito mundial, como de alcance regional. Entre los primeros cabe destacar el Convenio adoptado por la U NESCO en 1972 para la Protección del patrimonio cultural y natural del mundo, el Convenio de Washington de 1973 sobre el comercio internacional de especies amenazadas (CITES), y el Convenio de Bonn de 1979 sobre conservación de las especies migrantes de animales silvestres. Entre el elevado número de acuerdos de alcance regional destacan especialmente el Convenio nórdico para la protección del medio ambiente, de 1974; el Convenio de 1976 para la conservación de la naturaleza en el Sur del Pacífico (Convenio A pia, en Burhenne 1974a); y el Convenio de Berna de 1979, para la conservación de la vida silvestre europea y los hábitats naturales (Serie Tratados Europeos). Es de destacar igualmente la Directiva de la Comunidad Europea 79/409, de 1979, sobre la conservación de las aves silvestres (DO 1979), modificada posteriormente por la Directiva 92/ 43 sobre conservación de los hábitats naturales y la fauna y flora (DO 1992); el Convenio de 1979 para la conservación y ordenación de la vicuña; y el Acuerdo de la ASEAN, de 1985, sobre conservación de la naturaleza y los recursos naturales (reproducido en K iss y Shelton 1991). Son igualmente dignos de mención los tratados relativos al Antártico, patrimonio común de la humanidad ajeno a la soberanía de los Estados: Convenio de C anberra, de 1980, para la conservación de la vida marina en el Antártico; el Convenio de Wellington, de 1988, sobre regulación de la explotación de los recursos minerales del A ntártico; y Protocolo de 1991 al Tratado del Antártico para la protección del medio ambiente, suscrito en $M$ adrid.

\section{Protección del medio ambiente marino}

En 1973 se iniciaron los trabajos de la Tercera Conferencia de la ONU sobre el Derecho del Mar (UNCLOS III). Nueve años de negociaciones en el marco de la UNCLOS culminaron en 1982 con la firma del Convenio de $\mathrm{M}$ ontego Bay sobre el Derecho del $M$ ar (LOSC), en cuya Parte XII se establece un marco global para la regulación de las cuestiones que afectan al medio ambiente marino, incluidos los vertidos y la contaminación procedentes, tanto de las embarcaciones como de tierra firme, además de establecerse algunas obligaciones generales de protección del medio ambiente marino.

En un nivel más específico, la O rganización M arítima Internacional $(\mathrm{OMI})$ ha patrocinado la elaboración de dos importantes convenios de ámbito mundial: el Convenio de $L$ ondres de 1972 sobre prevención de la contaminación marina por el vertido de residuos y otras materias y el Convenio internacional de 1973 para prevenir la contaminación por los buques, modificado en 1978 (M ARPOL, 1973/1978); y un tercer convenio sobre los vertidos de petróleo, denominado Convenio internacional sobre preparación, respuesta y cooperación respecto a la contaminación por hidrocarburos, firmado en 1990, en el que se establece un marco jurídico mundial para la colaboración y asistencia en caso de graves vertidos de petróleo. O tros convenios marítimos importantes, a pesar de no ser de carácter específicamente ambiental, son el Convenio de 1972 sobre la regulación internacional de la prevención de colisiones en el mar (COLREG); el Convenio internacional de 1974 para la seguridad de la vida humana en el mar (SO LAS); el Convenio de la O IT sobre la marina mercante (normas mínimas) 1976 (no 147), y el Convenio de 1978 sobre normas de formación, titulación y supervisión de los trabajadores del mar.

En el Convenio de Londres de 1972 se adoptó el sistema, actualmente generalizado, de relacionar las sustancias que no se pueden verter en el océano (Anexo I) y las que sólo pueden verterse previa autorización (A nexo II). La normativa reguladora, que obliga a los Estados signatarios a imponer estas obligaciones a la tripulación de los barcos que carguen en sus puertos y a las embarcaciones de bandera que se encuentren en cualquier punto del mundo, se ha hecho progresivamente más estricta, hasta el punto de que las partes signatarias han puesto efectivamente fin al vertido marino de residuos industriales. EI Convenio MARPOL 1973/1978, que ha reemplazado al Convenio O ILPO L de 1954 (véase anteriormente), constituye la principal normativa reguladora de la contaminación producida por todo tipo de embarcaciones, incluidos los buques cisterna. En el MARPOL se exige a los Estados que abanderan buques la imposición de controles sobre las "descargas operativas" de todas las sustancias sujetas a control. La normativa del MARPOL se modificó en 1978 en el sentido de extender progresivamente su cobertura a las distintas modalidades de contaminación producida por embarcaciones que se relacionan en los cinco anexos. Los anexos actualmente vigentes se aplican a los hidrocarburos (Anexo I), sustancias líquidas nocivas (Anexo II), residuos envasados (Anexo III), aguas residuales (Anexo IV) y basuras (A nexo V). Determinadas áreas delimitadas por las partes signatarias están sometidas a unas normas más estrictas. 
En el ámbito regional, el Programa de $M$ ares Regionales del PNUMA ha servido de marco a una serie extensa, aunque no exhaustiva, de acuerdos para la protección del medio ambiente marino, que abarcan el M editerráneo (C onvenio para la protección del M ar M editerráneo contra la contaminación, Barcelona, 16 de febrero de 1976; protocolos de 1976 (2), 1980 y 1982); el Golfo Pérsico (C onvenio Regional de K uwait sobre cooperación en la protección del medio ambiente marino contra la contaminación, K uwait, 24 de abril de 1978; protocolos de 1978, 1989 y 1990); Africa occidental (Convenio sobre cooperación en la protección y el desarrollo del medio ambiente marino y costero del Africa central y occidental (Abidján, 23 de marzo de 1981), con un protocolo de 1981); el Pacífico suroriental (Convenio para la protección del medio ambiente marino y las áreas costeras del Pacífico suroriental (Lima, 12 de noviembre de 1981); protocolos de 1981, 1983 (2) y 1989); el Mar Rojo (Convenio regional para la protección del medio ambiente del Mar Rojo y el Golfo de Adén (Yidda, 14 de febrero de 1982); protocolo de 1982); el M ar Caribe (Convenio para la protección y el desarrollo del medio ambiente marino de la cuenca del Caribe; (C artagena de Indias, 24 de marzo de 1983); protocolos de 1983 y 1990); Africa oriental (Convenio para la protección, ordenación y desarrollo del medio ambiente marino y costero del Africa oriental (Nairobi, 21 de junio de 1985); 2 protocolos de 1985); y el Pacífico Sur (Convenio para la protección de los recursos naturales y el medio ambiente del Pacífico Sur; (Noumea, 24 de noviembre de 1986); 2 protocolos de 1986). Además, hay otros seis convenios en diversos estadios de negociación (véanse en Sand, 1987, el texto de los convenios anteriormente citados y de sus protocolos, además de detalles de los programas en desarrollo). Diversos protocolos complementan estos acuerdos internacionales. En ellos se aborda un amplio espectro de cuestiones, como la regulación de las fuentes terrestres de contaminación, los vertidos marinos, la contaminación procedente de las plataformas de prospección petrolífera submarina (y el cierre de las mismas), las áreas especialmente protegidas y la protección de la fauna y flora.

Al margen del marco del PNUMA se han desarrollado otros ordenamientos jurídicos regionales, especialmente en el Atlántico nororiental, región en la que existe un extenso cuerpo de acuerdos internacionales que regulan materias como los vertidos marinos (Convenio de 0 slo de 1972 para la prevención de la contaminación marina producida por vertidos desde naves y aeronaves; protocolos de 1983 y 1989); la contaminación procedente de fuentes terrestres (Convenio de París de 1974 para la prevención de la contaminación marina causada por fuentes terrestres; protocolo de 1986); vigilancia y cooperación respecto a la contaminación por hidrocarburos (Acuerdo de Bonn de 1983 para la cooperación en la lucha contra la contaminación del $\mathrm{M}$ ar del N orte por hidrocarburos y otras sustancias nocivas; Decisión de modificación de 1989); inspección de embarcaciones con fines de seguridad y protección del medio ambiente marino (Acuerdo de París de 1982 sobre el control estatal en los puertos para la aplicación de los acuerdos sobre la seguridad en el mar y protección del medio ambiente marino); así como la conservación de la naturaleza y las pesquerías. (V éase, sobre estas materias, Freestone e IJIstra 1991). Es de destacar igualmente el nuevo Convenio de París de 1992 para la protección del medio ambiente marino del Atlántico nororiental, llamado a reemplazar a los convenios de 0 slo y de París (véanse el texto y un análisis del nuevo instrumento en $\mathrm{Hey}$, IJIstra y Nollkaemper 1993). En la región del Báltico, se ha modificado recientemente el Convenio de $\mathrm{H}$ elsinki para la protección del medio ambiente marino del $\mathrm{M}$ ar Báltico (véanse el texto y un análisis del Convenio de 1992 en Ehlers 1993). A simismo, se ha elaborado un nuevo convenio para la región del $M$ ar Negro (Convenio de Bucarest, de 1992, para la protección del Mar Negro; véase igualmente la Declaración M inisterial de 0 desa, de 1993, sobre la protección del M ar N egro).

\section{Impactos transnacionales}

En el Principio 21 de la Declaración de Estocolmo se declaraba que los E stados tienen "la responsabilidad de evitar que las actividades realizadas bajo su control y competencia produzcan daños al medio ambiente de otros Estados o áreas allende su jurisdicción nacional". Si bien este principio se ha incorporado desde entonces al derecho consuetudinario internacional, su enunciado precisa una elaboración cuidadosa para servir de base a la regulación de dichas actividades. En un intento de resolver este problema y en respuesta a varios incidentes que han tenido notable repercusión pública, se han concertado diversos convenios en los que se abordan cuestiones como la contaminación atmosférica transnacional a gran distancia, la protección de la capa de ozono, la comunicación y cooperación en los casos de accidente nuclear, el transporte internacional de residuos peligrosos y el cambio climático mundial.

\section{Contaminación atmosférica transnacional a gran distancia}

EI Convenio sobre contaminación transnacional a gran distancia, suscrito en Ginebra en 1979, fue el primero de ámbito europeo en el que se abordó el problema de la contaminación atmosférica. No obstante, era un simple convenio marco cuyo objetivo se circunscribía a "limitar y, en la medida de lo posible, reducir gradualmente y prevenir la contaminación atmosférica, incluida la contaminación transnacional a gran distancia". El progreso efectivo en la regulación de las emisiones de determinadas sustancias vino de la mano de los protocolos, de los que hasta ahora se han suscrito cuatro: en el Protocolo de Ginebra de 1984 (Protocolo de G inebra sobre financiación a largo plazo del programa de cooperación para la supervisión y evaluación de la difusión a gran distancia de la contaminación atmosférica en Europa) se creó una red de estaciones de control de la calidad del aire; en el Protocolo de Helsinki de 1985 (sobre la reducción de las emisiones de azufre) se estableció el objetivo de reducir las emisiones de azufre en un $30 \%$ para 1993; en el Protocolo de Sofía de 1988 (sobre control de las emisiones de óxidos de nitrógeno 0 de sus flujos transnacionales), posteriormente reemplazado por el Segundo Protocolo del A zufre, firmado en 0 slo en 1994, se fijaba el objetivo de mantener en 1994 los niveles de emisión de óxidos de nitrógeno registrados en 1987; por último, en el Protocolo de Ginebra de 1991 (sobre el control de las emisiones de compuestos orgánicos volátiles o de sus flujos transnacionales) se fijaron una serie de alternativas para la reducción de las emisiones y los flujos de compuestos orgánicos volátiles.

\section{Efectos transnacionales de los accidentes nucleares}

Aunque el siniestro ocurrido en Chernóbil en 1986 atrajo la atención mundial hacia las repercusiones transnacionales de los accidentes nucleares, anteriormente se habían adoptado algunos convenios en los que se habían abordado diversos riesgos derivados del uso de ingenios nucleares, incluidos el Convenio de 1961 sobre responsabilidad por daños a terceros en el campo de la energía nuclear (1960) y la Convención de Viena sobre responsabilidad civil por daños nucleares (1963). Es de destacar asimismo el Tratado de 1963 de prohibición de las pruebas de armas nucleares submarinas, atmosféricas y en el espacio exterior. El Convenio de Viena de 1980 sobre la protección física del material nuclear había constituido un intento de establecer normas para la protección del material nuclear contra una serie 
de riesgos, incluido el terrorismo. En la estela de Chernóbil, se adoptaron en 1986 dos convenios: uno sobre la comunicación temprana de los accidentes (C onvenio de Viena sobre la comunicación temprana de accidentes nucleares) y otro sobre la cooperación internacional cuando se producen tales accidentes (C onvenio de Viena sobre asistencia en caso de accidente nuclear 0 emergencia radiológica).

\section{Protección de la capa de ozono}

En el Convenio de Viena de 1985 sobre protección de la capa de ozono se impone a las partes contratantes la obligación general, "dentro de sus posibilidades y de acuerdo con los medios a su alcance", de:

(a) cooperar mediante la observación, la investigación y el intercambio de observación sistemáticos, a mejorar la comprensión y evaluación, tanto de los efectos de la actividad humana sobre la capa de ozono, como de la alteración de ésta sobre la salud y el medio ambiente; (b) adoptar las medidas legislativas o administrativas adecuadas y cooperar en la armonización de las estrategias apropiadas para controlar, limitar, reducir o prevenir la ejecución, bajo su jurisdicción o control, de cualquier actividad humana que produzca o sea capaz de producir efectos adversos como consecuencia de la modificación real o potencial de la capa de ozono; (c) cooperar en la adopción de los procedimientos, medidas y normas consensuados para la aplicación del Convenio, con vistas a la adopción de protocolos y anexos al mismo; y (d) cooperar con los organismos internacionales competentes en la aplicación efectiva del Convenio y los protocolos suscritos por dicha partes.

El Convenio de Viena fue desarrollado por el Protocolo de M ontreal de 1987 sobre las sustancias químicas que destruyen la capa de ozono, que, a su vez, ha sido adaptado y modificado en la reunión de Londres, de 1990 y, más recientemente, en la reunión de Copenhague, de 1992. En el artículo 2 del Protocolo se exige a las partes contratantes que impongan determinados controles sobre las sustancias químicas que destruyen la capa de ozono, concretamente los derivados fluorocarbonados, los haluros, otros derivados fluorocarbonados completamente halogenados, el tetracloruro de carbono y 1,1,1-tricloroetano (cloruro de metilo).

En el artículo 5 se excluye de los límites impuestos a las emisiones, bajo las condiciones establecidas en el artículo 5(2) (3) y por un período máximo de diez años, a determinados países en desarrollo, "con objeto de que puedan satisfacer sus necesidades domésticas básicas". En el Protocolo se prevé igualmente la prestación de asistencia técnica y financiera a las naciones en desarrollo firmantes del documento que soliciten acogerse a los beneficios del artículo 5. Se acordó la creación de un Fondo M ultilateral destinado a financiar la investigación en esos países y el cumplimiento de sus obligaciones (artículo 10). A la luz de los resultados de la Evaluación Científica de la D estrucción de la Capa de 0 zono, realizada en 1991 y en la que se determinó la progresiva destrucción de la capa de ozono atmosférico en las latitudes medias y altas de ambos hemisferios, en noviembre de 1992 se acordó en Copenhague la adopción de varias nuevas medidas, naturalmente, en el marco del régimen general antes definido. Los países en desarrollo conservan su derecho a acogerse a los aplazamientos previstos en el artículo 5. Todas las partes contratantes se comprometieron a no utilizar haluros a partir de 1994, y a dejar de emplear los derivados fluorocarbonados, el hidroxibutilfluorocarbono, el tetracloruro de carbono y cluorurometilo a partir de 1996. El empleo de HCFC se estabilizará en 1996, se reducirá en un $90 \%$ a partir de 2015 y se eliminará desde 2030. El bromuro de metilo, utilizado todavía en la conservación de frutas y cereales, se someterá a controles voluntarios y las partes contratantes se comprometen a "hacer cuanto estuviese en su poder para estabilizar su empleo a partir de 1995 en los niveles de 1991. El objetivo estratégico consiste en estabilizar el contenido de cloro en la atmósfera en el año 2000, para luego reducirlo por debajo de los niveles críticos para el 2060.

\section{Transporte internacional de residuos peligrosos}

Como consecuencia de una serie de graves incidentes provocados por el descubrimiento en países en desarrollo de diversos cargamentos de residuos peligrosos procedentes de las naciones industrializadas, el transporte internacional de residuos peligrosos se reguló en 1989 en virtud de la Convención de Basilea sobre control del transporte internacional y la eliminación de los residuos peligrosos (véase igualmente K ummer 1992). EI Convenio se basa en el principio del consentimiento informado de cada Estado afectado con anterioridad al inicio del transporte de los residuos. La O rganización de la U nidad Africana (OUA) fue más lejos y adoptó el Convenio de Bamako de 1991 sobre prohibición de la importación en Africa y el control del transporte internacional y la ordenación dentro del continente de los residuos peligrosos.

\section{Evaluación de impacto ambiental (EIA) en un contexto transnacional}

En el Convenio de Espoo de 1991 sobre evaluación de impacto ambiental en un contexto transnacional se establece un marco de relaciones entre los Estados vecinos. El convenio extendió la aplicación del concepto de la EIA, que hasta entonces se había desarrollado dentro de los estrechos límites de los procedimientos y normas de planificación de ámbito nacional, a los impactos ambientales transnacionales de los proyectos de desarrollo y los procedimientos y normas asociados a los mismos.

\section{Los convenios de 1992 y los posteriores a la Conferencia de Río}

La CNU M AD de Río alentó o coincidió con un gran número de nuevos convenios de protección ambiental de alcance regional o mundial, así como una importante declaración de principios para el futuro, contenida en la Declaración de Río sobre M edio Ambiente y Desarrollo. Además de los dos convenios concertados en Río - el Convenio marco sobre el cambio climático y el Convenio sobre diversidad biológica- en 1992 se suscribieron nuevos convenios sobre la regulación del uso de las corrientes fluviales internacionales y los efectos transnacionales de los accidentes industriales. En el ámbito regional, en 1992 se suscribieron el Convenio de $\mathrm{H}$ elsinki sobre el uso y protección del área del Mar Báltico (véanse el texto y un análisis del convenio en Ehlers 1993) y el Convenio de Bucarest sobre la protección del $\mathrm{M}$ ar Negro contra la contaminación. M erecen especial atención la Declaración Ministerial de 1993 sobre la protección del $\mathrm{M}$ ar N egro, en la que se propugna una estrategia global de prevención, y el Convenio de París para la protección del medio ambiente marino del Atlántico nororiental (véanse el texto y un análisis del convenio en $\mathrm{Hey}$, IJstra y N ollkaemper 1993).

\section{Convenio M arco de las Naciones Unidas sobre el cambio climático}

El Convenio $\mathrm{M}$ arco de las $\mathrm{N}$ aciones U nidas sobre el cambio climático, suscrito en Río de Janeiro en 1992 por unos 155 E stados se inspiró en líneas generales en el Convenio de Viena de 1985. Como su nombre indica, el documento constituye un marco de negociación de unas obligaciones concretas que se 
plasmarían en unos protocolos detallados. El objetivo básico del convenio consiste en lograr:

la estabilización de las concentraciones de gases de efecto invernadero en la atmósfera a un nivel que impida interferencias antropógenas peligrosas en el sistema climático. Ese nivel debería lograrse en un plazo suficiente para permitir que los ecosistemas se adapten naturalmente al cambio climático, asegurar que la producción de alimentos no se vea amenazada y permitir que el desarrollo económico prosiga de manera sostenible (artículo 2)

En el artículo 4(a) se imponen a las partes contratantes dos obligaciones fundamentales de: a) elaborar, actualizar periódicamente, editar y dar a conocer un inventario nacional de emisiones antropogénicas, por fuentes, y de eliminaciones, por sumideros, de todos los gases causantes del efecto invernadero, aplicando unas metodologías homologables (y aún pendientes de aprobación); y b) formular, aplicar, publicar y actualizar regularmente unos programas nacionales y regionales de medidas destinadas, tanto a mitigar el cambio climático actuando sobre las emisiones antropogénicas, por fuentes, y la eliminación, por sumideros, de todos los gases causantes del efecto invernadero, como a facilitar la adaptación al cambio climático. Además, las naciones industrializadas signatarias del documento han contraído diversas obligaciones generales que se desarrollarán en unos protocolos más específicos. Por ejemplo, se han comprometido a promover y colaborar en el desarrollo de la tecnología; controlar, prevenir o reducir las emisiones antropogénicas de los gases causantes del efecto invernadero; promover el desarrollo sostenible y la conservación y ampliación de los sumideros y reservorios, como la biomasa, los bosques, océanos y otros ecosistemas terrestres, costeros y marinos; colaborar en la adaptación a los efectos del cambio climático mediante la elaboración de planes de ordenación integral de las zonas costeras, los recursos hídricos y la agricultura, y para la protección y rehabilitación de las zonas afectadas por fenómenos como las riadas; promover y colaborar en los procesos asociados de educación, formación y concienciación pública.

\section{El Convenio sobre diversidad biológica}

Los objetivos del Convenio sobre diversidad biológica, adoptado igualmente en la CNUMAD celebrada en Río de Janeiro en 1992, consisten en la conservación de la diversidad biológica, el uso sostenible de sus componentes y la distribución justa y equitativa de los beneficios derivados de la utilización de los recursos genéticos (artículo 1) (véase una útil crítica del convenio en Boyle 1993). Al igual que el Convenio marco de las Naciones U nidas sobre el cambio climático, este convenio será desarrollado por diversos protocolos; no obstante, en el mismo se establecen diversas obligaciones generales en materia de conservación y uso sostenible de los recursos naturales, identificación y supervisión de la diversidad biológica, la conservación in situ y ex situ, la investigación y formación, la concienciación y educación del público y la evaluación de impacto ambiental de las actividades potencialmente peligrosas para la biodiversidad. En el documento figuran igualmente disposiciones generales relativas al acceso a los recursos genéticos, así como al acceso y la transferencia de la tecnología pertinente, incluida la biotecnología, y a la cooperación y el intercambio de información en el plano internacional.

\section{Regulación del aprovechamiento de las corrientes fluviales internacionales}

El Convenio de $\mathrm{H}$ elsinki sobre protección y uso de las corrientes fluviales transnacionales y los lagos internacionales se adoptó con la finalidad de establecer un marco de cooperación para la supervisión y evaluación comunes, la investigación y desarrollo conjuntos y el intercambio de información entre los E stados ribereños. En el convenio se impone a dichos Estados una serie de obligaciones básicas de prevenir, controlar y reducir los impactos transnacionales sobre los recursos compartidos, en especial por lo que respecta a la contaminación del agua, mediante la aplicación de unas técnicas correctas de gestión, incluida la evaluación de impacto ambiental, y la previsión de contingencias, así como a través de la adopción de tecnologías de bajo o nulo nivel de generación de residuos y la reducción de la contaminación generada por fuentes, tanto puntuales como difusas.

\section{E fectos transna cionales de los accidentes industriales}

En el Convenio sobre efectos transnacionales de los accidentes industriales, adoptado igualmente en H elsinki en marzo de 1992, se regula la previsión, prevención y respuesta a los accidentes industriales capaces de producir efectos transfronterizos. L as obligaciones básicas consisten en la cooperación y el intercambio de información con los demás Estados contratantes. En una serie de trece anexos pormenorizados se establecen métodos de identificación de las actividades peligrosas con repercusiones transnacionales, para el desarrollo de una evaluación de impacto ambiental con una perspectiva transnacional (de conformidad con el Convenio de E spoo de 1991), para la toma de decisiones sobre la ubicación de las actividades potencialmente peligrosas. En el documento se prevé igualmente la previsión de situaciones de urgencia y el acceso del público y de las demás partes contratantes a la información.

\section{Conclusiones}

Como se ha intentado poner de relieve en este breve examen, en los dos últimos decenios se ha producido un cambio sustancial en la actitud de la comunidad internacional ante a la conservación y ordenación del medio ambiente. Parte de este cambio ha sido el sustancial incremento del número y el alcance de los acuerdos internacionales sobre el medio ambiente. La proliferación de nuevos convenios ha estado acompañada por la aparición de nuevos principios e instituciones. El principio de que el que contamina paga, el principio cautelar (Churchill y Freestone 1991; Freestone y H ey 1996) y la preocupación por los derechos de las futuras generaciones se han reflejado en los convenios internacionales anteriormente citados. La importancia del Programa de las Naciones Unidas para el Medio Ambiente (PNU M A) y de las secretarías creadas con objeto de supervisar y gestionar el volumen creciente de ordenamientos nacidos de los tratados ha inducido a los tratadistas a reconocer que, al igual que ha ocurrido, por ejemplo, con el derecho internacional de los derechos humanos, el derecho internacional ambiental ha emergido como una rama autónoma del derecho de gentes (Freestone 1994). La CNU M AD, que ha prestado una contribución sustancial a este proceso, ha elaborado una importante agenda, buena parte de la cual no se ha materializado. Q uedan por adoptarse algunos protocolos detallados que confieran sustantividad al marco creado con el Convenio sobre el cambio climático y, quizás también, al Convenio sobre Biodiversidad. La preocupación por el impacto ambiental de las pesquerías de altura inspiraron el Acuerdo de las Naciones U nidas sobre los bancos de peces pelágicos y altamente migratorios, suscrito en 1995. También en 1995 se celebró una Conferencia de las Naciones U nidas sobre las fuentes terrestres de la contaminación marina, que, según se reconoce en la actualidad, causan más del $70 \%$ de la contaminación total de los océanos. Las repercusiones ambientales del comercio internacional y de la deforestación y la desertización constituyen otros tantos problemas que habrá que abordar en el futuro en el ámbito mundial, mientras prosigue el esfuerzo por enriquecer nuestro conocimiento de impacto de la actividad humana en los ecosistemas mundiales. El reto que 
deberá afrontar este derecho internacional ambiental emergente no consiste simplemente en reaccionar con un aumento del número de convenios sobre el medio ambiente, sino también en ampliar sus efectos y su eficacia.

\section{- Evaluaciones de impacto AMBIENTAL}

Ron Bisset

La expresión utilizada como título del presente artículo, "evaluaciones de impacto ambiental" ha sido reemplazada de forma creciente, aunque no generalizada, por la de "evaluaciones ambientales". Un análisis somero de la razón de este cambio de denominación nos ayudará a definir el carácter esencial de la actividad que unos y otros nombres designan, así como uno de los principales factores que subyacen en la oposición o la reticencia al empleo del término "impacto".

En 1970 se promulgó en Estados U nidos la Ley nacional de política ambiental, en la que se fijan los objetivos de la política ambiental de la administración federal y se reconoce la necesidad de tomar en consideración los factores ambientales en la toma de decisiones. Ciertamente, es fácil formular objetivos políticos, pero más difícil alcanzarlos. Para darle más "mordiente" al texto legal, el legislador introdujo en él una disposición por la que se exigía que la administración federal elaborase una "Declaración de impacto ambiental" para cada actuación prevista "capaz de alterar sustancialmente la calidad del medio ambiente humano". Habría que examinar el contenido de este documento antes de tomar una decisión sobre el inicio de la actuación prevista. El trabajo de preparación de la Declaración de impacto ambiental dio en denominarse "evaluación de impacto ambiental" (EIA), dado que comprendía la identificación, predicción y evaluación de impacto de las actuaciones federales previstas.

Lamentablemente, en inglés, como en otros idiomas, la voz "impacto" no tiene una connotación positiva. La noción de impacto se asocia casi por antonomasia a la de daño. Por consiguiente, cuando la práctica de evaluar el impacto ambiental se extendió de Estados U nidos a Canadá, Europa, Asia suroriental y O ceanía, numerosos gobiernos - y sus asesores- prefirieron desmarcarse de las connotaciones negativas del término "impacto" y nació la expresión "evaluación ambiental" (EA). Así, la evaluación de impacto ambiental y la evaluación ambiental son conceptos idénticos, excepto en Estados U nidos y un reducido grupo de países que han adoptado el sistema norteamericano, en los que EIA y EA poseen unos significados precisos y diferenciados. Aunque en el presente artículo se menciona únicamente la evaluación de impacto ambiental, el lector no debe olvidar que su contenido es aplicable en su totalidad a la evaluación ambiental y que ambas expresiones se utilizan internacionalmente.

A demás de la elección del término "impacto", el contexto en que se aplicó la evaluación de impacto ambiental (especialmente en Estados U nidos y C anadá) influyó en ciertas concepciones de la EIA que eran - y, en algunos casos, son todavía- comunes entre los políticos, altos funcionarios y "promotores inmobiliarios" de los sectores público y privado. La planificación de la explotación del suelo era escasa en Estados U nidos y Canadá, y los trabajos de preparación, tanto de las declaraciones sobre impactos ambientales, como de los informes de EIA, eran a menudo "secuestrados" por grupos interesados y prácticamente convertidos en una labor de planificación. Esto alentó la producción de voluminosos documentos de varios tomos, laboriosos y costosos de producir y, por supuesto, virtualmente imposibles de leer y de tomarse como base de actuación. A veces, los proyectos se demoraban hasta la finalización de esta actividad, con la consiguiente irritación de promotores e inversores.

Además, durante los primeros cinco a seis años de vigencia de la Ley nacional de política ambiental se interpusieron numerosas demandas judiciales en las que los adversarios del proyecto impugnaron la idoneidad de las declaraciones de impacto ambiental por causas técnicas 0 , a veces, de procedimiento. Estos contenciosos también contribuyeron a demorar los proyectos. Sin embargo, a medida que adquiría experiencia y se emitían directrices más estrictas e inequívocas, el número de litigios judiciales se fue reduciendo significativamente.

L amentablemente, todos estos problemas contribuyeron a dar a muchos observadores independientes una impresión nítida de que la evaluación de impacto ambiental era una idea bien intencionada que, por desgracia, se había aplicado mal y había terminado por convertirse, más en un obstáculo que en una ayuda al desarrollo. Para muchas personas, parecía una actividad adecuada, si no absolutamente necesaria, para las autocomplacientes naciones industrializadas, pero para los países en desarrollo constituía un lujo costoso que no podían permitirse.

A pesar de las reacciones adversas iniciales registradas en algunos lugares, la difusión de la evaluación de impacto ambiental se reveló imparable. Desde que se inició en Estados Unidos en 1970, la EIA se extendió a Canadá, Australia y Europa. En varios países en desarrollo, como Filipinas, Indonesia y Tailandia, las técnicas de la EIA se implantaron antes que en muchas naciones de la E uropa occidental. C uriosamente, los diversos bancos de desarrollo, como el Banco Mundial, fueron a la zaga de otras organizaciones en la incorporación de la EIA a sus respectivos sistemas de toma de decisiones. Ciertamente, hasta finales del decenio de 1980 y principios del siguiente los bancos y organismos de cooperación bilateral se pusieron al nivel del resto del mundo. No se tiene la impresión de que el ritmo de incorporación de las leyes y los reglamentos normativos de la evaluación de impacto ambiental a los distintos sistemas nacionales de toma de decisiones se esté desacelerando. Por el contrario, como consecuencia de la Cumbre de la Tierra celebrada en Río de Janeiro en 1992, la aplicación de la EIA ha ido creciendo gradualmente a medida que los organismos internacionales y los gobiernos se esfuerzan por hacer efectivas las recomendaciones de $\mathrm{R}$ ío respecto a la necesidad de perseguir un desarrollo sostenible.

\section{¿Que es la EIA?}

¿Cómo explicar la creciente aceptación de la EIA? ¿Q ué puede hacer la EIA por la administración, los promotores inmobiliarios de los sectores público y privado, los trabajadores y sus familias y las comunidades en que éstos residen?

Antes de la aparición de la EIA, determinados proyectos de construcción, como los de autopistas, centrales hidroeléctricas e instalaciones industriales, se solían evaluar con criterios técnicos, económicos y, naturalmente, políticos. Estos proyectos persiguen siempre unos objetivos económicos y sociales, por lo que los responsables de la toma de decisiones que concedían los permisos y licencias querían conocer si los proyectos servirían para alcanzar tales objetivos (al margen de las obras concebidas y ejecutadas con fines políticos o de prestigio). Esta necesidad obligaba a realizar un estudio económico (por lo general, un análisis de coste/ beneficio) y una valoración técnica. Lamentablemente, no se tomaban en consideración los efectos sobre el medio ambiente $y$, con el tiempo, el público adquirió mayor conciencia del creciente deterioro del medio ambiente producido por los proyectos de desarrollo. En muchos casos, los efectos económicos y ambientales imprevistos generaron costes 
económicos; por ejemplo, la construcción de la presa de K ariba, en la frontera entre Zambia y Zimbabwe, obligó al reasentamiento de muchas poblaciones en áreas inadecuadas para la agricultura tradicional practicada por sus habitantes. Los alimentos empezaron a escasear en los nuevos asentamientos y los gobiernos tuvieron que aplicar programas urgentes de suministro de alimentos. 0 tros casos imprevistos de generación de costes añadidos y deterioro ambiental condujeron gradualmente a la convicción de que era preciso incorporar nuevos criterios a la evaluación de los proyectos con objeto de reducir el riesgo de producir impactos imprevistos y no deseados.

La creciente conciencia de los gobiernos, organizaciones no gubernamentales $(\mathrm{ONG})$ y parte de la opinión pública respecto a los imprevistos perjuicios económicos que pueden producir algunos proyectos de inversión coincidió con el enriquecimiento del conocimiento humano del medio ambiente. La atención se centró especialmente en las repercusiones del incremento demográfico y la correlativa expansión de la actividad económica, así como en las posibles restricciones ambientales a ese crecimiento. Se produjo un reconocimiento creciente de la importancia de los procesos planetarios biogeoquímicos y de otro tipo para la conservación de la pureza del aire y del agua, así como de recursos renovables tales como la madera y los alimentos. M uchos quedaron convencidos así de que el medio ambiente no podía seguir considerándose como una fuente inerte e inagotable de bienes y como un vertedero de los residuos humanos. M ás bien, debía valorarse como un factor activo del proceso de desarrollo que, si se trata incorrectamente, puede reducir las posibilidades de alcanzar los objetivos de crecimiento. Esta conciencia ha inspirado el desarrollo y aplicación de diversos procedimientos y técnicas que incorporan el medio ambiente al proceso de desarrollo mediante la valoración de los posibles efectos positivos o negativos sobre el mismo. La EIA es una de estas técnicas. El objetivo global consiste en reducir el riesgo - para la humanidad en su conjunto y para las comunidades locales- de que el deterioro ambiental tenga consecuencias nefastas para la vida, como la hambruna y las riadas.

Básicamente, la EIA es un medio de detectar, prever y evaluar los futuros impactos ambientales de un determinado proyecto de desarrollo y sus alternativas, previamente a la decisión de ejecutarlo. Se trata de incorporar la EIA a la evaluación estándar, de previabilidad y de viabilidad, y diseñar los medios de verificar si la propuesta es capaz de alcanzar los resultados previstos. La realización de la EIA paralelamente a estos otros estudios permite identificar en un estadio temprano los principales impactos negativos (y positivos) y excluir en la fase de "diseño", en la medida de lo posible, los impactos nocivos. Además, permite incrementar los beneficios. EI resultado de la EIA debe ser un proyecto que, por su localización, diseño, método de construcción y forma de funcionamiento, resulte "favorable al medio ambiente" en el sentido de que los eventuales deterioros ambientales causen, previsiblemente, escasas dificultades. Esto convierte la EIA, expresado con un símil médico, en un tratamiento preventivo. En la medicina comunitaria, resulta mejor y más barato prevenir las enfermedades que curarlas. En la protección del medio ambiente, es preferible reducir el daño ambiental (sin perjuicio de alcanzar los objetivos económicos) que financiar costosas operaciones de rehabilitación o de limpieza.

\section{Aplicación de la EIA}

¿A qué actividades constructivas se aplica la EIA? No hay normas ni respuestas absolutas. Cada país toma sus propias decisiones respecto a la magnitud de las actividades que se someten a la EIA. Por ejemplo, la construcción de una carretera de $10 \mathrm{~km}$ en una pequeña isla tropical puede tener serias repercusiones en el medio ambiente; en cambio, la construcción de esa misma carretera en un gran país semiárido y con escasa densidad de población podría ser neutra desde el punto de vista ambiental. En todos los países se aplica la EIA a los proyectos de construcción física de conformidad con una normativa nacional; en algunas naciones, se aplica igualmente a los planes, programas y políticas de desarrollo (como los planes sectoriales de desarrollo para el suministro energético y los planes nacionales de desarrollo) que pueden producir graves impactos ambientales. La EIA se aplica a este tipo de actuaciones en países como Estados U nidos, Países Bajos y China. N o obstante, tales países constituyen la excepción de la regla. En efecto, la mayoría de las EIA se dedican a los proyectos de construcción física, aunque es indudable que la importancia de la EIA "estratégica" crecerá en el futuro.

$¿ Q$ ué clase de impactos se analizan en la EIA? También a este respecto se registran variaciones de un país a otro, aunque en menor escala que las observadas en los tipos de actividad sujetos a la EIA. Se suele responder que se analizan los "impactos" ambientales, a lo que casi invariablemente se suele replicar: "Sí, pero, ¿qué se entiende por "ambiental"?. Por regla general, la EIA se centra en el medio biofísico, esto es en los impactos que afectan a elementos como los siguientes:

- calidad y cantidad del agua;

- calidad del aire;

- ecosistemas y procesos ecológicos,

- niveles de ruido.

En algunos casos se excluyen de la EIA otro tipo de impactos. No obstante, se ha llamado la atención sobre los efectos de la limitación de la EIA a los impactos biofísicos, y la EIA se basa cada vez en mayor medida en un concepto más amplio del medio ambiente en el que se incluyen, en su caso, los impactos sobre los elementos siguientes:

- comunidades locales (impactos "sociales");

- economía local;

- salud y seguridad;

- paisajes,

- recursos culturales (emplazamientos arqueológicos e históricos, aspectos ambientales espiritualmente significativos para las comunidades locales, etc.).

D os consideraciones permiten comprender mejor esta definición más amplia de los impactos "ambientales". En primer lugar, se considera social y políticamente inaceptable evaluar los impactos de un determinado proyecto sobre el entorno biofísico $y$, al mismo tiempo, pasar por alto sus efectos sociales, sanitarios y económicos en las comunidades y poblaciones locales. Esta cuestión se ha planteado con especial virulencia en las naciones industrializadas, especialmente en las que adolecen de unos sistemas pobres de planificación de los usos del suelo en los que se incluyen objetivos económicos y sociales.

En los países en desarrollo también opera este factor, junto con una consideración complementaria. En efecto, en la mayoría de ellos, la población tiene una relación más íntima y, en muchos aspectos, más compleja con el medio ambiente que en los países industrializados. Por consiguiente, la interacción de las comunidades locales y sus habitantes con su medio puede verse afectada por los impactos ambientales, sociales y económicos. Por ejemplo, en una comunidad pobre, la ejecución de una obra importante, como la construcción de una central eléctrica de 2.400 megavatios constituye una fuente de puestos de trabajo y de construcción de infraestructuras sociales (escuelas, hospitales, etc.) para atender a la nutrida plantilla de la planta. Fundamentalmente, la renta que fluye a la economía local convierte el emplazamiento de la central en una isla de prosperidad en un mar de pobreza. Esta situación atrae a la población 
más pobre hacia esa localidad, impulsada por el deseo de mejorar su nivel de vida mediante el acceso a mejores puestos de trabajo y el disfrute de las nuevas superestructuras. No todos los inmigrantes triunfan y los que fracasan intentan convertirse en proveedores de servicios a los que han conseguido trabajo, por ejemplo, suministrándoles leña o carbón vegetal. Se incrementa así la presión sobre el medio ambiente, a veces, en localidades distantes de la central eléctrica. Estos impactos se suman a los producidos por la llegada de los trabajadores y familiares de las personas directamente empleadas en la central. De este modo, el principal efecto social inducido del proyecto - la inmigracióngenera impactos ambientales. Si estas consecuencias socioeconómicas no se analizan, existe el peligro de que la EIA no alcance uno de sus objetivos centrales: identificar, prever, evaluar y reducir los impactos sobre el medio biofísico.

Prácticamente toda la EIA asociada a un proyecto se centra en el medio ambiente exterior, esto es, en el que se sitúa fuera de los límites del emplazamiento. Esta tendencia es un reflejo de la historia de la EIA. Como se ha indicado, la EIA nació en las naciones industrializadas, en las que existía un sólido marco legal de protección de la higiene industrial que desaconsejaba referirla simultáneamente al medio ambiente exterior y al medio ambiente interno de trabajo, pues esto entrañaría una duplicación de esfuerzos y un derroche de recursos escasos.

En muchos países en desarrollo se produce, exactamente, lo contrario. En sus condiciones, lo más aconsejable es que la EIA, especialmente de las instalaciones industriales, se extienda a los impactos en el medio ambiente interno. El objetivo principal de la evaluación de efectos como la calidad del aire en los locales cerrados y los niveles de ruido es proteger la salud de los trabajadores. Existen otras consideraciones que merecen tomarse en consideración en este contexto. En primer lugar, en un país pobre, la pérdida del sostén de la familia por causa de fallecimiento, enfermedad o lesión puede forzar al resto del núcleo familiar a explotar los recursos naturales para mantener el nivel de ingresos. Si un número apreciable de familias se ve afectado, los efectos acumulados pueden ser localmente importantes. En segundo lugar, las sustancias químicas que llegan a las viviendas impregnadas en la ropa de los trabajadores pueden afectar directamente a la salud de los miembros de la familia. La inclusión del medio ambiente interior en la EIA ha recibido escasa atención en la literatura especializada y brilla por su ausencia de leyes, reglamentos y directrices aplicables a la EIA. Sin embargo, no existen razones lógicas ni prácticas que desaconsejen - siempre que las circunstancias locales sean idóneas- centrar la EIA en los principales problemas de la higiene industrial y en las eventuales repercusiones externas del deterioro del bienestar físico y mental de los trabajadores.

\section{Costes y beneficios de la EIA}

Posiblemente, la cuestión que susciten con mayor frecuencia los adversarios e indiferentes al EIA sea la del coste. Ciertamente, la realización de la EIA consume un tiempo y unos recursos que, al final, se traducen en dinero. Esto obliga a evaluar los aspectos económicos de la EIA.

Los mayores costes de implantar las técnicas de EIA en un país recae en los promotores o los inversores en los proyectos, así como en la administración central o local (en función de la naturaleza de las técnicas). En la práctica totalidad de los países, los promotores e inversores en los proyectos asumen los costes de realización de la EIA de sus respectivos proyectos. Del mismo modo, los promotores de los programas de inversiones sectoriales y de los planes de desarrollo regional (por regla general, organismos públicos), financian su EIA. La experiencia compartida por los países desarrollados y en desarrollo indica que el coste de realización de la EIA oscila entre el $0,1 \%$ y el $1 \%$ de los costes de inversión en un proyecto, porcentaje que se incrementa si se toman en consideración las medidas de aminoración de los impactos propuestas en la EIA. Este coste es una función del tipo de medidas propuestas. Es evidente que el asentamiento de 5.000 familias realizado de forma que no se resienta su nivel de vida es una operación relativamente costosa. En estos casos, los costes de la EIA y de las medidas de aminoración de los impactos pueden llegar al $15 \%$ o el $20 \%$ de los costes de inversión; en otras situaciones, se pueden situar entre el $1 \%$ y el $5 \%$. Estas cifras pueden parecer excesivas e indicar que la EIA constituye una onerosa carga financiera. Sin duda, la EIA cuesta dinero; sin embargo, el autor no sabe de proyecto alguno que se haya paralizado por causa de los costes de realización de la EIA, y ha conocido muy pocos proyectos que hayan resultado antieconómicos por culpa de los costes de adopción de medidas de aminoración de impactos.

Las técnicas de EIA también imponen costes a las administraciones locales y centrales, causados por la necesidad de asignar personal y otros recursos a la gestión del sistema y a la realización y verificación de la EIA. También en este nivel los costes son una función de la naturaleza de las técnicas de EIA aplicadas y del número de evaluaciones anuales que se realicen. El autor no tiene conocimiento de cálculo alguno del valor medio de estos costes.

Volviendo a nuestro símil médico, la prevención de las enfermedades exige una considerable inversión inicial que facilite la generalización futura $y$, a ser posible, a largo plazo, de unos beneficios concretados en la mayor salud de la población; la EIA no es diferente. Los beneficios económicos se deben ponderar desde la perspectiva, tanto del promotor, como de la administración y de la sociedad en su conjunto. El promotor se puede beneficiar de varios modos:

- evitación de demoras en la obtención de autorizaciones;

- concreción de unas medidas de aminoración de impactos que impliquen el reciclaje y recuperación de los componentes de los flujos de residuos;

- creación de un medio ambiente de trabajo más limpio,

- determinación de alternativas menos costosas.

Si bien no todos estos beneficios se materializan en todos los casos, conviene ponderar las distintas posibilidades de ahorro para el promotor.

En todos los países se precisan diversos permisos, licencias y autorizaciones antes de iniciar la ejecución y explotación de un proyecto. La tramitación de las autorizaciones lleva un tiempo que se puede prolongar si no existen mecanismos formales de identificación, investigación y estudio de los problemas. Parece evidente que los tiempos en que una población inerte acogía cualquier proyecto como un signo de progreso económico y social seguro pertenecen prácticamente a la historia. Todos los proyectos se someten en medida creciente a la crítica de ámbito local, nacional e internacional, como ha ocurrido, por ejemplo, con la persistente oposición suscitada en India a la construcción del complejo de presas de Sardar Sarovar (N armada).

En este sentido, la EIA contiene un mecanismo para abordar, si no eliminar, las preocupaciones públicas. Algunos estudios realizados en países desarrollados, como el Reino Unido, han puesto de relieve la capacidad de la EIA para reducir el riesgo de demoras en la tramitación de las licencias, iy el tiempo es oro! En efecto, un estudio realizado por British $G$ as a finales del decenio de 1970 demostró que, en promedio, el tiempo preciso para obtener las licencias era menor con la EIA que en los proyectos en que no se aplicaba la EIA.

Ya se han mencionado los costes añadidos de aminoración de los impactos; sin embargo, conviene considerar el supuesto 
contrario. En las instalaciones que producen una 0 varias corrientes de desecho, la EIA puede contribuir a diseñar medidas de aminoración del volumen de residuos mediante la aplicación de métodos de recuperación o de reciclaje. En el primer supuesto, la recuperación de un componente de un flujo de residuos puede posibilitar su comercialización por parte del promotor, siempre que exista un mercado. Por su parte, el reciclaje de un elemento, como el agua, puede contribuir a reducir el consumo y, así, a disminuir el gasto en materias primas.

Si la EIA se centra en el medio ambiente interno, se pueden mejorar las condiciones de trabajo respecto a las prevalentes sin la EIA. En un lugar de trabajo más limpio y seguro, los trabajadores experimentan menos descontento, enfermedades y ausencias. Es probable que el resultado global se traduzca en una plantilla más productiva y, por lo tanto, en beneficios económicos para el promotor 0 el operador.

Por último, es posible que la opción finalmente elegida sobre la base exclusiva de criterios técnicos y económicos no sea, realmente, la mejor solución. Por ejemplo, en Botswana se había elegido el emplazamiento de un depósito de agua destinada al suministro de $\mathrm{G}$ aborone, capital del país. En los estadios iniciales de la EIA que se realizó se había puesto de relieve que los impactos ambientales de la obra proyectada serían muy adversos. EI equipo responsable de la EIA descubrió un emplazamiento alternativo para el depósito y fue autorizado a incluirlo en la EIA. La comparación entre ambos emplazamientos reveló que los impactos ambientales de la segunda solución serían mucho menos severos; además, los estudios realizados en el segundo emplazamiento mostraron que el mismo satisfacía los criterios técnicos y económicos exigidos. En efecto, se demostró que el emplazamiento alternativo permitía lograr los objetivos de desarrollo fijados con un menor deterioro del medio ambiente y con un coste de construcción de $50 \%$ (IUCN y Gobierno de la R epública de Botswana, sin fecha). Lógicamente, se optó por la segunda solución, en beneficio, no sólo de la entidad promotora (un ente público autónomo), sino de los contribuyentes de Botswana. Aunque estas situaciones no sean demasiado frecuentes, constituyen un ejemplo de la capacidad de la EIA para "verificar" diferentes vías de desarrollo.

LoS mayores beneficios de las técnicas de EIA se reparten entre los diversos estamentos sociales: gobierno, comunidades y particulares. Evitando un deterioro inaceptable del entorno, la EIA coadyuva a conservar los "procesos vitales" de los que dependen la vida y actividad del hombre. Este es un resultado generalizado y perdurable. En ciertos casos, la EIA previene la producción de daños puntuales en el medio ambiente que obligarían, más tarde, a la adopción de medidas de aminoración de impactos generalmente costosas. El coste de estas medidas suele recaer sobre las administraciones locales o centrales y no sobre los promotores u operadores de las instalaciones causantes de los daños.

La evolución reciente, sobre todo desde la "Cumbre de la Tierra" de R ío, ha modificado gradualmente los objetivos de los proyectos de desarrollo. Hasta hace poco, los objetivos del desarrollo consistían en mejorar las condiciones económicas y sociales de una determinada región. Actualmente, la satisfacción de los criterios u objetivos de un desarrollo "sostenible" ocupa un lugar destacado en la escala tradicional de objetivos (que sigue siendo importante). La adopción de la "sostenibilidad" como un objetivo importante - aunque aún no esencial- del proceso de desarrollo repercutirá profundamente en la futura validez de la falsa disyuntiva entre "puestos de trabajo o medio ambiente", que ha perjudicado a la EIA. Esta disyuntiva tenía algún sentido cuando el medio ambiente se consideraba periférico del proceso de desarrollo. En la actualidad, el medio ambiente es un factor importante y el debate se centra en el modo de compatibilizar de forma sostenible los puestos de trabajo con el medio ambiente. La EI A puede contribuir todavía de forma sustancial y creciente a este objetivo como un vector importante del impulso hacia la sostenibilidad y de su conquista.

\section{EVALUACION Del CIClo VITAL (DE LA CUNA A LA TUMBA)}

Sven-0 lof R yding

La necesidad de conservar el medio ambiente para las generaciones futuras no sólo obliga al análisis de los problemas ambientales emergentes, sino también a tratar de diseñar estrategias eficaces en función del coste y ambientalmente correctas, así como a aplicar las medidas que se adopten como consecuencia del análisis. Existen motivos fundados para dar prioridad a la mejora del medio ambiente y a la adopción de medidas encaminadas a la protección ambiental en esta generación y la próxima. Si bien esta opinión es compartida por los gobiernos y grupos ecologistas, la industria, los investigadores y la opinión pública, existe un amplio debate sobre cómo mejorar las condiciones ambientales sin sacrificar los actuales niveles económicos. Por otra parte, la protección del medio ambiente se ha convertido en una cuestión política de primera magnitud y la estabilidad ambiental se ha situado en un lugar preeminente de muchos programas políticos.

L os esfuerzos pasados y presentes por preservar el medio ambiente se han caracterizado en gran medida por un enfoque unidimensional. En efecto, los problemas se han abordado de forma casuística. En los problemas causados por la contaminación generada por emisiones fácilmente identificables procedentes de fuentes específicas, este enfoque ha facilitado la reducción de los impactos ambientales. Hoy en día, la situación es más compleja. Gran parte de la contaminación actual procede de emisiones de fuentes diversas que se difunden fácilmente de un país a otro. Por otra parte, todos contribuimos al nivel global de contaminación ambiental con nuestra actividad cotidiana. Estas fuentes dispersas de contaminación son difícilmente identificables y su combinación en el deterioro ambiental no es bien conocida.

Es probable que los crecientes problemas ambientales de alcance global y naturaleza compleja impliquen es especial la participación de extensos sectores sociales en la adopción de medidas de reparación. Si desean desempeñar una función importante en la protección del medio ambiente, todos los agentes sociales que participan en el proceso - científicos, sindicatos, organizaciones no públicas, empresas, organismos públicos de ámbito nacional y medios de comunicación socialdeben aplicar de forma concertada políticas globales adecuadas de protección ambiental en el marco de un esfuerzo complementario de carácter multidisciplinario. Por consiguiente, es preciso coordinar las aspiraciones ambientales de todos los intereses sectoriales con objeto de inducir las interacciones y reacciones necesarias para alcanzar los resultados previstos. Es probable que se produzca un consenso unánime en torno a los objetivos últimos de la mejora de la calidad ambiental. No es menos probable, sin embargo, que se produzca desacuerdo en cuanto al ritmo, los medios y el tiempo necesarios para alcanzar esos objetivos.

La protección ambiental se ha convertido en una cuestión de creciente importancia estratégica para la industria y el mundo de la empresa, tanto por lo que respecta al emplazamiento de las plantas como al comportamiento de los procesos tecnológicos y los productos. La industria muestra un interés cada vez mayor 
por adquirir una visión global de las repercusiones ambientales de sus operaciones. La legislación ha dejado de ser el único factor contextual por causa de la creciente importancia de los problemas ambientales asociados a los productos. La idea del desarrollo de productos ambientalmente inocuos y de producciones "verdes", esto es, favorables al medio ambiente, ha ido ganando en aceptación entre productores y consumidores.

Se trata, ciertamente, de un importante desafío para la industria; sin embargo, los criterios ambientales no siempre se toman en consideración en los estadios iniciales del diseño de un producto, en los que suele ser más fácil prevenir los impactos negativos. Hasta hace poco, los impactos ambientales solían reducirse aplicando controles en el último "eslabón" del proceso y modificando el diseño de éste, en lugar del diseño del producto. Sin embargo, se precisa un ingente esfuerzo de desarrollo de un sistema viable y aceptable de incorporación de los impactos ambientales a los diferentes estadios productivos y actividades industriales, desde la compra de materias primas y la producción al uso de los productos y su evacuación.

A parentemente, el único método conocido para abordar estas nuevas y complejas cuestiones es un enfoque del problema basado en el ciclo vital. La evaluación del ciclo vital disfruta de amplio reconocimiento como futura herramienta de ordenación del medio ambiente, a medida que las cuestiones asociadas a los productos adquieren mayor relieve a los ojos de la opinión pública. Si bien la evaluación del ciclo vital promete ser un valioso elemento de los planes de desarrollo de diseños y tecnologías productivas limpios para el medio ambiente, se trata de un concepto relativamente nuevo que precisa una mayor elaboración para ser aceptado como método de aplicación general al desarrollo de procesos y productos ambientalmente inocuos.

\section{El marco empresarial de la evaluación \\ del ciclo vital}

La nueva filosofía de protección del medio ambiente que precisa el mundo empresarial, consistente en considerar los productos y servicios como un todo, se debe asociar a la elaboración de un concepto común, sistemático y estructurado, que permita tomar las decisiones y fijar las prioridades precisas. Debe ser un concepto flexible y extensible, aplicable tanto a los diversos contextos de la toma de decisiones en la industria como a elementos nuevos del progreso científico y tecnológico. No obstante, este nuevo concepto debe basarse en determinados principios y consideraciones básicos, como la identificación de problemas, la evaluación de las medidas de reparación de daños, el análisis de costel beneficio y la evaluación final (Figura 54.1).

En la identificación de problemas se ponen de relieve diferentes clases de problemas ambientales y sus causas. Se trata de juicios multidimensionales en los que se toman en consideración diversos factores contextuales. Existe, ciertamente, una relación estrecha entre el medio ambiente de trabajo y el ambiente exterior. Por consiguiente, la intención de preservar el medio ambiente se debe traducir en dos objetivos: reducir el impacto de todas las actividades humanas en el medio ambiente exterior y fomentar el bienestar de los trabajadores mediante la creación de un entorno de trabajo seguro y perfectamente planificado.

En la evaluación de las posibles medidas de reparación de daños se incluyen todas las posibles alternativas prácticas para reducir las emisiones contaminantes y el uso de recursos naturales no renovables. En la medida de lo posible, las soluciones técnicas se deben formular tanto en términos monetarios como en función de su capacidad para reducir el uso de los recursos naturales y los niveles de contaminación. El objetivo del análisis de coste/ beneficio es la generación de una lista de prioridades mediante la comparación de los diferentes tipos establecidos de medidas de reparación de daños desde la perspectiva de las

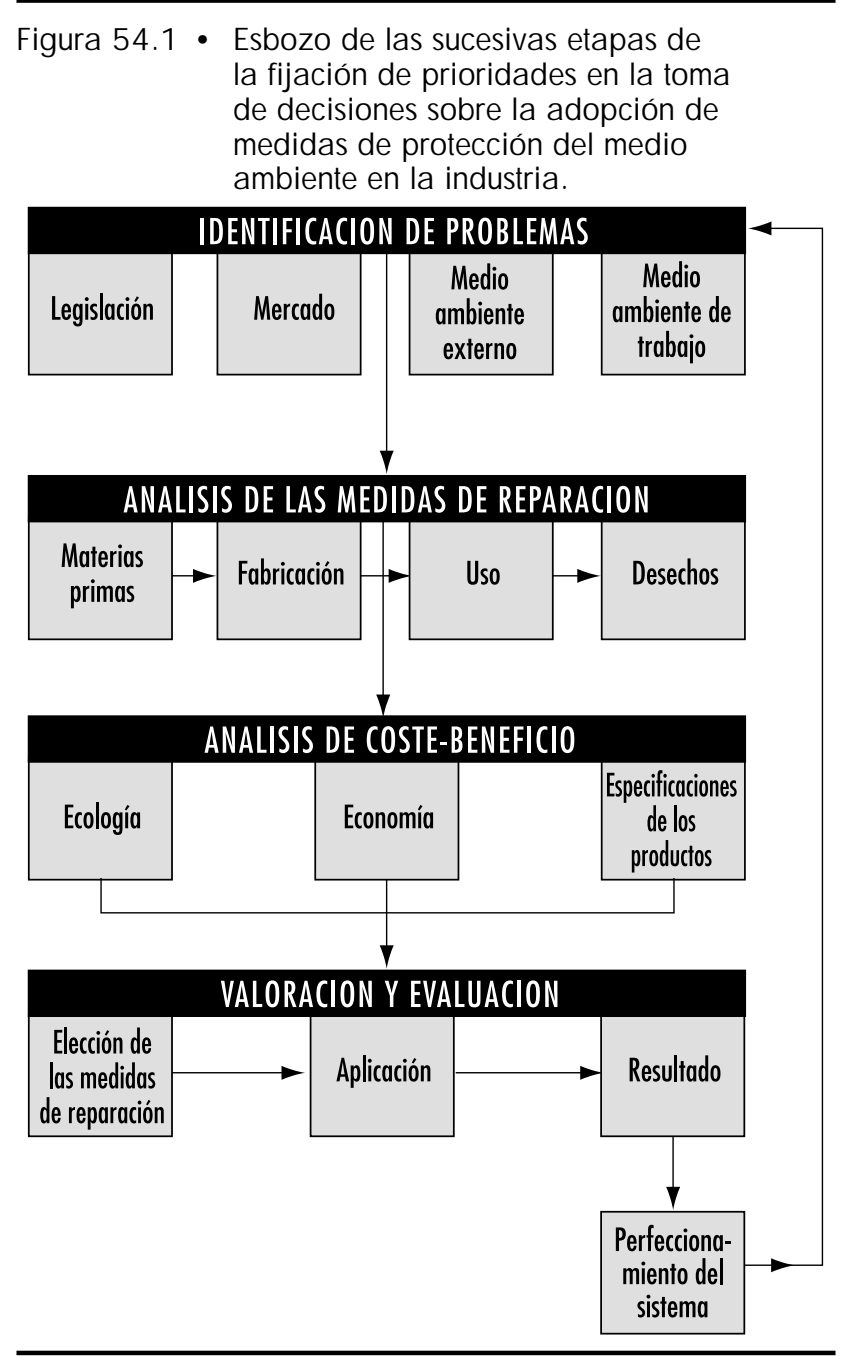

especificaciones de los productos y de los objetivos fijados, la viabilidad económica y la eficacia ambiental. No obstante, la experiencia demuestra que suelen producirse serias dificultades para traducir el patrimonio ambiental en términos monetarios.

La fase de evaluación y cuantificación se debe considerar parte integrante del proceso de establecimiento de unas prioridades que aporten los elementos necesarios para la emisión de un juicio definitivo sobre la eficacia de las medidas propuestas para la reparación de daños. El proceso continuo de evaluación a raíz de la adopción o aplicación de una medida aporta una retroinformación adicional que contribuye a perfeccionar un modelo global de toma de decisiones en la formulación de estrategias de prioridad ambiental para las decisiones relativas a los productos. Es probable que el valor estratégico de este modelo sea mayor para la industria cuando se evidencie gradualmente la necesidad de conceder a las prioridades ambientales un peso igualmente importante en el futuro sistema de planificación de los nuevos procesos y productos. Puesto que la evaluación del ciclo vital constituye un medio de identificación de las emisiones en el medio ambiente y de evaluación de los correspondientes impactos producidos por un determinado proceso, producto 0 actividad, es probable que aquélla sea la vía principal que canalice los esfuerzos de la industria por adoptar unos modelos prácticos y favorables al usuario de toma de decisiones en los procesos de desarrollo de productos inocuos para el medio ambiente. 


\section{Concepto de evaluación del ciclo vital}

El objeto de la evaluación del ciclo vital consiste en evaluar los impactos ambientales de toda actividad humana, desde la extracción inicial de las materias primas hasta la devolución de los residuos al seno de la tierra. De ahí que el proceso se haya denominado en ocasiones "evaluación de la cuna a la tumba". Aunque los estudios del ciclo vital se iniciaron a principios del decenio de 1970, han sido escasos los intentos rigurosos de ofrecer una descripción integral del procedimiento de una forma que facilite la comprensión del proceso en su conjunto, incluidos los datos necesarios, las presunciones subyacentes y las posibles aplicaciones prácticas de la metodología. No obstante, a partir de 1992 se han publicado diversos informes que ofrecen una descripción teórica de los distintos aspectos de la evaluación del ciclo vital (Heijungs 1992; Vigon y cols. 1992; Keoleian y M enerey 1993; C anadian Standards Association 1993; Society of Envirnomental Toxicology and Chemistry 1993). Se han publicado igualmente algunos manuales y guías que reflejan los enfoques específicos de los diseñadores de productos en la aplicación práctica de un concepto integral de la evaluación del ciclo vital al desarrollo de productos ambientalmente inocuos (Ryding 1996).

Se ha definido la evaluación del ciclo vital como un procedimiento objetivo de evaluación de los efectos ambientales producidos por procesos, productos, actividades o sistemas de servicios mediante la identificación y cuantificación de los materiales y la energía usados y liberados en el medio ambiente con objeto de evaluar el impacto producido por el uso y liberación de los mismos y de estudiar y aprovechar las posibilidades de mejorar el medio ambiente. La evaluación abarca la totalidad del ciclo vital del proceso, producto, actividad o sistema de servicios en cuestión, incluidos los procesos de extracción y elaboración de las materias primas, fabricación, transporte y distribución, uso, reutilización, mantenimiento, reciclaje y evacuación final.

El objetivo central de la evaluación del ciclo vital consiste en describir con la máxima fidelidad posible la interacción de una determinada actividad con el medio ambiente, contribuir al conocimiento de la naturaleza global de los efectos ambientales de la actividad humana y facilitar a los responsables de la toma de decisiones la información precisa para determinar las posibilidades de mejorar el medio ambiente.

El marco metodológico de la evaluación del ciclo vital es un proceso escalonado de cálculo compuesto por cuatro elementos: definición y alcance de los objetivos, análisis de inventario, evaluación de impactos e interpretación. Por tratarse de un componente de una técnica más amplia, ninguno de estos elementos constituye por sí sólo una evaluación del ciclo vital, que está integrada por los cuatro. M uchas evaluaciones del ciclo vital se centran en el análisis de inventario, por lo que suelen denominarse "inventarios del ciclo vital".

La definición y el alcance de los objetivos consiste en una definición de la finalidad y del sistema del estudio: su alcance, definición de la unidad funcional (la medida del comportamiento generada por el sistema) y la implantación de un procedimiento de garantía de la calidad de los resultados.

Al iniciar un trabajo de evaluación del ciclo vital, es primordial definir claramente el objetivo del estudio, a ser posible mediante una formulación clara e inequívoca de los motivos que informan su realización y el uso previsto de sus resultados. U n aspecto clave es la decisión de utilizar los resultados, bien en aplicaciones intrasocietarias con objeto de mejorar los efectos ambientales de un proceso industrial 0 un producto, bien en aplicaciones externas, con objeto, por ejemplo, de influir en la política oficial o en las elecciones del consumidor al realizar una compra.

Si no se fija por anticipado un objetivo claro para la evaluación del ciclo vital, es posible que el análisis de inventario y la evaluación de impactos se elaboren excesivamente y los resultados definitivos no sean válidamente aplicables a la toma de decisiones prácticas. La decisión de centrar los resultados en las emisiones al medio ambiente, en un determinado problema ambiental 0 en una evaluación global de los impactos ambientales permite optar directamente entre realizar un análisis de inventario, una clasificación/ caracterización o una valoración (Figura 54.2). Es preciso lograr que todos los elementos consecutivos de la evaluación del ciclo vital sean "visibles" con objeto de facilitar al usuario la tarea de elegir el nivel de complejidad que desea utilizar.

El objetivo central de muchos programas globales de desarrollo de métodos productivos limpios, de diseño orientado al medio ambiente 0 de desarrollo de productos ambientalmente inocuos suele consistir en reducir el impacto ambiental global producido durante el ciclo vital de un producto. El logro de estos objetivos suele exigir un alto grado de segregación del proceso de evaluación de impacto ambiental, que, a su vez, entraña la necesidad de adoptar un sistema generalmente aceptado de valoración que haga posible el empleo de un sistema de puntuación para comparar entre sí los distintos efectos sobre el medio ambiente.

El alcance de la evaluación del ciclo vital define el sistema y determina sus límites, necesidades de datos, hipótesis y limitaciones. Es preciso formular una definición del alcance lo suficientemente rigurosa para garantizar que la amplitud y profundidad del análisis sean tanto suficientes para lograr el objetivo propuesto y sus límites como compatibles con los mismos; y que las presunciones se formulen claramente y sean comprensibles y visibles. No obstante, dado que la evaluación del ciclo vital

Figura 54.2 - O bjetivos e integridad de la evaluación del ciclo vital.

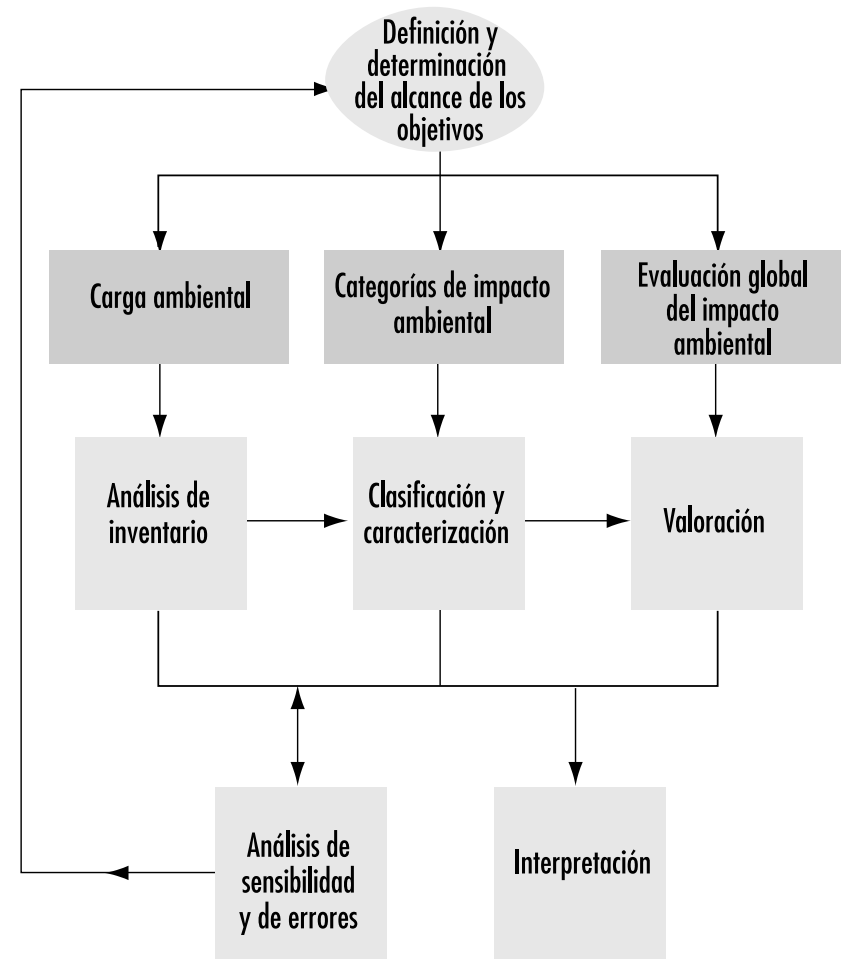

Uustración de la relación existente entre los diferentes objetivos de los estudios de evaluación del ciclo vital y la integridad resultante de la realización de sus diferentes componentes. 
Figura 54.3 - Elementos sucesivos de un análisis de inventario del ciclo vital.

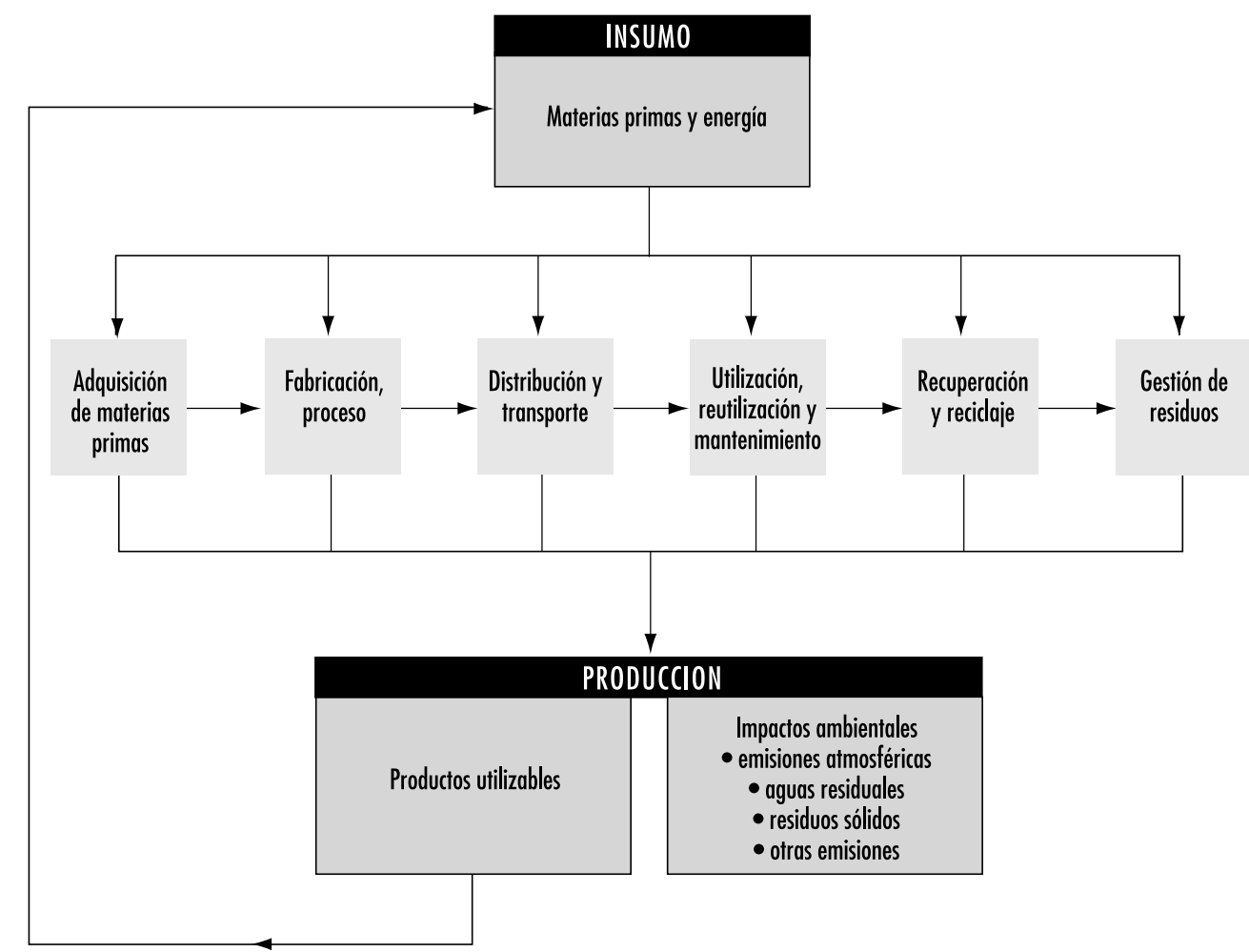

constituye un proceso iterativo, el algunos casos es preferible no fijar permanentemente todos los elementos que configuran su alcance. Se recomienda utilizar análisis de sensibilidad y de errores que posibiliten la verificación y validación sucesivos del objetivo y el alcance en función de los resultados obtenidos con objeto de realizar correcciones y adoptar nuevas hipótesis.

EI análisis de inventario es un proceso objetivo basado en datos de cuantificar las necesidades de energía y materias primas, las emisiones atmosféricas, las aguas residuales, los residuos sólidos y otras emisiones al medio ambiente que se producen durante el ciclo vital de un proceso, producto, actividad o sistema de servicios (Figura 54.3).

El cálculo de insumos y productos del análisis de inventario se refiere al sistema definido. En muchos casos, las operaciones de proceso generan más de un producto, por lo que es preciso desglosar este sistema complejo en una serie de subprocesos independientes, cada uno de los cuales genera un único producto. Durante la producción de un material de construcción, se producen emisiones de agentes contaminantes en cada subproceso, desde la adquisición de materias primas hasta el producto final. El proceso productivo global se puede representar mediante un "árbol", cuyo tronco simboliza el principal flujo de materiales y energía, al tiempo que las ramas ilustran los distintos subprocesos y las hojas arrojan los valores específicos de la emisión de contaminantes, etcétera. Sumados, estos subprocesos reúnen las características globales del sistema único original de coproductos.

Se recomienda realizar análisis de sensibilidad y de errores con objeto de estimar la exactitud de los datos generados por el análisis de inventario. Por consiguiente, los datos utilizados se deben "etiquetar" con la información pertinente, no sólo por lo que respecta a la fiabilidad sino también en relación con la fuente, el origen, etcétera, con la finalidad de facilitar la actualización y concreción futuras de los datos (los denominados metadatos). El uso del análisis de sensibilidad y de errores permite identificar los datos esenciales de mayor importancia para el resultado del análisis del ciclo vital, que podría precisar una elaboración complementaria para mejorar su fiabilidad.

La evaluación de los impactos es una técnica cualitativa 0 cuantitativa - 0 ambas cosas - utilizada para caracterizar y evaluar los efectos de la carga ambiental concretada en la fase de inventario. La evaluación debe comprender tanto los aspectos de la sanidad ambiental y la salud humana como otros efectos del tipo de la modificación del hábitat y la contaminación acústica. La dimensión de la evaluación de impactos se puede desglosar en tres fases sucesivas: clasificación, caracterización y valoración, todas los cuales expresan los efectos de las cargas ambientales determinadas en el análisis de inventario, en diferentes niveles agregados (Figura 54.4). La clasificación es la fase en que los análisis de inventario se consolidan en varias categorías de impactos; la caracterización es la fase en que se producen el análisis y la cuantificación y en la que, cuando es posible, se lleva a cabo la agregación de los impactos dentro de las categorías de impacto existentes; y la valoración es la fase en que se ponderan los datos correspondientes a las distintas categorías específicas de impacto con objeto de que resulten comparables entre sí para perfeccionar la interpretación y agregación de los datos resultantes de la evaluación de datos.

En la fase de clasificación, los impactos se pueden agrupar en las siguientes categorías generales de protección ambiental: agotamiento de los recursos, higiene ambiental y salud humana. A su vez, estas áreas se pueden subdividir en categorías específicas de impactos, basadas principalmente en el proceso ambiental implicado, con objeto de generar una perspectiva congruente con los actuales conocimientos científicos de estas cuestiones. 
Figura 54.4 - Marco conceptual de los niveles sucesivos de agregación de datos en los componentes de la evaluación de impacto.
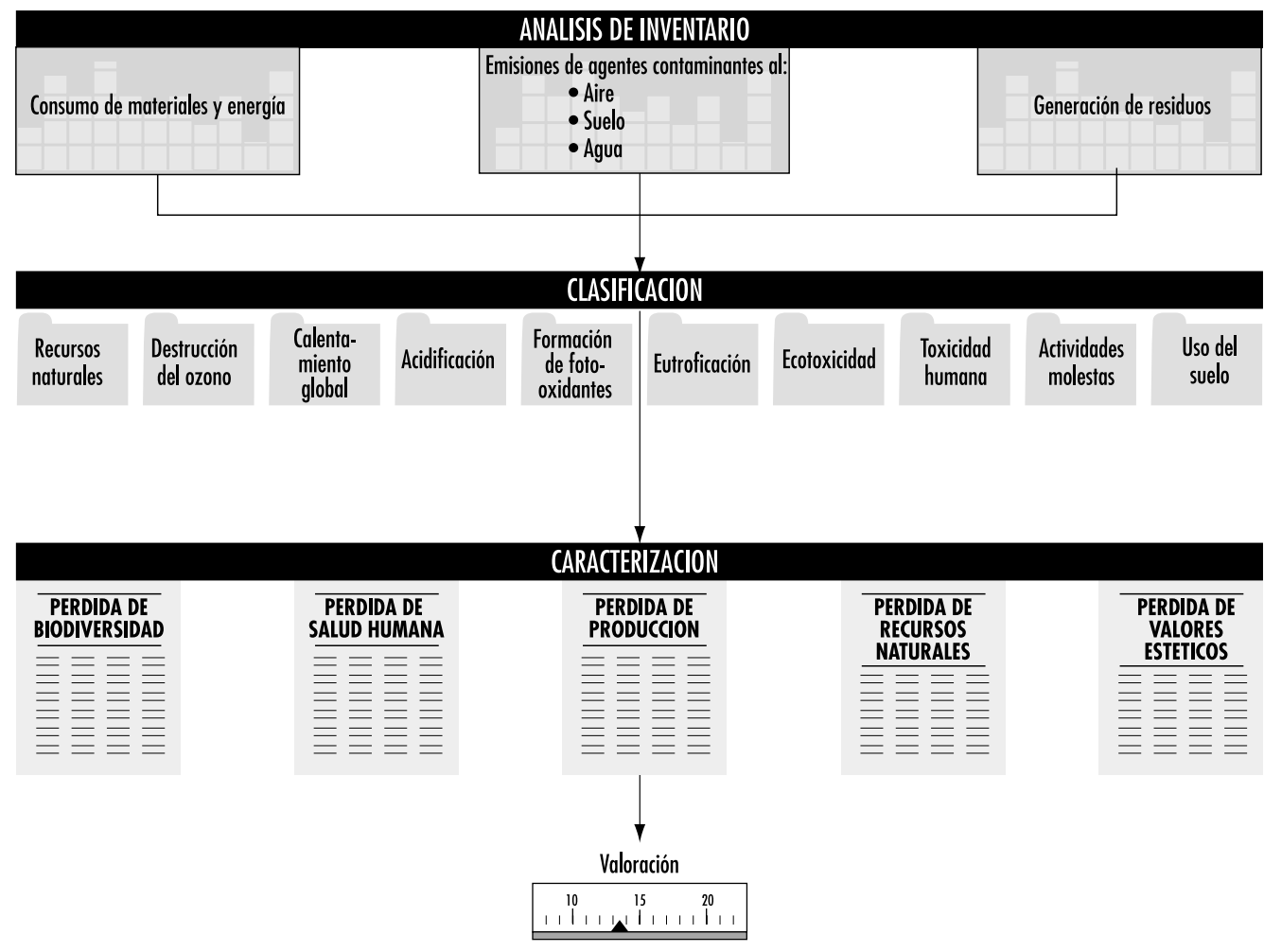

Existen diversas técnicas de caracterización: asociar los datos a las concentraciones de efectos inobservables 0 a los niveles ambientales, elaborar modelos de la exposición y sus efectos y aplicar los modelos con un criterio puntual a cada emplazamiento, o bien aplicar factores de equivalencia a las diferentes categorías de impactos. 0 tro sistema consiste en homologar los datos segregados de cada categoría de impactos con la magnitud real de los impactos en un área determinada, con objeto de mejorar la comparabilidad de los datos correspondientes a las distintas categorías de impactos.

La valoración efectuada con vistas a una mayor agregación de los datos generados por la evaluación de impactos es, probablemente, el componente de la evaluación del ciclo vital que ha suscitado mayor controversia. Se pretende que determinados métodos, que suelen denominarse "técnicas de la teoría de la decisión", permiten convertir la valoración en un método explícito y racional. Los principios de valoración se basan en consideraciones científicas, políticas o sociales, y existen actualmente métodos que abarcan las tres dimensiones. Especial importancia reviste el empleo del análisis de sensibilidad y de errores. El análisis de sensibilidad permite identificar los criterios de valoración elegidos que pueden alterar la prioridad resultante entre dos posibles productos o procesos por causa de las incertidumbres de los datos. El análisis de errores se puede utilizar para conocer la probabilidad de que un producto sea más benigno para el medio ambiente que un producto competidor.

Muchos son de la opinión de que las valoraciones deben basarse en gran medida en información relativa a los valores y preferencias sociales. Sin embargo, aún están por enunciarse las condiciones específicas que debe satisfacer un método de valoración fiable y generalmente aceptado. En la Figura 54.5 se mencionan algunas condiciones específicas que podrían ser de utilidad. No obstante, hay que insistir en que todo sistema de valoración aplicado a la evaluación de la "gravedad" de los impactos ambientales causados por cualquier actividad humana se debe basar en gran medida en juicios subjetivos de valor. Probablemente no resulte factible fijar para tales valoraciones unos criterios válidos en todo tipo de situaciones en el plano mundial.

La interpretación de los resultados consiste en una evaluación sistemática de las necesidades y posibilidades de reducir la carga ambiental producida por el consumo de energía y materias

\section{Figura 54.5 - Especificaciones que debe satisfacer un método de valoración de la evaluación del ciclo vital.}

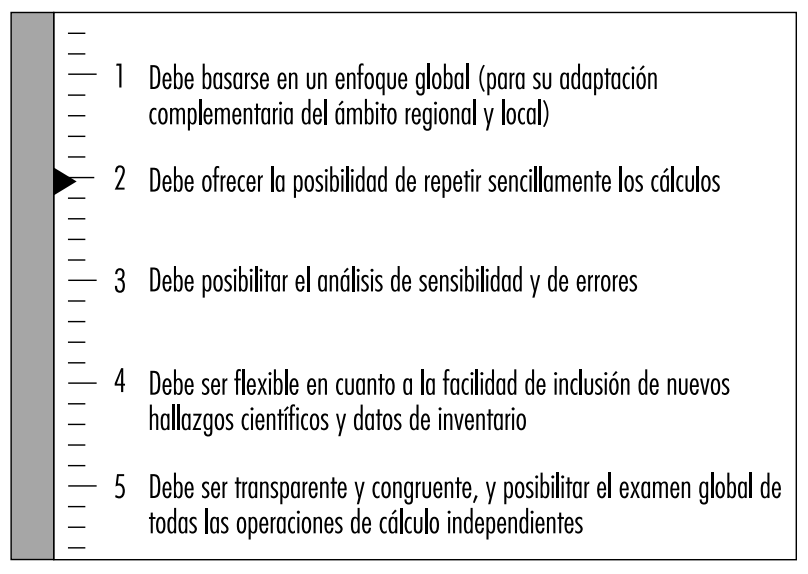


primas y por las emisiones de residuos durante el ciclo vital de un producto, proceso o actividad. En esta evaluación se pueden incluir medidas cuantitativas y cualitativas de las mejoras, como la modificación del diseño de los productos, el consumo de materias primas, la elaboración industrial, la demanda de los consumidores y la gestión de los residuos.

La interpretación de los resultados es la parte de la evaluación del ciclo vital en la que se identifican y evalúan las posibilidades de reducir los impactos y cargas ambientales de los procesos y productos analizados. Se aplica a la identificación, evaluación y selección de posibilidades de mejora del diseño de procesos y productos, esto es, de la reformulación técnica de un proceso 0 producto con objeto de reducir el correspondiente impacto ambiental, sin merma de los niveles previstos de funcionamiento y rendimiento. Es preciso informar al responsable de la toma de decisiones de los posibles efectos de las incertidumbres existentes en los datos subyacentes y en los criterios adoptados para lograr los resultados, con objeto de reducir el riesgo de extraer falsas conclusiones sobre los procesos y productos examinados. También en este caso se precisa un análisis de sensibilidad y de errores con objeto de fomentar la credibilidad de la metodología de la evaluación del ciclo vital, ya que dicho análisis aporta al responsable de la toma de decisiones datos referentes a: 1) los principales parámetros e hipótesis que se deben ponderar y elaborar en mayor profundidad con objeto de reforzar la validez de las conclusiones, y 2) la significación estadística de la diferencia calculada en las respectivas cargas ambientales de las distintas opciones de procesos o productos.

Se asegura que la interpretación es la parte de la evaluación del ciclo vital menos documentada. No obstante, los resultados preliminares de algunos importantes estudios de la evaluación del ciclo vital realizados por equipos multidisciplinarios integrados por investigadores universitarios, empresas de consultoría y numerosas empresas indican sin excepción que, desde una perspectiva general, algunos serios impactos ambientales causados por los productos parecen estar asociados al uso de los mismos (Figura 54.6). Por lo tanto, parecen abrirse posibilidades de que las iniciativas de la industria contribuyan a reducir los impactos ambientales a través del desarrollo de productos.

Un estudio de la experiencia internacional adquirida en el desarrollo de productos ambientalmente inocuos basado en la evaluación del ciclo vital (Ryding 1994) ha puesto de relieve la existencia de algunas perspectivas prometedoras para la evaluación del ciclo vital: 1) en el ámbito interno de la empresa, como base de la formulación de pautas para la planificación estratégica a largo plazo del diseño de productos, y también 2) en cierta medida, para ser utilizada por los organismos reguladores en la satisfacción de las necesidades generales de la planificación social y la toma de decisiones. M ediante el desarrollo y uso de información generada por la evaluación del ciclo vital respecto a los efectos ambientales producidos "antes" 0 "después" de la actividad analizada, se puede crear un modelo de toma de decisiones, tanto de gestión social, como de la regulación oficial.

\section{Conclusiones}

Nuestro conocimiento de los riesgos ambientales de origen humano parece crecer a mayor velocidad que nuestra capacidad para afrontarlos. Esto hace que las decisiones que afectan al medio ambiente suelan encerrar mayores incertidumbres que otras. Además, los márgenes de seguridad suelen ser muy reducidos. En efecto, los actuales conocimientos ecológicos y técnicos no siempre bastan para elaborar una estrategia integral y fiable de protección del medio ambiente. No es posible adquirir un conocimiento integral de todas las reacciones ecológicas al estrés ambiental antes de adoptar medidas. No obstante, la ausencia de
Figura 54.6 - Esbozo de algunas experiencias generales sobre los momentos del ciclo vital de los productos en los que se producen las principales cargas a mbientales.

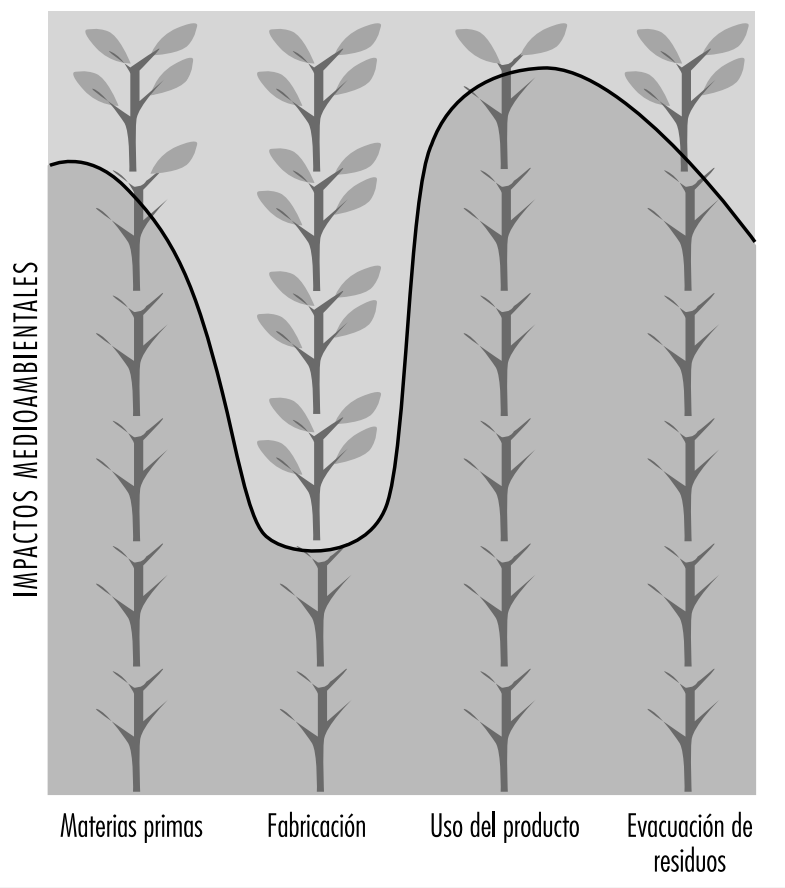

una información científica completa e indubitable no debe impedir la toma de decisiones relativas a los programas de eliminación de la contaminación ni la aplicación de los mismos. Por lo tanto, nuestros conocimientos sobre la naturaleza y el alcance de la mayoría de los problemas justifican la adopción de medidas y, en muchos casos, tales conocimientos permiten la aplicación de políticas eficaces de reparación de la mayor parte de los problemas ambientales.

La evaluación del ciclo vital es un nuevo modo de afrontar las complejas cuestiones ambientales del futuro. Sin embargo, no existen atajos ni respuestas sencillas a todas las cuestiones planteadas. Sin duda, la creciente preferencia por los enfoques globales de los problemas ambientales permitirán descubrir numerosas carencias en nuestros conocimientos que será preciso subsanar. Por otra parte, muchos de los datos disponibles que podrían utilizarse se han elaborado para otros fines. A pesar de todos los problemas, no hay motivo alguno para esperar al perfeccionamiento de la técnica de evaluación del ciclo vital. No resulta, ciertamente, difícil encontrar dificultades e incertidumbres en el actual concepto de la evaluación del ciclo vital si se desea esgrimir tales deficiencias para justificar la reticencia a la utilización de esta técnica. Es preciso decidir si vale la pena desarrollar un enfoque global, basado en el ciclo vital, de los problemas ambientales, a pesar de las dificultades. Cuanto más se utilice la evaluación del ciclo vital, más aprenderemos sobre su estructura.

En la actualidad, la decisión de utilizar la evaluación del ciclo vital puede ser más un problema de voluntad y ambición que certidumbres. La idea misma de la evaluación del ciclo vital debe consistir en extraer el máximo rendimiento de los actuales conocimientos técnicos y científicos y en aplicar los resultados con modestia e inteligencia a un tiempo. Es más que probable que este tipo de enfoque contribuya a mejorar la credibilidad del método. 


\section{- EVALUACION Y COMUNICACION DE RIESGOS}

\section{Adrian V. G heorghe y H ansjörg Seiler}

La administración, el sector privado y la opinión pública coinciden en reconocer la necesidad de detectar, evaluar y controlar los riesgos industriales (tanto profesionales como generales) para las personas y el medio ambiente. La conciencia de los peligros y de los accidentes capaces de provocar graves pérdidas materiales y de vidas humanas ha inducido el desarrollo y aplicación de unos métodos, conceptos e instrumentos sistemáticos de evaluación y comunicación de los riesgos.

El proceso de evaluación de los riesgos comprende la descripción de sistemas, la identificación de peligros y el desarrollo de escenarios de accidentes y de resultados de los sucesos asociados al uso de un proceso industrial o una instalación de almacenamiento determinados; la estimación de los efectos o consecuencias de esos sucesos peligrosos sobre bienes y personas y sobre el medio ambiente; la estimación tanto de la probabilidad de que tales sucesos peligrosos se produzcan en la práctica como de sus consecuencias, tomando en consideración los distintos controles tanto operativos como organizativos; la cuantificación de los consiguientes niveles de riesgo fuera de los muros de la fábrica; y la evaluación de tales niveles de riesgo en función de criterios de riesgo cuantificados.

El proceso de evaluación cuantificada del riesgo es de naturaleza probabilística. Como no es seguro que se produzcan accidentes graves a lo largo de la vida útil de un proceso o una planta, no es correcto basar el proceso de evaluación en las consecuencias de accidentes aislados. Es preciso tomar en consideración la probabilidad de que se produzcan efectivamente tales accidentes. Esta probabilidad y los niveles de riesgo resultantes deben reflejar el nivel del diseño y de los controles organizativos y operativos existentes en la planta. La cuantificación del riesgo implica cierto número de incertidumbres (por ejemplo, modelos matemáticos de estimación de las consecuencias, determinación de las respectivas probabilidades de distintos escenarios de accidentes, efectos probables de tales accidentes). En todos los casos, el proceso de evaluación de riesgos debe hacer aflorar y permitir la identificación de tales incertidumbres.

La principal utilidad del proceso de evaluación de riesgos no debe residir en el valor numérico (aislado) de los resultados. El proceso de evaluación, por sí mismo, ofrece sustanciales posibilidades de identificación sistemática de los peligros y de evaluación del riesgo. En efecto, el proceso de evaluación de riesgos permite la detección e identificación de los peligros y hace posible la asignación de unos recursos necesarios y suficientes a la actividad de control de riesgos.

Los objetivos y aplicaciones del proceso de identificación de peligros determinan, a su vez, el ámbito del análisis, la elección de los métodos y procedimientos adecuados y el personal, fondos, conocimientos prácticos, recursos financieros y tiempo precisos para el análisis, así como la correlativa documentación necesaria. La identificación de peligros es una herramienta necesaria y eficaz en el análisis de riesgos y la toma de decisiones en la evaluación de riesgos y la gestión de la salud y seguridad en el trabajo. Se pueden definir varios objetivos centrales:

- determinar las situaciones peligrosas que se producen en una planta o un proceso;

- averiguar cómo se producen esas situaciones

- colaborar en la evaluación de la seguridad de una instalación peligrosa.
El primer objetivo central consiste en enriquecer el conocimiento global de las principales cuestiones y situaciones que pueden influir en el proceso de análisis del riesgo en determinados procesos y plantas; las sinergías entre los peligros concretos y el nivel de estudio del área poseen una significación especial. Es posible identificar los problemas operativos y de diseño, y estudiar un esquema de clasificación de los peligros.

El segundo objetivo contiene elementos de evaluación de riesgos y se cifra en el desarrollo de escenarios de accidentes e inter pretación de los resultados. La evaluación de las consecuencias de varios accidentes y la difusión de su impacto en el tiempo y el espacio son especialmente importantes en la fase de identificación de los peligros.

El tercer objetivo consiste en aportar información utilizable en las etapas posteriores de la evaluación de riesgos y el control de los peligros en la explotación de las plantas. Esto puede lograrse mejorando las especificaciones de los escenarios de análisis de riesgos o diseñando medidas de seguridad adecuadas que satisfagan determinados criterios de riesgo (por ejemplo, individuales 0 a escala de la empresa), o asesorando en la previsión de situaciones de urgencia y en la gestión de los accidentes.

U na vez definidos los objetivos, la definición del ámbito del proceso de identificación de peligros es el segundo elemento en orden de importancia en la gestión, organización y aplicación del proceso de identificación de peligros. El ámbito de este proceso en un ejercicio complejo de evaluación de riesgos se puede definir básicamente en función de los parámetros siguientes: 1) fuentes potenciales de peligro (por ejemplo, emisiones radiactivas, sustancias tóxicas, fuego, explosiones), 2) situaciones de daños causados por plantas y procesos, 3) hechos desencadenantes; 4) posibles consecuencias, y 5) fijación de prioridades de los peligros. Los factores determinantes de la medida en que estos parámetros se incluyen en el proceso de identificación de peligros son los siguientes: a) objetivos y aplicaciones previstas del proceso de identificación de peligros, b) disponibilidad de información adecuados, c) recursos y conocimientos prácticos disponibles. La identificación de los peligros exige analizar toda la información pertinente relativa a la instalación (por ejemplo, proceso, planta). En este análisis se incluye por regla general la ubicación y el plano de la planta; información pormenorizada sobre los procesos, mediante diagramas de diseño, y sobre las condiciones operativas y de mantenimiento; naturaleza y cantidades de materiales que se manipulan; medidas de protección operativas, organizativas y físicas; y normas de diseño.

Al evaluar los resultados materiales de un accidente se pueden identificar diversos resultados (por ejemplo, número de fallecidos, número de personas hospitalizadas, diversas clases de daños en el ecosistema, pérdidas económicas, etc.). Los resultados materiales producidos por la sustancia (i) en una determinada actividad (j) se pueden calcular a partir de la ecuación $\mathrm{C} i j=\Lambda a \mathrm{f}_{\mathrm{a}} \mathrm{f}_{\mathrm{m}}$, en la que $\mathrm{Cij}$ es el número de muertes provocadas por la sustancia i en una determinada actividad $j, \Lambda$ es el área afectada (ha); a es la densidad demográfica de las áreas pobladas dentro de la zona afectada (personas/ área afectada), y $f_{a}$ y $f_{m}$ son factores de corrección.

Los efectos de los accidentes graves sobre el medio ambiente son más difíciles de estimar, debido, tanto a la diversidad de sustancias que pueden estar implicadas como a la cantidad de indicadores de impactos ambientales aplicables en un determinado accidente. Por regla general, se puede aplicar a diversos efectos ambientales una escala de utilidad en la que se pueden incluir las circunstancias relacionadas con accidentes, incidencias o resultados catastróficos.

La evaluación de las consecuencias económicas de los (posibles) accidentes se basa en una estimación pormenorizada de las 
eventuales consecuencias y de los costes correspondientes. No siempre se acepta a priori un valor monetario para determinadas categorías de consecuencias (por ejemplo, pérdida de vidas o de hábitats específicos). En la valoración monetaria de las consecuencias se deben incluir los costes externos, que suelen ser extremadamente difíciles de determinar.

Se suele considerar que las técnicas de identificación de peligros que pueden afectar al equipo y las instalaciones productivas constituye el elemento más desarrollado y contrastado del proceso de evaluación de las instalaciones peligrosas. Es preciso tener en cuenta que: 1) la amplitud y el nivel de detalle de los procedimientos varían desde las listas de control comparativas a los diagramas lógicos muy estructurados; y 2) las técnicas son aplicables en varios estadios de la elaboración y ejecución de los proyectos (desde la toma de las decisiones iniciales relativas al emplazamiento de una planta hasta las sucesivas fases de diseño, construcción y explotación).

Existen, fundamentalmente, tres categorías de técnicas de identificación de peligros. Las siguientes son las técnicas más utilizadas dentro de cada categoría:

- Categoría 1. Métodos comparativos: Lista de control de procesos o sistemas, auditoría de seguridad, clasificación relativa (índices de peligro de D ow y M ond), análisis preliminar de peligros.

- Categoría 2. M étodos fundamentales: Estudios de operabilidad de riesgos (H AZOP), análisis del tipo "Q ué ocurre si", análisis de modos y efectos de fallos.

- M étodos basados en diagramas lógicos: análisis en árbol de fallos, análisis en árbol de sucesos.

\section{Análisis de causas-consecuencias y análisis de fiabilidad humana}

La idoneidad y pertinencia de una determinada técnica de identificación de peligros depende en gran medida del objeto de la evaluación de riesgos. Si se dispone de datos complementarios, resulta posible combinarlos en el proceso global de evaluación de distintos riesgos. Con frecuencia se puede aplicar el criterio de expertos e ingenieros en la evaluación en profundidad del riesgo inherente a procesos e instalaciones. El concepto básico consiste en realizar un examen inicial del proceso o la planta desde la perspectiva más amplia con objeto de detectar sistemáticamente los posibles riesgos. EI empleo de técnicas complejas como herramienta principal de este examen puede crear problemas y determinar que se pasen por alto algunos peligros evidentes. $A$ veces resulta necesario aplicar más de una técnica, en función del nivel de detalle exigido y de que se trate de una nueva instalación 0 una explotación en funcionamiento.

Los criterios probabilísticos de seguridad se asocian a un proceso racional de toma de decisiones que exige el establecimiento de un marco coherente con unas normas que expresen el nivel de seguridad deseado. En la evaluación de la aceptabilidad de una instalación industrial peligrosa se deben tomar en consideración los riesgos sociales o para determinados grupos. En el desarrollo de los criterios de seguridad probabilísticos basados en el riesgo social se deben tomar en consideración factores como la alarma pública ante los accidentes con graves consecuencias (esto es, que el nivel de riesgo elegido se debe reducir a medida que las consecuencias se agravan). Si bien en los niveles individuales de riesgo de fallecimiento se incluyen todos los factores de riesgo (por ejemplo, incendio, explosión y toxicidad), se pueden producir incertidumbres al correlacionar las concentraciones tóxicas con los niveles de riesgo de muerte. Lejos de basarse en una determinada relación entre dosis y efectos, el concepto de "mortal" debe elaborarse a partir de la valoración de los datos disponibles. El concepto de riesgo social implica que el riesgo de que se produzcan resultados graves con una menor frecuencia se valora como más importante que el de resultados menos graves con una frecuencia superior.

Independientemente del valor numérico del nivel de los criterios de riesgo que se adopte a efectos de la evaluación de riesgos, es preciso aplicar algunos criterios cualitativos como parámetros de la evaluación de riesgos y la gestión de la seguridad: 1) se deben evitar todos los riesgos "evitables"; 2) el riesgo resultante de un peligro importante se debe reducir en la medida de lo posible; 3) las eventuales consecuencias de los sucesos peligrosos más probables se deben circunscribir a los límites de la instalación; y 4) si existe un elevado nivel de riesgo producido por una determinada instalación, no se debe autorizar la construcción de nuevas instalaciones peligrosas que puedan incrementar sustancialmente el actual nivel de riesgo.

En el decenio de 1990 se ha concedido una importancia creciente a la comunicación del riesgo, que se ha convertido en una rama autónoma de la gestión del riesgo.

La comunicación del riesgo comprende varias tareas centrales:

- identificación de los aspectos controvertibles de los riesgos percibidos;

- transmisión y explicación de la información del riesgo;

- influencia en los comportamientos individuales frente al riesgo;

- elaboración de estrategias de información para casos de emergencia,

- desarrollo de métodos de solución de conflictos basados en la cooperación y la participación.

Tanto el ámbito como los objetivos de la comunicación de riesgos pueden diferir en función tanto de los agentes participantes en el proceso de comunicación como de la función que asignen a dicho proceso y de las expectativas que depositen en él y en su entorno.

Las personas y empresas participantes en el proceso de comunicación de riesgos utilizan varios medios y canales de comunicación. L os contenidos principales son la protección de la salud y el medio ambiente, la mejora de la seguridad y la aceptabilidad del riesgo.

Según la teoría general de la comunicación, ésta puede cumplir las funciones siguientes:

- presentación de la información

- llamamiento

- autopresentación

- definición de un cauce de relaciones o de toma de decisiones

Por lo que respecta específicamente al proceso de comunicación de riesgos, cabría establecer una distinción entre estas funciones. En dependencia de la función, se podrían examinar diferentes condiciones del éxito del proceso de comunicación.

La comunicación de riesgos consiste a veces en una simple exposición de hechos. La información es una necesidad generalizada en toda sociedad moderna. En particular, en el campo ambiental existen leyes que, por una parte, obligan a las autoridades a informar al público y, por otra, consagran el derecho de éste a conocer los problemas ambientales y las situaciones de riesgo. Ejemplos de ello son la denominada Directiva Seveso de la Comunidad Europea y la legislación norteamericana basada en el "derecho a conocer de la comunidad". La información se puede elaborar para un determinado segmento del público; por ejemplo, cuando hay que informar a los trabajadores de una fábrica de los riesgos que afrontan en su lugar de trabajo. A este respecto, la comunicación de riesgos debe ser:

- $\tan$ neutra y objetiva como sea posible;

- completa,

- comprensible para los destinatarios de la información. 
Un llamamiento se suele hacer para inducir a alguien a que haga algo. En materia de riesgos se pueden distinguir las siguientes funciones del llamamiento:

- llamamiento al gran público o a un segmento específico del mismo acerca de las medidas de prevención de riesgos que pueden o deben adoptarse (por ejemplo, llamamiento a los trabajadores de una fábrica hacia la necesidad de adoptar medidas de seguridad en el trabajo),

- Ilamamiento al gran público o a un determinado segmento del mismo acerca de la necesidad de tomar medidas preventivas para casos de emergencia,

- llamamiento al gran público o a un determinado segmento del mismo acerca de la necesidad de tomar medidas en situaciones de emergencia (gestión de crisis).

\section{La comunicación de un Ilamamiento debe ser:}

- tan simple e inteligible como sea posible, y tan completa como sea preciso,

- fiable: la confianza en las personas, autoridades e instancias que realizan el llamamiento es esencial para su eficacia.

La autopresentación no consiste en transmitir información objetiva, sino que se integra en una estrategia de persuasión o de marketing diseñada para vigorizar la imagen pública de una persona, recabar la aceptación pública de una determinada actividad o suscitar el apoyo del público a una posición dada. La medida del éxito de este tipo de comunicación es su nivel de credibilidad para el público. Desde una perspectiva normativa, aunque la autopresentación se orienta a convencer a las personas, debe ser honrada y sincera.

E stas formas de comunicación suelen ser unidireccionales. En cambio, la comunicación dirigida a lograr un acuerdo o la toma de una decisión suele ser bi o multidireccional. En tales casos, lejos de existir una única fuente de información, hay varios agentes implicados en un proceso de comunicación de riesgos que intercambian información. Esto es lo que suele ocurrir en las sociedades democráticas. Especialmente en materia de riesgos y medio ambiente, la comunicación se valora como una alternativa reguladora en las situaciones complejas en que no existen 0 no son viables soluciones sencillas. Esto hace que las decisiones arriesgadas y políticamente trascendentes se deben tomar en un contexto comunicativo. En este sentido, en la comunicación de riesgos se puede incluir, entre otras, la información sobre aspectos del riesgo muy politizados, aunque se puede incluir igualmente la comunicación que se establece entre un operador, los trabajadores y los servicios de urgencia con objeto de mejorar el nivel de preparación del primero para afrontar emergencias. Por lo tanto, diversos agentes pueden participar en el proceso de comunicación, en función del ámbito y el objetivo del mismo. Los principales agentes de la comunicación pueden ser:

- el operador de una instalación peligrosa;

- las víctimas potenciales de un siniestro (por ejemplo, trabajadores y vecinos);

- las autoridades reguladoras y los organismos públicos competentes;

- los servicios de urgencia y el público en general;

- los grupos de presión;

- los medios de comunicación social;

- las compañías de seguros,

- los científicos y expertos.

Desde una perspectiva de la teoría de sistemas, todas estas categorías de agentes se insertan en un determinado sistema social y, por lo tanto, emplean diversos códigos de comunicación y poseen valores e intereses diferentes que comunicar. Esto hace que resulte generalmente difícil establecer una base común para la intercomunicación de riesgos. Es preciso, por consiguiente, diseñar unas estructuras que permitan integrar estos criterios divergentes y lograr resultados prácticos. Este tipo de comunicación de riesgos se centra en cuestiones como la adopción de un acuerdo consensuado sobre el posible emplazamiento de una planta peligrosa en una región determinada.

En todas las sociedades existen medios legales y políticos de abordar los problemas relacionados con el riesgo (por ejemplo, leyes, decisiones administrativas, actuaciones judiciales, etc.). En muchos casos, tales medios no permiten alcanzar soluciones totalmente eficaces para la solución pacífica de los conflictos relacionados con el riesgo. Las propuestas consistentes en integrar elementos de comunicación del riesgo en los procedimientos actuales han acreditado su capacidad de perfeccionamiento del proceso de toma de decisiones políticas.

En el diseño de procedimientos de comunicación del riesgo se deben tomar en consideración dos cuestiones básicas:

- estructura formal y trascendencia jurídica del proceso y sus resultados,

- estructura del proceso de comunicación en sí.

Existen varias opciones respecto a la estructura formal del proceso de comunicación de riesgos:

- La comunicación se puede desarrollar dentro o entre los agentes actuales (por ejemplo, un organismo de la administración central, una corporación local y losactualesgruposde presión),

- Se pueden crear nuevos órganos especializados en el proceso de comunicación de riesgos. A este fin, se han ensayado diversos modelos (por ejemplo, jurados y juntas de ciudadanos, cauces de negociación y mediación, comités conjuntos de operadores, autoridades y ciudadanos). La mayor parte de estos modelos se basan en el fomento de un discurso estructurado en pequeños grupos. Existe disparidad de criterios en torno a si estos grupos deben estar integrados por expertos, legos, representantes de las instancias políticas, etc.

En cualquier caso, es preciso clarificar la relación entre estas estructuras de comunicación y las actuales instancias jurídicas y de toma de decisiones. Por regla general, los resultados de los procesos de comunicación de riesgos se traducen en una recomendación no vinculante a los organismos decisorios.

Por lo que respecta a la estructura del proceso de comunicación, las normas generales que rigen el discurso concreto admiten cualquier argumento que satisfaga las condiciones siguientes: - suficiente coherencia lógica;

- sinceridad (esto es, que el argumento no se encuentre sesgado por consideraciones tácticas o estratégicas),

- que quien esgrima un argumento se muestre dispuesto a aceptar las consecuencias del mismo, incluso si le fuesen desfavorables.

Se han formulado algunas reglas aplicables al proceso de comunicación de riesgos, junto con diversas propuestas tendentes a concretar la aplicación de esas reglas. Entre ellas destacan las siguientes:

En el proceso de comunicación de riesgoscabe distinguir entre:

- asertos comunicativos;

- asertos cognitivos;

- asertos normativos,

- asertos afirmativos.

Consiguientemente, las diferencias de opinión pueden obedecer a causas como las siguientes:

- diferencias en la información;

- diferencias en la interpretación de los hechos,

- diferencias en los valores normativos. 
Q uizás sea conveniente reflejar en el proceso de comunicación de riesgos el nivel de diferencias y su importancia. Se han formulado diversos modelos estructurales orientados a mejorar las condiciones del discurso y, al mismo tiempo, ayudar a los responsables de la toma de decisiones a encontrar soluciones justas y eficaces; por ejemplo:

- En un discurso franco, el resultado debe quedar abierto; si el objetivo consiste en lograr la aceptación de una decisión tomada previamente, no sería correcto iniciar una discusión.

- Si determinadas soluciones resultan, sencillamente, inviables por razones prácticas, políticas o jurídicas, así se debe indicar desde el principio.

- A veces es preferible examinar en un principio los criterios aplicables en la evaluación de las alternativas en lugar de examinar directamente las alternativas.

Se puede definir la eficacia de la comunicación de riesgos como la medida en que una situación inicial no deseada se puede reconducir hacia la situación deseada y definida en los objetivos iniciales. En la evaluación de los programas de comunicación de riesgos se deben tomar igualmente en consideración las cuestiones de procedimiento. Entre estos criterios se incluyen la viabilidad (por ejemplo, la flexibilidad, adaptabilidad y aplicabilidad) y los costes (en tiempo, personal y dinero) del programa.

\section{- AUDITORIA AMBIENTAL: DEFINICION Y METODOLOGIA}

Robert Coyle

\section{Orígenes de la auditoría ambiental}

La auditoría de la salud y seguridad ambiental se inició a principios del decenio de 1970, principalmente en las empresas de los sectores ambientalmente sensibles, como el petróleo y la química. D esde entonces, la auditoría ambiental ha conocido una considerable difusión, con el consiguiente desarrollo de los métodos y técnicas adoptados.

- Accidentes de trabajo. Las grandes catástrofes, como las de Bophal y Chernóbil y el siniestro del Exxon-Valdez, han mostrado a las empresas que no basta con promulgar unas normas y políticas internas de salud y seguridad ambiental sin verificar si se cumplen en la práctica. Las auditorías contribuyen a prevenir sorpresas desagradables.

- Desarrollo normativo. La normativa reguladora de la protección ambiental se ha desarrollado sustancialmente desde principios del decenio de 1970 y esto hace que sea cada vez más difícil para una empresa determinar si una de sus fábricas, situada en un determinado país, cumple todos los requisitos exigidos en la legislación local.

- Sensibilización pública. La opinión pública ha tomado conciencia y desarrollado un interés creciente en las cuestiones ambientales y de seguridad. H oy las empresas tienen que demostrar al público que afrontan correctamente los riesgos ambientales.

- J udicialización. El desarrollo legislativo ha producido una proliferación de demandas judiciales en reclamación de daños y perjuicios, principalmente en Estados Unidos. En Europa y otras regiones se hace especial hincapié en la responsabilidad personal de los directivos y en la información del público.

\section{¿Qué es una auditoría ambiental?}

Es importante establecer una distinción entre la auditoría ambiental y ciertas técnicas del tipo de la evaluación de impacto ambiental (EIA). Esta última se aplica a la evaluación de los posibles efectos ambientales de una instalación proyectada. El objetivo central de la auditoría ambiental consiste en la investigación sistemática de los efectos ambientales globales de la actividad de una empresa. En el mejor de los casos, la auditoría es un estudio exhaustivo de los sistemas de gestión y las instalaciones; en el peor, se limita a un examen superficial.

La auditoría ambiental tiene diversos significados para distintas personas. Se utilizan términos como evaluación, investigación y examen para describir el mismo tipo de actividad. A demás, mientas algunas empresas consideran que la "auditoría ambiental" se ciñe a los problemas ambientales, en otras, la expresión comprende la auditoría de las cuestiones de salud, seguridad y medio ambiente. Aunque no existe una definición universal, la auditoría ambiental, tal como se practica en muchas grandes empresas, se basa en el mismo concepto y filosofía básicos reflejados en la definición genérica adoptada por la Cámara de Comercio Internacional (CCI) en la obra Environmental Auditing (1989). La CCI ofrece la definición siguiente de la auditoría ambiental:

“T écnica de gestión que comprende una evaluación sistemática, documentada, periódica y objetiva del esfuerzo de la organización, la dirección y el equipo de protección ambiental por asegurar la protección del medio ambiente,

i) coadyuvando al control de la dirección sobre la actividad de protección ambiental,

ii) evaluando la observancia de la política de la empresa,

incluido el cumplimiento de las disposiciones legales".

En su propuesta de reglamento sobre la auditoría ambiental, la Comisión Europea ha asumido la definición de la $\mathrm{CCl}$.

\section{Objetivos de la auditoría ambiental}

El objetivo global de la auditoría ambiental es contribuir a conservar el medio ambiente y a reducir el riesgo para la salud humana. Es evidente que la auditoría por sí sola no permite alcanzar estos objetivos y de ahí que se utilice el término "contribuir". Ciertamente, la auditoría es una herramienta de gestión; por lo tanto, la auditoría ambiental persigue varios objetivos principales:

- evaluar la calidad de la labor del equipo y los sistemas de ordenación ambiental;

- verificar la observancia de los reglamentos y leyes vigentes de ámbito local o nacional o de otro tipo,

- reducir el nivel de exposición de las personas a los riesgos para su salud y seguridad producidos por factores ambientales.

\section{Ambito de la auditoría}

Como el objetivo principal de la auditoría es verificar la idoneidad de los actuales sistemas de gestión, su función es diametralmente diferente de la desempeñada por la supervisión de la actividad de protección ambiental. Una auditoría puede centrarse en un único problema u ocuparse de una serie de cuestiones. Cuanto más extenso sea el ámbito de la auditoría, mayores serán el equipo de investigadores, el tiempo de trabajo de campo y la profundidad del estudio. Si un mismo grupo tiene que realizar una auditoría internacional, puede ser aconsejable examinar más de una cuestión durante los desplazamientos.

Además, el ámbito de la auditoría puede oscilar entre una simple verificación de la observancia de las normas y un examen en profundidad, en función de las necesidades percibidas por la dirección. Lejos de limitarse a la gestión operativa de la protección de la salud y seguridad y del medio ambiente, la aplicación de esta técnica se ha venido extendiendo de forma creciente a la seguridad de los productos y el control de su calidad, y a 
Tabla 54.1 - Ambito de una auditoría ambiental.

Medio ambiente
Historia del emplazamiento
Procesos y materiales
Almacenamiento de materiales:
- sobre el nivel del suelo
- subterráneo
Emisiones atmosféricas
Aguas residuales
Residuos líquidos/ peligrosos
Asbesto
Eliminación de residuos:
- en el emplazamiento
- fuera del emplazamiento
Prevención de vertidos de
petróleos y sustancias
químicas
Permisos y licencias

Seguridad

Política y medidas de seguridad Comunicación de accidentes

Registro de accidentes Investigación de accidentes

Sistemas de autorización del trabajo

Procedimientos especiales de entrada en espacios cerrados, trabajo con equipo eléctrico, penetración en conducciones, etc.

Reacción de urgencia

Lucha contra incendios

Análisis de la seguridad en el puesto

de trabajo

Formación en materia de seguridad

Comunicaciones y promoción de la seguridad Mantenimiento

Observancia de las normas legales
Salud en el trabajo

Exposición de los trabajadores a los contaminantes atmosféricos

Exposición a los agentes físicos, como ruidos, radiación, calor

Medición de la exposición de los trabajadores

Registros de exposiciones Controles del diseño/ ventilación

Equipo de protección individual Información y formación sobre los riesgos para la salud

Programa de vigilancia médica

Conservación de la audición

Primeros auxilios

Disposiciones legales

\author{
(n)
}

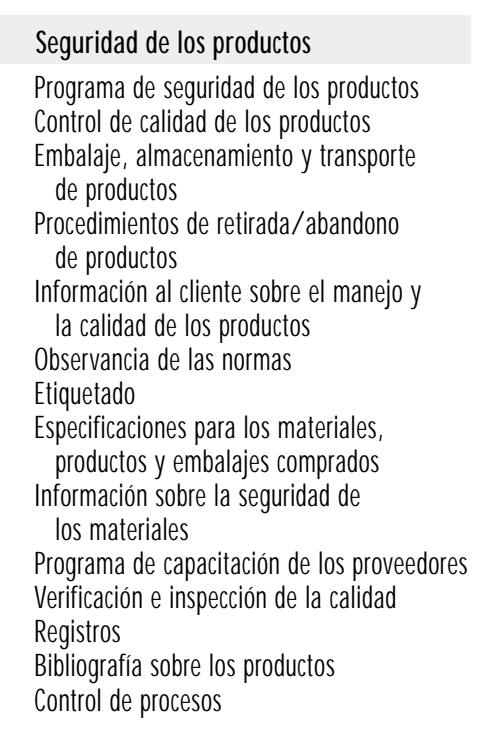

cuestiones como la prevención de pérdidas. Si el objeto de la auditoría consiste en garantizar la gestión correcta de estas áreas globales, será preciso auditar la totalidad de las cuestiones implicadas. En la Tabla 54.1 se relacionan los asuntos que pueden ser objeto de auditoría, como el medio ambiente, la salud y seguridad humanas y la seguridad de los productos.

Aunque en algunas empresas se realizan auditorías a intervalos fijos (por ejemplo, anuales), la frecuencia de éstas responde a consideraciones de necesidad y prioridad. Esto hace que no todas las instalaciones y operaciones de una empresa se evalúen con idéntica frecuencia ni con igual profundidad.

\section{Procedimiento habitual de la auditoría}

Las auditorías se suelen encomendar a un grupo de personas que recopilan datos antes y durante un estudio sobre el terreno, analizan y contrastan esos datos con los criterios informativos de la auditoría, extraen conclusiones y las vierten en un informe. Estas labores se suelen desarrollar en el marco de una estructura formal, como un programa de auditoría, que haga posible que el proceso se reproduzca en otras instalaciones con un nivel de confianza en el mantenimiento de la calidad. La auditoría debe comprender determinados procedimientos, que se resumen y explican en la Tabla 54.2, que garanticen su fiabilidad.

\section{Etapas básicas de la auditoría ambiental}

\section{Criterios que informan la auditoría}

Un aspecto fundamental de la implantación de un programa de auditoría es la adopción de sus criterios informativos y la comunicación de estos a todos los niveles de la dirección. Estos criterios suelen ser:

- políticas y actuaciones de la empresa en materia ambiental;

- leyes y reglamentos aplicables,

- prácticas correctas de ordenación ambiental.

\section{Medidas previas a la auditoría}

Entre las medidas previas a la auditoría se incluyen los aspectos administrativos asociados a la preparación de la misma, la selección de los miembros del equipo de auditoría (procedentes, por regla general, de diferentes unidades de la empresa o de un departamento especializado), la elaboración del programa de auditoría de la organización y la recopilación de información básica de la instalación.

Si la auditoría es una práctica reciente, se debe prestar especial atención a la formación de las personas implicadas en el proceso (en calidad de auditores o auditados). Este principio es igualmente válido para las empresas multinacionales que se propongan aplicar el programa de auditoría utilizado en su país de origen a las filiales extranjeras. En esos casos, el tiempo invertido en formación e información se rentabiliza al traducirse en un mayor espíritu de cooperación con la auditoría y despejar las reticencias de la dirección local.

Cuando una importante empresa norteamericana decidió aplicar su sistema de auditoría a sus filiales europeas, se preocupó especialmente de que se informase suficientemente al personal de las plantas, de que los programas de auditoría fuesen adecuados al contexto europeo y de que el equipo de auditores conociese las normas legales aplicables. Se efectuaron auditorías piloto en varias fábricas. Además, el procedimiento de auditoría se implantó de forma que se primasen los beneficios de las actitudes de cooperación, en detrimento de los métodos de "vigilancia".

La obtención de información básica sobre una fábrica y los procesos que se desarrollan en ella contribuye a reducir el tiempo que los auditores emplean en los estudios de campo y a centrar su labor, con el consiguiente ahorro de recursos.

La composición del equipo de auditoría es una función del método utilizado por la empresa. Si falta personal cualificado 0 no se pueden asignar recursos a la función de auditoría, las empresas suelen encargar el trabajo a consultores independientes. 0 tras organizaciones prefieren para sus equipos de auditoría una estructura mixta de personal propio y consultores externos, con objeto de lograr un enfoque "independiente". Algunas grandes organizaciones optan por utilizar exclusivamente personal propio y crean equipos especializados en la función de auditoría ambiental. Algunas de ellas que cuentan con personal propio de auditoría incluyen en sus equipos un consultor independiente en algunos de los procedimientos que llevan a cabo. 
Tabla 54.2 - Etapas fundamentales de una auditoría ambiental.
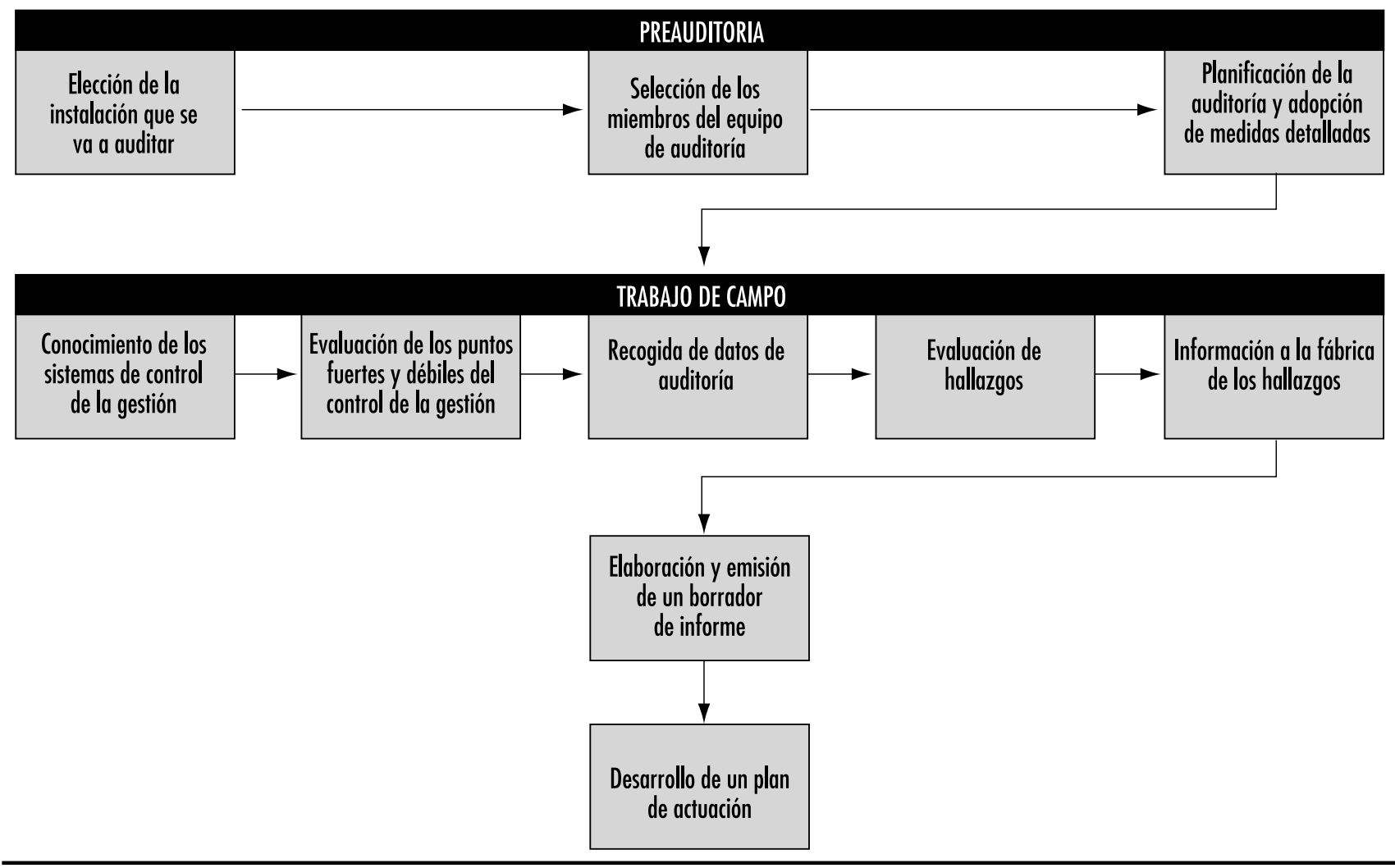

\section{Procedimientos de campo}

- Conocimiento de los controles internos. El primer paso consiste en conocer los controles presunta o efectivamente aplicados, que comprenden la evaluación de los procedimientos y prácticas formales, el registro y supervisión, los programas de inspección y mantenimiento y los controles físicos destinados a prevenir fugas. El equipo de auditores recoge información en el curso de los diversos controles mediante observaciones, entrevistas con el personal y uso de unos cuestionarios pormenorizados.

- Evaluación de los puntos fuertes y débiles de los controles internos. La evaluación de los puntos fuertes y débiles de los controles internos aporta la base de los siguientes procedimientos de auditoría. Los auditores examinarán aspectos como la claridad en la definición de responsabilidades, la competencia del personal y la existencia de un sistema de registro, documentación y autorización adecuados.

- Recogida de datos de auditoría. El equipo de auditores verifica si los procedimientos y controles funcionan en la forma prevista. L os datos se recogen realizando indagaciones (por ejemplo, preguntando a un operario de la planta qué haría si se produjese una importante fuga de alguna sustancia química), observaciones (por ejemplo, de la realización de determinados procesos y actividades) y verificaciones (por ejemplo, de los registros, con objeto de comprobar el cumplimiento de la normativa).

- R egistro de los hallazgos. Toda la información obtenida se registra (por regla general en el protocolo de auditoría y en documentos de trabajo) y se crea una documentación exhaustiva de la auditoría y del estado de la instalación en el momento de realizarse. Todas las deficiencias detectadas se registran como "hallazgos" de la auditoría.
- Evaluación de los hallazgos. El equipo de auditoría consolida y evalúa los hallazgos de todos los auditores A veces, los hallazgos son comunes a los auditores. En algunos casos basta con una conversación informal con el director de la planta; en otros es preferible reflejar los hallazgos en el informe final.

- Información de los hallazgos de la auditoría. Suele realizarse en una reunión con la dirección de la planta, al final de la visita de los auditores. Los distintos hallazgos y su importancia respectiva se pueden analizar igualmente con el personal de la planta. Antes de marcharse, el equipo de auditores suele entregar a la dirección de la fábrica un resumen escrito de los hallazgos, con objeto de evitar sorpresas cuando conozcan el informe final.

\section{Procedimientos posteriores a la auditoría}

EI paso siguiente a la visita de los auditores consiste en la elaboración de un borrador de informe que revisa la dirección de la planta para confirmar su exactitud. A continuación, el informe se pone en conocimiento de los altos directivos designados por la empresa.

La siguiente medida importante consiste en elaborar un plan de actuación para subsanar las deficiencias. Algunas empresas especifican la inclusión en el informe final de la auditoría de recomendaciones relativas a la adopción de medidas de subsanación, y entonces la fábrica elabora un plan basado en la aplicación de tales recomendaciones. 0 tras empresas exigen que en el informe de auditoría se consignen meramente los hallazgos y deficiencias, sin referencia alguna al modo de subsanarlas. Corresponde entonces a la dirección de la planta idear los medios de solucionar los fallos. 
Una vez implantado el programa de auditoría, entre los hallazgos de las auditorías subsiguientes se incluyen los informes de las anteriores y el progreso realizado en la aplicación de las posibles recomendaciones.

\section{Ampliación del procedimiento de auditoría: otros tipos de auditorías \\ Si bien el objeto más generalizado de la auditoría ambiental consiste en evaluar el impacto ambiental de las operaciones de una empresa, existen otras posibilidades. En determinadas circunstancias se aconsejan otros tipos de auditoría:}

- Auditoría previa a una absorción. La preocupación por las eventuales responsabilidades legales ha causado un notable incremento de las auditorías ambientales previas a una operación de absorción. E stas auditorías constituyen un modo de detectar problemas reales o potenciales que se toman en consideración en la negociación definitiva de la operación. En tales casos los horizontes temporales suelen ser muy cortos. Sin embargo, la información recogida sobre las actividades anteriores (posiblemente, previas a la llegada de los actuales propietarios), las operaciones actuales, las pasadas incidencias, etcétera) sean inestimables.

- Auditorías previas a una venta. Aunque menos utilizada que la anterior, la auditoría previa a una venta tiende a generalizarse y engloba las actuaciones realizadas por los propietarios de una fábrica o una empresa antes de venderla. U n número creciente de grandes empresas, como la sociedad química holandesa DSM y el conglomerado Neste, de Finlandia, realizan sistemáticamente auditorías previas a la venta de una unidad. Esta política obedece a su deseo de conocer la situación ambiental con antelación a la venta de la planta, con objeto de adoptar las medidas que estime pertinentes para solucionar posibles problemas. I gualmente importante es la posibilidad de facilitar los resultados de una auditoría independiente al futuro comprador como prueba de la situación. Si se producen problemas ambientales con posterioridad a la venta, se cuenta con un referente para la adjudicación de las eventuales responsabilidades

- Auditorías monográficas. En algunas empresas se aplica la técnica de auditoría a cuestiones concretas - como los residuos- que pueden afectar al conjunto de la empresa. La multinacional británica British Petroleum ha dedicado algunas auditorías a estudiar el impacto de la destrucción de la capa de ozono y las consecuencias de la alarma pública ante la deforestación tropical.

\section{Beneficios de la auditoría ambiental}

Si se aplica con criterios constructivos, la auditoría ambiental puede aportar múltiples beneficios. El sistema de auditoría expuesto en el presente artículo contribuye a varios objetivos:

- proteger el medio ambiente;

- verificar el cumplimiento de las leyes de ámbito local y nacional

- poner de relieve los problemas actuales o potenciales que precisan atención

- evaluar los programas de formación y aportar información aprovechable en los mismos;

- hacer posible que las empresas capitalicen los buenos resultados de su política ambiental, reconocer los méritos y poner de relieve las deficiencias:

- determinar las posibilidades de ahorrar costes, por ejemplo, mediante la reducción del volumen de residuos;

- facilitar el intercambio y la comparación de datos entre distintas plantas y filiales,
- demostrar a trabajadores, público y autoridades por igual el compromiso de la empresa con la protección del medio ambiente.

\section{ESTRATEGIAS DE GESTION DEL MEDIO AMBIENTE Y PROTECCION DE LOS TRABAJADORES}

Cecilia Brighi

\section{Evolución de las estrategias de respuesta a los problemas ambientales}

Diversos factores se han aunado para producir en estos últimos treinta años un acusado incremento de los problemas ambientales: explosión demográfica (a un ritmo que se mantendrá y hará que para el año 2030 la población mundial alcance los 8.000 millones de personas); pobreza; hegemonía de modelos económicos que favorecen el crecimiento y la cantidad en perjuicio de la calidad; consumo elevado de recursos naturales inducido por la expansión de la industria; reducción de la biodiversidad, especialmente como consecuencia del incremento de la producción agrícola conseguido mediante el monocultivo; erosión del suelo; cambio climático; uso insostenible de los recursos naturales y contaminación del aire, los suelos y los recursos hídricos. Por otra parte, los efectos negativos de la actividad humana sobre el medio ambiente también han despertado la conciencia y la sensibilidad social de la población de muchos países y han conducido a la modificación de las estrategias tradicionales y los modelos de respuesta.

Las estrategias de respuesta también han evolucionado, pasando del desconocimiento a la subestimación del problema y de aquí a la reducción y el control de los niveles de contaminación abordando el problema en sus manifestaciones, esto es, mediante las denominadas estrategias del "ultimo eslabón". En 1970 se produjeron las primeras catástrofes ambientales locales ampliamente difundidas y se inició el desarrollo de una nueva conciencia de la contaminación ambiental. Estas circunstancias indujeron la promulgación de una serie inicial de leyes y reglamentos nacionales y convenios internacionales destinados al control y regulación de la contaminación. Pronto se puso de manifiesto la fragilidad de esta estrategia del "último eslabón", diseñada con criterios autoritarios para actuar sobre las manifestaciones y no sobre las causas de los problemas ambientales. Al mismo tiempo, la contaminación de origen industrial puso de relieve las crecientes discrepancias conceptuales entre empresas, trabajadores y grupos ecologistas.

Durante el decenio de 1980 se plantearon problemas ambientales de ámbito mundial, como la catástrofe de Chernóbil, la Iluvia ácida, la destrucción de la capa de ozono y el agujero de ozono, el efecto invernadero y el cambio climático, y el aumento de las emisiones de residuos tóxicos y su exportación. Estos fenómenos y los problemas que causaron crearon una mayor conciencia pública y contribuyeron a reforzar el apoyo a los nuevos métodos y soluciones centrados en el uso de instrumentos de ordenación del medio ambiente y de tecnologías de producción limpias. Organizaciones como el PNUMA, la $O C D E$, la U nión Europea y numerosas instituciones nacionales empezaron a definir la cuestión y a colaborar en un marco más general basado en los conceptos de prevención, innovación, información, educación y participación de los agentes sociales implicados. A comienzos del decenio de 1990 se produjo otro reforzamiento sustancial de la conciencia de que la crisis ambiental empeoraba, principalmente en las naciones en 
desarrollo y en la Europa central y oriental. Esta conciencia alcanzó un nivel crítico en la Conferencia de las Naciones Unidas sobre el Medio Ambiente y el Desarrollo (CNUMAD) celebrada en Río de Janeiro en 1992.

Hoy en día, la política cautelar constituye uno de los principales factores que es preciso tomar en consideración en la evaluación de las políticas y soluciones de los problemas ambientales. Según esta concepción, aunque exista incertidumbre o controversia científica respecto a los problemas y políticas ambientales, las decisiones deben basarse en la necesidad de adoptar las cautelas que sean económica, social y técnicamente factibles para evitar futuras repercusiones negativas. Se debe aplicar la política cautelar en la elaboración de reglamentos y políticas y en la planificación y ejecución de proyectos y programas.

En efecto, las políticas cautelares y preventivas persiguen un enfoque más integral de la actuación ambiental, que evolucione desde una atención casi exclusiva a los procesos productivos hacia el desarrollo de medios y técnicas de gestión del medio ambiente aplicables a todo tipo de actividad económica y a los procesos de toma de decisiones. A diferencia del control de la contaminación, que constituía una táctica de reacción puntual, la política de gestión ambiental y empleo de tecnologías productivas limpias se orienta a la integración de la política cautelar con otras estrategias más amplias en la generación de un proceso destinado a ser continuamente evaluado, supervisado y perfeccionado. Sin embargo, para ser eficaces, las estrategias basadas en la gestión del medio ambiente y las tecnologías productivas limpias deben aplicarse cuidadosamente, con la participación de todos los agentes sociales implicados en todos los niveles de actuación.

L ejos de considerarse meras herramientas técnicas de actuación ambiental, estas nuevas estrategias se deben valorar como métodos integradores globales que contribuirán a definir nuevos modelos de una economía de mercado social y ambientalmente solventes. Para ser plenamente eficaces, estas nuevas estrategias precisarán igualmente de un marco regulador, unos acuerdos dinamizadores y un consenso social configurado con la participación de instituciones, agentes sociales y organizaciones ecologistas y de consumidores interesadas. Para que la aplicación de la gestión ambiental y las tecnologías productivas limpias induzca escenarios de desarrollo socioeconómicos más sostenibles, será preciso tomar en consideración diversos factores en la formulación de políticas, en la elaboración y aplicación de normas y reglamentos, en los convenios colectivos y en los planes de actuación. no sólo en el marco de la empresa, sino también en los ámbitos local, nacional e internacional. D adas las considerables diferencias en las condiciones económicas y sociales imperantes en el mundo, las posibilidades de éxito serán igualmente una función de la situación política, económica y social de cada lugar.

La mundialización, la desregulación de los mercados y las políticas de ajuste estructural plantearán nuevos desafíos a nuestra capacidad de análisis integral de las consecuencias económicas, sociales y ambientales de los complejos cambios que se producen en nuestras sociedades, una de las cuales - en modo alguno desdeñable- es el riesgo de que tales cambios desemboquen en una modificación profunda de las relaciones y responsabilidades de poder, quizás incluso, de control y propiedad. Será preciso un esfuerzo para evitar que estos cambios generen un estado de impotencia y parálisis en el desarrollo de la ordenación del medio ambiente y de las técnicas de producción limpia. Por otra parte, estos cambios, además de generar riesgos, abren nuevas posibilidades de mejorar nuestras actuales condiciones sociales, económicas, culturales, políticas y ambientales. Sin embargo, la materialización de estos cambios positivos pasa por la adopción de una estrategia cooperadora, participativa y flexible de la gestión del cambio en nuestras empresas y nuestra sociedad. Si se quiere evitar la parálisis, habrá que adoptar medidas tendentes a fortalecer la confianza y emprender una actuación parcial, evolutiva y gradual, capaz de generar apoyos e incrementar la capacidad de inducir cambios más sustanciales en nuestras futuras condiciones de vida y de trabajo.

\section{Principales repercusiones internacionales}

C omo se ha indicado anteriormente, la nueva coyuntura internacional se caracteriza por la desregulación de los mercados, la eliminación de las barreras comerciales, las nuevas tecnologías de la información, las rápidas y cuantiosísimas transferencias cotidianas de capitales y la mundialización de la producción, principalmente a través de las empresas multinacionales. La desregulación y la competitividad constituyen los criterios dominantes en las estrategias de inversión. Sin embargo, estos cambios coadyuvan también al desmantelamiento de fábricas y a la creación de zonas francas industriales en las que se exime a las empresas de la observancia de la legislación ambiental y otras obligaciones legales. Estos resultados pueden inducir unos costes de mano de obra sumamente bajos y, por consiguiente, mayores beneficios para la industria, pero tales beneficios suelen ir acompañados de situaciones de lamentable explotación humana y deterioro ambiental. A demás, la falta de regulación y control facilita la exportación, en especial, a los países en desarrollo, de equipo, fábricas y tecnologías obsoletos, al igual que se exportan peligrosas sustancias químicas que en algunos países se han prohibido, retirado o severamente restringido por razones de seguridad 0 de protección ambiental.

Para responder a estos retos, es imprescindible que se fijen nuevas normas de la O rganización Mundial del Comercio (O M C ) que promuevan un intercambio social y ambientalmente aceptable. Esto implica que, para promover la libre competencia, la OMC deba exigir a todos los países que observen las normas laborales internacionales fundamentales (esto es, los convenios fundamentales de la OIT) y los convenios y reglamentos de protección ambiental. Es igualmente preciso aplicar efectivamente las normas y directrices del tipo de las elaboradas por la OCDE sobre la transferencia de tecnologías, con objeto de prevenir la exportación de procesos de producción inseguros y altamente contaminantes.

Se deben tomar en consideración cuestiones internacionales como las siguientes:

- comercio internacional de fábricas y equipo;

- mecanismos financieros y asistencia técnica;

- normas de la O rganización M undial de Comercio;

- precios de las materias primas;

- sistemas fiscales;

- transferencias de técnicas y tecnologías;

- difusión internacional de la contaminación;

- estrategias productivas de las empresas multinacionales;

- elaboración y aplicación de convenios, acuerdos, normas y directrices internacionales,

- participación de las organizaciones internacionales de trabajadores y empresarios y de los grupos ecologistas.

Las naciones en desarrollo y otros países que necesitan ayuda deben disfrutar de asistencia financiera especial, reducciones de impuestos, incentivos y asistencia técnica que les permita aplicar las principales normas laborales y de protección ambiental anteriormente citadas e implantar unas tecnologías productivas limpias y consumir unos productos inocuos. Un método innovador que merecerá una mayor atención en el futuro es la elaboración de códigos de conducta consensuados por algunas empresas con sus sindicatos con objeto de promover la 
observancia de los derechos sociales básicos y las normas de protección ambiental. La OIT desempeña una función singular en la evaluación de este proceso en el ámbito internacional, dadas la estructura tripartita de la organización y su íntima coordinación con otros organismos de las $\mathrm{Naciones} \mathrm{U}$ nidas y con las instituciones financieras internacionales responsables de la ayuda internacional y la asistencia financiera.

\section{Principales repercusiones nacionales y locales}

Será preciso crear un marco normativo general de ámbito local y nacional que facilite el desarrollo de técnicas efectivas de gestión del medio ambiente. Esto precisará un procedimiento de toma de decisiones en el que se integren consideraciones presupuestarias, fiscales, industriales, económicas, laborales y ambientales y se establezcan amplios cauces de consulta con los agentes sociales más interesados, como empresas, sindicatos, grupos ecologistas y organizaciones de consumidores. En este enfoque sistemático se incluyen vínculos entre los diversos programas y políticas como los siguientes:

- El sistema fiscal debe alentar la penetración en el mercado de bienes y materias primas ambientalmente favorables, y penalizar los productos, actividades económicas y comportamientos sociales e individuales negativos para el medio ambiente.

- Es preciso adoptar políticas y asignar recursos que promuevan la investigación y desarrollo de infraestructuras, tecnologías y procesos productivos social y ambientalmente solventes.

- Es preciso crear centros de información, asesoramiento y formación destinados a colaborar con las empresas, especialmente con las pequeñas y medianas, en la adquisición, adaptación y utilización segura y efectiva de las tecnologías.

Es preciso formular y aplicar las estrategias industriales de ámbito nacional y local en estrecha colaboración con las organizaciones sindicales, de modo que las políticas económicas y laborales satisfagan las necesidades sociales y ambientales. U na política de negociación y consulta directas en el ámbito nacional puede contribuir a la prevención de posibles conflictos provocados por las consecuencias de las nuevas políticas industriales para la salud y seguridad y el medio ambiente. Sin embargo, las negociaciones de ámbito nacional deben coincidir en el ámbito de la empresa con un proceso de negociación y consulta que posibilite la presencia en el puesto de trabajo de un sistema adecuado de controles, incentivos y asistencia.

En resumen, se deben tomar en consideración los siguientes factores nacionales y locales:

- reglamentos, pautas, convenios y políticas nacionales y locales;

- sistemas de relaciones laborales;

- participación de los agentes sociales (sindicatos y organizaciones empresariales), las O N G ecologistas y las organizaciones de consumidores en todos los procesos de toma de decisiones;

- políticas industriales;

- política de precios de las materias primas;

- política comercial;

- sistemas fiscales;

- incentivos a la investigación y desarrollo;

- incentivos a la aplicación de estrategias innovadoras de ordenación del medio ambiente;

- integración de los sistemas y normas de salud y seguridad;

- creación de centros de asesoramiento, información y formación que promuevan la difusión de las tecnologías productivas limpias,

- ayuda para la superación de los obstáculos (conceptuales, organizativos, técnicos, financieros y de cualificación) a la implantación de las nuevas tecnologías, políticas y normativas.

\section{La gestión ambiental a escala de la empresa}

La gestión ambiental a escala de una empresa u otra organización económica precisa una consideración y evaluación sistemáticas de los impactos ambientales - tanto en el lugar de trabajo (esto es, el medio ambiente de trabajo) como fuera de los muros de la fábrica (esto es, el entorno exterior) - de toda la gama de actividades y decisiones que afectan a la explotación. Esta función implica igualmente la modificación consiguiente de la organización del trabajo y de los procesos de producción para reaccionar efectiva y eficazmente a esos impactos ambientales.

Las empresas deben prever las posibles repercusiones ambientales de un determinado producto, proceso 0 actividad desde las etapas iniciales de planificación, con objeto de facilitar la aplicación puntual de medidas de respuesta participativas y cooperativas. El objetivo consiste en lograr que la industria y otros sectores económicos sean económica, social y ambientalmente sostenibles. Sin duda, en muchos casos será todavía preciso un período de transición caracterizado por las medidas de control de la contaminación y reparación de los efectos. De ahí que la gestión del medio ambiente deba valorarse como un proceso complejo de prevención y control orientado a compatibilizar la estrategia de la empresa con el objetivo de sostenibilidad ambiental. Para lograrlo, es preciso que las empresas elaboren y apliquen en el marco de su política general de gestión ambiental ciertos métodos de evaluación de los procesos productivos limpios y de auditoría de la actuación ambiental.

La gestión ambiental y la producción "limpia" generarán una serie de beneficios que, además de influir en la actuación ambiental, pueden producir mejoras en los aspectos siguientes:

- salud y seguridad de los trabajadores;

- tasas de absentismo:

- prevención y solución de los conflictos con los trabajadores y comunidades;

- promoción de un clima de cooperación en la empresa;

- imagen pública de la empresa;

- penetración de los nuevos productos ecológicos en el mercado;

- uso eficiente de energías y materias primas;

- gestión de residuos, incluida su evacuación segura,

- productividad y calidad de los productos.

Lejos de centrar su esfuerzo en la evaluación de la propia observancia de los reglamentos y leyes vigentes, las empresas deben fijarse objetivos ambientales factibles que puedan lograrse dentro de un horizonte temporal determinado y mediante un proceso gradual que comprenda los aspectos siguientes:

- definición de los objetivos y políticas de la empresa en materia ambiental;

- formulación de estrategias a corto, medio y largo plazo;

- adopción de un enfoque integral, "de principio a fin";

- asignación de recursos presupuestarios adecuados;

- incorporación de la salud y seguridad a los procedimientos de auditoría ambiental;

- participación de los trabajadores y representantes sindicales en los procesos de análisis y toma de decisiones,

- creación de un equipo de auditoría ambiental con participación de los representantes de los trabajadores.

Las actividades se pueden evaluar desde muchas y diversas perspectivas. He aquí algunos elementos que pueden incluirse en esos programas:

- definición de los diagramas de flujo de cada unidad operativa

- supervisión del consumo de factores productivos por unidad operativa: por ejemplo, agua, energía, materias primas, mano de obra, evaluación de los riesgos para la salud y seguridad y el medio ambiente, organización del trabajo 
Tabla 54.3 - Agentes sociales intervinientes en los acuerdos voluntarios relativos al medio ambiente.

$\begin{array}{lllll}\text { País } & \text { Empresa/ Estado } & \text { Empresa/ sindicato/ Estado } & \text { Empresa/ sindicato } & \text { Empresa/ comité de empresa } \\ \text { Países Bajos } & X & X & X & X \\ \text { Bélgica } & X & X & X & X \\ \text { Dinamarca } & X & X & X \\ \text { Austria } & X & X & X \\ \text { Alemania } & X & X & X \\ \text { Reino Unido } & & X & X \\ \text { Italia } & & X & X \\ \text { Francia } & & X & X\end{array}$

Fuente: Hildebrandt y Schmidt 1994

- supervisión de la producción total por unidad operativa: por ejemplo, cuantificación de los productos y subproductos, aguas residuales, emisiones gaseosas, residuos sólidos evacuables en la fábrica y fuera de ella;

- fijación de los objetivos de la empresa;

- análisis de viabilidad de las posibles barreras (económicas, técnicas, ambientales y sociales) y elaboración de los programas correspondientes;

- adopción y aplicación de una política informativa;

- adopción y aplicación de una política de formación que sensibilice a los trabajadores y facilite su plena participación,

- supervisión y evaluación de la actuación y sus resultados.

\section{Relaciones laborales y gestión del medio} ambiente

M ientras que en algunos países se desconocen aún los derechos laborales fundamentales y los trabajadores se ven imposibilitados tanto de proteger su salud y seguridad y sus condiciones de trabajo como de mejorar la actuación ambiental, en otras naciones se ha aplicado con buenos resultados la concepción participativa de la sostenibilidad ambiental de las empresas. En los últimos diez años, no sólo se ha modificado progresivamente el sistema tradicional de relaciones laborales en el sentido de incluir los programas y cuestiones de salud y seguridad que reflejan la regulación nacional e internacional de la materia, sino que también se ha iniciado la integración de las cuestiones ambientales en los mecanismos de relaciones laborales. L a cooperación entre empresas y organizaciones sindicales en la empresa y a escala sectorial y nacional se ha definido, en función de las circunstancias, en los convenios colectivos y, a veces, también, en la normativa y en los procedimientos de consulta establecidos por las autoridades locales y nacionales para superar los conflictos que afectan al medio ambiente. Véanse las Tablas 54.3, 54.4 y 54.5 .

\section{Reparación de los efectos de la contaminación: limpieza}

La limpieza de los lugares contaminados se ha convertido en una actividad cada vez más generalizada y costosa desde el decenio de 1970, cuando se adquirió una mayor conciencia de la gravedad de los casos de contaminación del suelo y el agua como consecuencia de la acumulación de residuos químicos, el abandono de instalaciones industriales, etcétera. $L a$ contaminación de estos lugares ha sido causada por actividades como las siguientes:

- vertederos de residuos (públicos e industriales);

- instalaciones industriales abandonadas (por ejemplo, industrias químicas y metalúrgicas);

- minería;

- explotaciones agrícolas;

- accidentes graves;

- incineradoras;

- vertido de aguas industriales,

- concentraciones de pequeñas y medianas empresas.

El diseño de un plan de reparación y limpieza exige una serie compleja de procesos y actividades que deben corresponderse con una formulación inequívoca de las obligaciones y consiguientes responsabilidades de la dirección. Estas iniciativas deben desarrollarse en el marco de una legislación nacional

Tabla 54.4 - Ambito de aplicación de los acuerdos voluntarios sobre medidas de protección del medio ambiente concertados entre las partes otorgantes de los convenios colectivos.

$\begin{array}{llll}\text { País } & \text { Nacional } & \begin{array}{l}\text { Sectorial } \\ \text { (regional) }\end{array} & \text { Fábrica } \\ \text { Países Bajos } & X & X & X \\ \text { Bélgica } & X & X & X \\ \text { Dinamarca } & X & X & X \\ \text { Austria } & & X & X \\ \text { Alemania } & & X & X \\ \text { Reino Unido } & & & \\ \text { Italia } & X & X & X \\ \text { Francia } & & & \\ \text { España } & & & \\ \text { Grecia } & X & & \end{array}$

Fuente: Hildebrandt y Schmidt 1994. 


\begin{tabular}{|c|c|c|c|}
\hline País & $\begin{array}{l}\text { Declaraciones } \\
\text { conjuntas, } \\
\text { recomendaciones, } \\
\text { convenios }\end{array}$ & $\begin{array}{l}\text { Convenios } \\
\text { colectivos de } \\
\text { ámbito sectorial }\end{array}$ & $\begin{array}{l}\text { Convenios } \\
\text { de fábrica }\end{array}$ \\
\hline Países Bajos & $x$ & $X$ & $x$ \\
\hline Bélgica & $X$ & & $x$ \\
\hline Dinamarca & $x$ & $x$ & $x$ \\
\hline Austria & & $X$ & \\
\hline Alemania & $x$ & $X$ & $x$ \\
\hline Reino Unido & & $x$ & \\
\hline Italia & $x$ & $x$ & $x$ \\
\hline Francia & & $x$ & $x$ \\
\hline España & & $x$ & \\
\hline Grecia & $x$ & & \\
\hline
\end{tabular}

Fuente: Hildebrandt y Schmidt 1994.

armoniosa en la que se prevea la participación de la población afectada, la aplicación de procedimientos sencillos de solución de conflictos y la prevención de posibles efectos socioambientales de los vertidos. En esos acuerdos, normas y planes se deben incluir no sólo los recursos naturales bióticos y abióticos, como el agua, el aire, el suelo y la flora y fauna, sino también el patrimonio cultural, otras perspectivas visuales del paisaje y los daños a cosas y personas. Por consiguiente, un concepto restrictivo del medio ambiente contribuiría a estrechar el alcance de la definición del daño ambiental y a limitar la recuperación efectiva de las áreas. Por otra parte, debería ser posible, no solamente que las personas y cosas directamente perjudicadas disfruten de unos derechos y de una cierta protección, sino también la adopción de iniciativas plurales para proteger el interés colectivo en el restablecimiento de la situación anterior.

\section{Conclusiones}

Será precisa una reacción vigorosa a la rápida modificación de la situación ambiental. El presente artículo se ha centrado en la necesidad de adoptar medidas tendentes a mejorar los resultados de la política ambiental de la industria y otros sectores económicos. Para que este esfuerzo sea efectivo y eficaz, los trabajadores y sus organizaciones sindicales deben participar activamente, no sólo en el ámbito de la empresa, sino en sus respectivas comunidades locales y en el plano nacional. Los trabajadores deben asumir su función de agentes sociales activos en el logro de los futuros objetivos de protección ambiental y desarrollo sostenible. La capacidad de los trabajadores y de sus organizaciones sindicales de participar como sujetos activos en este proceso de ordenación ambiental no depende únicamente de su capacidad y conciencia, si bien se precisan y, ciertamente, se realizan esfuerzos por fomentar esa capacidad, sino igualmente de la disposición de la dirección y las comunidades locales a fomentar un medio ambiente favorable que facilite el desarrollo futuro de nuevas modalidades de cooperación y participación.

\section{CONTROL DE LA CONTAMINACION AMBIENTAL: LA PREVENCION DE LA CONTAMINACION COMO OBJETIVO PRIORITARIO DE LA EMPRESA}

\author{
Robert $P$. B ringer y Tom Zosel
}

La prevención de la contaminación implica vislumbrar las posibilidades y convertirlas en realidad. Consiste en decantarse por productos y procesos que produzcan impactos ambientales mínimos.

La prevención de la contaminación no es algo nuevo, sino la manifestación de una ética ambiental de la que han sido portadores los primitivos representantes de muchas otras culturas, incluidos los indoamericanos. Los primitivos americanos vivían en armonía con un entorno que les brindaba refugio, alimento y los fundamentos mismos de su religión. A pesar de vivir en un medio enormemente duro, lo trataban con veneración y respeto.

A medida que las naciones se desarrollaban y la Revolución Industrial avanzaba, se materializó una actitud muy diferente frente al medio ambiente. La sociedad empezó a considerar el medio ambiente como una fuente inagotable de materias primas y como un vertedero ideal para los residuos.

\section{Esfuerzos iniciales de reducción de los residuos}

No obstante, en algunas industrias se practicó algún tipo de prevención de la contaminación desde que se desarrollaron los primeros procesos químicos. En un principio, la industria se centró más en la eficiencia y en el incremento de los rendimientos de los procesos mediante la reducción de los desechos que en la prevención real de la contaminación mediante el impedimento de la emisión de residuos al medio ambiente. No obstante, el resultado de ambas políticas es el mismo: disminución de la emisión de desechos materiales al medio ambiente.

U no de los primeros esfuerzos de prevención de la contaminación, aunque con otra forma, se produjo en el siglo XIX en una fábrica alemana de producción de ácido sulfúrico. La mejora de la explotación permitió reducir el volumen de emisiones de dióxido de azufre por kilogramos de producto obtenido. Estos resultados se valoraban generalmente como incrementos de la eficiencia o la calidad. Sólo hace poco se han asociado estos cambios tecnológicos con la idea de prevención de la contaminación.

Esta última, tal como se conoce actualmente, surgió a mediados del decenio de 1970, en respuesta a la creciente magnitud y complejidad de los problemas ambientales. La Environmental Protection Agency (EPA) de Estados U nidos se creó en esa época. Las primeras medidas de control de la contaminación fueron la colocación de dispositivos de control en el "último eslabón de la cadena" o la adición de costosas instalaciones de control de la contaminación. En estos casos, se trataba más de un esfuerzo por mejorar la eficiencia o la rentabilidad que de una política sistemática de protección del medio ambiente.

Sólo recientemente se han decidido algunas empresas a aplicar una política mas estrictamente ambiental y a supervisar los progresos. No obstante, las empresas pueden abordar la prevención de la contaminación desde perspectivas muy diversas.

\section{Prevención o control}

Gradualmente, el interés comenzó a desplazarse del control a la prevención de la contaminación. Se hizo evidente que todos (los científicos que desarrollan el producto, los ingenieros que diseñan el equipo, los especialistas que hacen funcionar las instalaciones 
productivas, el personal de comercialización que trabaja con los clientes para mejorar los efectos ambientales de los productos, los vendedores que transmiten al laboratorio la preocupación de los clientes por el medio ambiente en busca de soluciones y los administrativos que se esfuerzan por reducir el consumo de papel) pueden contribuir a reducir el impacto ambiental de las operaciones y actividades que controlan.

\section{Desarrollo de programas eficaces de prevención de la contaminación}

En la práctica actual de prevención de la contaminación se deben examinar tanto los programas de prevención como las tecnologías específicas de prevención. El programa global de prevención de la contaminación y las tecnologías específicas de prevención son igualmente importantes para lograr los resultados ambientales. Si bien el desarrollo de la tecnología es absolutamente imperativo, sin una estructura organizativa de apoyo y aplicación de las tecnologías los resultados ambientales nunca se materializarán plenamente.

El objetivo consiste en lograr la plena participación de la empresa en el esfuerzo de prevención de la contaminación. Algunas empresas aplican unos programas detallados y bien estructurados de prevención de la contaminación en todos los niveles de la organización. Los tres programas mejor valorados en Estados Unidos son, probablemente, el Pollution Prevention Pays (3P), de 3M ; el Save M oney and Reduce Toxics (SM ART), de Chevron; y el Waste Reduction Always Pays (WRAP), de D ow Chemical.

El objetivo de todos ellos es reducir la contaminación en la máxima medida posible. Sin embargo, no siempre resulta técnicamente factible controlar la contaminación exclusivamente en las fuentes. EI reciclaje y la reutilización se deben integrar igualmente en el esfuerzo de prevención de la contaminación, como se han incorporado a los programas anteriormente citados. Cuando se pide a cada trabajador que, además de desarrollar los procesos de forma eficaz, busque una aplicación productiva a cada subproducto y a cada flujo de residuos, la prevención de la contaminación se ha convertido en parte de la cultura de la empresa.

A finales de 1993, Business Roundtable publicó en Estados U nidos los resultados de un notable estudio de los esfuerzos más fructíferos en la prevención de la contaminación. En el estudio se relacionaban los mejores programas de prevención de la contaminación de las instalaciones y se hacía hincapié en los elementos necesarios para integrar plenamente la prevención de la contaminación en el funcionamiento de las empresas. Se incluían instalaciones pertenecientes a Proctor \& Gamble $(P \& G)$, Intel, D uPont, M onsanto, $M$ artin $M$ arietta y $3 M$.

\section{Programas de prevención de la contaminación}

En el estudio se determinó que los programas de prevención de la contaminación que daban resultados en esas empresas compartían las características siguientes:

- apoyo de la alta dirección;

- participación de todos los trabajadores;

- reconocimiento de los logros;

- libertad para la empresa de optar por los métodos más adecuados para lograr los objetivos de aquélla;

- comunicación de información entre los centros;

- evaluación de los resultados,

- inclusión en todos los programas del reciclaje y la reutilización.

En el estudio se puso igualmente de relieve que el esfuerzo en cada una de las instalaciones había evolucionado desde el interés por la prevención de la contaminación en el proceso de producción hasta la integración de esta función en la toma de decisiones previa a la producción. La prevención de la contaminación se había convertido en uno de los valores nucleares de la empresa.

El apoyo de la alta dirección es imprescindible para que el programa de prevención de la contaminación sea plenamente operativo. Los altos directivos de la instalación y de la empresa deben transmitir a todos los trabajadores un mensaje inequívoco de que la prevención de la contaminación es parte de su trabajo. El ejemplo debe comenzar por el primer ejecutivo, que fija la pauta de la actividad de la empresa. EI mensaje debe transmitirse públicamente y en el marco de la empresa para que sea atendido por los destinatarios.

La segunda condición del éxito es la participación de los trabajadores. Si bien el personal técnico y de producción está más volcado en el desarrollo de nuevos procesos y en el diseño de productos, los trabajadores de todos los niveles pueden colaborar en la reducción del volumen de residuos mediante el reciclaje, la reutilización y la recuperación desarrollados en el contexto de la prevención de la contaminación. Los trabajadores conocen la situación existente en su área de responsabilidad mucho mejor que los profesionales de la protección ambiental. Para fomentar la participación de los trabajadores, la empresa debe sensibilizarles respecto a los riesgos que afronta. $L a$ inclusión en el boletín de la empresa de artículos dedicados a cuestiones del medio ambiente puede contribuir a crear conciencia en el personal. El primer ejecutivo de $3 \mathrm{M}$ concede un premio especial a la conciencia ambiental, no sólo a los trabajadores que contribuyen a lograr los objetivos de la empresa, sino también a todos los que colaboran con los esfuerzos de la comunidad en favor del medio ambiente. Asimismo, los logros del esfuerzo ambiental se reconocen en el resumen de actividad anual.

La enorme importancia de la cuantificación de los resultados se debe a que constituye la fuerza motriz del esfuerzo de los trabajadores. $M$ ientras que algunos programas diseñados para las empresas o sus instalaciones permiten cuantificar todos los residuos, otros se centran en el Inventario de Emisiones Tóxicas o en la medición de otras magnitudes más acordes con su cultura social o con sus programas concretos de prevención de la contaminación.

\section{Algunos programas de protección ambiental}

La prevención de la contaminación ha enraizado en la cultura social de 3M a lo largo de los últimos veinte años. La dirección de 3M se propuso ir más allá de la normativa legal, en parte mediante el desarrollo de unos planes de ordenación del medio ambiente en los que los objetivos ambientales se fusionen con la estrategia de la empresa.

La idea consiste en prevenir la contaminación antes de que se produzca y en aprovechar las posibilidades de prevención que se presentan a lo largo de la vida del producto y no únicamente al final. Las empresas que han tenido éxito en su esfuerzo son las que comprenden que la prevención es más efectiva para la protección ambiental, más solvente técnicamente y menos costosa que las medidas tradicionales de control que no solucionan el problema. La prevención de la contaminación resulta económica debido a que, si se evita la contaminación en origen, no hay que controlarla posteriormente.

Desde el inicio del programa 3P, los trabajadores de 3M han ideado y aplicado más 4.200 medidas de prevención de la contaminación. En estos últimos veinte años, esas medidas han permitido eliminar unas 640.000 toneladas de agentes contaminantes, con un ahorro para la empresa de 750 millones de dólares.

Entre 1975 y 1993, 3M redujo el consumo de energía por unidad de producción en 3.900 BTU, esto es, el $58 \%$. Sólo en Estados U nidos, el ahorro energético anual logrado por 3M es de 22 billones de BTU, cantidad suficiente para calentar, 
refrigerar e iluminar más de 200.000 viviendas en ese país y que supone la eliminación de más de 2 millones de toneladas de bióxido de carbono. A demás, las instalaciones de $3 \mathrm{M}$ en Estados U nidos recuperaron y reciclaron 41 toneladas más de residuos sólidos que las transportadas a los vertederos.

\section{Tecnologías de prevención de la contaminación}

Aunque el concepto de diseño para el medio ambiente adquiere importancia creciente, las tecnologías aplicadas a la prevención de la contaminación son tan diversas como las empresas que las aplican. En líneas generales, el concepto se puede concretar a través de la renovación técnica en cuatro áreas:

- replanteamiento de los productos mediante el desarrollo de procesos o productos menos o nada contaminantes en los que se utilicen materias primas diferentes;

- modificación de los procesos, consistente en variar los procesos de producción de modo que resulten menos o nada contaminantes;

- modificación del diseño del equipo para que pueda mejorar su rendimiento en determinadas condiciones operativas o utilizar los recursos disponibles,

- recuperación de recursos mediante el reciclado de subproductos, bien para su venta o aprovechamiento por otras empresas, bien para su utilización en otros productos y procesos de la misma empresa.

La concentración de esfuerzos en todas estas áreas permite crear nuevos productos más seguros, ahorrar costes e incrementar la satisfacción del cliente.

El replanteamiento de los productos puede ser lo más difícil. En efecto, muchas de las características de los materiales que los convierten en idóneos para los fines previstos pueden ser igualmente una fuente de problemas ambientales. Un ejemplo notable es el de un equipo de científicos ocupados en el replanteamiento de cierto producto que eliminaron el cloroformo de metilo, sustancia química destructiva del ozono, de la composición de un producto protector de los tejidos. EI nuevo producto, con base en agua, permite reducir sustancialmente el empleo de disolventes y confiere a la empresa una ventaja competitiva en el mercado.

Los trabajadores de un laboratorio farmacéutico dedicado a la producción de comprimidos desarrollaron una nueva solución de recubrimiento basada en el agua para reemplazar la solución basada en disolventes utilizada hasta entonces. El cambio, que costó 60.000 dólares, hizo innecesaria una inversión de 180.000 dólares en equipo de control de la contaminación, permite reducir el coste de los materiales en 150.000 dólares y evita la emisión a la atmósfera de 24 toneladas anuales de sustancias contaminantes.

0 tro ejemplo de modificación de los procesos consistió en el abandono del uso de ciertas sustancias químicas peligrosas para la limpieza de las planchas de cobre antes de su empleo en la producción de artículos de este metal. Anteriormente, las planchas se limpiaban utilizando un aerosol que contenía tres sustancias químicas peligrosas: persulfato amónico, ácido fosfórico y ácido sulfúrico. El procedimiento se sustituyó por otro basado en una solución ligera del inofensivo ácido cítrico. El nuevo proceso permitió eliminar la generación de 18,2 toneladas de residuos peligrosos al año y ha supuesto a la empresa un ahorro de unos 15.000 dólares anuales en los costes de materias primas y evacuación de residuos.

La modificación del diseño del equipo también contribuye a reducir los residuos. Cierta empresa dedicada a la producción de resinas tomaba regularmente muestras de una determinada resina fenólica líquida colocando un grifo en la conducción del producto. Parte del producto se perdía antes y después de la toma de la muestra. La simple colocación de un embudo debajo del grifo de muestreo y de un conducto que devuelve el producto al flujo del proceso permite tomar las muestras sin merma del producto. De este modo, con una inversión en inmovilizado de unos 1000 dólares, se previene la producción de unas nueve toneladas de residuos al año, se ahorran 22.000 dólares, mejoran los rendimientos y se reducen los costes de evacuación.

La recuperación de recursos, esto es, el aprovechamiento productivo de los materiales de desecho, reviste enorme importancia para la prevención de la contaminación. Ciertas esponjas de baño sintéticas se fabrican ahora con botellas de plástico recicladas. Durante los dos primeros años de producción del nuevo artículo, la empresa utilizó más de 450 toneladas de este material. Esta cifra equivale a más de diez millones de botellas de refrescos de dos litros. Asimismo, en Brasil se emplean los recortes de caucho procedentes del acabado de los felpudos para hacer sandalias. Sólo en 1994, se recuperaron en la fábrica unas 30 toneladas de material, suficientes para fabricar más de 120.000 pares de sandalias.

0 tro ejemplo: Post-it ${ }^{\circledR}$ Recycled Paper $N$ otes utiliza el $100 \%$ de papel reciclado. Cada tonelada de papel reciclado permite salvar 17 árboles y supone, además, un ahorro de más de 3 metros cúbicos de espacio en el vertedero, unos 25.000 litros de agua y 4.100 kilovatios-horas de energía, suficientes para calentar una vivienda media durante seis meses.

\section{Análisis del ciclo vital}

En todas las empresas eficaces se aplica el análisis del ciclo vital o una técnica similar. Por lo tanto, en cada etapa de la vida de un producto, del desarrollo a la eliminación, pasando por la fabricación y el uso, se presentan posibilidades de mejora ambiental. La respuesta de la industria a los desafíos del medio ambiente ha consistido en el desarrollo de productos de óptimas características ambientales.

Por ejemplo, $P \& G$ fue el primer fabricante de productos de consumo doméstico en desarrollar detergentes concentrados que precisan envases entre un $30 \%$ y un $60 \%$ más pequeños que los empleados anteriormente. $P \& G$ produce asimismo envases retornables para más de 57 marcas en 22 países. Los envases retornable suelen costar menos y permiten ahorrar hasta un $70 \%$ en residuos sólidos.

Dow ha desarrollado un nuevo y eficaz herbicida que no produce efectos tóxicos. R esulta menos peligroso para personas y animales y las dosis se miden en gramos, no en kilos, por hectárea. Por su parte, M onsanto ha desarrollado una variedad de patata cuya planta es resistente a los insectos, por lo que se reduce la necesidad de emplear insecticidas químicos. 0 tro herbicida desarrollado por M onsanto contribuye a la recuperación del hábitat natural de las zonas húmedas mediante un control más eficaz de las malas hierbas.

\section{Compromiso con la protección del medio ambiente}

Es preciso abordar la prevención de la contaminación con criterios globales que comprendan la decisión de mejorar programas y tecnologías. La industria manufacturera ha procurado desde antiguo mejorar la eficacia y el rendimiento de los procesos y reducir la producción de desechos. Sin embargo, sólo en el último decenio se ha centrado esa actividad en la prevención directa de la contaminación. Actualmente se realizan serios esfuerzos dirigidos a mejorar el control en las fuentes y a desarrollar procesos de separación, reciclaje y reutilización de los subproductos. Todas éstas son técnicas de prevención contrastadas. 


\section{Referencias}

Abecassis y Jarashow. 1985. Oil Pollution from Ships. Londres: Sweet \& M axwell.

African Convention on Conservation of $\mathrm{N}$ ature and N atural R esources, Algiers. 1968. U nited N ations T reaty Series. Ginebra: N aciones U nidas.

ASEAN. 1985. ASEAN Agreement On the Conservation of $N$ ature and $N$ atural R esources. K uala L umpur: ANSA.

Bamako Convention on the Ban of the Import into Africa and the Control of Transboundary M ovement and $\mathrm{M}$ anagement of $\mathrm{H}$ azardous Wastes within Africa. 1991. Int L egal M ater 30:775.

Berne Convention on the Conservation of European Wildlife and Natural Habitats. 1979. European Treaty Series (ET S) N o. 104.

Birnie, P, A Boyle. 1992. International Law and the Environment. Oxford: OUP.

Birnie, PW. 1985. The International Regulation of W haling. 2 vols. Nueva Y ork: O ceana.

Bonn Agreement for Co-operation in Dealing with Pollution of the North Sea by Oil and Other $\mathrm{H}$ armful Substances: Amending Decision. 1989. En Freestone e IJ Istra 1991.

Bonn Convention on the Conservation of $\mathrm{M}$ igratory Species of Wild A nimals, 1979. 1980. Int L egal M ater 19:15

Boyle, AE. 1993. The convention on biodiversity. En The Environment After Rio, dirigido por L Campiglio, L Pineschi y C Siniscalco. Dordrecht: $M$ artinus $\mathrm{Nijhoff.}$

Burhenne, W. 1974a. Convention on Conservation of Nature in the South Pacific, A pia Convention. En International Environmental Law: M ultilateral T reaties. Berlín: E Schmidt.

-. 1974b. International Environmental Law: M ultilateral T reaties. Berlín: E Schmidt.

-. 1994c. Selected M ultilateral T reaties in the Field of the Environment. Berlín: E Schmit.

Cámara de Comercio Internacional. 1989. Environmental Auditing. Paris: $\mathrm{CCl}$.

Canadian Standards Association. 1993. Life Cycle Assessment Guideline. R exdale, O ntario: CSA.

$C$ anberra $C$ onvention on the $C$ onservation of Antarctic M arine Living R esources. 1980. Int L egal M ater 19:837.

Churchill, R, D Freestone. 1991. International Law and Global Climate Change Londres: Graham \& Trotman.

Code permanent environment et nuisances. N.d. Vol. $1 \& 2$ $M$ ontrouge, Francia: Editions législatives et administratives.

Convenio de Basilea sobre el control de los movimientos transfronterizos de los desechos peligrosos y su eliminación. 1989.

Convention for $\mathrm{Co}$-operation in the Protection and D evelopment of the $M$ arine and C oastal Environment of the West and Central African R egion, 23 $M$ arch, A bidjan. 1981. Int Legal M ater 20:746.

Convention for the Conservation and $M$ anagement of the Vicuna. 1979. En International Environmental Law: M ultilateral Treaties, dirigido por W Burhenne. Berlín: E Schmidt.

Convention for the Protection and Development of the $\mathrm{M}$ arine Environment of the Wider Caribbean R egion, $24 \mathrm{M}$ arch, Cartagena des Indias. 1983. Int L egal $M$ ater 22:221.

Convention for the Protection of Birds U seful to Agriculture. 1902. British and Foreign State Papers (BFSP), N 0. 969.

Convention for the Protection of the $\mathrm{M}$ arine Environment and C oastal A reas of the South-East Pacific 12 N ovember, Lima. En Sand 1987.
Convention for the Protection of the M editerranean Sea against Pollution, Barcelona, 16 February. 1976. Int L egal M ater 15:290.

Convention for the Protection of the Natural Resources and Environment of the South Pacific Region, 24 N ovember 1986, N oumea. Int L egal M ater 26:38.

Convention for the Protection, $\mathrm{M}$ anagement and $\mathrm{De}$ velopment of the Marine and Coastal Environment of the East African Region, 21 June, Nairobi. 1985. En Sand 1987.

Convention on Biological Diversity. 1992.Int Legal $M$ ater 31:818.

Convention on Conservation of $\mathrm{N}$ ature in the South Pacific. 1976. En International Environmental Law: M ultilateral T reaties, dirigido por W Burhenne. Berlín: E. Schmidt

Convention on Long-R ange Transboundary Air Pollution. 1979. Int Legal M ater 18:1442.

Convention on the Protection of the Black Sea. 1992. Int J $M$ arine Coast $L$ aw 9:76-100.

Convention on the Transboundary Effects of Industrial Accidents. 1992. Int L egal M ater 31:1330.

Convention on Third Party Liability in the Field of Nuclear Energy. 1961. Am J Int Law 55:1082.

Ehlers, P. 1993. H elsinki Convention on the Protection and U se of the Baltic Sea Area. Int J M arine Coast Law 8:191-276.

Espoo Convention on Environmental Impact Assessment in a T ransboundary C ontext. 1991. Int L egal $M$ ater 30:802.

Estatuto del Tribunal Internacional de Justicia. 1945.

Framework Convention on Climate Change. 1992. Int L egal M ater 31:848.

Freestone, D, T IJ Istra. 1991. T he N orth Sea: B asic L egal Documents On Regional Environmental Co-operation. D ordrecht: Graham \& T rotman.

Freestone, D. 1994. The Road from Rio: International Environmental Law after the Earth Summit. J E nviron Law 6:193-218.

Freestone, D. y E Hey (dirs.). 1996. The Precautionary Principle in International Law: The Challenge of Imple mentation. La H aya: K luwer Law International.

Geneva Protocol Concerning the Control of Emissions of Volatile Organic Compounds or their Transboundary Fluxes. 1991. Int Legal M ater 31:568.

Geneva Protocol on L ong-term Financing of the $\mathrm{Co}$ operative Programme for $\mathrm{M}$ onitoring and Evaluation of the L ong-R ange T ransmission of Air Pollution in Europe. 1984. Int L egal M ater 24:484.

H eijungs, R. 1992. E nvironmental L ife Cycle Assessment of Products- National R euse of $W$ aste $R$ esearch Programme. Novem \& Rivm.

$\mathrm{H}$ elsinki Convention on the Protection and $U$ se of Transboundary Watercourses and International Lakes. 1992. Int L egal M ater 31:1312.

$\mathrm{H}$ elsinki Convention on the Protection of the $\mathrm{M}$ arine Environment of the Baltic Sea Area. 1974. Int Le gal $M$ ater 13:546.

$\mathrm{H}$ elsinki Protocol on the R eduction of Sulphur Emissions. 1988. Int L egal M ater 27:64.

Hey, E, T IJIstra, A Nollkaemper. 1993. Int J M arine Coast Law 8:76.

Hildebrandt, E, E Schmidt. 1994. Industrial Relations and Environmental Protection in E urope. Dublín: Fundación Europa para la M ejora de las Condiciones de $\checkmark$ ida y de Trabajo.

H ohmann, H. 1992. B asic D ocuments of I nternational Environmental L aw. Londres: Graham \& T rotman.

International Convention for the Prevention of Pollution of the Sea by O il. 1954. U nited N ations T rea- ties Series (UNTS), No. 327. Ginebra: Naciones Unidas.

International Convention for the Prevention of Pollution from Ships (1973), as amended in 1978. Int egal M ater 17:546.

International Convention on Civil Liability for $\mathrm{O}$ il Pollution Damage. 1969. Int L egal M ater 16:617.

International Convention on O il Pollution Preparedness, Response and Cooperation. 1991. Int Legal $M$ ater 30:735.

International Convention on the Establishment of an International Fund for Compensation for $\mathrm{O}$ il Polution Damage, Brussels, 1971. Amended 1976, Protocols in 1984 and 1992. 1972. Int Legal M ater 11:284.

International Convention relating to Intervention on the High Seas in cases of O il Pollution Damage, 1969. 1970. Int $L$ egal $M$ ater 9:25.

K eoleian, GA, D M enerey. 1993. Life Cycle Design Guidance M anual. Washington, DC : Environmental Protection Agency.

K iss, A, D Shelton. 1991. International Environmental aw. N ueva Y ork: T ransnational.

K ummer, K. 1992. The Basel Convention. Int Comp Law Q 41:530.

K uwait Regional Convention for Co-operation on the Protection of the $\mathrm{M}$ arine Environment from Pollution, 24 April, K uwait. 1978. Int Legal M ater 17:511.

Lac Lanoux Arbitration. 1957. En 24 International Law Reports, 101.

Lloyd, GER. 1983. H ippocratic W ritings. Londres: Penguin Books.

London Convention on the Prevention of $M$ arine Pollution by Dumping of $W$ astes and $O$ ther $M$ atter. 1972. Int L egal M ater 11:1294.

Lyster, S. 1985. International W ildlife Law. Cambridge: Grotius.

$M$ inisterial D eclaration on the Protection of the Black Sea. 1993. Int J M arine Coast Law 9:72-75.

M olitor, M R. 1991. International E nvironmental Law: Primary $M$ aterials. Deventer: K luwer Law \& T axation.

Montego Bay Convention on the Law of the Sea (LOSC). 1982. Int L egal M ater 21:1261.

Naciones U nidas. N.d. Declaration of the $U$ nited Nations Conference $\mathrm{On}$ the $\mathrm{H}$ uman $\mathrm{E}$ nvironment (Stockholm). Ginebra: N aciones $U$ nidas.

Nordic Convention on the Protection of the Environment. 1974. Int Legal M ater 13:511.

$O$ dessa M inisterial Declaration on the Protection of the Black Sea, 1993. 1994. Int J M arine Coast Law 9:72-75.

Of L103/ 1, 24 April 1979, y OJ L206/ 7, 22 July 1992. 1991. En Freestone y IJIstra 1991.

O rganización Internacional del T rabajo (OIT). 1990. Environment and the $\mathrm{W}$ orld of W ork . Informe del $\mathrm{Di}$ rector General presentado en la Conferencia Internacional del Trabajo, 77a Sesión. Ginebra: OIT

O slo Convention for the Prevention of $\mathrm{M}$ arine Pollution by Dumping from Ships and Aircraft. 1972. En Freestone e IJIstra 1991.

Paris Convention for the Prevention of $\mathrm{M}$ arine Pollution from Land Based Sources. 1974. Int L egal M ater 13:352.

Paris Convention for the Protection of the $M$ arine Environment of the North East Atlantic. 1993. Int $M$ arine Coast Law 8:1-76.

Paris M emorandum of U nderstanding on Port State Control in Implementing Agreements on M aritime Safety and Protection of the $\mathrm{M}$ arine Environment. 1982. Int Legal M ater 21:1. 
Protocol to the Antarctic T reaty on Environmental Protection. 1991. Int L egal M ater 30:1461.

Ramsar C onvention on Wetlands of International Importance, especially as Waterfowl $\mathrm{H}$ abitat 1971. Int L egal M ater 11:963.

R egional Convention for the Conservation of the R ed Sea and Gulf of Aden Environment, 14 February, Jeddah. 1982. En Sand 1987

Resolución de la AGNU. Resolución 2997, XXVII. 15 de diciembre de 1972

$\mathrm{R}$ io Declaration on Environment and Development. 1992. Int L egal M ater 31:814.

Robinson, NA (dir.). 1993. Agenda 21: Earths's Action Plan. Nueva Y ork: $O$ ceana.

Ryding, S-0. 1994. International Experiences of Environmentally-Sound Product D evelopment Based On L ife Cycle Assessments. Estocolmo: C onsejo Sueco de Investigación de R esiduos.

—. 1996. Sustainable P roduct D evelopment. Ginebra: IOS.

Sand, PH (dir.). 1987. M arine E nvironmental Law in the U nited Nations Environment Programme: An Emergent $\mathrm{E}$ co-R egime. Londres: T ycooly.

-. 1992. The E ffectiveness of International Environmental A greements: A Survey of Existing L egal Instruments. C ambridge: Grotius.

Society of Environmental Toxicology and Chemistry (SET AC). 1993. Guidelines for L ife Cycle Assessment: A "Code of Practice". Boca R aton:L ewis.

Sofia Protocol Concerning the Control of Emissions of Nitrogen $\mathrm{Oxides}$ or their Transboundary Fluxes. 1988. Int L egal M ater 27:698.

T rail Smelter Arbitration. 1939. Am J Int Law 33:182.

—. 1941. Am J Int Law 35:684.

T reaty Banning N uclear W eapon T ests in the A tmos phere, in O uter Space and Under Water. 1963. Am J Int Law 57:1026.

UICN y G obierno de la R epública de Botswana. N.d. E nvironmental I mpact Assessment: M anual for In-Service Training. G land, Suiza: UICN

UNESCO Convention Concerning the Protection of the World Cultural and Natural Heritage, 1972. Int L egal M ater 11:1358.

Vienna Convention on Assistance in the Case of a Nuclear Accident or Radiological Emergency. 1986a. Int L egal M ater 25:1377.

Vienna Convention on Civil Liability for Nuclear Damage. 1963. Int L egal M ater 2:727.

Vienna Convention on the Early Notification of N uclear Accident. 1986b. Int L egal M ater 25:1370.

$\mathrm{V}$ ienna Convention on the Physical Protection of $\mathrm{Nu}$ clear M aterial. 1980. Int Legal M ater 18:1419.
Vigon, BW y cols. 1992. Life Cycle Assessment: I nventory Guidelines and Principles. Boca R aton: L ewis.

Washington Convention for the R egulation of Whaling. 1946. League of $N$ ations Treaty Series (LNTS), N o. 155.

Washington Convention on International Trade in Endangered Species (CITES). 1973. Int L egal M ater 12:1085.

Wellington Convention on the R egulation of Antarc tic M ineral R esource Activities, 1988. Int L egal M ater 27:868.

\section{0 tras lecturas recomendadas}

Banco M undial. N.d. Environmental Assessment Source book. Technical Paper, N o. 140. Washington,DC: Banco M undial

Bennett, D. 1991. Pesticide reduction, a case study from Canada. N ew Solutions (Fall).

Blanpain, R. 1991. International Encyclopedia of Laws: E nvironmental Law. V ol. 1-3. Deventer: K luwer Law $\&$ Taxation

Bonyhady, T. 1992. Environmental Protection and Legal Change. Annandale, Australia: Federation Press.

Canadian Labour Congress. 1992. A C ritique of the $0 \mathrm{n}$ tario $\mathrm{H}$ azard Assessment System. O ttawa: Canadian Labour Congress.

Center for Chemical Process Safety of the American Institute of Chemical Engineers (AICE). 1989 Guidelines for Chemical Process Q uantitative R isk Analysis. Nueva Y ork: AICE.

Chance, C. 1992. European Environmental Law Guide Londres: Environment Group.

Comisión Europea. 1993. Compendium of EC Environmental Law. Luxemburgo: O ficina de Publicaciones O ficiales de la Comisión Europea.

Comisión M undial de M edio Ambiente y Desarrollo (WCED ). 1987. O ur Common F uture O xford: O UP.

Commoner, B. 1990. M aking Peace $W$ ith the Planet Nueva Y ork: Pantheon Books.

Covello, V y cols. 1989. Effective Risk Communication. Nueva Y ork: Plenum Press.

de Casadevante Romani, CF. 1992. La Proteccion de $M$ edio Ambiente en $D$ erecho Internacional, D erecho C omunitario E uropeo y Derecho E spañol. Vitoria-Gasteiz: Publicaciones del G obierno V asco.

Environment Canada. 1993. Pollution Prevention L egislative $\mathrm{T}$ ask $\mathrm{F}$ orce, Final Report. $\mathrm{O}$ ttawa: Environment Canada.

Foran, J, B Glenn. 1993. Criteria to Identify Chemica Candidates for Sunsetting in the Great Lakes Basin. W ashington, DC: G eorge W ashington U niv.
Geiser, K. 1990. Toxics use reduction and pollution prevention. N ew Solutions (Primavera).

G reat L akes Scientific Advisory Board. 1991. Informe al Comité M ixto Internacional. Edición revisada, diciembre 1991

H awke, N. 1995. Environmental H ealth Law. Londres: Sweet \& M axwell.

K iss, AC. 1983. Selected M ultilateral T reaties in the F ield of the Environment. Nairobi: Programa de las Naciones Unidas para el M edio A mbiente (PNUM A).

LeBlansch, K, E Hildebrandt, D Pearson. 1992. Industrial Relations and the Environment: Case Studies. Dublín: Fundación Europea para la M ejora de las Condiciones de Vida y de T rabajo.

M arco Berg y cols. 1994. W as ist ein Schaden? Zürich: V erlag der Fachvereine.

Naciones U nidas. 1995. W orld Summit on Social D evelopment: Action Programme. Copenhague: Naciones U nidas.

OCDE. 1991. Climate Change Evaluating the SocioE conomic Impact. París: O CDE.

Ontario M inistry of the Environment (OME). 1990. Scoring System for Assessing E nvironmental Contaminants. Toronto: OM E

-. 1993. Candidate Substances List for Bans and Phase Outs. T oronto: OME.

Plater, ZJB, RH Abrams, W Goldfarb. 1992. E nvironmental Law and Policy: Nature, Law and Society. St. Paul, M innesota: W est Publishing.

Rossi, M, M Ellenbecker, K Geiser. 1991. Techniques in toxics use reduction: From concept to action. N ew Solutions (Fall).

R ummel-Bulska, I, S O safo. 1991. Selected M ultilateral Treaties in the Field of the Environment. Cambridge: Grotius.

Ruster, B, B Simma. 1975. International Protection of the Environment: Treaties and Related D ocuments. D obbs Ferry, Nueva Y ork: O ceana.

Schrecker, T. 1993. Sustainable D evelopment: G etting There From $\mathrm{H}$ ere, A $\mathrm{H}$ andbook for U nion Environment Committees and J oint Labour- $M$ anagement Environment Committees. O ttawa: CLC/NRTEE.

Storm, P-C. 1992. E inführung in das U mweltrecht. Berlín: E Schmidt.

US O ffice of Technology Assessment. 1986. Serious Reduction of $\mathrm{H}$ azardous $\mathrm{W}$ aste for Pollution Prevention and Industrial E fficiency. Washington, DC: US O ffice of T echnology Assessment.

V iscusi, WK. 1987. Learning About Risk. Cambridge, $M$ assachussetts: $\mathrm{H}$ arvard U niv. Press. 
Directores del capítulo

J erry Spiegd y Lucien Y. M aystre

\section{Sumario}

Control y prevención de la contaminación ambiental

J erry Spiegel y L ucien $Y . M$ aystre . . . . . . . . . . . . . 55.2

Gestión de la contaminación atmosférica

D ietrich Schwela y B erenice G oelzer . . .

Contaminación atmosférica: modelos de dispersión de contaminantes atmosféricos

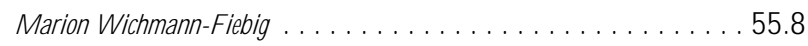

Vigilancia de la calidad atmosférica

H ans-U Irich P feffer y Peter B ruckmann. . . . . . . . . . . . . . . . . 55.12

Control de la contaminación atmosférica

J ohn Elias .............................. 55.20

Control de la contaminación del agua

Herbert C. Preul ........................ 55.26

Proyecto de regeneración de aguas residuales en la

Región de $D$ an: estudio de caso

Alexander D onagi . . . . . . . . . . . . . . . . . . . 55.38

Principios de la gestión de residuos

Lucien Y. M aystre. . . . . . . . . . . . . . . . . . . . . . . . . . . . 55.42

Gestión y reciclado de residuos sólidos

Niels J orn $H$ ahn y Poul $S$. Lauridsen . . . . . . . . . . . . . . . . . 55.44

Estudio de caso: control y prevención de la contaminación

de los $G$ randes L agos de Canadá

T homas Tseng, Victor Shantora el an R. Smith . . . . . . . . . . . . . . 55.46

Tecnologías de producción más limpias

$D$ avid $B$ ennett . . . . . . . . . . . . . . . . . . . . . . 55.52 


\section{- CONTROL Y PREVENCION DE LA CONTAMINACION AMBIENTAL}

\author{
Jerry Spiegel y L ucien Y. M aystre
}

Durante el siglo $X X$, la creciente sensibilización respecto al impacto de las actividades humanas en el medio ambiente y la salud pública (analizado en el capítulo 53: R iesgos ambientales para la salud), ha dado lugar al desarrollo y la utilización de diferentes métodos y tecnologías para reducir los efectos de la contaminación. En este sentido, los gobiernos han adoptado medidas de carácter normativo y político (analizadas en el capítulo 54: Política en materia de medio ambiente) para minimizar los efectos negativos y garantizar el cumplimiento de las normas sobre calidad ambiental.

El objetivo del presente capítulo es describir los métodos utilizados para el control y la prevención de la contaminación ambiental. En primer lugar se presentan los principios básicos aplicados para eliminar los impactos negativos sobre la calidad del agua, la atmósfera y el suelo; a continuación se considera cómo la atención se ha desviado del control a la prevención y por último se analizan las limitaciones de las soluciones propuestas para un medio en particular. Así, por ejemplo, no es suficiente con proteger la atmósfera eliminando los metales traza de un gas de combustión si por otro lado estos contaminantes son transferidos al suelo por unas prácticas inadecuadas de tratamiento de residuos sólidos. Se impone, por lo tanto, la utilización de soluciones integradas para distintos medios.

\section{Estrategias para el control de la contaminación}

La rápida industrialización ha dado lugar a innumerables accidentes que han contaminado los recursos terrestres, atmosféricos y acuáticos con materiales tóxicos y otros contaminantes, amenazando a las personas y los ecosistemas con graves riesgos para la salud. El uso cada vez más generalizado e intensivo de materiales y energía ha originado una creciente presión en la calidad de los ecosistemas locales, regionales y mundiales.

Antes de que se emprendiera un esfuerzo concertado para reducir el impacto de la contaminación, el control ambiental apenas existía y se orientaba principalmente al tratamiento de residuos para evitar daños locales, aunque siempre con una perspectiva a muy corto plazo. Sólo en aquellos casos excepcionales en los que se consideró que el daño era inadmisible se tomaron medidas al respecto. A medida que se intensificó el ritmo de la actividad industrial y se fueron conociendo los efectos acumulativos, se impuso el paradigma del control de la contaminación como principal estrategia para proteger al medio ambiente.

\section{D os conceptos sirvieron de base para este control:}

- el concepto de capacidad de asimilación, que reconoce la existencia de un cierto nivel de emisiones al medio ambiente sin efectos apreciables en la salud humana y ambiental,

- el concepto del principio de control, que supone que el daño ambiental puede evitarse controlando la forma, la duración y la velocidad de la emisión de contaminantes al medio ambiente.

Como parte de la estrategia del control de la contaminación, los intentos de proteger el medio ambiente han consistido principalmente en aislar los contaminantes del medio ambiente y en utilizar depuradoras y filtros en las fuentes emisoras. Estas soluciones, orientadas a objetivos de calidad ambiental o límites de emisión específicos para un medio, se han dirigido especialmente a eliminar los puntos de vertido de residuos a determinado medios (aire, agua, tierra).

\section{Aplicación de las tecnologías de control de la contaminación}

Los métodos para controlar la contaminación han demostrado una gran eficacia, especialmente los de ámbito local. Para su aplicación es preciso analizar de forma sistemática la fuente y la naturaleza de la emisión o el vertido en cuestión, su interacción con el ecosistema y el problema de contaminación ambiental que debe solucionarse, para a continuación elegir las tecnologías más adecuadas que permitan reducir y vigilar estos impactos por contaminación.

En su artículo sobre el control de la contaminación atmosférica, Dietrich Schwela y Berenice Goelzer analizan la importancia y las implicaciones de la adopción de un enfoque integrado de la evaluación y el control de las fuentes localizadas y dispersas de contaminación atmosférica. Estos autores examinan también los retos (y oportunidades) a los que se enfrentan los países que han experimentado una rápida industrialización sin aplicar una política firme de control de la contaminación desde el inicio de su desarrollo industrial.

$M$ arion Wichman-Fiebig analiza los métodos que se utilizan en los modelos de dispersión de los contaminantes atmosféricos para determinar y caracterizar la naturaleza de los problemas de contaminación. Estos modelos son fundamentales para saber qué controles deben adoptarse y evaluar su eficacia. A medida que se han conocido mejor los impactos potenciales, la valoración de los efectos ha pasado del ámbito local al regional y después al mundial.

$\mathrm{H}$ ans-U Irich Pfeffer y Peter Bruckmann ofrecen una introducción a los equipos y métodos utilizados para supervisar la calidad del aire, valorar los posibles problemas de contaminación y evaluar la eficacia de las medidas de control y prevención aplicadas.

John Elias analiza los tipos de control de contaminación atmosférica que existen en la actualidad y los aspectos que deben considerarse para elegir el método de control más adecuado.

El problema del control de la contaminación del agua es analizado por $\mathrm{Herbert}$ Preul en un artículo que describe la manera en que las aguas naturales de nuestro planeta pueden ser contaminadas por fuentes localizadas, dispersas y discontinuas, los fundamentos del control de la contaminación acuática y los diferentes criterios que pueden aplicarse para diseñar los programas de control. Preul explica también la forma en que las masas de agua reciben los vertidos y cómo ésta puede analizarse y evaluarse para valorar y controlar los riesgos. Finalmente, se incluye un resumen de las técnicas utilizadas para el tratamiento a gran escala de las aguas residuales y el control de la contaminación del agua.

El estudio de un caso ofrece un ejemplo claro de cómo pueden reciclarse las aguas residuales, tema de gran importancia en la búsqueda de nuevas formas para hacer un uso eficaz de los recursos ambientales, especialmente en circunstancias de escasez. Alexander Donagi analiza el método utilizado para el tratamiento de las aguas residuales municipales y la renovación de las aguas subterráneas para una población de 1,5 millones de habitantes en I srael.

\section{Control integrado de los residuos}

Bajo la óptica del control de la contaminación, los residuos se consideran como un subproducto no deseado del proceso de producción que debe controlarse para garantizar que los recursos de tierra, agua y aire no sean contaminados por encima de unos niveles considerados como aceptables. L ucien M aystre estudia los aspectos que deben considerarse en el control de residuos y establece un vínculo teórico con la función cada vez más importante del reciclado y la prevención de la contaminación. 
En respuesta a las numerosas evidencias de la grave contaminación producida por el tratamiento descontrolado de los residuos, los gobiernos han adoptado normativas para imponer unas prácticas aceptables de recogida, tratamiento y eliminación de residuos y garantizar la protección del medio ambiente. Se ha dedicado una especial atención a la definición de los criterios de un vertido sin riesgos para el medio ambiente basados en vertederos controlados, incineración y tratamiento de residuos peligrosos.

Para evitar una posible sobrecarga ambiental y los costes asociados a la eliminación de residuos y para promover una gestión más cuidadosa de unos recursos escasos, cada vez se está dedicando mayor atención a la minimización y el reciclado de los residuos. $\mathrm{Niels} \mathrm{H}$ ahn y Poul Lauridsen resumen los aspectos que deben considerarse cuando se propone el reciclado como la mejor estrategia para el tratamiento de los residuos, y consideran también los riesgos potenciales para los trabajadores.

\section{Del control a la prevención de la contaminación}

El control de las fuentes emisoras conlleva el riesgo de transferir la contaminación de un medio a otro, donde pueden causar problemas ambientales igual de graves, 0 incluso acabar actuando como fuente indirecta de contaminación para el mismo medio. Aunque menos caro que las acciones correctoras, el control de las fuentes emisoras puede aumentar considerablemente los costes de los procesos de producción sin añadir valor alguno. Asimismo, este tipo de controles conllevan unos costes adicionales derivados del obligado cumplimiento de la normativa vigente.

Aunque el control de la contaminación ha logrado éxitos considerables en la resolución a corto plazo de problemas de contaminación de ámbito local, su eficacia ha sido menor para solucionar los problemas acumulativos que se detectan cada vez más a nivel regional (p. ej., Iluvia ácida) o mundial (p. ej., destrucción de la capa de ozono).

El objetivo de un programa de control de la contaminación ambiental orientado a la salud es promover una mejor calidad de vida reduciendo la contaminación al menor nivel posible. Los programas y políticas de control de la contaminación ambiental, cuyas implicaciones y prioridades varían de un país a otro, abarcan todos los aspectos de la contaminación (aire, agua, tierra, etc.) y requieren la coordinación entre distintas áreas, como desarrollo industrial, planificación urbanística, desarrollo de recursos hídricos y políticas de transporte.

T homas Tseng, Victor Shantora e Ian Smith han estudiado el caso de los Grandes Lagos de Norteamérica, como ejemplo del impacto en distintos medios que puede tener la contaminación en un ecosistema vulnerable sometido a gran estrés. En este estudio se examina en particular la limitada efectividad del modelo de control de la contaminación aplicado para solucionar el problema de las toxinas permanentes que se disipan en el medio ambiente. EI análisis de la estrategia utilizada en este país y sus posibles implicaciones a escala internacional permite determinar sus implicaciones en términos de medidas de prevención y control.

Al aumentar el grado de sofisticación y el coste de las tecnologías de control de la contaminación ambiental, ha surgido un creciente interés por incorporar la prevención al diseño de los procesos industriales, con el objetivo de eliminar los efectos nocivos ambientales y mejorar la competitividad de las industrias. Entre los métodos de prevención de la contaminación más utilizados, destacan las tecnologías limpias y la reducción del uso de sustancias tóxicas para eliminar los riesgos para la salud de los trabajadores.
David Bennett analiza las razones de que la prevención de la contaminación se esté imponiendo como estrategia preferida, así como su relación con otros métodos de control ambiental. Esta estrategia es fundamental para promover el desarrollo sostenido, una necesidad ampliamente reconocida desde la creación de la Comisión de Comercio y Desarrollo de las $\mathrm{N}$ aciones U nidas en 1987 y respaldada en la Conferencia de las Naciones U nidas sobre el M edio A mbiente y el D esarrollo (C N U M AD) en 1992.

La prevención de la contaminación se centra directamente en la utilización de procesos, prácticas, materiales y fuentes de energía que eviten o reduzcan al mínimo la creación de contaminantes y residuos en la fuente, en lugar de tener que recurrir a otras medidas de control. Aunque el compromiso de las empresas es un factor crítico para prevenir la contaminación (véase E nvironmental Policy de Bringer y Zoesel), Bennett llama la atención sobre las ventajas sociales de la reducción de riesgos para el ecosistema y la salud, especialmente la salud de los trabajadores. A simismo, identifica los principios que pueden aplicarse con éxito para evaluar la viabilidad de este enfoque.

\section{GESTION DE LA CONTAMINACION AT MO SFERICA}

\section{Dietrich Schwela y Berenice G oelzer}

La gestión de la contaminación atmosférica pretende la eliminación, o la reducción hasta niveles aceptables, de aquellos agentes (gases, partículas en suspensión, elementos físicos y hasta cierto punto agentes biológicos) cuya presencia en la atmósfera puede ocasionar efectos adversos en la salud de las personas (p. ej., irritación, aumento de la incidencia o prevalencia de enfermedades respiratorias, morbilidad, cáncer, exceso de mortalidad) o en su bienestar ( $p$. ej., efectos sensoriales, interferencias con la visibilidad), efectos perjudiciales sobre la vida de las plantas y de los animales, daños a materiales de valor económico para la sociedad y daños al medio ambiente (p. ej., modificaciones climatológicas). Los graves riesgos asociados a los contaminantes radiactivos, así como los procedimientos especiales para su control y evacuación, exigen que se les preste la mayor atención.

La importancia de una gestión eficiente de la contaminación atmosférica no puede ser subestimada. A no ser que se lleve a cabo un control adecuado, la multiplicación de las fuentes contaminantes del mundo moderno puede llegar a producir daños irreparables para el medio ambiente y para toda la humanidad.

El objetivo de este artículo es ofrecer una visión general de las posibles estrategias para controlar la contaminación atmosférica, particularmente la producida por las emisiones de vehículos y fuentes industriales. No obstante, debe insistirse desde el principio en que la contaminación del aire interior (especialmente en los países en vías de desarrollo) puede revestir una importancia aún mayor que la contaminación del aire exterior, ya que los contaminantes atmosféricos alcanzan con frecuencia concentraciones mayores en espacios cerrados que al aire libre.

Al margen de las consideraciones referentes a emisiones de fuentes estáticas o móviles, el control de la contaminación atmosférica exige también tener en cuenta otros factores (como la topografía y la meteorología, la participación del gobierno y de los municipios, etc.) que deben ser integrados en un programa global. Por ejemplo, las condiciones meteorológicas pueden agravar los efectos de una misma emisión de contaminantes a nivel del suelo. Por su parte, las fuentes de contaminación atmosférica pueden estar diseminadas por toda una región y sus efectos pueden incidir, o su control debe involucrar, a más de una administración. Además, la contaminación atmosférica 
no respeta fronteras y las emisiones en una región pueden provocar efectos en otra situada a gran distancia.

La gestión de la contaminación atmosférica exige, por tanto, un planteamiento multidisciplinario, así como los esfuerzos conjuntos de diferentes entidades, tanto públicas como privadas.

\section{Fuentes de contaminación atmosférica}

Las fuentes antropogénicas de contaminación atmosférica (o fuentes emisoras) son básicamente de dos tipos:

- estáticas: a su vez pueden subdividirse en fuentes zonales (producción agrícola, minas y canteras, zonas industriales), fuentes localizadas y zonales (fábricas de productos químicos, productos minerales no metálicos, industrias básicas de metales, centrales de generación de energía) y fuentes municipales ( $p$. ej., calefacción de viviendas y edificios, incineradoras de residuos municipales y fangos cloacales, chimeneas, cocinas, servicios de lavandería y plantas de depuración),

- móviles: como los vehículos con motor de combustión (p. ej. vehículos ligeros con motor de gasolina, vehículos pesados y ligeros con motor diesel, motocicletas, aviones incluyendo fuentes lineales con emisión de gases y partículas del conjunto del tráfico de vehículos).

Existen también fuentes naturales de contaminación (p. ej., zonas erosionadas, volcanes, ciertas plantas que liberan grandes cantidades de polen, focos bacteriológicos, esporas 0 virus). Los agentes físicos, biológicos y vegetales no serán analizados en este artículo.

\section{Clases de contaminantes atmosféricos}

Los contaminantes atmosféricos se clasifican normalmente en: partículas en suspensión (polvo, nieblas, humos), contaminantes gaseosos (gases y vapores) y olores. A continuación se indican algunos de los contaminantes más frecuentes:

Las partículas en suspensión (SPM, PM-10) incluyen gases de escape de motores diesel, cenizas en suspensión, polvos minerales (carbón, amianto, caliza, cemento), polvos y humos metálicos (zinc, cobre, hierro, plomo), nieblas ácidas (ácido sulfúrico), fluoruros, pigmentos, nieblas de pesticidas, hollín y humos. Las partículas en suspensión, además de sus efectos respiratorios corrosivos, cancerígenos, irritantes y destructores de la vida vegetal, producen también daños materiales (p. ej., acumulación de suciedad), interfieren con la luz del sol (p. ej., formación de nieblas que dificultan la penetración de los rayos solares) y actúan como superficies catalíticas para la reacción de las sustancias químicas adsorbidas.

Los contaminantes gaseosos incluyen compuestos azufrados (p. ej., dióxido de azufre ( $\mathrm{SO}_{2}$ ) y trióxido de azufre $\left(\mathrm{SO}_{3}\right)$, monóxido de carbono, compuestos nitrogenados (p. ej., óxido nítrico (NO), dióxido de nitrógeno ( $\mathrm{NO}_{2}$ ), amoníaco), compuestos orgánicos (p. ej., hidrocarburos $(\mathrm{HC})$, compuestos orgánicos volátiles (COV), hidrocarburos aromáticos policíclicos (PAH ), aldehídos), compuestos halogenados y haluros (p. ej., $\mathrm{H} \mathrm{F}$ y H Cl), sulfuro de hidrógeno, bisulfuro de carbono y mercaptanos (olores).

Estos compuestos pueden generar contaminantes secundarios a través de reacciones térmicas, químicas o fotoquímicas. Por ejemplo, por la acción del calor, el dióxido de azufre puede oxidarse, convirtiéndose en trióxido, que, disuelto en agua, da lugar a la formación de una niebla de ácido sulfúrico (catalizado por óxidos de manganeso y hierro). Las reacciones fotoquímicas entre los óxidos de nitrógeno y los hidrocarburos reactivos pueden producir ozono $\left(\mathrm{O}_{3}\right)$, formaldehído y nitrato de peroxiacetilo (PAN); asimismo, las reacciones entre formaldehído y el ácido clorhídrico forman el éter bisclorometílico.

Aunque es sabido que algunos olores son producidos por agentes químicos específicos, como el sulfuro de hidrógeno
Tabla 55.1 • Contaminantes atmosféricos más comunes y sus fuentes

\begin{tabular}{|c|c|c|}
\hline Categoría & Fuente & Contaminantes emitidos \\
\hline Agricultura & Combustión abierta & $\mathrm{SPM}, \mathrm{CO}, \mathrm{COV}$ \\
\hline \multirow{4}{*}{$\begin{array}{l}\text { Minas y } \\
\text { canteras }\end{array}$} & Minas de carbón & $\mathrm{SPM}, \mathrm{SO}_{2}, \mathrm{NO}_{x}, \mathrm{COV}$ \\
\hline & $\begin{array}{l}\text { Petróleo crudo y producción } \\
\text { de gas natural }\end{array}$ & $\mathrm{SO}_{2}$ \\
\hline & Minas no ferrosas & $\mathrm{SPM}, \mathrm{Pb}$ \\
\hline & Canteras de piedra & SPM \\
\hline \multirow[t]{4}{*}{ Fabricación } & Alimentos, bebidas y tabaco & $\mathrm{SPM}, \mathrm{CO}, \mathrm{COV}_{1} \mathrm{H}_{2} \mathrm{~S}$ \\
\hline & Industrias textiles y de curtidos & SPM, COV \\
\hline & Productos de madera & SPM, COV \\
\hline & $\begin{array}{l}\text { Productos de papel, artes } \\
\text { gráficas }\end{array}$ & $\mathrm{SPM}, \mathrm{SO}_{2}, \mathrm{CO}, \mathrm{COV}, \mathrm{H}_{2} \mathrm{~S}, \mathrm{R}-\mathrm{SH}$ \\
\hline \multirow{14}{*}{$\begin{array}{l}\text { Fabricación } \\
\text { de productos } \\
\text { químicos }\end{array}$} & Anhídrido ftálico & $\mathrm{SPM}, \mathrm{SO}_{2}, \mathrm{CO}, \mathrm{COV}$ \\
\hline & Cloro & $\mathrm{Cl}_{2}$ \\
\hline & Acido clorhídrico & $\mathrm{HCl}$ \\
\hline & Acido fluorhídrico & $\mathrm{HF}_{1} \mathrm{SiF}_{4}$ \\
\hline & Acido sulfúrico & $\mathrm{SO}_{2}, \mathrm{SO}_{3}$ \\
\hline & Acido nítrico & $\mathrm{NO}_{\mathrm{x}}$ \\
\hline & Acido fosfórico & $S P M, F_{2}$ \\
\hline & Oxido de plomo y pigmentos & SPM, Pb \\
\hline & amoníaco & $\mathrm{SPM}, \mathrm{SO}_{2}, \mathrm{NO}_{x}, \mathrm{CO}, \mathrm{COV}, \mathrm{NH}_{3}$ \\
\hline & Carbonato sódico & $\mathrm{SPM}, \mathrm{NH}_{3}$ \\
\hline & Carburo cálcico & SPM \\
\hline & Acido adípico & $\mathrm{SPM}, \mathrm{NO}_{\mathrm{x}}, \mathrm{CO}, \mathrm{COV}$ \\
\hline & Plomo alquílico & $\mathrm{Pb}$ \\
\hline & Anhídrido maleico y & $\mathrm{CO}, \mathrm{COV}$ \\
\hline
\end{tabular}

ácido tereftálico

Producción de fertilizantes y $\mathrm{SPM}, \mathrm{NH}_{3}$ plaguicidas

Nitrato amónico $\quad \mathrm{SPM}, \mathrm{NH}_{3}, \mathrm{HNO}_{3}$

Sulfato amónico $\quad \mathrm{COV}$

Resinas sintéticas, materiales SPM, COV, $\mathrm{H}_{2} \mathrm{~S}, \mathrm{CS}_{2}$ plásticos, fibras

Pinturas, barnices, lacas SPM, COV

Jabón SPM

Negro carbón y tintas de $\quad \mathrm{SPM}_{1} \mathrm{SO}_{2}, \mathrm{NO}_{x^{\prime}} \mathrm{CO}, \mathrm{COV}, \mathrm{H}_{2} \mathrm{~S}$ impresión

Trinitrotolueno

Refinerías de Productos derivados de

petróleo petróleo y del carbón

Fabricación de Productos de vidrio

productos Productos arcillosos

minerales

no metálicos estructurales

Cemento, cal y yeso

Industrias Hierro y acero

básicas del Industrias no ferrosas

metal

Generación de Electricidad, gas y vapor

energía

Comercio

mayorista y

minorista

Almacenaje de combustibles operaciones de llenado

Transporte

Servicios municipales

Incineradores municipales

$\mathrm{SPM}, \mathrm{SO}_{2}, \mathrm{NO}_{x}, \mathrm{SO}_{3}, \mathrm{HNO}_{3}$

$\mathrm{SPM}, \mathrm{SO}_{2}, \mathrm{NO}_{x}, \mathrm{CO}, \mathrm{COV}$

$\mathrm{SPM}, \mathrm{SO}_{2}, \mathrm{NO}_{x}, \mathrm{CO}, \mathrm{COV}, \mathrm{F}$

$\mathrm{SPM}, \mathrm{SO}_{2}, \mathrm{NO}_{x}, \mathrm{CO}, \mathrm{COV}, \mathrm{F}_{2}$

$\mathrm{SPM}, \mathrm{SO}_{2}, \mathrm{NO}_{x,} \mathrm{CO}$

$\mathrm{SPM}, \mathrm{SO}_{2}, \mathrm{NO}_{\mathrm{X}}, \mathrm{CO}, \mathrm{COV}, \mathrm{Pb}$

$\mathrm{SPM}, \mathrm{SO}_{2}, \mathrm{~F}, \mathrm{~Pb}$

$\mathrm{SPM}, \mathrm{SO}_{2}, \mathrm{NO}_{x}, \mathrm{CO}, \mathrm{COV}$

$\mathrm{SO}_{3}, \mathrm{~Pb}$

$\mathrm{COV}$

$\mathrm{SPM}, \mathrm{SO}_{2}, \mathrm{NO}_{x}, \mathrm{CO}, \mathrm{COV}, \mathrm{Pb}$ $\mathrm{SPM}, \mathrm{SO}_{2}, \mathrm{NO}_{x}, \mathrm{CO}, \mathrm{COV}, \mathrm{Pb}$ 
$\left(\mathrm{H}_{2} \mathrm{~S}\right)$, el bisulfuro de carbono $\left(\mathrm{CS}_{2}\right)$ y los mercaptanos ( $\mathrm{R}-\mathrm{SH} 0$ R 1-S-R 2), otros son difíciles de definir químicamente.

En la Tabla 55.1 (Economopoulos 1993) se ofrecen algunos ejemplos de los principales contaminantes asociados a algunas fuentes de contaminación de origen industrial.

\section{Planes para el control de la calidad del aire}

La vigilancia de la calidad del aire tiene como objetivo conservar la pureza ambiental estableciendo los límites tolerables de contaminación y dejando en manos de las administraciones locales y los contaminadores el diseño y la adopción de medidas para garantizar que no se supere ese grado de contaminación. Un ejemplo de este tipo de legislación es el establecimiento de normas sobre la calidad atmosférica basadas, en la mayoría de los casos, en directrices sobre la calidad atmosférica (O M S 1987) para los diferentes contaminantes. Estas normas suelen indicar los niveles máximos permisibles de contaminantes (o indicadores de la contaminación) por zonas ( $p$. ej., a nivel del suelo en un lugar específico del municipio en cuestión) y pueden ser de tipo primario o secundario. Las normas primarias (O M S 1980) establecen los niveles máximos de contaminación compatibles con un margen de seguridad adecuado y con la protección de la salud pública, debiendo alcanzarse en un cierto plazo de tiempo. Las normas secundarias son aquellas que se juzgan necesarias para garantizar la protección contra efectos adversos, conocidos o previstos, de peligros que no afectan a la salud (sino principalmente a la vegetación), debiendo cumplirse dentro de "un plazo de tiempo razonable". Las normas sobre la calidad atmosférica establecen valores a corto, medio y largo plazo que deben mantenerse 24 horas al día, siete días a la semana, para la exposición mensual, estacional o anual de todos los seres vivos (incluidos los más vulnerables, como niños, ancianos y enfermos) al igual que para objetos inanimados. Estas limitaciones contrastan con los máximos niveles permisibles de exposición en el trabajo, que se refieren a una exposición semanal parcial (p. ej., 8 horas al día, 5 días a la semana) de adultos y trabajadores supuestamente sanos.

Entre las medidas típicas de vigilancia de la calidad atmosférica se encuentran los controles de las propias fuentes como, por ejemplo, uso obligatorio de catalizadores en los vehículos 0 imposición de límites a las emisiones de los incineradores, planificación del uso del suelo, cierre de fábricas o reducción de tráfico en condiciones climáticas desfavorables. El control óptimo de la calidad atmosférica exige que se reduzcan al mínimo las emisiones contaminantes a la atmósfera. Estos mínimos se definen básicamente como el nivel de contaminación que se permite a cada fuente emisora y pueden alcanzarse, por ejemplo, utilizando sistemas confinados o instalando colectores y depuradores de alta eficiencia. Un límite de emisión se expresa como la cantidad o la concentración de contaminante que se permite como máximo a una sola fuente. Este tipo de legislación implica la necesidad de decidir, para cada industria, la forma óptima de controlar las emisiones (es decir, fijando unos límites de emisión).

El objetivo básico del control de la contaminación atmosférica es establecer un plan de control de la calidad del aire (o un plan de reducción de la contaminación atmosférica) (Schwela y K öth-Jahr 1994) que abarque los siguientes aspectos:

- descripción del área en cuanto a topografía, meteorología y socioeconomía;

- inventario de emisiones;

- comparación con los límites de emisión;

- inventario de las concentraciones de contaminantes atmosféricos;

- concentraciones simuladas de contaminantes atmosféricos;
- comparación con las normas sobre la calidad atmosférica;

- inventario de efectos sobre la salud pública y el medio ambiente;

- análisis de las causas:

- medidas de control;

- coste de las medidas de control;

- coste de los efectos sobre la salud pública y el medio ambiente;

- análisis de coste/ beneficio (coste del control frente al coste del esfuerzo);

- planificación del uso del suelo y del transporte;

- plan de ejecución; recursos comprometidos;

- previsiones de población, tráfico, industrias y consumo de combustibles,

- estrategias de seguimiento.

\section{A continuación se analizan algunos de estos aspectos.}

\section{Inventario de emisiones y comparación con los límites de emisión}

El inventario de emisiones es una lista lo más completa posible de las fuentes contaminantes y sus emisiones en una determinada zona, estimadas con la mayor exactitud posible para todas las fuentes emisoras localizadas, lineales y zonales (difusas). C uando se comparan estas emisiones con los límites de emisión establecidos para una determinada fuente, se obtienen los primeros datos sobre las posibles medidas de control en caso de sobrepasar dichos límites. El inventario de emisiones también sirve para establecer prioridades entre las principales fuentes dependiendo de la cantidad de contaminantes emitidos y para determinar la importancia relativa de las diferentes fuentes; por ejemplo, tráfico frente a fuentes industriales 0 residenciales. El inventario de emisiones permite también estimar las concentraciones de contaminantes atmosféricos cuando resulta difícil o demasiado costoso medir las concentraciones ambientales.

\section{Inventario de concentraciones de contaminantes atmosféricos y comparación con las normas sobre calidad atmosférica}

El inventario de concentraciones de contaminantes atmosféricos resume los resultados de la vigilancia de los contaminantes atmosféricos en términos de medias anuales, porcentajes y tendencias de estos valores. Entre los compuestos incluidos en este tipo de inventario se encuentran los siguientes:

- dióxido de azufre;

- óxidos de nitrógeno:

- partículas en suspensión

- monóxido de carbono

- ozono;

- metales pesados ( $\mathrm{Pb}, \mathrm{Cd}, \mathrm{Ni}, \mathrm{Cu}, \mathrm{Fe}, \mathrm{As}, \mathrm{Be}$ )

- hidrocarburos aromáticos policíclicos: benzo[a]pireno, benzo[e]pireno, benzo[a]antraceno, dibenzo[a,h]antraceno, benzo[ghi]perileno, coroneno,

- compuestos orgánicos volátiles: n-hexano, benceno, 3-metilhexano, n-heptano, tolueno, octano, etilbenceno xileno (o-, m-, p-), n-nonano, isopropilbenceno, propilbenceno, n-2-/ 3-/ 4-etiltolueno, 1,2,4-/ 1,3,5-trimetilbenceno, triclorometano, 1,1,1tricloroetano,tetraclorometano,tri-/ tetracloroeteno.

La comparación de las concentraciones de contaminantes atmosféricos con las normas o directrices sobre la calidad atmosférica indican las áreas problemáticas que deben ser objeto de un análisis de las causas para identificar las fuentes responsables del incumplimiento de la normativa. En estos análisis se utilizan modelos de dispersión (véase "Contaminación atmosférica: modelos de dispersión de contaminantes atmosféricos"). LoS dispositivos y los procedimientos utilizados actualmente para 
vigilar la contaminación atmosférica se describen en "Vigilancia de la calidad atmosférica".

\section{Concentraciones simuladas de contaminantes atmosféricos; comparación con las normas sobre la calidad atmosférica}

El inventario de emisiones incluye miles de compuestos, pero la concentración atmosférica de muchos de ellos no puede ser controlada por razones económicas. El uso de modelos de dispersión puede ayudar a estimar las concentraciones de los compuestos más "exóticos". U tilizando el modelo de dispersión y los parámetros meteorológicos adecuados, pueden estimarse y compararse los porcentajes y medias anuales con las normas y directrices sobre la calidad atmosférica, si es que existen.

\section{Inventario de efectos sobre la salud pública y e medio ambiente; análisis de las causas}

0 tra importante fuente de información es el inventario de efectos (M inisterium für U mwelt 1993), que consiste en los resultados de los estudios epidemiológicos realizados en el área en cuestión y los efectos de la contaminación atmosférica observados en receptores biológicos e inanimados tales como plantas, animales, metales y materiales de construcción. Los efectos atribuidos a la contaminación atmosférica deben ser analizados para identificar sus causas y el componente responsable; por ejemplo, aumento de la prevalencia de bronquitis crónica en un área contaminada. Una vez definido el compuesto o compuestos en el análisis causal (análisis compuesto-causa), debe realizarse un segundo análisis para establecer las fuentes responsables (análisis fuente-causa).

\section{Medidas de control y su coste}

Entre las medidas de control de las fuentes industriales se encuentran los sistemas de depuración del aire, que deben ser adecuados y correctamente diseñados, instalados, manejados y mantenidos. Estos dispositivos son conocidos como separadores o colectores. Un separador o colector puede definirse como un "aparato utilizado para separar en un medio gaseoso uno o varios de los elementos siguientes, que se encuentran mezclados o en suspensión en dicho medio: partículas sólidas (filtros y separadores de polvo), partículas líquidas (filtros y separadores de gotas) y gases (purificador de gases)". L os principales equipos para el control de la contaminación del aire (analizados más adelante en la sección "Control de la contaminación atmosférica") son los siguientes:

- para partículas: separadores por velocidad (p. ej., ciclones); filtros textiles (mangas); precipitadores electrostáticos; colectores húmedos (torres de lavado "scrubbers"),

- para contaminantes gaseosos: colectores húmedos (torres de lavado); unidades de adsorción (p. ej., lechos adsorbentes); postquemadores, que pueden ser con aplicación directa de fuego (incineración térmica) o catalítica (combustión catalítica).

Los colectores húmedos (torres de lavado) pueden utilizarse para retirar simultáneamente contaminantes gaseosos y otras partículas. También algunos aparatos de combustión pueden quemar gases y vapores, así como aerosoles combustibles. D ependiendo del tipo de efluente, se puede utilizar un tipo de colector o una combinación de varios de ellos.

El control de los olores que son químicamente identificables se basa en el control de los agentes químicos de los que emanan (p. ej., por absorción o por incineración). Cuando un olor no está definido químicamente, o el agente que lo produce se encuentra en concentraciones extremadamente pequeñas, pueden utilizarse otras técnicas que lo enmascaran (con un agente de olor más fuerte, agradable e inofensivo) o contrarrestan (mediante un aditivo que neutraliza, al menos en parte, su olor desagradable).
Debe tenerse en cuenta que el manejo y el mantenimiento correctos del colector son condiciones indispensables para conseguir la eficacia esperada. Estas circunstancias deben ser analizadas a la hora de diseñar las instalaciones, tanto desde el punto de vista técnico como financiero. EI consumo de energía es otro factor que debe considerarse. Cualquier sistema de purificación del aire no sólo debe ser elegido por su coste inicial, sino teniendo en cuenta sus costes operativos y de mantenimiento. Cuando se trate de contaminantes radiactivos 0 de alta toxicidad, se requiere el mayor grado de eficacia purificadora, así como procedimientos especiales para el almacenamiento y la evacuación de los residuos.

Las principales medidas de control de las fuentes industriales son las siguientes:

Sustitución de materiales. Ejemplos: sustitución de disolventes altamente tóxicos, utilizados en ciertos procesos industriales, por otros menos nocivos; utilización de combustibles con menor contenido en azufre ( $p$. ej., carbones lavados) cuya combustión desprende menos compuestos azufrados, etc.

M odificación o cambio de procesos o equipos industriales. Ejemplos: en la industria siderúrgica, sustitución del mineral sin procesar por mineral peletizado (para reducir la cantidad de polvo generado durante la manipulación del metal); sustitución de sistemas abiertos por sistemas cerrados; sustitución de sistemas de calefacción con combustible por sistemas de vapor, agua caliente 0 eléctricos; utilización de catalizadores en los tubos de escape (procesos de combustión), y otros.

La modificación de los procesos o de la distribución en planta también puede facilitar y/ o mejorar las condiciones para la dispersión o condensación de contaminantes. Por ejemplo, una distribución en planta diferente puede facilitar la instalación de un sistema de extracción localizada; el funcionamiento del proceso de producción a un ritmo más lento puede permitir la utilización de algún colector (con limitaciones de volumen, pero en otras ocasiones adecuado). Los sistemas de depuración que concentran los contaminantes en pequeños volúmenes de aire ofrecen la ventaja de que su coste está íntimamente relacionado con la cantidad de residuos que deben recibir tratamiento, y la eficacia de algunos de estos equipos aumenta con la concentración de contaminantes en el efluente. Tanto la sustitución de materiales como la modificación de los procesos de producción pueden tener limitaciones técnicas y/ 0 económicas que deberán ser tenidas en cuenta.

Limpieza y almacenamiento adecuados. Ejemplos: estricta higiene en el procesamiento de alimentos animales y vegetales; eliminación del almacenamiento al aire libre de productos químicos (p. ej., montones de azufre) 0 de materiales pulverulentos (arenas); en caso de que esto no sea posible, rociar estos montones con agua para que no se dispersen (si es posible) 0 cubrirlos con lonas, plásticos o agentes humidificantes para evitar que las partículas pasen a la atmósfera.

Correcta evacuación de los residuos. Ejemplos: evitar el simple amontonamiento de los residuos químicos (como los residuos de los reactores de polimerización), así como el vertido de residuos (sólidos o líquidos) a los cursos de agua. Esta última práctica no sólo contamina el agua, sino que también puede crear una fuente secundaria de contaminación atmosférica, como es el caso de los vertidos sulfurosos de las papeleras, que desprenden olores y gases muy molestos.

$M$ antenimiento. Ejemplo: una conservación y una puesta a punto esmerada de los motores de combustión interna reduce la contaminación por monóxido de carbono e hidrocarburos.

Prácticas de trabajo. Ejemplo: cuando se fumiga con plaguicidas, tienen que tenerse en cuenta las condiciones meteorológicas y, en especial, la dirección de los vientos dominantes. 
Por analogía con unas prácticas adecuadas de trabajo, en el ámbito doméstico o municipal también se puede reducir la contaminación adoptando precauciones similares; por ejemplo, modificando el comportamiento ciudadano en cuanto a la utilización de los vehículos (más transporte público, coches más pequeños, etc.) y controlando los sistemas de calefacción (mejor aislamiento térmico de los edificios para reducir el consumo de combustibles, combustibles de mejor calidad, etc.).

Las medidas para controlar las emisiones de los vehículos consisten en programas adecuados y eficientes de inspección y mantenimiento obligatorios para el parque de vehículos existente, programas de instalación obligatoria de catalizadores en los nuevos coches fabricados, sustitución de los vehículos con motor de combustión por vehículos accionados con energía solar o baterías, regulación del tráfico de carretera y modelos de planificación del transporte y del uso de suelo.

Las emisiones de los motores de los vehículos se controlan vigilando las emisiones asociadas al parámetro 'milla recorrida por vehículo' (V M T) y el propio parámetro V M T (Walsh 1992). L as emisiones por V M T pueden reducirse controlando el rendimiento del vehículo (estructura y mantenimiento), ya sea nuevo o usado. Se puede controlar la composición de la gasolina con plomo empleada como combustible, reduciendo el contenido en plomo o azufre, lo cual tendrá, a su vez, un efecto beneficioso, disminuyendo las emisiones de hidrocarburos $(\mathrm{HC})$ de los vehículos. La reducción del contenido de azufre en el gasóleo para disminuir la emisión de partículas contaminantes tiene el efecto beneficioso de aumentar el potencial para el control catalítico de la emisión de estas partículas y de HC orgánicos.

0 tra importante herramienta para reducir las emisiones por evaporación y reposición del combustible de los vehículos es controlando la volatilidad de la gasolina. De esta forma pueden reducirse considerablemente las emisiones de $\mathrm{HC}$ por evaporación. La adición de sustancias oxigenadas a la gasolina reduce el contenido de $\mathrm{HC}$ y $\mathrm{CO}$ en los gases de escape siempre que no aumente la volatilidad del combustible.

La reducción del valor VMT es otro medio de controlar las emisiones de los vehículos mediante estrategias como las siguientes:

- utilizar medios de transporte más eficientes;

- aumentar el número medio de pasajeros por vehículo;

- distribuir las sobrecargas de tráfico en horas punta,

- reducir la demanda de desplazamiento.

Aunque estas estrategias promueven el ahorro de combustible, todavía no han sido ampliamente aceptadas, ni los gobiernos se han planteado seriamente su implantación.

Todas estas soluciones tecnológicas y políticas al problema de los vehículos motorizados, excepto la sustitución por coches eléctricos, se ven contrarrestadas cada vez más por el crecimiento del parque móvil, de manera que sólo abordando este último aspecto podrá resolverse el problema.

\section{Coste de los efectos en la salud pública y el
medio ambiente; análisis de coste-beneficio}

En un plan de control de la calidad atmosférica, la parte más compleja es la estimación del coste de los efectos en la salud pública y el medio ambiente, ya que resulta muy difícil estimar el coste de los años de vida perdidos por una enfermedad discapacitante, los índices de hospitalización y las horas de trabajo perdidas. Sin embargo, esta estimación y su comparación con el coste de las medidas de control resultan absolutamente necesarias para poder determinar el balance entre el coste de las medidas de control y el coste de no adoptar dichas medidas por sus efectos en la salud pública y el medio ambiente.

\section{Planificación del transporte y el uso del suelo}

EI problema de la contaminación está íntimamente ligado al uso del suelo y el transporte, especialmente en lo que respecta a cuestiones como la planificación urbanística, el diseño de carreteras, el control del tráfico y el transporte público; y a consideraciones demográficas, topográficas, económicas y sociales (Venzia 1977). En general, las aglomeraciones urbanas de rápido crecimiento presentan serios problemas de contaminación derivados de una planificación deficiente del transporte y del uso del suelo. La planificación del transporte con el fin de controlar la contaminación atmosférica integra los controles y políticas del transporte, la organización del transporte público y el coste de la congestión de las autovías. Los controles del transporte tienen un importante impacto en la sociedad en términos de equidad, medidas represivas y conflictos sociales y económicos, especialmente los controles directos como restricciones en el uso de los vehículos, racionamiento de la gasolina o reducción de las emisiones de los vehículos. La reducción de las emisiones conseguida con los controles directos puede estimarse y verificarse con métodos fiables. Los controles indirectos, como la reducción del número de millas recorridas gracias a la mejora de los sistemas de transporte público, las normativas para mejorar el flujo de tráfico, las normativas sobre aparcamientos, peajes, impuestos aplicados a la gasolina y permisos de conducir, así como la creación de incentivos para reducir voluntariamente la utilización de los vehículos, se basan en la mayoría de los casos en la experiencia previa de ensayo y error y presentan demasiadas incertidumbres como para poder formar parte de un plan de transporte viable.

L os planes nacionales con controles indirectos del transporte pueden afectar a la planificación del transporte y del uso del suelo por su impacto en las autovías, los aparcamientos y los centros comerciales. La planificación a largo plazo del sistema de transportes y de su área de influencia evitará un deterioro importante de la calidad del aire y permitirá vigilar la aplicación de las normas sobre la calidad atmosférica. En las ciudades se considera que el transporte público podría solucionar los problemas de contaminación atmosférica. La organización del sistema de transporte público para atender a una determinada área y el reparto del tráfico entre el uso de autovías y los servicios de autobuses y trenes altera las pautas de uso del suelo. Existe un reparto óptimo para reducir al mínimo la contaminación atmosférica, aunque no siempre es aceptable cuando se consideran otros factores además de los ambientales.

El automóvil está considerado como el mayor generador de factores económicos externos (externalidades) de la historia. Algunos de ellos, como el trabajo y la movilidad, son positivos, aunque los negativos, como la contaminación atmosférica, los accidentes que causan heridos y muertos, los daños materiales, el ruido, la pérdida de tiempo y la irritación asociada, llevan a la conclusión que el transporte no es una industria de coste decreciente en las zonas urbanas. L os costes de congestión de las autovías y el consiguiente tiempo perdido constituyen otro factor externo que resulta difícil de estimar. Si el coste de los desplazamientos por motivos de trabajo no incluye los costes de congestión, es imposible realizar una evaluación correcta de las distintas modalidades de transporte.

La planificación del uso del suelo para el control de la contaminación atmosférica incluye códigos de zonificación y normas de explotación, controles del uso del suelo, desarrollo urbanístico y políticas de planificación del uso del suelo. La zonificación del uso de suelo supuso un primer intento de proteger a la población, sus propiedades y sus oportunidades económicas. Pero la dispersión de los contaminantes atmosféricos exigía algo más que la simple separación física de los polígonos industriales y las zonas residenciales para proteger al individuo. Por esta razón se introdujeron en algunos códigos de zonificación normas de 
explotación basadas inicialmente en decisiones estéticas o cualitativas en un intento de establecer criterios para identificar los problemas potenciales.

La planificación a largo plazo del uso del suelo exige la identificación de las limitaciones en la capacidad de asimilación del medio ambiente. A cto seguido pueden establecerse controles del uso del suelo que distribuyan de forma equitativa esta capacidad entre las distintas actividades locales. Los controles del uso del suelo comprenden sistemas de autorización de nuevas fuentes estáticas, clasificación de zonas industriales y residenciales, restricciones por la designación de servidumbres de paso 0 expropiación de terrenos, control del emplazamiento del receptor, zonificación en función de la densidad de las emisiones y regulación de la distribución de las emisiones.

Las políticas sociales de la vivienda, cuyo objetivo es poner ésta al alcance de todas aquellas personas que de otra forma no tendrían acceso a ella (mediante ventajas fiscales e hipotecarias) estimulan el crecimiento urbano y desincentivan indirectamente un desarrollo residencial de mayor densidad. Actualmente estas políticas han resultado ser desastrosas para el medio ambiente, ya que no contemplan un desarrollo simultáneo de sistemas eficientes de transportes que atiendan las necesidades de los habitantes de las nuevas comunidades que se desarrollan. La lección que debemos aprender de este tipo de desarrollo es la necesidad de coordinar los diferentes programas que tienen un impacto ambiental y de realizar asimismo una planificación integral en el ámbito en el que se produce el problema y a una escala lo suficientemente amplia como para abarcar todo el sistema.

La planificación del uso del suelo debe plantearse a escala nacional, provincial, regional y local para garantizar una adecuada protección a largo plazo del medio ambiente. Por lo general, los programas gubernamentales comienzan ubicando las centrales de generación de energía, los lugares de extracción de minerales, las zonas costeras y los desiertos, montañas y otras áreas de interés turístico. Puesto que la multiplicidad de administraciones locales en una determinada región no les permite a éstas afrontar de forma adecuada los problemas ambientales regionales, son los gobiernos o administraciones regionales quienes deben coordinar el desarrollo urbanístico y los patrones de densidad, supervisando la gestión del espacio, el emplazamiento y el uso de nuevas construcciones y los servicios de transporte. La planificación del transporte y del uso del suelo debe ir acompañada de la vigilancia del cumplimiento de las normas para mantener la calidad atmosférica deseada. En un caso ideal, la planificación del control de la contaminación atmosférica debería ser realizada por la misma entidad regional responsable de la planificación del uso del suelo, ya que ambas áreas presentan factores externos comunes.

\section{Plan de ejecución, recursos comprometidos}

El plan de calidad atmosférica debe incluir siempre un plan de ejecución que especifique la forma en que deben aplicarse las medidas de control. Este plan incluye también un compromiso de recursos para que, de acuerdo con el principio de quien contamina paga, se establezcan las acciones que deberán emprender los que contaminan y la manera en que el gobierno les ayudará a respetar ese compromiso.

\section{Previsiones}

Al ser también un plan preventivo, el plan de calidad atmosférica debe incluir estimaciones de las tendencias de la población, el tráfico, la industria y el consumo de combustibles para poder evaluar respuestas a futuros problemas. La adopción de medidas con antelación a los supuestos problemas evitará multitud de dificultades en el futuro.

\section{Estrategias de seguimiento}

Una estrategia para el seguimiento del control de la calidad del aire consiste en planes y políticas referentes a la manera de poner en práctica futuros planes de calidad atmosférica.

\section{Importancia de la evaluación del impacto ambiental}

La evaluación del impacto ambiental (EIA) es el proceso por el cual el organismo responsable prepara un informe detallado sobre el impacto ambiental de una acción propuesta que afecta considerablemente a la calidad del entorno humano (Lee 1993). La EIA es un instrumento de prevención que tiene como finalidad evaluar el entorno humano en la fase inicial del desarrollo de un programa o proyecto.

La EIA resulta especialmente importante en los países donde se desarrollan proyectos como parte de su reorientación o reestructuración económicas. La EIA se ha incorporado a la legislación en muchos países desarrollados y cada vez se aplica más en los países en vías de desarrollo y con economías en transición.

La EIA es una herramienta que integra la planificación y gestión del medio ambiente, considerando las interacciones entre diferentes medios. Por otra parte, la EIA incorpora la estimación de las consecuencias ambientales al proceso de planificación, con lo que se convierte en un instrumento adecuado para el desarrollo sostenible. La EIA combina asimismo propiedades técnicas y participativas al recoger, analizar y aplicar datos científicos y técnicos considerando el control de calidad y la garantía de calidad e incluye consultas con los organismos responsables de la protección del medio ambiente y las personas que pueden verse afectadas por ciertos proyectos antes de aprobar ningún procedimiento. Un plan de calidad atmosférica puede considerarse como parte integrante del proceso EIA aplicado a la atmósfera.

\section{CONTAMINACION ATMOSFERICA: MODELOS DE DISPERSION DE CONTAMINANTES ATMOSFERICOS}

Marion Wichmann-Fiebig

La finalidad de los modelos de contaminación atmosférica es estimar las concentraciones de contaminantes en el aire exterior como consecuencia, por ejemplo, de procesos industriales, fugas o el tráfico. Estos modelos se utilizan para estimar la concentración total de un contaminante e identificar la causa de unos niveles extraordinariamente altos de contaminación. En la fase de planificación de los proyectos, permite anticipar la contribución al estrés ambiental y optimizar las condiciones de emisión.

Dependiendo de las normas sobre la calidad atmosférica establecidas para el contaminante en cuestión, se utilizan los valores medios anuales o las concentraciones máximas durante cortos períodos de tiempo. Por lo general, las concentraciones deben determinarse en el lugar donde viven las personas, es decir, cerca de la superficie a una altura de unos dos metros del suelo.

\section{Parámetros que influyen en la dispersión de los contaminantes}

En la dispersión de contaminantes influyen dos tipos de parámetros: los parámetros de la fuente y los parámetros meteorológicos. En los primeros las concentraciones son proporcionales a la cantidad de contaminante emitido. Cuando se trata de polvo, debe conocerse el diámetro de las partículas para poder determinar la sedimentación y la precipitación del material 


\section{Programas internacionales de vigilancia}

0 rganismos internacionales como la 0 rganización $M$ undial de la Salud (O MS), la O rganización Meteorológica Mundial (O M M ) y el Programa de las $\mathrm{N}$ aciones Unidas para el Medio Ambiente (PN UMA) han instituido proyectos de vigilancia e investigación para aclarar las cuestiones relacionadas con la contaminación atmosférica y promover medidas que eviten un mayor deterioro de la salud pública y de las condiciones ambientales y climáticas.

El Global Environmental Monitoring System-G EM S/ Air (Sistema M undial de Vigilancia Ambiental/ Aire) (O MS/ PN UMA 1993), organizado y patrocinado por la O MS y el PN UMA, ha desarrollado un amplio programa cuya finalidad es proporcionar los instrumentos necesarios para un control racional de la contaminación atmosférica (véase Figura 55.1). El núcleo de este programa es una base de datos mundial de concentraciones de contaminantes atmosféricos en las zonas urbanas, como dióxido de azufre, partículas en suspensión, plomo, óxido de nitrógeno, monóxido de carbono y ozono. Pero tan importantes como esta base de datos son las herramientas de gestión, como guías para la rápida elaboración de inventarios de las emisiones, programas para elaborar modelos de dispersión, estimaciones de riesgos para la población, medidas de control y análisis de coste/ beneficio. A este respecto, GEMS/ Air proporciona manuales de metodología (O M S/ PN UMA 1994, 1995), realiza estudios globales de la calidad atmosférica, facilita la revisión y validación de estudios, actúa como intermediario de datos/ información, elabora documentación técnica de apoyo sobre todos los aspectos del control de la calidad atmosférica, facilita el establecimiento de vigilancia, prepara y distribuye informes anuales y crea o localiza centros regionales de colaboración y/ o expertos para coordinar y apoyar las actividades de acuerdo con las necesidades de cada región (O M S/ PN UMA 1992, 1993, 1995).

El programa Global Atmospheric W atch (G AW )(Vigilancia Atmosférica M undial) (M iller y Soudine, 1994) proporciona datos y otro tipo de información sobre la composición química y las características físicas de la atmósfera y de sus tendencias, para poder entender la relación entre los cambios en la composición atmosférica y los cambios climáticos mundiales y regionales, el transporte atmosférico a larga distancia y la precipitación de sustancias potencialmente nocivas sobre los ecosistemas terrestres, de agua dulce y marinos, así como el ciclo natural de los elementos químicos en el sistema global de atmósfera/ océanos/ biosfera y los impactos antropogénicos en dicho ciclo. El programa GAW comprende cuatro áreas de actividad: el G lobal 0 zone 0 bserving System (G O 30 S)(Sistema M undial de 0 bservación de la $\mathrm{C}$ apa de 0 zono), que consiste en la vigilancia mundial de la composición atmosférica de fondo y que incluye a la Background Air Pollution Monitoring $N$ etwork (BAPM ON) (Red de Vigilancia de la Contaminación Atmosférica de Fondo); la dispersión, el transporte, la transformación química y la precipitación de contaminantes atmosféricos sobre la tierra y el mar a diferentes escalas de tiempo y espacio; el intercambio de contaminantes entre la atmósfera y otros medios naturales; $y$, por último, la vigilancia integrada. Una de las tareas más importantes de la G AW es establecer los C entros de Actividad C ientífica para el Control de la Calidad cuya labor es vigilar la calidad de los datos obtenidos con el programa G AW

(VDI 1992). Puesto que las concentraciones en la superficie son menores cuanto mayor sea la altura de la fuente, este parámetro tiene que ser también tenido en cuenta. Además, las concentraciones dependen de la cantidad total de gases liberados, así como de su temperatura y velocidad. Si la temperatura es superior a la del aire exterior, los gases estarán sometidos a flotación térmica. $L$ a velocidad de liberación, que puede calcularse conociendo el diámetro interior de la fuente y el volumen de gases liberados, produce fuerzas ascensionales dinámicas. Existen una serie de fórmulas empíricas que puede utilizarse para describir estos parámetros (VDI 1985; Venkatram y Wyngaard 1988). Debe recordarse que la flotación térmica y las fuerzas dinámicas no dependen de la masa del contaminante en cuestión, sino de la cantidad total de gas liberado.

L os parámetros meteorológicos que influyen en la dispersión de contaminantes son la velocidad y la dirección del viento, así como la estratificación térmica vertical. La concentración de contaminante es inversamente proporcional a la velocidad del viento, debido principalmente a su movimiento acelerado. Además, el mezclado turbulento aumenta con la velocidad del viento. Las inversiones térmicas (es decir, situaciones en las que la temperatura aumenta con la altura) dificultan el mezclado turbulento, razón por la cual cuando se producen estratificaciones muy estables se observan concentraciones máximas a ras de suelo. Por el contrario, las situaciones de convección intensifican el mezclado vertical, dando lugar a valores deconcentración másbajos.

Las normas sobre la calidad atmosférica (por ejemplo, valores anuales medios o percentiles 98 ) suelen basarse en estadísticas y por ello es preciso obtener datos de series cronológicas de los principales parámetros meteorológicos. Lo ideal es que las estadísticas se basen en diez años de observación. Si sólo se dispone de series cronológicas más cortas, debe comprobarse que éstas sean representativas de un período de tiempo más largo analizando, por ejemplo, series cronológicas más largas obtenidas en otros puntos de observación.

La serie cronológica utilizada tiene que ser también representativa del lugar en cuestión, es decir, debe reflejar las características locales. Esto es especialmente importante en el caso de las normas sobre la calidad atmosférica que se basan en fracciones máximas de la distribución, como los percentiles 98 . Si no se dispone de una serie cronológica de este tipo, puede utilizarse un modelo de flujo meteorológico calculado a partir de otros datos, según se describe a continuación.

\section{Modelos de contaminación atmosférica}

Como ya se mencionó antes, la dispersión de los contaminantes depende de las condiciones de emisión, el transporte y el mezclado turbulento. La ecuación global que describe estas características se denomina modelo de dispersión de Euler (Pielke 1984). C on este modelo se determinan las pérdidas y ganancias del contaminante en cuestión en todos los puntos de una rejilla espacial imaginaria en diferentes periodos de tiempo. Este método es muy complejo y requiere un tiempo de procesamiento informático muy largo, razón por la cual no puede aplicarse de forma rutinaria, aunque en muchos casos puede simplificarse aplicando los supuestos siguientes:

- las condiciones de emisión no varían con el tiempo;

- las condiciones meteorológicas no varían durante el transporte,

- la velocidad del viento es superior a $1 \mathrm{~m} / \mathrm{s}$.

En este caso, la ecuación mencionada antes puede resolverse analíticamente. La fórmula resultante describe un penacho con una distribución gaussiana de la concentración, el denominado modelo gaussiano de penacho (VDI 1992). Los parámetros de distribución dependen de las condiciones meteorológicas, de la distancia recorrida por el viento y de la altura de la fuente y deben ser determinados de forma empírica (Venkatram y Wyngaard 1988). Cuando las emisiones y/ o los parámetros meteorológicos varían a lo largo de un período considerable de tiempo y/o en el espacio, pueden describirse mediante el modelo gaussiano de ráfaga (VDI 1994). En este modelo se 
Figura 55.1 - Sistema mundial de vigilancia ambiental/ Control de la contaminación atmosférica.

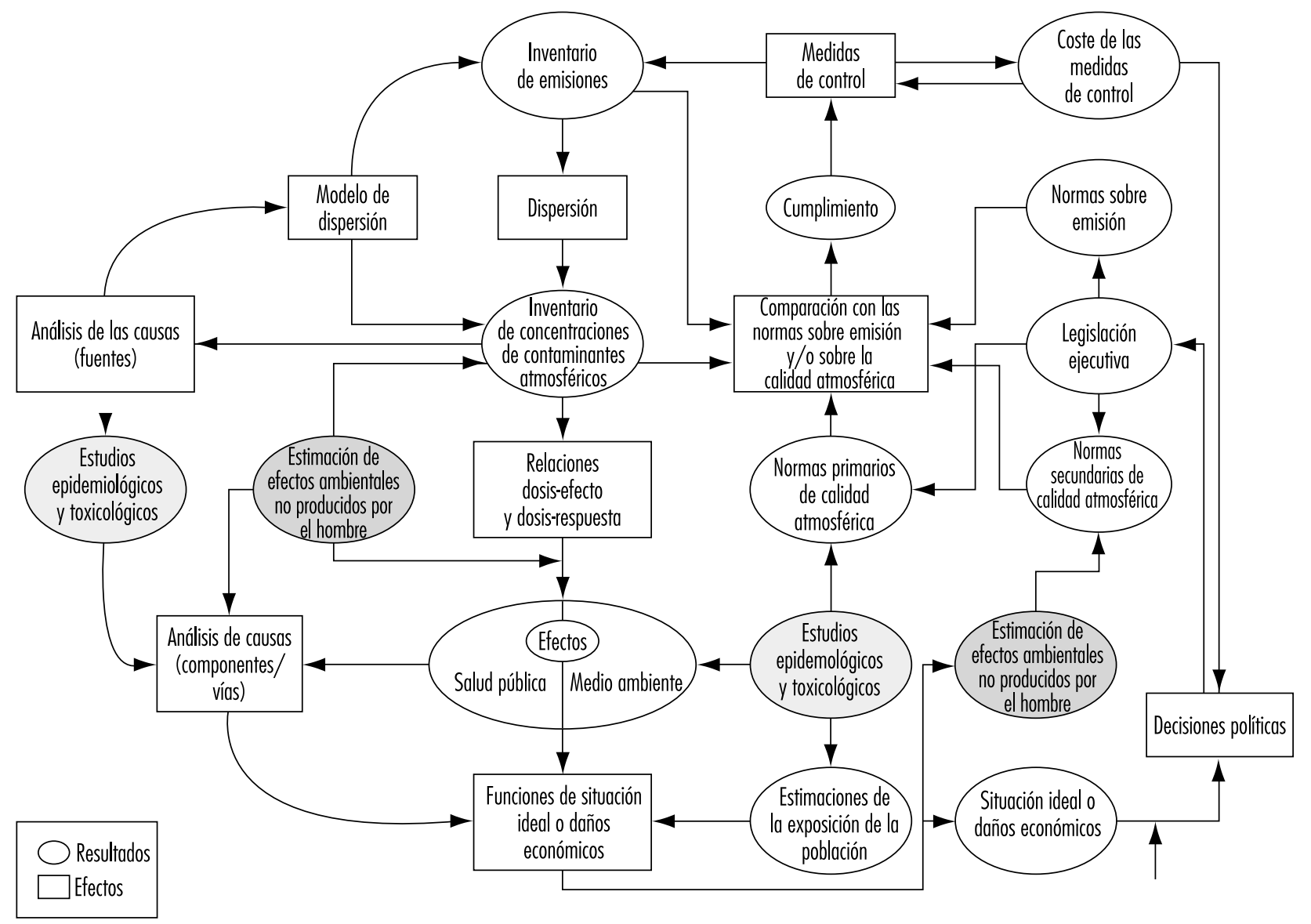

emiten diferentes ráfagas en periodos de tiempo fijos y cada una de ellas sigue su propia trayectoria de acuerdo con las condiciones meteorológicas del momento. En su camino, cada ráfaga crece dependiendo del mezclado turbulento. Los parámetros que describen este crecimiento deben determinarse a partir de datos empíricos (Venkatram y Wyngaard 1988), aunque para ello será necesario disponer de datos en el tiempo y/o en el espacio con la resolución necesaria.

En el caso de emisiones accidentales o estudios de casos individuales, se recomienda utilizar un modelo de Lagrange 0 de partículas (VDI G uideline 3945, Parte 3), que calcula las trayectorias de un gran número de partículas, cada una de las cuales representa una cantidad fija del contaminante en cuestión. Las trayectorias individuales están determinadas por el desplazamiento debido al viento medio y a las alteraciones estocásticas que, aunque impiden que las trayectorias coincidan totalmente, representan el mezclado turbulento. En principio, los modelos de Lagrange son capaces de representar condiciones meteorológicas complejas, en especial de viento y turbulencias. Los campos calculados mediante los modelos de flujo que se describen a continuación pueden utilizarse para los modelos de dispersión de Lagrange.

\section{Modelos de dispersión en terrenos complejos}

Cuando se tienen que determinar las concentraciones de contaminantes en un terreno estructurado, a veces es necesario incluir los efectos topográficos en los modelos de dispersión de los contaminantes. Estos efectos son, por ejemplo, el transporte según la topografía o los sistemas de vientos térmicos como brisas marinas o vientos de montaña, que cambian su dirección en el transcurso del día.

Si estos efectos tienen lugar a una escala mucho mayor que el área del modelo, su influencia puede considerarse utilizando datos meteorológicos que reflejen las características locales. Si no se dispone de este tipo de datos, puede obtenerse la estructura tridimensional del flujo en la topografía utilizando un modelo de flujo adecuado. A partir de estos datos se obtiene un modelo de dispersión suponiendo que existe homogeneidad horizontal, como se describió antes para el modelo gaussiano de penacho. Sin embargo, cuando las condiciones del viento varían de forma significativa dentro del área del modelo, el modelo de dispersión debe tener en cuenta el flujo tridimensional afectado por la estructura topográfica. Como hemos visto ya, esto puede realizarse con un modelo gaussiano de ráfaga o con un modelo de Lagrange. Otra alternativa es utilizar el modelo más complejo de Euler.

Para determinar la dirección del viento de acuerdo con la estructura topográfica del terreno, puede utilizarse un modelo de flujo de diagnóstico o de masa constante (Pielke 1984). En estos modelos, el flujo se adapta a la topografía modificando al mínimo los valores iniciales y manteniendo su masa constante. Puesto que con este modelo se obtienen resultados rápidos, puede utilizarse también para calcular estadísticas del viento en un determinado lugar cuando no se dispone de observaciones. 
Figura 55.2 • Estructura topográfica de una región modelo.

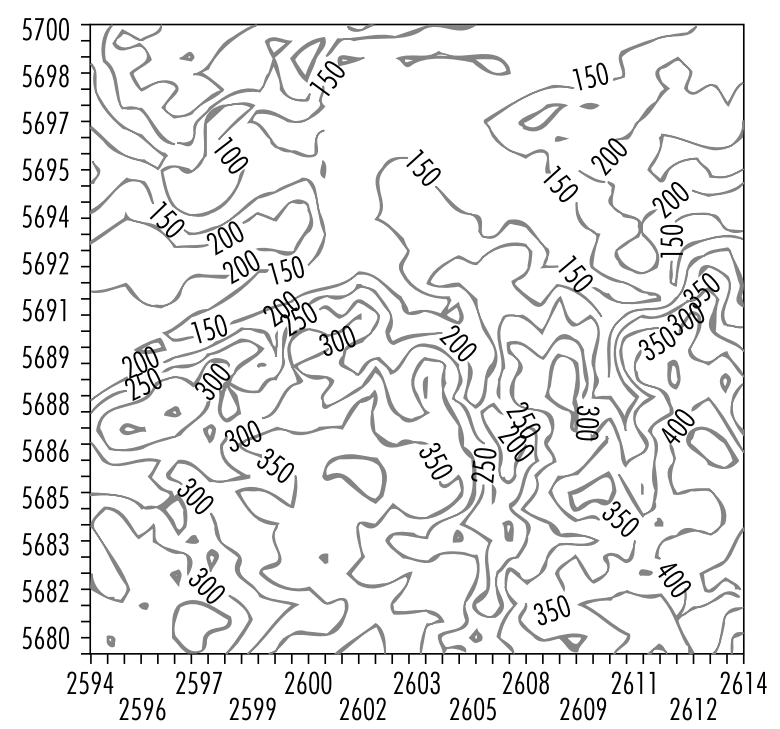

Topografía de un modelo de región de $20 \times 20 \mathrm{~km}^{2}$ con una supuesta fuente de $8.760 \mathrm{~kg} / \mathrm{año} \mathrm{en}$ las coordenadas Gauss-Kruger 2607/5687 a una altura de $20 \mathrm{~m}$ por encima del nivel del suelo. Fuente: Wichmann-Fiebig y Brüchner 1997.

Figura 55.3 • Distribución de frecuencias superficiales determinada a partir de la distribución de frecuencias geostróficas.

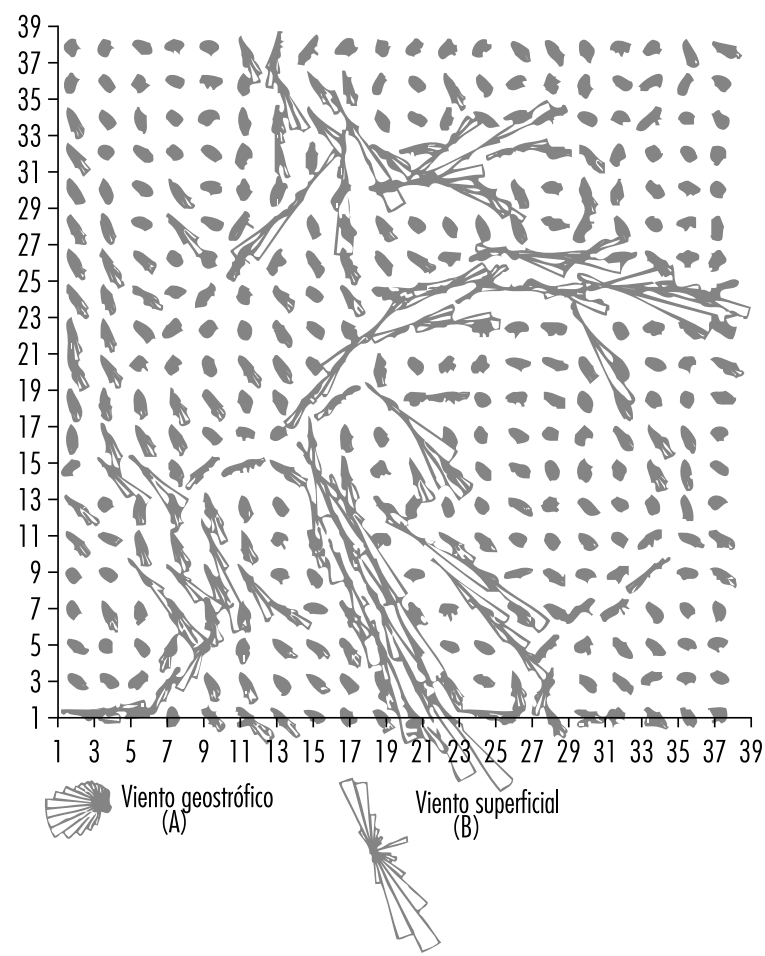

(A) y (B) representan la distribución de frecuencias geostróficas en la fuente y la distribución resultante de frecuencias superficiales. La distribución de frecuencias superficiales para todo el área del modelo refleja la estructura topográfica del área.

Fuente: Wichmann-Fiebig y Brüchner 1997.
Figura 55.4 - Concentraciones medias anuales de contaminantes en una región hipotética calculadas a partir de la distribución de frecuencias geostróficas para campos de viento heterogéneos.

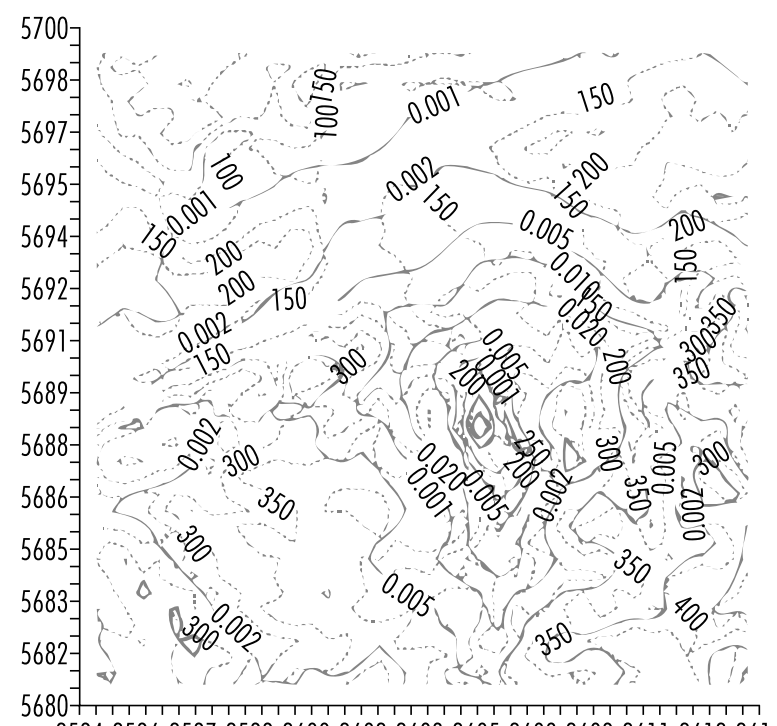

2594259625972599260026022603260526082609261126122614

Las isopletas topográficas están representadas por líneas de puntos y las de concentración de contaminantes, por líneas continuas. Se observa la tendencia al transporte a lo largo de los ejes del valle, produciéndose una orientación norte-sur de la distribución de concentraciones en las proximidades de la fuente. Fuera del valle y hacia el norte se observa una distribución más homogénea. Fuente: Wichmann-Fiebig y Brüchner 1997

Para ello se utilizan estadísticas del viento geostrófico (datos sobre la capa superior de la atmósfera obtenidos con radiosondas).

En el caso de que sea necesario conocer con más detalle los sistemas térmicos del viento, se utilizarán los denominados modelos de pronóstico. Según la escala y la pendiente del área del modelo, puede que sea conveniente utilizar un modelo hidrostático o incluso un modelo no hidrostático de mayor complejidad (VDI 1981). Este tipo de modelos exigen un ordenador de gran potencia y una gran experiencia en su aplicación. Por lo general, no sirven para determinar concentraciones basadas en medias anuales, pero pueden realizarse estudios del caso más desfavorable considerando sólo una dirección del viento y parámetros de velocidad de viento y estratificación obtenidos con los valores más altos de concentración a ras de suelo. Si estos valores del caso más desfavorable son inferiores a los establecidos por las normas sobre la calidad atmosférica, no será necesario realizar estudios más detallados.

En las Figuras 55.2, 55.3 y 55.4 se indica la manera de representar el transporte y la dispersión de contaminantes en relación con la influencia del terreno y los parámetros climatológicos del viento teniendo en cuenta las frecuencias de viento superficial y geostrófico.

\section{Modelo de dispersión en el caso de fuentes de poca altura}

Para el estudio de la contaminación atmosférica originada por fuentes de poca altura (p. ej., fuentes a la altura de un edificio 0 emisiones del tráfico rodado) deberá tenerse en cuenta la influencia de los edificios circundantes. Las emisiones del tráfico 
rodado quedan atrapadas en los cañones de aire que forman las calles. Existen fórmulas empíricas que describen este efecto (Yamartino y Wiegand 1986).

Los contaminantes emitidos por una fuente de poca altura situada en un edificio se acumulan en el lateral del edificio que se encuentra al abrigo del viento. El volumen de esta circulación al abrigo del viento dependerá de la altura y de la anchura del edificio, así como de la velocidad del viento. Por lo tanto, los modelos simplificados que se utilizan para representar la dispersión de los contaminantes en estos casos y que en general consideran únicamente la altura del edificio, no suelen ser válidos. $L a$ fuerza vertical y horizontal de la circulación al abrigo del viento se ha obtenido de estudios de túneles de viento (H osker 1985) y puede utilizarse en modelos de diagnóstico de masa constante. Una vez determinado el campo de flujo, éste puede utilizarse para calcular el transporte y el mezclado turbulento del contaminante emitido con los modelos de dispersión de Lagrange o de Euler.

Para estudios más detallados (de emisiones accidentales, por ejemplo) se tienen que utilizar modelos de flujo no hidrostático y de dispersión en lugar de modelos de diagnóstico. Puesto que estos modelos requieren ordenadores de gran potencia, se recomienda utilizar primero un modelo del caso más desfavorable como el descrito, antes de recurrir a un modelo estadístico completo.

\section{- Vigilancia de LA CALIDAD ATMO SFERICA}

\section{H ans-U Irich Pfeffer y Peter Bruckmann}

La vigilancia de la calidad atmosférica consiste en la medición sistemática de los contaminantes atmosféricos para evaluar la exposición de receptores vulnerables ( $p$. ej., personas, animales, plantas y obras de arte) basándose en normas y directrices derivadas de los efectos observados, y/ o identificar la fuente de contaminación atmosférica (análisis de las causas).

Las concentraciones de contaminantes atmosféricos se ven influidas por las variaciones en el tiempo y en el espacio de las emisiones de sustancias peligrosas y la dinámica de su dispersión en la atmósfera, que originan importantes variaciones diarias y anuales. Resulta prácticamente imposible determinar de una manera uniforme todas estas variaciones de la calidad de la atmósfera (en el lenguaje estadístico, la población de estados de calidad de la atmósfera). Por ello, las mediciones de las concentraciones de contaminantes atmosféricos tienen siempre carácter de muestras aleatorias en el espacio o en el tiempo.

\section{Planificación de las mediciones}

El primer paso en la planificación de las mediciones consiste en definir el objetivo de la medición con la mayor precisión posible. Entre las principales actividades de vigilancia de la calidad atmosférica se encuentran las siguientes:

M edición de un área:

- determinación representativa de la exposición en un área (vigilancia general de la atmósfera);

- medición representativa de la contaminación ya existente en el área donde se ubicará la instalación (autorización, TA Luft [Instrucción técnica, atmósfera]);

- alerta de esmog (esmog invernal, altas concentraciones de ozono);

- mediciones en puntos de especial contaminación atmosférica para estimar la exposición máxima de los receptores (directiva
Tabla 55.2 - Parámetros para la planificación de la medición de concentraciones de contaminantes atmosféricos y ejemplos de su aplicación.

\begin{tabular}{|c|c|}
\hline Parámetro & $\begin{array}{l}\text { Ejemplo de aplicación: Procedimiento } \\
\text { de concesión de licencias para plantas } \\
\text { industriales en Alemania }\end{array}$ \\
\hline Objetivo & $\begin{array}{l}\text { Determinación de la contaminación previa en } \\
\text { el procedimiento de autorización; medición } \\
\text { preliminar mediante muestreo aleatorio } \\
\text { representativo }\end{array}$ \\
\hline
\end{tabular}

Area de medición

Círculo alrededor del emplezamiento, con un radio 30 veces mayor a la altura de la chimenea (simplificado)

Normas de evaluación (dependiendo del lugar y del tiempo): valores característicos que deben obtenerse de los resultados de las mediciones

Valores umbral IW1 (media aritmética) e IW2 (percentil 98) de TA Luft [Instrucción técnica, aire]; cálculo de I1 (media aritmética) e 12 (percentil 98) a partir de las mediciones realizadas para $1 \mathrm{~km}^{2}$ (superficie de análisis) y comparación con IW1 e IW2

Ordenación, elección y densidad de los puntos de medición

Período de medición

Altura de la medición

Frecuencia de las mediciones

Exploración periódica de $1 \mathrm{~km}^{2}$, para conseguir una elección "aleatoria" de los puntos de medición

1 año, como mínimo 6 meses

Entre 1,5 y 4 metros por encima del nivel del suelo

52 (104) mediciones por área de análisis para contaminantes gaseosos, según la altura de la contaminación

Duración de cada medición

1/ 2 hora para contaminantes gaseosos,

24 horas para polvo en suspensión,

1 mes para precipitación de polvo

Momento de la medición

Al azar

Objeto medido

Procedimiento de medición

Contaminación atmosférica emitida por la planta prevista

Procedimiento de medición normalizado nacional ( directrices VDI)

Certeza necesaria de

los resultados de las mediciones

Requisitos de calidad, control de calidad, calibrado, mantenimiento

Registro de los datos de las mediciones, validación, archivo, evaluación

Alta

\section{Directrices VDI}

Cálculo de la magnitud de los datos IIV e I2V para cada área de análisis

Costes

Según el área y los objetivos de la medición

de la UE sobre el $\mathrm{NO}_{2}$, mediciones en cañones formados por las calles de acuerdo con la Ley federal de control de inmisiones en Alemania);

- comprobación de los resultados de las medidas de control de la contaminación y tendencias a lo largo del tiempo;

- mediciones preliminares (de screening),

- investigaciones científicas (p. ej., transporte de contaminantes atmosféricos, conversiones químicas, calibrado de los cálculos de la dispersión). 
M edición de una instalación:

- mediciones en respuesta a quejas;

- identificación de las fuentes emisores, análisis de las causas;

- mediciones en caso de incendio o fugas;

- comprobación de éxito de las medidas de reducción,

- vigilancia de fugas en la instalación.

El objetivo de la planificación de las mediciones es utilizar los procedimientos adecuados de medición y análisis para responder a preguntas concretas con la suficiente seguridad y el mínimo coste posible.

En la Tabla 55.2 se ofrece un ejemplo de los parámetros que deberían utilizarse para planificar las mediciones con relación a la evaluación de la contaminación atmosférica en la zona elegida para erigir una planta industrial. Los requisitos formales varían según la jurisdicción y en este caso se han tenido especialmente en cuenta los procedimientos de concesión de licencias para plantas fabriles en Alemania.

El ejemplo de la Tabla 55.2 presenta una red de mediciones que se supone que vigila, con la mayor representatividad posible, la calidad atmosférica de un área, para compararla con los límites fijados de calidad del aire. En este caso la selección de los puntos de medición se realiza de forma aleatoria para abarcar emplazamientos equivalentes en un área con calidad atmosférica variable (p. ej., zonas residenciales, calles, zonas industriales, parques, centro urbano, suburbios). Este enfoque puede ser muy costoso para áreas extensas debido a la gran cantidad de puntos de medición necesarios.

0 tro tipo de red de medición es la que utiliza una selección representativa de puntos basándose en el supuesto de que si se realizan mediciones de calidad atmosférica variable en los puntos más importantes y se sabe cuánto tiempo permanecen los objetos protegidos en estos "microentornos", podrá también determinarse la exposición. Este enfoque puede ampliarse a otros microentornos (p. ej., habitaciones, coches) para estimar la exposición total. L os modelos de difusión o las mediciones preliminares pueden ayudar a determinar los puntos correctos de medición.

U na tercera posibilidad consiste en realizar las mediciones en los puntos de supuesta exposición máxima (p. ej., $\mathrm{NO}_{2}$ y benceno en los cañones de las calles). $\mathrm{Si}$ en estos puntos se cumplen los criterios de evaluación, existe una probabilidad suficiente de que lo mismo ocurra en todos los demás puntos. Este método centrado en los puntos críticos requiere un número relativamente pequeño de puntos de medición, aunque elegidos con especial cuidado. Además, en algunos casos puede sobrestimar la exposición real.

Los parámetros del período de medición, la evaluación de los datos obtenidos de las mediciones y la frecuencia de las mediciones dependerán principalmente de las normas de evaluación (límites) y el nivel deseado de certidumbre de los resultados. Los valores umbral y las condiciones periféricas que deben considerarse en la planificación de las mediciones también están relacionados entre sí. Si se utilizan procedimientos de medición continuos, puede conseguirse una resolución casi constante en el tiempo. Pero esto sólo es necesario para vigilar valores máximos y/ o alertas de esmog. Para la vigilancia de valores medios anuales, es suficiente con realizar mediciones discontinuas.

En la siguiente sección se describen las características de los métodos de medición y la garantía de calidad como otro parámetro fundamental de la planificación de las mediciones.

\section{Garantía de la calidad}

Las mediciones de las concentraciones de contaminantes atmosféricos puede ser costosas y sus resultados pueden condicionar decisiones importantes con graves repercusiones económicas y ecológicas. Por lo tanto, las medidas de garantía de calidad deben formar parte del proceso de medición. En este sentido, pueden distinguirse dos tipos de medidas:

\section{M edidas orientadas al procedimiento}

Todo procedimiento completo de medición incluye muestreo, preparación y tratamiento de la muestra, separación, detección (última fase analítica); y toma y análisis de los datos. En algunos casos, especialmente cuando se realizan mediciones continuas de gases inorgánicos, pueden eliminarse algunas fases del procedimiento (p. ej., la separación). Las mediciones tienen que realizarse estrictamente de acuerdo con los procedimientos establecidos. Deben seguirse procedimientos normalizados y ampliamente documentados, como las normas DIN/ISO, las normas CEN o las directrices VDI.

\section{Medidas orientadas al usuario}

La utilización de equipos y procedimientos normalizados y homologados para medir las concentraciones de contaminantes atmosféricos no garantiza por sí sola una calidad aceptable si el usuario no utiliza asimismo métodos adecuados de control de calidad. La aplicación por parte del usuario de la serie de normas DIN/EN/ISO 9000 (normas sobre el control de calidad y la garantía de calidad), la norma EN 45000 (en la que se establecen los requisitos que deben cumplir los laboratorios de ensayo) y la Guía ISO 25 (requisitos generales para la competencia de los laboratorios de ensayo y calibración) son fundamentales para garantizar la calidad.

Entre los aspectos importantes de las medidas de control de calidad figuran lo siguientes:

- aceptación y aplicación del contenido de medidas como buenas prácticas de laboratorio (BPL);

- mantenimiento correcto de los equipos de medición, adopción de las medidas oportunas para evitar averías y asegurar las reparaciones;

- realización de calibraciones y controles regulares que garanticen un funcionamiento adecuado,

- participación en ensayos de intercomparación.

\section{Procedimientos de medición}

\section{Procedimientos de medición para gases inorgánicos}

Se dispone de multitud de procedimientos de medición para la gran variedad de gases inorgánicos que existen. Estos procedimientos pueden clasificarse en manuales y automáticos.

\section{Procedimientos manuales}

En los procedimientos manuales de medición de gases inorgánicos, la sustancia objeto de la medición es normalmente adsorbida durante el muestreo en una solución o en un material sólido. En la mayoría de los casos se realiza una determinación fotomé trica después de una reacción de coloración adecuada. Algunos procedimientos manuales revisten una importancia especial como procedimientos de referencia. Como consecuencia del coste relativamente alto de personal, en la actualidad estos procedimientos manuales sólo se realizan en raras ocasiones para mediciones de campo cuando no se dispone de procedimientos automáticos alternativos. En la Tabla 55.3 se resumen los procedimientos más importantes.

Un método especial de muestreo que se utiliza principalmente en los procedimientos manuales de medición es el tubo de separación por difusión (separador). En esta técnica la separación de las fases de gas y de partículas se consigue por las diferentes velocidades de difusión y se utiliza a menudo para realizar 
Tabla 55.3 - Procedimientos manuales para la medición de gases inorgánicos.

\begin{tabular}{|c|c|c|c|}
\hline Material & Método & Ejecución & Comentarios \\
\hline $\mathrm{SO}_{2}$ & Método TCM & $\begin{array}{l}\text { Absorción en solución de tetracloromercurato ( frasco de lavado); reacción } \\
\text { con formaldehído y pararosanilina para formar ácido sulfónico rojo-violeta; } \\
\text { determinación fotométrica }\end{array}$ & $\begin{array}{l}\text { Método de determinación de refe- } \\
\text { rencia de la CE; } L D=0,2 \mu \mathrm{S} \mathrm{SO}_{2} ; \\
\mathrm{S}=0,03 \mathrm{mg} / \mathrm{m}^{3} \text { a } 0,5 \mathrm{mg} / \mathrm{m}^{3}\end{array}$ \\
\hline $\mathrm{SO}_{2}$ & Método de gel de sílice & $\begin{array}{l}\text { Eliminación de sustancias de interferencia mediante } \mathrm{H}_{3} \mathrm{PO}_{4} \text { concentrado; adsorción } \\
\text { en gel de sílice; desorción térmica en corriente de } \mathrm{H}_{2} \text { y reducción a } \mathrm{H}_{2} \mathrm{~S} \text {; conversión } \\
\text { a azul de molibdeno; determinación fotométrica }\end{array}$ & $\begin{array}{l}\mathrm{LD}=0,3 \mu \mathrm{g} \mathrm{SO} ; \\
\mathrm{S}=0,03 \mathrm{mg} / \mathrm{m}^{3} \text { a } 0,5 \mathrm{mg} / \mathrm{m}^{3}\end{array}$ \\
\hline $\mathrm{NO}_{2}$ & Método de Saltzman & $\begin{array}{l}\text { Absorción en solución de reacción con formación de un colorante azídico rojo (frasco } \\
\text { de lavado); determinación fotométrica }\end{array}$ & $\begin{array}{l}\text { Calibrado con nitrito sódico; } \\
L D=3 \mu \mathrm{g} / \mathrm{m}^{3}\end{array}$ \\
\hline $\mathrm{O}_{3}$ & Método de yoduro potásico & $\begin{array}{l}\text { Formación de yodo a partir de solución acuosa de yoduro potásico (frasco de lavado); } \\
\text { determinación fotométrica }\end{array}$ & $\begin{array}{l}L D=20 \mu g / m^{3} ; \\
\text { s. rel. }= \pm 3,5 \% \text { a } 390 \mu g / \mathrm{m}^{3}\end{array}$ \\
\hline$F^{-}$ & $\begin{array}{l}\text { Método de perla de plata; } \\
\text { versión } 1\end{array}$ & $\begin{array}{l}\text { Muestreo con preseparador de polvo; carga de } \mathrm{F}^{-} \text {en perlas de plata recubiertas con } \\
\text { carbonato sódico; elución y determinación con cadena de electrodos de fluoruro de } \\
\text { lantano sensible a iones }\end{array}$ & $\begin{array}{l}\text { Inclusión de una porción indetermi- } \\
\text { nada de inmisiones de fluoruro en } \\
\text { partículas }\end{array}$ \\
\hline$F^{-}$ & $\begin{array}{l}\text { Método de perla de plata; } \\
\text { versión } 2\end{array}$ & $\begin{array}{l}\text { Muestreo con filtro de membrana calentado; carga de F- en perlas de plata recu- } \\
\text { biertas con carbonato sódico; determinación mediante procedimiento electroquímico } \\
\text { (versión 1) o fotométrico (alizarina-complexona) }\end{array}$ & $\begin{array}{l}\text { Peligro de obtener valores inferiores } \\
\text { a los reales debido a la absorción } \\
\text { parcial de inmisiones de fluoruro } \\
\text { gaseoso en el filtro de membrana; } \\
L D=0,5 \mu \mathrm{g} / \mathrm{m}^{3}\end{array}$ \\
\hline $\mathrm{Cl}^{-}$ & $\begin{array}{l}\text { Método de rodianuro de } \\
\text { mercurio }\end{array}$ & $\begin{array}{l}\text { Absorción en solución de hidróxido sódico 0,1 N (frasco de lavado); reacción con } \\
\text { rodianuro de mercurio e iones Fe(III) para formar un complejo de tiocianato de hierro; } \\
\text { determinación fotométrica }\end{array}$ & $\mathrm{LD}=9 \mu \mathrm{g} / \mathrm{m}^{3}$ \\
\hline $\mathrm{Cl}_{2}$ & Método de naranja de metilo & $\begin{array}{l}\text { Reacción de blanqueo con solución de naranja de metilo (frasco de lavado); } \\
\text { determinación fotométrica }\end{array}$ & $L D=0,015 \mathrm{mg} / \mathrm{m}^{3}$ \\
\hline $\mathrm{NH}_{3}$ & Método de indofenol & $\begin{array}{l}\text { Absorción en } \mathrm{H}_{2} \mathrm{SO}_{4} \text { diluido (impingerl frasco de lavado); conversión con fenol } \\
\text { e hipoclorito para formar colorante de indofenol; determinación fotométrica }\end{array}$ & $\begin{array}{l}\mathrm{LD}=3 \mu \mathrm{g} / \mathrm{m}^{3} \text { (impinger); inclusión } \\
\text { parcial de compuestos y aminas }\end{array}$ \\
\hline $\mathrm{NH}_{3}$ & Método Nessler & $\begin{array}{l}\text { Absorción en } \mathrm{H}_{2} \mathrm{SO}_{4} \text { diluido (impinger/ frasco de lavado); destilación y reacción } \\
\text { con reactivo Nessler, determinación fotométrica }\end{array}$ & $\begin{array}{l}L D=2,5 \mu \mathrm{g} / \mathrm{m}^{3} \text { (impinger); } \\
\text { inclusión parcial de compuestos } \\
\text { y aminas }\end{array}$ \\
\hline $\mathrm{H}_{2} \mathrm{~S}$ & Método de azul de molibdeno & $\begin{array}{l}\text { Absorción como sulfuro de plata en perlas de vidrio tratadas con sulfato de plata y } \\
\text { sulfato ácido de potasio (tubo de absorción); liberado como sulfuro de hidrógeno y } \\
\text { conversión a azul de molibdeno; determinación fotométrica }\end{array}$ & $L D=0,4 \mu g / \mathrm{m}^{3}$ \\
\hline $\mathrm{H}_{2} \mathrm{~S}$ & Método de azul de metileno & $\begin{array}{l}\text { Absorción en suspensión de hidróxido de cadmio para formar CdS; conversión a azul } \\
\text { de metileno; determinación fotométrica }\end{array}$ & $\mathrm{LD}=0,3 \mu \mathrm{g} / \mathrm{m}^{3}$ \\
\hline
\end{tabular}

separaciones complejas (p. ej., amoníaco y compuestos amónicos; óxidos de nitrógeno, ácido nítrico y nitratos; óxidos de azufre, ácido sulfúrico y sulfatos 0 ácidos halogenados/ haluros). En la técnica clásica de separación, el aire que debe analizarse se succiona a través de un tubo de vidrio con un recubrimiento especial, que varía según el material que se pretende recoger. Esta técnica de separación ha sido mejorada posteriormente por numerosas versiones con automatizaciones parciales pero, aunque ha aumentado considerablemente las posibilidades de muestreo diferenciado, puede resultar muy laboriosa y su utilización requiere gran experiencia.

\section{Procedimientos automatizados}

En el mercado existen numerosos monitores que realizan mediciones continuas del dióxido de azufre, los óxidos de nitrógeno, el monóxido de carbono y el ozono y que se utilizan principalmente para redes de mediciones. En la Tabla 55.4 se indican las principales características de estos métodos.

Debe insistirse en que todos los procedimientos automáticos de medición que se basan en principios fisicoquímicos deben ser calibrados utilizando procedimientos de referencia (manuales).
Puesto que los equipos automáticos utilizados en las redes de medición se utilizan a menudo durante largos periodos de tiempo (p. ej., varias semanas) sin supervisión humana directa, resulta indispensable comprobar su correcto funcionamiento de forma periódica y automática. Estos controles suelen realizarse con gases de valor cero y gases de ensayo obtenidos por diferentes métodos (preparación del aire ambiente, cilindros de gas presurizado, permeación, difusión o dilución estática y dinámica).

\section{Procedimientos de medición para contaminantes en forma de polvo y su composición}

Entre los contaminantes atmosféricos particulados, se puede diferenciar entre la fracción sedimentable y la fracción de partículas en suspensión (suspended particulate matter, SPM). La primera está formada por partículas más grandes que se depositan en el suelo por su tamaño y grosor. La segunda corresponde a las partículas que se dispersan en la atmósfera de una forma casi estable y homogénea y, por lo tanto, permanecen en suspensión durante un cierto tiempo. 
Tabla 55.4 • Procedimientos automáticos para la medición de gases inorgánicos.

$\begin{array}{ll}\text { Material } & \text { Método de determinación } \\ \mathrm{SO}_{2} & \text { Reacción de conductometría del } \\ & \mathrm{SO}_{2} \text { con } \mathrm{H}_{2} \mathrm{O}_{2} \text { en } \mathrm{H}_{2} \mathrm{SO}_{4} \text { dilluido; } \\ & \text { determinación del aumento de } \\ & \text { la conductividad } \\ \mathrm{SO}_{2} & \text { Fluorescencia UV; excitación } \\ & \text { de moléculas de } \mathrm{SO}_{2} \text { con } \\ & \text { radiación UV (190-230 nm); } \\ & \text { determinación de la radiación } \\ & \text { por fluorescencia } \\ & \text { Quimioluminiscencia; reacción } \\ & \text { de NO con } \mathrm{O}_{3} \text { para formar } \mathrm{NO}_{2} ; \\ & \text { detección de la radiación de } \\ & \text { quimioluminiscencia mediante } \\ & \text { fotomultiplicador } \\ & \\ & \text { Absorción IR no dispersiva; } \\ & \text { determinación de la absorción } \\ & \text { IR con detector específico frente } \\ & \text { a celda de referencia } \\ & \\ & \end{array}$

Comentarios

Eliminación de interferencias con filtro selectivo $\left(\mathrm{KHSO}_{4} / \mathrm{AgNO}_{3}\right)$

Deben eliminarse las interferencias, p. ej., de hidrocarburos, con sistemas de filtro adecuados

$\mathrm{NO}_{2}$ sólo medible de forma indirecta; utilización de conversores para reducir el $\mathrm{NO}_{2}$ a NO; determinación de $\mathrm{NO}$ y $\mathrm{NO}_{x}\left(=\mathrm{NO}+\mathrm{NO}_{2}\right)$ en canales separados

Referencia: (a) celda con $\mathrm{N}_{2} ;$ (b) aire ambiente después de eliminar el $\mathrm{CO}$; (c) eliminación óptica de la absorción de CO ( correlación de filtro de gas)

Referencia: aire ambiente después de eliminar el ozono (p. ej., Cu/ $\mathrm{MnO}_{2}$ )

Selectividad satisfactoria; el etileno es necesario como gas reactivo

únicas que pueden inhalarse y penetrar en los pulmones. La Unión Europea tiene previsto adoptar este procedimiento PM -10 como procedimiento de referencia. El coste de las determinaciones fraccionadas de SPM es bastante superior al de la determinación del polvo total en suspensión, ya que hay que acoplar a los equipos de medición dispositivos de muestreo especiales y costosos que requieren un mantenimiento igualmente

Tabla 55.5 - Procedimientos para la medición de partículas en suspensión.

\begin{tabular}{|c|c|}
\hline Procedimiento & Método de determinación \\
\hline $\begin{array}{l}\text { Dispositivo } \\
\text { de filtro } \\
\text { reducido }\end{array}$ & $\begin{array}{l}\text { Muestreo no fraccionado; } \\
\text { flujo de aire 2,7-2,8 } \mathrm{m}^{3} / \mathrm{h} ; \\
\text { diámetro del filtro } 50 \mathrm{~mm} ; \\
\text { análisis gravimétrico }\end{array}$ \\
\hline Dispositivo LIB & $\begin{array}{l}\text { Muestreo no fraccionado; } \\
\text { flujo de aire } 15-16 \mathrm{~m}^{3} / \mathrm{h} ; \\
\text { diámetro del filtro } 120 \mathrm{~mm} \text {; } \\
\text { análisis gravimétrico }\end{array}$ \\
\hline $\begin{array}{l}\text { Muestreador } \\
\text { de gran } \\
\text { volumen }\end{array}$ & $\begin{array}{l}\text { Inclusión de partículas de hasta } \\
30 \text { um de diámetro aprox.; } \\
\text { flujo de aire aproximado } \\
100 \mathrm{~m}^{3} / \mathrm{h} \text {; diámetro del filtro } \\
257 \mathrm{~mm} \text {; análisis gravimétrico }\end{array}$ \\
\hline
\end{tabular}

FH 62I Dispositivo radiométrico para determinación continua del polvo; muestreo no fraccionado; flujo de aire $1.3 \mathrm{~m}^{3} / \mathrm{h}$; registro independiente de la masa de polvo en una banda de filtro mediante determinación de la atenuación de la radiación $\beta$ (cripton 85) al pasar a través de un filtro expuesto (cámara de ionización)

Medidor de Dispositivo radiométrico para polvo BETA determinación continua del F 703 polvo; muestreo no fraccionado; flujo de aire $3 \mathrm{~m}^{3} / \mathrm{h}$; registro independiente de la masa de polvo en una banda de filtro mediante determinación de la atenuación de la radiación $\beta$ (carbono 14) al pasar a través de un filtro expuesto (contratubo Geiger Müller)

TEOM 1400 Dispositivo para la determinación continua del polvo; muestreo no fraccionado; flujo de aire $1 \mathrm{~m}^{3} / \mathrm{h}$; recogida del polvo en un filtro integrado en un sistema vibratorio de autorresonancia, en corriente lateral ( $3 \mathrm{l} / \mathrm{min}$ ); registro de la reducción de la frecuencia al aumentar la carga de polvo en el filtro

\section{Comentarios}

Manejo sencillo; reloj de control; dispositivo operable con preseparador PM-10

Separación de cantidades grandes de polvo; indicado para el análisis de componentes del polvo; reloj de control

Separación de cantidades grandes de polvo, indicado para el análisis de componentes del polvo; nivel de ruido relativamente alto

Calibrado gravimétrico mediante empolvado de filtros individuales: dispositivo también operable con preseparador PM-10

Calibrado gravimétrico mediante empolvado de filtros individuales; dispositivo operable con preseparador PM-10

Debe establecerse mediante calibrado la relación entre la reducción de la frecuencia y la masa de polvo sión. Esto significa que en la mayoría de los casos, solo se realizan medidas de la SPM total. En estados U nidos, por el contrario, se suele utilizar el procedimiento denominado PM -10 (partículas en suspensión $\leq 10 \mu \mathrm{m}$ ). En este procedimiento sólo se tienen en cuenta las partículas con un diámetro aerodinámico de hasta $10 \mu \mathrm{m}$ (fracción del $50 \%$ de inclusión), ya que son las 
costoso. En la Tabla 55.5 se detallan los principales procedimientos de medición de SPM.

Recientemente se han desarrollado también cambiadores automáticos de filtro. Estos aparatos contienen un número de filtros que son proporcionados sucesivamente al muestreador a intervalos fijos de tiempo. Los filtros expuestos se almacenan en un depósito. Por lo general, los límites de detección de los procedimientos con filtro se sitúan entre 5 y $10 \mu \mathrm{g} / \mathrm{m}^{3}$ de polvo.

Por último, mencionaremos el procedimiento del humo negro para mediciones de la SPM. Este método, desarrollado en Gran Bretaña, ha sido incorporado a las directrices de la U nión Europea para el $\mathrm{SO}_{2}$ y el polvo en suspensión. En este procedimiento, después del muestreo, el ennegrecimiento del filtro se mide con un fotómetro reflex. Los valores de negro de humo obtenidos fotométricamente se convierten con la ayuda de una curva de calibrado en unidades gravimétricas $\left(\mu \mathrm{g} / \mathrm{m}^{3}\right)$. No obstante, esta curva de calibrado depende en gran medida de la composición del polvo y especialmente del contenido de hollín, de manera que la conversión puede resultar problemática.

Actualmente se suelen realizar determinaciones rutinarias de compuestos metálicos en muestras de inmisión de polvo en suspensión. Por lo general, después de recoger el polvo en suspensión depositado en los filtros, se realiza una disolución química de los diferentes polvos, puesto que las fases analíticas finales más habituales exigen convertir de los compuestos metálicos y metaloides en una solución acuosa. Los métodos más utilizados en la práctica son la espectroscopia de absorción atómica (EAA) y la espectroscopia con excitación por plasmá (ICP-OES). O tros métodos para la determinación de compuestos metálicos en polvo en suspensión son el análisis de fluorescencia de rayos $X$, la polarografía y el análisis de activación de neutrones. Aunque los compuestos metálicos se miden desde hace más de una década como un componente de la SPM de la atmósfera exterior en puntos específicos de medición, todavía quedan preguntas importantes sin responder. El muestreo convencional por separación en filtros del polvo en suspensión presupone que la separación de los metales pesados en el filtro es completa, un hecho que se cuestiona en muchas publicaciones al haberse obtenido resultados muy heterogéneos.

0 tro problema es que en el análisis de los compuestos metálicos presentes en el polvo en suspensión, los procedimientos de medición convencionales no permiten distinguir entre diferentes formas de un mismo compuesto o compuestos individuales de los elementos respectivos. M ientras que en muchos casos se pueden realizar determinaciones totales correctas, en otros sería necesaria una diferenciación más exacta, sobre todo cuando se trata de metales especialmente cancerígenos ( $\mathrm{As}, \mathrm{C} \mathrm{d}, \mathrm{Cr}, \mathrm{Ni}, \mathrm{Co}$, $\mathrm{Be}$ ). En muchas ocasiones existen grandes variaciones entre los efectos cancerígenos de los elementos y de sus compuestos individuales (p. ej., de los compuestos de cromo con niveles de oxidación III y VI, sólo los del nivel VI son cancerígenos). En estos casos sería conveniente realizar una determinación de los compuestos individuales (análisis de especies-especiación). A pesar de la importancia que reviste este problema, hasta el momento sólo se han realizado algunos intentos de análisis por especies con esta técnica de medición.

Medición del polvo sedimentable y sus compuestos metálicos Para recoger el polvo sedimentable se utilizan dos métodos totalmente diferentes:

- muestreo en colectores y

- muestreo en superficies adhesivas.

Un procedimiento habitual para medir el polvo sedimentable (polvo depositado) es el método Bergerhoff, que consiste en recoger durante $30 \pm 2$ días toda la precipitación atmosférica (precipitación seca y húmeda) en colectores situados a 1,5 - 2,0 metros por encima del nivel del suelo (precipitación aparente). A continuación, los colectores se envían al laboratorio y se preparan mediante filtrado, evaporación del agua, secado y pesado. El resultado se calcula en función de la superficie del colector y el tiempo de exposición ( $\mathrm{g} / \mathrm{m}^{2} /$ día). El límite relativo de detección es de $0,035 \mathrm{~g} / \mathrm{m}^{2} /$ día.

0 tros procedimientos para la recogida del polvo sedimentable son el aparato de Liesegang-Löbner y los métodos que recogen el polvo depositado sobre láminas adhesivas.

Las mediciones del polvo sedimentable son valores relativos que dependen del aparato utilizado, ya que en la separación del polvo influyen, además de otros parámetros, las condiciones del flujo en el dispositivo. Las diferencias entre los valores obtenidos con los diferentes métodos pueden llegar a ser hasta del $50 \%$.

También influye la composición del polvo depositado como, por ejemplo, el contenido de plomo, cadmio u otros compuestos metálicos. Los métodos analíticos utilizados en este caso son prácticamente iguales a los utilizados para el polvo en suspensión.

\section{Medición de materiales especiales en forma de polvo}

Entre los materiales especiales en forma de polvo se encuentran el amianto y el hollín. La recogida de fibras como contaminantes atmosféricos es importante, ya que algunas de ellas, como el amianto, han sido declaradas cancerígenas. Todas las fibras con un diámetro de $D \leq 3 \mu \mathrm{m}$ y una longitud de $L \geq 5 \mu \mathrm{m}$, siendo $L: D$ $\geq 3$, se consideran cancerígenas. Los métodos utilizados para medir materiales fibrosos se basan en el recuento al microscopio del volumen de fibras adheridas a los filtros. Para las mediciones de la atmósfera exterior sólo son válidos los procedimientos que utilizan el microscopio electrónico. Las fibras se separan en filtros porosos recubiertos de oro. Antes de realizar el análisis en el microscopio electrónico se eliminan de la muestra las sustancias orgánicas mediante incineración por plasma en el mismo filtro. EI recuento de fibras se realiza en una parte de la superficie del filtro elegida aleatoriamente y las fibras se clasifican según su forma y tipo. M ediante análisis de dispersión de energía por rayos $X$ (EDXA), se diferencian las fibras de amianto, sulfato cálcico y otra materias inorgánicas según su composición elemental. Todo el procedimiento es extremadamente costoso y requiere un extremo cuidado para obtener resultados fiables.

O tro elemento de interés es el hollín en forma de partículas emitido por los motores diesel, ya que también ha sido clasificado como cancerígeno. Por su compleja y variable composición y el hecho de que algunos de sus componentes son emitidos por otras fuentes, no se dispone actualmente de un procedimiento específico para medir el hollín emitido por los motores diesel. N o obstante, para poder decir algo concreto sobre las concentraciones atmosféricas, el hollín se define generalmente como carbono elemental que forma parte del carbono total. Se determina mediante muestreo seguido de una etapa de extracción y/o desorción térmica. La determinación del contenido de carbono se consigue mediante combustión en corriente de oxígeno y valoración culombimétrica o detección IR no dispersiva del dióxido de carbono formado durante el proceso.

Para determinar el contenido de hollín se utilizan asimismo el etalómetro y el sensor fotoeléctrico de aerosoles.

\section{Medición de las precipitaciones húmedas}

Junto con las precipitaciones secas, las precipitaciones húmedas por lluvia, nieve, niebla o rocío constituyen la principal forma por la cual los materiales nocivos descienden de la atmósfera al suelo, al agua 0 a la superficie de las plantas.

Para poder distinguir claramente la precipitación húmeda por Iluvia y nieve (la niebla y el rocío plantean problemas especiales) 
de la precipitación total (precipitación aparente, véase la sección anterior "M edición del polvo sedimentable y sus compuestos metálicos") y de la precipitación seca, en el muestreo se utilizan colectores de lluvia cuya entrada se cubre cuando no llueve (muestreador exclusivamente para precipitaciones húmedas). Al disponer de sensores de lluvia, que en su mayoría funcionan por el principio de variación de conductividad, la tapa se abre cuando comienza a llover y se vuelve a cerrar cuando la cesa la Iluvia.

Las muestras se transfieren a través de un embudo (boca de aprox. $500 \mathrm{~cm}^{2}$ o superior) a un colector oscuro y preferiblemente aislado (de vidrio o de polietileno sólo para componentes inorgánicos).

Por lo general, para el análisis de los compuestos inorgánicos del agua recogida no es necesario preparar la muestra. El agua tiene que centrifugarse o filtrarse si está visiblemente turbia. La conductividad, el valor $\mathrm{pH}$ y los principales aniones $\left(\mathrm{NO}_{3}^{-}\right.$, $\left.\mathrm{SO}_{4}{ }^{2-}, \mathrm{Cl}^{-}\right)$y cationes $\left(\mathrm{Ca}^{2+}, \mathrm{K}^{+}, \mathrm{M} \mathrm{g}^{2+}, \mathrm{Na}^{+}, \mathrm{NH}_{4}{ }^{+}\right.$, etc.) se miden de forma rutinaria. También se miden los compuestos traza inestables y los estados intermedios como $\mathrm{H}_{2} \mathrm{O}_{2} \mathrm{O} \mathrm{HSO}_{3}^{-}$para fines de investigación.

EI análisis se realiza utilizando los métodos habituales para soluciones acuosas como, por ejemplo, la conductiometría para medir la conductividad, los electrodos para el pH, la espectroscopia de absorción atómica para los cationes (véase la sección anterior "M edición de materiales especiales en forma de polvo") y, cada vez más, la cromatografía de intercambio iónico con detección de conductividad para los aniones.

Los compuestos orgánicos se extraen del agua de lluvia, por ejemplo, con diclorometano, o bien insuflando argón y adsorbiendo con tubos Tenax (sólo materiales de alta volatilidad). A continuación los materiales se analizan por cromatografía de gases (véase más adelante "Procedimientos de medición para contaminantes atmosféricos orgánicos").

Las precipitaciones secas están directamente correlacionadas con las concentraciones atmosféricas. No obstante, las diferencias de concentración de los materiales nocivos en suspensión en la lluvia son relativamente pequeñas, de manera que para medir la precipitación húmeda pueden utilizarse redes de medición de malla amplia como, por ejemplo, la red europea EMEP que recoge iones sulfato y nitrato, algunos cationes y valores $\mathrm{pH}$ de la precipitación en unas 90 estaciones. También existen extensas redes de medición en América del $\mathrm{N}$ orte.

\section{Procedimientos de medición ópticos de larga distancia}

$M$ ientras que los métodos descritos hasta el momento miden la contaminación atmosférica en un solo punto, los procedimientos de medición ópticos de larga distancia realizan mediciones integradas a lo largo de trayectos de luz de varios kilómetros o determinan la distribución espacial. Estos métodos se basan en las características de absorción de los gases en la atmósfera en el rango del espectro UV, visible o IR y en la ley de Lambert-Beer, según la cual el producto del trayecto recorrido por la luz y la concentración es proporcional a la atenuación medida. Variando la longitud de onda del emisor y el receptor en la instalación de medición, se pueden medir simultánea o secuencialmente distintos componentes con un solo equipo.

En la Tabla 55.6 se indican los sistemas de medición más utilizados en la práctica.

\section{Procedimientos de medición para contaminantes atmosféricos orgánicos}

La medición de la contaminación atmosférica producida por componentes orgánicos es compleja por la gran diversidad de
Tabla 55.6 - Procedimientos para mediciones a grandes distancias.

\begin{tabular}{|c|c|c|}
\hline ocedimiento & Aplicación & Ventajas y desventajas \\
\hline $\begin{array}{l}\text { pectroscopia } \\
\text { nsformada } \\
\text { Fourier } \\
\text { TIR) }\end{array}$ & $\begin{array}{l}\text { Rango IR (aprox. } \\
700 \text { - } 3.000 \mathrm{~cm}^{-1} \text { ), } \\
\text { trayecto de luz de varios } \\
\text { cientos de metros. Para } \\
\text { vigilancia de fuentes } \\
\text { superficiales difusas } \\
\text { (barrera óptica), } \\
\text { determina compuestos } \\
\text { orgánicos individuales }\end{array}$ & $\begin{array}{l}\text { + Sistema multicomponente } \\
+ \text { Id pocos ppb } \\
\text { - Caro }\end{array}$ \\
\hline $\begin{array}{l}\text { pectrometría } \\
\text { absorción } \\
\text { tica } \\
\text { erencial } \\
\text { OAS) }\end{array}$ & $\begin{array}{l}\text { Trayecto de luz de varios } \\
\mathrm{km} \text {; determina } \mathrm{SO}_{2}, \mathrm{NO}_{2} \text {, } \\
\text { benceno, } \mathrm{HNO}_{3} ; \text { para vigi- } \\
\text { lancia de fuentes lineales } \\
\text { y superficiales, utilizada } \\
\text { en redes de medición }\end{array}$ & $\begin{array}{l}\text { + Fácil manejo } \\
\text { + Ensayo de rendimiento } \\
\text { satisfactorio } \\
\text { + Sistema multicomponente } \\
\text { - } \text { Alto Id en condiciones } \\
\text { de escasa visibilidad } \\
\text { (p. ej., niebla) }\end{array}$ \\
\hline $\begin{array}{l}\text { Espectroscopia } \\
\text { de absorción } \\
\text { láser } \\
\text { de larga } \\
\text { distancia } \\
\text { (TDLAS) }\end{array}$ & $\begin{array}{l}\text { Area de investigación, en } \\
\text { cubetas de baja presión } \\
\text { para } \mathrm{OH}^{-}\end{array}$ & $\begin{array}{l}\text { + Alta sensibilidad (a ppt) } \\
\text { + Determina compuestos traza } \\
\text { inestables } \\
\text { - Alto coste } \\
\text { - Difícil manejo }\end{array}$ \\
\hline $\begin{array}{l}\text { Absorción } \\
\text { diferencial } \\
\text { LIDAR (DIAL) }\end{array}$ & $\begin{array}{l}\text { Para vigilancia de fuentes } \\
\text { superficiales, determina } \\
\text { inmisiones en grandes } \\
\text { superficies }\end{array}$ & $\begin{array}{l}\text { + Medición de distribuciones } \\
\text { espaciales } \\
+ \text { Mide puntos } \\
\text { inaccesibles ( } p . \text { ej., trayecto- } \\
\text { rias de gas de humo) } \\
\text { - Alto coste } \\
\text { - Número limitado de } \\
\text { componentes } \\
\left(\mathrm{SO}_{2}, \mathrm{O}_{3}, \mathrm{NO}_{2}\right)\end{array}$ \\
\hline
\end{tabular}

LIDAR = Detección de luz y determinación de distancias; DIAL = Absorción diferencial LIDAR Id = Límite de detección.

estos compuestos. En los registros de emisión y en los planes de calidad atmosférica para áreas muy congestionadas, se engloban bajo la denominación general de "contaminantes atmosféricos orgánicos" varios centenares de componentes con características toxicológicas, químicas y físicas muy diferentes.

D ebido principalmente a las grandes diferencias en su impacto potencial, se ha impuesto cada vez más la recogida de componentes individuales frente a los métodos generales utilizados en el pasado (p. ej., detector de ionización a la llama (FID), método del carbono total), cuyos resultados no pueden someterse a una evaluación toxicológica. El método FID se sigue utilizando, aunque incorporando una columna corta de separación para aislar el metano, no muy activo desde el punto de vista fotoquímico, y para recoger los compuestos orgánicos volátiles (COV) precursores en la formación de los fotooxidantes.

La frecuente necesidad de separar las mezclas complejas de compuestos orgánicos en componentes individuales hace que su medición sea verdaderamente un trabajo de cromatografía aplicada. Los métodos cromatográficos están indicados cuando los compuestos orgánicos son suficientemente estables, tanto desde el punto de vista térmico como químico. Para la detección de los materiales orgánicos con grupos funcionales reactivos, se siguen utilizando los métodos basados en las características físicas de los 
Tabla 55.7 - Métodos cromatográficos más habituales para la determinación de compuestos orgánicos contaminantes de la atmósfera y ejemplos de su aplicación.

\begin{tabular}{|c|c|c|}
\hline Grupo de materiales & $\begin{array}{l}\text { Rango de } \\
\text { concentración }\end{array}$ & Muestreo y preparación \\
\hline Hidrocarburos $C_{1}-C_{9}$ & $\mu \mathrm{g} / \mathrm{m}^{3}$ & $\begin{array}{l}\text { Ratón de gas (muestreo rápido), jeringuilla impermeable al gas, } \\
\text { trampa refrigerante delante de la columna capilar (de enfoque), } \\
\text { desorción térmica }\end{array}$ \\
\hline $\begin{array}{l}\text { Hidrocarburos con bajo punto de ebulli- } \\
\text { ción, hidrocarburos halogenados de } \\
\text { alta volatilidad }\end{array}$ & $n g / m^{3}-\mu g / m^{3}$ & $\begin{array}{l}\text { Cilindro de acero de alta calidad vaciado y pasivado (también para } \\
\text { mediciones de aire limpio). Distribución de muestreos a través de } \\
\text { circuitos de gas, trampa refrigerante, desorción térmica }\end{array}$ \\
\hline $\begin{array}{l}\text { Compuestos orgánicos con punto de } \\
\text { ebullición dentro del rango de } C_{6} \cdot C_{30} \\
(60-350 \stackrel{-C}{ })\end{array}$ & $\mu \mathrm{g} / \mathrm{m}^{3}$ & $\begin{array}{l}\text { Adsorción sobre carbono activado, (a) desorción con } \mathrm{CS}_{2} \\
\text { (b) desorción con disolventes } \\
\text { (c) análisis de espacio de cabeza }\end{array}$ \\
\hline $\begin{array}{l}\text { Compuestos orgánicos con punto de } \\
\text { ebullición entre } 20 \text { y } 300^{\circ} \mathrm{C}\end{array}$ & $\mathrm{ng} / \mathrm{m}^{3}-\mu \mathrm{g} / \mathrm{m}^{3}$ & $\begin{array}{l}\text { Adsorción sobre polímeros orgánicos ( } p \text {. ej., Tenax) o tamiz molecular de } \\
\text { carbono (carbopack), desorción térmica con trampa refrigerante delante de } \\
\text { la columna capilar (de enfoque) o extracción con disolvente }\end{array}$ \\
\hline $\begin{array}{l}\text { Modificación para compuestos con bajo } \\
\text { punto de ebullición (a partir de } \\
-120 \stackrel{\text { OC) }}{ }\end{array}$ & $\mathrm{ng} / \mathrm{m}^{3}-\mu \mathrm{g} / \mathrm{m}^{3}$ & $\begin{array}{l}\text { Adsorción sobre polímeros refrigerados ( } p \text {. ej., tubo de termogradiente), } \\
\text { refrigerado a - } 120^{\circ} \mathrm{C} \text {, utilización de carbopack }\end{array}$ \\
\hline $\begin{array}{l}\text { Compuestos orgánicos con alto punto } \\
\text { de ebullición adheridos parcialmente } \\
\text { a partículas (esp. PAH, PCB, } \\
\text { PCDD/ PCDF), alto volumen de } \\
\text { muestreo }\end{array}$ & $\mathrm{fg} / \mathrm{m}^{3}-\mathrm{ng} / \mathrm{m}^{3}$ & $\begin{array}{l}\text { Muestreo en filtros ( } p \text {. ej., dispositivo reducido de filtro o muestreador de } \\
\text { alto volumen) con cartuchos de poliuretano para la fracción gaseosa, desor- } \\
\text { ción con disolvente del filtro y del poliuretano, varias etapas de purificación } \\
\text { y preliminares, para PAH también sublimación }\end{array}$ \\
\hline $\begin{array}{l}\text { Compuestos orgánicos con alto punto } \\
\text { de ebullición, esp. PCDD, PCDF, PBDD, } \\
\text { PBDF, bajo volumen de muestreo }\end{array}$ & $\mathrm{fg} / \mathrm{m}^{3}-\mathrm{ng} / \mathrm{m}^{3}$ & $\begin{array}{l}\text { Adsorción sobre polímeros orgánicos ( } p \text {. ej., cilindro de espuma de } \\
\text { poliuretano) con filtros previos ( } p \text {. ej., fibra de vidrio) o adsorción } \\
\text { inorgánica. ( } p \text {. ej., gel de sílice), extracción con disolventes, varias } \\
\text { etapas de purificación y preliminares (incluida cromatografía } \\
\text { multicolumna), derivación para clorofenoles }\end{array}$ \\
\hline $\begin{array}{l}\text { Compuestos orgánicos con alto punto } \\
\text { de ebullición adheridos a partículas, } \\
\text { p. ej., componentes de aerosoles orgá- } \\
\text { nicos, muestras de precipitado }\end{array}$ & $\begin{array}{l}\mathrm{ng} / \mathrm{m}^{3} \\
\mathrm{ng}-\mu \mathrm{g} / \mathrm{g} \text { aerosol } \\
\mathrm{pg}-\mathrm{ng} / \mathrm{m}^{2} \text { día }\end{array}$ & $\begin{array}{l}\text { Separación de aerosoles con filtros de fibra de vidrio ( } p \text {. ej., muestreador } \\
\text { de alto o de bajo volumen) o recogida de polvo en superficies estandari- } \\
\text { zadas, extracción con disolventes (también para precipitación del resto } \\
\text { del agua filtrada), varias etapas de purificación y preliminares }\end{array}$ \\
\hline
\end{tabular}

Etapa analítica final

CG/ FID

CG/ FID/ ECD/ PID

ción, hidrocarburos halogenados de

e

ECD/PID

CG/ FID capilar

Compuestos orgánicos con punto de

Adsorción sobre carbono activado, (a) desorción con $\mathrm{CS}_{2}$ $160-350 \div 0$

Compuestos orgánicos con punto de
ebullición entre 20 y 300 ㅇ

Modificación para compuestos con bajo punto de ebullición (a partir de

-120 -C)

$P C D D / P C D F)$, alto volumen de

muestreo de ebullición, esp. PCDD, PCDF, PBDD PBDF, bajo volumen de muestreo

\footnotetext{
$C G=$ cromatografía de gases;

$F I D=$ detector de ionización de llama;

$E C D=$ detector de captura de electrones;

$\mathrm{PID}=$ detector de fotoionización.
}

(b) desorción con disolventes

Adsorción sobre polímeros orgánicos (p. ej., Tenax) o tamiz molecular de carbono (carbopack), desorción térmica con trampa refrigerante delante de

CG/ FID/ ECD/ MS capilar

CG/ FID/ ECD/ MS capilar

CG-GCMS capilar

(PCDD/ PCDF),

CG-FID capilar 0

MS (PAH), detector de

fluorescencia HPLC (PAH)

HRCG/ ECD

HRGC/ MS

HPLC (para PAH) grupos funcionales o en la reactividad química. Así, por ejemplo, puede citarse la utilización de aminas para convertir aldehídos en hidrazonas, que a continuación se determinan fotométricamente; la derivación con 2,4-dinitrofenilhidrazina y la separación de la 2,4-hidrazona obtenida; o la formación de colorantes azínicos con p-nitroanilina para detectar fenoles y cresoles.

Entre los métodos cromatográficos más utilizados para separar estas complejas mezclas se encuentran la cromatografía de gases (GC) y la cromatografía líquida de alta resolución (H PLC). En lo que se refiere a la cromatografía de gases, actualmente sólo se utilizan columnas de separación de diámetros muy reducidos (aprox. 0,2 a 0,3 $\mathrm{mm}$ ) y longitudes de aprox. 30 a $100 \mathrm{~m}$, denominadas columnas capilares de alta resolución (H RG C). Para detectar los diferentes componentes a la salida de la columna de separación existen una serie de detectores como el FID ya mencionado, el ECD (detector de captura de electrones, específico para compuestos con sustitutos electrófilos como los halógenos), el PID (detector de fotoionización, especialmente sensible a los hidrocarburos aromáticos y a otros sistemas con electrones $\pi$ ) y el NPD (detector termoiónico específico para compuestos de nitrógeno y fósforo). La H PLC utiliza detectores especiales con cubeta de paso de flujo, cuyo diseño es similar a la de un espectrómetro U V.

Especialmente eficaz, pero también más costoso, es el uso como detector de un espectrómetro de masas. En muchos casos, especialmente con mezclas desconocidas de compuestos, sólo se consigue una identificación correcta analizando el espectro de masas del compuesto orgánico. La información cualitativa del denominado tiempo de retención (tiempo que el material permanece en la columna) obtenida del cromatograma con detectores convencionales puede complementarse con una detección específica de los diferentes componentes mediante fragmentogramas de masas con alta sensibilidad de detección.

Antes de realizar el análisis real debe elegirse el tipo de muestreo más adecuado. Esta elección dependerá de la volatilidad, aunque también del rango de concentración esperado, la polaridad y la estabilidad química. Además, en el caso de 
compuestos no volátiles, debe elegirse entre determinar la concentración o la sedimentación.

En la Tabla 55.7 se presentan los métodos habituales de vigilancia atmosférica con enriquecimiento activo y análisis cromatográfico de los compuestos orgánicos, así como ejemplos de su aplicación.

Las mediciones de la precipitación de compuestos orgánicos de baja volatilidad (p. ej., dibenzodioxinas y dibenzofuranos (PCDD/ PCDF) o hidrocarburos aromáticos policíclicos (PAH) cada vez reviste mayor importancia desde el punto de vista del impacto ambiental. Puesto que los alimentos son la principal fuente de ingesta humana, las partículas en suspensión en el aire que se depositan en las plantas destinadas al consumo humano tienen un gran interés, aunque parece ser que la transferencia de material por sedimentación de partículas es menos importante que la precipitación seca de compuestos casi gaseosos.

Para medir la precipitación total se utilizan equipos normalizados para precipitación de polvo (p. ej., método Bergerhoff), que han sido ligeramente modificados para oscurecerlos como protección frente a la luz intensa. Con el fin de optimizar los métodos de muestreo para compuestos orgánicos, en la actualidad se están investigando de forma sistemática algunos problemas técnicos importantes, como la resuspensión de partículas ya separadas, la evaporación o la posible descomposición fotolítica.

\section{Investigaciones olfatométricas}

Las investigaciones de inmisiones olfatométricas se utilizan para cuantificar olores desagradables denunciados y determinar la contaminación basal en los procedimientos de concesión de licencias. Estas investigaciones sirven fundamentalmente para determinar si olores existentes o potenciales deben clasificarse como significativos.

En principio, pueden diferenciarse tres enfoques metodológicos:

- medición de la concentración emitida (número de unidades de olor) mediante olfatómetro y modelos de dispersión;

- medición de componentes individuales (p. ej., $\mathrm{NH}_{3}$ ) o mezclas de compuestos (p. ej., cromatografía de gases para gases procedentes de vertederos) con olor característico,

- determinación de olores mediante inspección.

El primer método combina la medición de las emisiones utilizando un modelo de dispersión y realmente no puede considerarse vigilancia de la calidad atmosférica. En el tercer método se utiliza el olfato humano como detector, con una precisión bastante reducida si se compara con los métodos fisicoquímicos.

A sí, por ejemplo, en algunas regiones alemanas la normativa de protección ambiental incluye detalles sobre la inspección, planes de medición y análisis de los resultados.

\section{Procedimientos para mediciones preliminares (screening)}

En ocasiones se utilizan procedimientos simplificados para realizar estudios preliminares; por ejemplo, muestreadores pasivos, tubos de ensayo o métodos biológicos. Al contrario que los muestreadores activos (aspiración de la muestra por bombeo), en los muestreadores pasivos (por difusión) el material objeto del análisis se recoge mediante procesos de flujo libre (difusión, permeación o adsorción) en colectores sencillos (tubos o placas) y se enriquece en filtros impregnados, mallas $u$ otros medios de adsorción. La cantidad de material enriquecido, determinada analíticamente al cabo de un tiempo de exposición prefijado, se convierte a unidades de concentración aplicando leyes físicas (p. ej., difusión) y considerando el tiempo de recogida y los parámetros geométricos del colector. Esta metodología, que procede del campo de la higiene del trabajo (muestreo personal) y hasta ahora se utilizaba para mediciones del aire en los interiores, se está utilizando cada vez más para medir la concentración de contaminantes atmosféricos (véase Brown 1993).

Los tubos indicadores se utilizan a menudo para muestreos y análisis preliminares rápidos de gases. Se aspira un determinado volumen de aire a través de un tubo de vidrio en el que se ha introducido un reactivo de adsorción adecuado para los fines del ensayo. El contenido del tubo cambia de color dependiendo de la concentración del material analizado en el aire muestreado. Los tubos pequeños se utilizan a menudo para la vigilancia de puestos de trabajo o como método rápido en caso de accidentes, como incendios. Sin embargo, no se utilizan para mediciones rutinarias de la concentración de contaminantes atmosféricos por presentar unos límites de detección demasiado altos y una selectividad demasiado limitada. Existen en el mercado tubos indicadores para gran cantidad de materiales y diferentes rangos de concentración.

Entre los procedimientos biológicos, dos métodos son los más utilizados para la vigilancia rutinaria. El método normalizado de exposición de líquenes determina la tasa de mortalidad del liquen durante un tiempo de exposición de 300 días. El segundo método utiliza hierba de pasto francesa y el tiempo de exposición es de $14 \pm 1$ días. A continuación se determina su crecimiento. Ambos procedimientos sirven como determinaciones generales de los efectos de las diferentes concentraciones de contaminantes atmosféricos.

\section{Redes de vigilancia de la calidad atmosférica}

En todo el mundo existen los más variados tipos de redes de vigilancia de la calidad atmosférica. En principio cabe distinguir entre redes de medición, formadas por estaciones de medición automáticas y controladas por ordenador (contenedores de medición), y redes virtuales de medición, que sólo definen los puntos de medición para diferentes tipos de contaminantes atmosféricos en un formato preconfigurado. En apartados anteriores ya se han analizado las funciones y los conceptos de las redes de medición.

\section{Redes de vigilancia continua}

Las redes de medición continua, basadas en estaciones automáticas, sirven fundamentalmente para vigilar la calidad atmosférica en zonas urbanas y medir contaminantes atmosféricos como dióxido de azufre $\left(\mathrm{SO}_{2}\right)$, polvo, monóxido de nitrógeno (NO), dióxido de nitrógeno $\left(\mathrm{NO}_{2}\right)$, monóxido de carbono (CO ), ozono $\left(\mathrm{O}_{3}\right)$ y, en cierta medida, también la concentración total de hidrocarburos (metano libre, $\mathrm{C}_{n} \mathrm{H}_{m}$ ) o componentes orgánicos individuales (p. ej., benceno, tolueno, xilenos). En caso necesario, también pueden determinar parámetros meteorológicos como dirección y velocidad del viento, temperatura del aire, humedad relativa, precipitación, radiación global o balance de radiación.

Los equipos utilizados en las estaciones de medición constan, por lo general, de un analizador, una unidad de calibrado y unidades electrónicas de control que gestionan todo el equipo de medición y que contienen una interface normalizada para la recogida de datos. El equipo de medición, además de los valores de las mediciones, transmite mensajes de error y de su estado de funcionamiento. Cada cierto tiempo, el ordenador comprueba automáticamente el calibrado de los dispositivos.

Por regla general, las estaciones de medición están conectadas, a través de líneas de datos específicas, redes telefónicas conmutadas u otros sistemas de transmisión de datos, a un ordenador (ordenador central, estación de trabajo o PC, según el sistema) en el que se introducen, procesan y visualizan los resultados de las mediciones. L os ordenadores de la red de medición $y$, en caso necesario, personal debidamente formado, vigilan continuamente que no se sobrepasen los valores umbral, 
Tabla 55.8 • Vigilancia sistemática de la atmósfera en la región de Renania del N orte/ W estfalia (Alemania).

\begin{tabular}{|c|c|c|}
\hline $\begin{array}{l}\text { Sistema } \\
\text { de medición } \\
\text { continuo }\end{array}$ & $\begin{array}{l}\text { Sistema } \\
\text { de medición } \\
\text { parcialmente } \\
\text { automatizado }\end{array}$ & $\begin{array}{l}\text { Sistema de medición } \\
\text { discontinuo / Medición } \\
\text { de componentes } \\
\text { múltiples }\end{array}$ \\
\hline $\begin{array}{l}\text { Dióxido de azufre } \\
\text { Monóxido de nitrógeno } \\
\text { Dióxido de nitrógeno } \\
\text { Monóxido de carbono } \\
\text { Partículas en suspensión } \\
\text { (SPM) } \\
\text { Ozono } \\
\text { Hidrocarburos } \\
\text { Dirección del viento } \\
\text { Velocidad del viento } \\
\text { Temperatura atmosférica } \\
\text { Presión atmosférica } \\
\text { Humedad relativa } \\
\text { Balance de radiación } \\
\text { Precipitaciones }\end{array}$ & $\begin{array}{l}\text { Composición de SPM: } \\
\text { Plomo } \\
\text { Cadmio } \\
\text { Níquel } \\
\text { Cobre } \\
\text { Hierro } \\
\text { Arsénico } \\
\text { Berilio } \\
\text { Benzo[a]pireno } \\
\text { Benzo[e]pireno } \\
\text { Benzo[a]antraceno } \\
\text { Dibenzo[a,h]antraceno } \\
\text { Benzo[ghi] perileno } \\
\text { Coroneno }\end{array}$ & $\begin{array}{l}\text { Benceno y otros } \\
\text { hidrocarburos } \\
\text { Hidrocarburos } \\
\text { halogenados } \\
\text { Sedimentación de polvo } \\
\text { y composición del } \\
\text { material } \\
\text { Hollín } \\
\text { Bifenilos } \\
\text { policlorados } \\
\text { Dibenzodioxinas } \\
\text { y dibenzofuranos } \\
\text { polihalogenados } \\
\text { (PCDD/ PCDF) }\end{array}$ \\
\hline
\end{tabular}

pudiendo así detectar en cualquier momento situaciones críticas de calidad atmosférica. Este sistema es especialmente eficaz para vigilar situaciones críticas de esmog en invierno y verano (fotooxidantes) y para actualizar la información pública.

\section{Redes de medición de muestras aleatorias}

Para vigilar la calidad atmosférica, además de las redes de medición telemétricas, se utilizan otros sistemas (a veces parcialmente automatizados) que determinan:

- la precipitación de polvo y sus componentes;

- polvo en suspensión (SPM ) y sus componentes;

- hidrocarburos e hidrocarburos clorados,

- materiales orgánicos poco volátiles (dioxinas, furanos, bifenilos policlorados).

Algunas de las sustancias medidas de esta forma han sido clasificadas como cancerígenas, entre ellas los compuestos de cadmio, Ios PAH o el benceno. Su vigilancia reviste, por lo tanto, una especial importancia.

Como ejemplo de un programa integrado, en la Tabla 55.8 se resume el método sistemático de vigilancia de la calidad atmosférica utilizado en Renania del N orte-Westfalia, una región que con 18 millones de habitantes presenta la mayor densidad de población de Alemania.

\section{- CONTROL DE LA CONTAMINACION ATMO SFERICA}

John Elias

\section{Control de la contaminación atmosférica}

El objetivo de un sistema de control de la contaminación atmosférica es asegurar que concentraciones excesivas de contaminantes atmosféricos no alcancen receptores sensibles. Estos receptores pueden ser personas, plantas, animales u objetos. Siempre debe prestarse atención a los grupos más sensibles. Los contaminantes atmosféricos pueden ser gases, vapores, aerosoles y, en algunos casos, materiales biopeligrosos. Un sistema bien
Tabla 55.9 • Etapas en la selección de los controles de contaminación.

Etapa 1:

Definición de

La primera parte consiste en determinar los materiales que se

las emisiones. liberarán de la chimenea. Tiene que elaborarse una lista de todas las emisiones potencialmente nocivas. A continuación se estima la cantidad que se liberará de cada material. Sin esta información, el gestor no puede comenzar a diseñar el programa de control.

Etapa 2: Identificación sean personas, animales, plantas o materiales. En todos los de los casos tiene que identificarse al miembro más sensible de cada receptores. $\quad$ grupo ( $p$. ej., personas asmáticas que residen en las proximidades de una planta con emisiones de isocianatos).

Etapa 3: $\quad$ Tiene que establecerse un nivel aceptable de exposición para Determinación el grupo de receptores más sensibles. Si el contaminante es de los niveles un material con efectos acumulativos ( $p$. ej., sustancias de exposición cancerígenas), tienen que establecerse niveles de exposición aceptables. * a largo plazo (anuales). Si el contaminante presenta efectos a corto plazo (p. ej., sustancias irritantes o sensibilizantes), tiene que establecerse un nivel de exposición a corto plazo o tal vez un nivel de exposición pico**.

Etapa 4: $\quad$ En la etapa 1 se identifican las emisiones y en la etapa 3 se Selección de determinan los niveles de exposición aceptables. En esta los controles. cuarta etapa se comprueba que ninguno de los contaminantes sobrepasa el nivel aceptable. De lo contrario, tendrán que añadirse controles adicionales y volver a comprobar los niveles de exposición. Este proceso se repite hasta que todas las exposiciones se encuentren al nivel o por debajo del nivel aceptable. Puede utilizarse un modelo de dispersión para estimar las exposiciones en plantas nuevas o para comprobar soluciones alternativas para instalaciones ya existentes.

* Cuando se establecen los niveles de exposición en la etapa 3, debe tenerse en cuenta que estas exposiciones son exposiciones totales, y no sólo exposiciones en la planta. Una vez establecido el nivel aceptable, deben restarse los niveles de fondo y las contribuciones de las demás plantas para determinar la cantidad máxima que la planta en cuestión puede emitir sin sobrepasar el nivel de exposición aceptable. Si se omite esta operación y existen tres plantas que emiten cada una de ellas la cantidad máxima permitida, los receptores estarán expuestos a un nivel tres veces superior al aceptable.

** Algunos materiales, como los cancerígenos, carecen de un umbral por debajo del cual no producen efectos nocivos. Por lo tanto, siempre que se permita que una parte de este material se libere al entorno, existirá un riesgo para las poblaciones receptoras. Con estos materiales no puede definirse un nivel sin efecto (salvo el nivel cero), pero como es necesario fijar un nivel aceptable de riesgo, éste se establece, por lo general, dentro del rango de 1 víctima por cada 100.000 . 1.000 .000 personas expuestas.

diseñado evitará la exposición de un receptor a una concentración nociva de contaminantes.

La mayoría de los sistemas de control de la contaminación atmosférica combinan distintas técnicas de control, normalmente tanto de tipo tecnológico como administrativo. Para fuentes de mayor volumen o complejidad puede utilizarse más de un tipo de control tecnológico.

La selección de los controles debe realizarse en función del problema que debe resolverse y teniendo en cuenta los aspectos siguientes:

- qué se emite y cuál es su concentración;

- cuál es el grupo receptor y cuál es el receptor más sensible;

- cuáles son los niveles permisibles de exposición de corta duración;

- cuáles son los niveles permisibles de exposición de larga duración, 
Tabla 55.10 • Normas sobre la calidad atmosférica para un contaminante controlado habitualmente (dióxido de azufre).

\begin{tabular}{lc} 
Países & $\begin{array}{l}\text { Normas sobre la calidad } \\
\text { atmosférica a largo plazo } \\
\text { para el dióxido de azufre } \\
\left(\mu \mathrm{g} / \mathrm{m}^{3}\right)\end{array}$ \\
Australia & 50 \\
Canadá & 30 \\
Finlandia & 40 \\
Alemania & 140 \\
Hungría & 70 \\
Taiwán & 133 \\
\hline
\end{tabular}

- cuál es la selección adecuada de controles para garantizar que no se sobrepasan dichos niveles.

En la Tabla 55.9 se muestran las diferentes etapas de este proceso.

Algunos territorios jurisdiccionales han avanzado en este sentido estableciendo normas basadas en la concentración máxima de un contaminante a la que puede verse expuesto un receptor sensible. Con este tipo de norma, el responsable del control de la contaminación atmosférica no necesita realizar las etapas 2 y 3 , puesto que habrán sido realizadas ya por el organismo regulador. Con este sistema, el responsable de la contaminación atmosférica sólo debe establecer los límites de emisión descontrolada de cada contaminante (etapa 1) y a continuación determinar los controles necesarios para asegurar el cumplimiento de las normas (etapa 4).

Cuando existen normas sobre la calidad atmosférica, los responsables de la regulación pueden medir exposiciones

\begin{tabular}{|c|c|}
\hline Ciudad/ Estado & $\begin{array}{l}\text { Normas sobre la calidad } \\
\text { atmosférica } 24 \text { horas al día } \\
\text { para el benceno }\left(\mu \mathrm{g} / \mathrm{m}^{3}\right)\end{array}$ \\
\hline Connecticut & 53,4 \\
\hline Massachusetts & 1,2 \\
\hline Michigan & 2,4 \\
\hline Carolina del Norte & 2,1 \\
\hline Nevada & 254 \\
\hline Nueva York & 1.718 \\
\hline Filadelfia & 1.327 \\
\hline Virginia & 300 \\
\hline
\end{tabular}

Los niveles se han ajustado a un período medio de 24 horas para facilitar la comparación (adaptación de Calabrese y Kenyon, 1991).

individuales y determinar así si existen receptores expuestos a niveles potencialmente nocivos. Se supone que los límites fijados en estas condiciones son lo suficientemente bajos como para proteger al grupo de receptores más vulnerables, aunque éste no siempre es el caso. Como se observa en la Tabla 55.10, las normas sobre calidad atmosférica varían ampliamente de un país a otro. Así, por ejemplo, el valor del dióxido de azufre varía entre 30 y $140 \mu \mathrm{g} / \mathrm{m}^{3}$ y en el caso de materiales menos controlados, esta variación puede ser incluso mayor (entre 1,2 y $1.718 \mu \mathrm{g} / \mathrm{m}^{3}$ ), como se observa para el benceno en la Tabla 55.11. Esta variación no resulta sorprendente si se tiene en cuenta que, al establecer las normas, el aspecto económico juega un papel tan importante como el toxicológico. Las normas que no establecen un límite suficientemente bajo como para proteger a toda la población sensible no benefician a nadie. Las poblaciones expuestas tienen una sensación de falsa confianza y, sin saberlo, pueden estar expuestas a riesgos. En un principio, el que contamina puede pensar que se beneficia de una norma más permisiva, pero los efectos de una exposición excesiva de la comunidad harán que ésta exija a la empresa rediseñar sus controles 0 instalar otros nuevos, lo que puede resultar más costoso que si lo hubiera hecho correctamente desde el principio.

A veces, este enfoque gradual de la selección de los controles de la contaminación atmosférica resulta insuficiente y las

Tabla 55.12 • Ejemplos de tecnología BACT (mejor tecnología de control disponible), indicando los métodos de control utilizados y la eficiencia estimada.

\begin{tabular}{|c|c|c|c|}
\hline Proceso & Contaminante & Método de control & $\begin{array}{l}\text { Eficiencia } \\
\text { estimada }\end{array}$ \\
\hline $\begin{array}{l}\text { Recuperación del } \\
\text { suelo }\end{array}$ & Hidrocarburos & Oxidante térmico & 99 \\
\hline $\begin{array}{l}\text { Caldera de recupera- } \\
\text { ción de pasta de } \\
\text { papel Kraft }\end{array}$ & Partículas & $\begin{array}{l}\text { Precipitador } \\
\text { electrostático }\end{array}$ & 99,68 \\
\hline $\begin{array}{l}\text { Producción de humo } \\
\text { de sílice }\end{array}$ & $\begin{array}{l}\text { Monóxido de } \\
\text { carbono }\end{array}$ & Buenas prácticas & 50 \\
\hline Pintura de vehículos & Hidrocarburos & $\begin{array}{l}\text { Postquemador de } \\
\text { horno }\end{array}$ & 90 \\
\hline $\begin{array}{l}\text { Horno de arco } \\
\text { eléctrico }\end{array}$ & Partículas & $\begin{array}{l}\text { Precipitador de } \\
\text { polvos }\end{array}$ & 100 \\
\hline $\begin{array}{l}\text { Refinería de } \\
\text { petróleo, pirólisis } \\
\text { catalítica }\end{array}$ & $\begin{array}{l}\text { Partículas } \\
\text { inhalables }\end{array}$ & $\begin{array}{l}\text { Ciclón + depurador } \\
\text { Venturi }\end{array}$ & 93 \\
\hline Incinerador sanitario & Acido clorhídrico & $\begin{array}{l}\text { Depurador húmedo + } \\
\text { depurador seco }\end{array}$ & 97,5 \\
\hline Caldera de carbón & $\begin{array}{l}\text { Dióxido de } \\
\text { azufre }\end{array}$ & $\begin{array}{l}\text { Secador por vapori- } \\
\text { zación + absorbente }\end{array}$ & 90 \\
\hline $\begin{array}{l}\text { Eliminación de resi- } \\
\text { duos por deshidrata- } \\
\text { ción e incineración }\end{array}$ & Partículas & $\begin{array}{l}\text { Ciclón + conden- } \\
\text { sador + depurador } \\
\text { Venturi + depurador } \\
\text { húmedo }\end{array}$ & 95 \\
\hline $\begin{array}{l}\text { Planta de producción } \\
\text { de asfalto }\end{array}$ & Hidrocarburos & Oxidante térmico & 99 \\
\hline
\end{tabular}


autoridades reguladoras y los diseñadores adoptan directamente una "solución universal", como, por ejemplo, la "mejor tecnología de control disponible" (B est A vailable C ontrol Technology, $B A C T$ ), basándose en el supuesto de que, utilizando en una fuente emisora la mejor combinación posible de depuradoras, filtros y buenas prácticas de trabajo, se conseguirá un nivel de emisión suficientemente bajo como para proteger al grupo de receptores más sensible. Con frecuencia, el nivel de emisión resultante se encuentra por debajo del mínimo necesario para proteger a los grupos más sensibles, evitando de esta forma exposiciones innecesarias. En la Tabla 55.12 se ofrecen ejemplos de la técnica BACT.

Esta técnica no garantiza por sí misma unos niveles de control adecuados. A pesar de que es el mejor sistema de control basado en sistemas de depuración de gases y buenas prácticas de trabajo, la BACT puede no ser suficiente si la fuente emisora es una fábrica de gran tamaño situada cerca de un receptor sensible. Por ello siempre debe comprobarse que la mejor tecnología disponible de control es suficientemente buena. Asimismo, deben comprobarse los niveles de emisión resultantes para saber si las emisiones siguen siendo nocivas aún después de aplicar los mejores controles de depuración de gases, en cuyo caso sería necesario seleccionar procesos o materiales más seguros o trasladar la fábrica a una zona menos sensible.

O tra "solución universal" que elimina algunas de las etapas son las normas sobre el rendimiento de la fuente. M uchos territorios jurisdiccionales establecen límites de emisión que no pueden sobrepasarse. Estos límites se basan en las emisiones en la fuente $y$, aunque habitualmente resultan adecuados, a veces, como ocurre con la BACT, pueden no ser suficientemente seguros. Deben servir para mantener las emisiones máximas suficientemente bajas y proteger a la población receptora sensible frente a las emisiones habituales. Esta tecnología, al igual que la BACT, puede resultar insuficiente para proteger a todos los grupos si existen fuentes de emisión significativas o poblaciones sensibles en las proximidades. En este caso deben utilizarse otros procedimientos que garanticen la seguridad de todos los grupos receptores.

Tanto la BACT como los límites de emisión presentan el defecto básico de suponer que si en las fábricas se cumplen

Tabla 55.13 - Métodos de depuración de gases para eliminar de las emisiones industriales partículas, gases, vapores nocivos.

\begin{tabular}{|c|c|c|c|}
\hline $\begin{array}{l}\text { Método de control } \\
\text { Gases/Vapores }\end{array}$ & Ejemplos & Descripción & Eficiencia \\
\hline Condensación & $\begin{array}{l}\text { Condensadores de } \\
\text { contacto } \\
\text { Condensadores } \\
\text { superficiales }\end{array}$ & $\begin{array}{l}\text { El vapor se enfría y se condensa a líquido. Esto resulta ineficiente y } \\
\text { se utiliza como preacondicionamiento para otros métodos }\end{array}$ & $80+\%$ si la concentración $>2.000$ ppm \\
\hline Absorción & $\begin{array}{l}\text { Depuradores húmedos } \\
\text { (absorbedores } \\
\text { rellenos o de placa) }\end{array}$ & El gas o el vapor se recoge en un líquido. & $\begin{array}{l}\text { 82- } 95 \% \text { si la concentración }<100 \text { ppm } \\
95-99 \% \text { si la concentración }>100 \text { ppm }\end{array}$ \\
\hline Adsorción & $\begin{array}{l}\text { Carbono } \\
\text { Oxido de aluminio } \\
\text { Gel de sílice } \\
\text { Tamiz molecular }\end{array}$ & El gas o el vapor se recoge en un sólido. & $\begin{array}{l}90+\% \text { si la concentración }<1.000 \mathrm{ppm} \\
95+\% \text { si la concentración }>1.000 \text { ppm }\end{array}$ \\
\hline Incineración & $\begin{array}{l}\text { Llama } \\
\text { Incinerador } \\
\text { Incinerador catalítico }\end{array}$ & $\begin{array}{l}\text { Se oxida un gas o un vapor orgánico calentándolo y } \\
\text { manteniéndolo a alta temperatura durante un tiempo } \\
\text { suficiente. }\end{array}$ & $\begin{array}{l}\text { No recomendado si la concentración }<2.000 \text { ppm } \\
80+\% \text { si la concentración }>2.000 \text { ppm }\end{array}$ \\
\hline \multicolumn{4}{|l|}{ Partículas } \\
\hline $\begin{array}{l}\text { Separadores de } \\
\text { inercia }\end{array}$ & Ciclones & $\begin{array}{l}\text { A gases cargados con partículas se les obliga a cambiar de } \\
\text { dirección. La inercia de las partículas hace que éstas se separen } \\
\text { de la corriente de gas. Esto resulta ineficiente y se utiliza como } \\
\text { preacondicionamiento para otros métodos. }\end{array}$ & $70-90 \%$ \\
\hline $\begin{array}{l}\text { Depuradores } \\
\text { húmedos }\end{array}$ & $\begin{array}{l}\text { Venturi } \\
\text { Filtros humificados } \\
\text { Depurador de bandeja } \\
\text { o de tamiz }\end{array}$ & $\begin{array}{l}\text { Gotas de líquido (agua) recogen las partículas por impacto, } \\
\text { interceptación o difusión. A continuación estas gotas y sus } \\
\text { partículas son separadas de la corriente de gas. }\end{array}$ & $\begin{array}{l}\text { Para partículas de } 5 \mu \mathrm{m}, 98,5 \% \text { a } 6,8 \text { hd.; } \\
99,99+\% \text { a } 50 \text { hd. } \\
\text { Para partículas de } 1 \mu \mathrm{m}, 45 \% \text { a } 6,8 \text { hd.; } 99,95 \\
\text { a } 50 \text { hd. }\end{array}$ \\
\hline $\begin{array}{l}\text { Precipitadores } \\
\text { electrostáticos }\end{array}$ & $\begin{array}{l}\text { Cable plano } \\
\text { Placa plana } \\
\text { Tubular } \\
\text { Húmedo }\end{array}$ & $\begin{array}{l}\text { Se utilizan fuerzas eléctricas para extraer las partículas de la } \\
\text { corriente de gas y colocarlas en placas de recogida }\end{array}$ & $\begin{array}{l}95-99,5 \% \text { para partículas de } 0,2 \mu \mathrm{m} \\
99,25-99,9+\% \text { para partículas de } 10 \mu \mathrm{m}\end{array}$ \\
\hline Filtros & Precipitador de polvos & $\begin{array}{l}\text { Un tejido poroso separa las partículas de la corriente de gas. } \\
\text { La pasta porosa de polvo que se forma en el tejido es la que } \\
\text { realmente realiza la filtración. }\end{array}$ & $\begin{array}{l}99,9 \% \text { para partículas de } 0,2 \mu \mathrm{m} \\
99,5 \% \text { para partículas de } 10 \mu \mathrm{m}\end{array}$ \\
\hline
\end{tabular}


Tabla 55.14 - Velocidad de emisiones no controladas de algunos procesos industriales.

\begin{tabular}{|c|c|}
\hline Fuente industrial & Velocidad de emisión \\
\hline Horno eléctrico de 100 toneladas & 257 t partículas / año \\
\hline $\begin{array}{l}\text { Turbina de aceite/ gas de } 1.500 \text { MM } \\
\text { BTU/ h }\end{array}$ & $201 \mathrm{~kg} / \mathrm{h}$ de $\mathrm{SO}_{2}$ \\
\hline Incinerador de $41,7 \mathrm{t} / \mathrm{h}$ & $94 \mathrm{~kg} / \mathrm{h}$ de $\mathrm{NO}_{\mathrm{x}}$ \\
\hline Vertido de 100 camiones/ día & $\begin{array}{l}1.721 \mathrm{~kg} \text { de materia } \\
\text { orgánica/ semana }\end{array}$ \\
\hline
\end{tabular}

ciertos criterios, los grupos receptores estarán automáticamente protegidos. Esto no siempre es cierto, pero una vez que un sistema de este tipo se aprueba por ley, los efectos sobre los receptores pasan a un plano menos importante que el cumplimiento de la ley.

La BACT y los límites de emisión de la fuente o los criterios de diseño deben utilizarse como criterios mínimos de control en tanto en cuanto protejan a los receptores más sensibles; en caso contrario deben elegirse otros controles administrativos.

\section{Medidas de control}

L os controles pueden dividirse básicamente en dos tipos: tecnológicos y administrativos. Los primeros corresponden a los equipos instalados en la fuente emisora para reducir los contaminantes en los gases liberados hasta un nivel que la comunidad considere aceptable y que proteja a los receptores más sensibles. Los controles administrativos se definen aquí como otros medidas de control.

\section{Controles tecnológicos}

L os sistemas de depuración de gases se instalan en la fuente, antes de la chimenea, con el fin de eliminar los contaminantes de los gases antes de que éstos se liberen al medio ambiente. En la Tabla 55.13 se presenta un breve resumen de los diferentes tipos de sistemas de depuración de gases. Este forma parte de un complejo sistema que incluye campanas, conductos, ventiladores, depuradoras y chimeneas. EI diseño, las características técnicas y el mantenimiento de cada componente afecta al funcionamiento de todos los demás componentes y al conjunto del sistema.

Cabe destacar que la eficiencia de los diferentes tipos de depuradoras varía mucho en función de su diseño, fuente de energía y características del chorro de la corriente de gas y del contaminante. Por lo tanto, los valores de eficiencia de la Tabla 55.13 son sólo orientativos. En dicha Tabla 55.13 se demuestra la variación de la eficiencia de las depuradoras húmedas, que oscila entre el $98,5 \%$ para partículas de $5 \mu \mathrm{m}$ y el $45 \%$ para partículas de $1 \mu \mathrm{m}$ con la misma caída de presión a lo largo de la depuradora (6,8 " hidrómetro (hd.). Para el mismo tamaño de partícula, $1 \mu \mathrm{m}$, la eficiencia oscila entre el $45 \%$ a 6,8 hd. y el 99,95 a 50 hd. Por lo tanto, las depuradoras de gas deben adaptarse a las características específicas de la corriente de gas y no se recomienda el uso de equipos genéricos.

\section{Eliminación de residuos}

Cuando se seleccionan y diseñan sistemas de depuración de gases, debe estudiarse una forma segura de eliminar los residuos. Como se observa en la Tabla 55.14, algunos procesos producen grandes cantidades de contaminantes. Si la mayor parte de los contaminantes son recogidos por el equipo de depuración de gases, se puede plantear un grave problema de eliminación de residuos peligrosos.

En algunos casos los residuos contienen productos valiosos que pueden ser reciclados, como los metales pesados procedentes de un horno de fusión o los disolventes de una fábrica de pintura. Los residuos pueden utilizarse asimismo como materia prima para otros procesos industriales, como sucede, por ejemplo, con el dióxido de azufre recogido como ácido sulfúrico y utilizado a continuación para la fabricación de fertilizantes.

Si no es posible reciclar o reutilizar los residuos, su eliminación puede constituir un problema, no tanto por su volumen, sino por la propia peligrosidad del material. Así, por ejemplo, si los residuos de ácido sulfúrico de una caldera u horno de fundición no pueden ser reutilizados, tendrán que ser neutralizados antes de proceder a su eliminación.

\section{Dispersión}

La dispersión puede reducir la concentración de un contaminante a la que se ve expuesto un determinado receptor, aunque no reduce la cantidad total de material procedente de una fábrica. U na chimenea alta sólo consigue que el penacho se abra y se diluya antes de alcanzar el nivel del suelo, donde es probable que alcance a receptores sensibles. Cuando el contaminante se reduce a una simple molestia, como un olor desagradable, la dispersión puede resultar un método adecuado. Pero si el material es de tipo permanente 0 acumulativo, como los metales pesados, la dilución no resolverá el problema de la contaminación atmosférica.

La dispersión debe utilizarse con cuidado y teniendo en cuenta las condiciones meteorológicas locales y superficiales del suelo. Así, por ejemplo, en los climas fríos, especialmente cuando se producen precipitaciones de nieve, se producen con frecuencia inversiones térmicas que atrapan a los contaminantes cerca del suelo y dan lugar a exposiciones especialmente altas. De forma análoga, si una fábrica está situada en un valle, los penachos pueden ascender y descender por el valle o quedar bloqueados por las montañas cercanas, sin expandirse ni dispersarse como sería deseable.

\section{Controles administrativos}

En el diseño global de un sistema de control de contaminación atmosférica además de los sistemas tecnológicos, existe otro grupo de controles que, en su mayor parte, utilizan las herramientas básicas de la higiene industrial.

\section{Sustitución}

Uno de los métodos preferidos de la higiene del trabajo para controlar los riesgos ambientales en el puesto de trabajo es la sustitución de un material o proceso por otro más seguro que evite emisiones nocivas y consiga un control óptimo. En principio, es preferible evitar el problema que intentar corregir una decisión inicial errónea. Entre los ejemplos de sustitución cabe citar el uso de combustibles más limpios, el uso de recubrimientos para almacenamientos a granel y la reducción de la temperatura en los secadores.

Este método puede aplicarse a compras de menor importancia y a los principales criterios de diseño de una fábrica. Si sólo se adquieren productos o procesos ecológicos, no existirá riesgo para el ambiente exterior o interior. En caso contrario, el resto del programa tendrá que consistir en intentar paliar esta decisión inicial errónea. Si se adquiere un producto o un proceso de bajo coste pero peligroso, posteriormente tendrán que utilizarse procedimientos y equipos de manipulación y métodos de eliminación especiales. Por lo tanto, los materiales de bajo coste pueden tener un coste de compra bajo, pero en cambio su utilización y su eliminación serán más costosos. Un material o un 
proceso más ecológico, aunque en principio sea más caro, suele resultar más económico a largo plazo.

\section{Extracción localizada}

D eben controlarse todos aquellos problemas identificados que no pueden evitarse mediante la sustitución de materiales o métodos por otros más seguros. Las emisiones se originan en el puesto de trabajo individual y no en la chimenea. Por lo tanto, un sistema de ventilación bien diseñado que recoja y controle las emisiones en la fuente ayudará a proteger a la comunidad. Las campanas y las tuberías del sistema de ventilación forman parte del sistema global de control de la contaminación atmosférica.

Los sistemas de extracción localizada son preferibles porque no diluyen los contaminantes y proporcionan una corriente de gas concentrado más fácil de depurar antes de liberarlo al medio ambiente. El sistema de depuración de gas es más eficiente cuanto mayor sea la concentración de contaminantes. Así, por ejemplo, una campana situada en la parte superior del canal de colada de un horno de fundición de metales evitará que los contaminantes salgan al entorno, enviando los humos al sistema de depuración de gas. En la Tabla 55.13 se observa que las eficiencias de las depuradoras de absorción y adsorción aumentan con la concentración del contaminante y que las depuradoras por condensación no están indicadas para niveles bajos $(<2,000 \mathrm{ppm})$ de contaminantes.

Cuando no se recogen los contaminantes en la fuente y se permite que escapen a través de ventanas y aberturas de ventilación, se convierten en fugas incontroladas. En algunos casos, estas fugaspueden tener un impacto importanteen laszonaspróximas.

\section{Aislamiento}

El emplazamiento de las fábricas lejos de receptores sensibles puede ser uno de los mejores métodos de control cuando los sistemas tecnológicos son insuficientes. Esta puede ser la única forma de conseguir un aceptable nivel de control debiéndose confiar en la mejor tecnología de control disponible (BACT). Si aún habiendo aplicado los mejores controles disponibles, sigue existiendo riesgo para algún grupo de receptores, deberá considerarse otro emplazamiento alejado de poblaciones sensibles.

El aislamiento consiste, por tanto, en alejar a la fábrica de los receptores sensibles. 0 tro sistema de aislamiento es cuando las administraciones locales utilizan la zonificación para separar las industrias de receptores sensibles. U na vez que las industrias se han alejado de la población sensible, no debe permitirse que la población se establezca cerca de la fábrica. Aunque esta solución parece de sentido común, en muchos casos no se respeta.

\section{Procedimientos de trabajo}

Deben desarrollarse procedimientos de trabajo para garantizar la utilización correcta y segura de los equipos, sin riesgo para los trabajadores o el medio ambiente. EI mantenimiento y utilización de los complejos sistemas de control de la contaminación atmosférica deben realizarse de forma adecuada y la formación del personal en este sentido es un factor muy importante. El personal debe aprender a utilizar y mantener los equipos para reducir 0 eliminar las emisiones de materiales peligrosos en el lugar de trabajo o en la comunidad. En algunos casos, la BACT obtendrá unos resultados aceptables sólo si existen unas buenas prácticas de trabajo.

\section{Vigilancia en tiempo real}

Los sistemas basados en la vigilancia en tiempo real no son muy populares y, por lo tanto, su utilización es escasa. En este caso, la vigilancia continua de las condiciones meteorológicas y de las emisiones puede combinarse con modelos de dispersión para predecir exposiciones a favor del viento. Cuando los niveles previstos de exposición se acercan a los considerados aceptables, esta información se utiliza para reducir las tasas de producción y las emisiones. Este es un método ineficiente, pero puede utilizarse como un método de control provisional en una fábrica ya existente. Puede utilizarse también para advertir a la población de que existen unas condiciones que pueden provocar concentraciones excesivas de contaminantes para que ésta adopte las medidas oportunas. Así, por ejemplo, si se advierte de que las condiciones atmosféricas son tales que el viento arrastrará niveles excesivos de dióxido de azufre procedentes de un horno de fundición, las poblaciones sensibles, como las personas asmáticas, podrán tomar las medidas oportunas (p. ej., no salir al exterior). Este método puede utilizarse también como control provisional hasta que se instalen los controles permanentes.

En algunas ocasiones, la vigilancia atmosférica y meteorológica en tiempo real se utiliza para evitar o reducir incidentes graves de contaminación atmosférica en lugares donde existen varias fuentes emisoras. Por ejemplo, si se esperan unos niveles excesivos de contaminación atmosférica, se puede limitar el transporte privado y proceder al cierre de las principales industrias contaminantes.

\section{Mantenimiento y limpieza}

En cualquier caso, la efectividad de los controles depende del mantenimiento y el uso correcto de los equipos, así como de los procesos que generan las emisiones. Valga como ejemplo un proceso industrial que utiliza un secador de virutas de madera con un controlador de temperatura defectuoso. Si el secador se utiliza a una temperatura excesiva, emitirá más materiales 0 quizá un tipo diferente de material a partir de la madera que se está secando. 0 tro ejemplo sería una depuradora de gases con un precipitador de polvos sometido a un mantenimiento defectuoso y cuyas bolsas estuvieran rotas, lo que permitiría que las partículas atravesaran el filtro.

La limpieza juega asimismo un papel importante en el control de la cantidad total de emisiones. L os polvos que no son depurados rápidamente dentro de la fábrica pueden volver a introducirse en ella, poniendo en riesgo al personal, o dispersarse en el exterior de la fábrica, poniendo en peligro a la comunidad. Asimismo, una limpieza insuficiente de las instalaciones de una fábrica puede ocasionar un riesgo importante para la comunidad. L os materiales que se almacenan a granel sin ningún tipo de recubrimiento, los residuos de los procesos de producción o el polvo levantado por los vehículos pueden hacer que los contaminantes sean transportados por el viento hacia una población. El mantenimiento de unas instalaciones limpias y la utilización de unos depósitos o almacenes adecuados son medidas importantes para reducir la cantidad total de emisiones. Para proteger a la comunidad, el sistema no sólo debe estar bien diseñado, sino también ser utilizado correctamente.

Un ejemplo del caso más desfavorable de mantenimiento defectuoso es el de una fábrica de recuperación de plomo con un transportador de polvo de plomo en malas condiciones. EI polvo pudo escapar del transportador y se fue acumulando hasta formar un montón tan alto que salió por una ventana rota. L os vientos locales lo transportaron hasta una población cercana a la fábrica.

\section{Equipos para el muestreo de emisiones}

\section{El muestreo de una fuente puede realizarse con distintos fines:}

- Caracterización de las emisiones. Para diseñar un sistema de control de contaminación atmosférica deben conocerse las emisiones, pero no sólo el volumen de gas, sino también la cantidad, identidad y, en el caso de partículas, la distribución de tamaños del material liberado. Esta información es también necesaria para determinar la exposición total de una población cercana. 
Figura 55.5 - Diagrama de un tren de muestreo isocinético para dióxido de azufre.

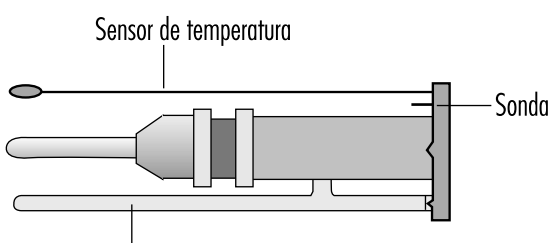

Tubo Pitot
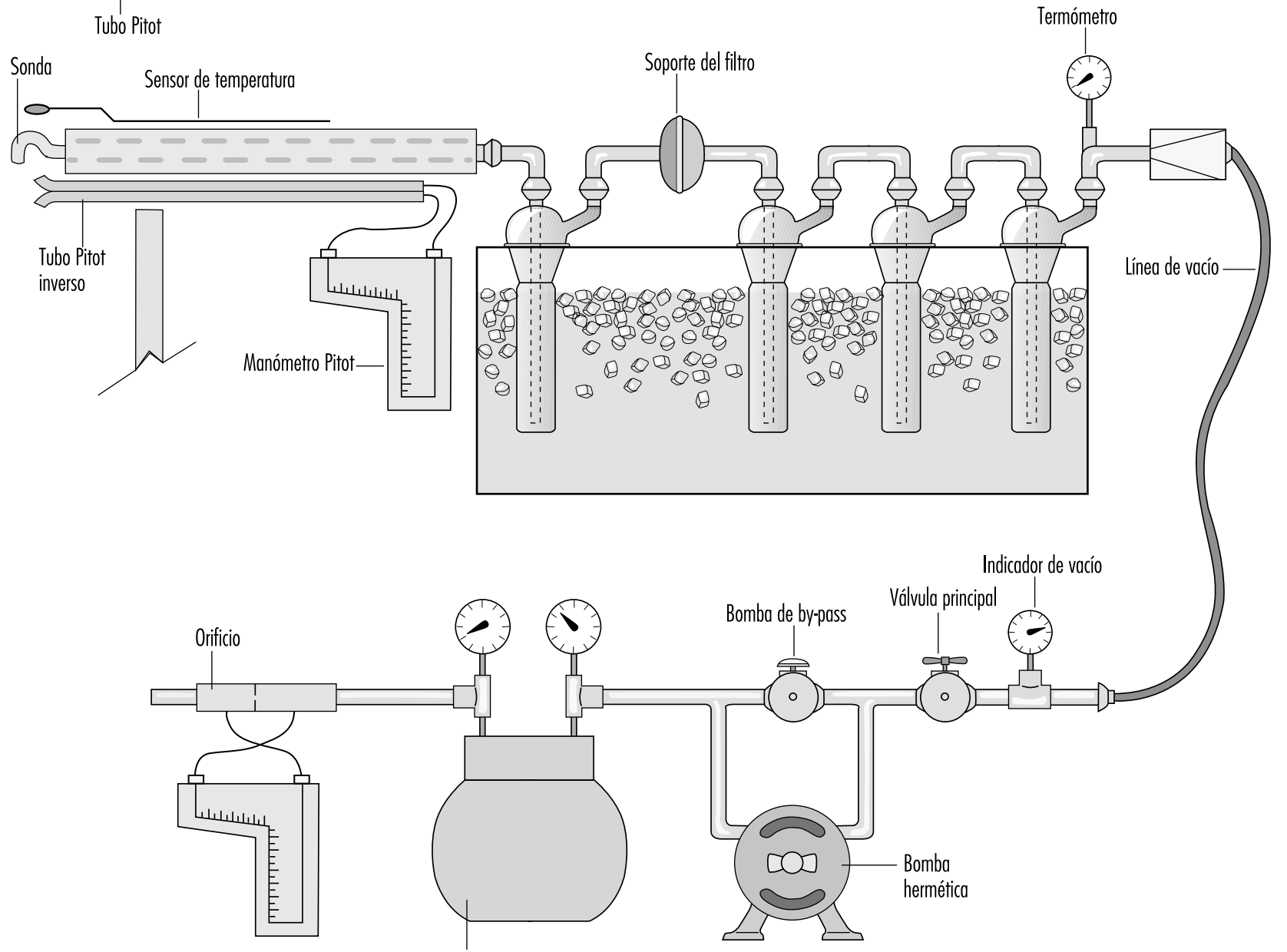

Medidor de ensayo en seco

- Control de la eficiencia de los equipos. U na vez adquirido un sistema de control de contaminación atmosférica, debe comprobarse que funciona correctamente.

- Como parte de un sistema de control. Cuando se lleva a cabo una vigilancia continua de las emisiones, los datos obtenidos pueden utilizarse para mejorar el sistema de control de contaminación atmosférica o el propio funcionamiento de la fábrica.

- Comprobación del cumplimiento de las normas. Si las normas y reglamentos establecen límites de emisión, el muestreo de emisiones puede utilizarse para comprobar su cumplimiento.

El tipo de sistema de muestreo utilizado dependerá de su objetivo, los costes, la disponibilidad de tecnología y la formación del personal.

\section{E misiones visibles}

Cuando se desea mejorar la calidad del aire, aumentar la visibilidad o evitar la emisión de aerosoles a la atmósfera, las normas pueden basarse en las emisiones visibles.
Las emisiones visibles están compuestas por pequeñas partículas o gases de color. Cuanto más opaco es un penacho, más cantidad de material se está emitiendo. Esta característica, evidente a simple vista, puede ser utilizada por observadores expertos para valorar los niveles de emisión.

$L$ as ventajas de este método de valoración de los niveles de emisión son las siguientes:

- No se necesitan equipos costosos.

- Una sola persona puede realizar múltiples observaciones en un mismo día.

- Los técnicos de la fábrica pueden valorar rápidamente y a un bajo coste el efecto de cambios en los procesos.

- Se puede amonestar a los infractores sin necesidad de realizar pruebas en la fuente emisora, que consumen mucho tiempo.

- Se pueden identificar emisiones dudosas y a continuación determinar las emisiones reales mediante pruebas en la fuente, según se describe en las secciones siguientes. 


\section{M uestreo extractivo}

Un método de muestreo mucho más riguroso consiste en tomar en la chimenea una muestra de la corriente de gas y analizarla a continuación. Aunque parece sencillo, el método de muestreo no lo es tanto.

Las muestras deben recogerse mediante un procedimiento isocinético, especialmente cuando se trata de partículas. EI muestreo isocinético consiste en introducir la muestra en la sonda a la misma velocidad con la que el material se desplaza por la chimenea o el conducto. Para ello se determina la velocidad de la corriente de gas con un tubo Pitot y se ajusta después la velocidad de muestreo de forma que la muestra se introduzca en la sonda a la misma velocidad. Este tipo de muestreo es fundamental cuando se trata de partículas, puesto que las partículas más grandes y pesadas no seguirán un cambio de dirección 0 velocidad. Como consecuencia, la concentración de las partículas mayores de la muestra no será representativa de la corriente de gas y el muestreo dará resultados erróneos.

En la Figura 55.5 se muestra un tren de muestreo para el dióxido de azufre, sistema que presenta una cierta complejidad y tiene que ser manejado por un técnico experto. Para muestrear sustancias diferentes al dióxido de azufre, se pueden eliminar los impingers y el baño de hielo e introducir un dispositivo de recogida adecuado.

El muestreo extractivo, y en especial el isocinético, pede ser muy exacto y versátil y utilizarse para distintos fines:

- Es un método de muestreo reconocido cuando se acompaña de controles de calidad adecuados y, por lo tanto, puede utilizarse para comprobar el cumplimiento de las normas.

- La precisión de este método lo hace indicado para determinaciones del rendimiento de nuevos equipos de control.

- Puesto que las muestras pueden tomarse y analizarse en condiciones controladas de laboratorio para un gran número de componentes, esta técnica de muestreo es útil para caracterizar la corriente de gas.

La vigilancia continua de las emisiones puede realizarse conectando un sistema de muestreo simplificado y automatizado a un analizador continuo de gases (sensores electroquímicos, fotométricos UV o de ionización de llama) o de partículas (nefelómetro). D e esta manera se obtienen datos sobre las emisiones y se puede conocer al instante el estado del sistema de control de la contaminación atmosférica.

Figura 55.6 • Transmisómetro sencillo para medir partículas en una chimenea.

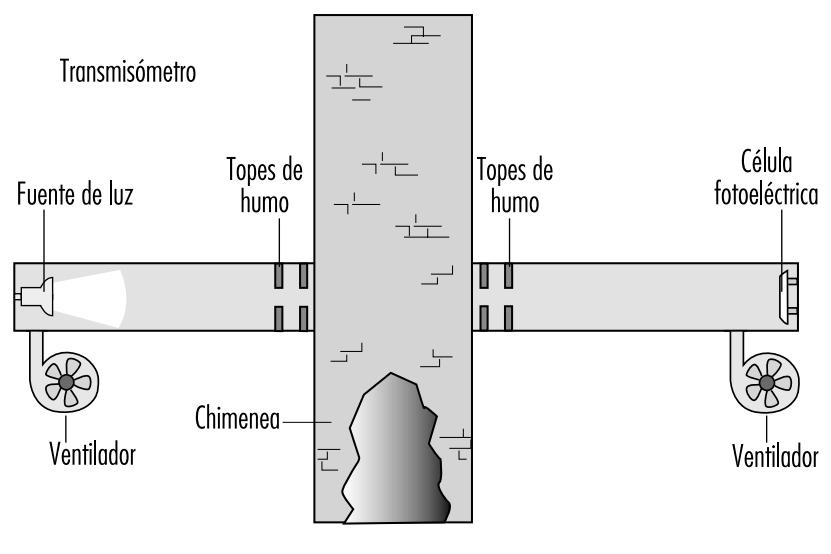

\section{M uestreo in situ}

L as emisiones pueden muestrearse también en la chimenea. En la Figura 55.6 se muestra un transmisómetro sencillo utilizado para determinar los materiales presentes en la corriente de gas. En este ejemplo se dirige un rayo de luz a una célula fotoeléctrica a través de la chimenea. Las partículas o los gases de color absorben 0 bloquean parte de la luz. Cuanto mayor sea la cantidad de material presente, menor será la cantidad de luz que llegue a la célula fotoeléctrica (véase Figura 55.6).

Con diferentes fuentes de luz y detectores como, por ejemplo, luz ultravioleta (UV), se detectan gases transparentes a la luz visible. Estos equipos pueden ajustarse a gases específicos para determinar la concentración de gases en el chorro liberado.

Los sistemas de vigilancia in situ pueden medir la concentración a lo largo de toda la chimenea o conducto, mientras que el método extractivo determina las concentraciones sólo en el punto en el que se toma la muestra, dando lugar a errores significativos si la muestra de la corriente de gas no está bien mezclada. No obstante, el muestreo extractivo dispone de un mayor número de métodos de análisis y puede utilizarse en numerosas aplicaciones.

Los sistemas in situ proporcionan una lectura continua y pueden utilizarse para documentar las emisiones o para mejorar el sistema operativo.

\section{CONTROL DE LA CONTAMINACION DEL AGUA}

H erbert C. Preul

Este artículo pretende ofrecer al lector una visión de conjunto de las tecnologías actualmente disponibles para el control de la contaminación del agua, basándose en el análisis de tendencias y casos realizado por $\mathrm{H}$ espanhol y $\mathrm{H}$ elmer en el capítulo 53: Riesgos ambientales para la salud. En las siguientes secciones se estudia el control de los problemas de contaminación del agua, primero bajo el título "Control de la contaminación de las aguas superficiales" y a continuación en "Control de la contaminación de las aguas subterráneas".

\section{Control de la contaminación de las aguas superficiales}

\section{Definición de contaminación del agua}

El concepto de contaminación del agua indica un estado cualitativo de impureza o suciedad de las aguas hidrológicas de una cierta región, tal como cuenca hidrográfica. Ello es consecuencia de una situación o un proceso que reduce la utilidad de las aguas de nuestro planeta, especialmente por sus efectos en la salud humana y el medio ambiente. El proceso de contaminación conlleva una pérdida de pureza como consecuencia de la intrusión o el contacto de una fuente externa. El término 'turbio' se aplica a niveles extremadamente bajos de contaminación del agua, es decir, en su etapa inicial de corrupción y descomposición. El ensuciamiento es una consecuencia de la contaminación y sugiere violación o profanación.

\section{Aguas hidrológicas}

Las aguas naturales de la Tierra pueden considerarse como un sistema de circulación continua, tal como se indica en la Figura 55.7, en donde se representa el ciclo hidrológico de las aguas, tanto superficiales como subterráneas.

Como referencia de calidad del agua, el agua destilada $\left(\mathrm{H}_{2} \mathrm{O}\right)$ representa el máximo estado de pureza. Las aguas del ciclo 
Figura 55.7 • El ciclo hidrológico.

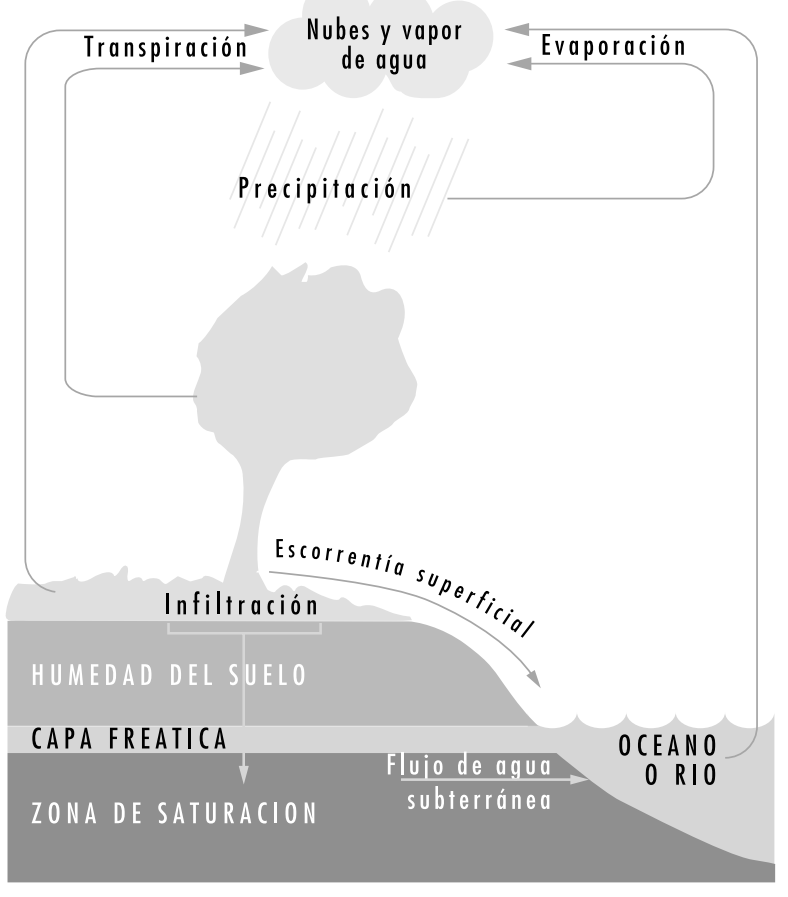

hidrológico pueden considerarse naturales, pero no son puras, ya que están contaminadas por actividades tanto naturales como humanas. Existen numerosas fuentes de degradación natural: fauna, flora, erupciones volcánicas, rayos que causan incendios,

Figura 55.8 • Distribución de las precipitaciones.

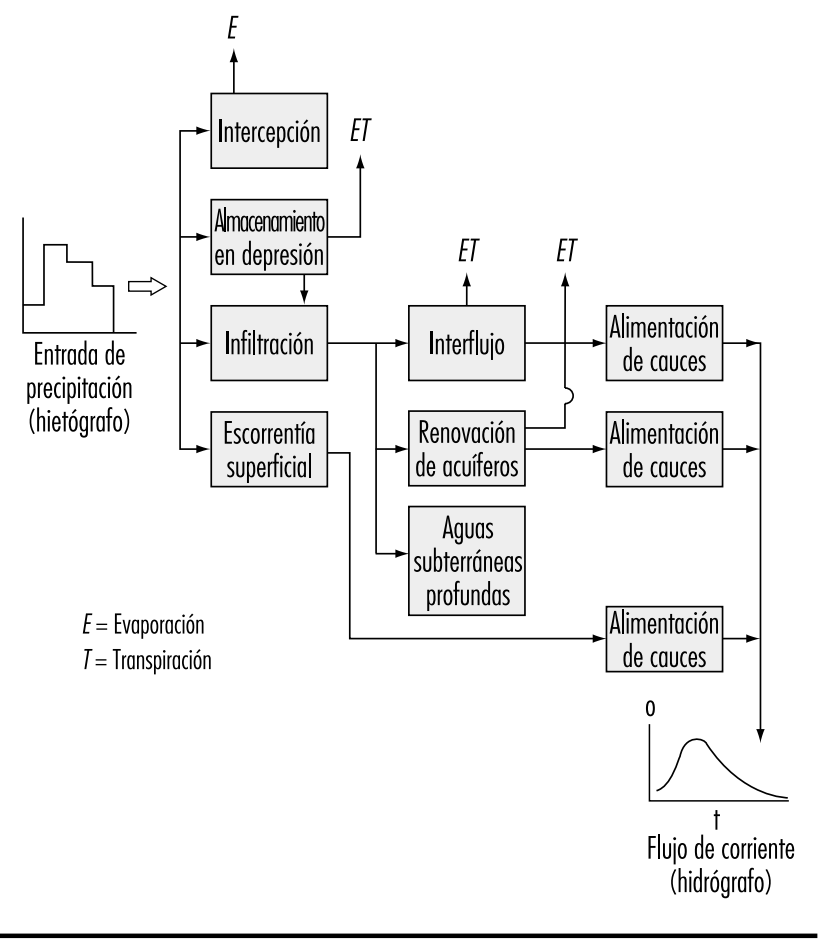

etc., que a largo plazo generan unos niveles de contaminación de fondo muy importantes para fines científicos.

La contaminación causada por el hombre altera el equilibro natural de las aguas al añadir residuos procedentes de diversas fuentes. Los contaminantes pueden introducirse en las aguas en cualquier punto del ciclo hidrológico. Así, por ejemplo, las precipitaciones atmosféricas (lluvia) pueden contaminarse por las sustancias presentes en la atmósfera; las aguas superficiales pueden contaminarse durante el proceso de escorrentía desde las cuencas hidrográficas; los arroyos y ríos pueden contaminarse por el vertido de aguas residuales y las aguas subterráneas, por infiltraciones y contaminación subterránea.

En la Figura 55.8 se muestra la distribución de las aguas hidrológicas. La contaminación afecta a estas aguas a través de lo que podría considerarse una condición ambiental artificial o desequilibrada. El proceso de la contaminación de las aguas puede tener lugar en cualquier punto del ciclo hidrológico, aunque resulta más evidente en la superficie de la tierra, en la escorrentía de cuencas hidrográficas que alimenta arroyos y ríos. Sin embargo, la contaminación de las aguas subterráneas también supone un impacto ambiental importante y se analiza en este documento a continuación de la sección dedicada a la contaminación de las aguas superficiales.

\section{Las cuencas hidrográficas como fuentes de contaminación del agua}

L as cuencas hidrográficas son las primeras afectadas por la contaminación de las aguas superficiales. U na cuenca hidrográfica se define como un área de la superficie de la tierra donde las aguas hidrológicas llegan, se acumulan, se utilizan, se extraen y, en algunos casos, se vierten en arroyos, ríos u otras masas de agua. Constan de un sistema de drenaje con escorrentía o vertido final a un arroyo o río. L as cuencas hidrográficas de los grandes ríos se denominan habitualmente cuencas de drenaje. En la Figura 55.9 se presenta el ciclo hidrológico de una cuenca hidrográfica

Figura 55.9 - Ciclo hidrológico regional.

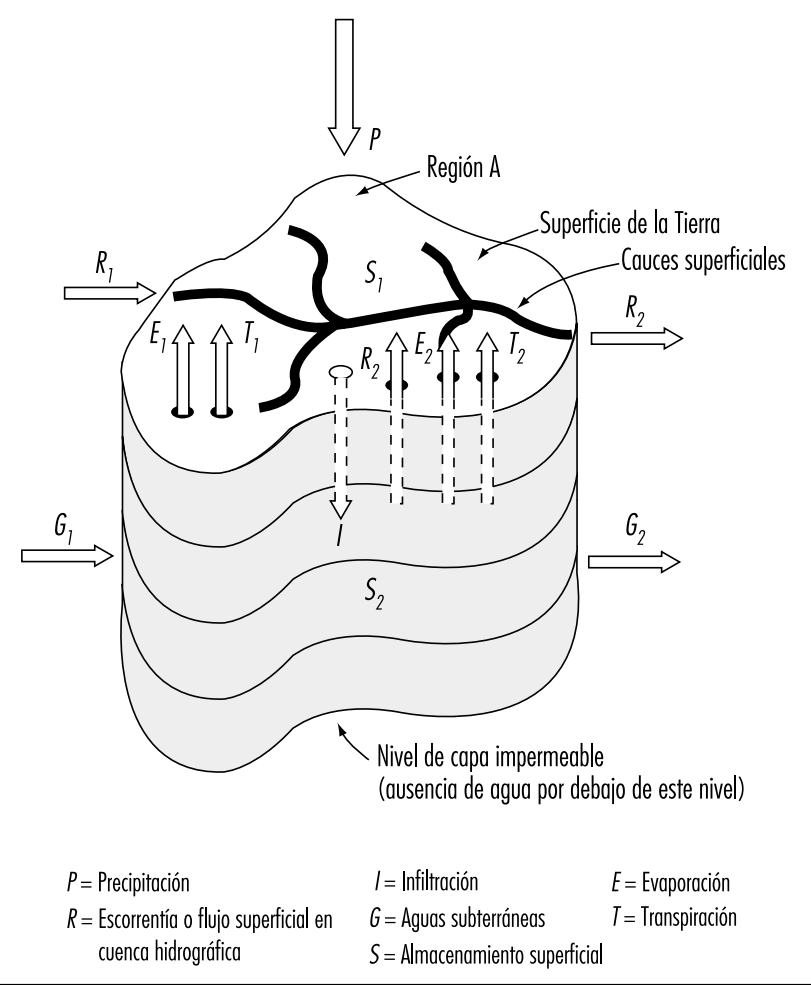


regional. En una determinada región, la disposición de las diferentes aguas puede expresarse como una sencilla ecuación, la ecuación básica de hidrología propuesta por Viessman, Lewis y $\mathrm{K}$ napp (1989) (unidades en $\mathrm{mm} /$ año):

$$
P-R-G-E-T= \pm A
$$

donde:

$P=$ precipitación ( $p$. ej., lluvia, nieve, granizo)

$R=$ escorrentía o corriente superficial dela cuenca hidrográfica

$G=$ aguas subterráneas

$\mathrm{E}=$ evaporación

$\mathrm{T}=$ transpiración

$A=$ almacenamiento en la superficie

Puede considerarse que el ciclo hidrológico comienza por las precipitaciones. El término escorrentía es sinónimo de cursos de agua. EI término almacenamiento se refiere a presas o sistemas de retención de aguas; así, por ejemplo, una presa artificial en un río crea un almacenamiento de agua. $L$ as aguas subterráneas constituyen otro sistema de almacenamiento y pueden fluir de un punto a otro, en el mismo sentido o en sentido contrario a los cursos de agua superficiales. La evaporación es un fenómeno asociado a las aguas superficiales y en la transpiración intervienen los seres vivos.

Aunque las cuencas hidrográficas pueden ser de tamaños muy diferentes, algunos sistemas de drenaje se clasifican como urbanos o no urbanos (agrícola, rural, no desarrollado) para estudiar los efectos de la contaminación de las aguas. La contaminación dentro de estos sistemas de drenaje procede de las siguientes fuentes:

Fuentes localizadas: vertido de residuos a una masa de agua receptora en un lugar específico, por ejemplo, a través de una alcantarilla o algún tipo de salida de un sistema cerrado.

Fuentes no localizadas (dispersas): contaminación de una masa de agua receptora procedente de fuentes dispersas en la cuenca hidrográfica, como ocurre en el caso de la escorrentía de la lluvia que fluye a un curso de agua. Las fuentes no localizadas reciben también el nombre de aguas "difusas", aunque el término de fuentes dispersas es quizá más descriptivo.

Fuentes inter mitentes: contaminación procedente de un punto o una fuente que sólo se descarga en determinadas circunstancias, como, por ejemplo, en condiciones de sobrecarga. Ejemplos típicos de estas fuentes son los desbordamientos de aguas residuales durante períodos de lluvias fuertes.

\section{Contaminación de arroyos y ríos}

Cuando las fuentes antes descritas vierten residuos nocivos a cursos de agua u otras masas de agua, se convierten en los contaminantes ya clasificados y descritos en una sección anterior de este mismo capítulo. Estos contaminantes pueden dividirse en:

- contaminantes degradables (no permanentes): impurezas que se descomponen en sustancias inofensivas o que pueden eliminarse con algún tratamiento como, por ejemplo, ciertos materiales orgánicos y químicos, residuos domésticos, calor, nutrientes vegetales, gran parte de las bacterias y virus o ciertos sedimentos

- contaminantes no degradables (permanentes): impurezas que permanecen en el medio acuático y no reducen su concentración salvo por dilución o por eliminación mediante tratamiento como, por ejemplo, ciertos productos químicos orgánicos e inorgánicos, sales o suspensiones coloidales

- contaminantes peligrosos transportados por el agua: formas complejas de residuos nocivos entre los que se encuentran metales traza tóxicos y ciertos compuestos inorgánicos y orgánicos

- contaminantes radionuclécos: materiales que proceden de una fuente radiactiva.

\section{Legislación en materia de contaminación de las aguas}

La legislación general en materia de control de la contaminación de las aguas suele ser promulgada por los organismos públicos nacionales, mientras que las disposiciones legales más detalladas son responsabilidad de las regiones, las provincias, los municipios, los distritos hidrográficos, los distritos de conservación, las comisiones de sanidad, etc. En el ámbito nacional y regional (o provincial), los responsables suelen ser las agencias de protección del medio ambiente y los ministerios de sanidad. En la siguiente sección se revisa la legislación actual; su formato y algunas partes de la misma se han extraído de las normas sobre la calidad del agua que se aplican actualmente en el estado americano de 0 hio.

\section{Designaciones de uso en función de la calidad del agua}

El objetivo último del control de la contaminación del agua sería la completa eliminación del vertido de contaminantes, pero este objetivo casi nunca es factible desde el punto de vista económico. El enfoque más utilizado es imponer ciertos límites al vertido de residuos para asegurar una protección razonable de la salud humana y el medio ambiente. Aunque estos límites varían ampliament esegún los territorios jurisdiccionales, por lo general se basan en designaciones de uso de las diferentes masas de agua, como veremos brevemente a continuación.

\section{Las designaciones de uso como abastecimiento de agua pueden ser:}

- abastecimientos de agua potable: aguas que, con un tratamiento convencional, son aptas para el consumo humano;

- abastecimientos agrícolas: aguas que, sin tratamiento, son aptas para el riego y el consumo animal,

- abastecimientos industriales y comerciales: aguas que, con o sin tratamiento, son aptas para uso industrial y comercial.

\section{Las designaciones de uso para actividades recreativas comprenden:}

- aguas para baño: aguas que durante ciertas épocas del año son aptas para practicar la natación con una calidad de agua homologada y en las que existen condiciones e instalaciones de seguridad;

- contacto primario: aguas que durante ciertas épocas del año son aptas para practicar actividades recreativas que implican un contacto total del cuerpo con el agua, como, por ejemplo, la natación, el piragüismo y el submarinismo, y que suponen un riesgo mínimo para la salud pública por la calidad del agua,

- contacto secundario: aguas que durante ciertas épocas del año son aptas para practicar actividades recreativas que implican un contacto parcial del cuerpo como, por ejemplo, el vadeado, y que suponen un riesgo mínimo para la salud pública por la calidad del agua.

Los recursos hídricos públicos se clasifican como masas de agua que se encuentran dentro de parques naturales, zonas húmedas o parajes naturales, ríos salvajes, pintorescos o recreativos, lagos de propiedad pública y aguas con especial interés recreativo o ecológico.

\section{Hábitats acuáticos}

Las designaciones típicas varían según el clima, pero siempre deben tenerse en cuenta las condiciones de las masas de agua necesarias para proteger y soportar la vida de ciertos organismos acuáticos, especialmente distintas especies de peces. Por ejemplo, en la normativa adoptada por la Agencia de Protección del 
M edio A mbiente (EPA) del estado de 0 hio (Estados U nidos), las designaciones de uso en un clima templado se subdividen en:

- aguas cálidas;

- aguas cálidas limitadas;

- aguas cálidas excepcionales;

- aguas cálidas modificadas;

- aguas de salmónidos de temporada;

- aguas frías,

- recursos hídricos limitados.

Criterios para el control de la contaminación del agua

Las aguas naturales y las aguas residuales se caracterizan por su composición física, química y biológica. Las principales propiedades físicas y los elementos químicos y biológicos presentes en las aguas residuales y sus fuentes forman una larga lista que puede encontrarse en un libro escrito por M etcalf y Eddy (1991). Los métodos analíticos utilizados para estas determinaciones se describen en un manual ampliamente utilizado: Standard M ethods for the Examination of W ater and W aste W ater de la A merican Public H ealth Association (1995).

Las masas de agua a las que se les designa un uso deben controlarse de acuerdo con la normativa vigente, que puede establecer criterios numéricos básicos y otros más detallados, como se comenta brevemente a continuación.

Ausencia básica de contaminación. En la práctica y en la medida de lo posible, todas las masas de agua deben cumplir los criterios básicos de los "cinco tipos de contaminantes ausentes":

1. ausencia de sólidos en suspensión o de otras sustancias que hayan llegado al agua como consecuencia de la actividad humana y que al sedimentarse formen masas de lodo putrefacto 0 rechazable desde cualquier otro punto de vista, 0 afecten negativamente a la vida acuática

2. ausencia de residuos flotantes, aceite, espuma u otras sustancias flotantes que hayan llegado al agua como consecuencia de la actividad humana en cantidad suficiente como para resultar desagradables a la vista o causar degradación

3. ausencia de materiales que hayan llegado al agua como consecuencia de la actividad humana y que produzcan color, olor u otras condiciones desagradables

4. ausencia de materiales que hayan llegado al agua como consecuencia de la actividad humana en concentraciones tóxicas o nocivas para la vida humana, animal o acuática y/ o que puedan ser rápidamente letales en la zona de mezclado

5. ausencia de nutrientes que hayan llegado al agua como consecuencia de la actividad humana en concentraciones que causen un crecimiento anormal de plantas acuáticas y algas.

Los criterios de calidad del agua consisten en límites cuantitativos y directrices para controlar los elementos químicos, biológicos y tóxicos en las masas de agua.

A ctualmente se utilizan más de 70.000 compuestos químicos, por lo que resulta imposible especificar el control al que debe someterse cada uno de ellos. No obstante, pueden distinguirse tres clases de criterios aplicados a los compuestos químicos según las limitaciones en el consumo y la exposición:

Clase 1: Los criterios aplicados a los productos químicos con la finalidad de proteger la salud humana son los más importantes y deben establecerse de acuerdo con las recomendaciones de las administraciones sanitarias, la O M S y las organizaciones reconocidas en el campo de la investigación sanitaria.

Clase 2: L os criterios aplicados a los productos químicos con la finalidad de controlar los abastecimientos de agua para actividades agrícolas deben basarse en estudios científicos reconocidos y en recomendaciones para proteger los cultivos y el ganado frente a posibles efectos nocivos.

Clase 3: L os criterios aplicados a los productos químicos con la finalidad de proteger la vida acuática deben basarse en estudios científicos reconocidos sobre la sensibilidad de estas especies a productos químicos específicos y con relación al consumo humano de peces y mariscos.

Los criterios aplicados al vertido de aguas residuales establecen límites en la presencia de contaminantes en estas aguas y constituyen otro método de control. Pueden establecerse en relación con las designaciones de uso de las masas de agua o en función de las tres clases anteriores de criterios químicos.

L os criterios biológicos se basan en las condiciones de hábitat de las masas de agua necesarias para mantener la vida acuática.

\section{Contenido de materia orgánica en las aguas residuales y naturales}

EI contenido de materia orgánica es un factor fundamental para caracterizar la capacidad contaminante de las aguas residuales y naturales. A estos efectos se suelen utilizar tres pruebas de laboratorio:

D emanda bioquímica de oxígeno (D B O ): el parámetro más utilizado es el DBO durante cinco días (DBO5), que corresponde al oxígeno disuelto utilizado por los microorganismos para la oxidación bioquímica de materia orgánica durante un período de cinco días.

Demanda química de oxígeno ( $\mathrm{QQO})$ : este parámetro permite determinar el contenido de materia orgánica procedente de residuos municipales e industriales que contienen compuestos tóxicos para la vida biológica; es una medida del equivalente de oxígeno de la materia orgánica que puede oxidarse.

Carbono orgánico total (COT ): este parámetro se utiliza principalmente cuando el agua contiene pequeñas concentraciones de materia orgánica; es una medida de la materia orgánica que se oxida a dióxido de carbono.

\section{Políticas contra la degradación}

Las políticas contra la degradación intentan también evitar la dispersión de los contaminantes acuáticos más allá de ciertos límites. Citaremos aquí como ejemplo las normas sobre la calidad del agua de la política contra la degradación de la Agencia de Protección del M edio Ambiente (EPA) del estado americano de $O$ hio, que constan de tres niveles:

Nivel 1: M antenimiento y protección de los usos actuales. No se permitirá una mayor degradación de la calidad del agua que pueda interferir con las actuales designaciones de uso.

Nivel 2: M antenimiento de una calidad del agua superior a la necesaria para proteger las designaciones de uso, salvo que existan razones económicas o sociales suficientemente

Figura 55.10 • Zonas de mezclado.

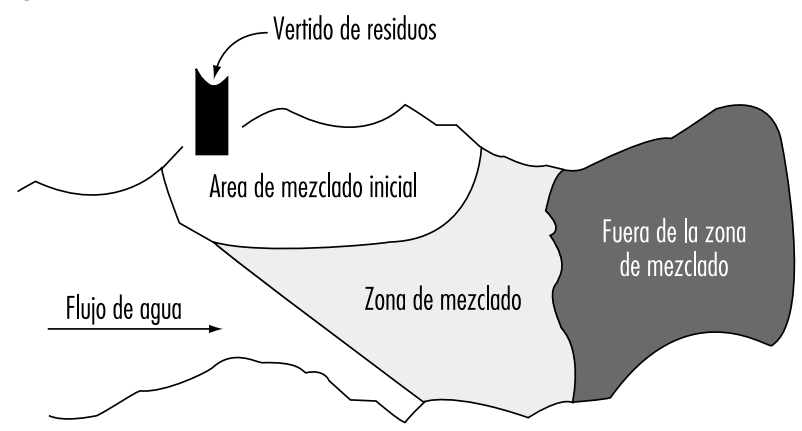

Fuente: Estado de Ohio 1995 
importantes para justificar una calidad inferior del agua, una decisión que tomará siempre el Director de la EPA.

Nivel 3: Mantenimiento y protección de la calidad de los recursos hídricos. La calidad del agua no podrá deteriorarse por el vertido de alguna sustancia que se haya comprobado que es tóxica o que interfiere con alguno de los usos designados. Se permitirán vertidos mayores de contaminantes a las masas de agua siempre que no deterioren la calidad del agua.

\section{Zonas de mezclado de los contaminantes vertidos al agua y} modelos para la selección del lugar de vertido de residuos

En una masa de agua, las zonas de mezclado son áreas en donde los vertidos de aguas residuales, hayan o no recibido tratamiento previo, alcanzan condiciones estabilizadas, como puede observarse en la Figura 55.10 para una corriente de agua. Inicialmente el vertido pasa por una fase transitoria en la que se diluye poco a poco de la concentración de la fuente a las condiciones del agua receptora. Este método no debe considerarse como un tratamiento y puede someterse a restricciones específicas. Las zonas de mezclado no deben:

- interferir con la migración, supervivencia, reproducción o crecimiento de las especies acuáticas;

- incluir áreas de reproducción o anidación;

- incluir puntos de abastecimiento de agua potable;

- incluir áreas de baño;

- abarcar más de la mitad del ancho del curso de agua;

- abarcar más de la mitad del área transversal del curso de agua,

- extenderse corriente abajo a una distancia cinco veces mayor al ancho del curso de agua.

Los estudios para la selección del lugar de vertido de residuos han cobrado especial interés debido al alto coste inherente al control de nutrientes en los vertidos de aguas residuales para evitar la eutrofización (definida más adelante). Estos estudios suelen recurrir a modelos informáticos para simular las condiciones de calidad del agua en un curso de agua, especialmente con respecto a nutrientes como los compuestos nitrogenados y fosforados que afectan a la dinámica del oxígeno disuelto. Los modelos tradicionales de calidad del agua están representados por el sistema QUAL2E de la Agencia de Protección de M edio Ambiente de Estados U nidos, propuesto por Brown y Barnwell (1987). El modelo más reciente de Taylor (1995), O mni Diurnal $M$ odel (ODM), incluye una simulación del impacto de la vegetación acuática con raíces sobre la dinámica del oxígeno disuelto y los nutrientes en la corriente de agua.

\section{Necesidad de una cierta flexibilidad}

Las normas sobre el control de la contaminación del agua son imperfectas y, por tanto, deben incluir disposiciones que permitan una cierta flexibilidad en aquellas circunstancias en las que resulte imposible su cumplimiento inmediato o estricto.

\section{Valoración y gestión de riesgos con relación a la contaminación del agua}

Las anteriores disposiciones legales sobre el control de la contaminación del agua son típicas de las estrategias de todos los gobiernos para conseguir que se respeten las normas sobre la calidad del agua y los límites de vertido de aguas residuales. Por lo general, estas normativas se basan en factores relacionados con la salud y en la investigación científica o, cuando existe una cierta incertidumbre sobre los posibles efectos, en criterios referentes a la seguridad. El cumplimiento de algunas de estas normas puede suponer un coste excesivo e injustificado para el público en general y para las empresas privadas. Por esta razón, la necesidad de una asignación más eficiente de los recursos es fundamental para mejorar la calidad del agua. C omo se dijo antes al hablar de las aguas hidrológicas, la pureza cristalina no se encuentra ni siquiera en las aguas naturales.

U n enfoque tecnológico cada vez más aceptado consiste en la evaluación y la gestión de los riesgos ecológicos como base de la legislación sobre la contaminación del agua. Este modelo se basa en el análisis de las ventajas y los costes ecológicos de cumplimiento de las normas o límites. Parkhurst (1995) propone realizar una valoración de los riesgos ecológicos acuáticos como ayuda para establecer los límites de control de la contaminación del agua, especialmente para proteger la vida acuática. Estos métodos de valoración de riesgos pueden utilizarse para estimar los efectos ecológicos de las concentraciones de productos químicos para una amplia variedad de condiciones de contaminación de las aguas superficiales como:

- contaminación por fuentes localizadas;

- contaminación por fuentes dispersas;

- sedimentos contaminantes en los cauces de los cursos de agua

- acumulación de residuos peligrosos en masas de agua,

- análisis de los criterios existentes para el control de la contaminación del agua.

El método propuesto consta de tres niveles, según se indica en la Figura 55.11.

Figura 55.11 • Métodos de valoración de riesgos para niveles sucesivos de a nálisis. $\mathrm{N}$ ivel 1: Mediciones preliminares. $\mathrm{N}$ ivel 2: Cuantificación de riesgos potencialmente significativos. $\mathrm{N}$ ivel 3: Cuantificación de riesgos específicos de un lugar.

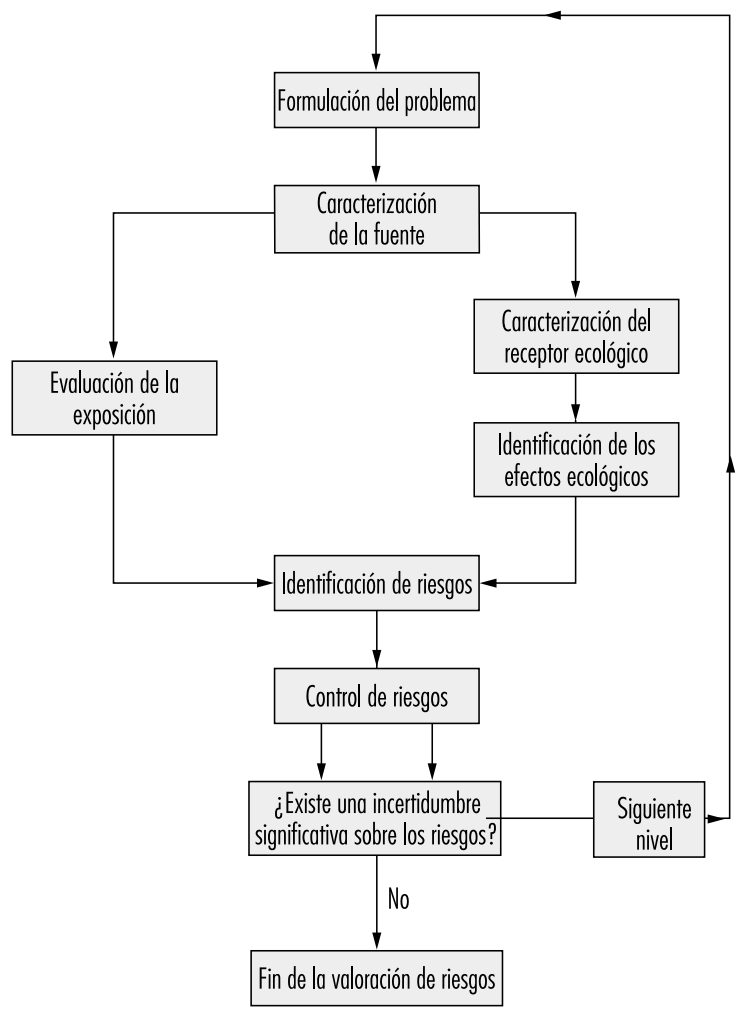




\section{Contaminación de lagos y pantanos}

Los lagos y los pantanos almacenan el agua que entra en la cuenca hidrográfica y pueden presentar períodos prolongados de descarga de agua en comparación con la rápida entrada y salida de agua en un cauce fluvial. Los lagos y pantanos tienen por tanto un especial interés por la retención de ciertos elementos, en especial nutrientes como los compuestos nitrogenados y fosforados que favorecen la eutrofización, un proceso natural de envejecimiento por el cual aumenta el contenido orgánico del agua, dando lugar a un crecimiento dominante de especies no deseadas, como algas, jacintos acuáticos, etc. El proceso eutrófico tiende a deteriorar la vida acuática e incide negativamente en el oxígeno disuelto. Tanto las fuentes naturales como artificiales de nutrientes pueden acelerar este proceso, como lo ilustra Preul (1974) en la Figura 55.12, donde aparece una lista esquemática de fuentes y sumideros de nutrientes en el Lago Sunapee, en el estado americano de $\mathrm{New} \mathrm{H}$ ampshire.

En los lagos y pantanos se realizan muestreos y análisis para determinar su estado trófico. L os estudios analíticos comienzan, por lo general, con un equilibrio básico de nutrientes como el siguiente:

(nutrientes en los afluentes del lago) $=$ (nutrientes en los efluentes del lago) + (nutrientes retenidos en el lago)

Figura 55.12 • Lista esquemática de fuentes y sumideros de nutrientes (nitrógeno y fósforo) en el Lago Sunapee, N ew Hampshire (Estados Unidos)

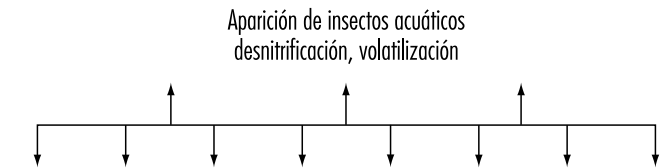

Fuentes naturales de nutrientes Precipitación (lluvias) Fuentes artificiales de nutrientes - Escorrentía forestal

- Escorrentía de praderas

- Erosión del suelo

- Residuos de pájaros y animales

- Hojas y polen

- Fijación del nitrógeno

- Reciclado de sedimentos

- Influjos de agua subterránea

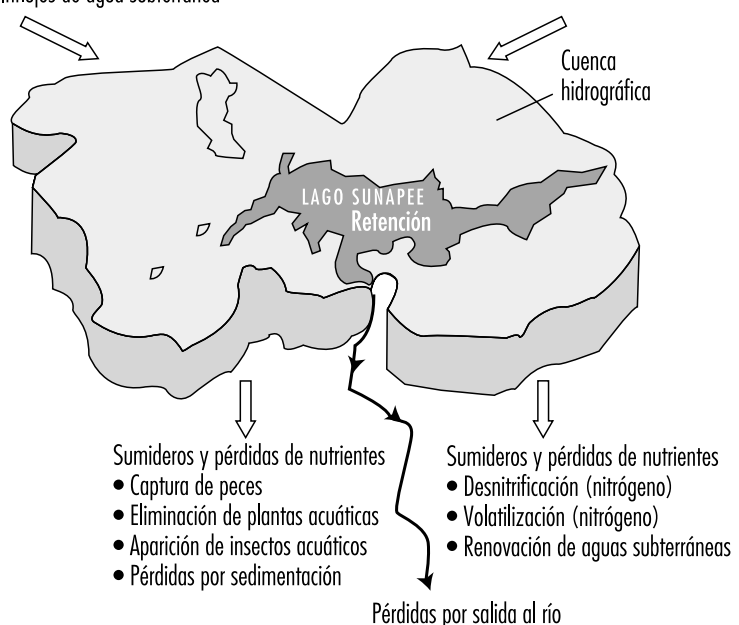

Pérdidas por salida al río
Este equilibrio básico puede ampliarse para incluir las diferentes fuentes que se muestran en la Figura 55.12.

En un sistema lacustre, el tiempo de descarga está relacionado con los aspectos relativos a la retención de nutrientes. Los lagos poco profundos, como el Lago Erie, presentan tiempos de descarga relativamente cortos que van unidos a una eutrofización avanzada, puesto que estos lagos suelen ser más propensos al crecimiento de plantas acuáticas. Los lagos profundos, como el Lago Tahoe y el Lago Superior, presentan tiempos de descarga muy prolongados que se asocian, por lo general, a estados de eutrofización mínima, ya que hasta el momento no han sufrido sobrecarga y sus extremas profundidades no favorecen un crecimiento masivo de plantas acuáticas, excepto en su epiliminión (zona superior). La mayoría de ellos son lagos oligotróficos, es decir, con un contenido relativamente bajo de nutrientes y un crecimiento acuático mínimo de algas y otras plantas.

Resulta interesante comparar los tiempos de descarga de algunos de los principales lagos de Estados U nidos, según el estudio realizado por Pecor (1973) basado en la siguiente fórmula:

tiempo de descarga del lago [T DL] = (volumen de almacenamiento del lago)/ (flujo de salida del lago)

Entre los lagos estudiados se encuentran los siguientes: Lago Wabesa (M ichigan), TDL $=0,30$ años; Lago Houghton (M ichigan), 1,4 años; Lago Erie, 2,6 años; Lago Superior, 191 años y Lago Tahoe, 700 años.

Aunque la relación entre el proceso de eutrofización y el contenido de nutrientes es compleja, se suele considerar que el fósforo es el nutriente limitante. Sawyer (1947) estudió condiciones mixtas y observó que la proliferación de algas se produce cuando el contenido de nitrógeno supera $0,3 \mathrm{mg} / \mathrm{I}$ y el del fósforo, $0,01 \mathrm{mg} / \mathrm{l}$. En lagos y pantanos estratificados, el primer indicio de eutrofización es un bajo contenido de oxígeno disuelto en el hipoliminión. Vollenweider $(1968,1969)$ ha establecido unos niveles críticos de contenido total de fósforo y nitrógeno en algunos lagos basándose en el aporte de nutrientes, la profundidad media y el estado trófico. Dillon (1974) ha realizado una revisión crítica del modelo del equilibrio de nutrientes de Vollenweider y otros modelos relacionados. En el mercado existen también modelos informáticos más recientes para simular los ciclos del nitrógeno y el fósforo a diferentes temperaturas.

\section{Contaminación de estuarios}

Un estuario es un tramo intermedio entre la desembocadura de un río y la costa marina. Está formado por un tramo de cauce fluvial con afluencia de agua dulce y una zona de desembocadura en donde el nivel del agua salada cambia constantemente. LoS estuarios se ven continuamente afectados por las fluctuaciones de las mareas y son una de las masas de agua más complejas para el control de la contaminación del agua. Las principales características de un estuario son una salinidad variable, una interface salina entre el agua dulce y el agua salada y a menudo extensas áreas de agua poco profunda y turbia que forman bancos de sedimentos y marismas. Los nutrientes son transportados al estuario por el río y se mezclan con el hábitat salino dando lugar a una profusa producción de biota y vida marina. Los mariscos de los estuarios son especialmente apreciados.

En lo que se refiere a la contaminación del agua, los estuarios son sistemas complejos que, por lo general, requieren investigaciones especiales con amplios estudios de campo y modelos informáticos. Para más información al respecto, se recomienda consultar la obra de Reish (1979) sobre la contaminación de mares y estuarios, así como la obra de R eid y Wood (1976) sobre la ecología de aguas terrestres y estuarios. 


\section{Contaminación de los mares}

Los océanos pueden considerarse como los últimos receptores o depósitos de agua, ya que los residuos transportados por los ríos son vertidos finalmente al medio ambiente marino. Aunque los océanos son masas enormes de agua salada con una capacidad de asimilación aparentemente ilimitada, la contaminación deteriora primero las costas y termina por afectar a la vida marina.

Muchas de las fuentes de contaminación del mar son las mismas que se encuentran en las aguas terrestres que reciben aguas residuales, además de otras relacionadas con las actividades del hombre en el mar. A continuación se ofrece una lista reducida de estas fuentes:

- aguas cloacales y fangos domésticos, residuos industriales, residuos sólidos, residuos de los barcos;

- residuos de la pesca, sedimentos y nutrientes de ríos y escorrentías terrestres;

- vertidos de petróleo, residuos de prospecciones petrolíferas y actividades de producción en alta mar, operaciones de dragado,

- residuos radiactivos, residuos de productos químicos, plaguicidas y herbicidas.

Todas estas fuentes requieren tratamientos y métodos de control especiales. EI vertido de aguas cloacales y fangos domésticos al océano es tal vez la principal fuente de contaminación marina.

Para más información sobre la tecnología actualmente disponible en este campo, se recomienda la obra sobre contaminación marina y su control de Bishop (1983).

\section{Técnicas para reducir la contaminación por el vertido de aguas residuales}

Por lo general, el tratamiento a gran escala de las aguas residuales es responsabilidad de municipios, distritos sanitarios, industrias, empresas comerciales y diferentes comisiones de control de la contaminación. En esta sección se describen los métodos actuales para el tratamiento las aguas residuales municipales y algunos aspectos del tratamiento de los residuos industriales, así como otros métodos más innovadores.

En general, los procesos de tratamiento de aguas residuales se clasifican en físicos, químicos 0 biológicos, pudiéndose utilizar uno o varios de ellos para obtener el efluente deseado. Esta clasificación es la más idónea para comprender los distintos métodos de tratamiento de las aguas residuales (véase la Tabla 55.15).

Tabla 55.15 - Clasificación general de las operaciones y los procesos de tratamiento de aguas residuales.

$\begin{array}{lll}\text { Operaciones físicas } & \text { Procesos químicos } & \text { Procesos biológicos } \\ \text { Determinación del flujo } & \text { Precipitación } & \text { Acción aeróbica } \\ \text { Tamizado y eliminación } & \text { Neutralización } & \text { Acción anaeróbica } \\ \text { de partículas } & \text { Adsorción } & \text { Combinación } \\ \text { Mezclado } & \text { Desinfección } & \text { aeróbica-anaeróbica } \\ \text { Floculación } & \text { Oxidación química } & \\ \text { Sedimentación } & \text { Reducción química } & \\ \text { Flotación } & \text { Incineración } & \\ \text { Filtración } & \text { Intercambio iónico } & \\ \text { Secado } & \text { Electrodiálisis } & \\ \text { Destilación } & & \\ \text { Centrifugado } & \\ \text { Congelación } & \\ \text { Osmosis inversa } & \end{array}$

Figura 55.13 • Esquema de un tratamiento convencional de aguas residuales.

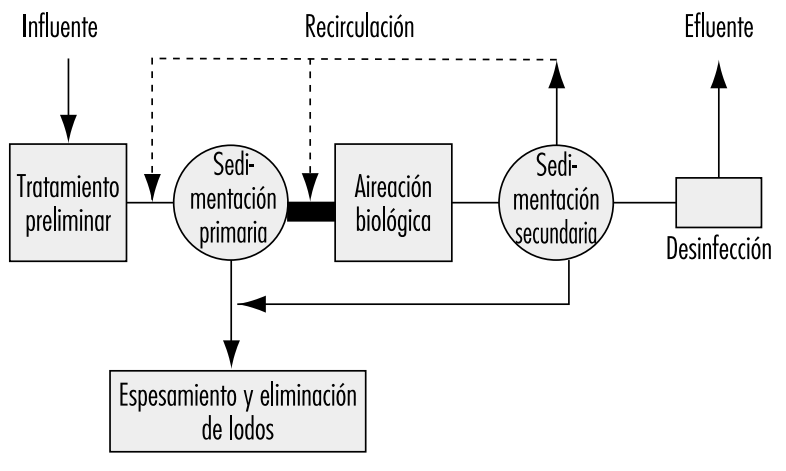

M étodos actuales para el tratamiento de las aguas residuales

El único objetivo de este artículo es proporcionar una visión conceptual de los métodos de tratamiento de aguas residuales que se utilizan actualmente en el mundo, sin describir con detalle los aspectos técnicos, que pueden consultarse en la obra de $M$ etcalf y Eddy (1991).

Las aguas residuales municipales y algunos residuos industriales y comerciales se procesan mediante sistemas que normalmente utilizan tratamientos primarios, secundarios y terciarios:

Sistema de tratamiento primario: Tratamiento previo $\rightarrow$ Sedimentación primaria

$\rightarrow$ Desinfección (cloración) $\rightarrow$ Efluente

Sistema de tratamiento secundario: Tratamiento previo $\rightarrow$ Sedimentación primaria

$\rightarrow$ U nidad biológica $\rightarrow$ Sedimentación secundaria $\rightarrow$ Desinfección (cloración) $\rightarrow$ Vertido a un curso de agua

Sistema de tratamiento terciario : Tratamiento previo $\rightarrow$ Sedimentación primaria

$\rightarrow$ U nidad biológica $\rightarrow$ Sedimentación secundaria $\rightarrow$ U nidad terciaria

$\rightarrow$ D esinfección (cloración) $\rightarrow$ Vertido a un curso de agua

En la Figura 55.13 se muestra un diagrama esquemático de un sistema convencional de tratamiento de aguas residuales. En la siguiente sección se describen con detalle todos estos procesos.

\section{Tratamiento primario}

El objetivo básico del tratamiento primario de las aguas residuales municipales, que contienen residuos domésticos mezclados con algunos residuos industriales y comerciales, es eliminar las partículas sólidas en suspensión y clarificar las aguas residuales para poder aplicarles un tratamiento biológico. Después de algunos tratamientos previos como cribado, eliminación de arenas y trituración, el proceso principal del tratamiento primario consiste en dejar que las aguas residuales sedimenten en grandes tanques de sedimentación durante períodos de hasta varias horas. Este proceso elimina entre el 50 y el $75 \%$ del contenido total de sólidos, que se depositan en el fondo del tanque formando lodos que se recogen y tratan aparte. El efluente por desbordamiento de este proceso se somete seguidamente a un tratamiento secundario. En algunos casos se utilizan productos químicos para mejorar la calidad del tratamiento primario.

\section{Tratamiento secundario}

EI tratamiento secundario elimina la materia orgánica suspendida o disuelta en las aguas residuales que no ha sido eliminada con el tratamiento primario. Para el tratamiento secundario 
suelen utilizarse filtros de percolación, sistemas de contacto biológico como los biodiscos, activación de lodos, estanques de estabilización de residuos, estanques aireados y métodos de aplicación terrestre, como los sistemas de humedales. Todos estos sistemas utilizan procesos biológicos de uno u otro tipo. A continuación se describen brevemente los procesos más utilizados en la práctica.

Sistemas de contacto biológico. Aunque los filtros de percolación constituyen uno de los métodos más antiguos para el tratamiento secundario, todavía se siguen utilizando ampliamente tras haber perfeccionado las técnicas de aplicación. En este tipo de sistemas, el efluente de los tanques primarios se aplica de forma uniforme a un lecho filtrante de materiales, como piedras o plástico sintético. La distribución uniforme del efluente se consigue percolando el líquido a través de un conducto perforado que gira sobre el lecho de manera intermitente o continua, según el proceso deseado. Dependiendo de la proporción entre el contenido orgánico e hídrico, los filtros de percolación pueden eliminar hasta el $95 \%$ de la materia orgánica, cuyo contenido se determina generalmente como demanda bioquímica de oxígeno (DBO). Existen otros sistemas de contacto biológicos más modernos que consiguen unas tasas de eliminación similares, algunos de los cuales ofrecen ventajas especiales, sobre todo cuando se utilizan en determinadas circunstancias de limitación de espacio, clima, etc. Debe recordarse que para completar el proceso es necesario disponer de un segundo tanque de sedimentación. En la sedimentación secundaria se retira del fondo un sedimento llamado lodo de humus y el desbordamiento del tanque se descarga como efluente secundario.

Lodos activados. En la forma más habitual de este proceso biológico, el efluente del tratamiento primario fluye a un tanque que contiene una suspensión biológica denominada lodo activado. Esta mezcla recibe el nombre de sólidos suspendidos en solución mixta (M LSS) y permanece en contacto normalmente durante varias horas, un día o más, dependiendo de los resultados deseados. Durante este tiempo, la mezcla se airea y se agita para conseguir una actividad biológica aeróbica. Cuando finaliza el proceso, una parte de la mezcla (M LSS) se devuelve al tanque de aireación para que continúe el proceso de activación biológica. La sedimentación secundaria se realiza después de la fase de activación de lodos para sedimentar la suspensión de lodo activado y descargar un agua clarificada como efluente. Este proceso es capaz de eliminar hasta el $95 \%$ del DBO del influente.

\section{Tratamiento terciario}

Cuando se desea un nivel más alto de eliminación de contaminantes puede utilizarse un tercer nivel de tratamiento, que consiste en filtros de arena, estanques de estabilización, métodos de vertido controlado, sistemas de humedales y otros sistemas que consiguen un mayor grado de estabilización del efluente secundario.

\section{Desinfección de efluentes}

Normalmente la desinfección es necesaria para reducir a niveles aceptables el contenido de bacterias y sustancias patógenas. Entre los procesos más utilizados para este fin se encuentran la cloración, el dióxido de cloro, el ozono y la luz ultravioleta.

\section{Eficiencia global de las estaciones depuradoras}

Las aguas residuales contienen una gran variedad de constituyentes que generalmente se dividen en sólidos en suspensión o disueltos y materia orgánica e inorgánica.

La eficiencia de un sistema de tratamiento puede determinarse en términos del porcentaje de eliminación de estos constituyentes. Los parámetros habituales de medida son los siguientes:

- DB 0: demanda bioquímica de oxígeno (mg/l);

- DQ0: demanda química de oxígeno (mg/l);

- T SS: contenido total de sólidos en suspensión (mg/ l);

- T SD : contenido total de sólidos disueltos (mg/ I);

- compuestos nitrogenados: nitratos y amoníaco (mg/l) (los nitratos presentan un interés especial como nutrientes en el proceso de eutrofización);

- fosfatos: (mg/ l) (también de especial interés como nutrientes en la eutrofización);

- pH : grado de acidez, con valores que oscilan entre 1 (máxima acidez) y 14 (máxima alcalinidad),

- recuento de bacterias coliformes: medido como el número más probable por $100 \mathrm{ml}$ (Escherichia y las bacterias coliformes fecales son los indicadores más habituales).

\section{Tratamiento de aguas residuales industriales}

\section{Tipos de residuos industriales}

Los residuos industriales (no domésticos) presentan tipos y composiciones muy diferentes; pueden ser muy ácidos o alcalinos y a menudo requieren un detallado análisis de laboratorio. En algunos casos tienen que ser neutralizados antes de su vertido. La toxicidad es uno de los principales problemas de la evacuación de aguas industriales.

Entre los residuos más representativos de este tipo se encuentran los procedentes de las industrias del papel, mataderos, cervezas, curtiduría, alimentación, conservas alimenticias, productos químicos, petróleo, textiles, azúcar, lavanderías, carnes, cría de cerdos, clarificación de aceites, etc. El primer paso en el diseño del tratamiento consiste en realizar un estudio de los residuos industriales para obtener datos sobre las variaciones en el flujo y las características de los residuos. Las características negativas de los residuos, según las describió Eckenfelder (1989), pueden resumirse como:

- sustancias orgánicas solubles que reducen el contenido de oxígeno disuelto;

- sólidos en suspensión;

- compuestos traza orgánicos;

- metales pesados, cianuros y compuestos orgánicos tóxicos;

- color y turbidez;

- nitrógeno y fósforo;

- sustancias refractarias resistentes a la biodegradación;

- aceites y materiales flotantes,

- sustancias volátiles.

La Agencia de Protección del Medio Ambiente (EPA) de Estados U nidos ha elaborado asimismo una lista de productos químicos orgánicos e inorgánicos tóxicos con limitaciones específicas de vertido. La lista incluye más de 100 compuestos y resultaría demasiado extensa para incluirla en el presente artículo, pero puede solicitarse a la EPA.

\section{Métodos de tratamiento}

El tratamiento de los residuos industriales es más especializado que el de los residuos domésticos. No obstante, siempre que es posible su reducción biológica, se utilizan métodos similares a los descritos antes (métodos de tratamiento biológico secundario y terciario) para los sistemas municipales.

Los estanques de estabilización de residuos se utilizan habitualmente para el tratamiento de las aguas residuales orgánicas cuando se dispone de una extensión de terreno suficiente. LoS estanques por los que pasan las aguas residuales se clasifican según su actividad bacteriana como aerobios, facultativos 0 
Figura 55.14 - Sección transversal de un estanque de estabilización de doble celda.
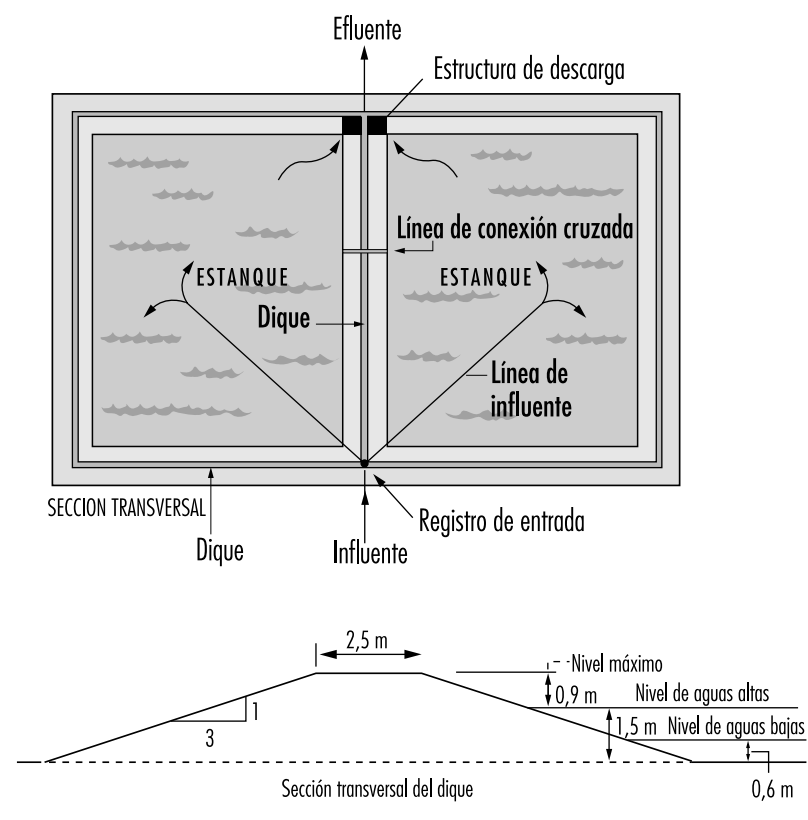

anaerobios. En el caso de los estanques aireados, el oxígeno se suministra mediante sistemas de aireación difusos o mecánicos.

En las Figuras 55.14 y 55.15 se muestran esquemas de estanques de estabilización de residuos.

\section{Prevención de la contaminación y minimización de residuos}

Cuando se analizan en la fuente las operaciones y los procesos industriales internos de tratamiento de residuos, se comprueba que en muchos casos el vertido de residuos puede controlarse para evitar descargas importantes de contaminantes.

Las técnicas de recirculación son un importante componente de los programas de prevención de la contaminación. Como ejemplo puede citarse el estudio del caso de un plan de reciclado de las aguas residuales de una fábrica de curtidos publicado por Preul (1981). Dicho plan incluía la recuperación/ reutilización del cromo y la recirculación completa de todas las aguas residuales de la fábrica, evitando el vertido de residuos al río excepto en caso de emergencia. En la Figura 55.16 se muestra el diagrama de flujo de este sistema.

Para más información sobre los últimos avances tecnológicos en este campo, se recomienda la lectura de un texto sobre prevención de la contaminación y minimización de los residuos publicado por la Water Environment Federation (1995).

Figura 55.15 - Esquema de los diferentes tipos de laguna aireada.

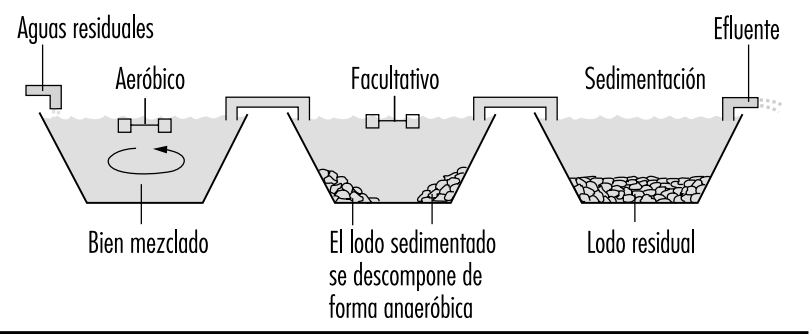

M étodos avanzados para el tratamiento de aguas residuales Existe una serie de métodos avanzados para conseguir niveles más altos de eliminación de contaminantes, entre ellos los siguientes:

filtración (arena y distintos medios)

precipitación química

adsorción por carbono

electrodiálisis

destilación

nitrificación

recogida de algas

regeneración de efluentes

microfiltración

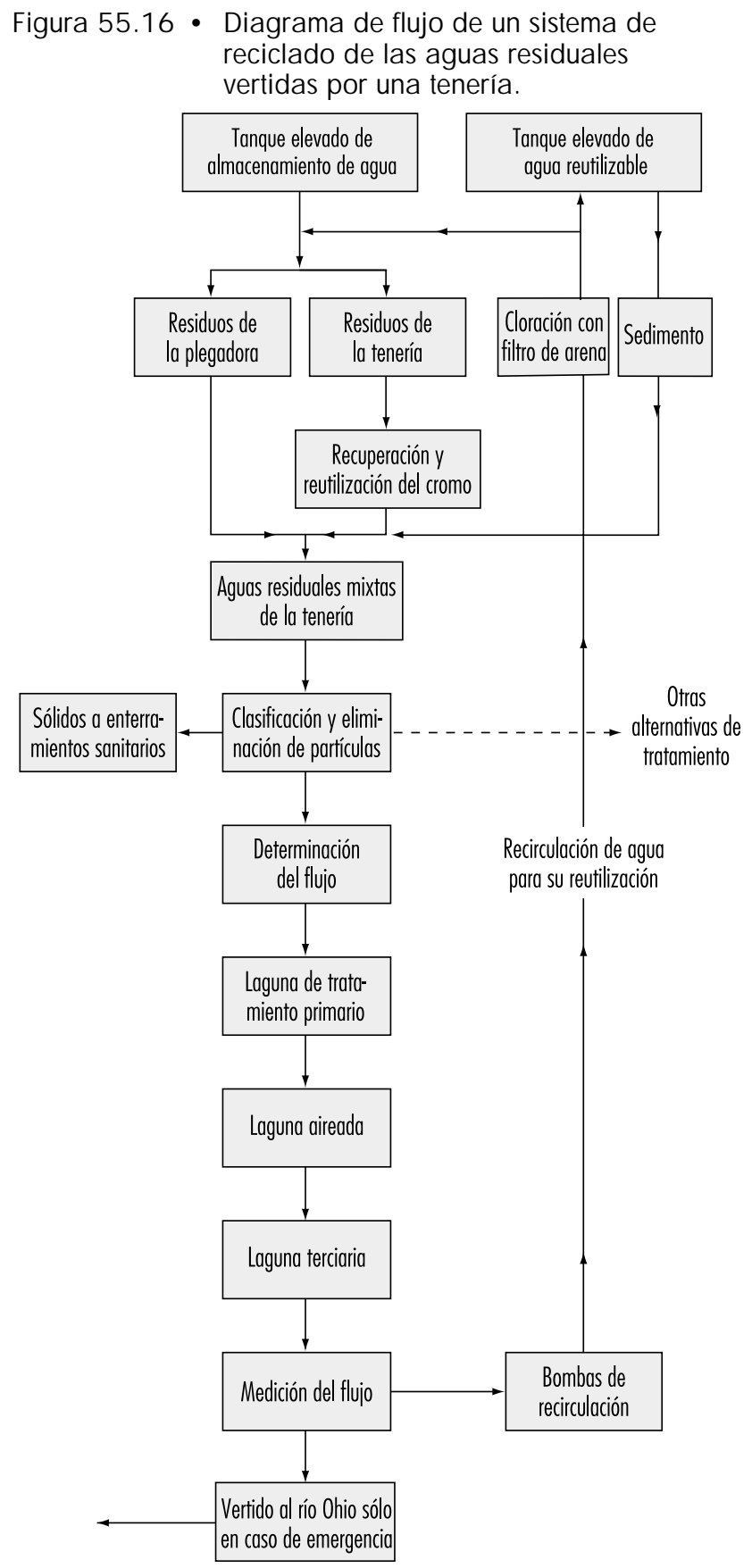


depuración de amoníaco

ósmosis inversa

intercambio iónico

aplicación al suelo

desnitrificación

zonas húmedas.

La selección del proceso más adecuado para una determinada situación debe hacerse teniendo en cuenta la calidad y la cantidad de las aguas residuales, los requisitos del agua receptora y, lógicamente, los costes. Se recomienda asimismo consultar la obra de M etcalf y Eddy (1991), que incluye un capítulo sobre tratamientos avanzados de aguas residuales.

\section{Estudio de un caso de tratamiento avanzado de aguas residuales}

El estudio del caso del Proyecto de regeneración de aguas residuales de la Región del Dan, que se incluye más adelante en el presente capítulo, es un ejemplo excelente de tratamiento y regeneración de las aguas residuales con métodos innovadores.

\section{Contaminación térmica}

La contaminación térmica es una forma de residuo industrial que se define como un cambio nocivo de la temperatura normal de las aguas receptoras causado por el calor generado por actividades humanas. Las industrias que producen un mayor calor residual son las fábricas de combustibles fósiles (petróleo, gas y carbón), las centrales nucleares, las industrias siderúrgicas, las refinerías de petróleo, las fábricas químicas, las papeleras, las destilerías y las lavanderías. Especialmente problemáticas son las centrales eléctricas que suministran energía a gran número de países (cerca del $80 \%$ en Estados U nidos).

\section{Impacto del calor residual en las aguas receptoras}

\section{Influencia en la capacidad de asimilación de residuos}

- El calor aumenta la oxidación biológica.

- El calor reduce el contenido de oxígeno saturado del agua y la velocidad de reoxigenación natural.

Figura 55.17 • Intercambio de calor en los límites de la sección transversal de una cuenca receptora de agua.

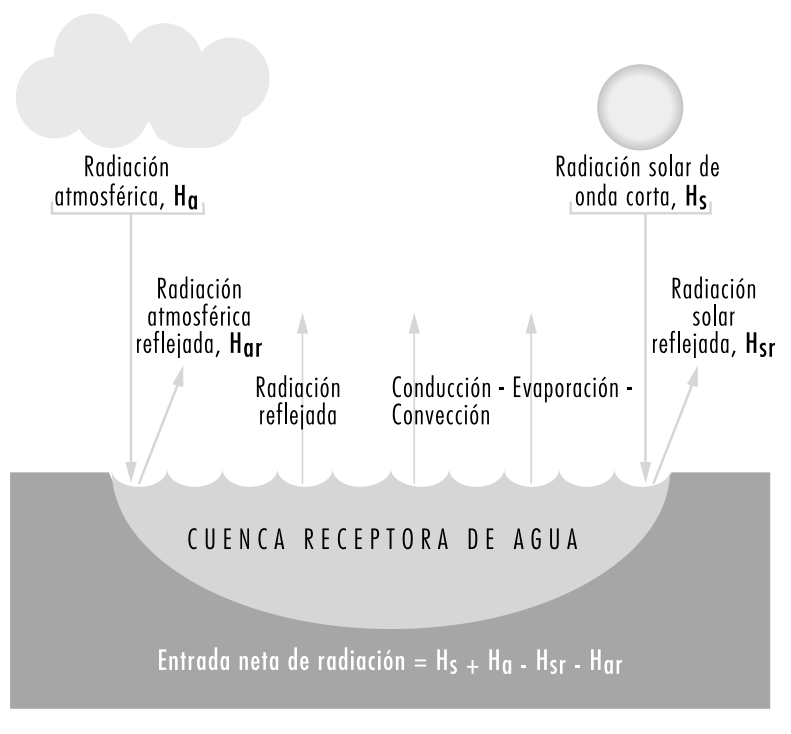

Figura 55.18 - Capacidad de un río para asimilar adiciones térmicas.

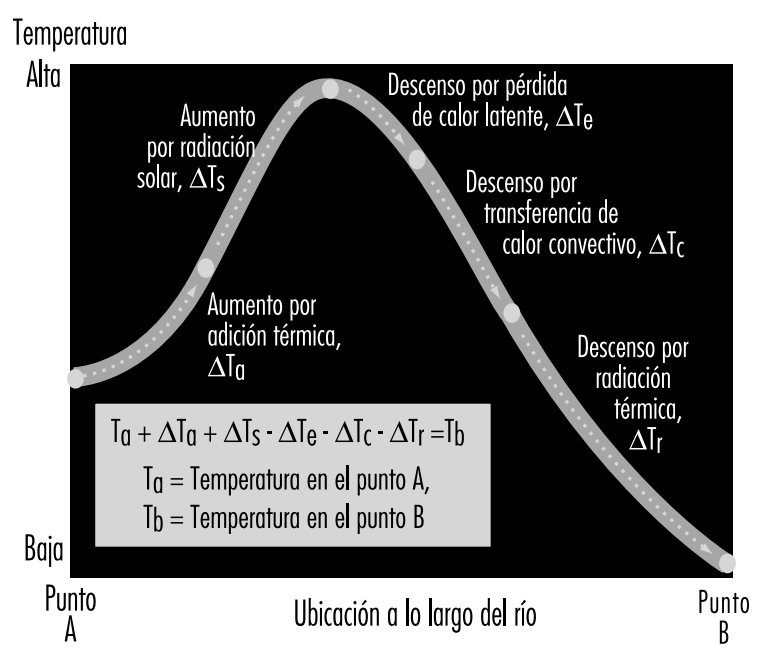

- El efecto neto del calor es, por lo general, nocivo durante los meses calurosos del año.

- El efecto del calor en el invierno puede resultar beneficioso en climas muy fríos donde, al romperse el hielo, se produce una aireación superficial para los peces y la vida acuática.

\section{Influencia en la vida acuática}

M uchas especies presentan una tolerancia limitada a las variaciones de la temperatura y necesitan protección, especialmente en los tramos afectados por el calor de una corriente o masa de agua. Así, por ejemplo, en los cursos de agua fría se encuentran generalmente las variedades de peces más apreciadas para la pesca deportiva, como la trucha y el salmón; en las aguas cálidas se encuentran poblaciones de peces más vulgares y en las aguas de temperatura intermedia habitan peces como el lucio y la perca.

\section{Análisis térmico de las aguas receptoras}

En la Figura 55.17 se ilustran las diferentes formas de intercambio natural de calor en los límites de una cuenca receptora. Cuando el calor se libera a aguas receptoras como ríos, es importante analizar su capacidad de asimilación de adiciones térmicas. El perfil de temperatura de un río puede calcularse resolviendo una ecuación térmica similar a la utilizada para calcular las curvas de pandeo del oxígeno en disolución. En la Figura 55.18 se indican los principales factores que influyen en el equilibrio térmico para un tramo de río comprendido entre los puntos $A$ y $B$. C ada factor tiene que calcularse por separado en función de ciertas variables térmicas. Al igual que en el caso de la ecuación del oxígeno disuelto, aquí también la ecuación térmica es una sencilla suma de las pérdidas y ganancias de temperatura en una cierta sección. En la bibliografía publicada sobre este tema pueden encontrarse otros métodos analíticos más sofisticados. Los resultados de la ecuación térmica se utilizan para establecer límites en la liberación de calor y posiblemente ciertas limitaciones de uso de una masa de agua.

\section{Control de la contaminación térmica}

Las principales estrategias para el control de la contaminación térmica son:

- optimización de la eficiencia del funcionamiento de las centrales eléctricas;

- torres de refrigeración; 
Figura 55.19 • Ciclo hidrológico y fuentes de contaminación de las aguas subterráneas.

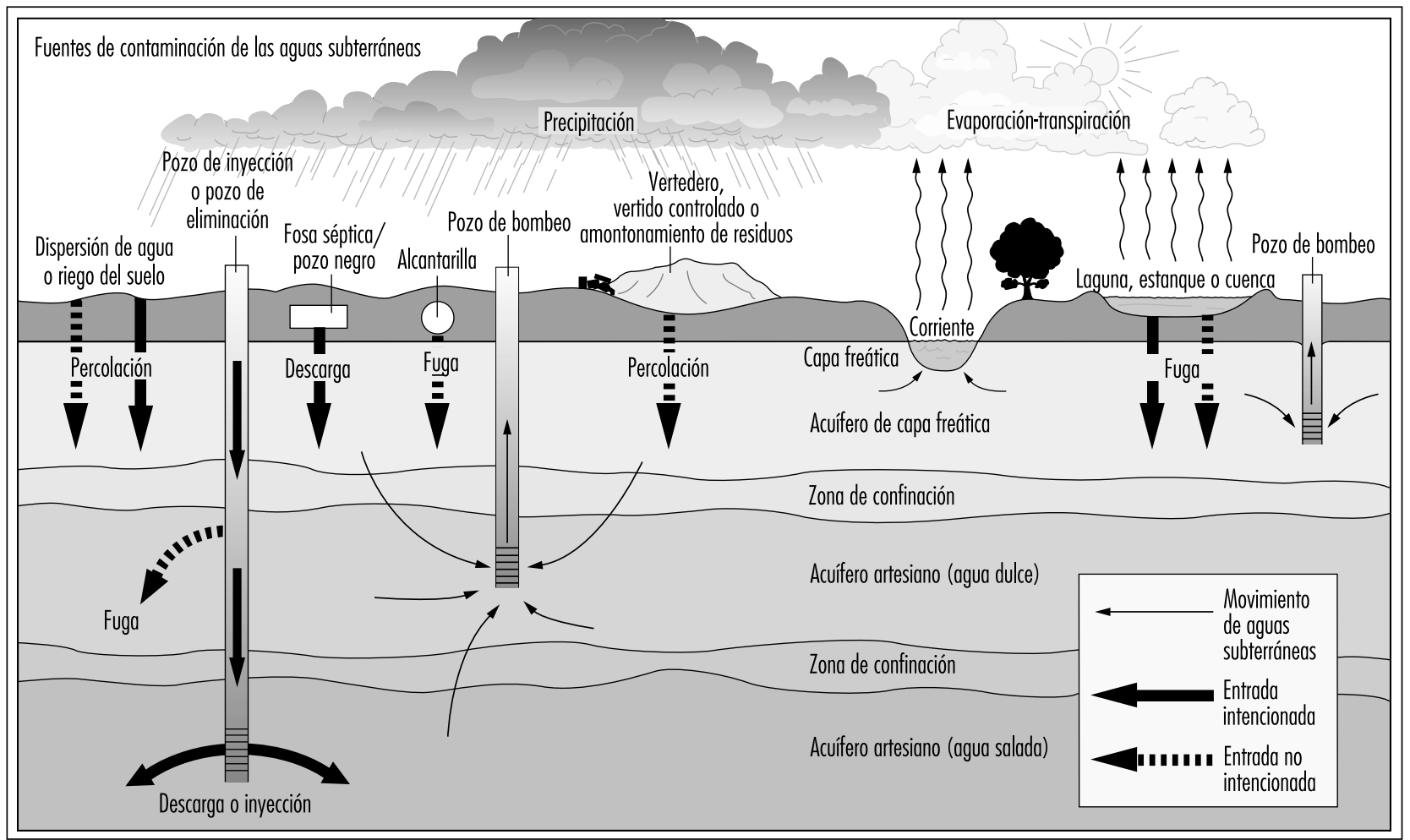

- tanques de refrigeración aislados,

- consideración de métodos alternativos de generación de energía, como las centrales hidroeléctricas.

C uando las condiciones físicas son favorables dentro de unos ciertos límites ambientales, la energía hidroeléctrica debe barajarse como una alternativa a las centrales nucleares 0 a las centrales eléctricas basadas en combustibles fósiles. Las centrales hidroeléctricas no generan residuos de calor ni vierten aguas residuales que contaminen el agua.

\section{Control de la contaminación de las aguas subterráneas}

\section{Importancia de las aguas subterráneas}

Puesto que una gran parte de los abastecimientos de agua se extraen de acuíferos, es evidente que su protección reviste una gran importancia. Se estima que, en nuestro planeta, más del $95 \%$ del agua dulce disponible se encuentra en el subsuelo. En Estados Unidos y según el Estudio Geológico de Estados U nidos realizado en 1984, aproximadamente el $50 \%$ del agua utilizada para consumo humano se extrae de pozos. La naturaleza sutil e invisible de la contaminación y los movimientos de las aguas subterráneas es la causa de que muchas veces se preste menos atención al análisis y control de la degradación de estas aguas que a la contaminación mucho más visible de las aguas superficiales.

\section{Fuentes de contaminación de las aguas subter ráneas}

En la Figura 55.19 se muestra el ciclo hidrológico y las fuentes de contaminación de las aguas subterráneas. U na lista completa de estas fuentes potenciales resultaría demasiado extensa, por lo que a continuación se citan, a título de ejemplo, las más obvias:
- vertido de residuos industriales;

- cursos de agua contaminados en contacto con acuíferos;

- operaciones de minería;

- eliminación de residuos sólidos y peligrosos;

- tanques de almacenamiento subterráneo, por ejemplo, para petróleo;

- sistemas de riego;

- renovación artificial:

- invasión de las aguas marinas;

- vertidos accidentales;

- embalses contaminados con fondos permeables;

- pozos de eliminación:

- soleras de fosas sépticas y pozos de lixiviado;

- perforaciones incorrectas de pozos;

- actividades agrícolas,

- sales para deshielo de carreteras.

Los contaminantes específicos de las aguas subterráneas se dividen a su vez en:

- compuestos químicos no deseados (los más habituales, no la lista completa) orgánicos e inorgánicos (p. ej., cloruros, sulfatos, hierro, manganeso, sodio, potasio);

- dureza total y contenido total de sólidos disueltos;

- compuestos tóxicos (los más habituales, no la lista completa): nitratos, arsénico, cromo, plomo, cianuros, cobre, fenoles, mercurio disuelto;

- características físicas desagradables: sabor, color y olor;

- plaguicidas y herbicidas: hidrocarburos clorados y otros;

- materiales radiactivos: diferentes formas de radiactividad;

- materiales biológicos: bacterias, virus, parásitos, etc.,

- sustancias ácidas (bajo pH ) 0 cáusticas (alto pH ).

De todas las sustancias anteriores, los nitratos son los más peligrosos tanto para las aguas subterráneas como para las 
superficiales. El consumo de agua subterránea con nitratos puede causar la enfermedad denominada metahemoglobinemia (cianosis infantil). Además, según Preul (1991), los nitratos, presentes en gran número de recursos hídricos, pueden causar una eutrofización nociva de las aguas superficiales. Preul (1964, 1967, 1972) y Preul y Schroepfer (1968) han realizado estudios del movimiento del nitrógeno y de otros contaminantes en las aguas subterráneas.

\section{Dispersión de los contaminantes en las aguas subter ráneas}

El movimiento de las aguas subterráneas es enormemente lento y sutil en comparación con el de las aguas superficiales dentro del ciclo hidrológico. Para predecir el movimiento normal de las aguas subterráneas en condiciones ideales de flujo constante se utiliza la ley de Darcy , un método básico para evaluar el movimiento de estas aguas con valores bajos de número de Reynolds (R):

$$
\mathrm{V}=\mathrm{K}(\mathrm{dh} / \mathrm{dl})
$$

siendo:

$\mathrm{V}=$ velocidad del agua subterránea en el acuífero, $\mathrm{m} /$ día

$\mathrm{K}=$ coeficiente de permeabilidad del acuífero

$(\mathrm{dh} / \mathrm{dl})=$ gradiente hidráulico que representa la fuerza de desplazamiento.

En cuanto a la dispersión de los contaminantes en las aguas subterráneas, generalmente el líquido que los transporta es agua subterránea normal $\left(\mathrm{H}_{2} \mathrm{O}\right)$, que se desplaza a una velocidad calculada aplicando la ley de D arcy. No obstante, la velocidad de desplazamiento o dispersión de un contaminante, $p$. ej., un compuesto químico orgánico o inorgánico, puede ser diferente como consecuencia de los procesos de advección y dispersión hidrodinámica. Algunos iones se desplazan más deprisa o más despacio que el flujo normal del agua subterránea como consecuencia de ciertas reacciones dentro del medio acuífero, de manera que pueden clasificarse como "reactivos" o "no reactivos". Las reacciones pueden ser:

- reacciones físicas entre el contaminante y el acuífero y/o el líquido transportador;

- reacciones químicas entre el contaminante y el acuífero y/ o el líquido transportador

- acciones biológicas sobre el contaminante.

Entre los contaminantes reactivos y no reactivos más habituales de las aguas subterráneas se encuentran los siguientes:

- contaminantes reactivos: cromo, ion amonio, calcio, sodio, hierro, etc.; cationes en general; elementos biológicos; elementos radiactivos,

- contaminantes no reactivos: cloruros, nitratos, sulfatos, etc.; algunos aniones; algunos plaguicidas y herbicidas.

En un principio puede parecer que los contaminantes reactivos son los más peligrosos, pero esto no siempre es así, porque las reacciones pueden detener o retardar la dispersión del contaminante, mientras que en el caso de los contaminantes no reactivos esta dispersión es casi libre. En la actualidad existen algunos productos domésticos y agrícolas "ecológicos" que se degradan biológicamente después de un cierto período de tiempo, evitando así la contaminación de las aguas subterráneas.

\section{Recuperación de los acuíferos}

Lógicamente, la prevención de la contaminación de las aguas subterráneas es la mejor alternativa. Sin embargo, la existencia de fuentes incontroladas de contaminación de las aguas subterráneas normalmente suele conocerse cuando ya es un hecho consumado; por ejemplo, cuando los usuarios de los pozos de agua de una zona expresan sus quejas. Por desgracia, en muchos casos cuando se detecta el problema ya se ha producido un daño grave y es necesario proceder a su reparación. Esta reparación puede exigir extensos estudios hidrogeológicos de campo y análisis de muestras de agua en el laboratorio para poder establecer la magnitud de la concentración de contaminantes y su área de dispersión. A menudo el muestreo inicial se realiza en los pozos existentes, pero en los casos más graves tienen que realizarse perforaciones profundas y muestreos de agua. El análisis de los datos así obtenidos permite conocer la situación actual y predecir la situación en el futuro. El análisis de la dispersión de contaminantes en las aguas subterráneas es un campo especializado que, con frecuencia, exige el uso de modelos informáticos para representar mejor la dinámica de estas aguas y hacer predicciones en diferentes condiciones. En la literatura publicada pueden encontrarse modelos informáticos bi y tridimensionales que se utilizan para estos fines. A simismo se recomienda el libro de Freeze y Cherry (1987), que incluye una descripción más detallada de los métodos analíticos.

\section{Prevención de la contaminación}

La mejor estrategia para la protección de las aguas subterráneas es prevenir la contaminación. Aunque las normas sobre el agua potable se aplican también a los abastecimientos de aguas subterráneas, estas fuentes de agua requieren una protección especial frente a la contaminación. Por lo general, estas actividades corren a cargo de los ministerios de sanidad, los organismos responsables de los recursos naturales y las agencias de protección del medio ambiente. Los esfuerzos para controlar la contaminación de las aguas subterráneas están dirigidos en gran parte a proteger los acuíferos y a prevenir su contaminación.

La prevención de la contaminación exige controles sobre el uso del suelo, como la zonificación y otras normativas específicas. La legislación puede imponer prohibiciones específicas de fuentes puntuales 0 actividades contaminantes. EI control mediante zonificación del uso del suelo es una herramienta de protección de las aguas subterráneas muy eficaz, sobre todo cuando es utilizada por las administraciones municipales 0 provinciales. Los programas de protección de acuíferos y manantiales que se comentan a continuación son importantes ejemplos de prevención de la contaminación.

En un programa de protección de acuíferos es necesario establecer los límites del acuífero y sus áreas de renovación. Los acuíferos pueden ser de tipo confinado o no confinado y, por lo tanto, tienen que ser estudiados por un hidrólogo para hacer esta diferenciación. Aunque en los países desarrollados los principales acuíferos se conocen bien, en otras zonas se necesitarán investigaciones de campo y análisis hidrogeológicos. El elemento clave de un programa de protección de acuíferos frente a la degradación de la calidad del agua es el control del uso del suelo que se encuentra encima del acuífero y de sus áreas de renovación.

La protección de los manantiales es una medida más limitada que se aplica a la zona de renovación que alimenta a un determinado pozo. Las enmiendas a la Ley sobre la seguridad del agua potable (SDWA) (1984), aprobadas por el gobierno federal norteamericano en 1986, establecen unas áreas de protección de manantiales específicas para los pozos de agua potable. EI área de protección de manantiales (wellhead protection area, WHPA) se define en la SDWA como "el área superficial y subsuperficial que rodea a un pozo de agua o a una zona de pozos que alimentan a un sistema público de abastecimiento de agua, a través de la cual los contaminantes pueden desplazarse y alcanzar ese pozo o esa zona de pozos". El principal objetivo del 
programa WH PA, según la EPA de Estados U nidos (1987), es la definición de las áreas de protección de pozos aplicando una serie de criterios, consideraciones hidrogeológicas y factores relacionados con la explotación de los pozos.

\section{- Proyecto de Regeneracion de AGUAS RESIDUALES EN LA REGION DE DAN : ESTUDIO DE CASO}

Alexander D onagi

\section{Concepto y diseño}

El proyecto de regeneración de las aguas residuales municipales de la región de $D$ an es el proyecto más ambicioso del mundo dentro de su género. Consiste en la construcción de una serie de instalaciones para el tratamiento de las aguas residuales municipales y un sistema de renovación de las aguas subterráneas del Area M etropolitana de la Región de $D$ an, un conglomerado de ocho ciudades próximas a Tel Aviv (I srael) con una población total de unos 1,5 millones de habitantes. Este proyecto tiene como objetivo la recogida, el tratamiento y la eliminación de las aguas residuales municipales. El efluente regenerado, tras un período relativamente prolongado de almacenamiento en un acuífero subterráneo, se bombea para uso agrícola sin restricciones en los regadíos de la zona árida de $\mathrm{N}$ egev (al sur de I srael). La Figura 55.20 muestra un esquema general del proyecto, que se inició durante el decenio de 1960 y que se ha ampliado progresivamente. En la actualidad, el sistema gestiona la recogida y el tratamiento de unos $110 \times 10^{6} \mathrm{~m}^{3}$ anuales de aguas residuales. Dentro de pocos años, en su fase final, tendrá una capacidad de 150 a $170 \times 10^{6} \mathrm{~m}^{3}$ anuales.

Es bien conocido que las plantas de tratamiento de aguas residuales plantean multitud de problemas que afectan al medio ambiente y a la higiene en el trabajo. El proyecto de la Región de $D$ an es un sistema único de alcance nacional que combina el beneficio nacional con un importante ahorro de recursos hídricos, un alto grado de eficacia en el tratamiento y una producción de agua a precios económicos, todo ello sin originar peligros laborales excesivos.

En el diseño, la instalación y la explotación regular del sistema se ha prestado especial atención al saneamiento de las aguas y a los problemas de higiene en el trabajo. Se han adoptado todas las precauciones necesarias para garantizar que las aguas residuale sregeneradas sean tan inocuas como el agua potable normal, una medida preventiva en caso de que sean ingeridas por accidente. Análogamente, se ha intentado reducir al mínimo cualquier posible exposición a accidentes o peligros biológicos, químicos o físicos para el personal que trabaja en las plantas de tratamiento o para los trabajadores que participan en la evacuación del agua regenerada o en su uso para fines agrícolas.

En la Fase I del proyecto, las aguas residuales fueron sometidas a un tratamiento biológico mediante un sistema de tanques de oxidación provistos de recirculación y tratamiento químico adicional con caliza y magnesio, seguido de un tratamiento del efluente de alto $\mathrm{pH}$ en los "tanques de acabado". El efluente parcialmente tratado se devolvían al acuífero subterráneo regional a través de las zonas de dispersión de Soreq.

En la Fase II, las aguas residuales que llegan a la planta de tratamiento se someten a un proceso biomecánico de activación de lodos mediante nitrificación-desnitrificación. El efluente secundario se devuelve al acuífero subterráneo a través de las zonas de dispersión Yavneh 1 y Yavneh 2.
Figura 55.20 • Plano del sistema de regeneración de aguas residuales en la Región de Dan.

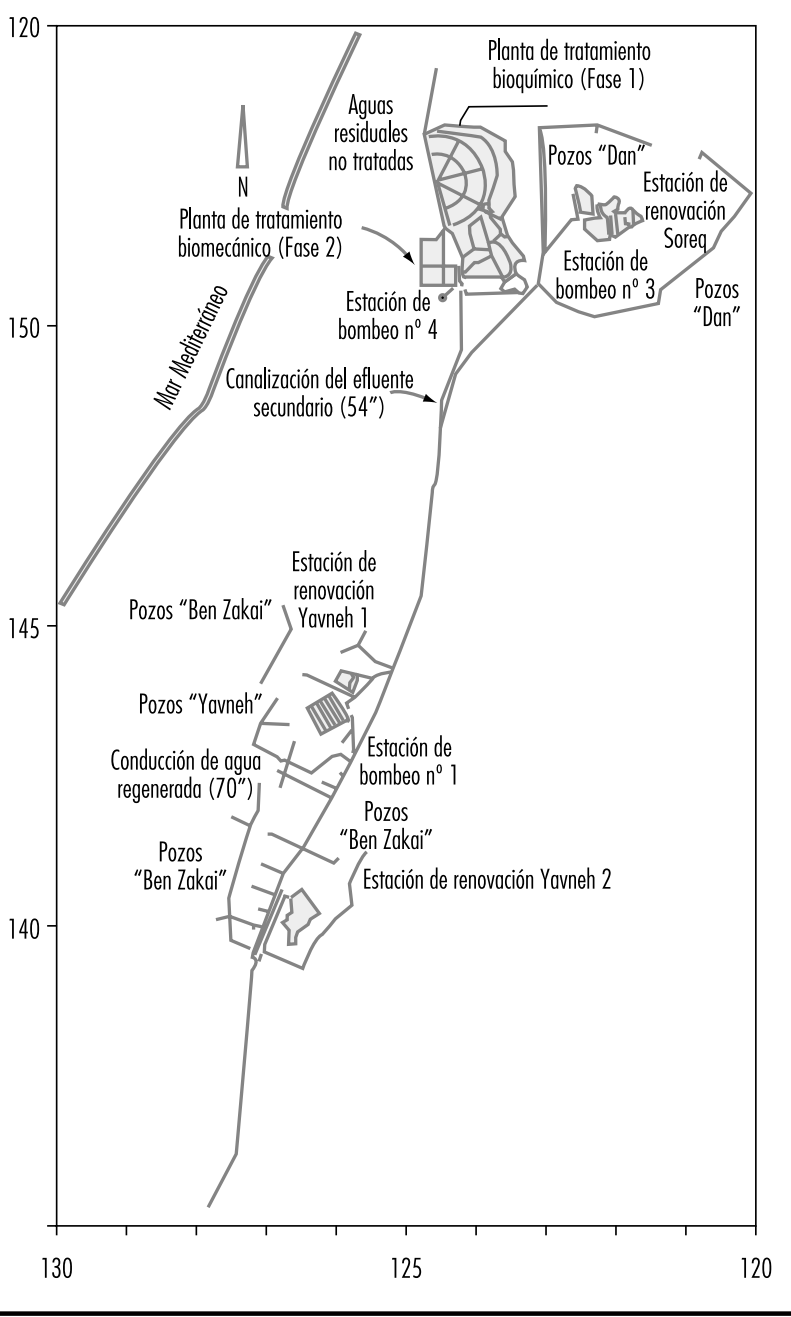

El sistema en su conjunto está formado por una serie de elementos que se complementan entre sí:

- un conjunto de plantas de tratamiento de aguas residuales, compuesto por una planta de activación de lodos (planta biomecánica), que se encarga del tratamiento de la mayor parte de los vertidos, y por un conjunto de tanques de oxidación y de acabado que básicamente se utilizan para el tratamiento del flujo excedente de aguas residuales;

- un sistema de renovación de las aguas subterráneas con el efluente ya tratado y formado por zonas de dispersión en dos puntos diferentes (Yavneh y Soreq) que se llenan periódicamente; el efluente absorbido pasa a través de la zona no saturada del suelo y de parte del acuífero, creando una zona especial de tratamiento complementario del efluente y un almacenamiento estacional denominado SAT (soil-aquifer-treatment, tratamiento suelo-acuífero);

- una red de pozos de observación (53 pozos en total) alrededor de las zonas de dispersión que permiten controlar la eficacia del proceso de tratamiento;

- una red de pozos de extracción de agua (un total de 74 pozos activos en 1993) alrededor de las estaciones de renovación del acuífero; 
- un sistema de canalización especial e independiente para el transporte de las aguas regeneradas a las zonas agrícolas de Negev, donde puede utilizarse sin restricciones para fines de riego; este sistema de canalización recibe el nombre de "Tercer Canal de N egev" y complementa a la red de abastecimiento de agua del $\mathrm{Negev}$, que incluye otros dos canales de abastecimiento de agua dulce;

- un equipo de cloración del efluente, formado en la actualidad por tres plantas de cloración (que en el futuro se completarán con otras dos);

- seis depósitos auxiliares a lo largo del sistema de transporte que regulan la cantidad de agua bombeada y consumida en todo el sistema;

- un sistema de distribución del efluente, compuesto por 13 grandes zonas de presión a lo largo del sistema de canalización que hacen llegar el agua tratada al consumidor final,

- un sistema global de vigilancia que supervisa y controla el funcionamiento de todo el proyecto.

\section{Descripción del sistema de regeneración}

El esquema general del sistema de regeneración se muestra en la Figura 55.20 y el diagrama de flujo, en la Figura 55.21. El sistema consta de los siguientes elementos: planta de tratamiento de aguas residuales, estaciones de renovación del acuífero, pozos de extracción de agua, sistema de canalización, equipo de cloración y sistema global de vigilancia.

\section{Planta de tratamiento de aguas residuales}

La planta de tratamiento de aguas residuales del Area M etropolitana de la Región de $D$ an recibe las aguas residuales domésticas de las ocho poblaciones de la región y gestiona, además, parte de sus vertidos industriales. La planta, emplazada en las dunas de $\mathrm{R}$ ishon-Lezion, realiza principalmente el tratamiento secundario de los vertidos mediante el método de la activación de lodos. U na parte de los residuos, especialmente en los momentos de máximo vertido, se someten a tratamiento en otro sistema más antiguo de tanques de oxidación que ocupan un área de 300 acres. En la actualidad, estos dos sistemas en conjunto pueden tratar unos $110 \times 10^{6} \mathrm{~m}^{3}$ al año.

\section{Estaciones de renovación del acuífero}

L os efluentes de la planta de tratamiento se bombean hasta tres lugares diferentes situados en la región de dunas, donde se procede a su dispersión sobre la arena, filtrándose hasta el yacimiento acuífero subterráneo para su almacenamiento temporal y su posterior tratamiento. D os de las zonas de dispersión, Yavneh 1 (60 acres, ubicada $7 \mathrm{~km}$ al sur de la planta) y Yavneh 2 (45 acres, $10 \mathrm{~km}$ al sur de la planta), se utilizan para recargar el acuífero con el efluente de la planta de tratamiento biomecánico. La tercera zona, Soreq, con una superficie de 60 acres y situada al este de los tanques de oxidación, se utiliza para recargar el acuífero con el agua procedente de dichos tanques, aunque para mejorar la calidad del efluente hasta el nivel exigido, se mezcla con una parte del agua procedente de la planta de tratamiento biomecánico.

\section{Pozos de extracción de agua}

Alrededor de las estaciones de renovación del acuífero existen varias redes de pozos de observación a través de los cuales se bombea el agua renovada. De los 74 pozos que funcionaban en 1993, no todos han permanecido activos durante todo el proyecto. En 1993 se extrajeron cerca de 95 millones de metros cúbicos de agua de los pozos del sistema y se bombearon al Tercer $\mathrm{C}$ anal del $\mathrm{N}$ egev.
Figura 55.21 • Diagrama de flujo del proyecto de la Región de Dan.

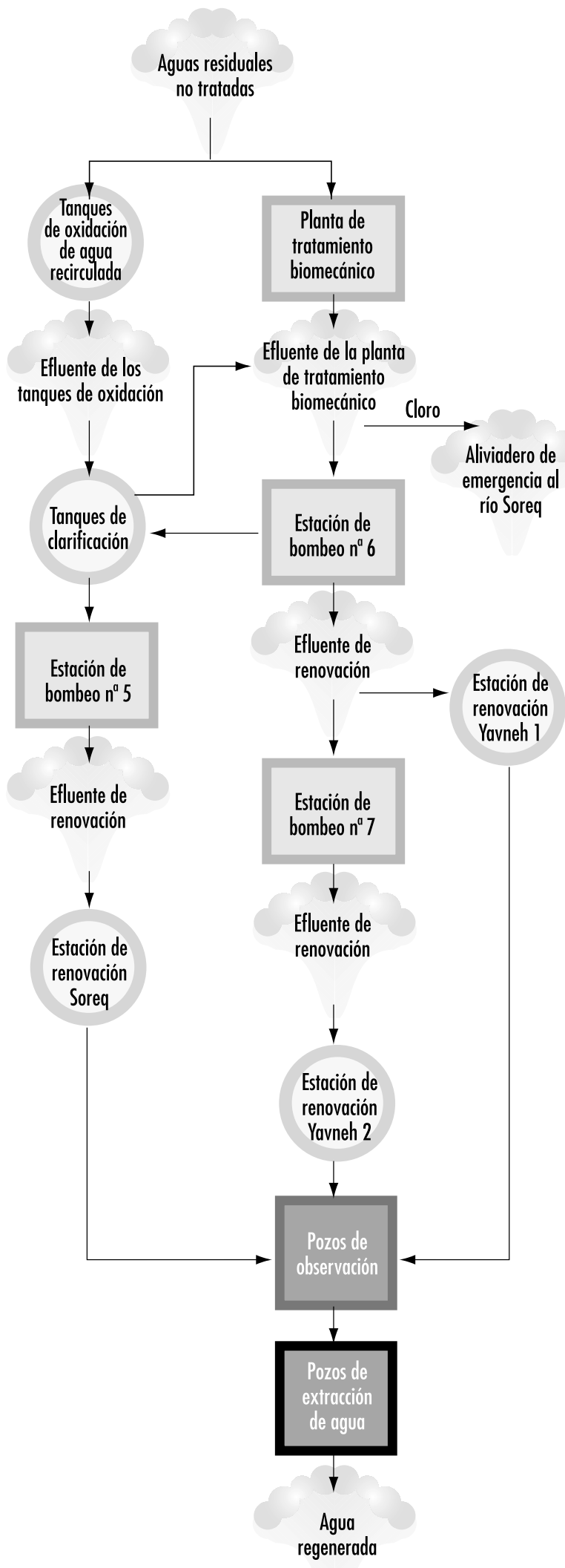




\begin{tabular}{|c|c|c|c|c|c|}
\hline $\mathrm{Ag}$ & Plata & $\mu g / l$ & $\mathrm{Mg}$ & Magnesio & $\mathrm{mg} / \mathrm{l}$ \\
\hline Al & Aluminio & $\mu \mathrm{g} / \mathrm{l}$ & $M n$ & Manganeso & $\mu g / l$ \\
\hline ALG & Algas & Cantidad/ $100 \mathrm{ml}$ & Mo & Molibdeno & $\mu g / l$ \\
\hline ALKM & Alcalinidad según $\mathrm{CaCO}_{3}$ & $\mathrm{mg} / \mathrm{l}$ & $\mathrm{Na}$ & Sodio & $\mathrm{mg} / \mathrm{l}$ \\
\hline As & Arsénico & $\mu \mathrm{g} / \mathrm{l}$ & $\mathrm{NH}_{4}^{+}$ & Amonio como NH${ }_{4}^{+}$ & $\mathrm{mg} / \mathrm{l}$ \\
\hline B & Boro & $\mathrm{mg} / \mathrm{l}$ & $\mathrm{Ni}$ & Níquel & $\mu g / l$ \\
\hline $\mathrm{Ba}$ & Bario & $\mu g / l$ & NKJT & Nitrógeno total Kjeldahl & $\mathrm{mg} / \mathrm{l}$ \\
\hline DBO & Demanda bioquímica de oxígeno & $\mathrm{mg} / \mathrm{l}$ & $\mathrm{NO}_{2}$ & Nitrito como NO${ }_{2}^{-}$ & $\mathrm{mg} / \mathrm{l}$ \\
\hline $\mathrm{Br}$ & Bromuro & $\mathrm{mg} / \mathrm{l}$ & $\mathrm{NO}_{3}$ & Nitrato como $\mathrm{NO}_{\overline{3}}^{-}$ & $\mathrm{mg} / \mathrm{l}$ \\
\hline $\mathrm{Ca}$ & Calcio & $\mathrm{mg} / \mathrm{l}$ & OLOR & Valor de umbral de olor & \\
\hline $\mathrm{Cd}$ & Cadmio & $\mu g / l$ & AyG & Aceite y grasa & $\mu g / l$ \\
\hline $\mathrm{Cl}$ & Cloruro & $\mathrm{mg} / \mathrm{l}$ & $\mathrm{Pb}$ & Plomo & $\mu g / l$ \\
\hline DECL & Demanda de cloro & $\mathrm{mg} / \mathrm{l}$ & PHEN & Fenoles & $\mu g / l$ \\
\hline CLRL & Clorofila & $\mu g / l$ & PHSITU & pH determinado in situ & \\
\hline CN & Cianuros & $\mu g / l$ & $\mathrm{PO}_{4}$ & Fosfatos como $\mathrm{PO}_{4} 2$ & $\mathrm{mg} / \mathrm{l}$ \\
\hline Co & Cobalto & $\mu g / l$ & РТОТ & Fósforo total como P & $\mathrm{mg} / \mathrm{l}$ \\
\hline COLR & Color ( platino cobalto) & & CLRS & Cloro libre residual & $\mathrm{mg} / \mathrm{l}$ \\
\hline DQO & Demanda química de oxígeno & $\mathrm{mg} / \mathrm{l}$ & RAS & Relación de adsorción de sodio & \\
\hline $\mathrm{Cr}$ & Cromo & $\mu g / l$ & Se & Selenio & $\mu g / l$ \\
\hline $\mathrm{Cu}$ & Cobre & $\mu g / l$ & $\mathrm{Si}$ & Sillice como $\mathrm{H}_{2} \mathrm{SiO}_{3}$ & $\mathrm{mg} / \mathrm{l}$ \\
\hline$O D$ & Oxígeno disuelto como $\mathrm{O}_{2}$ & $\mathrm{mg} / \mathrm{l}$ & Sn & Estaño & $\mu g / l$ \\
\hline COD & Carbono orgánico disuelto & $\mathrm{mg} / \mathrm{l}$ & $\mathrm{SO}_{4}$ & Sulfato & $\mathrm{mg} / \mathrm{l}$ \\
\hline $\mathrm{SD}_{10}$ & Sólidos disueltos a $105^{\circ} \mathrm{C}$ & $\mathrm{mg} / \mathrm{l}$ & $\mathrm{Sr}$ & Estroncio & $\mu g / l$ \\
\hline $\mathrm{SD}_{55}$ & Sólidos disueltos a $550 \stackrel{0}{C}$ & $\mathrm{mg} / \mathrm{l}$ & $\mathrm{SS}_{10}$ & Sólidos suspendidos a $100 \stackrel{0}{ } \mathrm{C}$ & $\mathrm{mg} / \mathrm{l}$ \\
\hline CE & Conductividad eléctrica & $\mu \mathrm{mhos} / \mathrm{cm}$ & $\mathrm{SS}_{55}$ & Sólidos suspendidos a $550^{\circ} \mathrm{C}$ & $\mathrm{mg} / \mathrm{l}$ \\
\hline ENTR & Enterococos & Cantidad/ $100 \mathrm{ml}$ & STRP & Estreptococos & Cantidad/ $100 \mathrm{ml}$ \\
\hline$F^{-}$ & Fluoruros & $\mathrm{mg} / \mathrm{l}$ & T & Temperatura & $\stackrel{\circ}{\circ}$ \\
\hline COLF & Coliformes fecales & Cantidad/ $100 \mathrm{ml}$ & TCOL & Coliformes totales & Cantidad/ $100 \mathrm{ml}$ \\
\hline $\mathrm{Fe}$ & Hierro & $\mu \mathrm{g} / \mathrm{I}$ & ТОТВ & Bacterias totales & Cantidad/ $100 \mathrm{ml}$ \\
\hline DUR & Dureza según $\mathrm{CaCO}_{3}$ & $\mathrm{mg} / \mathrm{l}$ & $\mathrm{ST}_{10}$ & Sólidos totales a $105^{\circ} \mathrm{C}$ & $\mathrm{mg} / \mathrm{l}$ \\
\hline $\mathrm{HCO}_{3}^{-}$ & Bicarbonato $\mathrm{COMO} \mathrm{HCO}_{3}$ & $\mathrm{mg} / \mathrm{l}$ & $\mathrm{ST}_{55}$ & Sólidos totales a $550 \stackrel{\circ}{-} \mathrm{C}$ & $\mathrm{mg} / \mathrm{l}$ \\
\hline $\mathrm{Hg}$ & Mercurio & $\mu g / l$ & TURB & Turbidez & NTU \\
\hline K & Potasio & $\mathrm{mg} / \mathrm{l}$ & UV & UV (absorb. a $254 \mathrm{~nm})(/ \mathrm{cm} \times 10)$ & \\
\hline Li & Litio & $\mu g / l$ & $\mathrm{Zn}$ & Zinc & $\mu g / l$ \\
\hline MBAS & Detergentes & $\mu g / l$ & & & \\
\hline
\end{tabular}

\section{Sistemas de transporte y distribución}

El agua bombeada de los distintos pozos de extracción es recogida por el sistema de transporte y distribución del Tercer Canal de Negev. Este sistema de canalización se compone de tres secciones, con una longitud total de $87 \mathrm{~km}$ y un diámetro que oscila entre 48 y 70 pulgadas. A lo largo de toda la conducción principal del sistema se construyeron seis depósitos "flotantes" para regular el flujo de agua del sistema. El volumen operativo de estos depósitos varía entre $10.000 \mathrm{~m}^{3}$ y $100.000 \mathrm{~m}^{3}$.

El agua que circula por el Tercer $C$ anal se comenzó a suministrar al público en 1993 por medio de un sistema de 13 zonas principales de presión. A estas zonas de presión se han conectado un gran número de consumidores de agua, en su mayoría para explotaciones agrícolas.

\section{Sistema de cloración}

El objetivo de la cloración que se realiza en el Tercer Canal es la "ruptura de la conexión humana", es decir, eliminar cualquier posibilidad de existencia de microorganismos de origen humano en el agua del Tercer $\mathrm{C}$ anal. El sistema de vigilancia detectó un aumento considerable de microorganismos fecales cuando el agua regenerada se almacenaba en los depósitos. Por ello se decidió agregar más puntos de cloración a lo largo del canal y en 1993 existían tres puntos diferentes de cloración. En breve se 
añadirán otros dos puntos de cloración al sistema. El cloro residual oscila entre 0,4 y $1,0 \mathrm{mg} / \mathrm{I}$ de cloro libre. Este método, mediante el cual se aplican concentraciones bajas de cloro libre en diversos puntos del sistema en lugar de una única dosis masiva al principio del canal, garantiza la ruptura de la conexión humana y al mismo tiempo permite la existencia de peces en los depósitos. Además, este método de cloración desinfecta las aguas en los tramos inferiores del sistema de transporte y distribución, en el caso de que algún agente contaminante penetre en el sistema en algún punto posterior al de la cloración inicial.

\section{Sistema de vigilancia}

La explotación del sistema de regeneración del Tercer $C$ anal de Negev depende del funcionamiento continuo de un sistema de vigilancia, supervisado y controlado por un organismo profesional e independiente, el Instituto de Investigación y Desarrollo del Technion-I srael Institute of Tecnology en $\mathrm{H}$ aifa, I srael.

La implantación de un sistema de vigilancia independiente fue un requisito obligatorio del M inisterio de Sanidad de Israel, que es la administración local competente según la ley nacional sobre la salud pública. La necesidad de implantar este sistema de vigilancia se debe a las razones siguientes:

1. Este proyecto es el mayor del mundo en regeneración de aguas residuales.

2. El proyecto contiene ciertos elementos atípicos que hasta ahora no se habían sometido a experimentación.

3. El agua regenerada está destinada al riego ilimitado de plantaciones agrícolas.

La principal función del sistema de vigilancia consiste, por tanto, en garantizar la calidad química y sanitaria del agua proporcionada por el sistema y en dar la voz de alarma ante cualquier variación de la calidad del agua. Además, este sistema realiza un seguimiento de todo el proyecto de regeneración de la Región de $\mathrm{D}$ an, comprobando de paso algunos aspectos como el funcionamiento rutinario de la planta y la calidad química y biológica de sus aguas. Esto es necesario para asegurar que el agua suministrada por el Tercer $C$ anal sea apta para el riego ilimitado, no sólo desde el punto de vista sanitario sino también agrícola.

EI diseño preliminar del sistema de vigilancia corrió a cargo de $\mathrm{Mekoroth}$ Water $\mathrm{Co}$., el mayor suministrador de agua de I srael y promotor del proyecto de la R egión de Dan. Un comité de dirección designado a este efecto ha supervisado de forma periódica el programa de vigilancia, modificándolo progresivamente de acuerdo con la experiencia obtenida en la explotación regular del sistema. El programa de vigilancia supervisaba los diferentes puntos de muestreo a lo largo del Tercer Canal, los diversos parámetros investigados y la frecuencia de muestreo. EI programa preliminar se centró en algunos componentes del sistema, como los pozos de extracción de agua, el sistema de canalización, los depósitos, un número limitado de conexiones de usuario, así como la presencia de pozos de agua potable en las proximidades de la planta. En la Tabla 55.16 se indica los parámetros incluidos en las actividades de vigilancia del Tercer Canal.

\section{Vigilancia de los pozos de extracción de agua}

El programa de muestreo de los pozos de extracción de agua se basa en la determinación cada dos o tres meses de algunos "parámetros indicadores" (grupo A) (Tabla 55.17). Cuando la concentración de cloruros en el pozo muestreado supera en más del $15 \%$ los niveles iniciales, se interpreta como un aumento "significativo" del porcentaje de efluente regenerado que se encuentra

\section{Tabla 55.17 • Parámetros investigados en los pozos de recuperación.}

Grupo A Grupo B Grupo C

Parámetros indicadores Parámetros característicos Parámetros de ensayo completo

$\begin{array}{lll}\text { 1. Cloruros } & \text { Grupo Ay: } & \text { Grupos A+By: } \\ \text { 2. Conductividad eléctrica } & \text { 6. Temperatura } & \text { 24. Sólidos }\end{array}$

3. Detergentes 7. $\mathrm{pH}$

4. Absorción UV 8. Turbidez

5. Oxígeno disuelto

9. Sólidos disueltos

11. Alcalinidad

12. Dureza

13. Calcio

14. Magnesio

15. Sodio

16. Potasio

17. Nitratos

18. Nitritos

19. Amoníaco

20. Nitrógeno total Kjeldahl

21. Fósforo total

22. Sulfato

23. Boro

Suspendidos

26. Recuento de bacterias

totales

27. Coliformes

28. Coliformes fecales

29. Estreptococos fecales

30. Zinc

31. Aluminio

32. Arsénico

33. Hierro

34. Bario

35. Plata

36. Mercurio
10. Carbono orgánico disuelto

37. Cromo

38. Litio

39. Molibdeno

40. Manganeso

41. Cobre

42. Níquel

43. Selenio

44. Estroncio

45. Plomo

46. Fluoruro

47. Cianuros

48. Cadmio

49. Cobalto

50. Fenoles

51. Aceites minerales

52. COT

53. Olor

54. Color

en el agua del yacimiento acuífero subterráneo, pasándose el pozo al siguiente grupo de muestreo (grupo B), donde se estudian 23 "parámetros característicos" una vez al trimestre. En algunos pozos se realiza una vez al año un estudio exhaustivo de las aguas determinando 54 parámetros diferentes (grupo C).

\section{Vigilancia del sistema de canalización}

El sistema de canalización, de $87 \mathrm{~km}$ de longitud, se controla en siete puntos, en donde se efectúa una vez al mes un muestreo para determinar 16 parámetros diferentes: $\mathrm{PHTE}, \mathrm{OD}, \mathrm{T}, \mathrm{CE}$, $\mathrm{SS}_{10}, \mathrm{SS}_{55}, \mathrm{UV}$, TURB, NO ${ }_{3}^{+}$, PTOT, ALKM, COD, TOTB, TCOL, COLF y ENTR. Cuando no se espera variación de los parámetros a lo largo de todo el sistema, se determinan únicamente en dos puntos de muestreo, al principio y al final del sistema de canalización. Estos parámetros son: $\mathrm{Cl}, \mathrm{K}, \mathrm{Na}, \mathrm{Ca}$, $\mathrm{Mg}, \mathrm{DUR}, \mathrm{B}, \mathrm{SD}, \mathrm{SO}_{+}^{-2}, \mathrm{NH}^{+}{ }_{4}, \mathrm{NO}_{2}$ y MBAS. En estos dos puntos de muestreo se analizan, una vez al año, metales pesados como Zn, Sr, Sn, Se, Pb, N i, M o, M n, Li, H g, Fe, Cu, Cr, Co, Cd, $\mathrm{Ba}, \mathrm{As}, \mathrm{Al}$ y Ag. 


\section{Vigilancia de los depósitos}

El sistema de vigilancia de los depósitos del Tercer $\mathrm{C}$ anal se basa principalmente en el estudio de un número limitado de parámetros que sirven como indicadores del desarrollo biológico en los depósitos y para comprobar la posible penetración de agentes contaminantes externos. U na vez al mes se obtienen muestras de cinco depósitos y se determinan los siguientes parámetros: $\mathrm{PHTE}$, T, D O, SS total, SS volátil, COD, CLRL, CLRS, TCOL, FCOL, STRP y ALG. En estos cinco depósitos se muestrea el Si con carácter bimestral. Todos estos parámetros se determinan también en otro depósito, el Zohar B, con una frecuencia bimestral.

\section{Resumen}

El Proyecto de Regeneración de la Región de $D$ an suministra agua regenerada de alta calidad para riego ilimitado en la región árida de N egev en Israel.

La Fase I de este proyecto se halla en explotación parcial desde 1970 y a pleno funcionamiento desde 1977. D esde 1970 hasta 1993, un total de 373 millones de metros cúbicos (M M C) de aguas residuales han sido enviados a los tanques de oxidación y durante el período 1974-1993 se han extraído 243 M M C de agua del acuífero para abastecer a la zona meridional del país. Una parte del agua se ha perdido, sobre todo por evaporación y filtración de los tanques. En 1993 estas pérdidas equivalieron al $6,9 \%$ de las aguas residuales enviadas a la planta de la Fase I (K anarek 1994).

La planta de tratamiento biomecánico, Fase II del proyecto, se encuentra en funcionamiento desde 1987. Durante el período 1987-1993, se transportó un volumen total de aguas residuales de 478 M M C hasta esta planta. En 1993 se transportó a través del sistema y se utilizó para riego ilimitado del Negev un volumen de 103 M M C de agua (95 M MC de agua regenerada más 8 M M C de agua potable).

El agua extraída de los pozos refleja la calidad de las aguas del acuífero subterráneo, la cual varía continuamente como consecuencia de la percolación del efluente. La calidad de las aguas del acuífero se aproxima a la del efluente en lo que respecta a los parámetros que no se ven influidos por los procesos de Tratamiento Suelo-A cuífero (SAT), mientras que los parámetros afectados por el drenaje a través de las capas del suelo (p. ej., turbidez, sólidos en suspensión, amoníaco, carbono orgánico disuelto, etc.) muestran valores bastante más bajos. Cabe destacar el contenido en cloro de las aguas del acuífero, que ha aumentado en los últimos cuatro años entre un 15 y un $26 \%$ según pone de manifiesto la calidad variable del agua extraída de los pozos. Esta variación refleja la sustitución continua del agua del acuífero por efluente con un contenido notablemente más alto de cloro.

La calidad del agua en los seis depósitos del sistema del Tercer Canal se ve afectada por los cambios biológicos y químicos que se producen en el seno de los depósitos abiertos. El contenido de oxígeno aumenta como consecuencia de la fotosíntesis de las algas y de la disolución del oxígeno atmosférico. La concentración de los diferentes tipos de bacterias también aumenta como consecuencia de la contaminación aleatoria causada por la diversa fauna acuática que habita en las proximidades de los depósitos.

La calidad de las aguas suministradas a los usuarios a través del sistema depende de la calidad del agua extraída de los pozos y almacenada en los depósitos. La cloración obligatoria del agua del sistema constituye una protección adicional contra la posible utilización por error del agua para consumo humano. La comparación de los datos sobre la calidad del agua del Tercer $\mathrm{C}$ anal con los requisitos del M inisterio de Sanidad de Israel respecto a la calidad de las aguas residuales destinadas a uso agrícola ilimitado demuestra que casi siempre se cumplen todos esos requisitos.
Como conclusión, cabe afirmar que el sistema de regeneración y utilización de las aguas residuales a través del Tercer Canal ha sido un proyecto medioambiental y nacional de Israel que ha tenido un gran éxito, ya que ha resuelto el problema de la evacuación segura de las aguas residuales de la Región de Dan y al mismo tiempo ha aumentado el equilibrio hidráulico nacional en un $5 \%$ aproximadamente. En un país árido como Israel, donde el abastecimiento de agua, especialmente para uso agrícola, es bastante limitado, este porcentaje supone una contribución importante

El coste de las actividades de renovación y mantenimiento del agua regenerada fue, en 1993, de unos 3 centavos US por $\mathrm{m}^{3}$ $\left(0,093 \mathrm{~N} / \mathrm{S} / \mathrm{m}^{3}\right)$.

El sistema funciona desde finales del decenio de 1960 bajo la estricta vigilancia del M inisterio de Sanidad de Israel y del Departamento de Sanidad e Higiene en el Trabajo de M ekoroth. No se ha registrado ninguna enfermedad profesional relacionada con la explotación de este complejo y vasto sistema.

\section{PRINCIPIOS DE LA GESTION DE RESIDUOS}

Lucien Y. M aystre

La sensibilización medioambiental está provocando una rápida transformación de las prácticas de gestión de residuos. Antes de analizar con mayor detenimiento los métodos aplicados a dicha gestión y al tratamiento de los residuos, conviene realizar una interpretación de esta nueva tendencia.

Los principios modernos de la gestión de residuos se basan en el paradigma de una conexión sincronizada entre la biosfera y la antroposfera. El modelo global (Figura 55.22) que interrelaciona estas dos esferas parte del supuesto de que todos los materiales extraídos del medio ambiente acaban siendo residuos, bien de forma directa (procedentes del sector industrial) o indirecta (procedentes del sector del reciclado), teniendo en cuenta que

\section{Figura 55.22 - Modelo global de los principios de la gestión de residuos.}

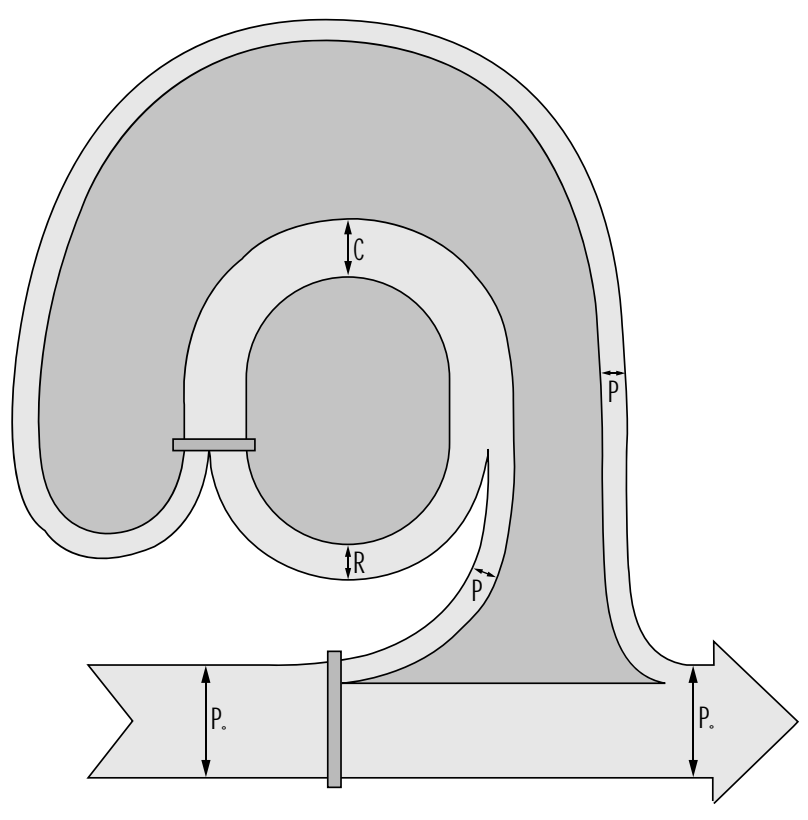


todos los vertidos de consumo regresan a este sector del reciclado para su reutilización o su evacuación.

Desde esta óptica, el reciclado debe entenderse de forma amplia, ya que comprende desde el reciclado de objetos completos (retornables) hasta el reciclado de piezas (p. ej., coches, ordenadores), pasando por la producción de nuevos materiales (p. ej., papel y cartón, latas) o productos similares (reciclado, descomposición, etc.). A largo plazo, este modelo puede entenderse como un sistema estable en el que todos los productos terminan convirtiéndose en residuos al cabo de unos pocos días o de varios años.

\section{Deducciones del modelo}

A partir de este modelo se pueden extraer algunas conclusiones importantes, siempre y cuando se definan con precisión los diferentes flujos. A los efectos de este modelo:

- $P_{0}=$ extracción anual de materiales presentes en el medio ambiente (biosfera, hidrosfera o litosfera). E $n$ un estado estable, esta extracción es igual al vertido final de residuos al cabo del año.

- $P=$ producción anual de bienes a partir de Po.

- $C=$ flujo anual de bienes en la antroposfera.

- $R$ = flujo anual de residuos convertidos en bienes mediante reciclado (en un estado estable: $C=R+P$ )

- $p=$ eficiencia de la producción, medida como la relación $\mathrm{P} / \mathrm{Po}$

- Si $r=$ eficiencia del reciclado, medida como el cociente $R / C$, entonces la relación es:

$C / P_{0}=p(1-r)$.

- Si C/P $=C^{*}$, entonces $C^{*}$ es la relación entre los bienes y los materiales extraídos de la naturaleza.

En otras palabras, $C^{*}$ es una medida de la intensidad de la conexión entre medio ambiente y antroposfera y está relacionada con el grado de eficiencia de la producción y de los sectores de reciclado. La relación entre $C *, p$ y $r$, que es una función de la utilidad, se puede representar como en la Figura 55.23, que muestra la interrelación entre $p$ y $r$, para un cierto valor de $C *$.

En las primeras etapas del desarrollo industrial, se persiguió una mayor eficiencia de la producción, p. En la actualidad, a finales del decenio de 1990, el coste de la evacuación de los residuos por dispersión en la atmósfera, las aguas o los suelos (vertidos incontrolados) o por enterramiento de los residuos en vertederos estancos, ha aumentado vertiginosamente como consecuencia de las leyes cada vez más estrictas de protección del medio ambiente. En estas circunstancias, el aumento de la eficiencia del reciclado (en otras palabras, el aumento de r) ha adquirido un mayor atractivo económico y se espera que esta tendencia se mantenga a lo largo de los próximos decenios.

Para aumentar la eficiencia del reciclado es necesario cumplir una condición importante: los residuos que tienen que reciclarse (dicho de otra forma, las materias primas de segunda generación) deben ser lo más "puros" posible (es decir, exentos de elementos no deseados que imposibiliten su reciclado). Esto puede lograrse mediante la puesta en práctica de una política universal de "separación" de los residuos domésticos, comerciales e industriales en los puntos de origen, que a menudo se denomina erróneamente 'clasificación en origen'. Clasificar equivale a separar; pero la idea consiste precisamente en no tener que separar al haber ya almacenado los distintos tipos de residuos en depósitos o lugares diferentes a la espera de su recogida. El objetivo de la gestión moderna de residuos es mantenerlos separados en el punto de origen, de manera que pueda conseguirse un reciclado más eficiente y, por consiguiente, una mejor relación entre los recursos naturales consumidos y los bienes producidos.
Figura 55.23 • Función de utilidad para representar la relación entre reciclado y producción.

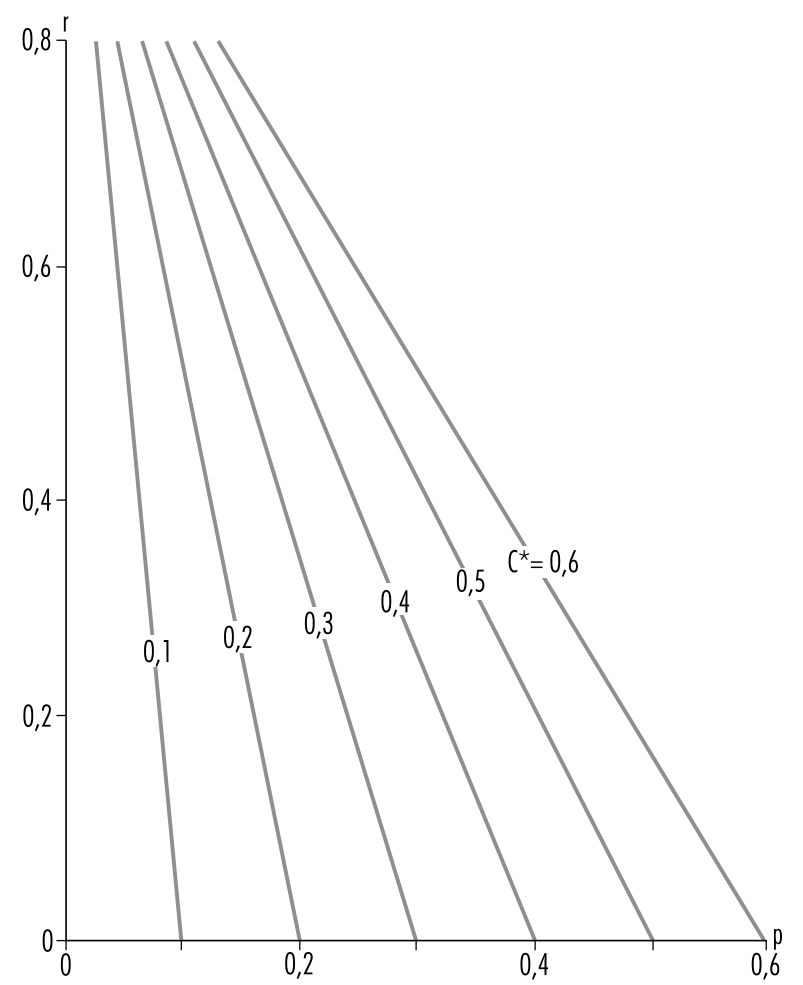

\section{Prácticas de gestión de residuos}

L os residuos se pueden clasificar en tres grandes categorías, según su origen:

1. procedentes del sector primario de producción (minería, silvicultura, agricultura, ganadería, pesca)

2. procedentes de la industria de fabricación y transformación (alimentos, equipos, todo tipo de productos)

3. procedentes del sector del consumo (hogares, empresas, transporte, comercio, construcción, servicios, etc.).

Desde el punto de vista legislativo los residuos pueden clasificarse también en:

- residuos municipales y residuos mixtos procedentes de empresas, pudiéndose considerar ambos como residuos municipales, ya que ambos pertenecen a la misma categoría y su tamaño es reducido (hortalizas, papel, metales, vidrio, plásticos, etc.), aunque estén presentes en diferentes proporciones;

- residuos urbanos voluminosos (mobiliario, equipos, vehículos, residuos de construcciones y derribos, excepto materiales inertes),

- residuos sujetos a legislación especial (p. ej. peligrosos, infecciosos, radiactivos).

Gestión de los residuos municipales y los residuos comerciales normales: Estos residuos, recogidos por camiones, pueden transportarse por diferentes medios (carretera, ferrocarril, barco u otros medios de transporte de larga distancia) hasta un vertedero o una planta de tratamiento para la recuperación de materiales (clasificación mecánica, compostaje, biometanización) o para la recuperación de energía (incineración en horno, pirólisis). 
L as plantas de tratamiento producen cantidades proporcionalmente pequeñas de residuos que pueden resultar más peligrosos para el medio ambiente que los residuos originales. Por ejemplo, las incineradoras producen cenizas volátiles con un contenido muy elevado de metales pesados y de sustancias químicas complejas. Estos residuos están a menudo clasificados por la legislación como residuos peligrosos y precisan una gestión específica. Las plantas de tratamiento se diferencian de los vertederos controlados en que son "sistemas abiertos" con entradas y salidas, mientras que los vertederos controlados son "sistemas cerrados" (sin tener en cuenta la pequeña cantidad de percolado que exige un tratamiento posterior y el biogas generado, que puede ser una fuente de explotación de energía en enterramientos sanitarios de gran magnitud).

Equipos industriales y domésticos: La tendencia actual, que responde asimismo a condicionantes comerciales, descarga sobre los productores de los sectores con residuos (p. ej., automóviles, ordenadores, máquinas) la responsabilidad de su reciclado. Estos residuos pueden ser materiales peligrosos 0 similares a los habituales de las empresas.

Residuos deconstrucción y demolición: EI coste creciente de los vertederos controlados obliga a clasificar tales vertidos con un criterio más acertado. La separación entre los residuos peligrosos y combustibles y los grandes volúmenes de materiales inertes permite que éstos últimos sean eliminados a un coste mucho menor que en el caso de residuos mixtos.

Residuos especiales: Los residuos químicos peligrosos deben tratarse mediante neutralización, mineralización, insolubilización o transformación en compuestos inertes antes de depositarlos en vertederos especiales. Los residuos infecciosos deben eliminarse en incineradoras especiales. L os residuos radiactivos están sujetos a una legislación muy estricta.

\section{Gestión de residuos}

Los residuos procedentes de la producción y el consumo que no pueden ser reciclados, reducidos, reutilizados o incinerados para producir energía deben ser eliminados. La toxicidad para el medio ambiente de estos residuos debe reducirse aplicando el principio de la "mejor tecnología disponible a un precio razonable". L os residuos, una vez sometidos a este tratamiento, deben depositarse en lugares que no contaminen las aguas y los ecosistemas, y no se propaguen a la atmósfera, los mares, los lagos o los cursos de agua.

La antigüedad de los vertederos se evalúa generalmente dependiendo del aislamiento proporcionado por capas múltiples (utilizando arcilla, geotextiles, láminas de plástico, etc.), la desviación de todo el agua exógena y las capas impermeables de cobertura. Los depósitos permanentes requieren vigilancia durante decenas de años. También tienen que controlarse las restricciones en el uso del suelo de los vertederos durante largos períodos de tiempo. En la mayoría de los casos tienen que instalarse sistemas controlados de drenaje para percolados y gases.

Los residuos bioquímicamente más estables y químicamente inertes, resultantes del tratamiento de residuos, exigen una condiciones menos estrictas para su eliminación definitiva, lo que facilita la búsqueda de un vertedero dentro de la misma región en la que se producen tales residuos. De esta forma se evita el transporte de residuos, lo que siempre provoca reacciones de protesta por parte de la población próxima al emplazamiento seleccionado.

\section{GESTION Y RECICLADO DE RESIDUOS SOLIDOS}

\author{
Niels Jorn Hahn y Poul S. Lauridsen
}

Los residuos sólidos suelen describirse como productos residuales cuya eliminación genera un coste.

La gestión de residuos conlleva una compleja serie de impactos potenciales en la seguridad y la salud humana y en el medio ambiente. Aunque los tipos de peligro pueden ser similares, los impactos pueden clasificarse en tres categorías de operaciones:

- manipulación y almacenamiento en el lugar de producción de los residuos;

- recogida y transporte,

- clasificación, tratamiento y evacuación.

No debe olvidarse que los peligros para la seguridad y la salud surgen allí donde se generan los residuos, en la fábrica o en el hogar del consumidor. Por consiguiente, el almacenamiento de residuos en el lugar de origen, y especialmente cuando se realiza allí su separación, puede traducirse en un impacto nocivo sobre el entorno próximo. El objeto del presente artículo es proporcionar un marco para comprender las técnicas de gestión de residuos sólidos y describir los riesgos para la seguridad y la higiene asociados a la recogida, el transporte, el tratamiento y la evacuación de residuos.

\section{¿Por qué es necesaria la gestión de los residuos sólidos?}

La gestión de los residuos sólidos se convierte en necesaria e importante en el momento en que la estructura de la sociedad deja de ser agrícola, de baja densidad y dispersa y se convierte en otra urbana de alta densidad. Además, la industrialización ha introducido una gran cantidad de productos que la naturaleza no es capaz de descomponer ni absorber o lo hace de forma muy lenta. Algunos productos industriales contienen sustancias que, por su baja capacidad de degradación o incluso sus características tóxicas, se acumulan en la naturaleza en cantidades tales que representan una amenaza para el aprovechamiento futuro de los recursos naturales por parte de la humanidad, como por ejemplo, el agua potable, la tierra de labor, el aire, etc.

El objeto de la gestión de los residuos sólidos es evitar la contaminación de la naturaleza.

Cualquier sistema de gestión de residuos sólidos debe estar basado en estudios técnicos y procedimientos de planificación global que incluyan:

- estudios y estimaciones sobre la composición y la cantidad de residuos;

- estudios sobre las técnicas de recogida;

- estudios sobre plantas de tratamiento y eliminación

- estudios sobre prevención de la contaminación del medio ambiente;

- estudios sobre las normas de seguridad e higiene en el trabajo,

- estudios de viabilidad.

Estos estudios deben contemplar aspectos relativos a la protección del medio ambiente y a la seguridad y la higiene en el trabajo, teniendo en cuenta las posibilidades de un desarrollo sostenido. Puesto que rara vez pueden resolverse todos los problemas a la vez, es importante que durante la fase de planificación se elabore una lista de prioridades. El primer paso para resolver los peligros ambientales y profesionales es reconocer la existencia de estos peligros. 
Tabla 55.18 - Fuentes de residuos.

$\begin{array}{ll}\text { Actividad } & \text { Descripción del residuo } \\ \text { Industria } & \text { Residuos de productos } \\ & \text { Productos defectuosos } \\ \text { Comercio mayorista } & \text { Productos defectuosos } \\ \text { Comercio minorista } & \text { Acondicionamiento para el transporte } \\ & \text { Productos defectuosos } \\ & \text { Productos orgánicos (del procesamiento } \\ \text { de alimentos) } & \text { Residuos alimenticios } \\ \text { Consumidor } & \text { Acondicionamiento para el transporte } \\ & \text { Acondicionamiento para minoristas (papel, } \\ & \text { vidrio, metal, plástico, etc.) } \\ & \text { Residuos de cocina (orgánicos) } \\ & \text { Residuos peligrosos (productos químicos, aceite) } \\ & \text { Residuos de mayor volumen (mobiliario usado), etc. } \\ & \text { Residuos de jardinería } \\ \text { Construcción y demolición } & \text { Hormigón, ladrillos, hierro, arena, etc. } \\ \text { Actividades de } & \text { Residuos abandonados } \\ \text { infraestructura } & \text { Residuos de limpieza de las calles } \\ & \text { Escorias, cenizas y gas de combustión procedentes } \\ \text { de las plantas de energía } & \text { Fangos residuales } \\ & \text { Residuos de hospitales } \\ \text { Procesamiento de residuos } & \text { Material rechazado en instalaciones de clasificación } \\ & \text { Escorias, cenizas y productos de depuración del gas } \\ \text { de combustión procedentes de la incineración }\end{array}$

\section{Principios de la gestión de residuos}

La gestión de residuos conlleva una compleja y amplia serie de interrelaciones relativas a la seguridad y la higiene en el trabajo. La gestión de los residuos es un proceso de producción "inversa"; el "producto" es la eliminación de los materiales excedentes. En un principio el objetivo era simplemente recoger los materiales, reutilizar los componentes valiosos de los mismos y desechar los sobrantes en un lugar próximo que no estuviera destinado a fines agrícolas, edificaciones, etc. En muchos países este planteamiento sigue vigente.

En una sociedad moderna, las fuentes de residuos pueden describirse por sus diferentes funciones (véase la Tabla 55.18).

Cada tipo de residuo se caracteriza por su origen o el tipo de producto del que procede. Por consiguiente, los peligros que entraña para la seguridad y la higiene son los que deberían caracterizarse para limitar su manipulación por parte del generador de residuos. En cualquier caso, el almacenamiento de los residuos puede crear nuevos y más graves factores de riesgo (actividad química o biológica durante la fase de almacenamiento).

En la gestión de los residuos sólidos pueden diferenciarse las siguientes fases:

- separación en origen de los diferentes componentes de los residuos de acuerdo con las características de los materiales;

- almacenamiento temporal en el lugar de producción de los residuos en cubos, sacos, contenedores o montones;

- recogida y transporte en vehículos:

- métodos manuales, carros de tracción animal, motorizados y otros;

- plataforma abierta, camión cerrado, unidad de compactación, y otros.;
- planta de tranferencia: compactación y traslado a unidades mayores de transporte;

- plantas de reciclado y tratamiento de residuos,

- tratamiento de residuos:

- separación manual o mecánica de los diferentes materiales para su reciclado;

- tratamiento de los materiales clasificados previamente para su conversión en materias primas secundarias;

- tratamiento para obtener materias (primas) nuevas;

- incineración para reducir su volumen o para obtener energía;

- descomposición anaeróbica de las sustancias orgánicas para la producción de abonos, fertilizantes y energía (biogas),

- tratamiento (compostaje) de sustancias orgánicas para producir abonos y fertilizantes.

- evacuación de residuos:

- en vertederos, diseñados y emplazados para evitar la fuga de aguas contaminadas (percolación de los vertederos), especialmente hacia fuentes de agua potable (aguas freáticas, pozos y ríos).

El reciclado de los residuos puede realizarse en cualquiera de las fases del sistema de tratamiento y en cada una de ellas pueden surgir peligros específicos para la seguridad y la higiene.

En las sociedades de rentas bajas y poco industrializadas, el reciclado de los residuos sólidos constituye una importante fuente de ingresos y habitualmente no se plantean los peligros que puede entrañar para la seguridad y la higiene.

En los países altamente industrializados existe una clara tendencia a dedicar cada vez más atención al reciclado de las inmensas montañas de residuos que se producen. Existen razones de peso que van más allá del mero valor de mercado de los residuos, entre ellas la ausencia de instalaciones adecuadas para la evaluación de los residuos y la creciente sensibilización pública acerca del desequilibrio entre consumo y protección del medio ambiente. Por tanto, a la recogida y eliminación de los residuos se les ha rebautizado con el nombre de reciclado para elevar de categoría de dicha actividad a los ojos de la población, lo que se ha traducido en una creciente sensibilización respecto a las condiciones de trabajo en el sector del tratamiento de residuos.

En la actualidad, las autoridades competentes en materia de seguridad e higiene en el trabajo han dirigido su atención a unas condiciones de trabajo que, hasta hace muy pocos años, eran ignoradas, admitiendo tácitamente prácticas como:

- manejo de pesos y volúmenes excesivos de materiales durante la jornada laboral;

- exposición peligrosa a polvos de composición desconocida;

- impacto inadvertido de microorganismos (bacterias, hongos) y endotoxinas,

- exposición inadvertida a sustancias químicas tóxicas.

\section{Reciclado}

Reciclado es el término que describe tanto la reutilización (utilización para una misma finalidad) como la recuperación de materiales o energía.

Los motivos del reciclado varían según las circunstancias nacionales y locales, aunque las principales justificaciones de esta actividad son las siguientes:

- destoxificación de residuos peligrosos en el caso de que las autoridades competentes hayan establecido normas ambientales rigurosas;

- recuperación de recursos en regiones de renta baja; 
- reducción del volumen de los residuos en zonas donde predomina la práctica del vertido controlado,

- recuperación de energía en zonas donde la conversión de los residuos en energía puede llegar a sustituir al combustible mineral (carbón, gas natural, petróleo, etc.).

Como ya se ha mencionado antes, el proceso de reciclado puede realizarse en cualquier fase del sistema de tratamiento de residuos, si bien es cierto que también puede aplicarse para prevenir la "aparición" de dichos residuos. Este es el caso de los productos diseñados para ser reciclados mediante un sistema de recompra una vez utilizados como, por ejemplo, los envases de vidrio por los que se abona una cantidad en concepto de depósito en el momento de su compra.

Así pues, el reciclado es algo más que la simple sistematización de la recogida o regeneración de materiales procedentes de la producción de residuos.

EI reciclado de los materiales implica, en la mayoría de los casos, la separación o clasificación de los materiales residuales según categorías, con un grado mínimo de selectividad como requisito previo para que residuos puedan sustituir a las materias primas originales.

La clasificación puede realizarse en origen (por el propio generador de los residuos) o después de su recogida en una planta central.

\section{Separación en origen}

La separación en origen produce, utilizando la tecnología actual grupos de residuos "diseñados" para su tratamiento. En origen sólo es posible conseguir un cierto grado de separación, ya que la individualización de mezclas de algunos tipos de residuos para su reutilización supone un gran esfuerzo (económico). Los sistemas de separación en origen siempre deben tener presente el tipo de reciclado final.

El objetivo del sistema de separación en origen debería ser el de evitar la mezcla o contaminación de los distintos grupos de residuos para facilitar su reciclado.

La separación de residuos en origen a menudo se traduce en peligros más específicos para la seguridad e higiene en el trabajo que la recogida en bruto. Esto se debe a la concentración de ciertos grupos específicos de residuos como, por ejemplo, las sustancias tóxicas. La separación de sustancias orgánicas que se degradan rápidamente puede dar lugar a un nivel muy elevado de exposición a organismos peligrosos como hongos, bacterias, endotoxinas, etc., en el momento de manipular o cargar las distintas sustancias.

\section{Clasificación centralizada}

La clasificación centralizada puede realizarse por medios mecánicos o manuales.

En general se acepta que con la tecnología actual la clasificación mecánica sin una separación previa en origen sólo debería emplearse para la producción de combustibles derivados de los residuos (refuse derived fue, RDF). Los requisitos previos para garantizar unas condiciones aceptables de trabajo es la utilización de equipos mecánicos estancos y de "trajes espaciales" personales cuando tienen que realizarse actividades de reparación o mantenimiento en las plantas

La clasificación mecánica centralizada con separación previa en origen no resulta satiffactoria con la tecnología actual debido a los problemas para conseguir una clasificación eficaz. A medida que se vayan definiendo con mayor precisión las características de los diferentes grupos de residuos clasificados y cuando, además, puedan aplicarse tanto a escala nacional como internacional, cabrá esperar el desarrollo de nuevas técnicas más específicas y eficaces. El éxito de estas nuevas técnicas estará íntimamente ligado al establecimiento de unas condiciones de trabajo aceptables.

La clasificación manual centralizada debe presuponer la separación previa en origen si se pretende evitar cualquier peligro funcional para la seguridad y la higiene en el trabajo (polvo, bacterias, sustancias tóxicas, etc.). La clasificación manual deberá restringirse a un conjunto limitado de "categorías" de residuos para evitar errores previsibles de clasificación en origen, así como para simplificar las medidas de control en la zona de recepción de la planta. A medida que se vayan definiendo con mayor nitidez las categorías de residuos, se podrán desarrollar nuevos sistemas de clasificación automática que reduzcan al mínimo la exposición de los trabajadores a sustancias nocivas.

\section{¿Por qué es necesario el reciclado?}

Es importante puntualizar que el reciclado no constituye un método de tratamiento de residuos que pueda enjuiciarse independientemente de otros planes de gestión de residuos. Para complementar el reciclado es necesario tener acceso a un vertedero correctamente gestionado y posiblemente a plantas de tratamiento más tradicionales, como plantas de incineración o de fabricación de abonos

El proceso de reciclado debe analizarse en conexión con:

- el suministro local de materias primas y energía,

- Io que se sustituye, recursos renovables (p. ej., papel/ árboles) 0 no renovables (p. ej., petróleo).

Siempre que, por ejemplo, el petróleo o el carbón se utilicen como fuentes de energía, la incineración de combustibles derivados de residuos y desechos con recuperación de energía constituye una opción válida de gestión de residuos. Sin embargo, los volúmenes de residuos reducidos a su mínima expresión por esta vía deben acabar en depósitos que cumplan unas normas ambientales muy rigurosas, lo cual puede resultar muy costoso.

\section{ESTUDIO DE CASO : CONTROL Y PREVENCION DE LA CONTAMINACION DE LOS G RAN DES LAGOS DE CANADA}

\author{
Thomas Tseng, Victor Shantora e
} Ian R. Smith

\section{El desafío}

Los Grandes Lagos constituyen un recurso compartido entre Canadá y Estados Unidos (véase la Figura 55.24). Los cinco grandes lagos contienen más del $18 \%$ del agua superficial mundial. En esta cuenca vive uno de cada tres canadienses (aproximadamente 8,5 millones) y uno de cada cinco norteamericanos (27,5 millones) y es el corazón industrial de ambos países, con la quinta parte del sector industrial de Estados Unidos y la mitad del canadiense. La actividad económica alrededor de la zona de los Grandes Lagos genera anualmente cerca de un billón de dólares de riqueza. A lo largo de los años, el desarrollo demográfico e industrial ha creado una serie de presiones en los lagos hasta que, a mediados del presente siglo, ambos países reconocieron la necesidad de actuar de forma conjunta para proteger la región de los $\mathrm{G}$ randes L agos.

\section{La respuesta}

A partir del decenio de 1950, ambos países pusieron en marcha programas nacionales y bilaterales para hacer frente a los problemas generales de contaminación, así como para responder a problemas más específicos de la calidad de las aguas. Como 
Figura 55.24 - Cuenca de drenaje de los Grandes Lagos: río St. Law rence.

Principales ríos y ciudades en la cuenca de drenaje de los Grandes Lagos

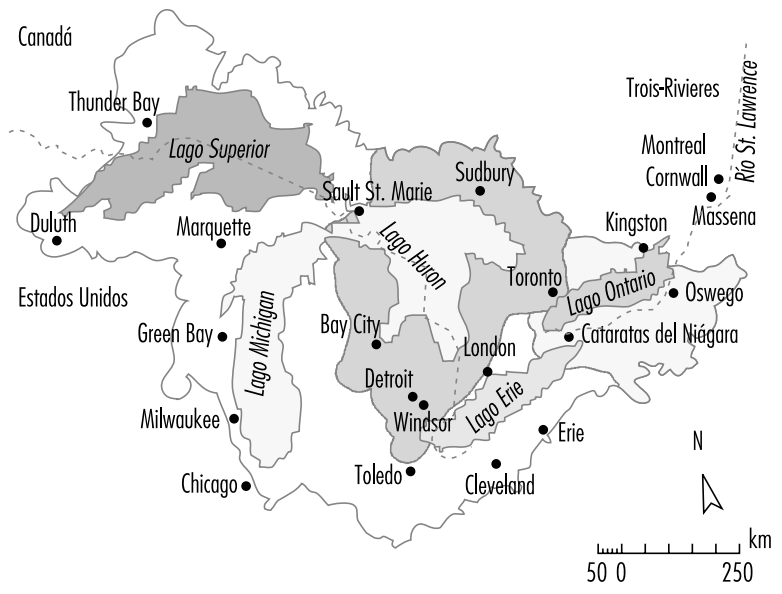

\begin{tabular}{|l|}
\hline Leyenda \\
$\square$ Cuenca de drenaje del Lago Hurón \\
$\square$ Cuenca de drenaje del Lago Michigan \\
$\square$ Cuenca de drenaie del Lago Erie \\
$\square$ Cuenca de drenaje del Lago Superior \\
$\square$ Cuenca de drenaje del Lago Ontario \\
$\cdots$ Frontera Estados Unidos/Canadá \\
- Ciudades/Poblaciones \\
\hline
\end{tabular}

Ministerio de Medio Ambiente de Canadá

consecuencia de esta actuación, las aguas de los Grandes Lagos están ahora mucho más limpias que a mediados de siglo, el vertido de metales pesados y de sustancias químicas orgánicas ha disminuido y se ha reducido drásticamente el grado de contaminación para peces y aves acuáticas. El éxito de las actividades de Canadá y E stados U nidos para regenerar y proteger los $G$ randes Lagos son fruto de un modelo de cooperación bilateral de gestión de recursos, aunque todavía quedan algunos problemas sin resolver.

\section{Perspectiva histórica del caso}

Las amenazas que suponen las sustancias tóxicas permanentes tienen un efecto a largo plazo y exigen la adopción de medidas integradas para controlar las fuentes emisoras. Para conseguir el objetivo a largo plazo de eliminar las sustancias tóxicas permanentes de los G randes Lagos, las autoridades responsables de la protección del medio ambiente, las industrias y las demás partes implicadas en la cuenca se vieron obligadas a desarrollar estrategias y programas innovadores. La finalidad de este estudio de caso es ofrecer un breve resumen de los programas canadienses para el control de la contaminación y de las mejoras logradas hasta 1995, así como describir las iniciativas de gestión de las sustancias tóxicas permanentes en los Grandes Lagos. En este contexto no se incluyen las iniciativas y los programas equivalentes que ha emprendido Estados U nidos. EI lector interesado puede ponerse en contacto con la $\mathrm{O}$ ficina del Programa $\mathrm{N}$ acional de los Grandes Lagos de la Agencia de Protección del M edio Ambiente de Estados Unidos (US Environmental Protection Agency, EPA) en Chicago para obtener información sobre los programas federales y estatales relativos a la protección de los Grandes L agos.

\section{Los decenios de 1970 y 1980}

U no de los problemas más graves que afectaba al Lago E rie en el decenio de 1960 era el enriquecimiento de sustancias nutritivas 0 el proceso de eutrofización. La necesidad evidente de adoptar medidas bilaterales llevó a C anadá y a Estados U nidos a firmar el primer Acuerdo sobre $C$ alidad de las A guas de los $G$ randes $L$ agos (G reat L akes W ater Q uality A grement, GLW Q A) en 1972. El Acuerdo fijaba objetivos de reducción de vertidos fosforados, sobre todo procedentes de detergentes para el lavado de la ropa y residuos municipales. En línea con este compromiso, Canadá y O ntario promulgaron leyes y programas para controlar las fuentes localizadas. Entre 1972 y 1987, Canadá y O ntario invirtieron más de 2.000 millones de dólares en la construcción y modernización de fábricas de tratamiento de residuos en la cuenca de los Grandes Lagos.

EI GLWQA de 1972 planteaba asimismo la necesidad de reducir el vertido de sustancias químicas tóxicas en los lagos por parte de las industrias y de otras fuentes (p. ej. fugas). En C anadá, la normativa federal adoptada durante el decenio de 1970 con relación al vertido de contaminantes tradicionales procedentes

Figura 55.25 - Progresos en el control de la contaminación de fuentes industriales.
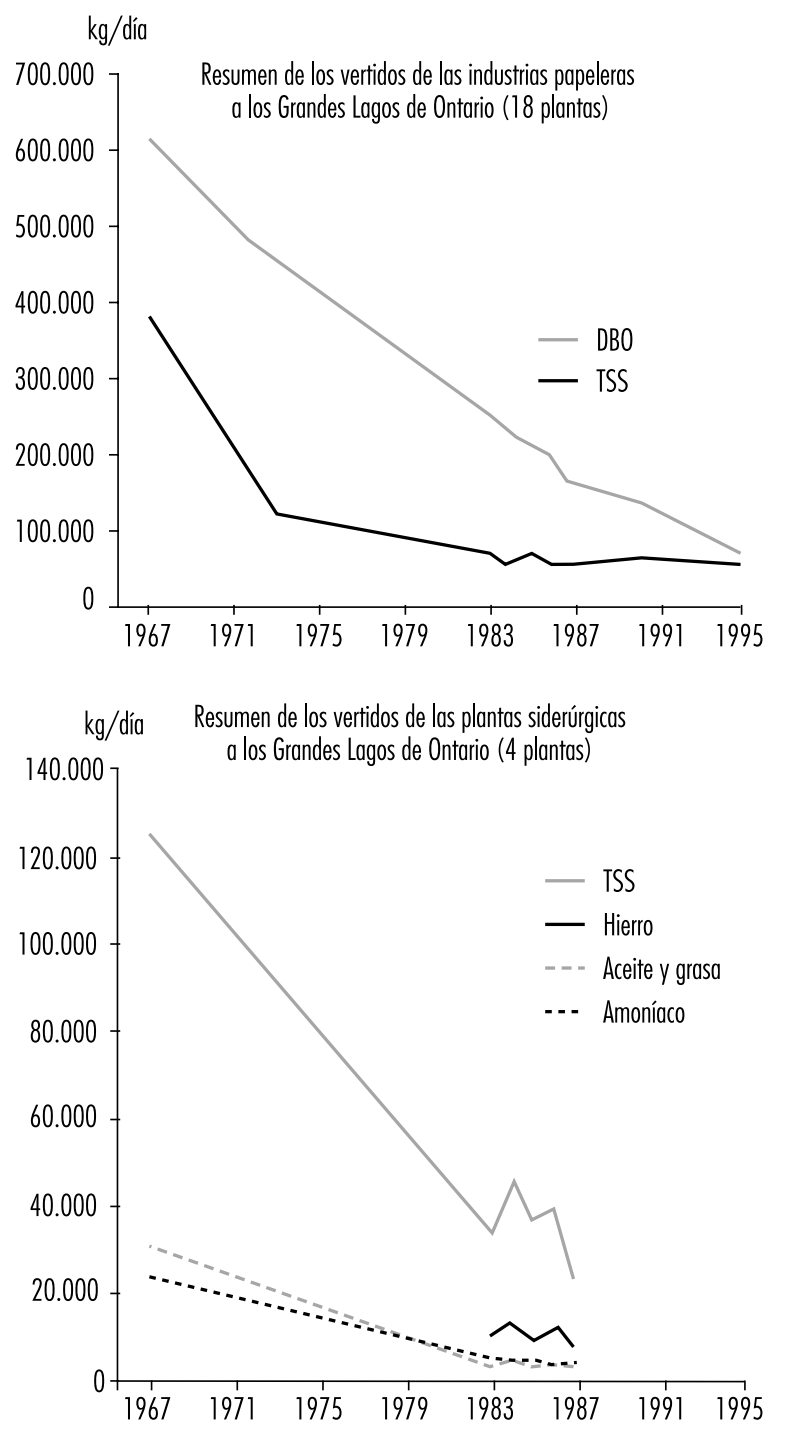
de los grandes sectores industriales (papel, minería de metales, refinado de petróleo, etc.) estableció límites de vertido a escala nacional, al tiempo que 0 ntario establecía directrices similares sobre los vertidos adaptadas a las necesidades locales, incluidos los $\mathrm{G}$ randes Lagos. Las acciones promovidas por las industrias y municipios para cumplir la normativa federal y la de 0 ntario sobre los vertidos obtuvieron resultados impresionantes; por ejemplo, el vertido de sustancias fosforadas procedentes de fuentes localizadas al Lago Erie disminuyeron en un $70 \%$ entre 1975 y 1989 y la liberación de sustancias contaminantes tradicionales por parte de las siete refinerías de petróleo en 0 ntario ha disminuido en un $90 \%$ desde principios del decenio de 1970. La Figura 55.25 muestra tendencias similares de reducción para los vertidos de los sectores del papel, el hierro y el acero.

$\mathrm{H}$ acia mediados del decenio de 1970, las evidencias de altas concentraciones de sustancias químicas tóxicas en los peces y en la fauna silvestre de los $G$ randes Lagos, las disfunciones reproductoras en determinadas aves ictiófagas y la disminución de la población de algunas especies revelaron la presencia de sustancias tóxicas bioacumulativas permanentes, convirtiéndose este problema en el nuevo objetivo de la actividad protectora de ambos países. Canadá y Estados U nidos firmaron en 1978 un segundo Acuerdo sobre la Calidad de las Aguas de los Grandes Lagos, por el que ambos países se comprometían a "restablecer y mantener la integridad química, física y biológica de las aguas del Ecosistema de los Grandes Lagos". U no de los principales retos fue la política "de prohibición del vertido de sustancias tóxicas en cantidades tóxicas y de total eliminación del vertido de cualquier sustancia tóxica permanente". Esta eliminación total resultaba obligada, ya que las sustancias químicas tóxicas permanentes se pueden concentrar y acumular en la cadena alimenticia, causando daños graves e irreparables en el ecosistema, mientras que en el caso de las sustancias químicas volátiles, sólo es necesario mantenerlas por debajo de los niveles que pueden entrañar peligro inmediato.

Además de ejercer un control más riguroso de las fuentes localizadas, Canadá y 0 ntario introdujeron y reforzaron el control de plaguicidas, productos químicos comerciales, residuos peligrosos y fuentes no localizadas de contaminación, como vertederos e incineradoras. Las iniciativas gubernamentales se orientaron a diferentes medios y la "vigilancia responsable" de las sustancias químicas se convirtió en la nueva filosofía de gestión medioambiental tanto para el gobierno como para las industrias. La Ley federal sobre los productos para el control de plaguicidas prohibió el uso de una serie de plaguicidas tóxicos permanentes (DDT, Aldrin, M irex, Toxafeno, Clordano) y la Ley sobre contaminantes del medio ambiente sirvió para (1) prohibir el uso comercial, la fabricación y el procesamiento de sustancias tóxicas permanentes (CFC, PPB, PCB, PPT, M irex, plomo) y (2) limitar el vertido de sustancias químicas utilizadas en determinados procesos industriales (mercurio, cloruro de vinilo, amianto).

A principios del decenio de 1980, estos programas y medidas, junto con los esfuerzos paralelos desarrollados por Estados U nidos, comenzaron a producir los primeros indicios de regeneración. Los niveles de sustancias contaminantes en los sedimentos, los peces y la fauna silvestre de los Grandes Lagos empezaron a disminuir y algunas de las mejoras ambientales observadas fueron el regreso del águila de cabeza blanca a las orillas canadienses del Lago Erie, un aumento del $200 \%$ en la población de cormoranes y la reaparición del águila pescadora en la Bahía Georgiana y de la gaviota común en la zona del puerto de Toronto, especies todas ellas que habían sufrido los efectos de los altos niveles de sustancias tóxicas permanentes. Su recuperación refleja el éxito obtenido hasta la fecha por estos planes de acción. Figura 55.26 - Contenido de M irex en los huevos de la
gaviota plateada.

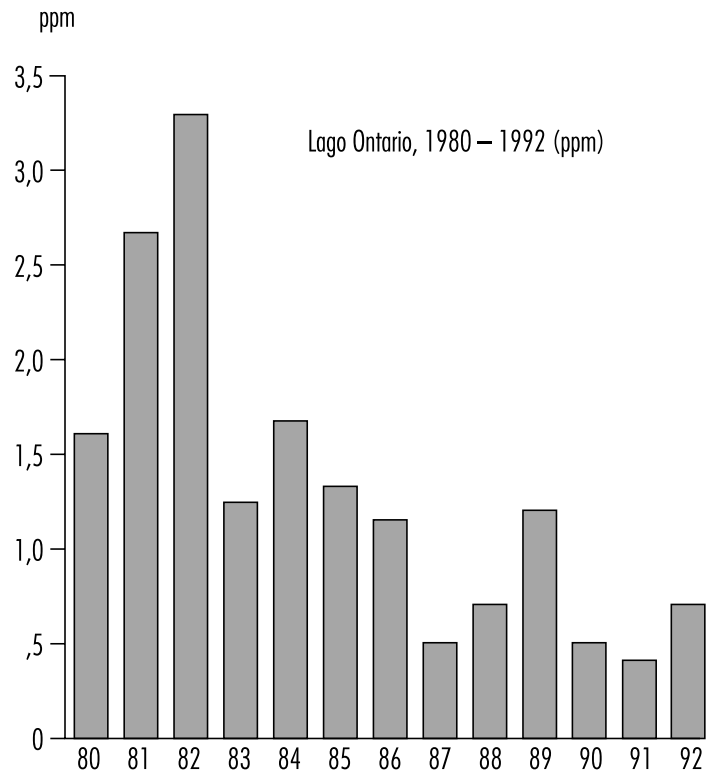

Fuente: Canadian Wildife Service

La tendencia hacia una menor concentración de algunas de las sustancias tóxicas permanentes en peces, fauna silvestre y sedimentos se estabilizó hacia mediados del decenio de 1980 (véase el contenido de Mirex en los huevos de la gaviota plateada en la Figura 55.26). Los científicos llegaron a las siguientes conclusiones:

1. Si bien los programas utilizados para controlar la contaminación de las aguas eran útiles, no tenían la eficacia suficiente para conseguir una reducción más drástica de la concentración de sustancias contaminantes.

2. Se precisaban medidas adicionales para controlar las fuentes no localizadas de sustancias tóxicas permanentes, incluidos los sedimentos contaminantes, los vertidos atmosféricos de contaminantes de largo alcance, los vertederos abandonados y otras fuentes similares.

3. Algunas sustancias contaminantes pueden permanecer en el ecosistema en concentraciones mínimas y bioacumularse en la cadena alimenticia durante mucho tiempo.

4. La estrategia más eficaz para combatir las sustancias tóxicas permanentes es prevenir o suprimir su generación en la fuente, más que prohibir su vertido.

Se acordó que para conseguir la eliminación total de contaminantes en el medio ambiente mediante la aplicación de la filosofía de prohibir los vertidos en las fuentes y el enfoque de ecosistema a la gestión de la calidad de las aguas de los $\mathrm{G}$ randes Lagos, era necesario seguir reforzando y promocionando esta línea de actuación.

Con el fin de reforzar su compromiso con el objetivo de eliminación total de sustancias tóxicas permanentes, Canadá y Estados U nidos añadieron en noviembre de 1987 un protocolo al acuerdo de 1978. En dicho protocolo se designaron unas zonas prioritarias que habían sufrido cierta degradación en el entorno de los Grandes Lagos y que requerían el desarrollo y la puesta en práctica de un plan de acciones correctoras para controlar las fuentes localizadas y no localizadas en dichas áreas. El protocolo establecía asimismo planes de gestión de los lagos 
Figura 55.27 • Proceso de toma de decisiones para la total eliminación de sustancias tóxicas permanentes en los $\mathrm{G}$ randes Lagos.

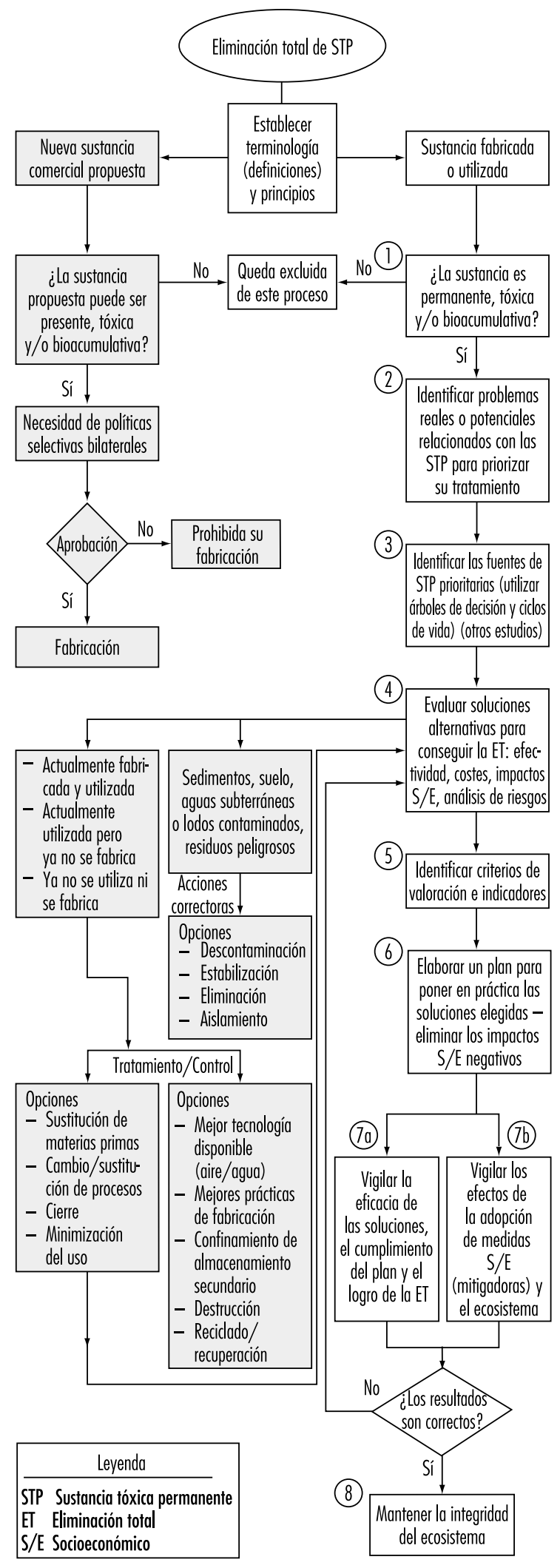

que debían servir de referencia básica para subsanar determinados daños en el conjunto de los lagos y para coordinar el control de las sustancias tóxicas permanentes que afectaban a cada uno de los Grandes Lagos. Además, el protocolo incluía nuevos anexos para establecer programas y medidas de control de las fuentes de contaminación atmosférica, los sedimentos y vertederos contaminados y las fugas, así como para proteger a las especies exóticas.

\section{El decenio de 1990}

Tras la firma del protocolo de 1987, el objetivo de la total eliminación fue promovido por grupos ecologistas a ambas orillas de los $G$ randes Lagos, cada vez más preocupados por la amenaza de las sustancias tóxicas permanentes. La Comisión M ixta Internacional (International J oint Commission, IJC), un organismo asesor bilateral creado en virtud del Tratado de las aguas fronterizas de 1909, apoyó también con firmeza el plan de la total eliminación. Un grupo de trabajo bilateral de la IJC diseñó una estrategia para la total eliminación en 1993 (véase la Figura 55.27). A mediados del decenio de 1990, la IJC y sus miembros intentaron definir un proceso para poner en práctica esta estrategia, que incluía algunos aspectos relativos a los impactos socioeconómicos.

L os gobiernos de $C$ anadá y de $O$ ntario respondieron con una serie de medidas para controlar o reducir el vertido de sustancias tóxicas permanentes. A continuación se resumen brevemente los programas e iniciativas más importantes.

\section{Ley canadiense de protección del medio a mbiente (CEPA)}

En 1989, el M inisterio de M edio Ambiente de Canadá consolidó y simplificó sus disposiciones legales en una única ley. La CEPA otorga al gobierno federal amplios poderes (p. ej. recogida de información, formulación de normas, vigilancia de su cumplimiento) durante todo el ciclo de vida de las sustancias químicas. De conformidad con la CEPA, el Reglamento de notificación de nuevas sustancias establece procedimientos de evaluación de nuevas sustancias químicas cuya finalidad es prohibir la importación, elaboración o utilización en Canadá de sustancias tóxicas permanentes que no puedan ser controladas de forma adecuada. La primera fase del programa de evaluación de la Lista de Sustancias Prioritarias finalizó en 1994; 25 de las 44 sustancias analizadas resultaron ser tóxicas según la definición de la CEPA, iniciándose el desarrollo de estrategias para la gestión de dichas sustancias químicas tóxicas con el Proceso de 0 pciones Estraté gicas. Para el año 2000 se habrán definido y evaluado otras 56 sustancias prioritarias dentro de la fase II del programa de la Lista de Sustancias Prioritarias. El Inventario Nacional de Vertidos Contaminantes (NPRI) se introdujo en 1994 para obligar a las empresas e instalaciones industriales que cumplen los criterios de notificación a informar anualmente sobre sus vertidos a la atmósfera, al agua o a la tierra, así como la transformación en residuos de 178 sustancias específicas. El inventario, creado a semejanza del Inventario de Vertidos T óxicos (T RI) de Estados U nidos, constituye una base de datos importante para establecer prioridades cuando se diseñan programas de prevención y erradicación de la contaminación.

Acuerdo Canadá-Ontario (Canada-Ontario A greement, COA) En 1994, Canadá y $O$ ntario pusieron en marcha un plan estraté gico coordinado para restaurar, proteger y conservar el ecosistema de los G randes Lagos. U no de sus principales objetivos era reducir para el año 2000 la utilización, generación o liberación de 13 sustancias tóxicas permanentes del nivel I (Canadá y O ntario 1994). EI COA contempla también una reducción significativa de otras 26 sustancias tóxicas prioritarias (del nivel II). En el caso concreto de las sustancias del nivel I, el COA: (1) confirmará la eliminación total del vertido de cinco plaguicidas (Aldrin, 
Figura 55.28 • Selección de objetivos de la política de gestión de sustancias tóxicas.

\section{SUSTANCIA CANDIDATA}

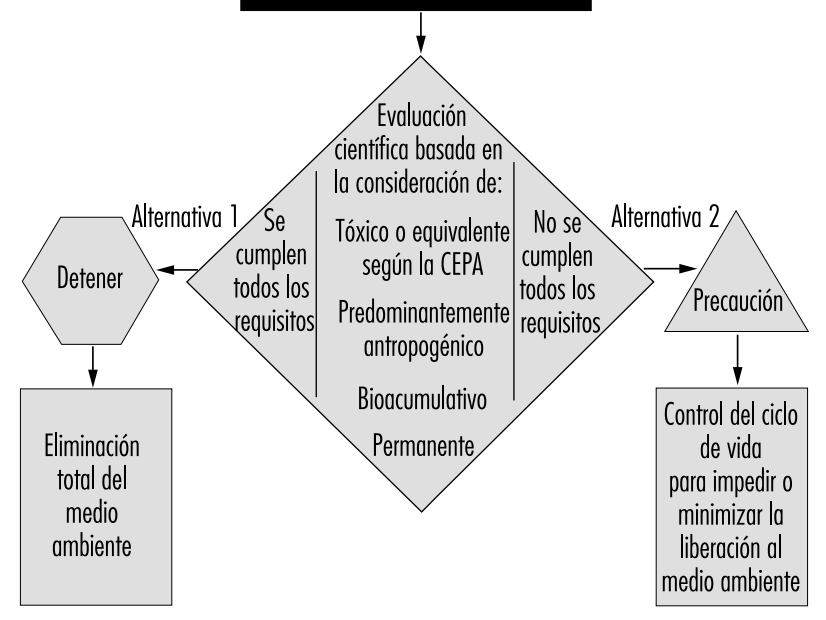

DDT, Clordano, M irex, Toxafeno); (2) intentará decomisar el $90 \%$ de los PCB de alto nivel, destruir el $50 \%$ de los PCB actualmente en almacén y acelerar la destrucción de los PCB de bajo nivel también actualmente en almacén; e (3) intentará reducir en un $90 \%$ el vertido de los restantes siete productos del nivel I (benzo(a)pireno, hexaclorobenceno, plomo alquílico, octacloroestireno, PCDD (dioxinas) PCDF (furanos) y mercurio). La estrategia del COA es conseguir una reducción cuantitativa siempre que sea posible y exigir a las fuentes que adopten medidas para prevenir la contaminación y otras medidas para cumplir los objetivos del COA. Las autoridades federales de O ntario ya han puesto en marcha catorce proyectos para conseguir la reducción/ eliminación de sustancias de los niveles I y II.

\section{Política de gestión de sustancias tóxicas}

Admitiendo la necesidad de un enfoque preventivo, el M inisterio de M edio Ambiente de Canadá anunció en junio de 1995 una política nacional de gestión de sustancias tóxicas como marco de referencia para la gestión eficaz de sustancias tóxicas en C anadá (M inisterio de M edio Ambiente de Canadá 1995a). C omo puede observarse en la Figura 55.28, esta política adopta una doble estrategia que reconoce la necesidad de adaptar la gestión a las características de las sustancias químicas; es decir:

Tabla 55.19 - Criterios de selección de sustancias para la Política de Control de Sustancias Tóxicas en la alternativa 1.

\begin{tabular}{|c|c|c|c|c|}
\hline \multicolumn{2}{|c|}{ Persistencia } & Bioacumulación & Toxicidad & $\begin{array}{l}\text { Predomi- } \\
\text { nantemente } \\
\text { antropogénico }\end{array}$ \\
\hline Medio & Vida media & & & \\
\hline $\begin{array}{l}\text { Aire } \\
\text { Agua } \\
\text { Sedimento } \\
\text { Tierra }\end{array}$ & $\begin{array}{l}\geq 2 \text { días } \\
\geq 182 \text { días } \\
\geq 365 \text { días } \\
\geq 182 \text { días }\end{array}$ & $\begin{array}{l}B A F \geq 5.000 \\
0 \\
B C P \geq 5.000 \\
0 \\
\log K_{0 w} \geq 5,0\end{array}$ & $\begin{array}{l}\text { Sustancia } \\
\text { tóxica según } \\
\text { la CEPA } \\
0 \\
\text { equivalente } \\
\text { a sustancia } \\
\text { tóxica según } \\
\text { la CEPA }\end{array}$ & $\begin{array}{l}\text { Concentración } \\
\text { en el medio } \\
\text { ambiente princi- } \\
\text { palmente como } \\
\text { consecuencia de } \\
\text { actividades } \\
\text { humanas }\end{array}$ \\
\hline
\end{tabular}

- eliminar por completo del medio ambiente aquellas sustancias que sean eminentemente antropogénicas, permanentes, bioacumulativas y tóxicas (Estrategia I)

- gestionar el ciclo completo de todas las demás sustancias contaminantes (Estrategia II).

Para asignar las sustancias contaminantes a una u otra estrategia, se aplicarán una serie de criterios científicos (M inisterio de Medio Ambiente de Canadá 1995b) (véase la Tabla 55.19). Si alguna de las sustancias asignadas a una u otra estrategia no pueden ser debidamente controladas con los programas existentes, se adoptarán medidas adicionales como parte del Proceso M ultilateral de 0 pciones Estratégicas. Esta política es coherente con el Acuerdo sobre Calidad de las Aguas de los Grandes Lagos (GLW Q A) y servirá de base para definir el objetivo ecológico último de diferentes programas nacionales, aunque los medios y el plazo de tiempo para alcanzar el objetivo dependerá de la sustancia química y de la fuente. A demás, esta política definirá en las conversaciones internacionales la posición de C anadá respecto de las sustancias tóxicas permanentes.

\section{Plan de acción contra el cloro}

EI M inisterio de M edio A mbiente de Canadá, como parte de la política de gestión de las sustancias tóxicas, anunció en octubre de 1994 un ambicioso plan para gestionar las sustancias cloradas (M inisterio de M edio Ambiente de Canadá 1994). Se trata de prevenir la utilización del cloro mediante un plan de acción que consta de cinco partes: (1) adoptar medidas dirigidas a las aplicaciones y productos críticos, (2) ampliar los conocimientos científicos del cloro y su impacto sobre la salud y el medio ambiente, (3) describir con detalle las implicaciones socioeconómicas, (4) facilitar el acceso público a la información y (5) promover acciones internacionales sobre las sustancias cloradas. La utilización del cloro ha disminuido en Canadá en los últimos años; así, por ejemplo, en el sector papelero esta utilización se ha reducido en un $45 \%$ desde 1988. La puesta en marcha del Plan de acción contra el cloro acelerará aún más esta tendencia.

\section{Iniciativa para la prevención de la contaminación en los G randes Lagos}

Se ha puesto en marcha un ambicioso programa de prevención de la contaminación en la cuenca de los $G$ randes Lagos. D esde marzo de 1991, el M inisterio de M edio Ambiente de Canadá y el $M$ inisterio de M edio Ambiente y Energía de 0 ntario colaboran con industrias y otras partes interesadas para desarrollar y ejecutar proyectos de prevención de la contaminación, en lugar de tener que recurrir al tratamiento de residuos o a la reducción de la contaminación una vez generada. En 1995/ 96 existirán más de 50 proyectos en marcha relacionados con productos químicos comerciales, gestión de residuos peligrosos, instalaciones federales, industrias, municipios y la cuenca del Lago Superior. En la Figura 55.29 se ofrece un esquema de todos estos proyectos agrupados en dos grandes categorías: integración en programas y acuerdos voluntarios. La Figura muestra asimismo la conexión entre estos programas y otros descritos anteriormente (inventario nacional de vertidos contaminantes, planes de acciones correctoras, planes de gestión de los lagos) así como instituciones que colaboran estrechamente con el M inisterio de M edio Ambiente de Canadá en temas relacionados con tecnologías verdes, procesos limpios, formación, información y comunicaciones. LoS proyectos de prevención de la contaminación pueden obtener resultados muy satiffactorios, como así lo ha demostrado el sector del automóvil, donde últimamente se han emprendido 15 proyectos piloto que han conseguido reducir o eliminar 2,24 millones de kilos de sustancias nocivas procedentes de la 
Figura 55.29 • Prevención de la contaminación en los G randes Lagos.

Propuesta de prevención

de la contaminación para

los Grandes Lagos

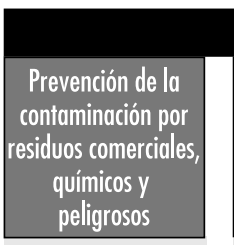

Recogida de pilas

alcalinas y de $\mathrm{Ni} / \mathrm{Cd}$

Mercurio y plata de

centros odontológicos

Minimización de

residuos peligrosos

Plan de acción

comunitaria de

Port Hope DIM

Control y conservación

de refrigerantes/

halones/esterilizantes/

disolventes DIM

Plan Oshawa de control

de CFC DIM

Control de sustancias

prioritarias clasificadas

por la CEPA como

"tóxicas" PMAO

\section{INTEGRACION DEL PROGRAMA /ACUERDOS P2}

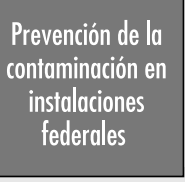

Información/educación

- Hojas de datos

- Seminarios

- Folletos/Bibliografía

- Proyectos de

demostración

Acuerdos con las princi-

pales instalaciones

federales (FB Trenton

(8 apéndices)

Colaboración con las instalaciones federales en áreas de interés

Control de SDO/STP

minimización de

residuos peligrosos y

prevención de

vertidos accidentales PMAO

\section{Clave de siglas}

ARET = Reducción acelerada/Eliminación de sustancias tóxicas

CEPA = Ley de protección del medio ambiente de Canadá

$\mathrm{CFC}=$ Clorofluorocarbonos

GLPPC = Centro de Prevención de la Contaminación de los Grandes Lagos

LAMP = Planes de gestión de los lagos

NPRI = Inventario nacional de vertidos contaminantes

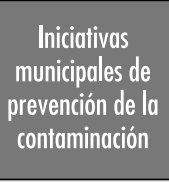

Plan global de

Hamilton/Wentworth

para la prevención de

la contaminación

Asociación de industrias

de limpieza en seco

EIM

Depósito verde limpio
MAC

Apoyo a las pequeñas

empresas en el área de

minación (Sarnia)

Laboratorios

universitarios

Prácticas verdes MAC

Consejo para la Conser-

vación de Ontario (cam-

paña contra productos

tóxicos, 4 guías verdes)

Comunidad verde de

Collingwood prevención a la conta-

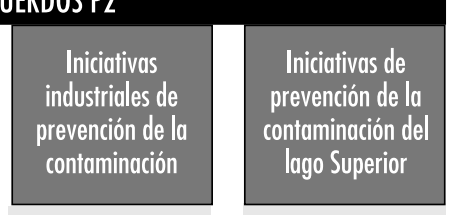

Fabricantes de

vehículos

Piezas de

vehículos

Acabado de

metales

Industrias gráfica y

de impresión EIM

Fabricantes

internacionales de

vehículos (Honda

y Toyota) DIM

Viverose

invernaderos DIM

Minería del metal

DIM

DIM$$
\text { en a }
$$

en el medio rural

de la prevención de

la contaminación

- Estudio para la DIM
planificación del

control de la

contaminación

Seminario/formación

sobre la prevención de la contaminación

Actividades pesqueras

y portuarias DIM

Minería del metal

Bombarderos DIM

Sensibilización frente

Sensibilización frente
Foro Binacional del

Lago Superior co

Campeonato de la

Semana Nórdica MAC

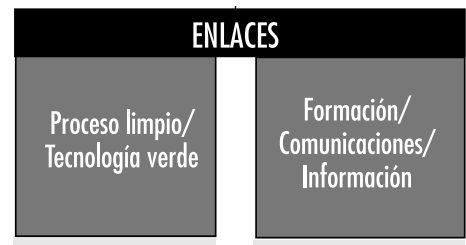

Centro de Tecnología

de Aguas Residuales

GLPPC

- Planificación global

CO

Industrias de Canadá

CO

Proyectos de

demostración

(Domtar-Red Rock,

pinturas acrílicas,

etc.)

MAC

Estrategia ambiental

para la industria

MAC

Programa de

asistencia técnica

para acabado de

metales PMAO

OWMC/OCETA

CO

- Formación (estimación

de costes totales,

prevención de lo

contaminación, G(T)

- Intercambio de

información

- Conferencias

- Consulta con partes

interesadas

NPRI/ARET

RAP/LAMP

(Collingwood, Sarnia,

Lago Superior)

Programa ambiental

para la Ciudadanía

Oficina Nacional de

Prevención de la

Contaminación

Mesa Redonda

norteamericana sobre

la prevención de la

contaminación en los

Grandes Lagos fabricación de automóviles en las instalaciones de Chrysler, Ford y G eneral M otors en 0 ntario.

\section{Reducción Acelerada/Eliminación de Sustancias Tóxicas (ARET)}

ARET es una iniciativa de cooperación multilateral emprendida en 1994 que pretende la total eliminación de 14 sustancias tóxicas prioritarias con el objetivo intermedio (para el año 2000) de un $90 \%$ de reducción/ eliminación de estas sustancias y un $50 \%$ de reducción de las emisiones de 87 sustancias tóxicas menos peligrosas (Secretaría del ARET 1995). En 1995, esta iniciativa voluntaria, en la que participan más de 200 empresas y organismos públicos, ha conseguido reducir las emisiones en unas 10.300 toneladas, tomando 1988 como año de referencia y existe el compromiso de reducir las emisiones en otras 8.500 toneladas para el año 2000.

\section{Estrategias bilaterales e internacionales}

Además de las estrategias nacionales ya mencionadas, Canadá y Estados U nidos están desarrollando en la actualidad una estrategia bilateral para coordinar el trabajo de distintos organismos y establecer unos objetivos comunes en lo referente a productos tóxicos permanentes en la cuenca de los $\mathrm{G}$ randes $\mathrm{L}$ agos. Se definirán unos objetivos similares a los del Acuerdo $C$ anadá-O ntario para las sustancias de los niveles I y II y se aprobará una lista similar a la de Estados Unidos. Se desarrollarán y ejecutarán proyectos conjuntos que faciliten el intercambio de información y las actividades de los organismos competentes en relación con productos químicos prioritarios tales como los PC B y el mercurio. 
Tabla 55.20 • Resumen de las reducciones conseguidas en las emisiones de dioxina y furano en Canadá.

\begin{tabular}{|c|c|c|c|}
\hline Fuentes de emisión & Reducciones & $\begin{array}{l}\text { Período } \\
\text { registrado }\end{array}$ & $\begin{array}{l}\text { Iniciativas del } \\
\text { gobierno de Canadá }\end{array}$ \\
\hline $\begin{array}{l}\text { Vertidos clorados proce- } \\
\text { dentes de industrias de } \\
\text { papel Kraft }\end{array}$ & $82 \%$ & $1989-94$ & $\begin{array}{l}\text { Disposiciones de la } \\
\text { CEPA sobre antiespu- } \\
\text { mante, virutas de } \\
\text { madera y } \\
\text { dioxinas/ furanos }\end{array}$ \\
\hline Plaguicida 2,4,5-T & $100 \%$ & 1985 & $\begin{array}{l}\text { Uso prohibido por la } \\
\text { PCPA }\end{array}$ \\
\hline Plaguicida 2,4-D & $100 \%$ & $1987-90$ & $\begin{array}{l}\text { El contenido en } \\
\text { dioxinas y su uso } \\
\text { están fuertemente } \\
\text { restringidos por la } \\
\text { PCPA }\end{array}$ \\
\hline \multicolumn{4}{|l|}{ Pentaclorofenol } \\
\hline $\begin{array}{l}\text { - conservación de } \\
\text { la madera }\end{array}$ & $6,7 \%$ & $1987-90$ & $\begin{array}{l}\text { Disposiciones de la } \\
\text { PCPA }\end{array}$ \\
\hline $\begin{array}{l}\text { - protector de la } \\
\text { madera }\end{array}$ & $100 \%$ & $1987-90$ & $\begin{array}{l}\text { Prohibido su uso por } \\
\text { la PCPA }\end{array}$ \\
\hline$P C B$ & $23 \%$ & $1984-93$ & $\begin{array}{l}\text { Plan de Acción CCME } \\
\text { PCB }\end{array}$ \\
\hline \multicolumn{4}{|l|}{ Incineración } \\
\hline $\begin{array}{l}\text { - residuos sólidos } \\
\text { municipales }\end{array}$ & $80 \%$ & $1989-93$ & $\begin{array}{l}\text { Directrices sobre } \\
\text { operación/ emisión } \\
\text { del CCME }\end{array}$ \\
\hline 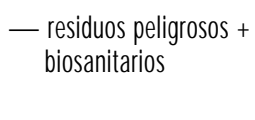 & $80 \%$ & $1990-95$ & $\begin{array}{l}\text { Directrices sobre } \\
\text { operación/ emisión } \\
\text { del CCME }\end{array}$ \\
\hline \multicolumn{4}{|c|}{$\begin{array}{l}\text { CCME: Canadian Council of Environmental Ministers (Consejo Canadiense de Ministros del } \\
\text { Medio Ambiente); } \\
\text { CCEPA: Ley sobre protección del medio ambiente de Canadá; } \\
\text { CPA: Ley sobre los productos para el control de plagas. }\end{array}$} \\
\hline
\end{tabular}

Al adoptar un enfoque agresivo de total eliminación, Canadá estará en condiciones de asumir el liderazgo en la promoción de acciones internacionales contra las sustancias tóxicas permanentes. En junio de 1995 Canadá organizó una conferencia de las Naciones Unidas en Vancouver para promover el diálogo mundial sobre las sustancias orgánicas contaminantes permanentes y para analizar las estrategias de prevención de la contaminación con el objetivo de reducir sus emisiones en todo el mundo. Canadá preside asimismo el grupo de trabajo de la Comisión Económica para Europa de las Naciones Unidas (CEPE) que tiene encomendado el desarrollo de un protocolo para las sustancias contaminantes permanentes de acuerdo con la Convención sobre la Contaminación Atmosférica Internacional de L argo Alcance.

\section{Ejemplo: dioxina y furanos}

Desde hace más de diez años se sabe que las dibenzodioxinas y los furanos policlorados constituyen un grupo de sustancias tóxicas permanentes que amenazan el medio ambiente canadiense y a los Grandes Lagos. En la Tabla 55.20 se resumen las acciones federales y las reducciones de los vertidos conseguidas hasta la fecha. En dicha tabla puede observarse que la combinación de distintos programas e iniciativas ha conseguido una reducción significativa de estas sustancias tóxicas. Pese a estos buenos resultados, las dioxinas y los furanos seguirán recibiendo prioridad en la política de gestión de sustancias tóxicas, el plan de acción contra el cloro, el Acuerdo entre Canadá y O ntario y la estrategia bilateral descrita anteriormente, ya que su completa eliminación exige una reducción aún mayor.

\section{Resumen}

Las iniciativas para el control de la contaminación emprendidas por los gobiernos y otras partes interesadas en Canadá y Estados Unidos desde principios del decenio de 1970 han conseguido una mejora considerable de la calidad de las aguas de los Grandes Lagos. En este artículo se han resumido las actividades y los logros canadienses para solucionar un problema general de contaminación y de sustancias contaminantes tradicionales. A demás, se describe la evolución de una nueva estrategia (política de gestión de sustancias tóxicas, plan de acción contra el cloro, prevención de la contaminación, acción voluntaria, consultas con partes interesadas, etc.) para gestionar los problemas mucho más complejos de las sustancias tóxicas permanentes en los Grandes Lagos. Se mencionan también otros programas (COA, inventario nacional de vertidos contaminantes, proceso de opciones estratégicas, lista de sustancias prioritarias, etc.) que se han emprendido para conseguir el objetivo de la completa eliminación. El lector que desee más información sobre la estrategia canadiense puede remitirse a la bibliografía que aparece al final de este capítulo.

\section{TECNOLOGIAS DE PRODUCCION MAS LIMPIAS}

David Bennett

\section{Prevención, control y reparación}

Tradicionalmente existen tres formas de abordar el problema de la contaminación: la prevención, el control y la reparación, que pueden considerarse jerárquicas en el sentido de que la principal prioridad u opción es la prevención, seguida por las medidas de control, quedando la reparación relegada al último lugar. La lucha contra la contaminación engloba todos los medios que tienen como objetivo reducirla o mitigarla, lo que en la práctica se traduce, por lo general, en un control. Aunque la anterior jerarquía de estrategias está planteada en términos de preferencias o prioridades, no siempre responde a la realidad, ya que a veces existen presiones legislativas para optar por una u otra alternativa. Así una estrategia puede ser menos costosa que otra 0 puede ocurrir que la reparación sea la medida más urgente en el caso de una fuga importante o una dispersión peligrosa de sustancias contaminantes desde un lugar contaminado.

\section{Prevención de la contaminación}

La prevención de la contaminación puede definirse como una 0 varias estrategias para evitar la generación de contaminantes en la fuente. Según Barry Commoner: "Si no existe, no puede contaminar". Por tanto, si se elimina una sustancia química cuya utilización provoca cierta contaminación, se producirá un "vertido cero" (o "emisión cero") de ese agente contaminante. EI vertido cero es más eficaz cuando la sustancia química no se sustituye por otra - alternativa o sustitutiva- que ocasione una contaminación diferente.

U na de las estrategias básicas para la prevención de la contaminación es la prohibición, eliminación o retirada gradual de ciertos productos químicos o grupos de ellos (como alternativa, pueden establecerse limitaciones de uso). Este tipo de estrategia se plasma en forma de leyes o reglamentos adoptados por los gobiernos nacionales y, con menor frecuencia, por organismos internacionales (convenciones 0 tratados) 0 administraciones locales. 
U na segunda estrategia consiste en reducir la contaminación, una vez más dentro del contexto de la prevención más que del control. Valgan como ejemplos de este tipo de estrategias los programas de reducción del uso de sustancias tóxicas (T UR ) en Estados Unidos, o los "programas de tecnologías limpias" en Europa.

A diferencia de las prohibiciones y retiradas graduales, que por lo general se aplican a todas las industrias (afectadas) comprendidas dentro de una jurisdicción política, los programas de reducción de la contaminación sólo afectan a determinados lugares de trabajo o categorías de estos. Normalmente son plantas de producción (incluidas las químicas) de cierta entidad, aunque los principios básicos de la reducción de la contaminación pueden aplicarse con carácter general, por ejemplo, a explotaciones mineras, centrales eléctricas, obras, oficinas, agricultura (fertilizantes y plaguicidas químicos) y municipios. Como mínimo, dos estados norteamericanos (M ichigan y Vermont) han aprobado programas TUR que afectan a los hogares que son, a su vez, centros de trabajo.

La reducción de la contaminación puede conseguir la eliminación de ciertas sustancias químicas, produciendo el mismo efecto que la prohibición o la retirada gradual. Este tipo de medidas consiguen también un vertido cero de la sustancia contaminante en cuestión, aunque sin establecer requisitos específicos para eliminar un producto químico concreto. Los programas de reducción de la contaminación son, más bien, de carácter general y permiten cierta flexibilidad en la elección de los métodos. La obligación de eliminar una sustancia química concreta constituye una "norma específica". La obligación de establecer un programa general constituye una "norma general de actuación" ya que permite cierta flexibilidad en la manera de ponerlo en práctica, aún cuando un objetivo obligatorio específico (resultado) para un programa general se entendería (erróneamente) como una norma específica. Siempre que pueden elegir, las empresas prefieren las normas generales de actuación a las normas específicas.

\section{Control de la contaminación}

Las medidas de control de la contaminación por sí solas no son capaces de eliminar la contaminación, aunque sí pueden atenuar sus efectos sobre el medio ambiente. Las medidas de control se aplican en la fuente emisora. La utilidad de estas medidas depende del agente contaminante y de las circunstancias industriales. Los principales métodos de control de la contaminación son los siguientes:

- recogida y almacenamiento posterior de los agentes contaminantes;

- filtración: los contaminantes atmosféricos o acuáticos son eliminados mediante métodos físicos, como mallas, filtros u otras barreras permeables (por ejemplo, de coque);

- precipitación: el agente contaminante se precipita por medios químicos y se recoge a continuación en estado transformado 0 mediante métodos físicos, como carga electrostática;

- destrucción, por ejemplo, mediante incineración o neutralización; el contaminante se transforma por medios químicos o biológicos en sustancias menos nocivas;

- dilución: el agente contaminante se diluye para reducir su efecto sobre un organismo concreto o sobre un ecosistema; o se rebaja su concentración para disminuir el efecto de su vertido;

- evaporación o disolución, por ejemplo, disolviendo un gas en agua;

- utilización, por ejemplo, transformando un agente contaminante en un producto potencialmente útil (aunque no necesariamente menos tóxico) (como, por ejemplo, transformación del dióxido de azufre en ácido sulfúrico o utilización de residuos sólidos para la construcción de cimientos y carreteras);

- reciclado al margen del proceso (cuando el reciclado no forma parte integrante del proceso de producción);

- cambio de medio: los vertidos se trasladan de un medio, como aire, tierra o agua, a otro diferente, siempre que dicho traslado consiga disminuir el efecto nocivo del agente contaminante,

- cambios de estado: cambio a estado sólido, líquido o gaseoso siempre que el nuevo estado sea menos nocivo.

\section{Reparación de la contaminación}

La reparación es necesaria cuando la prevención o el control de la contaminación no resultan eficaces. No obstante, es una medida muy costosa y la inversión no siempre recae sobre el contaminador. Las diferentes formas de reparación son:

\section{Limpieza de los lugares contaminados}

La palabra limpieza tiene un significado obvio, como cuando, por ejemplo, se le pide a un empleado que "limpie su puesto de trabajo", que puede significar muchas cosas diferentes. En el contexto de la protección del medio ambiente, "limpieza" es un término técnico que denota uno varios tipos de reparación. En su sentido restringido, este término puede significar (1) eliminación de contaminantes en un lugar contaminado o (2) rehabilitación de un lugar para restablecer su pleno potencial de uso. En ocasiones, el término limpieza hace referencia sólo al confinamiento de los agentes contaminantes en un lugar, zona o superficie acuática, por ejemplo, embalsando, sellando o construyendo un fondo impermeable.

La limpieza, para que resulte satisfactoria, ha de ser eficaz al $100 \%$, ofreciendo protección total a los trabajadores y a la población en general. 0 tro aspecto que tiene que tenerse en cuenta es que las sustancias, los métodos y las tecnologías depuradoras no deben originar peligros adicionales. Aún cuando se aconseja el uso de dispositivos mecánicos de control para proteger a los trabajadores que se dedican a labores de limpieza, casi siempre es necesario proporcionar equipos específicos de protección individual. Generalmente, estos trabajadores está catalogados como personal que trabaja con residuos peligrosos, si bien ciertas funciones son realizadas, entre otros, por bomberos y empleados municipales.

L a limpieza de lugares contaminados exige el uso de una gran variedad de agentes y métodos físicos, químicos, biológicos y biotécnicos.

\section{Tratamiento de residuos peligrosos}

En la actualidad, el tratamiento de residuos peligrosos (o tóxicos) es realizado por trabajadores especializados en instalaciones diseñadas para tal fin. Desde el punto de vista ambiental, la eficacia de una planta de tratamiento de residuos peligrosos se evalúa en función de que evite la producción de sustancias nocivas, como sílice, compuestos inorgánicos insolubles, escorias insolubles y corrosivas, nitrógeno gaseoso o dióxido de carbono, un "gas con efecto invernadero" que influye en el cambio climático $y$, por consiguiente, constituye un peligro adicional para el medio ambiente.

0 tro de los factores que deben considerarse es la eficiencia energética de la planta, es decir, que no derroche energía y que su consumo de energía sea mínimo (esto es, que el cociente entre consumo de energía y volumen de residuos tratados sea el menor posible). Por regla general, cuanto más eficaz es la estrategia de eliminación de contaminantes (o residuos), mayor es la cantidad de energía consumida, lo cual constituye un problema adicional para conseguir un desarrollo sostenible.

Aunque los trabajadores vayan debidamente protegidos, el tratamiento de residuos peligrosos como estrategia para abordar 
el problema de la contaminación presenta una serie de inconvenientes evidentes. Los métodos de prevención de la contaminación pueden aplicarse a los procesos de tratamiento, pero no al "elemento" principal: los residuos que necesitan tratamiento. Las plantas de tratamiento de residuos peligrosos consumen generalmente tanta energía en el tratamiento de los residuos como la consumida en su producción, generando siempre nuevos residuos, aunque sean inertes o no tóxicos.

\section{Derrames y fugas}

En lo que se refiere a derrames y fugas de productos químicos, pueden aplicarse las mismas consideraciones que para la limpieza de lugares contaminados, aunque con los peligros añadidos por la urgencia de este tipo de actividades de limpieza. L os trabajadores encargados de combatir estos derrames y fugas son casi siempre especialistas en emergencias. Dependiendo de la magnitud y la naturaleza del agente contaminante, los derrames y fugas pueden convertirse en graves accidentes industriales.

\section{Métodos de prevención de la contaminación}

\section{Definición y filosofía}

La definición de la prevención de la contaminación puede parecer una cuestión trivial, pero es importante puesto que los defensores de este enfoque basan su política en una estrategia preventiva muy estricta y agresiva basada en métodos de control para evitar la reparación. Desde su punto de vista, cuanto mayor sea el rigor con que se defina la prevención de la contaminación, mayor serán sus posibilidades de éxito como estrategia práctica. A la inversa, cuanta más libertad tengan las empresas para definir este término, mayor será la probabilidad de que sus actividades terminen siendo una combinación de las viejas estrategias de siempre (de escaso éxito). Las empresas alegan en ocasiones que incluso los residuos tóxicos pueden tener un valor de mercado y que los métodos de control son importantes para que la contaminación sólo sea un problema potencial. Por otro lado, el vertido cero de contaminantes es imposible y únicamente conduce a falsas expectativas y a estrategias equivocadas. Q uienes abogan por la prevención de la contaminación responden que, a menos que se plantee el vertido cero como objetivo o ideal práctico, la prevención nunca podrá triunfar y la protección del medio ambiente jamás mejorará.

La mayoría de las definiciones rigurosas de la prevención de la contaminación tienen como objetivo único o elemento básico la eliminación del uso de sustancias químicas productoras de agentes contaminantes, de manera que se evite su generación en la fuente. Algunas de las discrepancias más importantes de las diferentes definiciones se refieren al reciclado, un tema que se analiza más adelante en el contexto de la prevención de la contaminación.

\section{Objetivos}

U no de los posibles objetivos de la prevención de la contaminación es el vertido cero de contaminantes, que en ocasiones recibe el nombre de "eliminación total", ya que ni siquiera el vertido cero es capaz de resolver el problema de los agentes contaminantes que ya están presentes en el medio ambiente. El vertido cero de agentes contaminantes es posible cuando se utilizan métodos de prevención de la contaminación, mientras que los métodos de control no pueden alcanzarlo a nivel teórico y en la práctica resultan aún menos eficaces, generalmente debido a la negligencia en su aplicación. Cabría imaginar, por ejemplo, una industria automovilística que generase un vertido cero de agentes contaminantes; todos los residuos serían reciclables y el producto final (el coche) estaría fabricado con piezas reutilizables o reciclables. $\mathrm{H}$ oy en día ya se ha conseguido eliminar por completo el vertido de algunos agentes modificando, por ejemplo, el proceso de producción de las fábricas de papel de forma que no viertan dioxinas o furanos en las aguas residuales. El objetivo del vertido cero también se recoge en las leyes del medio ambiente y en las políticas de los organismos responsables del control de la contaminación.

En la práctica, la eliminación completa de los vertidos pasa por definir ciertos objetivos de reducción, como por ejemplo, reducir en un $50 \%$ las emisiones de contaminantes en un plazo de tiempo determinado. Estos objetivos finales o intermedios pueden adoptar la forma de "retos" o logros con los que se evalúa el éxito de los programas de prevención de la contaminación. En muy contadas ocasiones son el resultado de un análisis o cálculo de viabilidad, nunca se aplican sanciones por el incumplimiento de tales objetivos y tampoco se miden con un cierto grado de precisión.

Las reducciones tendrían que medirse (no estimarse) aplicando la siguiente fórmula:

Contaminación $(C)=$ Toxicidad del agente contaminante $(\mathrm{T})$ $\times$ Volumen $(\mathrm{V})$ vertido al medio ambiente

0 :

$$
C=T \times V \times E \text { (riesgo de exposición). }
$$

Esta medición entraña una enorme dificultad desde el punto de vista teórico y resulta muy costosa en la práctica, aunque en principio podría realizarse utilizando técnicas de valoración de riesgos (véase más adelante). Todas estas dificultades sugieren que sería preferible destinar los recursos a otros fines como, por ejemplo, unos planes adecuados de prevención de la contaminación.

En cuanto a los plaguicidas químicos, su utilización podría reducirse aplicando los métodos de la gestión global de plagas, aunque este término es también susceptible de una definición tan amplia o estricta como se desee.

\section{Métodos}

Los principales métodos para la prevención de la contaminación son:

- Eliminación o retirada gradual de sustancias químicas peligrosas

- Sustitución de algunas materias primas, reemplazando las sustancias tóxicas o peligrosas por otras que lo sean menos 0 por procesos que no sean tóxicos. Valgan como ejemplos la sustitución de colorantes orgánicos sintéticos por otros hidrosolubles en la industria de las artes gráficas; la sustitución de disolventes orgánicos por otros solubles en agua o en cítricos y, en determinadas aplicaciones, la sustitución de aceites minerales por otros vegetales. Como ejemplo de sustituciones no químicas pueden citarse la sustitución de decapantes químicos líquidos por la tecnología de impacto con perdigones; la sustitución de detergentes cáusticos por sistemas de agua caliente a alta presión y la sustitución de pentaclorofenoles (PCP) por el secado en horno en la industria maderera.

En todos los casos tiene que realizarse un análisis de la sustitución para comprobar que los nuevos elementos son realmente menos peligrosos que los originales, lo cual implica, como mínimo, un ejercicio de sentido común y en el mejor de los casos, la aplicación de técnicas de valoración de riesgos (véase más adelante) sobre los productos químicos y los sustitutos propuestos.

- Reformulación del producto, reemplazando el producto final por otro menos tóxico o inocuo tras su utilización, vertido o evacuación.

M ientras que el término sustitución hace referencia a las materias primas y afecta a la "fase inicial" del proceso de 
producción, la reformulación de los productos aborda el problema en el producto final del ciclo de producción.

Los programas generales para fabricar productos menos nocivos para el medio ambiente constituyen ejemplos de "conversión económica". Entre las medidas concretas que se han adoptado para la reformulación de productos destaca la sustitución de pilas desechables por pilas recargables y la utilización de revestimientos hidrosolubles en lugar de los revestimientos solubles en disolventes orgánicos y similares.

U na vez más se impone la necesidad de realizar un análisis de la sustitución para comprobar que el beneficio neto ambiental es superior con los productos reformulados que con los originales.

- Modernización o modificación del rediseño de la unidad de producción que se traduzca en una menor utilización de productos químicoso en el empleo de sustancias menos tóxicas.

- Mejora del funcionamiento y el mantenimiento de la unidad de producción y de sus métodos, incluida una mejor gestión interna, un control de calidad de la producción más eficaz y una inspección más exhaustiva de los procesos.

Como ejemplos pueden citarse las medidas de prevención de fugas, la utilización de contenedores a prueba de fugas, la prevención de vertidos accidentales y el uso de tapas flotantes en los tanques de disolventes.

- Menor utilización y mayor reutilización. En ocasiones, por ejemplo, se realizan con excesiva frecuencia operaciones de desengrasado en un mismo equipo. 0 tras veces se puede reducir el uso de productos químicos en todos los procesos o existe la posibilidad de reutilizar los líquidos descongelantes, lo que supone un ejemplo de "utilización prolongada".

- M étodos de circuito cerrado y de reciclado dentro del propio proceso. En sentido estricto, un proceso de circuito cerrado es aquel en el que no se producen emisiones en el lugar de trabajo o hacia el entorno exterior, ni siquiera de aguas residuales a las aguas superficiales 0 de dióxido de carbono a la atmósfera. Sólo existen materias primas, productos acabados y residuos inertes 0 carentes de toxicidad. En la práctica, los métodos de circuito cerrado eliminan gran parte, aunque no todos, los residuos peligrosos. Siempre que se consiga este objetivo, podrá hablarse de reciclado integrado en el propio proceso (véase más adelante).

\section{Reciclado}

Cualquier definición que se proponga de la prevención de la contaminación presentará "zonas oscuras" en las que no resulta sencillo diferenciar entre medidas de prevención y control de las emisiones. Por ejemplo, para que una fase de un proceso de producción pueda catalogarse como método preventivo deberá "formar parte de la unidad de producción". Sin embargo, no siempre está claro hasta qué punto dicha fase debe estar alejada de la periferia del proceso de producción para que pueda considerarse una medida preventiva. Algunos procesos pueden hallarse tan alejados del núcleo de la operación que parezcan más bien procesos "añadidos" y, por consiguiente, más bien medidas de control de la fuente que métodos de prevención. U na vez más, existen situaciones ambiguas, como sería el caso de la canalización de residuos de una fábrica que sirven como materia prima para otra fábrica cercana. Consideradas en conjunto, las dos plantas constituyen una especie de circuito cerrado, pero la primera planta sigue produciendo vertidos $y$, por consiguiente, no cumple los requisitos de la prevención.

Algo similar ocurre con el reciclado. Existen tres tipos tradicionales de reciclado:

- reciclado integrado en el propio proceso; por ejemplo, cuando un disolvente para limpieza en seco se somete a filtrado, depuración y secado y se reutiliza, todo ello dentro de un mismo proceso;

- reciclado al margen del proceso pero dentro de las instalaciones, como cuando los residuos de la producción de plaguicidas se depuran y se reutilizan como base inerte en un nuevo ciclo de producción,

- reciclado al margen del proceso y fuera de las instalaciones.

De todos ellos, el tercer tipo suele descartarse por no cumplir las características de prevención de la contaminación: cuanto más alejado éste el lugar del reciclado, menor será la garantía de que vuelva a utilizarse realmente el producto reciclado. Además, el transporte de los residuos hasta el lugar de su reciclado entraña ciertos peligros y existe incertidumbre económica sobre el valor de mercado de los residuos. Consideraciones similares, aunque menos precisas, resultan válidas para el reciclado al margen del proceso pero dentro de las instalaciones, ya que siempre existe la posibilidad de que los residuos no sean sometidos a reciclado, o si lo son, que no vuelvan a ser utilizados.

En las primeras estrategias de prevención de la contaminación emprendidas en el decenio de 1980, se excluyó el reciclado al margen del proceso pero dentro de las instalaciones por no considerarse una verdadera medida de prevención de la contaminación. Existía el temor de que un programa eficaz de prevención pudiera verse condicionado o debilitado por un hincapié excesivo en el reciclado. A mediados del decenio de 1990, existen ya algunos políticos que proponen el reciclado al margen del proceso pero dentro de las instalaciones como método válido de prevención de la contaminación. U na de las razones que alegan es que existen auténticas "zonas oscuras" entre la prevención y el control. 0 tra es que ciertos procesos de reciclado dentro de las instalaciones son realmente útiles aún cuando desde el punto de vista técnico no alcancen el nivel de prevención de la contaminación. U na tercera razón es la presión ejercida por las empresas, que no entienden el motivo de descartar ciertas técnicas si cumplen los objetivos de los programas de prevención de la contaminación.

\section{Planificación de la prevención de la contaminación}

La planificación constituye una parte esencial de la metodología de prevención de la contaminación, sobre todo porque casi siempre sus beneficios en términos de productividad industrial y protección del medio ambiente no son inmediatos, sino a largo plazo, y reflejan el tipo de planificación incorporada al diseño y la comercialización de los productos. L os planes de prevención de la contaminación suelen elaborarse periódicamente y, aunque no existe un modelo único que pueda servir como referencia, una posible propuesta podría incluir:

- propósitos y objetivos;

- inventarios de productos químicos y estimación del vertido de residuos al medio ambiente;

- métodos utilizados y propuestos para la prevención de la contaminación,

- responsabilidades y medidas en caso de que el plan no pueda cumplirse o ser llevado a la práctica.

O tra propuesta podría contemplar:

- análisis de los procesos de producción;

- identificación de las oportunidades de prevención de la contaminación;

- clasificación de las oportunidades y planes para poner en practica las opciones seleccionadas,

- evaluación del éxito del plan al final del período de implantación. 
El carácter de estos planes es muy diverso. A lgunos son voluntarios, aunque pueden reflejarse en normativas tales como códigos (voluntarios) de conducta. Otros son obligatorios y deben ser (1) mantenidos dentro de las instalaciones para su posible inspección, (2) remitidos a la autoridad competente una vez finalizados o (3) remitidos a la autoridad competente para su estudio y aprobación. Existen otras alternativas, como, por ejemplo, exigir un cierto plan en caso de que otro "voluntario" sea inadecuado o ineficaz.

El carácter obligatorio de estos planes también varía, por ejemplo, en cuanto a penalizaciones y sanciones. Aunque muy pocos organismos tienen la potestad para exigir cambios específicos en el contenido de los planes de prevención de la contaminación, casi todos ellos la tienen para obligar a modificar el plan en el caso de incumplimiento de los requisitos formales; por ejemplo, cuando el plan no abarca algunos aspectos básicos. A penas se conocen ejemplos de penalizaciones o sanciones por incumplimiento de los requisitos básicos de un plan. Dicho de otra forma, los requisitos legales de los planes de prevención de la contaminación distan mucho de ser estrictos.

La elaboración de este tipo de planes exige un cierto grado de confidencialidad. En algunos casos sólo se publica un resumen, mientras que en otros los planes sólo se hacen públicos cuando el fabricante incumple la ley en algún aspecto. Prácticamente en ningún caso los requisitos de los planes de prevención de la contaminación anulan las leyes vigentes sobre el secreto profesional o la confidencialidad de las empresas respecto a materias primas, procesos o componentes de los productos. En alguna rara ocasión se ha permitido el acceso de los grupos ecologistas municipales al proceso de planificación, pero no existe prácticamente ningún caso en que la ley imponga este acceso, ni tampoco es habitual que los trabajadores tengan derecho por ley a participar en la elaboración de estos planes.

\section{Legislación}

En las provincias canadienses de Columbia Británica y O ntario, las medidas de prevención de la contaminación son "voluntarias" y su eficacia depende de la "capacidad de persuasión moral" de los gobiernos y los grupos ecologistas. En Estados U nidos, alrededor de la mitad de los estados (26) poseen algún tipo de legislación de este tipo, mientras que en Europa algunos países nórdicos ya han aprobado programas de tecnologías limpias. Estas disposiciones difieren ampliamente en cuanto a su contenido y eficacia. Algunas leyes definen la prevención de la contaminación de una manera estricta y otras lo hacen de forma más vaga y cubren un sinfín de actividades de protección del medio ambiente que afectan a la contaminación y a los residuos y no sólo a la prevención de la contaminación. La legislación de Nueva Jersey es muy exigente, la de Massachusetts y los estados de M innesota y O regón contempla un alto grado de inspección y apoyo gubernamentales, mientras que la de Alaska no pasa de ser una declaración de intenciones por parte del gobierno.

\section{Salud, seguridad y empleo}

La prevención de la contaminación tiene una importancia vital para la salud de los trabajadores: al disminuir el uso de sustancias tóxicas, disminuirá también la exposición de los trabajadores a dichas sustancias y, por consiguiente, las enfermedades profesionales. Este es un ejemplo clásico de prevención del riesgo "en la fuente" y, en muchos casos, la eliminación de riesgos mediante "controles técnicos" (es decir, métodos) es la principal y mejor arma de defensa contra los peligros químicos. Sin embargo, estas medidas preventivas difieren de la estrategia habitual de "aislamiento total" 0 "confinamiento total" del proceso químico. Aunque el confinamiento total resulta extremadamente útil y muy aconsejable, no puede considerarse un método de prevención de la contaminación, ya que sólo controla., sin reducir intrínsicamente, un peligro existente.

Los agentes contaminantes que suponen un peligro para los trabajadores, las comunidades y el medio ambiente físico han sido normalmente los primeros en combatirse por su impacto sobre las comunidades humanas (salud ambiental). Aunque a menudo los trabajadores son los que sufren una mayor exposición en el lugar de trabajo (contaminación del lugar de trabajo), por el momento no han sido el centro principal de atención de las medidas preventivas de la contaminación. La legislación de Massachusetts (similar a la de Nueva Jersey), por ejemplo, intenta reducir los riesgos para la salud de los trabajadores, los consumidores y el medio ambiente sin tener que redistribuir los riesgos entre ellos. Pero no se ha realizado ningún intento de evaluar la contaminación en el lugar de trabajo como un riesgo importante, ni se ha exigido dar prioridad a las exposiciones peligrosas (en general de los trabajadores). Tampoco se ha planteado la necesidad de impartir a los trabajadores formación sobre la prevención de la contaminación.

Existen varias razones que explican todo lo anterior. La primera de ellas es que la prevención de la contaminación es una nueva disciplina en el contexto de un fracaso tradicional y generalizado en la forma de entender la protección del medio ambiente como una función de los procesos utilizados y adoptados en el lugar de trabajo. La segunda razón es la escasa participación de los trabajadores en el campo de la protección ambiental. En muchos países los trabajadores tienen derechos legales reconocidos, por ejemplo, para participar en comités de salud y seguridad en el trabajo, rechazar trabajos peligrosos, acceder a información sobre salud y seguridad o recibir formación en estos campos y procedimientos. Pero apenas sí tienen derechos legales en el área paralela, y a veces superpuesta, de la protección del medio ambiente, como el derecho a participar en los comités de medio ambiente, el derecho a manifestarse en contra de cualquier práctica de la empresa que resulte perjudicial para el medio ambiente, el derecho a negarse a contaminar o degradar el medio ambiente, el derecho a la información sobre el medio ambiente y el derecho a participar en las inspecciones ambientales de los lugares de trabajo (véase más adelante).

El impacto de los planes de prevención de la contaminación sobre el empleo es difícil de cuantificar. El objetivo explícito de muchos de estos planes es aumentar, de forma simultánea y con las mismas medidas, la eficacia industrial y la protección ambiental. El efecto de estas iniciativas suele ser una reducción general de la plantilla (como consecuencia de la innovación tecnológica), pero también un aumento del grado de especialización necesario y, como consecuencia, una mayor seguridad en el trabajo (al existir una planificación a más largo plazo). En la medida en que se reduzca la utilización de materias primas y accesorios, se destruirán puestos de trabajo en las fábricas de productos químicos, aunque probablemente esta destrucción se verá compensada por la transición implícita hacia productos químicos especializados y por el desarrollo de productos alternativos y sustitutivos.

Existe una faceta del empleo que la planificación de la prevención de la contaminación no puede abordar. Las emisiones de contaminantes de una fábrica pueden disminuir, pero al existir una estrategia industrial de creación de riqueza y empleo con valor añadido, el aumento del número de plantas de producción (por muy "limpias" que sean) tenderá a anular las mejoras ya conseguidas en cuanto a protección del medio ambiente. El fracaso más notable de las medidas de protección del medio ambiente (cuando la reducción y el control de las emisiones contaminantes se ven anulados por el aumento del número de fuentes emisoras) es aplicable, por desgracia, a la prevención de la contaminación y a cualquier otra forma de 
intervención. Según una teoría ampliamente aceptada, los ecosistemas poseen una "capacidad de estrés" límite que puede superarse cuando existe un reducido número de fuentes altamente contaminantes 0 "sucias" o un gran número de fuentes limpias.

\section{Inspección de los ambientes de trabajo}

Los planes de prevención de la contaminación puede formar parte o complementar las inspecciones de los ambientes de trabajo. Aunque existen multitud de variantes de dichas inspecciones, las más habituales son las "inspecciones del lugar de trabajo" y las "inspecciones de la producción", donde se analiza todo el ciclo de producción tanto desde el punto de vista ambiental como económico.

A grandes rasgos, una inspección del lugar de trabajo cubre tres áreas de desarrollo sostenible y protección del medio ambiente:

- conservación de los recursos naturales utilizados como, por ejemplo, minerales, agua y maderas;

- consumo de energía, que también puede incluir la evaluación de las fuentes de energía, la eficiencia energética y la conservación de energía,

- la prevención, el control y la reparación de la contaminación.

Cuando existe una prevención eficaz de la contaminación, las medidas de control y reparación no son tan importantes. Por eso las medidas de prevención de la contaminación constituyen un componente importante de las inspecciones de los ambientes de trabajo.

Tradicionalmente las empresas han tenido la posibilidad de "externalizar" los residuos ambientales a través de prácticas como el uso indiscriminado de agua o el vertido de sus residuos al entorno exterior y al medio ambiente. Esta situación ha motivado la creación de impuestos sobre las fuentes contaminantes, ya sean aplicados a los materiales utilizados, como el consumo de agua, o a los productos finales, como los productos nocivos para el medio ambiente o los residuos ("impuestos por contaminación").

Esta es una forma de "internalizar" los costes para las empresas. Sin embargo, la experiencia demuestra que no es fácil cuantificar el coste asociado a los productos consumidos o a los efectos nocivos de los productos obtenidos; por ejemplo, el coste de los residuos para las comunidades y para el medio ambiente. Tampoco está claro que los impuestos por contaminación reduzcan ésta en proporción directa a la cantidad recaudada; los impuestos tal vez permitan "internalizar" los costes, pero por lo demás lo único que consiguen es encarecer el coste de la actividad económica.

La ventaja de la inspección ambiental radica en que puede tener un sentido económico sin necesidad de estimar "costes" externos. Por ejemplo, el "valor" de los residuos puede calcularse en función de las materias primas desperdiciadas y la "no utilización" (ineficiencia) de energía, es decir, la diferencia entre el valor de los recursos y la energía consumidos por un lado y el valor del producto obtenido por otro. Por desgracia, el aspecto financiero de los planes de prevención de la contaminación y su importancia como componente de la inspección del lugar de trabajo no se encuentra demasiado desarrollado.

\section{Evaluacion de peligros}

Algunos planes de prevención de la contaminación no incluyen la evaluación de peligros, es decir, no establecen criterios para decidir si una fábrica o instalación es más o menos benigna para el medio ambiente como resultado de ciertas medidas de prevención de la contaminación. Estos planes se basan en una lista de sustancias químicas consideradas peligrosas o que definen el alcance del programa de prevención de la contaminación. Pero esta lista no evalúa las sustancias químicas de acuerdo con su peligro relativo, ni tampoco existe garantía alguna de que un producto sustitutivo que no aparezca en la lista sea, de hecho, menos peligroso que otro que sí está incluido. El sentido común, y no el análisis científico, es quien marca las pautas que deben seguirse cuando se desarrolla un programa de prevención de la contaminación.

Otros métodos aplican criterios de evaluación de peligros basados en parámetros ambientales como la permanencia y la bioacumulación en el medio ambiente y parámetros relacionados con la salud humana que sirven como indicadores de la toxicidad; por ejemplo, toxicidad aguda, carcinogenicidad, mutagenicidad, toxicidad reproductiva, etc.

Seguidamente se aplica un sistema de ponderación y un procedimiento para la toma de decisiones que permite estimar aquellos parámetros para los que no se dispone de información suficiente sobre las sustancias químicas. A continuación se evalúan y clasifican los productos químicos más significativos, distribuyéndose en grupos por orden decreciente de peligrosidad.

Aunque algunos de estos métodos se diseñan con fines específicos, por ejemplo, para establecer medidas prioritarias de control o eliminación (prohibición), normalmente son de carácter general y pueden aplicarse a una gran variedad de medidas de protección del medio ambiente, incluida la prevención de la contaminación. Por ejemplo, las sustancias químicas consideradas más peligrosas podrían ser objeto de un programa obligatorio de prevención de la contaminación o de medidas de sustitución o retirada gradual. En otras palabras, este tipo de planes no indican la medida en que deben reducirse los peligros para la salud ambiental; sólo establecen la necesidad de que, sea cual sea la medida adoptada, se base en este método de evaluación de peligros.

Por ejemplo, si tiene que tomarse la decisión de sustituir una sustancia química peligrosa por otra más inocua, este método puede servir para juzgar a primera vista si la decisión tomada es la correcta, ya que permite valorar si existen o no diferencias en la peligrosidad de ambas sustancias.

Existen dos tipos de factores que rara vez se consideran en los métodos de evaluación de peligros. El primero de ellos es la exposición real 0 potencial del ser humano a la sustancia química. La exposición potencial es difícil de estimar y, aparentemente, puede distorsionar el "peligro intrínseco" de la sustancia química en cuestión. Por ejemplo, se podría asignar una prioridad artificiosamente baja a una sustancia química si su potencial de exposición es bajo, aunque, en realidad, sea altamente tóxica y fácil de controlar.

El segundo tipo de factores es el impacto socioeconómico de la eliminación o reducción del uso de una sustancia química. Aunque inicialmente podrían tomarse decisiones basadas en un análisis de los peligros, después habría que efectuar un segundo y más profundo análisis socioeconómico para determinar, por ejemplo, la utilidad social del producto asociado a su aplicación química (por ejemplo, una droga útil) y considerar asimismo el impacto en los trabajadores y sus comunidades. La razón de realizar este análisis por separado es la imposibilidad de juzgar los resultados de un estudio socioeconómico aplicando los mismos criterios que a los peligros intrínsecos de las sustancias químicas. Se trata de dos conjuntos de valores totalmente diferenciados con lógicas distintas.

Pese a todo, los métodos de evaluación de peligros son imprescindibles para evaluar el éxito de los programas de prevención de la contaminación (también son bastante novedosos, tanto por su impacto como por su utilidad). Por ejemplo, pueden aplicarse sin hacer referencia alguna a la valoración y análisis de riesgos 0 
(con ciertas reservas) a los análisis de coste-beneficio. U na de las primeras formas de abordar el problema de la contaminación consistió en realizar primero una valoración del riesgo y, a continuación, decidir el tipo de acciones necesarias para reducir el riesgo a un nivel "aceptable". Nunca se consiguieron resultados satisfactorios. La evaluación de peligros, por el contrario, puede realizarse con gran celeridad y sin retrasar ni comprometer la eficacia de un programa de prevención de la contaminación. La prevención de la contaminación es, ante todo, un programa pragmático capaz de afrontar rápidamente los problemas de contaminación en el momento en que aparecen o incluso antes de que aparezcan. Puede afirmarse que las medidas tradicionales de control han alcanzado su techo y que los programas globales de prevención de la contaminación constituyen la única forma de abordar de una manera práctica y eficaz la fase siguiente de la protección ambiental.

\section{Referencias}

American Public Health Association (APHA). 1995. Standard $M$ ethods for the Examination of $W$ ater and W astewater. Alexandria, Virginia: Water Environment Federation.

Bishop, PL. 1983. M arine Pollution and Its Control. Nueva Y ork: $M$ cG raw-Hill.

Brown, LC, TO Barnwell. 1987. E nhanced Stream W ater $Q$ uality M odels QUAL2E and QUAL2E-UNCAS: $D$ ocumentation and $U$ ser $M$ anual. Athens, Georgia: USEPA, Environmental R esearch $L a b$.

Brown, RH . 1993. Pure Appl Chem 65(8):1859-1874.

Calabrese, EJ, EM K enyon. 1991. Air T oxics and Risk Assessment. Chelsea, M ichigan:L ewis.

Canadá y O ntario. 1994. T he Canada-O ntario A greement Respecting the Great Lakes E cosystem. H ull, Q uebec: Environment $C$ anada's Public Enquiry $O$ ffice.

Comisión M ixta Internacional (IIC). 1993. A Strategy for Virtual Elimination of Persistent Toxic Substances. Vol. 1, 2, Windsor, O ntario: JIC

Dillon, PJ. 1974. A critical review of Vollenweider's nutrient budget model and other related models. W ater R esour B ull 10(5):969-989.

Eckenfelder, WW. 1989. Industrial W ater Pollution Control. Nueva Y ork: M cG raw-H ill.

Economopoulos, AP. 1993. Assessment of Sources of Air $W$ ater and $L$ and Pollution. A Guide to Rapid Source $I n$ ventory $T$ echniques and $T$ heir $U$ se in $F$ ormulating $E$ nvironmental Control Strategies. Part One: Rapid Inventory Techniques in Environmental Pollution. Part T wo: Approaches for Consideration in Formulating Environmental Control Strategies. (D ocumento no publicado WH O/YEP/ 93.1.) G inebra: O M S.

Environment Canada. 1995a. Pollution Prevention A Federal Strategy for Action. O ttawa: Environment Canada.

-. 1995b. Pollution Prevention - A F ederal Strategy for Action. O ttawa: Environment $C$ anada.

Environmental Protection Agency (EPA). 1987. Guide lines for $D$ edineation of $W$ ellhead Protection A reas. Englewood Cliffs, Nueva Jersey: EPA.

Estado de O hio. 1995. Water quality standards. En Capítulo 3745-1 de Administrative Code. Columbus, O hio: O hio EPA.

Estados U nidos y Canadá. 1987. R evised Great Lakes W ater $Q$ uality A greement of 1978 As Amended By Protocol Signed November 18, 1987. Hull, Q uebec: Environmental $C$ anada's Public Enquiry $O$ ffice.

Freeze, RA, JA Cherry. 1987. Groundwater. Englewood Cliffs, N ueva Jersey: Prentice $\mathrm{H}$ all.

Global Environmental M onitoring System (GEM S/ Air). 1993. A Global Programme for U rban Air Quality M onitoring and Assessment. Ginebra: PNUMA.

Hosker, RP. 1985. Flow around isolated structures and building clusters, a review. ASH RAE T rans 91.

K anarek, A. 1994. Groundwater R echarge W ith M unicipal Effluent, Recharge Basins Soreq, Yavneh $1 \&$ Yavneh 2. Israel: M ekoroth Water $\mathrm{Co}$.
Lee, N. 1993. O verview of EIA in Europe and its application in the New Bundeslander. En UVP Leitfaden, dirigido por $\mathrm{V} K \mathrm{~K}$ leinschmidt. Dortmund.

M etcalf y Eddy, I. 1991. W astewater E ngineering T reatment, Disposal, and Reuse. Nueva Y ork: M CG rawHill.

M iller, JM, A Soudine. 1994. The W M O global atmospheric watch system. $\mathrm{H}$ vratski meteorolski casopsis 29:81-84.

M inisterium für Umwelt. 1993. Raumordnung Und $L$ andwirtschaft $D$ es $L$ andes N ordrhein-W estfalen, L uftreinhalteplan R uhrgebiet W est [Plan de protección atmosférica para el área del R uhr 0 ccidental].

Organización Mundial de la Salud (OMS) y Programa de las $\mathrm{N}$ aciones $\mathrm{U}$ nidas para el $\mathrm{M}$ edio Ambiente (PNUMA). 1994. GEM S/ AIR M ethodology Reviews $\mathrm{H}$ andbook Series. V ol. 1-4. Q uality Insurance R eviews H andbook Series. V ol. 1-4. Q uality Insurance

-. 1995a. City Air Quality T rends. V ol. 1-3. Ginebra: OM S.

-. 1995b. GEM S/ AIR M ethodology Reviews $H$ andbook Series. V ol. 5. Guidelines for GEM S/ AIR Collaborative R eviews. Ginebra: O M S.

O rganización Mundial de la Salud (OMS). 1980 Glossary On Air Pollution. European Series, No. 9. Copenhague: Publicaciones Regionales de la OMS.

-. 1987. Air Quality Guidelines for Europe. European Series, No. 23. Copenhague: Publicaciones Regionales de la OMS.

Parkhurst, B. 1995. Risk M anagement M ethods, W ater Evironment and T echnology. W ashington, DC: Water Environment Federation.

Pecor, CH. 1973. Houghton Lake Annual Nitrogen and Phosphorous Budgets. Lansing, M ichigan: Department of $\mathrm{N}$ atural R esources.

Pielke, RA. 1984. M esoscale M eteorological M odeling. O rlando: A cademic Press

Preul, HC, GJ Schroepfer. 1968. Travel of nitrogen compounds in soils. J W ater Pollut Contr Fed (A bril).

Preul, HC. 1964. Travel of nitrogen compounds in soils. Tesis doctoral, Universidad de M innesota, $M$ inneapolis, M innesota.

- . 1967. U nderground M ovement of Nitrogen. V ol. 1. Londres: Asociación Internacional para la Calidad del Agua.

-. 1972. Underground pollution analysis and control. Water R esearch. J Int Assoc W ater Q uality (O ctubre):1141-1154.

-. 1974. Subsurface waste disposal effects in the Lake Sunapee watershed. Estudio e informe de la Lake Sunapee Protective Association, Estado de $\mathrm{N}$ ew $\mathrm{H}$ ampshire, no publicado.

-. 1981. Recycling Plan for L eather T annery W astewater Effluent. A sociación Internacional de R ecursos $\mathrm{Hi}$ dráulicos

—. 1991. Nitrates in W ater Resources in the U SA. : Water R esources Association.

Reid, G, R Wood. 1976. E cology of Inland W aters and E stuaries. Nueva Y ork: $V$ an N ostrand.
Reish, D. 1979. Marine and estuarine pollution. J W ater Pollut C ontr F ed 51(6):1477-1517.

Sawyer, CN. 1947. Fertilization of lakes by agricultural and urban drainage. J New Engl W aterworks Assoc 51:109-127.

Schwela, DH, I K öth-Jahr. 1994. Leitfaden für die Aufstellung von Luftreinhalteplänen [D irectrices para la ejecución de los planes de protección atmosférica]. Landesumweltamt des Landes N ordrhein Westfalen.

Secretaría del ARET. 1995. Environmental Leaders 1, Voluntary Commitments to Action On Toxics Through ARET. Hull, Quebec: Environment Canada's Public Enquiry O ffice.

Taylor, ST. 1995. Simulating the impact of rooted vegetation on instream nutrient and dissolved oxygen dynamics using the $\mathrm{OMNI}$ diurnal model. En Proceedings of the W EF Annual Conference. Alexandria, V irginia: W ater Environment Federation.

Venkatram, A, J Wyngaard. 1988. Lectures On Air Pollution $M$ odeling. Boston, M assachussetts: American $M$ eteorological Society.

V enzia, RA. 1977. L and use and transportation planning. En Air Pollution, dirigido por AC Stern. Nueva Y ork: Academic Press.

Verein Deutscher Ingenieure (VDI) 1981. Guideline 3783, Part 6: Regional dispersion of pollutants over complex train. Simulation of the wind field. Dusseldorf: VDI.

-. 1985. Guideline 3781, Part 3: Determination of plume rise. Dusseldorf: VDI.

- . 1992. Guideline 3782, Part 1: G aussian dispersion model for air quality management. Dusseldorf: VDI.

- . 1994. Guideline 3945, Part 1 (borrador): G aussian puff model. Dusseldorf: VDI.

- . n.d. Guideline 3945, Part 3 (en preparación): Particle models. Dusseldorf: VDI.

V iessman, W, GL Lewis, JW K napp. 1989. Introduction to $H$ ydrology. N ueva Y ork: $H$ arper $\&$ R ow.

Vollenweider, RA. 1968. Scientific Fundamentals of the Eutrophication of Lakes and Flowing $W$ aters, $W$ ith Particular R eference to Nitrogen and Phosphorous Factors in Eutrophication. París: OCDE.

-. 1969. M öglichkeiten and Grenzen elementarer Modelle der Stoffbilanz von Seen. Arch $\mathrm{H}$ ydrobiol 66:1-36.

Walsh, MP. 1992. R eview of motor vehicle emission control measures and their effectiveness. En M otor Vehicle Air Pollution, Public $\mathrm{H}$ ealth Impact and Control $M$ easures, dirigido por D M age y $O$ Zali. R epública y Cantón de Ginebra: Servicios de E cotoxicología de la O M S, D epartamento de Salud Pública.

W ater Environment Federation. 1995. Pollution P revention and $\mathrm{W}$ aste $\mathrm{M}$ inimization Digest. Alexandria, V irginia: Water Environment Federation.

Yamartino, RJ, G Wiegand. 1986. Development and evaluation of simple models for the flow, turbulence and pollutant concentration fields within an urban street canyon. Atmos E nviron 20(11): S2137S2156. 


\section{O tras lecturas recomendadas}

Analytische Chemie [A nalytical Chemistry]. 1991. Nachr. Chem. Tech. Lab. 40, 146-154.

Atkins, DHF, I Q uirino. 1992. A Survey of Nitrogen Dioxide in Paris. Bruselas: Comisión Europea.

Bartels, U, J Block. 1985. Plant Nutr Soil Sci 148:689693.

Beier, R, M Buck, H-U Pfeffer. n.d. Proceedings of the 8th W orld Clean Air Congress. Amsterdam: Elsevier Science.

Beier, R, PL Gonzales, G M c Innes, E M ullye, K Stevenson, K -H Zierrock 1987. A Study of N etwork De sign and $M$ easurement $M$ ethods in the $M$ ember States for the EC Air Q uality D irective for N itrogen D ioxide. Bruselas: Comisión Europea.

Bennett, D. 1991. Pesticide reduction, a case study from Canada. N ew Solutions (O toño).

Both, R, K Otterbeck, B Prinz. 1993. O dorous emissions guidelines (en alemán). Staub-R einhalt 53:407-412

Bruckmann, P, H-U Pfeffer. 1991. VDI-Berichte [VDI reports] Report 888. Dusseldorf: VDI.

Buck, M , H-U Pfeffer. 1988. Clean Air 22:7-12.

Buck, M . 1989. Staub-R einhaltung der L uft 49:337-342.

Canadian Labour Congress. 1992. A Critique of the Ontario $\mathrm{H}$ azard Assessment System. $\mathrm{O}$ ttawa: Canadian Labour Congress.

Clement, RE, CJ K oester. 1993. Anal chem 65:85R $116 \mathrm{R}$.

Commoner, B. 1990. Making Peace $W$ ith the Planet. N ueva Y ork: Pantheon Books.

Elbers, G, S Lutz. 1993. VDI-Berichte [informe del VDI]. Informe 1059: 337-356. Dusseldorf: VDI.

Ellermann, K, A Borowiak, H-U Pfeffer. 1993. LIM ES-I ahresbericht. LIM ES- I nforme A nual 1993 , No. Series B. Renania del Norte-Westfalia: $O$ ficina Estatal del M edio Ambiente.

Environment Canada. 1993a. Pollution Prevention L egislative T ask Force Final Report. O ttawa: Environment Canada.

—. 1993b. Pollution Prevention L egislative T ask F orce, Final Report. O ttawa: Environment Canada.

Erste Allgemeine Verwaltungsvorschrift zum Bundes-Immissionsschutzgesetz (TA L uft) vom [Primer reglamento administrativo general en aplicación de la Ley federal de protección contra las inmisiones (TA Aire)] de 27 de febrero de 1986, G M BI 95-143.

Foran, J, B Glenn. 1993. Criteria to Identify Chemical Candidates for Sunsetting in the Great Lakes Basin. Washington, DC: U niversidad George Washington.

Fox, DL. 1993. Air pollution. Anal chem 65:156R170R.
Geiser, K. 1990. T oxics use reduction and pollution prevention. N ew Solutions (Primavera).

Grant, WB, RH K agann, WA M cClenny. 1992. J Air $W$ aste $M$ anage $A$ ssoc 42:18-30.

Great Lakes Scientific Advisory Board (1991): R eport to the International J oint Commission. Edición revisada, diciembre 1991

Grefen, K . 1991. Staub-R einhaltung der L uft 51:199-205.

K lockow, D, Z Fresenius. 1987. Anal chem 326:5-24.

Lahmann, E. 1990. Luftverunreinigung-L uftreinhaltung [Polluting the Air and Keeping It Clean ]. Berlín: V erlag Paul Parey.

-. 1992. Determination and Evaluation of Ambient Air Q uality-M anual of Ambient Air Q uality Control in $\mathrm{Ger}$ many. Berlín: M inisterio Federal para el M edio Ambiente, la Conservación de la Naturaleza y la Seguridad Nuclear.

- 1993. Feststellung U nd Bewertung Von Immissionen-Leitfaden Zur Immissionsüberwachung in D eutschland [D eterminación y evaluación de las inmisiones: Directrices para la vigilancia de inmisiones en Alemania]. Berlín: O ficina Federal de M edio A mbiente.

Lodge, JPJ. 1989. M ethods of Air Sampling and Analysis. Chelsea, M ichigan: Lewis.

McClenny, W, J Pleil, G Evans, $\mathrm{K}$ Oliver, $\mathrm{M} \mathrm{Hol}$ dren, W W einbery. 1991. VDI-R ichtlinie 3482 BI. 3-6 Gaschromatographische Bestimmung organischer $V$ erbindungen [D eterminación de compuestos orgánicos mediante cromatografía de gases]. J Air W aste M anage Assoc 41:1308-1318.

Medrow, W. 1990. Gerüche, Schriftenreihe Der VDI. Kommission Reinhaltung Luft, Band 12. Düsseldorf: VDI.

M inisterium für Umwelt, $R$ und $L$ Nordrhein-W. 1992. K rebsrisiko D urch L uftverunreinigungen, Studie $D$ es $L$ änderausschusses F ür I mmissionsschutz [R iesgo de cáncer por contaminantes atmosféricos. E studio del Comité E statal para la Protección de M edio Ambiente ]. Düsseldorf: Ministerio de M edio Ambiente Planificación Regional y Agricultura de Renania del NorteWestfalia.

M ohnen, V, J Wilson, J K adlecek. 1982. En Chemistry of the U npolluted and Polluted T roposphere, dirigido por HW Georgii y W Jaeschke. Boston: D. Reichel Publishing $\mathrm{C} 0$.

O ntario M inistry of the Environment (O M E). 1990a. Scoring System for Assessing E nvironmental Contaminants. T oronto: $\mathrm{OM} \mathrm{E}$

- . 1990b. Scoring System for Assessing E nvironmental Contaminants. T oronto: O M E.

-. 1992. Candidate Substances List for $B$ ans and Phase 0 uts. T oronto: OM E.

—. 1993. Candidate Substances List for B ans and Phase $\mathrm{O}$ uts. T oronto: $\mathrm{OM} \mathrm{E}$

Petzold, A, R Niessner. 1993. VDI-Berichte [Informes del VDI]. Informe 1059. Dusseldorf: VDI.
Pfeffer, H-U, M Buck. 1988. Proceedings of the 11th Triennial World Congress of the International $M$ easurement Confederation (IM EK O), H ouston, T exas (USA). Acta I meko 4:527-536.

Pfeffer, H-U. 1982. Staub-Reinhaltung der Luft 42:233236.

Pott, F. 1991. VDI-B erichte [I nformes del VDI]. Informe 888. Dusseldorf: VDI.

Rabano, ES, NT Castillo, KJ Torre, PA Solomon. 1989. J Air Pollut Contr Assoc 39:76-80.

Rossi, M, M Ellenbecker, K Geiser. 1991. Techniques in toxics use reduction: From concept to action. N ew Solutions (Fall).

Schrecker, T. 1993. Sustainable Development: Getting There From $\mathrm{H}$ ere, $\mathrm{A} H \mathrm{H}$ andbook for $\mathrm{U}$ nion Environment Committees and I oint Labour-M anagement Environment Committees. O ttawa: CLC/NRTEE.

Shelef, G, Y Azov. 1994. Vigilancia del Tercer Canal (en hebreo). Haifa: Centro de Investigación Técnica sobre la Ingeniería Ambiental y los Recursos $\mathrm{H}$ ídricos.

Slanina, J, GP Wyers, J Fresenius. 1994. Anal chem 350:467-473.

US O ffice of Technology Assessment. 1986. Serious $\mathrm{R}$ eduction of $\mathrm{H}$ azardous $\mathrm{W}$ aste for Pollution Prevention and Industrial E fficiency. W ashington, DC: U S O ffice of T echnology Assessment

Vereine Deutscher Ingenieure (VDI). 1993 Verwaltungsvorschrift des Sächsischen Staatsministeriums für U mwelt und Landesentwicklung zur Feststellung und Beurteilung von Geruchsimmissionen Geruchsimmions-R ichtlinie vom 16.03.93. Sächs. Amtsblatt Nr. 17 vom 22.04.1993. [R eglamento administrativo del M inisterio de M edio Ambiente y Desarrollo del estado de Sajonia relativo a la detección y evaluación de inmisiones olorosas - Inmisiones olorosas- directrices del 16 de marzo de 1993.] D usseldorf: VDI.

-. 1995a: VDI 4280 Blatt 1 (E). Planung von Immissonsmessungen. Allgemeine Regeln (Ausgabe 5 1995). [VDI número 1 (E). Plan de medición de inmisiones. N ormas generales (5a edición, 1995).]

-. 1995b. VDI-Richtlinie 2465 Blatt 1 (Entwurf), M ärz 1995, M essen von Ruß [Equipos de medición].

—. n.d. VDI-H andbuch Reinhaltung $D$ er L uft. Düsseldorf: VDI.

Weber, K, V K lein, W Diehl. 1990. O ptische Fernmeßverfahren zur Bestimmung gasförmiger Luftschadstoffe in der Troposphäre [Procedimientos ópticos de medición a larga distancia para la determinación de contaminantes atmosféricos gaseosos en la troposfera]. En VDI Berichte [I nformes del VDI] Düsseldorf: VDI.

Wight, G. 1994. F undamentals of Air Sampling. Boca Raton: Lewis.

Winkler, P. 1985. Staub-R einhaltung der Luft. 45:256260. 



\section{PREVENCION DE ACCIDENTES}

Director del capítulo

J orma Saari

\section{Sumario}

Introducción

J orma Saari . ............................ 56.2

Conceptos del análisis de accidentes

Kirsten J ørgensen . . . . . . . . . . . . . . . . . . . . 56.3

Teoría de las causas de los accidentes

Abdul Raouf . . . . . . . . . . . . . . . . . . . . . . . . . . . . . . 56.6

Factores humanos en los modelos de accidentes

Anne M arie Feyer y Ann M. W illiamson . . . . . . . . . . . . . 56.8

M odelos de accidentes: homeostasis del riesgo

Gerald J. S. W ilde.

M odelos de accidentes

Andrew R. Hale . . . . . . . . . . . . . . . . . . . . . . . . . . . . . 56.14

M odelos de secuencia de accidentes

Ragnar Andersson. .......................... 56.18

M odelos de desviación de accidentes

U rban Kjellén .

EI M AIM : modelo de información de accidentes de $M$ erseyside

$H$ arry S. Shannon y J ohn D avies

Principios de la prevención: el planteamiento de la

sanidad pública respecto a la reducción de las

lesiones en el lugar de trabajo

Gordon S. Smith y M ark A. Veazie . . . . . . . . . . . . . . . . . . . 56.28

Principios teóricos de la seguridad en el trabajo

Reinald Skiba . . . . . . . . . . . . . . . . . . . . . . . . . . . . . . . 56.34

Principios de prevención: información sobre seguridad

M ark R. Lehto y J ames M. M iller ................... . 56.37

Costes de los accidentes relacionados con el trabajo

D iego Andreoni 


\section{- INTRODUCCION}

Jorma Saari

De acuerdo con las estadísticas de la O ficina Internacional del Trabajo, se producen cada año 120 millones de accidentes laborales en los lugares de trabajo de todo el mundo. De éstos, en 210.000 se registran fallecimientos. Cada día, más de 500 hombres y mujeres no regresan a sus hogares víctimas de este tipo de accidentes mortales. Son cifras escalofriantes que apenas interesan a la opinión pública. Habida cuenta del precio tan elevado que los accidentes suponen para los países, las empresas y las personas, su difusión pública es más bien limitada.

Por fortuna, hay personas que trabajan, conscientes del fin perseguido y a menudo entre bastidores, para mejorar la comprensión y la gestión de la seguridad y la prevención de accidentes, y sus esfuerzos no han sido en vano. N uestros conocimientos en este terreno son más amplios que nunca. M uchos investigadores y profesionales de prestigio mundial en materia de seguridad comparten con nosotros estos nuevos conocimientos en los artículos de la presente E nciclopedia. En los últimos veinte decenios, el conocimiento de los accidentes ha evolucionado considerablemente. A trás ha quedado el modelo simplista que dividía el comportamiento y las condiciones en dos categorías: seguros 0 inseguros. $L a$ creencia firme en que toda actividad puede clasificarse en uno de estos dos apartados ha ido dejando paso a otros modelos sistemáticos más elaborados cuya eficacia en la gestión de la seguridad está comprobada.

Es importante subrayar que dos condiciones que son seguras por separado, pueden no serlo juntas. Los trabajadores constituyen el nexo de unión, ya que su comportamiento varía según su entorno y su medio físico. Por ejemplo, las sierras mecánicas provocaron numerosos accidentes cuando comenzaron a utilizarse en el decenio de 1960, debido a un movimiento peligroso conocido como "retroceso", que coge por sorpresa al operario cuando los dientes articulados de la herramienta tropiezan con una rama, un nudo o un punto de mayor dureza en la madera. Fue el causante de cientos de muertes y lesiones antes del invento de un mecanismo de protección. Cuando Suecia adoptó disposiciones que exigían su instalación, el número de lesiones se redujo de 2.600 en 1971 a 1.700 en 1972, lo cual supuso un enorme avance en la prevención de accidentes provocados por la utilización de sierras mecánicas.

Cualquier usuario de estas ruidosas, vibrantes y, desde luego, afiladas herramientas sabe por experiencia que son muy peligrosas; de ahí la extrema precaución con que la usan los principiantes. Con todo, tras muchas horas de trabajo, los operarios van perdiendo la conciencia del peligro y comienzan a utilizar la sierra con menos cuidado. Algo similar sucede con el dispositivo antirretroceso. Los trabajadores que saben que es posible que se produzca ese movimiento tratan de evitarlo, y al contar con un mecanismo de protección se vuelven menos cautelosos. La industria forestal, otro sector en el que se utilizan las sierras mecánicas de cadena, los estudios han demostrado que la protección de las piernas reduce la precaución de los trabajadores, quienes se exponen con mayor frecuencia a los retrocesos, ya que se creen a salvo.

A pesar de que la protección antirretroceso ha ayudado a prevenir lesiones, el mecanismo es incierto. Aunque resulta eficaz desde el punto de vista de la protección, no existe un análisis definitivo que garantice que sus efectos corren parejos con la seguridad. Se dan dos condiciones que aumentan ésta: el dispositivo antirretroceso y el protector de piernas, pero no significa que la dupliquen. La lógica aritmética de "uno más uno igual a dos" $(1+1=2)$ no es aplicable en este caso, ya que uno y uno pueden ser menos que dos. Por fortuna, uno más uno $(1+1)$ son más que cero en ciertas ocasiones. En otras, por el contrario, la suma puede llegar a ser negativa.

Se trata de fenómenos que los profesionales de la seguridad han comenzado a comprender mejor que antes. La división simple de comportamientos y condiciones en seguros e inseguros no permite avanzar mucho en el camino de la prevención. La confianza en cuanto al progreso ha de ponerse en la gestión de sistemas. Si entendemos que las per sonas, sus tareas, sus equipos y el entorno componen un sistema dinámico, habremos avanzado considerablemente en la prevención de accidentes. LoS ejemplos siguientes ponen de relieve la naturaleza dinámica de las personas y el trabajo. Si se modifica un componente, los otros no se mantienen inalterados y el efecto definitivo sobre la seguridad resulta difícil de prever.

En la aviación y en otros sistemas donde la ingeniería y automatización son elevadas, se ha observado que un aumento de ésta no genera necesariamente una mejora de la seguridad. Por ejemplo, puede que los operarios no consigan la práctica suficiente para mantener su nivel de cualificación, y cuando se exige su intervención, es posible que carezcan de la competencia o la capacidad necesarias.

Algunos fabricantes de papel han señalado que los trabajadores más jóvenes no comprenden las funciones de las máquinas tan bien como los de más edad, quienes han trabajado con máquinas no automáticas y han visto cómo funcionan. Los nuevos equipos automáticos se manejan desde salas de control a través de teclados y pantallas informáticos. Los trabajadores ignoran la localización exacta de cada uno de los componentes de los aparatos que utilizan, por lo que pueden colocar alguno de ellos en una situación que, por ejemplo, constituya un peligro para el personal de mantenimiento que trabaja en su proximidad. U na mejora técnica de la maquinaria o los controles que no vaya acompañada de un perfeccionamiento simultáneo de las cualificaciones, los conocimientos y los valores de los operarios es posible que no mejore la seguridad.

Tradicionalmente, la prevención se ha basado en el aprendizaje a partir de los accidentes y cuasiaccidentes. Al investigarlos por separado, conocemos sus causas y podemos adoptar medidas para reducirlas o erradicarlas. El problema es que, en ausencia de teorías apropiadas, no hemos sido capaces de elaborar métodos de investigación que permitan manejar todos los factores importantes para la prevención. Un estudio puede ofrecer una visión bastante aproximada de las causas, pero siempre estará limitado al caso específico examinado. Es posible que existan condiciones y factores que han intervenido en el accidente y cuyas conexiones desconocen o no comprenden los investigadores. La generalización de las conclusiones de un accidente a otras situaciones conlleva un cierto riesgo.

D esde un punto de vista más positivo, cabe destacar que se ha avanzado considerablemente en el área de la gestión de la seguridad basada en la predicción. Se han desarrollado varias técnicas que se han convertido en un elemento rutinario del análisis de riesgo y seguridad industrial. A partir de ellas pueden estudiarse los centros de producción industrial de forma sistemática para determinar posibles peligros y emprender las acciones preventivas adecuadas.

Los sectores químico y petroquímico sobresalen en este campo en todo el mundo. Como consecuencia de grandes catástrofes, como las de Bhopal o Chernóbil, se ha generalizado la utilización de nuevas técnicas de predicción. El avance en materia de seguridad ha sido notable desde mediados del decenio de 1970. Asimismo, numerosos gobiernos se han destacado por hacer obligatorios los análisis de seguridad. Suecia, Finlandia, Japón y la República Federal de Alemania han reducido sus tasas de accidentes de trabajo mortales entre un 60 y un $70 \%$ en este período. M uchos otros países registran resultados 
similares. El reto actual es llevar a la práctica los conocimientos alcanzados a partir de la investigación y en perfeccionar las iniciativas preventivas.

Uno de los nuevos avances en la gestión de la seguridad es el concepto de cultura de la seguridad. Tal vez sea de difícil aprehensión, ya que la cultura no es una entidad tangible. Se trata de un concepto abstracto admitido en el seno de una organización o una sociedad. No hay formas directas de ajustarlo. Con todo, es crucial para comprender las posibilidades de la prevención. U no de los objetivos de este artículo es analizar este nuevo concepto.

La presente edición de la Enciclopedia ofrece una revisión exhaustiva de las teorías y los modelos de prevención de accidentes, con el fin de desarrollar estrategias preventivas mejor elaboradas y más eficaces. Los accidentes de trabajo pueden evitarse. No debemos tolerar esta carga innecesaria para nuestro bienestar y nuestra economía.

\section{- CONCEPTOS DEL ANALISIS DE ACCIDENTES}

\section{Kirsten Jørgensen}

El presente artículo pretende ser una guía para calcular la magnitud del problema de los accidentes, más que una mera descripción de la misma. En los accidentes laborales puede estimarse de formas diferentes, en función de si lo que se desea es averiguar la magnitud que ha tenido el problema o la que tendrá en el futuro. (Puede pensarse que esta distinción es innecesaria, pues el conocimiento del alcance actual de un problema servirá para indicar cuál tendrá en el futuro). La magnitud de un problema, así como sus diferentes tipos, varía según los países, los sectores y los lugares de trabajo.

Un accidente puede definirse como el resultado de una cadena de acontecimientos en la que algo ha funcionado mal y no ha llegado a buen término. Se ha demostrado que la intervención humana puede evitar que se produzcan las lesiones y los daños a que conduciría esa cadena de sucesos. Ahora bien, si tenemos en cuenta la intervención humana, podemos concluir que hay muchas más cadenas de acontecimientos potencialmente peligrosas de las que llegan realmente a producir lesiones. $\mathrm{H}$ a de tenerse esto en cuenta al evaluar en toda su extensión los riesgos existentes en los lugares de trabajo. La asunción de que los acontecimientos que acaban produciendo lesiones se deben a ciertos factores existentes en los lugares de trabajo, lleva a concluir que la magnitud del problema debe determinarse en función de la existencia y frecuencia de tales factores.

En el caso de los accidentes de trabajo, la magnitud del problema puede estimarse retrocediendo en el tiempo y comparando el número de accidentes (tasa de incidencia) con su gravedad (jornadas de trabajo perdidas). Sin embargo, si se pretende realizar un cálculo prospectivo, habrá que evaluar la presencia de factores de riesgo en el lugar de trabajo, es decir, de aquéllos que puedan dar lugar a accidentes.

Puede obtenerse una visión completa y precisa de la situación de los accidentes en el lugar de trabajo mediante la aplicación de un sistema global de partes y registros. El análisis de partes de accidente bien elaborados puede facilitar el conocimiento de las relaciones básicas esenciales para comprender sus causas. La determinación de los factores de riesgo es fundamental para estimar con precisión la magnitud del problema. Es posible llegar a conocer los factores de riesgo más importantes analizando la información detallada que ofrece cada parte relativa a la situación de los trabajadores y los operarios en el momento del accidente, lo que estaban haciendo y manipulando, los medios que utilizaban, los daños y lesiones producidas y otras cuestiones afines.

\section{Riesgo}

La medición del riesgo debe efectuarse en función de la información relativa al número y la gravedad de las lesiones sufridas en el pasado, lo que ofrece una estimación retrospectiva. $\mathrm{H}$ ay dos tipos de datos que permiten definir los riesgos de lesiones que corren las personas:

- La medición del riesgo ofrece un cálculo de la frecuencia de las lesiones y una medida de su gravedad. Puede definirse como el número de días de trabajo perdidos (o de fallecimientos) por número de trabajadores ( $p$. ej., en Dinamarca el riesgo de morir en un accidente de trabajo es de 3 por cada 100.000 trabajadores).

- La evaluación del tipo de riesgo o elemento de peligro indica no sólo las fuentes de exposición y otros factores nocivos que pueden provocar un accidente, sino también las circunstancias que dan lugar a la lesión o el daño. Por ejemplo, el trabajo realizado en un lugar elevado entraña un riesgo de caída que puede producir lesiones graves; lo mismo sucede en el trabajo con instrumentos cortantes respecto al contacto con piezas afiladas, o el trabajo con máquinas muy ruidosas durante períodos prolongados, que puede generar daños en la capacidad auditiva.

El sentido común está presente en numerosos tipos de riegos. Por ejemplo, si uno trabaja en un sitio alto, puede caerse; si el suelo está resbaladizo, puede patinar; si hay cerca objetos punzantes, puede cortarse. No obstante, a otros muchos tipos de riesgo no puede aplicárseles el sentido común, pues pasan inadvertidos. El trabajador debe ser informado de tales riesgos (p. ej., de los daños que origina el ruido en el oído; de cómo afectan al cerebro determinados disolventes; del envenenamiento agudo que causa la inhalación de algunas sustancias químicas).

En todo caso, nuestro conocimiento sobre los tipos de riesgos, sean o no evidentes, adquiridos gracias a la experiencia diaria 0 a trabajos de investigación, se basan en acontecimientos pasados. Con todo, una cosa es saber qué ha ocurrido y otra predecir lo que ocurrirá en el futuro. D ebe señalarse que la base para el reconocimiento del riesgo viene dada tanto por el conocimiento de las fuentes de exposición y otros factores potencialmente nocivos que pueden causar daños o lesiones cuando se unen a determinadas tareas, como por el de los factores capaces de aumentar o reducir los factores de riesgo que influyen en la medición de éste.

\section{Factores que determinan el riesgo}

L os factores de mayor importancia al determinar el riesgo son:

- los que determinan la presencia o la ausencia (o la posibilidad) de cualquier tipo de riesgo;

- los que aumentan o reducen la probabilidad de que tales riesgos se traduzcan en lesiones o accidentes,

- los que afectan a la gravedad de las lesiones asociadas con tales riesgos.

Para aclarar el primero de estos puntos es necesario establecer las causas del accidente, es decir, las fuentes de exposición y otros factores nocivos. Los otros dos puntos se refieren a los factores que influyen en la medición del riesgo.

Los factores fundamentales del entorno de trabajo que son causa directa de los daños, tanto en forma de enfermedades como de accidentes profesionales, son los siguientes: 


\section{Fuentes de exposición y trastor nos profesionales}

El concepto de lesiones debidas a fuentes de exposición suele vincularse al de enfermedad (o trastorno), ya que ésta puede considerarse provocada por la exposición a uno o varios agentes durante un período de tiempo breve (exposición aguda) o prolongado (crónica). Los agentes de exposición crónicos no suelen ser nocivos directamente, y sus efectos se sienten tras un período de exposición relativamente largo y constante, mientras que los perjuicios de las exposiciones agudas son casi instantáneos. Tanto su intensidad y nocividad como la duración de la acción son de gran importancia para el desarrollo de las lesiones que, a menudo, son el resultado de una combinación de varios agentes diferentes; ello hace más difícil precisar las fuentes de exposición porque, entre otras razones, casi nunca existe una correlación monocausal entre trastornos específicos y fuentes de exposición concretas.

He aquí algunas de las fuentes de exposición que pueden dar lugar a lesiones o daños con carácter de enfermedad:

- exposiciones químicas (disolventes, compuestos para limpiar o desengrasar, etc.);

- exposiciones físicas (ruido, radiación, calor, frío, iluminación inapropiada, falta de oxígeno, etc.);

- exposiciones fisiológicas (cargas pesadas, posturas forzadas o trabajo repetitivo);

- exposiciones biológicas (virus, bacterias, mohos, sangre o piel de animales, etc.),

- exposiciones psicológicas (trabajo en situación de aislamiento, amenaza de violencia, horarios de trabajo variables, exigencias del puesto de trabajo poco habituales, etc.).

\section{Factores nocivos y accidentes de trabajo}

El concepto de factor nocivo (del que se excluyen las fuentes de exposición) está relacionado con el de accidente de trabajo, puesto que es en este entorno en el que se producen los daños y los trabajadores se ven expuestos al tipo de acciones que causan lesiones instantáneas. EI daño o la lesión se reconocen inmediatamente en el momento en que ocurren estas últimas lesiones, por lo que son fáciles de identificar. La dificultad inherente a este tipo de lesión reside en el contacto inesperado de la víctima con el factor nocivo.

He aquí algunos de los factores nocivos capaces de provocar lesiones en accidentes de trabajo, que suelen estar relacionados con diversas formas de energía, fuentes o actividades:

- energía vinculada a las operaciones de cortar, dividir o desbastar, normalmente relacionada con objetos cortantes, como cuchillos, sierras o herramientas de filo;

- energía vinculada a las operaciones de prensar y comprimir por lo común aplicada con distintas máquinas de modelado como prensas y herramientas de fijación;

- conversión de energía cinética en energía potencial: por ejemplo, cuando algo golpea o cae sobre un trabajador;

- conversión de la energía potencial de un individuo en energía cinética, como cuando un trabajador cae de un sitio elevado a otro más bajo:

- calor y frío, electricidad, sonido, luz, radiación y vibraciones;

- sustancias tóxicas y corrosivas;

- energía por la que se somete al cuerpo a un estrés excesivo, como en el traslado de cargas pesadas o la torsión del cuerpo,

- factores de estrés mental y psicológico, como la amenaza de violencia.

\section{Control de las exposiciones}

Las fuentes de exposición y otros factores nocivos se rigen en gran medida por la naturaleza de los procesos, las tecnologías, los productos y los equipos existentes en el lugar de trabajo, pero también dependen de la organización del propio trabajo. D esde el punto de vista de los riesgos mensurables, debe tenerse en cuenta que el control de la probabilidad de las exposiciones y la gravedad de las lesiones de los trabajadores suelen depender de los tres factores siguientes:

- M edidas de seguridad de eliminación/ sustitución. Los peligros en el lugar de trabajo en forma de fuentes de exposición u otros factores nocivos pueden diminarse o mitigarse mediante sustitución ( $p$. ej., un producto químico menos dañino puede reemplazar a otro más perjudicial en un determinado proceso). D ebe tenerse en cuenta que esta medida no es posible en todos los casos, ya que dichas fuentes y factores siempre estarán presentes en el hábitat humano (y especialmente en el entorno de trabajo).

- M edidas técnicas de seguridad. Suelen denominarse controles técnicos y consisten en separar a las personas de los factores nocivos mediante el aislamiento de los elementos dañinos o la instalación de barreras entre los trabajadores y los factores que pueden provocar lesiones. La automatización, el control remoto, la utilización de equipos auxiliares y la protección de la maquinaria son ejemplos de este tipo de medidas.

- M edidas de seguridad relacionadas con la organización. Se las conoce también como controles administrativos y consisten en aislar a las personas de los factores dañinos, ya sea mediante la adopción de métodos de trabajo especiales o la separación en el tiempo 0 en el espacio. Algunos ejemplos de estas medidas son la reducción del tiempo de exposición, los programas de mantenimiento preventivo, el aislamiento de los trabajadores con equipos de protección individual y la organización eficaz del trabajo.

\section{Control de la conducta humana}

No siempre es posible el aislamiento de todos los peligros con la aplicación de las medidas de control citadas. Suele pensarse que el análisis de la prevención de accidentes acaba en este punto, ya que los trabajadores han de ser capaces de cuidar de sí mismos "si siguen las reglas". De manera que la seguridad y el riesgo pasan a depender de los factores que rigen la conducta humana, como el conocimiento, las cualificaciones, la oportunidad y la voluntad individuales de actuar de un modo que garantice la seguridad en el lugar de trabajo. A continuación se explica la función que desempeñan estos factores.

- Conocimientos. En primer lugar, los trabajadores deben ser conscientes de los diferentes tipos de riesgo y elementos de peligro existentes en su lugar de trabajo, lo que suele exigir educación, formación y experiencia en el puesto. Asimismo, es necesario determinar, analizar, registrar y describir los riesgos de un modo que facilite su comprensión, para conseguir que los trabajadores sepan cuándo se encuentran en una situación de riesgo específica y qué consecuencias pueden tener sus acciones.

- La oportunidad de actuar. En segundo lugar, es preciso que los trabajadores puedan actuar con seguridad. Es necesario que sean capaces de utilizar las oportunidades técnicas y organizativas (así como físicas y psicológicas) que se les brindan para la acción. La dirección, los supervisores y los integrantes del entorno de trabajo en general deben prestar su apoyo al programa de seguridad y ocuparse de los riesgos asumidos, el diseño y cumplimiento de los métodos de trabajo teniendo en cuenta la seguridad, la utilización segura de las herramientas apropiadas, la definición inequívoca de las tareas, la creación y el seguimiento de los procedimientos de seguridad y el suministro de instrucciones claras sobre el modo más seguro de manejar materiales y equipos. 
- La voluntad de actuar con seguridad. En lo que se refiere a la disposición de los trabajadores para comportarse de manera que se garantice la seguridad en el lugar de trabajo, los factores técnicos y de organización son de gran importancia; pero también lo son, y no en menor medida, los factores de tipo social y cultural. Si comportarse de manera segura resulta, por ejemplo, difícil, o requiere mucho tiempo, o no está bien considerado o valorado por la dirección o los compañeros, los riesgos aumentarán. La dirección debe mostrar claramente su interés por la seguridad, adoptar las medidas pertinentes para darle prioridad y manifestar una actitud positiva respecto a la necesidad de una conducta segura.

La información sobre las causas de los accidentes cumple los objetivos siguientes:

- Muestra los errores e indica qué debe cambiar.

- Indica los tipos de factores nocivos que causan accidentes (o cuasiaccidentes), y detalla las situaciones que dan lugar a daños y lesiones.

- Identifica y describe las circunstancias subyacentes que determinan la presencia de peligros potenciales y situaciones de riesgo, cuya modificación o eliminación irán en beneficio de la seguridad.

EI análisis exhaustivo de los daños, las lesiones y las circunstancias en que se han producido los accidentes facilita una información de tipo general. Los datos de otros accidentes similares pueden facilitar algunos factores importantes más generales, revelando así relaciones causales cuya determinación no es inmediata. Por otra parte, la información específica y detallada que proporciona el estudio de accidentes concretos ayuda a establecer las circunstancias precisas que deben examinarse. El estudio de una lesión concreta suele ofrecer datos que no pueden conseguirse con un análisis general; pero éste, al mismo tiempo, puede señalar factores que el estudio individual nunca mostraría. L os datos obtenidos con estos dos tipos de análisis son importantes para facilitar la determinación de relaciones causales obvias y directas en cada caso.

\section{Análisis de accidentes específicos}

\section{Este tipo de análisis tiene dos objetivos principales:}

En primer lugar, puede utilizarse para determinar las c ausas de un accidente y los factores del trabajo concretos que han contribuido a que se produzca. Permite evaluar hasta qué punto se ha determinado el riesgo y decidir sobre las medidas de seguridad técnicas y organizativas que se han de adoptar, así como dilucidar si una mayor experiencia en el puesto podría haber disminuido dicho riesgo. Además, proporciona una visión más clara de las acciones que habrían podido evitar el riesgo y de la motivación necesaria en los trabajadores para llevarlas a cabo.

En segundo lugar, se adquieren conocimientos que sirven para analizar accidentes semejantes en el ámbito de la empresa y en otros más generales (como el de una organización 0 un país). En este sentido, es importante recopilar datos sobre lo siguiente:

- identidad del lugar de trabajo y de la actividad laboral en sí (es decir, información relativa al sector o rama a los que pertenece el centro), y de los procesos y las tecnologías que caracterizan al trabajo;

- naturaleza y gravedad del accidente;

- factores causantes del accidente, como fuentes de exposición, forma en que ocurrió y situación de trabajo específica que lo desencadenó;

- condiciones generales del lugar de trabajo y de la situación de trabajo (incluidos los factores citados en el párrafo anterior).

\section{Tipos de análisis}

Existen cinco tipos fundamentales de análisis de accidentes, cada uno con un objetivo específico:

- Análisis y determinación de los tipos de accidentes y los lugares en que se produjeron. El objetivo es establecer la incidencia de los accidentes en relación con factores como los diferentes sectores, ramas de actividad, empresas, procesos de trabajo y tipos de tecnologías.

- Análisis a partir del control de la incidencia de los accidentes. Tienen por objeto alertar sobre los cambios, tanto positivos como negativos. El resultado puede ser una cuantificación de los efectos de las iniciativas preventivas; el aumento de nuevos tipos de accidentes en un área específica puede indicar la existencia de nuevos elementos de riesgo.

- Análisis para establecer prioridades entre diferentes iniciativas que exigen un nivel elevado de medición de riesgos, lo que a su vez exige el cálculo de la frecuencia y la gravedad de los accidentes. El objetivo es sentar las bases para fijar prioridades al decidir dónde resulta más importante adoptar medidas preventivas.

- Análisis para determinar cómo han ocurrido los accidentes y, sobre todo, para establecer las causas tanto directas como indirectas. U na vez recopilada esta información, se utiliza en la selección, la elaboración y la aplicación de las medidas correctivas y las iniciativas de prevención concretas.

- Análisis para dilucidar qué áreas especiales han suscitado curiosidad por alguna razón (se trata de una forma de análisis de revisión o de control). Son ejemplos de este tipo de estudios los análisis de la incidencia de un riesgo de lesión concreto o el descubrimiento de un riesgo no determinado hasta entonces en el curso del examen de otro riesgo previamente conocido.

$\mathrm{H}$ ay distintos niveles en que pueden realizarse estos tipos de análisis, desde el empresarial al nacional. La adopción de medidas preventivas exige distintos niveles. Los análisis relacionados con las tasas generales de incidencia, el control, la precaución y la determinación de prioridades se llevarán a cabo fundamentalmente a niveles superiores, mientras que los que describen las causas directas e indirectas de los accidentes se efectuarán a niveles más bajos, y los resultados serán, respectivamente, más generales o más específicos.

\section{Fases de un análisis}

Con independencia del nivel al que se inicie un análisis, éste suele constar de las fases siguientes:

- Identificación de los lugares en los que ocurren los accidentes en el nivel general seleccionado.

- Especificación de los lugares en los que ocurren los accidentes a un nivel más detallado dentro del nivel general.

- Determinación de los objetivos en función de la incidencia (o la frecuencia) y la gravedad de los accidentes.

- Descripción de las fuentes de exposición y otros factores nocivos, es decir, de las causas directas de los daños y las lesiones.

- Estudio de las relaciones causales subyacentes y de la evolución de las causas.

En la Figura 56.1 se ofrecen ejemplos de los diferentes niveles de análisis.

\section{Resumen}

El estudio de los accidentes a nivel nacional puede mejorar los conocimientos sobre los sectores, los grupos profesionales, las tecnologías y los procesos de trabajo en los que se producen daños y lesiones. El objetivo consiste únicamente en determinar los lugares de trabajo en los que se produjeron accidentes. La medición de éstos en función de su frecuencia y gravedad permite 
Figura 56.1 • Diferentes niveles de análisis de accidentes.

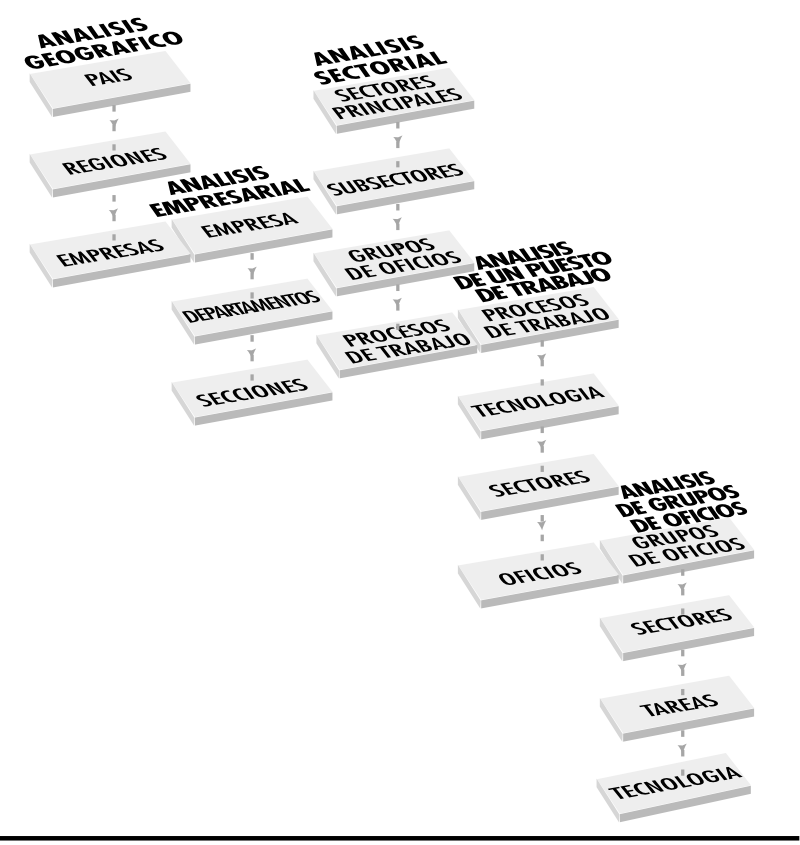

por una parte establecer dónde algo funciona mal y, por otra, dónde ha variado el riesgo.

El tipo de riesgo del lugar de trabajo se establece mediante la descripción de los diferentes accidentes y las formas en que se producen éstos en cada área del lugar de trabajo. De este modo se consigue información sobre las fuentes de exposición y otros factores nocivos presentes en el centro de trabajo, cuando las medidas preventivas (atención a las condiciones de seguridad, conciencia del riesgo, facilidad de acción y apelación a la voluntad de los trabajadores) hayan demostrado ser insuficientes para impedir los accidentes.

La identificación, la medición y la descripción de los accidentes constituyen la base sobre la que se establece qué acciones emprender y quién debe encargarse de las mismas para reducir los riesgos. Por ejemplo, la vinculación de fuentes de exposición específicas a una tecnología concreta puede facilitar la determinación de las medidas de seguridad especiales necesarias para controlar el riesgo. A simismo, esta información puede utilizarse para influir en sus fabricantes y proveedores. Si se demuestra que los accidentes frecuentes y graves están asociados a ciertos procesos, puede intentarse ajustar las características de los equipos, la maquinaria, las operaciones y los procedimientos de trabajo vinculados a dichos procesos. Por desgracia, un rasgo habitual de tales iniciativas y ajustes es que requieren una relación exclusiva y casi inequívoca entre los accidentes y las causas, lo que no ocurre más que en contadas ocasiones.

C ualquier empresa puede llevar a cabo el análisis de los accidentes desde un nivel superior a otro más específico. A hora bien, lo difícil es reunir una base de datos suficientemente amplia. Si se recogen datos correspondientes a las lesiones por accidente en una empresa en varios años (incluida la información sobre lesiones menores y cuasiaccidentes), podrá crearse una base de datos útil incluso a este nivel. El análisis global de la empresa mostrará si existen problemas especiales en determinadas secciones, relacionados con tareas específicas o con la utilización de tecnologías concretas. Un posterior análisis detallado permitirá determinar qué funciona mal y, a partir de ahí, evaluar las medidas preventivas.
Si se pretende influir en el comportamiento de un trabajador dentro de un sector, un grupo profesional o una empresa (o en el de una persona determinada), es necesario disponer de conocimientos sobre muchos accidentes para aumentar la sensibilización de los trabajadores. Al mismo tiempo, debe difundirse información sobre los factores que elevan la probabilidad de los accidentes, así como sobre las líneas de actuación que puedan minimizar el riesgo de daño o lesión. U na vez cumplidos estos requisitos, la seguridad se convierte en una cuestión de motivar a los responsables del comportamiento de las personas en los distintos sectores, organizaciones industriales, organizaciones sindicales, así como a las empresas y a los trabajadores.

\section{TEORIA DE LAS CAUSAS DE LOS ACCIDENTES}

Abdul Raouf

Los accidentes se definen como sucesos imprevistos que producen lesiones, muertes, pérdidas de producción y daños en bienes y propiedades. Es muy difícil prevenirlos si no se comprenden sus causas. $\mathrm{H}$ a habido muchos intentos de elaborar una teoría que permita predecir éstas, pero ninguna de ellas ha contado, hasta ahora, con una aceptación unánime. Investigadores de diferentes campos de la ciencia y de la técnica han intentado desarrollar una teoría sobre las causas de los accidentes que ayude a identificar, aislar y, en última instancia, eliminar los factores que causan o contribuyen a que ocurran accidentes. En el presente artículo se ofrece un breve resumen de las diferentes teorías sobre sus causas, además de una estructura de los accidentes.

\section{Teorías sobre la causalidad de los accidentes}

\section{La teoría del dominó}

Según W. H. Heinrich (1931), quien desarrolló la denominada teoría del "efecto dominó", el $88 \%$ de los accidentes están provocados por actos humanos peligrosos, el 10\%, por condiciones peligrosas y el $2 \%$ por hechos fortuitos. Propuso una "secuencia de cinco factores en el accidente", en la que cada uno actuaría sobre el siguiente de manera similar a como lo hacen las fichas de dominó, que van cayendo una sobre otra. He aquí la secuencia de los factores del accidente:

1. antecedentes y entorno social;

2. fallo del trabajador;

3. acto inseguro unido a un riesgo mecánico y físico;

4. accidente,

5. daño o lesión.

$\mathrm{H}$ einrich propuso que, del mismo modo en que la retirada de una ficha de dominó de la fila interrumpe la secuencia de caída, la eliminación de uno de los factores evitaría el accidente y el daño resultante, siendo la ficha cuya retirada es esencial la número 3. Si bien H einrich no ofreció dato alguno en apoyo de su teoría, ésta presenta un punto de partida útil para la discusión y una base para futuras investigaciones.

\section{Teoría de la causalidad múltiple}

Aunque procede de la teoría del dominó, la teoría de la causalidad múltiple defiende que, por cada accidente, pueden existir numerosos factores, causas y subcausas que contribuyan a su aparición, y que determinadas combinaciones de éstos provocan 
accidentes. De acuerdo con esta teoría, los factores propicios pueden agruparse en las dos categorías siguientes:

D e comportamiento. En esta categoría se incluyen factores relativos al trabajador, como una actitud incorrecta, la falta de conocimientos y una condición física y mental inadecuada.

Ambientales. En esta categoría se incluye la protección inapropiada de otros elementos de trabajo peligrosos y el deterioro de los equipos por el uso y la aplicación de procedimientos inseguros.

La principal aportación de esta teoría es poner de manifiesto que un accidente pocas veces, por no decir ninguna, es el resultado de una única causa o acción.

\section{La teoría de la casualidad pura}

De acuerdo con ella, todos los trabajadores de un conjunto determinado tienen la misma probabilidad de sufrir un accidente. Se deduce que no puede discernirse una única pauta de acontecimientos que lo provoquen. Según esta teoría, todos los accidentes se consideran incluidos en el grupo de hechos fortuitos de $\mathrm{H}$ einrich y se mantiene la inexistencia de intervenciones para prevenirlos.

\section{Teoría de la probabilidad sesgada}

Se basa en el supuesto de que, una vez que un trabajador sufre un accidente, la probabilidad de que se vea involucrado en otros en el futuro aumenta o disminuye respecto al resto de los trabajadores. La contribución de esta teoría al desarrollo de acciones preventivas para evitar accidentes es escasa o nula.

\section{Teoría de la propensión al accidente}

De acuerdo con ella, existe un subconjunto de trabajadores en cada grupo general cuyos componentes corren un mayor riesgo de padecerlo. Los investigadores no han podido comprobar tal afirmación de forma concluyente, ya que la mayoría de los estudios son deficientes y la mayor parte de sus resultados son contradictorios y poco convincentes. Es una teoría, en todo caso, que no goza de la aceptación general. Se cree que, aun cuando existan datos empíricos que la apoyen, probablemente no explica más que una proporción muy pequeña del total de los accidentes, sin ningún significado estadístico.

\section{Teoría de la transferencia de energía}

Sus defensores sostienen que los trabajadores sufren lesiones, o los equipos daños, como consecuencia de un cambio de energía en el que siempre existe una fuente, una trayectoria y un receptor. La utilidad de la teoría radica en determinar las causas de las lesiones y evaluar los riesgos relacionados con la energía y la metodología de control. Pueden elaborarse estrategias para la prevención, la limitación o la mejora de la transferencia de energía.

El control de energía puede lograrse de las siguientes formas:

- eliminación de la fuente;

- modificación del diseño o de la especificación de los elementos del puesto de trabajo,

- mantenimiento preventivo.

La trayectoria de la transferencia de energía puede modificarse mediante:

- aislamiento de la trayectoria;

- instalación de barreras;

- instalación de elementos de absorción,

- colocación de aislantes.

Figura 56.2 • Estructura de los accidentes.

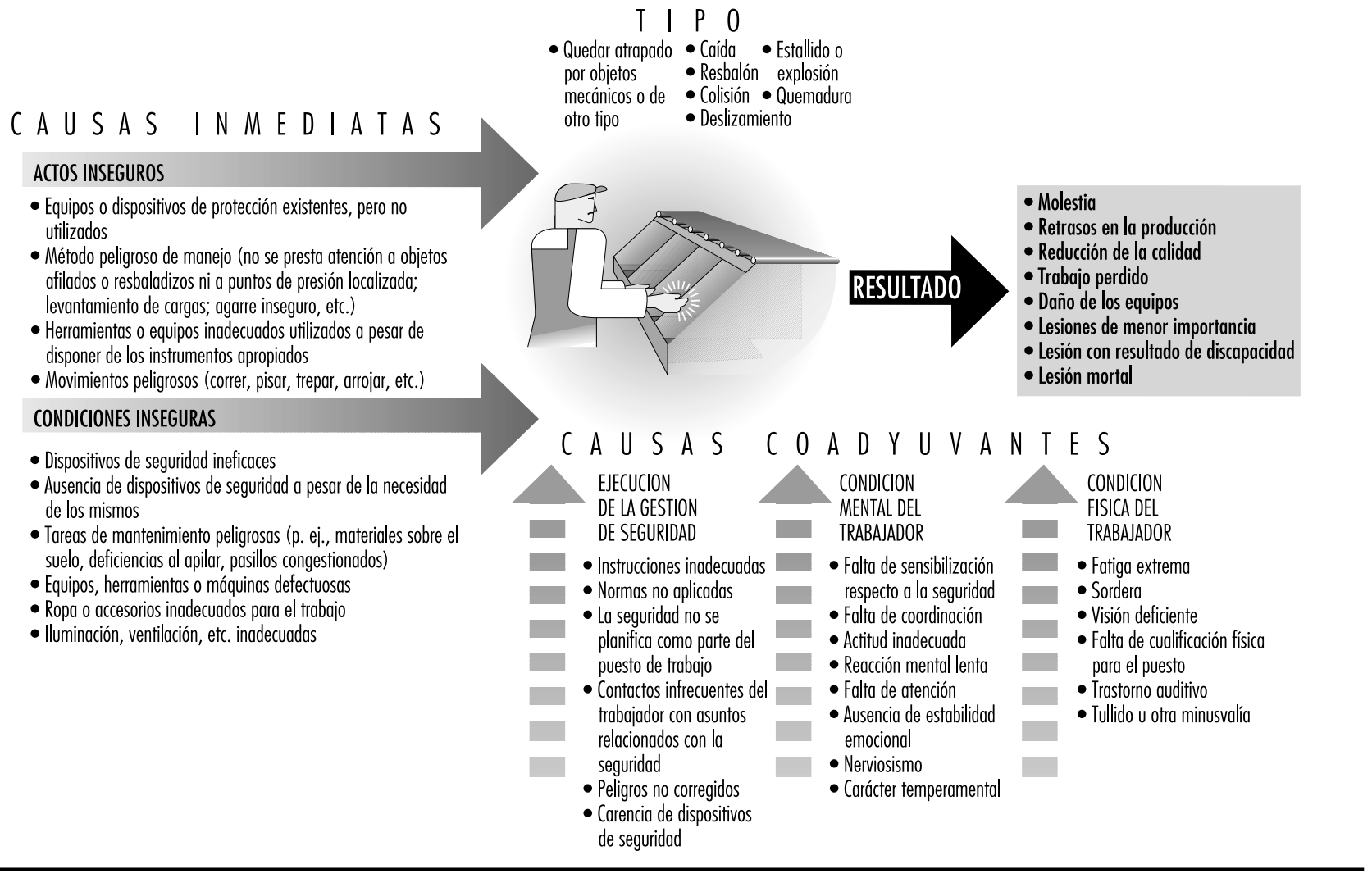


La adopción de las medidas siguientes puede ayudar al receptor de la transferencia de energía:

- limitación de la exposición,

- utilización de equipo de protección individual.

Teoría de "los síntomas frente a las causas"

No es tanto una teoría cuanto una advertencia que debe tenerse en cuenta si se trata de comprender la causalidad de los accidentes. Cuando se investiga un accidente, se tiende a centrar la atención en sus causas inmediatas, obviando las esenciales. Las situaciones y los actos peligrosos (causas próximas) son los síntomas y no las causas fundamentales de un accidente.

\section{Estructura de los accidentes}

La creencia de que los accidentes tienen causas y pueden prevenirse nos obliga a estudiar los factores para prevenirlos. Al analizar estos factores, pueden aislarse las causas primordiales y adoptarse las medidas necesarias para impedir que se repitan. Las causas esenciales pueden clasificarse en "inmediatas" y "concurrentes". En el primer caso se trata de actos peligrosos del trabajador y de condiciones de trabajo inseguras. En el segundo, de factores relacionados con la gestión y de las condiciones físicas y mentales del trabajador. Tienen que converger varias de estas causas para que se produzca un accidente.

En la Figura 56.2 se muestra la estructura de los accidentes y se detallan las causas inmediatas, las concurrentes, los tipos de accidentes y sus resultados. No se trata, en modo alguno, de una relación exhaustiva. Con todo, es necesario comprender la relación de "causa-efecto" de los factores inductores de accidentes para emprender una mejora continua de los procesos de seguridad.

\section{Resumen}

La causalidad de los accidentes es muy compleja y debe comprenderse de manera adecuada para mejorar su prevención. Puesto que la seguridad carece de una base teórica, no puede considerarse aún como una ciencia. Ahora bien, esta circunstancia no debe desalentarnos, ya que la mayoría de las disciplinas científicas (matemáticas, estadística, etc.) pasaron por fases de indecisión similares en un momento u otro. El estudio de las causas de los accidentes resulta muy prometedor para los interesados en la elaboración de una teoría. Por el momento, las que existen son de naturaleza conceptual y, como tales, su aplicación en la prevención y el control de accidentes es limitada. Con tanta diversidad de teorías no resulta difícil comprender que no exista una única considerada correcta y aceptada unánimemente. En cualquier caso, estas teorías son necesarias, aunque no suficientes, para establecer un marco de referencia que permita comprender la aparición de accidentes.

\section{- FACTORES HUMANOS EN LOS MODELOS DE ACCIDENTES}

\section{Anne-Marie Feyer y Ann M. Williamson}

Los factores humanos figuran entre las principales causas de accidentes en el lugar de trabajo. Las estimaciones sobre su alcance real varían enormemente, pero según los resultados de un estudio realizado a principios del decenio de 1980 sobre las causas del total de muertes por accidente de trabajo registradas en Australia en un período de tres años, los factores del comportamiento habían intervenido en más del $90 \%$ de los accidentes mortales. A la vista de datos como éste, es importante conocer el papel que desempeñan en los accidentes los factores humanos, a los que los modelos tradicionales han concedido siempre escasa importancia; si los tenían en cuenta, era sólo como parte del error que ocurría en la secuencia inmediata de acontecimientos que daba lugar al accidente. Un conocimiento más completo de cómo, por qué y cuándo intervienen tales factores en los accidentes mejorará nuestra capacidad para predecir el papel que desempeñan aquéllos y evitar éstos. Se han propuesto varios modelos para describir la intervención de los factores humanos en los accidentes.

\section{Modelos de causalidad de los accidentes.}

Los modelos recientes han ampliado el papel de los factores humanos más allá de los acontecimientos causales inmediatos al accidente y tienden a incorporar otros elementos en un conjunto general de circunstancias ligadas al accidente. En la Figura 56.3 se muestra con detalle este enfoque; por ejemplo, los factores humanos, como las prácticas de trabajo y la supervisión, pueden considerarse errores en la secuencia de acontecimientos que llevan de forma inmediata al accidente, por una parte, y elementos preexistentes que contribuyen a que se produzca esa secuencia, por otra. Debe entenderse que los dos componentes principales (factores concurrentes y secuencia de acontecimientos) de este modelo de los factores humanos ocurren en una misma línea temporal imaginaria, en la que el orden (primero los factores, luego la secuencia de errores) es fijo, pero la escala del tiempo en que ocurren, no. Ambos elementos son parte esencial de la causalidad de los accidentes.

\section{La naturaleza del error}

Así pues, un elemento fundamental para la prevención de los accidentes es el conocimiento de la naturaleza, la sincronización y las causas del error. U na de las características importantes y singulares del error, que lo distingue de otros factores que intervienen en un accidente, es que forma parte normal del comportamiento. El error es decisivo en el aprendizaje de nuevas destrezas y comportamientos, así como en la conservación de estos últimos. Al poner a prueba los límites de nuestra interacción con el entorno, y, en consecuencia, cometer errores, aprendemos precisamente lo que son esos límites. Es un proceso esencial no sólo para adquirir nuevas destrezas, sino también para actualizar y conservar otras ya aprendidas. EI grado en el que ponemos a prueba los límites de nuestra habilidad está relacionado con el nivel de riesgo que estamos dispuestos a aceptar.

Parece que el error es una característica permanente de todo comportamiento. Los estudios muestran, además, que está presente en las causas de unas dos terceras partes de los accidentes de trabajo mortales. Por tanto, es fundamental desarrollar algunas ideas sobre la forma que suelen adoptar los errores, y sobre cuándo y por qué pueden ocurrir. Aunque todavía no se comprenden bien ciertos aspectos del error humano, el nivel actual de los conocimientos permite hacer algunas predicciones sobre los tipos de error. Es de esperar que el conocimiento de éstos nos ayude a prevenirlos 0 , al menos, a modificar sus consecuencias adversas.

U na de las características más importantes de la naturaleza del error es que no se trata de un fenómeno unitario. Aunque en el análisis tradicional de los accidentes suele interpretarse el error como si fuera una entidad singular que no admitiera un estudio ulterior, aquél puede producirse de diversas formas. Los errores difieren unos de otros por la función de procesamiento de la información a la que afectan; por ejemplo, pueden adoptar la forma de sensaciones falsas debidas a una estimulación deficiente 0 atenuada de los órganos sensoriales, a fallos de atención debidos a la exigencia de una estimulación prolongada o compleja del entorno, a distintos tipos de lapsus de la memoria 0 a errores de juicio o de razonamiento. Todos estos tipos se diferencian por las características de la situación 0 de la 
Figura 56.3 • Modelo de causalidad de los accidentes.

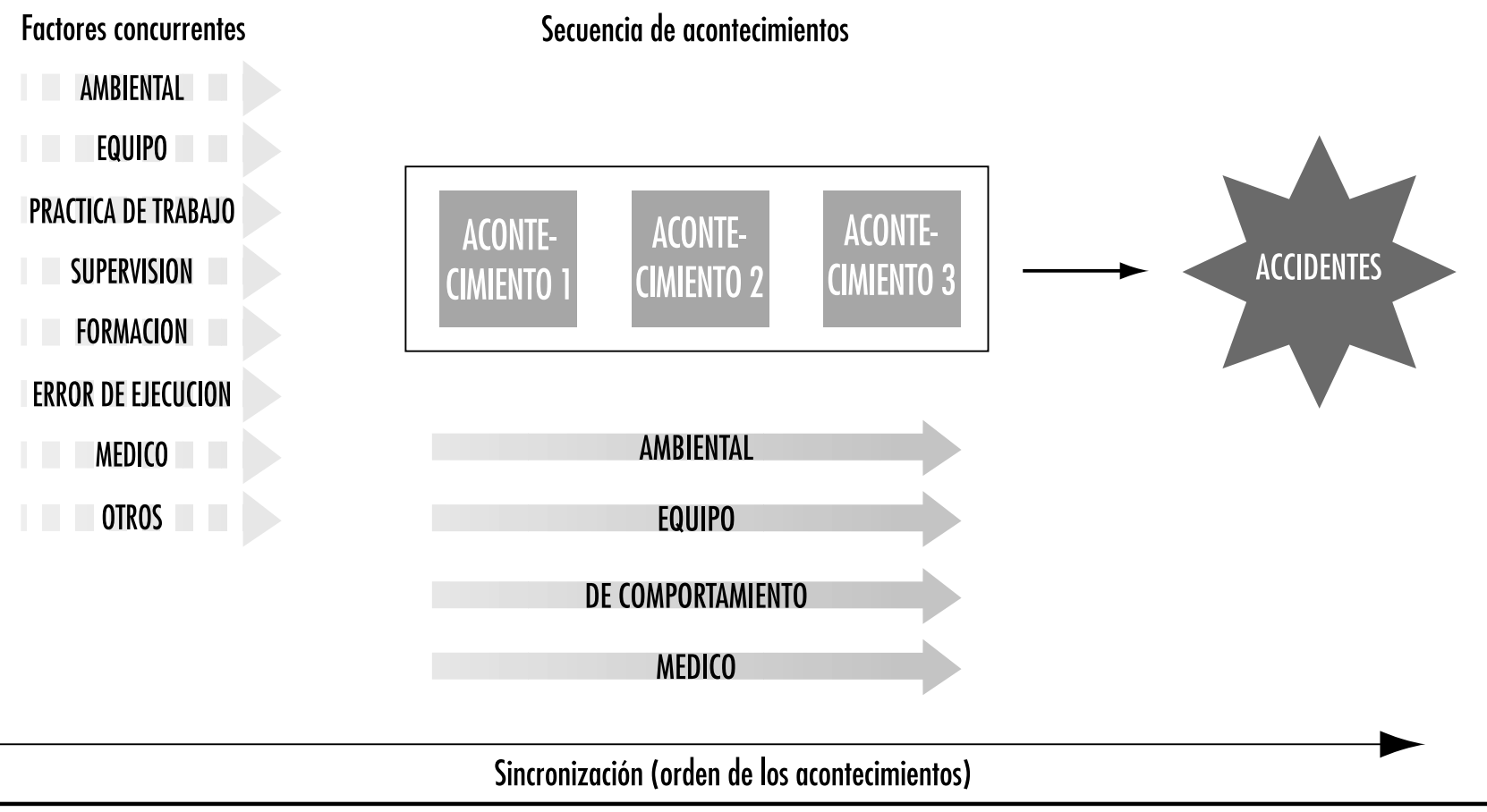

actividad en la que ocurren. Representan una interrupción de diversas funciones de procesamiento de información y, por tanto, requieren enfoques diferentes para superar cada una de ellas.

Los diferentes tipos de error pueden clasificarse también en función de comportamientos basados o no en la destreza del individuo. Suele decirse que la formación es una solución a los problemas de error humano, ya que el comportamiento basado en la destreza permite ejecutar la secuencia de acciones pertinente sin un proceso consciente y permanente de atención y reacción, y sólo exige comprobaciones conscientes intermitentes para asegurar que todo sigue su curso normal. La ventaja de este tipo de comportamiento es que, una vez que se pone en marcha, requiere poco esfuerzo del operador. Permite realizar otras actividades simultáneamente (por ejemplo, se puede conducir un automóvil y hablar al mismo tiempo) y hace posible que el operador haga planes sobre aspectos futuros de su actividad. Además, el comportamiento basado en la destreza suele ser previsible. Lamentablemente, aunque una cualificación mayor reduce la probabilidad de muchos tipos de error, aumenta la de otros. L os errores cometidos por personas diestras en una tarea son consecuencia de lapsus y distracciones o de actos involuntarios, y son diferentes a las equivocaciones que comete alguien que no esté cualificado. El error basado en la cualificación suele estar vinculado a cambios en el grado de atención del control que se ejerce sobre las tareas. Puede aparecer durante un proceso consciente de comprobación o deberse a la conclusión de pautas similares de comportamiento basado en la destreza.

Una segunda característica de los errores es que no son ni aleatorios ni novedosos. Las formas de error son limitadas. Adoptan formas similares en todos los tipos de funciones. Por ejemplo, los errores "de distracción" ocurren en tareas que impliquen el habla o la percepción, y en actividades relacionadas con el conocimiento y con la resolución de problemas. De igual forma, no parece que la localización de los errores en la secuencia de causalidad de un accidente sea aleatoria, ni en el tiempo ni en el espacio. U na peculiaridad importante del procesamiento de información es que se expresa de la misma forma, sea cual sea la situación; lo que significa que los tipos de errores que se cometen cotidianamente en la cocina, por ejemplo, suceden de la misma forma en las actividades industriales de mayor riesgo. No obstante, las consecuencias de estos errores son muy diferentes y están determinadas por la situación en la que se presentan, más que por su propia naturaleza.

\section{Modelos del error humano}

Al establecer una clasificación del error y elaborar modelos del error humano, hay que tener en cuenta todos sus aspectos en la medida de lo posible. Sin embargo, el conjunto de categorías que se establezca debe tener una utilidad práctica. Probablemente ésta es la mayor restricción. Al desarrollar una teoría de la causalidad de los accidentes, puede hacerse muy difícil su aplicación práctica. Cuando se analizan las causas de un accidente, o se intenta predecir el papel de los factores humanos en un proceso determinado, no es posible llegar a comprender todos los aspectos del procesamiento humano de información real o potencialmente relevantes. Por ejemplo, nunca se podrá conocer el papel de la intencionalidad antes de que haya ocurrido el accidente. Incluso después, el propio hecho de que se haya producido puede modificar el modo en que las personas recuerdan los acontecimientos que lo rodearon. Las clasificaciones del error más correctas hasta ahora son las que se ocupan de la naturaleza del comportamiento manifestado en el momento en que se cometió. Así se permite que el análisis del error sea relativamente objetivo y fácil de reproducir.

Se trata de clasificaciones del error que distinguen entre los que ocurren durante la práctica de un comportamiento basado en la destreza (deslices, lapsus o actos involuntarios) y los que se producen en el desarrollo de uno no cualificado o durante la resolución de problemas (equivocaciones).

Los deslices o los errores basados en la destreza se definen como errores involuntarios que se presentan cuando el 
comportamiento es de carácter automático o consiste en una rutina habitual.

Las equivocaciones se han clasificado, a su vez, en dos categorías:

- los errores basados en las reglas, que tienen lugar cuando el comportamiento requiere la aplicación de reglas,

- errores basados en el conocimiento, cometidos al resolver problemas cuando la persona carece de cualificación y de reglas que aplicar.

De ello se deduce que los errores basados en el conocimiento tienen lugar por falta de conocimientos de orden práctico; los errores basados en las reglas, por no aplicar esos conocimientos prácticos adecuadamente; y los errores basados en la destreza, por una interrupción en la ejecución de un programa de acciones, normalmente debida a cambios en el nivel de atención (R asmussen 1982).

En un estudio de población sobre accidentes de trabajo mortales se aplicaron estas categorías y se comprobó que podían utilizarse de forma fiable. Los resultados del estudio mostraron que los errores basados en la destreza eran, en conjunto, los más frecuentes, y que el número de casos de los tres tipos de error se distribuía de forma diferente en la secuencia de acontecimientos. Por ejemplo, los errores basados en la destreza fueron la mayoría de las veces el acto inmediatamente anterior al accidente (79\% de las muertes). Puesto que en ese instante se dispone de poco tiempo para corregir la situación, sus consecuencias pueden ser más graves. Las equivocaciones, en cambio, parecen presentarse en fases anteriores de la secuencia del accidente.

\section{Factores humanos en las circunstancias generales de los accidentes}

La inclusión de los factores humanos, y no sólo de los errores, en el conjunto de circunstancias que rodean al accidente, representa un avance importante en la comprensión de la génesis de los accidentes. Si bien no existe duda alguna de que el error está presente en la mayoría de las secuencias de accidente, los factores humanos también intervienen en un sentido más amplio, adoptando la forma, por ejemplo, de procedimientos de trabajo normalizado y de influencias que determinan la naturaleza y la aceptación de los procedimientos de trabajo, entre los que figuran las decisiones de la dirección tomadas en las primeras fases del proceso. Es evidente que las decisiones equivocadas y los procedimientos de trabajo deficientes están relacionados con el error, ya que incorporan errores de juicio y de razonamiento. Sin embargo, los procedimientos de trabajo deficientes se caracterizan porque en ellos se ha permitido que los errores de juicio y de razonamiento se conviertan en formas normalizadas de trabajo, ya que, al no tener consecuencias inmediatas, no se manifiestan de forma inmediata. No obstante, eso no impide que se reconozca su carácter de sistemas de trabajo inseguros, con vulnerabilidades fundamentales que constituyen precisamente las circunstancias que, en algún momento y de forma involuntaria, pueden combinarse con una acción humana y provocar directamente un accidente.

La expresión factores humanos se refiere en este contexto a un amplio conjunto de elementos presentes en la interacción entre las personas y su entorno de trabajo. Algunos son aspectos directos y observables de las formas de funcionamiento de los sistemas de trabajo y no tienen consecuencias adversas inmediatas. El diseño, la utilización y el mantenimiento de los equipos, la provisión, la utilización y el mantenimiento de equipos de seguridad y de protección de los trabajadores, así como los procedimientos operativos normalizados propuestos por la dirección o por los trabajadores son ejemplos de este tipo de prácticas en curso.
Tales aspectos observables de los factores humanos en el funcionamiento de los sistemas constituyen en gran medida manifestaciones de la situación global de la organización, que es a su vez un elemento humano que se considera aún menos relacionado directamente con los accidentes. Al conjunto de las características de una organización se le ha denominado cultura 0 clima de la organización. $\mathrm{H}$ ace referencia al conjunto de objetivos y creencias de cada persona y a la repercusión que sobre éstos ejercen los objetivos y creencias de la organización. En última instancia, es probable que los valores colectivos o normativos que reflejan las características de la organización, ejerzan una influencia decisiva sobre la actitud y la motivación que llevan a adoptar un comportamiento seguro a todos los niveles. Por ejemplo, el nivel de riesgo tolerado en un lugar de trabajo está determinado por esos valores. De este modo, la cultura de una organización, claramente reflejada en su sistema de trabajo y en los procedimientos operativos normalizados que adoptan sus trabajadores, es un aspecto decisivo del papel que desempeñan los factores humanos en la causalidad de los accidentes.

La visión convencional de los accidentes como una serie de elementos que empiezan a fallar repentinamente en el momento y en el lugar en que ocurre el accidente, centra la atención en el acontecimiento mensurable y manifiesto que coincide en el tiempo con el accidente. Sin embargo, en la práctica, los errores ocurren en un contexto que propicia que el acto peligroso 0 el error tenga consecuencias. Para conocer las causas de un accidente originadas en las condiciones existentes en los sistemas de trabajo, es necesario tener en cuenta todas las formas diferentes en que el elemento humano puede contribuir a provocarlo. Tal vez sea ésta la consecuencia más importante de considerar con una perspectiva amplia el papel de los factores humanos en la causalidad de los accidentes. Las decisiones y las prácticas deficientes en los sistemas de trabajo, aun sin tener una repercusión inmediata, propician la aparición de las condiciones que dan lugar a un error del operario (o a que el error tenga consecuencias) en el momento del accidente.

Las cuestiones relacionadas con la organización han sido siempre el aspecto más descuidado del diseño de los análisis de accidentes y de la recopilación de datos. Como su relación en el tiempo es lejana con respecto a la aparición del accidente, el vínculo causal entre éste y los factores organizativos no suele ser obvio. En algunas teorías recientes se han estructurado específicamente los sistemas de análisis y de recopilación de datos para incorporar al estudio de los accidentes el elemento organizativo. Según Feyer y Williamson (1991), que utilizaron uno de los primeros sistemas destinados específicamente a considerar los factores organizativos relacionados con los accidentes, en una parte importante del total de casos de muerte en el trabajo registrados en Australia $(42,0 \%)$ existían prácticas de trabajo inseguras y continuas entre los factores causales. A partir de un marco teórico parecido, en el que se reconocía la incidencia organizativa en los accidentes, Waganaar, Hudson y Reason (1990) señalaron que los factores relacionados con la organización y la gestión constituyen fallos latentes de los sistemas de trabajo, semejantes a los patógenos residentes en los sistemas biológicos. Los defectos organizativos interactúan con los acontecimientos y las circunstancias que desencadenan la secuencia que rodea a un accidente, de una forma muy parecida a los patógenos residentes en el cuerpo, que se combinan con agentes desencadenantes como los factores tóxicos para provocar una enfermedad.

La idea central de este marco teórico es que las deficiencias de organización y de gestión están presentes mucho antes de que se ponga en marcha la secuencia del accidente; es decir, son factores de acción latente o retardada. Por tanto, para comprender cómo se producen accidentes, cómo contribuyen las 
personas a que sucedan y por qué actúan como lo hacen, es necesario asegurarse de que los análisis no se limiten a las circunstancias que de forma más directa e inmediata ocasionan un daño.

\section{El papel de los factores humanos en los accidentes y su prevención}

Al reconocer el posible significado etiológico de las circunstancias generales que rodean al accidente, el modelo óptimo para describir su causalidad debe tener en cuenta la sincronización relativa de los elementos y el modo en que se relacionan entre sí. En primer lugar, los factores causales varían en importancia, tanto intrínseca como temporal. A demás, estas dos dimensiones pueden variar por separado; es decir, las causas pueden ser importantes porque están muy próximas en el tiempo al accidente $y$, por tanto, revelan algo sobre el momento en que se produjo, o por su carácter fundamental y subyacente al accidente, o por ambas razones. Al examinar la importancia causal y temporal de los factores que intervienen en las circunstancias generales y concretas de un accidente, el análisis se ocupa de explicar por qué ocurrió, y no se limita a describir cómo ocurrió.

En segundo lugar, el acuerdo suele ser general respecto a que los accidentes se deben a múltiples causas. Los componentes humanos, técnicos y ambientales del sistema de trabajo pueden interactuar de forma decisiva. Tradicionalmente, los métodos de análisis de los accidentes han sido limitados en lo referente a la variedad de categorías definidas. R estricción que, a su vez, limita la naturaleza de la información que se obtiene y, por tanto, reduce el número de opciones viables para la acción preventiva. $C$ uando se tienen en cuenta las circunstancias generales de un accidente, el modelo debe considerar un conjunto mucho más amplio de factores. Es probable que los factores humanos interactúen entre sí y con otros factores no humanos. Las pautas de incidencia, incidencia conjunta e interrelación entre los diferentes elementos del amplio conjunto que integra la red causal constituye la descripción más completa y, por tanto, más informativa de la génesis de un accidente.

En tercer lugar, ambos elementos, la naturaleza del acontecimiento y la de su contribución al accidente, interactúan. Aunque siempre están presentes muchas causas, no todas desempeñan funciones equivalentes. El elemento esencial para comprender por qué ocurren los accidentes y cómo puede evitarse su repetición es el conocimiento preciso de la función de los distintos factores. Por ejemplo, las causas ambientales inmediatas de los accidentes pueden producir sus efectos debido a la existencia de factores anteriores relacionados con el comportamiento, que adoptan la forma de procedimientos normalizados de trabajo. De igual modo, hay aspectos preexistentes de los sistemas de trabajo que pueden constituir el contexto en el que los errores rutinarios en la práctica de un comportamiento basado en la destreza desencadenan un accidente de consecuencias adversas. Normalmente, estos errores suelen ser inocuos. Para que la prevención sea eficaz debe dirigirse a las causas latentes subyacentes, y no a los factores desencadenantes inmediatos. Sólo es posible este grado de comprensión de la red causal y de su influencia en los resultados si se consideran todos los tipos de factores, si se estudia su sincronización relativa y si se determina su importancia relativa.

A pesar de la variedad casi infinita de formas en que la acción humana puede contribuir directamente a que se produzca un accidente, la mayor parte de sus causas se ajustan a unas cuantas pautas causales. En concreto, el conjunto de condiciones latentes subyacentes que constituyen el marco en el que los factores humanos y de otro tipo ejercerán posteriormente su efecto, se ciñen básicamente a un número reducido de aspectos del sistema de trabajo. De acuerdo con Feyer y Williamson (1991), sólo cuatro pautas de factores constituyeron la causa de unos dos tercios del total de muertes por accidente de trabajo registradas en Australia en un período de tres años. No puede sorprender que, en casi todos los casos, los factores humanos intervinieron de una forma u otra.

\section{Resumen}

La participación humana como causa de los accidentes varía en cuanto a naturaleza, sincronización e importancia (Williamson y Feyer 1990). En la mayoría de los casos, son los factores humanos que forman un conjunto limitado de sistemas de trabajo deficientes y preexistentes los que generan las causas fundamentales subyacentes de los accidentes mortales. Posteriormente, estas causas se combinan con lapsus en la práctica de un comportamiento basado en la destreza o con condiciones ambientales peligrosas, y dan lugar al accidente. En tales pautas se observa la función estratificada que caracteriza la participación de los factores humanos en la génesis de los accidentes. Con todo, no basta con definir las diferentes formas en que participa el elemento humano para formular estrategias preventivas, sino que es preciso determinar dónde y cómo puede intervenirse con mayor eficacia. La consecución de este objetivo sólo es posible si el modelo utilizado describe con precisión y exhaustividad la compleja red de factores interrelacionados que intervienen en la causalidad de los accidentes, teniendo en cuenta la naturaleza de estos factores y su sincronización e importancia relativas.

\section{MODELOS DE ACCIDENTES: HOMEOSTASIS DEL RIESGO}

Gerald J. S. Wilde

Dadme una escalera el doble de estable y subiré $d$ doble de alto. Pero si me dais una causa para ser prudente, me mostraré el doble de reticente. Consideremos el supuesto siguiente: se inventa un cigarrillo cuya incidencia en las muertes relacionadas con el consumo de tabaco equivale al $50 \%$ de la de los cigarrillos actuales, aunque, por lo demás, no se diferencia del resto. ¿Esta invención constituye un avance? Cuando se sustituyan los antiguos cigarrillos por los nuevos, dado que no se modifica el deseo de las personas de mantenerse sanos (y éste es el único factor que inhibe el consumo de tabaco), los fumadores reaccionarán consumiendo el doble. Así, aunque la tasa de muerte por cigarrillo fumado se reduce en un $50 \%$, el riesgo de morir por tabaquismo sigue siendo el mismo por fumador. $Y$ no es el único efecto: al disponer de cigarrillos "más seguros" la cifra de personas que dejan de fumar será menor que la actual e incitará a un mayor número de no fumadores a ceder a la tentación del tabaco. Como consecuencia, la tasa de muertes relacionadas con el tabaquismo en la población aumenta. No obstante, puesto que las personas no están dispuestas a correr más riesgos con su salud y su vida que los que consideren adecuados a cambio de la satisfacción de sus deseos, reducirán otros hábitos inseguros o insanos menos atractivos. Al final, el porcentaje de muertes debidas al estilo de vida se mantiene esencialmente inalterado.

El supuesto anterior ilustra las siguientes premisas básicas de la teoría de la homeostasis del riesgo (T H R ) (Wilde 1988; 1994):

La primera es la idea de que las personas se fijan un nivel de riesgo asumido, es decir, aquél que aceptan, toleran, prefieren, desean 0 eligen. Es un nivel que depende de las ventajas e inconvenientes percibidos respecto a las alternativas de comportamiento seguras e inseguras, y determina el grado de riesgo para la salud y la seguridad al que se exponen. 
La segunda premisa se basa en que la frecuencia real de las muertes, las enfermedades y las lesiones que dependen del estilo de vida se mantiene en el tiempo mediante un proceso de control autorregulador de ciclo cerrado. De este modo, las fluctuaciones en el grado de precaución aplicado por las personas a su comportamiento determina las subidas y las bajadas en el deterioro de su salud y su seguridad, y viceversa.

Además, los altibajos en el grado de deterioro real ocasionado por el estilo de vida determinan a su vez las fluctuaciones en el grado de precaución con que las personas se comportan.

Por último, de acuerdo con la tercera premisa, el nivel de deterioro de la vida y la salud provocado por el comportamiento humano, puede atenuarse mediante intervenciones eficaces en la reducción del nivel de riesgo que las personas están dispuestas a correr; es decir, no a través de medidas del tipo del "cigarrillo seguro" u otras propuestas de "solución tecnológica" al problema, sino mediante la aplicación de programas que aumenten el deseo de la población de estar vivos y sanos.

\section{La teoría de la homeostasis del riesgo y la causalidad y la prevención de accidentes}

Entre las numerosas contribuciones psicológicas a la bibliografía sobre accidentes y enfermedades laborales, accidentes de tráfico y trastornos de salud dependientes del estilo de vida, sólo unas pocas se ocupan de los factores de motivación y su influencia en las causas y la prevención de estos problemas. En la mayoría de las publicaciones se abordan variables como los rasgos permanentes o semipermanentes ( $p$. ej., sexo, personalidad o experiencia), los estados transitorios (fatiga, nivel de alcohol en sangre), la sobrecarga o la insuficiencia de información (estrés 0 aburrimiento), la formación y las cualificaciones, los factores medioambientales y la ergonomía de los puestos de trabajo. No obstante, puede argüirse que todas las variables que no sean las de motivación (es decir, aquéllas que afectan al nivel de riesgo asumido) sólo influyen marginalmente en la frecuencia de los accidentes por hora de actividad y trabajador. En cualquier caso, algunas pueden tener un efecto positivo en la tasa de accidentes por unidad de productividad o por distancia unitaria de movilidad.

Aplicada, por ejemplo, al tráfico rodado, la THR establece que la tasa de accidentes de tráfico por unidad temporal de exposición de cada usuario es el resultado de un proceso de control de ciclo cerrado en el que el nivel de riesgo asumido funciona como la única variable de control. Así, a diferencia de las fluctuaciones temporales, el riesgo de accidente medio en un intervalo de tiempo se considera independiente de factores como las características físicas del vehículo, la situación de la carretera y la destreza del conductor. Por el contrario, depende en última instancia del nivel de riesgo de accidente aceptado por la población usuaria del transporte por carretera a cambio de las ventajas percibidas y recibidas de la movilidad general en vehículos de motor (como la acumulación de horas de conducción) y de los actos peligrosos específicos asociados con dicha movilidad en particular (como la conducción por encima de la velocidad media).

Por tanto, se argumenta que los conductores de vehículos, dotados de sus capacidades sensoriales, perciben en todo momento un cierto nivel de riesgo de accidente y lo comparan con el grado de riesgo que están dispuestos a aceptar, determinado este último por el patrón de compensación entre los costes y beneficios previstos asociados a las alternativas de acción disponibles. Así, el nivel de riesgo asumido es aquél al que se considera máxima la utilidad global del modo y de la medida de la movilidad. Los costes y los beneficios previstos son una función de las variables económicas, culturales y personales y sus fluctuaciones a largo plazo, a corto plazo y momentáneas. Tales variables controlan el nivel de riesgo asumido en cada momento específico.

Siempre que los usuarios del transporte por carretera perciban una discrepancia entre el riesgo asumido y el riesgo experimentado de una manera u otra, tratarán de restablecer el equilibrio mediante algún ajuste del comportamiento. Para lograrlo dependerán de su capacidad para la toma de decisiones y de sus destrezas psicomotoras. Con todo, las acciones emprendidas conllevan una cierta probabilidad de riesgo de accidente. El total de todas las acciones en una jurisdicción y en un tiempo determinado (p. ej., 1 año) produce la frecuencia y la gravedad de los accidentes de tráfico en la misma. Se supone que la tasa de accidentes resultante influye a su vez (mediante retroinformación) en el nivel de riesgo de accidente percibido por los supervivientes y, por tanto, en sus acciones y en los accidentes posteriores, y así sucesivamente. Por consiguiente, mientras el nivel de riesgo asumido se mantenga inalterado, la tasa de accidentes y la precaución en el comportamiento tienen una relación causal circular.

\section{El proceso de homeostasis del riesgo}

Este proceso homeostático, en el que la tasa de accidentes es a la vez causa y consecuencia de los cambios en el comportamiento del operario, se ilustra en el modelo de la Figura 56.4. El carácter autocorrector del mecanismo homeostático puede comprobarse en el ciclo cerrado que pasa por los recuadros e, b, c, d, y nuevamente e. Puede que las personas tarden algún tiempo en ser conscientes de un cambio en la tasa de accidentes (la retroinformación puede retrasarse, lo que se representa mediante f ). T éngase en cuenta que el recuadro a se sitúa fuera del ciclo cerrado, lo que significa que las intervenciones que reducen el nivel de riesgo asumido pueden provocar una disminución duradera de la tasa de accidentes (recuadro e).

EI proceso anterior puede explicarse con mayor amplitud y claridad mediante la utilización de otro ejemplo de regulación homeostática: el control termostático de la temperatura en una casa. La temperatura fijada (comparable al recuadro a) en el termostato se compara en cualquier momento con la temperatura real (recuadro b). Siempre que se registre una diferencia entre las dos, es necesario realizar un ajuste (recuadro c), que pone en marcha una acción correctiva (es decir, el suministro de aire caliente o frío, recuadro d). Como resultado, el aire distribuido en la casa se enfría (a través del aire acondicionado) o se calienta (a través de la calefacción, recuadro e), a discreción. Transcurrido un tiempo (simbolizado por $f$ ) el aire a la nueva temperatura alcanza el nivel fijado en el termostato y da lugar a una nueva lectura, que vuelve a compararse con la temperatura fijada (recuadro a), etc.

La temperatura de la casa registrará grandes fluctuaciones si el termómetro no es muy sensible. Lo mismo ocurrirá cuando la acción correctiva tarda en adoptarse, ya sea por la inercia del mecanismo de puesta en marcha o por una capacidad limitada del sistema de calefacción y refrigeración. No obstante, debe tenerse en cuenta que estas deficiencias no alterarán la temperatura media en el tiempo de la casa. Nótese asimismo que la temperatura deseada (análoga al recuadro a en la Figura 56.4 es el único factor ajeno al ciclo cerrado. El reajuste del termostato a otra temperatura dará lugar a cambios duraderos en la temperatura media en el tiempo. Al igual que una persona elige un nivel de riesgo asumido en función de los beneficios y los costes percibidos que ofrecen las alternativas de comportamiento seguras y peligrosas, la temperatura se selecciona según la pauta de costes y beneficios previstos por mantener temperaturas superiores 0 inferiores (p. ej., gastos de energía y bienestar físico). Para que haya una discrepancia duradera entre el riesgo asumido y el riesgo real ha de producirse un error continuo por exceso o por defecto 
Figura 56.4 • Modelo homeostático en el que se relacionan los cambios en las pérdidas por accidente con los cambios en el comportamiento de los operarios y viceversa; el nivel de riesgo asumido es la variable de control.

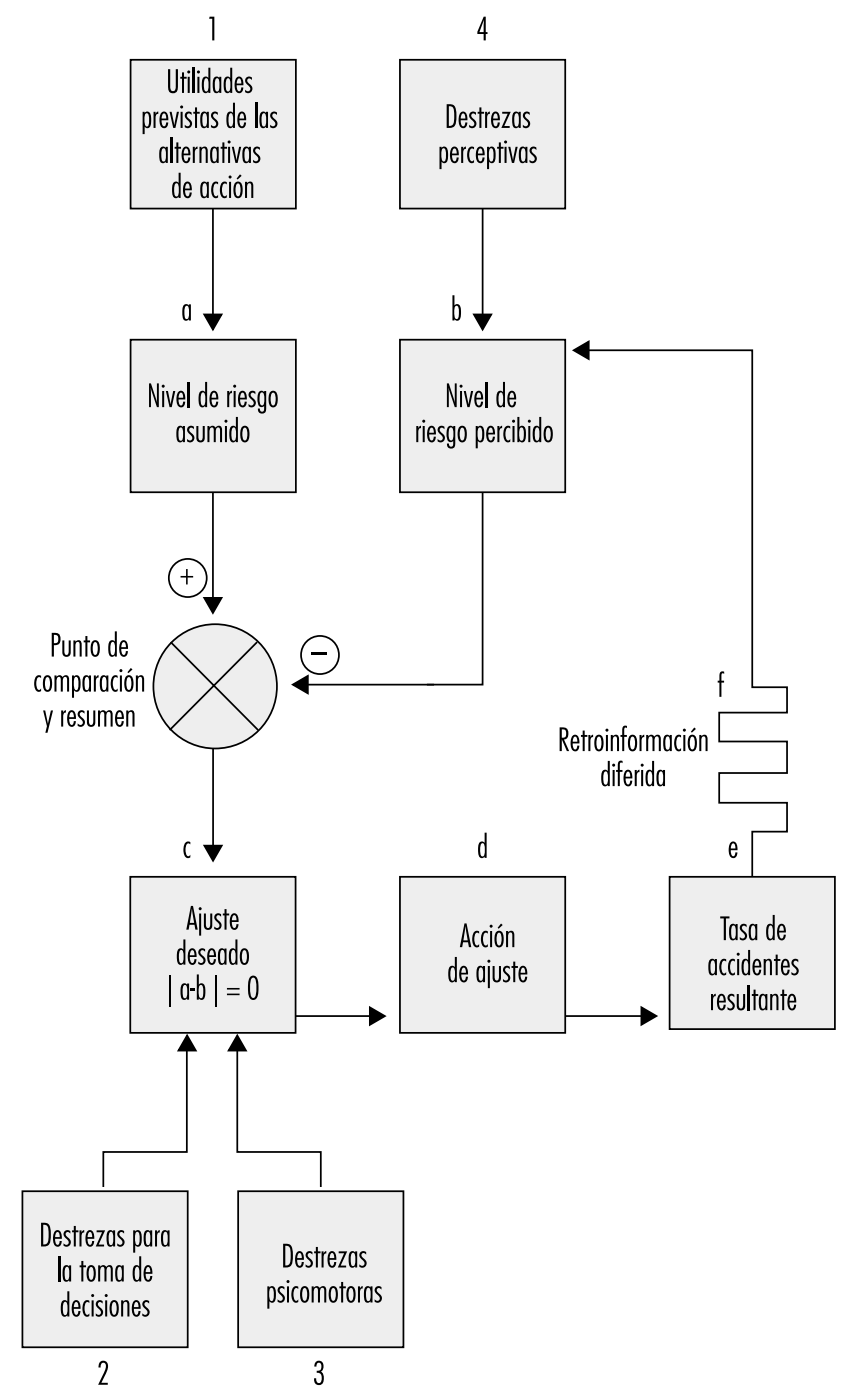

Fuente: Adaptado de Wilde 1982.

en la estimación del riesgo, del mismo modo que un termómetro que ofrece constantemente lecturas de temperatura excesivamente altas o bajas provocará que la temperatura real se desvíe sistemáticamente de la fijada como objetivo.

\section{Datos que respaldan el modelo}

Del modelo anterior se deduce que a la adopción de medidas para la prevención de accidentes que no alteren el nivel de riesgo asumido le sigue la estimación por parte de los usuarios del transporte por carretera de su efecto intrínseco sobre la seguridad, es decir, del cambio en la tasa de accidentes que se producirá si el comportamiento del usuario no se modifica en respuesta a la nueva medida de prevención. La estimación formará parte de la comparación entre el nivel de riesgo percibido y aceptado y, por tanto, influirá en el comportamiento de ajuste posterior. Si las estimaciones iniciales son, como media, incorrectas, se registrará una perturbación en la tasa de accidentes, pero sólo temporalmente, debido al efecto corrector relacionado con el proceso de retroinformación.

Este fenómeno se ha analizado en un informe de la OCDE. Puede que la mejora del nivel de cualificación y el aumento de las oportunidades para perfeccionar la seguridad no se utilicen para favorecer ésta, sino para mejorar el rendimiento: "Las adaptaciones del comportamiento de los usuarios de las carreteras que pueden producirse tras la adopción de medidas de seguridad en el sistema de transporte son de especial interés para las autoridades de tráfico, los órganos reguladores y los fabricantes de vehículos de motor, sobre todo en los casos en que dichas adaptaciones puedan reducir la ventaja prevista en materia de seguridad" (OCDE 1990). En este informe se mencionan numerosos ejemplos, entre los que figuran los siguientes:

En Alemania, el número de accidentes sufridos por taxis equipados con sistemas de frenado antibloqueo no fue menor que el de los que carecen de este mecanismo, y se redujeron las precauciones adoptadas por sus conductores. Se ha observado que la ampliación de la anchura de la calzada en las autopistas de dos carriles de N ueva G ales del Sur, Australia, va asociada a un aumento de la velocidad de conducción, en una proporción de $3,2 \mathrm{~km} / \mathrm{h}$ por cada $30 \mathrm{~cm}$ de anchura adicional en el caso de los turismos, y de unos $2 \mathrm{~km} / \mathrm{h}$ en el de los camiones. En un estudio realizado en Estados U nidos acerca de los efectos de la reducción de la anchura de los carriles, se observó que los conductores habituados a la carretera en cuestión redujeron su velocidad en $4,6 \mathrm{~km} / \mathrm{h}$, y los no habituados, en $6,7 \mathrm{~km} / \mathrm{h}$. En O ntario, las velocidades se redujeron en unos $1,7 \mathrm{~km} / \mathrm{h}$ por cada $30 \mathrm{~cm}$ de reducción en la anchura de la calzada. En las carreteras de Texas con arcenes pavimentados se conducía a velocidades al menos un $10 \%$ superiores a las registradas en las carreteras sin tal prestación. En general, se ha comprobado que los conductores alcanzan velocidades más altas al desplazarse por la noche por carreteras con líneas de señalización claramente marcadas.

En un estudio reciente elaborado en Finlandia se analizó el efecto de la instalación de postes reflectores en las autopistas con un límite de velocidad de $80 \mathrm{~km} / \mathrm{h}$. Se colocaron las señales en $548 \mathrm{~km}$ de carretera seleccionados aleatoriamente y se compararon los resultados con los obtenidos en otros $586 \mathrm{~km}$ sin postes. La instalación de estos dispositivos aumentó la velocidad por la noche. No se registró indicio alguno de que esta medida redujera la tasa de accidente por km en estas carreteras; en todo caso, sucedió lo contrario (K allberg 1992).

Pueden mencionarse otros muchos ejemplos. No se ha observado que la legislación relativa al uso de cinturón de seguridad haya reducido las tasas de muerte por accidente de tráfico (Adams 1985). L os conductores que habitualmente no utilizaban este dispositivo y que fueron obligados a emplearlo aumentaron su velocidad y redujeron la distancia de seguridad entre vehículos (Janssen 1994). D espués del cambio de la conducción por la izquierda a la realizada por la derecha en Suecia e I slandia, se registraron inicialmente reducciones importantes en el número de accidentes graves, pero sus tasas volvieron a la tendencia anterior al cambio cuando los conductores comprobaron que las carreteras no se habían vuelto tan peligrosas como pensaron al principio (Wilde 1982). Se han producido grandes reducciones de la tasa de accidente por $\mathrm{km}$ conducido en el transcurso del presente siglo, pero la estimada por persona no ha mostrado una tendencia a la baja (si se tienen en cuenta los períodos de desempleo elevado, en los que el nivel de riesgo de accidente asumido se reduce; Wilde 1991). 


\section{Motivación para la prevención de accidentes}

Es interesante que la mayoría de los datos relativos a los fenómenos que postula la THR procedan del área del tráfico rodado, mientras que las perspectivas que esta teoría mantiene en materia de prevención de accidentes se han confirmado en gran medida en los centros de trabajo. En principio, hay cuatro formas en las que puede motivarse a los trabajadores y los conductores para reducir su nivel de riesgo asumido:

- R educir los beneficios previstos de las alternativas de comportamiento peligrosas.

- Aumentar los costes previstos de las alternativas de comportamiento peligrosas.

- Aumentar los beneficios previstos de las alternativas de comportamiento seguras.

- Reducir los costes previstos de las alternativas de comportamiento seguras.

Aunque se ha comprobado que algunos de estos planteamientos son más eficaces que otros, la idea de que la seguridad puede mejorarse influyendo en la motivación es muy antigua, como demuestra la existencia universal de una legislación sancionadora.

\section{Sanción}

Aunque la aplicación de legislación sancionadora es uno de los intentos tradicionales de la sociedad de motivar a las personas en materia de seguridad, los datos relativos a su eficacia son inciertos. Existen otros problemas al respecto, en algunos casos descritos en el contexto de la psicología organizativa (Arnold 1989)

En primer lugar, cabe destacar el efecto "profético" de la atribución: si se atribuyen características indeseables a las personas, éstas pueden comportarse como si realmente las tuvieran. No hay más que tratar a las personas como si fueran irresponsables y algunos acabarán comportándose como tales.

En segundo lugar, suele prestarse una atención especial a los controles de los procesos; es decir, a comportamientos específicos, como la utilización de un dispositivo de seguridad o el respeto de un límite de velocidad, en lugar de ocuparse del resultado final, que es la seguridad. El diseño y la aplicación de tales controles resultan engorrosos, y nunca pueden abarcar totalmente el conjunto de comportamientos específicos indeseables de todas las personas en cualquier momento.

En tercer lugar, la sanción tiene efectos secundarios negativos. Genera un clima organizativo disfuncional, marcado por el resentimiento, la falta de cooperación, el antagonismo e, incluso, el sabotaje. Como resultado, es posible que el mismo comportamiento que se trataba de prevenir se fomente en la práctica.

\section{Incentivación}

A diferencia de la sanción, los programas de incentivos producen el resultado para el que fueron concebidos, así como el efecto secundario positivo de crear un clima social favorable (Steers y Porter 1991). La eficacia de los programas de incentivos y reconocimiento para perfeccionar la seguridad se ha establecido inequívocamente. En un estudio reciente de más de 120 evaluaciones publicadas de distintos tipo de prevención de accidentes de trabajo, se comprobó que los incentivos y el reconocimiento, en general, eran más eficaces en materia de seguridad que las mejoras técnicas, la selección de personal y otras formas de intervención, como la acción disciplinaria, la concesión de permisos especiales y los programas de ejercicios y reducción del estrés (Guastello 1991).

\section{Adaptación del comportamiento}

De acuerdo con la teoría de la homeostasis del riesgo, la tasa de accidente por persona y hora de ejecución de tareas y la tasa anual de accidentes por persona no dependen fundamentalmente de la capacidad ni de la oportunidad del individuo para estar seguro, sino de su deseo de estarlo. Por tanto, aunque la educación y la técnica puedan proporcionar la capacidad o la oportunidad para favorecer la seguridad, como medidas de prevención no reducirán la tasa de accidentes por hora, ya que no limitan el nivel de riesgo que las personas están dispuestas a asumir. En consecuencia, la respuesta a estas intervenciones adoptará normalmente la forma de un determinado ajuste del comportamiento en el que una posible ventaja en materia de seguridad queda compensada en la práctica por un aumento de la productividad, una mayor movilidad o una elevación de la velocidad en los desplazamientos

Puede interpretarse como la consecuencia de un proceso de control homeostático en el que el grado de precaución en el comportamiento determina la tasa de accidente y viceversa. En este proceso de ciclo cerrado, el nivel de riesgo asumido es la única variable independiente que explica en última instancia la tasa de accidentes. EI nivel depende de la percepción que tenga la persona de las ventajas y los inconvenientes de varias alternativas de acción. A firmar que la seguridad constituye una recompensa en sí misma equivale a ignorar el hecho de que las personas asumen riesgos conscientemente respecto a diversas contingencias susceptibles de modificación.

Por tanto, de todas las medidas de prevención de accidentes que pueden aplicarse en la actualidad, las que aumentan la motivación del individuo respecto a la seguridad parecen ser las más prometedoras, y las que le recompensan por actuar sin provocar accidentes, las más eficaces. De acuerdo con la revisión bibliográfica de M cA fee y Winn: “EI principal resultado fue que, en todos los estudios, sin excepción, se observó que los incentivos y la retroinformación mejoran la seguridad y reducen los accidentes en el lugar de trabajo, al menos a corto plazo. En pocas revisiones bibliográficas se registran resultados tan coherentes" (1989).

\section{Resumen}

De todos los posibles sistemas que recompensan a las personas por una actuación que no provoque accidentes, unos prometen mejores resultados que otros porque incluyen elementos que parecen aumentar la motivación respecto a la seguridad. Los ejemplos de las pruebas empíricas relativas al proceso de homeostasis del riesgo se han seleccionado de una gran base de datos (Wilde 1994), mientras que los ingredientes de un programa de incentivos eficaz se han analizado con mayor detenimiento en el Capítulo 60. Se ha aludido a que la deficiencia en la presentación de partes de accidentes es el único efecto secundario negativo de los planes de incentivos. No obstante, este fenómeno se limita a los accidentes de menor importancia. Es posible ocultar la rotura de un dedo; pero ocultar un cadáver resulta más difícil.

\section{MODELOS DE ACCIDENTES}

Andrew R. H ale

Los seres humanos desempeñan papeles importantes en la mayoría de los procesos que dan lugar a accidentes y en la mayor parte de las medidas encaminadas a su prevención. Por tanto, es esencial que estos modelos del proceso de generación de accidentes ofrezcan una orientación inequívoca acerca de los vínculos entre éstos y las acciones humanas. Sólo así será posible llevar a 
cabo estudios sistemáticos de los accidentes con el fin de entender tales vínculos y realizar predicciones sobre el efecto de los cambios en el diseño y la disposición de los lugares de trabajo, en la formación, en la selección y la motivación de trabajadores y directivos, así como en la organización del trabajo de los sistemas de seguridad.

\section{Primeros modelos}

H asta el decenio de 1960 los modelos creados sobre la participación de los factores humanos y organizativos en los accidentes habían sido bastante sencillos. La diferenciación de los elementos humanos relacionados con los accidentes se limitaba al establecimiento de subdivisiones generales, como las relativas a destrezas, factores referentes a la personalidad, factores de motivación y fatiga. L os accidentes se consideraban problemas indiferenciados para los que se buscaban soluciones de la misma naturaleza (como hace dos siglos los médicos trataban de curar numerosas enfermedades indiferenciadas mediante el sangrado del paciente).

Las revisiones de la bibliografía sobre investigación de accidentes publicadas por Surry (1969) y H ale y Hale (1972) son algunos de los primeros intentos de ahondar en este campo y ofrecer una base para la clasificación de accidentes en tipos que reflejen etiologías diferenciadas, vinculados a su vez a fracasos en los diversos aspectos de las relaciones entre el hombre, la tecnología y el entorno. En ambas revisiones, los autores se inspiraron en los conceptos acumulados de la psicología

Figura 56.5 • Resolución de problemas específicos al enfrentarse al peligro.

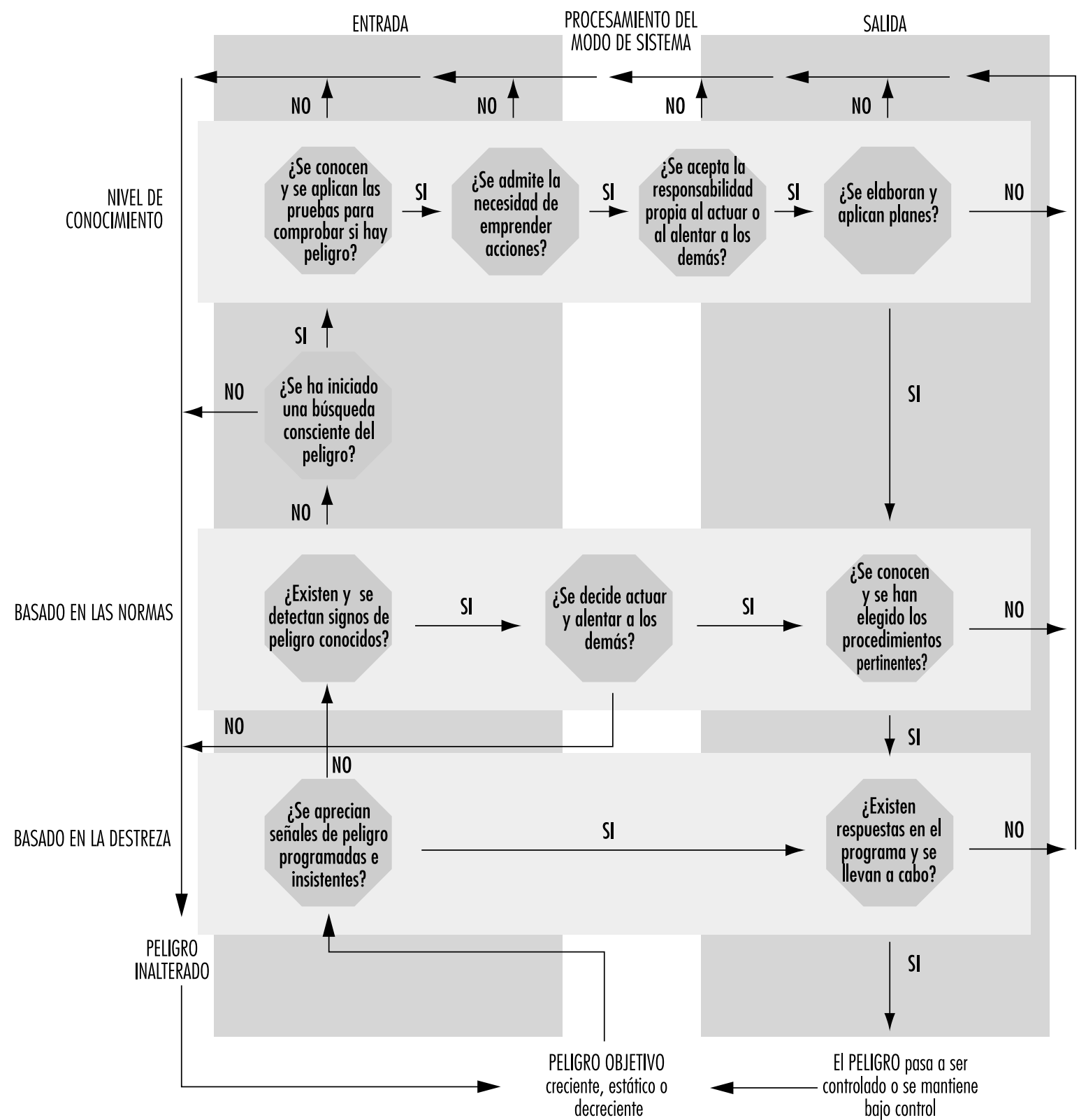


cognitiva para desarrollar modelos en los que se presenta a las personas como procesadores de información que responden a su entorno y a los riesgos de éste intentando percibir y controlar los riesgos existentes. En tales modelos, los accidentes se consideraban fallos de las distintas partes de este proceso de control, que se producen cuando una o varias de sus fases no se completan satisfactoriamente. Asimismo, dejó de inculparse a las personas por los fallos o los errores y se prestó mayor atención al desequilibrio entre el comportamiento que exigen la tarea o el sistema y las posibilidades inherentes al modo en que se genera y se organiza el comportamiento.

\section{Comportamiento humano}

$\mathrm{H}$ ale y Glendon (1987) profundizaron posteriormente en esos modelos, vinculándolos con el trabajo de Rasmussen y Reason

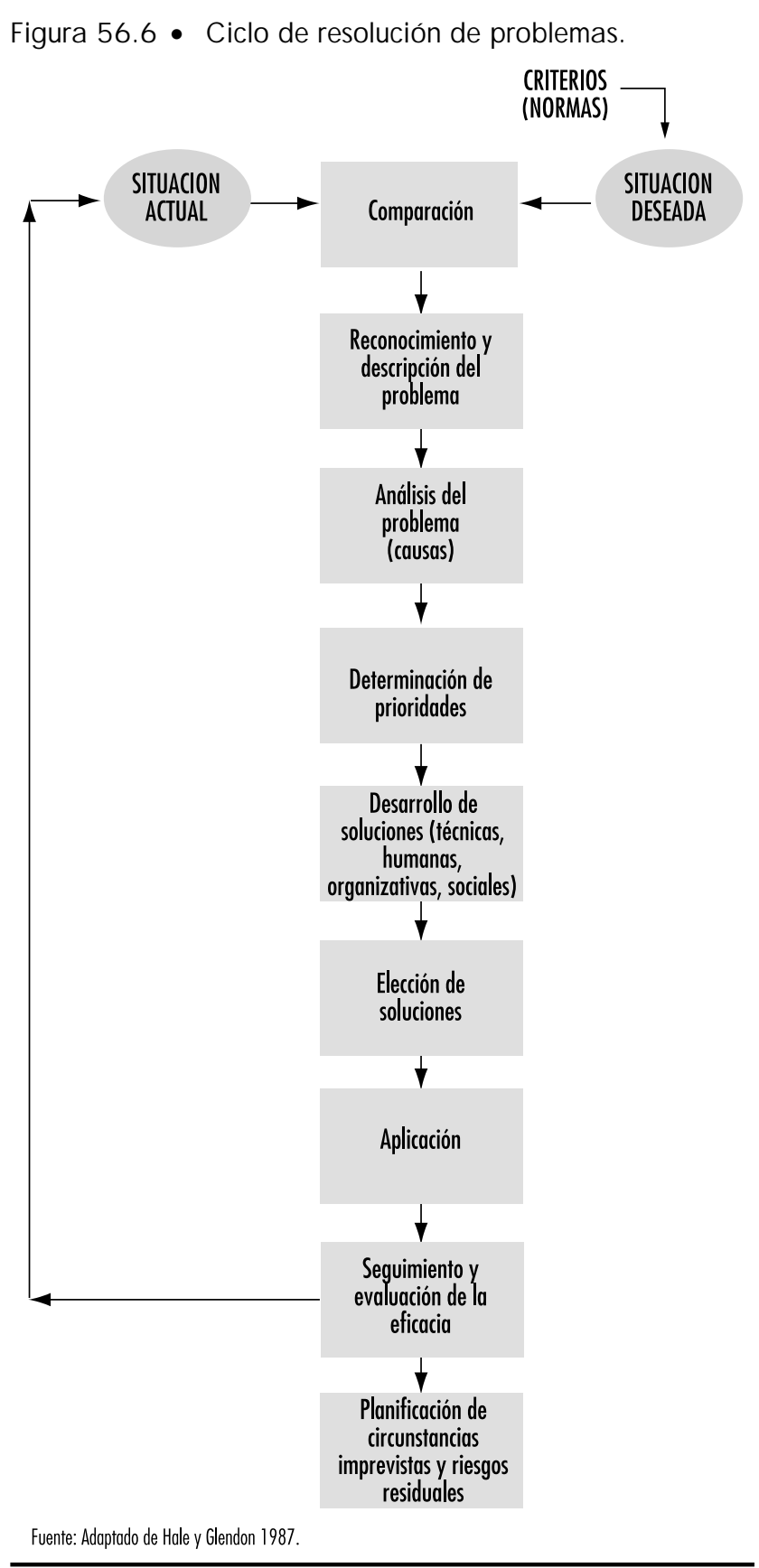

(Reason 1990), en el que se clasifica el comportamiento humano en tres niveles de procesamiento:

- respuestas automáticas, en gran medida inconscientes, a situaciones rutinarias (comportamiento basado en la destreza);

- aplicación de las normas aprendidas a un diagnóstico correcto de la situación existente (comportamiento basado en las normas),

- resolución de problemas consciente y prolongada en el tiempo en situaciones novedosas (comportamiento basado en el conocimiento).

Los fallos de control habituales difieren de un nivel de comportamiento a otro, al igual que los tipos de accidentes y las medidas de seguridad apropiadas para controlarlos. EI modelo de $\mathrm{H}$ ale y $\mathrm{G}$ lendon, actualizado con conceptos más recientes, se describe en la Figura 56.5. Se compone de diversos módulos que irán explicándose para facilitar la comprensión del funcionamiento global del modelo.

\section{Vínculo con los modelos de desviación}

El punto de partida del modelo de $\mathrm{H}$ ale y $\mathrm{G}$ lendon es el modo en que se desarrolla el peligro en un lugar de trabajo o sistema. Se considera que el peligro siempre está presente, aunque se mantiene bajo control mediante numerosas medidas de prevención de accidentes asociadas a los equipos físicos (p. ej., el diseño de los equipos y los dispositivos de protección), a las personas (p. ej., operarios cualificados), a los procedimientos (p. ej., el mantenimiento preventivo) y a la organización ( $p$. ej., la asignación de competencias respecto a las principales tareas de seguridad). Siempre que se hayan previsto todos los peligros y riesgos potenciales importantes y se hayan diseñado y elegido adecuadamente las medidas de prevención pertinentes, no se producirán daños. Sólo si se produce una desviación respecto a este estado normal y conveniente, puede iniciarse el proceso de un accidente. (Los modelos de desviación se abordan con detalle en "M odelos de desviación de accidentes".)

La tarea de las personas que componen el sistema es garantizar un funcionamiento correcto de las medidas de prevención de accidentes, con el fin de evitar las desviaciones mediante la utilización de los procedimientos oportunos para cada eventualidad, el manejo de los equipos de seguridad con precaución y la realización de las comprobaciones y los ajustes necesarios. Asimismo, estas personas deben ocuparse de detectar y corregir muchas de las desviaciones potenciales y de adaptar el sistema y sus medidas preventivas a las nuevas exigencias, peligros y conceptos. Todas estas acciones se incluyen en el modelo de $\mathrm{H}$ ale y $\mathrm{G}$ lendon como tareas de detección y control relacionadas con el peligro.

\section{Resolución de problemas}

En el modelo de $\mathrm{H}$ ale y $\mathrm{G}$ lendon, el papel de la acción humana en el control del peligro se considera una tarea de resolución de problemas. Sus fases pueden disponerse genéricamente como en la Figura 56.6.

La tarea es un proceso de consecución de objetivos, basado en las normas establecidas en la primera fase de la Figura 56.6. Se trata de las normas de seguridad que los trabajadores se autoimponen o que son estipuladas por las empresas, los fabricantes 0 los legisladores. El modelo ofrece la ventaja de que puede aplicarse no sólo a determinados trabajadores enfrentados a un peligro inminente o futuro, sino también a grupos de trabajadores, departamentos u organizaciones que tratan de controlar simultáneamente el peligro existente en un proceso 0 una actividad y el peligro futuro originado por las nuevas tecnologías o por productos en la fase de diseño. Por tanto, los sistemas de gestión de la seguridad pueden ajustarse a un modelo 
Figura 56.7 • Comportamiento ante el peligro.

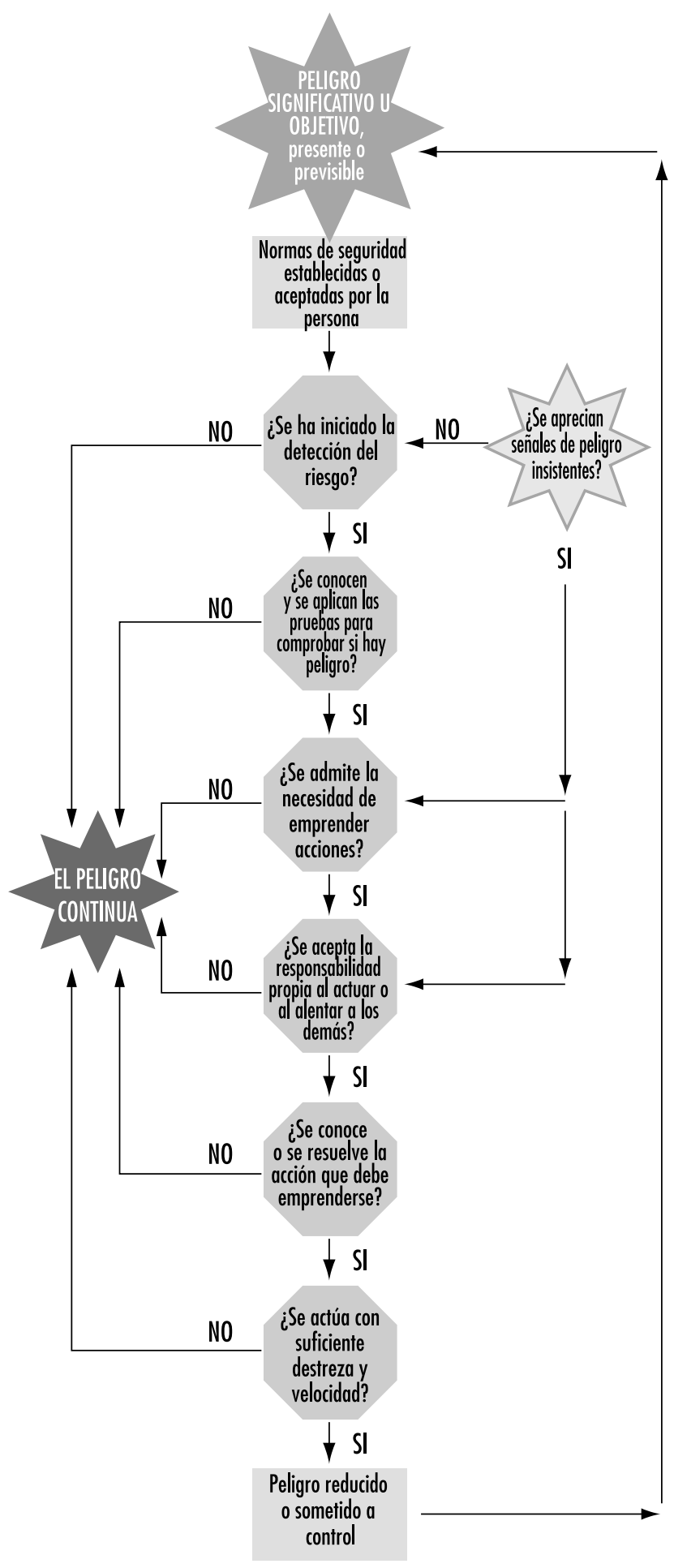

compatible con el comportamiento humano, lo que facilita al diseñador 0 al evaluador de dicha gestión una visión general 0 selectiva de las tareas interrelacionadas en los diferentes niveles que componen una organización (H ale y cols. 1994)

Al aplicar estas fases al comportamiento individual ante un peligro, obtenemos la Figura 56.7. Ciertos ejemplos de cada fase pueden aclarar la tarea de la persona. Como se ha señalado anteriormente, en cualquier situación se supone que existe en todo momento un cierto grado de peligro. La cuestión es si un trabajador concreto responde al mismo. La capacidad de respuesta dependerá en parte de la insistencia con que se advierta el peligro y en parte de la sensibilización del trabajador respecto al mismo y a las normas sobre nivel de riesgo aceptable. Cuando, de repente, un componente de la maquinaria se pone al rojo vivo, o una carretilla elevadora se aproxima a gran velocidad o comienza a salir humo por debajo de una puerta, el trabajador pasa inmediatamente a considerar la necesidad de acción, o incluso a decidir lo que él u otra persona puede hacer.

Tales situaciones de peligro inminente son infrecuentes en la mayoría de los sectores y, por lo común, es conveniente alentar a los trabajadores a que controlen el peligro antes de que se haga inminente. Por ejemplo, éstos deben reconocer un ligero desgaste en los dispositivos de protección de la maquinaria e informar del problema, además de darse cuenta de que ciertos niveles de ruido pueden provocarles sordera si se exponen a los mismos durante varios años. Los diseñadores deben prever que un trabajador poco experimentado tiende a utilizar los nuevos productos de un modo potencialmente peligroso.

Para lograr estos objetivos, todos los responsables en materia de seguridad deben tener presente en primer lugar que es posible que el peligro exista o vaya a existir. Tener presente el peligro es, por un lado, una cuestión de personalidad y, por otro, de experiencia; puede fomentarse mediante la formación y garantizarse haciéndolo parte explícita de las tareas y los procedimientos incluidos en las fases de diseño y ejecución de un proceso, en las que puede ser confirmado y alentado por compañeros y superiores. En segundo lugar, los trabajadores y los supervisores deben saber cómo prever y reconocer los signos de peligro. Para asegurarse de que el grado de alerta es el apropiado, deben acostumbrarse a advertir posibles situaciones de accidente, es decir, indicaciones y conjuntos de señales que puedan dar lugar a una pérdida de control y, por tanto, a un daño. Se trata en parte de entender las redes de causas y efectos, como el modo en que puede perderse el control de un proceso, la forma en que el ruido deteriora la capacidad auditiva o la manera y el momento en que una zanja puede derrumbarse.

La misma importancia reviste la adopción de una actitud de desconfianza creativa, es decir, de considerar que las herramientas, las máquinas y los sistemas pueden utilizarse erróneamente, funcionar mal o mostrar propiedades e interacciones ajenas a las intenciones de sus diseñadores. Se trata de aplicar "la L ey de M urphy" (lo que puede ir mal irá mal) de forma creativa, previendo posibles fallos y brindando la oportunidad de suprimirlos o controlarlos. Tal actitud, junto con el conocimiento y la capacidad de interpretación, también contribuye al éxito de la siguiente fase: creer realmente que un determinado peligro tiene la suficiente probabilidad o gravedad para justificar la adopción de medidas.

I dentificar algo como suficientemente peligroso para requerir una acción correctiva es, de nuevo, en parte una cuestión de personalidad; por ejemplo, puede tener relación con el grado de pesimismo de una persona respecto a la tecnología y, lo que es más importante, está influida en gran medida por el tipo de experiencia que lleva a los trabajadores a plantearse preguntas como: "¿Ha funcionado mal en el pasado?" O " $\mathrm{iH}$ a funcionado durante años con el mismo nivel de riesgo y sin accidentes?". Los resultados de las investigaciones sobre la percepción de riesgos y sobre los intentos de influir en ésta mediante la comunicación de riesgos y la retroinformación acerca de las experiencias de accidentes e incidentes se detallan en otros artículos.

Aun cuando se detecte la necesidad de emprender alguna acción, puede que los trabajadores no la adopten por varias 
razones: por ejemplo, es posible que consideren que no es su misión interferir en el trabajo de otra persona, puede que no sepan qué hacer, que perciban que la situación es inalterable ("son gajes del oficio") o que teman las represalias por comunicar un posible problema. En este sentido son importantes las creencias y los conocimientos sobre las causas y los efectos y la atribución de competencias en materia de accidentes y su prevención. Por ejemplo, los supervisores que piensan que los accidentes se deben en gran medida a trabajadores descuidados y propensos a sufrirlos no considerarán la necesidad de emprender acciones por su parte, salvo quizá las que consisten en suprimir a ese tipo de trabajadores de su sección. Asimismo, una comunicación eficaz para movilizar y coordinar a las personas que pueden y deben adoptar medidas es esencial en esta fase.

Las etapas restantes aluden al conocimiento de las acciones oportunas para controlar el peligro y las destrezas necesarias para adoptar las medidas pertinentes. El conocimiento se adquiere mediante la formación y la experiencia, pero un diseño adecuado puede ayudar enormemente, especificando claramente el modo de obtener un determinado resultado que permita evitar el peligro o protegerse frente a él; por ejemplo, mediante una parada de emergencia o desconexión, 0 una acción encaminada a evitar las consecuencias. U nos recursos informativos apropiados, como los manuales de instrucciones 0 los sistemas de apoyo informático pueden proporcionar a los supervisores y los trabajadores unos conocimientos de los que no disponen en el curso de su actividad diaria. Por último, la cualificación y la práctica determinan si la acción de respuesta exigida puede llevarse a cabo con la suficiente precisión y en el momento justo para garantizar su éxito. Aquí se plantea una difícil paradoja: cuanto más alerta y preparadas estén las personas y más fiables sean los equipos, menor será la frecuencia con que se requieran los procedimientos de emergencia y mayor será la dificultad de mantener el nivel de destreza necesario para llevarlos a cabo en las situaciones que lo exijan.

\section{Vínculos con el comportamiento basado en la destreza, las normas y el conocimiento}

El elemento final del modelo de $\mathrm{H}$ ale y Glendon, que permite pasar de la Figura 56.7 a la Figura 56.5, es la adición del vínculo al trabajo de Reason y Rasmussen. En éste se subraya que el comportamiento puede manifestarse a tres niveles diferentes de control consciente (basado en la destreza, en las normas y en el conocimiento), que implican diversos aspectos del funcionamiento humano y son objeto de distintos tipos y grados de perturbación y error a causa de señales externas o fallos de procesamiento internos.

B asado en la destreza. EI nivel basado en la destreza es muy fiable, pero está sometido a lapsus y descuidos en situaciones de perturbación y cuando otra rutina similar requiere la atención. Es un nivel especialmente relacionado con el tipo de comportamiento rutinario que exige una respuesta automática a señales conocidas que indican peligro, ya sea inminente 0 no. Las respuestas son rutinas conocidas y practicadas, como mantener los dedos alejados de una muela abrasiva al afilar un buril, conducir un vehículo sin que se salga de la carretera o agachar la cabeza para esquivar un objeto que vuela hacia nosotros. Son tan automáticas que los trabajadores ni siquiera son conscientes de que controlan activamente un peligro que les afecta.

B asado en las normas. EI nivel basado en las normas se refiere a la elección, entre un conjunto de rutinas o normas conocidas, de una que resulta apropiada para cada situación, como la determinación de qué secuencia debe iniciarse para cerrar un reactor que, de otro modo, podría quedar sometido a una presión excesiva, la selección de las gafas de seguridad correctas para trabajar con ácidos (frente a las adecuadas para trabajar con polvo) o la decisión, por parte de un directivo, de llevar a cabo la revisión de seguridad completa de un nuevo centro de trabajo en lugar de una breve inspección informal. En este caso, los errores suelen relacionarse con la insuficiencia del tiempo dedicado al cotejo de la opción con la situación real, con la confianza en la expectativa y no en la observación para comprender la situación o con la equivocación consistente en dejarse influir por información externa para llevar a cabo un diagnóstico erróneo. En el modelo de $\mathrm{H}$ ale y $\mathrm{G}$ lendon, el comportamiento a este nivel está especialmente relacionado con la detección de los riesgos y la elección de los procedimientos correctos en situaciones habituales.

B asado en el conocimiento. Se aplica únicamente cuando se carece de planes o procedimientos preestablecidos para abordar una situación en pleno desarrollo. Así ocurre sobre todo en la detección de nuevos riesgos en la fase de diseño, la observación de problemas no anticipados en las inspecciones de seguridad o el tratamiento de emergencias imprevistas. Se utiliza especialmente en las fases de la parte superior de la Figura 56.5. Se trata del modo de operación menos predecible y fiable, pero también de aquél en el que una máquina o un ordenador no pueden sustituir a una persona en la detección de posibles peligros y en la recuperación de desviaciones.

La combinación de todos los elementos se recoge en la Figura 56.5, en la que se establece un marco tanto para la clasificación de los momentos en que se produjeron fallos del comportamiento humano en un accidente pasado, como para el análisis de las acciones posibles encaminadas a favorecer este comportamiento en lo que respecta al control del peligro en una situación 0 tarea determinada antes de que tenga lugar un accidente.

\section{MODELOS DE SECUENCIA DE ACCIDENTES}

\section{Ragnar Andersson}

En el presente artículo se analiza un grupo de modelos de accidente con un mismo diseño básico. La interacción entre las personas, la maquinaria y el ambiente, y la conversión de esta interacción en posibles riesgos, peligros, daños y lesiones se trata a partir de una secuencia de preguntas dispuestas y enumeradas en un orden lógico. A continuación, esta secuencia se aplica de un modo similar a diversos niveles de análisis mediante la utilización de modelos. El primero de éstos lo planteó Surry (1969). U nos años más tarde, el Fondo Sueco para el M edio Ambiente de Trabajo (1983) presentó una versión modificada, conocida a partir de entonces por la sigla de este organismo en inglés, WEF. Posteriormente, un equipo sueco de investigación evaluó el modelo WEF y propuso nuevos cambios, que dieron lugar a la creación de una tercera versión.

Los modelos se describen aquí por separado y se comentan las razones de los cambios y de la evolución experimentada. Por último, se ofrece una síntesis provisional de los tres modelos. Así pues, se presentan y examinan cuatro modelos en total, con semejanzas considerables. Aunque esta propuesta pueda parecer confusa, refleja la falta de unanimidad respecto a una sola versión aceptada como "EI Modelo". Entre otras cosas, se produce un conflicto obvio entre simplicidad e integridad en lo referente a los modelos de accidentes.

\section{El modelo de Surry}

En 1969, Jean Surry publicó Industrial Accident R esearch- A H uman Enginering Appraisal, obra que contiene una revisión de los modelos y los enfoques más aplicados en la investigación de 
accidentes. Surry agrupó los marcos teóricos y conceptuales en cinco categorías diferentes: 1) modelos de cadenas de acontecimientos múltiples, 2) modelos epidemiológicos, 3) modelos de intercambio de energía, 4) modelos de comportamiento, y 5) modelos de sistemas. Llegó a la conclusión de los modelos no son incompatibles entre sí; simplemente, en cada uno se subrayan aspectos distintos, lo que la llevó a combinar los diversos marcos en un modelo amplio y general. No obstante, Surry especificó claramente que su modelo debe considerarse provisional y no definitivo.

En opinión de Surry, un accidente puede describirse mediante una serie de preguntas que forman una jerarquía secuencial de niveles, en la que las respuestas a cada una de ellas determinan si un suceso acaba en accidente o no. EI modelo de Surry (véase la Figura 56.8) refleja los principios del procesamiento de información humano y se basa en un concepto del accidente como desviación del proceso previsto. Consta de tres fases principales, unidas por dos ciclos similares.

En la primera fase se considera a las personas en su medio global, incluidos todos los parámetros medioambientales y humanos. El agente potencial causante de lesión se describe asimismo en esta etapa. Se supone que, mediante las acciones (o la ausencia de las mismas) de las personas, se erradican los peligros existentes en dicho entorno. A efectos del análisis, se establece un ciclo de "desarrollo del peligro" basado en la primera secuencia de preguntas. Si se dan respuestas negativas a alguna de ellas, el peligro en cuestión se convierte en inminente.

La segunda secuencia de preguntas o "ciclo de materialización del peligro", vincula el nivel de éste con posibles resultados alternativos cuando el peligro se pone en marcha. Debe tenerse en cuenta que, mediante el seguimiento de diversas rutas del modelo, es posible distinguir entre los peligros deliberados (o aceptados conscientemente) y los resultados negativos involuntarios. La diferencia entre actos inseguros "parecidos a un accidente", contratiempos y accidentes propiamente dichos se aclara asimismo en el modelo.

\section{El modelo WEF}

En 1973, un comité creado por el Fondo Sueco para el Medio Ambiente de Trabajo para analizar la situación de la investigación sobre accidentes de trabajo en Suecia propuso un "nuevo" modelo y lo presentó como un instrumento universal que debía emplear cualquier estudio en este terreno. Se definió como una síntesis de los modelos de comportamiento, epidemiológicos y de sistemas existentes y se afirmó que incluía todos los aspectos importantes en materia de prevención. Se hizo referencia, entre otros, al modelo de Surry, pero sin mencionar que éste era casi idéntico al propuesto. Sólo se habían realizado algunos cambios para perfeccionarlo.

Como suele ocurrir cuando las perspectivas y los modelos científicos son recomendados por organismos y autoridades centrales, el modelo sólo se adopta posteriormente en ciertos proyectos. No obstante, el informe publicado por el WEF contribuyó a aumentar rápidamente el interés de los investigadores escandinavos en general y suecos en particular en la creación de modelos y el desarrollo de teorías y al poco tiempo se plantearon otros nuevos modelos de accidentes.

EI punto de partida en el modelo WEF (a diferencia del nivel del "hombre y el entorno" en el de Surry) radica en el concepto de peligro, limitado en este caso al "peligro objetivo" y diferenciado de la percepción subjetiva del mismo. El peligro objetivo se define como una parte integrante de un determinado sistema y se determina básicamente en función de la cantidad de recursos disponibles para la inversión en materia de seguridad. El aumento de la tolerancia del sistema respecto a la variabilidad humana se cita como un modo de reducir el peligro.
Figura 56.8 • El modelo de Surry.
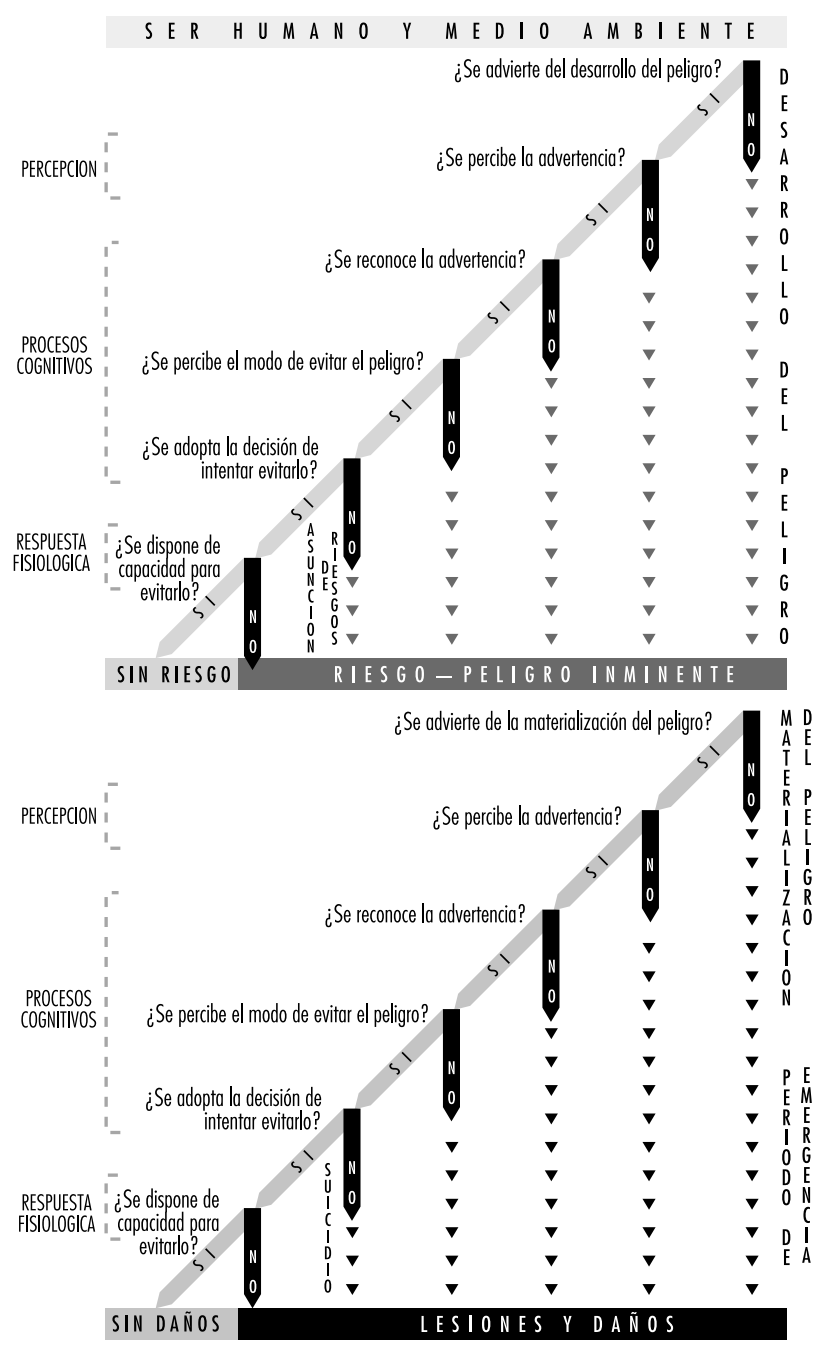

Fuente: Surry 1969

Cuando alguien entra en contacto con un determinado sistema y sus riesgos, se inicia un proceso. D ebido a las características del sistema y el comportamiento de cada persona, puede plantearse una situación de peligro. De acuerdo con algunos autores, lo más importante (en lo que se refiere a dichas características) es el modo en que se indican los riesgos mediante diversos tipos de señales. La inminencia del riesgo se establece en función de la percepción, la interpretación y las acciones de la persona en relación con tales señales.

La siguiente secuencia en el proceso, que, en principio, es idéntica a la del modelo de Surry, está relacionada directamente con el suceso y con la posibilidad de que provoque una lesión o no. Si el peligro se materializa, ¿puede ser detectado en la práctica?, ¿es percibido por la per sona a la que afecta, y es capaz ésta de evitar la lesión o el daño? Las respuestas a estas preguntas explican el tipo y el grado de resultados adversos a que puede dar origen este período crítico.

Se consideró que el modelo WEF (Figura 56.9) ofrece las ventajas siguientes:

- Aclara que unas condiciones de trabajo seguras exigen la adopción de acciones en la fase más temprana posible. 
Figura 56.9 - El modelo W EF.
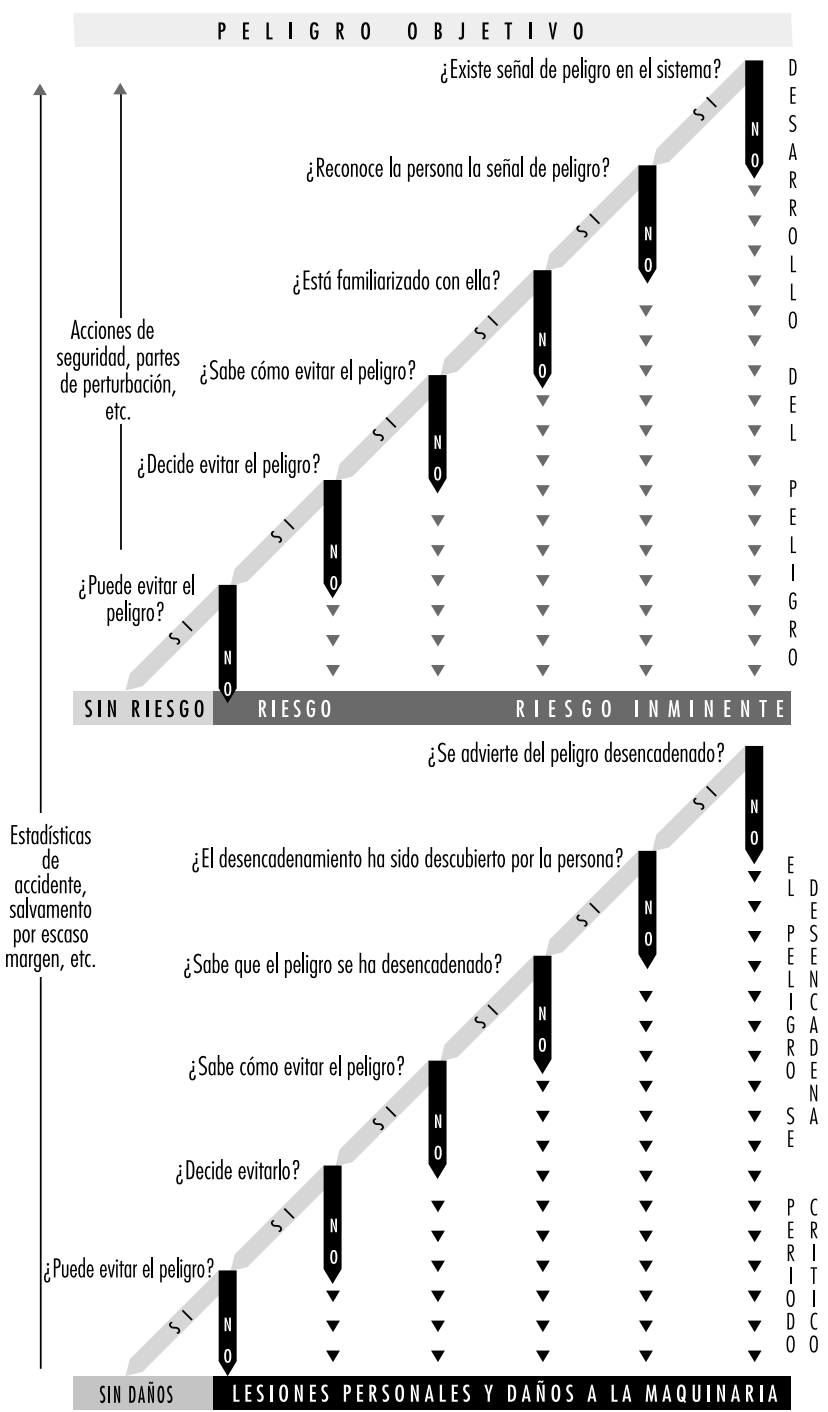

Fuente: Work Environment Fund 1983

- Demuestra la importancia de trabajar con perturbaciones y cuasiaccidentes, así como con los accidentes que producen daños o lesiones. EI resultado real reviste menor importancia desde el punto de vista de la prevención.

- Describe los principios del procesamiento humano de la información.

- Facilita sistemas de seguridad que se autocorrigen mediante la retroinformación de los resultados obtenidos de los incidentes analizados.

\section{Evaluación y desarrollo posterior}

En la época en que se publicó el informe WEF, se elaboraba un estudio epidemiológico sobre accidentes de trabajo en M almoe, Suecia. Estaba basado en una versión modificada de la denominada matriz de $\mathrm{H}$ addon, en la que se realiza una tabulación de entradas múltiples de variables en dos dimensiones: el tiempo con respecto a las fases de accidente y previa y posterior al mismo y la tricotomía epidemiológica de anfitrión, agente (o vehículo/ vector) y entorno. Aunque este tipo de modelo ofrece una base sólida para la recopilación de datos, el equipo de investigación lo consideró insuficiente para comprender y explicar los mecanismos causales que subyacen a los fenómenos de accidente y lesión. EI modelo WEF parecía representar un nuevo planteamiento y, por tanto, fue recibido con enorme interés. Se decidió realizar una evaluación inmediata del mismo mediante su comprobación respecto a una selección aleatoria de 60 casos reales de accidentes de trabajo que habían sido previamente analizados y documentados por el grupo de $\mathrm{M}$ almoe como parte del estudio que estaban llevando a cabo.

Los resultados de la evaluación se resumen en cuatro puntos:

- El modelo no es el instrumento universal que se pensó que sería. En cambio, debe considerarse fundamentalmente como un modelo de comportamiento. El "peligro" viene dado y el análisis se ocupa del comportamiento de la persona en relación con aquél. En consecuencia, las opciones de prevención que ofrece este análisis se basan en factores humanos, y no en los equipos o el entorno. EI "peligro" como tal apenas se cuestiona en el marco del modelo.

- En el modelo no se presta la atención debida a las restricciones técnicas y organizativas del proceso de trabajo. Se crea la ilusión de una libre elección entre las alternativas peligrosas y seguras. Se observó en la práctica que algunos riesgos son inevitables para los trabajadores, aunque la dirección puede evitarlos claramente. Por tanto, carece de sentido y puede conducir a error preguntar si las personas saben cómo evitar (y optar por evitar) algo que, en realidad, es ineludible excepto si desean renunciar a su empleo.

- En el modelo no se aborda una cuestión tan importante como qué hizo necesaria la actividad peligrosa, o por que la realizó el trabajador en cuestión. En algunas ocasiones es posible conseguir que las tareas peligrosas dejen de ser necesarias y, en otras, pueden desempeñarlas otros trabajadores más adecuados con una cualificación superior.

- El análisis se limita a una sola persona, pero muchos accidentes ocurren por la interacción de dos o más. No obstante, se planteó la posibilidad de superar esta dificultad combinando los resultados de análisis paralelos, realizados en cada caso desde el punto de vista de una de las personas interesadas.

Sobre la base de estas observaciones, el modelo fue perfeccionado por el grupo de investigación de Malmoe. La innovación más importante fue la introducción de una tercera secuencia de preguntas que complementase las otras dos. Fue diseñada para analizar y explicar la existencia y la naturaleza del "peligro" como característica inherente al sistema de interrelación de hombre y máquina. Se aplicaron los principios generales de la teoría de sistemas y la tecnología de control.

Además, el proceso de trabajo, entendido en función de la interrelación de hombre, máquina y entorno, debe contemplarse a la luz de sus contextos organizativos y estructurales, tanto a escala de la empresa como de la sociedad. A simismo, se considera necesario tener en cuenta las características personales y los motivos para la actividad en cuestión, así como los motivos de cada persona para llevarla a cabo (véase la Figura 56.10)

\section{Resumen}

Al volver a considerar estos primeros modelos hoy, más de veinte años después de su presentación, y habida cuenta de los avances alcanzados en lo que respecta a las teorías y los modelos de investigación de accidentes, se comprueba que siguen siendo sorprendentemente actuales y competitivos. 
Figura 56.10 El modelo W EF ampliado mediante la introducción de otra primera secuencia.

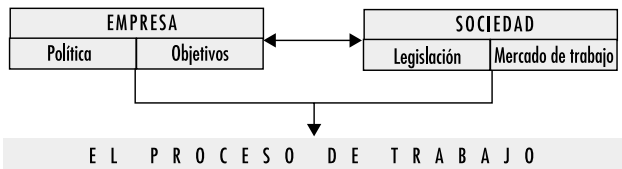

EL PROCESO DE TRABA J O
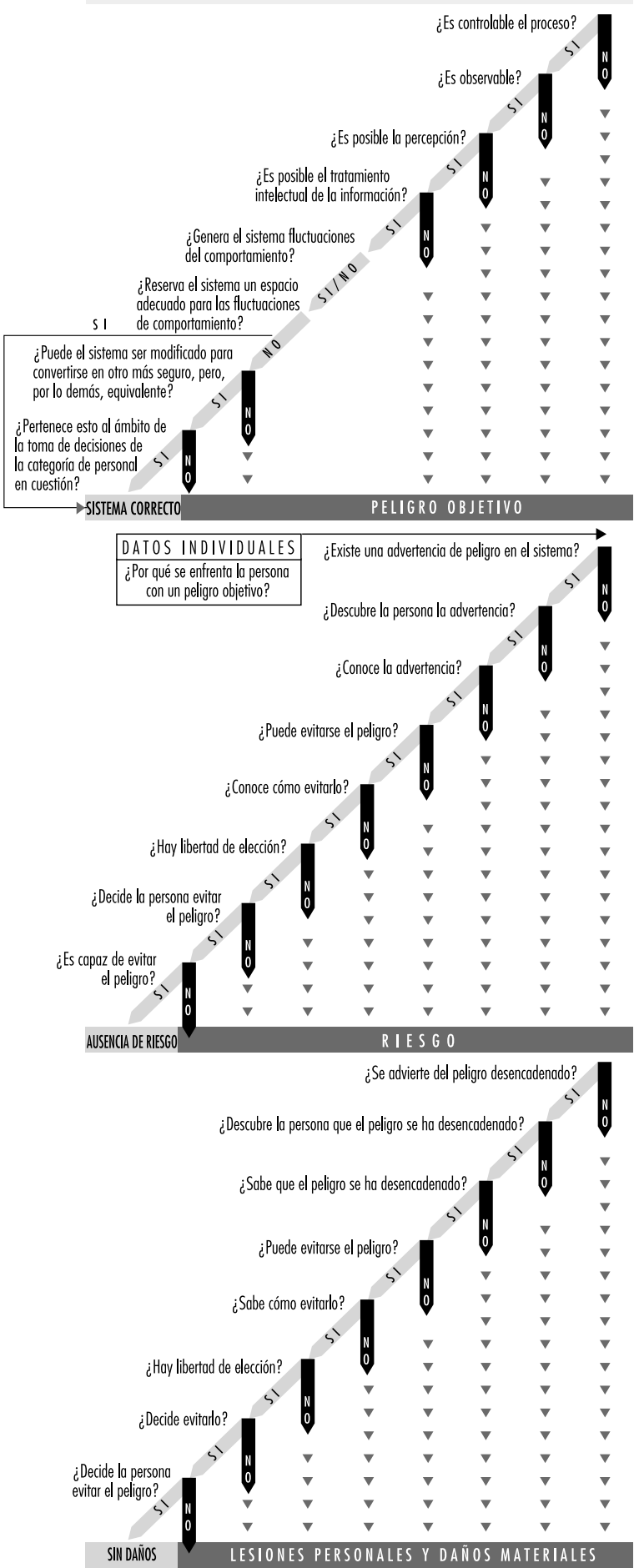

Fuente: Basado en Work Environment Fund 1983.
Figura 56.11 - Modelo general aproximado de la causalidad de los accidentes (basado en Surry 1969 y versiones posteriores).
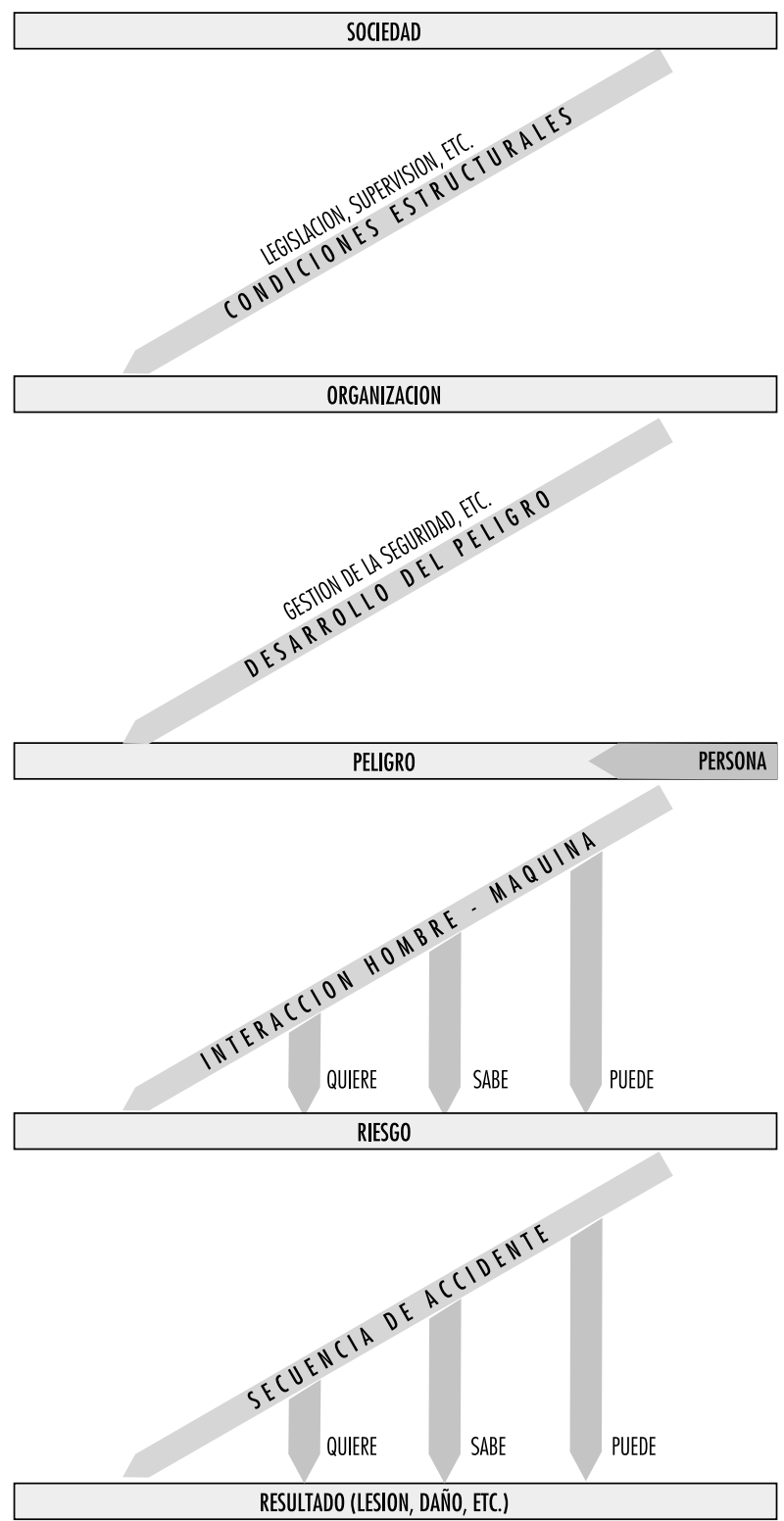

Fuente: Basado en Suny 1969

La suposición básica que implican (los accidentes, al igual que sus causas, deben considerarse desviaciones respecto al proceso previsto) sigue constituyendo una premisa generalizada (véase, entre otros, Benner 1975; K jellén y Larsson 1981).

Los modelos establecen una distinción inequívoca entre el concepto de lesión como consecuencia para la salud y el de accidente como suceso precedente. Además, ponen de relieve que un accidente no es un mero "acontecimiento", sino más bien un proceso que puede analizarse como una serie de fases (Andersson 1991)

Con posterioridad se han elaborado numerosos modelos, como un conjunto de "módulos" organizados en un orden temporal o jerárquico, que indican la existencia de varias fases temporales o niveles de análisis, como el modelo ISA 
(Andersson y Lagerlöf 1983), el modelo de desviación (K jellén y Larsson 1981) y el denominado modelo finlandés (Tuominen y Saari 1982). Tales niveles de análisis también son fundamentales para los modelos descritos aquí. A hora bien, en los modelos de secuencia se propone asimismo un instrumento teórico para el análisis de los mecanismos que relacionan dichos niveles entre sí. Autores como $\mathrm{H}$ ale y Glendon (1987), desde la perspectiva de los factores humanos, y Benner (1975), desde un punto de vista sistémico, han realizado contribuciones importantes al respecto.

Como se deduce claramente de la comparación de estos modelos, Surry no asignó una posición esencial al concepto de peligro, a diferencia de las propuestas del WEF. Su punto de partida fue la interacción de hombre y entorno, lo que refleja un enfoque más amplio, similar al planteado por el grupo de $M$ almoe. Por otra parte, al igual que el comité WEF, Surry no se refirió a otros niveles de análisis ajenos al trabajador y su medio ambiente, como los organizativos y sociales. Además, las observaciones del estudio de Malmoe citadas aquí en relación con el modelo WEF también parecen oportunas para el modelo de Surry.

Una síntesis actual de los tres modelos presentados podría incluir menos detalles sobre el procesamiento humano de la información y más datos sobre las condiciones "estructurales" (remontándose más atrás en el "flujo" de causas) en los niveles organizativo y social. Los elementos clave en una secuencia de preguntas destinada a abordar la relación entre los niveles organizativo y de interacción de hombre y máquina, podrían deducirse de los principios modernos de gestión de la seguridad, incluidas las metodologías de garantía de calidad (control interno y otras). Del mismo modo, una secuencia de preguntas referente a la vinculación entre los niveles organizativo y social podría basarse en los principios actuales de supervisión e inspección centradas en los sistemas. En la Figura 56.11 se esboza un modelo general aproximado que se basa en el diseño original de Surry, al que se añaden estos elementos.

\section{- MOdELOS DE DESVIACION DE ACCIDENTES}

Urban Kjellén

Un accidente de trabajo puede considerarse como un efecto anormal o no deseado de los procesos desarrollados en un sistema industrial, o como algo que no funciona como estaba previsto. Además de las lesiones personales, puede tener otras consecuencias indeseables, como daños materiales, emisiones accidentales de contaminación al medio ambiente, retrasos o reducción de la calidad de los productos. El modelo de desviación tiene sus raíces en la teoría de sistemas. Su aplicación conlleva la consideración de los accidentes como desviaciones.

\section{Desviaciones}

La definición de desviación en lo que se refiere a requisitos especificados coincide con la de disconformidad recogida en las normas de gestión de calidad ISO 9000 de la O rganización Internacional de N ormalización (ISO 1994). EI valor de la variable de sistemas se clasifica como desviación si se sale de la norma. Las variables de sistemas son las características mensurables del mismo, que pueden adoptar distintos valores.

\section{Normas}

Existen cuatro tipos diferentes de normas, referidos a los aspectos siguientes: a) los requisitos especificados, b) lo que se ha planificado, c) lo que es normal o habitual, y d) lo que es aceptado.
C ada uno de ellas se caracteriza por el modo en que se ha establecido y su grado de formalización.

Las disposiciones, las normativas y los procedimientos de seguridad son ejemplos de requisitos especificados. Un caso típico de desviación respecto a estos requisitos es un "error humano", definido como la transgresión de una norma. Las normas relativas a lo que es "normal o habitual" y lo que es "aceptado" están menos formalizadas. Su aplicación es característica de los establecimientos industriales, en los que la planificación se centra en los resultados y la ejecución del trabajo se deja a discreción de quienes lo realizan. Un ejemplo de desviación respecto de una norma "aceptada" es el "factor incidental", es decir, un acontecimiento poco habitual que puede producir (o no) un accidente (Leplat 1978). O tro ejemplo es el "acto peligroso", tradicionalmente definido como una acción personal que infringe un procedimiento seguro aceptado por la mayoría (ANSI 1962).

\section{Variables del sistema}

Al aplicar el modelo de desviación, el conjunto o serie de valores de las variables del sistema se divide en dos clases: normales y de desviación. La distinción entre ambas puede resultar problemática. Es posible que se planteen diferencias de opinión sobre lo que es normal, por ejemplo, entre los trabajadores, los supervisores, la dirección y los diseñadores del sistema. Un segundo problema se refiere a la ausencia de normas en las situaciones de trabajo que no se han presentado anteriormente ( $R$ asmussen, Duncan y Leplat 1987). Tanto las diferencias de opinión como la falta de normas pueden contribuir por sí mismas a un aumento de los riesgos.

\section{La dimensión temporal}

El tiempo es una dimensión básica en el modelo de desviación. El accidente se analiza como un proceso, y no como un acontecimiento único o como una cadena de factores causales. EI proceso se desarrolla a través de fases consecutivas, de forma que existe una transición de las condiciones normales del sistema industrial a condiciones anómalas o de falta de control. A continuación tiene lugar una pérdida de control de las energías del sistema y se produce el daño o la lesión. En la Figura 56.12 se muestra, en relación con esta transición, un ejemplo de análisis de un accidente, basado en un modelo desarrollado por la U nidad de Investigación de Accidentes de Trabajo (UIAT) de Estocolmo.

\section{El control del accidente como centro de atención}

Cada modelo de accidentes tiene un único centro de atención y su correspondiente estrategia de prevención de accidentes. El modelo de desviación sitúa el centro de atención en la fase inicial de la secuencia del accidente, caracterizada por las condiciones anómalas o falta de control. La prevención de accidentes se lleva a cabo mediante la retroalimentación en los casos en que se utilizan sistemas de información para la planificación de la producción y la gestión del control y la seguridad. El objetivo es lograr una ejecución uniforme de las operaciones, con el menor número posible de interferencias e improvisaciones, para evitar el aumento del riesgo de accidentes.

$\mathrm{H}$ ay que diferenciar las acciones correctivas de las preventivas. La corrección de las desviaciones coincide con el primer orden de retroinformación establecido en la jerarquía de Van $\mathrm{C}$ ourt $\mathrm{H}$ are y no da lugar a un aprendizaje organizativo basado en las experiencias de accidentes ( $H$ are 1967). Las acciones preventivas se llevan a cabo mediante órdenes más elevadas de retroinformación, cuya ejecución requiere aprendizaje. Un ejemplo de este tipo de acciones es la elaboración de instrucciones para desempeñar un trabajo nuevo, basadas en normas comúnmente admitidas sobre métodos de trabajo seguros. 
Figura 56.12 • Análisis de un accidente en una obra de construcción conforme al modelo UIAT.
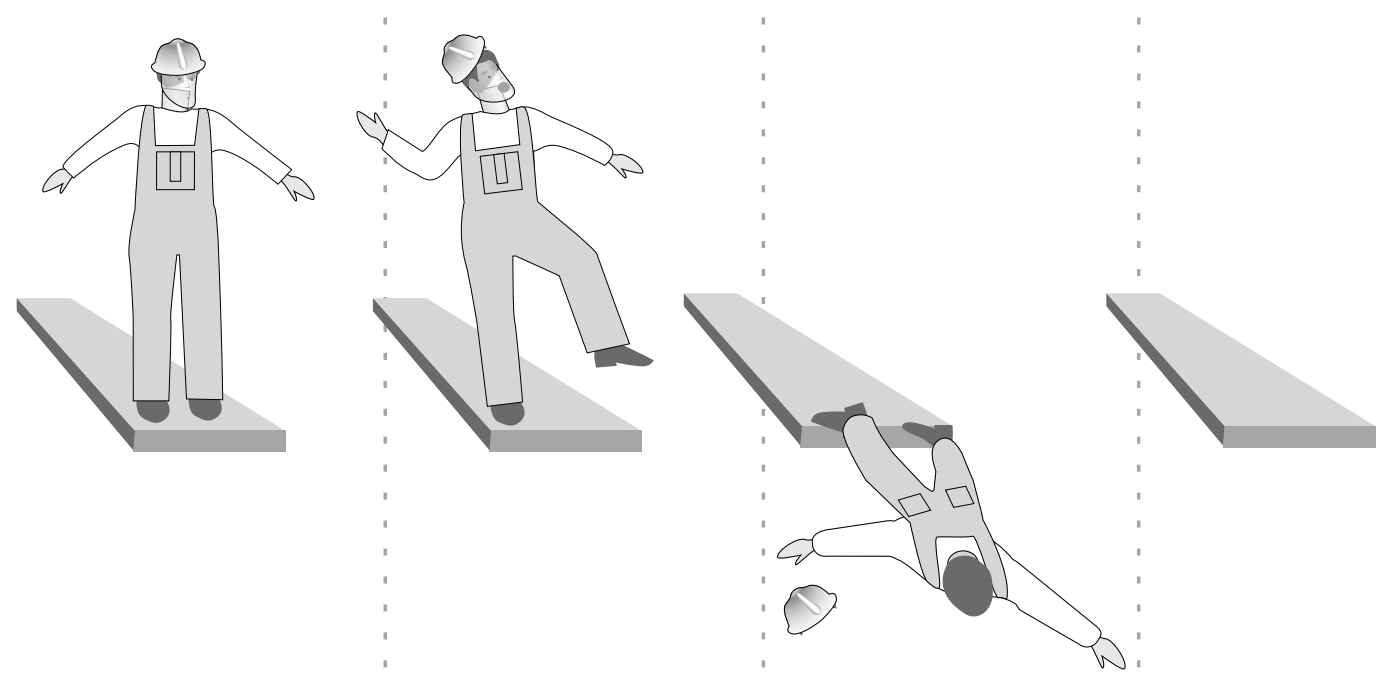

FALTA DE CONTROL
- Ausencia de protección contra
caídas
- Compañero de trabajo enfermo,
sustituido por un aprendiz
- También necesitaban la grúa en
otro sitio
- El trabajador de la construcción
colocó una plancha torcida
- El trabajador avanza por una viga
para volver a poner la plancha en
la posición correcta

PERDIDA DE CONTROL

CUERPO EXPUESTO A LA ENERGIA

El trabajador resbala, pierde el equilibrio...

y cae...

al suelo

Fuente: Kelllén y Hovden 1993.

En general, las acciones preventivas tienen tres objetivos diferentes: a) reducir la probabilidad de desviaciones, b) atenuar las consecuencias de éstas, y c) acortar el tiempo que transcurre entre la desviación y su descubrimiento y corrección.

Para ilustrar sus características, puede compararse el modelo de desviación con el modelo de energía (H addon 1980), que sitúa el centro de atención de la prevención en las últimas fases del proceso del accidente, es decir, en la pérdida de control de las energías y en el daño consiguiente. Lo característico en estos casos es prevenir los accidentes limitando o controlando las energías existentes en el sistema o interponiendo barreras entre las energías y la víctima.

\section{Taxonomías de las desviaciones}

Existen distintas taxonomías para la clasificación de las desviaciones, que han sido desarrolladas para simplificar la recopilación, el procesamiento y la retroalimentación de datos sobre las desviaciones. En la Tabla 56.1 se ofrece un resumen.

Una taxonomía clásica de las desviaciones es la distinción entre "acto peligroso individual" y "condiciones mecánicas 0 físicas peligrosas" (ANSI 1962). En esta taxonomía se combinan la clasificación en función de la duración y la división entre sujeto y objeto. EI modelo UIAT se basa en una visión de los sistemas de ingeniería industrial (K jellén y Hovden 1993) en el que cada tipo de desviaciones se corresponde con un sistema típico de control de la producción. De ahí que, por ejemplo, las desviaciones relacionadas con los materiales de trabajo se controlen mediante el control del material, y que las desviaciones técnicas se controlen mediante procedimientos de inspección y mantenimiento. Los mecanismos de protección permanentes suelen controlarse mediante inspecciones de seguridad. Las desviaciones correspondientes a la pérdida de control de las energías se clasifican según los distintos tipos de ésta (Haddon 1980). Se establece asimismo una distinción entre los fallos en los sistemas humanos y en los técnicos destinados al control de las energías (K jellén y H ovden 1993).

\section{La validez del concepto de desviación}

No existe una relación general entre las desviaciones y el riesgo de lesión. No obstante, los resultados de las investigaciones al respecto indican que ciertos tipos de desviaciones están asociados a un aumento del riesgo de accidentes en algunos sistemas industriales (K jellén 1984). Se incluyen aquí los equipos defectuosos, las perturbaciones de la producción, la irregularidad de las cargas de trabajo y la utilización de herramientas con fines poco habituales. En función del tipo y la cantidad de energía que queda fuera de control, las consecuencias pueden predecirse con bastante precisión. 
Figura 56.13 - Alcance de diferentes instrumentos utilizados en la práctica de la seguridad.

INSPECCIONES DE SEGURIDAD

MUESTREOS DE SEGURIDAD

PARTES DE CUASIACCIDENTES

INVESTIGACIONES DE ACCIDENIIES

\section{Aplicación del modelo de desviación}

Los datos sobre desviaciones se recopilan en las inspecciones y muestreos de seguridad, en los partes de cuasiaccidentes y en las investigaciones de accidentes (véase la Figura 56.13).

El muestreo de seguridad es un método de control de las desviaciones respecto de las normas de seguridad basado en la oferta de información a los trabajadores obtenida del estudio de su actividad. Se han observado efectos positivos de esta técnica sobre el nivel de seguridad, medido en función del riesgo de accidentes (Saari 1992).

EI modelo de desviación se ha aplicado a la construcción de herramientas de investigación de accidentes. En el método de

Tabla 56.1 - Ejemplos de taxonomías para la clasificación de desviaciones.

$\begin{array}{ll}\begin{array}{l}\text { Teoría o modelo y variable } \\ \text { Modelo de proceso } \\ \text { Duración } \\ \text { Fase de la secuencia del accidente }\end{array} & \begin{array}{l}\text { Clases } \\ \text { Fase inicial, fase final, fase de la } \\ \text { lesión }\end{array} \\ \begin{array}{l}\text { Teoría de sistemas } \\ \text { Sujeto-objeto }\end{array} & \begin{array}{l}\text { (Acto) individual, condiciones mecánicas o } \\ \text { físicas } \\ \text { Individuo, tarea, equipo, ambiente }\end{array} \\ \begin{array}{l}\text { Ergonomía de sistemas } \\ \text { Ingeniería industrial }\end{array} & \begin{array}{l}\text { Materiales, fuerza de trabajo, información, } \\ \text { actividades técnicas, humanas, concurren- } \\ \text { tes y paralelas, mecanismos de protec- } \\ \text { ción permanentes, equipos de protección } \\ \text { individual }\end{array}\end{array}$

Errores humanos

Acciones humanas

Modelo de energía

Tipo de energía

Tipo de sistema de control de la energía

Consecuencias

Tipo de pérdida

Alcance de la pérdida

Omisión, acción, actos extraños, error secuencial, error de tiempo

Térmica, de radiación, mecánica, eléctrica, química

Técnico, humano

Pérdida de tiempo insignificante, degradación de la calidad del producto, daños a los equipos, pérdidas materiales, contaminación ambiental, lesiones personales

Despreciable, marginal, crítica, catastrófica análisis de los factores incidentales, las desviaciones observadas en la secuencia de un accidente se identifican y disponen en una estructura lógica en forma de árbol (Leplat 1978). El modelo UIAT ha servido de base para el diseño de formularios y listas de control para la investigación de los accidentes y la estructuración de los procedimientos de esa investigación. Los estudios de evaluación han puesto de manifiesto que este tipo de métodos ayuda a describir y valorar las desviaciones de forma más fiable y completa (véase K jellén y Hovden 1993 para su revisión). El modelo de desviación ha inspirado asimismo el desarrollo de métodos de análisis de riesgos.

EI análisis de desviaciones es un método de análisis de riesgos y consta de tres etapas: 1) resumen de las funciones del sistema y de las actividades de sus operarios, agrupándolas en subsecciones; 2) estudio de las distintas actividades para determinar las posibles desviaciones y valorar sus consecuencias potenciales, y 3) desarrollo de soluciones ( $\mathrm{H}$ arms-R ingdahl 1993). El proceso del accidente se estructura tal como se muestra en la Figura 56.12, y el análisis del riesgo cubre las tres etapas. Se utilizan listas de control parecidas a las empleadas en la investigación de accidentes. Es posible incorporar este método a las tareas de diseño; de este modo, es más eficaz en la determinación de las necesidades de acciones paliativas.

\section{Resumen}

L os modelos de desviación se ocupan de la fase inicial del proceso de accidente, en la que se producen perturbaciones en la operación. La prevención se consigue mediante el control basado en la retroinformación, con el fin de lograr un funcionamiento uniforme en el que se minimizan las interferencias y las improvisaciones que pueden dar lugar a un accidente.

\section{EL MAIM: MODELO DE INFORMACION DE ACCIDENTES DE MERSEYSIDE}

H arry S. Shannon y John Davies

En general, el término accidente se utilizar para hacer referencia a acontecimientos que dan lugar a una lesión o un daño físico no deseado o imprevisto; un modelo de accidente es una estructura conceptual aplicada al análisis de estos acontecimientos. En algunos modelos puede afirmarse explícitamente que los "cuasiaccidentes" (en ocasiones denominados "cuasierrores") también son tenidos en cuenta; con todo, esta distinción no es importante en el presente artículo. Los modelos de accidente pueden servir a distintos fines. Pueden ofrecer una explicación conceptual del modo en que ocurren los accidentes, sirven para

Fuente: Kjellén 1984 
registrar y almacenar información sobre los accidentes y pueden ser un mecanismo para su investigación. Esos tres objetivos no son muy distintos entre sí, aunque constituyen un medio de clasificación útil.

En este artículo se describe el M odelo de Información de Accidentes de $M$ erseyside (M erseyside Accident Information $M$ odel, MAIM), que, por sus características, responde más adecuadamente al segundo de los objetivos citados, registrar y almacenar información sobre los accidentes. Siguiendo esquemáticamente un análisis fundamentado del M AIM, se describen algunos estudios iniciales en los que se evalúa el modelo. El artículo finaliza con la referencia a los últimos avances del MAIM, incluida la utilización de "software inteligente" para recopilar y analizar información sobre accidentes con lesiones.

\section{Primeros modelos de accidente}

En el modelo de Heinrich (1931), la secuencia causal que da lugar a un accidente se equiparó con una sucesión de cinco fichas de dominó que caen unas sobre otras, siendo necesarias las cuatro primeras para que se produzca el acontecimiento final. En un trabajo que puede considerarse precursor del MAIM, M anning (1971) estableció que "el requisito básico para que se de una lesión por accidente es que exista un sujeto receptor (un trabajador, por ejemplo) y un objeto del entorno que contribuya al accidente. El objeto, el sujeto 0 ambos se mueven el uno respecto del otro". K jellén y Larsson (1981) desarrollaron su propio modelo, en el que se planteaban dos niveles: la secuencia de accidente y los factores determinantes subyacentes. En un trabajo posterior, K jellén y Hovden (1993) describieron avances posteriores alcanzados en otras publicaciones y señalaron la necesidad de una "utilización eficaz de la información existente obtenida de los partes rutinarios de accidentes y cuasiaccidentes, mediante el recurso a un potente sistema de recuperación de información". EI MAIM ha atendido esa necesidad.

\section{Fundamento del MAIM}

Parece existir una aceptación general de la idea de que la información sobre accidentes útil no debe limitarse a las circunstancias inmediatas del daño o la lesión, sino que debe extenderse también a la cadena precedente de acontecimientos y a los factores que determinan la existencia de la secuencia del accidente. Sin embargo, algunos de los primeros sistemas de clasificación no cumplían este requisito; los objetos, los movimientos (de las personas o de las cosas) y los acontecimientos solían mezclarse y no se distinguía entre acontecimientos sucesivos.

Un ejemplo sencillo puede ilustrar este problema. Un trabajador resbala en una mancha de aceite, cae, se golpea la cabeza contra una máquina y sufre una conmoción. En este caso, es fácil distinguir entre la causa previa (inmediata) del accidente (haber resbalado con el aceite) y la causa de la lesión (golpearse la cabeza contra la máquina). No obstante, algunos sistemas de clasificación comprenden categorías como "caída de personas" y "golpes contra objetos". El accidente podría incluirse en cualquiera de ambas clases, aun cuando ninguna describa siquiera la causa inmediata del accidente (resbalar con el aceite) ni los factores causales (como la razón por la que había aceite en el suelo).

En esencia, el problema consiste en que se considera únicamente un factor, cuando deberían ser muchos. U n accidente no siempre consiste en un solo acontecimiento; puede haber muchos. De estas observaciones partió el Dr. Derek M anning, médico del trabajo, para desarrollar el M AIM.

\section{Descripción del MAIM}

El elemento central de un accidente es el primer acontecimiento imprevisto (no deseado 0 no planeado), en el que interviene el equipo dañado o la persona lesionada (Figura 56.14). Tal acontecimiento no es siempre el primero en el proceso del accidente denominado acontecimiento precedente. En el ejemplo anterior, el resbalón se considera el primer acontecimiento imprevisto del accidente. (D ada la presencia de manchas de aceite en el suelo, no es imprevisible que alguien resbale con una y se caiga, pero la persona que viene andando no lo prevé.)

El comportamiento del equipo o de la víctima se describe en función de la actividad general que estuviera realizando en el momento de la lesión y de la descripción más detallada del movimiento corporal desarrollado en el instante en que ocurrió el primer acontecimiento. Se describen asimismo los objetos presentes y, en el caso de los que además están relacionados con los acontecimientos, se indican sus características, incluidas su posición, movimiento y condición. En ocasiones, puede intervenir un segundo objeto interrelacionado con el primero (por ejemplo, si se golpea un cincel con un martillo).

Como se ha indicado, puede haber más de un acontecimiento y es posible que el segundo acontecimiento incluya también un objeto (tal vez diferente). Además, el equipo o la víctima puede haber realizado un segundo movimiento corporal, como el de intentar agarrarse a algo para evitar la caída. Todo estos elementos se incorporan al modelo. Puede haber también un tercer acontecimiento, y otros posteriores, antes de que termine la secuencia que da lugar a la lesión. Es posible ampliar el modelo en todas las direcciones, incorporando factores relacionados con cada componente. Por ejemplo, en las ramas que nacen de

Figura 56.14 • El modelo de accidente MAIM.

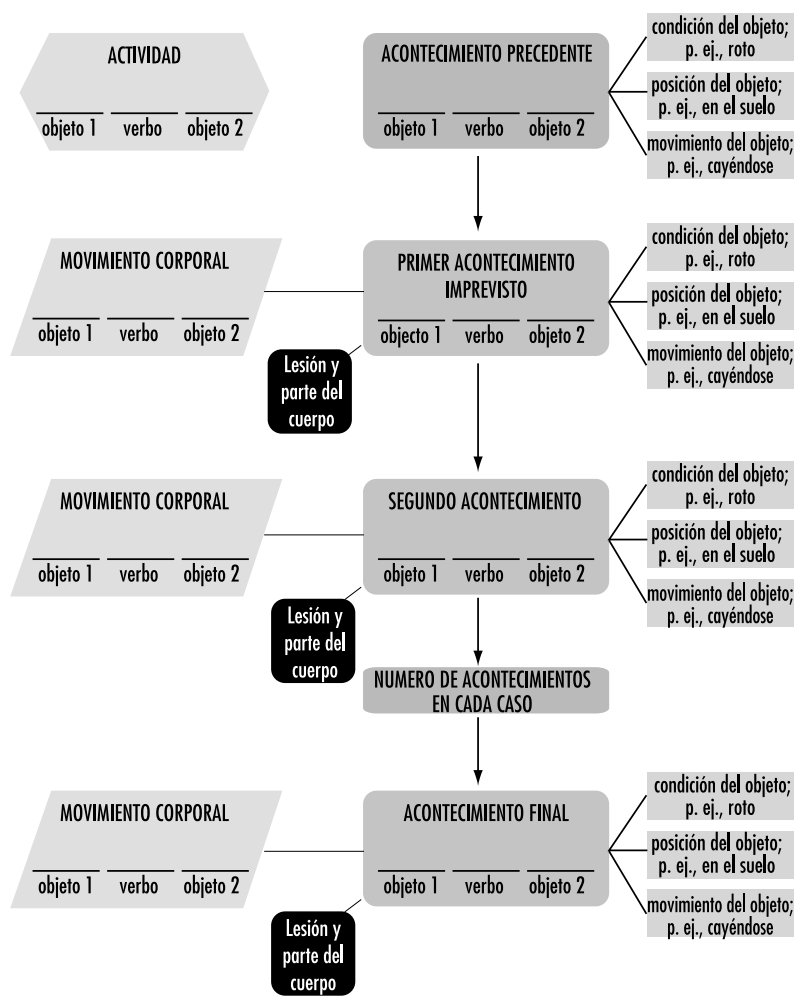

Fuente: Basado en Davies y Manning 1994b. 
"actividades" y de "movimientos corporales" podrían registrarse los factores psicológicos, las medicaciones y las limitaciones físicas de un trabajador.

En general, es fácil diferenciar de forma intuitiva los distintos acontecimientos, pero puede ser útil una definición más estricta: un acontecimiento es un cambio inesperado, o la ausencia de éste, en las condiciones energéticas de una situación. (Por energía se entiende tanto energía cinética como energía potencial). El primer acontecimiento siempre es inesperado; los siguientes pueden ser previsibles, incluso inevitables, una vez que el primero ha ocurrido, pero siempre son inesperados antes del accidente. Un ejemplo de ausencia de cambio de energía inesperada es el de un martillo que golpea sobre un clavo y falla el golpe. El ejemplo antes citado de una persona que resbala con una mancha de aceite, cae y se golpea la cabeza puede servir de ilustración. El primer acontecimiento es: "el pie resbala" (en lugar de permanecer fijo, el pie adquiere energía cinética). El segundo: "la persona cae", y en él se adquiere aún más energía cinética. La energía es absorbida por el golpe de la cabeza contra la máquina, momento en el que ocurre la lesión y finaliza la secuencia. He aquí cómo puede ajustarse la sucesión al modelo:

1. $1^{\mathrm{er}}$ acontecimiento: el pie resbaló con el aceite.

2. 2acontecimiento: la persona se cayó.

3. $3^{\text {er }}$ acontecimiento: la cabeza golpeó contra la máquina.

\section{Experiencia con el MAIM}

U na de las primeras versiones del modelo se utilizó para realizar un estudio de los 2.428 accidentes de los que se dio parte en 1973 en una fábrica de cajas de cambio, situada en las instalaciones de una empresa de automóviles (para más información, véase Shannon 1978). L as operaciones eran cortar y pulir los engranajes, someterlos a un tratamiento térmico y montar las cajas de cambio. En el proceso de corte se producen virutas y recortes de metal muy afilados y se utiliza aceite como refrigerante. La información se recopiló mediante unos formularios especialmente destinados al efecto. Dos personas procedieron, por separado, a registrar cada accidente según el modelo, resolviéndose después las diferencias mediante el análisis conjunto. Se asignaron códigos numéricos a los distintos componentes de cada accidente, para almacenar los datos en un ordenador y proceder al análisis. A continuación se refieren algunos resultados básicos y se examinan las enseñanzas específicas extraídas del uso del modelo.

La tasa de accidentes se redujo de manera sustancial (casi en un $40 \%$ ), al parecer, como resultado de la realización del estudio. Se indicó a los investigadores que, puesto que había que responder a otras preguntas y eso llevaba tiempo, "no podía molestarse" a muchos trabajadores para que dieran parte de pequeñas lesiones. Algunos datos confirmaron esta observación:

1. La tasa subió de nuevo en 1975 , una vez finalizado el estudio.

2. La tasa de lesiones con baja no varió.

3. L as consultas efectuadas en el centro médico por motivos no laborales no varió.

4. Las tasas de accidentes en el resto de las instalaciones no variaron.

Por lo tanto, parece que la reducción de la tasa no fue sino una consecuencia del proceso de recopilación de información.

0 tra conclusión interesante fue que se observaron 217 casos de lesión (8 \%) cuyas víctimas no podían asegurar cómo 0 cuándo habían ocurrido, lo cual se descubrió preguntando explícitamente a los lesionados si estaban seguros de lo que había sucedido. La mayor parte de estas lesiones fueron cortes 0 rasguños, relativamente comunes habida cuenta del tipo de trabajo realizado en la fábrica.

Del resto de los accidentes, casi la mitad (1.102) se debieron a un único acontecimiento. Los provocados por dos o tres fueron reduciéndose gradualmente, y sólo 58 se debieron a cuatro 0 más acontecimientos. EI porcentaje de accidentes con baja aumentó de forma proporcional al incremento del número de acontecimientos. U na posible explicación es que la energía cinética aumenta con cada acontecimiento, de manera que, al elevarse el número de éstos, aumenta la cantidad de energía disipada al entrar el objeto en colisión con la víctima.

De hecho, un estudio posterior de las diferencias entre los accidentes con y sin baja puso de manifiesto diferencias muy marcadas en la distribución correspondiente a los distintos elementos del modelo. Por ejemplo, cuando el primer acontecimiento era "la persona resbala", casi la cuarta parte de los accidentes daban lugar a una baja, mientras que si era "el cuerpo recibe una punzada", la proporción se reducía al $1 \%$. Y si se daban varios componentes, las diferencias se acentuaban. Por ejemplo, si tomamos los acontecimientos finales y los objetos relacionados con ellos, se observa que ninguno de los 132 accidentes en los que la víctima "recibió una punzada" o "se cortó con viruta" dio lugar a una baja, pero cuando el acontecimiento final fue "torcedura o deformación" y no hubo "ningún objeto implicado", el $40 \%$ de las lesiones dieron lugar a baja.

Son resultados que contradecían la opinión de que la gravedad de la lesión es en gran medida una cuestión de suerte y de que la prevención de todo tipo de accidentes daría lugar a la reducción de las lesiones graves. Lo cual significa que el análisis del conjunto de accidentes y el intento de prevenir los tipos más comunes no habría de influir necesariamente en aquéllos que producen lesiones graves.

Se realizó un estudio complementario para evaluar la utilidad de la información en el modelo. Se definieron varios usos posibles de los datos sobre accidentes:

- Medir los resultados de las acciones adoptadas en materia de seguridad, es decir, el grado en que los accidentes ocurridos en una instalación, o en una zona de ella, continúan ocurriendo a lo largo del tiempo.

- Identificar las causas.

- Identificar los errores (en el más amplio sentido del término).

- Verificar controles, es decir, comprobar si las medidas de seguridad adoptadas para evitar algún tipo de accidentes son realmente eficaces

- Facilitar el conocimiento de orden práctico, ya que el conocimiento sobre muchas situaciones y circunstancias de accidentes podría ayudar a prestar servicios de asesoramiento para su prevención.

Tres agentes de seguridad (profesionales) calificaron la utilidad de las descripciones verbales y de los modelos registrados para varios accidentes (al menos 75 cada uno), en una escala de 0 (ninguna información útil) a 5 (información perfectamente adecuada para su uso). En la mayoría de los accidentes, las calificaciones fueron idénticas; es decir, no se había perdido ninguna información al transcribir las descripciones escritas al modelo. En la mayor parte de los casos en los que hubo pérdida de información, se cifró en un solo punto en la escala de 0 a 5 , es decir, una pérdida pequeña.

C on todo, pocas veces se calificó la información de "perfectamente adecuada". En parte se debe a que los agentes de seguridad estaban acostumbrados a realizar investigaciones detalladas en el lugar mismo donde ha ocurrido el suceso, algo que en este estudio no se había hecho, ya que se incluyeron todos los accidentes de los que se había dado parte, los graves y los menos graves. Cabe recordar, sin embargo, que 
la información registrada en los modelos se había extraído directamente de las descripciones por escrito. D ebido a la escasa cuantía de la información "perdida", cabía la posibilidad de suprimir el paso intermedio. La generalización del uso de los ordenadores personales y la mejor calidad del software permiten una recopilación de datos automatizada y el uso de listas de control para garantizar que se obtiene toda la información pertinente. Se ha elaborado un programa a este efecto, del que ya se han realizado algunas pruebas iniciales.

\section{El software inteligente del MAIM}

Troup, Davies y M anning (1988) utilizaron el M AIM para llevar a cabo una investigación sobre los accidentes que provocan lesiones de espalda. Se creó una base de datos en un ordenador personal IBM, codificando los resultados obtenidos mediante entrevistas a pacientes realizadas por un experto en este modelo. A simismo, él analizó las entrevistas para obtener las descripciones según el M AIM (Figura 56.14), y fue en esta fase cuando se incorporó la información a la base de datos. Aunque el método resultó bastante satisfactorio, se observaron posibles problemas al generalizar el acceso al mismo. En concreto, se necesitaban dos tipos de conocimientos de orden práctico: cualificaciones para entrevistar y conocimiento del análisis necesario para elaborar la descripción del accidente según el M AIM

Davies y M anning (1994a) crearon un software para realizar entrevistas a los pacientes y elaborar una base de datos de accidentes utilizando el MAIM. El objetivo de estos programas informáticos era cubrir dos áreas de conocimientos de orden práctico, la entrevista y el análisis, a fin de construir la estructura de acontecimientos del MAIM. De hecho, el software del MAIM constituye el "escaparate" inteligente de una base de datos, y en 1991 ya estaba lo bastante desarrollado para someterlo a prueba en un entorno clínico. Se trata de un software interactivo, que se comunica con el paciente por medio de menús; éste selecciona opciones de unas listas, que exigen únicamente la utilización de las teclas del cursor y la de "Intro". La elección de una entre las distintas opciones determina, en cierta medida, el curso posterior de la entrevista y permite registrar la información en la parte pertinente de la descripción del accidente según el MAIM. Con este método de recopilación de datos se evitaba la necesidad de escribir bien o de saber mecanografía, y hacía la entrevista susceptible de repetición además de coherente.

En la estructura de acontecimientos del modelo MAIM se utilizan verbos y objetos para construir frases sencillas. LoS verbos en los acontecimientos pueden asociarse con diferentes escenarios de accidente, y esta posibilidad del modelo constituye la base para la elaboración de un conjunto de preguntas relacionadas con él que configuran la entrevista. L as preguntas se plantean de manera que en todas las fases sólo sea necesario efectuar una elección sencilla, con lo que la complejidad del accidente como un todo se descompone en un conjunto de descripciones sencillas. U na vez identificado el verbo de un acontecimiento, se asocian a él los substantivos correspondientes, mediante la localización de los objetos, hasta construir la frase que ofrece la descripción completa del acontecimiento en cuestión. O bviamente, esta técnica requiere la utilización de un amplio diccionario de objetos en el que pueda realizarse una búsqueda rápida y eficaz.

El Home Accident Surveillance System (HASS) (Departamento de Comercio e Industria 1987) controla los objetos que intervienen en los accidentes. El diccionario del software del M AIM se basó en la relación de objetos empleada por el H ASS, a lo que se añadieron los objetos de uso en los lugares de trabajo.
Figura 56.15 • Resumen de un accidente registrado en una entrevista con el paciente.

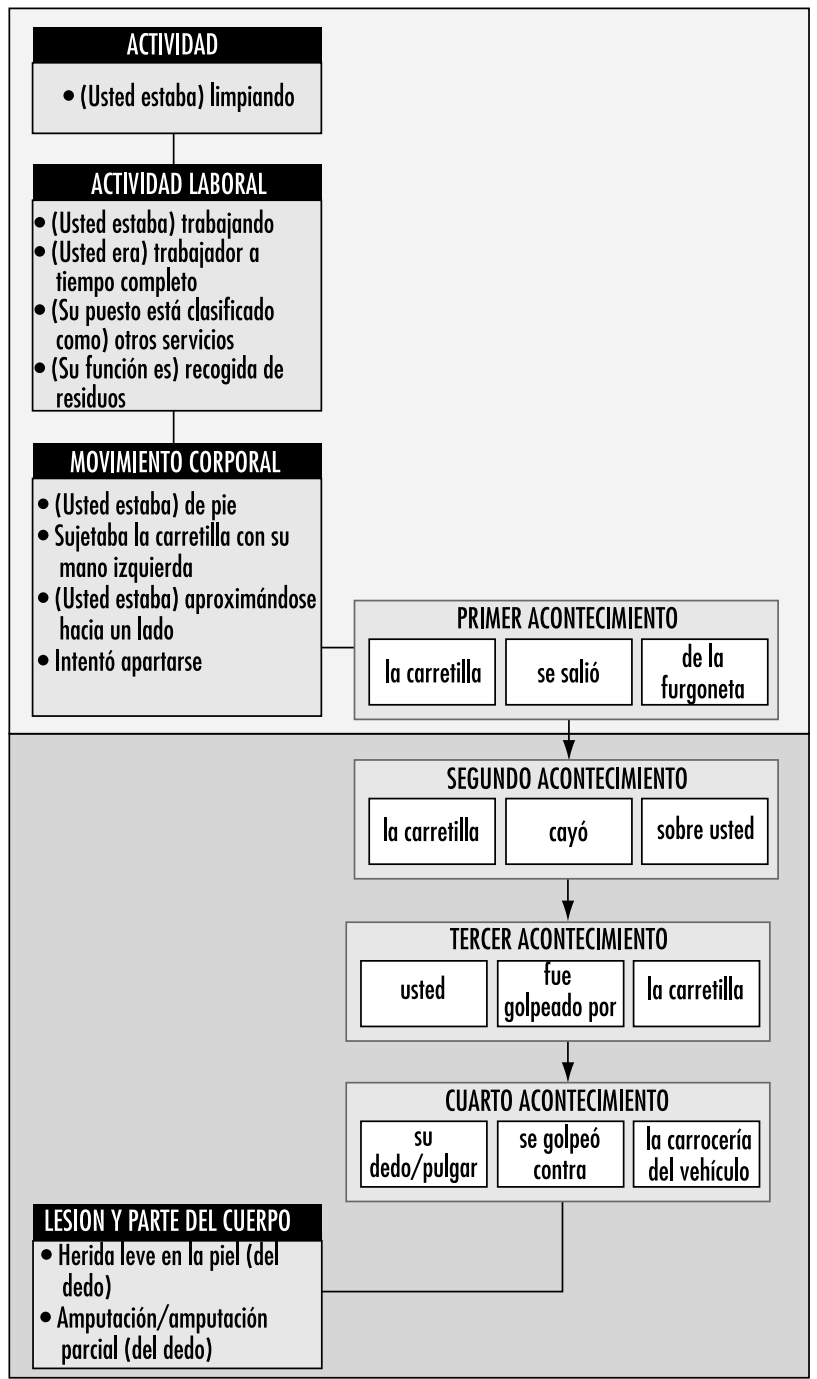

Fuente: Basado en Davies y Manning 1994b.

Los objetos pueden agruparse en clases, lo que permite definir una jerarquía de menús, en la que estas clases son niveles que se corresponden con listas del menú. Así pues, una lista estructurada de objetos asociados puede utilizarse para localizar artículos concretos; por ejemplo, el objeto martillo puede encontrarse seleccionando, por orden: a) herramientas, b) herramientas manuales, y c) martillo en tres listas de menú sucesivas. U n objeto determinado puede estar clasificado en varios grupos diferentes; por ejemplo, un cuchillo se asocia con artículos de cocina, con herramientas o con objetos cortantes. De manera que existen referencias repetidas en el diccionario de objetos, lo que permite encontrar el elemento a través de muchas vías de acceso diferentes. El diccionario de objetos tiene en la actualidad un vocabulario de unas 2.000 entradas, referentes al entorno laboral y de ocio.

En la entrevista del MAIM también se recopila información sobre las actividades en el momento del accidente, los movimientos corporales, el lugar en el que ocurrió el accidente, los factores que contribuyeron al mismo, las lesiones y las incapacidades. Todos estos elementos pueden darse más de una vez en 
cada accidente, posibilidad que queda reflejada en la estructura de la base de datos relacional utilizada para registrar el accidente.

Al final de la entrevista se han registrado varias frases en las que se describen los acontecimientos del accidente; se pide entonces al paciente que las coloque en el orden correcto y que relacione las lesiones con los acontecimientos archivados. A continuación, aparece en pantalla un resumen informativo de todos los datos recopilados.

En la Figura 56.15 se ofrece un ejemplo de resumen de un accidente, tal como lo ve el paciente. Los datos de este accidente se han superpuesto en el diagrama ajustado al MAIM de la Figura 56.15. Se han omitido los detalles sobre los factores y la localización del accidente.

El primer acontecimiento imprevisto o involuntario (primer acontecimiento) en el que participa la persona lesionada suele ser el primero en la secuencia del accidente; por ejemplo, si una persona resbala y cae, el resbalón es normalmente el primer acontecimiento del accidente. Por otra parte, si una persona resulta lesionada por una máquina, debido a que otra persona la ha puesto en marcha antes de darle tiempo a retirarse, el primer acontecimiento en el que participa el herido es "la máquina le atrapa", cuando, en realidad, es "otra persona pone en funcionamiento la máquina antes de tiempo". En el software del M AIM se registra el primer acontecimiento del accidente, ya sea el primero de los que afectan a la víctima u otro previo (Figura 56.14). Teóricamente, este enfoque resulta insatisfactorio, pero no desde el punto de vista de la prevención de accidentes, ya que se identifica el inicio de su secuencia, y puede ser objeto de análisis para evitar accidentes similares en el futuro. (Algunos autores utilizan la expresión acción de desviación para referirse al comienzo de la secuencia del accidente, pero aún no está claro que éste y el primer acontecimiento que lo desencadena coincidan siempre).

Cuando se utilizó el software del MAIM por primera vez en un centro hospitalario, se observó que existían problemas para estimar correctamente algunos tipos de accidente que afectan a la región situada "por debajo de los pies". EI MAIM identifica el primer acontecimiento imprevisto con el punto de inicio de la secuencia del accidente. Ahora bien, tomemos dos accidentes similares, uno en el que el paciente pisa intencionadamente un objeto y éste se rompe, y otro en el que el paciente pisa involuntariamente un objeto, que también se rompe. En el primer caso, el acto de pisar el objeto es un movimiento corporal y el primer acontecimiento imprevisto es la ruptura del objeto. En el segundo accidente, el acto de pisar el objeto es ya el primer acontecimiento imprevisto. Para diferenciar estos dos supuestos, hay que plantear la pregunta: "¿Pisó usted algo accidentalmente?". Es un ejemplo que demuestra la importancia de una elaboración correcta de las entrevistas para que los datos obtenidos sean precisos. El análisis de estos dos accidentes permite formular las siguientes recomendaciones para evitar su repetición: el primer accidente podría haberse evitado haciendo saber al paciente que el objeto se rompería; el segundo, informándole de que el objeto constituía un peligro bajo sus pies.

El software del MAIM se ha probado con éxito en tres centros hospitalarios; en una de las ocasiones, en el marco de un proyecto de un año de duración realizado en el Departamento de Accidentes y U rgencias del Hospital Real Universitario de Liverpool. Las entrevistas con los pacientes duraron de cinco a quince minutos y se entrevistó a un promedio de dos pacientes por hora. Se registraron en total 2.500 accidentes. En la actualidad se prepara la publicación de trabajos basados en estos datos.

\section{PRINCIPIOS DE LA PREVENCION: EL PLANTEAMIENTO DE LA SANIDAD PUBLICA RESPECTO A LA REDUCCION DE LAS LESIONESEN EL LUGAR DE TRABAJO}

Gordon S. Smith y M ark A. Veazie

EI planteamiento de la sanidad pública respecto a la prevención de las lesiones profesionales se basa en el supuesto de que éstas constituyen un problema de salud y, como tal, puede optarse por su prevención o por la atenuación de sus consecuencias (0 ccupational Injury Prevention Panel 1992; Smith y Falk 1987; Waller 1985). Cuando un trabajador se cae de un andamio, el daño en los tejidos, la hemorragia interna, la conmoción y la muerte que siguen al percance constituyen, por definición, un proceso de enfermedad y, por la misma razón, una preocupación para los profesionales de la sanidad pública. Al igual que la malaria se define como una enfermedad cuyo agente causal es un protozoo específico, las lesiones representan una familia de trastornos provocados por la exposición a una determinada forma de energía (cinética, eléctrica, térmica, de radiación o química) (National Committee for Injury Prevention and Control 1989). El ahogamiento, la asfixia y la intoxicación se consideran asimismo lesiones porque representan una desviación relativamente rápida respecto a la norma estructural o funcional del cuerpo, al igual que el trauma agudo.

C omo problema de salud, las lesiones representan la primera causa de muerte prematura (es decir, producida antes de los 65 años de edad) en la mayoría de los países (Smith y Falk 1987; Baker y cols. 1992; Smith y Barss 1991). En Estados U nidos, por ejemplo, las lesiones son la tercera causa más importante de muerte tras las enfermedades cardiovasculares y el cáncer, la primera causa de hospitalización de personas menores de 45 años y supusieron una carga económica de 158.000 millones de dólares en costes directos e indirectos en 1985 (R ice y cols. 1989). U na de cada tres lesiones no mortales y una de cada seis de las mortales en la población en edad de trabajar de Estados Unidos se producen en el puesto de trabajo (Baker y cols. 1992). En la mayoría de los países desarrollados se registran cifras semejantes (Smith y Barss 1991). En los países de renta media y baja, un ritmo de industrialización rápido y relativamente desregulado puede dar a lugar a una pandemia muy extendida de lesiones profesionales.

\section{Modelos de la sanidad pública para el control de las lesiones}

La práctica tradicional de la seguridad en el lugar de trabajo suele ocuparse sobre todo de reducir al mínimo los riesgos y las pérdidas en cada empresa. Los profesionales de la sanidad pública dedicados al control de las lesiones profesionales no sólo se interesan por centros de trabajo específicos, sino también por la mejora del estado de salud de la población en áreas geográficas que pueden verse expuestas a los riesgos asociados con numerosos sectores y profesiones. Algunos sucesos, como los fallecimientos en el lugar de trabajo, pueden ser poco habituales en una fábrica en concreto, pero el estudio del total de muertes ocurridas en una comunidad puede facilitar la determinación de las pautas de riesgo y la formulación de principios de prevención.

La mayoría de los modelos de práctica de la sanidad pública se basan en tres elementos: a) valoración, b) desarrollo de estrategias de prevención, y c) evaluación. La práctica suele tener un carácter interdisciplinario y basarse en la aplicación de la 
ciencia de la epidemiología, que es el estudio de la distribución y los determinantes de las enfermedades y las lesiones en una población. Sus tres aplicaciones principales son: la vigilancia, la investigación etiológica y la evaluación.

L a vigilancia es "la recogida, análisis e interpretación continuos y sistemáticos de datos sobre salud en el proceso de descripción y seguimiento de un suceso sanitario. La información se utiliza para planificar, aplicar y evaluar las intervenciones y los programas de sanidad pública" (CDC 1988).

La investigación etiológica permite comprobar las hipótesis referentes a los determinantes de las enfermedades y las lesiones mediante la utilización de estudios controlados, normalmente basados en la observación.

La evaluación, tanto en las ciencias sociales aplicadas como en la epidemiología, es "un proceso con el que se pretende determinar del modo más sistemático y objetivo posible la importancia, la eficacia y la repercusión de las actividades, teniendo en cuenta sus objetivos" (Last 1988). La evaluación epidemiológica suele exigir la utilización de diseños de estudio controlados para medir los efectos de una intervención en la existencia de sucesos relacionados con la salud en una población.

EI modelo básico de práctica de la sanidad pública se describe como un ciclo de vigilancia epidemiológica, estudio de las causas, intervención (dirigida a las poblaciones de alto riesgo y específica de enfermedades graves) y evaluación epidemiológica. Entre las modificaciones importantes de este modelo figuran la asistencia primaria orientada a la comunidad (Tollman 1991), la educación sanitaria y la promoción de la salud basadas en la comunidad (Green y K reuter 1991), el desarrollo de la sanidad comunitaria (Steckler y cols. 1993), la investigación de la acción participativa (Hugentobler, Israel y Schurman 1992) y otras formas de sanidad pública centradas en las comunidades que dependen de una mayor participación de éstas y de la población activa (no de los funcionarios públicos y los directivos de empresas) para definir problemas, elaborar soluciones y evaluar su eficacia. Las explotaciones familiares agrícolas, pesqueras y de caza, el trabajo por cuenta propia, muchas pequeñas empresas y las actividades económicas informales se ven influidos en gran medida por los sistemas familiares y comunitarios y se desarrollan fuera del contexto del sistema de gestión industrial. La práctica de la sanidad pública de orientación comunitaria constituye un planteamiento especialmente viable para ocuparse de la prevención de las lesiones profesionales en estas poblaciones.

\section{Resultados de interés}

El planteamiento de la sanidad pública respecto a la seguridad en el lugar de trabajo oscila entre el concepto de prevención de accidentes y un enfoque más amplio del control de lesiones, en el que los principales resultados de interés son la existencia y la gravedad de la lesión. Esta se define como un daño físico debido a la transferencia de energía. U na transferencia de energía mecánica puede provocar un trauma, como en los casos de una caída o un accidente de automóvil. La energía térmica, química, eléctrica o de radiación puede provocar quemaduras y otras lesiones (R obertson 1992). Para los profesionales de la sanidad pública no sólo es de interés la lesión en sí, sino también su gravedad y sus consecuencias a largo plazo. La gravedad puede medirse desde distintas perspectivas, como la anatómica (la cantidad y la naturaleza del daño tisular en las diversas zonas del cuerpo), la fisiológica (el grado de proximidad a la muerte del paciente, en función de sus signos vitales), la de la discapacidad, el deterioro de la calidad de vida y los costes directos e indirectos.

Para los epidemiólogos de las lesiones reviste una importancia considerable la gravedad anatómica, que suele medirse mediante la Calificación de lesiones abreviada y la Escala de gravedad de lesiones (M acK enzie, Steinwachs y Shankar 1989). Son medidas que permiten predecir la supervivencia y constituyen un útil indicador de la energía transferida en los sucesos graves, pero no son lo bastante sensibles para distinguir entre niveles de gravedad en los casos de lesiones de menor consideración relativa, pero de muy superior frecuencia, como los esguinces y las torceduras.

Entre las medidas de la gravedad menos útiles, pero más comunes se encuentran los días de baja en el trabajo por lesión. Desde un punto de vista epidemiológico, los días de trabajo perdidos suelen resultar difíciles de interpretar, ya que dependen de una combinación desconocida de discapacidad, demandas del puesto de trabajo, disponibilidad de trabajo alternativo más ligero, políticas aplicadas en el lugar de trabajo, como la concesión de baja laboral por enfermedad, criterios de calificación de las discapacidades y diferencias individuales en cuanto a tolerancia del dolor, la disposición para trabajar a pesar de éste y, posiblemente, los mismos factores que motivan la asistencia al trabajo. Es necesario seguir investigando para desarrollar y validar medidas de la gravedad de las lesiones profesionales más fáciles de interpretar y, en concreto, escalas anatómicas y de discapacidad y medidas del deterioro en las distintas dimensiones de la calidad de vida.

A diferencia de la práctica tradicional en materia de seguridad, la comunidad de la sanidad pública no limita su interés a las lesiones involuntarias ("accidentales") y a los acontecimientos que las originan. Al examinar las causas específicas de muerte en el lugar de trabajo, se observó que, por ejemplo, en Estados U nidos, el homicidio (lesión voluntaria) es la principal causa de muerte en el trabajo en el caso de las mujeres y la tercera más importante en el de los hombres (Baker y cols. 1992; Jenkins y cols. 1993). Son sucesos muy poco habituales en los lugares de trabajo y, por tanto, a menudo se olvida su importancia, como se olvida también que las lesiones en vehículos de motor constituyen la causa principal de fallecimiento en el puesto de trabajo (Figura 56.16). Si se tienen en cuenta estos datos extraídos de la vigilancia, las lesiones y las muertes debidas a la violencia en el lugar de trabajo y a los accidentes con vehículos de motor son prioridades en el planteamiento de la sanidad pública respecto a la prevención de lesiones profesionales en Estados U nidos.

\section{Valoración en la sanidad pública}

La valoración en la sanidad pública constituye un esfuerzo interdisciplinario en el que intervienen la vigilancia, la investigación etiológica y la valoración de necesidades comunitarias y organizativas. El objetivo de la vigilancia de las lesiones es la identificación de las poblaciones de alto riesgo, la determinación de las lesiones con una repercusión significativa en la salud pública, la detección y el seguimiento de las tendencias y la formulación de hipótesis. Los programas de vigilancia pueden recopilar datos sobre las lesiones mortales 0 no, los incidentes que pueden provocar lesiones y la exposición a los riesgos. Entre las fuentes de información para la vigilancia de las lesiones profesionales figuran los proveedores de asistencia sanitaria (hospitales y médicos), los certificados de defunción, los informes de médicos forenses, los informes empresariales remitidos a los departamentos de trabajo 0 sanidad, las agencias encargadas de las indemnizaciones por accidente de trabajo, las encuestas periódicas de empresas y hogares y los registros corporativos. $M$ uchos de estos informes y registros son exigidos por la legislación, pero a menudo ofrecen una información incompleta debido a la falta de cobertura de la totalidad de los trabajadores, los incentivos a la presentación deficiente de informes y la escasa especificidad de los datos sobre lesiones.

En las investigaciones pormenorizadas de incidentes concretos se emplean diversos enfoques que permiten la utilización de opiniones cualificadas para extraer conclusiones sobre 
las causas del suceso y el modo en que podría haberse evitado (Ferry 1988). La acción preventiva suele adoptarse en función de los resultados de incidentes específicos. En cambio, la vigilancia basada en índices generales tiene mayor significación que un incidente aislado. De hecho, parte de la información extraída de investigaciones de accidentes tradicionales puede caracterizarse por una limitada interpretación epidemiológica cuando se agrega para elaborar estadísticas. Por ejemplo, la investigación de accidentes conforme a las directrices de $\mathrm{H}$ einrich (1959) suele generar estadísticas que indican que más de un $80 \%$ de las lesiones profesionales se deben exclusivamente a los actos inseguros. D esde un punto de vista epidemiológico, estas estadísticas son difíciles de interpretar, excepto como una encuesta de juicios de valor y rara vez se tienen en cuenta en la vigilancia basada en índices generales. 0 tros muchos factores de riesgo, como el trabajo por turnos, el estrés en el trabajo, los entornos de trabajo de diseño deficiente, etc., no suelen figurar en los formularios de investigación y, por tanto, no se consideran al examinar las estadísticas sobre causas de lesión.

U no de los fines primordiales de la vigilancia es la determinación de grupos de alto riesgo para orientar adecuadamente la investigación y la prevención. Las lesiones, al igual que las enfermedades infecciosas y crónicas, presentan pautas de riesgo diferenciadas, que varían en función de la edad, el sexo, la raza, la región geográfica, el sector y la profesión (Baker y cols. 1992). Por ejemplo, en Estados U nidos en el decenio de 1980, la vigilancia emprendida por el National Institute for O ccupational Safety and $\mathrm{H}$ ealth (NIOSH) puso de relieve la existencia de loS siguientes grupos de alto riesgo en cuento a la mortalidad provocada por lesiones profesionales: varones; trabajadores de edad avanzada, personas de raza negra, trabajadores en los estados rurales del oeste, actividades relacionadas con el transporte y el traslado de materiales, actividades agrícolas, silvícolas y pesqueras y personal no cualificado (Jenkins y cols. 1993). 0 tro aspecto importante de la vigilancia es la determinación de los tipos de lesiones que se producen con mayor frecuencia y gravedad, como las principales causas externas de muerte por lesión relacionada con el trabajo en Estados U nidos (véase la Figura 56.16). A escala empresarial, problemas como el homicidio y las muertes en accidentes con vehículos de motor son sucesos poco habituales $y$, por tanto, no suelen abordarse en numerosos programas de seguridad tradicionales. Con todo, en los datos de vigilancia nacional, éstos sucesos figuran entre las tres causas principales de fallecimiento por lesión profesional. La valoración de la repercusión de las lesiones no mortales exige la utilización de medidas de la gravedad para obtener interpretaciones significativas. Por ejemplo, las lesiones de espalda constituyen una causa habitual de pérdida de jornadas de trabajo, pero rara vez obligan a la hospitalización.

Los datos de vigilancia aislados no facilitan una valoración completa en la tradición de la sanidad pública. Sobre todo en la práctica de la salud pública de orientación comunitaria, la valoración de necesidades y el diagnóstico comunitario en los que se utilizan encuestas, grupos focales y otras técnicas, son acciones significativas para establecer qué problemas consideran importantes los trabajadores o las comunidades, cuáles son las actitudes, las intenciones y las restricciones generalizadas respecto a la adopción de medidas preventivas y cómo funciona en realidad una organización o una comunidad. Por ejemplo, un programa de seguridad agraria de base comunitaria podría exigir que se determine si los agricultores consideran un problema esencial que los tractores vuelquen, qué limitaciones económicas o temporales pueden impedir la instalación de estructuras de protección y quiénes deben encargarse de la aplicación de la estrategia de intervención (p. ej., una asociación sindical, una
Figura 56.16 • Causas principales de muerte por lesión profesional, Estados Unidos 1980 -1989.

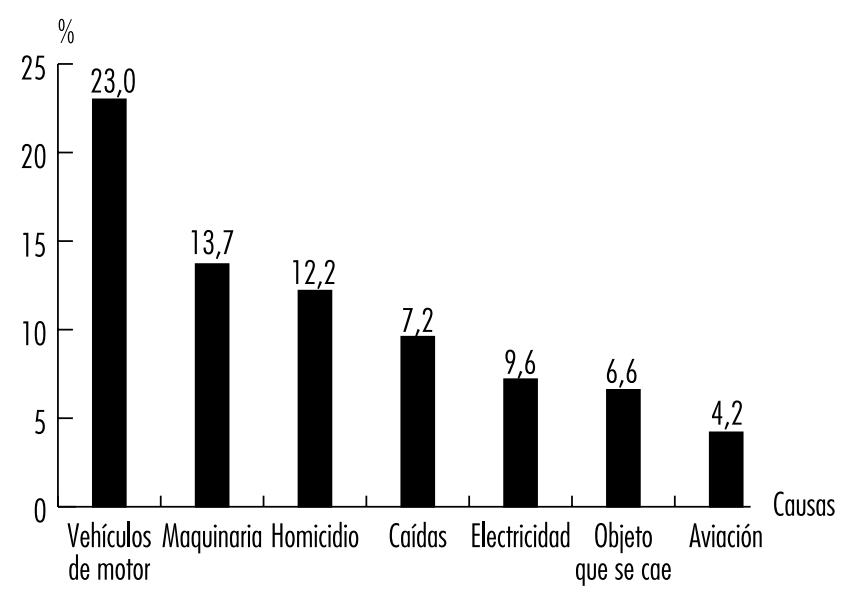

Fuente: Jenkins y colsl. 1993

organización juvenil, una organización de esposas de agricultores). Además del diagnóstico de la comunidad, en la valoración de las necesidades de una organización se determina la capacidad, la carga de trabajo y las restricciones de ésta para aplicar plenamente los programas de prevención preexistentes, como las actividades de ejecución de un departamento público de trabajo (o sanidad) o el departamento de seguridad de una gran empresa.

La investigación de la etiología o la causalidad de los incidentes de pérdida y las lesiones es otra fase en el planteamiento de la sanidad pública respecto al control de las lesiones profesionales. Se trata de estudios de las enfermedades laborales que han servido de base para el desarrollo de programas destinados al control de las mismas en el lugar de trabajo. La investigación etiológica requiere la aplicación de la epidemiología para establecer los factores de riesgo de lesión. Asimismo, exige la intervención de otras ciencias sociales aplicadas para identificar los determinantes de los comportamientos organizativos e individuales que dan lugar a la existencia de condiciones inseguras. Con la investigación epidemiológica se pretende detectar los factores de riesgo modificables mediante la utilización de diseños de estudio controlados normalmente basados en la observación, como los estudios de caso-control, de cohortes, de panel de especialistas y transversales. Como ocurre con los estudios epidemiológicos de otros sucesos de salud agudos (p. ej., ataques de asma, paradas cardíacas repentinas), la investigación etiológica de las lesiones se enfrenta al reto que plantea la necesidad de examinar acontecimientos infrecuentes 0 recurrentes influidos en gran medida por las exposiciones eventuales que se producen inmediatamente antes del suceso (p. ej., distracción por el ruido de un impacto) y por los elementos sociales y del comportamiento que resultan difíciles de medir (p. ej., ambiente de seguridad, tensión en el puesto de trabajo) (Veazie y cols. 1994). Recientemente se han desarrollado métodos epidemiológicos y estadísticos para adaptar el estudio de estos tipos de sucesos de salud.

Los estudios epidemiológicos que se ocupan de la existencia de lesiones son caros y no siempre necesarios. No hace falta un estudio epidemiológico controlado para documentar la repercusión de la ausencia de un mecanismo de protección en las amputaciones debidas a un equipo concreto; bastaría con algunos estudios de caso. Del mismo modo, si un comportamiento 
individual fácilmente mensurable, como la no utilización del cinturón de seguridad, es un factor de riesgo conocido, los trabajos de investigación que se ocupan de los determinantes de este comportamiento y del modo de mejorar las tasas de utilización, son más útiles que el examen de las lesiones resultantes. En todo caso, los estudios epidemiológicos controlados de las lesiones y su gravedad son necesarios para comprender la diversidad de mecanismos causales responsables de las deficiencias de la actuación de las personas y la tecnología, cuya medición es compleja. Por ejemplo, es poco probable que el efecto de la exposición al ruido o el trabajo por turnos sobre el riesgo y la gravedad de las lesiones pueda cuantificarse mediante estudios de caso o de comportamientos de fácil medición.

En una reciente revisión de estudios sobre factores de riesgo de las lesiones profesionales se puso de relieve que la edad, la categoría profesional, las características o deficiencias físicas y la experiencia en el puesto de trabajo o en el desempeño de la tarea eran las variables humanas analizadas más habitualmente (Veazie y cols. 1994). EI trabajo por turnos y la programación de actividades eran las variables relacionadas con el contenido del puesto de trabajo objeto de mayor atención en los estudios, mientras que el entorno de trabajo era la menos abordada. La mayoría de los factores estaban relacionados con características del diseño o con riesgos materiales declarados. En algunos estudios se examinaban los factores asociados a la organización y el entorno social. En otros se evalúaban las causas de estrés físico, como el calor y la exposición al ruido, como factores de riesgo de lesión. M uchos de esos estudios se caracterizaban por una escasa calidad metodológica y pocos se repitieron en poblaciones diferentes. Por tanto, se sabe poco de los factores de riesgo de lesión en el trabajo, salvo en lo que se refiere a las causas inmediatas más obvias. Las investigaciones que se emprendan en el futuro pueden beneficiarse del examen de la repercusión sobre las tasas de lesión de los factores de riesgo considerados por la teoría de los factores humanos, la ergonomía, el estrés en el trabajo y el comportamiento organizativo. Aquí pueden incluirse el diseño y la programación de tareas y actividades, los factores psicosociales (como el control de los trabajadores, el apoyo social, las demandas psicológicas) y la estructura y el cambio organizativos (p. ej., la mejora continua de la calidad y el compromiso de la dirección con la seguridad).

El planteamiento de la sanidad pública integra asimismo la epidemiología de las lesiones con las ciencias del comportamiento aplicadas (sobre todo, la promoción de la salud, el comportamiento en relación con la salud y la investigación en materia de política sanitaria), con el fin de determinar las razones ambientales modificables de los comportamientos peligrosos de los trabajadores y, lo que es más importante, de los comportamientos de las empresas y los directivos que dan lugar a la generación y el mantenimiento de los riesgos. En las grandes organizaciones, este esfuerzo debe acompañarse de la investigación en el campo del comportamiento organizativo y la psicología industrial. De este modo, la fase de valoración en el planteamiento de la sanidad pública comprende la vigilancia epidemiológica, la realización de investigaciones pormenorizadas, la valoración de las necesidades comunitarias y organizativas y los estudios etiológicos basados en la utilización de la epidemiología y las ciencias del comportamiento aplicadas.

\section{Estrategias de prevención}

Varios principios rigen la selección y la aplicación de las medidas de prevención en el planteamiento de la sanidad pública respecto al control de lesiones. Son los siguientes:

(1) L a importancia de basar las medidas de prevención en la valoración y la evaluación previas. En el primer principio se reconoce la importancia de seleccionar intervenciones concebidas para tener una gran repercusión en el estado de salud de la comunidad, y cuya aplicación tiene muchas probabilidades de ser eficaz. Así, aumenta la posibilidad de que las intervenciones elegidas en función de una fase de valoración exhaustiva, y no únicamente del sentido común, sean eficaces. Las intervenciones cuya eficacia se ha comprobado en el pasado son aún más prometedoras. Por desgracia, son muy pocas las intervenciones relacionadas con las lesiones profesionales que han sido evaluadas científicamente (Goldenhar y Schulte 1994)

(2) L a importancia relativa de las medidas de control que protegen automáticamente al trabajador. Con el segundo principio se hace hincapié en la continuidad entre la protección activa y la pasiva. La primera exige una acción individual repetitiva constante; la segunda ofrece una protección relativamente automática. Por ejemplo, los cinturones de seguridad requieren una acción individual para iniciar la protección cada vez que alguien entre en un vehículo. Por el contrario, un "airbag" ofrece protección a los ocupantes de un vehículo sin necesidad de efectuar ninguna acción: lo hace de forma automática. L as intervenciones activas obligan a modificar y a mantener el cambio de comportamiento individual, lo que ha constituido hasta la fecha la estrategia de prevención de lesiones menos eficaz. Coincide con la tradicional jerarquía de controles en materia de seguridad en el trabajo, en la que se subraya la importancia de los controles técnicos respecto de los administrativos, del equipo de protección individual y de la formación.

(3) La importancia de la modificación del comportamiento frente a la educación. Con el tercer principio se reconoce la importancia de la modificación del comportamiento y la imposibilidad de eliminar todos los riesgos del entorno en la fase de fabricación. La modificación del comportamiento de empresas, directivos y trabajadores es esencial, no sólo para la instalación y el mantenimiento de la protección pasiva, sino también para la mayoría de las restantes estrategias de control de las lesiones profesionales. 0 tro aspecto importante de este principio es que la instrucción teórica, los carteles, los folletos y otras formas de educación que se limitan a buscar la ampliación de conocimientos suelen tener un efecto escaso sobre el comportamiento cuando se utilizan de forma aislada. La mayoría de las teorías del comportamiento relacionado con la salud aplicadas a la promoción de ésta se ocupan de los diversos factores que motivan un cambio de comportamiento, en lugar de atender a la sensibilización sobre un riesgo físico o un comportamiento seguro. Por ejemplo, en el $M$ odelo de creencia de salud se hace hincapié en que el comportamiento relativo a la autoprotección está influido en gran medida por la percepción del riesgo, de la gravedad y de las ventajas y dificultades asociadas a la adopción de acciones de protección (G reen y K reuter 1991).

Aunque los mensajes educativos creíbles pueden alterar algunas de estas percepciones, en ocasiones, el mejor modo de modificarlas consiste en cambiar el entorno físico y social. U n planteamiento de posible eficacia respecto a la modificación del comportamiento es el basado en la remodelación de los equipos y el entorno físico, con el fin de lograr que el comportamiento seguro sea más fácil, rápido, cómodo y apreciado socialmente que el inseguro. Si la disposición del equipamiento mecánico en una fábrica se ha diseñado para que el desplazamiento a través de zonas peligrosas resulte difícil e innecesario, este tipo de comportamiento inseguro se reducirá. I gualmente, si los cascos se diseñan pensando en la comodidad y en la mejora de la imagen social de los trabajadores de la construcción, podrán utilizarse más a menudo.

El entorno social también puede modificarse para cambiar el comportamiento. Por ejemplo, la legislación y su aplicación forman parte de otra estrategia de gran alcance para la prevención de lesiones que permite transformar el comportamiento y 


\section{Figura 56.17 • Los efectos de las disposiciones sobre la minería del carbón en las tasas de mortalidad del sector, Estados Unidos 1950-1990.}

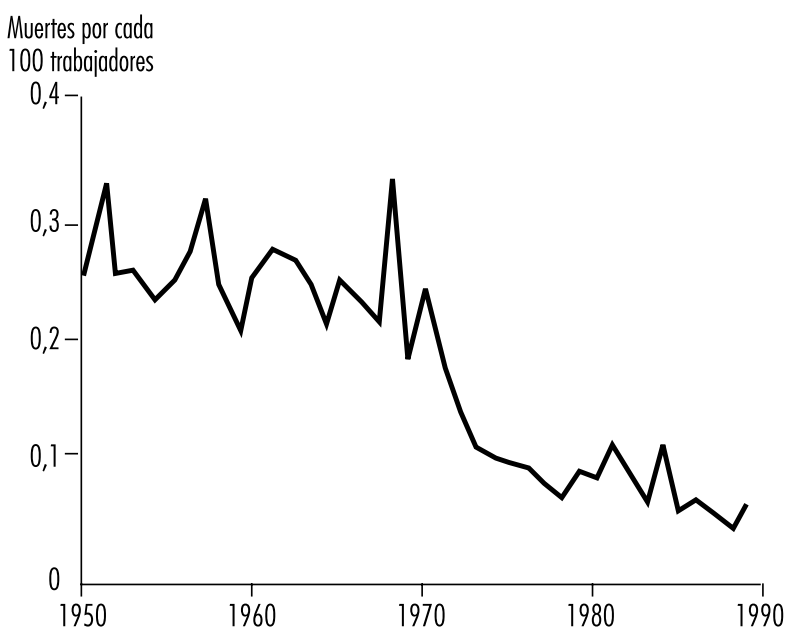

Fuente: Weeks 1991

va más allá de la mera actividad educativa. Las normas relativas al cinturón de seguridad y las que exigen la utilización de asientos de seguridad para niños, por ejemplo, han reducido drásticamente las muertes por accidente con vehículo de motor en Estados Unidos. No obstante, no se ha descrito con tanta precisión el efecto de la legislación y su aplicación sobre la seguridad en el trabajo. Una excepción notable es el descenso acusado, inequívoco y documentado en las muertes en la minería de Estados U nidos que siguió a la aplicación de la Ley federal de salud y seguridad en la minería del carbón, de 1969 (Figura 56.17). En cualquier caso, los recursos y las capacidades administrativas dedicadas al mantenimiento de la seguridad en las minas son muy superiores a las que disponen la mayoría de organismos (Weeks 1991).

La formación para la seguridad en el trabajo bien diseñada suele exigir la modificación del entorno social mediante la consideración de procesos de configuración de funciones, de incentivos y de retroinformación sobre las actuaciones en materia de seguridad (Johnston, Cattledge y Collins 1994). O tro concepto de formación, la educación laboral, representa una alteración del entorno social (Wallerstein y Baker 1994). Capacita a los trabajadores para reconocer los riesgos y modificar el comportamiento de sus superiores, con el fin de reducir dichos riesgos. Aunque, normalmente, la educación por sí sola no basta, suele ser un componente necesario de todo programa de prevención de lesiones (G ielen 1992). La educación de los directivos y los trabajadores es una parte ineludible de la aplicación de este tipo de programas. Asimismo, la educación de los legisladores, de los responsables de la formulación de políticas, de los proveedores de asistencia sanitaria y de otros agentes es importante para emprender y mantener iniciativas de prevención de lesiones de ámbito comunitario. De hecho, en las intervenciones con más probabilidades de tener éxito en la práctica, se utiliza un enfoque de múltiples facetas en el que se combinan las modificaciones ambientales con el cambio de las políticas y la educación (N ational Committee for I njury Prevention and Control 1989).

(4) Consideración sistemática de todas las opciones disponibles, incluidas las que reducen no sólo la existencia de lesiones, sino también su gravedad y sus consecuencias a largo plazo. De acuerdo con el cuarto principio, en el proceso de elección de intervenciones debe considerarse sistemáticamente una amplio conjunto de opciones. La selección de medidas de compensación no debe determinarse en función de la importancia relativa de los factores causales o de su aparición precoz en la secuencia de sucesos; en cambio, la prioridad ha de concederse a aquéllas que reduzcan las lesiones con mayor eficacia. H addon (1972) propuso un sistema útil para considerar sistemáticamente las opciones de control de lesiones. La matriz de $\mathrm{H}$ addon pone de relieve que las intervenciones destinadas a personas, los vehículos que pueden transferir energía perjudicial (p. ej., automóviles, maquinaria), o el entorno físico o psicosocial pueden actuar para controlar las lesiones en las fases de desarrollo del suceso y previa y posterior a éste. En la Tabla 56.2 se muestra la aplicación de la matriz de $\mathrm{H}$ addon a la prevención de lesiones por accidente con vehículos de motor, que constituyen la principal causa de muerte por lesión profesional en muchos países.

Las intervenciones tradicionales en materia de seguridad en el trabajo suelen hacerse en la fase anterior al suceso, con el fin de impedir el inicio de un incidente que pueda causar lesión (es decir, un accidente). Las intervenciones en la fase de desarrollo del suceso, como la fabricación de vehículos con mayor resistencia estructural a los impactos o la utilización de cuerdas de seguridad al trabajar en alturas, no evitan los accidentes, pero minimizan la probabilidad y la gravedad de la lesión. Tras la conclusión del suceso (los vehículos en un choque han dejado de moverse 0 el trabajador ha dejado de caer), las intervenciones posteriores, como los primeros auxilios y el transporte urgente a una unidad de asistencia quirúrgica tratan de reducir en la medida de lo posible las consecuencias de la lesión para la salud (es decir, la probabilidad de fallecimiento o discapacidad de larga duración).

En el planteamiento de la sanidad pública, es importante evitar el bloqueo en una fase de la matriz. Puesto que las lesiones se deben a múltiples factores causales, las estrategias de prevención deben abordar tantas fases y aspectos de las mismas como sea posible (aunque no necesariamente todos).

Tabla 56.2 • La matriz de Haddon aplicada a las lesiones por accidente con vehículo de motor.

Fases

Factores

Humanos

Vehículos y equipos Medio ambiente

Previa al

suceso

Educar a la población Frent en la utilización de cinturones de seguridad y dispositivos de protección para niños

Desarrollo Prevención de la "Airbags" y diseño

del suceso osteoporosis para reducir la probabilldad de fractura

del vehículo a prueba de choques

Mejora del diseño de e seguridad las carreteras; restricción de la publicidad del alcohol y de la disponibilidad de éste en las gasolineras

Postes indicativos de desviación y barreras para evitar la salida de la calzada

Posterior al Tratamiento de la Diseño seguro de los Asistencia médica de suceso hemofilia y otras tanques de com- emergencia y afecciones que difi- bustible para impe- rehabilitación cultan la curación dir su rotura y los adecuadas incendios

Fuente: National Committee for Injury Prevention and Control 1989. 
Por ejemplo, en la matriz de $\mathrm{H}$ addon se subraya que el control de las lesiones no se limita a la prevención de accidentes. De hecho, muchas de las estrategias de control más eficaces no impiden éstos, ni las lesiones, pero pueden reducir considerablemente su gravedad. Los cinturones de seguridad y los "airbags" en los automóviles, los cascos de seguridad, las protecciones contra caídas en la construcción, las estructuras de protección en caso de vuelco del vehículo en la agricultura y las fuentes para el lavado de ojos en caso de emergencia en los laboratorios son algunos de los ejemplos de estrategias aplicadas en la fase de desarrollo del suceso que no evitan que ocurra el accidente. Lo que hacen es reducir la gravedad de las lesiones que éste pueda provocar una vez iniciado. Incluso después de que se haya producido el daño anatómico, es mucho lo que puede hacerse para reducir el riesgo de muerte y discapacidad de larga duración. En Estados U nidos se ha estimado que muchas de las muertes por grandes traumas podrían evitarse mediante la aplicación de sistemas que reduzcan al mínimo el período de tiempo transcurrido desde que se produce la lesión hasta la administración de la asistencia quirúrgica definitiva. Este marco de mayor amplitud se denomina control de lesiones y trasciende a la prevención de accidentes tradicional. Una frase utilizada habitualmente para ilustrar esta cuestión es: "Las lesiones no son un accidente". Pueden predecirse y es posible controlar su repercusión en la sociedad.

0 tro instrumento que suele emplearse para considerar sistemáticamente las opciones de control de lesiones es el de las D iez estrategias de prevención de $\mathrm{H}$ addon (H addon 1973).

Tabla 56.3 • Las diez estrategias de prevención de Haddon aplicadas a las lesiones debidas a caídas en el sector de la construcción.

Estrategia de prevención

Prevenir la creación del peligro.

Reducir el grado de peligro creado.

Impedir la materialización de peligro.

Modificar la tasa de materializa ción del peligro en su origen.

Alejar el peligro del trabajador en el tiempo y en el espacio.

Separar el peligro del trabajador Instalar barandillas en superficies elevadas. mediante la colocación de ba rreras físicas.

Modificar las características básicas del peligro.

Lograr que el trabajador esté lo más preparado posible para resistir las lesiones.

Comenzar a contrarrestar el da- Aplicar los primeros auxilios. ño producido por el peligro.

Estabilizar, tratar, y rehabilitar al trabajador
Intervención (y notas relevantes)

$$
\text { opción práctica) }
$$

Situar la altura del proyecto de construcción por debajo de los niveles que puedan provocar la muerte; normalmente no es práctica, pero puede ser posible en algunas zonas de trabajo

Instalar superficies antideslizantes en los techos y otras superficies en altura.

Utilizar cuerdas y redes de seguridad

No programar un tráfico a pie innecesario cerca de los riesgos de caída hasta que éstos se hayan controlado.

Eliminar los salientes afilados o protuberantes en la superficie del suelo donde los trabajadores puedan caer; práctica sólo para bajas alturas

Exigir, por ejemplo, la utilización de cascos de seguridad.

Elaborar un sistema de atención de los traumas por regiones; garantizar una rehabilitación y una readaptación profesional eficaces.
En la Tabla 56.3 se muestra su modo de aplicación para controlar las lesiones debidas a las caídas en el sector de la construcción. Como puede observarse, no todas las estrategias son aplicables a determinados problemas

(5) Participación de la comunidad, los trabajadores y los directivos. El quinto principio se refiere a la importancia de contar con la participación de la población objetivo (comunidades, trabajadores, directivos) en la elección y la aplicación de las estrategias de intervención. El coste, la viabilidad, la conveniencia y la aceptabilidad pueden ser barreras al desarrollo de estrategias de prevención eficaces (Schelp 1988).

\section{La evaluación en la sanidad pública}

L a evaluación, tanto en las ciencias sociales aplicadas, como en la epidemiología, es "un proceso con el que se pretende determinar de la forma más sistemática y objetiva posible la importancia, la eficacia y la repercusión de las actividades, teniendo en cuenta sus objetivos" (Last 1988). La evaluación es un componente esencial de la práctica de la sanidad pública. Se realiza a dos niveles. El primero depende de los sistemas de vigilancia para determinar si una comunidad ha satisfecho sus objetivos de reducción de enfermedades y lesiones, sin intentar establecer la causa de los cambios. Por ejemplo, los organismos de la Administración federal, estatal y local de Estados U nidos se han fijado unos objetivos para el año 2000. U no de ellos es reducir las lesiones relacionadas con el trabajo que exigen tratamiento médico y dan lugar a una pérdida de jornadas de trabajo o a la restricción de la actividad laboral, hasta alcanzar una proporción no superior a 6 casos por cada 100 trabajadores a tiempo completo por año. El avance en la consecución de estos fines será objeto de seguimiento por parte de los sistemas nacionales de vigilancia existentes.

El segundo nivel de evaluación se centra en la determinación de la eficacia de las políticas, los programas y las intervenciones específicas. En teoría, este objetivo exige la aplicación de diseños de estudio controlados experimentales o cuasiexperimentales. Por ejemplo, M ohr y Clemmer (1989) llevaron a cabo un estudio de series temporales sobre los índices de lesión en las plataformas petrolíferas móviles en alta mar que optaron por incorporar una nueva tecnología que ayudara a los trabajadores a conectar los tubos de perforación, y compararon esos índices con los registrados en las plataformas que no habían adoptado esta medida. A unque las tasas de lesión ya se estaban reduciendo en el período de instalación de los nuevos equipos, los autores atribuyeron a la utilización del nuevo equipo de seguridad una reducción de 6 lesiones por cada 100 trabajadores al año, y demostraron que el ahorro debido a la prevención de lesiones permitió la plena recuperación del capital invertido y los costes de instalación en un período de 5,7 años. Por desgracia, este tipo de evaluación científica de programas e intervenciones en materia de salud y seguridad en el trabajo no es habitual y suele padecer deficiencias metodológicas (G oldenhar y Schulte 1994).

\section{Resumen}

El programa antes mencionado es una buena muestra de los diversos componentes que forman parte del planteamiento de la sanidad pública respecto a la reducción de lesiones en el lugar de trabajo. La valoración del problema y la creación de un sistema de vigilancia continuo constituían una parte esencial de éste y de otros estudios anteriores sobre lesiones en plataformas petrolíferas realizados por estos autores. A la formulación posterior de una estrategia de prevención técnica sencilla le siguió la aplicación de una estrategia de evaluación rigurosa, que incluía la evaluación del ahorro de costes. Son estudios sobre los que se ha fundado el planteamiento de la sanidad pública respecto a la prevención de otras enfermedades profesionales. En el futuro, la integración de 
la prevención de lesiones profesionales en las fases de valoración intervención y evaluación de la práctica de la sanidad pública puede representar un paso importante hacia la consecución de una protección y una promoción de la salud más eficaces en las comunidades

\section{- PRINCIPIOS TEORICOS DE LA SEGURIDAD EN EL TRABAJO}

\section{Reinald Skiba}

En el presente artículo se abordan los principios teóricos de la seguridad en el trabajo y los principios generales de la prevención de accidentes. $\mathrm{N}$ o se incluyen las enfermedades relacionadas con el trabajo que, aunque están relacionadas con la cuestión tratada, son diferentes en muchos aspectos.

\section{Teoría de la seguridad en el trabajo}

La seguridad en el trabajo está vinculada a la interrelación entre las personas y la actividad laboral; a los materiales, a los equipos y la maquinaria; al medio ambiente y a los aspectos económicos como la productividad. En teoría, el trabajo debe ser sano, no dañino y no exageradamente difícil. Por razones económicas, debe procurarse un nivel de productividad tan alto como sea posible.

La seguridad en el trabajo debe comenzar en la fase de planificación y continuar a lo largo de las distintas etapas productivas. En consecuencia, sus requisitos deben establecerse antes del inicio de la actividad y ser aplicados en todo el ciclo de trabajo, de forma que los resultados puedan valorarse a efectos de asegurar la retroinformación, entre otras razones. Asimismo debe considerarse durante la planificación la responsabilidad de la supervisión para mantener la salud y la seguridad de los participantes en el proceso productivo. En el proceso de fabricación hay una interacción entre las personas y los objetos. (El término objeto se utiliza en un sentido amplio, tal y como se aplica en la designación tradicional de "sistema de personas-(máquinas)-entorno". No sólo se refiere a los instrumentos técnicos de trabajo, las máquinas y los materiales, sino también a todos los elementos del entorno, como suelos, escaleras, corriente eléctrica, gas, polvo, ambiente, etc.)

\section{Relaciones entre el trabajador y el trabajo}

A continuación se exponen las tres relaciones posibles en el proceso de fabricación, que indican el modo en que los incidentes que provocan lesiones personales (sobre todo, los accidentes) y las condiciones de trabajo perjudiciales son efectos involuntarios de la combinación de las personas y el medio ambiente de trabajo objetivo para la producción.

1. La relación entre el trabajador y el medio ambiente de trabajo objetivo es óptima. Es una situación equivalente al bienestar, la seguridad en el puesto y la aplicación de métodos de ahorro de trabajo para los trabajadores, así como a la fiabilidad de las partes objetivas del sistema, como las máquinas. Además, significa la inexistencia de defectos, accidentes, incidentes, cuasierrores (posibles incidentes) y lesiones. EI resultado es una mejora de la productividad.

2. El trabajador y el entorno de trabajo objetivo son incompatibles. Esta situación puede deberse a una falta de cualificación de la persona, a la inadecuación del equipo o los materiales a la actividad o a una organización deficiente de la operación. En consecuencia, el trabajador sufre involuntariamente un exceso de trabajo o es infrautilizado. Las partes objetivas del sistema, como las máquinas, pueden llegar a ser poco fiables. Son factores que crean condiciones de inseguridad y peligros que pueden dar lugar a cuasierrores (cuasiaccidentes) y a incidentes de menor importancia, con el resultado de retrasos en el flujo productivo y la reducción de la producción.

3. La relación entre el trabajador y el entorno de trabajo objetivo se encuentra completamente distorsionada, lo que provoca una alteración con el resultado de daños, lesiones personales e interrupción de la producción. La relación alude específicamente a la cuestión de la seguridad en el trabajo en el sentido de evitar accidentes.

\section{Principios de seguridad en el lugar de trabajo}

Puesto que, obviamente, las cuestiones de la prevención de accidentes no pueden resolverse de forma aislada, sino únicamente en el contexto de su relación con la producción y el entorno de trabajo, pueden deducirse los siguientes principios de prevención de accidentes:

1. La prevención de accidentes debe incorporarse a la planificación de la producción con el objetivo de evitar las disfunciones.

2. El objetivo último es lograr un flujo productivo tan exento de obstáculos como sea posible. Su consecución no sólo mejora la fiabilidad y contribuye a la eliminación de defectos, sino que también favorece el bienestar de los trabajadores, los métodos de ahorro de trabajo y la seguridad en el trabajo.

A continuación se refieren algunas de las prácticas utilizadas habitualmente en el lugar de trabajo para lograr la seguridad, y que son necesarias para lograr que no haya disfunciones en la producción:

- Los trabajadores y los supervisores deben estar informados y ser conscientes de los peligros y los posibles riesgos (p. ej., mediante la educación).

- Los trabajadores deben estar motivados para actuar de forma segura (modificación del comportamiento).

- Los trabajadores deben ser capaces de actuar de modo seguro. Y ello se logra mediante los procedimientos de certificación, la formación y la educación.

- El entorno de trabajo personal ha de ser seguro y sano mediante la utilización de controles administrativos y técnicos, la sustitución de materiales y condiciones por otros menos peligrosos y la utilización de equipos de protección individual.

- El equipo, la maquinaria y los objetos deben funcionar de manera segura conforme a su uso previsto, con controles de funcionamiento diseñados para las capacidades humanas.

- Debe preverse la adopción de medidas de urgencia adecuadas con el fin de atenuar las consecuencias de los accidentes, los incidentes y las lesiones.

Los principios siguientes son importantes para comprender el modo en que se relacionan los conceptos de la prevención de accidentes con la producción sin disfunciones:

1. En ocasiones, la prevención de accidentes se considera una carga social en lugar de una parte fundamental de las acciones encaminadas a evitar las disfunciones. La prevención de éstas es un factor de motivación mejor que la de accidentes, ya que de la primera se espera que dé lugar a una mejora de la producción.

2. Las medidas destinadas a garantizar la seguridad en el lugar de trabajo deben combinarse con las utilizadas para procurar una producción sin diffunciones. Por ejemplo, las instrucciones relativas a los riesgos deben formar parte de las directrices generales que rigen el flujo productivo en el lugar de trabajo. 


\section{Teoría de los accidentes}

Un accidente (incluidos los que conllevan lesión) es un suceso repentino y no deseado, provocado por un factor externo, que causa daños a las personas y que resulta de la interacción entre éstas y los objetos.

A menudo, la utilización del término accidente en el lugar de trabajo se vincula a la lesión personal. Cuando es una máquina la que resulta dañada, suele denominarse alteración o daño, pero no accidente. El daño al medio ambiente suele denominarse incidente. L os accidentes, los incidentes y las disfunciones que no dan lugar a una lesión o un daño se conocen como "cuasiaccidentes" o "cuasierrores". Por tanto, aunque pueda considerarse apropiado referirse a los accidentes como casos de lesión de los trabajadores y definir los términos incidente, disfunción y daño por separado, ya que se aplican a objetos y al medio ambiente, en el contexto del presente artículo, se denominará a todos ellos accidentes.

En el modelo conceptual para el término accidente se indica que los accidentes en el lugar de trabajo se deben a la interacción entre trabajadores y objetos a través de la liberación de energía. U n accidente puede ser causa de las características de la víctima (p. ej., incapacidad para desempeñar su trabajo con seguridad) o del objeto ( $p$. ej., inseguridad o inadecuación del equipo). Asimismo, la causa puede ser la acción de otro trabajador (quien ha facilitado una información errónea), de un supervisor (quien ha dado instrucciones de trabajo incompletas) o de un formador (quien ha prestado una formación incompleta 0 incorrecta). En lo que respecta a la prevención de accidentes, puede deducirse lo siguiente:

Suponiendo que los trabajadores, así como su medio ambiente objetivo, pueden ser portadores de riesgos o peligros, la prevención de accidentes consistirá básicamente en la eliminación de éstos y en atenuar sus consecuencias manteniendo a los portadores alejados de los mismos o minimizando los efectos de la energía.

\section{Riesgos y peligros potenciales}

Aunque un objeto constituya un riesgo o un peligro, si éste y el trabajador se encuentran tan alejados entre sí que no pueden entrar en contacto, el accidente es imposible. Así, si el objeto plantea un peligro potencial (p. ej., una carga suspendida trasladada por una grúa), éste no podrá causar una lesión si no hay personas en la zona donde cabe la posibilidad de que caiga la carga. Sólo cuando un trabajador entra en dicha zona surge el peligro real, porque la interacción entre el trabajador y el objeto es posible. D ebe tenerse en cuenta que un objeto puede poner en peligro a otros objetos, como en el caso de un vehículo aparcado bajo la carga sostenida por una grúa. El riesgo, como medio de cuantificar el peligro, es el producto de la frecuencia y el alcance del daño previstos. El riesgo de accidente es, en consecuencia, el producto de la frecuencia (frecuencia de accidente relativa) y la gravedad del accidente previstas. La frecuencia de accidente relativa es el número de accidentes por período de riesgo (accidentes por cada millón de horas o lesiones por año de trabajo). La gravedad de un accidente puede expresarse cuantitativamente en función del tiempo perdido (p. ej., pérdida de jornadas de trabajo), la clase de lesión (accidente menor o caso de primeros auxilios, lesión objeto de parte, caso de indemnización por período de tiempo perdido y accidente mortal), el tipo de lesión y el coste de ésta. Los datos sobre el riesgo deben registrarse empíricamente y en función de un pronóstico teórico.

Los riesgos de accidente difieren en cada lugar de trabajo y bajo la influencia de diversas situaciones. Por ejemplo, los riesgos que conlleva una perforación petrolífera, utilizando los mismos trabajadores y equipos idénticos difieren enormemente en función de la geografía (perforación en tierra firme o en alta mar) y el clima (explotación ártica o desierto). EI nivel de riesgo de accidente depende de:

- la frecuencia prevista de error del trabajador y de la tecnología (número por cada millón de horas, etc.);

- la probabilidad de que los errores provoquen accidentes (accidente: error = 1:x)

- la probabilidad del nivel de gravedad del accidente.

La aceptación de los riesgos de accidente también presenta grandes variaciones. En el ámbito del tráfico rodado parece que la aceptación del riesgo es elevada, mientras que en el campo de la energía nuclear se prevé una tolerancia nula. Por tanto, a efectos de la prevención de accidentes, se deduce que el factor impulsor es la consecución de la menor aceptación posible del riesgo de que se produzcan.

\section{Causas de los accidentes}

La existencia de una accidente requiere la clasificación en una escala que va de la causa al efecto. Deben diferenciarse tres niveles:

- el nivel de las causas de los accidentes posibles y reales;

- el nivel de los orígenes del accidente,

- el nivel de las consecuencias del accidente concretadas en daños personales y materiales.

La causa es la razón del accidente. Casi todos se deben a múltiples causas, como la existencia de condiciones peligrosas, las conjunción de factores, el curso de los acontecimientos, las omisiones, etc. Por ejemplo, la explosión de una caldera puede deberse a una o varias de las razones siguientes: deficiencias de los materiales de las paredes de la caldera, formación inadecuada de la persona para garantizar un funcionamiento seguro, fallo en el dispositivo de reducción de la presión e incumplimiento de un procedimiento como el sobrecalentamiento. Si no se dan uno o varios de estos factores, el accidente podría no haber ocurrido. Deben distinguirse de otras condiciones que no son causas del accidente: en el ejemplo, serían la información sobre el tiempo, la temperatura ambiente y el tamaño de la sala de la caldera.

Es importante diferenciar los factores asociados al proceso productivo de las causas del accidente relacionadas con los trabajadores (comportamiento del operario inmediato), de la organización (políticas o procedimientos de trabajo seguros) y de las causas de carácter técnico (cambios ambientales y fallos de los objetos). A hora bien, en el análisis final todos los accidentes se deben a un comportamiento erróneo de las personas, ya que éstas siempre están situadas en el extremo de la cadena causal. Por ejemplo, si se determina que un material defectuoso es la causa de la explosión de la caldera, entonces puede deducirse una conducta impropia por parte del constructor, del fabricante, del encargado de su comprobación, del instalador o del propietario (p. ej., la corrosión debida a un mantenimiento inadecuado). En sentido estricto, no puede hablarse de "fallo técnico" ni de causa técnica de un accidente. La tecnología sólo es el vínculo intermedio con las consecuencias de un comportamiento inadecuado. Con todo, la división habitual de las causas en técnicas, organizativas y del comportamiento es útil, ya que permite establecer qué grupo de personas ha actuado de modo incorrecto y ayuda a seleccionar las medidas correctivas pertinentes.

Como ya se ha señalado, la mayoría de los accidentes son el resultado de un conjunto de causas. Por ejemplo, una persona resbala con una mancha de aceite en un pasillo oscuro y poco iluminado y se golpea con el borde afilado de un repuesto allí almacenado, lesionándose la cabeza. Las causas inmediatas del 
accidente son una iluminación inadecuada en la zona, un piso inseguro (mancha de aceite), unas suelas antideslizamiento inapropiadas, la falta de protección en la cabeza y la mala colocación del repuesto. El accidente podría no haberse producido si se hubiese evitado la conjunción de causas o se hubiera interrumpido la cadena causal. Por tanto, la prevención eficaz de los accidentes exige el reconocimiento de esta cadena y su ruptura, de forma que se impida un nuevo accidente.

\section{Efecto de las tensiones y las demandas}

La mecanización y la automatización de los procesos productivos ha avanzado considerablemente en los últimos años. Puede parecer que las causas de numerosos accidentes han dejado de ser los errores humanos y están vinculadas al mantenimiento y la relación con los procesos automatizados. No obstante, a estas consecuencias positivas de la tecnología hay que oponer otras negativas, sobre todo el aumento de las tensiones psicológicas y las correspondientes demandas físicas ergonómicas que afectan a los trabajadores en las instalaciones automatizadas, debido al aumento de la atención y la responsabilidad necesarias para supervisar los procesos de operaciones automáticas, a un entorno de trabajo impersonal y a la monotonía de la actividad laboral. Las tensiones y las demandas consiguientes elevan el número de accidentes y pueden resultar perjudiciales para la salud.

1. Las tensiones son efectos sobre los trabajadores cuyo origen está en el lugar de trabajo, como las de carácter ambiental (temperatura, calor, humedad, luz, ruido y contaminación del aire), o las de tipo estático o dinámico debidas directamente al proceso de trabajo (levantamiento de pesos, trabajo en alturas, exposición a sustancias químicas, etc.). Los niveles de tensión pueden medirse físicamente (ruido, fuerza, exposiciones atmosféricas, etc.), a diferencia de los factores que la provocan (fatiga, estrés mental, relaciones entre trabajadores y directivos, etc.).

2. Las demandas que afectan a los trabajadores dependen del tipo y el grado de tensión, así como de la distinta capacidad individual para soportarla. Los efectos de las demandas se aprecian física y psicológicamente en el cuerpo humano. Pueden ser deseables 0 indeseables, en función del tipo y el grado. Los segundos, como el agotamiento físico y psicológico, el empeoramiento del trabajo, la enfermedad, la falta de coordinación y concentración y el comportamiento inseguro, aumentan el riesgo de accidente.

A efectos de la prevención de accidentes, se deduce que los trabajadores, basándose en sus competencias, capacidades y disposición individual, deben ser capaces de trabajar con seguridad desde el punto de vista físico y psicológico, siempre que no existan factores externos, como un equipo inadecuado, un medio ambiente deficiente o unas condiciones de trabajo insatisfactorias. La seguridad puede mejorarse organizando el proceso de trabajo de manera que incluya estímulos apropiados, como los cambios de puesto planeados, la expansión del trabajo y las tareas y el enriquecimiento de la actividad.

\section{Cuasiaccidentes (cuasierrores)}

U na gran parte de las pérdidas productivas se debe a alteraciones que se materializan en cuasierrores (cuasiaccidentes), que son la base para que se produzcan accidentes. No todas las alteraciones afectan a la seguridad en el trabajo. Los cuasiaccidentes (cuasierrores) son aquellos incidentes que no provocan ninguna lesión 0 daño, pero que, de haberse producido éstos, se habrían clasificado como accidentes. Por ejemplo, una máquina que deja de funcionar inesperadamente sin dañar el equipo o el trabajo se considera un cuasiaccidente. Además, la alteración puede causar otro cuasiaccidente si la máquina vuelve a ponerse en marcha súbitamente en el momento en que un trabajador se encuentra en su interior tratando de determinar la causa de la detención y nadie resulta herido.

\section{La pirámide de los accidentes}

Los accidentes son sucesos relativamente infrecuentes y, por lo general, cuanto más graves son, menor es su frecuencia. Los cuasiaccidentes se sitúan en la base de la pirámide de los accidentes, cuyo vértice superior ocupan los mortales. Si se utiliza el tiempo perdido como criterio para establecer la gravedad, se observa que la correspondencia con dicha pirámide es relativamente alta. (Puede existir una ligera desviación como resultado de los requisitos de presentación de partes de los distintos países, empresas y jurisdicciones.)

La pirámide de los accidentes puede diferir en gran medida en función de sus diversos tipos y clasificaciones. Por ejemplo, los accidentes relacionados con la electricidad son enormemente graves. Cuando la clasificación se hace según la profesión, se observa que en ciertas actividades laborales se registran accidentes muchísimo más graves que en otras. En ambos casos, la pirámide se caracteriza por una gran densidad en su vértice, debido a la proporción relativamente elevada de accidentes graves y mortales.

Al considerar la pirámide, puede deducirse a efectos de la prevención de accidentes que:

1. La prevención de accidentes empieza por evitar los cuasiaccidentes (cuasierrores).

2. La eliminación de los accidentes de menor importancia suele tener un efecto positivo en la erradicación de otros más graves.

\section{Prevención de accidentes}

H e aquí diversas maneras de prever accidentes para garantizar la seguridad en el lugar de trabajo:

1. Eliminación del riesgo o del peligro, de forma que se hagan imposibles la lesión o el daño.

2. Separación entre el trabajador (o el equipo) y el riesgo (equivalente a la eliminación del riesgo). El peligro se mantiene, pero la lesión (o el daño) es imposible, ya que se garantiza que las zonas naturales de influencia de los trabajadores (los equipos) y el objeto (riesgo o peligro) no coincidan.

3. U tilización de mecanismos de protección, como ropa ignífuga o respiradores, para atenuar el riesgo. Aunque sigue existiendo, la posibilidad de lesión o daño se reduce al minimizar las oportunidades de que produzca un efecto, bloqueando así el peligro.

4. A daptación al riesgo mediante la adopción de medidas como la instalación de sistemas de alarma y equipos de control, la información sobre los peligros, la motivación para adoptar un comportamiento seguro, la formación y la educación.

\section{Resumen}

En 1914, M ax Planck (físico alemán, 1858-1947) señaló: "En todas las ciencias, la consigna principal es la tarea de buscar el orden y la continuidad a partir de la abundancia de experiencias y factores individuales, con el fin de integrarlos, mediante la supresión de las diferencias, en una visión coherente." Este principio también se aplica a las complejas cuestiones científicas y prácticas de la seguridad en el trabajo, ya que éstas no sólo están relacionadas con otras muchas disciplinas, sino que también presentan multitud de facetas en sí mismas. Aunque resulta difícil, por esta razón, sistematizar los numerosos problemas vinculados a la seguridad en el trabajo, es necesario organizar adecuadamente las cuestiones individuales de acuerdo con su significación y contexto, además de plantear opciones eficaces para su mejora. 


\section{PRINCIPIOS DE PREVENCION: INFORMACION SOBRE SEGURIDAD}

Mark R. Lehto y James M. M iller

\section{Fuentes de información sobre seguridad}

Los fabricantes y las empresas de todo el mundo ofrecen una gran cantidad de información sobre seguridad a los trabajadores para fomentar el comportamiento seguro y desincentivar el inseguro. Entre las fuentes de datos sobre seguridad figuran los reglamentos, los códigos y las normas, las prácticas industriales, los cursos de formación, las fichas técnicas de seguridad (FTS), los procedimientos escritos, las señales de seguridad, las etiquetas de los productos y los manuales de instrucciones. La información que ofrece cada una de estas fuentes varía en cuanto a objetivos de comportamiento, público de destino, contenido, nivel de detalle, formato y modo de presentación. Asimismo, la información puede diseñarse en cada fuente para su utilización en las diferentes fases de ejecución de una tarea en una posible secuencia de accidente.

\section{Las cuatro fases de la secuencia de accidente}

Los objetivos en cuanto a comportamiento de cada fuente de información sobre seguridad se corresponden o "encajan" de forma natural con las cuatro fases de la secuencia de un accidente (Tabla 56.4).

Primera fase En la primera fase de la secuencia de accidente, las fuentes de información suministradas con anterioridad al desempeño de la tarea, como los materiales de formación en seguridad, los programas de comunicación de peligros y diversos materiales de programas de seguridad (incluidos los carteles y las campañas) se utilizan para instruir a los trabajadores acerca de los riesgos y convencerles de la necesidad de actuar de forma segura. Con los métodos de educación y persuasión (modificación del comportamiento) se intenta no sólo reducir los errores mejorando el conocimiento y las destrezas del trabajador, sino también rebajar el número de infracciones de las normas de seguridad mediante el cambio de las actitudes peligrosas. LoS trabajadores sin experiencia suelen ser el grupo objetivo en esta fase y, por tanto, el contenido de la información sobre seguridad en este caso es mucho más detallado que en otras fases. D ebe subrayarse que la motivación y la cualificación de una plantilla constituyen un requisito previo para que la información sobre seguridad sea eficaz en las tres fases siguientes de la secuencia de accidente.

Segunda fase. En la segunda fase de la secuencia de accidente, fuentes como los procedimientos por escrito, las listas de comprobación, las instrucciones, las señales de aviso y las etiquetas de producto prestan una información sobre seguridad esencial durante la ejecución de tareas rutinarias. Suele tratarse de mensajes breves con los que se instruye a los trabajadores menos cualificados o se recuerda a los cualificados la pertinencia de adoptar las precauciones necesarias. Su cumplimiento puede ayudar a evitar que los trabajadores omitan éstas u otras medidas esenciales en una tarea. Son mensajes que suelen formar parte de instrucciones pormenorizadas en las que se describe el modo de desempeñar una tarea. Las señales de aviso pueden desempeñar una función similar: por ejemplo, un letrero situado a la entrada de un lugar de trabajo puede recordar la necesidad de usar cascos de seguridad en el interior.

Tercera fase En la tercera fase de la secuencia de accidente, las fuentes de información sobre seguridad en lugares destacados y visibles alertan a los trabajadores de las condiciones anormales 0 inusualmente peligrosas. Se trata, por ejemplo, de letreros de aviso, marcas de seguridad, etiquetas, señales, barreras y bloqueos. Las señales de aviso pueden ser visuales (luces intermitentes, movimientos, etc.), sonoras (sirenas, bocinas, tonos, etc.), olfativas (olores), táctiles (vibraciones) o cinestéticas. $\mathrm{H}$ ay señales inherentes a ciertos productos cuando éstos se encuentran en estado de peligro ( $p$. ej., el olor emitido al abrir un recipiente de acetona). 0 tras están destinadas a formar parte de la maquinaria o los entornos de trabajo ( $p$. ej., la señal de marcha atrás en una carretilla elevadora). L as marcas de seguridad se refieren a métodos de identificación no verbal o de indicación de elementos potencialmente peligrosos del medio ambiente (p. ej., la pintura en amarillo de los bordes de los escalones, y en rojo de las paradas de emergencia). Las etiquetas, barreras, signos y bloqueos de seguridad se sitúan en lugares de riesgo y suelen emplearse para evitar que los trabajadores entren en ciertas áreas o pongan en funcionamiento equipos durante su mantenimiento, reparación u otras situaciones anormales.

Cuarta fase En la cuarta fase de la secuencia de accidente, se hace hincapié en facilitar la ejecución por parte de los trabajadores de los procedimientos de emergencia en el momento en que se produce un accidente y en adoptar las medidas paliativas poco después del mismo. Los signos y las marcas de información sobre seguridad indican de forma llamativa los hechos esenciales para lograr una ejecución adecuada de los procedimientos de emergencia (p. ej. la localización de salidas, los extintores de incendios, los puestos de primeros auxilios, las duchas de emergencia, los lugares para el lavado de ojos y las puertas de emergencia). En las etiquetas de seguridad de los productos y las fichas técnicas de seguridad, FT S, pueden especificarse los procedimientos correctivos y de emergencia que deben seguirse.

Tabla 56.4 - O bjetivos y ejemplos de fuentes de información sobre seguridad adaptadas a la secuencia de accidente.

\begin{tabular}{|c|c|c|c|c|}
\hline \multicolumn{5}{|c|}{ Fase de la tarea en la secuencia del accidente } \\
\hline & Previa a la tarea & Ejecución de tarea rutinaria & Condiciones de tarea anormales & Condiciones de accidente \\
\hline $\begin{array}{l}\text { Objetivos } \\
\text { (de compor- } \\
\text { tamiento) }\end{array}$ & $\begin{array}{l}\text { Educar y convencer al trabajador de } \\
\text { la naturaleza y el nivel del riesgo, } \\
\text { de las precauciones, de las medi- } \\
\text { das paliativas y de los procedi- } \\
\text { mientos de emergencia. }\end{array}$ & $\begin{array}{l}\text { Enseñar o recordar al trabajador } \\
\text { que utilice procedimientos segu- } \\
\text { ros y tome precauciones. }\end{array}$ & $\begin{array}{l}\text { Alertar al trabajador de la existencia } \\
\text { de condiciones anormales. Especi- } \\
\text { ficar las acciones necesarias. }\end{array}$ & $\begin{array}{l}\text { Indicar la ubicación de los equipos de se- } \\
\text { guridad y primeros auxilios, las salidas y } \\
\text { los procedimientos de emergencia. Espe- } \\
\text { cificar los procedimientos paliativos y de } \\
\text { emergencia. }\end{array}$ \\
\hline $\begin{array}{l}\text { Ejemplos de } \\
\text { fuentes }\end{array}$ & $\begin{array}{l}\text { Manuales de formación, vídeos o } \\
\text { programas, programas de comuni- } \\
\text { cación de peligros, fichas técnicas } \\
\text { de seguridad, propaganda y re- } \\
\text { troinformación sobre seguridad }\end{array}$ & $\begin{array}{l}\text { Manuales de instrucciones, ayudas } \\
\text { para la ejecución del trabajo, lis- } \\
\text { tas de comprobación, procedi- } \\
\text { mientos por escrito, señales y } \\
\text { etiquetas de advertencia }\end{array}$ & $\begin{array}{l}\text { Señales de advertencia: visuales, } \\
\text { sonoras y olfativas. Etiquetas, se- } \\
\text { ñales, barreras y bloqueos } \\
\text { temporales }\end{array}$ & $\begin{array}{l}\text { Señales, etiquetas y marcas con informa- } \\
\text { ción sobre seguridad, fichas técnicas de } \\
\text { seguridad }\end{array}$ \\
\hline
\end{tabular}


Con todo, si se pretende garantizar la eficacia de la información sobre seguridad en todas las fases de la secuencia de accidente, esta información debe ser primero detectada y comprendida, y si ya se conoce previamente, debe ser también recordada. A continuación el trabajador ha de decidir si se atiene al mensaje recibido y si es capaz físicamente de ello. La superación correcta de cada una de estas fases para garantizar la eficacia puede ser difícil; no obstante, las directrices que describen el modo de diseñar la información sobre seguridad pueden resultar de alguna ayuda.

\section{Diseño de directrices y requisitos}

Tradicionalmente, las organizaciones encargadas de formular normativas, las agencias reguladoras y los tribunales a través de sus sentencias han establecido las directrices y han impuesto los requisitos relativos al momento y el modo en que debe ofrecerse información sobre seguridad. A lo que se tiende últimamente es a elaborar directrices basadas en la investigación científica relativa a los factores que influyen en la eficacia de este tipo de información.

\section{Requisitos jurídicos}

En la mayoría de los países industrializados, las normativas públicas exigen que se faciliten a los trabajadores ciertos tipos de información sobre seguridad. Por ejemplo, en Estados U nidos, la Environmental Protection Agency (EPA) ha elaborado diversos requisitos de etiquetado de las sustancias químicas tóxicas. El Departamento de Transporte (DT) ha establecido disposiciones específicas respecto al etiquetado de materiales peligrosos durante su transporte. L a O ccupational Safety and H ealth A dministration (O SH A) ha promulgado una norma de comunicación de riesgos aplicable a los lugares de trabajo en los que se utilizan materiales tóxicos o peligrosos y que exige la prestación de formación, el etiquetado de los recipientes, la elaboración de FTS y otros tipos de advertencia.

En Estados U nidos puede iniciarse una causa contra fabricantes, empresas y otros agentes por el hecho de no advertir de un peligro que ha provocado lesiones a los trabajadores. En cuanto a la asignación de responsabilidades, en la Teoría de la negligencia se tiene en cuenta si la ausencia de advertencias adecuadas puede considerarse una conducta inapropiada en función de: 1) el grado de previsión del peligro por parte del fabricante, 2) el grado de sentido común implícito en la suposición de que el usuario se daría cuenta del peligro, y 3) el cuidado que puso el fabricante en informar al usuario acerca del peligro. La Teoría de la responsabilidad estricta sólo exige que la lesión 0 la pérdida se provocara por la ausencia de advertencias.

\section{Normas voluntarias}

Un gran número de normativas vigentes comprenden recomendaciones voluntarias referentes a la utilización y el diseño de la información sobre seguridad. Son normas elaboradas por grupos y organismos multilaterales, como las $\mathrm{N}$ aciones U nidas, la Comunidad Económica Europea (Comité Europeo de Normalización, CEN y Comité Europeo de Normalización Electrotécnica, CENELEC), la O rganización Internacional de Normalización (ISO ) y la Comisión Electrotécnica Internacional (CEI); así como por grupos nacionales, como el American National Standards Institute (ANSI), el British Standards Institute, la Canadian Standards Association, el Instituto Alemán de Normalización (DIN ) y el Comité Japonés de Normalización Industrial.

Entre las normas de consenso, las desarrolladas por el ANSI en Estados U nidos tienen una significación especial. Desde mediados del decenio de 1980, se han elaborado cinco nuevas normas ANSI sobre señales y etiquetas de seguridad y se ha revisado una norma importante. Las nuevas normas son: 1) ANSI Z535.1, Código de colores de seguridad, 2) ANSI Z535.2, Señales de seguridad en el entorno y en las instalaciones, 3) AN SI Z535.3, Criterios relativos a los símbolos de seguridad, 4) AN SI Z535.4, Signos y etiquetas de seguridad en los productos, y 5) ANSI Z535.5, E tiquetas para la prevención de accidentes. La norma revisada recientemente es ANSI Z129.1-1988, Sustancias químicas industriales peligrosas-E tique tado preventivo. Además, el ANSI ha publicado Guide for D eveloping Product Information (Guía para la elaboración de información sobre productos).

\section{E specificaciones de diseño}

Las especificaciones de diseño pueden ser establecidas por consenso, y en las normas de seguridad gubernamentales se detalla lo siguiente sobre el modo de diseñar:

1. Fichas técnicas de seguridad (FT S). En la norma sobre comunicación de riesgos de la OSHA se especifica que las empresas deben tener una FT S en el lugar de trabajo para cada una de las sustancias químicas peligrosas que se utilicen. La norma exige que la ficha sea redactada en inglés y que en ella figuren la fecha de elaboración y las denominaciones científica y común de la sustancia en cuestión. A simismo, establece la obligación de describir en la FTS: 1) las características físicas y químicas de la sustancia, 2) los riesgos físicos, incluida la posibilidad de incendio, explosión y reactividad, 3) los riesgos para la salud, incluidas las señales y síntomas de exposición y las enfermedades que pueden agravarse por influencia de la sustancia química, 4) la ruta principal de acceso, 5) el límite de exposición admisible para la O SH A, el Valor Límite U mbral (TLV) establecido por la Conferencia Americana de Higienistas Industriales del Gobierno (ACGIH) u otros límites recomendados, 6) las propiedades carcinógenas, 7) las precauciones de aplicación general, 8) las medidas de control de aplicación general, 9) los procedimientos de emergencia y primeros auxilios, y 10) el nombre, la dirección y el teléfono de alguna persona capaz de ofrecer, en caso necesario, más información sobre la sustancia química peligrosa y los procedimientos de emergencia.

2. E tiquetas y manuales de instrucciones. Algunas normas de consenso en vigor especifican el modo de diseñar las etiquetas y los manuales de instrucciones. No obstante, esta situación cambia con rapidez. En 1990 se publicó la Guía para la elaboración de información sobre productos de ANSI y hay otras organizaciones de consenso trabajando en proyectos de documentos. Sin disponer de un fundamento excesivamente científico, el Consejo para el Interés de los Consumidores del ANSI, responsable de la formulación de las directrices anteriores, ha presentado a los fabricantes un proyecto razonable referente a los elementos que deben tenerse en cuenta al elaborar manuales de instrucciones y de funcionamiento. Se han incluido secciones denominadas "Elementos organizativos", "Ilustraciones", "Instrucciones", "Avisos", "N ormas", "Cómo utilizar el lenguaje" e "Instrucciones para el desarrollo de listas de comprobación". A pesar de su brevedad, este documento constituye una primera iniciativa útil en este terreno.

3. Símbolos de seguridad. Numerosas normas de todo el mundo incluyen disposiciones relativas a los símbolos de seguridad. De éstas, la ANSI Z535.3, Criterios referentes a los símbolos de seguridad, es especialmente importante para los usuarios de la industria. La norma presenta un conjunto significativo de símbolos seleccionados que, de acuerdo con estudios anteriores, fueron bien comprendidos por los trabajadores de Estados U nidos. Q uizá más importante es que en la norma se especifican asimismo métodos para el diseño y la evaluación 
de este tipo de símbolos. En ciertas disposiciones se exige que: 1) durante su comprobación, los símbolos nuevos sean identificados correctamente al menos por el $85 \%$ de 50 o más sujetos representativos, 2) los símbolos que no satisfagan los criterios anteriores sean utilizados únicamente cuando vayan acompañados de sus correspondientes mensajes verbales impresos, y 3) las empresas y los fabricantes de productos formen a los trabajadores y los usuarios respecto al significado que se pretende transmitir a través de los símbolos. En la norma se establece asimismo que los nuevos símbolos desarrollados conforme a estas directrices podrán ser considerados para su inclusión en futuras revisiones de la misma.

4. Señales y etiquetas de advertencia. En las normas del ANSI y otros organismos se formulan recomendaciones específicas acerca del diseño de las señales y las etiquetas de advertencia. Se refieren, entre otros factores, a las palabras y los textos utilizados en las señales, los esquemas de codificación mediante colores, la tipografía, los símbolos, la disposición y la identificación de los peligros (T abla 56.5). Entre las palabras recomendadas más habituales en las señales figuran las de: PELIGRO, para indicar el nivel de peligro más alto; ATENCION, para señalar un peligro intermedio, y CUIDAD 0, para denotar la existencia de un peligro moderado. Los métodos de codificación mediante colores deben utilizarse para asociar coherentemente éstos a determinados niveles de riesgo. Por ejemplo, el rojo se emplea en todas las normas recogidas en la T abla 56.5 para indicar PE LIGRO, el nivel más alto de peligro. Las recomendaciones explícitas relativas a la tipografía se formulan en casi todos los sistemas. L a coincidencia más generalizada entre los sistemas es la invitación a utilizar caracteres sin trazos terminales. Son varias las recomendaciones relativas a la utilización de símbolos y pictogramas. Los sistemas de FMC y W estinghouse abogan por el empleo de símbolos para definir el riesgo y comunicar el nivel de éste (FMC 1985; Westinghouse 1981). En otras normas se aconseja la aplicación de símbolos únicamente como complemento de las palabras. Las recomendaciones en cuanto a la disposición de las etiquetas es otra cuestión donde las variaciones son notables, como se muestra en la Tabla 56.4. En general, en las propuestas se incluyen elementos analizados anteriormente y se especifica la imagen (contenido gráfico y color), el fondo (forma, color), el contorno (forma, color) y la zona que la rodea (forma, color). Asimismo, muchos de los sistemas describen con precisión la disposición del texto escrito y orientan respecto a los métodos de identificación de peligros.

En determinadas normas puede especificarse además el contenido y el texto de las señales y las etiquetas de advertencia con cierto grado de detalle. Por ejemplo, en la AN SI Z129.1, se establece que las etiquetas de advertencia en sustancias químicas deben incluir: 1) la identificación del producto químico o de sus componentes peligrosos, 2) una palabra clave, 3) una exposición de los peligros, 4) medidas de precaución, 5) instrucciones en caso de contacto o exposición, 6) antídotos, 7) notas para los médicos, 8) instrucciones en caso de incendio y derrame o fuga y (9) instrucciones para el manejo y almacenamiento de los recipientes. Esta norma también especifica un formato general para las etiquetas químicas que incorpora esos aspectos. En esta norma se indican igualmente los textos desarrollados y específicos recomendados para su inclusión en mensajes concretos.

\section{Directrices cognitivas}

Las especificaciones de diseño, como las analizadas anteriormente, pueden ser útiles para las personas encargadas de elaborar la información sobre seguridad. No obstante, muchos productos y situaciones no se abordan directamente en las normas o los reglamentos. Existen especificaciones de diseño que no están científicamente comprobadas y, en casos extremos, el cumplimiento de dichas normas y reglamentos puede reducir en la práctica la eficacia de la información sobre seguridad. Para evitarlo, es posible que los responsables de desarrollar este tipo de información tengan que ir más allá de las normas de seguridad. Así, la Asociación Internacional de Ergonomía (AIE ) y la Fundación Internacional para la Investigación sobre la Ergonomía Industrial y la Seguridad (IFIESR) apoyaron recientemente una iniciativa para elaborar directrices relativas a las señales y las etiquetas de advertencia (L ehto 1992), que reflejan los resultados de los estudios, publicados y pendientes de publicación, sobre su eficacia y afectan al diseño de casi todas las formas de información sobre seguridad. He aquí seis de estas directrices, presentadas con ligeras modificaciones.

1. Adaptar las fuentes de información sobre seguridad al nivel de actuación en el que se producen errores críticos en una población determinada. Al especificar el tipo y el modo de información sobre seguridad que debe ofrecerse, esta directriz subraya la necesidad de prestar atención a: 1) los errores críticos que pueden provocar un daño significativo, y 2) al nivel de actuación del trabajador en el momento en que se comete el error. A menudo, este objetivo puede alcanzarse si las fuentes de información sobre seguridad se adaptan a los objetivos relativos al comportamiento tal y como aparece organizado en la Tabla 56.4, analizada anteriormente.

2. Integrar la información sobre seguridad en el contexto de la tarea y los peligros asociados a ella. La información sobre seguridad debe ofrecerse de un modo que facilite su constatación en el momento más oportuno, que casi siempre coincide con aquél en el que deben emprenderse acciones. En estudios recientes se ha confirmado que este principio es aplicable tanto a la ubicación de mensajes de seguridad en instrucciones, como a la colocación de las fuentes de información sobre seguridad (como señales de advertencia) en el medio ambiente físico. Un estudio en concreto puso de manifiesto que la probabilidad de que las personas observaran y cumplieran las precauciones de seguridad era mucho mayor cuando éstas se incluían como un paso necesario en las instrucciones, que en los casos en que se separaban de éstas y formaban un apartado de advertencia aislado. Por el contrario, en muchas normas de seguridad se recomienda o se exige que la información preventiva y de aviso se sitúe en una sección aparte, lo que no deja de extrañar.

3. Ser selectivo. Si la cantidad de información sobre seguridad que se ofrece es excesiva, aumentan el tiempo y el esfuerzo que deben dedicarse a encontrar lo fundamental para satisfacer una necesidad apremiante. En consecuencia, las fuentes de este tipo de información deben facilitar los datos pertinentes e imprescindibles para alcanzar un objetivo inmediato. LoS programas de formación deben ofrecer la información más pormenorizada. El grado de detalle de los manuales de instrucciones, las FT S y otros materiales de referencia ha de superar al de las señales y etiquetas de advertencia.

4. H acer que el cumplimiento de la información no sea muy difícil de cumplir. En muchos estudios se ha indicado que la probabilidad de que las personas se atengan a las precauciones en materia de seguridad se reduce cuando se percibe que esta actitud "cuesta cumplirla". Por tanto, la información debe ofrecerse de modo que se minimice la dificultad de cumplir con su mensaje. En ocasiones, este objetivo puede alcanzarse facilitando la información en el momento y el lugar adecuados para su cumplimiento. 
Tabla 56.5 • Resumen de las recomendaciones incluidas en una selección de sistemas de advertencia.

\begin{tabular}{|c|c|c|c|c|c|}
\hline Sistema & Palabras en las señales & $\begin{array}{l}\text { Codificación por } \\
\text { colores }\end{array}$ & Tipografía & Símbolos & Disposición \\
\hline $\begin{array}{l}\text { ANSI Z129.1 } \\
\text { Productos químicos } \\
\text { industriales peligrosos: } \\
\text { etiquetado preventivo } \\
\text { (1988) }\end{array}$ & $\begin{array}{l}\text { Peligro } \\
\text { Atención } \\
\text { Cuidado } \\
\text { Tóxico } \\
\text { palabras opcionales para } \\
\text { peligros "diferidos" }\end{array}$ & № especificado & No especificado & $\begin{array}{l}\text { Calavera y tibias cruzadas } \\
\text { como complemento a las } \\
\text { palabras. Símbolos acepta- } \\
\text { bles para otros } 3 \text { tipos de } \\
\text { peligros. }\end{array}$ & $\begin{array}{l}\text { Disposición de la etiqueta no } \\
\text { especificada; se ofrecen } \\
\text { ejemplos }\end{array}$ \\
\hline $\begin{array}{l}\text { ANSI } 7535.2 \\
\text { Señales de seguridad en } \\
\text { el medio ambiente y en } \\
\text { las instalaciones (1993) }\end{array}$ & $\begin{array}{l}\text { Peligro } \\
\text { Atención } \\
\text { Cuidado } \\
\text { Nota } \\
\text { [seguridad general] } \\
\text { [flechas] }\end{array}$ & $\begin{array}{l}\text { Rojo } \\
\text { Naranja } \\
\text { Amarillo } \\
\text { Azul } \\
\text { Verde } \\
\text { como las indicadas } \\
\text { anteriormente; en } \\
\text { todo caso, blancas }\end{array}$ & $\begin{array}{l}\text { Caracteres sin trazos } \\
\text { terminales, caja alta, } \\
\text { caracteres aceptables, } \\
\text { alturas de letra }\end{array}$ & $\begin{array}{l}\text { Símbolos y pictogramas } \\
\text { conforme a ANSI Z535.3 }\end{array}$ & $\begin{array}{l}\text { Define el texto de la señal, } \\
\text { el mensaje escrito, los paneles } \\
\text { de símbolos en diseños del } 1 \\
\text { al 3. Cuatro formas de } \\
\text { uso especial. Puede utilizarse } \\
\text { la ANSI Z535.4 a efectos de } \\
\text { uniformidad. }\end{array}$ \\
\hline
\end{tabular}

$\begin{array}{lll}\text { ANSI Z535.4 } & \text { Peligro } & \text { Rojo } \\ \text { Signos y etiquetas de } & \text { Atención } & \text { Naranja } \\ \text { seguridad en los } & \text { Cuidado } & \text { Amarillo } \\ \text { productos (1993) } & & \text { conforme a ANSI } \\ & & \text { Z535.1 }\end{array}$

Caracteres sin trazos termina- Símbolos y pictogramas Define el texto de las señales, les, caja alta, se proponen ca- conforme a ANSI Z535.3; el mensaje, los paneles gráfiracteres, alturas de letras además el símbolo de alerta cos por orden: de generales a de seguridad SAE 284 específicos. Puede utilizar ANSI Z535.2 a efectos de uniformidad. Utilización de ANSI Z129.1 en el caso de los peligros químicos.

$\begin{array}{lll}\text { Directrices NEMA: NEMA } & \begin{array}{l}\text { Peligro } \\ \text { Atención }\end{array} & \text { Rojo } \\ & & \text { Rojo } \\ & & \\ \text { Señales de seguridad } & \text { Peligro } & \text { Rojo } \\ \text { SAE J115 (1979) } & \text { Atención } & \text { Amarillo } \\ & \text { Cuidado } & \text { Amarillo }\end{array}$

(1967); ISO 3864

(1984)

OSHA 1910.145

Especificación de las señales y las etiquetas para la prevención de accidentes (1985)

OSHA 1910.1200 Comunicación de peligros [químicos] (1985) etiquetas:

Detención/ prohibición Acción obligatoria

Rojo Aviso

Azul

Peligro Rojo

Atención (sólo en etiquetas) Amarillo

Cuidado

Amarillo

Peligro biológico, PELIGRO Fluorescente

BIOLOGICO, o símbolo

Naranja/ naranja-rojo

[instrucciones de seguridad] Verde

[vehículo de desplazamiento Fluorescente lento]

amarillo -narania y rojo oscuro conforme a ANSI Z535.1

Conforme a requisitos aplicables de EPA, FDA, BATF y CPSC;

si no se especifica lo contrario.

Manual de Westinghouse Peligro

(1981); Directrices de Atención

FMC (1985)

Cuidado
Nota
No especificado

Caracteres sin trazos terminales, caja alta

Se añade un panel de mensaje Símbolos y pictogramas debajo en caso necesario Símbolo de descarga
eléctrica

Disposición para acomodar los símbolos; no se prescriben símbolos ni pictogramas específicos

Puede leerse a 1,5 metros de distancia o según exija cada tarea

Símbolo de peligro biológico. El mensaje principal puede transmitirse mediante un pictograma (sólo en etiquetas). Vehículo de desplazamiento lento (SAE J943)

En inglés

Helvética negrita

y negruras regulares,

caja altal baja
Define el texto de las señales, el peligro, las consecuencias, las instrucciones, los símbolos. No se especifica el orden.

Define 3 áreas: panel de texto en las señales, panel gráfico, panel del mensaje. Se clasifican en orden de general a específico.

El pictograma o el símbolo se sitúa dentro de un contorno adecuado. Forma con panel del mensaje debajo, si es necesario.

Texto de la señal y mensaje principal (sólo en etiquetas)

Unicamente como las fichas técnicas de seguridad

Recomienda 5 componentes: texto de la señal, símbolo/ pictograma, peligro, resultado de pasar por alto la advertencia, evitar el peligro 
5. U tilizar símbolos y textos tan concretos como sea posible Las investigaciones en materia de información sobre seguridad han demostrado que las personas entienden mejor las palabras y los símbolos concretos que los abstractos. No obstante, la cualificación y la experiencia desempeñan un papel importante para determinar el valor de la concreción. No es infrecuente que los trabajadores más cualificados prefieran y comprendan mejor la terminología abstracta.

6. Simplificar la sintaxis y la gramática del texto y las combinaciones de símbolos. R edactar textos para que los lectores poco avezados, o incluso otros más capaces, puedan entender no es tarea fácil. Se han elaborado numerosas directrices en un intento de atenuar este problema. Algunos principios básicos son: 1) utilizar palabras y símbolos comprensibles para la población a la que van dirigidos, 2) emplear una terminología coherente, 3) recurrir a oraciones breves y sencillas construidas conforme al esquema habitual sujeto-verbo-complemento, 4) evitar las negaciones y las oraciones condicionales complejas, 5) utilizar la voz activa más que la pasiva, 6) evitar el empleo de pictogramas complejos para describir acciones, y 7) evitar la combinación de múltiples significados en una sola figura.

El cumplimiento de estas directrices exige la consideración de varias cuestiones detalladas que se abordan en el próximo apartado.

\section{Elaboración de la información sobre seguridad}

La elaboración de información sobre seguridad concebida para acompañar a los productos, como los avisos, las etiquetas y las instrucciones, suele exigir la realización de estudios y actividades que requieren una cantidad considerable de recursos y tiempo. En teoría, estas actividades consisten en: 1) la coordinación entre el diseño del producto y la elaboración de la información, 2) el análisis de las características del producto que afectan a las expectativas y los comportamientos de los usuarios, 3) la determinación de los peligros asociados a la utilización y el probable abuso del producto, 4) la investigación de las percepciones y expectativas del usuario respecto a la función y las características de peligrosidad del producto, y 5) la evaluación de la información del producto basada en métodos y criterios coherentes con los objetivos de cada componente de la misma. Las actividades que permiten la consecución de estos objetivos pueden agruparse en varios niveles. Aunque los diseñadores de producto internos son capaces de abordar muchas de las tareas designadas, algunas de éstas exigen la aplicación de metodologías muy conocidas por profesionales con formación en materia de técnica de factores humanos, técnica de seguridad, diseño de documentos y ciencias de la comunicación. L as tareas correspondientes a estos niveles se muestran en la Figura 56.18 y se resumen a continuación :

\section{Nivel 0: estado de diseño del producto}

EI nivel 0 es el punto de partida para emprender un proyecto de información sobre un producto, tanto como el momento en que se recibirá la retroinformación relativa a las alternativas de diseño y se propondrán nuevas repeticiones a la escala del modelo básico. Al inicio de un proyecto de información de producto, el investigador parte de un diseño concreto. Puede encontrarse en la fase de concepto 0 de prototipo o coincidir con el del producto vendido y utilizado. U na razón importante para designar un

Figura 56.18 • Modelo para el diseño y la evaluación de la información de un producto.

NIVEL 0

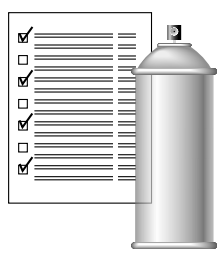

ESTADO DE DISEÑO

DEL PRODUCTO

Estado del producto en cuestión

- Características físicas

- Características

funcionales

- Información del

producto
NIVEL 1
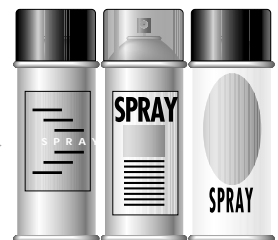

INVESTIGACIONES SOBRE

EL TIPO DE PRODUCTO

- Información de los

competidores

- Características del producto

- Historial de accidentes

- Investigación especifica del tipo

de producto

- Normas y disposiciones

- Anuncios y atención de los medios de comunicación
NIVEL 2

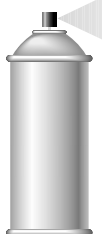

INVESTIGACION DEL USO

DEL PRODUCTO Y DEL

GRUPO DE USUARIOS

- Métodos de utilización

previstos

- Identificación del grupo de

usuarios

- Selección de mensajes

- Percepciones del usuario

respecto a los riesgos

- Identificación y análisis del

peligro

- Análisis cognitivo y del

comportamiento

- Probables errores de los

usuarios
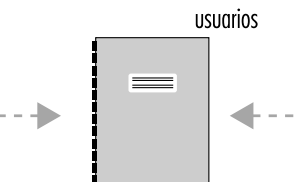

ECOMENDACIONES

PARA LA REMODELACION

FISICA DEL PRODUCTO
NIVEL 3

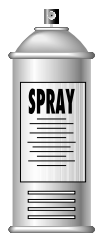

CRITERIOS DE DISEÑO Y

DISENOS DE PROTOTIPOS

- Papel desempeñado por las normas/requisitos

reglamentarios

- Tipos de información sobre tareas

- Selección de mensajes

- Modos de comunicación

- Ubicación temporal y espacial

- Resumen de las características

de diseño idóneas

- Diseño de prototipos de texto

e ilustraciones

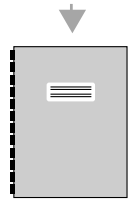

RECOMENDACIONES PARA LA

REMODELACION DE IA INFORMACION

SOBRE EL PRODUCTO EXISTENTE

NIVEL 4

NIVEL 5

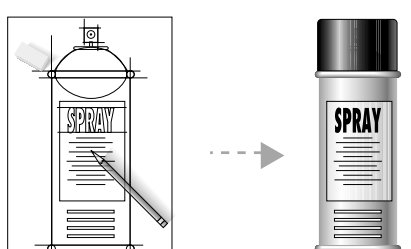

EVALUACION Y REVISION

- Medidas de evaluación

- Metodología de evaluación

- Selección de una muestra de usuarios

- Ejecución del plan de evaluación

- Modificación de los prototipos

de información (repeticiones)

- Texto e ilustraciones definitivos

PUBLICACION

- Impresión y comprobación

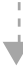

NIVEL 6

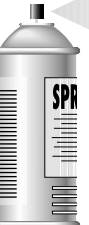

EVALUACIONES

POSTERIORES A LA VENTA 
nivel 0 es la constatación de que es preciso gestionar la elaboración de la información de producto. Es un tipo de proyectos que requiere presupuestos formales, recursos, planificación y asignación de responsabilidades. Las principales ventajas de un diseño sistemático de la información de producto se logran cuando éste se encuentra en la fase de concepto previo a la producción o de prototipo. Con todo, la aplicación de la metodología a los productos existentes y la información sobre ellos es bastante apropiada y extremadamente útil.

\section{Nivel 1: investigaciones sobre el tipo de producto}

En esta fase deben acometerse al menos siete tareas: a) documentar las características del producto existente (p. ej., componentes, funcionamiento, montaje y embalaje); b) investigar las características del diseño y de la información que se adjunta a otros productos similares o de la competencia; c) recopilar datos sobre accidentes relacionados con el producto o con otros similares o de la competencia; d) determinar los estudios sobre factores humanos y seguridad, en los que se aborda este tipo de producto; e) establecer las normas y las disposiciones aplicables; f) analizar la atención por parte de la Administración y de los medios comerciales a este tipo de producto (incluida la información de recuerdo), y g) investigar el historial de litigios de éste y otros productos semejantes.

\section{Nivel 2: investigación del uso del producto y del grupo de usuarios}

En esta fase deben realizarse al menos siete tareas: a) determinar los métodos de utilización del producto apropiados (incluido el montaje, la instalación, la utilización y el mantenimiento); b) identificar los grupos de usuarios del producto existentes y posibles; c) investigar la utilización, el abuso y el conocimiento del producto o productos similares por parte del usuario; d) estudiar las percepciones del usuario respecto a los riesgos del producto; e) determinar los riesgos asociados con los usos indicados y los abusos previsibles del producto; f) analizar las demandas cognitivas y de comportamiento durante la utilización del producto, y g) establecer los errores probables del usuario, sus consecuencias y posibles soluciones.

T ras completar los análisis de los niveles 1 y 2, deben considerarse los cambios en el diseño del producto antes de avanzar en el proceso. Desde el punto de vista de la técnica de seguridad tradicional, esta acción podría denominarse: "eliminar los riesgos del producto a partir de la técnica". Algunas modificaciones pueden ir dirigidas a la salud del usuario y otras al intento de beneficiar a la empresa, que trata de lograr un éxito de marketing.

\section{Nivel 3: criterios de diseño de la información y prototipos}

En el nivel 3 se llevan a cabo al menos nueve tareas: a) basándose en las normas y los requisitos aplicables a un producto concreto, determinar, en su caso, cuál de esos requisitos imponen el diseño y los criterios de ejecución en esta parte del proceso de diseño de la información; b) establecer los tipos de tareas que exigen la oferta de información a los usuarios (p. ej., funcionamiento, montaje, mantenimiento y evacuación); c) determinar, para cada tipo de información sobre tareas, los mensajes que deben trasladarse al usuario; d) decidir el modo de comunicación apropiado para cada mensaje (p. ej., texto, símbolos, señales o características del producto); el determinar la ubicación temporal y espacial de cada mensaje; f) desarrollar las características idóneas de la información en función de los mensajes, los modos y las ubicaciones establecidas en fases anteriores; g) elaborar prototipos de cada componente del sistema de información del producto (p. ej., manuales, etiquetas, avisos, letreros, embalaje y señales); h) verificar que los distintos tipos de información son coherentes (p. ej., manuales, letreros, etiquetas y embalaje), y i) comprobar que la información de los productos con otras denominaciones de marca u otros productos similares de la misma empresa sea coherente.

Tras superar los niveles 1, 2 y 3, el investigador habrá desarrollado el formato y el contenido de la información, se supone que correctamente. En este momento, puede optar por formular unas recomendaciones iniciales relativas a la remodelación de la información del producto de la que ya se disponga, antes de pasar al nivel 4 .

\section{Nivel 4: evaluación y revisión}

En el nivel 4 deben acometerse al menos seis tareas: a) definir los parámetros de evaluación para cada componente prototipo del sistema de información del producto; b) elaborar una plan de evaluación de cada uno de estos componentes; c) seleccionar usuarios, instaladores y otros agentes representativos que participen en la evaluación; d) ejecutar el plan de evaluación; e) modificar los prototipos de información del producto y el diseño del mismo en función de los resultados obtenidos en la evaluación (es probable que sean necesarias varias repeticiones), y f) especificar el texto y la disposición gráfica definitivos.

\section{Nivel 5: publicación}

En el nivel 5, la publicación efectiva de la información se revisa, aprueba y lleva a cabo de acuerdo con lo especificado. El objetivo de este nivel es confirmar que las especificaciones de los diseños, incluidas las clasificaciones lógicas del material, la ubicación y la calidad de las ilustraciones, así como las características de comunicación especiales, se han cumplido con precisión y no han sido modificadas involuntariamente en la imprenta. Aunque la publicación suele ser ajena al control de la persona encargada de los diseños de la información, se ha considerado necesario comprobar que éstos diseños se respetan rigurosamente, ya que se sabe que los impresores se toman muchas libertades en la manipulación de la maquetación.

\section{Nivel 6: evaluaciones posteriores a la venta}

En el último nivel del modelo se abordan las evaluaciones posteriores a la venta, que consisten en un control final que garantice que la información cumple los objetivos para los que fue diseñada. El diseñador de la información, así como el fabricante, tienen la oportunidad de obtener una retroinformación valiosa e instructiva de este proceso. Entre los ejemplos de evaluación posterior a la venta figuran: a) la retroinformación procedente de los programas sobre satiffacción del cliente, b) los posibles resúmenes de datos obtenidos de la cumplimentación de la garantía y de las tarjetas de respuesta de la garantía, c) el almacenamiento de datos de las investigaciones de accidentes en las que intervinieron el mismo producto $u$ otros similares, d) el seguimiento de las normas de consenso y las actividades regulatorias, y e) el control de las medidas recordatorias de seguridad y de la atención prestada por los medios de comunicación a productos semejantes.

\section{COSTES DE LOS ACCIDENTES RELACIONADOS CON EL TRABAJO}

\section{D iego Andreoni}

L os trabajadores que son víctimas de accidentes relacionados con el trabajo padecen consecuencias que pueden ser materiales, como gastos y pérdida de ingresos, e intangibles, como el dolor y 
el sufrimiento, en ambos casos pueden ser de corta o de larga duración. E sas consecuencias incluyen:

- el pago de honorarios médicos, el coste de la ambulancia u otra forma de transporte, los gastos de hospital o la remuneración por los cuidados de enfermería a domicilio, los pagos efectuados a personas que prestaron su asistencia, el coste de miembros artificiales, etcétera;

- la pérdida inmediata de ingresos durante la ausencia del puesto de trabajo (salvo que se esté asegurado o se obtenga indemnización);

- la pérdida de ingresos futuros si la lesión discapacita de manera permanente 0 a largo plazo, o impide el ascenso normal de la víctima en su carrera profesional;

- los trastornos permanentes a consecuencia del accidente, como la mutilación, la cojera, la pérdida de visión, las cicatrices desagradables o la desfiguración, las alteraciones mentales, etc., que pueden reducir la esperanza de vida y provocar sufrimiento físico o psicológico, así como elevar los gastos derivados de la necesidad de la víctima de encontrar una nueva profesión u otros intereses;

- las consiguientes dificultades económicas para el presupuesto familiar si otros parientes se ven obligados a trabajar para compensar los ingresos perdidos o a abandonar su empleo para cuidar de la víctima. Pueden producirse otras reducciones de ingresos si el sujeto accidentado trabajaba al margen de la jornada normal de trabajo y ya no puede seguir haciéndolo,

- la ansiedad para el resto de la familia y el deterioro de su futuro, sobre todo en el caso de los niños.

Los trabajadores accidentados suelen recibir una indemnización 0 un subsidio en efectivo o en especie. Aunque estas prestaciones no afectan a las consecuencias intangibles del accidente (salvo en circunstancias excepcionales), son una parte más 0 menos importante de las materiales, puesto que influyen en la cuantía de los ingresos que sustituirán al sueldo. No cabe duda de que una parte de los costes generales de un accidente, excepto en condiciones muy favorables, debe ser afrontada directamente por las víctimas.

Considerando la economía nacional en conjunto, debe admitirse que la dependencia entre todos sus miembros es tal que las consecuencias de un accidente que afecta a una persona tienen un efecto adverso sobre el nivel de vida general. He aquí las consecuencias:

- un aumento en el precio de los productos manufacturados, ya que los gastos directos e indirectos y las pérdidas resultantes de un accidente pueden dar lugar a una elevación del coste de fabricación de un artículo;

- una reducción del producto nacional bruto, como resultado de los efectos perjudiciales de los accidentes sobre las personas, los equipos, las instalaciones y los materiales. Estos efectos variarán de acuerdo con la mano de obra, el capital y los recursos materiales de que disponga cada país,

- un aumento de los gastos destinados a cubrir el coste de las indemnizaciones a los accidentados y el pago de primas de seguro de mayor cuantía, así como a reunir la cantidad necesaria para adoptar las medidas de seguridad que exige la prevención de sucesos similares.

U na de las funciones de la sociedad es proteger la salud y la renta de sus miembros. Y lo hace mediante la creación de instituciones de seguridad social, programas de salud (algunas Administraciones ofrecen asistencia médica gratuita o de bajo coste a sus ciudadanos) y sistemas de seguridad y de seguro de indemnización por lesión (incluida la legislación, la inspección, la asistencia, la investigación y otras actividades), cuyos costes administrativos representan una carga para la sociedad.

El nivel de las indemnizaciones y la cuantía de los recursos que dedican las Administraciones a la prevención de accidentes son limitados porque dependen: 1) del valor adjudicado a la vida y el sufrimiento humanos, que varía de un país a otro y de una época a otra, y 2) de los fondos disponibles y las prioridades asignadas a otros servicios prestados para la protección de la población

En consecuencia, se escatima una cantidad de capital considerable para la inversión productiva. Ahora bien, el dinero dedicado a la acción preventiva brinda beneficios económicos sustanciales, en cuanto que da lugar a la reducción del número total de accidentes y de su coste. Gran parte del esfuerzo dedicado a la prevención de accidentes, como la aplicación de normas de seguridad más exigentes a la maquinaria y a los equipos, y la educación general de la población antes de alcanzar la edad para trabajar, son igualmente útiles dentro y fuera del lugar de trabajo. Es una circunstancia que cobra cada vez mayor importancia, ya que el número y el coste de los accidentes que ocurren en el hogar, en las carreteras o en otras actividades de la vida moderna no relacionadas con el trabajo siguen aumentando. El coste total de los accidentes puede definirse como la suma del coste de prevención y el coste de los cambios resultantes. No parece descabellado reconocer que el coste social de los posibles cambios que resulten de la aplicación de una medida preventiva puede superar ampliamente el coste real de la medida. Los recursos financieros necesarios se extraen del grupo de población económicamente activo, compuesto por los trabajadores, las empresas y otros contribuyentes, mediante sistemas que funcionan sobre la base de la cotización a las instituciones que ofrecen las prestaciones, a través de los impuestos recaudados por el Estado u otras Administraciones públicas, 0 mediante ambos procedimientos. A escala empresarial, el coste de los accidentes incluye gastos y pérdidas, como los que se refieren a continuación:

- gastos realizados al establecer el sistema de trabajo e instalar los equipos y la maquinaria correspondientes con vistas a garantizar la seguridad en el proceso productivo. La estimación de estos gastos es difícil, ya que resulta imposible trazar una línea divisoria entre la seguridad del proceso en sí y la de los trabajadores. Se trata de grandes cantidades, que son desembolsadas en su totalidad antes de que comience la producción y se incluyen en las partidas de costes generales 0 especiales para su amortización a lo largo de varios años;

- gastos soportados durante la producción, que, a su vez, incluyen: a) los costes fijos relacionados con la prevención de accidentes, como los dedicados a los servicios médicos, de seguridad y educativos y a la organización de la participación de los trabajadores en el programa de seguridad; b) los costes fijos de los seguros de accidente, además de los costes variables en los regímenes que vinculan la cuantía de las primas al número de accidentes; c) los costes variables de las actividades relativas a la prevención de accidentes (éstos dependen en gran medida de la frecuencia y la gravedad de los accidentes, e incluyen el coste de las actividades de formación e información, las campañas de seguridad, los programas y la investigación en materia de seguridad y la participación de los trabajadores en estas actividades); d) los costes originados por las lesiones personales (aquí se incluyen el coste de la asistencia médica, el transporte, los subsidios concedidos a los accidentados y a sus familias, las consecuencias administrativas y jurídicas de los accidentes, los sueldos abonados a las personas lesionadas durante su ausencia del trabajo y a otros trabajadores durante las interrupciones de su actividad tras un 
accidente y en las encuestas e investigaciones posteriores, etc.); e) los costes derivados de los daños y las pérdidas materiales que no tienen que coincidir necesariamente con una lesión personal. De hecho, los daños materiales más habituales y caros en ciertas ramas de la industria se producen en circunstancias ajenas a las que dan lugar a una lesión personal. D ebe prestarse atención a los escasos puntos en común entre las técnicas de control de daños materiales y las aplicadas a la prevención de lesiones personales.

- pérdidas debidas a una caída en la producción o a los costes de adoptar medidas de compensación especiales, pudiendo resultar ambas causas muy gravosas.

Además de afectar al lugar donde se ha producido el accidente, pueden registrarse pérdidas sucesivas en otros puntos de la instalación o en instalaciones asociadas. A parte del quebranto económico resultante de la interrupción del trabajo debida a los accidentes y las lesiones, deben tenerse en cuenta las pérdidas que se acumulan cuando los trabajadores dejan de trabajar o convocan una huelga durante los conflictos laborales planteados por la existencia de accidentes graves, repetidos o generalizados.

EI valor total de estos costes y pérdidas difiere de una empresa a otra. Las disparidades más obvias dependen de los riesgos específicos asociados a cada rama de la industria o tipo de actividad y de la medida en que se apliquen las precauciones pertinentes. En lugar de intentar valorar los costes iniciales en los que se incurre al incorporar medidas de prevención de accidentes en el sistema en las fases iniciales, numerosos autores han tratado de estimar los costes de las consecuencias. Entre éstos puede citarse a Heinrich, que propuso la división de los costes en "directos" (en particular, los seguros) e "indirectos" (gastos realizados por el fabricante); a Simonds, que planteó la división entre costes asegurados y no asegurados; a Wallach, que propuso una división de acuerdo con los distintos apartados utilizados para el análisis de los costes de producción, es decir, mano de obra, maquinaria, mantenimiento y gastos temporales, y Compes, quien clasificó los costes en generales e individuales. En todos estos ejemplos (con la excepción de Wallach), se consideran dos grupos de costes que, aunque diferentes en definición, tienen numerosos puntos en común.

$\mathrm{H}$ abida cuenta de la dificultad de estimar los costes generales, se ha intentado calcular un valor adecuado para esta cifra mediante la expresión del coste indirecto (costes no asegurados 0 individuales) como un múltiplo del directo (costes asegurados o generales). H einrich fue el primero en intentar obtener un valor para esta cifra y propuso que la cuantía de los costes indirectos fuese cuatro veces mayor que los costes directos, es decir, que el coste total equivaliese al coste directo multiplicado por cinco. Aunque la estimación es válida para el grupo de empresas estudiado por $\mathrm{H}$ einrich, no puede aplicarse a otros grupos, y menos aún en el caso de fábricas específicas. En ciertos sectores de diversos países industrializados, se ha observado que este valor oscila entre 1 y $7(4 \pm 75 \%)$, pero en algunos estudios se ha puesto de manifiesto que puede ser considerablemente superior (hasta 20 veces) e incluso variar con el tiempo en una misma empresa.

No cabe duda que las cantidades dedicadas a la incorporación de las medidas de prevención de accidentes en el sistema en las fases iniciales de un proyecto de fabricación, se verán compensadas por la reducción de las pérdidas y los gastos que, de no haber sido así, se habrían registrado. No obstante, este ahorro no se somete a ninguna ley específica o proporción fija, y variará de un caso a otro. Puede ser que un gasto reducido dé lugar a un ahorro sustancial, mientras que, en otros casos, un gasto mucho mayor generará una ganancia aparente muy escasa. Al llevar a cabo cálculos de este tipo, debe tenerse en cuenta siempre el factor tiempo, que actúa de dos modos: los gastos actuales pueden reducirse mediante la amortización del coste inicial en varios años, y la probabilidad de que ocurra un accidente, por baja que sea su frecuencia, aumentará con el paso de los años.

En un sector determinado, siempre que lo permitan los factores sociales, puede no existir un incentivo económico para reducir los accidentes, teniendo en cuenta que su coste se añade al de producción y, por tanto, revierte en el consumidor. Sin embargo, la cuestión cambia cuando se considera desde el punto de vista de una empresa concreta. Es posible que existan grandes incentivos para que una empresa adopte medidas con el fin de evitar los efectos económicos graves de los accidentes que afectan al personal clave y a los equipos esenciales. Así ocurre especialmente en el caso de las pequeñas fábricas que carecen de una reserva de personal cualificado o que se dedican a ciertas actividades especializadas, así como en el de las grandes instalaciones complejas, como las de la industria de transformación, en las que el coste de sustitución puede exceder la capacidad de obtener capital. Asimismo, pueden darse casos en los que una gran empresa pueda mejorar su competitividad y aumentar con ello sus beneficios mediante la adopción de medidas destinadas a reducir accidentes. Además, ninguna empresa puede permitirse pasar por alto las ventajas económicas que se derivan del mantenimiento de una buenas relaciones con los trabajadores y sus sindicatos.

Por último, al pasar del concepto abstracto de una empresa a la realidad concreta de los que ocupan puestos de mando en la actividad empresarial (es decir, los empresarios y la alta dirección), hay que considerar un incentivo personal que no es sólo económico y que alude al deseo o la necesidad de estas personas de impulsar su carrera profesional y evitar las sanciones, legales y de otro tipo que pueden imponérseles en el caso de cierto tipo de accidentes. Por tanto, el coste de los accidentes en el trabajo repercute en la economía nacional y en la de cada componente de la población, por lo que existe un incentivo general e individual para que todos intervengamos en la reducción de este coste.

\section{Referencias}

Adams, JGU . 1985. Risk and F reedom; The R ecord of Read Safety Regulation. Londres: Transport Publishing Projects.

American N ational Standards Institute (ANSI). 1962. $M$ ethod of Recording and M easuring W ork Injury Experience. ANSI Z-16.2. Nueva York: ANSI.

- . 1978. American National Standard M anual on U niform T raffic Control D evices for Streets and $\mathrm{H}$ ighways. ANSI D6.1. Nueva Y ork: ANSI.

-. 1988. H azardous Industrial Chemicals- Precautionary Labeling. ANSI Z129.1. N ueva Y ork: ANSI.

—. 1993. Safety Color Code. ANSI Z535.1. N ueva Y ork: ANSI.
1993. Environmental and Facility Safety Signs. ANSI Z535.2. Nueva Y ork: ANSI

-. 1993. Criteria for Safety Symbols. ANSI Z535.3. Nueva Y ork: ANSI.

—. 1993. Product Safety Signs and Labels. ANSI Z535.4. Nueva Y ork: AN SI.

—. 1993. Accident Prevention T ags. ANSI Z535.5. Nueva York: ANSI.

Andersson, R, E Lagerlöf. 1983. Accident data in the new Swedish information system on occupational injuries. E rgonomics 26.

Andersson, R. 1991. The role of accidentology in occupational accident research. Arbete och halsa. 1991. Solna, Suecia. T esis doctoral.
Arnold, HJ 1989 Sanctions and rewards: O rganizational perspectives. In Sanctions and R ewards in the Le gal System: A M ultidisciplinary Approach. Toronto: U niversity of T oronto Press.

Baker, SP, B O 'N eil, MJ G insburg, G Li. 1992. I jury F act B ook. N ueva Y ork: $\mathrm{O}$ xford U niversity Press.

Benner, L. 1975. Accident investigations-multilinear sequencing methods. I Saf Res 7 .

Centers for Disease Control and Prevention (CDC). 1988. Guidelines for evaluating surveillance systems. M orb M ortal W eakly Rep 37(S-5):1-18.

Davies, JC, DP M anning. 1994a. M AIM : the concept and construction of intelligent software. Saf $\mathrm{SC}$ $17: 207-218$ 
-. 1994b. Data collected by M AIM intelligent software: The first fifty accidents. Saf Sci 17:219-226.

Department of T rade and Industry. 1987. Lesure Accident Surveillance System (LASS): H ome and Lesure Accident Research $1986 \mathrm{D}$ ata. 11th Annual Report of the $\mathrm{H}$ ome Accident Surveillance System. L ondres: Department of T rade and Industry.

Ferry, TS. 1988. M odern Accident I nvestigation and Analysis. N ueva Y ork: Wiley.

Feyer, A-M , AM Williamson. 1991. An accident classification system for use in preventive strategies. Scand J W ork Environ H ealth 17:302-311.

FM C. 1985. Product Safety Sign and Label System. Santa Clara, California: FM C Corporation.

Gielen, AC. 1992. Health education and injury control: Integrating approaches. Health Educ Q 19(2):203-218.

Goldenhar, LM , PA Schulte. 1994. Intervention research in occupational health and safety. J 0 ccup M ed 36(7):763-775.

Green, LW, M W K reuter. 1991. H ealth Promotion Planning: An Educational and Environmental Approach. Mountainview, California Mayfield Publishing Company.

Guastello, SJ. 1991. T he Comparative E ffectiveness of O ccupational Accident Reduction Programs. Artículo presentado en un simposio internacional sobre accidentes y lesiones relacionadas con el alcohol. Y verdon-les-Bains, Suiza, 2-5 de diciembre.

Haddon, WJ. 1972. A logical framework for categorizing highway safety phenomena and activity. I Trauma 12:193-207.

- . 1973. Energy damage and the 10 countermeasure strategies. J T rauma 13:321-331.

-. 1980. The basic strategies for reducing damage from hazards of all kinds. $\mathrm{H}$ azard Prevention. Septiembre/ 0 ctubre: 8-12.

$\mathrm{H}$ ale, AR, AI Glendon. 1987. Individual B ehaviour in the $F$ ace of $D$ anger. A msterdam: Elsevier.

H ale, AR, B H eming, J Carthey, B K irwan. 1994. Extension of the $M$ odel of $B$ ehaviour in the $C$ ontrol of $D$ anger. Vol. 3: Extended M odel D escription. Sheffield: $\mathrm{H}$ ealth and Safety Executive, Proyecto H F/ G N SR / 28.

H ale, AR, M H ale. 1972. R eview of the Industrial Accident R esearch Literature. Research paper No. I, Committee on Safety \& H ealth. Londres: H M SO

Hare, V C. 1967. System Analysis: A Diagnostic Approach. N ueva Y ork: H arcourt Brace W orld.

H arms-R ingdahl, L. 1993. Safety Analysis. Principles and Practice in 0 ccupational Safety. Vol. 289. A msterdam: Elsevier

Heinrich, HW. 1931. Industrial Accident Prevention. Nueva Y ork: M cG raw-Hill.

-. 1959. Industrial Accident Prevention: A Scientific Approach. N ueva Y ork: M CG raw-Hill Book Company.

H ugentobler, M K, BA Israel, SJ Schurman. 1992. An action research approach to workplace health: Integrating methods. H ealth E duc Q 19(1):55-76.

Janssen, W. 1994. Seat-belt wearing and driving behavior: An instrumented-vehicle study. Accident analysis and prevention. Accident Anal. Prev. 26: 249-261.

Jenkins, EL, SM K isner, D Fosbroke, LA Layne, M A Stout, DN Castillo, PM Cutlip, R Cianfrocco. 1993. Fatal Injuries to W orkers in the U nited States 1980-1989: A Decade of Survellance. Cincinnati, O hio: NIOSH.

Johnston, JJ, GTH Cattledge, JW Collins. 1994. The efficacy of training for occupational injury control. 0 ccup M ed: State Art R ev 9(2):147-158.

$K$ allberg, VP. 1992. T he E ffects of R eflector P osts on D riving $B$ ehaviour and Accidents on T wo-lane R ural Roads in Finland. Report 59/ 1992. Helsinki: Centro $\mathrm{Na}$ cional Finlandés de Desarrollo Técnico de la $\mathrm{Ad}$ ministración de $\mathrm{C}$ arreteras.
K jellén, U, J H ovden. 1993. R educing risks by deviation control-a retrospection into a research strategy. Saf Sci 16:417-438.

K jellén, U, TJ Larsson. 1981. Investigating accidents and reducing risks- a dynamic approach. J 0 ccup Acc 3:129-140.

K jellén, U. 1984. The deviation concept in occupational accident control. Part I: D efinition and classification; Part II: Data collection and assesment of significance. A ccident Anal Prev 16:289-323.

Last, JM. 1988. A Dictionary of E pidemiology. Nueva Y ork: $O$ xford U niversity Press.

Lehto, M R, D Clark. 1990. Warning signs and labels in the workplace. En W orkspace, Equipment and Tool Design, dirigido por A M ital y W K arwowski. Amsterdam: Elsevier.

Lehto, M R, JM M iller. 1986. W arnings: Volume I: Fundamentals, Design, and Evaluation M ethodologies. Ann Arbor, M ichigan: Fuller T echnical Publications.

Lehto, M R . 1992. D esigning warning signs and warning labels: Part I-Guidelines for the practitioner. Int J Ind E rg 10:105-113.

Leplat, J. 1978. Accident analyses and work analyses. J 0 ccup Acc 1:331-340.

M ack enzie, EJ, DM Steinwachs, BS Shankar. 1989. Classifying severity of trauma based on hospital discharge diagnoses: Validation of an ICD-9CM to AIS-85 conversion table. M ed Care 27:412-422.

M anning, DP. 1971. Industrial accident-type classifications-A study of the theory and practice of accident prevention based on a computer analysis of industrial injury records. T esis M.D., U niversidad de Liverpool.

MCAfee, RB, AR Winn. 1989. The use of incentives/ feedback to enhance work place safety: A critique of the literature. J Saf Res 20:7-19.

M ohr, DL, D Clemmer. 1989. Evaluation of an occupational injury intervention in the petroleum in dustry. Accident Anal Prev 21(3):263-271.

$\mathrm{N}$ ational Committee for Injury Prevention and Control. 1989. Injury Prevention: M ecting the Challenge Nueva Y ork: $\mathrm{O}$ xford U niversity Press.

$N$ ational Electronic $M$ anufacturers Association (NEM A). 1982. Safety Labels for Padmounted Switch $G$ ear and Transformers Sited in Public Areas. NEMA 260. R osslyn, V irginia: NEM A.

O ccupational $\mathrm{Health}$ and Safety Administration (OSH A). 1985. Specification for Accident Prevention Signs and Tags. CFR 1910.145. Washington DC: OSHA.

- 1985. [Chemical] Hazard Communication. CFR 1910.1200. Washington DC: O SH A.

O ccupational Injury Prevention Panel. 1992. O ccupational injury prevention. In Centers for Disease Control. Position Papers from the Third National Injury Control Conference: Setting the National Agenda for Injury Control in the 1990s. Atlanta, Georgia: CDC.

O rganización Internacional de Normalización (ISO). 1967. Symbols, Dimensions, and Layout for Safety Signs. ISO R 557. Ginebra: ISO

-. 1984. Safety Signs and Colors. ISO 3864. Ginebra: ISO.

- . 1991. Industrial Automation Systems- Safety of Inte grated $M$ anufacturing Systems- Basic R equirements (CD 11161 ). TC 184/ WG 4. Ginebra: ISO.

-. 1994. Quality M anagement and Quality Assurance Vocabulary. ISO/DIS 8402. París: Association française de normalisation.

Organización para la Cooperación y el Desarrollo Económico (O CDE). 1990. B ehavioural Adaptation to Changes in the R oad T ransport System. París: O CDE.

Rasmussen, J, K D uncan, J Leplat. 1987. N ew T echnology and $\mathrm{H}$ uman $\mathrm{E}$ rror. Chichester: Wiley.

R asmussen, J. 1982. H uman errors. A taxonomy for describing human malfunction in industrial installations. J 0 ccup Acc 4:311-333.
R eason, JT . 1990. H uman E rror. Cambridge: CU P.

Rice, DP, EJ M acK enzie y cols. 1989. Cost of I njury in the U nited States: A R eport to Congress. San Francisco: Institute for $\mathrm{H}$ ealth and Aging, U niversidad de California; y Baltimore: Injury Prevention Center, U niversidad Johns H opkins.

R obertson, LS. 1992. Injury E pidemiology. N ueva Y ork: 0 xford U niversity Press.

Saari, J. 1992. Successful implementation of occupational health and safety programs in manufacturing for the 1990s. J H um F actors $M$ anufac 2:55-66.

Schelp, L. 1988. The role of organizations in community participation-prevention of accidental injuries in a rural Swedish municipality. Soc Sci M ed 26(11):1087-1093.

Shannon, H S. 1978. A statistical study of 2,500 consecutive reported accidents in an automobile factory. T esis doctoral, $U$ niversidad de $L$ ondres.

Smith, GS, H Falk. 1987. U nintentional injuries. Am J Prev M edicine 5, Supl.:143-163.

Smith, GS, PG Barss. 1991. U nintentional injuries in developing countries: The epidemiology of a neglected problem. E pidemiological R eviews :228-266.

Society of Automotive Engineers (SAE). 1979. Safety Signs. SAE J115: SAE.

Steckler, AB, L Dawson, BA Israel, E Eng. 1993. Community health development: An overview of the works of Guy W. Stewart. $H$ ealth $E$ duc $Q$ Supl. 1: S3-S20.

Steers, R M , LW Porter.1991. M otivation and W ork Be havior (5a ed). Nueva Y ork: M cG raw-H ill.

Surry, J. 1969. Industrial A ccident R esearch: A H uman Engineering Appraisal. Canadá: Universidad de Toronto.

Tollman, S. 1991. Community-oriented primary care: $O$ rigins, evolutions, applications. Soc Sci M ed 32(6):633-642.

Troup, JDG, J Davies, DP M anning. 1988. A model for the investigation of back injuries and manual handling problems at work. I Soc 0 ccup $\mathrm{Med}$ 10:107-119.

T uominen, R, J Saari. 1982. A model for analysis of accidents and its applications. J 0 ccup Acc 4.

Veazie, M A, DD Landen, TR Bender, HE Amandus. 1994. E pidemiologic research on the etiology of injuries at work. Ann R ev Pub H ealth 15:203-21.

Waganaar, WA, PT Hudson, JT Reason. 1990. Cognitive failures and accidents. Appl Cogn Psychol 4:273-294.

Waller, JA. 1985. I njury Control: A Guide to the Causes and Prevention of $T$ rauma. Lexington, M assachussetts: Lexington Books.

Wallerstein, N, R Baker. 1994. Labor education programs in health and safety. 0 ccup M ed State Art R ev 9(2):305-320.

Weeks, JL. 1991. O ccupational health and safety regulation in the coal mining industry: Public health at the workplace. Annu Rev Publ $\mathrm{H}$ ealth 12:195-207.

Westinghouse Electric Corporation. 1981. Product Safety $L$ abel $H$ andbook. T rafford, Pensilvania: Westinghouse Printing Division.

Wilde, GJS. 1982. The theory of risk homeostasis: Implications for safety and health. Risk Anal 2:209225.

-. 1991. Economics and accidents: A commentary. J Appl B ehav Sci 24:81-84.

-. 1988. Risk homeostasis theory and traffic accidents: propositions, deductions and discussion of dissemsion in recent reactions. E rgonomics 31:441468.

—. 1994. T arget Risk. T oronto: PDE Publications.

Williamson, AM, A-M Feyer. 1990. Behavioural epidemiology as a tool for accident research. J 0 ccup Acc 12:207-222. 
Work Environment Fund [Arbetarskyddsfonden]. 1983. Olycksfall i arbetsmiljön- Kartläggning och analys av forskningsbehov [A ccidentes en el lugar de trabajo- encuesta y análisis]. Solna: Arbetarskyddsfonden

\section{0 tras lecturas recomendadas}

Andersson, R, B Johansson, $K$ Lindén, L Svanström. 1978. Development of a model for research on occupational accidents. I 0 ccup Acc 1.

Apple, J. 1972. M aterials H andling Systems D esign. Nueva Y ork: The R onald Press.

Bainbridge, L. 1983. Ironies of automation. Automatica 19:775-779.

Bamber, L. 1979. Accident costing in industry. $\mathrm{H}$ ealth and Safety at W ork (C royden) 2/ 4:32-34.

Barnett, R, D Brickman. 1986. Safety hierarchy. I Saf Res 17:49-55.

Booth, R. 1979. M aking factories safe for forklift truck drivers. 0 ccup $H$ ealth 4:193-197.

Collinson, IL. 1980. Safety - the cost of accidents and their prevention. The M ining Engineer (Londres), 561-571.

Corbett, JM . 1988. Ergonomics in the development of human-centred AM T. A ppl E rgon 19:35-39.

Diekershoff, K, W H amacher, G Kliemt. 1986. Gefährdungen und Belastungen beim innerbetrieblichen T ransport und V erkehr. D ie B erufsge nossenschaft 7:378-384.
Franke, A, S Joki. 1975. Die volkwirtschaftlichen K osten der Arbeitsunfälle [C oste económico de los accidentes profesionales]. Bundesanstalt für Arbeitsschutz und U nfallforschung. Forschungsbericht $\mathrm{Nr} .148$ Dortmund: $M$ arten.

Goodstein, LP, HB Anderson, SE O Isen. 1988. T asks, E rrors and $M$ ental $M$ odels. Londres: T aylor \& Francis.

Häkkinen, K. 1992. Failures in materials handling systems with the framework of EN 292. En Proceedings of the Fourth International Conference on Structural F ailure, Product L iability and T echnical Insurance, T echnical U niversity Vienna J uly 6-9, 1992, dirigido por H P R ossmanith. Amsterdam: Elsevier.

-. 1991. Accidents and technological change in materials handling. En XIIth W orld Congress on 0 ccupational Safety and $\mathrm{H}$ ealth, $\mathrm{H}$ amburg 6-11 M ay 1990 , proceedings. Sankt Augustin: O IT .

$\mathrm{H}$ ale, AR, M Hale. 1970. Accidents in perspective. 0 ccup P sychol 44:115-122.

$\mathrm{H}$ ealth and Safety Executive. 1992. R oad T ransport in Factories and Similiar W orkplaces. Guidance Note GS9(R). Londres: H M SO .

- . 1982. T ransport Kills. A Study of $F$ atal Accidents in Industry 1978-1980. Londres: H M SO.

H ollnagel, E, D W oods. 1983. Cognitive systems engineering: $N$ ew wine in new bottles. Int J $M$ an $M$ ach Stud 18:593-600.
K idd, P. 1994. Skill-based automated manufacturing En Organization and $M$ anagement of $A$ dvanced $M$ anufacturing Systems, dirigido por W Karwowski y $\mathrm{G}$ Salvendy. Nueva Y ork: Wiley.

K uivanen, R. 1990. The impact on safety of disturbances in flexible manufacturing systems. En E rgonomics of $\mathrm{H}$ ybrid Automated Systems II, dirigido por W K arwowski y M Rahimi. Amsterdam:E Isevier.

LeN et, M . 1978. Le prix de la vie humaine [T he cost of a human life]. Notes et études documentaires. N o. 4455. París: La D ocumentation française.

M iller, JM , M R Lehto, JP Frantz. 1994. W arnings and Safety Instructions: Annotated and Indexed. Ann Arbor, M I: Fuller Technical Publications.

R asmussen, J. 1983. Skills, rules, and knowledge: signals, signs, and symbols, and other distinctions in human performance models. IEEE T Syst M an Cyb 13(3):257-266.

Sinclair, T C. 1972. A Cost-effectiveness A pproach to Industrial Safety. Londres: H M SO.

-. 1975. Safety Alert Symbol for Agricultural, Construction, and Industrial E quipment. SAE J284: SAE.

- . 1983. Slow M oving Vehicle I dentification E mblem. SAE 1943: SAE.

Sugimoto, N. 1987. Subjects and problems of robot safety technology. En $\mathrm{O}$ ccupational Safety and $\mathrm{H}$ ealth in Automation and Robotics, dirigido por $\mathrm{K}$ Noro. Londres:T aylor \& Francis. 
Director del capítulo

J orma Saari

\section{Sumario}

Auditorías de seguridad y de gestión

J ohan Van de Kerckhove . . . . . . . . . . . . . . . . . 57.2

A nálisis de riesgos: el modelo de causalidad de accidentes

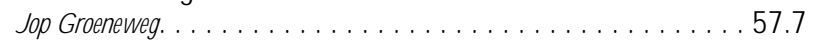

$R$ iesgos de los equipos

Carsten D. Groenberg. . . . . . . . . . . . . . . . . . . . 57.13

Análisis de riesgos: factores organizativos-M ORT

U rban Kjellén . . . . . . . . . . . . . . . . . . . . . . 57.19

Inspección en el lugar de trabajo y aplicación normativa

Anthony Linehan . ......................... 57.21

Análisis y presentación de informes: investigación de accidentes

M. M onteau .

Comunicación y recopilación de estadísticas sobre accidentes

Kirsten J orgensen 


\section{- AUDITORIAS DE SEGURIDAD Y DE GESTIO N}

\section{Johan Van de Kerckhove}

En el decenio de 1990 los factores de organización en la política de seguridad van cobrando cada vez mayor importancia. Al mismo tiempo, la visión de las organizaciones respecto a la seguridad han experimentado un cambio radical. Así, los expertos en esta materia, en su mayoría dotados de una formación técnica, se enfrentan con una doble tarea. Por una parte, deben aprender a comprender los aspectos de organización y a tenerlos en cuenta al elaborar los programas de seguridad. Por otra, es importante que tomen conciencia de que las organizaciones conceden cada vez menos importancia al concepto la máquina y prestan una mayor atención a factores menos tangibles y mensurables, como la cultura organizativa, la modificación del comportamiento, el aumento de la responsabilidad y el compromiso. En la primera parte de este artículo se trata brevemente la evolución de las opiniones relativas a las organizaciones, la gestión, la calidad y la seguridad. En la segunda, se especifican las repercusiones de esta evolución en los sistemas de auditoría. Posteriormente se analizan de forma concisa estos efectos en un contexto material, utilizando el ejemplo de un sistema real de auditoría de seguridad basado en las normas 9001 de la O rganización Internacional de Normalización (ISO ).

\section{$\mathrm{N}$ uevas opiniones relativas a la organización y a la seguridad}

\section{Cambios de las circunstancias socioeconómicas}

La crisis económica que comenzó a afectar al mundo occidental en 1973 ha ejercido una influencia notable en el pensamiento y en la práctica en el campo de la gestión, la calidad y la seguridad en el trabajo. En el pasado, en el ámbito del desarrollo económico, se hacía hincapié en la expansión del mercado, en el incremento de las exportaciones y en una mejora de la productividad. Con todo, los objetivos cambiaron con el tiempo y pasó a concederse mayor importancia a la reducción de pérdidas y a la optimización de la calidad. Para mantener a los clientes y captar a otros nuevos, comenzaron a atenderse más directamente sus exigencias y expectativas. Con esta tendencia se hizo necesario ampliar la diferenciación de los productos, lo que obligó a flexibilizar las organizaciones para garantizar en todo momento su capacidad de respuesta inmediata a las fluctuaciones del mercado sobre la base de "just in time" (justo a tiempo). El compromiso y la creatividad de los trabajadores se consideraron prioritarios como principal ventaja competitiva en el contexto de la competencia económica. A demás del momento de la calidad, la limitación de las actividades que generaban pérdidas llegaron a ser un medio importante para mejorar los resultados de las operaciones.

Los expertos en seguridad implantaron esta estrategia mediante el desarrollo e institucionalización de programas de "control total de pérdidas". En éstos, no sólo se tienen en cuenta los costes directos de los accidentes o el aumento de las primas de seguro, sino también todos los costes y pérdidas innecesarios, directos 0 indirectos. Al estudiar en qué medida debería aumentar la producción en términos reales para compensar estas pérdidas, se deduce de inmediato que actualmente la reducción de costes es más eficaz y rentable que el incremento de la producción.

En este contexto de mejora de la productividad, recientemente se han hecho referencias a las grandes ventajas que reporta la reducción del absentismo por enfermedad, así como la motivación de los trabajadores. En el marco de esta evolución, la política de seguridad adopta cada vez más claramente una nueva forma con diferentes prioridades. Antes, la mayoría de los directivos de las empresas consideraban la seguridad en el trabajo como una mera obligación legal, como una carga que trasladaban inmediatamente a los especialistas técnicos. En la actualidad, la política de seguridad se está considerando como un medio de alcanzar los objetivos de reducción de pérdidas y optimización de la política corporativa. Por tanto, evoluciona hacia su consolidación como un barómetro fiable de la adecuación del éxito de una empresa respecto a dichos objetivos. Con el fin de medir los avances logrados, se presta cada vez más atención a las auditorías de seguridad y de gestión.

\section{Teoría organizativa}

No son sólo las circunstancias económicas las que han modificado las opiniones de los dirigentes empresariales. Los nuevos conceptos referentes a la gestión, la teoría organizativa, la atención a la calidad total y, en esta misma línea, la atención a la seguridad, están generando cambios significativos. Un cambio fundamental en las opiniones sobre la organización se fue elaborando en la conocida obra publicada por Peters y Waterman (1982) En busca de la excelencia. En ella se exponían las ideas que Pascale y A thos (1980) descubrieron en Japón y describieron en E I Arte de la gestión japonesa. Se trata de una nueva concepción que puede representarse en cierto sentido mediante la estructura de los " 7 factores" de McK insey (en Peters y Waterman 1982). Además de los tres aspectos tradicionales de gestión (E strategia, Estructura y Sistemas), las empresas hacen hincapié actualmente en otros tres (Personal, Cualificaciones y E stilo). E stos seis factores constituyen la base del séptimo factor: los 0 bjetivos de 0 rden Superior (Figura 57.1). Con este planteamiento, es evidente la prioridad concedida a los aspectos de carácter humano de la organización.

Los cambios fundamentales pueden ilustrarse mediante el modelo propuesto por Scott (1978), utilizado asimismo por

Figura 57.1 • Los valores, la misión y la cultura organizativa de una empresa de acuerdo con la estructura de los 7 factores de McKinsey.

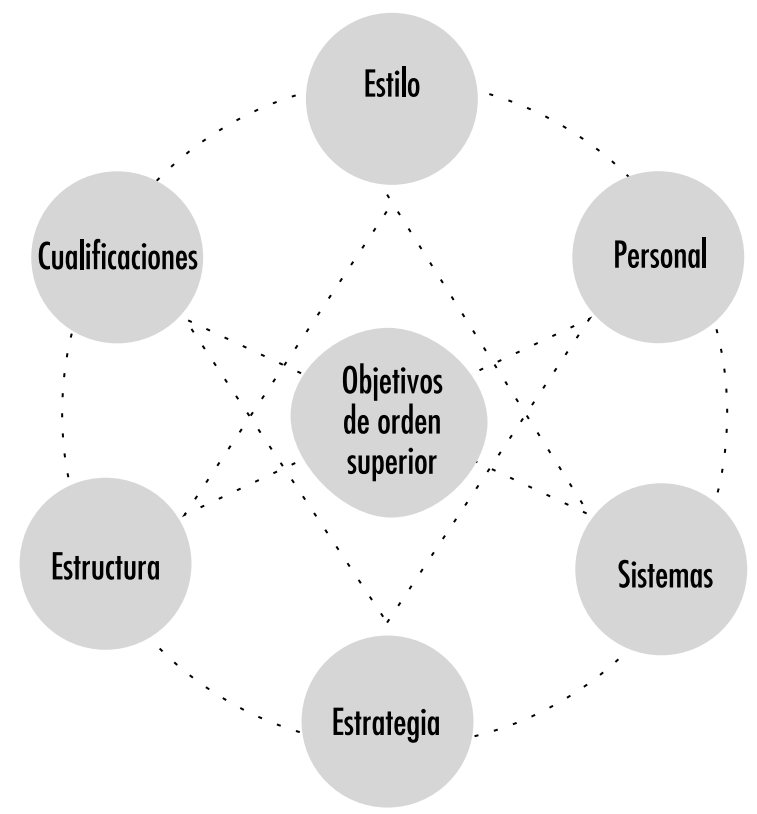

Fuente: Peters y Waterman 1982. 
Figura 57.2 - Teorías organizativas.

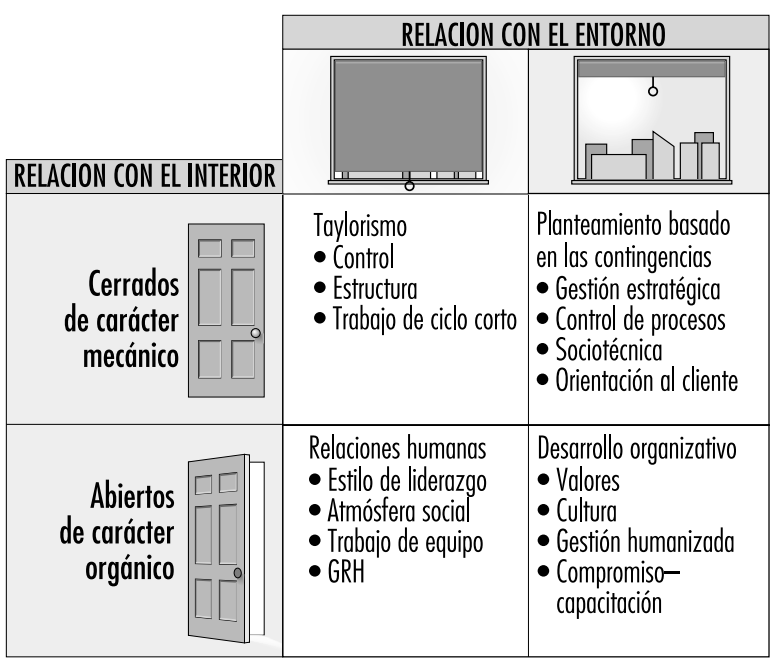

Fuente: Scott 1978

Peters y Waterman (1982). Este modelo utiliza dos tipos de planteamientos:

1. Los planteamientos de un sistema cerrado que desprecia la influencia de los factores externos a la organización. C on este tipo de enfoque mecanicista, los objetivos de una organización se definen claramente y pueden ser determinados de un modo lógico y racional.

2. Los planteamientos de un sistema abierto, que tienen plenamente en cuenta las influencias de los factores externos, y los objetivos son más el resultado de procesos diversos en los que la toma de decisiones se ve afectada por factores claramente irracionales. Este tipo de planteamiento reflejan con mayor precisión la evolución de una organización, que no puede ser determinada matemáticamente 0 sobre la base de la lógica deductiva, sino que avanza orgánicamente sobre la base de las personas reales y de sus interacciones y valores (Figura 57.2).

Así, en la Figura 57.2 se crean cuatro campos. Dos de ellos (Taylorismo y planteamiento de contingencias) son mecánicamente cerrados, y los otros dos (relaciones humanas y desarrollo organizativo) son orgánicamente abiertos. Se ha experimentado un enorme desarrollo en la teoría de gestión, pasando del modelo mecanicista autoritario, racional y tradicional (taylorismo), al modelo orgánico de orientación humana de la gestión de recursos humanos ( $\mathrm{R} \mathrm{H}$ ).

La eficacia y la eficiencia organizativas se vinculan cada vez con mayor claridad a la gestión estratégica óptima, a la estructura organizativa horizontal y a los sistemas de calidad. A demás, actualmente se está prestando mayor atención a los objetivos de orden superior y los valores significativos que tienen un efecto de interconexión en el seno de la organización, como las cualificaciones (sobre las que la organización basa su ventaja respecto a sus competidores) y un personal motivado para lograr la máxima creatividad y flexibilidad haciendo hincapié en el compromiso y la capacitación. Con estos planteamientos abiertos, una auditoría de gestión no puede limitarse a ciertas características formales o estructurales de la organización. La auditoría debe también incluir un estudio de métodos que permitan determinar los aspectos culturales menos materiales y mensurables
Del control del producto a la gestión de la calidad total

En el decenio de 1950, la preocupación por la calidad se limitaba a un control a posteriori del producto final; se trataba del control de la calidad total (CCT). En el de 1970, en parte debido al impulso de la OTAN y del gigante de la automoción Ford, se comenzó a conceder prioridad a la consecución del objetivo del aseguramiento de la calidad total (ACT) en el proceso productivo. Fue sólo durante el decenio de 1980 cuando estimulado por las técnicas japonesas, se pasó a centrar la atención en la calidad del sistema de gestión total y nació la gestión de la calidad total (GCT). El cambio fundamental en el sistema de la calidad ha sido gradual, ya que cada una de las fases se ha ido integrando en la siguiente. Asimismo, es obvio que, mientras que el control del producto y la inspección de seguridad son elementos relacionados más estrechamente con un concepto organizativo taylorista, el aseguramiento de la calidad se asocia más con un planteamiento sociotécnico respecto a los sistemas, en el que el objetivo consiste en no traicionar la confianza del cliente (externo). Por último, la GCT se relaciona con la adopción por parte de la organización de un enfoque centrado en la GR H, y la mejora del producto ha dejado de ser el único factor tomado en consideración: ahora también se tienen en cuenta la optimización continua de los aspectos organizativos y se presta una atención específica a las trabajadores.

En el planteamiento de liderazgo de la calidad total (LCT) adoptado por la Fundación Europea para la Gestión de la $C$ alidad (E FQ M ), se concede una gran importancia a la repercusión equitativa de la organización sobre el cliente, los trabajadores y el conjunto de la sociedad, considerándose el medio ambiente un aspecto fundamental. Son objetivos que pueden alcanzarse mediante la consideración de conceptos como el "liderazgo" y la "gestión de personas".

Es evidente que existen asimismo diferencias importantes en cuanto a prioridad entre el aseguramiento de la calidad descrita en las normas ISO y el planteamiento del LCT de la EFQM. El primero constituye una forma ampliada y mejorada de la inspección de la calidad, que no sólo se centra en los productos y los clientes internos, sino también en la eficiencia de los procesos técnicos. El objetivo de la inspección es investigar la conformidad con los procedimientos establecidos en ISO. Por otra parte, la GCT se propone satisfacer las expectativas de todos los clientes internos y externos, así como del conjunto de los procesos de la organización, incluidos los menos complejos y los de orientación humana. Es evidente que la participación, el compromiso y la creatividad de los trabajadores son aspectos importantes de la GCT.

\section{Del error humano a la seguridad integrada}

La política en materia de seguridad ha evolucionado de un modo similar a la gestión de la calidad. Se ha pasado de prestar atención al análisis a posteriori de los accidentes, haciendo hincapié en la prevención de las lesiones, a adoptar un planteamiento más global. La seguridad se concibe más en el contexto del "control total de pérdidas": una política encaminada a evitar las pérdidas mediante una gestión de la seguridad en la que interviene la interacción de las personas, los procesos, los materiales, los equipos, las instalaciones y el medio ambiente. Por tanto, la seguridad se centra en la gestión de los procesos que pueden generar pérdidas. En el período inicial de desarrollo de la política de seguridad, se concedía prioridad al planteamiento del error humano. En consecuencia, se asignaba a los trabajadores una amplia responsabilidad respecto a la prevención de los accidentes de trabajo. Siguiendo una filosofía Taylorista, se elaboraban condiciones y procedimientos y se establecía un sistema de control para mantener las normas de comportamiento prescritas. Esta filosofía puede reflejarse en la moderna política de seguridad a través de 
los conceptos ISO 9000, que dan lugar a la imposición en los trabajadores de cierto sentimiento de culpa implícito e indirecto, con todas las consecuencias adversas que tiene ésta en la cultura corporativa; por ejemplo, puede desarrollarse una tendencia a dificultar en lugar de facilitar la ejecución de las tareas.

En una fase posterior de la evolución de la política de seguridad, se tomó conciencia de que los trabajadores llevan a cabo su actividad en un entorno concreto con recursos laborales bien definidos. Los accidentes de trabajo eran considerados como sucesos multicausales en un sistema hombre/ máquina/ entorno en el que comenzó a adoptarse prioritariamente un planteamiento basado en el sistema técnico. En este caso nos encontramos de nuevo la analogía con el aseguramiento de la calidad, en la que se hace especial hincapié en el control estadístico de los procesos técnicos a través de medios como el control de procesos.

Recientemente, en parte debido a la influencia de los principios de la GCT, en los sistemas de formulación de la política de seguridad se ha optado por un planteamiento basado en el sistema social, lo que constituye un paso lógico en el camino hacia el perfeccionamiento del sistema de prevención. Para optimizar el sistema hombre/ máquina/ entorno, no basta con garantizar la disposición de máquinas y herramientas seguras mediante la aplicación de una política preventiva sólida, sino que también es necesario establecer un sistema de mantenimiento preventivo y el aseguramiento de todos los procesos técnicos. Además, es esencial que los trabajadores cuenten con la formación, la capacitación y la motivación suficientes en lo que respecta a la consecución de los objetivos de salud y seguridad. En la sociedad actual, este último objetivo no puede alcanzarse a través de planteamientos tayloristas de carácter autoritario, ya que la retroinformación positiva incentiva mucho más que un sistema de control represivo que, a menudo, sólo tiene efectos negativos. La gestión moderna exige la generalización de una cultura empresarial abierta y motivadora, en la que se asuman compromisos comunes con la consecución de los objetivos corporativos esenciales en un planteamiento basado en la participación y el trabajo en equipo. En el planteamiento de la cultura de la seguridad, ésta se concibe como una parte íntegra de los objetivos de las organizaciones y, por tanto, como un elemento esencial de la actividad de todos, desde la alta dirección, pasando por el conjunto del escalafón jerárquico, hasta los trabajadores de base.

\section{Seguridad integrada}

El concepto de seguridad integrada presenta de inmediato un número de factores centrales en un sistema de seguridad integrada, las más importantes de las cuales se resumen a continuación:

Un compromiso manifiesto por parte de la alta dirección. Es un compromiso que no sólo se expone por escrito, sino que también es trasladado hacia abajo en los centros de trabajo en acciones prácticas.

Participación activa de la escala jerárquica y de los departamentos de apoyo central. El interés por la seguridad, la salud y el bienestar forma parte no sólo de las tareas del conjunto de participantes en el proceso de producción, sino también de la política de recursos humanos, del mantenimiento preventivo, de la fase de diseño y del propio trabajo en terceras partes.

Participación plena de los trabajadores. Los trabajadores se constituyen en agentes activos de los debates, con los que es posible una comunicación abierta y constructiva, y su contribución es objeto de la máxima consideración. De hecho, su participación es esencial para aplicar la política empresarial y de seguridad de un modo eficaz y motivador.

Adecuación del perfil del experto en seguridad. EI experto en seguridad ya no es un técnico o un factótum, sino un asesor cualificado de la alta dirección que se ocupa en especial de la opitimización de los procesos de formulación de políticas y del sistema de seguridad. Por tanto, no es alguien con una formación solamente técnica, sino que debe ser un buen organizador, capaz de relacionarse con las personas y motivarlas y de colaborar con otros expertos en prevención de un modo sinérgico.

U na cultura de seguridad proactiva. El aspecto esencial de una política de seguridad integrada consiste en una cultura de seguridad proactiva caracterizada, entre otros, por los siguientes factores:

- La seguridad, la salud y el bienestar son los ingredientes clave del sistema de valores de una organización y de los objetivos que trata de alcanzar.

- Prevalece un ambiente de franqueza, basado en la confianza y el respeto mutuos.

- Existe un alto nivel de cooperación, el flujo de información es sencillo y el nivel de coordinación, apropiado.

- Se aplica una política proactiva, junto a un sistema dinámico de mejora constante que encaja perfectamente con el concepto de prevención.

- La promoción de la seguridad, la salud y el bienestar es un componente fundamental de todos los procesos de toma de decisiones, de consultas y de trabajo en equipo.

- Cuando se producen accidentes de trabajo, se trata de adoptar las medidas preventivas adecuadas, no buscan un responsable.

- Se anima a los miembros de la plantilla a actuar por iniciativa propia, de modo que posean la mayor competencia, conocimiento y experiencia posible que les permita intervenir adecuadamente en situaciones imprevistas.

- Se ponen en marcha procesos con vistas a promover la formación individual y colectiva en la mayor medida posible.

- Se celebran regularmente debates sobre objetivos de salud, seguridad y bienestar motivadores y alcanzables.

\section{Auditorías de seguridad y de gestión}

\section{Descripción general}

Las auditorías de seguridad son una forma de análisis y evaluación de riesgos en la que se lleva a cabo una investigación sistemática con el fin de determinar en qué medida se dan las condiciones que permiten el desarrollo e implantación de una política de seguridad eficaz y eficiente. Por tanto, en cada auditoría se establecen los objetivos que deben alcanzarse y las mejores circunstancias organizativas para llevarlos a la práctica.

En principio, todo sistema de auditoría debe determinar lo siguiente:

- ¿Cuáles son los objetivos de gestión a alcanzar, por qué medios y mediante qué estrategia?

- ¿Cuáles son las disposiciones necesarias en lo que se refiere a los recursos, las estructuras, los procesos, las normas y los procedimientos para lograr los objetivos propuestos y cuáles han sido adoptadas?

- ¿Cuáles son los criterios operativos y mensurables que deben satisfacer los objetos del estudio para que el sistema funcione de forma óptima?

Acto seguido, la información se somete a un análisis exhaustivo para determinar en qué medida satisfacen los criterios previstos la situación actual y el grado de consecución de objetivos, y se elabora un informe con una retroalimentación positiva que hace especial hincapié en los puntos fuertes y una retroalimentación negativa referente a los aspectos que requieren un posterior perfeccionamiento. 


\section{Auditorías y estrategias cambio}

Cada sistema de auditoría explícita o implícitamente contiene una visión específica del diseño y la concepción de una organización ideal, así como del modo óptimo de aplicar las mejoras.

B ennis, B enne y C hin (1985) distinguen tres estrategias respecto a los cambios previstos, cada una de ellas basada en una visión diferente de las personas y de los medios para influir en su comportamiento:

- Estrategias de aplicación de la fuerza se basan en la idea de que el comportamiento de los trabajadores puede ser modificado mediante la imposición de sanciones.

- Estrategias racionales-empíricas se basan en el axioma de que las personas realizan elecciones racionales en función de la maximización de su propio beneficio.

- Estrategias normativas-reeducativas se basan en la premisa de que las personas son seres irracionales y emocionales, por lo que, para llevar a cabo un cambio real, también debe prestarse atención a su percepción de los valores, la cultura, las actitudes y las destrezas sociales.

La estrategia para el ejercicio de influencia que resulta más apropiada en una situación específica no sólo depende de la visión inicial, sino también de la situación real y de la cultura organizativa existentes. En este sentido, es muy importante saber sobre qué tipo de comportamiento ha de influirse. En el famoso modelo concebido por R asmussen (1988), especialista danés en riesgos, se distinguen los tres tipos de comportamiento siguientes:

- Acciones rutinarias (comportamiento basado en las destrezas) siguen automáticamente a la señal asociada. Son acciones que se llevan a cabo sin que se les preste atención conscientemente (por ejemplo, la mecanografía o el cambio manual de marchas al conducir).

- Acciones efectuadas conforme a unas instrucciones (basadas en las normas) exigen una atención más consciente, ya que no existe una respuesta automática a la señal y debe elegirse entre las diversas instrucciones y normas disponibles. Con frecuencia, estas acciones pueden describirse mediante una secuencia "si..., entonces", como en "si el contador sube a 50, entonces debe cerrarse esta válvula".

- Acciones basadas en el conocimiento y en la percepción (basadas en el conocimiento) se realizan después de una interpretación y una evaluación consciente de las diversas señales de problema y las posibles soluciones alternativas. Por tanto, un requisito previo para efectuar este tipo de acciones es contar con un elevado grado de conocimiento y percepción del proceso en cuestión, así como en la capacidad para interpretar señales poco habituales.

\section{Niveles en el cambio de cultura y de comportamiento}

Basándose en lo anterior, la mayoría de los sistemas de auditoría (incluidos los que se fundamentan en las serie de normas ISO ) se apartan implícitamente de las estrategias de aplicación de la fuerza y de las racionales empíricas, que conceden prioridad al comportamiento rutinario o de procedimiento. Así, en estos sistemas se presta una atención insuficiente al "comportamiento basado en el conocimiento" que puede modificarse principalmente mediante las estrategias normativas reeducativas. En la tipología utilizada por Schein (1989), se centra el interés únicamente en los fenómenos superficiales materiales y conscientes de la cultura organizativa y no en otros niveles de mayor calado, invisibles y subconscientes más relacionados con valores y presupuestos fundamentales
La mayoría de los sistemas de auditoría se limitan a considerar si se aplica una disposición o un procedimiento concreto. Por tanto, se asume de modo implícito que la mera existencia de estos mecanismos constituye una garantía suficiente para el buen funcionamiento del sistema. Además de éstos, existen siempre otros "estratos" diferentes (o niveles de respuesta probable) que deben abordarse en un sistema de auditoría para proporcionar información suficiente y garantizar un funcionamiento óptimo del sistema.

En términos más concretos, el siguiente ejemplo se refiere a la respuesta a una emergencia de incendio:

- Existe una disposición, una instrucción o un procedimiento ("activar la alarma y utilizar el extintor").

- Las partes interesadas están familiarizadas con ciertas instrucciones y procedimientos (los trabajadores saben dónde se halla las alarmas y los extintores y cómo activarlos y utilizarlos).

- Las partes interesadas conocen tanto como sea posible "el cómo y el por qué" de una determinada medida (los trabajadores han sido entrenados o educados en el seno de los extintores y los tipos de incendio habituales).

- Los trabajadores están también motivados para aplicar las medidas necesarias (autoprotección, salvaguardia del puesto de trabajo, etc.).

- Hay suficiente motivación, competencia y capacidad para actuar en circunstancias imprevistas (los trabajadores saben qué hacer en el caso de que el incendio escape a su control, solicitando la ayuda de servicios de extinción de incendios profesionales).

- Existen buenas relaciones humanas y una atmósfera de comunicación abierta (los supervisores, los directivos y los trabajadores han debatido y acordado los procedimientos de respuesta en caso de emergencia por incendio).

- En una organización donde se fomenta el aprendizaje, se instituyen procesos creativos espontáneos (se aplican cambios en los procedimientos tras haber "aprendido la lección" en situaciones de incendio reales).

En la Tabla 57.1 se especifican ciertos niveles en la política de calidad y seguridad.

Tabla 57.1 - N iveles en la política de calidad y seguridad.

\begin{tabular}{|c|c|c|c|}
\hline \multirow[t]{2}{*}{ Estrategias } & \multicolumn{3}{|c|}{ Comportamiento } \\
\hline & Destrezas & Normas & Conocimiento \\
\hline $\begin{array}{c}\text { Aplicación de } \\
\text { la fuerza }\end{array}$ & $\begin{array}{l}\text { Planteamiento basado } \\
\text { en el error humano } \\
\text { Taylorismo } \\
\text { CCT }\end{array}$ & & \\
\hline $\begin{array}{l}\text { Racional- } \\
\text { empírica }\end{array}$ & & $\begin{array}{l}\text { Planteamiento basado } \\
\text { en el sistema } \\
\text { técnico } \\
\text { SAP } \\
\text { ACT } \\
\text { ISO } 9000\end{array}$ & \\
\hline $\begin{array}{l}\text { Normativa- } \\
\text { reeducativa }\end{array}$ & & $\begin{array}{l}\text { Planteamiento basado } \\
\text { en el sistema social } \\
\text { CCT }\end{array}$ & $\begin{array}{l}\text { Planteamiento } \\
\text { basado en la } \\
\text { cultura de la } \\
\text { seguridad } \\
\text { SAP } \\
\text { EFQM }\end{array}$ \\
\hline
\end{tabular}




\section{El sistema de auditoría de Pellenberg}

La denominación de sistema de auditoría de Pellenberg (SAP) se debe al lugar en el que solían reunirse sus diseñadores para elaborarlo (el castillo de M aurissens en Pellenberg, un edificio de la U niversidad Católica de Lovaina). EI SAP es el resultado de la intensa colaboración de un equipo multidisciplinar de expertos con años de experiencia práctica, tanto en el área de la gestión de la calidad, como en la de los problemas de seguridad y ambientales, caracterizada por el planteamiento de diversos enfoques y experiencias. Asimismo, el equipo recibió la ayuda de los departamentos científicos y de investigación de la universidad y se benefició de la disposición de los conocimientos más actuales en los campos de la gestión y la cultura organizativa.

EI SAP consta de un conjunto completo de criterios que un sistema empresarial de prevención de categoría superior debe cumplir (véase la Tabla 57.2). Los criterios se clasifican de acuerdo con el sistema de normas ISO (aseguramiento de la calidad en el diseño, desarrollo, producción, instalación y prestación de servicios). A hora bien, el SA P no es una mera traslación del sistema ISO al ámbito de la seguridad, la salud y el bienestar. Se desarrolla una nueva filosofía, que se aparta del producto específico obtenido mediante la política de seguridad: puestos de trabajo significativos y seguros. El contrato del sistema ISO se sustituye por las disposiciones legales y por las expectativas en evolución de las partes que conforman el espectro social respecto a la salud, la seguridad y el bienestar. La creación de puestos de trabajo seguros y significativos se considera un objetivo esencial de cada organización en el marco de su responsabilidad social. La empresa es el suministrador y los clientes los empleados.

$\mathrm{H}$ ay otros sistemas integrados en el SAP:

- A un nivel estratégico, los conceptos y requisitos de la Norma ISO revisten especial importancia. En la medida de lo posible, éstos se complementan con la visión de la gestión que originalmente desarrolló la Fundación Europea para la Gestión de la Calidad.

- A un nivel táctico, la sistemática de M O RT (M anagement's O versight and Risk Tree: Supervisión de la dirección y árbol de riesgos) anima a las personas a establecer cuáles son las condiciones necesarias y suficientes para lograr el resultado deseado en materia de seguridad.

- A un nivel operativo, se puede recurrir a múltiples fuentes, como la legislación, las disposiciones y otros criterios vigentes, como el Sistema Internacional de Evaluación de la seguridad (SIES), en el que se hace hincapié en ciertas condiciones concretas que deben garantizar la consecución del resultado previsto en materia de seguridad.

EI SAP se refiere constantemente a la política corporativa general de la que forma parte la política de seguridad. Después de todo, una política de seguridad óptima es, simultáneamente, un producto y un producto de una política empresarial proactiva. Suponiendo que una empresa segura es, al mismo tiempo, una organización eficaz y eficiente y viceversa, debe prestarse especial atención a la integración de la política de seguridad en la política general de la empresa. Los elementos esenciales de una política empresarial orientada al futuro incluye una cultura corporativa sólida, un compromiso de amplio alcance, la participación de los trabajadores, un interés especial en la calidad del trabajo y un sistema dinámico de mejora continua. Aunque estos conceptos también fundamentan en parte el SAP, no siempre son fáciles de conciliar con el enfoque más formal y basado en los procedimientos de los principios ISO.

No hay duda de que los procedimientos formales y los resultados directamente identificables son importantes en la polí-

Tabla 57.2 - Elementos de la auditoría de seguridad del SAP.

Elementos de la auditoría de

seguridad del SAP

1. Responsabilidad de la dirección

1.1. Política de seguridad

1.2. Organización

1.2.1. Responsabilidad y autoridad

1.2.2. Personal y recursos de verificación

1.2.3. Servicio de salud y seguridad

1.3. Revisión del sistema de gestión de la seguridad

2. Sistema de gestión de la seguridad

3. Obligaciones

4. Control del diseño

4.1. General

4.2. Diseño y planificación del desarrollo

4.3. Factores aplicados al diseño

4.4. Resultados del diseño

4.5. Comprobación del diseño

4.6. Variaciones del diseño

5. Control de documentos

5.1. Aprobación y expedición de documentos

5.2. Cambios y modificaciones de documentos

6. Adquisición y contratación

6.1. General

6.2. Evaluación de proveedores y contratistas

6.3. Datos sobre adquisiciones

6.4. Productos de terceros

7. Identificación

8. Control de procesos

8.1. General

8.2. Control de la seguridad de los procesos

9. Inspección

9.1. Recepción e inspección previa a la puesta en funcionamiento

9.2. Inspecciones periódicas

9.3. Registros de la inspección

9.4. Equipos de inspección

9.5. Estado de la inspección

10. Accidentes e incidentes

11. Acción correctora y preventiva

12. Registros de seguridad

13. Auditorías de seguridad internas

14. Formación

15. Mantenimiento

16. Técnicas estadísticas
Correspondencia con ISO 9001

4.1.3.

4.2 .

4.3.

4.4.1.

4.4.2.

4.4.3.

4.4.4.

4.4.5.

4.4.6.

4.5.1.

4.5.2.

4.6.1.

4.6.2.

4.6.3.

4.7 .

4.8.

4.9.1.

4.11 .

4.10.1.

4.10.3.

4.10.2.

4.10.4.

4.11 .

4.12 .

4.13.

4.13 .

4.14 .

4.16 .

4.17 .

4.18 .

4.19 .

4.20 . 
tica de seguridad. Ahora bien, no basta con basar el sistema de seguridad únicamente en este planteamiento. Los resultados de dicha política en el futuro dependen de la política actual, de las iniciativas sistemáticas, de la búsqueda constante de mejoras y, sobre todo, de la optimización fundamental de los procesos que aseguren resultados duraderos. En el SAP se incorpora esta visión y se hace especial hincapié, entre otras cosas, en el perfeccionamiento sistemático de la cultura de seguridad.

Una de las principales ventajas del SAP es la oportunidad para la sinergia. Al alejarse de la sistemática de la ISO, las diversas líneas de planteamiento resultan reconocibles de inmediato para todos los interesados en la gestión de la calidad total. 0 bviamente, se presentan varias opciones para la sinergia entre las distintas áreas de formulación de políticas, ya que, en todas ellas, la mejora de los procesos de gestión constituye un aspecto fundamental. U na política cuidadosa de compras, un adecuado sistema de mantenimiento preventivo, unos servicios de conservación eficaces, una gestión propicia a la participación y el fomento de la adopción de un planteamiento emprendedor por parte de los trabajadores tienen una importancia capital para el conjunto de las áreas mencionadas.

Los diversos sistemas de vigilancia se organizan de manera análoga, basándose en principios como el compromiso de la alta dirección, la implicación de la línea jerárquica, la participación activa de los trabajadores y la contribución valorada de expertos específicos. Los diferentes sistemas también contienen instrumentos semejantes para la formulación de políticas, como la declaración de intenciones, los planes de acción anuales, los sistemas de medición y control, las auditorías internas y externas, etc. Por tanto, el SA P invita claramente a la cooperación sinérgica eficaz y dirigida al recorte de gastos entre todos estos sistemas.

EI SAP no ofrece la vía más fácil para la consecución de resultados a corto plazo. Son pocos los directivos que se dejan seducir por un sistema que promete grandes ventajas inmediatas con un pequeño esfuerzo. Cada política sólida exige un planteamiento pormenorizado y el establecimiento de bases firmes en las que asentar su desarrollo futuro. A corto plazo, más que los resultados, es importante garantizar la consolidación de un sistema que los genere de manera sostenible en el futuro, no sólo en el campo de la seguridad, sino también en el contexto de una política empresarial general eficaz y eficiente. En este sentido, trabajar a favor de la salud, la seguridad y el bienestar equivale a actuar para la consecución de puestos de trabajo seguros y significativos, trabajadores motivados, clientes satisfechos y resultados de explotación óptimos. Todo esto realizado en una atmósfera dinámica y proactiva.

\section{Resumen}

La mejora continua es una condición previa esencial para cada sistema de auditoría de seguridad con los que se pretende cosechar un éxito duradero en una sociedad en rápida transformación como la actual. La mejor garantía para que un sistema dinámico mejore continuamente y mantenga una flexibilidad constante consiste en el compromiso pleno aceptado por trabajadores competentes, que crecen con la organización porque sus esfuerzos se valoran sistemáticamente y se les brinda la oportunidad de desarrollar y actualizar regularmente sus cualificaciones. En el proceso de una auditoría de seguridad, la mejor garantía de lograr resultados duraderos es la consolidación de una organización que promueve el aprendizaje, en la que los trabajadores y la propia entidad se instruyen y evolucionan de forma constante.

\section{ANALISIS DE RIESGOS: EL MODELO DE CAUSALIDAD DE ACCIDENTES}

Jop G roeneweg

Este artículo examina el papel de los factores humanos en los procesos de causalidad de accidentes y revisa las diferentes medidas preventivas (y su eficacia) por las que puede controlar el error humano y su aplicación al modelo de causalidad de accidentes. El error humano es una causa de contribución importante en al menos el $90 \%$ de los accidentes de trabajo. Aunque los fallos estrictamente técnicos y las circunstancias físicas incontrolables también pueden contribuir a que se produzca un accidente, el error humano constituye la principal fuente de incidencia. El avance y la mejora de la fiabilidad de la maquinaria da lugar a un aumento de la proporción de accidentes atribuidos al error humano a medida que el número absoluto de accidentes disminuye. Asimismo, el error humano es la causa de muchos de los incidentes que, aunque no producen lesión o muerte, provocan un daño económico importante para las empresas. Por tanto, constituye un objetivo esencial de la prevención y revestirá cada vez más importancia en el futuro. Para que los sistemas de gestión de la seguridad y los programas de identificación de riesgos sean eficaces, es importante que puedan determinar con precisión el componente humano mediante la utilización de análisis de fallo general.

\section{La naturaleza del error humano}

El error humano puede considerarse como el fallo en la consecución de un objetivo del modo en que había sido planificado, ya sea desde un punto de vista específico o general, y debido a un comportamiento deliberado 0 involuntario. Las acciones planeadas pueden dejar de ofrecer los resultados deseados por alguna de las cuatro razones siguientes:

1. Comportamiento involuntario:

- Las acciones no se desarrollaron según lo planificado (descuidos).

- Las acciones no se llevaron a cabo (omisiones).

2. Comportamiento intencionado:

- El plan en sí era inadecuado (equivocaciones).

- Se produjeron desviaciones respecto al plan original (violaciones).

Las desviaciones pueden dividirse en tres clases: errores basados en las destrezas, en las normas y en el conocimiento.

1. En lo que se refiere a las destrezas, el comportamiento se rige por pautas de acción programadas previamente. Las tareas son rutinarias y continuas, y la retroalimentación suele ser escasa.

2. En cuanto a las normas, el comportamiento se rige por reglas generales simples y que pueden aplicarse en múltiples ocasiones en situaciones específicas. Las tareas consisten en secuencias de acción relativamente frecuentes, iniciadas después de realizar una elección entre las diversas normas y procedimientos. El usuario dispone de una opción, las normas no se aplican automáticamente, sino que se eligen de forma activa.

3. El comportamiento basado en el conocimiento se manifiesta en situaciones completamente nuevas, en las que se carece de normas y donde se requiere un pensamiento creativo y analítico.

En algunas situaciones, el término limitación humana sería más apropiado que el de error humano. La capacidad para prever el 
comportamiento futuro de sistemas complejos también es restringida (G leick 1987; Casti 1990).

En el modelo de Reason y Embrey, el Sistema de creación de modelos de error genérico (SCMEG) (Reason 1990), se tienen en cuenta los mecanismos de corrección de errores a escala de las destrezas, las normas y los conocimientos. U n supuesto básico del SCMEG es que el comportamiento día a día implica la adquisición de rutinas. El comportamiento rutinario se comprueba con regularidad, pero entre estos momentos de acumulación de información, el comportamiento es plenamente automático. Puesto que se basa en las destrezas, los errores son descuidos. Cuando la información acumulada indica una desviación respecto al objetivo deseado, se aplica la corrección basada en las normas. El problema se diagnostica sobre la base de los síntomas detectados y una norma de corrección es aplicada automáticamente una vez determinada la naturaleza de la situación. La aplicación de una norma errónea constituye una equivocación.

Cuando la situación se desconoce por completo, se utilizan las normas basadas en el conocimiento. L os síntomas se estudian a la luz del conocimiento sobre el sistema y sus componentes. Este análisis puede llevar a la elección de una solución cuya aplicación constituya un caso de comportamiento basado en el conocimiento. (Asimismo, es posible que el problema no pueda resolverse de un modo determinado y que deba recurrirse a otras normas basadas en el conocimiento). En este contexto, todos los errores son equivocaciones. Se comete una violación si se aplica una norma y se sabe que es inadecuada: el trabajador puede pensar que el recurso a una norma alternativa llevará menos tiempo o resultará más adecuado para la situación actual, probablemente excepcional. El tipo de violación más perverso es el sabotaje, una cuestión que no se considera en el presente artículo. Cuando las organizaciones traten de eliminar el error humano, deben tener en cuenta a qué categoría pertenecen (a los basados en las destrezas, en las normas o los conocimientos), ya que cada una exige la utilización de técnicas específicas (G roeneweg 1996).

\section{La influencia en el comportamiento humano: visión general}

Al hacer referencia a un determinado accidente, suele comentarse "puede que no se diera cuenta en ese momento, pero si

\begin{tabular}{|c|c|c|c|c|}
\hline NN. $\underline{0}$ & Modo de influencia & Coste & $\begin{array}{l}\text { Efecto a } \\
\text { largo plazo }\end{array}$ & Evaluación \\
\hline 1 & $\begin{array}{l}\text { No inducir un comporta- } \\
\text { miento seguro, sino } \\
\text { lograr un sistema "a } \\
\text { prueba de torpezas". }\end{array}$ & Alto & Limitado & Poco satisfactorio \\
\hline 2 & $\begin{array}{l}\text { Decir a los interesados lo } \\
\text { que deben hacer. }\end{array}$ & Bajo & Limitado & $\begin{array}{l}\text { Satisfacción } \\
\text { intermedia }\end{array}$ \\
\hline 3 & Premio y sanción. & Medio & Medio & $\begin{array}{l}\text { Satisfacción } \\
\text { intermedia }\end{array}$ \\
\hline 4 & $\begin{array}{l}\text { Aumentar la motivación y } \\
\text { la sensibilización. }\end{array}$ & Medio & Limitado & Poco satisfactorio \\
\hline 5 & $\begin{array}{l}\text { Seleccionar personal } \\
\text { capacitado. }\end{array}$ & Alto & Medio & $\begin{array}{l}\text { Satisfacción } \\
\text { intermedia }\end{array}$ \\
\hline 6 & Modificar el entorno. & Alto & Significativo & Satisfactorio \\
\hline
\end{tabular}

hubiese actuado de cierta manera, el accidente no se habría producido". Gran parte de la prevención de accidentes tiene como fin influir en el momento crucial del comportamiento humano al que se alude en este comentario. En muchos sistemas de gestión de la seguridad, las soluciones y las políticas propuestas se encaminan a influir directamente en el comportamiento humano. Con todo, es muy poco frecuente que las organizaciones evalúen la eficacia real de estos métodos. Los psicólogos han prestado gran atención a determinar cuál es la mejor manera de influir en el comportamiento humano. A continuación se exponen seis formas de ejercer control sobre el error humano y se evalúa la eficacia relativa de cada alternativa para vigilar el comportamiento humano a largo plazo (Wagenaar 1992). (V éase la Tabla 57.3.)

No intentar inducir a la adopción de un comportamiento seguro, sino hacer el sistema "a prueba de torpezas"

La primera opción consiste en abstenerse de influir en el comportamiento de las personas y diseñar el lugar de trabajo de forma que, haga lo que haga el trabajador, sus acciones no provoquen resultados indeseables. $\mathrm{H}$ ay que admitir que, gracias a la ayuda de la robótica y la ergonomía, los diseñadores han mejorado considerablemente la adecuación al usuario de los equipos empleados en el lugar de trabajo. Ahora bien, es casi imposible anticiparse a todos los tipos de comportamiento que una persona puede manifestar. Además, los trabajadores suelen considerar los diseños a prueba de torpezas como un desafío a "vencer al sistema". Por último, como los diseñadores también son humanos, los equipos, por más precauciones que se adopten al concebirlos, puede tener defectos (véase, p. ej., Petroski 1992). $L$ a ventaja adicional que aporta este planteamiento respecto a los niveles de riesgo es marginal y, en cualquier caso, los costes iniciales de diseño e instalación pueden aumentar de forma exponencial.

\section{Instruir a los interesados respecto a lo que deben hacer}

0 tra posibilidad consiste en instruir a los trabajadores respecto a cada una de las actividades existentes, con el fin de poner su comportamiento bajo el control estricto de la dirección. Ello exige la adopción de un sistema de control para la instrucción y el inventario de tareas, extenso y no muy práctico. Puesto que todos los comportamientos dejan de ser automáticos, se eliminarán en gran medida los descuidos y las omisiones, hasta que las instrucciones formen parte de la rutina y el efecto vaya desapareciendo.

$\mathrm{N}$ o es de gran ayuda decir a las personas que lo que hacen es peligroso (la mayoría lo saben perfectamente), ya que tomarán sus propias decisiones respecto al riesgo con independencia de los intentos de persuadirles de lo contrario. Su motivación para actuar de este modo se basa en la pretensión de facilitar el trabajo, ahorrar tiempo, desafiar a la autoridad y, quizá, mejorar sus perspectivas profesionales o reivindicar algún tipo de compensación económica. La instrucción a las personas es relativamente asequible y la mayoría de las organizaciones celebran sesiones formativas antes de iniciar una actividad. A pesar de la adopción de un sistema de instrucción, se estima que la eficacia de este planteamiento es escasa.

\section{Premio y sanción}

Aunque los sistemas de premio y sanción constituyen un medio poderoso y muy popular para controlar el comportamiento humano, no están exentos de problemas. El premio funciona adecuadamente sólo si su receptor lo percibe como algo de valor en el momento de su obtención. La sanción del comportamiento ajeno al control del trabajador (un descuido) no es eficaz. Por ejemplo, es más rentable mejorar la seguridad en el tráfico mediante el cambio de las condiciones que subyacen al 
comportamiento en este contexto que a través del lanzamiento de campañas públicas o de programas de premio y sanción. $\mathrm{Ni}$ siquiera un aumento de las posibilidades de ser "cogido" modificarán necesariamente la actitud de una persona, ya que las oportunidades de violar la norma siguen existiendo, al igual que el reto que supone salir airoso de la violación. Si las situaciones de trabajo invitan a cometer este tipo de violaciones, las personas optarán automáticamente por el comportamiento inadecuado, ya sean sancionados o recompensados. La eficacia de este planteamiento se califica de calidad media, y sus efectos suelen sentirse a corto plazo.

\section{Aumentar la motivación y la sensibilización}

En ocasiones se cree que las personas causan accidentes porque carecen de motivación o no son conscientes del peligro. Este supuesto es falso, como han demostrado varios estudios (p. ej., Wagenaar y Groeneweg 1987). A demás, aun en el caso de que los trabajadores sean capaces de juzgar el peligro con precisión, no actúan necesariamente en consecuencia (K ruysse 1993). L os accidentes se producen incluso en personas con el grado más elevado de motivación y sensibilización en materia de seguridad. Existen métodos eficaces para mejorar la motivación y la conciencia, analizados más adelante en el apartado "Cambiar el entorno". Se trata de una opción delicada: a diferencia de la dificultad que conlleva optimizar la motivación, es más fácil (quizá demasiado) desmotivar a los trabajadores hasta el punto de que llegue a considerarse el sabotaje.

Los efectos de los programas de mejora de la motivación son positivos sólo cuando se combinan con técnicas de modificación del comportamiento, como el fomento de la participación de los trabajadores.

\section{Seleccionar personal formado}

La primera reacción ante un accidente suele ser la de afirmar que los implicados en el mismo han actuado de manera incompetente. A posteriori, las situaciones de accidente parecen sencillas y fáciles de prevenir para alguien con la inteligencia suficiente y la formación apropiada, pero esta percepción es engañosa: en la práctica, los trabajadores afectados no podían haber previsto lo sucedido de ningún modo. Por tanto, la mejora de la formación y la selección no tendrá el efecto oportuno. Con todo, un nivel básico de instrucción es un requisito previo para desarrollar actividades en condiciones de seguridad. La tendencia observada en algunas empresas a sustituir personal con años de servicio por trabajadores sin experiencia y con una formación inadecuada no es recomendable, ya que el aumento de la complejidad de las situaciones exige una forma de pensamiento basada en las normas y los conocimientos y en un nivel de experiencia que el personal con menores costes de mano de obra no suele poseer. Un efecto secundario negativo de instruir adecuadamente y seleccionar en exclusiva a las personas de mayor cualificación es que el comportamiento puede automatizarse y es posible que se produzcan descuidos. La selección resulta cara, mientras que el efecto no pasa de ser intermedio.

\section{Cambiar el ambiente de trabajo}

Los distintos comportamientos se deben en gran medida a una reacción a los factores existentes en el ambiente de trabajo: horarios, planes, y expectativas y demandas de la dirección. Antes de que el ambiente de trabajo pueda modificarse en la práctica, deben resolverse varios problemas. En primer lugar, deben determinarse los factores ambientales que provocan el comportamiento no deseado. En segundo lugar, estos factores deben ser controlados. Por último, la dirección debe permitir el debate acerca del papel que desempeñan en la creación de un entorno de trabajo perjudicial.
Resulta más práctico influir en el comportamiento mediante la consolidación del entorno de trabajo apropiado. LoS problemas cuya resolución debe acometerse antes de la aplicación de esta medida son: a) conocer los factores ambientales que causan el comportamiento no deseado, b) controlar estos factores, y c) considerar las decisiones previas de la dirección (Wagenaar 1992; Groeneweg 1996). De hecho, todas estas condiciones pueden satisfacerse, como se argumentará a continuación en el presente artículo. La eficacia de la modificación del comportamiento puede ser elevada, aunque es posible que la transformación del entorno sea costosa.

\section{EI modelo de causalidad de accidentes}

Para comprender mejor los aspectos susceptibles de control en el proceso de causalidad de accidentes, es necesario conocer los posibles flujos de datos existentes en un sistema de información sobre seguridad. En la Figura 57.3, se presenta la estructura completa de un sistema de este tipo, que puede servir como base para el control de los errores humanos por parte de la dirección. Se trata de una versión adaptada del sistema propuesto por Reason y cols. (1989).

\section{Investigación de accidentes}

Al investigar accidentes se elaboran informes sustanciales, y los encargados de la toma de decisiones reciben información acerca del componente de error humano del accidente. Por fortuna, esta práctica está cayendo en desuso en numerosas empresas. Es más eficaz analizar las "perturbaciones operativas" que preceden a los accidentes y los incidentes. Por ejemplo, si un accidente se define como una perturbación operativa seguida por las consecuencias, entonces el salirse de la carretera es una perturbación, y la

Figura 57.3 - Un sistema de información sobre seguridad.

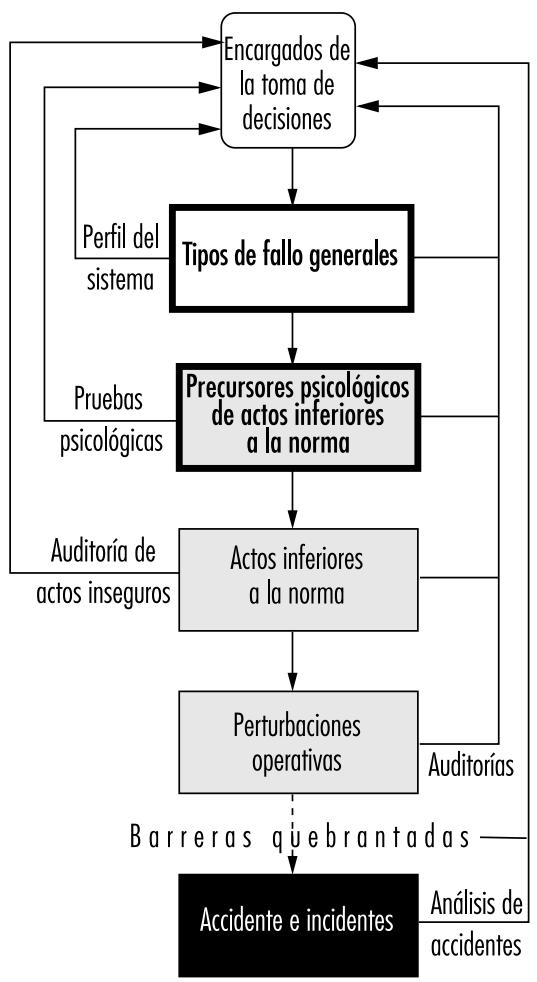

Fuente: Adaptado de Reason y cols. 1989 
muerte del conductor por no llevar el cinturón de seguridad es un accidente. Pueden haberse colocado barreras entre la perturbación operativa y el accidente, pero han fallado, se han infringido 0 evitado.

\section{Auditoría de actos inseguros}

En este artículo, un acto erróneo cometido por un trabajador se denomina "acto deficiente" y no de "acto inseguro": la noción de "inseguro" parece limitar su aplicabilidad al campo de la seguridad, cuando también puede referirse, por ejemplo, a problemas ambientales. LoS actos deficientes se registran a veces, pero la información detallada sobre qué descuidos, equivocaciones y violaciones se cometieron y por qué razón no suele llegar a los niveles de dirección superiores.

\section{Investigación del estado mental del trabajador}

Antes de cometer un acto deficiente, la persona implicada se encuentra en un estado mental determinado. Si los precursores psicológicos, como la sensación de prisa o el sentimiento de tristeza, pudiesen controlarse adecuadamente, las personas no alcanzarían un estado mental propenso al acto deficiente. Puesto que tales estados no pueden controlarse eficazmente, dichos precursores se consideran material semejante al que figura en una "caja negra" (Figura 57.3).

\section{Tipos de fallo general}

En el recuadro de TFG (tipos de fallo general) de la Figura 57.3 se presentan los mecanismos generadores de un accidente; es decir, las causas de las situaciones y los actos deficientes. Puesto que éstos actos deficientes no pueden controlarse directamente, es necesario modificar el ambiente de trabajo, que queda determinado por 11 de los mecanismos mencionados (Tabla 57.4).

Al recuadro de TFG le precede el de los "encargados de la toma de decisiones", ya que estas personas determinan en gran medida la bondad de la gestión de los TFG. La dirección se encarga de controlar el entorno de trabajo mediante la gestión de los 11 TFG, supervisando así indirectamente los posibles errores humanos.

Todos estos tipos pueden contribuir a la existencia de accidentes de forma sutil, al permitir combinaciones indeseables de situaciones y acciones, incrementar la probabilidad de que ciertas personas realicen actos deficientes y dejar de ofrecer los medios de interrupción de las secuencias de accidentes iniciadas.

$\mathrm{H}$ ay dos TFG que requieren una explicación adicional: gestión del mantenimiento y defensas.

\section{Gestión del mantenimiento (GM)}

Puesto que la gestión del mantenimiento es una combinación de factores que pueden encontrarse en otros TFG, la GM no es, en sentido estricto, un tipo independiente; por el contrario, no difiere fundamentalmente de otras funciones de gestión. Puede tratarse como una actividad específica porque el mantenimiento desempeña un papel importante en numerosas situaciones de accidente y porque la mayoría de las organizaciones disponen de una función de mantenimiento autónoma.

\section{Defensas (DF)}

La categoría de defensas tampoco constituye un verdadero TFG, ya que no está relacionada con el proceso de causalidad de accidentes propiamente dicho. Este TFG tiene que ver con lo que sucede después de una perturbación operativa. No genera estados mentales psicológicos ni actos deficientes en sí mismo. Es una reacción al fallo debido a la acción contemplada en uno o varios TFG. Aunque es cierto que un sistema de gestión de la seguridad debe ocuparse de los elementos controlables de la cadena de causalidad de accidentes antes y no después del incidente no
Tabla 57.4 - Tipos de fallo general y sus definiciones.

\begin{tabular}{|c|c|}
\hline Fallos generales & Definiciones \\
\hline 1. Diseño & $\begin{array}{l}\text { Fallos debidos al diseño deficiente de toda la insta- } \\
\text { lación, así como de elementos espećíficos de los } \\
\text { equipos }\end{array}$ \\
\hline 2. Equipos & $\begin{array}{l}\text { Fallos debidos al estado deficiente o a la ausencia } \\
\text { de equipos y herramientas }\end{array}$ \\
\hline 3. Procedimientos & $\begin{array}{l}\text { Fallos debidos a la escasa calidad de los procedi- } \\
\text { mientos operativos con respecto a la utilidad, la } \\
\text { disponibilidad y la exhaustividad }\end{array}$ \\
\hline $\begin{array}{l}\text { 4. Condiciones } \\
\text { favorables al error }\end{array}$ & $\begin{array}{l}\text { Fallos debidos a la calidad deficiente del entorno de } \\
\text { trabajo, respecto a las circunstancias que } \\
\text { aumentan la probabilidad de equivocación }\end{array}$ \\
\hline $\begin{array}{l}\text { 5. Actividades de } \\
\text { conservación }\end{array}$ & $\begin{array}{l}\text { Fallos debidos a la deficiencia de las actividades de } \\
\text { conservación }\end{array}$ \\
\hline 6. Formación & $\begin{array}{l}\text { Fallos debidos a una formación inadecuada o a una } \\
\text { experiencia insuficiente }\end{array}$ \\
\hline $\begin{array}{l}\text { 7. Objetivos } \\
\text { incompatibles }\end{array}$ & $\begin{array}{l}\text { Fallos debidos a la escasa prioridad concedida a la } \\
\text { seguridad y el bienestar interno respecto a otros } \\
\text { objetivos }\end{array}$ \\
\hline 8. Comunicación & $\begin{array}{l}\text { Fallos debidos a una calidad deficiente o a la } \\
\text { ausencia de vías de comunicación entre las } \\
\text { diversas divisiones, los departamentos y los } \\
\text { trabajadores }\end{array}$ \\
\hline 9. Organización & $\begin{array}{l}\text { Fallos debidos al modo en que se gestiona el } \\
\text { proyecto y se administra la compañía }\end{array}$ \\
\hline $\begin{array}{l}\text { 10. Gestión } \\
\text { del mantenimiento }\end{array}$ & $\begin{array}{l}\text { Fallos debidos a la escasa calidad de los procedi- } \\
\text { mientos de mantenimiento en lo que se refiere } \\
\text { a la calidad, la utilidad, la disponibilidad y la } \\
\text { exhaustividad }\end{array}$ \\
\hline 11. Defensas & $\begin{array}{l}\text { Fallos debidos a la calidad deficiente de la protec- } \\
\text { ción frente a las situaciones peligrosas }\end{array}$ \\
\hline
\end{tabular}

deseado, la idea de defensas puede utilizarse para describir la eficacia percibida de las barreras de seguridad después de una perturbación y para mostrar el modo en que fallaron en la prevención del accidente real.

Los directivos necesitan disponer de una estructura que les permita relacionar los problemas detectados con las acciones preventivas. Las medidas adoptadas respecto a las barreras de seguridad y los actos deficientes siguen siendo necesarias, aunque nunca pueden ser plenamente eficaces. Confiar en las barreras "de última línea" es confiar en factores que, en gran medida, son ajenos al control de la dirección, que no debe intentar abordar tales dispositivos externos incontrolables, sino tratar de hacer sus organizaciones intrínsecamente seguras a todas las escalas.

\section{Medición del nivel de control sobre el error humano} Comprobar la presencia de los TFG en una organización permitirá a los investigadores de los accidentes identificar los puntos fuertes y débiles de la organización. Con esta información, se puede proceder al análisis de los accidentes, eliminar o reducir sus causas, e identificar los defectos estructurales en una empresa y fijarlos antes de que contribuyan de hecho a un accidente.

\section{Investigación de accidentes}

La tarea de un analista de accidentes consiste en identificar los factores que contribuyen a su existencia y clasificarlos. EI número 
Figura 57.4 - Perfil de un tipo de accidente.

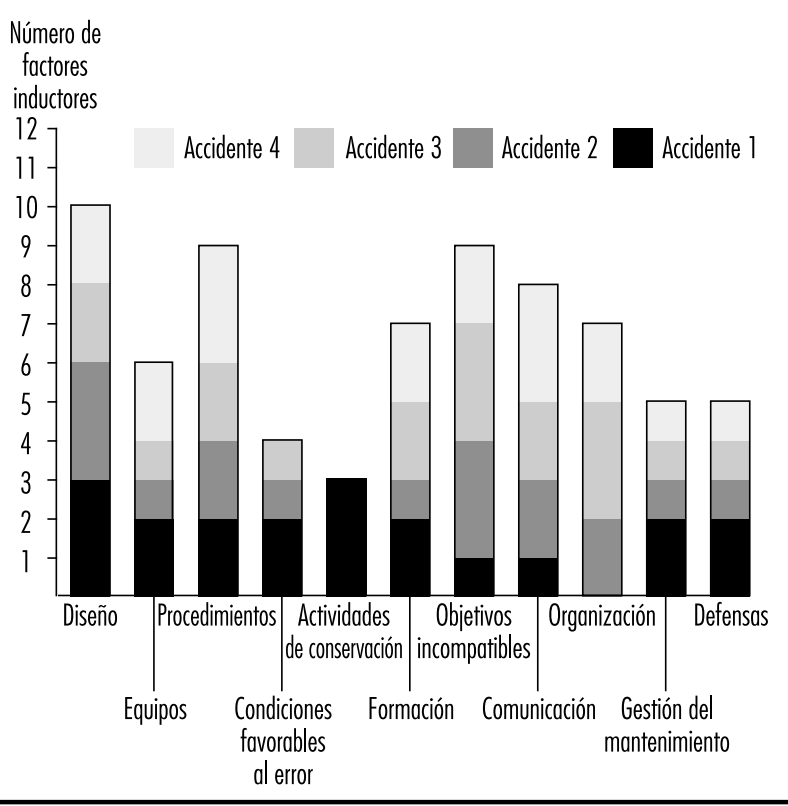

de veces que un factor contribuye es identificado y catalogado en términos de un TFG e indica en qué medida está presente. A menudo, esta actividad se basa en la utilización de una lista de comprobación o de un programa informático de análisis.

Es posible y conveniente combinar los perfiles de diferentes, aunque similares, tipos de accidentes. Las conclusiones basadas en la acumulación de investigaciones de accidentes en un período de tiempo relativamente corto son mucho más fiables que las extraídas de los estudios en los que las características del accidente se obtienen de un único suceso. En la Figura 57.4 se presenta un ejemplo de este perfil combinado y se ofrecen los datos relativos a cuatro manifestaciones de un único tipo de accidente

Algunos de los TFG (diseño, procedimientos y objetivos incompatibles) registran cifras elevadas en los cuatro accidentes concretos. Lo cual significa que en cada accidente se han detectado factores relacionados con estos TFG. En lo que respecta al perfil del accidente 1, el diseño es un problema. La actividad de conservación, aunque representa una dificultad esencial en el accidente 1, reviste menor importancia si se analizan otros accidentes aparte del número 1. Es aconsejable investigar y combinar unos diez tipos similares de accidentes en un perfil antes de adoptar medidas correctivas de gran envergadura y, posiblemente, costosas. De este modo, la identificación de los factores contribuyentes y su posterior clasificación puede realizarse de un modo muy fiable (Van der Schrier, Groeneweg y Van Amerongen 1994).

\section{Determinación proactiva de los TFG en una organización}

Es posible cuantificar proactivamente la presencia de los distintos TFG, con independencia de que existan accidentes 0 incidentes. Para ello, es necesario buscar indicadores de la presencia de estos TFG. Los indicados para este fin consisten en una respuesta afirmativa o negativa a una pregunta sencilla. La contestación del modo no deseado es una indicación que algo no funciona apropiadamente. Un ejemplo de pregunta indicativa es: "En los últimos tres meses, ¿ha asistido a una reunión que resultó cancelada? U na respuesta afirmativa del trabajador no significa necesariamente que exista peligro, pero pone de manifiesto una deficiencia en uno de los TFG : la comunicación. Ahora bien, si un número suficiente de preguntas de comprobación de un determinado TFG obtienen respuesta que indican una tendencia incorrecta, la dirección debe asumir que carece del control necesario sobre este TFG.

Para elaborar un perfil de seguridad del sistema (PSS), deben contestarse 20 preguntas para cada uno de los 11 TFG. A cada TFG se le asigna una puntuación que oscila entre 0 (nivel de control bajo) y 100 (nivel de control alto). La puntuación se calcula respecto a la media del sector en una determinada área geográfica. U n ejemplo de este procedimiento de clasificación se presenta en el recuadro.

L os indicadores se extraen pseudoaleatoriamente de una base de datos con algunos cientos de preguntas. Las listas de comprobación consecutivas no incluyen preguntas en común y éstas se disponen de forma que se cubran todos los aspectos de los TFG. Por ejemplo, un fallo de los equipos físicos puede ser el resultado de su ausencia o de su deficiencia. A mbos aspectos deben considerarse en la lista de comprobación. Las distribuciones de respuesta de todas las preguntas son conocidas y las listas se equilibran para igualar la dificultad.

Es posible comparar resultados obtenidos con listas de comprobación diferentes, así como con las obtenidas por otras organizaciones o departamentos, o las mismas unidades tras un cierto período de tiempo. Se han realizado pruebas de validación de gran amplitud para asegurar que todas las preguntas de la base de datos son válidas e indicativas del TFG a ser medido. Las puntuaciones altas indican un mayor nivel de control; es decir, un mayor número de preguntas se ha respondido "como era deseable". Un resultado de 70 indica que la organización en cuestión forma parte del $30 \%$ de las mejores organizaciones similares del sector. Aunque una puntuación de 100 no significa que la organización controle plenamente un TFG, sí indica que, en lo que se refiere a ese tipo de fallo, es la mejor del sector.

Figura 57.5 - Ejemplo del perfil de seguridad de un sistema.

Nivel de control

Alto

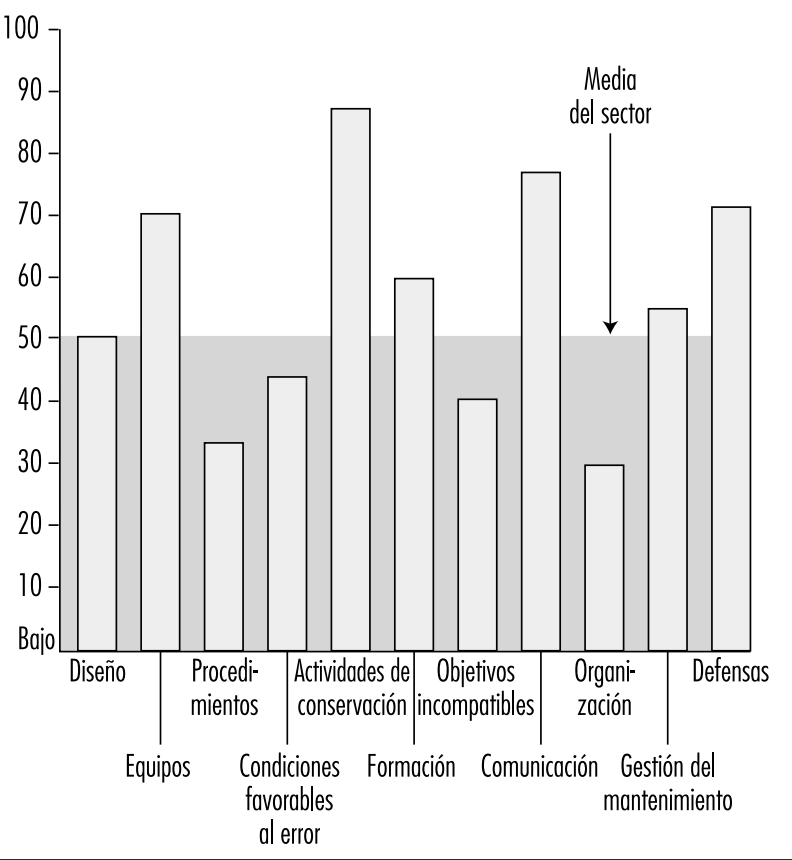




\section{Indicación del nivel de control de su organización respecto al TFG "comunicación"}

En este recuadro se presenta una relación de 20 preguntas. Han sido respondidas por trabajadores de más de 250 organizaciones de Europa occidental. Estas entidades operan en distintos ámbitos, que van desde el sector químico a las refinerías, pasando por la construcción. N ormalmente, las preguntas se adaptan específicamenet a cada rema de actividad. La relación ofrecida sirve únicamente como ejemplo para ilustrar el modo en que funciona esta herramienta en el caso de uno de los TFG. Se han seleccionado aquellas preguntas que han demostrado tener un carácter tan "general", que son aplicables en al menos un $80 \%$ de los sectores.

En "la vida real", los trabajadores no sólo tendrían que responder estas preguntas (anónimamente), sino también justificar sus contestaciones. No basta con decir que "si", por ejemplo, al indicador " ¿ $\mathrm{Ha}$ tenido que trabajar durante las 4 últimas semanas con un procedimiento obsoleto?" El trabajador tendría que indicar qué procedimiento era y en qué condiciones debió aplicarse. Esta justificación cumple un doble objetivo: aumenta la fiabilidad de las respuestas y ofrece a la dirección datos en los que basar su actuación.

Asimismo, hay que tomar precauciones al interpretar el resultado en percentiles; en una medición real, la organización se habría comparado con una muestra representativa de las entidades del sector para cada uno de los 11 TFG. La distribución de percentiles data de mayo de 1995, y esta distrubución cambia ligeramente con el tiempo.

\section{¿Cómo medir el "nivel de control"?}

Debe responder a los 20 indicadores teniendo en cuenta la situación propia y siendo consciente de las limitaciones temporales de las preguntas. Algunas de las cuestiones pueden no ser aplicables en su caso particular; en ese caso, anote "n.a.". Algunas de las preguntas le resultarán imposibles de contestar; anote entonces un signo de interrogación.

Una vez contestadas todas las preguntas, compare sus respuestas con las de referencia. Se obtiene un punto por cada cuestión respondida "correctamente".

Sume el número de puntos logrados. Calcule el porcentaje de las preguntas respondidas correctamente dividiendo los puntos obtenidos entre el número de preguntas que haya respondido mediante un "sí" o un "no". Las respuestas "n.a." y "?" no se tienen en cuenta. El resultado es un porcentaje que oscila entre 0 y 100 .

La medición puede realizarse con mayor fiabilidad aumentando el número de personas que contesta las preguntas y obteniendo la media de sus resultados respecto a los niveles o las funciones en la organización o en departamentos comparables.

\section{Veinte preguntas sobre el TFG "comunicación"}

Respuestas posibles a las preguntas: $\mathrm{S}=\mathrm{Síes} ; \mathrm{N}=\mathrm{N} 0 ; \mathrm{n} . \mathrm{a} .=$ no aplicable; ? = no sabe.

1. En las últimas cuatro semanas, ¿ha obtenido en la guía de teléfonos informaciones incorrectas o insuficientes?

2. En las últimas 2 semanas, ise ha visto interrumpida su conversación debido al mal funcionamiento del sistema telefónico?

3. ¿Ha recibido correo la semana pasada que no era de su incumbencia?

4. ¿Se ha realizado una auditoría interna o externa en los últimos 9 meses sobre el seguimiento de su documentación administrativa?

5. ¿Más del $20 \%$ de la información que ha recibido en las últimas 4 semanas ha sido calificada como "urgente"?
6. ¿Ha tenido que trabajar en las últimas 4 semanas con un procedimiento que resultaba difícil de leer ( $p$. ej., por problemas de redacción o lingüísticos)?

7. ¿Ha asistido a una reunión en las últimas 4 semanas que acabase no celebrándose?

8. ¿Ha tenido cinco 0 más reuniones algún día de las últimas 4 semanas?

9. ¿Existe un "buzón de sugerencias" en su organización?

10. En los últimos 3 meses, ¿se le ha invitado a debatir una cuestión sobre la que ya se había tomado una decisión?

11. ¿Ha remitido en las últimas 4 semanas algún tipo de información que nunca llegó a su destino?

12. En los últimos 6 meses, ¿ha recibido información acerca de cambios en las políticas o los procedimientos más de un mes después del comienzo de su aplicación?

13. ¿Se han enviado a su personal directivo las actas de las tres últimas reuniones de seguridad?

14. ¿Permaneció el personal directivo "administrativo" un mínimo de 4 horas en las instalaciones con ocasión de la última visita realizada sobre el terreno?

15. ¿Ha tenido que trabajar en las últimas 4 semanas con procedimientos basados en datos incompatibles?

16. Ha recibido en los últimos 3 días retroinformación relativa a las solicitudes de datos efectuadas en las 4 últimas semanas?

17. El personal de su organización, ¿habla idiomas o dialectos (distintos de su lengua materna)?

18. ¿Tuvo más del $80 \%$ de la retroinformación que usted recibió (o remitió) de la dirección en los últimos 6 meses un "carácter negativo"?

19. ¿Hay partes de la instalación/ lugar de trabajo donde resulta difícil entenderse debido a la existencia de niveles de ruido extremos?

20. En las últimas 4 semanas, ¿se han entregado herramientas y/ o equipos que no habían sido solicitados?

\section{Respuestas de referencia:}

$1=\mathrm{N} ; 2=\mathrm{N} ; 3=\mathrm{N} ; 4=\mathrm{S} ; 5=\mathrm{N} ; 6=\mathrm{N} ; 7=\mathrm{N} ; 8=\mathrm{N}$; $9=\mathrm{N} ; 10=\mathrm{N} ; 11=\mathrm{N} ; 12=\mathrm{N} ; 13=\mathrm{S} ; 14=\mathrm{N} ; 15=\mathrm{N}$; $16=\mathrm{S} ; 17=\mathrm{N} ; 18=\mathrm{N} ; 19=\mathrm{S} ; 20=\mathrm{N}$.

\section{Puntuación del TFG “comunicación”}

Puntuación porcentual $=(a / b) \times 100$

Donde $a=\mathrm{N}$ ․ de preguntas contestada correctamente y $b=n$. . de preguntas contestadas " $S$ " 0 "N".

\begin{tabular}{|l|l|l|c|}
\hline Puntuación (en \%) & Percentil & $\%$ & Igual o mejor \\
\hline $0-10$ & $0-1$ & 100 & 99 \\
\hline $11-20$ & $2-6$ & 98 & 94 \\
\hline $21-30$ & $7-14$ & 93 & 86 \\
\hline $31-40$ & $15-22$ & 85 & 78 \\
\hline $41-50$ & $23-50$ & 79 & 50 \\
\hline $51-60$ & $51-69$ & 49 & 31 \\
\hline $61-70$ & $70-85$ & 30 & 15 \\
\hline $71-80$ & $86-97$ & 14 & 3 \\
\hline $81-90$ & $98-99$ & 2 & 1 \\
\hline $91-100$ & $99-100$ & & \\
\hline
\end{tabular}


En la Figura 57.5 se ofrece un ejemplo de PSS. Las áreas débiles de la organización 1, indicadas por las columnas del cuadro, son los procedimientos, los objetivos incompatibles, y las condiciones favorables al error, ya que su puntuación no alcanza el nivel medio del sector, señalado mediante el sombreado en gris. Los resultados en materia de conservación, equipos y defensas son muy buenos en la organización 1. A parentemente, esta organización bien equipada y ordenada, con todos los dispositivos de seguridad coloreados adecuadamente, parece un lugar de trabajo seguro. La organización 2 iguala exactamente la puntuación media del sector. No presenta grandes deficiencias y, aunque los resultados en equipos, conservación y defensas son menores, la empresa gestiona (como media) el componente de error humano mejor que la organización 1 . De acuerdo con el modelo de causalidad de accidentes, la organización 2 es más segura que la 1, aunque esta conclusión no sería necesariamente evidente al realizar comparaciones basadas en auditorías "tradicionales".

Si estas organizaciones tuvieran que decidir dónde asignar sus recursos limitados, las cuatro áreas situadas por debajo de la media del sector serían prioritarias. Con todo, no debe concluirse que, puesto que los demás resultados de los TFG son tan favorables, es posible detraer recursos de estas áreas manteniendo la seguridad, ya que, probablemente, es esta dotación la que les ha mantenido a ese nivel elevado.

\section{Conclusiones}

Este artículo ha abordado la cuestión del error humano y la prevención de accidentes. El análisis de la bibliografía sobre control del componente de error humano en los accidentes deparó un conjunto de seis vías mediante las que puede tratarse de influir en el comportamiento. Sólo una, la reestructuración del ambiente o la modificación del comportamiento con el fin de reducir el número de situaciones en las que las personas es factible que comentan un error, tiene un efecto razonablemente favorable en una organización industrial consolidada en la que se hayan realizado con anterioridad otros muchos intentos. La dirección debe afrontar con firmeza la existencia de estas situaciones adversas y movilizar los recursos que sean necesarios para proceder al cambio de la empresa. Las otras cinco opciones no representan alternativas útiles, ya que su repercusión es escasa o nula y su coste, elevado.

"Controlar lo controlable" es el principio esencial que subyace al planteamiento presentado en este artículo. Los TFG deben ser detectados, abordados y eliminados. Se ha comprobado que los 11 tipos de fallos generales son mecanismos integrantes del proceso de causalidad de los accidentes. Con la determinación de diez de ellos se pretende prevenir las perturbaciones operativas, y con el restante (defensas), evitar que estas perturbaciones se conviertan en accidentes. La erradicación de los efectos de los TFG influye directamente en la atenuación de las causas inductoras de los accidentes. El objetivo de las preguntas incluidas en las listas de comprobación es medir el "estado de salud" de un determinado TFG, desde el punto de vista general y del de la seguridad. Esta se concibe como un elemento integrado de las operaciones habituales: realizar cada tarea de la forma debida. Es una visión coherente con los más recientes planteamientos de la gestión "orientados a la calidad". La disponibilidad de políticas, procedimientos y herramientas no es la principal preocupación de la gestión de la seguridad: la cuestión es si estos métodos se utilizan, se comprenden y se cumplen en la práctica.

El planteamiento descrito en el presente artículo se ocupa de los factores del sistema y del modo en que las decisiones de gestión pueden traducirse en condiciones inseguras en el lugar de trabajo, en contraste con la creencia extendida según la cual, debe prestarse atención a los trabajadores que realizan actos inseguros, así como a sus actitudes, sus motivaciones y sus percepciones del riesgo.

\section{RIESG OS DE LOSEQUIPOS}

\section{Carsten D. G roenberg}

Este artículo aborda los riesgos de las "máquinas", que son específicos de los accesorios y los equipos utilizados en los procesos industriales asociados a conductos a presión, equipos de procedimiento, máquinas guiadas por motor y otras operaciones de riesgo intrínsecamente peligrosas. Por el contrario, no se tratan los riesgos del trabajador, vinculados a las acciones y el comportamiento de las personas, como el deslizamiento sobre superficies de trabajo, caídas de altura y los riesgos de utilización de herramientas ordinarias. E ste artículo se centra en los peligros de las máquinas, característicos de un ambiente de trabajo industrial. Puesto que estos riesgos son una amenaza para las personas en contacto con las fuentes de peligro, y pueden serlo incluso para la población circundante y el medio ambiente externo, los métodos de análisis y los medios de prevención y control son semejantes a los métodos usados para eliminar los riesgos para el medio ambiente que generan las actividades industriales.

\section{Riesgos asociados a las máquinas}

Los equipos de buena calidad son muy fiables y la mayoría de los fallos se deben a efectos secundarios, como incendios, corrosión, desgaste y uso, etc. Claro está que, en ciertos accidentes, los equipos pueden ser objeto de una atención especial porque la deficiencia de uno de sus componentes constituye, a menudo, el vínculo más llamativo y visible de la cadena de acontecimientos. Aunque el término equipos se utiliza en un sentido amplio, los ejemplos ilustrativos de sus fallos y de su "entorno" inmediato en la causalidad de accidentes se han obtenido de los lugares de trabajo industriales. Entre los candidatos típicos para la investigación de los riesgos de las "máquinas" figuran los siguientes:

- conductos de presión y tuberías;

- motores, turbinas y otras máquinas de rotación;

- reactores químicos y nucleares;

- andamios, puentes, etcétera;

- láseres y otros radiadores de energía;

- maquinaria de corte y taladro, etcétera,

- equipo de soldadura.

\section{Efectos de la energía}

Los riesgos de los equipos pueden incluir una utilización incorrecta, errores en su construcción o sobrecarga frecuente y, por tanto, su análisis y disminución o prevención puede seguir diferentes direcciones. Con todo, las formas de energía física y química que eluden el control humano subyacen con frecuencia a este tipo de riesgos. Por tanto, un método general para determinar los riesgos de los equipos consiste en detectar las energías controladas normalmente en cada elemento del equipo o maquinaria, por ejemplo, en un aparato a presión que contiene amoniaco o cloro. Otros métodos utilizan el fin o la función prevista de los equipos reales como punto de partida y, posteriormente, se intenta establecer los efectos probables de las deficiencias de funcionamiento y de los fallos. Por ejemplo, un puente que no cumpla su función esencial expondrá a los sujetos situados sobre él un riesgo de caídas de altura; otros efectos secundarios consistirán en la caída de objetos, ya sean componentes 
estructurales del puente u objetos situados sobre él. $M$ ás adelante en la cadena de consecuencias, pueden observarse efectos derivados relacionados con funciones en otras partes del sistema que dependían de que el puente desempeñara su papel adecuadamente, como en el caso de la interrupción del tráfico de vehículos de urgencias que atendían otro incidente.

Además de los conceptos de "energía controlada" y "función prevista", la cuestión de las sustancias peligrosas puede abordarse mediante el planteamiento de preguntas como "¿Cómo pudo salir el agente $X$ de los depósitos, los tanques o los sistemas de tuberías y cómo se produjo el agente $Y$ ?" (puede que uno de los dos 0 ambos sean peligrosos). El agente $X$ puede ser un gas a presión 0 un disolvente, y el agente $Y$, una dioxina extremadamente tóxica cuya formación es propiciada por las temperaturas "adecuadas" en algunos procesos químicos o que podría producirse por oxidación rápida, como resultado de un incendio. En cualquier caso, los riesgos posibles son mucho más importantes que los generados por las sustancias peligrosas. Pueden existir condiciones o influencias que propicien que la presencia de un elemento específico de los equipos produzca consecuencias perjudiciales para las personas.

\section{Ambiente de trabajo industrial}

Entre los riesgos asociados a las máquinas también se encuentran los factores de carga o estrés que pueden resultar peligrosos a largo plazo, como los siguientes:

- temperaturas de trabajo extremas;

- altas intensidades de iluminación, ruido u otros estímulos;

- calidad del aire deficiente,

- demandas o cargas de trabajo excesivas.

Es posible detectar estos riesgos, y tomar precauciones porque las condiciones peligrosas ya están presentes. No dependen de que se produzca un cambio estructural de los equipos con resultados perjudiciales, ni de que un suceso concreto provoque daños o lesiones. Asimismo, los riesgos a largo plazo proceden de fuentes específicas en el entorno de trabajo, pero deben identificarse y evaluarse mediante la observación de los trabajadores y las tareas que desempeñan y no a través del mero análisis de la construcción y las funciones de los equipos.

Los equipos peligrosos o máquinas peligrosas suelen ser excepcionales y rara vez se encuentran en un entorno de trabajo adecuado, pero no pueden evitarse por completo. $\mathrm{H}$ ay varias formas de energía incontrolada, como la que generan los agentes de riesgo siguientes, que pueden ser consecuencia inmediata de un mal funcionamiento de los equipos:

- emisiones dañinas de gases, líquidos, polvo u otras sustancias peligrosas;

- incendios y explosiones;

- alta tensión;

- caída de objetos, misiles, etcétera;

- campos eléctricos y magnéticos;

- cortes, bloqueos, etcétera;

- desplazamiento de oxígeno;

- radiación nuclear, rayos X y luz láser;

- inundación y sumersión,

- chorros de líquido caliente o vapor.

\section{Agentes de riesgo}

objetos en movimiento. Los objetos en caída o vuelo, los flujos de líquido, los chorros de líquido o vapor son a menudo las primeras consecuencias externas de fallos de equipos, y a ellos se debe una gran proporción de accidentes.
Sustancias químicas. Los riesgos químicos también contribuyen a accidentes de trabajo y repercuten en el medio ambiente y la población en general. Los accidentes de Seveso y Bhopal implicaron emisiones de sustancias químicas que afectaron a muchas personas, y numerosos incendios y explosiones industriales liberan productos químicos y humos a la atmósfera. En los accidentes de tráfico en los que intervienen camiones de distribución de gasolina u otros vehículos de transporte de mercancías peligrosas, coinciden dos agentes de riesgo: los objetos en movimiento y las sustancias químicas.

E nergía el ectromagnética. Los campos eléctricos y magnéticos, los rayos $\mathrm{X}$ y los rayos gamma son manifestaciones del electromagnetismo, pero suelen abordarse por separado, ya que se dan en circunstancias bastante diferentes. Sin embargo, los peligros del electromagnetismo tienen el mismo tratamiento general: los campos y la radiación penetran en el cuerpo humano en lugar de limitarse a entrar en contacto con el área de aplicación, y no pueden percibirse directamente, aunque a intensidades muy elevadas provocan calentamiento de la zona del cuerpo afectada. Los campos magnéticos son creados por el flujo de la corriente eléctrica y se encuentran campos magnéticos intensos en las proximidades de grandes motores eléctricos, equipos de soldadura por arco eléctrico, aparatos de electrólisis, trabajos del metal y otros. Los campos eléctricos acompañan a la tensión eléctrica; incluso los voltajes de la red eléctrica ordinaria (200 a 300 voltios) causan la acumulación de suciedad al cabo de varios años, lo que constituye el signo visible de la existencia del campo y un efecto también conocido en el caso de las líneas eléctricas de alta tensión, los tubos de rayos catódicos de televisión, los monitores de ordenador, etc.

L os campos electromagnéticos suelen encontrarse cerca de sus fuentes, pero la radiación electromagnética recorre largas distancias, como lo demuestran las ondas de radar y de radio. La radiación electromagnética es dispersada, reflejada y se amortiguada a su paso a través del espacio y en su encuentro con objetos, superficies y diversas sustancias y atmósferas; por tanto, su intensidad se reduce de varias formas.

En general, las fuentes de riesgo electromagnéticas (EM) se caracterizan por:

- Es necesario utilizar instrumentos para detectar la presencia de campos EM o radiación EM.

- No dejan rastros primarios en forma de "contaminación".

- Los efectos peligrosos suelen demorarse o se manifiestan a largo plazo, aunque en los casos graves se producen quemaduras de inmediato.

- Los rayos X y gamma con amortiguados, pero no parados, por el plomo y otros elementos pesados.

- Los campos magnéticos y los rayos X son parados inmediatamente cuando se elimina la energía de la fuente o se apaga el equipo.

- Los campos eléctricos pueden mantenerse durante períodos prolongados después de desconectar los sistemas generadores.

- Los rayos gamma se producen como consecuencia de procesos nucleares, y estas fuentes de radiación no pueden apagarse como muchas de las fuentes $E M$.

Radiación nuclear. Los riesgos asociados a la radiación nuclear revisten especial importancia para los trabajadores de centrales nucleares y de instalaciones donde se trabajen con materiales nucleares, como fabricación de combustible y reelaboración, transporte y almacenamiento de material radiactivo. Las fuentes de radiación nuclear también se utilizan en medicina y en algunas industrias a efectos de medición y control. Un uso muy común es en alarmas contra incendios y en detectores de humo, en los que se emplea un emisor de partículas alfa como el americio para controlar la composición del aire. 
Los riesgos nucleares se concentran fundamentalmente en cinco factores:

- rayos gamma;

- neutrones;

- partículas beta (electrones);

- partículas alfa (núcleos de helio),

- contaminación.

Los riesgos se deben a los procesos radiactivos en la fisión nuclear y el deterioro de los materiales radiactivos. La emisión de este tipo de radiación deriva de los procesos de los reactores nucleares, del combustible utilizado en ellos, del material moderador, de los productos gaseosos de la fisión que pueden desarrollarse y de ciertos materiales de construcción que quedan activados por la exposición a emisiones radiactivas procedentes del funcionamiento del reactor.

0 tros agentes de riesgo. A continuación se refieren otras clases de agentes de riesgo que liberan o emiten energía:

- radiación ultravioleta y luz láser;

- infrasonido;

- sonido de alta intensidad,

- vibración.

\section{Multiplicación de los riesgos de los equipos}

La transformación repentina y gradual de una situación controlada (o "segura") a otra en la que aumenta el peligro puede producirse a causa de las circunstancias siguientes, que pueden ser controladas mediante la utilización de los medios de organización apropiados, como la experiencia del usuario, la educación, las cualificaciones, la vigilancia y la comprobación del equipo:

- desgaste y sobrecarga;

- impacto externo (incendio o colisión):

- envejecimiento y fallo;

- suministro erróneo (energía, materias primas);

- mantenimiento y reparación insuficientes;

- error de control o de proceso;

- utilización o aplicación incorrectas;

- avería de los equipos,

- funcionamiento inadecuado de las barreras.

Puesto que una correcta operación no puede compensar de manera fiable la inadecuación del diseño y de la instalación, es importante considerar el conjunto del proceso, desde la selección y la concepción, hasta la instalación, el uso, el mantenimiento y la comprobación, con el fin de evaluar el estado y las condiciones reales de cada elemento del equipo.

\section{Caso de riesgo: el tanque de gas presurizado}

El gas puede conservarse en depósitos adecuados para el almacenamiento o transporte, como las botellas de gas y oxígeno utilizadas por los soldadores. A menudo, el gas se manipula a alta presión, lo que permite un gran aumento en la capacidad de almacenamiento, pero con un mayor riesgo de accidente. El fenómeno inductor de accidentes fundamental en el almacenamiento de gas a presión es la creación repentina de un orificio en el tanque, con los siguientes resultados:

- la función de confinamiento del tanque se interrumpe,

- el gas confinado pasa de inmediato a la atmósfera que le rodea.

Q ue se produzca un accidente de este tipo depende los factores siguientes:

- tipo y cantidad de gas en el tanque;

- situación del orificio en relación con el contenido del tanque;

- tamaño inicial y ritmo de crecimiento posterior del orificio;

- temperatura y presión del gas y del equipo,
- condiciones del ambiente de trabajo inmediato (fuentes de ignición, presencia de personas, etc.).

El contenido del tanque puede quedar liberado casi de inmediato o tras un cierto período de tiempo, y dar lugar a diversas situaciones, desde la explosión del gas liberado por el tanque deteriorado, hasta una emisión moderada y más bien lenta a través de pequeñas perforaciones.

\section{Comportamiento de diversos gases en caso de fuga}

Al desarrollar modelos de cálculo de emisiones, es esencial determinar las condiciones siguientes, que afectan al posible comportamiento del sistema:

- estado del gas próximo al orificio (¿gaseoso, líquido?);

- temperatura y condiciones del aire;

- posible entrada de otras sustancias en el sistema o presencia de éstas en las proximidades del mismo,

- barreras y otros obstáculos.

Es difícil realizar el cálculo exacto relativo al proceso de emisión en el que un gas licuado escapa a través de un orificio en forma de chorro y posteriormente se evapora (o bien se presenta inicialmente pulverizado). Asimismo, la especificación de la dispersión posterior de las nubes resultantes constituye un problema complejo. Deben tenerse en cuenta los movimientos y la dispersión de las emisiones de los gases liberados, si el gas forma nubes visibles o invisibles y si se eleva o se mantiene al nivel del suelo.

Aunque el hidrógeno es un gas ligero comparado con la atmósfera, el gas amoniaco $\left(\mathrm{NH}_{3}\right.$, con un peso molecular de $17,0)$ se eleva en una atmósfera ordinaria de oxígeno y nitrógeno con idénticas temperatura y presión. $\mathrm{El}$ cloro $(\mathrm{C} / 2$, con un peso molecular de 70,9) y el butano $\left(\mathrm{C}_{4} \mathrm{H}_{10}\right.$, con un peso molecular de 58) son ejemplos de sustancias químicas cuyos gases son más densos que el aire, incluso a temperatura ambiente. El acetileno ( $C 2 \mathrm{H}_{2}$, peso molecular: 26,0) tiene una densidad de unos $0,90 \mathrm{~g} / \mathrm{l}$, próxima a la del aire $(1,0 \mathrm{~g} / \mathrm{l})$, lo que significa que, en un entorno de trabajo, el gas de soldadura emitido no tendrá una tendencia pronunciada a elevarse 0 descender, por lo que podrá combinarse fácilmente con la atmósfera.

Ahora bien, el amoniaco emitido por un depósito a presión en forma de líquido se enfriará inicialmente como consecuencia de su evaporación y, después, podrá escapar a través de diversas vías:

- El amoniaco líquido, presurizado, emana del orificio del tanque en forma de chorro o de nube.

- El amoniaco líquido puede depositarse sobre las superficies adyacentes.

- El amoniaco se evapora, enfriándose y refrigerando el entorno más próximo.

- El gas amoniaco intercambia calor gradualmente con el entorno y se equilibra con la temperatura ambiente.

Puede suceder que incluso una nube de gas ligero no ascienda de inmediato a raíz de una emisión de gas líquido; es posible que primero se forme una niebla (una nube de pequeñas gotas) que permanezca próxima al suelo. El movimiento de la nube de gas y su gradual mezcla o dilución con la atmósfera que la rodea depende de los parámetros meteorológicos y del entorno (área cerrada o abierta, viviendas, tráfico, presencia de personas, trabajadores, etc.).

\section{Fallo del tanque}

Las consecuencias de la avería de un tanque supone desde incendio y explosión, hasta asfixia, envenenamiento y pérdida del conocimiento, como lo demuestra la experiencia acumulada con 
los sistemas de producción y manipulación de gas (propano, metano, nitrógeno, hidrógeno, etc.), con los depósitos de amoniaco o cloro y en las actividades de soldadura con gas (en las que se utiliza acetileno y oxígeno). Lo que inicia realmente la formación de un orificio en un tanque tiene gran influencia en el "comportamiento" de dicho orificio (que, a su vez, influye en el flujo de salida del gas) y es esencial para la eficacia de las medidas de prevención. Los depósitos de presión se diseñan y construyen para soportar ciertas condiciones de uso e impacto ambiental, así como para contener un determinado gas, o quizá un conjunto específico de gases. La capacidad real de un tanque depende de su forma, materiales, soldadura, protección y utilización, así como del clima del lugar en el que se emplea; por tanto, al evaluar su idoneidad como recipiente de gases peligrosos deben considerarse las especificaciones del fabricante, el historial del depósito, sus inspecciones y las pruebas a las que se le haya sometido. Las áreas críticas incluyen las soldaduras utilizadas en la mayoría de los depósitos de este tipo, los puntos en que se conectan al depósito dispositivos como los mecanismos de entrada y de salida, soportes y otros instrumentos; los extremos planos de los tanques cilíndricos, como los utilizados en los ferrocarriles, y otros aspectos de formas geométricas aún menos adecuadas. Las soldaduras se analizan visualmente, mediante rayos $X$ o pruebas destructivas de muestras, ya que éstas ponen de relieve defectos locales, por ejemplo, de solidez, que pueden poner en peligro la solidez global del depósito o incluso desencadenar una avería grave.

La solidez de un tanque se ve afectada por su historial de utilización y, en primer lugar, por los procesos normales de desgaste y las erosiones y ataques de la corrosión típicos de cada sector y aplicación. 0 tros parámetros históricos de especial interés son:

- exceso de presión ocasional;

- calentamiento o enfriamiento extremos (internos o externos);

- impactos mecánicos;

- vibraciones y tensiones;

- sustancias que han sido almacenadas o han pasado a través del tanque,

- sustancias utilizadas durante su limpieza, mantenimiento y reparación.

El material de construcción (chapa de acero, chapa de aluminio, hormigón para aplicaciones no presurizadas, etc.) puede deteriorarse debido a la influencia de estos elementos de modo que no siempre es posible comprobar sin sobrecargar 0 destruir el equipo durante la prueba.

\section{Un caso de accidente: Flixborough}

La explosión de una gran nube de ciclohexano en Flixborough (Reino U nido) en 1974, que causó la muerte a 28 personas y grandes daños en la planta, es un caso sumamente instructivo. El suceso desencadenante fue la avería de una tubería temporal utilizada como sustitutoria en una unidad de reactor. El accidente fue "causado" por una pieza del equipo averiada, pero una investigación más pormenorizada reveló que el fallo se debió a una sobrecarga y que, de hecho, la instalación temporal era inadecuada para el uso que se le asignó. Después de dos meses de servicio, la tubería quedó expuesta a la acción de fuerzas de flexión debidas a un ligero aumento de la presión del ciclohexano contenido a 10 bar $\left(10^{6} \mathrm{~Pa}\right)$ y a unos $150^{\circ} \mathrm{C}$. Los dos conductos flexibles entre la tubería y los rectores cercanos se rompieron, y se liberaron de 30 a 50 toneladas de ciclohexano que se incendiaron de inmediato, probablemente por la influencia de un horno situado a cierta distancia del punto de fuga. ( $V$ éase la Figura 57.6.) K letz (1988) ofrece una cuidada descripción de este caso.

\section{Análisis de riesgos}

Los métodos elaborados para determinar los riesgos que pueden afectar a cada elemento de un equipo, a un proceso químico 0 a cierta operación se denominan "análisis de riesgos". En estos estudios se plantean preguntas como: "¿Qué puede ir mal?" “¿Podría ser grave?" y "¿Q ué puede hacerse al respecto?" Los diversos métodos de llevar a cabo los análisis suelen combinarse para lograr una cobertura razonable, pero estos sistemas únicamente servirán de orientación o ayuda para que el equipo de analistas tome sus determinaciones. Las principales dificultades afrontadas en los análisis de riesgos son las siguientes:

- disponibilidad de datos relevantes;

- limitaciones de los modelos y los cálculos;

- materiales, montajes y procesos nuevos y desconocidos;

- complejidad de los sistemas;

- limitaciones de la imaginación humana,

- limitaciones de las pruebas prácticas.

Para elaborar evaluaciones de riesgos útiles en estas circunstancias, es importante definir estrictamente el alcance y el nivel de "ambición" adecuado para el análisis en cuestión; por ejemplo, es obvio que no es necesario disponer del mismo tipo de información a efectos de seguridad o de diseño, para la planificación de dispositivos de protección o para la construcción de sistemas de emergencia. En general, la determinación de los riesgos debe basarse en la combinación de técnicas empíricas (p. ej., estadísticas) con el razonamiento deductivo y la imaginación creativa.

$\mathrm{H}$ ay varias herramientas de evaluación de riesgos (incluso programas informáticos para el análisis de riesgos) que pueden resultar de gran utilidad. El estudio de riesgos y capacidad operativa (HAZOP) y modo de fallos y análisis de efectos (FMEA) son métodos utilizados habitualmente en la investigación de riesgos, especialmente en la industria química. El punto de partida del método HAZOP es el estudio de posibles situaciones de riesgo basándose en un conjunto de palabras de orientación; para cada situación se deben identificar las posibles

Figura 57.6 • Conexión temporal entre depósitos en Flixborough.
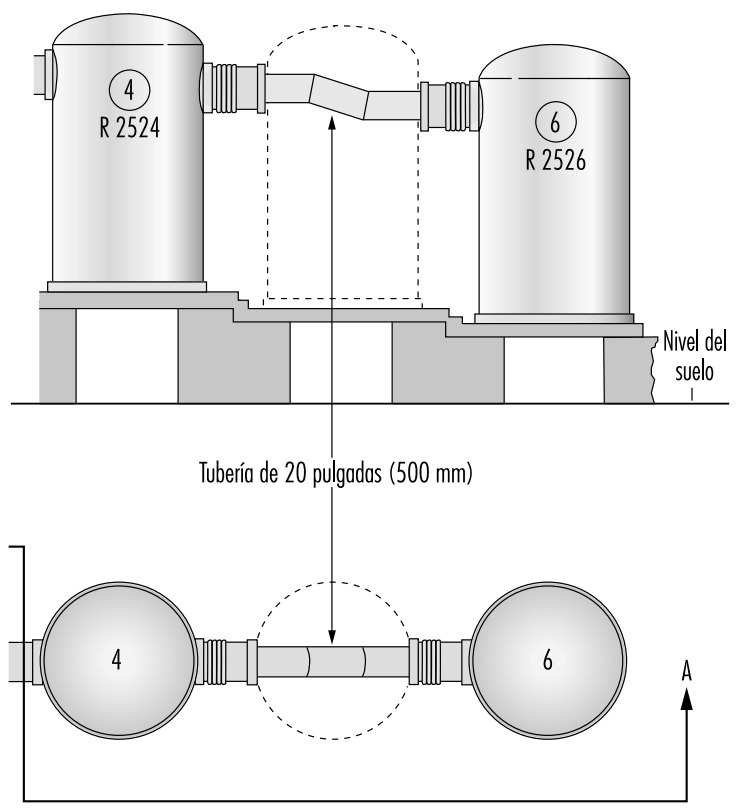

Fuente: Advisory Committee on Major Hozards 1984 
causas y consecuencias. En una segunda fase se intenta encontrar los medios de reducir las probabilidades 0 atenuar las consecuencias de esas situaciones consideradas inaceptables. Charsley (1995) lleva a cabo un examen de este método. En el método FM EA se plantea una serie de preguntas del tipo: "¿qué pasaría si... ?" para detectar todos los componentes de riesgo posibles, determinar con precisión los tipos de modo de fallos que pueden producirse y determinar por último los efectos de estos fallos en el funcionamiento del sistema. En el ejemplo de un sistema de transporte de gas que se cita más adelante en el presente artículo se describe este análisis.

Los árboles de fallos y de sucesos y los modos de análisis lógico característicos de las estructuras de causalidad de accidentes y del razonamiento de probabilidad no son específicos en absoluto del análisis de riesgos de los equipos, ya que se trata de herramientas generales para evaluar los riesgos de los sistemas.

\section{Determinación de los riesgos de los equipos en una planta industrial}

Para determinar posibles riesgos, puede recabarse información sobre la construcción y el funcionamiento de:

- equipo e instalaciones;

- sustitutos y modelos;

- planos, diagramas eléctricos, diagramas de disposición de las tuberías e instrumentación (T / I), etc.;

- descripción de procesos;

- planes de control;

- fases y los modos de operación,

- órdenes de trabajo, órdenes de modificación, informes de mantenimiento, etc.

Al seleccionar y elaborar esta información, los analistas se hacen una idea del objeto de riesgo en sí, de sus funciones y de su utilización en la práctica. En caso de que los distintos elementos no estén ensamblados (o no se encuentren disponibles para la inspección), no pueden realizarse observaciones significativas y la evaluación debe basarse enteramente en las descripciones, los proyectos y los planos. Algunas evaluaciones pueden parecer pobres, pero, en la práctica, la mayoría de las evaluaciones de riesgos se efectúan de este modo, ya sea con el fin de procurar una aprobación autorizada que permita adoptar una nueva estructura en las aplicaciones o para comparar la seguridad relativa de las soluciones de diseño alternativas. Se consultan los procesos elaborados en la realidad para recopilar la información que no figura en los diagramas formales o no se describe oralmente mediante una entrevista, así como para comprobar que los datos recopilados procedentes de estas fuentes son objetivos y se corresponden con las condiciones reales. Las fuentes de información son las siguientes:

- cultura y práctica real;

- datos sobre estructura/ mecanismos de fallos adicionales;

- "desvíos" (véase más adelante)

- causas comunes de error;

- riesgos derivados de fuentes externas/ misiles;

- exposiciones o consecuencias específicas,

- incidentes, accidentes y cuasiaccidentes en el pasado.

La mayor parte de esta información adicional, y en especial los "desvíos", sólo puede ser recabada por observadores avezados con una experiencia considerable, y en el caso de algunos datos, resulta casi imposible especificarlos mediante cuadros y diagramas. Por desvíos se entiende las interacciones involuntarias e imprevistas entre sistemas, en las que el funcionamiento de uno afecta a las condiciones o el funcionamiento del otro a través de vías ajenas a las funcionales. Suele darse esta
Figura 57.7 - Conducto de transmisión para el transporte de gas licuado de un buque a un tanque de almacenamiento.

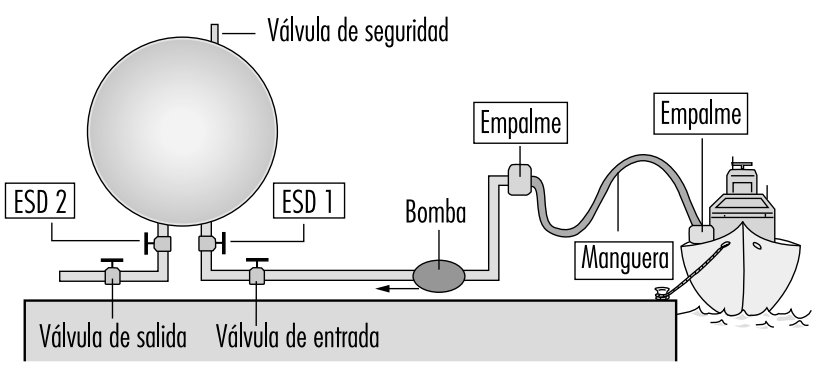

forma de influencia cuando se sitúan juntos componentes con funciones diferentes 0 , por ejemplo, cuando una fuga hace que una sustancia caiga sobre un equipo situado debajo y provoca una avería. 0 tra posibilidad es la introducción de sustancias 0 componentes erróneos en un sistema mediante la utilización de instrumentos o herramientas durante la operación o el mantenimiento: las estructuras y las funciones previstas se modifican a través de los "desvíos". C on averías comunes se alude a ciertas situaciones (como una inundación, una descarga eléctrica o una interrupción de la corriente eléctrica) capaces de perturbar varios sistemas a un tiempo, quizá dando lugar a bloqueos y accidentes de gravedad inesperada. En general, los efectos de los desvíos y las averías comunes tratan de evitarse mediante una instalación adecuada y la introducción de distancias, aislamiento y diversidad en las distintas operaciones.

\section{U n caso de análisis de riesgos: transporte de gas desde un buque a un tanque}

En la Figura 57.7 se muestra un sistema de transporte de gas desde un buque a un tanque de almacenamiento. Puede producirse una fuga en cualquier punto del mismo: el buque, la línea de transmisión, el tanque o la línea de salida; teniendo en cuenta las características de los dos depósitos del tanque, una fuga en la canalización podría permanecer activa durante horas.

L os componentes esenciales del sistema son los siguientes:

- el tanque de almacenamiento;

- el conducto entre el tanque y el buque;

- otras mangueras, conductos, válvulas y conexiones;

- la válvula de seguridad en el tanque de almacenamiento,

- las válvulas de cierre de emergencia VCE 1 y 2.

El tanque de almacenamiento dotado de un gran depósito de gas líquido se sitúa en el primer lugar de la lista, ya que resulta difícil detener una fuga procedente de este tipo de dispositivos en poco tiempo. El segundo elemento de esta relación (la conexión con el buque) es crítica, puesto que los escapes en las mangueras y los conductos, las conexiones y empalmes con juntas desgastadas y las variaciones entre los distintos buques pueden dar lugar a la pérdida de producto. Los componentes flexibles, como las mangueras y los conductos flexibles, revisten mayor importancia que las partes rígidas y exigen regularidad en el mantenimiento y la inspección. Los dispositivos de seguridad, como la válvula de regulación de la presión situada en la parte superior del tanque y las dos válvulas de cierre de emergencia, son críticas, ya que su comprobación debe permitir la detección de averías latentes o en proceso de desarrollo.

H asta aquí, la clasificación de los componentes del sistema según su importancia para la fiabilidad se ha realizado de acuerdo con criterios generales. A continuación, a efectos analíticos, se hará hincapié en las funciones específicas del sistema; 
obviamente, la principal es el traslado de gas licuado del buque al tanque de almacenamiento hasta que el depósito del primero quede vacío. EI riesgo más importante es una fuga, y los factores inductores de la misma son los siguientes:

- pérdidas en los empalmes o las válvulas;

- rotura del tanque;

- rotura de tuberías o mangueras,

- avería del tanque.

\section{Aplicación del método FMEA}

La idea central del enfoque FM EA, análisis basado en el planteamiento de preguntas del tipo "¿qué pasaría si...?", consiste en registrar explícitamente, para cada componente del sistema, sus modos de fallo y, para cada fallo, determinar las posibles consecuencias para el sistema y el medio ambiente. Para componentes normalizados como un tanque, una tubería, una válvula, una bomba, un medidor de flujo, etc., los modos de fallo siguen pautas generales. Por ejemplo, en el caso de una válvula, incluye las siguientes condiciones:

- la válvula no puede cerrarse a voluntad (existe un flujo limitado a través de una válvula "abierta");

- la válvula tiene pérdidas (existe un flujo residual a través de una válvula "cerrada",

- la válvula no puede abrirse a voluntad (la posición de la válvula oscila).

En el caso de una tubería, los modos de fallo pueden concretarse en las siguientes:

- flujo limitado;

- fuga;

- flujo detenido a causa de un bloqueo,

- ruptura del conducto.

Los efectos de las fugas parecen obvios, pero, en ocasiones, las repercusiones más importantes pueden no ser las primeras: por ejemplo, ¿qué sucede si una válvula se bloquea en una posición semiabierta? Una válvula de apertura y cierre situada en el conducto de transporte que no se abre completamente a voluntad retrasará el proceso de llenado del tanque, lo que no resulta muy peligroso. En todo caso, si esta posición semiabierta se mantiene en el momento en que se pretende cerrar el dispositivo, cuando el tanque se encuentra casi completo, puede producirse un llenado en exceso (salvo en el caso de que la válvula de cierre de emergencia se active con éxito). En un sistema de diseño y funcionamiento correctos, la probabilidad de que estos dos tipos de válvula se bloqueen simultáneamente será relativamente baja.

No cabe duda de que una válvula de seguridad que no funciona a voluntad puede provocar un desastre; de hecho, es posible afirmar que todos los dispositivos de seguridad están amenazados de manera constante por la posibilidad de averías latentes. Por ejemplo, las válvulas reguladoras de la presión pueden presentar deficiencias debido a la corrosión, la suciedad o la pintura (normalmente a causa de un mal mantenimiento) y, en el caso del gas licuado, estos defectos, unidos a la reducción de temperatura asociada a la fuga de gas, pueden producir hielo y, por tanto, reducir o incluso detener el flujo del material a través de la válvula de seguridad. Si una válvula reguladora no funciona a voluntad, la presión puede aumentar en el tanque o en los sistemas conectados al mismo, causando en última instancia otras fugas o la rotura del depósito.

Para simplificar, en la Figura 57.7 no se muestran los instrumentos, es evidente que se instalarán instrumentos relativos a la presión, el flujo y la temperatura, que son los parámetros esenciales para controlar el estado del sistema, transmitiéndose las señales pertinentes a consolas de operador o a una sala de control para fines de muestreo y control. Además, existirán conductos de suministro distintos de los previstos para el transporte del material (eléctricos, hidráulicos, etc.) y dispositivos adicionales de seguridad. Un análisis exhaustivo debe comprobar estos mecanismos y determinar los modos de fallo y los efectos de estos componentes. En concreto, las tareas de investigación de los efectos comunes y de los desvíos exigen el conocimiento pormenorizado de los principales componentes, controles, instrumentos, suministros, operadores, regímenes de actividad, mantenimiento y otros elementos esenciales del sistema.

Los ejemplos de efectos comunes que deben considerarse en relación con los sistemas de transporte de gas se abordan mediante el planteamiento de preguntas como:

- ¿Se transmiten las señales de activación correspondientes a las válvulas de suministro y a las de cierre de emergencia a través de un conducto común (cable, canales de cableado)?

- ¿Comparten dos válvulas el mismo conducto de transporte de energía?

- ¿Se lleva a cabo el mantenimiento por la misma persona de acuerdo con un plan determinado?

Incluso un sistema de diseño excelente, dotado de conductos de transporte de energía redundantes e independientes, puede ser objeto de un mantenimiento deficiente en el que, por ejemplo, se dejen una válvula y su dispositivo de reserva correspondiente (la válvula de cierre de emergencia en el ejemplo) en mal estado después de una prueba. U n efecto común importante en los sistemas de manipulación de amoniaco consiste en la propia situación de fuga de material: un escape moderado puede dificultar (y retrasar) la totalidad de las operaciones manuales relativas a los componentes de la instalación debido a la utilización de la protección de emergencia necesaria.

\section{Resumen}

En contadas ocasiones puede culparse a los componentes de los equipos de los accidentes producidos; por el contrario, deben determinarse las causas fundamentales en otros eslabones de la cadena: conceptos erróneos, diseños inadecuados, errores de mantenimiento, de los operarios o de gestión, etc. Ya se han planteado varios ejemplos de las condiciones y los actos específicos que pueden provocar una avería; a continuación se refieren algunos de ellos:

- colisión;

- corrosión, erosión.

- cargas excesivas;

- soporte deficiente y componentes envejecidos o desgastados;

- soldaduras de escasa calidad;

- misiles;

- ausencia de componentes;

- exceso de calor o enfriamiento;

- vibración,

- utilización de material de construcción inapropiado.

El control de los riesgos de los equipos en un ambiente de trabajo exige el estudio de todas las causas posibles y el respeto de las condiciones de los sistemas reales consideradas esenciales. Las consecuencias de este requisito para la organización de los programas de gestión de riesgos se abordan en otros artículos, pero, como indica claramente la relación anterior, el seguimiento y el control de las condiciones de los equipos pueden ser necesarios desde el mismo momento de la elección de los conceptos y los diseños correspondientes a los sistemas y los procesos seleccionados. 


\section{- ANALISIS DE RIESG O S: FACTORES ORGANIZATIVOS- MORT}

\section{Urban Kjellén}

A raíz de la industrialización, los trabajadores fueron organizándose en fábricas a medida que se generalizó la utilización de la máquina de vapor. Comparada con la artesanía tradicional, la producción mecanizada, con mayores fuentes de energía, presentó nuevos riesgos de accidente. Con el aumento de la energía empleada, los trabajadores quedaron al margen del control directo de esta energía. L as decisiones que afectaban a la seguridad eran adoptadas normalmente por el nivel de dirección y no por las personas expuestas directamente a dichos riesgos. En este estado de industrialización se hizo evidente la necesidad de aplicar una gestión de la seguridad.

A finales del decenio de 1920, Heinrich formuló el primer marco teórico global relativo a la gestión de la seguridad, según el cuál, ésta debe realizarse a través de las decisiones adoptadas por la dirección basadas en la identificación y el análisis de las causas de los accidentes. En esta fase del desarrollo de la gestión de la seguridad, los accidentes se atribuían a los fallos en el sistema de relación entre el trabajador y la máquina; es decir, a los actos y las condiciones inseguras.

Posteriormente se elaboraron diversas metodologías para la identificación y la evaluación de los riesgos de accidente. Con el método MORT (Supervisión de la gestión y árbol de riesgos), comenzó a concederse prioridad a las escalas superiores del control de los riesgos de accidente; es decir, al control de las condiciones a escala de la dirección. La iniciativa para desarrollar el método MORT fue emprendida a finales del decenio de 1960 por la Administración para la Investigación y el Desarrollo de la Energía de Estados U nidos, que pretendía optimizar sus programas de seguridad con el fin de reducir las pérdidas debidas a accidentes.

\section{EI diagrama MO RT y los principios fundamentales}

El objetivo del método MORT era formular un sistema de gestión de la seguridad teórico basado en una síntesis de los

Figura 57.8 • Una versión del diagrama analítico MO RT (Supervisión de la gestión y diagrama de riesgos).

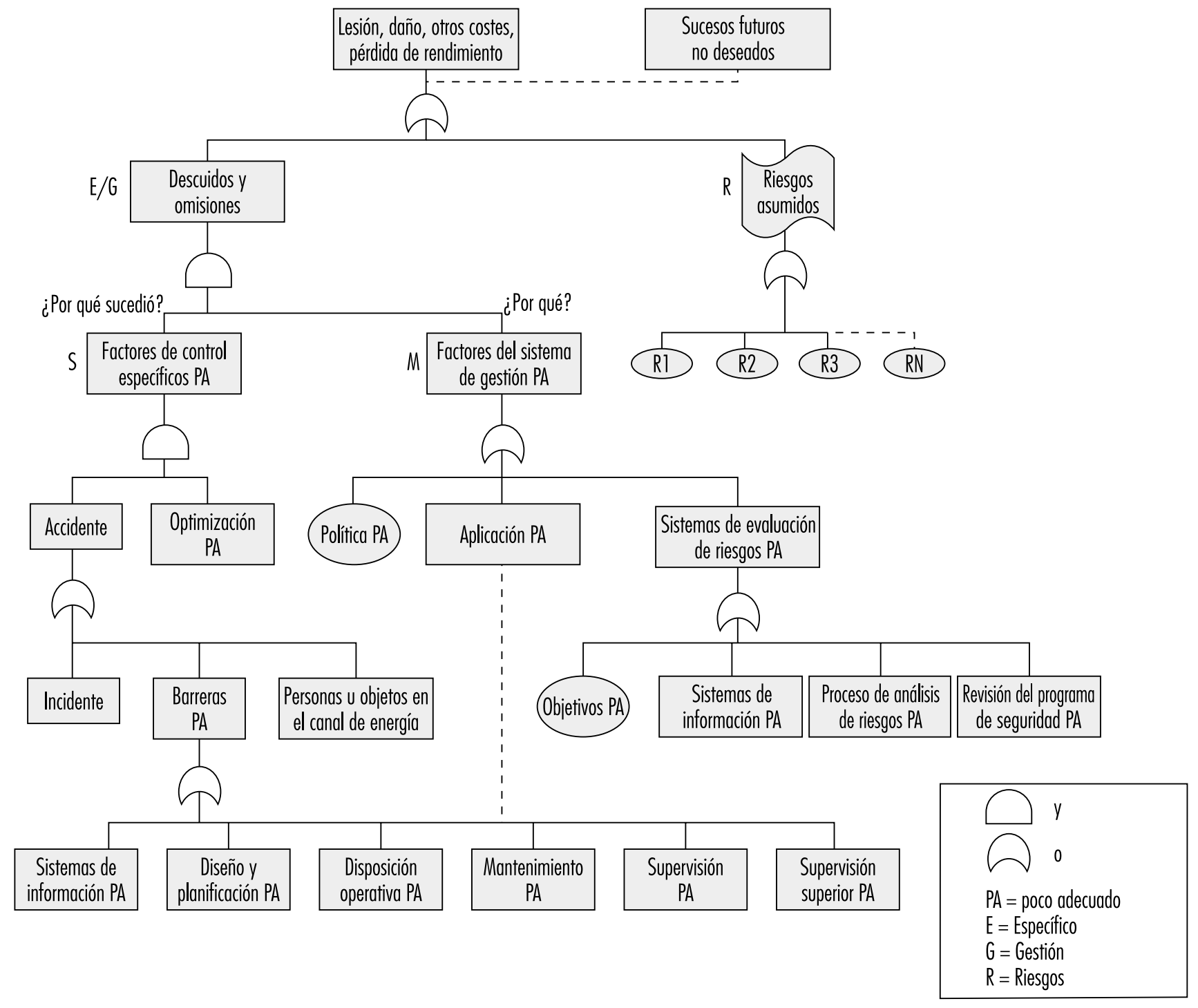


mejores elementos de los programas de seguridad y de las técnicas de gestión de la seguridad disponibles en esos momentos. Puesto que los principios fundamentales de la iniciativa M ORT se aplicaron a la situación de la gestión de la seguridad en aquel momento, los conocimientos prácticos y la bibliografía sobre seguridad, en gran medida desestructurados, se organizaron de acuerdo con un árbol analítico. La primera versión de este árbol se publicó en 1971. En la Figura 57.8 se muestran los elementos básicos de la versión publicada por Johnson en 1980. Asimismo, este árbol aparece modificado en publicaciones posteriores sobre el concepto M O RT (véase, por ejemplo, K nox y Eicher 1992).

\section{El diagrama MORT}

MORT se utiliza como herramienta práctica en investigaciones de accidentes y para evaluar programas de seguridad ya existentes. En la parte superior del árbol de la Figura 57.8 (Johnson 1980) se representan las pérdidas (experimentadas o posibles) debidas a un accidente. Debajo de ese recuadro figuran tres ramas principales: descuidos y omisiones específicas $(E)$, descuidos y omisiones de la dirección $(G)$ y riesgos asumidos $(R)$. La rama $R$ consta de los riesgos asumidos que son sucesos y condiciones conocidas por la dirección que han sido evaluadas y aceptadas al nivel de gestión apropiado. Otros sucesos y condiciones que se ponen de manifiesto mediante las evaluaciones efectuadas a lo largo de las ramas $E$ y $R$ se denominan "menos que adecuados" (M QA).

La rama $E$ se ocupa de los sucesos y las condiciones que pueden darse 0 se dan en la práctica. (En general, el factor tiempo transcurre de izquierda a derecha en el diagrama y el sentido de la secuencia de causas es de abajo arriba.) L as estrategias de $\mathrm{H}$ addon (1980) para la prevención de accidentes son elementos esenciales en esta rama. U n suceso se denota como accidente cuando un objetivo (persona u objeto) es expuesto a una transferencia de energía incontrolada y sufre daños. En la rama $\mathrm{E}$ de MORT, los accidentes se previenen mediante la disposición de barreras. $\mathrm{H}$ ay tres tipos básicos de barreras: 1) las barreras que rodean y confinan la fuente de energía (el riesgo); 2) las barreras que protegen al objetivo, y 3) las barreras que separan físicamente el objetivo y el riesgo, en el tiempo o en el espacio. Estos tipos diferentes de barreras se encuentran en la estructura de las ramas debajo del suceso del accidente. La optimización se refiere a las acciones emprendidas después del accidente para limitar las pérdidas. En el siguiente nivel de la rama $E$, se establecen los factores relacionados con las distintas fases del ciclo vital de un sistema industrial. Son: la formulación del proyecto (diseño y planificación), la puesta en marcha (disponibilidad operativa) y el funcionamiento (supervisión y mantenimiento).

La rama $\mathrm{G}$ describe un proceso en el que los resultados específicos de una investigación de accidente o una evaluación de un programa de seguridad son hechos más generales. Por tanto, los sucesos y las condiciones incluidos en la rama $E$ suelen tener sus referentes en la G. Cuando considera el sistema desde la perspectiva de esta rama, el analista amplía su razonamiento al conjunto del sistema de gestión. A sí, sus recomendaciones afectarán a un gran número de supuestos de accidente. Las funciones más importantes en materia de gestión de seguridad pueden encontrarse en la rama G : formulación de política, aplicación y seguimiento. Figuran los mismos elementos básicos incluidos en los principios de aseguramiento de la calidad de la serie ISO 9000 publicada por la O rganización Internacional de Normalización (ISO).

Cuando las ramas del diagrama MORT se elaboran en detalle, se encuentran elementos procedentes de campos tan diversos como el análisis de riesgos, el análisis de factores humanos, los sistemas de información de seguridad y los análisis organizativos. En total, el diagrama M O RT cubre unos 1.500 sucesos básicos.

\section{Aplicación del diagrama MORT}

Como se ha indicado, el diagrama MORT tiene dos usos inmediatos (K nox y E icher 1992): 1) analizar los factores organizativos y de gestión relativos a un accidente que ha tenido lugar, y 2) evaluar o auditar un programa de seguridad en relación con un accidente significativo que tiene la posibilidad de ocurrir. EI diagrama M ORT funciona como herramienta de exploración selectiva en la planificación de análisis y evaluaciones. A simismo, se emplea como lista de comprobación en la comparación de las condiciones reales con el sistema teórico. En esta aplicación, M O RT facilita la comprobación de la exhaustividad del análisis y evita los sesgos personales.

En esencia, MORT se compone de un conjunto de preguntas. Los criterios que rigen la determinación de los sucesos y las condiciones específicas como satisfactorios o menos que adecuados se derivan de estas cuestiones. A pesar del diseño orientativo de las preguntas, los dictámenes emitidos por los analistas son en parte subjetivos. Por tanto, es importante asegurar una calidad adecuada y cierto grado de intersubjetividad a través de los análisis M O RT efectuados por los distintos analistas. Por ejemplo, en Estados U nidos existe un programa de formación para la certificación de los analistas M O RT.

\section{Experiencias con el diagrama MORT}

La bibliografía sobre las evaluaciones de MORT es escasa. Johnson señala mejoras significativas en la exhaustividad de las investigaciones de accidente registradas tras la introducción de M ORT (Johnson 1980). Las deficiencias en los niveles de supervisión y gestión se han puesto de manifiesto más sistemáticamente. Asimismo, se ha acumulado experiencia con las evaluaciones de las aplicaciones M ORT en la industria de Finlandia (Ruuhilehto 1993). Se han detectado ciertas limitaciones en los estudios de este país. EI diagrama M ORT no permite la determinación de riesgos inmediatos debidos a fallos y perturbaciones. Además, en el concepto MORT no se incorpora la capacidad de establecer prioridades. En consecuencia, los resultados de los análisis MORT requieren una evaluación adicional para su traducción en acciones correctoras. Por último, la experiencia indica que este método exige la asignación de un período de tiempo considerable y la participación de expertos.

A parte de su capacidad para centrarse en los factores organizativos y de gestión, M O RT cuenta con la ventaja de vincular la seguridad con las actividades productivas habituales y con la gestión general. Por tanto, su aplicación facilita el control y la planificación global y ayuda a reducir la frecuencia de perturbaciones en la producción.

\section{Métodos y técnicas asociadas con la gestión de seguridad}

Con la introducción del concepto de MORT a principios del decenio de 1970 se inició el desarrollo de un programa en Estados U nidos. El punto focal de este programa ha sido el System Safety Development Center de Idaho Falls. Como resultado de este programa se han tenido diversos métodos y técnicas afines a MORT en áreas como el análisis de factores humanos, los sistemas de información sobre seguridad y el análisis de seguridad. Uno de los primeros métodos obtenidos a partir del programa de desarrollo MORT es el Programa de Disposición Operativa (Nertney 1975). Su introducción coincidió con el desarrollo de nuevos sistemas industriales y la modificación de los preexistentes. Su objetivo es garantizar, desde el punto de vista de la gestión de la seguridad, que el sistema nuevo o modificado está preparado en el momento del comienzo de la actividad. La disposición 
operativa supone que las barreras y los controles necesarios han sido instalados en los equipos, el personal y los procedimientos del nuevo sistema. 0 tro ejemplo de elemento del programa M ORT es el análisis de causas fundamentales basado en este instrumento (Cornelison 1989). Se utiliza en la detección de los problemas básicos de gestión de la seguridad de una organización. Para ello, se comparan los resultados específicos de los análisis M O RT con 27 problemas genéricos de gestión de la seguridad.

En Escandinavia, aunque M ORT no se ha concebido para su utilización directa en la recogida de información en las investigaciones de accidentes y las auditorías de seguridad, las preguntas que en él se incluyen han servido como base para el desarrollo de una herramienta de diagnóstico utilizada con tal fin: se denomina Técnica de gestión de seguridad y revisión organizativa (SM ORT) (K jellén y Tinmannsvik 1989). LoS análisis SM O RT tienen un carácter inductivo, partiendo de la situación específica y finalizando a la escala de la gestión general. El punto de partida (nivel 1) es una secuencia de accidente 0 una situación de riesgo. En el nivel 2 se examinan la organización, la planificación de sistemas y los factores técnicos relacionados con la actividad diaria. En los niveles siguientes se incluye el diseño de nuevos sistemas (nivel 3) y las funciones directivas superiores (nivel 4). Las conclusiones obtenidas a un nivel se extienden a los niveles superiores. Por ejemplo, los resultados relativos a las secuencias de accidente y a las actividades diarias se utilizan en el análisis de la organización de la empresa y de las rutinas para el proyecto de trabajo (nivel 3). Los resultados del nivel 3 no afectan a la seguridad de las operaciones existentes, pero pueden aplicarse a la planificación de nuevos sistemas y modificaciones. Asimismo, SMORT difiere de MORT en el modo en que se determinan los resultados. Al nivel 1 , éstos consisten en sucesos y condiciones que se apartan de las normas de aceptación general. Cuando los factores organizativos y de gestión se someten a análisis en los niveles 2 a 4, los resultados se establecen mediante juicios de valor emitidos por un grupo de análisis y se comprueban con la ayuda de un procedimiento de control de calidad. El objetivo es asegurar una interpretación compartida de los problemas organizativos.

\section{Resumen}

MORT ha contribuido al avance de la gestión de la seguridad desde el decenio de 1970. Puede observarse la influencia de este instrumento en áreas como la bibliografía sobre la investigación en materia de seguridad, la bibliografía sobre gestión de seguridad y herramientas de auditoría y la legislación sobre autorregulación y control interno. A pesar de este impacto, sus limitaciones deben considerarse con suma precaución. M O RT y los métodos asociados tienen un carácter normativo, en cuanto que prescriben el modo en que deben organizarse y ejecutarse los programas de gestión de la seguridad. La situación ideal consiste en una organización perfectamente estructurada con objetivos claros y realistas y una línea de responsabilidad y autoridad bien definida. Por tanto, M O RT se adapta mejor a las grandes organizaciones burocráticas.

\section{- INSPECCION EN EL LUGAR DE TRABAJO Y APLICACION NORMATIVA}

Anthony Linehan

\section{Sistemas de inspección}

La auditoría ha sido definida como "el proceso estructurado de recogida de información independiente sobre la eficacia, la eficiencia y la fiabilidad del sistema global de gestión de la seguridad y de elaboración de planes de acción correctora" (Successful H ealth \& Safety M anagement 1991).

Por tanto, la inspección en el lugar de trabajo no sólo es la fase final en la institución de un programa de gestión de la seguridad, sino que también es un proceso continuo para su mantenimiento. Sólo puede llevarse a cabo allí donde se haya establecido un sistema adecuadamente diseñado que garantice la satisfacción del objetivo de dicho programa. En este tipo de sistemas, el personal directivo concibe inicialmente una declaración formal de formulación de políticas en la que se determinan los principios para la creación de un entorno de trabajo seguro y sano y se señalan los mecanismos y las estructuras de la organización que permitirán la aplicación eficaz de dichos principios. A demás, la dirección debe comprometerse con la prestación de los recursos adecuados, tanto humanos como financieros, para soportar el desarrollo de estos mecanismos y estructuras. A continuación se acometerá la planificación detallada de la salud y la seguridad y la definición de objetivos mensurables. L os sistemas son realizados de manera que puedan asegurar que el rendimiento en materia de salud y seguridad pueda estimarse en la práctica respecto a las normas establecidas y los resultados obtenidos con anterioridad. Sólo después de la instalación y el inicio de la actividad de esta estructura, puede aplicarse un sistema de auditoría de gestión eficaz.

Los sistemas completos de gestión de la salud y la seguridad pueden diseñarse, elaborarse y aplicarse sobre la base de los recursos de que disponen las grandes empresas. Además, existen varios sistemas de control de la gestión de seguridad que ofrecen consultores, compañías de seguros, organismos públicos, asociaciones y empresas especializadas. C ada compañía debe decidir si debe confeccionar su propio sistema o recurrir a servicios externos. L os resultados de ambas alternativas pueden ser excelentes si existe un compromiso auténtico por parte de la dirección con su aplicación diligente y su puesta en funcionamiento. Desde luego, el éxito de estos sistemas depende en gran medida de la calidad del sistema de auditoría.

\section{Inspecciones de gestión}

El procedimiento de inspección debe ser tan esmerado y objetivo como la inspección financiera de la compañía. En primer lugar, debe determinar si la declaración de la compañía sobre la política de salud y seguridad se refleja oportunamente en las estructuras y los mecanismos creados para aplicarla; en caso negativo, la inspección puede recomendar una reevaluación de la política fundamental o proponer ajustes o modificaciones de las estructuras y mecanismos existentes. U n proceso similar puede ser aplicado para la planificación de la salud y la seguridad, la validación de las normas sobre determinación de objetivos y la medición del rendimiento. Los resultados de una inspección deben ser considerados por la alta dirección de la empresa y las medidas correctoras que se adopten serán avaladas y adoptadas a esa escala jerárquica.

En la práctica, no es deseable y, con frecuencia, impracticable, emprender una inspección completa de todas las características del sistema y sus aplicaciones en el conjunto de todos los departamentos empresariales al mismo tiempo. M ás usualmente, los procedimientos de inspección suelen concentrarse en una característica concreta del sistema empleado en una instalación, o bien en la aplicación del sistema completo en un único departamento o subdepartamento. En cualquier caso, el objetivo es abarcar todas las características en todos los departamentos a lo largo de un período acordado, con el fin de validar los resultados.

En este sentido, la inspección de gestión debe considerarse como un proceso de vigilancia continuo. O bviamente, la necesidad de objetividad reviste gran importancia. Si las inspecciones se realizan internamente, debe adoptarse un procedimiento 
normalizado, el personal encargado habrá recibido la formación pertinente y los seleccionados como inspectores no evaluarán los departamentos en los que desarrollen normalmente su actividad ni valorarán otras tareas en las que tengan una implicación personal. Cuando se confía en los servicios de consultores, este problema se minimiza.

Muchas grandes compañías han adoptado este tipo de sistema, ya sea diseñado internamente u obtenido como proyecto patentado. Cuando los sistemas han sido cuidadosamente seguidos, desde la declaración de política hasta la inspección, la retroinformación y las acciones correctoras, se consigue una reducción sustancial en las tasas de accidente, que constituye la justificación primordial del procedimiento, y una mejora de la rentabilidad, que supone un efecto secundario bien recibido.

\section{Inspecciones realizadas por órganos de inspección}

El marco jurídico diseñado para garantizar la protección de los trabajadores debe administrarse adecuadamente y aplicarse con eficacia si se pretende llevar a la práctica el objetivo contemplado en la legislación. En consecuencia, la mayoría de los países han adoptado el modelo general de un servicio de inspección encargado de asegurar el cumplimiento de la legislación sobre salud y seguridad. En muchos de ellos se consideran estas cuestiones parte de un conjunto más amplio de asuntos relativos a las relaciones laborales, en el que se incluyen además los acuerdos sobre salarios y vacaciones y las prestaciones sociales. En este modelo, las inspecciones de salud y seguridad constituyen una más de las tareas competencia de los inspectores de trabajo. Existe un modelo alternativo en el que los órganos de inspección públicos se ocupan en exclusiva de la legislación sobre salud y seguridad, por lo que las inspecciones en el lugar de trabajo se concentran únicamente en este aspecto. Pueden observarse otras variaciones en la división de las funciones que desempeñan los órganos de inspección nacionales y regionales/ provinciales 0 , como sucede en Italia o el Reino Unido, en la combinación operativa de ambos órganos. Por supuesto, con independencia del modelo adoptado, la función esencial del órgano de inspección es determinar el cumplimiento de la legislación mediante un programa de inspecciones e investigaciones planificadas efectuadas en el lugar de trabajo.

No puede existir un sistema de inspección eficaz si no se dan a los encargados de esta tarea poderes para poder llevarse a cabo. Los órganos de inspección tienen muchos puntos en común en lo que se refiere a los poderes que les confieren sus legisladores. Se concede en todo caso el derecho a acceder a las instalaciones, obviamente fundamental para su cometido. Asimismo, se reconoce en la legislación el derecho a examinar los documentos, registros e informes pertinentes, a entrevistar individual o colectivamente a los miembros de las plantillas de trabajadores, a disponer de acceso no restringido a los representantes de los sindicatos en el lugar de trabajo, a tomar muestras de sustancias o materiales utilizados en el mismo, a realizar fotografías y, en su caso, a tomar declaración por escrito a los trabajadores del centro inspeccionado.

Con frecuencia se asignan otras facultades a los inspectores que les permiten rectificar las condiciones que podrían constituir una fuente inmediata de peligro 0 enfermedad para los trabajadores. También en este caso la variedad de prácticas es amplia. Cuando los niveles son tan deficientes que existe un riesgo inminente para la plantilla, un inspector puede ser autorizado a expedir en el acto un documento legal por el que se prohibe la utilización de la maquinaria o la instalación en cuestión, o se detiene el proceso hasta que el riesgo haya sido plenamente controlado. Si el riesgo es de menor orden, los inspectores puede expedir una notificación oficial exigiendo formalmente la adopción de medidas de mejora de la situación en un plazo determinado. Son acciones que constituyen un medio eficaz de optimizar con rapidez las condiciones de trabajo y, a menudo, una forma de ejecución preferible a los procedimientos judiciales, que pueden resultar incómodos y lentos para garantizar la aplicación de soluciones.

Los procedimientos legales ocupan un lugar destacado en la jerarquía de la aplicación de la normativa. Para algunas personas, puesto que estos procedimientos son únicamente sancionadores y no siempre dan lugar a un cambio de actitud respecto a la salud y la seguridad en el trabajo, sólo deberían utilizarse como último recurso cuando el resto de iniciativas de mejora hayan fracasado. Con todo, este argumento debe matizarse al considerar que, en los casos en los que los requisitos jurídicos se han obviado o incumplido o la salud y la seguridad de las personas se han expuesto a un riesgo significativo, la legislación debe aplicarse y los tribunales deben decidir acerca de estas cuestiones. Desde otro punto de vista, las empresas que hacen caso omiso de la legislación sobre salud y seguridad pueden obtener una ventaja económica respecto a sus competidores que les depara los recursos necesarios para cumplir con sus obligaciones jurídicas. Por tanto, el procesamiento de aquellos que incumplen con reiteración sus obligaciones constituye una forma de disuadir a los carentes de escrúpulos y un incentivo para los que intentan atenerse a la legislación.

Los servicios de inspección deben determinar el equilibrio adecuado entre la prestación de asesoramiento y la aplicación de la legislación en el curso de su actividad. Existe una dificultad especial en lo que se refiere a la inspección de las pequeñas empresas. Las economías locales, y por supuesto las nacionales, suelen basarse en instalaciones industriales en las que se da empleo a menos de 20 personas; en el caso de la agricultura, la cifra de trabajadores por empresa es mucho menor. La función de la inspección en estos casos es utilizar la inspección en el lugar de trabajo para ofrecer información y asesoramiento, no sólo sobre requisitos legales, sino también acerca de las normas prácticas y las formas eficaces de satisfacerlas. La técnica empleada debe fomentar y estimular, y no dar lugar a la aplicación inmediata de la legislación basada en la acción punitiva. Desde luego, también en este caso el equilibrio es difícil. LoS trabajadores tienen derecho a disfrutar de un determinado nivel de salud y seguridad con independencia del tamaño de la empresa y, por tanto, sería muy poco aconsejable para un servicio de inspección obviar o minimizar los riesgos y atenuar e incluso renunciar a la aplicación simplemente para facilitar la existencia de las pequeñas empresas económicamente frágiles.

\section{Consistencia de las inspecciones}

A la vista del carácter complejo de su trabajo (para el que se demanda una combinación de habilidades jurídicas, técnicas y científicas y una actitud prudente) los inspectores no adoptan (ni deben adoptar) un planteamiento mecanicista con respecto a su actividad. Esta limitación, unida al difícil equilibrio existente entre las funciones de asesoramiento y de aplicación de la normativa, constituye otro motivo de inquietud: la consistencia de los servicios de inspección. Los industriales y los sindicatos tienen derecho a esperar una aplicación coherente de las normas, ya sean técnicas o jurídicas, por parte de los inspectores de un determinado país. En la práctica, esta homogeneidad no siempre es fácil de lograr, pero debe constituir en todo caso un objetivo de las autoridades competentes.

$\mathrm{H}$ ay formas de conseguir una consistencia aceptable. En primer lugar, los órganos de inspección deben ser tan abiertos como sea posible en la publicación de sus normas técnicas y en la difusión de sus políticas de aplicación. En segundo lugar, basándose en la formación, la realización de ejercicios de 
revisión entre iguales y la utilización de instrucciones internas, deben ser capaces de reconocer un problema y de dotar los sistemas necesarios para eliminarlos. Por último, deben asegurar la existencia de procedimientos para que las empresas, los trabajadores, la población en general y los interlocutores sociales puedan exigir una reparación en caso de queja legítima respecto a la inconsistencia u otras formas de incompetencia administrativa asociadas con la inspección.

\section{Frecuencia de las inspecciones}

$¿ C$ on qué frecuencia deben llevar a cabo las inspecciones en el lugar de trabajo los órganos competentes en la materia? De nuevo en esta ocasión, existe una variabilidad considerable en cuanto al modo en las respuestas dadas a esta pregunta. La 0 rganización Internacional del Trabajo (O IT ) considera que el requisito mínimo debe consistir en que cada lugar de trabajo se someta a una inspección de las autoridades encargadas de llevarla a cabo al menos una vez al año. En la práctica, son pocos los países capaces de elaborar un programa de inspecciones de trabajo que satiffaga este objetivo. De hecho, desde la gran depresión económica de finales del decenio de 1980, algunas Administraciones han reducido la dimensión de los servicios de inspección por limitaciones presupuestarias que han dado lugar a recortes en el número de inspectores, o la restricción en la contratación de nuevos trabajadores que sustituyan a los que se jubilan.

Existen diversos planteamientos respecto a la determinación de la frecuencia con que deben acometerse las inspecciones. Uno de ellos es estrictamente cíclico. Se dotan recursos para llevar a cabo la inspección del conjunto de instalaciones con una periodicidad bianual 0 , más probablemente, cuatrienal. Por lo demás, este enfoque, aunque puede parecer equitativo, trata igualmente a todas las instalaciones con independencia de su tamaño o riesgos existentes. Es evidente que las empresas difieren en cuanto a sus condiciones de salud y seguridad y, en consecuencia, este planteamiento puede calificarse de mecanicista o deficiente.

Un enfoque diferente, adoptado por algunos órganos de inspección, ha consistido en el intento de elaborar un programa de trabajo basado en el riesgo; cuanto mayor sea éste para la salud o la seguridad, con mayor frecuencia se realiza la inspección. Por tanto, los recursos son aplicados por dichos órganos en los lugares donde la posibilidad de daño para los trabajadores es mayor. Aunque esta opción presenta ventajas, sigue planteando problemas considerables asociados a él. En primer lugar, hay dificultades para evaluar con precisión y objetividad el peligro y el riesgo. En segundo lugar, amplía considerablemente los intervalos entre inspecciones en las instalaciones donde se considera que los riesgos son bajos. Por tanto, pueden transcurrir períodos de tiempo prolongados en los que gran parte de los trabajadores deba renunciar a la sensación de seguridad que la inspección es capaz de transmitir. A demás, en este sistema se tiende a suponer que los peligros y los riesgos, una vez evaluados, no cambian radicalmente. $\mathrm{N}$ ada más lejos de la realidad; por otra parte, existe el peligro de que una empresa calificada de poco peligrosa modifique o desarrolle su producción de un modo que dé lugar a un agravamiento de los riesgos, sin que los órganos de inspección sean conscientes de la nueva situación.

0 tros planteamientos para una industria en particular de las inspecciones se basan en la existencia de tasas de lesiones superiores a la media nacional de un sector determinado, o se realizan inmediatamente después de una lesión con resultado de muerte o una catástrofe. No existen respuestas fáciles ni breves para el problema de la determinación de la frecuencia de las inspecciones, pero parece comprobarse que, muy a menudo, la dotación de recursos de los servicios encargados de las mismas en numerosos países es tremendamente escasa, lo que da lugar a la reducción progresiva de la protección real ofrecida por el servicio a los trabajadores.

\section{O bjetivos de la inspección}

Las técnicas de inspección en el lugar de trabajo varían de acuerdo con el tamaño y la complejidad de la empresa. En las empresas pequeñas, las inspecciones serán generales y evaluarán todos los peligros existentes y la medida en que los riesgos derivados de éstos se han minimizado. Por tanto, la inspección asegurará que los empresarios son plenamente conscientes de los problemas de salud y seguridad y que reciban una orientación práctica sobre el modo en que pueden abordarse. Desde luego que, incluso en la empresa más pequeña, el órgano de inspección debe evitar dar la impresión de que la determinación de errores y la aplicación de las soluciones pertinentes constituyen una responsabilidad de la inspección, y no del empresario. La inspección ha de animar a los empresarios a controlar y gestionar con eficacia las cuestiones de salud y seguridad y éstos no deben eludir sus responsabilidades esperando la actuación de las autoridades competentes antes de adoptar las medidas necesarias.

En las grandes empresas, las prioridades de la inspección son bastante diferentes. Estas empresas disponen de los recursos técnicos y financieros para abordar los problemas de salud y seguridad. Deben diseñar sistemas de gestión eficaces que les permitan superar estas dificultades, así como procedimientos de gestión con el fin de comprobar que los sistemas funcionan. En estas circunstancias, la inspección ha de ocuparse de la verificación y la validación de los sistemas de control de la gestión disponibles en el lugar de trabajo. Por tanto, no debe consistir en un estudio exhaustivo de todos los elementos de las instalaciones y los equipos concebido para determinar su seguridad, sino utilizar una selección de ejemplos para comprobar la eficacia 0 ineficacia de los sistemas de gestión y garantizar así la salud y la seguridad en el trabajo.

\section{Participación de los trabajadores en las inspecciones}

Con independencia de las instalaciones de que se trate, un elemento crítico en cualquier tipo de inspección es el contacto con los trabajadores. En muchas pequeñas empresas es posible que no exista una estructura sindical formal o que ni siquiera se disponga de una simple organización de trabajadores. Con todo, para asegurar la objetividad y la aceptación del servicio de inspección, el contacto con la plantilla debe formar parte integral de la inspección. En grandes empresas se debe establecer un contacto con los sindicatos o con otras representaciones de los trabajadores. En la legislación de algunos países (Suecia y Reino Unido, por ejemplo), se reconoce oficialmente y se asignan competencias a los representantes sindicales en materia de seguridad, incluido el derecho a realizar inspecciones en el lugar de trabajo, a investigar los accidentes y los sucesos peligrosos y, en ciertos casos (aunque esta opción es excepcional) a paralizar la maquinaria del centro de trabajo o el proceso de producción si el peligro es inminente. Puede obtenerse una gran cantidad de datos útiles gracias a estos contactos con los trabajadores, que deben incluirse en todas las inspecciones y con más motivo cuando los órganos competentes intervengan a consecuencia de un accidente 0 una queja.

\section{Resultados de una inspección}

L a última fase de una inspección consiste en revisar los resultados obtenidos con el máximo responsable de la dirección en el lugar de trabajo investigado. El personal directivo debe encargarse fundamentalmente de cumplir con los requisitos legales en materia de salud y seguridad y, por tanto, una inspección no se completa hasta que los directivos son plenamente conscientes de la medida en que han atendido tales obligaciones y de las 
acciones que deben emprenderse para garantizar y mantener unos niveles adecuados. O bviamente, si se expiden notificaciones legales como resultado de la inspección o es probable el inicio de un procedimiento judicial, la alta dirección debe conocer esta situación a la mayor brevedad posible.

\section{Inspecciones internas}

Las inspecciones internas son un factor importante en el mantenimiento de un nivel adecuado de salud y seguridad en el trabajo. Son apropiadas para todas las empresas y, en las grandes empresas, pueden constituir un elemento del procedimiento de inspección de la gestión. Para pequeñas empresas, es esencial aplicar algún tipo de inspección interna regular. No es conveniente depender de los servicios prestados por los órganos de inspección de las autoridades competentes. Suelen ser demasiado infrecuentes, sirven en gran medida como incentivo para la mejora o el mantenimiento de los niveles existentes y no constituyen la fuente esencial para la evaluación de éstos. Las inspecciones internas puede ser realizadas por consultores o por empresas especializadas en esta actividad, pero el debate actual se centra en las llevadas a cabo por el propio personal de la empresa analizada.

¿Con qué frecuencia deben realizarse inspecciones internas? En cierta medida, la respuesta depende de los riesgos asociados al trabajo desarrollado y a la complejidad de la instalación. Con todo, incluso en los centros de riesgo moderado, debe existir alguna forma de inspección de periodicidad regular (mensual, trimestral, etc.). Si la empresa recurre a los servicios de un profesional de la seguridad, es evidente que la organización y la realización de la inspección deben constituir una parte importante de esta función. La inspección consistirá normalmente en un esfuerzo de equipo en el que participan el mencionado profesional, el director del departamento en cuestión y un representante sindical o un trabajador cualificado, así como un miembro del comité de seguridad y salud. La inspección ha de tener un carácter general; es decir, se llevará a cabo un estudio pormenorizado de los componentes lógicos de la seguridad (por ejemplo, sistemas, procedimientos y permisos de trabajo) y de los físicos (por ejemplo, las protecciones de la maquinaria, el equipo de lucha contra incendios, la ventilación por aspiración y el equipo de protección individual). Debe prestarse especial atención a los "cuasierrores", incidentes que no provocan daños o lesiones personales, pero que pueden generar de inmediato lesiones graves. Se espera que, después de un accidente que da lugar a la ausencia del puesto de trabajo, el equipo de inspección se reúna acto seguido para investigar las circunstancias del mismo como una cuestión ajena al ciclo normal de inspección. En todo caso, incluso durante una inspección rutinaria en el centro de trabajo, el equipo también debe considerar la gravedad de las lesiones menores ocurridas en el departamento investigado desde la inspección anterior.

Es importante que las inspecciones internas no se consideren como un aspecto negativo. Cuando existan errores, es importante que sean identificados y rectificados, pero también es conveniente alabar el cumplimiento de niveles adecuados, comentar de forma positiva la pulcritud y la eficacia de los servicios de conservación y alentar a los que utilizan los equipos de protección individual suministrados para su seguridad. Para completar la inspección, debe redactarse un informe oficial por escrito sobre las deficiencias significativas detectadas. D ebe prestarse especial atención a los errores observados en inspecciones anteriores y que aún no se hayan corregido. Cuando exista un comité de empresa especializado en seguridad y salud, 0 un comité de seguridad conjunto compuesto por representantes de la empresa y de los trabajadores, el informe de la inspección debe clasificarse como un componente permanente del conjunto de cuestiones abordadas por estos órganos. El informe se remitirá y debatirá con la alta dirección de la empresa, que, a continuación, determinará si es necesario emprender acciones y, en caso afirmativo, las autorizará y respaldará.

Incluso en las empresas más pequeñas, en las que no se dispone de profesionales de la seguridad y puede que no haya sindicatos, debe considerarse la oportunidad de realizar inspecciones internas. Muchos órganos de inspección han elaborado directrices sencillas que ilustran los conceptos básicos de la salud y la seguridad, su aplicación en diversos sectores y las formas prácticas de materializarlos en este tipo de pequeñas empresas. $N$ umerosas asociaciones de seguridad se dirigen específicamente a las pequeñas empresas mediante la oferta de publicaciones (a menudo gratuitas) que facilitan la información básica para establecer unas condiciones de trabajo seguras y sanas. Con este tipo de información y dedicando un período de tiempo pequeño, el propietario de un pequeño negocio puede lograr unos niveles de salud y seguridad razonables y, quizás, eludir el tipo de accidentes que pueden ocurrir a los trabajadores incluso en este tipo de instalaciones.

\section{ANALISIS Y PRESENTACION DE INFORMES: IN VESTIGACION DE ACCIDENTES}

\section{M ontea u}

Resulta paradójico que la prevención de accidentes de trabajo no se planteara desde etapas muy tempranas como una necesidad absoluta, ya que la salud y la seguridad son fundamentales para el trabajo en sí. De hecho, sólo desde principios del presente siglo los accidentes dejaron de considerarse inevitables y su causalidad se sometió a investigación y se utilizó como base para la prevención. Con todo, la investigación de accidentes mantuvo durante mucho tiempo un carácter superficial y empírico. Desde un punto de vista histórico, los accidentes se consideraron inicialmente fenómenos simples, es decir, el resultado de una causa única (o principal) y un número reducido de causas secundarias. En la actualidad se reconoce que su investigación, encaminada a la determinación de la causalidad del fenómeno para impedir su reaparición, depende tanto del concepto que subyace al proceso de investigación, como de la complejidad de la situación a la que se aplica.

\section{Causas de accidentes}

O bviamente, es cierto que en la mayoría de las situaciones precarias, los accidentes suelen ser la consecuencia de una secuencia bastante simple de un número limitado de causas que pueden clasificarse rápidamente como problemas técnicos básicos que incluso un análisis breve puede poner de relieve (equipos mal diseñados, métodos de trabajo indefinidos, etc.). Por otra parte, cuanto mayor sea el grado de cumplimiento de los elementos materiales del trabajo (máquinas, instalaciones, disposición del lugar de trabajo, etc.) con los requisitos de los procedimientos de seguridad, normas y regulaciones, menos peligrosa será la situación de trabajo. En definitiva, un accidente sólo puede ocurrir cuando se produce simultáneamente un conjunto de condiciones excepcionales, cada vez más numerosas. En estos casos, la lesión o los daños aparecen como el resultado final de una red de causas con frecuencia complejas. En realidad, esta complejidad es una prueba de los avances logrados en materia de prevención y exige la aplicación de métodos de investigación apropiados. En la 
Tabla 57.5 - Conceptos principales del fenómeno del accidente, sus características y las repercusiones para la prevención

Concepto o "fenómeno del
accidente"
Concepto básico (accidente como
fenómeno con pocas causas o
incluso una única

Concepto centrado en las medidas de regulación

Concepto lineal ( 0 cuasilineal) (modelo "dominó")

Concepto multifactorial

Concepto sistemático (árbol de causas, STEP)

\author{
Elementos significativos (objetivos, procedimientos, \\ limitaciones, etc.)
}

El objetivo es determinar la causa única o principal

Ningún método en particular

Poco tiempo dedicado a la investigación

Suelen evocarse la suerte y el destino

Prioridad concedida a la determinación del responsable; en la

"consulta" se determinan esencialmente infracciones y fallos

Rara vez se presta atención a las condiciones que generan las situaciones analizadas

Determinación de una sucesión cronológica de "condiciones y actos peligrosos"

Utilización frecuente de listas de comprobación

La investigación depende en gran medida de la experiencia del investigador

Componente preventivo débil (la naturaleza peligrosa de los actos se determina a posteriori)

Investigación exhaustiva para recopilar los hechos

(circunstancias, causas, factores, etc.)

El interés se centra en el carácter contingente de cada situación de accidente

No se aplican criterios de relevancia respecto a los hechos recopilados

Necesidad de un tratamiento estadístico complejo

Determinación de la trama de factores de cada accidente Utilización de relaciones lógicas

Necesidad de formación de los investigadores
Consecuencias principales para la prevención

Medidas de prevención simples relativas al antecedente inmediato de la lesión (protección individual, instrucciones sobre las precauciones necesarias, protección de la maquinaria peligrosa)

La prevención suele limitarse a insistir sobre los requisitos normativos e instrucciones formales vigentes

Las conclusiones se refieren generalmente a los actos peligrosos

Concepto que no propicia la búsqueda de soluciones caso por caso (análisis clínico) y que se adapta mejor a la determinación de aspectos estadísticos (tendencias, tablas, gráficos, etc.)

Los métodos se centran en el análisis clínico (efectuado de un modo participativo)

Posibilidad de utilizar la totalidad de sucesos indeseados (incidentes, averías)
Tabla 57.5 se presentan los conceptos principales del fenómeno accidente, sus características y las repercusiones en la prevención.

Actualmente, un accidente de trabajo es visto generalmente como un indicador (o un síntoma) de la disfunción de un sistema consistente en una unidad de producción simple, como una fábrica, un taller, un equipo o un puesto de trabajo. Al analizar cada sistema, su naturaleza exige al investigador que examine no sólo los elementos que lo componen, sino también las relaciones entre estos elementos y con el ambiente de trabajo. En el marco de un sistema, la investigación de accidentes pretende explorar hasta sus orígenes la secuencia de las disfunciones básicas que han dado lugar al accidente y, más generalmente, la red de antecedentes del suceso no deseado (accidente, cuasiaccidente 0 incidente).

La aplicación de este tipo de métodos, como el STEP (procedimientos de detección de sucesos en secuencias temporales) y los "árboles de causas" (similares a los árboles de fallos o de sucesos), permite la visualización del proceso de accidente en forma de un gráfico ajustado que ilustra la multicausalidad del fenómeno. Puesto que estos dos métodos son muy semejantes, describir ambos constituiría una duplicación de esfuerzos; en consecuencia, el presente artículo se ocupa del segundo y, en su caso, se comentan sus principales diferencias con el método STEP.

\section{Información útil para la investigación}

La recopilación de información, que constituye la fase inicial de la investigación, debe permitir la descripción del curso del accidente en términos concretos, precisos y objetivos. Por tanto, con la investigación se pretende comprobar los hechos tangibles, teniendo cuidado de no inter pretarlos ni expresar opiniones sobre ellos. Estos son los antecedentes del accidente, de los que existen dos tipos:

1. los de carácter inhabitual (cambios o variaciones) en relación con el curso "normal" o previsto del trabajo,

2. los de carácter permanente que han desempeñado un papel activo en la aparición del accidente a través de los antecedentes inhabituales o en combinación con éstos.

Por ejemplo, una protección insuficiente de una máquina (antecedente permanente) puede acabar conviritiéndose en un factor inductor de un accidente si permite que un operador adopte una posición en un área peligrosa con el fin de abordar un determinado incidente (antecedente inhabitual).

La recopilación de información se lleva a cabo en el lugar del accidente tan pronto como sea posible después de que se haya producido. Es preferible que la realicen personas que conozcan la actividad o el proceso e intenten obtener una descripción precisa del trabajo sin limitarse a las circunstancias inmediatas del daño o la lesión. La investigación se efectúa principalmente por medio de entrevistas, si es posible con el trabajador o el operario, las víctimas y los testigos oculares, otros miembros del equipo de trabajo y los supervisores jerárquicos. En su caso, puede completarse mediante una investigación técnica y el recurso de expertos externos.

Con la investigación se trata de establecer, en orden de prioridad, los antecedentes inhabituales y deter minar sus conexiones lógicas. Al mismo tiempo se procura detectar los antecedentes permanentes que han permitido la ocurrencia del accidente. De este modo, la investigación puede remontarse a una fase más 
Figura 57.9 - Vínculos lógicos utilizados en el método del "diagrama de causas".

\begin{tabular}{|c|c|c|c|}
\hline & SECUENCIA & SEPARACION & CONJUNCION \\
\hline \multirow[t]{2}{*}{ Definición } & $\begin{array}{l}\text { Un antecedente }(Y) \\
\text { tiene un único origen directo }(X)\end{array}$ & $\begin{array}{l}\text { Dos o varios antecedentes }\left(Y_{1}, Y_{2}\right) \\
\text { tienen un único origen directo idéntico }(X)\end{array}$ & $\begin{array}{l}\text { Un antecedente }(Y) \\
\text { tiene varios orígenes directos }\left(X_{1}, X_{2}\right)\end{array}$ \\
\hline & & $\begin{array}{l}\text { Compañero de } \\
\text { trabajo disponible }\end{array}$ & $\begin{array}{l}\text { Compañero de } \\
\text { trabajo ausente }\end{array}$ \\
\hline \multicolumn{4}{|l|}{$\begin{array}{l}\text { Representación } \\
\text { (ejemplo) }\end{array}$} \\
\hline & $\begin{array}{l}\text { Método de trabajo } \\
\text { difícil para un único } \\
\text { trabajador }\end{array}$ & $\begin{array}{l}\mathrm{Y}_{2} \\
\text { Método de trabajo } \\
\text { más difícil }\end{array}$ & $\begin{array}{l}\mathrm{X}_{2} \\
\text { Trabajo urgente }\end{array}$ \\
\hline Características & $\begin{array}{l}X \text { era necesario y suficiente para que } \\
\text { se produjera } Y\end{array}$ & $\begin{array}{l}X \text { era necesario para que se } \\
\text { produjeran } Y_{1} \text { e } Y_{2}\end{array}$ & $\begin{array}{l}\text { Cada uno de los antecedentes } X_{1} \text { y } X_{2} \text { era } \\
\text { necesario para que se produjera } Y \text {, pero nin- } \\
\text { guno de los dos era suficiente en sí mismo: } \\
\text { juntos constituyen una causa suficiente. }\end{array}$ \\
\hline
\end{tabular}

remota que los antecedentes inmediatos del accidente. Tal fase anterior puede referirse a personas, sus tareas, el equipo que utilizan, el ambiente de trabajo en el que desarrollan su actividad y la cultura de seguridad. Al proceder de la manera descrita, es posible, en general, elaborar una lista de antecedentes amplia, pero suele resultar difícil utilizar los datos de inmediato. La interpretación de los datos es posible mediante la representación gráfica de todos los antecedentes que intervienen en la génesis del accidente; es decir, un árbol de causas.

\section{Elaboración del árbol de causas}

El árbol de causas presenta todos los antecedentes recopilados que han dado lugar al accidente, así como los vínculos lógicos y cronológicos que los relacionan; se trata de una representación de la red de antecedentes que han provocado directa 0 indirectamente la lesión. EI árbol de causas se elabora partiendo del final del acontecimiento, es decir, de la lesión o el daño y retrocediendo hasta la causa mediante el planteamiento sistemático de las preguntas siguientes respecto a cada uno de los antecedentes detectados:

- ¿Q ué antecedente $X$ causó directamente el antecedente $Y$ ?

- ¿Era el antecedente suficiente en sí mismo para dar lugar al antecedente $Y$ ?

- En caso negativo, ¿ha habido otros antecedentes (X 1 , $\mathrm{X} 2 \ldots \mathrm{Xn}$ ) que eran igualmente necesarios para generar directamente el antecedente $Y$ ?

A partir de este conjunto de preguntas pueden ponerse de relieve tres tipos de conexión lógica entre los antecedentes, resumidos en la Figura 57.9.

La coherencia lógica del árbol se comprueba mediante el planteamiento de las cuestiones siguientes respecto a cada antecedente:

- Si X no se hubiese producido, ¿se habría dado $Y$ en cualquier caso?

- Para que se produjera $Y$, fue $X$, y sólo $X$, necesario?

Además, la elaboración del árbol de causas en sí induce a los investigadores a perseguir la recogida de información y, por tanto, la investigación, hasta un punto muy anterior al accidente. Una vez completado, el árbol representa la red de antecedentes que han provocado la lesión; se trata de hecho de los factores inductores del accidente. Como ejemplo, el accidente resumido a continuación generó el árbol de causas que se muestra en la Figura 57.10.

Informe breve del accidente: U n aprendiz de mecánico, recién contratado, tuvo que trabajar solo en una emergencia. Se utilizó una eslinga desgastada para suspender un motor que debía ser montado de nuevo y, durante esta operación, la eslinga se rompió, el motor cayó y el mecánico se lesionó en el brazo.

\section{Análisis basado en el método STEP}

De acuerdo con el método STEP (Figura 57.11), cada suceso se presenta gráficamente para mostrar el orden cronológico de su aparición, asignando una fila por "agente" participante (un agente es la persona o la cosa que determina el curso de los acontecimientos que constituyen el proceso de accidente). Cada uno de los sucesos se describe con precisión mediante la indicación de su comienzo, duración, lugar de inicio y finalización, etc. Cuando se dispone de varias hipótesis posibles, el investigador puede reflejarlas en la red de sucesos mediante la utilización de la relación lógica "o".

\section{Análisis mediante el método del árbol de causas}

$\mathrm{H}$ aciendo uso del árbol de causas para el análisis de accidentes tiene dos objetivos:

- impedir que vuelva a ocurrir el mismo accidente,

- evitar que se produzcan accidentes más o menos similares, es decir, accidentes cuya investigación pondría de manifiesto factores comunes con los accidentes acaecidos previamente.

Dada la estructura lógica del árbol, la ausencia de un único antecedente habría evitado el accidente. Por tanto, la adopción de una medida preventiva juiciosa habría sido suficiente, en principio, para satisfacer el primer objetivo de impedir que se repita el mismo accidente. La consecución del segundo objetivo exigiría que todos los factores detectados fuesen eliminados, pero, en la práctica, no todos los antecedentes revisten la misma 
Figura 57.10 - Arbol de causas de un accidente sufrido por un aprendiz de mecánico al volver a montar un motor en un coche.

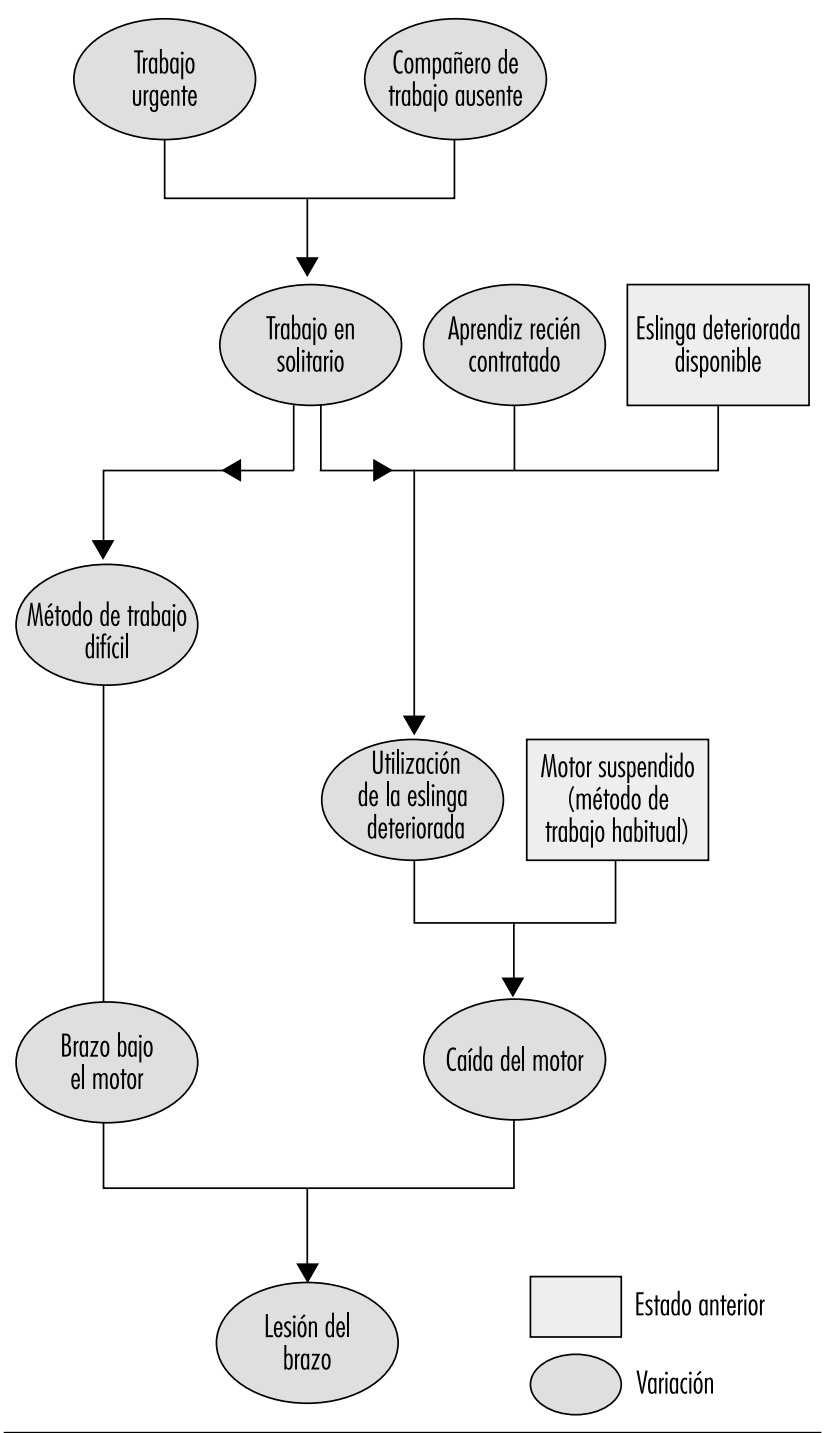

importancia a efectos de la prevención. En consecuencia, es necesario elaborar una lista de antecedentes que exija una acción preventiva razonable y realista. Si la lista es amplia, debe realizarse una elección. Es más probable que la opción preferida sea la apropiada si se elige en el marco de un debate entre las partes interesadas en el accidente. A demás, el debate ganará en claridad en cuanto sea posible evaluar el coste-beneficio de cada una de las medidas propuestas.

\section{Eficacia de las medidas preventivas}

La eficacia de una medida preventiva puede ser juzgada con la ayuda de los siguientes criterios:

E stabilidad de la medida. Los efectos de una medida preventiva no deben desaparecer con el tiempo: informar a los trabajadores (en concreto, recordándoles instrucciones) no es una medida muy estable, ya que sus efectos suelen ser transitorios. Lo mismo puede decirse de ciertos dispositivos de protección que pueden desmontarse con facilidad.
Posibilidad de integrar la seguridad. Cuando se añade una medida de seguridad, es decir, cuando ésta no contribuye directamente a la producción, se dice que la seguridad no está integrada. En estos casos se ha observado que las medidas tienden a desaparecer. En general, las medidas preventivas que suponen un coste adicional para el operario deben evitarse, ya sean de carácter fisiológico (aumentando la carga física o nerviosa), psicológico, económico (en lo que se refiere al sueldo o la producción) o representen una simple pérdida de tiempo.

El no desplazamiento del riesgo. Ciertas medidas preventivas pueden tener efectos indirectos perjudiciales para la seguridad. Por tanto, siempre es necesario prever las posibles repercusiones de estas medidas en el sistema (puesto de trabajo, equipo o taller) en el que se introducen.

Posibilidad de aplicación general (la noción de factor de accidente potencial). En este criterio se refleja el interés en que una misma acción preventiva pueda ser aplicable en otros puestos de trabajo ajenos al afectado por el accidente objeto de la investigación. Siempre que sea posible, debe procurarse trascender al caso particular que ha provocado el estudio, en un esfuerzo que a menudo exige la reformulación de los problemas detectados. Así, la información obtenida del accidente puede dar lugar a la adopción de una acción preventiva relativa a factores desconocidos, pero presentes en otras situaciones de trabajo en las que aún no han provocado incidentes. Por esta razón, se denominan "factores de accidente potenciales". Es una noción que abre el camino a la detección precoz de riesgos, mencionada más adelante.

E fecto en las "causas" fundamentales. Como norma general, la prevención de los factores inductores de accidente cerca del momento de la lesión elimina ciertos efectos de situaciones peligrosas, mientras que la prevención acometida remontándose en la secuencia de causas tiende a erradicar las situaciones peligrosas en sí. U na investigación pormenorizada de un accidente está justificada en la medida en que la acción preventiva se ocupe con el mismo interés de los factores iniciales.

Tiempo dedicado a la aplicación. La necesidad de actuar tan rápido como sea posible después de un accidente con el fin de evitar su repetición suele reflejarse en la aplicación de una medida preventiva simple (por ejemplo, una instrucción), pero esta acción no elimina la necesidad de adoptar otras más duraderas y eficaces. En consecuencia, todo accidente debe dar lugar al planteamiento de un conjunto de propuestas cuya aplicación será objeto de seguimiento.

Con los criterios anteriores se pretende dar una mejor apreciación de la calidad de las acciones preventivas propuestas después de cada investigación de accidente. Claro está que la elección final no se toma únicamente sobre esta base, ya que deben tenerse en cuenta también otras consideraciones, como las económicas, las culturales o las sociales. Por último, es obvio que las medidas que se hayan decidido deben respetar la normativa vigente.

\section{Factores de accidente}

Las lecciones extraídas de cada análisis de accidente deben registrarse sistemáticamente para facilitar el paso de la adquisición de conocimiento a la acción. La Figura 57.12 consta de tres columnas. En la columna de la izquierda, figuran los factores de accidente que exigen la adopción de medidas preventivas. En la del medio se describen las acciones posibles correspondientes a cada factor sobre el que se ha tomado una decisión. Después del análisis antes mencionado, las acciones seleccionadas se registran en esta parte del documento.

En la columna de la derecha se incluyen los factores de accidente potenciales que indican los factores referidos en la de la izquierda: se considera que, con frecuencia, cada factor 
Figura 57.11 • Ejemplo de representación posible mediante el método STEP.

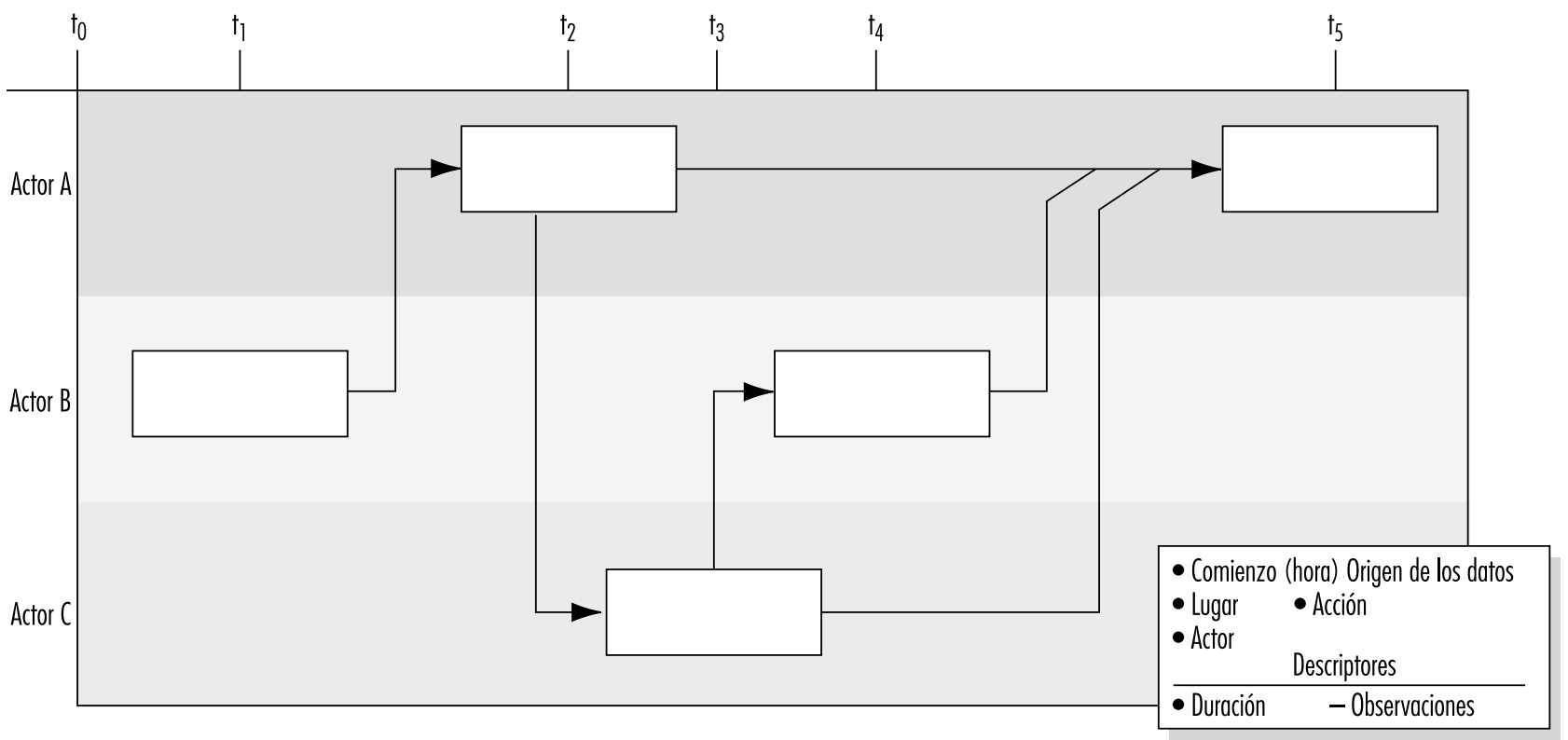

Fuente: Hendrick y Benner 1987

Figura 57.12 - Lecciones extraídas de los accidentes y utilización de las mismas.

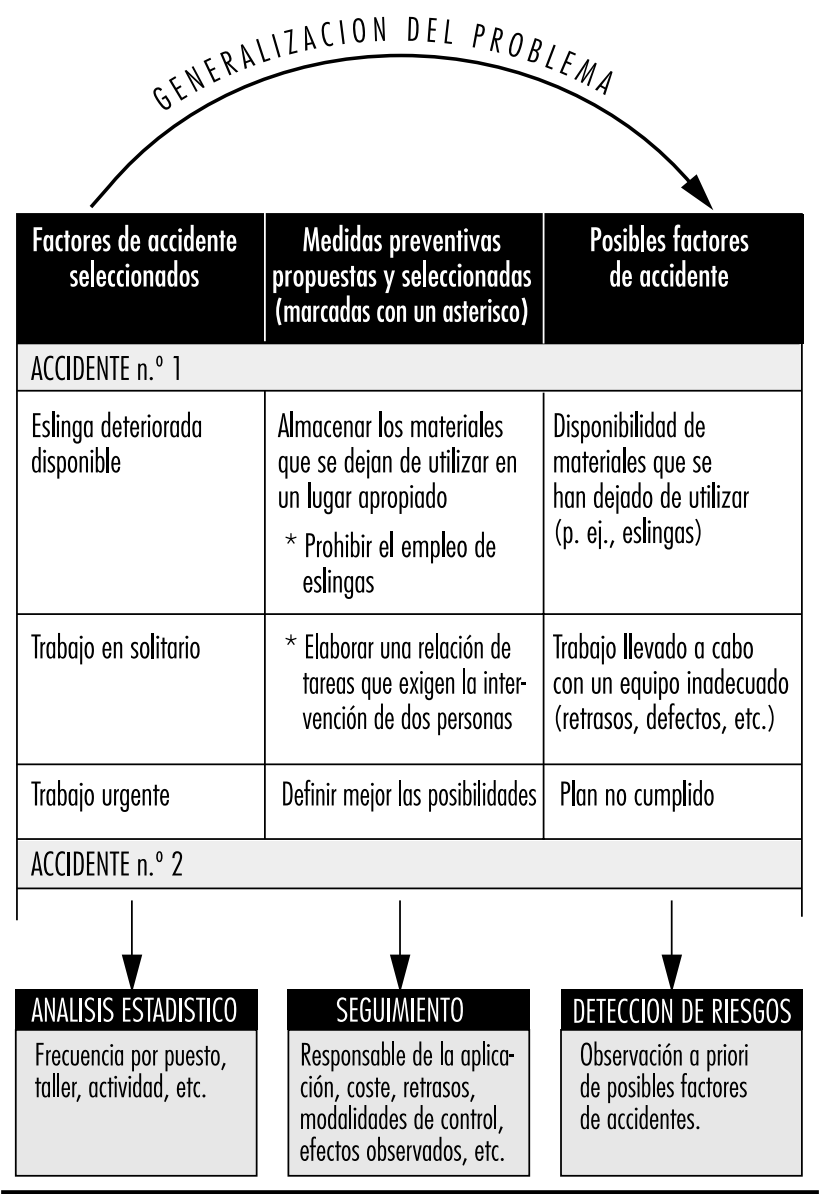

detectado constituye únicamente un caso particular de otro más general denominado factor de accidente potencial. El paso del caso particular al caso más general se realiza a menudo de forma espontánea. Ahora bien, cada vez que un factor de accidente se expresa de un modo en que no es posible encontrarlo en otra situación distinta a aquélla en la que ha aparecido, debe considerarse una formulación más general. Para ello, es necesario evitar dos dificultades opuestas en la utilización de la noción de factor de accidente potencial con eficacia en la detección temprana de riesgos prevista para más adelante. U na formulación demasiado limitada no permite una determinación sistemática de los factores, mientras que una excesivamente amplia elimina la funcionalidad y el interés práctico de la noción. Por tanto, la detección de factores de accidente potenciales exige una formulación adecuada de los mismos. L a detección puede llevarse a cabo a través de dos caminos complementarios:

1. mediante la búsqueda de la posible presencia de factores potenciales ya conocidos a escala del puesto de trabajo 0 en un ámbito superior (taller, servicio),

2. o mediante la investigación de los puestos de trabajo en los que puede observarse un factor previamente determinado.

\section{U tilidad, eficacia y limitaciones de la investigación de accidentes}

U tilidad. Comparados con las investigaciones no sistemáticas, los métodos de investigación de accidentes basados en un concepto sistemático presentan numerosas ventajas, entre las que figuran las siguientes:

- Permiten alcanzar la red causal de cada accidente a ser definido colectivamente, que facilita el diseño de nuevas medidas preventivas y la previsión de su repercusión, sin limitarse a las causas directas de la lesión.

- O frecen a los participantes en el análisis una representación mental más completa y realista del "fenómeno del accidente", 
que permite una interpretación global de las situaciones de trabajo.

- Las investigaciones de accidentes pormenorizadas (sobre todo cuando se amplían para abarcar incidentes y sucesos no deseados) pueden convertirse en un medio y en una ocasión adecuada para el diálogo entre la dirección y los trabajadores.

E ficacia. Para ser eficaz, la investigación de accidente exige la satisfacción simultánea de cuatro condiciones:

1. un evidente compromiso de parte de la más alta dirección de la empresa, que debe ser capaz de garantizar la aplicación sistemática de los procedimientos oportunos;

2. la formación de los investigadores;

3. la dirección, los supervisores y los trabajadores deben estar plenamente informados de los objetivos de la investigación, de sus principios, de los requisitos del método empleado y de los resultados previstos,

4. la obtención de mejoras reales en las condiciones de seguridad, que alentará a los participantes en futuras investigaciones.

Limitaciones. Incluso cuando se lleva a cabo adecuadamente, la investigación de un accidente se enfrente a una doble limitación:

- Sigue siendo un procedimiento para examinar los riesgos a posteriori (al modo del análisis de sistemas), con el objetivo de corregir las situaciones existentes. Por tanto, no aborda la necesidad de investigaciones a priori (prospectivas), como el estudio ergonómico de los puestos de trabajo o, en el caso de sistemas complejos, la investigaciones de seguridad.

- Asimismo, la utilidad de las investigaciones de accidentes varía con el nivel de seguridad del centro de trabajo en el que se apliquen. En concreto, si este nivel es elevado (la tasa de accidentes es baja o muy baja), es evidente que los accidentes graves se deben a la conjunción de numerosos factores aleatorios independientes relativamente inocuos desde el punto de vista de la seguridad cuando se consideran fuera del contexto investigado.

\section{- COMUNICACION Y RECOPILACION DE ESTADISTICAS SOBRE ACCIDENTES}

Kirsten Jorgensen

\section{La necesidad de comunicar y recopilar datos sobre accidentes}

El objetivo esencial de la recopilación y el análisis de los datos sobre accidentes de trabajo es proporcionar unos conocimientos para su utilización en la prevención de lesiones profesionales, fallecimientos en el trabajo y otras formas de perjuicio como las exposiciones a productos tóxicos con efectos a largo plazo. A simismo, estos datos resultan de utilidad en la evaluación de las necesidades de compensar a las víctimas por las lesiones sufridas con anterioridad. O tros fines más específicos de la recogida de estadísticas de accidentes son:

- determinar las causas y la magnitud de los problemas de accidente;

- establecer las necesidades de medidas preventivas y clasificar éstas según su prioridad;

- evaluar la eficacia de las medidas preventivas;

- supervisar los riesgos, advertir y llevar a cabo campañas de sensibilización

- ofrecer retroinformación a los participantes en la prevención.
A menudo, desea obtenerse una visión general del número de accidentes anuales. Para ello se utiliza una frecuencia y se compara el número de accidentes con una medida referida al grupo de riesgo y se expresa, por ejemplo, en términos de accidentes por cada 100.000 trabajadores o por cada 100.000 horas de trabajo. Tales recuentos anuales se emplean para determinar las variaciones de la tasa de accidente de un ejercicio a otro. Ahora bien, aunque pueden indicar el tipo de accidentes que exigen una acción preventiva con mayor urgencia, no constituyen en sí mismos un instrumento de orientación respecto a la forma que dicha acción debe adoptar.

L a necesidad de información sobre accidentes difiere entre los tres niveles de función que la utilizan:

- Al nivel del lugar de trabajo de cada empresa en particular, los datos de accidentes se utilizan en las actividades de seguridad locales. Las mejores oportunidades para abordar factores de riesgo específico se encuentran en el entorno inmediato: el lugar de trabajo.

- Al nivel de la autoridad competente en materia legislativa, los datos de accidentes se utilizan para regular el ambiente de trabajo y promover la seguridad en el lugar de trabajo. Es posible no sólo ejercer control sobre éste a dicha escala, sino también llevar a cabo análisis estadísticos generales para su empleo en las actividades preventivas generales.

- A la escala de la autoridad responsable del pago de indemnizaciones a las víctimas de accidentes, estos datos se utilizar para facilitar la determinación de las tasas.

\section{El papel de la organización en la recopilación de información sobre accidentes}

En muchos países, las empresas están obligadas por ley a mantener de estadísticas de accidentes de trabajo que hayan provocado lesiones, fallecimientos o la exposición a sustancias tóxicas de los trabajadores. N ormalmente, el objeto de este requisito es llamar la atención sobre los riesgos que han dado lugar en la práctica a este tipo de accidentes, centrándose las actividades de seguridad sobre todo en el accidente específico y en el estudio del suceso en sí. Con todo, es más habitual que la información sobre accidentes se recoja y se registre de manera sistemática en lo que constituye una función que suele llevarse a cabo a una escala superior.

Puesto que las circunstancias reales de la mayoría de los accidentes son especiales, es poco frecuente que se produzcan dos accidentes idénticos y la prevención basada en el análisis de un accidente concreto tiende fácilmente a convertirse en una cuestión altamente específica. Al recoger la información sistemáticamente, es posible obtener una visión más general de las áreas en las que deben encontrarse riesgos particulares y descubrir factores menos obvios inductores de accidentes. Los procesos y los equipos de trabajo específicos y la utilización de ciertos equipos pueden provocar accidentes muy circunstanciales. En cualquier caso, un estudio detallado de los tipos de accidente asociados a una forma determinada de trabajo uniforme puede poner de relieve factores como la inconveniencia de los procesos de trabajo, el uso incorrecto de los materiales, la existencia de condiciones de trabajo difíciles o la falta de formación adecuada de los trabajadores. Un análisis de numerosos accidentes recurrentes puede indicar los factores fundamentales que deben abordarse al emprender acciones preventivas.

\section{Comunicación de la información sobre accidentes a} las autoridades en materia de seguridad

La legislación que requiere una comunicación de los accidentes de trabajo varía ampliamente de un país a otro, y las diferencias se centran sobre todo en el tipo de empresas y de otros agentes a 
los que se aplica la normativa. Los países que conceden gran importancia a la seguridad en el lugar de trabajo suelen estipular que los datos sobre accidentes se remitan a las autoridades competentes para la supervisión del cumplimiento con la legislación en la materia. (En algunos casos, la legislación exige la comunicación de los accidentes de trabajo que dan lugar a la ausencia del puesto, cuya duración oscila entre 1 y 3 días más el día del suceso.) En la mayoría de las normativas, la comunicación de datos se vincula con alguna forma de sanción o indemnización por las consecuencias de los accidentes

Con el fin de establecer unos fundamentos sólidos para la prevención de los accidentes de trabajo, es necesario garantizar la oferta de información al respecto relativa a la totalidad de sectores y de actividades. Debe establecerse una base para la comparación a escala nacional que permita la determinación de prioridades respecto a las acciones preventivas y el aprovechamiento de los conocimientos sobre los riesgos asociados a las tareas de los distintos sectores en las iniciativas de prevención. Por tanto, es recomendable que la obligación de recopilar información sobre accidentes de trabajo a escala nacional se aplique en todos los casos de una gravedad determinada, con independencia de que afecten a trabajadores por cuenta ajena 0 propia, en puestos temporales o fijos y en los sectores público o privado.

Aunque los empresarios, generalmente, están obligadas a comunicar los accidentes, este requisito se satisface con diversos grados de entusiasmo. La medida de cumplimiento de esta imposición depende de los incentivos ofrecidos a los empresarios. Por ejemplo, algunos países, tienen una regla en virtud de la cuál, las empresas son indemnizadas por los pagos efectuados a las víctimas de un accidente por las horas de trabajo perdidas, lo que les anima a comunicar los accidentes de trabajo. 0 tros países, sancionan a los empresarios que no informan de los accidentes acaecidos. Cuando estos tipos de incentivos no existen, la mera obligación jurídica que vincula al empresario no siempre es observado. Por otra parte, se recomienda que la información sobre accidentes de trabajo destinada a las aplicaciones preventivas sea remitida a la autoridad responsable de llevarlas a cabo y se mantenga al margen de la autoridad encargada de las indemnizaciones.

Tabla 57.6 - Variables informativas que caracterizan un accidente.

$$
\text { Acciones }
$$

Elementos

Fase 1

Actividad de la víctima: p. ej., utilizar una máquina, realizar actividades de mantenimiento, conducir, caminar, etcétera.

\section{Componente relacionado con la} actividad de la víctima: p. e.. prensa mecánica, herramienta, vehículo, suelo, etc.

Fase 2

Acción irregular: p. ej., explosión, avería estructural, tropezón, pérdida de control, etc

Componente relativo a la acción irregular: p. ej., depósito a presión, muro, cable, vehículo, máquina, herramienta, etc.

Fase 3

Acción que origina la lesión: p. ej., golpe, aplastamiento, bloqueo, contacto, mordedura, etc.

\section{¿Q ué información debe recopilarse?}

$\mathrm{H}$ ay tres tipos básicos de información que puede obtenerse mediante el registro de accidentes:

- La información que establece dónde ocurren los accidentes; es decir, sectores, actividades, procesos de trabajo, etc. Tales conocimientos pueden utilizarse para determinar dónde se necesita la acción preventiva.

- La información que indica cómo ocurren los accidentes y el modo en que se producen las lesiones. Pueden utilizarse estos conocimientos para determinar el tipo de acción preventiva necesaria.

- La información relativa a la naturaleza y la gravedad de las lesiones, en la que se describe, por ejemplo, las partes del cuerpo afectadas y las consecuencias de las lesiones para la salud. D eben utilizarse estos datos para establecer las prioridades de la acción preventiva, con el fin de garantizar que se adoptan medidas allí donde el riesgo es mayor.

Es necesario recopilar una cierta cantidad de datos básicos complementarios para documentar adecuadamente cuándo y dónde se produce un accidente y analizar cómo ocurre. A nivel empresarial, los datos recogidos son más detallados que los agregados en el ámbito nacional, pero los informes elaborados a escala local contienen información valiosa en todos los contextos. En la Tabla 57.6 se recogen tipos de información específicos que pueden registrarse mediante la descripción de un accidente concreto. Las cuestiones de especial importancia para la tarea de elaborar las estadísticas relacionadas con un accidente se describen con mayor detalle a continuación.

$N$ úmero de identificación del accidente. $A$ todos los accidentes de trabajo se les debe asignar un único número de identificación. R esulta especialmente ventajoso emplear un indicador numérico a efectos del registro y posterior procesamiento informatizado.

$N$ úmero de identificación personal y fecha. El registro de la víctima constituye una parte esencial de la identificación del accidente. Puede elegirse entre la fecha del cumpleaños del trabajador, el número de empleo, el número de la seguridad social u otro identificador singular. La anotación del número de identificación personal y la fecha del accidente evitará la duplicación del registro del mismo accidente y, además, facilitará la comprobación de la comunicación del accidente. El vínculo entre la información contenida en el informe del accidente y este número puede protegerse por razones de seguridad.

$\mathrm{N}$ acionalidad. La nacionalidad de la víctima será un elemento importante de la información en los países con una proporción significativa de trabajadores extranjeros en la población activa. Puede seleccionarse un código de dos dígitos entre los que figuran en la N orma DS/ ISO 3166.

Profesión. El número de registro de la profesión puede elegirse entre la lista de códigos internacionales de ocupación de cuatro dígitos propuestos en la Clasificación Internacional U niforme de 0 cupaciones (CIUDO).

E mpresa. El nombre, la dirección y el número de identificación de la empresa se utiliza en el registro de accidentes a escala nacional (aunque el nombre y la dirección no pueden emplearse para el archivo informático). N ormalmente, el sector productivo de la empresa se inscribe en su entidad aseguradora especializada en lesiones profesionales o en relación con el registro de su plantilla. Puede asignarse un identificador numérico de sector de acuerdo con el sistema de clasificación internacional NACE de cinco dígitos.

Proceso de trabajo. Un componente esencial de la información referente a los accidentes de trabajo es la descripción del proceso de trabajo efectuado en el momento en que se produjo el accidente. La identificación del este proceso de trabajo constituye un requisito previo para lograr una prevención orientada 
adecuadamente. Cabe señalar que el proceso de trabajo consiste en la función real que la víctima desempeñaba en el momento del accidente y no debe ser necesariamente idéntico al que provocó la lesión, el fallecimiento o la exposición.

Desarrollo de accidente Un accidente suele consistir en una cadena de acontecimientos. Los investigadores suelen centrarse en la parte del ciclo de sucesos en la que se produjo la lesión. A hora bien, desde el punto de vista de la prevención, es también importante la descripción de la fase en la que algo funcionó mal y de lo que hacía la víctima cuando ocurrió el suceso.

Consecuencias del accidente Después de especificar la parte del cuerpo lesionada y de describir el tipo de lesión (en parte mediante los códigos que figuran en una lista de comprobación y en parte a través de la descripción incluida en el ciclo de sucesos), se informa de la gravedad de la lesión y se especifica si ésta dio lugar a la ausencia del puesto de trabajo (y su duración) y si tuvo como consecuencia el fallecimiento o la invalidez. $\mathrm{N}$ ormalmente, puede obtenerse información detallada sobre las ausencias al trabajo de larga duración, las hospitalizaciones o las discapacidades en las entidades encargadas de las indemnizaciones y en el sistema de seguridad social.

Por tanto, a efectos de registro, el examen de un accidente se divide en los tres componentes informativos siguientes:

- La actividad asociada con un accidente es la que desarrollaba la víctima en el momento en que se produjo el accidente. Se registra mediante un código de acción y un código tecnológico. En este sentido, se considera un concepto de tecnología amplio en el que se incluyen elementos como las máquinas, los materiales, los componentes de la construcción e incluso los animales. Actualmente, no existe una clasificación internacional de tecnología, aunque Dinamarca ha desarrollado un sistema de clasificación en este contexto.

- El suceso de la lesión es el acontecimiento irregular que dio lugar al accidente. Se registra mediante un código para la irregularidad y uno o dos códigos para la tecnología que intervino en la misma.

- El modo de la lesión se registra mediante la utilización de un código para la manera en que la víctima entró en contacto con el factor causante de la lesión y de otro código para la tecnología que provocó ésta.

Los ejemplos siguientes ilustran la aplicación de estas categorías de análisis:

1. En el caso de que un trabajador tropiece con un tubo flexible al caminar y se caiga, golpeándose en la cabeza con una mesa, la actividad es caminar, el suceso de la lesión es tropezar con el tubo flexible y el modo de la lesión es el golpe de la cabeza con la mesa.

2. Un trabajador permanece de pie cerca de un muro, un depósito explota y el muro se viene abajo sobre la víctima. La actividad consiste en estar de pie junto al muro, el suceso de la lesión es la explosión del depósito y el modo de la lesión es el impacto del muro sobre la víctima.

\section{La comunicación de la información sobre los accidentes}

La información que debe obtenerse de cada accidente puede ser registrada en un formulario semejante al que se muestra en la Figura 57.13.

La información contenida en el formulario del informe puede registrarse en un ordenador mediante la utilización de claves de clasificación. (En los casos en que puede recomendarse la aplicación de sistemas de clasificación internacionales, éstos se mencionan en la descripción de cada variable de información antes referida.) Las clasificaciones correspondientes a otras variables utilizadas para registrar las lesiones profesionales han sido desarrolladas por el Servicio Danés para el Ambiente de Trabajo, y los principios en que debe basarse la creación de un sistema de registro armonizado forman parte de una propuesta elaborada por la U nión Europea.

\section{La utilización de las estadísticas de accidentes}

Las estadísticas de accidentes constituyen un valioso instrumento en una amplia gama de contextos: catalogación, seguimiento y advertencia, establecimiento de prioridades respecto a las áreas de prevención, medidas de prevención específicas e investigación y recuperación de la información. Un área puede solaparse con otra, pero los principios de aplicación varían.

\section{Mapas}

Los mapas de datos de accidentes de trabajo exige la obtención de ciertos tipos de información predeterminados de un conjunto de datos registrados, así como el análisis de las interrelaciones existentes entre dichos tipos. Los ejemplos siguientes ilustrarán la utilidad de las aplicaciones de catalogación.

- M apas de sectores industriales. Los mapas de datos relativos a los sectores industriales pueden obtenerse de una selección adecuada de los informes contenidos en los registros de información y la realización del análisis deseado. Si una actividad como la construcción reviste un interés especial, pueden seleccionarse los informes registrados en la Clasificación Industrial Internacional U niforme (CIIU) y codificados con los números del 50.000 al 50.199 (edificación y construcción). Los informes correspondientes a este sector pueden servir para determinar, por ejemplo, la localización geográfica de las empresas, así como la edad, el sexo y la profesión de las víctimas de los accidentes.

- M apa de lesiones. Si la selección se basa en una categoría específica de lesión, se pueden obtener los mapas e informes para poner de manifiesto, por ejemplo, los sectores en que se produce este tipo de accidentes, las categorías profesionales y los grupos de edad afectados, las actividades realizadas en el momento del accidente y el tipo de tecnología más frecuentemente involucrado.

- M apas de las empresas. Una evaluación a escala empresarial de las tendencias de los accidentes (y, por tanto, del ambiente de trabajo interno en cada caso) puede llevarse a cabo mediante la elaboración de mapas de los accidentes de trabajo notificados ocurridos en un período de tiempo determinado. Además, la empresa podrá comparar su posición individual respecto a la tecnología, la composición de su personal y otras áreas de interés con el conjunto del sector, y determinar así si su situación en estos aspectos es la habitual en el mismo. Por otra parte, si se comprueba que una actividad sufre varios problemas característicos relacionados con el ambiente de trabajo, es aconsejable investigar si éstos se plantean en la empresa en cuestión.

\section{Seguimiento y advertencia}

El seguimiento consiste en un proceso de vigilancia continua combinado con la advertencia de los riesgos principales y, en especial, de sus variaciones. Los cambios observados en los informes de accidentes recibidos pueden ser indicativos de modificaciones en el patrón de comunicación o, lo que resulta más grave, reflejar auténticas alteraciones de los factores de riesgo. Puede afirmarse la existencia de riesgos importantes en los casos en que se registra una frecuencia de lesiones elevada, se producen muchas lesiones graves y el grupo de personas expuesto al riesgo es numeroso. 
Figura 57.13 - Formulario tipo.

NN.으 de serie

\begin{tabular}{|c|c|c|}
\hline & Señale la fecha de reincorporación al trabajo & Año Mes Día \\
\hline Nombre de la persona lesionada & & Fecha de nacimiento \\
\hline Dirección de la persona lesionada & & Código postal \\
\hline
\end{tabular}

Remítase a la dirección que figura al dorso - औะ

a serie

PARTE DE ACCIDENTE DE TRABAJO

Persona lesionada

\begin{tabular}{|c|c|c|c|c|c|}
\hline Nombre & Fecha de nacir & ento & & & \\
\hline Dirección & Código postal & Naci & lidad & & \\
\hline Profesión & $\begin{array}{l}\text { Momento Año } \\
\text { del accid. }\end{array}$ & Mes & Día & Hora & $\begin{array}{l}\square \text { Alumno en formación } \\
\square \text { Miembro de la familia }\end{array}$ \\
\hline
\end{tabular}

Información de la empresa

\begin{tabular}{|l|l|l|c|}
\hline \multicolumn{2}{|l|}{ Nombre de la empresa } & \multicolumn{2}{l|}{ № de registro de la empresa } \\
\hline Dirección & \multicolumn{2}{l|}{ Código postal } & Número de trabajadores \\
\hline \multicolumn{2}{|l|}{ Actividad económica } & Duración del servicio Años Meses \\
\hline $\begin{array}{l}\text { Si el accidente no se produjo en las ins- } \\
\text { talaciones de la empresa, declare dónde }\end{array}$ & Dirección & & Código postal \\
\hline
\end{tabular}

Tipo y entorno de trabajo

¿Qué tipo de trabajo desarrollaba la persona lesionada en el momento del accidente? (p. ej., fundición de hierro, cosechado, sacrificio de animales)

¿Dónde se encontraba la persona lesionada en el momento del accidente? (dentro de un edificio, en una zona subterránea, etc.)

Circunstancias del accidente

Describa qué hacía la persona lesionada en el momento del accidente y qué elemento (herramienta, equipo) estaba asociado con la actividad

Describa la acción irregular, incluyendo el elemento (herramienta, equipo, etc.) asociado con la irregularidad

Describa la acción que causa la lesión, incluido el agente (herramienta, equipo, etc.) inductor de la misma

Consecuencias del accidente

Tipo de lesión

$\square$ Contusión

Conmoción y lesiones internas

$\square$ Herida abierta

$\square$ Amputación

$\square$ Fractura abierta

$\square$ Fractura cerrada

$\square$ Luxación, dislocación

$\square$ Torcedura, esguince, dist. ligamentos $\square$ Otros

Describa con detalle la naturaleza de la lesión y la parte del cuerpo afectada

Consecuencias del accidente

$\square$ Sin ausencias/ausencia de menos de 1 dia $\square$ Ausencia de 1 a 3 dias $\quad \square$ Ausencia de 4 a 14 dias $\square$ Ausencia previsiblemente superior a 14 dias $\square$ Discapacidad permanente $\square$ Muerte

Fecha Firma de la persona que presenta la reclamación
Parte del cuerpo lesionada

$\square$ Cabeza excepto los ojos $\quad \square$ Manos

Ojos

Espalda, columnaverebral

$\square$.

Abdomen

$\square$ Cadera, muslo, rótula

$\square$ Lesión por calor o congelación

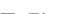

Hombros, brazos, codos

Antebrazos, muñecas

$\square$ Rodilla, pantorrila, tobillo

$\square$ Pies

Dedos de los pies, uno o varios

Varias partes del cuerpo

$\square$ Otras lesiones 


\section{Establecimiento de prioridades}

El establecimiento de prioridades consiste en la selección de las áreas de riesgo o los problemas del ambiente de trabajo más importantes para realizar la acción preventiva. A través de los resultados de los mapas y las actividades de seguimiento y advertencia, puede crearse un registro de accidentes de trabajo capaz de contribuir a la determinación de prioridades, y cuyos elementos podrían ser los siguientes:

- riesgos con consecuencias graves;

- riesgos con una alta probabilidad de lesión en una gran proporción del grupo expuesto,

- riesgos a los que se ven expuestos grupos de personas numerosos.

Los datos extraídos de un registro de accidentes de trabajo pueden utilizarse en el establecimiento de prioridades a varias escalas, quizá a la nacional o a otra más específica como la empresarial. Con independencia de la escala elegida, los análisis y las evaluaciones pueden efectuarse en función de los mismos principios.

\section{Prevención}

En general, los análisis y la documentación utilizados con fines preventivos son muy específicos y se concentran en áreas limitadas abordadas, no obstante, con gran detalle. U n ejemplo de este tipo de análisis es la campaña contra los accidentes mortales realizada por el Servicio Nacional de Inspección del Trabajo de D inamarca. En los mapas preliminares se determinaron las actividades y las funciones laborales en que se producían los fallecimientos. L os tractores agrícolas fueron seleccionados como objeto principal del análisis. Su objetivo era determinar porqué estos vehículos eran tan peligrosos. Se investigó quién los conducía, dónde se utilizaban, cuándo se producían los accidentes y, en concreto, qué tipos de situaciones daban lugar a los accidentes con más frecuencia. Basándose en este estudio, se formuló un programa preventivo.
El número de accidentes de trabajo en una empresa es a menudo demasiado pequeño para realizar estadísticas útiles para el análisis preventivo. Un análisis de la pauta de los accidentes puede utilizarse para evitar la repetición de lesiones específicas, pero es difícil que resulte eficaz en la prevención de accidentes que, de un modo u otro, difieren de casos anteriores. Por tanto, salvo que el objeto de la investigación sea una empresa bastante grande, estos análisis son más adecuados para un grupo de empresas de carácter similar o un conjunto de procesos productivos del mismo tipo. Por ejemplo, un análisis del sector maderero pone de manifiesto que los accidentes vinculados a las máquinas cortadoras producen principalmente lesiones en los dedos. Los accidentes de transporte suelen provocar lesiones en los pies y las piernas y los daños cerebrales y el eczema son los riesgos más comunes en el sector de tratamientos superficiales. Un análisis más detallado de los procesos de trabajo pertinentes en un sector puede indicar qué situaciones suelen causar accidentes. Basándose en esta información, los expertos del sector en cuestión puede determinar con precisión cuándo es probable que se planteen tales situaciones, así como las posibilidades de prevención.

\section{Investigación y recuperación de información}

Uno de los usos más comunes de sistemas de información como los bibliográficos y de archivo es la recuperación de información de carácter específico y bien definido como base para la investigación en materia de seguridad. Por ejemplo, en un estudio cuyo objetivo era formular disposiciones respecto al trabajo sobre techos, surgió la duda de si un determinado riesgo estaba asociado a esa tarea. Se creía comúnmente que los trabajadores rara vez resultaban lesionados por caer de los tejados al desarrollar su actividad. A hora bien, en este ejemplo se utilizó un registro de accidentes de trabajo para recuperar todos los informes con datos sobre personas que hubiesen resultado lesionadas al caerse de un tejado y se descubrió un número considerable de casos, confirmando la importancia de proseguir con la formulación de normas en esta área. 


\section{Referencias}

Advisory Committee on M ajor H azards. 1976, 1979 1984. First, Second and Third Reports. Londres: HMSO.

Bennis WG, KD Benne, R Chin (dirs.). 1985. The Planning of Change N ueva Y ork: $\mathrm{H}$ olt, R inehart and Winston.

Casti, JL. 1990. Searching for Certainty: W hat Scientists Can Know About the Future Nueva York: William M orrow.

Charsley, P. 1995. HAZOP and risk assessment (D N V London). L oss Prev Bull 124:16-19.

Cornelison, JD. 1989. M ORT Based R oot Cause Analysis. Working Paper No. 27. Idaho Falls, Estados U nidos: System Safety D evelopment C enter.

Gleick, J. 1987. Chaos: M aking a New Science. Nueva Y ork: V iking Penguin.

Groeneweg, J. 1996. Controlling the Controllable: The M anagement of Safety. 3a edición revisada. Países Bajos: DSWO Press, U niversidad de Leiden.

$\mathrm{H}$ addon, W. 1980. The basic strategies for reducing damage from hazards of all kinds. $\mathrm{H}$ azard Prev Septiembre/ 0 ctubre:8-12.

H endrick K, L Benner. 1987. Investigating Accidents with ST E P. Nueva Y ork: D ekker.

Johnson, WG. 1980. M ORT Safety Assurance Systems. N ueva Y ork: $M$ arcel D ekker.

K jellén, U, RK Tinmannsvik. 1989. SM ORT - Säkerhetsanalys av industriell organisation. Estocolmo: Arbetarskyddsnämnden.
K letz, T. 1988. Learning from Accidents in Industry. Londres: Butterworth.

K nox, NW, RW Eicher. 1992. M ORT U ser's M anual Report No. SSD C -4, Rev. 3. I daho Falls, Estados U nidos: System Safety D evelopment Center.

K ruysse, H W. 1993. Conditions for safe traffic behaviour. T esis doctoral, Facultad de Ciencias Sociales, U niversidad de L eiden, Países Bajos.

Nertney, RJ. 1975. O ccupancy-use Readiness M anual - Safety Considerations. R eport No. SSD C - 1 . Idaho Falls, Estados U nidos: System Safety D evelopment Center.

Pascale, RTA, AG Athos. 1980. The Art of J apanese $M$ anagement. Londres: Penguin.

Peters, T J, RH Waterman. 1982. In Search of Excellence. Lessons from America's Best-run Companies. Nueva York: H aysen \& R ow.

Petroski, H. 1992. To Engineer is H uman: The Role of F ailure in Successful D esign. N ueva Y ork: V intage

Rasmussen, J. 1988. Information Processing and H umanmachine Interaction, and Approach to Cognitive E ngineering. Amsterdam: Elsevier.

Reason, JT, R Shotton, WA Wagenaar, PTW H udson. 1989. TRIPOD, A Principled Basis for Safer Operations. Informe elaborado para Shell Internationale Petroleum $M$ aatschappij, Exploration and Production.

Reason, JT . 1990. H uman E rror. C ambridge: CU P

Roggeveen, V. 1994. Care Structuur in Arbeidsomstandighedenzorg. Reader of the Post $\mathrm{H}$ oger $\mathrm{O}$ derwijs $\mathrm{H}$ ogere $V$ eiligheids course, Amsterdam.
Ruuhilehto, K. 1993. The management oversight and risk tree (MORT). En Quality M anagement of Safety and Risk Analysis, dirigido porj Suokas y $\checkmark$ R ouhiainen. Amsterdam: Elsevier.

Schein, EH . 1989. Organizational Culture and L eadership. 0 xford: Jossey-Bass.

Scott, WR. 1978. Theoretical perspectives. En Environments and Organizations, dirigido por M W M eyer. San Francisco: J ossey-Bass.

Successful Health \& Safety M anagement: Appl.1. 1991. Londres: H M SO.

V an der Schrier, JH , J Groeneweg, VR van Amerongen. 1994. Accident analysis using the TRIPOD top-down method. Tesina, Centro para la Investigación de la Seguridad, U niversidad de Leiden, Países Bajos.

Waganaar, WA. 1992. Influencing human behavior. Toward a practical approach for E\&P. I Petrol T ech 11:1261-1281.

Wagenaar, WA I G roeneweg. 1987. Accidents at sea: $M$ ultiple causes and impossible consequences. International J ournal of $M$ an- $M$ achine Studies 27:587598.

\section{O tras lecturas recomendadas}

H eselmans, M, J Roels, J Stijnen, J V an de K erckhove, E V an Gils. 1994. El Sistema de Auditoría de Pellenberg, PAS (en holandés). Leuven, Bélgica: Garant.

Van Gils, E. 1993. Safety management system elements. A point of view of the Belgian Labour Inspectorate based on ISO 9001. Seminario de la CCE sobre los procesos industriales, $R$ avello. 


\section{APUCACIONES DE LA SEGURIDAD}

Directores del capítulo

Kenneth G ereckey

Charles T. Pope

\section{Sumario}

\section{A nálisis de sistemas}

$M$ anh Trung $\mathrm{H} O$

Seguridad de las herramientas portátiles y de mano

D epartamento de Trabajo de E E.U U. - O ccupational Safety and

$\mathrm{H}$ ealth Administration; dirigido por Kenneth G erecke. .

Partes móviles de máquinas

Tomas B ackström y M arianne D öos.

$D$ efensas de máquinas

$D$ epartamento de T rabajo de la 0 ccupational Safety and $\mathrm{H}$ ealth

Administration; dirigido por Kenneth $G$ erecke.

D etectores de presencia

Paul Schreiber.

D ispositivos para controlar, aislar y conmutar energía René Troxler.

A plicaciones relacionadas con la seguridad

D ietmar R einert y Karlheinz $M$ effert.

Software y ordenadores: sistemas híbridos automatizados

W aldemar Karwowski y J ozef Z urada

Principios del diseño de sistemas de control seguros

$G$ eorg Vondracek.

Principios de seguridad para máquinas

herramienta CNC

Toni R etsch, Guido Schmitter y Albert M arty

Principios de seguridad para robots industriales

Toni R essch, Guido Schmitter y Albert M arty

Sistemas de control de seguridad eléctricos, electrónicos y programables

Ron Bell
Requisitos técnicos para sistemas relacionados con

la seguridad basados en dispositivos eléctricos,

electrónicos y programables

J ohn B razendaley $R$ on $B$ ell.

Vuelco

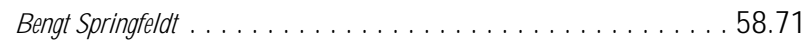

Caídas desde alturas

J ean Arteau . . . . . . . . . . . . . . . . . . . . . . . 58.74

Espacios confinados

$\mathrm{Neil} \mathrm{M}$ CM anus

Principios de la prevención: manipulación de materiales y tráfico interno

Kari H äkkinen.

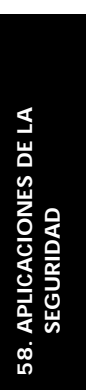




\section{- ANALISIS DE SISTEMAS}

\section{Manh Trung Ho}

Un sistema se define como un conjunto de componentes interdependientes combinados de tal manera que ejecuten una función dada en determinadas condiciones. En este sentido, una máquina es un ejemplo tangible y especialmente claro de sistema; pero hay otros, en los que intervienen hombres y mujeres que trabajan en equipo 0 en un taller o en una fábrica, mucho más complejos y no tan fáciles de definir. El término seguridad indica ausencia de peligro 0 riesgo de accidente 0 daño. Para evitar ambigüedades, se utilizará el término general de incidente no deseado. La seguridad absoluta, en cuanto a imposibilidad de que se produzca un incidente más o menos desafortunado, es inasequible. Lo que ha de perseguirse para ajustarse a la realidad es reducir al mínimo (no eliminar totalmente) la probabilidad de que se produzcan incidentes no deseados.

U n sistema sólo se considera seguro o inseguro en función de los resultados que se esperan realmente del mismo. Teniendo esto en cuenta, el nivel de seguridad de un sistema se define así: "Para cualquier conjunto dado de incidentes no deseados, el nivel de seguridad (o inseguridad) de un sistema está determinado por la probabilidad de que estos incidentes se produzcan durante un período de tiempo dado". Para ilustrar lo anterior, cabe citar como ejemplos de interés los incidentes no deseados siguientes: fallecimientos múltiples, muerte de una o varias personas, lesiones graves, lesiones leves, daños ambientales, efectos perjudiciales a seres vivos, destrucción de plantas o edificios y daños materiales graves o limitados.

\section{Objeto del análisis de los sistemas de seguridad}

El objeto del análisis de un sistema de seguridad es determinar los factores que influyen en la probabilidad de que ocurran incidentes no deseados, estudiar cómo se producen y, por último, elaborar medidas preventivas para reducir su probabilidad.

La fase analítica del problema se divide en dos aspectos principales:

1. identificación y descripción de los tipos de disfunción o ajuste defectuoso,

2. identificación de las secuencias de disfunciones que, combinadas entre sí o con incidentes más "normales", conducen finalmente al propio incidente no deseado, y evaluación de su probabilidad.

Una vez estudiadas las diversas disfunciones y sus consecuencias, los analistas de seguridad de sistemas se ocupan de las medidas preventivas. La investigación en este campo se basa directamente en los hallazgos previos y sigue los dos aspectos principales del análisis de la seguridad de sistemas.

\section{Métodos de análisis}

EI análisis de la seguridad del sistema se hace antes o después del acontecimiento (a priori o a posteriori); en ambos casos, el método utilizado puede ser directo 0 inverso. El análisis a priori se hace antes del incidente no deseado. El analista selecciona varios incidentes e intenta descubrir las diversas fases que pueden conducir a ellos. Por el contrario, un análisis a posteriori se hace después de haberse producido el incidente no deseado. Su objeto es prestar orientación para el futuro y, en concreto, sacar conclusiones útiles para posteriores análisis a priori.

Aunque aparentemente un análisis a priori es mucho más valioso que uno a posteriori, ya que aquél precede al incidente, ambos son complementarios. Se empleará un método u otro en función de la complejidad del sistema y de lo que ya se conozca

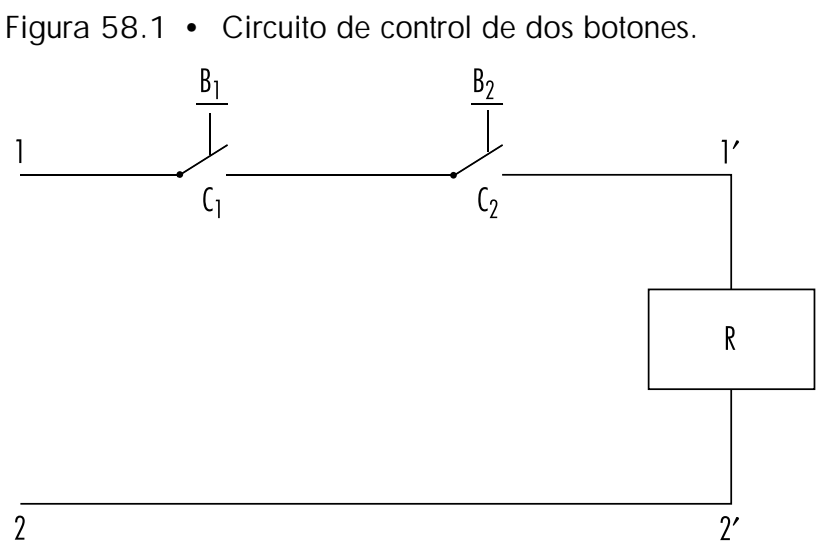

sobre la cuestión. Cuando se trata de sistemas tangibles, como las máquinas o las instalaciones industriales, la experiencia previa sirve normalmente para preparar un análisis bastante detallado a priori. Aun así, el análisis no es necesariamente infalible, por lo que le beneficiará un análisis a posteriori basado esencialmente en un estudio de los incidentes que se producen durante la operación. En cuanto a los sistemas más complejos en los que intervienen personas, como los turnos de trabajo, los talleres o las fábricas, un análisis a posteriori es aún más importante. En tales casos, la experiencia previa no basta para llevar a cabo un análisis a priori detallado y fiable.

Es posible transformar un análisis a posteriori en otro a priori si el analista va más allá del proceso concreto que ha originado el incidente en cuestión y examina los diversos casos que razonablemente pueden conducir a dicho incidente 0 a otros similares.

0 tra forma de transformar un análisis a posteriori en uno a priori es dar prioridad no ya al suceso que se pretende prevenir con el análisis, sino a incidentes menores, como los problemas técnicos, los daños en materiales y los accidentes potenciales 0 menos graves, cuya importancia por sí mismos es relativamente escasa, pero que pueden constituir señales de aviso de incidentes más graves. En tales casos, aunque realizado después de incidentes menores, el análisis será a priori con respecto a incidentes más graves que no han ocurrido aún.

$\mathrm{H}$ ay dos métodos posibles para estudiar el mecanismo o la lógica que subyace tras la secuencia de dos o más sucesos:

1. El método directo, o inductivo, que comienza por las causas a fin de predecir sus efectos.

2. El método inverso, o deductivo, que examina los efectos y retrocede hacia las causas.

La Figura 58.1 es un esquema de un circuito de control que requiere la pulsación simultánea de dos botones $\left(B_{1}\right.$ y $\left.B_{2}\right)$ para excitar la bobina del relé (R) y poner en marcha la máquina. Es un ejemplo que ilustra, en términos prácticos, los métodos directo e inverso utilizados en el análisis de seguridad de sistemas.

\section{Método directo}

En el método directo, el analista comienza por a) hacer una lista de fallos, disfunciones y desajustes; b) estudiar sus efectos, y c) determinar si esos efectos son una amenaza para la seguridad. En el caso de la Figura 58.1, cabe la posibilidad de que ocurran los fallos siguientes:

- rotura del cable entre 2 y 2 ;

- contacto no intencionado en $C_{1}\left(0 C_{2}\right)$ como consecuencia de un bloqueo mecánico;

- cierre accidental de $B_{1}\left(0 B_{2}\right)$,

- cortocircuito entre 1 y 1 .' 
Tabla 58.1 - Posibles disfunciones de un circuito de control de dos botones y sus consecuencias

\section{Fallos \\ Rotura del cable entre 2 y $2^{\prime}$ \\ Cierre accidental de $B_{1}\left(0 B_{2}\right)$ \\ Contacto en $C_{1}\left(0 C_{2}\right)$ como resultado de un bloqueo mecánico}

Cortocircuito entre 1 y 1

\section{Consecuencias}

Imposible arrancar la máquina*

Sin consecuencias inmediatas

Sin consecuencias inmediatas pero posibilidad de que arranque la máquina pulsando simplemente el botón $B_{2}\left(0 B_{1}\right)^{* *}$

Excitación de la bobina del relé $\mathrm{R}$ - arranque accidental de la máquina***

* Incidente con una influencia indirecta en la fiabilidad del sistema

** Incidente responsable de una reducción importante del nivel de seguridad del sistema

*** Incidente peligroso que es necesario evitar

Véase texto y Figura 58.1

EI analista deduce entonces las consecuencias de estos fallos y las expresa en forma tabular (Tabla 58.1).

En la Tabla 58.1 las consecuencias peligrosas o susceptibles de reducir seriamente el nivel de seguridad del sistema, se designan con signos convencionales, como ***

Nota: En la Tabla 58.1, una rotura del cable entre 2 y 2'(como se muestra en la Figura 58.1) es un incidente que no se considera peligroso, ya que este incidente no tiene efectos directos sobre la seguridad del sistema; ahora bien, la probabilidad de que ocurra incide directamente sobre la fiabilidad del sistema.

EI método directo es especialmente adecuado para la simulación. En la Figura 58.2 se muestra un simulador analógico diseñado para estudiar la seguridad de circuitos de control de prensas. La simulación del circuito de control permite verificar que mientras no se produzca ningún fallo, el circuito es realmente capaz de asegurar la función asignada sin infringir los criterios en materia de seguridad. A demás, el simulador permite al analista introducir fallos en los diversos componentes del circuito, observar sus consecuencias y distinguir así los circuitos que han sido diseñados correctamente (con fallos pequeños o no peligrosos) de los que no. Los análisis de seguridad de este tipo también se hacen con un ordenador.

Figura 58.2 - Simulador para el estudio de circuitos de control de prensas.

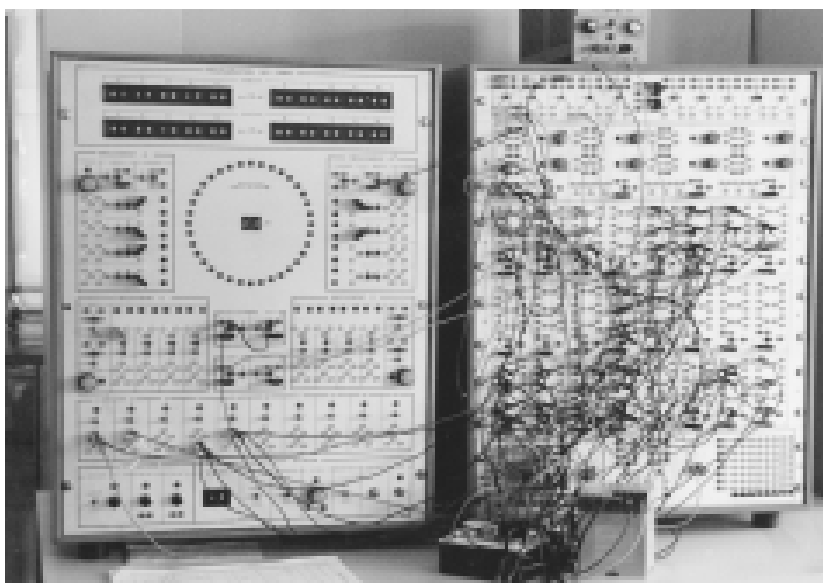

\section{Método inverso}

En el método inverso, el analista hace una labor retrospectiva, remontándose desde el incidente no deseado o accidente hasta los diversos acontecimientos previos para determinar cuál permite que no se produzca el incidente. En la Figura 58.1, el último incidente que debía haberse evitado es la puesta en marcha no intencionada de la máquina.

- La puesta en marcha de la máquina puede haberla causado la activación incontrolada de la bobina del relé $(R)$.

- La activación de la bobina, a su vez, puede ser el resultado de un cortocircuito entre 1 y 1 'o del cierre simultáneo y no intencionado de los interruptores $\mathrm{C}_{1}$ y $\mathrm{C}_{2}$.

- El cierre no intencionado de $C_{1}$ puede ser consecuencia de un bloqueo mecánico de $C_{1} 0$ de la pulsación accidental de $B_{1}$. A $\mathrm{C}_{2}$ puede aplicársele un razonamiento similar.

Los resultados de este análisis se representan en un diagrama en forma de árbol (de ahí que el método inverso se denomine también "análisis del árbol de fallos"), como el que se muestra en la Figura 58.3.

El diagrama sigue las operaciones lógicas, de las cuales las más importantes son las operaciones " $O$ " e " $Y$ ". La operación " $O$ " significa que $\left[X_{1}\right]$ ocurrirá si ocurre $[A]$ o [B] (o ambas). La operación " $Y$ " significa que antes de que pueda ocurrir $\left[\mathrm{X}_{2}\right]$, tienen que haber ocurrido [C ] y [D] (véase la Figura 58.4).

El método inverso se utiliza muy a menudo en el análisis a priori de sistemas tangibles, sobre todo en las industrias química, aeronáutica, espacial y nuclear. También ha resultado ser de gran utilidad como método para investigar accidentes industriales.

Aunque son muy distintos, los métodos directo e inverso son complementarios. EI método directo está basado en un conjunto de fallos o disfunciones, y el valor de un análisis de este tipo depende por tanto de la relevancia de las distintas disfunciones que se hayan considerado al comienzo. Desde este punto de vista, el método inverso parece ser más sistemático. Suponiendo que el analista sabe qué tipos de accidentes o incidentes ocurren, en teoría puede aplicar este método y buscar de manera retrospectiva todas las disfunciones o combinaciones de disfunciones susceptibles de provocarlos. Ahora bien, puesto que no necesariamente se conocen de antemano todos los comportamientos peligrosos de un sistema, pueden descubrirse por el método directo aplicándolo, por ejemplo, por simulación. Una vez descubiertos los peligros, se analizan con más detalle mediante el método inverso.

\section{Problemas del análisis de seguridad de sistemas} Los métodos analíticos descritos anteriormente no son simples procesos mecánicos que se aplican automáticamente y a partir de los cuales se sacan conclusiones útiles que hacen mejorar la seguridad del sistema. Lejos de ello, los analistas encuentran diversos problemas durante su trabajo, y la utilidad de sus análisis depende en gran medida de la forma de solucionarlos. Algunos de esos problemas se explican a continuación.

\section{Conocimiento del sistema objeto del estudio y de sus condiciones operativas}

L os problemas fundamentales en cualquier análisis de seguridad de sistemas son la definición del sistema, de sus limitaciones y de las condiciones en las que se supone que ha de funcionar durante su existencia.

Si el analista considera un subsistema demasiado limitado, el resultado consiste en la adopción de una serie de medidas preventivas aleatorias (una situación en la que todo está pensado para impedir que se produzcan ciertos tipos de incidentes, mientras que se pasan por alto 0 se subestiman otros peligros 
Figura 58.3 - Posible cadena de sucesos.

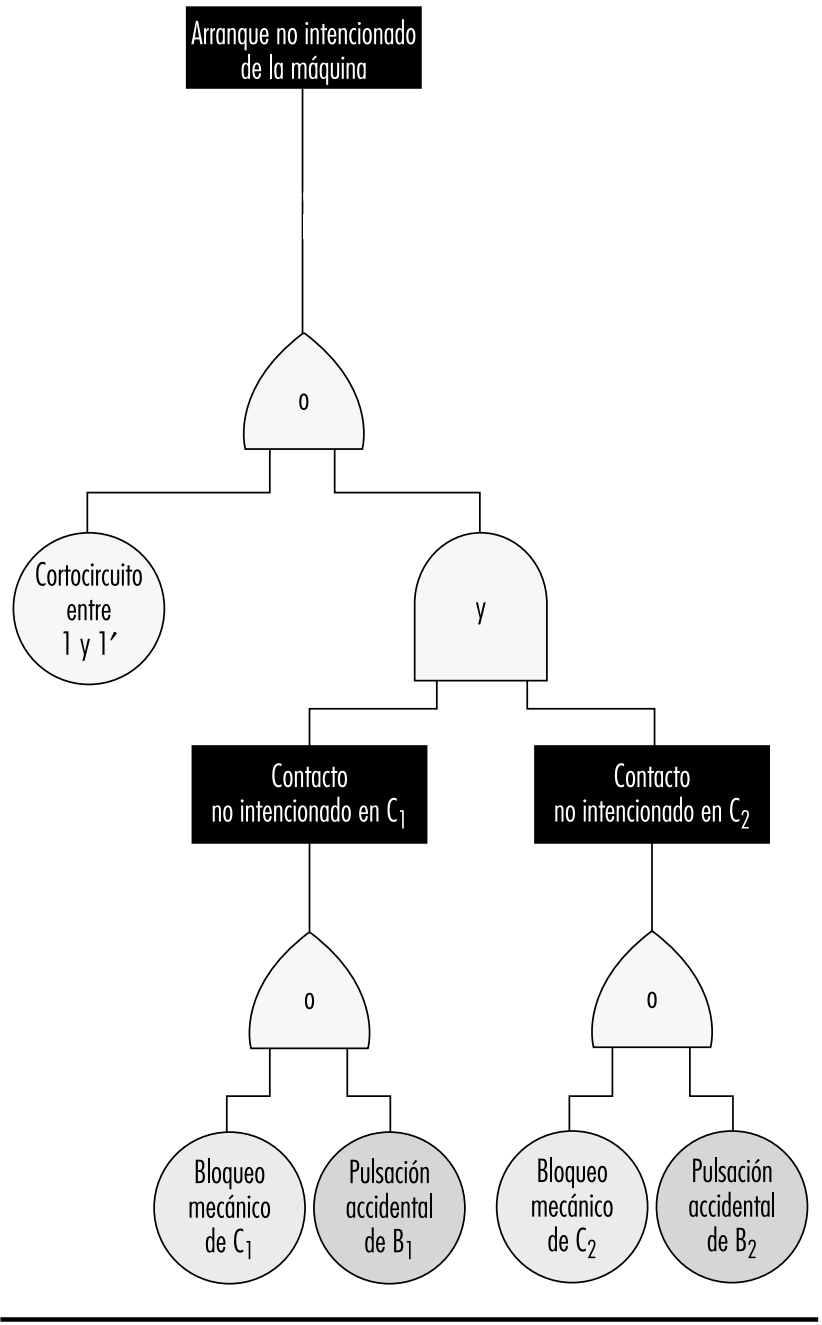

igualmente graves). Si, por el contrario, el sistema es demasiado amplio o general respecto a un problema dado, el resultado pecará de excesiva vaguedad en los conceptos y las responsabilidades, y es posible que el análisis no conduzca a la adopción de medidas preventivas adecuadas.

Un ejemplo típico que ilustra el problema de definir un sistema sometido a estudio es la seguridad de las máquinas o los equipos industriales. En este tipo de situación, es posible que el analista se sienta tentado por considerar únicamente el equipo sin tener en cuenta que hay una o más personas que lo manejan. Aunque es una simplificación que resulta válida en ocasiones, lo que ha de analizarse es no sólo el subsistema de la máquina, sino la totalidad del sistema hombre/ máquina en las diversas etapas de la vida del equipo (entre ellas, por ejemplo, el transporte y la manipulación, el montaje, las pruebas y los ajustes, el funcionamiento normal, el mantenimiento, el desmontaje y, en algunos casos, la destrucción). En cada etapa, la máquina forma parte de un sistema específico cuyo objeto, funciones y disfunciones son totalmente distintos de los que tiene en otras etapas. Por tanto, se debe diseñar y fabricar de tal manera que permita la realización de las funciones asignadas en buenas condiciones de seguridad en cada una de las etapas.

De forma más general, cuando los estudios de seguridad se hacen en empresas, hay varios niveles de sistemas: la máquina,
Figura 58.4 • Representación de dos operaciones lógicas.

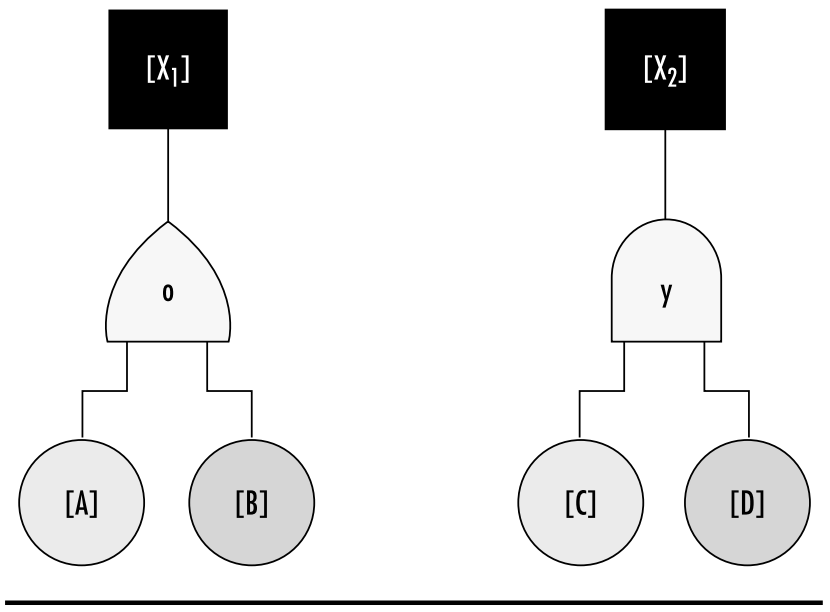

el puesto de trabajo, el turno, el departamento, la fábrica y la empresa en conjunto. Los posibles tipos de diffunciones y las medidas preventivas pertinentes varían significativamente en función del nivel del sistema considerado. Una buena política preventiva debe dejar margen para las disfunciones que puedan producirse a distintos niveles.

Es posible definir las condiciones de funcionamiento del sistema en términos de cómo se supone que funciona el sistema y las condiciones ambientales a las que está sujeto. La definición ha de ser lo suficientemente realista como para contemplar las condiciones reales en las que el sistema va a funcionar. Un sistema que sólo es muy seguro en unas condiciones de funcionamiento muy restringidas, puede no serlo si el usuario es incapaz de mantenerlo dentro de las condiciones teóricas de funcionamiento. Por tanto, un sistema ha de ser suficientemente sólido para soportar variaciones razonables en sus condiciones de funcionamiento y capaz de tolerar determinados errores sencillos pero previsibles por parte de los operadores.

\section{Creación de modelos de sistemas}

Para analizar la seguridad de un sistema a menudo suele ser necesario elaborar un modelo. $Y$ ello plantea ciertos problemas que vale la pena examinar.

En el caso de un sistema conciso y relativamente sencillo, como una máquina convencional, el modelo se obtiene casi directamente de las descripciones de los componentes materiales y sus funciones (motores, transmisión, etc.) y de la interrelación de dichos componentes. EI número de modos posibles en que puedan fallar los componentes es igualmente limitado.

Las máquinas modernas, como los ordenadores y los robots, que tienen componentes complejos (microprocesadores y circuitos electrónicos con integración a gran escala), plantean un problema especial que no ha sido totalmente resuelto ni por lo que se refiere a la creación de un modelo ni a la predicción de los posibles modos de fallo, debido al gran número de transistores elementales de cada chip y al uso de distintos tipos de software.

Cuando es una organización humana lo que se está sometiendo a análisis, la creación de modelos presenta un interesante problema: la elección y definición de ciertos componentes que no son materiales, en su totalidad o parcialmente. Por ejemplo, un puesto de trabajo concreto puede representarse por un sistema que comprende operarios, software, tareas, máquinas, materiales y entorno. (EI componente "tarea" es difícil de definir porque lo que importa no es la tarea especificada, sino la tarea realmente realizada). 
Al crear modelos de organizaciones humanas, el analista puede optar por descomponer el sistema en un subsistema de información y uno o más subsistemas de acción. El análisis de los fallos en las distintas fases del subsistema de información (adquisición, transmisión, procesamiento y uso de la información) resulta muy instructivo.

\section{Problemas asociados con múltiples niveles de análisis}

Los niveles de análisis múltiples suelen llevar asociados problemas, debido a que al partir de un incidente no deseado, el analista se remonta hasta incidentes cada vez más remotos en el tiempo. La naturaleza de las diffunciones que se producen, al igual que las medidas preventivas, dependen del nivel de análisis considerado. Es importante poder decidir el nivel al cual se interrumpirá el análisis y el nivel al cual deberán tomarse medidas preventivas. U n ejemplo es el caso sencillo de un accidente originado por un fallo mecánico debido a la utilización repetida de una máquina en malas condiciones de funcionamiento. Tal vez el origen se halle en la falta de formación del operador o en una mala organización del trabajo. En función del nivel de análisis, la acción preventiva consistirá en la sustitución de la máquina por otra que soporte condiciones de utilización más severas, en el uso de la máquina sólo en condiciones normales, en cambios en la formación del personal o en una reorganización del trabajo.

La eficacia y el alcance de una medida preventiva depende del nivel al que se aplique. Es posible que los efectos de una acción preventiva en los alrededores inmediatos del incidente sean rápidos y directos, pero sus consecuencias serán limitadas; por otra parte, trabajando de manera retrospectiva y remontándose hasta un punto razonable en el análisis de los acontecimientos, se encuentran disfunciones comunes a numerosos accidentes. Cualquier acción preventiva adoptada a este nivel tendrá un alcance más amplio, pero su efectividad es menos directa.

Al igual que hay varios niveles de análisis, hay también muchas formas de acción preventiva, cada una de las cuales desempeña su propia función en el trabajo de prevención. Se trata de un aspecto muy importante y basta con volver al accidente que estamos considerando para apreciar este hecho. Al proponer la sustitución de la máquina por otra capaz de soportar condiciones más severas se hace recaer sobre la máquina la responsabilidad de la prevención. Decidir que la máquina sólo debe usarse en condiciones normales significa asignar la responsabilidad al usuario. D el mismo modo ésta puede recaer sobre la formación del personal, la organización del trabajo o, de forma conjunta, sobre la máquina, el usuario, la función de formación y la función de organización. Para cualquier nivel de análisis dado, parece ser que un accidente suele ser resultado de la combinación de varias disfunciones 0 desajustes. El tipo de acción preventiva estará en función de que la acción se aplique a una u otra disfunción, 0 a varias simultáneamente.

\section{SEGURIDAD DE LAS HERRAMIENTAS PORTATILES Y DE MANO}

\section{Departamento de Trabajo deEE.UU. - Occupational Safety and Health Administration; editado por Kenneth Gerecke}

Las herramientas son tan corrientes en nuestra vida que en ocasiones se hace difícil recordar que entrañan peligros. Todas las herramientas se fabrican pensando en la seguridad, pero a veces se produce un accidente antes de que se adviertan los peligros derivados de ellas. Los trabajadores tienen que aprender a reconocer los peligros asociados a los distintos tipos de herramientas y las precauciones de seguridad necesarias para evitarlos. Deben utilizarse equipos de protección individual apropiados, como gafas o guantes de seguridad, contra los peligros potenciales que entraña el uso de herramientas motorizadas portátiles y de herramientas de mano.

\section{Herramientas de mano}

Las herramientas de mano no funcionan con motor y entre ellas se cuentan desde las llaves hasta las hachas. Los mayores peligros que entrañan las herramientas de mano se basan en el uso incorrecto, la utilización de una herramienta inadecuada para el trabajo y el mantenimiento indebido. He aquí algunos de ellos, aunque la lista no es exhaustiva:

- El uso de un destornillador como cincel puede hacer que la punta se rompa y salga proyectada, hiriendo al usuario o a otros empleados.

- Si el mango de madera de una herramienta como un martillo o un hacha está flojo, astillado o agrietado, la cabeza de la herramienta puede salir despedida y golpear al usuario 0 a otro trabajador.

- Una llave no debe usarse si las mandíbulas están abiertas, ya que puede resbalar.

- Las herramientas de impacto, como los cinceles, las cuñas o los botadores, son inseguras si tienen las cabezas aplastadas, porque cabe la posibilidad de que se partan con el impacto y proyecten fragmentos con bordes afilados.

La empresa es responsable de que el estado de las herramientas y de los equipos facilitados a los operarios sea seguro, pero sobre éstos recae la responsabilidad de utilizar y mantener las herramientas correctamente. L os operarios deben colocar las hojas de sierra, cuchillas y otras herramientas de manera que no se dirijan a las zonas de paso ni a otros empleados que trabajen cerca. Las cuchillas y tijeras deben mantenerse bien afiladas, ya que las que están embotadas son más peligrosas (véase la Figura 58.5)

La seguridad requiere que se mantengan los suelos lo más limpios y secos posible para evitar que se produzcan resbalones accidentales cuando se trabaja o se anda con herramientas peligrosas. Aunque las chispas producidas por las herramientas de mano de hierro 0 acero no alcanzan normalmente temperaturas suficientes para provocar la ignición, cuando se manipulan o se trabaja con materiales inflamables, pueden utilizarse herramientas antichispa de latón, plástico, aluminio o madera para que no se formen chispas.

\section{Herramientas motorizadas}

Las herramientas motorizadas son peligrosas si se usan incorrectamente. $\mathrm{H}$ ay varios tipos, que se clasifican normalmente según su fuente de energía (eléctricas, neumáticas, de combustible líquido, hidráulicas de vapor y de pólvora explosiva). Los operarios deben estar cualificados o recibir formación sobre todas las herramientas motorizadas que utilicen en su trabajo, comprender los peligros potenciales que entrañan su uso y, para evitar que se produzcan, observar las precauciones generales de seguridad siguientes:

- No llevar nunca una herramienta colgando del cable o tubo flexible.

Figura 58.5 - Destornillador.

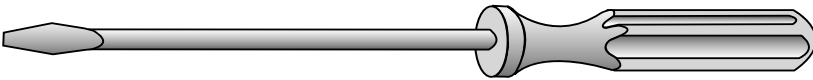


- No tirar nunca del cable o del tubo flexible para desconectar la herramienta de la toma.

- M antener cables y tubos flexibles alejados de fuentes de calor, aceite y bordes afilados.

- Desconectar las herramientas cuando no estén en uso, antes del servicio y al cambiar accesorios como cuchillas, brocas y cortadores.

- Todos los observadores debe estar a una distancia segura de la zona de trabajo.

- A segurar el trabajo con mordazas o un tornillo de banco a fin de tener ambas manos libres para manejar la herramienta.

- Evitar la puesta en marcha accidental. El operario no debe mantener el dedo en el botón de arranque mientras transporta una herramienta conectada. Las herramientas con bloqueo de la posición de marcha deben desbloquearse para que no se pongan en marcha automáticamente al restablecer la alimentación.

- El mantenimiento ha de ser cuidadoso y las herramientas deben estar afiladas y limpias para que rindan al máximo. Deben seguirse las instrucciones del manual del usuario sobre lubricación y cambio de accesorios.

- Los operarios deben apoyar firmemente los pies y estar bien equilibrados cuando usen herramientas motorizadas. La ropa de trabajo debe ser adecuada, ya que las ropas sueltas, las corbatas y las joyas pueden quedar atrapadas por las partes móviles.

- Todas las herramientas eléctricas portátiles averiadas deberán ser retiradas y marcadas con una indicación de "No utilizar", para evitar descargas eléctricas.

\section{Defensas}

Las partes móviles peligrosas de las herramientas motorizadas tienen que estar protegidas. Por ejemplo, las correas, los engranajes, los ejes, las poleas, los piñones, los vástagos, los tambores, los volantes, las cadenas y otras partes móviles, con movimiento rotativo 0 alternativo, tienen que estar protegidas si hay posibilidad de que el usuario entre en contacto con ellas. Cuando sea necesario, deberá haber defensas para proteger al operador y a otras personas contra peligros asociados con:

- el punto de operación;

- los puntos de atrapamiento para la introducción de material;

- las partes con movimiento rotativo o alternativo,

- la proyección de virutas y chispas, así como niebla o pulverización de líquidos para el trabajo con metales.

Figura 58.6 - Sierra circular con defensa.

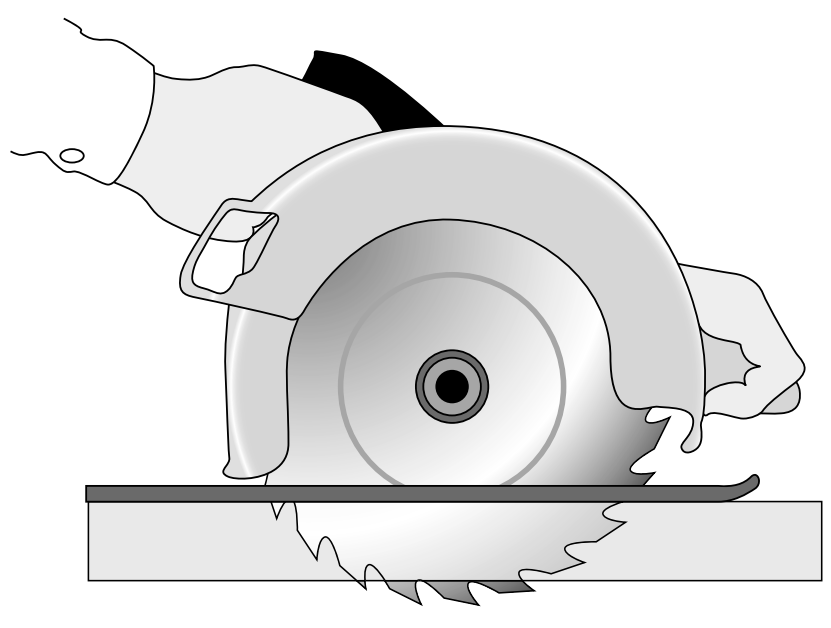

L as defensas no deben retirarse nunca mientras se utiliza una herramienta. Por ejemplo, las sierras de disco portátiles tienen que estar equipadas con defensas. U na defensa superior debe cubrir toda la hoja de la sierra y una defensa retraíble inferior debe cubrir los dientes de la sierra excepto cuando están en contacto con el material que se está trabajando. La defensa inferior debe volver automáticamente a la posición de cobertura al retirar la herramienta del trabajo. 0 bsérvense las defensas de la cuchilla de una sierra eléctrica en la Figura 58.6.

\section{Interruptores de seguridad y controles}

A continuación se citan algunos ejemplos de herramientas motorizadas de mano que tienen que estar equipadas con un interruptor de control de "marcha/ parada" de contacto momentáneo:

- taladros, terrajadoras y aprietatuercas;

- esmeriladoras horizontales, verticales y angulares con muelas de más de 5,1 cm de diámetro:

- lijadoras de disco y cinta,

- Sierras alternativas y de sable

Estas herramientas pueden estar dotadas también de un bloqueo en posición de funcionamiento, siempre que el desbloqueo se pueda conseguir con un solo movimiento del mismo dedo (o dedos) usado para aplicarlo.

L as siguientes herramientas motorizadas de mano están equipadas únicamente con un interruptor de control positivo "marcha/ parada":

- Lijadoras de rodillo;

- lijadoras de disco con discos de 5,1 cm o menos de diámetro;

- esmeriladoras con muelas de 5,1 cm o menos de diámetro;

- alisadoras y cepillos;

- recortadoras de laminado, sacabocados y cizallas,

- sierras de hélice y sierras alternativas con mangos de las hojas de 0,64 cm de anchura o menos.

0 tras herramientas motorizadas de mano que tienen que estar equipadas con un interruptor de presión permanente que corta la alimentación cuando se libera la presión, incluyen:

- sierras circulares con un diámetro de disco superior a 5,1 cm;

- sierras de cadena,

- herramientas de percusión sin medios de sujeción adicional positiva.

\section{Herramientas eléctricas}

Los usuarios de herramientas eléctricas deben ser conscientes de varios peligros, de los cuales el más importante es la posibilidad de electrocución seguida de quemaduras y descargas leves. En determinadas condiciones, incluso una pequeña corriente puede provocar fibrilación del corazón con resultados mortales. U na descarga también puede provocar la caída de un operario desde una escalera o superficie de trabajo elevada.

Para reducir el riesgo de lesiones a causa de descargas, las herramientas tienen que estar protegidas como mínimo de una de las maneras siguientes:

- Conectadas a tierra por un cable de 3 conductores (con un conductor de tierra). Estos cables tienen dos conductores para el paso de corriente y otro para conexión a tierra. Un extremo del conductor de tierra se conecta a la carcasa metálica de la herramienta y el otro se conecta a tierra a través de una patilla del conector. Siempre que se utilice un adaptador para conectar a una toma de dos patillas, el conductor del adaptador deberá conectarse a una tierra conocida. La tercera patilla no debe quitarse nunca del conector (véase la Figura 58.7).

- Con dobleaislamiento. El usuario y la herramienta están protegidos de dos maneras: a) por el aislamiento normal de los conductores 
Figura 58.7 - Taladro eléctrico.

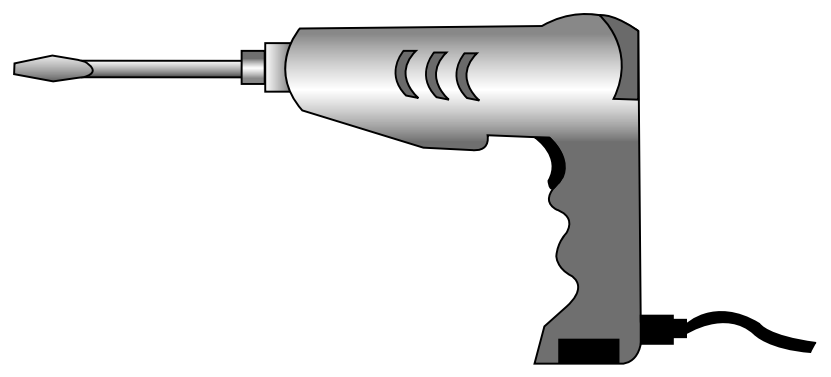

interiores, y b) por una carcasa que no puede conducir electricidad al operario en el caso de un fallo de funcionamiento.

- Alimentadas por un transformador de aislamiento de baja tensión.

- Conectadas a través de interruptores del circuito de defecto o fuga a tierra. Se trata de dispositivos permanentes y portátiles que desconectan instantáneamente un circuito cuando hay fuga a tierra detectan tierra a través del cuerpo del operador o de objetos conectados a tierra.

En el uso de herramientas eléctricas deben seguirse las prácticas generales de seguridad siguientes:

- Las herramientas eléctricas deben ser utilizadas dentro de sus limitaciones de diseño.

- Se recomienda llevar guantes y calzado de seguridad mientras se usan herramientas eléctricas.

- Cuando no estén en uso, deberán guardarse en un sitio seco.

- No deben usarse las herramientas si los cables o conectores están deshilachados, doblados o dañados.

- Las herramientas eléctricas no deben utilizarse en lugares húmedos o encharcados.

- Las zonas de trabajo deben estar bien iluminadas.

\section{Muelas abrasivas motorizadas}

L as muelas abrasivas para esmerilar, cortar y pulir y los cepillos de alambre para pulir crean problemas especiales de seguridad debido a que se pueden desintegrar y proyectar fragmentos

Antes de montar una muela abrasiva debe inspeccionarse cuidadosamente y hacer una prueba de sonido (o timbre) golpeándola ligeramente con un instrumento no metálico ligero para asegurar que no tiene grietas ni defectos. Si la muela está agrietada o el sonido es apagado, puede desintegrarse durante el funcionamiento y por tanto no se debe utilizar. U na muela en buenas condiciones producirá un tono metálico claro o "timbre".

Para evitar que la muela se agriete, el usuario debe asegurarse de que entra libremente en el eje. La tuerca del eje debe apretarse lo suficiente como para sujetar la muela sin deformar la brida. Deben seguirse las instrucciones del fabricante y asegurarse de que la muela montada en el eje no superará las especificaciones correspondientes. Debido a la posibilidad de que se desintegre (explosionando) la muela durante la puesta en marcha, el operario no debe ponerse nunca frente a la muela mientras ésta es acelerada hasta alcanzar la velocidad máxima. Las esmeriladoras portátiles tienen que estar equipadas con defensas para proteger al usuario no sólo de la superficie móvil de la muela, sino también de los fragmentos proyectados en caso de rotura. Además, cuando se utilice una esmeriladora motorizada deberán tomarse las siguientes precauciones:

- Utilizar siempre protección ocular;

- Cortar la alimentación cuando la herramienta no esté en uso,

- No sujetar nunca una esmeriladora de mano en un tornillo de banco.

\section{Herramientas neumáticas}

Las herramientas neumáticas se alimentan con aire comprimido y entre ellas se cuentan las cinceladoras, los taladros, los martillos y las lijadoras. Aunque son varios los peligros potenciales que entrañan, el principal es ser alcanzado por alguno de los accesorios de la herramienta o por algún tipo de elemento de fijación que el usuario esté utilizando con la herramienta. Cuando se trabaja con herramientas neumáticas, la protección ocular es necesaria, y la facial, recomendable. El ruido es otro peligro. EI trabajo con herramientas ruidosas, como martillos perforadores, requiere el uso correcto de protecciones auditivas adecuadas.

Cuando utiliza una herramienta neumática, el trabajador debe asegurarse de que está firmemente conectada a la manguera para evitar su desconexión. Un alambre corto o un dispositivo de bloqueo positivo que fije la manguera de aire a la herramienta sirve de protección adicional. Si la manguera de aire tiene un diámetro superior a $1,27 \mathrm{~cm}$, se debe instalar una válvula de seguridad de exceso de caudal en la fuente de aire comprimido para cortar la alimentación automáticamente en caso de rotura de la manguera. En general, con las mangueras de aire deben tomarse las mismas precauciones que con los cables eléctricos, ya que aquéllas están sujetas a daños o golpes accidentales del mismo tipo y también son un obstáculo con el que se puede tropezar.

Las pistolas de aire comprimido no deben apuntar jamás a una persona. Los trabajadores no deben aplicar nunca la boquilla sobre sí mismos ni sobre otras personas. Se debe instalar un clip o retén de seguridad para impedir que accesorios como un cincel de una cinceladora salga despedido involuntariamente del cuerpo de la herramienta. $\mathrm{H}$ an de instalarse pantallas para proteger a los trabajadores cercanos contra los fragmentos proyectados por cinceladoras, pistolas remachadoras, martillos neumáticos, grapadoras o taladros neumáticos.

Las pistolas de pulverización sin aire que atomizan pinturas y líquidos a altas presiones (68,9 o más bares) irán equipadas con dispositivos de seguridad ocular manuales o automáticos que impidan la activación hasta que se libere manualmente el dispositivo de seguridad. Los martillos perforadores pesados pueden provocar fatiga y requerir esfuerzos que pueden reducirse mediante el uso de mangos de goma gruesos que permitan sujetarlos con firmeza. Un trabajador que maneje un martillo perforador ha de llevar gafas y calzado de seguridad como protección contra lesiones en el caso de que el martillo resbale o se caiga. También debe utilizar protección facial.

\section{Herramientas accionadas por combustible}

Las herramientas accionadas por combustible utilizan normalmente pequeños motores de combustión interna de gasolina. Los mayores peligros que entraña el uso de estas herramientas son los vapores de combustible, que pueden arder 0 explotar y emitir gases de escape nocivos. El trabajador tiene que ser cuidadoso y manipular, transportar y almacenar gasolina o combustible sólo en recipientes homologados para líquidos inflamables, de acuerdo con procedimientos apropiados para líquidos inflamables. Antes de rellenar el depósito de una herramienta de este tipo, el trabajador debe parar el motor y esperar a que se enfríe para evitar la inflamación accidental de vapores peligrosos. Si se utiliza una herramienta accionada por combustible en un recinto confinado, es necesaria una ventilación eficaz o un equipo de protección para evitar la exposición a monóxido de carbono. También debe haber extintores en la zona.

\section{Herramientas accionadas por pólvora explosiva}

Son herramientas que funcionan como una pistola cargada y deben tratarse con el mismo respeto y precauciones. De hecho, son tan peligrosas que tienen que ser manejadas por empleados 
cualificados o con una formación especial. Cuando se utiliza una herramienta accionada por pólvora, es esencial una protección adecuada para oídos, ojos y cara. Todas las herramientas accionadas por pólvora deben diseñarse para distintas cargas de pólvora, de forma que el usuario pueda seleccionar la carga necesaria para hacer el trabajo sin excesivo esfuerzo.

El extremo de la boca de la herramienta debe tener un escudo protector o defensa perpendicular al cañón para proteger al usuario contra fragmentos o partículas proyectados que pueden suponer un peligro cuando se dispara la herramienta. El diseño debe imposibilitar el disparo mientras esté colocado el dispositivo de seguridad. Para evitar que la herramienta se dispare accidentalmente se requieren dos movimientos distintos para el disparo: uno para poner la herramienta en posición y otro para accionar el gatillo. Las herramientas no deben poder funcionar sin que estén apoyadas contra la superficie de trabajo con una fuerza mínima superior a 2,5 kilos con respecto al peso total de la herramienta.

Si falla el disparo de una herramienta accionada por pólvora, el usuario debe esperar al menos 30 segundos antes de repetir el disparo. Si sigue sin producirse el disparo, deberá esperar al menos otros 30 segundos para que disminuya la probabilidad de explosión del cartucho defectuoso, y retirará después la carga con cuidado. El cartucho defectuoso se introduce en agua o se desecha de una manera segura de acuerdo con los procedimientos establecidos por la empresa.

Si se avería durante el uso una herramienta accionada por pólvora, deberá ser etiquetada y puesta fuera de servicio inmediatamente hasta que sea debidamente reparada. Las precauciones para el uso y manipulación con seguridad de herramientas accionadas por pólvora, incluyen lo siguiente:

- Las herramientas accionadas por pólvora no deben utilizarse en atmósferas inflamables o explosivas excepto con un permiso para trabajosen calienteconcedido por una persona autorizada.

- Antes de usar la herramienta, el trabajador debe inspeccionarla para determinar que está limpia, que todas las piezas móviles funcionan libremente y que el cañón no está obstruido.

- La herramienta no debe colocarse jamás de manera que apunte hacia alguien.

- La herramienta no se debe cargar si no va a utilizarse inmediatamente. Una herramienta cargada no debe estar sin vigilancia, sobre todo si está al alcance de personas no autorizadas.

- Las manos han de mantenerse alejadas de la boca del cañón.

Al utilizar herramientas accionadas por pólvora para aplicar elementos de fijación, se deben adoptar las siguientes precauciones:

- No disparar elementos de fijación sobre materiales que puedan ser atravesados por aquéllos.

- No disparar elementos de fijación sobre materiales como ladriIlos u hormigón a menos de 7,6 cm de un borde o esquina, y si se trata de acero, esa distancia no será inferior a $1,27 \mathrm{~cm}$.

- No disparar elementos de fijación sobre material muy duro o frágil que se pueda romper, fragmentar o hacer rebotar el elemento de fijación.

- U tilizar una guía de alineación para disparar elementos de fijación en agujeros existentes. No disparar elementos de fijación sobre una zona astillada creada por una fijación incorrecta.

\section{Herramientas hidráulicas}

El líquido utilizado en las herramientas hidráulicas tiene que estar homologado para el uso en cuestión y conservar sus propiedades a las temperaturas más extremas a las que vaya a estar expuesto. No deberán superarse las presiones de funcionamiento seguras recomendadas por el fabricante para tubos flexibles y rígidos, válvulas, filtros y otros accesorios. Cuando puedan producirse fugas a alta presión en una zona donde haya fuentes de inflamación, como llamas desnudas o superficies calientes, se deberá considerar el uso de líquidos resistentes al fuego como medio hidráulico.

\section{Gatos}

Todos los gatos (de palanca y cremallera, de tornillo e hidráulicos) deben tener un dispositivo que impida que se eleven demasiado. L a carga máxima del fabricante debe figurar siempre en un lugar destacado del gato y no debe superarse. Si es necesario, se utilizarán tacos de madera debajo de la base para que el gato quede nivelado y seguro. Si la superficie de elevación es metálica, se coloca un taco de madera dura o equivalente de $2,54 \mathrm{~cm}$ de grosor entre la cara inferior de la superficie y la cabeza metálica del gato, para reducir el peligro de resbalamiento. Un gato no debe utilizarse nunca para soportar una carga elevada. U na vez elevada la carga, deben colocarse inmediatamente bloques para soportarla.

Para preparar un gato es necesario comprobar que se cumplen las siguientes condiciones:

1. La base se apoya en una superficie nivelada y firme

2. El gato está perfectamente centrado.

3. La cabeza del gato se apoya contra una superficie nivelada.

4. La fuerza de elevación se aplica uniformemente.

El mantenimiento correcto de los gatos es esencial para la seguridad. Antes de cada uso, todos los gatos deben inspeccionarse y, periódicamente, lubricarse. Si un gato sufre una carga 0 choque anormales, deberá ser inspeccionado cuidadosamente para comprobar que no ha sufrido daños. Los gatos hidráulicos expuestos a temperaturas por debajo de cero deben llenarse con un líquido anticongelante adecuado.

\section{Resumen}

Los trabajadores que utilicen herramientas motorizadas y de mano, expuestos a peligros por caída, proyección, abrasión y salpicadura de objetos y materiales, y a peligros por polvos, humos, nieblas, vapores o gases nocivos deberán recibir los equipos personales apropiados para protegerlos contra dichos peligros. L os trabajadores pueden prevenir todos los peligros relacionados con el uso de herramientas motorizadas siguiendo cinco reglas básicas de seguridad:

1. Conservar todas las herramientas en buen estado con un mantenimiento periódico.

2. U tilizar la herramienta adecuada para el trabajo.

3. Examinar todas las herramientas antes de utilizarlas para ver si están dañadas.

4. U tilizar las herramientas de acuerdo con las instrucciones del fabricante.

5. Seleccionar y utilizar equipos de protección adecuados.

Trabajadores y empresarios tienen la responsabilidad de colaborar para aplicar métodos de trabajo de reconocida seguridad. Si se encuentran ante una herramienta insegura o una situación peligrosa, comunicarán el hecho inmediatamente a la persona responsable.

\section{Partes MOVILES De MAQ UINAS}

\section{Tomas Backström y Marianne Döös}

En este artículo se examinan situaciones y cadenas de sucesos que conducen a accidentes susceptibles de atribuir al contacto con partes móviles de las máquinas. Los encargados del funcionamiento y mantenimiento de las máquinas corren el riego de ser 
víctimas de accidentes graves. Las estadísticas americanas indican que en EE.UU. se producen 18.000 amputaciones y más de 800 fallecimientos cada año, atribuibles a estas causa. Según el $\mathrm{N}$ ational Institute for $\mathrm{O}$ ccupational Safety y $\mathrm{H}$ ealth (NIO SH ), las lesiones adscritas a la categoría de "pillado por, debajo de 0 entre" ocuparon el primer lugar entre los tipos más importantes de lesiones profesionales en 1979. En ellas habían intervenido por lo general máquinas (Etherton y M yers 1990). "EI contacto con partes móviles de máquinas" figura como el principal incidente con lesiones en algo más del $10 \%$ de los accidentes de trabajo desde que se introdujo esta categoría en las estadísticas suecas de lesiones profesionales en 1979.

La mayoría de las máquinas tienen partes móviles susceptibles de producir lesiones. Estos elementos se pueden encontrar en el punto de operación donde se realiza el trabajo en el material (donde tienen lugar las operaciones de corte, conformación, taladrado o deformación, por ejemplo); en los aparatos que transmiten energía a las partes de la máquina que realiza el trabajo (volantes, poleas, bielas, acoplamientos, levas, ejes, cadenas, cigüeñales y engranajes); en otras partes móviles de las máquinas (volantes de equipos móviles, motorreductores, bombas, compresores, etc.), y en otros tipos de maquinaria, sobre todo en elementos auxiliares de equipos de manipulación y transporte de cargas (piezas de trabajo, materiales, residuos 0 herramientas).

Todas las partes de una máquina que requieren movimiento para realizar su función pueden contribuir a que se produzcan accidentes con lesiones y daños. Por su parte, los movimientos rotativos y lineales alternativos, así como sus fuentes de energía, entrañan peligros.

M ovimiento rotativo. Incluso los ejes rotativos lisos pueden enganchar una prenda de vestir y, por ejemplo, arrastrar el brazo de una persona hasta una posición peligrosa. El peligro de los ejes rotativos aumenta si tienen salientes, superficies afiladas o irregulares, como prisioneros, tornillos, ranuras, muescas 0 bordes cortantes. Las partes rotativas de las máquinas originan "puntos de atrapamiento" de tres formas distintas:

1. Puntos entre dos elementos rotativos que giran en sentido opuesto y tienen ejes paralelos, como engranajes o ruedas dentadas, rodillos de transporte o rodillos de escurrir.

2. Puntos de contacto entre partes rotativas y partes con movimiento lineal, como entre una correa de transmisión y su polea, una cadena y una rueda dentada o un piñón y una cremallera.

3. Los movimientos rotativos pueden entrañar riesgo de cortes y lesiones por aplastamiento cuando están próximos a objetos estacionarios, como por ejemplo, entre un transportador de tornillo y su caja, entre los radios de un volante y el cuerpo de la máquina o entre un muela y una plantilla.

M ovimiento lineal. Los movimientos verticales, horizontales y alternativos producen lesiones de varias maneras: la parte de una máquina puede empujar o golpear a una persona, que queda atrapada entre esa parte y otro objeto, o sufre un corte producido por un borde afilado, o queda atrapada entre una parte móvil y otro objeto (Figura 58.8).

Fuentes de energía. A menudo se utilizan fuentes de energía externas para accionar máquinas que requieren cantidades de energía importantes. Se incluyen aquí fuentes de energía eléctrica, de vapor, hidráulica, neumática y mecánica, todas las cuales, controladas o sin controlar, pueden provocar lesiones 0 daños graves. Un estudio de los accidentes producidos durante un año (1987 a 1988) entre agricultores de nueve pueblos del norte de la India puso de manifiesto que las máquinas de corte de forraje, todas del mismo diseño, son más peligrosas cuando son accionadas por un motor o tractor. La frecuencia relativa de accidentes con más de una lesión leve (por máquina) fue de 5,1 por mil para las cortadoras manuales y de 8,6 por mil para las motorizadas. (M ohan y Patel 1992).

\section{Lesiones asociadas con movimientos de máquinas}

Las fuerzas asociadas con movimientos de máquinas suelen ser elevadas, de lo que se deduce que las lesiones a las que dan lugar son graves. Esta hipótesis la confirman varias fuentes. "EI contacto con máquinas o materiales en movimiento representó solo el $5 \%$ de todos los accidentes profesionales, pero supuso el $10 \%$ de los accidentes mortales y graves (fracturas, amputaciones, etc.), según las estadísticas inglesas (H SE 1989). L os estudios realizados en dos plantas de fabricación de vehículos en Suecia apuntan en la misma dirección. Los accidentes debidos a movimientos de máquinas duplicaron los días de baja por enfermedad, en valor promedio, en comparación con los accidentes no relacionados con máquinas. Los relacionados con máquinas difieren también de otros accidentes con relación a la parte del cuerpo lesionada. Los resultados indican que el $80 \%$ de las lesiones sufridas en accidentes por "máquina" afectaron a manos y dedos, mientras que la proporción para "otros" fue del $40 \%$. (Backström y Döös 1995).

La situación de riesgo en instalaciones automatizadas ha resultado ser distinta (por lo que se refiere al tipo de accidente, a la secuencia de sucesos y a la gravedad de las lesiones) y más complicada (en términos técnicos y en relación con la necesidad de conocimientos especializados) que en instalaciones donde se utiliza maquinaria convencional o clásica. El término automatizado se utiliza aquí para referirse a equipos que sin intervención humana directa pueden iniciar el movimiento de una máquina 0 cambiar su dirección o función. Tales equipos requieren dispositivos sensores (por ejemplo, sensores de posición o microinterruptores) 0 alguna forma de control secuencial (por ejemplo, un programa de ordenador) para dirigir y supervisar sus actividades. En los últimos decenios se ha utilizado cada vez más el controlador lógico programable (CLP) como unidad de control en sistemas de producción. Los pequeños ordenadores son ahora los medios más corrientes utilizados para controlar los equipos de producción en el mundo industrializado, mientras que se emplean cada vez menos otros medios de control, como las unidades electromecánicas. En la industria manufacturera sueca,

Figura 58.8 - Ejemplos de movimientos mecánicos que pueden lesionar a una persona.
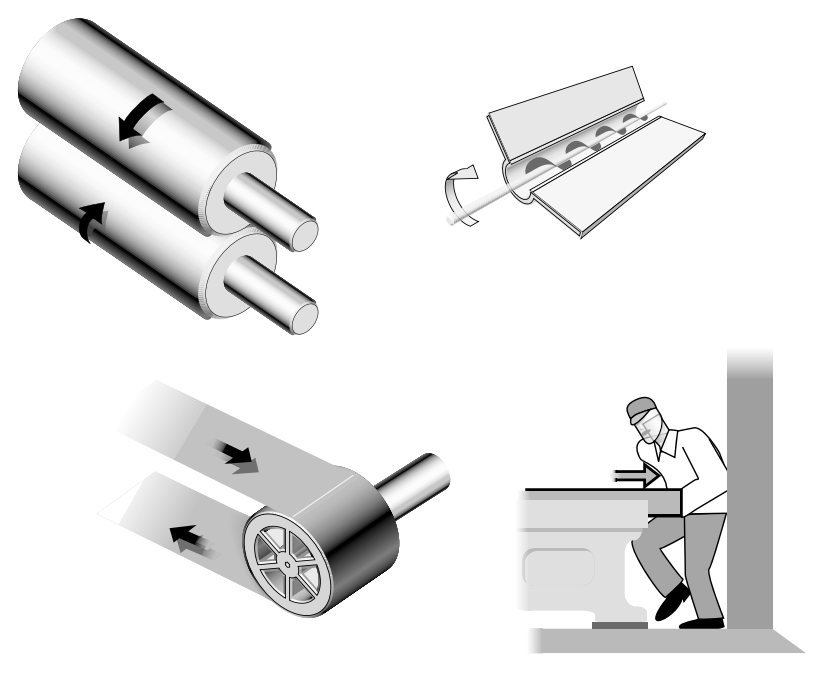
el uso de máquinas de control numérico $(\mathrm{CN})$ ha aumentado del 11 al $12 \%$ anual en el decenio de 1980 ( $\mathrm{H}$ örte y Lindberg 1989). En la moderna producción industrial, las lesiones producidas por "partes móviles de máquinas" equivalen cada vez más a las producidas por "movimientos de máquinas controladas por ordenador"

La automatización de instalaciones es cada vez más frecuente en la industria y está aumentando sus funciones, que vemos aplicadas a la gestión de almacenes, la manipulación de materiales, los procesos, el montaje y el envasado. La fabricación en serie ha terminado por parecerse a un proceso de producción. Si la alimentación, mecanización y expulsión de las piezas están mecanizadas, el operador ya no tiene que estar en la zona de riesgo durante la producción normal. Estudios de investigación sobre la fabricación automatizada han puesto de manifiesto que los accidentes se producen principalmente en la resolución de problemas que afectan a la producción. Con todo, las personas también interfieren con los movimientos de las máquinas al ejecutar otras tareas, como limpieza, ajuste, reajuste, control y reparación.

Cuando la producción está automatizada y el proceso ya no está bajo el control directo de una persona, el riesgo de que se produzcan movimientos inesperados de las máquinas aumenta. La mayoría de los operadores que trabajan en grupos o líneas de máquinas interrelacionadas han experimentado este tipo de movimientos inesperados, causa de muchos accidentes de automatización, o accidente en el que el equipo automático controlaba (o debería haber controlado) la energía determinante de las lesiones. Es decir, que la fuerza que lesiona a la persona procede de la propia máquina (por ejemplo, la energía de una máquina en movimiento). En un estudio de 177 accidentes de automatización realizado en Suecia, se observó que las lesiones fueron causadas por la "puesta en marcha inesperada" de una parte de la máquina en el $84 \%$ de los casos (Backström y $H$ arms-Ringdahl 1984). En la Figura 58.9 se muestra un ejemplo típico de lesión causada por una máquina controlada por ordenador.

Figura 58.9 - Ejemplo típico de lesión causada por el movimiento de una máquina controlada por ordenador.

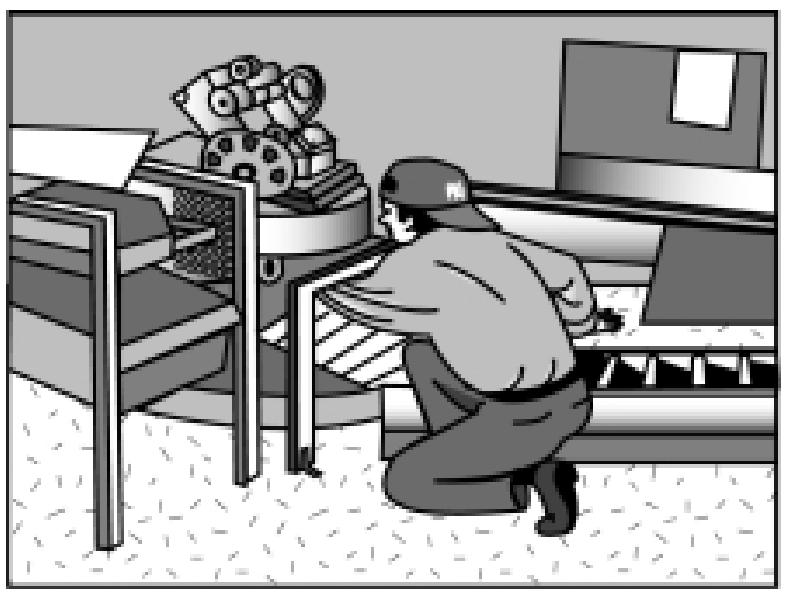

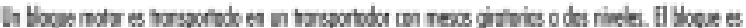

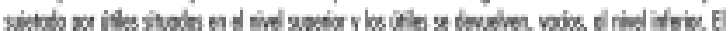

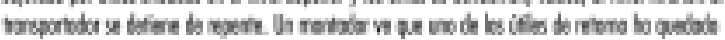

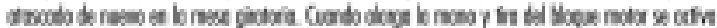

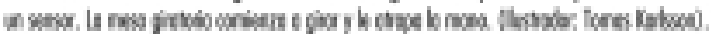

U no de los estudios mencionados anteriormente (Backström y Döös 1995) demostró que los movimientos de la máquina controlados automáticamente estaban ligados de manera causal a períodos más largos de baja por enfermedad que las lesiones debidas a otros tipos de movimientos de máquinas, siendo el valor promedio o medio cuatro veces superior en uno de los puestos de trabajo. La forma de la lesión de los accidentes de automatización resultó ser similar a la de otros accidentes por máquinas (afecta principalmente a manos y dedos), pero se observó una tendencia a que el primer tipo de lesiones fueran más graves (amputaciones, aplastamientos y fracturas).

El control por ordenador, igual que el manual, tiene puntos débiles en relación con la fiabilidad. No hay ninguna garantía de que un programa de ordenador funcione sin error. La electrónica, con sus señales de bajo nivel, puede ser sensible a interferencias si no está bien protegida y las consecuencias de los fallos resultantes no siempre son predecibles. Además, es frecuente que se dejen sin documentar cambios en la programación. Un método aplicado para compensar estos puntos débiles es, por ejemplo, utilizar sistemas dobles en los que hay dos cadenas independientes de componentes funcionales y un método para vigilar que esas dos cadenas proporcionan el mismo valor. Si los sistemas dan valores distintos, es porque hay un fallo en uno de ellos. Pero existe la posibilidad de que ambas cadenas de componentes tengan el mismo fallo y que ambas queden fuera de servicio por la misma perturbación, dando entonces una falsa respuesta positiva (puesto que los dos sistemas coinciden). A hora bien, sólo en muy pocos de los casos investigados ha sido posible seguir un accidente hasta que se produce un fallo en el ordenador (véase más abajo), a pesar de que es corriente que un solo ordenador controle todas las funciones de una instalación (incluso la parada de una máquina como consecuencia de la activación de un dispositivo de seguridad). Como alternativa, se puede considerar la instalación de un sistema ensayado y probado para las funciones de seguridad con componentes electromecánicos.

\section{Problemas técnicos}

En general, un accidente tiene muchas causas: técnicas, individuales, ambientales y de organización. A efectos de prevención, es mejor considerar un accidente no como un suceso aislado, sino como una secuencia de sucesos o un proceso (Backström 1996). En el caso de accidentes de automatización se ha observado que los problemas técnicos suelen formar parte de dicha secuencia y que se producen en las primeras fases del proceso o en la cercanía del suceso con lesiones del accidente. L os estudios en los que se han examinado los problemas técnicos involucrados en accidentes de automatización indican que éstos están presentes en el 75 al $85 \%$ de los casos. Al mismo tiempo, en cualquier caso concreto, hay normalmente otras causas, como las de organización. Sólo en la décima parte de ellos se ha encontrado que la fuente directa de la energía que ha dado lugar a las lesiones se podía atribuir a un fallo técnico, como por ejemplo, un movimiento de la máquina, a pesar de encontrarse ésta en posición de parada. En otros estudios se han ofrecido cifras similares. $\mathrm{N}$ ormalmente, un problema técnico en el equipo hace que el operador tenga que cambiar de tarea (por ejemplo, cambiar la posición de una pieza que estaba colocada incorrectamente). El accidente se produce entonces durante la ejecución de la tarea inducida por el fallo técnico. U na cuarta parte de los accidentes de automatización fueron precedidos por una perturbación del flujo de materiales, como una pieza atascada o colocada en posición incorrecta (véase la Figura 58.10).

En un estudio de 127 accidentes relacionados con la automatización, en 28 de ellos (descritos en la Figura 58.10), se profundizó para determinar los tipos de problemas técnicos que 
Figura 58.10 Tipos de problemas técnicos relacionados con accidentes de automatización (número de accidentes $=127$ )

Tipos de problemas técnicos como porcentaje $\quad(\mathrm{N}=127)$ de los accidentes de automatización

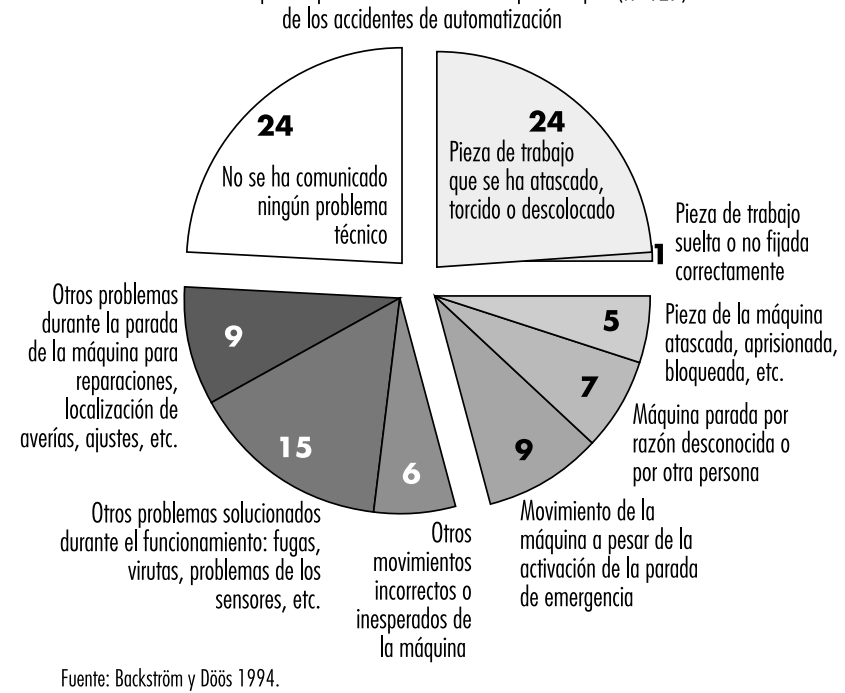

intervinieron como factores causales (Backström y Döös, en prensa). Los problemas especificados en las investigaciones de los accidentes fueron debidos sobre todo a componentes atascados, defectuosos o desgastados. En dos casos, un error del programa informático originó el problema, y en otro se debió a interferencias electromagnéticas. En más de la mitad de los casos (17 de 28) los fallos habían estado presentes cierto tiempo sin que se hubieran solucionado. Sólo en 5 de los 28 casos en los que se hacía referencia a una desviación o fallo técnico tenía un defecto que no se había manifestado previamente. Algunos defectos habían estado presentes desde la instalación, mientras que otros eran el resultado del desgaste y de los efectos ambientales.

La proporción de los accidentes de automatización ocurridos durante la corrección de una perturbación en la producción viene a estar entre un tercio y dos tercios de todos los casos, según la mayoría de los estudios. En otras palabras: hay un acuerdo general en que el tratamiento de las perturbaciones de la producción es una tarea peligrosa. La variación en la producción de tales accidentes tiene muchas explicaciones, entre ellas las relacionadas con el tipo de producción y con la clasificación de las tareas. En algunos estudios de perturbaciones sólo se han considerado problemas y paradas de máquinas en el curso de la producción normal, mientras que en otros se ha tratado un conjunto más amplio de problemas, por ejemplo los relacionados con la preparación del trabajo.

Una medida muy importante en la prevención de accidentes de automatización es preparar procedimientos para eliminar las causas de las perturbaciones de la producción para que no se repitan. En un estudio especializado de las perturbaciones de la producción en el momento de los accidentes (D öös y Backström 1994), se observó que la tarea más común a la que daba lugar la perturbación era liberar la pieza o corregir su posición porque se había atascado o estaba colocada incorrectamente. Los problemas de este tipo iniciaban una de las dos secuencias de sucesos muy similares: a) la pieza era liberada y situada en posición correcta, la máquina recibía la señal de arranque y la persona resultaba lesionada por el movimiento iniciado por la máquina, y b) no daba tiempo a liberar la pieza o a cambiar su

posición antes de que la persona resultara lesionada por un movimiento inesperado de la máquina realizado con más rapidez o fuerza que la esperada por el operador. 0 tros tratamientos de las perturbaciones implicaban el envío de un impulso por un sensor, la liberación de una parte de la máquina atascada, la realización de operaciones sencillas de seguimiento de fallos y la preparación para volver a arrancar (véase la Figura 58.11).

\section{Seguridad del trabajador}

Las categorías del personal susceptible de sufrir lesiones en accidentes de automatización depende de la organización del trabajo; es decir, del grupo profesional que ejecuta las tareas peligrosas. En la práctica depende de la persona a la que se le asigna la tarea de ocuparse de los problemas y las perturbaciones de forma rutinaria. En la moderna industria sueca, son normalmente los operadores de las máquinas los que solicitan las intervenciones activas. Por este motivo, en el estudio de puestos de trabajo en fabricación de vehículos en Suecia mencionado anteriormente (Backström y Döös, aceptado para publicación), el $82 \%$ de las personas que habían sufrido lesiones con máquinas automatizadas eran trabajadores de producción u operadores. L os operadores presentaban también una frecuencia relativa de accidentes más alta (15 accidentes de automatización por mil operadores y por año) que los trabajadores de mantenimiento (6 por mil). Los hallazgos de los estudios que indican que los trabajadores de mantenimiento se ven más afectados, pueden explicarse, al menos en parte, por el hecho de que en algunas empresas no se permite a los operadores entrar en las zonas de mecanización. En organizaciones con un tipo distinto de organización del trabajo, es posible encomendar la resolución de los problemas que surgen en producción a otras categorías de personal, por ejemplo, a los preparadores.

La medida correctiva que más suele adoptarse a este respecto a fin de aumentar el nivel de seguridad personal, es proteger a la persona contra movimientos peligrosos de la máquina mediante algún tipo de dispositivo de seguridad, como una defensa de la máquina. Aquí, el principio principal es el de la seguridad "pasiva", es decir, una protección que no requiere acción alguna del trabajador. Ahora bien, es imposible juzgar la eficacia de los dispositivos de protección sin un profundo conocimiento de los requisitos reales del trabajo en la máquina en cuestión, forma de conocimiento que normalmente sólo poseen los propios operadores de las máquinas.

Figura 58.11 - Tipos de correcciones de las perturbaciones en el momento del accidente (número de accidentes $=76$ ).

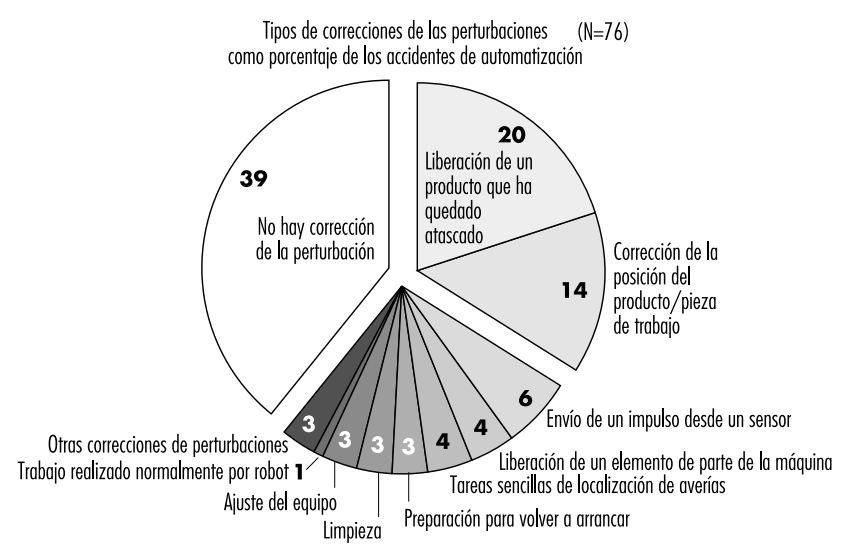
Tipos de correcciones de las perturbaciones $\quad(\mathrm{N}=76)$ 
$\mathrm{H}$ ay muchos factores que invalidan lo que aparentemente es una buena protección de la máquina. Para realizar su trabajo, es posible que los operadores se vean obligados a desconectar 0 derivar un dispositivo de seguridad. A esa conclusión se llegó en un estudio (D öös y Backström 1993), puesto que se había procedido así en 12 de los 75 accidentes de automatización estudiados. A menudo es consecuencia de la tenacidad del operador, que no está dispuesto a aceptar problemas de producción ni retrasos en el proceso a costa de la corrección de las perturbaciones conforme a las instrucciones. U na manera de solucionar este problema es hacer imperceptibles los dispositivos de protección para que no afecten al ritmo de producción, a la calidad del producto o a la ejecución de la tarea. Pero esto no siempre es posible y cuando se producen perturbaciones repetidas en la producción, incluso inconvenientes poco importantes pueden inducir a las personas a no utilizar los dispositivos de seguridad. U na vez más, deben prepararse rutinas para eliminar las causas de las perturbaciones de la producción para que éstas no se repitan. La falta de medios para confirmar que los dispositivos de seguridad funcionan realmente según lo previsto es otro factor de riesgo importante. Conexiones defectuosas, señales de arranque que permanecen en el sistema y dan después lugar a puestas en marcha inesperadas, aumento de la presión de aire y sensores que se han aflojado, pueden ser causas de fallos del equipo de protección.

\section{Resumen}

Como se ha indicado, las soluciones técnicas de los problemas pueden originar nuevos problemas. Aunque son los movimientos de las máquinas (por naturaleza elementos técnicos) los que causan las lesiones, ello no significa que la posibilidad de su erradicación esté solamente en factores puramente técnicos. Los sistemas técnicos seguirán fallando y las personas seguirán cometiendo errores al enfrentarse a situaciones a las que den lugar dichos fallos. Los riesgos seguirán existiendo y sólo se podrán limitar utilizando diversos medios: legislación y control, medidas de organización específicas en empresas (formación, rondas de seguridad, análisis de riesgos e informes de perturbaciones y "cuasiaccidentes"), además de mejoras permanentes y continuadas, como complemento del desarrollo puramente técnico.

\section{- DEFENSAS DE MAQUINAS}

\section{Departamento de Trabajo de la Occupational Safety and Health Administration; editado por Kenneth Gerecke}

Al parecer, las partes móviles de las máquinas entrañan tantos peligros potenciales como tipos distintos de máquinas existen. Las defensas son esenciales para proteger a los trabajadores contra lesiones previsibles e innecesarias relacionadas con las máquinas. Por tanto, cualquier parte, función o proceso de máquina que pueda producir lesiones tiene que tener una defensa. Cuando el funcionamiento de una máquina o el contacto accidental con ella puede lesionar al operador 0 a otras personas próximas, es necesario controlar o eliminar el peligro.

\section{Movimientos y acciones mecánicos}

Los peligros mecánicos se refieren típicamente a partes móviles peligrosas de las tres áreas básicas siguientes:

- el punto de operación: punto donde se realiza el trabajo en un material, como corte, conformado, perforación, estampado, taladrado o almacenamiento;
- aparatos de transmisión de energía: cualquier componente de un sistema mecánico que transmite energía a las partes de la máquina que realizan el trabajo. Entre los componentes se incluyen volantes, poleas, correas, bielas, acoplamientos, levas, ejes, cadenas, cigüeñales y engranajes,

- otros elementos móviles: todos los elementos de la máquina que se mueven mientras está funcionando, como las partes móviles rotativas y alternativas y transversales, los mecanismos de alimentación y las partes auxiliares de la máquina.

U n gran número de movimientos y acciones mecánicos que entrañan peligro para los trabajadores incluyen el movimiento de elementos rotativos, brazos alternativos, correas en movimiento, engranajes acoplados, dientes de corte y cualquier elemento que choque o cizalle. Los distintos tipos de acciones y movimientos mecánicos de este tipo son básicos para casi todas las máquinas y su reconocimiento es el primer paso hacia la protección de los trabajadores frente a los peligros que se puedan presentar.

\section{Movimientos}

$\mathrm{H}$ ay tres tipos básicos de movimientos: rotativo, alternativo y transversal.

M ovimiento rotativo: entraña peligros, ya que incluso los ejes lisos que giran lentamente pueden enganchar la ropa y arrastrar un brazo o una mano a una posición peligrosa. Las lesiones por contacto con elementos giratorios pueden ser graves (véase la Figura 58.12).

Casquillos, acoplamientos, levas, embragues, volantes, extremos de ejes, vástagos y transmisiones horizontales o verticales son ejemplos de mecanismos rotativos corrientes que pueden ser peligrosos. El peligro aumenta si a ellos se añade la presencia de tornillos, muescas, abrasiones y chavetas o prisioneros salientes, como se muestra en la Figura 58.13.

Figura 58.12 - Prensa mecánica de perforar.

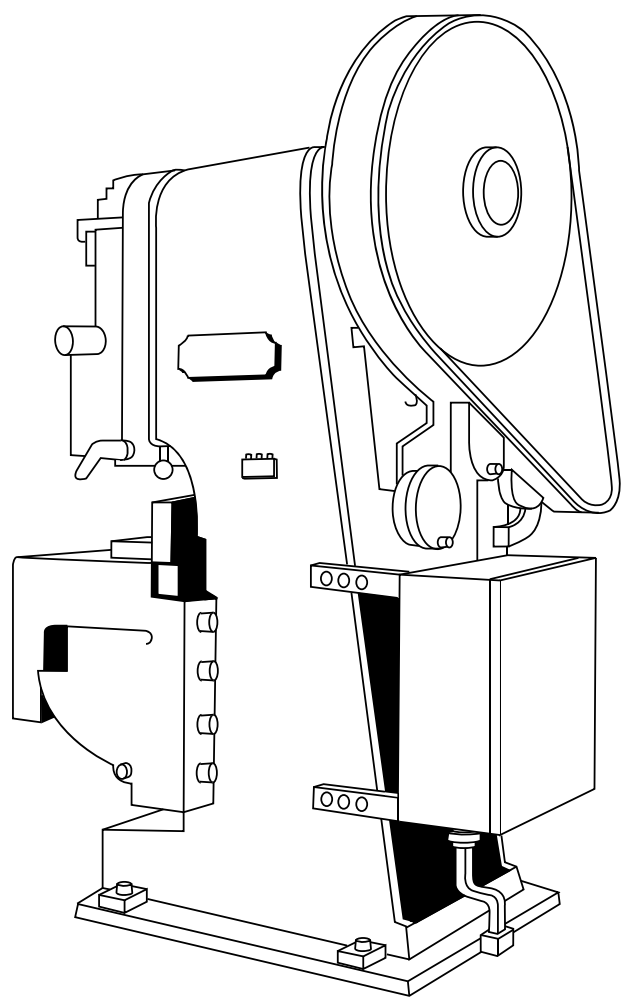


Figura 58.13 - Ejemplos de salientes peligrosos en máquinas rotativas.

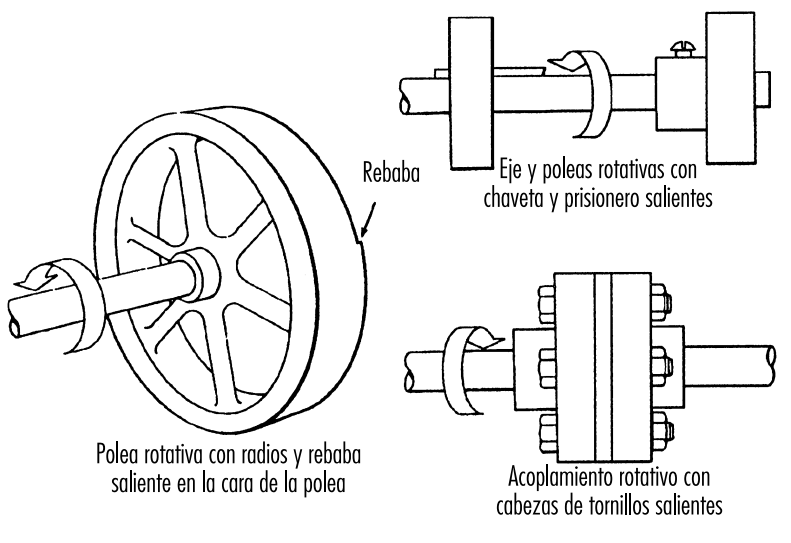

Puntos de atrapamiento interiores: creados por elementos rotativos de máquinas. $\mathrm{H}$ ay tres tipos principales:

1. Elementos con ejes paralelos que giran en sentidos opuestos. Los elementos pueden estar en contacto (creando un punto de atrapamiento) o muy próximos entre sí, en cuyo caso el material alimentado entre los rodillos crea los puntos de atrapamiento. Es un peligro corriente en máquinas con engranajes, molinos de rodillos y calandrias, como se muestra en la Figura 58.14.

2. O tro tipo de punto de atrapamiento es el creado entre partes móviles rotativas y con movimiento tangencial, como el punto de contacto entre una correa de transmisión y su polea, una cadena y una rueda dentada o una cremallera y su piñón, como se muestra en la Figura 58.15.

3. También existen puntos de atrapamiento entre partes giratorias y fijas que dan lugar a una acción de desgarramiento, aplastamiento o abrasión. Ejemplos de esto son los volantes con radios, las manivelas, los transportadores de tornillo, la periferia de una muela abrasiva y el ajuste incorrecto del apoyo o soporte de trabajo, como se muestra en la Figura 58.16.

M ovimientos alternativos: entrañan peligros porque durante las operaciones de avance, retroceso, ascenso y descenso, un trabajador puede ser golpeado por una parte móvil o quedar atrapado entre ésta y una parte estacionario. En la Figura 58.17 se ofrece un ejemplo.

M ovimiento transversal: (movimiento en una línea continua recta) su peligro reside en que un trabajador resulte golpeado 0

Figura 58.14 - Puntos de atrapamiento corrientes en partes en rotación.

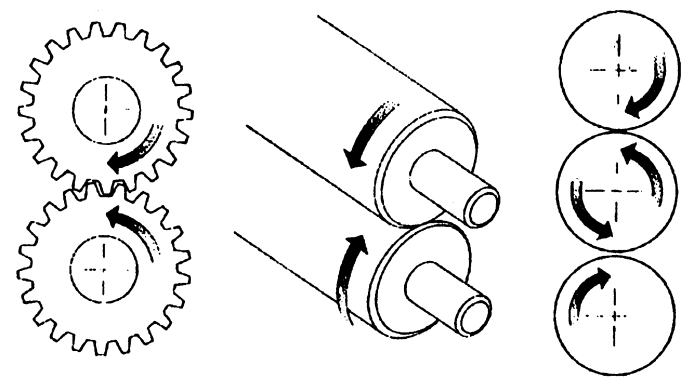

Figura 58.15 - Puntos de atrapamiento entre elementos rotativos y partes con movimientos longitudinales.

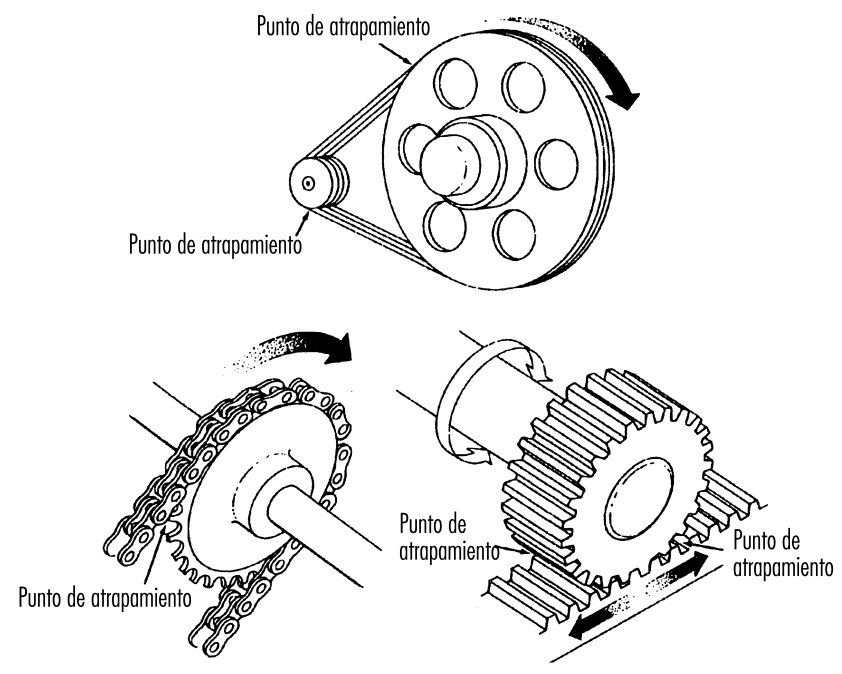

atrapado en un punto de atrapamiento o desgarramiento por una parte móvil. En la Figura 58.18 se muestra un ejemplo de movimiento transversal.

\section{Acciones}

H ay cuatro tipos básicos de acción: corte, perforación, cizallamiento y doblado.

La acción de corte supone movimiento rotatorio, alternativo 0 transversal. Entraña peligros en el punto de la operación donde se pueden producir lesiones en los dedos, la cabeza y los brazos, y allí donde pueden salir proyectados virutas o material residual y chocar con los ojos o la cara del operario. Ejemplos típicos de máquinas con peligros de corte son: sierras de cinta, sierras

Figura 58.16 - Puntos de atrapamiento entre componentes rotativos de máquinas.

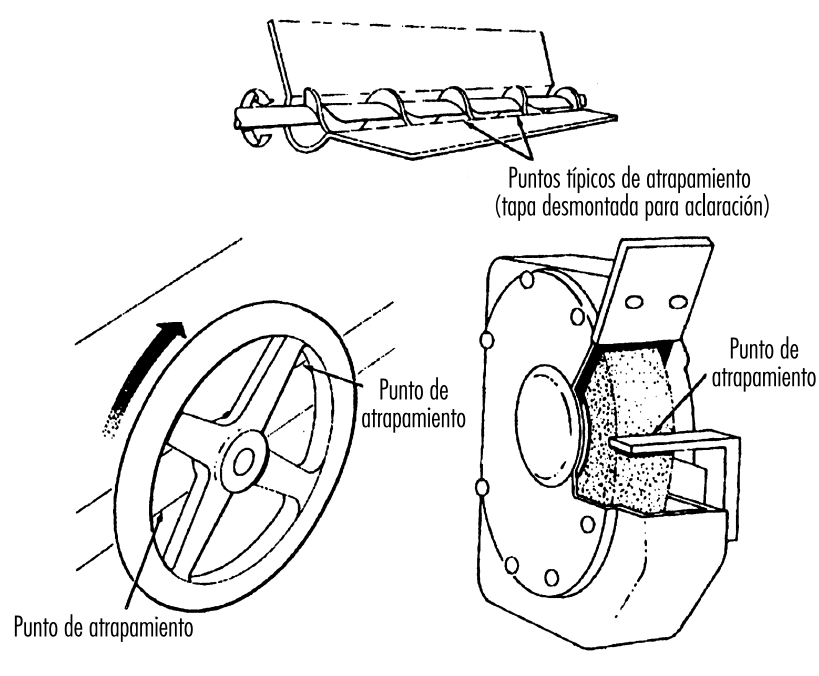


Figura 58.17 - Movimiento alternativo peligroso.
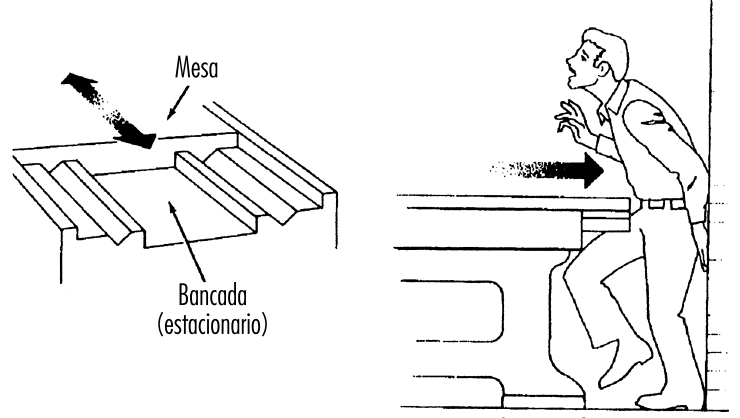

circulares, máquinas de taladrar, tornos y fresadoras (véase la Figura 58.19).

La acción de perforación se produce cuando se aplica fuerza a un elemento deslizante (vástago) con objeto de cerrar, estirar 0 estampar metal u otros materiales. El peligro de este tipo de acción existe en el punto de la operación cuando se introduce, sostiene o retira el material a mano. Las máquinas típicas que utilizan la acción de perforación son las prensas mecánicas y las máquinas utilizadas para trabajos con hierro (véase la Figura 58.20).

La acción de cizallamiento supone aplicar fuerza a un elemento deslizante o cuchilla para cortar o cizallar metal u otros materiales. $\mathrm{H}$ ay un peligro en el punto de la operación donde se introduce, sostiene y retira el material. Ejemplos típicos de máquinas utilizadas para operaciones de cizallamiento son las cizallas mecánicas, hidráulicas o neumáticas (véase la Figura 58.21).

La acción de doblado se produce cuando se aplica fuerza a un elemento deslizante con objeto de conformar, estirar o estampar metal $\mathrm{u}$ otros materiales. $\mathrm{H}$ ay un peligro en el punto de la operación donde se introduce, sostiene y retira el material. Entre los equipos que utilizan la acción de doblado están las prensas mecánicas, los frenos de prensas y las dobladoras de tubos (véase la Figura 58.22).

\section{Requisitos de las defensas}

Las defensas deben cumplir como mínimo los siguientes requisitos generales para proteger a los trabajadores contra los peligros mecánicos:

I mpedir el contacto. La defensa ha de impedir que manos, brazos o cualquier parte del cuerpo o de la ropa de un trabajador entre en contacto con elementos móviles peligrosos, eliminando la

Figura 58.18 - Ejemplo de movimiento transversal.

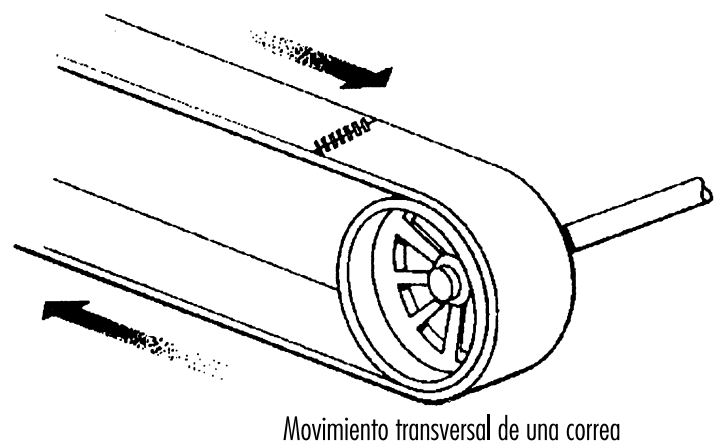

Figura 58.19 - Ejemplos de peligros en el corte.

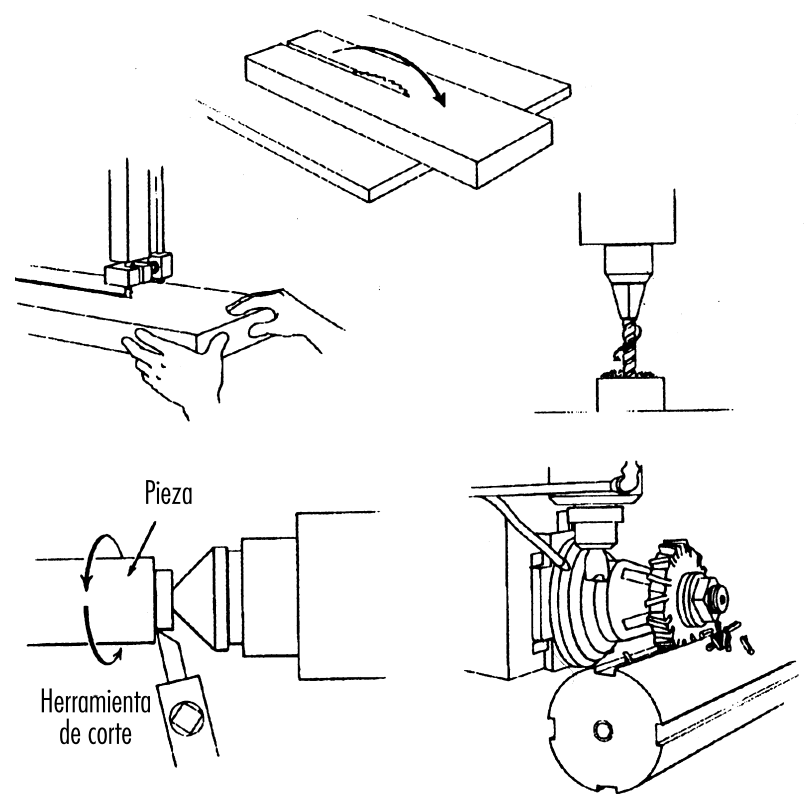

posibilidad de que los operarios u otros trabajadores pongan alguna parte de su cuerpo cerca de partes móviles peligrosos.

Proporcionar seguridad. Los trabajadores no deben poder retirar o manipular con facilidad la defensa. Las defensas y dispositivos de seguridad deben ser de material duradero que soporte las condiciones de uso normal y tienen que estar firmemente fijadas a la máquina.

Proteger contra la caída de objetos. La defensa debe impedir totalmente que puedan caer objetos sobre partes móviles que puedan dañar el equipo o convertirse en proyectiles susceptible de golpear o lesionar a alguien.

No crear nuevos peligros. Si una defensa crea peligros por sí misma contradice su razón de ser: es posible que ocurra en un punto de cizallamiento, un borde dentado o una superficie

Figura 58.20 - O peración típica de perforación.
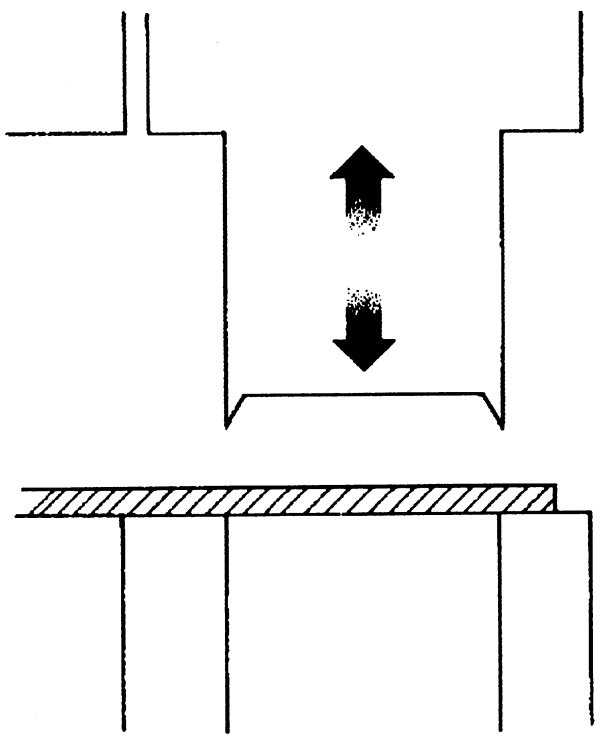

ENCICLOPEDIA DE SALUD Y SEGURIDAD EN EL TRABAJO 
Figura 58.21 - O peración de cizallamiento.

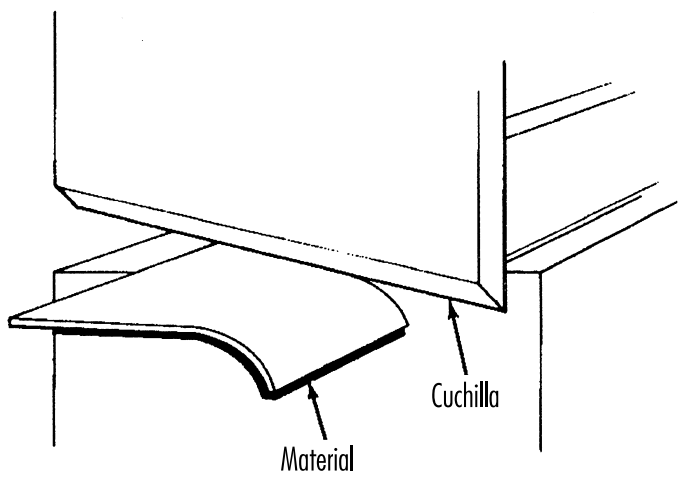

rugosa. Por ejemplo, los bordes de las defensas deben estar enrollados 0 atornillados de manera que no existan aristas afiladas.

No crear interferencias. Si las defensas impiden que los trabajadores ejecuten sus tareas, deberá prescindirse de ellas. A ser posible, los trabajadores lubricarán sus máquinas sin desconectar ni retirar las defensas. Por ejemplo, si se colocan depósitos de aceite fuera de la defensa y se hace llegar una línea hasta el punto de lubricación, se reduce la necesidad de acceso a la zona peligrosa.

\section{Formación en materia de defensas}

$\mathrm{Ni}$ el sistema de defensa más elaborado ofrece una protección eficaz a menos que los trabajadores sepan cómo utilizarlo y porqué. U na formación específica y detallada es parte importante de cualquier esfuerzo para implantar protecciones contra los peligros que entrañan las máquinas. Es posible que una protección correcta mejore la productividad y la eficacia, ya que puede suprimir el temor de los trabajadores a sufrir lesiones. La formación sobre las defensas es necesaria para los trabajadores nuevos, y para el personal de mantenimiento e instalación cuando se

Figura 58.22 - O peración de doblado.

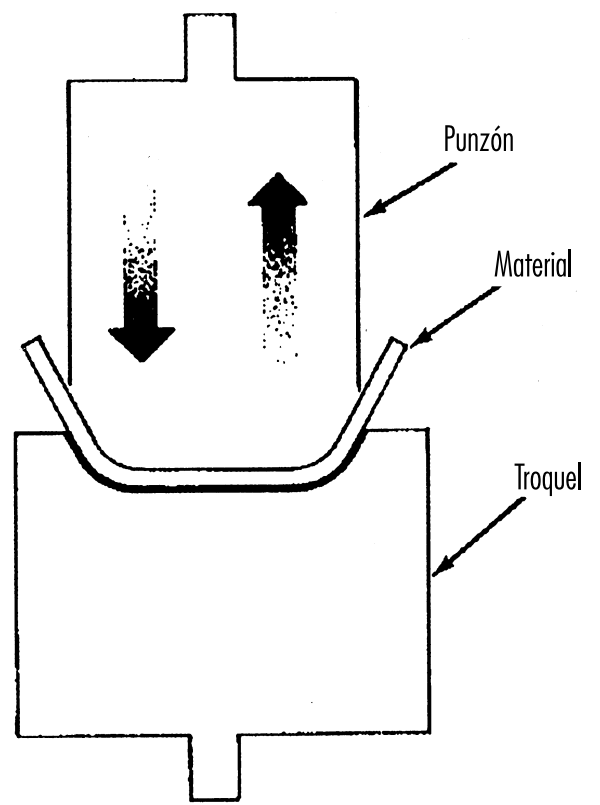

Figura 58.23 • Defensa fija en una prensa mecánica.

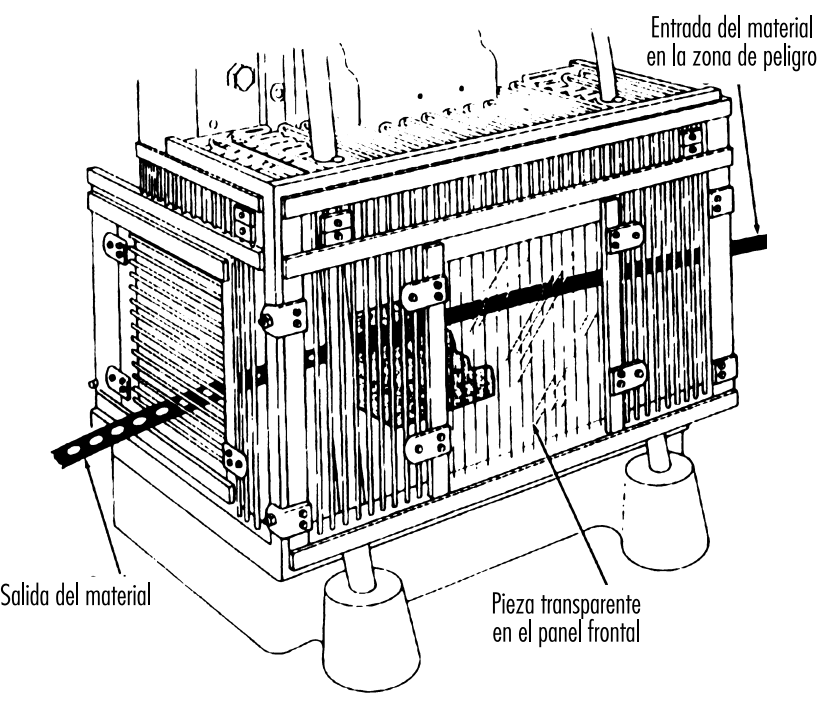

ponen en servicio defensas nuevas o éstas se modifican, y también cuando los trabajadores son asignados a máquinas u operaciones nuevas. Debe incluir instrucción o formación práctica sobre lo siguiente:

- descripción e identificación de los peligros asociados con máquinas concretas y defensas específicas contra cada peligro;

- cómo proporcionan protección las defensas, cómo deben utilizarse y porqué;

- cómo y en qué circunstancias pueden retirarse las defensas y por quién (en la mayoría de los casos, sólo por personal de reparaciones o mantenimiento)

- qué hacer (por ejemplo, informar al supervisor) si una defensa está dañada, falta o no proporciona la protección adecuada.

\section{Métodos de protección de las máquinas}

$\mathrm{H}$ ay muchas maneras de proteger las máquinas. El tipo de operación, el tamaño o forma del material, el método de manipulación, la disposición física de la zona de trabajo, el tipo de material y las necesidades o limitaciones de la producción ayudan a determinar el método de protección adecuado para cada máquina específica. El diseñador de la máquina o el encargado de seguridad deben elegir la protección más efectiva y práctica disponible.

Figura 58.24 - Defensa fija que encierra correas y poleas.

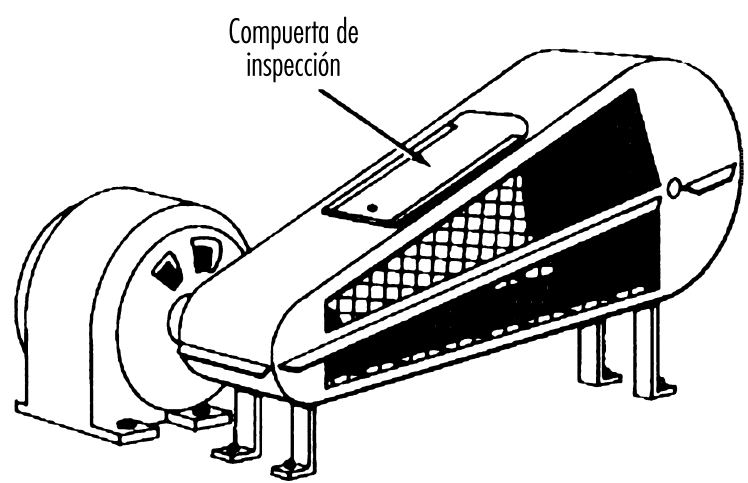


Las protecciones se clasifican en cinco tipos generales: a) defensas; b) dispositivos; c) separación; d) operaciones, y e) otras.

\section{Protección con defensas}

$\mathrm{H}$ ay cuatro tipos generales de defensas (barreras que impiden el acceso a las zonas de peligro) que son los siguientes:

D efensas fijas. U na defensa fija forma parte permanente de la máquina y no depende de partes móviles para ejecutar su función. Puede estar hecha de chapa, rejillas, tela de alambre, barras, plástico o cualquier otro material capaz de resistir los choques y el uso prolongado. Por lo común, son preferibles a los otros tipos debido a su sencillez relativa y permanencia (véase la Tabla 58.2).

En la Figura 58.23, una defensa fija de una prensa mecánica encierra por completo el punto de operación. El material se introduce a través del lateral de la defensa, entra en la zona del troquel y el material de desecho sale por el lado opuesto.

En la Figura 58.24 se muestra una defensa cerrada fija que envuelve las poleas y la correa de una unidad de transmisión. En la parte superior tiene una compuerta de inspección para reducir al mínimo la necesidad de desmontar la defensa.

En la Figura 58.25 se muestran defensas cerradas fijas en una sierra de cinta. Son defensas que protegen a los operadores de las ruedas giratorias y de la cinta de sierra móvil. L o normal es que únicamente se abran o retiren para cambiar la cinta o para mantenimiento. Es muy importante que estén perfectamente aseguradas mientras la sierra está en uso.

D efensas con enclavamiento. Cuando se abren o retiran defensas con enclavamiento, el mecanismo de disparo corta la alimentación y/ o desconecta la máquina, que no puede realizar ciclos o ponerse en marcha hasta que se coloca de nuevo la defensa con enclavamiento en su lugar. Ahora bien, ello no significa que la máquina vuelve a ponerse en marcha automáticamente. LoS dispositivos que utilizan estas defensas son eléctricos, mecánicos, hidráulicos o neumáticos o cualquier combinación de ellos. Los enclavamientos no deben impedir, por ejemplo, los movimientos progresivos manuales "de aproximación" mediante mando a distancia, si son necesarios.

En la Figura 58.26 se muestra un ejemplo de defensa con enclavamiento, dispuesta de forma que cubre el mecanismo del batán de la máquina plegadora (utilizada en la industria textil). Es imposible levantar la defensa mientras la máquina está en movimiento, e imposible que la máquina se ponga en marcha mientras la defensa esté levantada.

$D$ efensas ajustables. Las defensas ajustables ofrecen flexibilidad para acomodar materiales de distintos tamaños. La Figura 58.27 muestra una defensa cerrada ajustable en una sierra de cinta.

$D$ efensas autoajustables. Las aberturas de las defensas autoajustables quedan determinadas por el movimiento del material. A medida que el operador desplaza el material a la zona de peligro la defensa se retira dejando una abertura suficientemente grande para admitir sólo el material. Al retirar el material, la defensa vuelve a la posición de reposo. La defensa (de plástico, metal u otro material apropiado) establece una barrera entre la zona de peligro y el operador, con lo que éste queda protegido. Las defensas autoajustables ofrecen distintos grados de protección.

En la Figura 58.28 se muestra una sierra de brazo radial con defensa autoajustable. Al pasar la hoja a través del material, la defensa asciende y permanece en contacto con el material.

\section{Protección con dispositivos}

Los dispositivos de seguridad detienen la máquina si una mano u otra parte del cuerpo se colocan inadvertidamente en la zona de peligro; limitan el acceso de las manos del operador a la zona de peligro o las retiran de ésta durante el funcionamiento; requieren

Tabla 58.2 • Defensas de máquinas.

$\begin{array}{ll}\text { Método } & \text { Acción de protección } \\ \text { Fija } & \text { - Proporciona una barrera }\end{array}$

Enclavada

- Corta o desconecta la energía e impide el arranque de la máquina estando la defensa abierta; debe requerir la parada de la máquina antes de que el operario acceda a la zona de peligro

Ajustable - Proporciona una barrera que se puede ajustar para facilitar diversas operaciones de producción

\footnotetext{
Autoajustable - Proporciona una barrera que se mueve de acuerdo con el tamaño del material que entra en la zona de peligro
}

Ventajas

- Válida para muchas aplicaciones específicas

- La construcción en la planta es frecuentemente posible

- Proporciona la máxima protección

- Necesita un mantenimiento mínimo

- Adecuada para alta producción, operaciones repetitivas

- Proporciona la máxima protección

- Permite el acceso a la máquina para eliminar atascos sin tener que dedicar tiempo a desmontar defensas fijas

- Se puede construir para muchas aplicaciones específicas

- Se puede ajustar para admitir varios tamaños de materiales
- Hay defensas prefabricadas disponibles comercialmente

\section{Limitaciones}

- Puede interferir con la visibilidad

- Limitada a operaciones específicas

- El ajuste y reparación de la máquina requiere con frecuencia su desmontaje, necesitando por tanto otros medios de protección para el personal de mantenimiento

- Requiere un ajuste y mantenimiento cuidadosos

- Puede ser fácil de desconectar o derivar

- El operador puede acceder a la zona de peligro: la protección puede no ser completa en todo momento

- Puede requerir mantenimiento y/ o ajuste frecuentes

- Puede ser inutilizada por el operador

- Puede interferir con la visibilidad

- No siempre proporciona la máxima protección

- Puede interferir con la visibilidad

- Puede requerir mantenimiento y ajuste frecuentes 
Figura 58.25 - Defensas fijas en una sierra de cinta.

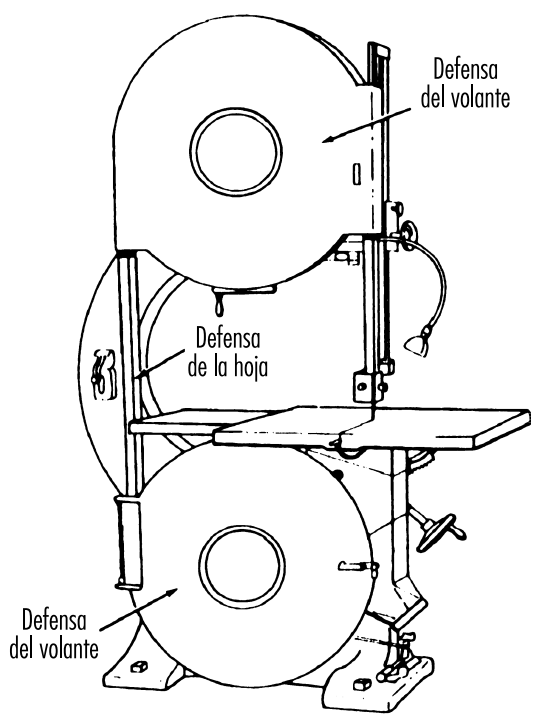

que el operador utilice simultáneamente ambas manos en los controles (manteniendo así fuera de peligro ambas manos y el cuerpo) o crean una barrera que esté sincronizada con el ciclo de la máquina, para impedir el acceso a la zona de peligro durante la parte peligrosa del ciclo. $\mathrm{H}$ ay cinco tipos básicos de dispositivos de seguridad:

\section{Dispositivos detectores de presencia}

A continuación se describen tres tipos de detectores que detienen la máquina o interrumpen el ciclo de trabajo si el trabajador está dentro de la zona de peligro.

EI detector de presencia fotoeléctrico (óptico) utiliza un sistema de fuentes luminosas y controles que interrumpen el ciclo de funcionamiento de la máquina. Si se interrumpe el campo luminoso, la máquina se para y no realiza el ciclo. Este dispositivo sólo debe usarse en máquinas que puedan parar antes de que el

Figura 58.26 • Defensa enclavada en una máquina plegadora.

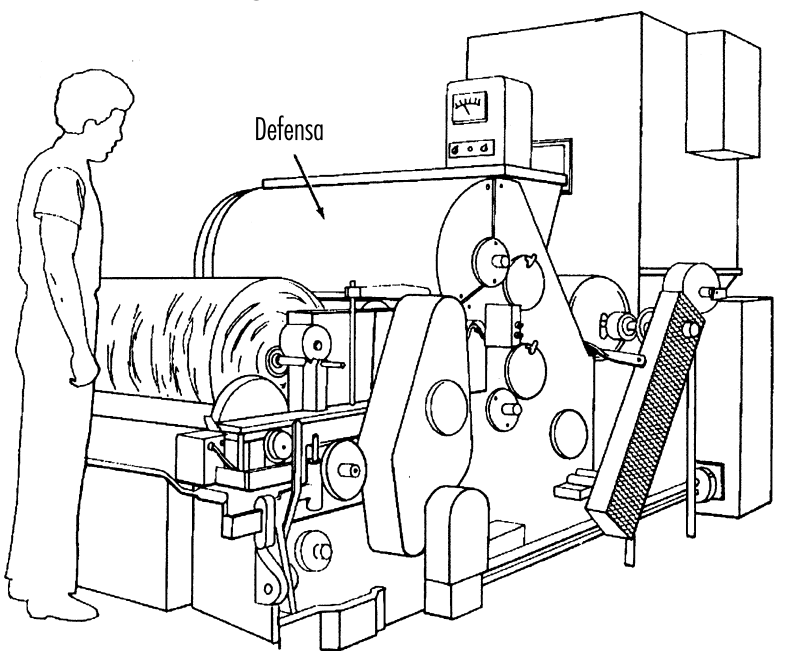

Figura 58.27 - Defensa ajustable en una sierra de cinta.

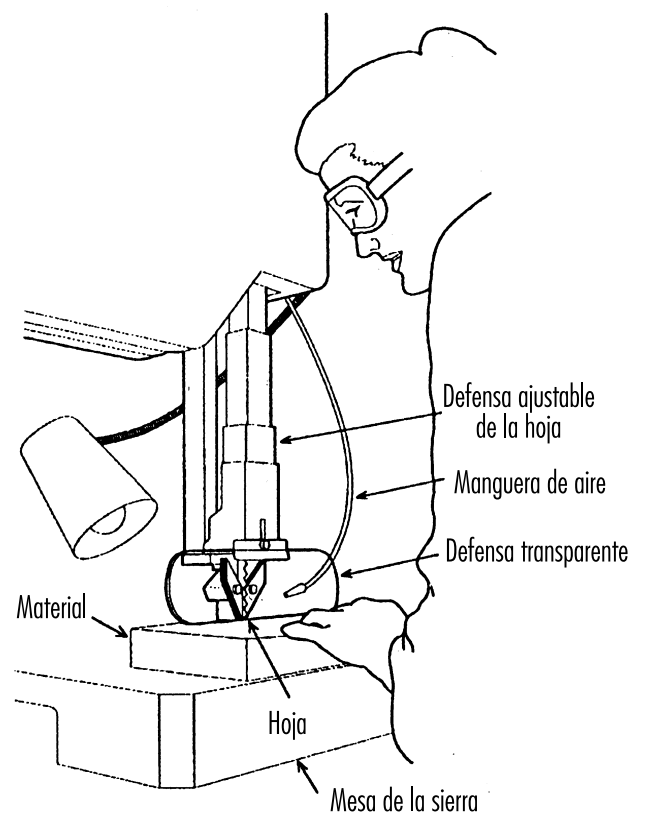

operador llegue a la zona de peligro. En la Figura 58.29 se muestra un detector fotoeléctrico de presencia utilizado en un plegadora. El dispositivo se puede girar hacia arriba o hacia abajo, según las necesidades de producción.

El detector de presencia por radiofrecuencia (capacitancia) utiliza un haz radioeléctrico que forma parte del circuito de control. Cuando se interrumpe el campo de capacitancia, la máquina se detiene y no puede activarse. Sólo debe usarse este dispositivo en máquinas que puedan detenerse antes de que el operador llegue a la zona de peligro, lo que supone que la máquina ha de tener un embrague de fricción u otro medio de parada fiable. En la Figura 58.30 se muestra un detector de presencia de radiofrecuencia montado en una prensa mecánica de rotación parcial.

El detector electromecánico tiene una sonda o barra de contacto que desciende una distancia predeterminada cuando el operador inicia el ciclo de la máquina. Si hay alguna

Figura 58.28 - Defensa autoajustable en una sierra de brazo radial.

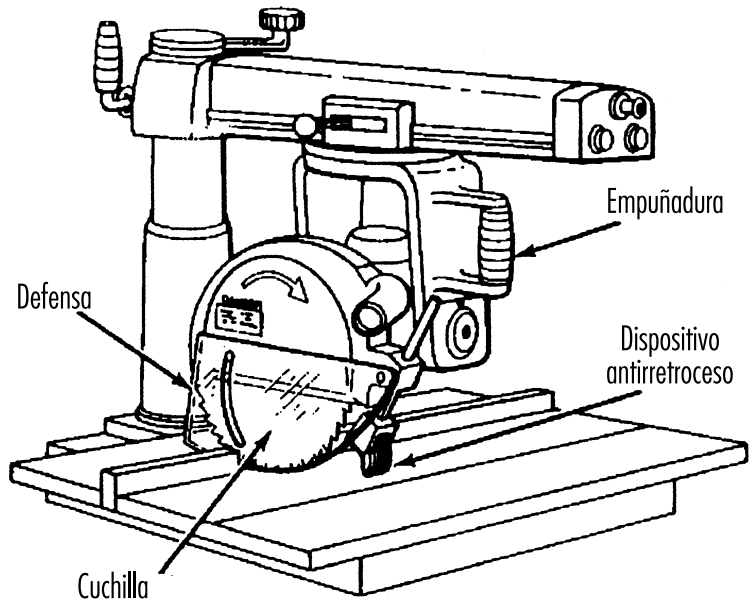


Figura 58.29 - Dispositivo fotoeléctrico de detección de presencia en una plegadora.

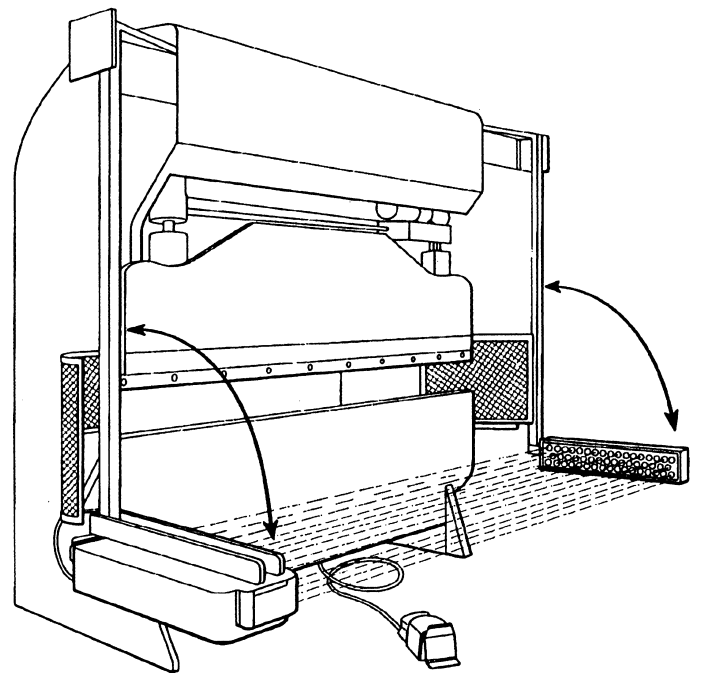

obstrucción que impide su carrera completa de descenso, el circuito de control no activa el ciclo de la máquina. En la Figura 58.31 se muestra un detector electromecánico en una máquina sacabocados. También se muestra la sonda detectora en contacto con el dedo del operador.

\section{Dispositivos de retirada}

U tilizan una serie de cables unidos a las manos, muñecas y/o brazos del operador y se usan sobre todo en máquinas que realizan carreras. Cuando el elemento deslizante o vástago está arriba, el operador tiene acceso al punto de operación. Cuando el elemento deslizante o vástago comienza a descender, un varillaje mecánico asegura la retirada automática de las manos del punto de operación. En la Figura 58.32 se muestra un dispositivo de retirada en una pequeña prensa.

\section{Figura 58.30 - Dispositivo detector de presencia por radiofrecuencia en una prensa mecánica de rotación parcial.}

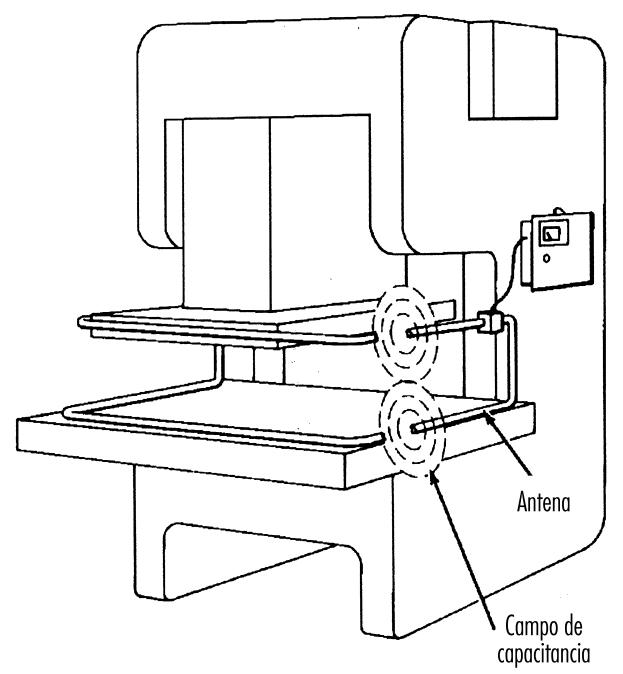

Figura 58.31 - Dispositivo detector electromecánico en una máquina sacabocados.

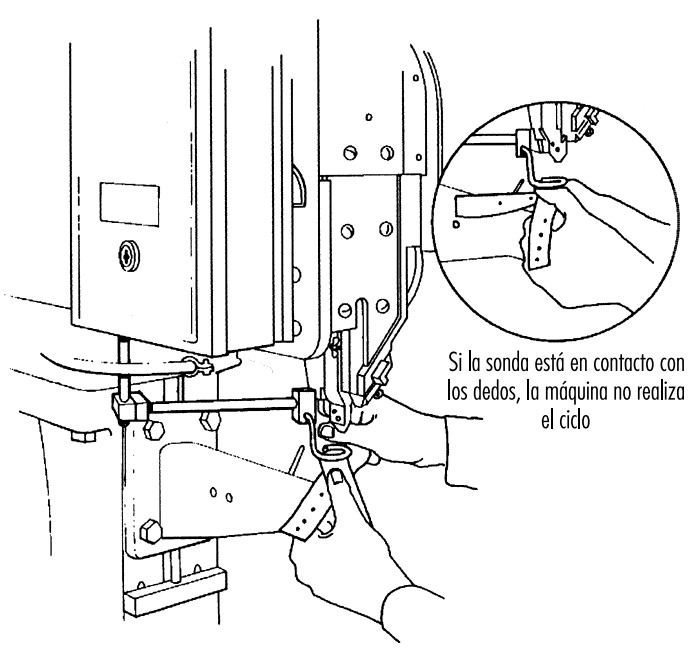

\section{Dispositivos limitadores}

En algunos países se han empleado dispositivos limitadores que utilizan cables o correas que unen un punto fijo con las manos del operador. En general, se considera que estos dispositivos no ofrecen protección suficiente, ya que el operador puede prescindir fácilmente de ellos y colocar las manos en la zona de peligro (véase la Tabla 58.3).

\section{Dispositivos de control de seguridad}

Todos estos dispositivos de control de seguridad se activan manualmente y tienen que rearmarse manualmente para volver a poner en marcha la máquina.

\section{Figura 58.32 • Dispositivo de retirada en una prensa} mecánica.

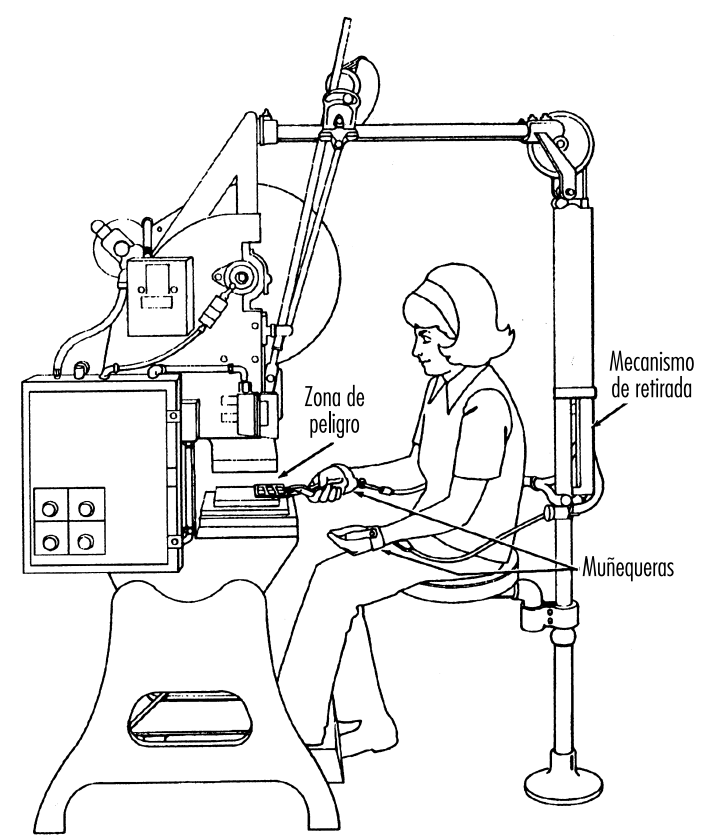


Tabla 58.3 - Dispositivos.

\begin{tabular}{|c|c|c|c|}
\hline Método & Acción de protección & Ventajas & Limitaciones \\
\hline Fotoeléctrico (óptico) & $\begin{array}{l}\text { - La máquina no iniciará el ciclo si se } \\
\text { interrumpe el campo luminoso } \\
\text { - Cuando el campo luminoso es interrumpido } \\
\text { por cualquier parte del cuerpo del operador } \\
\text { durante el ciclo de la máquina, se activa } \\
\text { inmediatamente el proceso de frenado de la } \\
\text { máquina }\end{array}$ & $\begin{array}{l}\text { - Permite mayor libertad de movimientos al } \\
\text { operador }\end{array}$ & $\begin{array}{l}\text { - No protege contra fallos mecánicos } \\
\text { - Puede requerir ajuste y calibración frecuentes } \\
\text { - Un exceso de vibraciones puede dañar } \\
\text { el filamento de la lámpara y el fallo } \\
\text { prematuro de ésta } \\
\text { - Limitado a máquinas que se pueden parar } \\
\text { sin terminar el ciclo }\end{array}$ \\
\hline $\begin{array}{r}\text { Radiofrecuencia } \\
\text { (capacitancia) }\end{array}$ & $\begin{array}{l}\text { - El ciclo de la máquina no comienza si se } \\
\text { interrumpe el campo de capacitancia } \\
\text { - Si el campo de capacitancia es perturbado } \\
\text { por cualquier parte del cuerpo del operador } \\
\text { durante el ciclo de funcionamiento, se activa } \\
\text { inmediatamente el frenado de la máquina }\end{array}$ & $\begin{array}{l}\text { - Permite mayor libertad de movimientos al } \\
\text { operador }\end{array}$ & $\begin{array}{l}\text { - No protege contra fallos mecánicos } \\
\text { - La sensibilidad de la antena se tiene que } \\
\text { ajustar correctamente } \\
\text { - Limitado a máquinas que se pueden parar } \\
\text { sin terminar el ciclo }\end{array}$ \\
\hline Electromecánico & $\begin{array}{l}\text { - Barra de contacto o sonda que recorre una } \\
\text { distancia determinada entre el operador y la } \\
\text { zona de peligro } \\
\text { - La interrupción de este movimiento impide } \\
\text { el comienzo del ciclo de la máquina }\end{array}$ & $\begin{array}{l}\text { - Puede permitir el acceso al punto de } \\
\text { operación }\end{array}$ & $\begin{array}{l}\text { - La barra de contacto o sonda se tiene que } \\
\text { ajustar correctamente para cada aplicación } \\
\text { y este ajuste se tiene que mantener } \\
\text { correctamente }\end{array}$ \\
\hline Retroceso o retirada & $\begin{array}{l}\text { - Al comenzar la máquina el ciclo, las manos } \\
\text { del operador son retiradas de la zona de } \\
\text { peligro }\end{array}$ & $\begin{array}{l}\text { - Elimina la necesidad de barreras auxiliares u } \\
\text { otras interferencias en la zona de peligro }\end{array}$ & $\begin{array}{l}\text { - Limita los movimientos del operador } \\
\text { - Puede obstruir el espacio de trabajo } \\
\text { alrededor del operador } \\
\text { - Requiere ajustes para operaciones espećificas } \\
\text { y para cada individuo } \\
\text { - Requiere inspecciones frecuentes y } \\
\text { mantenimiento periódico } \\
\text { - Requiere estrecha vigilancia del uso del } \\
\text { equipo por el operador }\end{array}$ \\
\hline $\begin{array}{l}\text { Controles de disparo } \\
\text { de seguridad: } \\
\text { - Barra para el cuerpo } \\
\text { sensible a la presión } \\
\text { - Varilla de disparo de } \\
\text { seguridad } \\
\text { - Cable de disparo de } \\
\text { seguridad }\end{array}$ & - Para la máquina cuando es disparado & - Sencillez de uso & $\begin{array}{l}\text { - Todos los controles se tienen que activar } \\
\text { manualmente } \\
\text { - Puede ser difícil activar los controles debido } \\
\text { a su ubicación } \\
\text { - Protege sólo al operador } \\
\text { - Puede requerir aparatos especiales para } \\
\text { sujjetar la pieza (utillajes, fijaciones) } \\
\text { - Puede requerir un freno en la máquina }\end{array}$ \\
\hline Control de dos manos & $\begin{array}{l}\text { - Se requiere el uso simultáneo de las dos } \\
\text { manos, impidiendo al operador acceder a la } \\
\text { zona de peligro }\end{array}$ & $\begin{array}{l}\text { - Las manos del operador están en un lugar } \\
\text { predeterminado fuera de la zona de peligro } \\
\text { - Las manos del operador quedan libres para } \\
\text { coger una nueva pieza después de completar } \\
\text { la primera mitad del ciclo }\end{array}$ & $\begin{array}{l}\text { - Requiere una máquina de ciclo parcial con } \\
\text { un freno } \\
\text { - Algunos controles de dos manos pueden } \\
\text { hacerse inseguros sujetando con el brazo } \\
\text { o bloqueando y permitiendo aś́ el } \\
\text { funcionamiento con una mano } \\
\text { - Protege sólo al operador }\end{array}$ \\
\hline $\begin{array}{l}\text { Disparo con las dos } \\
\text { manos }\end{array}$ & $\begin{array}{l}\text { - El uso simultáneo de las dos manos en } \\
\text { controles separados impide que las manos } \\
\text { se encuentren en la zona de peligro cuando } \\
\text { comienza el ciclo de la máquina }\end{array}$ & $\begin{array}{l}\text { - Las manos del operador están fuera de la } \\
\text { zona de peligro } \\
\text { - Se puede adaptar a múltiples operaciones } \\
\text { - No hay obstrucción a la alimentación manual } \\
\text { - No requiere ajustes para cada operación }\end{array}$ & $\begin{array}{l}\text { - El operador puede intentar acceder a la zona } \\
\text { de peligro después de disparar la máquina } \\
\text { - algunos disparos se pueden hacer inseguros } \\
\text { por sujeción con el brazo o bloqueo, permi- } \\
\text { tiendo así el funcionamiento con una mano } \\
\text { - Protege sólo al operador } \\
\text { - Puede requerir aparatos especiales (utillajes, } \\
\text { fijaciones) }\end{array}$ \\
\hline Compuerta & $\begin{array}{l}\text { - Proporciona una barrera entre la zona de } \\
\text { peligro y el operador u otras personas }\end{array}$ & $\begin{array}{l}\text { - Puede impedir la entrada en la zona de } \\
\text { peligro }\end{array}$ & $\begin{array}{l}\text { - Puede requerir inspecciones frecuentes y } \\
\text { mantenimiento periódico } \\
\text { - Puede interferir con la capacidad del } \\
\text { operador para ver el trabajo }\end{array}$ \\
\hline
\end{tabular}


Figura 58.33 - Barra para el cuerpo sensible a la presión en un molino de goma.

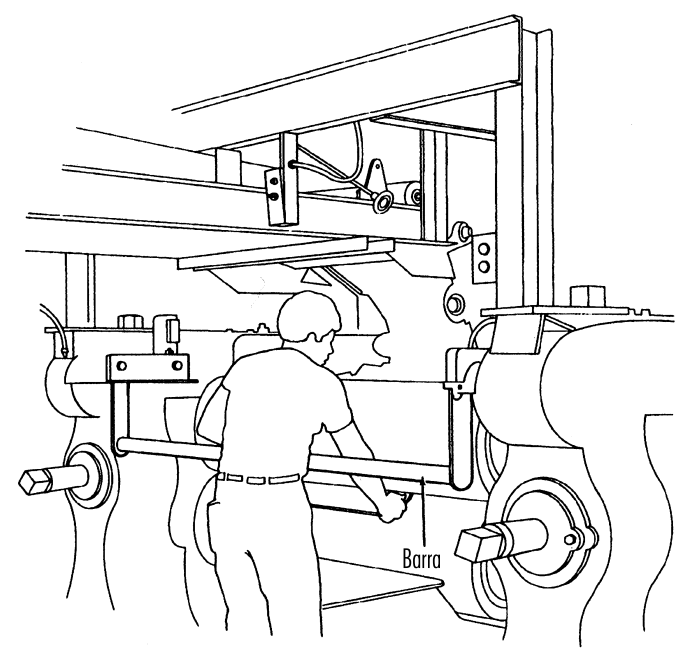

- Controles de disparo de seguridad: son controles manuales, como barras de presión, varillas de disparo y cables de disparo, que proporcionan un medio rápido de desactivar la máquina en caso de emergencia.

- Barras corporales sensibles a la presión: cuando se presionan desactivan la máquina si el operador o alguien tropieza, pierde el equilibrio o es arrastrado hacia la máquina. La posición de la barra es fundamental, ya que tiene que parar la máquina antes de que una parte del cuerpo llegue a la zona de peligro. En la Figura 58.33 se muestra una barra corporal sensible a la presión situada en la parte delantera de un molino de goma.

- D ispositivos de varilla de disparo de seguridad: desactivan la máquina cuando se presionan con la mano. Puesto que tienen que ser accionados por el operador en una situación de emergencia, su correcta colocación es fundamental. En la Figura 58.34 se muestra la varilla de disparo situada encima de un molino de goma.

- Cables de disparo de seguridad: se sitúan alrededor del perímetro o cerca de la zona de peligro. El operador tiene que alcanzar el cable con cualquiera de las manos para parar la máquina. En

Figura 58.34 - Varilla de disparo de seguridad en un molino de goma.

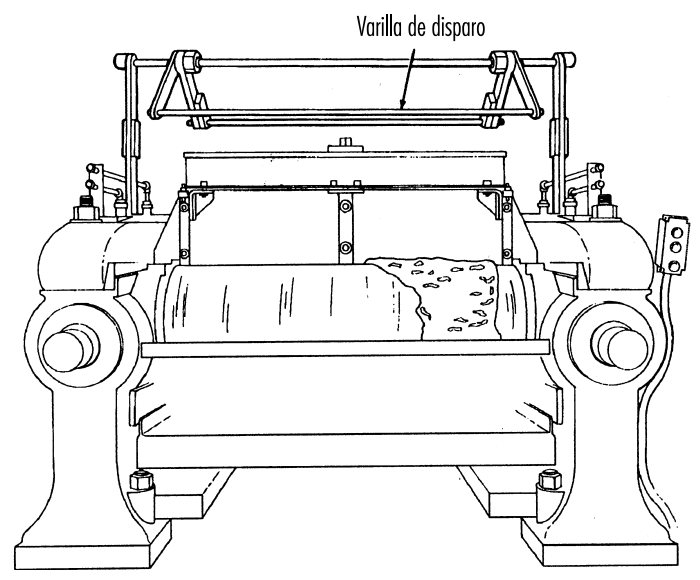

Figura 58.35 - Cable de disparo de seguridad en una calandria.

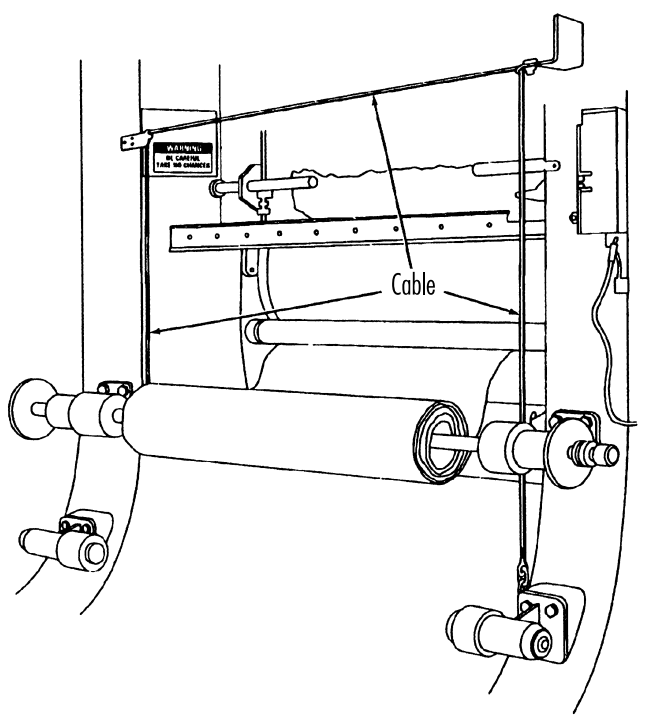

la Figura 58.35 se muestra una calandria equipada con este tipo de control.

- Controles con dos manos: requieren una presión constante y simultánea con ambas manos para que se active la máquina. Cuando se instalan en prensas mecánicas, utilizan un embrague de rotación parcial y un monitor de frenado, como se muestra en la Figura 58.36. Con este tipo de dispositivo, las

Figura 58.36 - Botones de control para las dos manos en una prensa con embrague de rotación parcial.

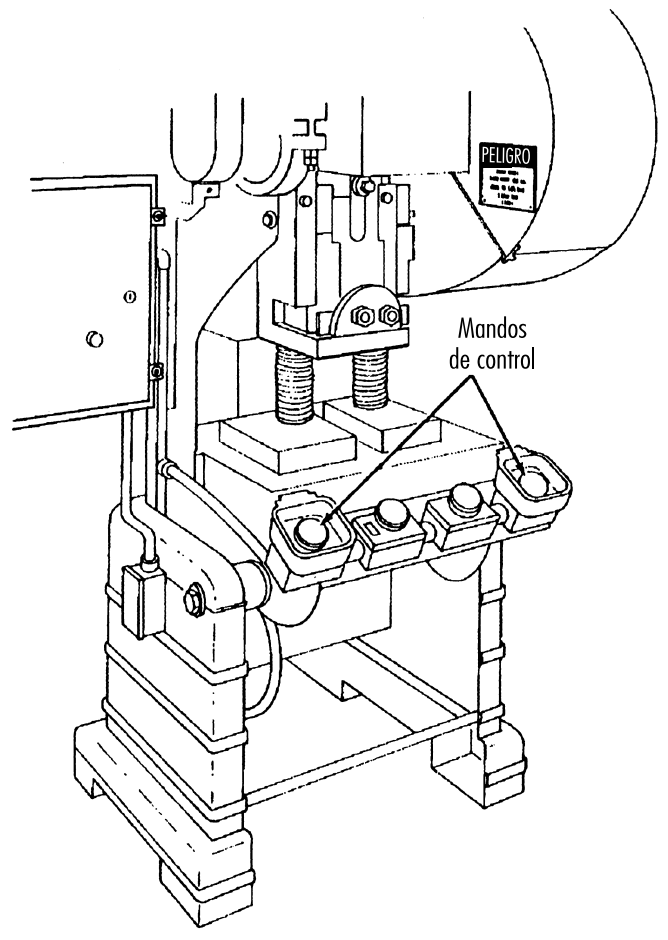


Figura 58.37 - Botones de control para las dos manos en una prensa con embrague de rotación completa.

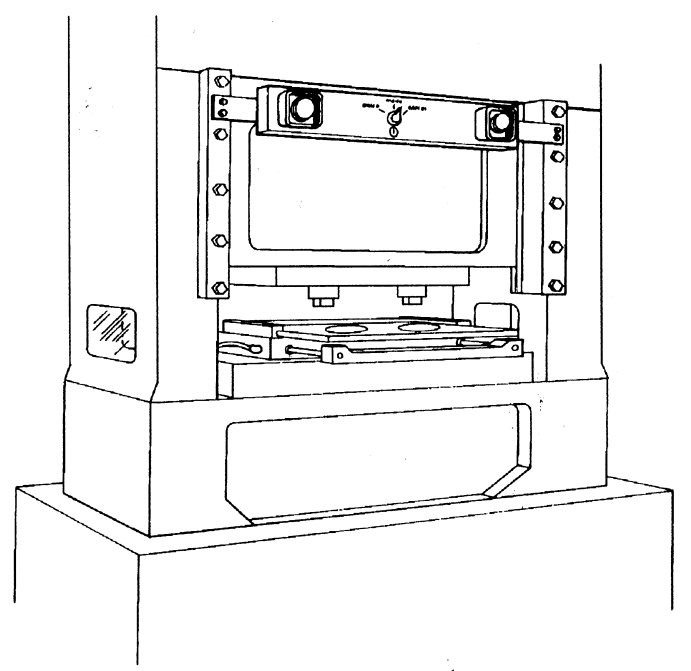

manos del operador permanecen en un lugar seguro (en los botones de control) y a una distancia segura de la zona de peligro mientras la máquina termina su ciclo final.

- Disparo con las dos manos. El disparo con las dos manos que se muestra en la Figura 58.37 se usa normalmente en máquinas equipadas con embragues de rotación completa. Requiere la aplicación simultánea de los dos botones de control por el operador para activar el ciclo de la máquina, tras lo cual las manos quedan libres. L os disparos tienen que hacerse suficientemente alejados del punto de operación para que resulte imposible que el operador pase las manos de los botones 0

Figura 58.38 - Prensa mecánica con compuerta.

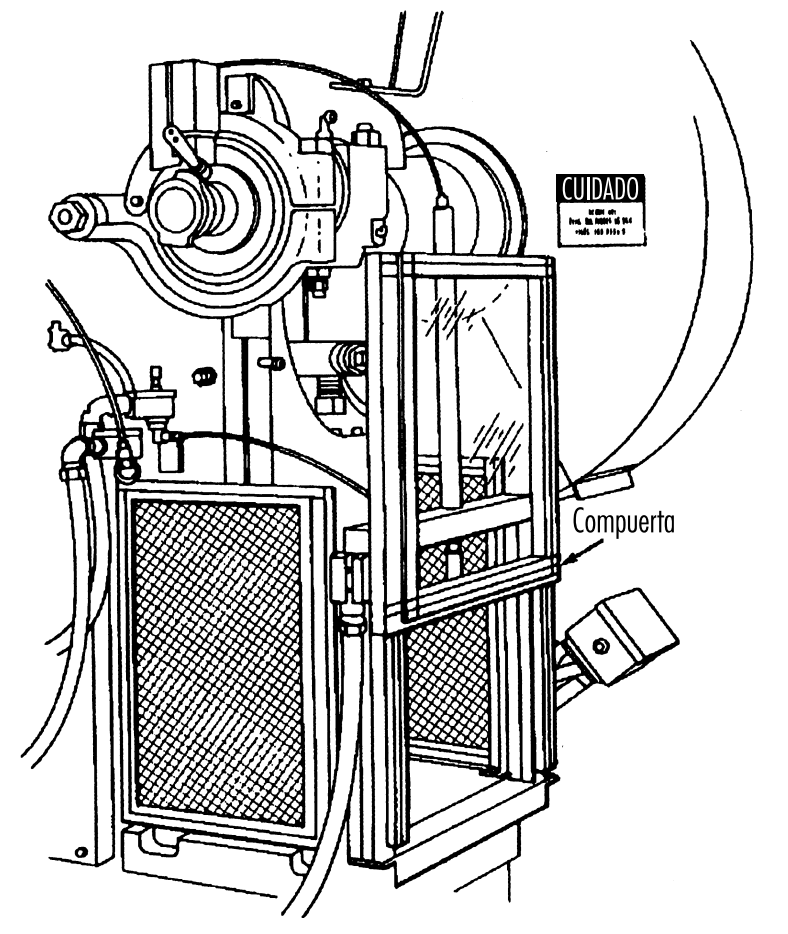

palancas de disparo al punto de operación antes de que se termine la primera mitad del ciclo. Las manos del operador se mantienen suficientemente lejos para evitar que se pongan de manera accidental en la zona de peligro antes de que el vástago o cuchilla baje hasta la posición inferior.

- Compuertas: son dispositivos de control de seguridad que proporcionan una barrera móvil que protege al operador en el punto de operación antes de que se pueda iniciar el ciclo de la máquina. Suelen estar diseñadas para ser utilizadas con cada ciclo de la máquina. En la Figura 58.38 se muestra una compuerta en una prensa mecánica. Si no se permite que la compuerta descienda hasta cerrar por completo, la prensa no funciona. 0 tra aplicación de las compuertas es utilizarlas como sistema de protección perimetral, en cuyo caso proporcionan protección a los operadores y los transeúntes.

\section{Protección por posición o distancia}

Para proteger una máquina por posición, la máquina o sus partes móviles peligrosas deben situarse de manera que no sean accesibles y no representen un peligro para el operador durante el funcionamiento normal de la máquina. Para ello, se utilizan encerramientos 0 vallas que limiten el acceso a las máquinas o se sitúan de manera que una parte de la instalación, (por ejemplo, una pared) proteja al trabajador y a otras personas. 0 tra posibilidad es situar los elementos peligrosos a suficiente altura para que estén fuera del alcance normal de cualquier trabajador. La aplicación de esta técnica de protección precisa de un análisis previo detallado de los peligros de cada máquina y su situación concreta. L os ejemplos que se mencionan a continuación son sólo unas cuantas de las numerosas aplicaciones del principio de protección por posición/ distancia.

Proceso de alimentación. Es posible protegerlo por medio de la posición, manteniendo una distancia segura que proteja las manos del trabajador. Las dimensiones del material que se va a trabajar pueden proporcionar una seguridad adecuada. Por ejemplo, cuando se maneja una máquina perforadora de un solo

Figura 58.39 • Prensa mecánica con alimentación automática.

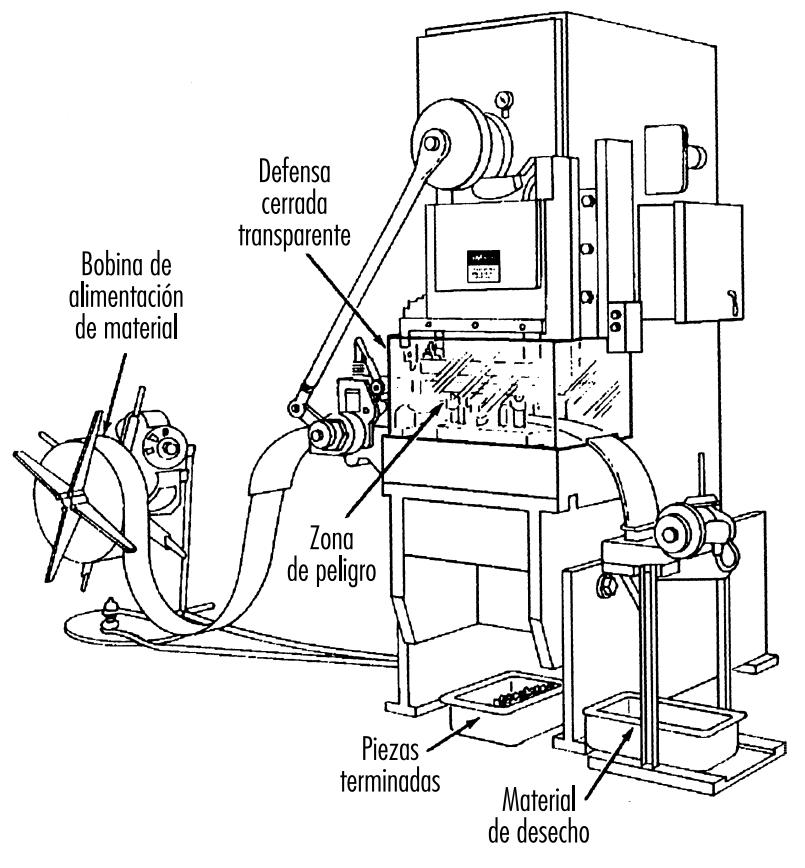


Tabla 58.4 • Métodos de alimentación y expulsión

\begin{tabular}{|c|c|c|c|}
\hline Método & Acción de protección & Ventajas & Limitaciones \\
\hline $\begin{array}{l}\text { Alimentación } \\
\text { automática }\end{array}$ & $\begin{array}{l}\text { - El material se alimenta desde bobinas, } \\
\text { clasificado por mecanismos de la } \\
\text { máquina, etc. }\end{array}$ & $\begin{array}{l}\text { - Elimina la necesidad de intervención del } \\
\text { operador en la zona de peligro }\end{array}$ & $\begin{array}{l}\text { - Se necesitan también otras defensas para } \\
\text { protección del operador, normalmente } \\
\text { barreras fijas } \\
\text { - Requiere mantenimiento frecuente } \\
\text { - Puede no ser adaptable a variaciones en el } \\
\text { material }\end{array}$ \\
\hline $\begin{array}{l}\text { Alimentación } \\
\text { semiautomática }\end{array}$ & $\begin{array}{l}\text { - El material se alimenta mediante tolvas, } \\
\text { troqueles móviles, discos de alimentación, } \\
\text { émbolos o cabezales deslizantes }\end{array}$ & $\begin{array}{l}\text { - Elimina la necesidad de intervención del } \\
\text { operador en la zona de peligro }\end{array}$ & $\begin{array}{l}\text { - Se necesitan también otras defensas para } \\
\text { protección del operador, normalmente } \\
\text { barreras fijas } \\
\text { - Requiere mantenimiento frecuente } \\
\text { - Puede no ser adaptable a variaciones en el } \\
\text { material }\end{array}$ \\
\hline $\begin{array}{l}\text { Expulsión } \\
\text { automática }\end{array}$ & $\begin{array}{l}\text { - Las piezas de trabajo se expulsan mediante } \\
\text { medios mecánicos o neumáticos }\end{array}$ & $\begin{array}{l}\text { - Elimina la necesidad de intervención del } \\
\text { operador en la zona de peligro }\end{array}$ & $\begin{array}{l}\text { - Puede crear un peligro por soplado de virutas o } \\
\text { residuos } \\
\text { - El tamaño del material limita el uso de este } \\
\text { método } \\
\text { - La expulsión por aire puede plantear un peligro } \\
\text { de ruido }\end{array}$ \\
\hline $\begin{array}{l}\text { Expulsión } \\
\text { semiautomática }\end{array}$ & $\begin{array}{l}\text { - Las piezas de trabajo se expulsan por } \\
\text { medios mecánicos iniciados por el operador }\end{array}$ & $\begin{array}{l}\text { - El operador no tiene que acceder a la zona } \\
\text { de peligro para retirar las piezas terminadas }\end{array}$ & $\begin{array}{l}\text { - Se necesitan otras defensas para la protección } \\
\text { del operador } \\
\text { - Puede no ser adaptable a variaciones en el } \\
\text { material }\end{array}$ \\
\hline Robots & $\begin{array}{l}\text { - Realizan trabajos hechos normalmente por } \\
\text { operadores }\end{array}$ & $\begin{array}{l}\text { - El operador no tiene que entrar en la zona } \\
\text { de peligro } \\
\text { - Son adecuados para operaciones en las que } \\
\text { hay importantes factores de estrés, como } \\
\text { calor y ruido }\end{array}$ & $\begin{array}{l}\text { - Pueden crear otros peligros propios } \\
\text { - Requieren el máximo mantenimiento } \\
\text { - Sólo son adecuados para operaciones específicas }\end{array}$ \\
\hline
\end{tabular}

extremo, si el material tiene varios centímetros o decímetros de longitud y únicamente se trabaja en un extremo, el operador puede sujetar el extremo opuesto mientras se realiza el trabajo. Ahora bien, tal vez sea necesaria la protección para otras personas, según la máquina en cuestión.

Controles de posición. La situación de los controles del operador es un posible planteamiento de la protección por posición. LoS controles del operador pueden situarse a una distancia segura de la máquina si no hay ninguna razón para que el operador esté junto a la máquina.

\section{M étodos de protección de la alimentación y la expulsión}

M uchos métodos de alimentación y expulsión no requieren que los operadores coloquen las manos en la zona de peligro. En algunos casos, una vez preparada la máquina, el operario no interviene, mientras que en otros ha de alimentar manualmente el material con la ayuda de un mecanismo de alimentación. Además, los métodos de expulsión pueden diseñarse para que el operador no tenga que intervenir tras poner en marcha la máquina. Algunos métodos de alimentación y expulsión entrañan peligros por sí mismos: por ejemplo, un robot que haga innecesario que un operador esté cerca de la máquina, pero cree un nuevo peligro por el movimiento de su brazo (véase la Tabla 58.4).

El uso de uno de los cinco métodos siguientes de alimentación y expulsión para proteger las máquinas no elimina la necesidad de defensas y otros dispositivos que deben usarse en la medida necesaria para evitar la exposición a riesgos.

Alimentación automática. La alimentación automática reduce la exposición del operador durante el proceso de trabajo y por lo común no precisa esfuerzo alguno por parte del operador después de preparar la máquina y ponerla en funcionamiento. La prensa mecánica de la Figura 58.39 tiene un mecanismo automático de alimentación con una defensa transparente colocada en la zona de peligro.

Alimentación semiautomática. Con la alimentación semiautomática, como es el caso de una prensa mecánica, el operador utiliza un mecanismo para colocar la pieza bajo el vástago en cada carrera, con lo que no entra en contacto con la zona de peligro, que se halla totalmente cerrada. En la Figura 58.40 se muestra una alimentación por rampa en la que cada pieza se coloca a mano. El uso de este tipo de alimentación por caída inclinada en una prensa no sólo ayuda a centrar la pieza mientas ésta se desplaza en el troquel, sino que además simplifica el problema de la expulsión.

Expulsión automática. Para retirar la pieza terminada de una prensa, que se enclava con los controles a fin de evitar el funcionamiento antes de que termine la expulsión, se utiliza aire comprimido 0 un aparato mecánico. El mecanismo de desplazamiento de la bandeja que se muestra en la Figura 58.41 se mueve bajo la pieza terminada mientras la resbaladera asciende a la posición superior. El mecanismo recoge entonces la pieza separada de la resbaladera por los pasadores de expulsión y la envía a una rampa. Cuando el vástago desciende hacia el 
Figura 58.40 - Prensa mecánica con alimentación por rampa.

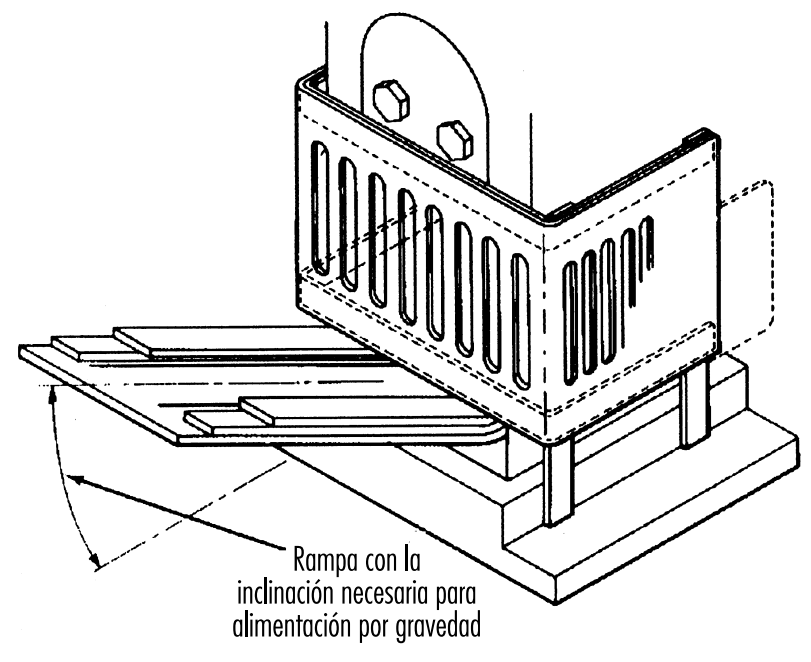

siguiente objetivo, la lanzadera de bandeja se retira de la zona del troquel.

Expulsión semiautomática. En la Figura 58.42 se muestra un mecanismo semiautomático de expulsión utilizado en una prensa mecánica. Cuando se retira el émbolo de la zona del troquel, la pata del eyector mecánicamente acoplada al émbolo, empuja hacia afuera la pieza terminada

Robots. Son dispositivos complejos que cargan y descargan material, montan piezas, transfieren objetos o realizan trabajos que, de no ser así, tendría que hacerlos un operador, con lo cual éste no ha de correr riesgos. Se adaptan mejor a procesos de grandes volúmenes de producción con rutinas repetidas, donde protegen a los empleados de otros peligros. Los robots generan sus propios peligros, por lo que precisan las defensas adecuadas. En la Figura 58.43 se muestra a un robot alimentando una prensa.

\section{Otras ayudas de protección}

Se trata de ayudas que, sin proporcionar una protección completa frente a los peligros de las máquinas, ofrecen a los operadores un margen de seguridad adicional. Para su aplicación y uso es necesario utilizar el sentido común.

Barreras de sensibilización. No proporcionan protección física, pero sirven para recordar a los operadores que se están acercando a una zona de peligro. En general, estas barreras no se

Figura 58.41 • Sistema de expulsión por lanzadera.
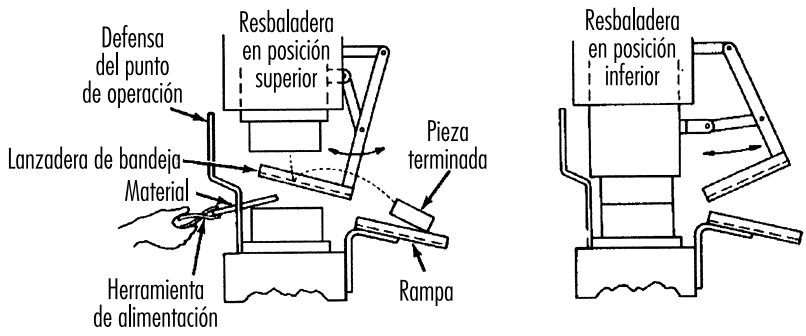

Figura 58.42 - Mecanismo semiautomático de expulsión.
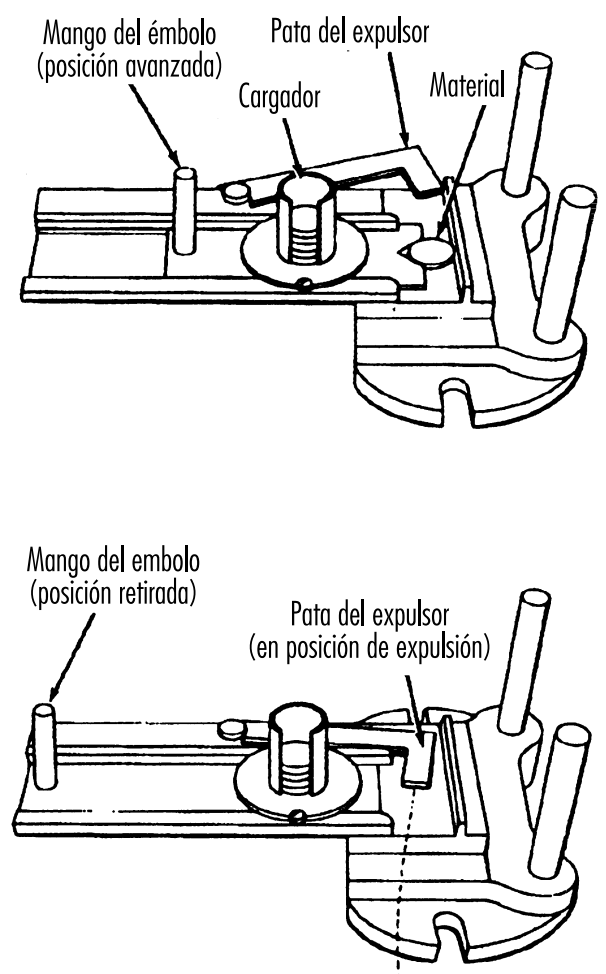

(2)

Figura 58.43 - Uso de barreras para proteger el recorrido del robot.

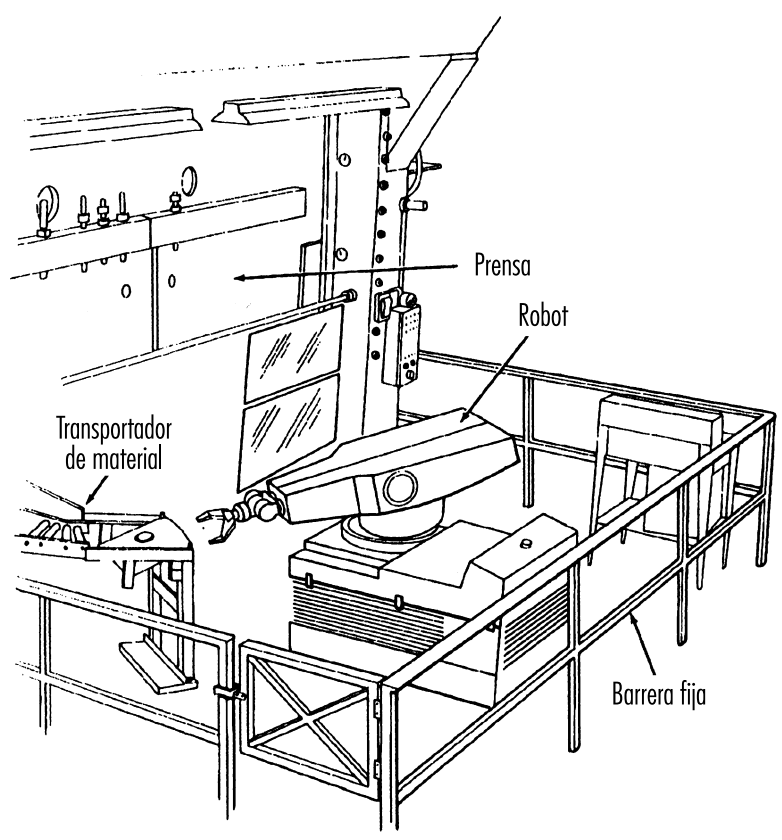


Figura 58.44 - Vista posterior de una cizalla.

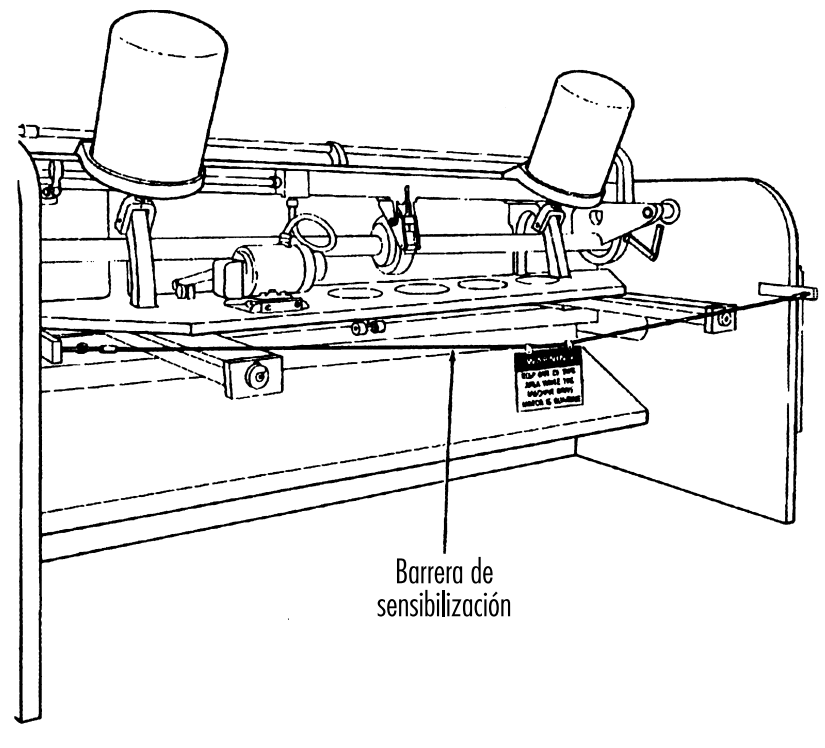

consideran adecuadas cuando hay una exposición continua al peligro. En la Figura 58.44 se muestra una cuerda utilizada como barrera de sensibilización en la parte trasera de una cizalla. Las barreras de este tipo no impiden físicamente a las personas el acceso a zonas de peligro; simplemente sirven de advertencia.

E scudos. Los escudos o pantallas se utilizan como protección contra partículas proyectadas y salpicaduras de refrigerantes 0 líquidos de corte empleados en el trabajo de metales. En la Figura 58.45 se muestran dos posibles aplicaciones.

$\mathrm{H}$ erramientas de sujeción. Sirven para colocar y retirar piezas. Es común encontrarlas en el acceso a una prensa o plegadora. En la Figura 58.46 se muestran diversas herramientas para este fin. Las herramientas de sujeción no deben utilizarse en lugar de otras protecciones de las máquinas, ya que aquéllas son un mero suplemento de la función de éstas.

Varillas o bloques de empuje. Tal como se ilustra en la Figura 58.47 , se utilizan para introducir material en un máquina, como una sierra de cuchilla. Cuando las manos se acercan a la cuchilla, la varilla o taco de empuje ofrece un margen de seguridad y evita lesiones.

Figura 58.45 - Aplicaciones de los escudos.
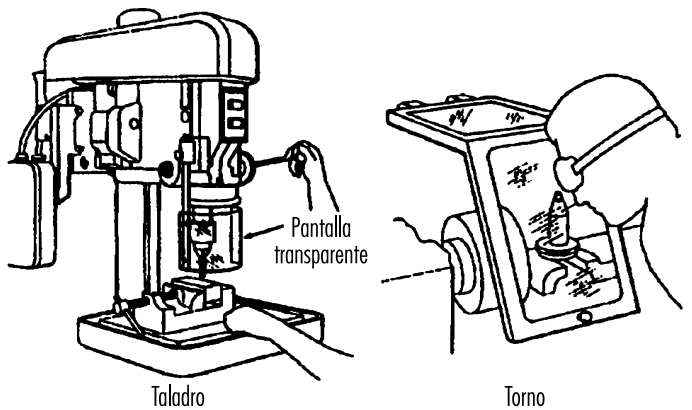

Torno
Figura 58.46 • Herramientas de sujeción.
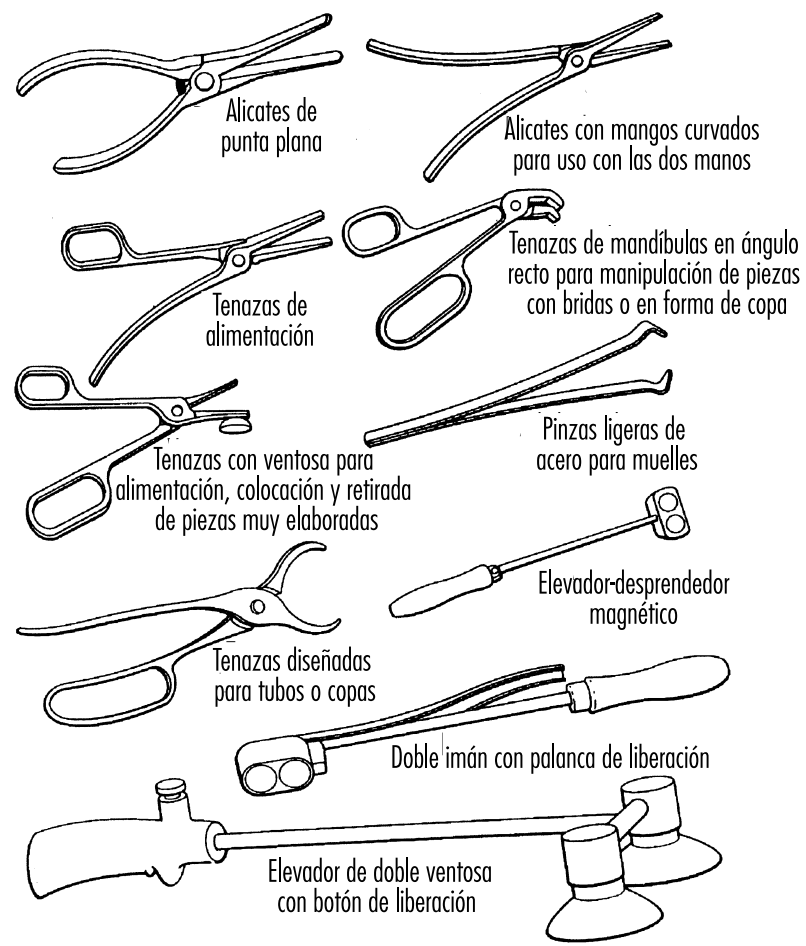

Figura 58.47 - Uso de varilla o bloque de empuje.

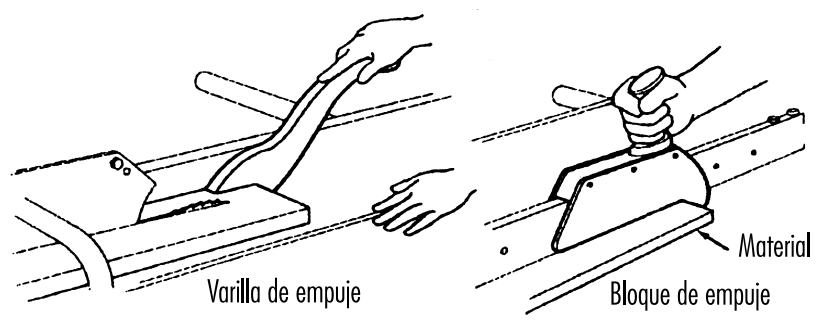

DETECTORES DE PRESENCIA

Paul Schreiber

L os avances generales logrados en microelectrónica y tecnología de sensores fundamentan la esperanza de que pueda mejorarse la seguridad en el trabajo gracias a la disponibilidad de detectores de presencia y aproximación fiables, resistentes, baratos y que apenas requieren mantenimiento. En este artículo se describe la tecnología de los sensores, los distintos procedimientos de detección, las condiciones y limitaciones aplicables al uso de sistemas de sensores y algunos estudios y trabajos de normalización realizados en Alemania.

\section{Criterios para los detectores de presencia}

El desarrollo y las pruebas prácticas de los detectores de presencia son uno de los mayores retos a los que habrán de responder los esfuerzos técnicos para mejorar la seguridad en el trabajo y la protección del personal en general. Los detectores de 
presencia son sensores que indican con fiabilidad y certidumbre la presencia cercana 0 aproximación de una persona. Además, este aviso tiene que producirse rápidamente para poder aplicar una acción evasiva, como el frenado o la parada de un máquina estacionaria, antes de que se produzca el contacto previsto. La estatura, la postura y la vestimenta de la persona no deben afectar a la fiabilidad del sensor, cuyo funcionamiento debe ser certero. Por otra parte, debe ser resistente y barato para poder utilizarlo en las condiciones más difíciles, como en obras y aplicaciones móviles, con un mantenimiento mínimo. Los sensores tienen que ser como un airbag, que no precisa mantenimiento y está siempre dispuesto. Dado que algunos usuarios son reacios a mantener un equipo que no consideran esencial, los sensores pueden estar sin servicio durante años. 0 tra característica de los detectores de presencia (probablemente, mucho más solicitada) es que puedan detectar otros obstáculos además de las personas y que avisen con tiempo al operador para que adopte medidas defensivas, reduciendo así los costes de reparaciones y daños materiales. Es una razón para instalar detectores de presencia que no conviene subestimar.

\section{Aplicaciones de los detectores}

Innumerables accidentes mortales y lesiones graves que parecen inevitables se podrían evitar o minimizar si los detectores de presencia gozaran de mayor aceptación como medidas preventivas en el campo de la seguridad en el trabajo. Es un tipo de accidente que suele ocupar con demasiada frecuencia las páginas de los periódicos: una persona alcanzada por el retroceso de una cargadora, un operador que no vio que las ruedas delanteras de una pala mecánica le pasaban por encima a alguien. Los camiones que se desplazan marcha atrás en calles, locales de empresas y obras causan muchos accidentes. Actualmente, en las empresas totalmente racionalizadas los conductores $u$ otras personas ya no cuentan con acompañantes que guíen al conductor al retroceder con el camión. Se trata de accidentes producidos en situaciones de movimiento, que se extienden con facilidad a otros equipos móviles, como carretillas elevadoras. Desde luego, en el caso de equipos semimóviles o estacionarios también es aconsejable la utilización de sensores para evitar accidentes. Un ejemplo son las zonas situadas detrás de las grandes máquinas de carga, identificadas desde el punto de vista de la seguridad personal como zonas de peligro potencial que se pueden paliar con el uso de sensores baratos. $Y$ existen otras muchas posibilidades innovadoras de utilización de los diferentes tipos de detectores de presencia existentes, adaptándolos a otros vehículos y grandes equipos móviles como protección contra los accidentes que se tratan en este artículo y que generalmente provocan daños materiales importantes y lesiones graves e incluso mortales.

Si ese tipo de soluciones innovadoras se generalizara, los detectores de presencia se convertirían en tecnología estándar de seguridad en otras aplicaciones, pero no ocurre así en todas partes. EI mayor avance en este sentido está previsto que se produzca, debido a los accidentes y a los grandes daños materiales, en la supervisión de la parte situada detrás de las furgonetas de reparto y los camiones pesados y en las áreas más innovadoras de las "nuevas tecnologías": los robots móviles del futuro.

La diversidad de los campos de aplicación de los detectores de presencia y las diferentes tareas que pueden cumplir (por ejemplo, tolerar objetos, incluso objetos móviles en determinadas condiciones, que pertenezcan a un campo de detección y que no deben emitir una señal), requieren sensores con una tecnología de evaluación "inteligente" que apoye los mecanismos de la función del sensor. Tal tecnología, que será objeto de desarrollo futuro, puede elaborarse a partir de métodos utilizados en el campo de la inteligencia artificial (Schreiber y K uhn 1995). H asta la fecha, la escasa generalización ha limitado mucho los usos actuales de los sensores. Hay cortinas de luz, barras de luz, alfombrillas de contacto, sensores pasivos de infrarrojos, detectores de movimiento por radar y ultrasonidos que se basan en el efecto Doppler, sensores que miden el tiempo transcurrido entre impulsos de ultrasonidos, radar y luz y escáneres de láser. Las cámaras normales de TV conectadas a monitores no se incluyen en esta lista porque no son detectores de presencia. A hora bien, las cámaras que se activan automáticamente al detectar la presencia de una persona sí están incluidas.

\section{Tecnología de los sensores}

Actualmente, los principales problemas de los sensores son: a) optimizar el uso de los efectos físicos (infrarrojos, luz, ultrasonidos, radar, etc.), y b) autosupervisión. Se están desarrollando intensamente escáneres de láser para utilizarlos como instrumentos de navegación para robots móviles. $\mathrm{H}$ ay que solucionar para ello dos tareas distintas en principio: el movimiento del robot y la protección de las personas (y materiales 0 equipos presentes) para que no sean golpeadas, atropelladas o agarradas (Freund, Dierks y Rossman 1993). Los futuros robots móviles no podrán conservar la misma filosofía de seguridad de "separación espacial de robot y persona" que se aplica estrictamente a los actuales robots industriales estacionarios, con lo que se asigna un importante papel al funcionamiento fiable de los detectores de presencia.

EI uso de "nuevas tecnologías" suele tener problemas de aceptación, por lo que es de prever que el uso generalizado por parte de las personas de robots móviles capaces de moverse y asir objetos, en una fábrica, en zonas abiertas al público o incluso en viviendas y zonas de recreo, sólo se aceptará si los robots van equipados con detectores de presencia de altoo desarrollo, sofisticados y fiables. Hay que evitar, ante todo, los accidentes espectaculares para no exacerbar el posible problema de aceptación. EI nivel actual de gastos para el desarrollo de este nuevo tipo de detectores de protección en el trabajo no es suficiente para tener en cuenta esta consideración. Para ahorrar costes, es necesario desarrollar y probar los detectores de presencia al mismo tiempo que los robots móviles y sistemas de navegación, y no después de ellos.

Respecto a los automóviles, los temas de seguridad han ido ganando importancia. Las innovaciones en materia de seguridad de los pasajeros incluyen: cinturones de seguridad con 3 puntos de anclaje, asientos para niños, airbags y sistema de frenos antibloqueo verificado mediante pruebas de choque en serie. Tales medidas de seguridad representan una parte cada vez mayor de los costes de producción. El airbag lateral y los sistemas de detección por radar para medir la distancia al vehículo precedente han supuesto un avance aún mayor en la protección de los pasajeros.

La seguridad externa de los automóviles, es decir, la protección de terceros, cada vez cobra mayor atención. No hace mucho se ha exigido la protección lateral, fundamentalmente en camiones, para evitar el riesgo de atropellar a motoristas, ciclistas y peatones con las ruedas traseras. El siguiente paso, lógicamente, sería supervisar la zona posterior a los grandes vehículos con detectores de presencia e instalar equipos de aviso en la zona posterior. Y ello supone otra ventaja: la de proporcionar la financiación necesaria para desarrollar, probar y fabricar sensores baratos de altas prestaciones, con autosupervisión, exentos de mantenimiento y con funcionamiento fiable, que podrían utilizarse para seguridad en el trabajo. EI proceso de pruebas que acompaña a la difusión de sensores o sistemas de sensores facilitaría considerablemente las innovaciones en otras áreas, como palas mecánicas, cargadoras pesadas y otras grandes máquinas que funcionan marcha atrás una gran parte 
del tiempo de trabajo. La evolución de los robots estacionarios a los móviles es una vía adicional para el desarrollo de detectores de presencia. Por ejemplo, pueden mejorarse los sensores utilizados actualmente en robots móviles, manipuladores de materiales o tractores de fábrica sin conductor que siguen trayectorias fijas y, por tanto, tienen requisitos de seguridad relativamente poco estrictos. El uso de detectores de presencia es el siguiente paso lógico para mejorar la seguridad en el campo del transporte de materiales y pasajeros.

\section{Procedimientos de detección}

Para evaluar y solucionar las tareas anteriormente mencionadas hay varios principios físicos relacionados con las medidas electrónicas y los métodos de autosupervisión y, en cierta medida, los procedimientos informáticos de altas prestaciones. El funcionamiento seguro y aparentemente sin esfuerzo de las máquinas automatizadas (robots), tan corriente en las películas de ciencia ficción, probablemente se logrará en el mundo real mediante técnicas de creación de imágenes y de algoritmos de reconocimiento de patrones de alto rendimiento, junto con métodos de medidas de distancias análogos a los utilizados por los escáneres de láser. Es necesario reconocer la paradójica situación de que todo lo que parece sencillo para las personas es difícil para los autómatas. Por ejemplo, una tarea difícil, como una buena partida de ajedrez (que requiere una gran actividad del lóbulo frontal del cerebro) se puede simular y realizar más fácilmente mediante máquinas automatizadas que una tarea tan sencilla como caminar erguido o realizar movimientos de manos/ ojos u otros movimientos coordinados (en los que intervienen los lóbulos centrales y posteriores). A continuación se describen algunos de estos principios, métodos y procedimientos válidos para aplicación de sensores. Además de estos, hay muchos procedimientos especiales para tareas específicas que se realizan en parte con una combinación de diversos tipos de efectos físicos.

Cortinas y barras de luz. Entre los primeros detectores de presencia estaban las barras y cortinas de luz. Poseen una geometría de supervisión plana: es decir, una vez que la persona pasa la barrera deja de ser detectada. La mano de un operador o la presencia de herramientas o piezas sostenidas por la mano de un operador, por ejemplo, los detectan con rapidez y fiabilidad estos dispositivos. Contribuyen en gran medida a la seguridad en el trabajo con máquinas (como prensas y máquinas perforadoras) que requieren la colocación del material a mano. La fiabilidad tiene que ser muy elevada estadísticamente porque la mano entra en la zona de peligro de dos a tres veces por minuto, lo que supone la realización de un millón de operaciones en unos pocos años. La autosupervisión de los componentes transmisores y receptores ha alcanzado tan altos niveles técnicos que se considera como una norma para todos los demás procedimientos de detección de presencia.

Alfombrillas de contacto (alfombrillas interruptoras). $\mathrm{H}$ ay alfombrillas y pisos de contacto eléctricos y neumáticos, pasivos o activos, utilizados en un principio masivamente para funciones de servicio (abridores de puertas), hasta que fueron sustituidos por detectores de movimiento. Con el uso de detectores de presencia en todo tipo de zonas de peligro se producen otros avances: por ejemplo, la evolución en la fabricación automatizada, en la que cambia la función del trabajador, que pasa de manejar la máquina a una mera supervisión de su funcionamiento, ha dado lugar a la demanda correspondiente de detectores adecuados. La normalización de su uso está muy avanzada (DIN 1995a) y las limitaciones especiales (disposición, tamaño, máximas zonas muertas permitidas) han exigido el desarrollo de conocimientos prácticos para la instalación en este campo de aplicación.

Los sistemas de robots múltiples controlados por ordenador llevan parejos otros posibles usos de interés. Un operador puede activar uno o dos elementos para que el detector de presencia determine su posición exacta e informe al ordenador, que gestiona los sistemas de control del robot con un sistema incorporado para evitar choques. En una prueba avanzada realizada por el instituto de seguridad alemán (BAU), se preparó un piso de alfombrillas de contacto formado por pequeñas alfombrillas de interruptores eléctricos debajo de la zona de trabajo del robot (Freund, Dierks y R ossman 1993). EI detector de presencia tenía forma de tablero de ajedrez. La alfombrilla activada indicaba al ordenador la posición del operador (Figura 58.48), de manera que el robot se retiraba cuando el operador se aproximaba demasiado. Sin el detector de presencia, el sistema del robot no habría sido capaz de determinar la posición del operador que, por tanto, no habría tenido protección.

R eflectores (sensores de movimiento y detectores de presencia). A pesar de los méritos a los que hemos hecho alusión, los sensores no son detectores de presencia en su sentido más amplio. Su adecuación, fundamentalmente por razones de seguridad en el trabajo, a grandes vehículos y grandes equipos móviles presupone dos importantes características: a) la capacidad de supervisar una zona desde una posición, y b) el funcionamiento sin errores que no requiere medidas adicionales, como por ejemplo, el uso de dispositivos reflectores. La detección de la presencia de una persona que entra en la zona supervisada y que permanece parada hasta que se marcha supone también la necesidad de detectar una persona que permanezca totalmente quieta. Existe, pues, la distinción entre los llamados sensores de movimiento y los detectores de presencia, al menos por lo que se refiere a equipos móviles; los sensores de movimiento casi siempre se disparan cuando el vehículo comienza a moverse.

Sensores de movimiento. Los dos tipos básicos de sensores de movimiento son: a) "sensores pasivos por infrarrojos" (PIRS), que reaccionan ante el más pequeño cambio del haz de rayos infrarrojos en la zona supervisada (el haz más pequeño detectable tiene aproximadamente $10^{-9} \mathrm{~W}$ con una longitud de onda comprendida entre 7 y $20 \mu \mathrm{m}$ ), y b) sensores de ultrasonidos y microondas que se basan en el efecto Doppler para determinar las características del movimiento de un objeto en función de los cambios de frecuencia. Por ejemplo, el efecto Doppler aumenta la frecuencia del silbato de una locomotora al aproximarse a un observador y la reduce al alejarse. El efecto Doppler hace posible la construcción de sensores de aproximación relativamente sencillos, ya que el receptor sólo tiene que supervisar la frecuencia de la señal de las bandas de frecuencia próximas para detectar la aparición de la frecuencia D oppler.

A mediados del decenio de 1970 se extendió el uso de detectores de movimiento en funciones de servicio, como apertura de puertas, seguridad contra robos y protección de objetos. Para uso estacionario, la detección de una persona que se aproxima hacia

Figura 58.48 - Una persona (a la derecha) y dos robots en cuerpos envolventes informatizados.

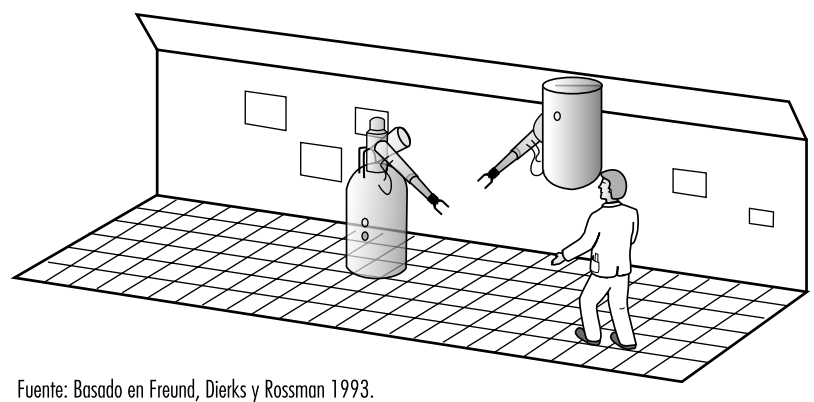

Fuente: Basado en Freund, Dierks y Rossman 1993 
Figura 58.49 - Detector pasivo por infrarrojos como detector de aproximación en una zona de peligro.
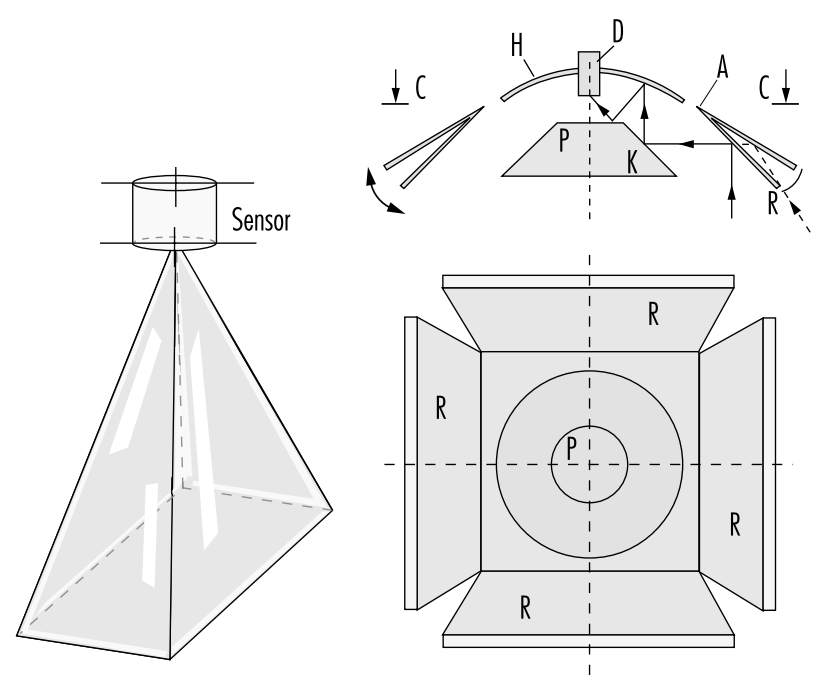

un punto de peligro resultaba adecuada para dar un aviso oportuno y parar una máquina. En ello se basaron los estudios de adecuación de detectores de movimiento para su utilización en el campo de la seguridad en el trabajo, especialmente por medio de PIR S (M ester y cols. 1980). D ebido a que una persona vestida tiene generalmente una temperatura más alta que su entorno (la cabeza: $34{ }^{\circ} \mathrm{C}$, las manos: $31{ }^{\circ} \mathrm{C}$ ), es más fácil detectar la aproximación de una persona que detectar objetos inanimados. $\mathrm{H}$ asta cierto punto, las piezas de la máquina pueden moverse por la zona supervisada sin que se dispare el detector.

El método pasivo (sin transmisor) tiene ventajas e inconvenientes. La ventaja es que un PIRS no plantea problemas de ruido eléctrico. Es muy importante para la seguridad contra robos y protección de objetos que el detector no pueda localizarse fácilmente. Ahora bien, un sensor que sea exclusivamente un receptor difícilmente supervisa su propia eficacia, lo que es esencial para la seguridad en el trabajo. Para superar este inconveniente se probaron pequeños emisores de infrarrojos modulados $(5 \mathrm{a} 20 \mathrm{~Hz}$ ) que se instalaban en la zona supervisada y que no disparaban el sensor, pero cuyos haces eran registrados por un equipo de amplificación electrónica fija ajustado a la frecuencia de modulación. Por esta modificación el sensor "pasivo" se convirtió en "activo". Así resultó también posible comprobar la exactitud geométrica de la zona supervisada. Los espejos pueden tener puntos ciegos y es posible que la intensa actividad en una fábrica desvíe la dirección de un sensor pasivo. En la Figura 58.49 se muestra una disposición de

Figura 58.50 - Robot móvil con escáner de láser para uso en desplazamiento y detección de presencia.

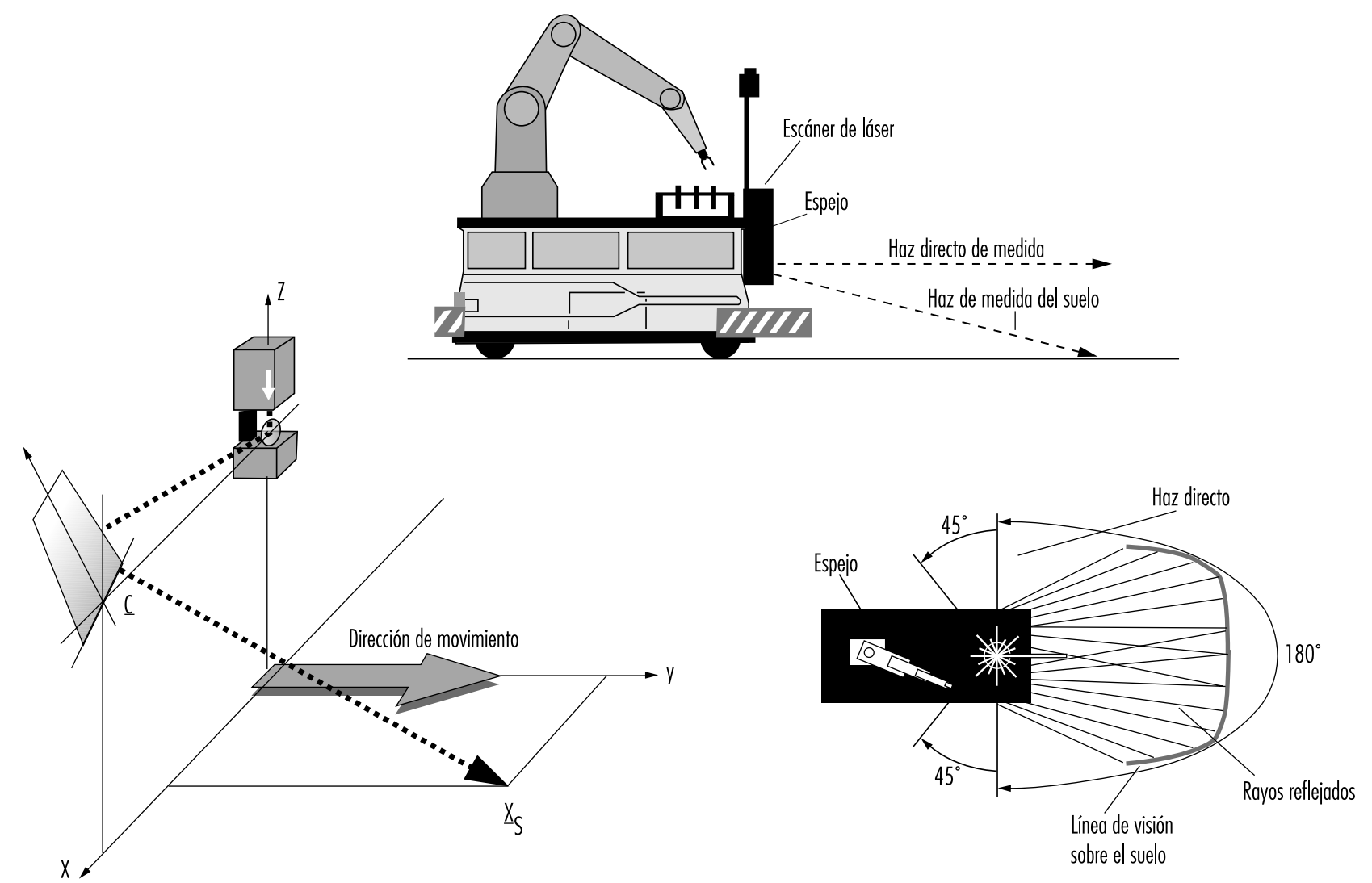

Fuente: Basado en Freund, Dierks y Rossman 1993. 
Figura 58.51 • Disposición del cabezal de medida y zona vigilada en la parte lateral posterior de un camión.

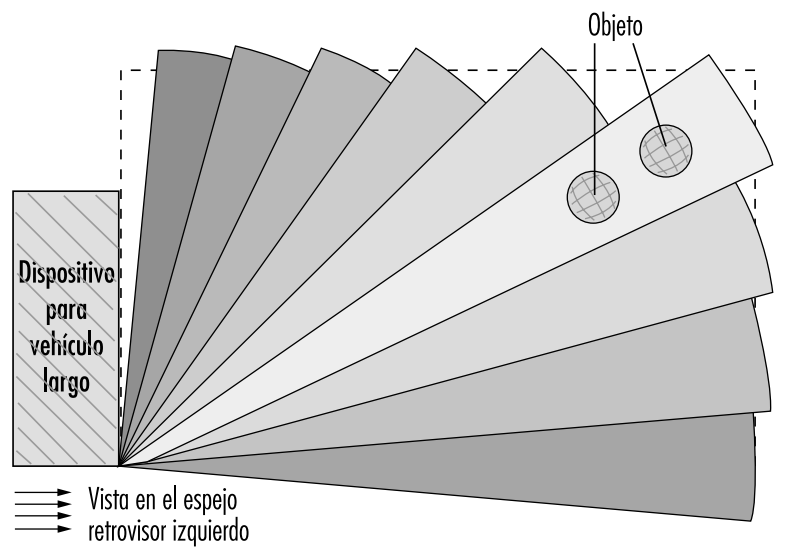

Fuente: Basado en Langer y Kurfürst 1995.

prueba con un PIR S con una geometría de supervisión en forma de pirámide truncada. Debido a su gran alcance, los sensores pasivos por infrarrojos se instalan, por ejemplo, en los pasillos de zonas de almacenamiento en estanterías.

En conjunto, las pruebas demostraron que los detectores de movimiento no son adecuados para la seguridad en el trabajo. Un piso de museo por la noche no es comparable a las zonas de peligro de un puesto de trabajo.

D etectores de ultrasonidos, radar e impulsos luminosos. Los sensores que se basan en el principio impulso/ eco, es decir, en medidas del tiempo transcurrido entre impulsos de ultrasonidos, de radar - luminosos, tienen un gran potencial como detectores de presencia. Con los escáneres de láser, los impulsos luminosos hacen barridos en rápida sucesión (normalmente en forma rotativa), por ejemplo, horizontalmente, y con la ayuda de un ordenador se obtiene un perfil de la distancia de los objetos en un plano que refleje la luz. Por ejemplo, si no se desea una sola línea, sino todo lo que se encuentra delante del robot móvil en una zona de una altura hasta 2 metros, es necesario procesar grandes cantidades de datos para obtener una imagen del área circundante. En el futuro, un detector de presencia "ideal" incluirá los dos procesos siguientes:

1. Se utilizará un proceso de reconocimiento de patrones formado por una cámara y un ordenador. El último puede ser también una "red neuronal".

2. Se requerirá además un proceso de exploración por láser para medir distancias; esto tiene que ver con el espacio tridimensional por encima de cierto número de puntos concretos seleccionados por el proceso de reconocimiento de patrones, establecido para obtener la distancia en función de la velocidad y la dirección.

En la Figura 58.50, basada en el proyecto citado anteriormente del BAU (Freund, Dierks y Rossman 1993), se muestra el uso de un escáner de láser en un robot móvil que también ejecuta tareas de desplazamiento (por medio de un haz de detección de la dirección) y de protección contra choques con objetos en la proximidad inmediata (a través de una haz de medida del suelo para detección de presencia). Dadas esas características, el robot móvil tiene capacidad para conducción activa libre automatizada (es decir, capacidad de rodear obstáculos). T écnicamente, esto se consigue utilizando la rotación de $45^{\circ}$ del escáner hacia atrás por ambos lados (a babor y a estribor del robot), además del ángulo de $180^{\circ}$ hacia el frente. Los haces se conectan por medio de un espejo especial que actúa como una cortina de luz en el piso situado delante del robot móvil (proporcionando una línea de visión del suelo). Si una reflexión del láser procede de ese punto, el robot se para. Aunque existen en el mercado escáneres de láser y de luz, homologados para su uso en el campo de la seguridad en el trabajo, estos detectores de presencia tienen un gran potencial para su desarrollo en el futuro.

L os sensores de ultrasonidos y radar que se basan en el tiempo transcurrido entre la señal y la respuesta para determinar la distancia son menos complicados técnicamente y, por tanto, más baratos. El área del sensor tiene forma de sector circular, con uno o más sectores laterales de tamaño menor dispuestos simétricamente. La velocidad de transmisión de la señal (sonido: $330 \mathrm{~m} / \mathrm{s}$; ondas electromagnéticas: $300.000 \mathrm{~km} / \mathrm{s}$ ) determina la velocidad necesaria de los dispositivos electrónicos utilizados.

D ispositivos de aviso para la zona posterior al vehículo. En la exposición de $\mathrm{H}$ annover de 1985, el BAU mostró los resultados de un proyecto inicial sobre el uso de sensores de ultrasonidos para asegurar la zona posterior a los grandes vehículos (Langer y Kurfürst 1985). Se colocó una maqueta a escala natural del cabezal sensor fabricado con sensores Polaroid ${ }^{\circledR}$ en la pared trasera de un camión de reparto. En la Figura 58.51 se muestra esquemáticamente su funcionamiento. EI gran diámetro de este sensor produce zonas de medida de largo alcance en forma de sectores de ángulo relativamente pequeño (aproximadamente $18^{\circ}$ ) adyacentes y ajustados para distintos alcances máximos de la señal. En la práctica, permite establecer cualquier geometría de supervisión, que los sensores exploran 4 veces por segundo aproximadamente para detectar la presencia 0 entrada de personas. Entre los sistemas de supervisión de la zona posterior al vehículo que se demostraron, había otros que tenían varios sensores dispuestos en paralelo.

Esta vívida demostración tuvo gran éxito en la exposición y puso de manifiesto que la seguridad en la zona posterior a los grandes vehículos y equipos era objeto de estudio en muchos lugares: por ejemplo, por parte de comités especializados para la industria y el comercio (B erufsgenossenschaften), de aseguradoras municipales de accidentes (responsables de los vehículos municipales), de inspectores oficiales de industrias y los fabricantes de sensores (quienes consideraban los automóviles principalmente como vehículos de servicio, es decir, se ocupaban más de asuntos como los sistemas de aparcamiento para protección de las

Figura 58.52 - Camión de tamaño medio equipado con dispositivo de aviso en la parte trasera (foto Microsonic).

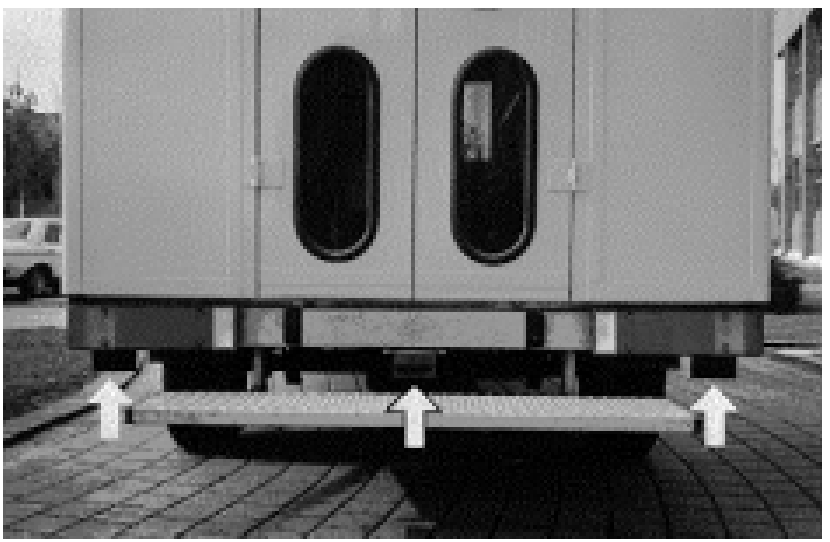


carrocerías de los automóviles). A partir de los grupos se formó espontáneamente un comité ad hoc para fomentar los dispositivos de aviso en la zona posterior al vehículo, que adoptó como primera tarea la preparación de una lista de requisitos desde el punto de vista de la seguridad en el trabajo. En los diez años que han transcurrido, se ha trabajado mucho en la supervisión de la zona trasera, posiblemente la tarea más importante de los detectores de presencia, pero no se ha conseguido todavía ningún avance importante.

Se han realizado muchos proyectos con sensores de ultrasonidos, por ejemplo en grúas de clasificación de troncos, palas hidráulicas, vehículos municipales especiales y otros vehículos de servicio, así como en carretillas elevadoras y cargadoras (Schreiber 1990). Los dispositivos de aviso de la zona posterior al vehículo son especialmente importantes para grandes máquinas que funcionan marcha atrás gran parte del tiempo. Por ejemplo, se utilizan detectores de presencia ultrasónicos para la protección de diversos vehículos especiales sin conductor, como robots de manipulación de materiales. En comparación con los parachoques de goma, estos sensores cubren una zona de detección mayor, lo que permite el frenado antes de que se produzca contacto entre máquina y objeto. Los sensores de este tipo para automóviles son útiles y los requisitos que han de cumplir son mucho menos estrictos.

Entre tanto, el Comité de Normas Técnicas de Sistemas de Transporte de DIN preparó la norma 75031, "Dispositivos de detección de obstáculos durante la marcha atrás" (DIN 1995b). Se establecieron requisitos y pruebas para dos alcances: $1,8 \mathrm{~m}$ para camionetas de reparto y 3,0 m - una zona adicional de aviso- para camiones más grandes. La zona supervisada se establece mediante el reconocimiento de cuerpos de prueba cilíndricos. El alcance de $3 \mathrm{~m}$ también responde al límite técnicamente posible hoy día, ya que los sensores ultrasónicos tienen que tener membranas metálicas cerradas, dadas las duras condiciones de trabajo. Así mismo se están estableciendo los requisitos para la autosupervisión del sistema de sensores, ya que la geometría de supervisión sólo se logra con 3 o más sensores. En la Figura 58.52 se muestra un dispositivo de aviso para la zona posterior al vehículo, formado por 3 sensores ultrasónicos (M icrosonic $\mathrm{G} \mathrm{mbH}$ 1996). Lo mismo puede decirse del dispositivo de comunicación en la cabina del conductor y del tipo de señal de aviso. EI contenido de la norma DIN 75031 está recogido también en el informe técnico internacional ISO TR 12155, "Vehículos comerciales-Dispositivos de detección de obstáculos durante la marcha atrás" (ISO 1994). Varios fabricantes de sensores han desarrollado prototipos basándose en esta norma.

\section{Conclusiones}

Desde comienzos del decenio de 1970, varias instituciones y fabricantes de sensores han estado trabajando para desarrollar y elaborar "detectores de presencia". La norma DIN 75031 y el informe ISO TR 12155 se hallan en la aplicación especial de dispositivos de aviso para la zona posterior a los vehículos. Actualmente, Deutsche Post AG está realizando una prueba importante. Varios fabricantes de sensores han equipado cada uno 5 camiones de tamaño medio con estos dispositivos. Si la prueba tiene éxito, beneficiaría mucho los intereses de la seguridad en el trabajo. Como se ha subrayado al principio, contar con un número suficiente de detectores de presencia es un reto difícil para la tecnología de la seguridad en los numerosos campos de aplicación mencionados. Por tanto, si deseamos que los daños en equipos y materiales y, sobre todo, las lesiones personales pasen a ser un recuerdo del pasado, el coste de fabricación ha de ser bajo.

\section{DISPO SITIVOS PARA CONTR O LAR,} AISLAR Y CONMUTAR ENERGIA

\section{RenéTroxler}

Los dispositivos de control y los utilizados para aislamiento y conmutación siempre se estudian en relación con los sistemas técnicos, término utilizado en este artículo que incluye máquinas, instalaciones y equipos. Todo sistema técnico ejecuta una tarea práctica específica que le ha sido asignada. Para que ésta sea realizable 0 incluso posible en condiciones de seguridad son necesarios unos dispositivos de conmutación y control de la seguridad apropiados, que se utilizan para iniciar, controlar, interrumpir o retardar la corriente así como los impulsos eléctricos, hidráulicos, neumáticos y también de energías potenciales.

\section{Aislamiento y reducción de la energía}

Los dispositivos de aislamiento se utilizan para aislar el sistema técnico de la fuente de energía mediante la desconexión de la línea de alimentación entre la fuente y el sistema. Por lo común, el dispositivo tiene que desconectar realmente la fuente de energía de manera inequívoca, lo que ha de ir siempre acompañado de una reducción de la energía almacenada en todas las partes del sistema técnico. Si son varias las fuentes de energía que lo alimentan, todas las líneas deben poder cortarse de manera fiable. Las personas formadas para manipular cada uno de los tipos de energía en cuestión, cuyo trabajo está relacionado con la alimentación del sistema técnico, utilizan dispositivos de aislamiento para protegerse de los peligros de la energía. Por razones de seguridad, estas personas tienen que cerciorarse siempre de que en el sistema técnico no queda energía residual potencialmente peligrosa; por ejemplo, determinando la ausencia de potencial eléctrico en el caso de la energía eléctrica. $\mathrm{H}$ ay determinados dispositivos de aislamiento que sólo pueden ser manipulados sin riesgo por técnicos debidamente formados, en cuyo caso las personas que no tengan autorización no podrán tener acceso a los dispositivos de aislamiento (véase la Figura 58.53).

Figura 58.53 - Principios de los dispositivos de aislamiento eléctricos y neumáticos.
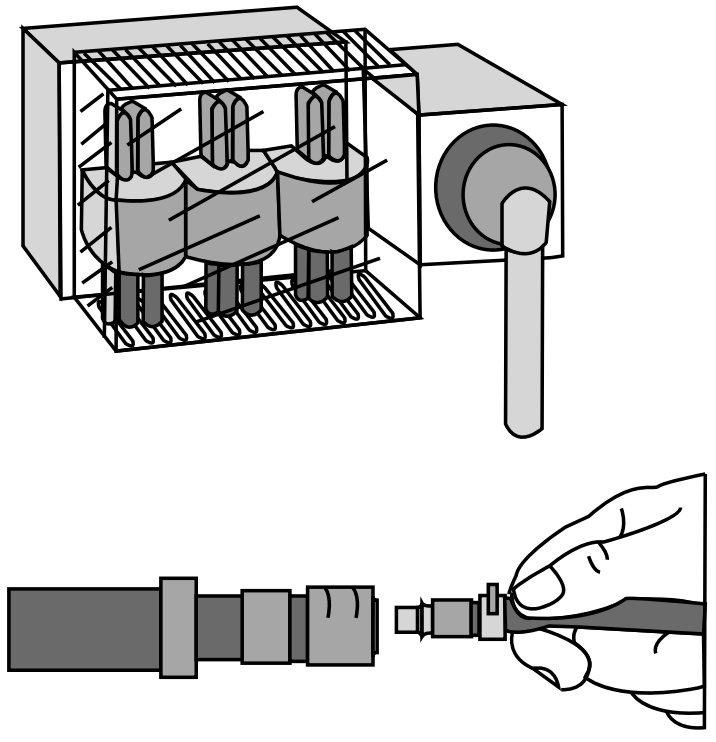


\section{El interruptor maestro}

Un interruptor maestro desconecta el sistema técnico de la fuente de energía. A diferencia del dispositivo de aislamiento, puede ser accionado sin peligro por personas que no son especialistas en materia de energía. El interruptor maestro se utiliza para desconectar sistemas técnicos que no están en uso en un momento dado en casos como, por ejemplo, que su funcionamiento se vea impedido por terceros no autorizados. Se emplea también para hacer la desconexión en tareas como el mantenimiento, la reparación, la limpieza, el reajuste y el recambio, siempre que estos trabajos puedan hacerse sin energía en el sistema. Naturalmente, cuando un interruptor maestro tiene también las características de un dispositivo de aislamiento, cumple asimismo esta función y/ o la comparte (véase la Figura 58.54).

\section{Dispositivo de desconexión de seguridad}

Un dispositivo de desconexión de seguridad no desconecta de la fuente de energía la totalidad del sistema técnico, sino que corta la alimentación a las partes del sistema que son críticas para un subsistema operativo concreto. Es posible aplicar intervenciones de corta duración en subsistemas operativos, por ejemplo, para la configuración o reajuste/ recambio de elementos del sistema, para la reparación de averías, para la limpieza habitual y para movimientos designados y secuencias de funciones esenciales necesarios durante la configuración, el reajuste/ recambio de elementos o las pruebas de funcionamiento. Los equipos e instalaciones de producción complejos no se desconectan en estos casos con un simple interruptor maestro, ya que es posible que el sistema técnico completo no pueda volver a ponerse en marcha en el punto donde se interrumpió tras la reparación de una avería. Por otra parte, en la mayoría de los sistemas técnicos el interruptor maestro no está situado en el lugar donde se tiene que intervenir. Por tanto, un dispositivo de desconexión de seguridad tiene que cumplir ciertos requisitos, como los siguientes:

- Interrumpir el flujo de energía de manera fiable y de modo que si se introducen o se envían señales de control erróneas, éstas no puedan originar movimientos o procesos peligrosos.

- Estar instalado precisamente donde tengan que producirse interrupciones en zonas de peligro de subsistemas operativos del sistema técnico. Si fuera necesario, se instala en varios

Figura 58.54 - Ejemplos de dispositivos de interruptores maestros eléctricos y neumáticos.
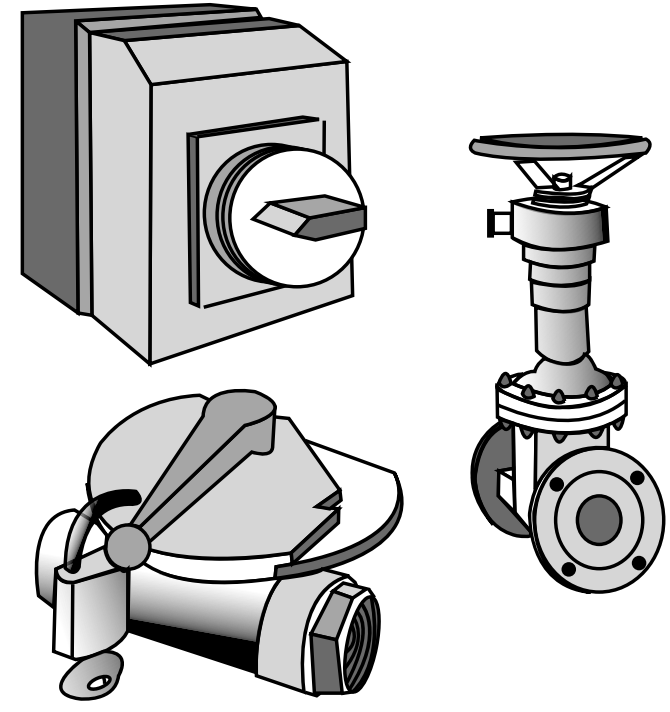

Figura 58.55 - Ilustración de principios elementales de un dispositivo de desconexión de seguridad.

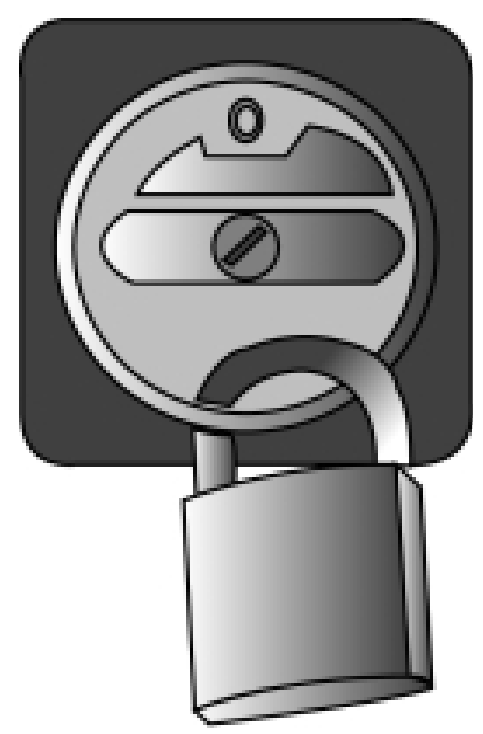

lugares (por ejemplo, en varios pisos, en varias salas o en varios puntos de acceso a máquinas o equipos).

- Su dispositivo de control ha de tener claramente marcada la posición de desconexión, que se activa sólo una vez después de cortado de forma fiable el flujo de energía.

- Una vez en la posición de desconexión, el dispositivo de control tiene que poder bloquearse para impedir la puesta en marcha sin autorización: a) si hay zonas de peligro que no se pueden supervisar de forma fiable desde la zona del control; b) si las personas situadas en la zona de peligro no pueden ver fácil y permanentemente el dispositivo de control, o c) si el bloqueo o la señalización de desconexión son obligatorios por reglamento o procedimiento de organización.

- Si el sistema técnico es amplio y se necesita que otras unidades funcionales continúen su labor independientemente, deberá poder desconectar sólo una unidad funcional sin peligro para la persona que realice la intervención

Si el interruptor maestro utilizado en un sistema técnico dado cumple todos los requisitos de un dispositivo de desconexión de seguridad, también cumple esta función, aunque no cabe duda de que es un método fiable exclusivamente en sistemas técnicos muy sencillos (véase la Figura 58.55).

\section{Equipos de control para subsistemas operativos}

Permiten realizar los movimientos y las secuencias funcionales que se necesitan para aplicar y controlar de manera segura los susbsistemas operativos del sistema técnico. Los equipos de control para subsistemas operativos se utilizan para tareas de configuración (cuando se hacen pruebas de funcionamiento), regulación (cuando es necesario reparar fallos de funcionamiento del sistema o eliminar obstrucciones) o formación (operaciones de demostración). En tales casos, el funcionamiento del sistema no puede reanudarse sin más, ya que los movimientos y procesos que generan las señales de control introducidas o emitidas erróneamente entrañan riesgos para la persona en cuestión. Un equipo de control para subsistemas operativos tiene que cumplir los siguientes requisitos:

- Debe permitir que los movimientos y procesos necesarios para los subsistemas operativos del sistema técnico se hagan de 
Figura 58.56 - Dispositivos actuadores en los equipos de control para subsistemas operativos móviles y estacionarios.

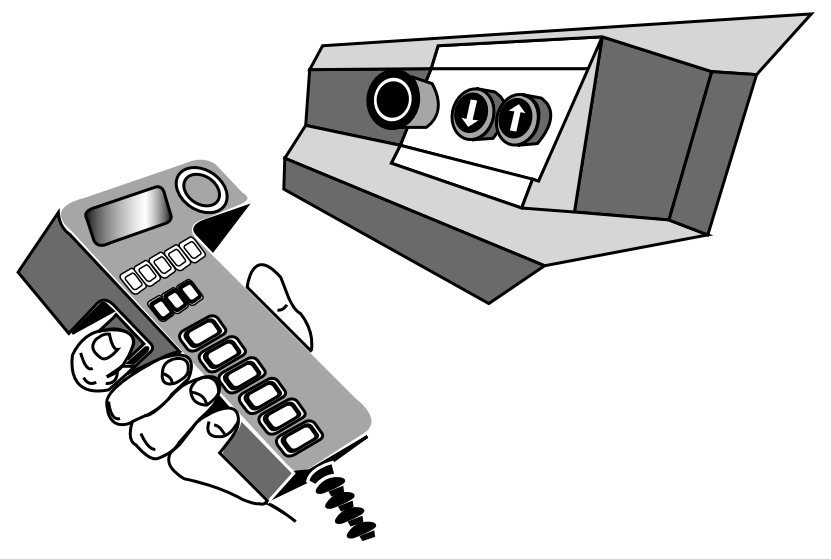

forma segura. Por ejemplo, ciertos movimientos se realizarán a velocidad reducida, gradualmente o con poca potencia (según los casos) y, como regla general, los procesos se interrumpirán inmediatamente si el panel de control deja de estar atendido.

- Sus paneles de control han de estar situados en zonas que no entrañen peligro para el operador que los maneja y desde las cuales éste pueda ver perfectamente los procesos controlados.

- Si hay varios paneles de control de distintos procesos en un mismo sitio, deberán estar claramente marcados y dispuestos de manera que se diferencien y sea imposible confundirlos.

- Sólo deberá activarse cuando se tenga la certeza de que el funcionamiento normal está desactivado, es decir, cuando sea imposible que se emita ninguna orden de control de funcionamiento normal que pueda anular el equipo de control.

- Debe ser posible evitar el uso no autorizado del equipo de control para subsistemas operativos, por ejemplo, haciendo necesario el uso de una clave o código especial para ejecutar la función en cuestión (véase la Figura 58.56).

\section{El interruptor de emergencia}

L os interruptores de emergencia son necesarios cuando el funcionamiento normal de los sistemas técnicos entraña peligros inevitables a pesar de contar con un diseño adecuado del sistema y de adoptar las debidas medidas de precaución. En los subsistemas operativos, el interruptor de emergencia suele formar parte del equipo de control del sistema operativo. C uando se activa en caso de peligro, origina procesos que restablecen la seguridad en el funcionamiento del sistema técnico con la mayor rapidez posible. En cuanto a las prioridades en materia de seguridad, la protección de las personas ocupa el primer lugar, seguida por los daños materiales, a menos que estos últimos supongan también peligros para las personas. El interruptor de emergencia tiene que cumplir los siguientes requisitos:

- Debe restablecer lo antes posible la seguridad en el funcionamiento del sistema técnico.

- Su panel de control tiene que ser fácilmente reconocible y estar diseñado y colocado de tal manera que pueda ser utilizado por personas que se hallen en peligro y esté al alcance de otras que respondan a la emergencia.

- Los procesos de emergencia puestos en marcha no deben determinar la aparición de nuevos peligros; por ejemplo, no deben liberar dispositivos de sujeción, desconectar aparatos magnéticos de retención o bloquear dispositivos de seguridad.
Figura 58.57 - Ilustración de los principios de paneles de control en interruptores de emergencia.

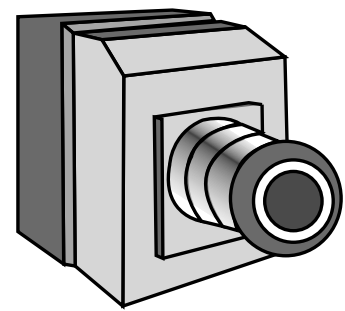

- U na vez iniciado un proceso por el interruptor de emergencia, el sistema técnico no debe poder ponerse en marcha automáticamente mediante el rearme del panel de control del interruptor de emergencia. Por el contrario, debe ser necesaria la introducción voluntaria de una nueva orden de control de la función (véase la Figura 58.57).

\section{Dispositivos de control de los interruptores de funciones}

Se utilizan para poner en marcha el sistema técnico para el funcionamiento normal y para iniciar, ejecutar e interrumpir los procesos y movimientos correspondientes al funcionamiento normal. Son dispositivos que se emplean exclusivamente en el transcurso del funcionamiento normal del sistema técnico, es decir, durante la ejecución sin perturbaciones de todas las funciones asignadas. En consecuencia, los utilizan las personas que controlan el sistema técnico. L os dispositivos de control de los interruptores de funciones han de cumplir los siguientes requisitos:

- Sus paneles de control deben ser accesibles y fáciles de utilizar sin peligro.

- Sus paneles de control tienen que estar dispuestos de forma clara y racional. Por ejemplo, los botones de control tienen que funcionar "racionalmente" en relación con los movimientos de arriba, abajo, izquierda y derecha. (Los movimientos controlados "racionales" y sus efectos correspondientes están sujetos a variaciones locales y a veces se definen por estipulación).

- Sus paneles de control tienen que estar etiquetados de forma clara e inteligible con símbolos de fácil comprensión.

- Los procesos que requieran concentración por parte del operador para que su ejecución sea segura no deberán poder dispararse por señales de control generadas erróneamente 0 por el accionamiento inadvertido de los dispositivos de control que los rigen. El procesamiento de las señales del panel de control tiene que ser suficientemente fiable y el accionamiento involuntario se tiene que impedir mediante un diseño adecuado del dispositivo de control (véase la Figura 58.58).

\section{Interruptores de supervisión}

L os interruptores de supervisión impiden la puesta en marcha del sistema técnico mientras no se cumplen las condiciones de seguridad previstas e interrumpen el funcionamiento tan pronto como 
Figura 58.58 - Representación esquemática de un panel de control de operaciones.

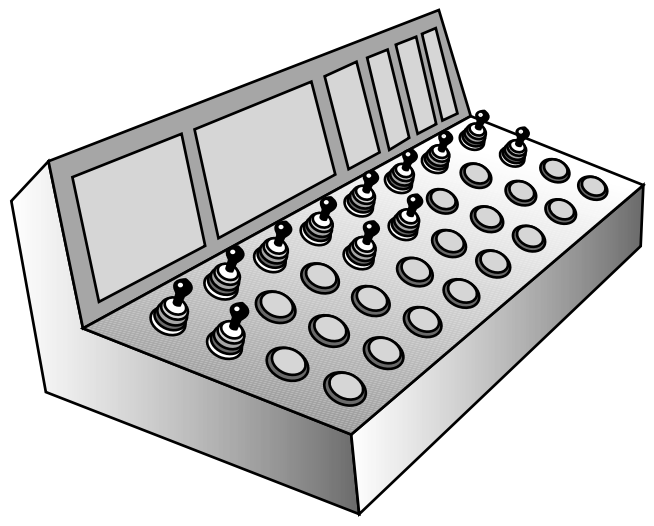

deje de cumplirse una de las condiciones. Se utilizan, por ejemplo, para vigilar puertas de compartimientos de protección, para comprobar la posición correcta de las defensas o para asegurar que no se superan los límites de velocidad o de recorrido. Por consiguiente, los interruptores de supervisión tienen que cumplir los siguientes requisitos de fiabilidad y seguridad:

- El equipo de interrupción utilizado para supervisión tiene que emitir la señal protectora de una manera especialmente fiable; por ejemplo, diseñándolo para interrumpir el paso del flujo de señales automáticamente y con especial fiabilidad.

- La herramienta de conmutación utilizada a efectos de supervisión debe poder accionarse de una manera especialmente

Figura 58.59 - Esquema de un interruptor con funcionamiento mecánico positivo y desconexión positiva.

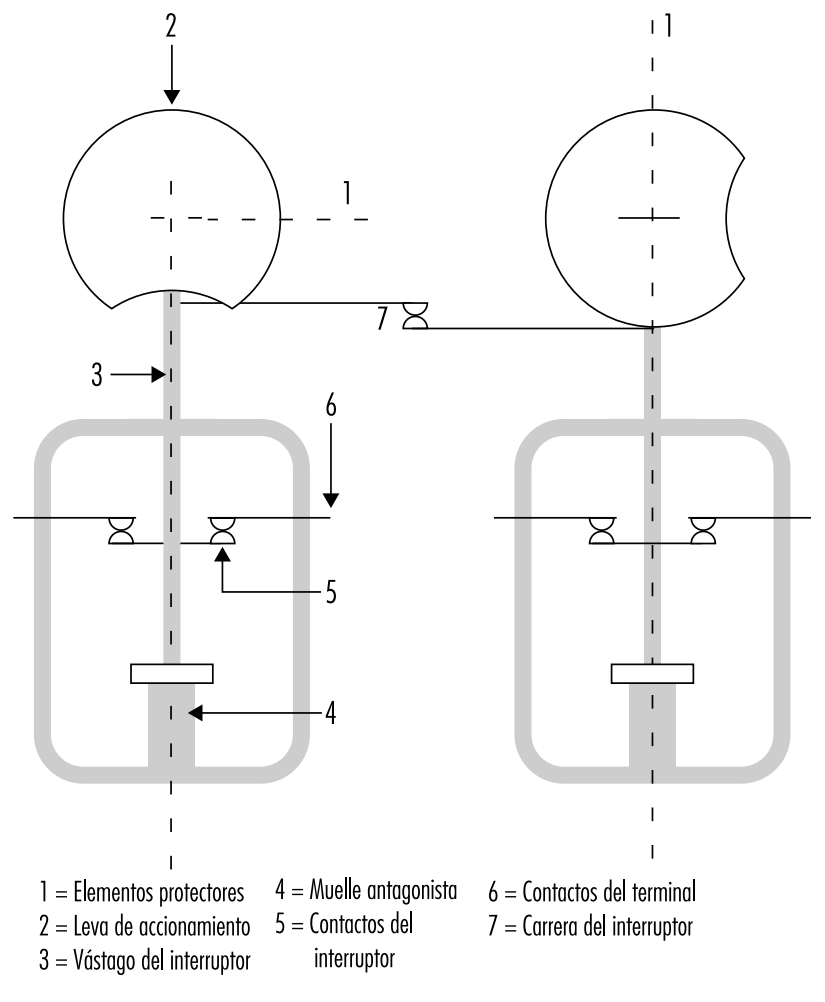

fiable cuando no se cumpla la condición de seguridad (por ejemplo, cuando se obliga al vástago de un interruptor de supervisión con interrupción automática a pasar mecánica y automáticamente a la posición de interrupción).

- Debe ser imposible desactivar incorrectamente el interruptor de supervisión, al menos no podrá hacerse si no es deliberadamente y con un cierto esfuerzo. Es una condición que cumple, por ejemplo, un interruptor mecánico controlado automáticamente con interrupción automática, cuando el interruptor y el elemento de accionamiento están montados de forma segura (véase la Figura 58.59).

\section{Circuitos de control de seguridad}

Varios de los dispositivos de conmutación de seguridad descritos anteriormente no ejecutan directamente la función de seguridad, sino que emiten una señal que es procesada y transmitida por un circuito de control de seguridad, que llega finalmente a las partes del sistema técnico que ejecutan realmente la función de seguridad. Por ejemplo, el dispositivo de desconexión de seguridad origina frecuentemente la interrupción de la alimentación de energía en puntos críticos de manera indirecta, mientras que es un interruptor principal el que suele desconectar directamente la alimentación de corriente al sistema técnico.

Debido a que los circuitos de control de seguridad tienen que transmitir señales de manera fiable, deben tenerse en cuenta los siguientes principios:

- La seguridad debe estar garantizada cuando la energía exterior falta o es insuficiente, por ejemplo, durante desconexiones 0 fugas.

- Las señales de protección funcionan con más fiabilidad por interrupción del flujo de señales, como es el caso de los interruptores de seguridad con contactos de apertura 0 de un contacto de relé abierto.

- La función de seguridad de amplificadores, transformadores y similares resulta más fiable sin energía exterior. Entre estos mecanismos se incluyen, por ejemplo, los dispositivos electromagnéticos de conmutación o las purgas que están cerrados en posición de reposo.

- Es inadmisible que haya conexiones erróneas y fugas en el circuito de control de seguridad, que originen falsos arranques o entorpezcan la parada, especialmente en los casos de cortocircuito entre conductores de entrada y salida, fugas a tierra y cortocircuitos a tierra.

- Las influencias exteriores que afecten al sistema sin superar las expectativas del usuario no deben interferir con la función de seguridad del circuito de control de seguridad.

L os componentes utilizados en los circuitos de control de seguridad tienen que ejecutar la función de seguridad de una manera especialmente fiable. Las funciones de los componentes que no cumplan este requisito se lograrán disponiendo una redundancia lo más diversificada posible y se someterán a supervisión.

\section{APLICACIONES RELACIONADAS CON LA SEGURIDAD}

\section{Dietmar Reinert y Karlheinz Meffert}

En los últimos años, los microprocesadores han pasado a desempeñar un papel cada vez más importante en el campo de la tecnología de la seguridad. Debido a que existen ordenadores completos (es decir, unidad de procesamiento central, memoria y periféricos) disponibles en un solo componente, "ordenadores de un solo chip", la tecnología de ordenadores se está utilizando no 
sólo para el control de máquinas complejas, sino también para la protección de elementos relativamente sencillos (por ejemplo, rejillas de luz, dispositivos de control de dos manos y límites de seguridad). EI software que controla estos sistemas comprende entre mil y varias decenas de miles de órdenes individuales y normalmente consta de varios cientos de derivaciones del programa. L os programas funcionan en tiempo real y se escriben sobre todo en el lenguaje de ensamblador de los programadores.

La introducción de sistemas controlados por ordenador en el campo de la tecnología de la seguridad ha ido acompañada en todos los equipos técnicos a gran escala, no sólo de proyectos de investigación y desarrollo caros, sino también de importantes limitaciones pensadas para mejorar la seguridad. (Las tecnologías aerospacial, militar y de centrales nucleares se pueden citar como ejemplos de aplicaciones a gran escala). El campo colectivo de la fabricación industrial en serie se ha tratado hasta ahora de una forma muy limitada, en parte porque los rápidos ciclos de innovación característicos del diseño de máquinas industriales dificultan la transmisión, salvo excepciones, de los conocimientos que pueden obtenerse de los proyectos de investigación relacionados con las pruebas finales de dispositivos de seguridad a gran escala. Esto convierte el desarrollo de procedimientos de evaluación rápidos y económicos en un desiderátum (Reinert y R euss 1991).

En este artículo se analizan en primer lugar las máquinas e instalaciones donde los sistemas informáticos ejecutan actualmente tareas de seguridad, examinando ejemplos de accidentes que se producen fundamentalmente en la zona de las defensas de las máquinas, para ilustrar el papel especial que desempeñan los ordenadores en la tecnología de seguridad. Estos accidentes sirven para llamar la atención sobre las precauciones que deben adoptarse, evitando así que el uso de los equipos de seguridad controlados por ordenador, cada vez más extendido actualmente, haga aumentar del número de accidentes. La sección final del artículo esboza un procedimiento que permitirá que hasta los pequeños sistemas informáticos se lleven hasta un nivel adecuado de seguridad técnica, a un coste justificable y en un período de tiempo aceptable. Los principios indicados en esta parte final se están introduciendo actualmente en procedimientos internacionales de normalización y afectarán a todas las áreas de tecnología de seguridad en las que tengan aplicación los ordenadores.

\section{Ejemplos del uso de software y ordenadores en el campo de las protecciones de máquinas}

L os cuatro ejemplos siguientes indican claramente que el software y los ordenadores se están utilizando cada vez más con fines de seguridad en el campo comercial.

Las instalaciones de señalización de emergencias personales constan, por regla general, de una estación receptora central y de cierto número de dispositivos de señalización de emergencia personal. Los dispositivos los llevan personas que trabajan independientemente. Si cualquiera de estas personas se encuentra en una situación de emergencia, puede utilizar el dispositivo para disparar una alarma mediante una señal de radio en la estación receptora central. EI disparo de una alarma a voluntad puede complementarse con un mecanismo de disparo independiente de la voluntad activado por sensores que los dispositivos de emergencia personal llevan incorporados. Tanto los dispositivos personales como la estación receptora central suelen controlarse mediante microordenadores. Cabe la posibilidad un fallo en funciones específicas individuales del ordenador incorporado, que puede conducir, en caso de emergencia, a que no se dispare la alarma. Por tanto, deben adoptarse precauciones para detectar y solucionar oportunamente el incumplimiento de la función en cuestión.
Las prensas utilizadas actualmente para la impresión de revistas son máquinas de gran tamaño. Es otra máquina la que suele preparar las bobinas de papel de modo que el paso a una nueva bobina de papel se hace sin discontinuidades. Una máquina plegadora dobla las páginas impresas, que pasan posteriormente a través de otra serie de máquinas en cadena. Al final del proceso, las revistas completas y ya cosidas se apilan en pallets. Aunque estos equipos están automatizados, hay dos puntos en los que se precisa intervención manual: a) en el paso del papel de una trayectoria a otra, y b) en la eliminación de las obstrucciones debidas a trozos de papel en puntos de peligro de rodillos rotativos. Por esta razón se debe disponer de una modalidad de funcionamiento a velocidad reducida o por pequeños saltos proporcionado por las tecnologías de control, mientras se está haciendo el ajuste de la prensa. D ebido a la complejidad de los procedimientos de control que intervienen, cada estación de impresión individual tiene que estar equipada con su propio controlador lógico programable. Debe evitarse que cualquier fallo que se produzca en un equipo de impresión mientras están abiertas las defensas, conduzca a la puesta en marcha inesperada de una máquina parada o al funcionamiento por encima de la velocidad reducida apropiada.

En grandes fábricas y almacenes hay vehículos robot sin conductor guiados automáticamente que se desplazan por pistas marcadas especialmente. Cualquier persona puede cruzar las pistas en cualquier momento, o se pueden dejar en las mismas inadvertidamente equipos o materiales, ya que no están separadas estructuralmente de las demás líneas de tráfico. Por esta razón es necesario utilizar algún tipo de prevención de choques para asegurar la detención del vehículo antes de que se produzca un choque peligroso contra una persona u objeto. En las aplicaciones más recientes, la prevención de choques se realiza mediante escáneres ultrasónicos o de láser utilizados en combinación con un parachoques de seguridad. Puesto que el funcionamiento de estos sistemas lo controla un ordenador, es posible configurar varias zonas permanentes de detección para que un vehículo pueda modificar su reacción en función de la zona de detección específica en la cual está situada una persona. Los fallos en el dispositivo protector no deben provocar choques peligrosos con una persona.

Las guillotinas con dispositivos de control de corte del papel se utilizan para prensar y a continuación cortar gruesas pilas de papel. Se disparan mediante un dispositivo de control que requiere el uso de las dos manos. El usuario tiene que entrar en la zona de peligro de la máquina después de hacer cada corte. Al alimentar la máquina con papel en la operación de corte, además del dispositivo de control accionado por las dos manos y del sistema de control de la máquina para evitar lesiones, se utiliza una defensa inmaterial, que por lo común se trata de una cortina de luz. Casi todas las grandes guillotinas modernas utilizadas actualmente son controladas por sistemas de microordenadores multicanal. También es necesario garantizar el funcionamiento seguro del control que requiere el uso de las dos manos y de la cortina de luz.

\section{Accidentes con sistemas controlados por ordenador}

En casi todas las aplicaciones industriales actuales se producen accidentes relacionados con los ordenadores y con el software (Neumann 1994). En la mayoría de los casos, los fallos de los ordenadores (que sólo se hacen públicos cuando tienen un interés general) no originan lesiones personales, pero cuando las originan, constituyen una proporción relativamente alta de todos los casos que han salido a la luz. Desgraciadamente, los accidentes que no causan sensación en la opinión pública no se investigan para determinar sus causas con el mismo interés que los 
más famosos, normalmente en plantas de fabricación a gran escala. Por esta razón, los ejemplos que siguen recogen cuatro descripciones de funcionamiento incorrecto 0 de accidentes típicos de sistemas controlados por ordenador fuera del campo de las defensas de las máquinas, con los que se pretende resaltar lo que debe tenerse en cuenta al emitir juicios relativos a la tecnología de seguridad.

\section{Accidentes debidos a fallos aleatorios del hardware}

El accidente siguiente fue debido a la conjunción de fallos aleatorios del hardware, a lo que se sumó un fallo de programación: el reactor de una planta química se recalentó, por lo cual se abrieron las válvulas de seguridad que permitieron la descarga del contenido del reactor a la atmósfera. Este incidente se produjo durante un breve período después de haberse dado un aviso de que el nivel de aceite de una caja de engranajes era demasiado bajo. U na investigación cuidadosa del incidente reveló que poco después de que el catalizador hubiera iniciado la reacción en el reactor (como consecuencia de lo cual habría requerido más refrigeración), el ordenador, sobre la base del informe de nivel de aceite bajo en la caja de cambios, congeló todas las magnitudes bajo su control en un valor fijo. Esto hizo que se mantuviera el caudal de agua en un valor muy bajo y como consecuencia el reactor se recalentó. Investigaciones adicionales demostraron que la indicación de nivel bajo de aceite había sido hecha por un componente defectuoso. El software había respondido, de acuerdo con la especificación, disparando una alarma y fijando todas las variables operativas. El origen de esta reacción se halla en el estudio HAZOP (análisis de riesgos y capacidad operativa) (K nowlton 1986) realizado antes del suceso, que requería que no se modificaran todas las variables controladas en caso de fallo. Puesto que el programador no estaba familiarizado con este procedimiento en profundidad, lo interpretó en el sentido de que los actuadores controlados (válvulas de control en este caso) no debían modificarse; no se prestó atención a la posibilidad de un aumento de la temperatura. El programador no se dio cuenta de que el sistema, después de haber recibido una señal errónea, podía encontrarse en una situación dinámica que exigiera la intervención del ordenador para evitar un incidente. Además, éste se produjo por una situación tan improbable que no se había analizado en detalle en el estudio HAZO P (Levenson 1986). Este ejemplo ofrece una transición a una segunda categoría de causas de accidentes por software y ordenadores. Se trata de fallos sistemáticos presentes en el sistema desde el principio, pero que sólo se manifiestan en determinadas situaciones muy concretas que el programador no ha tenido en cuenta.

\section{Accidentes debidos a fallos operativos}

En unas pruebas de campo durante la inspección final de robots, un técnico tomó prestado el casete de un robot próximo para utilizarlo en el suyo sin informar de ello a su colega. A I volver a su puesto de trabajo, éste último introdujo el casete equivocado. Puesto que se encontraba junto al robot, esperaba del mismo una secuencia concreta de movimientos, que resultó ser distinta debido al cambio de programa, produciéndose un choque entre el robot y la persona. Es un ejemplo del clásico fallo operativo. EI papel de este tipo de fallos en averías y accidentes está aumentando en la actualidad debido a la creciente complejidad de los mecanismos de seguridad controlados por ordenador.

Accidentes debidos a fallos sistemáticos de hardware o software En unos entrenamientos en alta mar, un torpedo cargado tenía que haberse disparado desde un buque de guerra. A causa de un defecto del aparato de lanzamiento, el torpedo permaneció en el tubo. El capitán decidió volver a puerto para recuperar el torpedo. Poco después de iniciar la singladura de vuelta, el torpedo explotó. U n análisis del accidente puso de manifiesto que los que diseñaron el torpedo habían incorporado un mecanismo pensado para evitar su retorno a la plataforma de lanzamiento después de haber sido disparado, destruyendo de esta manera el barco que lo había lanzado. El mecanismo elegido para esto consistía en lo siguiente: después de disparar el torpedo se hacia una comprobación utilizando el sistema inercial de navegación para ver si el rumbo se había modificado en $180^{\circ}$. Tan pronto como el torpedo detectaba que había girado $180^{\circ}$, detonaba inmediatamente, puesto que daba por supuesto que se encontraba a una distancia segura de la plataforma de lanzamiento. Este mecanismo de detección actuó en el caso del torpedo que no se había lanzado correctamente, originando la explosión tras haber cambiado el barco su rumbo en $180^{\circ}$. Es un ejemplo típico de accidente causado por un fallo en las especificaciones, en las que no se había formulado con suficiente precisión que el torpedo no destruyera su propio barco en el caso de que cambiara el rumbo y, por tanto, la precaución se programó erróneamente. El error sólo se advirtió en una situación concreta que el programador no había considerado como una posibilidad.

El 14 de septiembre de 1993, un Airbus A 320 de Lufthansa se estrelló durante el aterrizaje en Varsovia (Figura 58.60). U na investigación cuidadosa del accidente reveló que ciertas modificaciones en la lógica de aterrizaje del ordenador de a bordo hechas tras el accidente con un Boeing 767 de Lauda Air en 1991 eran parcialmente responsables de este accidente. Lo que ocurrió en el accidente en 1991 fue que la derivación del empuje, que desvía parte de los gases del motor para frenar el avión durante el aterrizaje, había actuado estando todavía el avión en el aire, lo que provocó que éste hiciera un picado incontrolable. De ahí que se hubiera incorporado un dispositivo electrónico de bloqueo de la derivación del empuje en los aviones Airbus. EI mecanismo sólo permitía que se aplicara la derivación del empuje después de que los sensores situados en ambos equipos de ater rizaje hubieran señalado la compresión de los amortiguadores bajo la presión de las ruedas al entrar en contacto con la pista. Sobre la base de una información incorrecta, los pilotos del avión de Varsovia supusieron que existía un fuerte viento lateral. Por esta razón, hicieron entrar el avión con una ligera inclinación y el Airbus tocó la pista sólo con la rueda derecha dejando que el equipo izquierdo soportara una carga inferior a la máxima. Debido al bloqueo electrónico de la

Figura 58.60 A Airbus de Lufthansa después del accidente de Varsovia en 1993.

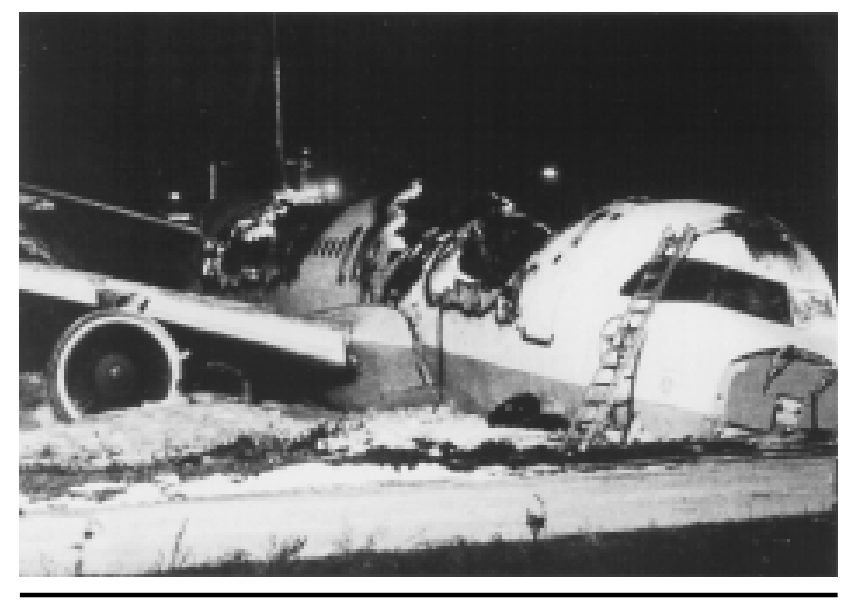


derivación del empuje, el ordenador de a bordo negó al piloto durante nueve segundos la posibilidad de realizar maniobras que hubieran permitido el aterrizaje seguro del avión a pesar de las circunstancias adversas. Este accidente es una clara muestra de que las modificaciones en los sistemas informáticos pueden originar nuevas y peligrosas situaciones si no se prevén todas sus posibles consecuencias.

El ejemplo siguiente de funcionamiento defectuoso también demuestra los efectos desastrosos que la modificación de una sola orden puede tener en los sistemas informáticos. El contenido de alcohol en sangre se determina en las pruebas químicas utilizando suero sanguíneo exento de corpúsculos sanguíneos separados previamente por centrifugación. El contenido en alcohol del suero es por tanto más alto (por un factor de 1,2) que el de la sangre entera. Por esta razón, el contenido de alcohol en suero se tiene que dividir por 1,2 para establecer las cifras críticas jurídica y médicamente en partes por mil. En las pruebas realizadas en varios laboratorios en 1984, los valores de alcohol en sangre se determinaron mediante pruebas idénticas realizadas en distintos centros de investigación utilizando suero, con objeto de comparar los resultados. Puesto que sólo se trataba de una comparación, la instrucción para dividir por 1,2 se borró en una de las instituciones durante el experimento. Después de terminar las pruebas en los distintos laboratorios, se introdujo erróneamente una instrucción para multiplicar por 1,2 en el programa de este laboratorio. Como consecuencia, se calcularon aproximadamente 1.500 valores erróneos del contenido en partes por mil entre agosto de 1984 y marzo de 1985. El error fue crítico para las carreras profesionales de los conductores de camiones con niveles de alcohol en sangre entre 1,0 y 1,3 por mil, ya que un valor de 1,3 por mil tiene una penalización jurídica que supone la confiscación del permiso de conducir durante un período prolongado.

\section{Accidentes causados por influencia de las tensiones inducidas por el trabajo o el ambiente}

Como consecuencia de una perturbación causada en la recogida de residuos en la zona efectiva de una máquina perforadora CNC (control numérico por computador), el usuario decidió aplicar la "parada programada". Al intentar retirar los residuos con sus manos, el vástago de empuje de la máquina comenzó a moverse a pesar de la parada programada y lesionó gravemente al usuario. Un análisis del accidente reveló que la causa no había sido un error del programa y no se pudo reproducir la puesta en marcha inesperada. Se han observado irregularidades similares en otras ocasiones en máquinas del mismo tipo. Parece plausible deducir de esto que el accidente tiene que haber sido causado por interferencias electromagnéticas. Se ha informado de accidentes similares con robots en Japón (N eumann 1987).

Un fallo en la sonda espacial Voyager 2, el 18 de enero de 1986, hace todavía más clara la influencia de las condiciones ambientales en sistemas controlados por ordenador. Seis días antes de alcanzar la posición más próxima a U rano, grandes campos de líneas blancas y negras cubrieron las imágenes enviadas por el Voyager 2. Un análisis preciso reveló que un solo bit de una palabra de órdenes del subsistema de datos de vuelo había provocado el fallo observado al comprimir las imágenes de la sonda. Lo más probable es que este bit hubiera sido desplazado fuera de su posición en la memoria del programa por el impacto de una partícula cósmica. La transmisión sin errores de las fotografías comprimidas desde la sonda sólo se pudo conseguir dos días después utilizando un programa de sustitución capaz de derivar el punto de memoria que había fallado (L aeser, M CLaughlin y Wolff 1987).

\section{Resumen de los accidentes presentados}

Los accidentes analizados muestran que ciertos riesgos que pueden descuidarse al utilizar tecnología electromecánica sencilla, cobran importancia cuando se utilizan ordenadores, ya que éstos permiten el procesamiento de funciones de seguridad complejas y específicas de cada situación. De ahí la importancia de que la especificación de todas las funciones de seguridad esté exenta de errores, sea inequívoca, completa y pueda someterse a prueba. Los errores en las especificaciones son difíciles de descubrir y suelen ser la causa de accidentes en sistemas complejos. Por lo común se introducen controles libremente programables con la intención de poder reaccionar de forma flexible y rápida a cambios en el mercado. Con todo, las modificaciones, especialmente en sistemas complejos, pueden tener efectos secundarios difíciles de prever. Por tanto, todas las modificaciones tienen que someterse a una gestión estrictamente formal de procedimientos de cambio en la que una clara separación de los sistemas de seguridad de los sistemas parciales no pertinentes para la seguridad ayude a facilitar la supervisión de las consecuencias de las modificaciones para la tecnología de seguridad.

Los ordenadores funcionan con baja tensión y por tanto son susceptibles de sufrir interferencias de fuentes de radiación externas. Puesto que la modificación de una sola señal entre millones puede provocar un fallo de funcionamiento, vale la pena atender al problema de la compatibilidad electromagnética en relación con los ordenadores

El servicio de sistemas controlados por ordenador es cada vez más complejo y, por tanto, menos claro. La ergonomía del software de configuración y del usuario se hace por ello más interesante desde el punto de vista de la tecnología de seguridad.

Ningún sistema informático puede probarse al cien por cien. Un mecanismo de control sencillo con 32 puertos de entrada binaria y 1.000 vías de software distintas requiere $4,3 \times 10^{12}$ pruebas para hacer una comprobación completa. A razón de 100 pruebas ejecutadas y evaluadas por segundo, harían falta 1.362 años para hacer una prueba completa.

\section{Procedimientos y medidas para mejorar los dispositivos de seguridad controlados por ordenador}

En los 10 últimos años se han desarrollado procedimientos que permiten dominar problemas específicos relacionados con la seguridad. Son procedimientos relacionados con los fallos informáticos descritos en esta sección. Los ejemplos descritos de software y ordenadores de protección de máquinas muestran que el alcance de los daños y, por tanto, el riesgo existente en diversas aplicaciones es muy variable. Resulta claro entonces que las precauciones necesarias para la mejora de ordenadores y software utilizados en tecnología de seguridad han de tomarse teniendo en cuenta el riesgo.

En la Figura 58.61 se muestra un procedimiento cualitativo que permite determinar la reducción de riesgo que puede conseguirse utilizando sistemas de seguridad independientemente de la envergadura de los daños y de su frecuencia. (Bell y Reinert 1992). Los tipos de fallos en sistemas informáticos analizados en la sección "Accidentes con sistemas controlados por ordenador" (arriba) pueden relacionarse con los denominados "niveles de integridad de la seguridad", es decir, las facilidades técnicas de reducción de riesgos.

En la Figura 58.62 se deja claro que la efectividad de las medidas adoptadas, en cualquier caso dado, para reducir errores en software y ordenadores tiene que aumentar al incrementarse el riesgo (DIN 1994; CEI 1993).

EI análisis de los accidentes descritos anteriormente muestra que el fallo de las protecciones controladas por ordenador no sólo es debido a fallos de componentes aleatorios, sino también a 
Figura 58.61 - Procedimiento cualitativo para determinación de riesgos.

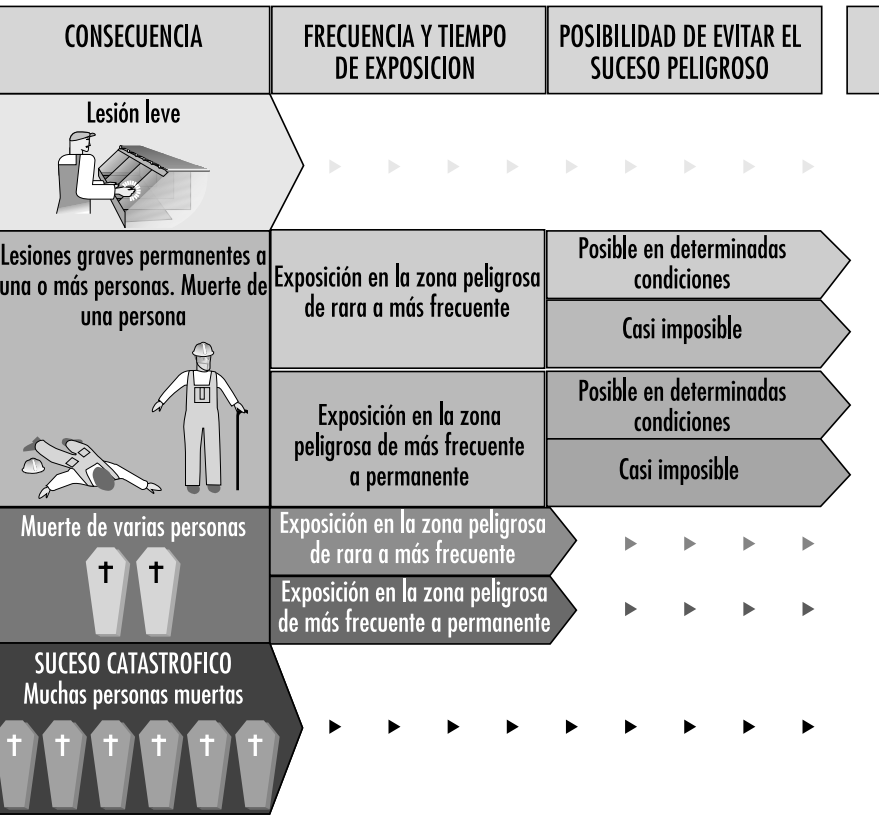

PROBABILIDAD DEL SUCESO

NO DESEADO

\begin{tabular}{|c|c|c|}
\hline MUY & BAJA & $\begin{array}{c}\text { RELATIVA- } \\
\text { MENTE ALTA }\end{array}$ \\
\hline
\end{tabular}

\begin{tabular}{|c|c|c|c|c|}
\hline$a$ & - & - & $\begin{array}{c}\text { REDUCCION } \\
\text { NECESARIA DEL } \\
\text { RIESGO MINIMO }\end{array}$ & $\begin{array}{c}\text { NIVEL DE } \\
\text { INTEGRIDAD DE } \\
\text { LA SEGURIDAD }\end{array}$ \\
\hline c & b & $a$ & - & $\begin{array}{l}\text { Sin requisitos de } \\
\text { seguridad }\end{array}$ \\
\hline$d$ & c & b & $a$ & $\begin{array}{l}\text { Sin requisitios } \\
\text { especiales de } \\
\text { seguridad }\end{array}$ \\
\hline e & $d$ & c & $b, c$ & 1 \\
\hline$f$ & e & d & $d$ & 2 \\
\hline g & $f$ & e & $e, f$ & 3 \\
\hline h & 0 & $f$ & g & 4 \\
\hline & 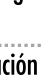 & & $h$ & $\begin{array}{l}\text { E sistema de } \\
\text { seguridad SEP } \\
\text { no es suficiente }\end{array}$ \\
\hline
\end{tabular}

del riesgo

Figura 58.62 - Eficacia de las precauciones adoptadas contra errores, independientemente del riesgo.

\begin{tabular}{|c|c|c|c|c|}
\hline CAUSAS DE LOS FALLOS & \multicolumn{4}{|c|}{$\begin{array}{l}\text { EFICACIA DE LAS MEDIDAS NECESARIAS PARA CONTROLLR O EVITAR } \\
\text { FALLOS PARA CADA NIVEL DE INTEGRIDAD DE LA SEGURIDAD }\end{array}$} \\
\hline \multirow[t]{2}{*}{$\begin{array}{l}\text { Integridad del hardware: } \\
\text { fallos individuales }\end{array}$} & \multicolumn{4}{|c|}{$\begin{array}{l}\text { Medidas para controlar fallos; conseguidas mediante } \\
\text { medidas de configuración } \mathrm{y} / \mathrm{o} \text { componentes }\end{array}$} \\
\hline & 1 & 2 & 3 & 4 \\
\hline \multirow{2}{*}{$\begin{array}{l}\text { Integridad del hardware: } \\
\text { fallos múltiples por } \\
\text { acumulación }\end{array}$} & \multicolumn{4}{|c|}{$\begin{array}{l}\text { Medidas para controlar fallos; conseguidas mediante } \\
\text { medidas de configuración } y / 0 \text { componentes } y / 0 \text { técnicas }\end{array}$} \\
\hline & 1 & 2 & 3 & 4 \\
\hline \multirow{4}{*}{$\begin{array}{l}\text { Integridad sistemática: } \\
\text { hardware y software } \\
\text { sistemáticos }\end{array}$} & \multicolumn{4}{|c|}{ Medidas para evitar fallos } \\
\hline & 1 & 2 & 3 & 4 \\
\hline & \multicolumn{4}{|c|}{ Medidas para controlar fallos } \\
\hline & 1 & 2 & 3 & 4 \\
\hline \multirow{4}{*}{$\begin{array}{l}\text { Integridad sistemática: } \\
\text { medioambiental }\end{array}$} & \multicolumn{4}{|c|}{ Medidas para evitar fallos } \\
\hline & 1 & 2 & 3 & 4 \\
\hline & \multicolumn{4}{|c|}{ Medidas para controlar fallos } \\
\hline & 1 & 2 & 3 & 4 \\
\hline \multirow{4}{*}{$\begin{array}{l}\text { Integridad sistemática: } \\
\text { funcionamiento }\end{array}$} & \multicolumn{4}{|c|}{ Medidas para evitar fallos } \\
\hline & 1 & 2 & 3 & 4 \\
\hline & \multicolumn{4}{|c|}{ Medidas para controlar fallos } \\
\hline & 1 & 2 & 3 & 4 \\
\hline Eficacia de las medidas: & básicc & bajo & med & alfa \\
\hline
\end{tabular}

condiciones de funcionamiento concretas que el programador no ha tenido en cuenta. Las consecuencias no evidentes de forma inmediata de las modificaciones del programa hechas durante el mantenimiento del sistema son otra fuente de errores. Se deduce de ello que puede haber fallos en sistemas de seguridad controlados por microprocesadores que, aunque hechos durante el desarrollo del sistema, pueden conducir a situaciones peligrosas sólo durante el funcionamiento. Por tanto, es necesario tomar precauciones contra dichos fallos no sólo en la fase conceptual, sino también en la de desarrollo, y adoptar medidas durante los procesos de desarrollo, instalación y modificación. Ciertos fallos pueden evitarse si se descubren y corrigen durante este proceso (DIN 1990).

Como pone de manifiesto el último accidente, la avería de un solo transistor puede determinar el fallo técnico de un equipo automatizado sumamente complejo. Puesto que cada circuito tiene miles de transistores y otros componentes, es necesario adoptar muchas medidas para evitar fallos y para reconocerlos cuando aparecen durante el funcionamiento e iniciar las reacciones adecuadas en el sistema del ordenador. En la Figura 58.63 se describen tipos de fallos en sistemas electrónicos programables y ejemplos de precauciones que pueden adoptarse para evitar y controlar fallos en sistemas informáticos (DIN 1990; CEI 1992).

\section{Posibilidades y perspectivas de los sistemas electrónicos programables en tecnología de seguridad}

Las máquinas y equipos modernos van ganando en complejidad y tienen que ejecutar tareas cada vez más amplias en períodos de tiempo cada vez más breves. Por esta razón, los sistemas informáticos se han introducido en todos los campos industriales desde mediados del decenio de 1970. Este aumento de complejidad por sí solo ha contribuido significativamente al aumento de los costes 
Figura 58.63 - Ejemplos de precauciones adoptadas para controlar y evitar errores en sistemas informáticos.

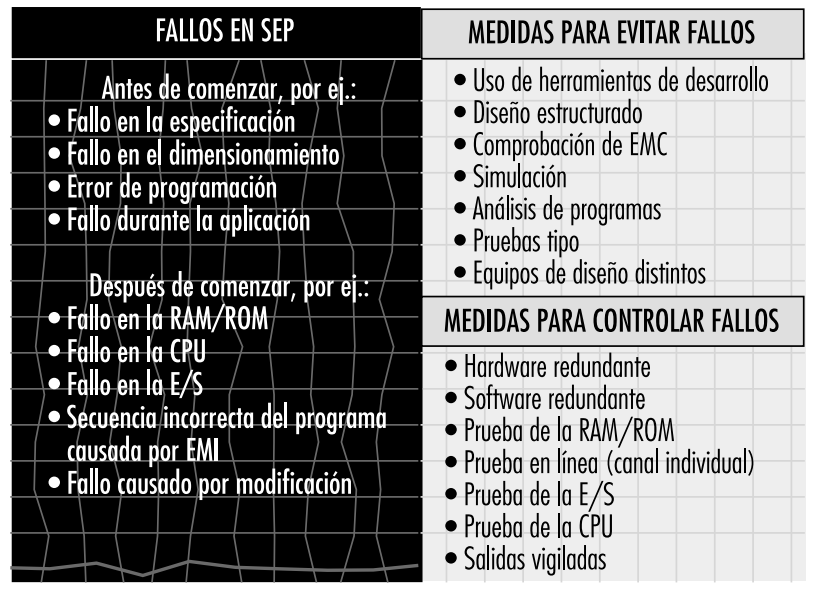

que supone la mejora de la tecnología de seguridad en dichos sistemas. Aunque el software y los ordenadores plantean un difícil reto a la seguridad en el puesto de trabajo, también hacen posible la implantación de nuevos sistemas tolerantes a fallos en el campo de la tecnología de seguridad.

U na divertida pero instructiva frase de Ernst Jyl explica lo que se entiende por tolerante a fallos: "Dilección: muchos cleen que delecho e izquieldo no se pueden intelcambial, qué elol"). A pesar del intercambio de la letras $r$ y l, la frase la entiende fácilmente cualquier adulto normal; incluso alguien con poco dominio del español podría formularla correctamente, algo casi imposible para un ordenador de traducción por sus propios medios.

El citado ejemplo muestra que un ser humano puede reaccionar de una forma mucho más tolerante a fallos que un ordenador, ya que las personas, como otros seres vivos, pueden recurrir a su propia experiencia. Examinando las máquinas utilizadas actualmente se advierte que en la mayoría se penalizan los fallos del usuario no con un accidente, sino con un descenso de la producción. Esta propiedad conduce a la manipulación 0 supresión de las defensas. La moderna tecnología informática utiliza sistemas en materia de seguridad en el trabajo que reaccionan inteligentemente, es decir, de forma modificada. Estos sistemas hacen posible un comportamiento tolerante a fallos en las nuevas máquinas. Como primera medida, avisan a los usuarios cuando el funcionamiento es incorrecto y sólo paran la máquina cuando es la única manera de evitar un accidente. El examen de los accidentes muestra las considerables posibilidades de reducción de accidentes en este campo (Reinert y Reuss 1991).

\section{- SO FT WARE Y ORDEN ADO RES: SISTEMAS HIBRIDOS AUT O MATIZADOS}

\section{Waldemar Karwowski y Jozef Zurada}

Un sistema híbrido automatizado (H AS) tiene por objeto integrar las capacidades de máquinas con inteligencia artificial (basadas en tecnología informática) con las de las personas que interactúan con estas máquinas durante su actividad laboral. Las principales preocupaciones suscitadas por el uso de HAS están relacionadas con la forma de diseñar los subsistemas humano y de la máquina para aprovechar al máximo los conocimientos y destrezas de ambas partes del sistema híbrido y cómo deben interactuar los operadores y componentes de la máquina para asegurar la complementariedad de sus funciones. M uchos sistemas híbridos automatizados han evolucionado como productos de aplicaciones de metodologías modernas basadas en control e información, para automatizar e integrar distintas funciones de sistemas tecnológicos frecuentemente complejos. EI HAS se identificó inicialmente con la introducción de sistemas basados en ordenador utilizados en el diseño y funcionamiento de sistemas de control en tiempo real para reactores nucleares, plantas químicas y tecnología de fabricación de piezas diversas. EI HAS se puede encontrar ahora en muchas industrias de servicios: control del tráfico aéreo y procedimientos de navegación de aviones en el sector de la aviación civil; diseño y uso de sistemas de navegación inteligentes para vehículos y autopistas en el transporte por carretera.

Con el aumento continuado de la automatización basada en ordenadores, la naturaleza de las tareas humanas en los sistemas tecnológicos modernos se aparta de las que requieren destrezas motoras y de percepción y se acerca a las que requieren actividades cognoscitivas que se necesitan para resolución de problemas, toma de decisiones en supervisión de sistemas y tareas de supervisión. Por ejemplo, los operadores humanos de sistemas de fabricación integrados con ordenadores actúan fundamentalmente para vigilar el sistema, tomar decisiones y resolver problemas. Las actividades cognoscitivas del supervisor humano en cualquier entorno de HAS son: a) planificación de lo que debe hacerse durante un período de tiempo dado; b) preparación de procedimientos (o pasos) para alcanzar los objetivos planificados; c) supervisión del progreso de los procesos (tecnológicos); d) "enseñanza" al sistema a través de un ordenador interactivo; e) intervención si el sistema se comporta anormalmente o si cambian las prioridades de los controles, y f) conocimiento por medio de información procedente del sistema de los efectos de las acciones de supervisión (Sheridan 1987).

\section{Diseño de sistemas híbridos}

Las interacciones hombre/ máquina en un HAS implican el uso de circuitos dinámicos de comunicación entre los operadores humanos y las máquinas inteligentes, un proceso que incluye detección y procesamiento de información y la iniciación y ejecución de tareas de control y toma de decisiones, dentro de una estructura dada de asignación de funciones entre personas y máquinas Como mínimo, las interacciones entre personas y máquinas tienen que reflejar la alta complejidad de los sistemas híbridos automatizados, así como las características pertinentes de los operadores humanos y los requisitos de las tareas. Por tanto, el sistema híbrido automatizado puede definirse formalmente como un sistema de cinco variables con la fórmula siguiente:

$$
H A S=(T, U, C, E, I)
$$

donde $T=$ requisitos de las tareas (físicos y cognoscitivos); $\mathrm{U}=$ características del usuario (físicas y cognoscitivas); $\mathrm{C}=$ características de la automatización (hardware y software, incluidos los interfaces informáticos); $\mathrm{E}=$ el entorno del sistema; $\mathrm{I}=$ un conjunto de interacciones entre los elementos anteriores.

El conjunto de interacciones I engloba todas las interacciones posibles entre $T, U$ y $C$ en $E$ independientemente de su naturaleza o de la intensidad de la asociación. Por ejemplo, una de las posibles interacciones podría involucrar la relación de los datos almacenados en la memoria del ordenador con los conocimientos correspondientes, si existieran, del operador humano. Las interacciones I pueden ser elementales (es decir, limitadas a una asociación uno a uno) o complejas, como las que involucran 
interacciones entre el operador humano, el software concreto utilizado para ejecutar la tarea deseada y el interface físico del que dispone el ordenador.

Los diseñadores de muchos sistemas híbridos automatizados se ocupan sobre todo de la integración asistida por ordenador de máquinas sofisticadas y otros equipos como partes de la tecnología basada en ordenador, y raras veces prestan atención a la importante necesidad de una integración humana eficaz en dichos sistemas. Por tanto, en la actualidad, muchos de los sistemas integrados por ordenador (tecnológicos) no son plenamente compatibles con las capacidades intrínsecas de los operadores humanos expresadas por las destrezas y conocimientos necesarios para el control y supervisión eficaces de estos sistemas. Dicha incompatibilidad surge en todos los niveles de funcionamiento de hombre, máquina y hombre/ máquina y se puede definir dentro de un marco individual o de la organización o facilidad completa. Por ejemplo, el problema de la integración de personas y tecnología en empresas de fabricación avanzadas se plantean en una fase temprana del diseño del HAS. Estos problemas se pueden conceptualizar utilizando el siguiente modelo de integración de sistemas de la complejidad de las interacciones, I, entre los diseñadores del sistema, $D$, operadores humanos, $\mathrm{H}, \mathrm{O}$ usuarios potenciales del sistema y tecnología, T:

$$
I(H, T)=F[I(H, D), I(D, T)]
$$

donde I representa las interacciones pertinentes que tienen lugar en una estructura dada de HAS, mientras que $F$ indica las relaciones funcionales entre diseñadores, operadores humanos y tecnología.

En el anterior modelo de integración de sistemas destaca el hecho de que las interacciones entre usuarios y tecnología vienen determinadas por el resultado de la integración de las dos interacciones anteriores, es decir: a) las existentes entre los diseñadores del HAS y los usuarios potenciales, y b) las existentes entre los diseñadores y la tecnología del HAS (a nivel de máquinas y de su integración). Nótese que, aunque existen normalmente fuertes interacciones entre diseñadores y tecnología, apenas hay ejemplos de interrelaciones igualmente fuertes entre diseñadores y operadores humanos.

Puede afirmarse que, incluso en los sistemas más automatizados, el papel humano sigue siendo crítico para el buen funcionamiento del sistema a nivel operativo. Bainbridge (1983) identificó un conjunto de problemas relativos al funcionamiento del HAS que son debidos a la propia naturaleza de la automatización y que son los siguientes:

1. O peradores "fuera del circuito de control". L os operadores humanos están presentes en el sistema para ejercer control cuando es necesario, pero estando "fuera del circuito de control" no pueden mantener las destrezas manuales y el conocimiento del sistema a largo plazo que suelen precisar los casos de emergencia.

2. "Imagen mental" anticuada. Los operadores pueden no responder rápidamente a los cambios en el comportamiento del sistema si no han seguido los eventos de su funcionamiento muy de cerca. Además, el conocimiento o imagen mental del operador sobre el funcionamiento del sistema puede ser inadecuado para iniciar o ejecutar las respuestas adecuadas.

3. Generaciones de destrezas que desaparecen. L os nuevos operadores pueden no ser capaces de adquirir suficientes conocimientos sobre el sistema informatizado a través de la experiencia y, por tanto, pueden ser incapaces de aplicar un control eficaz cuando es necesario.
4. Autoridad de la automática. Si el sistema informatizado se ha implantado porque puede realizar las tareas necesarias mejor que las personas, se plantea la pregunta, “ ¿sobre qué base puede decidir el operador que el sistema automatizado está adoptando decisiones correctas o incorrectas?".

5. A parición de nuevos tipos de errores humanos debidos a la automatización. Los sistemas automatizados originan nuevos tipos de errores $y$, por consiguiente, de accidentes que no pueden analizarse en el marco de las técnicas de análisistradicionales.

\section{Asignación de tareas}

U no de los problemas más importantes del diseño de HAS es determinar cuántas y qué funciones y responsabilidades hay que asignar a los operadores humanos y a los ordenadores. En general, hay tres clases básicas de problemas de asignación de tareas que deben considerarse: a) la asignación de tareas supervisor humano/ordenador; b) la asignación de tareas humano/ humano, y c) la asignación de tareas ordenador supervisor/ ordenador. Lo ideal es que las decisiones de asignación se hagan mediante algún procedimiento estructurado antes de comenzar el diseño básico del sistema. Por desgracia, pocas veces es posible un proceso sistemático semejante, ya que las funciones que han de asignarse requieren un examen posterior o tienen que realizarse interactivamente entre el componente humano y los componentes del sistema de la máquina, es decir, mediante la aplicación del ejemplo de control de supervisión. La asignación de tareas en sistemas híbridos automatizados debe centrarse en el alcance de las responsabilidades de supervisión del hombre y del ordenador y debe considerar la naturaleza de las interacciones entre el operador humano y los sistemas informatizados de apoyo a las decisiones. También debe considerarse el significado de la transferencia de información entre máquinas e interfaces humanos de entrada/ salida y la compatibilidad del software con la capacidad cognoscitiva humana de resolución de problemas.

En los planteamientos tradicionales del diseño y gestión de sistemas híbridos automatizados, los trabajadores se consideraban como sistemas deterministas de entrada/ salida y había cierta tendencia a ignorar la naturaleza teleológica del comportamiento humano, es decir, la búsqueda de objetivos en la adquisición de la información pertinente y en la selección de los objetivos (G oodstein y cols. 1988). Para tener éxito, el diseño y la gestión de sistemas híbridos automatizados tienen que estar basados en una descripción de las funciones mentales humanas necesarias para una tarea específica. El planteamiento de la "ingeniería cognoscitiva" (descrito más adelante) propone que los sistemas hombre/ máquina (híbridos) se tienen que concebir, diseñar, analizar y evaluar en términos de procesos mentales humanos (es decir, teniendo en cuenta el modelo mental del operador de los sistemas adaptativos). Se exponen a continuación los requisitos del planteamiento del diseño y funcionamiento del HAS basado en la persona según lo formulado por Corbett (1988):

1. Compatibilidad. El funcionamiento del sistema no debe requerir destrezas no relacionadas con las existentes, pero debe permitir que éstas evolucionen. El operador humano debe introducir y recibir información que sea compatible con la práctica convencional, con objeto de que el interface esté adaptado a los conocimientos y destrezas previas del usuario.

2. T ransparencia. No es posible controlar un sistema sin comprenderlo. Por tanto, el operador humano ha de poder "ver" los procesos internos del software de control del sistema si se quiere facilitar el aprendizaje. Un sistema transparente facilita a los usuarios la creación de un modelo interno de toma de decisiones y funciones de control que el sistema puede realizar. 
3. Sorpresas mínimas. El sistema no debe hacer nada que sea inesperado para el operador de acuerdo con la información disponible que detalla el estado actual del sistema.

4. Control de las perturbaciones. Las tareas inciertas (según lo definido por el análisis de la estructura elegida) deben estar controladas por el operador humano con la ayuda de la toma de decisiones asistida por ordenador.

5. Falibilidad. Las destrezas y conocimientos implícitos de los operadores humanos no deben dejarse fuera del diseño del sistema. L os operadores no deben verse nunca en la situación de asistir impotentes a la realización de una operación incorrecta por parte del software.

6. Reversibilidad de los errores. EI software debe avanzar suficiente información como para permitir al operador humano prever las consecuencias de una operación o estrategia concretas.

7. Flexibilidad operativa. EI sistema debe ofrecer a los operadores humanos libertad para intercambiar requisitos y límites de recursos mediante el cambio de estrategias de funcionamiento sin perder el apoyo del software de control.

\section{Ingeniería de los factores cognoscitivos humanos}

La ingeniería de los factores cognoscitivos humanos se ocupa de cómo los operadores humanos toman decisiones en el puesto de trabajo, resuelven problemas, formulan planes y adquieren nuevas destrezas (H ollnagel y Woods 1983). Los papeles de los operadores humanos que trabajan en cualquier HAS pueden clasificarse, según el esquema de R asmussen (1983), en tres categorías principales:

1. Comportamiento basado en la destreza: es la actividad sensomotora desarrollada en actos que tienen lugar sin control consciente, como pautas de comportamiento tranquilo, automatizado y altamente integrado. Las actividades humanas incluidas en esta categoría se consideran una secuencia de actos hábiles preparados para una situación dada. El comportamiento basado en la destreza es, por tanto, la expresión de pautas más o menos almacenadas de comportamientos o instrucciones preprogramadas de un dominio de espacio/ tiempo.

2. Comportamiento basado en las normas: es una categoría de actuación estructurada a partir del control de la información sobre acciones futuras por medio de una norma o procedimiento almacenado; es decir, una actuación ordenada que permite componer una secuencia de subrutinas en una situación de trabajo conocida. La norma se selecciona por lo común a partir de experiencias anteriores que limitan el comportamiento del entorno. El comportamiento basado en las normas parte de conocimientos explícitos en relación con el uso de las normas pertinentes. El conjunto de datos para la toma de decisiones consta de referencias para el reconocimiento o identificación de estados, eventos o situaciones.

3. Comportamiento basado en el conocimiento: es una categoría de actuación controlada por objetivos, en la que éstos se formulan explícitamente sobre la base del conocimiento del entorno y de lo que pretende la persona. La estructura interna del sistema se representa mediante un "modelo mental". Este tipo de comportamiento permite el desarrollo y la prueba de planes distintos en condiciones de control no conocidas y, por tanto, inciertas y es necesario cuando no se dispone de destrezas o normas o éstas son inadecuadas, por lo que no es posible recurrir a resolución y planificación de problemas.

En el diseño y gestión de un HAS deben considerarse las características cognoscitivas de los trabajadores con objeto de asegurar la compatibilidad del funcionamiento del sistema con el modelo interno del trabajador que describe sus funciones. En consecuencia, el nivel de descripción del sistema debe pasar de estar basado en la destreza a estarlo en reglas y en los aspectos basados en el funcionamiento humano, y deben utilizarse métodos apropiados de análisis de tareas cognoscitivas para identificar el modelo del operador de un sistema. Un problema relacionado en el desarrollo de un HAS es el diseño de medios de transmisión de información entre el operador humano y los componentes del sistema automatizado, a nivel físico y cognoscitivo. La transferencia de información debe ser compatible con los modos de información utilizados a distintos niveles de funcionamiento del sistema, es decir, visual, verbal, táctil o híbrido. Esta compatibilidad informativa asegura que las distintas formas de transferencia de información requerirán incompatibilidades mínimas entre el medio y la naturaleza de la información, Por ejemplo, una pantalla visual es mejor para transmitir información espacial, mientras que se puede utilizar una entrada acústica para transportar información de texto.

Con frecuencia el operador humano desarrolla un modelo interno que describe el funcionamiento y las funciones del sistema de acuerdo con su experiencia, formación e instrucciones en relación con el tipo dado de interface hombre/ máquina. Teniendo en cuenta esta realidad, los diseñadores de un HAS deben intentar incorporar en las máquinas (u otros sistemas artificiales) un modelo de las características físicas y cognoscitivas del operador humano, es decir, la imagen que el sistema tiene del operador (H ollnagel y Woods 1983). L os diseñadores de un HAS tienen que tener también en cuenta el nivel de abstracción en la descripción del sistema, así como varias categorías pertinentes de los comportamientos del operador humano. Estos niveles de abstracción para crear modelos del funcionamiento humano en el entorno de trabajo son los siguientes (R asmussen 1983): a) forma física (estructura anatómica); b) funciones físicas (fisiológicas); c) funciones generalizadas (mecanismos psicológicos y procesos cognoscitivos y afectivos); d) funciones abstractas (procesamiento de la información), y e) propósito funcional (estructuras de valores, mitos, religiones, interacciones humanas). L os diseñadores tienen que considerar simultáneamente estos cinco niveles con objeto de asegurar un comportamiento eficaz del HAS.

\section{Diseño del software del sistema}

Dado que el software es un componente primario de cualquier entorno de HAS, su desarrollo (incluidos el diseño, la prueba, el funcionamiento y la modificación), así como los problemas de fiabilidad tienen que considerarse desde la primeras fase del HAS. De esta manera será posible reducir el coste de la detección y eliminación de errores de software. Con todo, es difícil estimar la fiabilidad de los componentes humanos de un HAS debido a limitaciones de nuestra capacidad para crear modelos de realización de tareas humanas, a la carga de trabajo consiguiente y a los posibles errores. Una carga de trabajo mental excesiva o insuficiente puede conducir a sobrecarga de información o aburrimiento respectivamente con lo que se deteriora el comportamiento humano y origina errores y aumento de la probabilidad de accidentes. Los diseñadores de un HAS deben emplear interfaces adaptativos que utilizan técnicas de inteligencia artificial para solucionar estos problemas. Además de la compatibilidad hombre/máquina, se tiene que considerar el problema de la adaptación mutua hombre/ máquina, con objeto de reducir los niveles de esfuerzo que surgen cuando se supera la capacidad humana.

Debido al alto nivel de complejidad de muchos sistemas híbridos automatizados, la identificación de cualquier peligro potencial relacionado con el hardware, el software, los procedimientos operativos y las interacciones hombre/ máquina, resulta crítica para el éxito de los esfuerzos encaminados a reducir lesiones personales y daños materiales. Los peligros para la 
seguridad y la salud asociados con sistemas híbridos automatizados complejos, como la tecnología de fabricación integrada por ordenador (CIM), es claramente uno de los aspectos más críticos del diseño y funcionamiento del sistema.

\section{Problemas de seguridad de sistemas}

Los entornos híbridos automatizados, por su importante potencial de comportamiento errático del software en condiciones de perturbación del sistema, crean un nuevo tipo de riesgos de accidente. A medida que los sistemas híbridos automatizados se han hecho más flexibles y complejos, las perturbaciones del sistema, incluidos los problemas de puesta en marcha y parada y las desviaciones del control del sistema, pueden aumentar significativamente la posibilidad de graves peligros para los operadores humanos. Irónicamente, en muchas situaciones anormales los operadores confían en el funcionamiento correcto de los subsistemas de seguridad automatizados, una práctica que puede aumentar el riesgo de lesiones graves. Por ejemplo, un estudio de accidentes relacionados con fallos de funcionamiento de sistemas técnicos de control mostró que un tercio aproximadamente de las secuencias de accidentes incluía intervención humana en el circuito de control del sistema perturbado.

Puesto que las medidas tradicionales de seguridad no pueden adaptarse fácilmente a las necesidades de los entornos de H AS, es necesario considerar estrategias de control de lesiones y prevención de accidentes teniendo en cuenta las características intrínsecas de estos sistemas. Por ejemplo, en el área de la tecnología avanzada de fabricación, muchos procesos se caracterizan por la existencia de cantidades importantes de flujos de energía que no pueden ser fácilmente previstos por los operadores humanos. A demás, suelen surgir problemas de seguridad en los interfaces entre susbsistemas 0 cuando una perturbación del sistema se propaga de un subsistema a otro. Según la O rganización Internacional de Normalización (ISO 1991), los riesgos asociados con peligros debidos a automatización industrial varían según las máquinas incorporadas en sistemas específicos de fabricación y con la forma de instalar, programar, operar, mantener y reparar el sistema. Por ejemplo, una comparación de accidentes relacionados con robots en Suecia con otros tipos de accidentes mostró que los robots pueden ser las máquinas industriales más peligrosas utilizadas en la industria manufacturera avanzada. La tasa estimada de accidentes para robots industriales fue de un accidente grave por 45 robots-años, una tasa más alta que la de las prensas industriales de 1 accidente por cada 50 máquinas-años. Se debe observar que, en EE.UU., las prensas industriales representaron aproximadamente el $23 \%$ de todos los fallecimientos relacionados con máquinas para trabajar metales en el período 1980-1985, ocupando las prensas la primera posición en cuanto al producto severidad/frecuencia de las lesiones no mortales.

En el campo de la tecnología avanzada de fabricación hay muchos elementos móviles que son peligrosos para los trabajadores, ya que cambian de posición de forma compleja fuera del campo visual de los operadores. Los rápidos cambios técnicos en fabricación integrada por ordenador han creado una necesidad acuciante de estudiar los efectos de la tecnología avanzada de fabricación sobre los trabajadores. Para identificar los peligros debidos a diversos componentes de un entorno de HAS de este tipo, es necesario analizar cuidadosamente los accidentes ocurridos. Por desgracia, es difícil aislar los accidentes con intervención de robots de los informes de accidentes con máquinas manejadas por hombres y puede haber, por tanto, un alto porcentaje de accidentes no registrados. Los reglamentos japoneses de seguridad y salud en el trabajo establecen que "los robots industriales no tienen actualmente medios fiables de seguridad y no es posible proteger a los trabajadores a menos que se reglamente su uso". Por ejemplo, los resultados del estudio realizado por el M inisterio de Trabajo de Japón (Sugimoto 1987) de accidentes relacionados con robots industriales en las 190 fábricas estudiadas (con 4.341 robots en funcionamiento) mostraron que se produjeron 300 perturbaciones relacionadas con robots, de las cuales resultaron 37 casos de actos no seguros que originaron "cuasiaccidentes", 9 accidentes con resultado de lesiones y 2 accidentes mortales. L os resultados de otros estudios indican que la automatización basada en ordenadores no aumenta necesariamente el nivel general de seguridad, ya que el hardware del sistema no puede hacerse a prueba de fallos mediante funciones de seguridad en el software del ordenador solamente y los controladores del sistema no son siempre altamente fiables. Además, en un HAS complejo, no se puede depender exclusivamente de dispositivos detectores de seguridad para detectar condiciones peligrosas y adoptar las estrategias apropiadas para evitar peligros.

\section{Efectos de la automatización sobre la salud humana}

Como se ha explicado antes, las actividades de los trabajadores en muchos entornos de HAS son básicamente de supervisión, vigilancia, apoyo al sistema y mantenimiento. Pueden clasificarse en los 4 grupos básicos siguientes: a) tareas de programación, es decir, codificación de información que guía y dirige el funcionamiento de la máquina; b) vigilancia de la producción del HAS y control de los componentes; c) mantenimiento de los componentes del HAS para prevenir o reducir los fallos de funcionamiento de la maquinaria, y d) realización de diversas tareas de apoyo, etc. En muchas revisiones recientes de los efectos de los HAS en el bienestar de los trabajadores se llegó a la conclusión de que aunque el uso de un H AS en el área de fabricación puede eliminar tareas pesadas o peligrosas, el trabajo en un entorno de HAS puede ser insatisfactorio y estresante para los trabajadores. Las fuentes de estrés incluían la constante supervisión necesaria en muchas aplicaciones de H AS, el limitado ámbito de las actividades asignadas, el bajo nivel de interacción del trabajador permitido por el diseño del sistema y los peligros para la seguridad asociados con la naturaleza imprevisible e incontrolable del equipo. Aunque algunos trabajadores que intervienen en la programación y mantenimiento sí encuentran elementos de reto que pueden tener efectos positivos sobre su bienestar, esos efectos están compensados con frecuencia por la naturaleza compleja y exigente de esas actividades, así como por la presión ejercida por la dirección para realizar esas actividades rápidamente.

Aunque en algunos entornos de H AS los operadores humanos están alejados de las fuentes tradicionales de energía (el flujo del trabajo y el movimiento de la máquina) en condiciones de funcionamiento normales, muchas tareas en sistemas automatizados tienen que realizarse en contacto directo con otras fuentes de energía. Puesto que el número de componentes distintos de los HAS aumenta continuamente, es necesario insistir en el confort de los trabajadores y en el desarrollo de los medios eficaces de control de lesiones, teniendo presente el hecho de que los trabajadores ya no pueden estar a la altura del refinamiento y complejidad de tales sistemas.

Para satisfacer las actuales necesidades de control de lesiones y seguridad de los trabajadores en sistemas de fabricación integrados por ordenador, el comité de sistemas de automatización industrial de la ISO ha propuesto una nueva norma internacional de seguridad denominada "Seguridad de sistemas integrados de fabricación" (1991). Desarrollada en reconocimiento de los peligros especiales existentes en los sistemas integrados de fabricación que incorporan máquinas industriales y equipos asociados, su intención es minimizar la posibilidad de lesiones al personal mientras trabaja en un sistema integrado de 
fabricación o en un lugar adyacente. Las principales fuentes de peligros potenciales para los operadores humanos de CIM identificados en esta norma se muestran en la Figura 58.64.

\section{Errores humanos y del sistema}

En general, los peligros en un HAS pueden proceder del propio sistema, de su asociación con otros equipos presentes en el entorno físico o de interacciones del personal con el sistema. U n accidente es sólo uno de los resultados de las interacciones hombre/ máquina que pueden darse en condiciones peligrosas; los cuasiaccidentes y los incidentes con daños materiales son mucho más corrientes (Zimolong y Duda 1992). Un error puede dar lugar a una de estas consecuencias: (1) el error no es detectado; (2) el sistema puede compensar el error; (3) el error provoca una avería de la máquina y/o una parada del sistema, y (4) el error origina un accidente.

Puesto que no todos los errores humanos que provocan un incidente crítico originan realmente un accidente, conviene distinguir entre las categorías de resultados de la forma siguiente: (1) un incidente de inseguridad (es decir, cualquier suceso no intencionado, independientemente de que termine en lesiones, daños, o pérdidas); (2) un accidente (es decir, un suceso de inseguridad con resultado de lesiones, daños o pérdidas); (3) un incidente con daños (es decir, un suceso de inseguridad con resultado de algún tipo de daños materiales solamente); (4) un cuasiaccidente (es decir, un suceso de inseguridad en el cual lesiones, daños o pérdidas se han evitado fortuitamente por un margen muy estrecho), y (5) la existencia de un accidente potencial (es decir, sucesos de inseguridad que podrían haber resultado en lesiones, daños o pérdidas pero que, debido a las circunstancias no resultaron ni siquiera en un cuasiaccidente).

Es posible distinguir tres tipos básicos de errores humanos en un HAS:

1. O misiones y olvidos basados en la destreza.

2. Errores basados en las reglas.

3. Errores basados en los conocimientos.

Esta taxonomía, ideada por Reason (1990), está basada en una modificación de la clasificación de destrezas-reglas-conocimientos de la actividad humana de Rasmussen como se ha descrito anteriormente. En el nivel basado en la destreza, la actividad humana está regida por pautas almacenadas de instrucciones programadas representadas como estructuras análogas en un dominio de espacio/ tiempo. El nivel basado en reglas es aplicable a problemas conocidos cuyas soluciones se rigen por reglas almacenadas (llamadas "producciones", puesto que se accede a ellas o se producen cuando se necesitan). Estas reglas requieren ciertos diagnósticos (o juicios) o la aplicación de ciertos remedios, dado que han surgido determinadas condiciones que exigen una respuesta apropiada. A este nivel, los errores humanos están normalmente asociados con una clasificación errónea de las situaciones que conducen a la aplicación de una regla incorrecta o al recuerdo incorrecto de juicios o procedimientos consiguientes. Los errores basados en el conocimiento se producen en situaciones nuevas, para las cuales es necesario planificar acciones "en línea” (en un momento dado), utilizando procesos analíticos conscientes y conocimientos almacenados. Los errores a este nivel surgen de limitaciones de recursos y de conocimientos incompletos o incorrectos.

Los sistemas genéricos de creación de modelos de errores (GEM S) propuestos por Reason (1990), que intentan localizar los orígenes de los tipos básicos de errores humanos, se pueden utilizar para obtener la taxonomía global del comportamiento humano en un HAS. Los GEMS tratan de integrar dos áreas distintas de investigación de errores: (1) omisiones y olvidos en
Figura 58.64 - Fuente principal de peligros en fabricación integrada por ordenador (CIM) (según ISO 1991).

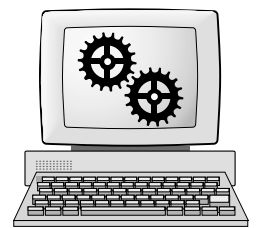

Componentes mecánicos móviles:

- Enfunci individualmente 0 junto con 0 equipos relacionados en la zona de peligro

- Una operación anormal (por ejemplo, caída, tropiezo)

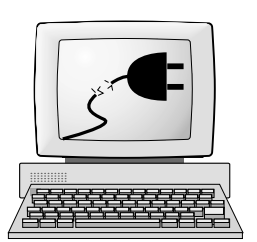

Fallo de las funciones 0 equipos siguientes:

- Disposiciones de protección (debido a que los trabajadores las quitan, desmontan 0 anulan)

- Diversos componentes, dispositivos o circuitos

- Fuentes de alimentación medios de distribución de energía, como las causadas por fluctuaciones 0 perturbaciones

- Transmisión de la información otros elementos del sistema

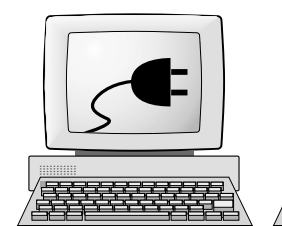

Fuentes de alimentación

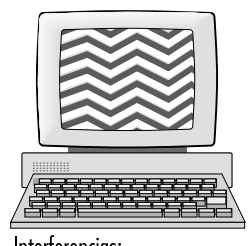

\section{Interferencias:}

- Eléctricas: por ejemplo,

electromagnéticas, descargas electrostáticas (ESD) 0

interferencias de radiofrecuencia (RFI)

- Mecánicas (por ejemplo, vibraciones 0 choques)

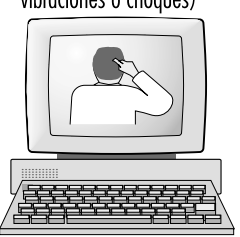

Errores humanos en las

siguientes áreas:

- Diseño, construcción 0 modificación

- Sistemas operativos, software de aplicaciones y programación

- Aplicación y ejecución

- Preparación, incluidas manipulación/sujeción de piezas y colocación de herramientas

- Funcionamiento o uso

- Mantenimiento y reparación

- Documentación y

formación/entrenamiento fuentes de radiaciones

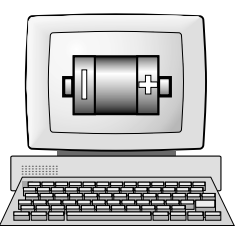

Energía almacenada

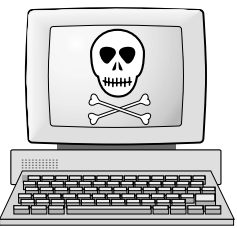

Atmósferas o materiales peligrosos

- Materiales explosivos 0

combustibles

- Agentes corrosivos

- Radiación (por ejemplo

ionizante 0 térmica)

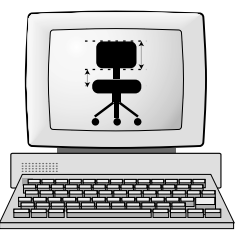

Consideraciones ergonómicas

- luminación

- Vibraciones

- Ruido

- Condiciones climáticas

- Estaciones de control de

operador, diseño y

disposición
Fuente: ISO 1991.

los que las acciones se desvían de la intención actual debido a fallos de ejecución y/ o fallos de almacenamiento, y (2) errores, en las que las acciones pueden estar de acuerdo con el plan, pero éste es inadecuado para conseguir el resultado deseado.

\section{Evaluación y prevención de riesgos en CIM}

Según la ISO (1991), la evaluación de riesgos en CIM debe realizarse para minimizar todos los riesgos y servir de base para determinar objetivos y medidas de seguridad en el desarrollo de programas o planes para crear un ambiente de trabajo seguro, así como para asegurar la salud y seguridad del personal. Por ejemplo, los peligros en el trabajo en un entorno de HAS basado en fabricación pueden caracterizarse como sigue: (1) el operador tiene que entrar en la zona de peligro para tareas de eliminación de perturbaciones, servicio y mantenimiento; (2) la zona de peligro es difícil de determinar, percibir y controlar; (3) el trabajo puede ser monótono, y (4) los accidentes que se producen en 
sistemas de fabricación integrados por ordenador suelen ser graves. Cada peligro identificado debe evaluarse en cuanto a riesgo y se deben determinar e implantar medidas apropiadas para minimizar ese riesgo. También se deben determinar los peligros de cualquier proceso dado en relación con los aspectos siguientes: la propia unidad individual; la interacción entre unidades individuales; las secciones operativas del sistema y el funcionamiento del sistema completo para todos los modos y condiciones de funcionamiento, incluidas las condiciones en las cuales puedan suspenderse los medios de protección normales para operaciones como programación, verificación, localización de averías, mantenimiento o reparación.

La fase de diseño de la estrategia de seguridad ISO (1991) para CIM incluye:

- especificación de los límites de los parámetros del sistema;

- aplicación de una estrategia de seguridad.

- identificación de riesgos;

- evaluación de los riesgos asociados,

- eliminación de los peligros o disminución de los riesgos en la medida de lo posible.

La especificación de la seguridad del sistema debe incluir:

- una descripción de las funciones del sistema;

- una disposición en planta del sistema o modelo;

- Ios resultados del estudio hecho para investigar la interacción de los distintos procesos de trabajo y las actividades manuales;

- un análisis de las secuencias del proceso, incluidas las interacciones manuales;

- una descripción de los interfaces con líneas de transporte;

- diagramas de flujo del proceso;

- planos fundamentales;

- planos de los servicios de alimentación y eliminación;

- determinación del espacio necesario para la alimentación y eliminación de materiales,

- registros de accidentes disponibles.

Según la ISO (1991), es necesario considerar todos los requisitos precisos para asegurar un funcionamiento seguro del sistema de CIM en el diseño de los procedimientos sistemáticos de planificación de la seguridad. En ello se incluyen todas las medidas de protección para reducir eficazmente los peligros, y requiere:

- integración del interface hombre/ máquina;

- definición en fase temprana de la posición de los que trabajan en el sistema (en el tiempo y en el espacio);

- consideración en fase temprana de medios de reducir el trabajo aislado,

- consideración de los aspectos ambientales.

El procedimiento de planificación de la seguridad debe tratar, entre otros, los siguientes problemas de seguridad en CI M :

- Selección de métodos operativos del sistema. El equipo de control debe estar previsto como mínimo para los siguientes modos operativos: (1) modo normal o de producción (es decir, con todas las protecciones normales conectadas y funcionando); (2) funcionamiento con algunas de las protecciones normales suspendidas, y (3) funcionamiento en el cual la iniciación por el sistema manual o remota de situaciones peligrosas no sea posible (por ejemplo, en el caso de funcionamiento local, corte de la alimentación o bloqueo mecánico de las condiciones peligrosas).

- Formación, instalación, puesta en marcha y pruebas funcionales. Cuando tenga que estar presente personal en la zona peligrosa, el sistema de control deberá contar con las siguientes medidas de seguridad: (1) bloqueo de la puesta en marcha; (2) dispositivo de activación; (3) velocidad reducida; (4) potencia reducida, y e) parada de emergencia móvil.
- Seguridad en programación, mantenimiento y reparación del sistema. Durante la programación, sólo se permitirá al programador que esté en la zona protegida. El sistema debe tener procedimientos de inspección y mantenimiento que aseguren el funcionamiento continuado del sistema según lo pretendido. EI programa de inspección y mantenimiento debe tener en cuenta las recomendaciones del proveedor del sistema y de los proveedores de los diversos elementos del mismo. No es necesario mencionar que el personal responsable del mantenimiento o reparaciones del sistema debe ser formado en materia de procedimientos necesarios para realizar las tareas requeridas.

- Eliminación de fallos. Cuando sea necesaria la eliminación de fallos desde dentro del espacio protegido, deberá realizarse después de una desconexión segura (0, si es posible, después de accionar un mecanismo de bloqueo). Deben adoptarse medidas adicionales contra la iniciación errónea de situaciones de peligro. Cuando puedan presentarse peligros durante la eliminación de fallos en secciones del sistema o en máquinas o sistemas adyacentes, éstos deberán ponerse también fuera de servicio y protegerse contra una puesta en marcha inesperada. En componentes del sistema que no se puedan observar en su totalidad, se deberá llamar la atención sobre la eliminación de fallos por medio de instrucciones y carteles de aviso.

\section{Control de perturbaciones del sistema}

En numerosas instalaciones de H AS utilizadas en el área de fabricación integrada por ordenador, los operadores humanos se necesitan normalmente para tareas de control, mantenimiento, programación, preajuste, servicio o localización de averías. Las perturbaciones del sistema originan situaciones que hacen necesaria la entrada de trabajadores en la zona de peligro. A este respecto, se puede suponer que las perturbaciones siguen siendo la razón más importante de las interferencias humanas en la CIM, debido a que lo más frecuente es que los sistemas se programen desde fuera de las zonas restringidas. U no de los problemas más importantes de la seguridad en CIM es evitar las perturbaciones, ya que la mayoría de los riesgos se presentan en la fase de localización de averías del sistema. Evitar las perturbaciones es un objetivo común de la seguridad y la economía.

U na perturbación en un sistema de CIM es un estado 0 función de un sistema que se desvía del estado planificado o deseado. Las perturbaciones durante el funcionamiento de un sistema de CIM afectan, además de a la productividad, a la seguridad de las personas que intervienen en el funcionamiento del sistema. En un estudio finlandés (K uivanen 1990) se indicaba que aproximadamente la mitad de las perturbaciones en fabricación automatizada disminuyen la seguridad de los trabajadores. Las causas principales de las perturbaciones fueron errores de diseño del sistema (34\%), fallos de componentes del sistema (31 \%), errores humanos (20\%) y factores externos. La mayoría de los fallos de las máquinas se debían al sistema de control y, dentro de éste, a los sensores. U na forma eficaz de aumentar el nivel de seguridad de las instalaciones de CIM es reducir el número de perturbaciones. Aunque las acciones humanas en sistemas perturbados impiden que se produzcan accidentes en el entorno de HAS, también contribuyen a ellos. Por ejemplo, un estudio de accidentes relacionados con fallos de funcionamiento de sistemas técnicos de control mostró que un tercio aproximadamente de las secuencias de accidentes incluía intervención humana en el circuito de control del sistema perturbado.

Los principales problemas investigados en la prevención de perturbaciones en CIM se refieren a: (1) principales causas de las perturbaciones; (2) componentes y funciones no fiables; (3) el efecto de las perturbaciones sobre la seguridad; (4) el efecto las perturbaciones en las funciones del sistema; (5) daños materiales, 
y (6) reparaciones. La seguridad del HAS debe planificarse en la fase inicial del diseño del sistema; ha de considerar la tecnología, las personas y la organización, y debe formar parte del proceso global de planificación técnica del HAS.

\section{Retos futuros para el diseño de HAS}

Para obtener las máximas ventajas de los sistemas híbridos automatizados se necesita una visión mucho más amplia del desarrollo del sistema, que esté basada en la integración de personas, organización y tecnología. Deben aplicarse aquí tres tipos principales de integración:

1. integración de personas, asegurando una comunicación eficaz entre ellas;

2. integración hombrel ordenador, diseñando interacciones e interfaces adecuados entre personas y ordenadores,

3. integración tecnológica, asegurando interacciones e interfaces efectivos entre máquinas.

Los requisitos mínimos de diseño para sistemas híbridos automatizados deben incluir lo siguiente: (1) flexibilidad; (2) adaptación dinámica; (3) mayor capacidad de respuesta, y (4) necesidad de motivar a las personas y hacer mejor uso de su destreza, juicio y experiencia. Lo anterior requiere también el desarrollo de estructuras de organización, métodos de trabajo y tecnologías del HAS para que las personas, a todos los niveles del sistema, adapten sus estrategias de trabajo a las diversas situaciones de control de los sistemas. Por tanto, las estructuras de organización, los métodos de trabajo y las tecnologías del HAS deberán ser diseñadas y desarrolladas como sistemas abiertos (K idd 1994).

Un sistema híbrido automatizado abierto (OHAS) es aquél que recibe entradas y envía salidas a su entorno. La idea de un sistema abierto puede aplicarse no sólo a arquitecturas de sistemas y estructuras de organización, sino también a métodos de trabajo, interfaces hombre/ ordenador y a las relaciones entre personas y tecnologías, por ejemplo: sistemas de planificación, sistemas de control y sistemas de apoyo a la toma de decisiones. Un sistema abierto es también uno adaptable que permita a las personas un alto grado de libertad para definir la modalidad de funcionamiento del sistema. Por ejemplo, en el área de fabricación avanzada, los requisitos de un sistema híbrido automatizado abierto pueden aplicarse mediante el concepto de fabricación integrada por ordenador y personas ( $\mathrm{HCIM}$ ). Desde este punto de vista, el diseño de la tecnología debe resolver la arquitectura global del sistema $\mathrm{H} \mathrm{CIM}$, incluido lo siguiente: a) consideraciones de la red de grupos; b) la estructura de cada grupo; c) las interacciones entre grupos; d) la naturaleza del software de apoyo, y e) las necesidades de comunicación e integración técnica entre módulos de software de apoyo.

El sistema híbrido automatizado adaptativo, a diferencia del sistema cerrado, no restringe lo que pueden hacer los operadores humanos. EI papel del diseñador del HAS es crear un sistema que satisfaga las preferencias personales del usuario para trabajar de la forma que considere más adecuada. Un requisito previo para permitir la entrada del usuario es el desarrollo de una metodología de diseño adaptativo, es decir, un sistema híbrido automatizado abierto que permita el uso de tecnología asistida por ordenador para su implantación en el proceso de diseño. La necesidad de desarrollar una metodología para diseño adaptativo es uno de los requisitos inmediatos para realizar el concepto del $\mathrm{OHAS}$ en la práctica. También es necesario desarrollar un nuevo nivel de tecnología de control de supervisión humana adaptativa. Dicha tecnología debe permitir al operador humano "traspasar con la vista" el impenetrable sistema de control del HAS en funcionamiento: por ejemplo, mediante la aplicación de un sistema de vídeo de alta velocidad en cada punto de funcionamiento y control del sistema. Finalmente, en los sistemas híbridos automatizados es muy necesaria una metodología para desarrollar un apoyo asistido por ordenador, inteligente y muy adaptable, a los papeles humanos y el funcionamiento.humano.

\section{PRINCIPIOS DEL DISEÑ O DE SISTEMAS DE CONTROL SEGUROS}

\section{Georg Vondracek}

Se acepta en general que los sistemas de control tienen que ser seguros durante el uso. A este fin, los sistemas de control modernos se diseñan tal como muestra la Figura 58.65.

La forma más sencilla de hacer seguro un sistema de control consiste en construir una barrera impenetrable a su alrededor para evitar el acceso o la interferencia de personas en la zona de peligro. Tal sistema sería muy seguro, pero impracticable, ya que no permitiría el acceso para realizar la mayoría de los trabajos de prueba, reparación y ajuste. Puesto que es necesario permitir el acceso a zonas de peligro en determinadas condiciones, se precisan medidas de protección distintas de tabiques, vallas, etc. para facilitar la producción, instalación, servicio y mantenimiento.

Algunas de estas medidas de protección pueden integrarse total o parcialmente en sistemas de control, a saber:

- El movimiento se puede interrumpir inmediatamente si alguien penetra en la zona de peligro, mediante botones de parada de emergencia (PE).

- Los controles de pulsador sólo permiten el movimiento cuando está accionado el pulsador.

- Los mandos bimanuales (M BM ) sólo permiten el movimiento cuando las dos manos están ocupadas presionando los dos elementos del mando (asegurando así que las manos estén fuera de la zona de peligro).

Es el personal quien activa este tipo de medidas de protección. A hora bien, debido a que los seres humanos constituyen a menudo un punto débil de las aplicaciones, muchas funciones, como las siguientes, se ejecutan automáticamente:

- Los movimientos de los brazos de los robots durante los trabajos de mantenimiento o la "instrucción" son muy lentos. No obstante, la velocidad se supervisa continuamente. Si debido a un fallo del sistema de control, la velocidad de los

Figura 58.65 - Diseño general de sistemas de control.

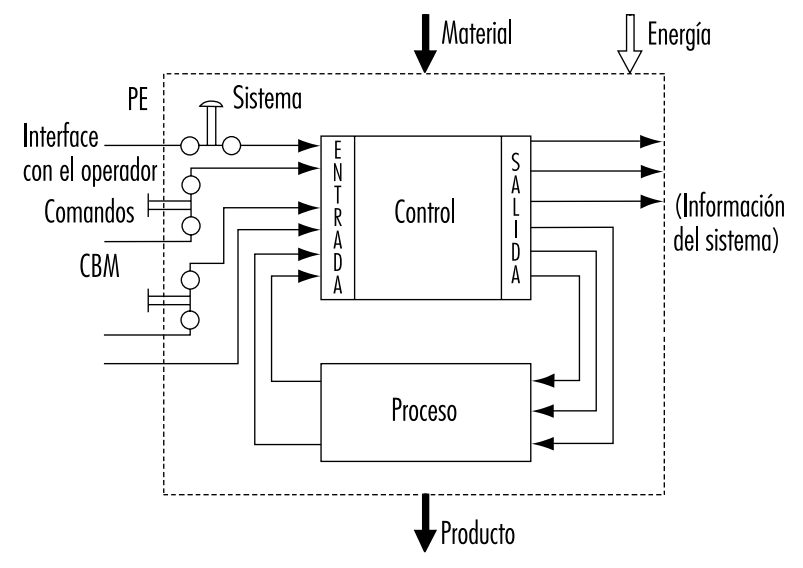


brazos del robot aumentara inesperadamente durante los trabajos de mantenimiento o la "instrucción", el sistema de supervisión se activaría y detendría el movimiento inmediatamente.

- Se instala una barrera de luz para evitar el acceso a la zona de peligro. Si se interrumpe el haz luminoso, la máquina se para automáticamente.

El funcionamiento normal de los sistemas de control es la principal condición necesaria para la producción. Si una función de producción se interrumpe debido a un fallo del control, ello supondrá a lo sumo un inconveniente, pero no un peligro. Si una función que afecta a la seguridad no se ejecuta, el resultado puede ser la pérdida de producción, daños materiales o personales, incluso mortales. Por tanto, las funciones del sistema de control relevantes para la seguridad tienen que ser más fiables y seguras que las funciones normales del sistema de control. Según la directiva del Consejo Europeo 89/392/ CEE (Directiva de maquinaria), los sistemas de control han de diseñarse de manera que sean seguros y fiables.

L os controles constan de varios componentes interconectados para ejecutar una o más funciones. Los controles se subdividen en canales. Un canal es la parte de un control que realiza una función específica (por ejemplo, puesta en marcha, parada, parada de emergencia). Físicamente, el canal se crea con una cadena de componentes (transistores, diodos, relés, puertas, etc.) a través de los cuales se transmite de uno a otro información (sobre todo eléctrica) que representa la función, desde la entrada hasta la salida.

Al diseñar canales de control para funciones relevantes para la seguridad (las funciones que implican a personas), es necesario cumplir los siguientes requisitos:

- Los componentes usados en canales de control con funciones relevantes para la seguridad tienen que poder soportar los rigores del uso normal. En general, tienen que ser suficientemente fiables.

- Los errores de lógica no deben originar situaciones peligrosas. En general, el canal relevante para la seguridad tiene que ser suficientemente a prueba de fallos.

- Las influencias externas (factores) no deben provocar fallos permanentes o temporales en canales relevantes para la seguridad.

\section{Fiabilidad}

Fiabilidad es la capacidad de un canal de control o componente para ejecutar una función requerida en las condiciones especificadas durante un período de tiempo dado sin fallos . (L a probabilidad de componentes o canales de control específicos se puede calcular utilizando métodos adecuados). La fiabilidad ha de especificarse siempre en relación con un espacio de tiempo concreto, Generalmente la fiabilidad se puede expresar mediante la fórmula de la Figura 58.66.

Figura 58.66 • Fórmula de la fiabilidad.

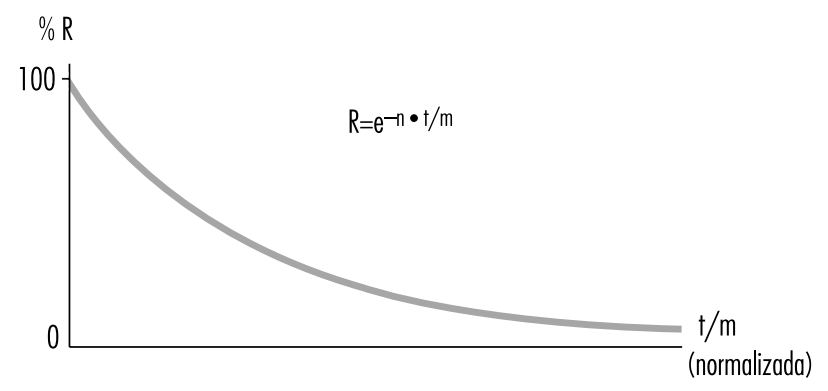

Figura 58.67 - Curvas de fiabilidad de componentes conectados en serie.

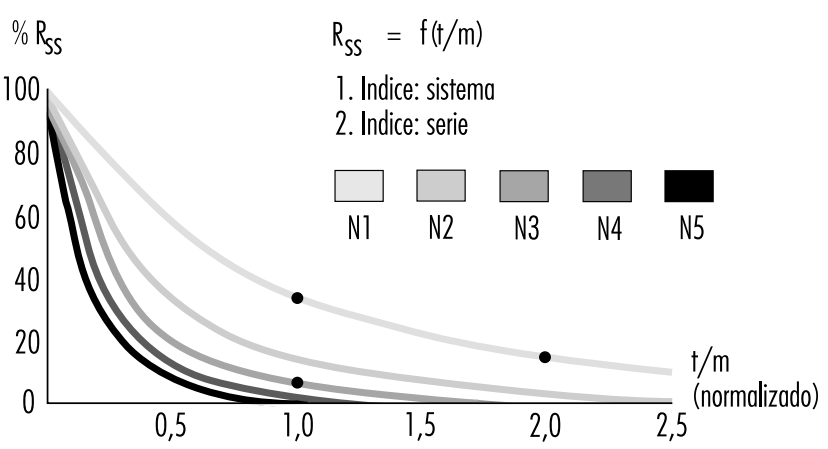

$R_{\text {tot }}=R_{c}^{N}$

(Fórmula para componentes conectados en serie con la misma fiabilidad)

\section{Fiabilidad de sistemas complejos}

L os sistemas están formados por componentes. Si se conocen las fiabilidades de los componentes, se puede calcular la del sistema en su conjunto. En tales casos, se aplica lo siguiente:

\section{Sistemas seriados}

La fiabilidad total $R_{\text {tot }}$ de un sistema serial que contiene $N$ componentes de la misma fiabilidad $R_{C}$ se calcula tal como se indica en la Figura 58.67.

L a fiabilidad total es menor que la fiabilidad del componente menos fiable. A medida que aumenta el número de componentes conectados en serie, la fiabilidad total de la cadena disminuye significativamente.

\section{Sistemas paralelos}

La fiabilidad total $R_{\text {tot }}$ de un sistema paralelo formado por $N$ componentes de la misma fiabilidad $R_{C}$ se calcula tal como se indica en la Figura 58.68.

La fiabilidad total puede aumentar significativamente mediante la conexión en paralelo de dos o más componentes.

Figura 58.68 - Curvas de fiabilidad de componentes conectados en paralelo.

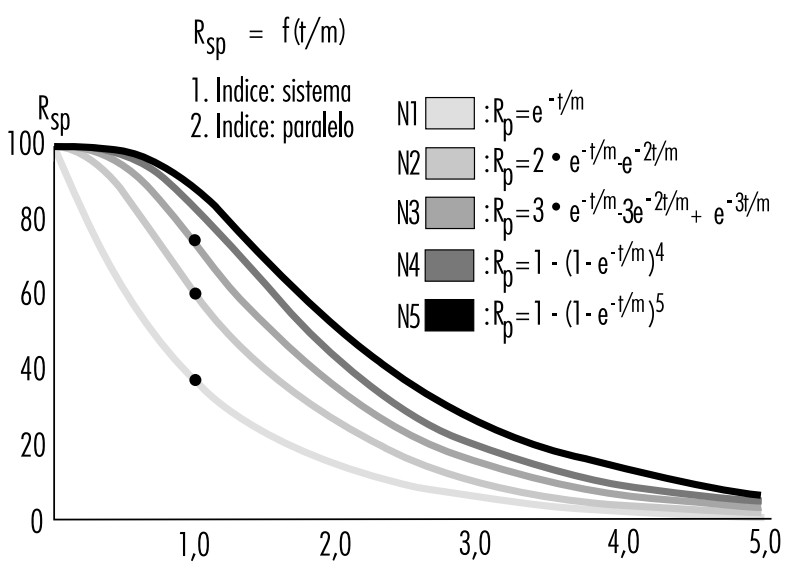

$R_{\text {tot }}=1-\left(1-R_{c}\right) \mathrm{N}$

(Fórmula para componentes conectados en paralelo con la misma fiabilidad) 
La Figura 58.69 ilustra un ejemplo práctico. 0 bsérvese que el circuito desconectará el motor más fiable. Incluso si los relés A o B no abren sus contactos, el motor se parará a pesar de todo.

El cálculo de la fiabilidad total de un canal es sencillo si se conocen las fiabilidades de todos los componentes necesarios. En el caso de componentes complejos (circuitos integrados, microprocesadores, etc.) el cálculo de la fiabilidad puede ser difícil o imposible si el fabricante no facilita la información necesaria.

\section{Seguridad}

Cuando los profesionales hablan de seguridad y piden máquinas seguras, se refieren a la seguridad de la máquina o sistema en su conjunto. D esde luego, es una seguridad demasiado general y que no está definida con precisión para el diseñador de los controles. La siguiente definición de seguridad puede ser práctica y utilizable por los diseñadores de los circuitos de control. Seguridad es la capacidad de un circuito de control para ejecutar la función requerida dentro de los límites especificados, durante un tiempo determinado, incluso si se producen uno o varios fallos previstos. En consecuencia, es preciso aclarar en la propia fase de diseño hasta qué punto tiene que ser seguro el canal relacionado con la seguridad. (EI diseñador puede desarrollar un canal que sea seguro contra el primer fallo, contra cualquier fallo, contra dos fallos, etc.). Además, un canal utilizado para evitar accidentes puede ser esencialmente fiable, pero no tiene que ser necesariamente a prueba de fallos. Esto se puede explicar mejor mediante los siguientes ejemplos:

\section{Ejemplo 1}

El ejemplo ilustrado en la Figura 58.70 es un canal de control asociado a la seguridad que ejecuta la función de seguridad requerida. El primer componente puede ser un interruptor que controla, por ejemplo, la posición de una puerta de acceso a una zona peligrosa. El último componente es un motor que acciona elementos mecánicos dentro de la zona de peligro.

La función de seguridad requerida en este caso es doble: si la puerta está cerrada, el motor puede funcionar. Si está abierta, el motor tiene que estar parado. Conociendo las fiabilidades $R_{1}$ a $R_{6}$, se puede calcular la fiabilidad $R_{\text {tot. }}$ Los diseñadores deben utilizar componentes fiables para mantener una fiabilidad suficientemente alta del conjunto del sistema de control (es decir, hay que tener en cuenta la probabilidad de que esta función se siga realizando al cabo de 20 años, por ejemplo). En consecuencia, los diseñadores tienen dos tareas: (1) el circuito ha de ejecutar la función requerida, y (2) la fiabilidad de los componentes y del canal de control completo tienen que ser suficientes.

Ahora cabe preguntar lo siguiente: ¿Realizará el canal mencionado las funciones de seguridad requeridas incluso si se

Figura 58.69 Ejemplo práctico de la figura 58.68.

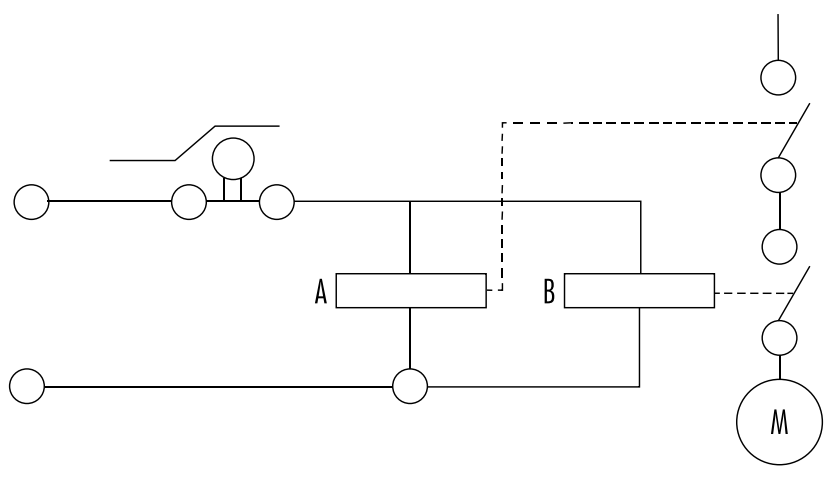

Figura 58.70 - Un canal de control de seguridad ejecutando la función de seguridad requerida.

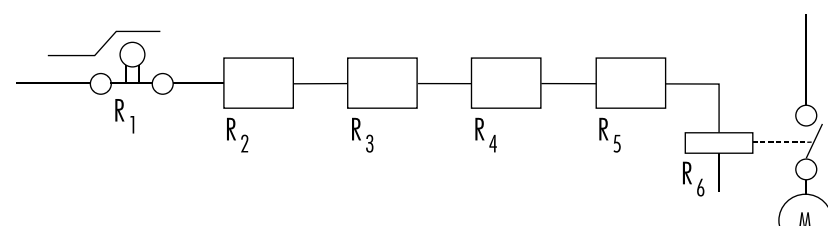

Figura 58.71 - Un canal de control de seguridad con dos subcanales totalmente separados.

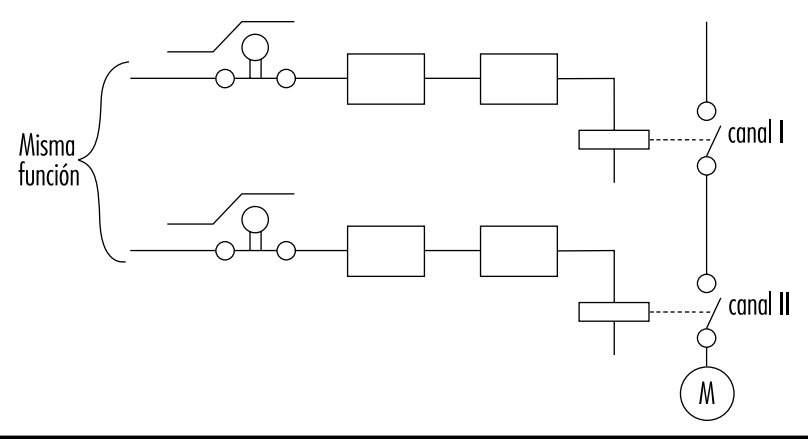

Figura 58.72 - Un canal de control de seguridad con dos subcanales totalmente separados que se supervisan recíprocamente.

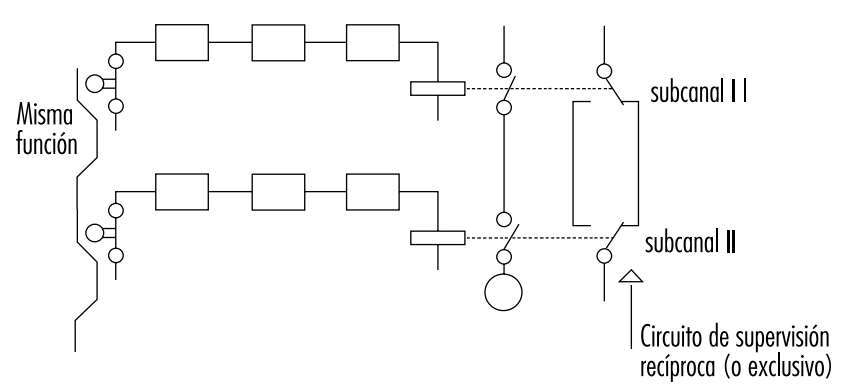

Figura 58.73 - Fiabilidad de sistemas redundantes con 0 sin detección de fallos.

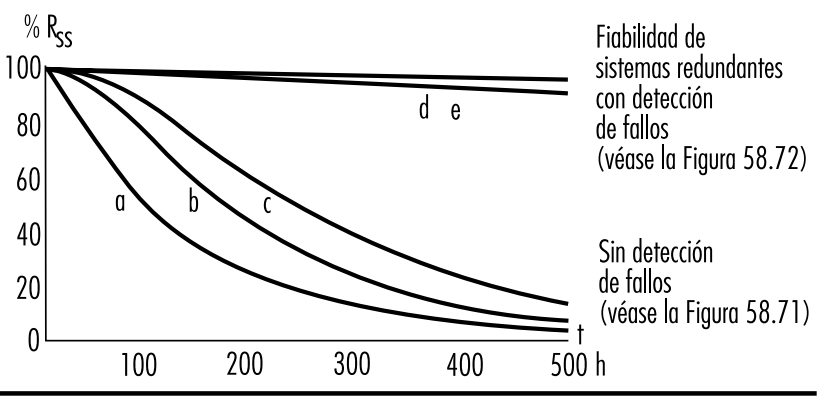


produce un fallo del sistema (por ejemplo, si el contacto de un relé permanece adherido o si falla un componente)? La respuesta es "no". La razón es que un solo canal formado por componentes conectados en serie y que operan con señales estáticas no es seguro contra un fallo. El canal sólo puede tener cierta fiabilidad, que garantiza la probabilidad de que la función se ejecutará. En estas situaciones, la seguridad siempre se entiende relacionada con los fallos.

\section{Ejemplo 2}

Si un canal de control tiene que ser fiable y seguro, el diseño ha de modificarse tal como se indica en la Figura 58.71. El ejemplo ilustrado es un canal de control relacionado con la seguridad y formado por dos subcanales totalmente independientes.

Este diseño es seguro contra el primer fallo (y posibles fallos adicionales en el mismo subcanal), pero no lo es contra dos fallos que puedan producirse en dos subcanales distintos (simultáneamente 0 en momentos distintos), porque no hay un circuito de detección de fallos. En consecuencia, ambos subcanales funcionan inicialmente con una alta fiabilidad (véase el sistema paralelo), pero después del primer fallo sólo funcionará un canal y disminuirá la fiabilidad. En caso de producirse un segundo fallo en el subcanal que todavía funciona, los dos habrían fallado y la función de seguridad dejaría de ejecutarse.

\section{Ejemplo 3}

El ejemplo ilustrado en la Figura 58.72 es un canal de control de seguridad formado por dos subcanales independientes que se supervisan mutuamente.

Este diseño es a prueba de fallos porque después de cualquier fallo sólo quedará fuera de servicio un subcanal, quedando el otro disponible para ejecutar la función de seguridad. A demás, el diseño tiene un circuito de detección de fallos. Si debido a un fallo ambos subcanales dejan de funcionar de la misma manera, esta situación la detecta el circuito de "OR exclusivo", con el resultado de que la máquina se para automáticamente. Esta es una manera óptima de diseñar controles de máquinas, a saber, mediante subcanales de seguridad. Son seguros contra un fallo y al mismo tiempo ofrecen fiabilidad suficiente para que la probabilidad de que se produzcan dos fallos simultáneamente sea minúscula.

\section{Redundancia}

Salta a la vista que hay varios métodos a disposición del diseñador para mejorar la fiabilidad y/ o seguridad (contra fallos). LoS ejemplos anteriores ilustran cómo una función (por ejemplo, puerta cerrada, el motor puede funcionar; puerta abierta, el motor tiene que estar parado) se puede realizar de distintas maneras. Algunos métodos son muy sencillos (un subcanal), y otros más complicados (dos subcanales con supervisión mutua) (véase la Figura 58.73).

Existe cierta redundancia en los circuitos y/ o componentes complejos en comparación con los sencillos. La redundancia se puede definir así: (1) redundancia es la presencia de más medios (componentes, canales, factores de seguridad más altos, pruebas adicionales, etc.) de los realmente necesarios para el simple cumplimiento de la función deseada; (2) evidentemente, la redundancia no "mejora" la función, que se ejecuta de todos modos. La redundancia sólo mejora la fiabilidad y/o la seguridad.

Algunos profesionales de la seguridad creen que la redundancia sólo consiste en duplicar o triplicar, etc. el sistema. Esta es una interpretación muy limitada, ya que la redundancia se puede interpretar mucho más amplia y flexiblemente. La redundancia se puede incorporar no sólo al hardware, sino también al software. La mejora del factor de seguridad (por ejemplo, un cable más resistente en lugar de uno más débil) se puede considerar también una forma de redundancia.

\section{Entropía}

Entropía, un término utilizado sobre todo en termodinámica y astronomía, se puede definir así: todo tiende a decaer. Por tanto, es absolutamente seguro que todos los componentes, subsistemas y sistemas, independientemente de la tecnología utilizada, fallarán alguna vez. Esto significa que no hay componentes, subsistemas ni sistemas fiables y/ o seguros al $100 \%$. Todos ellos son más o menos fiables y seguros en función de la complejidad de la estructura. Los fallos que inevitablemente se producen antes o después reflejan la acción de la entropía.

El único medio que tienen los diseñadores para contrarrestar la entropía es la redundancia que se logra: (a) introduciendo más fiabilidad en los componentes, y (b) proporcionando más seguridad a toda la arquitectura del circuito. Sólo aumentando suficientemente la probabilidad de que se ejecute la función requerida durante el período de tiempo necesario, pueden los diseñadores defenderse de alguna manera de la entropía.

\section{Evaluación de riesgos}

Cuanto mayor es el riesgo potencial, mayor es la fiabilidad y/ 0 seguridad (contra fallos) necesaria (y viceversa). Esto se ilustra en los dos casos siguientes:

\section{Caso 1}

El acceso al molde en un máquina de moldeo por inyección está protegido por una puerta. Si la puerta está cerrada, la máquina puede funcionar, y si está abierta es necesario parar todos los movimientos peligrosos. En ningún caso (ni siquiera si falla el canal de seguridad) debe producirse movimiento alguno, especialmente los que accionan el molde.

\section{Caso 2}

El acceso a una línea de montaje controlada automáticamente que monta pequeños componentes de plástico a presión neumática, está protegido por una puerta. Si se abre la puerta, la línea tiene que pararse.

En el caso 1, si falla el sistema de supervisión de la puerta, puede producirse una lesión grave si el molde se cierra inesperadamente. En el caso 2, sólo pueden producirse lesiones leves 0 pequeños daños si falla el sistema de supervisión de la puerta.

Es evidente que en el primer caso hay que incorporar un mayor grado de redundancia para obtener la fiabilidad $\mathrm{y} / 0$ seguridad (contra fallos) necesarias a fin de prevenir un riesgo muy elevado. De hecho, según la norma europea EN 201, el sistema de supervisión de la puerta de la máquina de moldeo por inyección tiene que tener tres canales, dos de ellos eléctricos y de supervisión mutua y uno equipado sobre todo con circuitos hidráulicos y de prueba. Las tres funciones de supervisión se refieren a la misma puerta.

Por el contrario, en aplicaciones como la del caso 2, un solo canal activado por un interruptor de acción positiva es suficiente para cubrir el riesgo.

\section{Categorías de controles}

D ebido a que todas las consideraciones anteriores están basadas generalmente en la teoría de la información y son por tanto válidas para todas las tecnologías, no importa que el sistema de control esté basado en componentes electrónicos, electromecánicos, mecánicos, hidráulicos o neumáticos (o en una combinación de los mismos) o en alguna otra tecnología. La inventiva del diseñador por una parte y las consideraciones económicas por otra son los factores principales que afectan a un número casi infinito de soluciones para diseñar canales de seguridad. 
Para evitar confusiones, resulta práctico establecer ciertos criterios de ordenación. Las estructuras de canales más típicas utilizadas en controles de máquinas para ejecutar funciones de seguridad se clasifican según las siguientes categorías:

- fiabilidad;

- comportamiento en caso de fallo,

- tiempo para detectar el fallo.

Sus combinaciones (no todas las posibles) se ilustran en la Tabla 58.5

La categoría aplicable a una máquina concreta y a su sistema de control de seguridad se especifica sobre todo en las nuevas normas europeas (EN), a menos que la autoridad nacional, el usuario y el fabricante acuerden aplicar otra categoría. El diseñador desarrolla entonces un sistema de control que cumple los requisitos. Por ejemplo, las consideraciones que rigen el diseño de un canal de control pueden incluir lo siguiente:

- Los componentes tienen que soportar las influencias esperadas. (SI/ NO)

- Su construcción debe estar de acuerdo con las normas más avanzadas. (SI/ NO)

- Se utilizan componentes y métodos bien probados. (SI/ NO)

- Los fallos tienen que ser detectados. (SI/ NO)

- ¿Tiene que ejecutarse la función incluso en caso de fallo? (SI/ NO)

- ¿Cuándo se detectará el fallo? (NUNCA, PRONTO, INMEDIATAMENTE)
Este proceso es reversible. U tilizando la misma pregunta se puede decidir a qué categoría pertenece un canal de control existente, desarrollado con anterioridad.

\section{Ejemplos de categorías}

\section{Categoría B}

Los componentes de control utilizados principalmente en productos de consumo tienen que soportar las influencias esperadas y diseñarse de acuerdo con los últimos conocimientos. Un interruptor bien diseñado puede servir de ejemplo.

\section{Categoría 1}

EI uso de componentes y métodos bien probados es típico de la categoría 1. U n ejemplo de esto es un interruptor de acción positiva (es decir, que requiere la apertura forzada de los contactos). Este interruptor se diseña con piezas robustas y se activa mediante fuerzas relativamente altas, alcanzando una fiabilidad muy elevada sólo en la apertura de los contactos. En vez de contactos pegados 0 adheridos, estos interruptores se abrirán. (N ota: componentes como transistores y diodos no se consideran componentes debidamente probados). La Figura 58.74 puede servir de ilustración de un control de la categoría 1.

Este canal utiliza un interruptor $\mathrm{S}$ de acción positiva. El contactor $K$ se supervisa mediante el piloto $L$, que avisa al operador de que los contactos normalmente abiertos (NA) están pegados. El contactor $\mathrm{K}$ tiene contactos con guía forzada. ( $N$ ota: los contactores o relés con guía forzada tienen, a diferencia de los normales, una jaula especial de material aislante,

Tabla 58.5 - Algunas posibles combinaciones de estructuras de circuitos en controles de máquinas para funciones relacionadas con la seguridad.

\begin{tabular}{|c|c|c|c|c|c|c|}
\hline \multirow[t]{2}{*}{ Criterios (preguntas) } & \multicolumn{6}{|l|}{ Estrategia básica } \\
\hline & \multicolumn{3}{|c|}{$\begin{array}{l}\text { Aumentando la fiabilidad (ise desplaza a un futuro posible- } \\
\text { mente lejano la producción del fallo?) }\end{array}$} & \multirow{2}{*}{\multicolumn{3}{|c|}{$\begin{array}{l}\text { Mediante una estructura adecuada del circuito se detecta al } \\
\text { menos el fallo (categoría 2), o los efectos del fallo sobre el } \\
\text { canal se eliminan (categoría 3) o el fallo se descubre } \\
\text { inmediatamente (categoría 4) }\end{array}$}} \\
\hline & \multirow{2}{*}{\multicolumn{6}{|c|}{ Categorías }} \\
\hline & & & & & & \\
\hline & $\begin{array}{l}\text { Esta solución es } \\
\text { básicamente } \\
\text { incorrecta }\end{array}$ & B & 1 & 2 & 3 & 4 \\
\hline $\begin{array}{l}\text { ¿Pueden los componentes de } \\
\text { los circuitos resistir las } \\
\text { influencias esperadas? ¿ Están } \\
\text { construidos de acuerdo con } \\
\text { los últimos conocimientos? }\end{array}$ & No & Sí & Sí & Sí & Sí & Sí \\
\hline $\begin{array}{l}\text { ¿Hasta qué punto estaban bien } \\
\text { probados los métodos y } \\
\text { componentes utilizados? }\end{array}$ & No & No & Sí & Sí & Sí & Sí \\
\hline $\begin{array}{l}\text { ¿Se puede detectar un fallo } \\
\text { automáticamente? }\end{array}$ & No & No & No & Sí & Sí & Sí \\
\hline $\begin{array}{l}\text { ¿Impide un fallo la ejecución de } \\
\text { la función de seguridad corres- } \\
\text { pondiente? }\end{array}$ & Sí & Sí & Sí & Sí & No & No \\
\hline \multirow[t]{2}{*}{ ¿Cuándo se detectará el fallo? } & \multirow[t]{2}{*}{ Nunca } & Nunca & Nunca & \multicolumn{2}{|c|}{$\begin{array}{l}\text { Pronto (a más tardar, al final de un intervalo } \\
\text { de no más duración que un ciclo de la } \\
\text { máquina) }\end{array}$} & $\begin{array}{l}\text { Inmediatamente } \\
\text { (cuando la señal } \\
\text { pierde su carácter } \\
\text { dinámico) }\end{array}$ \\
\hline & & $\begin{array}{r}\text { En pro } \\
\text { cons }\end{array}$ & Para utilizar e & áqui & & \\
\hline
\end{tabular}


Figura 58.74 - Un interruptor de acción positiva.

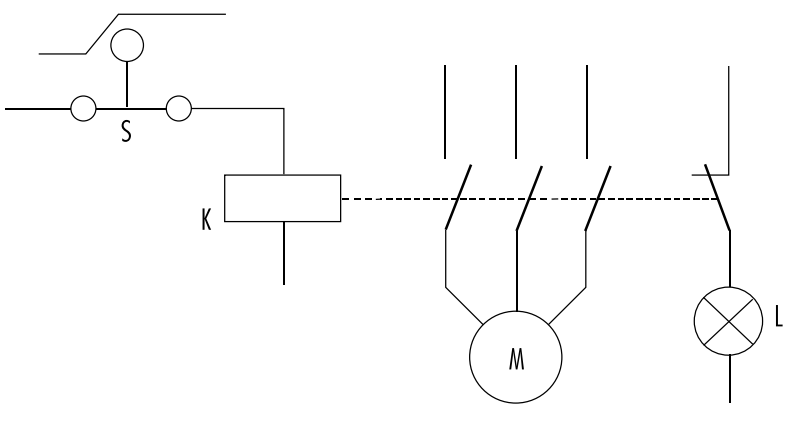

de manera que si los contactos normalmente cerrados (NC) están cerrados, todos los contactos NA tienen que estar abiertos y viceversa. Esto significa que, mediante el uso de contactos NC, se puede hacer una comprobación para determinar que los contactos de trabajo no están pegados o soldados).

\section{Categoría 2}

La categoría 2 permite la detección automática de fallos, que ha de generarse antes de cada movimiento peligroso. Sólo si la prueba da resultado positivo se puede ejecutar el movimiento; de lo contrario, la máquina se para. Los sistemas de detección automática de fallos se utilizan para barreras de luz, a fin de comprobar que siguen funcionando. Este principio se ilustra en la Figura 58.75.

Este sistema de control se prueba periódicamente (u ocasionalmente) introduciendo un impulso en la entrada. En un sistema que funcione correctamente, este impulso se transfiere a la salida y se compara con un impulso procedente de un generador de prueba. Cuando ambos impulsos están presentes, el sistema evidentemente funciona. Por el contrario, si no hay impulso de salida, puede afirmarse que el sistema falla.

\section{Categoría 3}

Los circuitos ya se han descrito en el ejemplo 3 del capítulo sobre seguridad de este artículo, Figura 58.72.

El requisito, es decir, la detección automática del fallo y la capacidad para realizar la función de seguridad incluso si se ha producido un fallo en otro lugar, se puede cumplir mediante estructuras de control de dos canales y la supervisión mutua de ambos canales.

Sólo en el caso de controles de máquinas es preciso investigar los fallos peligrosos. N ótese que hay dos tipos de fallos:

- No peligrosos son los que, después de ocurrir, dan lugar a un "estado seguro" de la máquina gracias a la desconexión del motor.

- Peligrosos son los que, después de ocurrir, dan lugar a un estado "no seguro" de la máquina porque el motor no se puede desconectar o puede ponerse en marcha inesperadamente.

\section{Categoría 4}

La categoría 4 corresponde normalmente a la aplicación en la entrada de una señal dinámica que cambia continuamente. La presencia de una señal dinámica en la salida significa en marcha ("1") y la ausencia de una señal dinámica significa parado ("0").

Para un circuito de este tipo, lo normal es que después del fallo de cualquier componente la señal dinámica no se encuentre en la salida. (N ota: el potencial estático en la salida es indiferente). Estos circuitos se pueden llamar "a prueba de fallos". Todos los fallos se manifiestan inmediatamente y no después del primer cambio (como en los circuitos de la categoría 3).

\section{Otros comenta rios sobre las ca tegorías de control}

La Tabla 58.5 se ha preparado para los controles habituales de las máquinas y muestra sólo las estructuras básicas de los circuitos. Según la directiva de maquinaria es preciso calcular partiendo de la hipótesis de que sólo se producirá un fallo en un ciclo de la máquina. Esta es la razón de que la función de seguridad no se tenga que realizar en el caso de dos fallos coincidentes. Se supone que un fallo se detectará dentro de un ciclo de la máquina. La máquina se parará y luego será reparada. EI sistema de control se pondrá de nuevo en funcionamiento, con todas sus funciones y sin fallos.

La primera intención del diseñador debe consistir en impedir los fallos "permanentes" que no se detecten durante un ciclo, ya que podrían combinarse después con nuevos fallos (acumulación de fallos). Esta combinación (un fallo permanente y un nuevo fallo) puede originar un fallo de funcionamiento hasta en un circuito de categoría 3.

A pesar de estas tácticas, es posible que se produzcan dos fallos independientes al mismo tiempo y dentro del mismo ciclo de la máquina. Esto es muy improbable, especialmente si se utilizan componentes altamente fiables. Para aplicaciones de muy alto riesgo deben utilizarse tres o más subcanales. Esta filosofía está basada en el hecho de que el tiempo medio entre fallos es mucho más largo que el ciclo de la máquina.

Con todo, esto no significa que la tabla no se pueda ampliar. La Tabla 58.5 es muy similar, tanto en su base como en su estructura, a la tabla 2 de la norma EN 954-1. Con todo, no pretende incluir demasiados criterios de clasificación. Los requisitos están definidos según los rigurosos principios de la lógica, por lo que sólo cabe esperar respuestas claras (SI o NO). Esto permite una evaluación, ordenación y clasificación más exactas de los circuitos examinados (canales de seguridad), y asimismo una significativa mejora de la reproducibilidad de la evaluación.

Lo ideal sería clasificar los riesgos en varios niveles, establecer después un enlace definido entre ellos y categorías de riesgo, y todo ello independientemente de la tecnología utilizada. A hora bien, esto no es totalmente posible. Poco después de crear las categorías se puso de manifiesto que incluso con la misma tecnología, varias preguntas no tenían respuesta suficiente. ¿Q ué es mejor, un componente fiable y bien diseñado de la categoría 1 o un sistema que cumpla los requisitos de la categoría 3 con escasa fiabilidad?

Para salir de este dilema es necesario diferenciar entre dos cualidades: fiabilidad y seguridad (contra fallos). No son cualidades comparables, ya que tienen distintas características:

- El componente con la máxima fiabilidad tiene la desventaja de que en caso de fallo (aunque sea altamente improbable) la función dejará de ejecutarse.

- Los sistemas de la categoría 3, en los cuales incluso en caso de fallo se ejecuta la función, no son seguros contra dos fallos simultáneos (un factor que puede ser importante es si se han utilizado componentes suficientemente fiables).

Figura 58.75 - Circuito que incluye un detector de fallos. Sistema de control $X$

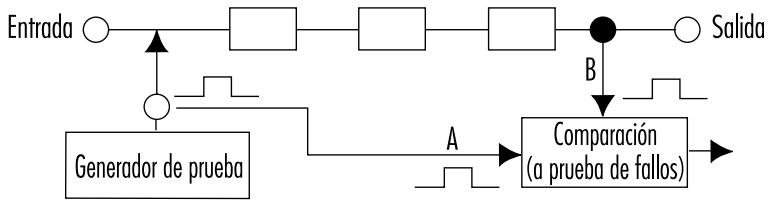

Si:

$A=B$....no hay fallo en el sistema de control $X$

$A \neq B$....fallo en el sistema de control $X$ 
Figura 58.76 - Un circuito de SEP.

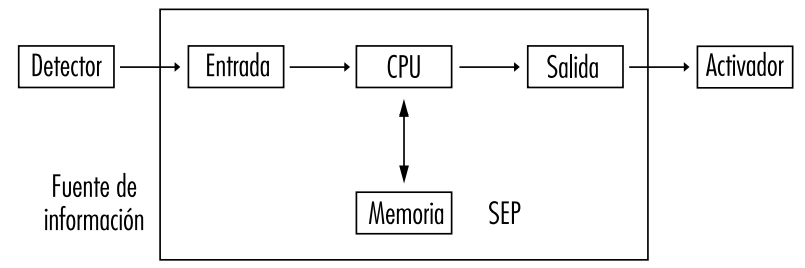

En vista de lo anterior, es posible que la mejor solución (desde el punto de vista del alto riesgo) consista en utilizar componentes muy fiables y configurarlos de manera que el circuito resulte seguro contra un fallo como mínimo (preferiblemente más). Es evidente que una solución de este tipo no será la más económica. En la práctica el proceso de optimización es, sobre todo, fruto de todas estas influencias y consideraciones.

La experiencia en el uso práctico de las categorías muestra que raras veces es posible diseñar un sistema de control que utilice exclusivamente una categoría. La combinación de dos o incluso tres componentes, cada uno de una categoría distinta, es corriente, como ilustra el siguiente ejemplo:

M uchas barreras de luz de seguridad se diseñan según la categoría 4, según la cual un canal funciona con una señal dinámica. En el extremo de este sistema hay normalmente dos subcanales supervisados mutuamente que funcionan con señales estáticas (esto cumple los requisitos de la categoría 3).

Según la norma EN 50100, estas barreras de luz se clasifican en la categoría de Dispositivos de protección electrosensibles de tipo 4, aunque constan de dos componentes. L amentablemente no hay acuerdo en torno al modo de denominar los sistemas de control formados por dos o más componentes de categorías distintas.

\section{Sistemas electrónicos programables (SEP)}

Los principios utilizados para crear la Tabla 58.5, también pueden aplicarse en general, con ciertas limitaciones como es natural, a los SEP.

\section{Sistema con SE P en exclusiva}

Al utilizar SE P para fines de control, la información se transfiere del sensor al activador a través de un gran número de componentes y pasa incluso "a través" del software (véase la Figura 58.76).

A unque los modernos SEP son muy fiables, la fiabilidad no es tan alta como la que puede ser necesaria para procesar funciones de seguridad. Además, los sistemas de SEP habituales no son suficientemente seguros, ya que en caso de fallo no ejecutan la función de seguridad. Por tanto, el uso de SEP para procesar funciones de seguridad sin medidas adicionales no está permitido.

\section{Aplicaciones de riesgo muy bajo: sistemas con un SE P y medidas adicionales}

Cuando se usa un solo SEP para fines de control, el sistema consta de los siguientes componentes principales:

\section{Componente de entrada}

La fiabilidad de un sensor y una entrada de un SEP se puede mejorar duplicándolos. Esta configuración de entrada doble se puede supervisar además por software para comprobar si ambos subsistemas proporcionan la misma información. De esta manera se pueden detectar fallos en el componente de entrada. Es casi la misma filosofía que la exigida para la categoría 3. Ahora bien, debido a que la supervisión se hace por software y una sola vez, se puede denominar 3- (o no tan fiable como 3).

\section{Componente intermedio}

Aunque este componente no es fácil de duplicar, se puede probar. Al proceder al encendido (o durante el funcionamiento) es posible comprobar el conjunto completo de instrucciones. C on los mismos intervalos se puede comprobar también la memoria mediante patrones de bits adecuados. Si estas pruebas se superan sin fallos, es evidente que ambos componentes (la CPU y la memoria) funcionan correctamente. El componente intermedio tiene ciertas características típicas de la categoría 4 (señal dinámica) y otras típicas de la categoría 2 (pruebas realizadas periódicamente en intervalos adecuados). EI problema es que estas pruebas, a pesar de su amplitud, no pueden ser realmente completas, ya que el sistema de un único SEP intrínsecamente no lo permite.

\section{Componente de salida}

I gual que la entrada, la salida (incluidos los activadores) puede duplicarse. Ambos subsistemas se pueden supervisar con respecto al mismo resultado. Los fallos se detectan y la función de seguridad se ejecuta. Con todo, tiene los mismos puntos débiles que el componente de entrada. Por consiguiente, se elige en este caso la categoría 3.

En la Figura 58.77 la misma función se lleva a los relés A y B. Los contactos de control $a$ y $b$, informan entonces a dos sistemas de entrada si ambos relés están haciendo el mismo trabajo (a menos que se haya producido un fallo en uno de los canales). De nuevo, la supervisión corre a cargo del software.

El sistema completo se puede clasificar en la categoría 3-/4/2/3- si se ha realizado correcta e íntegramente. No obstante, los puntos débiles de este tipo de sistemas, descritos anteriormente, no se pueden eliminar por completo. De hecho, actualmente los sistemas de un solo SEP para funciones de seguridad sólo se utilizan si los riesgos son muy bajos (H ölscher y R ader 1984).

\section{Aplicaciones de riesgo bajo y medio con un SE P}

Actualmente, casi todas las máquinas están equipadas con una unidad de control basada en un SEP. Para solucionar el problema de la insuficiente fiabilidad y la normalmente insuficiente seguridad contra fallos, suelen aplicarse los siguientes métodos de diseño:

- En máquinas relativamente sencillas, como ascensores, las funciones se dividen en dos grupos: (1) las funciones no

Figura 58.77 - Un circuito de SEP con un sistema de detección de fallos

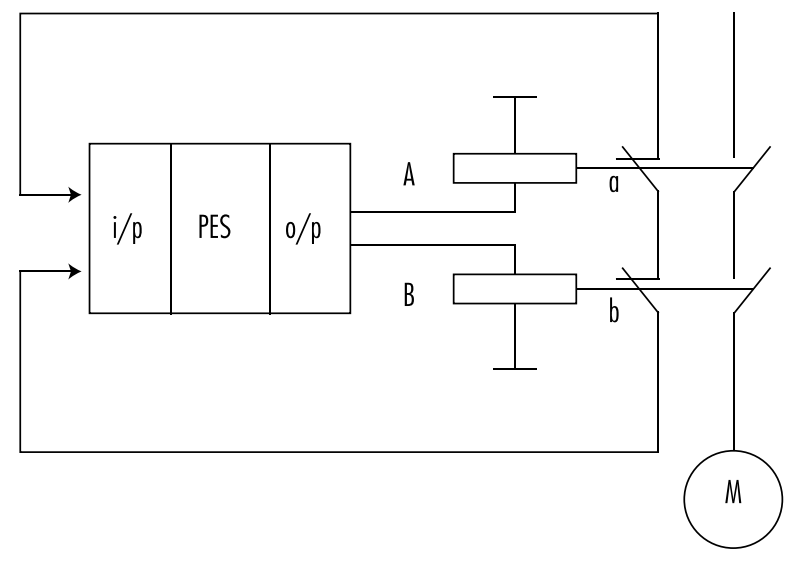


relacionadas con la seguridad, que son procesadas por el SEP, y (2) las relacionadas con la seguridad, que se combinan en una cadena (circuito de seguridad) y se procesan fuera del SEP (véase la Figura 58.78).

- El método anterior no es adecuado para máquinas más complejas. U na razón es que esas soluciones no suelen ser suficientemente seguras. Para aplicaciones de riesgo medio, las soluciones deben cumplir los requisitos de la categoría 3. En las Figuras 58.79 y 58.80 se presentan los rasgos generales de posibles concreciones de este tipo de diseños.

\section{Aplicaciones de riesgo alto: sistemas con dos (o más) SE P}

A parte de la complejidad y el coste, no hay otros factores que impidan a los diseñadores utilizar SEP totalmente duplicados como Siemens Simatic S5-115F, 3B6 Typ CAR -M IL, etc. Estos suelen incorporar dos SEP idénticos con software homogéneo y suponen el uso de SEP y compiladores "probados" (se puede considerar "probado" un SEP o compilador si en numerosas aplicaciones prácticas durante tres o más años se ha demostrado que se ha eliminado todo fallo sistemático). A unque estos sistemas de SEP duplicados no tienen los puntos débiles de los de un solo SEP, eso no significa que aquéllos resuelvan todos los problemas (véase la Figura 58.81).

Figura 58.78 - Estado de la técnica en categoría de parada 0 .

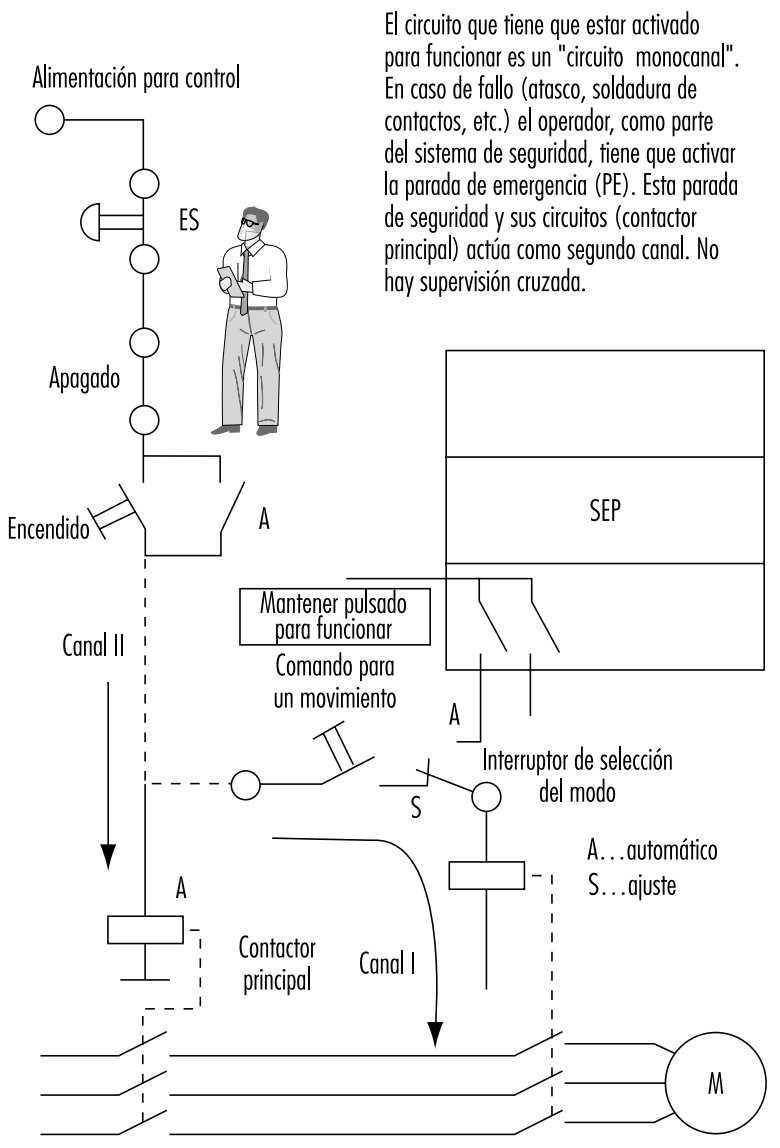

Fuente: según EN 60204-1: 1992, párrafo 9.2.2.

\section{Fallos sistemáticos}

L os fallos sistemáticos pueden deberse a errores de especificación, diseño y otras causas y son posibles tanto en el soporte físico como en el soporte lógico. LoS SEP dobles sirven para aplicaciones relacionadas con la seguridad. Estas configuraciones permiten la detección de fallos aleatorios del soporte físico. M ediante la diversificación del hardware, utilizando por ejemplo dos modelos distintos o productos de distintos fabricantes, podrían descartarse fallos sistemáticos del hardware (es altamente improbable que se produzca un fallo sistemático de hardware en ambos SEP).

\section{Software}

EI software es un elemento nuevo en materia de seguridad. El software es correcto o incorrecto (respecto a los fallos). U na vez es correcto, no se puede tornar de pronto incorrecto (a diferencia del hardware). Los objetivos son erradicar todos los errores del software 0 al menosidentificarlos.

\section{Figura 58.79 - Estado de la técnica en categoría de} parada 1.

Para que funcione el accionamiento, el pussador de activación y el pulsador de comando tienen que accionarse simultáneamente. Un fallo en el canal I no se detecta automáticamente. Sin embargo, para la mayoría de los fallos en el canal I, la máquina no funcionará correctamente y por tanto el operador advertirá el fallo. Un fallo en el canal II será detectado por el SEP (véase el circuito de vigilancia X). La interrupción del movimiento es segura (S), ya que la energía se interrumpe dos veces. La vigilancia cruzada se puede considerar casi completa.

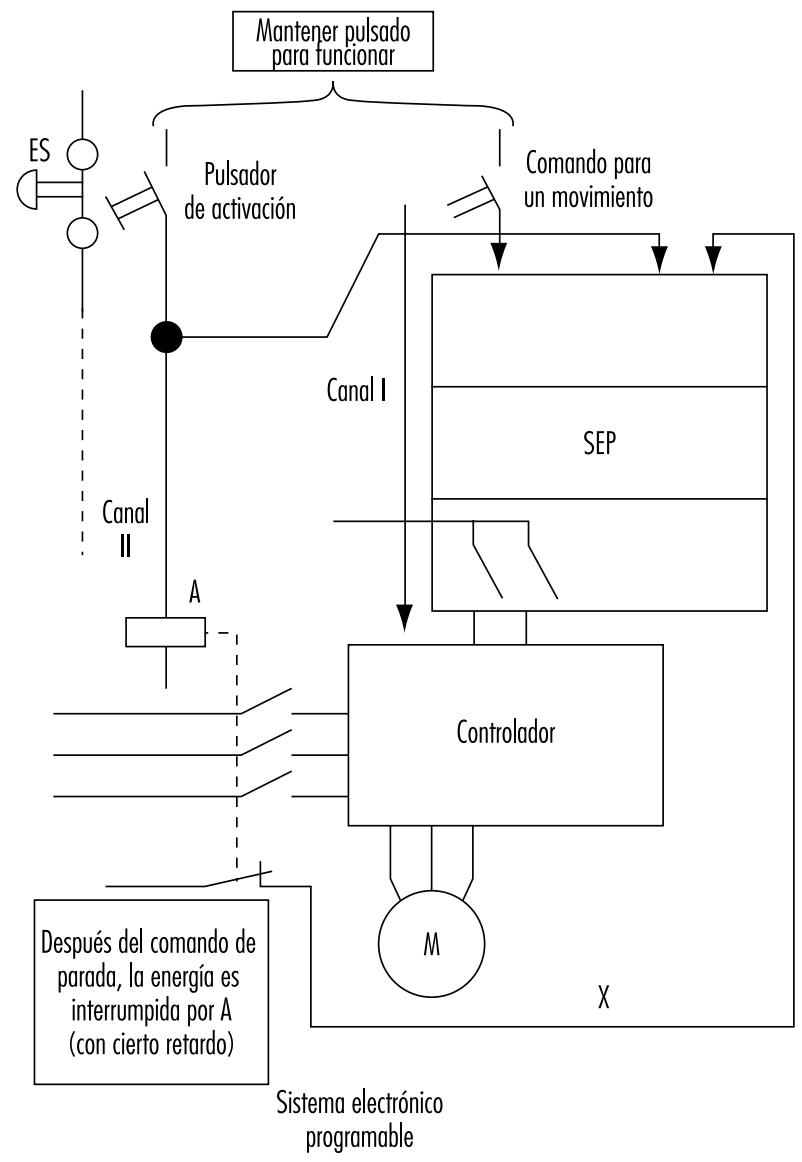

Fuente: Según EN 60204-1: 1992, párrafo 9.2.2. 
Figura 58.80 - Estado de la técnica en categoría de parada 2.

Los comandos de funcionamiento o parada los ejecuta el sistema operativo solo, que por sí mismo no es suficientemente seguro. Por consiguiente, es necesario un "sistema seguro de supervisión de la velocidad" adicional para "ausencia de movimiento" y "movimiento a velocidad baja". En caso de fallo del sistema operativo (SEP, unidad de control/accionamiento), el sistema adicional de supervisión de la velocidad detectará el estado no Seguro uro y parará la máquina en condiciones de seguridad.

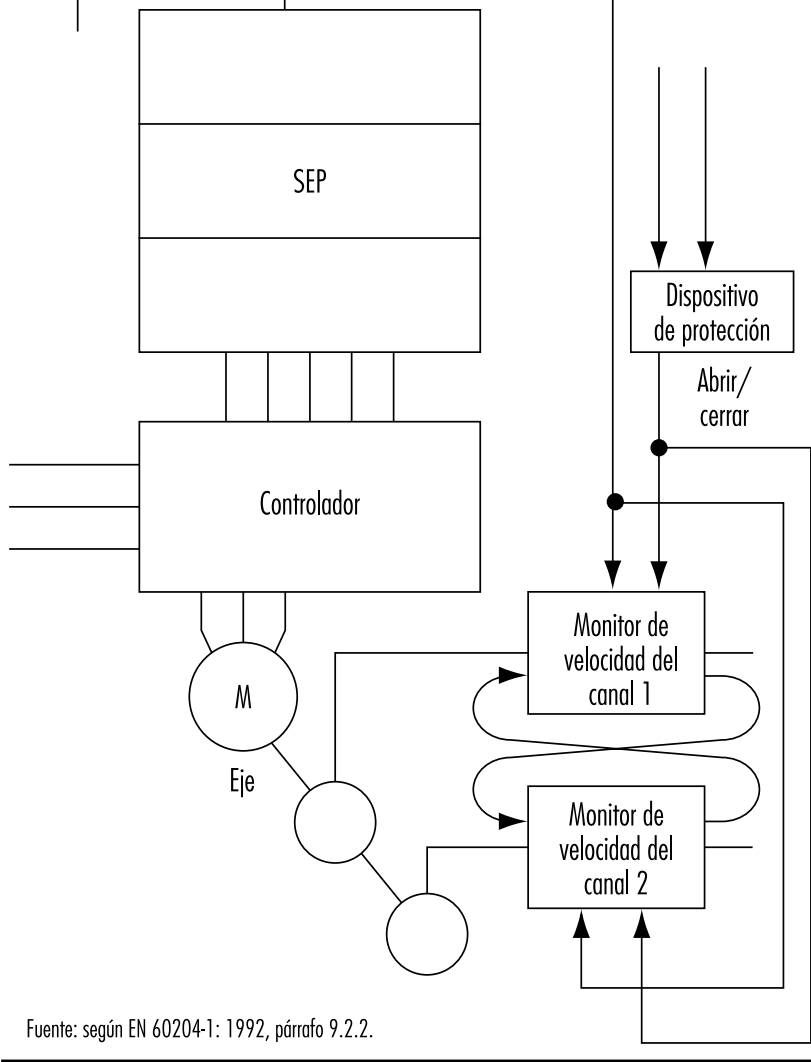

$\mathrm{H}$ ay varias maneras de alcanzar este objetivo. U na es la verificación del programa (una segunda persona intenta descubrir los errores en una prueba posterior). 0 tra posibilidad es la diversidad del software, mediante la cual dos programas distintos escritos por dos programadores diferentes tratan el mismo problema. Si los resultados son idénticos (dentro de ciertos límites), se puede suponer que ambos programas son correctos. Si son distintos, se puede suponer que hay errores. (N ota: Por supuesto, también hay que tener en cuenta la arquitectura del hardware).

\section{Resumen}

En general, cuando se utilizan SEP hay que partir siempre de las siguientes consideraciones básicas (descritas en capítulos anteriores).

- Un sistema de control único sin redundancia se puede asignar a la categoría B. Un sistema de control único con medidas adicionales puede ser de categoría 1 o superior, pero nunca superior a la categoría 2.
Figura 58.81 - Sistema sofisticado con dos SEP.

Todas las funciones de seguridad se procesan electrónicamente, pero por dos SEP independientes con supervisión cruzada completa y permanente. Obsérvese que esto arquitectura describe sólo una arquitectura básica del sistema. Se pueden introducir numerosas mejoras.

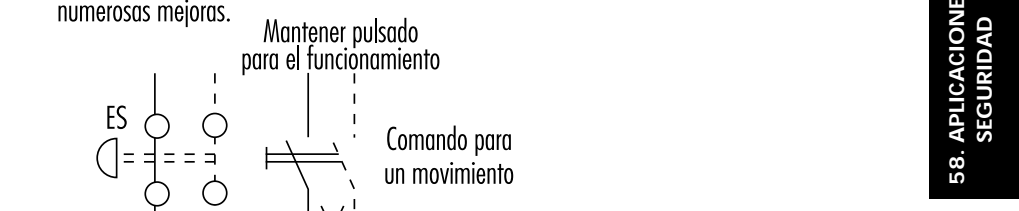

- Un sistema de control de dos componentes con comparación recíproca de resultados se puede asignar a la categoría 3 . Un sistema de control de dos componentes con comparación recíproca de resultados y más o menos diversificado se puede asignar a la categoría 3 y sirve para aplicaciones de riesgo más elevado.

Un nuevo factor es que para el sistema con un SEP es preciso evaluar incluso el software desde el punto de vista de la corrección. El software, si es correcto, es fiable al $100 \%$. En esta fase de desarrollo tecnológico no se utilizarán probablemente las mejores soluciones técnicas posibles y conocidas, ya que los factores limitadores siguen siendo económicos. A demás, diversos grupos de expertos siguen desarrollando normas para aplicaciones de seguridad de SEP (por ejemplo, CE, EWICS). Aunque ya existen varias normas (VDE 0801, CEI 65A, etc.) este tema es tan amplio y complejo que ninguna se puede considerar definitiva.

\section{PRINCIPIOS DE SEGURIDAD PARA MAQUINAS HERRAMIENTA CNC}

\section{Toni Retsch, Guido Schmitter y Albert Marty}

Siempre que se automatizan equipos de producción sencillos y convencionales como máquinas herramienta, resultan sistemas técnicos complejos y nuevos peligros. Esta automatización se 
logra mediante el uso de sistemas de control numérico por computador (CNC) en máquinas herramienta que pasan a llamarse máquinas herramienta CNC (por ejemplo, fresadoras, centros de mecanizado, taladradoras y rectificadoras). Para poder identificar los peligros potenciales intrínsecos de las máquinas herramienta automáticas, es necesario analizar las diversas modalidades de funcionamiento de cada sistema. Análisis anteriores indican la conveniencia de distinguir entre dos tipos de funcionamiento: normal y especial.

A menudo es imposible especificar requisitos de seguridad para máquinas herramienta CNC en forma de medidas específicas. Esto puede ser debido a que hay pocos reglamentos y normas específicos para estos equipos que ofrezcan soluciones concretas. Sólo es posible especificar los requisitos de seguridad si pueden determinarse sistemáticamente los peligros realizando un análisis de riesgos, especialmente si estos sistemas técnicos complejos tienen sistemas de control programables a voluntad (como ocurre con las máquinas herramienta C NC).

En el caso de las máquinas herramienta CNC de nueva concepción, el fabricante está obligado a realizar un análisis de riesgos del equipo para identificar los peligros presentes y mostrar, mediante soluciones de diseño, que se han eliminado todos los peligros para las personas en todas los modalidades posibles de funcionamiento. Todos los peligros identificados tienen que someterse a una evaluación de riesgos en la que cada riesgo de un suceso dependa del alcance de los daños y de la frecuencia con la que pueda ocurrir. Al peligro a evaluar se le asigna también una categoría de riesgo (minimizado, normal, aumentado). Siempre que no se pueda aceptar el riesgo a la luz de su evaluación, será necesario encontrar soluciones (medidas de seguridad). Estas soluciones tienen por objeto reducir la frecuencia y el alcance de los daños de un incidente no planificado y potencialmente peligroso (un "suceso").

Los planteamientos de las soluciones para riesgos normales y aumentados han de basarse en la tecnología de seguridad directa e indirecta; para los riesgos minimizados, se basarán en la tecnología de seguridad de referencia:

- T ecnología de seguridad directa. Se adoptan medidas en la fase de diseño para eliminar cualquier peligro (por ejemplo, la eliminación de puntos de cizallamiento y atenazado).

- Tecnología de seguridad indirecta. El peligro permanece; claro está que la adición de dispositivos técnicos impide que se convierta en un suceso (por ejemplo, tales medidas pueden incluir la prevención del acceso a elementos móviles peligrosos por medio de cubiertas físicas de seguridad, dispositivos de seguridad que cortan la alimentación, barreras de retención de elementos proyectados, uso de defensas, etc.).

- Tecnología de seguridad de referencia. Esta sólo es aplicable a peligros residuales y riesgos minimizados, es decir, peligros que pueden provocar un suceso como consecuencia de factores humanos. Dicho suceso se puede prevenir mediante un comportamiento adecuado de la persona afectada (por ejemplo, normas de conducta en manuales de funcionamiento y mantenimiento, formación del personal, etc.

\section{Requisitos de seguridad internacionales}

La Directiva sobre máquinas de la CE (89/392/ CEE; véase el recuadro) de 1989 establece los principales requisitos de seguridad y salud en relación con las máquinas. (Según la directiva, se considera una máquina la suma total de componentes o dispositivos interconectados, de los cuales al menos uno se puede mover y tiene una función asociada). A demás se elaboran normas específicas por parte de organismos internacionales de normalización para ilustrar posibles soluciones (por ejemplo, atendiendo a aspectos fundamentales de la seguridad o examinado equipos eléctricos montados en máquinas industriales). La finalidad de estas normas es especificar objetivos de protección. Estos requisitos internacionales de seguridad proporcionan a los fabricantes la base jurídica necesaria para especificarlos en los análisis y evaluaciones de riesgos anteriormente mencionados.

\section{Modalidades de funcionamiento}

Al utilizar máquinas herramienta se distingue entre funcionamiento especial y normal. Las estadísticas e investigaciones indican que la mayoría de accidentes e incidentes no tienen lugar durante el funcionamiento normal (es decir, durante la ejecución automática de cada tarea). Estos tipos de máquinas e instalaciones destacan en particular por modalidades de funcionamiento especiales, como la puesta en marcha, preparación, programación, pruebas de funcionamiento, comprobaciones, localización de averías o mantenimiento. En estas modalidades de funcionamiento, las personas suelen permanecer en una zona de peligro. EI dispositivo de seguridad tiene que proteger al personal frente a sucesos perjudiciales en tales situaciones.

\section{Funcionamiento normal}

Cuando una máquina automática funcionan normalmente ocurre lo siguiente: a) la máquina ejecuta el trabajo asignado para el que ha sido diseñada y construida, sin intervención adicional del operador, y b) aplicado a un torno sencillo, esto significa que tornea la pieza a la forma correcta y que se desprenden virutas. Si se cambia manualmente la pieza, el cambio es una modalidad de funcionamiento especial.

\section{M odalidades de funcionamiento especiales}

Las modalidades de funcionamiento especiales son procesos de trabajo imprescindibles para el funcionamiento normal. Bajo esta denominación se incluirían, por ejemplo, cambios de piezas 0 herramientas, rectificación de un error en un proceso de producción, preparación, programación, pruebas de funcionamiento, limpieza y mantenimiento. En funcionamiento normal, los sistemas automáticos ejecutan las tareas asignadas independientemente. Con todo, desde el punto de vista de la seguridad del trabajador, el funcionamiento automático normal es crítico cuando el operador tiene que intervenir en los procesos de trabajo. De ningún modo las personas que intervienen en tales procesos deberán exponerse a un peligro.

\section{Personal}

Al considerar la protección de máquinas herramienta es necesario tener en cuenta a las personas que trabajan en las distintas modalidades de funcionamiento y también a terceros. Entre estos últimos se incluyen a quienes se ven afectados indirectamente por la máquina, como capataces, inspectores, auxiliares que transportan el material y realizan trabajos de desmontaje, visitantes y otros.

\section{Exigencias y medidas de seguridad para los accesorios de máquinas}

Las intervenciones en tareas asociadas a modalidades de funcionamiento especiales suponen que es necesario utilizar accesorios especiales para asegurar que el trabajo se podrá realizar con seguridad. El primer tipo de accesorios incluye los equipos y elementos utilizados para intervenir en procesos automáticos sin que el operador tenga que acceder a una zona peligrosa. Este tipo de accesorios incluye: (1) ganchos y tenazas para virutas que se han diseñado de manera que las virutas de la zona de la máquina puedan retirarse o extraerse a través de aberturas dispuestas en las defensas, y (2) dispositivos de fijación de la pieza de trabajo con los cuales el material de producción se puede introducir o retirar manualmente de un ciclo automático. 
Varias modalidades de funcionamiento especiales, como por ejemplo los trabajos de reparación o mantenimiento, implican la intervención del personal en un sistema. También en estos casos existe una amplia gama de accesorios diseñados para aumentar la seguridad en el trabajo, por ejemplo, dispositivos para manipular muelas pesadas cuando éstas se cambian en las rectificadoras, así como eslingas especiales de grúas para desmontar o montar componentes pesados cuando se realizan revisiones generales de las máquinas. Estos dispositivos son el segundo tipo de accesorios de máquinas para aumentar la seguridad en el trabajo en modalidades especiales. También se puede considerar que los sistemas especiales de control del funcionamiento representan un segundo tipo de accesorios de máquinas. Con tales accesorios es posible desempeñar con seguridad actividades concretas. Por ejemplo, se puede poner un dispositivo en los ejes de la máquina cuando es necesario ejecutar movimientos de alimentación con las defensas abiertas.

Estos sistemas de control de modalidades especiales tienen que satisfacer requisitos de seguridad especiales. Por ejemplo, tienen que asegurar que sólo se realizará el movimiento necesario, en la forma necesaria y durante el tiempo necesario. Por tanto, el sistema de control tiene que diseñarse de manera que impida cualquier acción incorrecta que pueda traducirse en movimientos o estados peligrosos.

Los equipos que aumentan el grado de automatización de una instalación se pueden considerar una tercera clase de accesorios de máquinas para aumentar la seguridad en el trabajo. Acciones que antes se realizaban manualmente pasan a ejecutarse automáticamente por la máquina en régimen de funcionamiento normal con equipos como cargadoras de pórtico que cambian automáticamente las piezas de trabajo en las máquinas herramienta. La protección del funcionamiento automático normal origina pocos problemas, porque no es necesario que intervenga el operador y las potenciales intervenciones se pueden impedir mediante dispositivos de seguridad.

\section{Requisitos y medidas de seguridad para la automatización de máquinas herramienta}

Por desgracia, la automatización no ha conducido a la eliminación de accidentes en las fábricas. L as investigaciones demuestran que sólo se ha producido un desplazamiento de los accidentes del régimen de funcionamiento normal al especial, debido sobre todo a la automatización del funcionamiento normal, de modo que las intervenciones durante la producción ya no son necesarias y el personal ya no está por tanto expuesto a peligros. Por otra parte, las máquinas muy automatizadas son sistemas complejos difíciles de evaluar cuando se producen fallos. Incluso los técnicos encargados de corregir fallos no siempre son capaces de hacerlo sin sufrir accidentes. El software necesario para hacer funcionar máquinas cada vez más complejas crece en volumen y complejidad, con el resultado de que sufren accidentes un número cada vez mayor de electricistas y técnicos de puesta en marcha. El software sin defectos no existe y toda variación del software comporta a menudo cambios en otros sitios, que no son esperados ni deseados. Para evitar que ello afecte a la seguridad, deben descartarse los comportamientos defectuosos y peligrosos debidos a influencias externas y fallos de componentes. Esta condición sólo se puede cumplir si el circuito de seguridad se diseña lo más sencillo posible y separado del resto de los controles. Los elementos o subconjuntos utilizados en el circuito de seguridad tienen que ser también a prueba de fallos.

Corresponde al diseñador desarrollar diseños que satisfagan los requisitos de seguridad. El diseñador no puede dejar de considerar atentamente los procedimientos de trabajo necesarios, incluidas las modalidades especiales. Es necesario hacer análisis para determinar qué procedimientos de seguridad en el trabajo son necesarios y el personal operativo tiene que familiarizarse con ellos. En la mayoría de los casos se precisará un sistema de control para operaciones especiales. N ormalmente, el sistema de control observa o controla un movimiento y evita al mismo tiempo que se inicie cualquier otro movimiento (ya que no se necesita ningún otro movimiento para este trabajo y el operador no lo espera). El sistema de control no tiene que llevar a cabo necesariamente las mismas tareas en las distintas modalidades de funcionamiento especiales.

\section{Requisitos y medidas de seguridad en modalidades de funcionamiento normales y especiales}

\section{Funcionamiento normal}

La especificación de los requisitos de seguridad no debe impedir el progreso técnico porque es posible seleccionar soluciones adaptadas. El uso de máquinas herramienta CNC plantea las máximas exigencias con respecto al análisis y evaluación de riesgos y conceptos de seguridad. Lo que sigue es una descripción más detallada de varios objetivos de seguridad y posibles soluciones.

\section{Objetivo de seguridad}

- Es necesario impedir el acceso manual o físico a zonas peligrosas durante los movimientos automáticos.

\section{Posibles soluciones.}

- Impedir el acceso manual o físico a zonas peligrosas por medio de barreras mecánicas.

- Incorporar dispositivos de seguridad que respondan a la aproximación (barreras de luz, alfombrillas de seguridad) y paren la máquina con seguridad durante las intervenciones o en caso de acceso.

- Permitir el acceso manual o físico a la maquinaria lo a su proximidad) sólo cuando el sistema completo se encuentre en estado seguro (por ejemplo, mediante dispositivos de enclavamiento con mecanismos de cierre en las puertas de acceso).

\section{Objetivo de seguridad}

- Eliminar la posibilidad de que alguna persona resulte lesionada como consecuencia de la liberación de energía (elementos proyectados o haces de energía).

\section{Posible solución}

- Impedir la liberación de energía desde la zona de peligro, por ejemplo, mediante una cubierta de seguridad de dimensiones adecuadas.

\section{Funcionamiento especial}

Se precisan interfaces entre el funcionamiento normal y el especial (por ejemplo, dispositivos de enclavamiento de puertas, barreras de luz, alfombrillas de seguridad) para permitir que el sistema de control de seguridad reconozca automáticamente la presencia de personas. Seguidamente se describen algunas modalidades de funcionamiento especiales (por ejemplo, preparación, programación) en máquinas herramienta CNC que requieren movimientos que tienen que ser evaluados directamente en el lugar de trabajo.

\section{Objetivos de seguridad}

- Los movimientos han de ejecutarse exclusivamente de manera que no supongan un peligro para las personas afectadas. Dichos movimientos han de ejecutar siempre en la forma y a la velocidad programadas y durante el tiempo especificado.

- Sólo deberán emprenderse si es posible garantizar que ninguna parte del cuerpo humano se encuentra en la zona de peligro. 


\section{Características principales de la Directiva sobre máquinas de la CEE}

La Directiva del Consejo del 14 de junio de 1989 relativa a la aproximación de las legislaciones de los Estados miembros sobre máquinas

$(89 / 392 /$ EEC) será aplicable a cada estado individual.

- Cada Estado individual deberá integrar la directiva en su legislación.

- Válida desde el 1 de enero de 1993.

- Requiere que todos los fabricantes apliquen los últimos métodos.

- El fabricante tiene que preparar un archivo técnico de construcción que contenga informa ción completa de todos los aspectos funda mentales de seguridad e higiene.

- El fabricante tiene que emitir la declaración de conformidad y la marca CE de las máquinas.

- Si no se pone documentación técnica completa a disposición de un centro de supervisión del estado, esto se considerará como un incumplimiento de las directrices de máquinas. La consecuencia puede ser la prohibición de su venta en toda la CEE.

\section{Objetivos de seguridad para la construcción y uso de máquinas herramientas CNC}

\section{Tornos}

\subsection{Modo normal de funcionamiento}

1.1.1 La zona de trabajo estará protegida de modo que sea imposible alcanzar o situarse en zonas de peligro de movimientos automáticos, voluntaria o involuntariamente.

1.1.2 El cargador de herramientas estará protegido de modo que sea imposible alcanzar o situarse en zonas de peligro de movimientos automáticos, voluntaria o involuntariamente.

1.1.3 El cargador de piezas de trabajo estará protegido de modo que sea imposible alcanzar o situarse en zonas de peligro de movimientos automáticos, voluntaria o involuntariamente.

1.1.4 La retirada de virutas no podrá dar lugar a lesiones personales debido a las propias virutas o a elementos móviles de la máquina.

1.1.5 Deberán impedirse las lesiones personales debidas al acceso a sistemas de accionamiento.

1.1.6 Deberá impedirse la posibilidad de acceder a las zonas de peligro de los transportadores de virutas.

1.1.7 Los operadores y terceros no podrán sufrir lesiones debidas a piezas de trabajo o partes de las mismas que sean proyectadas. Por ejemplo, esto puede ocurrir:

- debido a sujeción insuficiente

- debido a fuerza de corte inadmisible

- debido a velocidad de giro inadmisible

- debido a choque con la herramienta 0 elementos de la máquina

- debido a rotura de la pieza de trabajo

- debido a dispositivos de sujeción defectuosos

- debido a fallo de la alimentación eléctrica

1.1.8 No se producirán lesiones personales como consecuencia de la proyección de dispositivos de sujeción de las piezas de trabajo

1.1.9 No se producirán lesiones personales como consecuencia de la proyección de virutas.

1.1.10 No se producirán lesiones personales como consecuencia de la proyección herramientas o partes de las mismas.

Por ejemplo, esto puede ocurrir

- debido a defectos del material

- debido a fuerza de corte inadmisible

- debido a choque con la pieza de trabajo o un elemento de la máquina

- debido a apriete o sujeción inadecuados

\subsection{Modos especiales de funcionamiento}

1.2.1 Cambio de la pieza de trabajo.

1.2.1.1 La sujeción de la pieza de trabajo deberá hacerse de modo que ninguna parte del cuerpo pueda quedar atrapada por los dispositivos de sujeción al cerrar y la pieza de trabajo o entre la punta del manguito que avanza y la pieza de trabajo.

1.2.1.2 Deberá evitarse el arranque de una unidad (ejes, husillos, manguitos, torretas o transportadores de virutas) como consecuencia de un comando incorrecto o no válido.

1.2.1.3 Deberá ser posible la manipulación sin peligro de la pieza de trabajo, manualmente o con herramientas.

1.2.2 Cambio de herramientas en el portaherramientas o en la torreta.

1.2.2.1 Deberán impedirse los peligros resultantes de un comportamiento defectuoso del sistema o de la introducción de un comando no válido.

1.2.3 Cambio de herramientas en el cargador de herramientas.

1.2.3.1 Deberán impedirse movimientos del cargador de herramientas resultantes de la introducción de un comando incorrecto o no válido durante el cambio de herramientas.

1.2.3.2 N o será posible acceder a otros elementos móviles de la máquina desde la estación de carga de herramientas.

1.2.3.3 No será posible acceder a zonas de peligro en los movimientos sucesivos del cargador de herramientas o durante la búsqueda. Si se hace con las defensas para el funcionamiento normal desmontadas, estos movimientos sólo podrán ser del tipo designado, sólo se podrán realizar durante el período de tiempo establecido y sólo cuando se pueda asegurar que ninguna parte del cuerpo se encontrará en esas zonas de peligro.

1.2.4 Comprobación de las medidas. 
1.2.4.1 El acceso a la zona de trabajo sólo será posible una vez que todos los movimientos se hayan detenido totalmente.

1.2.4.2 Deberá impedirse el arranque de una unidad como consecuencia de un comando incorrecto o no válido.

1.2.5 Preparación.

1.2.5.1 Si es necesario ejecutar movimientos durante la preparación con las defensas del modo normal de funcionamiento desmontadas, el operador deberá estar protegido por otros medios.

1.2.5.2 No deberá iniciarse ningún movimiento o cambio de movimiento peligroso como consecuencia de la introducción de un comando incorrecto o no válido.

1.2.6 Programación.

1.2.6.1 Durante la programación, no se podrá iniciar ningún movimiento que pueda poner en peligro a una persona situada en la zona de trabajo.

1.2.7 Fallo de producción.

1.2.7.1 Deberá impedirse el arranque de una unidad como consecuencia de la introducción de un comando incorrecto o no válido.

1.2.7.2 El movimiento o retirada de la pieza de trabajo o residuos no deberá dar lugar a movimientos o situaciones peligrosas.

1.2.7.3 Si es necesario realizar movimientos con las defensas del modo normal de funcionamiento desmontadas, estos movimientos sólo podrán ser del tipo designado, sólo se podrán realizar durante el período de tiempo establecido y sólo cuando se pueda asegurar que ninguna parte del cuerpo se encontrará en esas zonas de peligro.

1.2.8 Localización de averías.

1.2.8.1 Deberá impedirse el acceso a zonas de movimientos automáticos peligrosos.

1.2.8.2 Deberá impedirse el arranque de una unidad como consecuencia de la introducción de un comando incorrecto o no válido.

1.2.8.3 Deberá impedirse cualquier movimiento de la má quina al manipular la pieza defectuosa.

1.2.8.4 Deberán impedir lesiones personales debidas a la desintegración o caída de piezas de la máquina.

1.2.8.5 Si, durante la localización de averías, es necesario realizar movimientos con las defensas del modo normal de funcionamiento desmontadas, estos movimientos sólo podrán ser del tipo designado, sólo se podrán realizar durante el período de tiempo establecido y sólo cuando se pueda asegurar que ninguna parte del cuerpo se encontrará en esas zonas de peligro.

1.2.9 Funcionamiento incorrecto y reparación de la máquina

1.2.9.1 Deberá impedirse el arranque de la máquina.

1.2.9.2 Deberá ser posible la manipulación sin ningún peligro de distintas partes de la máquina, manualmente o con herramientas

1.2.9.3 No será posible tocar partes de la máquina bajo tensión.

1.2.9.4 No deberán producirse lesiones personales como consecuencia de la proyección de líquidos o gases.

\section{Fresadoras}

\subsection{Modo normal de funcionamiento}

2.1.1 La zona de trabajo deberá protegerse de modo que sea imposible alcanzar o situarse en zonas de peligro de movimientos automáticos, voluntaria o involuntariamente.

2.1.2 La retirada de virutas no dará lugar a lesiones personales debido a las propias virutas o a elementos móviles de la máquina.

2.1.3 Deberá impedirse cualquier lesión personal debida al acceso a sistemas de accionamiento.

Los operadores y terceros no podrán sufrir lesiones debidas a piezas de trabajo o partes de las mismas que sean proyectadas.

Por ejemplo, esto puede ocurrir

- debido a sujeción insuficiente

- debido a fuerza de corte inadmisible

- debido a choque con la herramienta o elementos de la máquina

- debido a rotura de la pieza de trabajo

- debido a dispositivos de sujeción defectuosos

- debido a fallo de la alimentación eléctrica

2.1.4 No deberán producirse lesiones personales como consecuencia de dispositivos de sujeción de la pieza de trabajo que sean proyectados.

2.1.5 No deberán producirse lesiones personales como consecuencia de la proyección de virutas.

2.1.6 No deberán producirse lesiones personales como consecuencia de herramientas o partes de las mismas que sean proyectadas.

Por ejemplo, esto puede ocurrir

- debido a defectos del material

- debido a velocidad de giro inadmisible

- debido a fuerza de corte inadmisible

- debido a choque con la pieza de trabajo o parte de la máquina

- debido a sujeción o apriete inadecuados

- debido a fallo de la alimentación eléctrica

\subsection{Modos especiales de funcionamiento}

2.2.1 Cambio de la pieza de trabajo.

2.2.1.1 Si se utilizan dispositivos de sujeción motorizados, no deberá ser posible que ninguna parte del cuerpo sea atrapada entre las piezas que cierren de los dispositivos de fijación y la pieza de trabajo.

2.2.1.2 Deberá impedirse el arranque de una unidad (eje, husillo) como consecuencia de la introducción de un comando incorrecto o no válido.

2.2.1.3 Deberá ser posible la manipulación sin peligro de la pieza de trabajo, manualmente o con herramientas. 
2.2.2 Cambio de herramientas.

2.2.2.1 Deberá impedirse el arranque de una unidad como consecuencia de la introducción de un comando incorrecto o no válido.

2.2.2.2 No deberá ser posible que los dedos sean atrapados al colocar herramientas.

2.2.3 Comprobación de las medidas.

2.2.3.1 El acceso a la zona de trabajo sólo será posible después de haber detenido todos los movimientos por completo.

2.2.3.2 Deberá impedirse el arranque de una unidad como consecuencia de la introducción de un comando incorrecto o no válido.

2.2.4 Preparación.

2.2.4.1 Si es necesario ejecutar movimientos durante la preparación con las defensas del modo normal de funcionamiento desmontadas, el operador deberá estar protegido por otros medios.

2.2.4.2 No deberá iniciarse ningún movimiento o cambio de movimiento peligroso como consecuencia de la introducción de un comando incorrecto o no válido.

2.2.5 Programación

2.2.5.1 Durante la programación, no se podrá iniciar ningún movimiento que pueda poner en peligro a una persona situada en la zona de trabajo.

2.2.6 Fallo de producción.

2.2.6.1 Deberá impedirse el arranque de una unidad como consecuencia de la introducción de un comando incorrecto o no válido.

2.2.6.2 El movimiento o retirada de la pieza de trabajo o residuos no deberá dar lugar a movimientos o situaciones peligrosas.

2.2.6.3 Si es necesario realizar movimientos con las defensas del modo normal de funcionamiento desmontadas, estos movimientos sólo podrán ser del tipo designado, sólo se podrán realizar durante el período de tiempo establecido y sólo cuando se pueda asegurar que ninguna parte del cuerpo se encontrará en esas zonas de peligro.

2.2.7 Localización de averías.

2.2.7.1 Deberá impedirse el acceso a zonas de movimientos automáticos peligrosos.

2.2.7.2 Deberá impedirse el arranque de una unidad como consecuencia de la introducción de un comando incorrecto o no válido.

2.2.7.3 Deberá impedirse cualquier movimiento de la máquina al manipular la pieza defectuosa.

2.2.7 Deberán impedirse lesiones personales debidas a la desintegración o caída de piezas de la máquina.

2.2.7.5 Si, durante la localización de averías, es necesario realizar movimientos con las defensas del modo normal de funcionamiento desmontadas, estos movimientos sólo podrán ser del tipo designado, sólo se podrán realizar durante el período de tiempo establecido y sólo cuando se pueda asegurar que ninguna parte del cuerpo se encontrará en esas zonas de peligro.

2.2.8 Funcionamiento incorrecto y reparación de la máquina

2.2.8.1 Deberá impedirse el arranque de la máquina.

2.2.8.2 Deberá ser posible la manipulación sin ningún peligro de distintas partes de la máquina, manualmente o con herramientas

2.2.8.3 No será posible tocar partes de la máquina bajo tensión.

2.2.8.4 No deberán producirse lesiones personales como consecuencia de la proyección de líquidos o gases.

\section{Centros de mecanizado}

\subsection{Modo normal de funcionamiento}

3.1.1 La zona de trabajo estará protegida de modo que sea imposible alcanzar o situarse en zonas de peligro de movimientos automáticos, voluntaria o involuntariamente.

3.1.2 El cargador de herramientas estará protegido de modo que sea imposible alcanzar o situarse en zonas de peligro de movimientos automáticos, voluntaria o involuntariamente.

3.1.3 El cargador de piezas de trabajo estará protegido de modo que sea imposible alcanzar o situarse en zonas de peligro de movimientos automáticos, voluntaria o involuntariamente.

3.1.4 La retirada de virutas dará lugar a lesiones personales debido a las propias virutas o a elementos móviles de la máquina.

3.1.5 Deberán evitarse las lesiones personales debidas al acceso a sistemas de accionamiento.

3.1.6 Deberá evitarse la posibilidad de acceder a las zonas de peligro de los transportadores de virutas.

3.1.7 Los operadores y terceros no deberán poder sufrir lesiones debidas a piezas de trabajo 0 partes de las mismas que sean proyectadas.

Por ejemplo, esto puede ocurrir:

- debido a sujeción insuficiente

- debido a fuerza de corte inadmisible

- debido a choque con la herramienta o elementos de la máquina

- debido a rotura de la pieza de trabajo

- debido a dispositivos de sujeción defectuosos

- debido a cambio a una pieza de trabajo incorrecta

- debido a fallo de la alimentación eléctrica

3.1.8 No se producirán lesiones personales como consecuencia de la proyección de dispositivos de sujeción de las piezas de trabajo

3.1.9 No se producirán lesiones personales como consecuencia de la proyección de virutas.

3.1.10 No se producirán lesiones personales como consecuencia de la proyección herramientas o partes de las mismas.

Por ejemplo, esto puede ocurrir

- debido a defectos del material

- debido a velocidad de giro inadmisible

- debido a fuerza de corte inadmisible

- debido a choque con la pieza de trabajo o un elemento de la máquina 
- debido a apriete o sujeción inadecuados

- debido a salir proyectada la herramienta del cambiador de herramientas

- debido a la selección de una herramienta incorrecta

- debido a fallo de la alimentación eléctrica

\subsection{Modos especiales de funcionamiento}

\subsubsection{Cambio de la pieza de trabajo.}

3.2.1.1 Si se utilizan dispositivos de fijación motorizados, no deberá ser posible que ninguna parte del cuerpo sea atrapada entre las piezas que cierren de los dispositivos de fijación y la pieza de trabajo.

3.2.1.2 Deberá impedirse el arranque de una unidad (eje, husillo) como consecuencia de la introducción de un comando incorrecto o no válido.

3.2.1.3 Deberá ser posible la manipulación sin peligro de la pieza de trabajo, manualmente o con herramientas.

3.2.1.4 Si las piezas de trabajo se cambian en una estación de sujeción, no deberá ser posible acceder o situarse en zonas de secuencias automáticas de movimientos de la máquina o del cargador de piezas. El control no deberá iniciar ningún movimiento estando presente una persona en la zona de sujeción.

La inserción automática de la pieza de trabajo sujeta en la máquina o cargador de piezas de trabajo sólo tendrá lugar cuando la estación de sujeción esté protegida por un sistema de protección equivalente al del modo normal de funcionamiento.

3.2.2 Cambio de herramientas en el eje.

3.2.2.1 Deberá impedirse el arranque de una unidad como consecuencia de la introducción de un comando incorrecto o no válido.

3.2.2.2 No deberá ser posible que los dedos queden atrapados al colocar herramientas.

3.2.3 Cambio de herramientas en el cargador de herramientas.

3.2.3.1 Durante el cambio de herramientas, deberán impedirse los movimientos debidos a la introducción de comandos incorrectos o no válidos.

3.2.3.2 N o será posible acceder a otras piezas móviles de la máquina desde la estación de carga de herramientas.

3.2.3.3 N o será posible acceder a zonas de peligro en movimientos sucesivos del cargador de herramientas o durante la búsqueda. Si se hace con las defensas para el funcionamiento normal desmontadas, estos movimientos sólo podrán ser del tipo designado, sólo se podrán realizar durante el período de tiempo establecido y sólo cuando se pueda asegurar que ninguna parte del cuerpo se encontrará en esas zonas de peligro.

3.2.4 Comprobación de medidas.

3.2.4.1 El acceso a la zona de trabajo sólo será posible después de haber detenido todos los movimientos por completo.

3.2.4.2 Deberá impedirse el arranque de una unidad como consecuencia de la introducción de un comando incorrecto o no válido.

3.2.5 Preparación.

3.2.5.1 Si es necesario ejecutar movimientos durante la preparación con las defensas del modo normal de funcionamiento desmontadas, el operador deberá estar protegido por otros medios.

3.2.5.2 No deberá iniciarse ningún movimiento o cambio de movimiento peligroso como consecuencia de la introducción de un comando incorrecto o no válido.

3.2.6 Programación

3.2.6.1 Durante la programación, no se podrá iniciar ningún movimiento que pueda poner en peligro a una persona situada en la zona de trabajo.

3.2.7 Fallo de producción.

3.2.7.1 Deberá impedirse el arranque de una unidad como consecuencia de la introducción de un comando incorrecto o no válido.

3.2.7.2 El movimiento o retirada de la pieza de trabajo o residuos no deberá dar lugar a movimientos o situaciones peligrosas.

3.2.7.3 Si es necesario realizar movimientos con las defensas del modo normal de funcionamiento desmontadas, estos movimientos sólo podrán ser del tipo designado, sólo se podrán realizar durante el período de tiempo establecido y sólo cuando se pueda asegurar que ninguna parte del cuerpo se encontrará en esas zonas de peligro.

3.2.8 Localización de averías.

3.2.8.1 Deberá impedirse el acceso a zonas de movimientos automáticos peligrosos.

3.2.8.2 Deberá impedirse el arranque de una unidad como consecuencia de la introducción de un comando incorrecto o no válido.

3.2.8.3 Deberá impedirse cualquier movimiento de la máquina al manipular la pieza defectuosa.

3.2.8.4 Deberán impedirse lesiones personales debidas a la desintegración o caída de piezas de la máquina.

3.2.8.5 Si, durante la localización de averías, es necesario realizar movimientos con las defensas del modo normal de funcionamiento desmontadas, estos movimientos sólo podrán ser del tipo designado, sólo se podrán realizar durante el período de tiempo establecido y sólo cuando se pueda asegurar que ninguna parte del cuerpo se encontrará en esas zonas de peligro.

3.2.9 Funcionamiento incorrecto y reparación de la máquina

3.2.9.1 Deberá impedirse el arranque de la máquina.

3.2.9.2 Deberá ser posible la manipulación sin ningún peligro de distintas partes de la máquina, manualmente 0 con herramientas

3.2.9.3 No será posible tocar partes de la máquina bajo tensión.

3.2.9.4 No deberán producirse lesiones personales como consecuencia de la proyección de líquidos o gases. 


\section{Rectificadoras}

\subsection{Modo normal de funcionamiento}

4.1.1 La zona de trabajo se tiene que proteger de modo que sea imposible alcanzar o situarse en zonas de peligro de movimientos automáticos, voluntaria o involuntariamente.

4.1.2 Deberán impedirse las lesiones personales debidas al acceso a sistemas de accionamiento.

4.1.3 Los operadores y terceros no deberán poder sufrir lesiones debidas a piezas de trabajo o partes de las mismas que sean proyectadas.

Por ejemplo, esto puede ocurrir:

- debido a sujeción insuficiente

- debido a fuerza de corte inadmisible

- debido a velocidad de giro inadmisible

- debido a choque con la herramienta o elementos de la máquina

- debido a rotura de la pieza de trabajo

- debido a dispositivos de sujeción defectuosos

- debido a fallo de la alimentación eléctrica

4.1.4 No deberán producirse lesiones personales debido a la proyección de dispositivos de fijación de la pieza de trabajo.

4.1.5 No deberán producirse lesiones personales o incendios a causa de las chispas.

4.1.6 No deberán producirse lesiones personales debidas a fragmentos de las muelas que sean proyectados.

Por ejemplo, esto puede ocurrir

- debido a velocidad de giro inadmisible

- debido a fuerza de corte inadmisible

- debido a defectos de material

- debido a choque con la pieza de trabajo o un elemento de la máquina

- debido a sujeción inadecuada (bridas)

- debido al uso de una muela inadecuado

\subsection{Modos especiales de funcionamiento}

\subsubsection{Cambio de la pieza de trabajo.}

4.2.1.1 Si se utilizan dispositivos de fijación motorizados, no deberá ser posible que ninguna parte del cuerpo sea atrapada entre las piezas que cierren de los dispositivos de fijación y la pieza de trabajo.

4.2.1.2 Deberá impedirse el arranque de una unidad de alimentación como consecuencia de la introducción de un comando incorrecto o no válido.

4.2.1.3 Deberán impedirse lesiones personales causadas por la muela en movimiento al manipular la pieza de trabajo.

4.2.1.4 No deberán ser posibles lesiones personales debidas a la desintegración de una muela.

4.2.1.5 Deberá ser posible la manipulación sin ningún peligro de la pieza de trabajo, manualmente o con herramientas.

4.2.2 Cambio de herramientas (cambio de la muela)

4.2.2.1 Deberá impedirse el arranque de una unidad de alimentación como consecuencia de la introducción de un comando incorrecto o no válido.

4.2.2.2 Durante los procedimientos de medida, no deberán ser posibles lesiones causadas por la muela en movimiento.

4.2.2.3 No deberán ser posibles lesiones causadas por la desintegración de una muela.

4.2.3 Comprobación de medidas.

4.2.3.1 Deberá impedirse el arranque de una unidad de alimentación como consecuencia de la introducción de un comando incorrecto o no válido.

4.2.3.2 Durante los procedimientos de medida, no deberán ser posibles lesiones causadas por la muela en movimiento.

4.2.3.3 No deberán ser posibles lesiones causadas por la desintegración de una muela.

4.2.4. Preparación.

4.2.4.1 Si es necesario ejecutar movimientos durante la preparación con las defensas del modo normal de funcionamiento desmontadas, el operador deberá estar protegido por otros medios.

4.2.4.2 No deberá iniciarse ningún movimiento o cambio de movimiento peligroso como consecuencia de la introducción de un comando incorrecto o no válido.

4.2.5 Programación

4.2.5.1 Durante la programación, no se podrá iniciar ningún movimiento que pueda poner en peligro a una persona situada en la zona de trabajo.

4.2.6 Fallo de producción

4.2.6.1 Deberá impedirse el arranque de una unidad de alimentación como consecuencia de la introducción de un comando incorrecto o no válido.

4.2.6.2 El movimiento o retirada de la pieza de trabajo o residuos no deberá dar lugar a movimientos o situaciones peligrosas.

4.2.6.3 Si es necesario realizar movimientos con las defensas del modo normal de funcionamiento desmontadas, estos movimientos sólo podrán ser del tipo designado, sólo se podrán realizar durante el período de tiempo establecido y sólo cuando se pueda asegurar que ninguna parte del cuerpo se encontrará en esas zonas de peligro.

4.2.6.4 Deberán impedirse las lesiones personales debidas a la muela en movimiento.

4.2.6.5 N o deberán ser posibles lesiones personales debidas a la desintegración de una muela.

4.2.7 Localización de averías

4.2.7.1 Deberá impedirse el acceso a las zonas de peligro de movimientos automáticos. 
4.2.7.2 Deberá impedirse el arranque de una unidad como consecuencia de la introducción de un comando incorrecto o no válido.

4 2.7.3 Deberá impedirse cualquier movimiento de la máquina durante la manipulación de la parte defectuosa.

4 2.7.4 Deberán impedirse lesiones personales resultantes de la fragmentación o caída de una parte de la máquina.

4.2.7.5 Deberán impedirse las lesiones personales del operador como consecuencia del contacto con la muela en movimiento o de la desintegración de ésta.

4.2.7.6 Si, durante la localización de averías, es necesario realizar movimientos con las defensas del modo normal de funcionamiento desmontadas, estos movimientos sólo podrán ser del tipo designado, sólo se podrán realizar durante el período de tiempo establecido y sólo cuando se pueda a segurar que ninguna parte del cuerpo se encontrará en esas zonas de peligro.

4.2.8 Funcionamiento incorrecto y reparación de la máquina

4.2.8.1 Deberá impedirse el arranque de la máquina.

4.2.8.2 Deberá ser posible la manipulación sin ningún peligro de distintas partes de la máquina, manualmente o con herramientas

4.2.8.3 No será posible tocar partes de la máquina bajo tensión.

4.2.8.4 N o deberán producirse lesiones personales como consecuencia de la proyección de líquidos o gases.

\section{Posible solución}

- Instalar sistemas especiales de control del funcionamiento que sólo permitan movimientos controlables y ajustables, como un control inmediato por medio de pulsadores del tipo de "acuse de recibo". Así se reduce de forma segura la velocidad de los movimientos (siempre que la energía se haya reducido por medio de un transformador separador de circuitos o un dispositivo de supervisión del estado de seguridad a prueba de fallo similar).

\section{Requisitos de los sistemas de control de seguridad}

Una de las características de un sistema de control de seguridad tiene que ser que esté garantizada la ejecución de la función de seguridad independientemente de cualquier fallo que se produzca, para trasladar los procesos de un estado peligroso a otro seguro.

\section{Objetivos de seguridad}

- Un fallo en el sistema de control de seguridad no debe provocar un estado peligroso.

- Un fallo en el sistema de control de seguridad tiene que ser identificado (inmediatamente o a intervalos).

\section{Posibles soluciones}

- Instalar sistemas de control electromecánicos redundantes y diversos, incluidos circuitos de prueba.

- Instalar sistemas de control por microprocesador reduntantes y diversificados, desarrollados por equipos distintos. Este planteamiento se considera acorde con el estado de la técnica, por ejemplo, en el caso de las barreras de luz de seguridad.

\section{Conclusiones}

Es evidente que la tendencia al aumento de los accidentes en las modalidades de funcionamiento normal y especial no se podrá detener sin un concepto de seguridad claro e inequívoco. Es necesario tener en cuenta este hecho al elaborar reglamentos y normas de seguridad. Se precisan nuevas directrices en forma de objetivos de seguridad para poder llegar a soluciones avanzadas. Estos objetivos permiten a los diseñadores elegir la solución óptima y demostrar al mismo tiempo las características de seguridad de sus máquinas de una forma bastante sencilla, describiendo una solución correspondiente a cada objetivo de seguridad. Esta solución se puede comparar entonces con otras soluciones existentes y aceptadas, y si es mejor, o al menos tiene el mismo valor, se podrá elegir entonces una nueva solución. De esta manera, el progreso no se verá obstaculizado por reglamentos formulados con estrechez de miras.

\section{PRINCIPIOS DE SEGURIDAD PARA ROBOTS INDUSTRIALES}

\section{Toni Retsch, Guido Schmitter y Albert Marty}

L os robots industriales se emplean en toda la industria, y concretamente en los lugares de trabajo donde se exige una productividad elevada. Ahora bien, el uso de robots requiere el diseño, aplicación e implantación de controles de seguridad apropiados para no crear peligros para el personal de producción, programadores, técnicos de mantenimiento e ingenieros de sistemas.

\section{¿Por qué son peligrosos los robots industriales?}

Una definición del robot es: "máquinas automáticas móviles programables a voluntad y capaces de funcionar con una interface humana reducida o nula". Estos tipos de máquinas se utilizan actualmente en muchas aplicaciones industriales y médicas, incluida la formación. L os robots industriales se utilizan cada vez más para funciones fundamentales como nuevas estrategias de fabricación (CIM, JIT, producción ajustada sin piezas sobrantes, etc.) en instalaciones complejas. Su número y ámbito de aplicación y la complejidad de los equipos e instalaciones dan lugar a peligros como los siguientes:

- movimientos y secuencias de movimientos que son casi imposibles de seguir, ya que los movimientos a alta velocidad de los robots dentro de su radio de acción se solapan a menudo con los de otras máquinas y equipos;

- liberación de energía en forma de partículas proyectadas 0 haces de energía como los emitidos por láseres o chorros de agua;

- libertad de programación en términos de dirección y velocidad;

- susceptibilidad a errores inducidos del exterior (por ejemplo, compatibilidad electromagnética),

- factores humanos.

Según investigaciones realizadas en Japón, más del $50 \%$ de los accidentes de trabajo con robots pueden atribuirse a fallos de los circuitos electrónicos de los sistemas de control. Según las mismas investigaciones, los errores humanos son responsables de menos del $20 \%$ de los accidentes. La conclusión lógica de esto es que los peligros debidos a fallos del sistema no se pueden evitar con medidas relativas al comportamiento del personal. Por tanto, diseñadores y operadores tienen que aportar y aplicar medidas técnicas de seguridad (véase la Figura 58.82). 
Figura 58.82 - Sistema especial de control del funcionamiento para la preparación de un robot de soldadura móvil.

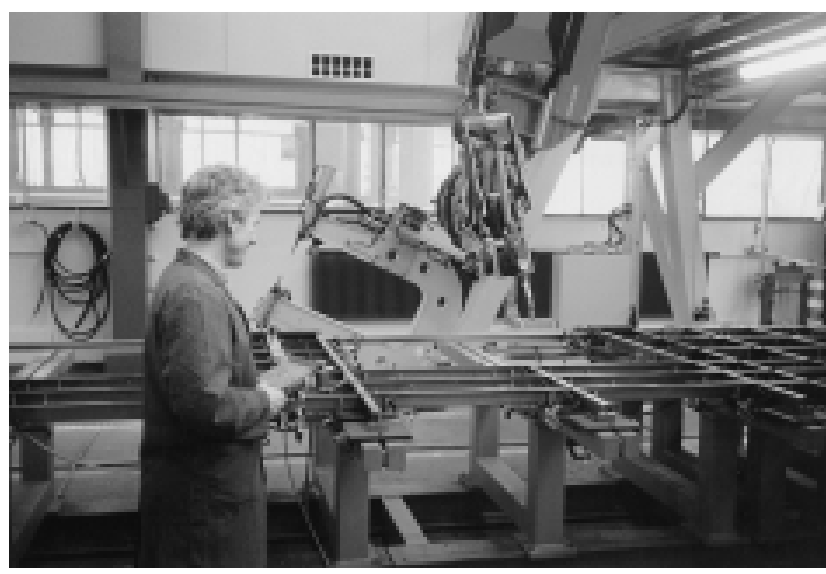

\section{Accidentes y modalidades de funcionamiento}

A principios del decenio de 1980 comenzaron a producirse accidentes mortales relacionados con robots. L as estadísticas e investigaciones indican que la mayoría de accidentes e incidentes no tienen lugar durante el funcionamiento normal (ejecución automática de la tarea asignada). Cuando se trabaja con máquinas e instalaciones de robots industriales cobran mayor importancia las modalidades de funcionamiento especiales, como la puesta en marcha, preparación, programación, pruebas de funcionamiento, localización de averías o mantenimiento. En estas modalidades de funcionamiento, las personas se encuentran normalmente en zonas de peligro. El concepto de seguridad tiene que proteger a las personas frente a sucesos negativos en situaciones de este tipo.

\section{Requisitos de seguridad internacionales}

La Directiva de M aquinaria de la CEE de 1989 (89/392/ CEE (véase el artículo "Principios de seguridad para máquinas herramienta CNC" en este capítulo y otras partes de esta E nciclopedia) establece los principales requisitos de seguridad y salud en relación con las máquinas. U na máquina se considera la suma total de elementos o dispositivos interconectados de los cuales uno al menos puede moverse y ejerce una función asociada. Si se trata de robots industriales debe tenerse en cuenta que es el sistema completo y no un solo equipo de la máquina el que tiene que cumplir los requisitos de seguridad y tiene que estar equipado con los dispositivos de seguridad apropiados. El análisis de peligros y la evaluación de riesgos son métodos adecuados para determinar si se cumplen estos requisitos (véase la Figura 58.83).

\section{Requisitos y medidas de seguridad en régimen de funcionamiento normal}

El uso de la tecnología de robots plantea las máximas exigencias en cuanto a análisis de peligros, evaluación de riesgos y conceptos de seguridad. Por esta razón, los ejemplos y sugerencias siguientes son sólo orientativos:

1. Dado el objetivo de seguridad de que es necesario impedir el acceso manual o físico a zonas peligrosas en las que se realicen movimientos automáticos, las soluciones sugeridas incluyen las siguientes:

- Impedir el acceso manual o físico a zonas peligrosas por medio de barreras mecánicas.
Figura 58.83 - Diagrama de bloques de un sistema de seguridad personal.

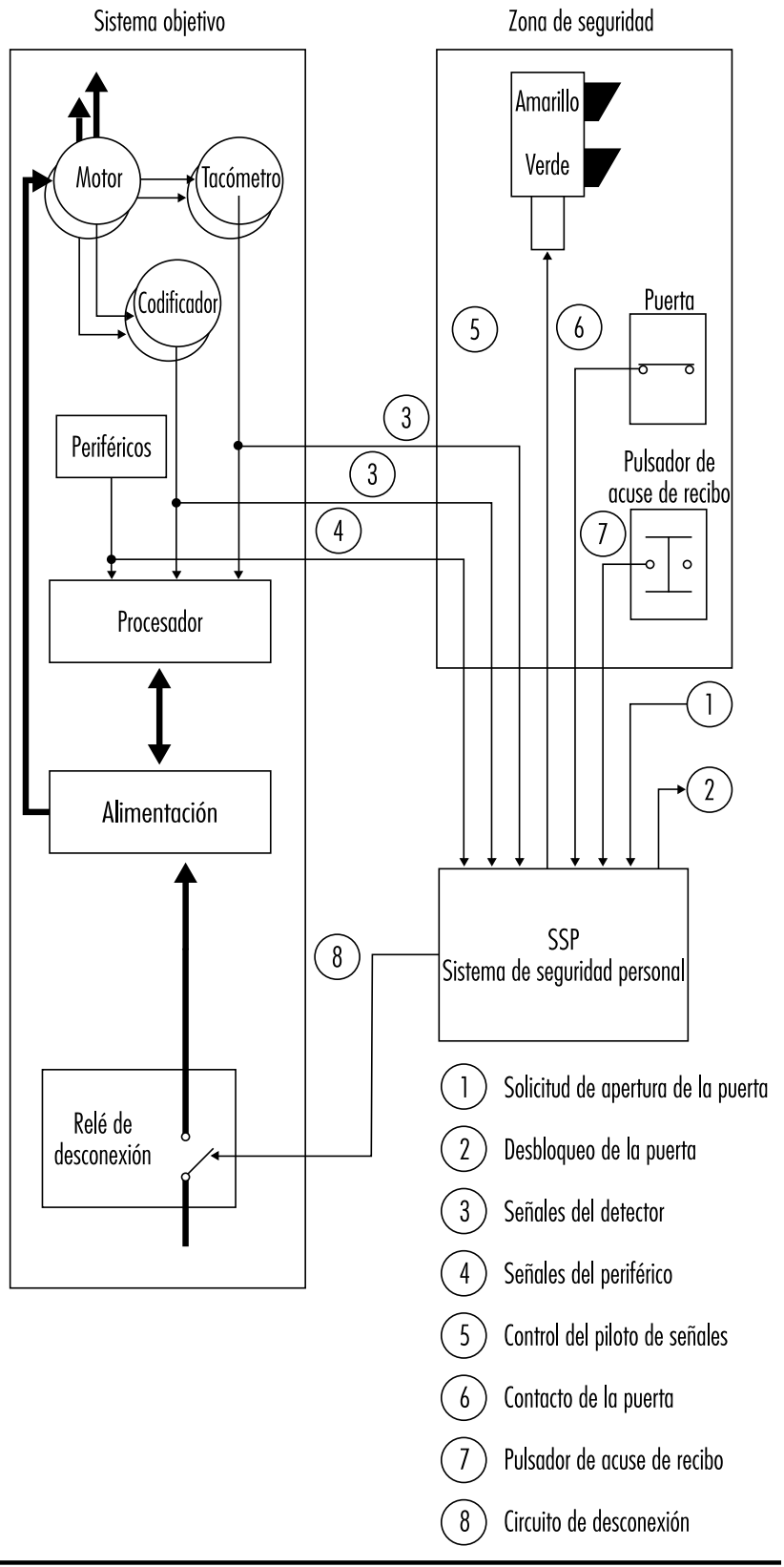

- U tilizar dispositivos de seguridad de un tipo que responda a la aproximación (barreras de luz, alfombrillas de seguridad) y que paren la máquina con seguridad cuando se produzca un acceso o penetración.

- Permitir el acceso manual o físico sólo cuando el sistema completo se encuentre en un estado seguro. Por ejemplo, esto se puede lograr mediante dispositivos de enclavamiento con mecanismos de cierre de las puertas de acceso.

2. Dado el objetivo de seguridad de que ninguna persona resulte lesionada como consecuencia de la liberación de energía (partículas proyectadas o haces de energía), las soluciones sugeridas incluyen:

- El diseño debe impedir toda liberación de energía (por ejemplo, conexiones bien dimensionadas, dispositivos 
Figura 58.84 - Robot industrial de seis ejes en una jaula de seguridad con puertas de entrada de materiales.

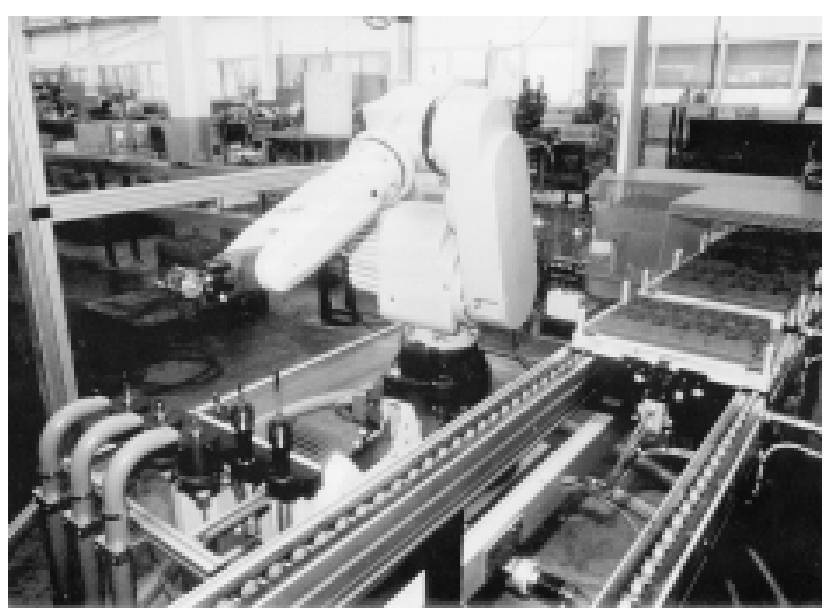

pasivos de enclavamiento para mecanismos de cambio de mordazas, etc.).

- Impedir la liberación de energía desde la zona de peligro, por ejemplo, mediante una cubierta de seguridad bien dimensionada.

3. Se precisan interfaces entre el funcionamiento normal y el especial (por ejemplo, dispositivos de enclavamiento de puertas, barreras de luz, alfombrillas de seguridad) para permitir que el sistema de control de seguridad reconozca la presencia de personas.

\section{Exigencias y medidas de seguridad en modalidades de funcionamiento especiales}

Determinadas modalidades de funcionamiento especiales (por ejemplo, preparación, programación) de un robot industrial requieren movimientos que tienen que ser evaluados directamente sobre el terreno. El objetivo de seguridad correspondiente es que ningún movimiento ponga en peligro a las personas que intervienen. Los movimientos deberán

- ejecutarse siempre en la forma y a la velocidad programadas;

- tener siempre la duración especificada,

- ser exclusivamente los que se puedan ejecutar con la garantía de que ninguna parte del cuerpo humano estará en la zona de peligro.

U na solución sugerida para alcanzar este objetivo sería el uso de sistemas de control especiales que sólo permitieran movimientos controlables y ajustables utilizando controles con acuse de recibo. De esta manera la velocidad de los movimientos se reduce con seguridad (reducción de energía mediante la conexión de un transformador separador de circuito o el uso de un dispositivo de supervisión del estado de seguridad a prueba de fallos) y se acusa recibo del estado de seguridad antes de permitir la activación del control (véase la Figura 58.84).

\section{Exigencias relativas a los sistemas de control de seguridad}

Una de las características de un sistema de control de seguridad ha de ser la garantía de la ejecución de la función de seguridad siempre que se produzca cualquier fallo. Los robots industriales deben pasar casi instantáneamente de un estado peligroso a un estado seguro. Las medidas de control de seguridad necesarias para conseguirlo incluyen los siguientes objetivos:

- Un fallo en el sistema de control de seguridad no debe dar lugar a un estado peligroso.

- Un fallo en el sistema de control de seguridad tiene que ser identificado (inmediatamente 0 a intervalos).

Las soluciones sugeridas para proporcionar sistemas de control de seguridad fiables serían:

- diseño redundante y diversificado de sistemas de control electromecánicos, incluidos circuitos de prueba,

- diseño redundante y diversificado de sistemas de control por microprocesador desarrollados por equipos distintos. Este planteamiento moderno se considera acorde con el estado de la técnica, como por ejemplo los que utilizan barreras de luz de seguridad.

\section{Objetivos de seguridad para la construcción y uso de robots industriales}

Cuando se construyen y usan robots industriales, los fabricantes y usuarios están obligados a instalar controles de seguridad acordes con el estado de la técnica. A parte del aspecto de la responsabilidad jurídica, puede haber también una obligación moral de asegurarse de que la robótica es asimismo una tecnología segura.

\section{M odalidad de funcionamiento normal}

Cuando los robots funcionan en modalidad normal, tienen que cumplirse las siguientes condiciones de seguridad:

- El campo de movimientos del robot y las zonas de procesado utilizadas por equipos periféricos tienen que asegurarse de tal manera que se impida a las personas el acceso manual o físico a las zonas que sean peligrosas como consecuencia de movimientos automáticos.

- También debe existir protección para que piezas o herramientas proyectadas no puedan causar daños.

- Ninguna persona debe poder sufrir lesiones causadas por partículas, herramientas o piezas proyectadas por el robot o por la liberación de energía debido a defectos de las mordazas, a la pérdida de fuerza de agarre de las mordazas, a una velocidad inadmisible, a colisiones o piezas de trabajo defectuosas.

- N inguna persona debe poder sufrir lesiones debido a la liberación de energía o a piezas proyectadas por equipos periféricos.

- Las aberturas de alimentación y retirada de piezas deberán diseñarse de manera que se impida el acceso manual o físico a zonas peligrosas a causa de movimientos automáticos. Esta condición deberá cumplirse también cuando se retire el material de producción. Si el material de producción se alimenta al robot automáticamente, no podrán crearse zonas peligrosas a causa de las aberturas de alimentación y retirada ni del material de producción en movimiento.

\section{M odalidades de funcionamiento especiales}

Deberán cumplirse las siguientes condiciones de seguridad cuando los robots estén funcionando en modalidades especiales:

\section{Durante la reparación de una avería en el proceso de} producción, deberá evitarse lo siguiente:

- acceso manual o físico a zonas que sean peligrosas debido a movimientos automáticos del robot 0 de los equipos periféricos;

- peligros derivados del comportamiento defectuoso del sistema o de la introducción de comandos inadmisibles, si personas o partes del cuerpo se encuentran en la zona expuesta a movimientos peligrosos; 
- movimientos o condiciones peligrosos iniciados por el movimiento o retirada de material de producción o desechos;

- lesiones causadas por equipos periféricos,

- movimientos que tengan que ejecutarse con las defensas de la modalidad de funcionamiento normal desmontadas y que sólo se llevarán a cabo dentro del ámbito operativo y a la velocidad especificados y durante el tiempo especificado. Además, ninguna persona o parte del cuerpo podrá estar presente en la zona de peligro.

\section{Durante la preparación deberán asegurarse las siguientes} condiciones de seguridad:

No se podrá iniciar ningún movimiento peligroso como consecuencia de un comando erróneo o de la introducción incorrecta de un comando.

- El cambio del robot o de los equipos periféricos no deberá dar lugar a estados o movimientos peligrosos.

- Si es necesario ejecutar movimientos con las defensas correspondientes a la modalidad de funcionamiento normal desmontadas al realizar operaciones de preparación, dichos movimientos sólo se realizarán dentro del ámbito operativo y a la velocidad especificados y durante el tiempo especificado. A demás, ninguna persona o parte del cuerpo podrá estar presente en la zona de peligro.

- Durante las operaciones de preparación, los equipos periféricos no deberán ejecutar movimientos peligrosos ni crear un estado peligroso.

\section{Durante la programación se aplicarán las siguientes}

condiciones de seguridad:

- Deberá impedirse el acceso manual o físico a zonas peligrosas debido a movimientos automáticos.

- Si se ejecutan movimientos con las defensas correspondientes al funcionamiento normal desmontadas, deberán cumplirse las siguientes condiciones:

- (a) Sólo podrá ejecutarse el comando de movimiento y sólo durante el tiempo que se emita.

- (b) Sólo podrán ejecutarse movimientos controlables (es decir, tendrán que ser movimientos claramente visibles a baja velocidad).

- (c) Solo podrán iniciarse movimientos si no constituyen un peligro para el programador u otras personas.

- Los equipos periféricos no podrán representar un peligro para el programador ni para otras personas.

\section{Las operaciones de prueba seguras requieren las precauciones siguientes: \\ Impedir el acceso manual o físico a zonas que sean peligrosas} debido a movimientos automáticos.

- Los equipos periféricos no deberán ser una fuente de peligro.

\section{Al inspeccionar robots, los procedimientos seguros deberán} incluir lo siguiente:

- Si es necesario entrar en el campo de movimientos del robot a efectos de inspección, esto sólo se podrá hacer si el sistema se encuentra en estado seguro.

- Deberán prevenirse los peligros debidos a un comportamiento incorrecto del sistema o a la introducción de comandos inadmisibles.

- Los equipos periféricos no deberán ser una fuente de peligro para el personal de inspección.
La localización de averías requiere con frecuencia poner en marcha el robot cuando este se halla en condiciones potencialmente peligrosas, por lo que deben utilizarse procedimientos especiales de trabajo seguros como los siguientes:

- D eberá impedirse el acceso a zonas que sean peligrosas debido a movimientos automáticos.

- Deberá impedirse la puesta en marcha de una unidad de accionamiento como consecuencia de un comando incorrecto o de la introducción de un falso comando.

- Al manipular una pieza defectuosa, deberán impedirse todos los movimientos del robot.

- Deberán prevenirse lesiones causadas por piezas que puedan ser expulsadas o caerse de la máquina.

- Si durante la localización de averías es necesario realizar movimientos con las defensas correspondientes al funcionamiento normal desmontadas, dichos movimientos sólo se realizarán dentro del ámbito operativo y a la velocidad especificados y durante el tiempo especificado. Además, ninguna persona 0 parte del cuerpo podrá estar presente en la zona de peligro.

- Deberán prevenirse las lesiones causadas por los equipos periféricos.

Los trabajos de reparación y mantenimiento pueden requerir también la puesta en marcha de la máquina en condiciones no seguras y por tanto es necesario adoptar las siguientes precauciones:

- El robot no debe poder ponerse en marcha.

- Debe ser posible manipular diversas piezas de la máquina, manualmente o con equipos auxiliares, sin riesgo de exposición a peligros.

- No debe ser posible el contacto con piezas en movimiento.

- Deben impedirse las lesiones causadas por escapes de líquidos o gases.

- D eben impedirse las lesiones causadas por equipos periféricos.

\section{SISTEMAS DE CONTROL DE SEGURIDAD ELECTRICOS, ELECTRONICOS Y PROGRAMABLES}

\section{Ron Bell}

En este artículo se trata del diseño e implantación de sistemas de control relacionados con la seguridad que cubren todo tipo de sistemas eléctricos, electrónicos y programables. EI planteamiento general es conforme a la norma 1508 propuesta por la Comisión Electrotécnica Internacional (CEI) (Seguridad funcional: sistemas relacionados con la seguridad) (CEI 1993).

\section{Antecedentes}

Durante el decenio de 1980 se ha expandido el uso de sistemas basados en ordenador, con el nombre genérico de sistemas electrónicos programables (SEP), para funciones de seguridad. Las principales razones que impulsaron esta tendencia fue (1) la mejora de la funcionalidad y ventajas económicas (especialmente considerando el ciclo de vida total del dispositivo), y (2) las ventajas concretas de algunos diseños que solo se podían realizar con tecnología informática. En las primeras fases de introducción de sistemas basados en ordenador se hicieron algunos descubrimientos:

- La introducción del control por ordenador estuvo mal planteada y planificada.

- Se especificaron requisitos de seguridad insuficientes. 
- Se desarrollaron procedimientos inadecuados respecto a la validación de software.

- Se encontraron pruebas de defectos de fabricación en relación con las normas de instalación de equipos.

- La documentación generada era insuficiente y carecía de una validación apropiada respecto a lo que realmente había en el equipo (distinto de lo que se creía que había).

- Se habían establecido procedimientos de funcionamiento y mantenimiento que no eran totalmente efectivos

- Había una preocupación justificada con respecto a la competencia de las personas para realizar las tareas que se requerían de ellas.

Para solucionar estos problemas, varios organismos publicaron o comenzaron a desarrollar directrices para permitir la explotación segura de la tecnología de SEP. En el Reino U nido, el Health and Safety Excutive (HSE) desarrolló directrices para sistemas electrónicos programables utilizados en aplicaciones relacionadas con la seguridad y en Alemania se publicó un proyecto de norma (DIN 1990). Dentro de la Comunidad Europea se impulsó un importante instrumento para la armonización de las normas europeas relativas a sistemas de control relacionados con la seguridad (incluidos los SEP), con la promulgación de la Directiva de M aquinaria. En Estados U nidos, la Instrument Society of America (ISA) ha preparado una norma sobre SEP para uso en la industria tranformadora y el Centro para la Seguridad de los Procesos Q uímicos (C enter for $C$ hemical Process Safety, CCPS), un órgano del American Institute of Chemical Engineers, ha elaborado directrices para la industria química.

Actualmente se está desarrollando una importante iniciativa en la CEI con miras a crear una norma internacional genérica para sistemas de seguridad eléctricos, electrónicos y programables (SE/ E / P ) que pueda ser utilizada por numerosos sectores, incluida la industria transformadora, el sector médico, los transportes y la construcción mecánica. La norma internacional CEI propuesta consta de 7 partes bajo el título general CEI 1508. Seguridad funcional de sistemas de seguridad eléctricos/ electrónicos/ programables. Dichas partes son las siguientes:

- Parte 1. R equisitos generales.

- Parte 2. Requisitos de los sistemas eléctricos, electrónicos y programables.

- Parte 3. Requisitos de software.

- Parte 4. D efiniciones

- Parte 5. Ejemplos de métodos para la determinación de los niveles de integridad de la seguridad.

- Parte 6. Directrices de aplicación de las partes 2 y 3.

- Parte 7. Descripción general de técnicas y medidas.

Cuando esté terminada, esta norma genérica internacional será una publicación básica sobre seguridad de la CEI que cubrirá la seguridad funcional de sistemas de seguridad eléctricos, electrónicos y programables y tendrá implicaciones en todas las normas CEI relativas a todos los sectores de aplicación, en relación con el diseño y uso de dichos sistemas en el futuro. Uno de los principales objetivos de la norma propuesta es facilitar el desarrollo de normas específicas para los distintos sectores (véase la Figura 58.85)

\section{Ventajas y problemas de los SEP}

$L a$ adopción de SEP con fines de seguridad encerraba muchas ventajas potenciales, pero se reconoció que éstas sólo se lograrían si se utilizaban metodologías de evaluación y diseño apropiadas porque: (1) muchas de las características de los SEP no permiten que la integridad de la seguridad (es decir, el comportamiento seguro de los sistemas que ejecutan las funciones de seguridad

requeridas) se pueda predecir con el grado de confianza que tradicionalmente han tenido los sistemas menos complejos basados en hardware (cableado permanente), (2) se reconoció que aunque los sistemas complejos requerían pruebas, no eran suficientes por sí solas. Esto significaba que incluso si el SEP tenía que ejecutar funciones de seguridad relativamente sencillas, el nivel de complejidad de los dispositivos electrónicos programables era mucho mayor que el de los sistemas con cableado permanente a los que estaban sustituyendo, y (3) este aumento de complejidad significaba que las tecnologías de diseño y evaluación tenían que ser objeto de mucha más atención que antes y que el nivel de cualificación del personal necesario para obtener prestaciones suficientes de los sistemas relacionados con la seguridad tenía que ser mayor.

Las ventajas de los SEP basados en ordenador son las siguientes:

- capacidad de realizar verificaciones de diagnóstico en línea para componentes críticos, con una frecuencia mucho mayor de la que sería posible de otra manera;

- posibilidad de establecer sofisticados enclavamientos de seguridad;

- posibilidad de realizar funciones de diagnóstico y supervisión de condiciones que se puede emplear para analizar y generar informes sobre el comportamiento de las máquinas y equipos en tiempo real;

- posibilidad de comparar condiciones reales del equipo con condiciones "ideales" del modelo;

- posibilidad de proporcionar una información más completa a los operadores y mejorar así la seguridad en la toma de decisiones;

- uso de avanzadas estrategias de control para permitir que los operadores humanos se sitúen lejos de entornos hostiles 0 peligrosos,

- posibilidad de diagnosticar el sistema de control desde un punto remoto.

El uso de sistemas basados en ordenador para aplicaciones relacionadas con la seguridad crea ciertos problemas que es necesario resolver adecuadamente, a saber:

- Las modalidades de fallo son complejas y no siempre previsibles.

Figura 58.85 - N ormas genéricas y de sectores de aplicación.

Norma internacional genérica

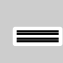

Utilizada como base para normas internacionales de sectores de aplicación

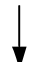

EJEMPLOS DE NORMAS INTERNACIONALES DE SECTORES DE APLICACION

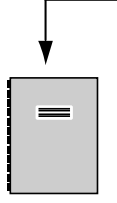

Construcción de máquinas

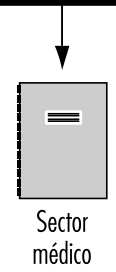


Figura 58.86 • Sistemas eléctricos, electrónicos y programables.

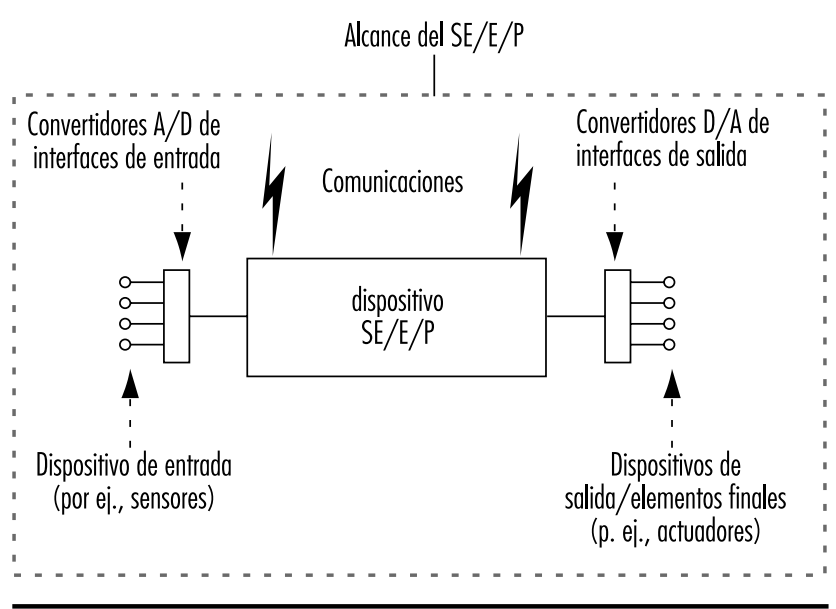

- La comprobación del ordenador es necesaria pero no suficiente por sí sola para determinar si las funciones de seguridad se ejecutarán con el grado de certidumbre exigido por la aplicación.

- Los microprocesadores pueden presentar sutiles variaciones entre los distintos lotes y por tanto pueden tener comportamientos distintos.

- Los sistemas basados en ordenador no protegidos son especialmente susceptibles a interferencias eléctricas (interferencias radiadas, sobretensiones en la red de alimentación, descargas electrostáticas, etc.)

- Es difícil y a veces imposible cuantificar la probabilidad de fallo de sistemas complejos relacionados con la seguridad que incorporan software. Debido a que no existe ningún método de cuantificación generalmente aceptado, la seguridad del software se ha basado en procedimientos y normas que describen los métodos a utilizar en el diseño, implantación y mantenimiento del software.

\section{Sistemas de seguridad considerados}

Los tipos de sistemas relacionados con la seguridad que se consideran son los eléctricos, electrónicos y programables (SE/E/P). El sistema incluye todos los elementos, especialmente las señales que van desde los sensores u otros dispositivos de entrada situados en el equipo sometido a control y transmitidos a través de líneas de datos u otras vías de comunicación a los actuadores u otros dispositivos de salida (véase la Figura 58.86).

EI término dispositivo eléctrico, electrónico y programable se ha utilizado para cubrir una amplia gama de dispositivos y abarca tres clases principales:

1. dispositivos eléctricos, como los relés electromecánicos

2. dispositivos electrónicos, como los instrumentos electrónicos de estado sólido y sistemas lógicos

3. dispositivos electrónicos programables, que incluyen una gran variedad de sistemas basados en ordenadores, como los siguientes:

- microprocesadores

- microcontroladores

- controladores programables (PC)

- circuitos integrados específicos de aplicación (ASIC)

- controladores lógicos programables (PLC)

- otros dispositivos basados en ordenador (por ejemplo, sensores "inteligentes", transmisores y actuadores).
Por definición, un sistema de seguridad sirve para dos fines:

1. Aplica las funciones de seguridad necesarias para que el equipo bajo control pase a un estado seguro o se mantenga en un estado seguro. El sistema de seguridad tiene que ejecutar las funciones de seguridad incluidas en la especificación de requisitos de seguridad del sistema. Por ejemplo, la especificación de requisitos de seguridad puede indicar que cuando la temperatura alcance un determinado valor $x$, la válvula y debe abrirse para permitir la entrada de agua en el recipiente.

2. Consigue por sí mismo o con otros sistemas relacionados con la seguridad el nivel necesario de integridad de la seguridad para la ejecución de las funciones de seguridad necesarias. Las funciones de seguridad tienen que ser ejecutadas por los sistemas relacionados con la seguridad con el grado de confianza suficiente para la aplicación, con objeto de conseguir el nivel requerido de seguridad en el equipo bajo control.

Este concepto se ilustra en la Figura 58.87.

\section{Fallos del sistema}

Para garantizar el funcionamiento seguro de los sistemas de seguridad SE/ E/ P, es necesario reconocer varias causas de fallos posibles de estos sistemas y asegurar que se adoptan las precauciones necesarias frente a cada una de ellas. Los fallos se clasifican en dos categorías, según se ilustra en la Figura 58.88.

1. Fallos aleatorios del hardware son aquéllos que resultan de diversos mecanismos de degradación del hardware. Hay muchos de estos mecanismos que actúan a distintos ritmos y en distintos componentes $y$, puesto que las tolerancias de fabricación pueden hacer que los componentes fallen a causa de estos mecanismos después de períodos de funcionamiento distintos, el fallo de un equipo completo formado por muchos componentes se puede producir al cabo de un tiempo

Figura 58.87 - Características principales de los elementos relacionados con la seguridad.

Sistemas relacionados con la seguridad (SRS)

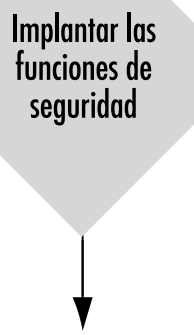

Proporciona suficiente integridad de la seguridad para cada función de seguridad

Nivel requerido de seguridad conseguido para el equipo bajo control 
Figura 58.88 - Categorías de fallos.

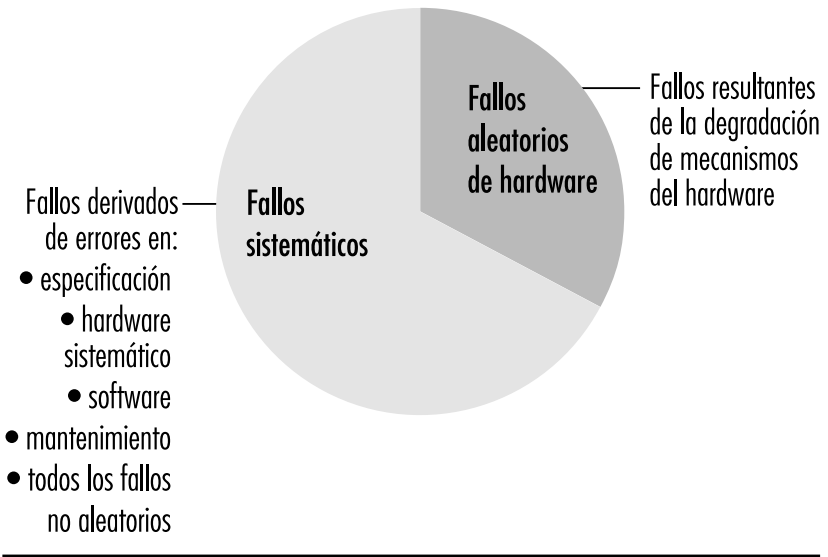

imprevisible (aleatorio). Las cuantificaciones de la fiabilidad del sistema, como el tiempo medio entre fallos (MTBF), proporcionan una información valiosa, pero normalmente sólo se refieren a fallos aleatorios del hardware y no incluyen los fallos sistemáticos.

2. Los fallos sistemáticos se producen como consecuencia de errores de diseño o construcción o del uso de un sistema que falla con una combinación concreta de entradas 0 en determinadas condiciones ambientales concretas. Si el fallo de un sistema se produce cuando se da un determinado conjunto de circunstancias, siempre que se presenten estas circunstancias en el futuro se producirá un fallo del sistema. Cualquier fallo de un sistema relacionado con la seguridad que no sea consecuencia de un fallo aleatorio del hardware es, por definición, un fallo sistemático. Estos fallos, en el contexto de los sistemas de seguridad SE/ E/P, son:

- fallos sistemáticos debidos a errores u omisiones en la especificación de los requisitos de seguridad

- fallos sistemáticos debidos a errores en el diseño, fabricación, instalación o funcionamiento del hardware. Aquí estarían incluidos los fallos atribuibles a causas ambientales o errores humanos (por ejemplo, del operador)

- fallos sistemáticos debidos a defectos del software

- fallos sistemáticos debidos a errores de mantenimiento y modificaciones.

\section{Protección de los sistemas de seguridad}

L os términos que se utilizan para indicar las medidas de precaución necesarias para proteger un sistema relacionado con la seguridad frente a fallos del hardware y fallos sistemáticos son medidas de integridad de la seguridad del hardware y medidas sistemáticas de integridad del software, respectivamente. Las medidas de precaución que un sistema relacionado con la seguridad puede aportar frente a los fallos aleatorios del hardware y los fallos sistemáticos, se denominan integridad de la seguridad. Estos conceptos se ilustran en la Figura 58.89.

D entro de la propuesta de norma internacional CEI 1508 hay cuatro niveles de integridad de la seguridad, que tienen asignados los números $1,2,3$ y 4 . El número 1 corresponde al nivel de integridad de la seguridad más bajo y el 4 al más alto. EI nivel de integridad de la seguridad $(1,2,3$ ó 4) para el sistema de seguridad dependerá del papel que dicho sistema esté desempeñando a fin de conseguir el nivel requerido de seguridad del
Figura 58.89 - Términos de prestaciones de seguridad.

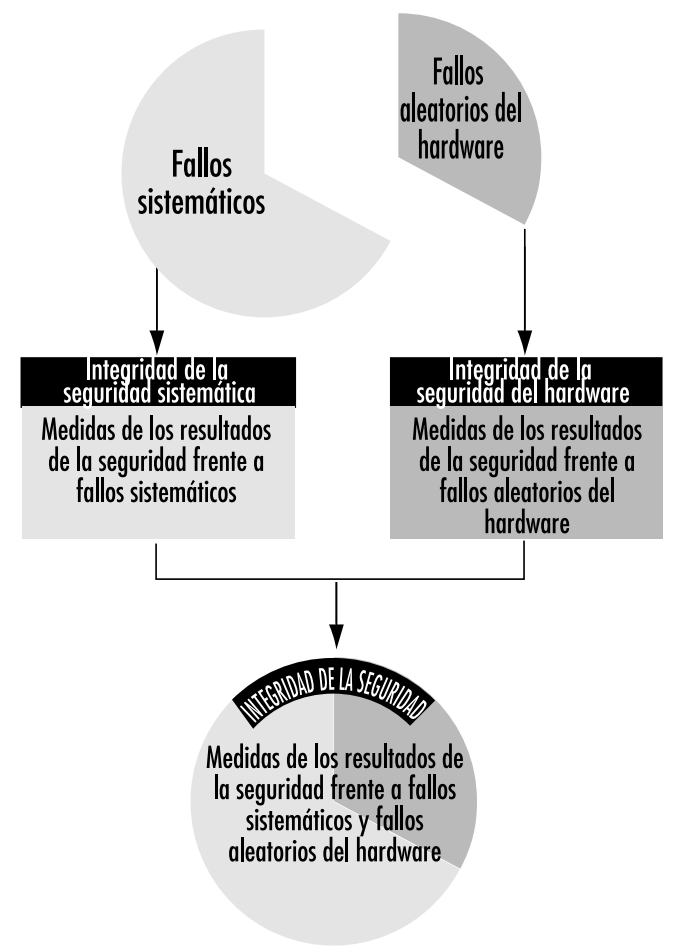

equipo bajo control. Pueden ser necesarios varios sistemas de seguridad, algunos de los cuales pueden estar basados en tecnología neumática o hidráulica.

\section{Diseño de sistemas de seguridad}

Un análisis reciente de 34 incidentes relacionados con sistemas de control (HSE) reveló que el $60 \%$ de todos los casos de fallo se habían "incorporado" antes de que el sistema de control relacionado con la seguridad hubiera empezado a utilizarse (Figura 58.90). Es necesario considerar todas las fases del ciclo de vida de la seguridad para preparar sistemas de seguridad adecuados.

La seguridad funcional de los sistemas relacionados con la seguridad no sólo depende de asegurar que se han especificado correctamente los requisitos técnicos, sino de asegurar también que dichos requisitos se implantan eficazmente y que se mantiene la integridad de diseño inicial durante toda la vida del equipo. Esto sólo se puede lograr si existe un sistema eficaz de gestión de la seguridad y si las per sonas que intervienen en todas las actividades son competentes en relación con los trabajos que tienen que realizar. Especialmente cuando se trata de sistemas relacionados con la seguridad complejos, es esencial que exista un sistema adecuado de gestión de la seguridad. Esto conduce a una estrategia que asegura lo siguiente:

- Existe un sistema eficaz de gestión de la seguridad.

- Los requisitos técnicos especificados para los sistemas de seguridad SE/E/P son suficientes para hacer frente a causas de fallo aleatorias del software y sistemáticas.

- La competencia de las personas que intervienen es suficiente para los trabajos que tienen que realizar.

Con objeto de satisfacer todas las necesidades técnicas pertinentes de seguridad funcional de una forma sistemática, se ha 


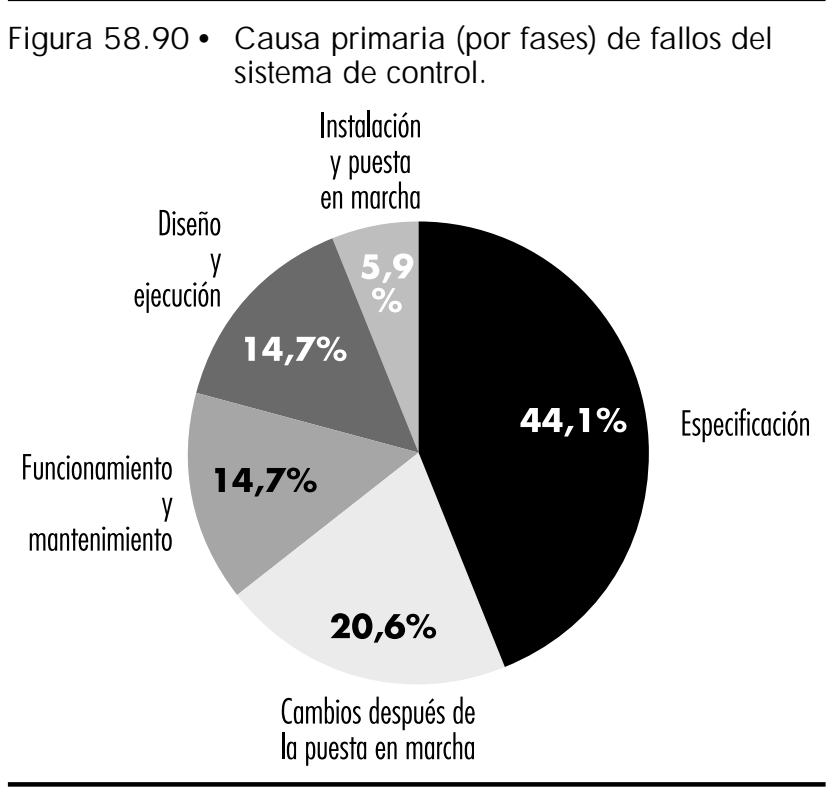

desarrollado el concepto de ciclo de vida de la seguridad. En la Figura 58.91 se muestra una versión simplificada del ciclo de vida de la seguridad de la norma internacional recientemente publicada CEI 1508. Las fases principales del ciclo de vida de la seguridad son:

- especificación;

- diseño e implantación;

- instalación y puesta en marcha;

- funcionamiento y mantenimiento,

- cambios después de la puesta en marcha.

\section{Nivel de seguridad.}

La estrategia de diseño para conseguir niveles adecuados de integridad de la seguridad en los sistemas relacionados con la seguridad se ilustra en las Figuras 58.92 y 58.93. Un nivel de integridad de la seguridad está basado en el papel que el sistema relacionado con la seguridad desempeña en la consecución del nivel global de seguridad para el equipo bajo control. EI nivel de integridad de la seguridad especifica las precauciones que es necesario adoptar en el diseño frente a fallos aleatorios del hardware y fallos sistemáticos.

El concepto de seguridad y nivel de seguridad se aplica al equipo bajo control. El concepto de seguridad funcional se aplica a los sistemas relacionados con la seguridad. Es necesario conseguir la seguridad funcional de los sistemas relacionados con la seguridad si se desea alcanzar un nivel de seguridad adecuado para el equipo que da lugar al peligro. El nivel especificado de seguridad para una situación concreta es un factor fundamental de cara a la especificación de los requisitos de integridad de la seguridad de los sistemas de seguridad.

El nivel requerido de seguridad dependerá de muchos factores, por ejemplo: la gravedad de las lesiones, el número de personas expuestas al peligro y la duración de la exposición al suceso peligroso. Para llegar a lo que constituye un nivel apropiado de seguridad para una aplicación específica, es necesario considerar diversos datos, entre otros los siguientes:

- requisitos legales relevantes para la aplicación concreta;

- directrices de la autoridad competente en materia de seguridad;
Figura 58.91 - Influencia del ciclo de vida de la seguridad en la consecución de la seguridad funcional.

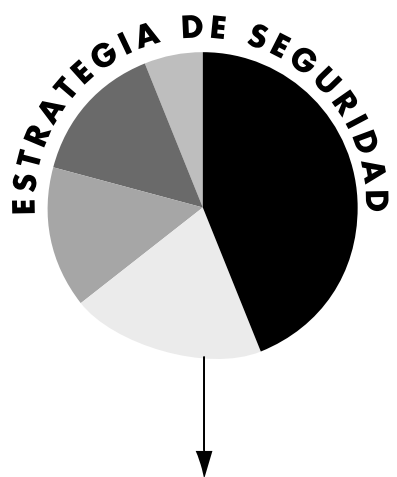

\section{GESTION DE LA SEGURIDAD}
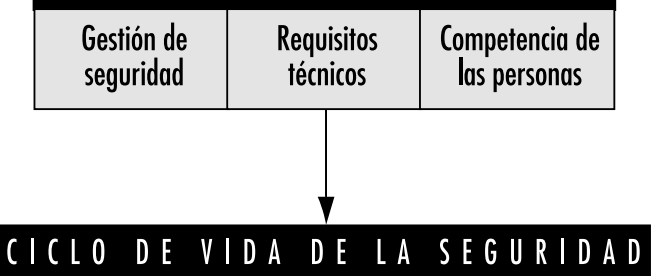

- negociaciones y acuerdos con las distintas partes que intervienen en la aplicación;

- normas industriales;

- normas nacionales e internacionales,

- un asesoramiento industrial, técnico y científico óptimo.

\section{Resumen}

Al diseñar y utilizar sistemas relacionados con la seguridad es necesario tener presente que es el equipo bajo control el que crea el peligro potencial. Los sistemas de seguridad se diseñan para reducir la frecuencia (o probabilidad) del suceso peligroso y/ 0 de las consecuencias del suceso peligroso. U na vez que se ha establecido el nivel de seguridad para el equipo, se puede determinar el nivel de integridad de la seguridad para el sistema de seguridad, y es ese nivel de integridad el que permite al diseñador especificar las precauciones que es necesario incorporar en el diseño a efectos de protección contra fallos aleatorios del hardware y fallos sistemáticos. 
Figura 58.92 - Influencia de los niveles de integridad de la seguridad en el proceso de diseño.

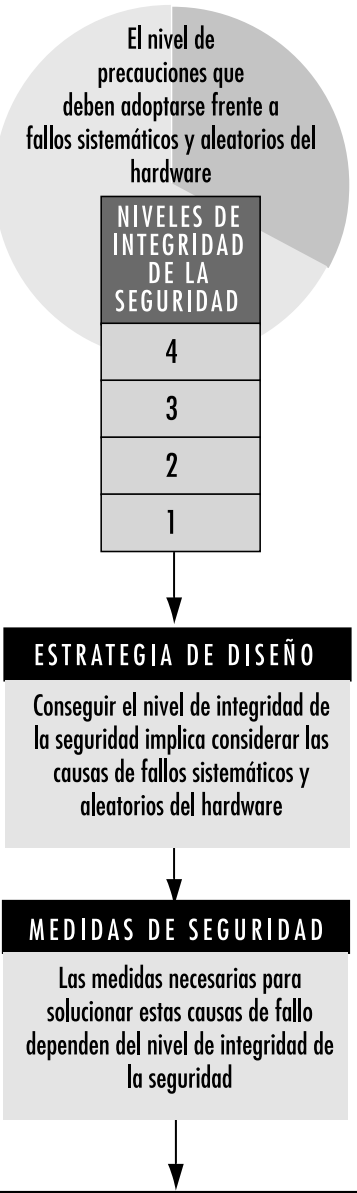

\section{INTEGRIDAD DE LA SEGURIDAD}

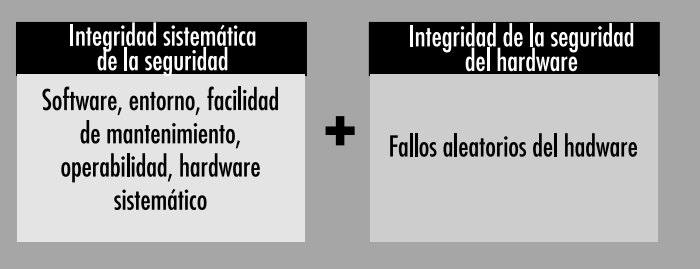

\section{- REQUISITOS TECNICOS PARA} SISTEMAS RELACIONADOS CON

\section{LA SEGURIDAD BASADOSEN} DISPO SITIVOS ELECTRICOS, ELECTRONICOS Y PROGRAMABLES

\section{John Brazendale y Ron Bell}

Las máquinas, instalaciones de proceso y otros equipos pueden generar riesgos debidos a sucesos peligrosos como incendios, explosiones, sobredosis de radiaciones y elementos en movimiento. Entre las posibles razones de que dichas máquinas,
Figura 58.93 • Influencia del ciclo de vida de la seguridad en el proceso de especificación y diseño.

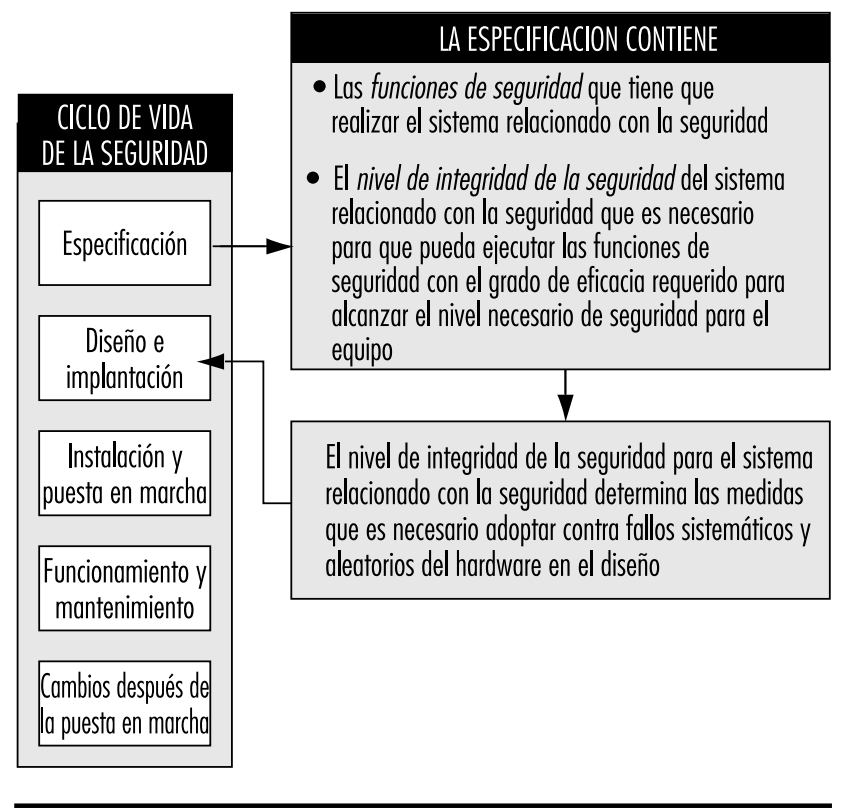

instalaciones y equipos puedan funcionar incorrectamente, están los fallos de los dispositivos electromecánicos, electrónicos y programables (SE/E/ P) utilizados en el diseño de sus sistemas de seguridad o control. Estos fallos pueden ser debidos a fallos físicos de los dispositivos [por ejemplo, desgaste que se produce aleatoriamente en el tiempo (fallos aleatorios del hardware)] o a fallos sistemáticos (por ejemplo, errores cometidos en la especificación de un sistema que hacen que falle debido a (1) alguna combinación concreta de circunstancias; (2) alguna condición ambiental;

(3) datos incompletos o incorrectos procedentes de sensores; (4) datos erróneos o incompletos introducidos por los operadores, y (5) fallos sistemáticos potenciales debidos a un deficiente diseño del interface).

Fallos de sistemas relacionados con la seguridad Este artículo trata de la seguridad funcional de sistemas de control relacionados con la seguridad y considera los requisitos técnicos del hardware y software necesarios para conseguir la necesaria integridad de la seguridad. EI planteamiento general se hace de acuerdo con la norma CEI 1508, partes 1 y 2 (CEI 1993) propuesta por la Comisión Electrotécnica Internacional. EI objetivo global del proyecto de norma internacional CEI 1508, Seguridad funcional: sistemas relacionados con la seguridad es asegurar que las instalaciones y equipos puedan automatizarse con seguridad. U n objetivo fundamental del desarrollo de la norma internacional propuesta es impedir o minimizar la frecuencia de:

- fallos de sistemas de control que disparen otros sucesos que a su vez puedan dar lugar a un peligro (por ejemplo, fallos del sistema de control, pérdida del control, proceso descontrolado con resultado de incendio, liberación de materiales tóxicos, etc.);

- fallos de sistemas de alarma y supervisión que determinan que los operadores no sean informados de manera que puedan identificar y comprender rápidamente lo ocurrido, para adoptar la medidas de emergencia necesarias,

- fallos no detectados de sistemas de protección que hacen que no estén disponibles cuando se necesitan para una acción de 
Figura 58.94 - Reducción de riesgos: conceptos generales.

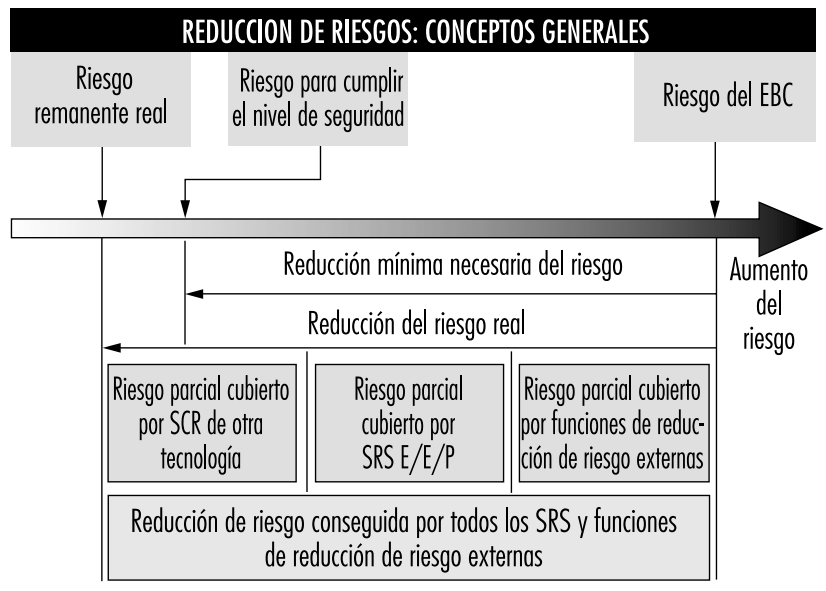

Figura 58.95 - Modelo global: niveles de protección.

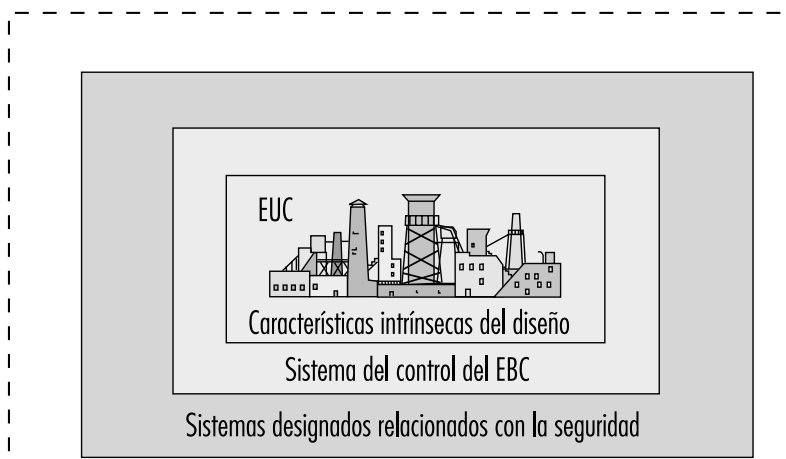

Funciones de reducción del riesgo externas

Figura 58.96 • Sistema típico de protección.

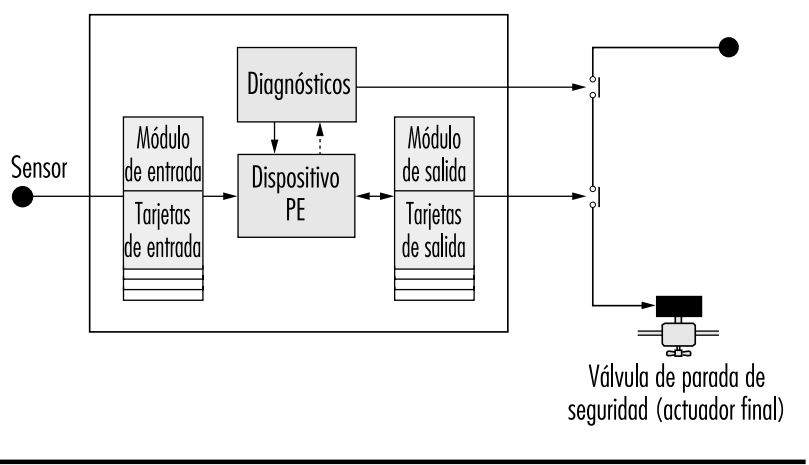

seguridad (por ejemplo, fallo de una tarjeta de entrada en un sistema de parada de emergencia).

El artículo "Sistemas de control de seguridad eléctricos, electrónicos y programables" expone el enfoque general de la gestión de la seguridad recogido en la parte 1 de la norma CEI 1508 para garantizar la seguridad de los sistemas de control y protección que afectan a la seguridad. Este artículo describe un diseño global de ingeniería conceptual que se necesita para reducir el riesgo de accidente a un nivel aceptable, incluido el papel de cualquier sistema de control o protección basado en tecnología SE / E / P.

En la Figura 58.94, el riesgo procedente del equipo, instalación de proceso o máquina (denominados genéricamente equipo bajo control (EBC) sin dispositivos de protección) está marcado en un extremo de la escala de riesgos del EBC y el nivel objetivo de riesgo que es necesario alcanzar para cumplir el nivel de seguridad requerido se encuentra en el otro extremo. En medio aparece la combinación de sistemas de seguridad y factores externos de reducción de riesgos que se precisan para conseguir la reducción de riesgos requerida. Estos pueden ser de distintos tipos: mecánicos (por ejemplo, válvulas limitadoras de presión), hidráulicos, neumáticos, físicos y también sistemas SE/E/ P. La Figura 58.95 resalta el papel de cada nivel de seguridad en la protección del EBC a medida que progresa el accidente.

Siempre que se haya realizado un análisis de peligros y riesgos en el EBC conforme a la parte 1 de la norma CEI 1508, se haya fijado el diseño conceptual global para la seguridad y por tanto se hayan definido las funciones requeridas y el objetivo de nivel de integridad de la seguridad (NIS) para cualquier sistema de control o protección SE/E/ P. El objetivo de nivel de integridad de la seguridad se establece en relación con una medida de fallo objetivo (véase la Tabla 58.6).

\section{Sistemas de protección}

Este artículo esboza los requisitos técnicos que debe considerar el diseñador de un sistema de seguridad SE/E/ P para alcanzar el objetivo requerido de nivel de integridad de la seguridad. La explicación se centra en un sistema de protección típico que utiliza dispositivos electrónicos programables para poder profundizar en los problemas fundamentales sin apenas merma de su generalidad. U n sistema típico de protección es el que aparece en la Figura 58.96, que muestra un sistema de seguridad de un solo canal con disyuntor secundario activado a través de un dispositivo de diagnóstico. En régimen normal, la condición no segura del EBC (por ejemplo, exceso de velocidad de una máquina, alta temperatura en una instalación química) es detectada por el sensor y transmitida al dispositivo electrónico programable que ordenará a los actuadores (a través del relé de salida) que pongan el sistema en un estado seguro (por ejemplo, cortando la alimentación eléctrica del motor de la máquina o abriendo una válvula para reducir la presión).

Pero ¿qué ocurre si fallan los componentes del sistema de protección? Esta es la función del disyuntor secundario que es activado por la función de diagnóstico (autocomprobación) de este diseño. Con todo, el sistema no es totalmente a prueba de fallos, ya que el diseño sólo tiene una cierta probabilidad de estar disponible cuando se le ordene que ejecute su función de seguridad (tiene un cierta probabilidad de fallo a demanda 0 un

\begin{tabular}{|c|c|}
\hline & $\begin{array}{l}\text { sistemas de protección: medidas de fallos } \\
\text { considerados como objetivos. }\end{array}$ \\
\hline $\begin{array}{l}\text { Nivel de inte- } \\
\text { gridad de la } \\
\text { seguridad }\end{array}$ & $\begin{array}{l}\text { Modo de funcionamiento bajo demanda (probabilidad de no } \\
\text { ejecutar su función de diseño bajo demanda) }\end{array}$ \\
\hline 4 & $10^{-5} \leq x<10^{-4}$ \\
\hline 3 & $10^{-4} \leq x<10^{-3}$ \\
\hline 2 & $10^{-3} \leq x<10^{-2}$ \\
\hline 1 & $10^{-2} \leq x<10^{-1}$ \\
\hline
\end{tabular}


cierto nivel de integridad de la seguridad). Por ejemplo, el diseño descrito puede detectar y tolerar ciertos tipos de fallos de la tarjeta de salida, pero no podría tolerar un fallo de la tarjeta de entrada. Por tanto, su integridad de la seguridad será mucho más baja que la de un diseño con una tarjeta de entrada más fiable, con un diagnóstico mejorado o con una combinación de ambas cosas.

$\mathrm{H}$ ay otras causas posibles de fallos de tarjetas, incluidos los fallos físicos tradicionales del hardware, los fallos sistemáticos, incluidos los errores de especificación de los requisitos, los fallos de implantación del software y una protección insuficiente frente a las condiciones ambientales (por ejemplo, humedad). Es posible que el diagnóstico en este diseño de un solo canal no cubra todos estos tipos de fallos y por tanto esto limitaría el nivel de integridad de la seguridad alcanzado en la práctica. ( $L$ a cobertura es una medida del porcentaje de fallos que un diseño puede detectar y tratar con seguridad).

\section{Requisitos técnicos}

Las partes 2 y 3 de la norma CEI 1508 ofrecen un marco para identificar diversas causas potenciales de fallos de hardware y software y para seleccionar características de diseño que permiten superar esas causas potenciales de fallo, apropiadas para el nivel de integridad de la seguridad requerido para el sistema relacionado con la seguridad. Por ejemplo, el planteamiento técnico global para el sistema de protección de la Figura 58.96 se reproduce en la Figura 58.97. La figura indica dos estrategias básicas para superar fallos y defectos: (1) evitación de fallos, cuando se adoptan medidas para evitar fallos, y (2) tolerancia a fallos, cuando se crea el sistema específicamente para que tolere los fallos especificados. El sistema monocanal mencionado arriba es un ejemplo de diseño con tolerancia a fallos (limitada) en el que se utilizan diagnósticos para detectar determinados fallos y situar el sistema en un estado seguro antes de que se produzca un fallo peligroso.
Tabla 58.7 • Diseño y desarrollo de software.

$\begin{array}{lllll}\text { Técnica/ medida } & \text { SIL } 1 & \text { SIL 2 } & \text { SIL } 3 & \text { SIL } 4 \\ \text { 1. Métodos formales incluidos, por ejemplo, } & - & R & R & \text { HR } \\ \quad \text { CCS, CSP, HOL, LOTOS } & & & & \\ \text { 2. Métodos semiformales } & \text { HR } & \text { HR } & \text { HR } & \text { HR } \\ \text { 3. Metodología estructurada incluidos, por } & \text { HR } & \text { HR } & \text { HR } & \text { HR } \\ \quad \text { ejemplo, JSD, MASCOT, SADT, SSADM y } & & & & \\ \quad \text { YOURDON } & & & & \\ \text { 4. Planteamiento modular } & \text { HR } & \text { HR } & \text { HR } & \text { HR } \\ \text { 5. Normas de diseño y codificación } & \text { R } & \text { HR } & \text { HR } & \text { HR }\end{array}$

$H R=$ altamente recomendado; $R=$ recomendado; $N R=$ no recomendado; - = neutro: la técnica de medida no está ni a favor ni en contra del SIL. Nota: se seleccionará una técnica/ medida numerada de acuerdo con el nivel de integridad de la seguridad.

\section{Evitación de fallos}

La evitación de fallos intenta impedir que estos se introduzcan en el sistema. El enfoque principal consiste en utilizar un método sistemático de gestión del proyecto para que la seguridad se trate como una cualidad gestionable y definible del sistema durante el diseño y después durante el funcionamiento y mantenimiento. EI planteamiento, que es similar al del aseguramiento de la calidad, está basado en el concepto de realimentación e implica: (1) planificación (definición de objetivos de seguridad, identificando la manera de alcanzar los objetivos); (2) medida logros conseguidos en comparación con el plan durante la implantación, y (3) aplicación de realimentación para corregir cualquier desviación. Las revisiones de los diseños son un buen ejemplo de esta técnica de evitación de fallos. En la norma CEI 1508 este enfoque de "calidad" para evitar fallos viene facilitado por los requisitos de utilizar un ciclo de vida de la seguridad y utilizar procedimientos de gestión de la seguridad para hardware y software. Para el

Figura 58.97 • Especificación de diseño: solución de diseño.

\section{ESPECIFICACION DE DISEÑO}

SOLUCION DE DISEÑO

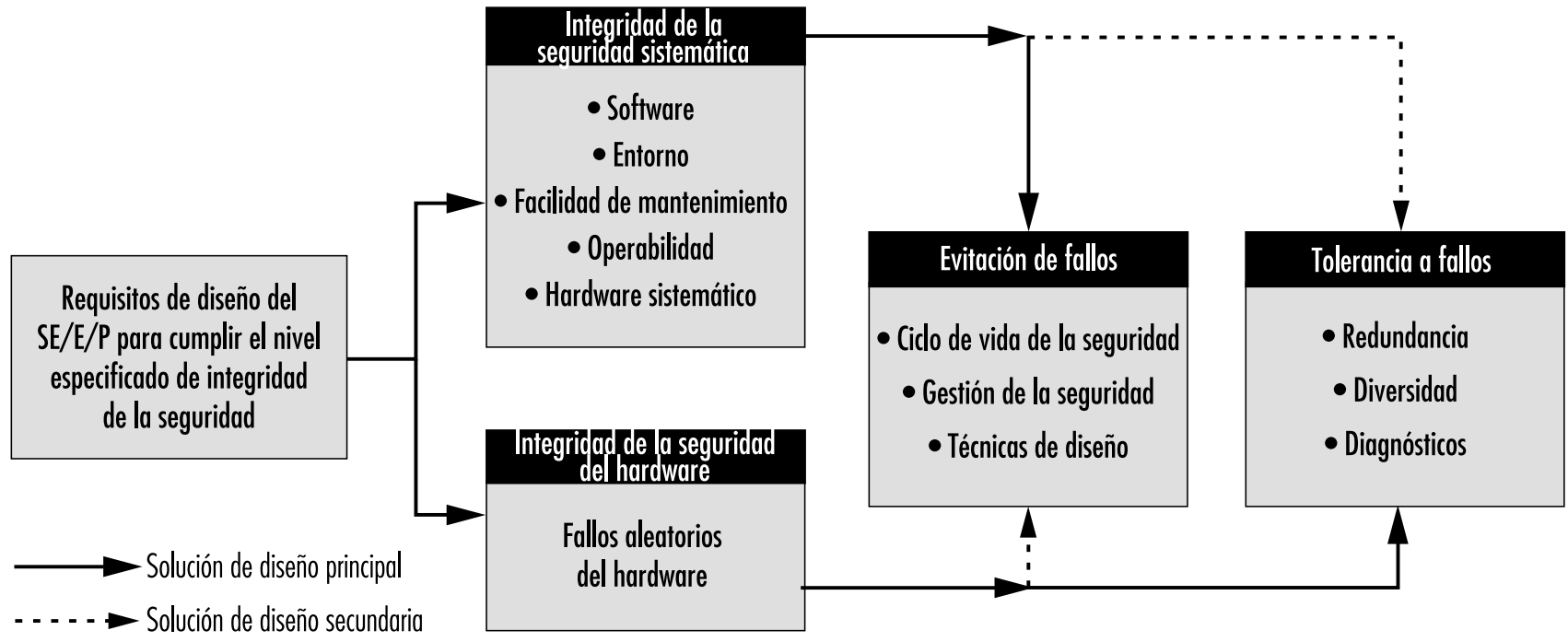


Tabla 58.8 - N ivel de integridad de la seguridad Requisitos de los fallos para componentes del tipo B.

1 Los fallos no detectados relacionados con la seguridad serán detectados por la verificación.

2 Para componentes sin cobertura media de diagnóstico en línea, el sistema podrá realizar la función de seguridad en presencia de un solo fallo. Los fallos no detectados relacionados con la seguridad serán detectados por la verificación.

3 Para componentes con cobertura alta de diagnóstico en línea, el sistema podrá realizar la función de seguridad en presencia de un solo fallo. Para componentes sin cobertura alta de diagnóstico en línea, el sistema podrá realizar la función de seguridad en presencia de dos fallos. Los fallos no detectados relacionados con la seguridad serán detectados por la verificación.

4 Los componentes podrán realizar la función de seguridad en presencia de dos fallos. Los fallos se detectarán mediante cobertura alta de diagnóstico en línea. Los fallos no detectados relacionados con la seguridad serán detectados por la verificación. El análisis cuantitativo del hardware estará basado en las hipótesis correspondientes al caso peor.

1 Componentes cuyos modos de fallo no estén bien definidos o no se puedan probar o para los cuales haya pocos datos de fallos por experiencia en campo (por ejemplo, componentes electrónicos programables)

último, estos se manifiestan con frecuencia por sí mismos como procedimientos de aseguramiento de la calidad del software, como los descritos en la norma ISO 9000-3 (1990).

Además, las partes 2 y 3 de la norma CEI 1508 (relativas a hardware y software, respectivamente) asignan grados a ciertas técnicas o medidas que se consideran útiles para evitar fallos durante las distintas fases del ciclo de vida de la seguridad. La Tabla 58.7 da un ejemplo de la parte 3 para la fase de diseño y desarrollo de software. El diseñador utilizaría la tabla como ayuda para la selección de técnicas encaminadas a evitar fallos, dependiendo del nivel requerido de integridad de la seguridad. Junto a cada técnica o medida de la tabla hay una recomendación para cada nivel de integridad de la seguridad, de 1 a 4. La gama de recomendaciones abarca los siguientes niveles: muy recomendado ( $M R$ ); recomendado $(R)$; neutral, es decir, ni a favor ni en contra (-), y no recomendado (NR).

\section{Tolerancia a fallos}

La norma CEI 1508 requiere mayores niveles de tolerancia a fallos al aumentar el objetivo de integridad de la seguridad. Con todo, la norma reconoce que la tolerancia a fallos es más importante cuando los sistemas, y los componentes que los constituyen, son complejos (denominados del tipo B en la norma CEI 1508). En sistemas menos complejos y "probados" es posible relajar la tolerancia a fallos.

\section{Tolerancia a fallos aleatorios del hardware}

La Tabla 58.8 muestra los requisitos de tolerancia a fallos aleatorios del hardware en el caso de componentes complejos (por ejemplo, microprocesadores) cuando se utilizan en sistemas de protección, como muestra la Figura 58.96. El diseñador puede tener que considerar una combinación apropiada de diagnósticos, tolerancia a fallos y comprobaciones manuales para superar este tipo de fallos, en función del nivel requerido de integridad de la seguridad.

La norma CEI 1508 ayuda al diseñador, ya que contiene tablas de especificación de diseños (véase la Tabla 58.9), con parámetros de diseño correlacionados con niveles de integridad de la seguridad para varias arquitecturas de sistemas de protección utilizadas corrientemente.

La primera columna de la tabla refleja arquitecturas con varios grados de tolerancia a fallos. En general, las arquitecturas situadas al final de la tabla tienen un mayor grado de tolerancia a fallos que las del principio. Un sistema 1de2 (1 de un total de 2) es capaz de soportar cualquier fallo individual, como también un sistema 2 de3.

La segunda columna describe la cobertura de los diagnósticos internos. Cuanto más alto sea el nivel de diagnóstico, más fallos serán detectados. En un sistema de protección, esto es importante, porque siempre que el componente defectuoso (por ejemplo, una tarjeta de entrada) sea reparado en un plazo razonable (normalmente 8 horas), la merma de seguridad funcional es escasa. (Nota: esto no sería así para un sistema de control continuo, porque cualquier fallo causaría probablemente una condición no segura inmediatamente y la posibilidad de un incidente).

La tercera columna muestra el intervalo entre pruebas de verificación. Estas son pruebas especiales realizadas para probar a fondo el sistema y verificar que no existen fallos latentes. N ormalmente, estas pruebas las realiza el fabricante del equipo aprovechando los tiempos muertos de la instalación.

La cuarta columna muestra la tasa de disparos en falso. Un disparo en falso es el que origina la parada del equipo o instalación no existiendo ninguna desviación en el proceso. Con frecuencia, el precio de la seguridad es una tasa más alta de disparos en falso. Un sistema con una protección redundante simple (1de2) tiene, si los demás factores de diseño permanecen inalterados, un nivel de integridad de la seguridad más alto, pero también una tasa de disparos en falso más alta que un sistema monocanal (1de1).

\section{Tabla 58.9 - Requisitos para el nivel 2 de integridad de la seguridad - A rquitecturas de sistemas electrónicos programables para sistemas de protección.}

$\begin{array}{lllrl}\text { Configuración del sistema EP } & \begin{array}{l}\text { Cobertura } \\ \text { de diagnós- } \\ \text { tico por } \\ \text { canal }\end{array} & \begin{array}{l}\text { Intervalo de } \\ \text { pruebas de } \\ \text { verificación } \\ \text { fuera de } \\ \text { línea (TI) }\end{array} & \begin{array}{l}\text { Tiempo medio } \\ \text { entre falsos } \\ \text { disparos }\end{array} \\ \text { EP sencillo, E/ S sencilla, WD ext. Alta } & \begin{array}{l}6+\text { meses } \\ \text { EP doble, E/ S sencilla }\end{array} & \begin{array}{l}\text { Alta } \\ 6+\text { meses }\end{array} & 10 \text { años } \\ \text { EP doble, E/ S doble, 2002 } & \text { Alta } & 3+\text { meses } & 1,81 \text { años } \\ \text { EP doble, E/ S doble, 1002 } & \text { Ninguna } & 2+\text { meses } & 1,4 \text { años } \\ \text { EP doble, E/ S doble, 1002 } & \text { Baja } & 5+\text { meses } & 1,0 \text { años } \\ \text { EP doble, E/ S doble, 1002 } & \text { Media } & 18+\text { meses } & 0,8 \text { años } \\ \text { EP doble, E/ S doble, 1002 } & \text { Alta } & 36+\text { meses } & 0,8 \text { años } \\ \text { EP doble, E/ S doble, 1002D } & \text { Ninguna } & 2+\text { meses } & 1,9 \text { años } \\ \text { EP doble, E/ S doble, 1002D } & \text { Baja } & 4+\text { meses } & 4,7 \text { años } \\ \text { EP doble, E/ S doble, 1002D } & \text { Media } & 18+\text { meses } & 18 \text { años } \\ \text { EP doble, E/ S doble, 1002D } & \text { Alta } & 48+\text { meses } & 168 \text { años } \\ \text { EP triple, E/ S triple, IPC, 2003 } & \text { Ninguna } & 1+\text { mes } & 20 \text { años } \\ \text { EP triple, E/ S triple, IPC, 2003 } & \text { Baja } & 3+\text { meses } & 25 \text { años } \\ \text { EP triple, E/ S triple, IPC, 2003 } & \text { Media } & 12+\text { meses } & 30 \text { años } \\ \text { EP triple, E/ S triple, IPC, 2003 } & \text { Alta } & 48+\text { meses } & 168 \text { años }\end{array}$


Si no se utiliza una de las arquitecturas de la tabla o si el diseñador quiere realizar un análisis más fundamental, la norma CEI 1508 permite esta alternativa. Las técnicas de ingeniería de la fiabilidad, como los modelos de Markov, se pueden utilizar entonces para calcular el elemento de hardware del nivel de integridad de la seguridad (Johnson 1989; G oble 1992).

\section{Tolerancia a fallos sistemáticos y de causas comunes}

Esta clase de fallos es muy importante en sistemas de seguridad y es el factor que limita la consecución de la integridad de la seguridad. En un sistema redundante se duplica un componente 0 subsistema, o incluso el sistema completo, para conseguir una mayor fiabilidad con componentes de menor fiabilidad. La mejora de la fiabilidad se consigue porque, estadísticamente, la probabilidad de que dos sistemas fallen simultáneamente por fallos aleatorios es el producto de las fiabilidades de los sistemas individuales y por tanto mucho menor. Por otra parte, los fallos sistemáticos y de causas comunes hacen que sistemas redundantes fallen simultáneamente cuando, por ejemplo, un error de especificación del software hace que componentes duplicados fallen a la vez. Otro ejemplo sería el fallo de una fuente de alimentación común para un sistema redundante.

La norma CEI 1508 incluye tablas de técnicas de ingeniería clasificadas en relación con el nivel de integridad de la seguridad que se considera eficaz para proporcionar protección contra fallos sistemáticos y de causas comunes.

Ejemplos de técnicas eficaces frente a fallos sistemáticos son la diversificación y la redundancia analítica. La diversificación se basa en que si el diseñador implanta un segundo canal en un sistema redundante utilizando una tecnología o lenguaje de software distintos, los fallos de los canales redundantes se pueden considerar independientes (es decir, la probabilidad de fallo coincidente es baja). Con todo, y especialmente en el área de sistemas basados en software, hay indicios de que esta técnica puede no ser eficaz, ya que la mayoría de las equivocaciones se cometen en la especificación. La redundancia analítica intenta aprovechar la información redundante existente en instalaciones o máquinas para identificar fallos. Para las demás causas de fallos sistemáticos (por ejemplo, esfuerzos externos), la norma incluye tablas con recomendaciones de buena práctica de ingeniería (por ejemplo, separación de los cables de señales y de alimentación) en relación con el nivel de integridad de la seguridad.

\section{Conclusiones}

Los sistemas basados en ordenador ofrecen muchas ventajas, no sólo económicas, y también la posibilidad de mejorar la seguridad. Ahora bien, la minuciosidad necesaria para convertir esta posibilidad en realidad es mucho mayor que en el caso de componentes de sistemas convencionales. En este artículo se han descrito en líneas generales los requisitos técnicos principales que tiene que tener en cuenta un diseñador para aprovechar esta tecnología.

\section{- Vuelco}

\section{Bengt Springfeldt}

Los tractores y otras máquinas móviles utilizadas en la agricultura, explotación forestal, construcción y minería, así como en la manipulación de materiales, pueden dar lugar a graves peligros cuando los vehículos vuelcan lateralmente, hacia adelante o hacia atrás. Los riesgos aumentan en el caso de tractores de ruedas con centros de gravedad altos. 0 tros vehículos que presentan riesgo de vuelco son los tractores de orugas, cargadoras, grúas, colectoras de frutas, excavadoras, volquetes, cucharas de arrastre y motoniveladoras. Normalmente, estos accidentes ocurren con demasiada rapidez para que los conductores y pasajeros puedan salir de la máquina, pudiendo quedar atrapados debajo del vehículo. Por ejemplo, los tractores que tienen el centro de gravedad alto pueden volcar con facilidad y los vehículos estrechos tienen menos estabilidad que los anchos. En los tractores se ha introducido un interruptor de mercurio para parar el motor al detectar un movimiento lateral, pero resulta demasiado lento para las fuerzas dinámicas generadas en el movimiento de vuelco (Springfeldt 1993) y por tanto se ha abandonado el uso de este dispositivo de seguridad.

El hecho de que estos vehículos se utilicen con frecuencia en pendientes 0 terrenos irregulares 0 en tierra blanda y en ocasiones cerca de zanjas o excavaciones, es un factor importante que favorece el vuelco. Si un equipo auxiliar está montado en el tractor en una posición elevada, la probabilidad de volcar hacia atrás al subir por una pendiente (o de volcar hacia delante al descender) es mayor. A demás, un tractor puede volcar debido a la pérdida de control provocada por la presión ejercida por un equipo remolcado (por ejemplo, cuando el tractor desciende por una pendiente y el equipo remolcado no tiene frenos y adelanta al tractor). Pueden producirse situaciones de peligro especiales cuando se utilizan los tractores para remolcar, especialmente si el gancho del tractor está situado a un nivel más alto que el eje de las ruedas.

\section{Historia}

El problema de los vuelcos ha sido objeto de atención a escala nacional en algunos países donde se han producido muchos vuelcos con consecuencias mortales. En Suecia y N ueva Zelanda ya se desarrollaron y probaron estructuras de protección contra vuelcos (EPV) en tractores (Figura 58.98) en el decenio de 1950, pero estos trabajos solo dieron lugar a reglamentos promulgados por las autoridades suecas, y que entraron en vigor en 1959 (Springfeldt 1993).

Los proyectos de reglamento que declaraban obligatorio el uso de EPV en tractores chocaron con la resistencia del sector agrícola en varios países. $\mathrm{H}$ ubo una fuerte oposición a los planes que exigían a los patronos instalar EPV en los tractores existentes e incluso a la propuesta de que los fabricantes equiparan únicamente los tractores nuevos. En su momento, muchos países consiguieron declarar obligatorios los EPV en los nuevos tractores y posteriormente algunos países impusieron el montaje de

Figura 58.98 - Tipos habituales de EPV en tractores.

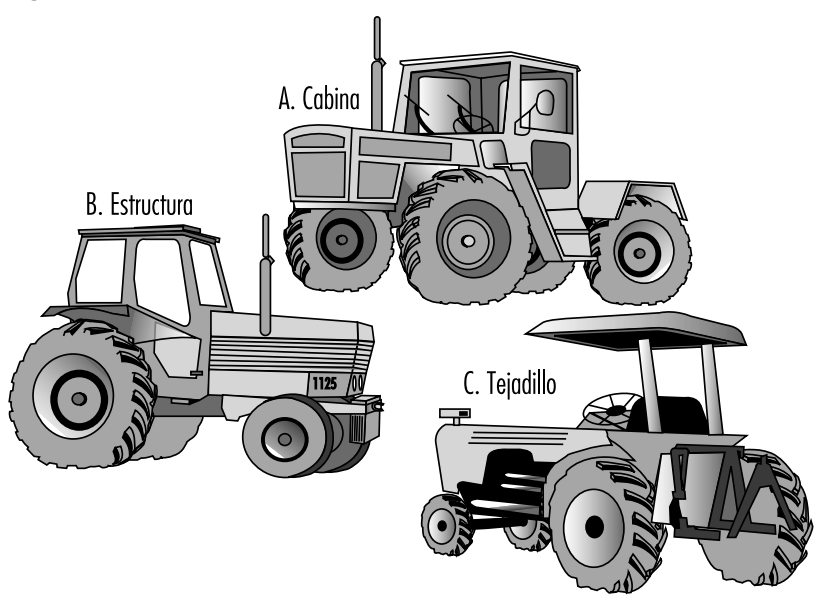


EPV en tractores existentes. Las normas internacionales relativas a tractores y maquinaria de movimiento de tierras, incluidas las normas de ensayo de EPV, contribuyeron a que los diseños fueran más fiables. Los tractores se diseñaron y fabricaron con centros de gravedad y ganchos de remolque en posición más baja. La tracción a cuatro ruedas ha reducido el riesgo de vuelco. Pero la proporción de tractores con EPV en países en los que existen muchos tractores antiguos y no es obligatorio el montaje de EPV en tractores existentes, es todavía bastante baja.

\section{Investigaciones.}

Los accidentes por vuelco, especialmente los relativos a tractores, han sido estudiados por investigadores de muchos países, pero no existen estadísticas internacionales centralizadas en relación con los accidentes causados por los tipos de máquinas móviles estudiados en este artículo. N o obstante, las estadísticas disponibles a nivel nacional muestran que el número es alto, especialmente en la agricultura. Según un informe escocés de accidentes por vuelco de tractores en el período 1968-1976, el $85 \%$ de los tractores implicados en accidentes llevaban un equipo adosado en el momento de producirse, y de estos, la mitad llevaban remolques y la otra mitad equipos montados fijamente. D os tercios de los accidentes por vuelco de tractores del informe escocés se produjeron en pendientes (Springfeldt 1993). Posteriormente se demostró que el número de accidentes se redujo después de la implantación de cursillos de formación para la conducción en pendientes y de la aplicación de un instrumento para medir la pendiente combinado con un indicador de límites de seguridad en pendientes.

En otros estudios, investigadores neozelandeses observaron que la mitad de los accidentes mortales por vuelco se habían producido en terreno llano o con pendiente ligera y sólo una décima parte se había producido en pendientes acusadas. En terreno llano, los conductores de los tractores pueden prestar menos atención al peligro de vuelco y pueden juzgar erróneamente el riesgo planteado por zanjas e irregularidades del terreno. De los accidentes mortales por vuelco de tractores en Nueva Zelanda en el período 1949-1980, el $80 \%$ correspondió a tractores de ruedas y el $20 \%$ a tractores de oruga (Springfeldt 1993). Según estudios realizados en Suecia y N ueva Zelanda, aproximadamente el $80 \%$ de los accidentes mortales por vuelco de tractores se produjeron por vuelco lateral. La mitad de los tractores con accidentes mortales en Nueva Zelanda habían dado una vuelta de campana.

Según estudios de correlación entre vuelcos con consecuencias mortales en Alemania 0 ccidental y el año de construcción de los tractores agrícolas (Springfeldt 1993), uno de cada 10.000 tractores antiguos sin protección fabricados antes de 1957 había sufrido un accidente por vuelco con efecto mortal. De los tractores con EPV obligatorios fabricados a partir de 1970, uno de cada 25.000 tractores había intervenido en un accidente mortal por vuelco. De los vuelcos de tractores con consecuencias mortales en el período 1980-1985, dos tercios de las víctimas habían salido despedidas de la zona protegida siendo después atropelladas o golpeadas por el tractor (Springfeldt 1993). De los vuelcos sin consecuencias mortales, la cuarta parte de los conductores habían salido despedidos de su asiento pero no habían sido atropellados. Es evidente que el riesgo de accidente mortal aumenta si el conductor sale despedido de la zona protegida (como ocurre en los accidentes de automóvil). La mayoría de los tractores implicados tenían un tejadillo con dos montantes (Figura 58.98), pero esto no impidió que el conductor saliera despedido de la zona protegida. En pocos casos habían sufrido los EPV roturas o deformaciones importantes.

Las frecuencias relativas de lesiones por cada 100.000 tractores en distintos períodos en los mismos países y la reducción de la tasa de accidentes mortales fue calculada por
Springfeldt (1993). La eficacia de los EPV en la disminución de accidentes por vuelco de tractores se ha demostrado en Suecia, donde el número de accidentes mortales por cada 100.000 tractores se redujo aproximadamente de 17 a 0,3 a lo largo de tres decenios (1960-1990). (Figura 58.99). Al final del periodo se estimó que aproximadamente el $98 \%$ de los tractores llevaban montados EPV, sobre todo en forma de una cabina resistente al aplastamiento (Figura 58.98 A). En Noruega, los accidentes mortales se redujeron aproximadamente de 24 a 4 por cada 100.000 tractores en un período similar, mientras que los resultados en Finlandia y N ueva Zelanda fueron peores.

\section{Prevención de lesiones debidas a vuelcos}

El riesgo de vuelco es máximo en el caso de los tractores; ahora bien, en trabajos agrícolas y forestales es poco lo que se puede hacer para evitar que los tractores vuelquen. M ontando EPV en tractores y en los demás tipos de maquinaria de movimientos de tierras con peligro de vuelco, se puede reducir el riesgo de lesiones personales, siempre que los conductores permanezcan en sus asientos durante el vuelco (Springfeldt 1993). La frecuencia de los accidentes mortales por vuelco depende en gran medida de la proporción de máquinas protegidas en uso y de los tipos de EPV utilizados. Un tejadillo (Figura 58.98) proporciona una protección mucho menor que una cabina o una estructura (Springfeldt 1993). La estructura más eficaz es una cabina a prueba de aplastamiento, que permite al conductor permanecer dentro, protegido, en caso de vuelco. (0 tra razón para elegir una cabina es que ofrece protección contra la intemperie.) EI medio más eficaz para mantener al conductor dentro de la protección del EPV durante un vuelco es un cinturón de seguridad, siempre que el conductor lo utilice mientras maneja el equipo. En algunos países se colocan placas informativas junto al asiento del conductor advirtiendo que el volante quedará bloqueado en caso de vuelco. Una medida de seguridad adicional es diseñar la cabina del conductor o el entorno interior y el EPV de manera que se impida la exposición a peligros como bordes afilados 0 protuberancias.

En todos los países, los vuelcos de maquinaría móvil, principalmente tractores, causan lesiones graves. Con todo, hay diferencias considerables entre los diversos países relativas a las especificaciones técnicas para el diseño de las máquinas y

Figura 58.99 - Lesiones por vuelco por 100.000 tractores en Suecia entre 1957 y 1990.

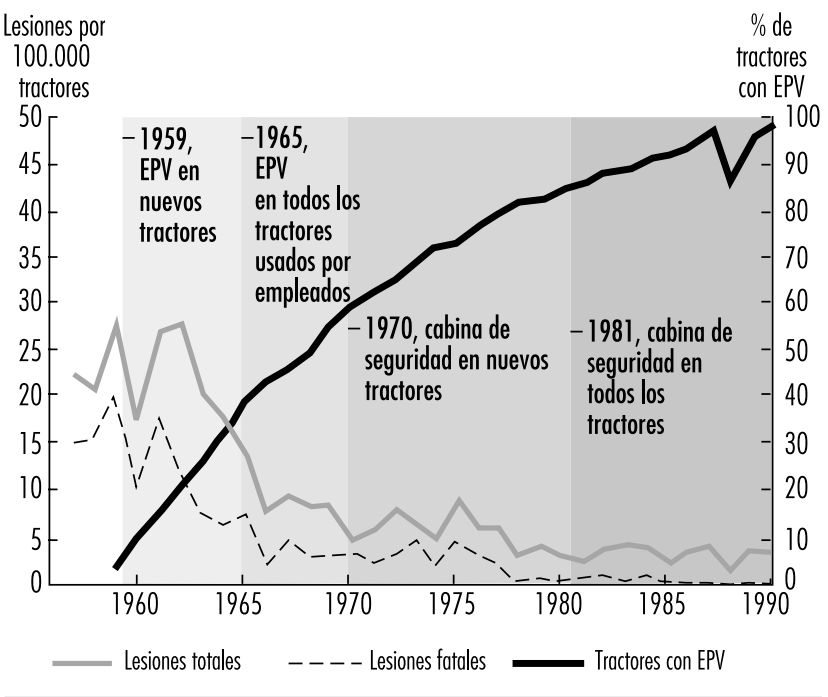


también a los procedimientos administrativos de examen, prueba, inspección y comercialización. La diversidad internacional que caracteriza los esfuerzos en materia de seguridad a este respecto se pueden explicar por consideraciones como las siguientes:

- la obligatoriedad del uso de EPV (en forma de reglamentos o leyes), la existencia de meras recomendaciones o la ausencia total de reglamentos;

- la necesidad de reglamentos para máquinas nuevas y de reglamentos aplicables a equipos más antiguos:

- la realización de inspecciones por parte de las autoridades, la existencia de una presión social y un clima cultural favorable al respeto de los reglamentos de seguridad; en muchos países, el cumplimiento de las directrices de seguridad no se comprueba mediante inspecciones en los trabajos agrícolas;

- la presión de los sindicatos; ahora bien, hay que tener en cuenta que las organizaciones de trabajadores tienen menos influencia en las condiciones de trabajo en la agricultura que en otros sectores, debido a que existen muchas explotaciones familiares en la agricultura;

- el tipo de EPV utilizada en el país;

- información y comprensión de los riesgos a los que están expuestos los conductores de tractores; a menudo existen problemas prácticos para llegar a los agricultores y trabajadores forestales con fines de información y educación,

- la geografía del país, especialmente en los lugares donde se realizan trabajos agrícolas, forestales y de obras públicas.

\section{Reglamentos de seguridad.}

$L$ a naturaleza de los reglamentos que rigen los requisitos para los EPV y el grado de aplicación de los reglamentos en un país, influyen mucho en los accidentes por vuelco, especialmente los mortales. Teniendo esto en cuenta, se ha favorecido el desarrollo de máquinas más seguras mediante directivas, códigos y normas publicados por organismos nacionales e internacionales. Además, muchos países han adoptado normas rigurosas para los EPV, con la consecuencia de una gran disminución en lesiones por vuelco.

\section{Comunidad E conómica E uropea}

A partir de 1974, la Comunidad Económica Europea (CEE) promulgó directivas relativas a la homologación de tractores agrícolas y forestales de ruedas y en 1997 publicó otras directivas especiales relativas a EPV, que incluían su fijación a los tractores (Springfeldt 1993; CEE 1974, 1977, 1979, 1982, 1987). Las directivas establecen un procedimiento para la homologación y la aprobación de modelo por los fabricantes de tractores, y los EPV tienen que ser revisados mediante un examen de aprobación de tipo de la CEE. Estas directivas han sido aceptadas por todos los países miembros.

Algunas directivas de la CEE relativas a EPV de tractores se abolieron el 31 de diciembre de 1995, siendo sustituidas por la directiva general de maquinaria que es aplicable a todo tipo de máquinas que presentan peligros debido a su movilidad (CEE 1991). L os tractores de ruedas, así como algunas máquinas de movimiento de tierras con una potencia superior a $15 \mathrm{~kW}$ (concretamente las cargadoras de ruedas y de orugas, las palas retrocargadoras, los tractores de orugas, las cucharas de arrastre, las motoniveladoras y los volquetes articulados) tienen que estar dotados de una EPV. En caso de vuelco, la EPV tiene que ofrecer al conductor y a los operadores un volumen adecuado que limite la deformación (es decir, espacio que permita el movimiento de los cuerpos de los ocupantes antes de que entren en contacto con elementos interiores en caso de accidente). Es responsabilidad del fabricante 0 de su representante autorizado la realización de las pruebas pertinentes.
Organización para la Cooperación y el Desarrollo Económicos En 1973 y en 1987 la O rganización para la Cooperación y el Desarrollo Económicos (OCDE) aprobó normas para la prueba de tractores (Springfeldt 1993; OCDE 1987). Estas normas reflejan los resultados de las pruebas de los tractores y describen los equipos y las condiciones de prueba. Las normas requieren la prueba de muchos elementos y funciones de máquinas, por ejemplo la resistencia de las EPV. Las normas de tractores de la O CDE describen un método estático y dinámico para la prueba de EPV en determinados tipos de tractores. U na EPV se puede diseñar para proteger exclusivamente al conductor en caso de vuelco del tractor. La EPV tiene que volver a probarse para cada modelo de tractor en el que se monte. Las normas también exigen que se pueda montar una protección contra la intemperie en la estructura de naturaleza más o menos temporal. Las normas aplicables a los tractores han sido aceptadas por todos los organismos miembros de la OCDE a partir de 1988, pero en la práctica Estados U nidos y Japón también aceptan EPV que no cumplen los requisitos de las normas si existen cinturones de seguridad. (Springfeldt 1993).

\section{Organización Internacional del Trabajo}

En 1965, la O rganización Internacional del Trabajo (O IT), en su manual Seguridad y salud en el trabajo agrícola, exigía montar en los tractores una cabina o estructura de resistencia suficiente para proporcionar una protección satisfactoria al conductor y los pasajeros en caso de vuelco del tractor (Springfeldt 1993; ILO 1965). Según los códigos de prácticas de la O IT, los tractores forestales y agrícolas deben estar dotados de EPV para proteger al operador y a cualquier pasajero en caso de vuelco, caída de objetos 0 desplazamiento de cargas (O IT 1976).

EI montaje de EPV no debe afectar adversamente

- el acceso entre el suelo y el puesto del conductor;

- el acceso a los controles principales del tractor;

- la maniobrabilidad del tractor en espacios limitados;

- el montaje o uso de cualquier equipo que se pueda conectar al tractor,

- el control y ajuste de los equipos asociados.

\section{Normas nacionales e inter nacionales}

En 1981 la Organización Internacional de Normalización (ISO) publicó una norma relativa a tractores y maquinaria agrícola y forestal (ISO 1981). La norma describe un método estático de prueba para EPV y establece las condiciones de aceptación. Esta norma ha sido aprobada por los organismos miembros de 22 países, pero Canadá y Estados U nidos no han aprobado el documento por razones técnicas. U na norma y práctica recomendada publicada en 1974 por la Sociedad de Ingenieros de Automoción (SAE) en N orteamérica contiene requisitos para $E P V$ en tractores agrícolas de ruedas y tractores industriales utilizados en la construcción, cucharas de arrastre con ruedas de goma, cargadoras frontales, excavadoras, cargadoras de orugas y motoniveladoras motorizadas (SAE 1974 y 1975). El contenido de la norma se ha adoptado con carácter reglamentario en Estados U nidos y en las provincias canadienses de Alberta y British Columbia.

\section{Reglamentos y su cumplimiento}

$\mathrm{H}$ ay códigos de la OCDE y normas internacionales que se refieren al diseño y construcción de EPV y al control de su resistencia, pero carecen de fuerza legal para imponer la aplicación de este tipo de protección (OCDE; ISO 1981). La Comunidad Económica Europea también ha propuesto que tractores y máquinas de movimiento de tierras se equipen con sistemas de protección (CEE 1974-1987). El objetivo de las directivas de la CEE es conseguir la uniformidad entre las entidades nacionales 
en relación con la seguridad de la maquinaria nueva en su fase de fabricación. Los países miembros están obligados a respetar las directivas y a publicar los reglamentos correspondientes. A partir de 1996, los países miembros de la CEE pretenden publicar reglamentos que exijan que los nuevos tractores y máquinas de movimiento de tierras estén equipados con EPV.

En 1959, Suecia fue el primer país que exigió EPV para nuevos tractores (Springfeldt 1993). Preceptos similares entraron en vigor en Dinamarca y Finlandia diez años más tarde. Posteriormente, en los decenios de 1970 y 1980 entraron en vigor requisitos para EPV en nuevos tractores en Gran Bretaña, Alemania O ccidental, N ueva Z elanda, Estados U nidos, España, Noruega, Suiza y otros países. En todos estos países, con excepción de Estados U nidos, los reglamentos se extendieron a tractores existentes algunos años después, pero estos reglamentos no siempre eran preceptivos. En Suecia, todos los tractores tienen que estar equipados con una cabina protectora, regla que en Gran Bretaña sólo es aplicable a todos los tractores utilizados por trabajadores agrícolas (Springfeldt 1993). En Dinamarca, Noruega y Finlandia, todos los tractores tienen que tener al menos una estructura, mientras que en Estados U nidos y Australia se aceptan los tejadillos. En Estados U nidos, los tractores tienen que llevar cinturones de seguridad.

En Estados U nidos, la maquinaria de manipulación de materiales fabricada después de 1972 y utilizada en obras públicas tiene que estar equipada con EPV que cumplan las normas de características mínimas (US Bureau of National Affairs 1975). Las máquinas sujetas a este requisito incluyen algunas cucharas de arrastre, cargadoras frontales, excavadoras, tractores de orugas, cargadoras y motoniveladoras. También se han montado EPV en máquinas fabricadas tres años antes aproximadamente.

\section{Resumen}

En países con requisitos obligatorios de EPV para nuevos tractores y tractores existentes, ha habido una disminución de las lesiones por vuelco y sobre todo de accidentes mortales. Es evidente que una cabina a prueba de aplastamiento es el tipo más eficaz de EPV. Un tejadillo proporciona una protección deficiente en caso de vuelco. Muchos países han declarado obligatorio el uso de EPV eficaces al menos en los tractores nuevos y, a partir de 1996, en máquinas de movimiento de tierras. A pesar de esto, algunas autoridades aceptan tipos de EPV que no cumplen los requisitos promulgados por la OCDE y la ISO. Se espera que se produzca gradualmente en todo el mundo, incluidos los países en vías de desarrollo, una armonización más general de los reglamentos relativos a las EPV.

\section{CAIDAS DESDE ALT URAS}

\section{Jean Arteau}

Las caídas desde alturas son accidentes graves que se producen en muchas industrias y profesiones y que tienen como resultado lesiones que se producen por contacto entre la persona que cae y el origen de la lesión en las siguientes circunstancias:

- El movimiento de la persona y la fuerza de choque se producen por gravedad.

- El punto de contacto con el origen de la lesión está más bajo que la superficie que soporta la persona al comienzo de la caída.

A partir de esta definición se puede suponer que las caídas son inevitables porque la gravedad siempre está presente. Las caídas son accidentes con frecuencia graves y en parte previsibles que se producen en todos los sectores de la industria y profesiones. En este artículo se proponen algunas estrategias para reducir el número de caídas o al menos reducir la gravedad de las lesiones que éstas producen.

\section{Altura de la caída}

La gravedad de las lesiones causadas por caídas está relacionada intrínsecamente con la altura de la caída. Pero esto es sólo una verdad parcial, ya que la energía de la caída libre es el producto de la masa que cae por la altura de la caída y la gravedad de las lesiones es directamente proporcional a la energía transferida durante el choque. Las estadísticas de los accidentes por caída confirman esta relación, aunque también indican que las caídas desde una altura inferior a $3 \mathrm{~m}$ pueden ser mortales. U n estudio detallado de las caídas mortales en el sector de la construcción muestra que el $10 \%$ de los accidentes mortales por caídas se produjeron desde un altura inferior a $3 \mathrm{~m}$ (véase la Figura 58.100). En este sentido, es necesario analizar cuestiones: el límite legal de $3 \mathrm{~m}$ y cómo y cuándo se detienen las caídas.

Figura 58.100 • Muertes por caídas y altura de caída en el sector de la construcción en EE.UU., 1985 - 1993.

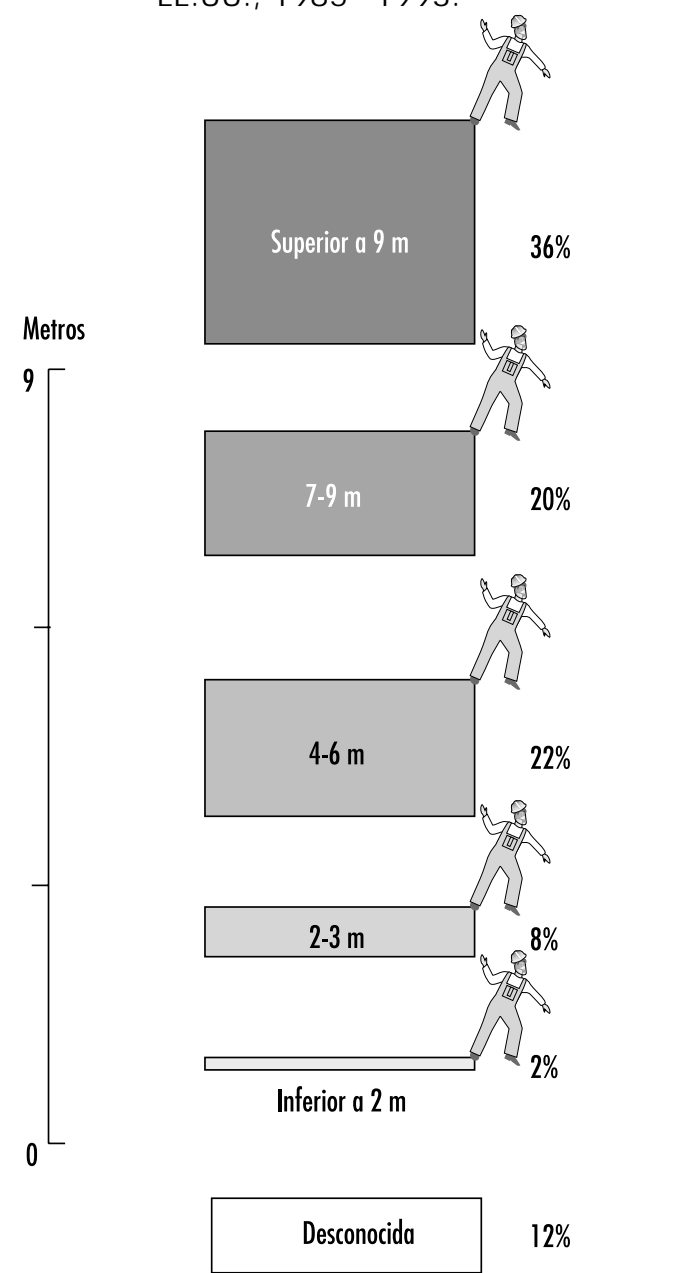

Número total de muertes debidas a caídas: 1.954 Número total de muertes (todas las causas): 5.964 Fuente: Culver y Connolly 1994. 
En muchos países, los reglamentos hacen obligatoria la protección contra caídas cuando el trabajador está expuesto a una caída de más de $3 \mathrm{~m}$. U na interpretación simplista es que las caídas desde menos de $3 \mathrm{~m}$ no son peligrosas. De hecho, el límite de $3 \mathrm{~m}$ es el resultado de un consenso social, político y práctico que no impone como obligatoria la protección contra caídas cuando se trabaja a la altura de un solo piso. Incluso existiendo el límite legal de $3 \mathrm{~m}$ para la protección obligatoria contra caídas, esta protección debería considerarse siempre. La altura de la caída no es el único factor que explica la gravedad de los accidentes y la mortalidad causada por caídas; también tiene que tenerse en cuenta dónde y cuándo se detiene la caída. Para ello es preciso analizar los sectores industriales con mayor incidencia de caídas desde alturas.

\section{Dónde se producen las caídas}

Las caídas desde alturas se asocian con frecuencia al sector de la construcción porque representan un alto porcentaje de todos los accidentes mortales. Por ejemplo, en Estados U nidos, el $33 \%$ de todos los accidentes mortales en este sector son debidos a caídas desde alturas y en el Reino U nido la cifra es del $52 \%$. También se producen caídas desde alturas en otros sectores industriales. $L a$ minería y la fabricación de equipos de transporte tienen también una alta tasa de caídas desde alturas. En Q uebec, donde muchas minas son subterráneas, estrechas y muy pendientes, el $20 \%$ de todos los accidentes corresponde a caídas desde alturas. La fabricación, el uso y el mantenimiento de equipos de transporte como aviones, camiones y vagones de ferrocarril, son actividades con una alta tasa de accidentes por caída. (Tabla 58.10). La proporción varía de un país a otro dependiendo del grado de industrialización, el clima, etc. pero las caídas desde alturas se producen en todos los sectores de la industria con consecuencias parecidas.

Después de tener en cuenta la altura de caída, el siguiente factor por orden de importancia es cómo se detiene la caída. Las caídas en líquidos calientes, carriles electrificados o trituradores de piedra pueden ser mortales aunque la altura de la caída sea inferior a $3 \mathrm{~m}$.

\section{Causas de las caídas}

H asta ahora hemos dicho que las caídas se producen en todos los sectores económicos y también desde alturas inferiores a $3 \mathrm{~m}$. Pero, ¿por qué se caen las personas? Existen muchos factores humanos que pueden intervenir en las caídas y cuya clasificación en grandes grupos es tan sencilla conceptualmente como útil en la práctica:

Las oportunidades de caer vienen determinadas por factores ambientales y originan el tipo más corriente de caída, es decir, un tropiezo o resbalón con resultado de caída desde el nivel del suelo. 0 tras oportunidades de caída están relacionadas con actividades que se realizan por encima del nivel del suelo.

Las propensiones a caer se asocian a enfermedades agudas y crónicas. Las enfermedades específicas que pueden causar una caída afectan normalmente a los sistemas nervioso, circulatorio y/ o musculosquelético.

La tendencias a caer se asocian a los cambios degenerativos intrínsecos que caracterizan el proceso normal de envejecimiento. Al caer, la capacidad de mantener la posición vertical o la estabilidad postural es la función que falla como consecuencia de una combinación de tendencias, propensiones y oportunidades

\section{Estabilidad postural}

Las caídas se producen por un fallo de la estabilidad postural que mantiene a la persona en posición vertical. La estabilidad postural es un sistema formado por numerosos ajustes rápidos a fuerzas perturbadores externas, especialmente la gravedad. Estos
Tabla 58.10 • Caídas desde alturas: Q uebec $1982-1987$

\begin{tabular}{lcc} 
& $\begin{array}{l}\text { Caídas desde alturas por } \\
\text { Construcción }\end{array}$ & $\begin{array}{l}\text { Caídas desde alturas en } \\
\text { todos los accidentes }\end{array}$ \\
Industria pesada & 14,9 & $10,1 \%$ \\
& 7,1 & $3,6 \%$ \\
\hline
\end{tabular}

ajustes son en su mayoría acciones reflejas servidas por un gran número de arcos reflejos, cada uno de ellos con su información sensorial, conexiones internas de integración y respuesta motora. Las fuentes de información sensorial son la visión, los mecanismos del oído interno que detectan la posición, el aparato somatosensor que detecta estímulos de presión en la piel y la posición de las articulaciones que soportan el peso corporal. Parece ser que la percepción visual desempeña un papel especialmente importante. Se sabe muy poco sobre las estructuras normales de integración y sobre las funciones de la médula espinal 0 del cerebro. El componente de la respuesta motora del arco reflejo es la reacción muscular.

\section{Visión}

La principal fuente de información sensorial es la visión. Existen dos funciones visuales relacionadas con la estabilidad postural y el control de la marcha:

- la percepción de lo vertical y horizontal es básica para la orientación espacial

- la capacidad de detectar y distinguir objetos en entornos atestados.

O tras dos funciones visuales importantes son:

- la capacidad de estabilizar la dirección de la vista para estabilizar el mundo circundante mientras nos movemos e inmovilizar un punto de referencia visual

- la capacidad de fijar y perseguir objetos definidos dentro del campo visual grande ("mantener la vista en"); esta función requiere una atención considerable y produce un deterioro en la realización de cualquier otra tarea simultánea que requiera atención.

\section{Causas de inestabilidad postural}

Las tres fuentes de información sensorial son interactivas y está interrelacionadas. La ausencia de una fuente de información (y/ o la existencia de información falsa) produce inestabilidad postural e incluso caídas. ¿Q ué puede causar inestabilidad?

\section{Visión}

- Ia ausencia de referencias horizontales y verticales, por ejemplo, un conector en la parte superior de un edificio;

- la ausencia de referencias visuales estables, por ejemplo, el agua que pasa por debajo de un puente o las nubes en movimiento no son referencias estables;

- la fijación de un objeto definido para fines de trabajo que deteriora otras funciones visuales, como la capacidad de detectar y distinguir objetos en un entorno atestado,

- un objeto móvil sobre un fondo o referencia móvil, por ejemplo, una viga de acero transportada por una grúa sobre un fondo de nubes en movimiento como referencia visual.

\section{Oído interno}

- tener a una persona cabeza abajo cuando el funcionamiento óptimo del sistema de equilibrio requiere la posición horizontal; 
Figura 58.101 - Instalaciones de lectura de un manómetro.
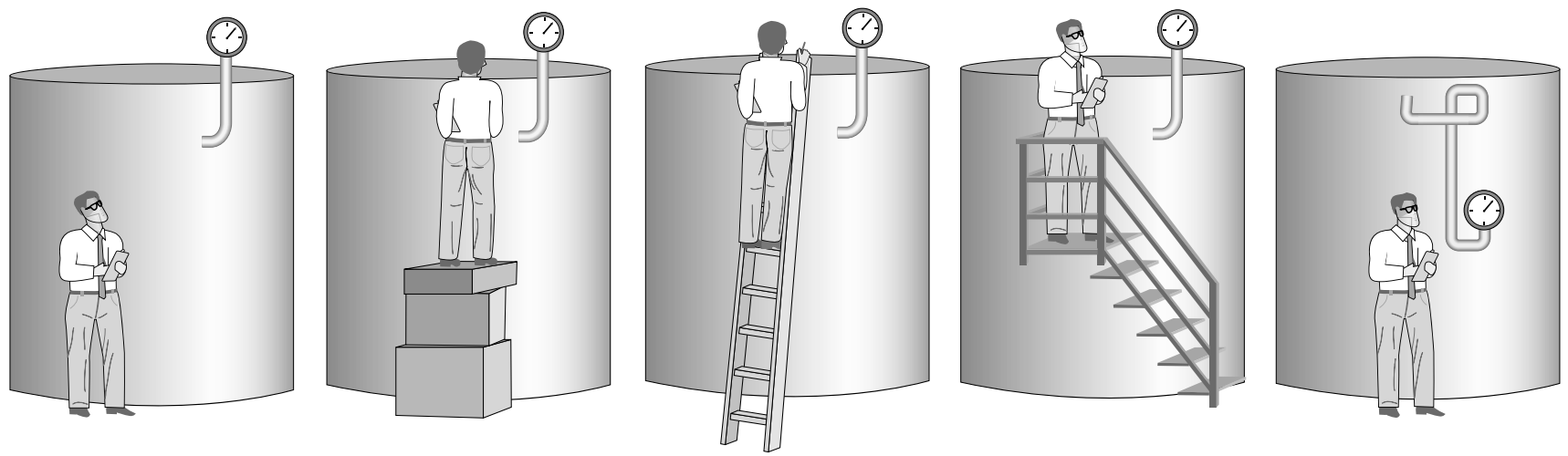

- viajar en un avión no presurizado;

- movimientos muy rápidos como en una montaña rusa,

- enfermedades.

\section{Aparato somatosensor (estímulos de presión en la piel y} posición de las articulaciones que soportan el peso corporal)

- permanecer vertical sobre un pie;

- extremidades dormidas por permanecer en la misma posición durante largo tiempo, por ejemplo, arrodillado;

- botas rígidas,

- extremidades muy frías.

\section{Respuesta motora}

- extremidades dormidas;

- cansancio muscular;

- enfermedades, lesiones;

- envejecimiento, discapacidades temporales o permanentes,

- ropas voluminosas.

La estabilidad postural y el control de la marcha son reflejos muy complejos del ser humano. Cualquier perturbación de la información sensorial puede originar caídas. Todas las perturbaciones descritas en esta sección son frecuentes en el lugar de trabajo. Por tanto, las caídas son episodios bastante naturales que deben prevenirse.

\section{Estrategia para la protección contra caídas}

Como se ha indicado antes, los riesgos de caída pueden ser identificados. En la Figura 58.101 se muestra una situación muy corriente que consiste en la lectura de un indicador. La primera ilustración corresponde a la situación tradicional: un manómetro instalado en la parte superior de un depósito sin medio de acceso. En la segunda, un trabajador improvisa un medio de acceso apilando varias cajas: una situación peligrosa. En la tercera, el trabajador utiliza una escalera, lo que supone una mejora. En cualquier caso, la escalera no está fijada permanentemente al depósito y es probable que se esté utilizando en otro lugar de la fábrica cuando se necesite hacer una lectura. El riesgo de caída sigue existiendo aún cuando se añada a la escalera o al tanque un equipo de detención de caídas, el trabajador lleve un arnés completo y se utilice una cuerda de seguridad unida al anclaje.

En la cuarta ilustración se mejora el acceso con una escalera, una plataforma y barandillas. De esta forma se reduce el riesgo de caída y se facilita la lectura (comodidad), disminuyendo la duración y precisión de la misma gracias a una postura de trabajo estable.
Figura 58.102 - Estrategia de prevención de caídas.
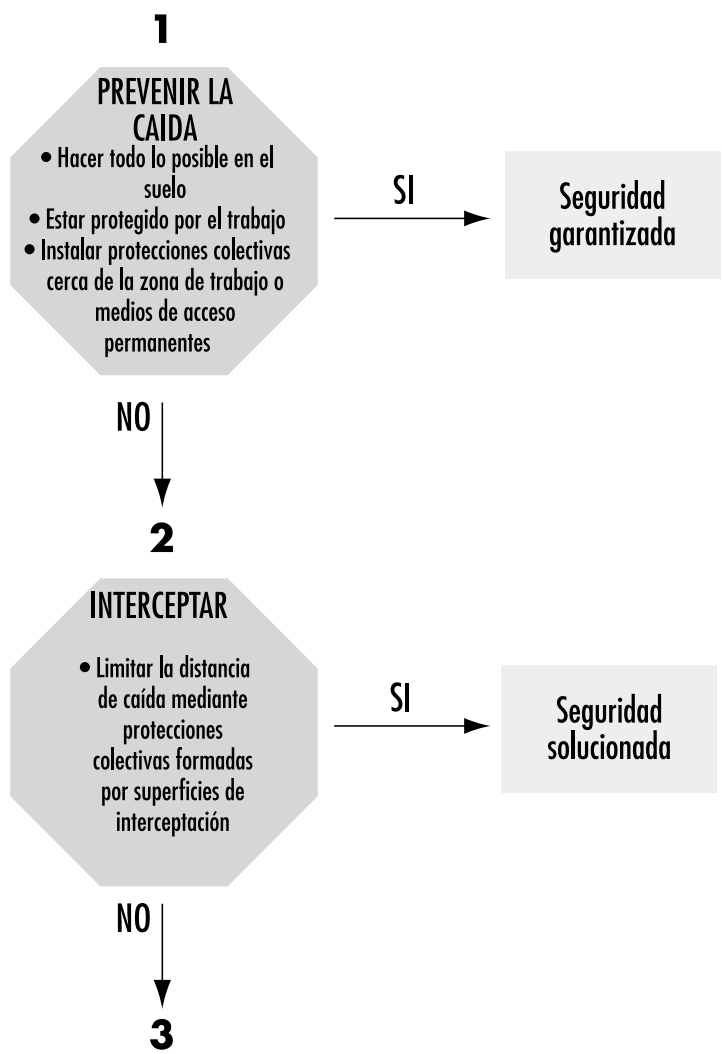

PROTEGER INDIVIDUALMENTE

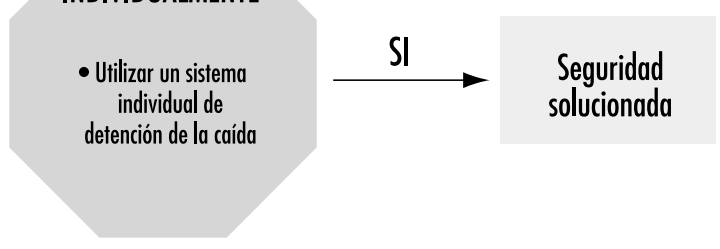

Fuente: OPPBTP 1984 
La última ilustración muestra la solución correcta. Durante la fase de diseño de la instalación se tuvieron en cuenta las actividades de manejo y mantenimiento y se instaló el manómetro de manera que se pudiera leer desde el suelo. De esta forma se elimina la posibilidad de una caída desde alturas y, por tanto, ya no existe ningún peligro.

Esta estrategia se centra en la prevención de caídas utilizando medios de acceso adecuados (por ejemplo, andamios, escaleras de mano, escaleras fijas) (Bouchard 1991). Si no se puede prevenirse la caída, tendrán que utilizarse sistemas de detención de la caída (Figura 58.102), cuya eficacia exige una correcta planificación. El punto de anclaje es un factor clave y se tiene que preparar con antelación. Los sistemas de detención de caídas tienen que ser eficaces, fiables y cómodos. Arteau, Lan y C orbeil (pendiente de publicación) y Lan, Arteau y Corbeil (pendiente de publicación) ofrecen dos ejemplos de estos sistemas. En la Tabla 58.11 se indican algunos sistemas típicos de prevención y detención de caídas. Sulowski (1991) describe con detalle los sistemas de detención de caídas y sus componentes.

El énfasis en la prevención no es una cuestión ideológica, sino más bien práctica. La Tabla 58.12 muestra las diferencias entre prevención y detención de caídas, la solución tradicional.

Para las empresas y los técnicos es más fácil construir sistemas de prevención de caídas porque sus requisitos de resistencia mínima a la rotura son de 10 a 20 veces menores que los correspondientes a los sistemas de detención de caídas. Por ejemplo, el requisito de resistencia mínima a la rotura de una barandilla es de $1 \mathrm{kN}$ aproximadamente, el peso de un hombre corpulento, mientras que el correspondiente al punto de anclaje de un sistema de detención de caídas podría ser de $20 \mathrm{kN}$, el peso de dos vehículos pequeños o 1 metro cúbico de hormigón. La prevención evita las caídas y, por tanto, elimina el riesgo de lesiones. Con los sistemas de detención de caídas, éstas se producen y aunque se detengan, existe un riesgo residual de lesiones.

Tabla 58.11 • Sistemas típicos de prevención y detención de caídas.

\begin{tabular}{|c|c|c|}
\hline & $\begin{array}{l}\text { Sistemas de prevención } \\
\text { de caídas }\end{array}$ & $\begin{array}{l}\text { Sistemas de detención de } \\
\text { caídas }\end{array}$ \\
\hline Protección colectiva & Barandillas & Red de seguridad \\
\hline Protección individual & $\begin{array}{l}\text { Sistema de limitación del } \\
\text { recorrido (TRS) }\end{array}$ & $\begin{array}{l}\text { Arnés, cuerda de seguridad, } \\
\text { dispositivo de absorción } \\
\text { de energía, anclaje, etc. }\end{array}$ \\
\hline
\end{tabular}

Tabla 58.12 • Diferencias entre la prevención de caídas y la detención de caídas.

\begin{tabular}{|c|c|c|}
\hline & Prevención & Detención \\
\hline $\begin{array}{l}\text { Producción de } \\
\text { la caída }\end{array}$ & No & Sí \\
\hline Equipo típico & Barandillas & $\begin{array}{l}\text { Arnés, cordón de seguridad, } \\
\text { dispositivo de absorción de } \\
\text { energía y anclaje (sistema } \\
\text { de detención de caídas) }\end{array}$ \\
\hline $\begin{array}{l}\text { Carga de diseño } \\
\text { (fuerza) }\end{array}$ & $\begin{array}{l}1 \text { a } 1,5 \mathrm{kN} \text { aplicada horizontal- } \\
\text { mente y } 0,45 \mathrm{kN} \text { aplicada } \\
\text { verticalmente en cualquier } \\
\text { punto de la parte superior }\end{array}$ & $\begin{array}{l}\text { Reistencia mínima a la rotura } \\
\text { del punto de anclaje } 18 \text { a } \\
22 \mathrm{kN}\end{array}$ \\
\hline Carga & Estática & Dinámica \\
\hline
\end{tabular}

\section{ESPACIOS CONFINADOS}

\section{Neil McManus}

Los espacios confinados se encuentran en todas las industrias y son lugares en los que repetidamente se producen accidentes mortales y no mortales. El término espacio confinado se ha utilizado tradicionalmente para designar estructuras concretas como depósitos, recipientes, pozos, vertederos, tolvas, etc. A hora bien, cualquier definición basada en una descripción de este tipo es excesivamente restrictiva y cuestiona la extrapolación directa a estructuras en las cuales se han producido accidentes. En teoría, cualquier estructura en la que trabajen personas puede ser 0 convertirse en un espacio confinado. Los espacios confinados pueden ser muy grandes 0 muy pequeños. Lo que realmente describe el término es un entorno en el que puede darse una gran variedad de condiciones peligrosas. Estas pueden incluir el confinamiento personal y peligros estructurales, de procesos, mecánicos, de materiales líquidos o a granel, atmosféricos, físicos, químicos, biológicos, de seguridad y ergonómicos. M uchas de las condiciones producidas por estos peligros no son privativas de los espacios confinados, pero se agravan por efecto de las superficies limitantes del espacio confinado.

Los espacios confinados son mucho más peligrosos que los normales. M odificaciones aparentemente mínimas de las condiciones pueden cambiar rápidamente estos espacios de trabajo de inocuos a muy peligrosos. Estas condiciones pueden ser transitorias y sutiles $y$, por tanto, difíciles de reconocer y corregir. Algunas de las tareas que se realizan en espacios confinados están relacionadas con la construcción, la inspección, el mantenimiento, la modificación y la rehabilitación. Suelen ser trabajos no rutinarios, de corta duración, no repetitivos e imprevisibles (con frecuencia, fuera de las horas de trabajo normales o cuando la unidad está fuera de servicio).

\section{Accidentes en espacios confinados}

Los accidentes que ocurren en espacios confinados difieren de los que ocurren en espacios de trabajo normales. Un error aparentemente mínimo o un descuido en la preparación del espacio, la selección 0 el mantenimiento del equipo o la actividad laboral puede precipitar un accidente. Esto se debe a que la tolerancia a errores en estas situaciones es más pequeña que en las actividades normales.

Las profesiones de las víctimas de accidentes en espacios confinados abarcan todo el espectro laboral. Aunque la mayoría son trabajadores, como cabría esperar, las víctimas también incluyen personal técnico y de ingeniería, capataces, directivos y personal de emergencia. El personal de seguridad e higiene industrial también se ha visto afectado por accidentes en espacios confinados. Los únicos datos disponibles sobre accidentes en espacios confinados proceden de Estados U nidos y sólo incluyen los accidentes mortales (NIO SH 1994). En todo el mundo, estos accidentes provocan unas 200 víctimas anuales en la industria, la agricultura y los hogares (Reese y Mills 1986). Esta es, en el mejor de los casos, una estimación basada en datos incompletos, pero parece aplicable en la actualidad. A proximadamente las dos terceras partes de los accidentes se produjeron por condiciones atmosféricas peligrosas en los espacios confinados. En casi el $70 \%$ de estos casos, dichas condiciones existían antes de la entrada de los trabajadores y del comienzo del trabajo. A veces, estos accidentes ocasionan varias víctimas, algunas como consecuencia del incidente original y otras como consecuencia de los intentos de rescate. Las condiciones de alto estrés durante los intentos de rescate someten con frecuencia a los rescatadores a riesgos mucho más altos que los corridos por la víctima inicial. 
Las causas y resultados de los accidentes de las personas que trabajan fuera de estructuras que confinan atmósferas peligrosas son similares a los que ocurren dentro de espacios confinados. Las explosiones 0 incendios relacionados con una atmósfera confinada causaron aproximadamente la mitad de los accidentes mortales en trabajos de corte y soldadura en Estados U nidos. A proximadamente en el $16 \%$ de estos accidentes intervinieron bidones "vacíos" de 205 I u otros recipientes (O SH A 1988).

\section{Identificación de espacios confinados}

EI análisis de los accidentes que tienen lugar en espacios confinados indica que la mejor defensa reside en la información y el entrenamiento de los trabajadores, así como en un programa de identificación y gestión de riesgos. También es esencial la adquisición de destrezas para que capataces y trabajadores puedan reconocer condiciones potencialmente peligrosas. U na contribución a este programa es un inventario exacto y actualizado de los espacios confinados que incluya el tipo de espacio, su ubicación, sus características, su contenido, las condiciones peligrosas, etc. En muchos casos, la elaboración de este tipo de inventario es difícil porque el tipo y número de espacios confinados varía constantemente. Por otra parte, los espacios confinados en operaciones de proceso son fácilmente identificables, aunque permanecen cerrados e inaccesibles la mayor parte del tiempo. En algunos casos, un espacio pasa de ser confinado a no serlo de un día para otro.

Una ventaja de la identificación de los espacios confinados es la oportunidad de colocar carteles de advertencia. Estos carteles permiten a los trabajadores relacionar el término espacio confinado con ciertos equipos y estructuras de su lugar de trabajo. Los aspectos negativos de esta medida son: (1) el cartel puede pasar desapercibido si se colocan muchas otras señales de advertencia; (2) las organizaciones con muchos espacios confinados pueden encontrar grandes dificultades para advertir de su presencia por medio de carteles; (3) los carteles sirven de poco cuando los espacios confinados cambian con frecuencia, y (4) el recurso de los carteles de advertencia como única forma de identificar los espacios confinados causa dependencia y puede hacer que estos espacios se pasen por alto.

\section{Valoración de riesgos}

El aspecto más complejo y difícil de los espacios confinados es la valoración de riesgos, que consiste en identificar la condiciones peligrosas existentes y potenciales y evaluar el nivel y aceptabilidad del riesgo. La dificultad de la valoración de riesgos se debe a que muchas de las condiciones peligrosas que pueden producir lesiones traumáticas o agudas son difíciles de identificar y evaluar y con frecuencia cambian dependiendo de las condiciones. Por tanto, la eliminación o reducción de riesgos durante la preparación del espacio para el acceso de los trabajadores es esencial para minimizar el riesgo durante el trabajo.

La valoración de riesgos proporciona una estimación cualitativa del nivel de preocupación que origina una situación concreta en un momento concreto (Tabla 58.13). El nivel de preocupación dentro de cada categoría varía entre un nivel mínimo y otro máximo. La comparación entre categorías no procede, ya que el nivel máximo de preocupación puede variar considerablemente.

C ada entrada de la T abla 58.13 puede ampliarse para facilitar detalles sobre las condiciones peligrosas que causan preocupación. También se pueden dar detalles para eliminar categorías que no son causa de preocupación.

Para el éxito de la identificación y valoración de riesgos, es fundamental la intervención de una persona cualificada. Se considera que una persona está cualificada cuando, por su experiencia, sus estudios y/ o su formación especializada, es capaz de prever, reconocer y evaluar exposiciones a sustancias peligrosas 0 a otras condiciones poco seguras y de recomendar medidas de control y/ o de protección. Es decir, la persona cualificada tiene que saber lo que es necesario en el contexto de una situación concreta de trabajo en un espacio confinado.

Se debe hacer una valoración de riesgos para cada uno de los cinco períodos del ciclo de vida de un espacio confinado (según proceda): espacio no perturbado, preparación previa al acceso, inspección previa al trabajo, actividades laborales (M CM anus, manuscrito) y respuesta de emergencia, ya que pueden producirse accidentes mortales en todos estos períodos. El espacio no perturbado se refiere a la situación existente desde la clausura de dicho espacio después del último acceso hasta el comienzo de la preparación para el siguiente acceso. L as preparaciones previas al acceso tienen como objetivo garantizar la seguridad del acceso y el trabajo en ese espacio. La inspección previa al trabajo consiste en el acceso inicial y el examen del espacio para

Tabla 58.13 • Ejemplo de formulario para evaluar situaciones peligrosas.

\begin{tabular}{|l|l|l|l|}
\hline Condición peligrosa & \multicolumn{3}{|c|}{ Consecuencia real o potencial } \\
\hline & Baja & Moderada & Alta \\
\hline Trabajo en caliente & & & \\
\hline Peligros atmosféricos & & & \\
\hline falta de oxígeno & & & \\
\hline exceso de oxígeno & & & \\
\hline químicos & & & \\
\hline biológicos & & & \\
\hline incendio/ explosión & & & \\
\hline Ingestión/ contacto con la piel & & & \\
\hline Agentes físicos & & & \\
\hline ruido/ vibraciones & & & \\
\hline estrés por calor/ frío & & & \\
\hline radiación ionizante/ no ionizante & & & \\
\hline láser & & & \\
\hline Confinamiento personal & & & \\
\hline Peligro mecánico & & & \\
\hline Peligro de proceso & & & \\
\hline Peligros para la seguridad & & & \\
\hline estructurales & & & \\
\hline absorción/ inmersión & & & \\
\hline enredamiento & & & \\
\hline eléctricos & & & \\
\hline caída & & & \\
\hline resbalmiento/ tropiezo & & \\
\hline nivel de iluminación/ visibilidad & & \\
\hline explosión/ implosión & & \\
\hline superficies calientes/ frías & & \\
\hline
\end{tabular}

NA = no aplicable

Los significados de ciertos términos, como "substancia tóxica", "falta de oxígeno", "exceso de oxígeno", "peligro mecánico", etc., requieren una especificación adicional de acuerdo con las normas existentes en cada jurisdicción concreta. 
Tabla 58.14 • Un ejemplo de permiso de acceso.

\section{EMPRESA ABC}

ESPACIO CONFINADO - PERMISO DE ACCESO

1. INFORMACION DESCRIPTIVA

Departmento:

Ubicación:

Edificio/ taller:

Equipo/ espacio:

Parte:

Fecha:

Asesor:

Duración:

Cualificación:

2. ESPACIOS ADYACENTES

Espacio:

Descripción:

Contenido:

Proceso:

3. CONDICIONES PREVIAS AL TRABAIO

\section{Peligros atmosféricos}

Falta de oxígeno

Concentración:

Exceso de oxígeno

$\square S$

\section{口No}

口Controlada

Concentration:

Químico

(Mínimo aceptable:

$\square S i ́ \quad \square$ №

$\%)$

(Máximo aceptable:

口Sí $\quad$ aNo $\quad \square$ Controlado

Concentración de la sustancia

(Normal aceptable:

$$
\text { Biológico }
$$

$\square$

Concentración de la sustancia

(Normal aceptable:

Incendio/ explosión

口Sí 口№

Concentración de la sustancia

(Máximo aceptable:

Peligro por ingestión/ contacto con la piel

$\square S$

$\square \mathrm{No}$

$\square$ Controlado

\section{Agentes físicos}

Ruido/ vibraciones

$\square S^{\prime}$

(Máximo aceptable:

Nivel:

Estrés por calor/ frío

$\square S i$

(Intervalo aceptable:

Temperatura:

Radiación ionizante/ no ionizante

$\square$

Tipo Nivel

(Máximo aceptable:

$\begin{array}{ll}\text { Láser } & \\ \text { Tipo Nivel } & \end{array}$

Confinamiento personal ( véase la acción correctiva)

$\square \mathrm{Si}^{\prime}$

(Máximo aceptable:

Peligro mecánico (véase el procedimiento)

asi

Peligro de proceso (véase el procedimiento)

$\square S^{\prime}$

$\square$ Sí

aNo aControlado

$\%$ LFL)

$\square$ Controlado

口No aControlado


Tabla 58.14 • Un ejemplo de permiso de acceso.

Continuación.

\begin{tabular}{|c|c|c|c|}
\hline \multicolumn{4}{|c|}{ EMPRESA ABC } \\
\hline \multicolumn{4}{|l|}{ Peligros para la seguridad } \\
\hline Peligro estructural (véase la acción correctiva) & $\square S_{1}^{\prime}$ & $\square N_{0}$ & $\square$ Controlado \\
\hline Absorción/ inmersión (véase la acción correctiva) & $\square S^{\prime}$ & 口No & DControlado \\
\hline Enredamiento (véase la acción correctiva) & $\square S_{i}^{\prime}$ & 口No & $\square$ Controlado \\
\hline Eléctrico (véase el procedimiento) & $\square S_{i}^{\prime}$ & 口No & $\square$ Controlado \\
\hline Caída (véase la acción correctiva) & $\square S^{\prime}$ & $\square$ No & $\square$ Controlado \\
\hline Resbalones/ tropiezo (véase la acción correctiva) & $\square S_{i}^{\prime}$ & 口No & $\square$ Controlado \\
\hline Nivel de visibilidad/ iluminación & $\square S_{i}^{\prime}$ & 口No & $\square$ Controlado \\
\hline Nivel: & (Intervalo aceptable: & & lux) \\
\hline Explosión/ implosión (véase la acción correctiva) & $\square S^{\prime}$ & $\square N_{0}$ & $\square$ Controlado \\
\hline Superficies calientes/ frías (véase la acción correctiva) & $\square S^{\prime}$ & 口No & DControlado \\
\hline \multicolumn{4}{|c|}{$\begin{array}{l}\text { Para las casillas marcadas, indicar datos adicionales y consultar las medidas de protección. Para los peligros susceptibles de pruebas, consultar los requisitos de prueba } \\
\text { Proporcionar datos de la calibración más reciente. Los valores máximo, mínimo, normal o de intervalo aceptables dependen de la jurisdicción. }\end{array}$} \\
\hline \multicolumn{4}{|l|}{ 4. Procedimiento de trabajo } \\
\hline \multicolumn{4}{|l|}{ Descripción: } \\
\hline Trabajo en caliente (Consultar las medidas de protección.) & $\square S^{\prime}$ & 口No & $\square$ Posible \\
\hline \multicolumn{4}{|l|}{ Peligro atmosférico } \\
\hline $\begin{array}{l}\text { Falta de oxígeno (Consultar los requisitos para pruebas adicionales. Registrar los resul- } \\
\text { tados. Consultar los requisitos para medidas de protección.) }\end{array}$ & $\square S^{\prime}$ & $\square N_{0}$ & $\square$ Posible \\
\hline Concentración: & (Mínimo aceptable: & & $\%$ \\
\hline $\begin{array}{l}\text { Exceso de oxígeno (Consultar los requisitos para pruebas adicionales. Registrar los } \\
\text { resultados. Consultar los requisitos para medidas de protección.) }\end{array}$ & $\square S^{\prime}$ & ano & 口Posible \\
\hline Concentración: & (Máximo aceptable: & & $\%)$ \\
\hline $\begin{array}{l}\text { Químico (Consultar los requisitos para pruebas adicionales. Registrar los resultados. } \\
\text { Consultar los requisitos para medidas de protección.) }\end{array}$ & $\square S^{\prime}$ & aNo & $\square$ Posible \\
\hline Concentración de la substancia & (Normal aceptable: & & 1 \\
\hline $\begin{array}{l}\text { Biológico (Consultar los requisitos para pruebas adicionales. Registrar los resultados. } \\
\text { Consultar los requisitos para medidas de protección.) }\end{array}$ & $\square S^{\prime}$ & $\square N_{0}$ & $\square$ Posible \\
\hline Concentración de la substancia & (Normal aceptable: & & 1 \\
\hline $\begin{array}{l}\text { Incendio/ explosión (Consultar los requisitos para pruebas adicionales. Registrar los } \\
\text { resultados. Consultar los requiisitos para medidas de protección.) }\end{array}$ & QSí & $\square N_{0}$ & 口Posible \\
\hline Concentración de la substancia & (Normal aceptable: & & 1 \\
\hline $\begin{array}{l}\text { Peligro de ingestión/ contacto con la piel (Consultar los requisitos para medidas de } \\
\text { protección.) }\end{array}$ & $\square S^{\prime}$ & aNo & $\square$ Posible \\
\hline \multicolumn{4}{|l|}{ Agentes físicos } \\
\hline $\begin{array}{l}\text { Ruido/ vibraciones (Consultar los requisitos para medidas de protección. Consultar los } \\
\text { requisitos para pruebas adicionales. Registrar los resultados.) }\end{array}$ & $\square s^{\prime}$ & $\square$ No & 口Posible \\
\hline Nivel: & (Máximo aceptable: & & $d B A)$ \\
\hline $\begin{array}{l}\text { Estrés por calor/ frío (Consultar los requisitos para medidas de protección. Consultar } \\
\text { los requisitos para pruebas adicionales. Registrar los resultados.) }\end{array}$ & $\square S^{\prime}$ & aNo & $\square$ Posible \\
\hline Temperatura: & (Intervalo aceptable: & & 1 \\
\hline $\begin{array}{l}\text { Radiación ionizante/ no ionizante } \\
\text { (Consultar los requisitos para medidas de protección. Consultar los requisitos para } \\
\text { pruebas adicionales. Registrar los resultados.) }\end{array}$ & $\square S^{\prime}$ & aNo & $\square$ Posible \\
\hline Tipo Nivel & (Máximo aceptable: & & 1 \\
\hline Láser (Consultar los requisitos para medidas de protección.) & $\square S^{\prime}$ & 口No & 口Posible \\
\hline
\end{tabular}

Continúa en la página siguiente. 
Tabla 58.14 • Un ejemplo de permiso de acceso.

continuación.

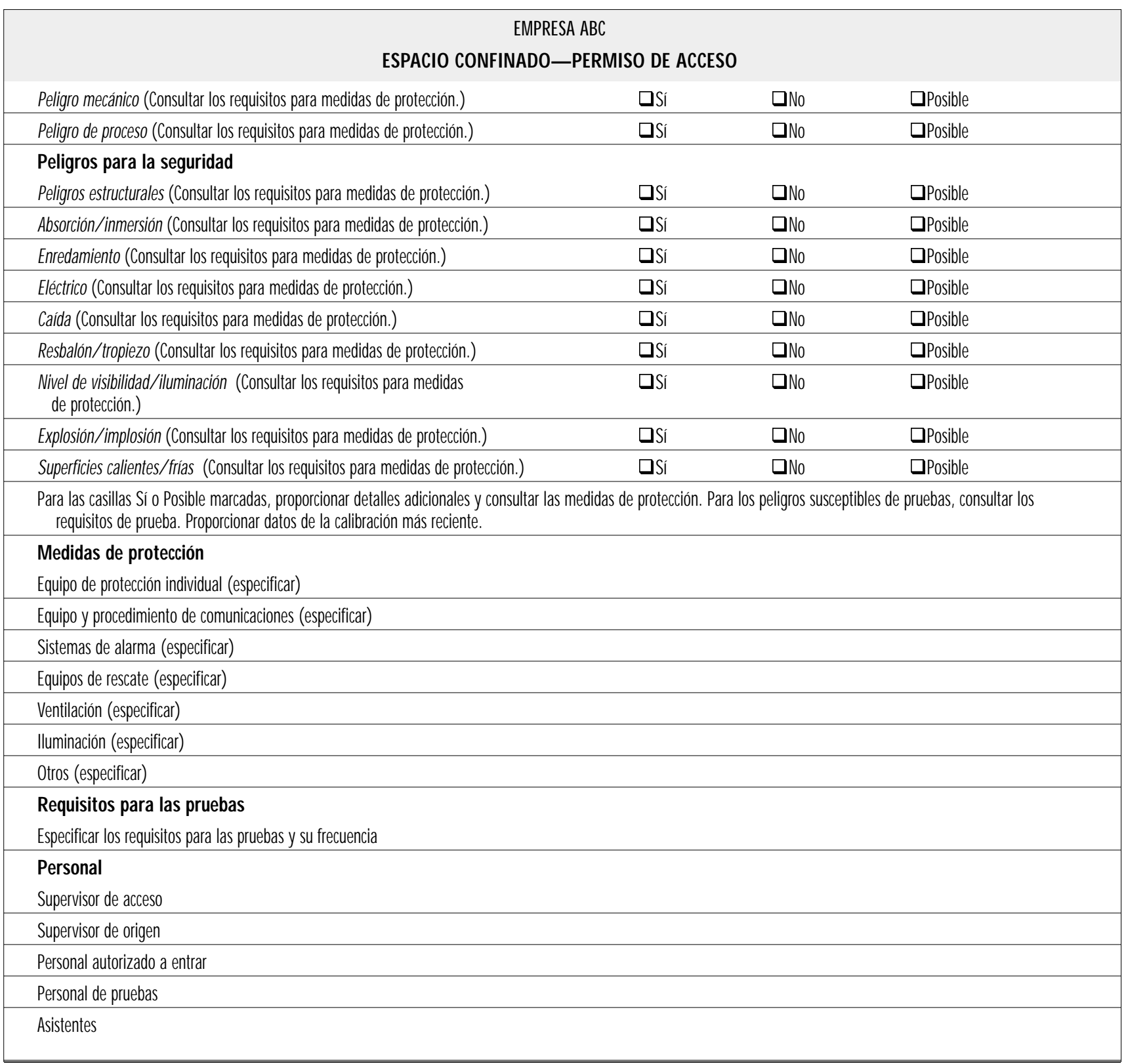

comprobar que es seguro para comenzar el trabajo. (Esta práctica es obligatoria en algunas jurisdicciones). Las actividades laborales son tareas individuales que tienen que realizar los trabajadores en el espacio confinado. La respuesta de emergencia consiste en las medidas que deben tomarse en caso de que sea necesario rescatar a los trabajadores 0 de que se produzca otra emergencia. Los peligros que persisten al comienzo de la actividad laboral o que son generados por ella dictan la naturaleza de los accidentes que pueden motivar un plan o respuesta de emergencia.

La valoración de riesgos en cada uno de estos períodos es esencial porque el enfoque varía continuamente. Por ejemplo, el nivel de preocupación por una condición específica puede desaparecer después de la preparación previa al acceso; sin embargo, puede reaparecer o surgir un peligro nuevo como consecuencia de una actividad realizada dentro o fuera del espacio confinado. Por esta razón, la evaluación del nivel de preocupación por una condición peligrosa durante todo el ciclo, basada sólo en la valoración de las condiciones previas al acceso o durante el acceso, es inadecuada.

Para determinar el estado de algunos agentes físicos, químicos y biológicos presentes en el espacio confinado o en sus alrededores, se utilizan instrumentos y otros métodos de vigilancia. La vigilancia puede ser necesaria antes del acceso, durante el acceso o durante la actividad laboral. Se recurre al bloqueo, a carteles de advertencia 0 a otros procedimientos técnicos para desactivar fuentes de energía. El aislamiento utilizando bridas ciegas, tapas y tapones, doble bloqueo, purgas u otras configuraciones de válvulas impide la entrada de sustancias a través de las tuberías. La ventilación mediante extractores se utiliza con frecuencia 
para conseguir un lugar de trabajo seguro con y sin protección respiratoria homologada. La evaluación y control de otras condiciones se basa en el juicio de la persona cualificada.

La última parte del proceso es la más crítica. La persona cualificada tiene que decidir si los riesgos asociados con el acceso y el trabajo son aceptables. El control es la mejor manera de garantizar la seguridad. Esta decisión no es difícil de tomar cuando se pueden controlar las condiciones peligrosas o potencialmente peligrosas. C uanto menor sea el nivel de control percibido, mayor será la posibilidad de contingencias. En algunos casos, la única alternativa posible es prohibir el acceso.

\section{Control del acceso}

Los métodos tradicionales de controlar las actividades en espacios confinados son la autorización de acceso y la presencia de una persona cualificada. En ambos casos, se necesita un reparto claro de autoridad y responsabilidad entre la persona cualificada y los trabajadores con autorización para acceder al espacio confinado, el personal de reserva, los responsables de la respuesta de emergencia y los directivos presentes.

La función de un documento de acceso es informar y documentar. El impreso que se muestra en la Tabla 58.14 puede servir para realizar la valoración de riesgos y documentar los resultados. Cuando se modifica para incluir sólo información relativa a una circunstancia concreta, sirve como autorización o certificado de acceso. La autorización de acceso tiene la máxima eficacia cuando incluye un resumen de las actividades realizadas e indica la necesidad de otras medidas de precaución. La autorización de acceso sólo debe ser emitida por una persona cualificada que tenga autoridad para cancelarla si cambian las condiciones. Esta persona debe ser además independiente de la jerarquía supervisora, de manera que no se vea sometida a presiones potenciales para acelerar el trabajo. La autorización especifica los procedimientos que deben seguirse y las condiciones en las puede realizarse el acceso y el trabajo, registrando asimismo los resultados de las pruebas y otra información. La autorización debidamente firmada debe colocarse en la puerta o entrada al espacio o según lo especificado por la empresa o el organismo de control. Allí permanecerá hasta que se cancele, se sustituya por otra 0 se termine el trabajo. Este documento de autorización se convierte en un registro al terminar el trabajo y se tiene que conservarse en los archivos de la empresa el tiempo exigido por el organismo de control.

Este sistema de autorizaciones funciona mejor cuando se conocen condiciones peligrosas por la experiencia previa, habiéndose probado medidas de control que han resultado eficaces. El sistema de autorizaciones permite un reparto más eficaz de los recursos de expertos, pero tiene limitaciones cuando existen peligros no identificados previamente. Si la persona cualificada no está fácilmente disponible, estos peligros pueden permanecer desatendidos.

El certificado de acceso es un mecanismo alternativo al control del acceso. Exige la presencia de una persona cualificada con experiencia práctica en la identificación, evaluación y control de peligros. Una ventaja añadida es la capacidad de responder rápidamente a peligros imprevistos. Algunas jurisdicciones exigen que la persona cualificada realice personalmente una inspección visual del espacio antes de comenzar el trabajo. Una vez examinado el espacio y adoptadas las medidas de control oportunas, la persona cualificada emite un certificado que describe el estado y las condiciones del espacio bajo las cuales puede proceder el trabajo (NFPA 1993). Este planteamiento es ideal para instalaciones que tienen numerosos espacios confinados o en donde las condiciones o la configuración de los espacios pueden sufrir rápidos cambios.

\section{PRINCIPIOS DE LA PREVENCION: MANIPULACION DE MATERIALES Y TRAFICO INTERNO}

\section{Kari Häkkinen}

La manipulación de materiales y el tráfico interno son factores que contribuyen a una buena parte de los accidentes que se producen en muchos sectores de la industria. D ependiendo del tipo de industria, la proporción de accidentes de trabajo atribuibles a la manipulación de materiales varía entre el $20 \%$ y el $50 \%$. El control de los riesgos de manipulación de materiales es el principal problema en muelles, obras de construcción, almacenes, serrerías, astilleros y otras industrias pesadas. En muchas industrias de proceso como la química, papelera y siderúrgica, los accidentes se producen principalmente durante la manipulación de los productos finales, ya sea manualmente o mediante grúas y carretillas elevadoras

Este elevado riesgo de accidentes durante las actividades de manipulación de materiales se debe al menos a tres características básicas:

- Durante la manipulación y el transporte de materiales se liberan cantidades importantes de energía cinética y potencial que pueden causar lesiones y daños.

- El número de trabajadores que realizan actividades de manipulación y transporte y que, por tanto, estas expuestos a los riesgos que conllevan estas actividades, sigue siendo relativamente elevado.

- Siempre que tengan que realizarse simultáneamente distintas operaciones dinámicas y éstas exijan la cooperación en varios entornos, existirá una necesidad especialmente urgente de información y comunicación clara y puntual. La alta probabilidad de errores y omisiones humanos puede crear situaciones peligrosas.

\section{Accidentes durante la manipulación de materiales}

Cada vez que los trabajadores o las máquinas transportan cargas, existen un riesgo de accidente. La magnitud del riesgo viene determinada por las características tecnológicas y organizativas, el entorno y las medidas de prevención de accidentes adoptadas. A efectos de seguridad es útil representar la manipulación de materiales como un sistema con varios elementos interrelacionados (Figura 58.103). Cuando se introducen cambios en cualquier elemento del sistema, ya sean equipos, mercancías, procedimientos, entorno, personas, dirección u organización, es también probable que cambien los riesgos de lesiones.

Los tipos más corrientes de manipulación de materiales y tráfico interno que intervienen en accidentes están asociados con la manipulación, el transporte o la carga manual (carretillas, bicicletas, etc.) o el uso de camiones, carretillas elevadoras, grúas y aparejos, cintas transportadoras y sistemas de transporte por carriles.

En los lugares de trabajo se producen con frecuencia distintos tipos de accidentes asociados a la manipulación y transporte de materiales. La lista siguiente recoge los más frecuentes:

- esfuerzo físico durante la manipulación manual;

- cargas que caen sobre personas;

- personas atrapadas entre objetos.

- choques entre equipos;

- caídas de personas,

- golpes y cortes que reciben las personas de los equipos 0 cargas. 
Figura 58.103 • Un sistema de manipulación de materiales.

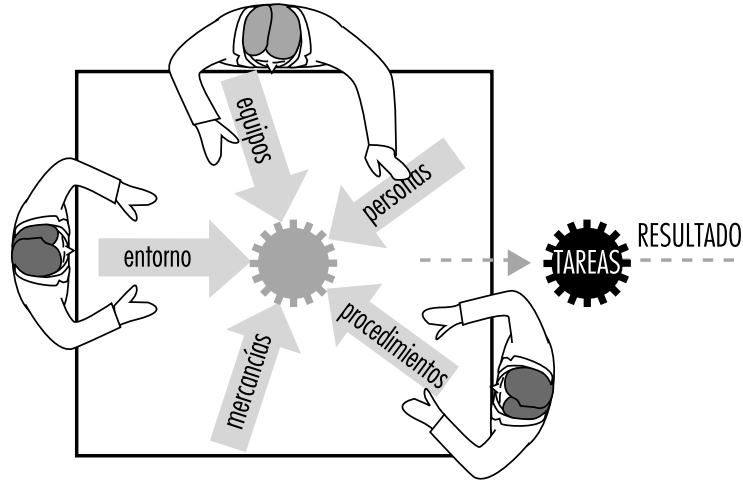

ORGANIZACION/GESTION • DISEÑOS • SISTEMAS DE SEGURIDAD

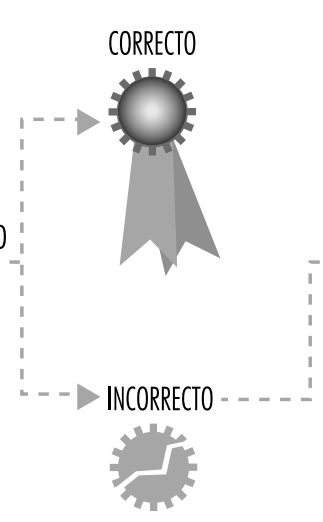

MEJORAS

\begin{tabular}{|c|c|c|c|c|c|c|c|}
\hline $\begin{array}{l}\text { ORGANIZACION/ } \\
\text { GESTION }\end{array}$ & $\begin{array}{l}\text { ENTORNO } \\
\text { - Exterior/interior }\end{array}$ & EQUIPOS & $\begin{array}{l}\text { PERSONAS } \\
\text { Conductores }\end{array}$ & PROCEDIMIENTOS & $\begin{array}{l}\text { MERCANCIAS } \\
\text { C Contenedores }\end{array}$ & TAREAS & $\begin{array}{l}\text { RESULTADO Y } \\
\text { CONSECUENCIAS }\end{array}$ \\
\hline $\begin{array}{l}\text { - Planificación } \\
\text { - Mantenimiento } \\
\text { - Control por } \\
\text { ordenador }\end{array}$ & $\begin{array}{l}\text { - Almacén } \\
\text { - Muelle de carga } \\
\text { - Obra }\end{array}$ & $\begin{array}{l}\text { - Camiones } \\
\text { - Transportadores } \\
\text { - Ascensores } \\
\text { - Grúas }\end{array}$ & $\begin{array}{l}\text { - Colocadores } \\
\text { de eslingas } \\
\text { - Registradores } \\
\text { - Personal ajeno }\end{array}$ & $\begin{array}{l}\text { - Instrucciones de } \\
\text { trabajo } \\
\text { - Precauciones de } \\
\text { seguridad }\end{array}$ & $\begin{array}{l}\text { - Largas en palets } \\
\text { - Bobinas de papel } \\
\text { - Chapa metálica } \\
\text { - Residuos } \\
\text { - Sacos }\end{array}$ & $\begin{array}{l}\text { - Transporte } \\
\text { - Carga } \\
\text { - Descarga } \\
\text { - Almacena- }\end{array}$ & $\begin{array}{l}\text { - Cantidad de } \\
\text { mercancías } \\
\text { - Distancia de } \\
\text { transporte }\end{array}$ \\
\hline - Iraba|0 en grupo & - Carretera & $\begin{array}{l}\text { aparejos ae } \\
\text { elevación }\end{array}$ & - Coordinación & $\begin{array}{l}\text { - Instícciones del } \\
\text { usuario }\end{array}$ & $\begin{array}{l}\text { proauctos a } \\
\text { granel }\end{array}$ & & dedicado \\
\hline - Eambios & - Utilización del & $\begin{array}{l}\text { - Grado de } \\
\text { automatización }\end{array}$ & - Formación & $\begin{array}{l}\text { - Símbolos de } \\
\text { seguridad }\end{array}$ & - Duración & & - Perturbaciones \\
\hline $\begin{array}{l}\text { comunicaciones } \\
\text { - Centralizadas/ } \\
\text { descentralizadas } \\
\text { - Grado de } \\
\text { integración }\end{array}$ & $\begin{array}{l}\text { - Calidad de la } \\
\text { disposición } \\
\text { - Obstáculos } \\
\text { - Trabajos de } \\
\text { limpieza }\end{array}$ & $\begin{array}{l}\text { - Visibilidad } \\
\text { - Velocidad } \\
\text { - Tiempo/distancia } \\
\text { de parada } \\
\text { - Tasa de averías }\end{array}$ & $\begin{array}{l}\text { - Estado de } \\
\text { salud } \\
\text { - Vestuario } \\
\text { - Motivación } \\
\text { - Actitud }\end{array}$ & $\begin{array}{l}\text { - Facilidad de } \\
\text { comprensión } \\
\text { - Claridad } \\
\text { - Disponibilidad } \\
\text { - Oportunidad }\end{array}$ & $\begin{array}{l}\text { - Rozamiento } \\
\text { - Estabilidad } \\
\text { - Facilidad de } \\
\text { manipulación } \\
\text { - Normalización }\end{array}$ & & $\begin{array}{l}\text { materiales } \\
\text { - Accidentes } \\
\text { - Absentismo } \\
\text { - Lesiones }\end{array}$ \\
\hline $\begin{array}{l}\text {-Utilizacion de } \\
\text { realimentación }\end{array}$ & - Grado de & - Guntos de peligro & & $\begin{array}{l}\text { - Correccion } \\
\text { - Simplicidad }\end{array}$ & & & \\
\hline & las puertas & $\begin{array}{l}\text { proteccion } \\
\text { - Compatibilidad }\end{array}$ & & & - Elementos & & \\
\hline & $\begin{array}{l}\text { - Visibilidad } \\
\text { - lluminación }\end{array}$ & & & CLAVE] & - Criterios & & \\
\hline
\end{tabular}

\section{Elementos de los sistemas de manipulación de materiales}

Para cada elemento de un sistema de manipulación de materiales existen distintas opciones de diseño que influyen en el riesgo de accidentes. A estos elementos se les pueden aplicar distintos criterios de seguridad. Es importante considerar todas las etapas del ciclo de vida del sistema: diseño, funcionamiento normal y seguimiento de accidentes y problemas ocurridos en el pasado para introducir mejoras en el sistema.

\section{Principios generales de la prevención}

Algunos principios prácticos de prevención se consideran generalmente aplicables a la seguridad en la manipulación de materiales. Estos principios se pueden aplicar a sistemas manuales y mecánicos de manipulación de materiales en un sentido general y siempre que se estudia una fábrica, almacén u obra. Para conseguir resultados óptimos en materia de seguridad, se pueden aplicar muchos principios distintos al mismo proyecto. Normalmente, ninguna medida puede por sí sola prevenir todos los accidentes. Por otra parte, no todos estos principios son necesarios y algunos pueden no ser adecuados para una situación concreta. Los profesionales de la seguridad y los técnicos de manipulación de materiales deben considerar los aspectos más importantes para orientar correctamente su trabajo en cada caso concreto. El problema más importante radica en la aplicación óptima de los principios para crear sistemas seguros y viables de manipulación de materiales, en lugar de apoyarse en un sólo principio técnico e ignorar los demás.

Durante el desarrollo y la evaluación de la seguridad de los sistemas pasados, presentes o futuros de manipulación de materiales, se pueden aplicar los 22 principios que se indican a continuación. Todos ellos pueden aplicarse a medidas de seguridad proactivas o reactivas. La lista no implica ningún orden de prioridad, aunque puede hacerse una distinción general: los principios que se citan primero son especialmente válidos para el diseño inicial de nuevas instalaciones y sistemas de manipulación de materiales, mientras que los últimos están más orientados al funcionamiento de sistemas de manipulación de materiales ya existentes. 


\section{Veintidós principios para la prevención de accidentes durante la manipulación de materiales}

1. Eliminar todas las operaciones innecesarias de transporte y manipulación. D ebido a que muchos procesos de transporte y manipulación son intrínsecamente peligrosos, siempre tiene que considerarse la posibilidad de eliminar algunas operaciones de manipulación de materiales. Muchos procesos modernos de fabricación se pueden organizar como un flujo continuo sin fases separadas de transporte y manipulación. Muchas operaciones de montaje y construcción se pueden planificar y diseñar para eliminar transportes de cargas complejos y fatigosos. También se pueden encontrar soluciones para un transporte más eficaz y racional analizando la logística y el flujo de materiales durante los procesos de fabricación y transporte.

2. Eliminar personas en el espacio dedicado a transporte y manipulación. Cuando los trabajadores se alejan físicamente de las cargas que deben moverse, las condiciones de seguridad mejoran ipso facto al reducirse la exposición a peligros. En las acerías no se permite que trabajen personas en la zona de manipulación de chatarra porque pueden caer materiales de los prensores magnéticos que se utilizan para mover la chatarra, presentando un riesgo continuo de caída de cargas. En muchos casos, la manipulación de materiales en entornos peligrosos se puede automatizar con el uso de robots y carretillas automáticas para reducir el riesgo de accidentes al que están expuestos los trabajadores por el movimiento de cargas. Además, la prohibición de pasar innecesariamente por los lugares de carga y descarga elimina básicamente la exposición a varios tipos de peligros asociados a la manipulación de materiales.

3. Separar al máximo entre sí las operaciones de transporte para minimizar los choques. Cuanto mayor sea la frecuencia de cruce entre vehículos o entre vehículos y otros equipos o personas, mayor será la probabilidad de que se produzcan choques. La separación de las operaciones de transporte es importante cuando se planifica un transporte seguro dentro de la fábrica. Se pueden considerarse distintos tipos de separaciones, como las de peatones/ vehículos, tráfico ligero/ pesado, tráfico interno/ externo hacia o desde el exterior, transporte entre lugares de trabajo/ manipulación de materiales dentro en un lugar de trabajo, transporte/ almacenamiento, transporte/ línea de producción, recepción/ expedición y transporte de materiales peligrosos/ normales.

Cuando la separación es imposible, se pueden asignar horas específicas para el acceso de medios de transporte y peatones a las zonas de trabajo (por ejemplo, en un almacén abierto al público). Si no pueden disponerse de vías distintas para los peatones, sus rutas deben indicarse con marcas y carteles. Para entrar en el edificio de una fábrica, los empleados deben disponer de puertas separadas para peatones. Si el tráfico peatonal y el tráfico de carretillas elevadoras se mezcla en las entradas, existe la tendencia a que la mezcla continúe más allá de la entrada, originando un peligro. Cuando se realizan obras en una fábrica, es necesario casi siempre restringir el transporte y el tráfico de personas en la zona de construcción o reparación. En cuanto al transporte con grúas elevadas, los choques pueden evitarse haciendo que las trayectorias de las grúas no se solapen e instalando interruptores de fin de carrera y barreras mecánicas.

4. Proporcionar suficiente espacio para las operaciones de transporte y manipulación. U na causa frecuente de accidentes es la existencia de un espacio insuficiente para la manipulación de materiales. Por ejemplo, las manos de los trabajadores pueden quedar pilladas entre la carga y una pared cuando los materiales se manipulan manualmente 0 las personas puede quedar atrapadas entre el montante móvil de una grúa de transporte y una pila de materiales si la distancia mínima de seguridad de $0,5 \mathrm{~m}$ no se ha respetado. El espacio necesario para las operaciones de transporte y manipulación debe considerarse cuidadosamente cuando se diseña la instalación o se planifican modificaciones. Es aconsejable reservar un "margen de seguridad" para poder realizar cambios futuros en las dimensiones de las cargas y los tipos de equipos. Con frecuencia, el volumen de los productos fabricados tiende a aumentar con el tiempo, pero el espacio para su manipulación se hace cada vez más pequeño. Aunque la exigencia de un uso rentable del espacio sea una razón para minimizar el espacio destinado a la producción, se debe tener en cuenta que el espacio de maniobra necesario para el giro y el retroceso de las carretillas elevadoras con contrapesos es mayor de lo que parece a primera vista.

5. Diseñar procesos de transporte continuos evitando puntos de discontinuidad en la manipulación de materiales. El flujo continuo de los materiales reduce la probabilidad de accidentes. EI diseño de una instalación tiene una importancia crucial para la aplicación de este principio de seguridad. Los accidentes se concentran en los puntos donde se interrumpe el flujo de materiales porque se cambian los equipos de transporte y manipulación o por razones de producción. Con frecuencia se requiere intervención humana para descargar y cargar, fijar, embalar, levantar y arrastrar, etc. Dependiendo de los materiales manipulados, las cintas transportadoras permiten en general un flujo más continuo de materiales que las carretillas elevadoras o las grúas. C onviene que las actividades de transporte se organicen de tal manera que los vehículos moverse por la fábrica describiendo un círculo de una sola dirección, sin movimientos en zigzag ni retrocesos. D ebido a que los puntos de discontinuidad tienden a producirse en las zonas que separan distintos departamentos o lugares de trabajo, la producción y el transporte deben planificarse de tal modo que se eviten esas "tierras de nadie" con movimiento incontrolado de materiales.

6. U tilizar elementos estándar en los sistemas de manipulación de materiales. A efectos de seguridad, en general es mejor utilizar elementos estándar de cargas, equipos y herramientas para la manipulación de materiales. El concepto de carga unitaria es bien conocido para los profesionales del transporte. Los materiales colocados en contenedores o pallets son más fáciles de fijar y mover cuando los demás elementos de la cadena de transporte (por ejemplo, estanterías de almacenamiento, carretillas elevadoras, vehículos motorizados y dispositivos de fijación grúas) están diseñados para estas cargas unitarias. EI uso de tipos estándar de carretillas elevadoras con controles similares reduce la probabilidad de errores de los conductores, habiéndose producido accidentes cuando un conductor ha cambiado de un tipo de equipo a otro con distintos controles.

7. Conocer los materiales que deben manipularse. El conocimiento de las características de los materiales que deben transportarse es un requisito previo para la seguridad del transporte. La selección de las sujeciones adecuadas de la carga o los mecanismos de elevación tiene que realizarse teniendo en cuenta el peso, el centro de gravedad y las dimensiones de la mercancía que tiene que sujetarse para su elevación y transporte. Cuando se manipulan materiales peligrosos, se necesita información sobre reactividad, inflamabilidad y peligros para la salud. Existen peligros especiales en el caso de elementos frágiles, afilados, polvorientos, resbaladizos, sueltos o cuando se manipulan materiales explosivos y animales vivos, por ejemplo. En 
los envases suele proporcionarse información importante para los trabajadores sobre los métodos correctos de manipulación, pero a veces se quitan las etiquetas o una envuelta protectora oculta información importante. Por ejemplo, en ocasiones el contenido de un paquete no es visible y no se puede estimar correctamente en centro de gravedad de la carga.

8. M antener la carga por debajo de la capacidad de carga de trabajo segura. L as sobrecargas son una causa corriente de lesiones asociadas a los sistemas de manipulación de materiales. La pérdida del equilibrio y la rotura de materiales son resultados típicos de la sobrecarga de los equipos de manipulación. La carga de trabajo segura de eslingas y otros aparejos de elevación debe estar correctamente marcada y se deben seleccionar configuraciones apropiadas de eslingas. La sobrecarga puede producirse cuando se juzga erróneamente el peso o el centro de gravedad de la carga, con el resultado de una fijación y manipulación incorrectas. Cuando se utilizan eslingas para manipular cargas, el operador del equipo debe saber que una trayectoria inclinada puede generar fuerzas suficientes para que la carga se caiga o el equipo pierda el equilibrio. La capacidad de carga de las carretillas elevadoras tiene que estar marcada en el equipo y varía dependiendo de la altura de elevación y el tamaño de la carga. Se puede producir una sobrecarga por fatiga al manipularse repetitivamente cargas muy inferiores a la máxima si el componente no ha sido diseñado correctamente contra este tipo de fallo.

9. E stablecer límites de velocidad suficientemente bajos para garantizar en todo momento un movimiento seguro. L os limites de velocidad de los vehículos en los lugares de trabajo varían entre $10 \mathrm{~km} / \mathrm{h}$ y 40 $\mathrm{km} / \mathrm{h}$. En corredores, puertas, cruces y pasillos estrechos se requieren velocidades menores. Un conductor competente puede adaptar la velocidad del vehículo según requiera cada situación, pero es aconsejable colocar carteles indicadores de la velocidad máxima en los lugares críticos. Por ejemplo, la velocidad máxima de una grúa móvil con mando a distancia se tiene que determinar primero fijando una velocidad del vehículo comparable a una velocidad de marcha razonable para una persona y dejando después un margen suficiente para considerar el tiempo necesario de observación y control simultáneos de las cargas, de manera que no se supere el tiempo de respuesta del operador humano.

10. E vitar la elevación de cargas por encima de los trabajadores. La elevación de materiales por encima de la altura de la cabeza siempre conlleva el riesgo de que la carga se caiga. A unque normalmente no se permite que nadie trabaje debajo de cargas suspendidas, el transporte rutinario de cargas por encima del personal de producción puede exponerle a peligros. La colocación de materiales en estanterías a gran altura con carretillas elevadoras y la elevación a pisos superiores son otros ejemplos de tareas de elevación por encima de las cabezas. Las cintas transportadoras elevadas de piedras, coque o piezas de fundición conllevan un riesgo de caída de materiales para las personas que pasan por debajo de ellas si no hay instaladas las defensas apropiadas. Cuando se considera un nuevo sistema de transporte elevado, los riesgos potencialmente mayores deben compararse con los riesgos menores asociados a un sistema de transporte al nivel del suelo.

11. Evitar métodos de manipulación de materiales que exijan subir a y trabajar en superficies elevadas. C uando un trabajador se ve obligado a trepar, por ejemplo para soltar ganchos de eslingas, para ajustar el toldillo de un vehículo o para marcar cargas, corre el riesgo de caerse. Este peligro puede evitarse con una mejor planificación, modificando la secuencia de trabajos, utilizando diversos accesorios de elevación y herramientas de mando a distancia o mediante mecanización y automatización.

12. Colocar defensas en los puntos de peligro. Deben instalarse defensas en los puntos de peligro de los equipos de manipulación de materiales, como las cadenas de las carretillas elevadoras, los accionamientos por cables de las grúas y los puntos de atenazado de las cintas transportadoras. La protección consistente en situar los puntos de peligro fuera del alcance de las personas no es normalmente suficiente porque se puede acceder a ellos con escaleras y otros medios. T ambién se deben utilizar defensas para protección contra fallos técnicos que puedan provocar lesiones (por ejemplo, retenes de cables en poleas de grúas, pestillos de seguridad en ganchos de elevación y almohadillas de protección de las lanzaderas textiles que protegen contra bordes afilados). Las barandillas y rodapiés instalados en los bordes de las plataformas de carga, las estanterías de almacenamiento elevado y los agujeros en el suelo pueden proteger contra la caída de personas y cosas. Este tipo de protección suele ser necesaria cuando se utilizan carretillas elevadoras y grúas para elevar cargas de un piso a otro. Se puede proteger a las personas contra la caída de objetos en operaciones de manipulación de materiales con redes de seguridad y defensas permanentes, como las cubiertas de chapa o malla de alambre en las cintas transportadoras.

13. T ransportar y elevar personas utilizando sólo equipos diseñados para ese fin. Las grúas, las carretillas elevadoras, las excavadoras y las cintas transportadoras son máquinas que se utilizan para el movimiento de materiales, no de personas. Existen plataformas especiales para elevar personas; por ejemplo, para cambiar lámparas de techo. Si se equipa una carretilla o grúa con una jaula especial que pueda fijarse con seguridad al equipo y que cumpla los requisitos de seguridad adecuados, se puede elevar a personas sin un riesgo excesivo de lesiones graves.

14. M antener la estabilidad de equipos y cargas. Algunos accidentes se producen como consecuencia de la pérdida de estabilidad de equipos, mercancías o estanterías de almacenamiento, especialmente en el caso de carretillas elevadoras o grúas móviles. La selección de equipos activamente estables es una primera medida para reducir el peligro. Además, es aconsejable utilizar equipos que emitan una señal de advertencia clara antes de alcanzar el límite de deformación. 0 tras medidas son la aplicación de unos métodos de trabajo correctos y la utilización de operarios cualificados. Los operarios con experiencia y formación saben estimar el centro de gravedad y reconocer condiciones de inestabilidad cuando se amontonan 0 apilan materiales, pudiendo hacer los ajustes necesarios.

15. Proporcionar una buena visibilidad. La visibilidad siempre está limitada cuando se manipulan materiales con carretillas elevadoras. Al comprar nuevos equipos es importante evaluar la visibilidad del conductor a través de las estructuras de los mástiles (y para carretillas de gran altura de elevación, la visibilidad a través del chasis elevado). En cualquier caso, los materiales originan pérdida de visibilidad y este efecto tiene siempre que considerarse. El campo de visión debe ampliarse al máximo, por ejemplo, quitando pilas de mercancías 0 disponiendo aberturas o secciones vacías en puntos críticos de las estanterías. Se pueden colocar espejos en los equipos y en puntos adecuados de la fábrica o el almacén para hacer las esquinas ciegas más seguras, pero los espejos son una medida preventiva menos importante que la eliminación de esquinas ciegas para permitir la visión directa. En el transporte por grúa es con frecuencia asignar a una persona encargada especialmente de comprobar que la zona donde se baje la carga no esté ocupada por personas. Una buena medida de 
seguridad consiste en pintar o marcar de alguna otra manera los puntos de peligro y las obstrucciones en la zona de trabajo, por ejemplo, columnas, bordes de puertas y muelles de carga, elementos salientes de las máquinas y partes móviles de los equipos. Una iluminación adecuada puede mejorar considerablemente la visibilidad, por ejemplo, en escaleras, pasillos y puertas de salida.

16. Sustituir la manipulación y el transporte manuales por manipulación mecánica y automatizada. Aproximadamente el $15 \%$ de todas las lesiones profesionales están relacionadas con la elevación y el transporte de cargas manualmente. La mayoría de las lesiones son provocadas por esfuerzos excesivos y el resto, por resbalones, caídas y lesiones en las manos por bordes afilados. Los trastornos traumáticos acumulativos y los problemas de espalda son problemas de salud típicos asociados a la manipulación manual de materiales. A unque la mecanización y la automatización han eliminado en gran medida las tareas manuales de manipulación, existen todavía lugares de trabajo en donde la elevación y el transporte de cargas pesadas someten a los trabajadores a esfuerzos físicos excesivos. Se debe considerar el uso de unos equipos de manipulación adecuados, por ejemplo, grúas, polipastos, plataformas elevadoras, ascensores, carretillas elevadoras, cintas transportadoras, palletizadores, robots y manipuladores mecánicos.

17. Proporcionar y mantener una comunicación eficaz. Un factor frecuente en los accidentes graves es un fallo en las comunicaciones. El conductor de una grúa tiene que comunicarse con el encargado de colocar las eslingas que fijan la carga y si las señales manuales entre ellos son incorrectas o la comunicación por radio es deficiente, se pueden producir errores graves. Los enlaces de comunicación son importantes entre los operadores de manipulación de materiales, el personal de producción, los cargadores, los trabajadores de los muelles, los conductores de equipos y el personal de mantenimiento. Por ejemplo, el conductor de una carretilla elevadora tiene que transmitir información sobre cualquier problema de seguridad encontrado, como pasillos con esquinas ciegas por la presencia de materiales apilados, al entregar la carretilla a su relevo en el cambio de turno. Cuando se subcontrata a los conductores de vehículos motorizados y grúas móviles, es probable que no estén familiarizados con los riesgos concretos que pueden encontrar en un lugar de trabajo y, por tanto, deben recibir formación u orientación especiales, entregándoles en su caso un plano de la fábrica en la puerta de entrada junto con las instrucciones esenciales para trabajar y conducir con seguridad. Las señales de tráfico para los lugares de trabajo no se conocen tan bien como las de las carreteras públicas. Con todo, muchos de los riesgos son comunes. Por consiguiente, es importante utilizar señales adecuadas para el tráfico interno para facilitar la comunicación de los avisos de peligro y advertir a los conductores de las precauciones necesarias.

18. A plicar los principios de la ergonomía a las interfaces humanas y los sistemas de manipulación manual. EI trabajo de manipulación de materiales se debe adaptar a la capacidad y destreza de los trabajadores, aplicando principios ergonómicos para evitar errores y esfuerzos innecesarios. Los controles y las pantallas de grúas y carretillas elevadoras deben ser compatibles con las expectativas y hábitos normales de las personas. Es importante asegurarse de que exista espacio suficiente para que los trabajadores puedan realizar los movimientos que requiere la manipulación manual de materiales. Además, deben evitarse posturas excesivamente forzadas como, por ejemplo, la elevación manual de cargas por encima de la cabeza, y no superar los pesos máximos admisibles para la elevación manual. Las variaciones individuales en edad, fuerza, salud, experiencia y características físicas pueden requerir la modificación de las tareas y del espacio de trabajo. La recogida de pedidos en un almacén es un ejemplo típico de una tarea en la que la ergonomía tiene la máxima importancia para la seguridad y productividad.

19. Proporcionar formación y asesoramiento adecuados. Los trabajos de manipulación de materiales suelen considerarse de baja categoría como para justificar la formación de los trabajadores. EI número de conductores especializados de grúas y carretillas elevadoras está diminuyendo en los lugares de trabajo y se observa una tendencia cada vez mayor a considerar el trabajo con grúas y carretillas elevadoras como una tarea que casi todos los trabajadores pueden hacer. Aunque las medidas técnicas y ergonómicas pueden reducir los peligros, la destreza del trabajador es el factor decisivo para evitar situaciones peligrosas en lugares de trabajo dinámicos. Las encuestas sobre accidentes indican que muchas de las víctimas de accidentes relacionados con la manipulación de materiales son personas que no intervienen por sí mismas en estas tareas. Por tanto, también los trabajadores que se encuentran en las zonas de manipulación de materiales deben recibir cierta formación.

20. Proporcionar al personal de transporte y manipulación de materiales los equipos personales apropiados. Algunos tipos de lesiones pueden prevenirse con el uso de equipos adecuados de protección individual durante las tareas de manipulación de materiales, como calzado de seguridad que evite resbalones y caídas, guantes gruesos, gafas de seguridad y cascos. Si existen peligros especiales que lo exijan, deberán utilizarse protecciones contra caídas, respiradores y ropas de seguridad especiales. Un equipo de trabajo adecuado para la manipulación de materiales debe permitir una buena visibilidad y no incluir elementos que puedan quedar fácilmente pillados por equipos o enganchados por elementos móviles.

21. Realizar labores adecuadas de inspección y mantenimiento. Cuando ocurren accidentes por fallos de equipos, los motivos se deben con frecuencia a unos procedimientos deficientes de inspección y mantenimiento. Las instrucciones referentes a las tareas de inspección y mantenimiento se incluyen en las normas de seguridad y los manuales de los fabricantes. EI incumplimiento de los procedimientos indicados puede originar situaciones peligrosas. Los usuarios de los equipos de manipulación de materiales son responsables de las rutinas diarias de inspección y mantenimiento, como comprobación de baterías, accionamientos por cadenas y cables, aparejos de elevación, frenos y controles, limpieza de ventanas y adición de aceite cuando sea necesario. Las inspecciones más minuciosas y menos frecuentes se realizan periódicamente a intervalos semanales, mensuales, semestrales 0 anuales, dependiendo de las condiciones de uso. La limpieza normal de los suelos y la zona de trabajo es también importante para la seguridad durante la manipulación de materiales. Los suelos húmedos y aceitosos pueden hacer que las personas y las carretillas patinen. Las estanterías y los pallets rotos deben desecharse tan pronto como se detecten. En las operaciones de transporte de materiales a granel mediante cintas transportadoras, es importante eliminar las acumulaciones de polvo y granos para evitar el riesgo de explosión e incendio.

22. Planificar los cambios en las condiciones ambientales. La capacidad de adaptación de las personas y los equipos a condiciones ambientales cambiantes es limitada. Los conductores de las carretillas elevadoras necesitan unos segundos para adaptarse al pasar de una nave oscura a un patio iluminado por el sol y viceversa. Para hacer estas operaciones más seguras, se pueden instalar en las puertas sistemas especiales de 
alumbrado. En el exterior, las grúas pueden verse sometidas a grandes cargas debidas al viento, que es necesario tener en cuenta en las operaciones de elevación. En casos extremos, la elevación con grúas se debe suspender por completo. El hielo y la nieve pueden imponer un esfuerzo adicional considerable a los trabajadores encargados de limpiar las superficies de las cargas. En ocasiones, estos factores climáticos suponen también un riesgo adicional cuando, por ejemplo, se trabaja por encima o por debajo de la carga durante la elevación. La planificación debe incluir también procedimientos seguros para realizar estas tareas. U na carga helada puede deslizarse de la horquilla durante el transporte con una carretilla elevadora. La atmósferas corrosivas, el calor, la escarcha y el agua del mar pueden deteriorar los materiales y originar fallos si los materiales no se han diseñado para resistir esas condiciones.

\section{Referencias}

Arteau, J, A Lan, J-F Corveil. 1994. U se of H orizontal Lifelines in Structural Steel E rection. Actas del simposio internacional sobre la protección contra caídas celebrado en San Diego, California (27-28 de octubre de 1994). Toronto: Sociedad Internacional para la Protección contra las $C$ aídas.

Backström, T, L H arms-Ringdahl. 1984. A statistical study of control systems and accidents at work. J 0 ccup Acc. 6:201-210.

Backström, T, M Döös. 1994. T echnical defects behind accidents in automated production. En Advances in Agile M anufacturing, dirigido por PT Kidd $y$ W K arwowski. Amsterdam: IOS Press.

-. 1995. A comparison of occupational accidents in industries with of advanced manufacturing technology. Int J H um F actors M anufac. 5(3). 267-282.

- En imprenta. The technical genesis of machine failures leading to occupational accidents. Int J Ind E rgonomics.

- . A ceptado para su publicación. Absolute and relative frequencies of automation accidents at different kinds of equipment and for different occupational groups. I Saf Res.

Backström, T. 1996. Accident risk and safety protection in automated production. Tesis doctoral. Arbete och $\mathrm{H}$ älsa 1996:7. Solna: Instituto Nacional de la Vida Laboral.

Bainbridge, L. 1983. I ronies of automation. Automatica 19:775-779.

Bell, R, D R einert. 1992. Risk and system integrity concepts for safety related control systems. Saf $\mathrm{Scl}$ 15:283-308.

Bouchard, P. 1991. É chafaudages. Guide série 4. M ontreal: CSST

Bureau of National Affairs. 1975. O ccupational Safety and $\mathrm{H}$ ealth Standards. Roll-over Protective Structures for $\mathrm{M}$ aterial $\mathrm{H}$ andling $\mathrm{E}$ quipment and $\mathrm{T}$ ractors, Section 1926, 1928. Washington, DC: Bureau of $\mathrm{N}$ ational Affairs.

Comisión Electrotécnica Internacional (CEI). 1992. 122 D raft Standard: Software for Computers in the Application of Industrial Safety-related Systems. IEC 65 (Sec). Ginebra: CEI

-. 1993. 123 D raft Standard: F unctional Safety of E lectrical/ E lectronic/ Programmable E lectronic Systems; Generic Aspects. Part 1, General requirements Ginebra: CEI.

Comunidad Europea (CE). 1974, 1977, 1979, 1982, 1987. Directivas del Consejo sobre dispositivos de protección en caso de vuelco de los tractores agrícolas o forestales de ruedas. Bruselas: CEE.

— . 1991. Directiva de Consejo relativa a la aproximación de las legislaciones de los E stados M iembros sobre máquinas. (91/ 368/ CEE) Luxemburgo: CEE.

Corbett, JM . 1988. Ergonomics in the development of human-centred AM T. A pplied E rgonomics 19:35-39.

Culver, C, C Connolly. 1994. Prevent fatal falls in construction. Saf H ealth Septiembre 1994:72-75.

Deutsche Industrie Normen (DIN). 1990. Grundsätze für Rechner in Systemen mit Sicherheitsauffgaben. DIN V VDE 0801. Berlín: Beuth Verlag.
—. 1994. G rundsätze für R echner in Systemen mit Sicherheitsauffgaben Änderung A 1. DIN V VDE 0801/A1. Berlín: Beuth Verlag.

- 1995a. Sicherheit von M aschinen-D ruckempfindliche Schutzeinrichtungen [Seguridad de la maquinaria- Equipos protectores sensibles a la presión]. DIN prEN 1760. Berlín: Beuth Verlag.

- . 1995b. R angier-W arneinrichtungen - Anforderungen und Prüfung [V ehículos comerciales- detección de obstáculos durante la inversión- requisitos y pruebas ]. DIN -N orma 75031. Febrero 1995

Döös, M, T Backström. 1993. Description of accidents in automated materials handling. En Ergonomics of $M$ aterials $\mathrm{H}$ andling and Information Processing at W ork, dirigido por WS M arras, W K arwowski, JL Smith y L Pacholski. Varsovia: Taylor and Francis.

- . 1994. Production disturbances as an accident risk. En Advances in Agile M anufacturing, dirigido por PT $\mathrm{K}$ idd y W K arwowski. Amsterdam: IOS Press.

Etherton, JR, M L M yers. 1990. M achine safety research at NIOSH and future directions. Int J Ind Erg 6:163-174.

Freund, E, F Dierks, I R oßmann. 1993. U nterschungen zum Arbeitsschutz bei $M$ obilen $R$ ototern und $M$ ehrrobotersystemen [P ruebas de seguridad laboral de los robots móviles y los sistemas robóticos múltiples]. Dortmund: Schriftenreihe der Bundesanstalt für Arbeitsschutz.

Goble, W. 1992. Evaluating Control System Reliability. N ueva Y ork: Instrument Society of America.

Goodstein, LP, H B Anderson, SE O Isen (dirs.). 1988. $T$ asks, E rrors and $M$ ental M odels. Londres: Taylor and Francis.

Gryfe, Cl. 1988. Causes and prevention of falling. En International Fall Protection Symposium. O rlando: Sociedad Internacional para la Protección contra Caídas.

H ealth and Safety Executive. 1989. H ealth and safety statistics 1986-87. E mploy Gaz 97(2).

H einrich, HW, D Peterson, N Roos. 1980. Industrial Accident Prevention. 5a ed. Nueva Y ork: M CGraw$\mathrm{H}$ ill.

H ollnagel, E, D Woods. 1983. Cognitive systems engineering: $\mathrm{N}$ ew wine in new bottles. Int J $\mathrm{M}$ an $\mathrm{M}$ achine Stud 18:583-600.

H ölscher, H, J R ader. 1984. M ikrocomputer in der Sicherheitstechnik. R heinland: V erlag T gV -R einland.

H örte, S- $\AA$, P Lindberg. 1989. D iffusion and I mplementation of Advanced $M$ anufacturing T echnologies in Sweden. W orking paper N o. 198:16. Institute of Innovation and Technology.

Johnson, B. 1989. Design and Analysis of Fault Tolerant Digital Systems. N ueva Y ork: Addison W esley.

K idd, P. 1994. Skill-based automated manufacturing. En Organization and $M$ anagement of Advanced $M$ anufacturing Systems, dirigido por W Karwowski y G Salvendy. Nueva Y ork: Wiley.

K nowlton, RE. 1986. An Introduction to $\mathrm{H}$ azard and $\mathrm{Op}$ erability Studies: T he Guide W ord Approach. V ancouver, BC: Chemetics.

K uivanen, R. 1990. The impact on safety of disturbances in flexible manufacturing systems. En E rgo- nomics of $\mathrm{H}$ ybrid Automated Systems II, dirigido por W K arwowski y M Rahimi. Amsterdam: Elsevier.

Laeser, R P, WI M CLaughlin, DM W olff. 1987. Fernsteurerung und Fehlerkontrolle von Voyager 2. Spektrum der W issenshaft (1):S. 60-70.

Lan, A I Arteau, J-F Corbeil. 1994. Protection Against Falls from Above ground Billboards. Simposio internacional sobre la protección contra caídas, San Diego, California, 27-28 de octubre, 1994. Actas de la Sociedad Internacional para la Protección contra Caídas.

Langer, HJ, W K urfürst. 1985. E insatz von Sensoren zur Absicherung des R ückraumes von Großfahrzeugen [U tilización de sensores para asegurar la zona de marcha atrás de los grandes vehículos]. FB 605. D ortmund: Schriftenreihe der bundesanstalt für A rbeitsschutz.

Levenson, NG. 1986. Software safety: Why, what, and how. ACM Computer Surveys (2):S. 129-163.

M CM anus, T N . N.d. Confined Spaces. M anuscrito.

M ester, U, T Herwig, G Dönges, B Brodbeck, HD Bredow, M Behrens, U Ahrens. 1980. Gefahrenschutz durch passive Infrarot-Sensoren (II) [Protección contra peligros mediante sensores infrarrojos]. FB 243. Dortmund: Schriftenreihe der bundesanstalt für Arbeitsschutz.

Microsonic GmbH. 1996. Comunicado de la empresa. D ortmund, Alemania: M icrosonic.

M ohan, D, R Patel. 1992. D esign of safer agricultural equipment: Application of ergonomics and epidemiology. Int I Ind E rg 10:301-310.

National Fire Protection Association (NFPA). 1993. NFPA 306: Control of Gas H azards on Vessels. Q uincy, $M$ assachussetts: NFPA.

$\mathrm{N}$ ational Institute for $\mathrm{O}$ ccupational Safety and $\mathrm{H}$ ealth (NIOSH). 1994. W orker Deaths in Confined Spaces. Cincinnati, Ohio, Estados Unidos: DHHS/PHS/CDCP/NIOSH Pub. No. 94-103. NIOSH.

Neumann, PG. 1987. The $\mathrm{N}$ best (or worst) computer-related risk cases. IEEE T Syst M an Cyb. N ueva Y ork: S.11-13.

-.1994 . Illustrative risks to the public in the use of computer systems and related technologies. Software E ngin N otes SIGSOFT 19, N o. 1:16-29.

O ccupational Safety and $\mathrm{H}$ ealth Administration (OSH A). 1988. Selected O ccupational F atalities R elated to $\mathrm{W}$ elding and $\mathrm{Cutting}$ as $\mathrm{F}$ ound in Reports of $\mathrm{OSH} \mathrm{A} F$ atality/ Catastrophe Investigations. Washington, DC: OSHA.

O rganisme professionel de prévention du bâtiment et des travaux publics (O PPBT P). 1984. Les équipe ments individuels de protection contre les chutes de hauteur. Boulogne-Bilancourt, Francia: O PPBT P.

O rganización Internacional de Normalización (ISO). 1981. Agricultural and Forestry W heded T ractors. Protective Structures. Static T est M ethod and Acceptance Conditions. ISO 5700. Ginebra: ISO

- . 1990. Quality M anagement and Q uality Assurance Standards: Guidelines for the Application of ISO 9001 to the Development, Supply and M aintenance of Software. ISO 9000-3. Ginebra: ISO. 
-. 1991. Industrial Automation Systems- Safety of Inte grated $M$ anufacturing Systems- Basic Requirements (CD 11161). TC 184/WG 4. Ginebra: ISO.

-. 1994. Commercial Vehicles- Obstacle Detection Device during Reversing- R equirements and T ests. T echnical R eport TR 12155. Ginebra: ISO.

O rganización Internacional del Trabajo (OIT). 1965 Safety \& $\mathrm{H}$ ealth in A gricultural W ork. G inebra: OIT.

-. 1969. Safety and $H$ ealth in Forestry W ork. Ginebra: OIT.

-. 1976. Safe Construction and Operation of T ractors. An IL 0 C ode of Practice G inebra: OIT.

Organización para la Cooperación y el Desarrollo Económico (OCDE). 1987. Standard Codes for the Official T esting of Agricultural T ractors. París: OCDE.

Rasmussen, J. 1983. Skills, rules and knowledge: Agenda, signs and symbols, and other distinctions in human performance models. IEEE T ransactions on Systems, M an and Cybernetics. SM C 13(3): 257-266.

Reason, J. 1990. H uman Error. Nueva York: Cambridge U niversity Press.

R eese, CD, GR M ills. 1986. T rauma epidemiology of confined space fatalities and its application to intervention/ prevention now. En T he Changing $N$ ature of W ork and W orkforce. Cincinnati, O hio: NIOSH .

Reinert, D, G Reuss. 1991. Sicherheitstechnische Beurteilung und Prüfung mikroprozessorgesteuerter Sicherheitseinrichtungen. En BIA$\mathrm{H}$ andbuch. Sicherheitstechnisches Informationsund Arbeitsblatt 310222. Bielefeld: Erich Schmidt Verlag.

Schreiber, P, K K uhn. 1995. Informationstechnologie in der F ertigungstechnik [T ecnología de la Información en las técnicas de producción, serie del Instituto Federal de Salud y Seguridad en el Trabajo]. FB 717. Dortmund: Schriftenreihe der bundesanstalt für Arbeitsschutz.
Schreiber, P. 1990. Entwicklungsstand bei Rückraumwarneinrichtungen [Situación del desarrollo de los dispositivos de alerta en la zona de marcha atrás]. T echnischeÜ berwachung, N r. 4, A bril, S. 161.

Sheridan, T. 1987. Supervisory control. En H andbook of $H$ uman $F$ actors, dirigido por $G$. Salvendy. Nueva Y ork: Wiley.

Society of Automotive Engineers (SAE). 1974. O perator Protection for Industrial Equipment. SAE Standard j1042. Warrendale, Estados U nidos: SAE.

- . 1975. Performance Criteria for Rollover Protection. SAE Recommended Practice. SAE standard j1040a. Warrendale, Estados U nidos: SAE.

Springfeldt, B. 1993. E ffects of Occupational Safety Rules and $M$ easures with Special Regard to I njuries. Advantages of Automatically W orking Solutions. Estocolmo: R eal Instituto de Tecnología, Departamento de Ciencias del T rabajo.

Sugimoto, N. 1987. Subjects and problems of robot safety technology. En $\mathrm{O}$ ccupational Safety and $\mathrm{H}$ ealth in Automation and Robotics, dirigido por $\mathrm{K} \mathrm{N}$ oto. Londres: T aylor \& Francis. 175.

Sulowski, AC (dir.). 1991. F undamentals of $F$ all Protection. Toronto, Canadá: Sociedad Internacional para la Protección contra Caídas.

Wehner, T. 1992. Sicherheit als Fehlerfreundlichkeit. O pladen: W estdeutscher V erlag.

Zimolong, B, L Duda. 1992. Human error reduction strategies in advanced manufacturing systems. En $H$ uman-robot Interaction, dirigido por M Rahimi y W $\mathrm{K}$ arwowski. Londres: T aylor \& Francis.

\section{O tras lecturas recomendadas}

Börner, F, F K reutzkampf. 1994. Infälle und Störfälle, verursacht durch das Versagen von Steuerungen. En BIA-H andbuch. Sicherheit- stechnisches Informations-und Arbeitsblatt 330250. Bielefeld: Erich Schmidt.

Emery, FE. 1969. Systems Thinking. H armondsworth, Reino Unido: Penguin.

Grams, T. 1990. Denkfallen und Programmierfechler. Berlín: Springer.

M effert, K , J Germer. 1985. Einsatz von Rechnern für Sicherheitsaufgaben-Standortbestimmung. DieB G 5:S. 246-253.

Schreibwer, P, G Becker, W Dicke. 1985. Gefahrenschutz durch Kontaktmatten und-böden [Protección contra peligros utilizando colchonetas y suelos de contacto]. FB 414. Dortmund: Schriftenreihe der bundesanstalt für A rbeitsschutz.

System Safety Society. 1993. System Safety Analysis $\mathrm{H}$ andbook. Albuquerque, Nuevo M éxico, Estados Unidos: New M exico Chapter, System Safety Society.

Thomas, M. 1988. Should we trust computers? En SH ARE. Nijwegen, Países Bajos: Eur. Assoc.

US Nuclear R egulatory Commission. 1975. Reactor Safety Study. W ash 1400. Washington, DC: N uclear Regulatory Commission. (Publicado también en francés: Projet R asmussen. E tude de la sûreté des réacteurs, París 1975, D ocumentation française.)

Villemeur, A. 1988. Sûreté de fonctionnement des systèmes industriels. Fiabilité Facteurs humains. Informatisation [Seguridad del funcionamiento de los sistemas industriales. Fiabilidad. Factores humanos. Informatización]. París: Editions Eyrolles.

Yoshinobu, Sato. 1985. Safety Assessment of Automated Production Systems using $M$ icroelectronics. The Compre hensive L ogic M odels for the Analysis of Accidents $C$ aused by Robots. (Informes del Instituto de Investigación de la Seguridad Industrial, marzo 1985 (21-31), en japonés con un resumen y los títulos de las ilustraciones en inglés.) T okio: Instituto de Investigación de la Seguridad Industrial. 
Director del capítulo

J orma Saari

\section{Sumario}

Política de seguridad, liderazgo y cultura

Dan Petersen............................. 59.2

Cultura y gestión de la seguridad

$M$ arcel Simard.

Clima organizativo y seguridad

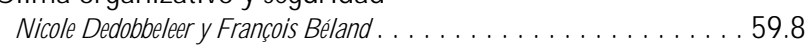

Proceso participativo de mejora del lugar de trabajo

J orma Saari . . . . . . . . . . . . . . . . . . . . . 59.12

M étodos de toma de decisiones en el campo de

la seguridad

Terje Sten. . . . . . . . . . . . . . . . . . . . 59.19

Percepción del riesgo

B ernhard Z imolong y R üdiger Trimpop . . . . . . . . . . . . 59.25

Aceptación de riesgos

R üdiger Trimpop y B ernhard Zimolong . . . . . . . . . . . . . . . . . . 59.32 


\section{- PolITICA DE SEGURIDAD, LIDERAZG 0 Y CULTURA}

Dan Petersen

El liderazgo y la cultura son los conceptos más relevantes de cuantos condicionan el logro de la perfección en la seguridad. La política de seguridad puede valorarse como más o menos importante, en función de la percepción del trabajador de la identificación y el apoyo cotidiano de la dirección a dicha política. Es frecuente que la dirección elabore una política de seguridad y luego no verifique si los directivos y supervisores la aplican cotidianamente en el trabajo.

\section{Cultura de seguridad y resultados}

Tradicionalmente se pensaba que un "programa de seguridad" constaba de determinados "elementos esenciales". En Estados U nidos, los organismos reguladores fijan pautas definitorias de dichos elementos (política, métodos, formación, inspección, investigación, etc.). En algunas provincias canadienses se definen 20 elementos esenciales, mientras que algunas organizaciones británicas propugnan la inclusión de treinta de estos elementos en los programas de seguridad. U n examen riguroso de los principios que subyacen en las distintas relaciones de elementos esenciales pone claramente de relieve que cada una de éstas constituye un simple reflejo de la opinión de un antiguo autor (como H einrich o Bird). Análogamente, los reglamentos aplicables a la programación suelen responder a la visión de un autor del pasado. Como estas opiniones no suelen estar respaldadas por investigación alguna, se producen situaciones en que los elementos esenciales funcionan en una organización y no en otra. Si realmente analizamos las investigaciones realizadas sobre la eficacia de los sistemas de seguridad, comenzamos a comprender que, aunque existen numerosos elementos de seguridad aplicables a los resultados de la política de seguridad, la percepción de la cultura por parte del trabajador es lo que determina la eficacia 0 inoperancia de un determinado elemento. En la bibliografía se citan diversos estudios que inducen a la conclusión de que no hay elementos "esenciales" u "obligados" en un sistema de seguridad.

Esto plantea algunos serios problemas, dado que en los reglamentos de seguridad se suele obligar a las organizaciones únicamente a "tener un programa de seguridad" compuesto por cinco, siete o cualquier otro número de elementos, cuando es evidente que alguno de los elementos prescritos no funcionan y suponen una pérdida de tiempo, trabajo y recursos que podrían aplicarse a tareas que contribuirían a reducir las pérdidas. Los resultados no están en función de los elementos considerados, sino del contexto cultural en que se aplican. En una cultura positiva hacia la seguridad prácticamente cualquier elemento funciona, y en una cultura de signo negativo casi ningún elemento produce buenos resultados.

\section{Crear cultura}

Si la cultura de la organización es tan importante, la labor de gestión de la seguridad se debe orientar en primer lugar a crear esa cultura, con objeto de que las medidas de seguridad que se establezcan produzcan resultados. La cultura se puede definir informalmente como "la forma de hacer las cosas en un lugar determinado". La cultura de seguridad es positiva si los trabajadores creen sinceramente que la seguridad es uno de los valores principales de la organización y perciben que ocupa un lugar importante entre las prioridades de la misma. La plantilla sólo adquiere esta conciencia si la dirección es creíble, esto es, si la letra de la política de seguridad se traduce en una experiencia cotidiana, si las decisiones de la dirección en relación con los gastos financieros reflejan un interés en invertir, no sólo en ganar más dinero, sino también en las personas, si el sistema de obligaciones y recompensas implantado por la dirección induce un rendimiento satisfactorio de la labor de los supervisores y mandos intermedios, si los trabajadores participan en la resolución de los problemas y la toma de decisiones, si existe un alto grado de confianza y lealtad entre trabajadores y dirección, si la comunicación entre ambos interlocutores es fluida y si se reconoce abiertamente la labor de los trabajadores.

En una cultura de seguridad positiva, como la anteriormente descrita, prácticamente todos los elementos del sistema de seguridad son eficaces. Ciertamente, las organizaciones que tienen una cultura adecuada apenas necesitan un "programa de seguridad", ya que ésta se integra en el proceso rutinario de gestión. El logro de una cultura positiva descansa en el cumplimiento de determinados criterios:

1. Es preciso establecer un sistema que sirva de cauce a la actividad cotidiana de los supervisores o de un equipo.

2. El sistema debe propiciar el desempeño de las tareas y responsabilidades de los mandos intermedios en las áreas siguientes:

- asegurar una conducta regular de los subordinados (supervisor o grupo);

- garantizar la calidad de esa conducta,

- realizar algunas actividades perfectamente definidas que muestren que la seguridad es tan importante que incluso los altos directivos hacen algo al respecto.

3. La alta dirección debe mostrar de forma ostensible, con su apoyo, que la seguridad disfruta de elevada prioridad en la organización.

4. Se debe permitir que todos los trabajadores que lo deseen participen en las principales actividades relacionadas con la seguridad.

5. El sistema de seguridad debe ser flexible y admitir alternativas en todos los niveles.

6. La plantilla debe valorar positivamente el trabajo de seguridad.

Estos seis criterios se pueden satisfacer con independencia de que el estilo de gestión sea autoritario 0 participativo y al margen del enfoque de la seguridad aplicado en la organización.

\section{Cultura y política de seguridad}

La mera existencia de una política de seguridad sirve de muy poco a menos que se complemente con unos sistemas que la hagan efectiva. Por ejemplo, si en dicha política los supervisores son responsables de la seguridad, esta disposición resulta inoperante si no se hace lo siguiente:

- Que la dirección aplique un sistema en el que las funciones relativas a la seguridad se definan claramente y se especifiquen las actividades que se deben realizar para desempeñar dichas funciones.

- Que los supervisores sepan desempeñar esas funciones con la ayuda de la dirección, confíen en su capacidad para desempeñarlas y las desempeñen efectivamente apoyados en una planificación y una formación adecuadas.

- Que se evalúe periódicamente el desempeño de las funciones especificadas (aunque el criterio de evaluación no debe basarse en la siniestralidad) y se obtenga una retroinformación que permita decidir si es o no preciso modificar las tareas.

- Que en el sistema de evaluación o en cualquier otro esquema rector de la actividad de la organización se prevea la concesión de recompensas por la ejecución de las tareas.

Estos criterios son aplicables en todos los niveles de la organización; en todos se deben definir las tareas, se deben establecer 
una medida válida del rendimiento (realización de las tareas) y un sistema de recompensas en función del rendimiento. Por tanto, la responsabilidad y no la política de seguridad es el factor determinante de la conducta en materia de seguridad. La responsabilidad es un elemento clave en la creación de cultura. La dirección únicamente adquiere credibilidad a los ojos de los trabajadores y éstos solamente se convencen de que la alta dirección tiene la intención de hacer cumplir los procedimientos de seguridad que implanta cuando perciben que, tanto la alta dirección, como los supervisores, desempeñan cotidianamente sus tareas respectivas en el ámbito de la seguridad.

\section{Liderazgo y seguridad}

De lo anterior se deduce lógicamente que el liderazgo es vital para lograr resultados en el campo de la seguridad, ya que genera la cultura que determina lo que funciona bien 0 mal en el esfuerzo de la organización en favor de la seguridad. Un buen líder comunica claramente los resultados que se persiguen y transmite con claridad lo que la organización piensa hacer para conseguirlos. El liderazgo es infinitamente más importante que la política, pues los mandos, con sus acciones y decisiones, envían mensajes claramente perceptibles en todos los niveles de la organización respecto a qué políticas son importantes y cuáles no lo son. En algunas organizaciones se promulgan políticas en las que la salud y la seguridad se definen como valores clave y luego se adoptan medidas y esquemas de recompensas que promueven lo contrario.

El liderazgo, a través de sus actuaciones, sistemas, medidas y recompensas, determina ineludiblemente el éxito o el fracaso de la política de seguridad de la organización. Esto nunca ha sido más evidente para todos los trabajadores de la industria que en el decenio de 1990. Nunca se ha ensalzado formalmente la importancia de la salud y la seguridad tanto como en estos últimos diez años. Al mismo tiempo, nunca antes se habían producido más recortes o "reajustes" ni más presión en favor del incremento de la producción y de la reducción de los costes, con las secuelas de mayor estrés, más horas extraordinarias forzadas, mayor carga de trabajo para menos trabajadores, mayor miedo al futuro y menos seguridad en el puesto de trabajo. L os reajustes han provocado la reducción del número de mandos intermedios y de supervisores, y han impuesto un mayor esfuerzo a los trabajadores (los actores principales de la seguridad). Existe la sensación generalizada de sobrecarga en todos los niveles de la organización. La sobrecarga provoca más accidentes, mayor fatiga física y psicológica, más casos de estrés, mayor número de lesiones por esfuerzo repetitivo y más trastornos por traumatismos acumulativos. Por otra parte, se ha producido un deterioro de las relaciones laborales en empresas que antes se caracterizaban por la tranquilidad y la confianza en la relación de los trabajadores con la dirección. En el antiguo contexto, era posible que los trabajadores "tocados" siguieran en su puesto. En cambio, si el trabajador teme por su futuro y observa cómo el número de directivos se reduce tanto que no hay supervisión, tienen la sensación de que la empresa se despreocupa de ellos, con el consiguiente deterioro de la cultura de seguridad.

\section{Análisis de desfases}

En numerosas organizaciones se aplica un modelo sencillo, conocido como análisis de desfases e integrado por tres fases: a) decidir dónde se quiere estar, b) determinar dónde se está y c) elegir el modo de llegar desde donde se está hasta donde se quiere estar, esto es, de "llenar el vacío".

$\mathrm{D}$ ecidir dónde se quiere estar. ¿Q ué perfil prefiere para el sistema de seguridad de su organización? Se han formulado seis criterios de evaluación del sistema de seguridad de una organización. Si se desestiman esos criterios, es preciso adoptar otros baremos de evaluación del sistema de seguridad de la organización. En este sentido, puede ser interesante considerar las siete variables de la eficacia derivadas del entorno organizativo enunciadas por el Dr. Rensis Likert (1967), quien mostró que, cuanto mejor es una organización en determinados campos, más probable es su éxito en el aspecto económico y, por lo tanto, en el de la seguridad. Estas variables del entorno son las siguientes:

- fomentar la confianza de los trabajadores y el interés global de la dirección por el conocimiento de los problemas de la seguridad;

- facilitar formación y apoyo donde y cuando se precise;

- impartir los conocimientos precisos para solucionar los problemas;

- fomentar el nivel de confianza necesario, para hacer posible la transferencia de información entre la dirección y los subordinados;

- recabar las opiniones e ideas de los trabajadores;

- facilitar el acceso a la alta dirección,

- recompensar al trabajador, más por un trabajo de calidad que por limitarse a dar respuestas.

Existen otros criterios de autovaloración, como los formulados por Zembroski (1991) para determinar la probabilidad de que se produzcan siniestros.

Determinar dónde se está. Esta es, posiblemente, la fase más difícil. En un principio se consideraba posible medir la eficacia del sistema de seguridad contabilizando el número de lesiones o de una determinada categoría de ellas (lesiones registrables, lesiones que producen pérdida de horas de trabajo, índices de frecuencia, etc.). L a escasez de datos disponibles les resta validez estadística. En los decenios de 1950 y 1960, los investigadores fueron conscientes de esta circunstancia y se distanciaron del método de cuantificación de los siniestros y se esforzaron por evaluar la eficacia de los sistemas de seguridad mediante auditorías. Se trataba de definir previamente lo que debía hacerse en una organización para obtener resultados y luego determinar, a partir de mediciones, hasta qué punto se habían realizado las acciones previstas.

Durante años, se presumió que los resultados de las auditorías permitían prever los resultados de la política de seguridad y que, cuanto mejores fuesen los resultados de las auditorías realizadas en un año, menor sería la tasa de accidentes al año siguiente. Los estudios realizados nos permiten afirmar ahora que no existe una correlación estrecha (si existe) entre los resultados de las auditorías y el nivel de seguridad. Dichos estudios indican que la mayoría de las auditorías (tanto externas, como, a veces, diseñadas internamente) tienen mucho más que ver con el cumplimiento de las normas que con el nivel de seguridad. Diversos estudios y publicaciones corroboran esta afirmación.

En diferentes estudios en los que los resultados de las auditorías se correlacionan con la frecuencia de las lesiones en grandes empresas a lo largo de diversos períodos de tiempo (con objeto de determinar el valor estadístico de los registros de accidentes) se ha establecido un valor cero - que, en algunos casos, es negativo- para dicha correlación. En cambio, las auditorías examinadas en dichos estudios arrojan una correlación positiva con la observancia de los reglamentos.

\section{Superar el desfase}

Existe únicamente un pequeño número de criterios válidos de evaluación de los resultados de la política de seguridad (esto es, que permitan correlacionar efectivamente la incidencia real de los 
accidentes en grandes empresas dentro de unos horizontes temporales amplios) que se puedan utilizar para "Ilenar el vacío".

- muestreo de comportamientos;

- entrevistas en profundidad con los trabajadores,

- encuestas de percepción.

Q uizás el criterio que merezca mayor atención sea la encuesta de percepción, que se utiliza para evaluar el estado de la cultura de seguridad de cualquier organización en un momento dado. En esta encuesta se perfilan las principales cuestiones de seguridad y se definen claramente las eventuales divergencias entre los trabajadores y la dirección respecto a la eficacia de los programas de seguridad de la empresa.

La encuesta se inicia con una breve serie de preguntas demográficas que se pueden utilizar para construir gráficos y tablas que reflejen los resultados (véase la Figura 59.1). N ormalmente se pregunta a los participantes sobre su categoría laboral, su lugar de trabajo y, quizás, también, sobre su profesión. En ningún momento se formulan preguntas a los trabajadores que faciliten su identificación por parte de las personas que evalúan los resultados.

La segunda parte de la encuesta consiste en una batería de preguntas. El objeto de las preguntas es conocer las preocupaciones de los trabajadores en relación con diversos aspectos de la seguridad. Cada pregunta puede influir en la valoración de más de un aspecto. Se calcula el porcentaje acumulado de respuestas positivas respecto a cada aspecto. Los porcentajes correspondientes a los distintos aspectos se plasman en un gráfico (véase la Figura 59.1) en el que los resultados se reflejan en orden descendente de valoración positiva por parte de los trabajadores. Los aspectos indicados a la derecha del gráfico son aquéllos que los trabajadores valoran como menos positivos y, por lo tanto, los que precisan más mejoras.

\section{Resumen}

M ucho se ha aprendido en estos últimos años respecto a lo que determina la eficacia de un sistema de seguridad. Se acepta que la clave está en la cultura. La percepción de la cultura de la organización por parte de sus trabajadores dicta el comportamiento de éstos y, por lo tanto, la cultura determina si un determinado elemento del programa de seguridad es o no eficaz.

La cultura no se crea mediante una política escrita, sino a través de un liderazgo que se traduce en actuaciones y decisiones

Figura 59.1 - Ejemplo de resultados de las encuestas sobre percepciones.

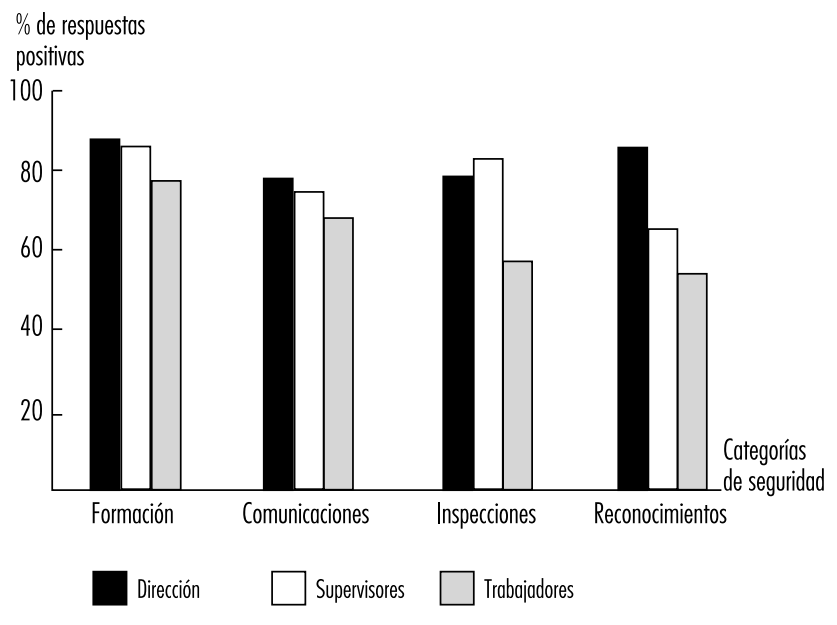

cotidianas, y mediante la aplicación de sistemas que encaucen la actividad (la conducta) de directivos, supervisores y equipos de trabajo en el campo de la seguridad. Es posible construir una cultura positiva mediante la implantación de sistemas de responsabilidad que aseguren las conductas y a través de esquemas que posibiliten, promuevan y hagan efectiva la participación del trabajador. Además, la cultura se puede evaluar válidamente a través de encuestas de percepción, y es posible mejorarla una vez que la organización determine dónde quiere estar.

\section{CULTURA Y GESTION DE LA SEGURIDAD}

M arcel Simard

La cultura de seguridad es un concepto nuevo para los profesionales de la seguridad y los investigadores universitarios. En la cultura de seguridad se pueden incluir otros conceptos relativos a los aspectos culturales de la seguridad en el trabajo, como los comportamientos y actitudes hacia la seguridad y el clima de seguridad en el lugar de trabajo, que se suelen manejar con más frecuencia y están perfectamente estudiados.

Se plantea la cuestión de si la cultura de seguridad es, simplemente, una nueva denominación de ideas antiguas o si posee un contenido propio, capaz de enriquecer nuestro conocimiento de la dinámica de la seguridad en las organizaciones. En la primera sección de este artículo se responde a ello definiendo la cultura de seguridad y examinando sus posibles implicaciones.

En relación con la cultura de seguridad cabe plantear igualmente la cuestión de su relación con los resultados obtenidos por las empresas en materia de seguridad. Es sabido que entre empresas similares que pertenecen a la misma categoría de riesgo pueden producirse sensibles divergencias en cuanto a los resultados efectivos en materia de seguridad. ¿Constituye la cultura de seguridad un factor determinante de la eficacia de la política de seguridad? En caso afirmativo, ¿qué cultura de seguridad contribuye efectivamente al logro de los efectos deseados? Ambos interrogantes se abordan en la segunda sección del presente artículo mediante la revisión de algunos datos empíricos de los efectos de la cultura de seguridad en la conducta.

En la tercera sección se aborda la cuestión práctica de la gestión de la cultura de seguridad, con objeto de ayudar a los directivos y líderes de las organizaciones a crear una cultura de seguridad que contribuya a reducir los accidentes de trabajo.

\section{Cultura de seguridad: concepto y realidades}

EI concepto de cultura de seguridad carece de una definición precisa y atañe a un amplio espectro de fenómenos. Algunos de estos fenómenos han sido parcialmente estudiados, como el comportamiento y las actitudes de directivos y trabajadores ante el riesgo y la seguridad (Andriessen 1978; Cru y Dejours 1983; D ejours 1992; D odier 1985; E akin 1992; Eyssen, Eakin-H offman y Spengler 1980; $\mathrm{H}$ aas 1977). Estos estudios constituyen fuentes de información valiosas sobre el substrato social y de organización de los diferentes comportamientos y actitudes frente a la seguridad (Simard 1988). N o obstante, al centrarse en los componentes de la organización, como los directivos y los trabajadores, pasan por alto la cuestión más general del concepto mismo de la cultura de seguridad, que caracteriza a las organizaciones.

U na línea de investigación más cercana al enfoque global propio de la cultura de seguridad es la constituida por los estudios del clima de seguridad realizados en el decenio de 1980. La noción de clima de seguridad se refiere a la percepción que 
tienen los trabajadores de su entorno laboral, especialmente del interés y del nivel de actuación de la dirección en el campo de la seguridad, y de su propia participación en el control de los riesgos en el lugar de trabajo (Brown y H olmes 1986; Dedobbeleer y Béland 1991; Zohar 1980). En teoría se cree que los trabajadores desarrollan y utilizan estos conjuntos de percepciones con objeto de determinar lo que se espera de ellos en el entorno de la empresa, y se comportan en consecuencia. Aunque desde una perspectiva psicológica se consideran características individuales, las percepciones que constituyen el clima de seguridad permiten evaluar válidamente la reacción habitual de los trabajadores ante una característica organizativa generada social y culturalmente, en este caso, por parte de los responsables de la seguridad en el trabajo. Por consiguiente, aunque el clima de seguridad no abarca totalmente la cultura de seguridad, se puede valorar como una fuente de información sobre la cultura de seguridad en el lugar de trabajo.

El concepto de la cultura de seguridad comprende: a) los valores, creencias y principios en los que se basa el sistema de gestión de la seguridad, y b) la serie de comportamientos y prácticas que ilustran y refuerzan esos principios básicos. Estas creencias y prácticas constituyen significados generados por los miembros de la organización en la elaboración de estrategias aplicables a cuestiones como los riesgos profesionales, los accidentes y la seguridad en el trabajo. Estos significados (creencias y prácticas), no sólo son compartidos en cierta medida por los interlocutores en el lugar de trabajo, sino que constituyen una fuente primordial de actividad motivada y coordinada en el campo de la seguridad en el trabajo. Se infiere de lo anterior la necesidad de diferenciar la cultura, tanto de las estructuras concretas de seguridad en el trabajo (como la existencia de un departamento de seguridad o de un comité paritario de salud y seguridad, etc.), como de los programas vigentes de seguridad en el trabajo (consistentes en la actividad de detección y control de riesgos del tipo de la investigación de accidentes, la inspección del lugar de trabajo, el análisis de la seguridad en el trabajo, etc).

Petersen (1993) aduce que la cultura de seguridad "subyace en la forma de aplicar [...] los sistemas y dispositivos de seguridad" e ilustra esta afirmación con el ejemplo siguiente:

Dos empresas aplicaban una política similar de investigación de accidentes e incidentes en el marco de sus respectivos programas de seguridad. En ambas empresas se produjeron sendos incidentes similares y se acordó realizar una investigación. En la primera empresa, el supervisor descubrió que el comportamiento de los trabajadores era peligroso, les advirtió inmediatamente que habían vulnerado las normas de seguridad y procedió a actualizar los respectivos historiales de seguridad. El mando superior felicitó al supervisor por velar por la seguridad en el lugar de trabajo. En la segunda empresa, el supervisor tuvo en cuenta las circunstancias que habían rodeado el incidente, concretamente, que el operario se encontraba sometido a una fuerte presión para cumplir el calendario de producción al cabo de un período de problemas con el mantenimiento mecánico que habían ralentizado la producción, en una coyuntura en la que las recientes reducciones de plantilla tenían a los trabajadores preocupados por su seguridad en el puesto de trabajo y habían desviado su atención de la política de seguridad. Los directivos de la empresa reconocieron la existencia de los problemas de mantenimiento y celebraron una reunión con los trabajadores para analizar la situación financiera y recabar del personal que cumpliese la normas de seguridad y contribuyese a incrementar la producción para garantizar la viabilidad de la empresa.
"¿Por qué" - se pregunta Petersen- "una empresa culpa al trabajador, rellena los impresos de investigación de accidentes y vuelve a la rutina de trabajo, mientras que la otra empresa reconoce la necesidad de analizar el fallo en todos los niveles de la organización?". La diferencia radica, más en la cultura de seguridad de cada entidad, que en los propios programas de seguridad, si bien la connotación cultural de la aplicación de los programas y los valores y creencias que sustentan la praxis efectiva, determinan en buena medida el contenido y el efecto prácticos del programa.

Del ejemplo anterior se deduce que la alta dirección es un elemento clave cuyos principios y actuaciones en el campo de la seguridad en el trabajo contribuyen en gran medida a crear la cultura de seguridad de la organización. En ambos casos, los supervisores obraron de acuerdo con lo que consideraban "el modo correcto de actuar", consideración que se vio reforzada por la intervención subsiguiente de la alta dirección. Evidentemente, en el primer caso, la dirección se decantó por una interpretación "al pie de la letra", esto es, por una concepción burocrática y jerárquica del control de la seguridad, mientras que, en el segundo caso, se prefirió un enfoque más amplio y favorable al compromiso de la dirección y a la participación de la plantilla en la labor de seguridad en el trabajo. Caben otras concepciones culturales. Por ejemplo, Eakin (1992) observa que en las empresas muy pequeñas es frecuente que la dirección delegue plenamente en los trabajadores la responsabilidad de velar por la seguridad.

Los ejemplos anteriores suscitan la importante cuestión de la dinámica de la cultura de seguridad y de los procesos que intervienen en la creación, la conservación y la modificación de la cultura organizativa en el campo de la seguridad en el trabajo. U no de estos procesos es el liderazgo ejercido por los altos directivos y otros líderes de la organización, como los delegados sindicales. El concepto de la cultura organizativa ha inducido una reconsideración del liderazgo en las organizaciones al poner de relieve la importancia de la función que desempeñan, tanto los líderes naturales, como los dirigentes de la organización, al demostrar su compromiso con los valores y difundir conceptos compartidos entre los miembros de la organización (Nadler y Tushman 1990; Schein 1985). El ejemplo de la primera compañía citada por Petersen ilustra una situación en la que el liderazgo de la dirección era estrictamente estructural y se limitaba a la fijación y exigencia del cumplimiento del programa y las normas de seguridad. En la segunda compañía, los altos directivos demostraron poseer un concepto más amplio de la seguridad, al combinar la función estructural consistente en conceder algún tiempo para realizar el trabajo de mantenimiento necesario, con una función más personal consistente en reunirse con los trabajadores para analizar los problemas de seguridad y de producción en una difícil coyuntura financiera. Por último, según el estudio de Eakin, la alta dirección de algunas pequeñas empresas aparentemente no ejerce liderazgo alguno.

Los mandos intermedios y supervisores también desempeñan una función sumamente importante en la dinámica cultural de la seguridad en el trabajo. En su estudio de más de un millar de supervisores de primera línea, Simard y Marchand (1994) observan que la inmensa mayoría de los supervisores están implicados en la seguridad en el trabajo, si bien el grado de participación puede variar. En algunos lugares de trabajo predomina lo que los autores denominan "intervención jerárquica", orientada principalmente al control, mientras que en otras organizaciones el esquema dominante es el de la "intervención participativa", ya que en ellas los supervisores permiten y promueven la participación de los trabajadores en la actividad de 
prevención de accidentes; por último, en un pequeño porcentaje de organizaciones, los supervisores se abstienen y dejan la seguridad en manos de los trabajadores. Se observa claramente la correlación entre estas modalidades de gestión de la seguridad por parte de los supervisores y lo que se ha dicho anteriormente respecto a las modalidades de liderazgo que los mandos superiores ejercen en la seguridad en el trabajo. No obstante, en el estudio de Simard y $M$ archand se pone de relieve empíricamente que dicha correlación no es perfecta, circunstancia ésta que avala la tesis de Petersen de que un serio problema que muchos ejecutivos afrontan es el de crear una cultura de seguridad orientada a las personas entre los directivos intermedios y los supervisores. Es posible que el problema se deba en parte a que el interés de la mayoría de los mandos inferiores está claramente centrado en la producción y tienden a culpar a los trabajadores de los accidentes y fallos de la seguridad que se producen en el lugar de trabajo (Dej oy 1987 y 1994; Taylor 1981).

Este protagonismo de la dirección no supone en modo alguno una infravaloración de la función de los trabajadores en la dinámica de la cultura de seguridad en el lugar de trabajo. La motivación y el comportamiento de los trabajadores en relación con la seguridad en el trabajo son una función de su percepción de la prioridad que los supervisores y directivos conceden a la seguridad en el trabajo (Andriessen 1978). Esta línea descendente de influencia se ha podido contrastar en numerosas experiencias de comportamiento en las que se ha utilizado una retroinformación (en inglés: fed-back) positiva por parte de los directivos para reforzar el cumplimiento de las normas escritas de seguridad (M cA fee y Winn 1989; Näsänen y Saari 1987). Además, Ios trabajadores suelen crear espontáneamente grupos de trabajo allí donde la organización del trabajo les ofrece unas condiciones favorables para intervenir en la gestión y regulación, formal e informal, de la seguridad en el lugar de trabajo (Cru y Dejours 1983; Dejours 1992; D wyer 1992). La dirección puede aprovechar este último esquema de comportamiento de los trabajadores - más orientado hacia las iniciativas de los grupos de trabajo en el campo de la seguridad- y la capacidad de autogestión de los mismos, con objeto de promover la participación de la plantilla en la seguridad en el proceso de desarrollo de una cultura de seguridad en el lugar de trabajo.

\section{Cultura de seguridad y resultados en el ámbito de la seguridad}

Existe una creciente evidencia empírica del influjo de la cultura de seguridad sobre resultados en este campo. Se han realizado numerosos estudios comparativos globales de las características de las empresas que gozan de una baja tasa de accidentes respecto de las organizaciones que sufren tasas de accidentes superiores a la media. U na de las conclusiones más persistentes de estos estudios - realizados, tanto en naciones industrializadas, como en países en vías de desarrollo- es la importancia del compromiso de la alta dirección con la seguridad y su liderazgo en las actuaciones relativas a la seguridad (Chew 1988; H unt y Habeck 1993; Shannon y cols. 1992; Smith y cols. 1978). Asimismo, en la mayoría de los estudios se pone de manifiesto que en las empresas que gozan de bajas tasas de accidentes la implicación personal de los mandos superiores en la seguridad en el trabajo es, por lo menos, tan importante como las decisiones que toman en la configuración del sistema de gestión de la seguridad (cuyas decisiones afectan, por ejemplo, a la aplicación de los recursos financieros y profesionales, a la promulgación de políticas y programas, etc.). Según Smith y cols. (1978), la implicación activa de la dirección contribuye a motivar, tanto a los diversos niveles de la línea de mando - al estimular su interés a través de la participación-, como a los trabajadores, al mostrar la preocupación de la dirección por su bienestar. Los resultados de numerosos estudios realizados muestran que uno de los medios más eficaces de difundir los valores humanos y la filosofía orientada a las personas de la dirección consiste en participar en las actividades más visibles, como las inspecciones de seguridad en el lugar de trabajo y las reuniones con los trabajadores.

En diversos estudios relativos a la relación entre la cultura de seguridad y la actuación en este campo se hace hincapié en el comportamiento de los supervisores de línea, observándose que la intervención de los supervisores en un sistema participativo de la seguridad se suele asociar a unos índices de siniestralidad más bajos (C hew 1988; M attila, H yttinen y R antanen 1994; Simard y Marchand 1994; Smith y cols. 1978). Este esquema de comportamiento de los supervisores se concreta en intercambios y comunicaciones frecuentes e informales con sus trabajadores en relación con la seguridad en el trabajo, prestando especial atención a la actuación de los trabajadores en este campo y ofreciendo retroinformación positiva, además de promover la participación de los trabajadores en la prevención de accidentes. Por otra parte, la eficiencia de la supervisión en el ámbito de la seguridad descansa sobre idénticos presupuestos que la supervisión eficaz de las operaciones productivas, lo que avala la tesis de que existe una correlación estrecha entre una gestión eficiente de la seguridad y una buena gestión global.

Se ha demostrado que una plantilla mentalizada hacia la seguridad contribuye positivamente a los resultados de la empresa en este campo. No obstante, la percepción y la concepción de la seguridad por parte de los trabajadores no deben limitarse a la prevención y a la observancia de las normas de seguridad dictadas por la dirección, aunque numerosas experiencias de comportamiento han puesto de manifiesto que un mayor grado de cumplimiento de las medidas de seguridad por parte de la plantilla contribuye a reducir los índices de siniestralidad (Saari 1990). Existen evidencias de que un aumento en la capacidad de decisión (empowerment) y participación de la plantilla contribuyen al éxito de los programas de seguridad en el trabajo. En algunos estudios se ha puesto igualmente de relieve que, el funcionamiento eficaz de los comités paritarios de salud y seguridad (integrado por personas suficientemente formadas en la seguridad en el trabajo, cooperan en la realización de las labores del comité y disfrutan del apoyo de sus compañeros) contribuye significativamente al éxito de la actividad de la empresa en el campo de la seguridad (Chew 1988; Rees 1988; Tuohy y Simard 1992). Análogamente, a nivel de trabajadores de base, los equipos de trabajo que se sienten alentados por la dirección a practicar la seguridad en equipo y la autorregulación obtienen mejores resultados en el campo de la seguridad que los equipos sometidos a sistemas autoritarios y a la desintegración de su identidad (D wyer 1992; Lanier 1992).

Puede inferirse de la información científica anteriormente citada que una determinada cultura de seguridad influye en mayor medida en los resultados obtenidos. En resumen, en esta cultura de seguridad se combinan el liderazgo y el apoyo de la alta dirección, el compromiso de los directivos de línea y la participación de los trabajadores en la seguridad en el trabajo. Esta cultura de seguridad es especialmente eficaz en las que pueden considerarse las dos dimensiones centrales del concepto mismo de la cultura de seguridad: la función de la seguridad y la participación en la seguridad, como se ilustra en la Figura 59.2.

La función de la seguridad es el grado de prioridad concedido a la seguridad en el trabajo en los objetivos de la empresa. En la literatura dedicada a la cultura organizativa se subraya la importancia de una definición explícita y compartida de una función que emane de los valores fundamentales de la organización y que les sirva de apoyo (Denison 1990). Por consiguiente, la función de la seguridad refleja la medida en que la alta dirección reconoce la seguridad y salud en el trabajo como uno de los 
valores fundamentales de la empresa, y el grado en que emplea su liderazgo para impulsar la incorporación de este valor a los esquemas y actuaciones de la dirección. Por tanto, cabe formular la hipótesis de que un elevado sentido de la función de la seguridad surte unos efectos positivos sobre los resultados en este campo, dado que impulsa a cada trabajador a adoptar un comportamiento orientado a los objetivos de la seguridad en el trabajo, además de facilitar la coordinación mediante la fijación de un objetivo común y de un criterio objetivo que guíe el comportamiento.

La participación en la seguridad consiste en el trabajo conjunto de supervisores y empleados en el desarrollo de la seguridad en equipo en la línea de producción. En la literatura relativa a la cultura organizativa se sustenta la tesis de que unos niveles elevados de intervención y participación contribuyen a los resultados al fomentar entre los miembros de la organización un sentido de propiedad y responsabilidad conducente a una mayor participación voluntaria que, a su vez, facilita la coordinación del comportamiento y reduce la necesidad de aplicar sistemas formales de control burocrático (Denison 1990). Además, en algunos estudios se muestra que la participación puede constituir tanto una herramienta de la dirección para conseguir una actuación eficaz, como un instrumento de los trabajadores para mejorar el medio ambiente de trabajo (Lawler 1986; Walton 1986).

Como se indica en la Figura 59.2, puede decirse que en los lugares de trabajo caracterizados por la presencia de un nivel elevado de ambas dimensiones existe lo que se denomina una cultura de seguridad integral, lo que implica que la seguridad en el trabajo constituye un valor fundamental de la cultura de la organización y se integra en el comportamiento de todos los miembros de la organización, con lo que se refuerza la participación de todos, desde la dirección hasta los trabajadores de fase. Las pruebas empíricas anteriormente mencionadas avalan la hipótesis de que esta cultura de seguridad produce mejores resultados en la seguridad que otras culturas.

\section{Gestión de una cultura de seguridad integral}

El primer requisito de una gestión de la cultura de seguridad integral es su incorporación por parte de la dirección a la cultura de

Figura 59.2 - Tipología de las culturas de la seguridad.

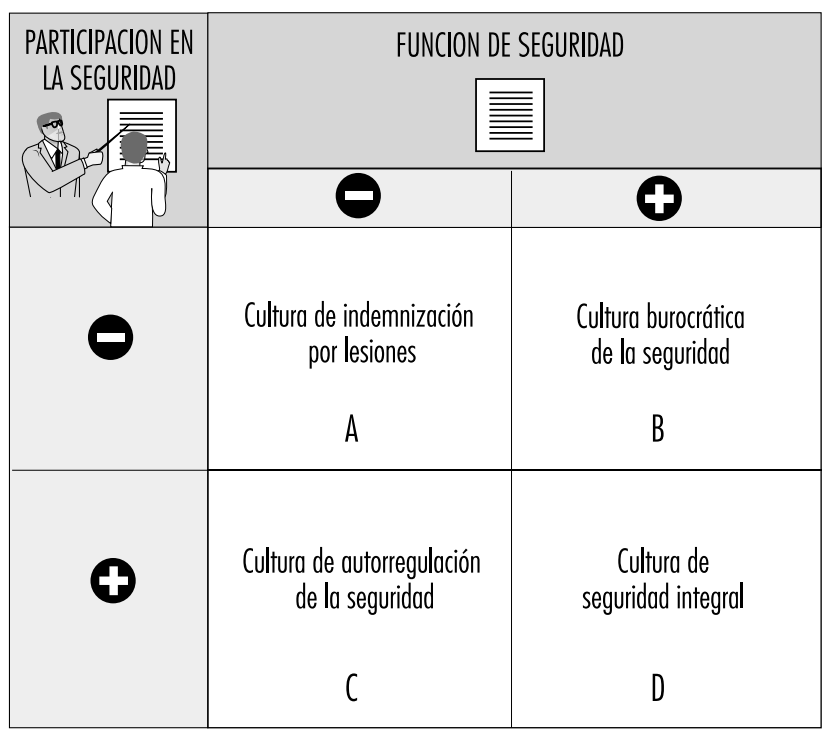

la empresa. No es una tarea fácil. Va más allá de la adopción de una política oficial que ponga de relieve el valor fundamental y la prioridad concedidos a la seguridad en el trabajo y a la filosofía de su gestión, si bien es cierto que la incorporación de la seguridad en el trabajo a los valores básicos de la organización es la piedra angular de la creación de una cultura de seguridad integral. Evidentemente, la dirección debe ser consciente de que esta política constituye el punto de partida de un importante proceso de cambio de la organización, ya que la mayoría de las empresas no funcionan aún de acuerdo con una cultura de seguridad integral. Por supuesto, los detalles de la estrategia de cambio varían en función de la naturaleza de la cultura de seguridad existente (véanse las celdas A, B y C de la Figura 59.2). En cualquier caso, una de las condiciones principales es que la alta dirección se comporte en consonancia con esa política (en otras palabras, que practique lo que predica). Esta congruencia se enmarca en el liderazgo personal que los altos directivos deben ejercer en la aplicación de esa política. 0 tro aspecto fundamental consiste en que la alta dirección facilite la estructuración o la reestructuración de diversos sistemas estructurados de gestión con objeto de sustentar la construcción de una cultura de seguridad integral. Por ejemplo, si ahora domina una cultura burocrática de la seguridad, habrá que reorientar la función del personal de seguridad y del comité paritario de salud y seguridad en el sentido de apoyar una mayor participación de los supervisores y los equipos de trabajo en la labor de seguridad. I gualmente, es preciso adaptar el sistema de evaluación de los resultados en el sentido de incorporar la responsabilidad de los directivos intermedios y la actuación de los equipos de seguridad en el trabajo.

Los directivos de los niveles inferiores, especialmente los supervisores, desempeñan igualmente una función decisiva en la gestión de una cultura integral de la seguridad. M ás concretamente, deben asumir la responsabilidad de la actuación de sus equipos de trabajo en el campo de la seguridad y promover la participación activa de los trabajadores en la labor de seguridad en el trabajo. Según Petersen (1993), la mayoría de los directivos de los niveles inferiores suelen mostrarse escépticos respecto a la seguridad, al tener que afrontar la realidad de los mensajes contradictorios transmitidos por la dirección y de la necesidad de aplicar una serie de programas que pasan sin dejar huella. Por consiguiente, la forja de una cultura de seguridad integral suele exigir la modificación de las pautas de comportamiento de los supervisores en el campo de la seguridad.

Según un estudio reciente de Simard y M archand (1995), una concepción sistemática de la modificación del comportamiento de los supervisores constituye el medio más eficaz de materializar el cambio. Esta concepción se traduce en una serie de medidas positivas dirigidas a la resolución de los tres principales problemas del proceso de cambio: a) la resistencia de las personas al cambio, b) la adaptación de los actuales sistemas formales de gestión para que sustenten el proceso de cambio, y c) el reajuste de los procesos informales, tanto políticos como culturales, de la organización. EI liderazgo personal y estructural de los altos directivos aludido en el párrafo anterior puede contribuir a la resolución de los dos problemas últimamente citados. No obstante, en los lugares de trabajo con presencia sindical, este liderazgo debe servir para configurar la dinámica política de la organización en el sentido de promover un consenso con los dirigentes sindicales que posibilite el desarrollo de una gestión participativa de la seguridad en la planta de producción. Por lo que respecta a la resistencia de los supervisores al cambio, el problema no se debe abordar con un criterio autoritario y de control, sino mediante un proceso de consultas que facilite la participación de los supervisores en la dinámica del cambio y el desarrollo de un sentimiento de propiedad. Se suelen utilizar técnicas del tipo de los grupos de interés y de los 
comités ad hoc - que sirven de foro para que los supervisores y los grupos de trabajo manifiesten sus opiniones sobre la gestión de la seguridad y aborden la resolución de los problemas- en combinación con la necesaria formación de los supervisores en el ejercicio de una supervisión participativa y eficaz.

Es difícil concebir una cultura de seguridad en el lugar de trabajo realmente integral sin un comité paritario de salud y seguridad o un delegado de prevención designado por los trabajadores. No obstante, en muchas naciones industrializadas y en algunos países en vías de desarrollo se han promulgado leyes y reglamentos destinados a promover 0 , incluso, exigir la creación de estos comités y delegados. Existe, sin embargo, el riesgo de que estos órganos se conviertan en una mera delegación de poder de los trabajadores de base en lo que respecta a su apoderamiento y participación en materia de seguridad en el trabajo, contribuyendo así a reforzar una cultura burocrática. Para propiciar el desarrollo de una cultura de seguridad integral, los comités conjuntos y los delegados deben promover el desarrollo de un sistema descentralizado de gestión de la seguridad, por ejemplo: a) impulsando actividades que fomenten la sensibilización de los trabajadores respecto a los peligros existentes en el lugar de trabajo y a la aceptación de riesgos; b) desarrollando programas y procedimientos que capaciten a los supervisores y equipos de trabajo para solucionar muchos de los problemas de seguridad que se producen en el ámbito de la línea de producción; c) participando en el proceso de evaluación de la actuación en el campo de la seguridad, y d) suministrando retroinformación de apoyo a los supervisores y trabajadores.

0 tra potente herramienta de difusión de una cultura de seguridad integral entre los trabajadores es la encuesta de percepción. Los trabajadores suelen conocer dónde residen los problemas de seguridad, pero, como nadie les pide su opinión, se resisten a participar en los programas de seguridad. U na encuesta anónima de percepción permite superar este círculo vicioso y fomenta el interés de los trabajadores por la seguridad, al tiempo que brinda a la alta dirección una retroinformación que puede servir para mejorar la gestión del programa de seguridad. La encuesta puede consistir en una entrevista combinada con un cuestionario que se suministra a la totalidad de la plantilla o a una muestra significativa de la misma (Bailey 1993; Petersen 1993). El seguimiento de la encuesta es fundamental para el desarrollo de una cultura de seguridad integral. U na vez conocidos los datos, la alta dirección aborda el proceso de cambio mediante la creación de grupos de trabajo ad hoc en los que participa el personal de todos los niveles de la organización, incluidos los trabajadores. Esto permite valorar en profundidad los problemas identificados en la encuesta y formular recomendaciones sobre el modo de mejorar los aspectos perfectibles de la gestión de la seguridad. Esta encuesta de percepción se puede realizar todos los años o con una frecuencia bienal, con objeto de evaluar periódicamente los progresos del sistema de gestión y de la cultura de seguridad.

\section{- CLIMA O RGANIZATIVO Y SEG URIDAD}

\section{Nicole Dedobbeleer y François Béland}

Vivimos en una época de nuevas tecnologías y de sistemas de producción crecientemente complejos, en la que las fluctuaciones de la economía mundial, las exigencias de los clientes y los acuerdos comerciales influyen en las relaciones de las organizaciones empresariales (M oravec 1994). La industria afronta nuevos desafíos en la creación y conservación de un medio ambiente de trabajo seguro y saludable. En diversos estudios realizados se han valorado, tanto el compromiso y el interés de la dirección en la seguridad en el trabajo, como el esfuerzo de los directivos en ese campo, como elementos clave del sistema de seguridad ( $M$ attila, $H$ yttinen y Rantanen 1994; Dedobbeleer y Béland 1989; Smith 1989; H einrich, Petersen y Roos 1980; Simonds y ShafaiSharai 1977; K omaki 1986; Smith y cols. 1978).

Según $\mathrm{H}$ ansen (1993a) el compromiso de la dirección con la seguridad no es suficiente si se traduce en una actitud pasiva; únicamente un liderazgo ostensible y activo que fomente un clima favorable a la actuación garantiza el logro de la seguridad en el lugar de trabajo. Rogers (1961) indica que "si un administrador, un mando militar o un líder empresarial fomenta este tipo de clima dentro de la organización, el personal se motiva y se vuelve más creativo y capaz de afrontar los nuevos problemas, más esencialmente colaborador". Por tanto, el liderazgo de la seguridad se percibe desde esta perspectiva como la creación de un clima propicio a valorar la seguridad: un clima de seguridad.

Existen escasos estudios dedicados al concepto del clima de seguridad (Zohar 1980; Brown y Holmes 1986; Dedobbeleer y Béland 1991; Oliver, Tomás y Meliá 1993; M eliá, Tomás y O liver 1992). Los trabajadores de las empresas se encuentran ante millares de hechos, prácticas y procedimientos, que perciben como conjuntos conexos. De ello se deduce que en los lugares de trabajo existen numerosos climas y que el clima de seguridad es uno de ellos. Como el concepto de clima es de naturaleza compleja y estratificada, el estudio del clima de la organización ha estado plagado de problemas teóricos, conceptuales y de cuantificación. Por consiguiente, parece imprescindible abordar estas cuestiones en el estudio del clima de seguridad si se desea que el mismo siga siendo un tema válido de investigación y una herramienta eficaz de gestión.

El clima de seguridad se ha valorado como un concepto relevante, con importantes repercusiones en la comprensión de la actuación de los trabajadores (Brown y Holmes 1986) y en el éxito de la prevención de lesiones ( $M$ attila, $H$ yttinen y $R$ antanen 1994). Si se logran evaluar acertadamente las distintas facetas del clima de seguridad, la dirección puede utilizarlas para identificar y evaluar posibles fuentes de problemas. Además, los resultados obtenidos mediante la aplicación de un sistema normalizado de evaluación del clima de seguridad permiten realizar comparaciones significativas entre sectores, independientemente de las diferencias en el campo tecnológico y en los niveles de riesgo. Por consiguiente, un sistema de valoración del clima de seguridad puede servir de pauta en la elaboración de una política de seguridad en las organizaciones empresariales. En el presente artículo se examina el concepto de clima de seguridad en el contexto de la literatura dedicada al clima organizativo, se analiza la relación entre política de seguridad y clima de seguridad, y se estudia la influencia del concepto de clima de seguridad en el liderazgo del desarrollo y aplicación de una política de seguridad en una organización industrial.

\section{El concepto de clima de seguridad en la investigación del clima organizativo}

\section{Investigación del clima organizativo}

El concepto de clima organizativo ha ganado un cierto predicamento desde hace algún tiempo. En efecto, desde mediados del decenio de 1960 han aparecido diversos estudios sobre el tema (Schneider 1975a; Jones y James 1979; N aylor, Pritchard e Ilgen 1980; Schneider y Reichers 1983; Glick 1985; K oys y $\mathrm{DeC}$ otiis 1991). Se han formulado varias definiciones del concepto. La expresión clima organizativo se ha utilizado genéricamente para identificar un amplio espectro de variables de organización y de percepción que reflejan la interacción entre las personas y la organización (Glick 1985; Field y Abelson 1982; 
Jones y James 1979). Según Schneider (1975a), la expresión debe definir un campo de investigación más que una unidad de análisis específica 0 un determinado conjunto de ámbitos. La expresión dima organizativo se debe reemplazar por la voz clima para designar el clima imperante en algún ámbito.

El estudio de los climas organizativos ha sido complicado por la circunstancia de tratarse de un fenómeno complejo y estratificado (G lick, 1985; K oys y D eC otiis 1991). No obstante, se han logrado progresos en conceptuar el contenido del clima (Schneider y Reichers 1983; K oys y DeCotiis 1991). La distinción, propuesta por James y Jones, entre climas psicológicos y climas organizativos ha sido generalmente aceptada. Esta distinción es una función del nivel del análisis. En efecto, el clima psicológico se estudia en el plano individual del análisis, mientras que el clima organizativo se examina en el plano organizativo del análisis. Es aconsejable emplear la expresión clima psicológico si se considera una realidad individual; en cambio, si el clima se enfoca como una realidad organizativa, procede emplear la expresión clima organizativo. A mbos aspectos del clima se consideran fenómenos multifacéticos que traducen la naturaleza de la percepción de las experiencias vividas en la empresa por parte de los trabajadores.

Si bien la distinción entre el clima psicológico y organizativo ha sido generalmente aceptado, no ha servido para liberar al estudio del clima organizativo de sus problemas conceptuales y metodológicos (G lick 1985). U no de los problemas no resueltos es el de la adición. El clima organizativo se ha definido a menudo como la mera adición del clima psicológico presente en una organización (James 1982; J oyce y Slocum 1984). Se plantea una pregunta: ¿Cómo se pueden añadir las percepciones personales del entorno de trabajo para configurar la unidad social mayor que es la organización? Schneider y Reichers (1983) observan que se precisa un "arduo trabajo conceptual previo a la recogida de datos, de modo que: a) los conjuntos de hechos evaluados reflejen el ámbito de problemas en cuestión; b) el objeto del estudio sea relativamente descriptivo y se refiera a la unidad (esto es, la persona, el subsistema, el conjunto de la organización) de interés a efectos analíticos". G lick (1985) añade que el clima organizativo se debe conceptuar como un fenómeno organizativo, no como una mera adición del clima psicológico. Este autor también reconoce la existencia de múltiples unidades de teoría y de análisis (esto es, personas, subunidades y organización). El clima organizativo implica una unidad de teoría organizativa; no se refiere al clima de una persona, un grupo de trabajo, una profesión, un departamento o un puesto de trabajo. Se deben emplear otras denominaciones y otras unidades de teoría y de análisis en relación con el clima de una persona y con el clima de un grupo de trabajo.

La coincidencia en las percepciones de los trabajadores de una organización ha suscitado un interés considerable (A bbey y Dickson 1983; James 1982). Un bajo nivel de coincidencia perceptiva en las evaluaciones del clima psicológico se puede atribuir, tanto a errores aleatorios, como a factores esenciales. Cuando se pide a los trabajadores que informen del clima de la organización, al margen del clima psicológico o del que reina en su grupo de trabajo, se considera que muchos de los errores aleatorios y causas de sesgo se compensan entre sí al agregarse las medidas de la percepción en el ámbito de la organización (Glick 1985). El uso de modelos estratificados se revela como fundamental para distinguir entre el clima psicológico y el organizativo y evaluar el peso relativo de los procesos organizativos y los psicológicos en la configuración de los climas organizativo y psicológico (H ox y K reft 1994; R abash y Woodhouse 1995). En estos modelos se toman en consideración los niveles psicológico y organizativo y no se utilizan las medidas ponderadas de los climas organizativos que se suelen tomar sobre una muestra representativa de personas en cierto número de organizaciones. Se puede demostrar (M anson, Wong y Entwisle 1983) que la adición en el ámbito organizativo de las medidas tomadas en el plano individual se traduce en estimaciones sesgadas de los valores medios de los climas organizativos y del efecto de las características organizativas en los climas. La creencia de que los errores de medición en el plano individual se compensan al promediarse en el ámbito de la organización es infundada.

0 tro problema constante del concepto de clima es la especificación de las dimensiones adecuadas del clima organizativo 0 del psicológico, o de ambos. Tanto Jones y James (1979) como Schneider (1975a) recomiendan utilizar unas dimensiones del clima capaces de influir en los criterios de interés del estudio o de asociarse a ellos. Schneider y Reichers (1983) desarrollaron esta idea al aducir que en las organizaciones hay distintos climas en cuestiones diferentes. como la seguridad, los servicios (Schneider, Parkington y Buxton 1980), las relaciones laborales internas (Bluen y D onald 1991), la producción, la seguridad y la calidad. Si bien la referencia a un criterio permite en alguna medida centrar la elección de las dimensiones del clima, éste continúa siendo un término genérico muy amplio. No se ha alcanzado el nivel de refinamiento preciso para conocer qué dimensiones de los procedimientos y prácticas coadyuvan a la comprensión de determinados criterios presentes en colectividades concretas (por ejemplo, grupos, cargos, funciones) (Schneider 1975a). Sin embargo, la exigencia de unos estudios orientados a los criterios no excluye, por sí sola, la posibilidad de que un conjunto relativamente reducido de dimensiones pueda servir todavía para describir un entorno múltiple, al tiempo que cualquier dimensión específica se puede asociar positivamente a algunos criterios, no vinculados a otros y asociados negativamente a un tercer conjunto de resultados.

\section{Concepto de clima de seguridad}

El concepto de clima de seguridad se ha desarrollado en el marco de las definiciones generalmente aceptadas del clima organizativo y psicológico. No se ha formulado aún una definición específica del concepto que aporte unas pautas para la medición y la elaboración teórica. Entre los escasos estudios dedicados a medir el concepto se incluye una muestra estratificada de 20 organizaciones industriales en I srael (Zohar 1980), 10 empresas industriales y de producción en los estados de Wisconsin e Illinois (Brown y H olmes 1986), nueve obras de construcción en el estado de $M$ aryland (D edobbeleer y Béland 1991), 16 obras de construcción en Finlandia (M attila, H yttinen y R antanen 1994; M attila, Rantanen y H yttinen 1994), y una muestra de trabajadores de Valencia (Oliver, Tomás y Meliá 1993; Meliá, Tomás y O liver 1992).

El clima se percibía como un resumen de las percepciones comunes que tienen los trabajadores de su entorno de trabajo. Las percepciones del clima compendian, más la descripción que hace una persona de sus experiencias en la organización, que su evaluación afectiva de lo experimentado (K oys y D eC ottis 1991). Según Schneider y Reichers (1983) y Dieterly y Schneider (1974), en los modelos del clima de seguridad se presumía que estas percepciones se desarrollan porque son necesarias como marco de referencia para evaluar la idoneidad del comportamiento. A partir de una serie de señales presentes en el entorno laboral, se espera que los trabajadores desarrollen una serie coherente de percepciones y expectativas relativas a la posible relación comportamiento-resultado y que se comporten en consecuencia (Freeriksen, Jensen y Beaton 1972; Schneider 1975a, 1975b).

En la Tabla 59.1 se refleja una cierta diversidad en el tipo y el número de dimensiones del clima de seguridad que se presentan en los estudios de validación del clima de seguridad. En la 
Tabla 59.1 - Medidas del clima de seguridad.

\begin{tabular}{|c|c|c|}
\hline Autor & Dimensiones & Elementos \\
\hline Zohar (1980) & $\begin{array}{l}\text { Importancia percibida de la formación en la } \\
\text { seguridad } \\
\text { Efectos percibidos del ritmo de trabajo exigido } \\
\text { en la seguridad } \\
\text { Nivel percibido del comité de seguridad } \\
\text { Nivel percibido del responsable de seguridad } \\
\text { Efectos percibidos del comportamiento seguro } \\
\text { en la promoción } \\
\text { Nivel percibido de riesgo en el lugar de trabajo } \\
\text { Actitudes percibidas de la dirección frente a la } \\
\text { seguridad } \\
\text { Efecto percibido del comportamiento seguro en } \\
\text { el nivel social }\end{array}$ & 40 \\
\hline $\begin{array}{l}\text { Brown y Holmes } \\
\text { (1986) }\end{array}$ & $\begin{array}{l}\text { Percepción de los trabajadores del grado de } \\
\text { interés de la dirección por el bienestar de } \\
\text { aquéllos } \\
\text { Percepción de los trabajadores del nivel de } \\
\text { diligencia de la dirección en su respuesta a } \\
\text { esta preocupación } \\
\text { Percepción de los trabajadores del riesgo físico }\end{array}$ & 10 \\
\hline $\begin{array}{l}\text { Dedobbeleer y } \\
\text { Béland (1991) }\end{array}$ & $\begin{array}{l}\text { Compromiso y participación de la dirección en } \\
\text { la seguridad } \\
\text { Participación de los trabajadores en la } \\
\text { seguridad }\end{array}$ & 9 \\
\hline $\begin{array}{l}\text { Melia, Tomas y } \\
\text { Oliver (1992) }\end{array}$ & Modelo bifactorial de Dedobbeleer y Béland & 9 \\
\hline $\begin{array}{l}\text { Oliver, Tomas y } \\
\text { Melia (1993) }\end{array}$ & Modelo bifactorial de Dedobbeleer y Béland & 9 \\
\hline
\end{tabular}

literatura dedicada al clima organizativo general se observa muy escaso consenso en torno a las dimensiones del clima organizativo. No obstante, se insta a los investigadores a utilizar las dimensiones del clima que tienen posibilidades de influir o estar relacionadas con los criterios de interés para su estudio. Este enfoque se ha aplicado con éxito en los estudios del clima de seguridad. Zohar (1980) desarrolló siete conjuntos de elementos descriptivos de los hechos, procedimientos y prácticas organizativos que demostradamente diferenciaban las fábricas con elevadas tasas de accidentes de las que soportaban tasas más bajas (Cohen 1977). Utilizando el cuestionario de 40 preguntas de Zohar, Brown y Holmes (1986) desarrollaron un modelo de tres factores, en lugar del modelo de ocho factores de Zohar. Dedobbeleer y Béland utilizaron nueve variables para medir el modelo de tres factores de Brown y Holmes. Las variables se seleccionaron para representar problemas de seguridad en la industria de la construcción y no todas eran idénticas a las del cuestionario de Zohar. Resultó un modelo bifactorial. Falta por analizar si las diferencias entre los resultados de Brown y $\mathrm{H}$ olmes y los de D edobbeleer y Béland son imputables al empleo de un procedimiento estadístico más idóneo (procedimiento LISREL de los mínimos cuadrados ponderados con coeficientes de correlaciones tetracóricas). O liver, Tomás y M eliá (1993) y M eliá, Tomás y O liver (1992) realizaron una nueva aplicación con nueve variables similares, aunque no idénticas para medir las percepciones del clima entre los trabajadores en situación postraumática y pretraumática en diversos tipos de industrias. L os resultados fueron similares a los del estudio de D edobbeleer y Béland.
Se han utilizado diversos métodos para mejorar la validez de las mediciones del clima de seguridad. Existen diversas clases de validez (por ejemplo, contenido, concurrente y de constructo) y diversos modos de evaluar la validez de un instrumento. La validez de contenido es la capacidad de evaluación del contenido de un instrumento de medición (N unnally 1978). LoS elementos de la investigación del clima de seguridad son los que la investigación precedente ha acreditado como medidas válidas de la seguridad en el trabajo. 0 tros jueces "competentes" suelen juzgar el contenido de los elementos, y en tales casos se utiliza algún método para integrar los juicios independientes. En los artículos dedicados al clima de seguridad no se alude a este tipo de procedimiento.

La validez de constructo es el grado en que un instrumento mide el constructo teórico que el investigador desea evaluar. Exige demostrar la existencia del constructo, que es diferente de otros constructos y que el instrumento en cuestión sirve para medir ese constructo concreto y no otros (N unnally 1978). En el estudio de Zohar se aplicaron diversas recomendaciones para mejorar la validez. Se seleccionaron muestras representativas de varias fábricas y se tomó una muestra aleatoria estratificada de 20 trabajadores de cada empresa. Todas las preguntas se centraban en el clima de seguridad de la organización. Para estudiar la validez de constructo de este instrumento de medición del clima de seguridad, el autor utilizó los coeficientes de correlación de rangos de Spearman, con objeto de verificar la concordancia entre las puntuaciones de las fábricas en cuanto al clima de seguridad y la clasificación realizada por los inspectores de seguridad de las fábricas seleccionadas en cada categoría productiva en función de los sistemas de seguridad y de los programas de prevención de accidentes. El nivel del clima de seguridad se correlacionó con la valoración del programa de seguridad realizada por los inspectores de seguridad. U tilizando el análisis de factores confirmatorios de LISREL, Brown y Holmes (1986) verificaron la validez factorial del modelo de medición de Zohar en una muestra de trabajadores norteamericanos. Los autores querían validar el modelo de Zohar mediante una nueva aplicación de las estructuras de factores (Rummel 1978). Los datos no validaron el modelo. En cambio, un modelo de tres factores mostró una mejor correlación. Los resultados mostraron igualmente la estabilidad de las estructuras del clima entre diferentes poblaciones. En efecto, los resultados obtenidos con los trabajadores que habían sufrido accidentes no se diferenciaban de los que no habían tenido ninguno, aportando subsiguientemente una medida válida y fiable del clima entre los diversos grupos. Posteriormente se compararon las puntuaciones de los grupos en lo relativo al clima y se descubrieron diferencias en la percepción del clima entre aquéllos. Como el modelo permite distinguir entre personas de las que se sabe que difieren, se ha evidenciado la validez concurrente.

Con objeto de verificar la estabilidad del modelo de tres factores de Brown y Holmes (1996), Dedobbeleer y Béland (1991) aplicaron dos procedimientos LISREL (el método de máxima probabilidad elegido por Brown y Holmes y el método de los mínimos cuadrados ponderados) a los trabajadores de la construcción. Los resultados demostraron que con un modelo de dos factores se obtenía una correlación muy superior. L a validación de constructo se verificó asimismo mediante la investigación de la relación existente entre una medida del clima de seguridad percibido y las medidas objetivas (por ejemplo, características estructurales y de los procesos de las obras de construcción). Se hallaron relaciones positivas entre las dos medidas. Se recogieron datos en diferentes fuentes (por ejemplo, trabajadores y supervisores) y aplicando distintos métodos (por ejemplo, cuestionarios y entrevistas). M attila, Rantanen y $\mathrm{H}$ yttinen (1994) aplicaron este estudio y mostraron que se habían obtenido 
resultados análogos mediante las mediciones objetivas del medio ambiente de trabajo - resultantes en un índice de seguridad- y las medidas del clima de seguridad percibido.

O liver, Tomás y M eliá (1993) y M eliá, Tomas y O liver (1992) realizaron una aplicación de la estructura de dos factores de Dedobbeleer y Béland (1991) utilizando dos muestras distintas de trabajadores de diferentes profesiones. La mejor correlación global se obtuvo con el modelo bifactorial. No se encontraron diferencias en las estructuras del clima entre los trabajadores norteamericanos de la construcción y los trabajadores españoles de diversos sectores, lo que aportó una medida válida del clima entre diferentes poblaciones y distintos tipos de profesiones.

La fiabilidad es un aspecto importante del uso de un instrumento de medición y se refiere a la precisión (coherencia y estabilidad) de la medición realizada con un instrumento (N unnally 1978). Zohar (1980) evaluó el clima organizativo de la seguridad en muestras de organizaciones con tecnologías diversas. Glick (1985) evaluó la fiabilidad de estas mediciones perceptivas agregadas del clima organizativo. El autor calculó la tasa media del nivel agregado de fiabilidad utilizando la fórmula de Spearman-Brown, basada en la correlación intraclase de un análisis de la variancia de un sentido, y halló un $\mathrm{ICC}_{(1, \mathrm{k})}$ de 0,981 . G lick llegó a la conclusión de que las medidas agregadas de Zohar constituían medidas coherentes del clima organizativo de seguridad. LOS análisis de factores confirmatorios LISREL realizado por Brown y $\mathrm{H}$ olmes (1986), Dedobbeleer y Béland (1991), O liver, Tomás y M eliá (1993) y M eliá, Tomás y Oliver (1992) también pusieron de relieve la fiabilidad de las medidas del clima de seguridad. En el estudio de Brown y Holmes, las estructuras de los factores permanecieron invariables respecto a los grupos sin antecedentes de accidentes en comparación con los grupos que habían sufrido accidentes. Tanto Oliver y cols. como M eliá y cols. demostraron la estabilidad de las estructuras de los factores de Dedobbeleer y Béland en dos muestras diferentes.

\section{Política de seguridad y clima de seguridad}

El concepto de clima de seguridad tiene importantes implicaciones para las organizaciones industriales. I mplica que los trabajadores desarrollan una serie integrada de percepciones sobre los aspectos de la seguridad en sus respectivos entornos de trabajo. Como estas percepciones se consideran un marco de referencia necesario para poder comparar la idoneidad de los comportamientos (Schneider 1975a), influyen directamente en la actuación de los trabajadores en el ámbito de la seguridad (Dedobbeleer, Béland y German 1990). Existen, por lo tanto, unas implicaciones básicas aplicadas del concepto de clima de seguridad en las organizaciones industriales. La medición del clima de seguridad constituye una herramienta práctica que la dirección puede utilizar a un bajo coste para identificar y evaluar áreas potencialmente problemáticas. Por lo tanto, resulta recomendable incluirla como componente del sistema de información sobre la seguridad de la organización. La información suministrada puede servir de pauta para la elaboración de una política de seguridad.

Como las percepciones que los trabajadores tienen del clima de seguridad son en gran medida una función de las actitudes y del compromiso de la dirección con la seguridad, se deduce de esto que la modificación de los comportamientos y actitudes de la dirección son una condición previa de cualquier intento fructífero de mejorar los niveles de seguridad en las organizaciones industriales. U na dirección excelente se traduce en política de seguridad. Zohar (1980) llegó a la conclusión de que la seguridad debe integrarse en el sistema de producción y vincularse estrechamente al control global que la dirección ejerce sobre los procesos productivos. Este aspecto se ha subrayado en la literatura dedicada a la política de seguridad, en la que la participación de la dirección se considera vital para la mejora del nivel de seguridad (M inter 1991). Por otra parte, los métodos tradicionales se han revelado como escasamente eficaces (Sarkis 1990). Estos métodos se basan en elementos del tipo de los comités de seguridad, las normas de seguridad, el uso de eslóganes y carteles, y los incentivos y concursos de seguridad. Según H ansen (1993b), en estos sistemas tradicionales la responsabilidad hacia la seguridad recae sobre un coordinador de staff al que se descarga de las funciones de línea y cuya labor se reduce casi exclusivamente a la inspección de los riesgos. El principal problema del sistema consiste en que no permite integrar la seguridad en el sistema de producción, lo que limita su capacidad para descubrir y solucionar las negligencias e insuficiencias de la dirección que contribuyen a la producción de accidentes (H ansen 1993b; Cohen 1977).

Contrariamente a los trabajadores industriales de los estudios de Zohar y Brown y de Holmes, los trabajadores de la construcción percibían las actitudes y acciones de la dirección en el campo de la seguridad como unidimensionales (D edobbeleer y Béland 1991). Estos trabajadores percibían igualmente la seguridad como una responsabilidad compartida entre las personas y la dirección. Estos resultados tienen importantes implicaciones para el desarrollo de la política de seguridad. En efecto, los mismos apuntan a que el compromiso y el apoyo de la dirección a la seguridad debe ser totalmente evidente, e indican, asimismo, que en la política de seguridad se deben abordar por igual las preocupaciones de la dirección y de los trabajadores. Las reuniones dedicadas a la seguridad en marcos como los "círculos culturales" de Freire (1988) pueden constituir un medio adecuado de involucrar a los trabajadores en la detección y resolución de los problemas de seguridad. Por tanto, las dimensiones del clima de seguridad se asocian estrechamente al espíritu de colaboración en la mejora de la seguridad en el trabajo, en contraste con el espíritu de aplicación de la política que se observaba en la industria de la construcción (Smith 1993). En el actual contexto de aumento de los costes de la asistencia sanitaria y de la indemnización por accidentes de trabajo, ha surgido una nueva actitud no antagónica de los trabajadores y la dirección en materia de salud y seguridad. (Smith 1993). Por tanto, este espíritu asociativo requiere una revolución en la gestión de la seguridad, que se distancie de los programas y políticas de seguridad tradicionales.

En Canadá, Sass (1989) observó una fuerte resistencia de la dirección y del gobierno, fundada en consideraciones económicas, al aumento de los derechos de los trabajadores en el campo de la salud y la seguridad en el trabajo. Por lo tanto, Sass abogaba por "el desarrollo de una ética del medio ambiente de trabajo, basada en principios igualitarios, y la transformación del grupo de trabajo primario en una comunidad de trabajadores capaz de moldear el medio ambiente de trabajo". A ducía igualmente el autor que el modelo de relaciones laborales idóneo para reflejar un medio ambiente de trabajo democrático es el de "sociedad", consistente en la unión de los grupos de trabajo primarios en pie de igualdad. Esta filosofía avanzada se ha puesto en práctica en Q uébec mediante la creación de los "comités paritarios" (Gouvernement de Q uébec 1978). Todas las organizaciones con más de diez trabajadores quedaron legalmente obligadas a constituir un comité paritario, integrado por representantes de la empresa y de los trabajadores. L os comités poseen facultades de decisión en diversas cuestiones asociadas a la política de prevención: elaboración del programa de servicios de salud, nombramiento del médico de la empresa, determinación de los peligros inminentes y desarrollo de los programas de información y formación. A simismo, el comité supervisa la actividad de prevención en la organización; atiende las quejas de ambos agentes sociales; analiza e informa sobre los partes de 
accidente; registra los accidentes, lesiones, enfermedades y quejas de los trabajadores; analiza los informes y estadísticas; y brinda información sobre sus actividades.

\section{Liderazgo y clima de seguridad}

Para impulsar una dinámica que conduzca a una empresa hacia nuevas concepciones culturales, la dirección ha de evolucionar desde el simple "compromiso" hacia un liderazgo participativo ( $H$ ansen 1993a). Por tanto, el lugar de trabajo precisa líderes con visión, capacidad de delegar poder y voluntad de generar cambios.

Las acciones de los mandos crean el clima de seguridad. Esto obliga a fomentar un clima de aprecio por la seguridad, animar a todos los trabajadores a que vean más allá de sus respectivos puestos de trabajo y a cuidarse y cuidar de sus compañeros, difundir y ejercer el liderazgo en el ámbito de la seguridad (Lark 1991). Para fomentar este clima, los mandos necesitan percepción y discernimiento; motivación y capacidad de comunicación; una dedicación o identificación con el grupo que trascienda los intereses personales; fuerza de carácter; capacidad para inducir una "reformulación de la cognición", elaborando y "vendiendo" nuevos conceptos e ideas; capacidad para promover el compromiso y la participación; y una visión de futuro (Schein 1989). Si quieren modificar cualquier aspecto de la organización, los líderes han de empezar por "descongelar" (L ewin 1951) su propia estructura.

Según Lark (1991), el liderazgo de la seguridad a nivel ejecutivo implica la creación de un clima global en el que se integre la seguridad como un valor y en el que supervisores y subordinados, consciente y alternativamente asuman el liderazgo del control de riesgos. Los líderes ejecutivos dictan una política de seguridad en la que reafirman el valor de cada trabajador y del grupo, así como su compromiso con la seguridad; vinculan la seguridad con la continuidad de la empresa y con el logro de sus objetivos; expresan su expectativa de que cada persona se responsabilice de la seguridad y participe activamente en el mantenimiento de la salud y seguridad en el lugar de trabajo; nombran formalmente un responsable de la seguridad, al que facultan para aplicar la política de seguridad de la empresa.

Los supervisores que ejercen un liderazgo exigen a sus subordinados la observancia de la seguridad y los involucran directamente en la detección y resolución de los problemas. Para el personal subordinado, el liderazgo en materia de seguridad supone comunicar las deficiencias, asumir como propia la resolución de los problemas y trabajar en esa resolución.

El mando anima y faculta a las personas a convertirse en líderes por derecho propio. En el núcleo de la idea de delegación de poder subyace la noción de poder, que se define como la capacidad para controlar los factores que rigen la propia vida. No obstante, en la nueva tendencia de la promoción de la salud se intenta replantear el poder, no como el "poder sobre" otros, sino como el "poder para" hacer cosas o como el "poder compartido" (Robertson y M inkler 1994).

\section{Conclusiones}

En el estudio del clima de seguridad sólo se han abordado algunos de los problemas conceptuales y metodológicos que preocupan a los investigadores del clima de seguridad. H asta ahora no se ha formulado una definición concreta de este concepto. No obstante, la investigación ha arrojado hasta ahora algunos resultados sumamente alentadores. La mayoría de los trabajos de investigación se han orientado hacia la validación de un determinado modelo del clima de seguridad. Se ha prestado especial atención a la especificación de las dimensiones idóneas del clima de seguridad. En las dimensiones propuestas en la literatura dedicada a las características de las organizaciones se ha establecido que la discriminación entre las empresas con tasas de accidentes elevadas y las que experimentan unas tasas más bajas constituía un útil punto de partida del proceso de identificación de las dimensiones. Se han propuesto modelos de ocho, tres y dos factores. Como la navaja de 0 ccam impone una cierta lentitud, parece aconsejable una cierta limitación de las dimensiones. Por tanto, el modelo de dos factores es el más adecuado, especialmente en un contexto laboral en el que es preciso utilizar cuestionarios breves. L os resultados de los análisis de los factores para las escalas basadas en dos dimensiones son muy satiffactorios. Además, se brinda una medida válida del clima entre poblaciones distintas y diferentes profesiones. No obstante, serán precisos nuevos estudios si se quieren cumplir las reglas de aplicaciones repetidas y generalización de la verificación de teorías. La dificultad estriba en formular un universo teóricamente significativo y analíticamente práctico de las posibles dimensiones del clima. A demás, la investigación futura debe centrarse en las unidades de análisis organizativas para la evaluación y el perfeccionamiento de la validez y fiabilidad del clima organizativo de la política de seguridad. Actualmente se realizan varios estudios en distintos países, y el futuro parece prometedor.

Las importantes implicaciones que el clima de seguridad tiene para la política de seguridad hace que sea particularmente importante solucionar los problemas conceptuales y metodológicos. Es evidente que este concepto impone una revolución en la gestión de la seguridad. Un cambio en los comportamientos y actitudes de la dirección se convierte en condición previa para lograr resultados en el campo de la seguridad. Es preciso que esta época caracterizada por las reestructuraciones y las reducciones de plantilla produzca un "liderazgo de la seguridad". El liderazgo es un reto y un proceso de delegación de poder en el que empresas y trabajadores incrementan, tanto su disposición a colaborar con un espíritu participativo, como su capacidad para escuchar y expresarse, para analizar los problemas y para crear consenso. De ello debe resultar una conciencia de comunidad y de eficacia personal. Empresas y trabajadores se beneficiarán por igual de este conocimiento y estas cualificaciones.

\section{Proceso participativo de Mejora DEL LUGAR DE TRABAJO}

Jorma Saari

\section{La modificación del comportamiento como técnica de gestión de la seguridad}

La gestión de la seguridad consta de dos tareas centrales. Corresponde a la estructura de seguridad: a) mantener los resultados de la empresa en materia de seguridad, y b) aplicar programas y medidas destinados a mejorar los resultados del trabajo de seguridad. Se trata de tareas diferentes que precisan unos enfoques distintos. En el presente artículo se examina un método de realización de la segunda tarea que ha sido aplicado en numerosas empresas con resultados excelentes. El método se basa en la modificación del comportamiento, técnica de mejora de la seguridad que posee numerosas aplicaciones en el comercio y en la industria. L os norteamericanos publicaron en 1978 los resultados de dos estudios, realizados independientemente, de las primeras aplicaciones científicas de la modificación del comportamiento. Las aplicaciones se efectuaron en marcos muy distintos. K omaki, Barwick y Scott (1978) llevaron a cabo su estudio en una panadería, al tiempo que el estudio de Sulzer-Azaroff (1978) se efectuó en los laboratorios de una universidad. 


\section{Consecuencias del comportamiento}

La modificación del comportamiento se centra en las consecuencias de un determinado comportamiento. Si los trabajadores pueden elegir entre varios comportamientos, optan por el que prometa unos resultados más positivos. Antes de actuar, el trabajador parte de una serie de actitudes, cualificaciones, equipo y servicios, que influyen en la elección de la acción. No obstante, la elección es, sobre todo, una función de las consecuencias previsibles. Como las consecuencias influyen en las actitudes, cualificaciones, etc., su peso es decisivo en la modificación del comportamiento en opinión de los teóricos (véase la Figura 59.3).

El problema que se plantea en el área de la seguridad es que muchos comportamientos de riesgo inducen a los trabajadores a optar por unas consecuencias más positivas (en el sentido de que aparentemente compensan a los trabajadores) en detrimento de los comportamientos más seguros. U n método de trabajo inseguro puede compensar más que otro si es más rápido, posiblemente, más fácil, y suscita la aprobación del supervisor. Las consecuencias negativas - como, por ejemplo, una lesión- no siempre se producen como consecuencia de cada comportamiento inseguro, puesto que la producción de una lesión precisa del concurso de otras condiciones adversas. Por consiguiente, el peso de las consecuencias positivas es abrumador, tanto en número como en frecuencia.

A modo de ilustración, se organizó un seminario en el que los participantes comentaron vídeos de la ejecución de diversos trabajos en una planta de producción. Los participantes en el seminario, ingenieros y operadores de la planta, observaron que una máquina funcionaba con el dispositivo de protección abierto. U no de los operarios afirmó con vehemencia: “EI dispositivo no se puede dejar cerrado. Si el funcionamiento automático se interrumpe, pulso el interruptor de seguridad para que la última pieza salga de la máquina". Y añadió: "Si no lo hago así, tengo que sacar la pieza no acabada, retroceder varios metros y colocarla de nuevo en la cinta transportadora. La pieza es muy pesada y es más fácil y más rápido pulsar el interruptor".

Esta pequeña anécdota ilustra perfectamente cómo las consecuencias previsibles influyen en nuestras decisiones. El operario quiere hacer su trabajo y no tener que cargar con una pieza pesada y difícil de transportar. Por lo tanto, el hombre prefiere correr riesgos a utilizar el método más seguro. Y el fenómeno se repite en todos los niveles de la organización. Por ejemplo, al jefe de producción le interesa optimizar la rentabilidad de las operaciones y recibir la recompensa correspondiente a los buenos resultados obtenidos. Si la dirección no presta atención a la seguridad, es posible que el jefe de producción deposite unas expectativas más positivas en las inversiones que optimizan la producción que en aquéllas que mejoran la seguridad.

\section{Consecuencias positivas y negativas}

L os gobiernos imponen obligaciones legales a los responsables de la toma de decisiones y sancionan los incumplimiento de aquéllas. Se trata de un mecanismo sencillo que permite a esos responsables prever las consecuencias directas del incumplimiento de la norma legal. La diferencia entre el sistema de aplicación de la ley y el que se propugna aquí estriba en la naturaleza de las consecuencias. M ientras que la aplicación de la legislación se funda en las consecuencias negativas de los comportamientos de riesgo, en las técnicas de modificación del comportamiento se utilizan las consecuencias positivas del comportamiento seguro. Las consecuencias negativas tienen ciertos inconvenientes, incluso si son eficaces. El recurso a las consecuencias negativas ha sido muy frecuente en el área de la seguridad, oscilando desde las sanciones de las autoridades hasta la amonestación del supervisor. Como todos tratan de sustraerse a las sanciones, la seguridad se suele asociar con la penalización, como lo menos deseable.
Figura 59.3 • La modificación del comportamiento como sistema de gestión de la seguridad.

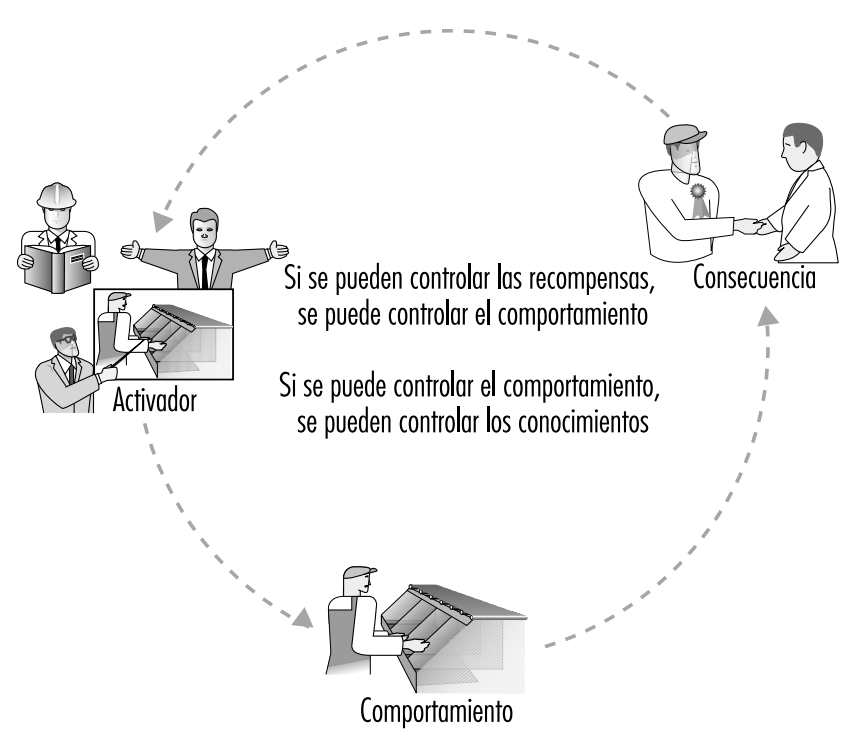

En materia de modificación del comportamiento, se supone que las consecuencias previstas del comportamiento determinan la elección entre las opciones que éste ofrece.

Las consecuencias positivas que promueven el comportamiento seguro son las más deseables, al asociar las sensaciones positivas a la seguridad. Si los operarios depositan expectativas más positivas en los métodos de trabajo seguros, se decantan por éstos como modelos de comportamiento deseables. Si los directores de producción se evalúan y se recompensan en base a unos criterios de seguridad, es mucho más probable que valoren en mucha mayor medida los aspectos de la seguridad.

EI espectro de posibles consecuencias positivas es amplio y oscila desde la aprobación social hasta una diversidad de privilegios y distinciones. Algunas consecuencias se asocian naturalmente al comportamiento, al tiempo que otras exigen unas medidas administrativas que pueden resultar enormemente gravosas. Afortunadamente, la mera posibilidad de obtener una recompensa es capaz de producir una modificación del comportamiento.

\section{Cambiar el comportamiento inseguro por un comportamiento seguro}

EI aspecto más interesante de las obras originales de Komaki, Barwick y Scott (1978) y de Sulzer-Azaroff (1978) es el empleo de información relativa al rendimiento como consecuencia. En lugar de utilizar las consecuencias sociales o las recompensas materiales, que pueden ser difíciles de administrar, los autores desarrollaron un método para medir el rendimiento de un grupo de trabajadores en el área de la seguridad, y utilizaron el baremo de rendimiento como consecuencia. El baremo se elaboró de forma que únicamente una cifra variaba de 0 a 100. Dada su sencillez, el baremo permitía transmitir eficazmente a los interesados el mensaje relativo al rendimiento actual. En un principio, esta técnica se utilizó exclusivamente para inducir a los trabajadores a modificar su comportamiento y se dejaban al margen otros aspectos de la mejora del lugar de trabajo, como la aplicación del diseño a la resolución de problemas y la modificación de los procedimientos. La aplicación del programa se confió a un equipo de investigadores, sin la participación directa de los trabajadores. 
Los usuarios de la técnica de modificación del comportamiento (MC) parten de la presunción de que un comportamiento de riesgo es una causa esencial de los accidentes y un factor susceptible de modificarse aisladamente, sin efectos ulteriores. Por consiguiente, el punto de partida lógico de un programa de modificación del comportamiento es la investigación de los accidentes para llegar hasta los comportamientos de riesgo (Sulzer-Azaroff y Fellner 1984). U na típica aplicación de la modificación del comportamiento aplicada a la seguridad es la que se describe en la Figura 59.4. Según los creadores de esta técnica, las conductas seguras se deben especificar de forma precisa. El primer paso consiste en definir las conductas correctas en un área determinada, como un departamento, una función de supervisión, etc. Ejemplo de un "acto seguro" sería el uso correcto de gafas protectoras en determinadas áreas. Por regla general, en un programa de modificación del comportamiento se especifica un número reducido de conductas seguras, como diez, por ejemplo.

Los siguientes son otros ejemplos corrientes de comportamientos seguros:

1. Antes de empezar a trabajar con una escalera, hay que fijarla.

2. Cuando se trabaja en un andén angosto, hay que evitar inclinarse sobre la barandilla.

3. Cuando se realizan labores de mantenimiento de equipo eléctrico, es preciso utilizar bloqueos.

4. Es imperativo el uso de equipo protector.

5. Al subir y bajar rampas con una carretilla elevadora, la horquilla debe mantenerse en la posición correcta (K rause, H idley y H odgson 1990; M CSween 1995).

Si en un área determinada trabaja un número suficiente de personas, por regla general entre 5 y 30, resulta posible elaborar una lista de comprobación de los comportamientos inseguros. EI principio básico consiste en que los componentes de la lista puedan tener únicamente dos valores: correcto o incorrecto. Por ejemplo, si se ha especificado el uso de gafas de seguridad como un acto seguro, el método indicado sería en observar a cada persona por separado para averiguar si utiliza o no las gafas de seguridad. Esto permite que las observaciones arrojen una información clara y objetiva sobre el nivel de observancia del comportamiento seguro. O tros comportamientos considerados seguros proporcionan el resto de los indicadores que deben incluirse en la lista de comprobación. Si la misma se compone, por ejemplo, de un centenar de puntos, resulta fácil hallar un índice de rendimiento en el área de la seguridad sobre la base del porcentaje de puntos que se hayan marcado como correctos al concluir las observaciones. El índice de rendimiento suele variar en el tiempo.

Una vez que la técnica de medición se encuentra a punto, los usuarios determinan la línea base. Las rondas de observaciones se realizan semanalmente (o durante varias semanas) con una frecuencia aleatoria. Si se lleva a cabo un número suficiente de observaciones, se obtiene una visión realista de las variaciones del rendimiento base. Esto es necesario para que los mecanismos positivos funcionen. La línea base debe situarse entre el $50 \%$ y el $60 \%$ para constituir un punto de partida efectivo con el fin de mejorar y conocer el rendimiento anterior. Esta técnica ha demostrado su capacidad de modificar el comportamiento en el área de la seguridad. En el análisis de Sulzer-Azaroff, H arris y M cC ann (1994) se relacionan 44 estudios en los que se acreditan los efectos concretos sobre el comportamiento. A parentemente, esta técnica funciona casi siempre, con algunas excepciones, como se indica en Cooper y cols. (1994).
Figura 59.4 • La modificación del comportamiento en la seguridad consta de los pasos siguientes.

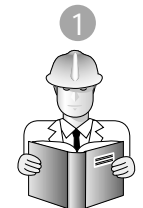

Analizar los registros de seguridad

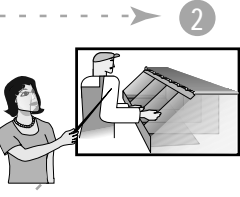

Detectar los comportamientos críticos

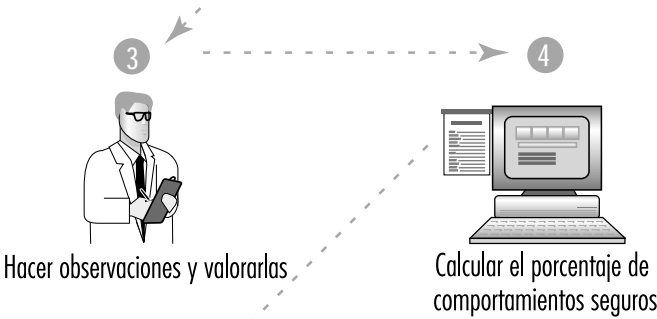
comportamientos seguros
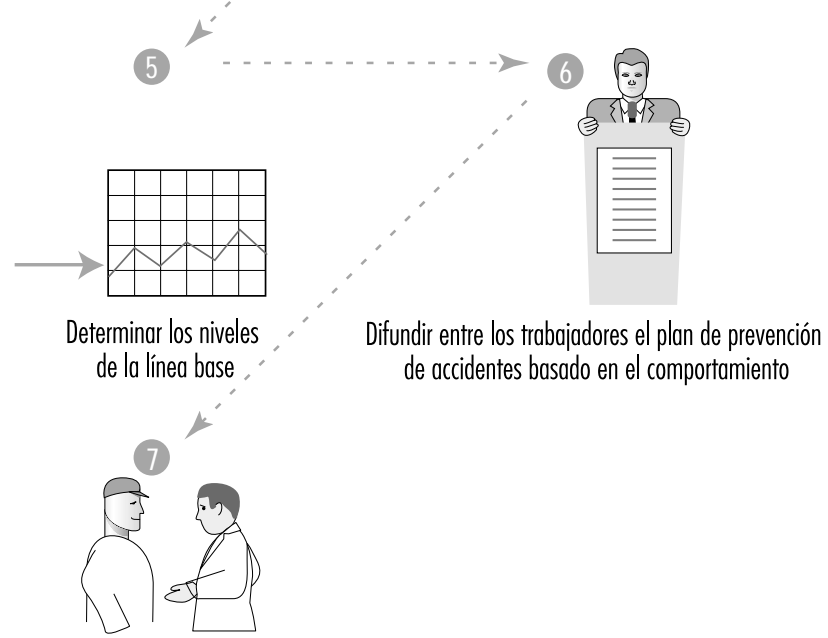

Facilitar retroinformación

Fuente: Krause, Hidley y Hodson 1990.

\section{Aplicación práctica de la teoría de comportamiento}

Ciertas deficiencias observadas en la modificación del comportamiento nos indujeron a desarrollar otra técnica orientada a subsanar algunas de esas deficiencias. El nuevo sistema se denomina Tuttava, acrónimo de la traducción finesa de seguramente productivo. En la Tabla 59.2 se indican las principales diferencias.

La filosofía de la seguridad subyacente en los programas de seguridad basados en el comportamiento es muy sencilla y responde a la presunción de que existe una nítida separación entre lo seguro y lo inseguro. Así, el uso de gafas de seguridad constituye un comportamiento seguro, al margen de que las cualidades ópticas de aquéllas sean pobres o de que el campo de visión pueda verse reducido. Expresado en términos generales, la dicotomía entre lo seguro y lo inseguro puede constituir una simplificación excesiva.

La recepcionista de una planta me pidió que me quitase mi alianza antes de inspeccionar la instalación. La mujer 
Tabla 59.2 - Diferencias entre el programa Tuttava y otros programas y técnicas.

\begin{tabular}{lll} 
Aspecto & $\begin{array}{l}\text { Modificación del } \\
\text { comportamiento en } \\
\text { pro de la seguridad }\end{array}$ & $\begin{array}{l}\text { Proceso participativo de } \\
\text { mejora del lugar de } \\
\text { trabajo, Tuttava }\end{array}$ \\
Base & $\begin{array}{c}\text { Accidentes, incidentes, } \\
\text { percepciones del riesgo } \\
\text { Las personas y su } \\
\text { comportamiento } \\
\text { Enfoque }\end{array}$ & $\begin{array}{c}\text { Anisis del trabajo, flujo de } \\
\text { trabajo } \\
\text { Condiciones }\end{array}$ \\
Aplicación & $\begin{array}{c}\text { Expertos, consultores } \\
\text { Equipo paritario } \\
\text { trabajadores-empresa }\end{array}$ \\
Objecto & $\begin{array}{c}\text { Temporal } \\
\text { Sostenible }\end{array}$ & $\begin{array}{c}\text { Modificación cultural } \\
\text { fundamental }\end{array}$ \\
\hline
\end{tabular}

realizó un acto seguro al pedirme que me despojase de la alianza y yo, otro, al obedecer. Sin embargo, la alianza poseía para mí un gran valor emocional y me sentía preocupada por la perspectiva de perderla durante la visita. Esta preocupación distrajo parte de mi capacidad mental y de percepción durante el recorrido. Como estaba menos concentrada, el riesgo de que me golpease una de las carretillas elevadoras que circulaban allí era superior al normal.

Sin duda, la prohibición de los anillos había tenido su origen en algún accidente anterior. Al igual que ocurre con las gafas de seguridad, no está en absoluto claro que la medida aporte seguridad alguna. La investigación de los accidentes y las experiencias de las personas afectadas constituyen la fuente más directa de determinación de los actos inseguros. Sin embargo, este procedimiento puede ser engañoso. En efecto, es posible que el investigador no comprenda realmente el nexo causal entre un acto y la lesión que investiga. Por consiguiente, es posible que un acto calificado de "inseguro" no lo sea en sí mismo. Por este motivo, en la aplicación desarrollada aquí (Saari y Näsänen 1989) se definen los objetivos en el plano del comportamiento desde la perspectiva del análisis del trabajo. La atención se centra en los materiales y herramientas, porque los trabajadores los utilizan cotidianamente y les resulta fácil empezar hablando de cosas familiares.

El empleo de métodos directos de observación conduce fácilmente a la inculpación, y la inculpación produce tensiones y antagonismo entre la dirección y los trabajadores, y esto no es positivo para la mejora continua de la seguridad. Por lo tanto, es mejor enfocar el esfuerzo hacia las condiciones materiales que forzar directamente un determinado comportamiento. En efecto, al orientar la aplicación a los comportamientos relativos a la manipulación de materiales y herramientas, el cambio se hace más ostensible. Aunque el comportamiento propiamente dicho sólo dure un segundo, es preciso que produzca unas consecuencias visibles. Por ejemplo, la reposición de una herramienta en el lugar destinado a este fin después de utilizarla puede durar únicamente un segundo, pero produce un resultado visible. La herramienta es observable y visible, por lo que no es preciso percibir el comportamiento propiamente dicho.

Un cambio ostensible tiene dos ventajas: a) se hace evidente para todos que se producen mejoras, y b) las personas aprenden a conocer su rendimiento observando directamente el entorno y no precisan conocer los resultados de las observaciones para conocer su rendimiento actual. De este modo, las mejoras comienzan a funcionar como consecuencias positivas del comportamiento correcto y el artificioso baremo de rendimiento resulta innecesario.
Los investigadores y asesores externos son los principales actores de la aplicación descrita anteriormente. No es preciso que los trabajadores recapaciten sobre su trabajo; basta con que modifiquen su comportamiento. No obstante, para obtener unos resultados efectivos y perdurables, es mejor que los trabajadores participen en el proceso. Por tanto, los trabajadores y la dirección se deben integrar por igual en la aplicación, de modo que el grupo para aplicación de los cambios esté compuesto por representantes de ambas partes. También resulta interesante desarroIlar una aplicación que produzca unos resultados perdurables sin necesidad de efectuar continuas mediciones. L amentablemente, los programas usuales de modificación del comportamiento no generan cambios ostensibles y, además, muchos comportamientos significativos duran un segundo o menos.

Esta técnica adolece, ciertamente, de algunas deficiencias si se aplica en la forma anteriormente descrita. En teoría, se debe producir una regresión a la línea base al finalizar las observaciones. Es posible que los recursos destinados al desarrollo del programa y a la realización de observaciones sean desproporcionados a la modificación temporal producida.

L os materiales y herramientas permiten vislumbrar la calidad de las funciones de una organización. Por ejemplo, si en un puesto de trabajo se observa una acumulación inusitada de piezas y recambios, esto puede deberse a problemas en el proceso de compra de la organización o en los métodos utilizados por los proveedores. La presencia tangible de una acumulación excesiva de piezas aporta una excusa concreta para abordar el examen de las funciones de la organización. Los trabajadores poco experimentados en la argumentación abstracta sobre temas organización pueden enriquecer el análisis con sus observaciones. Los materiales y herramientas suelen conducir a los factores subyacentes enmascarados que contribuyen al riesgo de accidentes. Estos factores suelen ser de naturaleza organizativa 0 de procedimiento, por lo que resultan difíciles de abordar si se carece de información concreta y sustantiva.

Las disfunciones organizativas también pueden ocasionar problemas de seguridad. Por ejemplo, en una reciente visita a una planta, se observó que unos trabajadores colocaban manualmente los productos en unas paletas con un peso total de varias toneladas. La causa era la disfunción entre el sistema de compras de la organización y el sistema del proveedor, que impedía que las etiquetas de los productos estuviesen disponibles a tiempo. Fue preciso almacenar los productos en paletas durante días, obstruyendo un pasillo. Cuando se recibieron las etiquetas, los productos se volvieron a colocar manualmente en la línea de producción. Todas estas operaciones supusieron un trabajo adicional y una fuente de posibles lesiones de espalda y de otro tipo.

\section{El éxito de un programa de mejora depende del cumplimiento de cuatro condiciones}

Un conocimiento cabal, tanto teórico, como práctico, del problema y de los mecanismos que lo subyacen constituye la condición previa del éxito. En esto se fundamenta la fijación de los objetivos del programa de mejora, por lo cual: a) las personas deben conocer los nuevos objetivos; b) deben poseer los medios técnicos y organizativos precisos para actuar en consecuencia, y c) han de estar motivados (Figura 59.5). Este esquema es aplicable para todo programa de modificación del comportamiento.

U na campaña de seguridad puede ser un buen cauce de difusión de información relativa a un objetivo. No obstante, la campaña sólo influye en el comportamiento humano si se satisfacen los demás criterios. Por ejemplo, la exigencia de utilizar casco protector no surte efectos en una persona que carezca de él, ni en el caso de que los cascos sean extraordinariamente 
Figura 59.5 - Las cuatro fases del éxito de un programa de seguridad.

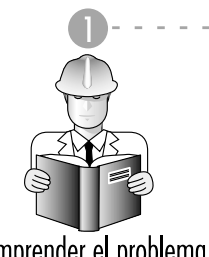

Comprender el problema

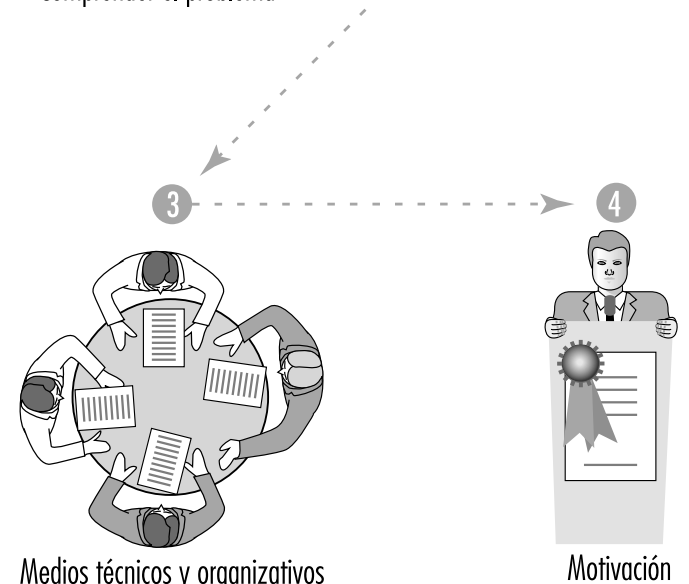

incómodos de usar, por ejemplo, por el tiempo frío reinante. A veces, las campañas de seguridad se dirigen a mejorar la motivación; sin embargo, resultan igualmente ineficaces si consisten en un simple mensaje abstracto, del tipo de "la seguridad es lo primero", a menos que los destinatarios posean la cualificación necesaria para traducir el mensaje en comportamientos concretos. O tro tanto ocurre a los directores de producción a quienes se insta a reducir la siniestralidad en el área en un $50 \%$ si ignoran totalmente la cadena causal de los accidentes.

Es preciso cumplir los cuatro criterios indicados en la Figura 59.5. Por ejemplo, se llevó a cabo un experimento en el que se pretendía que los operarios utilizasen pantallas autosustentadas para impedir que la luz de la llama de soldadura alcanzase el área de trabajo de los compañeros. La experiencia fracasó porque no se habían adoptado las disposiciones organizativas precisas. ¿Q uién colocaría la pantalla, el soldador o el trabajador cercano, expuesto a la luz? Como ambos trabajaban a destajo y no querían perder tiempo, habría tenido que adoptarse una disposición organizativa reguladora de la remuneración antes de realizarse el experimento. Para ser eficaz, el programa de seguridad debe enfocarse a estas cuatro áreas simultáneamente; de lo contrario, los progresos serán limitados.

\section{El programa Tuttava}

El programa Tuttava (Figura 59.6) dura de 4 a 6 meses y abarca el área donde trabajan simultáneamente de 5 a 30 personas. La ejecución del programa se encomienda a un equipo compuesto por representantes de la dirección, los supervisores y los trabajadores.

\section{Objetivos de actuación}

El primer paso consiste en elaborar una lista de objetivos de actuación o de prácticas de trabajo correctas, constituida por unos diez objetivos perfectamente definidos (Tabla 59.3). Los objetivos deben ser: a) positivos y facilitadores del trabajo; b) generalmente aceptables; c) simples y sucintos; d) enunciarse comenzando con verbos activos que hagan resaltar los principales objetivos fijados, y e) fáciles de observar y medir.

Las palabras clave para la especificación de los objetivos son materiales y herramientas. Por regla general, los objetivos consisten en reglas del tipo de colocar correctamente los materiales y herramientas, mantener los pasillos despejados, subsanar inmediatamente las fugas y otros fenómenos perturbadores del proceso y mantener el libre acceso a los extintores de incendios, las salidas de emergencia, las subestaciones eléctricas, los conmutadores de seguridad, etc. En la Tabla 59.4 se reproducen

Figura 59.6 - El programa Tuttava se compone de cuatro etapas y ocho pasos.

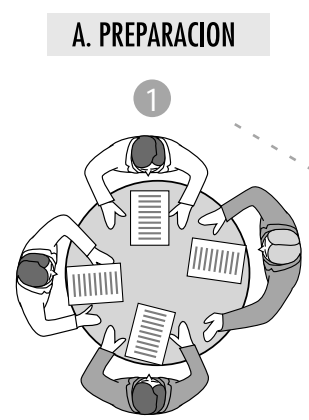

Iniciación del proyecto

B. ADAPTACION $+$

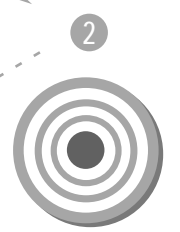

Definición de los métodos de trabajo correctos

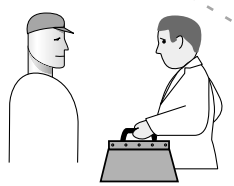

Garantía del cumplimiento de las normas
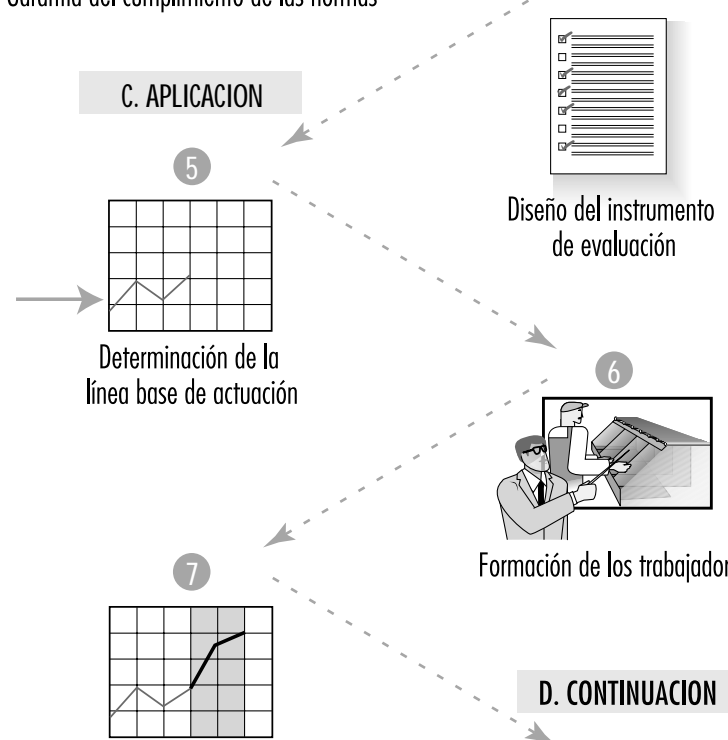

Suministro de retroinformación 
Tabla 59.3 - Ejemplo de prácticas de trabajo correctas.

- Mantener los pasillos despejados.

- Almacenar las herramientas en sitios adecuados cuando no se utilicen.

- Utilizar contenedores y sistemas de eliminación adecuados para los productos químicos.

- Guardar los manuales en el lugar indicado después de utilizarlos.

- Verificar si los instrumentos de medición se han graduado correctamente.

- Colocar las carretillas y paletas en el lugar indicado después de utilizarlas.

- Extraer únicamente la cantidad necesaria de piezas ( tuercas, tornillos, etc.) de los cajones y volver a poner el material no utilizado en el lugar adecuado.

- Sacar de los bolsillos los objetos sueltos que puedan caerse en un descuido.

los objetivos de actuación fijados en una fábrica de tintas para impresión.

Estos objetivos son comparables a los comportamientos seguros definidos en los programas de modificación del comportamiento, con la diferencia de que los comportamientos del programa Tuttava producen consecuencias ostensibles. Por ejemplo, es posible que se tarde menos de un minuto en cerrar las botellas que no se utilizan; sin embargo, para comprobar si esto se ha hecho o no, basta observar las botellas que no se utilizan. No es preciso observar a las personas, con lo que se evita inculpar o señalar a los trabajadores con el dedo.

Los objetivos definen la modificación del comportamiento que el equipo espera de los trabajadores. En este sentido, los objetivos son comparables con el concepto de comportamiento seguro en la modificación del comportamiento. No obstante, la mayoría de los objetivos se refieren a cuestiones que, lejos de constituir comportamientos de los trabajadores, poseen un significado mucho más amplio. Por ejemplo, el objetivo puede consistir en almacenar en el área de trabajo únicamente los materiales que hayan de necesitarse inmediatamente. Esto, sin embargo, exige analizar y comprender los procesos de trabajo, y puede poner de manifiesto la existencia de problemas en los esquemas técnicos y organizativos. A veces, los materiales no se almacenan convenientemente para su empleo cotidiano. En ocasiones, los sistemas de entrega son tan lentos y tan vulnerables a las perturbaciones que inducen a los trabajadores a acumular demasiado material en el área de trabajo.

Tabla 59.4 - O bjetivos de actuación en una fábrica de tintas para impresión.

- Mantener los pasillos despejados.

- Tapar los contenedores siempre que sea posible.

- Cerrar las botellas después de usarlas.

- Limpiar y colocar en su sitio las herramientas después de usarlas.

- Apoyar en el suelo los contenedores al transportar sustancias inflamables.

- Utilizar los equipos de protección indicados en cada situación individual.

- Utilizar ventilación aspirante local.

- Almacenar en las zonas de trabajo sólo los materiales y las sustancias que se necesiten de inmediato.

- Utilizar sólo las carretillas elevadoras en el departamento donde se estén haciendo tintas de impresión flexográficas.

- Colocar etiquetas en todos los contenedores.

\section{G uía de observación}

U na vez que los objetivos de actuación se han definido suficientemente, el equipo diseña una guía de observación con objeto de conocer la medida en que se cumplen los objetivos. Se extraen del área alrededor de 100 puntos de medición. Por ejemplo, en la fábrica de tinta existían 126 de estos puntos. En cada uno de estos, el equipo observa uno o más aspectos concretos. Por ejemplo, en relación con el contenedor de residuos, se puede observar si: a) el contenedor se encuentra saturado; b) se vierte en el mismo el tipo de desperdicios correcto, y c) se tapa, en caso necesario. La respuesta a cada punto sólo puede ser "correcto" o "incorrecto". Las observaciones dicotómicas constituyen la garantía de la fiabilidad y la objetividad del método de medición. El método permite calcular un baremo de conducta al cabo de una ronda de observación que abarcan la totalidad de los puntos de medición. EI baremo consiste, simplemente, en el porcentaje de aspectos valorados como correctos. O bviamente, el baremo puede oscilar entre 0 y 100 y refleja directamente la medida del cumplimiento de las normas. U na vez concluida la primera versión de la guía de observación, el equipo realiza una ronda de verificación. Si el resultado se sitúa en el entorno del $50 \%$ o el $60 \%$ y todos los miembros del equipo obtienen unos resultados aproximados, se puede iniciar la fase siguiente del Tuttava. Si el resultado de la primera ronda de observaciones es excesivamente bajo - por ejemplo, del $20 \%$ - el equipo procede a revisar la lista de objetivos de actuación. Esto es así porque es preciso que todos los aspectos del programa sean positivos. U na línea base excesivamente baja no permitiría evaluar correctamente la actuación previa y sólo serviría para buscar responsables de una actuación pobre. Una buena línea base se sitúa en el entorno del $50 \%$.

\section{M ejoras técnicas, organizativas y de procedimiento}

U na de las principales medidas del programa consiste en garantizar el cumplimiento de los objetivos de actuación. Por ejemplo, si el suelo está lleno de desechos, esto puede deberse, simplemente, a que el número de contenedores de basura es insuficiente. Es posible que exista una cantidad excesiva de materiales y piezas debido a que el sistema de suministros no funciona correctamente. Es imprescindible que el sistema mejore antes de que se pueda exigir una modificación del comportamiento de los trabajadores. Al examinar la viabilidad de cada objetivo, el equipo suele descubrir muchas posibilidades de mejora técnica, organizativa y de procedimiento. Esto permite a los trabajadores del equipo aportar su experiencia al proceso de desarrollo.

Los trabajadores conocen los procesos productivos mucho mejor que la dirección, ya que pasan toda la jornada en su lugar de trabajo. El análisis del cumplimiento de los objetivos de actuación brinda a los trabajadores la posibilidad de transmitir sus ideas a la dirección. Como ya se han producido mejoras, los trabajadores se muestran mucho más receptivos cuando se les pide que cumplan los objetivos. Por regla general, este procedimiento resulta en la adopción de medidas correctoras fácilmente aplicables. Supongamos, por ejemplo, que se ha retirado un número de productos de la línea de producción para dar algunos retoques. Algunos productos estaban en buenas condiciones; otros no. Los operarios querían que algunas áreas del taller se destinasen a los productos buenos y a los malos, con objeto de saber cuáles tenían que reponer en la línea y cuáles tenían que rectificarse. Esta medida puede exigir igualmente la realización de importantes modificaciones técnicas, como la instalación de un nuevo sistema de ventilación en el área de almacenamiento de los productos rechazados. El número de estas modificaciones puede ser muy elevado. Por ejemplo, en una planta de derivados del petróleo con una plantilla de sólo 60 trabajadores se realizaron más de 300 modificaciones técnicas. Es preciso planificar correctamente la realización de estas mejoras con objeto de 
Figura 59.7 - Resultados generados por un departamento de unos astilleros.

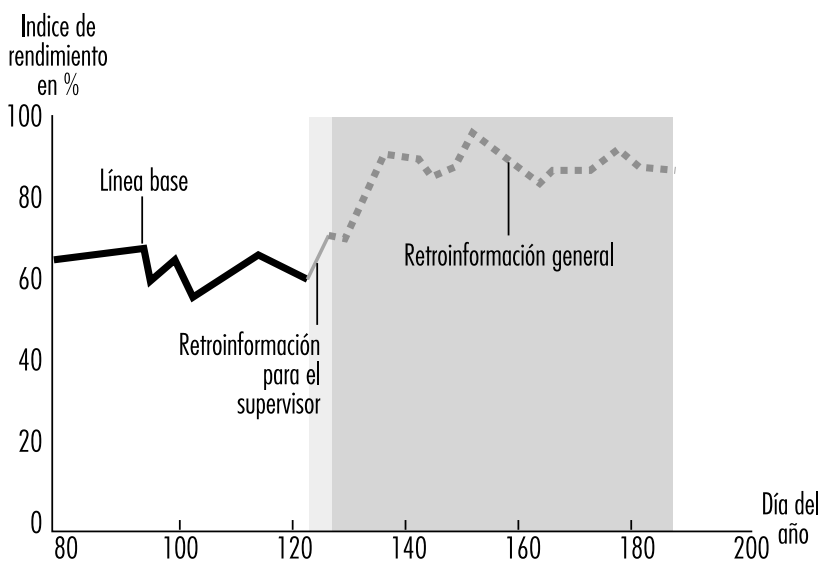

Fuente: Saari y Näsänen 1989

evitar frustraciones y no sobrecargar de trabajo los departamentos afectados.

\section{M odificaciones de la línea base}

Las observaciones de la línea base comienzan cuando el logro de los objetivos de actuación se encuentra razonablemente asegurado y la lista de control de las observaciones es lo bastante fiable. A veces es preciso revisar los objetivos al prolongarse la implantación de las mejoras. El equipo realiza rondas semanales de inspección durante algunas semanas para conocer el nivel existente. Esta fase es importante, ya que permite comparar el rendimiento logrado en fases posteriores con el inicial. Se suele olvidar con facilidad cómo eran las cosas hace sólo dos meses. Es importante tener la sensación de que se progresa para seguir apoyando el esfuerzo continuo de mejora.

\section{Retroinformación}

En la fase siguiente, el equipo suele organizar un seminario de una hora para impartir formación a todos cuantos trabajan en el área. Esta es la primera ocasión en que se dan a conocer las mediciones de la línea base. La fase de retroinformación comienza inmediatamente después del seminario. Las rondas de observación prosiguen con una periodicidad semanal y el resultado de cada observación se hace inmediatamente público mediante la colocación de un gráfico con el baremo en un lugar visible. Se excluye terminantemente cualquier observación crítica, inculpación u otro comentario negativo. Si bien el equipo identifica a los trabajadores que no se comportan de conformidad con los objetivos especificados, tiene instrucciones de mantener reserva sobre esta información. En ocasiones, los trabajadores se incorporan al proceso desde el principio, especialmente si hay pocas personas trabajando en el área. Esto es preferible a establecer equipos de aplicación compuesto por representantes; sin embargo, no resulta posible en todas partes.

\section{Efectos sobre el rendimiento}

El cambio se produce un par de semanas después de iniciarse la retroinformación (Figura 59.7). Empieza a ser ostensible que el lugar de trabajo está mucho mejor ordenado. El baremo de rendimiento suele subir del $50 \%$ al $60 \%$ e, incluso, al $80 \%$ o el $90 \%$. Es posible que estos porcentajes no impresionen en términos absolutos; sin embargo, representan un cambio sustancial en la línea de producción.
Como la finalidad consciente de los objetivos de actuación no se limita a los problemas de seguridad, los beneficios abarcan desde la seguridad a la productividad, pasando por el ahorro de los materiales y el aprovechamiento de la superficie del taller, la mejora del aspecto físico, etc. Para que las mejoras interesen a todos, en algunos objetivos se asocia la seguridad con otras metas, como el aumento de la productividad y la calidad. Esto es preciso para que la seguridad interese a la dirección y la predisponga a invertir en las mejoras de la seguridad menos importantes.

\section{Comprobación de resultados}

En la fase inicial de desarrollo del programa se llevaron a cabo 12 experimentos para verificar los distintos componentes. En un astillero se realizaron observaciones de seguimiento del experimento durante un período de dos años y se pudo determinar que el nuevo nivel de actuación se había mantenido durante ese período. La presencia de unos resultados estables distingue este proceso de la modificación ordinaria del comportamiento. Los cambios visibles en la colocación de los materiales, herramientas, etcétera, impiden que las mejoras logradas en la seguridad se deterioren. Al cabo de tres años, se llevó a cabo una evaluación de los efectos del experimento en la tasa de accidentes ocurridas en el astillero y los hallazgos fueron impresionantes. Los accidentes se habían reducido entre un $70 \%$ y un $80 \%$. Estos resultados eran mucho mejores de los previsibles con la modificación del comportamiento. También se redujo el número de accidentes debidos a causas distintas de las comprendidas en los objetivos de comportamiento.

El principal efecto sobre la frecuencia de los accidentes no se puede atribuir directamente a los cambios directos impulsados por este proceso. Más bien, se trata de un punto de partida de los procesos que siguen. La eficacia del modelo Tuttava y las mejoras ostensibles que promueve contribuyen a mejorar las relaciones laborales e induce a los equipos a buscar nuevas mejoras

\section{Cambio cultural}

Una importante acería era uno de los numerosos usuarios de Tuttava, cuyo principal objetivo consiste en modificar la cultura de seguridad. Cuando se inició la aplicación del programa en 1987, la siniestralidad era de 57 accidentes por millón de horas trabajadas. H asta entonces, la gestión de la seguridad se basaba en muy gran medida en la ejecución de las órdenes emanadas de la dirección. Lamentablemente, el presidente ejecutivo se jubiló y todos se desentendieron de la seguridad, ya que los nuevos directivos eran incapaces de generar idénticas exigencias de una cultura de seguridad. Entre los mandos intermedios, la seguridad se valoraba negativamente, como un trabajo suplementario que había que hacer porque el presidente lo exigía. En 1987 crearon diez equipos Tuttava y en cada año sucesivo se añadieron nuevos equipos. Actualmente, la tasa de accidentes ha descendido a menos de 35 por millón de horas trabajadas y la producción ha experimentado un incremento sostenido en los últimos años. El proceso desencadenó un enriquecimiento de la cultura de seguridad al constatar los mandos intermedios las mejoras que se producían en sus respectivos departamentos, que no sólo eran buenas para la seguridad, sino también para la producción. Esto les hizo mostrarse más receptivos hacia otros programas e iniciativas en el área de la seguridad.

Los beneficios efectivos fueron considerables. Por ejemplo, el servicio de mantenimiento de la planta siderúrgica, que contaba con una plantilla de 300 trabajadores, informó de una reducción de 400 días en el número de jornadas de trabajo perdidas por causa de lesiones profesionales, esto es, de 600 a sólo 200 días. La tasa de absentismo se redujo igualmente en un punto 
porcentual. Los supervisores aseguraron que "resulta más agradable venir a un lugar de trabajo bien organizado, tanto física, como mentalmente". La inversión supuso únicamente una fracción del beneficio económico.

Otra empresa con una plantilla de 1.500 trabajadores informó de la reducción del área de producción en 15.000 metros cuadrados, debido a que los materiales, el equipo, etc., se almacenan ahora de forma más racional. Los alquileres pagados por la empresa se han reducido en 1,5 millones de dólares de Estados Unidos. U na empresa canadiense ahorra cerca de un millón de dólares canadienses al año gracias a la reducción de las mermas de materiales lograda mediante la aplicación del programa Tuttava.

Estos resultados sólo son posibles mediante un cambio cultural. El aspecto más importante de la nueva cultura es el intercambio de experiencias positivas. Un directivo comentó: "Se puede comprar el tiempo de las personas y su presencia física en un lugar determinado; se puede, incluso, comprar una cantidad determinada de movimientos corporales cualificados por hora. Pero no se puede comprar la lealtad, como no se puede comprar la adhesión del corazón, la mente y el alma. Esto hay que ganárselo". El enfoque positivo del Tuttava ayuda a los directivos a ganarse la lealtad y la adhesión de sus equipos de trabajo. Esto hace que el programa permita implicar a los trabajadores en los proyectos de mejora futuros.

\section{- METOdOS DE TOMA DE DECISIONES EN EL CAMPO DE LA SEGURIDAD}

Terje Sten

Una empresa es un sistema complejo, en el que las decisiones se toman en muy diversos contextos y a la luz de circunstancias muy distintas. La seguridad es sólo una de las consideraciones que los directivos deben ponderar al elegir entre diversas líneas de actuación. Tanto el alcance como la naturaleza de las decisiones en el campo de la seguridad varían sensiblemente en función de los riesgos que se afrontan y de la posición que el directivo ocupa en la organización.

Se han realizado numerosos estudios sobre el modo en que las decisiones se toman efectivamente, tanto en el plano individual, como en el contexto de una organización; véase, por ejemplo, Janis y Mann (1977); K ahnemann, Slovic y T versky (1982); M ontgomery y Svenson (1989). En este artículo se examinan los resultados de algunos estudios realizados en este campo para fundamentar los métodos de toma de decisiones aplicados en la gestión de la seguridad. En principio, la toma de decisiones en el área de la seguridad no se diferencia mucho del proceso aplicado en otras áreas de la gestión. No existe un método sencillo ni hay reglas fijas para la toma de decisiones correctas en todos los contextos, dado que las funciones que intervienen en la gestión de la seguridad son demasiado complejas y de naturaleza muy variada.

El objeto del presente capítulo no consiste en proponer recetas o soluciones sencillas, sino en profundizar en el conocimiento de algunos de los principios y problemas que subyacen en el proceso de toma de decisiones acertadas en el campo de la seguridad. Se ofrecerá una visión global del ámbito, los niveles y las etapas de la resolución de los problemas relacionados con la seguridad, inspirada en la obra de $\mathrm{H}$ ale y cols. (1994). L a resolución de un problema consiste en descubrirlo y en formular soluciones viables. Este es un primer e importante paso en todo proceso de toma de decisiones que se examine. Para lograr una perspectiva adecuada de las dificultades que plantea la toma de decisiones en la vida real, se analizarán los principios que informan la teoría de la elección racional. En la parte final del artículo se aborda la toma de decisiones en el marco de una organización y se introduce la perspectiva sociológica en la toma de decisiones. También se abordan algunos de los principales métodos y problemas de la toma de decisiones en el contexto de la gestión de la seguridad, con objeto de profundizar en el conocimiento de los principales retos, dimensiones y escollos de la toma de decisiones en materia de seguridad, considerada como un reto y una función importantes dentro de la gestión de la seguridad.

\section{Contexto de la toma de decisiones en materia de seguridad}

No es fácil intentar una exposición global de los métodos de toma de decisiones relativas a la seguridad, porque tanto los problemas de seguridad como la naturaleza de las dificultades de la toma de decisiones varían sensiblemente durante la vida de la empresa. En efecto, la vida de una empresa atraviesa seis grandes etapas desde su concepción y constitución hasta su desaparición:

1. diseño;

2. creación;

3. puesta en marcha;

4. funcionamiento;

5. mantenimiento y modificación,

6. descomposición y demolición.

Cada una de la etapas del ciclo vital implica la toma de decisiones relativas a la seguridad que, lejos de circunscribirse a la etapa en cuestión, influye en una o varias de las otras etapas. Durante la fase de diseño, creación y puesta en marcha, los principales problemas se asocian a la elección, el desarrollo y formalización de las normas y especificaciones de seguridad adoptadas. Durante los períodos de funcionamiento, mantenimiento y demolición, los principales objetivos de la gestión de la seguridad consisten en el mantenimiento y la eventual mejora del nivel de seguridad alcanzado. La etapa de creación es también, en cierto sentido, una "etapa de producción", dado que, al tiempo que resulta imprescindible observar los principios de seguridad propios de esta etapa de creación, es igualmente preciso elaborar las especificaciones de seguridad de lo que se crea.

\section{Niveles de decisión en la gestión de la seguridad}

La naturaleza de las decisiones relativas a la seguridad difiere, asimismo, en función del nivel organizativo en el que se adoptan aquéllas. H ale y cols. (1994) distinguen tres grandes niveles decisorios en la gestión de la seguridad en las organizaciones:

La ejecución es el nivel en que los actos de las personas implicadas (los trabajadores) influyen directamente en la generación y el control de los peligros en el lugar de trabajo. Este nivel decisorio está relacionado con la detección de los peligros y la elección y ejecución de medidas tendentes a su control, reducción y eliminación. Esto hace que la libertad de opción sea limitada en este nivel. Por consiguiente, los circuitos de retroinformación y corrección se orientan esencialmente a corregir las desviaciones respecto a los procedimientos establecidos y a devolver la praxis a los cauces normativos. Tan pronto como se descubre una situación en que la norma fijada ha quedado desfasada, entra en funcionamiento automáticamente el nivel siguiente.

El nivel de planificación, organización y procedimientos se centra en el diseño y formalización de las actividades previstas para realizarse en el nivel de ejecución en relación con todo el espectro de riesgos previsibles. Este nivel de planificación y organización, en el que se establecen responsabilidades, procedimientos, líneas jerárquicas, etc., se suele describir en los manuales de seguridad. 
En este nivel se elaboran los nuevos procedimientos aplicables frente a los nuevos peligros que afronta la organización y se modifican los procedimientos vigentes. También en este nivel se traducen los principios abstractos en acciones concretas de asignación y aplicación, en correlación con el circuito de perfeccionamiento aplicado en muchos sistemas de control de la calidad.

EI nivel de estructura y gestión atañe a los principios generales de gestión de la seguridad. Este nivel se activa cuando la organización estima que los niveles actuales de planificación y organización resultan inadecuados en aspectos fundamentales para lograr los resultados deseados. En este nivel se ejerce un control crítico del funcionamiento "normal" del sistema de gestión de la seguridad, que se procura mantener o mejorar continuamente frente a los cambios que se producen en el entorno externo de la organización.

$\mathrm{H}$ ale y cols. (1994) insisten en que los tres niveles constituyen abstracciones correspondientes a tres niveles distintos de retroinformación. No hay que confundir estos tres niveles con los tres niveles jerárquicos presentes en la planta de producción, la primera línea y la alta dirección, ya que las actividades especificadas en cada nivel de abstracción se pueden realizar de muy distintas maneras. EI modo en que se asignan las tareas reflejan la cultura y los métodos de trabajo de la empresa.

\section{Proceso de toma de decisiones en el campo de la seguridad}

La gestión de los problemas de seguridad se debe encauzar a través de un proceso de resolución de problemas y de toma de decisiones. Según H ale y cols. (1994), este proceso, denominado ciclo de resolución de problemas, está presente en los tres niveles de gestión de la seguridad anteriormente descritos. El ciclo de resolución de problemas es un modelo de un procedimiento gradual idealizado de análisis y toma de decisiones relativas a los problemas de seguridad causados por las desviaciones reales 0 potenciales respecto a los resultados previstos 0 deseados (Figura 59.8).

Aunque los pasos son, en principio, idénticos en los tres niveles de gestión de la seguridad, su aplicación práctica puede variar en cierta medida en función de la naturaleza de los problemas que se abordan. En el modelo se muestra que las decisiones relativas a la gestión de la seguridad abarcan numerosos tipos de problemas. En la práctica, cada uno de los seis problemas básicos siguientes de la toma de decisiones en la gestión de la seguridad se tienen que desglosar en varias decisiones parciales que constituyen la base de las opciones en cada uno de las principales fuentes de problemas.

1. ¿Cual es el nivel o criterio de seguridad aceptable en la actividad, departamento, empresa, etc.?

2. ¿Qué criterio se aplicará en la evaluación del nivel de seguridad?

3. ¿C ual es el nivel de seguridad actual?

4. ¿Cuáles son las causas de las desviaciones observadas entre el nivel de seguridad aceptable y el contrastado?

5. ¿Q ué medidas deben adoptarse para corregir las desviaciones y mantener el nivel de seguridad?

6. ¿Como se deben aplicar y desarrollar las medidas correctoras?

\section{Teoría de la elección racional}

Los métodos de toma de decisiones aplicados por los directivos deben fundarse en un principio de racionalidad si se quiere que aquéllas sean asumidas por los miembros de la organización. En la práctica, lo racional no siempre es fácil de definir, y los presupuestos lógicos de las decisiones consideradas racionales no siempre son fáciles de cumplir. La teoría de la elección racional (TER ), fundamento de la toma de decisiones racionales, se desarrolló inicialmente para explicar el comportamiento económico de los agentes del mercado, y se reelaboró posteriormente para explicar, no sólo el comportamiento económico, sino también el comportamiento estudiado en la práctica totalidad de las ciencias sociales, desde la filosofía política a la psicología.

El estudio psicológico del proceso humano de toma de decisiones se denomina teoría de la utilidad subjetiva prevista (USP). La teoría de la elección racional y la teoría de la utilidad subjetiva prevista son, básicamente, idénticas y sólo difieren las aplicaciones. La teoría de la utilidad subjetiva prevista se centra en el proceso mental de la toma de decisiones individuales, mientras que la teoría de la elección racional posee un campo de aplicación más amplio en la explicación del comportamiento en el conjunto de una organización o una institución: véase, por ejemplo, N eumann y Politser (1992). La mayoría de los instrumentos de la moderna investigación operativa se basan en los conceptos de la teoría de la utilidad subjetiva prevista. Esta se basa en la presunción de que lo que se persigue es asegurar el logro de un objetivo, en unas circunstancias concretas y suponiendo que todas las posibles alternativas o consecuencias (o su distribución probabilística) son conocidas (Simon y cols. 1992). La esencia de las teorías de la elección racional y de la utilidad subjetiva prevista se pueden resumir en la forma siguiente (M arch y Simon 1993):

Cuando los responsables de la toma de decisiones se encuentran abocados a tomar decisiones, se plantean y analizan toda la gama de alternativas, entre las que seleccionan su línea de actuación. Estas posibilidades son datos objetivos que no se pueden obtener aplicando la teoría.

C ada alternativa lleva aparejada una serie de consecuencias, consistentes en los hechos que se derivan de cada alternativa. En este punto, las teorías actuales se pueden agrupar en tres clases:

- En las teorías de la certidumbre se presume que el responsable de la toma de decisiones conoce perfectamente las consecuencias de la elección de cada alternativa. Si existe certidumbre, la elección es inequívoca.

- En las teorías del riesgo se presume un conocimiento preciso de una distribución probabilística de las consecuencias de cada alternativa. Si existe un riesgo, la racionalidad se suele definir como la elección de la alternativa de la que puede esperarse una mayor utilidad.

- En las teorías de la incertidumbre se presume que las consecuencias de cada alternativa pertenecen a un subconjunto de posibles consecuencias, pero que el responsable de la toma de decisiones no puede atribuir unas posibilidades determinadas a unas consecuencias concretas. En caso de incertidumbre, la definición de la racionalidad resulta problemática.

Al principio, el responsable de la toma de decisiones utiliza una "función de utilidad" o un "orden de preferencia" en el que todas las series de alternativas se ordenan de las más deseables a las menos deseables. Es de subrayarse que existe también la posibilidad de aplicar la regla del "mínimo riesgo", consistente en ponderar la "peor serie de consecuencias" posibles de cada alternativa, para elegir a continuación la alternativa cuya "peor serie de consecuencias" sea preferible a las peores series atribuibles a las demás alternativas.

EI responsable de la toma de decisiones elige la alternativa más cercana a la serie de consecuencias más deseable.

U na dificultad de la teoría de la elección racional es que el término racionalidad es en sí mismo problemático. La racionalidad de una decisión es una función del contexto social en que se toma. Como indica Flanagan (1991), es importante distinguir entre racionalidad y lógica. $L$ a racionalidad alude a las cosas que tienen que ver con el significado y la calidad de la vida de las 
personas; la lógica no. El problema para el "benefactor" es, precisamente, la cuestión que los modelos de elección racional no clarifican, debido a que parten de la presunción de una neutralidad en el terreno de los valores que pocas veces se produce en el proceso real de toma de decisiones (Zey 1992). Si bien el valor explicativo, tanto de la teoría de la elección racional, como de la teoría de la utilidad subjetiva prevista, es limitado, se ha utilizado con provecho como modelo teórico de la toma "racional" de decisiones. La evidencia de que el comportamiento suele desviarse de los resultados esperados según la teoría de la utilidad subjetiva prevista no implica necesariamente que la teoría indique incorrectamente cómo se deben tomar las decisiones. Como modelo normativo, la teoría ha demostrado su utilidad para generar estudios sobre cómo y por qué se toman decisiones que vulneran el axioma de la utilidad máxima.

La aplicación de la teoría de la elección racional y de la teoría de la utilidad subjetiva prevista a la toma de decisiones en el ámbito de la seguridad puede servir de base a la evaluación de la "racionalidad" de las elecciones realizadas en materia de seguridad, por ejemplo, en la selección de medidas preventivas frente a un problema de seguridad que se desea mitigar. Con suma frecuencia es imposible aplicar los principios de elección racional por falta de datos fiables. Es posible que no se disponga de una idea precisa de las líneas de actuación posibles o disponibles; otras veces, existe un alto grado de incertidumbre respecto a los posibles efectos de diferentes líneas de actuación, por ejemplo, sobre la aplicación de diferentes medidas preventivas. Así, la teoría de la elección racional puede ayudar a poner de manifiesto algunos puntos débiles del proceso de toma de decisiones, pero vale de poco para mejorar la calidad de las elecciones que se realizan. 0 tra limitación de los modelos de elección racional es que en la mayoría de las decisiones que se adoptan en las organizaciones no se persiguen necesariamente las soluciones óptimas.

\section{Resolución de problemas}

En los modelos de elección racional se describe el proceso de evaluación y elección entre alternativas. No obstante, la decisión sobre una línea de actuación implica igualmente lo que Simon y cols. (1992) describen como resolución de problemas. Es un trabajo de selección de cuestiones que demandan atención, de fijación de objetivos y de buscar o seleccionar líneas de actuación correctas. ( $\mathrm{E} n$ efecto, aunque los directivos sean conscientes de que tienen problemas, es posible que no conozcan la situación lo suficientemente bien para elegir una línea de actuación plausible). Como se ha indicado anteriormente, la teoría de la elección racional se ha originado principalmente en la economía, la estadística y la investigación operativa, y sólo recientemente ha despertado el interés de los psicólogos. La teoría y los métodos de la resolución de problemas tienen una historia muy distinta. En efecto, la resolución de problemas fue utilizada principalmente en un principio por los psicólogos y, más recientemente, por los investigadores de la inteligencia artificial.

La investigación empírica ha demostrado que el proceso de resolución de problemas se desarrolla de forma similar en un vasto espectro de actividades. En primer lugar, en la resolución de problemas se suele realizar una investigación selectiva de grandes conjuntos de posibilidades, utilizando el método empírico (heurística) para dirigir la investigación. Dado que el número de posibilidades existentes en las situaciones reales de resolución de problemas es virtualmente infinito, una investigación realizada según el método de ensayo y error, simplemente, no funcionaría. La investigación debe ser altamente selectiva. U no de los procedimientos generalmente utilizados para dirigir la investigación es el denominado escalamiento, en el que se emplea alguna medida de aproximación al objetivo para determinar qué resulta más provechoso investigar después. 0 tro procedimiento, más usual y eficaz, es el análisis medios-fines. Según este método, el analista compara la situación con el objetivo, descubre las diferencias entre ambos y busca en la memoria las posibles actuaciones susceptibles de reducir esa diferencia. 0 tro conocimiento adquirido respecto a la teoría de resolución de problemas, especialmente si el analista es experto, es que el proceso mental del analista descansa sobre una gran cantidad de información almacenada en la memoria y que se puede recuperar cuando el analista descubre alguna pista que denota su relevancia.

U no de los logros de la teoría contemporánea de la resolución de problemas ha sido la aportación de una explicación de los fenómenos de intuición y juicio frecuentemente observados en el comportamiento de los expertos. Combinada con algunas técnicas deductivas básicas (consistentes, quizás en un análisis medios-fines), el experto utiliza esta función de indización para encontrar soluciones satiffactorias a problemas difíciles.

La mayoría de las dificultades que los directores de seguridad afrontan requieren la aplicación de alguna técnica de resolución de problemas, consistente, por ejemplo, en descubrir las verdaderas causas subyacentes en un accidente 0 un problema de seguridad, con objeto de diseñar alguna medida preventiva. El ciclo de resolución de problemas desarrollado por $\mathrm{H}$ ale y cols. (1994) (véase la Figura 59.8) constituye una buena descripción del contenido de las diferentes etapas de la resolución de los problemas de seguridad. Lo que parece evidente es que actualmente no resulta posible $-y$ quizás, no sea tampoco deseabledesarrollar un modelo estrictamente lógico o matemático de un proceso ideal de resolución de problemas, como se ha hecho respecto a las teorías de la elección racional. Esta opinión se sustenta en el conocimiento de otras dificultades suscitadas en los casos reales de resolución de problemas y toma de decisiones que se examinan posteriormente.

\section{Problemas mal estructurados, programación y formulación}

En la vida real se suelen producir situaciones en las que los procesos de resolución de los problemas se enturbian debido a que los objetivos son complejos y, a veces, están mal definidos. Lo que suele ocurrir es que la naturaleza misma del problema se transforma en el curso de la investigación. Se puede decir que un problema de estas características está mal estructurado. Ejemplos típicos de procesos de resolución de problemas de estas características son: a) el desarrollo de nuevos diseños y b) los descubrimientos científicos.

La resolución de problemas mal definidos sólo se ha empezado a estudiar recientemente. Si los problemas están mal definidos, el proceso de resolución de los mismos exige un conocimiento profundo, tanto de los criterios de resolución como de los medios de satisfacer esos criterios. Ambos tipos de conocimientos son aplicables durante el proceso, y el recuerdo de los criterios y restricciones produce una modificación y remodelación continuas de la solución que se persigue en el proceso de resolución del problema. Puede resultar de utilidad revisar algunos estudios publicados en relación con el análisis y estructuración de los problemas en el campo de los riesgos y la seguridad; véanse, por ejemplo, Rosenhead 1989, y Chicken y $\mathrm{H}$ aynes 1989.

La programación, que es el primer paso del proceso de resolución de problemas, es también el menos conocido. Lo que hace que un problema se sitúe en el lugar preferente del programa es la identificación del mismo y de las eventuales dificultades, que permiten decidir el modo de formular el problema de forma que se facilite su resolución; se trata de cuestiones que sólo recientemente se han abordado en los estudios de los procesos de toma 
Figura 59.8 • Ciclo de resolución de los problemas.

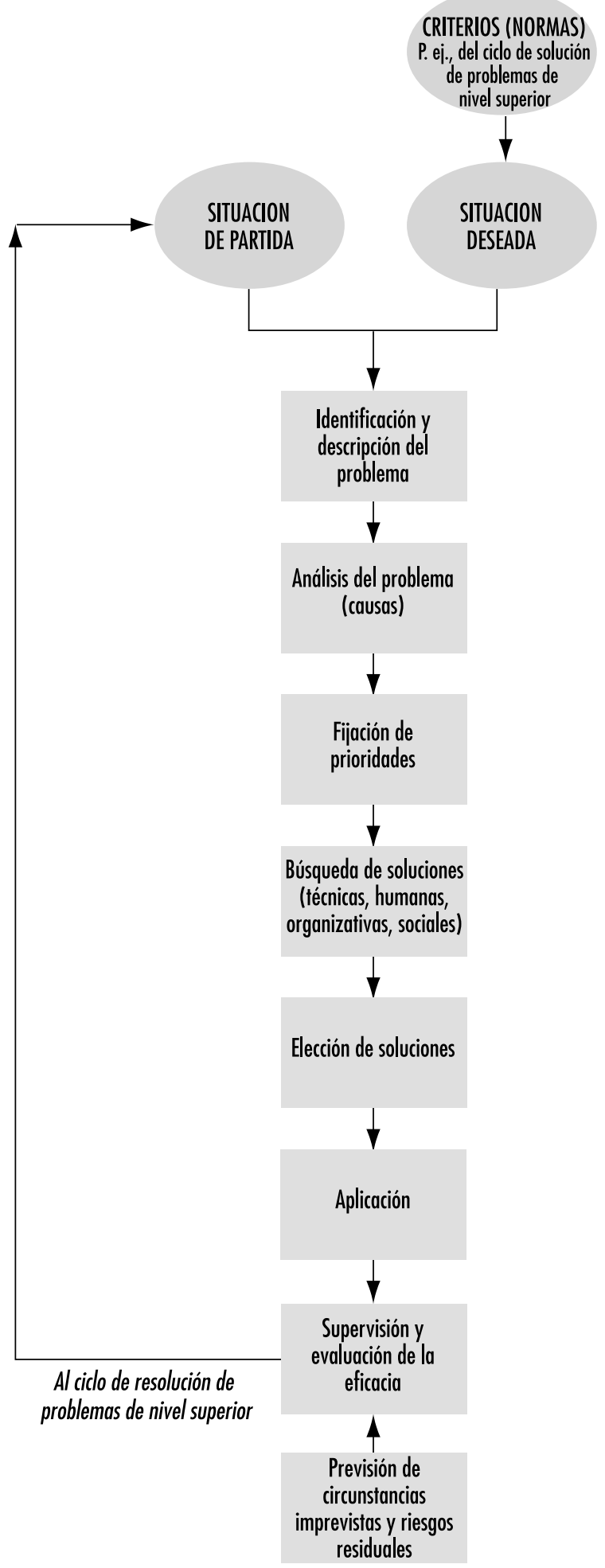

Fuente: Adaptado de Hale y cols. 1994

de decisiones. La elaboración de un programa es de la máxima importancia, debido a que las personas como las instituciones tienen una capacidad limitada para realizar varias tareas simultáneamente. Cuando la atención se centra en un grupo de problemas, se descuidan otros. Si surgen repentina e inesperadamente nuevos problemas (como la lucha contra incendios), se abandona la planificación y el estudio sistemáticos.

El modo en que se formulan los problemas tiene mucho que ver con la calidad de las soluciones a las que se llega. Actualmente, el enunciado o formulación de los problemas es, incluso, menos conocido que la elaboración de programas. U na característica común a muchos progresos científicos y tecnológicos es que el cambio de la formulación genera un enfoque totalmente nuevo de la resolución del problema. U n ejemplo de este tipo de cambios en la formulación de los problemas que se ha producido en años recientes en la ciencia de la seguridad es el desplazamiento del interés desde los detalles de las operaciones de producción hacia las decisiones y condiciones organizativas que configuran el contexto mismo del trabajo; véase, por ejemplo, Wagenaar y cols. (1994).

\section{La toma de decisiones en las organizaciones}

En los modelos de toma de decisiones en la empresa, la cuestión de la elección se considera un proceso lógico en el que los responsables de la toma de decisiones se esfuerzan por garantizar el logro de sus objetivos en una sucesión lógica de pasos (Figura 59.9). En principio, este proceso es idéntico respecto a las decisiones relativas a la seguridad que en las que afectan a otras cuestiones que la organización debe abordar.

Estos modelos pueden servir de marco general para la "toma de decisiones racionales" en las organizaciones; sin embargo, estos modelos ideales adolecen de diversas limitaciones y de los mismos se excluyen algunos aspectos esenciales de los procesos que se pueden producir en la realidad. Posteriormente se examinan algunas de las características más relevantes de los procesos de toma de decisiones en las organizaciones.

\section{Criterios de elección aplicados en las organizaciones}

$M$ ientras que los modelos de elección racional se centran en la búsqueda de la alternativa óptima, otros criterios pueden ser más importantes para la toma de decisiones en las organizaciones. C omo observan M arch y Simon (1993), diversas causas inducen a las organizaciones a buscar soluciones satisfactorias en lugar de soluciones óptimas.

- Alternativas óptimas. U na alternativa se puede considerar óptima si: a) existe una serie de criterios que permiten comparar todas las alternativas, y b) la alternativa en cuestión se prefiere, en aplicación de esos criterios, al resto de las alternativas (véase, asimismo, anteriormente, el examen de la elección racional).

Figura 59.9 - El proceso de toma de decisiones en las organizaciones.

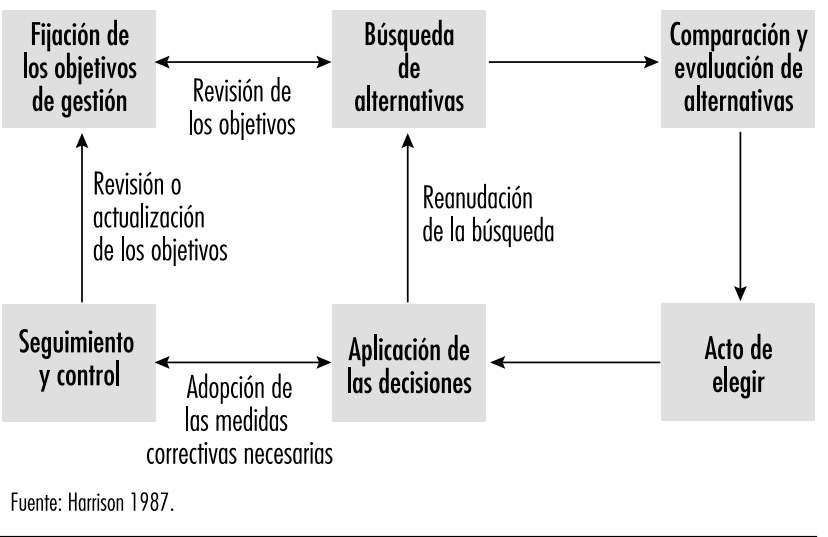


- Alternativas satisfactorias. Una alternativa es satisfactoria si: a) existe una serie de criterios descriptivos de unas alternativas mínimamente satisfactorias, y b) la alternativa elegida satisface o rebasa esos criterios.

Según M arch y Simon (1993), la mayoría de los procesos de toma de decisiones, tanto individuales como colectivas, tratan de buscar y elegir alternativas satisfactorias y sólo en casos excepcionales consisten en la búsqueda y elección de alternativas óptimas. En la gestión de la seguridad, las alternativas satisfactorias relativas a la seguridad suelen ser suficientes, por lo que se exige que una determinada resolución a un problema de seguridad satisfaga determinados criterios. Las limitaciones generalmente aplicadas a las decisiones óptimas en materia de seguridad suelen ser consideraciones económicas del tipo de: "Q ue sea bueno, pero lo más barato posible".

\section{Programación de la toma de decisiones}

Al estudiar las concordancias entre la toma de decisiones individuales y la que se produce dentro de las organizaciones, $M$ arch y Simon (1993) adujeron que el comportamiento de las organizaciones nunca puede ser absolutamente racional, debido a que sus integrantes poseen una capacidad limitada de tratamiento de la información. Se aduce que los responsables de la toma de decisiones únicamente pueden alcanzar un grado limitado de racionalidad, debido a que: a) generalmente deben actuar sobre la base de una información incompleta; b) únicamente pueden analizar un número limitado de alternativas relacionadas con una determinada decisión, y c) no pueden valorar adecuadamente los resultados. $M$ arch y Simon aducen que los límites de la racionalidad humana se institucionalizan en la estructura y las formas de funcionamiento de nuestras organizaciones. Para controlar el proceso de toma de decisiones, las organizaciones dividen, sistematizan y limitan de diversas formas los procesos de toma de decisiones. Los departamentos y unidades operativas tienen como consecuencia segmentar el medio organizativo, dividir las responsabilidades y, por ende, simplificar el campo de actuación y de toma de decisiones de los directivos, supervisores y trabajadores. La línea jerárquica desempeña una función análoga al aportar cauces de resolución de problemas que hacen la vida más soportable. Esto genera una estructura de observación, interpretación y actuación que influye decisivamente en lo que se consideran elecciones "racionales" del responsable de la toma de decisiones en el marco de la organización. M arch y Simon denominan a estas series sistemáticas de respuestas programas de actuación 0 , simplemente, programas. El término programa no tiene aquí una connotación de rigidez absoluta, pues el contenido de aquél puede ser adaptable a un gran número de factores que lo han desencadenado. El programa puede responder igualmente a una serie de datos ajenos a los estímulos iniciales. En este caso se puede denominar con mayor propiedad una estrategia de actuación.

Diversas actividades se tienen por sistematizadas hasta el punto de haberse simplificado el procedimiento de elección mediante la implantación de mecanismos de respuesta automática a determinados estímulos. Si la búsqueda ha sido eliminada pero la elección permanece en forma de unas rutinas de control sistemáticas, se considera que la actividad se ha rutinizado. Se considera que una actividad no está rutinizada si ha de ir precedida de determinadas tareas de desarrollo de programas orientados a la resolución de problemas. La distinción realizada por Hale y cols (1994) - comentada anteriormente- entre los niveles de ejecución, planificación y gestión de las estructuras del sistema posee unas implicaciones similares respecto a la estructuración del proceso de toma de decisiones.
La programación influye en la toma de decisiones de dos formas: a) definiendo cómo se debe desarrollar un proceso de toma de decisiones, quién debe participar en el mismo, etcétera, y b) especificando qué opciones pueden elegirse sobre la base de la información y de las alternativas disponibles. L os efectos de la programación son, por una parte, positivos, en el sentido de que pueden incrementar la eficiencia del proceso de toma de decisiones y garantizar que los problemas no queden sin resolver y que se abordan de forma bien estructurada. Por otra parte, una programación rígida puede reducir la flexibilidad que resulta especialmente necesaria en la fase de resolución de problemas del proceso decisorio con objeto de generar nuevas soluciones. Por ejemplo, en muchas líneas aéreas existen procedimientos formales de tramitación de las denuncias de desviaciones mediante los denominados informes de vuelo y partes de mantenimiento, que exigen que cada caso sea estudiado por la persona competente y que se tome una decisión en relación con las medidas preventivas que deban adoptarse como consecuencia de la incidencia. Aunque la decisión consista a veces en abstenerse de tomar medidas, los procedimientos garantizan que se toma una decisión informada y no como fruto de una negligencia, y que ha sido tomada por una persona responsable.

La medida en que las actividades se programan influye en la asunción de riesgos. Wagenaar (1990) sostiene que la mayoría de los accidentes ocurren por causa de un comportamiento rutinario al margen de toda consideración de riesgo. El verdadero problema del riesgo se produce en los niveles superiores de la organización, en los que se adoptan las decisiones no programadas. Sin embargo, la mayoría de las veces, los riesgos no se asumen conscientemente y suelen ser el resultado de la toma de decisiones que no se relacionan directamente con la seguridad, pero que influyen involuntariamente en las condiciones de un funcionamiento seguro. Por lo tanto, los directivos y otros responsables de la toma de decisiones de alto nivel son más propensos a tolerar situaciones de riesgo que a asumir riesgos.

\section{Toma de decisiones, poder y conflicto de intereses}

La capacidad para influir en los resultados de los procesos de toma de decisiones es una fuente reconocida de poder que ha merecido especial atención en la investigación teórica de las organizaciones. Puesto que las organizaciones son, en gran medida, sistemas de toma de decisiones, una persona o un grupo puede ejercer una influencia considerable en el proceso de toma de decisiones de la organización. Según Morgan (1986), el poder que se ejerce en el proceso de toma de decisiones consta de los siguientes tres elementos conexos:

1. Las circunstancias previas de la decisión. Se puede influir en las circunstancias previas de una decisión de varias maneras. U na de las formas más eficaces de tomar decisiones es dejar que se materialicen por omisión. Por consiguiente, buena parte de la función política de una organización depende del control de las programaciones y de otras premisas de la toma de decisiones que influyen en la forma de abordar determinadas decisiones, evitando, a veces, que cuestiones importantes emerjan a la superficie. Además, las circunstancias previas a las decisiones se ven sutilmente alteradas por la selección del lenguaje, formas de comunicación, actitudes, creencias, reglas y procedimientos aceptados sin discusión. Estos factores contribuyen a configurar las decisiones al influir en nuestras ideas y nuestras acciones. Según M organ (1986), nuestras percepciones de la naturaleza de los problemas suelen encorsetar nuestros procesos mentales e impedir que descubramos otros modos de formular nuestros objetivos básicos y las posibles soluciones alternativas. 
2. Los procesos decisorios. El control de los procesos decisorios suele ser más obvio que el de los presupuestos de la toma de decisiones. En el modo de enfocar una cuestión están implícitas consideraciones como quiénes deben participar, cuándo se debe adoptar la decisión, cómo se debe plantear la cuestión en las reuniones y de qué forma se debe comunicar. Las normas básicas que regulan un proceso decisorio constituyen variables importantes que los miembros de la organización pueden manipular para influir en el resultado.

3. Contenido y objetivos de las decisiones. Una última forma de controlar el proceso de toma de decisiones consiste en influir en el contenido y los objetivos de las mismas, así como en los criterios de evaluación aplicables. La forma más directa de influir en el contenido y los objetivos de las decisiones consiste en elaborar informes e influir en las discusiones que han de servir de base a las decisiones. Subrayando la importancia de determinadas condiciones, seleccionando y evaluando las alternativas que hayan de servir de base a la decisión y destacando la importancia de determinados valores y resultados, los responsables de la toma de decisiones pueden influir considerablemente en la decisión que emerge de la discusión.

Algunos problemas que se suscitan en torno a las decisiones pueden originar un conflicto de intereses, por ejemplo, entre los trabajadores y la dirección. EI desacuerdo se puede plantear en torno a la definición misma del problema. Estos son los problemas que Rittel y Webber (1973) denominan problemas "feroces", en contraposición a los problemas "suaves" por lo que respecta a la facilidad de lograr un consenso. En otros casos, las partes implicadas logran ponerse de acuerdo en torno a la definición de un problema, pero no respecto al modo de resolverlos ni en torno a las soluciones o a los criterios de resolución aceptables. Las actitudes y estrategias de las partes en conflicto determinan, no sólo sus comportamientos en la resolución de problemas, sino también las posibilidades de llegar a una resolución de consenso a través de la negociación. La forma en que las partes en conflicto intentan imponer sus puntos de vista en

Figura 59.10 - Siete clases de comportamientos negociadores.

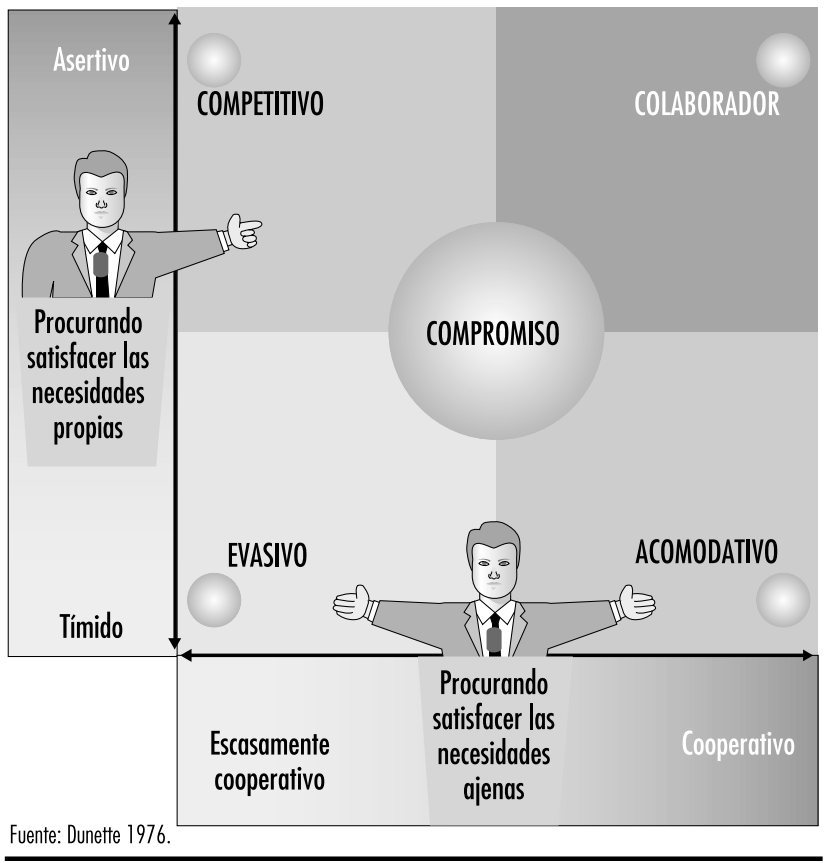

Figura 59.11 - Tipología de la política de resolución de problemas.

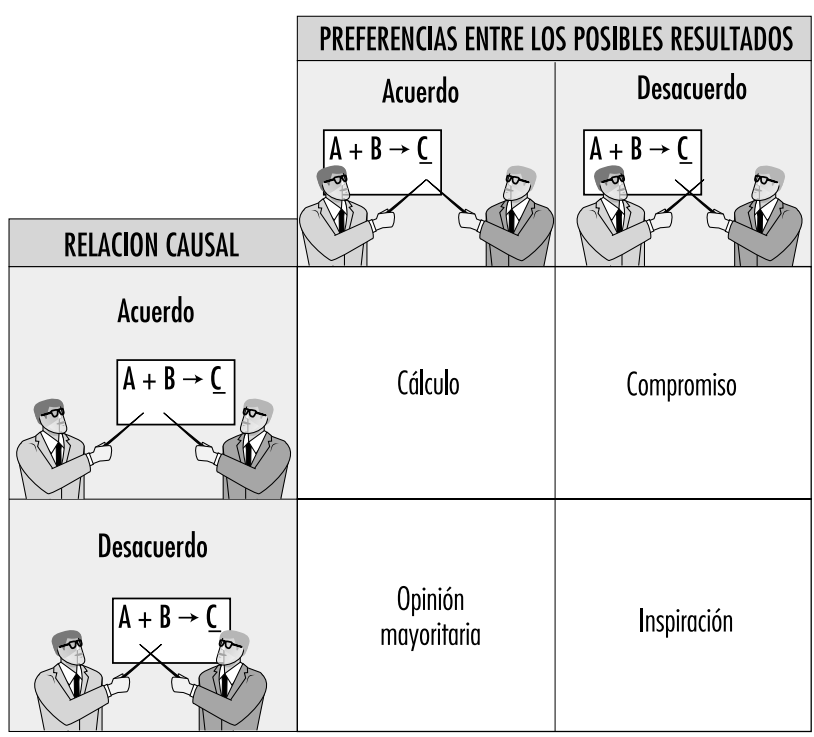

Fuente: Thompson y Tuden 1959

detrimento de los contrarios da lugar a variables significativas (Figura 59.10). Para lograr una colaboración fructífera, es preciso que cada parte exponga claramente sus necesidades y que, al mismo tiempo, se muestre dispuesta a tomar en consideración las necesidades de la otra parte.

Thompson y Tuden (1959), citados en Koopman y Pool (1991), elaboraron otra interesante clasificación, basada en el grado de coincidencia entre medios y objetivos. Formularon una "estrategia de aproximación" basada en el conocimiento de las impresiones de las partes sobre las causas del problema y de los resultados preferidos (Figura 59.11).

Si existe coincidencia entre medios y objetivos, es posible calcular una decisión que, por ejemplo, puede ser elaborada por un grupo de expertos. Si los medios para alcanzar los fines deseados no están claros, los expertos tendrán que llegar a una resolución realizando consultas (criterio mayoritario). Si el conflicto afecta a los objetivos, se impone un proceso de consultas entre las partes implicadas. En cambio, si el desacuerdo afecta a medios y objetivos por igual, la organización corre serio peligro. U na situación así requiere un liderazgo carismático, capaz de "inspirar" una resolución aceptable a las partes en conflicto.

Por consiguiente, la toma de decisiones en un marco organizativo abre unas perspectivas que exceden con mucho de los modelos de elección racional y de resolución de problemas específicos. Los procesos decisorios se deben considerar en el marco de los procesos organizativos y de gestión, en los que el concepto de racionalidad puede adquirir nuevas dimensiones, distintas de las que se pueden definir aplicando la lógica de los conceptos de elección racional inherentes, por ejemplo, en los modelos de investigación operativa. La toma de decisiones en el contexto de la gestión de la seguridad se debe abordar desde una perspectiva que permita una comprensión profunda de todos los aspectos de los problemas planteados.

\section{Resumen y conclusiones}

L a toma de decisiones se puede definir en líneas generales como un proceso que comienza con una situación inicial (estadio inicial) que, en opinión de los responsables de la toma de 
decisiones, se desvía de la situación deseada (estadio deseado), si bien no saben por anticipado cómo transformar ese estadio inicial en el estadio deseado (H uber 1989). El responsable de la resolución de problemas convierte el estadio inicial en el deseado aplicando uno o más operadores, esto es, actividades concebidas para alterar los estadios. A menudo se precisa una serie de operadores para producir el cambio deseado.

Los estudios de esta materia no aportan soluciones simples al problema de cómo tomar decisiones en el ámbito de la seguridad; por consiguiente, los métodos de toma de decisiones deben ser lógicos y racionales. La teoría de la elección racional es una concepción brillante de cómo se deben tomar las decisiones. Sin embargo, la elección racional no siempre es aplicable en la gestión de la seguridad. La limitación más evidente de esta teoría es la falta de datos válidos y fiables sobre las posibles opciones, por lo que respecta, tanto a su suficiencia, como al conocimiento de las consecuencias. O tra dificultad consiste en que el concepto racional supone la existencia de un benefactor, que puede diferir en función de la perspectiva que se adopte en un determinado contexto decisorio. No obstante, el modelo de elección racional puede ser útil para poner de relieve algunas de las dificultades y limitaciones de las decisiones que se adoptan.

Con frecuencia, el problema no consiste en hacer una elección acertada entre varias opciones, sino, más bien, en analizar una situación para descubrir la verdadera naturaleza del problema. La estructuración suele ser la función más importante del análisis de los problemas de gestión de la seguridad. La comprensión del problema es una condición previa para lograr una resolución aceptable. L o más importante en la resolución de problemas no consiste en adoptar un único método supremo que probablemente no existe dada la gran variedad de problemas posibles en las áreas de evaluación del riesgo y la gestión de la seguridad. Lo más importante es, por el contrario, utilizar un método estructurado y documentar los análisis y las decisiones tomadas de forma que los procedimientos y evaluaciones sean identificables.

Las organizaciones encauzan una parte de la función de toma de decisiones a través de actividades programadas. La implantación de programas o de procedimientos fijos para la toma de decisiones rutinarias puede ser muy útil en la gestión de la seguridad. La programación puede constituir un medio eficaz de gestionar los procesos de toma de decisiones en las organizaciones, siempre que los problemas de seguridad y las reglas aplicables a la toma de decisiones sean inequívocos.

En la vida real, las decisiones se toman en un contexto organizativo y social en el que a veces se producen conflictos de intereses. Los procesos decisorios pueden verse afectados por percepciones divergentes de la naturaleza de los problemas, de los criterios y de la aceptabilidad de las soluciones propuestas. La gestión de la seguridad comprende un amplio espectro de problemas que están en función del ciclo vital, el nivel organizativo y el estadio de resolución o de mitigación del riesgo se plantee el problema. En este sentido, la toma de decisiones en materia de seguridad reviste idéntica amplitud de alcance y de naturaleza que las decisiones tomadas en cualquier otro campo de la gestión.

\section{- Percepcion del Riesgo}

\section{Bernhard Zimolong y Rüdiger Trimpop}

En la percepción del riesgo cabe distinguir dos procesos psicológicos: la percepción del peligro y la valoración del riesgo. Saari (1976) define la información tratada durante la realización de una tarea en función de los dos elementos siguientes: a) la información precisa para realizar una tarea (percepción del peligro), y b) la información precisa para mantener los riesgos presentes bajo control (valoración del riesgo). Por ejemplo, si un trabajador de la construcción que se ha subido en una escalera para abrir agujeros en una pared se ve obligado, simultáneamente, a mantener el equilibrio y coordinar los movimientos del cuerpo y de las manos, la percepción del peligro es vital para coordinar los movimientos corporales con objeto de controlar el peligro, al tiempo que la valoración consciente del riesgo es insignificante 0 nula. La actividad humana parece responder a un mecanismo automático de identificación de señales que desencadenan una secuencia de acciones flexibles, aunque escalonadas jerárquicamente. (En otro artículo se estudia el proceso más consciente que conduce a la aceptación o el rechazo de los riesgos).

\section{Percepción del riesgo}

Desde el punto de vista técnico, un peligro es una fuente de energía capaz de producir inmediatamente lesiones a los trabajadores 0 daños al equipo, a las estructuras 0 al medio ambiente. L os trabajadores pueden igualmente quedar expuestos a diversos agentes tóxicos, como los gases, los productos químicos o la radiactividad, algunos de los cuales pueden causar problemas de salud. A diferencia de las energías peligrosas, que surten efectos inmediatos en el organismo, los parámetros temporales de las sustancias tóxicas son muy diversos y van desde los efectos inmediatos hasta los efectos a largo plazo, de meses o años. A menudo se produce un efecto acumulativo de las pequeñas dosis de sustancias tóxicas que resulta imperceptible para los trabajadores expuestos.

Recíprocamente, las energías peligrosas y las sustancias tóxicas pueden resultar inocuas para las personas siempre que no exista peligro. Peligro es la exposición relativa al riesgo. De hecho, la presencia de determinados riesgos puede suponer muy poco peligro si se han adoptado las precauciones adecuadas. Existen muchas publicaciones sobre los factores que se utilizan en la valoración de si una situación es peligrosa y, en caso de serlo, en la determinación del nivel de peligro. Esto es lo que se conoce como percepción del riesgo. (EI término riesgo se utiliza aquí con el mismo significado con el que se emplea la voz peligro en los textos dedicados a la seguridad en el trabajo; véase H oyos y Zimolong 1988.)

La percepción del riesgo está relacionada con la comprensión de las percepciones y los indicadores de riesgo y de sustancias tóxicas, esto es, a la percepción de objetos, sonidos y sensaciones olfativas y táctiles. El fuego, la altura, los objetos en movimiento, los ruidos intensos y los olores ácidos son algunos de los peligros más evidentes que no precisan interpretación. En algunos casos, las personas experimentan reacciones similares en su respuesta a los peligros inminentes. Un episodio repentino de ruido intenso, pérdida de equilibrio o rápido aumento de la imagen de algún objeto (que, por tanto, parece a punto de golpear al observador) son otras tantas reacciones de miedo que desencadenan respuestas automáticas consistentes en saltar, escurrirse, aferrarse y huir. 0 tra reacción instintiva es la de retirar rápidamente la mano que ha estado en contacto con una superficie caliente. Rachman (1974) llega a la conclusión de que los mayores estímulos que producen miedo son los más novedosos, repentinos y de gran intensidad.

Es probable que la mayoría de los riesgos y sustancias tóxicas no sean directamente perceptibles por los sentidos humanos, sino que se perciban a partir de ciertos indicadores. Ejemplos de estos son la electricidad; los gases incoloros e inodoros, como el metano y el monóxido de carbono; los rayos $\mathrm{X}$ y las sustancias radiactivas, así como las atmósferas pobres en oxígeno. Su presencia se debe indicar mediante el uso de dispositivos que 
Figura 59.12 - Detección y percepción de los indicadores de riesgos en la industria.

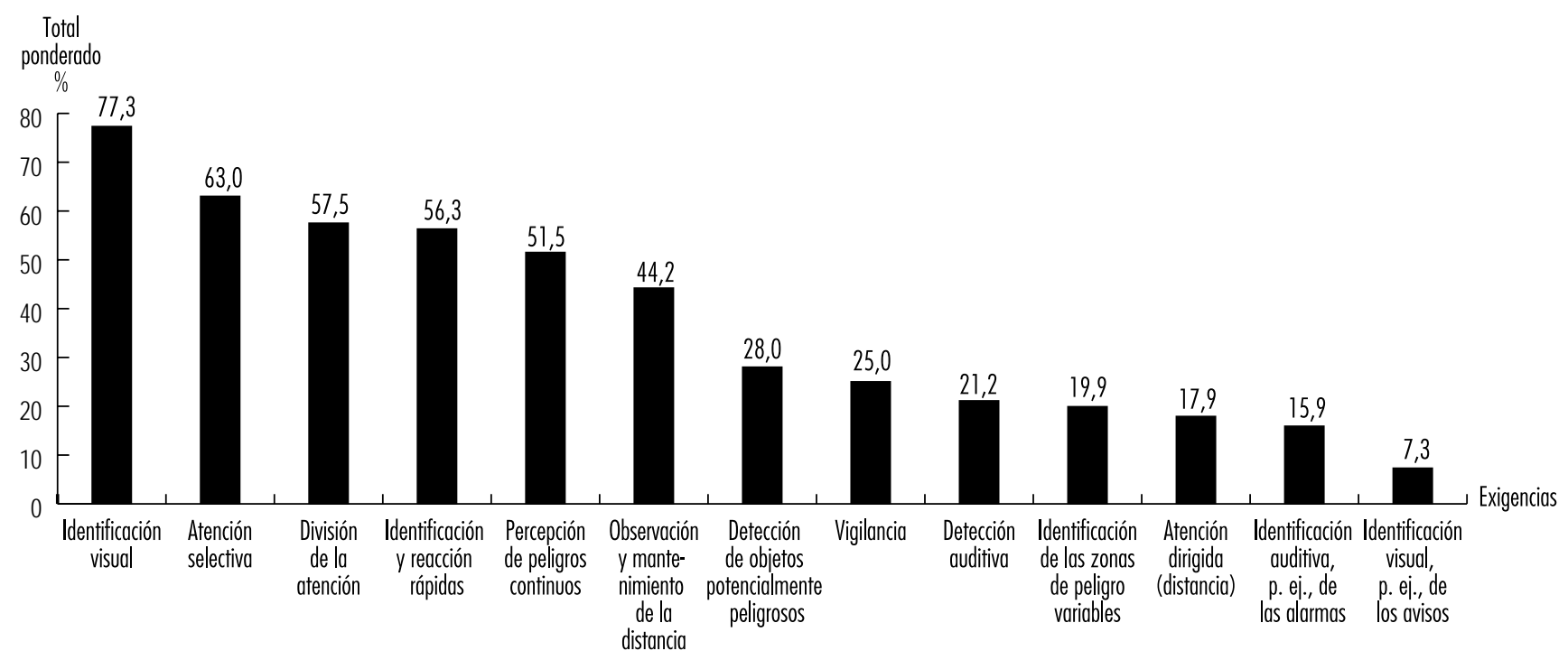

Fuente: Hoyos y Ruppert 1993.

traduzcan la existencia del peligro en una señal identificable. La corriente eléctrica se detecta utilizando un dispositivo de control de la corriente, como los que se suelen utilizar en los contadores e indicadores colocados en los registros de las salas de control para indicar los niveles normales y anormales de temperatura y de presión en una determinada fase de un proceso químico. Existen igualmente situaciones en las que se producen peligros absolutamente inapreciables 0 que no se pueden percibir en un momento determinado. Un ejemplo de esto es el riesgo de infección al abrir frascos con muestras de sangre para realizar análisis clínicos. La percepción de la existencia de un peligro se adquiere a partir, bien de la experiencia personal, bien del conocimiento de las relaciones causales.

\section{Evaluación de riesgos}

El siguiente paso en el tratamiento de la información es la evaluación de los riesgos, que consiste en la aplicación del proceso decisorio a cuestiones del tipo de si una persona va a exponerse a un peligro y, en el caso afirmativo, el grado de exposición. Considérese el ejemplo de la conducción de un coche a gran velocidad. Desde una perspectiva personal, estas decisiones sólo se tienen que tomar en circunstancias imprevistas, como las urgencias. La mayor parte del comportamiento requerido por la conducción es automático y se desarrolla regularmente, sin necesidad de una atención extraordinaria ni de una evaluación consciente del riesgo.

Tanto H acker (1987) como Ramussen (1983) aprecian tres niveles de comportamiento: a) comportamiento basado en la destreza, casi totalmente automático; b) comportamiento basado en las normas, que consiste en la aplicación de unas normas deliberadamente elegidas, aunque totalmente programadas, y c) comportamiento basado en el conocimiento, que abarca todas las modalidades de planificación deliberada y resolución de problemas. En el comportamiento basado en la destreza, la información recibida se conecta directamente con una respuesta memorizada que se ejecuta automáticamente sin control ni reflexión algunos. Si no se dispone de una respuesta automática o si se produce un hecho imprevisto, el proceso de evaluación del riesgo pasa al nivel basado en las normas, en el que se extrae y ejecuta la respuesta adecuada de una gama de reacciones extraída de la memoria. Cada paso responde a una dinámica perceptivomotriz perfectamente sincronizada, sin que, por regla general, intervenga en esta jerarquía organizativa decisión alguna basada en consideraciones de riesgo. U nicamente en las situaciones de transición se realiza un control condicional con el exclusivo objeto de comprobar si el proceso se desarrolla según lo previsto. En el caso contrario, se paraliza el control automático y el problema planteado se resuelve en un nivel superior.

En el modelo GEM S, de Reason (1990), se expone cómo la transición del control automático a la resolución consciente de los problemas se produce cuando se presentan situaciones extraordinarias o circunstancias imprevistas. La evaluación del riesgo no existe en el nivel inferior, pero puede estar plenamente presente en el superior. En el nivel intermedio, se puede esperar alguna medida de evaluación rápida y aproximativa del riesgo, si bien R asmussen excluye toda evaluación que no se ajuste a unas normas fijas. En la mayoría de los casos, no se produce una percepción o consideración consciente de los peligros como tales. Para Hale y Glendon (1987): "La falta de conciencia de seguridad es una situación normal y saludable, a pesar de lo que se ha dicho en innumerables libros, artículos y discursos. La conciencia permanente del peligro es una definición válida de la paranoia". Q uienes realizan un trabajo de forma rutinaria no suelen apreciar anticipadamente los riesgos de accidente; se corren riesgos, pero no se asumen.

\section{Percepción del peligro}

La percepción de los peligros y las sustancias tóxicas, considerada como percepción de formas y colores, intensidad y tono, olores y vibraciones, se ve limitado por la capacidad de los sentidos, que puede verse mermada de resultas de la fatiga, la enfermedad, el alcohol o las drogas. Agentes como el brillo, los destellos o la niebla pueden mermar gravemente la percepción, además de que, a veces, los peligros se pasan por alto por causa de una distracción o de una atención insuficiente.

Como se ha indicado anteriormente, no todos los peligros son directamente perceptibles por los sentidos humanos. La mayoría de las sustancias tóxicas ni siquiera son visibles. En su estudio de una planta de forja de hierro y acero, de los servicios municipales de recogida de basuras y de unos laboratorios 
farmacéuticos, Ruppert (1987) descubrió que sólo el $42 \%$ de los 2.230 indicadores de riesgo citados por 138 trabajadores eran perceptibles por los sentidos. El $22 \%$ de los indicadores (por ejemplo, los niveles de ruido) se valoraban mediante comparación con las normas. En el 23 \% de los casos, la percepción del peligro se basa en unos fenómenos claramente perceptibles que han de interpretarse en función de los conocimientos adquiridos acerca de las situaciones de peligro (por ejemplo, que la superficie brillante de un suelo húmedo denota que el mismo está resbaladizo). En el $13 \%$ de los casos, los indicadores de riesgo sólo son accesibles en la memoria de las medidas de prevención adecuadas (por ejemplo, que la existencia de corriente en un enchufe de pared sólo se puede detectar utilizando el dispositivo de control correspondiente). Estos resultados demuestran que la complejidad de la percepción del peligro van desde la simple detección y percepción a los más complejos procesos inductivos de anticipación y evaluación. En ocasiones, la relación causal es equívoca o escasamente detectable, o bien se interpreta erróneamente, y los efectos acumulados o a más largo plazo de los peligros y sustancias tóxicas pueden imponer un esfuerzo adicional a las personas.

H oyos y cols. (1991) han elaborado una relación exhaustiva de los indicadores de riesgo, los comportamientos necesarios y las condiciones de seguridad en la industria y los servicios públicos. Se ha elaborado un Cuestionario de diagnóstico de seguridad (CDS) que constituye una herramienta práctica de observación y análisis de los riesgos y peligros. (H oyos y Ruppert 1993). Se han evaluado más de 390 lugares de trabajo y las condiciones de trabajo y ambientales existentes en 69 empresas agrícolas, industriales, artesanales y de servicios. Dado que las empresas en cuestión sufrían unos índices de siniestralidad superiores a 30 accidentes por cada 1.000 empleados, con un mínimo de tres jornadas de trabajo perdidas por accidente, parece observarse un sesgo en estos estudios hacia los lugares de trabajo más peligrosos. En total, los observadores han informado de 2.373 riesgos utilizando el SDQ , para una tasa de detección de
6,1 riesgos por lugar de trabajo, habiéndose detectado, asimismo, entre 7 y 18 riesgos en alrededor del $40 \%$ de los puestos de trabajo investigados. Esta tasa media, sorprendentemente baja, de 6,1 riesgos por puesto de trabajo se debe interpretar en el contexto de las medidas de seguridad que se han generalizado en la agricultura y la industria en los últimos veinte años. Entre los riesgos detectados no se incluyen los imputables a las sustancias tóxicas ni los controlables mediante dispositivos y medidas técnicas de seguridad, por lo que reflejan la distribución de los "riesgos residuales".

En la Figura 59.12 se ofrece un resumen de los requisitos de los procesos cognitivos de detección y percepción de riesgos. Como se observa en dicha figura, los observadores tenían que evaluar todos los riesgos presentes en un determinado puesto de trabajo en función de 13 requisitos. Como media, se detectaron 5 requisitos por riesgo, incluidas la identificación visual, la atención selectiva, la identificación auditiva y la vigilancia. Como era previsible, la identificación visual predominaba sobre la auditiva (el $77,3 \%$ de los riesgos se detectaban visualmente, contra sólo un $21,2 \%$ que eran objeto de detección auditiva). En el $57 \%$ del total de riesgos observados, los trabajadores tenían que dividir su atención entre la realización de sus tareas y el control de riesgos, situación que supone un serio esfuerzo mental capaz de provocar errores. Se ha podido determinar que muchos accidentes se producen por causa de distracciones provocadas por atender a dos tareas. M ás alarmante, incluso, resulta la comprobación de que, en el $56 \%$ de los riesgos, los trabajadores tenían que moverse rápidamente y reaccionar con agilidad para evitar lesiones. Sólo el $15,9 \%$ y el 7,3 \% de los riesgos se indicaban, respectivamente, mediante alarmas acústicas y ópticas; esto es, que la detección y percepción de los riesgos partía de la propia persona.

Aunque en algunos casos (16,1\%) la percepción de los riesgos se basa en señales y alarmas, los trabajadores suelen depender de sus conocimientos, su formación y su experiencia laboral. En la Figura 59.13 se indican los requisitos de anticipación y

Figura 59.13 • Previsión y evaluación de los indicadores de peligro.

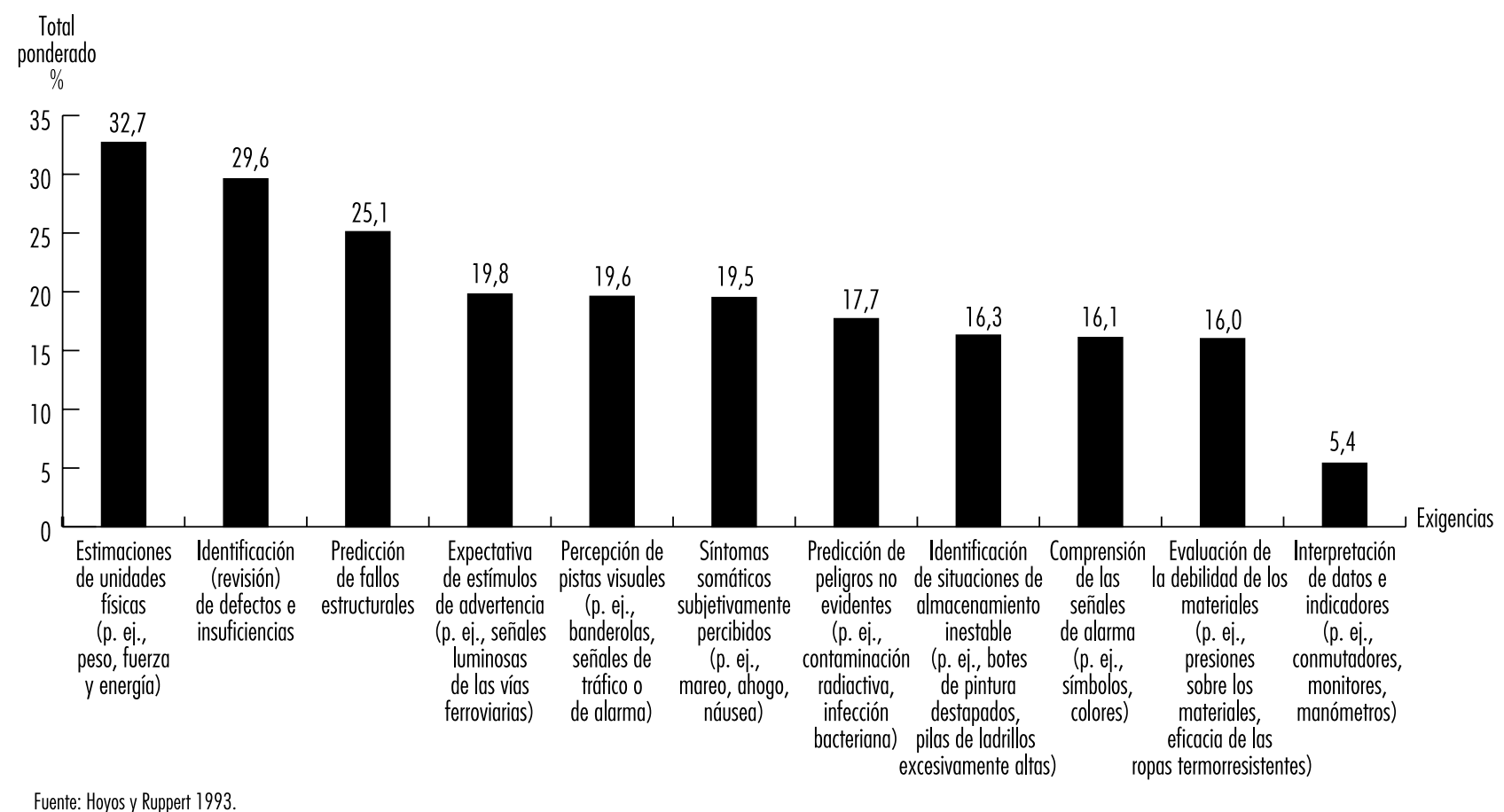


evaluación exigidos para el control de los riesgos en el lugar de trabajo. La característica básica de las actividades que se resumen en esta figura es la necesidad de poseer conocimientos y experiencia en los procesos productivos, incluidos el conocimiento técnico de pesos, fuerzas y energías, la capacidad para detectar defectos e insuficiencias en las herramientas de trabajo y la maquinaria, y la experiencia necesaria para detectar las deficiencias estructurales del equipo, el material y las instalaciones. Como han demostrado H oyos y cols. (1991), los trabajadores conocen mal los riesgos, las normas de seguridad y los comportamientos personales preventivos. Sólo el $60 \%$ de los trabajadores de la construcción y de los mecánicos del automóvil preguntados conocían la resolución correcta a los problemas de seguridad más frecuentes en sus respectivos puestos de trabajo.

EI análisis de la percepción de riesgos denota que en la misma intervienen diversos procesos cognitivos, como la percepción visual, la atención selectiva y dividida, la rapidez en la identificación y en la capacidad de respuesta, las estimaciones de los parámetros técnicos y las predicciones de los riesgos y peligros inobservables. De hecho, los trabajadores desconocen con frecuencia los riesgos y peligros; éstos suponen una pesada carga para quienes se ven obligados a prestar atención alternativamente a decenas de indicadores visuales y auditivos y que predisponen al error cuando el trabajo y el control de riesgos se realizan simultáneamente. Esto exige prestar mucha más atención al análisis e identificación sistemáticos de los riesgos y peligros presentes en el lugar de trabajo. En varios países, la evaluación formal del riesgo en los lugares de trabajos es preceptiva. Por ejemplo, en las D irectivas sobre salud y seguridad de la CEE se exige la evaluación del riesgo en los puestos de trabajo con ordenadores, tanto antes de iniciarse el trabajo en los mismos, como cada vez que se efectúe una modificación importante del sistema de trabajo; y la Administración para la Salud y la Seguridad en el Trabajo de Estados U nidos (O SH A) exige la realización periódica de análisis de riesgos en las unidades procesadoras.

\section{Coordinación del trabajo y del control de riesgos}

Como señalan Hoyos y Ruppert (1993); a) a veces es preciso atender simultáneamente al trabajo y al control de los riesgos; b) ambas funciones se pueden desempeñar alternativamente, en una secuencia de actos, o bien c) se pueden adoptar medidas de precaución antes de comenzar a trabajar (por ejemplo, el uso del casco de seguridad).

En caso de producirse exigencias simultáneas, el control del riesgo se basa en la identificación visual, auditiva y táctil. De hecho, no es fácil separar el trabajo y el control de los riesgos en la ejecución de tareas rutinarias. Por ejemplo, la tarea de cortar los hilos de la hilaza en una hilandería de algodón utilizando una cuchilla afilada, entraña un peligro constante. Las únicas protecciones posibles contra eventuales cortes consisten en la destreza en el manejo de la cuchilla y el uso de equipo protector. Para que ambas medidas resulten eficaces, se deben integrar plenamente en la secuencia de movimientos del trabajador. Precauciones como la de realizar los cortes hacia fuera de la mano que sostiene el hilo se deben integrar en la rutina del trabajador desde el principio. En este ejemplo, el control de riesgos se integra plenamente en el control de la tarea sin que se precise un proceso independiente de control de riesgos. Lo más probable es que se produzca un proceso continuo de integración en el proceso de trabajo cuya intensidad está en función de la destreza del trabajador y de las exigencias de la tarea. Por una parte, la percepción y el control de riesgos se integran absolutamente en la cualificación laboral; por otra, la ejecución de la tarea y el control de riesgos constituyen actividades perfectamente independientes. El trabajo y el control de riesgos se pueden realizar de forma alternativa, en una secuencia de movimientos, si, durante la ejecución de la tarea, el peligro potencial se incrementa gradualmente 0 se produce una repentina señal de alarma. Cuando esto ocurre, los trabajadores interrumpen el proceso o la ejecución de la tarea y adoptan medidas preventivas. La verificación de un indicador es un ejemplo típico de prueba de diagnóstico. Un operador de una sala de control detecta en un indicador una desviación respecto al valor normal que, aunque a primera vista, no parece constituir una alarma grave de peligro inminente, impulsa al operador a verificar otros indicadores y contadores. Si se dan otras desviaciones, se ejecuta una rápida secuencia de operaciones de comprobación, que se desarrollan a nivel de decisiones basadas en las normas. Si las desviaciones constatadas en otros contadores no se ajustan a un esquema conocido, el proceso de diagnóstico deriva hacia el nivel basado en el conocimiento. En la mayoría de los casos a partir de distintas estrategias, se buscan activamente indicios y señales que permitan localizar las causas de las desviaciones (K onradt 1994). Los recursos del sistema de control de la atención se desvían hacia la supervisión general. U na señal repentina del tipo de una alarma sonora o, como en el ejemplo anterior, la desviación de varios indicadores respecto a los valores normales, dirige el control de la atención hacia la cuestión concreta del control de riesgos. Se desencadena entonces una actividad dirigida a descubrir las causas de las desviaciones dentro del nivel basado en las normas, o bien, si esto no se logra, en el nivel basado en los conocimientos (R eason 1990).

El comportamiento preventivo constituye la tercera modalidad de coordinación del trabajo y el control. El ejemplo más destacado de esta actividad, que se produce antes de iniciarse el trabajo, es el empleo de equipo de protección individual (EPI).

\section{Significados del riesgo}

En los ámbitos de la economía, la ingeniería, la química, las ciencias de la seguridad y la ergonomía se han elaborado un número de definiciones del riesgo y de métodos de evaluación de los riesgos en la industria y en la sociedad en general (H oyos y Zimolong 1988). El término riesgo ha sido objeto de muy diversas interpretaciones. En un sentido, se interpreta como "la probabilidad de que se produzca un hecho no deseado". Esta definición expresa la probabilidad de que produzca algo indeseable. Yates (1992a) ha formulado una definición más neutra del riesgo, aduciendo que debe considerarse un concepto multidimensional que globalmente se refiere a una posible pérdida. La geografía, la sociología, la antropología, la psicología y la ciencia política han contribuido sustancialmente a enriquecer nuestros conocimientos de la evaluación de los riesgos sociales. Aunque los estudios se centraron en un principio en la investigación del comportamiento humano frente a los peligros naturales, su perspectiva se ha ido ampliando para incluir el riesgo tecnológico. La investigación sociológica y los estudios antropológicos han puesto de manifiesto que la evaluación y aceptación de riesgos se arraiga en consideraciones sociales y culturales. Short (1984) aduce que la respuesta a los riesgos está condicionada por los valores sociales transmitidos por los amigos, familiares, compañeros y dirigentes políticos respetados. La investigación psicológica de la evaluación de riesgos se originó en estudios empíricos de la evaluación de probabilidades, la evaluación de utilidad y los procesos de toma de decisiones (Edwards 1961).

La evaluación de los riesgos tecnológicos se centra en los daños potenciales, entre los que se incluye, tanto la probabilidad de que se produzca una pérdida como la magnitud de la misma en cuanto a muertes, lesiones o daños. El riesgo es la probabilidad de que un sistema sufra un determinado tipo de daños durante un período de tiempo especificado. Se utilizan diversas técnicas de evaluación para satisfacer las distintas necesidades de 
la industria y la sociedad. Los métodos formales de análisis diseñados para evaluar los niveles de riesgo se han derivado de diferentes tipos de análisis de árbol de fallos, utilizando, bien unos bancos de datos en los que se incluyan las probabilidades de error, como THERP (Swain y Guttmann 1983), bien métodos de descomposición basados en valoraciones subjetivas, como el SLIM -M aud (Embrey y cols. 1984). La capacidad de estas técnicas para predecir acontecimientos futuros del tipo de errores, accidentes e incidentes difiere sensiblemente de una a otra. Desde la perspectiva de la predicción de errores en los sistemas industriales, los expertos han logrado los mejores resultados con el THER P. En una simulación realizada por Zimolong (1992) se estableció una estrecha correlación entre las probabilidades de error derivadas objetivamente y las estimaciones derivadas utilizando el TH ER P. Zimolong y Trimpop (1994) aducen que, si se realizan correctamente, tales análisis formales alcanzan la máxima "objetividad", ya que en los mismos se distingue entre hechos y creencias y se toman en consideración los sesgos de apreciación.

La sensación de riesgo de la población se basa en algo más que la probabilidad y la magnitud de la pérdida. En efecto, puede estar en función de otras consideraciones, como la posible entidad del riesgo, el desconocimiento de las posibles consecuencias, la naturaleza involuntaria de la exposición al riesgo, la inevitabilidad del daño y el posible sesgo de la cobertura de los medios de comunicación. La sensación de controlar una situación puede ser un factor de especial importancia. M uchos creen que volar es una actividad de alto riesgo, debido a que nadie puede controlar su integridad mientras vuela. Rumar (1988) llegó a la conclusión de que el riesgo percibido en la conducción de un coche suele ser bajo, dado que, en la mayoría de los casos, los conductores confían en su capacidad para controlar los riesgos y están acostumbrados a ellos. 0 tros estudios se han centrado en las reacciones emocionales a las situaciones de riesgo. La posibilidad de incurrir en graves pérdidas desencadena una serie de reacciones emocionales, no todas las cuales son necesariamente desagradables. La línea divisoria entre el miedo y la excitación es muy tenue. Asimismo, uno de los factores determinantes de la percepción del riesgo y de las reacciones emocionales a las situaciones de peligro es, aparentemente, la sensación de control o de ausencia de control del sujeto. Por consiguiente, para muchas personas, el riesgo puede ser, simplemente, una sensación.

\section{Toma de decisiones en situaciones de riesgo}

La aceptación de riesgos puede ser el resultado de un proceso decisorio deliberado en el que intervienen diversas actividades: determinación de las posibles líneas de actuación, concreción de las consecuencias, valoración de la aceptabilidad y de las posibilidades de que se produzcan esas consecuencias, o decisión sobre la base de un conjunto de las evaluaciones anteriores. La evidencia abrumadora de que las personas suelen tomar decisiones equivocadas en situaciones de riesgo implica la posibilidad de tomar decisiones más acertadas. En 1738, Bernoulli definió la noción de la "mejor apuesta" como la opción que optimiza la utilidad prevista (UP) de la decisión. Según el concepto de la racionalidad fundada en la utilidad prevista, las personas deben tomar decisiones evaluando incertidumbres y ponderando sus opciones, las posibles consecuencias y las preferencias personales respecto a las mismas (von Neumann y M orgenstern 1947). Posteriormente, Savage (1954) generalizó la teoría en el sentido de admitir el empleo de valores probabilísticos para representar probabilidades personales o subjetivas.

La utilidad subjetiva prevista (USP) es una teoría normativa, descriptiva de cómo deben actuar las personas al tomar decisiones. Slovic, Kunreuther y White manifiestan (1974): "La optimización de la utilidad prevista es válida como pauta del comportamiento correcto, debido a que se infiere de unos principios axiomáticos que cualquier hombre racional asume". Gran parte del debate y de la investigación empírica se ha centrado en la cuestión de si esta teoría sirve también para definir, tanto los objetivos que inspiran en la práctica la toma de decisiones, como los procesos que estos aplican para llegar a una decisión. Simon (1959) critica esta teoría en la que la persona elige entre varias alternativas conocidas e invariables, cada una de las cuales lleva aparejadas unas consecuencias igualmente conocidas. Algunos investigadores han llegado a preguntarse si las personas deben observar los principios de la teoría de la utilidad prevista y tras décadas de investigación las aplicaciones de la USP siguen siendo discutibles. Las investigaciones realizadas han puesto de manifiesto que los factores psicológicos influyen considerablemente en la toma de decisiones y que en el modelo de la utilidad subjetiva prevista no se toman suficientemente en consideración estos factores.

Específicamente, la investigación de los procesos de valoración y elección ha puesto de manifiesto que las personas tienen deficiencias metodológicas como la infravaloración de las probabilidades, el desprecio de la relevancia del tamaño de las muestras, la dependencia de experiencias personales engañosas, la valoración de los hechos con una certidumbre injustificada y la subestimación de los riesgos. Las personas que han estado voluntariamente expuestas a riesgos durante largos períodos de tiempo, como las que han vivido en áreas expuestas a riadas o seísmos, suelen ser más propensas a subestimar los riesgos. En la industria se han registrado unos resultados similares (Zimolong 1985). Los mineros, guardagujas y trabajadores de la construcción tienden a valorar la peligrosidad de sus actividades habituales muy por debajo de la que se refleja en las estadísticas objetivas de siniestralidad; en cambio, suelen sobrevalorar cualquier peligrosidad evidente de las actividades realizadas por sus compañeros cuando se les pide una valoración de las mismas.

Lamentablemente, los juicios de los expertos parecen adolecer de muchos de los sesgos que aquejan a las opiniones del vulgo, en especial cuando se ven forzados a trascender los límites de los datos disponibles y fiarse de sus intuiciones (K ahneman, Slovic y T versky 1982). Los resultados de las investigaciones ponen igualmente de manifiesto que las discrepancias en cuanto a los riesgos no desaparecen por completo aunque se disponga de datos suficientes. Es difícil superar unos prejuicios arraigados que influyen en el modo de interpretar la información recibida con posterioridad. Los nuevos datos se valoran como fiables y útiles si son congruentes con nuestras opiniones previas; al tiempo que la información contradictoria con aquéllas se suele desechar por pretendidamente errónea, escasamente fiable 0 poco representativa ( $N$ isbett y Ross 1980). En las personas que carecen de una opinión previa se suele producir, exactamente, la situación contraria y son fácilmente impresionables por la formulación del problema. En efecto, si una misma información relativa a los riesgos se presenta de modo diferente (por ejemplo, las tasas de mortalidad en lugar de las tasas de supervivencia), se modifica su percepción y se influye en su actuación (T versky y $\mathrm{K}$ ahneman 1981). El descubrimiento de esta serie de procesos mentales (heurística) que las personas aplican para ordenar su propio mundo y prever sus futuras líneas de actuación, ha permitido conocer en profundidad la dinámica de la toma de decisiones en situaciones de riesgo. Si bien estas reglas son válidas en muchas circunstancias, en otras generan importantes y persistentes sesgos que influyen sustancialmente en la evaluación de los riesgos. 


\section{La evaluación personal de los riesgos}

El método más frecuentemente aplicado para estudiar cómo se realiza la evaluación personal de los riesgos se basa en el uso de escalas psicofísicas y de técnicas de análisis multivariantes con objeto de producir representaciones cuantitativas de las evaluaciones y actitudes frente al riesgo (Slovic, Fischhoff y Lichtenstein 1980). Numerosos estudios han demostrado que la evaluación del riesgo basada en juicios subjetivos es cuantificable y predecible. Dichos estudios han demostrado igualmente que el concepto de riesgo significa cosas distintas para distintas personas. Cuando los expertos evalúan el riesgo sobre la base de su experiencia personal, sus conclusiones se correlacionan íntimamente con las estimaciones técnicas de la tasa de siniestralidad anual. En cambio, las evaluaciones del riesgo que realizan los legos se relacionan en mayor medida con otros aspectos, como el potencial de producción de daños o la amenaza para las generaciones futuras, lo que hace que sus estimaciones de las posibilidades de que se produzcan pérdidas suelan desviarse de las que realizan los expertos.

Según Slovic (1987), en la evaluación de riesgos que los legos realizan en situaciones de peligro intervienen dos factores, uno de los cuales es la medida en que las personas comprenden el riesgo. La comprensión de un riesgo está en función de la medida en que el mismo resulta observable, es conocido por las personas expuestas y es inmediatamente detectable. EI otro factor tiene que ver con la medida en que el riesgo suscita un sentimiento de temor. El temor es una función del grado de inevitabilidad, de graves consecuencias, de exposición a serios riesgos para las generaciones futuras y de incremento involuntario del riesgo. Cuanto mayor es el valor que este último factor recibe en la evaluación del riesgo, mayor es el deseo de las personas de reducir el riesgo actual y mayor es, asimismo, su exigencia de que se promulguen normas estrictas que produzcan la deseada reducción del riesgo. Por consiguiente, los puntos de vista divergentes de los expertos y de los legos, derivados de definiciones dispares del riesgo, son fuente de no pocos conflictos. En estos casos, la remisión de los expertos a las estadísticas de riesgos 0 a los resultados de las evaluaciones técnicas de los riesgos no logran modificar las actitudes y valoraciones de la gente (Slovic 1993).

La explicación del riesgo en función de los "conocimientos" y las "amenazas" nos lleva de nuevo al análisis realizado previamente en esta sección de las señales de riesgo y de peligro en la industria, que se han examinado desde la perspectiva de la "perceptibilidad". El cuarenta y dos por ciento de los indicadores de riesgos industriales son directamente perceptibles por los sentidos humanos, otro $45 \%$ de indicadores se interpretan mediante comparación con los valores normales, y el $3 \%$ recurren a la memoria. La perceptibilidad, el conocimiento y las amenazas y emociones creados por los riesgos constituyen realidades estrechamente vinculadas a las experiencias personales de riesgo y al control percibido; sin embargo, para llegar a comprender y predecir el comportamiento individual frente al peligro es preciso profundizar en el conocimiento de su relación con la personalidad, las exigencias de las tareas y las variables sociales.

Las técnicas psicométricas parecen ser perfectamente idóneas para determinar las similitudes y diferencias entre grupos por lo que respecta, tanto a las actitudes, como a los hábitos personales de evaluación de riesgos. Sin embargo, otros métodos psicométricos, como el análisis multidimensional de los juicios sobre similitud de riesgos, aplicados a unos grupos de riesgos bien diferenciados, generan representaciones distintas. El método de análisis factorial, aunque instructivo, no permite en absoluto una representación universal de los riesgos. O tra deficiencia de los estudios psicométricos consiste en que en los mismos las personas afrontan los riesgos en descripciones escritas en las que la evaluación del riesgo difiere del comportamiento real en las situaciones de riesgo efectivas. Los factores que influyen en las estimaciones de la evaluación personal de los riesgos en los experimentos psicométricos pueden ser irrelevantes en comparación con los riesgos reales. Howarth (1988) sugiere que este conocimiento intelectual suele reflejar unos determinados patrones sociales. Por contra, las reacciones de aceptación de riesgos en un contexto laboral o de tráfico están regidas por el conocimiento intuitivo que subyace en todo comportamiento cualificado o rutinario.

La mayoría de las decisiones personales que se adoptan en la vida cotidiana en relación con los riesgos no son en absoluto conscientes. Por regla general, las personas no tienen siquiera conciencia del riesgo. Por contra, la noción implícita de los experimentos psicométricos se presenta como una teoría de la elección consciente. La evaluación de riesgos que se realiza comúnmente mediante un cuestionario tiene un carácter deliberado de estudio teórico. Sin embargo, en muchos sentidos, las reacciones personales en situaciones de riesgo provienen en la mayoría de los casos de unos automatismos adquiridos que se sitúan por debajo del nivel general de conciencia. N ormalmente, las personas no evalúan los riesgos, por lo que no puede aducirse que su forma de evaluar los riesgos sea imprecisa y deba mejorar. La mayoría de los actos relacionados con el riesgo se ejecutan necesariamente en el nivel profundo del comportamiento automático, en el que, sencillamente, no hay lugar para considerar los riesgos. La idea de que los riesgos, identificados después de producirse los accidentes, se aceptan al cabo de un análisis consciente, podría provenir de una confusión entre la utilidad subjetiva prevista y los modelos descriptivos (Wagenaar 1992). Se prestaba menos atención a las condiciones en que las personas reaccionan automáticamente, se guían por sus impulsos profundos o aceptan la primera opción que se brinda. Sin embargo, existe un amplio consenso, tanto en la sociedad, como entre los profesionales de la salud y la seguridad, en el sentido de que la aceptación del riesgo es un factor causante de percances y errores. El $90 \%$ de una muestra representativa de ciudadanos suecos de entre 18 y 70 años de edad se mostró de acuerdo en que la aceptación del riesgo es la causa principal de accidentes (H ovden y Larsson 1987).

\section{Comportamiento preventivo}

Las personas pueden adoptar medidas deliberadas de prevención para evitar los riesgos, atenuar la intensidad del peligro o protegerse mediante la adopción de determinadas precauciones (por ejemplo, mediante el uso de casco y gafas protectoras). Frecuentemente, la dirección o la legislación vigente obligan a los trabajadores a tomar medidas de protección. Por ejemplo, los techadores colocan un andamio antes de ponerse a trabajar en un tejado, con objeto de protegerse contra posibles caídas. Esta decisión puede resultar de un proceso consciente de evaluación del riesgo y de la capacidad individual de previsión o, más sencillamente, puede ser el resultado de un proceso de habituación 0 , incluso, de una obligación legal. Los avisos se suelen utilizar para recordar las medidas preventivas impuestas por la ley.

H oyos y Ruppert (1993) han examinado diversos tipos de actividades preventivas, algunas de las cuales se indican en la Figura 59.14, conjuntamente con la frecuencia con que son requeridas. Como se ha comentado anteriormente, el comportamiento preventivo es autónomo en parte y, en parte también, viene impuesto por la dirección de la empresa y por imperativo legal. En la prevención se incluyen algunas de las medidas siguientes: planificación previa de los procesos y operaciones de producción; uso de equipo de protección individual; aplicación de técnicas de seguridad en el trabajo, elección de unos métodos 
Figura 59.14 - Ejemplos típicos de comportamientos preventivos individuales en la industria y frecuencia de las medidas preventivas.

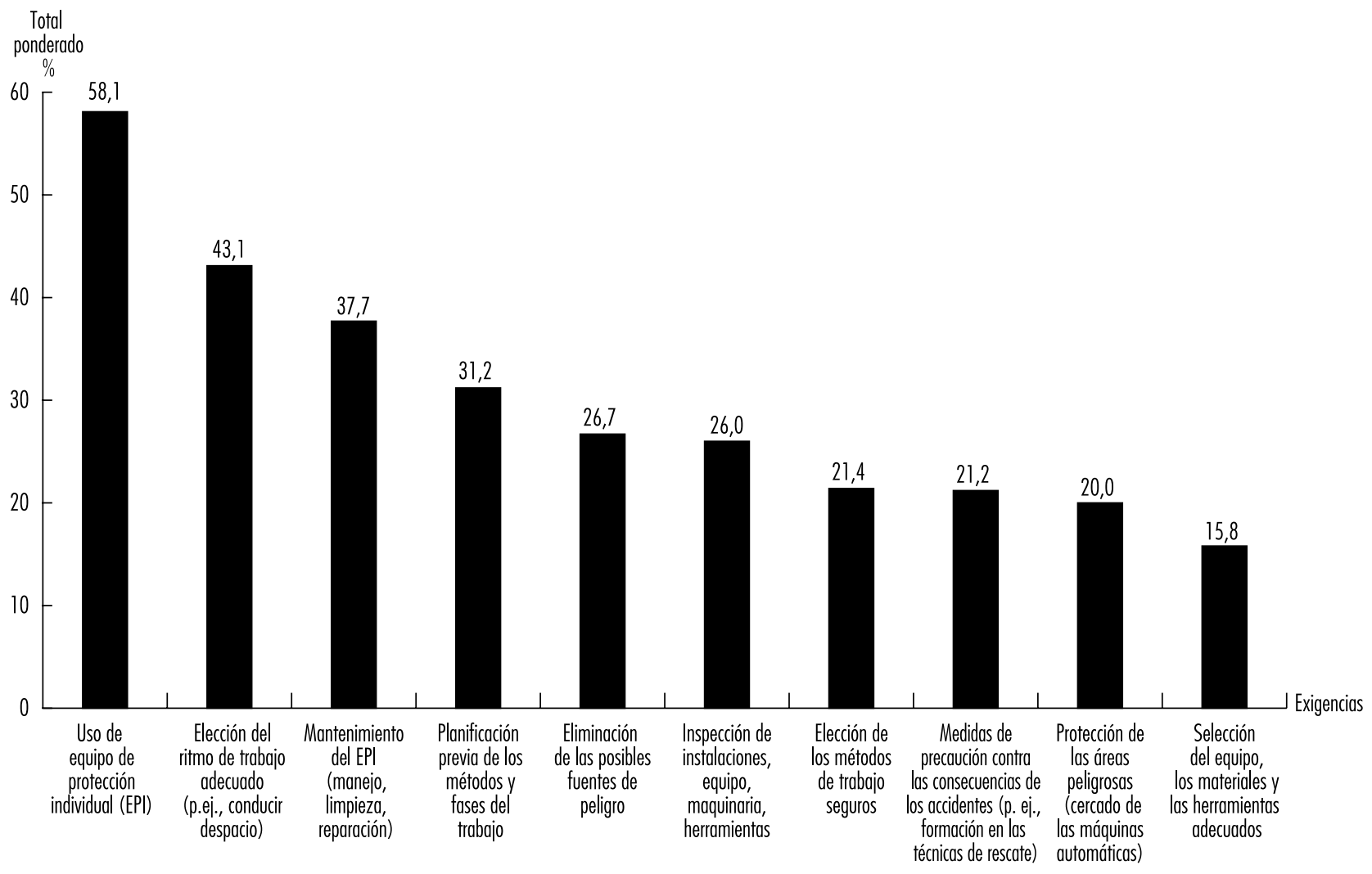

Fuente: Hoyos y Ruppert 1993.

de trabajo seguros, basados en el empleo de los materiales y herramientas idóneos; fijación de un ritmo de trabajo adecuado, e inspección del equipo, las instalaciones, la maquinaria y las herramientas.

\section{Equipo de protección individual}

La medida de protección más comúnmente exigida es el uso de equipo de protección individual. Junto con una manipulación correcta y un mantenimiento adecuado, esta es, con mucho, la medida más extendida en la industria. El esquema de uso de equipo de protección individual varía sensiblemente de una a otra empresa. En algunas de las mejores empresas, específicamente, en las refinerías de petróleo y las plantas químicas, el indice de utilización de equipo de protección individual se aproxima al $100 \%$. Por el contrario, en el sector de la construcción, los responsables de seguridad tienen problemas, incluso, para imponer el uso sistemático de determinado equipo de protección individual. Resulta dudoso que la percepción del riesgo sea el factor determinante de este contraste. En efecto, algunas empresas han logrado implantar el uso de equipo de protección individual, que con el tiempo se convierte en costumbre (por ejemplo, el uso de cascos de seguridad) mediante el desarrollo de una "cultura correcta de la seguridad", hasta el punto de modificar la evaluación personal de los riesgos. En su breve examen del uso de los cinturones de seguridad, Slovic (1987) comenta que alrededor del $20 \%$ de los usuarios de la carretera utilizan voluntariamente los cinturones, otro 50 \% los utilizaría únicamente si su empleo se impusiese por imperativo legal y, el resto de los conductores únicamente adquirirían el hábito de emplearlos si el control y el temor al castigo los forzase a ello. Por consiguiente, es importante conocer los factores que inciden en la percepción del riesgo, y no menos importante resulta saber cómo modificar el comportamiento y, posteriormente, cómo modificar la percepción del riesgo. A parentemente, es preciso adoptar un mayor número de medidas de precaución en el nivel organizativo, entre los directivos, planificadores, diseñadores y autoridades responsables de la toma de decisiones que afectan a millares de personas. $\mathrm{H}$ asta ahora, en esos niveles se conocen mal los factores que influyen en la percepción y evaluación de riesgos. Si las empresas se consideran sistemas abiertos en los que diversos niveles de organización se influyen mutuamente y realizan un intercambio constante con la sociedad, un criterio sistemático puede poner de manifiesto los factores que integran e influyen en la percepción y evaluación de riesgos

\section{Etiquetas de advertencia}

El uso de etiquetas y señales de advertencia en la prevención de riesgos constituye un método discutido de combatir los peligros. Se ha dicho a menudo que aquéllas constituyen una estratagema de los fabricantes para eximirse de responsabilidad por unos productos innecesariamente peligrosos. O bviamente, las etiquetas sólo resultan eficaces si los destinatarios son capaces de leer y comprender su contenido. Frantz y R hoades (1993) comentan que el $40 \%$ del personal administrativo que utilizaba un archivador percibía una placa de advertencia situada en el primer cajón, el 33 \% leía parte del texto y nadie leía el texto completo. Contrariamente a lo previsto, el $20 \%$ observaba plenamente la advertencia absteniéndose de iniciar la colocación de materiales por el primer cajón. O bviamente, no basta con observar únicamente los principales elementos del aviso. Letho y Papastavrou 
(1993) realizaron un análisis exhaustivo de los hallazgos de un estudio sobre las etiquetas y advertencias de seguridad examinando los factores relacionados con los destinatarios, los comunicadores, las tareas y los mensajes. Además, los autores contribuyeron significativamente a enriquecer nuestros conocimientos de la eficacia de las advertencias examinando diferentes niveles de comportamiento.

Del análisis del comportamiento basado en el conocimiento parece inferirse que las advertencias influyen poco en el modo de realizar las tareas rutinarias, sencillamente, porque no se leen. Lehto y Papastavrou (1993) interpretan los resultados de las investigaciones en el sentido de que la interrupción de la ejecución de tareas rutinarias puede contribuir efectivamente a incrementar el nivel de atención de los trabajadores a las señales y etiquetas. En el experimento efectuado por Frantz y R hodes (1993), el nivel de percepción de la placa de aviso colocada en el armario archivador se incrementó en un $93 \%$ cerrando el primer cajón con un dispositivo de aviso de que, en el interior del cajón había una etiqueta. N o obstante, los autores observaron que no siempre resultaba posible interrumpir la ejecución de las tareas rutinarias y que, además, la eficacia de estas medidas puede disminuir considerablemente después de su implantación.

En el nivel de actuación basado en las normas, las advertencias se deben integrar en las tareas (L ehto 1992), con objeto de facilitar su inmediata traducción en las acciones correspondientes. Expresado de otro modo, debe procurarse que las tareas se ejecuten en la forma indicada en la advertencia. Frantz (1992) halló que el $85 \%$ de los trabajadores consultados expresaron la necesidad de contar con instrucciones sobre las instrucciones de uso de una protección de madera 0 un desatascador. En el aspecto negativo, los estudios de comprensión realizados han revelado que el texto y los símbolos utilizados en las etiquetas y señales de advertencia a veces se interpretan mal. En particular, K oslowski y Zimolong (1992) descubrieron que los trabajadores del sector químico sólo comprendían el significado de alrededor del $60 \%$ de las principales señales de advertencia empleadas en la industria.

En el nivel de comportamiento basado en el conocimiento, parece ser mayor la probabilidad de percibir las advertencias cuando se está atento a ellas. Las personas esperan que los avisos se encuentren cerca del producto. Frantz (1992) descubrió que las personas que se encuentran en un entorno extraño observan las instrucciones el $73 \%$ de las veces si las leen, en contraste con el $9 \%$ de las ocasiones en que no las leen. A demás de leerse, las etiquetas deben entenderse y recordarse. Varios estudios de comprensión y memoria han puesto de manifiesto que a algunas personas les resulta difícil recordar el texto de las etiquetas con instrucciones y advertencias. EI National Research Council (1989) de Estados U nidos colabora en el diseño de las advertencias. Este organismo subraya la importancia de la comunicación en ambos sentidos para mejorar el nivel de comprensión. El comunicador debe facilitar la retroinformación y las consultas del destinatario. Las conclusiones del informe se resumen en dos listas de control, una de las cuales está destinada a los directivos, mientras que la otra es una guía para los destinatarios de la información.

\section{- ACEPTACION DE RIESG OS}

Rüdiger Trimpop y Bernhard Zimolong

El concepto de aceptación de riesgos responde al interrogante de " ¿cuánta seguridad es suficiente?"; esto es, expresado en términos más precisos: "El carácter condicional de la evaluación de riesgos suscita la cuestión de qué nivel de riesgos estamos dispuestos a asumir como parámetro de los sesgos humanos (Pidgeon 1991). Este interrogante adquiere importancia en cuestiones como las siguientes: a) ¿Se debe colocar un armazón de confinamiento adicional en torno de las centrales nucleares?; b) ¿Se deben cerrar las escuelas construidas con amianto, $\mathrm{O}$ bien $\mathrm{c}$ ) $\mathrm{H}$ ay que evitar cualquier posible problema, al menos a corto plazo? Algunas de estas preguntas se dirigen a los gobiernos y otros organismos reguladores; otras se plantean a las personas que deben optar entre determinadas vías de actuación y eventuales peligros inciertos.

La cuestión de aceptar o rechazar riesgos es el resultado de decisiones tendentes a determinar el nivel óptimo de riesgo en una situación determinada. En muchos casos, estas decisiones son un resultado casi directo de los hábitos y percepciones adquiridos con la formación y la experiencia. Sin embargo, siempre que se suscita una situación nueva o se producen modificaciones en una tarea aparentemente rutinaria, el proceso de toma de decisiones se complica. Para comprender mejor por qué las personas aceptan determinados riesgos y rechazan otros, es preciso definir antes qué es la aceptación de riesgos, y luego explicar los procesos psicológicos que conducen a la aceptación o el rechazo. Por último, se estudian los medios de modificar los niveles excesivamente altos o bajos de aceptación de riesgos.

\section{Comprensión del riesgo}

Se puede afirmar en términos generales que, siempre que no se rechaza un riesgo, es porque el mismo se ha asumido de forma consciente 0 irreflexiva 0 , incluso, por costumbre. Por ejemplo, cuando las personas se incorporan al tráfico rodado, asumen el riesgo de sufrir contaminación, daños, lesiones o muerte, a cambio de la ventaja de una mayor movilidad; cuando alguien decide someterse o no a una intervención quirúrgica, elige entre los costes y los beneficios inherentes a cada opción; y cuando uno decide invertir en los mercados financieros o modificar una gama de productos, todas las decisiones que implican la aceptación de unos riesgos financieros a cambio de determinadas oportunidades están sujetas a un cierto grado de incertidumbre. Por último, la decisión de acceder a un determinado puesto de trabajo implica igualmente la asunción de diversos niveles de riesgo de sufrir lesiones que pueden ser mortales, sobre la base de los índices históricos de siniestralidad.

La definición del riesgo en función únicamente de lo que no se ha rechazado deja sin aclarar dos grandes cuestiones: a) qué se entiende exactamente por riesgo, y b) la presunción frecuente de que los riesgos no son otra cosa que posibles daños que es preciso evitar, cuando, en realidad, existe una diferencia entre la simple tolerancia del riesgo, la plena aceptación del mismo o, incluso, el deseo de que se produzcan para disfrutar de la excitación consiguiente. Aunque todas estas facetas pueden estar presentes en un mismo comportamiento (como la incorporación al tráfico rodado) responden a distintos procesos implícitos cognitivos, emocionales y psicológicos. Parece evidente que la

Figura 59.15 - Aspectos de la aceptación y el rechazo de riesgos.

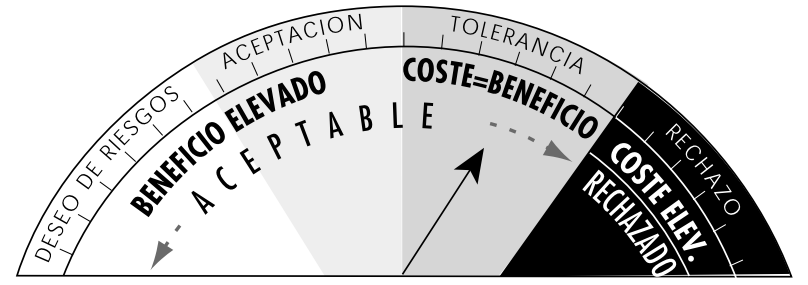


simple tolerancia de un riesgo responde a un nivel de identificación distinto que el del supuesto en que alguien desea, incluso, experimentar una cierta sensación de riesgo. En la Figura 59.15 se resumen distintas facetas de la aceptación de riesgos.

Si se busca la voz riesgo en los diccionarios de distintos idiomas, se observa que suele tener dos acepciones. Por una parte, significa "oportunidad" y, por otra, posee el significado de "peligro" o de "pérdida" (por ejemplo, wè-ji en chino, Risiko en alemán, risico en neerlandés y en italiano, risque en francés, etc.). EI término riesgo nació y su uso se generalizó en el siglo XVI, de resultas de la evolución de la conciencia popular, de sentirse totalmente dominada por los "buenos y malos espíritus" a las nociones de peligro y de la posibilidad de las personas libres de decidir su futuro. Probablemente haya que buscar la etimología de la voz riesgo, bien en la palabra griega rhiza, que posee el doble significado de "raíz" y "risco", bien en la voz árabe rizq, que quiere decir "lo que Dios y el destino deparen a tu vida". De forma análoga, en el lenguaje cotidiano se emplean expresiones como "de los cobardes no se ha escrito nada" y "sólo se muere una vez", que incitan a la aceptación y la búsqueda del riesgo. Un concepto que siempre se vincula estrechamente con el riesgo es el de incertidumbre. Como casi siempre existe un grado de incertidumbre respecto a las perspectivas de éxito o de fracaso, o en relación con la probabilidad y la entidad de las consecuencias previstas, aceptar riesgos implica casi siempre aceptar incertidumbres (Schafer 1978).

Los estudios de la seguridad han reducido en gran medida el significado del riesgo a sus perfiles de peligro (Yates 1992b). Sólo últimamente se han revalorizado las consecuencias positivas del riesgo, gracias a la popularización de los pasatiempos peligrosos (motociclismo, puenting, turismo de aventuras, etc.) y a un mayor conocimiento del proceso de motivación de las personas para asumir y aceptar riesgos (Trimpop 1994). Se aduce que únicamente podemos comprender e influir en la aceptación y aceptación de riesgos si ponderamos, tanto los aspectos positivos, como los negativos.

Por consiguiente, la aceptación de riesgos se refiere al comportamiento de una persona en una situación de incertidumbre resultante de la decisión de adoptar (o abstenerse de adoptar) tal comportamiento, después de valorar los beneficios previstos como mayores (o menores) que los costes a la luz de las circunstancias en presencia. Este proceso puede ser extraordinariamente rápido y no traspasar, incluso, el umbral de la toma de decisiones consciente en los comportamientos automáticos 0 habituales, como en el cambio de marchas al aumentar el volumen del rugido del motor. En el otro extremo del espectro, el proceso puede ser muy dilatado e implicar análisis ponderados y consultas entre varias personas, como ocurre en el proceso de planificación de una operación arriesgada, como un vuelo espacial.

Un elemento significativo de esta definición es el de percepción. Como la percepción y posterior evaluación se basan en la experiencia, los valores y la personalidad de cada individuo, el comportamiento de aceptación de los riesgos es más una función del riesgo subjetivo que del riesgo objetivo. Por otra parte, mientras un riesgo no se percibe o no se aprecia, no es posible reaccionar ante el mismo, por grave que sea. Por lo tanto, el proceso cognitivo que conduce a la aceptación del riesgo es un proceso de tratamiento y evaluación de información que es propio de cada persona y puede ser extraordinariamente rápido.

Yates y Stone (1992) han formulado un modelo en el que la identificación de riegos se describe como un proceso de identificación, memorización y recuperación. Se pueden producir problemas en cada etapa del proceso. Por ejemplo, la exactitud en la identificación de los riesgos es bastante dudosa, especialmente en situaciones complicadas o en relación con agentes como la radiación, el veneno u otros estímulos difícilmente perceptibles. Por otra parte, los mecanismos de identificación, memorización y recuperación están implícitos en fenómenos psicológicos comunes, como los efectos de primacía y novedad, así como de familiaridad y habituación. Esto significa que las personas familiarizadas con un determinado riesgo, como el de conducir a gran velocidad, se habitúan al mismo, lo aceptan como una situación objetiva "normal" y realizan una evaluación del riesgo muy inferior al de las personas no familiarizadas con esa actividad. Una forma sencilla de representar el proceso consiste en un modelo compuesto por los elementos siguientes:

$$
\begin{aligned}
& \text { Estímulo } \Rightarrow \text { percepción } \Rightarrow \text { evaluación } \Rightarrow \text { decisión } \Rightarrow \\
& \quad \text { comportamiento } \Rightarrow \text { circuito de retroinformación }
\end{aligned}
$$

Por ejemplo, un vehículo lento que marcha delante de un conductor puede constituir un estímulo para adelantarlo. La verificación del tráfico existente en la vía es una percepción. La estimación del tiempo necesario para efectuar el adelantamiento en función de la potencia del vehículo propio constituye una evaluación. El valor atribuido al ahorro de tiempo conduce a tomar una decisión, a la que sigue el comportamiento de adelantar 0 no. La medida del éxito o el fracaso se conoce inmediatamente, y esta retroinformación influye en las decisiones subsiguientes de emprender un comportamiento de adelantamiento. En cada etapa del proceso se puede influir en la decisión final de aceptar o rechazar el riesgo. El coste y los beneficios se evalúan en función de factores individuales, contextuales y objetivos que, según ha demostrado la investigación científica, influyen de modo importante en la aceptación de riesgos.

\section{¿Qué factores influyen en la aceptación de riesgos?}

Para Fischhoff y cols. (1981), la percepción individual, el tiempo, el espacio y el contexto del comportamiento constituyen factores de gran peso en la aceptación de riesgos y se deben tomar en consideración en el estudio del riesgo. 0 tros autores han adoptado distintas categorías y denominaciones para los factores y contextos que influyen en la aceptación de riesgos. Como se ilustra en la Figura 59.16, se han tomado, tanto las categorías de propiedades de la tarea o del objeto del riesgo, como los factores individuales y los factores contextuales, con objeto de estructurar el gran número de factores determinantes.

En los modelos normales de aceptación de riesgos, las consecuencias de los nuevos riesgos tecnológicos (por ejemplo, la investigación genérica) se solían expresar en medidas cuantitativas globales (por ejemplo, daños, lesiones, muertes) y se obtenían distribuciones probabilísticas de las consecuencias mediante estimaciones o simulaciones (Starr 1969). Los resultados se contrastaban con los riesgos que ya habían sido "aceptados" por el público para obtener así una medida de la aceptación del nuevo riesgo. A veces, los datos se ofrecían en un índice de riesgos que permitía comparar los distintos tipos de riesgos. Fischhoff y cols. (1981) clasificaron los métodos más frecuentemente utilizados en juicios profesionales emitidos por expertos, información histórica y estadística, y análisis formales del tipo de Ios análisis de árbol de fallos. Los autores aducían que, si se realizan adecuadamente, los análisis formales revisten la máxima "objetividad", al discernir entre hechos y creencias y tomar en consideración numerosas influencias. N o obstante, los expertos en seguridad han manifestado que la aceptación de riesgos, tanto pública, como individual, puede basarse, más en unos juicios de valor sesgados y en las opiniones difundidas por los medios de comunicación que en unos análisis lógicos.

Se ha asegurado que los medios de comunicación y los grupos políticos que generan estadísticas brindan al gran público una información sesgada en favor de sus respectivas posiciones 
Figura 59.16 - Factores que influyen en la aceptación de riesgos.

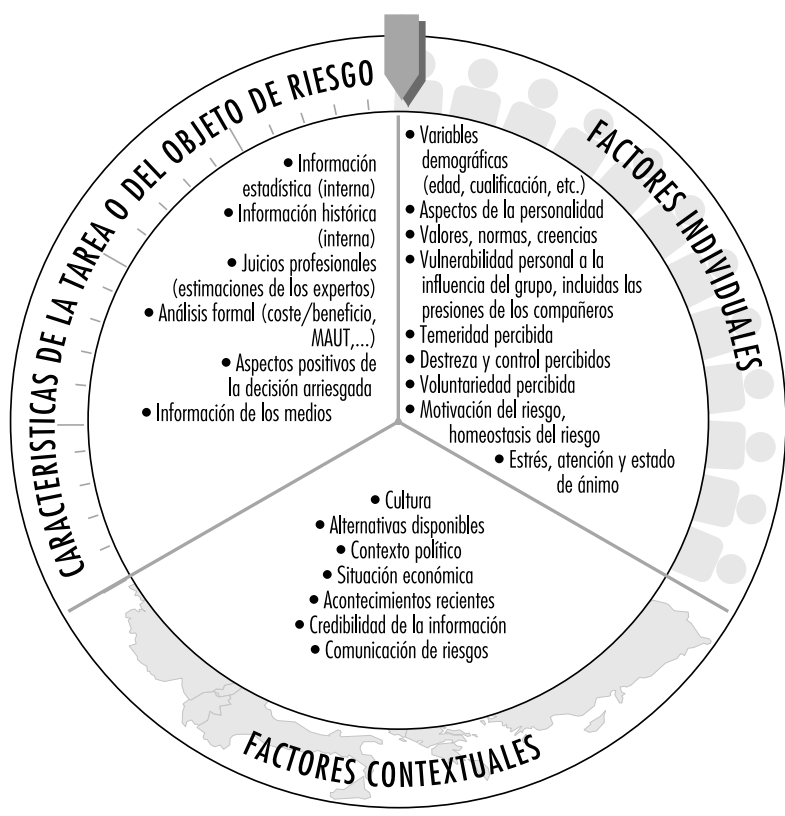

políticas. Estos sesgos individuales se deben desestimar en favor de los juicios profesionales fundados en el conocimiento de los especialistas como base de la aceptación de riesgos, y el gran público debe quedar al margen de las decisiones importantes. Esta tesis ha sido objeto de fuertes críticas, tanto desde la perspectiva de los valores democráticos (sobre la base de que la población debe participar en los asuntos que pueden tener graves repercusiones en su salud y seguridad), como desde el punto de vista de los valores sociales (iaportan la tecnología y las decisiones arriesgadas a los beneficiarios más ventajas que costes a los que pagan?). Fischhoff, Furby y Gregory (1987) recomienda el uso, bien de las preferencias expresadas (entrevistas y cuestionarios), bien de las preferencias descubiertas (observaciones) del público "interesado" para determinar la aceptabilidad de los riesgos. Jungermann y Rohrmann ponen de relieve las dificultades de concretar el "público pertinente" en relación con tecnologías como las aplicadas en las centrales nucleares y en la manipulación genética, dado que un grupo de naciones 0 , incluso, todo el planeta, se pueden beneficiar o sufrir las consecuencias.

También se han examinado las dificultades que supone la dependencia exclusiva del juicio de los expertos. Los juicios de este tipo basados en modelos normales se aproximan más a las estimaciones estadísticas que los juicios del público ( 0 tway y von Winterfeldt 1982). Sin embargo, cuando se pide que se valore la probabilidad o la frecuencia de las muertes o las lesiones producidas por una nueva tecnología, las opiniones del público se aproximan bastante más a los juicios de los expertos y a los índices estadísticos. Las investigaciones han demostrado igualmente que, aunque la gente no modifica sus impresiones iniciales frente a la evidencia objetiva, dicha modificación sí se produce si los expertos arguyen y explicitan unos beneficios y peligros plausibles. Por otra parte, $\mathrm{H}$ aight (1986) puntualiza que, como los juicios de los expertos son subjetivos y suelen diferir en cuanto a las estimaciones del riesgo, los juicios del público pueden resultar más acertados en sus valoraciones del riesgo cuando éstas se formulan después de producirse un accidente (por ejemplo, el desastre de Chernóbil). Se llega así a la conclusión de que, en sus juicios, el público se basa en unas dimensiones del riesgo distintas de las cifras estadísticas de muertes y lesiones.

0 tra consideración que influye en la aceptación de riesgos es la de si los efectos percibidos de la aceptación de los riesgos se valoran positivamente, como la sensación grata de una elevada descarga de adrenalina o la exaltación social a la categoría de héroe. M achlis y Rosa (1990) han contrastado el concepto de riesgo deseado con el de riesgo tolerado o temido, y llegan a la conclusión de que, muchas veces, el mayor riesgo actúa, más como un incentivo que como un factor disuasorio. Los autores hallaron que, a pesar de la tendencia de los medios de comunicación social a subrayar los peligros, el comportamiento de las personas puede no ser en absoluto contrario al riesgo. Por ejemplo, los operadores de un parque de atracciones informaron de una mayor afluencia de público a una de ellas al reabrir después de un accidente mortal. Asimismo, después del hundimiento de un transbordador noruego cuyos náufragos permanecieron en unos icebergs durante 36 horas, la empresa informó de una demanda sin precedentes de billetes para viajar en sus barcos. Los investigadores llegaron a la conclusión de que el fenómeno del riesgo deseado modifica la percepción y aceptación de riesgos y precisa diferentes esquemas porcentuales para explicar el comportamiento en relación con la aceptación de riesgos. Estas afirmaciones están respaldadas por los resultados de una investigación según los cuales, paradójicamente, los funcionarios de policía que realizaban labores de patrulla percibían el peligro de ser atacados y morir en acto de servicio como un elemento enriquecedor de su trabajo, al tiempo de que los funcionarios dedicados a funciones administrativas percibían ese mismo riesgo como algo temible. V lek y Stallen (1980) recomendaron la inclusión de un mayor número de elementos de remuneración personal e intrínseca en los análisis de coste-beneficio con objeto de ofrecer una explicación más vasta de los procesos de evaluación y aceptación de riesgos.

Factores individuales que influyen en la aceptación de riesgos Jungermann y Slovic (1987) han aportado datos reveladores de diferencias en la percepción, evaluación y aceptación de riesgos "objetivamente" idénticos entre estudiantes, técnicos y ecologistas. Se ha demostrado que la edad, el sexo y el nivel de educación influyen en la aceptación del riesgo y que los varones jóvenes con un bajo nivel de instrucción asumen los mayores riesgos (por ejemplo, en la guerra y los accidentes de tráfico. Zuckerman (1979) cita diversos ejemplos ilustrativos de las diferencias individuales en el nivel de aceptación de riesgos y manifiesta que en éstas influyen normalmente factores de personalidad, como la búsqueda de sensaciones, la extroversión, el exceso de confianza o la curiosidad por vivir nuevas experiencias. Los costes y beneficios de los riesgos influyen igualmente en los procesos individuales de evaluación y decisión. Diferentes personas llegan a conclusiones sumamente divergentes en la evaluación de la peligrosidad de una situación. La variedad puede residir en una valoración producida, por ejemplo, por los sesgos inducidos por determinados valores que hacen aparecer a la decisión preferida como menos arriesgada, de modo que las personas más confiadas se aferran a un valor distinto. Sin embargo, los componentes de la personalidad explican únicamente del $10 \%$ al $20 \%$ de la decisión de aceptar o rechazar un riesgo. Es, pues, necesario descubrir otros factores que expliquen el $80 \%$ o $90 \%$ restante.

Slovic, Fischhoff y Lichtenstein (1980) han llegado a la conclusión, a partir de un número de entrevistas y análisis factoriales, de que los profanos valoran el riesgo de forma 
cualitativamente diferente al tomar en consideración aspectos como la evitabilidad, la voluntariedad, el temor o el conocimiento previo del riesgo. Fischhoff y cols. (1981) han estudiado en profundidad la voluntariedad y la evitabilidad percibida. Se ha estimado que los riesgos voluntariamente asumidos (como el motociclismo y el alpinismo) poseen un nivel de aceptación unas 1.000 veces superior al de los riesgos sociales involuntariamente asumidos. En un estudio de von Winterfeldt, John y Borcherding (1981) se ha subrayado la importancia de la voluntariedad y la evitabilidad en apoyo de la distinción entre los riesgos sociales y los individuales. Los autores informan de una menor peligrosidad percibida en las carreras automovilísticas, el motociclismo y los trabajos que exigen sentido del equilibrio que en las centrales nucleares y el trafico rodado. Renn (1981) informa de un estudio sobre la voluntariedad y los efectos negativos percibidos. En el estudio se permitió que un grupo de sujetos eligiese entre tres clases de pastillas, al tiempo que a otro grupo le fueron administradas las pastillas. Si bien todas las pastillas eran idénticas, el grupo de voluntarios acusó menos "efectos secundarios" que el otro grupo.

Si los riesgos se perciben individualmente como capaces de producir consecuencias temibles para muchas personas 0 , incluso, consecuencias catastróficas asociadas a un nivel de probabilidad de que se produzcan cercano a cero, se suelen considerar inaceptables, aunque se sepa que se han producido pocos 0 ningún accidente fatal. Esto es más acentuado si los riesgos son desconocidos con anterioridad por la persona que juzga. Las investigaciones realizadas revelan igualmente que las personas utilizan su experiencia y sus conocimientos personales del riesgo en cuestión como base del juicio de aceptación de los riesgos perfectamente definidos, al tiempo que los riesgos anteriormente desconocidos se juzgan más bien sobre la base de los niveles de temor y gravedad. Las personas se muestran más propensas a subestimar, incluso los riesgos elevados, si han estado expuestas a ellos durante largos períodos de tiempo, como ocurre a las personas que viven más abajo de la presa de una central hidroeléctrica o en zonas sísmicas, o que realizan trabajos con un nivel de riesgo "normalmente" elevado, como la minería subterránea, la tala de árboles y la construcción (Zimolong 1985). Por otra parte, las personas suelen valorar los riesgos de origen humano de forma muy distinta de los naturales, y aceptan de mejor grado que los riesgos artificiales de origen humano. A parentemente, el público no considera adecuado el método utilizado por los expertos para enmarcar los riesgos inherentes a las nuevas tecnologías dentro de los "riesgos objetivos" de bajo y alto perfil correspondientes a los peligros naturales y a los riesgos previamente aceptados. Se puede aducir que los riesgos previamente "aceptados" son riesgos simplemente tolerados, que los nuevos riesgos se añaden a los existentes y que los nuevos peligros no han sido aún experimentados ni afrontados. Por lo tanto, las afirmaciones de los expertos se valoran fundamentalmente como promesas. Por último, resulta muy difícil determinar qué se ha aceptado realmente, dado que muchas personas parecen no ser conscientes de muchos de los riesgos del entorno.

Incluso si las personas son conscientes de los riesgos del entorno, se produce el problema del comportamiento de adaptación. Este proceso se describe perfectamente en la teoría de la compensación de riesgos y del equilibrio del riesgo (Wilde 1986), según la cual las personas ajustan sus decisiones de aceptación del riesgo y su comportamiento de asunción de riesgos al nivel prefijado del riesgo percibido. Esto significa que las personas se comportan con mayor cautela y aceptan menos riesgos si se sienten amenazadas y, recíprocamente, se muestran más temerarias y aceptan niveles superiores de riesgo si se sienten seguras y protegidas. Por consiguiente, es sumamente difícil que los

expertos en seguridad diseñen equipo y medios de seguridad, como los cinturones de seguridad, las botas para esquiar, los cascos, las autovías anchas, la maquinaria cerrada, etcétera, sin que los usuarios comparen el eventual beneficio de la mayor seguridad con algún beneficio personal, como la mayor velocidad, la comodidad, la disminución de la atención u otro comportamiento más "arriesgado".

La modificación del nivel de riesgo aceptado mediante el aumento del valor del comportamiento seguro puede reforzar la motivación para aceptar la alternativa menos peligrosa. El objetivo de este procedimiento es modificar los valores, normas y creencias individuales con objeto de inducir a la aceptación del riesgo alternativo y el comportamiento tendente a la aceptación de riesgos. Entre los factores que contribuyen a incrementar 0 reducir la probabilidad de aceptación de los riesgos se incluyen aspectos tales como si la tecnología aporta un beneficio que satisfaga las necesidades actuales, contribuye a mejorar el nivel de vida o a la creación de puestos de trabajo, promueve el crecimiento económico, aumenta el prestigio y la independencia nacionales, exige la adopción de estrictas medidas de seguridad, refuerza el poder del gran capital o conduce a la centralización de las estructuras políticas y económicas ( 0 tway y von Winterfeldt 1982). K ahneman y T versky (1979 y 1984) citan otras situaciones que influyen igualmente en la evaluación del riesgo. A firman los autores que, si se cifran las probabilidades de sobrevivir a una intervención quirúrgica o un tratamiento de radioterapia en el $68 \%$, el $44 \%$ de los pacientes lo aceptan. Esto contrasta con el $18 \%$ de pacientes que optan por el mismo tratamiento de radioterapia o idéntica operación si e les dice que tienen un $32 \%$ de posibilidades de no sobrevivir, lo cual es matemáticamente equivalente a la primera formulación. Con frecuencia, las personas recurren a un valor personal esperanzador (Lopes y Ekberg 1980) para juzgar la aceptabilidad de los

Figura 59.17 - Sesgos individuales que influyen en la evaluación y aceptación de riesgos.

Deficiencias en la evaluación de contingencias (por ejemplo, algunas personas creen en la existencia de una relación causal entre las cartas astrológicas y el éxito)

Sesgos respecto a las funciones personales (por ejemplo, una ilusión de control del tipo de la creencia en un ángel de la guarda para los motocidistas, que conduce a muchas personas a infravalorar la peligrosidad de sus actos

Efectos del estado de ánimo y de las diferencias individuales [por ejemplo, Johnson y Tversky (1983) subrayan que las personas que sufren una situación anímica depresiva sobrevaloran el riesgo de fracasar]

La exposición prolongada al riesgo induce a una acentuada subestimación del mismo (Zimolong 1985)
Valores sesgados (por ejemplo, las personas sobrevaloran sus probabilidades de éxito si desean el resultado, como ganar millones en una lotería)

Sesgos originados en las percepciones (por ejemplo, la velocidad de desplazamiento de un objeto voluminoso, como una locomotora, se percibe como inferior a la de un objeto menor)

Efecto nivel [(Fischhoff y MacGregor (1991) demuestran que una presentación positiva de una situación por lo demás idéntica induce a una mayor aceptación del riesgo)]

Efectos de atención [(por ejemplo, March y Shappira (1992) comentan que la estimación y aceptación del riesgo depende del nivel y enfoque de la atención)] 
riesgos, especialmente si han de afrontar una acumulación de riesgos en el tiempo.

Johnson y T versky (1983) han subrayado la influencia de los "contextos emocionales" (esto es, de situaciones afectivas que generan emociones) en la evaluación y aceptación de riesgos. En los respectivos contextos, se generaron emociones positivas y negativas mediante la exposición de acontecimientos como un éxito personal o la muerte de un joven. Los autores hallaron que las personas que experimentaban sentimientos negativos inducidos juzgaban los riesgos de muerte accidental y violenta como mucho más elevados, al margen de otras variables contextuales, que las personas con sentimientos positivos. 0 tros factores que influyen en la aceptación individual del riesgo, son los valores colectivos, las creencias personales, las normas sociales, los valores culturales, la situación política y económica y las experiencias recientes, como la de haber presenciado un accidente. Dake (1992) aduce que el riesgo, al margen del elemento físico, es un concepto sumamente dependiente del conjunto de creencias y mitos vigentes en un determinado contexto cultural. Yates y Stone (1992) ofrecen una relación de los sesgos individuales (Figura 59.17) que ejercen una influencia en la evaluación y aceptación de riesgos.

\section{Factores culturales que influyen en la aceptación de riesgos}

Pidgeon (1991) define la cultura como el conjunto de creencias, normas, actitudes, funciones y prácticas compartidos por un determinado grupo social o población. Las diferencias culturales son causa de distintos niveles de percepción y aceptación del riesgo, por ejemplo, si se comparan los niveles de seguridad en el trabajo y los índices de siniestralidad de los países industrializados con los prevalentes en las naciones en vías de desarrollo. A pesar de las divergencias, uno de los hallazgos más persistentes en los contextos inter e intraculturales es que, por lo general, emergen los mismos conceptos de temor y desconocimiento del riesgo, así como los de voluntariedad y evitabilidad, si bien gozan de prioridades diferentes (K asperson 1986). Es discutible que estas prioridades sean 0 no una cuestión exclusivamente cultural. Por ejemplo, en la estimación de los peligros implícitos en la eliminación de los residuos tóxicos y radiactivos, la atención de los británicos se centra más en los riesgos del transporte, al tiempo que los húngaros prestan más interés a los riesgos operativos y, los norteamericanos, a los riesgos de origen ambiental. Aunque estas diferencias se atribuyen a la diversidad cultural, podrían obedecer igualmente a la percepción de la alta densidad demográfica del Reino U nido, a la preocupación de los húngaros por la seguridad operativa y a la conciencia ambiental de los norteamericanos, que constituyen factores de situación. En otro estudio, K leinhesselink y Rosa (1991) hallaron que los japoneses perciben la energía nuclear como un riesgo terrible, mientras que, para los norteamericanos, la energía del átomo es fuente de un peligro más bien ignoto. L os autores atribuyen esta divergencia al distinto grado de exposición, caracterizado, por ejemplo, por las bombas atómicas lanzadas sobre Hiroshima y Nagasaki en 1945. Sin embargo, se han hallado divergencias similares entre los americanos y los hispanos residentes en el área de San Francisco. Por consiguiente, las diferencias culturales, cognitivas e individuales de ámbito local pueden influir en la percepción del riesgo tanto como los sesgos culturales generales (Rohrmann 1992a).

Estas y otras discrepancias similares en las conclusiones e interpretaciones generadas por hechos idénticos indujeron a Johnson (1991) a advertir que se debe ir con cautela al atribuir las causas de la percepción y la aceptación del riesgo a diferencias culturales. Preocupaban al autor las divergencias generalizadas en la definición de cultura, que la convierten en un término que lo engloba prácticamente todo. Por otra parte, las diferencias de opinión y de comportamiento entre los grupos de población o entre las empresas de un mismo país hacen aún más difícil una valoración clara de la cultura o de sus efectos sobre la percepción y la aceptación de los riesgos. Asimismo, las muestras estudiadas son pequeñas y escasamente representativas del conjunto de las culturas, además de que las causas no se suelen discernir adecuadamente de los efectos (R ohrmann 1995). O tros aspectos culturales examinados constituían visiones del mundo, como individualismo contra igualitarismo, contra aceptación de las jerarquías, así como factores sociales, políticos, religiosos 0 económicos.

Wilde (1994) informa, por ejemplo, de que la frecuencia de los accidentes es inversamente proporcional al nivel de prosperidad económica de un país. En las épocas de recesión, los accidentes de tráfico disminuyen, para aumentar nuevamente durante los períodos de expansión económica. Wilde atribuye esta relación a diversos factores; por ejemplo, en las situaciones de recesión económica hay más desempleados y tanto la gasolina como los recambios se encarecen, por lo que los conductores están más atentos a evitar accidentes. Por otra parte, Fischhoff y cols. (1981) afirman que en los períodos de recesión las personas se muestran más dispuestas a asumir riesgos y unas condiciones de trabajo incómodas con tal de conseguir o conservar un puesto de trabajo.

En su examen de la función del lenguaje y su utilización en los medios de comunicación, Dake (1991) cita un número de ejemplos en los que los mismos "hechos" se han manipulado en su presentación con objeto de promover los objetivos políticos de determinados grupos, organizaciones o gobiernos. Por ejemplo, ¿se pueden calificar las denuncias de los trabajadores sobre la presunta existencia de determinados riesgos profesionales de "preocupaciones legítimas" o de "fobias narcisistas"? ¿Constituye la información que se aporta a los juzgados en las causas por lesiones "prueba fehaciente" o mera "charlatanería pseudocientífica? ¿Afrontamos "catástrofes ecológicas" o simples "incidencias" o "desafíos"? Por lo tanto, la aceptación de los riesgos depende, tanto de la percepción de la situación y del contexto del riesgo que se juzga, como de la percepción de la situación y del contexto en que se encuentran los propios "jueces" (von Windeterfeldt y Edwards 1984). Como se deduce de los ejemplos anteriores, la percepción y aceptación de los riesgos es, en gran medida, una función de la formulación concreta de los "hechos" básicos. La credibilidad de la fuente, el volumen y el tipo de cobertura ofrecida en los medios de comunicación - en resumen, la comunicación de los riesgos- determinan la aceptación de los riesgos con más frecuencia de lo que indican los resultados de los análisis formales y el juicio de los expertos. Por consiguiente, la comunicación de los riesgos constituye un factor contextual que se utiliza con la finalidad específica de modificar la aceptación de los riesgos.

\section{Modificar la aceptación de los riesgos}

Se ha podido probar que, si se desea alcanzar un elevado grado de aceptación del cambio, resulta muy recomendable comprometer en el proceso de planificación, decisión y control a las personas presuntamente predispuestas a la aceptación del cambio, con objeto de inducirlas a prestar su apoyo a la decisión. En la Figura 59.18 se ofrecen seis fases, basadas en los informes sobre los programas más fructíferos, que se deben tomar en consideración si se trata de riesgos.

\section{Determinación de los "riesgos óptimos"}

En las fases 1 y 2 se producen serios problemas para determinar la conveniencia y el "riesgo objetivo" del objetivo, mientras que en la fase 3 no parece fácil eliminar las peores opciones. Tanto para las personas como para las organizaciones, el peligro de experimentar catástrofes sociales, materiales o letales de gran 
Figura 59.18 - Seis fases de la elección, decisión y aceptación de los riesgos óptimos.

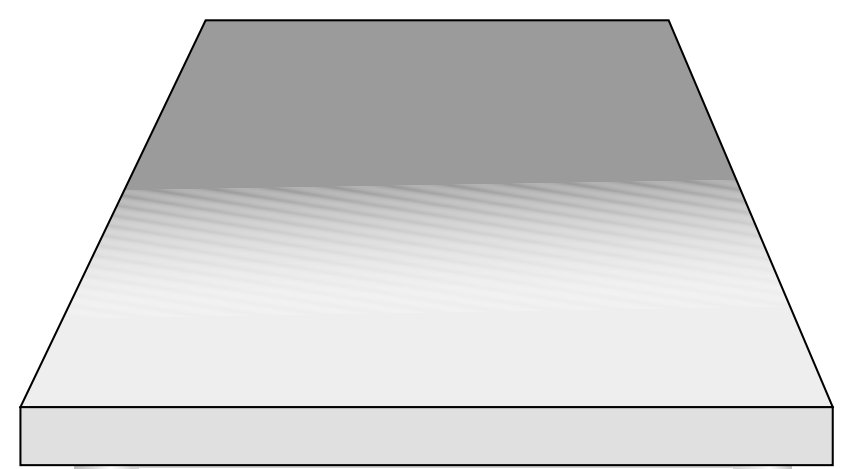

Los "grupos interesados" deben participar en las fases iniciales del proyecto "arriesgado". Esto permite determinar la conveniencia de los objetivos y sus consecuencias.

1

Es preciso concretar las posibles alternativas. Es necesario realizar una evaluación formal de los eventuales costes y beneficios de todas las opciones, incluidas las consecuencias de no adoptarlas. Esta evaluación debe consistir en una combinación de análisis formal, análisis informal y valoración profesional, tomando en consideración los intereses y sesgos del público. 2

Se deben eliminar las peores opciones posibles, y las mejores se deben comunicar adecuadamente al público.

\section{3}

Si se utilizan los métodos de selección adecuados, el "público interesado" (afectado) debe tener la posibilidad de elegir entre varias posibilidades.

4

Se debe aceptar esta decisión e iniciarse el proceso de búsqueda continua de mejoras o de mejores alternativas.

\section{5}

El "público interesado" debe ser regularmente informado de los progresos logrados e inducido a participar en la creación de una cultura de la seguridad y optimización de riesgos.

\section{6}

magnitud suelen ser las opciones más temidas y menos aceptables. Perrow (1984) aduce que en la mayoría de los riesgos para la sociedad, como la investigación del ADN, las centrales nucleares y las carreras de armas nucleares, existen numerosos subsistemas íntimamente vinculados entre sí, en el sentido de que, si se produce un error en un subsistema, el mismo puede desencadenar muchos otros errores. Esta cadena de errores puede pasar inadvertida a causa de la naturaleza del error inicial, como puede ser el fallo de un sistema de alarma. El riesgo de que se produzcan accidentes de resultas de diversos fallos interactivos es mayor en los sistemas tecnológicos complejos. Por lo tanto, Perrow (1984) recomendó una vinculación laxa entre los riesgos para la sociedad que permitiese un control independiente de los mismos y que posibilitase una evaluación y una protección independientes contra dichos riesgos, además de abogar por un estudio en profundidad de las tecnologías capaces de producir consecuencias catastróficas.

\section{Comunicación de las "elecciones óptimas"}

En las fases 3 a 6 se aborda la exactitud en la comunicación de riesgos, que constituye una herramienta para fomentar el comportamiento idóneo de percepción, evaluación y asunción óptima de los riesgos. La comunicación de riesgos se dirige a un público heterogéneo, compuesto por internos, pacientes, trabajadores, etcétera. Los riesgos se comunican a través de diversos cauces, como la prensa escrita, la radio, la televisión y la transmisión oral, todos los cuales operan en diversos marcos o "escenarios", como sesiones de formación, vistas públicas, artículos, campañas y relaciones personales. A pesar de los escasos estudios

Figura 59.19 - O bjetivos de la comunicación de riesgos.

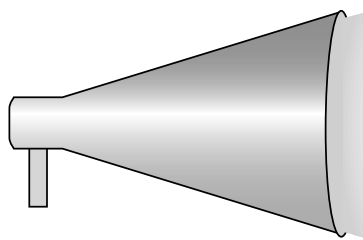

La comunicación de los riesgos sirve para informar a las personas de los cambios y para mejorar sus conocimientos y actitudes frente a los riesgos.

Ayuda a las personas que sienten una amenaza en encontrar un foro de debate de sus preocupaciones.
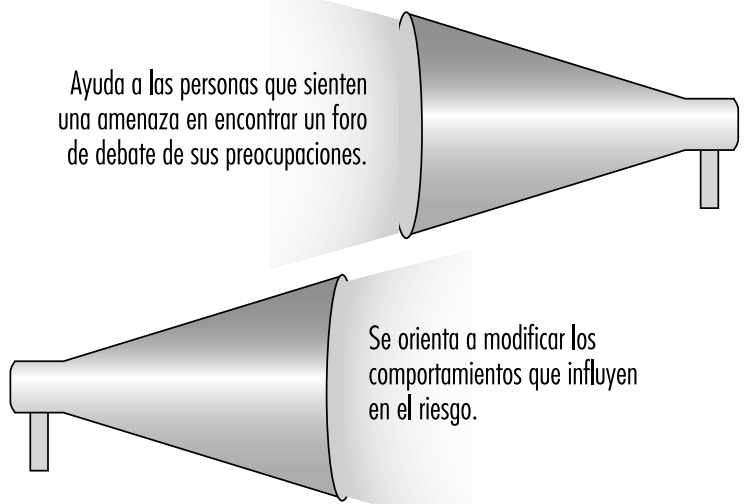

Se orienta a modificar los comportamientos que influyen en el riesgo.

La comunicación de riesgos entre subgrupos puede reducir las diferencias culturales en la percepción de riesgos, influir en la políica de los gobiernos, en relación, por ejemplo, con los peligros ambientales, y coadyuvar a la colaboración en la solución de los problemas. 
Figura 59.20 - Factores que influyen en la eficacia de la comunicación de riesgos.

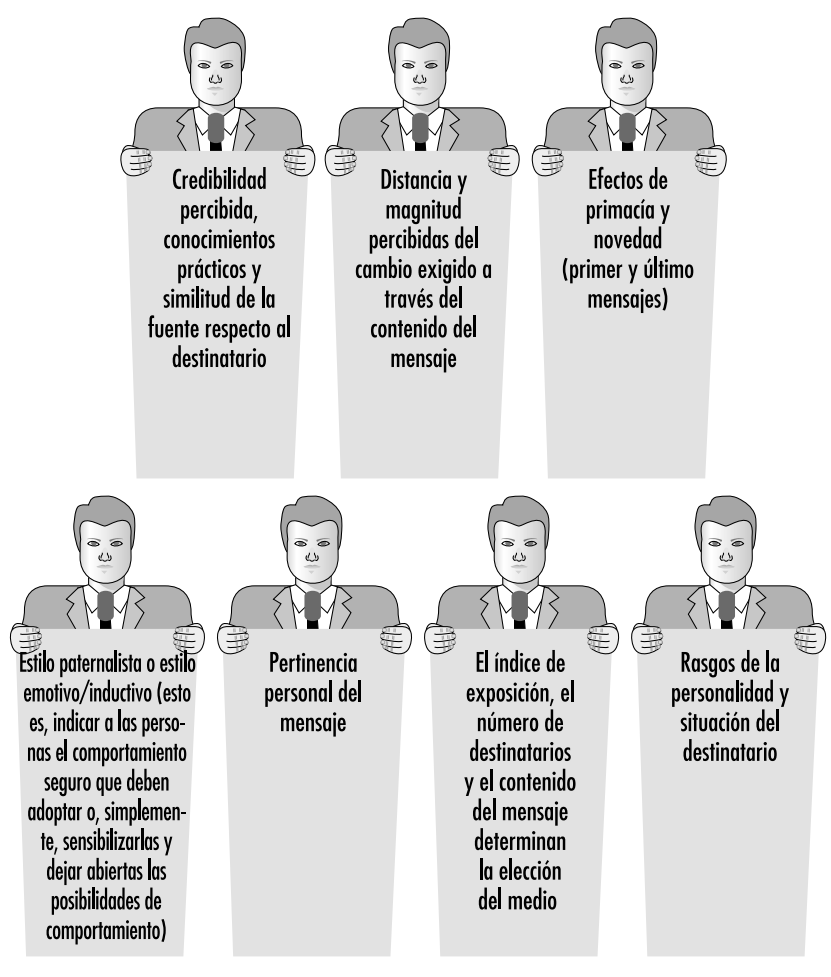

existentes de la eficacia de los medios de comunicación social en el área de la salud y seguridad, la mayoría de los autores están de acuerdo en que la calidad de la comunicación determina en gran medida la probabilidad de que se produzcan cambios de actitud y de comportamiento en la aceptación de los riesgos por parte del público destinatario. Según R ohrmann (1992a), la comunicación del riesgo persigue, además, otras finalidades, algunas de las cuales se han relacionado en la Figura 59.19.

La comunicación de riesgos es un tema complejo cuya eficacia raras veces se ha demostrado con precisión científica. Rohrmann (1992a) enuncia los elementos necesarios de la evaluación de la comunicación de riesgos y ofrece algunas recomendaciones para mejorar la eficacia de la comunicación. Wilde
(1993) distingue entre la fuente, el mensaje, el canal y el destinatario, y brinda algunas recomendaciones sobre cada aspecto de la comunicación. El autor cita datos que muestran, por ejemplo, que el grado de eficacia de la comunicación en el área de la salud y seguridad depende de cuestiones como las que se indican en la Figura 59.20.

\section{Creación de una cultura de optimización de los riesgos}

Pidgeon (1991) define la cultura de seguridad como un sistema convencional de significados a través del cual un grupo o una población determinados entienden los peligros del mundo. En este sistema se define lo que es importante y legítimo y se explican sus relaciones con las cuestiones de la vida y la muerte, el trabajo y el peligro. Una cultura de seguridad se crea y se reconstruye a medida que quienes la comparten se comportan de una forma considerada natural, obvia e incuestionable $y$, al hacerlo así, generan una expresión concreta del riesgo, el peligro y la seguridad. En estas expresiones de los peligros del mundo se inscriben, asimismo, determinados esquemas explicativos de la causalidad de los accidentes. En una organización como una empresa 0 un país, las reglas y normas tácitas y expresas que rigen la seguridad están en el núcleo de la cultura de seguridad. Sus componentes principales son las reglas de prevención de riesgos, las actitudes hacia la seguridad y el análisis crítico de las medidas de seguridad.

En las organizaciones empresariales que ya viven en el contexto de una cultura de seguridad desarrollada se subraya la importancia de los objetivos, concepciones, valores y comportamientos comunes en la aceptación y asunción de riesgos. Como siempre existen incertidumbres en todo contexto laboral, es importante perseguir el equilibrio óptimo entre el aprovechamiento de las oportunidades y el control de los peligros. V lek y $C$ vetkovitch (1998) comentan:

La correcta gestión del riesgo consiste, más en crear y mantener un nivel suficiente de control (dinámico) de una determinada actividad tecnológica, que en cuantificar continuamente - o una sola vez- las probabilidades de que se produzcan accidentes y difundir el mensaje de que las mismas son "despreciables". Por consiguiente, la mayoría de las veces, "riesgo aceptable" equivale a "control suficiente".

\section{Resumen}

Cuando las personas creen ejercer suficiente control sobre los posibles riesgos, se muestran dispuestas a controlar los peligros para lograr un beneficio. Sin embargo, el control suficiente debe basarse en datos, evaluaciones y percepciones fiables $y$, finalmente, en una decisión óptima de asumir o rechazar el "objetivo arriesgado".

\section{Referencias}

Abbey, A, JW Dickson. 1983. R\&D work climate and innovation in semiconductors. Acad $M$ anage J 26:362-368.

Andriessen, JHTH. 1978. Safe behavior and safety motivation. I O ccup Acc 1:363-376.

Bailey, C. 1993. Improve safety program effectiveness with perception surveys. Prof Saf O ctubre: 28-32.

Bluen, SD, C Donald. 1991. The nature and measurement of in-company industrial relations climate. S Afr J Psychol 21(1):12-20.

Brown, RL, H Holmes. 1986. The use of a factoranalytic procedure for assessing the validity of an employee safety climate model. Accident Anal Prev 18(6):445-470.

CCPS (Center for Chemical Process Safety). N.d Guidelines for Safe Automation of Chemical Processes.
Nueva York: Center for Chemical Process Safety of the American Institution of Chemical Engineers.

Chew, DCE. 1988. Q uelles sont les mesures qui assurent le mieux la sécurité du travail? Etude menée dans trois pays en développement d'Asie. Rev Int T ravail 127:129-145.

Chicken, JC, M R H aynes. 1989. The Risk Ranking $M$ ethod in $D$ ecision $M$ aking. $O$ xford: Pergamon.

Cohen, A. 1977. Factors in successful occupational safety programs. I Saf Res 9:168-178.

Comisión Electrotécnica Internacional (CEI). N.d. Draft Standard IEC 1508; F unctional Safety: Safetyrelated Systems. Ginebra: CEI.

Cooper, M D, RA Phillips, VF Sutherland, PJ M akin. 1994. Reducing accidents using goal setting and feedback: A field study. J O ccup Organ Psychol 67:219-240.
Cru, D, Dejours C. 1983. Les savoir-faire de prudence dans les métiers du bâtiment. Cahiers médicosociaux 3:239-247.

Dake, K. 1991. O rienting dispositions in the perception of risk: An analysis of contemporary worldviews and cultural biases. I Cross Cult Psychol 22:61-82.

-. 1992. M yths of nature: Culture and the social construction of risk. J Soc Issues 48:21-37.

Dedobbeleer, N, F Béland, P G erman. 1990. Is there a relationship between attributes of construction sites and workers' safety practices and climate perceptions? En Advances in Industrial E rgonomics and Safety II, dirigido por D Biman. Londres: Taylor \& Francis.

Dedobbeleer, N, F Béland. 1989. The interrelationship of attributes of the work setting and workers' 
safety climate perceptions in the construction industry. En Proceedings of the 22 nd Annual Conference of the $\mathrm{H}$ uman $\mathrm{F}$ actors $\mathrm{Association}$ of $\mathrm{C}$ anada. T oronto.

-. 1991. A safety climate measure for construction sites. J Saf Res 22:97-103.

D ejours, C. 1992. Intelligence ouvrière et organisation du travail. París: $\mathrm{H}$ armattan.

Dejoy, DM. 1987. Supervisor attributions and re sponses for multicausal workplace accidents. I $\mathrm{OC}$. cup Acc 9:213-223.

- . 1994. M anaging safety in the workplace: An attribution theory analysis and model. I Saf Res 25:3-17.

Denison, DR . 1990. Corporate Culture and Organizational E ffectiveness. N ueva Y ork: Wiley.

Dieterly, D, B Schneider. 1974. The effect of organizational environment on perceived power and climate: A laboratory study. O rgan B ehav $\mathrm{H}$ um Perform 11:316-337.

Dodier, N. 1985. La construction pratique des conditions de travail: Préservation de la santé et vie quotidienne des ouvriers dans les ateliers. Sci Soc Sante 3:5-39.

Dunette, M D. 1976. H andbook of Industrial and Organizational Psychology. Chicago: R and $\mathrm{M}$ CN ally.

D wyer, T . 1992. Life and D eath at W ork. Industrial Accidents as a Case of Socially Produced E rror. N ueva Y ork: Plenum Press.

Eakin, JM . 1992. Leaving it up to the workers: Sociological perspective on the management of health and safety in small workplaces. Int I H ealth Serv 22:689-704.

Edwards, W. 1961. Behavioural decision theory. Annu Rev Psychol 12:473-498.

Embrey, DE, P H umphreys, EA R osa, B K irwan, K R ea. 1984. An approach to assessing human error probabilities using structured expert judgement En Nuclear Regulatory Commission NUREG/ CR-3518, Washington, DC: NUREG

Eyssen, G, J Eakin-H offman, R Spengler. 1980. $M$ anager's attitudes and the occurrence of accidents in a telephone company. I O ccup Acc 2:291-304.

Field, RHG, MA Abelson. 1982. Climate: A reconceptualization and proposed model. Hum Relat 35:181-201.

Fischhoff, B, D M acGregor. 1991. Judged lethality: H ow much people seem to know depends on how they are asked. R isk Anal 3:229-236.

Fischhoff, B, L Furby, R Gregory. 1987. Evaluating voluntary risks of injury. Accident Anal Prev 19:51-62.

Fischhoff, B, S Lichtenstein, P Slovic, S Derby, RL K eeney. 1981. A cceptable risk. C ambridge: CU P.

Flanagan, O . 1991. T he Science of the M ind. Cambridge: MIT Press.

Frantz, JP, TP R hoades.1993. H uman factors. A task analytic approach to the temporal and spatia placement of product warnings. H uman Factors 35:713-730.

Frantz, JP. 1992. Effect of location, procedural explicitness, and presentation format on user processing of and compliance with product warnings and instructions. Tesis doctoral. U niversidad de M ichigan, Ann Arbor.

Frederiksen, M , 0 Jensen, AE Beaton. 1972. Prediction of Organizational Behavior. Elmsford, Nueva Y ork Pergamon.

Freire, P. 1988. Pedagogy of the Oppressed. Nueva Y ork: Continuum.

G lick, WH . 1985. Conceptualizing and measuring organizational and psychological climate: Pitfalls in multi-level research. Acad $M$ anage $R e$ 10(3):601-616.
Gouvernement du Q uébec. 1978. Santé et sécurité au travail: Politique québecoise de la santé et de la sécurité des travailleurs. Q uébec: Editeur officiel du Q uébec.

H aas, J. 1977. Learning real feelings: A study of high steel ironworkers' reactions to fear and danger. Sociol W ork 0 ccup 4:147-170.

H acker, W. 1987. A rbeitspychologie. Stuttgart: $\mathrm{H}$ ans H uber.

H aight, FA. 1986. Risk, especially risk of traffic accident. Accident Anal Prev 18:359-366.

$\mathrm{H}$ ale, AR, AI Glendon. 1987. Individual B ehaviour in the Control of Danger. $V$ ol. 2. Industrial Safety Series. Amsterdam: Elsevier.

Hale, AR, B Hemning, I Carthey, B K irwan. 1994. $E$ xtension of the $M$ odel of $B$ ehaviour in the $C$ ontrol of $D$ anger. Volume 3-Extended model description. U niversidad Tecnológica de Delft, Safety Science Group (Informe para el HSE). Birmingham, R eino U nido: U niversidad de Birmingham, Industrial Ergonomics $\mathrm{G}$ roup.

$\mathrm{H}$ ansen, L. 1993a. Beyond commitment. O ccup H azards 55(9):250

-. 1993b. Safety management: A call for revolution. Prof Saf 38(30):16-21.

$H$ arrison, EF. 1987. The M anagerial Decision-making Process. Boston: H oughton M ifflin.

Heinrich, H, D Petersen, N Roos. 1980. Industrial Accident Prevention. N ueva Y ork: M cG raw-H ill.

H ovden, J, TJ Larsson. 1987. Risk: Culture and concepts. En Risk and Decisions, dirigido por WT Singleton y J H ovden. N ueva Y ork: Wiley.

H owarth, $\mathrm{Cl}$. 1988. The relationship between objective risk, subjective risk, behaviour. E rgonomics 31:657-661.

Hox, JJ, IGG K reft. 1994. M ultilevel analysis methods. Sociol M thods R es 22(3):283-300.

H oyos, CG, B Zimolong. 1988. O ccupational Safety and Accident Prevention. B ehavioural Strategies and $M$ ethods. Amsterdam: Elsevier.

H oyos, CG, E R uppert. 1993. D er F ragebogen zur Sicherheitsdiagnose (FSD). Berna: H uber

Hoyos, CT, U Bernhardt, G Hirsch, T Arnhold. 1991. Vorhandenes und erwünschtes sicherheitsrelevantes W issen in Industriebetrieben. Z eitschrift für A rbeits-und 0 rganisationspychologie 35:68-76.

Huber, O. 1989. Information-procesing operators in decision making. En Process and Structure of $\mathrm{H}$ uman Decision $\mathrm{M}$ aking, dirigido por $\mathrm{H}$ M ontgomery y $\mathrm{O}$ Svenson. C hichester: Wiley.

H unt, H A, RV H abeck. 1993. The M ichigan disability prevention study: R esearch highlights. Informe no publicado. K alamazoo, M ichigan: E.E. U pjohn Institute for Employment R esearch.

Instrument Society of America (ISA). N .d. D raft Standard: Application of Safety Instrumented Systems for the Process Industries. Carolina del Norte, Estados U nidos: ISA.

James, LR, AP Jones. 1974. O rganizational climate: $A$ review of theory and research. Psychol Bull 81(12):1096-1112.

James, LR. 1982. Aggregation bias in estimates of perceptual agreement. J A ppl Psychol 67:219-229.

Janis, IL, L M ann. 1977. Decision-making: A Psychological Analysis of Conflict, Choice and Commitment. Nueva Y ork: Free Press.

Johnson, BB. 1991. Risk and culture research: Some caution. J Cross Cult Psychol 22:141-149.

Johnson, EJ, A T versky. 1983. Affect, generalization, and the perception of risk. J Personal Soc Psychol 45:20-31.

Jones, AP, LR James. 1979. Psychological climate: Dimensions and relationships of individual and aggregated work environment perceptions. 0 rgan $\mathrm{Be}$ hav $\mathrm{H}$ um Perform 23:201-250.
Joyce, WF, JWJ Slocum. 1984. Collective climate: Agreement as a basis for defining aggregate climates in organizations. A cad M anageJ 27:721-742.

Jungermann, H, P Slovic. 1987. Die Psychologie der $\mathrm{K}$ ognition und Evaluation von $\mathrm{R}$ isiko. O riginal no publicado. Technische U niversität Berlin.

K ahneman, D, A T versky. 1979. Prospect theory: An analysis of decision under risk. Econometrica 47:263-291.

-. 1984. Choices, values, and frames. Am Psychol 39:341-350.

K ahnemann, D, P Slovic, A T versky. 1982. J udgement under U ncertainty: Heuristics and Biases. Nueva Y ork: Cambridge U niversity Press.

K asperson, RE. 1986. Six propositions on public participation and their relevance for risk communication. Risk Anal 6:275-281.

K leinhesselink, RR, EA R osa. 1991. Cognitive representation of risk perception. I Cross Cult Psychol 22:11-28.

Komaki, J, K D Barwick, LR Scott. 1978. A behavioral approach to occupational safety: Pinpointing and reinforcing safe performance in a food manufacturing plant. I A ppl Psychol 4:434-445.

K omaki, JL. 1986. Promoting job safety and accident precention. En $\mathrm{H}$ ealth and Industry: A Behavioral $M$ edicine Perspective, dirigido por M F Cataldo y TJ C oats. N ueva Y ork: Wiley.

Konradt, U. 1994. Handlungsstrategien bei der Störungsdiagnose an flexiblen Fertigungseinrichtungen. Z eitschrift für Arbeits-und Organisations-pychologie 38:54-61.

Koopman, P, J Pool. 1991. O rganizational decision making: M odels, contingencies and strategies. En $D$ istributed D ecision M aking. Cognitive M odels for Cooperative W ork, dirigido por J R asmussen, B Brehmer y J Leplat. Chichester: Wiley.

K oslowski, M, B Zimolong. 1992. G efahrstoffe am Arbeitsplatz: O rganisatorische Einflüsse auf $\mathrm{Ge}$ fahrenbewußstein und R isikokompetenz. En W orkshop Psychologie der Arbeitssicherheit, dirigido por B Zimolong y R T rimpop. H eidelberg: A sanger.

K oys, DJ, TA DeC otiis. 1991. Inductive measures of psychological climate. H um R dat 44(3):265-285.

$\mathrm{K}$ rause, TH, JH Hidley, SJ Hodson. 1990. The $B$ ehavior-based Safety Process. Nueva Y ork: $V$ an N orstrand R einhold.

Lanier, EB. 1992. Reducing injuries and costs through team safety. ASSE J July:21-25.

Lark, J. 1991. Leadership in safety. Prof Saf 36(3):33-35

Lawler, EE. 1986. High-involvement M anagement. San Francisco: Jossey Bass.

Lehto, MR, JD Papastavrou. 1993. Models of the warning process: Important implications towards effectiveness. Safety Science 16:569-595.

Lehto, M R . 1992. D esigning warning signs and warnings labels: Scientific basis for initial guideline. Int I Ind E rg 10:115-119.

Lewin, K. 1951. Field Theory in Social Science. Nueva York: $\mathrm{H}$ arper and R ow.

Likert, R. 1967. The H uman O rganization. N ueva Y ork: $M c G$ raw Hill.

Lopes, LL, P-H S Ekberg. 1980. T est of an ordering hypothesis in risky decision making. Acta Physiol 45:161-167.

M achlis, GE, EA R osa. 1990. Desired risk: Broadening the social amplification of risk framework. Risk Anal 10:161-168.

M anson, WM , GY Wong, B Entwisle. 1983. Contextual analysis through the multilevel linear model. En Sociologic M ethodology, 1983-1984. San Francisco: J ossey-Bass.

M arch, J, H Simon. 1993. Organizations. Cambridge: Blackwell. 
M arch, JG, Z Shapira. 1992. V ariable risk preferences and the focus of attention. Psychol Rev 99:172-183.

Mattila, M, E Rantanen, M Hyttinen. 1994. The quality of work environment, supervision and safety in building construction. Saf Sci 17:257-268.

M attila, M, M H yttinen, E R antanen. 1994. Effective supervisory behavior and safety at the building site. Int J Ind E rg 13:85-93.

M CAfee, RB, AR Winn. 1989. The use of incentives/ feedback to enhance work place safety: A critique of the literature. J Saf Res 20(1):7-19.

M CSween, TE. 1995. The Values-based Safety Process. N ueva Y ork: $V$ an N orstrand R einhold.

M elia, JL, JM Tomas, A O liver. 1992. Concepciones del clima organizacional hacia la seguridad laboral: Replication del modelo confirmatorio de $\mathrm{De}$ dobbeleer y Béland. R evista de Psicologia del Trabajo y de las 0 rganizaciones $9(22)$.

M inter, SG. 1991. Creating the safety culture. 0 ccup $\mathrm{H}$ azards A gosto: $17-21$

M ontgomery, H , O Svenson. 1989. Process and Structure of $\mathrm{H}$ uman $\mathrm{D}$ ecision $\mathrm{M}$ aking. Chichester: Wiley.

Moravec, M. 1994. The 21st century employeremployee partnership. H R M ag Enero: 125-126.

M organ, G. 1986. I mages of O rganizations. Beverly $\mathrm{H}$ ills: Sage.

Nadler, D, M L Tushman. 1990. Beyond the charis matic leader. Leadership and organizational change. Calif $M$ anage $R$ ev 32:77-97.

Näsänen, M ，」 Saari. 1987. The effects of positive feedback on housekeeping and accidents at a shipyard. J 0 ccup Acc 8:237-250.

National R esearch Council. 1989. Improving Risk Communication. Washington, DC: National Academy Press.

Naylor, JD, RD Pritchard, DR Ilgen. 1980. A Theory of $B$ ehavior in Organizations. Nueva Y ork: Academic Press.

N eumann, PJ, PE Politser. 1992. Risk and optimality. En Risk-taking Behaviour, dirigido por FJ $Y$ ates. Chichester: Wiley.

Nisbett, R, L R oss. 1980. H uman I nference: Strategies and Shortcomings of Social J udgement. Englewood Cliffs: Prentice-H all.

Nunnally, JC. 1978. Psychometric T heory. Nueva Y ork: $\mathrm{M}$ cG raw-H ill.

O liver, A, JM Tomas, JL M elia. 1993. U na segunda validacion cruzada de la escala de clima organizacional de seguridad de Dedobbeleer y Béland. Ajuste confirmatorio de los modelos unofactorial, bifactorial y trifactorial. Psicologica 14:59-73.

O rganización Internacional de N ormalización (ISO) 1990. ISO 9000-3: Quality M anagement and Quality Assurance Standards: Guidelines for the A pplication of ISO 9001 to the D evelopment, Supply and M aintenance of Software. Ginebra: ISO .

O tway, HJ, D von Winterfeldt. 1982. Beyond acceptable risk: On the social acceptability of technologies. Policy Sci 14:247-256.

Perrow, C. 1984. Normal Accidents: Living with H igh-risk T echnologies. N ueva Y ork: Basic Books.

Petersen, D. 1993. Establishing good "safety culture" helps mitigate workplace dangers. 0 ccup $\mathrm{H}$ ealth Saf 62(7):20-24.

Pidgeon, NF. 1991. Safety culture and risk manage ment in organizations I Cross Cult Psycho 22:129-140.

Rabash, J, G W oodhouse. 1995. M Ln command reference. V ersión 1.0 M arzo 1995, ESR C.

R achman, SJ. 1974. T he M eanings of $F$ ear. $H$ armondsworth: Penguin.

R asmussen, J. 1983. Skills, rules, knowledge, signals, signs and symbols and other distinctions. IEEE T Syst $M$ an Cyb 3:266-275.
Reason, JT. 1990. H uman E rror. C ambridge: CU P.

Rees, JV. 1988. Self-regulation: An effective alternative to direct regulation by $\mathrm{OSHA}$ ? Stud 16:603-614.

R enn, 0. 1981. M an, technology and risk: A study on intuitive risk assessment and attitudes towards nuclear energy. Spezielle B erichte der Kernforschungsanlage Jülich.

Rittel, H WJ, M M W ebber. 1973. Dilemmas in a general theory of planning. Pol Sci 4:155-169.

Robertson, A, M M inkler. 1994. New health promotion movement: A critical examination. $\mathrm{H}$ ealth $\mathrm{E}$ duc Q 21(3):295-312.

Rogers, CR. 1961. On Becoming a Person. Boston: $\mathrm{H}$ oughton M ifflin.

R ohrmann, B. 1992a. The evaluation of risk communication effectiveness. Acta Physiol 81:169-192.

- . 1992b. Risiko Kommunikation, AufgabenK onzepte-Evaluation. En P sychologie der Arbeitssicherheit, dirigido por B Zimolong y R Trimpop. Heidelberg: A sanger.

- 1995. R isk perception research: R eview and documentation. En Arbeiten zur R isikokommunikation. $\mathrm{H}$ eft 48. Jülich: Forschungszentrum Jülich.

- . 1996. Perception and evaluation of risks: A cross cultural comparison. En Arbeiten zur R isikokommunikation $\mathrm{H}$ eft 50. Jülich: Forschungszentrum Jülich.

Rosenhead, J. 1989. Rational Analysis for a Problematic W orld. Chichester: Wiley.

R umar, K. 1988. Collective risk but individual safety. E rgonomics 31:507-518.

Rummel, RJ. 1970. Applied Factor Analysis. Evanston, Illinois: N orthwestern U niversity Press.

R uppert, E. 1987. G efahrenwahrnehmung-ein Modell zur Anforderungsanalyse für die verhaltensabbhängige $\mathrm{K}$ ontrolle von Arbeitsplatzge fahren. Z eitschrift für A rbeitswissenschaft 2:84-87.

Saari, J, M Näsänen. 1989. The effect of positive feedback on industrial housekeeping and accidents: A long-term study at a shipyard. Int J Ind Erg 4:3:201-211.

Saari, J. 1976. Characteristics of tasks associated with the occurrence of accidents. I O ccup Acc 1:273-279.

Saari, J. 1990. O n strategies and methods in company safety work: From informational to motivational strategies. I 0 ccup Acc 12:107-117.

Sarkis, H. 1990. What really causes accidents. Presentation at Wausau Insurance Safety Excellence Seminar. Canandaigua, N ueva Y ork, Estados U nidos, junio 1990.

Sass, R. 1989. The implications of work organization for occupational health policy: The case of $\mathrm{C}$ anada. Int J H ealth Serv 19(1):157-173.

Savage, LJ. 1954. The Foundations of Statistics. Nueva Y ork: Wiley.

Schäfer, RE. 1978. W hat Are W e T alking About W hen We T alk About "Risk"? A Critical Survey of Risk and Risk Preferences Theories. R.M.-78-69. Laxenber, Austria: Instituto Internacional para el Análisis A plicado de Sistemas.

Schein, EH. 1989. Organizational Culture and Leadership. San Francisco: Jossey-Bass.

Schneider, B, AE R eichers. 1983. On the etiology of climates. Pers Psychol 36:19-39.

Schneider, B, IJ Parkington, VM Buxton. 1980. Em ployee and customer perception of service in banks. Adm Sci Q 25:252-267.

Schneider, B. 1975a. O rganizational climates: An essay. Pers P sychol 28:447-479.

-. 1975b. O rganizational climate: Individual preferences and organizational realities revisited. J Appl Psychol 60:459-465.

Shannon, HS, V Walters, W Lewchuk, J Richardson, V erma, $T$ H aines, LA M oran 1992. Health and safety approaches in the workplace. Informe no publicado. T oronto: U niversidad M cM aster.

Short, JF. 1984. The social fabric at risk: T oward the social transformation of risk analysis. Amer Social $R$ 49:711-725.

Simard, M, A M archand. 1994. The behaviour of first-line supervisors in accident prevention and effectiveness in occupational safety. Saf $\mathrm{Sc}$ 19:169-184

Simard, M, A M archand. 1995. L'adaptation des superviseurs à la gestion parcipative de la prévention des accidents. Relations Industrielles 50: 567-589.

Simard, M. 1988. La prise de risque dans le travail: un phénomène organisationnel. En La prise de risque dans le travail, dirigido por $\mathrm{P}$ Goguelin y $\mathrm{X}$ Cuny. $M$ arsella: Editions $O$ ctares.

Simon, HA y cols. 1992. Decision making and problem solving. En Decision M aking: Alternatives to $R$ ational Choice M odels, dirigido por M Zev. Londres: Sage.

Simon, HA. 1959. Theories of decision making in economics and behavioural science. Am E con Rev 49:253-283.

Simonds, RH, Y Shafai-Sahrai. 1977. Factors apparently affecting the injury frequency in eleven matched pairs of companies. J Saf Res 9(3):120-127.

Slovic, P, B Fischhoff, S Lichtenstein. 1980. Perceived risk. En Societal Risk Assessment: H ow Safe Is Safe E nough?, dirigido por RC Schwing and WA Albers Ir. N ueva Y ork: Plenum Press.

- . 1984. Behavioural decision theory perspectives on risk and safety. Acta Physiol 56:183-203.

Slovic, P, H K unreuther, GF White. 1974. Decision processes, rationality, and adjustment to natural hazards. En Natural $\mathrm{H}$ azards, Local, National and Global, dirigido por GF White. Nueva York: OXford U niversity Press.

Slovic, P. 1987. Perception of risk. Science 236:280-285.

- . 1993. Perceptions of environmental hazards: Psychological perspectives. En Behaviour and Environment, dirigido por GE Stelmach y PA Vroon. Amsterdam: N orth $\mathrm{H}$ olland.

Smith, MJ, HH Cohen, A Cohen, RJ Cleveland. 1978. Characteristics of succesfful safety programs. Saf Res 10:5-15.

Smith, R B. 1993. Construction industry profile: Getting to the bottom of high accident rates. 0 ccup $H$ ealth Saf J une:35-39.

Smith, TA. 1989. Why you should put your safety program under statistical control. Prof Sa 34(4):31-36.

Starr, C. 1969. Social benefit vs. technological risk. Science 165:1232-1238.

Sulzer-Azaroff, B, D Fellner. 1984. Searching for performance targets in the behavioral analysis of occupational health and safety: An assessment strategy. J O rgan B ehav M anage 6:2:53-65.

Sulzer-Azaroff, B, TC Harris, K B M CCann. 1994. Beyond training: Organizational performance management techniques. 0 ccup M ed: State Art Rer 9:2:321-339.

Sulzer-Azaroff, B. 1978. Behavioral ecology and accident prevention. J Organ $B$ ehav $M$ anage 2:11-44.

Swain, AD, HE Guttmann. 1983. $H$ andbook of $H$ uman Reliability Analysis with Emphasis on Nuclear Power Plant Applications. Sandia National Laboratories, NUREG / CR-1278, Washington, DC: US Nuclear R egulatory Commission.

Taylor, DH. 1981. The hermeneutics of accidents and safety. E rgonomics 24:48-495.

Thompson, JD, A T uden. 1959. Strategies, structures and processes of organizational decisions. En Comparative Studies in Administration, dirigido por JD Thompson, PB H ammond, RW H awkes, BH Jun- 
ker y A Tuden. Pittsburgh: Pittsburgh U niversity Press.

T rimpop, R M . 1994. T he Psychology of R isk T aking Be havior. Amsterdam: Elsevier.

Tuohy, C, M Simard. 1992. The impact of joint health and safety committees in $\mathrm{O}$ ntario and Q uebec. Informe no publicado, Canadian Association of Administrators of Labour Laws, O ttawa.

T versky, A, D K ahneman. 1981. The framing of decisions and the psychology of choice. Science 211:453-458.

V lek, C, G C vetkovich. 1989. Social Decision M ethodology for T echnological Projects. Dordrecht, Holanda: Kluwer.

V lek, CAJ, PJ Stallen. 1980. Rational and personal aspects of risk. Acta Physiol 45:273-300.

Von Neumann, J, O M orgenstern. 1947. Theory of Games and Ergonomic Behaviour. Princeton, Nueva Jersey: Princeton U niversity Press.

Von Winterfeldt, D, RS John, K Borcherding. 1981. Cognitive components of risk ratings. Risk Anal 1:277-287.

V on Winterfeldt, D, W Edwards. 1984. Patterns of conflict about risky technologies. Risk Anal 4:55-68.

Wagenaar, W, J Groeneweg, PT W H udson, JT R eason. 1994. Promoting safety in the oil industry. E rgonomics 37, N 0. 12:1,999-2,013.

Wagenaar, W. 1990. Risk evaluation and causes of accidents. E rgonomics 33, N Os. 10/ 11.

Wagenaar, WA. 1992. Risk taking and accident causation. En Risk-taking Behaviour, dirigido por JF Y ates. Chichester: Wiley.

Walton, RE. 1986. From control to commitment in the workplace. $H$ arvard B us R ev 63:76-84.

Wilde, GJS. 1986. Beyond the concept of risk homeostasis: Suggestions for research and application towards the prevention of accidents and lifestyle-related disease. Accident Anal Prev 18:377-401.

- . 1993. Effects of mass media communications on health and safety habits: An overview of issues and evidence. Addiction 88:983-996.

- 1994. Risk homeostatasis theory and its promise for improved safety. En Challenges to Accident Prevention: T he Issue of R isk Compensation B ehaviour, dirigido por R Trimpop y GJS Wilde. Groningen, Países Bajos: ST YX Publications.

Yates, JF, ER Stone. 1992. The risk construct. En $R$ isk T aking $B$ ehaviour, dirigido por JF Y ates. Chichester: Wiley.

Yates, JF. 1992a. The risk construct. En Risk T aking $B$ ehaviour, dirigido por JF $Y$ ates. C hichester: Wiley.

—. 1992b. R isk T aking B ehaviour. Chichester: Wiley.

Zembroski, EL. 1991. Lessons learned from manmade catastrophes. En Risk M anagement. Nueva Y ork: $\mathrm{H}$ emisphere.

Zey, M. 1992. Decision M aking: Alternatives to Rational Choice M odds. Londres: Sage.

Zimolong, B, R Trimpop. 1994. M anaging human reliability in advanced manufacturing systems. En $D$ esign of $W$ ork and D evelopment of Personnel in Advanced $M$ anufacturing Systems, dirigido por G Salvendy y W $\mathrm{K}$ arwowski. N ueva Y ork: Wiley.

Zimolong, B. 1985. H azard perception and risk estimation in accident causation. $\mathrm{En} T$ rends in $\mathrm{E}$ rgonomics/ H uman F actors II, dirigido por RB Eberts y CG Eberts. Amsterdam: Elsevier.

Zimolong, B. 1992. Empirical evaluation of THERP SLIM and ranking to estimate HEPs. Reliab Eng Sys Saf 35:1-11.

Zohar, D. 1980. Safety climate in industrial organizations: Theoretical and applied implications. J Appl Psychol 65, N 0.1:96-102.
Zuckerman, M. 1979. Sensation Secking: B eyond the 0 ptimal Level of Arousal. H illsdale: Lawrence Erlbaum.

\section{0 tras lecturas recomendadas}

Baily, CW. 1988. U sing B ehavioral T echniques to Improve Safety Programme E ffectiveness. Washington, DC: Association of A merican $R$ ailroads.

Deutsche Industrie Normen (DIN). 1990. Grundsatze für Rechner in System mit Sicherheitsaufgaben [Principios de informática en los sistemas relacionados con la seguridad]. DIN V VDE 0801. Berlín: Beuth Verlag.

Grandjean, E. 1988. Fitting the T ask to the $M$ an. Londres: T aylor and Francis.

Heller, FA, PJD Drenth, PL K oopman, V R us. 1988. Decisions in Organizations: A Three country Comparative Study. Londres: Sage.

H SE. N.d. O ut of Control: Control Systems- W hy T hey Go $W$ rong, and $\mathrm{H}$ ow to Prevent Failure. Sudbury, R eino Unido: H SE Books.

-. N.d. Programmable E lectronic Systems in Safety-related Applications: 1. An Introductory Guide. Sudbury, R eino Unido: H SE Books.

-. N.d. Programmable Electronic Systems in Safety-related Applications: 2. General T echnical Guidelines. Sudbury, Reino Unido: HSE Books.

Johnson, B. 1989. Design and Analysis of F ault T olerant Digital Systems. Nueva Y ork: Addison W esley.

Jones, PG. N.d. Computers in chemical plant: A need for safety awareness. En $\mathrm{H}$ azards XI, dirigido por PG Jones. R ugby, R eino U nido: D avis Building.

Jungermann, H, B Rohrmann, P Wiedemann. 1991. R isikokontroversen-Konzepte, Konflikte, Kommuni-kation. Berlín: Springer.

Larprie, JC. 1991. D ependability: B asic Concepts and T erminology. Berlín: Springer.

Levy, S, S G reene. 1988. The effectiveness of safety education materials. En Safety M anagement, A H uman Approach, dirigido por DC Petersen. Goshen, Nueva York: Aloray. 

Director del capítulo

J orma Saari

\section{Sumario}

Investigación de la seguridad en el trabajo: panorama general

H erbert I. Linn y Alfred A. A mendola.

Servicios de la Administración pública

Anthony Linehan

Servicios de seguridad: consultores

$D$ an Petersen.

Ejecución de un programa de seguridad

Tom B. Leamon .

El éxito en los programas de seguridad

Tom B. Leamon . .

Programas de incentivos a la seguridad

Gerald J.S. W ilde.

Promoción de la seguridad

T homas W. Plankk. .

Estudio de caso: campañas nacionales de salud y

seguridad en el trabajo en la India

K. C. Gupta 


\section{- INVESTIGACION DE LA SEGURIDAD EN EL TRABAJO : PANORAMA GENERAL}

\author{
H erbert I. Linn y Alfred A. Amendola
}

La investigación de la seguridad en el trabajo es el estudio de la incidencia, características, causas y prevención de las lesiones profesionales. Desde los trabajos iniciales de John Gordon (1949) y William H addon, hijo (H addon, Suchman y K lein 1964) y, en medida creciente, en los decenios de 1980 y 1990, las lesiones se han valorado como un problema de salud pública que era preciso enfocar desde la perspectiva, históricamente eficaz, de la salud pública. Se ha aplicado la epidemiología - la ciencia de la salud pública - al problema de las lesiones, incluidas las de carácter profesional. El modelo epidemiológico describe la relación existente entre el agente (el elemento o fenómeno ambiental que constituye la causa eficiente de la lesión o enfermedad) y el medio ambiente. La aplicación de la epidemiología al estudio de las lesiones en el lugar de trabajo se ha debido en gran medida al talento de dos precursores de la investigación de las lesiones: James J. Gibson (1961) y posteriormente Haddon (Haddon, Suchman y K lein 1964). H addon postuló que las diversas formas de energía (mecánica, térmica, química y eléctrica) eran los "agentes" causantes de las lesiones, al igual que los microorganismos productores de enfermedades contagiosas. Investigadores y profesionales dedicados a diversas disciplinas, principalmente la epidemiología, la ingeniería, la ergonomía, la biomecánica, la psicología del comportamiento, la gestión de la seguridad y la higiene industrial, se han volcado en el estudio de los factores asociados al trabajador (el huésped), el medio ambiente, el tipo y fuente de energía implicada (el agente) y las distintas herramientas, máquinas y tareas (los vectores) causantes o coadyuvantes a la producción de lesiones en el lugar de trabajo.

\section{Dos modelos complementarios: el de la salud pública y el del análisis de seguridad}

EI modelo de la salud pública ofrece un marco para la investigación de la seguridad en el trabajo y comprende de los elementos siguientes:

- identificación, caracterización y descripción de los casos de lesiones, peligros y exposiciones a través de la supervisión;

- análisis en profundidad de determinados problemas de lesiones presentes en grupos específicos de población trabajadora, con objeto de identificar, cuantificar y comparar los riesgos y factores causales;

- formulación y desarrollo de estrategias y medidas de prevención;

- evaluación de las estrategias preventivas en ensayos de laboratorio y experiencias de campo,

- transmisión de información sobre riesgos y desarrollo de estrategias y programas tendentes a reducir riesgos y prevenir lesiones.

En principio, este sistema permite la detección y solución sistemática de los problemas de seguridad en el lugar de trabajo.

El análisis de seguridad es otro modelo relevante para abordar la cuestión de las lesiones en el lugar de trabajo. $\mathrm{Ha}$ sido definido como un "examen sistemático de la estructura y las funciones de un sistema, concebido para detectar los factores causales de los accidentes, elaborar modelos de posibles accidentes y diseñar medidas de reducción del riesgo" (Suokas 1988). Se trata de un modelo centrado en la ingeniería que requiere el análisis de los posibles fallos del sistema (una de cuyas consecuencias podría ser la producción de lesiones a los trabajadores) durante el diseño 0 la evaluación de los procesos, equipo, herramientas, tareas y entornos de trabajo. Este modelo presupone capacidad para analizar y comprender las interacciones entre los componentes de los sistemas presentes en el lugar de trabajo con objeto de prever los posibles tipos de fallos antes de que los sistemas se implanten. La solución ideal consiste en establecer la seguridad de los sistemas en la fase de diseño, en vez de tener que modificarlos cuando se produce algún daño o lesión.

\section{El modelo de la salud pública aplicado a la investigación de la seguridad en el trabajo}

La investigación de la seguridad en el trabajo evoluciona a medida que diferentes enfoques y perspectivas, como la epidemiología y la ingeniería, convergen para forjar nuevos métodos de evaluación y documentación de los peligros en el lugar de trabajo y, en consecuencia, elaborar posibles estrategias de prevención. En el presente artículo se examinan el modelo de la salud pública aplicado a la investigación de la seguridad en el trabajo y las áreas en que el análisis de seguridad se inserta en él con objeto de generar tanto una perspectiva global de este campo como un conocimiento más detallado de los problemas y posibilidades futuros. U n objetivo secundario de este artículo consiste en examinar: a) la relación existente entre la investigación de la seguridad en el trabajo y la gestión, reglamentación y transferencia de tecnología de seguridad; y b) los efectos de los avances tecnológicos sobre la investigación y la comunicación de la seguridad en el trabajo.

\section{Vigilancia}

La solución de los problemas de salud y seguridad en el trabajo pasa por la identificación de las dificultades específicas que aquejan a poblaciones trabajadoras concretas. Esto hace que el modelo de la salud pública aplicado a la investigación de la seguridad en el trabajo comience por la vigilancia epidemiológica, que se ha definido como "un procedimiento sistemático y continuo de recogida, análisis e interpretación de datos en el proceso de descripción y supervisión de un fenómeno sanitario" (CDC 1988). En la investigación de la seguridad, este proceso se refiere a la recogida, análisis e interpretación de datos relativos a peligros, lesiones, exposiciones, procesos productivos y poblaciones trabajadoras.

La vigilancia da respuesta a las principales cuestiones que se plantean en torno a las lesiones profesionales. En efecto, puede proporcionar información por segmentos demográficos, como sexo, edad, profesión y sector que emplea a los trabajadores, además de información relativa al tiempo y lugar de producción de las lesiones y, a veces, también a las circunstancias que han rodeado los accidentes. Con esta información básica sobre casos y sobre el empleo que proporciona los denominadores utilizables en el cálculo de los índices, los investigadores han logrado describir el riesgo en función de: a) la frecuencia de las lesiones, lo cual facilita la exposición del ámbito o la magnitud de un problema, y b) la frecuencia de las lesiones (expresada por el número de lesiones o fallecimientos por cada 100.000 trabajadores), lo cual facilita la definición del riesgo relativo que acecha a determinadas categorías de trabajadores en algunas circunstancias. Estos análisis y comparaciones facilitan el trabajo de los investigadores en la identificación de los problemas, incluidos los problemas emergentes y crecientes; la fijación de prioridades; la formulación de hipótesis de investigación avanzada y la supervisión de las tendencias que permiten evaluar la efectividad de los programas de prevención. L os hallazgos generados por la supervisión de los fallecimientos y lesiones profesionales han permitido a los investigadores diseñar y realizar estudios en profundidad orientados, en primer lugar, a descubrir las causas y los factores coadyuvantes y, en última instancia, al desarrollo de estrategias de prevención. Por otra parte, la información 
generada por la vigilancia desempeña una importante función social, en la medida en que se sensibiliza respecto a su situación a los grupos de riesgo y a los responsables de la gestión del riesgo y de la formulación de políticas, y al público en general, y pone de relieve las áreas problemáticas que precisan mayor atención e inversión de más recursos en investigación y prevención.

\section{Investigación analítica}

A medida que la vigilancia pone de relieve la existencia de las principales fuentes de riesgos de lesiones, los investigadores pueden diseñar nuevos estudios dirigidos a dar respuesta más detallada a cuestiones referentes a los riesgos que afrontan las poblaciones afectadas. Existen métodos analíticos de ingeniería y epidemiología que confieren un conocimiento en mayor profundidad de los factores y circunstancias que causan o contribuyen a la producción de lesiones. Por regla general, la vigilancia de las lesiones profesionales no genera datos suficientemente pormenorizados para establecer los factores de riesgo, esto es, las características de los elementos presentes en el lugar de trabajo (incluidos los trabajadores) directa o indirectamente capaces de producir lesiones accidentales. Esta información pormenorizada es imprescindible para conocer las posibilidades de prevención. Se trata de una información, descriptiva de las circunstancias que rodean un siniestro, necesaria para analizar la secuencia de las tareas; la interacción entre las circunstancias que rodeaban a las víctimas y a sus compañeros, tareas, herramientas y procesos; la secuencia temporal del hecho (el antes y el después); las medidas preventivas aplicadas, y la filosofía organizativa y de seguridad dominante en la empresa.

Un método de recogida de información detallada es el basado en la investigación de las muertes y lesiones por accidente de trabajo. En esta investigación se suele aplicar una metodología formal en la que se combinan la recogida de datos mediante entrevista y el análisis de los informes de accidentes y otros documentos, así como análisis y observaciones de ingeniería, tanto de campo como de laboratorio (esto es, ingeniería forense), en un esfuerzo por reconstruir los hechos y circunstancias que han generado el siniestro. Las técnicas analíticas de investigación epidemiológica precisan varios tipos de diseños de estudio, como el de casos-controles, el prospectivo y el retrospectivo para la verificación de hipótesis relativas a factores de riesgo específicos y a su contribución relativa a la producción de determinados resultados. También se pueden utilizar técnicas de análisis de seguridad - como el análisis de riesgos, el análisis de puestos de trabajo y tareas, el análisis del árbol de errores y otros instrumentos de ingeniería de la seguridad de los sistemas- para definir los riesgos y sus causas y para predecir o determinar la probabilidad de diversos tipos de fallos capaces de producir lesiones a los trabajadores. Es posible que el futuro de la investigación de los riesgos y lesiones de trabajo esté en alguna combinación de estas modalidades de investigación que facilitan la construcción de modelos causales basados en métodos analíticos de ingeniería de sistemas validados por una experiencia basada en los hallazgos de las encuestas y la investigación epidemiológica.

\section{Desarrollo de estrategias y actuaciones de prevención}

A medida que se descubren y caracterizan los factores causales y de riesgo y se determina la importancia relativa de diversos factores de riesgo, se ponen de manifiesto diversas oportunidades de prevención. El conocimiento de los factores causales y de riesgo permite a los investigadores y profesionales de la seguridad en el trabajo ponderar diversas estrategias de prevención para la reducción del riesgo o examinar posibles actuaciones dirigidas a interrumpir la cadena causal de los accidentes. Actualmente existe una extensa gama de tecnologías y estrategias de protección que ya se aplican a la protección de los trabajadores y que se pueden utilizar en un campo más extenso con resultados positivos. A simismo, algunas tecnologías y estrategias desarrolladas y aplicadas en otros campos son aprovechables en la protección de los trabajadores. El objetivo de la investigación de la seguridad en el trabajo consiste en identificar, desarrollar y aplicar medidas de prevención eficaces que reduzcan el riesgo de lesiones a los trabajadores.

H addon (1973) postuló diez estrategias generales básicas para reducir los daños causados por los factores de riesgo presentes en el medio ambiente 0 en el lugar de trabajo. La máxima prioridad de los investigadores de la seguridad en el trabajo que estudian las estrategias preventivas consiste en identificar, diseñar y evaluar medidas de control técnico perfectamente integradas en el medio ambiente de trabajo, el equipo, las herramientas o los procesos y capaces de prestar una protección automática (controles "pasivos") sin necesidad de un comportamiento 0 actuación específicos por parte del trabajador. De los tres tipos de estrategias preventivas - las basadas en la persuasión (mediante la información y la educación), las que responden a exigencias imperativas (formuladas en normas y leyes) (Robertson 1983) y las que ofrecen una protección automática-, se suele preferir esta última por considerarla más eficaz. Entre los ejemplos de controles pasivos o automáticos podría citarse la colocación de un dispositivo de bloqueo de seguridad de un circuito eléctrico que automáticamente interrumpa éste si se eliminan o se soslayan los topes de seguridad; otro ejemplo es el de los airbags instalados en los coches que se activan automáticamente al producirse una colisión.

\section{Evaluación y demostración de las estrategias y actuaciones de prevención}

Un aspecto esencial que suele estar ausente del proceso de investigación de la seguridad es una evaluación formal de eventuales estrategias y actuaciones preventivas que garanticen su efectividad, tanto en un entorno controlado de laboratorio como en un medio ambiente de trabajo real, con anterioridad a su aplicación universal 0 generalizada. A veces, la implantación bien intencionada de una determinada medida preventiva puede dar lugar a la aparición de un nuevo riesgo imprevisto. Aunque haya razones de peso para aplicar una medida de seguridad antes de poderla evaluar íntegramente, no es posible descartar de inicio la evaluación. Esta es importante, no sólo para los controles y modificaciones de orden técnico, sino también para los procesos, procedimientos, tareas, normas, programas de formación y productos de información sobre la seguridad, esto es, para toda estrategia, actuación o modificación dirigida a la eliminación o la reducción del riesgo.

\section{Información sobre los riesgos y la prevención de las lesiones profesionales}

La información es la clave de la aplicación de las estrategias eficaces de prevención que se descubren o se desarrollan. La investigación de la seguridad en el trabajo genera dos tipos de información útil para las personas y organizaciones ajenas a la comunidad científica: la información sobre el riesgo y la relativa a la prevención.

- Los mensajes sobre el riesgo incluyen la comunicación de la existencia del riesgo; la información relativa a las personas y poblaciones incluidas en los grupos de riesgo; la información sobre cuándo, dónde, cómo y por qué existe el riesgo, y la información sobre los factores causales o coadyuvantes del riesgo y su importancia relativa. La información sobre el riesgo es un 
resultado importante de la vigilancia y la investigación analítica.

- Los mensajes sobre la prevención incluyen la relativa a los medios de reducción del riesgo y pueden comprender una extensa gama de estrategias y actuaciones.

Los principales destinatarios de la información sobre el riesgo y su prevención son los grupos de riesgo y las personas y organizaciones que tienen el poder de modificar o inducir la modificación de las condiciones de riesgo en el lugar de trabajo mediante las decisiones que toman y los programas y políticas que aplican. Los destinatarios, entre los que se incluyen trabajadores, empresarios, profesionales de la salud y seguridad, legisladores, aseguradores y responsables de la adopción de políticas, se determinan en el momento en que los investigadores elaboran, bien nueva información sobre la existencia o el alcance de los riesgos de producción de lesiones profesionales, bien recomendaciones dirigidas a la reducción del riesgo. O tros importantes destinatarios de los métodos y hallazgos de la investigación son los compañeros de los propios investigadores y los científicos que trabajan en los organismos públicos y en el sector privado, así como las instituciones docentes que se esfuerzan por conocer y suprimir los riesgos de accidentes y enfermedades profesionales. Los investigadores deben igualmente prestar atención a los medios de comunicación generales y regionales y continuar divulgando la idea de que las enfermedades profesionales y las muertes por accidente de trabajo constituyen un serio problema de salud pública que puede solucionarse.

\section{Comunicación}

Existe un déficit de investigación de la difusión y aplicación práctica de los hallazgos de la investigación de la seguridad en el trabajo. Pocas veces se evalúa la comunicación de la información sobre la seguridad para determinar los métodos, mensajes, cauces y formatos más eficaces en situaciones concretas con determinados grupos. La creciente necesidad de comunicación de información sanitaria ha conducido al desarrollo de varios métodos aplicables a la comunicación de información de seguridad. La actividad de comunicación es objeto de sistematización y estudio científico en áreas como la educación y comunicación sanitarias, la promoción de la salud, la información sobre riesgos y el marketing social. La investigación del comportamiento, motivación, conocimiento y percepción humanos desempeña una importante función en la determinación de la posibilidad y el modo en que los procesos de información y comunicación son capaces de generar conciencia de la seguridad y comportamientos seguros en las personas y los grupos de riesgo. Muchas de las técnicas centradas en el cliente que se emplean en el marketing comercial han sido adaptadas por los especialistas en el marketing "social" para inducir cambios en comportamientos y actitudes que persiguen un beneficio social, incluidos los que persiguen mejorar la seguridad, la salud y el bienestar de los trabajadores.

\section{Relación entre los hallazgos de la investigación y la gestión de la seguridad}

Los gestores y profesionales de la seguridad deben mantenerse al tanto de los últimos hallazgos de la investigación que tengan repercusiones prácticas en la seguridad en el lugar de trabajo. $L a$ información que se va recibiendo sobre el riesgo o su prevención induce a veces a la revisión y modificación de los procedimientos y programas vigentes. En los apartados que siguen se examina la relación existente entre la investigación y la ordenación del lugar de trabajo y la tranfferencia de tecnología, esto es, de nuevas estrategias y técnicas contrastadas desde su lugar de origen a otros lugares de trabajo similares en los que existen unas condiciones análogas.

\section{Investigación y regulación}

L os organismos reguladores - esto es, los que elaboran y aplican las normas de seguridad en el trabajo- deben mantenerse al tanto de los hallazgos de la investigación que influyen en las exigencias de la regulación. En efecto, las obligaciones impuestas a las empresas deben basarse en unos métodos de prevención científicamente contrastados que hayan acreditado su eficacia en la reducción del riesgo de lesiones. Este objetivo se basa en una relación estrecha y una comunicación efectiva entre la investigación de la seguridad en el trabajo y los organismos reguladores. $C$ on independencia de que estos últimos sean entes públicos u organizaciones privadas de ámbito sectorial, los hallazgos científicos más recientes se deben incorporar a las normas de seguridad que promulgan. Corresponde a organismos reguladores e investigadores por igual esforzarse por una comunicación eficaz.

\section{Investigación y transferencia de tecnología}

C ada trabajador, supervisor, empresa, especialista en seguridad e investigador soluciona cotidianamente problemas de seguridad mediante el desarrollo y ejecución de programas y medidas de seguridad. Lamentablemente, sin embargo, son muy escasos los mecanismos e incentivos que permiten e impulsan a individuos y empresas a compartir las medidas de prevención eficaces con quienes se enfrentan con idénticos problemas de seguridad. A sociaciones sectoriales, sindicatos, compañías de seguros y otras organizaciones recogen información sobre la prevención entre sus miembros y clientes. Sin embargo, las pequeñas empresas y los trabajadores mal asistidos desaprovechan buena parte de los beneficios que podrían derivarse de compartir información sobre la prevención. L os hallazgos de los estudios realizados en materia de difusión de innovaciones, comunicaciones y gestión de la información, pueden contribuir a superar esta deficiencia.

\section{Investigación y tecnología}

El progreso tecnológico se ha centrado en el diseño y ejecución de los programas de investigación, la detección y cuantificación, y el registro, comunicación y reducción de la exposición a los agentes de riesgo. Las principales tecnologías de investigación de la seguridad se asientan en las áreas de los sensores, los materiales y, lo que quizás sea más importante, la electrónica digital; la capacidad de almacenamiento y el trabajo en red de los ordenadores han establecido las pautas de una nueva era de simulación, automatización y comunicaciones mundiales. El desafío que se plantea a investigadores y profesionales de la seguridad en el trabajo consiste en aplicar a la investigación las herramientas tecnológica más avanzadas y mejorar la comunicación del riesgo y la información del control de riesgos. Algunas de estas herramientas pueden mejorar nuestra capacidad para realizar trabajos de investigación difíciles o peligrosos. Ejemplos de ellas son las simulaciones que no precisan la destrucción de equipo y herramientas costosos ni la exposición de vidas humanas. Algunas de estas herramientas permiten mejorar el análisis o los procesos de toma de decisiones, por ejemplo, simulando las destrezas humanas y explotar así un recurso escaso: el conocimiento del modo de realizar investigaciones sobre lesiones profesionales y lograr su prevención efectiva. Las herramientas tecnológicas pueden mejorar nuestra capacidad para transmitir información sobre riesgos a quienes la necesitan y facilitar a estos la búsqueda activa de tal información.

\section{Necesidades y tendencias de la investigación}

Los investigadores de la seguridad en el trabajo deben estar dispuestos a aprovechar el progreso tecnológico y las señales de creciente preocupación social para centrar su esfuerzo en las 
áreas en que son más necesarios, en las que se incluyen las siguientes:

- nuevos métodos científicos en los que se incorporan e integran métodos y técnicas epidemiológicos y de ingeniería al estudio de la seguridad en el trabajo;

- un sistema de supervisión ampliado y normalizado en el que se incluyan subsistemas para los accidentes no fatales, los siniestros, riesgos y exposiciones con resultado de peligro;

- mayor atención a la importancia de los factores organizativos y económicos en la seguridad en el trabajo, incluido el estudio de los efectos de las técnicas y tendencias de la gestión, como el movimiento mundial en favor de la calidad desencadenado por el trabajo de W. Edwards Deming;

- un mayor interés, tanto por los grupos de población de alto riesgo escasamente atendidos, incluidos los ocupados en la agricultura, la explotación forestal, la construcción y las pequeñas empresas de todos los sectores, como por las causas principales de muertes y lesiones graves que requieren más estudio, incluidas las producidas por accidentes de circulación relacionados con el trabajo y por actos de violencia (Veazie y cols. 1994);

- evaluación y demostración del funcionamiento de los controles técnicos y otras estrategias de prevención, como la educación, la reglamentación y las comunicaciones;

- transferencia de tecnologías, esto es, aplicación de las tecnologías utilizadas en otros campos a los problemas de la investigación y la gestión de la seguridad en el trabajo, y adaptación correcta de las técnicas o estrategias de protección aplicadas en un lugar o en un entorno limitado a la prevención de riesgos similares en otros campos más amplios;

- influencia de los factores psicosociales, incluido el estrés, en la frecuencia de las lesiones profesionales,

- antiguas y nuevas perspectivas tecnológicas de los sistemas pasivos de protección de los trabajadores, como los sensores y microprocesadores, la robótica, la inteligencia artificial, la tecnología de la visualización y de la imagen, las telecomunicaciones inalámbricas y los dispositivos de enclavamiento.

\section{Resumen}

Tradicionalmente, los investigadores y profesionales de la salud pública han aplicado la epidemiología, la bioestadística, la medicina, la microbiología, la toxicología, la farmacología, la educación sanitaria y otras disciplinas a la identificación, evaluación y prevención de las infecciones y, más recientemente, de las enfermedades crónicas. Las lesiones y los accidentes mortales, incluidos los que se producen en el trabajo, constituyen graves problemas de salud pública y se suelen asociar a otros factores y causas concretos que contribuyen a su producción. Lejos de ser fenómenos aleatorios, las lesiones y los accidentes mortales son productos de una relación causal. Estos resultados traumáticos pueden abordarse utilizando los mismos métodos de resolución de problemas que se aplican en la detección, el diagnóstico y la prevención de enfermedades.

Una diferencia esencial entre los respectivos modos de enfocar las enfermedades y las lesiones estriba en la naturaleza de las medidas de prevención que se pueden adoptar. Para prevenir 0 reducir el riesgo de que contraigan enfermedades crónicas e infecciosas, los profesionales de la salud pueden prescribir 0 administrar vacunas y fármacos, cambios del régimen dietético y de la forma de vida, o implantación de controles ambientales. Para prevenir o reducir el riesgo de que se produzcan lesiones laborales, los profesionales de la seguridad pueden utilizar 0 recomendar la utilización, bien de controles técnicos, como los dispositivos protectores del equipo, los dispositivos de bloqueo y las máquinas y herramientas de diseño ergonómico, bien de controles administrativos, como los métodos y calendarios de trabajo y la formación; o bien de equipo de protección individual, como cascos, mascarillas y dispositivos protectores contra caídas. Esto significa que, en el campo de la prevención de lesiones, los epidemiólogos, bioestadísticos y educadores sanitarios colaboran con ingenieros, médicos, ergónomos y especialistas en higiene industrial. Aunque el proceso de resolución de problemas es idéntico, algunos de los métodos de actuación y, por consiguiente, las disciplinas aplicadas a la definición, el desarrollo y la verificación de las actuaciones, pueden variar.

El mecanismo de la investigación de la salud y seguridad en el trabajo se basa en el concepto de salud pública, que es un concepto integral y multidisciplinario de identificación mediante: a) la vigilancia e investigación, b) el análisis epidemiológico y de seguridad, c) la investigación y desarrollo de técnicas y estrategias de prevención, d) la evaluación y educación precisas para que estas técnicas y estrategias sean eficaces, y e) la difusión de información de riesgos, métodos de investigación y hallazgos, y de las tecnologías y estrategias eficaces. El concepto de salud pública se consolida con el de análisis de seguridad en el estudio de la seguridad en el trabajo. Los especialistas en las principales ramas de la ingeniería y la epidemiología colaboran para mejorar nuestros conocimientos de las formas de producción y prevención de lesiones. Las nuevas tecnologías en desarrollo, particularmente la electrónica digital y la tecnología informática, se están adaptando a la solución de los problemas de seguridad en el lugar de trabajo.

\section{SERVICIOS DE LA AdMINISTRACION PUBLICA}

Anthony Linehan

Está generalmente aceptado que la promulgación y supervisión de la aplicación de unas normas aceptables de salud y seguridad en el trabajo es una función de la Administración pública, a pesar de que la responsabilidad jurídica por la aplicación de aquellas recaiga en la empresa. Es de subrayar que, en muchos países, las normas de seguridad se elaboran mediante consenso entre fabricantes, usuarios, compañías de seguros, Administración pública y público en general, para ser recogidas o reconocidas a continuación en la normativa legal. La Administración pública desempeña sus responsabilidades prestando una variedad de servicios de seguridad. En este sentido, se incluyen en el concepto de Administración pública tanto los organismos nacionales como los de ámbito regional y provincial.

\section{Marco legal}

Uno de los principales puntos de apoyo de la seguridad en el trabajo es el marco legal en el que opera, y la creación de ese marco legal es una responsabilidad primordial de la Administración pública. La normativa legal debe ser amplia en alcance y ámbito de aplicación, reflejar las normas internacionales y las necesidades nacionales, basarse en las prácticas industriales demostradamente seguras y aportar los medios de materializar sus objetivos. La legislación sobre salud y seguridad avalada por extensas consultas con los agentes sociales, la industria y los representantes comunitarios suele ser objeto de una mayor valoración y una observancia más estricta, y contribuye en gran medida a lograr unos niveles óptimos de protección.

\section{Observancia}

Aunque importante, el marco legislativo se debe traducir efectivamente en medidas prácticas en el seno de la empresa. U na de las 
principales funciones de la Administración pública consiste en la creación de un servicio de inspección capaz de aplicar la ley con eficacia. Por lo tanto, la Administración debe crear ese servicio de inspección, dotarlo de unos medios financieros y humanos adecuados, y conferirle los poderes necesarios para realizar su trabajo.

\section{Información sobre salud y seguridad}

La difusión de información sobre salud y seguridad es una de las funciones principales. 0 bviamente, no se trata de una función exclusiva de la Administración: asociaciones de empresarios y de profesionales de la seguridad, sindicatos y consultores pueden contribuir a difundir el conocimiento de la normativa legal, las normas, las soluciones técnicas y los nuevos riesgos y peligros. La Administración puede asumir un protagonismo especial en la fijación de pautas para la aplicación de leyes y normas reguladoras de una estrategia de seguridad que varían desde la aplicación de unas medidas adecuadas de protección de la maquinaria a la publicación de los de limites de exposición a las sustancias peligrosas.

La Administración debe promover la definición de temas adecuados para las campañas e iniciativas monográficas. Estas iniciativas se suelen desarrollar en colaboración con los sindicatos y asociaciones de empresarios y suelen basarse en el análisis de las estadísticas sobre siniestralidad y morbilidad publicadas por la propia Administración o por asociaciones sectoriales y de otro tipo. En la elaboración de su estrategia publicitaria e informativa, la Administración debe procurar que el mensaje llegue, no sólo a los sectores más avanzados y desarrollados, sino también a los que adolecen de conocimientos y conciencia limitados de las cuestiones de salud y seguridad. E sto es particularmente importante en las naciones en desarrollo y en las que dependen fuertemente de la agricultura y de la familia como unidad económica básica.

La recogida y el análisis y publicación de estadísticas de salud y seguridad es una tarea importante. En algunos países funciona un servicio de comunicación de accidentes de forma absolutamente independiente del sistema de prestaciones sociales y de indemnización por lesiones laborales. El sistema se basa en la obligación legal de comunicar los accidentes a los organismos competentes. Sin embargo, los estudios estadísticos muestran que en este sistema se puede producir un importante déficit en la comunicación de accidentes no mortales. En algunos sectores se deja de comunicar a las autoridades hasta un $60 \%$ de los siniestros. O bviamente, este déficit reduce la credibilidad de las estadísticas que se generan. La integridad y exactitud de las estadísticas de accidentes y enfermedades profesionales debe ser materia prioritaria para la Administración pública.

\section{Formación para la seguridad}

O tro servicio que puede prestar la Administración pública es el de la formación para la seguridad. En las leyes de salud y seguridad se suelen incluir disposiciones sobre una formación adecuada. La participación directa de la Administración en la organización y prestación de la formación varía considerablemente. En los niveles superiores de formación, esto es, en el caso de los profesionales de la seguridad, esta función suele corresponder a las universidades y los institutos de enseñanza superior. Aunque la contribución directa de la Administración es relativamente infrecuente en estos niveles, los científicos y juristas que trabajan a su servicio y los técnicos de las inspecciones suelen colaborar como docentes y aportar financiación y materiales didácticos.

En los niveles inferiores de la formación para la seguridad se observa una situación similar. Los cursos de formación de los trabajadores, como los destinados a incrementar la conciencia de seguridad de los trabajadores, suelen estar a cargo de asociaciones sectoriales 0 institutos de formación, financiados y apoyados por las inspecciones. La función de la Administración no consiste tanto en gestionar y prestar los servicios de formación, como en estimular y alentar a las organizaciones no gubernamentales a desempeñar esta función y en colaborar directamente cuando hace falta. U na modalidad de colaboración más directa consiste en los subsidios públicos destinados a financiar los costes de formación de las empresas. Buena parte de los materiales de apoyo de la formación para la seguridad consisten en publicaciones oficiales, directrices y normas promulgadas por los organismos públicos.

\section{Servicios a las pequeñas empresas}

La prestación de servicios a las pequeñas empresas es un problema especialmente complejo. Existe, por una parte, la necesidad de brindar un verdadero apoyo y estímulo a este componente importante de la economía local y nacional. Al mismo tiempo, es preciso lograr este objetivo sin reducir el nivel de protección de los trabajadores ni poner en peligro su salud y seguridad. Los servicios públicos pueden desempeñar una función clave en la solución de esta compleja situación.

M uchas administraciones prestan a las pequeñas empresas un servicio especial de gestión de la salud y seguridad. Este servicio puede revestir diversas formas, consistentes, por ejemplo, en paquetes especiales de material informativo "de iniciación" en los que se ofrecen: a) consejos sobre la observancia práctica de las normas legales, b) orientación sobre la búsqueda de fuentes de información, y c) modos de establecer contacto con los organismos de inspección. Algunos de estos últimos emplean personal especializado en atender a las necesidades específicas de las pequeñas empresas y, en colaboración con las asociaciones sectoriales, organizar seminarios y reuniones en los que se abordan las cuestiones de salud y seguridad con un espíritu constructivo y no antagónico.

\section{Investigación de la seguridad}

La investigación es otro servicio que presta la Administración pública, bien directamente, a través de sus laboratorios y programas de investigación de salud y seguridad, bien indirectamente, mediante la financiación de los proyectos específicos desarrollados por institutos de investigación independientes. La investigación de la salud y seguridad se puede enmarcar en las dos categorías generales siguientes:

- investigación forense, ilustrada por las investigaciones que se realizan para determinar las causas de los accidentes graves,

- investigación a largo plazo, destinada a determinar, por ejemplo, los niveles de exposición a sustancias potencialmente peligrosas.

Existen igualmente los servicios de laboratorio que facilitan las instalaciones necesarias para pruebas del tipo del análisis de muestras y para la homologación de los sistemas de equipo de protección. Estos servicios son importantes tanto para los organismos de inspección, como para los agentes sociales implicados en la certificación de los niveles de sanidad vigentes en las empresas. Aunque existen discrepancias respecto a si la Administración pública debe gestionar laboratorios e instalaciones de investigación o si, por el contrario, resulta preferible delegar estas funciones en universidades y centros independientes de investigación, el debate se centra más en los medios que en el objetivo primordial. Pocos dudan de que la investigación, en el sentido más amplio del término, es una contribución imprescindible del Estado a la salud y seguridad, con independencia de que la realice en sus propias instalaciones o estimule y financie el trabajo de las organizaciones no gubernamentales. 


\section{Representación en materia de seguridad}

Por último, la Administración pública presta unos servicios de representación ante la comunidad internacional. En efecto, muchos problemas de salud y seguridad son de ámbito internacional que no se puede confinar dentro de unas fronteras nacionales. La cooperación y el intercambio de información entre Estados, la promulgación de normas internacionalmente aceptadas sobre las sustancias peligrosas, y el apoyo a las organizaciones internacionales que se ocupan de la salud y seguridad, son funciones públicas cuyo desempeño efectivo contribuye indudablemente a fortalecer los niveles y la valoración de la salud y seguridad en el ámbito nacional e internacional.

\section{- SERVICIOS DE SEGURIDAD: CONSULT ORES}

\section{Dan Petersen}

A veces, los responsables de la seguridad de una organización, con independencia de que su función se centre en el comportamiento, el sistema de seguridad o el entorno físico, acuden a los servicios de profesionales independientes, como los consultores. Cuando esto ocurre, es preciso tener en cuenta que la responsabilidad por la culminación feliz de la tarea (al margen de la ejecución misma de ésta) de analizar un determinado sistema y efectuar mejoras en el mismo no se puede delegar en otros. Los analistas internos (en contraste con los consultores externos) que estudian un sistema suelen obtener datos más fiables debido a su conocimiento profundo de la organización. Sin embargo, la colaboración de un consultor externo con una amplia experiencia en el análisis de los problemas de seguridad que le permita formular unas recomendaciones adecuadas posee un valor inapreciable.

\section{Recurrir a la colaboración externa}

Si nadie en la organización conoce las leyes y normas de seguridad vigentes en el país, convendría contratar los servicios de un especialista en la normativa de seguridad. A veces tampoco existe en la estructura organizativa un servicio capaz de analizar el sistema de comportamiento y en ese caso resulta aconsejable acudir a los servicios de quienes pueden hacerlo. Kenneth Albert (1978) enumera seis situaciones concretas en las que procede acudir a los servicios externos:

- si se precisan unos conocimientos especializados;

- en las cuestiones políticamente delicadas;

- si es necesaria la imparcialidad;

- cuando el tiempo apremia y no se dispone de inmediato de medios internos;

- si es preciso conservar el anonimato,

- si conviene rentabilizar el prestigio de un servicio externo.

Aunque los comentarios de Albert no se formularon en el contexto de la política de seguridad, su casuística resulta válida en la determinación de la necesidad de acudir a un consultor de seguridad independiente. A menudo, los problemas de seguridad están imbricados con contrastes de personalidad entre los directiva y son extremadamente difíciles de solucionar internamente. En tales casos, es posible que una recomendación sea aceptada por todos los interesados por el simple hecho de proceder de un independiente. Si una organización precisa urgentemente un análisis, es probable que un consultor externo pueda concluirlo antes y, además, sus opiniones suelen pesar más que las de un miembro de la organización. En el campo de la seguridad, muchas organizaciones precisan servicios externos para el análisis de los sistemas de comportamiento; algunas, respecto al análisis de los sistemas de seguridad; y algunas, en relación con el análisis de las condiciones físicas. Sin embargo, la disponibilidad de consultores de seguridad parece ser inversamente proporcional a su demanda, ya que, mientras la oferta de consultores especializados en las condiciones físicas es abundante, hay menos analistas de sistemas de seguridad y apenas se encuentran especialistas en el análisis del comportamiento de seguridad.

\section{Consultores de seguridad}

Si bien el tipo de servicios prestados por los consultores independientes de seguridad varía de un país a otro, se suelen clasificar en seis grandes categorías:

- ingenieros o consultores de seguridad de campo de las compañías de seguros;

- consultores de seguridad de los organismos oficiales de ámbito nacional, estatal, provincial o local;

- empresas privadas de consultoría y consultores de seguridad profesionales de plena dedicación;

- consultores particulares a tiempo parcial;

- consultores de los consejos o asociaciones de seguridad,

- consultores de las asociaciones sectoriales.

Consultores de seguros. En Estados U nidos, la mayoría de los consultores e ingenieros de seguridad que no trabajan en la Administración pública son empleados de las compañías de seguros, y muchos otros profesionales de la seguridad han iniciado su vida profesional trabajando en compañías aseguradoras. La práctica totalidad de las empresas, excepto las muy grandes y las autoaseguradas, requieren regularmente los servicios del personal de control de pérdidas de las aseguradoras.

Consultores de la Administración pública. Los organismos que prestan servicios públicos de consultoría varían de un país a otro en cuanto a su ámbito político (federal, estatal, provincial o local) y al tipo de funciones que están autorizados y en las condiciones de prestarlas. En Estados U nidos, el objetivo oficial del servicio de consultoría de campo de la $\mathrm{O}$ ccupational Safety and $\mathrm{H}$ ealth Administration (O SHA) es conseguir "unos lugares de trabajo saludables y seguros para los trabajadores". Por tanto, los servicios de consultoría han de limitarse por imperativo legal a las condiciones físicas. La empresa que precise este tipo de servicios debe estudiar la oferta de la $\mathrm{O} \mathrm{SH}$ A; si, por el contrario, las necesidades de consultoría se reducen al sistema de seguridad 0 al de comportamiento, la O SH A no es una buena elección.

Las tareas de campo que reglamentariamente realizan los consultores de la O SH A son las siguientes:

- descubrir y clasificar correctamente los peligros;

- recomendar la adopción de medidas correctivas (excluida la asistencia técnica);

- fijar plazos para la reducción de los riesgos graves.

- informar a sus superiores de todo grave riesgo que la empresa no haya intentado reducir,

- supervisar la actuación de la empresa.

Es obvio que algunos aspectos del servicio de consultoría prestado por la OSHA por este método son inusuales. Aunque el objetivo central de los consultores consiste en mejorar las condiciones físicas, asumen también responsabilidades complementarias en dos casos:

- En caso de infracción grave de las normas de la OSHA, los consultores deben fijar unos plazos para la subsanación y supervisar su cumplimiento.

- Si existe un riesgo inminente de infracción de las normas de la OSH A, los inspectores deben, bien ponerlo en conocimiento 
de sus supervisores (y, por tanto, de las instancias apropiadas del Departamento de Trabajo), bien de los responsables ejecutivos de la organización para que adopten medidas inmediatas.

Dicho de otro modo, la consultoría de la O SH A es exclusivamente tal mientras no se descubre una anomalía grave. Si se detecta algún peligro grave, actual o potencial, el proceso decisorio respecto a cómo y cuando prevenir el riesgo, escapa del control del "cliente".

E mpresas de consultoría privadas. U na tercera fuente de asistencia son los consultores privados de plena dedicación y las empresas de consultoría que pueden prestar asistencia en cualquier área - sistemas de comportamiento, sistemas de seguridad y condiciones físicas- sin las limitaciones concretas anteriormente mencionadas. La única dificultad en estos casos consiste en seleccionar un consultor con el conocimiento y la capacidad necesarios para prestar el servicio deseado.

Consultores a tiempo parcial y otros. La cuarta fuente de asesoramiento es la constituida por los profesionales que prestan servicios de consultoría para redondear sus ingresos. Se trata, bien de profesionales de la seguridad ya jubilados que permanecen en activo, bien de profesores universitarios o de centros de estudios superiores que complementan de esta forma sus ingresos y permanecen al tanto de la realidad exterior al claustro universitario. También en este caso el problema reside en localizar los consultores y cerciorarse de que la persona elegida posee la competencia necesaria. Parte de la oferta de servicios procede de los consultores que trabajan a través de los consejos de seguridad locales o nacionales y los que trabajan en asociaciones sectoriales.

\section{Localización de un consultor}

En las dos primeras clases de consultoría externa - las prestada por organismos oficiales y por las compañías de seguros- resulta fácil conseguir un consultor. En Estados U nidos, por ejemplo, los interesados se pueden poner en contacto con la entidad gestora del seguro de indemnización por accidentes de trabajo o la oficina local de la OSHA y solicitar que visiten la empresa. En muchos otros países existen servicios similares a cargo de organismos estatales y entidades aseguradoras.

M ás difícil resulta encontrar un consultor en las otras dos categorías: consultores particulares y empresas de consultoría. En Estados U nidos, por ejemplo, algunas organizaciones editan guías de consultores. Así, la American Society of Safety Engineers (ASSE) edita una guía nacional con los nombres de unos 260 consultores. No obstante, el uso de esta guía es bastante complicado. En efecto, del examen del directorio se infiere que el 56 por ciento de los nombres que figuran en el mismo corresponden a consultores que ofrecen sus servicios, sin especificar si se trata de profesionales empleados en una empresa que buscan unos ingresos complementarios, de consultores que trabajan a jornada completa o de especialistas en seguridad jubilados que prestan servicios a tiempo parcial. 0 tro 32 por ciento de los abonados al directorio son personas vinculadas a firmas de consultoría, el 5 por ciento pertenecen a universidades, el 3 por ciento son agentes de seguros, otro 3 por ciento colaboran con empresas industriales y el 1 por ciento está vinculado a los gobiernos de los Estados. Aunque la publicación se anuncia como una guía para encontrar "profesionales de la salud y seguridad en el trabajo", se trata, en realidad, de una relación de personas que han pagado la cuota de inserción y pertenecen a la sección de consultoría de la ASSE.

No resulta fácil encontrar un consultor con los conocimientos prácticos necesarios. Es probable que las mejores soluciones, al margen de los servicios estatales y de las entidades aseguradoras, consistan en: a) indagar cerca de otras organizaciones que experimentan problemas similares a quiénes han contratado y si están satisfechas con los resultados, b) acudir a una asociación profesional de ámbito nacional, o c) utilizar las guías profesionales del tipo de la anteriormente citada, con las reservas apuntadas sobre ellas.

\section{Consultoría de seguros}

L os consultores de las entidades de seguros son los más asequibles entre los profesionales externos. En efecto, el sector del seguro se ha interesado en la seguridad desde los esfuerzos iniciales por garantizar la seguridad en el lugar de trabajo. Durante muchos años, para la mayoría de las empresas no existía otra fuente de asistencia que la procedente de su compañía aseguradora.

$\mathrm{H}$ abitualmente, los servicios de seguridad de las grandes aseguradoras desempeñan tres funciones específicas:

- asistencia en la actividad de ventas:

- asistencia en la suscripción,

- servicio al cliente.

U nicamente la tercera de las funciones citadas es de interés para el cliente que precisa asistencia en materia de seguridad. La asistencia en la suscripción está a cargo de un representante itinerante que es "Ios ojos y oídos" de la compañía aseguradora, observa el desarrollo de los acontecimientos en las instalaciones del asegurado e informa a la oficina del suscriptor. La tercera de las funciones mencionadas consiste en ayudar a los clientes a perfeccionar sus programas de seguridad y prevención y así reducir el riesgo de accidentes y quebrantos económicos. La asistencia ofrecida varía sensiblemente de una empresa a otra.

Con el tiempo se han ido perfilando diversos criterios determinantes del valor de los servicios que la compañía de seguros puede brindar. Los servicios de seguridad de algunas compañías se encuentran aún excesivamente integrados en la función de suscripción y su labor se limita a observar e informar; en otras, el departamento de control técnico depende del servicio de suscripción. En algunas compañías de seguros, el departamento de control de pérdidas es independiente y su función esencial consiste en prestar servicios al cliente y sólo subsidiariamente en colaborar con los servicios de ventas y suscripción. Si la función principal del servicio consiste en asistir en las ventas, la atención al cliente se resiente. Si el departamento de control de pérdidas se enmarca en la función de suscripción, a veces resulta difícil conseguir que preste servicios de seguridad, debido, sencillamente, a que carece de personal debidamente formado y cualificado para prestar ese tipo de servicio. El departamento de control de pérdidas se encuentra en mejores condiciones de prestar un buen servicio al cliente si no está integrado en la función de suscripción. Recíprocamente, el departamento puede resultar absolutamente inoperante por los efectos de numerosos factores capaces de prevenir la prestación efectiva de servicios de seguridad.

Cuando el servicio es meramente de inspección, que es el caso más frecuente, el sistema de seguridad y el de comportamiento se pasan absolutamente por alto. Si el servicio se limita exclusivamente al suministro de equipo y materiales de seguridad, su valor es virtualmente nulo. Si consiste principal o únicamente, bien en organizar reuniones sobre seguridad con el cliente, como es el caso de los cursillos de seguridad "estandarizados" que la oficina central de la entidad aseguradora prepara para todas las empresas aseguradas, bien en comprobar si las condiciones físicas se ajustan a la normativa, el servicio es igualmente pobre.

En función de la filosofía que informa los servicios de la compañía aseguradora, se pueden crear servicios adicionales a los que presta el representante que visita al cliente. En la Figura 60.1 se esbozan algunos de estos servicios 
Figura 60.1 - Servicios complementarios prestados por los consultores.

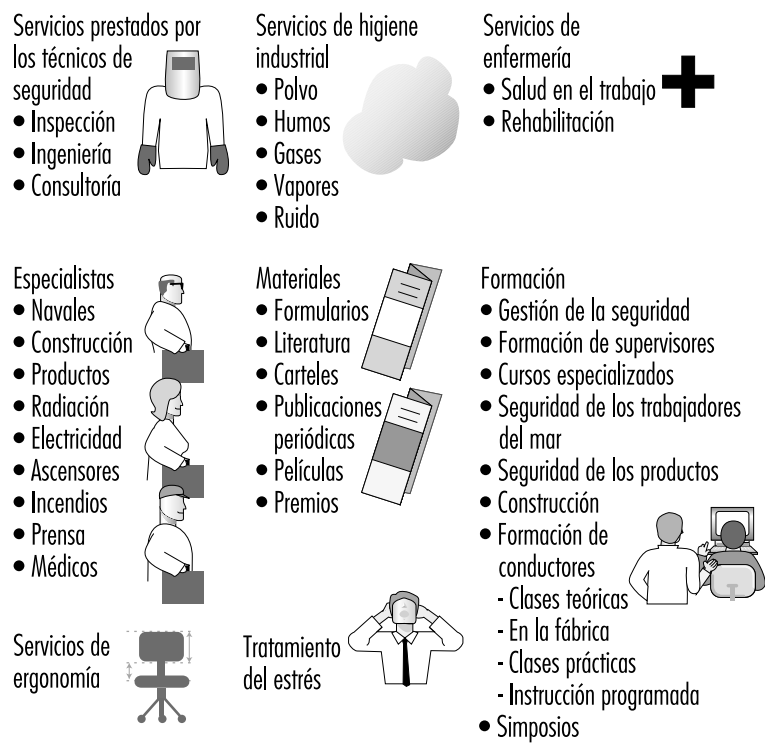

complementarios que pueden ser de especial utilidad para el cliente, como los de higiene industrial, personal de enfermería y especialistas (control técnico y protección contra incendios), en función de las necesidades actuales de la organización. Aunque los servicios de formación son algo menos frecuentes, también resultan útiles.

\section{Servicios de consultoría desempeñados por la Administración pública}

Al igual que ocurre con los consultores de seguros, las empresas deben ponderar diversos factores, como los que se indican posteriormente, antes de decidirse por solicitar o no los servicios públicos de consultoría.

- si las condiciones en que se ofrecen los servicios de la Administración pública son aceptables;

- la competencia del personal;

- el alcance limitado de la consultoría,

- la imposibilidad de determinar el contenido de la consultoría.

Probablemente, lo primero que hay que ponderar es si la empresa desea establecer cualquier clase de contactos con un organismo público. En efecto, si se utilizan los servicios de otros tipos de consultores (particulares o pertenecientes a una compañía de seguros), los eventuales hallazgos quedan entre la organización y el consultor, y lo que la empresa haga es exclusivamente responsabilidad del cliente, que puede disponer libremente de la información. Si se recurre a consultores de la Administración pública, esto no es siempre posible. Por ejemplo, si los consultores detectan uno de dos tipos de peligros, o ambos - infracción de la normativa legal o factores que extrañen un riesgo inminente para la salud o la vida-, es posible que la empresa pierda su libertad de acción respecto a cómo y cuándo hay que hacer algo para prevenir el peligro.

Los consultores de la Administración pública pueden contribuir a determinar si en una organización se cumplen o no las leyes y normas vigentes. Se trata de un enfoque sumamente limitado con numerosos puntos débiles, como comenta Peters (1978) en un artículo titulado "Por qué sólo los tontos se guían por las normas de seguridad": "A los que saben poco sobre seguridad les parece perfectamente plausible y razonable la pretensión de que la existencia y observancia de unas buenas normas de seguridad constituyan un indicador adecuado de la garantía de la seguridad". Peters no sólo asegura que se trata de una falsa expectativa, sino también que la dependencia de tales normas perturba la actividad profesional necesaria para reducir las pérdidas.

\section{Consultores privados}

La contratación de un consultor privado, con independencia de que se trate de un profesional independiente o de un empleado de una empresa de consultoría a tiempo parcial o de plena dedicación, no obliga al cumplimiento de normas legales imperativas. El consultor privado no está obligado a cumplir las disposiciones de ningún sistema de comunicación preceptiva y su relación se establece exclusivamente con el cliente. Además, el alcance de la consulta es restringido, dado que el "cliente" está en situación de delimitar perfectamente el ámbito de la actividad del consultor. Por lo tanto, lo único que debe preocupar al cliente es la competencia del consultor en las áreas que precisan asesoramiento y la racionalidad de sus honorarios. En la Figura 60.2 se mencionan algunas de las principales funciones de los consultores de gestión.

G. Lippit (1969), autor de una extensa obra sobre el proceso de consultoría, identifica ocho funciones específicas del consultor:

1. colaborar con la dirección en el examen de los problemas organizativos (por ejemplo, convocando una reunión de directivos para la identificación de los problemas existentes en la relación entre el personal de la oficina central y el de las sucursales);

2. colaborar con la dirección en la evaluación de la contribución de un diálogo serio a la resolución de estos problemas (por ejemplo, respecto a los problemas entre la oficina central y las delegaciones, el consultor examina con la dirección cómo una reunión dedicada a distintos paquetes de comunicación puede facilitar la solución de los problemas);

Figura 60.2 - Funciones básicas del consultor de gestión.

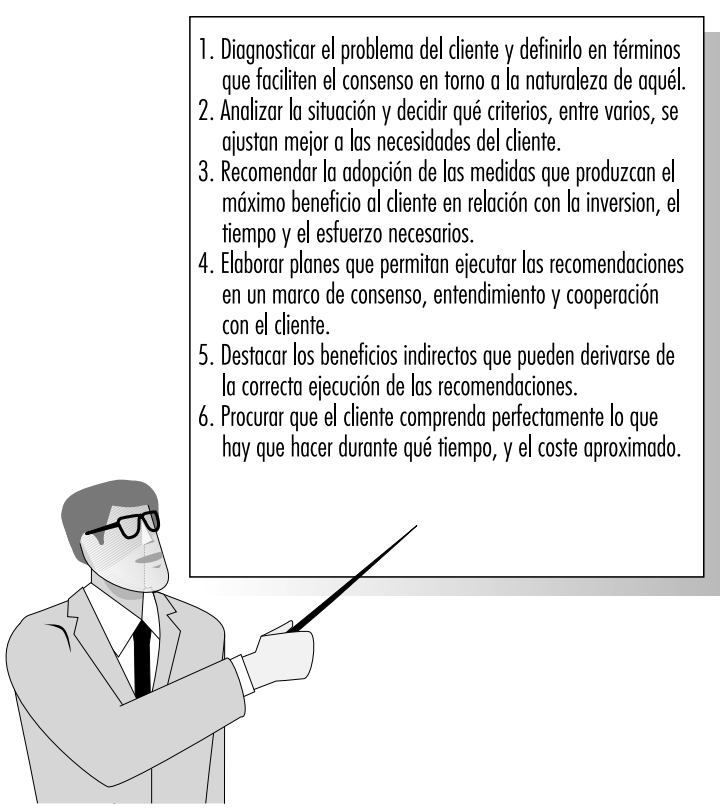

Fuente: Association of Consulting Management Engineers 1966. 
Figura 60.3 - Cinco estilos de consultoría.

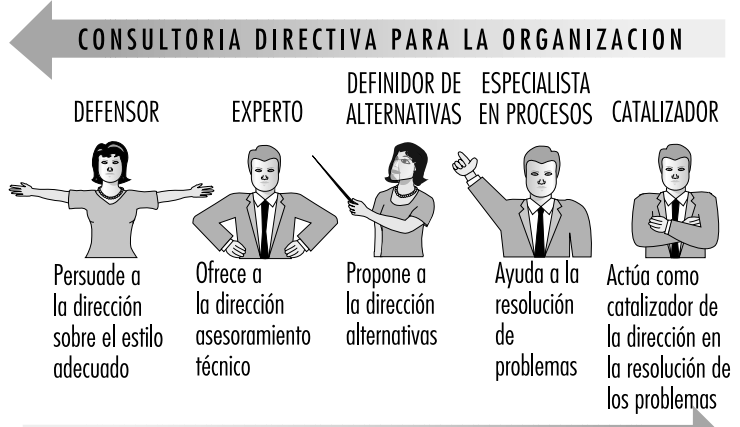

CONSULTORIA NO DIRECTIVA PARA LA ORGANIZACION

Fuente: Lippit 1969.

3. contribuir al análisis de los objetivos a corto y largo plazo del plan de renovación (esto es, implicar a la dirección en la fijación y concreción de los objetivos);

4. examinar con la dirección diversas alternativas de renovación;

5. colaborar con la dirección en la formulación de los planes de renovación (esto es, sobre la base de los objetivos, colabora con un equipo de trabajo en el desarrollo de un proceso provisto de un mecanismo intrínseco de evaluación, en lugar de limitarse a someter a la aprobación de la dirección un plan elaborado independientemente);

6. analizar los recursos necesarios para ejecutar los planes de renovación (esto es, aporta a la dirección una gama de recursos, tanto internos, como externos a la organización; el promotor de la renovación debe ayudar a la dirección a comprender la contribución potencial de cada recurso a la resolución de problemas);

7. asesorar a la dirección sobre el análisis y evaluación del proceso de renovación (esto es, la evaluación debe hacerse en función de la solución de los problemas; en colaboración con la dirección, el promotor de la renovación debe evaluar el estado actual del problema, en vez de limitarse a verificar si se han realizado o no determinadas actividades);

8. estudiar con la dirección las medidas de seguimiento precisas para fortalecer el procedimiento de resolución de problemas y los resultados del proceso de renovación (esto es, insta a la dirección a examinar las consecuencias de las medidas adoptadas hasta el momento y a valorar la situación actual de la organización desde las perspectiva de las medidas que podrían precisarse para proseguir la ejecución del proceso de renovación).

Por su parte, Lippit (1969) enumera cinco actitudes distintas que el consultor puede adoptar frente a las necesidades de sus clientes (véase la Figura 60.3).

\section{Elección del consultor}

En la selección de un consultor se debe seguir el procedimiento indicado en la Figura 60.4.

La decisión sobre contratar o no un consultor debe ser una función de las necesidades reconocidas por el usuario y de los conocimientos y competencias que se esperan del consultor para que sus servicios sean de utilidad. Parece lógico, por lo tanto, que la elección recaiga en per sonas u organizaciones que posean tales conocimientos o competencias. Este proceso puede culminar en la decisión de hacer el trabajo sin ayuda exterior, por ejemplo, buscando dentro de la organización las personas con las cualificaciones necesarias y encomendándoles la solución de los problemas de seguridad conocidos. También se puede optar por acudir a fuentes externas para conseguir la capacidad requerida.

\section{Evaluación de la actuación del consultor}

D espués de haber trabajado con un consultor durante un tiempo, la empresa se encuentra en condiciones de valorar su actuación y su valía para la organización con mucho más conocimiento de causa (Figura 60.5). El análisis realizado por el consultor puede inducir la conclusión de que el resto de la tarea y otras similares se puede confiar al personal propio. Muchas empresas aplican actualmente este sistema y otras se están decantando por el mismo, tanto en el área de la seguridad como en otras cuestiones.

\section{Métodos de resolución de problemas}

En el libro de $\mathrm{K}$. Albert titulado $\mathrm{H}$ ow to Be Your O wn M anagement Consultant (1978) se enumeran cuatro categorías de métodos de solución interna de los problemas de gestión:

- contratar un consultor interno en régimen de plena dedicación,

- asignar temporalmente la tarea a un miembro de la plantilla,

- crear un equipo de trabajo y encomendarle la solución del problema,

- contratar un consultor externo para que colabore con un especialista de la plantilla.

Figura 60.4 - Elección de un consultor.
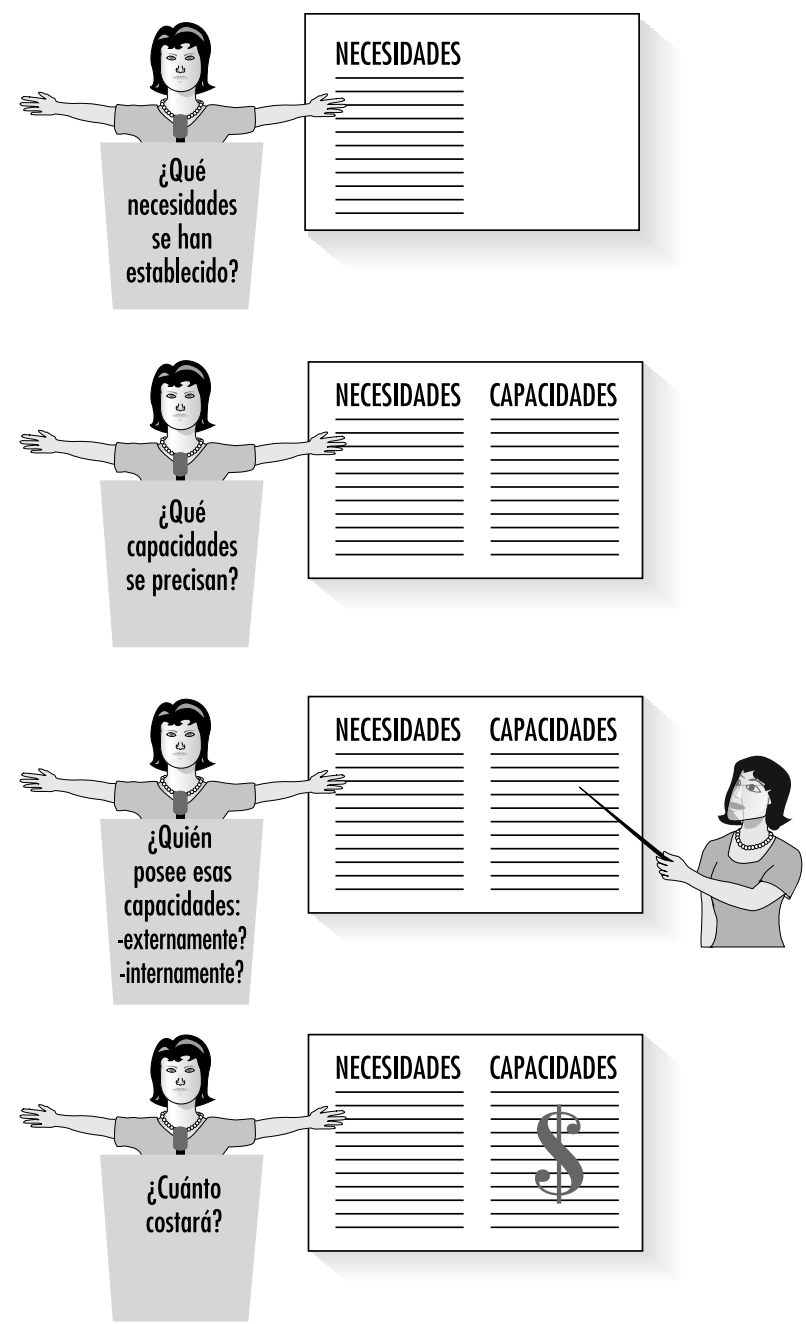
Figura 60.5 • Evaluación de la actuación del consultor.

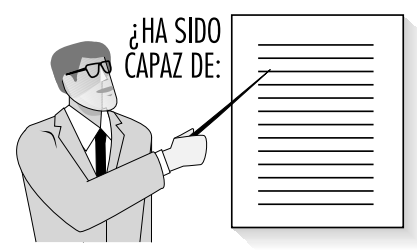

- diagnosticar y definir el problema?

- proponer varias soluciones posibles?

- recomendar la mejor solución

posible?

- presentar su propuesta de forma comprensible para usted?

- subrayar los beneficios indirectos de la solución propuesta?

- hacer que usted lo comprenda todo, incluido el coste?

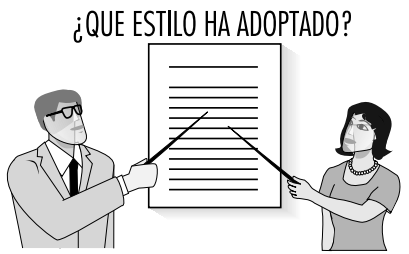

- Defensor

- Experto

- Definidor de alternativas

- Especialista en procesos

- Catalizador

- ¿Ha adoptado el estilo más adecuado a la situación de usted?

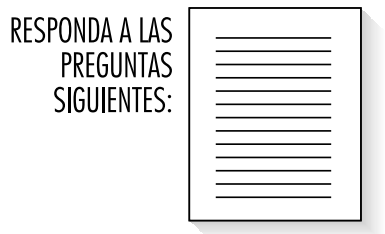

- ¿Ha concretado el objetivo y alcance de su estudio?

- ¿Se ha ajustado su actuación a su bosquejo inicial?

- ¿Ha presentado informes de situación?

- ¿Ha mostrado un estilo profesional?

- ¿Se ha entendido bien con su personal?

- ¿Se ha entendido su personal con él?

- ¿Le ha enseñado algo a usted y su personal?

- ¿Ha servido esa enseñanza para enriquecer la competencia suya y de su personal?

- ¿Ha alcanzado sus objetivos?

- ¿Ha incluido sus opiniones y las de su personal en el programa propuesto?

- ¿Está usted satisfecho con la presentación de sus propuestas?

- ¿Ha mantenido un estrecho contacto con usted durante todo el proceso?

- ¿Se ha realizado dentro de unos límites razonables de tiempo y dinero?

- ¿Cómo lo valoran sus directivos?

- ¿Le contrataría de nuevo?

- ¿Ha logrado buenos resultados? ¿Qué indicadores se han utilizado?

A demás, Albert afirma que, con independencia del método elegido, se deben seguir las siguientes reglas básicas:

- Conseguir el apoyo total de la alta dirección.

- Establecer un clima de confianza.

- Conseguir la aceptación de las unidades operativas.

- Evitar toda implicación en los conflictos internos de la empresa.

- Depender de las altas instancias directivas

- Comenzar lentamente y conservar la objetividad.

\section{- EJECUCION DE UN PROGRAMA DE SEGURIDAD}

Tom B. Leamon

La ejecución de un programa de seguridad debe ser un reflejo de su valoración como tarea ordinaria y cotidiana de la dirección general. El uso de información en todas las fases del proceso decisorio y el flujo de comunicación entre los distintos niveles de la empresa constituyen la base del éxito en la ejecución de estos programas.

\section{Nivel de la alta dirección}

Inicialmente, la implantación de un programa de seguridad nuevo o modificado precisa la aprobación de la alta dirección, que puede enfocarla como una decisión sobre coste/ beneficios que debe tomarse a la luz de la competencia por los recursos procedentes de otros ámbitos de la empresa. EI deseo de prevenir daños, lesiones y padecimientos en el lugar de trabajo mediante la ejecución de un programa de seguridad puede verse atemperado por la capacidad de la empresa para realizar el esfuerzo necesario. U na decisión informada de la dirección se basa en tres elementos:

1. descripción detallada del programa, con una indicación clara del método propuesto:

2. evaluación de los efectos del programa sobre el funcionamiento de la empresa:

3. estimación de los costes de ejecución y predicción de los beneficios probables.

La única excepción a esta regla se produce cuando el programa de seguridad se ejecuta por imperativo legal, como condición necesaria para que la empresa siga funcionando.

En este último supuesto, es conveniente añadir una estimación, tanto del coste real de la situación actual de la seguridad en la empresa, como de los costes sufragados a través de una cobertura directa de seguro o de los gastos directos de bolsillo. L os costes indirectos suelen ser considerables en todos los casos; en efecto, las estimaciones realizadas en el Reino U nido del coste de los siniestros graves indican que los costes reales (soportados por la empresa como costes indirectos) oscilan entre el duplo o el triplo y el décuplo de los verdaderos costes directos del seguro. En los países en que existe el seguro obligatorio, el coste $y$, por consiguiente, el ahorro varía sustancialmente en función de las condiciones sociales de cada país. En los países en que las entidades aseguradoras están obligadas a soportar la totalidad de los costes de asistencia médica y recuperación, como ocurre en Estados U nidos, los costes de seguro suelen ser más elevados que en los países en que el tratamiento de los trabajadores lesionados se enmarca en el contrato social. La forma ideal de subrayar la importancia de las pérdidas consiste en estimar el volumen de producción anual preciso para recuperar el ingreso perdido al tener que sufragar esas pérdidas. Esta solución es perfectamente compatible con el concepto de que, si bien la empresa debe necesariamente asumir los riesgos inherentes a la explotación, también debe gestionar ese riesgo con objeto de reducir las pérdidas y mejorar sus resultados financieros.

\section{Nivel de los directivos}

Aceptado el programa por la alta dirección, se debe crear un equipo de trabajo encargado de diseñar la estrategia y el plan de aplicación del programa del plan progresivo. Este sistema tiene más posibilidades de resultar eficaz que el método consistente en responsabilizar de la seguridad a una persona designada como técnico de seguridad. La dimensión y el nivel de compromiso de este equipo de trabajo varía considerablemente en función de la empresa y del entorno social. En todo caso, se precisa, como mínimo, el concurso de los responsables de las funciones operativas y de personal, gestión de riesgos y formación, así como de los representantes principales de las categorías de trabajadores que han de resultar afectadas por el programa. Es probable que un equipo así estructurado detecte los posibles conflictos (por ejemplo, entre producción y seguridad) en los estadios iniciales del proceso, antes de que actitudes, posturas y 
procedimientos se hayan inmovilizado tanto como el "hardware" y el equipo físico. Este es el momento en que la colaboración, más que la confrontación, abre mayores posibilidades de solucionar los problemas. El trabajo de este equipo se debe plasmar en un documento en el que se expongan los criterios de la empresa sobre el programa y los elementos clave del mismo, el calendario de ejecución y las responsabilidades respectivas de los participantes

Es preciso lograr que el compromiso de ejecución sea especialmente evidente para los directivos del nivel funcional en que el programa de seguridad se puede ejecutar. Es posible que el modo más efectivo de lograr este objetivo consista en implantar un sistema de retrocesión o imputación directa de los costes reales de un accidente a este nivel de dirección. L a dirección no debe asumir los costes de asistencia médica e indemnización (ni los correspondientes costes de seguros) como gastos generales de la organización. El director de la unidad, responsable del control financiero cotidiano de la misma, debe procurar que los costes reales de los programas de seguridad inadecuados aparezcan en el mismo balance de situación que los costes de producción y desarrollo. Por ejemplo, el director de una unidad de una organización en la que todos los costes de indemnización por accidente de trabajo se contabilicen como gastos generales de la empresa carecería de medios de justificar la inversión de recursos en la eliminación de un gravísimo peligro que afecte a un número reducido de trabajadores. El problema se puede presentar en el ámbito local, a pesar de que los gastos pueden generar importantes ahorros para el conjunto de la empresa. Es imprescindible que los directivos responsables del diseño y funcionamiento del lugar de trabajo asuman las cargas y recojan los beneficios de los programas de seguridad de los que se hacen responsables.

\section{Nivel de los supervisores}

El supervisor se responsabiliza de comprender, transmitir y velar por el cumplimiento de los objetivos fijados por la dirección para el programa de seguridad. El éxito de un programa pasa por formar y educar a los supervisores en el desempeño de esta responsabilidad. Aunque a veces se utilizan los servicios de instructores especializados en la seguridad para la educación de los trabajadores, el supervisor se debe responsabilizar, tanto de impartir esta formación, como de las actitudes de los trabajadores. Específicamente, para un buen supervisor, la prevención de toda actividad insegura y la intransigencia absoluta frente a toda relajación de las condiciones de seguridad en el lugar de trabajo son parte inseparable de su función. El control de los procesos productivos se valora como la principal actividad de los supervisores, y su aplicación contribuye a la reducción de los daños y las lesiones fortuitas. Con independencia de que la función de seguridad se encomiende a unos agentes de seguridad, a consultores 0 a un comité paritario, la responsabilidad cotidiana por el funcionamiento seguro e ininterrumpido del proceso debe constar por escrito en la descripción del puesto de trabajo de los supervisores.

\section{Nivel del personal de producción}

A principios de siglo, el principal incentivo de la seguridad en el trabajo consistía en la política punitiva. Se dictaban normas que los trabajadores estaban obligados a cumplir sin hacer preguntas y toda violación de las normas llevaba aparejada la adopción de medidas disciplinarias. La creciente complejidad de los lugares de trabajo, la implantación de sistemas flexibles de gestión y el aumento de las reivindicaciones sociales de los trabajadores han puesto de relieve las deficiencias y debilidades de este sistema. La flexibilidad y la delegación de responsabilidades en los mandos locales no sólo son condiciones necesarias de la eficacia operativa en las unidades militares. Este concepto ha contribuido a reforzar la importancia de las vías no punitivas de ejecución y del apoderamiento de la plantilla, con la consiguiente necesidad de mejorar el conocimiento y la educación. Esta evolución de la seguridad es un reflejo del esfuerzo de los trabajadores de todo el mundo por mejorar la calidad de su vida laboral y del desarrollo de los equipos de trabajo autodirigidos.

\section{Plan progresivo}

Los elementos clave del programa de seguridad permiten identificar las necesidades de familiarización con el fundamento conceptual del programa, el desarrollo de unos conocimientos específicos de seguridad y la aplicación de instrumentos de medición. Se asignan las responsabilidades a determinadas personas en el marco de un programa gradual, en el punto de introducción. El final del proceso progresivo consiste en la implantación de un sistema de medición, o de auditoría del programa de seguridad, que permita la evaluación continua del comportamiento del programa. En el plan se debe prever expresamente el funcionamiento de unas comunicaciones adecuadas. En muchos contextos culturales, coexisten en el lugar de trabajo diversos idiomas y dialectos, y es posible que el idioma o dialecto de los directivos no sea el utilizado comúnmente por la plantilla. Este problema se plantea también cuando se utilizan abreviaturas 0 una jerga en las comunicaciones entre determinados grupos. La participación de los trabajadores puede contribuir a prevenir estas dificultades y a la adopción de soluciones como la redacción de instrucciones y pautas en varios idiomas, el empleo de símbolos y pictografías y el uso de un lenguaje simple. Esta perspectiva más generosa de la participación de los trabajadores en el plan se traduce en una mayor aceptación y asunción de los objetivos y métodos del plan.

El proceso de revisión, o auditoría del programa de seguridad, se debe repetir a intervalos regulares (anuales) y constituirán la base de unos planes progresivos (o cíclicos). Estos planes determinarán la dirección futura del programa y aportarán el impulso de una mejora continua, incluso en el caso de que los procesos y sistemas de producción varíen.

\section{Mejora continua}

Lejos de permanecer invariable, un buen programa de seguridad se adapta a los cambios que se producen en el entorno social y de la empresa. Del mismo modo, un programa eficaz es aquél en que se fijan unos objetivos ambiciosos, pero alcanzables. La filosofía más acertada consiste, por el contrario, en perseguir una mejora gradual y una elevación continua del nivel. El plan gradual trienal estructurado en fases anuales constituye un medio adecuado de conseguir ese objetivo. C ada año se identifican en el plan unos fines amplios y se estimas sus costes y beneficios probables para el próximo período trienal. De este modo se garantizan la adaptación y una mejora continua. A medida que el plan es revisado anualmente por la dirección, se obtiene el beneficio adicional de que los objetivos de la función de seguridad se van ajustando a los objetivos corporativos.

\section{Conclusión}

La ejecución del programa de seguridad debe reflejar la condición de éste de componente integrante de la gestión de la empresa. El éxito dependerá de una clara identificación de las responsabilidades de los distintos niveles de la dirección. L a participación de los trabajadores en el programa de ejecución, especialmente en el plan gradual, puede generar los beneficios inherentes en la adhesión general al plan. El plan gradual es un documento en el que se enuncian las actividades necesarias, el calendario de las mismas y la responsabilidad por la realización de cada actividad. Los elementos de cada actividad, con 
independencia de que se trate de la formación, del desarrollo de un procedimiento de trabajo o de la educación, se deben transmitir de forma inequívoca a todos los niveles de la empresa. La etapa final del plan gradual consiste en producir un ciclo de mejora continua mediante la implantación de una auditoría del programa de seguridad con una periodicidad mínima anual.

\section{- El EXITO EN LOS PROGRAMAS DE SEGURIDAD}

Tom B. Leamon

El imperativo ético de una empresa de esforzarse por prevenir daños, sufrimientos y siniestros en el lugar de trabajo se ve atemperado por la capacidad de la organización para realizar ese esfuerzo. La mayoría de las actividades humanas entrañan algún riesgo, y los peligros en el lugar de trabajo varían sustancialmente, desde los que son mucho menores que los inherentes a la actividad ordinaria no profesional, hasta los que son mucho mayores. Aspecto esencial de la vida de una organización es su disposición a aceptar los riesgos derivados de las actividades que pueden producir pérdidas financieras y descansan sobre el dolor y el sufrimiento de los empleados que son víctimas de accidentes. Un buen programa de seguridad se orienta al control parcial de estas pérdidas mediante la reducción de los riesgos, específicamente de los generados por actos o situaciones inseguros. Por consiguiente, un programa de seguridad no es más que un subsistema de gestión. Al igual que otros programas de gestión, el programa de seguridad está integrado por unos procedimientos, normas y estrategias complementarios, y al igual que otros programas de gestión, un programa de seguridad se mide por su rendimiento, esto es, por su eficacia en la reducción de accidentes y de las pérdidas resultantes.

La seguridad en el lugar de trabajo está en función del control de los peligros y los comportamientos inseguros, y este control es la función primordial de la dirección. El programa de seguridad debe producir unos beneficios complementarios consistentes en la reducción de los daños y de los padecimientos en el lugar de trabajo (resultantes de las lesiones y enfermedades crónicas y agudas) y en la consiguiente reducción de las cargas financieras que los accidentes irrogan a la organización. Para conseguir estos resultados, en un buen programa de seguridad se sigue la orientación general de todas las técnicas de gestión consistente en la fijación de objetivos, la supervisión del comportamiento y la corrección de desviaciones. Este criterio se aplica a una gama bastante extensa de actividades sociales, incluidos el organigrama, los procesos productivos y el comportamiento de los trabajadores.

\section{La seguridad en la empresa}

Un lugar de trabajo seguro es el producto final de un proceso complejo e interactivo, y un proceso es siempre el reflejo de las características de la organización. En la Figura 60.6 se ilustra un proceso típico. En un buen programa se enfocan los distintos aspectos de un sistema.

Aunque la seguridad se suele valorar como una cuestión que afecta exclusivamente al trabajador en su lugar de trabajo, en la Figura 60.6 se ilustra la función estratégica de la dirección en una gestión de la seguridad que responde a los objetivos globales de la organización. Esto se infiere de la indiscutida responsabilidad de la dirección en la elección del proceso industrial aplicado, el control de la supervisión, las condiciones de trabajo y las actitudes y rutinas del trabajador, todos los cuales son factores que determinan la magnitud de un riesgo en un determinado
Figura 60.6 - El proceso de gestión y la seguridad en el trabajo.

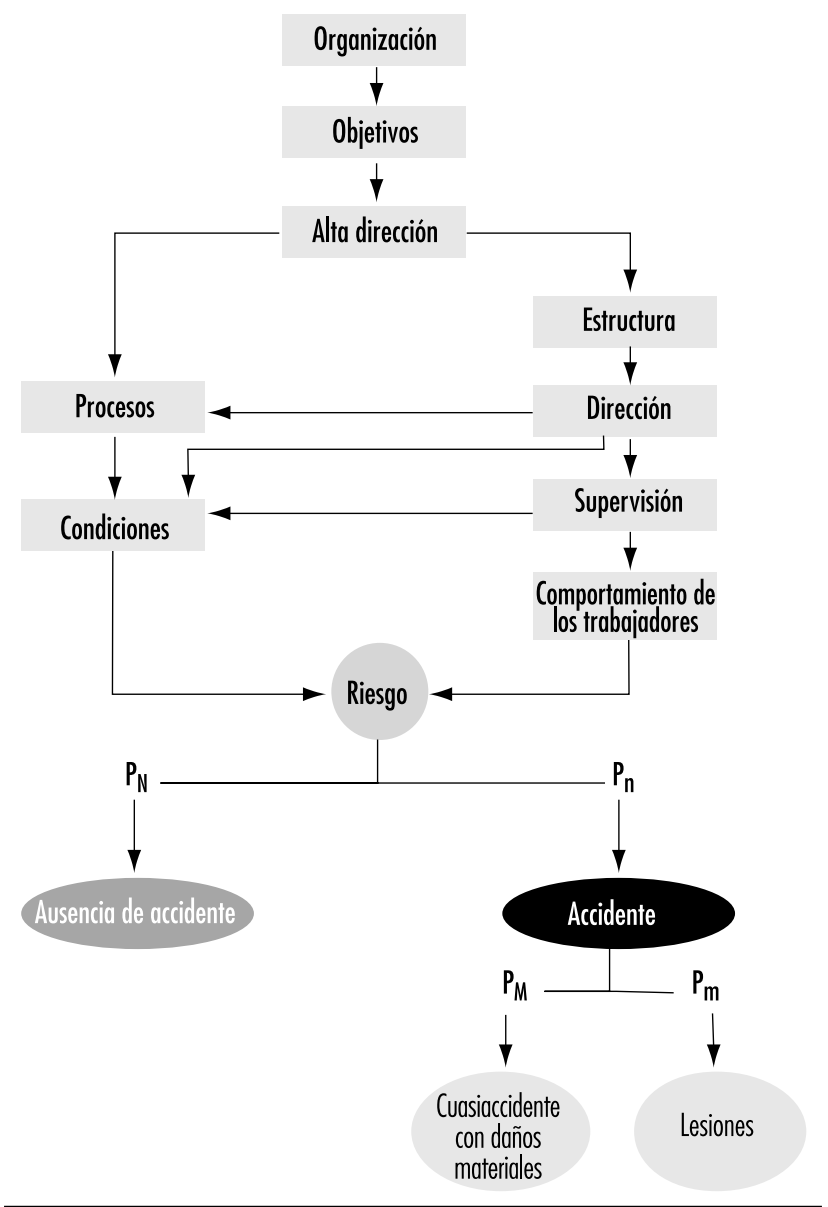

lugar de trabajo. Por regla general, existe una elevada probabilidad de que no se produzcan accidentes y una pequeña probabilidad de que ocurra algún accidente que cause daños materiales o lesiones a un trabajador. Un programa de seguridad debe orientarse a prevenir ese riesgo y reducir las posibles lesiones.

\section{Comprensión de la secuencia del accidente}

Aunque existen diversas teorías que compiten por explicar la secuencia causal de los accidentes, el modelo propuesto inicialmente por Frank Bird (1974) es particularmente valioso por presentar analogías con numerosas prácticas de gestión. Bird compara la cadena causal de los daños y lesiones con una fila de fichas de dominó colocadas de canto (véase la Figura 60.7). Si cae una ficha, puede desplazar a las otras y desencadenar una secuencia que finaliza con la caída de la última ficha, que en el símil se corresponde con la producción de una lesión. En esta comparación, si una de las fichas se retira de la fila 0 es lo bastante resistente para absorber el impacto de la ficha anterior, la cadena causal se quiebra y el daño o la lesión no llega a producirse.

A pesar de la existencia de modelos más recientes, esta teoría conserva su utilidad, debido a que en la misma se define nítidamente el concepto de intervención en el proceso causal del accidente y la importancia de un programa de seguridad eficaz en la producción de tales intervenciones para abortar la secuencia causal de la lesión. 
Figura 60.7 - Teoría del dominó de Bird, modificada por Adams.

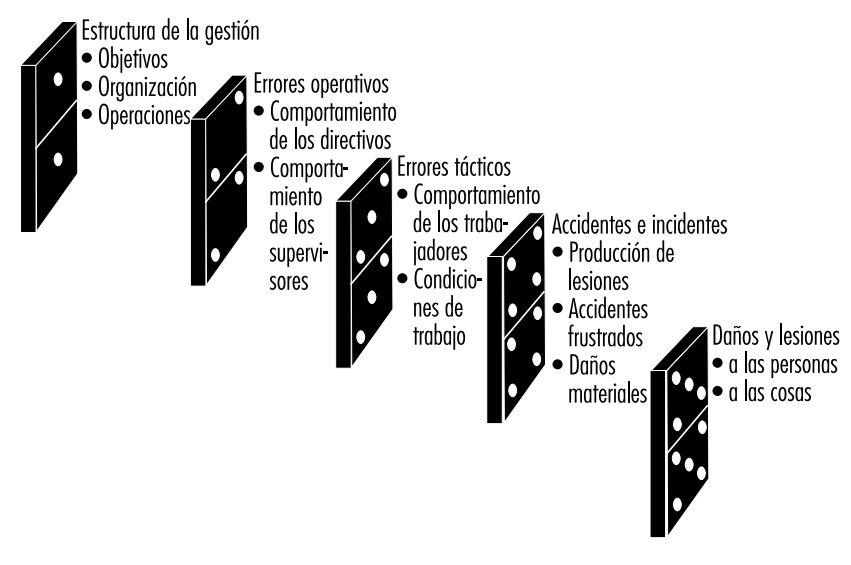

\section{Objetivos de la organización}

Existe una práctica unanimidad entre los autores en torno a que el elemento más relevante de todo programa de seguridad es la adhesión continua y abierta de la alta dirección. Esta adhesión se debe transmitir y asumir a los sucesivos niveles de la dirección hasta el escalón de los supervisores. Ciertamente, la dirección ejecutiva suele dar por sentado que su compromiso con la seguridad es evidente para todos los escalones sucesivos de la dirección y la supervisión. El éxito de un programa de seguridad depende de que la dirección ejecutiva demuestre una adhesión claramente perceptible al principio de que la seguridad es una responsabilidad de todos, desde los altos directivos hasta los trabajadores temporales. Esta adhesión se ha de reflejar en un breve documento que debe distribuirse entre todo el personal y utilizarse en el estadio inicial de la integración de los nuevos trabajadores en la organización. Algunas empresas han reforzado recientemente este compromiso suscribiendo el principio de que el mantenimiento de un lugar de trabajo seguro y saludable es un valor explícitamente asumido por la empresa. Estas empresas suelen reconocer este principio en sus documentos, junto con otros valores más tradicionales, como la rentabilidad, la fiabilidad, el servicio al cliente y la vocación comunitaria.

La fluidez de las comunicaciones es especialmente importante en las grandes empresas, en las que el contacto directo entre los dueños de la compañía y los trabajadores es sumamente frágil. Un modo eficaz de lograr este objetivo es la elaboración de una serie de procedimientos y políticas escritos, comenzando por una declaración de la alta dirección de los objetivos del programa de seguridad, que deben ser claros, concisos, posibles, sostenibles y. sobre todo, inequívocos. No basta con que un alto directivo dé por sentado que todos los niveles de la jerarquía comparten su cultura, sus conocimientos y su percepción del programa de seguridad; es preciso comunicar inequívocamente estas dimensiones. Asimismo, es imprescindible fijar unos objetivos realistas en la elaboración del procedimiento escrito.

\section{Control ejercido por la dirección}

El desarrollo de unos programas de seguridad eficaces a partir de este compromiso inicial pasa por integrar la medición de los resultados del esfuerzo de seguridad en la evaluación global anual del trabajo de todo el personal directivo y de supervisión. A plicando el criterio de que la seguridad es uno más entre los muchos indicadores del control del proceso ejercido por la dirección, los resultados del esfuerzo de seguridad se deben tomar en consideración, al igual que la producción, el coste unitario y la rentabilidad del departamento. Dado que los accidentes se producen por una falta de control del proceso, esta filosofía resulta perfectamente compatible con la tendencia actual a la gestión de calidad. Ambos procedimientos se basan en la necesidad de reducir las desviaciones de los valores normales con objeto de mejorar el control del cumplimiento de los objetivos sociales. Además, el concepto de mejora sostenida, año tras año, en que descansa la gestión de calidad, es particularmente significativa en la gestión a largo plazo de los programas de seguridad.

\section{Formación y educación}

La formación y la educación son elementos centrales de todo programa de seguridad, que debe iniciarse con la difusión desde los altos niveles directivos, no sólo de los objetivos del programa, sino de información acerca de los progresos realizados hacia el logro de los mismos, medidos sobre la base de los registros y la contabilidad de costes. La educación, que entraña un conocimiento más general de la naturaleza de un peligro y de los métodos para reducirlo, produce resultados positivos, especialmente cuando subsisten dudas sobre los factores individuales de riesgo. Un ejemplo de esto es la epidemia de trastornos acumulativos en las extremidades superiores que ha azotado Australia, Europa y Norteamérica. Estos trastornos han adquirido mayor importancia, debido especialmente a que no existe un consenso generalizado sobre los medios de control. Sin embargo, ese carácter acumulativo facilita considerablemente su control mediante la educación. La mayor conciencia del riesgo induce a los trabajadores a prevenirlo identificando la exposición al mismo y modificando los procedimientos. Análogamente, el conocimiento del mecanismo generador de las molestias lumbares puede hacer que los trabajadores eviten algunos movimientos potencialmente peligrosos y los sustituyan por métodos de trabajo más seguros.

La formación es tan necesaria para los directivos y supervisores como para los trabajadores si quieren comprender en profundidad sus obligaciones y responsabilidades y aumentar sus conocimientos de los peligros potenciales. Es preciso facilitar a cada trabajador unas instrucciones claras, inequívocas y vinculadas a los procesos que incrementen la seguridad en el trabajo. Cada trabajador debe conocer perfectamente los riesgos inherentes a cada operación, así como los probables efectos de la exposición a los agentes tóxicos y físicos. Además, directivos, supervisores y trabajadores deben conocer por igual los medios de reducir las pérdidas cuando se produce un accidente.

\section{Comportamiento seguro}

La filosofía de la seguridad ha experimentado durante el siglo XX diversos bandazos que se han reflejado en los programas de seguridad en la imputación de distintos grados de responsabilidad por el comportamiento de los trabajadores a cada individuo, a la empresa y a la sociedad. En todo caso, es evidente que los comportamientos seguros constituyen un elemento absolutamente esencial del proceso de seguridad. Un ejemplo de la importancia de tal comportamiento es el desarrollo de las normas éticas de grupo, según las cuales la asunción de un determinado riesgo por un individuo puede ser percibida negativamente por otros miembros del grupo. También se produce la reacción inversa, en la que la aceptación de una práctica peligrosa puede terminar asumiéndose como "normal". Tales comportamientos pueden modificarse aplicando técnicas específicas de formación y refuerzo, como demostró la tremenda eficacia de los programas destinados a prevenir el contagio del SIDA producido por la utilización negligente de jeringuillas en el sector de la sanidad. En efecto, una campaña insistentemente librada por la dirección, combinada con un esfuerzo de 
formación apoyado en materiales didácticos, produjo una modificación sustancial de los procedimientos aplicados y una reducción de la frecuencia de este riesgo.

\section{Participación}

Existe una creciente demanda social de participación de los trabajadores en los programas de seguridad. Si bien el reconocimiento de tal participación suele variar un tanto, la participación de los trabajadores puede ser valiosa en diversas fases del programa de seguridad. Sin duda, las personas expuestas a los peligros suelen ser una fuente de ayuda inestimable para su identificación y, a menudo también, conocen el modo de reducirlos. Identificados los problemas y conocidas las soluciones, la ejecución del programa se facilita considerablemente si la plantilla ha participado activamente en el proceso de registro, identificación, desarrollo y validación de las actuaciones propuestas. Por último, la incorporación de la participación en el programa de seguridad contribuye a comprender la adhesión de la dirección y la limitación de los recursos.

\section{Incentivos}

En algunos países se ha venido implantando un número creciente de incentivos al comportamiento seguro. Aunque no existen indicios mínimamente concluyentes de la eficacia de estos incentivos, su incorporación al programa de seguridad puede servir contribuir a demostrar el compromiso permanente de la dirección con la seguridad, además de constituir una importante fuente de retroinformación del rendimiento. Esta es la razón de la ineficacia de los programas de seguridad consistentes en remitir por correo una pequeña recompensa financiera a ciertos destinatarios. Esa misma recompensa, concedida públicamente por la alta dirección sobre la base de unos indicadores objetivos del rendimiento, como serían, por ejemplo, 2.500 horas consecutivas de trabajo sin accidentes, podría constituir una medida de reafirmación positiva de la norma. En la práctica, en muchos sectores se produce exactamente lo contrario y se conceden numerosos incentivos que premian un pobre comportamiento en materia de seguridad. Por ejemplo, en el sistema de pago a destajo se premia abiertamente a los trabajadores por eliminar del ciclo productivo las prácticas que suponen un consumo sensible de tiempo, incluidas las medidas asociadas a la seguridad en el trabajo. Las empresas que utilizan incentivos suelen tener más necesidad de aplicar medidas de control técnico y técnicas de vigilancia activa si están realmente volcadas en la protección de la salud y seguridad de sus trabajadores.

\section{Medición y control}

La información es la savia de la dirección y los registros son una parte esencial de la información de la dirección. Sin una buena fuente de información, los resultados del esfuerzo por reducir la frecuencia de los accidentes son dudosos y es posible que la disposición de la dirección a incrementar la inversión en la reducción del riesgo se resienta de ello. A parte de que, en algunos países, la recogida de este tipo de datos constituye un imperativo legal, es evidente que el éxito de un programa de seguridad se mide por la medida en que facilita la recogida y sistematización de tales datos. La observancia de las disposiciones legales es condición necesaria aunque, con frecuencia, no suficiente para el éxito de un programa de seguridad. Ciertamente, se pueden producir diferencias en la regulación legal de la recogida de datos - por ejemplo, entre distintos territorios- que difuminen el valor de la información recogida. Esta circunstancia puede plantear dificultades, especialmente a las empresas que cuentan con un gran número de centros sometidos a diferentes ordenamientos legales de ámbito nacional o local. Esto hace aconsejable estandarizar la recogida de datos e incorporar el sistema al programa de seguridad. Por lo tanto, en cada programa se debe definir inicialmente la información precisa para cumplir las disposiciones legales y, a continuación, formular los objetivos de recogida y análisis de datos precisos para la reducción del riesgo de accidentes.

\section{Coste de los accidentes}

Un aspecto esencial de la gestión del sistema de información es la determinación del coste de las pérdidas. EI análisis del origen de las pérdidas, esto es, la determinación del origen efectivo de las pérdidas, comprende la cuantificación del número y la gravedad de los siniestros y de los costes directos de los daños, lesiones y enfermedades. Estos datos son imprescindibles para que la dirección pueda abordar sistemáticamente los verdaderos problemas que se producen en el lugar de trabajo. En algunos países, los costes de indemnización por accidentes de trabajo - con independencia de que sean asumidos directamente por la empresa 0 imputados a una asociación o un organismo estatal- se pueden reputar proporcionales a los daños sufridos por los trabajadores. Por consiguiente, al determinar el origen de las pérdidas, la dirección cumple su obligación de garantizar a la plantilla unas condiciones de trabajo seguras en una forma claramente compatible con el análisis coste-beneficio utilizado en otras actividades.

L os costes directos no reflejan el verdadero coste económico soportado por la empresa por causa de los accidentes y lesiones. En muchos países del mundo se han realizado esfuerzos más 0 menos rigurosos por determinar los costes indirectos producidos por los accidentes. En estos costes indirectos se incluyen el tiempo dedicado por los supervisores, la pérdida de tiempo de producción causada por la investigación del accidente y la limpieza del lugar de trabajo, y las horas extraordinarias precisas para recuperar el tiempo perdido. Está demostrado que estos costes indirectos superan considerablemente a los costes directos y que pueden llegar a ser entre el triplo y el décuplo de las pérdidas directas aseguradas.

\section{Determinación de los costes}

La cuantificación de las pérdidas suele basarse en la vigilancia pasiva, que implica un examen de los antecedentes por lo que respecta a la frecuencia y gravedad de los accidentes. Esta vigilancia pasiva resulta insuficiente en algunos casos, especialmente si existen escasas posibilidades de que se produzcan errores que, no obstante, de producirse, sean capaces de producir graves daños incontrolables. En tales casos, especialmente en las grandes plantas procesadoras, es imprescindible realizar una evaluación de las posibles pérdidas. Es de todo punto inadmisible que, simplemente porque ningún proceso haya provocado víctimas, los procesos basados en el consumo de enormes cantidades de energía o de sustancias tóxicas no deban analizarse antes de que se produzca un accidente. Por consiguiente, en algunos sectores es preciso establecer una vigilancia activa, particularmente en las plantas que utilicen procesos similares a los que hayan producido pérdidas en otros lugares. La información procedente de las asociaciones sectoriales y las organizaciones de trabajadores y de seguridad de ámbito nacional e internacional pueden ser de gran utilidad en la elaboración de unas estimaciones previas a los accidentes que pueden resultar válidas y valiosas. En otros capítulos de esta E nciclopedia se describen otras técnicas, como el análisis del árbol de errores y el de los modos de fallos. En algunos casos, como los de exposición a los agentes químicos, se puede incluir en la vigilancia activa la exploración médica habitual del trabajador, sistema que reviste particular importancia en los casos en que existen unos límites precisos a la exposición. Este método de estimación de las pérdidas potenciales y reales pone de relieve un aspecto que no se debe pasar por alto en un buen programa de 
seguridad y que es la diferencia entre el riesgo cotidiano y los efectos de una posible catástrofe.

\section{Retroinformación}

La retroinformación se ha revelado esencial en una multiplicidad de actividades de la empresa, incluidos los programas de seguridad. EI cálculo de las tasas de siniestralidad y de los índices de gravedad es la base de la asignación racional de los recursos de la empresa y constituye la medida del éxito del programa. Esta información es tan útil para la dirección en la evaluación de la función de seguridad, como para los trabajadores en la ejecución del programa. No obstante, la presentación de los datos debe estar en función del usuario final; así, los datos globales permiten a la dirección realizar comparaciones entre las unidades operativas, mientras que los datos específicos de un departamento y los medios auxiliares visuales (como los gráficos que reflejan el número de días sin accidentes de trabajo en el taller de producción) fomentan el conocimiento y la aceptación del programa en todos los niveles de la plantilla.

\section{Observación sobre el terreno}

El sistema de información es un componente "fuera de línea" de todo buen programa de seguridad, que se debe complementar con un enfoque práctico de la seguridad en el lugar de trabajo que comprenda un sistema de rondas en el que un observador formado y cualificado identifica subjetivamente los peligros existentes en el lugar de trabajo. Además de la identificación de los peligros, el sistema de rondas es particularmente idóneo para detectar posibles incumplimientos de las normas internas de la empresa y las disposiciones legales. Por ejemplo, el uso de dispositivos de protección resulta ineficaz si, como se suele comprobar en las rondas, han sido retirados de muchas de las máquinas. Por tratarse de un sistema flexible y adaptable, las rondas constituyen igualmente el método más sencillo de descubrir deficiencias en el proceso de formación de los trabajadores y, posiblemente también, de sus supervisores.

En un buen programa de seguridad se utiliza esta técnica de forma sistemática, aunque aleatoria. Sin embargo, las rondas no constituyen el único medio de detectar peligros. Los propios trabajadores pueden suministrar información esencial, pues, en diversas ocasiones, habrán presenciado situaciones de riesgo inminente no materializado que no se han comunicado y esto les permite analizar los siniestros abortados con el agente de seguridad que hace la ronda. Los supervisores deben alentar a los trabajadora a informar de los fallos de seguridad, tanto reales como potenciales.

\section{Investigación de accidentes}

El supervisor responsable debe investigar todos los accidentes que se produzcan. La investigación de los accidentes del tipo de los que suelen producirse en la industria transformadora suele exigir la creación de un equipo de expertos representativos de diversos intereses, a los que se puede añadir algún especialista externo. En los buenos programas de seguridad se suele involucrar a los trabajadores en el proceso de esclarecimiento de tales accidentes. En efecto, la participación de la plantilla produce beneficios al contribuir al conocimiento de las causas del accidente y a la rápida difusión de las consiguientes recomendaciones entre la plantilla. De la Figura 60.7 se infiere que, en este sentido, los accidentes no son únicamente los siniestros que provocan lesiones a los trabajadores, sino también los hechos que irrogan daños al equipo o los materiales 0 , incluso, algunos fenómenos significativos que no producen resultados (los denominados "accidentes frustrados"). En la figura citada se indica que la dirección debe investigar y controlar esos casos, incluso, si, casualmente, ningún trabajador se ha lesionado, pues la evitación de fenómenos similares en el futuro tiende a reducir el riesgo de que se produzcan lesiones. La investigación de accidentes orientada a depurar responsabilidades por su producción suele ser menos eficaz que la dirigida al conocimiento de las causas. Ciertamente, si la investigación se percibe como un expediente para culpar a un trabajador, la presión de los compañeros y otros factores psicosociales pueden reducir sensiblemente la fiabilidad de la información recogida.

El informe de un accidente debe revestir una estructura normalizada en la que se incluya una descripción pormenorizada de los acontecimientos desarrollados antes, durante y después del accidente, así como una evaluación de las causas del mismo. El informe debe concluir con una indicación inequívoca de las medidas que se deben adoptar. Dichas medidas pueden variar desde la modificación inmediata del proceso productivo hasta, en las situaciones más complejas, la realización de una investigación complementaria a cargo de especialistas. EI informe debe ir firmado por el supervisor responsable o el jefe del equipo de investigadores. El examen y aceptación por parte de la dirección de las medidas recomendadas constituye un elemento esencial del proceso de información de los accidentes. En efecto, la firma del directivo competente debe indicar su aceptación o desestimación, motivada, en este último caso, de los cambios propuestos para prevenir futuros accidentes. Toda investigación de accidentes que no se traduce en la asignación de responsabilidades personales por la adopción de las medidas recomendadas suele resultar estéril y no tarda en ser valorada como irrelevante por todos los interesados. En un buen programa de seguridad se procura que las lecciones derivadas de cada siniestro se comunican a todos los niveles de la organización.

\section{Control de riesgos}

EI mejor modo de controlar el riesgo consiste en eliminarlo aplicando medidas de diseño técnico, modificación o sustitución. Si el riesgo se elimina (0, alternativamente, se adoptan medidas de protección física), los operarios estarán protegidos con independencia de la variabilidad humana derivada de la formación, las diferencias personales de la fuerza muscular, atención, fatiga 0 biorritmos.

Lamentablemente, en ciertos casos, el coste de aplicar este diseño técnico puede igualar o rebasar los límites de la responsabilidad económica. Algunos procesos son intrínsecamente más arriesgados que otros y los diseños técnicos viables sólo constituyen soluciones parciales. Los trabajos de construcción de edificios altos, la minería subterránea y la conducción en autovías obligan al trabajador a soportar riesgos superiores a los "normales". En estos casos, los controles administrativos y el empleo de medios de protección individual pueden hacerse imprescindibles. Entre los controles administrativos se incluyen una formación especial y las técnicas de reducción de riesgos, como, por ejemplo, la prohibición del acceso de algunos trabajadores a ciertos espacios restringidos o la instalación de dispositivos de bloqueo que aislen a los operarios del equipo y los procesos peligrosos durante el ciclo productivo. Si bien estos procedimientos pueden ser eficaces, precisan un mantenimiento continuo. Específicamente, los métodos de trabajo suelen desviarse de la adhesión a los procedimientos administrativos establecidos y es preciso contrarrestar esta tendencia mediante la ejecución de programas de educación y formación continua de los trabajadores y supervisores implicados en el sistema.

El último elemento del control de riesgos es el uso de equipo de protección individual, como, por ejemplo, guantes, cascos, filtros de aire y ropa protectora de todo el cuerpo. En términos generales, este equipo resulta útil si el peligro no se ha erradicado totalmente del lugar de trabajo ni se ha logrado controlar 
mediante las medidas administrativas. Su objeto es reducir los efectos de los riesgos para el trabajador y suelen plantear problemas por el uso indebido, las deficiencias de diseño, la falta de exigencia de los supervisores y la pobreza de mantenimiento.

\section{Primeros auxilios}

Además de las estrategias de prevención de riesgos, en un buen programa de seguridad se debe prever igualmente la adopción de medidas en caso de accidente. La adquisición de medios de prestación de primeros auxilios y tratamiento médico de emergencia puede reforzar la eficacia del programa de seguridad. En este sentido, se debe elaborar un protocolo del tratamiento médico preciso en caso de accidente. Se debe informar por escrito a un grupo de trabajadores del procedimiento para solicitar asistencia médica en el lugar de trabajo. La prestación del servicio se debe planificar por anticipado, ya que una demora puede afectar seriamente el estado del trabajador accidentado. R especto a los accidentes que producen daños menores, los perjuicios consiguientes se pueden reducir mediante la prestación de asistencia médica en el lugar del siniestro. En efecto, el tratamiento médico en el lugar de trabajo de pequeñas heridas, magulladuras, contusiones, etc., contribuye a reducir el tiempo de ausencia del trabajador de sus obligaciones habituales.

En los medios de prestación de primeros auxilios se deben incluir un nivel aceptable de suministros y, lo que es más importante, una formación médica y de primeros auxilios adecuada. En efecto, la calidad de la formación puede influir directamente en las posibilidades de supervivencia en caso de producirse una lesión potencialmente fatal, y reducir la gravedad real de una serie de accidentes menos graves. Ciertamente, la prestación de primeros auxilios del tipo de la reanimación cardiopulmonar y de la contención de hemorragias puede suponer la diferencia entre la vida y la muerte de los pacientes necesitados de tratamientos de urgencia importantes. A menudo la prestación inmediata de primeros auxilios en el lugar del accidente permite ganar tiempo para una posterior intervención quirúrgica seria. Los servicios de primeros auxilios son particularmente importantes en las empresas situadas en entornos no urbanos, en los que el inicio del tratamiento médico puede demorarse varias horas.

Los primeros auxilios facilitan igualmente la reincorporación al trabajo de las víctimas de accidentes menores. Está demostrado que estas intervenciones puntuales tienden a reducir la necesidad de prolongados tratamientos ambulatorios $y$, por ende, a prevenir la pérdida de productividad. Q uizás resulte más significativa la posibilidad de prevenir totalmente el tratamiento médico de la lesión, que en algunos países comienza a ser un problema.

\section{Prevención de catástrofes}

En el programa de seguridad se debe prever el control periódico, como mínimo anual, de las posibles causas de catástrofes. En algunos casos, por ejemplo, cuando se almacena una gran cantidad de materiales inflamables o peligrosos, la identificación de las posibles causas no resulta difícil; en otras situaciones, por el contrario, se requiere una gran destreza para contribuir significativamente a la prevención de catástrofes. L as catástrofes son raras por definición y no es probable que una misma empresa haya experimentado antes una catástrofe similar. En el programa de seguridad se deben incluir la especificación del tratamiento médico, los flujos de comunicación y el control de las situaciones catastróficas por parte de la dirección. Aunque resulta evidente que, en muchas empresas, el alcance de estos controles anuales puede ser muy reducido, su ejecución misma puede reforzar la conciencia de la dirección de algunos de los riesgos que la empresa afronta.

\section{Conclusión}

Un buen programa de seguridad no es un manual ni un archivador lleno de instrucciones, sino un plan lógico de prevención del riesgo de lesiones, medido en función del número de siniestros y de su gravedad. Como todos los demás procesos que se desarroIlan en la empresa, la gestión de la seguridad es una responsabilidad de la dirección no delegable en un ingeniero de seguridad ni en un trabajador. En efecto, la dirección fija los objetivos, asigna los recursos, implanta el método de cuantificación de los progresos hacia el logro de esos objetivos y corrige el rumbo cuando esos progresos no son satisfactorios. La información constituye un factor clave del éxito de esta política, seguido en importancia por la comunicación de los objetivos a todos los niveles de la empresa. En todos los niveles, desde la alta dirección a los trabajadores, pasando por los supervisores, se puede contribuir a mejorar las condiciones de seguridad en el trabajo. No obstante, la presencia de disfunciones organizativas, procedimentales y de comportamiento puede frustrar esta contribución. El éxito de un programa de seguridad depende del conocimiento y la utilización de esos factores en la elaboración de un método integral de reducción de los sufrimientos que lesiones y accidentes causan a los trabajadores.

\section{Programas de InCENTIVOS A LA SEGURIDAD}

Gerald J.S. Wilde

El objetivo de los programas de incentivos a la seguridad es reducir las pérdidas causadas por accidentes. Además, producen efectos secundarios positivos: por una parte, constituyen una inversión rentable para la industria, ya que el ahorro suele exceder del coste, y por otra, contribuyen a mejorar la moral de la empresa. Ciertamente, los incentivos contribuyen a mejorar el clima general imperante en la organización y, por tanto, contribuir a incrementar la productividad por encima de la ganancia debida a la reducción de accidentes. Los programas de incentivos colectivos de seguridad fomentan el espíritu de cooperación entre los trabajadores y de todos con la dirección. En efecto, al incentivarse los comportamientos seguros "se eliminan los aspectos no deseados de la disciplina y el recurso a las sanciones, se incrementa la satisfacción de los trabajadores con el puesto de trabajo y se mejoran las relaciones entre supervisores y trabajadores" (M cAfee y Winn 1989).

\section{Eficacia en función del coste de los programas de incentivos}

Se han producido numerosos casos en la industria, la construcción y otros sectores en que el índice de siniestralidad por trabajador se ha reducido entre un 50 y un $80 \%$. En algunos casos, los resultados han sido aún mejores, como ocurrió en dos empresas mineras en las que el número de días perdidos se había reducido en un 89 y un $98 \%$, respectivamente (Fox, Hopkins y Anger 1987). A veces, los resultados son más modestos. Por ejemplo, en cierta fábrica de cables, el coste por empleado de los accidentes disminuyó en un $35 \%$; en una industria de productos de tabaco, en un 31 \% (Stratton 1988); en una empresa de tratamiento y transporte de cereales, en un $30 \%$; en cierto complejo turístico de la costa del Pacífico, en un $39 \%$; y en una empresa de productos de alimentación, en un $10 \%$ (Bruening 1989).

Los efectos favorables se prolongan durante períodos de tiempo considerables. Por ejemplo, los planes de incentivos aplicados en dos minas de Estados U nidos se estudiaron durante 11 y 12 años, respectivamente. En una de las minas, el número 
de días perdidos por accidentes se redujo hasta cerca del $11 \%$ de la cifra de referencia, y en la otra, hasta el $2 \%$ aproximadamente. Las relaciones coste-beneficios oscilaron entre el 18 y el $28 \%$ en una de las minas, y entre el 13 y el $21 \%$ en la otra. $L a$ eficacia de los programas de incentivos no mostró señales de debilitamiento en ninguna de las minas (Fox y cols. 1987). También se ha observado una elevada relación coste-beneficios, en el entorno de 23:1, en el complejo hotelero.

La relación entre los beneficios (esto es, el ahorro producido por la prevención de accidentes) y los costes del programa (primas y gastos de administración) suele ser superior a 2:1, lo que significa que los esfuerzos de prevención de accidentes pueden ser rentables para las empresas. Esto se debe, en gran medida, a la reducción de las cuotas abonables a las entidades aseguradoras de accidentes de trabajo y de otras primas de seguro, así como al incremento de la producción, la reducción del tiempo perdido y la menor necesidad de contratar trabajadores de reemplazo.

\section{Requisitos de una programación eficaz de los incentivos}

Un programa de incentivos adecuadamente diseñado suscita la adhesión de sus destinatarios y en este sentido se compara favorablemente con otras modalidades de promoción de la seguridad como las normas legales, los manuales y las políticas, que son menos populares. Expresado con una parábola, una pequeña zanahoria no sólo resulta mucho más apetecible que un gran palo, sino también mucho más eficaz. Hasta ahora sólo se ha señalado un efecto negativo del sistema, que es la tendencia de las personas a omitir la comunicación de los accidentes allí donde se aplican incentivos. Por suerte, hasta el momento este déficit de información sólo se ha detectado en relación con los accidentes menores (M cAfee y Winn 1989).

La experiencia acumulada en la gestión de los programas de incentivos demuestra que algunos han sido mucho más eficaces que otros. Así, un plan de incentivos ejecutado en Alemania, en el que se prometía a los conductores profesionales de vehículos industriales una gratificación de 350 marcos por cada semestre transcurrido sin haber causado accidentes permitió reducir los costes directos de accidentes a menos de la tercera parte durante el primer año del plan y mantener ese nivel durante más de tres decenios (Gros 1989). Asimismo, el programa piloto ejecutado en California bajo el lema del "buen conductor", en virtud del cual se ofrecía a todos los conductores una prórroga gratuita de un año del permiso de conducir por cada año transcurrido sin accidentes, produjo una reducción del $22 \%$ del índice de siniestralidad durante el primer año de vigencia del programa (H arano y H ubert 1974).

En el presente artículo se ha procurado extraer de los informes conocidos los componentes de los programas de incentivos más eficaces. Este ha sido necesariamente, en gran medida, un proceso de inferencia, dado que, hasta ahora, no se ha producido una experiencia suficientemente controlada en la que se haya modificado un elemento de los incentivos y hayan permanecido constante el resto de los factores. Por razones obvias, no es previsible que estos experimentos se realicen en el futuro, pues la industria no es proclive a efectuarlos. No obstante, los elementos integrantes de la lista de control que figura a continuación parecen ser bastante significativos (Wilde 1988; M cAfee y Winn 1989; Peters 1991).

\section{Energía de la dirección}

La dirección debe actuar de forma enérgica, coherente y comprometida en la implantación y ejecución a largo plazo de los programas de incentivos. $\mathrm{N}$ o basta con informar a los trabajadores -0 , en su caso, a los conductores- de la existencia del programa; es preciso recordarles su vigencia utilizando técnicas especialmente diseñadas para captar su atención. Si se quiere motivar e informar a los destinatarios, los responsables de los programas de incentivos deben transmitirles mensajes frecuentes e inequívocos de los resultados (K omacki, Barwick y Scott 1978).

\section{Premiar los resultados}

Los programas de incentivos deben premiar los resultados (esto es, la ausencia de accidentes) y no las variables del proceso, como el uso de gafas o cinturones de seguridad, la abstinencia o la observancia de las normas de seguridad en el taller. Esto es así porque la recompensa de determinados comportamientos no redunda necesariamente en un reforzamiento de la motivación para actuar de forma segura. Es posible que los beneficios potenciales de la mayor frecuencia de una forma determinada de comportamiento "seguro" se vea, sencillamente, contrarrestada por la menor frecuencia de otros comportamientos "seguros" por parte, por ejemplo, de los usuarios de la carretera. "Aquí se corre el riesgo de que el comportamiento recompensado mejore a expensas del deterioro de otros comportamientos de seguridad asociados" (M cAfee y Winn 1989).

\section{Atractivo de la recompensa}

El éxito de un programa de incentivos suele ser una función de la medida en que magnifica la diferencia entre los beneficios percibidos de la ausencia de accidente y los perjuicios percibidos de causar un accidente. La recompensa por la erradicación de los accidentes de trabajo en la industria ha adoptado distintas formas que oscilan entre las gratificaciones en metálico y el elogio público. Las gratificaciones pueden igualmente consistir en participaciones de lotería, acciones de la empresa, vacaciones extraordinarias, vales, ascensos y otros beneficios. Al tiempo que el recurso flexible a las gratificaciones en efectivo previene la pérdida de interés, las recompensas en especie, particularmente si se personalizan, pueden constituir un recordatorio perenne del valor de la seguridad. Un valor añadido de las recompensas en especie es la posibilidad de adquirirlas a un precio inferior al que el recipiendario estaría dispuesto a pagar en una tienda. En Estados U nidos, la producción y venta de objetos destinados a recompensar los comportamientos seguros ha dado lugar al surgimiento de una pujante industria. Los vales ocupan una posición intermedia como medio de recompensa entre el efectivo y los objetos de regalo, pues se prestan a una utilización flexible y, al mismo tiempo, se pueden personalizar e imprimirse con una inscripción conmemorativa. Se suele recompensar a los conductores, bien en metálico, bien mediante la reducción de la prima del seguro o la renovación gratuita del permiso de conducir.

La recompensa no precisa ser cuantiosa para ser eficaz. De hecho, existen razones que hacen aconsejable la concesión de pequeñas recompensas, como los distintivos de reconocimiento a la seguridad al volante de uno o cinco años, que resultan más aconsejables en algunos casos. En efecto, los pequeños premios permiten incrementar la frecuencia de las recompensas, suelen propiciar en menor medida la ocultación de los accidentes y pueden contribuir a la internalización de actitudes más favorables a la seguridad a través del proceso de reducción de la disonancia cognitiva (G eller 1990). Ciertamente, si una recompensa modifica el comportamiento de una persona, ésta puede justificar el cambio argumentando que ha actuado en interés de la seguridad y no movida por un incentivo insignificante. Esta internalización de las actitudes favorables a la seguridad no es precisa si el incentivo externo es considerable, ya que, en este caso, el incentivo justifica por sí solo la modificación del comportamiento.

D ebe subrayarse, sin embargo, que los efectos educadores de las pequeñas recompensas sólo se producen una vez que los 
operarios han modificado su comportamiento por efectos de algún estímulo externo menor. Por lo tanto, la recompensa debe ser lo suficientemente apetecible para inducir un cambio de comportamiento inicial, esto es, que debe poseer algún "valor percibido" por los recipiendarios. En algunos casos, una pequeña recompensa material puede entrañar un importante reconocimiento social en virtud de su "función simbólica". Esto puede convertir el comportamiento seguro en "lo que hay que hacer". Esto explica parcialmente el hecho de que la simple renovación gratuita por un año del permiso de conducir indujese una reducción sustancial del índice de siniestralidad entre los conductores californianos. A demás, del mismo modo en que los antiguos estudios permitieron establecer que los índices de siniestralidad presentes en la realización de tareas peligrosas como las del trabajo a destajo eran exponencialmente proporcionales (llegando a ser del cubo) de los salarios más altos, se puede afirmar que un modesto incremento salarial en recompensa por la ausencia de accidentes puede inducir una reducción mayor del índice de siniestralidad (Starr 1969).

\section{Créditos de seguridad graduales}

El montante del incentivo debe seguir aumentando gradualmente a medida que el operario acumula ininterrumpidamente tiempo de trabajo sin accidentes; así, por ejemplo, la gratificación correspondiente a diez años consecutivos de trabajo sin accidentes debe ser mayor que el décuplo de la recompensa concedida por un solo año libre de siniestros.

\section{Normas del programa}

Las normas de ejecución del programa deben ser sencillas, con el fin de que sean fácilmente comprensibles por todos los destinatarios del mismo. Es imprescindible que el programa de incentivos se desarrolle en un marco de cooperación y consulta con sus destinatarios. En efecto, la gente se siente más predispuesta a trabajar por los objetivos a cuya fijación han contribuido personalmente (Latham y Baldes 1975).

\section{Equidad percibida}

Es preciso que los destinatarios del programa de incentivos lo consideren equitativo. La recompensa debe revestir unas características que la hagan valorable como un justo premio por evitar accidentes durante un determinado período de tiempo. Análogamente, el sistema de incentivos se debe diseñar de modo que no induzca a los trabajadores que no puedan optar por el premio máximo a volverse contra el esquema, y sí los mueva a reconocer la justeza de los premios concedidos a sus compañeros. D ado que la producción de un accidente es un fenómeno en parte aleatorio, la concesión de la recompensa se puede supeditar a la condición complementaria de que el trabajador se preocupe por la limpieza y la seguridad en su puesto de trabajo. Si también se aplican desincentivos, es preciso que todos consideren justas las sanciones impuestas.

\section{Factibilidad percibida}

El diseño de un programa debe proyectar la idea de que la recompensa es susceptible de alcanzarse. Esto reviste particular importancia si la gratificación se adjudica por sorteo. Los sorteos hacen posible aumentar la cuantía de la gratificación, lo cual incrementa el interés por el programa de incentivos, a cambio de reducir, no obstante, el número de agraciados con los premios entre quienes han acumulado idénticos créditos de seguridad. Esto, a su vez, puede tener, entre otros efectos, el de desalentar a muchas personas del esfuerzo por conseguir los créditos de seguridad.

\section{B revedad del período de acumulación}

El período de tiempo durante el cual los operarios tienen que trabajar sin causar accidentes para optar por la gratificación debe ser relativamente breve. En efecto, los castigos y recompensas a largo plazo se suelen compensar y por ello contribuyen menos a configurar el comportamiento humano que las consecuencias más inmediatas. A veces se utilizan períodos de sólo un mes y, si se utilizan períodos de tiempo mayores, se deben emplear recordatorios, informes de situación y otras técnicas similares con una periodicidad mensual. En el proyecto piloto desarrollado en California que se ha mencionado anteriormente, los conductores cuyos permisos de conducir caducaban al año de la fecha en que se les informó del programa de incentivos experimentaron una reducción mayor del índice de siniestralidad que los conductores cuyos permisos tenían aún por delante uno o dos años de validez.

\section{Recompensar la actuación individual y colectiva}

En el diseño de los programas de incentivos se debe prever la posibilidad de que los compañeros presionen en favor de la prevención de accidentes. Por consiguiente, el programa no sólo debe promover el interés de cada operario por su seguridad personal, sino también inducirlo a influir en sus compañeros a trabajar por la disminución de los accidentes. En los entornos industriales, este objetivo se consigue estableciendo una recompensa por el historial de seguridad del equipo de trabajo, adicional a las recompensas individuales. Ciertamente, las primas colectivas fomentan el espíritu de competición por la obtención de la recompensa colectiva. Asimismo, se ha demostrado la eficacia intrínseca - esto es, en ausencia de premios individuales- de este tipo de recompensas. La eficacia de los esquemas mixtos de gratificación, (a las personas y al grupo) se vigoriza cuando se informa a las respectivas familias del sistema de recompensas a la seguridad, sus objetivos y las posibles recompensas.

\section{Prevención de la ocultación de accidentes}

Se ha analizado en profundidad la cuestión de cómo contrarrestar la tendencia de los trabajadores a no comunicar los accidentes que sufren. La posibilidad de que los programas de incentivos estimulen esta tendencia parece ser la única secuela negativa identificada hasta el momento de estos programas (sin perjuicio de las objeciones éticas que ocasionalmente se han formulado contra la política de recompensar a las personas por obtener un resultado que, en principio, deberían perseguir por sus propios méritos, sin necesidad de recibir "sobornos por un comportamiento seguro"). En algunos programas de incentivos se prevé la posibilidad de descontar créditos de seguridad por la ocultación de accidentes (Fox y cols. 1987). Aunque, por fortuna, sólo se dejan de comunicar ocasionalmente los accidentes menos graves, esta práctica puede hacerse más frecuente a medida que se incrementa la cuantía de las primas a los comportamientos seguros.

\section{Recompensas en todos los niveles organizativos}

L ejos de limitarse a los trabajadores del taller, las recompensas por los comportamientos seguros deben concederse igualmente a sus supervisores y a los mandos intermedios. E sta política contribuye a crear un clima coherente y generalizado de interés por la seguridad dentro de la empresa (y, por lo tanto, a forjar una "cultura de la seguridad").

\section{¿Formar además de recompensar?}

Si bien la educación para la seguridad es diferente de la motivación hacia la seguridad y la capacidad de una persona para trabajar con seguridad se debe distinguir claramente de su disposición hacia la seguridad, algunos autores que han abordado la 
cuestión de los incentivos en los entornos industriales piensan que sería conveniente para la seguridad educar a los trabajadores en la prevención de determinados comportamientos peligrosos (p. ej., Peters 1991).

\section{¿Fomentar el ahor ro neto o mejorar la relación coste-beneficio?}

En el diseño de un programa de seguridad se debe prestar especial atención a la cuestión de cuál es realmente su objetivo principal: reducir en la máxima medida posible el índice de siniestralidad o mejorar en la mayor medida posible la relación coste-beneficio. En efecto, algunos programas que únicamente producen una ligera reducción del índice de siniestralidad permiten lograr este objetivo a muy bajo coste, por lo que la relación coste-beneficio puede ser superior a la de otros programas que, a pesar de adolecer de una relación coste-beneficios más modesta, permiten reducir el índice de siniestralidad en una medida mucho mayor. Al margen de la cuestión del valor de la relación coste-beneficio, el ahorro monetario global puede perfectamente ser mucho mayor en este último caso. V éase el ejemplo siguiente: el programa de seguridad A puede generar un ahorro de 700.000 dólares a un coste de ejecución de 200.000, al tiempo que el programa B puede hacer posible un ahorro de 900.000 dólares a un coste de 300.000 . La relación coste-beneficio del programa $A$ es de 3,5 , al tiempo que la del programa $B$ es de 3 . Por consiguiente, desde la perspectiva de la relación coste-beneficio, el programa A es superior; en cambio, si se toma en consideración el beneficio neto, la situación es distinta. En efecto, mientras que el programa A permite ahorrar 700.000 . $200.000=500.000$ dólares, el programa $B$ genera un ahorro de $900.000-300.000=600.000$ dólares. Por lo tanto, este último programa es preferible desde el punto de vista del ahorro neto.

\section{Comentario final}

Al igual que con cualquier otra medida de prevención de accidentes, no se debe implantar un sistema de incentivos sin haber evaluado su viabilidad a corto y medio plazo y la mejor forma de aplicarlo, y sin una adecuada evaluación científica de los costes de aplicación y de su eficacia probada en la reducción de los índices de siniestralidad. Si no se realizan estos análisis, el efecto sorpresa de un determinado programa de recompensas no se materializa. Aunque no parece factible que un incentivo al comportamiento seguro surta efectos verdaderamente negativos, una determinada versión de una serie de programas de incentivos y recompensas aplicados en California a todos los conductores se tradujo en un empeoramiento efectivo del índice de siniestralidad. En este caso concreto, se concedía a los conductores que no habían provocado accidentes un beneficio que no les había sido comunicado previamente. El beneficio se concretaba en una recompensa inesperada y no en un incentivo, y el resultado pone de relieve la importancia de distinguir ambos conceptos en la promoción de la seguridad. En efecto, el término incentivo se refiere a una gratificación o prima prometida a los trabajadores o los conductores a condición de no provocar accidentes dentro de un determinado período de tiempo.

\section{- Promocion DE LA SEgURIDAD}

Thomas W. Planek

El objetivo de la promoción de la seguridad consiste en inducir a los trabajadores a proteger su seguridad personal y la de sus compañeros, así como perseguir el logro de los objetivos de seguridad fijados por la empresa. Entre los fines de la promoción de la seguridad se incluyen el incremento de la conciencia de la seguridad en todos los niveles de la organización y la confirmación de que la seguridad de los trabajadores es una preocupación prioritaria de la dirección.

En última instancia, la eficacia de un programa u otra actividad de promoción es una función directa de la calidad de la gestión del programa de seguridad de la empresa. La promoción de la seguridad puede contribuir sustancialmente a la mejora de la seguridad en el lugar de trabajo, siempre que en todos los estadios operativos se apliquen unos sistemas rigurosos de gestión de riesgos que comprendan el diseño de las instalaciones y la maquinaria, la formación y supervisión de los trabajadores, el uso de equipo de protección individual, la conservación del medio ambiente, el mantenimiento y limpieza, las medidas de urgencia y la rehabilitación.

Por mucha que sea la eficacia y utilidad intrínsecas de un método de promoción de la seguridad para modificar los comportamientos y actitudes de los trabajadores, su éxito precisa el apoyo de la dirección, concretado en un liderazgo y una adhesión ostensibles. Este apoyo es una condición indispensable del éxito de un programa de promoción, con independencia de que se trate de la producción, la calidad de los productos o la salud y seguridad de los trabajadores. Se trata igualmente de un elemento común a todo buen programa de seguridad, al margen de las características específicas del mismo.

\section{Motivación de los trabajadores}

La promoción de la seguridad se asocia directamente al concepto de motivación, que ha sido objeto de profusos estudios. N o existe acuerdo en cuanto a cómo y por qué se motiva a las personas a adoptar nuevos comportamientos o a modificar viejas pautas. De importancia capital en este sentido es la relación entre actitudes y comportamiento ¿Debe preceder el cambio de actitudes a la modificación del comportamiento? ¿Se puede modificar el comportamiento sin un cambio de actitudes? ¿Constituye el cambio de actitudes un anticipo del cambio de comportamiento? ¿Se traduce la modificación del comportamiento en un cambio de actitudes?

No hay respuestas claras para estas preguntas. En efecto, mientras que algunos sostienen que la simple modificación del comportamiento externo es lo que más motiva, otros piensan que las actitudes subjetivas y el desarrollo cognitivo se deben integrar en el proceso de modificación del comportamiento. A mbos criterios han influido en la evolución de la promoción de la seguridad.

Aunque no puede percibirse directamente, la motivación se puede inferir del cambio de comportamientos y actitudes. Tres variables definen la motivación:

- La dirección del comportamiento precisa la especificación de unos objetivos y la oferta de la formación y educación necesarias para alcanzarlos.

- La intensidad de la actuación implica la consecución y vigorización del cambio de comportamientos y actitudes, principalmente a través del refuerzo y la realimentación.

- La persistencia en el esfuerzo supone incorporar permanentemente los cambios de comportamiento y actitudes a todas las facetas de la actuación del trabajador.

\section{Modelos de promoción de la seguridad}

En la literatura dedicada a la seguridad se describe una serie de métodos y teorías de la promoción de la seguridad que abordan todas las variables de la motivación. D os modelos se han revelado particularmente eficaces para mejorar los resultados del esfuerzo en la seguridad. U no es el modelo de gestión del comportamiento organizativo (organization behaviour management - OBM), centrado en la modificación del comportamiento y la aplicación 
de los modelos de control del comportamiento desarrollado por B.F. Skinner. El otro modelo, de gestión de calidad (total quality management TQ M ), se basa en la modificación de los procesos y la aplicación de los métodos de control de la calidad desarrollados por W.E. D emming.

La modificación del comportamiento parte de la premisa de que las causas del comportamiento son de índole ambiental. Esto permite prever y controlar el comportamiento estudiando la interacción de las personas con el medio ambiente. Existen tres presupuestos de este estudio:

1. los antecedentes del comportamiento, esto es, la ocasión en que se produce una respuesta;

2. el comportamiento 0 actuación que se produce,

3. las consecuencias que refuerzan el comportamiento o actuación.

La mejora de la calidad implica una "constancia en el esfuerzo", esto es, la determinación de los trabajadores y la dirección de convertir la mejora de la calidad de productos y servicios en una prioridad de la empresa. Esta cambio de actitud se basa en la decisión consciente de la dirección de hacer lo necesario para convertir en realidad el ideal de la mejora de la calidad. La mejora de la calidad persigue unos objetivos más amplios y aplica unos métodos menos uniformes que la modificación del comportamiento. En efecto, los métodos y objetivos de aquélla se centran, más en la modificación 0 , incluso, la eliminación de procesos completos, que en la modificación de comportamientos individuales.

Como se observa en la Tabla 60.1, ambos modelos responden a las variables y actuaciones coadyuvantes que exige la motivación. El modelo difiere, en cambio, por lo que respecta al énfasis en la seguridad que se precisa para motivar a los trabajadores. Esto hace que los modelos difieran en cuanto a su respectiva eficacia para satisfacer las expectativas de las tres variables anteriormente mencionadas.

\section{Modelo OBM}

\section{Dirección del comportamiento}

L os objetivos de seguridad del modelo O BM suelen ser reducidos y se centran en lograr la reiteración de determinados comportamientos seguros y la consiguiente disminución de la frecuencia de los actos inseguros. Se pueden utilizar los siguientes métodos de

Tabla 60.1 • Comparación de los modelos O BM y TQ M de motivación de los trabajadores.

\begin{tabular}{|c|c|c|c|}
\hline \multirow{2}{*}{$\begin{array}{l}\text { Variable de } \\
\text { motivación }\end{array}$} & \multirow{2}{*}{$\begin{array}{l}\text { Actuación de } \\
\text { apoyo }\end{array}$} & \multicolumn{2}{|c|}{ Orientación de la política de seguridad } \\
\hline & & OBM & TQM \\
\hline $\begin{array}{l}\text { Dirección del } \\
\text { comporta- } \\
\text { miento }\end{array}$ & $\begin{array}{l}\text { Especificar } \\
\text { objetivos } \\
\text { Impartir formación }\end{array}$ & $\begin{array}{l}\text { Comportamiento } \\
\text { Formación del } \\
\text { comportamiento }\end{array}$ & $\begin{array}{l}\text { Actitudes/ } \\
\text { comportamiento } \\
\text { Educación en los } \\
\text { procesos }\end{array}$ \\
\hline $\begin{array}{l}\text { Intensidad de la } \\
\text { actuación }\end{array}$ & $\begin{array}{l}\text { Ofrecer refuerzo } \\
\text { Mantener la } \\
\text { retroinformación }\end{array}$ & $\begin{array}{l}\text { Producción del } \\
\text { comportamiento } \\
\text { Datos del } \\
\text { comportamiento }\end{array}$ & $\begin{array}{l}\text { Mejora de los } \\
\text { procesos } \\
\text { Indicadores } \\
\text { operativos }\end{array}$ \\
\hline $\begin{array}{l}\text { Persistencia del } \\
\text { esfuerzo }\end{array}$ & $\begin{array}{l}\text { Comprometer al } \\
\text { trabajador } \\
\text { Comprometer a } \\
\text { la dirección }\end{array}$ & $\begin{array}{l}\text { Cambio de } \\
\text { comportamiento } \\
\text { Cambio de estilo }\end{array}$ & Cambio cultural \\
\hline
\end{tabular}

selección de actos y comportamientos inseguros como objeto de estudio y posterior reducción:

- estudio de las investigaciones de accidentes y de la documentación de seguridad correspondiente;

- entrevistas con los trabajadores de todos los niveles con objeto de recoger datos sobre siniestros no comunicados, peligros, etcétera,

- observación de las inspecciones internas de seguridad.

Sobre la base de la información obtenida en estas fuentes, se pide a los trabajadores que colaboren en la elaboración de una lista de comportamientos considerados esenciales para la mejora del trabajo de seguridad. Se establece un dispositivo de supervisión encargado de vigilar la observancia de estos comportamientos esenciales, se forma un equipo de observadores y se elabora un calendario de observación. A continuación, se observa la frecuencia de los comportamientos considerados prioritarios durante un período previo a la intervención. En esta fase del proceso de definición del problema se generan los datos básicos que permiten cuantificar el éxito del proceso de modificación del comportamiento. Estos datos sirven igualmente para alertar a los trabajadores sobre posibles comportamientos inseguros en el lugar de trabajo.

A continuación se somete a los trabajadores a un proceso de formación en el que se incluyen los comportamientos favorecidos, se ofrecen pautas para un comportamiento seguro y se facilita la retroinformación sobre los problemas de comportamiento. Así, se proyectan vídeos y diapositivas que ilustran diversos comportamientos seguros e inseguros y, a continuación, se debate el contenido de la proyección. En este estadio se comunican a los trabajadores los datos básicos y se les alienta a mejorar el comportamiento seguro en las áreas críticas. Los datos, que se suelen presentar en forma de gráficos, se exponen en la fábrica como preparación para los estadios siguientes del programa OBM. Los supervisores o un grupo de trabajadores especialmente cualificados realizan un esfuerzo continuo de observación e identificación. En caso necesario, se incorporan al proceso de formación nuevos elementos de comportamiento seguro en el lugar de trabajo que se integran en el programa.

\section{Intensidad de la actuación}

En el modelo O BM se utilizan tanto el refuerzo personal como la retroinformación de grupo para modificar el comportamiento. El refuerzo se aplica en el ámbito individual y consiste en el elogio verbal u otra forma de reconocimiento del comportamiento seguro en el lugar de trabajo. A lo largo de la ejecución del programa se brinda igualmente retroinformación del grado de comportamiento seguro del grupo.

El comportamiento seguro se refuerza ofreciendo recompensas como las siguientes:

- incentivos monetarios individuales (como gratificaciones en metálico y vales para la compra de bienes de consumo);

- reconocimiento y retroinformación (como divulgación de los resultados, comentarios favorables y notas de felicitación),

- competiciones entre los equipos, que pueden incluir la concesión de premios en metálico.

Como las recompensas se suelen combinar, resulta difícil aislar los efectos de un determinado tipo de refuerzo. Sin embargo, es indudable que una reacción positiva ante un comportamiento seguro contribuye a incrementar su frecuencia.

En el refuerzo se incluye la retroinformación del grupo sobre los resultados en materia de seguridad, que suele adoptar la forma de diagramas de barras que reflejan el porcentaje de comportamientos seguros observados durante el tiempo de intervención. Estos datos se exponen en lugares destacados, con la 
finalidad de que el equipo de trabajo conozca los progresos realizados. Esta información contribuye a mantener el nivel de resultados del trabajo del grupo y estimula los futuros esfuerzos por mejorar el rendimiento.

En el modelo OBM, el refuerzo y la retroinformación se basan en la ejecución de un programa permanente de observación del comportamiento. Este sistema facilita una comunicación puntual efectiva cuando se observan comportamientos seguros 0 si hay que corregir alguna actuación insegura. Si bien la modificación del comportamiento se basa más en las medidas positivas de refuerzo que en la disciplina, los defensores del modelo reconocen que las amonestaciones y otras medidas correctivas pueden resultar necesarias en ciertos casos. Sin embargo, siempre que sea posible, se deben evitar estas medidas, ya que sus efectos suelen ser efímeros y pueden quebrantar la identificación de los trabajadores con el conjunto del programa.

\section{Persistencia en el esfuerzo}

La eficacia del modelo OBM en la sustentación de la modificación del comportamiento se basa en un proceso continuo de observación y refuerzo de determinados comportamientos seguros, hasta tanto no se conviertan en prácticas autosustentadas y en parte de la rutina de un puesto de trabajo. EI valor del O BM reside en la creación de un sistema de medidas que permite el control y supervisión permanentes de los comportamientos críticos en la empresa. El éxito de este sistema a largo plazo es una función de su integración en la cultura de gestión de la organización.

Es evidente que el modelo O BM produce resultados positivos en un plazo relativamente breve. La mayoría de los estudios realizados indican que las medidas positivas de refuerzo basadas en los incentivos o la retroinformación, contribuye a incrementar la seguridad y reducir el índice de siniestralidad en el lugar de trabajo, al menos a corto plazo. En cambio, la investigación no ha establecido plenamente la continuidad de la modificación del comportamiento generada por el modelo OBM. En efecto, la mayoría de los estudios realizados han sido de corta duración (menos de un año). Esta situación ha suscitado dudas respecto a la perennidad de los efectos del OBM, si bien dos estudios de la aplicación de las técnicas del O BM, realizados en Estados U nidos y Finlandia, respectivamente, han revelado algunos efectos positivos de larga duración.

En Estados Unidos, el uso de un sistema de vales de recompensa indujo una mejora de la seguridad en dos minas de carbón durante más de diez años. En este experimento, se concedían vales a los trabajadores que no habían perdido tiempo de trabajo por causa de lesiones, que pertenecían a equipos de trabajo cuyos miembros no habían perdido horas de trabajo por causa de lesiones, que no se habían visto implicados en accidentes con resultado de daños al equipo, que hayan propuesto con éxito la adopción de medidas de seguridad o que hayan tenido un comportamiento inusualmente eficaz en la prevención de accidentes y lesiones. Esta función de formación se ha valorado como muy importante para la mejora de los resultados.

En Finlandia se lograron mejoras significativas en el mantenimiento de unos astilleros gracias a la ejecución de un programa de tres fases basado en el suministro de retroinformación a supervisores y trabajadores, al cabo de una fase de cuantificación de los datos básico y de formación de los trabajadores. Estas mejoras, concretadas en un nivel superior de mantenimiento, se mantuvieron durante un período de seguimiento de dos años, durante el cual no se ofreció retroinformación. Se observó igualmente una sustancial reducción del índice de siniestralidad durante todo el tiempo que se prolongó el programa. Los efectos del programa a largo plazo se han atribuido a una actividad de refuerzo más centrada en los resultados del comportamiento y persistente en el medio ambiente (como ocurre con el mantenimiento) que en un mero comportamiento, que sólo influye en los trabajadores durante unos segundos.

A pesar de estos estudios, resulta difícil estimar la capacidad a largo plazo del modelo OBM para mantener las mejoras logradas en el nivel de seguridad. En el estudio norteamericano, si bien el empleo del sistema de vales se incorporó a la cultura de gestión de las minas, se puso igualmente un gran interés en la formación. Según el informe del estudio finlandés, una sólida retroinformación de los cambios ambientales producidos por la modificación del comportamiento puede dar muy buenos resultados. No obstante, también en este caso existen indicios de que otros factores pueden haber influido en el comportamiento de los trabajadores del astillero durante el período de seguimiento "sin retroinformación".

Teniendo en cuenta los datos anteriores, la mayoría de los estudios indican que es preciso mantener el flujo de retroinformación si se quiere que los programas basados en el OBM logren resultados permanentes y que este proceso debe ir acompañado de un estilo de dirección que lo permita. Si estas condiciones no existen, los efectos positivos en la modificación del comportamiento disminuyen rápidamente y se regresa a los niveles anteriores. Existen algunos indicios de que, si se produce una mejora del mantenimiento, el incremento de los niveles de seguridad se prolonga durante un período de tiempo relativamente largo; empero, las causas de este resultado permanecen ignotas.

\section{Modelo TQM}

\section{Dirección del comportamiento}

Los objetivos del modelo TQM son de amplio espectro y se centran en la mejora de los procesos. Se presta especial atención al descubrimiento y eliminación de los factores que contribuyen a producir o mantener los comportamientos de riesgo, en lugar de centrarse en los comportamientos inseguros como origen de las lesiones.

En el modelo TQ M se aplican muchos de los métodos propios del O BM para descubrir las deficiencias de los sistemas de seguridad que es preciso superar. El modelo se centra igualmente en los sistemas y prácticas de gestión que contribuyen a causar problemas. Estos factores pueden estar presentes en todas las funciones, desde la planificación y organización, hasta la toma de decisiones y el análisis de la eficacia en función del coste. En aquéllos se incluye igualmente la presencia o ausencia de sistemas que incorporan elementos de seguridad personal del trabajador en los procesos operativos habituales, como la aplicación de principios ergonómicos en el diseño del lugar de trabajo y el equipo, la revisión de las especificaciones de los suministros por parte de profesionales de la salud y seguridad y la eliminación puntual de los peligros denunciados. Indicadores funcionales como el últimamente citado, junto con las estadísticas de lesiones, tiempo perdido y absentismo de los trabajadores, aportan información básica sobre la eficacia del apoyo que los sistemas de gestión prestan a la función de seguridad.

Las encuestas sobre la percepción de los programas de seguridad por los trabajadores se han convertido en un medio habitual de evaluación del sistema de gestión de la seguridad. En estas encuestas se pregunta a los trabajadores su opinión sobre la eficacia de los sistemas de gestión y las medidas de mantenimiento de la seguridad aplicados en la empresa. Los datos se compilan respetando el anonimato, de conformidad con unos procedimientos administrativos normalizados. Los resultados de 
las encuestas permiten priorizar determinadas mejoras y constituyen otro punto de referencia para evaluar los progresos.

Lo mismo que los objetivos de actuación del modelo TQ M se definen en términos más amplios que el $O B M$, también ofrece a los trabajadores un espectro más amplio de formación. En efecto, la formación basada en el modelo TQ M no sólo enseña a los trabajadores la forma de actuar con seguridad, sino que también les enseña métodos de autosuperación y de trabajo en equipo que posibilitan una contribución continua a la mejora de la seguridad en el conjunto de la organización.

Es preciso valorar en toda su importancia la planificación de las tareas en el ámbito de los sistemas y a ofrecer una formación de seguridad suficiente a los trabajadores cuyos puestos de trabajo se desarrollan y enriquecen gracias a la modificación de los procesos. Existen algunos indicios de que, a medida que se incrementan el número y variedad de tareas no repetitivas, la frecuencia de los accidentes crece paralelamente. No parece que esta posibilidad no deseada haya sido reconocida en la literatura dedicada al modelo TQM .

\section{Intensidad de la actuación}

En el modelo TQM se utilizan varios métodos de refuerzo de la mejora de los procesos. El objetivo es fomentar una cultura organizativa que sustente el esfuerzo sostenido de los trabajadores por mejorar los procesos. EI mecanismo de modificación de los procesos comprende igualmente la utilización de técnicas de refuerzo y retroinformación en la identificación y recompensa de la mejora de los resultados

Varias condiciones contribuyen de modo importante a la mejora de los procesos:

- un clima de apertura dentro de la organización, que fomente el intercambio de información y la eliminación de las barreras formales entre los departamentos;

- promoción de la participación de los trabajadores, el trabajo en equipo y la formación en todos los niveles;

- eliminación de las barreras informales a la satisfacción por el trabajo bien hecho;

- una cultura empresarial que promueva la participación de los trabajadores en los procesos de mejora,

- una estrategia de explotación o desarrollo de las nuevas aportaciones a la mejora de los procesos.

La adopción de estas medidas produce una elevación de la moral y la satisfacción de los trabajadores al punto de inducirlos a mejorar los niveles de seguridad.

Debe subrayarse que en el modelo TQM se utiliza la técnica de refuerzo en el nivel de los trabajadores de producción. Sin embargo, en lugar de reaccionar ante unos determinados comportamientos críticos, se reconoce la seguridad en el trabajo de las personas en todas las fases del proceso, con objeto de inducir a los trabajadores a internalizar un proceso que supone mejorar los resultados en materia de seguridad.

Periódicamente se ofrece retroinformación sobre las mejoras observadas en la salud y seguridad en boletines, reuniones y encuestas de seguimiento. En estos resultados, que se traducen en indicadores de funcionamiento, se incluyen índices como días de trabajo perdidos por causa de enfermedades y lesiones profesionales, número de propuestas de mejora de la salud y seguridad, niveles de asistencia al trabajo, costes de indemnización por accidentes de trabajo y actitudes de los trabajadores respecto a la seguridad.

\section{Persistencia del comportamiento}

L a eficacia del modelo TQ M a largo plazo reside en su capacidad para crear o mejorar sostenidamente unos procesos que contribuyan a mejorar la seguridad en el trabajo. Para perdurar, estas mejoras precisan un cambio de actitudes y comportamientos y, quizás también, un refrendo en el núcleo más profundo de la práctica y la filosofía de la dirección; esto es, precisan integrarse en la cultura de la organización. Esto hace que los resultados positivos no se manifiesten de forma inmediata. Por ejemplo, según los usuarios más satisfechos con el modelo TQ M , se precisa una media de tres años para mejorar los niveles de calidad.

La evidencia de la relación entre el uso del TQ M y la mejora de los niveles de seguridad procede, tanto del historial de seguridad de las empresas que han utilizado con éxito el T Q M para mejorar la calidad de sus productos y servicios, como de las técnicas de refuerzo de la seguridad aplicada en las empresas con un excelente historial de seguridad. En efecto, doce de las catorce empresas norteamericanas que han sido galardonadas con el Premio Nacional a la Calidad Malcolm Baldridge en reconocimiento a los excelentes métodos utilizados y resultados obtenidos en la gestión de calidad disfrutaban de unos índices de siniestralidad y de enfermedades profesionales inferiores a la media de sus respectivos sectores. O nce de esas empresas manifestaron igualmente que sus índices respectivos habían mejorado de resultas de la implantación del modelo TQM, en contra de sólo tres empresas que acusaban unos índices más bajos.

Las empresas pertenecientes al National Safety Council de Estados Unidos que tienen un historial más brillante en la promoción de la seguridad avalan la eficacia de las aplicaciones del TQ M aplicado a la seguridad en el trabajo. El éxito de estos programas responde a una filosofía "humanista" de la dirección del personal, basada en menos disciplina, una participación más activa de los trabajadores y mejores relaciones entre trabajadores y empresa.

La posibilidad de consolidar los cambios se incrementa debido al énfasis que se pone en el modelo TQ M en la participación y el apoderamiento de los trabajadores en la aplicación de mejoras en la salud y seguridad en los sistemas y procesos. Además, el énfasis en la educación de los trabajadores para fomentar su capacidad de contribuir a futuras mejoras de los niveles de seguridad sienta igualmente las bases de la efectividad a largo plazo. Por último, en el modelo TQM se considera a los trabajadores sujetos activos en la toma de unas decisiones que los hacen responder del medio ambiente y no al medio ambiente

\section{Comparación entre OBM y TQM}

El objeto del modelo OBM es reducir la frecuencia de unos determinados comportamientos inseguros aplicando un criterio estructurado que comprende la definición de los comportamientos críticos, la formación de los trabajadores sobre los comportamientos seguros e inseguros, la implantación de un sistema de observación del comportamiento y la aplicación de un baremo de refuerzo y retroinformación para supervisar el comportamiento de los trabajadores. L as ventajas del modelo son su énfasis en la observación del comportamiento y la cuantificación de los resultados y la rápida producción de consecuencias positivas cuando se ejecuta el programa; y sus desventajas residen en centrarse en comportamientos específicos que pueden no estar asociados a la necesidad de modificar los sistemas de gestión, el uso de un programa externo de control del comportamiento de los trabajadores y la falta de unas posibilidades contrastadas de perdurabilidad.

El objetivo del TQM consiste en mejorar los procesos del sistema de gestión que influyen en la salud y seguridad de los trabajadores. En el modelo se hace hincapié en la modificación de actitudes y comportamientos y se basa en un amplio espectro de programas de formación y participación de los trabajadores en la definición, tanto de los objetivos del esfuerzo por mejorar la salud y seguridad, como de los medios para conseguirlo. Se 
emplean técnicas de refuerzo y retroinformación diseñadas para reconocer las mejoras del proceso y la contribución de los empleados a esas mejoras. Las ventajas del modelo son su énfasis en la participación de los trabajadores y el control interno (que facilitan y refuerzan los cambios de comportamientos y actitudes), su capacidad de sustentación de las mejoras de la salud y seguridad y su integración en la función global de gestión de la empresa. Sus desventajas estriban en su dependencia de: a) un elevado nivel de participación de los trabajadores y la dirección que tarda en cristalizar y ofrecer resultados positivos, b) los nuevos sistemas de medición de los procesos, y c) la disposición de la dirección a dedicar el tiempo y los recursos necesarios para obtener resultados positivos.

\section{Programas y prácticas de promoción de la seguridad}

En las siguientes secciones se analizará la relación entre seguridad y sistemas salariales; estos últimos influyen sustancialmente en la motivación de los trabajadores en general y pueden afectar a la seguridad de los comportamientos y actitudes de los trabajadores en el contexto de la realización de su trabajo. Se examinarán los incentivos - incluidas las remuneraciones monetarias y de otro tipo- en función del valor atribuido como medio de promoción de la seguridad. Finalmente, se examinará la función de las comunicaciones y campañas de promoción de la seguridad.

\section{Sistemas salariales y seguridad}

Los sistemas salariales pueden afectar indirectamente a la seguridad si se aplican esquemas de pago de incentivos, distribución de primas o participación en los beneficios para incrementar la producción; o si se utiliza el sistema de trabajo a destajo. Estos sistemas pueden inducir a los trabajadores a marginar las medidas de seguridad en el trabajo para incrementar sus ingresos. A simismo, los sistemas salariales se pueden vincular directamente a esquemas de promoción de la seguridad consistentes en el pago de complementos por realizar trabajos de una peligrosidad superior a la media.

\section{Pago de incentivos}

Los programas de pago de incentivos y de participación en los beneficios pueden servir para recompensar la productividad, el historial de seguridad, unos índices favorables de mermas, repetición de trabajos y rendimiento, y varios otros indicadores del rendimiento, aisladamente 0 en combinación. Estos programas sirven de cauce para transmitir a los trabajadores la estrategia y las prioridades de la dirección. Esto confiere una trascendencia especial a los criterios de evaluación del rendimiento que la organización incorpora a su sistema de incentivos. Si los resultados en materia de seguridad y otros factores asociados forman parte del conjunto, los trabajadores suelen percibir su importancia para la dirección. De lo contrario, el mensaje proyectado es de signo contrario.

En algunos casos, el rendimiento en el trabajo se incluye entre los criterios para la concesión de incentivos salariales destinados a inducir a los trabajadores a transigir con unas condiciones peligrosas o a omitir la comunicación de accidentes. Algunos estudiosos han llamado la atención sobre una frecuencia creciente de este tipo de abusos, especialmente en los convenios colectivos de empresa y en los casos en que se pretende reducir el pago de las primas de seguro de accidentes de trabajo. Es evidente que este sistema no sólo proyecta una imagen negativa en los trabajadores, sino que, además, resulta contraproducente y contribuye, a largo plazo, a incrementar los costes de la empresa.

Aunque la teoría que informa el pago de incentivos es aparentemente sólida, sus efectos prácticos sobre la productividad de los trabajadores son más que dudosos. En efecto, los estudios realizados sobre los efectos de los sistemas de incentivos económicos en la productividad muestran una enorme variabilidad de los resultados, lo que indica que un diseño y ejecución simplistas de los programas de pago de incentivos puede provocar problemas. No obstante, si se aplican correctamente, estos programas pueden contribuir sustancialmente al incremento de la productividad, en especial de la producción.

Un estudio realizado en 72 minas norteamericana sobre los efectos de los esquemas de pago de primas en la productividad y la siniestralidad no arrojó evidencias concluyentes de que surtiesen efectos significativamente positivos en la seguridad o la producción. En el 39 \% de estos esquemas se incluía la seguridad entre los elementos de cálculo de las primas, y en el resto no. En la muestra del estudio se observaba una considerable variación en la periodicidad del pago de las primas. Aunque el período medio de devengo de las primas era mensual, en algunas minas se abonaban las primas de productividad una 0 dos veces al año y, en ocasiones, con menor frecuencia. En esos casos, los efectos sobre la producción eran desdeñables y, como era de esperarse, los resultados en materia de seguridad no se vieron afectados. Incluso en las minas que abonaban primas de producción durante más del $80 \%$ del tiempo no se observaron efectos significativamente adversos en la seguridad de los trabajadores (como incremento de la frecuencia de los accidentes causantes de pérdida de tiempo, etc.). Tampoco se redujo la tasa de siniestralidad en las minas que abonaban primas únicamente por los buenos resultados en materia de seguridad. En la mayoría de estos esquemas se utilizaban la frecuencia de los accidentes con pérdida de tiempo y la violación de las normas como criterio de evaluación del rendimiento y adolecían de idéntico nivel mediocre de resultados que muchos de los planes basados en la productividad.

La falta de una correlación nítida establecida en el estudio entre el pago de incentivos y la productividad o la seguridad pone de relieve la complejidad de gestionar con éxito un programa de incentivos salariales. Si bien el incremento de la remuneración es importante, el valor atribuido al dinero varía de unos trabajadores a otros. Además, muchos otros factores pueden influir en la capacidad de motivación de los incentivos monetarios. En efecto, los programas de incentivos o de participación en los beneficios no suelen producir los resultados previstos si los trabajadores creen que el programa es injusto. Se pueden adoptar diversas medidas para evitar estos resultados y reforzar la capacidad de motivación de un programa de incentivos:

- fijar unos baremos de rendimiento que los trabajadores consideren razonable;

- acortar los plazos de devengo de las primas;

- aplicar múltiples criterios de rendimiento,

- fijar unos objetivos de rendimiento que los trabajadores puedan controlar

EI trabajo a destajo es igualmente controvertido. A pesar de ser el sistema retributivo que asocia de forma más directa la remuneración al rendimiento, múltiples estudios han puesto de relieve los efectos negativos del trabajo a destajo. En efecto, el sistema suele generar unas relaciones laborales antagónicas en aspectos que afectan a la productividad, como la fijación de los índices de productividad y de unos límites informales a la producción, y la negociación de esquemas atípicos de trabajo a destajo. A veces, el rendimiento se reduce a pesar de abonarse unas tarifas más altas.

Lamentablemente, la aplicación misma de un sistema de trabajo a destajo, con independencia de que sirva o no para incrementar la productividad, genera unas condiciones adversas 
a la seguridad en el trabajo. Por ejemplo, en un estudio sobre la transición del trabajo a destajo al sistema de tarifas horarias en la industria forestal sueca se puso de relieve una disminución de la frecuencia y gravedad de los accidentes. A raíz del cambio del sistema retributivo, se realizó una encuesta entre varios centenares de trabajadores forestales de ese país sobre los efectos del nuevo sistema en su rendimiento laboral. En las respuestas se citaron predominantemente tres causas para la disminución de la siniestralidad:

- menor presión para aumentar el ritmo de trabajo, asumir riesgo e incumplir las normas específicas de seguridad;

- menos errores de cálculo de resultas de un menor estrés,

- más tiempo para estudiar los problemas de seguridad, experimentar nuevos métodos y beneficiarse de la comunicación con los compañeros.

La experiencia sueca vino a confirmar únicamente de forma parcial los resultados de un estudio realizado en la provincia canadiense de la Columbia Británica. En este documento no se informó de diferencia alguna entre el índice de siniestralidad de los taladores asalariados y los registrados entre los empleados a destajo, si bien se registró un número mayor de accidentes graves entre los taladores contratados a destajo que entre sus compañeros asalariados.

En el análisis global, persiste la división de opiniones respecto a los posibles usos y abusos de los sistemas de pago de incentivos, su contribución al incremento de la productividad y sus efectos sobre la seguridad. Sin embargo, existen pocos estudios cuyos resultados refrenden una u otra opinión, y los escasos indicios existentes son todo menos concluyentes. Resulta evidente, en todo caso, que los efectos de los planes de pago de incentivos sobre la seguridad son una función de su contenido, su modo de aplicación y el contexto en que se aplican.

\section{Salarios compensatorios}

Los economistas han estudiado la cuestión del pago de complementos por realizar trabajos de alto riesgo, en un esfuerzo por asignar un valor económico a la vida humana y de establecer si el mercado compensa por sí solo la exposición a riesgos elevados. En caso afirmativo, cabe aducir que los esfuerzos de los poderes públicos por reducir el riesgo en estas áreas no son eficaces en función del coste, puesto que ya se compensa a los trabajadores por su exposición a mayores riesgos. En Estados U nidos e Inglaterra se han realizado esfuerzos por validar la teoría de los salarios compensatorios a partir de las estimaciones conocidas de las tasas de mortalidad. Hasta ahora, la teoría de los salarios compensatorios parece haberse corroborado en alguna medida en Inglaterra, pero no así en Estados U nidos.

O tra deficiencia de la teoría de los salarios compensatorios reside en que muchos trabajadores son inconscientes del verdadero riesgo implícito en los trabajos que realizan, particularmente por lo que respecta a la exposición a enfermedades profesionales. En este sentido, algunas encuestas realizadas en Estados U nidos indican que un importante porcentaje de los trabajadores no es consciente de su exposición a unas condiciones de trabajo peligrosas. Además, desde una perspectiva psicológica, las personas tienden a subestimar el riesgo de muerte si las probabilidades de que se produzca son escasas. Esto hace que, incluso si los trabajadores son conscientes de los riesgos asociados a su puesto de trabajo, se muestren dispuestos a asumirlo.

Si bien la cuestión de los salarios compensatorios plantea algunas complejas cuestiones teóricas que aún no han podido resolverse, el verdadero peligro de los esquemas de salarios compensatorios reside en las causas subyacentes. En efecto, si las empresas recurren al pago de algún tipo de complemento salarial como excusa para mantener unas condiciones deficientes de salud y seguridad en el trabajo, el sistema es perjudicial y absolutamente inaceptable.

\section{Incentivos a la seguridad}

Se puede definir el incentivo como un medio de inducir la realización de una tarea con un celo especial con objeto de obtener una recompensa. Aunque el pago de incentivos para motivar a los trabajadores constituye una práctica común en todo el mundo, la eficacia de los planes de incentivos es una cuestión controvertida entre científicos y profesionales. Las posturas oscilan entre la de quienes niegan toda relación entre incentivos y motivación y la de quienes ven en aquéllos un factor determinante del proceso de cambio de comportamiento. Entre estas dos posiciones extremas se sitúan, tanto quienes creen que los planes de incentivos constituyen un medio eficaz de incrementar la productividad, como los que aseguran que los incentivos fomentan entre los trabajadores comportamientos indeseables con unos resultados absolutamente contrarios a los deseados.

Las opiniones sobre la utilidad de los planes de incentivos en el campo de la salud y seguridad en el trabajo no son menos dispares. Así, en algunas organizaciones, la dirección se muestra reticente a conceder incentivos complementarios vinculados a la seguridad, por estimar que ésta es parte integrante de la ejecución del trabajo y no precisa de una recompensa especial. Según otro punto de vista, la oferta de incentivos por mejorar la seguridad en el trabajo disminuye la apreciación de la importancia intrínseca de la satisfacción en el puesto de trabajo, que constituye, después de todo, el principal motivo de priorizar la seguridad.

Al margen de las razones de principio para cuestionar el valor de los planes de incentivos, existen otros aspectos que se deben tomar en consideración al valorar sus méritos o su posible contribución a la mejora de la seguridad. Se trata de problemas asociados a los criterios que informan los planes de incentivos, al peligro de que empresas y trabajadores por igual abusen de los incentivos y a la garantía de la participación de los trabajadores.

L os criterios de concesión de los incentivos son vitales para el éxito de los planes. Los planes de incentivos adolecen de algunas deficiencias que se asocian exclusivamente a: a) la acumulación de un determinado número de días sin accidentes, b) el número de accidentes que causan pérdida de días de trabajo (esto es, a la reducción de la prima del seguro de accidentes de trabajo), y c) varios otros indicadores asociados a los accidentes. Los accidentes no son un indicador excesivamente sensible. En efecto, el éxito se mide en función de unos indicadores negativos, como la disminución o la ausencia de determinados acontecimientos. Pero, como los accidentes son acontecimientos infrecuentes, puede transcurrir mucho tiempo antes de que se produzcan mejoras realmente significativas. Además, estos índices no permiten valorar la situación de la seguridad en la empresa, sino únicamente la evolución de los accidentes comunicados, en los que pueden influir diversos factores ajenos a la voluntad de los participantes en el programa.

Empresas y trabajadores por igual pueden abusar de los planes de incentivos a la seguridad. En efecto, a veces las empresas utilizan los planes de incentivos a la seguridad, bien como sucedáneo de la implantación de un verdadero sistema de gestión de la salud y seguridad en el trabajo, bien como una solución a corto plazo de viejas deficiencias del sistema de salud y seguridad que precisan soluciones más radicales que las previsibles de un esfuerzo de promoción. Por parte de los trabajadores, el mayor abuso suele consistir en ocultar la producción de accidentes y lesiones por temor a que los mismos supongan la pérdida de recompensas para el trabajador o el grupo. El riesgo de que se produzca este problema parece incrementarse cuando 
están en juego incentivos monetarios y si los esquemas de incentivos financieros a la mejora de los niveles de seguridad se incorporan a los convenios colectivos.

El éxito de los planes de incentivos depende en gran medida de la naturaleza de la participación de los trabajadores y de la percepción que tengan de la equidad del plan. Si los objetivos son sumamente exigentes o si los trabajadores no llegan a percibir cómo su esfuerzo personal puede contribuir al logro de esos objetivos, el plan no resulta eficaz. Por otra parte, cuanto más tiempo medie entre el comportamiento seguro en el trabajo y la percepción de la recompensa, menores serán los resultados del sistema de incentivos. En efecto, resulta difícil mantener la capacidad de motivación de un plan de incentivos cuyos beneficios tardan meses, o incluso más, en percibirse e, incluso entonces, sólo se perciben si las cosas marchan bien durante todo el tiempo.

O bviamente, las deficiencias anteriormente mencionadas explican en parte que muchas organizaciones duden en implantar sistemas de incentivos para promover la seguridad. No es difícil diseñar un plan de incentivos que no funcione; empero, existen múltiples indicios, unos circunstanciales, más o menos empíricos los otros, de que los incentivos pueden contribuir positivamente al éxito de los programas de salud y seguridad. EI uso de incentivos, recompensas y reconocimientos como medio de fomentar los comportamientos seguros de los trabajadores es parte reconocidamente integrante de los modelos OBM y TQM. En el primer modelo, el uso de incentivos para reforzar el comportamiento de los trabajadores constituye un factor vital del éxito de los programas. En el modelo TQ M , la promoción y los incentivos y recompensas sirven para reconocer las aportaciones de los trabajadores a la mejora de los procesos. Además, en el ámbito de la empresa, los grupos y los equipos de trabajo, se fijan días especiales y se organizan otras actividades para reconocer los logros.

En términos generales, es preciso reconocer la influencia positiva del uso de incentivos en los comportamientos y actitudes de los trabajadores. Si la evaluación de los resultados en materia de salud y seguridad se integra en el proceso de toma de decisiones relativas al incremento de los salarios, aumenta la importancia de estos factores como factores significativos relacionados con el puesto de trabajo.

Como se ha indicado anteriormente, el índice de siniestralidad y otros indicadores análogos plantean graves problemas si se utilizan como criterio exclusivo de la concesión de incentivos. En cambio, el empleo de indicadores positivos de los logros en materia de seguridad, como las mejoras del comportamiento o los procesos, confieren especificidad a los objetivos del esfuerzo de los trabajadores y permiten una mayor frecuencia de la retroinformación y de la distribución de incentivos. Las características de los buenos planes de incentivos contribuyen a subsanar algunos de los problemas asociados a los indicadores del rendimiento: el abuso de los beneficios del plan y la índole de la participación de los trabajadores. Aunque la investigación realizada en estas áreas dista mucho de ser exhaustivas, se dispone de información suficiente para aportar pautas utilizables por las organizaciones que desean integrar los planes de seguridad en sus programas de salud y seguridad.

Los abusos cometidos por empresas y trabajadores son en gran medida de naturaleza circunstancial. Las razones que informan el uso de programas de incentivos para subsanar las insuficiencias del sistema de gestión de la seguridad determinan en considerable medida las posibilidades de subsanar esas insuficiencias. Si la dirección no valora la salud y seguridad de los trabajadores como una cuestión prioritaria, es probable que se sigan produciendo abusos hasta que las circunstancias fuercen el cambio de política. En cambio, si la dirección apuesta por la mejora de la salud y seguridad, se producirán, tanto una mayor comprensión y aceptación de la necesidad de un enfoque global de la solución de los problemas, como un mayor reconocimiento y valoración de la función de apoyo que corresponde a los planes de incentivos. Análogamente, el problema de la ocultación de los accidentes puede remitir sensiblemente si se modifican los criterios informativos de la concesión de incentivos.

Las investigaciones han demostrado que la capacidad de las recompensas para mantener el interés de los trabajadores depende de la frecuencia de aquéllas y de su vinculación a la mejora del rendimiento. Siempre que sea posible, se debe estimular la sensación de participación en el programa de incentivos implicando a los trabajadores en la fijación de las prioridades del programa de seguridad. A este fin, es preciso evitar que el interés prioritario en los comportamientos seguros induzca a los trabajadores a descuidar otras funciones esenciales. Conviene transmitir a los participantes unos criterios y medios específicos para la correcta ejecución de las tareas, y facilitarles informes de situación frecuentes de los progresos obtenidos.

Existen igualmente indicios de una distinción entre los efectos considerados "de control" y los valorados como "informativos" de las recompensas. El estudio de estas diferencias ha inducido a la conclusión de que las recompensas de los logros que implican un reconocimiento de la competencia personal "son más eficaces que las que se limitan a suministrar retroinformación positiva sobre el rendimiento". U na explicación de esta conclusión es que los trabajadores perciben que las recompensas "informativas" - que premian los logros y la competencia personal- se encuentran bajo su control y no dependen de otra persona que conceda o niegue recompensas en base al rendimiento observado. Por consiguiente, las recompensas informativas se centran en el trabajador y son, por lo tanto, intrínsecas, en contraste con las recompensas que tienen un enfoque extrínseco al trabajador, como ocurre con las recompensas de control.

En resumen, los incentivos pueden ser de gran ayuda a las organizaciones que los emplean acertadamente. En efecto, los incentivos estimulan el interés de las personas por la seguridad y promueven un comportamiento más seguro en el trabajo.

\section{La comunicación en la promoción de la seguridad}

En todo esfuerzo de promoción de la seguridad se utilizan diversas formas de comunicación destinadas a reforzar los efectos de aquél. ¿Q uién dice qué, a través de que cauces, a quién y con qué efectos? Por lo tanto, en todo programa de comunicación hay que distinguir entre fuente, mensaje, medio, destinatarios y objetivos.

La cobertura y los efectos varían de uno a otro medio de comunicación. Así los carteles y gallardetes de promoción de la seguridad y otros medios de comunicación de masas disfrutan de una elevada cobertura, debido a que llegan a un gran número de personas a lo largo de un período de tiempo. En cambio, se suele atribuir a esos medios un bajo perfil de efectos, dado que no todos los mensajes así proyectados producen los efectos deseados. La eficacia de los medios de comunicación de masas y los mensajes unidireccionales es mayor en la concienciación general sobre los problemas de salud y seguridad y en la difusión de pautas y mensajes de seguridad. También pueden ser útiles como cauces para comunicar a los trabajadores el interés de la dirección por la seguridad de aquéllos. Por el contrario, las comunicaciones personales 0 bidireccionales, en grupo 0 mediante contactos individuales, aunque adolecen de escasa cobertura, pueden surtir mayor efecto y conducir a la decisión de modificar el comportamiento.

La credibilidad de la fuente es de suma importancia en la comunicación de mensajes de salud y seguridad. Por ejemplo, en un lugar de trabajo, el conocimiento de una determinada tarea y 
de los riesgos que implica, así como el apoyo de un buen ejemplo, contribuyen en medida importante a establecer la credibilidad de los supervisores como fuentes de información sobre salud y seguridad.

Por lo que respecta al contenido de las comunicaciones, el recurso al temor ha sido objeto de investigación y debate durante años. Los mensajes que explotan el temor se utilizan para modificar las actitudes personales frente a los riesgos implícitos en la realización de tareas peligrosas atemorizando a los destinatarios. La segunda parte de la comunicación consiste en mitigar el miedo que el propio mensaje ha suscitado mediante la recomendación de técnicas de prevención del peligro 0 de reducción del riesgo. Ejemplos de las comunicaciones de este tipo que se utilizan en el lugar de trabajo son las campañas de promoción del uso de equipo protector, y entre las comunicaciones de carácter general pueden citarse las campañas contra el hábito de fumar y las de promoción del uso del cinturón de seguridad. El principal argumento contra la proyección de mensajes basados en el temor es que sus destinatarios bloquean o suprimen el mensaje. Este tipo de reacciones son más probables si la segunda parte de los mensajes alarmistas no logran reducir el temor y las personas experimentan una incapacidad personal o circunstancial para afrontar el peligro.

Si se transmite un temor en el mensaje, se deben adoptar las precauciones siguientes:

- en el mensaje se debe proyectar un alto grado de preocupación y subrayarse las ventajas de las medidas que se deben adoptar.

- las medidas preventivas recomendadas deben ser concretas y relativamente pormenorizadas.

- las pautas de reducción del riesgo se deben comunicar en un solo bloque, inmediatamente después de la incitación de la reacción de temor.

- las medidas preventivas recomendadas deben ser comprensibles y percibidas por los destinatarios como eficaces en la prevención del peligro.

- la fuente de la comunicación debe ser altamente fiable.

- el uso de datos o estadísticas del riesgo debe ser pertenecientes al lugar de trabajo o la situación concreta.

Por último, en las comunicaciones sobre salud y seguridad en el trabajo se deben tomar en consideración los grupos destinatarios de los mensajes. Así, los estudios realizados han puesto de relieve que los mensajes que explotan el temor son más eficaces entre los nuevos trabajadores que con el personal más antiguo, cuya experiencia le permite asumir críticamente el mensaje. Asimismo, se ha podido establecer la capacidad de los mensajes que despiertan temor para influir en los trabajadores que no están sometidos a una supervisión directa y en los que, por consiguiente, hay que confiar que observen por sí mismo las normas de seguridad.

Como medio auxiliar en la determinación de los destinatarios y la fijación de los objetivos, se sugiere someter a los trabajadores a encuestas que permitan evaluar los niveles de conocimiento de la salud y seguridad, las actitudes frente los programas y medidas de seguridad y la observancia de las normas y reglas. Estos indicadores permiten establecer las prioridades de los programas de educación y formación, así como fijar el criterio de la ulterior evaluación de la eficacia de los esfuerzos de comunicación.

\section{Campañas de promoción de la seguridad}

El objeto de las campañas de promoción de la seguridad suele consistir en llamar la atención de los trabajadores hacia un determinado riesgo de accidentes y se suelen basar en un determinado eslogan o tema diseñado para mantener el interés y la presencia. Suele utilizarse una diversidad de medios, como carteles, gallardetes, vídeos, folletos y otras comunicaciones orales y escritas. El objetivo de las campañas puede consistir en suscitar conciencia, difundir información y modificar las actitudes, en un effuerzo por cambiar los comportamientos.

El efecto perseguido en las campañas de promoción de la seguridad es idéntico al de los planes de modificación del comportamiento y otros programas orientados a lograr que directivos, supervisores y trabajadores por igual conviertan la seguridad en parte integrante de la calidad en la ejecución del trabajo. Sin embargo, en comparación con los programas de modificación del comportamiento, las campañas de seguridad son mucho menos precisas en la definición de los comportamientos y resultados deseados, además de bastante menos rigurosas en el refuerzo de tales comportamientos. No obstante, el objetivo central de ambos effuerzos consiste en destacar la importancia de la seguridad en el trabajo, en la expectativa de que se conviertan en práctica habitual.

L amentablemente, pocas veces se ha examinado la eficacia de las campañas de seguridad en los entornos industriales. Si bien en las publicaciones dedicadas a la salud y seguridad en el trabajo se suelen comentar los éxitos de este tipo de campañas, pocos de estos informes se sustentan en datos empíricos convincentes. Aunque se han realizado estudios de los efectos sobre el comportamiento de determinados medios de comunicación, como los carteles, que han arrojado algunos resultados positivos y aportado directrices para la elección de los medios de comunicación de las campañas, no existen estudios significativos de la eficacia de las campañas de seguridad en la industria. Por el contrario, la mayor parte de la información relevante sobre la eficacia de las campañas de seguridad procede del área de la seguridad vial, especialmente de Estados U nidos y Australia.

Entre las conclusiones generales que pueden extraerse de los informes puntuales, del estudio de la eficacia de los medios de comunicación y de la experiencia generada por la promoción de la seguridad en autopistas, las siguientes merecen especial atención por su capacidad para reforzar la proyección de las campañas de salud y seguridad:

- analizar las necesidades con objeto de determinar los destinatarios de las campañas, recurriendo a la retroinformación de los trabajadores para complementar los datos procedentes de otras fuentes.

- facilitar la participación de los trabajadores en la planificación de las campañas y la selección de los materiales.

- verificar experimentalmente el objeto y los materiales de la campaña sobre los grupos destinatarios.

- involucrar en la campaña a todos los niveles de la dirección, desde los altos directivos hasta los supervisores de los niveles inferiores de la línea.

- proyectar mensajes más emotivos y persuasivos que racionales e informativos.

El objeto de las campañas de seguridad es apoyar el programa global de seguridad de la organización. Por esto, suele ser preferible juzgar su efectividad en función de su capacidad para desempeñar las funciones de apoyo deseadas, entre las que figuran el mantenimiento del interés en la seguridad, la proyección de la preocupación de la dirección por la seguridad del personal, la promoción de la participación de los trabajadores en las actividades de promoción de la seguridad, el fomento de la moral y el estímulo a los trabajadores para que adopten precauciones especiales.

Los esfuerzos por utilizar los criterios de reducción de los índices de siniestralidad como indicadores de la eficacia de las campañas, aunque aparentemente acertados, se suelen desdibujar en virtud de los efectos del programa de seguridad vigente. Además, como los accidentes y lesiones son infrecuentes, 
constituyen unos criterios relativamente inelásticos para evaluar los efectos de los cambios en los programas de seguridad específicamente centrados en los aspectos humanos o de comportamiento del sistema de seguridad.

\section{EST UDIO DE CASO : CAMPAÑAS NACIO NALES DE SALUD Y SEGURIDAD EN EL TRABAJO EN LA INDIA}

\section{K. C. Gupta}

\begin{abstract}
Antecedentes
El presente estudio de caso, en el que se describe el éxito de una campaña nacional de seguridad, se basa en la experiencia adquirida durante 24 años de la campaña del Día Nacional de la Seguridad en la India. En la campaña se conmemora la creación por parte del Gobierno de ese país, el 4 de marzo de 1966, del Consejo Nacional de Seguridad, como ente autónomo sin fines políticos ni ánimo de lucro de ámbito nacional, destinado a fomentar, desarrollar y mantener un movimiento voluntario de apoyo a la salud y seguridad en el trabajo. La Junta de Gobernadores del C onsejo N acional de Seguridad es ampliamente representativa, al estar integrada por delegados de todas las confederaciones sindicales y organizaciones empresariales de implantación nacional. En abril de 1995, había unos 4.000 miembros, procedentes en su mayor parte del sector industrial, aunque los otros sectores también están representados. En 1966 se inició en los centros de trabajo industriales indios una tendencia ascendente de los accidentes de trabajo que las medidas coactivas de la Administración pública no logró contener. En este contexto, por lo tanto, la creación del Consejo Nacional de Seguridad como organismo de afiliación voluntaria constituyó un punto de inflexión. Durante muchos años, el interés del Consejo se centró en la seguridad en la industria; sin embargo, la reciente ampliación del campo de actividad a diversos sectores no industriales ha supuesto una evolución desde la seguridad industrial a la seguridad en el trabajo. Sin embargo, la cobertura de la higiene industrial es aún muy pobre en la India. Al popularizarse la iniciativa de conmemorar la fundación del Consejo Nacional de Seguridad mediante el lanzamiento de una campaña nacional de divulgación, la primera campaña del Día N acional de la Seguridad se puso en marcha en 1972. EI Día Nacional de la Seguridad se convirtió en una efemérides anual y, aunque actualmente dura una semana, el arraigo adquirido por el nombre ha motivado que se la siga conociendo como Campaña del Día N acional de la Seguridad.
\end{abstract}

\section{Objetivos}

Los objetivos de la Campaña del Día Nacional de la Seguridad, que siguen caracterizándose por su amplitud, flexibilidad y generalidad, son los siguientes:

- mejorar los niveles de salud y seguridad en el trabajo en todo el país;

- conseguir el apoyo y participación de los principales agentes sociales de distintos sectores y en diferentes niveles, como el gobierno central y las administraciones locales, y sus respectivos organismos reguladores e instituciones; las administraciones locales y de distrito; los sindicatos y organizaciones no gubernamentales (ONG); y las organizaciones empresariales; las empresas públicas, privadas y del sector mixto;

- promover el concurso de las empresas en la formación de sus trabajadores para alcanzar los objetivos de salud y seguridad

\section{Texto del compromiso con el Día Nacional de la Seguridad}

En el día de la fecha, me comprometo solemnemente a dedicarme a la causa de la salud, la seguridad y la protección del medio ambiente, así como a cumplir los reglamentos, normas y procedimientos dictados con ese objeto y a observar unos comportamientos y actitudes congruentes con el logro del mismo.

Soy perfectamente consciente de que accidentes y enfermedades perjudican la economía nacional y pueden causar discapacidades, muertes, daños materiales y quebrantos de salud, calamidades sociales y el deterioro general del medio a mbiente.

Colaboraré en la medida de lo posible a la prevención de accidentes y enfermedades profesionales y a la protección del medio ambiente, en interés mío, de mi familia, de la comunidad y del conjunto de la nación.

(En algunos Estados, el Gobernador estatal ha recibido personalmente este compromiso de sus ministros y de los altos funcionarios y responsables de la Administración pública, así como de directivos y trabajadores industriales y de los ciudadanos participantes en las actividades del Día $\mathrm{N}$ acional de la Seguridad. En las empresas privadas, el director general u otro alto directivo recibe el compromiso de todos los trabajadores).

en su lugar de trabajo, utilizando el talento, los conocimientos y la experiencia existentes localmente;

- fomentar el desarrollo de programas y la realización de actividades ajustados a las necesidades, la observancia voluntaria de las normas legales y el fortalecimiento de los sistemas profesionales de gestión de la seguridad e higiene en el trabajo,

- atraer al movimiento voluntario de promoción de la higiene industrial a determinados sectores que aún no disfrutan de la cobertura de la legislación sobre seguridad e higiene en el trabajo, como la construcción, la investigación y desarrollo, y los pequeños establecimientos y talleres que utilizan equipo, maquinaria y materiales peligrosos.

Estos objetivos se integran en la finalidad general de crear y enriquecer una cultura de seguridad e higiene en el lugar de trabajo e integrarla en la cultura laboral. En un país en vías de desarrollo, el logro de este objetivo sigue siendo una apuesta importante.

\section{Enfoque y metodología}

El enfoque y metodología empleados inicialmente para lanzar y vigorizar la Campaña constaba de dos elementos: 1) cartas de invitación a los miembros de las organizaciones afiliadas al Consejo Nacional de Seguridad a colaborar en la Campaña; y 2) suministro a dichos miembros de materiales de promoción de diseño, como insignias, ejemplares del "compromiso" con el Día $\mathrm{N}$ acional de la Seguridad (véase el recuadro), gallardetes de tela, carteles, pegatinas, etcétera; así como de obsequios de doble uso, personal y de promoción, como llaveros, bolígrafos y pisapapeles con mensajes impresos alusivos a la salud y seguridad en el trabajo. El Consejo Nacional de Seguridad centraliza el diseño, producción y distribución de estos materiales con los fines siguientes:

1. inducir a los participantes a organizar la Campaña sin necesidad de recurrir al laborioso y costoso expediente de diseñar y producir los materiales por sí mismos en pequeñas cantidades;

2. garantizar la calidad y el diseño profesional de unos materiales que transmiten unos mensajes atrayentes sobre los problemas nacionales de salud y seguridad en el trabajo;

3. generar unos ingresos que contribuyen a sustentar la autonomía financiera del esfuerzo del Consejo Nacional de 
Seguridad por lograr su objetivo global de vigorizar el movimiento voluntario de salud y seguridad en el trabajo en la India.

Aunque, en sus años iniciales, la Campaña se dirigía exclusivamente a los miembros del Consejo Nacional de Seguridad, su alcance creció gradualmente. Al cabo de un decenio, el enfoque y metodología se desarrollaron en varias direcciones estratégicas:

1. Se pidió al M inisterio de T rabajo de la U nión, responsable de la política de salud y seguridad en el trabajo, que colaborase en los esfuerzos del Consejo Nacional de Seguridad por lograr la cooperación de los gobiernos estatales en la ejecución de las campañas. De resultas de esta petición, el ministro de Trabajo de la Unión recabó de sus homólogos de los distintos E stados la creación de Comités de Campaña encargados de organizar las campañas de ámbito estatal y de distrito; estos comités estarían integrados por representantes de los trabajadores, empresas y delegados de los organismos ministeriales afectados. Este apoyo ha conferido a la Campaña su dimensión nacional.

2. La Administración ha indicado a los medios de comunicación electrónicos (televisión y radio) bajo control estatal que otorguen cobertura a la Campaña. Esta cobertura ha incrementado sensiblemente la proyección de la Campaña.

3. Ha mejorado el nivel de participación, tanto de los periódicos editados por el propio Consejo $\mathrm{N}$ acional de Seguridad, como de los diarios y revistas publicados por las organizaciones sindicales y empresariales y de la prensa local y nacional.

4. La C ampaña ha ganado en duración (una semana) y en flexibilidad para que los participantes la inicien y concluyan en las fechas que estimen convenientes, siempre que en la semana se incluya el 4 de marzo (aniversario de la creación del Consejo Nacional de Seguridad). Estas medidas también han contribuido a promover la proyección de la Campaña.

5. Las filiales de ámbito estatal y los centros de acción local del Consejo Nacional de Seguridad se han esforzado por comprometer la participación de los gobiernos estatales y administraciones locales en la ejecución de la Campaña en el nivel local.

6. El alcance de la Campaña se ha incrementado a lo largo de los años. En las Figuras $60.8,60.9$ y 60.10 se ilustra este crecimiento por lo que respecta tanto al número de personas a quienes se ha colocado la insignia, como a los ingresos generados por la venta de materiales asociados a la C ampaña.

\section{Participación en diferentes niveles}

La participación de todos los agentes sociales en los ámbitos nacional, estatal, local y de la empresa ha contribuido sensiblemente al éxito y eficacia de la C ampaña. Sin embargo, el nivel de compromiso de todos esos agentes sociales no ha sido el mismo. En primer lugar, los diferentes agentes sociales se han incorporado a ella en años distintos, además de que sus respectivas percepciones de sus correlativas funciones y necesidades varía sensiblemente. Por ejemplo, mientas que algunos gobiernos, principalmente los de los Estados más industrializados, han planificado diversas actividades originales y de gran alcance, en algunos Estados menos desarrollados esas actividades han sido sumamente modestas. D el mismo modo, al tiempo que algunas organizaciones empresariales han apoyado decididamente la Campaña, otras no han iniciado aún su participación. Por otra parte, mientras que las actividades desarrolladas en los ámbitos nacional, estatal y local se han centrado en cuestiones de interés general, las realizadas en empresas y centros de trabajo han sido mucho más específicas y orientadas a sus necesidades.

\section{Figura 60.8 • Desarrollo de la campaña de celebración del Día $N$ acional de la Seguridad: número de receptores de insignias.}

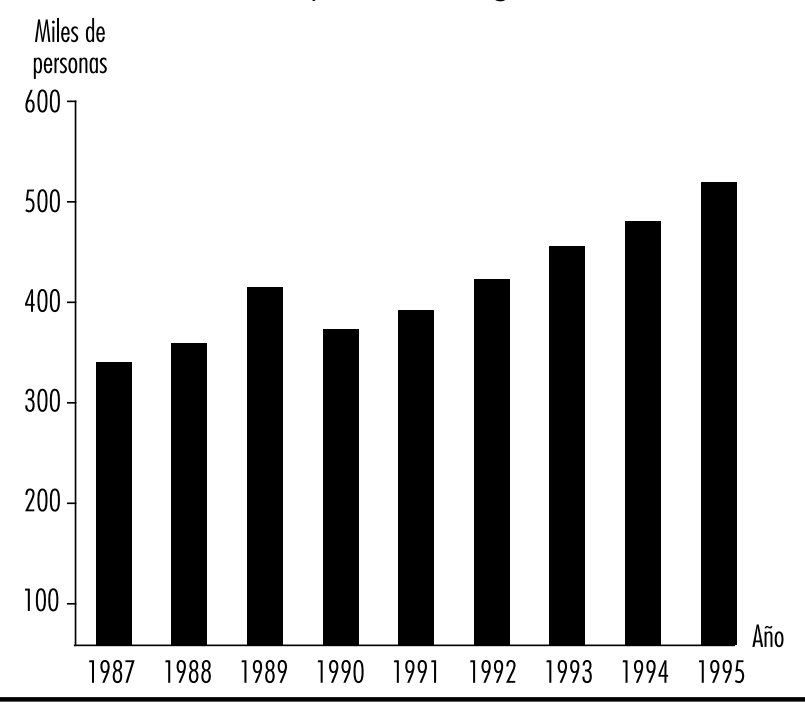

\section{Materiales utilizados en la Campaña}

Un equipo de expertos del propio Consejo Nacional de Seguridad y de las organizaciones sindicales y empresariales diseña todos los años las cuestiones que han de abordarse en los mensajes proyectados por los materiales de promoción producidos por el Consejo Nacional de Seguridad. Se encarga a un grupo de prestigiosos dibujantes la creación de unas imágenes visuales que transmitan de forma simple, humorística y eficaz los mensajes elegidos. Así se logra que los materiales de promoción resulten originales, interesantes y ajustados a la cultura del país.

Estos materiales se clasifican en dos grandes grupos: a) materiales exclusivamente publicitarios, utilizados con fines de exposición y educación, y b) materiales de utilidad múltiple, que, aparte de servir a los fines de proyectar mensajes de salud y seguridad en el trabajo, tienen aplicaciones cotidianas. Los

Figura 60.9 - Aumento de los ingresos generados por la venta de materiales de promoción del Día $\mathrm{N}$ acional de la Seguridad (1972-1982).

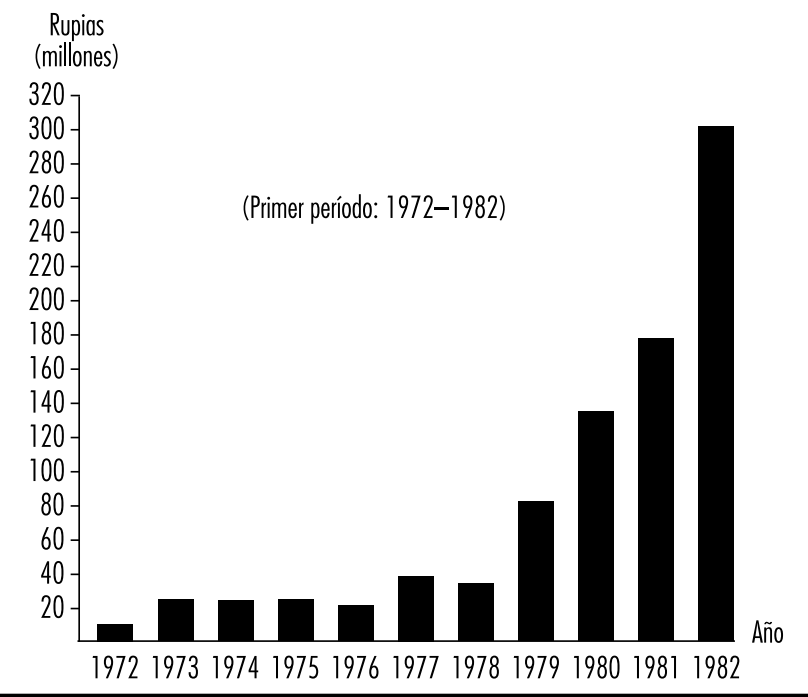




\section{Figura 60.10 - Aumento de los ingresos generados por la venta de materiales de promoción del Día N acional de la Seguridad (1983-1995).}

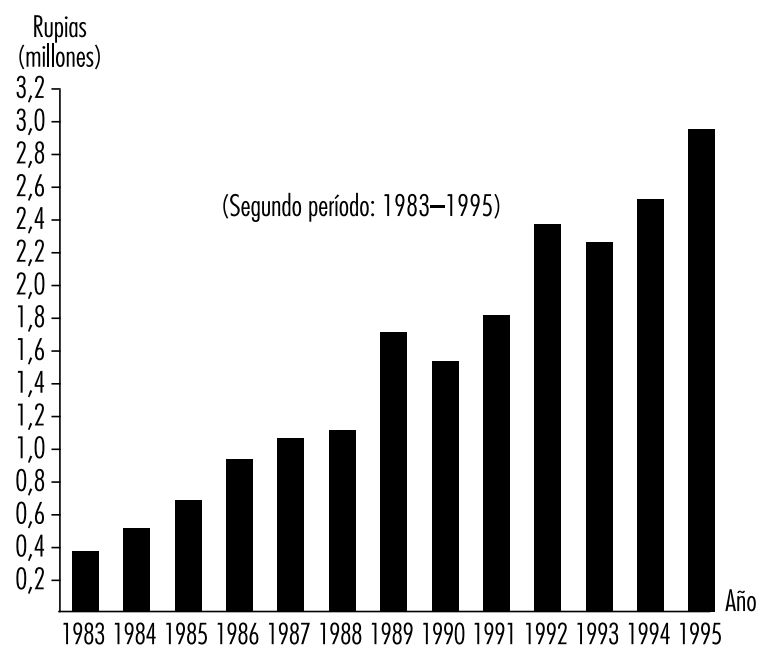

materiales incluidos en la segunda categoría son principalmente objetos de uso personal de los trabajadores, relativamente bajos de precio y asequibles para la economía de numerosas empresas que las distribuyen gratuitamente entre sus trabajadores. También se producen algunos materiales destinados a los directivos, con objeto de estimular su participación. Para evitar la sensación de monotonía, el diseño o la naturaleza misma de los materiales se renueva todos los años.

A medida que el alcance de la Campaña se ha ido incrementando y la demanda de materiales de promoción ha crecido con los años, han ido surgiendo en el sector privado nuevos productores y proveedores que fabrican estos materiales de acuerdo con los resultados de sus propias investigaciones del mercado, lo cual ha constituido una feliz innovación. Algunas empresas también producen materiales destinados a subrayar los temas de la campaña que les afectan directamente. En algunos casos se convocan concursos entre los trabajadores para generar nuevas ideas, y luego se identifica a los ganadores en los materiales publicitarios.

\section{Actividades}

En el ámbito nacional, las actividades consisten en actos públicos, seminarios, coloquios y debates, difusión de reclamos y mensajes, y distribución de películas cinematográficas dedicadas a las cuestiones de salud y seguridad en el trabajo que interesan a todo el país. La participación del ministro y otros altos cargos del M inisterio de Trabajo de la Unión, así como del Presidente y altos directivos del Consejo $\mathrm{N}$ acional de Seguridad y de los dirigentes de las organizaciones sindicales y empresariales, de personalidades destacadas de diversas instituciones y O NG, y de personas del público en general, han otorgado a estas actividades el nivel de proyección deseado. Las cadenas nacionales de radio y televisión, la prensa y otras publicaciones periódicas han otorgado una amplia cobertura a estas actividades.

Si bien dentro de los Estados las actividades varían de uno a otro caso, suelen ser semejantes a las que se desarrollan en el plano nacional. En estas actividades se suele hacer hincapié en la transmisión, en la lengua local, de mensajes relativos a los problemas específicos de cada Estado. En estos últimos años se ha venido produciendo en las actividades de nivel estatal una tendencia positiva, consistente en hacer coincidir el importante acontecimiento que supone la distribución de los premios estatales a la seguridad con la semana de la C ampaña.

Las actividades desarrolladas en las empresas son más prácticas y variadas. Por regla general, la organización de estas actividades corresponde al comité de seguridad (allí donde existe, por imperativo de las disposiciones legales aplicables a las empresas que emplean un número mínimo de trabajadores) o a un equipo de trabajo creado "ad hoc" por la dirección. Entre las actividades más frecuentes destacan los concursos entre el personal de diversos departamentos por una buena labor de mantenimiento, un índice menor de siniestralidad, tiempo de operación sin accidentes, carteles y eslóganes de seguridad, recomendaciones para mejorar la seguridad, exposiciones, representaciones humorísticas y dramáticas en un sólo acto, canciones, programas y seminarios de formación, conferencias, proyección de películas, demostraciones, organización de simulacros de accidentes, etcétera. Se suele recabar la presencia de expertos externos como conferenciantes.

Las siguientes son algunas de las actividades más comunes que contribuyen al éxito de las campañas de seguridad en las empresas:

- Las representaciones dramáticas escenificadas por los trabajadores de algunas empresas alcanzan un buen nivel artístico y resultan un medio realmente entretenido y convincente de transmitir el conocimiento de accidentes reales y de las enseñanzas que se derivan de ellos. La difusión de algunas de estas dramatizaciones se ha incrementado gracias a su grabación en videos que luego se han transmitido por las cadenas estatales y nacionales de televisión.

- El qwaali, un género de canción popular en el subcontinente indio, ha servido habitualmente de cauce para transmitir mensajes sobre la salud y seguridad en el trabajo de forma entretenida y congruente con las tradiciones culturales indias.

- Algunas grandes empresas, tanto públicas como privadas, construyen bloques de viviendas y escuelas para sus trabajadores. Algunas de estas empresas han organizado concursos y otras actividades destinadas a promover la participación de los alumnos y familiares en el trabajo de salud y seguridad. Esta actividad ha contribuido positivamente a mejorar la motivación de los trabajadores. Incluso algunas empresas que no ofrecen vivienda ni escolarización a las familias de sus trabajadores utilizan con idénticos resultados este sistema para fomentar la participación de los hijos de edad escolar y demás familiares en estas actividades.

- En la estela de la catástrofe de Bhopal, muchas empresas que producen, almacenan o utilizan sustancias químicas peligrosas o procesos capaces de provocar accidentes graves han diseñado actividades destinadas a incrementar la conciencia sobre la salud y seguridad en el trabajo en las comunidades locales. Se invita a personas representativas de esas comunidades a presenciar las funciones y demostraciones que tienen lugar en la fábrica durante la Campaña. Las autoridades públicas a veces asisten también como invitados de honor. Esta idea ha contribuido a fomentar la colaboración entre la industria, la comunidad y la Administración pública que resulta imprescindible para lograr una respuesta rápida y efectiva a los vertidos de sustancias químicas en el ámbito local.

- Las actividades que implican la aplicación práctica de los principales medios de seguridad, como el empleo de equipo y sistemas de lucha contra incendios y de equipo de protección individual, los simulacros de accidentes y los cursos y seminarios diseñados internamente y adaptados a las necesidades específicas de la empresa, han demostrado su capacidad para generar el entusiasmo y apoyo del personal. 
Tabla 60.2 - N úmero de fábricas en funcionamiento en la India, media estimada de las jornadas de trabajo diarias, lesiones de declaración obligatoria y su frecuencia.

\begin{tabular}{|c|c|c|c|c|c|c|}
\hline \multirow[t]{2}{*}{ Año } & \multirow[t]{2}{*}{$\begin{array}{l}\text { Número de fábricas en } \\
\text { funcionamiento }\end{array}$} & \multirow[t]{2}{*}{$\begin{array}{l}\text { Media estimada de las } \\
\text { jornadas de trabajo diarias } \\
\text { (en miles) }\end{array}$} & \multicolumn{2}{|c|}{ Lesiones profesionales } & \multicolumn{2}{|c|}{$\begin{array}{l}\text { Número de lesiones por millar de } \\
\text { trabajadores de las fábricas que } \\
\text { comunican los siniestros }\end{array}$} \\
\hline & & & Mortales & Totales & Mortales & Totales \\
\hline 1971 & 81.078 & 5.085 & 635 & 325.180 & 0,15 & 75,67 \\
\hline 1972 & 86.297 & 5.349 & 655 & 285.912 & 0,15 & 63,63 \\
\hline 1973 & 91.055 & 5.500 & 666 & 286.010 & 0,15 & 62,58 \\
\hline 1974 & 97.065 & 5.670 & 650 & 249.110 & 0,14 & 53,77 \\
\hline 1975 & 104.374 & 5.771 & 660 & 242.352 & 0,14 & 50,86 \\
\hline 1976 & 113.216 & 6.127 & 831 & 300.319 & 0,17 & 61,54 \\
\hline 1977 & 119.715 & 6.311 & 690 & 316.273 & 0,14 & 63,95 \\
\hline 1978 & 126.241 & 6.540 & 792 & 332.195 & 0,15 & 68,62 \\
\hline 1979 & 135.173 & 6.802 & 829 & 318.380 & 0,16 & 62,19 \\
\hline 1980 & 141.317 & 7.017 & 657 & 316.532 & 0,14 & 66,92 \\
\hline 1981 & 149.285 & 7.240 & 687 & 333.572 & 0,16 & 76,73 \\
\hline 1982(P) & 157.598 & 7.388 & 549 & 296.027 & 0,13 & 69,10 \\
\hline 1983(P) & 163.040 & 7.444 & 456 & 213.160 & 0,13 & 55,63 \\
\hline $1984(P)^{*}$ & 167.541 & 7.603 & 824 & 302.726 & 0,10 & 36,72 \\
\hline $1985(P)^{*}$ & 175.316 & 7.691 & 807 & 279.126 & 0,23 & 58,70 \\
\hline 1986(P) & 178.749 & 7.795 & 924 & 276.416 & 0,14 & 49,31 \\
\hline 1987(P) & 183.586 & 7.835 & 895 & 236.596 & 0,14 & 41,54 \\
\hline 1988(P) & 188.136 & 8.153 & 694 & 200.258 & 0,15 & 41,68 \\
\hline 1989(P) & 193.258 & 8.330 & 706 & 162.037 & 0,16 & 35,11 \\
\hline 1990(P) & 199.826 & 8.431 & 663 & 128.117 & 0,21 & 33,11 \\
\hline 1991(P)* & 207.980 & 8.547 & 486 & 60.599 & 0,21 & 26,20 \\
\hline $1992(P)^{*}$ & 207.156 & 8.618 & 573 & 74.195 & 0,20 & 26,54 \\
\hline
\end{tabular}

Todas estas actividades son especialmente idóneas para la realización de campañas dentro de cada unidad.

\section{Efectos}

La Campaña del Día Nacional de la Seguridad ha surtido efectos positivos en la evolución de la frecuencia de los accidentes de trabajo (de comunicación preceptiva de conformidad con la Ley de centros industriales) en la India. Como se observa en la Tabla 60.2, el índice de lesiones profesionales (número de lesiones por cada 1.000 trabajadores) se redujo de 75,67 en 1971 a 26,54 en 1992 (último año del que existen estadísticas conocidas), para una reducción de alrededor del $65 \%$. Es de subrayar que esta reducción obedece a los efectos combinados sobre el nivel de salud y seguridad en el trabajo de la acción de la Administración y la legislación, las sanciones, la educación y formación, la promoción, la modernización de los procesos y operaciones industriales, etcétera, además de la actividad realizada por el Consejo Nacional de Seguridad.

El sector de la investigación y desarrollo dependiente de la Administración central, compuesto por unos 40 laboratorios diseminados por todo el país que emplean a más de 26.000 trabajadores, de ellos más de 9.000 científicos, no está amparado por la normativa legal de salud y seguridad en el trabajo. En los últimos tres años, las empresas y los distintos laboratorios han iniciado la celebración del Día Nacional de la Seguridad, la creación de grupos de trabajo de seguridad y un esfuerzo sistemático por establecer un sistema eficaz de gestión de la salud y seguridad en el trabajo. Este proceso ilustra la contribución de la C ampaña del Día Nacional de la Seguridad al desarrollo del movimiento voluntario de promoción de la salud y seguridad en el trabajo en la India.

Tanto las organizaciones responsables de las centrales nucleares, de las plantas de tratamiento de agua pesada y de los reactores de investigación como el resto de las secciones del D epartamento de Energía A tómica han realizado actividades en el marco de las Campañas del Día Nacional de la Seguridad. Estos organismos convocan concursos entre departamentos que culminan con la concesión de premios por los avances logrados en los campos de la salud y seguridad y la protección del medio ambiente. La aplicación de las normas de salud y seguridad en los centros anteriormente citados corresponde a un organismo autónomo dependiente del D epartamento de Energía A tómica; sin embargo, dichos centros no se encuentran sujetos a inspección por parte de los organismos estatales competentes para inspeccionar otros lugares de trabajo. Además de propiciar la coordinación entre los servicios del Departamento y los 
organismos reguladores externos y entre el Consejo Nacional de Seguridad y otras instituciones, las actividades desarrolladas en el marco de la Campaña han servido de cauce para la difusión pública de información sobre la salud y seguridad en el trabajo.

EI Estado de G ujarat, en la costa occidental, es uno de los más industrializados de la India y alberga 525 fábricas grandes y medianas que producen, almacenan 0 utilizan una o más de las 38 sustancias químicas consideradas tóxicas. En todas estas fábricas se han diseñado y ensayado diversos planes de urgencia. En el marco de la última C ampaña del Día N acional de la Seguridad, el inspector jefe de Centros de Producción pidió a cada una de las grandes unidades que impartiesen formación práctica en el uso de extintores de incendios y respiradores a los trabajadores responsables de los servicios de urgencia de 10 pequeñas fábricas situadas en la comarca. D e cada unidad se seleccionaron seis trabajadores (dos de cada turno) en cada una de las pequeñas unidades, para un total de 31.500 trabajadores procedentes de 5.520 unidades. Este es un caso ilustrativo de la capacidad de la C ampaña para propiciar la formación práctica de urgencia a las pequeñas unidades que utilizan procesos peligrosos.

Resumiendo, la principal aportación de la Campaña del Día Nacional de la Seguridad consiste en suscitar en los medios empresariales e industriales y en el público en general la conciencia de que la salud y seguridad y la protección del medio ambiente constituyen parte integrante y esencial de toda política de desarrollo sostenible. No obstante, queda un largo camino por recorrer antes de que esta política se convierta en realidad. Sin duda, la Campaña del Día N acional de la Seguridad tendrá un protagonismo creciente en el esfuerzo por alcanzar esta realidad.

\section{Referencias}

Albert, K. 1978. H ow to Be Your Own M anagement Consultant. N ew Y ork: M cG raw-Hill.

American Society of Safety Engineers (ASSE). 1974. Directory of Safety Consultants. O akton, Illinois, Estados U nidos: ASSE.

Association of Consulting $M$ anagement Engineers 1966. Professional Practices in $M$ anagement $C$ onsulting Nueva Y ork: Association of Consulting $M$ anagement Engineers.

Bird, FE. 1974. M anagement Guide to Loss Control. Atlanta: Institute Press.

Bruening, JC. 1989. Incentives strengthen safety awareness. 0 ccup $\mathrm{H}$ az 51:49-52.

Centers for Disease Control and Prevention (CDC). 1988. Guidelines for Evaluating Surveillance Systems. M M WR 37 (supl. No. S-5). Atlanta: CDC.

Fox, DK, BL Hopkins, WK Anger. 1987. The longterm effects of a token economy on safety performance in open pit mining. I App B ehav Anal 20:215 224.

Geller, ES. 1990. En Bruening, JC. Shaping workers' attitudes toward safety. $O$ ccup $H$ az 52:49-51.

Gibson, JJ. 1961. The contribution of experimental psychology to the formulation of the problem of safety: A brief for basic research. En B ehavioral Approaches to Accident Research. Nueva Y ork: Association for the Aid of C rippled C hildren.

Gordon, JE. 1949. The epidemiology of accidents. Am J Public H ealth 39, A bril:504-515.

Gros J. 1989. Das K raft-Fahr-Sicherheitsprogramm. Personalführung 3:246-249.
Haddon, W, EA Suchman, D K lein. 1964. Accident Research: M ethods and Approaches. Nueva Y ork: $\mathrm{H}$ arper and Row.

Haddon, W, Jr. 1973. Energy damage and the ten countermeasure strategies. J T rauma 13:321-331.

H arano, RM, DE H ubert. 1974. An Evaluation of California's Good D river Incentive Program. R eport N o. 6 . Sacramento: California Division of $\mathrm{H}$ ighways.

K omaki, J. KD Barwick, LR Scott. 1978. A behavioural approach to occupational safety: pinpointing and reinforcing safe performance in a food manufacturing plant. J App Psy 63:434-445.

Latham, GP, JJ Baldes. 1975. The practical significance of Locke's theory of goal setting. I App Psy 60: 122-124.

Lippit, G. 1969. Organization Renewal. Nueva York: $M$ eredith Corp.

M CAfee, RB, AR Winn. 1989. The use of incentives/ feedback to enhance work place safety: a critique of the literature. J Saf Res 20:7-19.

Peters, G. 1978. Why only a fool relies on safety standards. Prof Saf M ayo 1978.

Peters, RH. 1991. Strategies for encouraging selfprotective employee behaviour. I Saf Res 22:53-70.

Robertson, LS. 1983. Injuries: Causes, Control Strategies, and Public Policy. Lexington, M assachussetts, Estados U nidos: Lexington Books.

Starr, C. 1969. Social benefits versus technological risk. What is our society willing to pay for safety? Science 165:1232-1238.

Stratton, J. 1988. L ow-cost incentive raises safety consciousness of employees. Occup $\mathrm{H}$ ealth $\mathrm{Sa}$ M arzo:12-15.
Suokas, ]. 1988. The role of safety analysis in accident prevention. Accident Anal Prev 20(1):67-85.

V eazie, M A, DD Landen, TR Bender, HE Amandus. 1994. Epidemiologic research on the etiology of injuries at work. Annu R ev Publ $\mathrm{H}$ ealth 15:203-221.

Wilde, GJS. 1988. Incentives for safe driving and insurance management. En CA O sborne (dir.), Re port of I nquiry into $M$ otor Vehicle Accident Compensation in Ontario. Vol. II. Toronto: Q ueen's Printer for O ntario.

\section{0 tras lecturas recomendadas}

Baker, SP. 1991. I njury F act B ook. N ueva Y ork: O xford U niversity Press.

$\mathrm{H}$ addon, WJ. 1980. Advances in the epidemiology of injuries as a basis for public policy. Publ $H$ ealth $R$ ep 95(5):411-421.

National Injury Control Conference. 1992. O ccupational Injury Prevention. Position Papers from the Third $N$ ational I njury Control Conference: Setting the National Agenda for I njury Control in the 1990s, April 22-25, 1991, D enver, Colorado. Washington, DC: US Government Printing 0 ffice.

$N$ ational Institute for $\mathrm{O}$ ccupational Safety and $\mathrm{H}$ ealth (NIO SH ). 1984. R equest for Assistance in Preventing the I njury of W orkers by Robots. DH HS (NIOSH) Publication N o. 85-103. Cincinnati, O hio: NIOSH.

-.1993 . Fatal Injuries to $W$ orkers in the U nited States. 1980-1989: A D ecade of Surveillance (National Profile). DHHS (NIOSH) Publication N o. 93-108. Cincinnati, O hio: NIOSH.

$N$ ational Research Council/ Institute of Medicine. 1985. Injury in America: A Continuing Public $\mathrm{H}$ ealth Problem. Washington, DC: National Academy Press. 


\section{UTIUZACION, ALMACENA- MIENTO Y TRANSPORTE DE PRODUCTOS QUIMICOS}

Directoras del capítulo

J eanne $M$ ager Stellman y

D ebra 0 sinsky

\section{Sumario}

Seguridad en la manipulación y la utilización de productos químicos.

Sistemas de clasificación y etiquetado para productos químicos

Konstantin K. Sidorov el gor V. Sanotskiy. . .

Seguridad en la manipulación y el almacenamiento de productos químicos

A. E. O uinn ...

Gases comprimidos: manipulación, almacenamiento y transporte

A. T ürkdogan y K. R. M athisen

$\mathrm{H}$ igiene en el laboratorio

F rank $M$ iller. .

M étodos para el control localizado de contaminantes atmosféricos

L ouis D iB ernardinis.

EI sistema de información química GEST IS:

estudio de caso

Karlheinz M effert y R oger Stamm . . 


\section{SEgURIDAD En LA MANIPULACION Y LA UTILIZACION DE PRODUCTOS QUIMICOS}

\section{El Repertorio de recomendaciones prácticas de la OIT*}

El objetivo (sección 1.1.1) del Repertorio de recomendaciones prácticas de la O IT Seguridad en la utilización de productos químicos en a trabajo es proteger a los trabajadores de los riesgos inherentes a los productos químicos, prevenir o disminuir la incidencia de las enfermedades y lesiones causadas al utilizar productos químicos en el trabajo y, en consecuencia, contribuir a la protección del público en general y del medio ambiente; con tal fin se presentan recomendaciones para:

- garantizar que todos los productos químicos de uso en el trabajo, incluidas las impurezas, los subproductos, los productos intermedios y los desechos que puedan producirse, sean evaluados a fin de determinar los riesgos que presentan;

- asegurar que se proporcionen a las empresas sistemas adecuados que les permitan obtener de los proveedores información sobre los productos químicos utilizados en el trabajo, de manera que puedan poner en práctica programas eficaces de protección de los trabajadores contra los riesgos de los productos químicos;

- proporcionar a los trabajadores información acerca de los productos químicos utilizados en sus lugares de trabajo y acerca de las medidas adecuadas de prevención que les permitan participar eficazmente en los programas de seguridad;

- establecer las orientaciones básicas de dichos programas para garantizar la utilización de los productos químicos en condiciones de seguridad,

- establecer disposiciones especiales para proteger la información confidencial, pues si ésta se revela a un competidor resultaría perjudicial para la actividad de la empresa, siempre y cuando la seguridad y la salud de los trabajadores no se vean comprometidas.

En la sección 2 del Repertorio de recomendaciones prácticas de la OIT se esbozan las obligaciones, responsabilidades y deberes generales de la autoridad competente, de las empresas y de los trabajadores. Asimismo, se detallan las responsabilidades generales de los proveedores y los derechos de los trabajadores, y se ofrecen directrices respecto a las disposiciones especiales relativas a la divulgación de información confidencial por parte de las empresas. En las recomendaciones finales se aborda la necesidad de cooperación entre empresas, trabajadores y sus representantes.

* Gran parte de la información y los extractos que figuran en el presente capítulo se han tomado del Repertorio de recomendaciones prácticas Seguridad en la utilización de productos químicos en el trabajo de la O rganización Internacional del Trabajo (OIT 1993). En este Repertorio se ofrecen directrices prácticas sobre la aplicación de las disposiciones del Convenio (núm. 170) sobre la seguridad en la utilización de los productos químicos en el trabajo, 1990 y la correspondiente Recomendación (núm. 177), 1990. El objetivo del Repertorio es orientar a aquéllos que pueden participar en la formulación de las disposiciones relativas a la utilización de productos químicos en el trabajo, como las autoridades competentes, los directivos de las empresas en que se suministran o utilizan este tipo de sustancias y los servicios de urgencia, que deben asesorar a su vez a las organizaciones de proveedores, empleadores y trabajadores. En el Repertorio se establecen requisitos mínimos y no se pretende desalentar a las autoridades competentes respecto a la adopción de otros más exigentes.

Para más información sobre productos químicos concretos y grupos de éstos, véase la Guía de productos químicos en el Volumen IV de la presente Enciclopedia.

\section{Obligaciones, responsabilidades y deberes generales}

Los organismos públicos pertinentes se atendrán a las prácticas y las medidas nacionales, previa consulta con las organizaciones interesadas más representativas de empresas y de trabajadores, con el fin de garantizar la seguridad en la utilización de productos químicos en el trabajo. La legislación y las prácticas nacionales deben considerarse en el contexto de los reglamentos, las normas y los sistemas internacionales, así como de las medidas y las prácticas recomendadas en el Repertorio de recomendaciones prácticas de la OIT, el Convenio de la O IT (núm. 170) y la Recomendación de la OIT (núm. 177).

Las medidas encaminadas a garantizar la seguridad de los trabajadores se centran fundamentalmente en:

- la producción y la manipulación de productos químicos peligrosos;

- el almacenamiento de productos químicos peligrosos;

- el transporte de productos químicos peligrosos, de conformidad con la reglamentación nacional e internacional al respecto,

- la eliminación y el tratamiento de productos químicos y residuos peligrosos, conforme a la reglamentación nacional e internacional.

La autoridad competente dispone de varios medios para conseguir este objetivo. Puede promulgar leyes y reglamentos nacionales; adoptar, aprobar o reconocer normas, repertorios 0 directrices vigentes, y fomentar, cuando no existan, la adopción de estos instrumentos por otra autoridad y reconocerlos posteriormente. Asimismo, puede solicitar a las empresas que justifiquen los criterios que aplican en el trabajo.

De acuerdo con el Repertorio de recomendaciones prácticas (sección 2.3.1), las empresas deberán consignar por escrito la política y las disposiciones relativas a la seguridad en la utilización de los productos químicos que hayan adoptado como parte de sus políticas y disposiciones generales en el campo de la seguridad y la salud en el trabajo, así como las distintas responsabilidades que les incumben en virtud de tales disposiciones, de conformidad con los objetivos y principios establecidos en el Convenio (núm. 155) y en la Recomendación (núm. 164) sobre seguridad y salud de los trabajadores, 1981. Esta información deberá comunicarse a los trabajadores en una lengua que éstos comprendan con facilidad.

L os trabajadores, por su parte, deberán velar, en la medida de lo posible y con arreglo a la capacitación que posean y a las instrucciones recibidas de su empresa, por su propia salud y seguridad y por las de otras personas a quienes puedan afectar sus actos u omisiones en el trabajo (sección 2.3.2).

De conformidad con las directrices establecidas en los apartados pertinentes del Repertorio, y en cumplimiento de las condiciones exigidas en el Convenio núm. 170 y en la Recomendación núm. 177, los proveedores de productos químicos, ya sean fabricantes, importadores o distribuidores, deberán asegurarse de que,

- tales productos hayan sido clasificados o que sus propiedades hayan sido evaluadas;

- dichos productos llevan una marca;

- los productos químicos peligrosos hayan sido etiquetados,

- se preparan y proporcionan a las empresas fichas de datos de seguridad para los productos químicos peligrosos.

\section{Medidas de control operativo}

En la sección 6 del Repertorio de recomendaciones prácticas de la O IT se abordan ciertos principios generales relativos al control operativo de los productos químicos en el trabajo y se establece 


\section{Comunicación de riesgos: la ficha de datos de seguridad o la ficha técnica de seguridad (FTS)}

La adopción de un planteamiento sistemático respecto a la seguridad requiere un flujo eficaz de información de los proveedores a los usuarios de productos químicos respecto a sus posibles riesgos y a las precauciones pertinentes. Al abordar la necesidad de establecer un programa de comunicación de riesgos por escrito, en el Repertorio de recomendaciones prácticas de la O IT Seguridad en la utilización de productos químicos en el trabajo (0 IT 1993) se establece que: "El proveedor de productos químicos peligrosos debería proporcionar al empleador las informaciones esenciales relativas a los productos que le suministra, mediante las fichas de datos de seguridad preparadas a tal efecto". En esta ficha de datos de seguridad o ficha técnica de seguridad (FTS) se describen los riesgos de un producto y se ofrecen instrucciones sobre el modo de manipularlo, utilizarlo y almacenarlo en condiciones de seguridad. Las FTS son elaboradas por el fabricante o el importador de las sustancias peligrosas. El fabricante debe remitir estas fichas a los distribuidores y otros clientes en la primera adquisición del producto en cuestión y si la FTS es objeto de modificación. Los distribuidores deben suministrar automáticamente las fichas a sus clientes comerciales. De acuerdo con el Repertorio de recomendaciones prácticas de la $0 \mathrm{IT}$, "Ios trabajadores y sus representantes deberían tener el derecho a obtener las fichas de datos de seguridad, así como a recibir información de las mismas, presentada en una forma y lenguaje tales que permitan su fácil comprensión". Puesto que parte de la información requerida puede estar dirigida a especialistas, es posible que sea necesario recabar aclaraciones al empleador. La FDS es sólo una fuente de información más sobre un producto y, por tanto, debe utilizarse junto con folletos técnicos, etiquetas, material pedagógico y otros documentos.

Los requisitos relativos a un programa de comunicación de riesgos por escrito se esbozan al menos en tres importantes directivas internacionales: la $\mathrm{N}$ orma de comunicación de riesgos de la $\mathrm{O}$ ccupational Safety and $\mathrm{Health}$ Administration $(\mathrm{O} \mathrm{SHA})$, el Sistema de información sobre materiales peligrosos en el lugar de trabajo de Canadá (W HMIS) y la Directiva 91/155/CEE de la Comisión de la $\mathrm{C}$ omunidad Europea. En estos tres instrumentos, se establecen las especificaciones relativas a la elaboración de una FTS completa. Entre los criterios de realización de estas fichas figura la oferta de información sobre la identidad del producto químico, su proveedor, su clasificación, sus riesgos, las precauciones de seguridad y los procedimientos de urgencia pertinentes. En el análisis que se ofrece a continuación se detalla el tipo de información exigida que se incluye en el Repertorio de recomendaciones prácticas de la O IT de 1992 Seguridad en la utilización de productos químicos en el trabajo. Aunque el Repertorio no se concibió como sustituto de las leyes, reglamentos y normas nacionales aceptadas, sus recomendaciones prácticas están dirigidas a todos aquellos responsables de garantizar una utilización segura de las sustancias químicas en el lugar de trabajo.

La siguiente descripción del contenido de la ficha de datos de seguridad se incluye en la sección 5.3 del Repertorio:

La ficha de datos de seguridad relativa a un producto químico peligroso debería proporcionar información sobre su identificación, su proveedor, su clasificación, su peligrosidad, medidas de seguridad y los procedimientos de urgencia pertinentes.

La ficha debería incluir los datos que hayan sido establecidos por la autoridad competente en la región en que se encuentran situados los locales del empleador, o por un organismo a probado 0 reconocido por la autoridad competente. A continuación se detalla el tipo de información que debería exigirse. (a) Identificación de los productos químicos del fabricante La denominación debería ser la misma que se haya utilizado en la etiqueta de un producto químico peligroso, ya sea el nombre común del producto químico o una denominación comercial de uso corriente. Se podrá hacer referencia a otras denominaciones en caso de que ello contribuya a la identificación. Debería incluirse el nombre completo, la dirección y el teléfono del proveedor. También debería indicarse un número de teléfono que permita comunicarse con quien corresponda en una situación de urgencia. Este número de urgencia puede ser el del proveedor mismo 0 el de un organismo de consulta reconocido, con la condición de que el uno o el otro sean accesibles en todo momento.

(b) Información sobre los componentes (composición)

Esta información debería permitir que el empleador identifique con claridad los riesgos inherentes a un producto químico determinado, de manera tal que pueda rea lizar una evaluación de los riesg os como la que se describe en la sección 6.2 (procedimientos de evaluación) del presente repertorio. En general, se debería indicar la composición de un producto químico en forma detallada y completa, pero ello no será necesario en casos en que los riesgos puedan ser evaluados debidamente. Salvo en los casos en que el nombre o la concentración de un componente en una mezcla química constituya una información confidencial, y se pueda retener de conformidad con la sección 2.6, se debería proporcionar las informaciones siguientes:

(i) una descripción de los componentes principales, incluida su natura leza química;

(ii) la identidad y las concentraciones de los componentes que entrañan riesgos para la seguridad y la salud;

(iii) la identidad y la concentración máxima en que se presentan ciertos componentes que alcanzan o rebasan el nivel de concentración por el que han sido clasifica dos como peligrosos para la seguridad y la salud, según las listas a probadas o reconocidas por la autoridad competente, o que han sido prohibidos en concentraciones superiores por la autoridad competente.

(c) Identificación de los riesgos

Se debería exponer, en forma clara y concisa, los riesgos más importantes, incluidos los riesgos más significativos para la salud, físicos y para el medio ambiente, a modo de compendio de situaciones de urgencia. La información proporcionada debería ser compatible con la que figure en la etiqueta.

(d) M edidas para los primeros a uxilios

Las medidas para los primeros auxilios y la autoasistencia se deberían explicar cuidadosamente. Se deberían definir las situaciones en que será necesario intervenir con atención médica de urgencia y cuáles serán las medidas que deberán aplicarse en tales intervenciones. Cuando se considere apropiado, se debería hacer hincapié en la necesidad de prever medidas especiales para emprender tratamientos médicos específicos e inmediatos.

(e) M edidas en caso de incendio

Se deberían incluir las disposiciones relativas a la extinción de incendios en instalaciones que contengan productos químicos, precisando por ejemplo:

(i) los equipos extinto res adecuados;

(ii) los equipos extintores cuyo uso debería evitarse por razones de seguridad;

(iii) el equipo de protección especial para las personas encargadas de la extinción de incendios. 
Se debería proporcionar también información sobre las propiedades de los productos químicos en combustión, los riesgos especiales que entraña la exposición a los productos resultantes de la combustión y las precauciones que se deberían adoptar al respecto.

(f) M edidas en caso de emisión accidental

Deberían indicarse las medidas necesarias en caso de que se produzca una emisión accidental de productos químicos. Entre ellas, deberían incluirse:

(i) precauciones relativas a la salud y la seguridad: eliminación de las fuentes de ignición, suministro de ventilación suficiente y de los equipos de protección individual adecuados;

(ii) precauciones ambientales: mantenerse alejado de los sistemas de desagüe, alertar sin demora a los servicios de urgencia y, de ser necesario, avisar a la población más próxima sobre riesgos inminentes;

(iii) métodos para realizar la limpieza de los sitios contaminados en condiciones de seguridad: el uso de materiales absorbentes adecuados, la exclusión del agua o de otros diluyentes que puedan causar reacciones productoras de gases o vapores, el empleo de agentes neutralizadores adecuados;

(iv) advertencias: la difusión de consejos para evitar acciones peligrosas razonablemente previsibles.

(g) M anipulación y a Imacenamiento

Se deberían indicar las condiciones de seguridad que el proveedor recomiende para la manipulación y almacenamiento de los productos químicos, incluyendo en particular las que se refieren a:

(i) el diseño y el emplazamiento de los locales y recipientes de almacenamiento de productos químicos;

(ii) la ubicación de la zona de almacenamiento en sitios apartados de los lugares de trabajo y de otros edificios ocupados por el personal

(iii) la incompatibilidad entre determinados materiales;

(iv) las condiciones para el almacenamiento, como por ejemplo la temperatura y la humedad adecuadas o la protección contra la luz solar

(v) la eliminación de las fuentes de ignición, con especial referencia a las medidas destinadas a evitar la acumulación de cargas electrostáticas;

(vi) el suministro de ventilación tanto local como general;

(vii) los métodos de trabajo que se recomiende adoptar y aquellos cuya utilización sea desaconsejada.

(h) Controles en caso de exposición y protección individual Se deberían proporcionar informaciones sobre la necesidad de hacer uso de equipo de protección individual al utilizar productos químicos, así como sobre la clase de equipo que proporciona una protección adecuada y conveniente. Cuando haya lugar, se debería formular un recordatorio para señalar que los medios de control básicos deberían estar contemplados en el diseño y la instalación de todos los equipos y otros dispositivos técnicos utilizados, como también en la información disponible sobre las prácticas que contribuyen a minimizar los riesgos de exposición de los trabajadores. Además de presentar algunos de los procedimientos que se recomienden para la vigilancia de los niveles de exposición, se deberían indicar ciertos parámetros de control específico, como los límites de exposición o los valores límite biológicos. (i) Propiedades físicas y químicas

Se debería suministrar una breve descripción de la apariencia del producto químico, informando si se trata de un sólido, un líquido 0 un gas, y acerca de su color y olor. Si se conocen, se deberían señalar también algunas de sus características y propiedades, y precisar en cada caso la índole de las pruebas que permitan su verificación. Dichas pruebas deberían estar en conformidad con la legislación nacional y con los criterios en vigor en el lugar de trabajo del empleador, y en caso de que no existan criterios 0 legislación nacional, se deberían utilizar como orientación los criterios de prueba del país exportador. La información facilitada debería comprender todos los datos a propiados que la utilización del producto químico requiera. Entre otros, se podrían incluir datos sobre:

- viscosidad

- punto de congelación/ rango de congelación

- punto de ebullición/ rango de ebullición

- punto de fusión/ rango de fusión

- punto de inflamación

- punto de autoencendido

- propiedades explosivas

- propiedades oxidantes

- presión de vapor

- peso molecular

- peso específico o la densidad

- $\mathrm{pH}$

- solubilidad

- coeficiente de reparto (agua/ n-octano)

- parámetros tales como la densidad de vapor

- miscibilidad

- velocidad de evaporación y conductividad.

(j) Estabilidad y reactividad

Se debería señalar que, en determinadas circunstancias, es posible que se produzcan reacciones químicas peligrosas. En consecuencia, deberían indicarse los factores de riesgo que es necesario evitar, ya sean:

(i) las condiciones físicas en que se encuentra el producto químico, como por ejemplo la temperatura, presión, luminosidad, exposición a golpes o sacudidas, contacto con la humedad 0 el aire; 0

(ii) las condiciones de proximidad o contacto con otros productos químicos, tales como ácidos, bases, agentes oxidantes o cualquier otra sustancia que pueda provocar una reacción peligrosa.

Se deberían identificar todas las sustancias que resultan de la descomposición de un producto químico, y señalar al mismo tiempo las precauciones que deben adoptarse respecto de cada una de ellas.

(k) Información toxicológica

Esta sección de la ficha de datos de seguridad debería informar sobre los efectos y las vías posibles de penetración de un producto químico en el organismo. Se deberían señalar las afecciones agudas, ya sean de efecto inmediato o diferido, como también las crónicas, resultantes tanto de exposiciones de corta duración como de exposiciones durante un largo período. También deberían mencionarse los peligros para la salud que podría entrañar el producto químico al entrar en reacción con otros productos químicos, y cuando haya lugar, las interacciones que resulten del consumo de medicamentos, tabaco 0 alcohol. 


\section{(I) Información ecológica}

Se deberían indicar las características más importantes que pueden tener repercusiones sobre el medio ambiente. La índole y el detalle de la información requerida dependerán de la legislación nacional y las prácticas vigentes que se aplican en la empresa. Entre los tipos de información que debería facilitarse cuando haya lugar, se deberían señalar las eventuales vías de escape del producto químico que origine la situación de riesgo, su capacidad de persistencia y degradación, su potencialidad de acumulación biológica y su toxicidad en medio acuático, así como otras informaciones relativas a sus repercusiones tóxicas sobre el medio ambiente, como, por ejemplo, los efectos en las técnicas de descontaminación del agua.

(m) Informaciones sobre la eliminación del producto

Se deberían proporcionar métodos seguros de eliminación de un producto químico que pueda contener residuos de productos químicos peligrosos. Se debería recordar a los empleadores que pueden existir ya una legislación nacional y prácticas sobre la materia.

(n) Informaciones sobre el transporte

Se deberían señalar las precauciones especiales que el empleador debería conocer u observar durante el transporte de productos químicos dentro o fuera de sus instalaciones. Se podría incluir también la información pertinente contenida en las Recomendaciones de las $\mathrm{N}$ aciones Unidas relativas al trans porte de mercancías peligrosas 0 en otros convenios internacionales.

(0) Informaciones sobre reglamentación

En esta sección de la ficha de datos de seguridad se deberían incluir las informaciones relativas al etiquetado y marcado de los productos químicos. Se deberían mencionar también las disposiciones reglamentarias o las prácticas nacionales aplicables a los usuarios. Se debería recordar a los empleadores que se informaran acerca de los requisitos establecidos por la legislación y la práctica nacionales.

\section{(p) 0 tras informaciones}

Deberían incluirse otras informaciones que puedan ser importantes para la salud y la seguridad de los trabajadores, como por ejemplo: orientaciones para capacitar a los trabajadores en la utilización del producto, recomendaciones sobre usos y restricciones, referencias, fuentes de información esenciales para la compilación de la ficha de datos de seguridad, las coordenadas del contacto de asistencia técnica y la fecha de puesta en circulación de la ficha.
En la sección 6 del Repertorio de recomendaciones prácticas de la OIT se abordan ciertos principios generales relativos al control operativo de los productos químicos en el trabajo y se establece que, tras examinar estos productos, recopilar la información relativa a los peligros que de ellos dimanen y evaluar sus riesgos virtuales, las empresas deberán adoptar medidas para limitar la exposición de los trabajadores a los productos químicos peligrosos (con arreglo a las que se esbozan en las secciones 6.4 a 6.9 del Repertorio) con el fin de protegerles respecto a los riesgos que implica su utilización en el trabajo. Las medidas adoptadas deben eliminar o minimizar tales riesgos, preferiblemente mediante la sustitución por otros productos de peligrosidad reducida o nula o la elección de una tecnología mejor. Cuando ni la sustitución ni los controles técnicos resulten factibles, otras medidas como la puesta en marcha de prácticas y sistemas de trabajo seguros, los equipos de protección personal (EPP) y la oferta de información y formación facilitarán la atenuación de los riesgos y podrán aplicarse en ciertas actividades que exigen la utilización de productos químicos.

En los casos en que los trabajadores puedan verse expuestos a la acción de productos químicos peligrosos para la salud, deben ser protegidos respecto al riesgo de lesión o de enfermedad que éstos generan. Las exposiciones no deben exceder los límites $u$ otros criterios de evaluación y control del medio ambiente de trabajo establecidos por la autoridad competente o por un organismo aprobado o reconocido por la misma de acuerdo con las normas nacionales o internacionales

A continuación se indican las medidas de control relativas a la protección de los trabajadores que pueden adoptarse, combinándolas de la manera que resulte más conveniente:

1. Diseño y métodos de funcionamiento adecuados de las instalaciones:

- sistemas de proceso y de manipulación en medios completamente aislados;

- separación de un proceso peligroso de los operadores o de otros procesos:
2. Instalaciones, procesos o sistemas de trabajo que reduzcan al mínimo, supriman o puedan retener polvos peligrosos, vapores nocivos, etc., y que, en el caso de derrames y escapes, puedan circunscribir el área de contaminación:

- recintos parcialmente aislados, dotados de sistemas de ventilación por extracción localizada (VEL);

- VEL,

- sistemas de ventilación general adecuada.

3. Sistemas y prácticas de trabajo:

- reducción del número de trabajadores sometidos a exposición y exclusión de todo acceso no indispensable;

- reducción del tiempo de exposición de los trabajadores;

- limpieza periódica de las paredes o superficies contaminadas, etc.;

- utilización y mantenimiento adecuados de las medidas de control técnico,

- suministro de medios adecuados para almacenar y eliminar en condiciones de seguridad los productos químicos peligrosos para la salud.

4. Protección personal (cuando las medidas que anteceden resulten insuficientes, debe ponerse a disposición de los trabajadores el EPP adecuado, el cual debe ser utilizado hasta que los riesgos queden eliminados o hayan sido reducidos a un nivel considerado inocuo para la salud);

5. Prohibición de comer, mascar, beber y fumar en zonas contaminadas;

6. Suministro de medios e instalaciones adecuados para lavar, cambiarse y guardar la ropa, incluidas las instalaciones para el lavado de ropa contaminada;

7. U tilización de rótulos y carteles,

8. Procedimientos adecuados en caso de emergencia.

Los productos químicos con efectos cancerígenos, mutagénicos o teratogénicos para la salud se someterán a un control estricto. 


\section{Registro de datos}

El registro de datos es un elemento esencial de las prácticas de trabajo que facilitan una utilización de productos químicos en condiciones de seguridad. Las empresas deben llevar registros en los que se consignen las mediciones de los productos químicos peligrosos en suspensión en el aire. Tales registros deben identificarse claramente, indicando la fecha, la zona de trabajo y la ubicación de las instalaciones. A continuación se refieren algunos aspectos de la sección 12.4 del Repertorio de recomendaciones prácticas de la O IT, en la que se abordan los requisitos relativos al registro de datos.

- Deben registrarse las mediciones efectuadas durante los muestreos individuales, con inclusión de los niveles de exposición calculados.

- Los registros mencionados deben estar a disposición de los trabajadores y sus representantes, así como de la autoridad competente.

Además de los resultados numéricos resultantes de las mediciones, la información obtenida mediante la vigilancia debe incluir, por ejemplo:

- el marcado de los productos químicos peligrosos;

- la ubicación, índole, dimensiones y otras características distintivas del lugar de trabajo en que se hayan realizado las mediciones estáticas; la ubicación exacta de los lugares donde se hayan efectuado las mediciones de vigilancia individuales, los nombres de los trabajadores implicados y la denominación de los cargos que ejercen;

- la fuente 0 fuentes de emisión de productos químicos en suspensión en el aire, su ubicación y el tipo de trabajo y operaciones que tenían lugar al tomarse las muestras;

- informaciones pertinentes sobre el desarrollo del proceso, las medidas de control técnico, la ventilación y las condiciones climáticas en relación con las emisiones;

- Ios instrumentos utilizados para el muestreo, sus accesorios y el método de análisis aplicado

- la fecha y la hora exacta del muestreo;

- el tiempo de exposición de los trabajadores, señalando si utilizaban o no equipos de protección respiratoria y otras observaciones relativas a la evaluación de la exposición,

- los nombres de las personas responsables de los muestreos y de las decisiones inferidas a partir de los análisis.

L os registros deben conservarse durante el período que determine la autoridad competente. Cuando no existan disposiciones al respecto, se recomienda que la empresa conserve los registros, 0 , en su defecto, un resumen apropiado de los mismos, durante:

1. treinta años, como mínimo, cuando los registros contengan datos sobre las exposiciones de trabajadores identificables,

2. cinco años, como mínimo, en todos los demás casos.

\section{Información y formación}

U na instrucción correcta y una formación de calidad son componentes esenciales de un programa de comunicación de riesgos eficaz. En el Repertorio de recomendaciones prácticas de la OIT Seguridad en la utilización de productos químicos en el trabajo se ofrecen principios generales de formación (secciones 10.1 y 10.2). Son los siguientes:

- Debe informarse a los trabajadores de los riesgos asociados a los productos químicos utilizados en el lugar de trabajo.

- Debe instruirse a los trabajadores sobre la forma de obtener y usar la información que aparece en las etiquetas y en las fichas de datos de seguridad.

- Debe impartirse a los trabajadores formación sobre el uso correcto y eficaz de las medidas de control, especialmente de las medidas de control técnico y de las de protección personal puesta a disposición, procurando que comprendan su importancia.

- Las empresas deben utilizar las fichas de datos de seguridad, junto con la información específica relativa al lugar de trabajo, como base para la preparación de instrucciones destinadas a los trabajadores que, en su caso, se consignarán por escrito.

- Debe impartirse a los trabajadores formación continua acerca de los procedimientos y las prácticas que deben seguirse y su importancia para la seguridad en la utilización de productos químicos en el trabajo, y sobre el modo de proceder en casos de emergencia.

\section{Revisión de las necesidades de formación}

El alcance de la formación y la instrucción recibidas y exigidas debe revisarse y actualizarse simultáneamente a la revisión de los sistemas y las prácticas de trabajo a las que se hace referencia en la sección 8.2 (Revisión de los sistemas de trabajo).

En el marco de dicha revisión debe analizarse:

- el grado de comprensión de los trabajadores de las circunstancias en que deben utilizarse los equipos de protección y sus limitaciones;

- el grado de comprensión de los trabajadores respecto a la utilización más eficaz de las medidas de control técnico adoptadas;

- el dominio de los trabajadores de los procedimientos aplicables en casos de emergencia en el uso de productos químicos peligrosos,

- los procedimientos de intercambio de información entre trabajadores de turnos diferentes.

\section{SISTEMAS DE CLASIFICACION Y ETIQUETADO PARA PRODUCTOS QUIMICOS}

\author{
Konstantin K. Sidorov e \\ Igor V. Sanotskiy
}

Los sistemas de clasificación y etiquetado de riesgos se incluyen en la legislación en materia de seguridad en la producción, el transporte, la utilización y la evacuación de productos químicos. Estas clasificaciones se diseñan para facilitar una transmisión sistemática y completa de información sanitaria. A escala nacional, regional e internacional sólo se dispone de un número reducido de sistemas clasificación y etiquetado significativos. Los criterios y las definiciones utilizadas en estos sistemas varían en cuanto al número y al grado de las escalas de riesgo, la terminología específica, los métodos de ensayo y la metodología para clasificar las mezclas de sustancias químicas o preparados. La creación de una estructura internacional para la armonización de dichos sistemas ejercería un efecto positivo en el comercio de productos químicos, el intercambio de información sobre los mismos, el coste de su evaluación de riesgos y su gestión y, en definitiva, la protección de los trabajadores, la población en general y el medio ambiente.

El fundamento de la clasificación de productos químicos consiste en la evaluación de los niveles de exposición y el impacto ambiental (agua, aire y suelo). En torno a la mitad de los sistemas internacionales incorporan criterios relacionados con el volumen de producción de cada sustancia química o los efectos de las emisiones de contaminantes. Los criterios más generalizados en la clasificación de productos químicos se basan en los valores de la dosis letal media $\left(L_{50}\right)$ y la concentración 
letal media $\left(\mathrm{LC}_{50}\right)$. Estos se evalúan en animales de laboratorio a través de tres vías principales (oral, dérmica e inhalación) en una exposición única. $L$ os valores de $L D_{50}$ y $L C_{50}$ se comprueban en las mismas especies animales y con las mismas vías de exposición. En la República de Corea se considera asimismo la $\mathrm{LD}_{50}$ mediante administración intravenosa e intracutánea. En Suiza y Yugoslavia, la legislación sobre gestión de productos químicos exige la aplicación de criterios cuantitativos en la estimación de la $L_{50}$ en la administración oral y contempla la posibilidad de establecer clasificaciones de riesgos diferentes en función de la vía de exposición.

Además, existen disparidades en las definiciones de niveles de riesgo comparables. $M$ ientras que en el sistema de la Comunidad Europea (CE) se utiliza una escala de toxicidad aguda de tres niveles ("muy tóxico", "tóxico" y "nocivo"), en la Norma de comunicación de riesgos de la Administración para la Salud y la

\section{Sistemas de clasificación}

\subsection{Generalidades}

3.1.1. La autoridad competente, o el órgano aprobado o reconocido por ella, debería establecer sistemas y criterios específicos de clasificación sobre la peligrosidad de los productos químicos y debería extender progresivamente estos sistemas, así como su aplicación. Podrán adoptarse los criterios de clasificación ya establecidos por otras autoridades competentes 0 en acuerdos internacionales, con la condición de que sean compatibles con los criterios y métodos expuestos en este repertorio, y se insta a proceder así cuando ello contribuya a armonizar los conceptos. Cuando hubiere lugar, deberían considerarse los resultados del trabajo del grupo de coordinación del Programa Internacional PN UMA/OIT/ OMS de Seguridad de las Sustancias Químicas (IPCS) para la armonización de la clasificación de productos químicos. Las responsabilidades y funciones de las autoridades competentes respecto a los sistemas de clasificación se establecen en los párrafos 2.1.8 (sistemas y criterios específicos), 2.1.9 (lista integrada) y 2.1 .10 (evaluación de los nuevos productos químicos). 3.1.2. Los proveedores deberían asegurarse de que los productos químicos que suministran han sido clasificados y de que sus propiedades han sido evaluadas e identificadas [véanse los párrafos 2.4.3 (evaluación) y 2.4.4 (clasificación)].

3.1.3. Los fabricantes o los importadores que no estén eximidos de hacerlo deberían facilitar a la autoridad competente información acerca de los elementos y los compuestos químicos que no se hayan incorporado aún en la lista integrada de clasificación elaborada por la autoridad competente, antes de su utilización en el trabajo [véase el párrafo 2.1 .10 (evaluación de los nuevos productos químicos)].

3.1.4. Las cantidades mínimas de un nuevo producto químico requeridas para la investigación y desarrollo se podrían producir en laboratorios y en plantas piloto, y manipular y transportar entre laboratorios y plantas piloto antes de que se conozcan los riesgos que comporte dicho producto químico, de conformidad con la legislación y las reglamentaciones nacionales. Se debería tener en cuenta toda la información disponible impresa o conocida por el empleador a lo largo de su experiencia con productos químicos y aplicaciones similares, y se deberían aplicar las medidas de protección adecuadas como si se tratase de un producto químico peligroso. Asimismo, a los trabajadores que traten con dicho producto se les debería comunicar la información obtenida sobre los peligros que conlleva.

\subsection{Criterios de clasificación}

3.2.1. Los criterios de clasificación de los productos químicos deberían basarse en los riesgos físicos y para la salud que entrañan dichos productos, entre ellos:

(a) propiedades tóxicas, incluidos los efectos agudos y crónicos sobre la salud en cualquier parte del cuerpo;

(b) características químicas o físicas, incluidas sus propiedades inflamables, explosivas, comburentes y aquellas que puedan provocar reacciones peligrosas;

(c) propiedades corrosivas e irritantes; (d) efectos alérgicos y sensibilizantes;

(e) efectos cancerígenos;

(f) efectos teratóg enos y mutágenos;

(g) efectos sobre el sistema reproductor.

\subsection{Métodos de clasificación}

3.3.1. La clasificación de los productos químicos debería basarse en las fuentes de información disponibles, es decir:

(a) datos obtenidos en las pruebas;

(b) información proporcionada por el fabricante 0 el importado, incluida la información sobre la labor de investigación realizada;

(c) información suministrada en las normas de transporte internacional, verbigracia, las Recomendaciones de las $\mathrm{N}$ aciones Unidas relativas al transporte de mercancías peligrosas, que deberían tenerse en cuenta para la clasificación de los productos químicos en lo que se refiere a su transporte, y el Convenio de Basilea del PN UM A sobre el control de los movimientos transfronterizos de los desechos peligrosos y su eliminación (1989), que debería tenerse en cuenta respecto de los desechos peligrosos;

(d) bibliografía o documentación de referencia;

(e) experiencia práctica;

(f) en el caso de mezclas, información obtenida a partir de las pruebas realizadas del compuesto 0 de los riesgos conocidos de sus componentes;

(g) información proporcionada por la Agencia Internacional para la Investigación sobre el Cáncer (IARC), el Programa Internacional PN UMA/OMS/ OIT de Seguridad de las Sustancias Q uímicas (IPCS), las Comunidades Europeas y distintas instituciones nacionales e internacionales, así como la información disponible mediante sistemas tales como el Registro Internacional de Productos $Q$ uímicos Potencialmente Tóxicos (RPQ PT) del PN UMA sobre la evaluación de los riesgos del trabajo efectuado.

3.3.2. Algunos de los sistemas de clasificación vigentes pueden limitarse de forma exclusiva a determinadas clases de productos químicos. En la Clasificación Recomendada de Plaguicidas según el Riesgo y Directrices para la Clasificación, de la OMS, por ejemplo, se clasifican los plaguicidas únicamente según el grado de toxicidad, en función de los riesgos más graves que entrañan para la salud. Los empleadores y los trabajadores deberían ser conscientes de las limitaciones de todos estos sistemas, que pueden ser útiles para complementar un sistema de aplicación más general. 3.3.3. Los compuestos químicos deberían clasificarse según los riesgos manifestados por las propias mezclas. En el caso de que no se hayan ensayado las mezclas en su totalidad, los compuestos deberían clasificarse sobre la base de los riesgos que entrañan sus componentes químicos. 
Seguridad en el Trabajo de Estados U nidos (O SH A) se recogen dos niveles de toxicidad aguda ("extremadamente tóxico" y "tóxico"). En la mayoría de las clasificaciones se aplican tres categorías (N aciones U nidas (NU), Banco M undial, O rganización $\mathrm{M}$ arítima Internacional (OMI), CE y otras) o cuatro (antiguo Consejo de Ayuda E conómica M utua (CAEM ), Federación Rusa, China, M éxico y Yugoslavia).

\section{Sistemas internacionales}

El análisis de los sistemas de etiquetado y clasificación de productos químicos existentes que se ofrece a continuación se centra fundamentalmente en las estructuras más importantes con una amplia experiencia de aplicación. Las evaluaciones de los riesgos de los plaguicidas no se incluyen en las clasificaciones generales de productos químicos, pero se abordan en las de la Organización de las $\mathrm{N}$ aciones U nidas para la Agricultura y la Alimentación/ O rganización M undial de la Salud (FAO/OMS), así como en diversas legislaciones nacionales (p. ej., Bangladesh, Bulgaria, China, Federación Rusa, Polonia, República de Corea, Sri Lanka, Venezuela y Zimbabwe).

\section{Clasificaciones basadas en el transporte}

Las clasificaciones basadas en el transporte, de amplia aplicación, fundamentan las normativas en materia de etiquetado, envasado y transporte de mercancías peligrosas. Entre estas clasificaciones figuran las Recomendaciones de las $\mathrm{N}$ aciones $\mathrm{U}$ nidas relativas al transporte de mercancías peligrosas (UNRTDG), el Código marítimo internacional de mercancías peligrosas de la OM I, la clasificación establecida por el Grupo mixto de expertos sobre los aspectos científicos de la contaminación marítima (GEAM C CM) respecto a las sustancias químicas peligrosas transportadas en buques y diversas clasificaciones de transporte nacionales. En general, éstas se ajustan a las clasificaciones de las Naciones Unidas, la OMI y otros organismos, en el marco de acuerdos internacionales sobre transporte de mercancías peligrosas, por vía aérea, ferrocarril, carretera y navegación fluvial, armonizadas con el sistema de las $\mathrm{N}$ aciones $\mathrm{U}$ nidas.

\section{Recomendaciones de las Naciones Unidas relativas al transporte de mercancías peligrosas y disposiciones afines en materia de transporte}

LaS UNRTDG han dado lugar a la creación de un sistema mundial de amplia aceptación que constituye un marco para la formulación de normativas en materia de transporte regional, internacional y combinado. Las Recomendaciones son cada vez más utilizadas como base de los reglamentos nacionales sobre transporte. Sus disposiciones son más bien generales en cuestiones como la notificación, la identificación y la comunicación de riesgos. Su alcance se ha restringido al transporte de sustancias peligrosas envasadas; las Recomendaciones no se aplican a los productos químicos expuestos ni al transporte a granel. Inicialmente, el objetivo era evitar que las mercancías peligrosas provocasen lesiones agudas a los trabajadores 0 a la población en general y que dañasen otros artículos o los medios de transporte empleados (aeronaves, buques, trenes o vehículos para el desplazamiento por carretera). A ctualmente, el sistema se ha ampliado para incluir el amianto y otras sustancias que entrañan riesgos para el medio ambiente.

Las UNRTDG se ocupan esencialmente de la comunicación de riesgos basada en la aplicación de etiquetas que consisten en una combinación de símbolos gráficos, colores, palabras de advertencia y códigos de clasificación. Asimismo, ofrecen datos fundamentales a los equipos de actuación en caso de emergencia. Las Recomendaciones se aplican a la protección de trabajadores del sector del transporte como los miembros de las tripulaciones aéreas, los marineros y las dotaciones de trenes y vehículos de transporte por carretera. En muchos países, se han incorporado en la legislación sobre protección de los trabajadores portuarios. Componentes del sistema como las Recomendaciones en materia de explosivos han sido adaptados a las normativas regionales y nacionales aplicadas en el lugar de trabajo, normalmente en lo que se refiere a su fabricación y almacenamiento. $\mathrm{O}$ tras organizaciones de las Naciones $U$ nidas que se ocupan de cuestiones relacionadas con el transporte han adoptado las UNRTDG. Los sistemas de clasificación para el transporte de mercancías peligrosas de Australia, C anadá, India, Jordania, Kuwait, Malaisia y el Reino U nido, por ejemplo, se atienen en esencia a los principios fundamentales de estas Recomendaciones.

En la clasificación de las $\mathrm{N}$ aciones U nidas se subdividen los productos químicos en nueve clases en función del riesgo:

- 1a clase: sustancias explosivas:

- 2a clase: gases comprimidos, licuados, disueltos bajo presión y altamente condensados;

- 3a clase: líquidos fácilmente inflamables;

- 4a clase: sustancias sólidas fácilmente inflamables;

- 5a clase: sustancias oxidantes, peróxidos orgánicos;

- 6a clase: sustancias nocivas (tóxicas) e infecciosas;

- 7a clase: sustancias radiactivas;

- 8a clase: agentes corrosivos,

- 9a clase: otras sustancias peligrosas.

El embalaje de mercancías para su transporte, un aspecto considerado en las UNRTDG, no se aborda con el mismo detenimiento en otros sistemas. Como ayuda a la aplicación de las Recomendaciones, organizaciones como la O M I y la O rganización de Aviación Civil Internacional (OACI) llevan a cabo programas muy significativos encaminados a la capacitación de los trabajadores portuarios y del personal aeroportuario en el reconocimiento de la información contenida en las etiquetas y en las normas de embalaje.

\section{La Organización Marítima Internacional}

La OMI, con un mandato derivado de la Conferencia sobre la seguridad de la vida en el mar de 1960 (SO LAS 1960), ha elaborado el Código marítimo internacional de mercancías peligrosas (IM DG ). Este instrumento completa las disposiciones obligatorias del capítulo VII (T ransporte de mercancías peligrosas) de SO LAS 74 y del A nexo III del Convenio sobre contaminación marítima (MARPOL 73/78). EI Código IMDG ha sido desarrollado y actualizado durante más de 30 años en estrecha colaboración con el Comité de Expertos de las Naciones U nidas sobre transporte de mercancías peligrosas (CETG) y ha sido adoptado por 50 miembros de la O MI, lo que permite su aplicación a un $85 \%$ del volumen de mercancías de este tipo transportadas en el mundo.

La armonización del Código IMDG con las UNRTDG garantiza la compatibilidad con las normas nacionales e internacionales aplicables al transporte de mercancías peligrosas a través de otros medios, en la medida en que estas otras normas se basen asimismo en las recomendaciones del UNCETG, es decir las Instrucciones técnicas de la $\mathrm{OACl}$ para el transporte seguro de mercancías peligrosas por vía aérea y los Reglamentos europeos relativos al transporte internacional de mercancías peligrosas por carretera (ADR) y por ferrocarril (RID).

En 1991, la 17a A samblea de la O MI adoptó una Resolución sobre la coordinación del trabajo en cuestiones relativas a las mercancías y las sustancias peligrosas, en la que, entre otras cosas, se instaba a los organismos de las $\mathrm{N}$ aciones $\mathrm{U}$ nidas y a los gobiernos a coordinar sus actividades con el fin de garantizar la compatibilidad de la legislación existente en materia de productos químicos y mercancías y sustancias peligrosas con las normas internacionales de transporte establecidas. 
Convenio de Basilea sobre el control de los movimientos transfronterizos de los desechos peligrosos y su eliminación, 1989 En los anexos al Convenio se definen 47 categorías de desechos, incluidos los domésticos. Aunque la clasificación de riesgos es comparable a la de las UNRTDG, una diferencia significativa entre ambas consiste en la inclusión en la primera de tres categorías adicionales que reflejan con mayor detalle la naturaleza de los desechos tóxicos: toxicidad crónica, liberación de gases tóxicos por la interacción de los desechos con el aire o el agua y capacidad de los desechos para generar material tóxico secundario tras su evacuación.

\section{Plaguicidas}

L os sistemas nacionales de clasificación relativos a la evaluación de riesgos de los plaguicidas suelen caracterizarse por su exhaustividad debido a la utilización generalizada de estos productos químicos y su capacidad para dañar el medio ambiente de forma permanente. En estos sistemas pueden identificarse de dos a cinco clasificaciones de riesgos. L os criterios se basan en las dosis letales medias con diversas vías de exposición. M ientras Venezuela y Polonia sólo reconocen una vía, la ingestión, la O M S y otros países consideran además el contacto con la piel.

L os criterios para evaluar los riesgos de los plaguicidas en los países de Europa oriental, Chipre, Zimbabwe, China y otros se basan en las dosis letales medias por inhalación. En cambio, en Bulgaria se tienen en cuenta la irritación de la piel y de los ojos, la sensibilización, la capacidad de acumulación, la persistencia en el medio ambiente, los efectos blastogénicos y teratogénicos, la embriotoxicidad, la toxicidad aguda y el tratamiento médico. Asimismo, en numerosas clasificaciones de plaguicidas se aplican criterios específicos basados en las dosis letales medias con diferentes estados de agregación. Por ejemplo, los criterios relativos a los plaquicidas líquidos son más estrictos que los aplicados a los sólidos.

\section{Clasificación de plaguicidas en función del riesgo recomendada por la OMS \\ Esta clasificación fue publicada por primera vez en 1975 por la O M S y ha sido actualizada periódicamente con posterioridad por el Programa Internacional de Seguridad de las Sustancias Q uímicas del Programa de las Naciones U nidas para el M edio Ambiente, la OIT y la OMS (PNUMA/OIT/OMS), en el que ha colaborado la O rganización de las $\mathrm{N}$ aciones U nidas para la Agricultura y la Alimentación (FAO). Consiste en una categoría de riesgo o criterio de clasificación, la toxicidad aguda, dividida en cuatro niveles de clasificación basados en la LD $_{50}$ (valores en ratas, orales y dérmicos para formas líquidas y sólidas), que van de la calificación de extremadamente peligroso a la de ligera- mente peligroso. A parte de las consideraciones generales, no se establecen normas específicas de etiquetado. La versión actuali- zada de 1996-1997 contiene una guía de la clasificación en la que figura una lista de los plaguicidas catalogados y procedimientos generales de seguridad. (V éase el capítulo $M$ inerales y productos químicos para la agricultura.)}

\section{Código internacional de conducta de la FAO sobre la distribución y el uso de plaguicidas.}

La clasificación de la O M S se apoya en otro documento, el Código internacional de conducta de la FAO sobre la distribución y el uso de plaguicidas. Aunque sólo se trata de una recomendación, la aplicación de esta clasificación es generalizada en los países en desarrollo, donde suele incluirse en la legislación nacional pertinente. En lo que respecta al etiquetado, la FAO ha publicado D irectrices sobre buenas prácticas de etiquetado de plaguicidas como anexo al código mencionado.

\section{Sistemas regionales (CE, AELC, CAEM)}

La Directiva del Consejo (CE) 67/ 548/ CEE se ha mantenido en vigor durante más de dos decenios y ha permitido la armonización de la legislación de 12 países en la materia. $\mathrm{H}$ a dado lugar a la creación de un sistema que comprende un inventario de las sustancias químicas existentes, un procedimiento de notificación de las nuevas sustancias con anterioridad a su comercialización, un conjunto de categorías de riesgos, criterios de clasificación para cada categoría, métodos de ensayo y un sistema de comunicación de riesgos en el que se aborda el etiquetado con mensajes codificados sobre riesgo y seguridad y símbolos indicativos de peligro. Los preparados químicos (mezclas de sustancias químicas) se rigen por la Directiva del Consejo 88/379/ CEE. La definición de los elementos que figuran en las fichas de datos de seguridad es prácticamente idéntica a la utilizada en la Recomendación núm. 177 de la OIT, como se ha referido en el presente capítulo. Se ha elaborado un conjunto de criterios de clasificación y una etiqueta destinada a las sustancias químicas peligrosas para el medio ambiente. Las Directivas regulan las sustancias químicas comercializadas, con el fin de proteger la salud humana y el medio ambiente. Las catorce categorías establecidas se dividen en dos grupos relacionados respectivamente con las propiedades fisicoquímicas (explosivas, oxidantes, extremadamente inflamables, altamente inflamables, inflamables) y las toxicológicas (muy tóxicas, tóxicas, nocivas, corrosivas, irritantes, cancerígenas, mutagénicas, tóxicas para la reproducción, peligrosas para la salud o el medio ambiente)

La Comisión de las Comunidades E uropeas (C CE) dispone de una ampliación del sistema específicamente dirigida al lugar de trabajo. Además, estas medidas relativas a las sustancias químicas deben considerarse en el marco general de la protección de la salud y la seguridad de los trabajadores contemplada en la Directiva 89/391/CEE y otras directivas específicas. A excepción de Suiza, los países de la AELC se atienen en gran medida al sistema de la CE.

\section{Antiguo Consejo de Ayuda Económica Mutua (CAEM)}

Este sistema fue elaborado bajo los auspicios de la Comisión Permanente para la Cooperación en M ateria de Salud Pública del CAEM, de la que formaban parte Polonia, Hungría, Bulgaria, la antigua URSS, M ongolia, Cuba, Rumania, Vietnam y Checoslovaquia. China sigue utilizando un sistema similar en concepto. Consta de dos categorías de clasificación, toxicidad y riesgo y se aplica una escala de catalogación de cuatro niveles. 0 tro elemento del sistema del CAEM es la imposición del requisito de preparar un "pasaporte toxicológico de los nuevos compuestos químicos introducidos en la economía y en la vida doméstica". Se definen asimismo los criterios de capacidad de irritación, efectos alérgicos, sensibilización, carcinogenicidad, mutagenicidad, teratogenicidad, antifertilidad y riesgo ecológico. N o obstante, la base científica y la metodología de comprobación relacionadas con los criterios de clasificación difieren significativamente de los utilizados por otros sistemas.

Las disposiciones relativas al etiquetado en el lugar de trabajo y los símbolos indicativos de riesgo también son diferentes. Se utiliza el sistema de las UNRTDG en el etiquetado de mercancías para su transporte, pero no parece existir ningún vínculo entre los dos sistemas. No se formulan recomendaciones específicas respecto a las fichas de datos de seguridad para productos químicos. El sistema se describe en detalle en el Estudio Internacional de Sistemas de C lasificación del Registro internacional de productos químicos potencialmente tóxicos (RIPQPT) del PNUMA. Aunque el sistema del CAEM incluye la mayoría de los elementos básicos de otros sistemas de clasificación, difiere significativamente de éstos en lo que respecta a la metodología 
de evaluación de riesgos y utiliza las normas de exposición como unos de los criterios de clasificación de riesgos.

\section{Ejemplos de sistemas nacionales}

\section{Australia}

Australia promulgó la Ley de notificación y evaluación de productos químicos industriales en 1989 y otra ley similar en 1992 relativa a los productos químicos de uso agrario y veterinario. El sistema australiano es similar al de la CE. La diferencia principal radica en su utilización de la clasificación de las UNRTDG (es decir, la inclusión de las categorías de gas comprimido, sustancias radiactivas y otras).

\section{Canadá}

EI Sistema de información sobre materiales peligrosos en el lugar de trabajo (WH M IS) comenzó a aplicarse en 1988 en virtud de una combinación de leyes federales y provinciales diseñadas para llevar a la práctica la transferencia de información sobre materiales peligrosos ofrecida por productores, proveedores e importadores a las empresas y, a través de éstas, a los trabajadores. Se aplica en todos los sectores y lugares de trabajo de Canadá. EI WHMIS es un sistema de comunicación dirigido principalmente a la gestión de los productos químicos industriales y compuesto por tres elementos interrelacionados que forman parte de la comunicación de riesgos: etiquetas, fichas de datos de seguridad sobre productos químicos y programas de formación de los trabajadores. A la consolidación de este sistema contribuyó la creación y la distribución comercial con anterioridad en todo el mundo de una base de datos informatizada, disponible actualmente en disco compacto, que contiene más de 70.000 de las fichas mencionadas, remitidas de forma voluntaria al Canadian Centre for $\mathrm{O}$ ccupational $\mathrm{H}$ ealth and Safety por fabricantes y proveedores.

\section{Japón}

En Japón, el control de los productos químicos se rige fundamentalmente por dos leyes. En primer lugar, la Ley de control de sustancias químicas, modificada en 1987, cuyo objetivo es la prevención de la contaminación ambiental debida a las sustancias químicas escasamente biodegradables y nocivos para la salud humana. En esta ley se define un procedimiento de notificación previo a la comercialización y tres clases de riesgo:

- Clase 1: sustancias químicas especificadas (baja biodegradación, alta bioacumulación, riesgo para la salud humana).

- Clase 2: sustancias químicas especificadas (bajas biodegradación y bioacumulación, riesgo para la salud humana y de contaminación del medio ambiente en grandes áreas).

- Clase 3: sustancias designadas (bajas biodegradación y bioacumulación, posibilidad de riesgo para la salud humana).

Se definen medidas de control y se ofrece una relación de las sustancias químicas existentes.

En segundo lugar, la L ey de salud y seguridad industrial, constituye un sistema paralelo con su propia relación de "sustancias químicas especificadas" que exigen etiquetado. Las sustancias se clasifican en cuatro grupos (plomo, tetralquilo de plomo, disolventes orgánicos, sustancias químicas especificadas). L os criterios de clasificación son: a) posibilidad de deterioro grave de la salud; b) posibilidad de deterioro frecuente de la salud, y c) deterioro de la salud en la práctica. O tras leyes en las que se aborda el control de las sustancias químicas peligrosas son la Ley de control de explosivos, la Ley de control de los gases de alta presión, la Ley de prevención de incendios, la Ley de higiene alimentaria y la Ley de medicamentos, cosméticos e instrumentos médicos.

\section{Estados Unidos}

La N orma de comunicación de riesgos (HCS), promulgada por la OSHA y de carácter obligatorio, es una disposición vinculante orientada al lugar de trabajo que se refiere a otras leyes vigentes. Su objetivo es garantizar que todas las sustancias químicas producidas o importadas sean evaluadas y que la información referente a sus riesgos sea transmitida a las empresas y a los trabajadores mediante un programa de comunicación exhaustivo. En éste se abordarán el etiquetado y otras formas de advertencia, así como las fichas de datos de seguridad sobre sustancias químicas y se impartirá formación. Se definen los contenidos mínimos de las etiquetas y las fichas de datos, pero la utilización de símbolos indicativos de peligro no es obligatoria.

De conformidad con la Ley de control de sustancias tóxicas (T SCA), por cuya aplicación vela la Environmental Protection Agency (EPA), se lleva un registro de unas 70.000 sustancias químicas. La EPA desarrolla reglamentos para complementar la HCS de la O SH A en los que se establecerán requisitos similares de evaluación y de comunicación a los trabajadores en el caso de los riesgos ambientales derivados de las sustancias químicas que figuran en el registro. De acuerdo con la TSCA, con anterioridad a la producción o la importación de sustancias que no consten en el registro, el fabricante debe remitir una nota de prefabricación. La EPA puede imponer la realización de pruebas $u$ otros requisitos basándose en el examen de dicha nota. Las nuevas sustancias químicas que acceden al mercado son incluidas en el registro.

\section{Etiquetado}

Las etiquetas que figuran en los recipientes de sustancias químicas peligrosas constituyen la primera señal de advertencia acerca del riesgo inherente a las mismas, y deben ofrecer información básica sobre los procedimientos de manipulación seguros, las medidas de protección, los primeros auxilios en caso de emergencia y los peligros de la sustancia en cuestión. A simismo, la etiqueta debe incluir la identidad de las sustancias químicas peligrosas y el nombre y la dirección de su fabricante.

El etiquetado consiste en la disposición de mensajes por escrito, así como de símbolos gráficos y colores, aplicados directamente al producto, el envase 0 la etiqueta. Las marcas debe ser claras, de fácil comprensión y capaces de soportar condiciones climáticas adversas. A demás, deben situarse contra un fondo que contraste con los datos que acompañan al producto o con el color del recipiente. La ficha técnica de seguridad (FTS) ofrece una información más detallada sobre el carácter de los riesgos inherentes al producto químico y las instrucciones de seguridad pertinentes.

Aunque actualmente no existen requisitos de etiquetado armonizados a escala mundial, se han adoptado normas internacionales, nacionales y regionales para el etiquetado de sustancias peligrosas. Así, la Ley sobre productos químicos (Finlandia), la Ley de productos peligrosos (Canadá) y la Directiva (CE) 67/548 incluyen disposiciones en esta materia. Los requisitos mínimos en cuanto al contenido de las etiquetas impuestos en los sistemas de la U nión Europea, Estados U nidos y Canadá son relativamente similares.

Varias organizaciones internacionales han establecido este tipo de requisitos para la manipulación de productos químicos en el lugar de trabajo y en el transporte. Las etiquetas, los símbolos indicativos de peligro, los mensajes de riesgo y seguridad y los códigos de emergencia de la O rganización Internacional de Normalización (ISO), las UNRTDG, la OIT y la UE se analizan a continuación.

En la sección sobre etiquetado de la guía 51 de ISO/CEI, Directrices para la inclusión de los aspectos de la seguridad en las normas, 
se recogen pictogramas comúnmente reconocidos (dibujo, color, signo). Además, se incluyen mensajes de advertencia breves y sencillos que alertan al usuario respecto a los posibles riesgos y ofrecen información sobre las medidas preventivas en materia de salud y seguridad.

En las directrices se recomienda la utilización de las siguientes expresiones de "aviso" para advertir al usuario:

- PELIGRO : peligro inminente

- MANEJAR CON PRECAUCION : peligro intermedio

- ATENCION : peligro potencial.

En las UNRT DG se establecen cinco pictogramas principales para un reconocimiento visual sencillo de las mercancías peligrosas y la identificación de los riesgos significativos:

- bomba: explosivo

- llama: inflamable

- calavera y huesos cruzados: tóxico

- trébol: radiactivo

- líquido que se derrama de dos tubos de ensayo en una mano y una pieza de metal: corrosivo.

Estos símbolos se completan con otras representaciones como:

- sustancias oxidantes: Ilama sobre un círculo

- gases no inflamables: una botella de gas

- sustancias infecciosas: tres símbolos de medialuna colocados sobre un círculo

- sustancias nocivas que deben almacenarse aisladas: cruz de San Andrés colocada sobre una espiga.

EI Convenio sobre la seguridad en la utilización de los productos químicos en el trabajo, 1990 (núm. 170) y la correspondiente Recomendación, 1990 (núm. 177) fueron adoptados en la 77ạ Reunión de la Conferencia Internacional del Trabajo (CIT ). En ellos se establecen los requisitos relativos al etiquetado de sustancias químicas con el fin de garantizar la comunicación de la información básica sobre riesgos. El Convenio estipula que la información contenida en las etiquetas debe ser fácilmente comprensible y referir al usuario los riesgos potenciales y las medidas de precaución pertinentes. En lo que respecta al transporte de mercancías peligrosas, el Convenio se remite a las UNRTDG.

En la Recomendación se esbozan los requisitos de etiquetado con arreglo a los sistemas nacionales e internacionales existentes y se definen los criterios para la clasificación de sustancias químicas, incluidas las propiedades físicas y químicas, la toxicidad, las propiedades necróticas e irritantes, y los efectos alérgicos, teratogénicos, mutagénicos y sobre la reproducción.

La Directiva (CE) del Consejo 67/ 548 establece la forma de la información que figura en las etiquetas: símbolos gráficos indicativos del peligro y pictogramas que incluyen mensajes sobre riesgos y seguridad. Los peligros se codifican mediante la letra latina $\mathrm{R}$, acompañada de combinaciones de número arábigos del 1 al 59. Por ejemplo, R 10 corresponde a "inflamable", R 23 a "tóxico por inhalación". A este código se adjunta uno de seguridad que consiste en la letra $\mathrm{S}$ y combinaciones de números del 1 al 60. Así, S39 significa "U tilizar protección ocular/ facial". Los requisitos de etiquetado de la $C E$ sirven como referencia para las empresas químicas y farmacéuticas de todo el mundo.

A pesar del esfuerzo significativo dedicado por las diversas organizaciones internacionales y regionales a la obtención, la evaluación y la organización de datos sobre riesgos químicos, aún falta coordinar todas las iniciativas, sobre todo en lo que se refiere a la normalización de los protocolos y los métodos de evaluación y la interpretación de la información. La OIT, la O rganización para la Cooperación y el Desarrollo Económico
(OCDE), el IPCS y otros órganos interesados han emprendido varias actividades internacionales encaminadas a facilitar la armonización mundial de los sistemas de clasificación y etiquetado de sustancias químicas. La creación de una estructura internacional que supervise las actividades de evaluación de los riesgos químicos beneficiaría en gran medida a los trabajadores, la población en general y el medio ambiente. Un proceso de armonización idóneo conciliaría la clasificación y el etiquetado de sustancias peligrosas aplicados al transporte, la comercialización y el lugar de trabajo y atendería a los intereses de los consumidores, los trabajadores y el medio ambiente.

\section{SEgURIDAD EN LA MANIPU LACION Y EL ALMACEN AMIENTO DE PRODUCTOSQUIMICOS}

\section{A. E, Quinn*}

Antes de la recepción de una sustancia peligrosa para su almacenamiento, debe ofrecerse información a todos los usuarios respecto a su correcta manipulación. La planificación y el mantenimiento de las áreas destinadas al efecto son necesarios para evitar las pérdidas de material, los accidentes y los desastres. $L a$ prestación de unos servicios de conservación adecuados es esencial, y debe prestarse especial atención a las sustancias incompatibles, la ubicación conveniente de los productos y las condiciones climáticas

Debe disponerse de instrucciones por escrito de las prácticas de almacenamiento oportunas, así como de fichas técnicas de seguridad (FTS) en las áreas donde se llevan a cabo estas tareas. La ubicación correspondiente a los distintos tipos de producto químico debe ilustrarse en un plano del almacén y en un registro químico. En éste figurarán la máxima cantidad permitida de todos los productos químicos en general y por clases. La totalidad de las sustancias debe recibirse en una sede central para su distribución a las distintas salas, depósitos y laboratorios. Asimismo, el área de recepción central resulta útil en el seguimiento de las sustancias que pueden acabar entrando en el sistema de evacuación de desechos. Un inventario de las sustancias ubicadas en las salas de almacén y los depósitos facilitará la estimación de la cantidad y la naturaleza de las destinadas a la evacuación en el futuro.

Los productos químicos almacenados serán examinados periódicamente, al menos una vez al año. Aquellos cuya vida útil en depósito haya expirado, estén deteriorados o se encuentren en recipientes con fugas deberán ser evacuados en condiciones de seguridad. Se utilizará un sistema FIFO ("primero en entrar, primero en salir") de gestión de existencias.

El almacenamiento de sustancias peligrosas debe ser supervisado por una persona competente y capacitada. Todos los trabajadores que deban acceder a las áreas de depósito recibirán una formación completa sobre las prácticas de trabajo seguras pertinentes, y un directivo encargado de la seguridad se ocupará de efectuar una inspección periódica de dichas áreas. D ebe situarse una alarma de incendios en el interior o en las proximidades de las instalaciones de almacenamiento. Se recomienda evitar que un trabajador desarrolle su actividad sólo en las áreas donde se conserven sustancias tóxicas. Estas áreas deben ubicarse lejos de las zonas de producción, de los edificios ocupados por personas y de otras áreas de almacenamiento. Además, no deben situarse cerca de fuentes de ignición fijas.

* Adaptado de la 3a edición, Encidopedia de la salud y la seguridad en el trabajo. 


\section{Requisitos en materia de etiquetado y reetiquetado}

La etiqueta es un elemento esencial par la organización de los productos químicos almacenados. Los depósitos y los envases deben identificarse mediante signos que indiquen el nombre del producto en cuestión. No deben aceptarse envases o botellas de gas comprimido que no presenten las etiquetas identificativas siguientes:

- identificación del contenido:

- descripción del riesgo principal (p. ej., líquido inflamable);

- precauciones para minimizar los riesgos y evitar accidentes;

- procedimientos correctos de primeros auxilios;

- procedimientos correctos para la limpieza de vertidos,

- instrucciones especiales para el personal médico en caso de accidente.

En la etiqueta podrán figurar asimismo mensajes de precaución para un almacenamiento correcto, como " $M$ antener en lugar fresco" o "M antener el envase en lugar seco". Cuando ciertos productos peligrosos se entregan en cisternas, barriles o sacos y vuelven a ser embalados en el lugar de trabajo, los nuevos envases deben ser reetiquetados, de manera que el usuario pueda identificar la sustancia química y reconocer de inmediato sus riesgos.

\section{Sustancias explosivas}

Se incluyen en esta categoría todas las sustancias químicas, productos pirotécnicos y cerillas que son explosivos per se, así como otras sustancias como las sales metálicas sensibles que por sí mismas, en ciertas mezclas o sometidas a determinadas condiciones de temperatura, choque, fricción o acción química, pueden transformarse y experimentar una reacción explosiva. En el caso de los explosivos, la mayoría de los países han adoptado normativas estrictas en lo que se refiere a los requisitos de almacenamiento seguro y las precauciones que deben tomarse con el fin de evitar el robo para su utilización en actividades criminales.

Los lugares de almacenamiento deben situarse alejados de otros edificios y estructuras, de forma que puedan minimizarse los daños en caso de explosión. Los fabricantes de este tipo de sustancias elaboran instrucciones respecto al modo de almacenamiento más adecuado. Las áreas designadas al efecto deben dotarse de una estructura sólida y mantenerse bien cerradas cuando no son utilizadas. L os almacenes no deben situarse cerca de un edificio que contenga petróleo, aceite, material de desecho combustible o sustancias inflamables, 0 en el que se mantengan fuegos o llamas desnudas.

En algunos países, la legislación obliga a la ubicación de los polvorines a una distancia mínima de 60 metros respecto a centrales generadoras de energía, túneles, pozos mineros, diques, autopistas 0 edificios. Debe aprovecharse la protección que ofrecen accidentes naturales como colinas, hondonadas 0 bosques o selvas densos. En ocasiones, pueden situarse alrededor de los lugares de almacenamiento barreras artificiales de tierra o muros de piedra.

Los almacenes deben estar bien ventilados y libres de humedad. D ebe utilizarse la iluminación natural, lámparas eléctricas portátiles o luces situadas fuera del área de almacenamiento. Los suelos han de construirse de madera o de otros materiales que no generen chispas. D ebe evitarse la presencia de hierba seca, basura u otros materiales susceptibles de arder en la zona que rodea al lugar de almacenamiento. La pólvora y otras sustancias explosivas deben conservarse en salas separadas, en las que no se dispondrá de detonadores, herramientas u otros materiales afines. Se emplearán instrumentos no ferrosos para abrir los recipientes de explosivos.

\section{Sustancias oxidantes}

Este tipo de sustancias constituyen fuentes de oxígeno y, por tanto, son capaces de facilitar la combustión e intensificar la violencia de un incendio. Algunas generan oxígeno a la temperatura ambiente del almacén en el que se conserven, pero otras requieren la aplicación de calor. Si los envases de los materiales oxidantes se han deteriorado, su contenido puede mezclarse con otras sustancias combustibles y provocar una ignición. E ste riesgo puede evitarse mediante el depósito de estos materiales en zonas de almacenamiento aisladas. No obstante, puede que esta práctica no siempre sea viable, como, por ejemplo, en el caso de los almacenes portuarios de mercancías en tránsito.

Es peligroso almacenar sustancias oxidantes potentes cerca de líquidos, aunque su punto de inflamación sea bajo, o de materiales inflamables, aunque lo sean sólo ligeramente. R esulta más seguro mantener todas las sustancias inflamables lejos del lugar en el que se conservan los oxidantes. El área de almacenamiento debe ser fresca, estar bien ventilada y tener una estructura ignífuga.

\section{Sustancias inflamables}

Se considera que un gas es inflamable cuando prende en presencia de aire u oxígeno. El hidrógeno, el propano, el butano, el etileno, el acetileno, el ácido sulfhídrico y el gas de carbón se encuentran entre los gases inflamables más comunes. Algunos como el cianuro de hidrógeno y el cianógeno son inflamables y tóxicos. L os materiales inflamables deben conservarse en lugares suficientemente frescos para evitar igniciones accidentales si los vapores se mezclan con el aire.

Los vapores de disolventes inflamables puede ser más pesados que el aire y moverse a ras de suelo hasta una fuente de ignición distante. Se han observado casos en los que los vapores inflamables generados por sustancias químicas derramadas han descendido por escaleras y huecos de ascensores y han prendido en pisos inferiores. Por tanto, es esencial la prohibición de fumar y de generar llamas desnudas en los lugares en que se manipulan 0 almacenan dichos disolventes.

Los bidones de seguridad portátiles aprobados constituyen los recipientes más seguros para almacenar sustancias inflamables. L os volúmenes de líquidos inflamables superiores a 1 litro deben depositarse en envases de metal. Habitualmente, se utilizan bidones de doscientos litros para transportar estas sustancias, pero estos recipientes no están concebidos para su almacenamiento a largo plazo. El tapón debe retirarse con cuidado y ser sustituido por una válvula de alivio de presión aprobada que evite el aumento de la presión interna debido al calor, el fuego o la exposición a la luz solar. Al transferir sustancias inflamables desde un equipo metálico, los trabajadores deben utilizar un sistema de traslado cerrado o disponer de una ventilación aspirante adecuada.

El área de almacenamiento debe situarse alejada de toda fuente de calor o de riesgo de incendio. Las sustancias altamente inflamables deben conservarse separadas de agentes oxidantes potentes y de materiales susceptibles de combustión espontánea. Cuando se almacenen líquidos de volatilidad elevada, deben instalarse aparatos y dispositivos eléctricos de iluminación de fabricación antideflagrante certificada y no se permitirá la generación de llamas desnudas en el lugar de almacenamiento o cerca de éste. Se dispondrá además de extintores de incendios y materiales inertes absorbentes como arena y tierra seca para su utilización en situaciones de emergencia.

Las paredes, los techos y los suelos de las salas de almacenamiento se construirán con materiales con una resistencia al fuego mínima de dos horas. Se utilizarán puertas cortafuegos de cierre automático. Las instalaciones de dichas salas dispondrán de toma a tierra eléctrica y serán inspeccionadas 
periódicamente, o se equiparán con dispositivos automáticos de detección de humo o fuego. Las válvulas de control en los recipientes de almacenamiento que contengan líquidos inflamables se etiquetarán claramente y las tuberías se pintarán con colores de seguridad distintivos para indicar el tipo de líquido y la dirección del flujo. Los depósitos que contengan sustancias inflamables deben situarse sobre el suelo, en pendiente y alejados de los principales edificios e instalaciones del centro de producción. Si se colocan al nivel del suelo, puede obtenerse protección contra la propagación del fuego mediante el mantenimiento de distancias de separación adecuadas y la disposición de diques. Preferiblemente, la capacidad de éstos debe superar en 1,5 veces la del depósito de almacenamiento, debido a la probabilidad de que el líquido inflamable se derrame al calentarse. Estos depósitos deben dotarse de dispositivos de ventilación y placas cortafuegos. D ebe disponerse asimismo de extintores de incendios, ya sean automáticos o manuales. No debe permitirse fumar.

\section{Sustancias tóxicas}

Las sustancias químicas tóxicas deben conservarse en áreas frescas y bien ventiladas lejos de fuentes de calor, ácidos, humedad y sustancias oxidantes. L os compuestos volátiles deben almacenarse en refrigeradores que no generen chispas $(-20 \stackrel{\circ}{ } \mathrm{C})$ para evitar la evaporación. Puesto que los envases pueden sufrir fugas, las salas de almacenamiento deben equiparse con campanas de evacuación de humos u otros dispositivos de ventilación local equivalentes. Los envases abiertos deben cerrarse con cinta u otro elemento obturador antes de su recolocación en la sala de almacenamiento. Las sustancias que pueden reaccionar químicamente entre sí deben mantenerse en ubicaciones separadas.

\section{Sustancias corrosivas}

Se trata de ácidos, álcalis y otras sustancias que pueden provocar quemaduras o irritación de la piel, las membranas mucosas o los ojos, o que deterioran la mayoría de los materiales. Son ejemplos típicos el ácido fluorhídrico, el ácido clorhídrico, el ácido sulfúrico, el ácido nítrico, el ácido fórmico y el ácido perclórico. Estos materiales pueden dañar sus recipientes y propagarse en la atmósfera del área de almacenamiento; algunos son volátiles y otros reaccionan violentamente con la humedad, la materia orgánica u otras sustancias químicas. Los vapores de ácido pueden corroer los materiales estructurales y los equipos y ejercer una acción tóxica sobre el personal. Este tipo de sustancias deben mantenerse a baja temperatura, pero muy por encima de su punto de congelación, ya que un compuesto como el ácido acético puede congelarse a una temperatura relativamente alta, romper su envase y propagarse cuando la temperatura vuelva a superar dicho punto.

A simismo, algunas sustancias corrosivas pueden tener otras propiedades peligrosas; por ejemplo, el ácido perclórico, además de ser sumamente corrosivo, constituye un potente agente oxidante capaz de causar incendios y explosiones. El Aqua regia presenta tres características peligrosas: a) combina las propiedades corrosivas de sus dos componentes, el ácido clorhídrico y el ácido nítrico; b) es un agente oxidante muy potente, y c) una aplicación limitada de calor basta para dar lugar a la formación de cianuro de cloro, un gas de gran toxicidad.

Las áreas de almacenamiento destinadas a las sustancias corrosivas deben aislarse del resto del centro de producción o de otros depósitos de mercancías mediante la disposición de paredes y suelos impermeables, previendo además la evacuación de derrames en condiciones de seguridad. Los suelos deben realizarse de bloques de hormigón que no haya sido tratado para reducir su solubilidad, o de otro material resistente. Dichas áreas deben contar con una ventilación adecuada. No se utilizará una misma área para el almacenamiento simultáneo de compuestos de ácido nítrico y compuestos de ácido sulfúrico. En ocasiones, es necesario depositar líquidos corrosivos y tóxicos en envases especiales; por ejemplo, el ácido fluorhídrico debe conservarse en botellas de plomo, gutapercha o de ozokerita refinada. Puesto que este ácido interactúa con el cristal, no debe almacenarse cerca de bombonas de este material o de barro que contengan otros ácidos.

Las bombonas que contengan ácidos corrosivos deben envasarse con diatomita (tierra de infusorios) u otro material inorgánico aislante eficaz. Los equipos de primeros auxilios necesarios, como las duchas de emergencia o las botellas de colirio, deben situarse en el lugar de almacenamiento o muy cerca de éste.

\section{Productos químicos que reaccionan con el agua}

Algunos productos químicos, como los metales de sodio y de potasio, reaccionan con el agua, generando calor y gases inflamables o explosivos. Algunos catalizadores de polimerización, como los compuestos alquílicos de aluminio, reaccionan violentamente y prenden en contacto con el agua. Las instalaciones para la conservación de este tipo de productos no deben presentar dicho elemento en el área de almacenamiento. Deben emplearse sistemas de pulverización automáticos sin agua.

\section{Legislación}

En numerosos países se ha desarrollado legislación detallada con el fin de regular el modo de almacenar diversas sustancias peligrosas; en estas leyes se abordan las especificaciones siguientes:

- tipo de edificio, localización, cantidades máximas de las diversas sustancias que pueden almacenarse en un lugar determinado:

- tipo de ventilación exigido;

- precauciones que deben adoptarse contra incendios, explosiones y emisión de sustancias peligrosas;

- tipo de iluminación (p. ej., equipos eléctricos y dispositivos de iluminación ininflamables cuando se almacenen materiales explosivoso inflamables)

- número y ubicación de salidas de incendios;

- medidas de seguridad para evitar el acceso de personas no autorizadas y los robos;

- etiquetado y marcado de los recipientes de almacenamiento y los conductos,

- notas de advertencia a los trabajadores relativas a las precauciones que deben adoptarse.

En muchos países, se carece de una única autoridad central que se encargue de la supervisión de las precauciones de seguridad para el almacenamiento de sustancias peligrosas, y son varias independientes las que ejercen su función. Son ejemplos de estas autoridades específicas los órganos de inspección de minas y fábricas, las autoridades portuarias, las autoridades en materia de transporte, la policía, los servicios contra incendios, los consejos nacionales y la administración local, que se ocupan, en cada caso, de una gama limitada de sustancias peligrosas de conformidad con diversas competencias legislativas. Habitualmente, es necesario obtener una licencia o un permiso de una de estas autoridades para almacenar ciertos tipos de sustancias peligrosas, como el petróleo, explosivos, celulosa y disoluciones de celulosa. En los procedimientos de concesión de licencia se exige que las instalaciones de almacenamiento cumplan con determinadas normas de seguridad. 
- G ASE S CO MPRIMIDO S:

\section{MANIPU LACION, ALMACENAMIENTO Y TRAN SPORTE}

\section{A. T ürkdogan y K. R, M athisen*}

Los gases en su estado de comprimidos, y especialmente el aire comprimido, son casi indispensables en la industria moderna, y también se utilizan mucho con fines médicos, para la producción de aguas minerales, en la práctica del buceo y en actividades relacionadas con vehículos de motor.

A los efectos de este artículo, los gases y el aire comprimidos se definen como los que tienen una presión manométrica que supera los 1,47 bar o como líquidos que tienen una presión de vapor superior a 2,94 bar. Por lo tanto, no se presta atención a casos tales como la distribución de gas ciudad, que se analizan en otros capítulos de esta E nciclopedia.

En la Tabla 61.1 se muestran los gases que suelen conservarse en botellas comprimidas.

Todos estos gases se caracterizan por ser irritantes 0 asfixiantes y por constituir un riesgo altamente tóxico para el aparato respiratorio, y también pueden ser inflamables y explosivos cuando se comprimen. La mayoría de los países siguen un sistema de codificación, con colores estándar, por el que se aplican diferentes bandas o etiquetas de color a las botellas de gas para indicar el tipo de riesgo que presentan. Particularmente los gases tóxicos, tales como el cianuro de hidrógeno, reciben además marcas especiales.

Todos los recipientes para gases comprimidos están construidos de manera que sean seguros en el cumplimiento de los fines para los que han sido concebidos cuando se ponen por primera vez en servicio. No obstante, pueden resultar graves accidentes de su mal uso, su abuso o mal manejo, y debe llevarse el mayor cuidado en el manejo, transporte, almacenamiento e incluso en la eliminación de dichos recipientes o botellas.

Tabla 61.1 - Gases que suelen presentarse en forma comprimida.

\begin{tabular}{ll} 
Acetileno* & Hidrógeno* \\
Amoniaco* & Cloruro de hidrógeno (ácido clorhídrico) \\
Butano* & Cianuro de hidrógeno* (ácido cianhídrico) \\
Dióxido de carbono & Metano* \\
Monóxido de carbono* & Metilamina* \\
Cloro & Neón \\
Clorodifluormetano & Nitrógeno \\
Cloroetano* & Dióxido de nitrógeno \\
Clorometano* & Oxido nitroso \\
Clorotetrafluoroetano & Oxígeno \\
Ciclopropano* & Fosgeno \\
Diclorodifluorometano & Propano* \\
Etano* & Propileno* \\
Etileno* & Dióxido de azufre \\
Helio & \\
*Estos gases son inflamables. & \\
\hline
\end{tabular}

* Adaptado de la 3a edición, Enciclopedia de la salud y la seguridad en el trabajo.

\section{Características y producción}

Según las características del gas, puede introducirse en el recipiente o botella en forma líquida o simplemente como gas a alta presión. Para licuar un gas, es necesario enfriarlo por debajo de su temperatura crítica y someterlo a una presión adecuada. Cuando más se reduce la temperatura por debajo de la temperatura crítica, menos presión se necesita.

Algunos de los gases enumerados en la Tabla 61.1 tienen propiedades contra las que deben tomarse ciertas precauciones. Por ejemplo, el acetileno puede reaccionar peligrosamente con el cobre y no debe estar en contacto con aleaciones que contengan más del $66 \%$ de este metal. Generalmente, se suministra en recipientes de acero de aproximadamente 14,7 a 16,8 bar. 0 tro gas que tiene una fuerte acción corrosiva sobre el cobre es el amoniaco, y debe mantenerse fuera del contacto con este metal, utilizándose igualmente botellas de acero y aleaciones autorizadas. En el caso del cloro, no ocurre ninguna reacción con el cobre ni con el acero, a excepción de en presencia de agua, y por esta razón en todo momento deben mantenerse libres de contacto con la humedad todos los recipientes de almacenamiento. El gas de flúor, por otra parte, aunque reacciona fácilmente con la mayoría de los metales, tiende a formar un revestimiento protector, como, por ejemplo, en el caso del cobre, donde una capa de fluoruro de cobre sobre el metal le protege de un posterior ataque por parte del gas.

Entre los gases enumerados, el dióxido de carbono es uno de los que licúan más fácilmente, ocurriendo esto a una temperatura de $15^{\circ} \mathrm{C}$ y a una presión de aproximadamente 14,7 bar. Tiene muchas aplicaciones comerciales y debe mantenerse en botellas de acero.

L os gases de hidrocarburos, entre los que los gases de petróleo licuado (LPG ) son una mezcla formada esencialmente de butano (alrededor del $62 \%$ ) y propano (alrededor del $36 \%$ ), no son corrosivos y generalmente se suministran en bombonas de acero y otros recipientes a presiones de 14,7 a 19,6 bar. El metano es otro gas que también se suele entregar en bombonas de acero a una presión de 14,7 a 19,6 bar por ser muy inflamable.

\section{Riesgos}

\section{Almacenamiento y transporte}

Cuando se selecciona un depósito de llenado, almacenamiento y envío, debe prestarse consideración a la seguridad, tanto del lugar como de su entorno. Las salas de bombas, la maquinaria de llenado, etc. deberán estar situadas en edificios pirorresistentes con techos de construcción ligera. Las puertas y otros sistemas de cierre deberán abrirse hacia fuera del edificio. Las instalaciones deberán estar adecuadamente ventiladas e instalarse un sistema de alumbrado con interruptores eléctricos antideflagrantes. Deben tomarse medidas para asegurar un libre movimiento en las instalaciones para las operaciones de llenado, comprobación y envío, proporcionándose salidas de seguridad.

Los gases comprimidos deben almacenarse en espacios abiertos sólo si están adecuadamente protegidos de la intemperie y de la luz del sol directa. Las zonas de almacenamiento deben estar situadas a una distancia segura de instalaciones ocupadas y de viviendas cercanas.

Durante el transporte y la distribución de los recipientes, debe cuidarse de que no se produzcan daños en las válvulas y conexiones. Habrá que tomar las precauciones necesarias para impedir que las botellas caigan de los vehículos y sean sometidas a un uso desconsiderado, choques excesivos o esfuerzos locales, así como un excesivo movimiento de los líquidos en los tanques de mayor tamaño. Cada vehículo irá equipado con un extintor de incendios y una tira eléctricamente conductiva para poner a tierra la electricidad estática, marcándose claramente "líquidos 
inflamables". Las tuberías de salida deberán tener un dispositivo de control de llama y durante las operaciones de carga y descarga los motores deberán estar parados. La velocidad máxima de estos vehículos habrá de ser rigurosamente limitada.

\section{Usos}

Los riesgos principales en el uso de los gases comprimidos se deben a su presión y a sus propiedades tóxicas y/ o inflamables. L as precauciones principales son las de asegurar que el equipo se utilice únicamente con los gases para los que ha sido diseñado, y que no se utilicen gases comprimidos para ningún fin distinto de aquel para el que ha sido autorizado.

Todas las mangueras y el resto del equipo deberá encontrarse en buen estado y revisarse con frecuencia. Siempre que sea necesario se obligará al uso de válvulas de retención. Todas las conexiones de las mangueras deberán encontrarse en buen estado y no se hará ninguna junta forzando entre sí roscas que no corresponden exactamente. En el caso del acetileno y de gases combustibles se utilizará una manguera roja; para el oxígeno será negra. Se recomienda que para todos los gases inflamables las roscas de los tornillos de conexión vayan a izquierdas, y para todos los demás gases, a derechas. Nunca deben intercambiarse entre sí las mangueras.

EI oxígeno y algunos gases anestésicos se transportan a menudo en grandes botellas. La transferencia de estos gases comprimidos a bombonas pequeñas es una operación muy peligrosa que deberá hacerse bajo supervisión competente, utilizando el equipo correcto en una instalación adecuada.

El aire comprimido se utiliza ampliamente en muchos sectores de la industria, y debe llevarse cuidado en la instalación de tuberías y su protección de daños. Las mangueras y accesorios deben mantenerse en buen estado y someterse a revisiones regulares. La aplicación de una manguera o chorro de aire comprimido a un corte o herida abierta a través del cual pueda entrar aire en los tejidos o en la corriente sanguínea es particularmente peligrosa; hay que tomar igualmente precauciones contra todas las formas de comportamiento irresponsable que podrían dar como resultado que el chorro de aire comprimido se pusiese en contacto con cualquier abertura del organismo (cuyo resultado sería fatal). 0 tro riesgo existe cuando los chorros de aire comprimido se utilizan para limpiar componentes mecanizados o lugares de trabajo; se sabe que las partículas volantes han provocado heridas o incluso ceguera, y debe insistirse en las precauciones contra tales peligros.

\section{Rotulación y marcado}

D ebe ser de acuerdo con la práctica estándar en el país o región en cuestión. El uso de un gas equivocadamente en lugar de otro, o bien el llenado de un recipiente con un gas diferente del que contenía previamente, sin los procedimientos necesarios de limpieza y descontaminación, puede provocar graves accidentes. El marcado por color constituye el mejor método para evitar tales errores y consiste en pintar unas zonas específicas de los recipientes o sistemas de tuberías de acuerdo con el código de color estipulado en las normas nacionales o recomendado por la organización nacional de seguridad.

\section{Botellas de gas}

Por razones de comodidad en la manipulación, el transporte y el almacenamiento, los gases suelen comprimirse en botellas metálicas a presiones que oscilan entre unas pocas atmósferas de sobrepresión y presiones de 200 bar, o incluso más. El acero aleado es el material más comúnmente empleado en la fabricación de botellas, aunque el aluminio también se aplica con numerosos fines, como en el caso de los extintores de incendios.

\section{Etiquetado y marcado}

4.1.1. La autoridad competente, 0 un organismo aprobado 0 reconocido por la autoridad competente, debería establecer las exigencias relativas al etiquetado y marcado de productos químicos que permitan a las personas que los manipulen 0 utilicen reconocer y distinguir esos productos, tanto al recibirlos como al utilizarlos, a fin de garantizar la seguridad en su utilización [véase el párrafo 2.1.8 (sistemas y criterios específicos)]. Podrán adoptarse los criterios para el marcado y el etiquetado ya establecidos por otras autoridades competentes, con la condición de que sean compatibles con las disposiciones del presente párrafo; se insta a proceder así cuando ello contribuya a armonizar los conceptos.

4.1.2. Los proveedores deberían garantizar que los productos químicos estén marcados y los productos químicos peligrosos estén etiquetados, y deberían velar por que se preparen etiquetas revisadas y se las suministren a los empleadores cada vez que aparezca nueva información pertinente en materia de salud y seguridad [véanse los párrafos 2.4.1 (responsabilidades de los proveedores) y 2.4 .4 (clasificación)].

4.1.3. Cuando los empleadores reciban productos químicos que no hayan sido etiquetados o marcados, deberían abstenerse de utilizarlos mientras no obtengan la información pertinente del proveedor 0 de otras fuentes razonablemente disponibles. Esta debería recabarse principalmente del proveedor, pero también podrá obtenerse de otras fuentes que figuran en la lista del párrafo 3.3.1 (fuentes de información), a los efectos de que el marcado y el etiquetado se efectúen de conformidad con las disposiciones de la autoridad nacional competente, antes de utilizar los productos químicos.

4.3.2. El objeto de la etiqueta es proporcionar información esencial sobre:

(a) la clasificación del producto químico;

(b) sus riesgos; y

(c) las precauciones que se deban adoptar.

La información debería referirse a los riesgos de exposición tanto crónica como aguda.

4.3.3. En el etiquetado, que debería efectuarse de conformidad con las exigencias nacionales, se debería considerar:

(a) la información que debe figurar en la etiqueta, incluyendo, si hubiere lugar:

(i) las denominaciones comerciales;

(ii) la identificación del producto químico;

(iii) el nombre, dirección y teléfono del proveedor;

(iv) los símbolos de peligro;

(v) la índole de los riesgos particulares que entrañe la utilización del producto químico;

(vi) las precauciones de seguridad;

(vii) la identificación del lote;

(viii) la indicación de que puede obtenerse del empleador una ficha de datos de seguridad con informaciones complementarias, y

(ix) la clasificación asignada con arreglo al sistema establecido por la autoridad competente;

(b) la legibilidad, durabilidad y tamaño de la etiqueta;

(c) la uniformidad de las etiquetas y de los símbolos, incluido el color.

Fuente: O IT 1993, capítulo 4. 
Los riesgos que deben tenerse en cuenta al manipular y utilizar gases comprimidos son:

- los habituales en la manipulación de objetos pesados;

- Ios relacionados con la presión (es decir, la cantidad de energía acumulada en los gases),

- los derivados de las propiedades especiales del gas contenido, que puede ser inflamable, tóxico, oxidante, etc.

Fabricación de botellas. Las botellas de acero pueden ser sin costura o soldadas. Las primeras se realizan con aceros aleados de gran calidad y son tratadas térmicamente con sumo cuidado con el fin de obtener la combinación deseada de fuerza y robustez para su utilización a presiones elevadas. Pueden forjarse y estirarse en caliente a partir de piezas de acero o moldearse en caliente con tubos sin costuras. Los cilindros soldados se fabrican con planchas. Las piezas embutidas superior e inferior se sueldan a una sección de tubo cilíndrica sin costuras o soldada y se tratan térmicamente para aliviar tensiones del material. Las botellas soldadas son muy utilizadas en operaciones a baja presión con gases licuados y gases disueltos como el acetileno.

Las botellas de aluminio se extruyen en grandes prensas con aleaciones especiales tratadas térmicamente para darles la robustez deseada.

Las botellas de gas deben diseñarse, fabricarse y comprobarse de acuerdo con normas estrictas. Cada lote debe someterse a pruebas en las que se verifique la calidad de sus materiales y el tratamiento térmico aplicado, y en algunas botellas debe analizarse su resistencia mecánica. En la inspección suele recurrirse a la ayuda de instrumentos sofisticados, y en todos los casos las botellas deben someterse al análisis y las pruebas hidráulicas a una determinada presión de comprobación efectuadas por un inspector autorizado. Los datos identificativos y el sello de la inspección deben fijarse de manera permanente al cuello de la botella 0 en otro lugar adecuado.

Inspección periódica. Las botellas de gas en uso pueden verse afectadas por un tratamiento deficiente, por la corrosión debida a agentes internos 0 externos, por incendios, etc. Por tanto, los reglamentos nacionales e internacionales exigen que, con anterioridad a su llenado, las botellas sean inspeccionadas y comprobadas cada cierto tiempo, en intervalos que oscilan entre los dos y los diez años, dependiendo del servicio que presten. U na inspección visual interna y externa, junto con una prueba de presión hidráulica, constituyen la base para conceder la aprobación correspondiente a un nuevo período en un servicio determinado. La fecha de la comprobación (mes y año) debe figurar en la botella.

Eliminación. Cada año, se desecha un gran número de botellas por diversas razones. Es importante que sean eliminadas de forma que se imposibilite su reutilización a través de canales no controlados. Por tanto, las botellas deben dejarse completamente inservibles mediante su corte, aplastamiento u otros procedimiento de seguridad similar.

Válvulas. Las válvulas y otros dispositivos de seguridad deben considerarse parte de la botella y, por tanto, mantenerse en buenas condiciones de funcionamiento. Las roscas del cuello y de salida deben conservarse intactas y la válvula debe ajustarse al cerrar sin que sea necesario la aplicación de una fuerza indebida. L as válvulas de cierre suelen equiparse de un dispositivo de alivio de la presión. Este puede adoptar la forma de una válvula de reajuste de seguridad, una cápsula de seguridad, un tapón fusible 0 una combinación de éstos dos últimos mecanismos. $L a$ práctica varía de un país a otro, pero las botellas diseñadas para gases licuados a baja presión siempre constan de válvulas de seguridad conectadas a la fase gaseosa.

\section{Riesgos}

En los diversos códigos de transporte se clasifica a los gases como comprimidos, licuados o disueltos bajo presión. A efectos del presente artículo, resulta útil recurrir al tipo de riesgo como criterio de clasificación.

Alta presión. Si las botellas o los equipos estallan, los daños y las lesiones pueden deberse a la acción de los restos proyectados 0 a la presión del gas. Cuanto mayor sea la compresión de un gas, mayor será la energía acumulada. Este riesgo siempre está presente en el caso de los gases comprimidos y aumenta con la temperatura en caso de calentamiento de las botellas. Por tanto:

- Deben evitarse los daños mecánicos en las botellas (abolladuras, cortes, etc.).

- Las botellas deben almacenarse lejos de fuentes de calor y de la luz solar directa.

- Las botellas deben mantenerse alejadas del fuego.

- Las botellas sólo deben conectarse a equipos adecuados para el uso previsto.

- Las válvulas de las botellas deben protegerse con su tapa durante el transporte.

- D eben evitarse las caídas de las botellas durante su uso, ya que éstas pueden romper la válvula.

- D ebe evitarse la manipulación de los dispositivos de seguridad.

- Las botellas deben manejarse con cuidado para evitar los choques mecánicos en climas muy fríos, ya que el acero puede volverse quebradizo a bajas temperaturas.

- Debe evitarse la corrosión, que reduce la solidez del revestimiento.

B aja temperatura. La mayoría de los gases licuados se evaporan con rapidez bajo los efectos de la presión atmosférica, y pueden alcanzar temperaturas muy bajas. U na persona cuya piel quede expuesta a la acción de tales líquidos puede sufrir lesiones en forma de "quemaduras frías". (EI CO líquido origina al expandirse partículas en forma de copos de nieve.) Por tanto, es necesario utilizar el equipo de protección adecuado (p. ej., guantes, gafas de montura ajustada).

0 xidación. El riesgo de oxidación es obvio en el caso del oxígeno, que es uno de los gases comprimidos más importantes. Este elemento no prende por sí solo, pero es necesario para la combustión. El aire norma contiene un $21 \%$ de oxígeno en volumen.

Todos los materiales combustibles prenden con mayor facilidad y se queman con mayor fuerza cuando aumenta la concentración de oxígeno. Así ocurre incluso en el caso de que el aumento sea moderado y, por tanto, deben adoptarse las máximas precauciones para evitar el enriquecimiento de oxígeno en la atmósfera del lugar de trabajo. En espacios restringidos, pequeñas fugas de oxígeno pueden dar lugar a incrementos de la concentración peligrosos.

El riesgo asociado al oxígeno se agrava con el aumento de la presión, hasta un punto en el que muchos metales prenden con fuerza. L os materiales divididos en múltiples fragmentos puede prender en oxígeno con una fuerza explosiva. Las ropas saturadas con este elemento se queman con suma rapidez y resultan difíciles de apagar.

EI aceite y la grasa siempre se han considerado peligrosos en combinación con el oxígeno. La razón es su facilidad para reaccionar con éste, su abundancia, la baja temperatura suficiente para su ignición y la posibilidad de que el calor desarrollado prenda el metal al que recubren. En los equipos de oxígeno a alta presión, la temperatura necesaria para la ignición puede alcanzarse con facilidad mediante el shock de comprensión que puede derivarse de una apertura rápida de una válvula (compresión adiabática). 
Por tanto:

- Las válvulas deben abrirse o cerrarse lentamente.

- Todos los equipos de oxígeno deben mantenerse limpios y sin aceite.

- Sólo se emplearán los materiales de seguridad comprobada en la utilización con oxígeno.

- Los trabajadores se abstendrán de lubricar los equipos de oxígeno.

- Debe evitarse el acceso a espacios restringidos en los que pueda existir una concentración elevada de oxígeno.

- D ebe comprobarse la atmósfera de trabajo y se evitará estrictamente la utilización de oxígeno en lugar de aire comprimido u otro gas.

Inflamabilidad. Los gases inflamables se caracterizan por tener puntos de inflamación inferiores a la temperatura ambiente y por formar mezclas explosivas con el aire (o el oxígeno) dentro de ciertos umbrales conocidos como los límites de explosión inferiores y superiores.

EI gas desprendido (también de válvulas de seguridad) puede prender y quemarse con una llama cuyo tamaño depende de la presión y de la cantidad de gas. A su vez, las llamas pueden calentar equipos cercanos, que pueden quemarse, fundirse 0 explotar. EI hidrógeno se quema con una llama casi invisible.

Incluso las fugas moderadas pueden generar mezclas explosivas en espacios restringidos. Algunos gases, como los del petróleo licuados, y en particular el propano y el butano, son más pesados que el aire y son difíciles de evacuar, ya que se concentran en las zonas inferiores de los edificios y "flotan" a través de canales de una sala a otra. Tarde o temprano, el gas puede alcanzar una fuente de ignición y explotar.

La ignición puede deberse a la acción de fuentes de calor, pero también a la de chispas eléctricas, aunque sean muy pequeñas. El acetileno ocupa un lugar destacado entre los gases combustibles debido a sus propiedades y a la generalización de su uso. Si se calienta, el gas puede comenzar a descomponerse con el aumento de la temperatura, incluso sin la presencia de aire. Si se permite el avance del proceso, éste puede dar lugar a la explosión de la botella que lo contiene. Por razones de seguridad, las botellas de acetileno se llenan con una masa altamente porosa que también contiene un disolvente del gas. El calentamiento provocado por agentes externos como un incendio 0 un soplete de soldar, 0 , en ciertos casos, la ignición interna provocada por la retrogresión de la llama en equipos de soldado, pueden iniciar una descomposición en el interior de la botella. En estos casos:

- D ebe cerrarse la válvula (utilizando guantes de protección si es necesario) y alejarse la botella del fuego.

- Si una parte de la botella se recalienta, debe sumergirse en un río, canal o similar para enfriarla o ser rociada con pulverizadores de agua.

- Si la botella está demasiado caliente para su manipulación, debe ser rociada con agua a una distancia de seguridad.

- El enfriamiento debe continuar hasta que la botella mantenga la temperatura adecuada por sí misma.

- La válvula se mantendrá cerrada, ya que el flujo de gas acelera la descomposición.

En varios países, las botellas de acetileno se equipan con tapones fusibles. Estos dispositivos alivian la presión del gas cuando se funden (normalmente a unos $100^{\circ} \mathrm{C}$ ) y evitan la explosión de la botella. Al mismo tiempo, existe el riesgo de que el gas liberado prenda y explote.
Las precauciones habituales que deben adoptarse respecto a los gases combustibles son las siguientes:

- Las botellas deben almacenarse separadas de otros gases en un área bien ventilada por encima del nivel del suelo.

- No deben utilizarse botellas o equipos con fugas.

- Las botellas de gas líquido deben almacenarse y utilizarse en posición vertical. Se desprenderán grandes cantidades si a través de las válvulas de seguridad sale líquido en lugar de gas. La presión se reducirá con mayor lentitud. Se producirán llamas de gran tamaño si el gas prende.

- En caso de fugas, debe evitarse toda fuente de ignición posible.

- D ebe prohibirse fumar en los lugares donde se almacenan o se utilizan gases inflamables.

- La forma más segura de apagar un fuego suele consistir en interrumpir el suministro de gas. La mera extinción de la llama puede dar lugar a la formación de una nube explosiva, que volverá a prender en contacto con un objeto caliente.

Toxicidad. Ciertos gases, aunque no son los más comunes, pueden resultar tóxicos. Además, pueden ser irritantes o corrosivos para la piel y los ojos.

Las personas que manipulan estos gases deben recibir una formación adecuada, ser conscientes del peligro que suponen y conocer las precauciones necesarias. Las botellas deben almacenarse en un área bien ventilada. No deben tolerarse fugas. Es necesario utilizar equipos de protección adecuados (máscaras de gas o dispositivos de respiración).

Gases inertes. Gases como el argón, el dióxido de carbono, el helio y el nitrógeno se utilizan muy a menudo para crear atmósferas protectoras que eviten reacciones no deseadas en las actividades de soldado, instalaciones químicas, acerías, etc. Estos gases no se etiquetan como peligrosos y la posibilidad de accidentes graves se debe únicamente al hecho de que sólo el oxígeno puede sostener la vida.

Cuando un gas o mezcla de gases desplaza el aire de forma que la atmósfera respirable resulta deficiente en oxígeno, existe peligro de asfixia. La inconsciencia o la muerte pueden constituir las consecuencias rápidas de la presencia escasa o nula de oxígeno, y no se producen señales de advertencia previas.

Antes de acceder a un espacio restringido en el que la atmósfera respirable sea deficiente en oxígeno, debe procederse a su ventilación. Si se utilizan equipos de respiración, la persona que entra en ese tipo de espacio debe ser supervisada. Estos equipos deben emplearse incluso en operaciones de rescate. Las máscaras de gas normales no protegen de la deficiencia de oxígeno. L a misma precaución debe adoptarse en grandes instalaciones permanentes de lucha contra incendios, que suelen ser automáticas, y las personas presentes en estas áreas serán avisados del peligro.

L lenado de botellas. El Ilenado de botellas exige la utilización de compresores de alta presión o de bombas de líquido. Estas pueden funcionar con líquidos criogénicos (a muy baja temperatura). Asimismo, las instalaciones de llenado pueden incorporar grandes depósitos de almacenamiento de gases líquidos en un estado presurizado y/ o de refrigeración extrema.

El personal encargado de llenar las botellas de gas debe comprobar que éstas se encuentran en una situación aceptable para llevar a cabo la operación y debe elegir el gas correcto en una cantidad y con una presión que no sean superiores a las autorizadas. El equipo de llenado debe diseñarse y comprobarse para cada presión y tipo de gas, y protegerse mediante la aplicación de válvulas de seguridad. Los requisitos en cuanto a material y limpieza respecto a la utilización con oxígeno deben cumplirse estrictamente. En las tareas de llenado con gases inflamables o tóxicos, debe prestarse especial atención a la seguridad 
de los operarios. La exigencia fundamental consiste en mantener una buena ventilación y emplear las técnicas y los equipos correctos. Las botellas contaminadas con otros gases 0 líquidos por los clientes constituyen un riesgo especial. Las que carecen de presión residual pueden purgarse o vaciarse antes de su llenado. Es necesario extremar las precauciones para garantizar que las botellas de gas de uso médico no contengan ningún material nocivo.

Transporte EI transporte local tiende a mecanizarse mediante la utilización de carretillas elevadoras, etc. Las botellas deben trasladarse en todo caso con las tapas puestas y bien sujetas para evitar su caída de los vehículos. No deben dejarse caer directamente de éstos al suelo. En el caso de utilización de grúas elevadoras, se emplearán las plataformas adecuadas. Se evitará la aplicación de dispositivos de elevación magnéticos o de tapas cuya rosca no ofrezca fiabilidad para alzar botellas.

En caso de que se junten botellas en unidades de mayor tamaño, debe tenerse mucho cuidado de evitar tensiones en las conexiones. Los riesgos existentes se multiplicarán debido a la gran cantidad de gas manejada en las distintas operaciones. Es conveniente dividir las grandes unidades en secciones y colocar válvulas de cierre donde puedan ser utilizadas en caso de emergencia.

L os accidentes más frecuentes ocurridos al manipular y transportar botellas son lesiones causadas por las unidades duras, pesadas y difíciles de manejar. D ebe utilizarse calzado de seguridad. Es necesario disponer de carretillas para el transporte individual de botellas en recorridos de mayor amplitud.

En los códigos internacionales de transporte, los gases comprimidos se clasifican como mercancías peligrosas. Asimismo, se especifica qué gases pueden ser transportados, los requisitos que deben cumplir las botellas, la presión permitida, el marcado, etc.

I dentificación del contenido. EI requisito más importante para una manipulación segura de los gases comprimidos consiste en la identificación correcta del contenido de los recipientes. EI sellado, etiquetado, estarcido y marcado en color son los medios utilizados con este fin. En las normas de la O rganización Internacional de Normalización (ISO ) se establecen ciertos requisitos respecto al marcado. En la mayoría de los países, el marcado en color de las botellas de gas de uso médico se atiene a lo estipulado en las normas ISO. A simismo, los colores normalizados se aplican a otros gases en muchos países, pero esta forma de identificación no es suficiente. En última instancia, sólo la palabra escrita puede considerarse prueba del contenido de una botella.

Tomas de válvula normalizadas. La utilización de una toma de válvula normalizada para un determinado gas o grupo de gases reduce en gran medida la posibilidad de conectar botellas y equipos concebidos para gases diferentes. Por tanto, debe evitarse el empleo de adaptadores, ya que desvirtúan las medidas de seguridad. Al efectuar conexiones, sólo se emplearán herramientas normales y no se aplicará una fuerza excesiva.

\section{Práctica segura para usuarios}

La utilización segura de gases comprimidos exige la aplicación de los principios de seguridad esbozados en el presente capítulo y en el Repertorio de recomendaciones prácticas de la OIT Seguridad en la utilización de productos químicos en el trabajo (O IT 1993). Este objetivo no podrá cumplirse si el usuario no posee ciertos conocimientos básicos sobre el gas y el equipo que manipula. Además, el usuario deberá adoptar las precauciones siguientes:

- Las botellas de gas sólo se utilizarán con los fines para los que fueron concebidas y no como rodillos o soportes de trabajo.

- Las botellas deben almacenarse y manipularse de forma que no se deteriore su resistencia mecánica (p. ej., a causa de una corrosión grave, abolladuras profundas, cortes, etc.).
- Las botellas se mantendrán alejadas del fuego y del calor excesivo.

- En las áreas de trabajo y en los edificios ocupados sólo se almacenará el número necesario de botellas de gas. Es preferible que sean ubicadas cerca de las puertas y evitar las rutas de salida de emergencia y las áreas de difícil acceso.

- Las botellas que hayan quedado expuestas al fuego deben marcarse claramente y devolverse al encargado de su llenado (propietario), ya que pueden volverse quebradizas o perder su solidez.

- Las botellas deben almacenarse en lugares adecuadamente ventilados, lejos de la lluvia y de la nieve y de depósitos de combustible.

- Las botellas en uso deben asegurarse para evitar su caída.

- El contenido en gas debe identificarse sin lugar a duda antes de su utilización.

- Es necesario leer las etiquetas y las instrucciones con atención.

- Las botellas sólo deben conectarse a los equipos concebidos para cada servicio específico.

- Las conexiones deben mantenerse limpias y en buenas condiciones, y su situación se comprobará periódicamente.

- Deben utilizarse herramientas adecuadas (es decir, de longitud normal, llaves de tuercas fijas).

- Las llaves para válvula sueltas deben colocarse en su lugar cuando la botella esté siendo utilizada.

- Las válvulas deben mantenerse cerradas cuando la botella no sea utilizada.

- Las botellas o los equipos conectados a las mismas deben retirarse de espacios restringidos cuando no sean utilizados (incluso durante pausas breves).

- Debe comprobarse el contenido de oxígeno de la atmósfera de trabajo y, si es posible, el de gases inflamables, antes de acceder a espacios restringidos y durante períodos de trabajo prolongados.

- Debe tenerse en cuenta que los gases pesados pueden concentrarse en áreas inferiores y que su eliminación mediante ventilación puede resultar difícil.

- Las botellas deben protegerse contra la contaminación de equipos con presión interior, ya que el reflujo de otros gases puede dar provocar accidentes graves. Deben utilizarse válvulas de retención adecuadas, dispositivos de bloqueo y descarga y otros mecanismos afines.

- Las botellas vacías deben devolverse al encargado de su llenado con las válvulas cerradas y las tapas en su sitio. Siempre debe mantenerse una pequeña presión residual para evitar la contaminación debida al aire y la humedad.

- Se notificará al encargado del llenado la existencia de botellas defectuosas.

- El acetileno sólo se empleará a una presión correctamente reducida.

- Los disipadores de llamas sólo se aplicarán en líneas de acetileno cuando este gas se utilice con aire comprimido u oxígeno.

- Al emplear equipos de soldadura por llama de gas, se dispondrá de extintores de incendios y guantes de protección contra el calor.

- Las botellas de gas líquido deben almacenarse y utilizarse en posición vertical.

- Los gases tóxicos e irritantes, como el cloro, deben ser manipulados únicamente por operarios bien informado dotados de equipos de seguridad personal.

- Las botellas no identificadas no se almacenarán. Las instalaciones fijas, con las botellas de gas conectadas en centrales suministradoras separadas, son más seguras cuando se utilizan gases con regularidad. 


\section{- Higiene EN EL LABORATORIO}

Frank M iller

\section{Creación de un laboratorio seguro y sano}

Un laboratorio sólo puede ser seguro e higiénico si las prácticas y los procedimientos de trabajo aplicados lo son igualmente. La forma de fomentar esta actitud consiste, en primer lugar, en asignar la responsabilidad y la competencia en materia de seguridad e higiene química a un director con autoridad en la materia que, en colaboración con un comité de seguridad del personal del laboratorio, decida qué tareas deben llevarse a cabo y asigne las competencias correspondientes a cada una.

L as labores específicas de dicho comité consisten en efectuar inspecciones periódicas y resumir los resultados en un informe remitido al director de seguridad. Estas inspecciones se realizarán de acuerdo con una lista de comprobación. 0 tro aspecto importante de la gestión de la seguridad son las inspecciones regulares del equipo utilizado para mantenerla, cuyo objetivo es garantizar que todos sus componentes se encuentran en buenas condiciones de funcionamiento y están ubicados en los lugares designados. Antes de completar esta actividad, debe llevarse a cabo un inventario anual de todos los equipos de seguridad, que comprenderá una descripción breve y la referencia al tamaño 0 la capacidad y al fabricante. I gualmente importante es el inventario semestral de todas las sustancias químicas del laboratorio, incluidos los productos patentados. Se clasificarán en grupos de sustancias químicamente similares y, además, en función de su riesgo de incendio. 0 tro criterio de clasificación de seguridad esencial depende del grado de riesgo asociado con cada sustancia, ya que el tratamiento que se le asigna está relacionado directamente con el daño que puede provocar y la facilidad con que éste se genera. Toda sustancia química se incluye en una de las tres clases siguientes con arreglo a la magnitud del riesgo asociado en cada caso:

\section{1. sustancias de riesgo ordinario;}

2. sustancias de alto riesgo,

3. materiales extremadamente peligrosos.

Las sustancias de riesgo ordinario son aquellas relativamente fáciles de controlar, bien conocidas por el personal del laboratorio, que no generan riesgos poco habituales. En esta clase se incluyen desde las sustancias inocuas como el bicarbonato de sodio y la sacarosa, hasta el ácido sulfúrico concentrado, el etilenglicol y el pentano.

Las sustancias incluidas en la segunda clase generan riesgos mucho mayores que las comprendidas en la primer grupo. Exigen una manipulación especial y, en ocasiones, vigilancia, y se caracterizan por presentar un grave riesgo de incendio 0 explosión y para la salud. En este grupo figuran las sustancias químicas que forman compuestos inestables y explosivos en reposo (p. ej., hidroperóxidos formados por éteres), las que poseen toxicidades agudas (p. ej., el fluoruro de sodio, con una toxicidad oral en ratones de $57 \mathrm{mg} / \mathrm{kg}$ ) y las que poseen toxicidades crónicas como los cancerígenos, los mutágenos o los teratógenos. Los elementos de este grupo presentan a menudo el mismo tipo de riesgo que los incluidos en el siguiente. $L$ a diferencia es de grado: las sustancias del grupo 3, materiales extremadamente peligrosos, generan riesgos más intensos, su magnitud es mucho mayor o sus efectos perniciosos se producen con mayor facilidad.

Estas sustancias, cuando no se manipulan correctamente, pueden causar sin dificultad accidentes importantes que den lugar a lesiones graves, pérdidas de vidas o grandes daños materiales. Es necesario extremar las precauciones al utilizarlas. En esta clase se incluyen el tetracarbonilo de níquel (un líquido volátil extremadamente tóxico, cuyos vapores han sido letales en concentraciones tan bajas como 1 ppm) y el trietilaluminio (un líquido que prende espontáneamente al exponerse al aire y reacciona explosivamente con el agua).

U na de las tareas más importantes del comité de seguridad es redactar el plan de higiene química y seguridad del laboratorio, un documento exhaustivo en el que se describe con detalle su política en la materia y los procedimientos normalizados para llevar a cabo las operaciones del laboratorio y cumplir las obligaciones reglamentarias; se incluyen aquí las directrices sobre utilización de las sustancias comprendidas en cualquiera de las tres categorías de riesgo, inspección del equipo de seguridad y actuación en caso de vertido químico, la política de gestión de residuos químicos, las normas relativas a la calidad del aire y los registros exigidos por las disposiciones vigentes. EI plan debe conservarse en el laboratorio y, en caso contrario, será de fácil acceso para todos los miembros de su plantilla. 0 tras fuentes de información impresa son las fichas de información química [denominadas asimismo fichas técnicas de seguridad (FTS)], el manual de seguridad del laboratorio, los datos toxicológicos y la información sobre el riesgo de incendio. El inventario de sustancias químicas del laboratorio y las tres listas derivadas asociadas (clasificación en función de la clase química, el tipo de seguridad respecto a incendios y los tres grados de riesgo) también debe estar a disposición junto con las referencias anteriores.

A simismo, debe aplicarse un sistema de archivo de registros de actividades relacionadas con la seguridad. No es necesario que esté presente en el laboratorio o que sea de acceso inmediato para sus trabajadores. Los registros son de utilidad fundamentalmente para el personal encargado de supervisar la seguridad y la higiene química en el laboratorio y para su examen por los inspectores del organismo regulador correspondiente. Por tanto, deben ponerse a disposición con facilidad y mantenerse actualizados. Es aconsejable que los archivos se conserven fuera del laboratorio, con el fin de reducir la posibilidad de su destrucción en caso de incendio. Entre los documentos archivados deberán figurar: los informes de las inspecciones efectuadas por el comité de seguridad, los informes de las inspecciones llevadas a cabo por organismos reguladores locales como departamentos de bomberos y entidades estatales y federales, los registros relativos a la evacuación de desechos peligrosos, los registros de los impuestos exigidos respecto a diversos tipos de desechos peligrosos, en su caso, una segunda copia del inventario de sustancias químicas presentes en el laboratorio, y copias de otros documentos pertinentes relacionados con la instalación y con su personal (p. ej., los registros de asistencia del personal a la sesiones anuales de seguridad en el laboratorio).

\section{Causas de enfermedad y lesión en el laboratorio}

L as medidas de prevención de las lesiones personales, las enfermedades y la ansiedad constituyen una parte esencial de los planes de funcionamiento ordinario de un laboratorio adecuadamente gestionado. Entre las personas afectadas por la falta de seguridad y de higiene en este tipo de instalación figuran no sólo los que trabajan en la misma, sino también el personal ubicado en lugares cercanos y las personas que prestan servicios mecánicos y de vigilancia. Puesto que las lesiones personales en los laboratorios se deben en gran medida a un contacto inapropiado entre las sustancias químicas y las personas, a una mezcla inadecuada de estas sustancias o a un suministro incorrecto de energía a las mismas, la protección de la salud exige la prevención de tales interacciones no deseadas. La consecución de este objetivo requiere, a su vez, una conservación adecuada de dichas sustancias, una combinación pertinente de las mismas y una regulación exhaustiva de la energía que se les proporciona. Los tipos principales de lesión 
personal en un laboratorio son la intoxicación, las quemaduras químicas, y las derivadas de incendios o explosiones. Este tipo de accidentes provocan quemaduras térmicas, laceraciones, conmociones y otros daños corporales graves.

A taque de las sustancias químicas al organismo. Estos ataques tienen lugar cuando los tóxicos son absorbidos por el organismo e interfieren en su funcionamiento ordinario mediante la perturbación del metabolismo u otros mecanismos. Las quemaduras químicas o las grandes destrucciones de tejido suelen producirse por contacto con ácidos o álcalis fuertes. Los materiales tóxicos que han penetrado en el organismo mediante absorción a través de la piel, los ojos o las membranas mucosas, ingestión o inhalación, pueden provocar una intoxicación generalizada, normalmente debido a su propagación a través del sistema circulatorio.

Existen dos tipos generales de intoxicación: aguda y crónica. La primera se caracteriza por la aparición de efectos perniciosos durante 0 justo después de una exposición específica a una sustancia tóxica. La segunda se hace evidente sólo con el paso del tiempo, y puede demorarse semanas, meses, años o incluso decenios. Se dice que la intoxicación crónica ocurre cuando se cumplen las condiciones siguientes: la víctima ha sido objeto de múltiples exposiciones durante períodos de tiempo prolongados y ha estado en contacto con cantidades metabólicamente significativas de un tóxico crónico.

Las quemaduras químicas, que suelen acaecer cuando sustancias líquidas corrosivas se derraman o salpican la piel o los ojos, también se producen cuando estos tejidos entran en contacto con sólidos corrosivos, cuyo tamaño oscila entre partículas de polvo y cristales de considerable tamaño, con líquidos corrosivos nebulizados en el aire, o con gases corrosivos como el cloruro de hidrógeno. Los bronquios, pulmones, lengua, garganta y epiglotis pueden sufrir asimismo la acción de sustancias químicas corrosivas en estado gaseoso, líquido o sólido. 0 bviamente, las sustancias químicas tóxicas también pueden introducirse en el organismo en cualquiera de estos tres estados físicos, y en forma de polvo o líquido nebulizado.

L esiones debidas a incendios 0 explosiones. Los incendios y las explosiones pueden provocar quemaduras térmicas. No obstante, algunas de las lesiones causadas por las explosiones son muy características de este tipo de accidente; son generadas por la fuerza de choque de la detonación en sí o por algunos de sus efectos, como el lanzamiento de fragmentos de cristal, causando la pérdida de dedos o de miembros en el primer caso y los desgarros de la piel y la pérdida de visión en el segundo.

Lesiones en el laboratorio debidas a otras causas. Un tercer tipo de lesiones no son provocadas ni por la acción de las sustancias químicas ni por la combustión. Por el contrario, se deben a la acción de otros factores diversos: mecánicos, eléctricos, fuentes de luz de alta energía (ultravioleta y láseres), quemaduras térmicas por contacto con superficies calientes, explosiones repentinas de recipientes químicos de cristal tapados con tapones metálicos roscados debidas al aumento inesperado de presiones internas de gases elevadas, heridas debidas al contacto con un borde afilado de un tubo de cristal recién roto. Entre las fuentes de lesión de origen mecánico más graves se cuentan las botellas altas de gas a alta presión que se inclinan y acaban cayendo al suelo. Este tipo de sucesos pueden dar lugar a la lesión de piernas y pies; además, si la parte central de la botella se rompe en la caída, ésta, impulsada por el escape de gas rápido, masivo e incontrolado, se convierte en un misil letal sin dirección y en una fuente potencial de daños más graves y generalizados.

\section{Prevención de lesiones}

Sesiones de seguridad y divulgación de información. La prevención de lesiones depende simultáneamente de la ejecución de las tareas

\section{Exposición profesional a productos químicos peligrosos en laboratorios}

\section{Norma sobre laboratorios de la OSHA, 1990, 29 CFR} 1910.1450

La siguiente descripción de un plan de higiene química en laboratorios se incluye en la sección (e:1-4) del Plan general de higiene química de la $\mathrm{N}$ orma sobre laboratorios de la OSHA, 1990. Este plan se pondrá a disposición de los trabajadores y de sus representantes a la mayor brevedad posible.

En el plan de higiene química se incluirán los elementos siguientes y se indicarán las medidas específicas que el empleador debe adoptar para garantizar la protección del personal de laboratorio:

(i) los procedimientos operativos normalizados relativos a la salud y la seguridad que deberán aplicarse cuando la actividad en el laboratorio exija la utilización de productos químicos peligrosos:

(ii) los criterios que utilizará el empleador para determinar y llevar a la prácticas las medidas encaminadas a reducir la exposición de los trabajadores a los productos químicos peligrosos, incluidos los relativos a los controles técnicos, la utilización de equipo de protección individual y las prácticas de higiene; se prestará especial atención a la selección de medidas de control aplicadas a los productos químicos que conllevan un peligro extremo;

(iii) la exigencia de que las campanas de humos y otros equipos de protección funcionen adecuadamente, y las medidas específicas que se adoptarán para garantizar un rendimiento correcto de estos equipos;

(iv) las disposiciones referentes a la información y la formación de los trabajadores establecidas [en otras secciones del presente plan];

(v) las circunstancias en las que una tarea, un procedimiento 0 una actividad en el laboratorio exigirán la aprobación del empleador o de la persona designada por éste al efecto previa a su realización;

(vi) las disposiciones relativas a las consultas y las exploración médicas;

(vii) la designación del personal encargado de la aplicación del plan de higiene química, incluida la designación de un responsable de higiene química y, en su caso, la creación de un comité competente en esta materia; y

(viii) las disposiciones relativas al perfeccionamiento de la protección de los trabajadores en las actividades con productos especialmente peligrosos. Se trata de "cancerígenos específicos", toxinas reproductivas y otros productos de alta toxicidad aguda. Se prestará atención específica a las disposiciones siguientes, que serán consideradas en el plan cuando resulte pertinente:

(a) establecimiento de un área designada;

(b) utilización de dispositivos de retención como campanas de humos o cajas de manipulación con guantes:

(c) procedimientos para la eliminación segura de los residuos contaminados; y

(d) procedimientos de descontaminación.

El empleador revisará y evaluará la eficacia del plan de higiene química al menos una vez año y lo actualizará en caso necesario.

propias de un laboratorio de un modo seguro y prudente y de la formación impartida a los trabajadores sobre la metodología correcta que debe seguirse en este tipo de instalación. Aunque 
hayan iniciado esta formación en la enseñanza preuniversitaria y universitaria, su capacitación debe completarse y consolidarse mediante la celebración periódica de sesiones de seguridad. En éstas, además de hacer hincapié en la comprensión de las bases físicas y biológicas de una práctica segura en el laboratorio, debe capacitarse al personal para rechazar con facilidad procedimientos cuestionables y seleccionar los métodos técnicamente aconsejables de una manera natural. En las sesiones también se instruirá a los trabajadores sobre los tipos de datos necesarios para diseñar procedimientos seguros y las fuentes de esta información.

A simismo, se facilitará su acceso directo, desde sus lugares de trabajo, a la información técnica y de seguridad pertinente. Se les proporcionarán materiales como manuales de seguridad en el laboratorio, fichas de información químicas e informes toxicológicos y de riesgo de incendios.

Prevención de intoxicaciones y quemaduras químicas. Las intoxicaciones y las quemaduras químicas poseen una característica en común: comparten los mismos lugares de acceso o ataque: a) la piel; b) los ojos; c) de la boca al estómago y los intestinos, y d) de la nariz a los bronquios y los pulmones. La prevención consiste en lograr que estas zonas sean inaccesibles para las sustancias tóxicas o corrosivas. Para conseguirlo, deben colocarse una 0 varias barreras físicas entre la persona protegida y la sustancia peligrosa o garantizar que la atmósfera del laboratorio no esté contaminada. Los procedimientos en los que se utilizan estos métodos incluyen el trabajo detrás de una pantalla de seguridad, el empleo de una campana de ventilación o la combinación de ambos sistemas. 0 bviamente, la utilización de una caja de manipulación con guantes ofrece una protección doble. L a minimización de los daños de la lesión, en caso de que se produzca una contaminación de tejidos, se consigue mediante la eliminación de la sustancia tóxica o corrosiva con la mayor rapidez y exhaustividad posible.

Prevención de quemaduras químicas e intoxicaciones agudas frente a la prevención de intoxicaciones crónicas. Aunque el planteamiento básico de aislar la sustancia peligrosa de la persona que debe protegerse es el mismo en la prevención de intoxicaciones agudas, quemaduras químicas e intoxicaciones crónicas, su aplicación debe diferir en cierta medida en este último caso. M ientras que los dos primeros pueden compararse con un ataque masivo en una guerra, el envenenamiento crónico se asemeja a un asedio. Suele deberse a la actuación de concentraciones muy inferiores que ejercen su influencia a través de múltiples exposiciones a lo largo de amplios períodos de tiempo, y sus efectos comienzan a acusarse de manera gradual e insidiosa mediante una acción sostenida y sutil. La adopción de medidas correctivas exige, en primer lugar, la detección de la sustancia química capaz de provocar la intoxicación crónica antes de la aparición de los síntomas y el reconocimiento de uno o varios aspectos del malestar de un trabajador como posibles síntomas físicos debidos a la misma. Si se sospecha la existencia de una intoxicación crónica, debe procurarse atención médica con prontitud. Cuando se detecta un tóxico de este tipo en una concentración que excede 0 se aproxima al nivel admisible, deben emprenderse las acciones necesarias para eliminarlo 0 , al menos, reducir su concentración hasta alcanzar un nivel seguro. La prevención de la intoxicación crónica suele exigir el empleo de los equipos de protección durante toda la jornada de trabajo o gran parte de la misma; no obstante, por razones de comodidad, el uso de una caja de manipulación con guantes o un aparato de respiración autónomo no siempre es factible.

Protección contra la intoxicación y las quemaduras químicas.

Para mejorar la protección contra la contaminación de la piel debida al rociado de un determinado líquido corrosivo o la presencia de un sólido tóxico en suspensión en el aire, es

\section{Apéndice $A$ a las recomendaciones 1910.1450 del National Research Council relativas a la higiene química en laboratorios (no preceptivo)}

Las directrices siguientes relativas a la adecuada ventilación en un laboratorio se incluyen en la sección $C$. La instalación de laboratorio; 4. Ventilación - (a) Ventilación general de laboratorios, apéndice $A$ a la $N$ orma sobre laboratorios de la OSHA, 1990, 29 CFR 1910.1450.

\section{Ventilación}

(a) Ventilación general de laboratorio. Este sistema: debe suministrar una fuente de aire para respirar y de entrada en los dispositivos de ventilación local; no debe considerarse como una garantía de protección respecto a las sustancias tóxicas emitidas en el laboratorio; debe asegurar una renovación continua del aire en el laboratorio, evitando el aumento de las concentraciones de sustancias tóxicas en la atmósfera de la instalación durante la jornada laboral; debe dirigir el flujo de aire desde las áreas circundantes al laboratorio, y desde éste al exterior del edificio.

(b) Campanas. Los laboratorios deben equiparse con campanas que asignen 2,5 pies lineales $[76 \mathrm{~cm}$ ] por persona cada 2 trabajadores si éstos dedican la mayor parte de su tiempo al trabajo con sustancias químicas; cada campana constará de un dispositivo de vigilancia continua que permita la confirmación de un rendimiento adecuado del equipo antes de su utilización. Si no pueden tomarse estas precauciones, debe evitarse el trabajo con sustancias de toxicidad desconocida 0 aplicarse otros tipos de dispositivos de ventilación local.

(c) 0 tros dispositivos de ventilación. En caso necesario, se instalarán armarios de almacenamiento ventilados, campanas de techo, tubos de respiración, etc. Las campanas de techo y los tubos de respiración dispondrán de un conducto de aspiración individual.

(d) Areas de ventilación especial. El aire extraído de las cajas de manipulación con guantes y las salas de aislamiento debe pasarse por torres depuradoras u otra forma de tratamiento antes de su evacuación al sistema de aspiración ordinario. Las cámaras de frío y de calor deben dotarse de dispositivos para la evacuación rápida y en caso de avería eléctrica.

(e) Modificaciones. Las modificaciones del sistema de ventilación se llevarán a cabo únicamente en el caso de que las pruebas exhaustivas realizadas indiquen que la protección de los trabajadores frente a las sustancias tóxicas en suspensión en el aire seguirá siendo adecuada.

(f) Rendimiento. Una tasa de renovación del aire de 4 a 12 veces cada hora suele indicar una ventilación general adecuada si se utilizan sistemas de aspiración local (campanas) como método de control principal.

(g) Calidad. El flujo general de aire no debe ser turbulento, sino relativamente uniforme en todo el laboratorio, evitando altas velocidades y áreas estáticas; el flujo de aire de entrada en la campana y dentro de ésta no debe excesivamente turbulento; la velocidad en cara de las campanas debe ser la adecuada (normalmente, 0,25-0,5 m/ s.).

(h) Evaluación. La calidad y la cantidad de la ventilación debe evaluarse en la instalación, controlarse periódicamente (al menos cada tres meses) y reevaluarse en los casos de modificación de la ventilación local. 
conveniente utilizar guantes de seguridad y un peto de laboratorio realizados en goma o polímeros naturales o sintéticos apropiados. Por apropiado se entiende un material que no se disuelva, ni se hinche ni sufra ninguna otra modificación debida a la acción de la sustancia de la que debe proteger, ni sea permeable a la misma. La utilización de una pantalla de seguridad en la mesa de trabajo del laboratorio, interpuesta entre los aparatos en los que las sustancias químicas se calientan, reaccionan o se destilan y el investigador es una medida de salvaguarda adicional contra las quemaduras químicas y la intoxicación por contaminación de la piel. Puesto que la velocidad con que se elimina una sustancia corrosiva o tóxica de la piel constituye un factor esencial en la prevención o la minimización de los daños que ésta puede provocar, una ducha de seguridad, ubicada en un lugar adecuado en el laboratorio, es un componente indispensable del equipo de seguridad.

Los ojos pueden protegerse mejor de las salpicaduras de líquido mediante el empleo de gafas de montura ajustada y de máscaras faciales. Entre los contaminantes atmosféricos, además de los gases y vapores, figuran los sólidos y los líquidos cuando se presentan subdivididos en pequeñas partículas en forma de polvo o rocío. La forma más eficaz de evitar su contacto con los ojos consiste en trabajar en una campana de humos o en una caja de manipulación con guantes, si bien las gafas de montura ajustada también ofrecen cierta protección en estos casos. Las gafas pueden utilizarse para mejorar la protección al emplear la campana. La presencia de fuentes para el lavado de ojos de fácil acceso en el laboratorio suele eliminar y reduce sin lugar a dudas los daños en esta parte del cuerpo provocados por la contaminación que generan las salpicaduras de sustancias corrosivas y tóxicas.

La vía boca-estómago-intestinos suele estar relacionada con la intoxicación más que con el ataque de sustancias corrosivas. La ingestión de materiales tóxicos suele producirse de manera inconsciente a través de la contaminación química de alimentos - cosméticos. Las fuentes de esta contaminación son los alimentos almacenados en frigoríficos junto con sustancias químicas, los que se consumen en el laboratorio y las barras de labios que se guardan o aplican en este tipo de instalación. La prevención en estos casos consiste en evitar las prácticas que los provocan, por ejemplo, utilizando ciertos frigoríficos exclusivamente para la conservación de alimentos y reservando lugares para comer fuera del laboratorio.

En lo que respecta a intoxicaciones y quemaduras químicas, la vía nariz-bronquios-pulmones, se ve afectada exclusivamente por las sustancias en suspensión en el aire, ya sea en forma de gases, vapores, polvo o neblina. Estos materiales pueden mantenerse alejados del sistema respiratorio de los trabajadores dentro y fuera del laboratorio mediante la práctica simultánea de: a) limitar la realización de las operaciones que los producen a las campanas de humos; b) ajustar el suministro de aire del laboratorio, de forma que la atmósfera en éste se renueve de 10 a 12 veces por hora, y c) mantener una presión atmosférica negativa en el laboratorio respecto a los pasillos y las salas que lo rodean. Las tareas que producen humo o polvo y exigen la utilización de aparatos muy voluminosos o recipientes del tamaño de un bidón de 218 litros, que son demasiado grandes para su utilización en una campana de humos ordinaria, deben llevarse a cabo en salas especiales dotadas de este tipo de sistemas de extracción. En general, los respiradores o los aparatos de respiración autónomos no deben emplearse en tareas de laboratorio que no tengan un carácter de emergencia.

La intoxicación crónica por mercurio, debida a la inhalación de vapores de este material, ocurre ocasionalmente en los laboratorios. Se produce cuando el mercurio acumulado en un lugar oculto (debajo del revestimiento del suelo, en cajones o en un armario) ha emitido vapores durante un período de tiempo suficiente para afectar a la salud del personal. Un servicio de mantenimiento adecuado evitará este problema. Si se sospecha de la existencia de una fuente de mercurio oculta, debe comprobarse si este elemento está presente en la atmósfera del laboratorio mediante la utilización de un detector especial diseñado al efecto o la remisión de una muestra de aire para su análisis.

Prevención de incendios y explosiones y extinción de incendios. La causa principal de incendio en un laboratorio es la ignición accidental de líquidos inflamables. En lo que respecta a la seguridad contra incendios, éstos se definen como aquellos líquidos con puntos de inflamación inferiores a $36,7^{\circ} \mathrm{C}$. L Las fuentes de ignición que provocan este tipo de suceso consisten en llamas desnudas, superficies calientes, chispas eléctricas generadas por interruptores y motores que forman parte de equipos como agitadores, frigoríficos domésticos y ventiladores eléctricos, y chispas producidas por electricidad estática. La ignición de un líquido inflamable no se produce en el líquido en sí, sino sobre éste, en la mezcla de sus vapores con el aire (cuando la concentración de vapor se encuentra entre ciertos límites superiores e inferiores).

La prevención de incendios en un laboratorio se basa en la retención completa de los vapores de líquidos inflamables en los recipientes que los contienen 0 en los aparatos en que son utilizados. Si esta retención completa no es posible, el coeficiente de fuga debe minimizarse en la medida de lo posible y debe suministrarse una corriente de aire continua y potente para eliminar dichos vapores, de forma que pueda mantenerse su concentración en todo momento muy por debajo del límite inferior de concentración crítica. Estos objetivos se cumplen cuando las reacciones en las que intervienen líquidos inflamables se llevan a cabo en campanas de humos y cuando los bidones que contienen estos líquidos se almacenan en cámaras con salida a un aparato aspirador.

U na práctica particularmente insegura es el almacenamiento de líquidos inflamables como el etanol en frigoríficos de tipo doméstico. Estos aparatos no mantienen los vapores generados lejos del contacto con las chispas generadas por sus interruptores, motores y relés. Por tanto, nunca deben conservarse recipientes de líquidos inflamables en este tipo de frigoríficos. Esta afirmación es especialmente válida en el caso de los recipientes y bandejas abiertos que contienen dichos líquidos. No obstante, incluso las botellas con tapones de rosca, guardadas en estos frigoríficos, han causado explosiones, supuestamente por la fuga de vapores a través de un cierre defectuoso o por la rotura de estos recipientes. Los líquidos inflamables que requieren refrigeración sólo se almacenarán en frigoríficos a prueba de explosiones.

Las chispas producidas por la acumulación de carga eléctrica debida al movimiento de un fluido constituyen un factor significativo causante de incendios, que actúa cuando se vierten 0 sifonan grandes cantidades de líquido inflamable de un bidón a otro. Este tipo de generación de chispas puede evitarse mediante la utilización de bidones con toma de tierra para descarga eléctrica.

La mayoría de incendios relacionados con sustancias químicas o disolventes que se producen en el laboratorio y son de una magnitud moderada pueden apagarse con extintores de dióxido de carbono o de polvo. Los laboratorios deben equiparse con uno o varios extintores de cualquiera de los dos tipos, dependiendo de su tamaño. Ciertos incendios especiales exigen la aplicación de otros agentes extintores. M uchos incendios en los que se queman metales se apagan con arena o grafito. La ignición de hidruros metálicos requiere el empleo de grafito o caliza en polvo.

Cuando se prenden ropas en un laboratorio, las llamas deben apagarse con rapidez para reducir al mínimo las lesiones 
producidas por las quemaduras térmicas. U na manta colgada en la pared con la que envolver a la víctima extingue este tipo de fuegos con eficacia. Puede utilizarse para sofocar las llamas por la persona cuyas ropas han prendido. También es posible emplear las duchas de seguridad para resolver este tipo de problemas. Existen límites respecto al volumen total de líquidos inflamables que pueden almacenarse en condiciones de seguridad en cada laboratorio. Estos límites, generalmente estipulados en las normativas locales contra incendios, son variables y dependen de los materiales de construcción de la instalación y de su equipación con un sistema de extinción de incendios automático. Suelen oscilar entre los 55 y los 135 litros.

EI gas natural suele suministrarse a través de varias válvulas localizadas en diversas partes de un laboratorio convencional. E stos accesos constituyen las fuentes más comunes de fuga, junto con los tubos de goma y los quemadores a los que están conectados. Estos escapes, cuando no se detectan poco después de su inicio, provocan explosiones graves. Los detectores de gas, diseñados para indicar el nivel de concentración de éste en el aire, pueden utilizarse para localizar el origen de la fuga con rapidez.

Prevención de lesiones debidas a diversas fuentes. Los daños provocados por la caída de botellas de gas a alta presión de gran tamaño, una de las causas de accidente más habituales de las comprendidas en este grupo, pueden evitarse con facilidad atando 0 encadenando firmemente estos recipientes a una pared 0 un banco de trabajo del laboratorio y tapando todas las botellas vacías no utilizadas.

La mayoría de las lesiones provocadas por los fragmentos cortantes de tubos de cristal se producen por la rotura de éstos al colocarles corchos o tapones de caucho. Para prevenirlas, debe recurrirse a la lubricación del tubo con glicerol y a la protección de las manos con guantes de trabajo de cuero.

\section{Materiales incompatibles}

Son incompatibles dos sustancias que, al entrar en contacto o mezclarse, generan un efecto dañino o potencialmente dañino. Los dos miembros de un par incompatible pueden ser sustancias químicas, o una sustancia química y un material de construcción como la madera o el acero. La mezcla o el contacto de dos materiales incompatibles da lugar a una reacción química o a una interacción física que genera una gran cantidad de energía. Los efectos perniciosos específicos o potenciales de estas combinaciones, que pueden provocar en última instancia accidentes graves o daños para la salud, incluyen la liberación de grandes cantidades de calor, incendios, explosiones, producción de gases inflamables y generación de gases tóxicos.

Puesto que en un laboratorio suele encontrarse una amplia gama de sustancias, la existencia de incompatibilidades entre ellas es muy habitual y representa un riesgo para la vida y la salud si no se tratan correctamente.

$\mathrm{R}$ ara vez se mezclan deliberadamente materiales incompatibles. Normalmente, su combinación es el resultado de una rotura accidental simultánea de dos recipientes adyacentes. En ocasiones, se debe a fugas o pérdidas, o a la mezcla de gases 0 vapores procedentes de botellas cercanas entre sí. Aunque en muchos de los casos en que se combinan dos elementos incompatibles los efectos perjudiciales pueden observarse con facilidad, al menos en uno de ellos, la detección de la formación de un tóxico crónico no resulta tan sencilla. Es el caso que consiste en la reacción del gas formaldehído derivado de la formalina al 37 \% con el cloruro de hidrógeno desprendido del ácido clorhídrico concentrado, que da lugar a la formación del potente cancerígeno bis(clorometil) éter. 0 tros casos de efectos de detección no inmediata consisten en la generación de gases inodoros e inflamables.
Evitar que dos materiales incompatibles se mezclen debido a la rotura simultánea de recipientes adyacentes o la fuga de vapores de botellas próximas entre sí es sencillo: los recipientes deben mantenerse separados. No obstante, en primer lugar es necesario identificar el par incompatible; esta tarea no siempre es sencilla u obvia. Para reducir al mínimo la posibilidad de pasar por alto un par incompatible, debe consultarse y hojearse de vez en cuando compendios sobre la cuestión para familiarizarse con los ejemplos menos conocidos. Para prevenir el contacto por fuga o rotura entre una sustancia química y el material incompatible con el que esté construido el estante en el que se apoya su recipiente, se colocará éste en un depósito de vidrio con la capacidad suficiente para dar cabida a la totalidad de su contenido.

\section{METODOS PARA EL CONTROL LOCALIZADO DE CONTAMINANTES ATMOSFERICOS}

\section{Louis DiBernardinis}

En general, los profesionales de la salud en el trabajo han confiado en la siguiente jerarquía de técnicas de control para eliminar o minimizar las exposiciones de los trabajadores: sustitución, aislamiento, ventilación, prácticas de trabajo, y ropas y equipos de protección personal. Suele aplicarse una combinación de dos o más de estas técnicas. Aunque en este artículo se analiza fundamentalmente la utilización de los métodos de ventilación, los demás planteamientos se refieren brevemente. No deben pasarse por alto al intentar controlar la exposición a sustancias químicas mediante la ventilación.

El profesional de la salud en el trabajo siempre debe considerar el concepto de la cadena fuente-medio-receptor. El objeto de atención principal será el control de la fuente, y al control del medio se concederá una importancia secundaria. El control del receptor debe considerarse como el último recurso. Ya sea en las fases de inicio o diseño de un proceso o durante la evaluación de un proceso existente, el procedimiento de control de la exposición a contaminantes atmosféricos debe comenzar en la fuente y avanzar hasta el receptor. Es probable que la totalidad 0 la mayor parte de estas estrategias de control deban ser utilizadas.

\section{Sustitución}

Este principio consiste en eliminar o reducir el riesgo mediante la sustitución por materiales inocuos o menos tóxicos o el rediseño del proceso para impedir la fuga de contaminantes en el lugar de trabajo. En teoría, las sustancias químicas sustitutas no serán tóxicas y el rediseño del proceso evitará plenamente la exposición. No obstante, puesto que estos objetivos no siempre son alcanzables, se recurrirá a otros controles incluidos en la jerarquía referida.

D eben extremarse las precauciones para asegurar que la sustitución no de lugar a una situación de mayor riesgo. Aunque aquí se analiza el peligro de toxicidad, la inflamabilidad y la reactividad química de los sustitutos también deben considerarse al valorar el riesgo.

\section{Aislamiento}

El principio de aislamiento consiste en eliminar o reducir el riesgo mediante la separación del proceso emisor de contaminantes del trabajador. Para ello, puede optarse por el cerramiento total del proceso o por su localización a una distancia de 
seguridad de las personas. No obstante, estas opciones pueden exigir la operación y/ o el control remoto del proceso. El aislamiento resulta especialmente útil en las tareas que requieren pocos trabajadores y cuando el control por otros medios es difícil. 0 tra posibilidad consiste en efectuar las operaciones peligrosas en turnos poco concurridos para limitar el número de trabajadores expuestos. En ocasiones, la utilización de esta técnica no elimina la exposición, pero reduce la cantidad de personas afectadas.

\section{Ventilación}

Habitualmente se emplean dos tipos de ventilación aspirante para reducir al mínimo los niveles de exposición a contaminantes atmosféricos. El primero se denomina ventilación general o por dilución. El segundo se conoce como control de la fuente o ventilación por extracción localizada (VEL) y se analiza con mayor detalle más adelante en el presente artículo.

Estos dos tipos no deben confundirse con la ventilación de climatización, cuyo fin principal es el suministro de cantidades medidas de aire externo para respirar y mantener una temperatura y una humedad específicas. En otros artículos de esta E nciclopedia se analizan diversas formas de ventilación.

\section{Prácticas de trabajo}

El control de las prácticas de trabajo comprende la supervisión de los métodos que emplean los trabajadores para llevar a cabo las distintas tareas y de la medida en que se atienen a los procedimientos correctos. En esta Enciclopedia se ofrecen diversos ejemplos de este procedimiento de control al analizar procesos generales o específicos. Al abordar conceptos generales como la educación y la formación, los principios de gestión y los sistemas de ayuda social se examina la importancia de las prácticas de trabajo en el control de las exposiciones.

\section{Equipos de protección personal}

Los equipos de protección personal (EPP) se consideran la última línea de defensa en el control de la exposición de los trabajadores. Comprenden la utilización de dispositivos respiratorios y ropa protectora. Suelen combinarse con otras prácticas de control, en particular con el fin de reducir al mínimo los efectos de emisiones 0 accidentes imprevistos. Estas cuestiones se analizar con mayor detenimiento en el capítulo dedicado a la protección personal.

\section{Ventilación por extracción localizada}

La forma más eficaz y rentable de control de contaminantes es la $V E L$. Consiste en la captura del contaminante químico en su fuente de generación. $H$ ay tres tipos de sistemas de VEL:

1. cerramientos;

2. campanas exteriores,

3. campanas receptoras.

Los cerramientos constituyen la forma de VEL preferible. Se diseñan fundamentalmente para contener los materiales que se generan en su interior. C uanto más completos sean, mejor será la retención del contaminante. Los cerramientos completos son los que carecen de aberturas. Son ejemplos de este tipo las cajas de manipulación con guantes, las cámaras de chorreo abrasivo y las cámaras de almacenamiento de gases tóxicos (véanse las Figuras $61.1,61.2$ y 61.3). En los cerramientos parciales, uno o varios lados están abiertos, pero la fuente se mantiene en su interior. Son ejemplos de este tipo de cerramientos las cabinas de pintura con pistola pulverizadora (véase la Figura 61.4) y una campana de laboratorio. A menudo, puede parecer que el diseño de los cerramientos responde más a fines artísticos que a criterios científicos. El principio básico es diseñar campanas con las aberturas más reducidas posibles. EI caudal de aire requerido suele basarse en el área del conjunto de aperturas y en el mantenimiento de
Figura 61.1 - Cerramiento completo: caja de manipulación con guantes.

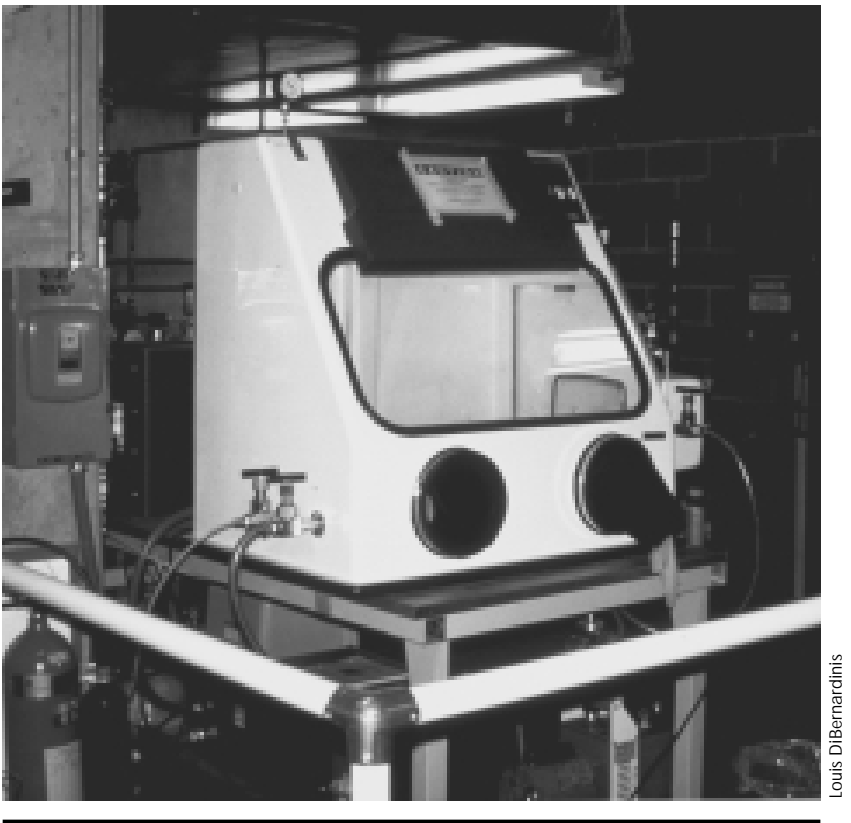

una velocidad del flujo de aire al pasar por éstas que oscile entre 0,25 y $1,0 \mathrm{~m} / \mathrm{s}$. La velocidad de control elegida dependerá de las características de la tarea, incluida la temperatura y las condiciones en que el contaminante es liberado y dispersado. En cerramientos complejos, deben extremarse las precauciones para

Figura 61.2 - Cerramiento completo: cámara de almacenamiento de gas tóxico.

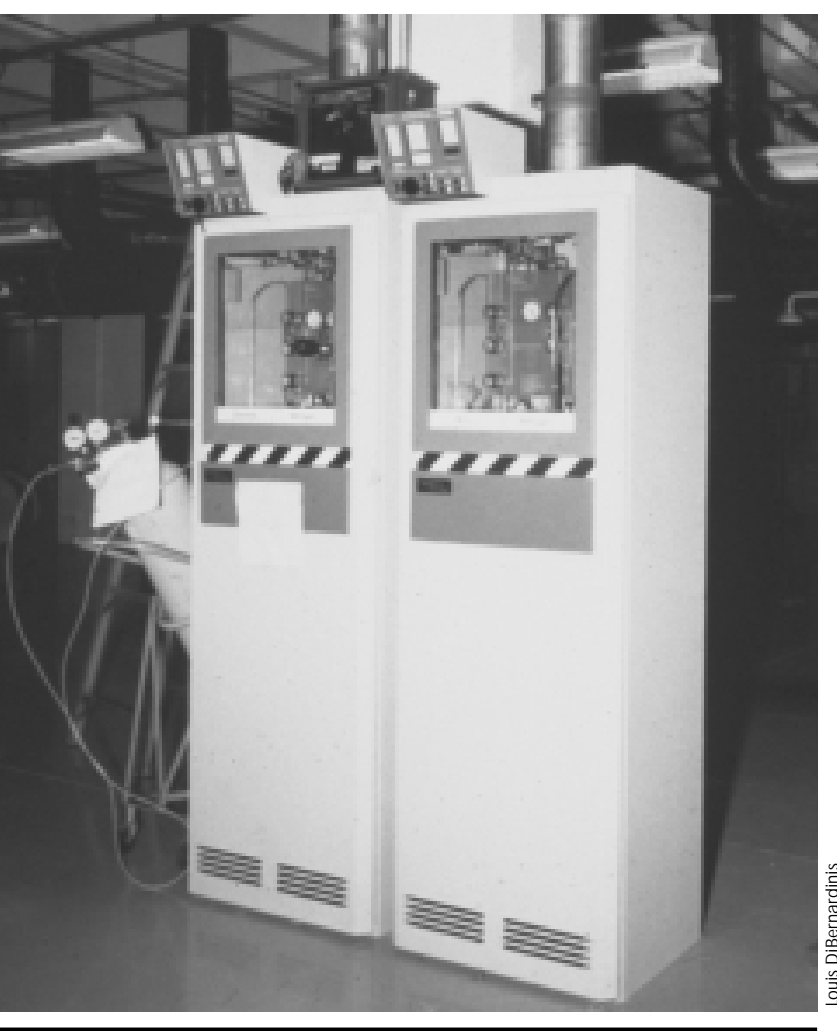


Figura 61.3 - Cerramiento completo: cámara de chorreo abrasivo.

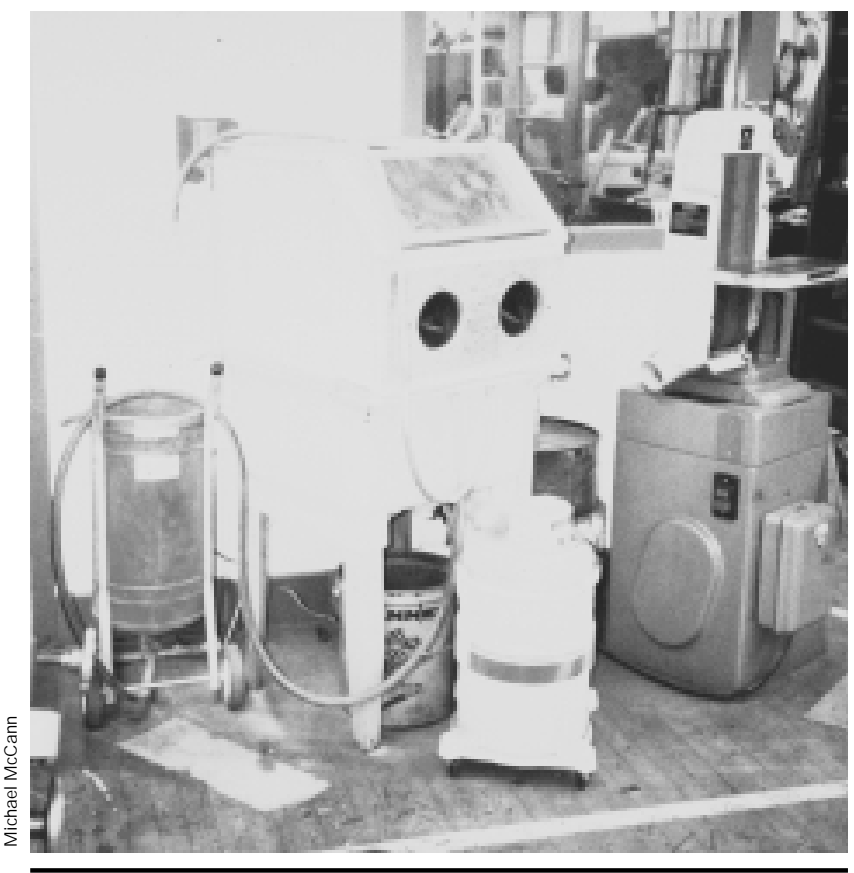

garantizar que el flujo de salida se distribuye homogéneamente en todo su interior, sobre todo si las aberturas se encuentran repartidas. Muchos diseños de cerramiento se evalúan en la práctica y, si se demuestra su eficacia, son incluidos como prototipos en el manual de ventilación industrial de la Conferencia Americana de Higienistas Industriales del Gobierno (ACGIH 1992).

Con frecuencia, el cerramiento total de la fuente no es posible o no es necesario. En estos casos, puede utilizarse otra forma de aspiración localizada, como una campana exterior o de captura. La primera evita la emisión de materiales tóxicos en el lugar de trabajo mediante su captura o arrastre en la fuente de generación o cerca de la misma, normalmente un puesto de trabajo 0 una operación incluida en un proceso. El volumen de aire que

Figura 61.4 - Cerramiento parcial: cabina de pintura con pistola pulverizadora.

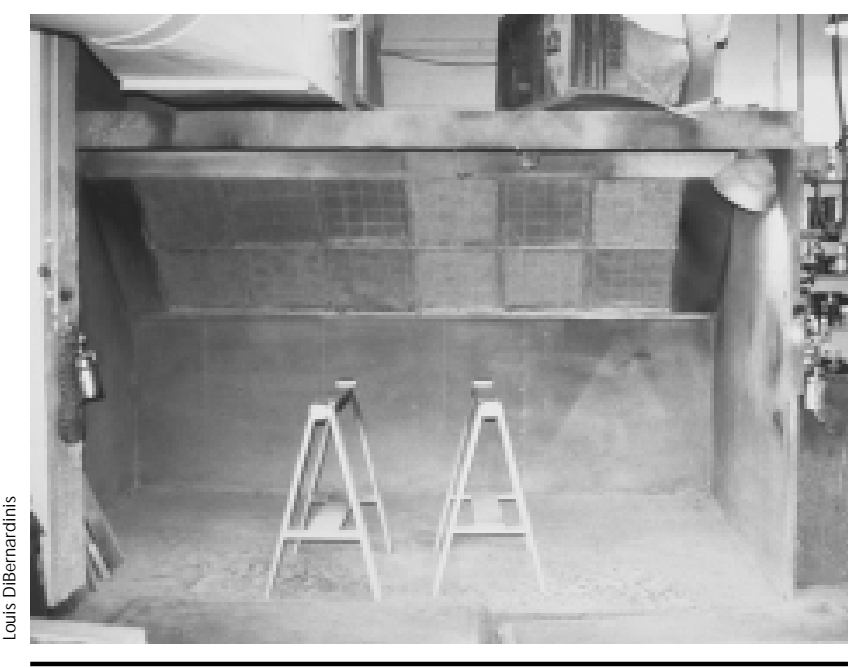

suele requerirse es considerablemente inferior al necesario en el caso del cerramiento parcial. No obstante, puesto que el contaminante se genera fuera de la campana, ésta debe diseñarse y utilizarse apropiadamente para ser tan eficaz como un cerramiento parcial. La forma más eficaz de control es un cerramiento completo.

Para funcionar eficazmente, la entrada de aire de una campana exterior debe tener un diseño geométrico adecuado y situarse cerca del lugar de emisión de sustancias químicas. La distancia de separación dependerá del tamaño y de la forma de la campana y de la velocidad del aire necesaria en la fuente de generación para capturar el contaminante y atraerlo hacia la campana. En general, cuanto más cerca de la fuente de generación, mejor. Las velocidades de los modelos frontales y de rendija suelen oscilar entre 0,25 y 1,0 y 5,0 y $10,0 \mathrm{~m} / \mathrm{s}$, respectivamente. Se ofrecen numerosas directrices en cuanto al diseño de este tipo de campanas de aspiración en el capítulo 3 del manual de la ACGIH (ACGIH 1992) y en Burgess, Ellenbecker y Treitman (1989). D os tipos de campanas exteriores de aplicación frecuente son las de "techo" y las de "rendija".

Las primeras se utilizan principalmente en la absorción de gases, vapores y aerosoles emitidos en una dirección con una velocidad que puede aprovecharse para facilitar dicha absorción. En ocasiones, estos dispositivos se denominan campanas "receptoras". Este tipo suele emplearse cuando el proceso que debe controlarse se desarrolla a temperaturas elevadas, con el fin de aprovechar la corriente aérea ascendente provocada por el calor, o cuando las emisiones se dirigen hacia arriba por la naturaleza del proceso. Son ejemplos de las operaciones que pueden controlarse de este modo las estufas de secado, los hornos de

Figura 61.5 - Campana de techo: aspiración en un horno.

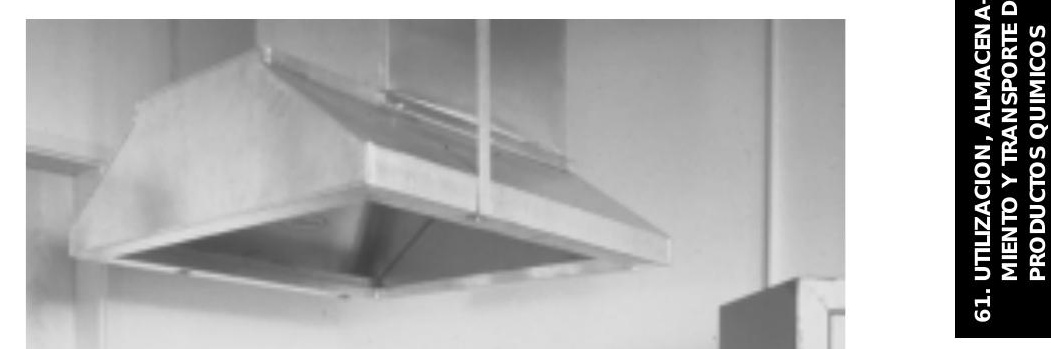

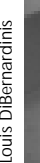

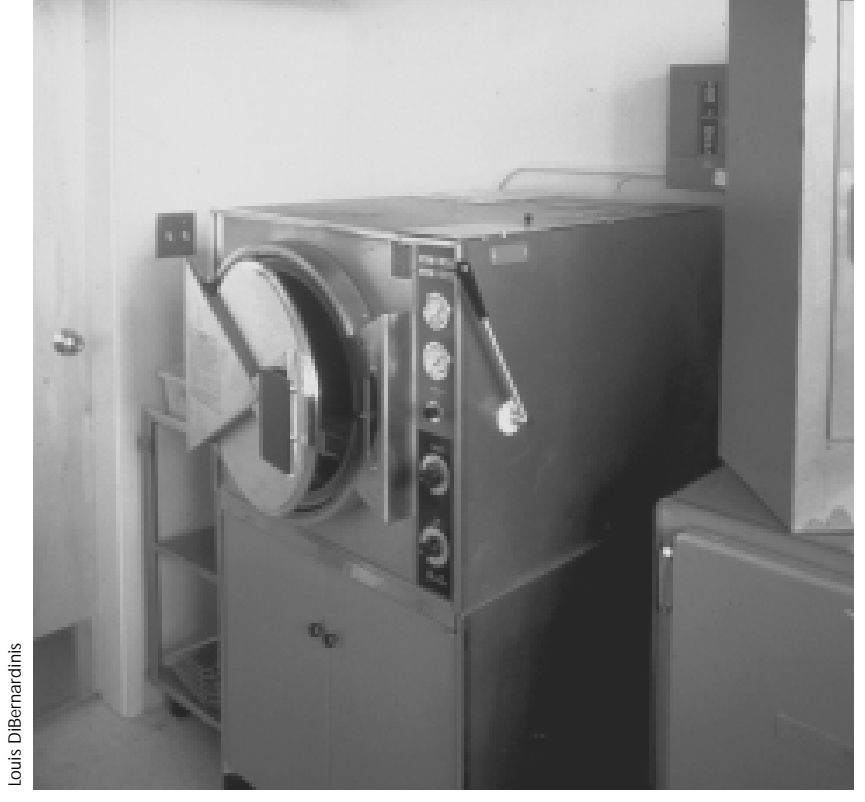


Figura 61.6 - Campana exterior: soldeo.

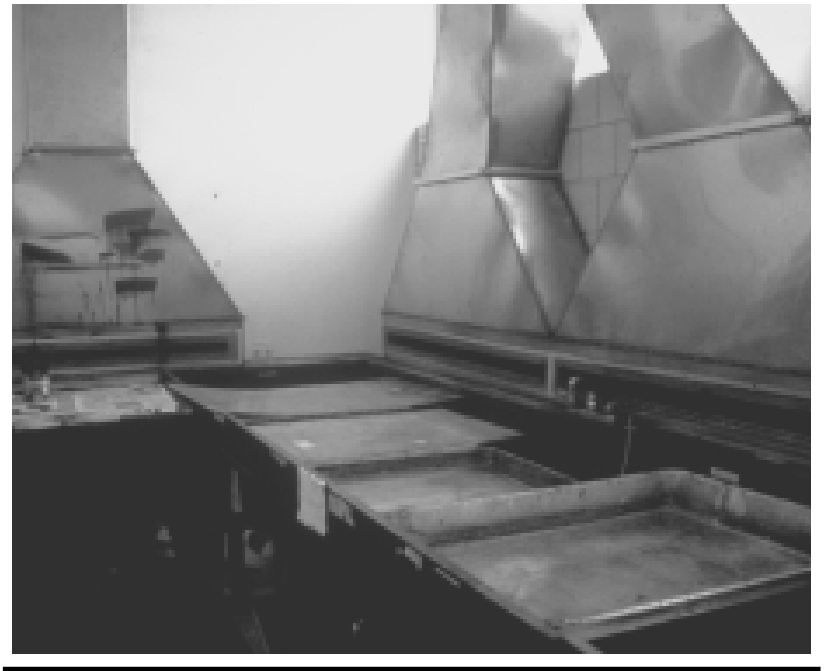

fusión y las autoclaves. M uchos fabricantes de equipos recomiendan configuraciones específicas para las campanas de aspiración adecuadas a las unidades que producen. Debe consultárseles para recibir asesoramiento. Las directrices de diseño también se encuentran en el capítulo 3 del manual de la ACGIH (ACGIH 1992). Por ejemplo, en el caso de una autoclave 0 un horno en los que la distancia entre la campana y la fuente de calor no excede, aproximadamente, de la menor de las magnitudes entre el diámetro de la fuente $01 \mathrm{~m}$, la campana puede considerarse de techo baja. En estas condiciones, el diámetro o la sección transversal de la columna de aire caliente será prácticamente igual al de la fuente. Por tanto, el diámetro 0 las dimensiones de los laterales de la campana sólo deben ser superiores en 0,3 $\mathrm{m}$ a las de la fuente.

El caudal total en el caso de una campana de techo baja es

$$
Q_{t}=0,04516\left(D_{f}\right)^{2,33}\left(D_{t}\right)^{0,42}
$$

donde:

$Q_{t}=$ caudal total de aspiración de aire, en $\mathrm{m}^{3} / \mathrm{s}$

$D_{f}=$ el diámetro de la campana, en $m$.

$D_{t}=$ la diferencia entre la temperatura de la fuente contro-

lada por la campana y la temperatura ambiente, en $\stackrel{ }{ } \mathrm{C}$.

Relaciones similares son aplicables en las campanas rectangulares y en las de techo altas. U n ejemplo de este último tipo puede observarse en la Figura 61.5.

Las campanas de rendija se utilizan en el control de operaciones que no pueden llevarse a cabo dentro de una campana de contención o debajo de una campana de techo. Son casos característicos de estas operaciones el llenado de barriles, la galvanoplastia, la soldadura y el desengrasado. En las Figuras 61.6 y 61.7 se ofrecen ejemplos de estas actividades. El flujo requerido puede calcularse mediante una serie de ecuaciones determinadas empíricamente en función del tamaño y de la forma de la campana y de la distancia entre ésta y la fuente. Así, en el caso de una campana de rendija con pestaña, el caudal se estima mediante la fórmula

donde:

$$
\mathrm{Q}=2,6 \mathrm{LVX}
$$

$\mathrm{Q}=$ caudal total de aire de la campana, en $\mathrm{m}^{3} / \mathrm{s}$

$L=$ la longitud de la rendija, en metros

$\mathrm{V}=$ la velocidad necesaria en la fuente para aspirarla, en $\mathrm{m} / \mathrm{s}$.

$X=$ la distancia de la fuente a la rendija, en metros.
En ocasiones, la velocidad necesaria en la fuente se denomina "de captación" y suele oscilar entre 0,25 y $2,5 \mathrm{~m} / \mathrm{s}$. L as directrices para seleccionar una velocidad de aspiración adecuada figuran en el manual de la ACGIH. En las áreas con un exceso de corrientes cruzadas 0 en el caso de materiales de toxicidad elevada, debe optarse por el extremo superior de la gama. En cuanto a las partículas, deben aplicarse velocidad de captación superiores.

Alguna campanas pueden configurarse como combinación de modelos de cerramiento, exteriores y receptores. Por ejemplo, la cabina de pintura con pistola pulverizadora mostrada en la Figura 61.4 es un cerramiento parcial y, a la vez, una campana receptora. Se ha diseñado para facilitar una aspiración eficaz de las partículas generadas al aprovechar la velocidad de éstas creada por la muela abrasiva rotante en la dirección de la campana.

Es necesario tener cuidado al seleccionar y diseñar los sistemas de aspiración locales. Debe considerarse: a) la capacidad para aislar la operación; b) las características de la fuente (es decir, concentración frente a dispersión) y el modo en que se genera el contaminante; c) la capacidad de los sistemas de ventilación existentes; d) los requisitos en cuanto a espacio, y e) la toxicidad y la inflamabilidad de los contaminantes.

U na vez instalada la campana, se aplicará un programa de mantenimiento y seguimiento rutinario de los sistemas para garantizar su eficacia en la prevención de la exposición de los trabajadores (OSHA 1993). El control de la campana química de laboratorio estándar está normalizado desde el decenio de 1970. No obstante, no existen procedimientos normalizados

Figura 61.7 - Campana exterior: llenado de bidones.

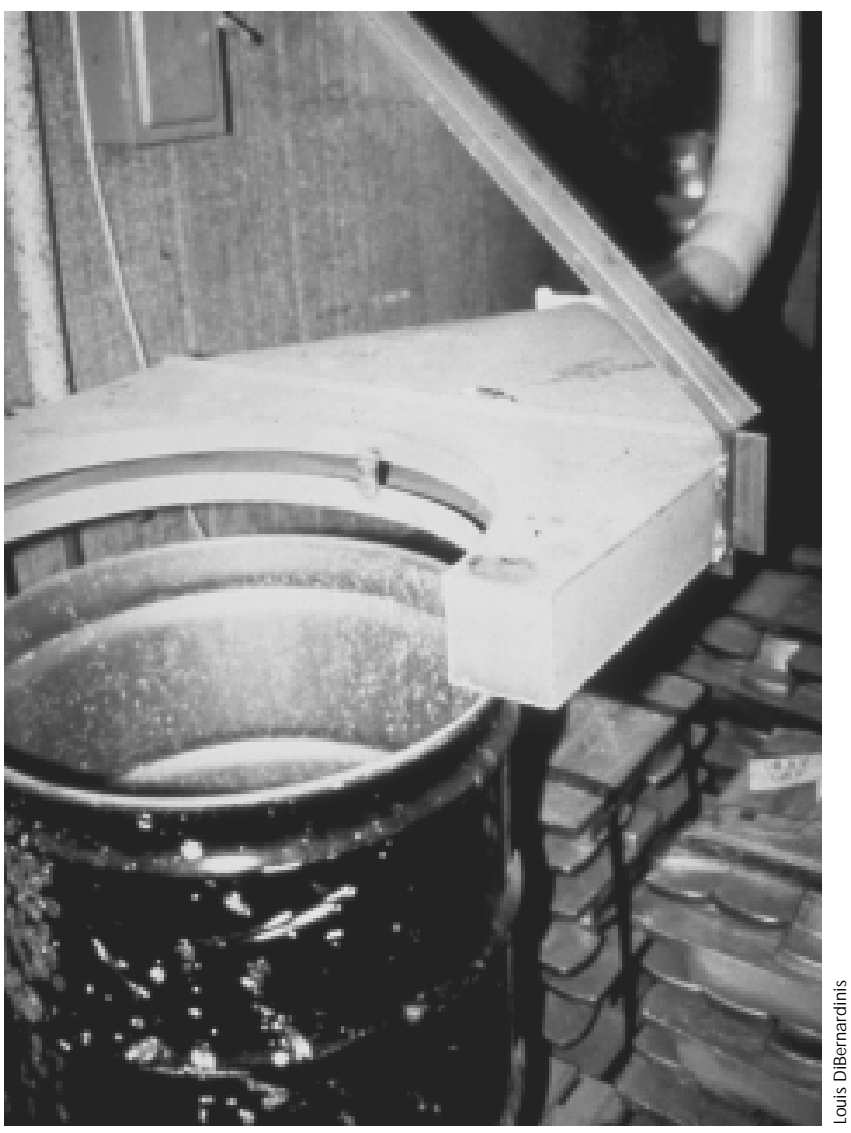


afines correspondientes a otras formas de aspiración local; por tanto, el usuario debe establecer uno propio. EI más eficaz es el control de flujo continuo. Este puede consistir en un método tan sencillo como la instalación de un indicador magnético de presión de agua que mida la presión estática en la campana (ANSI/ AIH A 1993). La presión estática requerida (cm de agua) podrá estimarse sobre la base de los cálculos de diseño, y podrán realizarse mediciones de flujo con ocasión de la instalación para verificarlas. Con independencia de que se adapte un control de flujo continuo o no, debe llevarse a cabo algún tipo de evaluación periódica del rendimiento de la campana. Para ello puede recurrirse a la aplicación de humo que permita visualizar la aspiración o a la medición del flujo total en el sistema y su comparación con el previsto en el diseño. En el caso de los cerramientos, suele resultar conveniente medir la velocidad frontal a través de las aberturas.

Asimismo, el personal debe recibir formación sobre la correcta utilización de estos tipos de campanas, sobre todo en los casos en que la distancia de éstas a la fuente puede ser modificada con facilidad por el usuario.

Si los sistemas de aspiración local se diseñan, instalan y utilizan apropiadamente, pueden constituir un medio eficaz y económico de controlar las exposiciones a sustancias químicas.

\section{- EL SISTEMA DE INFORMACION Q UIMICA GESTIS: ESTUDIO DE CASO}

\section{Karlheinz M effert y Roger Sta mm}

GESTIS, el sistema de información sobre sustancias peligrosas de las $B$ erufsgenossenschaften (BG, compañías de seguros de accidente obligatorios) en Alemania, se presenta en este artículo como un estudio de caso de un sistema de información integrado para la prevención de los riesgos generados por las sustancias y los productos químicos en el lugar de trabajo.

Con la promulgación y la aplicación de la normativa sobre sustancias peligrosas en Alemania a mediados del decenio de 1980, aumentó en gran medida la demanda de datos e información sobre este tipo de sustancias. Esta necesidad debía ser satisfecha directamente por las BG en el marco de sus actividades industriales de asesoramiento y supervisión.

Los especialistas, incluidas las personas que trabajan para los servicios de inspección técnica de las BG, los ingenieros de seguridad en el lugar de trabajo, los médicos del trabajo y las personas que cooperan con los equipos de expertos, requieren datos específicos sobre salud. No obstante, la información relativa a los riesgos químicos y las medidas de seguridad apropiadas no son menos importantes para el personal no especializado que trabaja con productos peligrosos. En las fábricas, la eficacia de las normas de protección laboral es lo que cuenta en última instancia; por tanto, es esencial garantizar que los propietarios, el personal responsable de la seguridad, los trabajadores y, en su caso, los comités de empresa, accedan con facilidad a la información pertinente.

En este contexto, GEST IS fue creado en 1987. La mayoría de las instituciones de las BG habían mantenido individualmente bases de datos durante más de 20 años. En el marco de GESTIS, estas bases se combinaron y completaron con nuevos componentes, incluida una base de datos prácticos sobre sustancias y productos, y sistemas de información específicos de ciertas ramas de la industria. GESTIS se organiza en torno a un eje central y un eje periférico, y dispone de datos exhaustivos sobre y para la industria en Alemania. Se estructura y clasifica con arreglo a las distintas ramas de la industria.

GESTIS consta de cuatro bases de datos esenciales centralizadas en la Asociación de B erufsgenossenschaften y su Instituto para la Seguridad en el Trabajo (BIA), además de sistemas de información periféricos específicos de cada rama, documentación sobre vigilancia en la medicina del trabajo y conexiones con bases de datos externas.

Los grupos a los que va dirigida la información sobre sustancias peligrosas, como los ingenieros de seguridad y los médicos del trabajo, requieren diversos tipos de la misma y datos específicos para desempeñar su labor. La información destinada a los trabajadores debe ser comprensible y estar relacionada con la manipulación concreta de sustancias. Es posible que los inspectores técnicos necesiten otros datos. Por último, el público en general tiene derecho y está interesado en recibir información sobre la salud en el lugar de trabajo, incluida la identificación y la situación de determinados riesgos y la incidencia de las enfermedades profesionales.

GEST IS debe ser capaz de satisfacer las necesidades de información de los diversos grupos objetivo suministrándoles datos centrados en la práctica.

\section{¿Qué información se necesita?}

\section{Información esencial sobre sustancias y productos}

Los hechos contrastados deben constituir la base fundamental. En esencia, se trata de datos sobre sustancias químicas puras basados en el conocimiento científico y en los requisitos legales. El alcance de las materias y de la información en las fichas técnicas de seguridad (FTS), como las definidas por la U nión Europea en la Directiva (UE) 91/ 155/ CEE, se corresponde con los requisitos de la protección del trabajo en los centros de producción y constituye un marco adecuado.

Estos datos se encuentran en la base central de sustancias y productos de GEST IS (ZeSP), una base de datos en línea recopilados desde 1987 en la que se ha prestado especial atención a las sustancias y a la cooperación con los servicios públicos de inspección del trabajo (es decir, las bases de datos de los Estados sobre sustancias peligrosas). La información correspondiente sobre productos (mezclas) se establece únicamente en función de los datos válidos relativos a sustancias. En la práctica, se plantea un grave problema ya que, con frecuencia, los productores de las fichas mencionadas no identifican las sustancias pertinentes en las preparaciones. La D irectiva de la UE antes referida establece la adopción de mejoras en las fichas técnicas de seguridad y exige una mayor precisión de los datos que figuran en la relación de componentes (dependiendo de los niveles de concentración).

La recopilación de las FTS en el marco de GESTIS es indispensable para combinar los datos de los productores con la información sobre sustancias independiente de éstos. Para lograr este objetivo se recurre tanto a las actividades de registro de la BG específicas de cada rama, como al desarrollo de un proyecto en colaboración con los productores, que garantizan la disponibilidad de las fichas actualizadas y, en gran parte, en formato de proceso de datos (véase la Figura 61.8) en la base ISI (fichas técnicas de seguridad del sistema de información).

Puesto que en las FTS no suele considerarse adecuadamente la utilización específica de un producto, los especialistas de cada rama de la industria recopilan información sobre grupos de productos (p. ej., lubricantes refrigerantes para la protección en la práctica del trabajo en las fábricas) basándose en la información de los productores y en los datos sobre sustancias. Estos grupos se definen con arreglo a su utilización y a su riesgo químico potencial. La información disponible al respecto es independiente de los datos que suministran los productores 
Figura 61.8 - Centro de recogida de datos e información para fichas de seguridad - estructura básica.

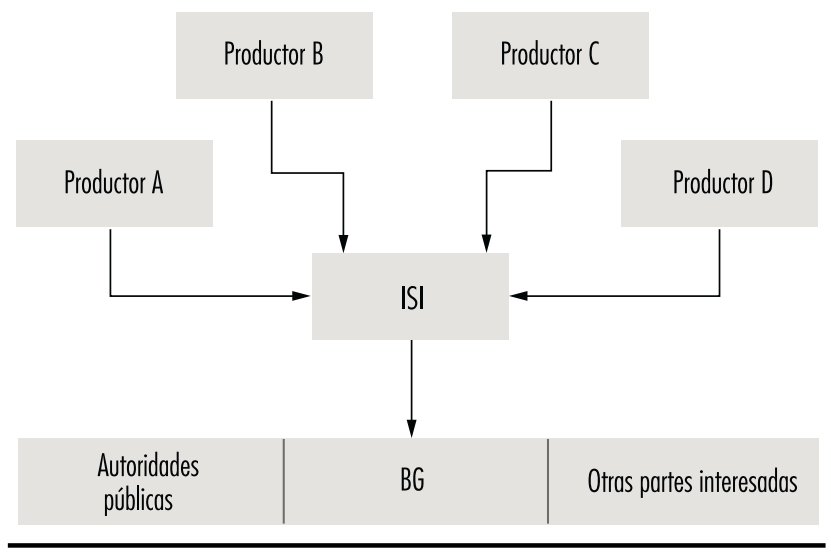

sobre la composición de cada producto, ya que ésta se basa en las fórmulas generales de composición. Por lo tanto, el usuario cuenta con el acceso a una fuente de información independiente complementaria aparte de la que le proporcionan las fichas técnicas de seguridad.

Un rasgo característico de la ZeSP es el suministro de información sobre la manipulación segura de sustancias peligrosas en el lugar de trabajo, incluidas las medidas específicas de prevención y de urgencia. Por otra parte, la ZeSP contiene información exhaustiva sobre medicina del trabajo organizada en un formato detallado, comprensible y relacionado con la práctica (Engelhard y cols. 1994).

Además de la información orientada a la práctica antes esbozada, es necesario disponer de otros datos en relación con la actividad de los equipos de expertos nacionales e internacionales con el fin de llevar a cabo evaluaciones de los riesgos de las sustancias químicas ( $p$. ej., el Reglamento de la UE sobre las sustancias químicas existentes). En lo que se refiere a la evaluación de riesgos, se requieren datos para la manipulación de sustancias peligrosas, incluidos los relativos a: a) la categoría de utilización de las sustancias o los productos; b) las cantidades empleadas en la producción y en la manipulación, así como el número de personas que trabajan con estas sustancias o se ven expuestos a las mismas, y c) las exposiciones. Esta información puede consultarse en los registros de sustancias peligrosas de los centros de producción, que son obligatorios de conformidad con la legislación europea en la materia, con el fin de poner en común los datos obtenidos a un nivel superior y crear registros sectoriales o generales. Estos instrumentos son cada vez más necesarios para dotar de las referencias pertinentes a los responsables de la adopción de decisiones políticas.

\section{Datos de exposición}

Los datos de exposición (es decir, los valores estimados de las concentraciones de sustancias peligrosas) se obtienen a través de las BG en el marco del sistema de medición de sustancias peligrosas (BGM G 1993), con el fin de llevar a cabo las mediciones obligatorias teniendo en cuenta los valores umbral en el lugar de trabajo. Su documentación es necesaria para considerar el nivel de tecnología al establecer dichos valores, efectuar análisis de riesgos ( $p$. ej., en lo que respecta a la determinación de los riesgos inherentes a las sustancias existentes), realizar estudios epidemiológicos y evaluar las enfermedades profesionales.

Por tanto, los valores determinado como parte de las tareas de vigilancia en el lugar de trabajo se registran en la Documentación relativa a los D atos de M edición sobre Sustancias Peligrosas en el Lugar de Trabajo (DOK-MEGA). Desde 1972, más de 800.000 valores de medición se han obtenido en más de 30.000 empresas. Actualmente, se añaden cada año unos 60.000 de estos valores. Las características específicas del BGMG son la aplicación de un sistema de aseguramiento de la calidad, la inclusión de componentes de educación y formación, el desarrollo de procedimientos normalizados para la toma de muestras y el análisis, la adopción de una estrategia de medición armonizada basada en fundamentos jurídicos y la utilización de instrumentos apoyada por el proceso de datos, la recopilación de información, la garantía de la calidad y la evaluación (Figura 61.9).

Los valores de medición de las exposiciones deben ser representativos, repetibles y compatibles. Los datos sobre exposiciones obtenidos de la vigilancia en el lugar de trabajo en el marco del BGMG se consideran estrictamente "representativos" de la situación específica de cada centro productivo, puesto que la selección de lugares para la medición se efectúa en cada caso de acuerdo con criterios técnicos, no estadísticos. No obstante, la cuestión de la representatividad se plantea cuando los valores medidos correspondientes a un lugar de trabajo idéntico 0

Figura 61.9 - Sistema de medición de las BG para las sustancias peligrosas (BG M G ) - cooperación entre el BIA y las BG.

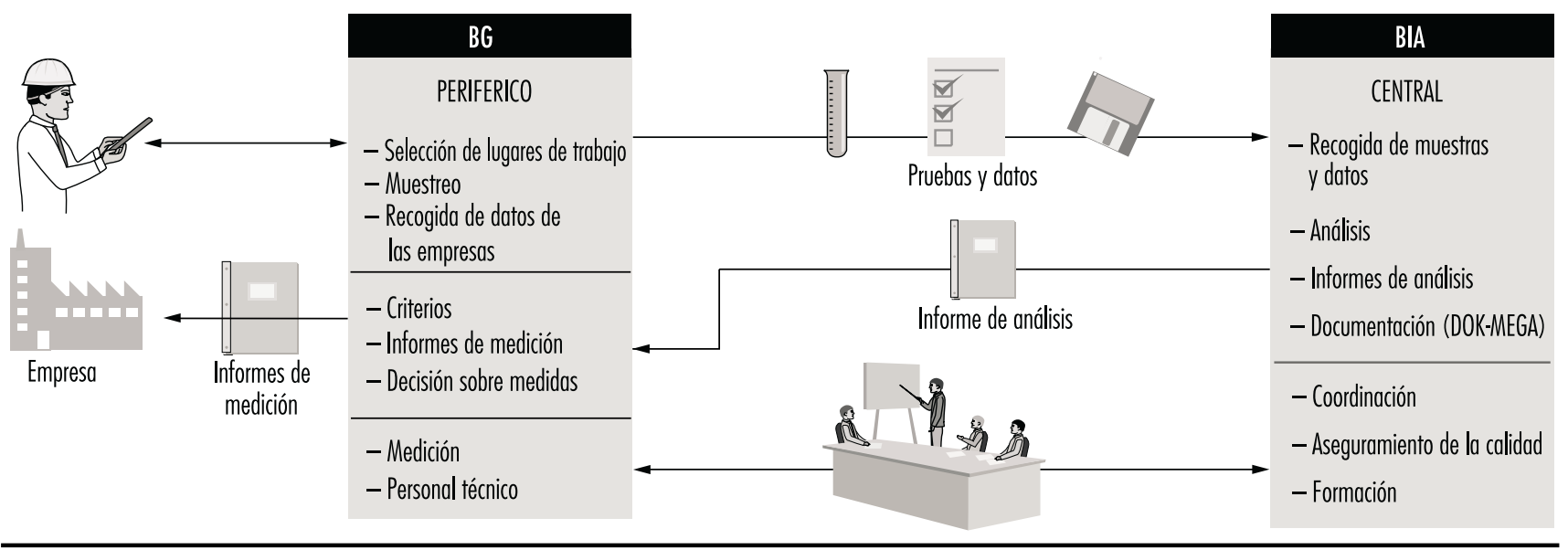


similar, o incluso a ramas completas de la industria, deben agruparse estadísticamente. En general, los datos determinados como parte de la actividad de vigilancia ofrecen valores medios superiores a los de los datos recogidos inicialmente para obtener una sección cruzada representativa de una rama de la industria.

En cada medición, es necesario un registro y una documentación diferenciados del centro productivo, el proceso y los parámetros de muestreo correspondientes, de forma que los valores medidos puedan combinarse de un modo estadísticamente razonable, evaluarse e interpretarse de manera adecuada desde el punto de vista técnico.

En la DOK-M EG A, este objetivo se consigue de conformidad con los siguientes criterios de registro de datos y documentación

- adopción de una estrategia de medición normalizada de acuerdo con las Normas técnicas sobre Sustancias Peligrosas (TRGS), documentando en concreto la toma de muestras y la duración de la exposición

- aplicación de procedimientos comparables y fiables en el muestreo, la medición y el análisis

- clasificación de los valores de medición de acuerdo con el área industrial, el proceso de trabajo o el lugar de trabajo, así como con las actividades de forma sistematizada y codificada (directorios de códigos de GEST IS)

- documentación de las condiciones ambientales específicas del proceso y del lugar de trabajo (p. ej., ventilación por extracción localizada) y de las sustancias químicas utilizadas (p. ej., tipo de electrodos empleados en las tareas de soldadura).

EI BIA aprovecha su experiencia con DOK-MEGA en un proyecto de investigación con representantes de otras bases de datos nacionales sobre exposición con el objetivo de mejorar la comparabilidad de los resultados de exposición y medición. En concreto, se pretende definir la información esencial que sirva como base de las comparaciones y desarrollar un "protocolo" para la documentación de datos.

\section{Datos sanitarios}

Además de la información relativa a las sustancias y los productos químicos y a los resultados de las medición de las exposiciones, es necesario disponer de datos sobre los efectos para la salud de la exposición real a sustancias peligrosas en el lugar de trabajo. De la mera observación general del potencial de riesgo, del peligro real y de sus efectos, pueden extraerse conclusiones adecuadas respecto a la seguridad en el trabajo a escala empresarial y en contextos más generales.

Por tanto, otro componente de GESTIS es la documentación sobre enfermedades profesionales (BK -DOK), en la que se han registrado todos los casos referidos desde 1975. Para la documentación de las enfermedades profesionales en el área de las sustancias peligrosas es esencial la determinación y el registro inequívocos y correctos de las asociadas con cada caso. En general, esta determinación lleva mucho tiempo, pero la adquisición de conocimientos en materia de prevención es imposible sin una identificación precisa de las sustancias y los productos implicados. Así, en el caso de las enfermedades respiratorias y de la piel, que requieren particularmente una mejora de la comprensión de los posibles agentes causantes, debe dedicarse un esfuerzo especial al registro de la información sobre utilización de sustancias y productos con la mayor exactitud posible.

\section{Datos bibliográficos}

EI cuarto componente propuesto para GEST IS fue la disposición de información de referencia en forma de documentos bibliográficos, de forma que los datos básicos pudiesen juzgarse con propiedad sobre la base del conocimiento vigente y fuera posible extraer conclusiones. A tal efecto, se desarrolló una interfase con la base de datos bibliográfica (ZIGUV-DOK), con un total de 50.000 referencias en la actualidad, de las que 8.000 versan sobre las sustancias peligrosas.

\section{Coordinación y elaboración de los datos orientada a la resolución de problemas}

\section{Coordinación de la información}

Los componentes de GESTIS antes descritos no pueden mantenerse aislados si se pretende utilizar este sistema eficazmente. Requieren la existencia de posibilidades de coordinación adecuadas, por ejemplo, entre los datos de exposición y los casos de enfermedad profesional. Esta vinculación permite la creación de un sistema información realmente integrado. La coordinación se basa en la información esencial disponible, codificada mediante el sistema de codificación GEST IS normalizado (véase la Tabla 61.2).

Con la ayuda del código GESTIS, pueden asociarse entre sí datos individuales (p. ej., datos de medición correspondientes a un determinado lugar de trabajo con un caso de enfermedad profesional que haya ocurrido en ese mismo lugar o en otro similar) y obtenerse información "tipificada" y condensada estadísticamente (p. ej., asociación de las enfermedades relacionadas con determinados procesos de trabajo con los datos de exposición medios). En cuanto a las asociaciones individuales de datos (p. ej., basadas en la utilización del número del seguro de pensión), la obligación de respetar estrictamente la legislación sobre protección de la información es obvia.

Por consiguiente, es evidente que sólo un mecanismo de codificación sistemática es capaz de estos requisitos de coordinación en un sistema de información. No obstante, debe llamarse la atención respecto a la posibilidad de la coordinación de varios de estos sistemas transcendiendo las fronteras nacionales. Estas opciones de coordinación y comparación dependen fundamentalmente de la utilización de normas de codificación unificadas a escala internacional, siempre que sean necesarias además de las normas nacionales.

Elaboración de la información orientada a la resolución de problemas y la utilización en la práctica

En el centro de la estructura de GESTIS se sitúan las bases de datos especificas sobre sustancias y productos, exposiciones, enfermedades profesionales y bibliografía. Los datos son recopilados por los especialistas que desarrollan su actividad en el centro y mediante las actividades periféricas de las BG. Para la aplicación y la utilización de los datos, es necesario acceder a los Tabla 61.2 - Sistema normalizado de codificación de
GESTIS.

\begin{tabular}{|c|c|c|}
\hline \multirow[t]{2}{*}{ Objeto } & Individual & Grupo \\
\hline & Código & Código \\
\hline $\begin{array}{l}\text { Sustancia, } \\
\text { producto }\end{array}$ & $\begin{array}{l}\text { Número de asignación } \\
\text { central ZVG (BG) }\end{array}$ & $\begin{array}{l}\text { SGS/ PGS, código de } \\
\text { grupo de sustancia/ } \\
\text { producto (BG) }\end{array}$ \\
\hline Lugar de trabajo & $\begin{array}{l}\text { Area de actividad IBA de } \\
\text { cada fábrica (BG) }\end{array}$ & Area de actividad AB (BIA) \\
\hline Persona expuesta & & $\begin{array}{l}\text { Actividad (BIA, de acuerdo } \\
\text { con la clasificación } \\
\text { sistemática de ocupa- } \\
\text { ciones del Instituto } \\
\text { Federal de Estadística) }\end{array}$ \\
\hline
\end{tabular}

El origen de los códigos se ofrece entre paréntesis. 
usuarios, de manera centralizada a través de la divulgación en publicaciones pertinentes (p. ej., sobre la cuestión de la incidencia de las enfermedades profesionales), y también de forma específica gracias a las actividades de asesoramiento de las BG en sus empresas afiliadas.

Para lograr la utilización más eficaz posible de la información de que dispone GEST IS, se plantea la cuestión de la elaboración de la información orientada a la resolución de problemas y dirigida a determinados grupos. Los requisitos de adecuación a los usuarios se abordan en las bases de datos específicas sobre sustancias y productos químicos, por ejemplo, en la exhaustividad de la información 0 en su presentación orientada a la práctica. No obstante, no todos los requisitos concretos de los posibles usuarios pueden atenderse directamente en estas bases de datos. Se requiere una elaboración adaptada a grupos y problemas específicos, en caso necesario, facilitada por el proceso de datos. Debe divulgarse información orientada al lugar de trabajo respecto a la manipulación de sustancias peligrosas. L os datos más importantes extraídos de la base correspondiente deben presentarse en un formato comprensible y apropiado para el lugar de trabajo, por ejemplo, adoptando la forma de unas "instrucciones", estipuladas en la legislación en materia de seguridad en el trabajo de muchos países. A menudo, se presta muy escasa atención a esta elaboración específica de los datos destinada a los trabajadores. Los sistemas especiales pueden preparar esta información, pero los centros especializados que responden a las consultas individuales también la ofrecen y prestan el apoyo necesario a las empresas. En el marco de GESTIS, estos procesos de recogida y elaboración de los datos se llevan a cabo, por ejemplo, mediante la acción de sistemas de ramas específicas como el GISBAU (Sistema de Información sobre Sustancias Peligrosas de las BG del Sector de la Construcción), el GeSi (Sustancias Peligrosas y Sistema de Seguridad), y de centros de información especializados en las BG, en el BIA 0 en la asociación de las Berufsgenossenschaften.

GEST IS ofrece las conexiones pertinentes para el intercambio de datos y fomenta la cooperación mediante el reparto de tareas:

- Las BG pueden acceder a la búsqueda directa en línea a través de la base de datos central sobre sustancias y productos (ZeSP) y la base de datos bibliográfica (ZIG UV -DOK).

- El intercambio sin conexión a red entre las bases de datos centrales y periféricas se consigue con la ayuda de los formatos de conexión apropiados.

- En los centros de información especializados pertenecientes a GEST IS, los expertos llevan a cabo evaluaciones orientadas y estudios previa solicitud

\section{Perspectivas de futuro}

En el desarrollo futuro se concederá prioridad a la prevención. En colaboración con los productores, los planes previstos comprenden la elaboración exhaustiva y actualizada de los datos sobre productos, el establecimiento de valores característicos del lugar de trabajo determinados estadísticamente y derivados de la medición de las exposiciones y una evaluación de la documentación relativa a enfermedades profesionales.

\section{Referencias}

American National Standards Institute (ANSI) y American Industrial H ygiene Association (AIHA). 1993. Laboratory Ventilation. Norma Z9.5. Fairfax VA: AIH A.

BG-M easuring System $\mathrm{H}$ azardous Substances (BGM G). 1995. H auptverband der gewerblichen Berufsgenossenschaften. Sankt Augustin: BGM G.

Burgess, WA, MJ Ellenbecker, RD T reitman. 1989. Ventilation for Control of the W ork Environment. Nueva Y ork: John W iley and Sons.

Conferencia Americana de $\mathrm{H}$ igienistas Industriales del Gobierno (ACGIH), Committee on Industria Ventilation. 1992. Industrial Ventilation: A M anual of Recommended Practices. 22 ed. Cincinnati, O hio: ACGIH

Engelhard, $\mathrm{H}, \mathrm{H}$ Heberer, $\mathrm{H}$ K ersting, $\mathrm{R}$ Stamm. 1994. Arbeitsmedizinische Informationen aus der Zentralen Stoff- und Productdatenbank ZeSP der gewerblichen Berufsgenossenschaften. Arbeitsme dizin, Sozialmedizin, U mweltmedizin. 29(3S): 136-142.

O rganización Internacional del Trabajo (OIT). 1993. Seguridad en la utilización de productos químicos en el trabajo. Repertorio de Recomendaciones prácticas de la OIT. Ginebra: OIT.

O ccupational Safety and $\mathrm{H}$ ealth Administration (OSHA). 1993. Norma en materia de salud y seguridad. Exposición profesional a sustancias peligrosas en laboratorios. F ederal Register. 51(42):22660-22684.

\section{0 tras lecturas recomendadas}

Comisión de las Comunidades Europeas (CCE). 1994. W orking with Dangerous Products. Año europeo de la seguridad, la higiene y la salud. Luxemburgo: CCE.

O rganización Internacional del T rabajo (O IT). 1993. Report on the Size of the Task of $\mathrm{H}$ armonization of
Existing Systems of Classification and Labelling for $\mathrm{H}$ azardous $\mathrm{C}$ hemicals. Papers of the $\mathrm{G}$ overning Body (ILO-G B.255/I0/4/4). Ginebra: O IT.

Programa Internacional de Seguridad de las Sustancias Q uímicas (IPCS) y la U nión International de Q uímica Pura y A plicada (UIQ PA). 1992. Chemical Safety M atters. UIQPA-IPCS. Cambridge: Cambridge U niversity Press.

Stückrath, M. 1992. Documentation MEGA: $M$ easurement data on hazardous substances at the workplace. En Clean Air at W ork: New Trends in Assessment and M easurement for the 1990s, dirigido por RH Brown. Londres: R oyal Society of Chemistry.

Vinzents, P, B Carton, P Fjeldstad, B Rajan, R Stamm. 1994. Exposure R egisters in E urope Extraction of Core Information and Possibilities for Comparison between European Databases for O ccupational Air Pollutant M easurements. Luxemburgo: O ficina de Publicaciones 0 ficiales de la Comunidades Europeas. 


\section{MINERALES $Y$ \\ PRODUCTOS QUIMICOS \\ PARA LA AGRICULTURA}

Directoras del capítulo

D ebra 0 sindky y

J eanne M ager Stellman

\section{Sumario}

M inerales . .

Productos químicos para la agricultura

Gary A. Page ...

Plaguicidas

Directrices de la O M S para la clasificación de los

plaguicidas según el riesgo. 


\section{- Minerales*}

Se utilizan minerales en las industrias de la cerámica, el vidrio, la joyería, el aislamiento, la talla de piedra, los abrasivos, los plásticos y otras varias, todas las cuales presentan sobre todo un riesgo por inhalación. También la cantidad y tipo de impurezas contenidas en ellas pueden afectar al riesgo asociado a la inhalación de polvo. El principal motivo de preocupación en las actividades mineras y de producción de minerales es la presencia de sílice y de asbesto. EI contenido de sílice en diferentes formaciones de rocas, como la arenisca, el feldespato, el granito y la pizarra, puede variar entre el $20 \%$ y casi el $100 \%$. Por lo tanto, resulta imprescindible reducir al mínimo la exposición de los trabajadores a las concentraciones de polvo mediante la aplicación de medidas de control estricto.

Para prevenir el desarrollo de enfermedades pulmonares en los trabajadores de la minería se recomienda mejorar los controles técnicos mediante el barrenado en húmedo, la ventilación y la manipulación a distancia. En los casos en que no sean posibles controles técnicos eficaces, es obligado el uso de equipos de protección respiratoria aprobados, incluidos los respiradores. La sustitución industrial de los agentes menos peligrosos puede reducir también la exposición ocupacional. Por último, es fundamental en cualquier programa de prevención la formación de los trabajadores y de las empresas en lo que respecta a los riesgos y medidas de control adecuadas.

Los reconocimientos médicos habituales de los trabajadores expuestos al polvo de minerales deben incluir evaluaciones de los síntomas respiratorios, de las alteraciones de la función pulmonar y de posibles enfermedades neoplásicas. L os trabajadores que presenten los primeros signos de cambios pulmonares han de ser asignados a otros puestos en los que no están expuestos a los riesgos del polvo. Además de los informes individuales de la enfermedad, se deben recopilar datos de grupos de trabajadores para los programas de prevención. En el capítulo Sistema respiratorio se ofrecen más detalles acerca de los efectos sobre la salud de varios minerales que se describen en éste.

\section{Apatita (fosfato cálcico)}

P resentación y usos. La apatita es un fosfato cálcico natural, normalmente con flúor. Se presenta en la corteza terrestre como mineral de fosfato, y constituye también el principal componente de la estructura ósea de los dientes. Pueden encontrarse depósitos de apatita en Canadá, Europa, Federación Rusa y E stados U nidos.

La apatita se utiliza en cristales de láser y como fuente de fósforo y de ácido fosfórico. También se emplean en la fabricación de fertilizantes.

Riesgos para la salud. EI contacto con la piel, la inhalación o la ingestión pueden provocar irritación de la piel, ojos, nariz, garganta o sistema digestivo. El polvo puede contener flúor, causante de efectos tóxicos.

\section{Arcillas (silicatos de aluminio hidratados)}

Presentación y usos. La arcilla es un material plástico maleable formado por los residuos procedentes de la desintegración de rocas de silicatos arcillosos por los agentes atmosféricos; normalmente contiene de un 15 a un $20 \%$ de agua y es higroscópica. Se presenta como sedimento en muchas formaciones geológicas en todas partes del mundo, y contiene cantidades variables de feldespato, mica y agregados de cuarzo, calcita y óxido de hierro.

*A daptado de la 3a edición de la E nciclopedia de salud y seguridad en el trabajo. La revisión incluye información de A. Bruusgaard, L.L. Cash, Jr., G. D onatello, V. D'O nofrio, G. Fararone, M. K leinfeld, M. L andwehr, A.'M eiklejohn, J.A. Pendergrass, S.A. Roach, T.A. Roscina, N.I. Sadkovskaja y R. Stahl.
La calidad de la arcilla depende de la cantidad de alúmina que contiene; así, una buena arcilla de porcelana tiene aproximadamente un $40 \%$ de alúmina, mientras que el contenido de sílice es del 3 al $6 \%$. Por término medio, el contenido de cuarzo de los depósitos de arcilla está comprendido entre el 10 y $20 \%$, pero en los peores casos, cuando hay menos alúmina de lo habitual, puede llegar al $50 \%$. El contenido puede variar dentro de un mismo depósito, y la separación de éstos puede realizarse en el pozo. En su estado plástico, la arcilla se puede moldear 0 comprimir, pero cuando se somete al fuego se endurece y conserva la forma que se le ha dado.

L a arcilla se extrae a menudo a cielo abierto, pero otras veces se extrae de minas subterráneas. En los yacimientos a cielo abierto, el método de extracción depende de la calidad del material y la profundidad del depósito; algunas veces se requiere el uso de herramientas neumáticas manuales, pero, siempre que sea posible, la mina debe estar mecanizada, utilizándose excavadoras, palas mecánicas, cortadoras de arcillas, máquinas dragadoras de profundidad, etc. La arcilla se saca a la superficie con camiones o transportándola por cable. U na vez en la superficie, puede someterse a un proceso preliminar antes de su expedición (secado, triturado, amasado, mezclado, etc.) o venderse tal cual (véase el capítulo M inas y canteras). En ocasiones, como ocurre en muchas fábricas de ladrillos, el yacimiento de arcilla está situado junto a la fábrica donde se elaboran los productos terminados

EI material básico para la fabricación de cerámica, ladrillos, tejas y refractarios está formado por diferentes tipos de arcillas. La arcilla puede utilizarse en estado natural en la construcción de diques; in situ, algunas veces sirve de cubierta para no dejar escapar gas almacenado en un estrato inferior. Se requiere una ventilación adecuada y controles de ingeniería.

Riesgos para la salud. Las arcillas contienen habitualmente grandes cantidades de ślice libre, por lo que la inhalación crónica puede provocar silicosis. El contacto cutáneo con la arcilla húmeda puede causar sequedad de piel e irritación. Existe un riesgo de silicosis para los trabajadores del subsuelo de minas mecanizadas de arcilla con un elevado contenido de cuarzo y poca humedad natural. En este caso, el factor decisivo no es solamente el contenido de cuarzo, sino también la humedad natural: si éste es inferior al $12 \%$, es probable que la extracción mecánica genere mucho polvo fino.

\section{Arenisca}

Presentación y usos. La arenisca es una roca sedimentaria siliciclástica que consta principalmente de arena, normalmente arena de cuarzo. Suele estar poco cementada y se puede disgregar fácilmente en arena. No obstante, la arenisca fuerte, duradera, en colores marrones y grises, se utiliza como arenisca a medida en paramentos y adornos de edificios, en casas, como piedra de bordillo, en estribos de puentes y en distintos muros de retención. Las areniscas firmes se trituran para su uso como agregados de hormigón, balastos de vías y encachado. No obstante, muchas areniscas comerciales están muy débilmente cementadas y por lo tanto se desmenuzan y utilizan para arena de moldeo y arena para vidrio. La arena para vidrio es el principal ingrediente del vidrio. En la industria del metal, la arena con buenas propiedades de cohesión y refractarias se utiliza para fabricar moldes de formas especiales en los que se vierte el metal fundido.

La arenisca se encuentra en todo el territorio de Estados U nidos: Illinois, I owa, M innesota, M issouri, N ueva York, O hio, Virginia y Wisconsin.

Riesgos para la salud. Los principales riesgos proceden de la exposición al sílice, tema tratado en el capítulo Sistema respiratorio. 


\section{Asbesto}

Presentación y usos. Se agrupan bajo el término asbesto un grupo de minerales fibrosos naturales, ampliamente distribuidos por todo el mundo. Dentro de ellos se distinguen dos grupos: el grupo de la serpentina, que incluye el crisotilo, y el de los anfíboles, del que forman parte la crocidolita, la tremolita, la amosita y la antofilita. Los dos grupos se diferencian en la estructura, en las características químicas y superficiales, y en las características físicas de las fibras.

Las propiedades industriales que hicieron de los asbestos un material tan útil en el pasado son la elevada resistencia a la tensión y la flexibilidad de las fibras, así como la resistencia al calor, a la abrasión y a muchas sustancias químicas. Son muchos los productos manufacturados que contienen asbesto, como productos para la construcción, materiales de fricción, fieltro, envases y juntas, baldosas, papel, aislamientos y tejidos.

Riesgos para la salud. La asbestosis, una enfermedad pleural relacionada con los asbestos, el mesotelioma maligno y el cáncer de pulmón son enfermedades específicas asociadas a la exposición al polvo de asbestos. Los cambios fibróticos que caracterizan la neumoconiosis, la asbestosis, son consecuencia de un proceso inflamatorio provocado por las fibras retenidas en el pulmón. Los asbestos se estudian en el capítulo 10, Aparato respiratorio

\section{Bauxita}

Presentación y usos. La bauxita es la principal fuente de aluminio. Se trata de una mezcla de minerales formada por la acción de los agentes atmosféricos sobre rocas que contienen aluminio. Las bauxitas constituyen la forma más rica de estas menas alteradas que contienen hasta un $55 \%$ de alúmina. Algunas menas lateríticas (con un porcentaje elevado de hierro) contienen hasta un $35 \%$ de $\mathrm{Al}_{2} \mathrm{O}_{3}$. Los depósitos comerciales de bauxita son sobre todo gibbsita $\left(\mathrm{Al}_{2} \mathrm{O}_{3} \cdot 3 \mathrm{H}_{2} \mathrm{O}\right)$ y boehmita $\left(\mathrm{Al}_{2} \mathrm{O}_{3} \cdot \mathrm{H}_{2} \mathrm{O}\right)$, y se encuentran enAustralia, Brasil, Francia, Ghana, Guinea, Guayana, H ungría, Jamaica y Surinam. La gibbsita se solubiliza con más rapidez en soluciones de hidróxido sódico que la boehmita, y por lo tanto se prefiere para la producción de alúmina.

La bauxita se extrae a cielo abierto. Las menas más ricas se utilizan tal y como se extraen, y las menas de grado inferior se pueden enriquecer triturando y lavando para retirar los restos de arcilla y sílice.

R iesgos para la salud. Se ha comunicado una grave discapacidad pulmonar en trabajadores dedicados a la fundición de bauxita combinada con carbón, hierro y cantidades muy pequeñas de sílice. La dolencia se conoce como "enfermedad de Shaver". D ado que la contaminación por ślice de las menas con aluminio es habitual, los riesgos para la salud asociados con la presencia de sílice cristalina libre en menas de bauxita se debe considerar un factor causal importante.

\section{Carbón}

Presentación y usos. El carbón es un combustible natural, sólido, formado a partir de plantas prehistóricas. Se presenta en capas o vetas en rocas sedimentarias. Las condiciones favorables para la formación natural de carbón se presentaron hace entre 40 y 60 millones de años en la Era Terciaria (formación de carbón blando) y hace más de 250 millones de años en la Era Carbonífera (formación de carbón bituminoso), cuando los bosques de los pantanos se extendieron en un clima cálido y gradualmente se hundieron durante los movimientos geológicos. Los depósitos principales de carbón blando se encuentran en Australia, Europa O riental, A lemania, Federación Rusa y Estados U nidos. Las principales reservas de carbón bituminoso se encuentran en Australia, China, India, Japón, Federación Rusa y Estados U nidos.
El carbón es una fuente importante de materias primas químicas. M ediante pirólisis o destilación destructiva se obtienen alquitrán de hulla y gases hidrocarbonados, que pueden ser mejorados mediante hidrogenación o metanación a petróleo sintético y gas combustible. La hidrogenación catalítica da lugar a hidrocarburos y gasolina. La gasificación produce monóxido de carbono e hidrógeno (gas sintético), de los que se obtienen amoniaco y otros productos. M ientras que en 1900 el $94 \%$ de las necesidades energéticas mundiales se cubrían con carbón y solamente un $5 \%$ con petróleo y gas natural, el carbón ha sido gradualmente sustituido por combustibles líquidos y gaseosos en todo el mundo.

Riesgos para la salud. Los riesgos de la minería y del polvo de carbón se comentan en los capítulos M inas y canteras y Sistema respiratorio.

\section{Corindón (óxido de aluminio)}

Presentación y usos. El corindón es uno de los principales abrasivos naturales. Tanto el corindón natural como el artificial (óxido de aluminio o esmeril artificial) son relativamente puros. EI material artificial se produce a partir de bauxita mediante fusión en un horno eléctrico. Debido a su dureza, el corindón se utiliza para moldear metales, madera, vidrio y cerámica, mediante un proceso de molturación o pulido. Los riesgos para la salud se comentan en otros capítulos de esta E nciclopedia.

\section{Erionita}

Presentación y usos. La erionita es una zeolita cristalina y fibrosa. Las zeolitas, un grupo de silicatos alumínicos encontrados en las cavidades de las rocas volcánicas, se utilizan en la filtración de agua dura y en el refino del petróleo. Se encuentra erionita en California, Nevada y O regón en Estados U nidos, y en Irlanda, Islandia, Nueva Zelanda y Japón.

Riesgos para la salud. La erionita es un cancerígeno humano conocido. La inhalación crónica puede provocar mesotelioma.

\section{Feldespato}

Presentación y usos. Se da con el nombre común de feldespato a un grupo de silicatos de aluminio y sodio, potasio, calcio y bario. Comercialmente, el término se aplica a los feldespatos potásicos de fórmula $\mathrm{KAISi}_{3} \mathrm{O}_{8}$, normalmente con un bajo contenido de sodio. Se encuentra feldespato en Estados U nidos. Se utiliza en alfarería, esmaltes y cerámica, vidrio, jabones, abrasivos, cementos y hormigones. El feldespato sirve de unión en ruedas abrasivas, y se utiliza en compuestos aislantes, materiales embreados para tejados y fertilizantes.

Riesgos para la salud. La inhalación crónica puede provocar silicosis debido a la presencia de cantidades sustanciales de ślice libre. Asimismo el feldespato puede contener óxido sódico irritante (espatos de sosa), óxido potásico (espato de potasa) y óxido de calcio (espatos de cal) en forma insoluble. V éase la sección "Sílice" más adelante.

\section{Fluorita (fluoruro cálcico)}

Presentación y usos. La fluorita es un mineral que contiene del 90 al $95 \%$ de fluoruro cálcico y del 3,5 al $8 \%$ de sílice. Se extrae mediante barrenado y voladura. La fluorita es la principal fuente de flúor y sus compuestos. Se utiliza como fluido en hornos de acero abiertos y en fundición de metales. Asimismo se emplea en cerámica, pinturas y en la industria óptica.

Riesgos para la salud. Están causados sobre todo por los efectos nocivos del contenido de flúor y de sílice. $L a$ inhalación aguda puede provocar problemas gástricos, intestinales, circulatorios y en el sistema nervioso. La inhalación crónica o la ingestión 
puede provocar pérdida de peso y apetito, anemia, y defectos óseos y dentales. Se han observado lesiones pulmonares en personas que inhalan polvo con un 92 a un $96 \%$ de fluoruro cálcico y un 3,5\% de ślice. Parece que el fluoruro cálcico estimula la acción fibrogénica de la sílice en los pulmones. Entre los mineros de fluorita se han comunicado casos de bronquitis y silicosis.

En la extracción de fluorita debe realizarse un control cuidadoso del polvo, mediante técnicas como el barrenado en húmedo, el regado de rocas sueltas y la ventilación por extracción o general. Al calentar la fluorita existe el riesgo de formación de ácido fluorhídrico, y deben aplicarse las medidas de seguridad pertinentes.

\section{Grafito}

Presentación y usos. El grafito se encuentra en casi todo el mundo, pero la mayor parte de la producción del mineral natural se concentra en Austria, Alemania, M adagascar, M éxico, N oruega, Federación Rusa y Sri Lanka. La mayoría de los grafitos naturales, si no todos, contienen sílice cristalina y silicatos.

$G$ rafito en masas. Se encuentra en filones que atraviesan diferentes tipos de rocas ígneas y metamórficas que contienen impurezas minerales como feldesfato, cuarzo, mica, piroxina, zirconio, rutilo, apatita y sulfuros de hierro. Frecuentemente las impurezas se encuentran en bolsas aisladas en los filones del mineral. La extracción se realiza generalmente en minas subterráneas, con taladros manuales para la extracción selectiva de venas estrechas.

LoS depósitos de grafito amorfo son también subterráneos, aunque suelen encontrarse en lechos mucho más gruesos que los filones de grafito en masas. En general están asociados con arenisca, pizarra, caliza y minerales de cuarzo y sulfuros de hierro. El mineral se barrena, se arranca con explosivos y se carga a mano en vagonetas para llevarlo a la superficie, donde se tritura y se separan las impurezas.

EI grafito en escamas está asociado generalmente con rocas sedimentarias metamorfoseadas como gneis, esquistos y mármoles. A menudo los depósitos están en la superficie o cerca de ella. En consecuencia, en la extracción a cielo abierto se utilizan equipos normales de excavación, como palas, buldozers o escarificadoras, siendo necesario un mínimo de perforación y voladura.

El grafito artificial se produce calentando carbón o coque de petróleo, y no suelen contener sílice libre. El grafito natural se utiliza en la fabricación de revestimientos de fundición, lubricantes, pinturas, electrodos, baterías secas y crisoles para metalurgia. La "mina" de los lápices también es de grafito.

Riesgos para la salud. Durante la extracción y tratamiento del grafito natural y durante la fabricación del grafito artificial se puede producir inhalación de carbón, así como del polvo asociado. Las exploraciones radiográficas de trabajadores que manipulan grafito natural y artificial han demostrado distintos tipos de neumoconiosis. El examen histopatológico ha revelado la existencia de acúmulos de pigmento, enfisema focal, fibrosis colagenosa, pequeños nódulos fibrosos, quistes y cavidades. Estas últimas contienen un líquido de aspecto semejante a la tinta en el que se han identificado cristales de grafito. En informes recientes se ha señalado que los materiales implicados en exposiciones que provocan casos graves de fibrosis pulmonar masiva son probablemente mezclas de polvos.

La neumoconiosis por grafito es progresiva, incluso después de que el trabajador haya abandonado el área contaminada. EI sujeto puede permanecer asintomático durante muchos años de exposición, y la incapacidad sobreviene a menudo repentinamente. Es esencial la realización de análisis periódicos de sílice cristalina y silicatos en el mineral bruto y en el polvo en suspensión en el aire, prestando especial atención al feldespato, talco y mica. Se pueden ajustar unos niveles de polvo aceptables para controlar el efecto nocivo para la salud de los trabajadores.

A demás de la exposición a los riesgos físicos de la minería, los trabajadores que manipulan grafito pueden enfrentarse también a riesgos químicos, como los relacionados con el ácido fluorhídrico y el hidróxido sódico, utilizados en la purificación de grafito. Cualquier programa de prevención sanitaria debería incluir la protección contra los riesgos asociados a estos productos químicos.

\section{Granito}

Presentación y usos. El granito, una roca ígnea de grano grueso, está compuesto por cuarzo, feldespato y mica en granos amorfos. Se utiliza en gravilla y como granito a medida. Después de romperlo al tamaño deseado, el granito se puede utilizar para agregados de hormigón, grava para carreteras, balasto ferroviario, lechos filtrantes, y para encachado (bloques grandes) en pilares y tajamares. Los colores - rosa, gris, salmón, rojo y blanco- son deseables para el granito a medida. La dureza, la uniformidad de la textura y otras propiedades físicas hacen de este último un producto ideal para monumentos, bloques de cimientos, escalones y columnas.

El granito en gravilla se produce principalmente en California, con cantidades importantes en otros estados de Estados Unidos como Georgia, Carolina del Norte, Carolina del Sur y Virginia. Las principales áreas de producción del granito a medida en Estados U nidos son G eorgia, M aine, M assachusetts, M innesota, Carolina del Norte, Dakota del Sur, Vermont y Wisconsin.

R iesgos para la salud. El granito presenta una elevada contaminación con sílice. Por consiguiente, la silicosis es un riesgo importante para la salud en la extracción de este mineral.

\section{Mármol (carbonato cálcico)}

Presentación y usos. El mármol se define geológicamente como una piedra caliza metamorfoseada (recristalizada) compuesta principalmente por granos cristalinos de calcita, dolomita o ambos, con una textura cristalina visible. EI uso generalizado del término en la industria de la cantería y del acabado ha llevado a la utilización del término "mármol comercial", que incluye todas las rocas cristalinas que pueden ser pulimentadas, y que están formadas principalmente por uno o más de los minerales siguientes: calcita, dolomita o serpentina.

El mármol se ha utilizado a lo largo de toda la historia como material de construcción importante debido a su resistencia, duración, facilidad de trabajado, adaptabilidad a la arquitectura y satisfacción estética. La industria del mármol comprende dos grandes ramas: la del mármol a medida y la del mármol machacado y partido. El mármol a medida es el que se extrae para obtener bloques o losas que cumplan las especificaciones de tamaño y forma. Sus usos son conocidos: piedras de construcción, monumentos, sillería, revestimientos, paneles, enlosados, estatuas, etc. El mármol machacado y partido tiene un tamaño variable desde grandes bloques hasta productos finamente pulverizados, y contiene aglomerados, lastres, gravilla para tejados, lascas de terrazo, aprestos, pigmentos, cal para abonos, etc.

R iesgos para la salud. No se han descrito enfermedades profesionales relacionadas específicamente con la minería, extracción y elaboración de mármol. En la minería subterránea puede producirse una exposición a gases tóxicos provocados por voladuras y algunos tipos de equipos motorizados; son necesarias una ventilación adecuada y equipo protector de la respiración. 
En las voladuras abrasivas podría producirse exposición a sílice si se utilizara arena, pero el carburo de silicio o el óxido de aluminio son igualmente eficaces, no tienen riesgo de silicosis y deberían emplearse en su lugar. $\mathrm{H}$ an de controlarse las grandes cantidades de polvo generado en la elaboración del mármol, bien mediante el uso de método húmedos, bien mediante métodos de ventilación por extracción.

\section{Mica}

Presentación y usos. La mica (del latín micare, fulgurar, brillar) es un silicato mineral, principal componente de las rocas ígneas, en particular los granitos. También es un constituyente común de silicatos como el caolín, producidos por la acción de los agentes atmosféricos sobre estas rocas. En las masas rocosas, especialmente en las vetas de pegmatita, la mica aparece en forma de masas lenticulares de hojas partidas (conocidas como libros) de más de $1 \mathrm{~m}$ de diámetro o como partículas. Existen muchas variedades, de las cuales las más útiles son la moscovita (mica común, transparente o blanca), flogopita (mica ámbar), vermiculita, lepidolita y sericita. La moscovita se encuentra generalmente en las rocas silíceas. Los mayores depósitos de esta variedad están en India, Sudáfrica y Estados U nidos. La sericita es una variedad de la moscovita en pequeñas láminas; se produce como consecuencia del desgaste por la acción de los agentes atmosféricos sobre esquistos y gneis. La flogopita, que se encuentra en rocas calcáreas, se concentra en $M$ adagascar. La principal característica de la vermiculita es su considerable poder de expansión cuando se calienta con rapidez a aproximadamente $300^{\circ} \mathrm{C}$. Existen grandes depósitos de vermiculita en Estados U nidos. EI principal valor de la lepidolita radica en su gran contenido de litio y rubidio.

La mica se utiliza aún para las estufas de combustión lenta, farolas o mirillas de los hornos. Su propiedad más sobresaliente es que es dieléctrica, lo que la convierte en un material esencial en la industria aeronáutica. El polvo de mica se utiliza en la fabricación de cables eléctricos, neumáticos, electrodos soldados, cartón bituminado, pinturas y plásticos, lubricantes secos, recubrimientos dieléctricos y aisladores ignífugos. A menudo se compacta con resinas alquídicas. La vermiculita se utiliza como material aislante en la industria de la construcción. La lepidolita se utiliza en las industrias de vidrio y cerámica.

Riesgos para la salud. Al trabajar con mica es posible la generación de electricidad estática, que puede descargarse técnicamente sin problemas. Los mineros de mica están expuestos a la inhalación de una gran variedad de polvos, como los de cuarzo, feldespato y silicatos. La inhalación crónica puede causar silicosis. La exposición al polvo de mica puede producir irritación del aparato respiratorio y, después de muchos años, neumoconiosis fibrótica nodular, considerada durante mucho tiempo como una forma de silicosis; hoy en día se ha descartado esta hipótesis debido a que el polvo de mica pura no contiene sílice libre. Sin embargo, el cuadro radiológico suele ser muy parecido al de la asbestosis. Se ha demostrado experimentalmente que la mica posee una citotoxicidad débil sobre los macrófagos y que sólo induce una pequeña respuesta fibrógena, limitada a la formación de fibras gruesas de reticulina.

La inhalación crónica de vermiculita, que a menudo contiene asbesto, puede provocar asbestosis, cáncer de pulmón y mesotelioma. Su ingestión puede causar cáncer de estómago y de intestino.

\section{Pedernal}

Presentación y usos. El pedernal es una forma cristalina de sílice nativa o cuarzo. Se encuentra en Europa y Estados Unidos. Se utiliza como abrasivo, diluyente de pinturas y relleno de fertilizantes. Se emplea también en insecticidas, caucho, plásticos, asfalto y cerámica. $\mathrm{H}$ istóricamente ha sido un mineral importante debido a que se utilizó para fabricar algunas de las primeras herramientas y armas conocidas.

Riesgos para la salud. R elacionados con las propiedades tóxicas de la sílice.

\section{Piedra caliza}

Presentación y usos. La piedra caliza es una roca sedimentaria compuesta principalmente por carbonato cálcico en forma de calcita mineral. Se puede clasificar según las impurezas que contenga (caliza dolomítica, que contiene cantidades importantes de carbonato magnésico; caliza arcillosa, con un alto contenido de arcilla; caliza silícea, con arena o cuarzo; etc.), o según la formación en la que se presente, (por ejemplo mármol, una caliza cristalina). Los depósitos de caliza están ampliamente distribuidos en toda la corteza terrestre y se extraen en canteras.

La piedra caliza se ha utilizado desde tiempos remotos en construcción. También se tritura para su uso como fundente en fundición, refino, y para la fabricación de cal. Se emplea como firme y balastro en la construcción de carreteras, y se mezcla con arcilla para la fabricación de cemento.

Riesgos para la salud. Durante la extracción deben adoptarse las medidas adecuadas de seguridad en la cantera, y observarse las normas de protección de la maquinaria en las trituradoras. El principal riesgo para la salud es el relacionado con la presencia, en el polvo de piedra caliza transportado en el aire, de sílice libre en proporción del 1 al $10 \%$ de la roca caliza. En estudios realizados con trabajadores de canteras y tratamiento de piedra caliza, los exámenes radiográficos revelaron cambios pulmonares, y la exploración clínica indicó la existencia de faringitis, bronquitis y enfisema. Los obreros que preparan la piedra para las obras de construcción deberían observar las medidas de seguridad apropiadas para la industria de la piedra.

\section{Piedra pómez}

P resentación y usos. La piedra pómez es una roca porosa, grisácea 0 blancuzca, frágil y de bajo peso específico, procedente de magma volcánico reciente; está compuesta por cuarzo y silicatos (principalmente feldespato). Se encuentra pura o mezclada con varias sustancias, sobre todo obsidiana, que se distingue por su color negro brillante y por su densidad relativa, cuatro veces mayor. Se encuentra sobre todo en Etiopía, Alemania, Hungría, Italia (Sicilia, Lípari), M adagascar, España y Estados U nidos. Algunas variedades, como la piedra pómez de Lípari, tienen un contenido elevado de sílice total $(71,2$ a $73,7 \%$ ) y una cantidad considerable de sílice libre (1,2 a $5 \%$ ).

En el comercio, y para aplicaciones prácticas, se distingue entre piedra pómez en bloques y en polvo. Cuando está en forma de bloque, se designa de forma diferente en función del tamaño del bloque, color, porosidad, etc. La forma en polvo se clasifica mediante números según el tamaño del grano. El proceso industrial comprende varias operaciones: selección para separar la obsidiana, molido y pulverización en máquinas con muelas de piedra o de metal, secado en hornos abiertos, cernido y tamizado usando cedazos abiertos manuales y tamices rotatorios y oscilantes, recuperándose generalmente la materia residual.

La piedra pómez se utiliza como abrasivo (en bloque o en polvo), como material ligero de construcción y para la fabricación de artículos de piedra, explosivos, etc.

Riesgos para la salud. Las operaciones más peligrosas son el secado al horno y el tamizado, debido a la gran cantidad de polvo producida. A parte de los signos característicos de silicosis observados en los pulmones y de la esclerosis de los ganglios linfáticos hiliares, el estudio de casos mortales ha revelado daño 
en varias capas del árbol arterial pulmonar. La exploración clínica ha revelado alteraciones respiratorias (enfisema y a veces daño pleural), trastornos cardiovasculares (corazón pulmonar) y renales (albuminuria, hematuria, cilindruria), así como signos de deficiencia suprarrenal. La prueba radiológica de aortitis es mucho más común y grave que en el caso de la silicosis. El aspecto radiológico típico de los pulmones en la liparitosis es la presencia de engrosamiento lineal debido a atelectasias lamelares.

\section{Pizarra}

Presentación y usos. La pizarra es una roca arcillosa o esquisto-arcillosa sedimentaria y muy compacta, que se divide en láminas con facilidad, de color gris plomo, rojizo o verdosos. Los principales depósitos se encuentran en Francia (Ardenas), Bélgica, Reino U nido (Gales, Connwall), Estados U nidos (Pennsylvania, $\mathrm{M}$ aryland) e I talia (Liguria). Junto a una gran cantidad de carbonato cálcico, contiene también silicatos (mica, clorita, hidrosilicatos), óxidos de hierro y sílice libre, amorfa o cristalina (cuarzo). El contenido de cuarzo de las pizarras duras es de aproximadamente un $15 \%$, y el de las pizarras blandas inferior al $10 \%$. En las canteras de $\mathrm{G}$ ales del N orte, el polvo de pizarra respirable contiene entre el 13 y el $32 \%$ de cuarzo respirable.

Las hojas de pizarra se utilizan para tejados, escaleras, cubiertas de puertas, ventanas y porches; solado, chimeneas, mesas de billar, paneles de conmutadores eléctricos y pizarras de escuelas. La pizarra en polvo se ha utilizado como tapaporos 0 pigmentos en pinturas inoxidables o aislantes, en mástiques y en pinturas y productos bituminosos para superficies de carreteras.

$R$ iesgos para la salud. La enfermedad de los trabajadores de la pizarra ha sido objeto de atención desde principios del siglo $X I X$, habiéndose descrito casos de "tisis del minero" sin intervención del bacilo tuberculoso. Se ha encontrado neumoconiosis en un tercio de los trabajadores estudiados en la industria de la pizarra en Gales del Norte, y en un $54 \%$ de los fabricantes de lápices de pizarra en la India. La neumoconiosis de los trabajadores de la pizarra puede tener características de silicosis debido al elevado contenido de cuarzo de algunas pizarras. Frecuentemente se observan bronquitis y enfisema crónicos, sobre todo en los trabajadores dedicados a la extracción.

La sustitución del pico manual por el equipo mecánico de baja velocidad reduce considerablemente la generación de polvo en las canteras de pizarra, y el uso de sistemas de ventilación por extracción local permite mantener las concentraciones de polvo transportado por el aire dentro de límites aceptables para una exposición de ocho horas. La ventilación de las minas subterráneas, el drenaje del agua del suelo en los pozos, la iluminación y la organización del trabajo están mejorando las condiciones generales de higiene y de trabajo.

El aserrado circular debe realizarse bajo chorros de agua, mientras que el desbastado no suele generar polvo siempre que los recortes no se dejen caer al suelo. Las láminas grandes se suelen pulimentar en húmedo; cuando se realiza el pulimentado en seco debe disponerse de una buena ventilación por extracción, ya que el polvo de pizarra no es fácil de recoger, ni aun con aspiradores, al obstruirse con rapidez los filtros de las bolsas.

Los talleres deben limpiarse diariamente para evitar la acumulación de depósitos de polvo; en algunos casos será preferible evitar que el polvo depositado en los pasillos sea llevado por el aire cubriéndolo con serrín, mejor que humedeciéndolo.

\section{Sílice}

Presentación y usos. La sílice se presenta en estado natural en formas cristalinas (cuarzo, cristobalita y tridimita), criptocristalinas (por ejemplo, la calcedonia) y amorfas (por ejemplo, el ópalo), dependiendo la densidad relativa y el punto de fusión de la forma cristalina.

La sílice cristalina es el mineral más extendido, encontrándose en la mayoría de las rocas. La forma más corriente de sílice es la arena de las playas de todo el mundo. La roca sedimentaria arenisca consta de granos de cuarzo cementados con arcillas.

La sílice es un componente del vidrio común y de la mayor parte de los ladrillos refractarios. También se utiliza ampliamente en la industria de la cerámica. Las rocas que contienen sílice constituyen un material habitual en construcción.

Sílice libre y combinada. La sílice libre es la que no está combinada con ningún otro elemento ni compuesto. El cuarzo es un ejemplo de sílice libre. EI término sílice combinada procede del análisis químico de rocas, arcillas y suelos naturales. Los constituyentes inorgánicos son casi siempre óxidos unidos químicamente, por lo común incluyen dióxido de silicio. La sílice así combinada con uno o más óxidos se conoce como ślice combinada. Por ejemplo, la sílice de la mica se presenta en estado combinado.

En la sílice cristalina, los átomos de silicio y oxígeno están dispuestos de forma regular y determinada en todo el cristal. Las caras características del cristal son la expresión externa de la disposición regular de los átomos. L as formas cristalinas de sílice libre son cuarzo, cristobalita y tridimita. El cuarzo cristaliza en el sistema hexagonal, la cristobalita en el cúbico o tetragonal y la tridimita en el ortorrómbico. El cuarzo es incoloro y transparente en estado puro; los colores que presenta de forma natural son debidos a la contaminación.

En la sílice amorfa, las moléculas diferentes guardan entre sí una relación espacial distinta; como resultado no existe un patrón regular definido entre moléculas algo separadas. Esta ausencia de orden prolongado es característica de los materiales amorfos. La sílice criptocristalina es un tipo intermedio entre la cristalina y la amorfa, ya que consta de cristales menudos o cristalitos dispuestos sin una orientación regular entre sí.

E I ópalo es una variedad amorfa de sílice con una cantidad variable de agua combinada. U na forma comercialmente importante de sílice amorfa es la tierra de diatomeas o de infusorios (kieselguhr). La calcedonia es una forma criptocristalina de sílice que rellena las cavidades de las lavas o que se presenta asociada con el pedernal. También se encuentra durante el recocido de materiales cerámicos cuando, en condiciones de temperatura determinadas, el cuarzo de los silicatos puede cristalizar en cristales diminutos en el cuerpo del artículo.

Riesgos para la salud. La inhalación de polvo de sílice transportado por el aire puede provocar silicosis, una enfermedad pulmonar fibrótica, grave y potencialmente mortal. Las formas crónica, acelerada y aguda de silicosis reflejan intensidades de exposición, períodos de latencia e historias naturales diferentes. La silicosis crónica puede evolucionar a fibrosis masiva progresiva, incluso después de que la exposición a polvo que contiene ślice haya cesado. En el capítulo Sistema respiratorio se exponen con más detalle los riesgos de la sílice.

\section{Talco}

Presentación y usos. El talco es un silicato de magnesio hidratado, cuya fórmula básica es $\left(\mathrm{M} \mathrm{g} \mathrm{Fe}^{+2}\right)_{3} \mathrm{Si}_{4} \mathrm{O}_{10}\left(\mathrm{H}_{2} \mathrm{O}\right)$, con los porcentajes teóricos de peso siguientes: $63 \% \mathrm{SiO}_{2}, 32 \% \mathrm{MgO}$ y $5 \%$ $\mathrm{H}_{2} \mathrm{O}$. Se encuentra en diversas formas y frecuentemente está contaminado con otros minerales, como sílice y asbestos. Se produce talco en Australia, Austria, China, Francia y Estados Unidos.

La textura, estabilidad y propiedades fribrosas o escamosas de los diversos talcos los hacen útiles para numerosos fines. L os más puros, esto es, los que se aproximan mucho a la composición 
teórica, tienen textura y color finos, y por lo tanto son muy utilizados en cosméticos y productos de tocador. 0 tras variedades que contienen mezclas de distintos silicatos, carbonatos y óxidos, y tal vez sílice libre, presentan una textura relativamente gruesa y se utilizan en la fabricación de pinturas, cerámica, neumáticos y papel.

Riesgos para la salud. La inhalación crónica puede provocar silicosis si contiene sílice, o asbestosis, cáncer de pulmón y mesotelioma si están presentes asbesto o minerales similares al asbesto. Los estudios de trabajadores expuestos a talco sin fibras de asbestos asociadas revelaron una tendencia a una mayor mortalidad a causa de silicosis, silicotuberculosis, enfisema y neumonía. Los principales síntomas y signos clínicos de la neumoconiosis por talco son tos crónica productiva, disnea, ruidos respiratorios disminuidos, expansión limitada del tórax, estertores difusos y dedos en palillos de tambor. El examen anatomopatológico del pulmón ha revelado varias formas de fibrosis pulmonar.

\section{Tierra de diatomeas (diatomita, kieselguhr, tierra de infusorios)}

Presentación y usos. La tierra de diatomeas es un material suave y compuesto en bloque por restos de plantas acuáticas pequeñas prehistóricas relacionadas con las algas. Algunos depósitos contienen hasta un $90 \%$ de sílice amorfa libre. Tienen formas geométricas intrincadas y están disponibles como bloques de colores claros, ladrillos, polvos, etc. La tierra de diatomeas absorbe de 1,5 a 4 veces su peso en agua y tiene una gran capacidad de absorción de aceite. Existen depósitos en Argelia, Europa, Federación Rusa y oeste de Estados U nidos. La tierra de diatomeas se puede utilizar en fundición, revestimientos de papel, cerámica y en el mantenimiento de filtros, abrasivos, lubricantes y explosivos. Se utiliza como medio filtrante en la industria química. Se emplea también como espesante en lodos de inyección, como extendedor en pinturas, caucho y productos de plástico, y como agente antiapelmazante en fertilizantes.

Riesgos para la salud. La tierra de diatomeas penetra con la respiración. Para muchas aplicaciones industriales se calcina a $800-1.000{ }^{\circ} \mathrm{C}$, produciéndose un polvo gris blanquecino llamado kieselguhr, que puede contener un $60 \%$ o más de cristobalita. Durante la extracción y tratamiento de la tierra de diatomeas, el riesgo de muertes por enfermedad respiratoria y cáncer de pulmón se ha relacionado con la inhalación de polvo así como con las exposiciones repetidas a sílice cristalina, como se describe en el capítulo 10, A parato respiratorio.

\section{Wollastonita (silicato de calcio)}

Presentación y usos. La wollastonita $\left(\mathrm{CaSiO}_{3}\right)$ es un silicato de calcio natural que se presenta en rocas metamórficas, en distintas formas, en Nueva York y C alifornia en Estados U nidos, así como en Canadá, Alemania, Rumania, Irlanda, Italia, Japón, M adagascar, M éxico, N oruega y Suecia.

La wollastonita se utiliza en cerámica, revestimientos de soldadura, geles de sílice, lana mineral y revestimientos de papel. También se utiliza como extendedor de pinturas, acondicionador de suelos, y como material de relleno en plásticos, caucho, cementos y maderas laminadas.

Riesgos para la salud. El polvo de wollastonita puede provocar irritación cutánea, ocular y respiratoria.

\section{Yeso (sulfato cálcico hidratado)}

Presentación y usos. Aunque se encuentra en todo el mundo, el yeso raramente se da en estado puro. Los depósitos de yeso contienen por lo general cuarzo, piritas, carbonatos o materiales arcillosos y bituminosos. Aparece en cinco variedades naturales: rocas de yeso, gipsita (forma terrosa e impura), alabastro (una variedad translúcida de grano fino y masiva), calcita fibrosa (una forma sedosa y fibrosa) y selenita (cristales transparentes).

La roca de yeso puede triturarse y molerse para su uso en la forma dihidratada, calcinándose a 190 a $200{ }^{\circ} \mathrm{C}$ (con lo cual se elimina parte del agua de cristalización) para producir sulfato cálcico hemidratado o yeso de París, o deshidratarse completamente mediante calcinación a más de $600{ }^{\circ} \mathrm{C}$ para producir yeso anhidro o muerto.

El yeso dihidratado triturado se utiliza en la fabricación de cemento portland y productos a base de mármol artificial; como acondicionador del suelo en la agricultura, como pigmento blanco, carga 0 aditivo en pinturas, esmaltes, productos farmacéuticos, papel, etc., y como agente de filtración.

Riesgos para la salud. Los trabajadores del yeso pueden estar expuestos a altas concentraciones atmosféricas de polvo de yeso, gases y humos de los hornos. D urante la calcinación del yeso, los trabajadores están expuestos a elevadas temperaturas medioambientales, y existe también el riesgo de quemaduras. EI empleo de los equipos de triturado, molturación, transporte y embalaje lleva implícitos los riesgos de accidentes asociados a la maquinaria. La neumoconiosis observada en los mineros de yeso se ha atribuido a la contaminación con sílice

La formación de polvo en la elaboración del yeso debe controlarse mediante la mecanización de las operaciones en las que se genere polvo (triturado, carga, transporte, etc.), la adición de hasta un $2 \%$ en volumen de agua al yeso antes del triturado, la utilización de transportadores neumáticos con cubiertas y trampillas de polvo, el aislamiento las fuentes de polvo y el empleo de sistemas de ventilación en las aberturas de los hornos y en los puntos de transferencia para el transporte. En los talleres donde se encuentren los hornos de calcinación es recomendable cubrir paredes y suelos con materiales lisos para facilitar la limpieza. Las tuberías calientes, las paredes de los hornos y las envolturas de los secadores deben recubrirse para reducir el riesgo de quemaduras y para limitar la irradiación de calor al medioambiente laboral.

\section{PROdUCTOS QUIMICOS PARA LA AGRICULTURA}

Gary A. Page

Los productos químicos para la agricultura se agrupan normalmente en tres clases: plaguicidas, fertilizantes y productos para la salud animal. La Environmental Protection Agency (EPA) de Estados U nidos define los plaguicidas como cualesquiera materiales fabricados o formulados con el fin de destruir alguna plaga. L os herbicidas, fungicidas, insecticidas y acaricidas son, por tanto, plaguicidas. Los fertilizantes son nutrientes químicos que estimulan el crecimiento de las plantas. Contienen principalmente nitrógeno, fósforo o potasio. EI nitrógeno se encuentra frecuentemente en forma de amoniaco, nitrato amónico, sulfato amónico, fosfato amónico o soluciones de estos compuestos. O tros productos químicos que contienen nitrógeno se utilizan para atender necesidades especiales de nutrientes. $L a$ fuente normal de fósforo es el fosfato amónico. La potasa (óxido potásico) es el nutriente de potasio. Los productos para la salud animal son los que se utilizan para promover la salud o el crecimiento de los animales. Se pueden aplicar por vía tópica mediante baño o aplicación de lociones, por vía oral como comprimido o gel, o en forma de inyectables. 


\section{Plaguicidas}

La innovación más significativa de la industria de fabricación de plaguicidas ha sido la introducción de los plaguicidas ecológicos. La familia de herbicidas de las imidazolinonas ha supuesto un beneficio para los cultivos de soja y otros cultivos al aire libre, que son ahora mucho más rentables; son además menos tóxicos para los seres humanos, animales terrestres y peces, tienen una menor persistencia en el suelo, y utilizan agua en lugar de disolventes inflamables, en comparación con la antigua generación de nitroaromáticos. Simultáneamente a estas innovaciones se han desarrollado semillas resistentes a las imidazolinonas que pueden ser protegidas frente al crecimiento de las malas hierbas. El cultivo más beneficiado en este aspecto ha sido el maíz. Por otra parte, el herbicida persistente de un año a otro es un problema insignificante, ya que en muchas áreas se rotan la soja y el maíz.

0 tra novedad reciente ha sido la producción de piretroides sintéticos, plaguicidas de amplio espectro. Se trata de productos eficaces pero menos tóxicos para los animales y los seres humanos que los antiguos organofosforados y carbamatos. Son activados por el sistema biológico del insecto y, por lo tanto, no suponen un peligro para los vertebrados. También son menos persistentes en el medio ambiente, ya que son biodegradables.

Se han producido igualmente avances en el uso de plaguicidas y herbicidas de generaciones antiguas. Se han desarrollado formulaciones de herbicidas que utilizan una tecnología de dispersión en agua que elimina el uso de disolventes volátiles. Con ello no solamente se reduce la cantidad de productos químicos orgánicos volátiles que escapan a la atmósfera, sino que se hacen más seguras la manipulación, conservación, formulación y transporte. En el ámbito de los plaguicidas se ha desarrollado un método de manipulación en el que el producto se transfiere del recipiente cerrado al pulverizador llamado "L ock$\mathrm{N}$-Load". C on ello se reducen las posibilidades de exposición a estos productos tóxicos. Los organofosforados se utilizan aún con éxito para erradicar problemas sanitarios como la malaria y la oncocercosis. Algunos de los organofosforados menos tóxicos son eficaces en el tratamiento de los mamíferos contra los insectos, tenias y ácaros, mediante aplicación directa sobre la piel utilizando formulaciones líquidas o en aerosol.

La industria de los plaguicidas está regulada en muchos países, controlándose el etiquetado, la aplicación a las plantas y al suelo, la formación en su uso y el transporte. M uchos plaguicidas pueden ser aplicados solamente por personas autorizadas. Las precauciones a adoptar en este ámbito se consideran en otros capítulos de la E nciclopedia. L os vehículos para el transporte de los plaguicidas a granel sólo pueden ser manejados por conductores cualificados. L os productores de plaguicidas tienen la obligación de facilitar su manipulación y aplicación seguras a través de un etiquetado completo, el desarrollo de actividades de formación y la entrega de $\mathrm{H}$ ojas de Datos de Seguridad del material (véase el capítulo U tilización, almacenamiento y transporte de productos químicos).

O tro problema es el que plantea la eliminación de los recipientes vacíos. No se recomienda, y en algunos lugares es ilegal, reutilizar los recipientes de plaguicidas. Se han realizado muchos avances para mitigar este problema. Así, los recipientes de plástico son recogidos por los distribuidores y reprocesados en tubos de plástico. Se emplean recipientes a granel rellenables. Con la llegada de los polvos humectables y de las dispersiones en agua, el triple aclarado del recipiente en el tanque de la solución permite al aplicador descontaminar el recipiente antes de su vertido o reciclado. Se utilizan lancetas manuales con bocas pulverizadoras que agujerean el recipiente y garantizan una limpieza adecuada y la destrucción del recipiente, de forma que no pueda ser reutilizado.
La finalidad de los plaguicidas es causar la muerte; por consiguiente, es necesario adoptar precauciones para manipularlos de forma segura. Algunos de los problemas han sido superados por los avances en los productos. En la mayoría de los casos, el lavado con agua abundante es el mejor tratamiento de primeros auxilios en caso de exposición superficial de piel y ojos. En caso de ingestión es preferible disponer de un antídoto específico. Es importante que el centro sanitario más próximo tenga información sobre el producto y disponga del antídoto adecuado. Por ejemplo, los organofosforados y los carbamatos provocan la inhibición de la colinesterasa. Debería disponerse de atropina, el antídoto específico para el tratamiento de esta reacción, allí donde se utilicen estos plaguicidas.

En el artículo epónimo de este capítulo se trata con más amplitud el tema de los plaguicidas.

\section{Fertilizantes}

EI amoníaco es la base de los fertilizantes más importantes. Los principales fertilizantes son el amoníaco, el nitrato amónico, la urea, el sulfato amónico y el fosfato amónico. Parece existir un problema medioambiental asociado al uso de nitrógeno, ya que el agua subterránea de muchas áreas de cultivo está contaminada con nitratos, lo que provoca problemas sanitarios cuando el agua se consume como agua de bebida. $\mathrm{H}$ ay que convencer a los agricultores para que utilicen menos fertilizantes y roten el maíz con leguminosas que fijan nitrógeno, como la soja y el ballico. El nitrato amónico, dotado de actividad oxidante, es explosivo cuando se calienta. Los riesgos de este compuesto como agente explosivo se demostraron en la destrucción de un edificio federal de O klahoma City, en Estados U nidos, en 1995. Para obtener nitrato amónico resistente a la detonación suelen añadirse ingredientes inertes. Hubo asimismo otra explosión industrial, con varias víctimas, en una planta de soluciones de nitrato amónico considerada segura contra la detonación en la que el nitrato amónico se manipulaba en solución al $85 \%$. Los resultados de la investigación indicaron que el incidente fue provocado por el efecto combinado de una determinada serie de factores de temperatura y contaminación, que no se dan normalmente en la venta al detalle ni en el sector agrícola. El amoníaco anhidro, por su parte, es un gas moderadamente tóxico a temperatura ambiente y debe mantenerse a presión o refrigerado durante su conservación o uso. Es un irritante de la piel, ojos y vías respiratorias, puede provocar quemaduras y es inflamable. Se aplica directamente sobre el suelo o se utiliza como solución acuosa. En muchas áreas agrícolas se almacena en grandes cantidades. Si este almacenamiento no se realiza correctamente, por ejemplo controlando las fugas y aplicando procedimientos de emergencia cuando se producen éstas, se crean condiciones de peligro.

\section{Productos para la salud animal}

El desarrollo y la comercialización de la somatotropina bovina (BST ) han suscitado una gran controversia. La BST, un producto de fermentación, aumenta la productividad de las vacas lecheras en un 10 a $20 \%$. M uchas personas se oponen al empleo de este producto porque implica la introducción de una sustancia química en la producción de leche. No obstante, la leche con BST es indistinguible de la leche ordinaria, ya que la vaca lechera produce BST de forma natural. AI parecer, este producto favorece las infecciones mamarias en las vacas, y aunque se dispone de antibióticos para combatirlas el uso de los mismos también es controvertido. Los principales beneficios de la BST son el aumento de la producción de leche con una reducción en el consumo de alimento y una reducción similar en el estiércol, material que plantea un problema de residuos sólidos en muchas zonas. U n producto similar, la somatotropina porcina (PST), está 
aún en fase experimental. Los animales crecen más deprisa, utilizan menos alimento y tienen menos grasa.

El uso de antibióticos en explotaciones de vacuno también es causa de controversia. Existe el temor de que el consumo de grandes cantidades de vacuno provoque problemas hormonales en humanos. A penas existe confirmación en este sentido, pero la preocupación persiste. Se han desarrollado productos para la salud animal que controlan las tenias. Antes se utilizaban con este fin productos químicos sintéticos, pero los productos de nueva generación son el resultado de la tecnología de fermentación biológica. Son eficaces en muchos tipos de animales a niveles muy bajos, incluso en animales domésticos; no obstante son muy tóxicos para la vida acuática, por lo que se debe evitar la contaminación de ríos y corrientes. Estos materiales son biodegradables, de modo que no parece haber problemas acuáticos residuales o largo plazo.

\section{Fabricación de productos químicos para la agricultura}

La fabricación de los productos químicos para la agricultura implica el desarrollo de muchos procesos y la utilización de numerosas materias primas. Algunos productos se obtienen mediante síntesis químicas que implican reacciones exotérmicas en las que son importantes el control de la temperatura y los dispositivos de seguridad de emergencia. Para garantizar que se han considerado todos los riesgos es preciso realizar evaluaciones de los mismos, a ser posible en la forma de estudios de riesgos y de operabilidad (HAZOP). En lo que se refiere a los dispositivos de emergencia, se debe utilizar la tecnología del Instituto de Diseño de Sistemas de Seguridad de Emergencia (DIERS) y datos de los equipos calorimétricos. N ormalmente, debido a la complejidad de las moléculas, la fabricación de productos químicos para la agricultura implica un elevado número de etapas. A veces se genera una gran cantidad de residuos líquidos acuosos y orgánicos. Algunos de estos últimos pueden ser reciclados, pero la mayor parte de los residuos acuosos han de ser tratados biológicamente o incinerados. Ambos métodos son difíciles debido a la presencia de sales orgánicas o inorgánicas. Los herbicidas de la generación anterior, que implicaban nitraciones, se producían utilizando reactores continuos para minimizar las cantidades de los materiales nitrados a las temperaturas de reacción. Pueden producirse reacciones incontroladas graves causantes de daños materiales y personales cuando los reactores intermitentes de los compuestos orgánicos nitrados sufren una desviación de temperatura o una contaminación.

Muchos plaguicidas modernos son polvos secos. Si se presentan simultáneamente una concentración dada, un tamaño de partícula determinado, una cierta concentración de oxígeno y una fuente de ignición, puede producirse una explosión de polvo. El uso de sustancias inertes, la exclusión de oxígeno y la utilización de nitrógeno o dióxido de carbono minimizan la fuente de oxígeno y pueden hacer el proceso más seguro. Estos polvos pueden constituir también un problema de higiene industrial. La ventilación, tanto general como local, es una solución a tales problemas.

Los principales fertilizantes se fabrican por procesos continuos, no por lotes. El amoníaco se prepara por conversión de metano a elevadas temperaturas y utilizando un catalizador específico. También se forman dióxido de carbono e hidrógeno, que deben ser separados del amoníaco. El nitrato amónico se prepara a partir de amoníaco y ácido nítrico en un reactor continuo. El ácido nítrico se forma mediante la oxidación continua de amoníaco sobre una superficie catalítica. El fosfato amónico se obtiene en una reacción entre amoníaco y ácido fosfórico. El ácido fosfórico se obtiene haciendo reaccionar ácido sulfúrico con minerales que contienen fosfato. El ácido sulfúrico se forma quemando azufre a dióxido de azufre, convirtiendo catalíticamente el dióxido de azufre a trióxido de azufre, y añadiendo después agua para formar ácido sulfúrico. La urea es un producto de la reacción continua a alta presión de dióxido de carbono y amoníaco, y el dióxido de carbono procede normalmente de los subproductos de la reacción continua del amoníaco.

M uchas de estas materias primas son tóxicas y volátiles. La liberación de las materias primas o productos terminados debido a un fallo en un equipo o a un error humano puede exponer a los empleados y a la población general. La existencia de un plan de respuesta de emergencia detallado es fundamental para minimizar los efectos de estos escapes. Para elaborar este plan debe determinarse un acontecimiento en el caso peor imaginable mediante la evaluación de los riesgos y prever después las consecuencias mediante un modelo de dispersión. $\mathrm{H}$ ay que incluir en el plan un método para notificar el suceso a los empleados y a la población, un plan de evacuación, unos servicios de emergencia y un plan de recuperación.

El transporte de los productos químicos para la agricultura ha de ser estudiado detenidamente para elegir la ruta más segura, esto es, la que minimice la exposición en caso de accidente. Debe disponerse asimismo de un plan de respuesta de emergencia para hacer frente a los incidentes que se produzcan durante el transporte, incluyendo en él un número de teléfono de emergencia, la disponibilidad de personal para atender a las llamadas $y$, en algunos casos, un equipo de emergencia que acuda al lugar del accidente.

Algunos de estos productos se obtienen por fermentación, proceso que normalmente no es peligroso, ya que implica el desarrollo de un cultivo mediante el empleo de medios nutritivos como aceite de manteca, glucosa o almidón. No obstante, en ocasiones se utiliza amoníaco anhidro para controlar el pH (acidez) o como nutriente, por lo que el proceso puede implicar algunos riesgos. Se pueden utilizar disolventes para extraer las células activas, pero las cantidades y la metodología aplicadas son tales que se puede actuar con seguridad. El reciclado de estos disolventes forma a menudo una parte del proceso.

\section{Plaguicidas*}

La palabra plaguicida designa en general cualquier sustancia química (mezclada o no con otras sustancias) utilizada para la destrucción de un microorganismo perjudicial para el hombre. Se trata, pues, de un término dotado de un significado muy amplio, comprensivo de otros térmicos como insecticida, fungicida, herbicida, rodenticida, bactericida, acaricida, nematocida o molusquicida, que designan los microorganismos o plagas que un producto químico determinado o clase de productos tiene por objeto destruir. Dado que se utilizan distintos tipos de agentes químicos en estas clases generales, es aconsejable indicar la clase concreta del plaguicida.

\section{Principios generales}

$L a$ toxicidad aguda se mide mediante la $D L_{50}$, valor que representa una estimación estadística del número de miligramos de producto químico por kilogramo de peso corporal que se requiere para causar la muerte del 50 \% de una amplia población de animales estudiados. La dosis se puede administrar por

*Adaptado de la 3a edición de la E nciclopedia de salud y seguridad en el trabajo. $L$ a revisión incluye información de $A$. Baiinova, J.F. Copplestone, L.A. D obrobolskij, F. K aloyanova-Simeonova, Y.I. K undiev y A.M. Shenker. 
diversas vías, aunque las más normales son la oral o la dérmica, y la rata es el animal más utilizado en las pruebas correspondientes. Se utilizan los valores $D_{5}$ según la vía oral o dérmica que presente el valor más bajo para un producto químico específico. Deben tenerse en cuenta también otros efectos, los derivados de exposiciones de corta duración, como la neurotoxicidad o la mutagenicidad, y los derivados de exposiciones de larga duración, como la carcinogenicidad, aunque los plaguicidas que presentan propiedades conocidas de este tipo no están registrado para su uso. La Clasificación R ecomendada de Plaguicidas según el R iesgo y las D irectrices para la Clasificación 1996-1997 de la OM S, publicadas por la O rganización M undial de la Salud (O M S), desglosan los productos de clase técnica en función del riesgo agudo para la salud humana de la forma siguiente:

- Clase IA - extremadamente peligrosos

- Clase IB - altamente peligrosos

- Clasell-moderadamente peligrosos

- Clase III-ligeramente peligrosos

Las directrices basadas en la clasificación de la O M S relacionan los plaguicidas según su toxicidad y estado físico; dicho listado se presenta en un artículo especial de este capítulo.

L os tóxicos pueden entrar en el cuerpo por la boca (ingestión), por los pulmones (inhalación), por la piel intacta (absorción percutánea) o por heridas en la piel (inoculación). El riesgo de inhalación depende de la forma física y solubilidad del producto químico. La posibilidad y el grado de absorción cutánea varían con el producto químico; algunos de éstos ejercen una acción directa sobre la piel, causando dermatitis. Los plaguicidas se aplican de distintas formas: como sólidos, rociando en forma diluida o concentrada, en polvo (fino o granulado), y como neblinas y gases. El método de empleo condiciona la probabilidad de absorción.

El producto se puede mezclar con sólidos (a menudo con comida, usada como cebo), agua, queroseno, aceites o disolventes orgánicos. Algunos de estos disolventes tienen cierto grado de toxicidad propia y pueden influir en el índice de absorción del plaguicida químico. Muchas formulaciones contienen otras sustancias químicas que no son por sí mismas plaguicidas, pero que aumentan la eficacia del plaguicida. Es lo que ocurre con los agentes tensioactivos. Cuando en una misma formulación se mezclan dos o más plaguicidas, la acción de alguno de ellos puede ser reforzada por la presencia de otros. En muchos casos no se conocen bien los efectos combinados de la mezcla; un buena norma es considerar siempre las mezclas más tóxicas que cualquiera de sus componentes por separado.

Debido a su naturaleza y finalidad, los plaguicidas tienen efectos biológicos adversos al menos sobre algunas especies, incluida la especie humana. A continuación se exponen los mecanismos de acción de los plaguicidas y algunos de sus efectos tóxicos. La carcinogenicidad, la monitorización biológica y las medidas de seguridad en el uso de plaguicidas se tratan con más detalle en otros capítulos de esta E nciclopedia.

\section{Plaguicidas organoclorados}

Los plaguicidas organoclorados (POC) han provocado intoxicaciones por absorción, por ingestión o por inhalación. Algunos ejemplos son el endrín, el aldrín y el dialdrín. La tasa de absorción y la toxicidad varían en función de la estructura química y de los disolventes, tensioactivos y emulsionantes utilizados en la formulación.

La eliminación de los POC del organismo se produce lentamente a través de los riñones. El metabolismo celular implica varios mecanismos, como los de oxidación, hidrólisis y otros. Los PO C tienen una fuerte tendencia a penetrar en las membranas celulares y a acumularse en la grasa corporal. D ebido a su atracción por los tejidos adiposos (propiedades lipotróficas), tienden a acumularse en el sistema nervioso central (SNC), hígado, riñones y miocardio. En estos órganos pueden dañar la función de importantes sistemas enzimáticos y alterar la actividad bioquímica de las células.

L OS PO C son muy lipófilos y tienden a acumularse en el tejido adiposo mientras persiste la exposición. Cuando ésta cesa, se liberan lentamente al torrente circulatorio, a menudo durante un período de muchos años, de donde pueden ser transportados a otros órganos en los que se pueden iniciar efectos genotóxicos, incluido el cáncer. La mayor parte de los habitantes de Estados U nidos tienen niveles detectables de plaguicidas organoclorados, entre ellos productos de degradación del DDT, en su tejido adiposo (grasa), y las concentraciones aumentan con la edad, como reflejo de acumulaciones durante toda la vida.

Se han utilizado varios POC en todo el mundo, ya que se ha probado o sospechado que los insecticidas y los herbicidas son carcinógenos para los humanos. Esta cuestión se aborda con más detalle en los capítulos Toxicología (33) y Cáncer (2) de esta Enciclopedia.

\section{Intoxicaciones agudas}

El aldrín, el endrín, el dieldrín y el toxafeno son los compuestos más frecuentemente implicados en las intoxicaciones agudas. EI retraso en la aparición de los síntomas en los casos graves es de unos 30 minutos. En POC con menor grado de toxicidad, el retraso es de varias horas, aunque nunca más de 12 .

La intoxicación se manifiesta por síntomas gastrointestinales: náuseas, vómitos, diarrea y dolores de estómago. Los síntomas básicos son cerebrales: cefalea, mareos, ataxia y parestesias. Gradualmente van apareciendo temblores que comienzan por los párpados y los músculos de la cara, descendiendo hacia el resto del cuerpo y las extremidades. En casos graves estos síntomas determinan la aparición de convulsiones tónico-clónicas, con extensión gradual a diversos grupos de músculos. Las convulsiones pueden estar relacionadas con hipertermia 0 inconsciencia, pudiendo llegar a producirse la muerte. Además de los signos cerebrales, las intoxicaciones agudas pueden producir parálisis bulbares de los centros respiratorio y/ o vasomotor, con insuficiencia respiratoria aguda o apnea y colapso grave.

Muchos pacientes desarrollan signos de hepatitis tóxica y nefropatía tóxica. Tras la desaparición de estos síntomas, algunos desarrollan signos de polineuritis tóxica prolongada, anemia y diátesis hemorrágica debido a una trombocitopoyesis alterada. Un signo típico de la intoxicación por toxafeno es la bronconeumonía alérgica.

Las intoxicaciones agudas con POC duran hasta 72 horas. Cuando las funciones orgánicas están muy alteradas, la enfermedad puede durar varias semanas. En caso de lesión hepática y renal, las complicaciones pueden ser de larga duración.

\section{Intoxicación crónica}

Las intoxicaciones asociadas a la producción y a la aplicación de Ios POC en agricultura, suelen ser de carácter crónico, esto es, vinculadas a la exposición a dosis bajas a lo largo del tiempo. Las intoxicaciones agudas (asociadas a exposiciones a dosis altas en un breve período de tiempo) son menos frecuentes y normalmente se deben a un uso incorrecto 0 a accidentes, tanto en el hogar como en la industria. Las intoxicaciones crónicas inducen lesiones del sistema nervioso central, del aparato digestivo, del sistema cardiovascular y hematopoyesis. Todos los POC son estimulantes del sistema nervioso central y pueden producir convulsiones, frecuentemente con características epilépticas. Se han registrado electroencefalogramas (EEG) anormales, como ritmos 
alfa irregulares y otras anomalías. En algunos casos se han observado ondas puntiagudas bitemporales de localización variable, bajo voltaje y actividad theta difusa. En otros casos se han registrado trazados paroxísticos constituidos por ondas puntiagudas lentas, complejos puntiagudos y picos rítmicos de bajo voltaje.

Se han descrito polineuritis, encefalopolineuritis y otros efectos sobre el sistema nervioso tras la exposición profesional a los POC. A simismo se han observado temblor de las extremidades y alteraciones electromiográficas (EM G ). En trabajadores que manipulan POC como BH C, policloropineno, hexaclorobutadieno y dicloroetano se han observado signos inespecíficos (p. ej., signos diencefálicos) que a menudo se presentan junto a otros típicos de la intoxicación crónica. Los signos más frecuentes de intoxicación son cefalea, vértigo, parestesias en las extremidades, cambios rápidos en la tensión arterial y otras alteraciones circulatorias. Con menos frecuencia, dolores cólicos bajo los arcos costales derechos y en la región umbilical, y discinesia de las vías biliares. También pueden aparecer alteraciones del comportamiento, como trastornos sensoriales y del equilibrio. Estos síntomas son a menudo reversibles una vez que cesa la exposición.

L os PO C causan lesiones hepáticas y renales. Se ha observado una inducción de las enzimas microsomales y un aumento de la actividad de ALF y aldolasa. También se alteran la síntesis de proteínas, la síntesis de lípidos, la destoxificación, la excreción y la función hepática. En trabajadores expuestos al pentaclorofenol se ha informado de una reducción del aclaramiento de creatinina y de la reabsorción de fósforo. El pentaclorofenol, junto con los miembros de la familia de los clorofenoles, se considera también un posible cancerígeno humano [grupo 2 B según la clasificación de la A gencia I nternacional para la Investigación sobre el Cáncer (IARC)]. El toxafeno se considera un cancerígeno del grupo 2B.

Se han observado alteraciones cardiovasculares en personas expuestas, generalmente manifestadas como disnea, taquicardia, opresión y dolor en la región cardíaca, aumento del volumen cardíaco y tonos cardíacos apagados.

También se han observado alteraciones hemáticas y capilares tras el contacto con POC, en forma de trombocitopenia, anemia, pancitopenia, agranulocitosis, hemólisis y alteraciones capilares. La aplasia medular puede llegar a ser completa. Las lesiones capilares (púrpura) se desarrollan al cabo de más 0 menos tiempo, pero siempre por exposiciones intensas. En trabajadores sometidos a exposiciones prolongadas se han observado eosinopenia, neutropenia con linfocitosis y anemia hipocrómica.

Se han producido casos de irritación cutánea después del contacto con algunos PO C, en particular los terpenos clorados. A menudo las intoxicaciones crónicas se hacen clínicamente evidentes por la aparición de cuadros alérgicos.

\section{Plaguicidas organofosforados}

Los plaguicidas organofosforados son ésteres químicamente relacionados del ácido fosfórico o algunos de sus derivados. Comparten la propiedad farmacológica de inhibir la acción de la enzima colinesterasa.

El paratión es uno de los organofosforados más tóxicos y se trata aquí con detalle. Aparte de sus efectos farmacológicos, ningún insecto es inmune a su acción letal. Sus propiedades físicas y químicas lo hacen útil como insecticida y acaricida para la agricultura. La descripción de su toxicidad es aplicable a otros organofosforados, aunque sus efectos puedan ser menos rápidos y extensos.

La acción tóxica de todos los plaguicidas organofosforados se ejerce sobre el SNC a través de la inhibición de la enzima colinesterasa, con la consiguiente estimulación excesiva y continua de los músculos y glándulas activados por la acetilcolina, hasta llegar a un punto incompatible con la vida. EI paratión es un inhibidor indirecto porque puede convertirse en el medio ambiente 0 in vivo antes de inhibir efectivamente la colinesterasa.

En general, los organofosforados pueden entrar en el organismo por cualquier vía. Si se ingiere una cantidad pequeña de paratión al comer o fumar, por ejemplo, existe el riesgo de una intoxicación grave e incluso mortal. Se puede inhalar asimismo al manipular, incluso brevemente, polvos o compuestos volátiles. Se absorbe además fácilmente a través de la piel y de los ojos. Su capacidad de penetrar en la piel en cantidades mortales sin producir la irritación hace que su manipulación sea especialmente difícil.

Los signos y síntomas de la intoxicación por organofosforados se pueden explicar sobre la base de la inhibición de la colinesterasa. La intoxicación inicial o leve puede ser difícil de distinguir debido a que otros cuadros, como el agotamiento por calor, la intoxicación alimentaria, la encefalitis, el asma y las infecciones respiratorias, comparten algunas de las manifestaciones y confunden el diagnóstico. Los síntomas pueden presentarse varias horas después de la última exposición, aunque casi nunca más tarde de 12 horas. Normalmente aparecen en este orden: cefalea, cansancio, mareos, náuseas, sudoración, visión borrosa, opresión torácica, espasmos abdominales, diarrea y vómitos. En una intoxicación más avanzada se observan después dificultad respiratoria, temblores, convulsiones, colapso, coma, edema pulmonar e insuficiencia respiratoria. Cuanto más avanzada esté la intoxicación, más evidentes serán los signos típicos de inhibición de la colinesterasa, a saber: miosis, respiración asmática rápida, debilidad acusada, sudoración excesiva, salivación excesiva y edema pulmonar.

En una intoxicación muy grave por paratión, en la que la víctima haya permanecido inconsciente durante algún tiempo, puede producirse lesión cerebral por anoxia. Tras una intoxicación aguda se han registrado cansancio, síntomas oculares, anomalías en el electroencefalograma, molestias gastrointestinales, sueños excesivos e intolerancia a la exposición a paratión. $\mathrm{N}$ o existen pruebas de que se produzcan lesiones permanentes.

La exposición crónica al paratión puede ser acumulativa, en el sentido de que exposiciones repetidas muy próximas pueden reducir la colinesterasa más rápidamente de lo que ésta puede regenerarse, hasta el punto de que una exposición muy pequeña precipite la intoxicación aguda. Si cesa la exposición, la recuperación clínica es a menudo rápida y completa en pocos días. Se debe realizar un análisis de la inhibición de la colinesterasa en hematíes y plasma cuando se sospeche una intoxicación con éster fosfato. En una intoxicación grave, la actividad de la colinesterasa de los hematíes está en la mayor parte de los casos reducida y próxima a cero. La colinesterasa plasmática también está muy reducida y es un indicador más sensible y rápido de exposición. No aporta ninguna ventaja la determinación química de paratión en sangre, debido a que el metabolismo del plaguicida es demasiado rápido. No obstante, el p-nitrofenol, un producto final del metabolismo del paratión, se puede determinar en orina. Se pueden realizar pruebas químicas para identificar el plaguicida en ropa contaminada u otro material con el que se sospeche que ha entrado en contacto.

\section{Carbamatos y tiocarbamatos}

La actividad biológica de los carbamatos se descubrió en 1923 , cuando se describió por primera vez la estructura del alcaloide eserina (o fisostigmina) contenido en las semillas del haba del Calabar. En 1929 se sintetizaron análogos de fisostigmina, y 
pronto se pudo disponer de derivados del ácido ditiocarbámico tales como tiram y ziram. El estudio de los compuestos carbámicos comenzó el mismo año, y ahora se conocen más de 1.000 derivados del ácido carbámico. De ellos, más de 50 se utilizan como plaguicidas, herbicidas, fungicidas y nematocidas. En 1947 se sintetizaron los primeros productos de esta clase dotados de propiedades insecticidas. Algunos tiocarbamatos han demostrado ser eficaces como aceleradores de la vulcanización, y se han utilizado derivados del ácido ditiocarbámico en el tratamiento de tumores malignos, hipoxia, neuropatías, heridas por radiación y otras enfermedades. También se utilizan como plaguicidas aril ésteres del ácido alquilcarbámico y alquil ésteres del ácido arilcarbámico.

Algunos carbamatos pueden producir una sensibilización en individuos expuestos; asimismo se han observado distintos efectos fetotóxicos, embriotóxicos y mutagénicos en miembros de la familia.

\section{E fectos crónicos}

Se han descrito efectos específicos derivados de la intoxicación aguda de cada una de las sustancias incluidas en la lista. U na revisión de estos efectos realizada a partir de los datos publicados permite distinguir ciertas características similares en la acción crónica de diferentes carbamatos. Algunos autores creen que el principal efecto tóxico de los ésteres del ácido carbámico es la afectación el sistema endocrino. U na de las peculiaridades de la intoxicación por los carbamatos es la posible reacción alérgica de los individuos expuestos. Los efectos tóxicos de los carbamatos pueden no ser inmediatos, lo que presenta un riesgo potencial debido a la falta de alarma. Los resultados de experimentos con animales indican efectos embriotóxicos, teratogénicos, mutagénicos y carcinogénicos de algunos productos.

El baygón (isopropoxifenil-N -metilcarbamato) se obtiene por la reacción de alquilisocianato con fenoles, y se utiliza como insecticida. Es un tóxico sistémico. Inhibe la actividad de la colinesterasa sérica hasta un $60 \%$ después de la administración oral de 0,75 a $1 \mathrm{mg} / \mathrm{kg}$. Esta sustancia altamente tóxica tiene un efecto muy débil sobre la piel.

El carbaril es un tóxico sistémico que produce efectos agudos moderadamente graves cuando se ingiere, inhala o absorbe a través de la piel. Puede provocar irritación cutánea local. Al ser un inhibidor de la colinesterasa, es mucho más activo en insectos que en mamíferos. L os reconocimientos médicos de trabajadores expuestos a concentraciones de 0,2 a $0,3 \mathrm{mg} / \mathrm{m}^{3}$ pocas veces revelan un descenso en la actividad de la colinesterasa.

El betanal (3-(metoxicarbonil) aminofenil-N-(3-metilfenil) carbamato; $\mathrm{N}$-metilcarbanilato) pertenece a los ésteres alquímicos del ácido arilcarbámico y se utiliza como herbicida. Es ligeramente tóxico para el aparato respiratorio y gastrointestinal. Su toxicidad dérmica y la irritación local son insignificantes.

El isoplan es un miembro muy tóxico del grupo; su acción, como la del sevin y otros, se caracteriza por la inhibición de la actividad de la acetilcolinesterasa. El isoplan se utiliza como insecticida. El pirimor (5,6-dimetil-2-dimetilamino-4-pirimidinil metilcarbamato) es un derivado de ésteres alquílicos del ácido arilcarbámico. Es muy tóxico para el tracto gastrointestinal. Su absorción general y el efecto irritante local no son muy pronunciados.

\section{Esteres del ácido tiocarbámico}

La ronita (sym -etilciclohexiletil tiocarbamato; Eurex); el eptam (sym -etil-N,N -dipropil tiocarbamato) y el tillam (sym -propil-N -etil-N -butiltiocarbamato) son ésteres sintetizados por reacción de alquiltiocarbamatos con aminas y de mercaptidas alcalinas con cloruros de carbamoílo. Son herbicidas efectivos de acción selectiva.

Los compuestos de este grupo son ligera a moderadamente tóxicos, y la toxicidad se reduce cuando se absorben a través de la piel. Pueden afectar el proceso oxidativo, así como los sistemas nervioso y endocrino.

Los ditiocarbamatos y bisditiocarbamatos comprenden los productos siguientes, que tienen mucho en común en lo que respecta a su uso y sus efectos biológicos. El ziram se utiliza como acelerador de la vulcanización para cauchos sintéticos y, en agricultura, como fungicida y fumigante de semillas. Es muy irritante de la conjuntiva y las mucosas de las vías respiratorias superiores. Puede provocar dolor ocular intenso, irritación de la piel y alteraciones de la función hepática. T iene efectos embriotóxicos y teratogénicos. EI T T D, que se utiliza como fumigante de semillas, irrita la piel, provoca dermatitis y afecta a la conjuntiva. Aumenta la sensibilidad al alcohol. El nobam es un fungicida y sirve de intermediario en la producción de otros plaguicidas. Es irritante de la piel y las mucosas, y tiene efecto narcótico a concentraciones elevadas. En presencia de alcohol puede provocar vómitos violentos. El ferbam es un fungicida de toxicidad relativamente baja, pero puede provocar alteraciones de la función renal. I rrita la conjuntiva, las mucosas nasales y las vías superiores. El zineb es un insecticida y fungicida que puede provocar irritación de los ojos, la nariz y la laringe, y que es nocivo si se inhala o ingiere. El maneb es un fungicida que puede causar irritación de los ojos, nariz y laringe, y nocivo si se inhala o ingiere. EI vapam (metilditiocarbamato sódico; carbatión) es un polvo blanco cristalino de olor desagradable, similar al del disulfuro de carbono. Es un fumigante eficaz del suelo que destruye las semillas de malas hierbas, hongos e insectos. Irrita la piel y las mucosas.

\section{Rodenticidas}

Los rodenticidas son compuestos químicos tóxicos utilizados para el control de ratas, ratones y otras especies de roedores. Un rodenticida eficaz debe cumplir unos criterios estrictos, lo que se confirma por el pequeño número de compuestos que se utilizan en la actualidad de forma satisfactoria.

L os cebos envenenados son los medios más efectivos y ampliamente utilizados de formulación de rodenticidas, pero algunos se utilizan como venenos de "contacto" (esto es, polvos, espumas y geles) en los que el tóxico se adhiere a la piel del animal y es ingerido durante el aseo ulterior, mientras que otros se aplican como fumigantes a madrigueras o locales infestados. Los rodenticidas se pueden dividir en dos categorías en función de su modo de acción: venenos agudos (dosis única) y venenos crónicos (dosis múltiple).

Los venenos agudos, como el fosfuro de zinc, la norbor mida, la fluoracetamida y la alfacloralosa, son compuestos muy tóxicos, con $D L_{50}$ habitualmente inferiores a $100 \mathrm{mg} / \mathrm{kg}$, y pueden provocar la muerte después de una dosis única consumida durante un período no superior a algunas horas.

La mayor parte de los rodenticidas agudos tienen los inconvenientes de producir síntomas de envenenamiento con gran rapidez, de ser generalmente inespecíficos y de carecer de antídotos satisfactorios. Se utilizan a concentraciones relativamente altas $(0,1$ al $10 \%)$ en cebos.

Los venenos crónicos, que pueden actuar, por ejemplo, como anticoagulantes (p. ej., calciferol), son compuestos que, debido a su modo de acción acumulativo, han de ser ingeridos por el animal durante varios días seguidos para que se produzca la muerte. Los anticoagulantes tienen la ventaja de producir los síntomas de envenenamiento muy tarde, normalmente mucho después de que la especie de destino haya ingerido una dosis letal. Para los animales expuestos accidentalmente se dispone de 
un antídoto efectivo. Los venenos crónicos se utilizan a concentraciones relativamente bajas $(0,002$ al 0,1 \%).

\section{Aplicaciones}

Los rodenticidas previstos para su uso en cebos están disponibles en una o más de las formas siguientes: como material de clase técnica o como cebo listo para su uso. Los venenos agudos se adquieren habitualmente como material de clase técnica y se mezclan con la base del cebo poco antes de su uso. Los venenos crónicos, debido a su uso a bajas concentraciones, se venden normalmente como concentrados en los que el principio activo se incorpora a una base de harina (o talco) finamente pulverizada.

Cuando el cebo final está preparado, se añade el concentrado a la base del cebo en la concentración correspondiente. Si la base del cebo tiene una consistencia rugosa, puede ser necesario añadir un aceite vegetal o mineral a la concentración prescrita para que actúe como "adhesivo". Normalmente es obligatorio añadir un colorante de advertencia a los concentrados o cebos listos para usar.

En tratamientos de control contra ratas y ratones, los cebos envenenados se dejan a intervalos frecuentes en todo el área infestada. Si se utilizan rodenticidas agudos, se obtienen mejores resultados cuando se deja el cebo no envenenado ("precebo") durante algunos días antes de administrar el veneno. En tratamientos "agudos" se ofrece cebo envenenado solamente durante algunos días. Cuando se utilizan anticoagulantes es innecesario el uso de precebos, pero el veneno debe mantenerse durante 3 a 6 semanas para completar el control.

Las formulaciones de contacto de los rodenticidas son especialmente útiles cuando por alguna razón la presentación de cebos es difícil, o cuando los roedores no cambian satisfactoriamente su dieta normal. El veneno suele incorporarse a un polvo finamente dividido (p. ej., talco) que se deja en los accesos y alrededor del cebo, o se espolvorea en madrigueras, huecos de los muros, etc. Los compuestos se pueden formular también en geles o espumas que se insertan en las madrigueras.

En los rodenticidas de contacto, el efecto se produce cuando el animal ingiere el veneno al asearse. Dado que la cantidad de polvo (o espuma, etc.) que se adhiere a la piel puede ser pequeña, la concentración del principio activo en la formulación suele ser relativamente elevada, lo que hace que su uso sólo sea seguro si no se pueden contaminar alimentos, etc. O tras formulaciones especializadas de rodenticidas comprenden cebos de agua o bloques impregnados de cera. Las primeras, que son soluciones acuosas de compuestos solubles, son especialmente útiles en ambientes secos. L as últimas se preparan impregnando el tóxico y la base del cebo en cera de parafina fundida (con bajo punto de fusión) y vaciando la mezcla en bloques. Los cebos impregnados de cera están diseñados para resistir climas húmedos y ataques de insectos.

\section{Riesgos de los rodenticidas}

Aunque los niveles de toxicidad de los rodenticidas pueden variar entre las especies de destino y otras especies, se debe considerar que todos los venenos son potencialmente letales para el ser humano. Los venenos agudos son potencialmente más peligrosos que los crónicos debido a su rapidez de acción, a su carácter inespecífico y a que, en general, no se cuenta con antídotos efectivos. En cambio, los anticoagulantes producen su acción de forma lenta y acumulativa, por lo que dan tiempo para la administración de un antídoto fiable, como la vitamina $\mathrm{K}$.

Como ya se ha indicado, las concentraciones de principios activos en las formulaciones de contacto son mayores que en los preparados para cebos, por lo cual el riesgo del manipulador es considerablemente mayor. Los fumigantes presentan un riesgo especial cuando se utilizan para tratar locales infestados, bodegas de barcos, etc., y han de ser utilizados solamente por técnicos cualificados. El gaseamiento de las madrigueras de roedores, aunque menos peligroso, debe realizarse también con mucho cuidado.

\section{Herbicidas}

Las malezas y las hierbas compiten con las plantas cultivadas por la luz, el espacio, el agua y los nutrientes. Son hospedadores de bacterias, hongos y virus, y obstaculizan las operaciones de cosechado mecánico. Las pérdidas en los rendimientos de las cosechas como resultado de la infestación por malas hierbas pueden ser muy altas, alcanzando normalmente del 20 al $40 \%$. L as medidas de control de malezas tales como el desherbado y la escardadura manuales no son eficaces en la agricultura intensiva. Los herbicidas han sustituido con éxito a los métodos mecánicos de control de malezas.

Además de su uso en la agricultura de cereales, praderas, campos al aire libre, pastizales, fruticultura, invernaderos y silvicultura, los herbicidas se aplican en zonas industriales, vías de ferrocarril y tendidos eléctricos para eliminar la vegetación. Se utilizan para destruir las malezas de canales, canales de drenaje y estanques naturales y artificiales.

L os herbicidas se pulverizan o espolvorean sobre las malezas 0 sobre el suelo que éstas infestan. Permanecen en las hojas (herbicidas de contacto) o penetran en la planta y de esta forma alteran su fisiología (herbicidas sistémicos). Se clasifican en no selectivos (totales, utilizados para matar toda la vegetación) y selectivos (utilizados para suprimir el crecimiento de malezas 0 matarlas, sin dañar los cultivos). Tanto unos como otros pueden ser de contacto o sistémicos.

La selectividad es verdadera cuando el herbicida, aplicado a la dosis correcta y en el momento adecuado, es activo solamente frente a ciertas especies vegetales. Un ejemplo de herbicidas realmente selectivos son los compuestos clorofenoxi, que eliminan la maleza pero no las hierbas. La selectividad se puede conseguir también por la aplicación ( $p$. ej., utilizando el herbicida de forma que entra en contacto solamente con las malezas). Por ejemplo, el paraquat se aplica a cultivos de huerta, en los que es fácil evitar el follaje. Se distinguen tres tipos de selectividad:

1. selectividad fisiológica, basada en la capacidad de la planta para degradar el herbicida en componentes no fitotóxicos;

2. selectividad física, que aprovecha un hábito concreto de la planta cultivada (p. ej., la verticalidad de los cereales) o una superficie de características específicas ( $p$. ej., cubierta de cera, cutícula resistente) para proteger a la planta de la penetración del herbicida,

3. selectividad posicional, en la que el herbicida se fija en las capas superiores del suelo, adsorbido en partículas del suelo coloidales, y no alcanza la zona de la raíz de la planta cultivada, 0 al menos no en cantidades peligrosas. La selectividad posicional depende del suelo, de las precipitaciones y de la temperatura, así como de la solubilidad en agua y la adsorción en el suelo del herbicida.

\section{Algunos herbicidas utilizados habitualmente}

A continuación se describen brevemente los efectos agudos y crónicos asociados a algunos herbicidas utilizados habitualmente.

L a atrazina disminuye el peso corporal, produce anemia y alteración del metabolismo de las proteínas y de la glucosa en ratas. Produce dermatitis de contacto ocupacional por sensibilización cutánea. Se considera un posible cancerígeno humano (IARC grupo 2B). 
El barban, en contacto repetido en forma de una emulsión de agua al $5 \%$, causa irritación cutánea grave en conejos. Produce sensibilización cutánea en animales experimentales y en trabajadores agrícolas, y causa anemia, metahemoglobinemia y cambios en el metabolismo lipídico y proteico. En animales de experimentación se han observado ataxia, temblores, espasmos, bradicardia y alteraciones del EEG.

EI clorprofarm puede producir irritación y penetración cutánea ligeras. En ratas, la exposición a atrazina causa anemia, metahemoglobinemia y reticulocitosis. La aplicación crónica provoca carcinoma cutáneo en ratas.

El cicloato produce polineuropatía y lesiones hepáticas en animales de experimentación. No se han descrito síntomas clínicos después de la exposición ocupacional de los trabajadores durante tres días consecutivos.

EI 2,4-D posee una toxicidad dérmica moderada y riesgo de irritación cutánea en las personas expuestas. Es muy irritante para los ojos. Las exposiciones agudas de los trabajadores provocan cefalea, mareos, náuseas, vómitos, hipertermia, hipotensión, leucocitosis y lesiones cardíacas y hepáticas. La exposición ocupacional crónica sin protección puede causar náuseas, alteraciones de la función hepática, dermatitis tóxica de contacto, irritación de las vías respiratorias y de los ojos, así como cambios neurológicos. Algunos de los derivados del 2,4-D son embriotóxicos y teratogénicos en animales de experimentación solamente a dosis elevadas.

EI 2,4-D y el herbicida fenoxi derivado 2,4,5-T están clasificados como cancerígenos del grupo 2B (posibles cancerígenos humanos) por la IARC. En trabajadores agrícolas suecos se ha asociado la aparición de cánceres linfáticos, en particular el linfoma no H odgkin ( $\mathrm{LNH}$ ), a exposiciones a una mezcla comercial de 2,4-D y 2,4,5-T (similar al herbicida Agente Naranja utilizado por el ejército de Estados U nidos en Vietnam durante los años 1965 a 1971). A menudo la posible carcinogenicidad se atribuye a la contaminación de 2,4,5-T con 2,3,7,8-tetraclorodibenzo-p-dioxina. No obstante, el grupo de investigación del $\mathrm{N}$ ational $\mathrm{C}$ ancer Institute de Estados U nidos señaló un riesgo de 2,6 de LNH del adulto entre los residentes de $K$ ansas expuestos solamente a 2,4-D, que no se considera contaminado con dioxinas.

EI dalapon- $\mathrm{N}$ a puede causar depresión, alteraciones del equilibrio, pérdida de peso corporal, alteraciones hepáticas y renales, disfunción tiroidea e hipofisaria y dermatitis de contacto en trabajadores expuestos. El dialate tiene toxicidad dérmica y causa irritación de la piel, ojos y mucosas. El diquat es irritante de la piel, los ojos y el tracto respiratorio superior. Puede causar retraso de la cicatrización de heridas y cortes, alteraciones gastrointestinales y respiratorias, catarata bilateral y alteraciones funcionales hepáticas y renales

El dinoseb es peligroso debido a su toxicidad por contacto dérmico. Puede causar irritación moderada de la piel e intensa de los ojos. La dosis mortal para el ser humano es de aproximadamente 1 a $3 \mathrm{~g}$. Tras una exposición aguda, el dinoseb produce alteraciones del sistema nervioso central, vómitos, eritema cutáneo, sudoración e hipertermina. La exposición crónica sin protección causa pérdida de peso, dermatitis de contacto (tóxica 0 alérgica) y alteraciones gastrointestinales, hepáticas y renales. El dinoseb no se utiliza en muchos países debido a sus efectos adversos graves.

El fluometurón es un sensibilizante moderado de la piel en cobayas y seres humanos. Se ha observado que produce pérdida de peso corporal, anemia y alteraciones hepáticas, esplénicas y de la glándula tiroides. La acción biológica de diurón es similar.

El linurón provoca irritación leve de piel y ojos, y tiene una toxicidad acumulativa baja (valor umbral después de inhalación única $29 \mathrm{mg} / \mathrm{m}^{3}$ ). Induce cambios en el SNC, hígado, pulmón y riñón en animales de experimentación, así como disfunción tiroidea.

EI M CPA es altamente irritante de la piel y las membranas mucosas, tiene una baja toxicidad acumulativa y es embriotóxico y teratogénico a dosis altas en conejos y ratas. La intoxicación aguda de seres humanos (una dosis estimada de $300 \mathrm{mg} / \mathrm{kg}$ ) causa vómitos, diarrea, cianosis, sensación de quemazón en las mucosas, espasmos clónicos y lesiones hepáticas y del miocardio, así como dermatitis de contacto tóxica grave en trabajadores. La exposición crónica sin protección causa mareos, náuseas, vómitos, dolores de estómago, hipotonia, hepatomegalia, alteraciones miocárdicas y dermatitis de contacto.

E I molinate puede alcanzar una concentración tóxica después de la inhalación de $200 \mathrm{mg} / \mathrm{m}^{3}$ en ratas. Causa alteraciones hepáticas, renales y tiroideas, y es gonadotóxico y teratogénico en ratas. Es un moderado sensibilizante cutáneo en seres humanos.

EI monurón a dosis elevadas puede producir alteraciones hepáticas, miocárdicas y renales. Causa irritación de la piel y sensibilización. El monolinurón, cloroxurón, clortolurón y dodina presentan los mismos efectos.

EI nitrofen es un fuerte irritante de la piel y los ojos. La exposición crónica ocupacional sin protección causa alteraciones en el SNC, anemia, hipertermia, pérdida de peso, cansancio y dermatitis de contacto. Es considerado un posible cancerígeno humano por la IARC (grupo 2B).

El paraquat presenta toxicidad dérmica y efectos irritantes sobre la piel y las mucosas. Causa lesiones en las uñas y epistaxis cuando se trabaja sin protección. Los casos de intoxicación oral accidental con paraquat suelen producirse al dejar el producto al alcance de los niños o trasvasarlo desde el envase original a una botella de bebidas vacía. Las manifestaciones precoces de la intoxicación son las de los efectos corrosivos gastrointestinales, lesiones a nivel de los túbulos renales y alteraciones de la función hepática. La muerte se produce por colapso circulatorio y lesiones pulmonares progresivas (edema y hemorragia pulmonar, fibrosis intraalveolar 0 intersticial con alveolitis y membranas hialinas). Todo esto desde el punto de vista clínico se traduce en disnea, hipoxemia, estertores basales, evidencia radiológica de infiltración y atelectasias. La insuficiencia renal va seguida de lesión pulmonar, acompañada en algunos casos de alteraciones hepáticas y miocárdicas. L a mortalidad es alta cuando la intoxicación se ha producido por preparados líquidos concentrados $(87,8 \%)$ y menor si se produce con formas granulares $(18,5 \%)$. La dosis mortal es de $6 \mathrm{~g}$ de ion paraquat (equivalente a $30 \mathrm{ml}$ de Gramoxone 0 cuatro saquitos de W edol), y con dosis mayores no ha habido supervivientes, con independencia del tiempo o de la intensidad del tratamiento. La mayor parte de los supervivientes habían tomado dosis inferiores a $1 \mathrm{~g}$ de ion paraquat.

El cianato potásico está asociado a una elevada toxicidad por inhalación y dérmica en animales de experimentación y en seres humanos debido a la conversión metabólica a cianuro; esto se tratará en otro punto de esta E nciclopedia.

La prometrina presenta toxicidad dérmica moderada e irritación cutánea y ocular. Causa una disminución de la coagulación y alteraciones enzimáticas en animales, y se ha observado que es embriotóxico en ratas. Los trabajadores expuestos pueden presentar náuseas y sequedad de boca. Con la propazina y la desmetrina se observan efectos análogos.

La toxicidad del propaclor es doble a temperaturas ambiente elevadas. La exposición a esta sustancia se asocia a irritación cutánea y de las membranas mucosas y a alergia cutánea leve. La concentración tóxica tras una inhalación única es de $18 \mathrm{mg} / \mathrm{m}^{3}$ en ratas, y se cree que presenta toxicidad acumulativa moderada. El propaclor causa polineuropatías; alteraciones 
hepáticas, miocárdicas y renales, anemia y lesiones testiculares en ratas. Durante las operaciones de pulverización desde el aire, la concentración en la cabina del avión es de aproximadamente $0,2-0,6 \mathrm{mg} / \mathrm{m}^{3}$. El propanil posee una toxicidad similar.

El profam presenta una toxicidad acumulativa moderada. Causa alteraciones hemodinámicas, y en animales de experimentación se han observado trastornos hepáticos, pulmonares y renales.

El simazine causa una irritación leve de la piel y las mucosas. Es un sensibilizante cutáneo moderado en cobayas. También provoca alteraciones del SNC, del hígado y de los riñones, y tiene acción mutágena en animales de experimentación. L os trabajadores pueden quejarse de cansancio, mareos, náuseas y alteraciones del olfato si trabajan en áreas de aplicación sin la debida protección.

El 2,4,5-T produce una irritación pronunciada y efectos embriotóxicos, teratogénicos y carcinogénicos en animales; también se dispone de datos de su acción gonadotóxica en mujeres. Dado que la dioxina extremadamente tóxica puede ser un contaminante de los triclorofenoxiácidos, el uso de 2,4,5-T se ha prohibido en muchos países. Entre trabajadores de la agricultura, la silvicultura y la industria se ha informado de un aumento del riesgo de sarcomas de tejidos blandos y de linfomas no H odgkin.

El trifluralin produce irritación ligera de la piel y mucosas. En hembras híbridas de ratón se ha comprobado un incremento de la incidencia de carcinoma hepático, probablemente a causa de la contaminación con compuestos $\mathrm{N}$-nitroso. El trifuralin causa anemia y alteraciones hepáticas, miocárdicas y renales en los animales de experimentación. Los trabajadores que sufrieron exposiciones intensas a esta sustancia desarrollaron dermatitis de contacto y fotodermatitis.

\section{Fungicidas}

Algunos hongos, como los añublos, mildius, mohos, tiznes, royas de almacenes y royas de la simiente pueden infectar y producir enfermedades en las plantas, los animales y el hombre. 0 tros pueden atacar y destruir materiales no vivos, como la madera y los productos de fibra. Los fungicidas se utilizan para prevenir estas enfermedades y se aplican mediante rociado, pulverización, revestido de la simiente, esterilización de los brotes y el suelo y fumigación de invernaderos y almacenes

L os hongos que provocan enfermedades de las plantas pueden dividirse en cuatro subgrupos que se diferencian por las características microscópicas del micelio, las esporas y los órganos en los que se desarrollan las esporas:

1. Ficomicetes: organismos en suelo que ocasionan el garrote de las crucíferas, las verrugas de las patatas, etc.;

2. Ascomicetes: hongos y mildius pulvurulentos formadores de peritecios que ocasionan la costra de la manzana, la mancha de la hoja de la grosella negra y la mancha negra de la rosa;

3. basidiomicetes, que incluyen el tizne del trigo y la cebada, y varias especies de añublos

4. hongos imperfectos, que incluye los géneros Aspergillus, Fusarium, Penicillium y otros, de gran importancia económica, ya que producen grandes pérdidas por plagas durante el desarrollo de la planta, la recolección y después de ésta (p. ej., las especies de F usarium infectan la cebada, la avena y el trigo; las especies de Penicillium ocasionan la roya marrón de las frutas pomáceas).

Los fungicidas se han utilizado durante siglos. Los primeros utilizados fueron los compuestos de cobre y azufre, y la aplicación del caldo bordolés a los viñedos data de 1885. Actualmente se utiliza en muchos países un gran número de compuestos químicos con actividad fungicida.
Según su modo de acción, los fungicidas pueden clasificarse en dos grupos: fungicidas protectores, aplicados antes de la llegada de las esporas de los hongos, como los compuestos de azufre y cobre, y fungicidas erradicadores, que se aplican una vez que la planta ha sido infectada, como los compuestos de mercurio y derivados nitrogenados de fenoles. Los fungicidas pueden actuar sobre la superficie de plantas y semillas, o penetrar en la planta y ejercer su acción tóxica directamente sobre el hongo (fungicidas sistémicos). También pueden alterar los procesos fisiológicos y bioquímicos de la planta, produciendo así una inmunización química artificial. Ejemplos de este grupo son los antibióticos y las rodananilidas.

Los fungicidas aplicados a las semillas actúan fundamentalmente contra las esporas presentes en la superficie. Sin embargo, en algunos casos es preciso que se mantengan en la cubierta de la semilla el tiempo suficiente para actuar sobre el micelio durmiente contenido en el interior de la semilla. Si se aplica a la simiente antes de la siembra, el fungicida recibe el nombre de desinfectante de semillas o fungicida para el revestimiento de semillas, aunque este último término puede incluir tratamientos no dirigidos contra los hongos de las semillas o de las plagas. Para proteger la madera, el papel, el cuero y otros materiales, los fungicidas se utilizan mediante impregnación o tinción. También se emplean fármacos especiales con acción fungicida en el control de las enfermedades por hongos en seres humanos y animales.

Algunos modos específicos de aplicación son:

- R evestimiento de semillas. Este es un método sencillo y barato de control de las enfermedades de las plantas. Las plagas se destruyen en las semillas y en el suelo durante el desarrollo de la simiente. A pesar de la disponibilidad de compuestos alternativos eficaces, los fungicidas mercúricos aún se emplean en gran medida con este fin. Los ditiocarbamatos, en particular el tiuram, son muy utilizados. También se emplean para el revestimiento de semillas el cloranilo y la diclona, del grupo de las quinonas, el hexaclorofeno, el formaldehído y algunos antibióticos. El tratamiento de las semillas puede realizarse por el método seco o el método húmedo.

- Desinfección del sudo. Esta es una acción más general, ejercida por fungicidas que se incorporan al suelo en fórmulas líquidas o sólidas que liberan compuestos volátiles o fácilmente solubles, por ejemplo cloropicrina, bromuro de metilo, dibromometano, formaldehído, vapam, dazomet, alcohol alílico, pentacloronitrobenceno y cloroneb. Estos fungicidas se utilizan especialmente en el suelo de invernaderos. Algunos de ellos son cancerígenos probables o conocidos.

- Aplicación sobre las plantas. En este caso los fungicidas se aplican a los cultivos anuales, frutales y bayas con el fin de controlar las enfermedades de transmisión aérea. Prácticamente todos los grupos de fungicidas se aplican con este fin. L os más frecuentes son los compuestos de cobre, los ditiocarbamatos, los derivados nitrogenados aromáticos, las quinonas, las ftalimidas, las guanidinas y los hidrocarburos clorados, así como algunos compuestos heterocíclicos y de níquel y ciertos antibióticos.

\section{Riesgos de los fungicidas}

Los fungicidas abarcan una amplia gama de compuestos químicos, muy diferentes en cuanto a su toxicidad. Se utilizan algunos compuestos altamente tóxicos como fungicidas de alimentos y almacenes, para el revestimiento de semillas y para la desinfección del suelo, y se han descrito casos de intoxicación por organomercuriales, hexaclorobenceno y pentaclorobenceno, así como por los ditiocarbamatos poco tóxicos. Estos y otros compuestos químicos se tratan con más detalle en otros puntos de 
este artículo, de este capítulo y de la Enciclopedia. Algunos se revisan a continuación brevemente.

El quinometionato tiene una gran toxicidad acumulativa e inhibe los grupos tiol y algunas enzimas que los contienen, reduce la actividad fagocítica y ejerce efectos antiespermatogénicos. Es irritante de la piel y del sistema respiratorio. Puede causar lesiones del SNC, hígado y tracto gastrointestinal. El glutation y la cisteína protegen frente a los efectos agudos del quinometionato.

El cloranil es irritante de la piel y del tracto respiratorio superior; también puede causar depresión del SNC y alteraciones distróficas en hígado y riñón. La monitorización biológica de las personas expuestas ha demostrado un aumento de los niveles urinarios de fenoles, tanto libres como ligados.

El dazomet se utiliza también como nematocida y contra las babosas. Este compuesto y sus productos de descomposición son sensibilizantes e irritantes leves oculares, nasales, orales y cutáneos. La intoxicación se caracteriza por diversos síntomas, como ansiedad, taquicardia y taquipnea, sialorrea, convulsiones clónicas, trastornos de la coordinación motora, hiperglucemia ocasional e inhibición de la colinesterasa. Los principales hallazgos anatomopatológicos son la hepatomegalia y las alteraciones degenerativas del riñón y otros órganos internos.

El diclofluanid inhibe los grupos tiol. En animales de experimentación origina alteraciones histológicas en el hígado, túbulos proximales del riñón y la corteza suprarrenal, con disminución del tejido linfático esplénico. Es un irritante moderado de la piel y las mucosas.

La diclona, además de compartir las propiedades irritantes y hemosupresoras comunes a las quinonas, es cancerígena en animales de experimentación.

El dinobuton, como el dinitro-o -cresol (D N O C), altera el metabolismo celular inhibiendo la fosforilación oxidativa, con la consiguiente pérdida de compuestos de gran valor energético, como el ácido adenosintrifosfórico (ATP). Puede ocasionar distrofia hepática grave y necrosis de los túbulos contorneados renales. Las manifestaciones clínicas de la intoxicación son fiebre, metahemoglobinemia y hemólisis, alteraciones nerviosas e irritación de la piel y mucosas.

El dinocap puede aumentar los niveles de fosfatasa alcalina en sangre; es un irritante moderado de la piel y las mucosas y produce alteraciones distróficas del hígado y riñón e hipertrofia miocárdica. En la intoxicación aguda se han observado alteraciones de la termorregulación, convulsiones clónicas y dificultad respiratoria.

El hexaclorobenzeno (HCB) se acumula en la grasa corporal. Interfiere con el metabolismo de las porfirinas, aumentando la excreción urinaria de coproporfirinas y uroporfirinas; asimismo aumenta los niveles de transaminasas y deshidrogenasas en sangre. Puede ocasionar daño hepático (hepatomegalia y cirrosis), fotosensibilidad cutánea, una profiria semejante a la porfiria cutánea tarda, artritis e hirsutismo (enfermedad del mono). Es un irritante cutáneo. La intoxicación crónica requiere un tratamiento prolongado, fundamentalmente sintomático, y no siempre revierte al cesar la exposición. Está clasificado como posible cancerígeno humano (grupo 2B) por la IARC.

EI milneb puede causar trastornos gastrointestinales, debilidad, descenso de la temperatura corporal y leucopenia.

EI nirit posee propiedades hemotóxicas y produce anemia y leucocitosis, con granulaciones tóxicas de los leucocitos, además de alteraciones degenerativas hepáticas, esplénicas y renales.

Las quinonas, en general, causan trastornos hemáticos (metahemoglobinemia, anemia), afectan al hígado, alteran el metabolismo de las vitaminas, en particular el del ácido ascórbico, y son irritantes de las vías respiratorias y los ojos. E I cloranil y la diclona son los derivados de quinonas más utilizados como fungicidas.
El tiabendazol causa involución tímica, depleción coloide en el tiroides y aumento del tamaño del hígado y del riñón. También se utiliza como antihelmíntico en el ganado vacuno.

\section{Medidas de salud y seguridad}

\section{E tiquetado y almacenamiento}

Los requisitos de etiquetado de los plaguicidas establecidos en la legislación nacional e internacional son de aplicación obligada tanto para los productos químicos importados como para los nacionales. La etiqueta debe contener la información esencial siguiente: nombre aprobado y nombre comercial del producto; nombre del fabricante, envasador o proveedor; instrucciones de uso; precauciones a adoptar durante su uso, incluyendo detalles del equipo protector necesario; síntomas de intoxicación y tratamiento de primeros auxilios para casos en que se sospeche el envenenamiento.

Cuanto más elevado sea el grado de toxicidad o riesgo del producto, más precisas deben ser las instrucciones de la etiqueta. Resulta práctico distinguir claramente los distintos grados de toxicidad mediante colores de fondo de la etiqueta y, en el caso de compuestos extremada o altamente peligrosos, incorporar el símbolo de peligro apropiado. A menudo, una cantidad adecuadamente etiquetada de plaguicida a granel se envasa localmente en recipientes más pequeños. Cada uno de éstos ha de llevar en tal caso una etiqueta similar y debe prohibirse el reenvasado en recipientes que hayan contenido productos alimenticios o que puedan confundirse fácilmente con recipientes de productos alimenticios. En el transporte de estos pequeños envases deben aplicarse las mismas normas que para el transporte de los grandes. (V éase el capítulo U tilización, almacenamiento y transporte de productos químicos).

L os plaguicidas de riesgo moderado o elevado deben almacenarse de tal forma que sólo tengan acceso a ellos personas autorizadas. En especial, hay que evitar cualquier contacto de los niños con concentrados o residuos de plaguicidas. A menudo se producen derrames en las salas de almacenamiento o reenvasado, y deben ser limpiados con cuidado. Las salas de almacenamiento deben estar sólidamente construidas y provistas de buenas cerraduras. Los suelos deben mantenerse limpios y los plaguicidas claramente identificados. Si se lleva a cabo en ellas el reenvasado, debe disponerse de iluminación y ventilación adecuadas; los suelos deben ser impermeables y sólidos; debe haber instalaciones de lavado y ha de prohibirse comer, beber y fumar en la zona.

A lgunos compuestos reaccionan con otros productos químicos o con el aire; esta circunstancia debe tenerse en cuenta cuando se planifican las instalaciones de almacenamiento. Algunos ejemplos son las sales de cianuro (que reaccionan con ácido para producir gas cianhídrico) y el diclorvos (que se vaporiza en contacto con el aire). (EI diclorvos está clasificado como posible cancerígeno humano del grupo 2B por la IARC).

\section{Mezcla y aplicación}

La mezcla y la aplicación pueden constituir las fases más peligrosas del uso de los plaguicidas, ya que es en ellas cuando el trabajador está expuesto al concentrado. La mezcla debe reservarse, por tanto, a determinadas personas que conozcan a fondo los riesgos y dispongan de todo lo necesario para hacer frente a una contaminación accidental. Incluso cuando la mezcla presenta una toxicidad tal que permita su utilización con un reducido equipo de protección individual (EPI), el personal ocupado de la mezcla debe disponer de un equipo más completo y utilizarlo.

$C$ on los plaguicidas de riesgo moderado o elevado casi siempre se requiere algún tipo de equipo de protección. La elección de los elementos concretos del equipo dependerá de la toxicidad del 
plaguicida y de la forma en que se manipule. Además de este equipo de protección habrá que contar con instrucciones para su limpieza, mantenimiento y renovación adecuados.

Allí donde las condiciones climáticas impidan el uso de algunos tipos de equipo de protección pueden aplicarse otros posibles métodos: la protección a través de la distancia, la protección por efecto del tiempo y la protección mediante el cambio del método de trabajo. La protección a través de la distancia implica la modificación del equipo utilizado para la aplicación, de forma que la persona esté lo más lejos posible del plaguicida, teniendo en cuenta las posibles rutas de absorción de un compuesto específico.

La protección por efecto del tiempo implica la limitación de las horas de trabajo. La idoneidad de este método depende de que el plaguicida se elimine rápidamente o sea acumulativo. Se produce acumulación de algunos compuestos en el cuerpo cuando la velocidad de excreción es más lenta que la de absorción. Con otros compuestos puede darse una acumulación del efecto cuando la persona está expuesta a dosis pequeñas repetidas, que individualmente no producen síntomas.

La protección mediante el cambio del método de trabajo implica una reconsideración de toda la operación. Los plaguicidas difieren de otros compuestos en que pueden ser aplicados desde la tierra o desde el aire. En la aplicación desde la tierra, los cambios de método dependen en gran parte de la elección del equipo y de la naturaleza física del producto a aplicar.

Los plaguicidas aplicados desde el aire pueden estar formulados como líquidos, polvos o gránulos. Los líquidos se pueden rociar desde altitudes muy bajas, frecuentemente en forma de gotas finas de formulaciones concentradas, conocidas como aplicaciones de volumen ultrabajo (VUB). La desviación por el viento constituye un problema, especialmente, en el caso de los líquidos y los polvos. La aplicación aérea es en general adecuada para tratar grandes extensiones, pero implica riesgos especiales para los pilotos y los trabajadores de tierra. Los pilotos pueden resultar afectados por el derrame de las tolvas, por la penetración de plaguicida en la cabina y por el vuelo sobre la franja recientemente tratada a través de la corriente formada. Incluso grados menores de absorción de algunos plaguicidas o sus efectos locales, como los que causa, por ejemplo, un compuesto organofosforado en el ojo, pueden afectar a un piloto hasta impedirle mantener el grado de vigilancia necesaria para volar bajo. No debe permitirse a los pilotos intervenir en estas operaciones de aplicación de plaguicidas a menos que hayan sido especialmente entrenados en los aspectos antes mencionados, aparte de los específicamente referidos al vuelo.

En tierra pueden resultar afectados los cargadores y los señalizadores. A los primeros se aplican los mismos principios que al resto de personas que manipulan plaguicidas a granel. Los señalizadores marcan la franja de terreno a rociar y pueden resultar seriamente contaminados si el piloto calcula mal el momento del rociado. Pueden colocarse globos 0 banderas por delante 0 enfrente, sin que los propios trabajadores deban actuar como señalizadores dentro del plan de vuelo.

\section{0 tras restricciones}

Los riesgos de los plaguicidas no terminan con su aplicación. En el caso de los compuestos más tóxicos, existe un peligro real para los trabajadores que penetran demasiado pronto en la zona tratada. Por consiguiente, es importante que tanto ellos como el público en general sean informados de las zonas tratadas con plaguicidas tóxicos y de las fechas en que se puede entrar en ellas. Es importante además proceder a la recolección de los cultivos una vez que haya transcurrido un período suficiente para que se haya degradado el plaguicida, a fin de evitar la presencia de residuos excesivos en los alimentos.
E liminación deplaguicidas y envases. L os derrames de plaguicidas en cualquier etapa de su almacenamiento o manipulación deben tratarse con sumo cuidado. L os preparados líquidos pueden reducirse a sólidos por evaporación. El barrido en seco de productos sólidos siempre es peligroso, por lo que ha de procederse a eliminarlospor aspiración o disolviéndolos con agua u otros disolventes. En el campo, los productos se han de eliminar con agua a través de un sumidero adecuado. Cuando en la zona haya animales domésticoso aves de corral, la capa de suelo más superficial contaminada debe ser retirada y enterrada. $\mathrm{H}$ an de utilizarse sumideros para la eliminación de las aguas contaminadas procedentes de la limpieza de los equipos de aplicación, la ropa o las manos. Estos sumideros deben tener una profundidad mínima de $30 \mathrm{~cm}$ y estar convenientemente separados de los pozos y cauces de agua.

Los envases de plaguicidas vacíos deben recogerse con cuidado o eliminarse de forma segura. Las envolturas de plástico y los envases de papel o de cartón se triturarán y se enterrarán profundamente, o bien se procederá a quemarlos en un incinerador. Los envases metálicos de algunos plaguicidas pueden descontaminarse siguiendo las instrucciones del fabricante. Deben señalizarse claramente con el aviso: "No utilizar para alimentos ni para agua de bebida, ni para uso doméstico".

\section{Higiene y primeros auxilios}

Los plaguicidas con un riesgo moderado o elevado que pueden ser absorbidos rápidamente por la piel, obligan a tomar precauciones especiales. Allí donde los trabajadores puedan resultar accidentalmente contaminados con grandes cantidades de concentrado, como en las fábricas o en los centros de mezclado, hay que instalar duchas, aparte de los lavabos habituales. D eben adoptarse las medidas necesarias para lavar las ropas y monos de trabajo; en todo caso, no debe permitirse que el trabajador los lave en su casa.

Dado que los plaguicidas se aplican normalmente fuera de la fábrica, debe disponerse de instalaciones de lavado en el lugar de trabajo, aun cuando éste se encuentre en campos alejados. Los trabajadores no han de lavarse en canales ni ríos, cuyas aguas podrán utilizarse con otros fines; el agua de los lavabos debe eliminarse según lo indicado más arriba. Debe prohibirse terminantemente fumar, comer y beber antes de lavarse cuando se manipulen 0 usen plaguicidas de toxicidad moderada 0 elevada.

Cuando exista un antídoto que pueda utilizarse rápidamente como medida de primeros auxilios para un plaguicida específico (como la atropina para la intoxicación con organofosforados), ha de ponerse al alcance de los trabajadores e instruir a éstos sobre el método de empleo. Cuando se utilice un plaguicida a gran escala, las personas responsables de su distribución han de informar al personal sanitario de la región. D ebe definirse bien la naturaleza del producto utilizado, a fin de que los médicos puedan disponer de antídotos específicos y saber dónde son aplicables y cómo reconocer los casos de intoxicación, aparte de disponer de los medios necesarios para realizar un diagnóstico diferencial adecuado, incluso del tipo más sencillo, como papeles reactivos para determinar los niveles de colinesterasa. Es esencial una rigurosa supervisión médica rutinaria de los trabajadores altamente expuestos a concentrados, como en la fabricación y envasado de los plaguicidas, incluidas la realización de pruebas de laboratorio y el mantenimiento de los registros.

\section{Formación}

Aunque todos los trabajadores que utilizan plaguicidas de riesgo moderado o elevado deben tener una sólida formación acerca de su uso, esta formación adquiere aún más importancia si el plaguicida es extremadamente tóxico. Los planes de formación deberán 
abarcar aspectos como los siguientes: toxicidad de los compuestos utilizados y vías de absorción; manipulación de los concentrados y formulaciones; métodos de uso; limpieza del equipo; precauciones a adoptar y equipo de protección necesario; mantenimiento del equipo de protección; evitación de la contaminación de otros cultivos, alimentos y aguas; síntomas precoces de intoxicación y medidas de primeros auxilios. La formación se debe adecuar rigurosamente al plaguicida utilizado y, en el caso de compuestos extremadamente peligrosos, es conveniente conceder un diploma previa superación de un examen en el que se demuestren poseer, efectivamente, buenos conocimientos de los riesgos y procedimientos a seguir.

\section{Medidas de salud pública}

Cuando se utilizan plaguicidas, deben realizarse todos los esfuerzos posibles para evitar la contaminación de los suministros de aguas, tanto si están reconocidos oficialmente como tales o no. No debe considerarse sólo la aplicación real (contaminación inmediata), sino también la contaminación remota por arrastres provocados por la lluvia en zonas recién tratadas. Aunque en las corrientes de agua naturales los plaguicidas pueden diluirse hasta tal punto que el agua contaminada no resulte peligrosa por sí misma, no debe olvidarse el efecto sobre los peces, las plantas acuáticas utilizadas como alimento y cultivadas en los cursos de agua, y la vida salvaje en general. Dichos riesgos pueden ser económicos, no directamente relacionados con la salud, pero no por ello son menos importantes.

\section{- DiRectrices de la O MS para la CLASIFICACION DE LOS PLAGUICIDAS SEGUN EL RIESG O*}

Los distintos productos se clasifican en una serie de tablas en función de su toxicidad oral y cutánea y de su estado físico. Los productos de clase técnica incluidos en la Clase IA (extremadamente peligrosos), en la Clase IB (altamente peligrosos), en la Clase II (moderadamente peligrosos) y en la Clase III (ligeramente peligrosos) figuran en las Tablas $62.1,62.2,62.3$ y 62.4 , respectivamente. En la Tabla 62.5 se indican los productos de clase técnica que es improbable que presenten riesgo agudo en el uso normal. La clasificación de las Tablas 62.1 a 62.5 se aplica a compuestos de clase técnica y sólo constituye un punto de partida para la clasificación final de la formulación real: la clasificación final de cualquier producto depende de su formulación. No se incluye la clasificación de las mezclas de plaguicidas; muchas de estas mezclas se comercializan con concentraciones variables de principios activos. (V éase información sobre el modo de determinar la clase de riesgo de las formulaciones y mezclas en OMS 1996). La clasificación no incluye productos de clase técnica considerados obsoletos o en desuso (véase la Tabla 62.6). La Tabla 62.7 incluye fumigantes gaseosos no incluidos en la Clasificación recomendada de plaguicidas según el riesgo de la 0 M S.

Seguidamente se explican los códigos y abreviaturas utilizados en las distintas columnas de las tablas.

\section{Nombre}

La primera columna de las tablas da el nombre aprobado de los principios activos. Dado su elevado número, no se incluyen nombres comerciales.

*Adaptado de la O M S 1996.

\section{Situación}

Se utilizan las abreviaturas siguientes:

- ISO : nombre común aprobado por la O rganización Internacional de Normalización (ISO ). Cuando existen estas denominaciones, la OMS las prefiere a cualesquiera otros nombres comunes. No obstante, algunos de estos nombres puede que no estén adoptados para su uso a nivel nacional en algunos países. Si las letras ISO aparecen entre paréntesis ( $p$. ej., en el caso de la fentina acetato), significa que la ISO ha normalizado (o está en proceso de normalizar) el nombre de la base, pero no el de los derivados incluidos en la columna "Nombre". (Fentina es un nombre ISO, pero fentina acetato no).

- $\mathrm{N}($ ): nombre aprobado por un ministerio u otro organismo nacional, que se expresa entre paréntesis de la forma siguiente: A: Environmental Protection Agency (EPA) de Estados Unidos, o American National Standards Institute (ANSI), o Weed Science Society of A merica, o Entomological Society of America; B: British Standards Institution o C omisión de la Farmacopea Británica; F: Asociación Francesa de Normalización; ]: M inisterio Japonés de Agricultura y Silvicultura; U : G osudarstvennyi K omitet Standartov, antigua U R SS.

- C: D enominación química, común u otra denominación.

\section{Uso principal}

En la mayoría de los casos solamente se cita un uso. Ello se hace así solamente con fines de identificación, sin que queden excluidos otros usos. Se utilizan las abreviaturas siguientes:

- AC: acaricida

- AP: aficida

- B: bacteriostático (tierra)

- FM : fumigante

- F: fungicida, diferente de los de tratamiento de semillas

- FST : fungicida, para tratamiento de semillas

- $\mathrm{H}$ : herbicida

- I: insecticida

- IGR : regulador del crecimiento de los insectos

- Ix: ixodicida (para la lucha contra garrapatas)

- L: larvicida

- M : molusquicida

- $\mathrm{N}$ : nematocida

- 0 : otros usos para patógenos de plantas

- PG R : regulador del crecimiento de las plantas

- R : rodenticida

- RP( ): repelente (especies)

- -S: aplicado al suelo; no utilizado con herbicidas ni reguladores del crecimiento de las plantas

- SY : sinérgico

\section{Tipo químico}

En esta columna se cita un número limitado de tipos químicos. La mayoría tienen interés en el sentido de que pueden poseer un antídoto común o pueden confundirse, en la nomenclatura, con otros tipos químicos. Por ejemplo, los tiocarbamatos no son inhibidores de la colinesterasa y no tienen los mismos efectos que los carbamatos. Se utilizan las abreviaturas siguientes.

- C: carbamato

- CNP: derivado del cloronitrofenol

- OC: compuesto organoclorado

- OM : compuesto organomercurial

- OP: compuesto organofosforado

- OT: compuesto organoestánnico

- P: derivado piridílico 
- PA: derivado del ácido fenoxiacético

- PY: piretroide

- T: derivado triazínico

- TC: tiocarbamato.

Estas clasificaciones de compuestos químicos se incluyen solamente por razones de comodidad, y no constituyen una recomendación de la OMS acerca de la forma en que deban clasificarse los plaguicidas. Además, algunos plaguicidas pueden estar incluidos en más de un tipo.

El tipo químico no se indica cuando el propio nombre lo aclara.

\section{Estado físico}

Se refiere solamente al compuesto de grado técnico. Se utilizan los siguientes.

- L: líquido, incluidos los productos sólidos con punto de fusión inferior a $50^{\circ} \mathrm{C}$

- aceite: líquido oleoso, se refiere únicamente al estado físico

- S: sólido, incluidas las ceras.

En algunos casos puede ocurrir que, cuando el producto técnico es un sólido, haya que clasificar las formulaciones líquidas muy concentradas en una clase más peligrosa. En la mayoría de los casos, los aceites se han clasificado como líquidos a no ser que sean muy viscosos a temperaturas normales.

\section{Vía}

Se utilizan valores correspondientes a la vía oral, a menos que los valores de la vía dérmica hagan que el producto se incluya en una clase peligrosa o sean significativamente más bajos que los valores orales, aun dentro de una misma clase. Se utilizan las abreviaturas siguientes:

- D: dérmico

- 0 : oral.

\section{$\mathrm{DL}_{50}(\mathbf{m g} / \mathbf{k g})$}

El valor de la $D L_{50}$ es una estimación estadística del número de mg de tóxico por $\mathrm{kg}$ de peso corporal que se requieren para provocar la muerte del $50 \%$ de una amplia población de animales estudiados; a no ser que se establezca otra especie, como animal de experimentación se utiliza la rata. Se indica un solo valor: cuando éste va precedido de una " $c$ ", significa que se encuentra comprendido en un intervalo más amplio del habitual, adoptado con fines de clasificación; cuando va precedido del signo " + ", se quiere indicar que los fallecimientos a la dosis especificada correspondían a menos del $50 \%$ de los animales estudiados.
Los datos de toxicidad de los piretroides son muy variables según las relaciones de isómeros, el vehículo para la administración oral y la cría de los animales estudiados. L a variabilidad se refleja en el prefijo "c". El valor único de $\mathrm{DL}_{50}$ elegido ahora con fines de clasificación se basa en la administración en aceite de maíz y es mucho menor que en solución acuosa. Como consecuencia se han producido cambios considerables en la clasificación de algunos productos y queda clara la necesidad de una clasificación según la formulación si el etiquetado debe reflejar el riesgo real.

L os datos de esta columna no son medianas; por el contrario, se incorpora un margen de seguridad eligiendo en la mayor parte de los casos el límite inferior de confianza. Cuando existe una diferencia relacionada con el sexo en los valores de la $\mathrm{DL}_{50}$, se utiliza el valor correspondiente al sexo más sensible. Se han realizado diversos ajustes de clasificación en algunos plaguicidas, los cuales se explican. Los casos límites han sido incluidos en la clase más o menos peligrosa después de considerar su toxicología y la experiencia en su uso.

En la Tabla 62.5 se incluyen varios plaguicidas que es improbable que presenten riesgos agudos en su uso normal. La clasificación de la OM S es abierta, pero es evidente que debe haber un punto en el que el riesgo agudo planteado por el uso de estos compuestos sea tan bajo que resulte despreciable siempre que se adopten las precauciones necesarias. A los efectos de esta tabla, se supone que este punto es una $D L_{50}$ de $2.000 \mathrm{mg} / \mathrm{kg}$ para los sólidos y de $3.000 \mathrm{mg} / \mathrm{kg}$ para los líquidos. En todo caso, no se debe olvidar que, en formulaciones de estos productos técnicos, los disolventes o los vehículos pueden presentar un riesgo mayor que el plaguicida real, por lo que quizá haya que clasificar la formulación en una clase de mayor riesgo.

Los plaguicidas biológicos no están incluidos en la clasificación de la O M S porque los métodos de los ensayos de seguridad de los agentes biológicos vivos no son apropiados para clasificar los métodos aplicados a los compuestos químicos.

\section{Observaciones}

Cuando se ha ajustado la clasificación de un producto de grado técnico, se explica la justificación en esta columna. Se han detectado propiedades irritantes importantes, pero éstas no afectan a la clasificación. Cuando la denominación de un producto de grado técnico tiene una referencia cruzada, el producto de referencia se encontrará en la misma tabla. Se utilizan abreviaturas para indicar que una $\mathrm{Hoja}$ de $\mathrm{D}$ atos (DS) de la OMS/FAO o una publicación de la serie sobre Criterios de Salud A mbiental (EHC) del Programa Internacional de Seguridad de los Productos Q uímicos (IPCS) o una Guía sobre Salud y Seguridad (HSG) contiene más información sobre el producto; el número correspondiente a la publicación sigue a la abreviatura. 
Tabla 62.1 - Lista de productos de grado técnico clasificados en la Clase IA: "Extremadamente peligrosos".

\begin{tabular}{|c|c|c|c|c|c|c|c|}
\hline Denominación & Situación & Uso principal & $\begin{array}{l}\text { Tipo } \\
\text { químico }\end{array}$ & $\begin{array}{l}\text { Estado } \\
\text { físico }\end{array}$ & Vía & $\begin{array}{l}\mathrm{DL}_{50} \\
(\mathrm{mg} / \mathrm{kg})\end{array}$ & Observaciones \\
\hline Acroleína & C & $H$ & & L & 0 & 29 & EHC 127; HSG 67 \\
\hline Alacloro & 150 & $H$ & & S & 0 & 930 & $\begin{array}{l}\text { Clasificación ajustada; cancerígeno en ratas y } \\
\text { ratón; DS } 84\end{array}$ \\
\hline Aldicarb & ISO & I-S & C & S & 0 & 0,93 & DS 53; EHC 121; HSG 64 \\
\hline Arsenioso, óxido & C & $R$ & & S & 0 & 180 & $\begin{array}{l}\text { Clasificación ajustada: dosis letal mínima } \\
\text { para humanos de } 2 \text { mg/ kg; la evidencia de } \\
\text { carcinogenicidad para humanos es suficiente; } \\
\text { EHC 18; HSG } 70\end{array}$ \\
\hline Brodifacum & ISO & R & & S & 0 & 0,3 & DS 57; EHC 175; HSG 93 \\
\hline Bromadialon & ISO & R & & S & 0 & 1,12 & DS 88; EHC 175; HSG 94 \\
\hline Brometalin & 150 & R & & S & 0 & 2 & \\
\hline Cálcico, cianuro & C & FM & & S & 0 & 39 & $\begin{array}{l}\text { Clasificación ajustada; el cianuro cálcico está } \\
\text { en la Clase IA y reacciona con la humedad } \\
\text { formando gas de cianuro de hidrógeno; el gas } \\
\text { no está clasificado por el sistema de la OMS } \\
\text { (véase Tabla 62.7) }\end{array}$ \\
\hline Captafol & ISO & $\mathrm{F}$ & & S & 0 & 5,000 & $\begin{array}{l}\text { Clasificación ajustada; cancerígeno en ratas y } \\
\text { ratón; HSG } 49\end{array}$ \\
\hline Cicloheximida & 150 & $\mathrm{~F}$ & & S & 0 & 2 & \\
\hline Clorfenvinfos & 150 & । & OP & $L$ & 0 & 10 & \\
\hline Clormefos & 150 & । & OP & $L$ & 0 & 7 & \\
\hline Clorofacinona & 150 & R & & S & 0 & 3,1 & DS 62; EHC 175 \\
\hline Clortiofos & 150 & । & OP & $L$ & 0 & 9,1 & \\
\hline Cumafos & 150 & $A C, M T$ & $O P$ & $L$ & 0 & 7,1 & \\
\hline CVP & $N(J)$ & & & & & & Véase clorfenvinfos \\
\hline DBCP & $N(J)$ & & & & & & Véase dibromocloropropano \\
\hline Demefion-0 y -S & ISO & । & OP & L & 0 & 15 & \\
\hline Demeton-0 y -5 & 150 & । & OP & L & 0 & 2,5 & DS 60 \\
\hline Dibromocloropropano & c & F-S & & L & 0 & 170 & $\begin{array}{l}\text { Clasificación ajustada; se ha encontrado } \\
\text { que provoca esterilidad en humanos y es } \\
\text { mutagénico y cancerígeno en animales }\end{array}$ \\
\hline Difacinona & 150 & $R$ & & $S$ & 0 & 2,3 & EHC 175 \\
\hline Difenacum & 150 & R & & S & 0 & 1,8 & EHC 175; HSG 95 \\
\hline Difetialone & ISO & $R$ & & $S$ & 0 & 0,56 & EHC 175 \\
\hline Difolatan & $N(J)$ & & & & & & Véase captafol \\
\hline Dimefox & 150 & । & OP & L & 0 & 1 & Volátil \\
\hline Disulfoton & 150 & । & OP & L & 0 & 2,6 & DS 68 \\
\hline EPN & $N(A)$, & । & OP & S & 0 & 14 & $\begin{array}{l}\text { Se ha comunicado que provoca } \\
\text { neurotoxicidad retardada en gallinas }\end{array}$ \\
\hline Escilirósido & C & R & & S & 0 & $c 0,5$ & Inductor del vómito en mamíferos \\
\hline Etiltiometon & $N(J)$ & & & & & & Véase disulfoton \\
\hline Etoprofos & ISO & I-S & OP & L & D & 26 & DS 70 \\
\hline Etoprop & $N(A)$ & & & & & & Véase etoprofos \\
\hline Fenamifos & 150 & N & OP & $L$ & 0 & 15 & DS 92 \\
\hline
\end{tabular}


Tabla 62.1 - Lista de productos de grado técnico clasificados en la Clase IA: "Extremadamente peligrosos". Continuación.

\begin{tabular}{|c|c|c|c|c|c|c|c|}
\hline Denominación & Situación & Uso principal & $\begin{array}{l}\text { Tipo } \\
\text { químico }\end{array}$ & $\begin{array}{l}\text { Estado } \\
\text { físico }\end{array}$ & Vía & $\begin{array}{l}\mathrm{DL}_{50} \\
(\mathrm{mg} / \mathrm{kg})\end{array}$ & Observaciones \\
\hline $\begin{array}{l}\text { Fenilmercurio, } \\
\text { acetato de }\end{array}$ & ISO & FST & & $S$ & 0 & 24 & $\begin{array}{l}\text { Clasificación ajustada; altamente tóxico } \\
\text { para mamíferos y dosis muy pequeñas } \\
\text { han producido lesiones renales; } \\
\text { teratogénico en rata }\end{array}$ \\
\hline Fensulfotion & ISO & I & $O P$ & L & 0 & 3,5 & DS 44 \\
\hline Flocumafen & $N(B)$ & $R$ & & $S$ & 0 & 0,25 & EHC 175 \\
\hline Fluoroacetato sódico & $c$ & $R$ & & S & 0 & 0,2 & DS 16 \\
\hline Fonofos & ISO & I-S & $O P$ & $L$ & 0 & $c 8$ & \\
\hline Forato & ISO & I & $O P$ & $L$ & 0 & 2 & DS 75 \\
\hline Fosfamidón & ISO & I & $O P$ & $L$ & 0 & 7 & DS 74 \\
\hline Fosfolán & ISO & I & $O P$ & $L$ & 0 & 9 & \\
\hline Hexaclorobenzeno & ISO & FST & & $S$ & D & 10.000 & $\begin{array}{l}\text { Clasificación ajustada; ha provocado un brote } \\
\text { grave de porfiria en humanos; DS } 26\end{array}$ \\
\hline Jacinto rojo & & & & & & & Véase escilirósido \\
\hline Leptofos & 150 & 1 & OP & $S$ & 0 & 50 & $\begin{array}{l}\text { Clasificación ajustada; se ha demostrado } \\
\text { que es un agente neurotóxico con efecto } \\
\text { retardado; DS } 38\end{array}$ \\
\hline M74 & $N(J)$ & & & & & & Véase disulfoton \\
\hline MBCP & $N(J)$ & & & & & & Véase leptofos \\
\hline Mefosfolán & ISO & I & OP & L & 0 & 9 & \\
\hline Mercaptofos & $N(U)$ & & & & & & $\begin{array}{l}\text { Cuando se mezcla con mercaptofosteolovi, } \\
\text { véase demeton }-0 \text { y }-5\end{array}$ \\
\hline Mercúrico, cloruro & ISO & F-S & & $S$ & 0 & 1 & \\
\hline Metafos & $N(U)$ & & & & & & Véase metilparation \\
\hline Metilparation & 150 & I & OP & L & 0 & 14 & DS 7; EHC 145; HSG 75 \\
\hline Mevinfos & ISO & I & OP & L & D & 4 & DS 14 \\
\hline Nitrofen & ISO & H & & S & 0 & $c 3,000$ & $\begin{array}{l}\text { Clasificación ajustada; cancerígeno en ratas } \\
\text { y ratón teratogénico en varias especies } \\
\text { ensayadas; DS } 84\end{array}$ \\
\hline Paration & ISO & । & OP & L & 0 & 13 & DS 6; HSG 74 \\
\hline Protoato & ISO & $A C, I$ & $O P$ & L & 0 & 8 & \\
\hline Scradán & ISO & I & $O P$ & L & 0 & 9 & \\
\hline Sulfotep & ISO & I & $O P$ & $L$ & 0 & 5 & \\
\hline TEPP & ISO & $A C$ & $O P$ & $L$ & 0 & 1.1 & \\
\hline Terbufos & ISO & I-S & $O P$ & L & 0 & $c 2$ & \\
\hline Timet & $N(U)$ & & & & & & Véase forato \\
\hline Tiofos & $N(U)$ & & & & & & Véase paration \\
\hline Tionazina & ISO & N & $O P$ & $L$ & 0 & 11 & \\
\hline
\end{tabular}

Fuente: OMS 1996. 
Tabla 62.2 - Lista de productos de grado técnico clasificados en la Clase IB: "A Itamente peligrosos".

\begin{tabular}{|c|c|c|c|c|c|c|c|}
\hline Denominación & Situación & $\begin{array}{l}\text { Uso } \\
\text { principal }\end{array}$ & $\begin{array}{l}\text { Tipo } \\
\text { químico }\end{array}$ & Estado físico & Vía & $\begin{array}{l}\mathrm{DL}_{50} \\
(\mathrm{mg} / \mathrm{kg})\end{array}$ & Observaciones \\
\hline 3-cloro-1,2-propanodiol & C & $\mathrm{R}$ & & L & 0 & 112 & $\begin{array}{l}\text { A dosis no letales provoca esterilidad de ratas } \\
\text { macho }\end{array}$ \\
\hline Aldoxicarb & ISO & $\mathrm{I}, \mathrm{N}$ & C & $S$ & 0 & 27 & \\
\hline Aldrín & ISO & 1 & $O C$ & $S$ & D & 98 & DS41; EHC 91; HSG 21 \\
\hline Alílico, alcohol & $c$ & H & & $\mathrm{L}$ & 0 & 64 & Altamente irnitante cutáneo y ocular \\
\hline Aminocarb & ISO & । & $c$ & $S$ & 0 & 50 & \\
\hline Antu & 150 & $R$ & & $S$ & 0 & 8 & $\begin{array}{l}\text { Inductor del vómito en perros. Algunas impurezas } \\
\text { son cancerígenas }\end{array}$ \\
\hline Benfuracarb & $N(B)$ & I & C & $\mathrm{L}$ & 0 & 138 & \\
\hline Bis(tributilestaño), óxido de & $c$ & $\mathrm{~F}, \mathrm{M}$ & & $L$ & 0 & 194 & Irritante cutáneo. DS 65; EHC 15 \\
\hline Blasticidin S & $N(J)$ & $\mathrm{F}$ & & $S$ & 0 & 16 & \\
\hline Butocarboxim & ISO & I & $c$ & $L$ & 0 & 158 & \\
\hline Butoxicarboxim & ISO & I & $C$ & $\mathrm{~L}$ & D & 288 & \\
\hline Cadusafos & ISO & $\mathrm{N}, \mathrm{l}$ & $O P$ & $\mathrm{~L}$ & 0 & 37 & \\
\hline Calcio, arseniato de & $C$ & । & & $S$ & 0 & 20 & \\
\hline Carbofenotion & ISO & I & $O P$ & $\mathrm{~L}$ & 0 & 32 & \\
\hline Carbofurán & ISO & I & $c$ & $S$ & 0 & 8 & DS 56 \\
\hline Crotoxifos & ISO & I & $O P$ & $\mathrm{~L}$ & 0 & 74 & \\
\hline Cumacloro & ISO & $R$ & & $S$ & D & 33 & \\
\hline Cumatetralilo & ISO & $R$ & & $S$ & 0 & 16 & \\
\hline DDVF & $N(U)$ & & & & & & Véase diclorvos \\
\hline DDVP & $N(J)$ & & & & & & Véase diclorvos \\
\hline Delnav & $N(U)$ & & & & & & Véase dioxation \\
\hline Demeton-S-metilo & ISO & I & $O P$ & $\mathrm{~L}$ & 0 & 40 & DS 61 \\
\hline Demeton-S-metilsulfona & ISO & I & $O P$ & $S$ & 0 & 37 & \\
\hline Diclorvos & ISO & I & $O P$ & $\mathrm{~L}$ & 0 & 56 & Volátil, DS 2; EHC 79; HSG 18 \\
\hline Dicrotofos & 150 & I & OP & $\mathrm{L}$ & 0 & 22 & \\
\hline Dieldrín & ISO & I & $O C$ & $S$ & 0 & 37 & DS 17: EHC 91 \\
\hline Dimetilán & $N(A, B)$ & I & $c$ & $S$ & 0 & 47 & \\
\hline Dinoseb & ISO & $H$ & CNP & $\mathrm{L}$ & 0 & 58 & \\
\hline Dinoseb, acetato de & ISO & $H$ & CNP & $\mathrm{L}$ & 0 & 60 & \\
\hline Dinoterb & ISO & $H$ & CNP & $S$ & 0 & 25 & \\
\hline Dioxation & ISO & I & $O P$ & $\mathrm{~L}$ & 0 & 23 & \\
\hline DMTP & $N(J)$ & & & & & & Véase metidation \\
\hline DNBP & $N(J)$ & & & & & & Véase dinoseb \\
\hline DNBPA & $N(J)$ & & & & & & Véase dinoseb, acetato de \\
\hline DNOC & 150 & $\mathrm{I}-\mathrm{S}, \mathrm{H}$ & CNP & $S$ & 0 & 25 & \\
\hline EDDP & $\mathrm{N}(J)$ & & & & & & Véase edifenfos \\
\hline Edifenfos & ISO & $\mathrm{F}$ & OP & $\mathrm{L}$ & 0 & 150 & \\
\hline Endrín & 150 & I & $O C$ & $S$ & 0 & 7 & DS 1; EHC 130; HSG 60 \\
\hline ESP & $N(J)$ & I & $O P$ & $\mathrm{~L}$ & 0 & 105 & \\
\hline Estricnina & $c$ & $R$ & & $S$ & 0 & 16 & \\
\hline Etil azinfos & ISO & I & $O P$ & $S$ & 0 & 12 & DS 72 \\
\hline Etil pirimifos & ISO & I & $O P$ & $\mathrm{~L}$ & 0 & 140 & \\
\hline Etilbromofos & ISO & I & $O P$ & $L$ & 0 & 71 & \\
\hline Famfur & $N(A)$ & I & $O P$ & $S$ & 0 & 48 & \\
\hline
\end{tabular}


Tabla 62.2 - Lista de productos de grado técnico clasificados en la Clase IB: "Altamente peligrosos". Continuación.

\begin{tabular}{|c|c|c|c|c|c|c|c|}
\hline Denominación & Situación & $\begin{array}{l}\text { Uso } \\
\text { principal }\end{array}$ & $\begin{array}{l}\text { Tipo } \\
\text { químico }\end{array}$ & Estado físico & Vía & $\begin{array}{l}\mathrm{DL}_{50} \\
(\mathrm{mg} / \mathrm{kg})\end{array}$ & Observaciones \\
\hline Fenilmercurio, nitrato de & C & FST & OM & $S$ & & & $\mathrm{DL}_{50}$ oral no disponible, $\mathrm{DL}_{50}$ i.v. de rata $27 \mathrm{mg} / \mathrm{kg}$ \\
\hline Flucitrinato & ISO & I & PY & L & 0 & $c 67$ & Irritante cutáneo y ocular \\
\hline Fluoroacetamida & $C$ & $R$ & & $S$ & 0 & 13 & \\
\hline Formetanato & ISO & $A C$ & C & $S$ & 0 & 21 & \\
\hline Fosmetilán & ISO & । & OP & $S$ & 0 & 49 & Irritante cutáneo y ocular. \\
\hline Furatiocarb & $N(B)$ & I-S & $C$ & $\mathrm{~L}$ & 0 & 42 & \\
\hline Heptenofos & ISO & । & OP & $L$ & 0 & 96 & \\
\hline Isazofos & ISO & I-S & OP & $\mathrm{L}$ & 0 & 60 & \\
\hline Isofenfos & ISO & I & OP & aceite & 0 & 28 & \\
\hline Isotioato & ISO & I & OP & $\mathrm{L}$ & 0 & 150 & \\
\hline Isoxation & ISO & I & OP & $\mathrm{L}$ & 0 & 112 & \\
\hline Mecarbam & 150 & I & $C$ & aceite & 0 & 36 & \\
\hline Mercúrico, óxido & ISO & 0 & $S$ & 0 & 0 & 18 & \\
\hline Metamidofos & ISO & । & OP & $L$ & 0 & 30 & HSG 79 \\
\hline Metidation & ISO & I & $O P$ & $\mathrm{~L}$ & 0 & 25 & \\
\hline Metil azinfos & ISO & I & OP & $S$ & 0 & 16 & DS 59 \\
\hline Metil mercaptofosoksid & $N(U)$ & & & & & & Véase metil oxidemeton \\
\hline Metil mercaptofosteolovi & $N(U)$ & & & & & & Véase demeton-S-metil \\
\hline Metil oxidemeton & ISO & I & OP & $L$ & 0 & 65 & \\
\hline Metil triazotion & $N(U)$ & & & & & & Véase metil azinfos \\
\hline Metomil & ISO & I & $C$ & $S$ & 0 & 17 & DS 55, EHC 178; HSG 97 \\
\hline Monocrotofos & 150 & I & OP & $S$ & 0 & 14 & HSG 80 \\
\hline MPP & $N(J)$ & & & & & & Véase fention \\
\hline Nicotina & ISO & & & $L$ & D & 50 & \\
\hline Ometoato & ISO & I & OP & $L$ & 0 & 50 & \\
\hline Oxamil & ISO & I & $C$ & $S$ & 0 & 6 & DS 54 \\
\hline Oxideprofos & $N(B)$ & & & & & & Véase ESP \\
\hline Pentadorofenol & ISO & $\mathrm{I}, \mathrm{F}, \mathrm{H}$ & CNP & $S$ & D & 80 & Irritante cutáneo; EHC 71; HSG 19 \\
\hline Plomo, arseniato de & $C$ & L & & $S$ & 0 & $\mathrm{clo}$ & \\
\hline Propafos & $N(J)$ & । & OP & $L$ & 0 & 70 & \\
\hline Propetamfos & ISO & । & OP & $L$ & 0 & 106 & \\
\hline Sódico, arsenito & $C$ & R & & $S$ & 0 & 10 & \\
\hline Sódico, cianuro & C & R & & $S$ & 0 & 6 & \\
\hline Talio, sulfato de & C & R & & $S$ & 0 & 11 & DS 10 \\
\hline TBTO & & & & & & & Véase bis-(tributiltin), óxido \\
\hline Teflutrin & $N(B)$ & I-S & PY & $S$ & 0 & $\mathrm{C22}$ & \\
\hline Tiofanox & ISO & I-S & $C$ & $S$ & 0 & 8 & \\
\hline Tiometon & ISO & । & $O P$ & aceite & 0 & 120 & DS 67 \\
\hline Tioxamil & & & & & & & Véase oxamil \\
\hline Triamifos & ISO & $\mathrm{F}$ & & $S$ & 0 & 20 & \\
\hline Triazofos & 150 & । & OP & $\mathrm{L}$ & 0 & 82 & \\
\hline Triazotion & $N(U)$ & & & & & & Véase etil azinfos \\
\hline Vamidotion & ISO & । & $O P$ & $L$ & 0 & 103 & \\
\hline Verde París & $c$ & $L$ & & $S$ & 0 & 22 & Complejo cobre-arsénico \\
\hline Warfarina & ISO & $R$ & & $S$ & 0 & 10 & DS 35, EHC 175; HSG 96 \\
\hline zeta-Cipermetrin & ISO & । & PY & $L$ & 0 & $c 86$ & \\
\hline Zinc, fosfuro de & $c$ & $R$ & & $S$ & 0 & 45 & DS 24, EHC 73 \\
\hline
\end{tabular}


Tabla 62.3 - Lista de productos de grado técnico clasificados en la Clase II: "Moderadamente peligrosos".

\begin{tabular}{|c|c|c|c|c|c|c|c|}
\hline Denominación & Situación & $\begin{array}{l}\text { Uso } \\
\text { principal }\end{array}$ & $\begin{array}{l}\text { Tipo } \\
\text { químico }\end{array}$ & $\begin{array}{l}\text { Estado } \\
\text { físico }\end{array}$ & Vía & $\begin{array}{l}\mathrm{DL}_{50} \\
(\mathrm{mg} / \mathrm{kg})\end{array}$ & Observaciones \\
\hline Alanicarb & ISO & I & $c$ & $S$ & 0 & 330 & \\
\hline alfa-Cipermetrin & ISO & I & PY & $S$ & 0 & $c 79$ & EHC 142 \\
\hline Alidoclor & ISO & $H$ & & $\mathrm{~L}$ & 0 & 700 & Irritante cutáneo y ocular \\
\hline Anilofos & ISO & $H$ & & $S$ & 0 & 472 & \\
\hline Azaconazol & $N(B)$ & $F$ & & $S$ & 0 & 308 & \\
\hline Azociclotin & ISO & $A C$ & ОТ & $S$ & 0 & 80 & \\
\hline Bendiocarb & ISO & I & $C$ & $S$ & 0 & 55 & DS 52 \\
\hline Bensulida & ISO & $H$ & & $L$ & 0 & 270 & \\
\hline Benzofos & $N(U)$ & & & & & & Véase fosalona \\
\hline beta-Ciflutrin & 150 & I & PY & $S$ & 0 & 450 & \\
\hline beta-Cipermetrin & ISO & I & PY & $S$ & 0 & 166 & \\
\hline $\mathrm{BHC}$ & ISO & & & & & & Véase HCH \\
\hline Bifentrin & $N(B)$ & I & PY & $S$ & 0 & $c 55$ & \\
\hline Bilanafos & ISO & $H$ & & $S$ & 0 & 268 & \\
\hline Binapacril & ISO & $A C$ & & $S$ & 0 & 421 & \\
\hline Bioaletrin & C & । & PY & L & 0 & c700 & $\begin{array}{l}\text { Bioaletrin, esbiotrin, esbiol y esdepaletrin son } \\
\text { miembros de la serie de aletrinas; su toxicidad } \\
\text { varía considerablemente dentro de la serie } \\
\text { según la concentración de isómeros. }\end{array}$ \\
\hline Bistiosemi & $N(J)$ & $R$ & & $S$ & 0 & c150 & Inductor de vómitos en no roedores \\
\hline BPMC & & & & & & & Véase fenobucarb \\
\hline Bromoxinil & ISO & $H$ & & $S$ & 0 & 190 & \\
\hline Bronopol & $N(B)$ & $B$ & & $S$ & 0 & 254 & \\
\hline Bufencarb & ISO & । & C & $S$ & 0 & 87 & \\
\hline Butanifos & ISO & $H$ & & L & 0 & 630 & \\
\hline Butenaclor & ISO & $H$ & & L & 0 & 1.630 & \\
\hline Butilamina & ISO & $\mathrm{F}$ & & $L$ & 0 & 380 & Irritante cutáneo \\
\hline Camfeclor & ISO & I & $O C$ & $S$ & 0 & 80 & DS 20; EHC 45 \\
\hline Carbaril & ISO & I & $C$ & $S$ & 0 & c300 & DS 3; EHC 153; HSG 78 \\
\hline Carbation & $N(U)$ & & & & & & Véase metam-sodio \\
\hline Carbosulfan & ISO & I & & $L$ & 0 & 250 & \\
\hline Cartap & ISO & I & & $S$ & 0 & 325 & \\
\hline Cianazina & ISO & $H$ & $\mathrm{~T}$ & $S$ & 0 & 288 & \\
\hline Cianofenfos & ISO & । & $O P$ & $S$ & 0 & 89 & $\begin{array}{l}\text { Se ha comprobado que es neurotóxico con } \\
\text { acción retardada para las gallinas; ha dejado } \\
\text { de fabricarse. }\end{array}$ \\
\hline Cianofos & ISO & 1 & $O P$ & $L$ & 0 & 610 & \\
\hline Cifenotrin[ isómeros-(1R)] & ISO & I & PY & $L$ & 0 & 318 & \\
\hline Ciflutrin & ISO & I & PY & $S$ & 0 & c250 & \\
\hline Cihalotrin & ISO & Ix & PY & aceite & 0 & C144 & EHC 99 \\
\hline Cipermetrin & ISO & I & PY & $S$ & 0 & $c 250$ & DS 58; EHC 82; HSG 22 \\
\hline Ciprofuram & ISO & $\mathrm{F}$ & & $S$ & 0 & 174 & \\
\hline cis-furconazol & ISO & $\mathrm{F}$ & & $S$ & 0 & 450 & \\
\hline
\end{tabular}


Tabla 62.3 • Lista de productos de grado técnico clasificados en la Clase II: "Moderadamente peligrosos". Continuación

\begin{tabular}{|c|c|c|c|c|c|c|c|}
\hline Denominación & Situación & $\begin{array}{l}\text { Uso } \\
\text { principal }\end{array}$ & $\begin{array}{l}\text { Tipo } \\
\text { químico }\end{array}$ & $\begin{array}{l}\text { Estado } \\
\text { físico }\end{array}$ & Vía & $\begin{array}{l}\mathrm{DL}_{50} \\
(\mathrm{mg} / \mathrm{kg})\end{array}$ & Observaciones \\
\hline Clomazona & ISO & $\mathrm{H}$ & & $\mathrm{L}$ & 0 & 1.369 & \\
\hline Cloralose & $C$ & $R$ & & $S$ & 0 & 400 & \\
\hline Clordán & ISO & । & $O C$ & $L$ & 0 & 460 & DS 36; EHC 34; HSG 13 \\
\hline Clordimeform & ISO & $A C$ & $O C$ & $S$ & 0 & 340 & \\
\hline Clorfenamidina & $N(J)$ & & & & & & Véase clordimeform \\
\hline Clorfonio & ISO & PGR & & $S$ & 0 & 178 & Irritante cutáneo y ocular \\
\hline Clorpinfos & ISO & I & OP & $S$ & 0 & 135 & DS 18 \\
\hline Cobre, sulfato de & $C$ & $\mathrm{~F}$ & & $S$ & 0 & 300 & \\
\hline Cuproso, óxido & C & $\mathrm{F}$ & & $S$ & 0 & 470 & \\
\hline CYAP & $N(J)$ & & & & & & Véase cianofos \\
\hline CYP & $N(J)$ & & & & & & Véase cianofenfos \\
\hline $2,4-D$ & ISO & H & $P A$ & $S$ & 0 & 375 & DS 37; EHC 29; EHC 84 \\
\hline DAPA & $N(J)$ & & & & & & Véase fenaminosulf \\
\hline DDT & ISO & । & $O C$ & $S$ & 0 & 113 & DS 21; EHC 9; EHC 83 \\
\hline Deltametrín & ISO & । & PY & $S$ & 0 & c135 & DS 50; EHC 97; HSG 30 \\
\hline Dialato & ISO & $H$ & TC & $L$ & 0 & 395 & \\
\hline Dialifor & $N(A, J)$ & & & & & & Véase dialifos \\
\hline Dialifos & 150 & । & OP & $S$ & D & 145 & \\
\hline Diazinon & ISO & । & OP & $L$ & 0 & 300 & DS 45 \\
\hline Dibrom & $\begin{array}{l}\mathrm{N} \\
\text { (Dinamarca) }\end{array}$ & & & & & & Véase naled \\
\hline Diclofention & ISO & I-S & OP & $L$ & 0 & 270 & \\
\hline Difenzoquat & ISO & $H$ & & $S$ & 0 & 470 & \\
\hline Dimetoato & ISO & I & $O P$ & $S$ & 0 & $\mathrm{c} 150$ & DS 42; EHC 90; HSG 20 \\
\hline Dinobuton & ISO & $A C, F$ & & S & 0 & 140 & \\
\hline Dioxabenzofos & $N(B)$ & I & OP & $S$ & 0 & 125 & \\
\hline Dioxacarb & 150 & । & $C$ & $S$ & 0 & 90 & \\
\hline Diquat & 150 & H & P & $S$ & 0 & 231 & $\begin{array}{l}\text { Irritante cutáneo, ungueal y ocular; } \\
\text { DS 40; EHC 39; HSG } 52\end{array}$ \\
\hline Drazoxolon & (ISO) & FST & & $S$ & 0 & 126 & \\
\hline ECP & $N(J)$ & & & & & & Véase diclofention \\
\hline Endosulfán & ISO & । & $O C$ & S & 0 & 80 & DS 15; EHC 40; HSG 17 \\
\hline Endotal-sodio & (ISO) & $H$ & & S & 0 & 51 & \\
\hline EPBP & $N(J)$ & I-S & $O P$ & aceite & 0 & 275 & \\
\hline EPTC & ISO & $H$ & TC & $L$ & 0 & 1.652 & \\
\hline Esbiol & & & & & & & Véase bioaletrin \\
\hline Esbiotrin & & & & & & & Véase bioaletrin \\
\hline Esdepaletrin & & & & & & & Véase bioaletrin \\
\hline Esfenvalerato & ISO & I & PY & $S$ & 0 & 87 & \\
\hline Etiofencarb & ISO & I & $c$ & L & 0 & 411 & \\
\hline Etión & ISO & I & $O P$ & $L$ & 0 & 208 & \\
\hline Etrimfos & 150 & I & $O P$ & L & 0 & 1.800 & \\
\hline
\end{tabular}


Tabla 62.3 - Lista de productos de grado técnico clasificados en la Clase II: "Moderadamente peligrosos". Continuación.

\begin{tabular}{|c|c|c|c|c|c|c|c|}
\hline Denominación & Situación & $\begin{array}{l}\text { Uso } \\
\text { principal }\end{array}$ & $\begin{array}{l}\text { Tipo } \\
\text { químico }\end{array}$ & $\begin{array}{l}\text { Estado } \\
\text { físico }\end{array}$ & Vía & $\begin{array}{l}\mathrm{DL}_{50} \\
(\mathrm{mg} / \mathrm{kg})\end{array}$ & Observaciones \\
\hline Fenaminosulf & ISO & F-S & & $S$ & 0 & 60 & \\
\hline Fenazaquin & ISO & $A C$ & & $S$ & 0 & 134 & \\
\hline Fenclorfos & ISO & I & $O P$ & $L$ & 0 & 1.740 & DS 69 \\
\hline Fenitrotión & ISO & I & $O P$ & $L$ & 0 & 503 & DS 30; EHC 133; HSG 65 \\
\hline Fenobucarb & $N(B)$ & I & $C$ & $S$ & 0 & 620 & \\
\hline Fenpropatrin & 150 & I & PY & $S$ & 0 & $c 66$ & \\
\hline Fentina acetato & (ISO) & $\mathrm{F}$ & ОТ & $S$ & 0 & 125 & DS 22 \\
\hline Fentina hidróxido & (ISO) & $\mathrm{F}$ & ОТ & $S$ & 0 & 108 & DS 22 \\
\hline Fention & ISO & $I_{,}, L$ & $O P$ & $L$ & D & 586 & DS 23 \\
\hline Fentoato & ISO & I & $O P$ & $L$ & 0 & $c 400$ & DS 48 \\
\hline Fenvalerato & ISO & I & PY & $L$ & 0 & $c 450$ & EHC 95, DS 90; HSG 34 \\
\hline Fipronil & $N(B)$ & I & Pirazol & $S$ & 0 & 92 & \\
\hline Fluvalinato & $N(B)$ & I & & aceite & 0 & 282 & Imitante cutáneo \\
\hline Fluxofenim & ISO & $H$ & & aceite & 0 & 670 & \\
\hline Formotion & ISO & I & $O P$ & $\mathrm{~L}$ & 0 & 365 & \\
\hline Fosalone & ISO & I & $O P$ & $L$ & 0 & 120 & \\
\hline Fosfamida & $N(U)$ & & & & & & Véase dimetoato \\
\hline Fosmed & ISO & $\mathrm{I}, \mathrm{AC}$ & OP & $S$ & 0 & 230 & \\
\hline Foxim & ISO & I & $O P$ & $L$ & D & 1.975 & DS 31 \\
\hline Ftalofos & $N(U)$ & & & & & & Véase fosmed \\
\hline gamma-BHC & & & & & & & Véase gamma-HCH \\
\hline Gamma-HCH & ISO & I & $O C$ & $S$ & 0 & 88 & DS 12; EHC 124; HSG 54 \\
\hline Guazatina & $N(B)$ & FST & & $S$ & 0 & 230 & $\mathrm{DL}_{50}$ referida al triacetato \\
\hline Haloxifop & $N(A, B)$ & $H$ & & $S$ & 0 & 393 & \\
\hline $\mathrm{HCH}$ & 150 & I & $O C$ & $S$ & 0 & 100 & $\begin{array}{l}\text { La DL } L_{50} \text { varía en función de la mezcla de isómeros. } \\
\text { Se ha elegido el valor y se ha asignado el } \\
\text { producto técnico a la Clase II teniendo en } \\
\text { cuenta el resultado de las propiedades } \\
\text { acumulativas del isómero beta }\end{array}$ \\
\hline Heptacloro & ISO & I & $O C$ & $S$ & 0 & 100 & DS 19; EHC 38; HSG 14 \\
\hline Imazalil & ISO & $\mathrm{F}$ & & $S$ & 0 & 320 & \\
\hline Imidacloprid & $N(B)$ & I & Nitroguanidina & $S$ & 0 & 450 & \\
\hline Iminoctadina & 150 & $\mathrm{~F}$ & & $S$ & 0 & 300 & Irritante ocular \\
\hline loxinil & ISO & $\mathrm{H}$ & & $S$ & 0 & 110 & \\
\hline Ioxinil, octanoato de & (ISO) & $H$ & & $S$ & 0 & 390 & \\
\hline Isoprocarb & ISO & I & $C$ & $S$ & 0 & 403 & \\
\hline lambda-Cihalotrin & $N(B)$ & I & PY & $S$ & 0 & $c 56$ & EHC 142; HSG 38 \\
\hline Lindane & ISO & & & & & & Véase gamma-HCH \\
\hline MEP & $N(J)$ & & & & & & Véase fenitrotión \\
\hline Mercaptodimetur & & & & & & & Véase metiocarb \\
\hline Mercurioso, cloruro & $C$ & $\mathrm{~F}$ & & $S$ & 0 & 210 & \\
\hline Metacrifos & ISO & I & $O P$ & $\mathrm{~L}$ & 0 & 678 & \\
\hline Metaldehído & ISO & M & & $S$ & 0 & 227 & \\
\hline
\end{tabular}


Tabla 62.3 • Lista de productos de grado técnico clasificados en la Clase II: "Moderadamente peligrosos". Continuación.

\begin{tabular}{|c|c|c|c|c|c|c|c|}
\hline Denominación & Situación & $\begin{array}{l}\text { Uso } \\
\text { principal }\end{array}$ & $\begin{array}{l}\text { Tipo } \\
\text { químico }\end{array}$ & $\begin{array}{l}\text { Estado } \\
\text { físico }\end{array}$ & Vía & $\begin{array}{l}\mathrm{DL}_{50} \\
(\mathrm{mg} / \mathrm{kg})\end{array}$ & Observaciones \\
\hline Metam-sodio & (ISO) & F-S & & $S$ & 0 & 285 & \\
\hline Metasulfocarb & ISO & $F$ & & $S$ & 0 & 112 & \\
\hline Metil isotiocianato & ISO & F-S & & $S$ & 0 & 72 & I ritante cutáneo y ocular \\
\hline Metiocarb & ISO & । & C & $S$ & 0 & 100 & \\
\hline Metolcarb & ISO & I & C & $S$ & 0 & 268 & \\
\hline MICP & $N(J)$ & & & & & & Véase isoprocarb \\
\hline Molinato & 150 & $H$ & TC & L & 0 & 720 & \\
\hline MPMC & & & & & & & Véase xililcarb \\
\hline Nabam & ISO & $\mathrm{F}$ & TC & $S$ & 0 & 395 & Bociógeno en ratas \\
\hline NAC & $N(J)$ & & & & & & Véase carbaril \\
\hline Naled & ISO & I & $O P$ & $L$ & 0 & 430 & DS 39 \\
\hline Norbormida & ISO & $R$ & & $S$ & 0 & 52 & \\
\hline $2,4 \cdot P A$ & $N(J)$ & & & & & & Véase 2,4-D \\
\hline PAP & $N(J)$ & & & & & & Véase fentoato \\
\hline Paraquat & 150 & $H$ & P & $S$ & 0 & 150 & $\begin{array}{l}\text { Tiene efectos retardados graves si se absorbe. } \\
\text { En condiciones reales de uso representa un } \\
\text { riesgo bajo }\end{array}$ \\
\hline Pebulato & ISO & $H$ & TC & L & 0 & 1.120 & \\
\hline Permetrin & ISO & । & PY & $L$ & 0 & $c 500$ & DS 51; EHC 94; HSG 33 \\
\hline PHC & $N(J)$ & & & & & & Véase propoxur \\
\hline Pindona & 150 & $R$ & & $S$ & 0 & 50 & \\
\hline Piperofos & ISO & $H$ & & aceite & 0 & 324 & \\
\hline Piraclofos & $N(B)$ & । & $O P$ & $L$ & 0 & 237 & \\
\hline Pirazofos & ISO & $\mathrm{F}$ & & $S$ & 0 & 435 & \\
\hline Piretrinas & $c$ & I & & L & 0 & $500-1.000$ & $\begin{array}{l}\text { Mezcla de compuestos presentes en Pyrethrum, } \\
\text { Cineraefolium y otras flores; DS } 11\end{array}$ \\
\hline Pirimicarb & ISO & $A P$ & C & $S$ & 0 & 147 & \\
\hline Piroquilon & ISO & $F$ & & $S$ & 0 & 320 & \\
\hline Policlorcamfeno & $N(U)$ & & & & & & Véase camfeclor \\
\hline Praletrin & ISO & । & PY & aceite & 0 & 460 & \\
\hline Profenofos & ISO & । & $O P$ & $\mathrm{~L}$ & 0 & 358 & \\
\hline Promacil & N(Aust) & Ix & $C$ & $L$ & 0 & 1.220 & \\
\hline Promecarb & ISO & । & C & $S$ & 0 & 74 & \\
\hline Propiconazol & ISO & $\mathrm{F}$ & & $L$ & 0 & 1.520 & \\
\hline Propoxur & ISO & I & C & $S$ & 0 & 95 & DS 25 \\
\hline Prosulfocarb & ISO & H & & $L$ & 0 & 1.820 & \\
\hline Protiofos & ISO & । & $O P$ & $L$ & 0 & 925 & \\
\hline Quinalfos & ISO & । & $O P$ & $S$ & 0 & 62 & \\
\hline Quizalofop-p-tefuril & ISO & $H$ & & $L$ & 0 & 1.012 & \\
\hline Reglone & $N(U)$ & & & & & & Véase diquat \\
\hline Ronnel & $N(A)$ & & & & & & Véase fenclorfos \\
\hline Rotenona & $c$ & I & & $S$ & 0 & $132-1.500$ & $\begin{array}{l}\text { Compuestos de raíces de Derris y } \\
\text { Lonchocarpus spp.; HSG } 73\end{array}$ \\
\hline
\end{tabular}


Tabla 62.3 - Lista de productos de grado técnico clasificados en la Clase II: "Moderadamente peligrosos". Continuación.

\begin{tabular}{|c|c|c|c|c|c|c|c|}
\hline Denominación & Situación & $\begin{array}{l}\text { Uso } \\
\text { principal }\end{array}$ & $\begin{array}{l}\text { Tipo } \\
\text { químico }\end{array}$ & $\begin{array}{l}\text { Estado } \\
\text { físico }\end{array}$ & Vía & $\begin{array}{l}\mathrm{DL}_{50} \\
(\mathrm{mg} / \mathrm{kg})\end{array}$ & Observaciones \\
\hline Salition & & & & & & & Véase dioxabenzofos \\
\hline SAP & $N(J)$ & & & & & & Véase bensulide \\
\hline Sec-butilamina & & & & & & & Véase butilamina \\
\hline Sevin & $N(U)$ & & & & & & Véase carbaril \\
\hline Sódico, fluoruro & ISO & I & & $S$ & 0 & 180 & \\
\hline Sódico, hexafluorosilicato & ISO & L-S & & S & 0 & 125 & \\
\hline Sulfallate & ISO & $H$ & & aceite & 0 & 850 & Irritante cutáneo y ocular \\
\hline Sulprofos & ISO & I & $O P$ & aceite & 0 & 130 & \\
\hline $2,4,5-T$ & ISO & $H$ & & S & 0 & 500 & $\begin{array}{l}\text { Puede contener el contaminante TCDD, que tiene } \\
\text { sus correspondientes efectos tóxicos; no debe } \\
\text { exceder de } 0,01 \mathrm{mg} / \mathrm{kg} \text { material técnico; DS } 13\end{array}$ \\
\hline TCA & ISO & & & & & & $\begin{array}{l}\text { Los datos indicados se refieren al ácido } \\
\text { tricloroacético. En muchos países, el término } \\
\text { TCA se refiere al ácido libre (ahora aceptado } \\
\text { por ISO); éste es un sólido con una DL } \mathrm{L}_{50} \text { de } \\
400 \mathrm{mg} / \mathrm{kg} \text { y si se usa como plaguicida se } \\
\text { incluye en la Clase II. Es muy corrosivo para } \\
\text { la piel. }\end{array}$ \\
\hline Terbumeton & ISO & $H$ & T & $S$ & 0 & 483 & \\
\hline Tetraconazol & ISO & $\mathrm{F}$ & & aceite & 0 & 1.031 & \\
\hline Tiazafluron & 150 & $H$ & & S & 0 & 278 & \\
\hline Tiazfluron & $N(B)$ & & & & & & Véase tiazafluron \\
\hline Ticiofen & 150 & $\mathrm{~F}$ & & $S$ & 0 & 368 & \\
\hline Tiobencarb & ISO & $H$ & $\mathrm{TC}$ & L & 0 & 1.300 & \\
\hline Tiociclam & ISO & । & & $S$ & 0 & 310 & \\
\hline Tiodán & $N(U)$ & & & & & & Véase endosulfán \\
\hline Tiodicarb & ISO & I & & $S$ & 0 & 66 & \\
\hline Tolil-metil-carbamato & & & & & & & Véase metolcarb \\
\hline Toxafeno & $N(A)$ & & & & & & Véase camfeclor \\
\hline Tralometrin & $N(B)$ & I & PY & $S$ & 0 & $c 85$ & \\
\hline Triciclazol & 150 & $\mathrm{~F}$ & & $S$ & 0 & 305 & \\
\hline \multicolumn{8}{|l|}{ Tricloroacético, ácido } \\
\hline Tridemorf & ISO & $\mathrm{F}$ & & aceite & 0 & 650 & \\
\hline Vernolato & 150 & $H$ & $\mathrm{TC}$ & $\mathrm{L}$ & 0 & 1.780 & \\
\hline Xililcarb & $N(B)$ & । & $c$ & S & 0 & 380 & \\
\hline
\end{tabular}

Fuente: OMS 1996. 
Tabla 62.4 - Lista de productos de grado técnico clasificados en la Clase III: "Ligeramente peligrosos".

\begin{tabular}{|c|c|c|c|c|c|c|c|}
\hline Denominación & Situación & Uso principal & $\begin{array}{l}\text { Tipo } \\
\text { químico }\end{array}$ & $\begin{array}{l}\text { Estado } \\
\text { físico }\end{array}$ & Vía & $\begin{array}{l}D L_{50} \\
(\mathrm{mg} / \mathrm{kg})\end{array}$ & Observaciones \\
\hline Acefato & ISO & I & OP & $S$ & 0 & 945 & \\
\hline Acetoclor & ISO & $H$ & & $L$ & 0 & 2.950 & \\
\hline Adifluorfen & 150 & $H$ & & S & 0 & 1.370 & Irritante ocular fuerte \\
\hline Aletrina & ISO & I & PY & aceite & 0 & $c 685$ & EHC 87; HSG 24 \\
\hline Ametrin & ISO & $H$ & $\mathrm{~T}$ & $S$ & 0 & 1.110 & \\
\hline Amitraz & ISO & $A C$ & & $S$ & 0 & 800 & \\
\hline Azametifos & 150 & 1 & OP & $S$ & 0 & 1.010 & \\
\hline Azidition & $N(F)$ & & & & & & Véase menazón \\
\hline Barbán & ISO & $H$ & & $S$ & 0 & 1.300 & \\
\hline Bensultap & ISO & I & & $S$ & 0 & 1.100 & \\
\hline Bentazona & ISO & $H$ & & $S$ & 0 & 1.100 & \\
\hline Benzoilprop-etil & (ISO) & $H$ & & $S$ & 0 & 1.555 & \\
\hline Benzotiazuron & ISO & $H$ & & $S$ & 0 & 1.280 & \\
\hline Bromofenoxim & ISO & $H$ & & $S$ & 0 & 1.217 & \\
\hline Bromofos & 150 & I & $O P$ & S & 0 & $c 1.600$ & DS 76 \\
\hline Butidazol & ISO & $H$ & & $S$ & 0 & 1.480 & \\
\hline Cacodílico, ácido & & & & & & & Véase ácido dimetilarsínico \\
\hline Carbofos & $N(U)$ & & & & & & Véase malatión \\
\hline Cicloato & 150 & $H$ & TC & $L$ & 0 & +2.000 & \\
\hline Cihexatin & ISO & $A C$ & ОТ & $S$ & 0 & 540 & \\
\hline Cimoxanil & ISO & $\mathrm{F}$ & & $S$ & 0 & 1.196 & \\
\hline Ciproconazol & $N(B)$ & $\mathrm{F}$ & & $S$ & 0 & 1.020 & \\
\hline Cismetrin & ISO & & & & & & $\begin{array}{l}\text { El resmetrin es una mezcla de isómeros; el } \\
\text { isómero trans }(70-80 \%) \text { se conoce también } \\
\text { como bioresmetrin, y el isómero cis }(20-30 \%) \\
\text { como cismetrin. El bioresmetrin aisladamente } \\
\text { (véase la tabla } 62.5) \text { tiene una toxicidad mucho } \\
\text { menor ( } \mathrm{DL}_{50} \text { oral } 9.000 \mathrm{mg} / \mathrm{kg} \text { (DS } 34 \text { ) }\end{array}$ \\
\hline Citrex & $N(U)$ & & & & & & Véase dodine \\
\hline Clofop & ISO & H & & L & 0 & 1.208 & \\
\hline Clorfenac & ISO & $H$ & $O C$ & $S$ & 0 & 575 & \\
\hline Clorfenetol & ISO & $A C$ & $O C$ & $S$ & 0 & 930 & \\
\hline Clorfenson & 150 & $A C$ & $O C$ & $S$ & 0 & $c 2.000$ & Irritante cutáneo \\
\hline Clorinat & $N(U)$ & & & & & & Véase barban \\
\hline Clormequat ( cloruro) & ISO & PGR & & S & 0 & 670 & \\
\hline Cloroacético, ácido & $C$ & $H$ & & S & 0 & 650 & $\begin{array}{l}\text { Irritante cutáneo y ocular; datos referidos a la } \\
\text { sal sódica }\end{array}$ \\
\hline Clorobenzilato & ISO & $A C$ & $O C$ & S & 0 & 700 & \\
\hline Clorocolina, cloruro de & $C$ & & & & & & Véase clormequat \\
\hline Clortiamida & ISO & $H$ & & $S$ & 0 & 757 & \\
\hline Cobre, hidróxido de & $C$ & $\mathrm{~F}$ & & $S$ & 0 & 1.000 & \\
\hline Cobre, oxicloruro de & $C$ & $\mathrm{~F}$ & & $S$ & 0 & 1.440 & \\
\hline 4-CPA & ISO & PGR & & $S$ & 0 & 850 & \\
\hline
\end{tabular}


Tabla 62.4 - Lista de productos de grado técnico clasificados en la Clase III: "Ligeramente peligrosos". Continuación

\begin{tabular}{|c|c|c|c|c|c|c|c|}
\hline Denominación & Situación & Uso principal & $\begin{array}{l}\text { Tipo } \\
\text { químico }\end{array}$ & $\begin{array}{l}\text { Estado } \\
\text { físico }\end{array}$ & Vía & $\begin{array}{l}\mathrm{DL}_{50} \\
(\mathrm{mg} / \mathrm{kg})\end{array}$ & Observaciones \\
\hline Crufomato & ISO & । & $O P$ & $S$ & 0 & 770 & \\
\hline Dazomet & ISO & F-S & & $S$ & 0 & 640 & Irritante cutáneo y ocular \\
\hline $2,4-D B$ & $N(B)$ & $H$ & & $S$ & 0 & 700 & \\
\hline DCBN & $N(J)$ & & & & & & Véase clortiamid \\
\hline Deet & & & & & & & Véase dietiltoluamida \\
\hline Dehidroacético, ácido & C & $F$ & & $S$ & 0 & 1.000 & \\
\hline 2,4-DES & $N(B, U)$ & & & & & & Véase disul \\
\hline Desmetrin & ISO & $H$ & T & $S$ & 0 & 1.390 & \\
\hline Dialil dicloroacetamida & & & & & & & Véase diclormid \\
\hline Dicamba & ISO & $H$ & & $S$ & 0 & 1.707 & \\
\hline Diclofob & ISO & $H$ & & $S$ & 0 & 565 & \\
\hline Diclona & ISO & FST & & $S$ & 0 & 1.300 & \\
\hline Diclormid & $N(A)$ & $H$ & & $L$ & 0 & 2.080 & \\
\hline Diclorobenceno & $c$ & FM & & $S$ & 0 & $500-5.000$ & Mezcla de isómeros \\
\hline Diclorofeno & ISO & $F$ & $O C$ & $S$ & 0 & 1.250 & \\
\hline Dicloroprop & ISO & $H$ & & $S$ & 0 & 800 & \\
\hline Dicofol & ISO & $A C$ & & $S$ & 0 & $c 690$ & DS 81 \\
\hline Dienocloro & ISO & $A C$ & & $S$ & 0 & 3.160 & Tóxico por inhalación; sensibilizante cutáneo \\
\hline Dietiltoluamida & ISO & $\mathrm{RP}$ (insectos) & & L & 0 & 02.000 & DS 80 \\
\hline Difenamida & 150 & $\mathrm{H}$ & & $S$ & 0 & 970 & \\
\hline Difenoconazol & ISO & $\mathrm{F}$ & T & $S$ & 0 & 1.453 & \\
\hline Dimepiperato & ISO & H & TC & S & 0 & 946 & \\
\hline Dimetacloro & ISO & H & & $S$ & 0 & 1.600 & \\
\hline Dimetametrin & ISO & H & T & L & 0 & 3.000 & \\
\hline Dimetilarśínico, ácido & C & H & & $S$ & 0 & 1.350 & \\
\hline Dimetipin & ISO & H & & $S$ & 0 & 1.180 & \\
\hline Diniconazol & ISO & $\mathrm{F}$ & & $S$ & 0 & 639 & \\
\hline Dinocap & ISO & $A C_{11} F$ & CNP & $S$ & 0 & 980 & \\
\hline Disul & ISO & $H$ & & $S$ & 0 & 730 & \\
\hline Ditianón & ISO & $\mathrm{F}$ & & $S$ & 0 & 640 & \\
\hline Dodina & ISO & $F$ & & $S$ & 0 & 1.000 & \\
\hline Doguadina & $N(F)$ & & & & & & Véase dodina \\
\hline 2,4-DP & $N(U)$ & & & & & & Véase dicloroprop \\
\hline DSMA & & & & & & & Véase ácido metilarsónico \\
\hline Efilsulfonato & $N(U)$ & & & & & & Véase dorfenson \\
\hline Empentrin [isómeros (1R)] & ISO & I & PY & aceite & 0 & +2.280 & \\
\hline Esprocarb & ISO & $\mathrm{H}$ & TC & L & 0 & +2.000 & Irritante cutáneo y ocular \\
\hline Etacelasil & ISO & PGR & & L & 0 & 2.065 & \\
\hline Etaconazol & ISO & $\mathrm{F}$ & & $S$ & 0 & 1.340 & \\
\hline Etohexadiol & $N(A)$ & RP (insectos) & & $L$ & 0 & 2.400 & \\
\hline Etridiazol & ISO & $\mathrm{F}$ & & $L$ & 0 & 2.000 & \\
\hline
\end{tabular}


Tabla 62.4 • Lista de productos de grado técnico clasificados en la Clase III: "Ligeramente peligrosos". Continuación.

\begin{tabular}{|c|c|c|c|c|c|c|c|}
\hline Denominación & Situación & Uso principal & $\begin{array}{l}\text { Tipo } \\
\text { químico }\end{array}$ & $\begin{array}{l}\text { Estado } \\
\text { físico }\end{array}$ & Vía & $\begin{array}{l}\mathrm{DL}_{50} \\
(\mathrm{mg} / \mathrm{kg})\end{array}$ & Observaciones \\
\hline Fenoprop & ISO & $H$ & & $S$ & 0 & 650 & \\
\hline Fenotiocarb & ISO & L & $C$ & $S$ & 0 & 1.150 & \\
\hline Fenpropidin & ISO & $\mathrm{F}$ & & $S$ & 0 & 1.440 & \\
\hline Fensona & ISO & $A C$ & & $S$ & 0 & 1.550 & \\
\hline Fentiaprop & $N(B)$ & $H$ & & $S$ & 0 & 915 & \\
\hline Ferimzone & 150 & $\mathrm{~F}$ & & $S$ & 0 & 725 & \\
\hline Flamprop & ISO & $H$ & & $S$ & 0 & 1.210 & \\
\hline Flucloralin & ISO & $H$ & & $S$ & 0 & 1.550 & \\
\hline Fluoroglicofen & $N(B)$ & $H$ & & $S$ & 0 & 1.500 & \\
\hline Flurprimidol & ISO & PGR & & $S$ & 0 & 709 & \\
\hline Flusilazol & $N(B)$ & $F$ & & $S$ & 0 & 1.110 & \\
\hline Flutriafol & ISO & $\mathrm{F}, \mathrm{FST}$ & $T$ & $S$ & 0 & 1.140 & \\
\hline Fomesafen & ISO & $\mathrm{H}$ & $O C$ & $S$ & 0 & 1.250 & \\
\hline Fuberidazol & ISO & $F$ & & $S$ & 0 & 1.100 & \\
\hline Furalaxil & ISO & $\mathrm{F}$ & & $S$ & 0 & 940 & \\
\hline Glufosinato & ISO & $H$ & & $S$ & 0 & 1.625 & \\
\hline Heptopargil & ISO & PGR & & L & 0 & 2.100 & \\
\hline Hexazinona & ISO & $H$ & & $S$ & 0 & 1.690 & \\
\hline Hidrametilnona & $N(A, B)$ & I & & $S$ & 0 & 1.200 & \\
\hline IBP & & & & & & & Véase iprobenfos \\
\hline Iprobenfos & $N(B)$ & $\mathrm{F}$ & & $S$ & 0 & 600 & \\
\hline Isoprotiolan & 150 & $\mathrm{~F}$ & & $S$ & 0 & 1.190 & \\
\hline Isoproturon & ISO & $H$ & & S & 0 & 1.800 & \\
\hline Isouron & 150 & H & & $S$ & 0 & 630 & \\
\hline Isoxapirifop & ISO & H & & $S$ & 0 & 500 & \\
\hline Keltane & $N(J)$ & & & & & & Véase dicofol \\
\hline Malatión & 150 & I & OP & L & 0 & c2.100 & $\begin{array}{l}\text { El valor de } \mathrm{DL}_{50} \text { puede variar según las impurezas. } \\
\text { Este valor se ha adoptado con vistas a la } \\
\text { clasificación y es el correspondiente a un } \\
\text { producto de grado técnico }\end{array}$ \\
\hline Maldison & N(Aus,NZ) & & & & & & Véase malatión \\
\hline MCPA & ISO & $\mathrm{H}$ & & $S$ & 0 & 700 & \\
\hline MCPA-tioetilo & ISO & H & & $S$ & 0 & 790 & \\
\hline MCPB & ISO & H & & $S$ & 0 & 680 & \\
\hline Mecoprop & ISO & H & & $S$ & 0 & 930 & \\
\hline Mecoprop-P & ISO & $H$ & & $S$ & 0 & 1.050 & \\
\hline Mefluidida & ISO & $H$ & & $S$ & 0 & 1.920 & \\
\hline Menazón & ISO & AP & $O P$ & $S$ & 0 & 1.950 & \\
\hline Mepiquat & ISO & PGR & & $S$ & 0 & 1.490 & \\
\hline Metalaxil & ISO & $\mathrm{F}$ & & $S$ & 0 & 670 & \\
\hline Metaxon & $N(U)$ & & & & & & Véase MCPA \\
\hline Metazol & $N(A, B)$ & $H$ & & $S$ & 0 & 4.543 & Irritante ocular ligero \\
\hline
\end{tabular}


Tabla 62.4 • Lista de productos de grado técnico clasificados en la Clase III: "Ligeramente peligrosos". Continuación.

\begin{tabular}{|c|c|c|c|c|c|c|c|}
\hline Denominación & Situación & Uso principal & $\begin{array}{l}\text { Tipo } \\
\text { químico }\end{array}$ & $\begin{array}{l}\text { Estado } \\
\text { físico }\end{array}$ & Vía & $\begin{array}{l}\mathrm{DL}_{50} \\
(\mathrm{mg} / \mathrm{kg})\end{array}$ & Observaciones \\
\hline Metilarsónico, ácido & ISO & $H$ & & S & 0 & 1.800 & \\
\hline Metoconazol & ISO & $\mathrm{F}$ & & $S$ & 0 & 660 & \\
\hline Metolaclor & ISO & $H$ & & $L$ & 0 & 2.780 & \\
\hline 2-Metoxietilmercurio, silicato de & $C$ & FST & OM & $S$ & 0 & 1.140 & \\
\hline Miclobutanil & $N(B)$ & $\mathrm{F}$ & & $S$ & 0 & 1.600 & \\
\hline MSMA & & & & & & & Véase ácido metilarsónico \\
\hline 2-Naftiloxiacético, ácido & ISO & $P G R$ & & $S$ & 0 & 600 & \\
\hline Nitrapirin & ISO & $B-S$ & & $S$ & 0 & 1.072 & \\
\hline N-octil-biciclohepten-dicarboximida & $c$ & SY & & $\mathrm{L}$ & 0 & 2.800 & \\
\hline Nuarimol & ISO & $\mathrm{F}$ & & $S$ & 0 & 1.250 & \\
\hline Octilinona & 150 & $\mathrm{~F}$ & & $S$ & 0 & 1.470 & \\
\hline Oxadixil & $N(B)$ & $\mathrm{F}$ & & $S$ & 0 & 1.860 & \\
\hline Paclobutrazol & ISO & PGR & & $S$ & 0 & 1.300 & \\
\hline Paletrina & $N(F)$ & & & & & & Véase aletrina \\
\hline Para-diclorobenceno & & & & & & & Véase diclorobenceno \\
\hline Pendimetalin & ISO & H & & $S$ & 0 & 1.050 & \\
\hline Perfluidona & ISO & $H$ & & $S$ & 0 & 920 & \\
\hline Pimarizina & $N(B)$ & $\mathrm{F}$ & & $S$ & 0 & 2.730 & Antibiótico, idéntico a tenecina y natamicina \\
\hline Piprooctanilo & 150 & PGR & & $S$ & 0 & 820 & \\
\hline Pirazoxifen & ISO & $H$ & & $S$ & 0 & 1.644 & \\
\hline Piridaben & ISO & $A C$ & & $S$ & 0 & 820 & \\
\hline Piridafention & $N(J)$ & I & OP & $S$ & 0 & 769 & \\
\hline Piridato & ISO & $H$ & & $S$ & 0 & $c 2.000$ & \\
\hline Pirifenox & ISO & $\mathrm{F}$ & & $\mathrm{L}$ & 0 & 2.900 & \\
\hline Pirimifos-metil & ISO & I & OP & L & 0 & 2.018 & DS 49 \\
\hline Procloraz & ISO & $\mathrm{F}$ & & $S$ & 0 & 1.600 & \\
\hline Propacloro & ISO & $H$ & & $S$ & 0 & 1.500 & DS 78 \\
\hline Propanil & ISO & $H$ & & $S$ & 0 & $c 1.400$ & \\
\hline Propargita & ISO & $A C$ & & $L$ & 0 & 2.200 & \\
\hline Quinoclamina & ISO & $H$ & & $S$ & 0 & 1.360 & \\
\hline Quizalofop & $N(B)$ & $H$ & & $S$ & 0 & 1.670 & \\
\hline Resmetrin & 150 & । & PY & $S$ & 0 & 2.000 & Véase cismetrin; EHC 92, DS 83, HSG 25 \\
\hline Riania & $c$ & । & & $S$ & 0 & $c 750$ & $\mathrm{DL}_{50}$ variable: producto vegetal \\
\hline Sesamex & $N(A)$ & SY & & $L$ & 0 & 2.000 & \\
\hline Setoxidim & ISO & $H$ & & $L$ & 0 & 3.200 & \\
\hline Silvex & $N(A)$ & & & & & & Véase fenoprop \\
\hline Simetrin & ISO & $H$ & $T$ & $S$ & 0 & 1.830 & \\
\hline Sódico,, clorato & ISO & $H$ & & $S$ & 0 & 1.200 & \\
\hline Sulfluramida & ISO & I & & $S$ & 0 & 543 & \\
\hline Sulfóxido & $N(A)$ & SY & & $L$ & 0 & 2.000 & \\
\hline 2,3,6-TBA & ISO & $H$ & & $S$ & 0 & 1.500 & \\
\hline
\end{tabular}


Tabla 62.4 Lista de productos de grado técnico clasificados en la Clase III: "Ligeramente peligrosos". Continuación

\begin{tabular}{|c|c|c|c|c|c|c|c|}
\hline Denominación & Situación & Uso principal & $\begin{array}{l}\text { Tipo } \\
\text { químico }\end{array}$ & $\begin{array}{l}\text { Estado } \\
\text { físico }\end{array}$ & Vía & $\begin{array}{l}\mathrm{DL}_{50} \\
(\mathrm{mg} / \mathrm{kg})\end{array}$ & Observaciones \\
\hline Tebutiron & ISO & $H$ & & $S$ & 0 & 644 & \\
\hline Tiram & ISO & $\mathrm{F}$ & & $S$ & 0 & 560 & DS 71 \\
\hline TMTD & $N(U)$ & & & & & & Véase tiram \\
\hline $2,4,5-\mathrm{TP}$ & $N(F, J, U)$ & & & & & & Véase fenoprop \\
\hline Tralcoxidim & ISO & $H$ & & $S$ & 0 & 934 & \\
\hline Triadimefon & ISO & $F$ & & $S$ & 0 & 602 & \\
\hline Triadimenol & ISO & FST & & $S$ & 0 & 900 & \\
\hline Trialate & ISO & H & $\mathrm{TC}$ & $\mathrm{L}$ & 0 & 2.165 & HSG 89 \\
\hline Triclopir & ISO & H & & $S$ & 0 & 710 & \\
\hline Triclorfon & ISO & $H$ & $O P$ & $S$ & 0 & 560 & DS 27; EHC 132; HSG 66 \\
\hline Tridifane & $N(B)$ & $H$ & & $S$ & 0 & 1.740 & \\
\hline Trifenmorf & ISO & M & & $S$ & 0 & 1.400 & DS 64 \\
\hline Triflumizol & $N(B)$ & $\mathrm{F}$ & & $S$ & 0 & 695 & \\
\hline Undecan-2-ona & $c$ & $\begin{array}{l}\text { RP (perros, } \\
\text { gatos) }\end{array}$ & & aceite & 0 & 2.500 & \\
\hline Uniconazol & ISO & PGR & & $S$ & 0 & 1,790 & \\
\hline XMC & $N(J)$ & । & C & $S$ & 0 & 542 & \\
\hline Ziram & ISO & $\mathrm{F}$ & & $S$ & 0 & 1.400 & Irritante cutáneo; DS 73 \\
\hline
\end{tabular}

Fuente: OMS 1996.

\begin{tabular}{|c|c|c|c|c|c|c|c|}
\hline Denominación & Situación & Uso principal & $\begin{array}{l}\text { Tipo } \\
\text { químico }\end{array}$ & $\begin{array}{l}\text { Estado } \\
\text { físico }\end{array}$ & Vía & $\begin{array}{l}\mathrm{DL}_{50} \\
(\mathrm{mg} / \mathrm{kg})\end{array}$ & Observaciones \\
\hline Aclonifeno & $N(B)$ & $H$ & & $S$ & 0 & +5.000 & \\
\hline Acrinatrina & ISO & MT & & $S$ & 0 & +5.000 & \\
\hline Aloxidina & ISO & $H$ & & $S$ & 0 & 2.260 & \\
\hline Aminotriazol & $N(F)$ & & & & & & Véase amitrol \\
\hline Amitrol & ISO & $H$ & T & $S$ & 0 & 5.000 & EHC 158, DS 79; HSG 85 \\
\hline Amónico, sulfamato & ISO & $H$ & & $S$ & 0 & 3.900 & \\
\hline Ancimidol & ISO & PGR & & $S$ & 0 & 4.500 & \\
\hline Anilazina & ISO & $\mathrm{F}$ & T & $S$ & 0 & 2.710 & Irritante cutáneo y ocular \\
\hline Antraquinona & 150 & RP (aves) & & $S$ & 0 & +5.000 & \\
\hline Asulam & ISO & $H$ & $\mathrm{TC}$ & $S$ & 0 & +4.000 & \\
\hline Atrazina & ISO & $H$ & T & $S$ & 0 & 02.000 & DS 82; HSG 47 \\
\hline Aziprotrina & ISO & $H$ & T & $S$ & 0 & 3.600 & \\
\hline Azufre & ISO & $\mathrm{F}, \mathrm{l}$ & & $S$ & 0 & +3.000 & $\begin{array}{l}\text { Irritante cutáneo y de mucosas. El polvo de } \\
\text { azufre puede arder espontáneamente a } \\
\text { menos que se diluya en aproximadamente } \\
\text { un } 50 \% \text { con un material inerte }\end{array}$ \\
\hline
\end{tabular}




\section{Tabla 62.5 - Lista de productos de grado técnico que es improbable que presenten riesgo agudo en condiciones de uso normales.}

Continuación.

\begin{tabular}{|c|c|c|c|c|c|c|c|}
\hline Denominación & Situación & Uso principal & $\begin{array}{l}\text { Tipo } \\
\text { químico }\end{array}$ & $\begin{array}{l}\text { Estado } \\
\text { físico }\end{array}$ & Vía & $\begin{array}{l}\mathrm{DL}_{50} \\
(\mathrm{mg} / \mathrm{kg})\end{array}$ & Observaciones \\
\hline Benalaxil & ISO & $\mathrm{F}$ & & $S$ & 0 & $c 4.200$ & \\
\hline Benazolina & ISO & $H$ & & $S$ & 0 & 3.200 & Irritante cutáneo y ocular \\
\hline Benefina & $N(A)$ & & & & & & Véase benfluralin \\
\hline Benfluralina & ISO & $H$ & & $S$ & 0 & +10.000 & \\
\hline Benfuresato & ISO & $H$ & & $S$ & 0 & 2.031 & \\
\hline Benomilo & ISO & $\mathrm{F}$ & TC & S & 0 & +10.000 & EHC 148, DS 87; HSG 81 \\
\hline Benoxacor & ISO & $H$ & & $S$ & 0 & +5.000 & \\
\hline Bensulfuron & $N(B)$ & $H$ & & $S$ & 0 & +5.000 & \\
\hline Bentrodina & $N(J)$ & & & & & & Véase benfluralina \\
\hline Benzamizol & & & & & & & Véase isoxaben \\
\hline Benzoximato & ISO & $A C$ & & $S$ & 0 & +10.000 & \\
\hline Bifenilo & ISO & $F$ & & $S$ & 0 & 3.280 & \\
\hline Bifenox & ISO & $H$ & & $S$ & 0 & +6.400 & \\
\hline Bioresmetrina & ISO & । & PY & L & 0 & +7.000 & DS 34 \\
\hline Bispiribac & ISO & $H$ & & $S$ & 0 & 2.635 & \\
\hline Bitertanol & ISO & $\mathrm{F}$ & & S & 0 & +5.000 & \\
\hline Bórax & ISO & $\mathrm{F}$ & & $S$ & 0 & 4.500 & \\
\hline Bromazilo & ISO & $H$ & & $S$ & 0 & 5.200 & \\
\hline Bromobutida & ISO & $H$ & & $S$ & 0 & +5.000 & \\
\hline Bromociclen & ISO & $I, A C$ & & $S$ & 0 & +10.000 & \\
\hline Bromopropilato & ISO & $A C$ & & $S$ & 0 & +5.000 & \\
\hline Bupirimato & ISO & $\mathrm{F}$ & & $S$ & 0 & $c 4.000$ & \\
\hline Buprofezina & 150 & I & & $S$ & 0 & 2.200 & \\
\hline Butaclor & ISO & $H$ & & L & 0 & 3.300 & \\
\hline Butilato & ISO & $\mathrm{F}$ & TC & L & 0 & +4.000 & \\
\hline Butiobato & ISO & $F$ & & L & 0 & 3.200 & \\
\hline Butopironoxil & $N(A)$ & RP (insectos) & & $L$ & 0 & 7.840 & \\
\hline Butralina & 150 & $\mathrm{H}$ & & $S$ & 0 & +10.000 & \\
\hline Buturon & ISO & $H$ & & $S$ & 0 & 3.000 & \\
\hline Caimuron & ISO & $H$ & & $S$ & 0 & +5.000 & \\
\hline Captán & ISO & $\mathrm{F}$ & & $S$ & 0 & 9.000 & Irritante cutáneo; DS 9; HSG 50 \\
\hline Carbendazima & ISO & $\mathrm{F}$ & & S & 0 & +10.000 & DS 89; EHC 149; HSG 82 \\
\hline Carbetamida & ISO & $H$ & & S & 0 & +10.000 & \\
\hline Carboxina & ISO & FST & & S & 0 & 3.820 & \\
\hline Cicloprotrina & 150 & । & PY & L & 0 & +5.000 & \\
\hline Cicloxidim & $N(B)$ & $H$ & & S & 0 & 3.900 & \\
\hline Cicluron & ISO & $H$ & & S & 0 & 2.600 & \\
\hline Cinmetilina & ISO & $H$ & & L & 0 & 3.960 & \\
\hline Cinosulfuron & ISO & $H$ & & S & 0 & +5.000 & \\
\hline Ciometrinil & $N(B)$ & $H$ & & s & 0 & 2.277 & \\
\hline
\end{tabular}


Tabla 62.5 - Lista de productos de grado técnico que es improbable que presenten riesgo agudo en condiciones de uso normales.

Continuación.

\begin{tabular}{|c|c|c|c|c|c|c|c|}
\hline Denominación & Situación & Uso principal & $\begin{array}{l}\text { Tipo } \\
\text { químico }\end{array}$ & $\begin{array}{l}\text { Estado } \\
\text { físico }\end{array}$ & Vía & $\begin{array}{l}\mathrm{DL}_{50} \\
(\mathrm{mg} / \mathrm{kg})\end{array}$ & Observaciones \\
\hline Ciromazina & ISO & $L$ & & $S$ & 0 & 3.300 & \\
\hline Clofentezina & $N(B)$ & $A C$ & & $S$ & 0 & +5.200 & \\
\hline Clomeprop & ISO & $H$ & & $S$ & 0 & +5.000 & \\
\hline Clometoxifeno & $N(B)$ & $\mathrm{H}$ & & $S$ & 0 & +10.000 & \\
\hline Clonitralida & $N(A)$ & & & & & & Véase niclosamida \\
\hline Clopiralida & $N(B)$ & $\mathrm{H}$ & & $S$ & 0 & 4.300 & Irritante ocular fuerte \\
\hline Clorambén & ISO & $H$ & & $S$ & 0 & 5.620 & \\
\hline Clorbromurón & ISO & $H$ & & $S$ & 0 & +5.000 & \\
\hline Clorbufam & ISO & $H$ & & $S$ & 0 & 2.500 & \\
\hline Clorfenidim & $N(U)$ & & & & & & Véase monuron \\
\hline Clorfluazurona & ISO & IGR & & $S$ & 0 & 8.500 & \\
\hline Clorflurecol & $N(B)$ & & & & & & Véase clorflurenol \\
\hline Clorflurenol & ISO & PGR & $O C$ & $S$ & 0 & +10.000 & \\
\hline Clorfoxim & ISO & I & $O P$ & $S$ & 0 & +2.500 & DS 32 \\
\hline Cloridazona & ISO & $H$ & & $S$ & 0 & 2.420 & \\
\hline Clorimuron & $N(B)$ & $H$ & & $S$ & 0 & 4.102 & \\
\hline Clornitrofen & ISO & $H$ & & $S$ & 0 & +10.000 & \\
\hline Clorometiuron & ISO & Ix & & $S$ & 0 & 2.500 & \\
\hline Cloroneb & ISO & $H$ & $O C$ & $S$ & 0 & +10.000 & \\
\hline Cloropropilato & ISO & $A C$ & $O C$ & $S$ & 0 & +5.000 & \\
\hline Clorotal-dimetil & ISO & $\mathrm{H}$ & & $S$ & 0 & +3.000 & \\
\hline Clorotalonil & ISO & $\mathrm{F}$ & & $S$ & 0 & +10.000 & \\
\hline Clorotoluron & ISO & $H$ & & $S$ & 0 & +10.000 & \\
\hline Cloroxifenidina & $N(U)$ & & & & & & Véase cloroxuron \\
\hline Cloroxuron & ISO & $H$ & & $S$ & 0 & +3.000 & \\
\hline Clorpirifos metil & ISO & I & OP & $L$ & 0 & +3.000 & DS 33 \\
\hline Clorprofam & ISO & $H$ & & $S$ & 0 & +5.000 & \\
\hline Clorsulfuron & ISO & $\mathrm{H}$ & & $S$ & 0 & 5.545 & \\
\hline Cloxifonac & ISO & $P G R$ & & $S$ & 0 & +5.000 & \\
\hline Clozolinato & $N(B)$ & $F$ & & $S$ & 0 & +4.000 & \\
\hline CNA & $N(J)$ & & & & & & Véase dicloran \\
\hline COMU & $N(J)$ & & & & & & Véase cicluron \\
\hline Credazina & $N(J)$ & $H$ & & $S$ & 0 & 3.090 & \\
\hline Criolita & $c$ & I & & $S$ & 0 & +10.000 & \\
\hline Dalapon & $N(A, B, F)$ & $H$ & & $S$ & 0 & 9.330 & \\
\hline Daminozida & ISO & $H$ & & $S$ & 0 & 8.400 & \\
\hline Desmedifam & ISO & $H$ & & $S$ & 0 & +9.600 & \\
\hline Diafentiuron & ISO & $A C$ & & $\mathrm{~S}$ & 0 & 2.068 & \\
\hline Diclobenil & ISO & $\mathrm{H}$ & & $\mathrm{S}$ & 0 & 3.160 & \\
\hline Diclobutrazol & ISO & $F$ & $\mathrm{~T}$ & $\mathrm{~S}$ & 0 & +4.000 & \\
\hline Diclofluanida & ISO & $F$ & & $S$ & 0 & +5.000 & \\
\hline
\end{tabular}


Tabla 62.5 - Lista de productos de grado técnico que es improbable que presenten riesgo agudo en
condiciones de uso normales. Continuación.

\begin{tabular}{|c|c|c|c|c|c|c|c|}
\hline Denominación & Situación & Uso principal & $\begin{array}{l}\text { Tipo } \\
\text { químico }\end{array}$ & $\begin{array}{l}\text { Estado } \\
\text { físico }\end{array}$ & Vía & $\begin{array}{l}D L_{50} \\
(\mathrm{mg} / \mathrm{kg})\end{array}$ & Observaciones \\
\hline Diclomezina & ISO & $\mathrm{F}$ & & $S$ & 0 & +10.000 & \\
\hline Dicloran & $N(B)$ & $\mathrm{F}$ & & $S$ & 0 & 4.000 & \\
\hline Diclorfenidim & $N(U)$ & & & & & & Véase diuron \\
\hline Dicloropicolínico, ácido & & & & & & & Véase clopiralida \\
\hline Dietatil & ISO & $H$ & & $S$ & 0 & 2.300 & \\
\hline Dietofencarb & ISO & $\mathrm{F}$ & & $S$ & 0 & +5.000 & \\
\hline Difenilo & & & & & & & Véase bifenilo \\
\hline Difenoxuron & ISO & $H$ & & $S$ & 0 & +7.750 & \\
\hline Diflubenzuron & ISO & $L$ & & $S$ & 0 & +4.640 & DS 77 \\
\hline Diflufenican & $N(B)$ & $H$ & & $S$ & 0 & +2.000 & \\
\hline Dikegulac & ISO & PGR & & S & 0 & +10.000 & \\
\hline Dimefuron & ISO & $H$ & & $S$ & 0 & +2.000 & \\
\hline Dimetilftalato & $C$ & RP (insectos) & & $L$ & 0 & 8.200 & \\
\hline Dimetirimol & ISO & $\mathrm{F}$ & & $S$ & 0 & 2.350 & \\
\hline Dimetomorf & 150 & $\mathrm{~F}$ & & S & 0 & +5.000 & \\
\hline Dinitramina & ISO & $H$ & & S & 0 & 3.000 & \\
\hline Dipropetrin & ISO & $H$ & T & $S$ & 0 & 4.050 & \\
\hline Dipropilisocincomerato & $c$ & $\mathrm{RP}$ (moscas) & & $L$ & 0 & 5.230 & \\
\hline Disódico, octaborato & & & & & & & Véase bórax \\
\hline Ditalmifos & ISO & $\mathrm{F}$ & $O P$ & $S$ & 0 & 5.660 & Irritante cutáneo; alergénico \\
\hline Ditiopir & ISO & $H$ & & & 0 & +5.000 & \\
\hline Diuron & ISO & $H$ & & $S$ & 0 & 3.400 & \\
\hline Dodemorf & 150 & $H$ & & $L$ & 0 & 4.500 & \\
\hline Eglinazina & ISO & $H$ & & $S$ & 0 & +10.000 & \\
\hline Etalfluralina & ISO & $H$ & & $S$ & 0 & +10.000 & \\
\hline Etefon & $N(A)$ & PGR & & $S$ & 0 & +4.000 & \\
\hline Etidimuron & 150 & $H$ & & S & 0 & +5.000 & \\
\hline Etirimol & ISO & FST & & $S$ & 0 & 6.340 & \\
\hline Etofenprox & $N(B)$ & 1 & & $S$ & 0 & +10.000 & \\
\hline Etofumesato & ISO & $H$ & & $S$ & 0 & +6.400 & \\
\hline Fenarimol & 150 & $\mathrm{~F}$ & & $S$ & 0 & 2.500 & \\
\hline Fenbutatin, óxido de & ISO & MT & ОТ & $S$ & 0 & 2.630 & EHC 15 \\
\hline Fenclorazol & ISO & $H$ & & $S$ & 0 & +5.000 & \\
\hline Fenclorim & ISO & $H$ & & $S$ & 0 & +5.000 & \\
\hline Fenfuram & ISO & FST & & $S$ & 0 & +10.000 & \\
\hline Fenidim & $N(U)$ & & & & & & Véase fenuron \\
\hline 2-Fenilfenol & ISO & $\mathrm{F}$ & & $S$ & 0 & 2.480 & \\
\hline Fenisobromolato & $N(J)$ & & & & & & Véase bromopropilato \\
\hline Fenisofam & ISO & $H$ & & $S$ & 0 & +4.000 & \\
\hline Fenitropan & 150 & $\mathrm{~F}$ & & $S$ & 0 & 3.230 & \\
\hline Fenmedifam & ISO & $H$ & & $S$ & 0 & +8.000 & \\
\hline
\end{tabular}


Tabla 62.5 - Lista de productos de grado técnico que es improbable que presenten riesgo agudo en condiciones de uso normales.

Continuación.

\begin{tabular}{|c|c|c|c|c|c|c|c|}
\hline Denominación & Situación & Uso principal & $\begin{array}{l}\text { Tipo } \\
\text { químico }\end{array}$ & $\begin{array}{l}\text { Estado } \\
\text { físico }\end{array}$ & Vía & $\begin{array}{l}\mathrm{DL}_{50} \\
(\mathrm{mg} / \mathrm{kg})\end{array}$ & Observaciones \\
\hline Fenotrin & ISO & I & PY & $\mathrm{L}$ & 0 & +5.000 & DS 85; EHC 96; HSG 32 \\
\hline Fenoxaprop-etilo & $N(B)$ & $H$ & & $S$ & 0 & 2.350 & \\
\hline Fenoxicarb & ISO & 1 & C & $S$ & 0 & +10.000 & \\
\hline Fenpiclonilo & ISO & FST & & $S$ & 0 & +5.000 & \\
\hline Fenpropimorf & ISO & $\mathrm{F}$ & & aceite & 0 & 3.515 & \\
\hline Fenurón & ISO & $H$ & & $S$ & 0 & 6.400 & \\
\hline Fenurón-TCA & (ISO) & $H$ & & $S$ & 0 & 4.000 & \\
\hline Ferbam & ISO & $\mathrm{F}$ & TC & $S$ & 0 & +10.000 & \\
\hline Flamprop-M & ISO & $H$ & & $S$ & 0 & +3.000 & \\
\hline Fluazifop & ISO & $H$ & $P$ & $\mathrm{~L}$ & 0 & 3.330 & \\
\hline Flubenzimina & ISO & $A C$ & & $S$ & 0 & 3.000 & \\
\hline Flucicloxuron & ISO & $A C$ & & $S$ & 0 & +5.000 & \\
\hline Flufenoxuron & 150 & I & & $S$ & 0 & +3.000 & \\
\hline Flumetralina & $N(B)$ & PGR & & $S$ & 0 & +5.000 & \\
\hline Flumetsulam & ISO & $H$ & & $S$ & 0 & +5.000 & \\
\hline Fluometuron & ISO & $H$ & & $S$ & 0 & +8.000 & \\
\hline Fluorodifeno & 150 & $H$ & & $S$ & 0 & 9.000 & \\
\hline Fluoromida & $N(J)$ & $\mathrm{F}$ & & $S$ & 0 & +10.000 & \\
\hline Flupropanato & ISO & $H$ & & $S$ & 0 & +10.000 & \\
\hline Flurecol-butil & & & & & & & Véase flurenol \\
\hline Flurenol & ISO & PGR & & $S$ & 0 & +5.000 & \\
\hline Fluridona & ISO & $H$ & & $S$ & 0 & +10.000 & \\
\hline Flurocloridona & ISO & $H$ & & $S$ & 0 & 4.000 & \\
\hline Fluroxipir & $N(B)$ & $H$ & & $S$ & 0 & $+5,000$ & \\
\hline Flutiacet & 150 & $H$ & & $S$ & 0 & +5.000 & \\
\hline Flutolanil & ISO & $\mathrm{F}$ & & $S$ & 0 & +10.000 & \\
\hline Folpet & ISO & $\mathrm{F}$ & & $S$ & 0 & +10.000 & HSG 72 \\
\hline Fosamina & ISO & $H$ & & $S$ & 0 & 2.400 & \\
\hline Fosdifen & $N(J)$ & $\mathrm{F}$ & & L & 0 & 6.200 & \\
\hline Fosetil & $N(B)$ & $\mathrm{F}$ & & $S$ & 0 & 5.800 & \\
\hline Ftalida & $N(J)$ & $\mathrm{F}$ & & $S$ & 0 & +10.000 & \\
\hline Furmeciclox & $N(B)$ & FST & & S & 0 & 3.780 & \\
\hline Gibberélico, ácido & $N(B)$ & PGR & & $S$ & 0 & +10.000 & \\
\hline Glifosato & ISO & $H$ & & $S$ & 0 & 4.230 & EHC 159, DS 91 \\
\hline Glifosina & 150 & $H$ & & $S$ & 0 & 3.920 & \\
\hline Hexaconazol & $N(B)$ & $\mathrm{F}$ & & $s$ & 0 & 2.180 & \\
\hline Hexaflumuron & ISO & । & & $s$ & 0 & +5.000 & \\
\hline Hexitiazox & $N(B)$ & $A C$ & & S & 0 & +5.000 & \\
\hline Hidropreno & $N(A)$ & IGR & & L & 0 & +10.000 & \\
\hline 2-Hidroxietiloctilsulfuro & 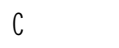 & RP (insectos) & & $L$ & 0 & 8.300 & \\
\hline Hidroxiisoxazol & $N(J)$ & & & & & & Véase himexazol \\
\hline
\end{tabular}


Tabla 62.5 - Lista de productos de grado técnico que es improbable que presenten riesgo agudo en
condiciones de uso normales. Continuación.

\begin{tabular}{|c|c|c|c|c|c|c|c|}
\hline Denominación & Situación & Uso principal & $\begin{array}{l}\text { Tipo } \\
\text { químico }\end{array}$ & $\begin{array}{l}\text { Estado } \\
\text { físico }\end{array}$ & Vía & $\begin{array}{l}\mathrm{DL}_{50} \\
(\mathrm{mg} / \mathrm{kg})\end{array}$ & Observaciones \\
\hline Himexazol & $N(B)$ & FST & & $S$ & 0 & 3.900 & \\
\hline Imazametabenz-metil & (ISO) & $H$ & & $S$ & 0 & +5.000 & \\
\hline Imazapir & ISO & $H$ & & $S$ & 0 & +5.000 & Irritante ocular \\
\hline Imazaquin & ISO & $H$ & & $S$ & 0 & +5.000 & \\
\hline Imazetapir & $N(B)$ & $H$ & & $S$ & 0 & +5.000 & \\
\hline Imibenconazol & 150 & $\mathrm{~F}$ & & $\mathrm{~S}$ & 0 & +5.000 & \\
\hline Inabenfida & ISO & $P G R$ & & $S$ & 0 & +10.000 & \\
\hline lodfenfos & ISO & । & $O P$ & $S$ & 0 & 2.100 & DS 43 \\
\hline lodofenfos & $N(A, B)$ & & & & & & Véase iodfenfos \\
\hline Iprodiona & ISO & $\mathrm{F}$ & & $S$ & 0 & 3.500 & \\
\hline Isopropalin & ISO & $H$ & & $L$ & 0 & +5.000 & \\
\hline Isoxaben & $N(B)$ & $H$ & & $S$ & 0 & +10.000 & \\
\hline Karbutilato & ISO & $H$ & & $S$ & 0 & 3.000 & \\
\hline Kasugamicina & $N(J)$ & $F$ & & $S$ & 0 & +10.000 & \\
\hline Kinopreno & ISO & IGR & & $S$ & 0 & 4.900 & \\
\hline Lenacil & ISO & $H$ & & $S$ & 0 & +10.000 & \\
\hline Linuron & ISO & $H$ & & $S$ & 0 & 4.000 & \\
\hline Maleico, hidrazida & ISO & PGR & & $S$ & 0 & 6.950 & \\
\hline Mancozeb & ISO & $\mathrm{F}$ & TC & $S$ & 0 & +8.000 & Irritante cutáneo en exposición múltiple; DS 94 \\
\hline Maneb & ISO & $\mathrm{F}$ & $\mathrm{TC}$ & $S$ & 0 & 6.750 & Irritante cutáneo en exposición múltiple; DS 94 \\
\hline Mefenacet & ISO & $H$ & & $S$ & 0 & +5.000 & \\
\hline Mepanipirim & ISO & $\mathrm{F}$ & & $S$ & 0 & +5.000 & \\
\hline Mepronilo & $N(J)$ & $\mathrm{F}$ & & $S$ & 0 & +10.000 & \\
\hline Metabenzotiazuron & ISO & $H$ & & $S$ & 0 & +2.500 & \\
\hline Metamitron & ISO & $H$ & & $S$ & 0 & 3.343 & \\
\hline Metazaclor & ISO & $H$ & & $S$ & 0 & 2.150 & \\
\hline Metildimron & $N(J)$ & $H$ & & $S$ & 0 & 3.948 & \\
\hline Metiram & $N(J)$ & $\mathrm{F}$ & & $S$ & 0 & +10.000 & \\
\hline Metobromuron & ISO & $H$ & & $S$ & 0 & 2.500 & \\
\hline Metopreno & ISO & IGR & & $L$ & 0 & +10.000 & DS 47 \\
\hline Metoprotrina & ISO & $H$ & & $S$ & 0 & +5.000 & \\
\hline Metosulam & ISO & $H$ & & $S$ & 0 & +5.000 & \\
\hline Metoxiclor & ISO & I & $O C$ & $S$ & 0 & 6.000 & DS 28 \\
\hline Metoxifenona & $N(J)$ & $H$ & & $S$ & 0 & +4.000 & \\
\hline Metoxuron & ISO & $H$ & & $S$ & 0 & +3.200 & \\
\hline Metribuzin & ISO & $H$ & $T$ & $S$ & 0 & 2.200 & \\
\hline Metsulfovax & 150 & $\mathrm{~F}$ & & $S$ & 0 & 3.929 & \\
\hline Metsulfuron & $N(A, B)$ & $H$ & & $S$ & 0 & +5.000 & \\
\hline Monalida & ISO & $H$ & & $S$ & 0 & +4.000 & \\
\hline Monolinuron & ISO & H & & $S$ & 0 & 2.250 & \\
\hline Monuron & ISO & $H$ & & $S$ & 0 & 3.600 & \\
\hline
\end{tabular}


Tabla 62.5 - Lista de productos de grado técnico que es improbable que presenten riesgo agudo en condiciones de uso normales.

Continuación

\begin{tabular}{|c|c|c|c|c|c|c|c|}
\hline Denominación & Situación & Uso principal & $\begin{array}{l}\text { Tipo } \\
\text { químico }\end{array}$ & $\begin{array}{l}\text { Estado } \\
\text { físico }\end{array}$ & Vía & $\begin{array}{l}\mathrm{DL}_{50} \\
(\mathrm{mg} / \mathrm{kg})\end{array}$ & Observaciones \\
\hline Monuron-TCA & $N(A)$ & $H$ & & $S$ & 0 & 3.700 & \\
\hline Naftaleno & $C$ & $F$ & & $S$ & 0 & 2.200 & \\
\hline Naftálico, anhídrido & $C$ & PGR & & $S$ & 0 & +10.000 & \\
\hline 1-naftilacético, ácido & ISO & $P G R$ & & $S$ & 0 & $c 3.000$ & \\
\hline 2-(1-naftil) acetamida & ISO & $P G R$ & & $S$ & 0 & 6.400 & \\
\hline Napropamida & ISO & $\mathrm{H}$ & & $S$ & 0 & 5.000 & \\
\hline Naptalam & ISO & $P G R$ & & $S$ & 0 & 8.200 & \\
\hline Neburon & ISO & $H$ & & $S$ & 0 & +10.000 & \\
\hline Niclosamida & ISO & M & & $S$ & 0 & 5.000 & DS 63 \\
\hline Nicosulfuron & ISO & $H$ & & $S$ & 0 & +5.000 & Irritante ocular \\
\hline Nitralin & ISO & $H$ & & $S$ & 0 & +2.000 & \\
\hline Nitrotal-isopropil & ISO & $F$ & & $S$ & 0 & 6.400 & \\
\hline Norflurazon & ISO & $\mathrm{H}$ & & $S$ & 0 & +8.000 & \\
\hline (Octiltio) etanol & $C$ & & & & & & Véase 2-hidroxietiloctil sulfuro \\
\hline Ofurace & ISO & $F$ & & $S$ & 0 & 2.600 & \\
\hline Orizalina & ISO & $H$ & & $S$ & 0 & +10.000 & \\
\hline Oxabetrinil & ISO & $H$ & & $S$ & 0 & +5.000 & \\
\hline Oxadiazon & ISO & $H$ & & $S$ & 0 & +8.000 & \\
\hline Oxicarboxina & ISO & $F$ & & $S$ & 0 & 2.000 & \\
\hline Oxifluorfen & ISO & $H$ & & $\mathrm{~S}$ & 0 & +5.000 & \\
\hline Oxinato de cobre & ISO & $F$ & & $S$ & 0 & 10.000 & \\
\hline Pencicuron & ISO & $F$ & & $S$ & 0 & +5.000 & \\
\hline Penconazol & $N(B)$ & $F$ & & $S$ & 0 & 2.120 & \\
\hline Pentanoclor & ISO & $H$ & & $S$ & 0 & +10.000 & \\
\hline Picloram & ISO & $H$ & & $S$ & 0 & 8.200 & \\
\hline Piperonil butóxido & $N(A)$ & SY & & aceite & 0 & +7.500 & \\
\hline Piracarbolid & ISO & $F$ & & $S$ & 0 & +10.000 & \\
\hline Pirazolinato & ISO & $H$ & & $S$ & 0 & 9.550 & \\
\hline Pirazon & $N(A)$ & & & & & & Véase cloridazon \\
\hline Pirazosulfuron & ISO & $H$ & & $S$ & 0 & +5.000 & \\
\hline Pirimetanil & ISO & $\mathrm{F}$ & & $S$ & 0 & 4.150 & \\
\hline Piriminobac & ISO & $H$ & & $S$ & 0 & +5.000 & \\
\hline Piriproxifen & $N(B)$ & I & & $S$ & 0 & +5.000 & \\
\hline Pretilaclor & ISO & $H$ & & $L$ & 0 & 6.100 & \\
\hline Primisulfuron & ISO & $H$ & & $S$ & 0 & +5.050 & \\
\hline Probenazol & $N(J)$ & $F$ & & $S$ & 0 & 2.030 & \\
\hline Procimidona & ISO & $F$ & & $S$ & 0 & 6.800 & \\
\hline Prodiamina & ISO & $\mathrm{H}$ & & $S$ & 0 & +5.000 & \\
\hline Profam & ISO & $H$ & & $S$ & 0 & 5.000 & \\
\hline Profluralina & ISO & $H$ & & $S$ & 0 & $\mathrm{c} 10.000$ & \\
\hline Proglinazina & ISO & $H$ & & $S$ & 0 & +8.000 & \\
\hline
\end{tabular}


Tabla 62.5 - Lista de productos de grado técnico que es improbable que presenten riesgo agudo en Continuación.

\begin{tabular}{|c|c|c|c|c|c|c|c|}
\hline Denominación & Situación & Uso principal & $\begin{array}{l}\text { Tipo } \\
\text { químico }\end{array}$ & $\begin{array}{l}\text { Estado } \\
\text { físico }\end{array}$ & Vía & $\begin{array}{l}\mathrm{DL}_{50} \\
(\mathrm{mg} / \mathrm{kg})\end{array}$ & Observaciones \\
\hline Prometon & ISO & $H$ & $\mathrm{~T}$ & $S$ & 0 & 2.980 & \\
\hline Prometrina & ISO & $H$ & $T$ & $S$ & 0 & 3.150 & \\
\hline Pronamida & $N(A)$ & & & & & & Véase propizamida \\
\hline Propamocarb & ISO & $F$ & & $S$ & 0 & 8.600 & \\
\hline Propaquizafop & ISO & H & & $S$ & 0 & +5.000 & \\
\hline Propazina & ISO & $H$ & $T$ & $S$ & 0 & +5.000 & \\
\hline Propineb & ISO & $H$ & $\mathrm{TC}$ & $S$ & 0 & 8.500 & \\
\hline Propizamida & ISO & $H$ & & $S$ & 0 & 5.620 & \\
\hline Quinclorac & ISO & $H$ & & $S$ & 0 & 2.680 & \\
\hline Quinmerac & ISO & $H$ & & $S$ & 0 & +5.000 & \\
\hline Quinometionato & ISO & $A C, F$ & & $S$ & 0 & 2.500 & \\
\hline Quinonamida & ISO & $F$ & & $S$ & 0 & +10.000 & \\
\hline Quintoceno & ISO & $F$ & & $S$ & 0 & +10.000 & EHC 41 \\
\hline Rimsulfuron & $c$ & $H$ & & $S$ & 0 & +5.000 & \\
\hline Secbumeton & ISO & $H$ & $T$ & $S$ & 0 & 2.680 & \\
\hline Siduron & ISO & $H$ & & $S$ & 0 & +7.500 & \\
\hline Simazina & ISO & $H$ & $T$ & $S$ & 0 & +5.000 & \\
\hline Sódico, metaborato & $C$ & & & & & & Véase bórax \\
\hline Sódico, tricloracetato & & & & & & & $\begin{array}{l}\text { Los datos presentados se refieren al tricloroa- } \\
\text { cetato sódico. En muchos países, el } \\
\text { término TCA se aplica al ácido libre (ahora } \\
\text { aceptado por ISO): éste es un sólido con } \\
\text { una } \mathrm{DL}_{50} \text { de } 400 \mathrm{mg} / \mathrm{kg} \text { y si se usa como } \\
\text { plaguicida debe incluirse en la Clase II. Es } \\
\text { altamente corrosivo para la piel }\end{array}$ \\
\hline Solan & $N(A)$ & & & & & & Véase pentanoclor \\
\hline Stirofos & $N(A)$ & & & & & & Véase tetraclorvinfos \\
\hline Sulfometuron & $N(B)$ & H & & $S$ & 0 & +5.000 & \\
\hline tau-fluvalinato & ISO & I & PY & aceite & 0 & +3.000 & Irritante cutáneo y ocular \\
\hline TCA & ISO & H & & $S$ & 0 & 3.200 & $\begin{array}{l}\text { Irritante cutáneo y ocular; } \\
\text { véase tricloroacetato sódico }\end{array}$ \\
\hline Tebuconazol & ISO & $\mathrm{F}$ & & $S$ & 0 & 4.000 & \\
\hline Tebutam & ISO & H & & aceite & 0 & 6.210 & \\
\hline Tecnaceno & ISO & $\mathrm{F}$ & & $S$ & 0 & +10.000 & EHC 42; HSG 12 \\
\hline Tedion & $N(U)$ & & & & & & Véase tetradifon \\
\hline Teflubenzuron & $N(B)$ & I & & $S$ & 0 & +5.000 & \\
\hline Temefos & ISO & । & $O P$ & $L$ & 0 & 8.600 & DS 8 \\
\hline Terbacilo & ISO & $H$ & & $S$ & 0 & +5.000 & \\
\hline Terbutilazina & ISO & H & $\mathrm{T}$ & $S$ & 0 & 2.160 & \\
\hline Terbutrina & ISO & H & $\mathrm{T}$ & $S$ & 0 & 2.400 & \\
\hline Tetraclorvinfos & ISO & I & $O P$ & $S$ & 0 & 4.000 & \\
\hline Tetradifon & ISO & $A C$ & & $S$ & 0 & +10.000 & EHC 67; HSG 11 \\
\hline Tetrametrina & ISO & 0 & PY & $S$ & 0 & +5.000 & EHC 98; HSG 31 \\
\hline
\end{tabular}


Tabla 62.5 - Lista de productos de grado técnico que es improbable que presenten riesgo agudo en condiciones de uso normales.

Continuación.

\begin{tabular}{|c|c|c|c|c|c|c|c|}
\hline Denominación & Situación & Uso principal & $\begin{array}{l}\text { Tipo } \\
\text { químico }\end{array}$ & $\begin{array}{l}\text { Estado } \\
\text { físico }\end{array}$ & Vía & $\begin{array}{l}\mathrm{DL}_{50} \\
(\mathrm{mg} / \mathrm{kg})\end{array}$ & Observaciones \\
\hline Tetrasul & ISO & $A C$ & & $S$ & 0 & 6.810 & \\
\hline Tiabendazol & ISO & $\mathrm{F}$ & & $S$ & 0 & 3.330 & \\
\hline Tidiazuron & ISO & PGR & & $S$ & 0 & +4.000 & \\
\hline Tifensulfuron & $N(B)$ & $H$ & & $S$ & 0 & +5.000 & \\
\hline Tiocarbacilo & ISO & $H$ & $\mathrm{TC}$ & $L$ & 0 & 10.000 & \\
\hline Tiofanato & ISO & $\mathrm{F}$ & & $S$ & 0 & +10.000 & \\
\hline Tiofanato-metil & ISO & $\mathrm{F}$ & & $S$ & 0 & +6.000 & \\
\hline Tolclofos-metil & ISO & $F-S$ & & $S$ & 0 & $c 5.000$ & \\
\hline Tolifluanida & ISO & $F$ & & $S$ & 0 & +5.000 & \\
\hline Transflutrin & ISO & I & PY & $S$ & 0 & +5.000 & \\
\hline Triasulfuron & ISO & $H$ & & $S$ & 0 & +5.000 & \\
\hline Tribenuron & $N(B)$ & $H$ & & $S$ & 0 & +5.000 & \\
\hline Triclamida & ISO & $\mathrm{F}$ & & $S$ & 0 & +5.000 & \\
\hline Trietacina & ISO & $H$ & T & $S$ & 0 & 2.830 & \\
\hline Triflumuron & ISO & PGR & & $S$ & 0 & +5.000 & \\
\hline Trifluralina & ISO & $H$ & & $S$ & 0 & +10.000 & \\
\hline Triforina & ISO & $F$ & & $S$ & 0 & +6.000 & \\
\hline Triticonazol & $N(B)$ & $F$ & triazol & $S$ & 0 & +2.000 & \\
\hline Validamicina & $N(J)$ & $F$ & & $S$ & 0 & +10.000 & \\
\hline Vinclozolina & ISO & $F$ & & $S$ & 0 & 10.000 & \\
\hline Zineb & ISO & $F$ & & $S$ & 0 & +5.000 & DS 94 \\
\hline
\end{tabular}


Tabla 62.6 - Productos de grado técnico no incluidos en la Clasificación de la O MS y considerados obsoletos o no utilizados ya como plaguicidas.

\begin{tabular}{|c|c|c|}
\hline Alixicarb & Dimexano & Mebenil \\
\hline Amidition & Dinex & Mecarbinzid \\
\hline Aramite & Dinocton & Mecarfon \\
\hline Atidition & Endotion & Medinoterb acetato \\
\hline Atraton & Erbon & Metacarbate \\
\hline Azotoato & Etilenglicol & Metilmercurio diciandiamida \\
\hline Bario, carbonato & Etiolate & Metiurón \\
\hline Benodanil & Etoato-metil & Met2-Metoximetil mercurio cloruro (DS 66) \\
\hline Benquinox & EXD & Mexacarbato \\
\hline Bis(tricloracetato) & Fenazaflor & Miclozolin \\
\hline Butacarb & Fenilmercurio dimetilditiocarbamato & Mipafox \\
\hline Butam & Fenkapton & Mirex (EHC 44; HSG 39) \\
\hline Butonato & Fenobenzuron & Morfamquat \\
\hline Cálcico, cianamida & Fluenetil & Nitrilacarb \\
\hline Carbamorf & Fluotrimazol & Noruron \\
\hline Carbanolato & Fosacetim & Oxapirazon \\
\hline Ciantoato & Fostietan & Oxidisulfoton \\
\hline Cipendazol & Gliodin & Parafluron \\
\hline Cipromid & Griseofulvina & Pidanon \\
\hline Cloetocarb & Halacrinato & Piridinitril \\
\hline Cloraniformetan & Haloxidine & Potásico, cianato \\
\hline Cloranil & Hexacloroacetona & Propil isome \\
\hline Cloranocril & Hexaflurato & Protiocarb \\
\hline Clorbenside & Hidroxiquinolina sulfato & Proxan \\
\hline Clorbiciclen & Ipazine & Quinacetol-sulfato \\
\hline Clordecone (EHC 43; HSG 41) & IPSP & Sabadilla \\
\hline Clorfenprop-metil & Isobenzan & Salicilanilide \\
\hline Clorfensulfuro & Isobornil tiocianoacetato & Schradan \\
\hline Clorfentezine & Isocarbamid & Swep \\
\hline Cloromebuform & Isocil & TDE \\
\hline Clorquinox & Isodrin & Terbucarb \\
\hline Crimidina & Isometiozin & Tioquinox \\
\hline Delaclor & Isonoruonlisoprotiolane & Triapentenol \\
\hline Diamidafos & Kelevan (EHC 66; HSG 2) & Triarimol \\
\hline Dibutil succinato & Litidation & Tricamba \\
\hline Dibutilftalato & Malonoben & Tricloronat \\
\hline Diclozolina & MCC & Trimetacarb \\
\hline
\end{tabular}

Fuente: OMS 1996.

Tabla 62.7 • Lista de fumigantes gaseosos o volátiles no incluidos en la Clasificación Recomendada de Plaguicidas según el Riesgo de la O MS.

Acrilonitrilo (EHC 28; HSG 1)

Bromuro de metilo (DS 5; EHC 166; HSG 86)

Cianuro de hidrógeno

Cloropicrina

Dibromuro de etileno (EHC 177)

Dicloruro de etileno (EHC 176)

Disulfuro de carbono (EHC 10)

1,2-dicloropropano (EHC 146; HSG 76) 1,3-dicloropropeno (EHC 146; HSG 76)

Epoxietano (óxido de etileno) (EHC 55; HSG 16)

Formaldehído (EHC 89; HSG 57)

Fosfina (DS 46; EHC 73; HSG 28)

Fosfuro de aluminio (EHC 73; HSG 28)

Fosfuro de magnesio (EHC 73; HSG 28)

Fluoruro de sulfurilo

Oxido de etileno (EHC 55; HSG 16)

Nota: La clasificación no establece ningún criterio sobre concentraciones ambientales en que pueda estar basada la misma. La mayoría de estos compuestos son de alto riesgo y las autoridades de muchos países han adoptado límites de exposición recomendables para las exposiciones de carácter profesional.

Fuente: OMS 1996 


\section{Referencias}

O rganización M undial de la Salud (O M S). 1996. The W H O Recommended Classification of Pesticides by $\mathrm{H}$ azard and Guidelines to Classification 1996-1997. International Programme on Chemical Safety (IPCS), OM S/ PCS/ 96.3. Ginebra: OMS.

\section{0 tras lecturas recomendadas}

Armstrong, LD, AR Stiles. 1973. Pesticides: Nomenclature, specifications, analysis, uses and residues in food. Bull W Id H Ith 0 rg 49:169-204.

International Programme on Chemical Safety (IPCS). 1994. Summary of T oxicological E valuations Performed by the I oint FAO/WHO M eting on Pesticide Residues (J M PR) 1990. O M S/ PCS/ 95.4. Ginebra: IPCS.
Tomlin, C. (dir.). 1994. The Pesticide M anual: A W orld Compendium, 10 ed. Thornton Weath, Reino U nido: British Crop Protection Council.

Wiswesser, WJ. 1976. Pesticide Index. College Park, M D: College Science Publishers and Entomological Society of America. 



\section{METALES: PROPIEDADES QUIMICAS Y TOXICIDAD}

Director del capítulo

Gunnar N ordberg

\section{Sumario}

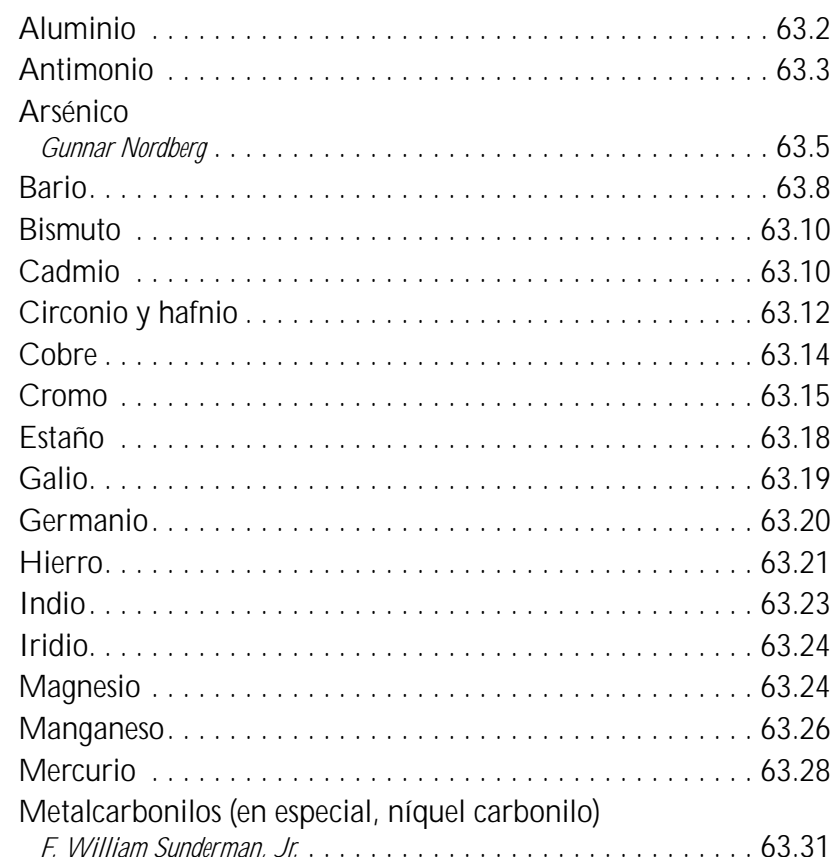

F. W illiam Sunderman, J

63.31
M olibdeno ........................... 63.33

Niobio .............................. 63.34

Níquel

F. W illiam Sunderman, J r. . . . . . . . . . . . . . . . 63.35

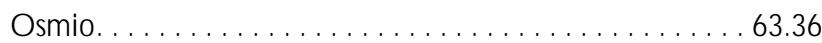

Paladio . . . . . . . . . . . . . . . . . . . . . . . . . . . . . . . . . . . . 63.37

Plata . . . . . . . . . . . . . . . . . . . . . . . . . . . . . . . . . . . 63.37

Platino . . . . . . . . . . . . . . . . . . . . . . 63.38

Plomo . . . . . . . . . . . . . . . . . . . . . 63.39

Renio . . . . . . . . . . . . . . . . . . . . . . . . . . . . . 63.44

Rodio . . . . . . . . . . . . . . . . . . . . . . . . . . . . . . . . . . . 63.44

Rutenio. . . . . . . . . . . . . . . . . . . . . . . . . . . . . . . . 63.45

Selenio . . . . . . . . . . . . . . . . . . . . . . . . 63.45

Talio ................................. 63.46

Tántalo................................ 63.47

Telurio . . . . . . . . . . . . . . . . . . . . . . . . . . . . 63.47

Titanio . . . . . . . . . . . . . . . . . . . . . . . . . . . . . . . . 63.48

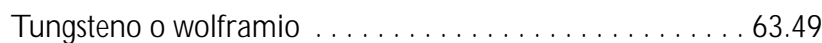

Vanadio ............................. 63.50

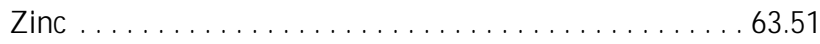




\section{Perfil general}

En este capítulo se ofrecen una serie de comentarios breves sobre gran número de metales y una tabla con los principales efectos para la salud, propiedades físicas y riesgos físicos y químicos asociados a estos metales y muchos de sus compuestos (véase la Tabla 63.2, en la pág. 63.52-63. y la Tabla 63.3, en la pág. 63.62-63.73). No se tratan todos los metales. El cobalto y el berilio, por ejemplo, se abordan en el capítulo Aparato respiratorio. 0 tros metales se tratan con más detalle en artículos específicos sobre las industrias en que predomina su uso. Los isótopos radiactivos son objeto del capítulo Radiación ionizante.

Para obtener información adicional sobre la toxicidad de las sustancias químicas y sus compuestos, el lector puede consultar la $G$ uía de sustancias químicas en el Volumen IV de esta Enciclopedia. En ella encontrará, en especial, los compuestos de calcio y boro. En el capítulo Control Biológico se incluye información específica sobre la monitorización biológica.

\section{Reconocimientos}

El material presentado en este capítulo es fruto de la revisión exhaustiva y la ampliación de la información sobre metales incluida en la 3 a edición de la Enciclopedia de salud y seguridad en el trabajo. Los miembros del Comité Científico sobre la Toxicología de los Metales y de la Comisión Internacional de Medicina del Trabajo que se citan a continuación, junto con otros revisores y autores, realizaron una parte importante de la revisión.

Los revisores fueron:

L Alessio

Antero Aitio

P. Aspostoli

M. Berlin

Tom W. Clarkson

\section{$C-G$. Elinder}

Lars Friberg

Byung-Kook Lee

N. Karle M ottet

D.J. $\mathrm{N}$ ager

Kogi Nogawa

Tor $\mathrm{N}$ orseth

C.N. O ng

Kensaborv Tsuchiva

$\mathrm{N}$ ies Tsukuab.

Las personas que contribuyeron a la 4 a edición son:

G unnar N ordberg

Sverre Langård.

F. W illiam Sunderman, Jr.

Jeanne Mager Stellman

Debra 0 sinsky

Pia Markkanen

Bertram D. Dinman

Agency for Toxic Substances and Disease Registry

(ATSDR).

Las revisiones se basaron en las contribuciones de los siguientes autores a la 3 a edición: A. Berlin, M. Berlin, P.L Bidstrup, H.L Boiteau, A.G. Cumpston, B.D. Dinman, A.T. Doig, J.L Egorov, C-G . Elinder, H.B. Elkins, I.D. G adaskina, J. G Irmme, J.R. G lover, G.A. Gudzovskij, S. Horiguchi, D. Hunter, Lars Järup, T. Karimuddin, R. Kehoe, R.K. Kye, Robert R. Lauwerys, S. Lee, C. Marti-Feced, Ernest M astromatteo, 0 . Ja M ogilevskaja, L Parmeggiani, N. Perales y Herrero, L Pilat, T.A. Roščina, M. Saric, Herbert E. Stokinger, H.I. Scheinberg, P. Schuler, H.J. Symanski, R.G. Thomas, D.C. Trainor, Floyd A. van Atta, R. W agg, M itchell R. Zavon and R. L Zielhuis.

\section{Aluminio}

\section{Distribución y usos}

El aluminio es el metal más abundante en la corteza terrestre, donde se encuentra combinado con oxígeno, flúor, sílice, etc., pero nunca en estado metálico. La principal fuente de aluminio es la bauxita, constituida por una mezcla de minerales formados por la acción de la intemperie sobre las rocas que contienen aluminio. Las bauxitas constituyen la forma más rica de estos depósitos y contienen hasta un $55 \%$ de alúmina. Algunos yacimientos lateríticos (que contienen porcentajes de hierro más elevados) poseen hasta un $35 \%$ de $\mathrm{Al}_{2} \mathrm{O}_{3}$. Los depósitos de bauxita más importantes desde el punto de vista comercial son la gibbsita $\left(\mathrm{Al}_{2} \mathrm{O}_{3} \cdot 3 \mathrm{H}_{2} \mathrm{O}\right)$ y la bohemita $\left(\mathrm{Al}_{2} \mathrm{O}_{3} \cdot \mathrm{H}_{2} \mathrm{O}\right)$ y están localizados en Australia, Guayana, Francia, Brasil, Ghana, Guinea, H ungría, Jamaica y Surinam. La producción mundial de bauxita en 1995 fue de 111.064 millones de toneladas. La gibbsita es más fácilmente soluble en soluciones de hidróxido sódico que la bohemita, por lo que se la prefiere para la producción de óxido de aluminio.

El aluminio tiene múltiples usos industriales y se utiliza en cantidades mucho mayores que cualquier otro metal no ferroso; se calcula que, en 1995, la producción de metal primario en todo el mundo ascendió a 20.402 millones de toneladas. El aluminio puede alearse con otros muchos elementos, como el cobre, el zinc, el silicio, el magnesio, el manganeso y el níquel, y puede contener además pequeñas cantidades de cromo, plomo, bismuto, titanio, circonio y vanadio para propósitos especiales. Los lingotes de aluminio y sus aleaciones pueden ser extruidos y procesados en laminadoras, trefiladores, forjas y fundiciones. LoS productos terminados se utilizan en la construcción de buques para la obra interior y las superestructuras; en la industria eléctrica, para la fabricación de cables e hilos conductores; en el sector de la construcción, para la fabricación de estructuras y marcos de ventanas, tejados y revestimientos; en la industria aeroespacial, para fuselajes, revestimientos y otros componentes; en la industria automotriz, para carrocerías, culatas y pistones; en la industria ligera, para aparatos domésticos y equipos de oficina, e incluso en joyería. U na de las aplicaciones más importantes de la hoja de aluminio es la fabricación de envases para bebidas 0 alimentos, en tanto que el papel de aluminio se utiliza para empaquetar. En la fabricación de pinturas y en la industria pirotécnica, el aluminio se emplea en forma de finas partículas. Los artículos fabricados con aluminio reciben frecuentemente un tratamiento de superficie, la anodización, como protección y con fines decorativos.

El cloruro de aluminio se utiliza en el cracking del petróleo y en la industria del caucho. Esta sustancia desprende vapores que, con el aire, forman ácido clorhídrico y se combinan con el agua formando compuestos explosivos. En consecuencia, los envases que contienen este producto deben conservarse herméticamente cerrados y protegidos de la humedad.

Compuestos alquilados de aluminio. La importancia de estos compuestos como catalizadores en los procesos de producción 
de polietileno a baja presión es cada vez mayor. Presentan riesgo de toxicidad, de quemaduras y de incendios. Se trata de sustancias sumamente reactivas con el aire, con la humedad y con todos los compuestos que contienen hidrógeno activo, por lo que deben guardarse bajo una capa de gas inerte.

\section{Riesgos}

Para la producción de aleaciones de aluminio, el metal refinado se funde en hornos de fuel-oil o de gas. A continuación, se añaden cantidades conocidas de un endurecedor que contiene bloques de aluminio con un determinado porcentaje de manganeso, silicio, zinc, magnesio, etc. La masa fundida se mezcla y se pasa a un horno de temperatura constante para desgasificarla, haciendo pasar argón-cloro o nitrógeno-cloro a través del metal. La emisión de gases resultante (ácido clorhídrico, hidrógeno y cloro) se ha asociado con enfermedades profesionales. En consecuencia, hay que prestar suma atención a la realización de unos controles de ingeniería adecuados, que capturen estas emisiones y eviten su llegada al medio exterior, donde también pueden causar daños. Las impurezas se recogen de la superficie del fundido y se colocan en recipientes para minimizar la exposición al aire al enfriar la aleación. En el horno, se añade un fundente que contiene sales de flúor o cloro para facilitar la separación del aluminio puro de las impurezas. Pueden desprenderse humos de fluoruro u óxido de aluminio, por lo que también es necesario controlar cuidadosamente este aspecto de la producción. Puede ser necesario el uso de un equipo de protección individual (EPI). El proceso de fundición del aluminio se describe en el capítulo $M$ etalurgia y metalistería. En los talleres de fundición también puede producirse una exposición al dióxido de azufre.

En los hornos de fundición, se utiliza una amplia variedad de formas cristalinas del óxido de aluminio, como abrasivos, productos refractarios y catalizadores. En varios informes publicados entre 1947 y 1949 se describen casos de fibrosis intersticial progresiva, no nodular, en la industria de abrasivos de aluminio con procesado de óxido de aluminio y sílice. Esta afección, conocida como enfermedad de Shaver, progresa con rapidez y a menudo es mortal. Las víctimas (trabajadores de la producción de óxido de aluminio) estuvieron expuestas a un humo denso formado por óxido de aluminio, ślice libre cristalino y hierro. La materia particulada se presentaba en unas dimensiones que la hacían perfectamente respirable. Es probable que la preponderancia de la enfermedad pueda atribuirse a los efectos pulmonares sumamente nocivos de la sílice libre cristalina finamente fragmentada, más que al óxido de aluminio inhalado, aunque se desconoce la etiología exacta de la enfermedad. En la actualidad, la enfermedad de Shaver tiene principalmente un interés histórico, pues no se ha descrito ningún caso durante la segunda mitad del siglo XX.

Estudios recientes sobre el efecto para la salud de la exposición a niveles elevados $\left(100 \mathrm{mg} / \mathrm{m}^{3}\right)$ de óxidos de aluminio entre los trabajadores que participan en el proceso Bayer (descrito en el capítulo $M$ etalurgia y metalistería) demuestran que los trabajadores con más de veinte años de exposición pueden desarrollar alteraciones pulmonares, que se caracterizan clínicamente por cambios restrictivos leves y predominantemente asintomáticos en la función pulmonar. Las radiografías torácicas mostraron opacidades pequeñas, irregulares y poco abundantes, especialmente en la base de los pulmones. Esta respuesta clínica se han atribuido al depósito del polvo en el parénquima pulmonar como resultado del alto grado de exposición profesional. Estos signos y síntomas no se pueden comparar con la respuesta extrema de la enfermedad de Shaver. Es importante señalar que otros estudios epidemiológicos realizados en el Reino U nido sobre el alto grado de exposición al óxido de aluminio en la industria de la alfarería no han encontrado indicios de que la inhalación del polvo de alúmina produzca signos químicos 0 radiológicos de enfermedad o alteración de la función pulmonar.

Los efectos toxicológicos de los óxidos de aluminio siguen teniendo un gran interés por su importancia comercial. Los resultados de los estudios en animales con frecuencia se contradicen. 0 xido de aluminio muy fino $(0,02 \mu \mathrm{m}$ a $0,04 \mu \mathrm{m})$ y catalíticamente activo, que no suele utilizarse comercialmente, indujo cambios pulmonares en los animales a los que se les inyectó directamente en las vías aéreas pulmonares. No se han observado efectos con dosis más bajas.

A simismo, es importante señalar que el llamado "asma de los alfareros", observado con frecuencia entre los trabajadores que participan en las operaciones de proceso del aluminio, probablemente pueda atribuirse a la exposición a fundentes con fluoruros, más que al propio polvo de aluminio.

La Agencia Internacional para la Investigación sobre el Cáncer (IARC) ha clasificado la producción de aluminio como una situación del Grupo 1: exposición humana cancerígena conocida. I gual que en las enfermedades antes descritas, la carcinogenicidad probablemente pueda atribuirse a otras sustancias presentes (por ejemplo, hidrocarburos aromáticos policíclicos y polvo de sílice), aunque se desconoce el papel exacto desempeñado por el polvo de óxido de aluminio.

Se ha observado la absorción de niveles elevados de aluminio y daños en el tejido nervioso en individuos que requieren diálisis renal. Esos elevados niveles de aluminio llegan a producir daños cerebrales graves, e incluso fatales. Sin embargo, esta respuesta también se ha observado en pacientes sometidos a diálisis que no presentaban unos niveles cerebrales de aluminio elevados. No se ha logrado replicar esta respuesta cerebral en los experimentos con animales, ni tampoco la enfermedad del Alzheimer, que también se ha relacionado con este tema en la literatura. Los estudios epidemiológicos y clínicos de seguimiento sobre este tema no son concluyentes y no se han observado indicios de este tipo de efectos en varios estudios epidemiológicos realizados a gran escala entre trabajadores del aluminio.

\section{ANTIMONIO}

El antimonio es estable a temperatura ambiente, pero cuando se calienta, arde brillantemente, desprendiendo un humo blanco y denso de óxido de antimonio $\left(\mathrm{Sb}_{2} \mathrm{O}_{3}\right)$ con un olor característico parecido al del ajo. D esde el punto de vista químico, el antimonio está muy relacionado con el arsénico. Se combina fácilmente con el arsénico, el plomo, el estaño, el zinc, el hierro y el bismuto.

\section{Distribución y usos}

El antimonio se encuentra en la naturaleza combinado con diversos elementos, en especial en minerales que contienen estibina $\left(\mathrm{Sb}_{2} \mathrm{~S}_{3}\right)$, valentinita $\left(\mathrm{Sb}_{2} \mathrm{O}_{3}\right)$, kermesita $\left(\mathrm{Sb}_{2} \mathrm{~S}_{2} \mathrm{O}\right)$ y senarmontita $\left(\mathrm{Sb}_{2} \mathrm{O}_{3}\right)$.

El antimonio con un alto grado de pureza se utiliza en la fabricación de semiconductores. El antimonio de pureza normal es ampliamente utilizado en la producción de aleaciones, a las que proporciona dureza, resistencia mecánica, resistencia a la corrosión y un bajo coeficiente de fricción. Las aleaciones que combinan estaño, plomo y antimonio se utilizan en la industria eléctrica. Entre las aleaciones de antimonio más importantes se encuentran el metal antifricción, el peltre, el metal blanco, el metal britania y el metal para cojinetes. Se utilizan en rodamientos, placas para baterías, apantallamiento de cables, soldaduras, piezas ornamentales y municiones. La resistencia del antimonio metálico a los ácidos y las bases se aprovecha en el montaje de las fábricas de productos químicos. 


\section{Riesgos}

El riesgo principal del antimonio es la intoxicación por ingestión, inhalación o absorción cutánea. La vía de entrada más importante es la respiratoria, pues es frecuente la existencia de finas partículas de antimonio en suspensión aérea. La ingestión puede producirse por deglución del polvo o por la contaminación de bebidas, alimentos o tabaco. La absorción cutánea es menos frecuente, pero puede ocurrir si el antimonio entra en contacto prolongado con la piel.

EI polvo de las minas de antimonio puede contener sílice libre y se han descrito casos de neumoconiosis (denominada sílico-antimoniosis) entre los mineros de este metal. Durante su proceso, el mineral de antimonio, que es un material extremadamente quebradizo, se convierte en polvo fino con más rapidez que las demás rocas, lo que produce concentraciones atmosféricas elevadas de polvo fino durante las operaciones de reducción y cribado. El polvo producido durante la trituración es relativamente grueso y el resto de las operaciones: clasificación, flotación, filtración, etc. son procesos en húmedo y, por tanto, no producen polvo. Los horneros que trabajan en el refinado del antimonio metálico y en la producción de aleaciones de antimonio y los trabajadores que colocan los tipos en las imprentas están expuestos al polvo y al humo del antimonio y presentan opacidades miliares difusas en los pulmones, sin signos clínicos ni funcionales de deterioro en ausencia de polvo de sílice.

La inhalación de aerosoles de antimonio puede producir reacciones localizadas en las mucosas, el tracto respiratorio y los pulmones. Los estudios realizados en mineros, concentradores y fundidores expuestos a polvos y humos de antimonio ponen de manifiesto la existencia de dermatitis, rinitis, inflamación de las vías respiratorias altas y bajas, neumonitis e, incluso, gastritis, conjuntivitis y perforaciones septales.

Se ha descrito neumoconiosis, en ocasiones combinada con cambios pulmonares obstructivos, tras la exposición prolongada en el hombre. A pesar de que la neumoconiosis por antimonio se considera benigna, los efectos respiratorios crónicos asociados con una exposición intensa al antimonio no se consideran inocuos. Además, se han relacionado efectos sobre el corazón, que pueden llegar a ser mortales, debido a la exposición profesional al trióxido de antimonio.

En personas que trabajan con antimonio y sales de antimonio se han llegado a observar infecciones cutáneas pustulares. Estas erupciones son transitorias y afectan principalmente a s áreas de piel que han estado expuestas al calor o a la sudoración.

\section{Toxicología}

Por sus propiedades químicas y acciones metabólicas, el antimonio es muy similar al arsénico y, puesto que ambos elementos se encuentran asociados en ocasiones, la acción del antimonio puede atribuirse al arsénico, especialmente en los obreros de las fundiciones. Sin embargo, los experimentos con antimonio metálico de alto grado de pureza demuestran que este metal tiene una toxicología totalmente independiente. Varios autores están de acuerdo en que la dosis letal media se sitúa entre 10 y $11,2 \mathrm{mg} / 100 \mathrm{~g}$

El antimonio puede penetrar en el organismo a través de la piel, aunque la vía principal es la respiratoria. Desde los pulmones, la sangre absorbe el antimonio, y en especial el antimonio libre, y lo distribuye a los tejidos. Los estudios sobre trabajadores y los experimentos con antimonio radiactivo muestran que la mayor parte del antimonio absorbido se metaboliza en las primeras 48 horas y se elimina con las heces y, en menor proporción, con la orina. La cantidad restante en el organismo permanece en la sangre durante bastante tiempo, observándose una concentración de antimonio varias veces superior en los eritrocitos que en el suero. En los trabajadores expuestos a antimonio pentavalente, la excreción urinaria está relacionada con la intensidad de la exposición. Se calcula que, después de 8 horas de exposición a $500 \mu \mathrm{gb} / \mathrm{m}^{3}$, el aumento de la concentración de antimonio excretado en la orina al final de un turno es de $35 \mu \mathrm{g} / \mathrm{g}$ de creatinina como media.

El antimonio inhibe la acción de determinadas enzimas, se une a los grupos sulfhidrilo del suero y altera el metabolismo de las proteínas y carbohidratos y la producción de glucógeno en el hígado. Experimentos prolongados con aerosoles de antimonio en animales han demostrado el desarrollo de una neumonía endógena de tipo lipoide. También se han descrito casos de alteraciones cardíacas y muerte súbita en trabajadores expuestos al antimonio. Asimismo, en estudios con animales se ha observado fibrosis pulmonar focal y efectos cardiovasculares.

El uso terapéutico de medicamentos que contienen antimonio ha permitido detectar, en especial, la toxicidad acumulativa sobre el miocardio de los derivados trivalentes del antimonio, que se excretan más lentamente que los derivados pentavalentes. En el electrocardiograma, se han observado reducciones en la amplitud de la onda $\mathrm{T}$, prolongación del intervalo $\mathrm{QT}$ y arritmias.

\section{Síntomas}

Los síntomas de una intoxicación aguda son los siguientes: gran irritación en la boca, nariz, estómago e intestino, vómitos, deposiciones sanguinolentas y respiración lenta y superficial. En ocasiones, se han observado casos de coma seguidos de muerte, debidos a complicaciones hepáticas y renales y al agotamiento. Los síntomas de una intoxicación crónica son: sequedad de garganta, náuseas, cefalea, insomnio, pérdida de apetito y mareos. Algunos autores han detectado diferencias en los efectos del antimonio sobre varones y mujeres, pero no están bien definidas.

\section{Compuestos}

La estibina $\left(\mathrm{SbH}_{3}\right)$ o hidruro de antimonio (hidrógeno antimoniado) se produce por disolución de aleaciones de zinc-antimonio 0 magnesio-antimonio en ácido clorhídrico diluido. Sin embargo, la estibina aparece frecuentemente como subproducto durante el proceso de los metales que contienen antimonio con ácidos reductores 0 en las baterías sobrecargadas. La estibina se ha utilizado como agente fumigante. La estibina de alto grado de pureza se utiliza como adulterante en fase gaseosa tipo $n$ para el silicio en los semiconductores. La estibina es un gas sumamente peligroso. Al igual que el arsénico, puede destruir las células sanguíneas y producir hemoglobinuria, ictericia, anuria y muerte. Los síntomas son: cefalea, náuseas, epigastralgias y orina de color rojo oscuro después de la exposición.

El trióxido de antimonio $\left(\mathrm{Sb}_{2} \mathrm{O}_{3}\right)$ es el más importante de los óxidos de antimonio. Cuando se encuentra en el aire, tiende a permanecer en suspensión durante un período de tiempo excepcionalmente largo. Se obtiene a partir del mineral de antimonio por calcinación o por oxidación del antimonio metálico y su sublimación posterior. Se utiliza en la fabricación de tártaro emético, como pigmento de pinturas, esmaltes y barnices y como producto incombustible.

El trióxido de antimonio es un veneno sistémico y presenta un riesgo de enfermedad cutánea, aunque su toxicidad es tres veces menor que la del metal. En experimentos prolongados con animales, las ratas expuestas al trióxido de antimonio por inhalación mostraron una frecuencia elevada de tumores pulmonares. En Newcastle, se describió un exceso de muertes por cáncer pulmonar entre los trabajadores empleados en la fusión del antimonio durante más de cuatro años, con una concentración media en el aire de $8 \mathrm{mg} / \mathrm{m}^{3}$. Además de los polvos y los humos de antimonio, los trabajadores estuvieron expuestos a 
efluentes de circonio y sosa cáustica. No se han descrito otras experiencias con relación al potencial cancerígeno del trióxido de antimonio. La Conferencia Americana de Higienistas Industriales del Gobierno (ACGIH) lo ha clasificado como una sustancia química asociada con procesos industriales sospechosa de inducir cáncer.

El pentóxido de antimonio $\left(\mathrm{Sb}_{2} \mathrm{O}_{5}\right)$ se produce por la oxidación en caliente con ácido nítrico del trióxido de antimonio o del metal puro. Se utiliza para la fabricación de pinturas y barnices, de cristal, en la alfarería y en la industria farmacéutica. Se caracteriza por su bajo grado de toxicidad.

El trisulfuro de antimonio $\left(\mathrm{Sb}_{2} \mathrm{~S}_{3}\right)$ se encuentra como mineral natural, la antimonita, pero también puede sintetizarse. Se utiliza en pirotecnia, en la fabricación de cerillas y de explosivos, en la fabricación de cristal de rubí y como pigmento y plastificante en la industria del caucho. En personas expuestas al trisulfuro de antimonio se ha observado un aumento aparente de anormalidades cardíacas. El pentasulfuro de antimonio $\left(\mathrm{Sb}_{2} \mathrm{~S}_{5}\right)$ tiene prácticamente los mismos usos que el trisulfuro, pero con un bajo nivel de toxicidad.

El tricloruro de antimonio $\left(\mathrm{SbCl}_{3}\right)$ o cloruro antimonioso (mantequilla de antimonio) se produce por la interacción del cloro y el antimonio o por disolución de trisulfuro de antimonio en ácido clorhídrico. El pentacloruro de antimonio $\left(\mathrm{SbCl}_{5}\right)$ se obtiene por la acción del cloro sobre tricloruro de antimonio fundido. Los cloruros de antimonio se utilizan para el pavonado en azul del acero y para colorear el aluminio, el peltre y el zinc, y como catalizadores en síntesis orgánica, especialmente en las industrias del caucho y farmacéuticas. Además, el tricloruro de antimonio se utiliza en la fabricación de cerillas y en la industria del petróleo. Son sustancias muy tóxicas y tienen un efecto corrosivo e irritante para la piel. El tricloruro de antimonio tiene una $\mathrm{DL}_{50}$ de $2,5 \mathrm{mg} / 100 \mathrm{~g}$.

El trifluoruro de antimonio $\left(\mathrm{SbF}_{3}\right)$ se prepara disolviendo el trióxido de antimonio en ácido fluorhídrico. Se utiliza en la fabricación de colorantes y cerámica y en síntesis orgánicas. Es un producto sumamente tóxico e irritante para la piel, y su $\mathrm{DL}_{50}$ es de $2,3 \mathrm{mg} / 100 \mathrm{~g}$.

\section{Medidas de salud y seguridad}

La esencia de cualquier programa de seguridad para prevenir las intoxicaciones por antimonio debe ser el control de la formación de polvo y humo en todas las etapas del proceso.

En la minería, las medidas de prevención de la formación de polvo son similares a las que se utilizan en toda la minería de metales en general. Durante los procesos de trituración, se debe rociar el mineral, o bien debe realizarse el proceso completamente en cerrado, acoplado a un sistema de extracción local y una ventilación general adecuada. En las fundiciones de antimonio, se deben eliminar siempre que sea posible todos los riesgos derivados de la preparación de la carga, el manejo de los hornos, la reparación de los revestimientos y el manejo de las cubas electrolíticas, mediante el aislamiento y la automatización de los procesos. Se debe proporcionar a los horneros rociadores de agua y una buena ventilación.

Cuando no sea posible eliminar completamente la exposición, los trabajadores deberán protegerse las manos, brazos y cara con guantes, ropa a prueba de polvo y gafas. En aquellas ocasiones en que la exposición atmosférica sea elevada, deberán proporcionarse respiradores. También se deberán aplicar cremas-barrera, especialmente cuando se manipulen compuestos solubles de antimonio; en este último caso se deben utilizar, además, ropas impermeables y guantes de goma. Se deben observar estrictamente las medidas de higiene personal; no se permitirá comer ni beber en los talleres y deberán proporcionarse unas instalaciones sanitarias adecuadas para que los obreros puedan lavarse antes de las comidas y al final de la jornada de trabajo.

\section{ARSENICO}

\section{G unnar N ordberg}

\section{Existen tres grandes grupos de compuestos de arsénico (As):}

1. compuestos de arsénico inorgánico

2. compuestos de arsénico orgánico

3. gas arsina y arsinas sustituidas.

\section{Distribución y usos}

El arsénico se encuentra ampliamente distribuido en la naturaleza y principalmente en los minerales sulfurosos. La arsenopirita (FeA sS) es la forma más abundante.

\section{Arsénico elemental}

El arsénico elemental se utiliza en aleaciones con el fin de aumentar su dureza y resistencia al calor, como en las aleaciones con plomo para la fabricación de municiones y de baterías de polarización. También se utiliza para la fabricación de ciertos tipos de vidrio, como componente de dispositivos eléctricos y como agente de adulteración en los productos de germanio y silicio en estado sólido.

\section{Compuestos inorgánicos trivalentes}

El tricloruro de arsénico $\left(\mathrm{AsCl}_{3}\right)$ se utiliza en la industria cerámica y en la fabricación de arsenicales con contenido de cloro. El trióxido de arsénico $\left(\mathrm{As}_{2} \mathrm{O}_{3}\right) 0$ arsénico blanco se utiliza en la purificación de gases sintéticos y como materia prima para todos los compuestos de arsénico. También se utiliza como conservante de cuero y madera, como mordente en la industria textil, como reactivo en la flotación de minerales y para la decoloración y refinamiento en la fabricación del vidrio. El arsenito cálcico [ $\left.\mathrm{Ca}\left(\mathrm{As}_{2} \mathrm{H}_{2} \mathrm{O}_{4}\right)\right]$ y el acetoarsenito cúprico (considerado generalmente como $\left.\mathrm{Cu}\left(\mathrm{COOCH}_{3}\right)_{2} 3 \mathrm{Cu}\left(\mathrm{AsO}_{2}\right)_{2}\right)$ son insecticidas. El acetoarsenito cúprico se utiliza también en la fabricación de pinturas para barcos y submarinos. El arsenito sódico $\left(\mathrm{NaAsO}_{2}\right)$ se utiliza como herbicida, como inhibidor de la corrosión y como agente de secado en la industria textil. El trisulfuro de arsénico es un componente del cristal de transmisión de infrarrojos y un agente para eliminar el pelo en el curtido del pieles. También se utiliza en la fabricación de material pirotécnico y de semiconductores.

\section{Compuestos inorgánicos pentavalentes}

El ácido arsénico $\left(\mathrm{H}_{3} \mathrm{AsO}_{4}{ }^{1 / 12} \mathrm{H}_{2} \mathrm{O}\right)$ se utiliza en la fabricación de arsenatos, de vidrio y en los procesos de tratamiento de la madera. El pentóxido de arsénico $\left(\mathrm{As}_{2} \mathrm{O}_{5}\right)$ se utiliza como herbicida y conservante de la madera, así como en la fabricación de vidrio coloreado.

El arseniato cálcico $\left(\mathrm{Ca}_{3}\left(\mathrm{AsO}_{4}\right)_{2}\right)$ se emplea como insecticida.

\section{Compuestos de arsénico orgánico}

EI ácido cacodílico $\left(\left(\mathrm{CH}_{3}\right)_{2} \mathrm{AsO} \mathrm{OH}\right)$ se utiliza como herbicida y defoliante. El ácido arsanílico $\left(\mathrm{NH}_{2} \mathrm{C}_{6} \mathrm{H}_{4} \mathrm{AsO}(\mathrm{OH})_{2}\right)$ se utiliza como cebo para saltamontes y como aditivo para piensos animales. En los organismos marinos como los camarones y los peces se encuentran compuestos de arsénico orgánico en concentraciones correspondientes a una concentración de arsénico de 1 a $100 \mathrm{mg} / \mathrm{kg}$. Este arsénico está compuesto principalmente por arsenobetaina y arsenocolina, compuestos de arsénico orgánico de baja toxicidad. 
Gas arsina y arsinas sustituidas. El gas arsina se utiliza en la síntesis orgánica y en el proceso de componentes electrónicos en estado sólido. El gas arsina también se puede generar inadvertidamente en procesos industriales en los que se forma hidrógeno naciente cuando existe arsénico presente.

Las arsinas sustituidas son compuestos arsenicales orgánicos trivalentes que, dependiendo del número de grupos alquilos o fenilos que tengan unidos al núcleo de arsénico, se conocen como arsinas mono, bi o trisustituidas. La dicloroetilarsina $\left(\mathrm{C}_{2} \mathrm{H}_{5} \mathrm{AsCl}_{2}\right) 0$ eildicloroarsina es un líquido incoloro de olor irritante. Este compuesto, al igual que el que se indica a continuación, se desarrolló como posible arma química.

La dicloro(2-clorovinil-)arsina ( $\mathrm{ClCH}: \mathrm{CH} \mathrm{AsCl}_{2}$ ) o clorovinildicloroarsina (lewisita) es un líquido de color verde oliva con un olor similar al germanio. Se desarrolló como posible arma química, aunque nunca llegó a utilizarse. Se desarrolló asimismo el agente dimercaprol 0 antilewisita británica (BAL) como un antídoto.

La dimetilarsina $\left(\mathrm{CH}_{3}\right)_{2} \mathrm{AsH}$ o cacodil hidruro y la trimetilarsina $\left.\left(\mathrm{CH}_{3}\right)_{3} \mathrm{As}\right) 0$ trimetilarsénico son líquidos incoloros. Estos dos agentes se producen tras la transformación metabólica de los compuestos de arsénico en bacterias y hongos.

\section{Riesgos}

\section{Compuestos de arsénico inorgánico}

A spectos generales de toxicidad. Aun cuando es posible que cantidades muy pequeñas de algunos compuestos de arsénico tengan un efecto benéfico, como indican algunos estudios en animales, los compuestos de arsénico, y en especial los inorgánicos, se consideran venenos muy potentes. La toxicidad aguda varía notablemente según el compuesto, dependiendo de su valencia y solubilidad en los medios biológicos. L os compuestos trivalentes solubles son los más tóxicos. La captación de compuestos de arsénico inorgánico en el tracto gastrointestinal es casi completa, aunque puede ser más lenta en las formas menos solubles, como el trióxido de arsénico en forma particulada. La captación tras la inhalación es también casi completa, ya que incluso el material menos soluble depositado sobre la mucosa respiratoria se transfiere al tracto gastrointestinal, donde se absorbe.

La exposición profesional a los compuestos de arsénico inorgánico puede producirse por inhalación, ingestión o contacto con la piel, con la consiguiente absorción. Se pueden observar efectos agudos en la vía de entrada si la exposición es excesiva. La dermatitis puede surgir como síntoma agudo, pero con mayor frecuencia es resultado de la toxicidad por exposición prolongada, y en ocasiones es posterior a la sensibilización [véase la sección "Exposición a largo plazo (intoxicación crónica)"].

\section{Intoxicación aguda}

La exposición a dosis elevadas de compuestos de arsénico inorgánico puede producirse como una mezcla de inhalación e ingestión o como resultado de accidentes en industrias en las que se manejan grandes cantidades de arsénico (por ejemplo, trióxido de arsénico). Dependiendo de la dosis, se pueden presentar diversos síntomas y, si ésta es excesiva, puede resultar fatal. Se han observado síntomas de conjuntivitis, bronquitis y disnea, seguidos por molestias gastrointestinales y vómitos, y posteriormente, síntomas cardíacos y shock irreversible, con un curso temporal de horas. En un caso fatal, se describieron niveles de arsénico en sangre superiores a $3 \mathrm{mg} / \mathrm{l}$.

La exposición a dosis subletales de compuestos de arsénico irritantes en el aire (por ejemplo, el trióxido de arsénico) puede producir síntomas relacionados con lesiones agudas en las membranas mucosas del aparato respiratorio y síntomas agudos por exposición cutánea. En estos casos, se observa una irritación grave de la mucosa nasal, la laringe y los bronquios, además de conjuntivitis y dermatitis. En algunos individuos se pueden observar perforaciones del tabique nasal algunas semanas después de la exposición. Se cree que la exposición reiterada permite desarrollar cierta tolerancia contra la intoxicación aguda. Sin embargo, este fenómeno no está bien documentado en la literatura científica.

Se han descrito efectos debidos a la ingestión accidental de arsenicales inorgánicos, fundamentalmente de trióxido de arsénico. Sin embargo, es muy raro que se produzcan este tipo de accidentes en la industria actual. La intoxicación se caracteriza por profundas lesiones gastrointestinales, que originan vómitos y diarrea graves, que pueden producir shock y la subsiguiente oliguria y albuminuria. 0 tros síntomas agudos son el edema facial, calambres musculares y alteraciones cardíacas. L os síntomas pueden aparecer unos minutos después de la exposición al tóxico en solución, pero pueden retrasarse varias horas si el compuesto de arsénico se encuentra en estado sólido o si se ha ingerido con una comida. Cuando se ingiere en forma de partículas, la toxicidad depende también de la solubilidad y del tamaño de las partículas del compuesto ingerido. La dosis letal de trióxido de arsénico ingerido oscila entre 70 y $180 \mathrm{mg}$. La muerte puede sobrevenir en un plazo de 24 horas, aunque el curso habitual es de 3 a 7 días. La intoxicación aguda con compuestos de arsénico suele ir acompañada de anemia y leucopenia, especialmente granulocitopenia. En los supervivientes, dichos efectos revierten generalmente en 2 ó 3 semanas. También se observa hepatomegalia reversible, pero las pruebas de función hepática y las enzimas hepáticas suelen ser normales.

En las personas que sobreviven a una intoxicación aguda, es frecuente que aparezcan alteraciones neurológicas periféricas algunas semanas después de la ingestión.

\section{Exposición a largo plazo (intoxicación crónica)}

Aspectos generales. La intoxicación crónica con arsénico puede presentarse en trabajadores expuestos durante un tiempo prolongado a concentraciones excesivas de compuestos de arsénico en suspensión aérea. Los rasgos más sobresalientes son los efectos locales sobre la mucosa del tracto respiratorio y la piel. También puede afectar a los sistemas nervioso y circulatorio y al hígado, y puede llegar a producirse cáncer del tracto respiratorio.

En el caso de una exposición a largo plazo al arsénico a través de la comida, el agua o la medicación, los síntomas son en cierto modo distintos de los que surgen tras la exposición por inhalación. Dominan en el cuadro clínico los síntomas abdominales vagos: diarrea o estreñimiento, enrojecimiento de la piel, pigmentación e hiperqueratosis. Además, puede producirse una afectación vascular, que en una región dio lugar a gangrena periférica.

En la intoxicación crónica por arsénico son habituales la anemia y la leucopenia. La afectación hepática se ha observado con mayor frecuencia en las personas expuestas durante largo tiempo por vía oral que en las expuestas por inhalación, especialmente en los trabajadores de viñedos, cuya vía de exposición principal parece ser el vino contaminado. Existe una mayor incidencia de cáncer de la piel en este tipo de intoxicación.

Trastornos vasculares. La exposición prolongada al arsénico inorgánico por la ingestión de agua puede dar lugar a trastornos vasculares periféricos con fenómeno de $R$ aynaud. En un área de Taiwan, China, se observó gangrena periférica (la llamada "enfermedad del pie negro"). En las personas expuestas profesionalmente no se han observado manifestaciones tan graves en la vasculatura periférica, pero en los trabajadores expuestos durante largo tiempo a arsénico inorgánico suspendido en el aire se han observado cambios leves con fenómeno de R aynaud y una mayor prevalencia de baja presión sanguínea periférica en 
condiciones de frío. M ás adelante se indican las dosis de arsénico absorbido.

P roblemas der matológicos. Las lesiones cutáneas arsenicales varían ligeramente dependiendo del tipo de exposición. Aparecen síntomas eczematoides de gravedad variable. En la exposición profesional al arsénico en suspensión aérea, pueden surgir lesiones cutáneas por irritación local. Se han descrito dos tipos de trastornos dermatológicos:

1. uno de tipo eczematoso, con eritema (enrojecimiento), tumefacción y aparición de pápulas o vesículas;

2. otro de tipo folicular, con eritema y tumefacción o pústulas foliculares.

La dermatitis se localiza principalmente en las áreas más expuestas, como la cara, la nuca, los antebrazos, las muñecas y las manos. Sin embargo, también puede aparecer en el escroto, la cara interna de los muslos, la parte superior del tórax, la parte inferior de las piernas y alrededor de los tobillos. $\mathrm{Ni}$ la hiperpigmentación ni la queratosis son rasgos sobresalientes de este tipo de lesiones arsenicales. M ediante pruebas cutáneas se ha demostrado que la dermatitis se debe al arsénico y no a las impurezas presentes en el trióxido de arsénico crudo. Según la concentración y la duración de la exposición, este tipo de reacción inicial puede ir seguido de lesiones dérmicas crónicas, que pueden aparecer después de muchos años de exposición profesional 0 ambiental. Los signos visibles son hiperqueratosis, verrugas y melanosis. La melanosis aparece con mayor frecuencia en los párpados, alrededor de las sienes, en el cuello, las areolas de los pezones y los pliegues axilares. En los casos graves, se observa arsenomelanosis en el abdomen, tórax, espalda y escroto, junto con hiperqueratosis y verrugas. En la intoxicación crónica por arsénico aparece también despigmentación (es decir, leucodermia), especialmente en las zonas pigmentadas, conocida habitualmente como pigmentación "en gota de Iluvia". Estas lesiones cutáneas crónicas, especialmente las hiperqueratosis, pueden transformarse en lesiones precancerosas y cancerosas. En la intoxicación crónica por arsénico también aparecen las líneas de M ees (estrías transversales) en las uñas. D ebe señalarse que las lesiones cutáneas crónicas pueden aparecer mucho tiempo después de suspenderse la exposición, cuando las concentraciones de arsénico en la piel han vuelto a la normalidad.

La lesión mucosa más clásica de la exposición crónica al arsénico es la perforación del tabique nasal tras la inhalación. Esta lesión es resultado de la irritación de la mucosa nasal y se extiende también a la laringe, tráquea y bronquios. Tanto en la exposición por inhalación como en la intoxicación por ingestión reiterada, la dermatitis de la cara y los párpados se extiende, en ocasiones, dando lugar a una queratoconjuntivitis.

Neuropatía periférica. En los supervivientes de intoxicaciones agudas se observan con frecuencia trastornos del sistema nervioso periférico. Estos trastornos suelen presentarse pocas semanas después de la intoxicación aguda y su recuperación es lenta. La neuropatía se caracteriza por disfunción motora y parestesias, aunque en los casos menos graves puede aparecer sólo una neuropatía sensorial unilateral. Las extremidades inferiores suelen resultar más afectadas que las superiores. En las personas que se recuperan de una intoxicación por arsénico pueden aparecer estrías transversales en las uñas: las Ilamadas líneas de M ees. El estudio histológico demuestra una degeneración Walleriana, especialmente en los axones más largos. La neuropatía periférica también puede observarse en la exposición industrial al arsénico; en la mayoría de los casos, se presenta en una forma subclínica que sólo puede detectarse por métodos neurofisiológicos. En un grupo de trabajadores de una fundición con una exposición prolongada correspondiente a una absorción total media acumulada de aproximadamente $5 \mathrm{~g}$ (absorción máxima de $20 \mathrm{~g}$ ), se observó una correlación negativa entre la absorción acumulada de arsénico y la velocidad de conducción nerviosa. En estos obreros (véase antes), también se observaron manifestaciones clínicas leves de afección vascular periférica. En niños expuestos al arsénico se ha descrito hipoacusia.

E fectos carcinogénicos. La Agencia Internacional para la Investigación sobre el Cáncer (IARC) clasifica los compuestos de arsénico inorgánico como cancerígenos pulmonares y cutáneos. Ciertos datos sugieren también que las personas expuestas a compuestos inorgánicos de arsénico presentan una mayor incidencia de angiosarcoma hepático y, posiblemente, de cáncer de estómago. Se ha descrito una mayor frecuencia de cáncer del tracto respiratorio entre los trabajadores empleados en la producción de insecticidas que contienen arsenato de plomo y arsenato cálcico, en los viticultores que utilizan insecticidas que contienen cobre inorgánico y compuestos arsenicales y en los fundidores expuestos a compuestos inorgánicos de arsénico y a otros metales. El tiempo de latencia entre el inicio de la exposición y la aparición del cáncer es prolongado, generalmente de 15 a 30 años. En el caso del cáncer de pulmón, se ha demostrado una acción sinérgica con el consumo de tabaco.

En Taiwan y Chile, la exposición al arsénico inorgánico a causa del agua de bebida se ha asociado con una incidencia del cáncer de piel superior a la normal. Se ha demostrado una relación entre este aumento y la concentración en el agua.

E fectos teratogénicos. Dosis elevadas de compuestos inorgánicos trivalentes de arsénico pueden originar malformaciones en hámsters cuando se inyectan por vía intravenosa. Con respecto a los humanos, no hay pruebas concluyentes de que los compuestos de arsénico produzcan malformaciones en condiciones industriales. No obstante, existen datos que indican este efecto en los trabajadores de fundición expuestos simultáneamente a diversos metales y otros compuestos.

\section{Compuestos de arsénico orgánico}

L os arsenicales orgánicos, como los que se utilizan en pesticidas y medicamentos, también pueden ser tóxicos, aunque sus efectos adversos no están totalmente documentados en humanos.

Se han descrito efectos tóxicos en el sistema nervioso de animales experimentales tras la administración en la alimentación de dosis elevadas de ácido arsanílico, que se utiliza frecuentemente como aditivo en los piensos para aves y porcinos.

Los compuestos de arsénico orgánico que se encuentran en alimentos de origen marino, como los camarones, los cangrejos y los peces están en forma de arsinocolina y arsinobetaina. Se sabe que las cantidades de arsénico orgánico presentes en pescados y mariscos pueden consumirse sin efectos nocivos. Estos compuestos se excretan rápidamente, principalmente en la orina.

Gas arsina y arsinas sustituidas. Se ha descrito un gran número de casos de intoxicación aguda con un alto índice de mortalidad. La arsina es uno de los agentes hemolíticos más potentes en la industria. Su actividad hemolítica se debe a su capacidad para reducir drásticamente el contenido de glutatión de los eritrocitos.

Los signos y síntomas de la intoxicación por arsina se relacionan principalmente con la hemólisis, que se desarrolla tras un período de latencia que depende de la intensidad de la exposición. La inhalación de 250 ppm de gas arsina es letal instantáneamente. $L$ a exposición a 25 a 50 ppm durante 30 minutos es letal y a $10 \mathrm{ppm}$ puede ser letal si la exposición es más prolongada. L os signos y síntomas de la intoxicación son los característicos de una hemólisis aguda y masiva. Inicialmente, se produce una hemoglobinuria indolora, trastornos gastrointestinales, como náuseas, y posiblemente vómitos. También pueden 
presentarse cólicos y dolor abdominal. A continuación, se observa ictericia, acompañada por anuria y oliguria. Pueden existir indicios de depresión de la médula ósea. Tras una exposición aguda e intensa, se puede desarrollar neuropatía periférica, que puede persistir durante varios meses después de la intoxicación. Se sabe poco sobre la exposición repetida o crónica a la arsina, pero puesto que el gas arsina se metaboliza a arsénico inorgánico en el organismo, se puede suponer que existe el riesgo de síntomas similares a los de una exposición prolongada a los compuestos de ar sénico inorgánico.

Para el diagnóstico diferencial se debe tener en cuenta la anemia hemolítica aguda, que puede deberse a otros agentes químicos, como la estibina, o a otros fármacos, y las anemias immunohemolíticas secundarias.

Las arsinas sustituidas no producen hemólisis como efecto principal, pero son potentes irritantes locales y pulmonares y venenos sistémicos. El efecto local sobre la piel produce ampollas circunscritas en el caso de la dicloro(2-clorovinil-)arsina (lewisita). Los vapores producen tos espasmódica con esputos densos o con sangre, que progresa como edema pulmonar agudo. El dimercaprol (BAL) es un antídoto eficaz si se administra en las primeras etapas de la intoxicación.

\section{Medidas de salud y seguridad}

El tipo más común de exposición profesional al arsénico es a los compuestos de arsénico inorgánico. Así, las medidas de salud y seguridad que indicamos a continuación se relacionan principalmente con este tipo de exposición. Cuando exista riesgo de exposición a gas arsina, debe tenerse especial precaución de evitar fugas accidentales, ya que las exposiciones a concentraciones elevadas durante intervalos cortos pueden ser especialmente graves.

El mejor método de prevención consiste en mantener la exposición en niveles muy inferiores a los límites de exposición aceptables. Por lo tanto, es importante contar con un programa de determinación de las concentraciones ambientales de arsénico. Además de la exposición por inhalación, debe controlarse la exposición por vía oral a través de la ropa, manos, tabaco, etc. contaminados. Se debe proporcionar a los trabajadores ropa de protección adecuada, botas protectoras y, cuando exista riesgo de que se sobrepase la exposición límite al arsénico en suspensión aérea, equipo de protección respiratoria. Las taquillas deberán constar de compartimentos separados para la ropa personal y la de trabajo y los trabajadores deberán disponer de instalaciones sanitarias adyacentes de buena calidad. D ebe estar prohibido fumar, comer y beber en el lugar de trabajo. Deben realizarse reconocimientos médicos previos al ingreso. En los trabajos con arsénico, no se recomienda emplear a personas con antecedentes de diabetes, enfermedades cardiovasculares, anemia, trastornos alérgicos o cutáneos de otro tipo y lesiones neurológicas hepáticas 0 renales. Se deben realizar reconocimientos médicos periódicos de todos los empleados expuestos al arsénico, prestando especial atención a los síntomas posiblemente relacionados con el arsénico.

La determinación del nivel de arsénico inorgánico y sus metabolitos en la orina permite calcular la dosis total de arsénico inorgánico captado por las distintas vías de exposición. Este método sólo es útil cuando se pueden determinar específicamente el arsénico inorgánico y sus metabolitos. Los valores de arsénico total en la orina proporcionan a menudo una información errónea sobre la exposición industrial, pues una sola comida a base de pescado u otros organismos marinos, que contienen cantidades considerables de compuestos arsenicales no tóxicos, puede producir concentraciones muy elevadas de arsénico en la orina durante varios días.

\section{Tratamiento}

Intoxicación por gas arsina. Cuando existan motivos para pensar que ha existido una exposición considerable al gas arsina, en cuanto aparezcan los primeros síntomas (es decir, la hemoglobinuria y el dolor abdominal), debe retirarse a la persona del ambiente contaminado y prestarle asistencia médica inmediata. El tratamiento recomendado, si existe algún indicio de insuficiencia renal, consiste en una transfusión sanguínea de sustitución total, asociada con diálisis artificial prolongada. En algunos casos, la diuresis forzada ha resultado útil, mientras que, según la mayoría de los autores, el tratamiento con BAL y otros agentes quelantes parece tener un efecto limitado.

La exposición a las arsinas sustituidas debe tratarse de la misma forma que la intoxicación por arsénico inorgánico (véase más adelante).

Intoxicación por arsénico inorgánico. En caso de exposición a dosis que se calcule que puedan producir una intoxicación aguda 0 cuando se observen síntomas graves del sistema respiratorio, la piel 0 el tracto gastrointestinal durante una exposición prolongada, el trabajador debe retirarse inmediatamente de la exposición y recibir tratamiento con un agente que forme complejo.

El agente más utilizado en estas situaciones es el 2,3-dimercapto-1-propanol o antilewisita británica (BAL, dimercaprol). En estos casos es vital una pronta administración: para obtener el máximo beneficio, el tratamiento debe iniciarse en un plazo de 4 horas desde la intoxicación. También pueden utilizarse otros compuestos, como el 2,3-dimercaptopropanosulfonato sódico (DM PS o unitiol) o el ácido meso-2,3-dimercaptosuccínico. E stos compuestos tienen menos probabilidades de producir efectos secundarios y se piensa que son más eficaces que el $B A L$. $\mathrm{En}$ un caso, resultó útil la administración intravenosa de $\mathrm{N}$-acetilcisteina. Además, es obligatorio un tratamiento general, como la prevención de una absorción continuada evitando la exposición y minimizando la absorción del tracto gastrointestinal mediante lavado gástrico y la administración por sonda de agentes quelantes o carbón. Puede ser necesario un tratamiento general de apoyo, como el mantenimiento de la respiración y la circulación, del equilibrio de agua y electrólitos y el control de los efectos sobre el sistema nervioso. Si es posible, se puede ayudar a la eliminación del tóxico absorbido mediante hemodiálisis y exanguinotransfusión.

Las lesiones cutáneas agudas, como la dermatitis de contacto y las manifestaciones leves de problemas vasculares periféricos, como el síndrome de R aynaud, no requieren por lo general más tratamiento que suspender la exposición.

\section{BARIO}

\section{Distribución y usos}

El bario $(\mathrm{Ba})$ es abundante en la naturaleza y representa aproximadamente el $0,04 \%$ de la corteza terrestre. Sus principales fuentes son los minerales barita (sulfato de bario, $\mathrm{BaSO}_{4}$ ) y witherita (carbonato de bario, $\mathrm{BaCO}_{3}$ ). EI metal bario se produce sólo en cantidades limitadas, por reducción del óxido de bario en presencia de aluminio en retorta.

El bario se utiliza mucho en la fabricación de aleaciones para las piezas de níquel-bario del sistema de encendido de automóviles y en la fabricación de vidrio, cerámica y tubos de imagen de los televisores. La barita ( $\mathrm{BaSO}_{4}$ ) o sulfato bárico se utiliza principalmente en la producción de litopán, un polvo blanco que contiene un $20 \%$ de sulfato de bario, un $30 \%$ de sulfuro de zinc y menos de un $8 \%$ de óxido de zinc. La litopona se emplea comúnmente como pigmento en las pinturas blancas. El sulfato 
de bario químicamente precipitado - blanco fijo - se utiliza en las pinturas de alta calidad, como contraste en el diagnóstico radiológico, y en la industria del vidrio y el papel. También se utiliza para la fabricación de papel fotográfico, marfil artificial y celofán. La barita cruda se utiliza como pasta tixotrópica en la perforación de pozos petrolíferos.

El hidróxido de bario $\left(\mathrm{Ba}(\mathrm{OH})_{2}\right)$ se encuentra en los lubricantes, pesticidas, en la industria azucarera, en los anticorrosivos, en los líquidos de perforación y en los ablandadores de agua. También se utiliza en la fabricación de vidrio, la vulcanización del caucho sintético, el refino de aceite animal y vegetal y en las pinturas al fresco. El carbonato de bario $\left(\mathrm{BaCO}_{3}\right)$ se obtiene en forma de precipitado de la barita y se utiliza en la fabricación de ladrillos, cerámica, pinturas y caucho, en la perforación de pozos petrolíferos y en la industria del papel, así como en la fabricación de esmaltes, sustitutos de mármol, cristales ópticos y electrodos.

El óxido de bario $(\mathrm{BaO})$ es un polvo alcalino de color blanco que se utiliza como desecante de gases y disolventes. A $450{ }^{\circ} \mathrm{C}$, se combina con oxígeno para producir peróxido de bario $\left(\mathrm{BaO}_{2}\right)$, un agente oxidante en la síntesis orgánica y material de blanqueo para sustancias animales y fibras vegetales. EI peróxido de bario se utiliza en la industria textil para teñir y estampar tejidos, en las soldaduras de polvo de aluminio y en pirotecnia.

El cloruro de bario $\left(\mathrm{BaCl}_{2}\right)$ se obtiene calcinando la barita con carbón y cloruro de calcio y se utiliza para la fabricación de pigmentos, lacas y vidrio de color y como mordente para tintes ácidos. También es útil para el aprestado y tinción de textiles y en la refinación del aluminio. El cloruro de bario se utiliza como pesticida, se añade a las calderas para ablandar el agua y se emplea como agente de curtido y acabado para el cuero. El nitrato de bario $\left(\mathrm{Ba}\left(\mathrm{NO}_{3}\right)_{2}\right)$ se utiliza en pirotecnia y en electrónica.

\section{Riesgos}

El bario metal tiene un uso limitado y presenta riesgo de explosión. Los compuestos solubles de bario (cloruro, nitrato, hidróxido) son sumamente tóxicos; la inhalación de los compuestos insolubles (sulfato) puede producir neumoconiosis. M uchos de los compuestos, como el sulfuro, el óxido y el carbonato, pueden producir irritación local en ojos, nariz, garganta y piel. Ciertos compuestos, en especial el peróxido, el nitrato y el clorato, presentan peligro de incendio durante su uso y almacenaje.

\section{Toxicidad}

L os compuestos solubles son sumamente tóxicos por vía oral, y la dosis letal de cloruro se ha establecido entre 0,8 y 0,9 g. Sin embargo, aunque de vez en cuando se observan intoxicaciones por ingestión de estos compuestos, se han descrito muy pocos casos de intoxicación industrial. La intoxicación puede producirse cuando los trabajadores están expuestos a determinadas concentraciones atmosféricas de polvo de los compuestos solubles, como puede ocurrir durante la molturación. D ichos compuestos ejercen una acción estimulante potente y prolongada sobre los músculos, aumentando la contractilidad de forma importante. En el corazón, las contracciones arrítmicas pueden derivar en fibrilación y existen indicios de una acción constrictora en las coronarias. Otros efectos son el aumento del peristaltismo intestinal, el espasmo vascular periférico, la contracción de la vejiga y un aumento en la tensión de los músculos voluntarios. Los compuestos de bario también tienen efectos irritantes sobre las membranas mucosas y los ojos.

El carbonato de bario, un compuesto insoluble, no parece producir efectos patológicos por inhalación; sin embargo, puede causar graves intoxicaciones por vía oral y, en ratas, produce un deterioro de las gónadas masculinas y femeninas; el feto es sensible al carbonato de bario durante la primera mitad del embarazo.

\section{Neumoconiosis}

El sulfato de bario se caracteriza por su extrema insolubilidad, lo que hace que no sea tóxico para los seres humanos. Por esta razón, y debido a su alta radioopacidad, el sulfato bárico se utiliza como medio opaco en los estudios de rayos $X$ de los aparatos gastrointestinal, respiratorio y urinario. También es inerte en el pulmón humano, como se ha demostrado por la falta de efectos adversos tras su introducción deliberada en el tracto bronquial como medio de contraste en broncografía y tras la exposición industrial a concentraciones elevadas de polvo fino.

Sin embargo, la inhalación puede conducir a su depósito en los pulmones en cantidad suficiente para producir baritosis, una neumoconiosis benigna que se observa principalmente en la minería, el molido y el ensacado de la barita, y que también se ha manifestado en la fabricación del litopán. En el primer caso descrito de baritosis se apreciaron síntomas de incapacidad, que posteriormente se asociaron con otra enfermedad pulmonar. En estudios posteriores se ha reseñado el contraste entre la naturaleza benigna del cuadro clínico y la ausencia total de síntomas y signos físicos anormales, y los notables cambios radiográficos, que revelan opacidades nodulares diseminadas en ambos pulmones. Estas opacidades son discretas, pero en ocasiones son tan numerosas que llegan a confluir en sombras mayores, no se han descrito sombras masivas. La característica más destacada de las radiografías es la marcada radioopacidad de los nódulos, lo que es comprensible dado que esta sustancia se utiliza como medio radioopaco. El tamaño de los elementos aislados puede variar entre 1 y $5 \mathrm{~mm}$ de diámetro, aunque el tamaño medio es de unos $3 \mathrm{~mm}$ o menos. Su forma se ha descrito como "redondeada" y "dendrítica". En algunos casos, se han observado puntos muy densos sobre un fondo de menor densidad.

En una serie de casos, se determinaron concentraciones de polvo de hasta 11.000 partículas/ $\mathrm{cm}^{3}$ en el lugar de trabajo y el análisis químico arrojó un contenido total de sílice de entre el 0,07 y el 1,96\%, no detectándose cuarzo por difracción de rayos $X$. L os trabajadores expuestos durante hasta 20 años que mostraban cambios radiológicos no presentaban síntomas, tenían una función pulmonar excelente y eran capaces de llevar a cabo trabajos muy pesados. Años después de haber dejado de trabajar, los reconocimientos de seguimiento mostraron una notable reducción de las anormalidades radiológicas.

Prácticamente no existen informes postmortem de baritosis puras. Sin embargo, la baritosis puede estar asociada con silicosis en los mineros debido a la contaminación de la roca silícea con barita, y en el molido, si se utilizan piedras de molino silíceas.

\section{Medidas de salud y seguridad}

Se debe proporcionar a los trabajadores expuestos a compuestos de bario soluble instalaciones sanitarias y de lavado adecuadas y se deben aconsejar medidas de higiene personal rigurosas. EI consumo de tabaco, alimentos y bebidas en el lugar de trabajo debe estar prohibido. Los suelos de los talleres han de ser de material impermeable y lavarse a fondo con frecuencia. Los trabajadores que trabajen en procesos como el blanqueado de barita con ácido sulfúrico deberán utilizar ropa resistente al ácido y protección adecuada para las manos y el rostro. Aunque la baritosis es una enfermedad benigna, se deben intentar reducir las concentraciones atmosféricas de polvo de barita al mínimo. Además, se debe prestar especial atención a la presencia de sílice libre en el polvo atmosférico. 


\section{BISMUTO}

\section{Distribución y usos}

En la naturaleza, el bismuto (Bi) está presente en forma de metal libre y en minerales como la bismutita (carbonato) y la bismutinita (doble sulfuro de bismuto y teluro), en los que se encuentra acompañado de otros elementos, fundamentalmente plomo y antimonio.

El bismuto se utiliza en metalurgia para la fabricación de un gran número de aleaciones, en especial aleaciones con bajo punto de fusión. Algunas de estas aleaciones se utilizan en soldadura. El bismuto también se utiliza en sistemas de seguridad para la detección de incendios y en los sistemas de extinción, así como en la producción de hierro maleable. El bismuto se emplea como catalizador en la fabricación de fibras acrílicas.

El teluro de bismuto se emplea como semiconductor. El óxido, hidróxido, oxicloruro, tricoloruro y nitrato de bismuto se utilizan en cosmética. O tras sales, como el succinato, ortoxiquinoleato, subnitrato, carbonato, fosfato, etc., se utilizan en medicina.

\section{Riesgos}

No existen informes de exposición profesional durante la producción de bismuto metálico y productos farmacéuticos, cosméticos y químicos industriales. Puesto que el bismuto y sus compuestos no parecen ser responsables de intoxicaciones relacionadas con el trabajo, se considera el menos tóxico de los metales pesados que se utilizan actualmente en la industria.

Los compuestos de bismuto se absorben a través de los tractos respiratorio y gastrointestinal. Los efectos sistémicos más importantes en el hombre y los animales se observan en los riñones y el hígado. Los derivados orgánicos producen alteraciones de los túbulos contorneados y pueden desembocar en nefrosis graves y, en ocasiones, mortales.

Se ha descrito la decoloración de las encías por la exposición al polvo de bismuto. Las sales minerales insolubles tomadas por vía oral durante períodos prolongados en dosis generalmente superiores a 1 gramo/día pueden provocar una encefalopatía caracterizada por trastornos mentales (estado confusional), trastornos musculares (mioclonía), trastornos de la coordinación motora (pérdida del equilibrio, inestabilidad) y disartria. Estos trastornos se originan por la acumulación de bismuto en los centros nerviosos, que se manifiesta cuando la bismutemia supera un cierto nivel, estimado en alrededor de $50 \mathrm{mg} / \mathrm{I}$. En la mayoría de los casos, la encefalopatía por bismuto desaparece gradualmente sin medicación en un plazo de 10 días a 2 meses, durante el cual se elimina el bismuto en la orina. N o obstante, se han descrito casos de encefalopatía mortales.

En Francia y Australia se han observado estos efectos neuropsíquicos desde 1973. Están originados por un factor que aún no se ha investigado a fondo y que promueve la absorción de bismuto a través de la mucosa intestinal, produciendo un aumento de la bismutemia a niveles tan altos como varios cientos de $\mathrm{mg} / \mathrm{l}$. EI riesgo de encefalopatía causada por la inhalación de polvo metálico o vapores de óxido en el lugar de trabajo es muy remoto. La baja solubilidad del bismuto y del óxido de bismuto en el plasma sanguíneo y su eliminación relativamente rápida en la orina (su semivida es de unos 6 días) hace muy improbable una impregnación de los centros nerviosos suficientemente aguda como para alcanzar proporciones patológicas.

En animales, la inhalación de compuestos insolubles, como el telururo de bismuto, produce la respuesta pulmonar habitual de un polvo inerte. Sin embargo, la exposición prolongada al telururo de bismuto "complementado" con sulfuro de selenio puede producir, en diversas especies, una reacción granulomatosa pulmonar leve y reversible.

Algunos compuestos de bismuto se descomponen en sustancias químicas peligrosas. EI pentafluoruro de bismuto se descompone al calentarlo y emite humos sumamente tóxicos.

\section{CADMIO}

\section{Distribución y usos}

L as propiedades químicas y físicas del cadmio $(\mathrm{C} d)$ son muy similares a las del zinc, y con frecuencia coexiste con este metal en la naturaleza. En los minerales y las menas, la proporción de cadmio y zinc suele oscilar entre 1:100 a 1:1.000.

El cadmio es muy resistente a la corrosión y se utiliza para su electrodeposición en otros metales, especialmente el acero y el hierro. Los tornillos, las tuercas de seguridad, los pestillos y diversas partes de los aviones y vehículos de motor están tratados con cadmio con el fin de protegerlos de la corrosión. Actualmente, sin embargo, sólo el $8 \%$ de todo el cadmio refinado se utiliza para el galvanizado y los recubrimientos. Los compuestos de cadmio se utilizan también como pigmentos y estabilizadores de plásticos (30\% de su uso en los países desarrollados) y en ciertas aleaciones (3\%). Las baterías pequeñas, portátiles y recargables de cadmio que se utilizan, por ejemplo, en los teléfonos móviles representan un uso del cadmio cada vez mayor (en 1994, en los países desarrollados, el $55 \%$ de todo el cadmio se utilizó en la fabricación de baterías).

Existen diversas sales de cadmio. La más importante es el estearato de cadmio, que se utiliza como estabilizador térmico en los plásticos de PVC (cloruro de polivinilo). El sulfuro de cadmio y el sulfoseleniuro de cadmio se utilizan como pigmentos amarillo y rojo en plásticos y tintes. El sulfuro de cadmio se utiliza también en células solares y fotográficas. El cloruro de cadmio se emplea como fungicida, componente de los baños galvanoplásticos, colorante en pirotecnia, aditivo en las soluciones de estañado y mordente en la tinción e impresión de textiles. También se utiliza para la producción de determinadas películas fotográficas, para la fabricación de espejos especiales y para el recubrimiento de tubos electrónicos de vacío. El óxido de cadmio se utiliza como agente para galvanoplastia. materia prima para los estabilizadores térmicos de PVC y componente de las aleaciones de plata, pigmentos fosforescentes y semiconductores, así como para el endurecimiento de cristales o el vitrificado de cerámica.

EI cadmio puede representar un peligro para el medio ambiente y en muchos países se han adoptado medidas legislativas para reducir su uso y la consiguiente dispersión ambiental de cadmio.

\section{Meta bolismo y acumulación}

La absorción gastrointestinal del cadmio ingerido es aproximadamente de un 2 a un $6 \%$ en condiciones normales. Las personas que poseen pocas reservas de hierro en su organismo, lo que se traduce en una baja concentración de ferritina en el suero, pueden presentar una absorción de cadmio mucho mayor, de hasta un $20 \%$ de la dosis administrada. Además, se pueden absorber cantidades significativas de este metal por vía pulmonar, como consecuencia de la inhalación de humo de tabaco o por la exposición profesional al polvo de cadmio atmosférico. Se calcula que la absorción pulmonar del polvo de cadmio respirable inhalado es del 20 al $50 \%$. Tras la absorción, ya sea por vía digestiva o respiratoria, el cadmio se transporta al hígado, donde se inicia la producción de una proteína de bajo peso molecular que se une al cadmio, la metalotioneina. 
Se considera que de un 80 a un $90 \%$ de la dosis total de cadmio que entra en el organismo se presenta unido a la metalotioneina. Esto evita que los iones de cadmio libres ejerzan su efecto tóxico. Es probable que exista un transporte continuo por vía hemática desde el hígado al riñón de pequeñas cantidades de metalotioneina unida al cadmio. El complejo metalotioneinacadmio se filtra a través de los glomérulos a la orina primaria. Al igual que en el caso de otras proteínas y aminoácidos de bajo peso molecular, las células de los túbulos proximales reabsorben el complejo metalotioneina-cadmio de la orina primaria; en estas células, las enzimas digestivas degradan las proteínas en péptidos de menor tamaño y aminoácidos. Los iones de cadmio libres que se liberan tras la degradación de la metalotioneina inician una nueva síntesis de metalotioneina, que se une al cadmio y protege a la célula de los efectos sumamente tóxicos de los iones libres de cadmio. Se piensa que cuando se supera la capacidad de producción de metalotioneína en las células de los túbulos, se produce la insuficiencia renal. Los riñones y el hígado presentan las concentraciones de cadmio más elevadas, puesto que contienen cerca del $50 \%$ de la carga corporal de cadmio. La concentración de cadmio en la corteza renal, antes de que se produzcan lesiones renales inducidas por este metal, es aproximadamente 15 veces superior a la concentración hepática. La eliminación del cadmio es muy lenta, y por ello se acumula en el organismo, aumentando su concentración con la edad y el tiempo de exposición. Tomando como base la concentración en un mismo órgano a diferentes edades, se ha calculado que la semivida biológica del cadmio en el hombre oscila entre 7 y 30 años.

\section{Toxicidad aguda}

La inhalación de compuestos de cadmio en concentraciones en el aire superiores a $1 \mathrm{mg} \mathrm{Cd} / \mathrm{m}^{3}$ durante 8 horas 0 en concentraciones superiores durante períodos más cortos puede producir una neumonitis química y, en los casos graves, edema pulmonar. Generalmente, los síntomas aparecen entre 1 y 8 horas después de la exposición y son similares a los de la gripe o la fiebre por humos de metales. Los síntomas más graves de la neumonitis química y del edema pulmonar pueden tener un período de latencia de hasta 24 horas. El fallecimiento puede sobrevenir después de 4 ó 7 días. Pueden producirse exposiciones a concentraciones de cadmio en la atmósfera superiores a $5 \mathrm{mg} \mathrm{Cd} / \mathrm{m}^{3}$ durante las operaciones de soldadura, corte al plasma o fundición de aleaciones de cadmio. La ingestión de bebidas contaminadas con cadmio en concentraciones superiores a $15 \mathrm{mg} \mathrm{C} \mathrm{d/I} \mathrm{produce}$ síntomas de intoxicación alimentaria. Los síntomas son: náuseas, vómitos, dolor abdominal y, en ocasiones, diarrea. Las fuentes de contaminación de los alimentos pueden ser las cacerolas y sartenes recubiertos con esmalte a base de cadmio o soldaduras realizadas con cadmio que se utilizan en las máquinas expendedoras de bebidas calientes y frías. En los animales, la administración parenteral de cadmio en dosis superiores a $2 \mathrm{mg} \mathrm{Cd/} \mathrm{kg} \mathrm{de}$ peso corporal produce necrosis testicular. Sin embargo, no se ha descrito este tipo de efectos en el hombre.

\section{Toxicidad crónica}

Se han producido casos de intoxicación crónica por cadmio tras exposiciones profesionales prolongadas a humos o polvo de óxido de cadmio y a estearatos de cadmio. Los cambios asociados con la intoxicación crónica por cadmio pueden ser locales, en cuyo caso se afectan las vías respiratorias, o sistémicos, debidos a la absorción de cadmio. Las alteraciones sistémicas incluyen lesiones renales, con proteinuria y anemia. Los principales síntomas derivados de la exposición a cadmio en el aire son los correspondientes a una neumopatía de carácter obstructivo, en forma de enfisema, en tanto que la insuficiencia y las lesiones renales constituyen las características más relevantes de las exposiciones prolongadas a niveles más bajos de cadmio en el aire de las naves de trabajo o de las intoxicaciones por alimentos contaminados con cadmio. En los trabajadores expuestos a niveles elevados de cadmio se encuentra frecuentemente una ligera anemia hipocrómica que podría deberse, por una parte, a un incremento de la destrucción de los hematíes y, por otra, a un déficit de hierro. Asimismo, en los casos de exposición a concentraciones muy elevadas de cadmio, pueden observarse manchas amarillas en los cuellos de las piezas dentarias y pérdida del sentido del olfato (anosmia).

El enfisema pulmonar se considera un posible efecto de la exposición prolongada al cadmio existente en el aire cuando se encuentra en concentraciones superiores a $0,1 \mathrm{mg} \mathrm{Cd} / \mathrm{m}^{3}$. Se ha descrito que la exposición a concentraciones de aproximadamente $0,2 \mathrm{mg} \mathrm{Cd} / \mathrm{m}^{3}$ durante más de 20 años puede producir ciertos efectos pulmonares. El enfisema pulmonar inducido por cadmio puede reducir la capacidad laboral y ser causa de invalidez y de acortamiento de la vida. En los casos de exposición de larga duración a niveles bajos de cadmio, los riñones son los órganos críticos, es decir, los primeros afectados. El cadmio se acumula en la corteza renal. Se calcula que las concentraciones superiores a $200 \mu \mathrm{g} \mathrm{Cd} / \mathrm{g}$ de peso en fresco producen disfunción de los túbulos renales y disminución de la reabsorción de las proteínas de la orina. Esto produce proteinuria tubular y un aumento en la excreción de proteínas de bajo peso molecular, como la $\alpha, \alpha$-1-microglobulina (proteína HC), la $\beta$-2-microglobulina y la proteína de unión al retinol (RTB). Estudios recientes indican, sin embargo, que puede producirse el daño tubular incluso con niveles inferiores de cadmio en la corteza renal. A medida que avanza la insuficiencia renal, también se pierden por la orina aminoácidos, glucosa y minerales, como el calcio y el fósforo. El aumento de la eliminación de calcio y fósforo puede alterar el metabolismo óseo y no es raro encontrar cálculos renales en los trabajadores expuestos a este metal. Tras la exposición prolongada a niveles medios-elevados de cadmio, también pueden verse afectados los glomérulos renales, produciéndose una disminución en la tasa de filtración glomerular. En casos graves, puede llegar a desarrollarse uremia. Estudios recientes muestran que la disfunción glomerular es irreversible y depende de la dosis. En casos de intoxicación crónica por cadmio de carácter grave se han detectado osteomalacias.

Con el fin de prevenir la insuficiencia renal que se manifiesta por $\beta$-2-microglobulinuria, en especial si la exposición profesional a los humos y polvo de cadmio puede durar hasta 25 años (con una jornada laboral de 8 horas y 225 días de trabajo/ año), se recomienda mantener la concentración media de cadmio respirable en niveles inferiores a $0,01 \mathrm{mg} / \mathrm{m}^{3}$.

Se han descrito casos de exposición excesiva al cadmio en la población general por la ingestión de arroz y otros alimentos contaminados, y posiblemente también de agua contaminada. En Japón, en zonas con un alto grado de exposición al cadmio, se han producido casos de enfermedad de itai-itai, un tipo de osteomalacia dolorosa, con múltiples fracturas e insuficiencia renal. Aunque hay una controversia acerca de la patogenia de esta enfermedad, hay unanimidad de criterios en cuanto a que el cadmio es un factor etiológico necesario. $H$ ay que señalar que las lesiones renales inducidas por cadmio son irreversibles y pueden seguir progresando incluso después de que cesa la exposición.

\section{Cadmio y cáncer}

Varios estudios epidemiológicos demuestran una relación dosisrespuesta y un aumento en la mortalidad por cáncer pulmonar en los trabajadores expuestos al cadmio. La interpretación se complica por la exposición simultánea a otros metales que son 0 
se sospecha que pueden ser cancerígenos. Sin embargo, la observación continuada de trabajadores expuestos al cadmio no ha permitido demostrar un aumento de la mortalidad por cáncer de próstata, como se sospechaba inicialmente. En 1993, la Agencia Internacional para la Investigación sobre el Cáncer (IARC) evaluó el riesgo de cáncer derivado de la exposición al cadmio y concluyó que debía considerarse cancerígeno para el hombre. Puesto que los resultados de los estudios epidemiológicos adicionales son relativamente contradictorios, la posible carcinogenicidad del cadmio aún no está clara. Sin embargo, está claro que el cadmio posee propiedades cancerígenas en los experimentos con animales

\section{Medidas de salud y seguridad}

La corteza renal es el órgano crítico en la exposición prolongada al cadmio a través del aire o los alimentos. Se calcula que la exposición crítica es de aproximadamente $200 \mu \mathrm{g} \mathrm{Cd} / \mathrm{g}$ de peso en fresco, aunque, como se indicó antes, puede ser inferior. Para mantener la concentración en la corteza renal por debajo de este nivel, incluso después de toda una vida de exposición, la concentración media de cadmio en el aire de las naves de trabajo (8 horas diarias) no debe superar $0,01 \mathrm{mg} \mathrm{Cd} / \mathrm{m}^{3}$.

Los procesos y las prácticas laborales que pueden liberar humo o polvo de cadmio al aire deben diseñarse de forma que se mantengan los niveles de concentración al mínimo y, si es factible, deberán realizarse en sistemas cerrados provistos de extractores. Cuando sea imposible disponer de una ventilación adecuada, por ejemplo, durante las operaciones de soldadura y corte al plasma, se deberán utilizar equipos de protección respiratoria y se procederá a controlar la atmósfera de trabajo para determinar las concentraciones de cadmio. En las zonas en que exista riesgo de partículas en suspensión aérea, salpicaduras de productos químicos, calor radiante, etc., por ejemplo, en las proximidades de depósitos de galvanoplastia o de hornos, los trabajadores deberán utilizar equipos de protección adecuados, como protectores de ojos, cara, manos y brazos, así como trajes impermeables. Los trabajadores deberán disponer de instalaciones sanitarias adecuadas y se les instará a lavarse antes de comer y a ducharse y cambiarse de ropa al finalizar la jornada laboral. Deberá estar prohibido fumar, comer y beber en las áreas de trabajo. EI tabaco contaminado con polvo de cadmio de la sala de trabajo puede ser una importante fuente de exposición, por lo que no deberán llevar cigarrillos ni tabaco en los bolsillos, etc. en las naves de trabajo. El aire contaminado procedente de los extractores deberá filtrarse y el personal encargado de los colectores de polvo y los filtros utilizará equipos de protección respiratoria durante todo el tiempo que dure el trabajo en estas instalaciones.

Para garantizar que no se produce una acumulación excesiva de cadmio en los riñones, se controlarán periódicamente los niveles de cadmio en sangre y orina. El nivel de cadmio en sangre constituye un buen indicador sobre los últimos meses, pero también puede utilizarse para evaluar la carga en el organismo varios años después de que ha cesado la exposición. Un valor de $100 \mathrm{nmol} \mathrm{Cd} /$ I de sangre total puede considerarse el nivel crítico aproximado, si la exposición es regular, para largos períodos de tiempo. Los valores de cadmio en orina se pueden utilizar para calcular la cantidad total de cadmio en el organismo, siempre que no exista lesión renal. La OMS ha determinado que $10 \mathrm{nmol} / \mathrm{mmol}$ de creatinina es la concentración por debajo de la cual no debe producirse insuficiencia renal. Sin embargo, estudios recientes demuestran que puede existir insuficiencia renal con niveles de aproximadamente $5 \mathrm{nmol} / \mathrm{mmol}$ de creatinina. Dado que los niveles hemáticos y urinarios mencionados son niveles en los que se ha observado un efecto del cadmio sobre el riñón, se recomienda aplicar medidas de control siempre que las concentraciones individuales de cadmio en orina 0 en sangre superen $50 \mathrm{nmol} /$ I de sangre total $03 \mathrm{nmol} / \mathrm{mmol}$ de creatinina, respectivamente. Los trabajadores que vayan a estar expuestos a humos o polvo de cadmio deberán someterse a reconocimientos médicos periódicos. Las personas que padezcan alguna alteración respiratoria o renal quedarán excluidas de estos trabajos. Los reconocimientos médicos de los trabajadores expuestos al cadmio se realizarán, cuando menos, una vez al año. En el caso de los trabajadores que hayan tenido una exposición al cadmio durante períodos prolongados, se realizarán regularmente determinaciones cuantitativas en orina de ß-2-microglobulina u otras proteínas de bajo peso molecular relevante. Normalmente, las concentraciones de ß-2-microglobulina en orina no deberán ser superiores a $34 \mu \mathrm{g} / \mathrm{mmol}$ de creatinina.

\section{Tratamiento de la intoxicación por cadmio}

Se debe inducir el vómito o realizar un lavado gástrico a las personas que hayan ingerido sales de cadmio; las personas expuestas a una inhalación aguda deberán retirarse del lugar de la exposición y recibir oxígeno en caso necesario. No hay un tratamiento específico para la intoxicación crónica por cadmio, debiendo aplicarse un tratamiento sintomático. Como norma, la administración de agentes quelantes como el BAL o el EDTA está contraindicada, pues al combinarse con el cadmio, se convierten en compuestos nefrotóxicos.

\section{CiRCONIO Y HAFNIO}

\section{Distribución y usos}

Se calcula que el circonio $(\mathrm{Zr})$ constituye aproximadamente un $0,017 \%$ de la litosfera. Por su elevada actividad química a temperaturas sólo ligeramente superiores a la temperatura ambiente, el elemento se encuentra únicamente en estados combinados. Los minerales más comunes son el circón $\left(\mathrm{ZrO}_{2}\right)$ y la badeleyita $\left(\mathrm{ZrSiO}_{4}\right)$. El circonio se encuentra en todos los tejidos animales.

El hafnio ( $\mathrm{Hf}$ ) aparece asociado al circonio en todas sus presentaciones terrestres. La cantidad de hafnio varía, pero en promedio se sitúa en torno a un $2 \%$ del circonio total más hafnio. Sólo en un mineral con bajo contenido de ambos elementos se ha comprobado una mayor cantidad de hafnio que de circonio. La espectrografía indica que la distribución del hafnio representa también en torno al $2 \%$ del circonio total más hafnio, en el universo. Estos dos elementos son más similares en sus propiedades químicas que cualquier otro par de la tabla periódica. Su similitud es tan grande que aún no se han encontrado diferencias cualitativas que permitan su separación. Por este motivo, puede considerarse que la mayoría del circonio que se ha utilizado y cuyos efectos fisiológicos se han descrito, contenía entre un 0,5 y un $2 \%$ de hafnio.

Desde tiempos remotos el circón se ha considerado una piedra preciosa, pues se presenta con frecuencia en grandes cristales simples. Ahora bien, la mayoría de los depósitos comerciales útiles de mineral de circonio se encuentran en arenas de playa u otros lugares en que se han depositado minerales de circonio relativamente pesados y químicamente inertes mientras que las partes más ligeras de las rocas en que se presentaban se desintegraron y eliminaron por la acción del agua. Se conocen depósitos importantes de estas arenas de playa en la India, M alasia, Australia y Estados U nidos. La badeleyita en depósitos comercialmente útiles se observó por primera vez en Brasil y, desde entonces, se ha encontrado en varios lugares más, como 
Suecia, Ia India e Italia. También se han extraído comercialmente algunos minerales de circonio en Madagascar, Nigeria, Senegal y Sudáfrica.

El circón se utiliza generalmente como arena de fundición, como abrasivo, como elemento de compuestos refractarios de circón y circonia para crisoles de laboratorio y en compuestos cerámicos, en los que actúa como opacificador de vitrificados y esmaltes. L os hornos de vidrio se revisten con ladrillos de circón y circonia, y se emplean moldes de circonia como matrices para la extrusión de metales tanto ferrosos como no ferrosos y como revestimiento de las boquillas para verter metales, especialmente en el moldeo continuo.

Más del $90 \%$ del circonio metálico se utiliza actualmente para la generación de energía nuclear debido a su baja sección transversal de absorción de neutrones y a su alta resistencia a la corrosión en el interior de reactores atómicos, siempre que no contenga hafnio. El circonio se utiliza también para la fabricación de hierro fundido, acero e instrumental quirúrgico. También encuentra aplicación en lámparas de arco eléctrico, pirotecnia, fundentes de soldadura especiales y como pigmento para plásticos.

El metal de circonio en polvo se utiliza como "recogedor" en los tubos termoiónicos para absorber las últimas trazas de gas después del bombeo y desgaseado de los elementos del tubo, y en forma de cinta fina o lana como relleno en las ampollas fotográficas para flash. El metal macizo se emplea puro o en forma de aleaciones para el revestimiento de recipientes de reacción y de bombas y sistemas de bombeo para procesos químicos. Se ha utilizado una excelente aleación superconductora de circonio y niobio en un imán con un campo de 6,7 T.

El carburo y el diboruro de circonio son compuestos metálicos duros y refractarios que se han empleado en herramientas de corte para metales. El diboruro se ha usado también como camisa de termopar en hornos de solera abierta, proporcionando termopares de muy larga duración. El tetracloruro de circonio se emplea en síntesis orgánicas para impermeabilizar tejidos y como agente de curtido.

El hafnio metalse ha utilizado sobre tántalo como revestimiento de piezas de los motores de los cohetes que actúan a temperaturas muy altas y en condiciones de erosión. Por su elevada sección transversal neutrón-térmica, se utiliza en las barras de control de los reactores nucleares. Se emplea además para la fabricación de electrodos y en los filamentos de lámparas.

\section{Riesgos}

No es totalmente correcto afirmar que los compuestos de circonio son fisiológicamente inertes, pero la tolerancia de la mayoría de los organismos al circonio parece mucho mayor que a la mayoría de los metales pesados. Se han utilizado sales de circonio para el tratamiento de la intoxicación por plutonio con el fin de desplazar el plutonio (y el itrio) depositado en el esqueleto y evitar su depósito cuando el tratamiento se inicia precozmente. Durante este estudio, se determinó que la dieta de las ratas puede contener hasta un $20 \%$ de circonia durante períodos relativamente largos sin efectos nocivos y que la $D_{L_{50}}$ intravenosa del citrato sódico de circonio en ratas es de aproximadamente $171 \mathrm{mg} / \mathrm{kg}$ de peso corporal. 0 tros investigadores han determinado una $\mathrm{DL}_{50}$ intraperitoneal de 0,67 g/ kg para el lactato de circonio y de 0,42 g/ kg para el zirconato de bario en ratas, y de $51 \mathrm{mg} / \mathrm{kg}$ para el lactato sódico de circonio en ratones.

Los compuestos de circonio se han recomendado y utilizado para el tratamiento tópico de la dermatitis de R hus (hiedra) y como desodorante corporal. Algunos de los compuestos utilizados son: la circonia hidrocarbonatada, la hidrocirconia y el lactato sódico de circonio. Existen varios informes sobre la producción de lesiones granulomatosas persistentes en la piel como resultado de estas aplicaciones.

El efecto de la inhalación de los compuestos de circonio tiene un interés más directo en relación con la exposición profesional $y$, sin embargo, se ha investigado menos que las otras vías de administración. Se han realizado varios experimentos y existe al menos un informe de exposición en humanos. En este caso, un ingeniero químico expuesto durante siete años al circonio y el hafnio en una planta de tratamiento presentó un estado granulomatoso pulmonar. Dado que el examen de todos los demás empleados no reveló ninguna lesión similar, se concluyó que podía deberse más probablemente a una exposición relativamente intensa al berilio, previa a la exposición al circonio.

La exposición de animales experimentales a los compuestos de circonio ha demostrado que el lactato de circonio y el zirconato de bario producen neumonitis intersticial crónica, persistente y grave en concentraciones atmosféricas de circonio de aproximadamente $5 \mathrm{mg} / \mathrm{m}^{3}$. También se ha demostrado que una exposición breve a concentraciones atmosféricas de lactato sódico de circonio mucho más elevadas, de $0,049 \mathrm{mg} / \mathrm{cm}^{3}$, produce abscesos y granulomas peribronquiales y neumonía lobular. Aunque no existen datos de neumoconiosis por circonio en humanos, los autores de un estudio concluyen que debería considerarse causa probable de esta enfermedad y recomiendan adoptar las precauciones pertinentes en los lugares de trabajo.

El pequeño número de investigaciones realizadas sobre la toxicidad de los compuestos de hafnio indica una toxicidad aguda ligeramente superior a la de las sales de circonio. El hafnio y sus compuestos producen lesiones hepáticas. EI cloruro de hafnio, en concentraciones de $10 \mathrm{mg} / \mathrm{kg}$, produjo colapso cardiovascular y paro respiratorio en un gato, al igual que las sales solubles de circonio. $L a D_{50}$ intraperitoneal de $112 \mathrm{mg} / \mathrm{kg}$ del hafnio no es mucho menor que la del circonio.

\section{Medidas de salud y seguridad}

Incendio y explosión. El circonio metálico en forma de polvo fino arde en contacto con el aire, el nitrógeno y el dióxido de carbono. EI polvo es explosivo en el aire en un rango de 45 a $300 \mathrm{mg} / \mathrm{l}$, y arde espontáneamente si se remueve, probablemente debido a la electricidad estática generada por la separación de los granos.

Los metales en polvo deben transportarse y manejarse en estado húmedo, para lo cual suele emplearse agua. Cuando el polvo se seca antes de utilizarlo, las cantidades empleadas deben ser lo más reducidas posibles y las operaciones realizarse en cubículos separados para impedir la propagación del fuego en caso de explosión. Todas las fuentes de ignición, incluidas las cargas eléctricas estáticas, deben eliminarse de las zonas en que se maneja el polvo. Las superficies han de ser impermeables y homogéneas, de forma que puedan lavarse con agua y mantenerse completamente libres de polvo. El polvo derramado debe limpiarse inmediatamente con agua antes de que llegue a secarse. Los papeles y paños utilizados que se hayan contaminado con polvo se mantendrán húmedos y en recipientes cubiertos hasta que se retiren para ser quemados, lo que ha de hacerse al menos una vez al día. El polvo seco debe removerse y manipularse lo menos posible y, en caso necesario, sólo con herramientas que no produzcan chispas. Si se utilizan delantales de goma o plástico sobre la ropa, deberán estar tratados con un compuesto antiestático. La ropa de trabajo será de fibra no sintética, a menos que esté eficazmente tratada con materiales antiestáticos.

Todos los procesos en que se utilice circonio o hafnio deberán estar organizados y ventilados de forma que se mantenga la contaminación ambiental por debajo de los límites de exposición. 


\section{COBRE}

El cobre $(\mathrm{Cu})$ es maleable y dúctil, un excelente conductor del calor y la electricidad, y su capacidad funcional se altera muy poco con la exposición al aire seco. Si se encuentra en una atmósfera húmeda con anhídrido carbónico, se cubre con una capa verde de carbonato. El cobre es un elemento esencial del metabolismo humano.

\section{Distribución y usos}

El cobre se encuentra principalmente en forma de compuestos minerales en los que el ${ }^{63} \mathrm{Cu}$ constituye el $69,1 \%$ y el ${ }^{65} \mathrm{Cu}$ el $30,9 \%$ del elemento. El cobre está ampliamente distribuido en todos los continentes y forma parte de la mayoría de los organismos vivos. Aunque se han descubierto algunos depósitos naturales de cobre metálico, generalmente se extrae en forma de sulfuros, como es el caso de la covelita (C uS), la calcocita $\left(\mathrm{Cu}_{2} \mathrm{~S}\right)$, la calcopirita $\left(\mathrm{CuFeS}_{2}\right)$ y la bornita $\left(\mathrm{Cu}_{3} \mathrm{FeS}_{3}\right) ; 0$ de óxidos, como la malaquita $\left(\mathrm{Cu}_{2} \mathrm{CO}{ }_{3}(\mathrm{OH})_{2}\right)$; la crisocola $\left(\mathrm{CuSiO}_{3} \cdot 2 \mathrm{H}_{2} \mathrm{O}\right)$ y la calcantita ( $\mathrm{CuSO}_{4} \cdot 5 \mathrm{H}_{2} \mathrm{O}$ ).

Debido a sus propiedades eléctricas, más del $75 \%$ del cobre que se produce se utiliza en la industria eléctrica. Entre otros usos de este metal se encuentra la fabricación de cañerías para el agua, material para techumbres, baterías de cocina, equipos químicos y farmacéuticos y producción de aleaciones de cobre. El cobre metálico también se utiliza como pigmento y como precipitante del selenio.

\section{Aleaciones y compuestos}

Las aleaciones no ferrosas más ampliamente utilizadas son las de cobre y zinc (latón), estaño (bronce), níquel (metal monel), aluminio, oro, plomo, cadmio, cromo, berilio, silicona o fósforo.

EI sulfato de cobre se utiliza como algicida y molusquicida en el agua; como fungicida vegetal, mezclado con cal; como mordente en galvanoplastia; como agente espumante para la separación por flotación del mineral de sulfuro de zinc; y como agente para el curtido del cuero y la conservación de pieles. El sulfato de cobre neutralizado con cal hidratada, conocido como mezcla de Burdeos, se utiliza para la prevención del mildiu en viñedos.

El óxido cúprico se ha utilizado como componente de las pinturas para los fondos de las embarcaciones y como pigmento para vidrio, cerámica, esmaltes, vitrificado de porcelanas y gemas artificiales. También se utiliza en la fabricación de rayón y otros compuestos de cobre, como agente para el pulido de cristales ópticos y como disolvente para los minerales de cromo y hierro. El óxido cúprico se utiliza como componente del fundente en la metalurgia del cobre, en los compuestos pirotécnicos, en los fundentes para la soldadura del bronce y en productos agrícolas, como insecticidas y fungicidas. El óxido cúprico negro se utiliza para corregir las deficiencias de cobre en el suelo y como complemento de piensos.

Los cromatos de cobre son pigmentos, catalizadores para la hidrogenación en fase líquida y fungicidas para las patatas. U na solución de hidróxido cúprico con un exceso de amoníaco se utiliza como disolvente de la celulosa en la fabricación del rayón (viscosa). El hidróxido cúprico se utiliza en la fabricación de los electrodos de baterías y para el tratamiento y la coloración del papel. También se utiliza como pigmento, aditivo para piensos, mordente para teñir textiles y como componente de fungicidas e insecticidas.

\section{Riesgos}

Los complejos aminados de clorato cúprico, ditionato cúprico, azida cúprica y acetílidos cuprosos son explosivos, pero no son importantes desde el punto de vista industrial o sanitario. El acetiluro de cobre ha sido causa de explosiones en las fábricas de acetileno, por lo que se ha eliminado el uso del cobre en la construcción de dichas plantas. Fragmentos de cobre metálico o de aleaciones de cobre pueden alojarse en los ojos, produciendo lo que se conoce como chalcosis, que puede dar lugar a uveítis, abscesos y pérdida de los ojos. Los trabajadores que fumigan los viñedos con la mezcla de Burdeos pueden padecer lesiones pulmonares (conocidas como "pulmón de fumigador de viñedos") y granulomas hepáticos cargados de cobre.

La ingestión accidental de sales de cobre solubles es generalmente inocua, ya que la inducción del vómito libera al paciente de gran parte del cobre. Puede existir un riesgo de toxicidad inducida por cobre en las siguientes situaciones:

- la administración oral de sales de cobre se utiliza en ocasiones con fines terapéuticos, especialmente en la India;

- se ha demostrado que el cobre disuelto procedente del filamento de ciertos dispositivos intrauterinos se absorbe sistémicamente;

- una fracción apreciable del cobre disuelto a partir de las conexiones utilizadas normalmente en los equipos de hemodiálisis puede ser retenida por los pacientes y producir aumentos significativos del cobre hepático;

- el cobre añadido frecuentemente al pienso del ganado y las aves de corral se concentra en el hígado de estos animales y puede incrementar considerablemente la ingesta de este elemento al ingerir este órgano. También se añade cobre en grandes cantidades, en comparación con la ingesta humana normal a través de la dieta, a diversos alimentos para animales domésticos que en ocasiones son consumidos por algunas personas. El empleo de estiércol de animales con dietas complementadas con cobre puede producir un exceso de cobre en las verduras y cereales cultivados en los terrenos abonados con este estiércol.

\section{Toxicidad aguda}

A pesar de que en los trabajos químicos de referencia se indica que las sales de cobre son tóxicas, en la práctica esto sólo es cierto cuando las disoluciones se utilizan de forma incontrolada, con fines suicidas o como tratamiento tópico de áreas con quemaduras graves. Cuando se ingiere sulfato de cobre, también conocido como piedra azul o azul vitriolo, en cantidades del orden de gramos, se producen náuseas, vómitos, diarrea, sudoración, hemólisis intravascular y posible fallo renal; en raras ocasiones, se observan también convulsiones, coma y la muerte. Cuando se beben aguas carbonatadas o zumos de cítricos que han estado en contacto con recipientes, cañerías, grifos o válvulas de cobre se puede producir irritación del tracto gastrointestinal, que pocas veces llega a ser grave. Este tipo de bebidas son suficientemente ácidas para disolver niveles de cobre irritantes. Existe un informe de úlceras corneales e irritación cutánea, con baja toxicidad de otro tipo, en un minero de cobre que cayó en un baño electrolítico, aunque la causa pudo haber sido la acidez más que el cobre. En algunos casos en que se utilizaron sales de cobre para el tratamiento de quemaduras, se observaron concentraciones elevadas de cobre sérico y manifestaciones tóxicas.

La inhalación de polvos, humos o nieblas de sales de cobre puede causar congestión nasal y de las mucosas, y ulceración con perforación del tabique nasal. Los humos desprendidos durante el calentamiento del cobre metálico pueden producir fiebre, náuseas, gastralgias y diarrea.

\section{Toxicidad crónica}

E fectos tóxicos crónicos atribuibles al cobre sólo parecen existir en personas que han heredado una pareja específica de genes 
recesivos autosómicos y que, como consecuencia, desarrollan una degeneración hepatolenticular (enfermedad de Wilson). Es una enfermedad rara. La mayor parte de la alimentación diaria que consume el hombre contiene de 2 a 5 mg de cobre, que prácticamente no se retiene en el organismo. El contenido corporal de cobre en una persona adulta es de 100 a 150 mg y es casi constante. En individuos normales (sin enfermedad de Wilson), casi todo el cobre está presente como parte integrante y funcional de una docena de proteínas y sistemas enzimáticos, como la citocromo oxidasa, la dopa-oxidasa y la ceruloplasmina sérica. En personas que ingieren grandes cantidades de ostras o mariscos de concha, hígado, setas, nueces y chocolate, alimentos todos ellos ricos en cobre, 0 en mineros que trabajan y comen durante 20 años o más en un ambiente cargado con un 1 ó $2 \%$ de polvo de minerales de cobre, pueden llegar a observarse concentraciones hasta 10 veces superiores a lo normal. Sin embargo, aún no se ha descrito ningún caso de toxicidad crónica primaria por cobre (perfectamente definida a partir de las observaciones de pacientes con toxicosis por cobre crónica heredada - la enfermedad de Wilson- como diffunción y lesiones estructurales hepáticas, del sistema nervioso central, de los riñones, los huesos y los ojos) excepto en personas que padecen la enfermedad de Wilson. Sin embargo, los depósitos excesivos de cobre hallados en el hígado de pacientes con cirrosis biliar primaria, colestasis y cirrosis infantil de la India pueden contribuir a la gravedad de la enfermedad hepática característica de estos procesos.

\section{Medidas de salud y seguridad}

Los trabajadores expuestos al polvo o nieblas de cobre deben utilizar ropa de protección adecuada para evitar el contacto repetido o prolongado con la piel. Cuando no sea posible controlar adecuadamente las concentraciones de polvo, deberán proporcionarse equipos de protección respiratoria y ocular adecuados. La limpieza del lugar y la existencia de instalaciones sanitarias adecuadas es fundamental, y debe estar prohibido fumar, comer y beber en el lugar de trabajo. En las minas en que existan minerales solubles en agua, como la calcantita, los trabajadores deberán tener especial cuidado de lavarse las manos con agua antes de las comidas.

La prevención de la fiebre por humos metálicos se logra manteniendo el nivel de exposición por debajo de las concentraciones aceptadas como satiffactorias para el trabajo con cobre en la industria. El empleo de sistemas de extracción de aire local es una medida necesaria para eliminar los humos de cobre en el lugar en que se producen.

Las personas que padecen la enfermedad de Wilson no deben trabajar en la industria del cobre. La determinación de la concentración sérica de ceruloplasmina es una forma de detectar este trastorno, ya que los individuos no afectados muestran niveles entre 20 y $50 \mathrm{mg} / 100 \mathrm{~cm}^{3}$ de esta proteína de cobre, mientras que el $97 \%$ de los pacientes con enfermedad de Wilson presentan menos de $20 \mathrm{mg} / 100 \mathrm{~cm}^{3}$. Sin embargo, este es un procedimiento relativamente caro para utilizarlo en programas de detección generalizados.

\section{CROMO}

\section{Distribución y usos}

El cromo elemental $(\mathrm{Cr})$ no se encuentra como tal en la naturaleza; el único mineral de cromo importante es la espinela, cromita o piedra de cromo hierro, que es cromito ferroso $\left(\mathrm{FeO} \mathrm{Cr}_{2} \mathrm{O}_{3}\right)$ y está ampliamente distribuida en la corteza terrestre. Además de ácido crómico, este mineral contiene cantidades variables de otras sustancias. Comercialmente, sólo se emplean los minerales o concentrados que contienen más del $40 \%$ de óxido de cromo $\left(\mathrm{Cr}_{2} \mathrm{O}_{3}\right)$. Los mayores depósitos se encuentran en la Federación Rusa, Sudáfrica, Zimbabue, Turquía, Filipinas e India. Los principales consumidores de cromitas son Estados U nidos, la Federación Rusa, Alemania, Japón, Francia y el Reino U nido.

La cromita puede obtenerse de minas subterráneas o a cielo abierto. El mineral se tritura y, si es necesario, se concentra.

La aplicación más importante del cromo puro es el cromado de una gran variedad de equipos, como piezas de automóvil y equipos eléctricos. También es ampliamente utilizado en aleaciones con hierro y níquel para formar acero inoxidable, y con níquel, titanio, niobio, cobalto, cobre y otros metales para formar aleaciones con fines específicos.

\section{Compuestos de cromo}

El cromo forma diversos compuestos en distintos estados de oxidación. Los más importantes son los estados de valencia II (cromosos), III (crómicos) y VI (cromatos). El estado II es básico, el III es anfótero y el VI es ácido. En las aplicaciones comerciales se utilizan principalmente compuestos de cromo en estado VI y, en algunos casos, en estado III.

El estado cromoso (C $\left.\mathrm{r}^{\prime \prime}\right)$ es inestable y se oxida rápidamente al estado crómico ( $\mathrm{Cr}^{\text {III }}$ ). Esta inestabilidad limita el uso de los compuestos cromosos. Los compuestos crómicos son muy estables y forman muchos otros compuestos con aplicaciones comerciales; los principales son: el óxido crómico y el sulfato básico de cromo.

El cromo en estado de oxidación $+6\left(\mathrm{Cr}^{\mathrm{VI}}\right)$ es el de mayor aplicación industrial por sus propiedades ácidas y oxidantes y su capacidad para formar sales muy coloreadas e insolubles. LoS compuestos hexavalentes de cromo $\left(\mathrm{Cr}^{\mathrm{VI}}\right)$ más importantes son: el dicromato sódico, el dicromato potásico y el trióxido de cromo. La mayoría de los demás compuestos de cromatos se producen industrialmente utilizando dicromato como fuente de $\mathrm{Cr}^{\mathrm{VI}}$.

\section{Producción}

El cromato y el dicromato sódico son los materiales iniciales a partir de los cuales se fabrican la mayoría de los compuestos de cromo. Estos dos compuestos se preparan directamente a partir del mineral de cromo, que se tritura, se seca y se muele; después, se le añade sosa o cal o lechada de cal. Tras el mezclado, se obtiene una mezcla que se tuesta en un horno giratorio a una temperatura óptima de aproximadamente $1.100^{\circ} \mathrm{C}$; es fundamental que exista una atmósfera oxidante para convertir el cromo al estado $\mathrm{Cr}^{\mathrm{Vl}}$. El fundido del horno se enfría y se lixivia y se aíslan el cromato o el dicromato sódicos de la solución por los procedimientos convencionales.

\section{Compuestos de cromo"II}

T écnicamente, el óxido de cromo $\left(\mathrm{Cr}_{2} \mathrm{O}_{3}\right.$, u óxido crómico), se obtiene por reducción del dicromato sódico, ya sea con carbón o con azufre. La reducción con azufre se emplea principalmente cuando el óxido crómico se va a utilizar como pigmento. Con fines metalúrgicos se utiliza habitualmente la reducción con carbón.

El material comercial suele ser sulfato crómico básico $\left[\mathrm{Cr}(\mathrm{OH})\left(\mathrm{H}_{2} \mathrm{O}\right)_{5}\right] \mathrm{SO}_{4}$, que se elabora a partir del dicromato sódico por reducción con carbohidratos en presencia de ácido sulfúrico, en una reacción muy exotérmica. La reducción de una solución de dicromato sódico con dióxido de azufre produce sulfato crómico básico, que se emplea en el curtido del cuero; el precio del material depende del contenido de $\mathrm{Cr}^{2} \mathrm{O}_{3}$, que oscila entre el 20,5 y el $25 \%$. 


\section{Compuestos de cromovi}

EI dicromato sódico puede convertirse en su sal anhidra. Este es el punto de partida para la preparación de compuestos de cromo.

El trióxido de cromo o anhidrido crómico, algunas veces denominado "ácido crómico", aunque el verdadero ácido crómico no puede aislarse de una solución, se obtiene tratando una solución concentrada de un dicromato con un exceso de ácido sulfúrico concentrado. Es un violento oxidante y, en solución, constituye el principal componente del cromado.

\section{Cromatos insolubles}

Los cromatos de bases débiles poseen una solubilidad limitada y tienen una coloración más intensa que los óxidos, por lo que se utilizan como pigmentos. Estos pigmentos no siempre son compuestos puros y pueden contener mezclas de otros materiales para conseguir el tono adecuado. Se elaboran añadiendo dicromato sódico o potásico a una solución de la sal apropiada.

EI cromato de plomo es trimórfico; la forma monocíclica estable es de color amarillo anaranjado, "amarillo de cromo", y la forma ortorrómbica inestable es de color amarilla, isomorfa con el sulfato de plomo y estabilizada por éste. Existe una forma tetragonal de color rojo anaranjado similar, isomorfa con el molibdato de plomo (VI) $\mathrm{PbMOO}_{4}$ y estabilizada por éste. De dichas propiedades depende la versatilidad del cromato de plomo para producir diversos pigmentos de color amarillo anaranjado.

\section{Usos}

LOS compuestos que contienen $\mathrm{CrVI}^{\mathrm{VI}}$ se utilizan en muchos procesos industriales, entre los que cabe destacar: la fabricación de importantes pigmentos inorgánicos como los cromatos de plomo (también utilizados para preparar verdes de cromo), los naranjas de molibdato, el cromato de zinc y el verde de óxido crómico; la conservación de la madera; la fabricación de anticorrosivos; y la fabricación de vidrios y esmaltes de color. Los sulfatos crómicos básicos se utilizan ampliamente en los procesos de curtido.

Otros usos conocidos de los compuestos químicos de cromo son la estampación de telas, la preparación de numerosos catalizadores importantes que contienen óxido crómico y la producción de coloides dicromados sensibles a la luz para litografías.

El ácido crómico se utiliza no sólo para el cromado "decorativo", sino también para el "duro", con capas mucho más gruesas para obtener una superficie sumamente resistente con un bajo coeficiente de fricción.

De la potente acción oxidante de los cromatos en solución acidulada se derivan muchas aplicaciones industriales, especialmente con materiales orgánicos, como la oxidación del trinitrotolueno (TNT) para producir fluoroglucinol y la oxidación de la picolina para obtener ácido nicotínico.

El óxido de cromo se utiliza también para producir cromo metálico puro adecuado para su incorporación en aleaciones de alta temperatura resistentes al arrastre y como óxido refractario. Puede formar parte de numerosas mezclas refractarias, como las de magnesita y magnesita-cromita.

\section{Riesgos}

Los compuestos con cromo en estado de oxidación $\mathrm{Cr}^{\prime \prime l}$ son considerablemente menos peligrosos que los compuestos de $\mathrm{Cr}$ VI. Los compuestos de $\mathrm{Cr}^{\prime \prime \prime}$ no se absorben fácilmente en el aparato digestivo y pueden combinarse con proteínas de las capas superficiales de la piel, formando complejos estables. En ausencia de una sensibilización previa con compuestos de $\mathrm{Cr}^{\mathrm{VI}}$, los compuestos de $\mathrm{C} \mathrm{r}^{\prime \prime \prime}$ no producen ulceraciones ni suelen producir dermatitis alérgicas.
Los compuestos de cromo en estado de oxidación $\mathrm{Cr}^{\mathrm{VI}}$ se absorben rápidamente después de la ingestión o la inhalación. La captación a través de la piel intacta es menos conocida. Los efectos irritantes y corrosivos del $\mathrm{Cr}^{\mathrm{VI}}$ se producen inmediatamente después de la absorción a través de la mucosa, que es muy rápida. La exposición profesional a los compuestos de $\mathrm{Cr}$ VI puede producir irritación o corrosión cutáneo-mucosa, reacciones cutáneas de tipo alérgico o ulceraciones de la piel.

Los efectos nocivos de los compuestos de cromo se observan generalmente entre las personas que trabajan en lugares donde está presente el $\mathrm{Cr}$ II, especialmente durante su fabricación 0 utilización, y afectan principalmente a la piel y al aparato respiratorio. Los riesgos industriales típicos son: la inhalación de polvo y humos procedentes de la fabricación del dicromato a partir del mineral de cromita y de la fabricación de los cromatos de plomo y zinc; la inhalación de nieblas de ácido crómico durante el cromado o el revestimiento de superficies metálicas; y el contacto cutáneo con compuestos de $\mathrm{Cr}^{\mathrm{VI}}$ durante su fabricación o uso. La exposición a humos que contienen $\mathrm{Cr} r^{\mathrm{VI}}$ también puede producirse durante la soldadura del acero inoxidable.

Ú Iceras por cromo. Este tipo de lesiones era bastante frecuente como resultado de la exposición profesional a los compuestos de $\mathrm{Cr}^{\mathrm{VI}}$. Las úlceras se deben a la acción corrosiva del $\mathrm{Cr}^{\mathrm{VI}}$, que penetra en la piel a través de cortes y abrasiones. La lesión comienza como una pápula indolora, habitualmente localizada en las manos, antebrazos y pies, que posteriormente se ulcera. La úlcera puede penetrar profundamente en el tejido blando y puede llegar a alcanzar el hueso subyacente. La curación es lenta, a menos que se trate precozmente, y deja una cicatriz atrófica, pero no existen informes de cáncer de piel como consecuencia de estas úlceras.

D ermatitis. Los compuestos de $\mathrm{Cr}^{\mathrm{VI}}$ ocasionan tanto irritación cutánea primaria como sensibilización. En la industria de producción de cromatos, algunos trabajadores pueden presentar irritación cutánea especialmente en el cuello y las muñecas, poco después de comenzar a trabajar con cromatos. En la mayoría de los casos, la irritación desaparece rápidamente y no recidiva. Sin embargo, en ocasiones puede ser necesario recomendar un cambio de ocupación.

Se han descrito numerosas fuentes de exposición al $\mathrm{Cr}^{\mathrm{v} \text {, }}$ como por ejemplo, el contacto con cemento, escayola, cuero, material de la industria gráfica, el trabajo de fabricación de ceriIlas, el curtido de pieles y varios tipos de trabajo con metales. También se han descrito alergias en las personas que trabajan en el lijado al agua de carrocerías. Las personas afectadas dan reacción positiva a la prueba del parche con dicromato al $0,5 \%$. En algunos casos, las personas afectadas sólo presentaron eritema o pápulas dispersas, mientras que en otros, las lesiones recordaban a la dishidrosis; el eczema numular puede conducir a un diagnóstico erróneo de los casos genuinos de dermatitis profesional.

Se ha demostrado que el $\mathrm{Cr}^{\mathrm{VI}}$ penetra en la piel a través de las glándulas sudoríparas, reduciéndose a $\mathrm{Cr}^{\prime \prime \prime}$ en el corion. Se ha demostrado que este $C r^{\prime \prime \prime}$ reacciona con las proteínas, formando complejos antígeno-anticuerpo. Esto explica la localización de las lesiones alrededor de las glándulas sudoríparas y el porqué cantidades muy pequeñas de dicromato pueden producir sensibilización. El carácter crónico de la dermatitis puede deberse al hecho de que el complejo antígeno anticuerpo se elimina más lentamente que si la reacción tuviera lugar en la epidermis.

E fectos respiratorios agudos. La inhalación de polvo o nieblas que contengan $\mathrm{Cr}^{\mathrm{VI}}$ produce irritación de las mucosas. A concentraciones elevadas, la aparición de estornudos, rinorrea, lesiones del tabique nasal y enrojecimiento de la garganta son efectos bien documentados. También se ha descrito sensibilización, que ha dado origen a crisis asmáticas típicas, que pueden repetirse 
en las siguientes exposiciones. Se ha observado asimismo tos, cefalea, disnea y dolor retroesternal tras una exposición durante varios días a una niebla de ácido crómico en concentraciones de aproximadamente 20 a $30 \mathrm{mg} / \mathrm{m}^{3}$. La aparición de broncoespasmo en una persona que trabajaba con cromatos podría indicar una irritación pulmonar de origen químico. El tratamiento es exclusivamente sintomático.

Ulceración de tabique nasal. Hace algunos años, cuando los niveles de exposición a los compuestos de $\mathrm{Cr}^{\mathrm{VI}}$ podía ser elevada, se observaban con frecuencia ulceraciones del tabique nasal en los trabajadores expuestos. Este efecto nocivo era resultado del depósito de partículas con $\mathrm{Cr}^{\mathrm{VI}}$ o pequeñas gotas de niebla en el tabique nasal, que producían úlceras en la parte cartilaginosa, seguidas en muchos casos de la perforación en el lugar de la úlcera. En estos casos, la costumbre de hurgarse la nariz puede favorecer la perforación. La mucosa que recubre la parte antero-inferior del tabique, también denominada área de $K$ iesselbach 0 de Little, es relativamente no vascularizada y está fuertemente adherida al cartílago subyacente. Se forman costras que contienen restos necróticos del cartílago del tabique y en una o dos semanas, se perfora éste. La periferia permanece en un estado de ulceración activa durante varios meses, en los que puede aumentar el tamaño de la perforación. L a curación se produce por la formación de tejido de cicatrización vascular. El sentido del olfato casi nunca se altera. Durante la fase activa, los síntomas más molestos suelen ser la rinorrea y la epistaxis. Si se cura correctamente, no suele dejar síntomas residuales y la perforación del tabique puede pasar desapercibida en muchos casos.

E fectos en otros órganos. Se ha descrito necrosis renal, que comienza con necrosis tubular, sin afectar a los glomérulos. También se ha descrito necrosis hepática difusa y la desorganización de la arquitectura. A principios de siglo hubo varios informes de ingestión de $\mathrm{Cr}{ }^{\mathrm{VI}}$ en humanos con hemorragia gastrointestinal grave debida a la ulceración de la mucosa intestinal. En ocasiones, estas hemorragias derivaron en shock cardiovascular como posible complicación. En los casos en que los pacientes sobrevivieron, se observó necrosis tubular en los riñones o necrosis hepática.

E fectos cancerígenos. En un gran número de estudios realizados en Francia, Alemania, Italia, Japón, N oruega, Estados U nidos y el Reino Unido se ha descrito un aumento de la incidencia de cáncer de pulmón entre los trabajadores empleados en la fabricación y el uso de compuestos de C $\mathrm{r}^{\mathrm{VI}}$. Los cromatos de zinc y calcio parecen ser los más cancerígenos y se cuentan entre los cancerígenos más potentes en humanos. También se ha descrito una mayor incidencia de cáncer de pulmón en personas expuestas a cromatos de plomo y a humos de trióxidos de cromo. La exposición intensa a los compuestos de $\mathrm{Cr}^{\mathrm{VI}}$ ha producido una incidencia muy elevada de cáncer de pulmón en trabajadores expuestos durante 15 años o más desde la primera exposición, según los resultados obtenidos tanto en estudios de cohortes como en informes de casos.

A sí, está bien establecido que el aumento de la incidencia de cáncer de pulmón en los trabajadores empleados en la fabricación de cromatos de zinc y de mono y dicromatos del mineral de cromita es un efecto a largo plazo de la exposición profesional intensa a los compuestos de $\mathrm{C} \mathrm{rl}^{\mathrm{V}}$. Algunos estudios de cohortes han determinado los niveles de exposición de las cohortes expuestas. Un pequeño número de estudios indica asimismo que la exposición a los humos generados durante la soldadura de las aleaciones de acero y cromo puede aumentar la incidencia de cáncer de pulmón entre los soldadores.

No existe un nivel de exposición "seguro" claramente establecido. Sin embargo, la mayoría de los informes ponen de manifiesto una asociación entre la exposición al $\mathrm{Cr}^{\mathrm{VI}}$ y el cáncer de los órganos respiratorios en exposiciones a niveles en el aire superiores a $50 \mathrm{mg} \mathrm{Cr} \mathrm{rl}^{\mathrm{V}} / \mathrm{m}^{3}$ aire.

Los síntomas, signos, curso, aspecto radiológico, método de diagnóstico y pronóstico del cáncer de pulmón derivado de la exposición a cromatos no difieren de los del cáncer de pulmón debido a otras causas. L os tumores se originan con frecuencia en la periferia del árbol bronquial y pueden ser de cualquier tipo histológico, aunque la mayoría corresponde a carcinomas anaplásticos de células pequeñas. En los pulmones de los trabajadores de cromatos se encuentran cantidades variables de cromo soluble e insoluble en agua y soluble en ácidos.

A pesar de que no se ha establecido claramente, algunos estudios indican que la exposición a los cromatos puede aumentar el riesgo de cáncer en los senos nasales y el tracto digestivo. Los estudios que reflejan una mayor incidencia de cáncer en el tracto digestivo son informes de casos del decenio de 1930 y estudios de cohortes que ponen de manifiesto exposiciones a niveles superiores a los que se encuentran generalmente en la actualidad.

\section{Medidas de salud y seguridad}

Desde el punto de vista técnico, la prevención de la exposición al cromo depende de un diseño adecuado de los procesos, de la existencia de sistemas de extracción adecuados y de la supresión de los polvos y nieblas que contengan cromo hexavalente. También son necesarias las medidas de control incorporadas, pues son las que requieren la menor actuación por parte de los operarios o del equipo de mantenimiento.

Siempre que sea factible, deberán utilizarse métodos de limpieza en húmedo. En otros lugares, la única alternativa aceptable es el uso de aspiradores. Las salpicaduras o derrames de líquidos o sólidos deben eliminarse inmediatamente para evitar la dispersión de polvo en el aire. La concentración de polvo y humos que contengan cromo en el ambiente de trabajo se debe medir a intervalos regulares mediante toma de muestras de las distintas áreas y con controles individuales. Si se detectan concentraciones inaceptables con alguno de estos métodos, se deberán identificar y controlar las fuentes de polvo y humo. LoS trabajadores deberán utilizar máscaras de polvo, preferiblemente con una eficacia superior al $99 \%$ para retener partículas de $0,5 \mu \mathrm{m}$, en todos aquellos casos en los que existan concentraciones que superen los niveles recomendados y se deberán suministrar equipos de protección respiratoria alimentados con aire para realizar tareas que se consideren peligrosas. La dirección deberá asegurarse de que los depósitos de polvo y otros contaminantes de superficie se eliminen por lavado o por succión antes de comenzar cualquier trabajo de este tipo. También es necesario proporcionar al personal monos de trabajo que se laven diariamente para evitar la contaminación de la piel. Se recomienda el uso de protección para las manos y ojos, y la inspección, reparación y sustitución de los equipos de protección individual (EPI) deben estar garantizados.

La vigilancia médica de las personas empleadas en procesos en los que existan compuestos de $\mathrm{Cr}^{\mathrm{VI}}$ debe comprender la formación sobre las propiedades tóxicas y cancerígenas de los compuestos de $\mathrm{C} \mathrm{r}^{\mathrm{VI}}$ y $\mathrm{Cr}^{\prime \prime \prime}$ y las diferencias entre ambos grupos de compuestos. Al inicio de la actividad laboral y a intervalos regulares a lo largo de la misma deberá informarse sobre los riesgos de la exposición y el riesgo consiguiente de varias enfermedades, como el cáncer de pulmón, haciendo especial hincapié en la necesidad de observar un alto grado de higiene personal.

Todos los efectos nocivos de la exposición al cromo se pueden evitar. Las úlceras cutáneas por cromo se pueden prevenir eliminando las fuentes de contacto y las lesiones cutáneas. L os cortes y abrasiones cutáneos, aunque sean pequeños, deben limpiarse de inmediato y tratarse con un ungüento de EDTA sódico al 
$10 \%$. Esto, junto con el empleo de ropa impermeable renovada con frecuencia, asegurará la curación rápida de cualquier úlcera que pudiera desarrollarse. Aunque el EDTA no forma quelatos con los compuestos de $\mathrm{CrVI}$ a temperatura ambiente, reduce rápidamente el $\mathrm{Cr}^{\mathrm{VI}}$ a C $\mathrm{Cr}^{\prime \prime \prime}$ y el exceso de EDTA forma un quelato con el $\mathrm{C} \mathrm{r}^{\prime \prime \prime}$. De esta forma, se evita tanto la acción irritante y corrosiva directa de los compuestos de $\mathrm{Cr}^{\mathrm{VI}}$ como la formación de complejos proteína/ $\mathrm{C} \mathrm{r}^{\mathrm{llI}}$. Tras la ingestión accidental de compuestos de $\mathrm{Cr}$ VI, la ingestión inmediata de ácido ascórbico también puede reducir rápidamente el $\mathrm{Cr}$ VI.

El lavado cuidadoso de la piel tras el contacto, y el cuidado de evitar la fricción y la sudoración son importantes para la prevención y el control de la irritación primaria por cromatos. Hace unos años, se aplicaba un ungüento de EDTA sódico al $10 \%$ regularmente en el tabique nasal antes de la exposición. Este tratamiento preventivo podía ayudar a mantener el tabique intacto. La aplicación regular de este ungüento cuando aparecen las molestias nasales y la ulceración precoz también puede contribuir a la curación sin que se produzca la perforación.

Los resultados de los estudios indican que el control de la excreción de cromo en la orina puede ser el adecuado para los trabajadores expuestos a concentraciones de $\mathrm{Cr}^{\mathrm{vl}}$ en el ambiente. Estos resultados, sin embargo, no tienen relación con el riesgo de alergias cutáneas. $\mathrm{H}$ asta la fecha, y debido al largo período de latencia del cáncer de pulmón relacionado con la exposición al $\mathrm{Cr}^{\mathrm{VI}}$, aún no es posible relacionar el riesgo de cáncer con los niveles urinarios de $\mathrm{C} r$.

\section{ESTAÑO}

El estaño se ha utilizado desde la antigüedad hasta la industria moderna porque es dúctil, se le puede dar forma fácilmente a temperaturas normales y se mezcla fácilmente con otros metales para formar aleaciones. U na de sus características más notables es su resistencia a los ácidos y las influencias atmosféricas.

\section{Distribución y usos}

Aunque los yacimientos de estaño están distribuidos por todo el mundo, hasta el siglo X VIII procedía principalmente de Inglaterra, Sajonia y Bohemia. En la actualidad, con excepción de algunos yacimientos de Nigeria, China, el Congo y Australia, las principales fuentes de estaño son el sudeste de Asia y Bolivia.

De los minerales que contienen estaño, la casiterita $\left(\mathrm{SnO}_{2}\right) 0$ piedra de estaño es el de mayor importancia comercial. Está presente en vetas de rocas de granito o de rocas eruptivas ácidas, pero cinco sextas partes de la producción mundial se obtiene de los yacimientos aluviales secundarios, que son resultado de la desintegración de los yacimientos primarios. En Bolivia, los minerales de sulfuro, como la estannita $\left(\mathrm{Cu}_{2} \mathrm{FeSnS}_{2}\right)$ y la tealita $\left(\mathrm{PbZnSnS}_{2}\right)$ tienen importancia comercial.

El estaño metálico se utiliza para obtener metales tipo Babbitt y tubos colapsables en la industria farmacéutica y cosmética. Por su resistencia a la corrosión, se emplea para dar un recubrimiento protector a otros metales. La hojalata es una lámina de acero o hierro que se sumerge en un baño de estaño fundido para recubrirla con una gruesa capa de este metal. Se utiliza principalmente para fabricar utensilios de uso doméstico y en la industria de enlatados de alimentos y bebidas. También se usa mucho con fines decorativos. La chapa emplomada es una lámina de acero o hierro revestida con una aleación de plomo y estaño que contiene un $85 \%$ de plomo y un $15 \%$ de estaño. Su principal aplicación es la fabricación de tejas para tejados. El espéculo es una aleación de cobre y estaño que contiene de un 33 a un $50 \%$ de estaño y que puede pulirse hasta alcanzar un alto grado de reflexión. Se utiliza como revestimiento aplicado por deposición electrolítica para dar brillo a los objetos de plata y artículos similares y para la fabricación de partes de telescopios. En la fabricación de cristales para ventanas se utiliza también un baño de estaño fundido.

U na propiedad importante del estaño es su capacidad para formar aleaciones con otros metales, de donde se derivan gran número de aplicaciones. U na aleación de estaño y plomo, conocida como soldadura blanda, se utiliza mucho para unir metales y aleaciones en fontanería y en las industrias eléctrica, automovilística y de otro tipo, además de como aparejo en el acabado de las carrocerías de los automóviles. El estaño entra en gran número de aleaciones no ferrosas, como el bronce fosforoso, el latón ligero, el bronce industrial, el latón de alta resistencia a la tracción, el bronce de manganeso, las aleaciones troquelables, los metales de rodamientos, el metal tipo y el peltre. La aleación de estaño y niobio es superconductora y se utiliza en la fabricación de potentes electromagnetos.

El cloruro estannoso $\left(\mathrm{SnCl}_{4}\right)$, o cloruro de estaño, se prepara calentando estaño en polvo con cloruro mercúrico o haciendo pasar una corriente de cloro sobre el estaño fundido. Se utiliza como agente deshidratante en síntesis orgánicas, como estabilizador para plásticos y como intermediario químico para otros compuestos de estaño. El cloruro estánnico se encuentra en los colorantes y perfumes de la industria del jabón y en determinados tipos de cerámica para producir resistencia a la abrasión o recubrimientos reflectantes. También se utiliza para blanquear el azúcar y como tratamiento de superficie del cristal y otros materiales no conductores. El pentahidrato de esta sal se utiliza como mordente. En el tratamiento de la seda sirve para proporcionar peso al tejido.

El dihidrato de cloruro estánnico $\left(\mathrm{SnCl}_{2} \cdot 2 \mathrm{H}_{2} \mathrm{O}\right)$, o sal de estaño, se produce disolviendo estaño metálico en ácido clorhídrico y evaporándolo hasta que comienza la cristalización. Se utiliza en los talleres de tinte como mordente y como agente reductor en la fabricación de cristal, cerámica y tintas.

El uso de compuestos organoestánnicos (alquilos y arilos) ha aumentado mucho en los últimos años. Los compuestos disustituidos y, en menor grado, los monosustituidos, se utilizan como estabilizadores y catalizadores en la industria del plástico. LoS trisustituidos se emplean como biocidas y los tetrasustituidos como intermediarios en la producción de otros derivados. Entre los más importantes se encuentran el tricloruro de butilestaño 0 triclorobutilestaño, el dicloro de dibutilestaño o diclorodibutilestaño, el trimetilestaño, el cloruro de trietilestaño, el cloruro de trifenilestaño o TPT C, y el tetraisobutilestaño o tetraisobutilestanano.

\section{Riesgos}

Si no se toman las precauciones necesarias, se pueden producir lesiones por el uso de la pesada y potente maquinaria utilizada en las operaciones de dragado y lavado. En los procesos de fusión existe un riesgo de quemaduras graves al manipular el metal fundido y las escorias calientes.

En la fase final del concentrado de la casiterita y durante el cocido del mineral de sulfuro, se desprende dióxido de azufre. El dióxido de azufre y el sulfuro estannoso representan un riesgo cuando el estaño derretido primario se separa del resto de la carga durante el refino. Este trabajo se realiza en un ambiente muy caliente, lo que puede dar lugar a desvanecimientos. El ruido producido por la descarga del cucharón de la draga en la primera planta de lavado puede causar problemas de audición a los trabajadores.

Varios estudios destacan los riesgos asociados a la exposición al radón, a los productos de degradación del radón y al sílice en las minas de estaño. A pesar de que la mayoría de las operaciones asociadas con la extracción y el tratamiento del mineral 
de estaño son procesos en húmedo, pueden liberarse humos y polvo de estaño durante el ensacado del concentrado, en las salas del mineral o durante las operaciones de fusión (en la planta de mezclado y en el sangrado de los hornos), así como durante la limpieza periódica de los filtros de bolsa que se utilizan para eliminar las partículas de mineral de los gases de combustión del horno de fusión antes de liberarlos al ambiente exterior. La inhalación de polvo de óxido de estaño sin sílice produce una neumoconiosis nodular benigna sin insuficiencia pulmonar. El cuadro radiológico es similar al de la baritosis. Este tipo de neumoconiosis benigna se ha llamado estannosis.

EI polvo de estaño es moderadamente irritante para los ojos y las vías aéreas. Es combustible y reacciona violentamente con los oxidantes, ácidos fuertes, azufre en polvo y algunos agentes extintores, como el polvo de bicarbonato y el dióxido de carbono.

El estaño ingerido en cantidades pequeñas (del orden de mg) no es tóxico (de aquí el amplio uso de la hojalata para el enlatado de alimentos). Los resultados obtenidos en experimentos con animales indican que la dosis letal por inyección intravenosa es de aproximadamente $100 \mathrm{mg} / \mathrm{kg}$ de peso corporal y que la ingestión de cantidades considerables de estaño en polvo puede provocar vómitos, pero no lesiones permanentes. Parece ser que el hombre puede tolerar una ingestión diaria de 800 a $1.000 \mathrm{mg}$ sin sufrir efectos nocivos. La absorción de estaño metálico 0 sus sales inorgánicas por el aparato digestivo es reducida.

Varias aleaciones de estaño son nocivas para la salud (especialmente a temperaturas elevadas) por las características nocivas de los metales con los que está aleado (como plomo, zinc o manganeso).

L os compuestos orgánicos de estaño son, en general, irritantes fuertes y se ha observado conjuntivitis aguda como consecuencia de salpicaduras en los ojos, aun cuando se hayan lavado inmediatamente; también se han descrito opacidades en la córnea. EI contacto prolongado de la piel con ropa humedecida por el vapor o el contacto directo de estos compuestos sobre la piel ha producido quemaduras agudas locales, dermatitis eritematoide subaguda difusa con prurito y cierta erupción pustular en las áreas cubiertas por cabello. La irritación de las vías aéreas y del tejido pulmonar puede producir edema pulmonar. También se han observado efectos sobre el tracto gastrointestinal y reacciones inflamatorias del conducto biliar, especialmente con los dialquilos. L os compuestos orgánicos de estaño pueden producir lesiones en el hígado y los riñones, causar inmunodepresión y tienen actividad hemolítica. En animales experimentales, se han asociado en algunos casos con una disminución de la fertilidad.

Los tri y tetraalquilos, en especial el cloruro de trietilestaño, producen encefalopatía y edema cerebral, con signos clínicos de depresión, convulsiones, parálisis flácida y retención urinaria, como se observa tras la administración oral en el uso terapéutico.

\section{Medidas de salud y seguridad}

Siempre que sea posible, deberán utilizarse sustitutos más seguros en lugar de los compuestos alquílicos de estaño. Cuando sea necesario prepararlos y utilizarlos, se deberá hacer en sistemas cerrados y con ventilación por extracción. El control de ingeniería debe garantizar que no se superen los límites de exposición. Se utilizarán equipos de protección individual y, en cuando sea el caso, protección respiratoria. Se instalarán duchas en el lugar de trabajo para que los trabajadores puedan lavarse inmediatamente en caso de salpicaduras.

En los reconocimientos médicos se prestará especial atención a los ojos, la piel y la radiología torácica cuando se trate de un caso de exposición a compuestos inorgánicos, y a los ojos, la piel, el sistema nervioso central, las funciones hepática y renal y la sangre en el caso de exposición a compuestos orgánicos. El uso de $\mathrm{M}$ ercaprol ha resultado útil para el tratamiento de las intoxicaciones por derivados dialquílicos y se ha propuesto el empleo de esteroides para las intoxicaciones por trietilestaño; sin embargo, la descompresión quirúrgica es lo único que parece tener alguna utilidad en la encefalopatía y el edema cerebral provocados por los compuestos tri y tetraalquílicos del estaño.

Dado que la mayoría de las minas de estaño están situadas en países en desarrollo, deberá prestarse especial atención a los factores climáticos y de otro tipo que influyen en la salud, el bienestar y la capacidad de producción de los trabajadores. Cuando las minas estén geográficamente aisladas, se deberá disponer de viviendas adecuadas para todo el personal. Los niveles de nutrición deberán elevarse mediante programas de educación sanitaria y se deberá proporcionar a los trabajadores una alimentación adecuada y una buena asistencia médica.

\section{G ALIO}

Q uímicamente, el galio ( $\mathrm{Ga}$ ) es parecido al aluminio. No es atacado por el aire y no reacciona con el agua. Cuando está frío, reacciona con el cloro y el bromo, y cuando se calienta, con el yodo, el oxígeno y el azufre. Existen 12 isótopos radiactivos artificiales conocidos, con pesos atómicos que oscilan entre 64 y 74 y semividas de 2,6 minutos a 77,9 horas. Cuando el galio se disuelve en ácidos inorgánicos, se forman sales que se transforman en hidróxidos insolubles $\mathrm{Ga}(\mathrm{OH})_{3}$ con propiedades anfotéricas (es decir, tanto ácidas como básicas) a pH superiores a 3. Los tres óxidos de galio son: $\mathrm{GaO}, \mathrm{Ga}_{2} \mathrm{O}$ y $\mathrm{Ga}_{2} \mathrm{O}_{3}$.

\section{Distribución y usos}

La fuente más rica de galio es el mineral denominado germanita, un mineral de sulfuro de cobre que puede contener de un 0,5 a un $0,7 \%$ de galio y que se encuentra en el sudeste de Africa. También está ampliamente distribuido, en pequeñas cantidades y junto con blendas de zinc, en arcillas de aluminio, feldespato, carbón de hulla y en los minerales de hierro, manganeso y cromo. En una escala relativamente reducida, el metal, las aleaciones, los óxidos y las sales se utilizan en industrias como la de construcción de maquinaria (revestimientos, lubricantes), la fabricación de instrumentos (soldadores, arandelas, chapas de suplemento), la producción de equipos eléctricos y electrónicos (diodos, transistores, láseres, revestimientos de conductores) y en la tecnología del vacío.

En la industria química, el galio y sus compuestos se utilizan como catalizadores. El arseniuro de galio se ha utilizado ampliamente en aplicaciones de semiconductores como transistores, celdas solares, láseres y la generación de microondas. El arseniuro de galio se utiliza en la producción de dispositivos optoelectrónicos y circuitos integrados. Entre otras aplicaciones se encuentra el empleo del ${ }^{72} \mathrm{G}$ a para estudiar las interacciones del galio en el organismo y del ${ }^{67} \mathrm{Ga}$ como agente detector de tumores. Dada la alta afinidad de los macrófagos del sistema linforreticular por el ${ }^{67} \mathrm{G}$ a, se puede emplear para el diagnóstico de la enfermedad de H odgkin, el sarcoide de Boeck y la tuberculosis ganglionar. La gammagrafía con galio es una técnica de diagnóstico por la imagen pulmonar que puede utilizarse en combinación con una radiografía torácica inicial para evaluar a los trabajadores con riesgo de desarrollar una enfermedad pulmonar de origen profesional. 


\section{Riesgos}

Los trabajadores de la industria electrónica que utilizan arseniuro de galio pueden sufrir exposiciones a sustancias peligrosas como el arsénico y la arsina. Existe la posibilidad de exposiciones por inhalación de polvo durante la producción de óxidos y sales en polvo $\left(\mathrm{Ga}_{2}\left(\mathrm{SO}_{4}\right)_{3}, \mathrm{Ga}_{3} \mathrm{Cl}\right)$ y durante la producción y proceso de monocristales de los compuestos semiconductores. Las salpicaduras y derrames de soluciones del metal y sus sales pueden actuar sobre la piel y las mucosas de los trabajadores. La pulverización de fosfuro de galio en agua produce cantidades considerables de fosfina, que hace necesaria la adopción de medidas preventivas. L os compuestos de galio pueden ingerirse a través de las manos contaminadas o cuando se come, se bebe o se fuma en el lugar de trabajo.

No se han descrito enfermedades profesionales debidas al galio, con excepción de un informe de un caso de erupción petequial seguida de neuritis radial tras una breve exposición a una pequeña cantidad de humo que contenía fluoruro de galio. La acción biológica del metal y sus compuestos se ha estudiado experimentalmente. La toxicidad del galio y sus compuestos depende de la vía de entrada al organismo. Cuando se administró por vía oral a conejos durante un período prolongado (4 o 5 meses), su efecto fue insignificante y se tradujo en alteraciones de las reacciones proteicas y una menor actividad enzimática. La baja toxicidad en este caso se explica por la absorción relativamente inactiva del galio en el tracto digestivo. En el estómago y los intestinos se forman compuestos insolubles o difíciles de absorber, como galatos metálicos e hidróxidos. EI polvo de óxido, nitruro y arseniuro de galio fue generalmente tóxico cuando se introdujo en el aparato respiratorio (inyecciones intratraqueales en ratas blancas) y produjo distrofia del hígado y los riñones. En los pulmones se produjeron alteraciones escleróticas e inflamatorias. En un estudio se llegó a la conclusión de que la exposición de ratas a partículas de óxido de galio en concentraciones próximas al valor umbral induce una lesión pulmonar progresiva similar a la inducida por el cuarzo. EI nitrato de galio tiene un fuerte efecto cáustico sobre la conjuntiva, la córnea y la piel. La elevada toxicidad del acetato, del citrato y del cloruro de galio se demostró por inyección intraperitoneal, que produjo la muerte de los animales por parálisis de los centros respiratorios.

\section{Medidas de salud y seguridad}

Para evitar la contaminación de la atmósfera del lugar de trabajo con polvo de dióxido y nitruro de galio y compuestos semiconductores, es necesario adoptar medidas de precaución como encerrar el equipo que produce polvo e instalar una ventilación local con extracción de gases eficaz. Durante la producción de galio deberán aplicarse las medidas de protección individual adecuadas para evitar la ingestión y el contacto de los compuestos de galio con la piel. Son muy importantes, por tanto, una buena higiene personal y el uso de equipos de protección individual (EPI). EI Instituto Nacional para la Salud y la Seguridad en el Trabajo (NIOSH) de EE.UU. recomienda controlar la exposición del trabajador al arseniuro de galio mediante la observación de los límites de exposición recomendados para el arsénico inorgánico y aconseja calcular la concentración de arseniuro de galio en el aire mediante la determinación del arsénico. Se debe dar a los trabajadores información sobre los posibles riesgos e instalar controles de ingeniería adecuados durante la producción de sistemas microelectrónicos, donde es probable la exposición al arseniuro de galio. En vista de la toxicidad del galio y sus compuestos, demostrada experimentalmente, todas las personas que trabajen con estas sustancias deben someterse a reconocimientos médicos periódicos, en los que se prestará especial atención al estado del hígado, los riñones, los órganos respiratorios y la piel.

\section{GERMANIO}

\section{Distribución y usos}

El germanio (Ge) se encuentra siempre en combinación con otros elementos, nunca en estado libre. Entre los minerales que contienen germanio más comunes cabe citar la argirodita $\left(\mathrm{Ag}_{8} \mathrm{GeS}_{6}\right)$, que contiene un $5,7 \%$ de germanio y la germanita (C US. FeS. $\mathrm{GeS}_{2}$ ), que contiene hasta un $10 \%$ de Ge. Hay pocos grandes depósitos de minerales de germanio, pero el elemento está ampliamente distribuido en la estructura de otros minerales, especialmente en los sulfuros $y$, sobre todo, en el sulfuro de zinc $y$ en los silicatos. También se encuentra en pequeñas cantidades en distintos tipos de carbón.

El principal uso del germanio en un producto final es la fabricación de sensores de infrarrojos y sistemas de identificación. Su empleo en los sistemas de fibras ópticas ha aumentado, mientras que ha disminuido en los semiconductores debido a los avances en la tecnología de los semiconductores de silicio. El germanio se utiliza también en el galvanizado y la producción de aleaciones, entre las que destaca el bronce al germanio, que se caracteriza por su gran resistencia a la corrosión. El tetracloruro de germanio $\left(\mathrm{G} \mathrm{eCl}_{4}\right)$ es un compuesto intermedio en la preparación del dióxido de germanio y los compuestos organogermánicos. El dióxido de germanio $\left(\mathrm{G} \mathrm{eO}_{2}\right)$ se utiliza para la fabricación de cristales ópticos y cátodos.

\section{Riesgos}

La dispersión de polvo durante la carga de germanio concentrado, durante la fragmentación y la carga de dióxido para la reducción a germanio y durante la carga de germanio en polvo para su fusión en lingotes pueden dar lugar a problemas de salud en el trabajo. En el proceso de producción del metal, la cloración del concentrado, la destilación, la rectificación, la hidrólisis y los humos del tetracloruro de germanio, el cloro y los productos de pirólisis del cloruro de germanio también pueden representar un riesgo para la salud. O tras fuentes de riesgo son la producción de calor radiante por los hornos tubulares utilizados para la reducción del $\mathrm{GeO}_{2}$ y el fundido de polvo de germanio en lingotes, y la formación de monóxido de carbono durante la reducción del $\mathrm{GeO}_{2}$ con carbón.

La producción de monocristales de germanio para la fabricación de semiconductores ocasiona una gran elevación de la temperatura del aire (hasta $45^{\circ} \mathrm{C}$ ), radiación electromagnética con campos de fuerza de más de $100 \mathrm{~V} / \mathrm{m}$ y radiación magnética de más de $25 \mathrm{~A} / \mathrm{m}$, así como contaminación de la atmósfera de trabajo con hidruros metálicos. En el proceso de aleación del germanio con arsénico, puede formarse arsina en el aire (1 a $3 \mathrm{mg} / \mathrm{m}^{3}$ ) y, durante la aleación con antimonio, estibina 0 hidruro antimonioso (1,5 a 3,5 mg/ $\left.\mathrm{m}^{3}\right)$. El hidruro de germanio, que se utiliza para la producción de germanio de alta pureza, también puede contaminar la atmósfera de trabajo. La limpieza frecuente y necesaria de los hornos verticales produce un polvo que contiene, además de germanio, dióxido de silicio, antimonio y otras sustancias.

El recorte y pulido de los cristales de germanio también genera polvo. Durante el mecanizado en seco, se han llegado a medir concentraciones de hasta $5 \mathrm{mg} / \mathrm{m}^{3}$.

El germanio absorbido se excreta rápidamente, principalmente por la orina. $\mathrm{H}$ ay poca información sobre la toxicidad de los compuestos de germanio inorgánico en el hombre. El tetracloruro de germanio puede producir irritación cutánea. En estudios clínicos y en casos de exposición oral prolongada a dosis acumuladas superiores a $16 \mathrm{~g}$ de espirogermanio, se ha demostrado que el agente antitumoral organogermanio y otros compuestos de 
germanio tienen efectos neurotóxicos y nefrotóxicos. Estas dosis no se absorben habitualmente en el ambiente profesional. Los experimentos con animales sobre los efectos del germanio y sus compuestos demuestran que el polvo de germanio metálico y de dióxido de germanio produce trastornos generales (inhibición del aumento de peso corporal) al ser inhalado en concentraciones elevadas. Los pulmones de los animales muestran alteraciones morfológicas del tipo de reacciones proliferativas, como engrosamiento de los tabiques alveolares e hiperplasia de los vasos linfáticos alrededor de los bronquios y vasos sanguíneos. EI dióxido de germanio no irrita la piel, pero en contacto con la conjuntiva húmeda, forma ácido germánico, que actúa como irritante ocular. La administración intra-abdominal prolongada de dosis superiores a $10 \mathrm{mg} / \mathrm{kg}$ produce alteraciones en la sangre periférica. Los efectos del polvo de concentrado de germanio no se deben al germanio, sino a otros constituyentes del polvo, y en especial a la sílice $\left(\mathrm{SiO}_{2}\right)$. El polvo de concentrado ejerce un marcado efecto fibrogénico que origina la formación de tejido conectivo y nódulos pulmonares parecidos a los que se observan en la silicosis.

Los compuestos de germanio más peligrosos son el hidruro $\left(\mathrm{GeH}_{4}\right)$ y el cloruro de germanio. El hidruro de germanio puede producir una intoxicación aguda. El estudio histológico de los órganos de animales muertos durante la fase aguda demuestra la existencia de trastornos circulatorios y cambios celulares degenerativos en los órganos parenquimatosos. Así, el hidruro parece ser un tóxico politropo que también puede afectar a las funciones neurológicas y a la sangre periférica.

El tetracloruro de germanio es un fuerte irritante del aparato respiratorio, la piel y los ojos. Su umbral de irritación es de $13 \mathrm{mg} / \mathrm{m}^{3}$. A esta concentración, deprime la reacción celular pulmonar en animales experimentales. A concentraciones mayores, produce irritación de las vías respiratorias altas y conjuntivitis, así como cambios en la frecuencia y el ritmo respiratorios. Los animales que sobreviven a la intoxicación aguda desarrollan, unos días después, bronquitis catarral descamativa y neumonía intersticial. El cloruro de germanio produce asimismo efectos tóxicos generales. Se han observado alteraciones morfológicas en el hígado, los riñones y otros órganos de los animales tratados.

\section{Medidas de salud y seguridad}

Las medidas básicas que se adopten durante la fabricación y el uso del germanio deben tener por objetivo evitar la contaminación del aire con polvo o humos. Durante la producción del metal, es conveniente que exista una continuidad de proceso y que éste se realice en un sistema encerrado. En las zonas en que pueda liberarse polvo de germanio metálico, del dióxido o del concentrado, deberán instalarse extractores de ventilación adecuados. También se deben instalar sistemas locales de extracción de gases cerca de los hornos de fundición durante la fabricación de semiconductores, por ejemplo, en los hornos de refinado de zona, y durante la limpieza de los hornos. El proceso de fabricación o aleación de monocristales de germanio debe realizarse en vacío, seguido de la evacuación de los compuestos formados bajo presión reducida. La ventilación con extracción de gases local es esencial en procesos como el corte y pulido en seco de los cristales de germanio y en las plantas de cloración, rectificación e hidrólisis de tetracloruro de germanio. Los instrumentos, conexiones y juntas de estas instalaciones deberán ser de un material resistente a la corrosión. Los trabajadores deberán utilizar siempre ropa y calzado resistentes al ácido y aparatos de protección respiratoria durante la limpieza de los instrumentos.

Los trabajadores expuestos al polvo, al ácido clorhídrico concentrado, al hidruro y al cloruro de germanio y a sus productos de hidrólisis deberán someterse a reconocimientos médicos periódicos.

\section{HIERRO}

\section{Distribución y usos}

EI hierro es el segundo metal más abundante y el cuarto de todos los elementos, superado únicamente por el oxígeno, el silicio y el aluminio. Los minerales de hierro más comunes son: la hematita o mineral de hierro rojo $\left(\mathrm{Fe}_{2} \mathrm{O}_{3}\right)$, que contiene un $70 \%$ de hierro; la limonita o mineral de hierro marrón $\left(\mathrm{FeO}(\mathrm{OH}) \cdot \mathrm{nH}_{2} \mathrm{O}\right)$, con un $42 \%$ de hierro; la magnetita 0 mineral de hierro magnético $\left(\mathrm{Fe}_{3} \mathrm{O}_{4}\right)$, con un alto contenido de hierro; la siderita o mineral de hierro espático $\left(\mathrm{FeCO}_{3}\right)$; la pirita $\left(\mathrm{FeS}_{2}\right)$, el mineral azufrado más común; y la pirrotita o pirita magnética (FeS). El hierro se utiliza para la fabricación de piezas de hierro y acero fundidos y en aleaciones con otros metales. También se emplea para aumentar la densidad de los líquidos en las perforaciones petrolíferas.

\section{Aleaciones y compuestos}

El hierro por sí mismo no es especialmente fuerte, pero su resistencia aumenta de forma notable cuando se alea con carbono y se enfría rápidamente para formar acero, lo que explica su importancia como metal industrial. Algunas características del acero, es decir, si es blando, suave, medio o duro, vienen determinadas por su contenido en carbono, que puede variar entre un 0,10 y un $1,15 \%$. U nos 20 elementos más, con cualidades muy distintas de dureza, ductilidad, resistencia a la corrosión, etc., se utilizan en diversas combinaciones y proporciones en la producción de aleaciones de acero. Los más importantes son el manganeso (ferromanganeso y spiegeleisen), el silicio (ferrosilicio) y el cromo, que se trata más adelante.

Desde el punto de vista industrial, los compuestos de hierro más importantes son los óxidos y el carbonato, que constituyen los minerales más importantes de los que se obtiene el metal. Los cianuros, nitruros, fosfuros, fosfatos y el hierro carbonilo tienen una importancia industrial menor.

\section{Riesgos}

Existen riesgos industriales durante la extracción, el transporte y la preparación de los minerales, durante la producción y el uso del metal y las aleaciones en las fábricas de hierro y acero y en las fundiciones, y durante la fabricación y el uso de ciertos compuestos. La inhalación de polvo o humos de hierro puede producirse en la minería del hierro, en la soldadura con arco eléctrico, el triturado, el abrillantado y el trabajo del hierro y en el rascado de calderas. Si se inhala, el hierro es un irritante local para los pulmones y el tracto gastrointestinal. Los informes indican que la exposición prolongada a una mezcla de polvo de hierro y otros metales puede afectar a la función pulmonar.

Pueden tener lugar accidentes durante la extracción, el transporte y la preparación de los minerales debido a la maquinaria pesada de corte, transporte, trituración y clasificación utilizada con este fin. También pueden producirse lesiones por la manipulación de explosivos durante las operaciones mineras.

La inhalación de polvo que contenga óxido de hierro o sílice puede originar neumoconiosis, pero no existen conclusiones definitivas con relación al papel de las partículas de óxido de hierro en el desarrollo del cáncer de pulmón en el hombre. Los experimentos en animales indican que el polvo de óxido de hierro podría actuar como una sustancia "co-cancerígena", favoreciendo el desarrollo del cáncer cuando se combina simultáneamente con la exposición a sustancias cancerígenas. 
Los estudios de mortalidad en mineros de la hematita han demostrado un mayor riesgo de cáncer de pulmón, generalmente entre fumadores, en varias regiones mineras como Cumberland, L orena, K iruna y K rivoi Rog. L os estudios epidemiológicos sobre trabajadores de fundiciones de hierro y acero suelen poner de manifiesto un aumento del riesgo de cáncer de pulmón de un 1,5 a un 2,5. La Agencia Internacional para la Investigación sobre el Cáncer (IARC) ha clasificado la fundición del hierro y el acero como un proceso cancerígeno para el hombre. Los agentes químicos específicos involucrados (por ejemplo, los hidrocarburos aromáticos polinucleares, la sílice y los humos metálicos) no se han identificado. También se ha descrito una mayor incidencia de cáncer de pulmón, aunque menos significativa, en los trituradores del metal. Los resultados en los soldadores son contradictorios.

En estudios experimentales no se ha demostrado que el óxido férrico sea cancerígeno; sin embargo, no se llevaron a cabo experimentos con hematita. Se ha avanzado que la presencia de radón en el aire de las minas de hematita constituye un importante factor cancerígeno.

Durante el tratamiento del hierro pueden producirse accidentes graves, como quemaduras durante el trabajo con el metal fundido, tal como se describe en otra sección de esta E nciclopedia. El polvo de hierro fino recién producido es pirofórico y se inflama al exponerse al aire a temperaturas normales. $\mathrm{H}$ an ocurrido incendios y explosiones de polvo en los conductos y separadores de las plantas de extracción de polvo asociados con el uso de las muelas de pulido y bruñido y las cintas de abrasión, al producirse chispas durante las operaciones de pulido que inflaman el polvo de acero fino en la planta de extracción.

Las propiedades peligrosas asociadas a los demás compuestos del hierro se deben por lo general al radical con que está asociado el hierro. Así, el arsenato $\left(\mathrm{FeAsO}_{4}\right)$ y el arsenito férricos $\left(\mathrm{FeAsO}_{3} \cdot \mathrm{Fe}_{2} \mathrm{O}_{3}\right)$ posen las propiedades venenosas de los compuestos arsenicales. El hierro carbonilo $\left(\mathrm{FeCO}_{5}\right)$ es uno de los carbonilos metálicos más peligrosos, con propiedades tóxicas e inflamables. Los carbonilos se tratan con más detalle en otra sección de este capítulo.

Sulfuro ferroso (FeS). Además de su presentación natural como pirita, este compuesto se produce de forma no intencionada cuando se tratan materiales que contienen azufre en recipientes de hierro y acero, como por ejemplo en las refinerías de petróleo. Si la planta se abre y el depósito de sulfuro de hierro se expone al aire, su oxidación exotérmica puede elevar la temperatura del depósito a la temperatura de inflamación de los gases y vapores en las proximidades. $\mathrm{H}$ ay que dirigir un chorro de agua finamente pulverizada sobre estos depósitos hasta que se hayan purgado todos los vapores inflamables. En las minas de pirita pueden encontrarse problemas similares cuando la temperatura del aire aumenta debido a la oxidación lenta y continua del mineral.

\section{Medidas de salud y seguridad}

Entre las precauciones para la prevención de los accidentes mecánicos se encuentran: el cercado y el control remoto de la maquinaria, el diseño de la planta, que en las acerías modernas incluye el control informatizado, y la formación de los obreros en las prácticas de seguridad.

El peligro derivado de los gases, vapores y polvos tóxicos e inflamables se contrarresta por medio de la extracción local y la ventilación general, junto con diversas formas de control remoto. Debe proporcionarse ropa adecuada y protección para los ojos, a fin de proteger al trabajador de los efectos de las sustancias calientes y corrosivas y del calor.
Es especialmente importante el mantenimiento regular de los conductos de las máquinas de pulido y bruñido y de las correas o cintas abrasivas, a fin de mantener la eficacia de la ventilación y la extracción de gases y reducir el riesgo de explosión.

\section{Ferroaleaciones}

Una ferroaleación es una aleación de hierro con un elemento distinto del carbono. Estas mezclas metálicas se utilizan como vehículo para introducir elementos específicos en la fabricación del acero, para producir aceros con propiedades concretas. El elemento puede alearse con el acero por disolución 0 bien neutralizar las impurezas nocivas.

Las aleaciones tienen propiedades únicas que dependen de la concentración de sus elementos. Estas propiedades varían en relación directa con la concentración de los componentes individuales y dependen, en parte, de la presencia de cantidades traza de otros elementos. Aun cuando el efecto biológico de cada uno de los elementos de la aleación puede servir de guía, existen pruebas suficientes de que su acción se modifica por la mezcla de los elementos, de forma que hay que extremar las precauciones al tomar decisiones críticas basadas en la extrapolación de los efectos de los elementos aislados.

Las ferroaleaciones comprenden una lista amplia y variada de aleaciones que contienen mezclas muy distintas dependiendo de la clase de aleación. En el comercio, el número de tipos de ferroaleaciones disponibles en cada clase suele ser limitado, pero los desarrollos metalúrgicos producen con frecuencia adiciones 0 cambios. Algunas de las ferroaleaciones más comunes son:

- ferroboro: $16,2 \%$ de boro;

- ferrocromo: 60 a $70 \%$ de cromo, y también puede contener silicio y manganeso;

- ferromanganeso: 78 a 90 \% de manganeso; 1,25 a 7 \% silicio;

- ferromolibdeno: 55 a $75 \%$ de molibdeno; $1,5 \%$ de silicio;

- ferrofósforo: 18 a $25 \%$ de fósforo;

- ferrosilicio: 5 a $90 \%$ de sílice;

- ferrotitanio: 14 a 45 \% de titanio; 4 a 13 \% de silicio;

- ferrotungsteno: 70 a $80 \%$ de tungsteno,

- ferrovanadio: 30 a $40 \%$ de vanadio; $13 \%$ de silicio; $1,5 \%$ de aluminio.

\section{Riesgos}

A pesar de que ciertas ferroaleaciones tienen un uso no metalúrgico, las principales situaciones de exposición peligrosa se producen durante la fabricación de estas aleaciones y durante su uso para la producción de acero. Algunas ferroaleaciones se producen y utilizan en forma de partículas finas; el polvo suspendido en el aire constituye un riesgo potencial de toxicidad, además de un riesgo de inflamación y explosión. Por otra parte, la exposición profesional a los humos de algunas aleaciones se ha asociado con problemas graves de salud.

Ferroboro. El polvo suspendido en el aire que se produce durante la limpieza de esta aleación puede causar irritación de nariz y garganta, debido posiblemente a la presencia de una película de óxido de boro en la superficie de la aleación. En algunos estudios con animales (per ros expuestos a concentraciones de ferroboro en el ambiente de $57 \mathrm{mg} / \mathrm{m}^{3}$ durante 23 semanas) no se observaron efectos adversos.

Ferrocromo. En un estudio realizado en Noruega sobre la mortalidad global y la incidencia de cáncer en los trabajadores de la producción de ferrocromo se observó una mayor incidencia de cáncer de pulmón relacionada con la exposición al cromo hexavalente en torno a los hornos. Algunos trabajadores presentaban perforación del tabique nasal. En otro estudio se llegó a la conclusión de que el aumento en la mortalidad global por cáncer de pulmón en los trabajadores de la fabricación del 
acero estaba asociado a la exposición a hidrocarburos aromáticos policíclicos ( $\mathrm{PHA}$ ) durante la producción de ferrocromo. En otro estudio se investigó la asociación entre la exposición profesional a los humos y el cáncer de pulmón, y se descubrió que los trabajadores del ferrocromo presentaban un aumento del número de casos de cáncer de pulmón y de próstata.

El ferromanganeso puede producirse reduciendo los minerales de manganeso en un horno eléctrico en presencia de coque, añadiendo dolomita y piedra caliza como fundente. El transporte, almacenamiento, selección y trituración de los minerales produce polvo de manganeso en concentraciones que pueden llegar a ser peligrosas. Los efectos patológicos derivados de la exposición al polvo tanto del mineral como de la aleación son prácticamente indistinguibles de los que se describen en el artículo "M anganeso" en este mismo capítulo. Se han observado intoxicaciones tanto agudas como crónicas. Las aleaciones de ferromanganeso que contienen proporciones muy elevadas de manganeso reaccionan con la humedad produciendo carburos de manganeso, que, al combinarse con la humedad, liberan hidrógeno, generando un riesgo de inflamación y explosión.

La producción de ferrosilicio puede generar aerosoles y polvo de ferrosilicio. L os estudios realizados en animales indican que el polvo de ferrosilicio puede producir un engrosamiento de las paredes alveolares y, en ocasiones, la desaparición de la estructura alveolar. Las materias primas utilizadas en la producción de la aleación también pueden contener sílice libre, aunque en concentraciones relativamente bajas. $\mathrm{H}$ ay cierta controversia en cuanto a si puede existir un riesgo potencial de silicosis clásica en la producción de ferrosilicio. Está claro, sin embargo, que la exposición excesiva al polvo o a los aerosoles presentes en las fábricas de ferrosilicio puede producir enfermedad pulmonar crónica de cualquier tipo.

Ferrovanadio. La contaminación atmosférica con polvo y humos también representa un riesgo en la producción de ferrovanadio. En condiciones normales, los aerosoles no producen una intoxicación aguda, pero pueden causar bronquitis y un proceso proliferativo intersticial pulmonar. Se ha descrito que el vanadio presente en la aleación de ferrovanadio es notablemente más tóxico que el vanadio libre, debido a su mayor solubilidad en los fluidos biológicos.

El acero plomado se utiliza en las láminas de acero de los automóviles con el fin de aumentar su maleabilidad. Este acero contiene aproximadamente un $0,35 \%$ de plomo. Cuando el acero plomado se somete a altas temperaturas, por ejemplo durante las soldaduras, existe siempre el riesgo de generar humos de plomo.

\section{M edidas de salud y seguridad}

El control de los humos, polvo y aerosoles durante la fabricación y el uso de las ferroaleaciones es esencial. $\mathrm{H}$ ay que mantener un buen control del polvo durante el transporte y la manipulación de los minerales y las aleaciones. Las pilas de mineral deben mojarse para reducir la formación de polvo. Además de estas medidas básicas de control del polvo, son necesarias precauciones especiales para la manipulación de ferroaleaciones específicas

EI ferrosilicio reacciona con la humedad produciendo fosfina y arsina; por este motivo, no se debe cargar este material cuando el clima es húmedo, y deben tomarse precauciones especiales para asegurarse de que permanezca seco durante el almacenamiento y el transporte. Siempre que se traslade o manipule ferrosilicio en cantidades importantes, deberán colocarse avisos para indicar el riesgo a los trabajadores y habrá que aplicar procedimientos de detección y análisis de fosfina y arsina en el aire a intervalos frecuentes. Es necesario un control adecuado del polvo y los aerosoles para la protección respiratoria y deberá disponerse de equipos de protección respiratoria adecuados para casos de emergencia.

Los trabajadores encargados de la producción y el uso de ferroaleaciones deber recibir una supervisión médica cuidadosa. El ambiente de trabajo deberá controlarse de forma continua 0 periódica, dependiendo del nivel de riesgo. Los efectos tóxicos de las distintas ferroaleaciones son suficientemente distintos de los de los metales puros como para justificar un mayor nivel de supervisión médica hasta que se puedan obtener más datos. Cuando las ferroaleaciones generan polvo, humos y aerosoles, los trabajadores deben someterse a exámenes radiológicos torácicos para la detección precoz de los cambios respiratorios. También puede ser necesario realizar pruebas de función pulmonar y controlar las concentraciones de metales en sangre y/ o orina de los trabajadores expuestos.

\section{INDIO}

\section{Distribución y usos}

El indio (In) se encuentra ampliamente distribuido en la naturaleza, casi siempre en combinación con minerales de zinc (esfalerita, marmatita, cristophita), su fuente principal desde el punto de vista comercial. También puede encontrarse en minerales de estaño, manganeso, tungsteno, cobre, hierro, plomo, cobalto y bismuto, pero generalmente en proporciones inferiores al 0,1\%.

El indio se suele utilizar en la industria para la protección de superficies 0 en aleaciones. Un fino revestimiento de indio aumenta considerablemente la resistencia de los metales a la corrosión y el desgaste. En los cojinetes, prolonga la vida de las partes móviles y, en consecuencia, se utiliza en la industria aeronáutica y automovilística. También se utiliza en aleaciones dentarias y su "mojabilidad" lo hace ideal para azogar espejos. Debido a su resistencia a la corrosión, se utiliza mucho para la fabricación de pantallas cinematográficas, osciloscopios de rayos catódicos y espejos. Aleado con antimonio y germanio, tiene un amplio uso en la fabricación de transistores y otros componentes electrónicos. Los radioisótopos del indio en compuestos como el tricloruro de indio y el hidróxido de indio coloidal se utilizan para la exploración orgánica y el tratamiento de tumores.

A demás del metal, los compuestos de indio más utilizados en la industria son: el tricloruro, en el galvanizado; el sesquióxido, en la fabricación de vidrio; el sulfato; y el antimónido y el arseniuro, como material para semiconductores.

\section{Riesgos}

No se han descrito casos de efectos sistémicos en humanos expuestos al indio. Probablemente, el mayor riesgo potencial resida en el uso del indio asociado con arsénico, antimonio y germanio en la industria electrónica. Ello se debe primordialmente a los humos que se liberan en los procesos de soldadura para la fabricación de componentes electrónicos. L os riesgos derivados de la purificación del indio se pueden atribuir posiblemente a la presencia de otros metales, como el plomo, o de compuestos químicos, como el cianuro, utilizados en los procesos de galvanizado. La exposición de la piel al indio no parece presentar un riesgo grave. La distribución del indio en los tejidos en sus distintas formas químicas se ha estudiado administrándolo a animales de laboratorio.

Las concentraciones más elevadas se detectaron en los riñones, el bazo, el hígado y las glándulas salivales. Tras la inhalación, se observaron extensos cambios pulmonares, como neumonitis intersticial descamativa, con la consiguiente insuficiencia respiratoria. 
Los resultados de los estudios en animales muestran que las sales más solubles del indio son muy tóxicas y producen la muerte en cantidades inferiores a $5 \mathrm{mg} / \mathrm{kg}$ por inyección parenteral. Sin embargo, por vía oral, el indio se absorbe en muy pequeña proporción y prácticamente no es tóxico. Los estudios histopatológicos indican que la muerte se debe principalmente a lesiones degenerativas del hígado y los riñones. También se observaron cambios de menor importancia en la sangre. En la intoxicación crónica por cloruro de indio, el principal trastorno registrado es la nefritis intersticial crónica con proteinuria. La toxicidad del compuesto más insoluble, el sesquióxido de indio, fue de moderada a leve y fueron necesarios varios cientos de $\mathrm{mg} / \mathrm{kg}$ para producir un efecto letal. Tras la administración de arseniuro de indio a hámsters, la captación en varios órganos fue distinta de la distribución del indio o el arsénico iónicos.

\section{Medidas de salud y seguridad}

La medida de seguridad más práctica consiste en prevenir la inhalación de humos de indio mediante la instalación de una ventilación adecuada. Durante la manipulación de arseniuro de indio se deben adoptar las mismas precauciones de seguridad que en el caso del arsénico. En el campo de la medicina nuclear, han de observarse las medidas de seguridad radiactiva aplicadas cuando se utilizan isótopos radiactivos de indio. La intoxicación en ratas por necrosis hepática inducida por el indio se ha logrado reducir considerablemente mediante la administración de dextrán férrico, cuya acción es aparentemente muy específica. El uso de dextrán férrico como tratamiento profiláctico en el hombre no ha sido posible por falta de casos graves de exposición industrial al indio.

\section{IRIDIO}

El iridio (Ir) pertenece a la familia del platino. D ebe su nombre a los colores de su sal, que recuerdan al arcoiris. A pesar de su dureza y de que es el metal más resistente a la corrosión que se conoce, puede ser atacado por algunas sales.

\section{Distribución y usos}

El iridio se encuentra en la naturaleza en estado metálico, generalmente aleado con osmio (osmiridio), platino u oro y se obtiene a partir de estos minerales. Se utiliza en la fabricación de crisoles para los laboratorios químicos y para endurecer al platino. Estudios recientes in vitro indican un posible efecto del iridio sobre la Leshmania donovani y el Trypanosoma bruce. El iridio se emplea en radiología industrial como emisor de radiaciones gamma $(0,31 \mathrm{M} \mathrm{eV}$ al $82,7 \%)$ y beta $(0,67 \mathrm{M} \mathrm{eV}$ al $47,2 \%)$. El ${ }^{192}$ Ir es un radioisótopo que se ha utilizado también en quimioterapia, especialmente del cáncer. Es uno de los isótopos utilizados con más frecuencia para la irradiación intersticial cerebral.

\section{Riesgos}

Se sabe muy poco sobre la toxicidad del iridio y sus compuestos. Dado que se utiliza en cantidades reducidas, no ha habido muchas oportunidades de observar efectos adversos en el hombre. Todos los radioisótopos son potencialmente dañinos y deben aplicarse las medidas de seguridad adecuadas para la manipulación de material radiactivo. Los compuestos solubles de iridio, como el tribromuro y el tetrabromuro de irido y el tricloruro de iridio producen los efectos tóxicos tanto del iridio como del halógeno, pero no existen datos sobre la toxicidad crónica. El tricloruro de iridio se ha descrito como un irritante leve para la piel y produce irritación ocular. En ratas, los aerosoles de iridio metálico inhalados se depositan en las vías respiratorias altas y posteriormente el metal se elimina con rapidez por el tracto gastrointestinal; aproximadamente un $95 \%$ puede detectarse en las heces. En el hombre, los únicos informes disponibles hacen referencia a lesiones por radiación debidas a la exposición accidental al ${ }^{192} \mathrm{r}$.

\section{Medidas de salud y seguridad}

Se deben aplicar las medidas de seguridad radiactiva pertinentes y un programa de vigilancia médica para las personas responsables de la asistencia sanitaria durante la braquiterapia intersticial. E ntre las medidas de seguridad radiactiva se encuentran la reducción de la exposición mediante el control del tiempo, la distancia y el apantallamiento. Las enfermeras que asisten a pacientes sometidos a braquiterapia deben utilizar mecanismos de control de las radiaciones para registrar la cantidad de exposición. Para evitar accidentes industriales de tipo radiológico, los radioisótopos deben ser manipulados únicamente por personal con la formación radiológica adecuada.

\section{MAGNESIO}

El magnesio ( $\mathrm{Mg}$ ) es el metal estructural más ligero que se conoce. Es un $40 \%$ más ligero que el aluminio. El magnesio metálico puede laminarse y estirarse cuando se calienta entre 300 y $475 \stackrel{\circ}{\circ}$, pero es quebradizo por debajo de esta temperatura y puede arder si se calienta mucho más. Es soluble y forma compuestos con varios ácidos, pero los ácidos fluorhídrico y crómico no lo afectan. A diferencia del aluminio, es resistente a la corrosión alcalina.

\section{Distribución y usos}

El magnesio no se encuentra en estado puro en la naturaleza, sino en una de las siguientes formas: dolomita $\left(\mathrm{CaCO}_{3} \cdot \mathrm{M} \mathrm{gCO}_{3}\right)$, magnesita ( $\left.\mathrm{M} \mathrm{gCO}_{3}\right)$, brucita $\left(\mathrm{M} \mathrm{g}(\mathrm{OH})_{2}\right)$, periclasa ( $\left.\mathrm{M} \mathrm{gO}\right)$, carnalita $\left(\mathrm{K} \mathrm{ClM} \mathrm{gCl}_{2} \cdot 6 \mathrm{H}_{2} \mathrm{O}\right)$ o kieserita $\left(\mathrm{M} \mathrm{gSO}_{4} \cdot \mathrm{H}_{2} \mathrm{O}\right)$. Además, se encuentra como silicato en el amianto y el talco. EI magnesio está tan ampliamente distribuido que el lugar de extracción se elige teniendo en cuenta las facilidades para el tratamiento y el transporte del mineral.

El magnesio se utiliza principalmente en forma de aleación, para componentes de aviones, barcos, automóviles y herramientas de mano que requieren resistencia y ligereza al mismo tiempo. También se utiliza en la fabricación de instrumentos de precisión y espejos ópticos, así como en la recuperación del titanio. Tiene además un gran empleo en el sector militar. D ebido a que arde con una luz muy intensa, se emplea mucho en pirotecnia, bengalas, balas incendiarias y trazadoras, y en los bulbos de los flash.

El óxido de magnesio tiene una elevada temperatura de fusión $\left(2.500{ }^{\circ} \mathrm{C}\right)$ y a menudo se incorpora en los revestimientos de los refractarios. También se utiliza como componente de piensos animales, fertilizantes, aislantes, placas para la construcción de tabiques, aditivos del petróleo y resistencias eléctricas. El óxido de magnesio se utiliza en la industria de la pulpa y el papel, como acelerador en la industria del caucho y como reflejante en instrumentos ópticos.

O tros compuestos importantes del magnesio son: el cloruro, el hidróxido, el nitrato y el sulfato de magnesio. El cloruro de magnesio es un componente de los extintores de incendios y objetos cerámicos. También se utiliza en el tratamiento de la madera para hacerla incombustible y en la fabricación de textiles y papel. EI cloruro de magnesio es un intermediario químico del oxicloruro de 
magnesio, que se utiliza para fabricar cemento. U na mezcla de óxido y cloruro de magnesio forma una pasta muy dura, que se utiliza para suelos. El hidróxido de magnesio se utiliza para neutralizar ácidos en la industria química, en el proceso del uranio y en la refinación del azúcar. El hidróxido de magnesio sirve como aditivo residual del fueloil y como componente de los dentífricos y antiácidos estomacales en polvo. EI nitrato de magnesio se utiliza en pirotecnia y como catalizador en la fabricación de productos petroquímicos. El sulfato de magnesio tiene varios usos en la industria textil, como el apresto del algodón y la seda, el tratamiento de los tejidos para hacerlos incombustibles y el estampado del algodón. Además, se utiliza en fertilizantes, explosivos, cerillas, agua mineral, cerámica y cosméticos y en la fabricación de la madreperla y el papel satinado. EI sulfato de magnesio potencia la acción blanqueadora de la lejía y se utiliza como corrector del agua en la fabricación de cerveza y como catártico y analgésico en medicina.

Aleaciones. Cuando el magnesio se alea con otros metales, como el manganeso, el aluminio y el zinc, mejora su dureza y resistencia a la tensión. En combinación con el litio, el cerio, el torio y el circonio se producen aleaciones que tienen una relación resistencia/ peso muy buena y una termorresistencia considerable. Esto las hace muy valiosas en las industrias de la aviación y aeroespacial para la construcción de motores de reacción, cohetes y vehículos espaciales. Un gran número de aleaciones, todas las cuales contienen más de un $85 \%$ de magnesio, se conocen con el nombre general de metal Dow.

\section{Riesgos}

E fectos biológicos. Al ser un componente esencial de la clorofila, las necesidades de magnesio del cuerpo humano quedan ampliamente satisfechas con el consumo de vegetales verdes. El cuerpo humano contiene, en promedio, unos $25 \mathrm{~g}$ de magnesio. Es el cuarto catión más abundante en el organismo, después del calcio, el sodio y el potasio. La oxidación de los alimentos libera energía, que se almacena en los enlaces de fosfato de alta energía. Se cree que este proceso de fosforilación oxidativa tiene lugar en las mitocondrias de las células y que el magnesio es necesario para esta reacción.

La inducción experimental de una deficiencia de magnesio en ratas produce una dilatación de los vasos sanguíneos periféricos y, posteriormente, hiperexcitabilidad y convulsiones. Las terneras alimentadas únicamente con leche presentan una tetania similar a la asociada con la hipocalcemia. Los animales de más edad con deficiencia de magnesio manifiestan "vértigos por hierba", un estado que parece estar asociado con un problema de absorción, más que con la falta de magnesio en el forraje.

En el hombre se han descrito casos de tetania por magnesio similar a la producida por la deficiencia de calcio. No obstante, en los casos descritos ha existido un "factor condicionante", como vómitos o deshidratación intensos, además de un aporte nutricional inadecuado. Dado que esta tetania es clínicamente similar a la causada por la deficiencia de calcio, sólo puede establecerse un diagnóstico determinando los niveles de calcio y magnesio en sangre. Los niveles séricos normales varían entre 1,8 y $3 \mathrm{mg}$ por $100 \mathrm{~cm}^{3}$, y se ha observado que las personas tienden a entrar en coma cuando la concentración sérica se aproxima a $17 \mathrm{mg}$ por 100. En animales, se han producido. "tumores aeroformes" debidos a la evolución del hidrógeno al introducir magnesio finamente dividido en los tejidos.

Toxicidad. El magnesio y las aleaciones que contienen un $85 \%$ del metal pueden considerarse conjuntamente por lo que se refiere a sus propiedades toxicológicas. En la industria, su toxicidad se considera baja. Los compuestos utilizados con más frecuencia, la magnesita y la dolomita, pueden irritar el aparato respiratorio. Sin embargo, los humos de óxido de magnesio, al igual que los de otros metales, pueden provocar fiebre por humo metálico. Algunos investigadores han descrito una mayor incidencia de trastornos digestivos en los trabajadores de las fábricas de magnesio y sugieren que puede existir una relación entre la absorción de magnesio y la úlcera gastroduodenal. Al moldear en fundición el magnesio o las aleaciones con un alto contenido de magnesio, se utilizan flujos de fluoruro e inhibidores que contienen azufre para separar el metal fundido del aire con una capa de dióxido de azufre. Esto impide la ignición durante las operaciones de moldeo, pero los humos de los fluoruros o del óxido de azufre pueden representar un riesgo mayor.

El principal peligro en la manipulación de magnesio es el fuego. Pequeños fragmentos del metal, como los resultantes del pulido, el bruñido o el mecanizado, pueden encenderse fácilmente por una chispa o llama casual y arder a una temperatura de $1.250 \stackrel{\circ}{\circ}$, ocasionando lesiones profundas y destructivas en la piel. Se han producido accidentes de este tipo al afilar una herramienta en una muela que se había utilizado previamente para pulir piezas fundidas de aleaciones de magnesio. Además, el magnesio reacciona con el agua y los ácidos, formando gas hidrógeno combustible.

L as esquirlas de magnesio que penetran en la piel o en heridas profundas pueden provocar "tumores aeroformes" del tipo ya mencionado, pero este caso es más bien excepcional; ahora bien, las heridas contaminadas con magnesio cicatrizan muy lentamente. El polvo fino del pulido del magnesio podría ser irritante para los ojos y las vías respiratorios, pero no es específicamente tóxico.

\section{Medidas de salud y seguridad}

Al igual que en cualquier proceso industrial potencialmente peligroso, se requiere una atención constante durante la manipulación y el trabajo del magnesio. Las personas dedicadas a la fundición del metal deben llevar delantales y guantes de piel u otro material adecuado para protegerse contra la "proyección" de pequeñas partículas. También deben llevar pantallas faciales transparentes, principalmente como protección para los ojos. Cuando los trabajadores estén expuestos al polvo de magnesio, no deberán utilizar lentes de contacto y dispondrán de los medios necesarios para poder lavarse los ojos de inmediato. Los obreros que mecanizan o pulen el metal deben llevar monos a los que no se adhieran pequeños fragmentos de metal. También es necesaria una ventilación local por extracción en aquellas zonas en que puedan producirse humos de óxido de magnesio, además de una buena ventilación general. Las herramientas de corte deberán estar bien afiladas, pues las romas pueden calentar el metal hasta la temperatura de ignición.

Los edificios en que se moldea o se mecaniza el magnesio deben construirse, de ser posible, con materiales incombustibles y sin bordes ni protuberancias en los que pueda acumularse el polvo de magnesio. $\mathrm{H}$ ay que evitar la acumulación de polvos y "fangos" formados por virutas metálicas, preferiblemente mediante un barrido en húmedo. $\mathrm{H}$ asta el momento de desecharlas finalmente, las virutas deberán recogerse en recipientes pequeños y retirarse periódicamente. El método más seguro para eliminar los desperdicios de magnesio es probablemente su humectación y enterramiento.

Dado que la inflamación accidental del magnesio presenta un grave riesgo de incendio, es esencial dar a los empleados instrucciones adecuadas en caso de incendio y contar con un buen sistema de extinción de incendios. $\mathrm{H}$ ay que advertir a los trabajadores que nunca utilicen agua contra este tipo de incendios, ya que así sólo se consigue dispersar los fragmentos que arden y se puede extender el fuego. Entre los materiales propuestos para el control de estos incendios se encuentran el carbón y la arena. 
También existen polvos contra incendios preparados comercialmente, uno de los cuales consiste en polietileno en polvo y borato sódico.

\section{- Manganeso}

\section{Distribución y usos}

El manganeso ( $\mathrm{M} n$ ) es uno de los elementos más abundantes de la corteza terrestre. Se encuentra en la tierra, los sedimentos, las rocas, el agua y los productos biológicos. Al menos un centenar de minerales contienen manganeso. Entre los minerales que contienen manganeso, los óxidos, carbonatos y silicatos son las formas más importantes. El manganeso puede presentarse en ocho estados de oxidación diferentes, de los que los más importantes son: $+2,+3 y+7$. El dióxido de manganeso $\left(\mathrm{M} \mathrm{nO}_{2}\right)$ es el óxido más estable. El manganeso forma diversos compuestos organometálicos. El de mayor interés práctico es el metilciclopentadienil manganeso tricarbonilo $\mathrm{CH}_{3} \mathrm{C}_{5} \mathrm{H}_{4} \mathrm{M} \mathrm{n}(\mathrm{CO})_{3}$, que suele denominarse M M T

La fuente comercial más importante de manganeso es el dióxido de manganeso $\left(\mathrm{MnO}_{2}\right)$, que se encuentra naturalmente en depósitos sedimentarios de pirolusita. También existen otros dos tipos de depósitos: las acumulaciones de carbonatos, que suelen estar compuestas por rodocrosita $\left(\mathrm{M} \mathrm{nCO}_{3}\right)$, y los depósitos estratiformes. A hora bien, sólo los depósitos sedimentarios tienen un tamaño adecuado, y suelen trabajarse con técnicas a cielo abierto. En ocasiones es necesario explotar los depósitos mediante minería subterránea, realizándose la extracción mediante la técnica de laboreo por cámaras y pilares; raras veces es necesario aplicar técnicas de explotación en profundidad.

El manganeso se utiliza en la producción del acero como reactivo para reducir el oxígeno y el azufre, y como agente de aleación para la fabricación de aceros especiales, aluminio y cobre. En la industria química se utiliza como agente oxidante y para la producción de permanganato de potasio y otros productos químicos derivados del manganeso. Además, se utiliza como recubrimiento de electrodos en varillas de soldadura, en los trituradores de rocas y en las agujas y cambios de vía de los ferrocarriles. También se emplea en la fabricación de cerámica, cerillas, vidrio y tintes.

Algunas sales de manganeso se utilizan como fertilizantes y como secantes para el aceite de linaza, en la fabricación de vidrio, como decolorantes de textiles y en el curtido de pieles. EI MMT se ha utilizado como aditivo del fuel-oil, como inhibidor de humos y como antidetonante en gasolinas.

\section{Riesgos}

\section{Absorción, distribución y excreción}

En situaciones laborales, el manganeso se absorbe principalmente por inhalación. El dióxido de manganeso y otros compuestos de manganeso utilizados o producidos como subproductos volátiles del proceso de refinado del metal son prácticamente insolubles en agua. Por este motivo, sólo llegan al torrente sanguíneo las partículas suficientemente pequeñas para alcanzar el alvéolo pulmonar. Las partículas de mayor tamaño inhaladas pueden ser depuradas por las vías respiratorias y deglutidas. EI manganeso también puede llegar al aparato digestivo a través de los alimentos o del agua contaminada. En la velocidad de absorción puede influir el nivel de manganeso y hierro contenido en la dieta, el tipo de compuesto de manganeso, la edad y las deficiencias de hierro. Sin embargo, el riesgo de intoxicación por esta vía no es grande. La absorción de manganeso a través de la piel puede considerarse despreciable.

Tras su inhalación o tras administración parenteral u oral, el manganeso absorbido se elimina rápidamente de la sangre y se distribuye principalmente en el hígado. Los patrones cinéticos para el aclaramiento hemático y la captación hepática del manganeso son similares, lo que indica que ambos depósitos de manganeso tienden a equilibrarse rápidamente. El exceso de metal se puede distribuir en otros tejidos, como los riñones, el intestino delgado, las glándulas endocrinas y los huesos. El manganeso se acumula en los tejidos ricos en mitocondrias y atraviesa las barreras hematoencefálica y placentaria. También se han observado concentraciones más elevadas de manganeso en las zonas más pigmentadas del organismo, como son la retina, la conjuntiva pigmentada y la piel morena. El pelo negro también acumula manganeso. Se calcula que la carga total de manganeso en el organismo oscila entre 10 y $20 \mathrm{mg}$ para un varón de $70 \mathrm{~kg}$. La semivida biológica del manganeso es de 36 a 41 días, pero en el caso del manganeso depositado en el cerebro, es considerablemente mayor. En la sangre, el manganeso se encuentra unido a las proteínas.

El compuesto orgánico M M T se metaboliza rápidamente en el organismo, con una distribución aparentemente similar a la que se observa tras la exposición al manganeso inorgánico.

La bilis constituye la principal vía de excreción del manganeso, por lo que se elimina casi completamente en las heces; sólo entre un 0,1 y un $1,3 \%$ de la ingesta diaria se elimina por vía urinaria. Parece ser que la excreción de bilis constituye el principal mecanismo regulador del control homeostático del contenido de manganeso en los tejidos, que es relativamente estable. Tras la exposición al compuesto orgánico M M T, la excreción del manganeso se produce mayoritariamente por la orina. Este hecho se ha explicado como resultado de la biotransformación del compuesto orgánico en el riñón. El manganeso, como parte de una metaloproteína de algunos complejos enzimáticos, es un elemento esencial para el hombre.

\section{Exposición}

Se han producido intoxicaciones por manganeso en la minería, durante el proceso de minerales de manganeso, en la producción de aleaciones de manganeso y en la fabricación de pilas secas, electrodos para soldadura, barnices y baldosas cerámicas. Los trabajos de minería presentan el mayor riesgo profesional, seguido en importancia por la industria del ferromanganeso. Las operaciones que producen las mayores concentraciones de polvo de dióxido de manganeso son las de triturado y pega de barrenos. En consecuencia, los trabajos más peligrosos son los de barrenado a alta velocidad.

C onsiderando la dependencia de las zonas de deposición y del índice de solubilidad de las partículas, los efectos peligrosos de la exposición estarán estrechamente relacionados con la composición de las partículas de aerosol de manganeso. A demás, se ha probado que los aerosoles formados por condensación resultan más nocivos que los formados por desintegración, lo que puede relacionarse con la diferencia de distribución de las partículas. La toxicidad de los distintos compuestos de manganeso parece depender del tipo de ion manganeso y de su estado de oxidación. Cuanto menos oxidado esté el compuesto, mayor será su toxicidad.

\section{Intoxicación crónica por manganeso (manganismo)}

La intoxicación crónica por manganeso puede tener manifestaciones nerviosas o pulmonares. Si afecta al sistema nervioso, se pueden distinguir tres fases. Durante el período inicial, es difícil diagnosticarla; sin embargo, el diagnóstico precoz es crítico, ya que la interrupción de la exposición parece frenar eficazmente el 
curso de la enfermedad. Los síntomas de esta fase son: indiferencia y apatía, somnolencia, pérdida de apetito, cefalea, vértigo y astenia. También pueden existir accesos de excitabilidad, dificultades para caminar y de coordinación, calambres y dolor de espalda. Todos estos síntomas pueden presentarse en diferentes grados y aparecer simultáneamente o aislados, y marcan el comienzo de la enfermedad.

La fase intermedia se caracteriza por la aparición de síntomas objetivos. En primer lugar, la voz se torna monótona y se convierte en un susurro, el habla es lenta e irregular, en ocasiones con tartamudeo. La expresión del rostro es impasible y sonriente 0 aturdida y vacía, lo que puede atribuirse a un aumento de tono de los músculos faciales. De repente, el paciente puede romper a reír 0 , más raramente, a llorar. Aunque sus facultades están muy disminuidas, parece que se encuentra en un estado perpetuo de euforia. Los gestos son lentos y toscos; la marcha es normal, pero puede existir un movimiento de vaivén en los brazos. El paciente es incapaz de correr y tiene grandes dificultades para caminar hacia atrás, en ocasiones con retropulsión. Se puede desarrollar una dificultad para realizar movimientos alternos rápidos (adiadocoquinesia), aunque el examen neurológico no revela ninguna alteración salvo, en ciertos casos, hiperreflexia patelar.

En pocos meses, el estado del paciente se deteriora notablemente y las distintas alteraciones, en especial las que afectan la marcha, se van acentuando progresivamente. El síntoma más precoz y evidente en esta fase es la rigidez muscular, que es constante aunque de grado variable, y determina una forma de caminar muy característica (lenta, espasmódica o inestable), en la que el paciente carga el peso sobre el metatarso y produce un movimiento que se ha descrito como "marcha de pollo" o "marcha de gallina". El paciente se torna absolutamente incapaz de caminar hacia atrás y, si lo intenta, se cae; al juntar los pies, tiene una gran dificultad para guardar el equilibrio y sólo puede girar muy lentamente. Puede existir temblor, frecuentemente en las extremidades inferiores, aunque en ocasiones es generalizado.

Los reflejos tendinosos, que rara vez son normales, aparecen aumentados. A veces existen alteraciones vasomotoras con sudoración súbita, palidez o enrojecimiento; también, ocasionalmente, el paciente puede presentar cianosis en las extremidades. $L$ as funciones sensoriales permanecen inalteradas. $L$ a mente del paciente trabaja con gran lentitud; su escritura se torna irregular, hasta el punto de que algunas palabras son ilegibles. Puede haber alteraciones de la frecuencia cardíaca. En esta fase, la enfermedad se vuelve progresiva e irreversible.

Forma pulmonar. Los informes de "neumoconiosis por manganeso" son muy discutidos debido al alto contenido en sílice de las rocas en los lugares de exposición; también se han descrito neumonías por manganeso. Al parecer, la correlación entre la neumonía y el manganeso no está bien establecida, a menos que éste actúe como un factor de agravamiento. Por su carácter epidémico y su gravedad, la enfermedad podría ser una neumopatía viral atípica. Estas neumonías mangánicas responden bien a los antibióticos.

Patología. Algunos autores sostienen que se producen lesiones dispersas en el cuerpo estriado y, posteriormente, en la corteza cerebral, el hipocampo y los tubérculos cuadrigéminos (en el polo posterior). 0 tros, sin embargo, opinan que las lesiones observadas en el lóbulo frontal explicarían mejor todos los síntomas que las lesiones en los ganglios basales; esto podría confirmarse por electroencefalografía. Las lesiones siempre son bilaterales y más o menos simétricas.

Curso. La intoxicación por manganeso termina por hacerse crónica. Ahora bien, si se diagnostica en las etapas iniciales y se retira al paciente de la exposición, puede ser reversible. U na vez bien establecido el cuadro patológico, se vuelve progresivo e irreversible, aun cuando cese la exposición. Los trastornos nerviosos no tienden a remitir y pueden ir seguidos de deformaciones articulares. Aunque es posible reducir la gravedad de ciertos síntomas, la marcha queda afectada permanentemente. El estado general del paciente es bueno y puede vivir durante mucho tiempo, falleciendo a final por una enfermedad intercurrente.

Diagnóstico. El diagnóstico de la enfermedad se basa principalmente en los antecedentes personales y laborales del paciente (el tipo de trabajo, la duración de la exposición, etc.). Sin embargo, la naturaleza subjetiva de los síntomas iniciales dificulta el diagnóstico precoz de la enfermedad. Por tanto, en esta etapa, la anamnesis deberá completarse con información recabada de los amigos, compañeros de trabajo y familiares. Durante las fases intermedia y avanzada de la intoxicación, la historia laboral y los síntomas objetivos facilitan el diagnóstico, aportando las pruebas de laboratorio información complementaria.

Los cambios hematológicos son variables: 0 bien no se produce ningún cambio, o bien se observa leucopenia, linfocitosis e inversión de la fórmula leucocitaria en el $50 \%$ de los casos 0 aumento en la tasa de hemoglobina (considerado como el primer signo de intoxicación) y una ligera policitemia.

La eliminación urinaria disminuye en 17 cetoesteroides y puede suponerse que la función suprarrenal esté afectada. Aumenta el nivel de albúmina en el líquido cefalorraquídeo, a menudo de forma muy acusada (40 a 55 e incluso $75 \mathrm{mg} \%$ ). L os síntomas digestivos y hepáticos no son indicativos; no existen signos de hepatomegalia ni esplenomegalia; sin embargo, la acumulación de manganeso en el hígado puede producir lesiones metabólicas que parecen relacionarse con el estado endocrino del paciente y verse influidas por la existencia de lesiones neurológicas

Diagnóstico diferencial. Puede ser difícil distinguir entre la intoxicación por manganeso y otras enfermedades, como la sífilis nerviosa, la enfermedad de Parkinson, la esclerosis múltiple, la enfermedad de Wilson, la cirrosis hepática y la enfermedad de Westphal-Strümpell (pseudoesclerosis).

\section{Medidas de salud y seguridad}

La prevención de la intoxicación por manganeso consiste básicamente en suprimir los polvos y humos de este metal. En las minas, se debe sustituir el barrenado en seco por métodos de perforación en húmedo. Las pegas con explosivos se realizarán al final de la jornada laboral, para poder ventilar la zona antes de que comience a trabajar el nuevo turno. Además, es necesario un buen sistema de ventilación general. En determinadas situaciones laborales, deberán utilizarse equipos de protección respiratoria con suministro de aire o respiradores autónomos, a fin de evitar una exposición excesiva de corta duración.

Es esencial un alto grado de higiene personal, así como instalaciones sanitarias adecuadas; se debe proporcionar a los trabajadores ropa de trabajo y tiempo para que, obligatoriamente, se duchen y se cambien de ropa al final de la jornada laboral. También deberá estar prohibido comer y fumar en el lugar de trabajo.

Es importante realizar determinaciones periódicas de los niveles de exposición, prestando especial atención a la distribución por tamaños de las partículas de manganeso en el ambiente. 0 tra fuente potencial de exposición que debe considerarse es la contaminación de los alimentos y el agua potable, así como los hábitos de alimentación de los trabajadores.

No se recomienda emplear a trabajadores con trastornos psicológicos 0 neurológicos en trabajos relacionados con la exposición al manganeso. Las carencias nutricionales 
pueden predisponer a la anemia y, por tanto, aumentar la susceptibilidad al manganeso. Por este motivo, los trabajadores que presenten este tipo de deficiencias deberán mantenerse bajo estricta vigilancia. Las personas que padezcan estados anémicos deberán evitar la exposición al manganeso mientras persista esa situación. Lo mismo ocurre con las personas que padecen lesiones de los órganos excretores o procesos respiratorios obstructivos crónicos. Un estudio indica que la exposición prolongada al manganeso puede contribuir al desarrollo de neumopatías crónicas de carácter obstructivo, sobre todo si la exposición se asocia con el hábito de fumar. Por otro lado, los pulmones dañados pueden ser más susceptibles a los efectos agudos potenciales de los aerosoles de manganeso.

Durante los reconocimientos médicos periódicos, se deben investigar los síntomas que pudieran estar relacionados con la fase subclínica de una intoxicación por manganeso. Asimismo, el trabajador deberá someterse a una exploración clínica, con el fin de detectar alteraciones psicomotoras y signos neurológicos precoces. Los síntomas subjetivos y los comportamientos anómalos a menudo constituyen el único indicio precoz de un cambio en la salud. El manganeso puede determinarse en sangre, orina, heces y pelo. El cálculo de la exposición al manganeso a partir de su concentración en la orina y en la sangre no es muy válido.

El nivel medio de manganeso en sangre de los trabajadores expuestos es similar al de las personas no expuestas. La contaminación durante la toma de muestras y los procedimientos analíticos puede explicar, al menos en parte, el amplio rango que se encuentra en la literatura, especialmente en sangre. EI uso de heparina como anticoagulante sigue siendo bastante común, aunque el contenido de manganeso de la heparina puede ser superior al de la sangre. Se calcula que la concentración media de manganeso en la orina de las personas no expuestas es de 1 a $8 \mathrm{mg} / \mathrm{l}$, aunque se han descrito valores de hasta $21 \mathrm{mg} / \mathrm{l}$. La ingesta diaria de manganeso a partir de la dieta varía considerablemente dependiendo de la cantidad de cereales integrales, nueces, verduras de hoja y té que se consuman, por su contenido relativamente alto de manganeso, e influye en el contenido normal de manganeso de los medios biológicos.

Se ha propuesto que una concentración de manganeso igual o superior $60 \mathrm{mg} / \mathrm{kg}$ de heces es un indicio de exposición profesional al manganeso. El contenido de manganeso en el cabello suele ser inferior a $4 \mathrm{mg} / \mathrm{kg}$. Puesto que la determinación de manganeso en orina, frecuentemente utilizada en la práctica, aún no está suficientemente validada como para valorar la exposición individual, sólo puede utilizarse como indicador grupal del nivel medio de exposición. La recogida de heces y la determinación de su contenido en manganeso no es fácil de realizar. Nuestro nivel actual de conocimientos no incluye ningún otro parámetro biológico fiable que pueda utilizarse como indicador de la exposición individual al manganeso. Así, la valoración de la exposición de los trabajadores al manganeso se sigue realizando a partir de los niveles de manganeso en el ambiente. Además, existe muy poca información fidedigna sobre la correlación entre el nivel de manganeso en la sangre y la orina y el desarrollo de signos y síntomas neurológicos.

Las personas que presenten signos de intoxicación por manganeso deberán retirarse de la fuente de exposición. Si esta separación del trabajador se realiza inmediatamente después de la aparición de los síntomas (antes de que se instaure un estado franco de manganismo), muchos de los signos y síntomas remitirán. Con todo, pueden quedar algunas alteraciones residuales, especialmente en el habla y en la marcha.

\section{MERCURIO}

\section{Mercurio inorgánico}

El mercurio se combina rápidamente con el azufre y los halógenos a temperatura normal y forma amalgamas con todos los metales excepto el hierro, el níquel, el cadmio, el aluminio, el cobalto y el platino. Reacciona exotérmicamente (generando calor) con los metales alcalinos, es atacado por el ácido nítrico, pero no por el clorhídrico y, cuando se calienta, se combina con el ácido sulfúrico.

El mercurio inorgánico se encuentra en la naturaleza en forma de sulfuro ( $\mathrm{H}$ gS), como mineral de cinabrio, que tiene un contenido medio de mercurio del 0,1 al $4 \%$. También se encuentra en la corteza terrestre en forma de geodas de mercurio líquido (Almadén) y como esquistos y pizarras impregnadas (por ejemplo, en la India y Yugoslavia).

Extracción. El mineral de mercurio se extrae por minería subterránea, y el mercurio metálico se separa del mineral mediante calentamiento en un horno rotatorio o de cuba o por reducción con óxido de hierro o calcio. El vapor sale junto con los gases de combustión y se condensa en tubos verticales.

Los usos más importantes del mercurio metálico y sus compuestos inorgánicos son: el tratamiento de los minerales de plata y oro, la fabricación de amalgamas, la fabricación y reparación de aparatos de medición o de laboratorio, la fabricación de bombillas eléctricas incandescentes, tubos con vapor de mercurio, válvulas de radio, tubos de rayos $X$, interruptores, baterías, rectificadores, etc.; como catalizador para la producción de cloro y álcalis y en la producción de ácido acético y acetaldehído a partir de acetileno; en la investigación en laboratorios químicos, físicos y biológicos; en la electrodeposición del oro, la plata, el bronce y el estaño; en el curtido y tratamiento flexibilizante de las pieles; en la fabricación de fieltros; en la taxidermia; en la fabricación de tejidos; en la fotografía y el fotograbado; en las pinturas y pigmentos a base de mercurio; y en la fabricación de seda artificial. Algunas de estas aplicaciones han caído en desuso debido a los efectos tóxicos de la exposición al mercurio para los trabajadores.

\section{Compuestos orgánicos de mercurio}

Los compuestos orgánicos de mercurio son aquellos en que el mercurio está unido directamente a un átomo de carbono. Las uniones entre el carbono y el mercurio tienen una amplia gama de estabilidades. En general, la unión carbono-mercurio en los compuestos alifáticos es más estable que en los aromáticos. Según una estimación fiable, se han sintetizado más de 400 compuestos fenilomercuriales y al menos un número igual de alquilos de mercurio. Los tres grupos más importantes, de uso común, son los alquilos, los hidrocarburos aromáticos o arilos y los alcoxialquilos. Como ejemplos de los arilos mercúricos pueden citarse el acetato fenilmercúrico (PMA), el nitrato, el oleato, el propionato y el benzoato. De este tipo de compuestos, del que más información se dispone es del PM A.

U sos. Los principales usos de los compuestos orgánicos de mercurio dependen de su actividad biológica. En la práctica médica, los compuestos de mercurio se utilizan como antisépticos, germicidas, diuréticos y anticonceptivos; en el campo de los pesticidas, como algicidas, fungicidas, herbicidas y limocidas $y$, en otros campos, como conservadores de pinturas, ceras y pastas; se emplean para suprimir el mildiu, en pinturas anti-incrustantes, en pinturas al látex y en el tratamiento antimoho de tejidos, papel, corcho y madera para su uso en climas húmedos; en la industria química, actúan de catalizadores en diversas 
reacciones y los alquilos de mercurio se utilizan como agentes alquilantes en síntesis orgánicas.

\section{Riesgos}

\section{Absorción y efectos: mercurio inorgánico y metálico}

La inhalación de vapor es la principal vía de entrada de mercurio metálico al organismo. Alrededor de un $80 \%$ de los vapores de mercurio inhalados se absorbe por los pulmones (a nivel alveolar). La absorción de mercurio metálico a través del aparato digestivo es despreciable (menos del $0,01 \%$ de la dosis administrada). También es posible la penetración subcutánea accidental de mercurio metálico, por ejemplo, por la ruptura de un termómetro.

Las principales vías de entrada de los compuestos inorgánicos de mercurio (sales mercuriales) son los pulmones (atomización de las sales de mercurio) y el tracto gastrointestinal. En este último caso, la absorción suele ser resultado de la ingestión accidental o voluntaria. Se calcula que entre un 2 y un $10 \%$ de las sales mercuriales ingeridas se absorbe a través del tracto gastrointestinal.

La absorción cutánea de mercurio metálico y algunos de sus compuestos también es posible, aunque la tasa de absorción es baja. U na vez en el organismo, el mercurio metálico permanece como tal durante un corto espacio de tiempo, lo que explica su capacidad de atravesar la barrera hematoencefálica. En la sangre y los tejidos, el mercurio metálico se oxida rápidamente para formar iones mercurio $\mathrm{H} \mathrm{g}^{2+}$, que se fijan a las proteínas. En la sangre, el mercurio inorgánico se distribuye entre el plasma y los eritrocitos.

Tras la exposición a vapores de mercurio metálico, éste se deposita en los riñones y el encéfalo y, cuando se produce exposición a sales inorgánicas, se deposita principalmente en los riñones.

\section{Intoxicación aguda}

Los síntomas de una intoxicación aguda son: irritación pulmonar (neumonía química), que puede producir edema pulmonar agudo. También es posible que resulte afectada la función renal. Casi siempre, la intoxicación aguda se debe a la ingestión accidental o voluntaria de sales de mercurio, lo que produce una grave inflamación del tracto gastrointestinal, seguida rápidamente de una insuficiencia renal por necrosis de los túbulos contorneados proximales.

La forma grave de intoxicación crónica por mercurio que hasta principios del siglo $X X$ se observaba en lugares como Almadén y se caracterizaba por importantes trastornos renales, digestivos, mentales y nerviosos que derivaban en caquexia, ha desaparecido gracias a las medidas preventivas. Sin embargo, en la minería del mercurio aún pueden producirse intoxicaciones crónicas "intermitentes", con alternancia de períodos de intoxicación activa y de intoxicación latente. En los períodos latentes, los síntomas remiten de forma que sólo son detectables mediante un análisis minucioso; persisten únicamente las manifestaciones neurológicas en forma de sudoración profusa, dermografismo y cierta inestabilidad emocional.

También se ha descrito un estado de "micromercurialismo", que se caracteriza por una neurosis funcional (histeria y neurastenia frecuentes y formas mixtas), labilidad cardiovascular y neurosis secretora del estómago.

A parato digestivo. La gingivitis es el trastorno gastrointestinal más frecuente en la intoxicación por mercurio. Una mala higiene bucal favorece este trastorno, que va acompañado de un sabor desagradable, metálico o amargo, en la boca. La estomatitis úlcero-membranosa es mucho menos frecuente y normalmente aparece en personas que ya padecen gingivitis y que inhalan de forma accidental vapores de mercurio. La estomatitis comienza con los síntomas subjetivos de la gingivitis y un aumento en la salivación (ptialismo mercurial) y el recubrimiento de la lengua. Al comer y beber, se produce una sensación de ardor y molestia en la boca, las encías se inflaman progresivamente, aparecen úlceras y sangrado espontáneo. En los casos agudos, los pacientes presentan fiebre alta, inflamación de los ganglios submaxilares y un aliento sumamente fétido. También se ha observado periostitis alveolodental.

Puede aparecer una línea azulada en las encías, en el borde de los dientes, especialmente cerca de áreas infectadas, pero esta línea nunca se observa en las personas sin dientes. También se ha descrito una pigmentación puntiforme de color gris pizarra de la mucosa oral, en el lado vestibular de las encías (generalmente en la mandíbula inferior), el paladar e incluso en la parte interior de las mejillas.

La gingivitis recurrente afecta al tejido que sostiene los dientes $y$, en muchos casos, es necesario extraerlos o se caen solos. 0 tros trastornos gastrointestinales de la intoxicación por mercurio son la gastritis y la gastroduodenitis.

La faringitis inespecífica es relativamente frecuente. Una manifestación más rara es la faringitis de K ussmaul, en la que se observa una coloración rojo brillante con una fina arborización en la faringe, las amígdalas y el paladar blando.

Los efectos sobre el sistema nervioso se pueden producir en presencia o ausencia de síntomas gastrointestinales y pueden evolucionar siguiendo dos cuadros clínicos principales: a) temblor fino en los movimientos voluntarios, que recuerda al de las personas que padecen esclerosis múltiple y b) parkinsonismo con temblor en reposo y pérdida de las funciones motoras. Generalmente predomina una de estas situaciones y el cuadro clínico global puede complicarse con irritabilidad e hiperactividad mental (eretismo mercurial).

El parkinsonismo por mercurio se caracteriza por una marcha inestable y vacilante, la ausencia de reflejos de recuperación del equilibrio e hipotonía; los síntomas vegetativos son leves y comprenden inexpresividad del rostro, sialorrea, etc. El parkinsonismo suele encontrarse en su forma más leve, en especial como micro-parkinsonismo.

L os síntomas más frecuentes son similares a los de la esclerosis múltiple, excepto porque no se observa nistagmo y porque la serología y el curso clínico son distintos en ambos trastornos. La característica más llamativa es temblor, que generalmente es un síntoma tardío, pero que puede desarrollarse antes que la estomatitis.

El temblor suele desaparecer durante el sueño, aunque pueden producirse calambres o contracciones generalizados, y aumenta en situaciones de estrés emocional, lo que constituye una característica tan distintiva que proporciona una base sólida para el diagnóstico de la intoxicación por mercurio. El temblor se acentúa notablemente en situaciones en que el paciente se siente cohibido 0 avergonzado; con frecuencia se ven obligados a comer solos porque de otra forma, no serían capaces de llevarse la comida a la boca. En su forma más aguda, el temblor puede afectar a todos los músculos voluntarios y ser continuo. $\mathrm{H}$ ay casos incluso en que es necesario atar al paciente para evitar que se caiga de la cama y se observan asimismo movimientos masivos tipo corea suficientementeintensoscomo para despertar al paciente.

El paciente tiende a hablar de forma entrecortada y es difícil entender lo que dice (pselismo mercurial); cuando cesa el espasmo, las palabras se producen demasiado rápido. En los casos más similares al parkinsonismo, el habla es lenta y monótona y la voz puede ser muy baja o completamente ausente; sin embargo, el habla espasmódica es más frecuente.

Un síntoma muy característico es el deseo de dormir, y el paciente suele dormir durante períodos prolongados, 
aunque con un sueño ligero e interrumpido con frecuencia por calambres y espasmos. En algunos casos puede ocurrir insomnio.

La pérdida de memoria es uno de los síntomas precoces, y la demencia uno de los terminales. Son frecuentes el dermografismo y la sudoración profusa sin motivo aparente. En la intoxicación crónica por mercurio, los ojos pueden mostrar un cuadro de "mercurialentis", que se caracteriza por una decoloración de color gris rojizo claro a oscuro de la cápsula anterior del cristalino debida al depósito de partículas finas de mercurio. La mercurialentis se puede detectar mediante un examen con microscopio de rendija y es bilateral y simétrica; habitualmente, aparece bastante tiempo antes del inicio de los síntomas generales de intoxicación por mercurio.

\section{Exposición crónica}

La intoxicación crónica por mercurio suele comenzar de forma insidiosa, lo que dificulta su detección precoz. El órgano diana principal es el sistema nervioso. Inicialmente, pueden aplicarse las pruebas empleadas para detectar los cambios psicomotores y neuromusculares y el temblor leve. En ocasiones es posible detectar efectos renales leves (proteinuria, albuminuria, enzimuria) antes que los efectos neurológicos.

Si no se corrige la exposición excesiva, los síntomas neurológicos y otras manifestaciones (como temblor, sudoración, dermatografismo) se acentúan y aparecen cambios de comportamiento y trastornos de la personalidad acompañados, en ocasiones, de trastornos digestivos (estomatitis, diarrea) y de un deterioro del estado general (anorexia, pérdida de peso). Una vez que se ha llegado a esta etapa, la retirada de la exposición no produce ya la recuperación total.

En la intoxicación crónica por mercurio predominan los síntomas digestivos y nerviosos y, aunque los primeros comienzan antes, los segundos son más evidentes. También pueden observarse otros síntomas significativos, pero de menor intensidad. La duración del período de absorción del mercurio que preceda a la aparición de los síntomas clínicos depende del nivel de absorción y de factores individuales. Los síntomas precoces más importantes son: trastornos digestivos leves, en especial pérdida de apetito, temblor intermitente, que en ocasiones afecta a grupos de músculos específicos, y trastornos neuróticos de intensidad variable. El curso de la intoxicación puede variar considerablemente de un caso a otro. Si la exposición termina inmediatamente después de la aparición de los primeros síntomas, suele producirse una recuperación completa; sin embargo, si la exposición continúa y la intoxicación se establece definitivamente, sólo cabe esperar una mejoría de los síntomas en la mayoría de los casos.

$\mathrm{R}$ iñones. Desde hace varios años se ha estudiado la relación entre la función renal y los niveles de mercurio en orina. Los efectos de la exposición a niveles bajos no están bien documentados ni se conocen claramente. A niveles más altos, superiores a $50 \mu \mathrm{g} / \mathrm{g}$ (microgramos por gramo) se han observado alteraciones de la función renal, determinadas mediante la N-acetil-B-D-glucosaminidasa (NAG), un indicador sensible del daño renal. Los niveles de NAG se han correlacionado tanto con los niveles de mercurio en la orina como con los resultados de las pruebas neurológicas y de comportamiento.

Sistema nervioso. En los últimos años se han obtenido más datos sobre la intoxicación con niveles bajos de mercurio, que se comentan con más detalle en el capítulo 7, Sistema nervioso, de esta E nciclopedia.

Sangre. La intoxicación crónica va acompañada de una anemia leve, precedida en ocasiones de policitemia como resultado de la irritación de la médula ósea. También se ha observado linfocitosis y eosinofilia.

\section{Compuestos orgánicos de mercurio}

A cetato fenilmercúrico (PM A). La absorción puede producirse por inhalación de aerosoles que contengan PM A, a través de la piel 0 por ingestión. La solubilidad del compuesto de mercurio y el tamaño de las partículas en aerosol son los factores que determinan el grado de absorción. EI PMA ingerido se absorbe de forma más eficaz que las sales inorgánicas de mercurio. El fenilmercurio se transporta principalmente por la sangre y se distribuye en las células sanguíneas (90\%), se acumula en el hígado y allí se descompone en mercurio inorgánico. Algunos compuestos fenilmercúricos se eliminan con la bilis. En su mayor parte, la cantidad absorbida por el organismo se distribuye en los tejidos como mercurio inorgánico y se acumula en el riñón. Cuando la exposición es crónica, la distribución del mercurio y su eliminación siguen el mismo patrón que en el caso de la exposición al mercurio inorgánico.

Puede producirse una exposición profesional a los compuestos fenilmercúricos durante la producción y manipulación de productos tratados con fungicidas que contengan estos compuestos. La inhalación aguda de grandes cantidades puede provocar lesiones pulmonares. En caso de contaminación cutánea con soluciones concentradas de compuestos fenilmercúricos pueden aparecer quemaduras de tipo químico con vesiculación. A simismo, es posible desarrollar una sensibilización a los compuestos fenilmercúricos. La ingestión de grandes cantidades de fenilmercurio ocasiona lesiones hepáticas y renales. La intoxicación crónica provoca lesiones renales por acumulación de mercurio inorgánico en los túbulos renales.

Los datos clínicos disponibles no permiten sacar conclusiones amplias sobre la relación dosis-respuesta. No obstante, parecen indicar que los compuestos fenilmercúricos son menos tóxicos que los compuestos inorgánicos de mercurio o que la exposición a largo plazo. También existen indicios de efectos adversos leves en la sangre.

Compuestos alquilmercúricos. D esde un punto de vista práctico, los compuestos alquilmercúricos de cadena corta, como el meilmercurio y el etilmercurio, son los más importantes, aunque existen otros compuestos de mercurio más sofisticados, generalmente utilizados en laboratorios de investigación, que han provocado muertes súbitas por intoxicación aguda. Los compuestos alquilmercúricos de cadena corta se han utilizado mucho para erradicar malezas y han ocasionado varias muertes. El cloruro metilmercúrico forma cristales blancos de un olor característico, mientras que el cloruro etilmercúrico (cloroetilmercurio) se presenta en escamas blancas. En un $80 \%$ de los casos, los compuestos volátiles de metilmercurio, como el cloruro de metilmercurio, se absorben debido a la inhalación de vapores. M ás del $95 \%$ de los compuestos alquílicos de mercurio de cadena corta se absorben por vía digestiva, aunque su absorción a través de la piel también puede ser importante, dependiendo de su solubilidad y concentración y del estado de la piel.

Transporte distribución y excreción. EI metilmercurio se transporta en los eritrocitos (95\%) y sólo una pequeña parte se encuentra unida a las proteínas del plasma. La distribución en los distintos tejidos del organismo es bastante lenta y el equilibrio se alcanza en aproximadamente cuatro días. EI metilmercurio se concentra en el sistema nervioso central, especialmente en la sustancia gris. A proximadamente el $10 \%$ de la carga total de mercurio en el organismo se encuentra en el cerebro, con una concentración mayor en la corteza occipital y el cerebelo. En las mujeres embarazadas, el metilmercurio atraviesa la barrera placentaria y llega al feto, acumulándose principalmente en el cerebro fetal.

\section{Riesgos del mercurio orgánico}

La intoxicación por compuestos alquilmercúricos puede producirse por la inhalación de vapores o polvo durante la fabricación 
de compuestos mercuriales y la manipulación de los productos finales. El contacto cutáneo con soluciones concentradas determina la aparición de quemaduras químicas y vesiculación. En las operaciones agrícolas existe el riesgo de que se mezclen las malezas tratadas con productos destinados al consumo alimentario, lo que puede producir la ingestión involuntaria de cantidades importantes de alquilmercurio. En las exposiciones agudas, los signos y síntomas de intoxicación tienen un comienzo insidioso y aparecen tras un período de latencia que puede oscilar entre una y varias semanas. Dicho período de latencia depende de la magnitud de la dosis: cuanto mayor sea ésta, más corto será el mismo.

En la exposición crónica, la aparición es más insidiosa, aunque los síntomas y signos sean esencialmente los mismos, debido a la acumulación de mercurio en el sistema nervioso central, que produce daño neuronal en la corteza sensorial, como la corteza visual, auditiva o las áreas pre y postcentrales. L os signos se caracterizan por alteraciones sensoriales con parestesias en las extremidades distales, en la lengua y alrededor de los labios. En los casos de intoxicación más grave, puede presentarse ataxia, reducciones concéntricas de los campos visuales, alteraciones auditivas y síntomas extrapiramidales. En los casos graves, se producen convulsiones crónicas.

El período de la vida más sensible a la intoxicación por metilmercurio es la fase intrauterina; el feto parece ser de 2 a 5 veces más sensible que el adulto. La exposición intrauterina se traduce en parálisis cerebral, debida en parte a la inhibición de la migración neuronal desde las zonas centrales a las áreas corticales periféricas. En los casos menos graves se ha detectado un retraso en el desarrollo psicomotor.

Compuestos al coxial quilmercúricos. L os compuestos alcoxialquílicos utilizados con más frecuencia son las sales metoxietilmercúricas, como el acetato de metoxietilmercurio, que ha reemplazado a los compuestos alquílicos de cadena corta para el tratamiento de la maleza en muchos países industrializados que han prohibido el uso de los compuestos alquílicos por su peligrosidad.

La información disponible es muy escasa. Los compuestos alcoxialquílicos se absorben por inhalación y por ingestión con más eficacia que las sales inorgánicas de mercurio. La distribución y excreción del mercurio absorbido sigue patrones idénticos a los de las sales inorgánicas de mercurio. La excreción se efectúa a través del tracto intestinal y los riñones. Se desconoce en qué magnitud se eliminan los alcoxialquilos de mercurio sin metabolizar en el hombre. La exposición a los alcoxialquilos de mercurio puede producirse durante la producción de los compuestos y la manipulación de los productos finales tratados con esos compuestos. El acetato de metoxietilmercurio tiene una acción vesicante cuando se aplica sobre la piel en soluciones concentradas. La inhalación de polvo de las sales de metoxietilmercurio puede causar lesiones pulmonares, y la exposición crónica a largo plazo, lesiones renales.

\section{Medidas de salud y seguridad}

D ebe hacerse todo lo posible para sustituir el mercurio por otras sustancias que entrañen menos riesgos. Por ejemplo, la industria del fieltro puede utilizar compuestos no mercuriales. En las minas, se deben aplicar técnicas de picado en húmedo. La ventilación es la principal medida de seguridad y, si no existe una ventilación adecuada, los trabajadores deberán utilizar equipos de protección respiratoria.

En la industria, siempre que sea posible, el mercurio se manipulará en sistemas herméticamente cerrados y en los puestos de trabajo se exigirán medidas de higiene estrictas. Cuando se derrama mercurio, es muy fácil que se infiltre en grietas, fracturas del suelo y bancos de trabajo. Por su presión de vapor, pueden producirse concentraciones atmosféricas elevadas, aun cuando la contaminación sea aparentemente despreciable. Por este motivo, es importante evitar cualquier contaminación de las superficies de trabajo, que deberán ser lisas, de un material no absorbente y tener un ligero declive hacia un colector 0 , a falta de ello, una rejilla metálica sobre un canalón lleno de agua para recoger cualquier gota de mercurio que pueda caer a través de la rejilla. Las superficies de trabajo deben limpiarse con regularidad y, en caso de contaminación accidental, todas las gotas de mercurio que hayan caído en la trampa de agua se recogerán lo antes posible.

Cuando exista riesgo de que el mercurio se volatilice, se deberá instalar un sistema de ventilación local por extracción, aunque hay casos en que no se puede aplicar esta solución, como en las instalaciones para la producción de cloro mediante el proceso de cuba de mercurio, debido a la enorme superficie de vaporización.

Los puestos de trabajo deberán diseñarse de forma que se reduzca al mínimo el número de personas expuestas al mercurio.

En la mayoría de las exposiciones a compuestos orgánicos de mercurio se produce una exposición mixta a vapores de mercurio y al compuesto orgánico, ya que estos compuestos se descomponen y liberan vapores de mercurio. Todas las medidas técnicas dirigidas a evitar la exposición a los vapores de mercurio deberán aplicarse en el caso de la exposición a los compuestos orgánicos de mercurio. Así, hay que evitar la contaminación de la ropa y las partes del cuerpo expuestas, que pueden constituir una peligrosa fuente de vapores de mercurio cercana a la zona respiratoria. Se deben utilizar ropas protectoras especiales, que se cambiarán después de cada turno de trabajo. Las operaciones de pintado aerográfico con pinturas que contengan compuestos mercuriales se deberán realizar con equipos de protección respiratoria y una ventilación adecuada. Los compuestos alquilmercúricos de cadena corta deben eliminarse y sustituirse por otros siempre que sea posible. Si no se puede evitar la manipulación, se recurrirá a sistemas cerrados combinados con una ventilación adecuada para limitar la exposición al mínimo.

Se debe poner mucho cuidado en evitar la contaminación de las fuentes de agua con los efluentes de mercurio, ya que el mercurio puede incorporarse en la cadena alimentaria, produciendo desastres como el ocurrido en M inamata, Japón.

\section{METALCARBONILOS (en especial, níquel carbonilo)}

F. William Sunderman, Jr.

\section{Distribución y usos}

Los carbonilos metálicos obedecen a la fórmula general $M e_{x}(C O)$ y y se obtienen mediante la combinación de un metal (Me) con monóxido de carbono (CO). Las propiedades físicas de algunos metalcarbonilos se indican en la Tabla 63.1. La mayoría son sólidos a temperatura normal, aunque el níquel carbonilo, el hierro pentacarbonilo y el rutenio pentacarbonilo son líquidos, y el cobalto hidrocarbonilo es un gas. En este artículo nos centraremos en el níquel carbonilo que, por su volatilidad, su excepcional toxicidad y su importancia industrial, merece una atención especial en relación con la toxicología profesional. Puesto que el hierro pentacarbonilo y el cobalto hidrocarbonilo también tienen una alta presión de vapor y pueden formarse inadvertidamente, está justificado considerarlos detenidamente como posibles tóxicos profesionales. La mayoría de los metalcarbonilos reaccionan vigorosamente con el oxígeno y las sustancias oxidantes y algunos pueden arder espontáneamente. Al exponerse al aire y a la luz, el níquel carbonilo se descompone 
Tabla 63.1 - Propiedades físicas de algunos metalcarbonilos.

\begin{tabular}{|c|c|c|c|c|c|}
\hline $\begin{array}{l}\text { Metal } \\
\text { carbonilos }\end{array}$ & p. m. & d. $\left(20^{\circ} \mathrm{C}\right)$ & p.f. $\left({ }^{\circ} \mathrm{C}\right)$ & p.e. $\left({ }^{\circ} \mathrm{C}\right)$ & $\begin{array}{l}\text { p. V. } \\
\left(25^{\circ} \mathrm{C}\right) \\
\mathrm{mm} \mathrm{Hg}\end{array}$ \\
\hline $\mathrm{Ni}(\mathrm{CO})_{4}$ & 170,75 & 1,31 & -19 & 43 & 390 \\
\hline $\mathrm{COH}(\mathrm{CO})_{4}$ & 171,99 & - & -26 & - & alto \\
\hline $\mathrm{CO}_{2}(\mathrm{CO})_{8}$ & 341,95 & 1,87 & 51 & $52 *$ & 1,5 \\
\hline $\mathrm{CO}_{4}(\mathrm{CO})_{12}$ & 571,86 & - & $60 *$ & - & muy bajo \\
\hline $\mathrm{Cr}(\mathrm{CO})_{6}$ & 220,06 & 1,77 & $110^{*}$ & 151 & 0,4 \\
\hline $\mathrm{Fe}_{2}(\mathrm{CO})_{9}$ & 363,79 & 2,08 & $80 *$ & - & - \\
\hline $\mathrm{Fe}(\mathrm{CO})_{5}$ & 195,90 & 1,46 & -25 & 103 & 30,5 \\
\hline $\mathrm{Fe}(\mathrm{CO})_{4}$ & 167,89 & 2,00 & $\begin{array}{l}\text { aprox. } \\
140^{*}\end{array}$ & - & - \\
\hline $\mathrm{Mo}(\mathrm{CO})_{6}$ & 264,00 & 1,96 & $150 *$ & 156 & 0,2 \\
\hline $\mathrm{Ru}(\mathrm{CO})_{5}$ & 241,12 & - & -22 & - & - \\
\hline$W(C O)_{6}$ & 351,91 & 2,65 & $\begin{array}{l}\text { aprox. } \\
150^{*}\end{array}$ & 175 & 0,1 \\
\hline
\end{tabular}

en monóxido de carbono y partículas de níquel metálico; el cobalto hidrocarbonilo se descompone en cobalto octacarbonilo e hidrógeno y el hierro pentacarbonilo, en nonacarbonilo de hierro y monóxido de carbono.

Los carbonilos metálicos pueden utilizarse para aislar ciertos metales, como el níquel, de minerales complejos, para producir acero al carbono y para el metalizado por vapor. También se utilizan como catalizadores en reacciones orgánicas (por ejemplo, el cobalto hidrocarbonilo o el níquel carbonilo en la oxidación de olefinas; el octacarbonilo de cobalto para la síntesis de aldehídos, o el níquel carbonilo para la síntesis de ésteres acrílicos). EI hierro pentacarbonilo se utiliza como catalizador para varias reacciones orgánicas y se descompone para formar un polvo muy fino de hierro de muy alto grado de pureza (llamado carbonilo de hierro) que se utiliza en las industrias informática y electrónica. El metilciclopentadienil manganeso tricarbonilo (M M T) $\left(\mathrm{CH}_{3} \mathrm{C}_{5} \mathrm{H}_{4} \mathrm{Mn}(\mathrm{CO})_{3}\right)$ es un aditivo antidetonante para la gasolina y se trata con más detalle en el artículo "M anganeso".

\section{Riesgos para la salud}

La toxicidad de un carbonilo metálico depende de la toxicidad del monóxido de carbono y del metal del que se deriva, así como de su volatilidad y de la inestabilidad del propio carbonilo. La vía principal de exposición es la inhalación, aunque se puede producir absorción cutánea en el caso de los carbonilos líquidos. La toxicidad aguda relativa ( $D L_{50}$ en la rata) del níquel carbonilo, el cobalto hidrocarbonilo y del hierro pentacarbonilo puede expresarse mediante la razón 1:0,52:0,33. La exposición por inhalación a estas sustancias en animales experimentales induce neumonitis intersticial aguda, con edema pulmonar y daño capilar, además de lesiones cerebrales, hepáticas y renales.

A juzgar por los pocos informes que existen sobre la toxicidad del cobalto hidrocarbonilo y del hierro pentacarbonilo, estos carbonilos no representan un riesgo importante para la salud en la industria. No obstante, el hierro pentacarbonilo puede formarse inadvertidamente cuando se almacena monóxido de carbono, o una mezcla de gases que lo contenga, a presión en botellas cilíndricas o cuando se distribuye por tuberías de acero, cuando se produce gas ciudad mediante el reformado del petróleo, o cuando se realizan soldaduras por gas. La presencia de monóxido de carbono en las descargas de emisión de los altos hornos, los hornos de arco eléctrico y los cubilotes durante la fabricación del acero también pueden dar lugar a la formación de hierro pentacarbonilo.

\section{Medidas de salud y seguridad}

Para el almacenamiento de los carbonilos metálicos es indispensable adoptar precauciones especiales; su manipulación debe mecanizarse tanto como sea posible y ha de evitarse su decantación. L os recipientes y tuberías deben purgarse con un gas inerte (como nitrógeno, dióxido de carbono, etc.) antes de ser abiertos, y los residuos de carbonilo quemarse o neutralizarse con agua de bromo. Cuando exista riesgo de inhalación, los trabajadores deberán contar con respiradores de suministro de aire o respiradores autónomos. Los talleres estarán dotados de un sistema de ventilación de tiro descendente.

\section{Níquel carbonilo}

El níquel carbonilo $\left(\mathrm{Ni}(\mathrm{CO})_{4}\right)$ se utiliza principalmente como intermediario en el proceso $M$ ond de refinado del níquel. También se emplea para el metalizado por vapor en la industria metalúrgica y electrónica y como catalizador en la síntesis de monómeros acrílicos en la industria del plástico. La formación inadvertida de níquel carbonilo puede tener lugar en los procesos industriales en que se utilizan catalizadores de níquel, como la gasificación del carbón, el refinado del petróleo y las reacciones de hidrogenación, o durante la combustión del papel copia recubierto de níquel que se utiliza en los formularios comerciales sensibles a la presión.

\section{Riesgos}

La exposición aguda accidental por inhalación de níquel carbonilo produce generalmente síntomas inmediatos leves e inespecíficos como náuseas, vértigo, cefalea, disnea y dolor en el pecho. E stos síntomas iniciales suelen desaparecer al cabo de unas horas. Transcurridas de 12 a 36 horas, y en ocasiones incluso 5 días después de la exposición, se desarrollan síntomas pulmonares graves con tos, disnea, taquicardia, cianosis, una gran debilidad y, con frecuencia, trastornos gastrointestinales. Se han producido muertes de 4 a 13 días después de la exposición al níquel carbonilo por neumonitis intersticial, hemorragia cerebral o edema cerebral. Además de las lesiones patológicas en pulmones y cerebro, se han observado lesiones en el hígado, los riñones, las glándulas suprarrenales y el bazo. En los pacientes que sobreviven a la intoxicación aguda por níquel carbonilo, la insuficiencia pulmonar causa generalmente una convalecencia prolongada. El níquel carbonilo es cancerígeno y teratógeno en ratas. La U nión Europea ha clasificado el níquel carbonilo como un teratógeno animal. Los procesos en que se utiliza níquel carbonilo presentan un elevado riesgo de accidentes, pues puede producirse un incendio o una explosión cuando éste se expone al aire, al calor, a la llama o a oxidantes. La descomposición del níquel carbonilo presenta el riesgo adicional de toxicidad por la inhalación de sus productos de degradación, monóxido de carbono y partículas finas de níquel metálico.

La exposición crónica de los trabajadores a la inhalación de concentraciones atmosféricas bajas de níquel carbonilo $\left(0,007\right.$ a $\left.0,52 \mathrm{mg} / \mathrm{m}^{3}\right)$ puede producir síntomas neurológicos (como insomnio, cefalea, vértigo y pérdida de memoria) y de otro tipo (opresión en el pecho, sudoración excesiva, alopecia). En trabajadores expuestos de forma crónica al níquel carbonilo se han observado alteraciones electroencefalográficas y un aumento en la actividad de la monoamino oxidasa en suero. En 
un estudio citogenético sobre trabajadores expuestos crónicamente al níquel carbonilo se observó un efecto sinérgico entre el consumo de tabaco y la exposición al níquel carbonilo en la frecuencia de intercambio genético entre cromátidas hermanas.

\section{Medidas de salud y seguridad}

Prevención de incendios y explosiones. Por su inflamabilidad y su tendencia a explotar, el níquel carbonilo debe conservarse en recipientes herméticamente cerrados, en lugar fresco y bien ventilado, y lejos de cualquier fuente de calor y oxidantes, como ácido nítrico y cloro. Se debe prohibir la presencia de llamas y fuentes de inflamación en los lugares en que se manipula, usa o almacena níquel carbonilo. El níquel carbonilo debe transportarse en botellas de acero. En caso de incendio, se deberán utilizar extintores de espuma, de polvo químico o de $\mathrm{CO}_{2}$ en lugar de agua, que podría extender y propagar el fuego.

Protección de la salud. Además de las medidas de vigilancia médica recomendadas para todos los trabajadores expuestos al níquel, las personas expuestas profesionalmente al níquel carbonilo deben someterse regularmente, en general una vez al mes, a controles biológicos de la concentración de níquel en orina. Las personas que entren en espacios cerrados en los que puedan estar expuestas al níquel carbonilo deben utilizar un respirador con suministro de aire y un arnés adecuado con un cable de seguridad tendido hasta otro trabajador que se encuentre fuera de ese espacio. Los instrumentos analíticos necesarios para la monitorización atmosférica continua del níquel carbonilo son: a) espectroscopios de absorción de infrarrojos de Fourier, b) cromatógrafos de plasma y c) detectores de quimioluminiscencia. También es posible analizar la presencia de níquel carbonilo en muestras de aire mediante d) cromatografía de gases, e) espectrofotometría de absorción atómica y f) procedimientos colorimétricos.

Tratamiento. Cuando se sospeche que un trabajador ha recibido una exposición aguda al níquel carbonilo, se le debe retirar inmediatamente del lugar y quitarle la ropa contaminada. Además, se le debe administrar oxígeno y mantenerlo en reposo hasta que lo vea un médico. Toda la orina producida durante este tiempo se guardará para realizar un análisis de níquel. La gravedad de la intoxicación aguda por níquel carbonilo se mide por las concentraciones de níquel en la orina durante los 3 días siguientes a la exposición. La exposición puede clasificarse de "leve" si la muestra de orina de las primeras 8 horas tiene una concentración de níquel inferior a $100 \mu \mathrm{g} / \mathrm{l}$; "moderada", si la concentración de níquel es de 100 a $500 \mu \mathrm{g} / \mathrm{l}$; y "grave", si la concentración de níquel supera los $500 \mu \mathrm{g} / \mathrm{l}$. El dietilditiocarbamato sódico es el quelante más adecuado para la intoxicación aguda por níquel carbonilo. Entre las medidas terapéuticas complementarias se encuentran el reposo en cama, la administración de oxígeno, corticosteroides y antibióticos profilácticos. Puede existir simultáneamente intoxicación por monóxido de carbono, que requiere tratamiento.

\section{MOLIBDENO}

\section{Distribución y usos}

El molibdeno (M o) está ampliamente distribuido por la corteza terrestre, pero sólo existen minas de este elemento en algunos países; hay muy pocos depósitos de mineral molibdenita ( $\mathrm{M} \mathrm{OSO}_{2}$ ) que tengan una calidad suficientemente alta. Cierta cantidad de molibdeno se obtiene como subproducto durante el proceso de los minerales de cobre. Las centrales eléctricas que utilizan carbón pueden ser fuentes importantes de molibdeno. EI molibdeno es un oligoelemento esencial.

Forma una gran variedad de compuestos comercialmente útiles con las valencias $0,+2,+3,+4,+5 y+6$. M odifica rápidamente su estado de valencia (se desproporciona) con cambios mínimos en las condiciones externas. Muestra una fuerte tendencia a formar complejos; con excepción de los sulfuros y los haluros, existen muy pocos compuestos simples más. EI molibdeno +6 forma ácidos isopólicos y heteropólicos.

M ás del $90 \%$ del molibdeno que se produce se utiliza como elemento de aleación para el hierro, el acero y metales no ferrosos, especialmente por sus propiedades de resistencia al calor; el resto se utiliza en la fabricación de productos químicos y lubricantes. Como aleación del acero, el molibdeno se utiliza en la industria eléctrica, electrónica, militar y automovilística, así como en ingeniería aeronáutica. 0 tro uso importante del molibdeno es la producción de pigmentos, tintes y lacas de molibdeno inorgánico. U na cantidad pequeña, aunque cada vez más importante, demolibdeno seutiliza como elemento traza en losfertilizantes.

El compuesto de molibdeno más importante es el trióxido de molibdeno $\left(\mathrm{M} \mathrm{OO}_{3}\right)$, que se obtiene por calcinación del mineral de sulfuro. El trióxido de molibdeno puro se utiliza para la fabricación de productos químicos y catalizadores, y también se añade al acero como agente de aleación. Se emplea asimismo como catalizador en la industria del petróleo y como componente de cerámicas, barnices y pigmentos. EI disulfuro de molibdeno $\left(\mathrm{M} \mathrm{OS}_{2}\right)$ se usa como lubricante resistente a altas temperaturas o como aditivo para lubricantes. El hexacarbonilo de molibdeno ( $\left.\mathrm{M} \mathrm{O}(\mathrm{CO})_{6}\right)$ es la materia prima utilizada para la fabricación de colorantes orgánicos de molibdeno y cada vez se emplea más para el recubrimiento con molibdeno mediante descomposición térmica.

L os compuestos de molibdeno se utilizan mucho como catalizadores y activadores o promotores de catalizadores, especialmente en las operaciones de hidrogenación-cracking, alquilación y reformado en la industria petrolífera. También se utilizan como reactivos de laboratorio (fosfomolibdatos), en galvanoplastia y en los procesos de curtido.

\section{Riesgos}

Puede producirse una exposición al polvo y a los humos del molibdeno y sus óxidos y sulfuros durante el proceso y la utilización industrial del molibdeno y sus compuestos, especialmente cuando los tratamientos se realizan a altas temperaturas, como en los hornos eléctricos. La exposición al disulfuro de molibdeno en forma de rociado como lubricante, al molibdeno hexacarbonilo y a sus productos de degradación durante el platinado con molibdeno, a las nieblas de hidróxido de molibdeno $\left(\mathrm{M} \mathrm{O}(\mathrm{OH})_{3}\right)$ durante la galvanoplastia y a los humos de trióxido de molibdeno, que se sublima a temperaturas superiores a los $800{ }^{\circ} \mathrm{C}$, puede ser peligrosa para la salud.

Según los resultados obtenidos en experimentos con animales, los compuestos de molibdeno son sumamente tóxicos. La intoxicación aguda produce irritación gastrointestinal grave con diarrea, coma y muerte por insuficiencia cardíaca. En los estudios en animales se han descrito efectos pulmonares similares a la neumoconiosis. Los trabajadores expuestos al molibdeno puro 0 al óxido de molibdeno $\left(\mathrm{M} \mathrm{OO}_{3}\right)$ en concentraciones de 1 a $19 \mathrm{mg}$ $\mathrm{Mo} / \mathrm{m}^{3}$ durante un período de 3 a 7 años han desarrollado neumoconiosis. La inhalación de polvo de molibdeno de las aleaciones o carburos puede causar la "enfermedad pulmonar por metales duros".

El riesgo derivado de la exposición es muy variable. Los compuestos insolubles de molibdeno, como el disulfuro de molibdeno y muchos de sus óxidos y haluros, se caracterizan por su baja toxicidad; sin embargo, los compuestos solubles, es decir, aquellos en los que el molibdeno se encuentra en forma de anión 
(como el molibdenato sódico- $\mathrm{Na}_{2} \mathrm{M} \mathrm{OO}_{4} \cdot 2 \mathrm{H}_{2} \mathrm{O}$ ), son considerablemente más tóxicos y deben manipularse con precaución. $\mathrm{H}$ ay que tomar también las precauciones necesarias para evitar la sobreexposición a los humos de molibdeno generados, por ejemplo, durante la descomposición térmica del molibdeno hexacarbonilo.

La exposición al trióxido de molibdeno produce irritación ocular y de las mucosas de la nariz y la garganta. U n síntoma característico de la intoxicación por molibdeno es la anemia, con concentraciones bajas de hemoglobina y disminución del recuento de células.

En bovinos, la administración de niveles elevados de molibdeno en la dieta provocó deformidades en las articulaciones de las extremidades. También se ha descrito una frecuencia anormalmente alta de gota entre los químicos que manipulan soluciones de molibdeno y tungsteno y se ha demostrado la relación existente entre el contenido en molibdeno de los alimentos y la incidencia de gota, uricemia y actividad de la xantinooxidasa.

\section{Medidas de seguridad}

Para el trabajo con molibdeno en la industria, se deben instalar sistemas de ventilación con extracción de gases adecuados para recoger los humos en el lugar en que se producen. Cuando las medidas de ingeniería y las prácticas sean insuficientes o mientras se procede a su instalación, los trabajadores que deban entrar en tanques 0 recipientes cerrados o por cuestiones de emergencia deberán utilizar equipos respiratorios. En las industrias de pinturas, estampación y recubrimientos, deberán existir sistemas de ventilación local y general adecuados, con extracción de gases, y se deberán utilizar gafas y ropa de protección, protectores faciales y equipos de respiración para reducir la exposición de los trabajadores que manipulen compuestos secos de molibdeno para la fabricación de colores inorgánicos y orgánicos.

\section{NIOBIO}

\section{Distribución y usos}

El niobio $(\mathrm{Nb})$ se encuentra con otros elementos, como el titanio $(\mathrm{T} i)$, el circonio $(\mathrm{Zr})$, el tungsteno $(\mathrm{W})$, el torio $(\mathrm{T} \mathrm{h})$ y el urano $(\mathrm{U})$, en minerales como la tantalita-columbita, la fergusonita, la samarskita, el pirocloro, la koppita y la loparita. Los principales depósitos están situados en Australia y Nigeria, pero en los últimos años se han descubierto algunos muy importantes en U ganda, K enya, Tanzania y C anadá.

El niobio se utiliza mucho en la industria del electrovacío, así como en la fabricación de ánodos, rejillas, condensadores electrolíticos y rectificadores. En la ingeniería química, el niobio se emplea como material resistente a la corrosión para termointercambiadores, filtros, válvulas de aguja, etc. Con aleaciones de niobio se fabrican herramientas de corte de gran calidad y materiales magnéticos. Para aparatos termonucleares se usa la aleación de ferroniobio.

EI niobio y sus aleaciones refractarias encuentran empleo en el ámbito de la tecnología de los cohetes, de los aviones supersónicos, del equipamiento para vuelos interplanetarios y de los satélites. EI niobio se utiliza además en cirugía.

\section{Riesgos}

Durante la extracción y la concentración del mineral de niobio, así como durante el tratamiento del concentrado, los obreros pueden estar expuestos a riesgos generales, como el polvo y los humos, que son típicos de estas operaciones. En las minas, la acción del polvo puede agravarse por la exposición a sustancias radiactivas como el torio y el uranio.

\section{Toxicidad}

Gran parte de la información sobre el comportamiento del niobio en el organismo se basa en estudios con el par de isótopos radiactivos ${ }^{95} \mathrm{Zr}-{ }^{95} \mathrm{Nb}$, un producto común de la fisión nuclear. $\mathrm{El}{ }^{95} \mathrm{Nb}$ es producto del ${ }^{95} \mathrm{Zr}$. Existe un estudio sobre la incidencia de cáncer en mineros de niobio expuestos a los productos de desintegración del radón y el torio en el que se encontró una asociación entre el cáncer de pulmón y la radiación alfa acumulada.

Las inyecciones intravenosas e intraperitoneales de niobio radiactivo y sus compuestos muestran una distribución bastante uniforme en todo el organismo, con tendencia a acumularse en el hígado, los riñones, el bazo y la médula ósea. La eliminación del niobio radiactivo del organismo puede acelerarse apreciablemente mediante la inyección de dosis masivas de nitrato de circonio. Después de inyecciones intraperitoneales de niobio estable en forma de niobato potásico, la $\mathrm{DL}_{50}$ para las ratas fue de 86 a $92 \mathrm{mg} / \mathrm{kg}$ y de $13 \mathrm{mg} / \mathrm{kg}$ para los ratones. EI niobio metálico no se absorbe en el estómago ni en los intestinos. $L a D_{50}$ del pentacloruro de niobio en estos órganos fue de $940 \mathrm{mg} / \mathrm{kg}$ para las ratas, mientras que la cifra correspondiente para el niobato potásico fue de $3.000 \mathrm{mg} / \mathrm{kg}$. La administración intravenosa, intraperitoneal u oral de compuestos de niobio produce un marcado efecto sobre los riñones. Este efecto puede atenuarse mediante la administración preventiva de ácido ascórbico. La administración oral de pentacloruro de niobio ocasiona, además, una irritación aguda de las membranas mucosas del esófago y el estómago y cambios hepáticos. La exposición crónica durante 4 meses provoca alteraciones temporales en la composición de la sangre (leucocitosis, hipotrombinemia).

El niobio inhalado se retiene en los pulmones, que son el órgano crítico en caso de exposición al polvo. La inhalación diaria de polvo de nitruro de niobio en una concentración de $40 \mathrm{mg} / \mathrm{m}^{3}$ de aire produce síntomas de neumoconiosis en pocos meses, aun cuando no se manifiesten signos visibles de acción tóxica. Entre dichos síntomas se encuentran: un engrosamiento de los septos interalveolares, el desarrollo de una cantidad considerable de fibras colágenas en el tejido peribronquial y perivascular y descamación del epitelio bronquial. Cambios semejantes aparecen por la administración intratraqueal de polvo de pentóxido de niobio, pero en este caso el polvo llega incluso a los ganglios linfáticos.

\section{Medidas de salud y seguridad}

D eben controlarse estrictamente las concentraciones atmosféricas de aerosoles de aleaciones y compuestos de niobio que contengan elementos tóxicos, como flúor, manganeso o berilio. Durante la extracción y la concentración de mineral de niobio que contenga uranio y torio, deberá protegerse al trabajador contra la radiactividad. Un diseño de ingeniería adecuado debe incluir una ventilación adecuada, con la entrada de aire fresco necesaria para controlar el polvo en el aire de la mina. En la extracción del niobio puro de sus compuestos por metalurgia de polvos, el lugar de trabajo deberá mantenerse libre de polvo y humos de niobio y los trabajadores deberán contar con protección contra los productos químicos, como los álcalis cáusticos y el benceno. Además, se recomienda realizar reconocimientos médicos regulares que incluyan pruebas de la función pulmonar. 


\section{NIQUEL}

\section{F. William Sunderman, Jr.}

Entre los compuestos del níquel $(\mathrm{Ni})$ de interés se encuentran el óxido ( $\mathrm{NiO}$ ), hidróxido $\left(\mathrm{Ni}(\mathrm{OH})_{2}\right)$, subsulfuro $\left(\mathrm{Ni}_{3} \mathrm{~S}_{2}\right)$, sulfato $\left(\mathrm{NiSO}{ }_{4}\right)$ y cloruro de níquel $\left(\mathrm{NiCl}_{2}\right)$. El níquel carbonilo $\left(\mathrm{Ni}(\mathrm{CO})_{4}\right)$ se trata en el artículo dedicado a los metalcarbonilos.

\section{Distribución y usos}

El níquel (Ni) representa entre un 5 y un $50 \%$ del peso de los meteoritos y se encuentra en forma de minerales, combinado con azufre, oxígeno, antimonio, arsénico y/ o sílice. Los depósitos de minerales de importancia comercial están constituidos principalmente por óxidos (como minerales de laterita que contienen óxidos de níquel y hierro mezclados) y sulfuros. $L a$ pentlandita ((N iFe $\left.)_{9} \mathrm{~S}_{8}\right)$, el principal mineral de sulfuro, se deposita habitualmente junto con pirrotita $\left(\mathrm{Fe}_{7} \mathrm{~S}_{6}\right)$, calcopirita $\left(\mathrm{CuFeS}_{2}\right)$ y pequeñas cantidades de cobalto, selenio, teluro, plata, oro y platino. Los principales depósitos de minerales de níquel se encuentran en Canadá, Rusia, Australia, Nueva Caledonia, Indonesia y Cuba.

A los minerales sulfuro que contienen níquel, cobre y hierro, se aplican métodos mecánicos de concentración, como la flotación y la separación magnética, después de triturar y moler el mineral. El concentrado de níquel se convierte en residuo sulfurado de níquel mediante calcinación o sinterización. A continuación, este residuo sulfurado se refina por electrólisis o mediante el proceso $\mathrm{M}$ ond. Durante el mismo, el residuo se somete a triturado y calcinación y se trata con monóxido de carbono a $50^{\circ} \mathrm{C}$ para formar níquel carbonilo gaseoso $\left(\mathrm{Ni}(\mathrm{CO})_{4}\right)$, que se descompone a temperaturas de entre 200 y $250{ }^{\circ} \mathrm{C}$ para depositar el polvo de níquel puro. La producción mundial de níquel es de aproximadamente 70 millones de $\mathrm{kg} / \mathrm{año}$.

Se producen comercialmente más de 3.000 aleaciones y compuestos de níquel. El acero inoxidable y otras aleaciones de $\mathrm{Ni}$-Cr-Fe se utilizan mucho para la fabricación de equipo resistente a la corrosión tanto en arquitectura como para utensilios de cocina. El metal M onel y otras aleaciones de $\mathrm{Ni}$ - $\mathrm{C}$ u se emplean para la fabricación de monedas y en la maquinaria de las industrias de alimentación y lácteas. Para la fabricación de imanes y la producción de catalizadores (por ejemplo, el níquel Raney) se usan aleaciones de $\mathrm{Ni}$-Al. L as aleaciones de $\mathrm{Ni}$ - $\mathrm{Cr}$ se destinan a elementos de calefacción, turbinas de gas y motores de reacción, y las aleaciones de níquel con metales preciosos se emplean en joyería. El níquel metálico, sus compuestos y sus aleaciones tienen muchos usos más, como el galvanizado, la fabricación de cintas magnéticas y componentes informáticos, varillas para soldadura al arco eléctrico, prótesis quirúrgicas y dentales, baterías de níquel-cadmio, pigmentos para pinturas (como el amarillo de titanato de níquel), moldes para recipientes cerámicos y de vidrio, y catalizadores para reacciones de hidrogenación, síntesis orgánica y el paso final de metanazación en la gasificación del carbón. También puede producirse una exposición profesional al níquel durante las operaciones de reciclado, ya que los materiales que contienen níquel, y en especial los que proceden de la industria del acero, se funden, se refinan y se utilizan con frecuencia para preparar aleaciones de composición similar a las introducidas en el proceso de reciclado.

\section{Riesgos}

L os riesgos para el hombre derivados de la exposición profesional a los compuestos de níquel pueden dividirse en tres categorías principales:

1. alergias;

2. rinitis, sinusitis y enfermedades respiratorias,
3. cánceres de las cavidades nasales, de pulmón y de otros órganos.

Los riesgos para la salud del níquel carbonilo se comentan en el artículo de los metalcarbonilos.

Alergia. El níquel y los compuestos de níquel se encuentran entre las causas más frecuentes de dermatitis alérgicas por contacto. Este problema no se limita a las personas expuestas profesionalmente a los compuestos de níquel, sino que se observa en la población en general debido a la exposición al níquel contenido en monedas, joyas, relojes y aprestos de tejidos. En las personas expuestas al níquel, la dermatitis comienza generalmente como un eritema papular en las manos. La piel se vuelve gradualmente eczematosa y, en la fase crónica, suele desarrollarse liquenificación. La sensibilización al níquel también produce conjuntivitis, neumonitis eosinófila y reacciones locales o sistémicas a las prótesis que contienen níquel (por ejemplo, clavos intraóseos, piezas dentarias, válvulas cardíacas artificiales y cables de los marcapasos). La ingestión de agua contaminada con níquel 0 de alimentos ricos en níquel puede exacerbar el eczema de las manos en las personas sensibles a este metal.

Rinitis, sinusitis y enfermedades respiratorias. Los trabajadores de las refinerías de níquel y de las industrias de galvanoplastia expuestos a la inhalación de polvo de níquel o aerosoles de compuestos solubles de níquel pueden desarrollar enfermedades crónicas de las vías respiratorias altas, como rinitis hipertrófica, sinusitis nasal, anosmia, poliposis nasal y perforación del tabique nasal. También se han descrito enfermedades crónicas de las vías respiratorias bajas, como bronquitis o fibrosis pulmonar, pero con una frecuencia muy baja. R endall y cols. (1994) describieron un caso de exposición aguda mortal por inhalación de partículas de níquel en un trabajador del proceso de este metal mediante arco eléctrico. Los autores resaltan la importancia de utilizar el equipo protector en este tipo de procesos con electrodos de níquel.

Cáncer. Los estudios epidemiológicos realizados sobre trabajadores de refinerías de níquel en Canadá, Gales, Alemania, N oruega y Rusia ponen de manifiesto un aumento en la tasa de mortalidad por cáncer de pulmón y de las cavidades nasales. También se ha descrito una mayor incidencia de otro tipo de tumores malignos, como carcinomas de la laringe, riñón, próstata o estómago y sarcoma de tejidos blandos en determinados grupos de trabajadores de las refinerías de níquel, aunque es discutible la significación estadística de estas observaciones. El aumento del riesgo de cáncer de pulmón y de las cavidades nasales se ha observado principalmente en los trabajadores que participan en los procesos que conllevan una elevada exposición al níquel, como la calcinación, fundido y electrólisis. Aunque el riesgo de este tipo de cánceres se ha asociado generalmente con la exposición a los compuestos insolubles de níquel, como el subsulfuro o el óxido de níquel, también se ha relacionado con la exposición a compuestos solubles de níquel durante los procesos de electrólisis.

Los estudios epidemiológicos sobre el riesgo de cáncer entre los trabajadores de las industrias en que se utiliza el níquel arrojan, por lo general, resultados negativos, pero estudios más recientes ponen de manifiesto un riesgo de cáncer de pulmón ligeramente superior entre los trabajadores que participan en los procesos de soldadura, triturado y galvanizado, y en la fabricación de baterías. En efecto, suelen estar expuestos a polvo y humos que contienen mezclas de metales cancerígenos, como níquel y cromo o níquel y cadmio. Basándose en una evaluación de los estudios epidemiológicos, la Agencia Internacional para la Investigación sobre el Cáncer (IARC) concluyó en 1990 que: "existen pruebas suficientes en humanos del potencial 
cancerígeno del sulfato de níquel y de las combinaciones de sulfuros y óxidos de níquel presentes en la industria del refinado del níquel. No existen, sin embargo, pruebas concluyentes en humanos de la carcinogenicidad del níquel y sus aleaciones". Los compuestos de níquel se han clasificado como cancerígenos para el hombre (Grupo 1) y el níquel metálico como posible cancerígeno para el hombre (G rupo 2B).

E fectos renales. Los trabajadores con un alto grado de exposición a los compuestos solubles de níquel pueden desarrollar alteraciones en la función de los túbulos renales, que se manifiestan por un aumento en la excreción renal de $\beta_{2}$-microglobulina $\left(\beta_{2} \mathrm{M}\right)$ y $\mathrm{N}$-acetil-glucosaminidasa (NAG).

\section{Medidas de salud y seguridad}

En 1994, la Nickel Producers Evironmental Research A ssociation ( $N$ iPER A) y el $\mathrm{N}$ ickel Development Institute ( $\mathrm{NiDI}$ ) desarrollaron un protocolo general para vigilar la salud de los trabajadores expuestos al níquel. Sus elementos clave son los siquientes:

Evaluación previa a la contratación. El objetivo de este reconocimiento es identificar situaciones médicas preexistentes que puedan influir en la contratación y el puesto de trabajo, además de recabar datos iniciales para comparar cambios funcionales, fisiológicos o patológicos posteriores. La evaluación incluye: a) una historia médica y profesional detallada, centrada en los problemas pulmonares, la exposición a toxinas pulmonares, alergias pasadas o presentes (especialmente al níquel), asma y hábitos personales (por ejemplo, consumo de tabaco o de alcohol); b) un reconocimiento físico completo, con especial atención a los problemas respiratorios y cutáneos; c) determinación del equipo de protección respiratoria que se puede utilizar. El estudio puede incluir radiografías torácicas, pruebas de función pulmonar, audiometrías y examen de la vista. Las pruebas de sensibilidad al níquel con parches cutáneos no se suelen realizar de forma rutinaria, pues podrían sensibilizar a los sujetos. Si la organización piensa establecer un programa de control biológico de los trabajadores expuestos al níquel (véase más adelante), se determinarán las concentraciones basales de níquel en orina o suero durante la evaluación previa a la contratación.

Evaluación periódica. La finalidad de los reconocimientos médicos periódicos, generalmente anuales, es controlar la salud general del trabajador y evaluar aspectos específicos relacionados con el níquel. Este reconocimiento incluye la historia de las enfermedades recientes, una revisión de los síntomas, un reconocimiento físico y una nueva evaluación de la capacidad del trabajador para utilizar el equipo de protección respiratoria necesario para tareas específicas. Los síntomas pulmonares se evalúan utilizando un cuestionario estándar sobre la bronquitis crónica. La realización de radiografías torácicas es un requisito legal en algunos países; las pruebas de función pulmonar (como la capacidad vital forzada (FVC) y el volumen espiratorio forzado en 1 segundo $\left(F V_{1}\right)$ se dejan por lo general a criterio del médico. Los procedimientos de detección precoz del cáncer (como rinoscopia, radiografías de senos nasales, biopsias de la mucosa nasal o estudios de citología exfoliativa) pueden estar indicados en los trabajadores sometidos a una exposición de alto riesgo, como en las refinerías de níquel.

Control biológico. L os análisis de las concentraciones de níquel en muestras de orina y suero pueden reflejar una exposición reciente de los trabajadores al níquel metálico y a los compuestos solubles de níquel, pero no proporcionan una indicación fiable de la carga total de níquel en el organismo. Sunderman y cols. (1986) han resumido los usos y limitaciones del control biológico de los trabajadores expuestos al níquel. En 1994, la Comisión de Toxicología de la
Unión Internacional de Química Pura y Aplicada (IUPAC) publicó un informe técnico sobre el análisis del níquel en los líquidos corporales. El Comité Nacional de Concentraciones M áximas en el Lugar de Trabajo (N M WCC) de los Países Bajos propuso que una concentración de níquel en orina de $40 \mu \mathrm{g} / \mathrm{g}$ creatinina o de níquel en suero de $5 \mu \mathrm{g} /$ I (medidas en muestras obtenidas al final de una jornada laboral o de un turno) debían considerarse como límites de aviso para realizar una exploración adicional de los trabajadores expuestos al níquel metálico o a los compuestos solubles de níquel. Si se aplica un programa de control biológico, debe ir acompañado de un programa de control ambiental, para que los datos biológicos no se utilicen en sustitución de los cálculos de exposición. En 1995, la UK Health and Safety Executive desarrolló un método estándar para el análisis del níquel en el ambiente del lugar de trabajo.

Tratamiento. En un caso de un grupo de trabajadores que bebieron accidentalmente agua muy contaminada con cloruro y sulfato de níquel, resultó eficaz el tratamiento conservador con líquidos intravenosos para inducir la diuresis (Sunderman y cols. 1988). EI mejor tratamiento para la dermatitis por níquel es evitar la exposición y prestar especial atención a las prácticas de higiene en el trabajo. El tratamiento para la intoxicación aguda por níquel carbonilo se trata en el artículo sobre los metalcarbonilos.

\section{O SMIO}

\section{Distribución y usos}

El osmio (O s) se encuentra casi exclusivamente en el osmiridio, una aleación natural de osmio e iridio, y en todos los minerales de platino. Los principales depósitos se localizan en los U rales, Canadá y Colombia, aunque también existen depósitos de menor importancia en Australia y en Alaska, California y Oregón, en Estados Unidos.

El osmio se alea fácilmente con los otros metales del grupo del platino y con el hierro, el cobalto y el níquel. También forma compuestos intermedios no dúctiles con el estaño y el zinc. U na de las características distintivas del osmio es la facilidad con que forma tetróxido de osmio $\left(\mathrm{O} \mathrm{SO}_{4}\right)$. El osmio en polvo tiene siempre el olor característico del tetróxido ya que incluso a temperatura ambiente se oxida por la acción del aire para formar $\mathrm{O} \mathrm{SO}_{4}$, aunque sólo sea en una pequeña proporción. EI tetróxido de osmio es sumamente volátil y tiene un olor desagradable, de donde le viene el nombre al elemento (osme $=$ olor). Este compuesto es un poderoso oxidante y se convierte fácilmente en dióxido de osmio $\left(\mathrm{O} \mathrm{SO}_{2}\right)$ e incluso en osmio metálico. En presencia de álcalis, forma compuestos inestables como el $\mathrm{O} \mathrm{sO}_{4} \cdot 2 \mathrm{~K} \mathrm{OH}$. Al calentarse, el osmio forma rápidamente disulfuro de osmio $\left(\mathrm{OsS}_{2}\right)$ y también los fluoruros $\mathrm{O} \mathrm{sF}_{4}$, $\mathrm{O} \mathrm{sF}_{6}$ and $\mathrm{O} \mathrm{sF}_{8}$. C uando se trata con cloro a altas temperaturas se producen diversos cloruros de osmio. Con monóxido de carbono se forman carbonilos. Además, el osmio es capaz de formar una serie de complejos con el anión complejo que contiene osmio, como por ejemplo, el hexacloruro de osmio amónico $\left.\left(\left(\mathrm{NH}_{4}\right)_{2} \mathrm{O} \mathrm{sC} \mathrm{I}\right)_{6}\right)$.

El osmio se utiliza como catalizador en la síntesis del amoníaco y en la hidrogenación de compuestos orgánicos. Aleado con indio se emplea para la fabricación de agujas de compases y rodamientos de maquinaria de precisión. Se puede encontrar en distintas partes de la maquinaria de relojería, en cerraduras y en las puntas de las plumas estilográficas. EI tetróxido de osmio, incorrectamente denominado ácido ósmico, se 
utiliza como agente oxidante, en especial para convertir las olefinas en glicoles. Los cloroosmiatos se utilizan para reemplazar las sales de oro en fotografía.

\section{Riesgos}

El osmio metálico es inocuo, pero las personas que trabajan en su producción están expuestas a la acción de los vapores de ácidos y de cloro. Los vapores de tetróxido de osmio son tóxicos y sumamente irritantes para los ojos: producen lagrimeo y conjuntivitis incluso en bajas concentraciones. También son irritantes para las vías respiratorias altas y provocan bronquitis, espasmos bronquiales y dificultad respiratoria, que puede durar varias horas. Una exposición más prolongada puede producir lesiones corneales, ceguera, trastornos digestivos y procesos inflamatorios pulmonares y renales. En contacto con la piel, produce una coloración verde o negra de la piel, y dermatitis y ulceraciones.

\section{Medidas de salud y seguridad}

Durante la producción de osmio, deberá existir una ventilación local adecuada, con extracción de gases y, si se utiliza cloro en forma gaseosa, el proceso deberá realizarse en un sistema cerrado. Para controlar la liberación de vapores de tetróxido de osmio en el ambiente de trabajo y evitar la irritación de los ojos y las vías respiratorias, habrá que disponer de un área cerrada y ventilada o de una campana de extracción. Los trabajadores expuestos deberán utilizar ropa protectora, guantes, protección ocular de seguridad química hermética a los gases y equipos de protección respiratoria adecuados. Los envases se almacenarán en locales con ventilación natural. L os vapores de este compuesto tienen un olor intenso y nauseabundo que sirve como señal de alarma de concentraciones tóxicas en el aire, en cuyo caso todo el personal deberá abandonar inmediatamente el área contaminada. La determinación en el aire y en la sangre se realiza por colorimetría del complejo con tiourea.

\section{- Paladio}

\section{Distribución y usos}

El paladio $(\mathrm{Pd})$ se encuentra en la naturaleza con platino o con oro, en forma de seleniuro, y también en los minerales de sulfuro de níquel y en los minerales estibiopaladinita, braggita y porpecita. La concentración de paladio en la corteza terrestre es de $0,01 \mathrm{ppm}$.

El paladio se ha utilizado en aleaciones con oro, plata y cobre en odontología. Las aleaciones de este metal se utilizan asimismo para rodamientos, muelles y volantes de relojes. El paladio se emplea como catalizador en la fabricación de ácido sulfúrico y, en forma de polvo, actúa también como catalizador en procesos de hidrogenación. Se usa esponja de paladio para la separación del hidrógeno de mezclas de gases. Las aleaciones con plata se emplean para contactos eléctricos. Los complejos de paladio (II) se han estudiado como medicamentos antineoplásicos.

El cloruro de paladio $\left(\mathrm{PdCl}_{2} \cdot 2 \mathrm{H}_{2} \mathrm{O}\right)$, o cloruro paladioso, se utiliza en las soluciones fotográficas de viraje y en la fabricación de tinta indeleble. A demás, se emplea para transferir imágenes a porcelana, como agente de electrodeposición para piezas de reloj y para detectar fugas en gasoductos enterrados. EI cloruro de paladio se asocia con cloruro de cobre para catalizar la producción de acetaldehído a partir del etileno.

El óxido de paladio ( $\mathrm{PdO}$ ), u óxido paladioso, se utiliza como catalizador reductor en la síntesis de compuestos orgánicos y el nitrato de paladio ( $\left.\mathrm{Pd}\left(\mathrm{NO}_{3}\right)_{2}\right)$ en la separación de haluros. EI trifluoruro de paladio $\left(\mathrm{PdF}_{3}\right)$ es un activo agente oxidante.

\section{Riesgos}

Los estudios indican casos de alergia y dermatitis por contacto causadas por el paladio de las aleaciones dentales y la joyería fina. Un estudio asocia las aleaciones de paladio con varios casos de estomatitis y reacciones liquenoides orales. En ese mismo estudio, la alergia al paladio se observó principalmente en pacientes sensibles al níquel. El cloruro de paladio produce dermatitis y sensibilización cutánea de tipo alérgico en trabajadores expuestos diariamente. Además, debe considerarse como irritante ocular. Antiguamente, se utilizaba el hidróxido de paladio inyectado para el tratamiento de la obesidad, pero se produjeron necrosis locales y se abandonó esta práctica.

\section{Medidas de salud y seguridad}

C uando se trabaja con paladio y sus compuestos es necesario un sistema de ventilación adecuado con extracción de gases. U na buena higiene personal, el uso de ropa protectora adecuada y la vigilancia médica son medidas importantes para prevenir los riesgos asociados a la sensibilización. D eberán existir las instalaciones sanitarias adecuadas.

\section{Plata}

\section{Distribución y usos}

La plata $(\mathrm{Ag})$ se encuentra en todo el mundo, pero la mayor parte se produce en M éxico, el oeste de Estados U nidos, Bolivia, Perú, C anadá y Australia. Gran parte de ella se obtiene como subproducto de los minerales argentíferos de plomo, zinc y cobre, en los que se encuentra como sulfuro de plata, argentita $\left(\mathrm{Ag}_{2} \mathrm{~S}\right)$. También se recupera durante el tratamiento de los minerales de oro y es un constitutivo esencial del teluro de oro, la calaverita $\left((\mathrm{AuAg}) \mathrm{Te}_{2}\right)$.

Dado que la plata pura es demasiado blanda para la fabricación de monedas, adornos, cuchillerías, objetos y joyería, se endurece aleándola con cobre. Como es muy resistente al ácido acético, en la industria del ácido acético, el vinagre, la sidra y la cerveza se utilizan recipientes de plata. También se emplea en las barras colectoras y devanados de plantas eléctricas, en soldadores de plata, amalgamas dentales, baterías de gran capacidad, cojinetes de motores, objetos de plata de ley y pinturas cerámicas. 0 tras aplicaciones son las aleaciones de broncesoldadura y el plateado de cuentas de vidrio.

La plata se utiliza para la fabricación del formaldehído, acetaldehído y aldehídos superiores por deshidrogenación catalítica de los alcoholes primarios correspondientes. En muchas instalaciones, el catalizador consiste en una capa fina de plata cristalina de muy alta pureza. Un uso importante de la plata es en la fotografía. La reacción única e instantánea de los haluros de plata al exponerlos a la luz es lo que hace que este metal sea prácticamente indispensable en películas, placas y papel de impresión fotográfica.

El nitrato de plata $\left(\mathrm{AgNO}_{3}\right.$ ) se utiliza en fotografía, fabricación de espejos, plateado, teñido, coloración de porcelana y grabado del marfil. Además, es un reactivo importante en química analítica y un intermediario químico. Se emplea en la fabricación de tintas simpáticas e indelebles, como inhibidor de la estática en alfombras y materiales tejidos y como desinfectante del agua. Con fines médicos, se utiliza para la profilaxis de la ophthalmia neonatorum, como antiséptico y como astringente y, en veterinaria, para el tratamiento de las heridas e inflamaciones locales.

EI nitrato de plata es un poderoso agente oxidante y presenta riesgo de incendio, además de ser sumamente cáustico, corrosivo y venenoso. En polvo o en forma sólida es peligroso para los ojos 
y puede producir quemaduras de la conjuntiva, argiria y ceguera.

El óxido de plata $\left(\mathrm{Ag}_{2} \mathrm{O}\right)$ se utiliza para purificar el agua potable, para pulir y colorear el cristal amarillo en la industria del vidrio y como catalizador. En veterinaria, se utiliza en forma de pomada o solución como germicida y parasiticida general. El óxido de plata es, además, un potente oxidante y presenta riesgo de incendio.

El picrato de plata $\left(\left(\mathrm{O}_{2} \mathrm{~N}\right)_{3} \mathrm{C}_{6} \mathrm{H}_{2} \mathrm{OAg} \cdot \mathrm{H}_{2} \mathrm{O}\right)$ se utiliza como antiséptico vaginal $\mathrm{y}$, en veterinaria, contra la vaginitis granular del ganado. Es muy explosivo y tóxico.

\section{Riesgos}

La exposición a la plata puede producir una afección benigna conocida como "argiria". Si se absorbe el polvo del metal o sus sales, la plata se precipita en los tejidos en estado metálico y no puede eliminarse del organismo. La reducción a estado metálico tiene lugar por la acción de la luz en las partes expuestas de la piel y las membranas mucosas visibles o por medio del sulfuro de hidrógeno en otros tejidos. El polvo de plata es irritante y puede producir ulceraciones de la piel y el tabique nasal.

Las ocupaciones que conllevan un mayor riesgo de argiria se dividen en dos grupos:

1. trabajos de manipulación de compuestos de plata, como el nitrato, el fulminato 0 el cianuro, que pueden producir argiria generalizada por inhalación o ingestión de la sal de plata;

2. trabajos de manipulación de plata metálica, pequeñas partículas de la cual pueden penetrar accidentalmente en la piel expuesta, produciendo argiria local por un proceso similar al del tatuaje.

No es probable que se produzca una argiria generalizada con concentraciones de plata respirable en el aire de $0,01 \mathrm{mg} / \mathrm{m}^{3} 0$ dosis orales acumuladas inferiores a 3,8 g. Las personas afectadas por una argiria generalizada suelen apodadas "hombres azules" por sus compañeros de trabajo. La cara, la frente, el cuello, las manos y los antebrazos desarrollan un color gris pizarra oscuro de distribución uniforme y profundidad variable dependiendo del grado de exposición. Pueden observarse cicatrices pálidas de hasta $6 \mathrm{~mm}$ de ancho en la cara, manos y antebrazos debido a los efectos cáusticos del nitrato de plata. Las uñas de los dedos adquieren un color chocolate oscuro. La mucosa bucal presenta un color gris pizarra o azulado. Puede producirse una pigmentación muy ligera en las partes cubiertas de la piel. Las uñas de los pies muestran a veces una ligera decoloración azulada. En la afección llamada argyrosis conjunctivae, el color de la conjuntiva varía de un gris claro a un marrón oscuro, especialmente en la porción palpebral inferior. El borde posterior del párpado inferior, la carúncula, y la plica semilunaris aparecen muy pigmentados y en ocasiones casi negros. EI examen con una lámpara de hendidura revela una red delicada de pigmentación gris claro en la lámina elástica posterior de la córnea (membrana de Descemet), conocida como argyrosis corneae. En los casos de larga duración, se detecta también argirolentis.

En el trabajo con plata metálica, pueden penetrar accidentalmente pequeñas partículas en la superficie de la piel expuesta originando lesiones pigmentadas por un proceso equivalente al del tatuaje. Esto puede ocurrir en los procesos de corte, taladrado, martillado, torneado, gravado, pulido, forjado, soldado y fusión de la plata. La mano izquierda de los plateros suele verse más afectada que la derecha y la pigmentación ocurre en los lugares que presentan heridas por los instrumentos. M uchos de éstos, como las herramientas para grabar, las limas, los cinceles y las brocas son afilados y puntiagudos y pueden producir heridas en la piel. La sierra de contornear, un instrumento parecido a la sierra de marquetería, se puede romper y provocar cortes en las manos. Si la lima se escapa, puede lesionar las manos que manipulan el artículo de plata, lo que ocurre frecuentemente con las puntas de los tenedores. Pequeñas esquirlas de plata pueden alojarse en los dedos de los obreros que estiran el alambre de plata a través de un orificio en las chapas destinadas a tal fin. Los puntos pigmentados varían desde pequeños lunares hasta superficies de $2 \mathrm{~mm} 0$ más de diámetro. Pueden ser lineales 0 redondeados y presentan distintas tonalidades de gris o azul. Las marcas permanecen durante toda la vida y no pueden eliminarse. El uso de guantes es poco práctico.

\section{Medidas de salud y seguridad}

Además de las medidas de prevención técnica necesarias para mantener las concentraciones ambientales de humos y polvo de plata lo más bajas posible y siempre por debajo de los límites de exposición, se recomienda tomar precauciones médicas para prevenir la argiria. Entre ellas se encuentran, sobre todo, los reconocimientos oculares, ya que uno de los signos precoces de la enfermedad es la alteración del color de la membrana de Descemet. Asimismo, es posible realizar un control biológico de la excreción de plata por vía fecal. No existe un tratamiento reconocido para la argiria. Esta afección tiende a estabilizarse cuando se suspende la exposición a la plata. Se ha logrado alguna mejoría clínica administrando agentes quelantes e inyecciones intradérmicas de tiosulfato sódico o ferrocianuro potásico. Se debe evitar la exposición al sol para prevenir una coloración adicional de la piel.

Para evitar los riesgos de incendio y de explosión deben tenerse en cuenta las principales incompatibilidades de la plata con el acetileno, el amoníaco, el agua oxigenada, la etilenimina y varios ácidos orgánicos.

Los compuestos de plata más inestables, como el acetiluro de plata, los compuestos de amonio y plata, la azida, el clorato, el fulminato y el picrato de plata han de mantenerse en lugares frescos y bien ventilados, protegidos de los golpes, las vibraciones y la contaminación con productos orgánicos u otros productos fácilmente oxidables y protegidos de la luz.

Durante el trabajo con nitrato de plata, se debe llevar ropa protectora para evitar el contacto con la piel y gafas de seguridad para productos químicos a fin de proteger los ojos de las posibles salpicaduras. Se debe disponer de equipos de protección respiratoria en los lugares de trabajo en que no se logre mantener un ambiente aceptable mediante los controles de ingeniería.

\section{Platino}

\section{Distribución y usos}

El platino (Pt) se encuentra en estado puro y como parte de otros minerales, como la esperrilita (PtAs $)$, la cooperita (Pt,Pd)S y la braggita (Pt,Pd,Ni)S. En ocasiones, el platino aparece mezclado con paladio en forma de arseniuro y seleniuro. La concentración de platino en la corteza terrestre es de 0,005 ppm.

EI platino y sus aleaciones se utilizan como catalizadores en el refino del petróleo, la oxidación del amoníaco, la oxidación del anhídrido sulfuroso y los procesos de hidrogenación y deshidrogenación. Se emplea además para el control de las emisiones de los vehículos, en los contactos eléctricos, electrodos y termopares, en toberas para hilar fibra de vidrio y rayón, en superficies ornamentales y reflectantes y en joyería. Por la inmutabilidad del 
platino, se utiliza para la fabricación de patrones nacionales e internacionales de peso, longitud y temperatura. El platino se prepara en forma de hojas, alambres y panes y tiene un amplio campo de aplicación en aparatos de laboratorio.

El níquel, el osmio, el rutenio, el cobre, el oro, la plata y el iridio se alean con platino para aumentar su dureza. Con cobre, oro, iridio, rodio y rutenio se preparan aleaciones de platino de importancia comercial. Las aleaciones con cobalto son importantes por sus potentes propiedades ferromagnéticas.

El ácido cloroplatínico, formado al disolver el platino en agua regia, se utiliza para la preparación de catalizadores, el hexacloroplatinato potásico en la industria fotográfica y el tetracloruro de platino como catalizador en la industria química. El hexafluoruro de platino es un agente oxidante sumamente potente y es la primera sustancia para oxidar un gas inerte (xenón). El cis-diclorodiaminoplatino II, un complejo de platino y sustancias afines es activo contra una amplia gama de tumores en animales y se ha utilizado con éxito en la remisión de varios cánceres humanos.

\section{Riesgos}

Se cree que los efectos tóxicos y potencialmente tóxicos del platino en los trabajadores están relacionados con determinadas sales hidrosolubles del platino, como el hexacloroplatinato potásico, el tetracloroplatinato potásico, el cloroplatinato sódico y el cloroplatinato amónico. La exposición por inhalación de estas sales provoca manifestaciones alérgicas respiratorias. EI primer informe de este tipo de reacciones a los compuestos de platino data de 1911, en trabajadores de la industria fotográfica que presentaban trastornos respiratorios y cutáneos. D esde entonces, se han descrito manifestaciones clínicas similares: rinitis, conjuntivitis, asma, urticaria y dermatitis de contacto principalmente en los trabajadores del refino del platino y en químicos. Asimismo, se han descrito manifestaciones alérgicas respiratorias en una elevada proporción de trabajadores de refinerías expuestos a sales solubles de hexacloroplatinato. Se diagnosticaron rinitis alérgicas y bronquitis a 52 de los 91 trabajadores procedentes de cuatro refinerías de platino de G ran Bretaña. L os síntomas más graves se observaron entre los que realizaban trabajos de triturado de las sales de cloroplatinato. El término platinosis se ha definido como el efecto de las sales solubles de platino sobre los individuos expuestos profesionalmente a estas sustancias y se caracteriza por una marcada irritación nasal y de las vías respiratorias superiores con estornudos, lagrimeo y tos. Posteriormente, aparecen síntomas asmáticos con tos, congestión torácica, jadeos y fatiga. Estos síntomas empeoran progresivamente a medida que aumenta la antigüedad en el trabajo. Algunos trabajadores pueden presentar las tres manifestaciones alérgicas, con afectación de la mucosa nasal, los bronquios y la piel. En Estados Unidos, el Reino Unido, Suiza, Alemania y Sudáfrica se han descrito casos de alergia en trabajadores expuestos a sales de cloroplatinato.

Es importante señalar que se han producido reacciones anafilácticas en algunos pacientes tratados con agentes antitumorales con platino.

En general, los efectos alérgicos de la exposición al platino sólo son provocados por determinados complejos de este metal. Los trabajadores sensibilizados sometidos a pruebas alérgicas de puntura con la mayoría de los compuestos de platino utilizados en la refinería no muestran reacciones positivas. U na vez instaurada la sensibilización, ésta persiste y los trabajadores suelen verse obligados a evitar la exposición al platino. El consumo de tabaco parece aumentar el riesgo de sensibilización por sales de platino.

Las emisiones de los silenciadores de escape catalíticos que contienen platino no parecen representar ningún riesgo para la salud desde el punto de vista de la emisión de platino.

\section{Medidas de salud y seguridad}

L os riesgos sólo pueden controlarse evitando la liberación de sales complejas solubles de platino a la atmósfera del lugar de trabajo. Debido a que el polvo es potencialmente más nocivo que las pulverizaciones, las sales complejas no se deben dejar secar, a menos que sea necesario. En las refinerías de platino debe existir un buen sistema de ventilación por extracción. Los procesos químicos que generen estas sales deben realizarse en campanas de extracción de humo con ventilación. No deben utilizarse centrífugas abiertas. 0 tros aspectos importantes de la prevención de riesgos son una buena higiene personal, la utilización de ropa protectora adecuada y la realización de reconocimientos médicos. Se recomendará a los trabajadores con antecedentes de enfermedades alérgicas o respiratorias que no trabajen con compuestos solubles de platino.

Se han desarrollado pruebas de puntura, nasales y bronquiales. $L$ as pruebas de puntura con concentraciones diluidas de complejos solubles de platino parecen proporcionar una indicación biológica reproducible, fiable y muy sensible de la respuesta alérgica.

\section{Plomo*}

\section{Distribución y usos}

Los minerales de plomo se encuentran en muchos lugares del mundo. El mineral más rico es la galena (sulfuro de plomo) y constituye la fuente principal de producción comercial de este metal. O tros minerales de plomo son: la cerusita (carbonato), la anglesita (sulfato), la corcoita (cromato), la wulfenita (molibdato), la piromorfita (fosfato), la mutlockita (cloruro) y la vanadinita (vanadato). En muchos casos, los minerales de plomo pueden contener otros metales tóxicos.

Los minerales de plomo se separan de la ganga y de otros elementos del mineral mediante el triturado en seco, la molturación en húmedo (para obtener una pasta), la clasificación gravimétrica y la flotación. Los minerales de plomo liberados se funden mediante un proceso en tres etapas: preparación de la carga (mezcla, condicionamiento, etc.), sinterizado y reducción en hornos altos. A continuación, el metal se refina mediante la separación del cobre, el estaño, el arsénico, el antimonio, el zinc, la plata y el bismuto.

El plomo metálico se utiliza en forma de planchas o tubos cuando se requiere una gran maleabilidad y resistencia a la corrosión, como en la industria química o en la construcción. También se utiliza para el revestimiento de cables, como componente de soldadura y como empaste en la industria automovilística. Es un material excelente como protector de radiaciones ionizantes. Se utiliza en los procesos de metalizado para proporcionar recubrimientos protectores, en la fabricación de acumuladores y como baño de termotratamiento en el revenido de hilos metálicos. El plomo se encuentra en una gran variedad de aleaciones y sus compuestos se preparan y utilizan en grandes cantidades en numerosas industrias.

A proximadamente un $40 \%$ del plomo se utiliza en forma metálica, un $25 \%$ en aleaciones y un $35 \%$ en compuestos químicos. Los óxidos de plomo se utilizan en las placas de las baterías eléctricas y los acumuladores ( $\mathrm{PbO}$ y $\left.\mathrm{Pb}_{3} \mathrm{O}_{4}\right)$, como agentes de mezcla en la fabricación de caucho ( $\mathrm{PbO}$ ) y en la fabricación de pinturas $\left(\mathrm{Pb}_{3} \mathrm{O}_{4}\right)$ y como componentes de barnices, esmaltes y vidrio.

*Adaptado de AT SDR 1995 
Las sales de plomo constituyen la base de muchas pinturas y pigmentos: el carbonato y el sulfato de plomo se utilizan como pigmentos blancos y los cromatos de plomo sirven para obtener amarillo, naranja, rojo y verde de cromo. El arseniato de plomo es un insecticida; el sulfato de plomo se utiliza en mezclas de caucho; el acetato de plomo tiene usos importantes en la industria química; el naftenato de plomo es un agente secante muy utilizado y el plomo tetraetilo se utiliza como agente antidetonante para la gasolina en aquellos países en que la legislación aún lo permite.

A leaciones de plomo. Al plomo se le pueden añadir otros metales como el antimonio, el arsénico, el estaño y el bismuto para mejorar sus propiedades mecánicas o químicas y, a su vez, el plomo puede añadirse a otras aleaciones, como el latón, el bronce 0 el acero con el fin de lograr determinadas características.

Compuestos de plomo inorgánicos. No tenemos espacio suficiente para describir todos los compuestos de plomo, tanto orgánicos como inorgánicos, que se utilizan en la industria. Sin embargo, entre los compuestos más comunes cabe citar: el monóxido $(\mathrm{PbO})$, el dióxido $\left(\mathrm{PbO}_{2}\right)$, el tetróxido $\left(\mathrm{Pb}_{3} \mathrm{O}_{4}\right)$, el sesquióxido $\left(\mathrm{Pb}_{2} \mathrm{O}_{3}\right)$, el carbonato, el sulfato, los cromatos, el arseniato, el cloruro, el silicato y la azida de plomo.

La concentración máxima de compuestos de plomo orgánico (alquilos) en las gasolinas está sujeta a restricciones legales en muchos países y a limitaciones de los fabricantes con apoyo gubernamental en otros. En muchas jurisdicciones se ha prohibido su uso por completo.

\section{Riesgos}

El principal riesgo del plomo es su toxicidad. La intoxicación por plomo ha sido siempre una de las enfermedades profesionales más importantes. Gracias a la prevención médica y técnica se ha logrado reducir notablemente el número de casos descritos y sus manifestaciones clínicas son menos graves. Sin embargo, ahora es evidente que pueden producirse efectos adversos con niveles de exposición antes considerados aceptables.

El consumo industrial de plomo va en aumento y los consumidores tradicionales se han ido reemplazando por nuevos usuarios, como la industria del plástico. Por este motivo, son muchas las profesiones en lasque puede tener lugar una exposición al plomo.

En la minería del plomo se produce una absorción considerable de este elemento a través del aparato digestivo; en consecuencia, el grado de riesgo en esta industria depende, en parte, de la solubilidad de los minerales que se manipulen. El sulfuro de plomo (PbS) en la galena es insoluble y su absorción por vía pulmonar es limitada; sin embargo, en el estómago, parte del sulfuro de plomo puede convertirse en cloruro de plomo ligeramente soluble y llegar a absorberse en cantidades moderadas.

En las fundiciones de plomo, los riesgos principales son los derivados del polvo de plomo que se produce durante las operaciones de triturado y molienda en seco y los humos y óxidos de plomo que se liberan durante la sinterización, la reducción en hornos altos y el refinado.

Las planchas y conducciones de plomo se utilizan principalmente para la fabricación de equipos de almacenamiento y manipulación de ácido sulfúrico. En la actualidad, el empleo de plomo para la conducción de agua o gas es muy limitado. Los riesgos del trabajo con plomo aumentan en función de la temperatura. Si el plomo se trabaja a temperaturas inferiores a $500{ }^{\circ} \mathrm{C}$, como ocurre en las operaciones de soldadura, el riesgo de exposición a humos es mucho menor que en la soldadura con plomo, en que la llama alcanza temperaturas más elevadas. El recubrimiento por rociado de metales con plomo fundido es muy peligroso, pues genera polvo y humos a temperaturas elevadas.

La demolición de estructuras de acero pintadas con pinturas fabricadas a base de plomo, como puentes y barcos, produce con frecuencia casos de intoxicación por plomo. Cuando el plomo metálico se calienta a una temperatura de $550^{\circ} \mathrm{C}$, se producen vapores de plomo que se oxidan. Es probable que así ocurra durante el refinamiento de metales, la fundición de bronce y latón, el rociado con plomo fundido, la soldadura autógena de plomo, la instalación de fontanería en las plantas químicas, la demolición de barcos y el cortado y soldadura de estructuras de acero recubiertas con pinturas que contienen tetróxido de plomo.

\section{Vías de entrada en el organismo}

En la industria, la principal vía de entrada es el aparato respiratorio. Puede absorberse cierta cantidad por las vías aéreas superiores, pero la proporción mayor se absorbe a través de la circulación pulmonar. El grado de absorción depende de la proporción de polvo en forma de partículas de un tamaño inferior a 5 micras y del volumen/ minuto respiratorio del trabajador. Por ello, una mayor carga de trabajo produce una mayor absorción de plomo. A pesar de que el aparato respiratorio es la vía principal de entrada, una mala higiene en el trabajo, el hábito de fumar durante el mismo (contaminación del tabaco o de las manos) y una mala higiene personal pueden aumentar considerablemente la exposición, sobre todo por vía oral. Este es uno de los motivos por los que no existe una gran correlación entre la concentración de plomo en el aire en las naves de trabajo y los niveles en sangre, sobre todo a nivel individual.

0 tro factor importante es el gasto de energía: el producto de la concentración en el aire y el volumen/minuto respiratorio determina la captación de plomo. Trabajar horas extras aumenta el tiempo de exposición y reduce el tiempo de recuperación. El tiempo total de exposición es mucho más complicado de calcular de lo que indican los registros oficiales de personal. Sólo pueden obtenerse datos relevantes mediante un análisis temporal del lugar de trabajo. El trabajador puede cambiar de ambiente entre las oficinas y la fábrica, desempeñar un trabajo que requiera cambios frecuentes de postura (como girarse 0 doblarse) y todo esto hace que esté expuesto a una amplia gama de concentraciones. U na medida representativa de la exposición al plomo es casi imposible de obtener sin utilizar un muestreador personal durante muchas horas y muchos días.

Tamaño de las partículas. Puesto que la vía de absorción de plomo más importante es a través de los pulmones, es muy importante determinar el tamaño de las partículas de polvo de plomo industrial, que depende de la naturaleza del proceso que origina el polvo. El polvo fino con partículas de un tamaño respirable se produce durante los procesos de pulverizado y mezcla de colores de plomo, el trabajo abrasivo del material de relleno de plomo en las carrocerías de automóviles y el lijado en seco de las pinturas de plomo. Los gases de escape de los motores de gasolina producen partículas de cloruro y bromuro de plomo de 1 micra de diámetro. Sin embargo, también partículas mayores pueden ingerirse y absorberse a través del estómago. Una imagen más real del riesgo asociado con una muestra de polvo puede obtenerse determinando la distribución de tamaños, además de determinar el plomo total. A hora bien, esta información quizá sea más importante para los investigadores que para los higienistas de campo.

\section{Destino biológico}

En el organismo humano, el plomo inorgánico no se metaboliza, sino que se absorbe, se distribuye y se excreta directamente. La velocidad a que se absorbe el plomo depende de su forma 
química y física y de las características fisiológicas de la persona expuesta (edad y estado nutricional). El plomo inhalado y depositado en las vías respiratorias bajas se absorbe por completo. La cantidad de plomo absorbida en el tracto gastrointestinal de los adultos suele estar comprendida entre el 10 y el $15 \%$ de la cantidad ingerida; en los niños y las mujeres embarazadas, la cantidad absorbida puede aumentar hasta en un $50 \%$. También se incrementa significativamente en condiciones de ayuno y en casos de déficit de hierro o calcio.

U na vez en la sangre, el plomo se distribuye en tres compartimentos: la sangre, los tejidos blandos (riñón, médula ósea, hígado y cerebro) y el tejido mineralizado (huesos y dientes). El tejido mineralizado contiene aproximadamente el 95 de la carga corporal total de plomo en los adultos.

EI plomo en los tejidos mineralizados se acumula en subcompartimentos que difieren en la velocidad de reabsorción del plomo. En el hueso existe un componente lábil, que intercambia rápidamente el plomo con la sangre, y un reservorio inerte. El plomo del reservorio inerte representa un riesgo especial, pues constituye una posible fuente endógena de plomo. Cuando el organismo se encuentra en condiciones fisiológicas de estrés, como durante el embarazo, la lactancia o una enfermedad crónica, este plomo normalmente inerte puede movilizarse y aumentar los niveles de plomo en sangre. D ebido a la existencia de estos depósitos de plomo móviles, con frecuencia deben transcurrir varios meses o incluso años para observar una disminución significativa en los niveles sanguíneos de plomo, incluso tras la eliminación total de la fuente de exposición.

EI $99 \%$ del plomo en la sangre está asociado con los eritrocitos; el $1 \%$ restante está presente en el plasma, donde se encuentra disponible para ser transportado a los tejidos. EI plomo en la sangre que no se retiene se excreta a través de los riñones o del aclaramiento biliar al tracto gastrointestinal. En estudios de exposición única en adultos, el plomo muestra una semivida en sangre de aproximadamente 25 días; en los tejidos blandos, de unos 40 días; y en la porción no lábil de los huesos, de más de 25 años. Así, tras una sola exposición, es posible que los niveles de plomo en sangre vuelvan a los niveles normales, pero la carga corporal total continuará siendo elevada.

Para que se desarrolle una intoxicación por plomo, no es necesaria una exposición aguda importante. El organismo acumula este metal durante toda la vida y lo libera lentamente, por lo que incluso dosis pequeñas pueden producir, con el transcurso del tiempo, una intoxicación por plomo, pues de la carga corporal total de plomo depende el riesgo de efectos adversos.

\section{E fectos fisiológicos}

Los efectos biológicos del plomo son los mismos independientemente de que entre en el organismo por inhalación o ingestión. El plomo interfiere con la función celular normal y con varios procesos fisiológicos.

E fectos neurológicos. El destino más sensible de intoxicación por plomo es el sistema nervioso. En niños, se han descrito deficiencias neurológicas con niveles de exposición que antes no se consideraban nocivos. A demás de la falta de un umbral preciso, la toxicidad del plomo en la infancia puede tener efectos permanentes. U n estudio demuestra que el daño al sistema nervioso central (SNC) como consecuencia de la exposición al plomo a los 2 años de edad produce una deficiencia continua en el desarrollo neurológico, que se manifiesta como una puntuación de CI más baja y una deficiencia cognitiva a la edad de 5 años. En un estudio en que se determinó la carga corporal total, niños en edad escolar que presentaban niveles elevados de plomo en los dientes, pero sin un historial conocido de intoxicación por plomo, mostraban deficiencias mayores en la puntuación de inteligencia de los tests psicométricos, en el procesamiento verbal y del lenguaje, en la atención y el rendimiento en clase que niños con niveles de plomo más bajos. En un informe de seguimiento de niños con niveles elevados de plomo en los dientes publicado en 1990, se describió una probabilidad siete veces mayor de tener problemas para aprobar el bachillerato, un menor rendimiento en clase, un mayor índice de absentismo, mayores dificultades para leer, carencias de vocabulario y problemas de psicomotricidad fina, tiempo de reacción y coordinación mano-ojos 11 años más tarde. Los efectos descritos se deben probablemente a la toxicidad perdurable del plomo más que a una exposición excesiva reciente, pues los niveles de plomo en sangre detectados en los adolescentes fueron bajos [inferiores a 10 microgramos por decilitro $(\mu \mathrm{g} / \mathrm{dL})$ ].

También se ha observado una disminución en la agudeza auditiva, especialmente a altas frecuencias, al aumentar los niveles de plomo en sangre. Esto puede contribuir a los problemas de aprendizaje aparentes o al mal comportamiento en clase que muestran los niños con intoxicación por plomo.

LoS adultos también presentan efectos sobre el SNC con niveles relativamente bajos de plomo en sangre, que se manifiestan en cambios de conducta sutiles, fatiga y problemas de concentración. Las lesiones del sistema nervioso periférico, en su mayoría motrices, se observan principalmente en los adultos. Se ha descrito neuropatía periférica y una disminución en la velocidad de conducción nerviosa en trabajadores del plomo asintomáticos. La neuropatía por plomo se considera una enfermedad de las neuronas motrices del asta anterior de la médula espinal, con degeneración de las terminales axónicas que avanza hacia el cuerpo neuronal. La parálisis evidente, con caída de la muñeca, sólo se manifiesta como un signo tardío de la intoxicación por plomo.

E fectos hematológicos. El plomo inhibe la capacidad del organismo para producir hemoglobina al interferir con varios pasos enzimáticos en la vía metabólica del grupo hemo. La ferroquelatasa, que cataliza la inserción del hierro en la protoporfirina IX, es bastante sensible al plomo. La disminución en la actividad de esta enzima produce un aumento en la concentración del sustrato, la protoporfirina eritrocítica (FEP). Datos recientes indican que el nivel de FEP, utilizado en el pasado para detectar la toxicidad por plomo, no es un índice suficientemente sensible para los niveles de plomo más bajos y, por tanto, no es útil como prueba diagnóstica de la intoxicación por plomo, como se creía anteriormente.

El plomo puede inducir dos tipos de anemia. La intoxicación aguda con niveles elevados de plomo se ha asociado con la anemia hemolítica. En la intoxicación crónica, el plomo induce anemia al interferir con la eritropoyesis y reducir la supervivencia de los eritrocitos. Cabe señalar, sin embargo, que la anemia no es una manifestación inicial de la intoxicación por plomo, sino que sólo se manifiesta cuando los niveles de plomo en sangre permanecen significativamente altos durante períodos prolongados.

E fectos endocrinos. Existe una correlación inversa clara entre los niveles de plomo en sangre y los niveles de vitamina D. Dado que en el sistema endocrino la vitamina $D$ es responsable en gran parte del mantenimiento de la homeostasis de calcio intra y extracelular, es probable que el plomo impida el crecimiento y la maduración celular y el desarrollo de huesos y dientes.

E fectos renales. U n efecto directo de la exposición prolongada al plomo es la nefropatía. La alteración de la función de los túbulos proximales se manifiesta como aminoaciduria, glicosuria e hiperfosfaturia (un síndrome parecido al de Fanconi). También existen pruebas de una asociación entre la exposición al plomo y la hipertensión, un efecto que puede estar mediado por mecanismos renales. Puede desarrollarse gota como resultado de la hiperuricemia inducida por el plomo, y una disminución 
selectiva de la excreción fraccional de ácido úrico previa a una disminución del aclaramiento de creatinina. La insuficiencia renal es responsable del $10 \%$ de las muertes de pacientes con gota.

E fectos sobre la reproducción y el desarrollo. Los depósitos maternos de plomo atraviesan rápidamente la barrera placentaria y representan un riesgo para el feto. A finales del siglo XIX se describió una mayor frecuencia de abortos y muertes fetales en mujeres que trabajaban en procesos relacionados con el plomo. Aun cuando no se dispone de datos completos sobre los niveles de exposición al plomo, esos efectos fueron resultado probablemente de exposiciones muy superiores a las que se registran actualmente en las industrias del plomo. Tampoco existen actualmente datos fiables de dosis respuesta sobre los efectos reproductores en mujeres.

Cada vez hay más pruebas que demuestran que el plomo no sólo afecta a la viabilidad del feto, sino también a su desarrollo. Las consecuencias sobre el desarrollo de una exposición prenatal a niveles bajos de plomo son, entre otras, un menor peso al nacer y un mayor número de nacimientos prematuros. El plomo es teratógeno en animales; sin embargo, la mayoría de los estudios en humanos no han logrado demostrar una relación entre los niveles de plomo y las malformaciones congénitas.

Los efectos del plomo sobre el aparato reproductor masculino en humanos no están bien caracterizados. L os datos disponibles indican que podrían existir efectos testiculares, como la reducción del recuento y la motilidad espermática, como consecuencia de una exposición crónica al plomo.

E fectos cancerígenos. La A gencia Internacional para la I nvestigación sobre el Cáncer (IARC) ha clasificado al plomo inorgánico y los compuestos de plomo inorgánico en el Grupo 2B como posibles cancerígenos para el hombre. Los informes de casos indican que el plomo es un posible cancerígeno para el hombre, pero la asociación aún no está claramente definida. Se ha descrito que las sales solubles, como el acetato y el fosfato de plomo, producen tumores renales en ratas.

\section{Secuencia de signos y síntomas asociados con la toxicidad del plomo}

La toxicidad leve por exposición al plomo puede producir:

- mialgia o parestesia;

- fatiga leve;

- irritabilidad:

- letargo,

- molestias abdominales ocasionales.

Los signos y síntomas asociados a una toxicidad moderada son los siguientes:

- artralgia;

- fatiga general;

- dificultad para concentrarse;

- agotamiento muscular;

- temblor;

- cefalea;

- dolor abdominal difuso:

- vómitos;

- pérdida de peso

- estreñimiento.

Los signos y síntomas de toxicidad grave son:

- paresis o parálisis;

- encefalopatía, que puede producir de forma repentina convulsiones, alteraciones de la consciencia, coma y la muerte;

- ribete azul (gris azulado) en las encías,

- cólicos (intermitentes o cólicos abdominales graves).
Algunos de los signos hematológicos de la intoxicación por plomo simulan otras enfermedades o trastornos. Para el diagnóstico diferencial de la anemia microcítica, suele ser posible descartar la intoxicación por plomo determinando la concentración de plomo en la sangre venosa; si el nivel de plomo en sangre es inferior a $25 \mu \mathrm{g} / \mathrm{dl}$, la anemia refleja una carencia de hierro o hemoglobinopatía. D os enfermedades raras, la porfiria intermitente aguda y la coproporfiria, producen alteraciones similares a las de la intoxicación por plomo. También otros efectos de la intoxicación por plomo pueden dar lugar a confusiones. Algunos pacientes con signos neurológicos debidos a la intoxicación por plomo fueron tratados únicamente de neuropatía periférica o síndrome del túnel carpiano, lo que retrasó el tratamiento de la intoxicación por plomo. Los errores de diagnóstico de las molestias gastrointestinales inducidas por plomo han dado lugar a cirugías abdominales inadecuadas.

\section{Análisis de la boratorio}

Si existen sospechas de pica o de ingestión accidental de objetos que contengan plomo (como los pesos de las cortinas o de las cañas de pescar) debe realizarse una radiografía abdominal. EI análisis del cabello no suele ofrecer una valoración adecuada de la toxicidad por plomo, pues no se ha encontrado una correlación entre la cantidad de plomo en el cabello y el nivel de exposición. La probabilidad de contaminación ambiental de las muestras de laboratorio con plomo y la preparación poco reproducible de las muestras hace que los resultados del análisis del cabello sean difíciles de interpretar. Las pruebas de laboratorio recomendadas para evaluar la intoxicación por plomo son las siguientes:

- RHC con frotis periférico;

- niveles de plomo en sangre;

- niveles de protoporfirina eritrocítica;

- NUS y niveles de creatinina,

- análisis de orina.

RHC con frotis periférico. En un paciente intoxicado por plomo, el hematocrito y los valores de hemoglobina pueden resultar moderadamente bajos Es posible que el recuento diferencial y el recuento leucocitario total sean normales. El frotis periférico puede ser normocrómico y normocítico o hipocrómico y microcítico. L os basófilos punteados generalmente sólo se observan en pacientes con una intoxicación significativa durante un período prolongado. Puede observarse eosinofilia en pacientes con toxicidad al plomo, pero no existe un efecto dosis respuesta claro.

Es importante destacar que no siempre se observan basófilos punteados en los pacientes intoxicados con plomo.

$\mathrm{N}$ ivel de plomo en sangre. El nivel de plomo en sangre es la prueba diagnóstica y de exploración más útil para la exposición al plomo. El nivel de plomo en sangre refleja el equilibrio dinámico entre la absorción, la excreción y el depósito en los compartimentos de tejidos blandos y duros. En el caso de la exposición crónica, los niveles de plomo en sangre generalmente subestiman la carga corporal total; sin embargo, es la medida de la exposición al plomo más común y ampliamente aceptada. LoS niveles de plomo en sangre responden de forma relativamente rápida a los cambios bruscos o intermitentes en la ingesta de plomo (por ejemplo, la ingestión de trocitos de pintura desprendidos en los niños) y, en un rango limitado, muestran una relación lineal con los niveles ingeridos.

Actualmente, el nivel medio de plomo en sangre en la población de EE. UU., por ejemplo, es inferior a $10 \mu \mathrm{g} / \mathrm{dl}$, y ha disminuido desde un nivel medio de $16 \mu \mathrm{g} / \mathrm{dl}$ en el decenio de 1970, antes de que la legislación regulara el contenido en plomo de la gasolina. Un nivel de plomo en sangre de $10 \mu \mathrm{g} / \mathrm{dl}$ es aproximadamente tres veces superior al nivel medio registrado en poblaciones más lejanas. 
Los niveles que definen la intoxicación por plomo se han ido rebajando progresivamente. En conjunto, pueden observarse efectos en una amplia gama de concentraciones de plomo en sangre, sin que existan indicios de un umbral. Para los niños no se ha determinado ningún nivel seguro. Incluso en los adultos, se han ido descubriendo efectos con dosis cada vez más bajas a medida que se desarrollan métodos de análisis y de medición más sensibles.

Nivel de protoporfirina en los eritrocitos. H asta hace poco, el ensayo más utilizado para la exploración de poblaciones asintomáticas en situación de riesgo era la determinación de la protoporfirina eritrocítica (FEP), generalmente valorada como zinc- protoporfirina (ZPP). Un nivel elevado de protoporfirina en sangre es resultado de la acumulación secundaria a la disfunción enzimática en los eritrocitos. El estado estacionario en la sangre sólo se alcanza después del recambio total de la población de eritrocitos circulantes, es decir, pasados unos 120 días. Por consiguiente, es un parámetro posterior a los niveles de plomo en sangre y constituye una medida indirecta de la exposición prolongada al plomo.

La principal desventaja de utilizar el ensayo de FEP (ZPP) como método para la exploración del plomo es que no es sensible a niveles bajos de intoxicación por plomo. Los resultados de la segunda encuesta nacional sobre salud y nutrición (NHANES II) realizada en EE.UU. indican que el $58 \%$ de 118 niños con niveles de plomo en sangre superiores a $30 \mu \mathrm{g} / \mathrm{dl}$ mostraban unos niveles de FEP dentro de los límites normales. De estos resultados se desprende que un número significativo de niños intoxicados por plomo no se detectarían si el diagnóstico sólo estuviese basado en la determinación de la FEP (ZPP). No obstante, los niveles de FEP (ZPP) siguen siendo útiles para el diagnóstico diferencial de la anemia ferropénica.

L os valores normales de ZPP suelen ser inferiores a $35 \mu \mathrm{g} / \mathrm{dl}$. La hiperbilirrubinemia (ictericia) puede producir falsos aumentos cuando se utiliza un hematofluorómetro. La FEP aparece elevada en la anemia ferropénica, la anemia falciforme y otros tipos de anemias hemolíticas. En la protoporfiria eritropoyética, una enfermedad extremadamente rara, la FEP se encuentra notablemente elevada (en niveles superiores a $300 \mu \mathrm{g} / \mathrm{dl}$ ).

NUS, creatinina y análisis de orina. Estos parámetros pueden revelar únicamente efectos tardíos y significativos del plomo sobre la función renal. La función renal en adultos también puede evaluarse midiendo la excreción fraccional de ácido úrico (rango normal de 5 a $10 \%$; inferior al $5 \%$ en la gota saturnina y superior al $10 \%$ en el síndrome de Fanconi).

\section{Intoxicación por plomo orgánico}

La absorción de una cantidad suficiente de tetraetilplomo, ya sea por una exposición intensa durante un tiempo corto o menor durante períodos prolongados, produce una intoxicación aguda del SN C. Las manifestaciones más leves son insomnio, laxitud y excitación nerviosa, que se manifiesta como sueños muy vívidos y estados de ansiedad similares al despertar de un sueño, asociados con temblor, reflejos acusados, contracciones musculares espasmódicas, bradicardia, hipotensión vascular e hipotermia. Las respuestas más graves incluyen episodios recurrentes (en ocasiones casi continuos) de desorientación completa con alucinaciones, contorsiones faciales y actividad muscular somática general intensa con resistencia a la restricción física. Estos episodios pueden transformarse abruptamente en crisis maníacas o convulsiones violentas con posible final en coma o la muerte.

La enfermedad puede persistir durante días o semanas, con intervalos de tranquilidad que dan paso abruptamente a una hiperactividad ante cualquier tipo de estímulo. En los casos menos agudos, es frecuente observar una disminución de la presión sanguínea y pérdida de peso corporal. Cuando este tipo de síntomas comienzan poco tiempo después (pocas horas después) de una exposición breve e intensa a tetraetilplomo y cuando la sintomatología evoluciona rápidamente, cabe temer un desenlace fatal rápido. Sin embargo, cuando se produce un retardo (de hasta 8 días) entre el fin de la exposición breve 0 prolongada y el inicio de los síntomas, el pronóstico es más optimista, aunque reservado, y la desorientación parcial o recurrente y la depresión de la función circulatoria pueden persistir durante varias semanas.

El diagnóstico inicial se basa en un historial válido de exposición significativa al tetraetilplomo o en el cuadro clínico de la enfermedad. Este diagnóstico puede ser confirmado por la evolución de la enfermedad y por la comprobación de una absorción significativa de tetraetilplomo mediante análisis de orina y sangre que muestren un aumento importante de la excreción de plomo en la orina y niveles insignificantes o ligeramente aumentados de la concentración de plomo en la sangre.

\section{Control del plomo en el ambiente de trabajo}

En el pasado, la intoxicación clínica por plomo fue una de las enfermedades profesionales más importantes, e incluso en la actualidad sigue representando un riesgo importante. El amplio bagaje de conocimientos científicos sobre los efectos tóxicos del plomo se ha enriquecido desde el decenio de 1980 con nuevos e importantes conocimientos sobre los efectos subclínicos más sutiles. Asimismo, en varios países se ha considerado necesario readaptar o modernizar las medidas de protección en el trabajo, establecidas desde hacía más de medio siglo.

En noviembre de 1979, la Administración para la Salud y la Seguridad en el Trabajo de Estados Unidos (O SH A), promulgó la Norma definitiva sobre exposición laboral al plomo, y en noviembre de 1980, se publicó en el Reino U nido un Código de instrucciones muy completo relativo al control del plomo durante el trabajo.

Las principales características de la legislación, normativas y códigos de instrucciones que aparecieron en el decenio de 1970 para la protección de la salud de los trabajadores en el ambiente de trabajo tendían a establecer sistemas exhaustivos que abarcaran todas las situaciones laborales en que esté presente el plomo y a conceder una importancia equivalente a las medidas de higiene, el control del ambiente y la vigilancia de la salud, incluidos los controles biológicos.

La mayoría de los códigos de instrucciones abordan los siguientes aspectos:

- evaluación del trabajo en que las personas resultan expuestas al plomo;

- información, instrucción y formación;

- medidas de control de los materiales, las instalaciones y los procesos

- aplicación y mantenimiento de las medidas de control;

- equipos de protección respiratoria y ropa protectora;

- limpieza e instalaciones para la higiene personal;

- separación de las áreas para comer, beber y fumar;

- obligación de evitar la dispersión de la contaminación por plomo;

- control del aire;

- vigilancia médica y controles biológicos,

- creación y actualización de registros.

Algunas normativas, como la relativa al plomo de la OSHA, especifican el límite de exposición admisible al plomo en el lugar de trabajo, la frecuencia y el nivel de los reconocimientos médicos y otras responsabilidades de la empresa. Con arreglo a esta norma, si el control en sangre muestra niveles de plomo superiores a $40 \mu \mathrm{g} / \mathrm{dl}$, se deberá notificar al trabajador por 
escrito y proceder a un reconocimiento médico. Si el nivel de plomo en sangre de un trabajador alcanza los $60 \mu \mathrm{g} / \mathrm{dl}$ (o presenta un nivel medio igual o superior a $50 \mu \mathrm{g} / \mathrm{dl}$ ), la empresa está obligada a retirar al trabajador del lugar de exposición excesiva, manteniendo su antigüedad y su salario, hasta que los niveles de plomo en sangre del empleado disminuyan a menos de $40 \mu \mathrm{g} / \mathrm{dl}$ (29 CFR 910.1025$)$ (prestaciones de protección por retirada médica).

\section{Medidas de salud y seguridad}

La finalidad de estas precauciones es, en primer lugar, prevenir la inhalación del plomo y, en segundo lugar, evitar su ingestión. La forma más eficaz de alcanzar estos objetivos es sustituir los compuestos de plomo por sustancias menos tóxicas. El uso de polisilicatos de plomo en la alfarería es un buen ejemplo. El abandono del uso de pinturas de carbonato de plomo para el interior de los edificios ha resultado muy eficaz para reducir los cólicos de los pintores; para estos usos, han aparecido sustitutos eficaces del plomo tan rápidamente que en algunos países se ha considerado razonable prohibir el uso de pinturas con plomo en el interior de los edificios.

En muchos casos en que no es posible evitar el uso del plomo, sí puede evitarse el polvo de este metal. Se puede rociar agua en grandes cantidades para evitar la formación de polvo y su dispersión en el aire. En la fundición de plomo, los minerales y restos pueden tratarse de la misma forma y se puede mantener húmedo el suelo en que se ha depositado el plomo. Por desgracia, cuando el material tratado o el suelo se dejan secar, siempre habrá una fuente potencial de polvo. En algunos casos, se modifican los procesos para que produzcan polvo grueso en lugar de fino. En otras secciones de esta $E$ nciclopedia se comentan otras precauciones de ingeniería específicas.

Los trabajadores que están expuestos al plomo en cualquiera de sus formas deben contar con un equipo de protección individual (EPI) adecuado, que debe lavarse o cambiarse regularmente. La ropa protectora de determinadas fibras sintéticas retiene menos polvo que los monos de algodón y debe utilizarse siempre que las condiciones de trabajo lo permitan. $\mathrm{H}$ ay que evitar la ropa con vueltas, pliegues y bolsillos en los que se pueda acumular el polvo.

Se debe disponer de armarios especiales para el EPI, con compartimentos separados para la ropa de calle, y de instalaciones sanitarias con duchas de agua caliente, que deberán utilizarse. Se ha de dar a los trabajadores el tiempo necesario para lavarse antes de comer y debe estar prohibido comer y fumar en las proximidades de las áreas en que se procesa el plomo. D eberán existir zonas adecuadas para comer.

La limpieza de las salas y el edificio en que se procesa el plomo es esencial y debe realizarse continuamente ya sea por un proceso en húmedo o con aspiradores. Cuando, a pesar de estas precauciones, los trabajadores sigan estando expuestos al plomo, deberán contar con un equipo de protección respiratoria adecuadamente mantenido. Dicho equipo deberá revisarse para garantizar su limpieza y eficacia; también se vigilará que se utilice en caso necesario.

\section{Plomo orgánico}

Las propiedades tóxicas de los compuestos de plomo orgánico y su facilidad de absorción hacen que sea indispensable evitar el contacto de la piel de los trabajadores con estos compuestos, ya sea solos 0 en mezclas concentradas, como las formulaciones comerciales, la gasolina u otros solventes orgánicos. Es esencial un control tanto tecnológico como de gestión, la formación de los trabajadores en las prácticas laborales seguras y el uso del EPI. También es muy importante mantener la concentración atmosférica de compuestos alquilados de plomo en el lugar de trabajo en niveles extremadamente bajos. $\mathrm{H}$ a de estar absolutamente prohibido que el personal coma, fume o introduzca alimentos 0 bebidas que no estén herméticamente cerrados en el lugar de trabajo. Deben existir instalaciones sanitarias adecuadas, con duchas, y se debe recomendar a los trabajadores que practiquen una buena higiene personal y se duchen 0 se laven después del turno de trabajo. Asimismo, deben proporcionarse armarios separados para la ropa de trabajo y de calle.

\section{RENIO}

\section{Distribución y usos}

El renio $(\mathrm{Re})$ se encuentra en estado combinado en los minerales de platino, gadolinita, molibdenita ( $\mathrm{M} \mathrm{OS}_{2}$ ) y columbita, y también en algunos minerales de sulfuro. Es un elemento traza que constituye aproximadamente 0,001 ppm de la corteza terrestre.

EI renio se utiliza en los tubos de electrones y en aplicaciones de semiconductores. Es un catalizador muy selectivo para la hidrogenación y la deshidrogenación. Se han utilizado experimentalmente anticuerpos marcados con renio para el tratamiento de adenocarcinomas de colon, pulmón y ovarios. El renio se usa en el instrumental médico, en equipo de alto vacío y en aleaciones para contactos eléctricos y termopares. También se emplea para el recubrimiento de joyería.

EI renio se alea con el tungsteno y el molibdeno para mejorar su maleabilidad.

\section{Riesgos}

Se desconocen las manifestaciones tóxicas crónicas del renio. Algunos compuestos, como el hexafluoruro de renio, son irritantes para la piel y los ojos. En animales experimentales, la inhalación de polvo de renio produce fibrosis pulmonar. El sulfuro de renio VII se inflama espontáneamente en contacto con el aire y emite humos tóxicos de óxidos de azufre al calentarse. EI hexametilrenio presenta un grave riesgo de explosión y debe manipularse con las máximas precauciones

\section{RODIO}

\section{Distribución y usos}

EI rodio es uno de los elementos más raros de la corteza terrestre (concentración media 0,001 ppm). Se encuentra en pequeñas cantidades asociado con el platino nativo y en algunos minerales de níquel-cobre. También se encuentra en los minerales rodita, esperrilita e iridosmita (u osmiridio).

El rodio se utiliza en recubrimientos resistentes a la corrosión para proteger los artículos de plata del ennegrecimiento, en espejos de alta reflectancia para proyectores eléctricos, para el recubrimiento de instrumentos ópticos y en las espirales de los hornos, como catalizador en diversas reacciones de hidrogenación y oxidación, en toberas para la producción de rayón y como componente de las decoraciones con oro sobre vidrio y porcelana.

El rodio se alea con el platino y el paladio para formar aleaciones muy duras que se utilizan en las toberas de hilado.

\section{Riesgos}

No existen datos experimentales significativos que indiquen problemas para la salud debidos al rodio, sus aleaciones 0 sus compuestos en el hombre. A pesar de que su toxicidad no está establecida, estos metales deben manipularse con precaución. Se ha descrito dermatitis de contacto en un trabajador que preparaba piezas metálicas para recubrirlas con rodio. Los autores 
indican que el reducido número de casos de sensibilización al rodio descritos puede deberse más a su poco uso que a la seguridad del metal. La Conferencia A mericana de H igienistas I ndustriales del Gobierno (ACGIH) ha recomendado un valor umbral bajo para el rodio y sus sales solubles basándose en una analogía con el platino. No está totalmente demostrada la capacidad de las sales solubles de rodio para producir manifestaciones alérgicas en el hombre.

\section{RUTENIO}

\section{Distribución y usos}

El rutenio se encuentra en los minerales osmiridio y laurita y en los minerales de platino. Es un elemento raro, que constituye aproximadamente $0,001 \mathrm{ppm}$ de la corteza terrestre.

El rutenio se utiliza como sustituto del platino en joyería y como endurecedor para plumines de estilográficas, relés de contacto eléctrico y filamentos eléctricos. También se emplea en los colores cerámicos, en galvanoplastia y como catalizador en la síntesis de hidrocarburos de cadena larga. Además, recientemente ha servido para el tratamiento de melanomas malignos de la úvea.

EI rutenio forma valiosas aleaciones con el platino, el paladio, el cobalto, el níquel y el tungsteno, aumentando su resistencia al desgaste. El rojo de rutenio $\left(\mathrm{Ru}_{3} \mathrm{Cl}_{6} \mathrm{H}_{42} \mathrm{~N}_{4} \mathrm{O}_{2}\right)$ u oxicloruro de rutenio amoniacado se utiliza como reactivo de microscopía para pectina, goma, tejidos animales y bacterias. El rojo de rutenio produce inflamación ocular.

\section{Riesgos}

El tetraóxido de rutenio es volátil e irritante para el tracto respiratorio.

Algunos complejos de galvanoplastia del rutenio pueden tener efectos irritantes para la piel y los ojos, pero no existe documentación en este sentido. Los radioisótopos del rutenio, principalmente el ${ }^{103} \mathrm{Ru}$ y el ${ }^{106} \mathrm{Ru}$, son productos de fisión en el ciclo del combustible nuclear. D ebido a que el rutenio puede transformarse en compuestos volátiles (forma numerosos complejos nitrogenados, como ya se indicó antes), la posibilidad de su presencia en el medio ambiente ha sido causa de preocupación. La importancia del radio-rutenio como riesgo potencial de radiación aún se desconoce.

\section{- SeLENIO}

\section{Distribución y usos}

El selenio (Se) se encuentra en las rocas y suelos de todo el mundo. No existen verdaderos depósitos de selenio y no puede recuperarse directamente de forma rentable. L os cálculos sobre la cantidad de selenio existente en la corteza terrestre varían entre 0,03 y 0,8 ppm, y las mayores concentraciones conocidas se encuentran en el azufre nativo de los volcanes, que contiene hasta $8.350 \mathrm{ppm}$. El selenio se encuentra junto con el telurio en los sedimentos y barros resultantes del refinado electrolítico del cobre. Las principales fuentes mundiales son las industrias refinadoras de cobre en Canadá, Estados U nidos y Zimbabwe, donde los barros contienen hasta un $15 \%$ de selenio.

La fabricación de rectificadores de selenio, que convierten la corriente alterna en continua, absorbe más de la mitad de la producción mundial de selenio. El selenio se utiliza también para decolorar el cristal verde y para la fabricación del cristal rojo, como aditivo en las industrias de goma sintética y natural, como insecticida y en aleaciones con acero inoxidable y cobre.

EI ${ }^{75}$ Se se emplea para la exploración con marcadores radiactivos del páncreas, para la xerografía de rayos $X$ y para la xerografía fotoestática. El óxido de selenio o dióxido de selenio $\left(\mathrm{SeO}_{2}\right)$ se produce quemando selenio en oxígeno y es el compuesto de selenio más utilizado en la industria. Se emplea en la fabricación de otros compuestos de selenio y como reactivo para alcaloides.

El cloruro de selenio $\left(\mathrm{Se}_{2} \mathrm{Cl}_{2}\right)$ es un líquido estable de color rojo o marrón oscuro que se hidroliza en el aire húmedo produciendo selenio, ácido selenioso y ácido clorhídrico. El hexafluoruro de selenio $\left(\mathrm{SeF}_{6}\right)$ se emplea como aislante eléctrico gaseoso.

\section{Riesgos}

Las formas elementales de selenio son probablemente inocuas para el hombre; sin embargo, sus compuestos son peligrosos y su efecto es similar al de los compuestos de azufre. Los compuestos de selenio se pueden absorber en cantidades tóxicas a través de los pulmones, el tracto intestinal o lesiones de la piel. M uchos compuestos de selenio pueden causar quemaduras graves de la piel y las membranas mucosas, y la exposición crónica de la piel a concentraciones bajas de polvo de determinados compuestos puede producir dermatitis y paroniquia.

La inhalación repentina de una gran cantidad de humo de selenio, óxido de selenio o seleniuro de hidrógeno puede producir edema pulmonar por sus efectos irritantes locales sobre los alvéolos; el edema puede aparecer entre 1 y 4 horas después de la exposición. La exposición al seleniuro de hidrógeno en concentraciones atmosféricas de $5 \mathrm{mg} / \mathrm{m}^{3}$ es intolerable, pero esta sustancia sólo se encuentra en pequeñas cantidades en la industria (por ejemplo, debido a la contaminación bacteriana de guantes manchados de selenio), aunque hay informes de exposiciones a altas concentraciones por accidentes de laboratorio.

El contacto de la piel con el óxido de selenio o el oxicloruro de selenio puede provocar quemaduras o sensibilización al selenio y sus compuestos, especialmente el óxido de selenio. El oxicloruro de selenio destruye fácilmente la piel por simple contacto, produciendo quemaduras de tercer grado a menos que se lave inmediatamente con agua. No obstante, las quemaduras con óxido de selenio rara vez son graves y, si se tratan adecuadamente, curan sin dejar cicatriz.

La dermatitis por exposición ambiental al polvo de óxido de selenio comienza generalmente en los puntos de contacto del polvo con las muñecas o el cuello y puede extenderse a las zonas adyacentes de los brazos, la cara y la parte superior del tronco. Generalmente, consiste en unas pápulas discretas, rojas y picantes, que pueden confluir en la muñeca, donde el dióxido de selenio puede penetrar entre el guante y la manga del mono. También puede producirse paroniquia dolorosa, aunque lo que se observa con más frecuencia son casos de hinchamiento muy doloroso de la parte interior de las uñas debido al dióxido de selenio que penetra en los bordes libres de las uñas de trabajadores que manipulan polvo de dióxido de selenio o de humo de selenio rojo de desecho sin utilizar guantes impermeables.

Las salpicaduras en los ojos de óxido de selenio pueden provocar conjuntivitis si no se tratan inmediatamente. Las personas que trabajan en ambientes que contienen polvo de dióxido de selenio pueden desarrollar una afección conocida entre los obreros como "ojo rosa", una alergia rosa de los párpados, que a menudo se hinchan. También suele observarse inflamación de la conjuntiva palpebral, pero rara vez de la conjuntiva bulbar.

El primer signo, y el más característico, de la absorción de selenio es el olor a ajo en el aliento. Este olor se debe probablemente al dimetilselenio que se produce en el hígado durante la destoxificación del selenio por metilación. El olor desaparece rápidamente si el obrero se retira de la exposición, pero no se 
conoce ningún tratamiento para combatirlo. Un signo más sutil y precoz que el olor a ajo es un sabor metálico en la boca, Es menos llamativo y a menudo los obreros no le dan importancia. Los efectos sistémicos, como palidez, laxitud, irritabilidad, síntomas gastrointestinales vagos y vértigos, no se pueden evaluar con precisión y no son específicos del selenio.

D ebe estudiarse más detenidamente la posibilidad de lesiones hepáticas y del bazo en personas expuestas a niveles elevados de compuestos de selenio, y hay que realizar más estudios sobre trabajadores para investigar el posible efecto protector del selenio contra el cáncer de pulmón.

\section{Medidas de salud y seguridad}

El óxido de selenio constituye el principal problema del selenio en la industria, ya que se forma siempre que se hierve selenio en presencia de aire. Todas las fuentes de óxido o humos de selenio deben estar dotadas de sistemas de ventilación con extracción y una velocidad de aire de al menos $30 \mathrm{~m} / \mathrm{min}$. Los trabajadores deben utilizar guantes, monos, protección para los ojos y el rostro y mascarillas de gasa. Cuando no sea posible garantizar una extracción adecuada, por ejemplo durante la limpieza de los conductos de ventilación, será necesario emplear un equipo de protección respiratoria con suministro de aire. Debe estar prohibido fumar, comer y beber en el lugar de trabajo y se dispondrá de comedores e instalaciones sanitarias adecuadas con duchas y armarios en un lugar alejado de las zonas de exposición. Siempre que sea posible, las operaciones deberán mecanizarse, automatizarse 0 realizarse por control remoto.

\section{TALIO}

\section{Distribución y usos}

EI talio (TI) está ampliamente distribuido en la corteza terrestre aunque en concentraciones muy bajas. También se encuentra asociado con otros metales pesados en piritas y blendas y en los nódulos de manganeso en el lecho de los océanos.

EI talio se utiliza en la fabricación de sales de talio, aleaciones de mercurio, cristales resistentes a la fusión, células fotoeléctricas, lámparas y componentes electrónicos. Aleado con mercurio, se emplea para la fabricación de termómetros de bajas temperaturas y de algunos interruptores. También ha encontrado aplicación en la investigación de los semiconductores y en el diagnóstico por imagen del miocardio. El talio es un catalizador en las síntesis orgánicas.

Los compuestos de talio se utilizan en los espectrómetros de infrarrojos, cristales y otros sistemas ópticos y se emplean asimismo para la coloración del vidrio. A pesar de que se han preparado muchas sales de talio, pocas tienen importancia comercial.

El hidróxido de talio ( $\mathrm{T} I \mathrm{OH}$ ), o hidróxido talioso, se produce disolviendo óxido de talio en agua o mediante el tratamiento del sulfato de talio con una solución de hidróxido de bario. Puede utilizarse para la preparación de óxido de talio, sulfato de talio o carbonato de talio.

El sulfato de talio $\left(\mathrm{TI}_{2} \mathrm{SO}_{4}\right.$ ), o sulfato talioso, se produce disolviendo talio en ácido sulfúrico concentrado, en caliente, 0 neutralizando el hidróxido de talio con ácido sulfúrico diluido, seguido de cristalización. Por su extraordinaria eficacia para la destrucción de animales nocivos, en particular ratas y ratones, el sulfato de talio es una de las sales de talio más importantes. Sin embargo, en algunos países de Europa occidental y en Estados Unidos se ha prohibido el uso del talio sobre el suelo por el peligro que representa su fácil acceso siendo una sustancia tan tóxica. En otros países, tras desarrollar las ratas resistencia a la warfarina, ha aumentado el uso del sulfato de talio. El sulfato de talio se utiliza también en la investigación de los semiconductores, en sistemas ópticos y en las células fotoeléctricas.

\section{Riesgos}

EI talio es un sensibilizador de la piel y un veneno acumulativo que resulta tóxico por ingestión, inhalación o absorción cutánea. La exposición profesional puede producirse durante la extracción del metal de los minerales que lo contienen. Se han registrado casos de inhalación de talio durante la manipulación de polvo de humo y polvo de calcinación de piritas. También puede tener lugar una exposición durante la fabricación y el uso de exterminadores de insectos con sales de talio, la fabricación de lentes que contienen talio y la separación de diamantes industriales. La acción tóxica del talio y sus compuestos está bien documentada en los informes de casos de intoxicación aguda no profesional (en muchas ocasiones fatales) y casos de uso homicida o suicida.

La intoxicación profesional por talio suele ser resultado de una exposición moderada a largo plazo y los síntomas son mucho menos acusados que los observados en una intoxicación aguda accidental, suicida $u$ homicida. EI curso es generalmente poco notable y se caracteriza por síntomas subjetivos como astenia, irritabilidad, dolor de piernas y trastornos nerviosos. Los síntomas objetivos de polineuritis pueden no ser evidentes durante algún tiempo. Los resultados neurológicos iniciales incluyen cambios en los reflejos de los tendones provocados superficialmente y una notable debilidad y disminución de la velocidad de los reflejos pupilares.

L os antecedentes laborales de la víctima suelen ser la primera pista para diagnosticar la intoxicación por talio, pues puede pasar mucho tiempo antes de que los síntomas iniciales vagos sean reemplazados por la polineuritis y la caída del cabello. Cuando se produce una pérdida masiva de cabello, se sospecha inmediatamente la intoxicación por talio. Sin embargo, en la intoxicación profesional, con una exposición habitualmente moderada pero prolongada, la pérdida de cabello puede ser un síntoma tardío, que con frecuencia sólo se percibe después de la aparición de la polineuritis. En los casos de intoxicación leve, puede incluso no producirse.

Los dos criterios principales para el diagnóstico de la intoxicación profesional por talio son:

1. la historia laboral, que muestre que el paciente ha estado o puede haber estado expuesto al talio en trabajos como la manipulación de raticidas, la producción de talio, plomo, zinc o cadmio, o la producción o el uso de diversas sales de talio;

2. síntomas neurológicos, dominados inicialmente por cambios subjetivos en forma de parestesias (tanto hiperestesia como hipoestesia) y, posteriormente, por cambios en los reflejos.

L as concentraciones de TI en la orina superiores a $500 \mathrm{mg} / \mathrm{I}$ se han asociado con la intoxicación clínica. La magnitud del riesgo y la gravedad de los efectos adversos en el hombre en concentraciones de 5 a $500 \mu \mathrm{g} / \mathrm{I}$ no se han determinado con precisión.

Experimentos a largo plazo con talio radiactivo demuestran una excreción importante de talio tanto en la orina como en las heces. En las autopsias, las mayores concentraciones de talio se encuentran en los riñones, aunque también pueden existir concentraciones moderadas en el hígado, otros órganos internos, los músculos y los huesos. Es sorprendente que, si bien los principales signos y síntomas de la intoxicación por talio tienen su origen en el sistema nervioso central, solamente se retienen en él concentraciones muy bajas de talio. Ello puede deberse a su 
extremada sensibilidad, incluso a cantidades muy pequeñas de talio que actúen sobre las enzimas, los neurotransmisores 0 directamente sobre las células del cerebro.

\section{Medidas de salud y seguridad}

La medida más eficaz contra los peligros que presenta la fabricación y empleo de este grupo de sustancias sumamente tóxicas es su sustitución por un material menos nocivo, algo que debe hacerse siempre que sea posible. Cuando sea necesario utilizar talio o sus compuestos, deberán adoptarse las precauciones de seguridad más estrictas para garantizar que la concentración en el aire del lugar de trabajo se mantiene por debajo de los límites permisibles y evitar el contacto con la piel. La inhalación continua de estas concentraciones de talio durante una jornada laboral normal de 8 horas puede hacer que los niveles en la orina sean superiores a los admisibles.

Las personas que trabajen con talio y sus compuestos deberán utilizar equipos de protección individual y, cuando exista la posibilidad de una inhalación peligrosa de polvo en el ambiente, será esencial que utilicen también equipos de protección respiratoria. Es indispensable que se cambien las ropas de trabajo, que deberán lavarse regularmente y guardarse en un lugar separado de la ropa de calle. Deberán existir instalaciones sanitarias adecuadas, con duchas, y se fomentará una escrupulosa higiene personal. Los lugares de trabajo deben mantenerse muy limpios $\mathrm{y}$ ha de estar prohibido comer, beber o fumar en ellos.

\section{TANTALO}

\section{Distribución y usos}

El tántalo $(\mathrm{T} a)$ se obtiene de los minerales tantalita y columbita, que son mezclas de óxido de hierro, manganeso, niobio y tántalo. A pesar de que se consideran elementos raros, la corteza terrestre contiene aproximadamente un $0,003 \%$ de niobio y tántalo juntos, que son elementos químicamente similares y generalmente se encuentran combinados.

EI uso principal del tántalo es la producción de capacitores eléctricos. El polvo de tántalo se comprime, se sinteriza y se somete a oxidación anódica. La película de óxido que se forma en la superficie sirve de aislante y cuando se introduce en una solución electrolítica, se obtiene un capacitor de alta calidad. Estructuralmente, el tántalo se utiliza cuando se requiere un elevado punto de fusión, una alta densidad y resistencia a los ácidos. Se emplea mucho en la industria química. Se usa asimismo en los rectificadores de las señales de ferrocarril, en hilo de sutura para cirugía y en la reparación de hueso, tubos de vacío, hornos, herramientas de corte, prótesis, toberas para hilar fibras y material de laboratorio.

El carburo de tántalo se utiliza como abrasivo y el óxido de tántalo en la fabricación de un vidrio especial con un alto índice de refracción para lentes de cámaras.

\section{Riesgos}

El polvo de tántalo metálico presenta riesgo de incendio y explosión, aunque no tanto como otros metales (circonio, titanio, etc.). L os trabajos con tántalo metálico conllevan un riesgo de quemaduras, descargas eléctricas y lesiones oculares y traumáticas. En los procesos de refino intervienen productos químicos tóxicos y peligrosos, como el fluoruro de hidrógeno, el sodio y disolventes orgánicos.

Toxicidad. La toxicidad sistémica del oxido de tántalo y del tántalo metálico es baja, probablemente por su escasa solubilidad. Sin embargo, constituye un riesgo para la piel, los ojos y el aparato respiratorio. Aleado con otros metales como el cobalto, el tungsteno y el niobio, se le ha atribuido un papel etiológico en la neumoconiosis por metales duros y en las afecciones de la piel provocadas por los polvos de metales duros. El hidróxido de tántalo no es demasiado tóxico para los embriones de pollo y el óxido no es tóxico para las ratas cuando se administra por vía intraperitoneal. El cloruro de tántalo, sin embargo, tiene una $\mathrm{DL}_{50}$ de $38 \mathrm{mg} / \mathrm{kg}$ (como Ta), mientras que la toxicidad de la sal compleja, $\mathrm{K}_{2} \mathrm{TaF}_{7}$ es aproximadamente de una cuarta parte.

\section{Medidas de salud y seguridad}

En la mayoría de las operaciones, una buena ventilación general puede ser suficiente para mantener las concentraciones de polvo de tántalo y de sus compuestos por debajo de los límites. Se debe evitar la presencia de llamas, arcos eléctricos y chispas en las zonas en que se manipulen polvos de tántalo. Cuando los trabajadores deban exponerse regularmente a concentraciones de polvo próximas al valor umbral, se recomienda realizar reconocimientos médicos periódicos con especial atención a la función pulmonar. En las operaciones con fluoruros de tántalo deben observarse, como con el fluoruro de hidrógeno, las precauciones adecuadas para estos compuestos.

El bromuro $\left(\mathrm{TaBr}_{5}\right)$, el cloruro $\left(\mathrm{TaCl}_{5}\right)$ y el fluoruro de tántalo $\left(\mathrm{TaF}_{5}\right)$ se deben mantener en botellas herméticamente cerradas, perfectamente rotuladas y conservadas en un lugar fresco y bien ventilado, alejadas de compuestos que reaccionen con los ácidos o los vapores de ácidos. EI personal que trabaje con estos compuestos debe conocer sus riesgos.

\section{TELURIO}

El telurio (Te) es un elemento pesado con las propiedades físicas y el brillo plateado de un metal, pero con las propiedades químicas de un no metal, como el azufre o el arsénico. Se sabe que el telurio existe en dos formas alotrópicas: la forma cristalina hexagonal (isomorfa con el selenio gris) y el polvo amorfo. Q uímicamente, se asemeja al selenio y al azufre. Se oscurece ligeramente en contacto con el aire, pero en estado fundido arde produciendo humos blancos de dióxido de telurio, muy poco soluble en agua.

\section{Distribución y usos}

La geoquímica del telurio no se conoce bien; probablemente sea entre 50 y 80 veces más raro que el selenio en la litosfera. Al igual que el selenio, es un subproducto de la industria del refinado del cobre. L os barros anódicos contienen hasta un $4 \%$ de telurio.

El telurio se utiliza para mejorar el mecanizado del cobre de "corte libre" y de algunos aceros. Es un potente estabilizador de carburos en el hierro fundido y se emplea para aumentar la profundidad de la lingotera en las fundiciones. La adición de telurio mejora las propiedades de carga máxima de tracción sin deformación aparente del estaño. Sin embargo, el uso principal del telurio es la vulcanización del caucho, ya que reduce el tiempo de curado y proporciona al caucho una mayor resistencia al calor y a la abrasión. En cantidades mucho menores, el telurio se utiliza en el vitrificado de la cerámica y como aditivo para el selenio en los rectificadores metálicos. El telurio actúa como catalizador en algunos procesos químicos. Se encuentra en explosivos, antioxidantes y en los cristales de transmisión de infrarrojos. El vapor de telurio se utiliza en las "lámparas de luz día", y el el ácido graso de telurio radioyodinado (T PDA) se ha utilizado para la exploración miocárdica. 


\section{Riesgos}

Se han descrito casos de intoxicación industrial aguda como resultado de la absorción pulmonar de humos de telurio metálico.

Un estudio realizado entre trabajadores de fundición que lanzan a mano el telurio al hierro fundido produciéndose la emanación de densos humos blancos demostró que las personas expuestas a concentraciones de telurio de 0,01 a $0,74 \mathrm{mg} / \mathrm{m}^{3}$ tienen niveles de telurio en orina $(0,01$ a $0,06 \mathrm{mg} / \mathrm{l})$ más elevados que los trabajadores expuestos a concentraciones de 0,00 a $0,05 \mathrm{mg} / \mathrm{m} 3$ (concentraciones urinarias de 0,00 a $0,03 \mathrm{mg} / \mathrm{I}$ ). El signo más común de la exposición es el olor del aliento a ajo (84 \% de los casos) y un sabor metálico en la boca (30 \% de los casos). Los trabajadores se quejaban de somnolencia por las tardes y pérdida de apetito, pero no se observó pérdida de la sudoración; las pruebas sanguíneas y del sistema nervioso central resultaron normales. Un trabajador siguió teniendo el aliento con olor a ajo y telurio en la orina después de haberse retirado del trabajo durante 51 días.

En trabajadores de laboratorio expuestos durante $10 \mathrm{~min}$ a los humos producidos por la fundición de la aleación de teluriocobre (50:50) no se observaron síntomas inmediatos, pero fueron muy marcados los efectos de olor en el aliento. Dado que el telurio forma un óxido muy poco soluble, sin dar ninguna reacción ácida, no existe riesgo para la piel o los pulmones por el polvo 0 el humo de telurio. El elemento se absorbe a través del tracto gastrointestinal y los pulmones y se excreta en el aliento, las heces y la orina.

El dióxido de telurio $\left(\mathrm{TeO}_{2}\right)$, el telururo de hidrógeno $\left(\mathrm{H}_{2} \mathrm{Te}\right.$ ) y la telurita potásica $\left(\mathrm{K}_{2} \mathrm{TeO}_{3}\right)$ son importantes desde el punto de vista de la salud industrial. Como el óxido de telurio se forma a temperaturas superiores a los 450 으 y el dióxido formado es prácticamente insoluble en agua y en los líquidos corporales, el telurio parece presentar un peligro industrial inferior al selenio.

EI telururo de hidrógeno es un gas que se descompone lentamente en sus elementos. Su olor y toxicidad son similares a los del seleniuro de hidrógeno y es 4,5 veces más pesado que el aire. Existen informes de casos de irritación de las vías respiratorias por telururo de hidrógeno.

Sólo se ha descrito un caso de un químico que fue hospitalizado tras inhalar por accidente gas de hexafluoruro de telurio durante la fabricación de ésteres de telurio. Presentaba estrías de pigmentación de color azul o negro bajo la superficie de la piel en la yema de los dedos y, en menor grado, en la cara y el cuello. L as fotografías muestran claramente este raro ejemplo de absorción cutánea de un éster de telurio, reducido a telurio elemental negro durante su paso a través de la piel.

En animales expuestos al telurio se han descrito efectos sobre el sistema nervioso central y los eritrocitos.

\section{Medidas de salud y seguridad}

Cuando se añada telurio al hierro, al plomo 0 al cobre fundidos 0 se vaporice en una superficie en condiciones de vacío, deberá instalarse un sistema de extracción de gases con una velocidad mínima del aire de $30 \mathrm{~m} / \mathrm{min}$ para controlar la emisión de vapores. Para su empleo en aleaciones es preferible utilizar telurio en forma de tabletas. Se deben realizar determinaciones atmosféricas de rutina para garantizar que la concentración se mantiene por debajo de los niveles recomendados. No se ha determinado ninguna concentración específica permisible para el telururo de hidrógeno, pero se considera conveniente adoptar el mismo nivel que para el selenuro de hidrógeno.

En los procesos del telurio se debe observar una higiene escrupulosa. Los trabajadores han de llevar batas blancas, utilizar guantes y mascarillas de gasa como protección respiratoria si manipulan polvo, y contar con las instalaciones sanitarias adecuadas. No debe permitirse la trituración manual, utilizándose sistemas de trituración mecánica bien ventilados.

\section{TITANIO}

\section{Distribución y usos}

Son muchos los minerales que contienen titanio $(\mathrm{Ti})$, pero sólo unos pocos tienen importancia industrial. Cabe citar: la ilmenita $\left(\mathrm{FeT} \mathrm{iO}_{3}\right)$, con un $52,65 \%$ de $\mathrm{Ti}$ y un $47,4 \%$ de $\mathrm{FeO}$; el rutilo $\left(\mathrm{TiO}_{2}\right)$, con mezclas de óxido ferroso; la perovskita ( $\mathrm{C} \mathrm{aT} \mathrm{iO}_{3}$ ), con un $58,7 \%$ de $\mathrm{TiO}_{2}$ y un $41,3 \%$ de $\mathrm{CaO}$; y el esfeno o titanita, $\left(\mathrm{CaOTiO} 2 \cdot \mathrm{SiO}_{2}\right)$, con un $38,8 \%$ de $\mathrm{TiO}_{2}$. Algunos minerales heterogéneos, como la loparita, el piroclor y los restos del procesado de los minerales de bauxita y cobre pueden ser también fuentes de titanio.

El titanio se utiliza como metal puro, en aleaciones y en forma de diversos compuestos. U na proporción muy elevada se emplea en la industria del hierro y el acero, para la construcción de barcos, aviones y naves especiales y para la fabricación de plantas químicas. 0 tra aplicación es como revestimiento protector de las mezcladoras de la industria de la pulpa y el papel, y en instrumental quirúrgico. Se ha utilizado asimismo para la fabricación de electrodos, filamentos de bombillas, pinturas, tintes y varillas de soldadura. El polvo de titanio se usa en pirotecnia y en la tecnología del vacío. También se emplea titanio en odontología y cirugía, para prótesis o implantes.

El carburo y el nitruro de titanio tienen aplicación en la metalurgia de polvo. El titanato de bario se utiliza para fabricar capacitores de gran rendimiento. El dióxido de titanio se utiliza como pigmento blanco en pinturas y barnices, en tapicería, en electrónica, para fabricar adhesivos, tejados y plásticos y en la industria cosmética. También se emplea como componente de los esmaltados y vitrificados de cerámica, como agente para comprimir las fibras de vidrio y para eliminar el brillo de las fibras sintéticas. El tetracloruro de titanio actúa como intermediario en la producción de titanio metálico y pigmentos de titanio y como catalizador en la industria química.

\section{Riesgos}

Entre los riesgos de la producción de titanio se encuentran la formación de polvo de dióxido de titanio $\left(\mathrm{TiO}_{2}\right)$ y de polvo de concentrado, procedente del aglomerado con alquitrán y que se produce durante la trituración, mezclado y carga de las materias primas, y el calor radiante proveniente de los hornos de coqueificación. En las plantas de cloración y rectificación, la existencia de corrosión o fugas en el equipo puede producir la liberación a la atmósfera de cloro, vapores de tetracloruro de titanio $\left(\mathrm{T} \mathrm{iCl}_{4}\right)$ y de sus productos de pirólisis. En la zona de reducción, el aire puede contener óxido de magnesio. El batido, triturado, separado y embolsado de la esponja de titanio puede arrojar polvo de titanio en la atmósfera. En la zona de horno de arco se produce exposición al calor y a la radiación infrarroja (hasta $3-5 \mathrm{cal} / \mathrm{cm}^{2}$ por $\mathrm{min}$ )

Durante el mantenimiento y la reparación de las instalaciones de cloración y rectificación, que incluye el desmontaje y la limpieza del equipo y las conducciones, se crean unas condiciones de trabajo especialmente adversas, con elevadas concentraciones de vapores de $\mathrm{TiCl}_{4}$ y sus productos de hidrólisis $(\mathrm{HCl}$, $\left.\mathrm{Ti}(\mathrm{OH})_{4}\right)$, que son muy tóxicos e irritantes. Los trabajadores de estas plantas padecen con frecuencia procesos de vías respiratorias altas y bronquitis agudas o crónicas. Las salpicaduras de $\mathrm{TiCl}_{4}$ líquido sobre la piel producen irritación y quemaduras. El contacto del $\mathrm{TiCl}_{4}$ con la conjuntiva, por breve que sea, 
produce una conjuntivitis y queratitis supurativa, que puede dejar como secuela opacidades en la córnea. Los experimentos con animales han demostrado que el polvo de titanio metálico, los concentrados de titanio, el dióxido y el carburo de titanio son ligeramente tóxicos. A pesar de que el dióxido de titanio no ha resultado fibrogénico en animales, parece potenciar la capacidad fibrogénica del cuarzo durante la exposición combinada. Una exposición prolongada a polvo que contenga titanio puede provocar formas leves de enfermedad pulmonar crónica (fibrosis). Existen pruebas radiológicas de que los trabajadores que manipulan $\mathrm{TiO}_{2}$ durante períodos prolongados desarrollan alteraciones pulmonares que recuerdan las observadas en las formas leves de silicosis. Un trabajador que estuvo en contacto con dióxido de titanio durante varios años y falleció de cáncer cerebral presentaba en los pulmones depósitos de $\mathrm{TiO}_{2}$ y cambios histológicos análogos a los de la antracosis. Reconocimientos médicos de los trabajadores de la metalurgia de polvo realizados en varios países han puesto de manifiesto casos de neumonitis crónica debidos a mezclas de polvos que contenían carburo de titanio. La gravedad del proceso depende de las condiciones de trabajo, la duración de la exposición al polvo y factores individuales.

Los trabajadores expuestos crónicamente al titanio y al dióxido de titanio muestran una elevada incidencia de bronquitis crónica (endobronquitis y peribronquitis). Las etapas precoces de la enfermedad se caracterizan por una alteración de la respiración pulmonar y la capacidad ventilatoria y una disminución de la alcalinidad de la sangre. L os registros electrocardiográficos de los trabajadores del titanio muestran cambios cardíacos característicos de la enfermedad pulmonar con hipertrofia de la aurícula derecha. En muchos de estos casos se observa hipoxia miocárdica de diversos grados, inhibición de la conducción aurículo-ventricular e intraventricular y bradicardia.

El polvo de titanio metálico en suspensión aérea es explosivo.

0 tros riesgos de la producción de titanio son la exposición al monóxido de carbono en los hornos de arco y de coqueificación, y las quemaduras.

\section{Medidas de salud y seguridad}

Se debe controlar el polvo durante la trituración del mineral mediante la humidificación del material (hasta un 6-8 \% de contenido de humedad) y establecer un proceso continuo que permita aislar el equipo e instalar sistemas de extracción de gases en todos los puntos en que se pueda formar polvo; el aire extraído cargado de polvo debe filtrarse, reciclando después el polvo recogido. Se dispondrá de sistemas de extracción de polvo en las unidades de batido, los trituradores, separadores e hinchadores de la planta de esponja de titanio. El batido con martillos neumáticos deberá sustituirse por el proceso en máquinas especiales de triturado o volteado.

\section{- TUNGSTENO 0 WOLFRAMIO}

\section{Distribución y usos}

El tungsteno (W) nunca se encuentra libre en la naturaleza, sino combinado en algunos minerales, en forma de tungstatos de calcio, hierro o manganeso. De los minerales de tungsteno conocidos, la scheelita $\left(\mathrm{CaWO}_{4}\right)$, la wolframita ((Fe,M n)WO $\left.{ }_{4}\right)$, la hubnerita $(\mathrm{M} \mathrm{nWO})$ y la ferberita $\left(\mathrm{FeWO}_{4}\right)$ tienen importancia comercial. Se calcula que las reservas mundiales totales de trióxido de tungsteno $\left(\mathrm{WO}_{3}\right)$ ascienden aproximadamente a 175.000.000 de toneladas. Los minerales de tungsteno se suelen extraer de yacimientos subterráneos, aunque también se emplean tajos a cielo abierto y otros métodos más primitivos. El contenido de tungsteno del mineral extraído se sitúa entre el 0,5 y el 2,0\%. Las impurezas más comunes son las gangas como el cuarzo y la calcita y minerales metálicos de cobre, bismuto, estaño y molibdeno.

El tungsteno es un componente de los metales duros. Se utiliza para aumentar la dureza, la resistencia, la elasticidad y la resistencia a la tracción del acero. También se emplea en la producción de aceros al tungsteno para automóviles y herramientas de corte a alta velocidad. Asimismo encuentra aplicación en lámparas, tubos de vacío, contactos eléctricos, tubos de rayos $X$ y tubos fluorescentes. En la industria textil, se usa para retardar la combustión.

El carburo de tungsteno (WC) sustituye al diamante en los grandes troqueles de estirado y en los barrenos para rocas debido a su extraordinaria dureza. Compuestos de tungsteno se emplean también en láseres, colorantes, tintas y fritas cerámicas. Algunas aleaciones de tungsteno se utilizan en la industria nuclear y aeroespacial en los inyectores de los motores de los cohetes y como pantallas protectoras en las naves espaciales.

\section{Riesgos}

Se sabe muy poco sobre la toxicidad del tungsteno. $L a L_{50}$ del tungstato sódico en ratas de 66 días de edad osciló entre 223 y $255 \mathrm{mg} / \mathrm{kg}$ y mostró un efecto posprandial y de envejecimiento significativo. De los tres compuestos de tungsteno, el tungstato sódico es el más tóxico, el óxido túngstico el intermedio y el paratungstato amónico el menos tóxico. La administración del 2,5 y el $10 \%$ de la dieta en forma de tungsteno metálico durante un período de 70 días no produjo efectos notables sobre el crecimiento de las ratas macho determinado en términos de aumento de peso, aunque en ratas hembras se observó una reducción del aumento de peso del $15 \%$ con respecto a los animales control.

La exposición industrial se relaciona principalmente con sustancias asociadas a la producción y la utilización del tungsteno, sus aleaciones y compuestos, más que con el tungsteno propiamente dicho. En los procesos de extracción y molturación, los principales riesgos parecen ser la exposición al polvo conteniendo cuarzo, al ruido, al sulfuro de hidrógeno, al dióxido de azufre y a productos químicos como el cianuro y el hidróxido sódicos. La exposición puede estar asociada a otros metales del mineral, como el níquel.

El metal duro es la mezcla de carburo de tungsteno y cobalto, a la que pueden añadirse pequeñas cantidades de otros metales. En la industria de las herramientas cortantes, los trabajadores pueden estar expuestos al polvo de carburo de tungsteno, a humos y polvo de cobalto y a los carburos de níquel, titanio y tántalo. Tras una exposición profesional por inhalación de polvo de carburo de tungsteno se han descrito casos de neumoconiosis o fibrosis pulmonar, aunque generalmente se acepta que esta "enfermedad por metales duros" se debe más probablemente al cobalto con que se fusiona el carburo de tungsteno. Durante el mecanizado y triturado del carburo de tungsteno, los trabajadores de metales duros pueden desarrollar enfermedad pulmonar intersticial obstructiva, un riesgo grave asociado con concentraciones elevadas de cobalto en el aire. Los efectos de los metales duros sobre los pulmones se tratan en otras secciones de esta Enciclopedia.

El tungsteno carbonilo presenta un riesgo moderado de incendio cuando se expone a la llama. Si se calienta hasta la descomposición, desprende monóxido de carbono. La incidencia de accidentes y enfermedades en las minas e industrias de tungsteno no esta bien documentada; sin embargo, según los escasos datos disponibles, puede decirse que es menor que en las minas de carbón. 


\section{- VANADIO}

\section{Distribución y usos}

Los minerales de vanadio (V) más importantes son la patronita (sulfuro de vanadio), que se encuentra en Perú, y la descloizita (vanadato de plomo-zinc), en Sudáfrica. 0 tros minerales, como la vanadinita, la roscolita y la carnotita, contienen vanadio en cantidad suficiente para que la extracción sea rentable. El petróleo crudo puede contener pequeñas cantidades de vanadio y los depósitos de gases de combustión de los hornos caldeados con petróleo pueden contener más de un $50 \%$ de pentóxido de vanadio. 0 tra fuente del metal son las escorias de ferrovanadio. Una de las fuentes más importantes de exposición al vanadio para el hombre son los óxidos de vanadio liberados al quemar combustibles de petróleo.

El vanadio se encuentra normalmente en pequeñas cantidades en el organismo humano, especialmente en el tejido adiposo y en la sangre.

La mayor parte del vanadio producido se emplea como ferrovanadio, cuyo uso directo más importante son aceros de alta velocidad y la fabricación de herramientas de acero. La adición de un 0,05 a un $5 \%$ de vanadio elimina el oxígeno y el nitrógeno ocluidos en el acero, aumenta la resistencia a la tracción y mejora el módulo de elasticidad y la resistencia a la corrosión de la aleación final. En el pasado se utilizaban compuestos de vanadio como agentes terapéuticos en medicina. La aleación de vanadio y galio tiene propiedades importantes para la producción de campos magnéticos de alta intensidad.

Algunos compuestos de vanadio tienen un uso limitado en la industria: el sulfato de vanadio $\left(\mathrm{VSO}_{4} \cdot 7 \mathrm{H}_{2} \mathrm{O}\right)$ y el teracloruro de vanadio $\left(\mathrm{VCl}_{4}\right)$ se utilizan como mordientes en tintorería; los silicatos de vanadio como catalizadores; y el dióxido $\left(\mathrm{VO}_{2}\right)$ y el trióxido de vanadio $\left(\mathrm{V}_{2} \mathrm{O}_{3}\right)$ en la industria metalúrgica. Sin embargo, los compuestos de vanadio más importantes desde el punto de vista de sus riesgos para la salud son el pentóxido de vanadio $\left(\mathrm{V}_{2} \mathrm{O}_{5}\right)$ y el metavanadato amónico $\left(\mathrm{NH}_{4} \mathrm{VO}_{3}\right)$.

El pentóxido de vanadio se obtiene de la patronita. Durante mucho tiempo se utilizó como importante catalizador industrial en varios procesos de oxidación, como los que intervienen en la fabricación de los ácidos sulfúrico, ftálico, maléico, etc., así como en el revelado de fotografía y como agente de tinción en la industria textil. T iene aplicación asimismo para la coloración de materiales cerámicos.

El metavanadato amónico se utiliza como catalizador del mismo modo que el pentóxido de vanadio, como reactivo en química analítica y como revelador fotográfico. También se usa para la tinción y estampado de tejidos.

\section{Riesgos}

La experiencia ha demostrado que los óxidos de vanadio, y en especial el pentóxido y su derivado el metavanadato amónico, producen efectos adversos en el hombre. Puede producirse una exposición al pentóxido de vanadio durante las siguientes actividades industriales: cuando se utiliza pentóxido de vanadio en forma de partículas para la producción de vanadio metálico, durante las operaciones de reparación de instalaciones en que se ha utilizado pentóxido de vanadio como catalizador, durante la limpieza de calderas de los hornos de fuel-oil en las centrales eléctricas, barcos, etc. La presencia de compuestos de vanadio en los productos del petróleo es especialmente importante y, dada la posibilidad de contaminación atmosférica en las centrales eléctricas de fuel-oil, existe un control de las autoridades sanitarias públicas y de los encargados de supervisar la salud laboral.
La inhalación de compuestos de vanadio puede producir efectos tóxicos graves, cuya gravedad depende de la concentración atmosférica de los compuestos de vanadio y de la duración de la exposición. Pueden aparecer problemas de salud incluso después de una exposición breve (por ejemplo, 1 hora), y los síntomas iniciales son: lagrimeo profuso, sensación de ardor en la conjuntiva, rinitis serosa o hemorrágica, dolor de garganta, tos, bronquitis, expectoración y dolor torácico. U na exposición intensa puede producir neumonía, con resultados fatales; ahora bien, si la exposición ocurre una sola vez, suele observarse una recuperación completa en 1 o 2 semanas; la exposición prolongada puede producir bronquitis crónica con o sin enfisema. La lengua puede sufrir una alteración del color, tornándose verdosa, al igual que las colillas de cigarros de los trabajadores del vanadio, como resultado de interacciones químicas.

En animales se laboratorio, se han observado efectos locales principalmente en las vías respiratorias. También se han descrito efectos sistémicos en el hígado, los riñones, el sistema nervioso, el aparato cardiovascular y los órganos formadores de sangre. Entre los efectos metabólicos cabe citar una interferencia con la biosíntesis de cistina y colesterol, e inhibición y estimulación de la síntesis de fosfolípidos. Concentraciones elevadas han ocasionado la inhibición de la oxidación de la serotonina. A demás, se ha demostrado que el vanadato inhibe varios sistemas enzimáticos. En el hombre, los efectos sistémicos de la exposición al vanadio están menos documentados, aunque se ha comprobado una disminución del colesterol en suero. En el ambiente de trabajo, el organismo humano capta el vanadio y sus compuestos por inhalación, principalmente durante la producción y las operaciones de limpieza de las calderas. La absorción gastrointestinal de vanadio es baja y no supera el 1-2 \%; los compuestos de vanadio ingeridos se eliminan en su mayor parte en las heces.

Se ha realizado un estudio para evaluar la respuesta bronquial en trabajadores recientemente expuestos a pentóxido de vanadio durante la retirada periódica de cenizas y escoria de las calderas de fuel-oil de una estación eléctrica. Los resultados indican que la exposición al vanadio aumenta la sensibilidad bronquial aun cuando no aparezcan síntomas bronquiales.

\section{Medidas de salud y seguridad}

Es importante evitar la inhalación de polvo de pentóxido de vanadio del aire. Para su uso como catalizador, puede obtenerse en forma de aglomerado o escamas, lo que evita la producción de polvo. Sin embargo, las vibraciones en las instalaciones pueden llegar a reducir cierta cantidad de material a polvo. En los procesos asociados con la obtención de vanadio metálico y durante el tamizado del catalizador en las operaciones de mantenimiento, debe evitarse el escape de polvo efectuando estos procesos en cerrado e instalando sistemas de ventilación con extracción.

D urante la limpieza de las calderas en las centrales eléctricas y los barcos, puede ser necesario que los trabajadores de mantenimiento entren en las calderas para retirar residuos y realizar reparaciones. En estas actividades, los trabajadores deben utilizar equipos de protección respiratoria adecuados y una mascarilla que les cubra completamente el rostro, con protección ocular. Siempre que sea posible, se mejorará la limpieza durante la carga para reducir la necesidad de que los trabajadores penetren en el interior de los hornos; cuando sea indispensable realizar la limpieza de descarga, se intentará realizarla con chorros de agua y métodos que no requieren la entrada física de los trabajadores. 


\section{ZINC}

\section{Distribución y usos}

El zinc $(Z n)$ se encuentra ampliamente distribuido en la naturaleza y constituye aproximadamente un $0,02 \%$ de la corteza terrestre. A dopta la forma de sulfuro (esfalerita), carbonato, óxido o silicato (calamina) de zinc, combinado con muchos minerales. La esfalerita, el principal mineral de zinc y fuente de al menos el $90 \%$ del zinc metálico, contiene hierro y cadmio como impurezas. C asi siempre aparece acompañado de galena, el sulfuro de plomo, y ocasionalmente se encuentra asociado con minerales que contienen cobre u otros sulfuros metálicos básicos.

Cuando se expone a la acción del aire, el zinc se recubre de una película de óxido que protege el metal de oxidaciones posteriores. En esta resistencia a la corrosión atmosférica reside uno de sus principales usos: la protección del acero mediante galvanización. La capacidad del zinc para proteger los metales ferrosos de la corrosión puede potenciarse mediante electrólisis. El zinc actúa como ánodo con el hierro y otros metales estructurales, a excepción del aluminio y el manganeso, y así, los agentes corrosivos atacan preferentemente al zinc, y se protegen los demás metales. Esta propiedad se aprovecha también en otras aplicaciones importantes, como en la utilización de planchas de zinc como ánodos para la protección catódica de los cascos de buques, tanques enterrados, etc. El zinc metálico se puede troquelar para la fabricación de piezas de automóviles, equipos eléctricos, herramientas de maquinaria ligera, equipos informáticos, juguetes y artículos ornamentales. También puede laminarse para la obtención de planchas destinadas a tejados y cubiertas, forros de pilas secas, placas de fotograbado, etc. Además, puede alearse con cobre, níquel, aluminio y magnesio. Cuando se alea con cobre, se obtiene el importante grupo de aleaciones denominadas bronces

El óxido de zinc (ZnO), o blanco de zinc (flores de zinc), se produce por oxidación de zinc puro vaporizado o mediante la calcinación del mineral de óxido de zinc. Se utiliza como pigmento para la fabricación de pinturas, lacas y barnices, y como carga en plásticos y caucho. También tiene aplicación en la fabricación de cosméticos, cementos de fraguado rápido y en la industria farmacéutica. Es útil para la fabricación de vidrio, ruedas de automóviles, cerillas, pegamento blanco y tintas para imprenta y como semiconductor en la industria electrónica.

EI cromato de zinc $\left(\mathrm{ZnCrO}_{4}\right)$, o amarillo de zinc, se produce por la acción del ácido crómico sobre la pasta de óxido de zinc o el hidróxido de zinc. Se utiliza en pigmentos, pinturas, barnices y lacas, y en la fabricación del linóleo. También se emplea como inhibidor de la corrosión para metales y laminados epoxi.

El cianuro de zinc $\left(\mathrm{Zn}(\mathrm{CN})_{2}\right)$ se obtiene por precipitación de una solución de sulfato o cloruro de zinc con cianuro potásico. Se utiliza para electrodeposición sobre metales y en el proceso de extracción del oro. Tiene aplicación también como reactivo químico y pesticida. El sulfato de zinc $\left(\mathrm{ZnSO}_{4} \cdot 7 \mathrm{H}_{2} \mathrm{O}\right)$, o vitriolo blanco, se obtiene por calcinación de la blenda o por la acción del ácido sulfúrico sobre el zinc o el óxido de zinc. Se utiliza como astringente, conservante de pieles y maderas, decolorante de papel, adyuvante de pesticidas y fungicida. Se emplea también como agente incombustible y tensoactivo en el proceso de flotación por espuma. 0 tro uso es el tratamiento del agua y la tinción y estampado de tejidos. El sulfuro de zinc se utiliza como pigmento para pinturas, lienzos, cuero, tintas, lacas y cosméticos. El fosfuro de zinc $\left(Z n_{3} P_{2}\right)$ se obtiene haciendo pasar fosfina a través de una solución de sulfato de zinc. Se emplea principalmente como rodenticida.
El cloruro de zinc $\left(\mathrm{ZnCl}_{2}\right)$, o manteca de zinc, tiene numerosos usos en la industria textil durante el teñido, estampado y apresto de los tejidos. Es un componente del cemento para metales, los dentífricos y las pastas de soldadura. Se utiliza sólo o con fenol y otros antisépticos para conservar las traviesas de los ferrocarriles. Es útil para el grabado del metal y la fabricación de asfalto. Sirve como agente vulcanizante para el caucho, retarda la combustión de la madera e inhibe la corrosión en el tratamiento del agua.

\section{Riesgos}

El zinc es un nutriente esencial. Es un componente de las metaloenzimas que participan en el metabolismo de los ácidos nucleicos y en la síntesis de las proteínas. El zinc no se acumula en el organismo y los expertos en nutrición recomiendan una ingesta diaria mínima de zinc. Su absorción es más fácil a partir de proteínas animales que de productos vegetales. El fitato que contienen los vegetales se une al zinc, impidiendo su absorción. Se han descrito estados carenciales de zinc en países donde los cereales constituyen la principal fuente de proteínas de la población. Algunas de las manifestaciones clínicas de los déficits crónicos de zinc en el hombre son: retraso del crecimiento, hipogonadismo en los varones, alteraciones cutáneas, falta de apetito, letargo mental y retardo en la cicatrización de las heridas.

En general, las sales de zinc son astringentes, higroscópicas, corrosivas y antisépticas. Su acción precipitante sobre las proteínas constituye la base de sus efectos astringente y antiséptico y se absorben con relativa facilidad por vía cutánea. El umbral de sabor de las sales de zinc es de aproximadamente 15 ppm; cuando el agua contiene 30 ppm de sales solubles de zinc, presenta un aspecto lechoso, y si la concentración alcanza 40 ppm, tiene además sabor metálico. Las sales de zinc son irritantes para el tracto gastrointestinal y su concentración en solución acuosa con efectos eméticos varía entre 675 y 2.280 ppm.

La solubilidad del zinc en líquidos ligeramente ácidos, en presencia de hierro, ha provocado la ingestión accidental de grandes cantidades de zinc por la preparación de alimentos ácidos, como zumos de frutas, en recipientes de hierro galvanizado desgastados. Entre 20 minutos y 10 horas después de la ingestión se presentó fiebre, náuseas, vómitos, dolor de estómago y diarrea.

Varias sales de zinc pueden entrar al organismo por inhalación, a través de la piel o por ingestión y producir intoxicación. El cloruro de zinc produce úlceras cutáneas. Varios compuestos de zinc presentan riesgo de incendio y de explosión. La fabricación electrolítica de zinc puede producir nieblas que contengan ácido sulfúrico y sulfato de zinc y que pueden irritar el aparato respiratorio y digestivo y producir erosión dental. En los procesos metalúrgicos en que se utiliza zinc puede tener lugar una exposición al arsénico, el cadmio, el manganeso, el plomo y posiblemente, el cromo y la plata, con sus correspondientes riesgos. Dado que el arsénico se encuentra frecuentemente asociado con el zinc, puede ser una fuente de exposición al gas arsina, sumamente tóxico, al disolver el zinc en ácidos o álcalis.

En la metalurgia y la producción de zinc, las operaciones de soldadura y corte de metales galvanizados o zincados, o las operaciones de fundición y soldadura del latón o el bronce, el riesgo más frecuente derivado del zinc y sus compuestos es la exposición a los humos de óxido de zinc, que puede causar la fiebre de los humos metálicos. Los síntomas de este trastorno son: ataques de escalofríos, fiebre irregular, sudoración profusa, náuseas, sed, cefalea, dolores en las extremidades y sensación de extremo cansancio. Las crisis son de corta duración (en la mayoría de los casos, se observa una recuperación completa en las 24 horas siguientes a la aparición de los síntomas), y parece que se desarrolla tolerancia. En los trabajadores que participan 
en las tareas de envasado de óxido de zinc se han descrito aumentos de la protoporfirina eritrocítica libre.

Los humos de cloruro de zinc son irritantes para los ojos y las mucosas. En un accidente sucedido con un generador de humos, las 70 personas que resultaron expuestas presentaron diversos grados de irritación de los ojos, nariz, garganta y pulmones. De los 10 fallecimientos, algunos se produjeron a las pocas horas por edema pulmonar y otros más tarde por bronconeumonía. En otra ocasión, dos bomberos se vieron expuestos a humos de cloruro de zinc procedentes de un generador de humos durante una demostración de extinción de incendios, uno de ellos por un breve espacio de tiempo y el otro durante varios minutos. El primero se recuperó rápidamente, en tanto que el segundo falleció al cabo de 18 días por insuficiencia respiratoria. Poco tiempo después de producirse la exposición se observó un rápido ascenso de la temperatura y una marcada inflamación de las vías respiratorias altas. En las radiografías de tórax se observaron infiltrados pulmonares difusos y la autopsia reveló una proliferación fibroblástica activa y cor pulmonale.

En un experimento diseñado principalmente para evaluar la carcinogénesis, se suministró a grupos de 24 ratones dosis de 1.250 a 5.000 ppm de sulfato de zinc en el agua de bebida durante un año. No se observaron efectos adversos por este tratamiento, a excepción de anemia grave en los animales que recibieron $5.000 \mathrm{ppm}$. La incidencia de tumores no fue significativamente distinta de la observada en los animales control.

El fosfuro de zinc, que se utiliza como rodenticida, es tóxico para el hombre tanto por vía oral, como inhalado o inyectado $y_{\text {, }}$ junto con el cloruro de zinc, es la más peligrosa de las sales de zinc. Estas dos sustancias han sido la causa de las únicas muertes claramente debidas a una intoxicación por zinc.

Efectos cutáneos. La presencia de cromato de zinc en las pinturas de imprimación utilizadas por los carroceros de automóviles, los hojalateros y los fabricantes de muebles metálicos se ha asociado con la aparición de ulceraciones nasales y dermatitis en los trabajadores expuestos. El cloruro de zinc tiene un efecto cáustico que puede producir ulceraciones en los dedos, manos y antebrazos de las personas que manipulan maderas impregnadas con esta sustancia o que la utilizan como fundente en operaciones de soldadura. Se ha descrito que el polvo de óxido de zinc puede bloquear los conductos de las glándulas sebáceas y provocar un eczema papular o pustuloso en los trabajadores encargados del envasado de este compuesto.

\section{Medidas de salud y seguridad}

Incendio y explosión. El polvo fino de zinc y de algunos de sus compuestos puede presentar un riesgo de incendio o explosión si se almacena en lugares húmedos, que son fuentes de combustión espontánea. Los residuos de las reacciones de reducción pueden inflamar materiales combustibles. EI nitrato amónico, el bromato, el clorato, el etilo, el nitrato, el permanganato y el picrato de zinc presentan, todos ellos, un importante riesgo de incendio y explosión. Además, el zinc etilo arde espontáneamente en contacto con el aire. Por este motivo, deben conservarse en lugares frescos, secos y bien ventilados, lejos de cualquier fuente de calor, llamas 0 agentes oxidantes fuertes.

Siempre que el zinc se caliente hasta el punto de producir humo, es muy importante contar con una ventilación adecuada. La mejor manera de garantizar la protección individual es la formación sobre el riesgo de fiebre por humos metálicos y la instalación de extractores de gases locales 0 , en determinadas situaciones, el uso de campanaso máscarascon suministro deaire.

Los trabajadores expuestos a los humos de cloruro de zinc deben utilizar equipos de protección individual constituidos por ropa protectora, protección facial y ocular contra productos químicos y equipos de protección respiratoria adecuados. La exposición a los humos de cloruro de zinc debe tratarse mediante la irrigación abundante de las áreas expuestas.

Tabla 63.2 • Riesgos físicos y químicos.

\begin{tabular}{|c|c|c|c|}
\hline $\begin{array}{l}\text { Nombre químico } \\
\text { Número CAS }\end{array}$ & Fórmula molecular & Riesgos físicos y químicos & $\begin{array}{l}\text { Clase UN/ div/ } \\
\text { riesgos subsidiarios }\end{array}$ \\
\hline $\begin{array}{l}\text { Aluminato sódico } \\
1302-42-7\end{array}$ & & $\begin{array}{l}\text { - La sustancia es una base fuerte, reacciona violentamente con los ácidos y es corrosiva } \\
\text { ' La solución en agua es una base fuerte, reacciona violentamente con los ácidos y es } \\
\text { corrosiva para el aluminio y el zinc }\end{array}$ & 8 \\
\hline $\begin{array}{l}\text { Cloruro de aluminio } \\
7446-70-0\end{array}$ & $\mathrm{AlCl}_{3}$ & & 8 \\
\hline $\begin{array}{l}\text { Cloruro de dietilaluminio } \\
96-10-6\end{array}$ & $\mathrm{AlClC}_{4} \mathrm{H}_{10}$ & & 4,2 \\
\hline $\begin{array}{l}\text { Dicloruro de etilaluminio } \\
563-43-9\end{array}$ & $\mathrm{AlCl}_{2} \mathrm{C}_{2} \mathrm{H}_{5}$ & & 4,2 \\
\hline $\begin{array}{l}\text { Fosfuro de aluminio } \\
20859-73-8\end{array}$ & AlP & $\begin{array}{l}\text { ' Reacciona con el aire húmedo, el agua y los ácidos, produciendo humos muy tóxicos } \\
\text { de fosfina ' Reacciona con el agua, el aire húmedo y los ácidos, produciendo riesgo de } \\
\text { incendio y de intoxicación (humos de fosfina) }\end{array}$ & $4,3 / 6,1$ \\
\hline $\begin{array}{l}\text { Hidróxido de aluminio } \\
\text { 21645-51-2 }\end{array}$ & $\mathrm{Al}(\mathrm{OH})_{3}$ & $\begin{array}{l}\text { ' Forma geles }\left(\mathrm{Al}_{2} \cdot 3 \mathrm{H}_{2} \mathrm{O}\right) \text { en contacto prolongado con el agua; absorbe ácidos y dióxido } \\
\text { de carbono }\end{array}$ & \\
\hline $\begin{array}{l}\text { Nitrato de aluminio } \\
13473-90-0\end{array}$ & $\mathrm{Al}_{2}\left(\mathrm{NO}_{3}\right)_{3}$ & & 5,1 \\
\hline
\end{tabular}


Tabla 63.2 • Riesgos físicos y químicos.

Continuación.

\begin{tabular}{|c|c|c|c|}
\hline $\begin{array}{l}\text { Nombre químico } \\
\text { Número CAS }\end{array}$ & Fórmula molecular & Riesgos físicos y químicos & $\begin{array}{l}\text { Clase UN/ div/ } \\
\text { riesgos subsidiarios }\end{array}$ \\
\hline $\begin{array}{l}\text { Sesquicloruro de } \\
\text { etilaluminio } \\
12075-68-2\end{array}$ & $\mathrm{Al}_{2} \mathrm{Cl}_{3} \mathrm{C}_{6} \mathrm{H}_{15}$ & & 4,2 \\
\hline $\begin{array}{l}\text { Trietilaluminio } \\
97-93-8\end{array}$ & $\mathrm{AlC}_{6} \mathrm{H}_{15}$ & & 4,2 \\
\hline $\begin{array}{l}\text { Triisobutilaluminio } \\
\text { 100-99-2 }\end{array}$ & $\mathrm{AlC}_{12} \mathrm{H}_{27}$ & & 4,2 \\
\hline $\begin{array}{l}\text { Antimonio } \\
7440-36-0\end{array}$ & Sb & $\begin{array}{l}\text { ' Durante la combustión, forma humos tóxicos (óxidos de antimonio) ' Reacciona } \\
\text { violentamente con los oxidantes fuertes (como halógenos, permanganatos de álcalis y } \\
\text { nitratos), produciendo un riesgo de incendio y explosión ' Reacciona con el hidrógeno } \\
\text { naciente en medio ácido, produciendo un gas muy tóxico ' En contacto con ácidos } \\
\text { calientes concentrados, emite un gas tóxico (estibina) }\end{array}$ & 6,1 \\
\hline $\begin{array}{l}\text { Estibina } \\
7803-52-3\end{array}$ & $\mathrm{SbH}_{3}$ & $\begin{array}{l}\text { ' La sustancia se descompone lentamente a temperatura ambiente, produciendo } \\
\text { antimonio metálico e hidrógeno ' Reacciona violentamente con el ozono y el ácido nítrico } \\
\text { concentrado con riesgo de incendio y explosión ' La sustancia se descompone al calentarla, } \\
\text { produciendo humos tóxicos de antimonio ' El gas es más pesado que el aire y puede } \\
\text { desplazarse a ras de suelo; puede inflamarse a distancia }\end{array}$ & $2,3 / 2,1$ \\
\hline $\begin{array}{l}\text { Pentacloruro de antimonio } \\
7647-18-9\end{array}$ & $\mathrm{SbCl}_{5}$ & & 8 \\
\hline $\begin{array}{l}\text { Pentafluoruro de antimonio } \\
7783-70-2\end{array}$ & $\mathrm{SbF}_{5}$ & & $3 / 6,1$ \\
\hline $\begin{array}{l}\text { Tartrato potásico de } \\
\text { antimonio } \\
28300-74-5\end{array}$ & $\mathrm{Sb}_{2} \mathrm{~K}_{2} \mathrm{C}_{8} \mathrm{H}_{4} \mathrm{O}_{12} \cdot 3 \mathrm{H}_{2} \mathrm{O}$ & & 6,1 \\
\hline $\begin{array}{l}\text { Tricloruro de antimonio } \\
10025-91-9\end{array}$ & $\mathrm{SbCl}_{3}$ & & 8 \\
\hline $\begin{array}{l}\text { Trióxido de antimonio } \\
1309-64-4\end{array}$ & $\mathrm{Sb}_{2} \mathrm{O}_{3}$ & $\begin{array}{l}\text { ' La sustancia se descompone al calentarla, produciendo humos tóxicos de antimonio } \\
\text { - Reacciona bajo ciertas circunstancias con el hidrógeno, produciendo un gas muy } \\
\text { venenoso, la estibina }\end{array}$ & \\
\hline $\begin{array}{l}\text { Acido arsénico, } \\
\text { sal diamónica } \\
7784-44-3\end{array}$ & $\left(\mathrm{NH}_{4}\right)_{2} \mathrm{AsOH}_{4}$ & $\begin{array}{l}\text { ' La sustancia se descompone al calentarla, produciendo humos tóxicos de arsénico, óxidos } \\
\text { de nitrógeno y amoníaco ' Reacciona con ácidos, produciendo humos tóxicos de arsénico } \\
\text { 'En presencia de agua, ataca a muchos metales, como el hierro, el aluminio y el zinc, } \\
\text { liberando humos tóxicos de arsénico y arsina }\end{array}$ & \\
\hline $\begin{array}{l}\text { Acido arsénico, } \\
\text { sal disódica } \\
7778-43-0\end{array}$ & $\mathrm{Na}_{2} \mathrm{AsOH}_{4}$ & $\begin{array}{l}\text { ' La sustancia se descompone al calentarla, produciendo humos tóxicos de arsénico } \\
\text { ' Reacciona con los ácidos, liberando gas arśnico tóxico ' En presencia de agua, ataca } \\
\text { a muchos metales, como el hierro, el aluminio y el zinc, liberando humos tóxicos de } \\
\text { arsénico y arsina }\end{array}$ & \\
\hline $\begin{array}{l}\text { Acido arsénico, } \\
\text { sal magnésica } \\
10103-50-1\end{array}$ & $\mathrm{Mg}_{\mathrm{x}} \mathrm{ASO}_{3} \mathrm{H}_{4}$ & $\begin{array}{l}\text { ' La sustancia se descompone al calentarla, produciendo humos tóxicos de arsénico } \\
\text { ' Reacciona con ácidos liberando humos tóxicos de gas arsínico }\end{array}$ & 6,1 \\
\hline $\begin{array}{l}\text { Acido arsénico, } \\
\text { sal monopotásica } \\
7784-41-0\end{array}$ & $\mathrm{KASO}_{2} \mathrm{H}_{4}$ & $\begin{array}{l}\text { ' La sustancia se descompone al calentarla, produciendo humos tóxicos de arsénico } \\
\text { - Reacciona con ácidos, liberando gas arsínico tóxico ' En presencia de agua, ataca a } \\
\text { muchos metales, como el hierro, el aluminio y el zinc, liberando humos tóxicos de } \\
\text { arsénico y arsina }\end{array}$ & \\
\hline $\begin{array}{l}\text { Acido arsénico, } \\
\text { sal de cobre } \\
10103-61-4\end{array}$ & $\mathrm{CuASOH}_{4}$ & $\begin{array}{l}\text { ' La sustancia se descompone al calentarla, produciendo humos tóxicos de arsénico en } \\
\text { comparación con otros compuestos ' Reacciona con los ácidos, liberando gas arsina tóxico }\end{array}$ & \\
\hline $\begin{array}{l}\text { Acido arsenioso, } \\
\text { sal de cobre(2+) (1:1) } \\
\text { 10290-12-7 }\end{array}$ & $\mathrm{CuAsH}_{3}$ & $\begin{array}{l}\text { ' La sustancia se descompone al calentarla, produciendo humos tóxicos de arsénico } \\
\text { - Reacciona con ácidos liberando humos tóxicos de gas arsínico }\end{array}$ & 6,1 \\
\hline
\end{tabular}


Tabla 63.2 • Riesgos físicos y químicos. Continuación.

\begin{tabular}{|c|c|c|c|}
\hline $\begin{array}{l}\text { Nombre químico } \\
\text { Número CAS }\end{array}$ & Fórmula molecular & Riesgos físicos y químicos & $\begin{array}{l}\text { Clase UN/ div/ } \\
\text { riesgos subsidiarios }\end{array}$ \\
\hline $\begin{array}{l}\text { Acido arsenioso, } \\
\text { sal potásica } \\
10124-50-2\end{array}$ & $\left(\mathrm{KH}_{3}\right)_{\times} \mathrm{AsO}_{3}$ & $\begin{array}{l}\text { ' La sustancia se descompone al calentarla, produciendo humos tóxicos de arsénico } \\
\text { y óxido de potasio ' Reacciona con ácidos, liberando gas arsina tóxico ' Se descompone } \\
\text { al contacto con el aire (por el dióxido de carbono atmosférico) y a través de la piel }\end{array}$ & 6,1 \\
\hline $\begin{array}{l}\text { Acido arsenioso, } \\
\text { sal de plomo(II) } \\
10031-13-7\end{array}$ & $\mathrm{PbAs}_{2} \mathrm{O}_{4}$ & $\begin{array}{l}\text { ' La sustancia se descompone al calentarla, produciendo humos muy tóxicos de } \\
\text { arsénico y plomo - Reacciona con oxidantes ' Reacciona violentamente con los } \\
\text { ácidos fuertes }\end{array}$ & \\
\hline $\begin{array}{l}\text { Acido metilarsénico } \\
124-58-3\end{array}$ & $\mathrm{AsCH}_{5} \mathrm{O}_{3}$ & $\begin{array}{l}\text { ' La sustancia se descompone al calentarla o calcinarla, produciendo humos tóxicos } \\
\text { (óxidos de arsénico) ' La solución en agua es un ácido fuerte moderado, que puede } \\
\text { reaccionar con sustancias reductoras y metales activos (como el hierro, el aluminio } \\
\text { o el zinc), produciendo gases tóxicos (metilarsina) }\end{array}$ & \\
\hline $\begin{array}{l}\text { Arseniato de plomo } \\
7784-40-9\end{array}$ & $\mathrm{PbAsO}_{4} \mathrm{H}$ & $\begin{array}{l}\text { ' La sustancia se descompone al calentarla, produciendo humos tóxicos de plomo, arsénico } \\
\text { y sus compuestos, como la arsina }\end{array}$ & 6,1 \\
\hline $\begin{array}{l}\text { Arseniato sódico } \\
10048-95-0\end{array}$ & $\mathrm{Na}_{2} \mathrm{AsO}_{4} \mathrm{H} \cdot 7 \mathrm{H}_{2} \mathrm{O}$ & $\begin{array}{l}\text { ' La sustancia se descompone al calentarla, produciendo humos tóxicos como el arsénico } \\
\text { y óxidos de arsénico' Reacciona violentamente con oxidantes fuertes, ácidos fuertes y } \\
\text { metales como el hierro, el aluminio y el zinc con riesgo de explosión y toxicidad }\end{array}$ & 6,1 \\
\hline $\begin{array}{l}\text { Arseniato de calcio } \\
7778-44-1\end{array}$ & $\mathrm{Ca}_{3} \mathrm{As}_{2} \mathrm{O}_{8}$ & $\begin{array}{l}\text { ' La sustancia se descompone al calentarla, produciendo humos tóxicos de arsénico ' Reac- } \\
\text { ciona con ácidos, liberando gas arsina tóxico }\end{array}$ & 6 \\
\hline $\begin{array}{l}\text { Arsénico } \\
7440-38-2\end{array}$ & As & ' Reacciona con ácidos, oxidantes y halógenos ' La sustancia produce humos tóxicos & 6,1 \\
\hline $\begin{array}{l}\text { Arsina } \\
7784-42-1\end{array}$ & $\mathrm{ASH}_{3}$ & $\begin{array}{l}\text { ' La sustancia se descompone al calentarla y al exponerla a la luz y la humedad, } \\
\text { produciendo humos tóxicos de arsénico ' Reacciona violentamente con los oxidantes } \\
\text { fuertes, el flúor, el cloro, el ácido nítrico y el tricloruro de nitrógeno, con riesgo de incendio } \\
\text { y explosión ' El gas es más pesado que el aire y puede desplazarse a ras de suelo; posible } \\
\text { ignición a distancia ' Se pueden generar cargas electrostáticas al trasvasarla, agitarla, etc.; } \\
\text { conductividad no determinada }\end{array}$ & $2,3 / 2,1$ \\
\hline $\begin{array}{l}\text { Pentóxido de arsénico } \\
1303-28-2\end{array}$ & $\mathrm{As}_{2} \mathrm{O}_{5}$ & $\begin{array}{l}\text { ' La sustancia se descompone al calentarla a temperaturas superiores a } 300^{\circ} \mathrm{C} \text {, } \\
\text { produciendo humos tóxicos (trióxido de arsénico) y oxígeno ' La solución en agua es un } \\
\text { ácido fuerte medio, que puede reaccionar con sustancias reductoras produciendo un gas } \\
\text { muy tóxico (arsina) ' Reacciona violentamente con el pentafluoruro de bromo, con riesgo } \\
\text { de incendio y explosión ' Corrosivo a los metales en presencia de humedad }\end{array}$ & 6,1 \\
\hline $\begin{array}{l}\text { Tricloruro arsenioso } \\
7784-34-1\end{array}$ & $\mathrm{AsCl}_{3}$ & $\begin{array}{l}\text { ' La sustancia se descompone al calentarla y exponerla a la luz, produciendo vapores } \\
\text { tóxicos de ácido clorhídrico y óxidos de arsénico ' Reacciona violentamente con las bases, } \\
\text { los oxidantes fuertes y el agua, con riesgo de incendio y de toxicidad ' Al entrar en } \\
\text { contacto con el aire, emite vapores corrosivos de ácido clorhídrico ' Ataca a muchos } \\
\text { metales formando gas combustible (hidrógeno) en presencia de humedad }\end{array}$ & 6,1 \\
\hline $\begin{array}{l}\text { Trióxido de arsénico } \\
1327-53-3\end{array}$ & $\mathrm{As}_{2} \mathrm{O}_{3}$ & $\begin{array}{l}\text { ' La sustancia es un fuerte agente reductor y reacciona con los oxidantes ' La solución en } \\
\text { agua es un ácido débil que puede reaccionar con sustancias reductoras produciendo un gas } \\
\text { muy tóxico (arsina) ' Produce humos tóxicos en caso de incendio }\end{array}$ & 6,1 \\
\hline $\begin{array}{l}\text { Bario } \\
7440-39-3\end{array}$ & $\mathrm{Ba}$ & $\begin{array}{l}\text { ' La sustancia puede arder espontáneamente en contacto con el aire (si se encuentra en } \\
\text { forma de polvo) ' Es un fuerte agente reductor y reacciona violentamente con oxidantes } \\
\text { y ácidos ' Reacciona con el agua, formando un gas combustible (hidrógeno) e hidróxido } \\
\text { de bario ' Reacciona violentamente con disolventes halogenados, con riesgo de incendio } \\
\text { y explosión }\end{array}$ & 4,3 \\
\hline $\begin{array}{l}\text { Carbonato de bario } \\
513-77-9\end{array}$ & $\mathrm{BaCO}_{3}$ & & 6,1 \\
\hline
\end{tabular}


Tabla 63.2 • Riesgos físicos y químicos.

Continuación.

\begin{tabular}{lll}
$\begin{array}{l}\text { Nombre químico } \\
\text { Número CAS }\end{array}$ & Fórmula molecular & Riesgos físicos y químicos \\
$\begin{array}{cc}\text { Clorato de bario } \\
13477-00-4\end{array}$ & $\mathrm{BaCl}_{2} \mathrm{O}_{6}$ & ' Al calentarlo puede producir una violenta combustión o explosión ' Con compuestos \\
& & $\begin{array}{l}\text { orgánicos, agentes reductores, compuestos que contengan amoníaco, metales en polvo } \\
\text { y ácido sulfúrico produce compuestos sensibles al choque ' La sustancia se descompone } \\
\text { violentamente la calentarla y al quemarla, produciendo oxígeno y humos tóxicos, con } \\
\text { riesgo de incendio y explosión ' La sustancia es un oxidante fuerte y reacciona con } \\
\text { materiales combustibles y reductores ' Puede explotar si está en forma de polvo o } \\
\text { granular, al mezclarse con el aire }\end{array}$ \\
\hline
\end{tabular}

\begin{tabular}{|c|c|c|c|}
\hline $\begin{array}{c}\text { Cloruro de bario } \\
10361-37-2\end{array}$ & $\mathrm{BaCl}_{2}$ & ' La sustancia se descompone al calentarla, produciendo humos tóxicos & 6,1 \\
\hline $\begin{array}{l}\text { Cloruro de bario, dihidrato } \\
10326-27-9\end{array}$ & $\mathrm{BaCl}_{2} \cdot 2 \mathrm{H}_{2} \mathrm{O}$ & ' La sustancia se descompone al calentarla, produciendo humos tóxicos & 6,1 \\
\hline $\begin{array}{l}\text { Cromato de } \\
\text { bario (VI) } \\
10294-40-3\end{array}$ & $\mathrm{BaCrH}_{2} \mathrm{O}_{4}$ & & 6,1 \\
\hline $\begin{array}{l}\text { Hidróxido de bario } \\
17194-00-2\end{array}$ & $\mathrm{Ba}(\mathrm{OH})_{2}$ & & 6 \\
\hline $\begin{array}{l}\text { Nitrato de bario } \\
10022-31-8\end{array}$ & $\mathrm{BaNO}_{3}$ & & $5,1 / 6,1$ \\
\hline $\begin{array}{l}\text { Oxido de bario } \\
1304-28-5\end{array}$ & $\mathrm{BaO}$ & $\begin{array}{l}\text { ' La solución en agua es una base fuerte moderada ' Reacciona violentamente con el } \\
\text { agua, el sulfuro de hidrógeno, la hidroxilamina y el trióxido de azufre, con riesgo de } \\
\text { incendio y explosión }\end{array}$ & 6,1 \\
\hline
\end{tabular}

\begin{tabular}{|c|c|c|c|}
\hline $\begin{array}{l}\text { Perclorato de bario } \\
13465-95-7\end{array}$ & $\mathrm{BaCl}_{2} \mathrm{O}_{8}$ & & $5,1 / 6,1$ \\
\hline $\begin{array}{l}\text { Peróxido de bario } \\
1304-29-6\end{array}$ & $\mathrm{BaO}_{2}$ & $\begin{array}{l}\text { ' Es probable que la sustancia forme peróxidos explosivos ' Es un oxidante fuerte y } \\
\text { reacciona con materiales combustibles y reductores ' También es un fuerte agente } \\
\text { reductor y reacciona con oxidantes ' Reacciona con el agua y los ácidos formando } \\
\text { peróxido de hidrógeno y óxido de bario ' Las mezclas con sustancias orgánicas } \\
\text { pueden arder o explotar por golpe, fricción o choque }\end{array}$ & $5,1 / 6$ \\
\hline $\begin{array}{l}\text { Sulfato de bario } \\
7727-43-7\end{array}$ & $\mathrm{BaSO}_{4}$ & $\begin{array}{l}\text { ' La sustancia emite humos tóxicos de óxidos de azufre cuando se calienta hasta su } \\
\text { descomposición ' La reducción del sulfato de bario con aluminio produce explosiones } \\
\text { violentas }\end{array}$ & 6,1 \\
\hline $\begin{array}{l}\text { Berilio } \\
7440-41-7\end{array}$ & $\mathrm{Be}$ & & 6,1 \\
\hline $\begin{array}{l}\text { Oxido de berilio } \\
1304-56-9\end{array}$ & $\mathrm{BeO}$ & & 6,1 \\
\hline $\begin{array}{l}\text { Acetato de cadmio } \\
543-90-8\end{array}$ & $\mathrm{Cd}\left(\mathrm{C}_{2} \mathrm{H}_{4} \mathrm{O}_{2}\right)_{2}$ & & 6,1 \\
\hline $\begin{array}{l}\text { Cadmio } \\
7440-43-9\end{array}$ & $\mathrm{Cd}$ & $\begin{array}{l}\text { ' Reacciona con ácidos produciendo gas hidrógeno inflamable ' El polvo reacciona con } \\
\text { oxidantes, azida de hidrógeno, zinc, selenio o telurio, con riesgo de incendio y explosión } \\
\text { ' Puede explotar si se encuentra en forma de polvo o granular, al mezclarse con el aire }\end{array}$ & \\
\hline $\begin{array}{l}\text { Cloruro de cadmio } \\
\text { 10108-64-2 }\end{array}$ & $\mathrm{CdCl}_{2}$ & $\begin{array}{l}\text { ' La sustancia se descompone al calentarla, produciendo humos muy tóxicos de cadmio } \\
\text { y cloro ' La solución en agua es un ácido débil ' Reacciona con oxidantes fuertes } \\
\text { ' Reacciona violentamente con fluoruros, bromuros, potasio y ácidos }\end{array}$ & 6,1 \\
\hline $\begin{array}{l}\text { Oxido de cadmio } \\
1306-19-0\end{array}$ & $\mathrm{CdO}$ & $\begin{array}{l}\text { - La sustancia se descompone al calentarla, produciendo humos tóxicos de cadmio } \\
\text { - Reacciona violentamente con magnesio al calentarse, con riesgo de incendio y explosión } \\
\text { - Reacciona con ácidos y oxidantes }\end{array}$ & 6,1 \\
\hline $\begin{array}{l}\text { Sulfato de cadmio } \\
10124-36-4\end{array}$ & $\mathrm{CdSO}_{4}$ & & 6,1 \\
\hline
\end{tabular}


Tabla 63.2 • Riesgos físicos y químicos. Continuación.

\begin{tabular}{|c|c|c|c|}
\hline $\begin{array}{l}\text { Nombre químico } \\
\text { Número CAS }\end{array}$ & Fórmula molecular & Riesgos físicos y químicos & $\begin{array}{l}\text { Clase UN/ div/ } \\
\text { riesgos subsidiarios }\end{array}$ \\
\hline $\begin{array}{l}\text { Sulfuro de cadmio } \\
1306-23-6\end{array}$ & $\operatorname{cds}$ & $\begin{array}{l}\text { 'Al calentarlo emite humos tóxicos ' Reacciona con oxidantes fuertes ' Reacciona con } \\
\text { ácidos formando un gas tóxico (sulfuro de hidrógeno) ' Produce humos tóxicos en caso } \\
\text { de incendio }\end{array}$ & 6,1 \\
\hline $\begin{array}{l}\text { Cloruro de cobalto } \\
7646-79-9\end{array}$ & $\mathrm{CoCl}_{2}$ & $\begin{array}{l}\text { ' La sustancia se descompone al calentarla, produciendo humos tóxicos de cloro y cobalto } \\
\text { ' Reacciona violentamente con metales alcalinos como el sodio y el potasio, con riesgo de } \\
\text { incendio y explosión }\end{array}$ & \\
\hline $\begin{array}{l}\text { Cobalto } \\
7440-48-4\end{array}$ & Co & $\begin{array}{l}\text { ' Reacciona con oxidantes fuertes (como el nitrato de amonio fundido), con riesgo } \\
\text { de incendio y explosión ' Algunas formas de polvo de cobalto metálico pueden arder } \\
\text { espontáneamente en contacto con oxígeno o con el aire (pirofórico) ' Puede promover } \\
\text { la descomposición de varias sustancias orgánicas }\end{array}$ & \\
\hline $\begin{array}{l}\text { Naftenato de cobalto } \\
61789-51-3\end{array}$ & $\mathrm{COC}_{22} \mathrm{H}_{20} \mathrm{O}_{4}$ & $\begin{array}{l}\text { ' Al calentarlo emite humos tóxicos ' Al trasvasarlo, agitarlo, etc., pueden generarse } \\
\text { cargas electrostáticas ' Puede explotar si está en forma de polvo o granular, al mezclarse } \\
\text { con el aire }\end{array}$ & \\
\hline $\begin{array}{l}\text { Oxido de cobalto (III) } \\
1308-04-9\end{array}$ & $\mathrm{CO}_{2} \mathrm{O}_{3}$ & ' Reacciona violentamente con el agua oxigenada ' Reacciona con agentes reductores & \\
\hline $\begin{array}{l}\text { Acetato cúprico } \\
142.71-2\end{array}$ & $\mathrm{CuC}_{4} \mathrm{H}_{6} \mathrm{O}_{4}$ & & 6,1 \\
\hline $\begin{array}{l}\text { Acido nafténico, sal de Cu } \\
\text { 1338-02-9 }\end{array}$ & & ' Durante la combustión, emite gases tóxicos & \\
\hline $\begin{array}{l}\text { Cloruro cúprico } \\
7447-39-4\end{array}$ & $\mathrm{CuCl}_{2}$ & & 8 \\
\hline $\begin{array}{l}\text { Cobre } \\
7440-50-8\end{array}$ & $\mathrm{Cu}$ & $\begin{array}{l}\text { ' Forma compuestos sensibles al choque con compuestos acetilénicos, óxidos de etileno } \\
\text { y azidas ' Reacciona con oxidantes fuertes como los cloratos, bromatos y yodatos, con } \\
\text { riesgo de explosión }\end{array}$ & \\
\hline $\begin{array}{l}\text { Hidróxido cúprico } \\
120427-59-2\end{array}$ & $\mathrm{Cu}(\mathrm{OH})_{2}$ & & 6,1 \\
\hline $\begin{array}{l}\text { Oxido de cobre (I) } \\
1317-39-1\end{array}$ & $\mathrm{Cu}_{2} \mathrm{O}$ & ' Reacciona con ácidos para formar sales cúpricas ' Corroe el aluminio & \\
\hline $\begin{array}{l}\text { Acido crómico } \\
7738-94-5\end{array}$ & $\mathrm{CrH}_{2} \mathrm{O}_{4}$ & & 8 \\
\hline $\begin{array}{l}\text { Cromilcloruro } \\
14977-61-8\end{array}$ & $\mathrm{CrO}_{2} \mathrm{Cl}_{2}$ & $\begin{array}{l}\text { ' La sustancia se descompone violentamente en contacto con el agua, produciendo humos } \\
\text { tóxicos y corrosivos (ácido clorhídrico, cloro, trióxido de cromo y tricloruro de cromo) ' Es } \\
\text { un oxidante fuerte y reacciona violentamente con materiales combustibles y reductores } \\
\text { ' Reacciona violentamente con el agua, los haluros e hidruros no metálicos, el amoníaco y } \\
\text { algunos disolventes comunes como el alcohol, el éter, la acetona y la trementina, con } \\
\text { riesgo de incendio y explosión ' En presencia de agua, ataca a muchos metales ' Es incom- } \\
\text { patible con los plásticos ' Puede encender sustancias combustibles }\end{array}$ & 8 \\
\hline $\begin{array}{l}\text { Cromo } \\
7440-47-3\end{array}$ & $\mathrm{Cr}$ & & 5,1 \\
\hline $\begin{array}{l}\text { Dicromato de amonio (VI) } \\
7789-09-5\end{array}$ & $\left(\mathrm{NH}_{4}\right)_{2} \mathrm{Cr}_{2} \mathrm{H}_{2} \mathrm{O}_{7}$ & & 5,1 \\
\hline $\begin{array}{l}\text { Trióxido de cromo } \\
\text { 1333-82-0 }\end{array}$ & $\mathrm{CrO}_{3}$ & & 5,1 \\
\hline $\begin{array}{l}\text { Cloruro estánnico } \\
7646-78-8\end{array}$ & $\mathrm{SnCl}_{4}$ & $\begin{array}{l}\text { ' Los vapores son más pesados que el aire ' La sustancia se descompone al calentarla } \\
\text { produciendo humos tóxicos ' Reacciona violentamente con el agua, formando humos } \\
\text { corrosivos de ácido clorhídrico y óxido de estaño ' Reacciona con la trementina } \\
\text { ' Ataca a muchos metales, algunos tipos de plásticos, al caucho y a los recubrimientos } \\
\text { - En contacto con alcohol o aminas puede incendiarse o explotar ' Reacciona con el aire } \\
\text { húmedo formando ácido clorhídrico }\end{array}$ & 8 \\
\hline
\end{tabular}

Continúa en la página siguiente. 
Tabla 63.2 • Riesgos físicos y químicos.

Continuación.

\begin{tabular}{|c|c|c|c|}
\hline $\begin{array}{l}\text { Nombre químico } \\
\text { Número CAS }\end{array}$ & Fórmula molecular & Riesgos físicos y químicos & $\begin{array}{l}\text { Clase UN/ div/ } \\
\text { riesgos subsidiarios }\end{array}$ \\
\hline $\begin{array}{l}\text { Cloruro estannoso } \\
7772-99-8\end{array}$ & $\mathrm{SnCl}_{2}$ & $\begin{array}{l}\text { ' Al calentarlo, emite humos tóxicos ' La sustancia es un fuerte agente reductor y } \\
\text { reacciona violentamente con los oxidantes ' Reacciona violentamente con el trifluoruro } \\
\text { de bromo, el sodio y los nitratos }\end{array}$ & \\
\hline $\begin{array}{l}\text { Cloruro estannoso dihidrato } \\
10025-69-1\end{array}$ & $\mathrm{SnCl}_{2} \cdot 2 \mathrm{H}_{2} \mathrm{O}$ & $\begin{array}{l}\text { ' La sustancia es un fuerte agente reductor y reacciona violentamente con oxidantes } \\
\text { - Al calentarlo, emite humos tóxicos y corrosivos ' La sustancia absorbe oxígeno del } \\
\text { aire y forma oxicloruro insoluble }\end{array}$ & \\
\hline $\begin{array}{l}\text { Dicloruro de di-N-butilestaño } \\
\text { 683-18-1 }\end{array}$ & $\mathrm{SnCl}_{2} \mathrm{C}_{8} \mathrm{H}_{18}$ & & 6,1 \\
\hline $\begin{array}{l}\text { Dilaurato de dibutilestaño } \\
77-58-7\end{array}$ & $\mathrm{SnC}_{32} \mathrm{H}_{64} \mathrm{O}_{4}$ & & 6,1 \\
\hline $\begin{array}{l}\text { Fluoruro estannoso } \\
7783-47-3\end{array}$ & $\mathrm{SnF}_{2}$ & $\begin{array}{l}\text { ' Reacciona con ácidos; puede formar humos de ácido fluorhídrico ' Reacciona } \\
\text { violentamente con el cloro ' Incompatible con sustancias alcalinas y agentes oxidantes }\end{array}$ & \\
\hline $\begin{array}{l}\text { Oxido de di-N-butilestaño } \\
\text { 818-08-6 }\end{array}$ & $\mathrm{C}_{8} \mathrm{H}_{18} \mathrm{SnO}$ & $\begin{array}{l}\text { ' La sustancia se descompone al calentarla, produciendo humos tóxicos de estaño y óxidos } \\
\text { de estaño ' Reacciona con oxidantes ' Puede explotar si se encuentra en forma de polvo o } \\
\text { granular, al mezclarse con el aire ' En seco, puede cargarse electrostáticamente cuando se } \\
\text { remueve, se transporta neumáticamente, se vierte, etc. }\end{array}$ & \\
\hline $\begin{array}{l}\text { Oxido de estaño } \\
21651-19-4\end{array}$ & Sno & $\begin{array}{l}\text { ' Al calentarlo a } 300{ }^{\circ} \mathrm{C} \text { en presencia de aire, se oxida a óxido estánnico en forma } \\
\text { incandescente ' Arde en óxido nitroso a } 400^{\circ} \mathrm{C} \text { y reacciona de forma incandescente } \\
\text { cuando se calienta en dióxido de azufre }\end{array}$ & \\
\hline $\begin{array}{l}\text { Oxido estánnico } \\
18282-10-5\end{array}$ & $\mathrm{SnO}_{2}$ & $\begin{array}{l}\text { ' Reacciona violentamente con el trifluoruro de cloro ' En contacto con el trisulfuro de } \\
\text { hidrógeno se descompone violentamente y arde ' Se reduce violentamente al calentarlo } \\
\text { en presencia de magnesio, con riesgo de incendio y explosión }\end{array}$ & \\
\hline $\begin{array}{l}\text { Cromato de estroncio } \\
7789-06-2\end{array}$ & $\mathrm{SrCrH}_{2} \mathrm{O}_{4}$ & $\begin{array}{l}\text { ' La sustancia se descompone al quemarla, produciendo humos tóxicos ' Reacciona } \\
\text { violentamente con hidrazina ' Incompatible con materiales combustibles, orgánicos o } \\
\text { rápidamente oxidables, como el papel, la madera, el azufre, el aluminio y los plásticos }\end{array}$ & \\
\hline $\begin{array}{l}\text { Cloruro férrico } \\
7705-08-0\end{array}$ & $\mathrm{FeCl}_{3}$ & & 8 \\
\hline $\begin{array}{l}\text { Pentacarbonilo de hierro } \\
13463-40-6\end{array}$ & $\mathrm{C}_{5} \mathrm{FeO}_{5}$ & & $6,1 / 3$ \\
\hline $\begin{array}{l}\text { Hidruro de litio y aluminio } \\
16853-85-3\end{array}$ & $\mathrm{LiAlH}_{4}$ & & 4,3 \\
\hline $\begin{array}{l}\text { Cloruro de magnesio } \\
7786-30-3\end{array}$ & $\mathrm{MgCl}_{2}$ & $\begin{array}{l}\text { ' La sustancia se descompone cuando se calienta lentamente hasta } 300{ }^{\circ} \mathrm{C} \text {, } \\
\text { produciendo cloro ' Su disolución en agua libera una cantidad considerable de calor }\end{array}$ & 5,1 \\
\hline $\begin{array}{l}\text { Fosfuro de magnesio } \\
12057-74-8\end{array}$ & $\mathrm{Mg}_{3} \mathrm{P}_{2}$ & $\begin{array}{l}\text { ' Reacciona con el agua, la humedad del aire y los ácidos, produciendo humos muy tóxicos } \\
\text { de fosfina ' Reacciona con el agua y la humedad del aire, y violentamente con los ácidos, } \\
\text { con riesgo de incendio y toxicidad (humos de fosfina) }\end{array}$ & $4,3 / 6,1$ \\
\hline $\begin{array}{l}\text { Magnesio } \\
7439-95-4\end{array}$ & $\mathrm{Mg}$ & $\begin{array}{l}\text { ' La sustancia puede arder espontáneamente en contacto con el aire o la humedad, } \\
\text { produciendo gases irritantes o venenosos, como el óxido de magnesio ' Reacciona } \\
\text { violentamente con oxidantes fuertes - Reacciona violentamente con muchas sustancias, } \\
\text { con riesgo de incendio y explosión ' Reacciona con ácidos o con el agua, formando gas } \\
\text { de hidrógeno inflamable y con riesgo de incendio y explosión ' Puede explotar si se } \\
\text { encuentra en forma de polvo o granular, al mezclarse con el aire }\end{array}$ & 4,1 \\
\hline $\begin{array}{l}\text { Nitrato de magnesio } \\
10377-60-3\end{array}$ & $\mathrm{Mg}\left(\mathrm{NO}_{3}\right)_{2}$ & & 5,1 \\
\hline $\begin{array}{l}\text { Oxido de magnesio } \\
1309-48-4\end{array}$ & $\mathrm{MgO}$ & $\begin{array}{l}\text { - Absorbe rápidamente la humedad y el dióxido de carbono cuando se expone al aire } \\
\text { - Reacciona vigorosamente con los halógenos y los ácidos fuertes }\end{array}$ & \\
\hline $\begin{array}{l}\text { Acetato de fenilmercurio } \\
62-38-4\end{array}$ & $\mathrm{C}_{8} \mathrm{H}_{8} \mathrm{HgO}_{2}$ & ' La sustancia se descompone al calentarla, produciendo vapores tóxicos de mercurio & 6,1 \\
\hline
\end{tabular}

Continúa en la página siguiente. 
Tabla 63.2 • Riesgos físicos y químicos. Continuación.

\begin{tabular}{|c|c|c|c|}
\hline $\begin{array}{l}\text { Nombre químico } \\
\text { Número CAS }\end{array}$ & Fórmula molecular & Riesgos físicos y químicos & $\begin{array}{l}\text { Clase UN/ div/ } \\
\text { riesgos subsidiarios }\end{array}$ \\
\hline $\begin{array}{l}\text { Acetato mercúrico } \\
1600-27-7\end{array}$ & $\mathrm{HgC}_{4} \mathrm{H}_{6} \mathrm{O}_{4}$ & $\begin{array}{l}\text { ' La sustancia se descompone al calentarla y al exponerla a la luz, produciendo humos } \\
\text { tóxicos de mercurio o de óxido mercúrico }\end{array}$ & 6,1 \\
\hline $\begin{array}{l}\text { Bromuro mercúrico } \\
7789-47-1\end{array}$ & $\mathrm{HgBr}_{2}$ & & 6,1 \\
\hline $\begin{array}{l}\text { Cloruro mercúrico } \\
7487-94-7\end{array}$ & $\mathrm{HgCl}_{2}$ & $\begin{array}{l}\text { ' La sustancia se descompone al calentarla, produciendo vapores tóxicos de mercurio } \\
\text { y cloro ' Reacciona con los metales ligeros ' Incompatible con formiatos, sulfitos, } \\
\text { hipofosfitos, fosfatos, sulfuros, albúmina, gelatina, álcalis, sales de alcaloides, } \\
\text { amoníaco, sosa, antimonio y arsénico, bromuro, bórax, carbonato, hierro, cobre, } \\
\text { plomo y sales de plata }\end{array}$ & 6,1 \\
\hline $\begin{array}{l}\text { Cloruro mercurioso } \\
10112-91-1\end{array}$ & $\mathrm{Hg}_{2} \mathrm{Cl}_{2}$ & $\begin{array}{l}\text { ' La sustancia se descompone al calentarla, produciendo humos tóxicos de cloro y } \\
\text { mercurio, o al exponerla a la luz, produciendo mercurio metálico y cloruro mercúrico } \\
\text { ' Reacciona con bromuros, yoduros, sulfatos, sulfitos, carbonatos, cloruros de álcalis, } \\
\text { hidróxidos, cianuros, sales de plomo, sales de plata, jabón, sulfuros, sales de cobre, } \\
\text { agua oxigenada, sosa, yodoformo, amoníaco y yodo }\end{array}$ & \\
\hline $\begin{array}{l}\text { Mercurio } \\
7439-97-6\end{array}$ & $\mathrm{Hg}$ & $\begin{array}{l}\text { ' Reacciona violentamente con acetileno, cloro y amoníaco ' Ataca al cobre y a las } \\
\text { aleaciones de cobre ' Incompatible con acetilenos y gases de amoníaco ' Emite vapores } \\
\text { tóxicos al calentarlo }\end{array}$ & 6,1 \\
\hline $\begin{array}{l}\text { Nitrato de fenilmercurio } \\
55-68-5\end{array}$ & $\mathrm{C}_{6} \mathrm{H}_{5} \mathrm{HgNO}_{3}$ & $\begin{array}{l}\text { ' La sustancia se descompone al calentarla, produciendo vapores de mercurio y otros } \\
\text { humos tóxicos ' Reacciona con agentes reductores }\end{array}$ & 6,1 \\
\hline $\begin{array}{l}\text { Nitrato mercúrico } \\
10045-94-0\end{array}$ & $\mathrm{Hg}\left(\mathrm{NO}_{3}\right)_{2}$ & $\begin{array}{l}\text { ' La sustancia se descompone al calentarla, produciendo humos tóxicos (mercurio, óxidos } \\
\text { de nitrógeno), o al exponerla a la luz ' Es un oxidante fuerte y reacciona violentamente } \\
\text { con materiales combustibles y reductores ' Reacciona con acetileno, alcohol, fosfina y } \\
\text { azufre formando compuestos sensibles al choque ' En solución ataca a la mayoría de los } \\
\text { metales ' Reacciona vigorosamente con los hidrocarburos del petróleo }\end{array}$ & 6,1 \\
\hline $\begin{array}{l}\text { Oxido mercúrico } \\
21908-53-2\end{array}$ & $\mathrm{HgO}$ & $\begin{array}{l}\text { ' La sustancia se descompone al exponerla a la luz, al calentarla por encima de } 500{ }^{\circ} \mathrm{C} \text {, } \\
\text { o al quemarla en presencia de luz, produciendo humos muy tóxicos con mercurio y oxígeno, } \\
\text { lo que aumenta el riesgo de incendio ' Al calentarla, emite humos tóxicos ' Reacciona } \\
\text { violentamente con cloro, agua oxigenada, ácido hipofosfórico, hidrato de hidrazina, } \\
\text { magnesio (al calentarla), dicloruro de azufre y trisulfuro de hidrógeno ' Reacciona } \\
\text { explosivamente con acetilnitrato, butadieno, etanol, yodo }\left(\text { a } 35^{\circ} \mathrm{C} \text { ), cloro, hidrocarburos, }\right. \\
\text { tetrafluoruro de boro, agua oxigenada, restos de ácido nitrico, agentes reductores } \\
\text { ' Incompatible con agentes reductores }\end{array}$ & 6,1 \\
\hline $\begin{array}{l}\text { Sulfato mercúrico } \\
7783-35-9\end{array}$ & $\mathrm{HgSO}_{4}$ & $\begin{array}{l}\text { ' La sustancia se descompone al calentarla o al exponerla a la luz, produciendo humos } \\
\text { tóxicos de mercurio y óxidos de azufre ' Reacciona con el agua produciendo sulfato básico } \\
\text { de mercurio insoluble y ácido sulfúrico ' Reacciona violentamente con el ácido clorhídrico }\end{array}$ & \\
\hline $\begin{array}{l}\text { Tiocianato de mercurio } \\
592-85-8\end{array}$ & $\mathrm{HgC}_{2} \mathrm{~N}_{2} \mathrm{~S}_{2}$ & & 6,1 \\
\hline $\begin{array}{l}\text { Carbonato de níquel } \\
3333-67-3\end{array}$ & $\mathrm{Ni}_{2} \mathrm{CO}_{3}$ & $\begin{array}{l}\text { ' La sustancia se descompone al calentarla y en contacto con ácidos, produciendo dióxido } \\
\text { de carbono ' Reacciona violentamente con anilinas, sulfuro de hidrógeno, disolventes } \\
\text { inflamables hidrazina y polvos metálicos, especialmente de zinc, aluminio y magnesio, } \\
\text { con riesgo de incendio y explosión }\end{array}$ & \\
\hline $\begin{array}{l}\text { Níquel } \\
7440-02-0\end{array}$ & $\mathrm{Ni}$ & $\begin{array}{l}\text { ' Reacciona con oxidantes fuertes ' En polvo, reacciona violentamente con el polvo de } \\
\text { titanio y el perclorato de potasio, y con oxidantes como el nitrato de amonio, con riesgo de } \\
\text { incendio y explosión ' Reacciona lentamente con ácidos no oxidantes y más rápidamente } \\
\text { con ácidos oxidantes ' Puede liberar gases y vapores tóxicos (como el níquel carbonilo) } \\
\text { durante un incendio en el que participe el níquel ' Puede explotar si se encuentra en forma } \\
\text { de polvo o granular, al mezclarse con el aire }\end{array}$ & \\
\hline
\end{tabular}


Tabla 63.2 • Riesgos físicos y químicos.

Continuación.

Nombre químico $\quad$ Fórmula molecular $\quad$ Riesgos físicos y químicos
Número CAS

Clase UN/ div/ riesgos subsidiarios

Níquel carbonilo $\quad \mathrm{NiC}_{4} \mathrm{O}_{4}$ 13463-39-3
' Puede explotar si se calienta a $60^{\circ} \mathrm{C}$ ' La sustancia puede arder espontáneamente en contacto con el aire ' Se descompone al calentarla a $180^{\circ} \mathrm{C}$ en contacto con ácidos, produciendo monóxido de carbono, sumamente tóxico ' Reacciona violentamente con oxidantes, ácidos y bromo ' Reacciona violentamente con oxidantes, con riesgo de incendio y explosión ' Se oxida en contacto con el aire formando depósitos que se peroxidan, con riesgo de incendio ' Los vapores son más pesados que el aire y pueden desplazarse a ras de suelo, con peligro de ignición a distancia

\begin{tabular}{|c|c|c|c|}
\hline $\begin{array}{l}\text { Oxido de níquel (II) } \\
\text { 1313-99-1 }\end{array}$ & $\mathrm{NiO}$ & $\begin{array}{l}\text { ' Reacciona violentamente con el yodo y el sulfuro de hidrógeno, con riesgo de incendio y } \\
\text { explosión }\end{array}$ & \\
\hline $\begin{array}{l}\text { Sulfato de níquel } \\
7786-81-4\end{array}$ & $\mathrm{NiSO}_{4}$ & $\begin{array}{l}\text { ' La sustancia se descompone al calentarla a } 848^{\circ} \mathrm{C} \text {, produciendo humos tóxicos de } \\
\text { trióxido de azufre y monóxido de níquel ' La solución en agua es un ácido débil }\end{array}$ & \\
\hline $\begin{array}{l}\text { Sulfuro de níquel } \\
12035-72-2\end{array}$ & $\mathrm{Ni}_{3} \mathrm{~S}_{2}$ & $\begin{array}{l}\text { ' La sustancia se descompone al calentarla a altas temperaturas produciendo óxidos de } \\
\text { azufre }\end{array}$ & \\
\hline $\begin{array}{l}\text { Tetróxido de osmio } \\
20816-12-0\end{array}$ & $\mathrm{OsO}_{4}$ & $\begin{array}{l}\text { ' La sustancia se descompone al calentarla, produciendo humos de osmio ' Es un oxidante } \\
\text { fuerte y reacciona con materiales combustibles y reductores ' Reacciona con el ácido } \\
\text { clorhídrico, formando gas tóxico de cloro ' Forma compuestos inestables con los álcalis }\end{array}$ & 6,1 \\
\hline $\begin{array}{l}\text { Plata } \\
7440-22-4\end{array}$ & $\mathrm{Ag}$ & $\begin{array}{l}\text { ' Forma compuestos sensibles al choque con acetileno ' La plata finamente dividida puede } \\
\text { explotar en contacto con una solución concentrada de agua oxigenada, al descomponerse } \\
\text { violentamente liberando oxígeno gaseoso ' En contacto con amoníaco puede formar } \\
\text { compuestos explosivos cuando se secan ' Reacciona rápidamente con el ácido nítrico } \\
\text { dilluido y el ácido sulfúrico concentrado caliente }\end{array}$ & \\
\hline $\begin{array}{l}\text { Nitrato de plata } \\
7761-88-8\end{array}$ & $\mathrm{AgNO}_{3}$ & $\begin{array}{l}\text { Forma compuestos sensibles al choque con acetileno, alcohol, fosfina y azufre } \\
\text { ' La sustancia se descompone al calentarla, produciendo humos tóxicos (óxidos de } \\
\text { nitrógeno) ' La sustancia es un oxidante fuerte y reacciona violentamente con materiales } \\
\text { combustibles y reductores ' Reacciona con sustancias incompatibles, como acetileno, } \\
\text { álcalis, haluros y otros compuestos, con riesgo de incendio y explosión ' Ataca a algunos } \\
\text { tipos de plásticos, al caucho y a los recubrimientos ' La sustancia se descompone al expo- } \\
\text { nerse a la luz, en contacto con contaminantes orgánicos }\end{array}$ & 5,1 \\
\hline $\begin{array}{l}\text { Acido selenioso } \\
7783-00-8\end{array}$ & $\mathrm{SeH}_{2} \mathrm{O}_{3}$ & $\begin{array}{l}\text { ' La sustancia se descompone al calentarla, produciendo agua y humos tóxicos de óxidos } \\
\text { de selenio ' Reacciona en contacto con ácidos, produciendo gases tóxicos de seleniuro de } \\
\text { hidrógeno }\end{array}$ & \\
\hline $\begin{array}{l}\text { Acido selenioso, } \\
\text { sal disódica } \\
10102-18-8\end{array}$ & $\mathrm{Na}_{2} \mathrm{SeO}_{3}$ & $\begin{array}{l}\text { ' La sustancia se descompone en contacto con llamas o superficies calientes, formando } \\
\text { gases tóxicos ' La solución en agua es una base fuerte moderada ' Reacciona con el } \\
\text { agua y los ácidos fuertes, con riesgo de toxicidad }\end{array}$ & 6,1 \\
\hline $\begin{array}{l}\text { Dióxido de selenio } \\
7446-08-4\end{array}$ & $\mathrm{SeO}_{2}$ & $\begin{array}{l}\text { ' La sustancia se descompone al calentarla, produciendo humos tóxicos de selenio } \\
\text { ' La solución en agua es un ácido fuerte moderado (ácido selenioso) ' Reacciona con un } \\
\text { gran número de sustancias, produciendo vapores tóxicos de selenio ' En presencia de agua, } \\
\text { ataca muchos metales }\end{array}$ & \\
\hline $\begin{array}{l}\text { Hexafluoruro de selenio } \\
7783-79-1\end{array}$ & $\mathrm{SeF}_{6}$ & $\begin{array}{l}\text { ' La sustancia se descompone al calentarla, produciendo humos tóxicos y corrosivos, como } \\
\text { fluoruro de hidrógeno, fluoruros y selenio }\end{array}$ & 2,318 \\
\hline $\begin{array}{l}\text { Oxicloruro de selenio } \\
7791-23-3\end{array}$ & $\mathrm{SeOCl}_{2}$ & $\begin{array}{l}\text { - La sustancia se descompone al calentarla, produciendo humos tóxicos de cloro y selenio } \\
\text { - La solución en agua es un ácido fuerte; reacciona violentamente con bases y es corrosiva } \\
\text { ' Reacciona violentamente con el fósforo blanco y el potasio, con riesgo de incendio y } \\
\text { explosión ' Reacciona violentamente con los óxidos metálicos }\end{array}$ & $3 / 6,1$ \\
\hline $\begin{array}{l}\text { Selenio } \\
7782-49-2\end{array}$ & $\mathrm{Se}$ & $\begin{array}{l}\text { ' Al calentarlo produce humos tóxicos ' Reacciona violentamente con oxidantes y ácidos } \\
\text { fuertes ' Reacciona con el agua a } 50^{\circ} \mathrm{C} \text {, formando hidrógeno inflamable y ácidos de } \\
\text { selenio ' Reacciona de forma incandescente al calentarse ligeramente en presencia de } \\
\text { fósforo y metales como níquel, zinc, sodio, potasio y platino }\end{array}$ & \\
\hline
\end{tabular}

Continúa en la página siguiente. 
Tabla 63.2 • Riesgos físicos y químicos. Continuación.

$\begin{array}{ll}\text { Nombre químico } & \text { Fórmula molecular } \\ \text { Número CAS } & \\ \text { Seleniuro de hidrógeno } & \mathrm{SeH}_{2} \\ 7783-07-5 & \end{array}$

Riesgos físicos y químicos

Clase UN/ div/ riesgos subsidiarios

La sustancia se descompone al calentarla a temperaturas superiores a $100^{\circ} \mathrm{C}$, generando productos tóxicos e inflamables como selenio e hidrógeno ' La sustancia es un fuerte agente reductor y reacciona violentamente con oxidantes, con riesgo de incendio y explosión ' En contacto con el aire emite humos tóxicos y corrosivos de dióxido de selenio - El gas es más pesado que el aire y puede desplazarse a ras de suelo; con riesgo de ignición a distancia

\begin{tabular}{|c|c|c|}
\hline $\begin{array}{l}\text { Trióxido de selenio } \\
13768-86-0\end{array}$ & $\mathrm{SeO}_{3}$ & $\begin{array}{l}\text { ' La sustancia se descompone al calentarla, produciendo humos tóxicos de selenio } \\
\text { '. Es un oxidante fuerte y reacciona con materiales combustibles y reductores } \\
\text { ' La solución en agua es un ácido fuerte; reacciona violentamente con bases y es corrosiva } \\
\text { ' Reacciona violentamente con el agua, produciendo ácido selénico ' Ataca muchos } \\
\text { metales en presencia de humedad }\end{array}$ \\
\hline
\end{tabular}

$2,3 / 2,1$

' Durante la combustión, forma gases corrosivos como el cloro ' La sustancia se

\begin{tabular}{|c|c|c|}
\hline $\begin{array}{l}\text { Tetracloruro de platino } \\
13454-96-1\end{array}$ & $\mathrm{PtCl}_{4}$ & $\begin{array}{l}\text { ' Durante la combustión, forma gases corrosivos como el cloro ' La sustancia se } \\
\text { descompone al calentarla o quemarla, produciendo humos tóxicos (cloro) ' Reacciona } \\
\text { con oxidantes fuertes }\end{array}$ \\
\hline
\end{tabular}
con oxidantes fuertes

\begin{tabular}{|c|c|c|c|}
\hline $\begin{array}{l}\text { Acetato de plomo } \\
301-04-2\end{array}$ & $\mathrm{PbC}_{4} \mathrm{H}_{6} \mathrm{O}_{4}$ & $\begin{array}{l}\text { ' La sustancia se descompone al calentarla y al quemarla, produciendo humos tóxicos y } \\
\text { corrosivos con plomo y ácido acético ' Reacciona violentamente con los bromuros, los } \\
\text { fosfatos, los carbonatos y los fenoles ' Reacciona con ácidos produciendo ácido acético } \\
\text { corrosivo }\end{array}$ & \\
\hline $\begin{array}{l}\text { Acido nafténico, } \\
\text { sal de Pb } \\
61790-14-5\end{array}$ & & ' Durante la combustión, forma humos tóxicos, como óxido de plomo & \\
\hline $\begin{array}{l}\text { Cromato de plomo } \\
7758-97-6\end{array}$ & $\mathrm{PbCrO}_{4}$ & $\begin{array}{l}\text { ' La sustancia se descompone al calentarla, produciendo humos tóxicos con óxidos de } \\
\text { plomo ' Reacciona con oxidantes fuertes, agua oxigenada, sodio y potasio ' Reacciona } \\
\text { con el dinitronaftaleno de aluminio, el hierro (III) y el hexacianoferrato (IV) } \\
\text { ' Reacciona con sustancias orgánicas a temperaturas elevadas con riesgo de incendio }\end{array}$ & \\
\hline $\begin{array}{l}\text { Dióxido de plomo } \\
1309-60-0\end{array}$ & $\mathrm{PbO}_{2}$ & & 5,1 \\
\hline $\begin{array}{l}\text { Nitrato de plomo } \\
10099-74-8\end{array}$ & $\mathrm{~Pb}\left(\mathrm{NO}_{3}\right)_{2}$ & & $5,1 / 6,1$ \\
\hline $\begin{array}{l}\text { Oxido de plomo (II) } \\
\text { 1317-36-8 }\end{array}$ & $\mathrm{PbO}$ & $\begin{array}{l}\text { ' Reacciona violentamente con oxidantes fuertes, polvo de aluminio y sodio ' Al calen- } \\
\text { tarse, emite humos tóxicos de compuestos de plomo }\end{array}$ & \\
\hline $\begin{array}{l}\text { Plomo } \\
7439-92-1\end{array}$ & $\mathrm{~Pb}$ & $\begin{array}{l}\text { ' La sustancia se descompone al calentarla, produciendo humos tóxicos con óxidos de } \\
\text { plomo ' La sustancia es un fuerte agente reductor }\end{array}$ & \\
\hline $\begin{array}{l}\text { Tetraetilplomo } \\
78-00-2\end{array}$ & $\mathrm{PbC}_{8} \mathrm{H}_{20}$ & $\begin{array}{l}\text { ' La sustancia se descompone al calentarla a temperaturas superiores a los } 110^{\circ} \mathrm{C} \text { y al } \\
\text { exponerla a la luz, produciendo humos tóxicos: monóxido de carbono, plomo ' Reacciona } \\
\text { violentamente con oxidantes fuertes, ácidos, halógenos, aceites y grasas, con riesgo de } \\
\text { incendio y explosión ' Ataca al caucho y a algunos plásticos y revestimientos ' Los vapores } \\
\text { son más pesados que el aire }\end{array}$ & 6,1 \\
\hline $\begin{array}{l}\text { Tetrametilplomo } \\
75-74-1\end{array}$ & $\mathrm{PbC}_{4} \mathrm{H}_{12}$ & & 6,1 \\
\hline $\begin{array}{l}\text { Sulfato de talio } \\
7446-18-6\end{array}$ & $\mathrm{Tl}_{2}\left(\mathrm{SO}_{4}\right)_{3}$ & $\begin{array}{l}\text { ' La sustancia se descompone al calentarla, produciendo humos muy tóxicos de talio y } \\
\text { óxidos de azufre }\end{array}$ & 6,1 \\
\hline $\begin{array}{l}\text { Talio } \\
7440-28-0\end{array}$ & $\mathrm{Tl}$ & $\begin{array}{l}\text { ' Reacciona violentamente con el flúor ' Reacciona con los halógenos a temperatura } \\
\text { ambiente ' Incompatible con los ácidos fuertes, los oxidantes fuertes y el oxígeno } \\
\text { ' La sustancia forma compuestos tóxicos en contacto con la humedad }\end{array}$ & 6,1 \\
\hline $\begin{array}{l}\text { Hexafluoruro de telurio } \\
7783-80-4\end{array}$ & $\mathrm{TeF}_{6}$ & & $2,3 / 8$ \\
\hline $\begin{array}{l}\text { Telurio } \\
13494-80-9\end{array}$ & Te & $\begin{array}{l}\text { ' Forma humos tóxicos al calentarlo ' Reacciona vigorosamente con los halógenos e } \\
\text { interhalógenos, con riesgo de ignición ' Reacciona de forma incandescente con el zinc } \\
\text { ' El siliciuro de litio ataca al telurio de forma incandescente }\end{array}$ & 6,1 \\
\hline
\end{tabular}

Continúa en la página siguiente. 
Tabla 63.2 - Riesgos físicos y químicos.

Continuación.

\begin{tabular}{|c|c|c|c|}
\hline $\begin{array}{l}\text { Nombre químico } \\
\text { Número CAS }\end{array}$ & Fórmula molecular & Riesgos físicos y químicos & $\begin{array}{l}\text { Clase UN/ div/ } \\
\text { riesgos subsidiarios }\end{array}$ \\
\hline $\begin{array}{l}\text { Tetracloruro de titanio } \\
7550-45-0\end{array}$ & $\mathrm{TiCl}_{4}$ & & 8 \\
\hline $\begin{array}{l}\text { Tricloruro de titanio } \\
7705-07-9\end{array}$ & $\mathrm{TiCl}_{3}$ & & 8 \\
\hline $\begin{array}{l}\text { Torio } \\
7440-29-1\end{array}$ & Th & & 7 \\
\hline $\begin{array}{l}\text { Pentóxido de vanadio } \\
1314-62-1\end{array}$ & $\mathrm{~V}_{2} \mathrm{O}_{5}$ & ' Al calentarlo, emite humos tóxicos ' Cataliza reacciones de oxidación & 6,1 \\
\hline $\begin{array}{l}\text { Tetracloruro de vanadio } \\
7632-51-1\end{array}$ & $\mathrm{VCl}_{4}$ & & 8 \\
\hline $\begin{array}{l}\text { Trióxido de vanadio } \\
1314-34-7\end{array}$ & $\mathrm{~V}_{2} \mathrm{O}_{3}$ & $\begin{array}{l}\text { 'Arde al calentarse en contacto con el aire ' La sustancia se descompone al calentarla } \\
0 \text { al quemarla, produciendo humos irritantes y tóxicos (óxidos de vanadio) }\end{array}$ & 6,1 \\
\hline $\begin{array}{l}\text { Vanadiltricloruro } \\
7727-18-6\end{array}$ & $\mathrm{VOCl}_{3}$ & & 8 \\
\hline $\begin{array}{l}\text { Cloruro de zinc } \\
7646-85-7\end{array}$ & $\mathrm{ZnCl}_{2}$ & & 8 \\
\hline $\begin{array}{l}\text { Estearato de zinc } \\
\text { 557-05-1 }\end{array}$ & $\mathrm{ZnC}_{36} \mathrm{H}_{70} \mathrm{O}_{4}$ & $\begin{array}{l}\text { ' La sustancia se descompone al calentarla, produciendo un humo acre y humos de óxido } \\
\text { de zinc ' Puede explotar si está en forma de polvo o granular, al mezclarse con el aire } \\
\text { ' En seco, puede cargarse electrostáticamente cuando se remueve, se transporta } \\
\text { neumáticamente, se vierte, etc. }\end{array}$ & \\
\hline $\begin{array}{l}\text { Fosfuro de zinc } \\
1314-84-7\end{array}$ & $Z n_{3} P_{2}$ & $\begin{array}{l}\text { ' La sustancia se descompone al calentarla y en contacto con ácidos o agua, } \\
\text { produciendo humos tóxicos e inflamables de fósforo y óxidos de zinc, y fosfina } \\
\text { ' Reacciona violentamente con los oxidantes fuertes, con riesgo de incendio }\end{array}$ & $4,3 / 6,1$ \\
\hline $\begin{array}{l}\text { Nitrato de zinc } \\
7779-88-6\end{array}$ & $\mathrm{Zn}\left(\mathrm{NO}_{3}\right)_{2}$ & & 1,5 \\
\hline $\begin{array}{l}\text { Zinc } \\
7440-66-6\end{array}$ & $\mathrm{Zn}$ & & $4,3 / 4,2$ \\
\hline
\end{tabular}

Los datos sobre los riesgos físicos y químicos se han tomado de la serie de Tarjetas Internacionales de Seguridad de las Sustancias Químicas (ICSC) producidas por el Programa Internacional de Seguridad de las Sustancias Químicas (IPCS), un programa conjunto de la Organización Mundial de la Salud (OMS), la Organización Internacional del Trabajo (OIT) y el Programa de las Naciones Unidas para el Medio Ambiente (PNUMA).

Los datos de clasificación de riesgo proceden de la publicación Recommendations on the Transport of Dangerous Goods, ga edición, elaborada por el Comité de Expertos sobre el Transporte de Mercancías Peligrosas de las Naciones Unidas y publicada por las Naciones Unidas (1995).

En la clasificación de riesgos de la ONU, se utilizan los siguientes códigos: 1,5 = sustancias sumamente insensibles con riesgo de explosión masiva; 2,1 = gas inflamable; $2,3=$ gas tóxico; 3 = líquido inflamable; $4,1=$ sólido inflamable; $4,2=$ sustancia que puede arder espontáneamente; $4,3=$ sustancia que emite gases inflamables en contacto con el agua; $5,1=$ sustancia oxidante; $6,1=$ tóxico; $7=$ radiactivo; $8=$ sustancia corrosiva. 
Tabla 63.3 - Riesgos para la salud.

\begin{tabular}{|c|c|c|c|c|c|c|}
\hline $\begin{array}{l}\text { Nombre } \\
\text { químico } \\
\text { Número CAS }\end{array}$ & $\begin{array}{l}\text { Exposición a } \\
\text { corto plazo }\end{array}$ & $\begin{array}{l}\text { Exposición a } \\
\text { largo plazo }\end{array}$ & $\begin{array}{l}\text { Vías de } \\
\text { exposición }\end{array}$ & Síntomas & $\begin{array}{l}\text { Organos diana, } \\
\text { vías de } \\
\text { entrada }\end{array}$ & Síntomas \\
\hline $\begin{array}{l}\text { Fosfuro de } \\
\text { aluminio } \\
20859-73-8\end{array}$ & Ojos; piel; ap. resp. & & $\begin{array}{l}\text { Inhalación } \\
\text { Piel } \\
\text { Ojos } \\
\text { Ingestión }\end{array}$ & $\begin{array}{l}\text { Dolor abdominal, sensación de } \\
\text { ardor, tos, mareos, sordera, cefalea, } \\
\text { dificultad para respirar, náuseas, } \\
\text { dolor de garganta } \\
\text { Enrojecimiento, dolor } \\
\text { Enrojecimiento, dolor } \\
\text { Dolor abdominal, convulsiones, } \\
\text { náuseas, desvanecimiento, vómitos }\end{array}$ & & \\
\hline $\begin{array}{l}\text { Antimonio } \\
7440-36-0\end{array}$ & $\begin{array}{l}\text { Ojos; piel; ap. } \\
\text { resp.; ; pulmones; } \\
\text { corazón }\end{array}$ & $\begin{array}{l}\text { Piel; pulmones; } \\
\text { ap. resp. }\end{array}$ & $\begin{array}{r}\text { Inhalación } \\
\text { Piel } \\
\text { Ojos } \\
\text { Ingestión }\end{array}$ & $\begin{array}{l}\text { Tos, fiebre, falta de aire, vómitos, } \\
\text { dolor de las vías respiratorias } \\
\text { altas; Véase Ingestión } \\
\text { Enrojecimiento } \\
\text { Enrojecimiento, dolor, conjuntivitis } \\
\text { Dolor abdominal, sensación de } \\
\text { ardor, diarrea, náuseas, falta de } \\
\text { aire, vómitos, arritmias cardíacas }\end{array}$ & $\begin{array}{l}\text { Ap. resp.; SCV; } \\
\text { piel; ojos } \\
\text { Inh.; ing.; con. }\end{array}$ & $\begin{array}{l}\text { Irrit. ojos, piel, nariz, garganta, } \\
\text { boca; tos; mar.; cefal.; náus., } \\
\text { vómit., diarr.; dolor de estómago; } \\
\text { insom.; anor.; problemas de olfato }\end{array}$ \\
\hline $\begin{array}{l}\text { Estibina } \\
7803-52-3\end{array}$ & $\begin{array}{l}\text { Sangre; riñones; } \\
\text { hígado; SNC }\end{array}$ & & Inhalación & $\begin{array}{l}\text { Dolor abdominal, cefalea, náuseas, } \\
\text { falta de aire, vómitos, debilidad, } \\
\text { pulso débil e irregular, hematuria, } \\
\text { shock }\end{array}$ & $\begin{array}{l}\text { Sangre; hígado; } \\
\text { riñones; ap. } \\
\text { resp. } \\
\text { Inh. } \\
\end{array}$ & $\begin{array}{l}\text { Cefal., debil.; náus., dolor } \\
\text { abdom.; dolor lumbar, hemog., } \\
\text { hema., anemia hemolítica; icter.; } \\
\text { irrit. pulm. }\end{array}$ \\
\hline $\begin{array}{l}\text { Trióxido de } \\
\text { antimonio } \\
1309-64-4\end{array}$ & Ojos; piel; ap. resp. & Piel; pulmones & $\begin{array}{r}\text { Inhalación } \\
\text { Piel } \\
\text { Ojos } \\
\text { Ingestión }\end{array}$ & $\begin{array}{l}\text { Tos, fiebre, náuseas, dolor de } \\
\text { garganta, vómitos } \\
\text { Enrojecimiento, dolor, vesículas } \\
\text { Enrojecimiento, dolor } \\
\text { Dolor abdominal, diarrea, dolor de } \\
\text { garganta, vómitos, sensación de } \\
\text { ardor }\end{array}$ & & \\
\hline $\begin{array}{l}\text { Acido } \\
\text { arsenioso, sal } \\
\text { de plomo (II) } \\
10031-13-7\end{array}$ & $\begin{array}{l}\text { Ojos; piel; ap. } \\
\text { resp.; SNC; tracto } \\
\text { Gl; aparato } \\
\text { circulatorio }\end{array}$ & $\begin{array}{l}\text { Piel; SNP; } \\
\text { membranas } \\
\text { mucosas; } \\
\text { hígado }\end{array}$ & $\begin{array}{r}\text { Inhalación } \\
\text { Piel } \\
\text { Ojos } \\
\text { Ingestión }\end{array}$ & $\begin{array}{l}\text { Tos, cefalea, dificultad para respirar, } \\
\text { debilidad; Véase Ingestión } \\
\text { Enrojecimiento, dolor } \\
\text { Enrojecimiento, dolor } \\
\text { Dolor abdominal, diarrea, vómitos, } \\
\text { sensación de ardor detrás del } \\
\text { esternón y en la boca }\end{array}$ & & \\
\hline $\begin{array}{l}\text { Acido } \\
\text { arsenioso, sal } \\
\text { potásica } \\
10124-50-2\end{array}$ & $\begin{array}{l}\text { Ojos; piel; ap. } \\
\text { resp.; SNC; tracto } \\
\text { digestivo; aparato } \\
\text { circulatorio }\end{array}$ & & $\begin{array}{r}\text { Inhalación } \\
\text { Piel } \\
\text { Ojos } \\
\text { Ingestión }\end{array}$ & $\begin{array}{l}\text { Tos, cefalea, dificultad para respirar, } \\
\text { debilidad; Véase Ingestión } \\
\text { Se puede absorber, soluble, } \\
\text { enrojecimiento, dolor } \\
\text { Enrojecimiento, dolor } \\
\text { Dolor abdominal, diarrea, vómitos, } \\
\text { sensación de ardor detrás del } \\
\text { esternón y en la boca }\end{array}$ & & \\
\hline $\begin{array}{l}\text { Acido } \\
\text { metilarsénico } \\
124-58-3\end{array}$ & $\begin{array}{l}\text { Ojos; piel; ap. } \\
\text { resp.; pulmones }\end{array}$ & $\begin{array}{l}\text { Médula ósea; } \\
\text { SNP; riñones; } \\
\text { hígado }\end{array}$ & $\begin{array}{r}\text { Inhalación } \\
\text { Piel } \\
\text { Ojos } \\
\text { Ingestión }\end{array}$ & $\begin{array}{l}\text { Tos } \\
\text { Enrojecimiento } \\
\text { Enrojecimiento } \\
\text { Dolor abdominal, diarrea, vómitos, } \\
\text { sensación de ardor en la garganta }\end{array}$ & $\begin{array}{l}\text { Compuestos de } \\
\text { arsénico orgá- } \\
\text { nicos: piel, ap. } \\
\text { resp, riñones, } \\
\text { SNC, hígado, } \\
\text { tracto Gl, ap. } \\
\text { repro. }\end{array}$ & $\begin{array}{l}\text { En animales: irrit. de la piel, } \\
\text { posible derm.; insuf, resp; diarr.; } \\
\text { daño renal; ; temblor musc., } \\
\text { convuls.; tracto Gl, posible terato, } \\
\text { efectos repro.; posible daño } \\
\text { hepático }\end{array}$ \\
\hline $\begin{array}{l}\text { Acido arsénico, } \\
\text { sal diamónica } \\
7784-44-3\end{array}$ & $\begin{array}{l}\text { Ojos; piel; ap. } \\
\text { resp.; SNC; tracto } \\
\text { digestivo; aparato } \\
\text { circulatorio }\end{array}$ & $\begin{array}{l}\text { SNP; piel; } \\
\text { membranas } \\
\text { mucosas; } \\
\text { hígado }\end{array}$ & $\begin{array}{r}\text { Inhalación } \\
\text { Piel } \\
\text { Ojos } \\
\text { Ingestión }\end{array}$ & $\begin{array}{l}\text { Tos, cefalea, dificultad para respirar, } \\
\text { debilidad; Véase Ingestión } \\
\text { Se puede absorber, soluble, } \\
\text { Enrojecimiento, dolor } \\
\text { Enrojecimiento, dolor } \\
\text { Dolor abdominal, diarrea, vómitos, } \\
\text { sensación de ardor detrás del } \\
\text { esternón y en la boca }\end{array}$ & & \\
\hline
\end{tabular}

Continúa en la página siguiente. 
Tabla 63.3 • Riesgos para la salud.

Continuación.

\begin{tabular}{|c|c|c|c|c|c|c|}
\hline $\begin{array}{l}\text { Nombre } \\
\text { químico } \\
\text { Número CAS }\end{array}$ & $\begin{array}{l}\text { Exposición a } \\
\text { corto plazo }\end{array}$ & $\begin{array}{l}\text { Exposición a } \\
\text { largo plazo }\end{array}$ & $\begin{array}{l}\text { Vías de } \\
\text { exposición }\end{array}$ & Síntomas & $\begin{array}{l}\text { Organos diana, } \\
\text { vías de } \\
\text { entrada }\end{array}$ & Síntomas \\
\hline $\begin{array}{l}\text { Acido arsénico, } \\
\text { sal magnésica } \\
10103-50-1\end{array}$ & $\begin{array}{l}\text { Ojos; ap. resp.; } \\
\text { SNC; tracto diges- } \\
\text { tivo; aparato } \\
\text { circulatorio }\end{array}$ & $\begin{array}{l}\text { SNP; piel; } \\
\text { membranas } \\
\text { mucosas; } \\
\text { hígado }\end{array}$ & $\begin{array}{r}\text { Inhalación } \\
\text { Piel } \\
\text { Ojos } \\
\text { Ingestión }\end{array}$ & $\begin{array}{l}\text { Tos, cefalea, dificultad para respirar, } \\
\text { debilidad; Véase Ingestión } \\
\text { Se puede absorber } \\
\text { Enrojecimiento, dolor } \\
\text { Dolor abdominal, diarrea, vómitos, } \\
\text { sensación de ardor detrás del } \\
\text { esternón y en la boca }\end{array}$ & & \\
\hline $\begin{array}{l}\text { Acido arsénico, } \\
\text { sal de cobre } \\
10103-61-4\end{array}$ & $\begin{array}{l}\text { Ojos; ap. resp.; } \\
\text { SNC; tracto } \\
\text { digestivo }\end{array}$ & $\begin{array}{l}\text { Piel; SNP; } \\
\text { membranas } \\
\text { mucosas; } \\
\text { hígado }\end{array}$ & $\begin{array}{r}\text { Inhalación } \\
\text { Piel } \\
\text { Ojos } \\
\text { Ingestión }\end{array}$ & $\begin{array}{l}\text { Tos, cefalea, dificultad para respirar, } \\
\text { debilidad; Véase Ingestión } \\
\text { Se puede absorber } \\
\text { Enrojecimiento, dolor } \\
\text { Dolor abdominal, diarrea, vómitos, } \\
\text { sensación de ardor detrás del } \\
\text { esternón y en la boca }\end{array}$ & & \\
\hline $\begin{array}{l}\text { Acido arsénico, } \\
\text { sal disódica } \\
7778-43-0\end{array}$ & $\begin{array}{l}\text { Ojos; piel; ap. } \\
\text { resp.; SNC; tracto } \\
\text { digestivo; aparato } \\
\text { circulatorio }\end{array}$ & $\begin{array}{l}\text { SNP; piel; } \\
\text { membranas } \\
\text { mucosas; } \\
\text { hígado }\end{array}$ & $\begin{array}{r}\text { Inhalación } \\
\text { Piel } \\
\text { Ojos } \\
\text { Ingestión }\end{array}$ & $\begin{array}{l}\text { Tos, cefalea, dificultad para respirar, } \\
\text { debilidad; Véase Ingestión } \\
\text { Se puede absorber, soluble, } \\
\text { enrojecimiento, dolor } \\
\text { Enrojecimiento, dolor } \\
\text { Dolor abdominal, diarrea, vómitos, } \\
\text { sensación de ardor detrás del } \\
\text { esternón y en la boca }\end{array}$ & & \\
\hline $\begin{array}{l}\text { Acido arsénico, } \\
\text { sal monopotá- } \\
\text { sica } \\
7784-41-0\end{array}$ & $\begin{array}{l}\text { Ojos; piel; ap. } \\
\text { resp.; membranas } \\
\text { mucosas }\end{array}$ & $\begin{array}{l}\text { Piel; SNP; } \\
\text { membranas } \\
\text { mucosas; } \\
\text { hígado }\end{array}$ & $\begin{array}{r}\text { Inhalación } \\
\text { Piel } \\
\text { Ojos } \\
\text { Ingestión }\end{array}$ & $\begin{array}{l}\text { Tos, cefalea, dificultad para respirar, } \\
\text { debilidad; Véase Ingestión } \\
\text { Se puede absorber, } \\
\text { enrojecimiento, dolor } \\
\text { Enrojecimiento, dolor } \\
\text { Dolor abdominal, sensación de } \\
\text { ardor, diarrea, vómitos }\end{array}$ & & \\
\hline $\begin{array}{l}\text { Acido arsenioso, } \\
\text { sal de cobre } \\
(2+)(1: 1) \\
10290-12-7\end{array}$ & $\begin{array}{l}\text { Ojos; piel; ap. } \\
\text { resp.; SNC; tracto } \\
\text { digestivo; aparato } \\
\text { circulatorio }\end{array}$ & $\begin{array}{l}\text { Piel; SNP; } \\
\text { membranas } \\
\text { mucosas; } \\
\text { hígado }\end{array}$ & $\begin{array}{r}\text { Inhalación } \\
\text { Piel } \\
\text { Ojos } \\
\text { Ingestión }\end{array}$ & $\begin{array}{l}\text { Tos, cefalea, dificultad para respirar, } \\
\text { debilidad; Véase Ingestión } \\
\text { Se puede absorber } \\
\text { Enrojecimiento, dolor } \\
\text { Dolor abdominal, diarrea, vómitos, } \\
\text { sensación de ardor detrás del } \\
\text { esternón y en la boca }\end{array}$ & & \\
\hline $\begin{array}{l}\text { Arsenato } \\
\text { de calcio } \\
7778-44-1\end{array}$ & $\begin{array}{l}\text { Ojos; piel; ap. } \\
\text { resp.; SNC; tracto } \\
\text { digestivo; aparato } \\
\text { circulatorio }\end{array}$ & $\begin{array}{l}\text { SNP; piel; } \\
\text { membranas } \\
\text { mucosas; } \\
\text { hígado }\end{array}$ & $\begin{array}{r}\text { Inhalación } \\
\text { Piel } \\
\text { Ojos } \\
\text { Ingestión }\end{array}$ & $\begin{array}{l}\text { Tos, cefalea, dificultad para respirar, } \\
\text { debilidad: Véase Ingestión } \\
\text { Se puede absorber, } \\
\text { enrojecimiento, dolor } \\
\text { Enrojecimiento, dolor } \\
\text { Dolor abdominal, diarrea, vómitos, } \\
\text { sensación de ardor detrás del } \\
\text { esternón y en la boca }\end{array}$ & $\begin{array}{l}\text { Ojos; ap. resp; } \\
\text { hígado; piel; } \\
\text { sistema linfá- } \\
\text { tico; SNC; } \\
\text { [cáncer } \\
\text { pulmonar } \\
\text { y linfático] } \\
\text { Inh.; abs.; ing.; } \\
\text { con. }\end{array}$ & $\begin{array}{l}\text { Debil; trast. Gl; neur. perif., } \\
\text { hiperpig. de la piel, hiperquera- } \\
\text { tosis palmar plantar; derm.; } \\
\text { [canc.]; en animales: lesión } \\
\text { hepática }\end{array}$ \\
\hline
\end{tabular}

\begin{tabular}{|c|c|c|c|c|}
\hline $\begin{array}{l}\text { Arsenato de } \\
\text { plomo } \\
7784-40-9\end{array}$ & Intestinos; SCV & $\begin{array}{l}\text { Piel; SNC; tracto } \\
\text { Gl; hígado; } \\
\text { riñones; sangre; } \\
\text { cancerígeno; } \\
\text { posible } \\
\text { toxicidad } \\
\text { reproductora }\end{array}$ & Inhalación & $\begin{array}{l}\text { Cólicos abdominales, diarrea, } \\
\text { cefalea, náuseas, vómitos, opresión } \\
\text { en el pecho, estreñimiento, } \\
\text { excitación, desorientación } \\
\text { Enrojecimiento } \\
\text { Enrojecimiento }\end{array}$ \\
\hline
\end{tabular}


Tabla 63.3 - Riesgos para la salud.

continuación.

\begin{tabular}{|c|c|c|c|c|c|c|}
\hline $\begin{array}{l}\text { Nombre } \\
\text { químico } \\
\text { Número CAS }\end{array}$ & $\begin{array}{l}\text { Exposición a } \\
\text { corto plazo }\end{array}$ & $\begin{array}{l}\text { Exposición a } \\
\text { largo plazo }\end{array}$ & $\begin{array}{l}\text { Vías de } \\
\text { exposición }\end{array}$ & Síntomas & $\begin{array}{l}\text { Organos diana, } \\
\text { vías de } \\
\text { entrada }\end{array}$ & Síntomas \\
\hline $\begin{array}{l}\text { Arseniato } \\
\text { de sodio } \\
10048-95-0\end{array}$ & $\begin{array}{l}\text { Ojos; piel; ap. } \\
\text { resp.; tracto diges- } \\
\text { tivo; corazón; } \\
\text { hígado; riñones; } \\
\text { SNC }\end{array}$ & $\begin{array}{l}\text { Piel; SNC; SCV; } \\
\text { sangre; hígado; } \\
\text { cancerígeno }\end{array}$ & $\begin{array}{r}\text { Inhalación } \\
\text { Piel } \\
\text { Ojos } \\
\text { Ingestión }\end{array}$ & $\begin{array}{l}\text { Tos, cefalea, dolor de garganta; } \\
\text { Véase Ingestión } \\
\text { Enrojecimiento, dolor } \\
\text { Enrojecimiento, dolor } \\
\text { Dolor abdominal, sensación de } \\
\text { ardor, diarrea, vómitos }\end{array}$ & & \\
\hline $\begin{array}{l}\text { Arsénico } \\
7440-38-2\end{array}$ & $\begin{array}{l}\text { Ojos; piel; ap. } \\
\text { resp.; hígado; } \\
\text { riñones; } \\
\text { tracto Gl }\end{array}$ & $\begin{array}{l}\text { Piel; hígado; } \\
\text { SNC; cancerí- } \\
\text { geno; posible } \\
\text { toxicidad } \\
\text { reproductora }\end{array}$ & $\begin{array}{r}\text { Inhalación } \\
\text { Piel } \\
\text { Ojos } \\
\text { Ingestión }\end{array}$ & $\begin{array}{l}\text { Dolor torácico, dolor abdominal, tos, } \\
\text { cefalea, debilidad, vértigo } \\
\text { Se puede absorber, irritante } \\
\text { Enrojecimiento, irritante } \\
\text { Diarrea, náuseas, vómitos }\end{array}$ & $\begin{array}{l}\text { Hígado; riñones; } \\
\text { piel; pulmones; } \\
\text { sist. linfático } \\
\text { (cáncer } \\
\text { pulmonar y linfá- } \\
\text { tico) } \\
\text { Inh.; abs.; con.; } \\
\text { ing. }\end{array}$ & $\begin{array}{l}\text { Ulceras del tabique nasal, derm., } \\
\text { Trastornos Gl, neur. perif., irrit. } \\
\text { resp., hiperpig. de la piel, [ canc.] }\end{array}$ \\
\hline $\begin{array}{l}\text { Arsina } \\
7784-42-1\end{array}$ & $\begin{array}{l}\text { Pulmones; sangre; } \\
\text { riñones }\end{array}$ & & $\begin{array}{r}\text { Inhalación } \\
\text { Piel } \\
\text { 0jos }\end{array}$ & $\begin{array}{l}\text { Dolor abdominal, confusión, mareos, } \\
\text { cefalea, náuseas, falta de aire, } \\
\text { vómitos, debilidad } \\
\text { En contacto con líquidos: } \\
\text { congelación } \\
\text { En contacto con líquidos: } \\
\text { congelación, enrojecimiento }\end{array}$ & $\begin{array}{l}\text { Sangre; riñones; } \\
\text { hígado (cáncer } \\
\text { pulmonar } \\
\text { y linfático) } \\
\text { Inh.; con. (liq.) }\end{array}$ & $\begin{array}{l}\text { Cefal., mal., debil., mar.; disn.; } \\
\text { dolor abdom., de espalda; náus., } \\
\text { vómit., piel de bronce; hema.; } \\
\text { icter.; neur. perif., liq.: congela- } \\
\text { ción; [ canc.] }\end{array}$ \\
\hline $\begin{array}{l}\text { Pentóxido } \\
\text { de arsénico } \\
1303-28-2\end{array}$ & $\begin{array}{l}\text { Ojos; piel; ap. } \\
\text { resp.; riñones; } \\
\text { hígado; SCV; SNC; } \\
\text { sangre }\end{array}$ & $\begin{array}{l}\text { Pulmones; piel; } \\
\text { médula ósea; } \\
\text { SCV; SNC; } \\
\text { cancerígeno; } \\
\text { posible toxi- } \\
\text { cidad } \\
\text { reproductora }\end{array}$ & $\begin{array}{r}\text { Inhalación } \\
\text { Piel } \\
\text { Ojos } \\
\text { Ingestión }\end{array}$ & $\begin{array}{l}\text { Tos, cefalea, mareos, debilidad } \\
\text { falta de aire, dolor en el pecho, } \\
\text { la aparición de los síntomas puede } \\
\text { retrasarse; Véase Ingestión } \\
\text { Enrojecimiento, quemaduras en la } \\
\text { piel, dolor } \\
\text { Enrojecimiento, dolor, conjuntivitis } \\
\text { Constricción de la garganta, vómitos, } \\
\text { dolor abdominal, diarrea, mucha } \\
\text { sed, calambres musculares, shock }\end{array}$ & & \\
\hline $\begin{array}{l}\text { Tricloruro } \\
\text { arsenioso } \\
7784-34-1\end{array}$ & $\begin{array}{l}\text { Ojos; piel; ap. } \\
\text { resp.; pulmones; } \\
\text { SCV; SNC; tracto Gl }\end{array}$ & $\begin{array}{l}\text { Membranas } \\
\text { mucosas; piel; } \\
\text { hígado; riñones; } \\
\text { SNP }\end{array}$ & $\begin{array}{r}\text { Inhalación } \\
\text { Piel } \\
\text { 0jos } \\
\text { Ingestión }\end{array}$ & $\begin{array}{l}\text { Corrosivo, tos, dificultad para } \\
\text { respirar; Véase Ingestión } \\
\text { Corrosivo, se puede absorber, } \\
\text { enrojecimiento, dolor } \\
\text { Corrosivo, dolor, quemaduras } \\
\text { profundas graves } \\
\text { Corrosivo, dolor abdominal, } \\
\text { sensación de ardor, diarrea, } \\
\text { vómitos, colapso }\end{array}$ & & \\
\hline $\begin{array}{l}\text { Trióxido } \\
\text { de arsénico } \\
1327-53-3\end{array}$ & $\begin{array}{l}\text { Ojos; piel; ap. } \\
\text { resp.; riñones; } \\
\text { hígado; SCV; SNC; } \\
\text { hemato- } \\
\text { poyético }\end{array}$ & $\begin{array}{l}\text { Pulmones; piel; } \\
\text { médula ósea; } \\
\text { SNP; SNC; SCV; } \\
\text { corazón; } \\
\text { riñones; hígado; } \\
\text { cancerígeno; } \\
\text { puede causar } \\
\text { defectos de } \\
\text { nacimiento }\end{array}$ & $\begin{array}{r}\text { Piel } \\
\text { 0jos } \\
\text { Ingestión }\end{array}$ & $\begin{array}{l}\text { Tos, mareos, cefalea, falta de aire, } \\
\text { debilidad, dolor en el pecho, la } \\
\text { aparición de los síntomas puede } \\
\text { retrasarse; Véase Ingestión } \\
\text { Enrojecimiento, dolor } \\
\text { Enrojecimiento, dolor, conjuntivitis } \\
\text { Constricción de la garganta, dolor } \\
\text { abdominal, diarrea, vómitos, mucha } \\
\text { sed, calambres musculares, shock }\end{array}$ & & \\
\hline $\begin{array}{l}\text { Bario } \\
7440-39-3\end{array}$ & Ojos; piel; ap. resp. & & $\begin{array}{r}\text { Inhalación } \\
\text { Piel } \\
\text { 0jos }\end{array}$ & $\begin{array}{l}\text { Tos, dolor de garganta } \\
\text { Enrojecimiento } \\
\text { Enrojecimiento, dolor }\end{array}$ & & \\
\hline
\end{tabular}


Tabla 63.3 - Riesgos para la salud.

Continuación.

\begin{tabular}{|c|c|c|c|c|c|c|}
\hline $\begin{array}{l}\text { Nombre } \\
\text { químico } \\
\text { Número CAS }\end{array}$ & $\begin{array}{l}\text { Exposición a } \\
\text { corto plazo }\end{array}$ & $\begin{array}{l}\text { Exposición a } \\
\text { largo plazo }\end{array}$ & $\begin{array}{l}\text { Vías de } \\
\text { exposición }\end{array}$ & Síntomas & $\begin{array}{l}\text { Organos diana, } \\
\text { vías de } \\
\text { entrada }\end{array}$ & Síntomas \\
\hline $\begin{array}{l}\text { Clorato } \\
\text { de bario } \\
13477-00-4\end{array}$ & $\begin{array}{l}\text { Ojos; piel; ap. } \\
\text { resp.; diversos } \\
\text { órganos y tejidos }\end{array}$ & $\begin{array}{l}\text { Organos y } \\
\text { tejidos }\end{array}$ & $\begin{array}{l}\text { Inhalación } \\
\text { Ojos } \\
\text { Ingestión }\end{array}$ & $\begin{array}{l}\text { Dolor abdominal, cólicos abdomi- } \\
\text { nales, sensación de ardor, náuseas, } \\
\text { vómitos, debilidad, parálisis } \\
\text { Enrojecimiento, dolor } \\
\text { cólicos abdominales, dolor } \\
\text { abdominal, labios o uñas azules, } \\
\text { piel azul, sensación de ardor, } \\
\text { diarrea, mareos, náuseas, dolor } \\
\text { de garganta, vómitos, debilidad, } \\
\text { arritmias cardíacas }\end{array}$ & & \\
\hline $\begin{array}{l}\text { Cloruro } \\
\text { de bario } \\
10361-37-2\end{array}$ & $\begin{array}{l}\text { Ojos; piel; ap. } \\
\text { resp.; SNC; } \\
\text { músculos }\end{array}$ & & $\begin{array}{l}\text { Inhalación } \\
\text { Ojos } \\
\text { Ingestión }\end{array}$ & $\begin{array}{l}\text { Cólicos abdominales, } \\
\text { desvanecimiento } \\
\text { Enrojecimiento } \\
\text { Cólicos abdominales, sordera, } \\
\text { desvanecimiento }\end{array}$ & $\begin{array}{l}\text { Corazón; SNC; } \\
\text { piel; ap. resp; } \\
\text { ojos } \\
\text { Inh.; ing.; con. }\end{array}$ & $\begin{array}{l}\text { Irrit. ojos, piel, vías resp. altas; } \\
\text { quemaduras en la piel, gastroente- } \\
\text { ritis; espasmo musc; pulso lento, } \\
\text { extrasístoles; hipocalemia }\end{array}$ \\
\hline $\begin{array}{l}\text { Cloruro } \\
\text { de bario, } \\
\text { dihidrato } \\
10362-27-9\end{array}$ & $\begin{array}{l}\text { Ojos; piel; ap. } \\
\text { resp.; SNC; } \\
\text { músculos }\end{array}$ & & $\begin{array}{l}\text { Inhalación } \\
\text { Ojos } \\
\text { Ingestión }\end{array}$ & $\begin{array}{l}\text { Cólicos abdominales, } \\
\text { desvanecimiento } \\
\text { Enrojecimiento } \\
\text { Cólicos abdominales, sordera, } \\
\text { desvanecimiento }\end{array}$ & & \\
\hline $\begin{array}{l}\text { Oxido de bario } \\
1304-28-5\end{array}$ & $\begin{array}{l}\text { Ojos; piel; ap. } \\
\text { resp.; músculos }\end{array}$ & Pulmones & $\begin{array}{r}\text { Inhalación } \\
\text { Piel } \\
\text { Ojos } \\
\text { Ingestión }\end{array}$ & $\begin{array}{l}\text { Tos, falta de aire, dolor de garganta } \\
\text { Enrojecimiento } \\
\text { Enrojecimiento, dolor } \\
\text { Dolor abdominal, diarrea, mareos, } \\
\text { náuseas, vómitos, parálisis } \\
\text { muscular, arritmias cardíacas, } \\
\text { hipertensión, muerte }\end{array}$ & & \\
\hline $\begin{array}{l}\text { Peróxido } \\
\text { de bario } \\
1304-29-6\end{array}$ & & Piel & $\begin{array}{r}\text { Inhalación } \\
\text { Piel } \\
\text { Ojos } \\
\text { Ingestión }\end{array}$ & $\begin{array}{l}\text { Tos, náuseas, falta de aire, dolor de } \\
\text { garganta } \\
\text { Enrojecimiento, quemaduras en la } \\
\text { piel, dolor, descoloración } \\
\text { Enrojecimiento, dolor, quemaduras } \\
\text { profundas graves } \\
\text { Dolor abdominal, sensación de } \\
\text { ardor, dolor de garganta }\end{array}$ & & \\
\hline $\begin{array}{l}\text { Sulfato } \\
\text { de bario } \\
7727-43-7\end{array}$ & & Pulmones & Inhalación & Tos & $\begin{array}{l}\text { Ojos; ap. resp } \\
\text { Inh.; con. }\end{array}$ & $\begin{array}{l}\text { Irrit. ojos, nariz, vías resp. altas; } \\
\text { neumoconiosis benigna (baritosis) }\end{array}$ \\
\hline $\begin{array}{l}\text { Cadmio } \\
7440-43-9\end{array}$ & $\begin{array}{l}\text { Ojos; ap. resp.; } \\
\text { pulmones }\end{array}$ & $\begin{array}{l}\text { Pulmones; } \\
\text { riñones }\end{array}$ & $\begin{array}{r}\text { Inhalación } \\
\text { Ojos } \\
\text { Ingestión }\end{array}$ & $\begin{array}{l}\text { Tos, cefalea, la aparición de los } \\
\text { síntomas puede retrasarse } \\
\text { Enrojecimiento, dolor } \\
\text { Dolor abdominal, diarrea, cefalea, } \\
\text { náuseas, vómitos }\end{array}$ & $\begin{array}{l}\text { Ap. resp; } \\
\text { riñones; } \\
\text { próstata; sangre } \\
\text { (cáncer de prós- } \\
\text { tata y pulmón) } \\
\text { Inh.; ing. }\end{array}$ & $\begin{array}{l}\text { Edema pulm., disn., tos, opres. en } \\
\text { el pecho, dolor subest.; cefal.; } \\
\text { escalofríos, dolor musc.; náus., } \\
\text { vómit., diarr.; anos., enfis., prot., } \\
\text { anemia leve; [canc.] }\end{array}$ \\
\hline $\begin{array}{l}\text { Cloruro } \\
\text { de cadmio } \\
10108-64-2\end{array}$ & $\begin{array}{l}\text { Ap. resp.; tracto } \\
\text { digestivo; pulmones }\end{array}$ & $\begin{array}{l}\text { Pulmones; } \\
\text { riñones; hueso; } \\
\text { probablemente } \\
\text { cancerígeno }\end{array}$ & $\begin{array}{r}\text { Inhalación } \\
\text { Piel } \\
\text { Ojos } \\
\text { Ingestión }\end{array}$ & $\begin{array}{l}\text { Tos, dificultad para respirar, la } \\
\text { aparición de los síntomas puede } \\
\text { retrasarse } \\
\text { Enrojecimiento } \\
\text { Enrojecimiento, dolor } \\
\text { Dolor abdominal, sensación de ardor, } \\
\text { diarrea, náuseas, vómitos }\end{array}$ & & \\
\hline
\end{tabular}


Tabla 63.3 - Riesgos para la salud. Continuación.

\begin{tabular}{|c|c|c|c|c|c|c|}
\hline $\begin{array}{l}\text { Nombre } \\
\text { químico } \\
\text { Número CAS }\end{array}$ & $\begin{array}{l}\text { Exposición a } \\
\text { corto plazo }\end{array}$ & $\begin{array}{l}\text { Exposición a } \\
\text { largo plazo }\end{array}$ & $\begin{array}{l}\text { Vías de } \\
\text { exposición }\end{array}$ & Síntomas & $\begin{array}{l}\text { Organos diana, } \\
\text { vías de } \\
\text { entrada }\end{array}$ & Síntomas \\
\hline $\begin{array}{l}\text { Oxido } \\
\text { de cadmio } \\
1306-19-0\end{array}$ & $\begin{array}{l}\text { Ap. resp.; tracto } \\
\text { digestivo; pulmones }\end{array}$ & $\begin{array}{l}\text { Pulmones; } \\
\text { riñones; } \\
\text { cancerígeno }\end{array}$ & $\begin{array}{r}\text { Inhalación } \\
\text { Piel } \\
\text { Ojos } \\
\text { Ingestión }\end{array}$ & $\begin{array}{l}\text { Tos, dificultad para respirar, } \\
\text { falta de aire, la aparición de los } \\
\text { síntomas puede retrasarse } \\
\text { Enrojecimiento } \\
\text { Enrojecimiento, dolor } \\
\text { Cólicos abdominales, diarrea, } \\
\text { náuseas, vómitos }\end{array}$ & $\begin{array}{l}\text { Ap. resp; } \\
\text { riñones; sangre; } \\
\text { (cáncer de prós- } \\
\text { tata y pulmón) } \\
\text { Inh. }\end{array}$ & $\begin{array}{l}\text { Edema pulm., disn., tos, opres. en } \\
\text { el pecho, dolor subest.; cefal.; } \\
\text { escalofríos, dolor musc.; náus., } \\
\text { vómit., diarr.; anos., enfis., prot., } \\
\text { anemia leve; [canc.] }\end{array}$ \\
\hline $\begin{array}{l}\text { Sulfuro } \\
\text { de cadmio } \\
1306-23-6\end{array}$ & & $\begin{array}{l}\text { Pulmones; } \\
\text { riñones; } \\
\text { cancerígeno }\end{array}$ & & & & \\
\hline $\begin{array}{l}\text { Cloruro } \\
\text { de cobalto } \\
7646-79-9\end{array}$ & Ojos; piel; ap. resp. & $\begin{array}{l}\text { Piel; ap. resp.; } \\
\text { corazón }\end{array}$ & $\begin{array}{r}\text { Inhalación } \\
\text { Piel } \\
\text { Ojos } \\
\text { Ingestión }\end{array}$ & $\begin{array}{l}\text { Tos, dificultad para respirar, } \\
\text { falta de aire } \\
\text { Enrojecimiento } \\
\text { Enrojecimiento } \\
\text { Dolor abdominal, diarrea, náuseas, } \\
\text { vómitos }\end{array}$ & & \\
\hline $\begin{array}{l}\text { Cobalto } \\
7440-48-4\end{array}$ & & $\begin{array}{l}\text { Piel; ap. resp.; } \\
\text { pulmones; } \\
\text { corazón }\end{array}$ & $\begin{array}{r}\text { Inhalación } \\
\text { Piel } \\
\text { Ojos } \\
\text { Ingestión }\end{array}$ & $\begin{array}{l}\text { Tos, dificultad para respirar, } \\
\text { falta de aire } \\
\text { Enrojecimiento } \\
\text { Enrojecimiento } \\
\text { Dolor abdominal, vómitos }\end{array}$ & $\begin{array}{l}\text { Ap. resp.; piel } \\
\text { Inh.; ing.; con. }\end{array}$ & $\begin{array}{l}\text { Tos, disn., jadeo, func. pulm. } \\
\text { dism.; bajo peso; derm.; fib. } \\
\text { nodular difusa; hipersensibilidad } \\
\text { resp., asma }\end{array}$ \\
\hline $\begin{array}{l}\text { Naftenato } \\
\text { de cobalto } \\
61789-51-3\end{array}$ & Ojos; ap. resp. & Piel & $\begin{array}{r}\text { Inhalación } \\
\text { Piel } \\
\text { Ojos }\end{array}$ & $\begin{array}{l}\text { Tos, dolor de garganta } \\
\text { Enrojecimiento, dolor } \\
\text { Enrojecimiento, dolor }\end{array}$ & & \\
\hline $\begin{array}{l}\text { Oxido de } \\
\text { cobalto (III) } \\
1308-04-9\end{array}$ & Ojos; piel; ap. resp. & $\begin{array}{l}\text { Piel; puede } \\
\text { causar asma; } \\
\text { pulmones; posi- } \\
\text { blemente } \\
\text { cancerígeno } \\
\end{array}$ & $\begin{array}{l}\text { Inhalación } \\
\text { Ojos }\end{array}$ & $\begin{array}{l}\text { Tos, dificultad para respirar, } \\
\text { falta de aire } \\
\text { Enrojecimiento }\end{array}$ & & \\
\hline $\begin{array}{l}\text { Cobre } \\
7440-50-8\end{array}$ & Ojos & Piel; pulmones & $\begin{array}{r}\text { Inhalación } \\
\text { Piel } \\
\text { Ojos } \\
\text { Ingestión }\end{array}$ & $\begin{array}{l}\text { Tos, cefalea, falta de aire, } \\
\text { dolor de garganta } \\
\text { Enrojecimiento } \\
\text { Enrojecimiento, dolor } \\
\text { Dolor abdominal, náuseas, vómitos }\end{array}$ & $\begin{array}{l}\text { Ojos; ap. resp.; } \\
\text { piel; hígado; } \\
\text { riñones ( mayor } \\
\text { riesgo con enfer- } \\
\text { medad de } \\
\text { Wilsons) } \\
\text { Inh.; ing.; con. }\end{array}$ & $\begin{array}{l}\text { Irrit. ojos, nariz, faringe; perf. } \\
\text { nasal; gusto metálico; derm.; en } \\
\text { animales: daño pulm., hepático, } \\
\text { renal; anemia }\end{array}$ \\
\hline $\begin{array}{l}\text { Oxido de } \\
\text { cobre (I) } \\
1317-39-1\end{array}$ & Ojos; ap. resp. & & $\begin{array}{r}\text { Inhalación } \\
\text { Ojos } \\
\text { Ingestión }\end{array}$ & $\begin{array}{l}\text { Tos, gusto metálico, fiebre por } \\
\text { humos metálicos } \\
\text { Enrojecimiento } \\
\text { Cólicos abdominales, diarrea, } \\
\text { náuseas, vómitos }\end{array}$ & & \\
\hline $\begin{array}{l}\text { Cromato } \\
\text { de plomo } \\
7758-97-6\end{array}$ & $\begin{array}{l}\text { Ap. resp.; puede } \\
\text { causar perforación } \\
\text { del tabique nasal }\end{array}$ & $\begin{array}{l}\text { Piel; la inhala- } \\
\text { ción puede } \\
\text { causar asma; } \\
\text { pulmones }\end{array}$ & $\begin{array}{r}\text { Inhalación } \\
\text { Piel } \\
\text { Ojos } \\
\text { Ingestión }\end{array}$ & $\begin{array}{l}\text { Tos, cefalea, dificultad para respirar, } \\
\text { náuseas, gusto metálico } \\
\text { Quemaduras en la piel, úlceras, } \\
\text { vesículas } \\
\text { Enrojecimiento } \\
\text { Dolor abdominal, estreñimiento, } \\
\text { convulsiones, tos, diarrea, } \\
\text { vómitos, debilidad, anorexia }\end{array}$ & & \\
\hline
\end{tabular}


Tabla 63.3 - Riesgos para la salud.

Continuación.

\begin{tabular}{|c|c|c|c|c|c|c|}
\hline $\begin{array}{l}\text { Nombre } \\
\text { químico } \\
\text { Número CAS }\end{array}$ & $\begin{array}{l}\text { Exposición a } \\
\text { corto plazo }\end{array}$ & $\begin{array}{l}\text { Exposición a } \\
\text { largo plazo }\end{array}$ & $\begin{array}{l}\text { Vías de } \\
\text { exposición }\end{array}$ & Síntomas & $\begin{array}{l}\text { Organos diana, } \\
\text { vías de } \\
\text { entrada }\end{array}$ & Síntomas \\
\hline $\begin{array}{l}\text { Cromilcloruro } \\
14977-61-8\end{array}$ & $\begin{array}{l}\text { Ojos; piel; ap. } \\
\text { resp.; pulmones; } \\
\text { corrosivo si se } \\
\text { ingiere }\end{array}$ & $\begin{array}{l}\text { Piel; asma; } \\
\text { probablemente } \\
\text { cancerígeno }\end{array}$ & $\begin{array}{r}\text { Inhalación } \\
\text { Piel } \\
\text { Ojos } \\
\text { Ingestión }\end{array}$ & $\begin{array}{l}\text { Tos, dificultad para respirar, } \\
\text { falta de aire, dolor de garganta } \\
\text { Enrojecimiento, quemaduras en la } \\
\text { piel, dolor, vesículas } \\
\text { Enrojecimiento, dolor, quemaduras } \\
\text { profundas graves } \\
\text { Dolor abdominal }\end{array}$ & $\begin{array}{l}\text { Ojos; piel; ap. } \\
\text { resp. (cáncer de } \\
\text { pulmón) } \\
\text { Inh.; abs.; ing.; } \\
\text { con. }\end{array}$ & $\begin{array}{l}\text { Irrit. ojos, piel, vías resp. altas; } \\
\text { ojos, quemaduras en la piel }\end{array}$ \\
\hline $\begin{array}{l}\text { Cromo } \\
7440-47-3\end{array}$ & $\begin{array}{l}\text { Ojos; piel; ap. } \\
\text { resp.; pulmones; } \\
\text { riñones }\end{array}$ & $\begin{array}{l}\text { Piel; asma; } \\
\text { laringe; } \\
\text { pulmones }\end{array}$ & $\begin{array}{r}\text { Ojos } \\
\text { Ingestión }\end{array}$ & $\begin{array}{l}\text { Irritación } \\
\text { Diarrea, náuseas, desvanecimiento, } \\
\text { vómitos }\end{array}$ & $\begin{array}{l}\text { Ap. resp; piel; } \\
\text { ojos } \\
\text { Inh.; ing.; con. }\end{array}$ & $\begin{array}{l}\text { Irrit. ojos, piel; fib. pulm. } \\
\text { (histológica) }\end{array}$ \\
\hline $\begin{array}{l}\text { Cloruro } \\
\text { estánnico } \\
7646-78-8\end{array}$ & $\begin{array}{l}\text { Ojos; piel; ap. } \\
\text { resp.; pulmones }\end{array}$ & Piel & $\begin{array}{r}\text { Inhalación } \\
\text { Piel } \\
\text { Ojos } \\
\text { Ingestión }\end{array}$ & $\begin{array}{l}\text { Sensación de ardor, tos, dificultad } \\
\text { para respirar, falta de aire, dolor } \\
\text { de garganta } \\
\text { Enrojecimiento, quemaduras en la } \\
\text { piel, vesículas } \\
\text { Quemaduras profundas graves } \\
\text { Cólicos abdominales, vómitos }\end{array}$ & & \\
\hline $\begin{array}{l}\text { Cloruro } \\
\text { estannoso } \\
7772-99-8\end{array}$ & $\begin{array}{l}\text { Ojos; piel; ap. } \\
\text { resp.; SNC; sangre }\end{array}$ & Hígado & $\begin{array}{r}\text { Inhalación } \\
\text { Piel } \\
\text { Ojos } \\
\text { Ingestión }\end{array}$ & $\begin{array}{l}\text { Tos, dificultad para respirar } \\
\text { Enrojecimiento } \\
\text { Enrojecimiento, dolor } \\
\text { Dolor abdominal, diarrea, náuseas, } \\
\text { vómitos }\end{array}$ & & \\
\hline $\begin{array}{l}\text { Cloruro } \\
\text { estannoso } \\
\text { dihidrato } \\
10025-69-1\end{array}$ & $\begin{array}{l}\text { Ojos; piel; ap. } \\
\text { resp.; SNC; sangre }\end{array}$ & Hígado & $\begin{array}{r}\text { Inhalación } \\
\text { Piel } \\
\text { Ojos } \\
\text { Ingestión }\end{array}$ & $\begin{array}{l}\text { Tos, dificultad para respirar } \\
\text { Enrojecimiento } \\
\text { Enrojecimiento, dolor } \\
\text { Dolor abdominal, diarrea, náuseas, } \\
\text { vómitos }\end{array}$ & & \\
\hline $\begin{array}{l}\text { Fluoruro } \\
\text { estannoso } \\
7783-47-3\end{array}$ & Piel; ap. resp.; ojos & Dientes; huesos & $\begin{array}{r}\text { Inhalación } \\
\text { Piel } \\
\text { Ojos } \\
\text { Ingestión }\end{array}$ & $\begin{array}{l}\text { Tos } \\
\text { Enrojecimiento } \\
\text { Enrojecimiento, dolor, quemaduras } \\
\text { profundas graves } \\
\text { Dolor abdominal, náuseas }\end{array}$ & & \\
\hline $\begin{array}{l}\text { Oxido de } \\
\text { di-N-dibutiles- } \\
\text { taño } \\
818-08-6\end{array}$ & $\begin{array}{l}\text { Ojos; piel; ap. } \\
\text { resp.; pulmones }\end{array}$ & $\begin{array}{l}\text { Piel; SNP; } \\
\text { hígado; } \\
\text { conducto biliar; } \\
\text { sistema } \\
\text { linfático; }\end{array}$ & $\begin{array}{l}\text { Inhalación } \\
\text { Piel } \\
\text { Ojos }\end{array}$ & $\begin{array}{l}\text { Cefalea, zumbido en los oídos, } \\
\text { pérdida de memoria, desorientación } \\
\text { Se puede absorber, quemaduras en } \\
\text { la piel, dolor } \\
\text { Enrojecimiento, dolor }\end{array}$ & & \\
\hline $\begin{array}{l}\text { Oxido de estaño } \\
21651-19-4\end{array}$ & Ap. resp. & Pulmones & Inhalación & Tos & $\begin{array}{l}\text { Ap. resp } \\
\text { Inh.; con. }\end{array}$ & $\begin{array}{l}\text { Estannosis (neumoconiosis } \\
\text { benigna): disn., func. pulm. dism. }\end{array}$ \\
\hline $\begin{array}{l}\text { Oxido estánnico } \\
18282-10-5 \\
\end{array}$ & Ap. resp. & Pulmones & Inhalación & Tos & $\begin{array}{l}\text { Ap. resp } \\
\text { Inh.; con. }\end{array}$ & $\begin{array}{l}\text { Estannosis (neumoconiosis } \\
\text { benigna): disn., func. pulm. dism. }\end{array}$ \\
\hline $\begin{array}{l}\text { Cromato } \\
\text { de estroncio } \\
7789-06-2\end{array}$ & $\begin{array}{l}\text { Ojos; piel; ap. } \\
\text { resp;; riñones; } \\
\text { hígado }\end{array}$ & $\begin{array}{l}\text { Piel; pulmones; } \\
\text { sangre; hígado; } \\
\text { riñones; } \\
\text { cerebro; eritro- } \\
\text { citos y leuco- } \\
\text { citos; hígado; } \\
\text { riñones; } \\
\text { cancerígeno }\end{array}$ & $\begin{array}{r}\text { Inhalación } \\
\text { Piel } \\
\text { Ingestión }\end{array}$ & $\begin{array}{l}\text { Tos, ronquera } \\
\text { Enrojecimiento, ulceraciones } \\
\text { Dolor de garganta }\end{array}$ & & \\
\hline $\begin{array}{l}\text { Cloruro } \\
\text { de magnesio } \\
7786-30-3\end{array}$ & Ojos; ap. resp. & & $\begin{array}{r}\text { Inhalación } \\
\text { Ojos } \\
\text { Ingestión }\end{array}$ & $\begin{array}{l}\text { Tos } \\
\text { Enrojecimiento } \\
\text { Diarrea }\end{array}$ & & \\
\hline
\end{tabular}

Continúa en la página siguiente. 
Tabla 63.3 - Riesgos para la salud.

continuación.

\begin{tabular}{|c|c|c|c|c|c|c|}
\hline $\begin{array}{l}\text { Nombre } \\
\text { químico } \\
\text { Número CAS }\end{array}$ & $\begin{array}{l}\text { Exposición a } \\
\text { corto plazo }\end{array}$ & $\begin{array}{l}\text { Exposición a } \\
\text { largo plazo }\end{array}$ & $\begin{array}{l}\text { Vías de } \\
\text { exposición }\end{array}$ & Síntomas & $\begin{array}{l}\text { Organos diana, } \\
\text { vías de } \\
\text { entrada }\end{array}$ & Síntomas \\
\hline $\begin{array}{l}\text { Fosfuro } \\
\text { de magnesio } \\
12057-74-8\end{array}$ & Ojos; piel; ap. resp. & & $\begin{array}{l}\text { Inhalación } \\
\text { Piel } \\
\text { Ojos } \\
\text { Ingestión }\end{array}$ & $\begin{array}{l}\text { Dolor abdominal, sensación de } \\
\text { ardor, tos, mareos, sordera, cefalea, } \\
\text { dificultad para respirar, náuseas, } \\
\text { dolor de garganta } \\
\text { Enrojecimiento, dolor } \\
\text { Enrojecimiento, dolor } \\
\text { Dolor abdominal, convulsiones, } \\
\text { náuseas, desvanecimiento, vómitos }\end{array}$ & & \\
\hline $\begin{array}{l}\text { Magnesio } \\
7439-95-4\end{array}$ & & & $\begin{array}{r}\text { Inhalación } \\
\text { Ojos } \\
\text { Ingestión }\end{array}$ & $\begin{array}{l}\text { Tos, dificultad para respirar } \\
\text { Enrojecimiento, dolor } \\
\text { Dolor abdominal, diarrea }\end{array}$ & & \\
\hline $\begin{array}{l}\text { Oxido } \\
\text { de magnesio } \\
1309-48-4\end{array}$ & Ojos; nariz & & $\begin{array}{r}\text { Inhalación } \\
\text { Ojos } \\
\text { Ingestión }\end{array}$ & $\begin{array}{l}\text { Tos } \\
\text { Enrojecimiento } \\
\text { Diarrea }\end{array}$ & $\begin{array}{l}\text { Ojos; ap, resp } \\
\text { Inh.; con. }\end{array}$ & $\begin{array}{l}\text { Irrit. ojos, nariz; fiebre por humos } \\
\text { metálicos, tos, dolor torácico, } \\
\text { fiebre tipo influenza }\end{array}$ \\
\hline $\begin{array}{l}\text { Sulfato } \\
\text { de manganeso } \\
10034-96-5\end{array}$ & Ojos; piel; ap. resp. & $\begin{array}{l}\text { Pulmones; SNC; } \\
\text { hígado; riñones; } \\
\text { testículos }\end{array}$ & $\begin{array}{r}\text { Inhalación } \\
\text { Piel } \\
\text { 0jos } \\
\text { Ingestión }\end{array}$ & $\begin{array}{l}\text { Sensación de ardor, tos, dificultad } \\
\text { para respirar } \\
\text { Se puede absorber, enrojecimiento, } \\
\text { sensación de ardor } \\
\text { Enrojecimiento, dolor, visión borrosa } \\
\text { Cólicos abdominales, náuseas, dolor } \\
\text { de garganta }\end{array}$ & & \\
\hline $\begin{array}{l}\text { Acetato } \\
\text { mercúrico } \\
1600-27-7\end{array}$ & $\begin{array}{l}\text { Ojos; piel; ap. } \\
\text { resp.; pulmones; } \\
\text { riñones }\end{array}$ & Piel; riñones & $\begin{array}{r}\text { Inhalación } \\
\text { Piel } \\
\text { 0jos } \\
\text { Ingestión }\end{array}$ & $\begin{array}{l}\text { Tos, cefalea, dificultad para respirar, } \\
\text { falta de aire, dolor de garganta, } \\
\text { la aparición de los síntomas puede } \\
\text { retrasarse; Véase Ingestión } \\
\text { Se puede absorber, quemaduras en } \\
\text { la piel, dolor } \\
\text { Dolor, visión borrosa, quemaduras } \\
\text { profundas graves } \\
\text { Dolor abdominal, sensación de ardor, } \\
\text { diarrea, vómitos, gusto metálico }\end{array}$ & & \\
\hline $\begin{array}{l}\text { Acetato } \\
\text { fenilmercúrico } \\
62-38-4\end{array}$ & $\begin{array}{l}\text { Ojos; piel; ap. } \\
\text { resp.; riñones }\end{array}$ & $\begin{array}{l}\text { Piel; SNC; posi- } \\
\text { bles efectos } \\
\text { tóxicos en la } \\
\text { reproducción } \\
\text { humana }\end{array}$ & $\begin{array}{r}\text { Inhalación } \\
\text { Piel } \\
\text { Ojos } \\
\text { Ingestión }\end{array}$ & $\begin{array}{l}\text { Tos, dificultad para respirar, dolor de } \\
\text { garganta, la aparición de los } \\
\text { síntomas puede retrasarse } \\
\text { Se puede absorber, enrojecimiento, } \\
\text { dolor } \\
\text { Enrojecimiento, dolor, visión borrosa } \\
\text { Dolor abdominal, diarrea, náuseas, } \\
\text { vómitos, debilidad, síntomas de } \\
\text { efectos retardados }\end{array}$ & & \\
\hline $\begin{array}{l}\text { Cloruro } \\
\text { mercúrico } \\
7487-94-7\end{array}$ & $\begin{array}{l}\text { Ojos; piel; ap. } \\
\text { resp.; pulmones; } \\
\text { riñones }\end{array}$ & Piel; riñones & $\begin{array}{l}\text { Inhalación } \\
\text { Piel } \\
\text { 0jos } \\
\text { Ingestión }\end{array}$ & $\begin{array}{l}\text { Sensación de ardor, tos, dificultad } \\
\text { para respirar, falta de aire, dolor } \\
\text { de garganta, la aparición de los } \\
\text { síntomas puede retrasarse; } \\
\text { Véase Ingestión } \\
\text { Se puede absorber, dolor, vesículas } \\
\text { Dolor, visión borrosa, quemaduras } \\
\text { profundas graves } \\
\text { Cólicos abdominales, dolor } \\
\text { abdominal, sensación de ardor, } \\
\text { diarrea, náuseas, dolor de garganta, } \\
\text { vómitos, gusto metálico }\end{array}$ & & \\
\hline $\begin{array}{l}\text { Cloruro } \\
\text { mercuroso } \\
10112-91-1\end{array}$ & 0jos & Riñones & $\begin{array}{r}\text { 0jos } \\
\text { Ingestión }\end{array}$ & $\begin{array}{l}\text { Enrojecimiento } \\
\text { Debilidad }\end{array}$ & & \\
\hline
\end{tabular}


Tabla 63.3 - Riesgos para la salud.

Continuación.

\begin{tabular}{|c|c|c|c|c|c|}
\hline $\begin{array}{l}\text { Nombre } \\
\text { químico } \\
\text { Número CAS }\end{array}$ & $\begin{array}{l}\text { Exposición a } \\
\text { corto plazo }\end{array}$ & $\begin{array}{l}\text { Exposición a } \\
\text { largo plazo }\end{array}$ & $\begin{array}{l}\text { Vías de } \\
\text { exposición }\end{array}$ & Síntomas & $\begin{array}{l}\text { Organos diana, } \\
\text { vías de } \\
\text { entrada }\end{array}$ \\
\hline
\end{tabular}

Compuesto

organoalquílico

de mercurio

\begin{tabular}{lll}
\hline $\begin{array}{c}\text { Mercurio } \\
7439-97-6\end{array}$ & $\begin{array}{l}\text { Ojos; piel; } \\
\text { pulmones; SNC }\end{array}$ & $\begin{array}{l}\text { SNC; sistema } \\
\text { nervioso; } \\
\text { riñones }\end{array}$ \\
\hline $\begin{array}{lll}\text { Nitrato } \\
\text { mercúrico } \\
10045-94-0\end{array}$ & $\begin{array}{l}\text { Piel; ap, resp.; } \\
\text { ojos; riñones }\end{array}$ & Riñones \\
& & \\
& & \\
& & \\
\hline Nitrato & Ojos; piel; ap. & Piel; SNC; \\
fenilmercúrico & resp.; riñones & posibles efectos \\
$55-68-5$ & & tóxicos en la \\
& & reproducción \\
& & humana
\end{tabular}

Ojos; piel; SNC;

SNP; riñones

Inh.; abs.; ing.;

con.

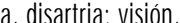
trast. de audición; espasticidad, tirones en las extremidades; mar.; saliv.; lagr.; náus., vómit., diarr., estreñ.; quemaduras en la piel; trast. emocionales; daño renal; posibles efectos terato

Piel; ap. resp; Irrit. ojos, piel; tos, dolor torácico, SNC; riñones; disn., neuitis bron.; temblor, ojos insom., irritab., indecisión, cefal., Inh.; abs.; ing.; fat., debil.; estomatitis, saliv.; con. trast. Gl, anor, bajo peso; prot.
Inhalación Tos, cefalea, dificultad para respirar, falta de aire, dolor de garganta

Piel Se puede absorber, enrojecimiento, dolor

Ojos Dolor, visión borrosa, quemaduras profundas graves

Ingestión Dolor abdominal, diarrea, vómitos, gusto metálico

Inhalación Tos, dificultad para respirar, dolor de garganta, la aparición de los síntomas puede retrasarse

Piel Se puede absorber, enrojecimiento, dolor

Ojos Enrojecimiento, dolor, visión borrosa

Ingestión Dolor abdominal, diarrea, náuseas, vómitos, síntomas de efectos retardados

\begin{tabular}{|c|c|c|c|c|c|c|}
\hline $\begin{array}{l}\text { Oxido } \\
\text { mercúrico } \\
21908-53-2\end{array}$ & Ojos; piel; ap. resp. & $\begin{array}{l}\text { Piel; riñones; } \\
\text { SNC }\end{array}$ & $\begin{array}{r}\text { Inhalación } \\
\text { Piel } \\
\text { Ojos } \\
\text { Ingestión }\end{array}$ & $\begin{array}{l}\text { Tos } \\
\text { Se puede absorber, enrojecimiento } \\
\text { Enrojecimiento } \\
\text { Dolor abdominal, diarrea }\end{array}$ & & \\
\hline $\begin{array}{l}\text { Sulfato } \\
\text { mercúrico } \\
7783-35-9\end{array}$ & $\begin{array}{l}\text { Ojos; piel; ap. } \\
\text { resp.; pulmones; } \\
\text { tracto Gl; corrosivo } \\
\text { si se ingiere }\end{array}$ & Riñones & $\begin{array}{r}\text { Inhalación } \\
\text { Piel } \\
\text { 0jos } \\
\text { Ingestión }\end{array}$ & $\begin{array}{l}\text { Sensación de ardor, tos, dificultad } \\
\text { para respirar, debilidad, la aparición } \\
\text { de los síntomas puede retrasarse; } \\
\text { Véase Ingestión } \\
\text { Se puede absorber, enrojecimiento, } \\
\text { sensación de ardor, dolor } \\
\text { Dolor, visión borrosa, quemaduras } \\
\text { profundas graves } \\
\text { Dolor abdominal, diarrea, náuseas, } \\
\text { vómitos, gusto metálico }\end{array}$ & & \\
\hline $\begin{array}{l}\text { Carbonato } \\
\text { de níquel } \\
3333-67-3\end{array}$ & Ojos; ap. resp. & $\begin{array}{l}\text { Piel; cancerí- } \\
\text { geno; asma }\end{array}$ & $\begin{array}{r}\text { Inhalación } \\
\text { Piel } \\
\text { 0jos }\end{array}$ & $\begin{array}{l}\text { Tos } \\
\text { Enrojecimiento } \\
\text { Enrojecimiento }\end{array}$ & & \\
\hline $\begin{array}{l}\text { Níquel } \\
7440-02-0\end{array}$ & Ojos; ap. resp. & $\begin{array}{l}\text { Piel; la inhala- } \\
\text { ción puede } \\
\text { causar asma; } \\
\text { puede afectar la } \\
\text { conjuntiva; } \\
\text { posible } \\
\text { cancerígeno }\end{array}$ & & & $\begin{array}{l}\text { Cavidades } \\
\text { nasales; } \\
\text { pulmones; piel } \\
\text { (cáncer } \\
\text { pulmonar y } \\
\text { nasal) } \\
\text { Inh.; ing.; con. }\end{array}$ & $\begin{array}{l}\text { Sensib. derm., asma alérgica, } \\
\text { neuitis; [ canc.] }\end{array}$ \\
\hline
\end{tabular}

Continúa en la página siguiente. 


\begin{tabular}{|c|c|c|c|c|c|c|}
\hline $\begin{array}{l}\text { Nombre } \\
\text { químico } \\
\text { Número CAS }\end{array}$ & $\begin{array}{l}\text { Exposición a } \\
\text { corto plazo }\end{array}$ & $\begin{array}{l}\text { Exposición a } \\
\text { largo plazo }\end{array}$ & $\begin{array}{l}\text { Vías de } \\
\text { exposición }\end{array}$ & Síntomas & $\begin{array}{l}\text { Organos diana, } \\
\text { vías de } \\
\text { entrada }\end{array}$ & Síntomas \\
\hline $\begin{array}{l}\text { Níquel } \\
\text { carbonilo } \\
13463-39-3\end{array}$ & $\begin{array}{l}\text { Ojos; piel; ap. } \\
\text { resp.; pulmones; } \\
\text { SNC }\end{array}$ & $\begin{array}{l}\text { Posible cancerí- } \\
\text { geno; puede } \\
\text { causar defectos } \\
\text { en el feto }\end{array}$ & $\begin{array}{l}\text { Inhalación } \\
\text { Piel } \\
\text { Ojos } \\
\text { Ingestión }\end{array}$ & $\begin{array}{l}\text { Dolor abdominal, piel azul, tos, } \\
\text { mareos, cefalea, náuseas, dificultad } \\
\text { para respirar, vómitos, los síntomas } \\
\text { se pueden retrasar } \\
\text { Se puede absorber, enrojecimiento, } \\
\text { dolor } \\
\text { Enrojecimiento, dolor } \\
\text { Dolor abdominal, cefalea, náuseas, } \\
\text { vómitos }\end{array}$ & $\begin{array}{l}\text { Pulmones; senos } \\
\text { paranasales; } \\
\text { SNC; ap. repro. } \\
\text { (cáncer } \\
\text { pulmonar y } \\
\text { nasal) } \\
\text { Inn.; abs.; ing.; } \\
\text { con. }\end{array}$ & $\begin{array}{l}\text { Cefal., vért.; náus., vómit., dolor } \\
\text { epigástrico; dolor subest.; tos, } \\
\text { hiperpnea; cian.; debil.; leucocit.; } \\
\text { neuitis; delirio; convuls.; [ canc.]; } \\
\text { en animales: efectos repro., terato }\end{array}$ \\
\hline $\begin{array}{l}\text { Oxido } \\
\text { de níquel (II) } \\
1313-99-1\end{array}$ & Ojos; ap. resp. & $\begin{array}{l}\text { Piel; la inhala- } \\
\text { ción puede } \\
\text { causar asma; } \\
\text { cancerígeno }\end{array}$ & $\begin{array}{r}\text { Inhalación } \\
\text { Piel } \\
\text { Ojos }\end{array}$ & $\begin{array}{l}\text { Tos } \\
\text { Enrojecimiento } \\
\text { Enrojecimiento }\end{array}$ & & \\
\hline $\begin{array}{l}\text { Sulfato } \\
\text { de níquel } \\
7786-81-4\end{array}$ & $\begin{array}{l}\text { Ojos; piel; ap. } \\
\text { resp.; tracto Gl; } \\
\text { SNC }\end{array}$ & $\begin{array}{l}\text { Piel; asma; } \\
\text { posible } \\
\text { cancerígeno }\end{array}$ & $\begin{array}{r}\text { Inhalación } \\
\text { Piel } \\
\text { Ojos } \\
\text { Ingestión }\end{array}$ & $\begin{array}{l}\text { Tos, dolor de garganta } \\
\text { Se puede absorber, enrojecimiento } \\
\text { Enrojecimiento } \\
\text { Dolor abdominal, mareos, cefalea, } \\
\text { náuseas, vómitos }\end{array}$ & & \\
\hline $\begin{array}{l}\text { Sulfuro } \\
\text { de níquel } \\
12035-72-2 \\
\end{array}$ & Ojos; piel; ap. resp. & $\begin{array}{l}\text { Piel; posible } \\
\text { cancerígeno }\end{array}$ & Inhalación & Tos, dolor de garganta & & \\
\hline $\begin{array}{l}\text { Tetróxido } \\
\text { de osmio } \\
20816-12-0\end{array}$ & $\begin{array}{l}\text { Ojos; piel; ap. } \\
\text { resp.; pulmones }\end{array}$ & Piel; riñones & $\begin{array}{r}\text { Inhalación } \\
\text { Piel } \\
\text { 0jos } \\
\text { Ingestión }\end{array}$ & $\begin{array}{l}\text { Tos, cefalea, respiración jadeante, } \\
\text { dificultad para respirar, alteraciones } \\
\text { visuales, la aparición de los síntomas } \\
\text { puede retrasarse } \\
\text { Enrojecimiento, quemaduras en la } \\
\text { piel, cambios de coloración en la piel } \\
\text { Visión borrosa, pérdida de visión } \\
\text { Sensación de ardor }\end{array}$ & $\begin{array}{l}\text { Ojos; ap. resp; } \\
\text { piel } \\
\text { Inh.; ing.; con. }\end{array}$ & $\begin{array}{l}\text { Irrit, ojos, ap, resp; lagr., alter. } \\
\text { vis.; conj.; cefal.; tos, disn.; derm }\end{array}$ \\
\hline $\begin{array}{l}\text { Nitrato de plata } \\
7761-88-8\end{array}$ & Ojos; piel; ap. resp. & Sangre; piel & $\begin{array}{r}\text { Inhalación } \\
\text { Piel } \\
\text { 0jos } \\
\text { Ingestión }\end{array}$ & $\begin{array}{l}\text { Sensación de ardor, tos, dificultad } \\
\text { para respirar } \\
\text { Enrojecimiento, quemaduras en la } \\
\text { piel, dolor } \\
\text { Enrojecimiento, dolor, pérdida de } \\
\text { visión, quemaduras profundas } \\
\text { graves } \\
\text { Dolor abdominal, sensación de } \\
\text { ardor, debilidad }\end{array}$ & & \\
\hline $\begin{array}{l}\text { Plata } \\
7740-22-4\end{array}$ & & $\begin{array}{l}\text { Ojos; nariz; } \\
\text { garganta; piel }\end{array}$ & & & $\begin{array}{l}\text { Tabique nasal; } \\
\text { piel; ojos } \\
\text { Inh.; ing.; con. }\end{array}$ & $\begin{array}{l}\text { 0jos, tabique nasal, garganta, pie } \\
\text { azul-grises; irrit, ulceración de la } \\
\text { piel; trast. Gl }\end{array}$ \\
\hline $\begin{array}{l}\text { Tetracloruro } \\
\text { de platino } \\
13454-96-1\end{array}$ & Ojos; piel; ap. resp. & & $\begin{array}{r}\text { Inhalación } \\
\text { Piel } \\
\text { 0jos }\end{array}$ & $\begin{array}{l}\text { Sensación de ardor, tos } \\
\text { Enrojecimiento } \\
\text { Enrojecimiento }\end{array}$ & $\begin{array}{l}\text { Ojos; piel; ap. } \\
\text { resp. } \\
\text { Inh.; ing.; con. }\end{array}$ & $\begin{array}{l}\text { Irrit. ojos, nariz; tos; disn., jadeo, } \\
\text { cian.; derm., sensib. cutánea; } \\
\text { linfocitosis }\end{array}$ \\
\hline $\begin{array}{l}\text { Acetato de } \\
\text { plomo } \\
301-04-2\end{array}$ & $\begin{array}{l}\text { Ojos; piel; ap. } \\
\text { resp.; sangre; SNC; } \\
\text { riñones }\end{array}$ & $\begin{array}{l}\text { Sangre; médula } \\
\text { ósea; SCV; } \\
\text { riñones; SNC }\end{array}$ & $\begin{array}{l}\text { Inhalación } \\
\text { Ojos } \\
\text { Ingestión }\end{array}$ & $\begin{array}{l}\text { Cefalea, crónica, pero no aguda; } \\
\text { Véase Ingestión } \\
\text { Enrojecimiento, dolor } \\
\text { Cólicos abdominales, estreñimiento, } \\
\text { convulsiones, cefalea, náuseas, } \\
\text { vómitos }\end{array}$ & & \\
\hline $\begin{array}{l}\text { Oxido de } \\
\text { plomo (II) } \\
1317-36-8\end{array}$ & & $\begin{array}{l}\text { SNC; riñones; } \\
\text { sangre }\end{array}$ & & & & \\
\hline
\end{tabular}


Tabla 63.3 - Riesgos para la salud.

Continuación

\begin{tabular}{|c|c|c|c|c|c|c|}
\hline $\begin{array}{l}\text { Nombre } \\
\text { químico } \\
\text { Número CAS }\end{array}$ & $\begin{array}{l}\text { Exposición a } \\
\text { corto plazo }\end{array}$ & $\begin{array}{l}\text { Exposición a } \\
\text { largo plazo }\end{array}$ & $\begin{array}{l}\text { Vías de } \\
\text { exposición }\end{array}$ & Síntomas & $\begin{array}{l}\text { Organos diana, } \\
\text { vías de } \\
\text { entrada }\end{array}$ & Síntomas \\
\hline $\begin{array}{l}\text { Plomo } \\
\text { 7439-92-1 }\end{array}$ & & $\begin{array}{l}\text { Sistema } \\
\text { nervioso; } \\
\text { riñones; efectos } \\
\text { sobre la ferti- } \\
\text { lidad; puede } \\
\text { retrasar el desa- } \\
\text { rrollo del recién } \\
\text { nacido }\end{array}$ & $\begin{array}{l}\text { Inhalación } \\
\text { Ingestión }\end{array}$ & $\begin{array}{l}\text { Cefalea, náuseas, espasmo } \\
\text { abdominal } \\
\text { Cefalea, náuseas, dolor de garganta, } \\
\text { espasmo abdominal }\end{array}$ & $\begin{array}{l}\text { Ojos; tracto Gl; } \\
\text { SNC; riñones; } \\
\text { sangre; tejido } \\
\text { gingival } \\
\text { Inh.; ing.; con. }\end{array}$ & $\begin{array}{l}\text { Debil., lasi., insom.; palidez } \\
\text { facial; falta de coord. visuomotriz, } \\
\text { anor., bajo peso, desnut.; estreñ., } \\
\text { dolor abdom., cólicos;; anemia; } \\
\text { línea de plomo gingival; temblor; } \\
\text { parál. de las muñecas, tobillos; } \\
\text { encefalopatía; enfermedad renal; } \\
\text { irrit. ojos; hipotensión }\end{array}$ \\
\hline $\begin{array}{l}\text { Tetraetil } \\
\text { plomo } \\
78-00-2\end{array}$ & $\begin{array}{l}\text { Ojos; piel; ap. } \\
\text { resp.; SNC }\end{array}$ & $\begin{array}{l}\text { Piel; SNC; } \\
\text { puede causar } \\
\text { alteraciones } \\
\text { genéticas; } \\
\text { posible } \\
\text { toxicidad } \\
\text { reproductora }\end{array}$ & $\begin{array}{r}\text { Inhalación } \\
\text { Piel } \\
\text { Ojos } \\
\text { Ingestión }\end{array}$ & $\begin{array}{l}\text { Convulsiones, mareos, cefalea, } \\
\text { desvanecimiento, vómitos, debilidad } \\
\text { Se puede absorber, enrojecimiento } \\
\text { Dolor, visión borrosa } \\
\text { Convulsiones, diarrea, mareos, } \\
\text { cefalea, desvanecimiento, vómitos, } \\
\text { debilidad }\end{array}$ & $\begin{array}{l}\text { SNC; SCV; } \\
\text { riñones; ojos } \\
\text { Inh.; abs.; ing.; } \\
\text { con. }\end{array}$ & $\begin{array}{l}\text { Insom., lasi., ansiedad; temblor, } \\
\text { hiperreflexia, espasticidad; bradi- } \\
\text { cardia, hipotensión, hipotermia, } \\
\text { palidez, náus., anor., bajo peso; } \\
\text { conf., desorientación, alu., } \\
\text { psicosis, manía, convuls., coma; } \\
\text { irrit. ocul. }\end{array}$ \\
\hline $\begin{array}{l}\text { Acido } \\
\text { selenioso, } \\
\text { sal disódica } \\
10102-18-8\end{array}$ & $\begin{array}{l}\text { Ojos; piel; ap. } \\
\text { resp.; pulmones; } \\
\text { hígado; riñones; } \\
\text { corazón; SNC; } \\
\text { tracto Gl }\end{array}$ & $\begin{array}{l}\text { Dientes; huesos; } \\
\text { sangre }\end{array}$ & $\begin{array}{r}\text { Piel } \\
\text { Ojos }\end{array}$ & $\begin{array}{l}\text { Cólicos abdominales, diarrea, } \\
\text { mareos, cefalea, caída del cabello, } \\
\text { dificultad para respirar, náuseas, } \\
\text { vómitos; los síntomas pueden } \\
\text { retrasarse } \\
\text { Enrojecimiento } \\
\text { Enrojecimiento }\end{array}$ & & \\
\hline $\begin{array}{l}\text { Acido selenioso } \\
7783-00-8\end{array}$ & Ojos; piel; ap. resp. & Piel & $\begin{array}{r}\text { Inhalación } \\
\text { Piel } \\
\text { 0jos } \\
\text { Ingestión }\end{array}$ & $\begin{array}{l}\text { Sensación de ardor, tos, dificultad } \\
\text { para respirar, dolor de garganta } \\
\text { Se puede absorber, enrojecimiento, } \\
\text { dolor, vesículas } \\
\text { Enrojecimiento, dolor, visión } \\
\text { borrosa, quemaduras profundas } \\
\text { graves, párpados hinchados } \\
\text { Dolor abdominal, sensación de } \\
\text { ardor, confusión, náuseas, dolor de } \\
\text { garganta, debilidad, hipotensión }\end{array}$ & & \\
\hline $\begin{array}{l}\text { Dióxido } \\
\text { de selenio } \\
7446-08-4\end{array}$ & $\begin{array}{l}\text { Ojos; piel; ap. } \\
\text { resp.; pulmones }\end{array}$ & Piel & $\begin{array}{r}\text { Inhalación } \\
\text { Piel } \\
\text { 0jos } \\
\text { Ingestión }\end{array}$ & $\begin{array}{l}\text { Sensación de ardor, tos, dificultad } \\
\text { para respirar, dolor de garganta } \\
\text { Se puede absorber, enrojecimiento, } \\
\text { dolor, vesículas } \\
\text { Enrojecimiento, dolor, visión } \\
\text { borrosa, quemaduras profundas } \\
\text { graves, párpados hinchados } \\
\text { Dolor abdominal, sensación de } \\
\text { ardor, confusion, náuseas, dolor de } \\
\text { garganta, debilidad, hipotensión }\end{array}$ & & \\
\hline $\begin{array}{l}\text { Hexafluoruro } \\
\text { de selenio } \\
7783-79-1\end{array}$ & Ap. resp.; pulmones & $\begin{array}{l}\text { Piel; SNC; } \\
\text { higado; riñones }\end{array}$ & $\begin{array}{l}\text { Inhalación } \\
\text { Piel } \\
\text { 0jos }\end{array}$ & $\begin{array}{l}\text { Corrosivo, tos, cefalea, náuseas, } \\
\text { dificultad para respirar, dolor de } \\
\text { garganta } \\
\text { Enrojecimiento, dolor, en contacto } \\
\text { con líquidos: congelación; corrosivo } \\
\text { Enrojecimiento, dolor, visión borrosa; }\end{array}$ & $\begin{array}{l}\text { Ap. resp. } \\
\text { Inh. }\end{array}$ & En animales: irrit. pulm., edema \\
\hline $\begin{array}{l}\text { Oxicloruro } \\
\text { de selenio } \\
7791-23-3\end{array}$ & $\begin{array}{l}\text { Ojos; piel; ap. } \\
\text { resp.; pulmones }\end{array}$ & Piel & $\begin{array}{r}\text { Inhalación } \\
\text { Piel } \\
\text { Ojos } \\
\text { Ingestión }\end{array}$ & $\begin{array}{l}\text { Sensación de ardor, tos, dificultad } \\
\text { para respirar, dolor de garganta } \\
\text { Corrosivo, se puede absorber, } \\
\text { enrojecimiento, dolor, vesículas } \\
\text { Enrojecimiento, dolor, visión borrosa, } \\
\text { quemaduras profundas graves } \\
\text { Cólicos abdominales, confusion, } \\
\text { náuseas, dolor de garganta, } \\
\text { hipotensión }\end{array}$ & & \\
\hline
\end{tabular}

Continúa en la página siguiente. 
Tabla 63.3 - Riesgos para la salud.

Continuación.

\begin{tabular}{|c|c|c|c|c|c|}
\hline $\begin{array}{l}\text { Nombre } \\
\text { químico } \\
\text { Número CAS }\end{array}$ & $\begin{array}{l}\text { Exposición a } \\
\text { corto plazo }\end{array}$ & $\begin{array}{l}\text { Exposición a } \\
\text { largo plazo }\end{array}$ & $\begin{array}{l}\text { Vías de } \\
\text { exposición }\end{array}$ & Síntomas & $\begin{array}{l}\text { Organos diana, } \\
\text { vías de } \\
\text { entrada }\end{array}$ \\
\hline
\end{tabular}

Número CAS

Selenio Pulmones Piel; ap. resp.; Inhalación Irritación de nariz, tos, mareos,

7782-49-2 tracto Gl; $\quad$ cefalea, dificultad para respirar,

integumentos náuseas, dolor de garganta,

vómitos, debilidad, la aparición de

los sintomas puede retrasarse

Piel Enrojecimiento, quemaduras en la

piel, dolor, cambios de coloración

ojos Enrojecimiento, dolor, visión borrosa

Ingestión Gusto metálico, diarrea, escalofríos, fiebre

\begin{tabular}{|c|c|c|c|c|c|c|}
\hline $\begin{array}{l}\text { Selenuro } \\
\text { de hidrógeno } \\
7783-07-5\end{array}$ & $\begin{array}{l}\text { Ojos; ap. resp.; } \\
\text { pulmones }\end{array}$ & $\begin{array}{l}\text { Piel; hígado; } \\
\text { bazo; riñones }\end{array}$ & $\begin{array}{l}\text { Inhalación } \\
\text { Piel } \\
\text { 0jos }\end{array}$ & $\begin{array}{l}\text { Sensación de ardor, tos, dificultad } \\
\text { para respirar, náuseas, dolor de } \\
\text { garganta, debilidad } \\
\text { En contacto con líquidos: } \\
\text { congelación } \\
\text { Enrojecimiento, dolor; }\end{array}$ & $\begin{array}{l}\text { Ap. resp; ojos; } \\
\text { hígado } \\
\text { Inh.; con. }\end{array}$ & $\begin{array}{l}\text { Irrit. ojos, nariz, garganta; náus., } \\
\text { vómit., diarr.; gusto metálico, } \\
\text { aliento con olor a ajo; mar., lasi., } \\
\text { fat.; liq.: congelación; en } \\
\text { animales: neuitis;' daño hepático }\end{array}$ \\
\hline $\begin{array}{l}\text { Trióxido de } \\
\text { selenio } \\
13768-86-0\end{array}$ & Ojos; piel; ap. resp. & Piel; pulmones & $\begin{array}{r}\text { Inhalación } \\
\text { Piel } \\
\text { 0jos } \\
\text { Ingestión }\end{array}$ & $\begin{array}{l}\text { Sensación de ardor, tos, dificultad } \\
\text { para respirar, dolor de garganta } \\
\text { Se puede absorber, enrojecimiento, } \\
\text { dolor } \\
\text { Enrojecimiento, dolor, visión } \\
\text { borrosa, párpados hinchados } \\
\text { Cólicos abdominales, confusion, } \\
\text { náuseas, dolor de garganta, } \\
\text { debilidad, hipotensión }\end{array}$ & & \\
\hline
\end{tabular}

\begin{tabular}{ll}
\hline Sulfato & Ojos; piel; SNC; \\
talioso & SCV; riñones; tracto \\
$7446-18-6$ & Gl
\end{tabular}

Inhalación Véase Ingestión

Piel Se puede absorber, enrojecimiento; Véase Ingestión

Ojos Enrojecimiento, dolor

Ingestión Dolor abdominal, convulsiones, diarrea, cefalea, vómitos, debilidad, delirio, taquicardia

\begin{tabular}{|c|c|c|c|c|c|c|}
\hline $\begin{array}{l}\text { Talio } \\
\text { metálico } \\
7440-28-0\end{array}$ & Sistema nervioso & $\begin{array}{l}\text { Ojos; hígado; } \\
\text { pulmones; } \\
\text { puede causar } \\
\text { defectos de } \\
\text { nacimiento }\end{array}$ & $\begin{array}{r}\text { Inhalación } \\
\text { Piel } \\
\text { Ojos } \\
\text { Ingestión }\end{array}$ & $\begin{array}{l}\text { Náuseas, vómitos, caída del cabello, } \\
\text { cólicos abdominales, dolor en las } \\
\text { piernas y el pecho, nerviosismo, } \\
\text { irritabilidad } \\
\text { Se puede absorber } \\
\text { Se puede absorber } \\
\text { Dolor abdominal, estreñimiento, } \\
\text { diarrea, cefalea, náuseas, vómitos, } \\
\text { pérdida de visión }\end{array}$ & $\begin{array}{l}\text { Ojos; SNC; } \\
\text { pulmones; } \\
\text { hígado; riñones; } \\
\text { tracto Gl, vello } \\
\text { corporal; ap. } \\
\text { resp. } \\
\text { Inh.; abs.; ing.; } \\
\text { con. }\end{array}$ & $\begin{array}{l}\text { Náus., diarr., dolor abdom., } \\
\text { vómit.; ptosis, estrabismo; neuritis } \\
\text { perif., temblor; opresión retroest., } \\
\text { dolor torácico, pulm. edema; } \\
\text { convuls., corea, psicosis; daño } \\
\text { hepático, renal; alopecia; pares en } \\
\text { las piernas }\end{array}$ \\
\hline $\begin{array}{l}\text { Telurio } \\
\text { 13494-80-9 }\end{array}$ & Ap, resp.; SNC & $\begin{array}{l}\text { Puede causar } \\
\text { malformaciones } \\
\text { en el feto } \\
\text { humano }\end{array}$ & $\begin{array}{r}\text { Inhalación } \\
\text { Piel } \\
\text { Ojos } \\
\text { Ingestión }\end{array}$ & $\begin{array}{l}\text { Sopor, cefalea, olor a ajo, náuseas } \\
\text { Se puede absorber } \\
\text { Enrojecimiento } \\
\text { Dolor abdominal, estreñimiento, } \\
\text { náuseas, vómitos, aliento con } \\
\text { olor a ajo }\end{array}$ & $\begin{array}{l}\text { Piel; SNC; } \\
\text { sangre } \\
\text { Inh.; ing.; con. }\end{array}$ & $\begin{array}{l}\text { Aliento y sudor con olor a ajo; } \\
\text { sequedad de boca, gusto metálico; } \\
\text { som.; anor., náus., sin sudor; } \\
\text { derm.; en animales: SNC, efectos } \\
\text { sobre los eritrocitos }\end{array}$ \\
\hline $\begin{array}{l}\text { Dióxido } \\
\text { de titanio } \\
13463-67-7\end{array}$ & Ojos; pulmones & Pulmones & $\begin{array}{r}\text { Inhalación } \\
\text { Ojos }\end{array}$ & $\begin{array}{l}\text { Tos } \\
\text { Enrojecimiento }\end{array}$ & $\begin{array}{l}\text { Ap. resp. [en } \\
\text { animales: } \\
\text { tumores pulmo- } \\
\text { nares] } \\
\text { Inh. }\end{array}$ & Fib. pulm.; [canc.] \\
\hline
\end{tabular}

Continúa en la página siguiente.

Ap. resp; ojos; Irrit ojos, piel, nariz, garganta; piel; hígado; alter. vis.; cefal.; escalofríos, riñones; sangre; fiebre, disn., bron.; gusto metábazo lico, aliento con olor a ajo, trast.

Inh.; ing.; con. Gl; derm., quemaduras en la piel, ojos; en animales: anemia; nec. hepatica, cirr.; daño renal, bazo

Ap. resp; ojos; Irrit. ojos, nariz, garganta; náus., vomit, diarr.; gusto metálico, animales: neuitis; daño hepático

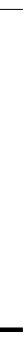


Tabla 63.3 • Riesgos para la salud.

continuación.

\begin{tabular}{|c|c|c|c|c|c|c|}
\hline $\begin{array}{l}\text { Nombre } \\
\text { químico } \\
\text { Número CAS }\end{array}$ & $\begin{array}{l}\text { Exposición a } \\
\text { corto plazo }\end{array}$ & $\begin{array}{l}\text { Exposición a } \\
\text { largo plazo }\end{array}$ & $\begin{array}{l}\text { Vías de } \\
\text { exposición }\end{array}$ & Síntomas & $\begin{array}{l}\text { Organos diana, } \\
\text { vías de } \\
\text { entrada }\end{array}$ & Síntomas \\
\hline $\begin{array}{l}\text { Pentóxido } \\
\text { de vanadio } \\
1314-62-1\end{array}$ & $\begin{array}{l}\text { Ojos; ap. resp.; } \\
\text { pulmones }\end{array}$ & $\begin{array}{l}\text { Piel; pulmones; } \\
\text { lengua }\end{array}$ & $\begin{array}{r}\text { Inhalación } \\
\text { Piel } \\
\text { Ojos } \\
\text { Ingestión }\end{array}$ & $\begin{array}{l}\text { Sensación de ardor, tos, dificultad } \\
\text { para respirar } \\
\text { Enrojecimiento, sensación de ardor } \\
\text { Enrojecimiento, dolor, conjuntivitis } \\
\text { Dolor abdominal, diarrea, sopor, } \\
\text { desvanecimiento, vómitos, síntomas } \\
\text { de intoxicación sistémica grave y } \\
\text { muerte }\end{array}$ & $\begin{array}{l}\text { Ap. resp; piel; } \\
\text { ojos } \\
\text { Inh.; con. }\end{array}$ & $\begin{array}{l}\text { Irrit. ojos, piel, garganta; lengua } \\
\text { verde, gusto metálico, eczema; } \\
\text { tos; estertores débiles, jadeo, } \\
\text { bron., disn. }\end{array}$ \\
\hline $\begin{array}{l}\text { Trióxido } \\
\text { de vanadio } \\
1314-34-7\end{array}$ & Ojos; piel; ap. resp. & $\begin{array}{l}\text { Ap. resp.; puede } \\
\text { afectar la } \\
\text { función hepática } \\
\text { y cardíaca }\end{array}$ & $\begin{array}{r}\text { Inhalación } \\
\text { Piel } \\
\text { Ojos } \\
\text { Ingestión }\end{array}$ & $\begin{array}{l}\text { Rinorrea, estornudos, tos, } \\
\text { diarrea, dificultad para respirar, } \\
\text { dolor de garganta, debilidad, dolor } \\
\text { en el pecho, lengua verde a negra } \\
\text { Sequedad y enrojecimiento de } \\
\text { la piel } \\
\text { Enrojecimiento } \\
\text { Cefalea, vómitos, debilidad }\end{array}$ & & \\
\hline $\begin{array}{c}\text { Cromato de zinc } \\
13530-65-9\end{array}$ & & Piel; ap. resp. & $\begin{array}{r}\text { Inhalación } \\
\text { Ojos } \\
\text { Ingestión }\end{array}$ & $\begin{array}{l}\text { Tos } \\
\text { Enrojecimiento } \\
\text { Dolor abdominal, diarrea, vómitos }\end{array}$ & & \\
\hline $\begin{array}{l}\text { Fosfuro } \\
\text { de zinc } \\
1314-84-7\end{array}$ & $\begin{array}{l}\text { Ap. resp.; } \\
\text { pulmones; hígado; } \\
\text { riñones; corazón; } \\
\text { SNC }\end{array}$ & & $\begin{array}{l}\text { Inhalación } \\
\text { Ingestión }\end{array}$ & $\begin{array}{l}\text { Tos, diarrea, cefalea, fatiga, } \\
\text { náuseas, vómitos } \\
\text { Dolor abdominal, tos, diarrea, } \\
\text { mareos, cefalea, dificultad para } \\
\text { respirar, náuseas, desvanecimiento, } \\
\text { vómitos, ataxia, fatiga }\end{array}$ & & \\
\hline
\end{tabular}

Los datos sobre la exposición a corto y largo plazo se han adaptado de la serie de Tarjetas Internacionales de Seguridad de las Sustancias Químicas (ICSC) elaboradas por el Programa Internacional de Seguridad de las Sustancias Químicas (véanse las notas de la Tabla 63.2). Las abreviaturas utilizadas son: SNC = sistema nervioso central; SCV = sistema cardiovascular; $5 N P=$ sistema nervioso periférico; ap. resp. = aparato respiratorio.

Los demás datos se han tomado de la NIOSH Pocket Guide to Chemical Hazards (NIOSH 1994). Se han utilizado las abreviaturas siguientes:

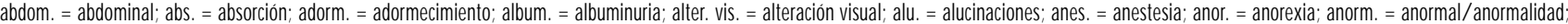
anos. = anosmia (pérdida del olfato); arrit. = arritmias; asfix. = asfixia; aspir. = aspiración; aturd $=$ aturdimiento; aum. $=$ aumento/ aumentado; bajo peso = pérdida de peso; bron. = bronquitis; broncoes. $=$ broncoespasmo; bronconeu. $=$ bronconeumonía; $[$ canc. $]=$ posible cancerígeno industrial; card. $=$ cardíaco; cefal. = cefalea; cian. = cianosis; cirr. $=$ cirrosis; colines. $=$ colinesterasa; con. = contacto; conc. = concentración; conf. = confusión; conj. = conjuntivitis; convuls. = convulsiones; corn. = corneal; crisp. = crispación; debil. = debilidad; depres. = depresivo/ depresión; derm. = dermatitis; desc. = falta de coordinación; desnut. $=$ desnutrición; desv. $=$ desvanecimiento; diarr. $=$ diarrea; dif. = dificultad; dism. $=$ disminución $/$ disminuido; disn. $=$ disnea (dificultad para respirar); embr. = embriaguez; enfis. = enfisema; eosin = eosinofilia; epilep. $=$ epileptiforme; epis. = epistaxis (hemorragia nasal); equi. = equilibrio; eri. = eritema (enrojecimiento de la piel); erit. = eritrocitos; estorn. = estornudos; estreñ $=$ estreñimiento;

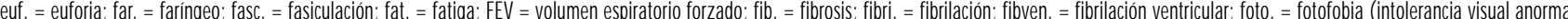
a la luz); func. = función; fund. = fundido; $\mathrm{Gl}=$ gastrointestinal; hema. = hematuria (sangre en la orina); hemato. = hematopoyético; hemog. = hemoglobinuria; hemorr. = hemorragia; hiperpig. = hiperpigmentación; hipox. = hipoxemia (disminución del oxígeno en la sangre); icter. = ictericia; inflam. = inflamación; ing. = ingestión; inh. = inhalación; inq. = inquietud; insom. = insomnio insuf. $=$ insuficiencia; irreg. $=$ irregularidad; irrit. = irritación; irritab. $=$ irritabilidad; jadeo $=$ respiración jadeante. lagr. = lagrimeo; lar. = laríngeo; lasi. = lasitud $($ debilidad, agotamiento); les. = lesión let. = letargo (sopor o indiferencia); leucocit. = leucocitosis (aumento de leucocitos en la sangre); leupen. = leucopenia (disminución de leucocitos en la sangre); liq. = líquido; local. = localizado; mal. = malestar mar. $=$ mareos; memb. muc. = membranas mucosas; metahem. = metahemoglobinemia; mied. = miedo; monoci. = monocitosis (aumento de monocitos en la sangre); musc. = músculo/ muscular narco. $=$ narcosis; náus. $=$ náuseas; nec. $=$ necrosis; nefr. $=$ nefritis; ner. $=$ nerviosismo; neu. = neumonía; neuitis. = neumonitis; neur. perif. = neuropatía periférica; Nus = nitrógeno uréico en sangre; opac. $=$ opacidad; opres. $=$ opresión; palp. $=$ palpitaciones; parál. $=$ parálisis; pares. $=$ parestesia; perf. $=$ perforation; periorb. $=$ periorbital $($ alrededor del ojo); polineur. $=$ polineuropatía; prot. $=$ proteinuria PS = presion sanguinea; pulm = pulmonar; pulsac = pulsaciones; quera = queratitis (inflamacion de la cornea) $;$ repro = reproductor; resp. = respiracion/ respiratorio; retroest. = retroesternal (detras de

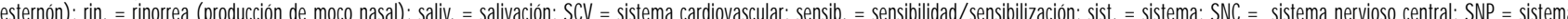
nervioso periférico; sol. = sólido; soln. = solución; som. = somnolencia (sueño, sopor anormal); sop. = sopor; subest. = subesternal $($ por debajo del esternón); sudor. $=$ sudoración; taqui. = taquicardia; terato. $=$ teratogénico; traqubronc. $=$ traqueobronquitis; tras. $=$ trastorno; tumef. $=$ tumefacción; vap. $=$ vapor; vért. $=$ vértigo (ilusión de movimiento); vesic. $=$ vesiculación; vómit. $=$ vómitos 


\section{Referencias}

Agencia Internacional para la Investigación sobre e Cáncer (IAR C). 1990. Chromium, Nickel and W elding. Lyon: IARC.

Agency for Toxic Substances and Disease Registry (ATSDR). 1995. Case Studies in Environmental M edicine: Lead T oxicity. Atlanta: AT SD R.

Brief, RS, JW Blanchard, RA Scala, JH Blacker. 1971. M etal carbonyls in the petroleum industry. Arch Environ $\mathrm{H}$ ealth 23:373-384.

Comité de Expertos de Naciones Unidas sobre el transporte de mercancías peligrosas. 1995. R ecommendations on the $T$ ransport of $D$ angerous $G$ oods, 9 a edición. Nueva Y ork: N aciones U nidas.

$\mathrm{N}$ ational Institute for $\mathrm{O}$ ccupational Safety and $\mathrm{H}$ ealth (NIOSH). 1994. NIOSH Pocket Guide to Chemical Hazards. DHHS (NIOSH) Publicación núm. 94-116. Cincinnati, O hio: NIOSH.

Rendall, REG, Jl Phillips, KA Renton. 1994. Death following exposure to fine particulate nickel from a metal arc process. Ann $\mathrm{O}$ ccup $\mathrm{H}$ yg 38:921-930.

Sunderman, FW, Ir., A O skarsson. 1991. Nickel. En $M$ etals and their compounds in the environment, dirigido por E Merian, Weinheim, Alemania: VCH Verlag.

Sunderman, FW, Jr., A Aitio, LO Morgan, T N orseth. 1986. Biological monitoring of nickel. $\mathrm{T}$ ox Ind $\mathrm{H}$ ealth 2:17-78.

\section{0 tras lecturas recomendadas}

Abener, W, H Holub, R Strohal, R Slavicek. 1993. Palladium in dental alloys-The dermatologists' responsibility to warn? Contact Dermat 28 (3):163-165.

Agencia Internacional para la Investigación sobre el Cáncer (IARC). 1984. Nickel in the Human Environment. Lyon: IARC.

-. 1987. Overall Evaluations of Carcinogenicity: An U pdating of Vol. 1-42. M onograph series Suppl. 7, 1987. Lyon: IARC.

— . 1990. Nickel and Nickel Compounds. Lyon: IAR C.

-. 1993. Cadmium and Cadmium Compounds. Lyon: IARC.

Akinfieva, TA, NI Nikolaeva, AA Silaev, IL Gerasimova, EP M akoilkina. 1992. [M agnesium sulphate as an industrial poison]. Gig T r Prof Zabol 3:33-35.

Alazraki, ND. 1993. Radionuclide imaging in the evaluation of infections and inflammatory disease. Radiol Clin N orth Am (4):783-94.

Bacin, F, E Albuisson, R Rozan, D Donnarieix, $P$ Verrelle, $H$ Dalens. 1991. [O ncologic and functional results of 57 malignant melanoma of the uvea treated by curietherapy]. I Fr 0 pthalmologie 14 (6-7):383.

Bartter, T, RS Irwin, JL Abraham, A Dascal, G Nash, JS H immelstein, PJ Jederlinic. 1991. Zirconium compound-induced pulmonary fibrosis. Arch Intern M ed 151(6):1197-1201.

Bolm, AU, HG Bienfait, J Burkhard, AH Bury, $R$ Merget, G Pressel, G Schultze-Werninghaus. 1991. Prevalence of respiratory allergy in a platinum refinery. Int Arch $\mathrm{O}$ ccup Environ $\mathrm{H}$ ealth 64(4):256-60.

Brewer, L, RH Lamoureaux, R Ferro, R M arazza, K Girgis. 1980. M olybdenum: Physico-chemical properties of its compounds and alloys. Atomic Energy Review, Edición especial núm. 7. Viena: O rganismo Internacional de Energía A tómica.

Bruevich, TS. 1980. Skin irritation by compounds of the precious metals- $\mathrm{G}$ old, platinum, ruthenium, rhodium, silver. Gig T r Prof Z abol 5:42.
Buchet, JP, R Lauwerys, H Roels, A Bernard, $P$ Bruaux, F Claeys, G Ducoffre, $P$ DePlaen, Staessen, A Amery, P Lijnen, L Thijs, D R ondia F Sartor, A Saint Remy, L Nick. 1990. Renal effects of cadmium body burden of the general population. Lancet 336:699-702.

Croft, SL, RA Neal, DG Craciunescu, $\mathrm{G}$ Certad-Fombona. 1992. The activity of platinum, iridium and rhodium drug complexes against Leishmania donovani. T rop $M$ ed Parasitol 43(1):24-8.

Cromwell, O , J Pepys, WE Parish, EG H ughes. 1979. Specific IgE antibodies to platinum salts in sensitised workers. Clinical Allergy 9(2):109-117.

Decheng, $C$, I $M$ ing, $H$ Ling, $W$ Shan, $X$ Ziqing, $Z X$ inshui. 1987. Cytogenetic analysis in workers occupationally exposed to nickel carbonyl. M utat Res 188:149-152.

Dutkiewicz, B, T Dutkiewicz, G M ilkowska. 1979. The effect of mixed exposure to lead and zinc on ALA level in urine. International Archives of $O$ ccupational and Environmental $\mathrm{H}$ ealth - Internationales Archiv für Arbeits und $U$ mweltmedizin 42(3-4):341-348.

Elinder, C-G, L Friberg, GF N ordberg, T K jellström G O berdoerster 1994. Biological M onitoring of $M$ etals. Chemical Safety M onographs. OMS/ EHG/94.2:1-80. Ginebra: Programa Internacional de Seguridad Q uímica.

Fayerweather, WE, ME K arns, PG Gilby JL Chen. 1992. Epidemiologic study of lung cancer mortality in workers exposed to titanium tetrachloride. J 0 ccup M ed 34(2):164-9.

Glasgow, GP. 1991. The safety of low melting point bismuth/lead alloys: A review. M ed Dosim 16(1):13-8.

G reene, R M , W PD Su. 1987. Argyria. American F amily Physician 36(6):151-4.

$\mathrm{H}$ adjimichael, O C, RE Brubaker. 1981. Evaluation of an occupational respiratory exposure to a zirconium-containing dust. I O ccup $\mathrm{Med}$ 23(8):543-547.

Hensten-Petterson, A. 1992. Casting alloys: Side effects. Adv D ent R es Sept 6:38-43.

H ryhorczuk, DO, SE Aks, JW T urk. 1992. U nusual occupational toxins. 0 ccup M ed. 7(3):567-86.

Järup, L, C-G Elinder. 1993. Renal stone incidence among cadmium exposed battery workers. B rit J Ind $M$ ed 50:598-602.

-. 1994. Dose-response relations between urinary cadmium and tubular proteinuria in cadmium exposed workers. Am J Ind M ed 26:759-769.

Järup, L, B Persson, C-G Elinder. 1995. Decreased glomerular filtration rate in solderers exposed to cadmium. $O$ ccup E nviron $\mathrm{H}$ ealth 52:818-822.

Joint Expert Committee on Food Additives (JECFA). 1993. T oxicological Evaluation of $C$ ertain F ood Additives and $C$ ontaminants. 41 encuentro del comité conjunto de expertos FAO/OMS sobre los aditivos alimentarios. Technical Reports Series No 837. Ginebra: OM S

K azantsis, G. 1986. Tungsten. $H$ andbook on the T oxicology of $M$ etals, dirigido por $G$. Friberg, GF N ordberg y V B V ouk. Amsterdam: Elsevier.

K ron, T, C Hansen, E Warner. 1991. Renal excretion of tellurium after peroral administration of tellurium in different forms to healthy human volunteers. I T race E lem E lectrolytes $\mathrm{H}$ ealth $\mathrm{D}$ is $\mathrm{Dec}$. 5(4):239-44.

Langård, S (dir.). 1982. Biological and Environmental Aspects of Chromium. Amsterdam: Elsevier/ N orth-H olland Biomedical Press.

L angård, S. 1990. O ne hundred years of chromium and cancer; A review of the epidemiological evidence and selected case reports. Am J Ind M ed 17:189-215.

Langård, S, A Andersen, B Gylseth. 1980. Incidence of cancer among ferrochromium and ferrosilicon workers. B rit । O ccup M ed 37(2):114-120.

Leonard, JF, PA Templeton. 1992. Pulmonary imaging techniques in the diagnosis of occupational interstitial lung disease. 0 ccup $\mathrm{M} \mathrm{ed}$ 7(2):241-60.

Lewis, RJ, Sr. 1992. Sax's Dangerous Properties of Industrial M aterials. 8a edición, $\mathrm{V}$ ol II. Nueva Y ork: $V$ an N ostrand R einhold.

Loiseau, PM , DG Craciunescu, JC D oadrio-V illarejo, G Certad-Fombona. 1992. Pharmacomodulations on new organometallic complexes of $\mathrm{Ir}, \mathrm{Pt}, \mathrm{Rh}$, $\mathrm{Pd}, \mathrm{O}$ s: In vitro and in vivo trypanocidal study against T rypanosoma bruce brucei. T rop M ed Parasitol 43(2):110-4

Maibach, HI, T Menn. 1989. Nicke and the Skin: Immunology and Toxicology. Boca Raton, FL: CRC Press.

M ancinella, A. 1993. [V anadium, an indispensable trace element in living organisms: Current data on biochemical, metabolic levels and therapeutic doses]. Clinica Terapeutica 142(3):251-255.

M erck and Co. 1976. M erck Index, 9a ed. Rahway, Nueva Jersey: M erck and Co.

M erget, $R, G$ Schulze-Werninghaus, $F$ Bode, EM Bergmann, W Azchgo, J M eier-Sydow. 1991. $\mathrm{Q}$ uantitative skin prick and bronchial provocation tests with platinum salt. $\mathrm{Br}$ J Ind $\mathrm{Med}$ 48(12):830-837.

M organ, LG, V Usher. 1994. Health problems associated with nickel refining and use. Ann 0 ccup H yg 38:189-198.

M oulin, JJ, P Portefaix, P Wild, JM M ur, G Smaggle, B M antout. 1990. M ortality study among workers producing ferroalloys and stainless steel in France. B rit J Indust M ed 47(8):537-43.

Moulin, JJ, P Wild, B M antout, M Fournier-Betz, JM M ur, G Smaggle. 1993. M ortality from lung cancer and cardiovascular diseases among stainless-steel producing workers. Cancer Causes Control 4(2):75-81.

National Academy of Sciences (NAS). Committee on $M$ edical and Biological Effects of Environmental Pollutants. 1997. Platinum-group M etals. Washington, DC: NAS.

National Institute for $\mathrm{O}$ ccupational Safety and $\mathrm{H}$ ealth (NIOSH ). 1976. Criteria for a Recommended Standard: $O$ ccupational Exposure to Organotin Compounds. Cincinnati, O hio: NIOSH.

-. 1987. Request for Assistance in Reducing the Potential $R$ isk of Developing Cancer from Exposure to Gallium Arsenide in the M icrodectronics Industry. NIOSH Alert. Cincinnati, O hio: NIOSH .

Nemery, B. 1990. M etal toxicity and the respiratory tract. E ur Resp J 3(3):202-211.

Nickel Development Institute. 1994. H ealth Guide: Safe $\mathrm{U}$ se of Nickel in the W orkplace. Toronto: Nickel D evelopment Institute.

N ieboer, E, JO N riagu. 1992. Nickel and $\mathrm{H}$ uman $\mathrm{H}$ ealth: Current Perspectives. N ueva Y ork: John W iley.

Nordman, H, M Berlin. 1986. Titanium. En H andbook on the Toxicology of $M$ etals, $\mathrm{Vol}$. II, dirigido por G. Friberg, GF N ordberg y V B V ouk. A msterdam: Elsevier.

O rganización M undial de la Salud (OM S). 1991. Nicke. Environmental Health Criteria 108. Ginebra: O M S.

-. 1992. Cadmium. Environmental Health Criteria. Ginebra: OM S.

Organización para la Cooperación y el Desarrollo Económico (OCDE). 1994. Cadmium Risk Reduction M onograph Núm. 5:. París: OECD. 
Pistelli, R, N Pupp, F Forastiere, N Agabiti, GM Corbo, F Tidei, CA Perucci. 1991. [Increase of nonspecific bronchial reactivity after occupational exposure to vanadium]. M ed Lav 82(3):270-275.

Rastogi, SK, BN Gupta, T H usain, H Chandra, N M athur, BS Pangtey, SV Chandra, N Garg. 1991. A cross-sectional study of pulmonary function among workers exposed to multimetals in the glass bangle industry. $\mathrm{Am}$ । Ind $\mathrm{Med}$ 20(3):391-9.

R eichrtova, E, L T akac. 1992. Issues related to dust aerosols in the magnesite industry. I $\mathrm{Hyg} \mathrm{Epi}$ M icrobiol I mmunol 36(3):235-44.

Reith, AK, S Reichborn-K enneruud, M Aubele, UJ Ÿtting, P Gais, G Burger. 1994. Biological monitoring of chemical exposure in nickel workers by imaging cytometry (ICM) of nasal smears. Anal Cell Pathol 6:9-21.

Sax, NI, RJ L ewis, Sr. (dirs.). 1989. D angerous Properties of Industrial M aterials, 7a ed. Nueva Y ork: $V$ an Nostrand R einhold.

Scansetti, G. 1992. Exposure to metals that have recently come into use. Sci Total Environ 120(1-2):85-91.

Schauss, AG. 1991. Nephrotoxicity-neurotoxicity in humans from organogermanium compounds and germanium dioxide. Biol Trace Elem Res 29(3):267-80.

Schrauzer, GN. 1991. Cobalt. En M etals and Their Compounds in the $\mathrm{E}$ nvironment, dirigido por $\mathrm{E} M$ erian. Weinheim, Germany: VCH V erlag.

Seidal, K, N Jörgensen, C-G Elinder, B Sjögren $M V$ ahter. 1993. A case of fatal cadmium induced pneumonitis. Scand I W ork \& Environ $\mathrm{H}$ ealth 19:429-431.

Sheehy, JW, JH Jones. 1993. Assessment of arsenic exposures and controls in gallium arsenide production. Am Ind H yg Assoc J 54(2):61-69.

Sittig, M. 1985. $\mathrm{H}$ andbook of $\mathrm{T}$ oxic and $\mathrm{H}$ azardous Chemicals and Carcinogens, 2aㅡ. ed. Park Ridge, New Jersey: N oyes Data Corporation.

Spencer, PJ, O K ubascewski-von Goldbeck, R Ferro, R M arazza, K Girgis, O Kubaschewski. 1981. $\mathrm{H}$ afnium: Physico-chemical properties of its compounds and alloys. Atomic Energy Review, Special Issue Núm. 8. Viena: Organización Internacional de Energía A tómica.

Sprince, NL, RI Chamberlin, CA Hales, AL Weber, $\mathrm{H}$ K azemi. 1984. Respiratory disease in tungsten carbide production workers. Chest 86(4):549-57.

Sunderman, FW, Jr. 1992. U se of sodium diethyldithiocarbamate in the treatment of nickel carbonyl poisoning. En Nickel and $\mathrm{H}$ uman $\mathrm{H}$ ealth: Current Perspectives, dirigido por $\mathrm{E}$ Nieboer y $\mathrm{O}$ N riagu. N ueva Y ork: John Wiley.

- . 1993. Biological monitoring of nickel in humans. Scand I W ork E nviron H ealth 19: 34-38.

Sunderman, FW, Jr., B Dingle, SM H opfer, T Swift. 1988. Acute nickel toxicity in electroplating workers who accidently ingested a solution of nickel sulfate and nickel chloride. Am J Ind $\mathrm{M} \mathrm{ed}$ 14:257-266

Templeton, DM . 1994. M easurement of total nickel in body fluids: Technical report of the IUPAC Commission on Toxicology. Pure Appl Chem 66:357-372.
Thun, MJ, C-G Elinder, L Friberg. 1991. Scientific basis for an occupational standard for cadmium. Amer J Ind M ed 20:629-42.

Underwood, EJ. 1977. M anganese. En T race Elements in $\mathrm{H}$ uman and Animal Nutrition, 4a ed. Nueva York: Academic Press.

Venables, KM, MB Dally, AJ Nunn, JF Stevens. 1989. Smoking and occupational allergy in workers in a platinum refinery. Brit $M$ ed J 299(6705):939-42.

Vyskocil, A, V Senft, C Viau, M Cizkova, J K ohout. 1994. Biochemical renal changes in workers exposed to soluble nickel compounds. H uman Exp T oxicol 13:257-261.

$X$ uan $X z$, JH Lubin, JY Li, LF Y ang, AS Luo, Y Lan, JZ Wang, WJ Blot. 1993. A cohort study in Southern China of tin miners exposed to radon and radon decay products. $H$ ealth Phys 64(2);120-31.

Zhicheng, S. 1986. Acute nickel carbonyl poisoning: A report of 179 cases. B rit J Ind M ed 43:422-424.

Zicheng, S, A L ata, H Y uhua. 1986. A study of serum monoamine oxidase (MAO) activity and the EEG in nickel carbonyl workers. B rit J Ind $M$ ed 43:425-426.

Zinsstag, J, R Brun, DG Craciunescu, E Parrondo-Iglesias. 1991. In vitro activity of organometallic complexes of $\mathrm{Ir}, \mathrm{Pt}$ and $\mathrm{Rh}$ on Trypanosoma $b$. gambiense, $T . b$. rhodesiense and $T . b$. brucei. T rop M ed Parasitol 42(1):41-4.

Zwennis, WCM, AC Franssen, MJ Wijnans. 1991. Biological monitoring of workers exposed to nickel products. $\mathrm{B}$ iol $\mathrm{M}$ onit 1:35-44. 

ENCICLOPEDIA DE SALUD Y SEGURIDAD EN EL TRABAJO 



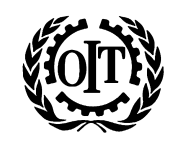

\title{
ENCICLOPEDIA DE SALUD Y SEGURIDAD EN EL TRABAJO
}

\author{
Directora de la publicación \\ Jeanne Mager Stellman, PhD \\ Subdirector general de la publicación \\ Michael McCann, PhD, ClH \\ Subdirectores de la publicación \\ Leon Warshaw, MD Carole Brabant, PhD \\ Redactores principales \\ John Finklea, MD, Dr PH Jacqueline Messite, MD \\ Georges H. Coppée, MD Steven L. Sauter, PhD \\ Vilma R. H unt, BDS, AM Jerry Spiegel, MA, MSC \\ Richard S. Kraus, PE, CSP Colin L. Soskolne, PhD \\ Wolfgang Laurig, Dr-Ing Benedetto Terracini, MD \\ Melvin L. Myers, BS, MPA \\ Gestión editorial \\ Chantal Dufresne, BA
}

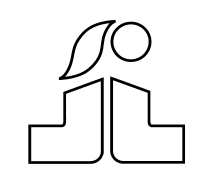


La edición original de esta obra ha sido publicada por la O ficina Internacional del Trabajo (G inebra) bajo el título "Encyclopaedia of 0 ccupational $\mathrm{H}$ ealth and Safety, fourth edition". Esta edición española se publica con la autorización de la O IT y bajo las condiciones del Acuerdo firmado entre la O ficina Internacional del Trabajo y el M inisterio de Trabajo y A suntos Sociales de España en materia de publicaciones.

Copyright (C) de la edición inglesa, O rganización Internacional del Trabajo, 1998

Copyright @ de la edición española, M inisterio de Trabajo y A suntos Sociales, 1998

Las denominaciones empleadas, en concordancia con la práctica seguida en $\mathrm{N}$ aciones $\mathrm{U}$ nidas, y la forma en que aparecen presentados los datos en las publicaciones de la O IT no implican juicio alguno por parte de la O ficina Internacional del Trabajo sobre la condición jurídica de ninguno de los países, zonas o territorios citados o de sus autoridades, ni respecto de la delimitación de sus fronteras.

La responsabilidad de las opiniones expresadas en los artículos, estudios y otras colaboraciones firmadas incumbe exclusivamente a sus autores y su publicación no significa que la O IT las sancione.

El lector asume que las partes facilitan la presente documentación sin garantía de ningún tipo. Las partes no se hacen responsables de la validez ni de la integridad de ninguno de los datos, incluidos errores, inexactitudes u omisiones, ni de las posibles consecuencias que implique la utilización de dichos datos. $\mathrm{Ni}$ los autores ni la OIT, ni las instituciones colaboradoras son responsables de los daños ni de cualquier otra reclamación o demanda que se deriven de la utilización de estos datos.

Las referencias a firmas, procesos o productos comerciales no implica aprobación alguna por la 0 ficina Internacional del Trabajo, y el hecho de que no se mencionen firmas, procesos o productos comerciales no implica desaprobación alguna.

La presente edición es la versión española de la cuarta edición inglesa, revisada y enriquecida con las aportaciones ofrecidas y destinadas a la misma por la O IT y con las peculiaridades y conceptos incorporados al cuerpo de la enciclopedia por especialistas, con objeto de hacer su utilización más asequible en los países de habla hispana. En la traducción, coordinación y financiación de la presente edición han colaborado:

- M inisterio de Sanidad y Consumo

- Instituto Nacional de la Salud

- Instituto Nacional de M edicina y Seguridad en el Trabajo

- M inisterio de Trabajo y Asuntos Sociales

- Instituto Nacional de Seguridad eH igiene en el Trabajo

- Agencia E spañola de Cooperación Internacional

- O ficina Internacional del Trabajo
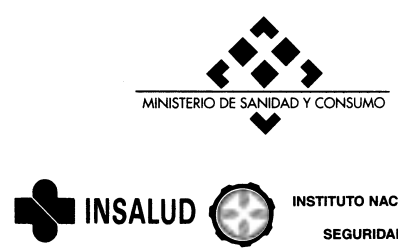

INSALUD

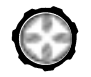

INSTITUTO NACIONAL DE MEDICINA
SEGURIDAD DEL TRABAJO
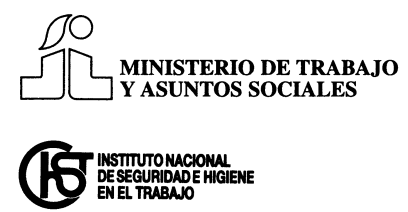

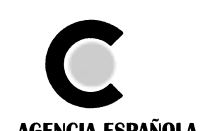

AGENCIA ESPAÑOLA DE COOPERACION INTERNACIONAL

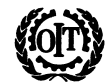

OFIIINA INTERNACIONAL

DEL TRABAJO

L os editores agradecen la colaboración y confianza demostradas por la A sociación de M utuas de Accidentes de Trabajo en la elaboración de esta obra.

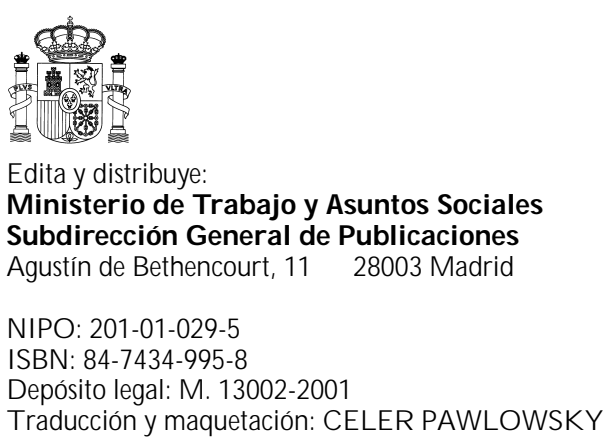




\section{AUTORES Y DIRECTORES}

Michael Adess, PhD

Chief

H uman Factors D ivision Commandant (G-WK S-3)

U nited States C oast G uard H eadquarters Washington, DC

Estados U nidos

\section{Agamennone, Dr Ing*}

Istituto Guidio D onegani

Centro Ricerche N ovara

Novara

Italia

\section{Leen Akkers}

D irector $G$ erente

Stichting Arbouw

Amsterdam

Países Bajos

\section{R.G. Aldi, MASc, BSc, P Eng}

Director

$\mathrm{Q}$ uality and Environmental Affairs

$H$ iram Walker and Sons, Ltd.

Windsor, 0 ntario

Canadá

Priscilla Alexander, BA

Coordinator

N orth American T ask Force on

Prostitution

N ueva Y ork, N ueva Y ork

Estados U nidos

\section{Sydney Alison, PhD}

Communications Division

M intek

R andburg

Sudáfrica

\section{Judith Anderson, MSc}

Research Associate

D epartment of Environmental-

$\mathrm{O}$ ccupational $\mathrm{H}$ ealth

G eorge Washington U niversity

Washington, DC

Estados U nidos

\section{W. Stanley Anthony, MSc}

Supervisory Agricultural E ngineer

U nited States Cotton G inning L aboratory

Agricultural R esearch Service

U nited States D epartment of A griculture

Stoneville, M isisipi

Estados U nidos

\section{Elías Apud, PhD, MSc}

Profesor

D epartment of Physiopathology

U niversity of C oncepción

Concepción

Chile
M.P. Arias, PhD, MSc

Je

D epartamento de Seguridad

H ospital C línico U niversitario

Barcelona

España

James R. Armstrong, CIH

T echnical Services Coordinator

O ntario Natural R esources Safety

Association

N orth Bay, O ntario

Canadá

\section{Ragnar Arnason, PhD}

Profesor

Departamento de E conomía

U niversidad de Islandia

R eikiavik

Islandia

Tony Ashdown, CPS, MS, CSP

$L$ oss P revention $M$ anager

Alpharma U SPD, Inc.

Baltimore, $\mathrm{M}$ aryland

Estados Unidos

George Astrakianakis, B Eng, M Eng

R esearch Scientist

Cancer $C$ ontrol R esearch

British Columbia Cancer Agency

V ancouver, Columbia Británica

Canadá

\section{Jörg Augusta, Dr med}

Arbeitsgruppenleiter

Arbeitsgruppe E rgonomie und W aldarbeit

L andesanstalt für Wald und

Forstwirtschaft

Gotha

Alemania

\section{William Avery, AS}

President

Systems Safety M anagement U SA, Inc.

O rlando, Florida

Estados U nidos

\section{Page Ayres, MS}

Senior E nvironmental E ngineer

N ewport N ews Shipbuilding

N ewport N ews, V irginia

Estados U nidos

\section{Angela Babin, MS}

Associate D irector

Center for Safety in the Arts

N ueva Y ork, N ueva Y ork

Estados U nidos

\section{G. Bachofen*}

Director de Sección

División de Información

Swiss $\mathrm{N}$ ational Accident I nsurance O rganization

Lucerna

Suiza

Dean B. Baker, MD, MPH

Professor, Director

Center for $O$ ccupational and

Environmental $\mathrm{H}$ ealth

U niversity of California-I rvine

Irvine, California

Estados Unidos

David E. Baker, CSP

Assistant Program D irector

Agriculture, Food and Natural R esources

U niversity of $\mathrm{M}$ issouri-C olumbia

Columbia, M isuri

Estados U nidos

David G. Baldwin, CIH

Corporate I ndustrial $\mathrm{H}$ ygiene $\mathrm{M}$ anager

H ewlett-Packard Company

Palo Alto, California

Estados U nidos

Gail Coningsby Barazani, MPH

F ormer E nvironmental $\mathrm{H}$ ealth Consultant

Chicago, Illinois

Estados U nidos

Hjálmar R. Bárdarson, MSc

D irector de la F lota E statal

Gardabaer

Islandia

\section{Donald Barnard, PhD}

Supervisory R esearch E ntomol ogist

Agricultural R esearch Service

U nited States D epartment of Agriculture

Gainesville, Florida

Estados U nidos

\section{Lynn Barroby}

$B$ reeder and $T$ rainer of $T$ horoughbred $R$ acehorses Langley, C olumbia Británica

Canadá

\section{Subhash K. Batra, PhD}

Director

N onwovens C ooperative R esearch Center

College of Textiles

N orth Carolina State U niversity

$R$ aleigh, Carolina del Norte

Estados U nidos

* Colaborador de la 3a edición de esta Enciclopedia. La información biográfica no se ha actualizado. 
Giuseppe Battista, MD

Profesor de M edicina Preventiva de los

T rabajadores

Cattedra di M edicina Preventiva

dei Lavoratori

Universidad de Siena

Siena

Italia

\section{J.M. Baztarrica*}

Facultad de Servicio Social de H igiene Industrial y M edicina

Buenos Aires

Argentina

Thomas L. Bean, PhD

Safety $L$ eader, P rofessor

D epartment of Food, A gricultural and Biological Engineering

O hio State U niversity

Columbus, 0 hio

Estados U nidos

Luc Beauchamp

ONRSA

North Bay, O ntario

Canadá

\section{Bernardo Bedrikow, MD, MPH}

Antiguo | efe

$\mathrm{O}$ ccupational Safety and $\mathrm{H}$ ealth

Serviço Social da Industria

São Paulo

Brasil

\section{Louis S. Beliczky, MS, MPH}

Consulting I ndustrial $\mathrm{H}$ ygienist

T echnical Advisors and Consultants to Trade U nionists

Wickliffe, $O$ hio

Estados U nidos

\section{David M. Bell, MD}

Assistant to the D irector

N ational Center for Infectious D iseases

Centers for Disease C ontrol and

Prevention

Atlanta, G eorgia

Estados U nidos

Joel Bender, MD, PhD

Vice President, Chief M edical O fficer

$\mathrm{H}$ ealth Sciences

$O$ wens-C orning

Toledo, $O$ hio

Estados U nidos
Deborah E. Berkowitz, BA

Director

O ffice of Safety and $\mathrm{H}$ ealth

U nited Food and C ommercial W orkers, AFL-CIO

W ashington, DC

Estados U nidos

\section{A.S. Bettenson, MA*}

F ormer D eputy Chief Inspector of $F$ actories

Cambridge

$R$ eino $U$ nido

\section{J.R. Bevan, Dr* \\ $M$ anager \\ C oated Products R esearch \\ British Steel Corporation, South Wales Group \\ Londres \\ $R$ eino $U$ nido}

\section{William Blackburn, MS}

Senior Research Associate

College of T extiles

N orth Carolina State U niversity

$\mathrm{R}$ aleigh, $\mathrm{C}$ arolina del $\mathrm{N}$ orte

Estados U nidos

\section{H.L. Boiteau}

Service d'A nesthésiologie

Faculté de M édecine

Nantes

Francia

\section{Denis Bourcier, PhD}

Senior Principle Scientist

Environmental A ffairs

Boeing D efence and Space Group

The Boeing Company

Seattle, W ashington

Estados U nidos

\section{Madeleine Bourdouxhe, MSc}

R esearcher

W ork $O$ rganization Programme Institute for $\mathrm{O}$ ccupational $\mathrm{H}$ ealth and

Safety R esearch

M ontreal, Q uebec

Canadá

\section{Carole Brabant, PhD}

Subdirectora de la Publicación

E nciclopedia de salud y seguridad en el trabajo

$O$ ficina Internacional del T rabajo

Ginebra

Suiza
P.E. Braid, PhD*

Consultant

L aboratory Services

$\mathrm{O}$ ccupational $\mathrm{H}$ ealth U nit

M edical Services Branch

$\mathrm{H}$ ealth and W elfare $C$ anada

O ttawa, O ntario

Canadá

Douglas F. Briggs, MPH, CIH

Group $M$ anager

Safety and $\mathrm{H}$ ealth

Boeing Commercial Airplane Group

The Boeing Company

Seattle, W ashington

Estados U nidos

Jere A. Brittain, PhD

C lemson U niversity

Clemson, Carolina del Sur

Estados U nidos

\section{T.J. Britton*}

$H$ er $M$ ajesty's I nspector of $F$ actories Plastics N ational Industry G roup

$\mathrm{H}$ ealth and Safety Executive

Northampton

R eino U nido

Mary O. Brophy, PhD, CIH, CPE

F ormer E nvironmental T oxicologist

Syracuse R esearch Corporation

N orth Syracuse, N ueva Y ork

Estados U nidos

\section{Jeremy Brown, MD, CM, FRCPC FACP \\ Chief \\ O ccupational $\mathrm{H}$ ealth Section \\ $\mathrm{H}$ ealth Services D irectorate \\ $\mathrm{R}$ oyal $\mathrm{C}$ anadian M ounted Police \\ O ttawa, 0 ntario \\ Canadá}

\section{Mary E. Brown, DVM, MPH}

M orehouse School of M edicine Senior R esearch Fellow

$\mathrm{N}$ ational Institute for $\mathrm{O}$ ccupational Safety and $\mathrm{H}$ ealth

$C$ enters for $D$ isease $C$ ontrol and Prevention

Cincinnati, 0 hio

Estados U nidos

Peter J. Bruno, MD, BS

Associate P rofessor of M edicine $\mathrm{N}$ ew $\mathrm{Y}$ ork U niversity

Senior Consultant

Insall Scott K elly Institute for O rthopedics N ueva Y ork, N ueva Y ork

Estados U nidos

* Colaborador de la 3a edición de esta Enciclopedia. La información biográfica no se ha actualizado. 
Norman Brusk, JD, CIH, CSP

$\mathrm{H}$ ealth and Safety $\mathrm{M}$ anager

$\mathrm{H}$ ealth, Safety and Environment

R esource Partner, Inc.

Columbus, $\mathrm{O}$ hio

Estados U nidos

\section{LaMont Byrd, MS}

$D$ irector of Safety and $\mathrm{H}$ ealth

International Brotherhood of T eamsters

Washington, DC

Estados U nidos

\section{Roxanne Cabral, MPH}

A merican Federation of State, C ounty and

$M$ unicipal Employees

Washington, DC

Estados U nidos

\section{I.T. Cabrera, Ing Dipl*}

Antiquo Funcionario

O ficina Internacional del Trabajo

Lima

Perú

\section{Buck Cameron, CIH}

Director

$H$ ealth $E$ ffects

Carpenters $\mathrm{H}$ ealth and Safety Fund

Seattle, W ashington

Estados U nidos

\section{Giovanni Capelli, MD}

Profesor A djunto

Istituto di I giene

U niversità C attolica D el Sacro Cuore

Roma

Italia

The Carpet and Rug Institute

M elbourne, V ictoria

Australia

Melvin E. Cassady, MS, CIH

Cassady Safety and H ealth Services

Southampton, Pensilvania

Estados U nidos

\section{Cesare Catananti, MD}

Director M édico

Policlinico "A. Gemelli" - I stituto di I giene U niversità $C$ attolica del Sacro Cuore

Roma

Italia

\section{J.A. Catton*}

$M$ anager

Safety, $\mathrm{H}$ ealth and W elfare

British Steel Corporation

Londres

Reino U nido

\section{Larry J. Chapman, PhD}

Associate Scientist

College of Agricultural and Life Sciences

U niversity of $W$ isconsin-M adison

$M$ adison, $W$ isconsin

Estados U nidos

\section{Tsun-Jen Cheng, BM, ScD}

Profesor Adjunto

Instituto de M edicina del T rabajo e H igiene Industrial

U niversidad $\mathrm{N}$ acional de T aiwan

Facultad de Salud Pública

Taipei

T aiwan, China

\section{V.I. Chernyuk, MD, SCD}

Profesor, D irector científico

Instituto de Salud en el T rabajo

$\mathrm{K}$ iev

U crania

\section{Corky Chew, MPH, MBA}

Program $M$ anager

Environmental T echnologies and Strategies

A pple Computer, Inc.

Cupertino, California

Estados U nidos

The Chlorine Institute, Inc.

Washington, DC

Estados U nidos

\section{John P. Chong, MD, FRCPC}

$M$ edical Director

Centre for $\mathrm{H}$ uman Performance and $\mathrm{H}$ ealth Promotion

$\mathrm{H}$ amilton, $\mathrm{O}$ ntario

Canadá

\section{Nancy Clark, MA, CIH, CSP}

Director

Center for 0 ccupational and Environmental M edicine

M ount Sinai School of M edicine

Nueva Y ork, N ueva Y ork

Estados U nidos

\section{Esther Cloutier, PhD}

Researcher

Programme 0 rganisation du T ravail

Institute for $\mathrm{O}$ ccupational $\mathrm{H}$ ealth and Safety R esearch

M ontreal, Q uebec

Canadá

\section{Lenora Colbert}

Vice President

$\mathrm{N}$ ational $\mathrm{H}$ ealth and $\mathrm{H}$ uman Services

Employees U nion

Nueva Y ork, N ueva Y ork

Estados U nidos
James J. Collins, CSP, CIH

General Mills

$M$ inneapolis, M innesota

Estados U nidos

\section{Zaida Colon, BS}

E specialista en Seguridad y M edio A mbiente $O$ peraciones $C$ entralizadas de Fabricación

Pepsic o PR, Inc.

Cidra

Puerto R ico

\section{James Cone, MD}

Assistant Clinical Professor

U niversity of California-Berkeley

Berkeley, California

Estados U nidos

\section{F.L. Conradi*}

Subdirector $\mathrm{G}$ eneral

$M$ edicina $L$ aboral

Instituto N acional de la Salud

Madrid

España

\section{George A. Conway, MD, MPH}

Chief

Alaska Activity Division of Safety R esearch $\mathrm{N}$ ational Institute for $\mathrm{O}$ ccupational Safety and $\mathrm{H}$ ealth

Anchorage, Alaska

Estados U nidos

\section{Georges H. Coppée, MD}

I efe de D epartamento M édico

Sección de Seguridad y Salud en el Trabajo

O ficina Internacional del T rabajo

Ginebra

Suiza

\section{Michael Crane, MD, MPH}

Assistant Vice-President

$\mathrm{O}$ ccupational $\mathrm{H}$ ealth

Con Edison

Brooklyn, Nueva Y ork

Estados U nidos

\section{Charles Crocker}

Safety $M$ anager

Burlington Industries, Inc

Greensboro, Carolina del N orte

Estados Unidos

\section{Neil Dalhouse}

$G$ eneral $M$ anager

$\mathrm{H}$ ealth and Safety E ducation Program

T ourism and H ospitality Industry

T oronto, O ntario

Canadá

\footnotetext{
* Colaborador de la 3a edición de esta Enciclopedia. La información biográfica no se ha actualizado.
} 
Gianfranco Damiani, MD

Profesor A djunto

Istituto di I giene

U niversità Cattolica del Sacro C uore

Roma

Italia

\section{Hugh Davies, MSc}

O ccupational $\mathrm{H}$ ygienist

$\mathrm{O}$ ccupational $\mathrm{H}$ ygiene Programme

University of British Columbia

V ancouver, Columbia Británica

Canadá

\section{DeBoer, Dr*}

Asesor I efe M édico

Shell International Petroleum

La H aya

Países Bajos

\section{Paul Demers, PhD}

Assistant P rofessor

O ccupational H ygiene Program

U niversity of British Columbia

V ancouver, Columbia Británica

Canadá

\section{Louis DiBerardinis, MS}

Associate D irector

Environmental M edical Services

M assachusetts Institute of T echnology

$C$ ambridge, $M$ assachusetts

Estados U nidos

\section{Bertram D. Dinman, MD, ScD}

Clinical Professor of $O$ ccupational $M$ edicine

G raduate School of Public H ealth

University of Pittsburgh

Pittsburgh, Pensilvania

Estados U nidos

\section{Basil Dolphin, MD, MPH \\ M edical D irector \\ H ealthworks \\ M uhlenberg $\mathrm{H}$ ospital \\ Bethlehem, Pensilvania \\ Estados U nidos}

\section{Kelley Donham, DVM}

D epartment of Preventive M edicine and Environmental $\mathrm{H}$ ealth

Institute for Rural and Environmental $\mathrm{H}$ ealth

College of M edicine

U niversity of I owa

Iowa City, I owa

Estados U nidos

Kyle B. Dotson, CIH, CSP, PE $G$ roup Vice President, Safety and $H$ ealth BH P Copper

San Francisco, California

Estados U nidos

\author{
Aluaro Durao, MD, OPHS* \\ J efe \\ Departamento de Salud en el T rabajo \\ Siderurgia $\mathrm{N}$ acional \\ Lisboa \\ Portugal
}

\section{Dennis Dykstra, PhD}

Subdirector General de I nvestigación

Centro de Investigación Forestal

Internacional

Yakarta

Indonesia

\section{Gary S. Earnest, MS, PE, CSP}

E ngineer Officer

Engineering C ontrol T echnology Branch

Division of Physical Sciences and Engineering

National Institute for $\mathrm{O}$ ccupational Safety and $\mathrm{H}$ ealth

Cincinnati, $O$ hio

Estados U nidos

\section{Alan Echt, MPH}

Industrial $\mathrm{H}$ ygienist

Engineering C ontrol T echnology Branch

Division of Physical Sciences and Engineering

$\mathrm{N}$ ational Institute for $\mathrm{O}$ ccupational Safety and $\mathrm{H}$ ealth

Cincinnati, $\mathrm{O}$ hio

Estados U nidos

\section{Olli Eeronheimo, MSc}

Investigador

Instituto Finlandés de Investigación Forestal

Vantaa

Finlandia

M.M. El-Attal, Dr, MB, ChB, DIH* J efe

Departamento de Salud en el T rabajo

$M$ inisterio de Salud

M anama

Bahrain

\section{M.A. EI Kadeem, Prof*}

J efe

Departamento T écnico de Producción

Facultad de Ingeniería

U niversidad de Alejandría

Alejandría

Egipto

Carl G. Elinder, MD, PhD

Profesor Adjunto

Departamento de M edicina del $\mathrm{R}$ iñón

$\mathrm{H}$ ospital U niversitario $\mathrm{H}$ uddinge

e Instituto $\mathrm{K}$ arolinska

$\mathrm{K}$ arolinska

Suecia
Daniel R. English, PhD

U nit Director

Environmental Sciences Section

Eastman K odak Company

R ochester, N ueva Y ork

Estados U nidos

Claës-W. Englund, BLL

Director, Asesor J urídico

A sociación de T eatros y O rquestas Suecos

T eatrarnas $\mathrm{R}$ iksförbund

Estocolmo

Suecia

Madeleine R. Estryn-Béhar, MD, PhD

Profesional de la Salud en el T rabajo

H ôpital Saint-L ouis

París

Francia

\section{J.F. Eustace, MB, DPH*}

$D$ ean of $F$ aculty

O ccupational M edicine

R oyal C ollege of Physicians of I reland

Dublín

Irlanda

\section{E. Evrard, Dr*}

O rganisation européenne pour la sécurité de la navigation aérienne

Bruselas

Bélgica

\section{Lynda Ewers, PhD, CHMM}

Industrywide Studies Branch

Division of Surveillance, $\mathrm{H}$ azard

Evaluations and Field Studies

National Institute for $O$ ccupational Safety and $\mathrm{H}$ ealth

Cincinnati, O hio

Estados U nidos

Michael J. Fagel, PhD

Corporate Safety D irector Aurora Packing C o., Inc.

N orth Aurora, Illinois

Estados U nidos

John Fajen, MS

Director of I ndustrial $\mathrm{H}$ ygiene and $\mathrm{E}$ rgonomics

AIG Consultants, Inc.

Cincinnati, O hio

Estados U nidos

\section{Joseph Fedoruk, MD}

$M$ edical D irector

Center for 0 ccupational and

Environmental $\mathrm{H}$ ealth

U niversity of C alifornia-Irvine

Irvine, California

Estados U nidos

\footnotetext{
* Colaborador de la 3a edición de esta Enciclopedia. La información biográfica no se ha actualizado.
} 
John B. Feldman, PE, CIH, CSP, MS

C orporate $O$ ccupational Safety and

$\mathrm{H}$ ealth

R aytheon Company

L exington, $M$ assachusetts

Estados U nidos

L.V.R. Fernando, MBBS, DPH, DHI*

A sesor laboral y de población

O ficina Internacional del T rabajo

Nueva Delhi

India

\section{William E. Field, EdD}

Professor

Agricultural and Biological

Engineering

Purdue U niversity

West L afayette, Indiana

Estados U nidos

\section{John Finklea, MD, Dr PH}

$M$ edical Officer

C enter to Protect W orkers' R ights

F ormer D irector

$\mathrm{N}$ ational Institute for $\mathrm{O}$ ccupational Safety and $\mathrm{H}$ ealth

W ashington, DC

Estados U nidos

\section{Manfred Fischer, Dr-Ing}

Director de la I nspección T écnica

V erwaltungs-Berufsgenossenschaft

$\mathrm{H}$ amburgo

Alemania

\section{N. Fish, MA*}

$\mathrm{H}$ er M ajesty's D istrict I nspector of F actories

D epartment of E mployment and

Productivity

Watford

R eino U nido

\section{Stewart Forbes, BSc}

E xecutive D irector

C anadian Centre for Pollution Prevention

Sarnia, O ntario

Canadá

\section{Janet Fox, MA}

Director

Safety and I ndustrial H ygiene

Con Edison

Brooklyn, N ueva Y ork

Estados U nidos

\section{David Franson, CSP, ARM}

$O$ ccupational $\mathrm{H}$ ealth and Safety C onsultant

Safety $M$ anagement Services Company

Dubuque, I owa

Estados U nidos
James S. Frederick

Industrial H ygienist

$\mathrm{H}$ ealth, Safety and Environment Department

U nited Steelworkers of America

Pittsburgh, Pensilvania

Estados U nidos

Barry R. Friedlander, MD, MPH

Senior E nvironmental $\mathrm{H}$ ealth Adviser

Exxon Biomedical Sciences, Inc.

East M illstone, N ueva J ersey

Estados U nidos

\section{I.D. Gadaskina*}

D oktor biologireskih nauk

R ukovoditel' toksikologiceskoj laboratorii

Leningradskogo I nstitut gigieny truda i profzabolevanij

Leningrado

Antigua URSS

\section{Nancy Garcia, MPH}

A irline Division

International Brotherhood of T eamsters

Fremont, California

Estados U nidos

\section{H. Gartmann, Dr \\ D irector M édico \\ Servicios M édicos \\ Swissair \\ Zurich \\ Suiza}

\section{Joel C. Gaydos, MD}

D irector

Clinical Preventive M edicine

$\mathrm{U}$ nited States A rmy Center for $\mathrm{H}$ ealth Promotion and Preventive $M$ edicine

Army Proving Ground, M aryland

Estados U nidos

\section{E. Gelpi*}

Educación Permanente

Division des structures, contenus et méthodes

O rganización de las $\mathrm{N}$ aciones U nidas para la Ciencia, E ducación y Cultura

París

Francia

\section{Afsaneh Gerami, BS}

E nvironmental $\mathrm{H}$ ealth and Safety Consul tant $\mathrm{H}$ ewlett-Packard Company

San J osé, California

Estados U nidos

\section{Gary A. Gibson, MBA}

Chief Executive 0 fficer

$M$ ines R escue Board

Sidney

Australia

\section{Gary Gibson, BSc}

$O$ ccupational $\mathrm{H}$ ealth and Safety 0 fficer

D urham Board of Education

Whitby, 0 ntario

Canadá

\section{Denis Giguère, MSc, DESS}

E rgonomist

Safety-Ergonomics R esearch Program

Institute for $\mathrm{O}$ ccupational $\mathrm{H}$ ealth and

Safety R esearch

M ontreal, Q uebec

Canadá

\section{David Gold, MOEd}

$O$ ccupational Safety and $\mathrm{H}$ ealth $\mathrm{O}$ fficer $\mathrm{O}$ ccupational Safety and $\mathrm{H}$ ealth Branch

International Labour $O$ ffice

Ginebra

Suiza

\section{J.C. Graham, MFCM, MFOM, DIH*} efe $M$ édico

H.J. H einz Company, Ltd.

Londres

Reino U nido

\section{Casey C. Grant, PE}

Assistant Vice President

Codes and Standards A dministration

$N$ ational Fire Protection Association International

Q uincy, M assachusetts

Estados U nidos

\section{Alfons Grösbrink, Dipl-Ing}

L e iter des T echnischen Aufsichtsdienstes Bahnen-Berufsgenossenschaft

$\mathrm{H}$ amburgo

Alemania

\section{Xavier Guardino Solá, PhD}

I efe de $D$ epartamento

Centro Nacional de Condiciones de Trabajo

Instituto Nacional de Seguridad e H igiene en el Trabajo

Barcelona

España

\section{Tee L. Guidotti, MD, MPH}

P rofessor, D irector

$\mathrm{O}$ ccupational H ealth Program Faculty of M edicine

U niversity of Alberta

Edmonton, Alberta

Canadá

\section{Paul D. Gunderson, PhD}

$M$ arshfield C linic

$N$ ational Farm $M$ edicine $C$ enter

$M$ arshfield, W isconsin

Estados U nidos

\footnotetext{
${ }^{*}$ Colaborador de la 3a edición de esta Enciclopedia. La información biográfica no se ha actualizado.
} 
J.C. Gunther, Jr.*

T écnico en Seguridad y Formación

Autoridad Imperial de Autopistas

Addis Abeba

Etiopía

John G. Hadley, PhD

Corporate T oxicologist

$\mathrm{H}$ ealth Sciences

$O$ wens-Corning

Granville, O hio

Estados U nidos

\section{Hans Hamrin, MSc}

A sesor Principal

M inería

Atlas Copco R ock D rills AB

Estocolmo

Suecia

\section{Jonathan T. Haney, MS}

$M$ anlius, N ueva Y ork

Estados U nidos

\section{David L. Hard, PhD}

R esearch Safety E nginer

Division of Safety R esearch

$\mathrm{N}$ ational Institute for $\mathrm{O}$ ccupational Safety and $\mathrm{H}$ ealth

M organtown, $V$ irginia $O$ ccidental

Estados U nidos

\section{Francis Hardy, P Eng}

Project C oordinator

C onstruction Safety Association of O ntario

South Etobicoke, O ntario

Canadá

\section{D.A. Hargrave*}

$H$ er $M$ ajesty's $D$ istrict I nspector of $F$ actories

$\mathrm{H}$ amilton

R eino U nido

\section{Susan Harman, MSLS, MEd}

Associate Librarian

$M$ edical and Chirurgical Faculty of $\mathrm{M}$ aryland

Baltimore, $\mathrm{M}$ aryland

Estados U nidos

\section{Robert Harris, PhD CIH}

Professor E meritus

U niversity of N orth Carolina at Chapel Hill

Chapel Hill, Carolina del Norte

Estados U nidos

\section{Thomas E. Hawkinson, MS, CIH} ROH, CSP

Safety and $E$ nvironmental $E$ ngineering $M$ anager G eneral Mills

$M$ inneapolis, M innesota

Estados U nidos

Dick Heederik, PhD, MSc

Profesor Adjunto de E pidemiología de T rabajo

U niversidad de Wageningen

Wageningen

Países Bajos

\section{Rudolf Heinrich, PhD}

J efe

Sección de A provechamiento, C omercio y

$M$ arketing Forestal

O rganización de las $\mathrm{N}$ aciones $\mathrm{U}$ nidas para la Agricultura y la Alimentación

Roma

I talia

Jonathan P. Hellerstein, MS, CIH, CSP

L eader

$\mathrm{O}$ ccupational $\mathrm{H}$ ealth and Safety

$O$ wens-Corning

Toledo, 0 hio

Estados U nidos

\section{Samuel H. Henao}

Principal A sesor Técnico

Director N acional de Salud en el T rabajo

Instituto de Seguridad Social

Bogotá

Colombia

\section{Robin Herbert, MD}

$M$ edical C o-D irector

M ount Sinai Center for Environmental and $O$ ccupational $M$ edicine

Nueva Y ork, Nueva Y ork

Estados U nidos

Fred W. Hermann, MSc, BSc, BA

Chief Inspector of $M$ ines

$M$ inistry of Employment and Investment

Victoria, Columbia Británica

Canadá

\section{Thomas A. Hethmon, MS, CIH,} ROH

D irector

O ccupational H ealth and Safety

Phelps Dodge Corporation

Phoenix, Arizona

Estados U nidos

\section{Jeffrey Hinksman, BA Law}

$H$ ealth and Safety Consultant

Epsom, Surrey

Reino U nido
Matthew Hirsheimer, BS

$N$ ational Safety $M$ anager

Safety and $R$ isk $M$ anagement

Pepsi-Cola Company

Somers, Nueva Y ork

Estados U nidos

Robert W. Hites, BS, AAS

Corporate Safety A nalyst

D elta Airlines

Atlanta, G eorgia

Estados U nidos

Friedrich Hofmann, PhD, MD

P rofesor de M edicina del T rabajo

U niversidad de W uppertal

W uppertal

Alemania

\section{Charles M. Hohman, BSME, MBA}

T echnical Consultant

East $\mathrm{O}$ hio $\mathrm{M}$ achinery $\mathrm{C}$ ompany

Newark, O hio

Estados U nidos

\section{Wendy Hord}

$O$ ccupational Safety and $\mathrm{H}$ ealth Specialist

Civil Service Employees Association

L atham, Nueva Y ork

E stados U nidos

\section{Ninica Howard, MS}

E rgonomist

SHAR P

D epartment of $L$ abor and Industries

O lympia, W ashington

Estados U nidos

\section{J. Howes, PhD}

Partner

R H P C onsultants

Camborne, Cornwall

R eino U nido

\section{Gordon Huie, MD}

Insall Scott K elly Institute

Nueva Y ork, N ueva Y ork

Estados U nidos

\section{Vilma Hunt, BDS, AM}

Adjunct Professor

D epartment of W ork Environment U niversity of M assachusetts-L owell

L owell, M assachusetts

Estados U nidos

David L. Huntzinger, PhD, M Sci

Vice President

Corporate Safety

America W est Airlines

Phoenix, A rizona

Estados U nidos

\footnotetext{
* Colaborador de la 3a edición de esta Enciclopedia. La información biográfica no se ha actualizado.
} 


\section{Marit Husmo, MSc}

Investigador

Facultad de Ciencias de la Pesca de Noruega

U niversity of T romso

Tromso

N oruega

\section{William E. Irwin, MS, MBA}

H ealth Physics Consultant, R adiation Safety Officer

$M$ assachusetts Institute of T echnology

Cambridge, $M$ assachusetts

E stados U nidos

\section{A. Lee I vester, MSPH}

D irector

Corporate Safety and Workers'

Compensation

Fieldcrest Cannon, Inc.

$\mathrm{K}$ annapolis, Carolina del $\mathrm{N}$ orte

Estados U nidos

\section{Anthony W. Jackson, PhD}

Senior $\mathrm{H}$ ealth and Safety Advisor

Fossil Business U nit

$\mathrm{O}$ ntario $\mathrm{H}$ ydro-Fossil

T oronto, O ntario

Canadá

\section{Lars Järup, MD, PhD}

$M$ édico A mbiental

D epartamento de Salud Ambiental

Sundyberg

Suecia

\section{Norman S. Jennings, BSc}

E specialista Industrial superior

D epartamento de Actividades Sectoriales

O ficina Internacional del T rabajo

G inebra

Suiza

\section{G. Jensen*}

Subdirector

Servicio D anés de Inspección

Laboral

Copenhage

Dinamarca

\section{Barry L. Johnson, PhD}

Assistant Surgeon General, Assistant

Administrator

A gency for T oxic Substances and Disease

Registry

A tlanta, G eorgia

Estados U nidos

\section{Steven Johnson, PhD}

Specialist

Cooperative Extension

$U$ niversity of $\mathrm{M}$ aine

Presque I sle, $M$ aine

Estados U nidos

\section{Alan D. Jones, \\ Fire Services A dvisor \\ Alberta Fire T raining School \\ Alberta Labour \\ V ermillion, Alberta \\ Canadá}

\section{J.G. Jones, Dr*}

Group M edical O fficer

British Steel Corporation, South Wales

Group

Londres

R eino U nido

\section{D.D. Joshi, DVM, MPVM}

Director

Centro de Investigación Nacional de la $\mathrm{H}$ igiene de la Alimentación y la Zoonosis

K atmandú

Nepal

\section{Marja-Liisa Juntunen, MSc}

Investigador

Centro de Investigación Suonenjok

Instituto Finlandés de Investigación

Forestal

Suonenjoki

Finlandia

\section{Mike Jurvélius, BSc}

Consultor Superior

D esarrollo Forestal EN SO

Imatra

Finlandia

\section{Yu S. Kagan, MD, PhD}

I fe de $D$ epartamento de T oxicología $G$ eneral Instituto Nacional de la Salud

$\mathrm{K}$ iev

U crania

Juhani Kangas, PhD, Professor

Director de Instituto R egional

Instituto Finlandés de Salud en el Trabajo

K uopio

Finlandia

\section{Valery P. Kaptsov}

Director

Instituto R uso de Higiene en el Transporte Ferroviario

M oscú

Federación R usa
Thomas Karsky, MS

E xtension Safety Specialist

D epartment of Biological and Agricultural Engineering

U niversity of Idaho

M oscow, I daho

Estados U nidos

\section{Timo Kauppinen, PhD}

J efe de la Sección de R egistro

Instituto Finlandés de Salud en el T rabajo

Helsinki

Finlandia

\section{Anya Keefe, MSc}

Research Associate

O ccupational $\mathrm{H}$ ygiene Program

University of British Columbia

V ancouver, Columbia Británica

Canadá

\section{Anat Keidar, PhD, CCC-SLP}

$V$ oice $L$ aboratory $D$ irector

V ox H umana V oice L aboratory, $\mathrm{H}$ ead and $\mathrm{N}$ eck Surgical G roup

$\mathrm{N}$ ew $\mathrm{Y}$ ork $\mathrm{C}$ enter for $\mathrm{V}$ oice and

Swallowing Disorders

N ueva Y ork, N ueva Y ork

E stados U nidos

\section{Barry P. Kelley, PhD}

$O$ ccupational $\mathrm{H}$ ygienist

Chloride Industrial Batteries, L td.

$M$ anchester

R eino U nido

\section{Susan Kennedy, PhD}

Associate P rofessor, D irector

$\mathrm{O}$ ccupational $\mathrm{H}$ ygiene Programme

University of British Columbia

V ancouver, C olumbia Británica

Canadá

\section{Robert W. Kilpper, PhD}

Senior T oxicologist

$X$ erox Corporation

W ebster, Nueva Y ork

Estados U nidos

\section{W. Klost, Dipl-Ing*}

Ingeniero jefe

A rbeitssicherheit Siemens AG

Berlín

Alemania

\section{L.W. Knapp, Jr.*}

Department of Preventive M edicine and Environmental $\mathrm{H}$ ealth

Institute of Agricultural M edicine

U niversity of lowa

Iowa City, I owa

Estados Unidos

\footnotetext{
* Colaborador de la 3a edición de esta Enciclopedia. La información biográfica no se ha actualizado.
} 


\section{Stephanie Knopp, MFA}

Associate $P$ rofessor of $G$ raphic $D$ esign

Tyler School of Art

Filadelfia, Pensilvania

Estados U nidos

\section{Y.C. Ko, MD*}

Instituto de Salud Pública

Facultad de M edicina

U niversidad N acional de T aiwan

Taipei

T aiwan, $C$ hina

\section{Eero Korhonen, MSc}

Investigador Principal

Instituto de Salud en el T rabajo

$\checkmark$ antaa

Finlandia

\section{Ludmila P. Korotich}

Investigador P rincipal

D epartamento de Investigación de H igiene

Instituto de Salud en el T rabajo

M oscú

Federación R usa

\section{Richard S. Kraus, PE, CSP}

Principal

Petroleum Safety Consultants

Annandale, Virginia

Estados U nidos

\section{J. Kroeger, Dipl-Chem*}

M utua de Seguros de Accidente de la

A sociación de la Industria Q uímica

$\mathrm{H}$ eidelberg

Alemania

J. Kubota, MD*
Director
C entro de Servicios de Salud en el T rabajo
T okio
Japón

\section{Yuri Kundiev, MD, Dr med sci}

Director

Instituto de Salud en el T rabajo

$\mathrm{K}$ iev

U crania

\section{Lucie Laflamme, PhD}

Investigador P rincipal

D epartamento de Ciencias de la Salud

Pública

Instituto $\mathrm{K}$ arolinska

Sundbyberg

Suecia
Paul A. Landsbergis, EdD, MPH

Assistant P rofessor of E pidemiology

Division of $\mathrm{H}$ ypertension

Cornell U niversity M edical College

Nueva Y ork, Nueva Y ork

Estados U nidos

\section{Sverre Langård}

Centro de M edicina del T rabajo y Ambiental

H ospital Nacional

O slo

N oruega

\section{Donald V. Lassiter, PhD, MSPH}

Consultant

Environmental and $\mathrm{O}$ ccupational $\mathrm{H}$ ealth

San José, California

Estados U nidos

\section{Wolfgang Laurig, Dr-Ing}

Profesor, D irector

Departamento de Ergonomía

Institut für Arbeitsphysiologie

U niversidad de D ortmund

Dortmund

Alemania

P.K. Law*

Group $M$ anager

British Plastics F ederation

Londres

R eino Unido

\section{Pam Tau Lee}

Labor O ccupational H ealth Program

U niversity of California-Berkeley

Berkeley, California

Estados U nidos

\section{Susan B. Lee, MBA, CIH}

$M$ anager

Environmental $\mathrm{H}$ ealth and Safety

Biogen, Inc.

Cambridge, $M$ assachusetts

Estados U nidos

\section{David LeGrande, MA}

D irector

O ccupational Safety and $\mathrm{H}$ ealth

Communications W orkers of A merica

Washington, DC

Estados U nidos

\section{Carol J. Lehtola, PhD}

Assistant Professor

Institute of F ood and A gricultural Science

Department of Agricultural and Biological

Engineering

U niversity of Florida

Gainesville, Florida

Estados U nidos
Steven W. Lenhart, CIH

Industrial $\mathrm{H}$ ygienist

Division of Surveillance, $\mathrm{H}$ azard Evaluations and Field Studies

National Institute for $O$ ccupational Safety and $\mathrm{H}$ ealth

Cincinnati, $O$ hio

Estados U nidos

\section{Yung Hian Leow, MD}

Section of Industrial Dermatology

Cleveland $\mathrm{C}$ linic Foundation

Cleveland, 0 hio

Estados U nidos

Charles Levenstein, PhD, MS

Professor of W ork E nvironment Policy

Work Environment D epartment

U niversity of M assachusetts-L owell

L owell, M assachusetts

Estados U nidos

Robert M. Lewy, MD, MPH

Director for M edical Affairs

Columbia Presbyterian M edical C enter Nueva Y ork, N ueva Y ork

Estados U nidos

Norbert Lichtenstein, PhD

Berufsgenossenschaftliches I nstitut für Arbeitssicherheit

Sankt Augustin

Alemania

\section{Hans Göran Linder, PhD}

Consejo N acional de Seguridad y Salud en el T rabajo

Solna

Suecia

Sydney Lipton, MS

Consultant

Port T ownsend, W ashington

Estados U nidos

J.W.G. Lund, MD*

Freshwater Biological Association

Windermere Laboratory

Ambleside

Reino U nido

\section{John Lund, PhD}

Professor

School for Workers

U niversity of W isconsin-Extension

$M$ adison, Wisconsin

Estados U nidos

\footnotetext{
*Colaborador de la 3a edición de esta Enciclopedia. La información biográfica no se ha actualizado.
} 
Paul V. Lynch, PE

Chief, Safety Staff (R etired)

Bureau of $L$ and $M$ anagement

$U$ nited States $D$ epartment of the Interior

Washington, DC

Estados U nidos

\section{G.S. Lyndon*}

Senior A rea D irector

West $M$ idlands A rea $O$ ffice

$\mathrm{H}$ ealth and Safety Executive

Birmingham

R eino U nido

\section{Paul Mackenzie-Wood, BSC}

$M$ anager, T echnology

Coal M ines T echnical Services

$M$ ines $R$ escue Services

Corrimal

Australia

\section{Susan Magor, RN, MSc}

Director

Environment, $\mathrm{H}$ ealth and Safety

Concordia U niversity

M ontreal, Q uebec

Canadá

\section{Andreas Mahr, Dipl-Ing}

T echnischer Aufsichtsbeamter

Bahnen-Berufsgenossenschaft

$\mathrm{H}$ amburgo

Alemania

\section{Kathryn A. Makos, MPH, CIH}

Senior I ndustrial H ygienist

O ffice of E nvironmental $M$ anagement and Safety

Smithsonian Institution

Washington, DC

Estados U nidos

\section{Malagié, Ing*}

Institut national de recherche et de sécurité pour la prévention des accidents du travail et des maladies

professionnelles

París

Francia

\section{Bohuslav Málek}

Instituto de H igiene de Praga

Praga

R epública C heca

\section{David E. Malter, MS, CIH, CSP,} ROH

$M$ alter Associates, Inc.

D owner Grove, Illinois

Estados U nidos
Adrienne Markowitz, MSc

Director of $\mathrm{H}$ ealth and Safety

R etail, W holesale and D epartment Store Union

U nited Food and Commercial Workers, AFL-CIO

N ueva Y ork, N ueva Y ork

Estados U nidos

\section{William S. Marras, PhD}

Professor, Director

Biodynamics L aboratory

D epartment of Industrial and Systems

Engineering

Columbus, O hio

Estados U nidos

\section{Linda S. Martin, PhD}

Director, H IV Activity

$N$ ational Institute for $O$ ccupational Safety and $\mathrm{H}$ ealth

Altanta, G eorgia

Estados U nidos

\section{John Masaitis, CIH}

Consultant

N ew Smyrna Beach, Florida

Estados U nidos

\section{Steve Mason, BS}

Senior M anager, Chemical T echnology

$O$ perations T echnology

Boeing C ommercial Airplane G roup

The Boeing Company

Seattle, W ashington

Estados U nidos

\section{K.R. Mathisen*}

División T écnica M ecánica

Comisión Sueca de Normas

Estocolmo

Suecia

Toshio Matsushita, MD, PhD

Profesor

Facultad de M edicina

U niversidad de K agoshima

Kagoshima

Japón

\section{Chester Matthews}

Bath I ron W orks

Brunswick, $M$ aine

Estados U nidos

R. Mattiussi, Dr*

Direttore Sanitario

M ontedison

Milán

Italia
John May, MD

D irector

$\mathrm{N}$ ew $\mathrm{Y}$ ork Center for Agricultural $M$ edicine and $\mathrm{H}$ ealth

$M$ ary I mogene Bassett H ospital

Coopertown, Nueva Y ork

Estados U nidos

\section{Michael McCann, PhD, CIH}

Senior A ssociate E ditor

E ncyclopaedia of $O$ ccupational $\mathrm{H}$ ealth and Safety

International Labour O ffice

N ueva Y ork, Nueva Y ork

Estados U nidos

\section{George J. McDonald}

$D$ irector of Safety and $\mathrm{H}$ ealth

International Transport Workers U nion of America

Nueva Y ork, Nueva Y ork

Estados U nidos

\section{Bruce McKay}

Senior R esearcher

SeaW eb

M ontreal, Q uebec

Canadá

\section{Shane McMahon, MSc}

Program $M$ anager

Liro Limited

R otorua

N ueva Zelanda

Neil McManus, MSc, M Eng

Consulting I ndustrial $\mathrm{H}$ ygienist

$\mathrm{N}$ orthW est $\mathrm{O}$ ccupational $\mathrm{H}$ ealth and Safety

N orth V ancouver, Columbia Británica

Canadá

\section{Nona McQuay, MS}

$H$ ealth and Safety Specialist

$\mathrm{N}$ ew Y ork State Public Employees

Federation, AFL-CIO

Buffalo, N ueva Y ork

Estados U nidos

\section{DougJ. McVittie, Dipl Eng}

$M$ anager-T echnical Services

C onstruction Safety Association of O ntario E tobicoke, O ntario

Canadá

\section{Karlheinz Meffert, Dr-Ing}

D irector

Berufsgenossenschaftliches Institut für Arbeitssicherheit

$H$ auptverband der gewerblichen Berufsgenossenschaften

Sankt Augustin

Alemania

\footnotetext{
* Colaborador de la 3a edición de esta Enciclopedia. La información biográfica no se ha actualizado.
} 


\section{Ronald L. Melnick, PhD}

T oxicologist

N ational Institute of Environmental

$\mathrm{H}$ ealth Sciences

R esearch Triangle Park, C arolina del

N orte

Estados U nidos

\section{Raji Menon}

R esearch 0 fficer

$M$ ining A ssociation of $C$ anada

0 ttawa, 0 ntario

Canadá

\section{Karen Messing, PhD \\ Professor of Biology \\ CINBIOSE \\ U niversity of Q uebec \\ M ontreal, $Q$ uebec \\ Canadá}

\section{Jacqueline Messite, MD}

Clinical Professor

D epartment of Environmental M edicine

$\mathrm{N}$ ew $\mathrm{Y}$ ork U niversity College of M edicine

N ueva Y ork, N ueva Y ork

Estados Unidos

Mark M. Methner, PhD

Industrial $\mathrm{H}$ ygienist

Division of Surveillance, $\mathrm{H}$ azard

Evaluation and Field Studies

$\mathrm{N}$ ational Institute for $\mathrm{O}$ ccupational Safety and $\mathrm{H}$ ealth

Cincinnati, O hio

Estados U nidos

John D. Meyer, MD, MPH

Associate R esidency D irector

Institute of $O$ ccupational and

Environmental $\mathrm{H}$ ealth

W est V irginia U niversity School of

M edicine

M organtown, $V$ irginia $O$ ccidental

Estados U nidos

Jack L. Mickle, PhD

Professor E meritus, Consultant

Jack L. M ickle and Associates

Boone, lowa

Estados U nidos

John Miles, PhD

D epartment of A gricultural Engineering

$U$ niversity of C alifornia-D avis

Davis, California

Estados U nidos
Frank Miller, PhD

$H$ azardous $M$ aterials $O$ fficer

Environmental $\mathrm{H}$ ealth and Safety $\mathrm{O}$ ffice

Columbia U niversity $\mathrm{H}$ ealth Sciences

Nueva Y ork, Nueva Y ork

Estados U nidos

\section{Gordon C. Miller, MSPH}

D irector

$\mathrm{H}$ ealth, Safety and Environment

R exam, Inc.

Charlotte, Carolina del N orte

Estados U nidos

\section{Bruce A. Millies, JD, MS, CIH \\ Industrial H ygienist \\ International Brotherhood of T eamsters \\ Bainbridge Island, Washington \\ Estados U nidos}

\section{Franklin E. Mirer, PhD}

D irector

$H$ ealth and Safety D epartment

International U nion of U nited Auto Workers

Detroit, M ichigan

Estados U nidos

Courtney S. Mitchell, MSc, MA

Consultant

CSM Consulting

Golden, Colorado

Estados U nidos

\section{William S. Mitchell, MSc}

$M$ anager, Exploration Administration

BH P M inerals International

Exploration, Inc.

Golden, Colorado

Estados U nidos

\section{Augustine Moffitt, ScD}

Vice President

Safety, $\mathrm{H}$ ealth and Environment

Bethlehem Steel Corporation

Pensilvania

Estados U nidos

W.G. Morison, BSc, MSc

President

Morwil Inc.

Ontario

Canadá

\section{K.M. Morse*}

Industrial $\mathrm{H}$ ealth Engineers, Inc.

Altamonte Springs, Florida

Estados U nidos
Robert J. Mullan, MD

$M$ edical 0 fficer

Centers for Disease Control and

Prevention

National Institute for 0 ccupational Safety and $\mathrm{H}$ ealth

Atlanta, G eorgia

Estados U nidos

Kieran Mulvaney
E ditor
0 cean U pdate
SeaW eb
Washington, DC
Estados U nidos

Eva Munk-Madsen, PhD

Profesor, C atedrático

Facultad de Ciencias de la Pesca de N oruega

U niversidad de T romso

Tromso

Noruega

\section{R.A. Munoz, MSW*}

Subdirector

D epartamento de E ducación Programación T écnica

$\mathrm{H}$ ato R ey

Puerto Rico

Dennis Murphy, PhD, CSP

Professor

Department of Agricultural and Biological Engineering

Pennsylvania State U niversity

U niversity Park, Pensilvania

Estados U nidos

Daniel Murphy, MB, FFOM, DIH

Director

O ccupational M edical Services

$N$ ational Authority for O ccupational

Safety and $\mathrm{H}$ ealth

Dublín

Irlanda

\section{Joshua E. Muscat, MPH}

A merican $\mathrm{H}$ ealth Foundation

Nueva Y ork, N ueva Y ork

Estados U nidos

Melvin L. Myers, BS, MPA

D eputy D irector

O ffice of Extramural C oordination and Special Projects

$\mathrm{N}$ ational Institute for $\mathrm{O}$ ccupational Safety and $\mathrm{H}$ ealth

Atlanta, G eorgia

Estados U nidos

\footnotetext{
${ }^{*}$ Colaborador de la 3 a edición de esta Enciclopedia. La información biográfica no se ha actualizado.
} 
Pranab Kumar Nag, PhD, DSc, MSc Subdirector

C onsejo Indio de Investigación M édica Instituto Nacional de Salud en el T rabajo Ahmedabad

India

\section{John D. Neefus, PhD, CIH}

Industrial $\mathrm{H}$ ygiene $\mathrm{C}$ onsultant

Durham, Carolina del N orte

Estados U nidos

\section{Barbara Neis, PhD}

Associate P rofessor, H ead

D epartment of Sociology

M emorial U niversity

St. John's, N ewfoundland

Canadá

\section{Christian E. Newcomer, VMD}

D irector, R esearch A ssociate P rofessor

L aboratory A nimal M edicine

U niversity of N orth Carolina

Chapel $\mathrm{H}$ ill, Carolina del $\mathrm{N}$ orte

Estados U nidos

\section{A.K. Niyogi, MBDPH, DIH*}

M iembro de la Comisión de B ecas de la U niversidad

D epartamento de M edicina Preventiva y Social

Instituto de Ciencias M édicas

Varanasi

India

\section{Susan Nobel, MSW, CsW}

M ount Sinai-I rving J. Selikoff Center for $O$ ccupational and

Environmental M edicine

$M$ ount Sinai M edical $C$ enter

N ueva Y ork, N ueva Y ork

Estados U nidos

\section{Gunnar Nordberg}

D epartamento de M edicina A mbiental U niversidad de U meå

U meå

Suecia

\section{Jacqueline Nubé, Dr}

D epartamento de Psicología

Facultad de M etodología

U niversidad de A msterdam

Amsterdam

Países Bajos

\section{Hulda Ólafsdóttir, MS}

Fisioterapeuta

D epartamento de M edicina del Trabajo

Dirección de Seguridad y Salud en el Trabajo

R eikiavik

Islandia
Edward A. Olmsted, CIH, CSP

President

O Imsted Environmental Services

Garrison, Nueva Y ork

Estados U nidos

\section{Gary W. Olmstead, PhD, CIH, CSP \\ D irector \\ Safety and Environmental M anagement \\ General M ills \\ $M$ inneapolis, M innesota \\ Estados Unidos \\ David A. O'Malley, MSc \\ $M$ anaging $D$ irector \\ Diamond Environmental Ltd. \\ Chester \\ R eino U nido}

\section{George R. Osborne, CIH, CSP \\ Industrial $\mathrm{H}$ ygiene $\mathrm{M}$ anager \\ Lucent T echnologies \\ N orcross, G eorgia \\ Estados U nidos}

\section{Debra Osinsky, MPH}

E ditorial C onsultant

E ncycl opaedia of $O$ ccupational $H$ ealth and Safety International Labour O ffice

$\mathrm{H}$ ighland Park, Nueva Jersey

Estados U nidos

\section{Gary A. Page BS, MS, MBA}

Fertilizer and Agricultural Chemicals

$\mathrm{N}$ ational Safety Council

Ridgewood, Nueva Jersey

Estados U nidos

\section{N.M. Pant, Dr, MBBS, DPH* \\ $M$ edical 0 fficer \\ $\mathrm{H}$ industan Lever, Ltd. \\ Bombay \\ India}

Jon Parish, BBA

D irector

L oss Control and Environment

Lane Corporation

A ltavista, V irginia

Estados U nidos

\section{Robert M. Park, MS}

Project E pidemiologist

$H$ ealth and Safety D epartment

International U nion of U nited A uto Workers

Detroit, M ichigan

Estados U nidos

\section{Relford Patterson, MD, MPH}

$M$ edical D irector

GM Truck Group-Baltimore Assembly Plant

General M otors C orporation

Baltimore, $\mathrm{M}$ aryland

Estados Unidos

\section{Gerald F. Peedin, PhD}

Philip M orris P rofessor

Crop Science Department

N orth Carolina State U niversity

$\mathrm{R}$ aleigh, $\mathrm{C}$ arolina del $\mathrm{N}$ orte

Estados U nidos

Peter W. Pickerill, BSc, M Eng, MBA

Regional D irector

Asia and Australia

M SA International

Pittsburgh, Pensilvania

Estados U nidos

Alexander C. Pittman, Jr., Dr

Con Edison

Brooklyn, Nueva Y ork

Estados U nidos

\section{Philip A. Platcow, MS, CIH}

Vice P resident, Senior Consultant

$\mathrm{R}$ isk $\mathrm{M}$ anagement

Sedgwick

Boston, M assachusetts

Estados U nidos

James W. Platner, PhD, CIH

Industrial and Labor R elations

Cornell U niversity

Albany, Nueva Y ork

Estados U nidos

Rebecca Plattus, JD

Political E ducation D irector

L ocal 89-22-1

U nion of N eedletrades, Industrial and

T extile Employees

Nueva Y ork, Nueva Y ork

Estados U nidos

\section{Lou Piombino, BS}

$M$ anager

Safety, $\mathrm{H}$ ealth and Environment

Lipton, Inc.

Englewood C liffs, Nueva Jersey

Estados U nidos

\section{Bengt Pontén}

Forest and T imber Group

U niversidad de Dalarna

Borlänge

Suecia

\footnotetext{
${ }^{*}$ Colaborador de la 3a edición de esta Enciclopedia. La información biográfica no se ha actualizado.
} 
William Popendorf, PhD, CIH

Professor

D epartment of Biology

U tah State U niversity

Logan, U tah

Estados U nidos

\section{Paulo Portich}

Fundacentro

Porte Alegro, R io Grande do Sul

Brasil

\section{Peter Poschen, PhD}

E specialista en Industrias F orestal y M aderera Sección de Actividades Industriales International Labour O ffice Ginebra

Suiza

\section{Christine Proctor, MS, CIH}

Proctor $\mathrm{O}$ ccupational Safety and $\mathrm{H}$ ealth Nueva Y ork, N ueva Y ork Estados U nidos

\section{Prodan, Dr* \\ CLUJ-NAPOCA \\ Rumania}

\section{John Quackenbush}

International Representative

International U nion of Elevator

Constructors

Springfield, V irginia

Estados U nidos

\section{A.E. Quinn, BSC, LLB*}

F ormer $\mathrm{H}$ er $\mathrm{M}$ ajesty's Inspector of $\mathrm{F}$ actories Londres

United K ingdom

\section{M.E. Radjabi, Ing*}

Subdirector G eneral, I nspección L aboral

$M$ inisterio de T rabajo y A suntos Sociales T eherán

R epública I slámica de I rán

\section{Vilhjálmur Rafnsson, MD, PhD Director J efe M édico \\ D epartamento de M edicina del T rabajo \\ Dirección de Seguridad y Salud en el Trabajo \\ R eikiavik \\ Islandia}

\section{Ray RaLonde, MS}

Agriculture Specialist

School of Fisheries and O cean Sciences

U niversity of Alaska

Anchorage, Alaska

Estados U nidos
Russell B. Rayman, MD, MPH

E xecutive $D$ irector

Aerospace M edical A ssociation

Alexandria, Virginia

Estados U nidos

\section{Beth Donovan Reh, MHS}

Industrial H ygienist

$H$ azard Evaluations and T echnical Assistance Branch

$\mathrm{N}$ ational Institute for $\mathrm{O}$ ccupational Safety and $\mathrm{H}$ ealth

Cincinnati, Ohio

Estados U nidos

\section{John Reimer, P Eng}

E nvironmental Protection E ngineer

$\mathrm{H}$ ealth Science $\mathrm{C}$ entre

Winnipeg, $M$ anitoba

Canadá

Toni Retsch, Dipl.-Ing, ETH*

B ereichsleiter-AL M 2

O rganización $\mathrm{N}$ acional Suiza de Seguros de Accidente

Lucerna

Suiza

Thomas Rhodarmer, BSC

Corporate D irector E nvironmental $H$ ealth and Safety

M ark IV Industries W orldwide

Dayco/ M ark IV

Waynesville, C arolina del Norte

Estados U nidos

David Richardson, MPH, DABT

U nit D irector, A pplied and R egulatory T oxicology

$\mathrm{H}$ ealth and Environment $\mathrm{L}$ aboratories

Eastman $\mathrm{K}$ odak Inc.

R ochester, Nueva Y ork

Estados U nidos

\section{Sandra Karen Richman}

Safety Consultant

$\mathrm{N}$ ational Board of Directors

American Federation of T elevision and Radio A rtists

$\mathrm{N}$ ew $\mathrm{H}$ ope, Pensilvania

Estados U nidos

Ted Rickard, MLS, CRSP

$M$ anager of $H$ ealth, Safety and Security

$O$ ntario C ollege of Art $\&$ D esign

T oronto, O ntario

Canadá

\section{Knut Ringen, Dr PH}

Director

C enter to Protect W orkers' R ights

Washington, DC

Estados U nidos
Richard D. Ringenwald, Jr., Dr

Exide Corporation

Reading, Pensilvania

Estados U nidos

\section{Jorge da Rocha Gomes}

Profesor emérito

Departamento de Salud A mbiental,

Escuela de Salud Pública

U niversidad de São Paulo

São Paulo

Brasil

John G. Rodwan, Jr., MA

O ficina Internacional del Trabajo

Ginebra

Suiza

T. A. Roscina, Dr*

Primer Instituto M édico de M oscú

M oscú

Antigua U R SS

\section{Jonathan Rosen, MS, CIH}

D irector

O ccupational H ealth and Safety Program

N ew Y ork State Public E mployees

Federation, AFL-CIO

Albany, Nueva Y ork

Estados U nidos

\section{Beth Rosenberg, SCD}

Assistant P rofessor

Department of Family M edicine and Community $\mathrm{H}$ ealth

T ufts School of M edicine

Boston, M assachusetts

Estados U nidos

\section{Monona Rossol, MS, MFA}

Industrial H ygienist

Arts, C rafts and T heater Safety

Nueva Y ork, Nueva Y ork

Estados U nidos

\section{Pekka Roto, MD, MSc, PhD}

I efe M édico

Instituto R egional de T ampere de Salud en el Trabajo

Tampere

Finlandia

James R. Rubin, MS

E nvironmental $H$ ealth and Safey Specialist

H ewlett-Packard Company

Fort Collins, Colorado

Estados U nidos

\footnotetext{
${ }^{*}$ Colaborador de la 3a edición de esta Enciclopedia. La información biográfica no se ha actualizado.
} 


\section{Avima M. Ruder, PhD}

Chief

Division of Surveillance, $\mathrm{H}$ azard Evaluations and Field Studies

National Institute for $\mathrm{O}$ ccupational Safety and $\mathrm{H}$ ealth

Cincinnati, $O$ hio

Estados U nidos

\section{L.A. Ryzik, Dr*}

Instituto de H igiene Industrial y Enfermedades de 0 rigen Profesional

Leningrado

Antigua UR SS

\section{David M. Sack, MD}

Navy Environmental $\mathrm{H}$ ealth Center U nited States $\mathrm{N}$ avy

Norfolk, Virginia

Estados $\mathrm{U}$ nidos

\section{Joyce Salg, PhD}

Senior R esearch Scientist

National Institute for $O$ ccupational Safety and $\mathrm{H}$ ealth

Cincinnati, 0 hio

Estados U nidos

\section{Igor V. Sanotsky, MD, PhD, Prof}

A sesor Científico

Instituto de Salud en el T rabajo

A cademia R usa de Ciencias M édicas

M oscú

Federación R usa

\section{Steven L. Sauter, PhD}

Chief

Applied Psychology and Ergonomics Branch

National Institute for $\mathrm{O}$ ccupational Safety and $\mathrm{H}$ ealth

Cincinnati, O hio

Estados U nidos

\section{E. Neil Schachter, MD}

$M$ aurice $H$ exter Professor of $M$ edicine

Pulmonary Division

M ount Sinai M edical Center

Nueva Y ork, Nueva Y ork

Estados U nidos

Ted Scharf, PhD

Division of Biomedical and Behavioral Science

National Institute for $\mathrm{O}$ ccupational Safety and $\mathrm{H}$ ealth

Cincinnati, O hio

Estados U nidos
Marc B. Schenker, MD, MPH

Director

U niversity of $\mathrm{C}$ alifornia Agricultural $\mathrm{H}$ ealth and Safety Center

U niversity of $C$ alifornia-D avis

Davis, California

Estados U nidos

\section{H. Schneider, Dr med*}

Antiguo D irector M édico

K R U PP H üttenwerke AG

Duisburg

Alemania

Scott P. Schneider, MSIH, CIH

E rgonomics P rogram D irector

Center to Protect W orkers' R ights

W ashington, DC

Estados U nidos

\section{Rudolf Scholbeck, Dipl-Ing Univ} Jefe

Servicio T écnico de Inspección

T iefbau-Berufsgenossenschaft

$M$ unich

Alemania

Stanley H. Schuman, MD, PhD, MPH

Professor

Family M edicine

Agromedicine Program

Clemson U niversity

$M$ edical Director

O ccupational and Environmental $M$ edicine $O$ ffice

M edical U niversity of South Carolina

Charleston, Carolina del Sur

Estados U nidos

\section{Charles Schwab, PhD}

Associate P rofessor

Agricultural and Biosystems Engineering

I owa State U niversity

Ames, lowa

Estados U nidos

\section{W. Norman Scott, MD}

Director

Insall Scott K elly Institute

New Y ork, N ew Y ork

Estados U nidos

Jane L. Seegal

E ditor

Center to Protect W orkers' R ights

Washington, DC

Estados Unidos

\section{Rita Seguin, BA}

Safety and D isability M anage

$\mathrm{H}$ iram W alker and Sons, Ltd.

W alkerville, O ntario

Canadá

Logan C. Shelman, BS, ChE, MEA

Senior E nvironmental E ngineer

Environmental $\mathrm{H}$ ealth and Safety Department

N ewport N ews Shipbuilding

$\mathrm{N}$ ewport N ews, V irginia

Estados U nidos

\section{Konstantin K. Sidorov, Dr med sci} Subdirector

R egistro R uso de Sustancias Biológicas y Q uímicas Peligrosas

M oscú

Federación R usa

\section{Itzhak Siev-Ner, MD}

Cirujano 0 rtopédico, M edicina Física y Rehabilitación

Centro M édico de Sheba, T el-H ashomer C entro M édico I sraelí de Artes E scénicas Tel Aviv

Israel

\section{Ken Sims}

Director

Thrigby $\mathrm{H}$ all W ildlife $\mathrm{G}$ ardens

Great Y armouth

$R$ eino U nido

Donald L. Smith, CIH, CSP, PE, DEE

N abisco, Inc.

E ast $\mathrm{H}$ anover, Nueva Jersey

Estados U nidos

\section{N.A. Smith, PhD}

Lighting C onsultant

D oncaster

$R$ eino U nido

\section{Marianne Smukowski, BS}

D airy Safety A pplications C oodinator C enter for D airy R esearch

$U$ niversity of W isconsin-M adison

$M$ adison, $W$ isconsin

Estados Unidos

Jack W. Snyder, MD, JD, MPH, PhD

Associate P rofessor

Emergency M edicine and L aboratory M edicine

Thomas J efferson U niversity

Filadelfia, Pensilvania

Estados Unidos

\footnotetext{
* Colaborador de la 3ạ edición de esta Enciclopedia. La información biográfica no se ha actualizado.
} 
Jerzy A. Sokal, Prof, PhD, DSc

Director

Instituto de M edicina del T rabajo y

Salud A mbiental

Sosnowiec

Polonia

\section{Colin L. Soskolne, PhD}

P rofessor, D irector of $G$ raduate $T$ raining D epartment of Public H ealth Sciences

U niversity of Alberta

Edmonton, Alberta

Canadá

\section{Jerry Spiegel, MA, MSc}

Director

Pollution Prevention

$M$ anitoba Environment

W innipeg, $M$ anitoba

Canadá

\section{J. Staal*}

Secretaría Técnica

Fédération européenne de la manutention,

Section VII: ascenseurs, lifts, A ufzüge

Amsterdam

Países Bajos

\section{Lorann Stallones, PhD, MPH}

D epartment of Environmental $\mathrm{H}$ ealth

Colorado State U niversity

Fort Collins, Colorado

Estados U nidos

\section{Roger Stamm, Dr}

J efe del D epartamento C entra

Berufsgenossenschaftliches Institut für Arbeitssicherheit

$\mathrm{H}$ auptverband der gewerblichen

Berufsgenossenschaften

Sankt A ugustin

Alemania

\section{William E. Steinke, PhD}

Extension A gricultural E ngineer

Biological and Agricultural Engineering

D epartment

U niversity of C alifornia-D avis

Davis, California

Estados U nidos

\author{
Jeanne M. Stellman, PhD \\ E ditor-in-Chief \\ Encyclopaedia of $\mathrm{O}$ ccupational $\mathrm{H}$ ealth and Safety \\ International Labour O ffice \\ Ginebra \\ Suiza
}

School of Public H ealth

Columbia U niversity

Nueva Y ork, N ueva Y ork

Estados U nidos
Steven D. Stellman, PhD, MPH

Chief

Division of Epidemiology

A merican $\mathrm{H}$ ealth Foundation

N ueva Y ork, Nueva Y ork

Estados Unidos

\section{Frank B. Stern, BBA, MS}

Senior R esearch E pidemiologist

$\mathrm{N}$ ational Institute for $\mathrm{O}$ ccupational Safety and $\mathrm{H}$ ealth

Cincinnati, O hio

Estados U nidos

\section{Laura Stock, MPH}

$\mathrm{L}$ abor $\mathrm{O}$ ccupational $\mathrm{H}$ ealth P rogram

School of Public $\mathrm{H}$ ealth

U niversity of California-Berkeley

Berkeley, California

Estados U nidos

\section{Ulrich Stössel, Dr phil}

Catedrático A cadémico

D epartamento de Sociología M édica

F acultad de M edicina

U niversidad de Friburgo

Friburgo

Alemania

\section{J.M. Strother, BS}

$M$ anager

R esearch Analytical and Finishing Laboratory

Fieldcrest Cannon, Inc.

$\mathrm{K}$ annopolis, Carolina del N orte

Estados U nidos

\section{Dean T. Stueland, MD, MPH}

$M$ edical Director

$\mathrm{N}$ ational Farm $\mathrm{M}$ edicine $\mathrm{C}$ enter

$M$ arshfield Clinic

$M$ arshfield, Wisconsin

Estados U nidos

\section{E.A. Suchman, PhD*}

D epartment of Sociology

U niversity of California

Santa Barbara, California

Estados U nidos

\section{F. William Sunderman, Jr., MD}

Professor

Departments of $L$ aboratory $M$ edicine and Pharmacology

U niversity of C onnecticut M edical School

Farmington, Connecticut

Estados U nidos
John J. Svagr, CIH

$M$ anager

Industrial $\mathrm{H}$ ygiene and Safety-N orth America

Safety and R isk M anagement Department

$\mathrm{K}$ raft Foods

R ye Brook, N ueva Y ork

Estados U nidos

\section{William B. Symons, PhD}

Associate P rofessor

Biological Systems Engineering

D epartment

Washington State U niversity

Pullman, Washington

Estados U nidos

\section{Keith Tait, CIH, CSP}

Assistant D irector

Corporate $\mathrm{H}$ ealth and Safety

Pfizer, Inc.

Nueva Y ork, Nueva Y ork

Estados U nidos

\section{James S. Taylor, MD \\ $\mathrm{H}$ ead}

Industrial Dermatology

Cleveland Clinic Foundation

Cleveland, $O$ hio

Estados U nidos

\section{Benedetto Terracini, MD}

Antiguo J efe

U nidad de E pidemilogía del Cáncer H ospital U niversitario y U niversidad de Turín

Turín

Italia

Kay Teschke, PhD, MPH, CIH, ROH

Associate P rofessor

Department of $\mathrm{H}$ ealth $\mathrm{C}$ are and Epidemiology

U niversity of British Columbia

Vancouver, Columbia Británica

Canadá

\section{Jamie Tessler, MPH}

$O$ ccupational $\mathrm{H}$ ealth and Safety Consultant Brooklyn, Nueva Y ork

Estados U nidos

\section{Richard J. Thomas, MD, MPH}

Officer in Charge, $O$ ccupational $M$ edicine Physician

Navy Environmental and Preventive M edicine U nit

U nited States Navy

Norfolk, Virginia

Estados U nidos 


\section{G. Thomas*}

R esearch D epartment

British Steel Corporation

D eeside

R eino U nido

\section{Frank H. Thorn, BS}

$M$ anager, E nvironmental E ngineering

Environmental $\mathrm{H}$ ealth and Safety

D epartment

N ewport N ews Shipbuilding

Newport N ews, V irginia

E stados U nidos

James R. Thornton, MS, CIH, CSP

Director, E nvi ronmental $\mathrm{H}$ ealth and Safety

Environmental $\mathrm{H}$ ealth and Safety

D epartment

N ewport N ews Shipbuilding

Newport News, V irginia

Estados U nidos

\section{Kendall Thu, PhD}

Institute for R ural and Environmental $\mathrm{H}$ ealth

College of M edicine

Iowa City, I owa

Estados Unidos

\section{Kjell Torén, MD}

Profesor A sociado

D epartment of O ccupational M edicine

Sahlgrenska U niversity H ospital

Göteborg

Suecia

\section{James R. Townhill, CSP}

Piedmont Environmental, Inc.

K annapolis, Carolina del Norte

Estados U nidos

\section{John N. Trent, PhD}

W ildlife B iologist

Division of Wildlife C onservation

Alaska D epartment of Fish and G ame

Anchorage, Alaska

Estados U nidos

\section{Don Trotter, M Eng}

Professor

School of Engineering

L aurentian U niversity

Sudbury, O ntario

Canadá

\section{A. Türkdogan, Ing-Chim*}

E x-I nspector de Seguridad I ndustrial

Estambul

Turquía
Timothy J. Ungs, MD, MS

Commandant (G -WK S-3)

U nited States $\mathrm{C}$ oast $\mathrm{G}$ uard $\mathrm{H}$ eadquarters

Washington, DC

Estados Unidos

\section{L.J.L.D. Van Griensven, PhD \\ Profesor \\ M icología aplicada \\ U niversidad C atólica de $\mathrm{N}$ ijmegen \\ Director \\ Estación Experimental de H ongos \\ Horst \\ Países Bajos}

\section{Anaide Vilasboas de Andrade}

I efe de los Servicios T écnicos

Centro R egional da Bahia

Fundação Jorge D uprat Figueiredo de

Segurança e M edicina do T rabalho

Salvador

Brasil

\section{R.F. Villard*}

Ingénieur EPU L

C hargé de cours à l'E cole supérieure technique de $G$ enève

Ginebra

Suiza

\section{Phillip J. Wakelyn, PhD}

Senior Scientist, E nvironmental Health Safety

$\mathrm{N}$ ational Cotton Council of America

Washington, DC

Estados U nidos

\section{Simon Walker, BSc, MSc}

Principal

IETS

Oxford

R eino U nido

\section{Anthony D. Walters, M Eng}

$M$ anager

Coal Division

K ilborn Engineering Pacific, Ltd.

V ancouver, Columbia Británica

Canadá

Jung-Der Wang, MD, ScD, MIH

Profesor

Instituto de M edicina del T rabajo y Epidemiología

$\mathrm{N}$ ational T aiwan U niversity C ollege of Public H ealth

Taipei

T aiwan, China

\section{Lance A. Ward, BA}

Corporate $\mathrm{D}$ irector of $\mathrm{H}$ ealth and Safety Pepsi-C ola General Bottlers, Inc.

Rolling M eadows, Illinois

Estados U nidos

\section{Leon J. Warshaw, MD}

Clinical Professor

Department of Environmental M edicine

N ew Y ork U niversity

Nueva Y ork, Nueva Y ork

Estados U nidos

James L. Weeks, SCD, CIH

Department of O ccupational and Environmental $\mathrm{H}$ ealth

School of Public $\mathrm{H}$ ealth and $\mathrm{H}$ ealth Services

G eorge Washington U niversity

Washington, DC

Estados U nidos

\section{Beat Wegmüller}

Safety E ngineer

O rganización Nacional Suiza de Seguros de Accidente

Lucerna

Suiza

\section{Merri Weinger, MPH}

O ficina de Salud A mbiental M undial e Integrada

O rganización M undial de la Salud

Ginebra

Suiza

\section{K. Welinder*}

D irector de I nvestigación

Slipmaterial-N axos

V astervik

Suecia

\section{Paul Westcott, B Eng}

D irector, C onsulting M ining E ngineer

$M$ ineC onsult

Chatswood, N ew South Wales

Australia

\section{Othmar Wettmann, Dipl Forest Ing ETH}

lefe

Sección Forestal

Organización Nacional Suiza de Seguros de Accidente

Lucerna

Suiza

\section{Aidan White}

Secretaría General

Federación Internacional de Periodistas Bruselas

Bélgica

\footnotetext{
* Colaborador de la 3a edición de esta Enciclopedia. La información biográfica no se ha actualizado.
} 
Michael E. Williams, CIH, CSP, ARM

Principal

$H$ ealth Safety and $R$ isk $M$ anagement Services

Sunnyvale, California

Estados U nidos

\section{Linda B. Wolfe, RBP}

Associate B iosafety O fficer

Environmental M edical Service

M assachusetts Institute of T echnology

Cambridge, $M$ assachusetts

Estados U nidos

\section{Malinee Wongphanich, MD}

Consultant on $\mathrm{O}$ ccupational $\mathrm{H}$ ealth

$D$ epartment of $\mathrm{H}$ ealth

$M$ inisterio de Salud

Provincia de N ondhaburi

T ailandia
Ray C. Woodcock, MS, CIH

$V$ ice $P$ resident

Safety and $\mathrm{H}$ ygiene

$M$ anagement, Inc.

W aynesville, Carolina del Norte

E stados U nidos

\section{B. H. Xu, PhD, MD}

Profesor Adjunto

Facultad de M edicina

Universidad de K agoshima

K agoshima

Japón

\section{Annalee Yassi, MD, MSc}

Director

O ccupational and Environmental M edicine

$\mathrm{H}$ ealth Sciences $C$ entre and $U$ nit

U niversity of $M$ anitoba

W innipeg, $M$ anitoba

Canadá

\section{Dennis D. Zaebst, CIH}

Industrial H ygienist

National Institute for $\mathrm{O}$ ccupational Safety and $\mathrm{H}$ ealth

Cincinnati, O hio

Estados U nidos

\section{Albert M. Zielinski, CIH}

Senior T echnical L eader, Industrial H ygiene

Lighting Environment

Safety and $\mathrm{H}$ ealth $\mathrm{D}$ epartment

GE Lighting

Cleveland, 0 hio

Estados U nidos

\section{A. Zober, Dr*}

Instituto de Salud en el T rabajo y

M edicina Social, y C línica de

Enfermedades de $\mathrm{O}$ rigen Profesional

U niversidad de E rlangen/ N uremberg

Erlangen

Alemania

Craig Zwerling, MD, PhD, MPH

Injury Prevention R esearch C enter

College of $M$ edicine

lowa City, I owa

Estados U nidos

$\mathrm{H}$ an colaborado de forma desinteresada en las diversas fases de correcciones técnicas los siguientes expertos del Instituto $\mathrm{N}$ acional de Seguridad e H igiene en el Trabajo:

M $\supseteq$ V ictoria Arriandiaga Abaroa

Félix Bernal Domínguez

$M$ anuel Bernaola Alonso

M anuel Bestraten Belloví

Pilar Casla Benito

Emilio C astejón Vilella

José M aría C uscó V idal

R afael Denia Candel

Angel Erkoreka M urnaga

E duardo G arcía M orilla

$\mathrm{M}$ a C armen G uardiola H uertas

Juan G uasch Farrás

Ana H ernández C alleja

M a J esús L edesma Díaz

José L uis L obato Puente
Pablo L una M endaza

L uis V icente $M$ artín M artín

Faustino $M$ enéndez Diez

Clotilde Nogareda Cuixart

Silvia Nogareda Cuixart

$M$ argarita $O$ ncins de Frutos

Jesús Pérez Bilbao

A dolfo Pérez Guerrero

Javier Pinilla García

L uis M a R omeo Saez

$M$ a J osefa R uiz Figueroa

José M aría T amborero del Pino

$\mathrm{M}$ a C armen T orres L acalle

Emilio T urmo Sierra

$\mathrm{M}$ a $\mathrm{C}$ armen $\mathrm{U}$ garte $\mathrm{O}$ terino

${ }^{*}$ Colaborador de la 3a edición de esta Enciclopedia. La información biográfica no se ha actualizado. 


\section{III}

Sectores basadosen Recursos Biologicos

INDUSTRIAS BASADASEN RECURSOS NATURALES

INDUSTRIAS QUIMICAS

INDUSTRIAS M ANUFACTURERAS

Industrias TEXTILESy de LA CONFECCION

INDUSTRIAS DEL TRANSPORTE

CONSTRUCCION

Servicios 



\section{SUMARIO}

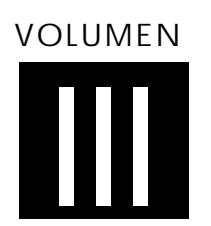

Autores y directores

PARTE X. SECTORES BASADOS EN RECURSOS BIOLOGICOS

\section{Agricultura y sectores basados en recursos naturales}

Perfil general .

Melvin L. Myers Director del capítulo

Explotaciones familiares. . M elvin L. M yers 64.2

SISTEM AS AGRICOLAS

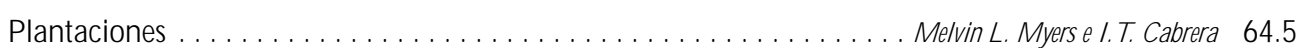

Trabajadores agrícolas migrantes y temporeros ................... M arc B. Schenker 64.8

Agricultura urbana . . . . . . . . . . . . . . . . . . . . . . . M elvin L. M yers 64.9

O peraciones en viveros e invernaderos . . . . . . . . . . . . . M ark M. M ethner y J ohn A. M iles 64.11

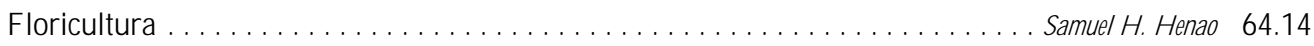

Educación de los trabajadores agrícolas sobre los plaguicidas: estudio de un caso. . . . M erri W einger 64.16

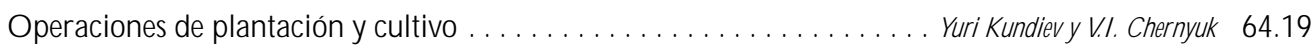

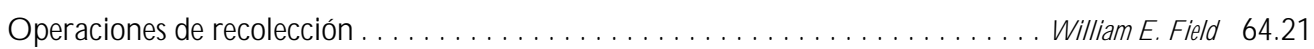

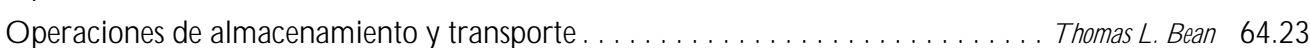

O peraciones manuales en la agricultura . . . . . . . . . . . . . . . . . . Pranab Kumar Nag 64.26

M ecanización ...................................... . . . . . . . . M urphy 64.33

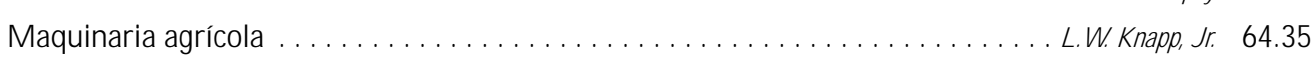

CULTIVO DE ALIMENTOSY FIBRAS

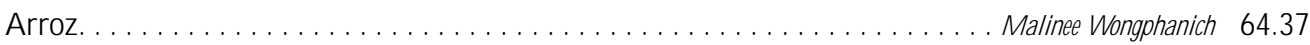

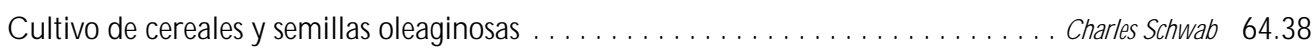

Cultivo y transformación de la caña de azucar . . . . . . . . . . . . . . R.A. M uñoz, E.A. Suchman,

J.M. B aztarrica y Carol J. Lehtola 64.40

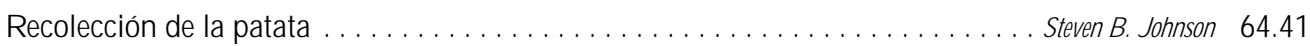

H ortalizas y melones. . . . . . . . . . . . . . . . . . . . . . . . . B.H. X u y Toshio M atsushita 64.42

CULTIVO DE ARBOLES, ZARZAS Y VIDES

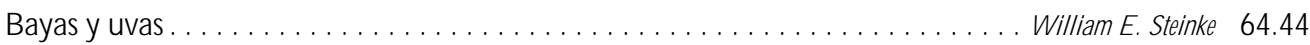

Cultivo de árboles frutales. . . . . . . . . . . . . . . . . . . . . . . M elvin L. M yers 64.47

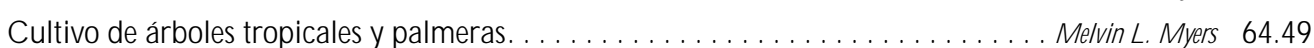

Producción de corteza de árbol y savia. . . . . . . . . . . . . . . . . . . . . M elvin L. M yers 64.51

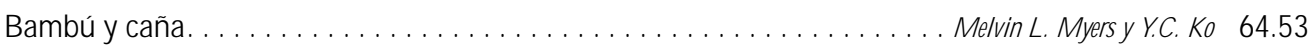

CULTIVOSESPECIALES

Cultivo de tabaco. . . . . . . . . . . . . . . . . . . . . . . . . . . Gerald F. Peedin 64.54

Ginseng, menta y otras hierbas culinarias y medicinales .............. Larry J. Chapman 64.58

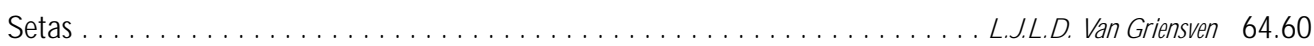

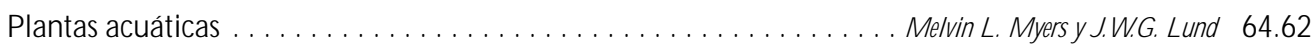


CULTIVO DE PLANTAS PARA LA PRODUCCION DE BEBIDAS

Cultivo de café. ........................ orge da R ocha Gomes y B ernardo B edrikow 64.63

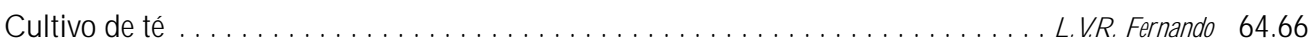

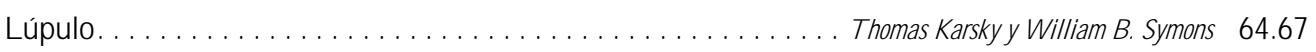

CUESTIONES DE SALUD Y AMBIENTALES

Problemas de salud y pautas patológicas en la agricultura . . . . . . . . . . . . M edvin L. M yers 64.68

Agromedicina ............................. Stanley H. Schuman y J ere A. B rittain 64.69

Cuestiones ambientales y de salud pública en la agricultura .............. M edvin L. M yers 64.73

65. Industria de las bebidas

Lance A. Ward, Director del capítulo

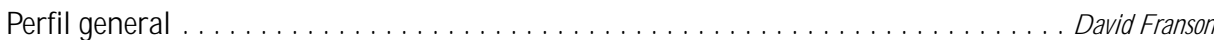

Fabricación de concentrados de bebidas refrescantes . . . . . . . . . . . . . . Zaida Colon

Embotellado y envasado de bebidas refrescantes. . . . . . . . . . . . . M atthew $\mathrm{H}$ irshemer

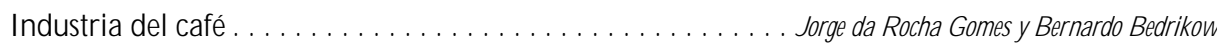

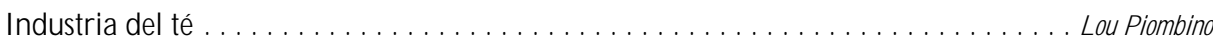

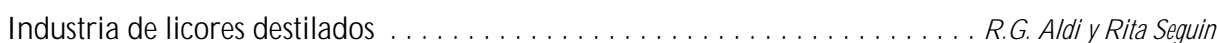

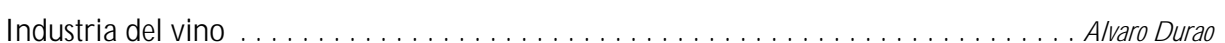

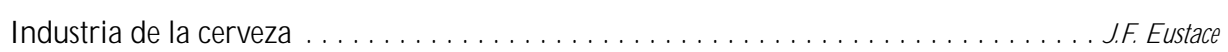

Cuestiones ambientales y de salud pública ............................. Lance A. W ard

66. Pesca H ulda Ó lafsdóttir y Vilhjálmur Rafnsson, Directores del capítulo

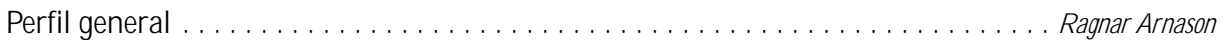

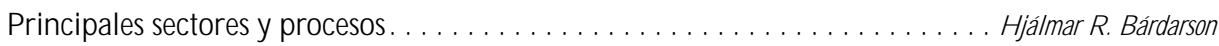

Características psicosociales de los trabajadores en el mar . . . . . . . . . . . va M unk-M adsen

Características psicosociales de los trabajadores del mar dedicados al

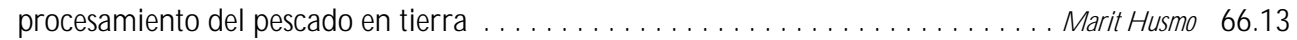

Efectos sociales de la dependencia de una sola industria pesquera. . . . . . . . . . . . B arbara N eis 66.14

Efectos sobre la salud y pautas patológicas. . . . . . . . . . . . . . . Vilhjálmur Rafnsson 66.16

A fecciones musculosqueléticas: pesca y procesamiento de pescado . . . . . . . . . u ulda Ólafsdóttir 66.18

Pesquerías comerciales: medio ambiente y sanidad pública. . . . . . . . . B ruce M ck ay y Kieran M ulvaney 66.19

\section{Industria alimentaria}

Deborah E. Berkowitz, Directora del capítulo

VISION GENERAL Y EFECTOS SOBRE LA SALUD

Procesos de la industria alimentaria . . . . . . . . . . M. M alagié, G. J ensen, J.C. Grahamy D onald L. Smith 67.2

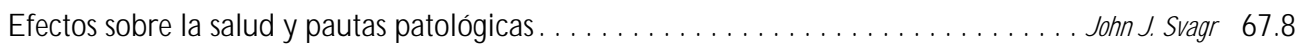

Protección ambiental y cuestiones de salud pública . . . . . . . . . . . . . . . . . erry Spiegel 67.13

SECTORES DE LA PRODUCCION ALIMENTARIA

Industria cárnica. . . . . . . . . . . . . . . . . . . D eborah E. B erkowitz y M ichael J. Fagel 67.16

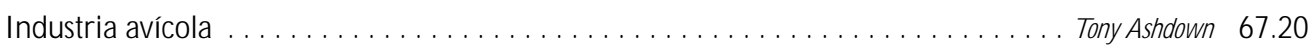

Industria láctea . . . . . . . . . . . . . . . . . . . M arianne Smukowski y N orman B rusk 67.26

Producción de cacao e industria del chocolate . . . . . . . . . . . Anaide Vilasboas de Andrade 67.27

Cereales, elaboración de cereales y productos de consumo basados

en cereales. . . . . . . . . . . . . . . . . . . . . . . Tomas E. H awkinson, J ames J. Collins y Gary W. O Imstead 67.28

Panaderias. . . . . . . . . . . . . . . . . . . . . . . . . . 67.30 
Industria de la remolacha azucarera $\ldots \ldots \ldots \ldots \ldots \ldots \ldots \ldots \ldots \ldots \ldots$ Carol $]$. Lentola

Aceites y grasas.

\section{Industria forestal}

\section{Peter Poschen, Director del capítulo}

Perfil general . Peter Poschen

A provechamiento maderero 68.2

Transporte de la madera . D ennis D ykstra y Peter Poschen 68.7

A provechamiento de productos forestales no madereros $\ldots \ldots \ldots \ldots \ldots \ldots \ldots$. Rudolf $\mathrm{H}$ einrich 68.14

Plantación de árboles $\ldots \ldots \ldots \ldots \ldots \ldots \ldots \ldots \ldots \ldots \ldots \ldots \ldots$ enis $G$ iguère

Tratamiento y control de incendios forestales. ..................... ike J urvélius 68.18

R iesgos para la seguridad física . . . . . . . . . . . . . . . . . . . . . . B engt Pontén 68.21

Carga física B engt Pontén

Factores psicosociales Peter Poschen y M arja-Liisa J untunen 68.22

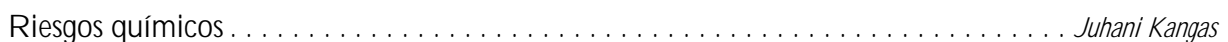
68.24

R iesgos biológicos entre los trabajadores forestales . . . . . . . . . . . . . . . . . . . A ugusta 68.26

N ormas, legislación, disposiciones y recomendaciones . . . . . . . . . . . . 0 thmar W ettmann 68.28

Equipos de protección personal . . . . . . . . . . . . . . . . . . . . . . E ero Korhonen 68.28

Condiciones de trabajo y seguridad en el trabajo forestal . . . . . . . . . L ucie L aflamme y E sther Cloutier Cualificación y formación . . . . . . . . . . . . . . . . . . . . . . . . Peter Poschen Condiciones de vida. . . . . . . . . . . . . . . . . . . . . . . . . . . Elias A pud Problemas para la salud del medio ambiente.

Shane M CM ahon

69. Caza

George A. Conway, Director del capítulo

U n perfil de la caza y de la caza con cepo en el decenio de $1990 \ldots \ldots$. . . . . . . . . . ohn N. Trent Enfermedades asociadas con la caza y la caza con cepo.

70. G anadería y cría de animales

Melvin L. Myers, Director del capítulo

G anadería: ámbito y efectos sobre la salud. M elvin L. M yers 70.2

Problemas de salud y pautas patológicas. Kendall T hu, Craig Z werling y K ell ey D onham Problemas de salud en el trabajo relacionados con los artrópodos. . . . . . . . . . . . . D onald B arnard

Cultivos forrajeros. . . . . . . . . . . . . . . . . . . . . . . . . . . . . L L orann Stallones

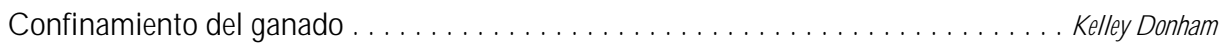

C ría de animales domésticos . . . . . . . . . . . . . . . . D ean T. Stueland y Paul D. G underson

Comportamiento de los animales . . . . . . . . . . . . . . . . . . . . . . . D avid L. H ard 70.11 70.15

Gestión del estiercol y de los excrementos . . . . . . . . . . . . . . . . W illiam Popendorf 70.16

Lista de comprobación de las prácticas de seguridad de la ganadería M elvin L. M yers 70.18

Vaquerías. .. . ohn M ay 70.18

Vacuno, ovino y caprino M elvin L. M yers

Porcino . M elvin L. M yers 70.20

Producción de aves de corral y de huevos.

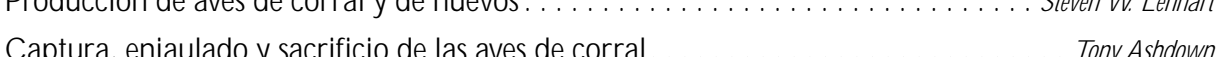
0.25

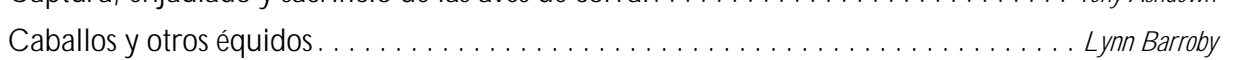
70.26

A nimales de tiro en Asia. . D.D. J oshi 0.28 M edvin L. M yers

Elefantes David L. H ard 70.32

Cría de toros 70.34

Producción de animales de compañía, de peleteria y de laboratorio 
Piscifactorias y acuicultura . . . . . . . . . . . . . . . . . George A. Conway y Ray RaL onde 70.37

A picultura, cría de insectos y producción de seda. . . . . . . . . . M elvin L. M yers y D onald B arnard 70.38

71. Industria de la madera Paul Demers y Kay Teschke, Directores del capítulo

Perfil general. . . . . . . . . . . . . . . . . . . . . . . . . . . Paul D emers

Principales sectores y procesos: riesgos profesionales y controles . . . . . . . . H ugh D avies, Paul D emers,

T imo Kauppinen y Kay Teschke 71.4

Lesiones y enfermedades . . . . . . . . . . . . . . . . . . . . . . . . . . . . . . Paul D emers

C uestiones ambientales y de salud pública. . . . . . . . . . . . . . Kay Teschke y A nya K efe

72. Industria del papel y de la pasta de papel

Kay T eschke y Paul Demers, Directores del capítulo

Perfil general

Kay Teschke

PRINCIPALES SECTORES Y PROCESOS

Fuentes de fibra para la fabricación de pasta y de papel . . . . . . . . . . . . Anya Kefe y Kay Teschke

M anipulación de la madera.

Anya Kefey Kay Teschke 72.6

Elaboración de la pasta . Anya Keefe, G eorge Astrakianakis y J udith Anderson

Blanqueo . George Astrakianakis y J udith Anderson 72.8

Fábricas de papel reciclado . Dick H eederik

Producción de papel y transformados: pasta papelera, papel, y cartón . George Astrakianakis y J udith Anderson

G eneración de energía y tratamiento de las aguas . . G eorge Astrakianakis y J udith Anderson

Producción de productos químicos y de subproductos . George Astrakianakis y J udith Anderson

\section{PAUTAS DE ENFERMEDADES Y LESIONES}

L esiones y enfermedades no malignas . . . . . . . . . . . . . . . . Susan Kennedy y Kjell Torén

Cáncer Kjell Torén y Kay Teschke

Cuestiones de salud pública y ambiental Anya Kefe y Kay Teschke

\section{PARTE XI. INDUSTRIAS BASADAS EN RECURSOS NATURALES}

\section{3. $\mathrm{H}$ ierro y acero}

Augustine Moffit, Directora del capítulo

La industria del hierro y el acero J ohn $M$ asaitis

Trenes de laminación.

Problemas y pautas de seguridad y salud.

Visión general de la minería ............................. Prospección. .............................W illiam S. M itchell y Courtney $\mathrm{S}$. M itchel

Tipos de minería de carbón Fred W. H ermann

T écnicas de minería subterránea . . . . . . . . . . . . . . . . . . . . . . H ans $\mathrm{H}$ amrin

M inas subterráneas Simon Walker 74.17

$M$ inas a cielo abierto T Thomas A. H ethmon y Kyle B. D otson 74.20

Control de la minería del carbón a cielo abierto . Paul W estcott 74.24 
Procesamiento del mineral Sydney Allison $\quad 74.25$

Preparación del carbón.

Control del terreno en las minas subterráneas. . . . . . . . . . . . . . . . . . . . L uc B eauchamp

Ventilación y refrigeración en las minas subterráneas . . . . . . . . . . . . . . . . . . . . H owes

Iluminación en las minas subterráneas.

Equipos de protección individual en las minas.

Incendios y explosiones en minas.

Peter W. Pickerill

D etección de gases

Preparación de emergencias Paul M ackenzie W ood

75. Petróleo: prospección y perforación

Richard S. Kraus, Director del capítulo

Prospección, perforación y producción de petróleo y gas natural . . . . . . . . . Richard S. Kraus

\section{Producción y distribución de energía eléctrica}

Michael Crane, Director del capítulo

Perfil general

Generación de energía hidroeléctrica. . N eil M cM anus

Generación de energía a partir de combustibles fósiles . . Anthony W. J ackson

Generación de energía nuclear W.G. M orison

Seguridad en la generación, transmisión y distribución de energía eléctrica:

un ejemplo de Estados U nidos. .

Riesgos.

M ichael Crane

Problemas para la salud pública y el medio ambiente. Alexander C. Pittman, J r.

PARTE XII. INDUSTRIAS QUIMICAS

\section{Procesado químico}

Jeanne Mager Stellman y Michael McCann, Directores del capítulo

Industria química L. DeB oer

Elaboración de un programa de gestión de seguridad de procesos . . . . . . . . . Richard S. Kraus O peraciones y actividades principales de las unidades de proceso: visión general . . . . Sydney Lipton

EJEM PLOS DE OPERACIONES DE TRATAMIENTO DE PRODUCTOS QUIMICOS

Producción de cloro y cáusticos . . . . . . . . . . . . . . . . . . . The Chlorine Institute, Inc.

Fabricación de pinturas y revestimientos. . M ichael M cCann Industria del plástico P.K. Law y T.J. B ritton Industria de la biotecnología . . . . . . . . . . . . . . . . . Susan B. Le y Linda B. W olfe 77.22 Industria pirotécnica

78. Petróleo y gas natural

Richard S. Kraus, Director del capítulo Proceso de refino del petróleo

79. Industria farmacéutica

Keith T ait, Director del capítulo

Industria farmacéutica Keith Tait

E fectos de los estrógenos sintéticos sobre los trabajadores de la industria farmacéutica: un ejemplo de Estados U nidos . . 
80. Industria del caucho Louis S. Beliczky y John Fajen, D irectores del capítulo Perfil general ...................................... Louis $S$. B Eliczky $y$ J ohn Fajen 80.2

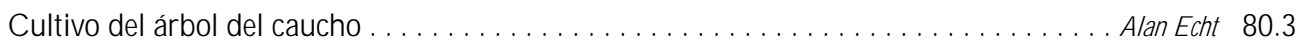

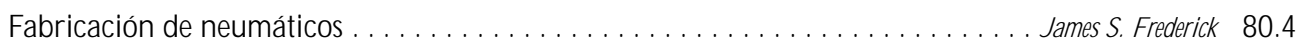

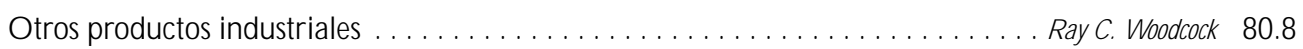

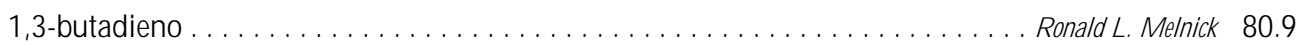

Controles de ingeniería ................................. Ray C. Woodcock 80.10

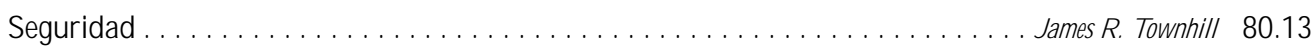

Estudios epidemiológicos .................................. Robert H arris 80.15

Dermatitis por contacto con caucho y alergia al látex. ........... . ames $\mathrm{S}$. Taylor $\mathrm{y} Y$ ung $\mathrm{H}$ ian L Low 80.16

Ergonomía. . . . . . . . . . . . . . . . . . . . . . . . . . . . . . . . . . . . . . . . W William S. M arras 80.17

C uestiones ambientales y de salud pública . . . . . . . . . . . . . . . . . . . . . T homas R hodarmer 80.17

PARTE XIII. INDUSTRIAS MANUFACTURERAS

81. Aparatos y equipos eléctricos

N .A. Smith, Director del capítulo

Perfil general . ....................... Smith

Fabricación de acumuladores de plomo $\ldots \ldots \ldots \ldots \ldots \ldots \ldots \ldots \ldots \ldots \ldots$ Barry P. Kelley 81.2

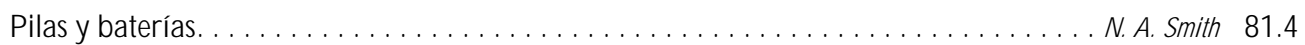

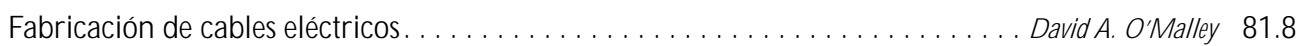

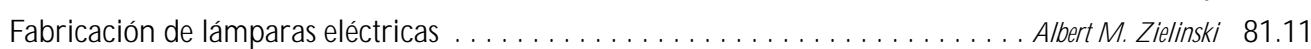

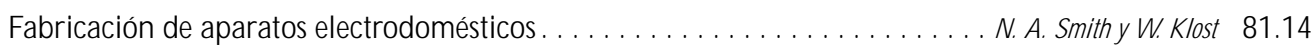

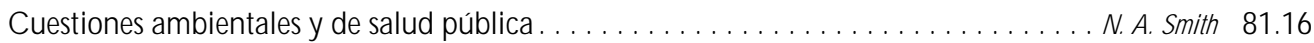

82. Metalurgia y metalistería Michael McCann, Director del capítulo

OPERACIONES DE FUNDICION Y AFINO

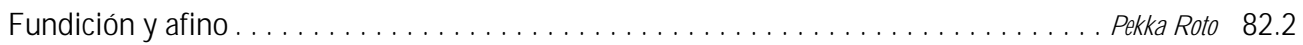

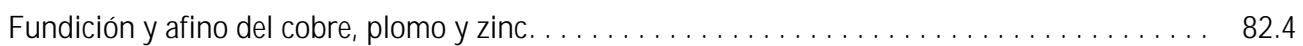

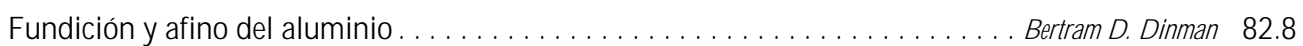

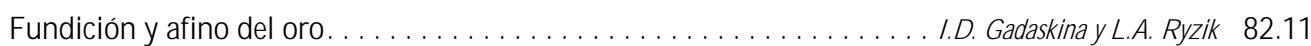

METALURGIA Y METALISTERIA

Fundiciones. . . . . . . . . . . . . . . . . . . . . . . . . . . . . . . F ranklin E. M irer 82.13

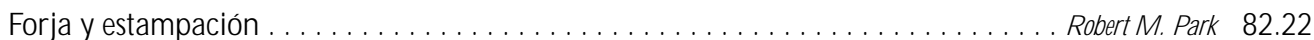

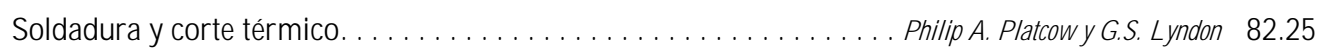

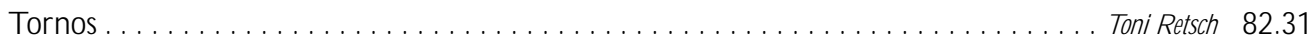

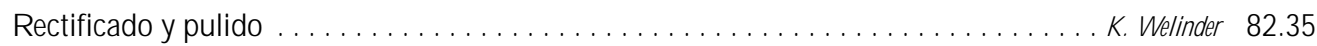

L ubricantes industriales, fluidos de mecanizado y aceites para automóviles. . . . . . Richard S. Kraus 82.37

M etales, tratamiento de superficie ... . . . . J.G. J ones, J.R. B evan, J .A. Catton, A. Z ober, N. Fish, K.M . M orse, G. T homas, M .A. EI Kadeem y Philip A. Platcow 82.42

Recuperación de metales . . . . . . . . . . . . . . . E elvin E. Cassady y Richard D. Ringenwald, J r. 82.48

Cuestiones ambientales en el acabado de superficies metálicas y los

recubrimientos industriales . . . . . . . . . . . . . . . . . . . . . . . . Stew art Forbes 82.61

83. Microelectrónica y semiconductores Michael E. Williams, Director del capítulo

Perfil general .............................................. Michad E. Williams 83.2 
Fabricación de semiconductores de silicio . . . . . . . . . D avid G. B aldwin, J ames R. R ubin y Afsaneh G erami 83.3

Indicadores de cristal líquido . . . . . . . . . . . . . D avid G. B aldwin, J ames R. Rubin y Afsaneh $G$ erami 83.20

Fabricación de semiconductores III-V . . . . . . . . . . D avid G. Baldwin, Afsaneh G erami y J ames R. R ubin 83.22

Instalación de placas de circuito impreso y ordenadores . . . . . . . . . . . . M ichael E. W illiams 83.27

Efectos sobre la salud y pautas patológicas ............................ D onald V. Lassiter 83.33

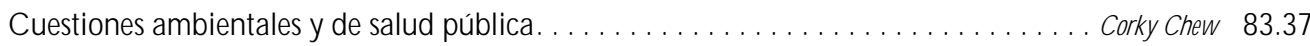

84. Vidrio, cerámica y materiales afines Joel Bender y Jonathan $\mathbf{P}$. H ellerstein, Directores del capítulo

Vidrio, cerámica y materiales afines. J onathan P. H ellerstein, J oel B ender, J ohn G. H adley y Charles M. H ohman 84.2

Fibras ópticas George R. Osborne 84.11

Piedras preciosas sintéticas.

. Basil Dolphin

85. Industria de las artes gráficas, fotografía y reproducción

David Richardson, Director del capítulo

Artes gráficas y publicación ............................

Características generales . . . . . . . . . . . . . . . . . . . . . . . D avid Richardson

Servicios de reproducción y duplicación $\ldots \ldots \ldots \ldots \ldots \ldots \ldots \ldots \ldots \ldots \ldots$ obert W. Kilpper

Efectos sobre la salud y pautas patológicas .......................... Barry R. Friedlander

D escripción general de riesgos para el medio ambiente . . . . . . . . . . . D anie R. E nglish

. David Richardson

Laboratorios fotográficos comerciales.

86. Carpintería

Jon Parish, Director del capítulo

Perfil general D ebra 0 sinsky 86.2

Procesos de carpintería .J on K. Parish 86.2

M áquinas copiadoras-fresadoras . . B eat W egmüller 86.7

M áquinas de cepillado de madera B eat W egmüller 86.10

Efectos sobre la salud y pautas patológicas.

Leon J. W arshaw

PARTE XIV. INDUSTRIAS TEXTIES Y DE LA CONFECCION

87. Confección y productos textiles acabados Robin H erbert y Rebecca Plattus, Directores del capítulo Principales sectores y procesos. . - R ebecca Plattus y R obin H erbert Accidentes en el sector de la confección . A.S. B ettenson

88. Cueros, pieles y calzado

Michael McCann, Director del capítulo Perfil general Debra 0 sinsky 88.2

Curtido, acabado de pieles . D ean B. B aker 88.2 Industria peletera . P.E. Braid 88.5

Calzado, industria. F.L. Conradi y Paulo Portich

Efectos sobre la salud y pautas patológicas. . Frank B. Stern

Cuestiones ambientales y de salud pública . J erry Spiegel

\section{Industria de productos textiles}

La industria textil: historia y salud y seguridad . Leon J. W arshaw 


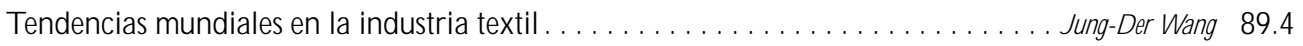

Producción y desmotado del algodón $\ldots \ldots \ldots \ldots \ldots \ldots \ldots \ldots \ldots \ldots \ldots \ldots \ldots$ Stanley Anthony 89.6

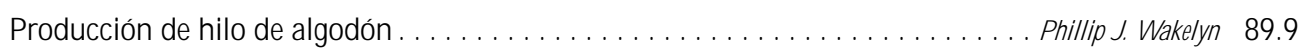

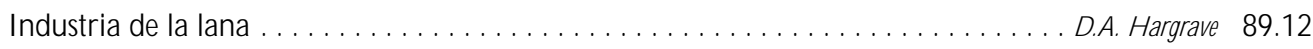

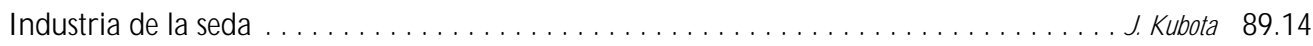

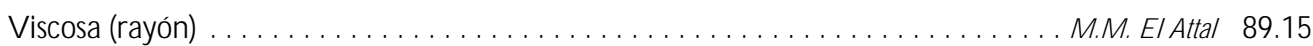

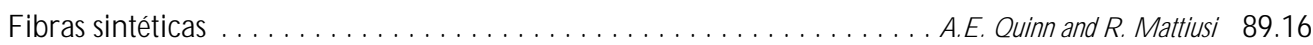

Productos de fieltro natural $\ldots \ldots \ldots \ldots \ldots \ldots \ldots \ldots \ldots \ldots \ldots \ldots \ldots \ldots \ldots \ldots \ldots \ldots$ erzy A. Sokal 89.17

T inción, estampado y acabado . . . . . . . . . . . . . . . . . . . . . . . J.M. Strother y A.K. Niyogi 89.18

Generos textiles no tejidos. . . . . . . . . . . . . . . . . . . . W illiam A. B lackburn y Subhash K. B atra 89.21

Tejido y tricotado . . . . . . . . . . . . . . . . . . . . . . . . . . Charles $\mathrm{Crocker} 89.23$

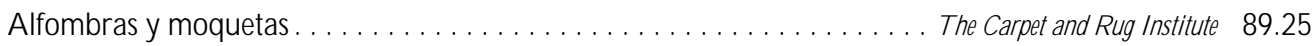

Alfombras tejidas 0 anudadas a mano ............................ Radjabi 89.28

A fecciones respiratorias y de otro tipo observadas en la industria textil . . . . . . . . E. N eil Schachter 89.30

\section{PARTE XV. INDUSTRIAS DEL TRANSPORTE}

\section{Construcción y mantenimiento aerospacial Buck Cameron,Director del capítulo}

La industria aeroespacial . .............................. Buck Cameron

Seguridad y ergonomía en la construcción aeronáutica . . . . . . . . . . . . . . D ouglas F. B riggs 90.4

Protección contra las caídas en la construcción y el mantenimiento de los

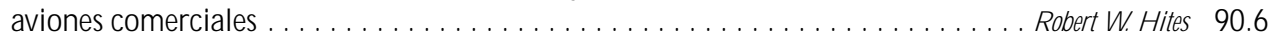

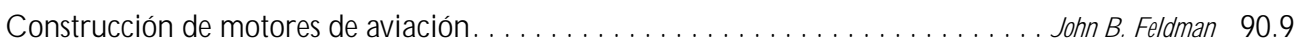

Controles y efectos sobre la salud $\ldots \ldots \ldots \ldots \ldots \ldots \ldots \ldots \ldots \ldots$. enis B ourcier 90.11

Cuestiones ambientales y de salud pública $\ldots \ldots \ldots \ldots \ldots \ldots \ldots \ldots \ldots$. $\ldots \ldots \ldots$ teve ason 90.13

\section{Vehículos de motor y maquinaria pesada Franklin E. Mirer,}

Director del capítulo

Industria del automóvil y el material de transporte . . . . . . . . . . . . . . . Franklin E. M irer 91.2

\section{Construcción y reparación de buques y} embarcaciones de recreo James $\mathbf{R}$. Thornton, Director del capítulo

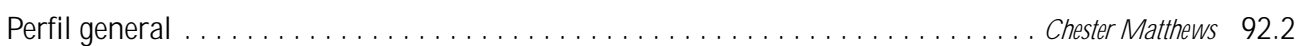

Construcción y reparación de buques y embarcaciones ................ ames R. T hornton 92.3

Cuestiones ambientales y de salud pública . . . . . . . . . . . F rank H. T horn, Page Ayres y L ogan C. Sheman 92.16

\section{PARTE XVI. CONSTRUCCION}

\section{Construcción}

\section{SALUD, PREVENCION Y GESTION}

R iesgos de salud y seguridad en el sector de la construcción. . . . . . . . . . . . . J ames $L$. W eeks

R iesgos para la salud en obras subterráneas . . . . . . . . . . . . . . . B ohuslav M álek

Servicios preventivos sanitarios en la construcción . . . . . . . . . . . . . . . . . Pekka R oto

Factores de organización que afectan a la salud y la seguridad . . . . . . . . . . . . . D oug J. M cVittie 93.14

Gestión de calidad y prevención integradas. . . . . . . . . . . . . . . . . . . Rudolf Scholbeck 93.17 
PRINCIPALES SECTORES Y SUS RIESGOS

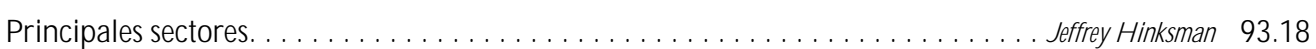

Tipos de proyectos y sus riesgos asociados. . . . . . . . . . . . . . . . . . effrey H inksman 93.25

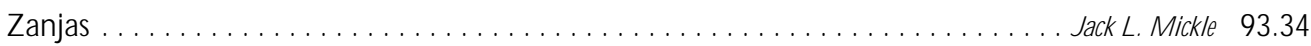

HERRAMIENTAS, MAQUINAS Y MATERIALES

H erramientas . . . . . . . . . . . . . . . . . . . . . . . . . . . . . . . . . . . . Scott P. Schneider

93.37

Equipos, máquinas y materiales $\ldots \ldots \ldots \ldots \ldots \ldots \ldots \ldots \ldots \ldots \ldots \ldots \ldots \ldots \ldots$ ans $G$ öran $L$ inder

Grúas. F rancis $\mathrm{H}$ ardy

Ascensores, escaleras mecánicas y elevadores 93.45

Cemento y hormigón J. Staal y J ohn Q uackenbush 93.50

Estudios de casos: Prevención de las dermatosis profesionales entre los trabajadores expuestos al polvo de cemento . . . . . . . . . . . . . . . . . . . . . . . . . . . Pekka R oto 93.54

Asfalto . J ohn F inklea

Grava . . .

\section{PARTE XVII. SERVICIOS}

\section{Servicios de educación y formación Michael McC ann, Director del capítulo}

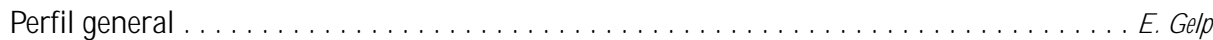

Centros de enseñanza elemental y secundaria. . . . . . . . . . . . . . . . . M ichael M cC ann

Formación profesional y aprendizaje. . . . . . . . . . . . . . . . . G Gary Gibson

Escuelas universitarias y universidades . . . . . . . . . . . . . . . . . . . . Susan M agor

Enseñanza artística . . . . . . . . . . . . . . . . . . . . . . . . . . . . . . . Ted Rickard

Problemas de salud y pautas patológicas...................... Steven D. Stellman y J oshua E. M uscat 94.2

Cuestiones ambientales y de salud pública. .

95. Servicios de seguridad y de emergencia T ee L. G uidotti, Director del capítulo Servicios de seguridad y de emergencia $\ldots \ldots \ldots \ldots \ldots \ldots \ldots \ldots \ldots \ldots$. Tee L. Guidotti M étodos de extinción de incendios ........................... Alan D. J ones 95 R iesgos de la lucha contra incendios. . . . . . . . . . . . . . . . . . . . . . . . . . . . Tæ L. Guidotti

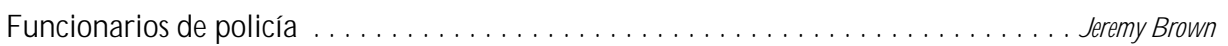
Guardias de seguridad: desarrollo y situación de la seguridad en el trabajo en Alemania. ........................................... anfred $\mathrm{Fischer} 95.14$

Fuerzas armadas .................. . oe C. Gaydos, Richard J. T homas, D avid M. Sack y R efford Patterson 95.16 R iesgos para la seguridad y la salud de los rescates marítimos. ............. T imothy J. U ngs 95.19 Personal auxiliar y de ambulancias ............................ ohn D. M eyer 95.21 Personal de control de riesgos por sustancias peligrosas .................. . J oseph Fedoruk 95.22

\section{Actividades artísticas, culturales y recreativas}

Michael McCann, Director del capítulo
ACTIVIDADES ARTISTICAS Y ARTESANALES
Actividades artísticas, culturales y recreativas. . M ichael M cCann 96.2
Dibujo, pintura y grabados. . J ack W. Snyder 96.7
Escultura. . Giuseppe B attista 96.8
Fotografía. David Richardson 96.11
M etalistería . Angela Babin 96.12
$\mathrm{N}$ uevas tecnologías en el arte. 
Artesanía textil . . . . . . . . . . . . . . . . . . . . . . . Gail Coningsby B arazani

Cerámica . . . . . . . . . . . . . . . . . . . . . . . . . . . . M onona R ossol

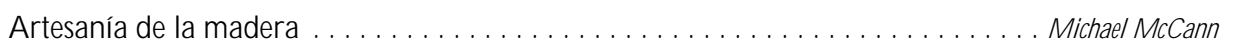

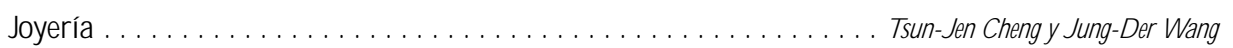

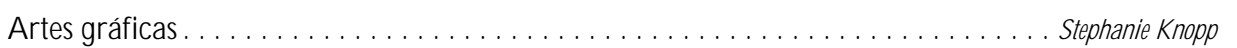
96.21

ARTESESCENICASY AUDIOVISUALES

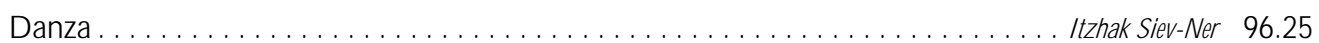

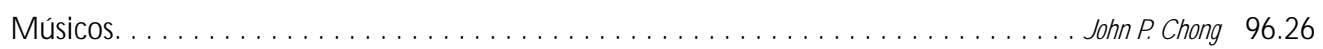

Cantantes ............................................ Anat Keidar 96.28

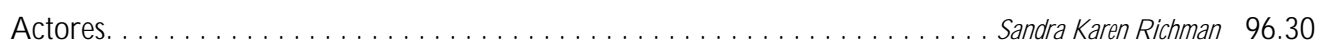

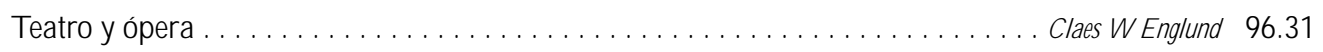

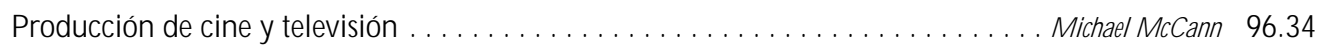

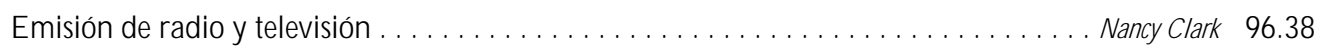

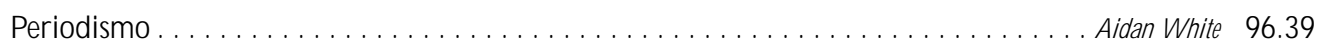

ACTIVIDADES CULTURALES Y RECREATIVAS

M useos y galerías de arte . . . . . . . . . . . . . . . . . . . . . . Kathryn A. M akos 96.41

Parques zoológicos y acuarios .............................. Ken Sims 96.44

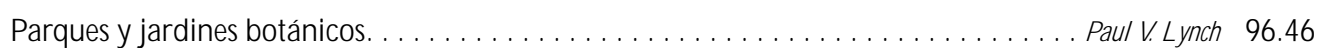

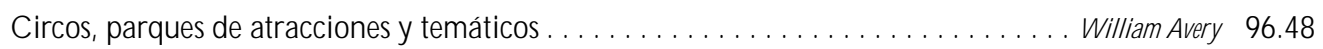

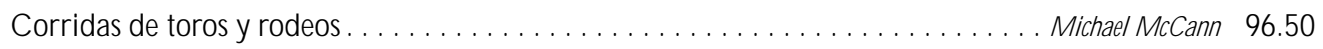

Deportes profesionales . . . . . . . . . . . . . . . . . G ordon H vie, Peter J. B runo y W. N orman Scott 96.52

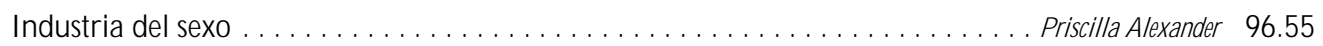

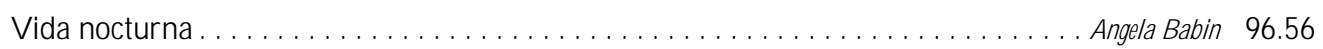

La protección del medio ambiente y la salud pública . . . . . . . . . . . . . . . . . M ichael M cC ann 96.57

97. Centros y servicios de asistencia sanitaria Annalee Yassi, Directora del capítulo

A sistencia sanitaria: naturaleza y problemas de salud en el trabajo. . . . Annalee Yassi y L eon J. W arshaw 97.2

¿Son también trabajadores sanitarios? . . . . . . . . . . . . . . . . . . . . . L eon J. W arshaw 97.2

Servicios sociales. . . . . . . . . . . . . . . . . . . . . . . . . . . Susan Nobel 97.10

Trabajadores de la atención domiciliaria: la experiencia de Nueva York . . . . . . . . L enora Colbert 97.11

Estudio de un caso: Violencia en el trabajo sanitario . . . . . . . . . . . . . . . Danie M urphy 97.12

L a práctica de la salud y seguridad en el trabajo: la experiencia rusa . . . . . . . . Valery P. Kaptsov

y L yudmila P. Korotich 97.13

\section{ERGONOMIA Y ASISTENCIA SANITARIA}

Perspectiva de la ergonomia hospitalaria. .................. M adelene R. Estryn-B éhar

La tensión en el trabajo de asistencia sanitaria . . . . . . . . . . . . . . M adelene R. Estryn-Béhar

$\mathrm{H}$ orarios de trabajo y trabajo nocturno en la asistencia sanitaria.

$M$ addelene R. E stryn-B céhar

\section{MEDIO AMBIENTE FISICO Y ASISTENCIA SANITARIA}

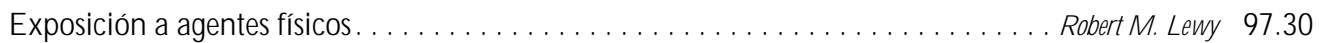

Ergonomía del medio ambiente físico de trabajo . . . . . . . . . . . . M adeleine E stryn-B éhar 97.33

Prevención y manejo de los dolores de espalda en el personal de enfermeria . . . . . . . . U Irich Stössel 97.38

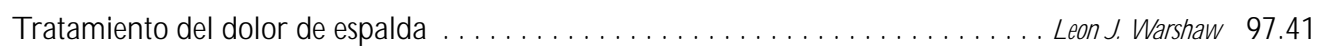


LOSTRABAJADORES SANITARIOSY LAS ENFERMEDADES INFECCIOSAS

Perspectiva de las enfermedades infecciosas $\ldots \ldots \ldots \ldots \ldots \ldots \ldots \ldots \ldots$ riedrich $\mathrm{H}$ ofmann

Prevención de la transmisión profesional de los agentes patógenos en sangre . . . . . L Linda S. M artin,

Robert J. M ullan y D avid M . Bell

Prevención, control y vigilancia de la tuberculosis.

SUSTANCIAS QUIMICAS PRESENTES EN EL MEDIO AMBIENTE SANITARIO

Perspectiva de los riesgos de origen químico en la asistencia sanitaria. . . . . . . . eanne M ager Stellman

A bordaje de los riesgos de origen químico en los hospitales. . . . . . . . . . . . . . . . . Annalee Yassi

Gases anestésicos residuales . . . . . . . . . . . . . . . . . . . . . . . . . . . X avier G uardino Solá

Los trabajadores sanitarios y la alergia al látex

Leon J. W arshaw

EL MEDIO AM BIENTE HOSPITALARIO

Edificios destinados a la asistencia sanitaria ..... . C Cesare Catananti, Gianfranco D amiani y Giovanni Capelli

H ospitales: problemas de salud pública y medioambientales . . . . . . . . . . . M.P. Arias

Tratamiento de los residuos hospitalarios . M.P. Arias

M anejo de la eliminación de los residuos sanitarios peligrosos

98. H oteles y restaurantes

Perfil general

Restaurantes

$\mathrm{H}$ oteles.

Efectos sobre la salud y pautas patológicas
Pam Tau Lee, D irector del capítulo . Pam Tau Lee 98.2 . Neil Dalhouse 98.2 . . Pam Tau Lee 98.6 L eon J. W arshaw

\section{O ficinas y comercio minorista}

Jonathan R osen, Director del capítulo

$\mathrm{N}$ aturaleza del trabajo en oficinas y comercios ....... C Charles L evenstein, B eth R osenberg y Ninica $\mathrm{H}$ oward Profesionales y directivos.

O ficinas: resumen de riesgo N ona M CQ uay

La seguridad del cajero: situación en Alemania . . . . . . . . . . . . . . . . . M anfred $F$ ischer

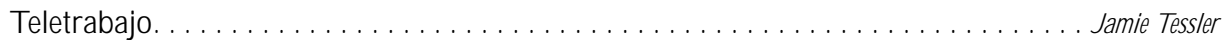

El comercio minorista . . . . . . . . . . . . . . . . . . . . . . . . . . . . . Adrienne $M$ arkowitz

\section{Servicios personales y comunitarios Angela Babin, D irectora del capítulo}

Servicios de limpieza en interiores . . . . . . . . . . . . . . . . . . . . . . . . . . Karen M essing 100.2

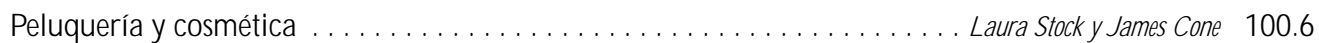

Lavanderías y limpieza en seco . . . . . . . . . . . . . . . . . Gary S. E arnest, L ynda E wers y Avima M . R uder 100.10

Servicios funerarios . . . . . . . . . . . . . . . . . . . . . . M ary 0. B rophy y $J$ onathan T. H aney 100.14

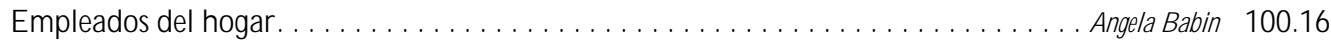

\section{Servicios públicos y estatales David LeG rande, Director del capítulo}

Riesgos para la seguridad y la salud en el trabajo en los servicios públicos y

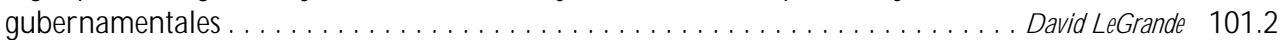

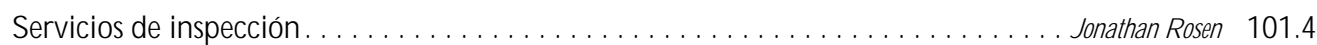

Servicios postales . . . . . . . . . . . . . . . . . . . . . . . . . . . . . . . . Roxanne Cabral 101.5

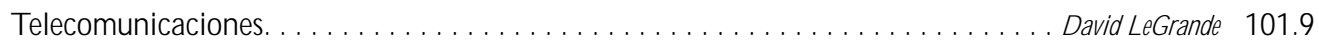

R iesgos en las plantas de tratamiento de aguas residuales (residuos) . . . . . . . . . M ary 0. B rophy 101.10

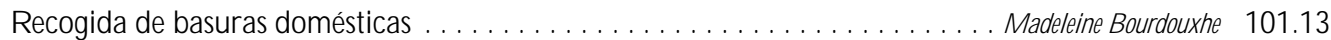




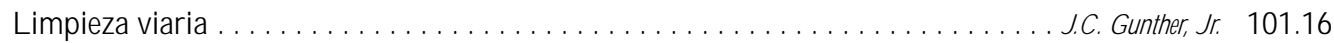

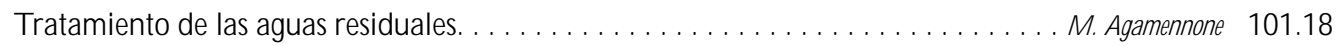

Industria de reciclado municipal. . . . . . . . . . . . . . . . . . . . . . . . . D avid E. M alter 101.21

O peraciones de eliminación de residuos . . . . . . . . . . . . . . . . . . . ames W. Platner 101.23

Generación y transporte de residuos peligrosos: problemas sociales y éticos. . . . . . C Colin L. Soskolne 101.27

102. Industria del transporte y el almacenamiento

LaMont Byrd, Director del capítulo

Perfil general . LaM ont Byrd 102.2

Retos para la salud y la seguridad de los trabajadores en la industria del transporte y del almacenamiento . . . . . . . . . . . . . . . . . . . . . . L eon $]$. W arshaw

TRANSPORTE AEREO

O peraciones aeroportuarias y de control del tráfico aéreo Christine Proctor Edward A. OImsted y E. Evrard 102.6

Estudios de caso de controladores del tráfico aéreo en Estados U nidos el talia . . . . . . . . . . . . . . . . . . . . . . . . . . . . . . . . . . . . . . Paul A. Landsbergis

O peraciones de mantenimiento de aeronaves. . . . . . . . . . . . . . . . . . . . Buck Cameron

O peraciones de vuelo de aeronaves . Nancy Garcia y H. Gartmann 102.14

M edicina aeroespacial: efectos de la gravedad, la aceleración y la microgravedad

en el entorno aeroespacial . . . . . . . . . . . . . . . . . . Relford Patterson y $R$ ussell $B$. R ayman

H elicópteros. . David L. H untzinger

\section{TRANSPORTE POR CARRETERA}

Conducción de camiones y autobuses. B ruce A. M illies

Ergonomía de la conducción de autobuses

O peraciones de suministro de combustible y mantenimiento de vehículos

Violencia en las gasolineras . Leon J. W arshaw

TRANSPORTE FERR OVIARIO

Explotaciones ferroviarias. $\mathrm{Ne}$ èl $\mathrm{M}$ CM anus

M etros. G eorge J. M CD onald

TRANSPORTE FLUVIAL Y MARITIM O

Transporte fluvial y marítimo e industrias marítimas . . T imothy J. U ngs y M ichael Adess

\section{ALM ACENAM IENTO}

Almacenamiento y transporte de petróleo crudo, gas natural, productos de petróleo licuados y otras sustancias químicas . . . . . . . . . . . . . . . . . . . Richard $\mathrm{S}$. Kraus Almacenamiento. J ohn L und 
Director del capítulo Melvin L. Myers

\section{Sumario}

Perfil general

$$
\text { Melvin L. Myers }
$$

Explotaciones familiares

Ted Scharf, David E. Baker y Foyce Salg. . .

\section{SISTEMAS AGRICOLAS}

Plantaciones

Melvin L. Myers e I.T. Cabrera

Trabajadores agrícolas migrantes y temporeros

Marc B. Schenker. .

Agricultura urbana

Melvin L. Myers . .

Operaciones en viveros e invernaderos

Mark M. Methner y Fohn A. Miles . .

Floricultura

Samuel H. Henao.

Educación de los trabajadores agrícolas sobre

los plaguicidas: estudio de un caso

Merri Weinger. . .

Operaciones de plantación y cultivo

Puri Kundiev y V.I. Chernyuk.

Operaciones de recolección

William E. Field .

Operaciones de almacenamiento y transporte

Thomas L. Bean . . .

Operaciones manuales en la agricultura

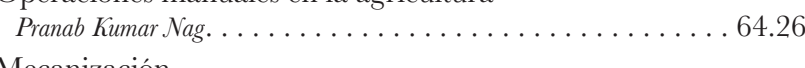

Mecanización

Dennis Murphy . .

Maquinaria agrícola

L.W. Knapp, Fr. .

\section{GULTIVO DE ALIMENTOS Y FIBRAS}

Arroz

Malinee Wongphanich .

Cultivo de cereales y semillas oleaginosas

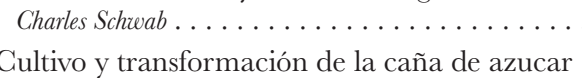

R.A. Muñoz, E.A. Suchman, F.M. Baztarrica y Carol F. Lehtola . . . . 64.40

Recolección de la patata

Steven B. Fohnson.

Hortalizas y melones

B.H. Xu y Toshio Matsushita

\section{GULTIVO DE ARBOLES, ZARZAS Y VIDES}

Bayas y uvas

William E. Steinke.

Cultivo de árboles frutales

Melvin L. Myers . . . . . . . . . . . . . . . . . . . 64.47

Cultivo de árboles tropicales y palmeras

Melvin L. Myers . . . . . . . . . . . . . . . . . . . . . . . . . 64.49

Producción de corteza de árbol y savia

Melvin L. Myers

Bambú y caña

Melvin L. Myers y Y.C. Ko . . . . . . . . . . . . . . . . . . 64.53

\section{CULTIVOS ESPECIALES}

Cultivo de tabaco

Gerald F. Peedin . . . . . . . . . . . . . . . . . . . . . . 64.54

Ginseng, menta y otras hierbas culinarias y medicinales

Larry f. Chapman ........................ 64.58

Setas

L.F.L.D. Van Griensven . . . . . . . . . . . . . . . . 64.60

Plantas acuáticas

Melvin L. Myers y f.W.G. Lund. . . . . . . . . . . . . . . . 64.62

CULTIVO DE PLANTAS PARA LA PRODUCGION DE BEBIDAS

Cultivo de café

Forge da Rocha Gomes y Bernardo Bedrikow. . . . . . . . . . . . . . . 64.63

Cultivo de té

L.V.R. Fernando . . ...................... 64.66

Lúpulo

Thomas Karsky y William B. Symons . . . . . . . . . . . . . . . . . 64.67

CUESTIONES DE SALUD Y AMBIENTALES

Problemas de salud y pautas patológicas

en la agricultura

Melvin L. Myers.

Agromedicina

Stanley H. Schuman y Fere A. Brittain . .

Cuestiones ambientales y de salud pública

en la agricultura

Melvin L. Myers . . 


\section{Perfil General}

Melvin L. Myers

\section{Introducción}

Hace doce mil años, la humanidad entró en la era del Neolítico y descubrió que podía obtener alimentos, forraje y fibra con el cultivo de las plantas. Ese descubrimiento ha permitido el suministro de alimentos y tejidos gracias al cual hoy en día se alimentan y visten 5.000 millones de personas.

Esta perspectiva general de la agricultura abarca su evolución y estructura, la importancia económica de los diferentes tipos de cultivos y las características del sector y de los trabajadores. Los sistemas de trabajo agrícola se dividen en tres tipos de actividades principales:

1. operaciones manuales

2. mecanización

3. tracción, proporcionada por quienes se dedican a la cría de animales de tiro y que se describe en el capítulo Ganadería y cría de animales.

El sistema agrícola abarca cuatro grandes procesos que representan fases secuenciales de la producción. El sistema agrícola produce alimentos, forraje y fibra, y tiene consecuencias para la salud de los agricultores y, de forma más general, para la salud pública y el medio ambiente.

Las principales materias primas, como el trigo y el azúcar, son productos de la agricultura que se utilizan como alimento, forraje o fibra. Están representadas en este capítulo por una serie de artículos que describen los procesos, los riesgos en el trabajo y las medidas preventivas específicas para cada una de ellas. Los piensos y forrajes se describen en el capítulo Ganadería y cría de animales.

\section{Evolución y estructura del sector agrícola}

La revolución neolítica - el paso de la caza y la recolección a la agricultura - se inició en tres lugares diferentes del planeta. Uno de ellos fue el oeste y sudoeste del mar Caspio; otro fue América Central y el tercero, Tailandia, cerca de la frontera con Birmania. La agricultura nació en torno al año 9750 a.C. en esta última región, donde se han encontrado semillas de guisantes, habas, pepinos y castañas de agua. Eso fue 2.000 años antes de que se descubriera la verdadera agricultura en las otras dos regiones. La esencia de la revolución neolítica y, por tanto, de la agricultura es la recolección de semillas, su reintroducción en el suelo y su cultivo para obtener una nueva cosecha.

En la zona meridional del mar Caspio, el trigo fue el primer producto cultivado. Al emigrar los agricultores llevándose consigo las semillas, descubrieron que las plantas silvestres de otras regiones también eran comestibles, como el centeno y la avena. En América Central, donde el maíz y las habas eran los alimentos básicos, se descubrió que una mala hierba producía un alimento muy nutritivo: el tomate.

La agricultura generó varios problemas:

- Las malas hierbas y otras plagas (insectos en los campos y ratas y ratones en los graneros) se convirtieron en un problema.

- Los primeros agricultores se limitaban a sacar todo lo que podían del suelo y tenían que pasar 50 años para que el suelo se recuperara por medios naturales.

- En algunas regiones, la destrucción de la vegetación natural para el labrado de la tierra convertía a ésta en un desierto. Para suministrar agua a los cultivos, los agricultores descubrieron el riego hace 7.000 años.

La búsqueda de soluciones a problemas dio lugar a la aparición de nuevas industrias. Los métodos para controlar las malas hierbas, los insectos y los roedores evolucionaron para dar lugar a la industria de los plaguicidas, y la necesidad de reponer el suelo dio lugar a la industria de los fertilizantes. La necesidad de suministrar agua para riego motivó la creación de sistemas de depósitos y redes de tuberías, canales y diques.

En los países en desarrollo, la agricultura se basa en las explotaciones familiares, muchas de las cuales se transmiten de generación en generación. Los campesinos constituyen la mitad de la población rural mundial por debajo del umbral de la pobreza, a pesar de producir las cuatro quintas partes del suministro de alimentos en los países en desarrollo. Por el contrario, en los países desarrollados las explotaciones agrícolas son cada vez más grandes, habiéndose convertido la agricultura en una actividad comercial a gran escala, donde la producción se integra con la transformación, la comercialización y la distribución para formar un sistema agroindustrial (Loftas 1995).

La agricultura ha constituido el medio de vida de los agricultores y sus familias durante siglos, pero recientemente se ha convertido en una actividad orientada a la producción. Una serie de "revoluciones" han contribuido al aumento de la producción agrícola. La primera de ellas fue la mecanización, es decir, la sustitución de la mano de obra por maquinaria en los campos. La segunda fue la revolución química que, después de la segunda Guerra Mundial, contribuyó a controlar las plagas, aunque con consecuencias para el medio ambiente. La tercera fue la revolución ecológica que contribuyó en Norteamérica y en Asia al aumento de la productividad gracias a mejores genéticas que dieron lugar a nuevas variedades de cultivos.

\section{Importancia económica}

La población mundial pasó de 2.500 millones de habitantes en 1950 a 5.600 millones en 1994. Según datos de las Naciones

Tabla 64.1 • Fuentes de nutrientes.

\begin{tabular}{lll} 
Nutriente & Fuentes vegetales & Fuentes animales \\
Hidratos de carbono (azúcares y almidón) & Frutas, cereales, tubérculos, leguminosas & Miel, leche \\
Grasas & Semillas oleaginosas, frutos secos, y legumbres & Carne, aves, mantequilla, ghee, pescado \\
Proteínas & Leguminosas, frutos secos, y cereales & Carne, pescado, productos lácteos \\
Vitaminas & Carotenos: zanahorias, mangos, papaya & Vitamina A: hígado, huevos, leche \\
& Vitamina C: frutas y hortalizas & Complejo de Vitaminas B: carne, aves, productos lácteos \\
& Complejo de Vitaminas B: cereales, leguminosas & \\
Minerales & Calcio: guisantes, judías & Calcio: leche, carne, queso \\
& Hierro: hortalizas de hoja verde oscura y frutos secos & Hierro: carne, pescado, marisco \\
\hline
\end{tabular}


Figura 64.1 - Millones de trabajadores agrícolas por regiones del mundo (1994).

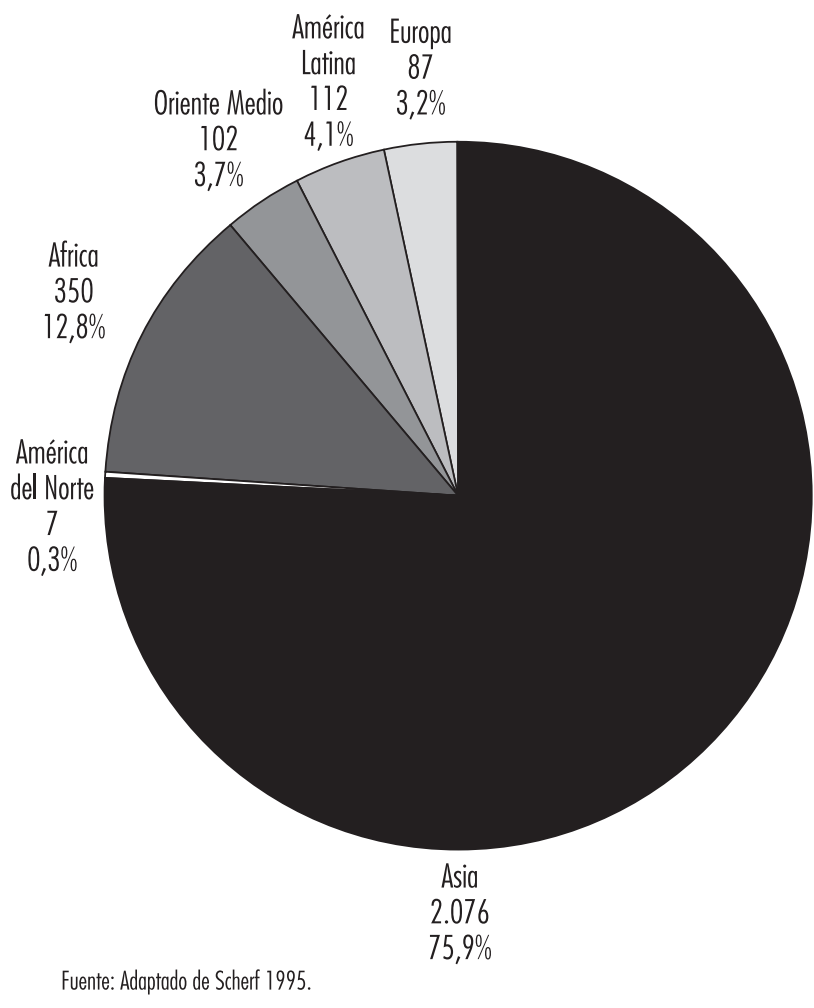

Unidas, seguirá aumentando hasta alcanzar 7.900 millones en el año 2025. Este crecimiento continuo implicará un aumento de la demanda de energía y nutrientes proporcionados por los alimentos, tanto debido al aumento de la población en sí como al deseo general de combatir la malnutrición (Brown, Lenssen y Kane 1995). En la Tabla 64.1 se ofrece una lista de los nutrientes obtenidos de los alimentos.

La agricultura puede concebirse hoy en día como una actividad que proporciona un medio de subsistencia a quienes se dedican a ella, alimentos básicos para la comunidad en que se inserta e ingresos por la venta de materias primas a un mercado exterior. Un alimento básico es aquel que satisface una parte importante de las necesidades de energía y nutrientes y que constituye una parte dominante de la dieta. Excluidos los productos animales, la dieta de la mayor parte de la población mundial se basa en uno o dos de los siguientes alimentos básicos: arroz, trigo, maíz, mijo, sorgo, raíces y tubérculos (patata, mandioca, batata y taro). Aunque existen 50.000 especies de plantas comestibles en el mundo, sólo 15 de ellas proporcionan el $90 \%$ del aporte mundial de energía obtenida de los alimentos.

Los cereales constituyen la principal materia prima de la que depende el mundo para su alimentación. Entre los cereales destacan el trigo y el arroz, los principales alimentos básicos, y cereales de grano grueso, que se utilizan como forraje. Tres de ellos - arroz, maíz y trigo - son alimentos básicos para más de 4.000 millones de personas. El arroz alimenta a casi la mitad de la población mundial (Loftas 1995).

Otros alimentos básicos son los cultivos amiláceos: mandioca, batata, patata, ñame, taro y llantén. Más de 1.000 millones de habitantes en los países en desarrollo utilizan raíces y tubérculos como alimentos básicos. La mandioca se cultiva como alimento básico en otros países para 500 millones de personas. En el caso de algunas de estas materias primas, gran parte de la producción y el consumo sigue estando al nivel de la mera subsistencia.

Las leguminosas constituye otro grupo de alimentos básicos, como los guisantes, garbanzos y lentejas. Todos ellos son importantes por su alto contenido en almidón y proteínas.

Otras leguminosas se cultivan para obtener aceite, como la soja y el cacahuete. También se emplean para obtener aceite vegetal el coco, el sésamo, las semillas de algodón, la palma, la aceituna y algunas variedades de maíz y arroz. Los cultivos de los que se obtiene aceite para consumo humano tienen otros usos, como la fabricación de pinturas y detergentes (Alexandratos 1995).

Los propietarios de pequeñas parcelas cultivan muchos de los mismos productos que en las plantaciones. Los cultivos de plantación, normalmente orientados a la exportación de materias primas, son el caucho, el aceite de palma, la caña de azúcar, bebidas tropicales (café, cacao, té), algodón, tabaco y plátano. Pueden cultivarse productos tanto para consumo local como para la exportación, como el café y la caña de azúcar (OIT 1994)

La agricultura urbana es intensiva en mano de obra, se caracteriza por el pequeño tamaño de las explotaciones y está

Figura 64.2 • Niño trabajando en la agricultura en la India.

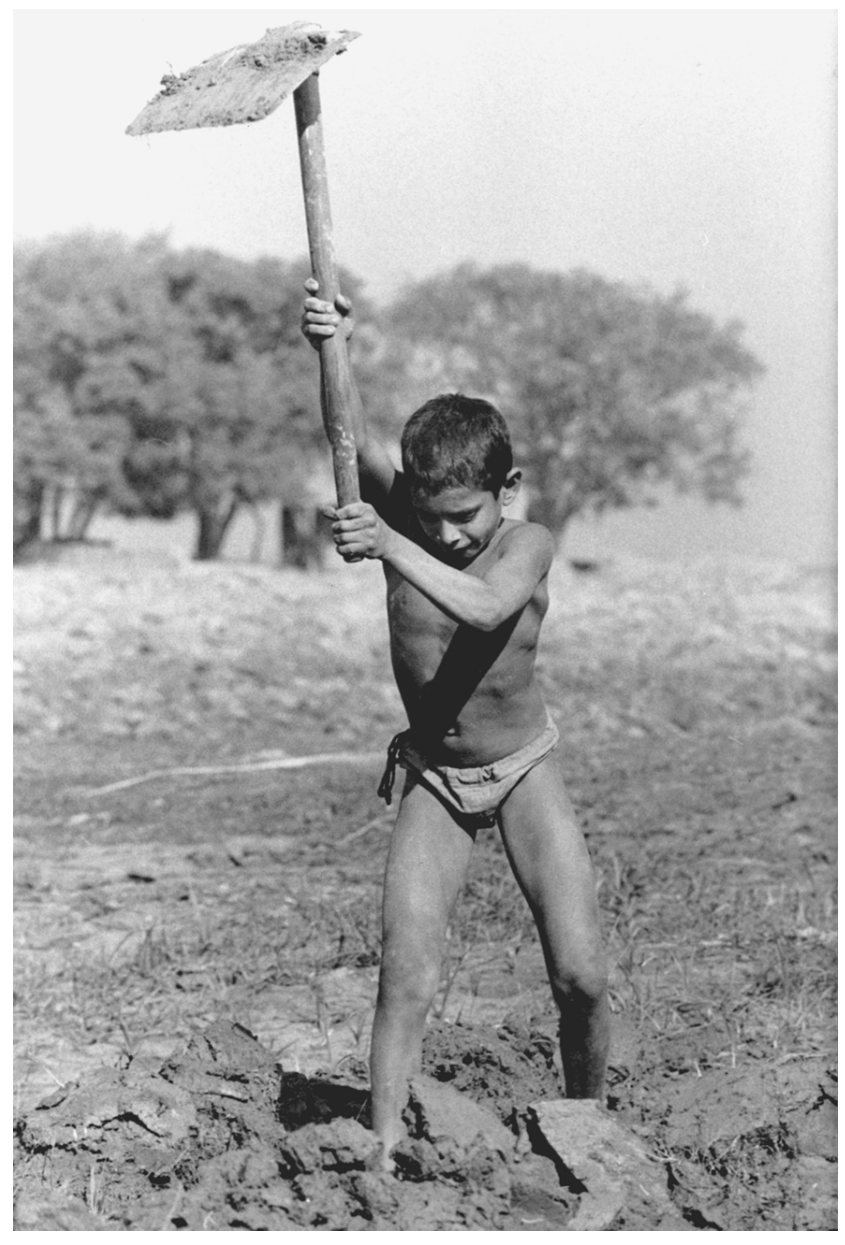




\section{Explotaciones familiares}

La explotación familiar es una empresa y una finca en la que con toda probabilidad hay niños y personas de edad avanzada. En algunas regiones del mundo, las familias rurales viven en pueblos situados cerca de sus terrenos de labor. De este modo combinan las relaciones familiares y la crianza de los hijos con la producción de alimentos y otras materias primas. Las explotaciones familiares pueden tener una extensión muy variada: desde las de pequeño tamaño, de subsistencia o a tiempo parcial, hasta las grandes empresas propiedad de una familia que contratan a numerosos trabajadores a tiempo completo. Por su parte, los diferentes tipos de explotaciones se distinguen por factores nacionales, regionales, culturales, históricos, económicos, religiosos y de otra índole. El tamaño y el tipo concretos determinan, en todo caso, la necesidad de recurrir a los miembros de la familia como mano de obra o de contratar a trabajadores a tiempo completo o parcial. Una explotación agraria típica puede combinar tareas como el cuidado del ganado, la evacuación del estiércol, el almacenamiento de granos, el manejo de maquinaria pesada, la aplicación de plaguicidas, el mantenimiento de la maquinaria, las tareas de construcción y muchos otros trabajos.

La Organización de Cooperación y Desarrollo Económico /OCDE 1994) ha observado algunas tendencias en la agricultura, como las siguientes:

1. El creciente predominio económico de los grandes productores altamente mecanizados

2. El aumento del empleo fuera de la explotación agrícola como principal fuente de ingresos para las pequeñas explotaciones.

3. La función controladora de las políticas agrarias y los acuerdos comerciales a escala nacional e internacional.

La concentración de fincas y la reducción del número de explotaciones familiares se vienen observando desde hace décadas. Estas tendencias influyen en los procesos de trabajo, la carga de trabajo y la salud y seguridad de los miembros de estas explotaciones. En ellas se están produciendo cambios tales como una mayor carga de trabajo, una creciente dependencia de mano de obra contratada, el uso de nuevas técnicas, el trabajo no supervisado de adolescentes y la lucha para mantener la viabilidad económica.

Los niños que se acercan a la adolescencia contribuyen a la productividad de las explotaciones familiares. Las explotaciones de pequeño y mediano tamaño suelen depender de esa mano de obra, especialmente cuando los miembros adultos de la familia trabajan en otros lugares. El resultado puede ser la falta de supervisión del trabajo infantil.

\section{Riesgos}

La explotación familiar constituye un entorno de trabajo peligroso. Es uno de los pocos lugares de trabajo peligrosos en el que varias generaciones de una misma familia pueden vivir, trabajar y jugar. Puede ser así fuente de numerosos y diferentes peligros para la vida. El indicador más importante de la seguridad y la salud es la carga de trabajo por trabajador, ya se trate de trabajo físico, de trabajo mental o de la necesidad de tomar decisiones. Muchos accidentes graves se producen en agricultores que trabajan con equipos que conocen bien, en campos familiares, cuando realizan tareas que llevan haciendo años o incluso décadas

Los materiales agrícolas peligrosos, como los plaguicidas, fertilizantes, líquidos inflamables, disolventes y otros limpiadores, son responsables de enfermedades agudas y crónicas en los trabajadores agrícolas y sus familiares. Los tractores, las barrenas y otros equipos mecanizados han permitido un gran aumento en la tierra y el ganado que un sólo agricultor puede cuidar, pero producen también accidentes graves. La posibilidad de quedar atrapado en la maquinaria, el vuelco de los tractores, la presencia del ganado, la conducción de máquinas en vías públicas, las caídas o los golpes producidos por la caída de objetos, la manipulación de materiales, los espacios confinados y la exposición a toxinas, polvo, mohos, sustancias químicas, vibración y ruido son los principales riesgos de enfermedad y lesiones en las explotaciones agrícolas. El clima y la topografía les decir, el agua, las pendientes, los sumideros y otros obstáculos) contribuyen asimismo.

En conjunto, el trabajo agrícola se asocia a unas tasas de mortalidad y morbilidad más altas que ningún otro tipo. Por desgracia, los niños que viven en las explotaciones agrícolas corren también, conjuntamente con sus padres, un mayor riesgo. Las familias rurales, forzadas a seguir siendo rentables a medida que crecen, inducen indirectamente a sus miembros a asumir una carga de trabajo excesiva y a colocarse en una situación de mucho mayor riesgo de fatiga, estrés y accidentes. En estas condiciones es cuando existe una mayor probabilidad de que los niños intenten ayudar, muchas veces trabajando sin supervisión. Además, los factores constantes de estrés asociados al trabajo agrícola pueden ocasionar depresión, conflictos familiares y suicidio. Por ejemplo, los trabajadores que son a su vez los principales propietarios de explotaciones pertenecientes a una única familia parecen presentar un riesgo especialmente elevado de suicidio en comparación con otros habitantes de las zonas rurales (Gunderson 1995). Además, los costes de las enfermedades y lesiones suelen ser soportados por los miembros de la familia y por la propia empresa, tanto en lo que respecta a los costes médicos directos como a la reducción de la mano de obra necesaria para mantener la explotación.

\section{Prevención}

Los programas tradicionales de salud y seguridad agrícola hacen hincapié en un mejor diseño de la maquinaria, en las actividades de educación y en unas buenas prácticas de trabajo. En las explotaciones familiares ha de prestarse una atención especial a la asignación de unas tareas propias de su edad a niños y adultos de edad avanzada. Nunca debe permitirse la presencia de niños de corta edad cerca de máquinas agrícolas en funcionamiento, ni dejarles que monten en tractores u otros equipos agrícolas. Se les debe prohibir asimismo la entrada a edificios agrícolas que presenten riesgos derivados de la electricidad de los espacios confinados, de las zonas de almacenamiento de sustancias químicas o de los equipos en funcionamiento (National Committee for Childhood Agricultural Injury Prevention 1996). En todos los equipos y sustancias químicas deben mantenerse las etiquetas de advertencia, de manera que los adultos estén informados de los peligros y puedan así proteger mejor a sus familias. La contratación a tiempo parcial o completo de trabajadores con experiencia reduce la carga de trabajo de la familia en períodos de intensa actividad. La capacidad de los adultos de edad avanzada es un factor que debe tenerse en cuenta al asignarles tareas.

Los agricultores autónomos, decididos a terminar las tareas con independencia de los riesgos, pueden ignorar unas prácticas de trabajo seguras si piensan que interfieren con la productividad agrícola. Para mejorar la salud y seguridad en las explotaciones familiares se requieren una participación activa de los agricultores y de los trabajadores agrícolas contratados; un cambio favorable en las actitudes, intenciones de conducta y prácticas de trabajo; el reconocimiento de la economía y la productividad agrícolas como importantes determinantes de la estructura y la organización de la empresa, y la colaboración de los agrónomos, vendedores de maquinaria, agentes de seguros, banqueros, medios de comunicación locales, jóvenes y otros miembros de la comunidad para crear y mantener un clima general de seguridad.

Ted Scharf, David E. Baker y Joyce Salg 
presente tanto en los países desarrollados como en desarrollo. En Estados Unidos, más de la tercera parte de la producción agrícola corresponde a zonas urbanas y la agricultura emplea como mucho al $10 \%$ de la población urbana. Por el contrario, en las pequeñas ciudades de Siberia y Asia hasta el $80 \%$ de la población trabaja en la producción y la transformación agrícola. La producción de un agricultor urbano puede también utilizarse para trueques, como el pago del arrendamiento de la tierra (PNUD 1996).

\section{Características del sector y de la mano de obra}

En 1994 la población mundial sumaba 5.623.500.000 habitantes, 2.735.021.000 (49\%) de los cuales trabajaban en la agricultura, como puede observarse en la Figura 64.1. El mayor componente de esta mano de obra se encuentra en los países en desarrollo y en las economías de transición. Menos de 100 millones trabajan en países desarrollados, donde la mecanización ha aumentado la productividad.

La agricultura emplea a hombres y mujeres, jóvenes y mayores. Sus funciones varían; por ejemplo, en el Africa subsahariana las mujeres producen y venden el $90 \%$ de la producción local. Las mujeres tienen también asignada la tarea de cultivar los alimentos de subsistencia para sus familias (Loftas 1995).

Los niños empiezan a trabajar en la agricultura a muy temprana edad en todo el mundo (Figura 64.2), generalmente con jornadas de hasta 45 horas semanales en las temporadas de recolección. La mano de obra infantil ha formado parte de la agricultura de plantación durante toda su historia y el uso generalizado de la contratación de trabajadores a destajo agrava el problema de la explotación infantil. Familias enteras trabajan para mantener o aumentar sus ingresos.

Los datos sobre el empleo en las plantaciones parecen indicar que el mayor nivel de pobreza se encuentra entre los trabajadores agrícolas asalariados que trabajan en la agricultura comercial. Las plantaciones están situadas en regiones tropicales y subtropicales y las condiciones de vida y de trabajo en ellas pueden agravar los problemas de salud que acompañan a la pobreza (OIT 1994).
La agricultura en las zonas urbanas es otro importante componente del sector. Se estima que 200 millones de personas trabajan a tiempo parcial - lo que equivale a 150 millones de trabajadores a tiempo completo - en la agricultura urbana produciendo alimentos y otros productos agrícolas para el mercado. Si se considera la agricultura de subsistencia en estas zonas urbanas, el número total de trabajadores aumenta a 800 millones (PNUD 1996).

En la Figura 64.1 se indica el número total de trabajadores agrícolas en distintas regiones del mundo. En Estados Unidos y Canadá, una pequeña proporción de la población trabaja en la agricultura y la consolidación del sector ha reducido el número de explotaciones agrícolas. En Europa Occidental, la agricultura se ha caracterizado siempre por los minifundios, debido a la división de las parcelas entre los hijos. Sin embargo, con la migración producida desde las zonas agrícolas, también en Europa las fincas han aumentado de tamaño. En Europa oriental la agricultura se ha basado en la explotación socializada de la tierra. El tamaño medio de las explotaciones agrícolas en la antigua URSS superaba las 10.000 hectáreas, mientras que en la Europa oriental no llegaba a la tercera parte. Esta situación está cambiando en algunos países como consecuencia de la transición a una economía de mercado. Muchos países asiáticos han modernizado sus actividades agrícolas y algunos de ellos han conseguido excedentes de arroz. En esta región más de 2.000 millones de personas siguen trabajando en el sector agrícola y gran parte del aumento de la producción se atribuye al cultivo de especies altamente productivas, como el arroz. América Latina es una región variada en la que la agricultura desempeña una importante función económica. Cuenta con grandes recursos y la producción ha aumentado, aunque a costa del deterioro de los bosques tropicales. Tanto en el Medio Oriente como en Africa, la producción de alimentos per capita se ha reducido. En el Medio Oriente el principal factor limitante de la agricultura es la disponibilidad de agua. En Africa, la agricultura tradicional se basa en pequeñas explotaciones de 3 a 5 hectáreas que son cultivadas por mujeres, mientras que los hombres realizan otros trabajos, viéndose obligados en ciertos casos a emigrar para ganar dinero. En algunos países se están desarrollando actividades agrícolas a mayor escala.

\section{SISTEMAS AGRICOLAS}

\section{Plantaciones}

Melvin L. Myers e I.T. Cabrera*

El término plantación denota la actividad basada en el desarrollo, en unidades agrícolas a gran escala, de ciertos recursos agrícolas mediante la aplicación de métodos industriales. Estas empresas agrícolas a gran escala, aunque pertenecientes principalmente a las regiones tropicales de Asia, Africa y América Central y del Sur, no están confinadas a los trópicos, sino que también se encuentran en algunas regiones subtropicales donde el clima y el suelo son adecuados para el cultivo de frutas y vegetación tropicales.

La agricultura de plantación se basa en cosechas de corta rotación, como la piña, la caña de azúcar y árboles como el plátano y el caucho. Además, se consideran generalmente productos de plantación los siguientes tipos de cosechas tropicales y subtropicales: té, café, cacao, coco, mango, sisal y quina.

* Adaptado de la $3^{\text {a }}$ edición de la Enciclopedia de salud y seguridad en el trabajo.
De todos modos, el cultivo a gran escala de otros productos, como el arroz, tabaco, algodón, maíz, frutos cítricos, ricino, cacahuete, yute, cáñamo y bambú, se incluye también en este apartado. Los cultivos de plantación presenta una serie de características:

- Son productos tropicales o subtropicales para los que existe un mercado de exportación.

- La mayoría de ellos requieren una rápida transformación inicial.

- Los productos pasan por centros locales de distribución o transformación antes de llegar al consumidor.

- Suelen exigir una importante inversión de capital en inmovilizado, como en plantas de transformación.

- Generan cierta actividad durante la mayor parte del año y, por consiguiente, ofrecen empleo continuo.

- Son típicos los monocultivos, que permiten la especialización de la tecnología y la gestión.

Aunque los cultivos de plantación requieren condiciones geográficas, geológicas y climáticas muy diversas, prácticamente 
Tabla 64.2 • Diez etapas en un estudio de los riesgos del trabajo en una plantación.

\author{
1. Definir el problema y su prioridad. \\ 2. Encontrar los datos existentes. \\ 3. Justificar la necesidad de más datos. \\ 4. Definir los objetivos del estudio, su diseño, población, tiempo y métodos. \\ 5. Definir las tareas y costes y su programación. \\ 6. Preparar un protocolo. \\ 7. Recabar datos. \\ 8. Analizar los datos y evaluar los riesgos. \\ 9. Publicar los resultados. \\ 10.Seguimiento.
}

Fuente: Partanen 1996.

todos ellos se dan mejor en zonas con condiciones climáticas y ambientales duras. Por otra parte, la gran extensión de las plantaciones y, en la mayoría de los casos su aislamiento, han dado origen a nuevos asentamientos que difieren considerablemente de los indígenas (NRC 1993).

\section{Trabajo de plantación}

La principal actividad de una plantación es el cultivo de una o dos clases de productos e implica los siguientes tipos de trabajo: preparación del suelo, plantación, cultivo, escarda, tratamiento de la planta, recolección, transporte y almacenamiento del producto. Estas operaciones exigen el uso de una gran variedad de herramientas, máquinas y productos fitosanitarios. Cuando se trata del cultivo de tierra virgen, puede que sea necesario despejar el terreno talando árboles, arrancando tocones y quemando maleza, para a continuación cavar zanjas para riego. Además del trabajo clásico de cultivo, pueden llevarse a cabo las siguientes actividades en una plantación: cría de animales de tiro, transformación de los productos recolectados; mantenimiento y reparación de edificios, plantas, maquinaria, herramientas, carreteras y vías férreas; generación de electricidad; excavación de pozos; mantenimiento de las zanjas de riego; trabajo en talleres de ingeniería y carpintería o transporte de los productos al mercado.

Todas las plantaciones del mundo emplean mano de obra infantil. Los niños trabajan con sus padres como parte de un equipo retribuido a destajo, o son contratados directamente para tareas especiales. Por lo general sus jornadas de trabajo son largas y agotadoras, con escasa seguridad y protección de la salud y una dieta, un descanso y una educación inadecuados. En lugar de ser contratados directamente, muchos niños son reclutados como mano de obra a través de contratistas, algo habitual en trabajos ocasionales y estacionales. El empleo de mano de obra a través de contratistas intermediarios es una antigua práctica en las plantaciones. Los dueños no establecen una relación laboral con los trabajadores de la plantación. En su lugar, contratan a un intermediario que les suministra la mano de obra. Generalmente las condiciones laborales de esos trabajadores son peores que las de los trabajadores empleados directamente.

Muchos trabajadores de las plantaciones son retribuidos en función de las tareas realizadas, no de las horas trabajadas. Esas tareas se miden, por ejemplo, por el número de filas de cañas de azúcar cortadas y cargadas en un camión, el número de árboles de caucho talados, el número de filas sembradas, el número de fanegas de sisal cortadas, el número de kilos de hojas de té arrancadas o el número de hectáreas en las que se ha aplicado un fertilizante. Condiciones como el clima y el terreno pueden influir en el tiempo que se tarda en realizar las tareas, y familias enteras pueden verse obligadas a trabajar desde la madrugada hasta el anochecer sin descanso. En la mayoría de los países con cultivos de plantación, los trabajadores de las plantaciones trabajan más de 40 horas a la semana. Además, la mayoría de ellos tienen que trasladarse al lugar de trabajo caminando y, debido a la gran extensión de las plantaciones, dedican mucho tiempo y esfuerzo a desplazarse hasta y desde el lugar trabajo, tardando en ocasiones varias horas en cada sentido (OIT 1994).

\section{Riesgos y su prevención}

El trabajo en las plantaciones entraña numerosos riesgos relacionados con el entorno de trabajo, las herramientas y los equipos utilizados y la propia naturaleza del trabajo. Una de las primeras medidas para mejorar la seguridad y la salud en las plantaciones es designar a un responsable de la seguridad y crear un comité mixto de salud y seguridad. Estos responsables de la seguridad deben garantizar que los edificios y equipos mantengan unas condiciones mínimas de seguridad y que el trabajo se realice de una forma segura. Los comités de seguridad están formados por representantes de la dirección y de los trabajadores y permiten a éstos últimos participar directamente en la mejora de la seguridad. Entre las funciones de este comité figuran el establecimiento de unas normas de trabajo que garanticen la seguridad, la participación en investigaciones de accidentes y enfermedades y la identificación de las circunstancias que ponen a los trabajadores y a sus familias en peligro.

Las plantaciones deben disponer de servicios médicos y equipos de primeros auxilios debidamente instruidos. Los médicos deben diagnosticar enfermedades profesionales relacionadas con el trabajo en una plantación, entre ellas las intoxicaciones por plaguicidas y el estrés por calor. En todas las plantaciones debe realizarse un estudio de los riesgos, encaminado a identificar situaciones peligrosas para que puedan adoptarse medidas preventivas. El comité de salud y seguridad puede participar en dicho estudio junto con los expertos, entre ellos el responsable de la seguridad, el supervisor médico y los inspectores. En la Tabla 64.2 se indican las etapas de las que consta un estudio de este tipo, el resultado del cual debe ser la adopción de medidas para controlar los riesgos potenciales y los que ya han producido accidentes o enfermedades (Partanen 1996). Seguidamente se describen algunos de los riesgos potenciales y su prevención.

\section{Fatiga y riesgos asociados al clima}

Las largas jornadas de trabajo y el esfuerzo físico que éste exige convierte a la fatiga en un grave problema. Los trabajadores fatigados pueden ser incapaces de tomar decisiones acertadas y, como resultado, sufrir accidentes o exposiciones inadvertidas. La fatiga puede reducirse con períodos de descanso y unas jornadas laborales más cortas.

El nivel de esfuerzo físico se ve incrementado por las altas temperaturas ambientales y la humedad relativa. Un consumo abundante de agua y períodos de descanso ayudan a evitar los problemas del estrés por calor.

\section{Accidentes relacionados con las herramientas y equipos}

Las herramientas mal diseñadas exigen a menudo la adopción de posturas forzadas durante el trabajo, y las herramientas cortantes con bordes mal afilados exigen la aplicación de un mayor esfuerzo físico. No debe trabajarse en una posición inclinada o encorvada, ya que impone una gran tensión en la espalda. Trabajar con los brazos levantados puede causar trastornos 
Figura 64.3 - Cortadores de plátanos trabajando en la plantación ecuatoriana "La Julia".

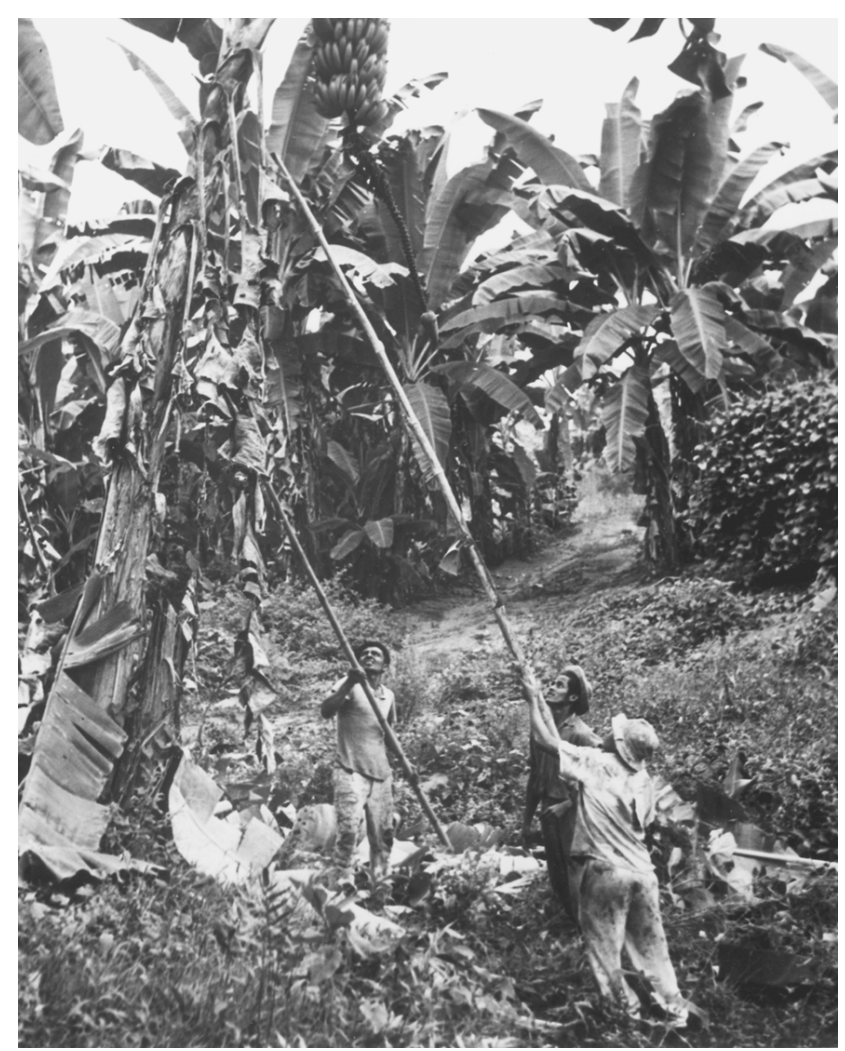

musculosqueléticos de las extremidades superiores (Figura 64.3). Una elección adecuada de las herramientas puede eliminar posturas forzadas y éstas deben mantenerse siempre en buen estado. El levantamiento de cargas pesadas puede evitarse aligerando su peso o repartiendo la carga entre un mayor número de trabajadores.

El uso incorrecto de herramientas manuales, como machetes, guadañas, hachas y otros utensilios afilados o puntiagudos, es causa de numerosos accidentes en las plantaciones. También se producen lesiones con herramientas eléctricas portátiles como las sierras eléctricas, por la mala colocación o negligencia en la reparación de escaleras, o por el uso de repuestos inadecuados para las cuerdas o cadenas que se han roto. Debe instruirse a los trabajadores sobre el modo correcto de utilizar y mantener las herramientas y aperos y sobre la necesidad de conseguir repuestos adecuados.

Las máquinas sin pantallas de protección pueden enganchar la ropa o el cabello o aplastar a los trabajadores, causándoles heridas graves o incluso la muerte. Todas las máquinas deben llevar mecanismos de seguridad y debe eliminarse la posibilidad de un contacto peligroso con partes móviles. Ha de existir un programa de bloqueo y puesta fuera de servicio para las operaciones de mantenimiento y reparación.

La maquinaria y los equipos son también fuentes de un ruido excesivo, pudiendo causar pérdida auditiva en los trabajadores. Siempre deben utilizarse protectores auditivos cuando se manejan máquinas que produce altos niveles de ruido. Los niveles de ruido constituyen un factor importante que debe tenerse en cuenta al elegir los equipos.

\section{Accidentes relacionados con vehículos}

Las carreteras y caminos de las plantaciones pueden ser estrechos, con el consiguiente peligro de colisiones frontales entre vehículos o vuelcos en la cuneta. Deben existir pasos a nivel seguros para los vehículos de transporte, entre ellos camiones, tractores o remolques de tracción animal. Cuando se utilizan carreteras de doble dirección, deben existir pasos más amplios a intervalos adecuados para que un vehículo pueda adelantar a otro. En los puentes y a lo largo de los precipicios y barrancos debe construirse un pretil.

Los tractores y otros vehículos imponen dos riesgos principales a los trabajadores. Uno de ellos es el vuelco, con el resultado frecuente de que el conductor es fatalmente aplastado, razón por la cual deben instalarse sistemas de seguridad contra vuelcos en los tractores. Los tractoristas deben llevar siempre cinturón de seguridad. El otro problema es el de los atropellos. Los trabajadores deben mantenerse alejados de los caminos por donde circulan los vehículos y no debe permitirse que en los tractores viajen pasajeros, a no ser dispongan de un asiento seguro.

\section{Electricidad}

El uso de la electricidad en las plantaciones se limita generalmente a la transformación de los cultivos y a la iluminación de edificios y terrenos. La falta de cuidado en el manejo de instalaciones y equipos eléctricos puede causar graves descargas, quemaduras y, con harta frecuencia, la muerte. El peligro es mayor en sitios húmedos o donde se trabaja con manos o ropas mojadas. En todos los lugares húmedos, o en el caso de los enchufes situados a la intemperie, deben instalarse circuitos de desconexión en caso de pérdidas a tierra. En lugares donde las tormentas son frecuentes o muy fuertes, todos los edificios deben estar provistos de protección contra los rayos y debe instruirse a los trabajadores sobre la forma de reducir el peligro de los rayos y de localizar refugios seguros.

\section{Incendios}

La electricidad, las hogueras o los cigarrillos pueden convertirse en la fuente de ignición de explosiones de combustible o polvo orgánico. Los combustibles -queroseno, gasolina o gasóleopueden causar incendios o explosiones cuando se manipulan o almacenan incorrectamente. Los residuos grasientos y combustibles entrañan el peligro de incendio en los talleres. Los combustibles deben mantenerse alejados de cualquier fuente de ignición. En presencia de materiales inflamables o explosivos deben utilizarse siempre dispositivos y aparatos eléctricos antideflagrantes. En los circuitos eléctricos han de instalarse fusibles o dispositivos de desconexión eléctrica.

\section{Plaguicidas}

El uso de productos fitosanitarios tóxicos constituye un grave problema, sobre todo cuando se hace un uso intensivo de plaguicidas, entre ellos herbicidas, fungicidas e insecticidas. Los trabajadores pueden verse expuestos a esas sustancias peligrosas durante la producción agrícola, el embalaje, el almacenamiento, el transporte, la venta minorista o la aplicación (normalmente manual o aérea), el reciclado y la evacuación de plaguicidas. El riesgo de la exposición a plaguicidas puede verse agravado por el analfabetismo, un etiquetado insuficiente o erróneo, las fugas de los recipientes, la ausencia o uso incorrecto de equipos protectores, las reformulaciones peligrosas, la ignorancia del peligro, el imcumplimiento de las normas o la falta de supervisión o formación técnica. Los trabajadores que aplican los plaguicidas deben utilizar prendas adecuadas y protección respiratoria, si bien ésta es una conducta muy difícil de conseguir en zonas tropicales en donde los equipos de protección aumentan el estrés por calor 
Figura 64.4 - Prendas protectoras para la aplicación de plaguicidas.

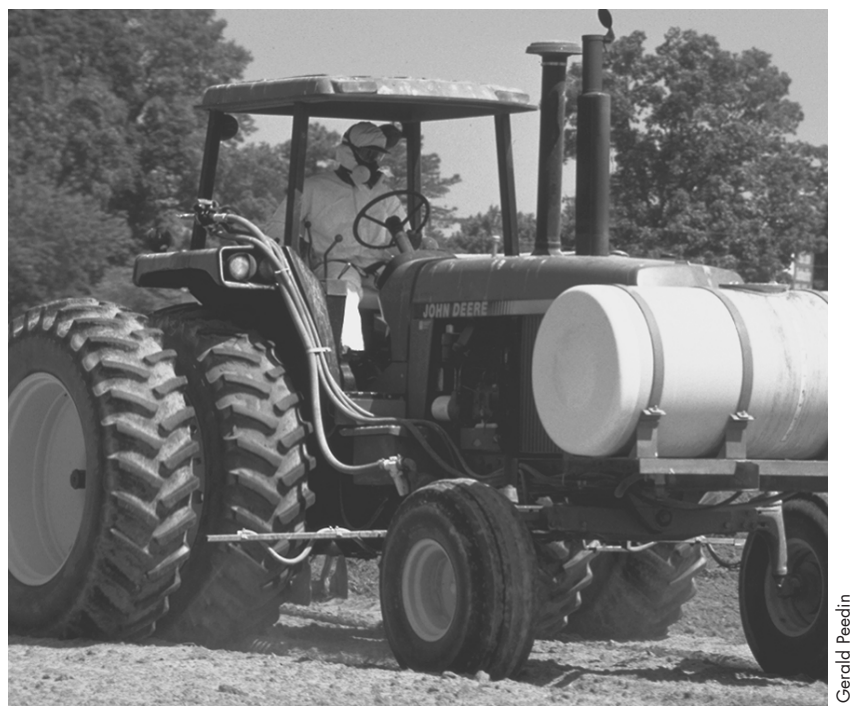

(Figura 64.4). La búsqueda de alternativas al uso de plaguicidas o la utilización de productos menos tóxicos debe ser una prioridad.

\section{Lesiones y enfermedades causadas por animales}

En algunas plantaciones se utilizan animales de tiro, como caballos, mulas, asnos o bueyes, para el arrastre o el transporte de cargas. Este tipo de animales pueden morder o cocear a los trabajadores. Asimismo, les exponen a enfermedades zoonóticas, como el ántrax, la brucelosis, la rabia, la fiebre amarilla o la tularemia. Los animales escogidos para trabajar en las plantaciones deben estar bien domados y no deben utilizarse los que tengan malos hábitos. Las bridas, arneses y sillas deben mantenerse en buenas condiciones y correctamente ajustados. Los animales enfermos han de identificarse para administrarles un tratamiento o deshacerse de ellos.

Algunas serpientes venenosas viven en el suelo y otras especies pueden caer de los árboles sobre los trabajadores. Estos deben tener acceso a un botiquín para el tratamiento de las mordeduras de serpiente, y deben estar previstos procedimientos para obtener asistencia médica y el antídoto adecuado. Ciertas regiones están habitadas por serpientes que viven en los árboles y que atacan a las personas que pasen por debajo. Para tales casos, los trabajadores han de llevar sombreros protectores hechos de material duro.

\section{Enfermedades infecciosas}

Las enfermedades infecciosas pueden ser transmitidas a los trabajadores por las ratas que infestan los edificios o a través del agua o la comida. La contaminación del agua produce disentería, un problema frecuente. Las instalaciones sanitarias y de lavado deben cumplir los requisitos de la legislación nacional, y los trabajadores y sus familias deben tener acceso a agua potable que cumpla la normativa nacional.

\section{Espacios confinados}

Los espacios confinados, como los silos, plantean problemas de gases tóxicos o deficiencia de oxígeno. Antes de entrar en estos espacios debe comprobarse que están bien ventilados; si no lo están, deben utilizarse los equipos protectores respiratorios adecuados.

\section{TRABAJADORES AGRICOLAS MIGRANTES Y TEMPOREROS}

Marc B. Schenker

Los trabajadores agrícolas migrantes y temporeros constituyen un sector importante caracterizado por una doble exposición a los riesgos para la salud: los propios del trabajo agrícola, sumados a los asociados a la pobreza y la migración. En Estados Unidos, por ejemplo, existen unos 5 millones de trabajadores agrícolas migrantes y temporeros, aunque el número exacto no se conoce. En ese país, si bien la población agrícola total se ha reducido, la proporción de trabajadores agrícolas contratados ha aumentado. A escala mundial, los trabajadores migran de todas las regiones del mundo en busca de un empleo, desplazándose de los países más pobres a los más ricos. En general, se ven obligados a realizar trabajos más peligrosos y difíciles y presentan mayores tasas de enfermedades y accidentes. La pobreza y la ausencia de protección legal agrava los riesgos de padecer enfermedades profesionales y de otro tipo.

La información que existe sobre las exposiciones peligrosas y los problemas de salud en esta población es limitada, debido a la escasez general de estudios sobre la salud en el trabajo y a las dificultades especiales que plantea el estudio de los trabajadores agrícolas a causa de sus cambios de residencia, las barreras idiomáticas y culturales y la disponibilidad de unos recursos económicos y políticos limitados.

En Estados Unidos, los trabajadores agrícolas migrantes y temporeros son en su mayoría hombres jóvenes de origen hispánico, aunque también los hay de raza blanca, negra, sudasiáticos y otros grupos técnicos. Casi las dos terceras partes son extranjeros; la mayoría tienen unos bajos niveles de educación y no saben hablar ni leer el inglés. La pobreza es el sello característico de los trabajadores agrícolas, con casi la mitad de los ingresos familiares por debajo del umbral de la pobreza. La mayoría tienen que soportar pésimas condiciones de trabajo, salarios muy bajos y escasas prestaciones extrasalariales. Por ejemplo, menos de la cuarta parte tienen un seguro de enfermedad. En Estados Unidos, los trabajadores temporeros y migrantes trabajan más o menos la mitad del año en el campo. Sus tareas suelen estar relacionadas con cultivos intensivos en mano de obra, como la recolección de frutas, frutos secos y hortalizas.

La situación sanitaria general de los trabajadores agrícolas está directamente vinculada a sus condiciones de trabajo y sus bajos salarios. Existen deficiencias en alimentación, vivienda, higiene, educación y acceso a la asistencia médica. Las malas condiciones de vivienda y la alimentación inadecuada contribuyen también a elevar el riesgo de padecer enfermedades infecciosas. Los trabajadores agrícolas acuden al médico con menos frecuencia que otros tipos de trabajadores y sus visitas están casi siempre motivadas por enfermedades y lesiones agudas. La medicina preventiva es muy deficiente en estas comunidades y en los estudios poblacionales se ha observado una alta prevalencia de personas con problemas médicos que exigen atención. Los servicios preventivos, como las revisiones oftalmológicas y odontológicas, son muy deficientes, y otros, como las vacunaciones, son inferiores a los de la población general. La anemia es un problema frecuente, probablemente como reflejo de una mala alimentación.

La pobreza y otras barreras para los trabajadores agrícolas migrantes y temporeros suelen tener como resultado unas malas condiciones de vida y de trabajo. Todavía hoy muchos trabajadores siguen sin tener acceso a instalaciones sanitarias básicas en el lugar de trabajo. Las condiciones de vida varían desde 
viviendas de protección oficial hasta chozas indignas y campamentos que se instalan hasta que termine el trabajo en una cierta zona. La falta de higiene y el apiñamiento son problemas particularmente graves que aumentan el riesgo de padecer enfermedades infecciosas. Estos problemas se agravan cuando se migra para seguir el trabajo agrícola, reduciéndose los recursos de la comunidad y las interacciones en cada lugar de residencia.

Algunos estudios han demostrado una mayor prevalencia de enfermedades infecciosas causantes de morbilidad y mortalidad en esta población. Las enfermedades parasitarias afectan con una mayor frecuencia a los trabajadores migrantes. Se ha observado un aumento de la mortalidad por tuberculosis, así como de muchas otras enfermedades crónicas, como las cardiovasculares, respiratorias o urinarias. El mayor aumento de las tasas de mortalidad se corresponde con las lesiones traumáticas y es similar al aumento observado por esta causa en los agricultores.

La situación sanitaria de los hijos de los trabajadores agrícolas es motivo de especial preocupación. Además de factores de estrés como la pobreza, la mala alimentación y las malas condiciones de vida, los deficientes servicios de medicina preventiva tienen un efecto particularmente grave en los niños, que también están expuestos a los peligros de las actividades agrícolas desde muy temprana edad, tanto por vivir en un entorno rural como por realizar ellos mismos trabajos agrícolas. Los niños menores de 5 años son los que más riesgo tienen de sufrir lesiones accidentales causadas por la maquinaria o los animales. Cumplidos los 10 años, muchos empiezan ya a trabajar, sobre todo en los períodos con mayor necesidad de mano de obra, como durante la recolección. Estos niños no siempre poseen la fortaleza física ni la coordinación necesaria para realizar los trabajos agrícolas, como tampoco suelen tener capacidad de juicio ante muchas situaciones. La exposición a productos fitosanitarios es un problema especial, puesto que pueden desconocer su aplicación reciente en un campo o ser incapaces de leer las etiquetas en los envases.

Los trabajadores agrícolas corren un mayor riesgo de intoxicación por plaguicidas. La exposición suele producirse por contacto directo con el pulverizador, por contacto prolongado con hojas recién fumigadas o por la dispersión del plaguicida aplicado desde una avioneta u otros equipos de fumigación. En algunos países se imponen unos períodos de prohibición del acceso para evitar el contacto con las hojas mientras el plaguicida sigue siendo tóxico, pero en muchos lugares no existe esa prohibición o se hace caso omiso de ella para terminar antes la recolección. Todo ello hace que entre los trabajadores agrícolas sigan produciéndose intoxicaciones masivas por la exposición a plaguicidas.

El mayor riesgo en el lugar de trabajo para los trabajadores agrícolas corresponde a dislocaciones, distensiones y lesiones traumáticas. Aumenta además por la naturaleza repetitiva de muchos trabajos agrícolas intensivos en mano de obra, que exige agacharse o encorvarse para alcanzar el producto. Algunas tareas de recolección obligan a transportar pesadas bolsas llenas con el producto recolectado, muchas veces al mismo tiempo que se baja de una escalera. En estas situaciones existe un elevado riesgo de padecer lesiones traumáticas y distensiones musculosqueléticas.

En Estados Unidos, una de las principales causas de lesiones mortales en los trabajadores agrícolas son los accidentes de tráfico. Estos suceden con frecuencia cuando los trabajadores agrícolas conducen o son conducidos hasta los campos al amanecer o al anochecer por caminos rurales muy poco seguros. También pueden producirse colisiones con maquinaria agrícola lenta.
La exposición a polvo y a sustancias químicas impone un mayor riesgo de síntomas y enfermedades respiratorias, dependiente en cada caso de las condiciones locales y de los productos cultivados. Por ejemplo, en los climas secos, la exposición a polvo inorgánico puede ocasionar bronquitis y enfermedades pulmonares

La enfermedades dermatológicas constituyen el problema de salud más común en los trabajadores agrícolas. Existen numerosos casos de enfermedades y lesiones cutáneas en esta población, entre ellas las producidas por el uso de herramientas manuales como las tijeras de podar, los irritantes y alergenos presentes en los productos fitosanitarios, los materiales alergénicos de origen animal y vegetal (como la hiedra venenosas), las ortigas y otras plantas irritantes, el calor o el contacto prolongado con el agua, que pueden causar o agravar infecciones de la piel, y la exposición al sol, que puede causar cáncer de piel.

Muchas otras enfermedades crónicas son también más frecuentes en estos trabajadores, aunque se dispone de información limitada sobre los riesgos reales. Entre ellas se encuentran el cáncer, los problemas reproductivos, como abortos, esterilidad o malformaciones congénitas, y los trastornos neurológicos crónicos. Todas ellas se han observado en otras poblaciones agrícolas, o en poblaciones con altos niveles de exposición a distintas toxinas agrícolas, pero se sabe poco sobre el verdadero riesgo al que están expuestos los trabajadores agrícolas.

\section{Agricultura URBANA}

Melvin L. Myers

La agricultura urbana realiza una importante contribución a la producción mundial de alimentos, combustibles y fibras, y sirve principalmente para atender las necesidades diarias de los consumidores que habitan en las ciudades y los pueblos. La agricultura urbana utiliza y recicla recursos naturales y residuos urbanos para la producción agrícola y ganadera.

En la Tabla 64.3 se resumen los distintos sistemas agrícolas que existen en las zonas urbanas. Se estima que la agricultura urbana constituye una fuente de ingresos para casi 100 millones de personas y una fuente de alimentos para otros 500 millones. Está orientada a los mercados urbanos más que a los mercados nacionales o mundiales y se basa en una multiplicidad de explotaciones de pequeño tamaño y algunas agroindustrias a gran escala. Los agricultores urbanos poseen desde un jardín o huerto en sus viviendas de $20 \mathrm{~m}^{2}$ o menos hasta parcelas de $200 \mathrm{~m}^{2}$, o incluso son propietarios a gran escala que arriendan 10 hectáreas en una zona industrial (PNUD 1996).

El paisajismo, una rama de la arquitectura, se ha convertido en una nueva disciplina de la agricultura urbana. La jardinería paisajística consiste en el cuidado de las plantas para su función ornamental en parques y jardines públicos, jardines y patios privados y alrededores de los edificios industriales y comerciales. La jardinería paisajística incluye el cuidado del césped, la plantación de especies anuales (plantas de jardín) y la plantación y el cuidado de arbustos y árboles perennes. Otra actividad relacionada con la jardinería paisajística es el mantenimiento de terrenos de juego, como campos de golf, parques municipales, etc. (Franck y Brownstone 1987). 
Tabla 64.3 - Sistemas agrarios en las zonas urbanas.

\begin{tabular}{|c|c|c|}
\hline Sistemas agrarios & Producto & Lugar o técnica \\
\hline Acuicultura & Pescados y mariscos, ranas, hortalizas, algas y forraje & $\begin{array}{l}\text { Estanques, cursos de agua, jaulas, estuarios, aguas residuales, lagunas, } \\
\text { humedales }\end{array}$ \\
\hline Horticultura & Hortalizas, frutas, gramíneas, bebidas, compost & $\begin{array}{l}\text { Viviendas, parques, servidumbres de paso, depósitos, tejados, cultivo } \\
\text { hidropónico, humedales, invernaderos, técnicas de lecho plano, horticul- } \\
\text { tura de acodado }\end{array}$ \\
\hline Floricultura & Flores, insecticidas, plantas de interior & $\begin{array}{l}\text { Horticultura ornamental, tejados, depósitos, invernaderos, servidumbres de } \\
\text { paso }\end{array}$ \\
\hline Ganadería & Leche, huevos, carne, estiércol, cueros, y pieles & $\begin{array}{l}\text { Alimentación estival en estabulación, servidumbres de paso, laderas, } \\
\text { cooperativas, establos, espacios abiertos }\end{array}$ \\
\hline Agrosilvicultura & $\begin{array}{l}\text { Combustible, frutas y frutos secos, compost, material de } \\
\text { construcción }\end{array}$ & $\begin{array}{l}\text { Arboles de las calles, viviendas, laderas escarpadas, viñedos, cinturones } \\
\text { verdes, humedales, huertos, parques forestales, setos }\end{array}$ \\
\hline Micocultura & Setas, compost & Cobertizos, bodegas \\
\hline Vermicultura & Compost, lombrices para alimento de animales y peces & Cobertizos, bandejas \\
\hline Sericultura & Seda & Viviendas, bandejas \\
\hline Apicultura & Miel, polinización, cera & Colmenas, servidumbres de paso \\
\hline Jardinería paisajística, arboricultura & $\begin{array}{l}\text { Diseño y mantenimiento de jardines, ornamentación, } \\
\text { céspedes, jardines }\end{array}$ & $\begin{array}{l}\text { Patios, parques, campos de juego, zonas comerciales, cunetas, equipo de } \\
\text { jardinería y cortacéspedes }\end{array}$ \\
\hline Cultivo de plantas para obtención de & Uvas (vino), hibisco, té de palma, café, caña de azúcar, & Laderas escarpadas, elaboración de bebidas \\
\hline
\end{tabular}
bebidas

qat (sustitutivo del té), mate, plátano (cerveza)

Fuentes: PNUD 1996; Rowntree 1987.

Tabla 64.4 • Medidas de seguridad en el empleo de equipos mecánicos de jardinería y cuidado del césped.

Tractores (maquinaria agrícola más pequeña de lo habitual)

Prevención del vuelco:

- No conducir por donde el tractor pueda volcar o resbalar; evitar las pendientes escarpadas; atención a las piedras, agujeros y peligros similares.

- Subir y bajar pendientes o laderas; evitar las laderas escarpadas.

- Reducir la marcha y tomar las curvas con cuidado para evitar el vuelco o la pérdida del control del volante y los frenos.

- Respetar los límites de carga del tractor; utilizar balastos para una mayor estabilidad; remitirse al manual del operador.

No permitir nunca que viajen otros pasajeros.

Mantener los acoplamientos de seguridad; garantizan la desconexión de equipos eléctricos cuando el operario no está sentado o cuando el tractor se pone en marcha.

Segadoras rotativas (acopladas a un tractor o remolcadas por éste)

Mantener los acoplamientos de seguridad.

Utilizar cuchillas y carcasas protectoras adecuadas.

Mantener todas las cuchillas y carcasas de seguridad en su sitio y en buen estado.

Utilizar calzado cerrado y fuerte para evitar resbalones y prevenir lesiones.

No permitir que nadie ponga las manos o los pies cerca de la cubierta o de la rampa de descarga cuando la máquina está funcionando; detener la máquina cuando haya niños cerca.

Cuando se termine de utilizar la máquina, dejarla apagada.

Para evitar lesiones por objetos lanzados:

- Despejar la zona que debe segarse.

- Mantener en su sitio las defensas de la cubierta de la máquina, la rampa de descarga o el saco.

- Detener la máquina siempre que alguien se acerque.

Cuando se trabaje montado en la máquina (o empujando o caminando detrás de ella), desconectar las bujías para evitar que el motor se ponga en marcha.
Prevenir incendios no derramando combustible sobre superficies calientes ni manipulándolo cerca de chispas o llamas; evitar la acumulación de combustible, petróleo y residuos cerca de superficies calientes.

Cargadores (acoplados a tractores para céspedes y jardines)

Evitar un exceso de carga.

Dar marcha atrás en rampas y pendientes inclinadas con la cuchara cargadora bajada.

Vigilar la dirección de la marcha más que la cuchara.

Manejar los controles del cargador hidráulico sólo desde el asiento del tractor. Utilizar el cargador sólo para materiales para los que haya sido diseñado.

Bajar la cuchara hasta el suelo cuando se abandone la máquina.

Vehículos utilitarios (similar a los vehículos todos terreno pero diseñados para trabajos fuera de carreteras)

Evitar vuelcos:

- Practicar en terrenos llanos antes de conducir por terrenos desiguales.

- No conducir deprisa; desacelerar antes de tomar una curva (especialmente en pendientes).

- Reducir la velocidad en pendientes y en terreno desigual.

- Atención a los agujeros, piedras y otros peligros ocultos.

No permitir nunca que viajen otros pasajeros.

Evitar los vuelcos distribuyendo la mercancía en el espacio de carga para que no sea demasiado alta ni quede demasiado lejos de la parte posterior.

Evitar accidentes cuando se eleva el espacio de carga manteniéndose lejos de los muelles o malecones de carga.

Cuando se remolquen cargas, colocar peso en el espacio de carga para asegurar la tracción.

Evitar la conducción por vías públicas.

Los niños no deben manejar estas máquinas.

Se recomienda el uso de un casco para proteger la cabeza.

Fuente: Adaptado de Deere \& Co. 1994. 


\section{Descripción del proceso}

La agricultura urbana es considerada como una alternativa para conseguir en un futuro la sostenibilidad ecológica de pueblos y ciudades. En general se dedica al cultivo de productos comerciales de ciclo más corto y valor mayor, recurriendo al multicultivo y al empleo de técnicas agrícolas integradas cuando existe escasez de espacio o de agua. Para sacar el mayor provecho se utiliza el espacio tanto vertical como horizontal. Su principal característica es el reciclaje de residuos. Sus procesos son los típicos de la agricultura, con los mismos materiales y las mismas etapas, pero diseñados para utilizar los residuos humanos y animales como fertilizantes y fuentes de agua para el crecimiento de las plantas. No obstante, en este modelo casi idealizado siguen necesitándose medios de producción externos, como los plaguicidas (PNUD 1996).

En el caso especial del paisajismo, el aspecto es el producto. El cuidado del césped y de árboles, arbustos y flores ornamentales constituye la base de las actividades paisajísticas. En general, el experto en paisajismo compra las plantas, esquejes o semillas en un vivero o a un productor de césped, los planta y los cuida de manera rutinaria y frecuente. Es una actividad típicamente intensiva en mano de obra y sustancias químicas y también es habitual el uso de herramientas manuales y eléctricas, cortadoras de césped y otros aperos de jardinería. Cortar el césped es una labor rutinaria en el paisajismo.

\section{Riesgos y su control}

La agricultura urbana es una actividad que suele desarrollarse a pequeña escala cerca de las viviendas, expuesta a contaminantes urbanos, con reciclado de residuos y riesgo de hurto de los productos u otros incidentes violentos. Los riesgos asociados a los distintos tipos de agricultura, plaguicidas y abonos que se describen en otras secciones de este volumen pueden aplicarse también a este caso (PNUD 1996).

En los países desarrollados, las explotaciones suburbanas y las empresas de paisajismo utilizan máquinas cortacésped y otros equipos de jardinería, como pequeños tractores (con accesorios como segadoras, cargadores delanteros y cuchillas) y vehículos utilitarios (parecidos a los todo terreno). Otros accesorios son arados, carros, quitanieves y recortadoras de setos. Estos tractores son accionados por motores, utilizan combustible, poseen partes móviles, son conducidos por un operario y muchas veces se utilizan con equipos instalados en ellos o remolcados. Son mucho más pequeños que el típico tractor agrícola, pero pueden también volcar y causar lesiones graves. El combustible utilizado supone un riesgo de incendio (Deere \& Co. 1994).

Muchos de los accesorios de los tractores presentan riesgos particulares. Se han dado casos de niños que se han caído de la máquina y han sido aplastados por las ruedas o rebanados por las cuchillas de la segadora. Las segadores plantean dos tipos de riesgos: uno el posible contacto con las cuchillas giratorias y el otro el golpe que pueden producir los objetos lanzados por las cuchillas. Las cuchillas y los cargadores delanteros funcionan por un mecanismo hidráulico y, si quedan desatendidos en posición elevada, existe el peligro de que se caigan encima de alguien que esté debajo y lo aplasten. Los vehículos utilitarios son mucho menos costosos que una camioneta. Pueden volcar en un terreno con mucha pendiente, especialmente en las curvas. Son también peligrosos cuando se utilizan en las vías públicas, debido a la posibilidad de colisión. (Véase en la Tabla 64.4 algunas medidas de seguridad que pueden adoptarse cuando se manejan ciertos tipos de cortacéspedes y equipos de jardinería).

\section{OPERACIONES EN VIVEROS E INVERNADEROS}

Mark M. Methner y John A. Miles

Los viveros crían plantas para el mercado de la replantación (véase la Figura 64.5). Las plantas resistentes se crían en el exterior y las menos resistentes se propagan y crían en interior, generalmente en invernaderos, para protegerlas de las temperaturas frías, los fuertes vientos o una radiación solar excesiva. Muchas plantas que se cultivan en interior cuando las condiciones son duras para su crecimiento, pueden crecer a la intemperie en condiciones climáticas favorables. Los cultivos típicos de los viveros son árboles y arbustos, y los típicos de invernadero son flores, hortalizas y plantas de huerto. La actividad de los viveros está orientada al mercado de la replantación, aunque también cultivan productos para mercados estacionales, como tomates durante los meses fríos del invierno.

Los viveros representan un sector grande y cada vez mayor de la agricultura. En California existen más de 3.000 viveros comerciales que cultivan productos con un gran valor por hectárea, ocupando el quinto lugar en los ingresos de este estado derivados de la agricultura. Al igual que ocurre con gran parte de la agricultura en la costa oeste de Estados Unidos, la mano de obra está dominada por trabajadores de México y de otros países de América Central. La mayoría de estos trabajadores no son migrantes, sino que se integran en las comunidades locales con sus familias (Mines y Martin 1986). Muchos de ellos sólo hablan español o ésa es su lengua materna, y su nivel de estudios es muy bajo. Los salarios son escasos en la mayoría de los puestos de trabajo y existe un exceso de mano de obra. Situaciones similares se dan en todas partes del mundo.

La mayoría de los trabajadores agrícolas consideran que el trabajo en los viveros es comparativamente mejor porque dura todo el año, se pagan salarios más elevados y se suele disfrutar de un seguro de indemnización y asistencia médica. En este sector son muy pocos los que están afiliados a sindicatos y la mayoría de los trabajadores son contratados directamente por

\section{Figura 64.5 • Plantación de café en un vivero de Costa de Marfil.}

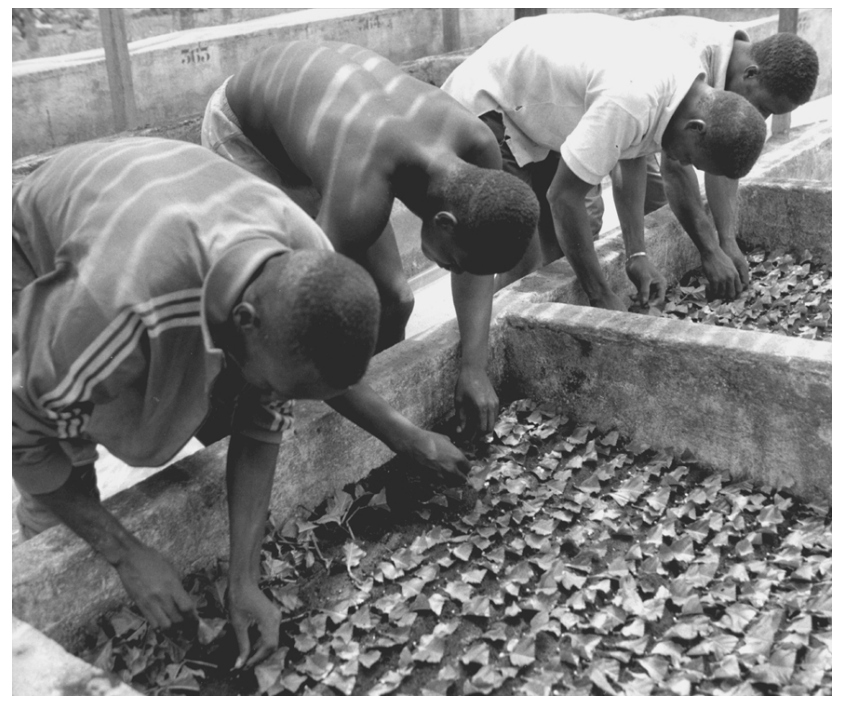


las empresas, sin que existan contratistas de mano de obra agrícola.

Los invernaderos proporcionan un entorno controlado para las plantas y se utilizan para distintos fines, como el cultivo de plantas raras y exóticas, la protección de plantas productoras (como flores, tomates y pimientos) contra el clima invernal y el cuidado de plantas de semillero. El ambiente controlado que ofrecen es una ventaja para quienes desean cultivar productos durante todo el año, con independencia de las condiciones climáticas en el exterior. Las actividades de los invernaderos se han expandido a climas templados. Por ejemplo, en Ucrania la superficie total de invernaderos pasó de 3.070 hectáreas (ha) en 1985 a 3.200 ha en 1990 y unas 3.400 ha en 1995 (Viten, Krashyyuh e Ilyna 1994).

Los invernaderos suelen tener cubiertas a dos aguas para lograr una buena exposición a la luz solar durante el invierno, así como drenaje y protección contra el viento. Suelen construirse con materiales como madera, aluminio o una combinación de tubos de acero y madera. Las paredes laterales pueden ser de contrachapado, aluminio, madera o vinilo. En Ucrania, el $60 \%$ de los invernaderos tienen paredes hechas con ladrillos de mampostería. Las cubiertas son de cristal o de plástico, que a su vez puede ser rígido o flexible. Son plásticos rígidos la fibra de vidrio, los acrílicos o los policarbonatados. Son plásticos flexibles el polietileno, el cloruro de polivinilo o el poliéster. Los plásticos policarbonatados resistentes el impacto de objetos y los plásticos flexibles requieren ser sustituidos con frecuencia. Las cubiertas pueden ser transparentes u opacas y sirven para tres fines. Uno de ellos es dejar que pase la luz del sol al interior para las plantas. Otro es calentar el espacio cerrado; el último es proteger a las plantas de factores de estrés ambiental, como la nieve, la lluvia, el granizo, los fuertes vientos, las aves, los pequeños mamíferos y los insectos.

En un invernadero han de controlarse la temperatura, la humedad y la ventilación utilizando fuentes de calor artificiales, ventiladores de admisión y extracción, estructuras que proporcionen sombra (como listones de madera o redes), sistemas de refrigeración (como tejidos húmedos o enfriamiento por evaporación), humidificadores y equipos de control climático (Jones 1978).

Los trabajadores de los viveros y los invernaderos están expuestos a una serie de peligros: productos irritantes de la piel, polvo, ruido, estrés por calor, trastornos musculosqueléticos (distensiones y dislocaciones), plaguicidas y accidentes relacionados con vehículos, máquinas, resbalones, caídas y electricidad. Seguidamente se describen únicamente los riesgos ergonómicos del trabajo en los viveros y los riesgos asociados a los plaguicidas del trabajo en los invernaderos. Muchos de ellos son comunes a ambos lugares de trabajo.

\section{Actividades en los viveros}

Las actividades típicas de un gran vivero mayorista especializado en el cultivo de plantas enmacetadas de exterior para jardines y usos ornamentales abarcan cuatro etapas:

1. Etapa de propagación. Las nuevas plantas inician su crecimiento en un medio especial utilizando uno de los siguientes cuatro métodos: esquejes de plantas maduras, cultivo de tejidos, semillas e injertos.

2. Fase de replantación. Cuando las plantas crecen, son replantadas en contenedores individuales de plásticos llamados "macetas" (normalmente 2 ó 3 veces al principio del ciclo de crecimiento). Una potente cinta transportadora hace pasar las macetas nuevas y de mayor tamaño por debajo de una tolva donde se llenan de tierra. A medida que las macetas avanzan por la cinta transportadora, las plantas son manualmente trasplantadas en ellas y por último transferidas manualmente a un remolque para su transporte al campo.

3. Etapa de crecimiento o tareas de campo. Las plantas se mantienen por grupos en el exterior hasta que alcanzan la plena madurez. Durante este período, las tareas consisten en regar, podar, fertilizar, eliminar las malas hierbas, colocar guías, dar forma y distanciar a las plantas a medida que éstas crecen.

4. Transporte. Las plantas maduras son trasladas a la zona de expedición, donde se etiquetan, organizan por pedidos $\mathrm{y}$ cargan en los camiones. Esta operación puede también incluir la descarga del camión en los puntos de venta minorista.

\section{Riesgos ergonómicos}

El trabajo en los viveros, así como otras actividades agrícolas, se asocian a elevadas tasas de lesiones por dislocaciones y distensiones. Los datos de AgSafe (1992) indican que el 38,9\% de las lesiones notificadas en los trabajos de horticultura (incluidos los viveros) fueron distensiones y dislocaciones, porcentaje ligeramente superior al resto del sector agrícola en su conjunto. Los esfuerzos excesivos fueron la causa del 30,2\% de las lesiones, tasa también ligeramente superior a la media del sector.

Los factores de riesgo más comunes para la aparición de problemas musculosqueléticos relacionados con el trabajo parecen estar asociados a las siguientes tareas:

Durante la multiplicación, el trabajador permanece de pie o sentado ante una mesa de trabajo, vacía una cesta con esquejes de las plantas y utiliza unas tijeras de mano para cortarlos en trozos más pequeños. Con la mano derecha se manejan las tijeras y con la izquierda se agarran los esquejes. Una vez cortado cada esqueje, las tijeras tienen que limpiarse sumergiéndolas en un pequeño recipiente con una disolución desinfectante.

$\mathrm{Al}$ cortar, una de las manos está ocupada en apretar las tijeras de forma muy repetitiva, con una media de entre 50 y 60 cortes por minuto. Durante todo este ciclo se produce una flexión leve o moderada de la muñeca y una desviación del cúbito. La otra mano se utiliza para agarrar los esquejes, orientarlos correctamente para su cortado y arrojar los restos en un bidón. Durante todo esta operación se produce también una extensión moderada de la muñeca y una desviación del cúbito.

Los trabajadores que realizan esta labor son muy especializados y se dedican a ella casi todo el año, sin rotación a otros puestos de trabajo. Es frecuente que sufran dolor y entumecimiento de la mano, la muñeca y el brazo. Al cabo de varios años de realizar esta actividad, registran una elevada incidencia del síndrome del túnel carpiano.

Para transportar las plantas de la cinta transportadora a un remolque, los trabajadores tienen que agarrar 3 ó 4 macetas de $4 \mathrm{~kg}$ en cada mano y colocarlas en un remolque situado a un lado o detrás de ellos. Este ciclo de trabajo se repite entre 13 y 20 veces por minuto. Los factores de riesgo son la acción altamente repetitiva de agarrar, la gran presión que se ejerce y las posturas forzadas, con flexión de tronco, la zona lumbar y la espalda.

Para transportar las plantas del remolque al lecho de plantación, el trabajador agarra 3 ó 4 macetas las carga unos 17 m y las coloca en el suelo formando una fila. Este ciclo de trabajo se repite 3 ó 5 veces por minuto. La manipulación de macetas es un trabajo a tiempo completo durante todo el año para muchos trabajadores. Se asocia con dolor en los dedos y las manos, las extremidades superiores y la parte inferior de la espalda. Puesto que estos trabajadores suelen ser más jóvenes, todavía no existen datos que avalen la elevada tasa de lesiones crónicas de espalda que puede preverse en ellos. 
Figura 64.6 - Corte de plantas trasplantadas de tabaco en un invernadero de Carolina del Norte.

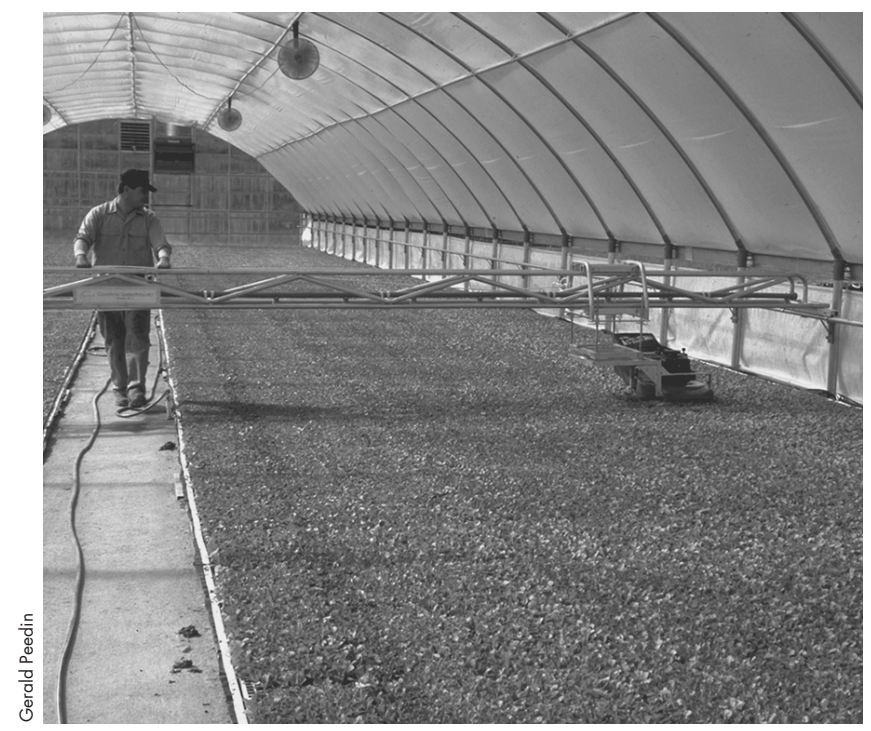

Esta operación se realiza con un cortacésped tradicional conectado a una barra pulverizadora, que se utiliza asimismo para aplicar agua y plaguicidas cuando es necesario.

Los podadores utilizan distintos tipos de tijeras para cortar partes no deseadas o muertas de la zona superior y los laterales de las plantas. Suelen permanecer de pie o han de inclinarse hacia delante para alcanzar las plantas. Con la mano dominante agarran las tijeras y realizan un movimiento muy repetitivo, con 40 ó 50 cortes por minuto. Los dedos de esa misma mano se utilizan también para arrancar ramitas u otras partes de la planta. Con la mano no dominante sujetan y mueven la maceta para una poda más rápida y también agarran las ramas cortadas aplicando una fuerza estática con una flexión moderada de la muñeca y cierta desviación del cúbito durante todo el ciclo del cortado. Puesto que la poda es una tarea a tiempo parcial para la mayoría de los trabajadores, éstos consiguen cierto alivio y recuperación de las molestias gracias a la variación de tareas. No obstante, el trabajo produce dolor en los dedos, la muñeca, las extremidades superiores y la parte inferior de la espalda.

Para que las plantas tengan un espacio adecuado que les permita crecer y expandirse, periódicamente deben realizarse labores de espaciado. Esta tarea exige agarrar y levantar 3 ó 4 plantas en cada mano, transportarlas una cierta distancia y colocarlas en el suelo formando hileras. Este ciclo se repite entre 3 y 5 veces por minuto. Al igual que la poda, el espaciado es una tarea a tiempo parcial para la mayoría de los trabajadores, que les permite el alivio y la recuperación. Es un trabajo que también produce dolor en los dedos y las manos, las muñecas, las extremidades superiores y la parte inferior de la espalda.

La mayoría de los trabajos en los viveros exigen un considerable esfuerzo físico y eso, sumado a la naturaleza repetitiva de muchas tareas, supone un riesgo considerable de lesiones por movimiento repetitivos. Hasta hace muy poco no han empezado a desarrollarse herramientas que ayuden a mejorar la postura corporal y reducir los requisitos energéticos de ciertas tareas.

\section{Operaciones en los invernaderos}

Las operaciones típicas en un invernadero varían según que la finalidad sea cultivar plantas raras y exóticas, plantas de producción o plantas de semillero. El cultivo de plantas raras y exóticas es una tarea que ocupa todo el año. Las plantas de producción suelen cultivarse en estas instalaciones para protegerlas del clima y, por consiguiente, los invernaderos se utilizan sólo en algunas estaciones del año. El cultivo de plantas de semillero es similar a las operaciones de los viveros, con la variante de que su mercado es el de plantas para la replantación de primavera después de la última helada. Las tareas asociadas al cultivo en invernadero implican llenar de tierra pequeñas macetas, plantar una semilla en cada maceta, regar y fertilizar, recortar o podar según sea necesario (véase la Figura 64.6), aplicar fumigantes o plaguicidas y transportar las plantas o productos desde el invernadero. En los invernaderos orientados a la producción se han mecanizado las operaciones de llenado con tierra de las macetas y plantación. Esta tierra de las macetas puede ser una mezcla de turba, perlita y vermiculita. La poda puede ser mecanizada, dependiendo del tipo de cultivo. El riego puede realizarse directamente con una manguera o con un aspersor automático o un sistema de tuberías, añadiendo nutrientes al agua. La aplicación de plaguicidas mediante rociado manual es lo más frecuente. La esterilización del suelo se realiza utilizando vapor o productos químicos, entre ellos dibromocloropropano (DBCP). El transporte de las plantas o los productos es casi siempre una actividad manual.

\section{Uso de plaguicidas en los invernaderos}

Las enfermedades e insectos que atacan a las plantas pueden causar graves problemas a los trabajadores de los invernaderos. En general, es más fácil prevenir estos daños que intentar

Figura 64.7 • Un trabajador con equipo de protección completo aplicando un plaguicida en un invernadero.

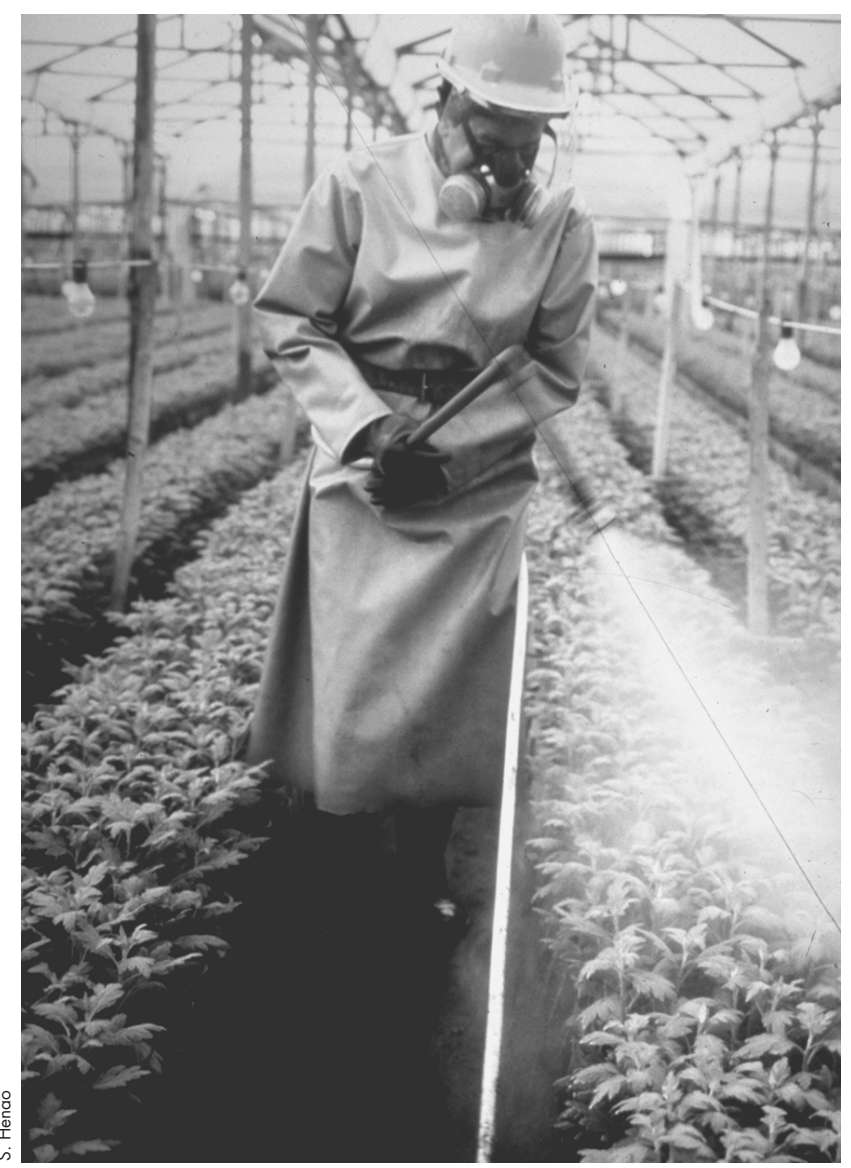


erradicar la plaga después. Algunas plagas comunes en invernaderos son insectos, hongos, virus, bacterias y nematodos. Para combatirlas se aplican productos químicos (plaguicidas).

Existen muchos métodos de aplicación de los plaguicidas para que sean eficaces. Los más comunes son: pulverización de líquidos, nebulización, o distribución de nieblas, polvos, vapores, humos, aerosoles y gránulos. Los pulverizadores constan de un recipiente con una mezcla de agua y plaguicida, dotado de un tubo flexible al que se ha conectado una boquilla rociadora. $\mathrm{Al}$ presionar, la mezcla se distribuye sobre las plantas en forma de gotas de líquido. Los nebulizadores utilizan una técnica similar, pero las gotas resultantes son más pequeñas. Los plaguicidas en polvo suelen liberarse al aire dejando que se depositen sobre la superficie de las plantas. Los vaporizadores utilizan dispositivos calefactores para generar gotas muy pequeñas dirigidas a las plantas. Los humos de plaguicida se generan mediante la ignición de un quemador y su introducción en un recipiente que contiene el compuesto químico.

Los aerosoles se introducen a presión en un envase provisto de un válvula que libera el producto a la atmósfera cuando se abre. Finalmente, los plaguicidas en grano se depositan en el suelo y se riega a continuación. El agua del riego los disuelve y transporta la sustancia química hasta las raíces de la planta, matando a los organismos en el mismo suelo o siendo absorbida por la planta y matando a los organismos que se alimentan de ella.

Todos estos métodos de aplicación de plaguicidas conllevan el riesgo de exposición a la sustancia química. Las dos vías más frecuentes de exposición son la piel (dérmica) y los pulmones (por inhalación). Otra, aunque menos común, es la ingestión de alimentos y bebidas contaminadas con plaguicidas. Los trabajadores de los invernaderos que manipulan los productos químicos o las plantas fumigadas pueden intoxicarse si no adoptan las oportunas medidas de precaución.

Las intoxicaciones por plaguicidas pueden evitarse instalando sistemas de ventilación adecuados en los invernaderos, utilizando los equipos de protección individual necesarios (trajes, guantes, respiradores, botas — véase la Figura 64.7) y manteniendo éstos en perfecto estado, respetando los tiempos recomendados antes de volver a entrar en el invernadero y siguiendo las instrucciones que aparecen en las etiquetas. Otras medidas de precaución se basan en almacenar todos los plaguicidas en una zona cerrada bajo llave y bien ventilada, colocar carteles en las zonas donde se han fumigado las plantas e instruir a los trabajadores sobre los plaguicidas y las técnicas correctas para su aplicación y manipulación. Finalmente, todos los trabajadores encargados de la aplicación de plaguicidas deben aprender unas técnicas adecuadas para la eliminación de los productos ya inservibles y de los recipientes vacíos.

\section{- Floricultura}

\section{Samuel H. Henao}

Desde principios del decenio de 1990, en muchos países y en diferentes continentes se ha desarrollado rápidamente la floricultura como actividad económica. Su creciente importancia en los mercados de exportación ha dado lugar al desarrollo integrado de los distintos aspectos de esta actividad, esto es, la producción, tecnología, investigación científica, transporte y conservación.

\section{Producción}

La producción de flores cortadas tiene dos componentes esenciales:
Figura 64.8 • Cuidado de las flores en un invernadero.

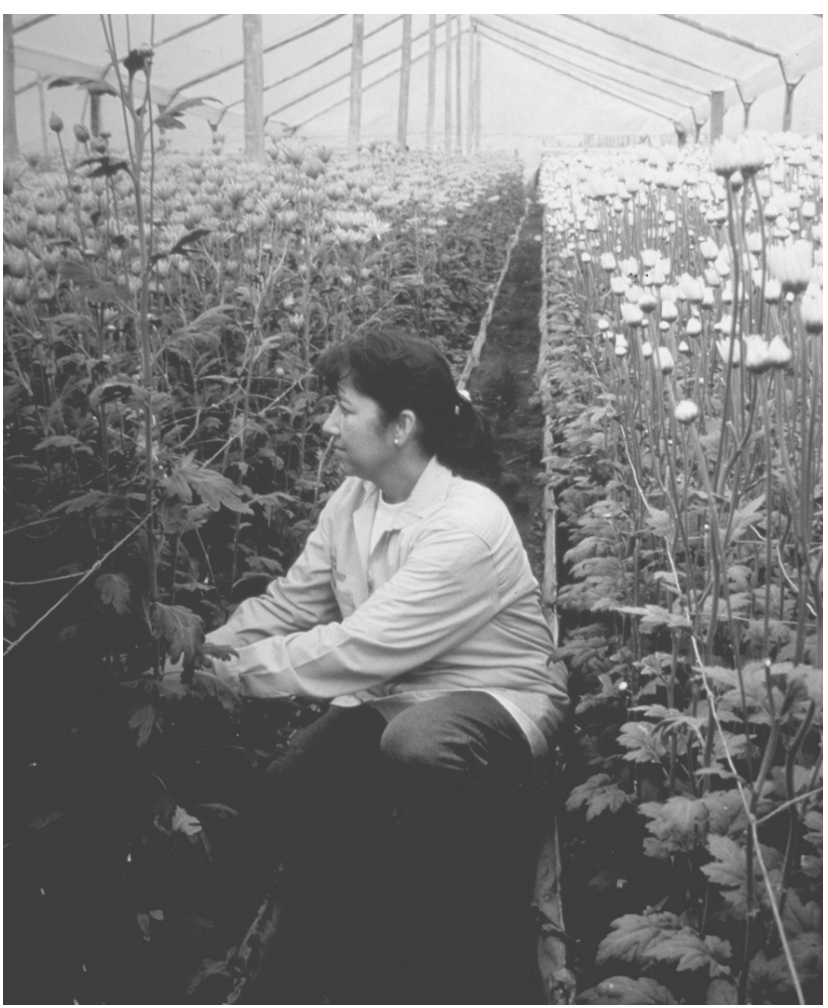

1. el proceso de producción, que abarca todas las actividades directamente relacionadas con la generación y el desarrollo del producto hasta el momento de su embalaje

2. las diversas actividades que ayudan a la producción, la comercialización y la distribución de flores cortadas.

El proceso de producción en sí mismo abarca tres fases: germinación, cultivo y procedimientos posteriores a la recolección.

La germinación se realiza con plantas progenitoras a partir de las cuales se obtienen esquejes para su cultivo.

Los esquejes de diferentes flores se plantan en lechos con un medio de enraizamiento. Los lechos se preparan con escoria tratada con vapor y productos químicos para desinfectar el medio de cultivo y facilitar el crecimiento de las raíces.

El cultivo tiene lugar en invernaderos que alojan los lechos del medio de enraizamiento donde las flores se plantan y crecen según se describe en el artículo "Operaciones de invernaderos y viveros" en este mismo capítulo y según se indica en la Figura 64.8. El cultivo incluye la preparación del suelo, la plantación de los esquejes (Figura 64.9) y la recogida de las flores.

La plantación comprende un ciclo que comienza con la colocación de los esquejes en el medio de enraizamiento y termina con la floración de la planta, abarcando las siguientes actividades: plantación, riego normal, riego por goteo con fertilizante, cultivo y escarda del suelo, poda de la yema de crecimiento de la planta para obligarla a ramificarse y obtener más flores, preparación de las guías que mantienen la planta derecha y crecimiento, ramificación y floración de la planta.

La producción concluye con la recogida de las flores y su clasificación. 
En la etapa posterior a la recolección - aparte de la selección y clasificación - las flores se cubren con plástico, se les aplica un tratamiento sanitario y se embalan para su transporte.

Otras actividades secundarias consisten en vigilar la salud de las plantas para detectar plagas y enfermedades, obtener materias primas del almacén y mantener los hornos.

\section{Factores de riesgo para la salud}

Los principales factores de riesgo en cada una de las diferentes áreas de trabajo son:

- sustancias químicas

- temperaturas extremas; calor

- radiación no ionizante

- enfermedades infecciosas

- factores ergonómicos

- factores mecánicos

- factores psicosociales.

\section{Sustancias químicas}

Intoxicaciones y enfermedades crónicas causadas por los plaguicidas

Las tasas de morbilidad y mortalidad observadas en los trabajadores por la exposición a plaguicidas no son la consecuencia de una sencilla relación entre el agente químico y la persona expuesta al mismo, sino que reflejan también la interrelación de muchos otros factores, como la duración de la exposición, la sensibilidad individual, el estado nutricional de la persona expuesta, variables educativas y culturales y condiciones socioeconómicas en las que viven los trabajadores.

Además de los principios activos presentes en los plaguicidas, tienen que tenerse en cuenta las sustancias que transportan estos principios activos y los aditivos, porque en algunos casos pueden tener efectos adversos más graves que el principio activo en sí.

La toxicidad de los plaguicidas organofosforados se debe a sus efectos en el sistema nervioso central, ya que inhiben la actividad de la enzima acetilcolinesterasa. Estos efectos son acumulativos, habiéndose observado también efectos diferidos en el sistema nervioso periférico y en el central. Según los estudios realizados en varios países, la prevalencia de la inhibición de esta enzima en los trabajadores que manipulan plaguicidas organofosforados fluctúa entre el $3 \%$ y el $18 \%$.

Los efectos a largo plazo son procesos patológicos que aparecen después de un período de latencia y que se deben a exposiciones repetidas. Entre los efectos a largo plazo que se han relacionado con la exposición a plaguicidas figuran lesiones epidérmicas, lesiones nerviosas y efectos mutagénicos.

\section{Problemas respiratorios}

Las plantas decorativas pueden irritar el sistema respiratorio y causar tos y estornudos. Además, sus fragancias u olores pueden agravar los síntomas de asma o rinitis alérgica, aunque no se ha demostrado que causen alergia. El polen del crisantemo y el girasol puede causar asma. El polvo de las plantas secas causa algunas veces alergias.

\section{Dermatitis}

El $90 \%$ de los casos de dermatitis profesional encontrados en la floricultura están causados por contacto. De ellos, casi el $60 \%$ están causados por irritantes primarios y el $40 \%$ son reacciones alérgicas. El cuadro agudo se caracteriza por irritación (eritema), hinchazón (edema), granos (pápulas), vesículas o ampollas. Afecta principalmente a manos, muñecas y antebrazos. El cuadro crónico puede consistir en fisuras profundas, liquenificación
Figura 64.9 • Plantación de esquejes en un invernadero.

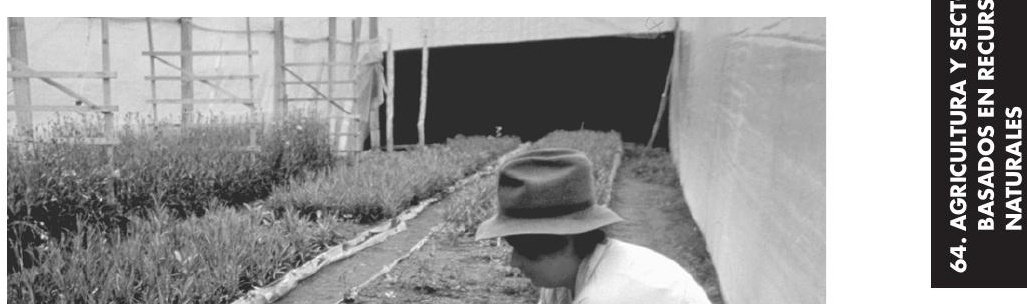

(engrosamiento y endurecimiento) de la piel y xerosis grave (sequedad). Puede ser incapacitante o incluso irreversible.

La floricultura es una actividad caracterizada por un fuerte contacto con irritantes primarios o sustancias alergénicas y por ese motivo es importante promover y adoptar medidas preventivas, como el uso de guantes.

\section{Temperaturas extremas; calor}

Cuando el trabajo ha de realizarse en un ambiente caluroso, como el de un invernadero, la carga térmica del trabajador es la suma del calor en el ambiente de trabajo más la energía consumida en la realización de la tarea.

Los efectos físicos de una exposición excesiva al calor son erupción, calambres y espasmos musculares, agotamiento y desvanecimiento. La erupción, además de ser muy molesta, reduce la tolerancia del trabajador al calor. Si se produce una sudoración abundante y no se reponen adecuadamente los líquidos y electrolitos perdidos, pueden aparecer calambres y espasmos musculares. El agotamiento por calor ocurre cuando el control vasomotor y el gasto cardíaco son insuficientes para compensar la demanda adicional impuesta a estos sistemas por el estrés térmico. El desvanecimiento constituye una situación clínica muy grave que puede desembocar en confusión, delirio y coma.

Las precauciones que deben adoptarse consisten en programar períodos de descanso frecuentes en zonas frescas, beber líquidos, rotar en las tareas que exigen un gran esfuerzo físico y utilizar ropa de colores claros.

\section{Radiación no ionizante}

Los principales tipos de radiación no ionizante a la que están expuestos los trabajadores de la floricultura son la radiación ultravioleta (UV), la luz visible y la radiación infrarroja. Los efectos más graves de la radiación UV son eritema solar, dermatitis actínica, conjuntivitis irritativa y fotoqueratitis. 
Figura 64.10 - Las posturas encorvadas durante largos períodos son una causa frecuente de problemas ergonómicos.

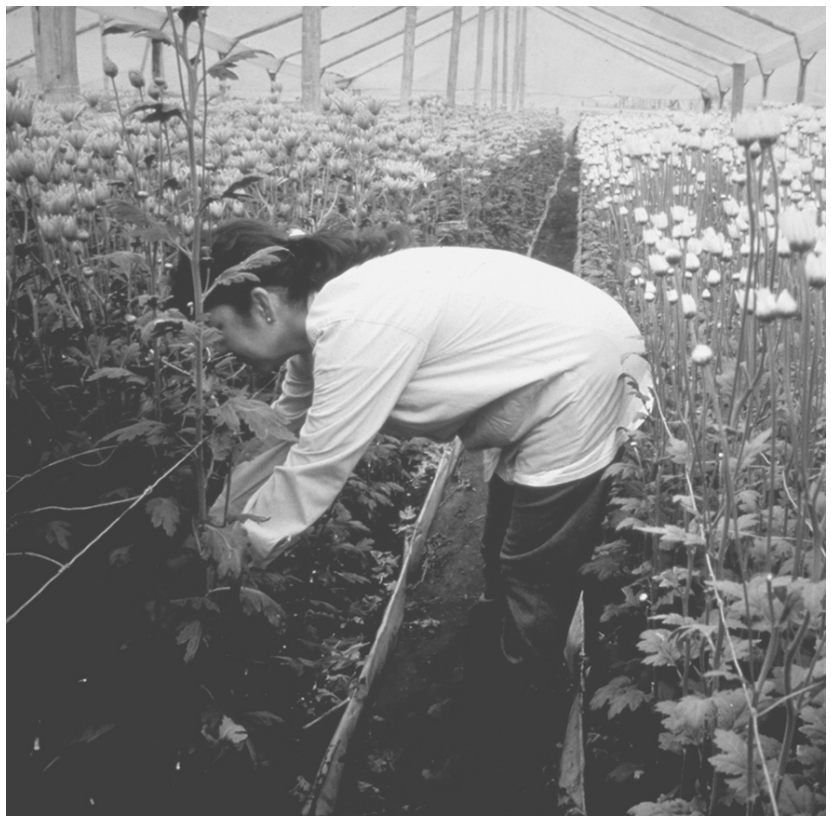

La radiación del espectro visible de la luz puede causar degeneración de la retina y la mácula. Un síntoma de la exposición a radiación infrarroja es la aparición de quemaduras superficiales en la córnea, y la exposición prolongada puede causar la aparición prematura de cataratas.

Las precauciones que deben adoptarse consisten en cubrir la piel, utilizar gafas oscuras e intensificar la vigilancia médica.

\section{Factores ergonómicos}

Los trabajadores que mantienen una postura corporal estática durante largos períodos de tiempo (véase la Figura 64.10) pueden sufrir contracturas musculares estáticas y alteraciones de los sistemas periférico, vascular y nervioso. Los movimientos repetitivos son más habituales en las tareas que requieren destreza manual. Por ejemplo, la acción de cortar con tijeras requiere una gran fuerza y exige un movimiento repetitivo. Los efectos observados con más frecuencia son trastornos musculosqueléticos, como tendinitis del codo y la muñeca, síndrome del túnel carpiano y restricción de la movilidad de los hombros.

La rotación en el puesto de trabajo y un diseño ergonómico adecuado de herramientas como las tijeras de podar son precauciones necesarias. La adaptación del lugar de trabajo para que los trabajadores no tengan que agacharse tanto es otra posible solución.

\section{Enfermedades infecciosas}

La floricultura puede exponer a los trabajadores a una serie de agentes biológicos. Los signos precoces de una infección rara vez son específicos, aunque en general están lo suficientemente bien definidos para sospechar una enfermedad. La sintomatología y las precauciones dependen del agente, que puede ser tétanos, rabia, hepatitis, etc. Las medidas preventivas consisten en disponer de una fuente de agua potable, unas buenas instalaciones sanitarias, un botiquín de primeros auxilios y asistencia médica para los cortes y abrasiones.

\section{Otros factores}

Los riesgos más comunes para la salud y la seguridad asociados a factores mecánicos son cortes, abrasiones y traumatismos múltiples, que casi siempre afectan a las manos y el rostro. Estas lesiones deben ser atendidas en el acto. Los trabajadores deben recibir cada cierto tiempo dosis de recuerdo de la vacuna del tétanos y tener siempre acceso a un equipo adecuado de primeros auxilios.

El entorno psicosocial puede poner también en peligro la salud de los trabajadores. La exposición a esos factores puede tener las siguientes consecuencias: cambios fisiológicos (indigestión, estreñimiento, palpitaciones, dificultad respiratoria, hiperventilación, insomnio y ansiedad); trastornos psicológicos (tensión y depresión); y trastornos de la conducta (absentismo, inestabilidad, insatisfacción).

\section{EDUCACION DE LOS TRABAJADORES AGRICOLAS SOBRE LOS PLAGUICIDAS: ESTUDIO DE UN CASO}

\section{Merri Weinger}

En la finca San Antonio, varios trabajadores se intoxicaron al aplicar el plaguicida Lannate. Una investigación del caso reveló que habían utilizado fumigadores colgados en la espalda sin llevar prendas protectoras, guantes o botas. El empleador nunca les había proporcionado el equipo necesario y tampoco disponían de jabón ni duchas. Después de las intoxicaciones, se obligó al empleador a emprender las acciones correctoras oportunas.

Cuando el Ministerio de Sanidad realizó una inspección de seguimiento, descubrió que muchos trabajadores seguían sin utilizar prendas ni equipos protectores. Cuando les preguntaron la razón, algunos respondieron que el equipo les daba demasiado calor y era incómodo. Otros explicaron que habían trabajado así durante años y que nunca habían tenido problemas. Algunos comentaron que no necesitaban el equipo porque bebían grandes vasos de leche después de aplicar los plaguicidas.

Esta experiencia, que tuvo lugar en Nicaragua, es común en muchas partes del mundo e ilustra la necesidad de un programa eficaz de educación de los trabajadores agrícolas. La educación debe ir acompañada de la creación de un entorno de trabajo seguro y de la aplicación de la legislación vigente, aunque también tienen que considerarse las barreras que existen para la adopción de unas prácticas de trabajo seguras e incorporarlas a los programas de educación. Estas barreras, como un entorno de trabajo poco seguro, la ausencia de equipos protectores y actitudes y creencias que no promueven la salud, deben abordarse directamente en las sesiones educativas y diseñar estrategias para su eliminación.

En este artículo se describe un programa de educación orientado a la acción incorporado a dos proyectos multidisciplinarios para solucionar los problemas de la intoxicación de los trabajadores agrícolas por plaguicidas. Estos proyectos fueron desarrollados en Nicaragua por CARE, Nicaragua y el American Friends Service Committee (entre 1985 y 1989) y en la región centroamericana por la Organización Internacional del Trabajo (OIT, desde 1993 hasta la actualidad). Además de su clara orientación educativa, el proyecto de Nicaragua desarrolló métodos perfeccionados para mezclar y cargar los plaguicidas, un plan de vigilancia médica para diagnosticar en los trabajadores un exceso de exposición a los plaguicidas y un sistema para recabar 
datos epidemiológicos (Weinger y Lyons 1992). En su proyecto multifacético, la OIT insistió en la necesidad de mejoras legislativas, formación y creación de una red regional de educadores sobre los plaguicidas.

Los elementos básicos de ambos proyectos fueron la evaluación de las necesidades de educación para adaptar el contenido del programa a la audiencia diana, el uso de una serie de métodos de enseñanza participativos (Weinger y Wallerstein 1990) y la elaboración de un manual para el educador y materiales didácticos para facilitar el proceso de aprendizaje. Los temas tratados fueron los efectos de los plaguicidas en la salud, los síntomas de la intoxicación por plaguicidas, los derechos de los trabajadores, los recursos y un componente de resolución de problemas que analizaba los obstáculos para un trabajo seguro y la manera de superarlos.

Aunque existían muchas similitudes entre los dos proyectos, el de Nicaragua hacía hincapie en la educación de los trabajadores, mientras que el proyecto regional se centraba en la formación de los educadores. En este artículo se ofrecen algunas directrices para la formación tanto de los trabajadores como de los educadores.

\section{Educación de los trabajadores}

\section{Evaluación de las necesidades}

La primera etapa en el desarrollo del programa de educación era la evaluación de necesidades o la "fase de escucha", para identificar los problemas y obstáculos a un cambio real, reconocer los factores que podían facilitar el cambio, definir valores y creencias en los trabajadores agrícolas e identificar exposiciones y experiencias peligrosas que tenían que incorporarse al programa. El equipo del proyecto de Nicaragua recurrió a inspecciones in situ para observar las prácticas de trabajo y las fuentes de exposición de los trabajadores a los plaguicidas. Se tomaron fotografías de los lugares y las prácticas de trabajo con fines de documentación, análisis y debate durante las sesiones educativas. El equipo prestó también atención a los problemas emocionales que podían constituir barreras para la acción: la frustración de los trabajadores por una protección personal inadecuada, la ausencia de jabón o agua o la inexistencia de alternativas seguras a los plaguicidas utilizados.

\section{Métodos y objetivos de la educación}

La siguiente etapa en el proceso de educación fue seleccionar los temas que debían tratarse basándose en la información recabada de los propios trabajadores y, a continuación, seleccionar métodos de enseñanza adecuados basándose en los objetivos del aprendizaje. La educación tenía cuatro objetivos: informar; identificar y cambiar actitudes/emociones; promover conductas saludables; y desarrollar destrezas para la acción y la resolución de problemas. A continuación se ofrecen algunos ejemplos de los métodos utilizados, agrupados en función del objetivo que perseguían e incorporados a un programa educativo de dos días de duración (Wallerstein y Weinger 1992).

\section{Métodos utilizados con fines de información}

Caballete de hojas móviles. En Nicaragua, el equipo del proyecto necesitaba herramientas didácticas visuales que pudieran transportarse fácilmente y cuyo uso no dependiera de la electricidad, de manera que pudieran utilizarse en los campos o durante las exploraciones médicas en las propiedades. El caballete de hojas móviles contenía 18 dibujos que representaban situaciones de la vida real y que pretendían servir para fomentar los debates. Cada dibujo se asociaba a unos objetivos específicos y a unas preguntas clave que se subrayaban en el manual de los educadores.

El caballete de hojas móviles podía utilizarse tanto para facilitar información como para promover el análisis de problemas y la elaboración de planes de acción. Por ejemplo, uno de los dibujos se utilizó para facilitar información sobre las rutas de entrada preguntando "¿Cómo se introducen los plaguicidas en el organismo?" Para iniciar el análisis del problema de la intoxicación por plaguicidas, el educador preguntaba a los participantes: “Qué está pasando aquí? ¿Les resulta familiar esta escena? ¿Por qué ocurre? ¿Qué podemos hacer al respecto?” Mostrando a dos o más personas un mismo dibujo (de dos personas que entraban en un campo recién fumigado), se desencadenaba un debate sobre las posibles motivaciones y sentimientos. “¿Por qué está leyendo el cartel? ¿Por qué se fue directamente a la zona recién fumigada?" Con imágenes visuales eficaces, el propio dibujo puede suscitar diferentes debates, dependiendo de cada grupo.

Diapositivas. Las diapositivas con imágenes o problemas familiares se utilizaron de la misma forma que el caballete de hojas móviles. Con fotografías tomadas durante la fase de evaluación de las necesidades se organizó una sesión de diapositivas siguiendo el proceso de la utilización de plaguicidas, desde su selección y adquisición hasta su eliminación y limpieza al final de la jornada de trabajo.

Métodos orientados al desarrollo de actitudes y emociones Las actitudes y emociones pueden realmente bloquear el aprendizaje e influir en la adopción de medidas de salud y seguridad al reincorporarse al trabajo.

Escenificación. Para analizar actitudes y promover un debate sobre los problemas de la exposición a plaguicidas se recurrió con frecuencia a la escenificación. Se entregó el siguiente guión a tres trabajadores, que leyeron sus respectivos papeles al resto del grupo.

\section{Fosé: ¿Cuál es el problema?}

Rafael: Estoy a punto de claudicar. Dos trabajadores han resultado intoxicados hoy, sólo una semana después de esa larga sesión educativa. Aquí nunca cambia nada.

fosé: ¿`Y qué esperabas? Los propietarios ni siquiera acudieron a la sesión.

Sara: Pero al menos organizaron una sesión educativa para los trabajadores. Eso ya es más de lo que están haciendo los propietarios de otras fincas.

Fosé: Organizar una sesión educativa es una cosa, ¿pero qué hay del seguimiento? ¿Nos han facilitado duchas y equipos de protección individual?

Sara: ¿Has pensado alguna vez si los trabajadores tendrán algo que ver con esas intoxicaciones? ¿Cómo sabes que están trabajando de una forma segura?

Rafael: No lo sé. Todo lo que sé es que esos dos chicos están hoy en el hospital y yo tengo que regresar a mi trabajo.

Este tipo de guiones se utilizaron para analizar los complejos problemas de la salud y seguridad de los plaguicidas y los múltiples factores implicados en su resolución, entre ellos la educación. En el debate que siguió, el educador preguntó al grupo si alguien compartía alguna de las actitudes expresadas por los trabajadores agrícolas en el guión, se identificaron los obstáculos para resolver los problemas aludidos y se sugirieron estrategias para superarlos. 
Cuestionario de trabajo. Además de inducir el debate y facilitar información sobre los hechos, los cuestionarios pueden servir para descubrir actitudes. A un grupo de trabajadores agrícolas de Nicaragua se le formularon preguntas como las siguientes:

1. Beber leche después del trabajo es eficaz para prevenir la intoxicación por plaguicidas.

Verdadero

2. Todos los plaguicidas tienen el mismo efecto en la salud. Verdadero

Se promovió un debate sobre actitudes invitando a los participantes con puntos de vista contrarios a exponer y justificar sus opiniones. En lugar de confirmar la respuesta "correcta", el instructor identificó elementos útiles en las distintas actitudes que se expresaron.

Métodos orientados al desarrollo de destrezas de conducta Las destrezas de conducta son las competencias que los trabajadores deberían adquirir como resultado de la educación. La manera más eficaz de mejorarlas es ofrecer a los participantes la oportunidad de practicar en clase, observar cómo se realiza una actividad e intentarla ellos mismos.

Demostración del uso de equipos de protección individual.

En una mesa se expuso toda una serie de equipos y prendas de protección, algunos adecuados y otros inadecuados. El educador pidió a un voluntario que se pusiera ropa de protección adecuada para la aplicación de plaguicidas. El trabajador eligió entre todos los artículos expuestos los que consideró más adecuados y se los puso; se pidió a la audiencia que hiciera comentarios. Posteriormente se entabló un debate sobre las prendas protectoras adecuadas y las alternativas para ropas poco cómodas.

Ejercicios prácticos. En Nicaragua, tanto los educadores como los trabajadores agrícolas aprendieron a interpretar las etiquetas de los plaguicidas leyéndolas en pequeños grupos durante la clase. Para realizar esta actividad la clase se dividió en dos grupos, a los que se les encomendó la tarea de leer diferentes etiquetas. En los casos en que todos los trabajadores del grupo eran analfabetos, se buscaron voluntarios entre los participantes para leer las etiquetas en voz alta y ayudar al grupo a rellenar un cuestionario sobre dicha etiqueta, en el que se insistía en las claves visuales para determinar el nivel de toxicidad. Reunidos todos los grupos, los portavoces voluntarios presentaron su plaguicida al resto de los participantes con instrucciones para usuarios potenciales.

Métodos orientados a la acción y la resolución de problemas. Uno de los principales objetivos del programa educativo era proporcionar a los trabajadores agrícolas información y destrezas para cuando se reincorporaran a sus trabajos.

Desencadenantes del debate. Estos desencadenantes del debate se utilizaron para plantear problemas o posibles obstáculos al cambio y analizarlos en grupo. Podían ser una escenificación, un dibujo en el caballete de hojas móviles o una diapositiva o el estudio de un caso. El debate se estructuró en un proceso de interrogación en cinco etapas que invitaba a los participantes a identificar el problema, ponerse ellos mismos en la situación descrita, compartir sus reacciones personales, analizar las causas del problema y sugerir estrategias para la acción (Weinger y Wallerstein 1990).

Estudios de casos. Los casos describían situaciones reales y familiares que habían ocurrido en Nicaragua y que se identificaron durante el proceso de planificación. En general ilustraban problemas como el incumplimiento de las medidas de seguridad por parte de la empresa o los trabajadores o el dilema de un trabajador con síntomas que podrían estar relacionados con la exposición a un plaguicida. En la introducción de este artículo se ha hecho referencia a uno de esos casos.

Los participantes leyeron el caso en pequeños grupos y respondieron a preguntas como: ¿Cuáles son algunas de las causas de la intoxicación por plaguicidas en este incidente? ¿Quién se beneficia? ¿Quién resulta perjudicado? ¿Qué medidas deberían adoptarse para prevenir un problema similar en el futuro?

Planificación de la acción. Antes de concluir el programa educativo, los participantes trabajaron individualmente o en grupos para elaborar un plan de acción que permitiera mejorar las condiciones de salud y seguridad en el lugar de trabajo cuando se utilizasen plaguicidas. Utilizando una hoja de trabajo, los participantes identificaron al menos una medida que podrían adoptar para promover unas condiciones y prácticas más seguras de trabajo.

\section{Evaluación y formación de los educadores}

La evaluación de la medida en que las sesiones cumplen sus objetivos es una parte crucial de los proyectos de educación. Como herramientas de evaluación se utilizaron cuestionarios impresos que se repartieron después del programa y visitas de seguimiento a las fincas, así como encuestas y entrevistas a los participantes 6 meses después de la sesión educativa.

La formación de los educadores llamados a utilizar los métodos descritos para informar y educar a los trabajadores agrícolas fue un componente esencial de los programas patrocinados por la OIT en América Central. Los objetivos del programa de formación de educadores eran ampliar sus conocimientos sobre la salud y seguridad de los plaguicidas y mejorar sus destrezas como educadores; aumentar el número y la calidad de las sesiones educativas dirigidas a los trabajadores agrícolas, los empleadores, otros trabajadores relacionados y los ingenieros agrónomos de los países participantes en el proyecto, e iniciar la creación de una red de educadores sobre la salud y seguridad de los plaguicidas en la región.

Los temas abordados durante la semana que duraba esta sesión de formación eran: resumen de los efectos de los plaguicidas en la salud, prácticas y equipos de trabajo seguros, principios de la educación de los adultos, etapas en la planificación de programas educativos y su desarrollo, demostración de algunos métodos de enseñanza, mejora de las destrezas de comunicación verbal, enseñanza práctica ofreciendo a los participantes la oportunidad de utilizar métodos participativos y críticos, y desarrollo de planes de acción para la futura educación sobre los plaguicidas y las alternativas a su utilización. Con una sesión de dos semanas de duración se disponía de tiempo suficiente para realizar una visita a los campos y evaluar las necesidades de formación durante el seminario, preparar materiales educativos para clase y realizar sesiones de formación de los trabajadores en el campo.

Durante el seminario se repartieron el manual para el educador y un ejemplo de programa educativo para facilitar la enseñanza práctica tanto en el aula como al salir de ella. Esta red de educadores constituye otra fuente de apoyo y un vehículo para compartir nuevos métodos y materiales educativos

\section{Conclusión}

El éxito de este enfoque didáctico con los trabajadores de los campos de algodón de Nicaragua, los sindicatos de Panamá y los educadores del Ministerio de Sanidad de Costa Rica, entre 
otros, demuestra su capacidad de adaptación a diferentes entornos de trabajo y destinatarios. Sus objetivos no son sólo aumentar los conocimientos y destrezas de los trabajadores, sino proporcionarles también herramientas para resolver problemas en el campo después de que hayan terminado las sesiones educativas. No obstante, debe decirse con claridad que la educación no puede, por sí sola, resolver los problemas del uso y abuso de plaguicidas. Si deseamos conseguir verdaderos cambios en el uso de plaguicidas, es esencial adoptar un enfoque multidisciplinario que integre la organización del trabajo agrícola con estrategias para el cumplimiento de la legislación, controles técnicos, vigilancia médica e investigación de alternativas a los plaguicidas.

\section{- OPERACIONES DE PLANTACION Y CULTIVO}

\section{Yuri Kundiev y V.I. Chernyuk}

La agricultura moderna se basa en equipos muy eficientes, especialmente tractores y máquinas potentes y de gran velocidad. Los tractores con accesorios montados y arrastrados permiten la mecanización de muchas operaciones agrícolas.

El uso de los tractores permite a los agricultores llevar a cabo las principales operaciones de labranza y de cuidado de las plantas en un tiempo óptimo sin un trabajo manual importante. El aumento continuo del tamaño de las explotaciones, la extensión de las fincas y la intensificación de la rotación de los cultivos favorecen asimismo una agricultura más eficiente. Son dos los factores que obstaculizan la generalización del uso de máquinas de alta velocidad: los métodos agrícolas existentes, basados sobre todo en aperos y herramientas pasivas, y las dificultades para asegurar una condiciones seguras de trabajo para el operador de los tractores de alta velocidad.

Mediante métodos mecanizados se pueden realizar aproximadamente el $70 \%$ de las operaciones de plantación y desarrollo. También se emplean en todas las etapas de cultivo y recolección. No obstante, cada etapa requiere su propia maquinaria, herramientas y condiciones medioambientales, y esta variabilidad

Figura 64.11 • Exposición de los tractoristas al polvo durante el trabajo.
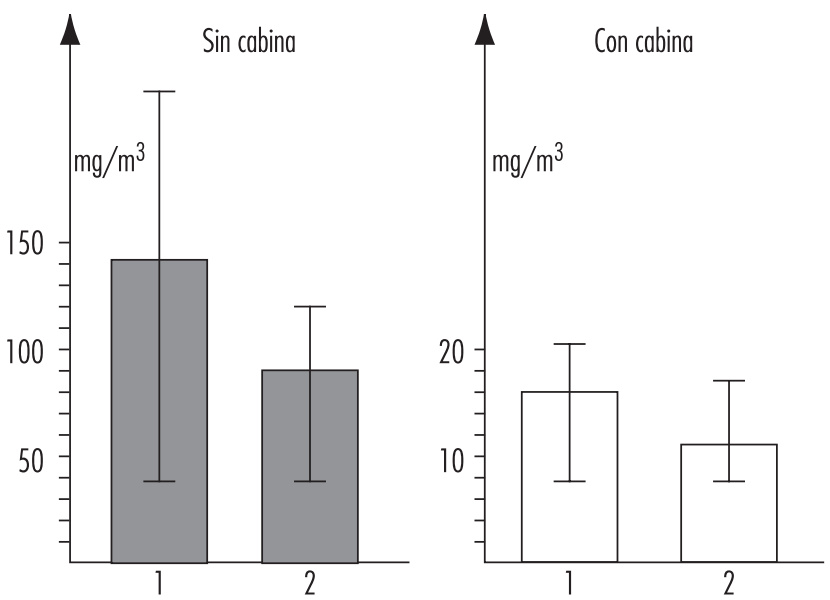

$1=$ Polvo total $\quad 2=$ Polvo respirable (menos de 5 micras) de la producción y factores medioambientales influye en el conductor del tractor.

\section{Gultivo de la tierra}

El cultivo de la tierra (arado, grada, binado, grada de disco, etc. es importante y constituye la etapa preliminar de la producción de la cosecha que requiere un trabajo más intenso. Estas operaciones suponen el $30 \%$ de los trabajos de plantación y cultivo.

Por lo general, el arado del suelo genera polvo. La naturaleza de éste es variable, y depende de las condiciones meteorológicas, la estación, el tipo de trabajo, el tipo de suelo, etc. La concentración de polvo en la cabina del tractor puede variar de algunos $\mathrm{mg} / \mathrm{m}^{3}$ a centenares de $\mathrm{mg} / \mathrm{m}^{3}$, en función sobre todo del cierre de la cabina. En un 60 a un $65 \%$ de los casos se supera el nivel de polvo total permisible; los niveles permisibles de polvo respirable (menor o igual a 5 micras) se sobrepasan durante el 60 al $80 \%$ del tiempo (véase la Figura 64.11). El contenido de sílice del polvo varía del 0,5 al $20 \%$ (Kundiev 1983).

El cultivo implica la realización de operaciones que consumen energía, especialmente durante el arado, y requiere una movilización considerable de los recursos de energía de las máquinas, generándose niveles considerables de ruido en el lugar donde se sienta el conductor. Estos niveles de ruido llegan a 86 a $90 \mathrm{dBA}$ e incluso más, creando un riesgo considerable de trastornos auditivos.

Por lo general, los niveles de vibración del cuerpo entero en el asiento del conductor pueden ser muy altos, sobrepasando los niveles establecidos por la Organización Internacional de Normalización (ISO 1985) para los límites de rendimiento disminuido por la fatiga y frecuentemente para el límite de exposición.

El suelo se prepara sobre todo a principios de la primavera y en otoño, de forma que el microclima de las cabinas en zonas templadas en las máquinas sin aire acondicionado no supone un problema para la salud, a excepción de los días calurosos.

\section{Siembra y crecimiento}

En la siembra y cuidado de los cultivos es esencial asegurar que los aperos de siembra o de arado se mueven en línea recta y que los tractores siguen las rodadas o el centro de la hilera.

En general, estas actividades obligan al conductor a trabajar en posiciones poco confortables e implican una considerable tensión nerviosa y emocional debido a la visibilidad restringida en el área de trabajo, lo que da lugar a una rápida fatiga.

La disposición de las máquinas sembradoras y su preparación para el uso, así como la necesidad de trabajo manual auxiliar, especialmente la manipulación de los materiales, pueden implicar cargas físicas considerables.

La amplia distribución geográfica de las variedades de cereales implica una gran diversidad de condiciones meteorológicas durante la siembra. La siembra de cereales de invierno puede hacerse, por ejemplo, cuando la temperatura exterior varía de $3-10{ }^{\circ} \mathrm{C}$ a $30-35^{\circ} \mathrm{C}$. Los cereales de primavera se siembran cuando la temperatura exterior varía de $0{ }^{\circ} \mathrm{C}$ a $15-20^{\circ} \mathrm{C}$. Las temperaturas en las cabinas del tractor sin aire acondicionado pueden ser muy altas en las regiones en las que el clima es suave y cálido.

En las zonas templadas, las condiciones microclimáticas de las cabinas son en general favorables durante la siembra de cultivos como la remolacha, el maíz o el girasol. El cultivo se realiza cuando la temperatura exterior es alta y la radiación solar intensa. La temperatura en las cabinas sin aire acondicionado puede llegar a $40{ }^{\circ} \mathrm{C}$ e incluso más. Los conductores pueden trabajar en condiciones poco confortables durante un 40 al $70 \%$ del tiempo de funcionamiento. 
En las operaciones de preparación del suelo se remueve éste considerablemente, lo que provoca la formación de polvo. Las concentraciones máximas de polvo en el aire de la zona de respiración no deben exceder de 10 a $20 \mathrm{mg} / \mathrm{m}^{3}$. El polvo es inorgánico en un $90 \%$, y contiene una gran cantidad de sílice libre. Los niveles de ruido y vibración en la cabina del conductor son algo menores que los existentes durante el cultivo.

Durante la siembra y el cultivo, los trabajadores pueden estar expuestos a abonos, fertilizantes químicos y plaguicidas. Cuando no se siguen las normas de seguridad para manipular estos materiales, o si las máquinas no funcionan adecuadamente, la concentración de los materiales peligrosos en la zona de respiración puede sobrepasar los valores permisibles.

\section{Recolección}

En general, la recolección dura de 25 a 40 días. El polvo, las condiciones del microclima y el ruido pueden suponer riesgos durante esta fase.

Las concentraciones de polvo en la zona de respiración dependen principalmente de la concentración externa y de la estanqueidad al aire de la cabina de la máquina. Las máquinas más antiguas sin cabina dejan a los conductores expuestos al polvo. La formación de polvo es más intensa durante la recolección de cereales secos, cuando la concentración de polvo en las cabinas no cerradas de las cosechadoras combinadas puede llegar a 60 a $90 \mathrm{mg} / \mathrm{m}^{3}$. El polvo consta sobre todo de trocitos de plantas, polen y esporas de hongos, en su mayoría formando partículas grandes no respirables (mayores de 10 micras). El contenido de sílice libre es inferior al 5,5\%.

La formación de polvo durante la recolección de remolacha es menor. La concentración máxima de polvo en la cabina no supera $\operatorname{los} 30 \mathrm{mg} / \mathrm{m}^{3}$.

La recolección de cereales se realiza generalmente en la estación más cálida. La temperatura de la cabina puede aumentar entonces hasta 36 a $40{ }^{\circ} \mathrm{C}$. El nivel de radiación solar directa puede alcanzar los $500 \mathrm{~W} / \mathrm{m}^{2}$ y aún más si se utiliza vidrio corriente para las ventanas de la cabina. El vidrio coloreado reduce la temperatura de la cabina en 1 a $1,6{ }^{\circ} \mathrm{C}$. Un sistema mecánico de ventilación forzada con un flujo de $350 \mathrm{~m}^{3} / \mathrm{h}$ puede crear una diferencia de temperatura entre el aire del interior y del exterior de 5 a $7^{\circ} \mathrm{C}$. Si la cosechadora está equipada con persianas ajustables, esta diferencia disminuye a 4 a $6{ }^{\circ} \mathrm{C}$.

Los cultivos de labranza se recogen en los meses del otoño. En general, las condiciones del microclima en las cabinas en este tiempo no suponen un gran problema de salud.

La experiencia de los países desarrollados indica que la agricultura en pequeñas explotaciones puede ser rentable con la mecanización a pequeña escala (minitractores - unidades motorizadas con una capacidad de hasta 18 caballos de fuerza, con diferentes tipos de equipo auxiliar)

El uso de este tipo de equipos da lugar a varios problemas de salud específicos. Entre éstos se incluyen la intensificación de la carga de trabajo en determinadas estaciones, el uso de mano de obra infantil y de personas ancianas, la ausencia de medios de protección frente al intenso ruido, las vibraciones del cuerpo entero y localizadas, las condiciones meteorológicas nocivas, el polvo, los plaguicidas y los gases de escape. El esfuerzo necesario para mover las palancas de control de las unidades motorizadas puede llegar a 60 a $80 \mathrm{~N}$ (Newtons).

Algunos tipos de trabajo se realizan con la ayuda de animales de tiro o manualmente, debido a la falta de equipo o a la imposibilidad de utilizar maquinaria por algún motivo. El trabajo manual requiere generalmente un esfuerzo físico considerable. Las necesidades de energía durante el arado, la siembra con tracción por caballos y la siega manual pueden llegar a 5.000 a $6.000 \mathrm{cal} /$ día o más.
Durante el trabajo manual son frecuentes las lesiones, especialmente entre los trabajadores sin experiencia, y asimismo las quemaduras por las plantas, las picaduras de insectos y reptiles y las dermatitis a causa de la savia de algunas plantas.

\section{Prevención}

Una de las principales tendencias en la construcción de tractores es la mejora de las condiciones de trabajo de sus operadores. Junto al perfeccionamiento del diseño de las cabinas se investigan formas de coordinar los parámetros técnicos de las distintas unidades del tractor con las capacidades funcionales humanas. El objetivo de esta investigación consiste en asegurar la eficacia de las funciones de control y conducción, así como los parámetros ergonómicos necesarios del medio ambiente laboral.

La eficacia del control y la conducción de los dispositivos del tractor está asegurada por una buena visibilidad de la zona de trabajo, por la optimización de los dispositivos y el diseño del panel de control y por el diseño ergonómico adecuado de los asientos del tractor.

Algunos métodos habituales de ampliación de la visibilidad son el aumento del campo visual de la cabina mediante el diseño de ventanas panorámicas, una mejor disposición del equipo auxiliar (por ejemplo, el depósito de gasóleo), la racionalización de la colocación del asiento, el uso de espejos retrovisores, etc.

La optimización de los elementos de control está relacionada con la construcción de sus mecanismos de mando. Junto a los mecanismos hidráulico y eléctrico, los pedales de control suspendido constituyen una nueva mejora. Permiten un mejor acceso y una mayor comodidad en la conducción. La codificación funcional (mediante formas, colores o símbolos) desempeña un papel importante en el reconocimiento de los elementos de control.

Para la disposición racional de la instrumentación (que incluye de 15 a 20 unidades en los tractores modernos) es necesario tener en cuenta los posteriores aumentos de indicadores debido al control remoto de las condiciones del proceso, con la automatización de la conducción y el funcionamiento del equipo tecnológico.

El asiento del operador está diseñado de forma que garantice una posición confortable y una conducción eficaz de la máquina y de los accesorios. Actualmente se tienen en cuenta los datos antropométricos del cuerpo humano. Los asientos tienen espalda y brazos ajustables que pueden adaptarse según el tamaño del operador en las direcciones horizontal y vertical (Figura 64.12).

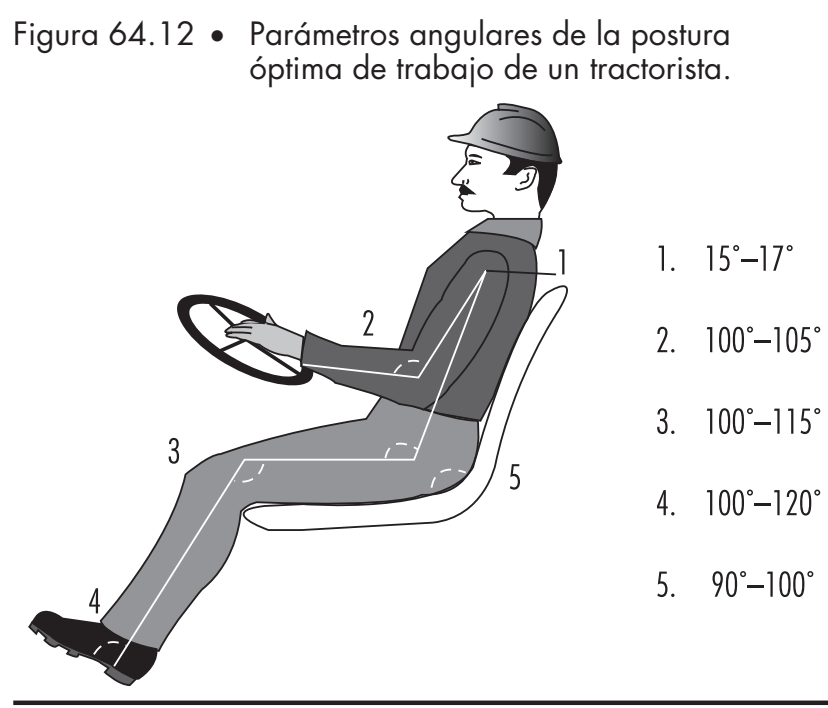


Entre las precauciones contra las condiciones de trabajo peligrosas para los conductores se incluyen medios para la protección contra el ruido y las vibraciones, la normalización del microclima y el sellado hermético de las cabinas.

A pesar de la construcción especial del motor para reducir el ruido en su origen, se consigue un efecto considerable montándolo sobre aislamiento antivibratorio, que aísla la cabina del resto con ayuda de absorbentes de choques y varias medidas de absorción del ruido en la cabina. Con este fin se aplica sobre las paredes de la cabina un revestimiento escamoso, absorbente de ruidos, con una superficie decorativa, y se disponen en el suelo alfombrillas de caucho y porolon. En el techo se aplica un empanelado perforado endurecido con un hueco para el aire de 30 a $50 \mathrm{~mm}$. Estas medidas permiten reducir los niveles de ruido en las cabinas a 80-83 dBA.

El principal medio para amortiguar la vibración de baja frecuencia en la cabina es el uso de una suspensión efectiva del asiento. No obstante, el efecto de amortiguación de la vibración del cuerpo entero conseguido de esta forma no es mayor de un 20 a un $30 \%$.

El nivelado del suelo agrícola permite disminuir considerablemente la vibración.

La mejora de las condiciones del microclima de las cabinas de los tractores se consigue con la ayuda de equipo estándar (p. ej., ventiladores con elementos filtrantes, vidrios coloreados termoaislantes, gorras visera protectoras frente al sol, palancas ajustables) y de dispositivos especiales (p. ej., aire acondicionado). Los sistemas de calefacción de los tractores modernos están diseñados como dispositivos autónomos unidos al sistema de refrigeración del motor que utilizan agua caliente para calentar el aire. También se dispone de aire acondicionado y calentadores de aire combinados.

Se pueden conseguir soluciones complejas a los problemas del ruido, el aislamiento de la vibración y del calor y el sellado de las cabinas mediante cápsulas especiales diseñadas con pedales de control suspendido y sistemas de transmisión antitorsión.

El fácil acceso al motor y a las piezas para su mantenimiento y reparación, así como la obtención de información regular sobre las condiciones técnicas de algunas de estas piezas, son índices importantes del nivel de las condiciones de trabajo del operador. En algunos tipos de tractores se dispone de la posibilidad de eliminar el capó de la cabina, de inclinarla hacia adelante, de instalar paneles desmontables en el capó del motor, etc.

En el futuro, probablemente las cabinas de los tractores estarán equipadas con unidades de control automático, con pantallas de televisión para observar los accesorios que se encuentran fuera del campo visual del operador y con unidades de climatización. Las cabinas se montarán sobre barras rotativas exteriores, de forma que puedan moverse a una posición determinada.

La organización racional del trabajo y el descanso tiene una gran importancia para la prevención de la fatiga y las enfermedades de los trabajadores agrícolas. En la estación cálida se debería trabajar sobre todo por la mañana y al caer la tarde, descansando durante las horas de más calor. Durante un trabajo duro (siega, cava) es necesario descansar cada cierto tiempo. Debe prestarse una atención especial a la alimentación equilibrada y racional de los trabajadores, que cubra las necesidades energéticas. Es muy importante beber regularmente durante las horas de calor. En general, los trabajadores toman bebidas tradicionales (té, café, zumos de frutas, infusiones, caldos, etc.) además de agua. Es muy importante la disponibilidad de cantidades suficientes de líquidos sanos de alta calidad.
Figura 64.13 • Recolección manual de mijo.

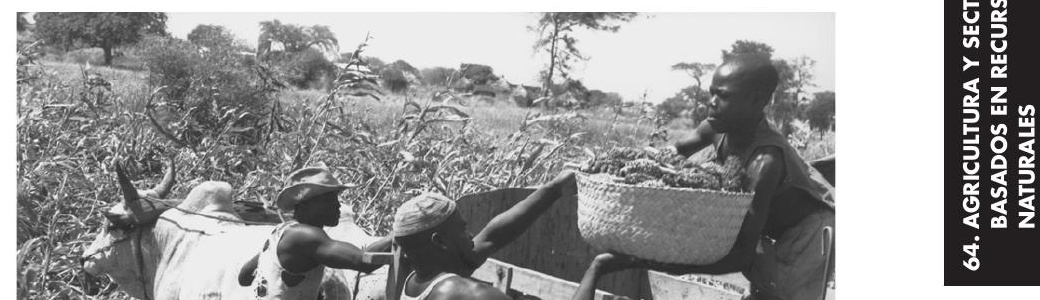

Asimismo es importante la disponibilidad de monos confortables y de equipo de protección individual (EPP) (respiradores, protectores auditivos), especialmente durante el contacto con polvo y productos químicos.

El control médico de la salud de los trabajadores agrícolas debe orientarse a la prevención de enfermedades laborales comunes, como las enfermedades infecciosas, las exposiciones a productos químicos, las lesiones, los problemas ergonómicos, etc. Tienen una gran importancia la enseñanza de métodos seguros de trabajo y la información sobre cuestiones de higiene y saneamiento.

\section{OPERACIONES DE RECOLECCION}

\section{William E. Field}

La recolección de los cultivos agrícolas cuanto alcanzan su madurez señala el final del ciclo de producción antes del almacenamiento y la transformación. El tamaño y la calidad de la cosecha retirada del campo, huerto o viñedo representa la medida más significativa de la productividad y el éxito del agricultor. El valor concedido al resultado de la cosecha se refleja en los términos utilizados casi universalmente para medir y comparar la productividad agrícola, como kilogramos por hectárea $(\mathrm{kg} / \mathrm{ha})$, balas por hectárea o toneladas por hectárea. Desde una perspectiva agronómica, realmente es la inversión la que determina el rendimiento; no obstante, es la cosecha la que indica en primer lugar si habrá o no suficientes recursos y semillas que aseguren el sostenimiento de la explotación y de las personas que dependen de ella. Debido a la importancia de la 
cosecha y de todas las actividades relacionadas, esta parte del ciclo agrícola ha adquirido un papel fundamental en las vidas de los agricultores de todo el mundo.

Pocas prácticas agrícolas ilustran con más claridad la amplitud y diversidad de los riesgos relacionados con la tecnología y el trabajo durante la producción agrícola que la recolección. Esta se realiza en condiciones muy variadas, en distintos tipos de terreno, utilizando máquinas simples o complejas que deben manejar distintos cultivos; implica un esfuerzo físico considerable (Snyder y Bobick 1995). Por estos motivos, cualquier intento de generalizar brevemente las características o la naturaleza de las prácticas de recolección y los riesgos relacionados con ella es extremadamente difícil. Por ejemplo, los cereales pequeños (arroz, trigo, cebada, avena, etc.), que dominan gran parte de la tierra cultivada en todo el mundo, no sólo figuran entre los cultivos más mecanizados, sino que en amplias regiones de Africa y Asia se recolectan de una forma que habría sido familiar a los agricultores de hace 2.500 años. La hoz, las eras de arcilla prensada y las trilladoras sencillas siguen siendo las herramientas primarias de recolección de muchos productores.

Los riesgos primarios asociados con las prácticas de recolección más laboriosas han cambiado poco a lo largo del tiempo y a menudo están eclipsados por los mayores riesgos asociados a una mayor mecanización. Históricamente, las largas horas de exposición a los elementos, el esfuerzo físico requerido para elevar cargas pesadas, los movimientos repetitivos y la postura incómoda o inmóvil, junto con los riesgos naturales representados, por ejemplo, por los insectos y serpientes venenosas, han causado, y continúan causando, una gran cantidad de víctimas (véase la Figura 64.13). La recolección de cereales o caña de azúcar con una hoz o un machete, la de fruta u hortalizas a mano y la de cacahuetes son operaciones sucias, incómodas y agotadoras que en muchas comunidades son realizadas frecuentemente por mujeres y niños. Una de las razones más fuertes de la introducción de las prácticas modernas de recolección ha sido el deseo de eliminar las faenas físicas asociadas a las tareas manuales.

Aunque se disponga de recursos para mecanizar la recolección y reducir sus riesgos (y para muchos pequeños agricultores de muchas partes del mundo, éste no es el caso), las inversiones para mejorar los aspectos de salud y seguridad tendrían probablemente menos repercusión que otras inversiones comparables en mejoras del alojamiento, la calidad del agua y la atención sanitaria, sobre todo si hay un elevado desempleo o subempleo. Las tasas altas de desempleo y las pocas oportunidades de trabajo ponen a muchos trabajadores jóvenes en peligro de lesiones durante la recolección debido a que salen más baratos que las máquinas. Incluso en muchos países con prácticas agrícolas muy mecanizadas, las leyes sobre el trabajo infantil frecuentemente excluyen a los niños implicados en actividades agrícolas. Por ejemplo, las disposiciones especiales de las leyes sobre el trabajo infantil del Departamento de Trabajo de Estados Unidos aún no consideran los niños menores de 16 años durante la recolección y les permiten operar equipos agrícolas en ciertas condiciones (DOL 1968).

Contrariamente a la idea general de que una mayor mecanización en la agricultura ha aumentado los riesgos asociados a la producción agrícola con respecto a la recolección, no hay nada más lejos de la realidad. Mediante la introducción de una mecanización intensiva en las principales regiones de producción de cereales y forraje, el tiempo necesario para producir una fanega de cereal, por ejemplo, ha disminuido de más de una hora a menos de un minuto (Griffin 1973). Este avance, aunque depende en gran medida de los combustibles fósiles, ha liberado a decenas de millones de personas de las condiciones de trabajo penoso e inseguro asociadas a la recolección manual. La mecanización ha producido no sólo grandes aumentos de la productividad y el rendimiento, sino también la casi eliminación de las lesiones más significativas históricamente, como aquéllas en las que interviene el ganado.

No obstante, la mecanización intensiva del proceso de recolección ha introducido también nuevos riesgos que han requerido períodos de adaptación y en algunos casos la sustitución de las máquinas por otras más productivas o menos peligrosas. Un ejemplo de esta evolución tecnológica se experimentó con la transición que tuvo lugar en la recolección de los cereales en Norteamérica entre 1930 y 1970. Hasta el decenio de 1930, las mazorcas de maíz se arrancaban casi por completo manualmente y se transportaban a los almacenes en vagones tirados por caballos. La primera causa de lesiones asociadas a la recolección se debía al trabajo con caballos (NSC 1942). Con la introducción y uso extendido de la arrancadora de mazorcas tirada por tractor en el decenio de 1940, las muertes y lesiones asociadas a los caballos y al ganado vacuno disminuyeron rápidamente durante el período de recolección, y se registró el aumento correspondiente del número de lesiones relacionadas con la nueva máquina. Esto no se debía a que la arrancadora fuera en sí más peligrosa, sino a que las lesiones reflejaban una transición rápida a una nueva práctica que no había sido completamente perfeccionada y con la que los agricultores no estaban familiarizados. A medida que éstos se adaptaron a la nueva tecnología y los fabricantes mejoraron el rendimiento de la máquina, y a medida asimismo que se plantaban variedades de maíz más uniformes y más adecuadas a la recolección mecanizada, disminuyó rápidamente el número de muertes y lesiones. En otras palabras, la introducción de la arrancadora de mazorcas tuvo como resultado final una disminución de las lesiones relacionadas con la recolección debido a la exposición a los riesgos tradicionales.

Con la introducción en el decenio de 1960 de la cosechadora combinada autopropulsada, que podía recoger variedades de maíz de alto rendimiento a velocidades diez o más veces mayores que la arrancadora de mazorcas, las lesiones causadas por ésta última casi desaparecieron. Pero una vez más, la cosechadora introdujo nuevos riesgos que requerían un período de adaptación. Por ejemplo, la capacidad de reunir, cortar, separar y limpiar el grano en el campo utilizando una máquina cambió la manipulación del grano. En consecuencia, en el decenio de 1970 se produjo un aumento espectacular en el número de lesiones asociadas a hélices y de los enterramientos y asfixias por cereales en los almacenes y vehículos de transporte de cereal (Kelley 1996). Asimismo se informó de nuevas categorías de lesiones, relacionadas con el tamaño y peso total de la cosechadora combinada, como caídas desde la plataforma y desde las escaleras, que pueden colocar al operador a más de $4 \mathrm{~m}$ del suelo, y aplastamientos bajo la unidad de recogida.

La mecanización del arranque del maíz contribuyó directamente a uno de los desplazamientos más intensos de la población rural nunca conocidos en Norteamérica. Menos de 75 años después de la introducción de variedades híbridas de maíz y la arrancadora de mazorcas, la población de las explotaciones agrarias había pasado de más del $50 \%$ a menos del $5 \%$ de la población total. Durante este período de mayor productividad y de demanda de trabajo muy reducida se redujo la exposición total a los riesgos de los lugares de trabajo en la agricultura, contribuyendo a un descenso de las muertes de más de 14.000 en 1942 a menos de 900 en 1995 (NSC 1995).

Las lesiones asociadas con las operaciones de recolección modernas están relacionadas con los tractores, la maquinaria, el equipo de manipulación de cereales y las instalaciones de almacenamiento. Desde el decenio de 1950, los tractores han 
contribuido a aproximadamente la mitad de todas las víctimas, siendo el principal factor contribuyente los vuelcos. Se ha demostrado que la utilización de estructuras de protección contra vuelcos (EPV) es la estrategia de intervención más importante en la reducción del número de víctimas (Deere \& Co. 1994). Otras características de diseño que mejoran la seguridad y salud de los operarios de los tractores son unas bases más anchas para las ruedas y unos diseños que bajan el centro de gravedad para mejorar la estabilidad, unas cabinas para todo tipo de condiciones climáticas a fin de reducir la exposición a los elementos y al polvo, unos asientos y mandos ergonómicamente diseñados y la reducción en los niveles de ruido.

No obstante, el problema de las lesiones asociadas a los tractores sigue siendo importante y una preocupación cada vez mayor en zonas que se mecanizan con rapidez, como China y la India. En muchas áreas del mundo, el tractor se utiliza más como vehículo de transporte por carretera o como fuente de energía estacionaria que para cultivar los campos, tarea para la que fue diseñado. En estas áreas, los tractores se introducen en muchos casos con una formación mínima del operador y se utilizan ampliamente como medio de transporte de muchos pasajeros, otro uso para el que no han sido diseñados. Como consecuencia, los atropellos de pasajeros que han caído al suelo durante el trabajo se han convertido en la segunda causa de víctimas asociadas a los tractores. Si continúa la tendencia a la mayor utilización de EPV, los atropellos podrían pasar a ser la principal causa de mortalidad relacionada con ellos en todo el mundo.

A pesar de utilizarse menos horas al año que los tractores, la maquinaria de recolección, como las cosechadoras, es responsable de aproximadamente el doble de accidentes por cada 1.000 unidades (Etherton y cols. 1991). Estas lesiones a menudo se producen durante el mantenimiento, reparación o ajuste de la máquina, cuando aún están en marcha sus componentes (NSC 1986). Recientemente se han realizado algunos cambios de diseño que incorporan más advertencias y enclavamientos pasivos y activos para el operador, como la instalación de interruptores de seguridad en su asiento para impedir el funcionamiento de la máquina cuando nadie está sentado, y la reducción del número de puntos de mantenimiento para disminuir así la exposición en funcionamiento. No obstante, muchos de estos conceptos de diseño son voluntarios, y frecuentemente se omiten y no se incorporan en todas las cosechadoras.

El equipo de recolección de heno y forraje expone a los trabajadores a riesgos similares a los que plantean las cosechadoras. Este equipo contiene componentes que cortan, aplastan, trituran, pican y soplan el cultivo a gran velocidad, dejando muy poco margen para el error humano. Como en la recolección de cereales, la de heno y forraje debe tener lugar en el momento adecuado, con el fin de evitar daños a las cosechas. Se produce así el estrés añadido de terminar las tareas rápidamente, que, junto a los riesgos de la maquinaria, lleva con frecuencia a lesiones (Murphy y Williams 1983).

Tradicionalmente, las empacadoras de heno han sido una fuente frecuente de lesiones graves. Estas máquinas se utilizan en algunas de las condiciones más rigurosas que se dan en la recolección. Las altas temperaturas, el terreno áspero, el polvo y la necesidad de frecuentes ajustes contribuyen a una elevada tasa de lesiones. La conversión en grandes fardos o balas de heno y los sistemas mecánicos han mejorado la seguridad con algunas pocas excepciones, como ocurrió con la introducción de los primeros diseños de la empacadora redonda. Los rollos de compresión de la parte frontal de esta máquina provocaron un gran número de amputaciones de manos y brazos. Este diseño fue sustituido más tarde por una unidad de recogida menos agresiva, que prácticamente eliminó el problema.
El fuego es un problema potencial para muchos tipos de operaciones de recolección. Los cultivos que se deben secar hasta una humedad inferior al $15 \%$ para su almacenamiento correcto constituyen un excelente combustible cuando se inflaman. Las cosechadoras combinadas y las cosechadoras de algodón son especialmente vulnerables a los incendios durante el trabajo de campo. Se ha demostrado que características de diseño tales como el uso de motores diesel y de sistemas eléctricos protegidos, un mantenimiento adecuado del equipo y el acceso del operario a extintores disminuyen el riesgo de daños o lesiones relacionados con el fuego (Shutske y cols. 1991).

El ruido y el polvo son otros dos riesgos intrínsecos a las operaciones de recolección. Ambos pueden afectar a largo plazo a la salud de los operadores de las máquinas. La inclusión de cabinas con un medio ambiente controlado ha permitido reducir la exposición. En todo caso, la mayor parte de los agricultores se benefician ya de esta medida de seguridad. El uso de equipo de protección individual como tapones para los oídos y mascarillas antipolvo desechables ofrece un medio alternativo, pero menos eficaz, de protección frente a estos riesgos.

A medida que las operaciones de recolección se mecanizan en todo el mundo, se produce una transición de las lesiones relacionadas con el medio ambiente, con los animales o con las herramientas manuales a las causadas por las máquinas. La experiencia de los agricultores y de los fabricantes de éstos será útil para reducir el período de adaptación y prevenir las lesiones causadas por la falta de adaptación y el diseño inadecuado. En todo caso, la experiencia de los agricultores incluso con el equipo más moderno sugiere que el problema de las lesiones no se eliminará completamente. Los errores del operador y el diseño de la máquina seguirán desempeñando un papel importante como causas de lesiones. Por lo demás es incuestionable que, además de una mayor productividad, el proceso de mecanización ha reducido significativamente los riesgos asociados con la recolección

\section{OPERACIONES DE ALMACENAMIENTO Y TRANSPORTE}

Thomas L. Bean

\section{Almacenamiento}

El cultivo y la recolección de las cosechas y la producción de ganado se han reconocido desde hace mucho tiempo como ocupaciones que figuran entre las más antiguas e importantes del mundo. Hoy en día las labores agrícolas y ganaderas son tan diversas como los numerosos cultivos, fibras y ganado producidos. En un extremo, la explotación pertenece a una sola familia que cultiva el suelo y recoge los cultivos, todo a mano en un área limitada. En el extremo opuesto se encuentran grandes cooperativas que se extienden en zonas muy amplias y muy mecanizadas, con maquinaria, equipo e instalaciones avanzados. Lo mismo es aplicable al almacenamiento de alimentos y de fibras. Los puntos de almacenamiento de los productos agrícolas pueden ser muy rudimentarios, como barracones y pozos excavados a mano, o tan complejos como silos torre, bunkers, contenedores y unidades refrigeradas.

\section{Riesgos y su prevención}

Los productos agrícolas, como los cereales, el heno, las frutas, los frutos secos, las hortalizas y las fibras vegetales, se almacenan a menudo para el consumo humano y animal posterior o se venden a la población general o a los fabricantes. Su almacenamiento antes del transporte al mercado se puede realizar en distintas 
estructuras: pozos, bunkers, contenedores, silos, unidades refrigeradas, carretas, vagones, graneros y vagones, entre otros. A pesar de la diversidad de productos que se almacenan y de las instalaciones de almacén, existen riesgos comunes a este proceso:

\section{Caídas y objetos que caen}

Las caídas pueden producirse desde una altura superior o en el mismo nivel. En caso de contenedores, silos, graneros y otras estructuras de almacenamiento, las caídas desde una altura superior ocurren con mayor frecuencia desde y dentro de las estructuras de almacenamiento. Las causas más frecuentes son los tejados desprotegidos, las aberturas del suelo, las escaleras, los desvanes y los pozos, y asimismo las escaleras que suben a áreas de trabajo a cierta altura, como una plataforma no protegida, o la permanencia en éstas últimas. También pueden ser resultados de la subida o bajada del vehículo de transporte (p. ej. vagones, carretas y tractores). Las caídas desde el mismo nivel se producen a causa de superficies resbaladizas, de tropiezos en objetos o de golpes dados por un objeto en movimiento. La protección frente a las caídas incluye medidas como las siguientes:

- provisión de cinturones de seguridad, arneses, guardacuerpos y botas de seguridad

- instalación de rampas de protección, tablas de pie, escaleras de cuerda o de listones sobre tejados inclinados

- protección de las aberturas del suelo, desvanes y pozos

- uso de la subida y recorrido estándar de las escaleras, instalaciones de pasamanos a ambos lados y aplicación de listones antideslizantes donde sea necesario

- mantenimiento de los suelos en buenas condiciones, exentos de superficies no uniformes, orificios y acumulaciones de residuos o sustancias resbaladizas

- instalación de asideros en las escaleras permanentes, plataformas y descansillos de protección

- mantenimiento de las escalas alargables o de escalones en buenas condiciones y formación de los trabajadores en su uso.

Los productos agrícolas pueden almacenarse sueltos en una instalación o empaquetados, ensacados, embalados en cajas o empacados. El almacenamiento suelto está asociado frecuentemente a cereales como el trigo, el maíz o la soja. Entre los productos empaquetados, ensacados, embalados en cajas o empacados se incluyen el heno, la paja, las hortalizas, los granos y los productos alimenticios. En todos los tipos de almacén se producen caídas de materiales. El aplastamiento de provisiones mal apiladas, los materiales salientes y los montones de mercancías son a menudo causas de lesiones. Se debe formar a los empleados para que apilen correctamente las mercancías y así evitar su aplastamiento. Los empresarios y los gerentes deben controlar el cumplimiento de las condiciones en el lugar de trabajo.

\section{Espacios reducidos}

Los productos agrícolas se pueden almacenar en dos tipos de instalaciones: las que contienen suficiente oxígeno para el mantenimiento de la vida, como graneros, carretas o vagones abiertos, y las que no contienen oxígeno, como algunos silos, tanques y unidades refrigeradas. Estos últimos son espacios reducidos, y deben tratarse con las precauciones adecuadas. Antes de entrar se debe controlar el nivel de oxígeno y utilizarse en caso necesario una unidad de respiración con admisión de aire o independiente; además ha de estar alguien cerca. La asfixia se puede producir en cualquier tipo de instalación si las mercancías que contiene presentan las características de un fluido. Es lo que suele ocurrir con los cereales y productos similares. El trabajador muere por sumersión. En los contenedores de grano, una práctica habitual es que los trabajadores entren en ellos debido a las dificultades de carga y descarga, causadas a menudo por la formación de cavidades en el grano. Los trabajadores, en un intento de eliminar dichas cavidades, andan sobre el grano y corren el riesgo de caer y ser cubiertos por el grano o ser succionados hacia dentro si está funcionando el equipo de carga y descarga. La formación de cavidades puede producirse también en los lados de dichas estructuras, en cuyo caso el trabajador puede entrar para golpear el material que se pega a los lados y acabar sumergido cuando cae éste. Son esenciales un sistema de bloqueo/desconexión y la protección de las caídas con cinturones y cables de seguridad si los trabajadores deben entrar en estos tipos de estructuras. La seguridad de los niños es especialmente preocupante; a menudo son inquisitivos, juguetones y quieren imitar a los adultos en su trabajo, por lo que son atraídos a dichas estructuras, con resultados demasiado a menudo mortales.

Las frutas y hortalizas se conservan con frecuencia en frío antes de su envío al mercado. Como se ha indicado en el párrafo anterior, en función del tipo de unidad, la conservación en frío se puede considerar un espacio reducido en el que se debe controlar el contenido de oxígeno. Otros riesgos son la congelación y las lesiones inducidas por frío o la muerte por hipotermia después de una exposición prolongada al frío. Se debe llevar ropa protectora, adecuada a la temperatura dentro de la unidad de conservación en frío.

\section{Gases y venenos}

En función del contenido de humedad del producto cuando se almacena y de las condiciones atmosféricas, entre otras, los alimentos, granos y fibras pueden producir gases peligrosos. Entre estos gases se incluyen el monóxido de carbono $(\mathrm{CO})$, dióxido de carbono $\mathrm{CO}_{2}$ ) y óxidos de nitrógeno $\left(\mathrm{NO}_{\mathrm{x}}\right)$, algunos de los cuales pueden provocar la muerte en algunos minutos, sobre todo si las mercancías se almacenan en un recinto en el que se dejan acumular gases no letales hasta niveles peligrosos, desplazando el oxígeno. Si la producción de gases, es posible debe realizarse un control de éstos. Asimismo, los alimentos y piensos pueden haber sido pulverizados o tratados con un plaguicida durante el período de desarrollo para la eliminación de malezas, insectos o enfermedades, o durante el almacenamiento para reducir el deterioro o el daño por hongos, esporas o insectos. Este factor se añade a los riesgos de producción de gases, inhalación de polvos y manipulación del producto. Los trabajadores deben llevar equipo de protección individual adecuado a la naturaleza y período de actividad del tratamiento, al producto utilizado y a las instrucciones de la etiqueta.

\section{Riesgos derivados de la maquinaria}

Las instalaciones de almacenamiento pueden contener diversas máquinas para el transporte del producto: desde transportadores de cinta o de rodillos hasta turbinas, taladros, rampas y otros dispositivos, cada uno con su propia fuente de energía. Entre los riesgos y las precauciones adecuadas deben mencionarse los siguientes:

- Puntos de retención formados por cintas, poleas y engranajes. Los trabajadores deben protegerse de los puntos de retención y cortadura mediante la protección adecuada en torno al punto de posible contacto.

- Fijadores de cinta, tornillos fijadores, llaves, pernos y estrías salientes. Los tornillos fijadores, llaves o pernos salientes en ejes giratorios deben ser avellanados, recubiertos o protegidos. Los fijadores de cinta deben ser inspeccionados y reparados.

- Puntos de cortadura provocados por brazos de volantes, taladros y sus cajas, radios de poleas, grúas y mecanismos elevadores. Han de protegerse o cubrirse. 
- Contacto con una transmisión en movimiento o elementos eléctricos. Han de protegerse o cubrirse.

- Puesta en marcha inadvertida de la maquinaria o el equipo. Debe instalarse y exigirse un sistema para bloquear o desconectar el equipo antes del mantenimiento o reparación.

- Ropa o cabellos sueltos que se enrollan o se enganchan en los ejes. Nunca debe llevarse ropa suelta, deshilachada ni con tiras que cuelgan. Han de llevarse ropa y calzado protector adecuados a la actividad realizada.

- Ruido excesivo. Debe controlarse la exposición al ruido y, en caso necesario, realizar controles administrativos, técnicos y de protección personal.

Los trabajadores han de conocer y ser conscientes de los riesgos, las normas básicas de seguridad y los métodos seguros de trabajo.

\section{Repercusiones sobre la salud}

Los trabajadores agrícolas que manipulan productos para el almacenamiento tienen riesgo de presentar enfermedades respiratorias. Las exposiciones a distintos polvos, gases, productos químicos, sílice, esporas de hongos y endotoxinas pueden dañar los pulmones. En estudios recientes se han asociado las alteraciones pulmonares provocadas por estas sustancias a la manipulación de cereales, algodón, lino, cáñamo, heno y tabaco. Por consiguiente, la población de riesgo se distribuye por todo el mundo. Las alteraciones pulmonares asociadas a la agricultura tienen muchos nombres comunes, como asma profesional, pulmón de agricultor, enfermedad del tabaco verde, pulmón marrón, síndrome tóxico por polvo orgánico, enfermedad del cargador o descargador de silos, bronquitis y obstrucción de las vías respiratorias. En principio, los síntomas se pueden manifestar como característicos de gripe (escalofríos, fiebre, tos, dolores de cabeza, mialgias y dificultad respiratoria). Esto es particularmente grave en el caso de los polvos orgánicos. La prevención de la disfunción pulmonar deberá incluir una evaluación del ambiente laboral, la ejecución de programas de promoción de salud dirigidos a la prevención primaria y el uso de respiradores de protección individual y otros dispositivos protectores sobre la base de la evaluación medioambiental.

\section{Operaciones de transporte}

Aunque parezca muy sencillo, el transporte de mercancías al mercado es a menudo tan complejo y peligroso como el cultivo y almacenamiento de los productos. El transporte puede ser tan variado como los tipos de operaciones agrícolas: desde el transporte por personas o animales con aparatos sencillos como bicicletas y carretas tiradas por animales, o bien mediante equipos complejos como grandes carretas y vagones tirados por tractores, hasta el uso de sistemas de transporte comerciales, que incluyen grandes camiones, autobuses, trenes y aviones. Al aumentar la población mundial y crecer las áreas urbanas, se ha intensificado el transporte por carretera de equipos agrícolas y accesorios para la ganadería. En Estados Unidos, según el National Safety Council (NSC), 8.000 tractores y otros vehículos agrícolas estuvieron implicados en accidentes de carretera en 1992 (NSC 1993). Muchas operaciones agrícolas se consolidan y expanden al adquirir o arrendar pequeñas explotaciones habitualmente dispersas pero no adyacentes. Un estudio realizado en 1991 en Ohio demostró que el 79 \% de las explotaciones supervisadas realizaban sus actividades en distintos lugares (Bean y Lawrence 1992).

\section{Riesgos y su prevención}

Aunque cada uno de los medios de transporte mencionados tienen sus propios riesgos, lo más preocupante es la coincidencia del tráfico civil con las máquinas y equipos de transporte agrícola. El aumento de viajes por carretera de los vehículos agrícolas ha provocado un mayor número de colisiones entre los automóviles y éstos, de marcha más lenta. A veces son más anchos que la carretera. Debido a la presión de cultivar en el momento adecuado para asegurar la cosecha y llevar el producto al mercado o almacén lo más rápido posible, en la mayor parte de los casos la maquinaria agrícola viaja por carretera en períodos de oscuridad, a primera hora de la mañana o por la tarde. Un estudio profundo de las normas de los 50 estados de los Estados Unidos reveló que los requisitos de iluminación y señalización varían mucho. Esta diversidad hace que los conductores de vehículos a motor no reciban un mensaje coherente (Eicher 1993). La mayor velocidad de otros vehículos, junto a la iluminación y señalización inadecuadas de los equipos agrícolas, es a menudo una combinación mortal. En un estudio realizado recientemente en los Estados Unidos se averiguó que los accidentes habituales eran colisiones por alcance o colisiones laterales en cruces, laterales en adelantamientos, angulares, frontales, en marcha atrás y otras. En un 20 \% de las 803 colisiones entre dos vehículos estudiados, el vehículo agrícola fue alcanzado desde un ángulo. En el $28 \%$ de los casos, había sido alcanzado lateralmente $(15 \%$ en cruces y $13 \%$ en adelantamientos). El $22 \%$ de los accidentes fueron colisiones por alcance (15\%), frontales (4\%) y en marcha atrás $(3 \%)$. El $25 \%$ restante fueron colisiones provocadas por algo distinto a un vehículo en movimiento (es decir, un vehículo estacionado, peatones, animales, etc.) (Glascock y cols. 1993).

$\mathrm{El}$ ganado se utiliza en muchas partes del mundo como medio de transporte de productos agrícolas. Aunque los animales de carga son en general fiables, la mayoría no distinguen los colores, tienen instintos territoriales y maternales, reaccionan de forma independiente e inesperada y tienen mucha fuerza. Así han provocado colisiones de vehículos. Son habituales las caídas de la maquinaria agrícola y de los accesorios para ganadería.

Se aplican a las operaciones de transporte los siguientes principios generales de seguridad:

- Deben aprenderse y respetarse las normas, reglamentos o leyes locales de la circulación.

- No se deben permitir más pasajeros que los necesarios para realizar las tareas de transporte y descarga.

- Los vehículos han de permanecer lo más cerca del arcén que permitan las condiciones de la carretera.

- El adelantamiento de vehículos (en movimiento o estacionados) y de peatones se debe hacer con precaución.

- Si es posible, los vehículos averiados se han de sacar de la carretera.

- La señalización e iluminación de la maquinaria y el equipo deben mantenerse limpias y en correcto estado.

- Nunca se debe conducir bajo los efectos del alcohol o de drogas.

Las leyes y reglamentos pueden establecer la iluminación y la señalización aceptables. No obstante, muchas de estas disposiciones describen solamente los estándares mínimos aceptables. A no ser que prohíban específicamente la modificación y adición de luces y señales adicionales, cabe considerar esta posibilidad. Es importante que tales dispositivos de iluminación y señalización se instalen no sólo en los accesorios autopropulsados, sino también en las piezas del equipo que puedan empujar o remolcar.

Las luces son particularmente críticas para el movimiento de los equipos agrícolas al amanecer, durante el crepúsculo y por la noche. Las exigencias mínimas son: dos faros delanteros, dos faros traseros, dos luces de giro y dos luces de freno. 
Los faros traseros, las luces de giro y las luces de freno se pueden incorporar en unidades simples o pueden añadirse como accesorios separados. Las normas aplicables se pueden encontrar en organizaciones de normalización como la American Society of Agricultural Engineers (ASAE), el American National Standards Institute (ANSI), el Comité Europeo de Normalización (CEN) y la Organización Internacional de Normalización (ISO).

Si el vehículo agrícola no tiene una fuente de energía propia, se pueden utilizan luces alimentadas por pilas, aunque no sean tan eficaces. Muchos de ellas se pueden adquirir comercialmente en diversos tipos (foco, parpadeante, rotativa y estroboscópica) y tamaños. Si es imposible obtenerlas se pueden utilizar reflectores, banderas u otros materiales alternativos comentados más adelante.

Actualmente se dispone de muchos materiales fluorescentes retrorreflex que ayudan a señalizar los vehículos agrícolas para aumentar la visibilidad. Se fabrican en forma de parches o tiras en diversos colores. Los colores o combinaciones de colores aceptables se han de consultar en los reglamentos locales.

Los materiales fluorescentes proporcionan una excelente visibilidad diurna al aprovechar la radiación solar para sus propiedades de emisión de luz. Cuando los pigmentos fluorescentes absorben la radiación solar no visible y emiten de nuevo la energía como una luz de mayor longitud de onda, se produce una reacción fotoquímica compleja. En cierto modo, estos materiales parecen "brillar" durante el día y son más brillantes que los colores convencionales en las mismas condiciones lumínicas. $\mathrm{Su}$ principal desventaja es el deterioro con una exposición prolongada a la radiación solar.

La reflexión es una propiedad de las ondas luminosas. Estas chocan contra un objeto y son absorbidas o rechazadas en todas direcciones (reflexión difusa) o en un ángulo exactamente opuesto a aquél con el que han chocado contra el objeto (reflexión especular). La retrorreflex es muy similar a la reflexión especular; no obstante, la luz se refleja directamente hacia atrás hacia la fuente luminosa. Existen tres tipos de materiales retrorreflectivos, cada uno con un grado diferente de retrorreflex. En orden creciente son: lentes encerradas (a menudo llamadas de grado técnico o tipo ID), lentes encapsuladas (de alta intensidad) y esquinas cúbicas (de clase diamante, prismática, DOT C2 o tipo IIIB). Estos materiales retrorreflex son excelentes para la identificación visual durante la noche, y ayudan a definir los extremos de los accesorios agrícolas. En esta aplicación, las tiras de material retrorreflex y fluorescente a lo ancho de la máquina, en la parte delantera y en la trasera, son las que mejor indican a los demás conductores la anchura real del equipo.

En Estados Unidos, Canadá y muchas otras partes del mundo se utiliza un triángulo rojo con el centro amarillo-naranja para designar una clase de vehículos como "lentos", esto es, vehículos que viajan a menos de $40 \mathrm{~km}$ por hora. Normalmente los demás viajan mucho más rápido, y la diferencia de velocidad puede conducir a un error de apreciación y afectar así a la capacidad para detenerse a tiempo y evitar un accidente. Se debe utilizar siempre este emblema u otro aceptable.

\section{Repercusiones sobre la salud}

Los trabajadores agrícolas que participan en el transporte de productos agrícolas pueden contraer enfermedades respiratorias. Las exposiciones a distintos polvos, productos químicos, sílice, esporas de hongos y endotoxinas pueden dañar los pulmones. Depende en cierto modo de si el vehículo de transporte tiene una cabina cerrada o si el operario participa en el proceso de carga y descarga. Si se ha utilizado el vehículo de transporte para la aplicación de plaguicidas, éstos podrían penetrar en las cabinas a no ser que tenga un sistema de filtración del aire. Los primeros síntomas pueden ser semejantes a los de la gripe, sobre todo cuando se trata de polvos orgánicos. La prevención de la disfunción pulmonar deberá incluir una evaluación del ambiente laboral, la adopción de programas de promoción de la salud dirigidos a la prevención primaria y el uso de mascarillas protectoras, respiradores y otros dispositivos de protección.

\section{OPERACIONES MANUALES EN LA AGRICULTURA}

\section{Pranab Kumar Nag}

Los métodos y prácticas agrícolas varían según los países:

- Agricultura industrial: países industrializados occidentales (clima templado) y sectores especializados de países tropicales.

- Agricultura de la revolución verde: áreas bien dotadas de los trópicos, llanuras de regadío y deltas de Asia, América Latina y norte de Africa.

- Agricultura de zonas con escasos recursos: regiones interiores, tierras de secano, bosques, montañas y colinas, tierras semidesérticas y pantanos. Cerca de 1.000 millones de personas en Asia, 300 millones en el Africa subsahariana y 100 millones en América Latina dependen de esta forma de agricultura. Las mujeres constituyen una gran proporción de los agricultores de subsistencia: cerca del $80 \%$ de los alimentos del Africa subsahariana, del 50 al $60 \%$ de los alimentos de Asia, del $46 \%$ de los alimentos del área del Caribe, del $31 \%$ del Norte de Africa y Medio Oriente y del $30 \%$ de los alimentos de América Latina son producidos por mujeres (Dankelman y Davidson 1988).

Según las distintas características agrícolas y climáticas, los cultivos se clasifican de la forma siguiente:

- Cultivos de campo (cereales, oleaginosas, fibras, azúcar y forraje), regados por el agua de lluvia o cultivados con regadío controlado.

- Cultivos de tierras altas y semialtas (trigo, cacahuetes, algodón, etc.) cuando los regadíos o el agua de lluvia no están disponibles en abundancia.

- Cultivo en tierras húmedas (cultivos de arroz), practicados en los lugares en que la tierra se ara y se enfanga con 5 a $6 \mathrm{~cm}$ de agua y se transplantan las plántulas.

- Horticultura, con cultivos de frutas, hortalizas y flores.

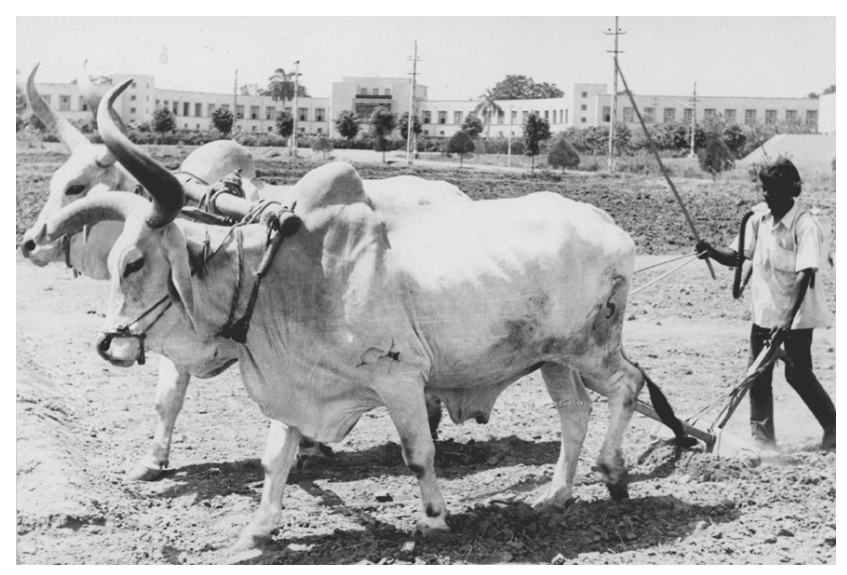


Tabla 64.5 • Clasificación de las actividades agrícolas.

\begin{tabular}{lll} 
Tipo de trabajo & & \\
& $\begin{array}{l}\text { Preparación de la cama de } \\
\text { siembra }\end{array}$ & Siembra \\
\hline Trabajo ligero & Rastrillado (dos trabajadores) & $\begin{array}{c}\text { Siembra a voleo de semi- } \\
\text { llas/dispersión de fertilizantes, } \\
\text { ahuyentado de aves, aporcado }\end{array}$
\end{tabular}

Trabajo moderadamente pesado

Marcha detrás de un apero tirado por animales, nivelación de la superficie del suelo con el rastrillo de madera, rastrillado (un trabajador), cava del suelo con la laya, corte de matas

\section{Trabajo pesado Arado, elevación de agua (con cesto oscilante), cava de suelo seco, repaso a mano en suelo húmedo, trabajo con laya, grada con disco}

Trabajo extremadamente pesado

Repaso a mano en suelo seco
Arranque manual de plántulas (postura agachada e inclinada), trasplante de plántulas (postura inclinada), marcha en un campo enfangado
Siembra en campos enfangados
Desherbado manual con la hoz y la azadilla (postura agachada e inclinada), regadío, aplicación de plaguicidas con pulverizador de mochila, desherbado en suelo húmedo 0 seco

Desherbado en suelos secos
Recolección entretenimiento

Dispersión de fertilizantes

Limpieza del grano, clasificación, esparcido de hortalizas (agachado), molienda del grano (ayudante), aventado (sentado)

Siega de cultivos, recolección de arroz, de trigo (posturo agachada e inclinada), arranque de hortalizas, aventado manual (sentado y de pie), corte de caña de azúcar, ayudante de trillado a pedal, transporte de cargas $(20-35 \mathrm{~kg})$

Trillado por batido, molienda de grano

Trillado a pedal, transporte de cargas en la cabeza 0 en un yugo $(60-80 \mathrm{~kg})$

Fuente: Basado en datos de Nag, Sebastian y Marlankar 1980; Nag y Chatteriee 1981.

- Cultivos de plantación o perennes, como cocos, caucho, café, té, etc.

- Pastizales, que crecen de forma natural sin intervención humana.

\section{Operaciones agrícolas, herramientas y maquinaria manuales}

La agricultura de los países tropicales requiere mucho trabajo. La proporción de la población rural con respecto a la tierra cultivable es en Asia dos veces mayor que en Africa y tres veces mayor que en América Latina. Se estima que más del $70 \%$ de la energía requerida para las tareas de producción de cultivos procede del esfuerzo humano (FAO 1987). La mejora de las herramientas, equipos y métodos de trabajo existentes tiene efectos significativos en la disminución del esfuerzo y la fatiga humanos y en el aumento de la productividad de las explotaciones. En cuanto a los cultivos de campo, las actividades agrícolas se pueden clasificar según la demanda fisiológica de trabajo para una capacidad de trabajo individual máxima (Tabla 64.5).

\section{Preparación de la cama de siembra}

Una cama de siembra adecuada es aquella que es mullida, mejor que compacta, y está exenta de vegetación que interfiera con la siembra. Su preparación implica el uso de diferentes tipos de herramientas manuales, el arado cincel poco profundo o un arado de vertedera tirado por animales (Figura 64.14) o accesorios de tractor para arado, rastrillado, etc. Un arado tirado por un buey puede cultivar 0,4 hectáreas de tierra en un día, y una pareja de bueyes puede proporcionar energía de hasta 1 caballo de fuerza.

$\mathrm{Al}$ utilizar equipo tirado por animales, el trabajador actúa como controlador de éstos y guía el apero con un mango. En la mayoría de los casos camina detrás del apero o se sienta sobre el equipo (por ejemplo, gradas de disco y enfangadoras). La conducción de accesorios tirados por animales implica un gran gasto de energía. Con un arado de $15 \mathrm{~cm}$, una persona puede caminar unos $67 \mathrm{~km}$ para cubrir una hectárea. Si se camina a una velocidad de $1,5 \mathrm{~km} / \mathrm{h}$, el gasto de energía humana llega a $21 \mathrm{~kJ} / \mathrm{min}$ (unos 5,6 $\times 10^{4} \mathrm{~kJ}$ por ha). Un mango de los accesorios que sea demasiado largo o corto produce molestias físicas.

Figura 64.15 • Escardado en el desherbado de un arrozal.

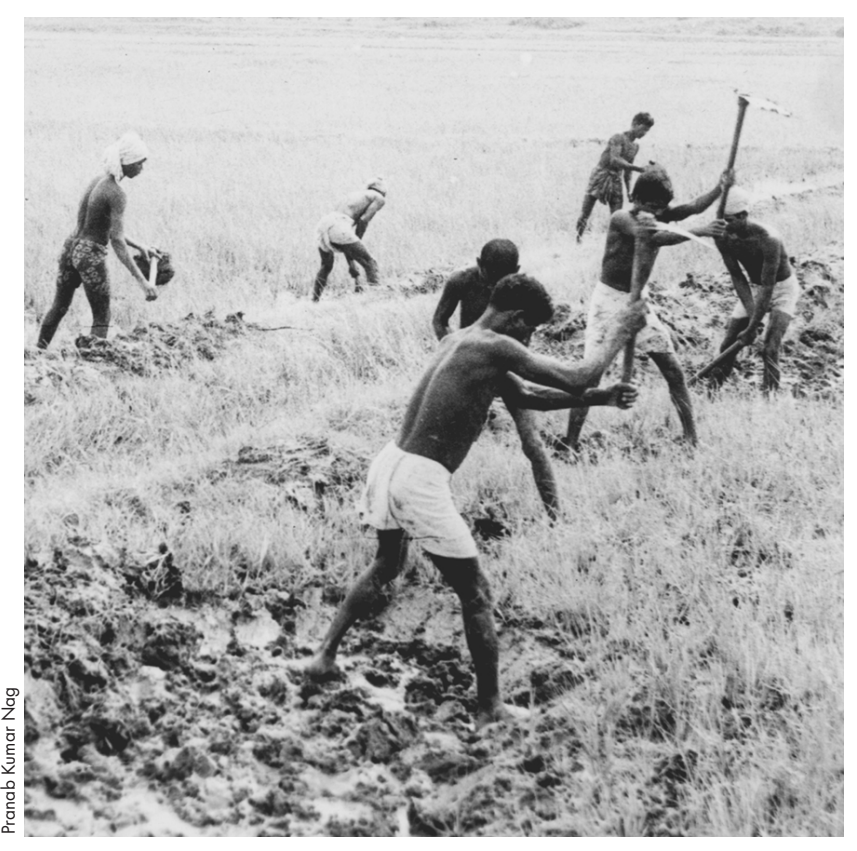


Gite (1991) y Gite y Yadav (1990) sugirieron que la altura óptima para el mango de un accesorio puede ajustarse entre 64 y $84 \mathrm{~cm}$ (1,0 a 1,2 veces la altura metacarpiana III del operario).

Se utilizan herramientas manuales (layas, palas, azadas, etc.) para cavar y mullir el suelo. Para minimizar el esfuerzo al palear, Freivalds (1984) dedujo la velocidad óptima de trabajo (es decir, la velocidad de paleado) (18 a 21 paladas/minuto), la carga de la pala (5 a $7 \mathrm{~kg}$ para 15 a 20 paladas/minuto, y $8 \mathrm{~kg}$ para 6 a 8 paladas/minuto), distancia de lanzamiento $(1,2 \mathrm{~m})$ y altura de lanzamiento (1 a 1,3 m). Las recomendaciones incluyen también un ángulo de elevación de la pala de $32^{\circ}$, un mango largo, una pala ancha y cuadrada para palear, una pala con punta redonda para cavar y una estructura hueca para reducir el peso de la pala.

Nag y Pradhan (1992) sugirieron tareas de cava de alta y baja altura de impulsión (véase la Figura 64.15), sobre la base de estudios fisiológicos y biomecánicos. Como norma general, el método de trabajo y la forma de la azada son los factores decisivos para la eficacia de las tareas de cava (Pradhan y cols. 1986). El modo de golpear la pala contra el suelo determina el ángulo con el que penetra en éste. Para el trabajo de baja altura de impulsión, el rendimiento se optimizó a 53 golpes/minuto, con un área de tierra excavada de $1,34 \mathrm{~m}^{2} /$ minuto, y una relación trabajo: descanso 10:7. Para el trabajo de alta altura de impulsión, las condiciones óptimas fueron 21 golpes por minuto y $0,33 \mathrm{~m}^{2} /$ minuto de tierra excavada. La forma de la pala - rectangular, trapezoidal, triangular o circular - depende del propósito y preferencia de los usuarios. Las dimensiones recomendadas para los distintos modos de escarda son: peso $2 \mathrm{~kg}$, ángulo entre pala y mango 65 a $70^{\circ}$, longitud del mango 70 a $75 \mathrm{~cm}$, longitud de la pala 25 a $30 \mathrm{~cm}$, anchura de la pala 22 a $24 \mathrm{~cm}$ y diámetro del mango 3 a $4 \mathrm{~cm}$.

\section{Siembra/plantación y aplicación de fertilizantes}

La siembra de semillas y la plantación de plántulas implica el uso de plantadoras o sembradoras, y la dispersión manual de semillas. Se requiere cerca del $8 \%$ del total de personas-hora para esparcir las semillas y descepar y trasplantar las plántulas.

- En la siembra a voleo/aplicación de los fertilizantes a mano, las sembradores centrífugas permiten una distribución uniforme con un esfuerzo mínimo.

- La siembra detrás de un arado consiste en sembrar la semillas en un surco abierto por un arado de madera.

- En la siembra en líneas, las semillas se colocan en el suelo mediante una sembradora-abonadora. La fuerza de empuje/ tracción requerida para que el trabajador maneje el apero (unidades manuales o tiradas por animales montadas sobre ruedas) es un aspecto importante a tener en cuenta en el diseño.

- En la siembra a golpes se colocan las semillas a mano o con un pequeño apero (una ahoyadora), con un espaciado promedio de $15 \times 15 \mathrm{~cm}$ o $25 \times 25 \mathrm{~cm}$. Algunas quejas habituales son la abrasión de los dedos y la incomodidad debido a las posturas inclinadas y en cuclillas.

- En la plantación, las cañas de azúcar se colocan a $30 \mathrm{~cm}$ en un surco; los bulbos de patatas de plantan lisos y se practican caballones.

- Aproximadamente 1/3 del arroz de todo el mundo se produce mediante el sistema de trasplante. También se utiliza este método para el tabaco y para algunas hortalizas. Habitualmente las semillas se esparcen a voleo densamente en un campo enfangado. Las plántulas se arrancan y trasplantan luego a un campo enfangado, bien manualmente, bien con trasplantadores manuales o a motor. El operario de un trasplantador accionado manualmente camina detrás de la unidad para manejar el mecanismo de recogida y trasplante.
Para el trasplante manual, el trabajador debe estar sumergido en barro hasta las rodillas. La postura agachada para plantar en tierra seca, con una o las dos piernas flexionadas por la rodilla, no se puede adoptar en un campo con agua. Se requieren unas 85 personas-hora para trasplantar las plántulas de cada hectárea de tierra. La postura incómoda y la carga estática afectan al sistema cardiovascular y pueden provocar lumbago (Nag y Dutt 1980). Las sembradoras manuales producen un mayor rendimiento (una sembradora es unas ocho veces más eficiente que el transplante a mano). No obstante, el mantenimiento del equilibrio de la máquina (véase la Figura 64.16) en un campo enfangado requiere unas 2,5 veces más energía que el trasplante manual.

\section{Protección de las plantas}

Los aplicadores de fertilizantes, plaguicidas, herbicidas y otros productos químicos funcionan a presión a través de toberas o mediante fuerza centrífuga. La pulverización a gran escala se realiza con atomizadores hidráulicos de toberas, manejados manualmente o utilizando equipos sobre tractores. Los pulverizadores de mochila son modelos a pequeña escala de pulverizadores sobre vehículos (Bull 1992).

- El pulverizador de mochila de compresión consta de un depósito, una bomba y un cilindro con tobera y manguera.

- El pulverizador de mochila de palanca (10 a 20 l) se acciona mediante una palanca.

- El pulverizador de mochila a motor consta de un depósito de aproximadamente $10 \mathrm{l}$ y un motor refrigerado por aire de 1 a 3 caballos de fuerza. El pulverizador y el motor están montados sobre un bastidor y son transportados en la espalda del operario.

- El pulverizador de cubo manual y el pulverizador accionado con el pie requieren dos personas para accionar la bomba y pulverizar. $\mathrm{El}$ pulverizador basculante funciona gracias al movimiento basculante (hacia adelante y hacia atrás) de la palanca del mango.

\section{Figura 64.16 - Trabajo con una sembradora germinadora} mejorada.

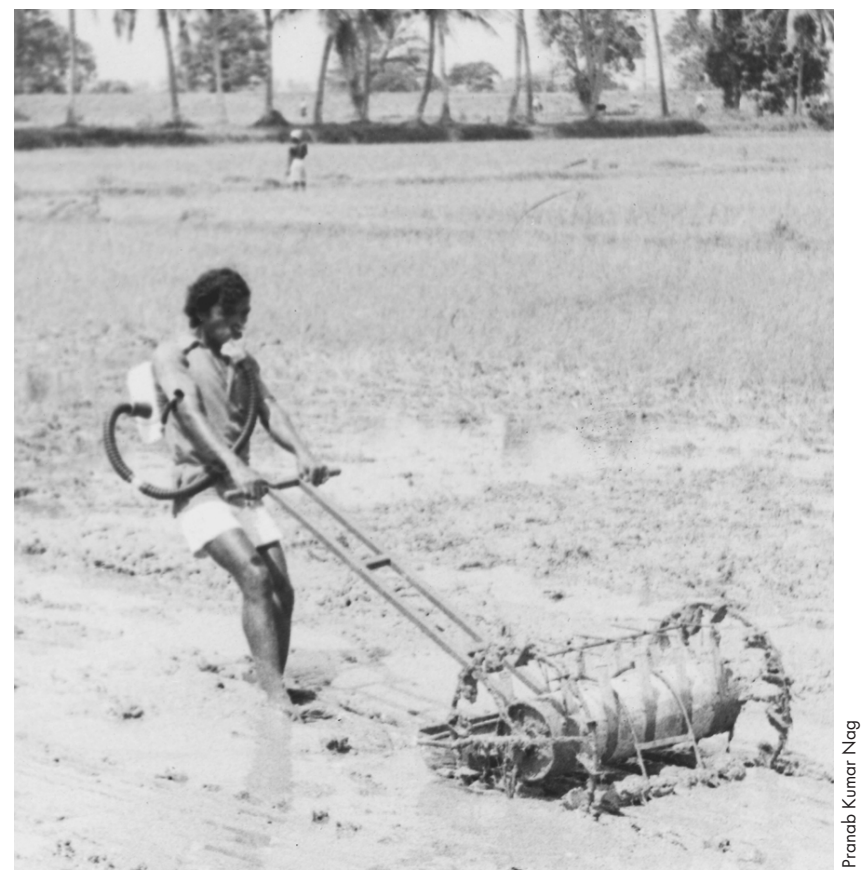


Cuando se transportan sobre los hombros durante largos períodos, las vibraciones de los pulverizadores de mochila/aplicadores de productos químicos tienen efectos perjudiciales sobre el cuerpo humano. La pulverización con un pulverizador de mochila supone un riesgo de exposición de la piel (las piernas reciben el $61 \%$ de la contaminación total, las manos el $33 \%$, el tronco el $3 \%$, la cabeza el $2 \%$ y los brazos el $1 \%$ ) (Bonsall 1985). La ropa de protección personal (incluidos guantes y botas) puede reducir la contaminación dérmica de los plaguicidas (Forget 1991, 1992). El trabajo es extenuante, debido a la carga sobre la espalda y el movimiento continuo del mango del pulverizador (20 a 30 golpes/minuto); a todo esto se une la carga termorreguladora debido a la ropa protectora. El peso y la altura del pulverizador, la forma del depósito, el sistema de montaje y la fuerza requerida para accionar la bomba son aspectos ergonómicos importantes.

\section{Riego}

El riego es un requisito previo para el cultivo intensivo en regiones áridas y semiáridas. Desde tiempos inmemorables se han utilizado variados dispositivos para la elevación de agua. La elevación de agua mediante métodos manuales es un trabajo físicamente agotador. A pesar de la disponibilidad de bombas de agua (eléctricas o a motor), son muy utilizados los dispositivos manuales (p. ej. cestos oscilantes, elevador hidráulico compensado, ruedas hidráulicas, bombas de cangilones y lavanderas, bombas de vaivén).

- El cesto oscilante se utiliza para elevar agua desde un canal de regadío (véase la Figura 64.17). Su capacidad es de 4 a 6 l y la frecuencia de manejo de 15 a 20 oscilaciones/minuto. Dos operarios trabajan en ángulo recto a la dirección del movimiento del cesta. El trabajo requiere una actividad física pesada, con posturas y movimientos incómodos.

- El elevador hidráulico compensado consta de un recipiente unido al extremo de un elevador horizontal apoyado sobre un poste vertical. El trabajador ejerce fuerza sobre el contrapeso para hacer funcionar el dispositivo.

- Las bombas de vaivén (bombas manuales de tipo pistón-cilindro) se manejan bien manualmente en modo de vaivén o mediante pedales en modo rotativo.

\section{Escarda y labores de entretenimiento}

Las plantas y malezas indeseables provocan pérdidas al disminuir los rendimientos y la calidad de las cosechas, albergando plagas vegetales y aumentando el coste del regadío. La reducción del rendimiento varía del 10 al $60 \%$ en función del crecimiento y del tipo de malezas. En la eliminación de malezas durante la estación de cultivo se gasta aproximadamente un $15 \%$ del trabajo humano. Una gran parte de la mano de obra dedicada a la escarda está formada por mujeres. En una situación típica, un trabajador emplea cerca de 190 a 220 horas escardando una hectárea de tierra con la azada. También se utilizan layas para la escarda y las labores de entretenimiento.

De los distintos métodos (mecánicos, químicos, biológicos, de cultivo), la escarda mecánica, bien arrancando la maleza a mano o con herramientas manuales como la azada y desherbadores sencillos, es útil tanto en tierras de regadío como de secano (Nag y Dutt 1979; Gite y Yadav 1990). En terrenos de secano, los trabajadores se agachan sobre el suelo con una o las dos piernas flexionadas por la rodilla y eliminan la maleza con una hoz o una azadilla. En tierras de regadío, adoptan una postura inclinada e inmóvil para retirar las malezas manualmente o con la ayuda de desherbadoras.

La demanda fisiológica para el uso de desherbadoras (por ejemplo, pala y rastrillo, dedo de proyección, desherbadoras
Figura 64.17 - Acarreo de agua de un canal de riego utilizando un cesto oscilante.

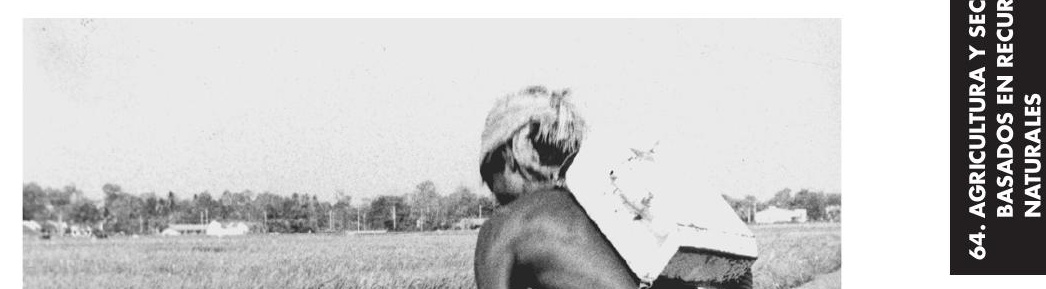

de doble barrido) es relativamente mayor que en la escarda manual. No obstante, la eficacia del trabajo en términos de área cubierta es significativamente mayor. La demanda de energía en los trabajos de escarda manual supone sólo un $27 \%$ de la capacidad de trabajo de una persona, mientras que con las distintas desherbadoras la demanda de energía llega hasta el $56 \%$. No obstante, el esfuerzo es relativamente menor en el caso de desherbadoras de rueda de tipo azada, con las que son necesarias unas 110 a 140 personas-hora para cubrir una hectárea. Una desherbadora de este tipo consta de una o dos ruedas, una

Figura 64.18 • Recolección de trigo con una hoz.

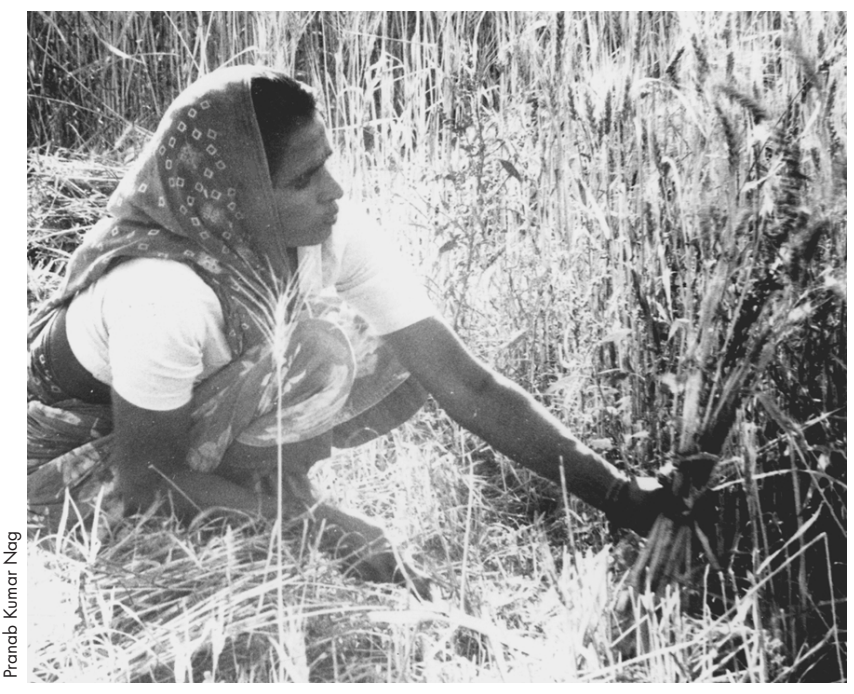




\section{Figura 64.19 • Recolección manual de patatas con una azada.}

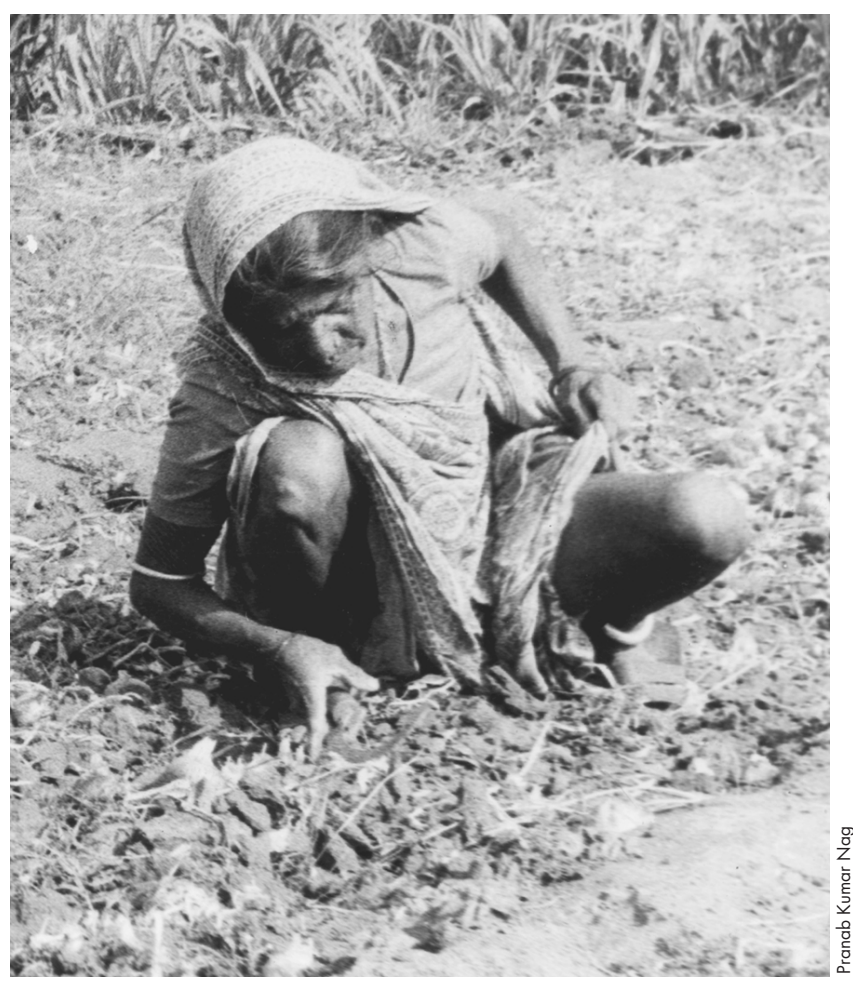

pala, un bastidor y un mango. Se requiere una fuerza (empuje/tracción) de aproximadamente 5 a 20 kilogramos de fuerza (1 kgf = 9,81 Newtons), con una frecuencia de aproximadamente 20 a 40 golpes por minuto. No obstante, es necesario normalizar las especificaciones técnicas de las desherbadoras de rueda de tipo azada para un mejor funcionamiento.

\section{Recolección}

En los cultivos de arroz y de cereal, la recolección requiere del 8 al $10 \%$ de las personas-hora utilizadas en la producción del cultivo. A pesar de la rápida mecanización en este ámbito, en los próximos años continuará la gran dependencia de los métodos manuales (véase la Figura 64.18). En la recolección manual se utilizan herramientas manuales (hoz, guadaña, etc.). La guadaña se utiliza habitualmente en muchas partes del mundo debido a que cubre un área amplia. No obstante, requiere más energía que la hoz.

La popularidad de la hoz se debe a la simplicidad de su construcción y manejo. Se trata de una hoja curva, con filo liso o dentado, unido a un mango de madera. El diseño varía de una región a otra, de forma que la carga cardiorrespiratoria es diferente según el tipo hoz. El rendimiento varía de 110 a $165 \mathrm{~m}^{2} /$ hora, valores que corresponden a 90 y 60 personas-hora por hectárea de tierra. Las posturas incómodas durante este trabajo pueden provocar complicaciones clínicas a largo plazo relacionadas con la espalda y las articulaciones de las extremidades. La recolección en posición inclinada tiene la ventaja de la movilidad tanto en regadío como en terreno de secano, y es aproximadamente un $16 \%$ más rápida que en posición agachada; no obstante, la postura inclinada requiere un $18 \%$ más de energía que la agachada (Nag y cols. 1988).
Los accidentes, laceraciones y heridas incisas durante la recolección son comunes en arrozales, trigales y campos de caña de azúcar. Las herramientas manuales están diseñadas principalmente para personas diestras, pero a menudo son utilizadas por personas zurdas, que no son conscientes de las posibles repercusiones sobre su seguridad. Los factores importantes del diseño de una hoz son la geometría de la hoja, su dentado, la forma y el tamaño del mango. Sobre la base de un estudio ergonómico, las dimensiones sugeridas para el diseño de una hoz son: peso, $200 \mathrm{~g}$; longitud total, $33 \mathrm{~cm}$; longitud del mango, $11 \mathrm{~cm}$; diámetro del mango, $3 \mathrm{~cm}$; radio de la curvatura de la hoja, $15 \mathrm{~cm}$; concavidad de la hoja, $5 \mathrm{~cm}$. Para una hoz dentada: paso dental, $0,2 \mathrm{~cm}$; ángulo dental, $60^{\circ}$, y relación de la longitud de la superficie cortante con la longitud de la cuerda, 1,2. Debido a que los trabajadores realizan estas actividades en condiciones climáticas extremas, los aspectos de salud y seguridad son muy importantes en los cultivos tropicales. Durante las largas horas de trabajo se acumula una gran carga respiratoria. Las condiciones climáticas extremas y las alteraciones por calor añaden tensión y disminuyen la capacidad de trabajo.

Las máquinas cosechadoras pueden ser segadoras, picadoras, empacadoras, etc. En la recolección de cultivos de campo se utilizan también segadoras de cereales a motor o tiradas por animales. Las cosechadoras combinadas (autopropulsadas o accionadas por tractor) son útiles para el cultivo intensivo cuando la mano de obra es escasa.

La recolección de sorgo se realiza cortando la cabeza de la espiga y después la planta, o viceversa. El algodón se recoge en 3 a 5 arrancamientos cuando la bola está madura. El arranque de patatas y de remolacha se realiza manualmente (véase la Figura 64.19) o con un rastrillo o arrancadora, tirados por

Figura 64.20 • Trillado de las cimas de arroz mediante batido.

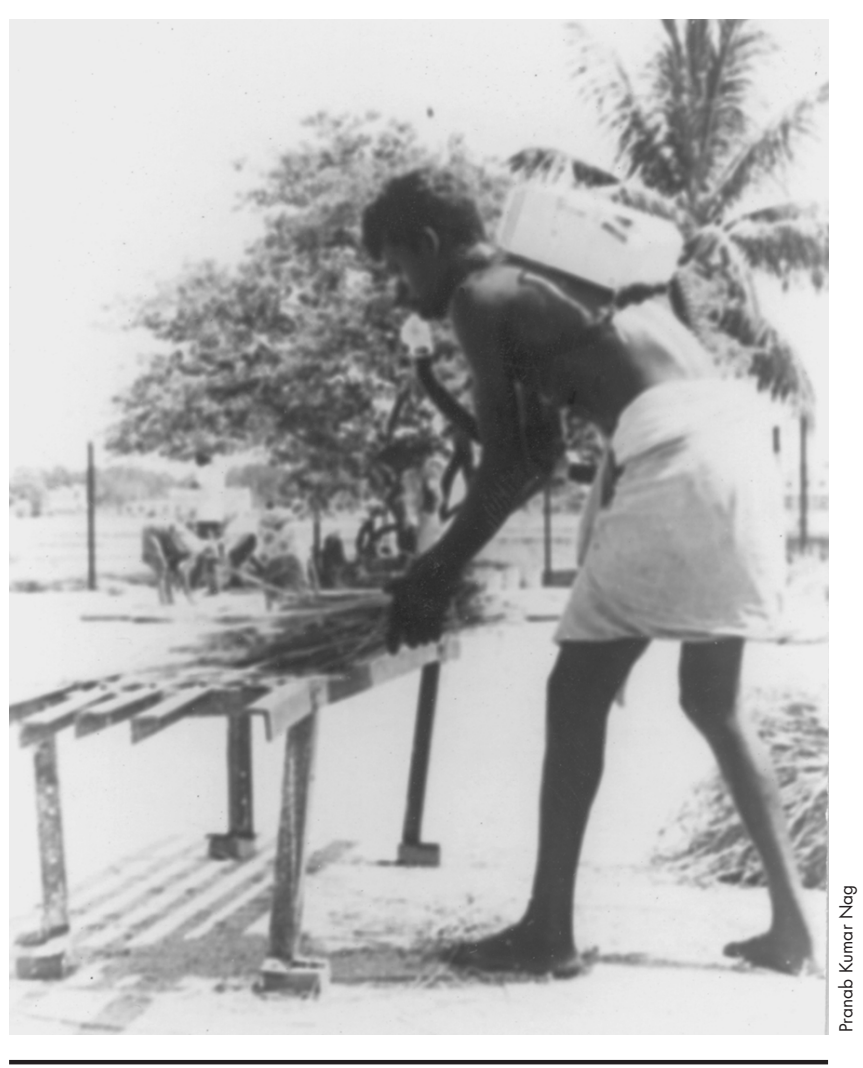


Figura 64.21 • Trilladora a pedales en funcionamiento.

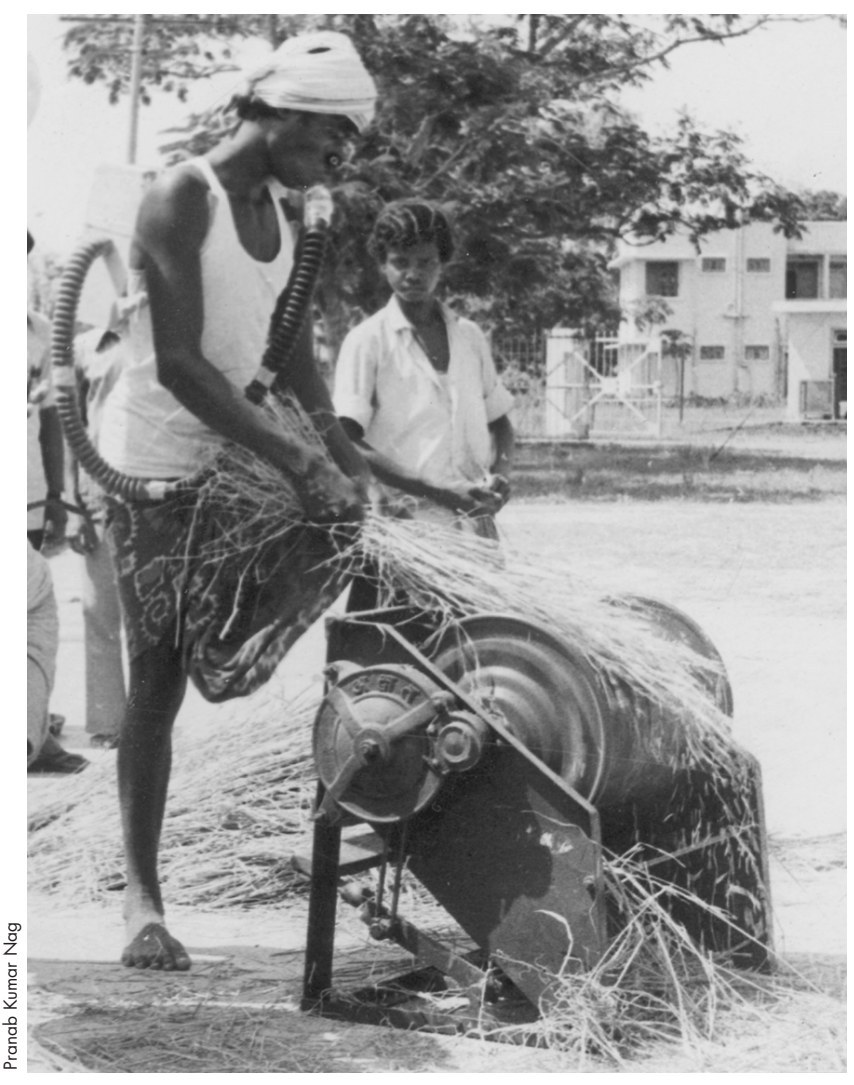

animales o un tractor. En el caso de los cacahuetes, las cepas se arrancan manualmente o se eliminan con arrancadoras, y las vainas se separan.

\section{Trillado}

El trillado supone la separación de los granos de las espigas. Algunos métodos manuales antiguos para trillar el grano de la cima del arroz son: frotamiento de las espigas con el pie, batido el cereal recogido sobre una tabla, pisado por animales, etc. El trillado está clasificado como una tarea moderadamente pesada (Nag y Dutt 1980). En el trillado manual mediante batido (véase la Figura 64.20) se separan aproximadamente de 1,6 a $1,8 \mathrm{~kg}$ de grano y de 1,8 a 2,1 $\mathrm{kg}$ de paja por minuto de plantas de arroz/trigo de tamaño medio.

Las trilladoras mecánicas realizan las operaciones de trillado y aventado simultáneamente. La trilladora a pedales (modo oscilante o rotativo) aumenta el rendimiento de 2,3 a $2,6 \mathrm{~kg}$ de grano (arroz/trigo) y de 3,1 a $3,6 \mathrm{~kg}$ de paja por minuto. El trillado a pedales (véase la Figura 64.21) es una actividad más extenuante que el trillado manual por batido. El pedaleo y sujeción de las plantas de arroz en el tambor rodante produce una elevada tensión muscular. Las mejoras ergonómicas en la trilladora a pedales pueden permitir un patrón rítmico de trabajo de piernas en posturas alternas de pie o sentada y minimizan las tensiones posturales. El momento óptimo de la trilladora puede alcanzarse a aproximadamente $8 \mathrm{~kg}$ de peso del tambor rodante.

Las trilladoras a motor se están introduciendo gradualmente en áreas de la revolución verde. En esencia constan de un motor primario, una unidad de trillado, una unidad de aventado, una unidad de alimentación y una salida para el grano limpio. Las cosechadoras combinadas autopropulsadas son una combinación de una cosechadora y una unidad trilladora para cereales.

Se han comunicado accidentes mortales en el trillado de grano utilizando trilladoras a motor y cortadoras de pienso. La incidencia de las lesiones de moderadas a graves por trilladoras fue de 13,1 por cada cien trilladores (Mohan y Patel, 1992). El rotor puede herir las manos y los pies. La posición del canal de alimentación puede provocar posturas incómodas cuando se introduce el cultivo en la trilladora. El accionamiento por correa de la trilladora es también una causa frecuente de lesiones. Con las cortadoras de forraje, los operarios pueden herirse al introducir el pienso en las paletas en movimiento. Los niños pueden lesionarse al jugar con las máquinas.

A menudo los trabajadores se encuentran sobre plataformas inestables. En el caso de una sacudida o pérdida de equilibrio, el peso del tronco empuja las manos hacia el tambor de la trilladora/cortadora de pienso. La trilladora debe estar diseñada de forma que el canal de alimentación se encuentre a la altura del codo y los operarios estén sobre una plataforma estable. El diseño de la cortadora de forraje debe mejorarse con vistas a una mayor seguridad de la forma siguiente (Mohan y Patel, 1992):

- un cilindro de advertencia colocado en el canal antes de los cilindros de alimentación

- una clavija de cierre para fijar el volante cuando no se utiliza la cortadora

- cubierta de los engranajes y protecciones en las palas de forma que las extremidades permanezcan alejadas y no se enrede la ropa.

En el caso de los cacahuetes, el trillado tradicional consiste en sostener las plantas con una mano y golpearlas contra una barra o reja. Para trillar el maíz se utilizan desgranadores de maíz tubulares. El trabajador sostiene el equipo en su palma e inserta y rota copos en el aparato para separar los granos de maíz de los copos. El rendimiento con este equipo es de aproximadamente $25 \mathrm{~kg} /$ hora. Las desgranadoras de maíz rotativas manuales tienen un rendimiento mayor, aproximadamente 50 a $120 \mathrm{~kg}$ /hora. La longitud del mango, la fuerza necesaria para manejarlo y la velocidad de la operación son los aspectos

Figura 64.22 • Aventado manual.

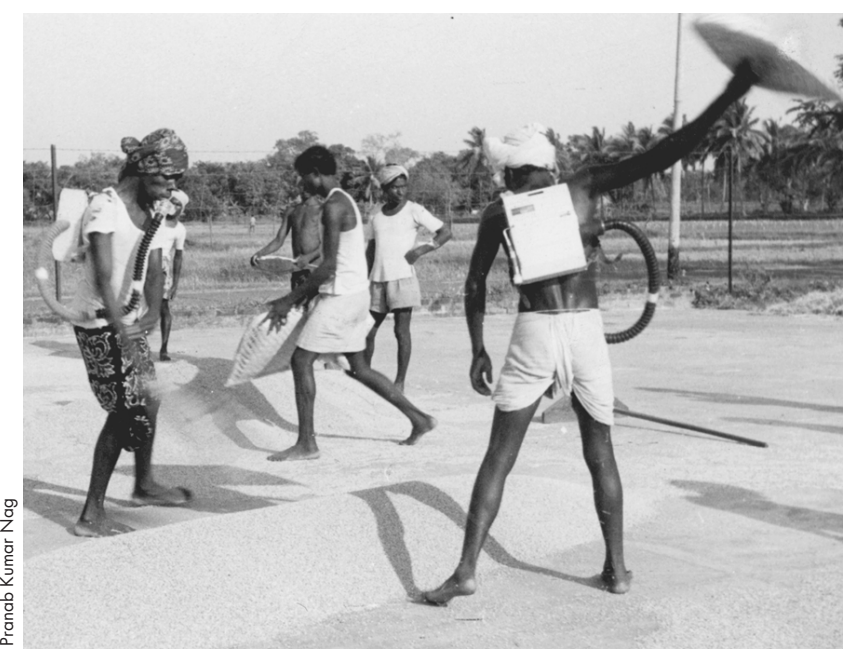


importantes a tener en cuenta en las desgranadoras de maíz rotativas manuales.

\begin{abstract}
Aventado
El aventado es el proceso de separación del grano de la gluma mediante soplado de aire, utilizando un ventilador manual o un ventilador a pedales o a motor. En los métodos manuales (véase la Figura 64.22), se arroja al aire todo el contenido, y el grano y la gluma se separan debido al momento diferencial. Una aventadora mecánica puede funcionar mediante pedales o manualmente, con un trabajo humano considerable.
\end{abstract}

Otras operaciones posteriores a la recolección son la limpieza y clasificación de los granos, el desgranado, el descortezado, el descascarillado, el pelado, el corte, la extracción de fibra, etc. En estas operaciones se utilizan distintos tipos de equipos manuales (p. ej. peladoras y cortadoras de patatas, descascarilladoras de cocos). El descortezado consiste en romper las cubiertas y sacar las semillas (p. ej. cacahuetes, semillas de ricino). Las descortezadoras de cacahuetes separan las pepitas de las vainas. El descortezado manual tiene un rendimiento muy bajo (aproximadamente $2 \mathrm{~kg}$ de vainas por persona-hora). Los trabajadores se quejan de la incomodidad de estar continuamente sentados o agachados. Las descortezadoras oscilantes o rotativas tienen un rendimiento de unos 40 a $60 \mathrm{~kg}$ de vainas por hora. El desgranado y descascarillado se refieren a la separación de la cubierta o cáscara de la semilla de la parte interna del grano (p. ej. arroz, soja). Las descascarilladoras de arroz tradicionales son manuales (con mano o pie) y se utilizan habitualmente en el Asia rural. La fuerza máxima que se puede ejercer con la mano o el pie determina el tamaño y otras características del dispositivo. Hoy en día, para el descascarillado se utilizan molinos de arroz motorizados. En algunos granos, como el guisante de Angola, la cubierta o cáscara de la semilla está fuertemente unida. En estos casos la eliminación de la cáscara se denomina descascarillado.

Para las diferentes herramientas manuales y los accesorios accionados a mano, el tamaño de la empuñadura y la fuerza ejercida con los mangos son aspectos importantes. En el caso de tijeras es importante la fuerza que se pueda aplicar con las dos manos. Aunque la mayor parte de las lesiones relacionadas con las herramientas manuales se clasifican como leves, sus consecuencias son a menudo dolorosas e incapacitantes debido al retraso en el tratamiento. Los cambios de diseño de las herramientas manuales deberán limitarse a aquellas que pueden ser fabricadas con facilidad por los artesanos rurales. En equipos a motor se deben considerar aspectos de seguridad. Actualmente los zapatos y guantes de seguridad son demasiado caros e inadecuados para los agricultores de los trópicos.

\section{Tareas manuales de manipulación de materiales}

La mayor parte de las actividades agrícolas implican tareas manuales de manipulación de materiales (p. ej. elevación, descenso, tracción, empuje y transporte de cargas pesadas), que son causa de tensiones musculosqueléticas, caídas, lesiones de la columna vertebral, etc. La tasa de lesiones por caídas aumenta extraordinariamente cuando la altura de la caída es mayor de $2 \mathrm{~m}$; la fuerza del impacto se reduce muchas veces si la víctima cae sobre tierra blanda, paja o arena.

En áreas rurales se deben transportar pesos de 50 a $100 \mathrm{~kg}$ diariamente y durante kilómetros (Sen y Nag 1975). En algunos países, las mujeres y los niños tienen que acarrear grandes cantidades de agua desde largas distancias. Es necesario reducir al mínimo posible estas arduas tareas. Algunas formas de llevar el agua son sobre la cabeza, en la cintura, en la espalda o sobre los
Figura 64.23 - Nomograma para optimizar la carga a transportar sobre la cabeza o yugo, con respecto a la velocidad de marcha y a la demanda de oxígeno del trabajo.

Carga transportada

$(\mathrm{kg})$

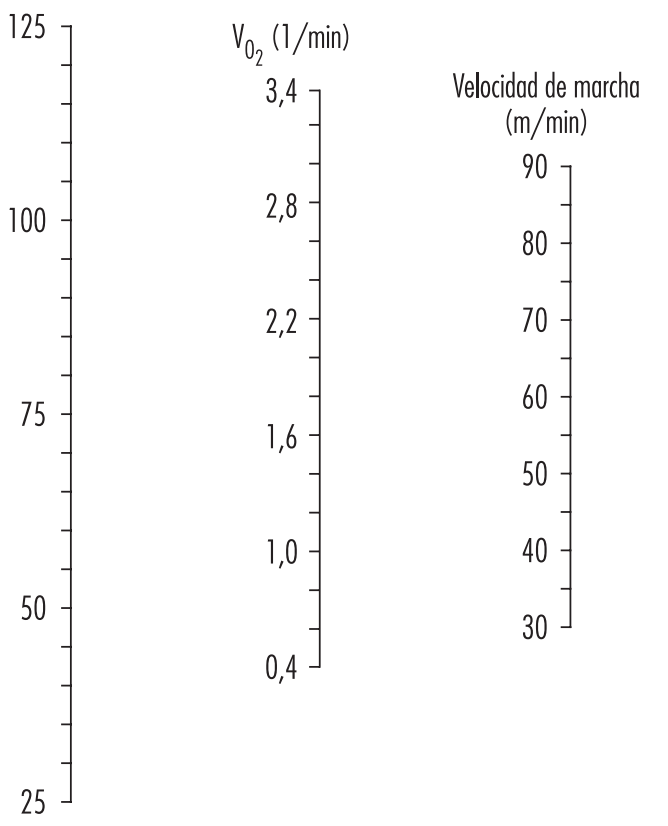

hombros. Estas se han asociado a varios efectos biomecánicos y alteraciones de la columna vertebral (Dufaut 1988). Se han intentado mejorar las técnicas de transporte de pesos sobre los hombros, los diseños de las carretillas, etc. El transporte de cargas utilizando yugos transversales y carga sobre la cabeza son más eficientes que los yugos frontales. En el nomograma de la Figura 64.23 puede consultarse la optimización de la carga que puede ser soportada por un hombre. El nomograma se basa en una regresión múltiple entre el consumo de oxígeno (variable independiente) y la carga transportada y la velocidad de marcha (variables dependientes). Para identificar el resultado se puede poner una regla sobre el gráfico entre las variables. Se han de conocer dos variables para conocer la tercera. Por ejemplo, con un consumo de oxígeno de 1,4 l/min (aproximadamente equivalente al $50 \%$ de la capacidad máxima de trabajo de un individuo) y una velocidad de marcha de $30 \mathrm{~m} / \mathrm{min}$, la carga óptima deberá ser de aproximadamente $65 \mathrm{~kg}$.

A la vista de la diversidad de las actividades agrícolas, algunas medidas de organización basadas en el nuevo diseño de las herramientas y la maquinaria, nuevos métodos de trabajo, instalación de protecciones de seguridad en la maquinaria, la optimización de la exposición humana a un medio ambiente laboral adverso, etc. pueden mejorar significativamente las condiciones de trabajo de las poblaciones agrícolas (Christiani 1990). La investigación ergonómica intensa sobre los métodos y prácticas, herramientas y equipos agrícolas puede conseguir grandes avances para la mejora de la salud, seguridad y productividad de miles de millones de trabajadores de la agricultura. Esta, que es el mayor sector del planeta, tiene una imagen primitiva, en particular la agricultura tropical de escasos recursos, que puede transformarse si se realiza una orientación a determinadas tareas. De esta forma, los 
trabajadores rurales pueden recibir una formación sistemática sobre los riesgos de los trabajos, y es posible desarrollar procedimientos operativos seguros.

\section{MECANIZACION}

\section{Dennis Murphy}

La mecanización del trabajo agrícola y de los procesos de trabajo ha liberado a muchos trabajadores de todo el mundo de un trabajo oneroso, monótono y perjudicial para la espalda. $\mathrm{Al}$ mismo tiempo, la velocidad y potencia asociadas a la mecanización contribuyen a las lesiones traumáticas graves. En todo el mundo los países que practican una agricultura mecanizada listan los tractores y la maquinaria agrícola como principales agentes de lesiones mortales e incapacitantes en el trabajo agrícola. Las herramientas a motor también contribuyen a la tasa de lesiones, aunque éstas son normalmente más leves. Algunas máquinas presentan también un riesgo medioambiental, como ruidos y vibraciones.

\section{Riesgos de los tractores}

Los tractores agrícolas tienen muchas características que hacen que sean la pieza más importante del equipo a motor de la granja. La mayor parte de los tractores tienen neumáticos de caucho, sistemas hidráulicos y toma de fuerza (TF), y utilizan una combinación de velocidades del motor y relaciones de engranajes. Estas características hacen los tractores sean rápidos, potentes, flexibles y adaptables. Los riesgos más graves asociados con el funcionamiento de los tractores son los vuelcos, atropellos y enredo con la TF. Los vuelcos hieren mortalmente a muchas más víctimas que cualquier otro tipo de accidente. La Tabla 64.6 lista los riesgos de los tractores y el modo en que se producen las lesiones.
Figura 64.24 • Línea base de estabilidad de un tractor de tres ruedas y de un tractor con parte frontal ancha.
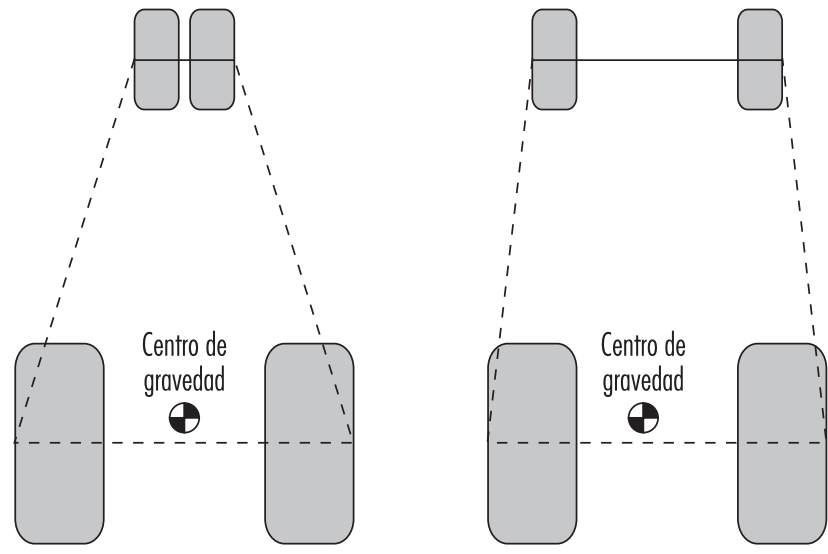

Fuente: Deere \& Co. 1994

\section{Vuelcos}

El concepto central en la estabilidad o inestabilidad del tractor es el de centro de gravedad (CG). El centro de gravedad de un tractor es el punto de éste en el que todas las partes se equilibran. Por ejemplo, cuando un tractor de dos ruedas motrices está situado con todas las ruedas a nivel del suelo, el CG es de 25,4 cm sobre y $0,6 \mathrm{~m}$ delante del eje posterior y en el centro del cuerpo del tractor. En los tractores de cuatro ruedas motrices y articulados en el centro, el CG está situado algo más adelante. Para que un tractor esté derecho, su CG debe estar en la línea base de estabilidad del tractor. Las líneas base de estabilidad son esencialmente líneas imaginarias trazadas entre los puntos en los que los neumáticos entran en contacto con el suelo (véase la Figura 64.24).

Tabla 64.6 • Riesgos comunes de los tractores y cómo se producen.

\begin{tabular}{|c|c|c|}
\hline Riesgo & Tipo de accidente & Cómo se produce la lesión \\
\hline \multirow[t]{2}{*}{ Vuelcos } & Vuelcos laterales & $\begin{array}{l}\text { Trabajo en pendientes, tomar curvas demasiado rápido, caída de rueda trasera en un agujero o } \\
\text { superficie fuera de la carretera. }\end{array}$ \\
\hline & Vuelcos hacia atrás & $\begin{array}{l}\text { Acoplamiento a un punto distinto de la barra de tracción, las ruedas traseras se hunden en } \\
\text { fango o están heladas y pegadas al suelo. }\end{array}$ \\
\hline \multirow[t]{4}{*}{ Atropellos } & Caída de un pasajero & $\begin{array}{l}\text { La mayor parte de los tractores están diseñados solamente para un operador; por lo tanto, } \\
\text { no existe en ellos ningún lugar seguro para otra persona. }\end{array}$ \\
\hline & Caída del operador & $\begin{array}{l}\text { Golpeado por la rama baja de un árbol, empujado fuera del asiento al atravesar un campo } \\
\text { accidentado. }\end{array}$ \\
\hline & $\begin{array}{l}\text { Atropello del operador mientras está de } \\
\text { pie en el suelo }\end{array}$ & $\begin{array}{l}\text { Salto del tractor en marcha cuando éste tiene puesta una marcha inadvertidamente. El tractor rueda } \\
\text { al subir o bajar. El tractor rueda al acoplar o desacoplar el equipo. }\end{array}$ \\
\hline & $\begin{array}{l}\text { Atropello de un espectador o de un } \\
\text { ayudante que está fuera }\end{array}$ & $\begin{array}{l}\text { Es frecuente el atropello de niños pequeños que el operador no ha visto. Los accidentes con un } \\
\text { ayudante que está fuera son semejantes a los que ocurren cuando el operador está fuera. }\end{array}$ \\
\hline Toma de fuerza (TF) & Enredo con el eje matriz de la TF & $\begin{array}{l}\text { Falta la carcasa principal y la TF se deja conectada mientras funciona el tractor. El operador puede } \\
\text { estar subiendo o bajando de la parte posterior. }\end{array}$ \\
\hline Resbalones y caídas & Subida y bajada del tractor & Pies húmedos o con barro \\
\hline $\begin{array}{l}\text { Pérdida auditiva inducida } \\
\text { por ruido }\end{array}$ & Funcionamiento del tractor & $\begin{array}{l}\text { El silenciador del tractor falta, está deteriorado o es una pieza de repuesto no recomendada; el } \\
\text { motor del tractor no está en buen estado de mantenimiento; la cabina de metal dirige el sonido } \\
\text { hacia el operario. El nivel de ruido periudicial puede proceder de una combinación del tractor y la } \\
\text { máquina acoplada. (Los tractores más antiguos son en general más ruidosos que los nuevos.) }\end{array}$ \\
\hline
\end{tabular}


Tabla 64.7 • Riesgos comunes de la maquinaria y cómo se producen.

$\begin{array}{ll}\text { Riesgos } & \text { Origen } \\ \text { Puntos de estrechamiento } & \begin{array}{l}\text { Dos piezas de la máquina se mueven juntas, y al menos una de } \\ \text { ellas en círculo }\end{array}\end{array}$

Puntos de arrollamiento

Componente de una máquina rotativa expuesto o desprotegido

Puntos de fricción/corte

Puntos de choque

Piezas de rotación libre

Objetos arrojados

Energía almacenada

Puntos calientes

Puntos de entrada

Pérdida auditiva por ruido
Los bordes de dos piezas móviles se mueven uno a lo largo del otro, o un solo borde se mueve contra un borde estacionario 0 un material blando

Dos objetos que se desplazan uno hacia otro, o un objeto que se desplaza hacia otro estacionario

Piezas de la maquinaria que continúan moviéndose después de haber terminado la transmisión, normalmente a partir de la rotación continua de las palas de la cuchilla 0 el ventilador

Los movimientos de picado, triturado, corte y lanzamiento de las máquinas. Algunos objetos pequeños como piedras, metal, vidrio, palos y plantas pueden introducirse y ser arrojados con gran fuerzo

Energía guardada y liberada accidental o inesperadamente

Quemaduras de la piel al entrar en contacto con las piezas calientes de las máquinas

Puntos donde la máquina toma el material de la cosecha para su transformación posterior

Maquinaria en funcionamiento

\section{Localizaciones}

Puntos donde las correas de transmisión entran en contacto con las roldanas, las cadenas de transmisión entran en contacto con las ruedas de engranajes, los rodillos de alimentación se engranan

Ejes de transmisión de la toma de fuerza (TF), brazos del batidor en vagones de ensilado autodescargables, palas de algunas esparcidoras de abono

Segadoras y cosechadoras de forraje, cosechadoras combinadas de granos partidos, picadoras de grano, sinfines de grano

Neumáticos/secciones delanteros y posteriores de tractores articulados, maquinaria acoplada, una mano atrapada debajo de una pieza de un equipo controlado hidráulicamente

Cosechadoras de forraje, picadoras de forraje, segadoras rotativas, ensiladoras

Segadoras rotativas, picadoras de forraje, cosechadoras combinadas con picadoras de paja y esparcidoras de abono

Muelles de máquinas, sistemas hidráulicos, aire comprimido, sistemas eléctricos

Silenciadores calientes, bloques motores, tuberías, líquidos (gasóleo, aceites, productos químicos)

Recolectoras y cosechadoras combinadas de maíz, picadoras de forraje, empacadoras de heno

Tractores, maquinaria de campo, sinfines de grano, secadoras, ensiladoras, picadoras de grano, picadoras de forraje. El nivel de ruido nocivo puede proceder de una 0 varias máquinas. Las máquinas más antiguas suelen producir más ruido que las nuevas.
El centro de gravedad de un tractor no puede moverse, pero sí cambiar su relación con las líneas base de estabilidad. Esto ocurre con más frecuencia cuando el tractor sale de una posición perfectamente nivelada, como una pendiente. El cambio de la relación entre el CG y la línea base de estabilidad significa que el tractor se desplaza hacia una posición inestable. Si la relación entre la línea base de estabilidad y el CG se modifica significativamente (p. ej. el CG del tractor se mueve más allá de la línea base de estabilidad), el tractor vuelca. Si el tractor lleva un equipo como un cargador frontal, una horquilla elevadora de pacas redondas o un tanque lateral con productos químicos, el peso adicional desplaza el CG hacia dicha pieza del equipo. Al subir el equipo montado, sube el CG.

Otros factores importantes para la estabilidad o inestabilidad del tractor son la fuerza centrífuga $(\mathrm{FG})$, el momento de torsión del eje posterior (TEP) y el apalancamiento de la barra de tracción (ABT). Cada uno de estos factores actúa a través del CG. La fuerza centrífuga es la fuerza hacia el exterior que la naturaleza ejerce sobre los objetos que se mueven en círculo. Aumenta cuando el ángulo de giro del tractor se hace más agudo (disminuye) y al aumentar la velocidad del tractor en un giro. El aumento de la FG es directamente proporcional al ángulo de giro del tractor. Por cada grado de giro del tractor, se produce un aumento equivalente en la FC. No obstante, la relación entre la FG y la velocidad del tractor no es directamente proporcional. Para hallar el aumento de la FG al girar el tractor a una velocidad mayor (asumiendo que el radio de giro es el mismo) se debe hallar la raíz cuadrada de la diferencia entre las dos velocidades del tractor.

El TEP es la transferencia de energía entre el motor del tractor y el eje posterior de un tractor de dos ruedas motrices. $\mathrm{El}$ accionamiento del embrague produce una fuerza de torsión llamada par de torsión sobre el eje posterior. Después este momento de torsión es transmitido a los neumáticos del tractor. En circunstancias normales, el eje posterior (y los neumáticos) deberán girar, y el tractor se desplazará hacia adelante. En términos sencillos, se dice que el eje posterior rota en torno al chasis del tractor. Si el eje posterior no puede girar, el chasis del tractor gira en torno al eje. Esta rotación inversa hace que la parte frontal del tractor se eleve del suelo hasta que el CG del tractor sobrepasa la línea base de estabilidad posterior. En este punto el tractor continuará hacia atrás por su propio peso hasta que choque contra el suelo u otro obstáculo.

El ABT es otro principio de estabilidad e inestabilidad relacionado con los vuelcos hacia atrás. Cuando un tractor de dos ruedas motrices tira de una carga, los neumáticos traseros empujan contra el suelo. Simultáneamente, la carga unida al tractor tira hacia atrás y hacia abajo en contra del movimiento hacia adelante del tractor. La carga tira hacia abajo debido a que descansa sobre la superficie de la tierra. Este empuje hacia atrás y hacia abajo hace que los neumáticos traseros sean un punto de giro, de forma que la carga actúa como una fuerza que trata de volcar el tractor hacia atrás. Se crea un "ángulo de tiro" entre la superficie del suelo y el punto de unión al tractor. 


\section{Maquinaria agrícola*}

La maquinaria agrícola está diseñada para labrar el suelo y hacerlo más adecuado para el crecimiento de cultivos, la siembra de semillas, la aplicación de sustancias químicas para mejorar el crecimiento de las plantas y controlar las plagas y enfermedades, y la recolección y almacenamiento de los cultivos maduros. Existe una gran variedad de máquinas agrícolas, pero en esencia todas son una combinación de engranajes, ejes, cadenas, correas, cuchillas, cribas oscilantes, etc., ensambladas para realizar determinadas tareas. Estas piezas están en general suspendidas de un bastidor que puede ser estacionario o, con más frecuencia, móvil y diseñado para realizar la operación deseada al desplazarse por un campo. Los principales grupos de maquinaria agrícola son: máquinas para trabajo del suelo; máquinas plantadoras; máquinas cultivadoras; máquinas cosechadoras de forraje; máquinas cosechadoras de grano, fibra, hortalizas y frutas y frutos secos; aplicadores de sustancias químicas para la agricultura; máquinas transportadoras y elevadoras; y máquinas clasificadoras y envasadoras.

Máquinas para trabajo del suelo. Se incluyen los arados, cultivadoras, subsoladoras, gradas, rodillos, niveladoras, aplanadoras, etc. Están diseñadas para girar, agitar, nivelar y compactar el suelo y prepararlo para la plantación. Pueden ser de pequeño tamaño y requerir solamente una pequeña fuente de energía (como en el caso de una rotocultivadora operada por una persona para cultivar un arrozal), o bien grandes y necesitar una fuente de energía considerable (como en el caso de una subsoladora combinada, sembradora perforadora y grada)

Máquinas plantadoras. Se incluyen plantadoras, sembradoras en líneas, sembradoras a voleo, etc., y están diseñadas para recoger las semillas de una tolva o cubo e insertarlas en el suelo a una profundidad determinada, espaciándolas o esparciéndolas uniformemente. Las plantadoras pueden tener un diseño muy sencillo y constar de un mecanismo de siembra de una hilera, o muy complejas (como en el caso de la plantadora múltiple con aperos que simultáneamente añaden fertilizantes, plaguicidas y herbicidas)

Máquinas cultivadoras. Se incluyen rotocultoras, cultivadoras, desherbadoras (mecánicas y de llama), etc. Se utilizan para erradicar malezas o hierbas indeseables que compiten con la planta por la humedad del suelo y hacen que la cosecha o el cultivo sean más difíciles. También mejoran el trabajo del suelo haciendo que absorba mejor la lluvia

Máquinas cosechadoras de forraje. Se incluyen segadoras, picadoras, empacadoras y otras, diseñadas para separar los tallos de las raíces y prepararlos para su almacenamiento o uso inmediato. Estas máquinas también varían en cuanto a su complejidad: la segadora simple corta el cultivo, mientras que la picadora no sólo separa el tallo de la raíz, sino que también pica toda la planta en trozos pequeños que carga en un vehículo, posiblemente un vagón remolcado. A menudo se utilizan acondicionadoras de forraje que golpean o rompen los tallos, con el fin de acelerar el proceso de secado en el campo para prevenir el deterioro, especialmente de leguminosas que van a ser almacenadas en seco o empacadas. Las prensas granuladoras se utilizan para comprimir el forraje en cubos compactos para la alimentación mecánica del ganado. Las empacadoras se utilizan para comprimir el forraje en balas redondas o cuadradas y facilitar su almacenamiento y manipulación. Algunas balas son lo bastante pequeñas (20 a $40 \mathrm{~kg}$ ) para poder manejarlas manualmente, mientras que otras son tan grandes (400 a $500 \mathrm{~kg}$ ) que necesiten sistemas de manipulación mecánica.

Máquinas cosechadoras de grano y fibra. Se incluyen segadoras, agavilladoras, arrancadoras de mazorcas, cosechadoras combinadas, trilladoras, etc. Se utilizan para recoger el grano y la fibra de la planta y colocarlos en un cubo o bolsa para transportarlos al área de almacenamiento. La recolección de cereales puede implicar el uso de algunas máquinas, como una segadora o agavilladora para cortar el grano, un vagón o camión para el transporte a las máquinas trilladoras o separadoras y vehículos para transporte al área de almacenamiento. En otros casos muchas de estas funciones son realizadas por una sola máquina, la cosechadora combinada (Figura 64.25), que corta el grano, lo separa del tallo, lo limpia y lo recoge en un contenedor, todo mientras se desplaza por el campo. También carga el grano en los vehículos de transporte. Algunas máquinas, como las cosechadoras de algodón y las arrancadoras de mazorcas pueden trabajar selectivamente y recoger solamente el grano o la bola de fibra del tallo o tronco.

Máquinas cosechadoras de hortalizas. Se incluyen arrancadoras, diseñadas para arrancar los cultivos de la tierra y separarlos del suelo o elevar o tirar de la planta. Por ejemplo, la arrancadora de patatas puede formar parte de una cosechadora combinada de patatas que incluye un dispositivo de clasificación y gradación, una glaseadora, una ensacadora y un elevador. En otro extremo se encuentra la arrancadora de remolacha, con dos ruedas y palas, accionada manualmente por los operarios.

Máquinas cosechadoras de frutas y frutos secos. Se utilizan para cosechar bayas, frutas y frutos secos. Pueden ser tan simples como un agitador vibratorio de árboles montado sobre un tractor, que separa el fruto maduro del árbol. $\bigcirc$ pueden ser muy complejas, como las que cosechan la fruta, recogen la fruta caída, la introducen en un recipiente de almacenamiento y después la transfieren a vehículos de transporte.

Máquinas transportadoras y elevadoras. También varían considerablemente en cuanto a su tamaño y complejidad: desde un simple vagón que consta solamente de una plataforma sobre ruedas hasta una unidad de transporte autocargadora y apiladora. Se utilizan transportadores inclinados de cinta o de cadena $u$ otros dispositivos de manipulación mecánica para mover el material a granel (heno, paja, espigas, etc.) del vagón al almacén o de un lugar a otro en un edificio. Se utilizan transportadores de tornillo para mover el material granular y el grano de un nivel a otro, y los transportadores de ventilador o neumáticos se utilizan para mover materiales ligeros horizontal o verticalmente.

Aplicadores de productos químicos para la agricultura. Se utilizan para aplicar fertilizantes para estimular el crecimiento de las plantas - herbicidas y plaguicidas para controlar las malezas y plagas. Los productos químicos pueden ser líquidos, en polvo o granulares, y el aplicador los distribuye mediante presión a través de una tobera o mediante fuerza centrífuga. Los aplicadores pueden ser portátiles o ir montados o sobre un vehículo; la utilización de aviones en estas tareas aumenta con rapidez.

Máquinas de clasificación y envasado. Normalmente estas máquinas son estacionarias. Pueden ser tan simples como un separador densitométrico, que clasifica y limpia el grano pasándolo por una serie de cedazos, o tan complejas como un molino de semillas, que no solamente clasifica y limpia, sino que también separa los diferentes tipos de semillas. Las máquinas envasadoras forman parte normalmente de un sistema avanzado de clasificación. Se utilizan sobre todo para frutas y hortalizas y pueden envolver el producto en papel o bolsas o insertarlo en recipientes de plástico.

Fuentes de energía Pueden utilizarse motores eléctricos para alimentar el equipo estacionario localizado permanentemente cerca de una fuente principal; no obstante, debido a que muchas de las máquinas agrícolas son móviles y deben trabajar en áreas remotas, normalmente se mueven gracias a un motor integrado de gasolina o por un motor separado como el de un tractor. La potencia de un tractor se puede transmitir a la máquina a través de una correa, cadena, engranaje o eje; la mayor parte de los tractores cuentan con una conexión de toma de fuerza diseñada especialmente para este propósito.

L.W. Knapp, Jr.

* Adaptado de la $3^{a}$ edición, Enciclopedia de salud y seguridad en el trabajo. 
Figura 64.25 - Cosechadora combinada para la recolección de trigo, sin cabina cerrada.

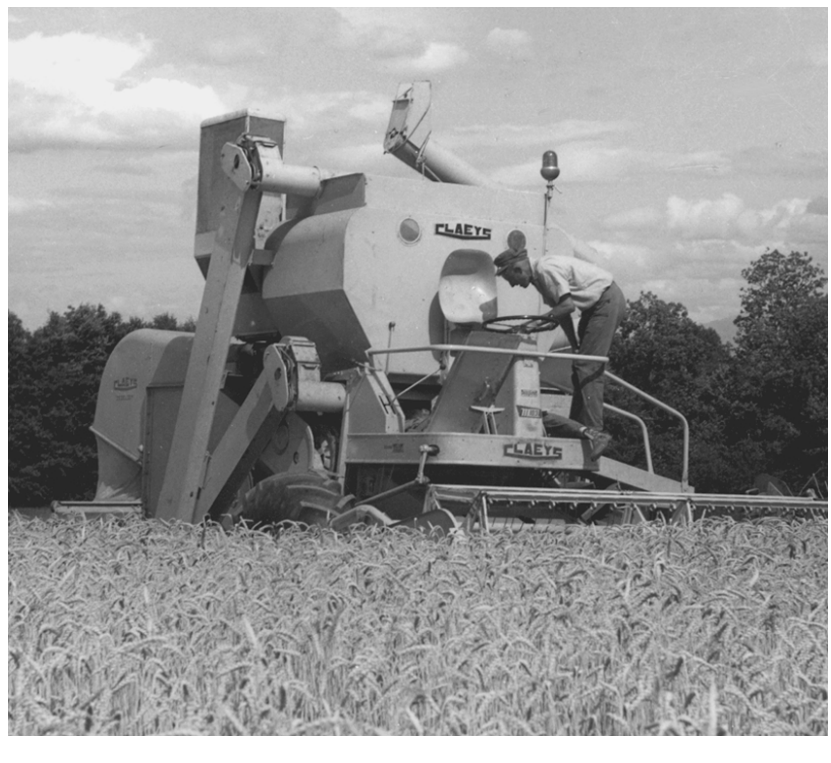

Cuanto más pesada es la carga y mayor sea el ángulo de tiro, la carga tendrá más fuerza para volcar el tractor hacia atrás.

\begin{abstract}
Atropellos
Existen tres tipos básicos de atropellos por un tractor. En el primero, un pasajero se cae del tractor. El segundo tiene lugar cuando el operador del tractor cae de éste. El tercero se produce cuando una persona ya en el suelo es atropellada por el tractor. Puede tratarse de un espectador (p. ej. un adulto que no está trabajando o un niño pequeño), de un compañero de trabajo o del propio operador del tractor. En el atropello interviene a menudo la maquinaria de remolque acoplada al tractor; puede ser ésta la que produzca la lesión. Los accidentes con pasajeros extra se producen porque en un tractor no hay sitio ningún sitio seguro para éstos, aunque la práctica de tomar pasajeros sea muy común, como medio para ahorrar tiempo, por comodidad, como ayuda en el trabajo o para el cuidado de los niños. La justificación de un pasajero extra por cualquier motivo depende exclusivamente del observador. Los expertos en seguridad y los fabricantes de tractores recomiendan que los operadores no lleven pasajeros por ningún motivo. No obstante, este consejo entra en conflicto con varios factores que los agricultores deben afrontar diariamente. Por ejemplo, es humano querer terminar el trabajo lo más sencilla y rápidamente posible; otro transporte requeriría más gasto o menos ingresos; puede que no sea posible cuidar los niños de otra forma; y se debe enseñar a los nuevos conductores de tractores a manejar la máquina.

Las personas que ya se encuentran en el suelo, normalmente operadores de los tractores o niños, son ocasionalmente atropellados por aquéllos o por sus equipos acoplados. Los operadores intentan a veces poner en marcha el tractor desde el suelo en lugar de desde su asiento. La mayor parte de estos accidentes se producen con tractores más antiguos que se ponen en marcha cuando tienen puesta una marcha, o con tractores nuevos cuando se ha saltado el bloqueo de la puesta en marcha. A veces son atropellados niños pequeños, normalmente menores de cinco años, por tractores y maquinaria que se desplaza en torno a la casa. A menudo el conductor del tractor no se da cuenta de
\end{abstract}

que el niño está cerca. Un ruido alto como la puesta en marcha de un tractor puede llamar la atención del niño y atraerle cerca. Y la práctica de permitir pasajeros extra puede hacer que se ponga a correr hacia el tractor.

\section{Las normas de seguridad del tractor son:}

- El dispositivo de seguridad más importante para un tractor es una estructura de protección contra vuelcos (EPV). Este dispositivo, junto a un cinturón de seguridad adecuadamente abrochado, impide que un operario sea aplastado por el tractor durante un vuelco.

- Una cabina cerrada con EPV proporciona una protección incluso mayor, ya que las cabinas protegen también de las condiciones climáticas adversas y de las caídas del tractor.

- Una defensa sobre el eje matriz de la TF protege frente a un enredo en la TF

- Deben seguirse la norma de un asiento-un pasajero y otras prácticas seguras de trabajo.

- Deben leerse los manuales de usuario para aprender cómo manejar la máquina con seguridad.

- Los trabajadores han de ser capaces física, psicológica y fisiológicamente de manejar la máquina en cuestión.

\section{Riesgos de la maquinaria}

En la agricultura mecanizada se utilizan multitud de máquinas. Estas funcionan gracias a distintos sistemas, como ejes de TF, presión hidráulica de aceite, electricidad, motores y tracción. Estas máquinas presentan diversos tipos de riesgos. En la Tabla 64.7 se exponen los riesgos de las máquinas, se describe cada uno de ellos y se dan ejemplos de dónde están éstos en las distintas máquinas.

\section{Potencia y velocidad de la maquinaria}

Aunque los trabajadores comprendan que la maquinaria es potente y funciona a velocidades altas, la mayor parte no se han parado a considerar lo potentes que son las máquinas en comparación con las propias fuerzas, ni tampoco son conscientes de lo rápidas que son. La potencia de estas máquinas varía considerablemente, pero incluso las pequeñas generan muchas veces más caballos de fuerza que cualquier persona. Una acción rápida de tracción de un brazo humano genera normalmente menos de un caballo de fuerza, a veces mucho menos. Una máquina pequeña de 16 caballos de fuerza, como una segadora de empuje, puede tener de 20 a 40 veces más fuerza empujando a una persona dentro de la máquina que la que persona pueda generar tirando hacia afuera. Una máquina de tamaño medio que funciona de 40 a 60 caballos de fuerza tendrá una potencia varias veces mayor que una persona.

Esta combinación de fuerza y potencia presenta muchas situaciones de riesgo para los trabajadores. Por ejemplo, el eje de TF del tractor transfiere la potencia entre el tractor y la maquinaria movida por la TF. La transferencia de potencia se consigue conectando un eje accionado desde la maquinaria a la TF del tractor. La matriz y el eje accionado de la TF giran a $540 \mathrm{rpm}$ (9 veces por segundo) o $1.000 \mathrm{rpm}$ (16,7 veces/segundo) cuando se opera a la velocidad máxima recomendada. La mayor parte de los accidentes en los que se implica la $\mathrm{TF}$ se producen porque una matriz o eje de la TF engranados pero sin proteger enganchan repentinamente la ropa. Incluso con una reacción relativamente rápida de 1 segundo (es decir, el trabajador intenta tirar fuera del eje) y un eje de $76 \mathrm{~mm}$ de diámetro que funciona solamente a la mitad de su velocidad (por ejemplo a $270 \mathrm{rpm}$, la mitad de 540), la ropa de la víctima ya se ha enganchado $1,1 \mathrm{~m}$ alrededor del eje. Una TF que funciona a mayor velocidad o 
una reacción más lenta da incluso menos de una oportunidad para que el trabajador evite el enganche con el eje.

Cuando una máquina funciona a la velocidad máxima recomendada de $\mathrm{TF}$, el material de la cosecha se desplaza hacia el área de entrada o transformación de la máquina a aproximadamente $3,7 \mathrm{~m} / \mathrm{s}$. Si un trabajador está retenido dentro del material cuando empieza a entrar en la máquina, muchas veces no puede salir lo bastante rápido para soltar el material antes de ser empujado dentro de la máquina. En 0,3 segundos será empujado 1,1 m dentro de la máquina. Esto ocurre con frecuencia cuando el material conecta el punto de entrada de la máquina y el trabajador intenta desconectarlo con la TF en funcionamiento.

\section{Seguridad de la maquinaria}

La seguridad de la máquina obliga ante todo a conservar las protecciones y las cubiertas originales en su sitio y a mantenerlas adecuadamente. Se deben utilizar etiquetas de advertencia para recordar que las protecciones y cubiertas deben mantenerse en su sitio. Si éstas tienen han de retirarse para el mantenimiento, servicio o ajuste, deberán ser sustituidas inmediatamente al terminar la reparación. Han de seguirse prácticas seguras de trabajo. Por ejemplo, el tractor debe apagarse y la TF o los sistemas hidráulicos de bloqueo inactivarse antes de desconectar o revisar el equipo. Se deben leer los manuales de usuario y seguir sus instrucciones de seguridad. Los trabajadores han de recibir la formación adecuada.

\section{CULTIVO DE ALIMENTOS Y FIBRAS}

\section{ARROZ}

\section{Malinee Wonghhanich}

El arroz es el alimento básico de la población asiática; se prepara cociéndolo o moliéndolo para obtener harina con la que se hace pan, ayudando así a alimentar al resto de la población mundial. Se cultivan distintas variedades de arroz para adaptarse a las preferencias de los consumidores. El cultivo de arroz se realiza en tierras bajas y pantanosas con abundancia de agua, o en zonas montañosas y mesetas donde el régimen natural de lluvias procura cantidades adecuadas de agua.

\section{Proceso de cultivo}

El arroz puede cultivarse manualmente o con mecanización parcial o total, según el desarrollo tecnológico del país y la necesidad de productividad. Cualquiera que sea el tipo de operación realizada, son siempre necesarias las siguientes etapas:

1. Arado. La tierra se ara en tres momentos distintos para eliminar terrones y ablandar el suelo lo más posible. Carabaos, bueyes o vacas suelen tirar de los arados, aunque está aumentando el uso de equipos mecánicos.

2. Escarda. La escarda se lleva a cabo tres veces irrigando el campo durante cinco días cada vez y luego dejándolo secar otros cinco. Al final de cada ciclo se golpea la tierra con una pesada herramienta de madera para matar las malas hierbas y que puedan servir de abono natural.

3. Preparación de la simiente. Se sumergen las semillas en un gran recipiente lleno de agua a la que se añade la concentración adecuada de sal para que las semillas sanas floten. A continuación se lavan bien estas semillas sanas, se dejan toda la noche en remojo y, después de envolverlas en una tela o saco gruesos durante dos noches más para que germinen, se siembran en la tierra preparada y se las deja crecer unos treinta días aproximadamente.

4. Trasplante. Las plantas jóvenes, en haces de 3 a 5, se introducen en el fango en hileras y se dejan durante diez días. Transcurridos éstos, se drena el agua para que el sol dé directamente en las raíces. A eso de los cuarenta y cinco días, las plantas han alcanzado su pleno desarrollo y empiezan a llevar grano.

5. Recolección. Cuando la planta tiene unos 100 días, suele segarse a mano (véase la Figura 64.26) utilizando una hoz o alguna herramienta similar.

6. Secado. El secado se realiza al sol para conseguir que el contenido de humedad descienda a menos del $15 \%$.
7. Trilla. La trilla tiene por objeto separar el grano con su cáscara o gluma del tallo. El arroz se suele trillar tan pronto como se cosecha. El método tradicional consiste en utilizar carabaos o bueyes para arrastrar lentamente el trillo sobre las gavillas extendidas y desprender el grano, aunque en muchos lugares la trilla se realiza mecánicamente.

8. Almacenamiento. El grano y la paja se almacenan en graneros o silos.

\section{Riesgos}

Los riesgos comunes y específicos son los siguientes:

- Las malas condiciones de vivienda y de higiene, sumado a una alimentación inadecuada y a la necesidad de beber grandes cantidades de agua no siempre pura, producen debilidad general, fatiga, posible insolación, trastornos intestinales y diarrea.

Figura 64.26 • Recolección manual de arroz en China, 1992.

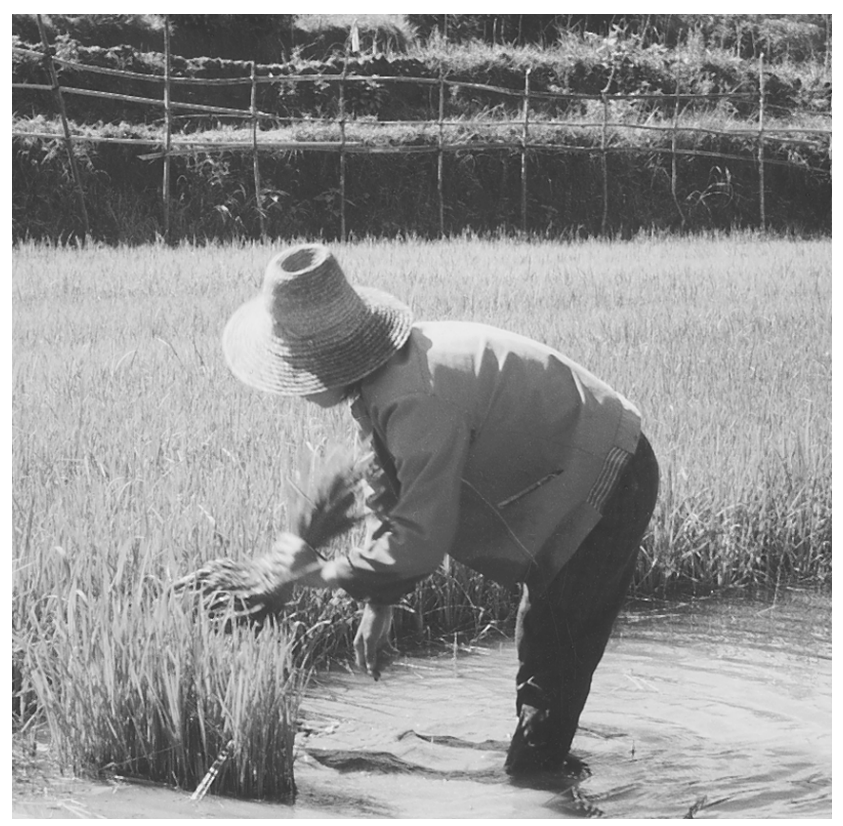


- La mayoría de las lesiones causadas por la maquinaria agrícola se producen cuando los trabajadores no están familiarizados con las máquinas. Los músculos, huesos y articulaciones se someten a un gran esfuerzo, tanto dinámico como estático, produciendo cansancio físico, reduciendo la capacidad para el trabajo y aumentando las lesiones traumáticas y los accidentes. Todos los años mueren niños y adolescentes, así como trabajadores migrantes, en los accidentes que tienen lugar en los campos.

- Los agentes químicos, como fertilizantes, plaguicidas, potentes herbicidas y otras sustancias utilizadas ampliamente, aumentan los riesgos tanto para los trabajadores como para los animales o plantas que éstos consumen (por ejemplo, pescado, cangrejos, plantas acuáticas, setas, hierbas medicinales, ratas de campo o incluso agua contaminada).

- Enfermedades como el paludismo, el tétanos, la anquilostomiasis, la esquitosomiasis, la leptospirosis, la fiebre del heno, la dermatitis, la blefaritis, la conjuntivitis, el resfriado y la insolación son muy corrientes, al igual que los trastornos de origen alimentario (por ejemplo, deficiencia de proteínas, toxinas), el alcoholismo, el consumo excesivo de tabaco y otros hábitos adictivos.

- Las enfermedades profesionales más corrientes son, sin embargo, las de la piel, entre ellas eritemas y pústulas causadas por las hojas de arroz aculeadas; abrasiones y lesiones de la piel causadas por plantas espinosas; callosidades en palmas, manos, rodillas y codos causadas por la mala postura y el uso de herramientas manuales; micosis (tiña) causada por epidermofitos y Monilia (candida) que puede complicarse con sensibilización secundaria; eritemas y pápulas, con frecuencia debidos a estafilococos; dermatitis vesicular (pequeñas ampollas) en los pies, a veces atribuida a Rhizopus parasiticus; sarna, generalmente causada por la penetración de la piel por Ancylostomae (anquilostomos); dermatitis esquistosomática causada directa o indirectamente por contacto con agua que contiene cercarias procedentes de huéspedes no humanos; y eritema, edema y pápulas resultantes de picaduras de insectos.

- Las enfermedades respiratorias causadas por polvo orgánico e inorgánico y sustancias químicas sintéticas son también comunes. Los niveles de endotoxinas de bacterias Gram negativas en la atmósfera son elevados en algunos países. La intoxicación con los gases de fermentación en los silos de substratos con alto contenido de nitratos es otro problema para la salud.

- Los agentes climáticos, como el calor, las fuertes lluvias, la humedad, los vientos, las tormentas y los rayos, conllevan riesgos tanto para los trabajadores como para el ganado.

- Los factores de estrés psicológico, como problemas económicos, sensación de inseguridad, baja posición social, falta de oportunidades de educación, falta de perspectivas para el futuro y riesgo de calamidades inesperadas, son especialmente comunes en los países en desarrollo.

\section{Medidas de salud y seguridad}

Las condiciones de trabajo deben ser mejoradas y reducidos los riesgos para la salud mediante una mayor mecanización. Las intervenciones ergonómicas para organizar el trabajo y la maquinaria utilizada, y el adiestramiento sistemático del cuerpo y de sus movimientos para asegurar unos buenos métodos de trabajo, son esenciales.

Los métodos necesarios de medicina preventiva deben ser estrictamente aplicados, entre ellos la formación en primeros auxilios, la dotación de medios de tratamiento, las campañas de promoción de la salud y la vigilancia médica de los trabajadores.

La mejora de las condiciones de higiene y vivienda, el acceso a agua potable, la higiene ambiental y de los alimentos y la estabilidad económica son factores esenciales para mejorar la calidad de vida de los que trabajan en los campos de arroz.

Deben respetarse los Convenios y Recomendaciones de la Organización Internacional del Trabajo (OIT), entre ellos los siguientes:

- El Convenio no 10 (1921): sobre la edad mínima (agricultura) establece que los niños menores de 14 años no pueden ser contratados ni trabajar en explotaciones agrarias públicas o privadas ni en ninguna actividad relacionada, durante el horario escolar.

- La Recomendación $n^{\circ} 14$ (1921): sobre el trabajo nocturno de niños y jóvenes (agricultura) exige a todos los Estados miembros que regulen el empleo de niños menores de 14 años para trabajos agrícolas nocturnos, dejándoles un período de descanso en ningún caso inferior a 10 horas consecutivas. Para los jóvenes de entre 14 y 18 años de edad, el período de descanso no debe ser nunca inferior a 9 horas consecutivas.

- El Convenio n ${ }^{\circ} 110$ (1958): sobre las plantaciones establece la obligación de someter a todos los trabajadores contratados a exámenes médicos. Este Convenio es, obviamente, de gran importancia para los trabajadores de todas las edades.

- El Convenio no 127 (1967): sobre el peso máximo indica las cargas óptimas que pueden ser manipuladas por el $90 \%$ de los trabajadores en todo tipo de tareas manuales rutinarias y repetitivas.

\section{CULTIVO DE CEREALES Y SEMILLAS OLEAGINOSAS}

Charles Schwab

Algunas plantas de la familia de las herbáceas, como el trigo, el centeno, la cebada, la avena, el maíz, el arroz, el sorgo y el mijo, son productos agrícolas valiosos que representan la mayor parte de la agricultura de producción. Los cereales son ricos en hidratos de carbono y constituyen una importante fuente de alimentos para los animales y los seres humanos.

En la dieta humana, los cereales pueden constituir hasta el $60 \%$ de toda las calorías y el $55 \%$ de las proteínas, utilizándose como alimento y también como bebida. El pan es el alimento más común que se obtiene de los cereales, aunque éstos son también importantes para la producción de cerveza y licores. Los cereales constituyen un ingrediente básico en la destilación de bebidas alcohólicas insípidas. Se utilizan también para fabricar piensos, entre ellos los destinados a animales de compañía, animales de tiro y animales criados para obtener productos cárnicos destinados al consumo humano.

El conocimiento de los cereales se remonta a los albores de la civilización. En 1996 la producción mundial fue de 2.003.380.000 toneladas. Este volumen ha aumentado más de un $10 \%$ desde el decenio de 1980 (FAO 1997).

Tres de los principales cereales cultivados por su aceite, llamados también semillas oleaginosas, son la soja, la colza y el girasol. Aunque existen diez tipos diferentes de cultivos de semillas oleaginosas, estos tres representan la mayoría del mercado, con la soja a la cabeza. Casi todas las semillas oleaginosas se trituran y transforman para obtener aceites vegetales $y$ alimentos con alto contenido protéico. Los aceites vegetales se utilizan en su mayor parte para cocinar o para aliñar ensaladas, y los alimentos derivados de estas semillas se utilizan principalmente para la fabricación de piensos. La producción mundial de semillas oleaginosas fue en 1996 de 91.377.790 toneladas, lo que supone un incremento de casi el 41 \% sobre 1986 (FAO 1997). 
La producción de cereales y semillas oleaginosas se ve afectada por factores regionales como el clima y la geografía. Los suelos y ambientes secos limitan la producción de maíz, mientras que los suelos húmedos pueden disminuir la producción de trigo. La temperatura, la pluviometría, la fertilidad del suelo y la topografía determinan también el tipo de cereales o semillas oleaginosas que pueden cultivarse con éxito.

Para la producción de cereales y semillas oleaginosas, el trabajo se divide en cuatro etapas: preparación del lecho de siembra y plantación, recolección, almacenamiento y transporte de los productos al mercado o a la planta de transformación. En la agricultura moderna, algunos de estos procesos han cambiado completamente, pero otros procesos han variado poco desde la civilización remota. No obstante, la mecanización de la agricultura ha creado nuevas situaciones y problemas de seguridad.

\section{Riesgos y su prevención}

Todas las herramientas utilizadas para la recolección de cereales - desde las cosechadoras hasta la sencilla guadaña - tienen un aspecto en común: son peligrosas. Son herramientas agresivas; están diseñadas para cortar, triturar o tronchar materiales de las plantas que se introducen en ellas y no son capaces de distinguir entre un cultivo y una persona. Algunos de los riesgos mecánicos asociados a la recolección de cereales corresponden a los puntos de corte, aspiración, trituración, enredado, enrollado y atenazado. Una cosechadora introduce en su interior las plantas de maíz a una velocidad de 3,7 metros por segundo $(\mathrm{m} / \mathrm{s})$, excesiva para que los seres humanos puedan evitar quedar enredados, incluso con un tiempo de reacción normal. Las hélices y unidades con toma de fuerza utilizadas para mover el grano, giran a una velocidad de $3 \mathrm{~m} / \mathrm{s}$ y $2 \mathrm{~m} / \mathrm{s}$, respectivamente, y también conllevan el riesgo de quedar enredado.

Los trabajadores agrícolas pueden también experimentar pérdidas auditivas causadas por el ruido producido por la potente maquinaria y los equipos utilizados en la producción agrícola. Los ventiladores helicoidales que empujan el aire calentado a través de un depósito o tanque de almacenaje para secar el grano pueden generar niveles de ruido iguales o superiores a $110 \mathrm{dBA}$. Puesto que las unidades de secado del grano suelen ubicarse cerca de los edificios habilitados como viviendas y funcionan ininterrumpidamente durante toda la temporada, suelen causar importantes pérdidas auditivas a los trabajadores agrícolas y a sus familiares durante largos períodos de tiempo. Otras fuentes de ruido que pueden contribuir a la pérdida auditiva son máquinas como tractores, cosechadoras y equipos de transporte, así como el movimiento de los granos a través de una tolva de descarga.

Los trabajadores agrícolas pueden también verse expuestos a importantes riesgos de asfixia si quedan sepultados bajo un alud de grano, ya sea por acceder inadvertidamente a la zona de descarga o por derrumbamiento de una superficie sobre la que se almacene éste. Una persona atrapada entre el grano no puede ser rescatada debido al tremendo peso de éste. Los trabajadores pueden evitar los accidentes en la zona de descarga del grano desconectando siempre todos los equipos de descarga y transporte antes de entrar en ella y bloqueando todas las tolvas de flujo por gravedad. El riesgo de derrumbamiento es también difícil de prevenir, pero los trabajadores pueden evitar la situación conociendo la estructura del almacén y el grano que contiene. Todos los trabajadores deben seguir estrictamente los procedimientos de acceso a espacios confinados para evitar el riesgo de quedar sepultados bajo el grano.
Durante la recolección, el almacenamiento y el transporte de cereales y semillas oleaginosas, los trabajadores agrícolas están expuestos a polvo, esporas, micotoxinas y endotoxinas que pueden ser nocivas para el aparato respiratorio. El polvo biológicamente activo es capaz de producir irritación y/o respuestas alérgicas, inflamatorias o infecciosas de los pulmones. Los trabajadores pueden evitar o reducir su exposición al polvo, o utilizar equipos de protección personal como respiradores con filtros mecánicos o suministro de aire en entornos polvorientos. Algunos sistemas de manipulación y almacenaje reducen al mínimo la formación de polvo y algunos aditivos, como los aceites vegetales, pueden evitar que el polvo quede suspendido en la atmósfera.

En algunas condiciones durante el almacenamiento, el grano puede estropearse y emitir gases que entrañan riesgo de asfixia. El dióxido de carbono $\left(\mathrm{CO}_{2}\right)$ puede acumularse encima de una superficie de grano desplazando al oxígeno y resultando nocivo para los trabajadores si los niveles de oxígeno descienden por debajo del 19,5 \%. En estas situaciones los respiradores con filtros mecánicos no sirven para nada.

Otro riesgo es la posibilidad de incendios y explosiones durante la manipulación y el almacenamiento de cereales o semillas oleaginosas. Las partículas de polvo que quedan suspendidas en el aire cuando el grano se mueve crean una atmósfera propensa a una potente explosión. Sólo se necesita una fuente de ignición, como un cojinete sobrecalentado o una correa que roce contra un componente de la carcasa. El mayor riesgo existe en los grandes elevadores de los puertos o en los elevadores comunitarios terrestres que mueven grandes cantidades de grano. Un mantenimiento preventivo adecuado y una buena higiene reducen el riesgo de una posible ignición y de atmósferas explosivas.

Los productos químicos utilizados al inicio del ciclo de producción agrícola para la preparación del lecho de siembra y la plantación imponen también riesgos para los trabajadores agrícolas. Los productos químicos pueden aumentar la fertilidad del suelo, reducir la competencia de malas hierbas e insectos y aumentar la productividad. El principal problema de los productos fitosanitarios son las exposiciones de larga duración; sin embargo, el anhídrido amónico, un fertilizante líquido comprimido, puede causar lesiones inmediatas. El anhídrido amónico $\left(\mathrm{NH}_{3}\right)$ es un compuesto higroscópico e hidrófilo que causa quemaduras cuando se disuelve en el tejido corporal. El gas amónico es un potente irritante pulmonar, pero sus propiedades permiten detectarlo fácilmente. Tiene también un bajo punto de ebullición y se congela por contacto, causando también quemaduras graves. El uso de equipos protectores es el mejor medio para reducir el riesgo de exposición. Cuando dicha exposición se produce, el tratamiento de primeros auxilios consiste en lavar rápidamente la zona afectada con agua abundante.

Los trabajadores de la producción de cereales están también expuestos a lesiones potenciales por resbalones y caídas. Una persona puede morir como consecuencia de las lesiones sufridas por una caída desde una altura de tan sólo $3,7 \mathrm{~m}$. lo que fácilmente se supera en las plataformas de la mayoría de las máquinas o los depósitos donde se almacena el grano. Estos depósitos tienen una altura de entre 9 y $30 \mathrm{~m}$, que solo puede alcanzarse utilizando escaleras. Las inclemencias climáticas pueden tornar resbaladizas las superficies por la lluvia, la niebla, el hielo o la nieve, de manera que el uso de defensas, barandillas y calzado con suelas antideslizantes es muy importante. Dispositivos como arneses corporales o cuerdas de seguridad pueden también utilizarse para frenar las caídas y prevenir accidentes. 


\section{- GULTIVO Y TRANSFORMACION DE LA CAÑA DE AZUCAR}

\section{R.A. Muñoz, E.A. Suchman, J.M. Baztarrica y Carol J. Lehtola*}

\section{Cultivo}

La caña de azúcar es una planta excepcionalmente alta que se cultiva en regiones tropicales y subtropicales por su contenido en sacarosa y productos derivados, como la melaza y el bagazo (residuo fibroso). Crece en haces o racimos de cañas cilíndricas que miden entre 1,25 y $7,25 \mathrm{~cm}$ de diámetro y $6-7 \mathrm{~m}$ de altura. Las cañas crecen rectas hacia arriba hasta que pesan demasiado para mantenerse derechas. Entonces se inclinan para formar una rama lateral y continúa el crecimiento hacia arriba. De esta forma se obtiene un campo de caña maduras que forman un dibujo de malla. La planta contiene una savia con la que se elabora azúcar. Se cultiva en toda la región del Caribe, en América Central y del Sur, en la India, islas del Pacífico, Australia, Africa Central y del Sur, Mauricio y el sur de los Estados Unidos. Su uso principal es la producción de azúcar, pero también la caña puede fermentarse y destilarse para producir ron. El bagazo, la materia celulósica que queda tras el prensado, puede emplearse en la fabricación de papel y otros productos o como combustible.

En condiciones favorables y con el uso adecuado de plaguicidas y fertilizantes, la caña crece rápidamente. Para lograr el máximo contenido de azúcar (10-17\% del peso total), deber ser cosechada tan pronto como alcanza su último período de crecimiento. Antes de la recolección se quema la maleza, eliminando las malas hierbas sin dañar la cosecha y destruyendo serpientes, insectos peligrosos y otras plagas que viven en la densa vegetación de los campos de cañas. La corta se realiza a mano empleando machetes o utilizando máquinas especiales para cortar las cañas de azúcar. La mecanización de la corta de la caña de azúcar se ha desarrollado en el decenio de 1990. Sin embargo, en muchas partes del mundo y en campos a los que no puede acceder la maquinaria, la caña se sigue cortando manualmente. En la época de la recolección se emplean en este menester gran número de trabajadores migrantes o temporeros, especialmente en las zonas donde dicha recolección se realiza a mano.

Para retener su contenido de azúcar, la caña ha de ser sometida al proceso de transformación lo antes posible después de ser cosechada, por lo que las fábricas de azúcar suelen estar cerca de las plantaciones o en las mismas. La cosecha es transportada hasta ellas mediante tractores o remolques y, a veces, por ferrocarril ligero.

\section{Riesgos y su prevención}

El machete es una causa frecuente de accidentes en las zonas donde la recolección se realiza fundamentalmente a mano. Estos accidentes pueden ser desde cortes sin importancia hasta la disección de alguna parte del cuerpo. El machete es también la herramienta más comúnmente utilizada por los trabajadores menos cualificados en una explotación agrícola o plantación. Los accidentes pueden reducirse manteniendo bien afilados los filos de los machetes, puesto que de esa manera los trabajadores no tienen que balancearlos tanto y pueden controlarlos mejor. Se han dado también casos de luchas entre trabajadores con machetes. El uso de guantes de seguridad con redes de cadena protege las manos de las heridas causadas por los machetes. El uso de botas con

\footnotetext{
* Adaptado de la $3^{\text {a }}$ edición de la Enciclopedia de salud y seguridad en el trabajo.
}

talones de acero y protectores de brazos y piernas también reducen este tipo de accidentes. Las botas proporcionan asimismo cierta protección contra las mordeduras de serpiente. El trabajo en los campos de cañas puede causar fácilmente lesiones y cortes en los ojos. Se recomienda el uso de protectores visuales durante la recolección manual, puesto que los trabajadores pueden ser heridos por las ramas de las cañas. La caña se cultiva en lugares tropicales y subtropicales, de manera que los trabajadores están también expuestos a problemas de salud relacionados con el calor, que pueden agravarse por la utilización de prendas protectoras necesarias. Estas regiones son zonas con altos niveles de exposición solar que pueden asociarse a distintos tipos de cánceres de piel. Los trabajadores tienen que tomar precauciones para limitar o protegerse de la exposición al sol.

La recolección manual puede causar lesiones musculosqueléticas por esfuerzos físicos y movimientos repetitivos. El tamaño del machete, su afilado y la frecuencia de los golpes de corte son factores que influyen. Véase también el artículo "Operaciones manuales en la agricultura" en este mismo capítulo.

Cuando se producen cortes o abrasiones, han de tomarse precauciones para prevenir infecciones. Con la recolección mecánica existen riesgos asociados al tipo de máquina utilizada y similares a los de otras máquinas de recolección utilizadas en agricultura.

Los plaguicidas y otras sustancias químicas pueden también entrañar riesgos tóxicos por absorción a través de la piel o inhalación. Debe instruirse a las personas que esparcen estas sustancias pulverizadas sobre los riesgos de la operación y debe dotárselas de equipos protectores e instalaciones adecuadas para poder lavarse. Los equipos tienen que ser sometidos a las operaciones adecuadas de mantenimiento y reparación para evitar fugas. Los fumigadores que se cuelgan en la espalda son particularmente propensos a sufrir fugas y verter el plaguicida sobre el trabajador. Las aplicaciones aéreas de plaguicidas pueden afectar a las personas que se encuentran en la zona fumigada. Asimismo, cuando se aplican plaguicidas debe leerse siempre la etiqueta del producto, donde se indican los requisitos legales y los procedimientos para un manejo y una eliminación seguras del producto después de su uso, así como los intervalos de tiempo que deben transcurrir antes de volver a entrar en los campos.

\section{Fábricas de azúcar (ingenios azucareros)}

La industria del azúcar tiene por objeto algo más que la producción de alimentos para el hombre. Por ejemplo, ciertas clases de azúcar y residuos del azúcar constituyen un alimento suplementario nutritivo para animales, y diversos productos de considerable valor comercial se obtienen de las primeras materias y sus subproductos.

Los principales subproductos son: sacarosa, glucosa, levulosa, rafinosa, pectina, ceras y betaínas; entre los subproductos se encuentran los tallos (utilizados para forraje), el bagazo, el ron y la melaza. Entre los productos fabricados a escala industrial se encuentran el octacetato de sacarosa, alcohol etílico y ácidos acético, cítrico, glutámico, oxálico, fórmico y sacárico. Diversas clases de papel y cartón se fabrican industrialmente a partir del bagazo, el cual también puede utilizarse, una vez seco, como fuente de biogás o combustible en la fábrica de azúcar.

En la fábrica de azúcar, la caña es machacada y se extrae el jugo mediante pesados rodillos. El jugo contiene sacarosa, glucosa, levulosa, sales orgánicas y ácidos en disolución, y está mezclado con las fibras de bagazo, arenilla, arcilla, materia colorante, albúmina y pectina en suspensión. Debido a las propiedades de la albúmina y la pectina, el jugo no puede filtrarse en 
frío; se precisa calor y agentes químicos para eliminar las impurezas y obtener sacarosa.

La clarificación de la mezcla se obtiene mediante calentamiento y adición de precipitantes con base de cal. Una vez aclarado, el jugo se concentra mediante evaporación por vacío hasta que se precipita en la forma de cristales verdosos. El jugo concentrado, o melaza, contiene un $45 \%$ de agua. El tratamiento centrífugo produce azúcar granulado de un tono grisáceo (azúcar moreno), para el cual existe un mercado. El azúcar blanco se obtiene mediante un proceso de refinado. En este proceso, el azúcar moreno se disuelve con diversos productos químicos (anhídrido sulfúrico, ácido fosfórico) y se filtra con o sin carbón animal, según la pureza que se desee obtener. El jarabe filtrado se evapora al vacío hasta que cristaliza. Después se aplica la centrifugación hasta que se obtiene un polvo blanco cristalino.

\section{Riesgos y su prevención}

Las condiciones de los trabajadores varían según la zona geográfica. Los trabajadores temporeros viven en condiciones muy poco atractivas. Los riesgos para la salud varían en función de los factores ambientales, las condiciones de trabajo, las condiciones de vida y la situación socioeconómica del trabajador.

Debido a las altas temperaturas en las zonas donde se cultiva la caña de azúcar, los trabajadores tienen que consumir grandes cantidades de líquidos.

En diversas fases del proceso de refinado se desprenden humos y gases de dióxido de carbono, dióxido de azufre, monóxido de carbono y ácido clorhídrico. Las altas temperaturas durante la transformación pueden hacer también que se desprendan humos y vapor molestos y en ocasiones tóxicos.

En algunas zonas de la fábrica, los niveles de ruido son excesivos.

La bagazosis es una enfermedad pulmonar de origen profesional del tipo alveolitis alérgica extrínseca, causada por la respiración de polvo que contiene esporas de actinomicetos termofílicos que crecen en el bagazo húmedo almacenado. La exposición a esta sustancia puede causar también neumonitis por hipersensibilidad.

En los países en desarrollo, muchos trabajadores son inexpertos y no tienen conocimientos sobre seguridad. Puede existir también una elevada tasa de rotación, lo que constituye un problema para mantener el nivel de formación y cualificación de los trabajadores. Aunque los datos estadísticos no indican una elevada incidencia de enfermedades profesionales, esto puede explicarse por el hecho de que el trabajo en la refinería sólo les ocupa de cinco a seis meses al año. Por eso las tasas de accidentes parecen bajas. Durante el resto del año, estos trabajadores temporeros se ocupan en las labores más diversas, mientras que los que tienen empleo permanente se dedican a labores de mantenimiento de la maquinaria y los equipos.

Los accidentes de trabajo en la industria azucarera (caídas, distensiones, dislocaciones, etc.) difieren poco de los habituales en otras actividades industriales y agrícolas. Con el aumento de la mecanización, los accidentes de trabajo han disminuido en número, pero han aumentado en gravedad. Las lesiones más frecuentes son insolación o estrés por calor, dermatitis, conjuntivitis, quemaduras y caídas.

Con el fin de planear y poner en práctica un programa de seguridad e higiene en la industria del azúcar, el primer paso esencial es realizar una valoración cualitativa y cuantitativa de los riesgos y peligros implicados en cada refinería, identificando las medidas correctoras, como el uso de extractores de polvo, gases y humos. El control del polvo es una medida eficaz para controlar el polvo de bagazo. Los locales deben estar debidamente aireados y ventilados para reducir el excesivo calor y debe disponerse de una iluminación adecuada. Debe existir un adecuado apantallamiento o protección de la maquinaria. Los trabajadores deben tener fácil acceso a prendas protectoras. En toda fábrica debe establecerse un programa de seguridad adecuado, del cual se encargue personal adiestrado.

El ruido es un riesgo generalizado. Las máquinas ruidosas deben estar insonorizadas y, en zonas donde el nivel de ruido no pueda reducirse lo suficiente, los trabajadores deben utilizar protectores auditivos y conviene instituir un programa de conservación de la audición que incluya pruebas audiométricas y educación de los trabajadores.

\section{RECOLECGION DE LA PATATA}

Steven B. Johnson

Las raíces y los tubérculos constituyen una parte importante de la dieta, la energía obtenida de los alimentos y la fuente de nutrientes para más de 1.000 millones de personas en el mundo subdesarrollado. El cultivo de raíces se utiliza para producir alimentos como harinas compuestas, fideos, patatas fritas y productos deshidratados. Proporcionan casi el $40 \%$ de la dieta de la mitad de la población del Africa subsahariana. La mandioca se ha convertido en uno de los principales alimentos básicos del mundo subdesarrollado, proporcionando una dieta básica a cerca de 500 millones de personas, así como en un importante producto de exportación para la fabricación de piensos en Europa.

Las raíces y tubérculos — patata, batata, mandioca, ñame y taro- son conocidos como alimentos amiláceos. Tienen un alto contenido en hidratos de carbono, calcio y vitamina $\mathrm{C}$, aunque bajo en proteínas. Estos alimentos son los cultivos de subsistencia en algunos de los países más pobres del mundo. El cultivo de algunas raíces proporciona alimentos básicos a grandes regiones del mundo, como el ñame en Indochina, Indonesia y Africa; la patata en América del Sur y Central, México y Europa; y la mandioca y la batata en América del Sur (Alexandratos 1995).

El cultivo de la patata se introdujo en Irlanda en torno a 1580, permitiendo alimentar con una pequeña parcela a una familia con seis hijos, una vaca y un cerdo. Además, el cultivo podía permanecer en el suelo protegido de las heladas del invierno y los incendios. La patata se convirtió en el alimento de los pobres en Irlanda, Inglaterra, Francia, Alemania, Polonia y Rusia. En 1845, la patata sufrió una plaga en toda Europa y trajo el hambre a una escala enorme y fatal en Irlanda, donde no se disponía de cultivos substitutivos (Tannahill 1973).

La patata es todavía el cultivo principal en el mundo desarrollado. Su producción sigue aumentando en Estados Unidos y gran parte de este aumento puede atribuirse a la transformación de la patata para obtener, sobre todo, patatas fritas, patatas paja, patatas fritas congeladas, otros productos congelados y patatas enlatadas. Los principales riesgos profesionales están relacionados con accidentes que se producen durante la recolección mecánica. En un estudio canadiense se observó que los trabajadores de la patata presentaban un mayor riesgo de cáncer de páncreas, aunque no consiguió demostrarse su asociación a alguna exposición.

\section{Riesgos}

Cada parte móvil de la cosechadora de patatas entraña el riesgo de accidente. El eje de la toma de fuerza del tractor, que conecta 
el tractor y la cosechadora mediante juntas universales u horquillas, es una fuente de energía cinética y accidentes. El eje de la toma de fuerza debe ir protegido con una carcasa protectora. Los accidentes más frecuentes con este eje ocurren cuando la horquilla atrapa una parte floja de la ropa, enredando al que la lleva puesta.

Todos los sistemas hidráulicos funcionan a presión. Esta presión puede llegar a $14.000 \mathrm{Kpa}$, que es tres veces la presión necesaria para perforar la piel. Por tanto, un trabajador no debe nunca tapar con un dedo una manguera hidráulica que pierda líquido, puesto que éste podría ser inyectado a través de la piel, en cuyo caso tendría que ser extirpado quirúrgicamente en el plazo de unas horas o podría desarrollarse gangrena. Si falla algún punto del sistema hidráulico, puede ocurrir un accidente grave. Una manguera hidráulica rota puede rociar líquido a gran distancia. Los sistemas hidráulicos almacenan energía. Un mantenimiento o ajuste poco cuidadosos pueden provocar accidentes.

Las lesiones por pellizco pueden producirse cuando dos partes de la maquinaria se mueven al mismo tiempo en círculo. Los engranajes y las correas de transmisión son ejemplos de puntos peligrosos para sufrir un pellizco. Las prendas de vestir o alguna parte del cuerpo pueden quedar enganchados y ser arrastrados hacia los engranajes. La utilización de carcasas protectoras en las cosechadoras de patatas reduce el riesgo de una lesión por pellizco.

Las lesiones por enrollamiento pueden ocurrir cuando un componente giratorio no protegido por una pantalla, como un eje de toma de fuerza, enrolla una prenda de vestir floja, como una manga, la cola de una camisa, un pieza deshilachada de la ropa o incluso el pelo largo. Los ejes de toma de fuerza lisos con óxido o muescas pueden ser suficientemente rugosos para atrapar ropa. Cualquier eje de este tipo, por muy lentamente que gire, debe considerarse con precaución. No obstante, los ejes redondos y lisos entrañan un menor riesgo de enganchar la ropa que los ejes cuadrados. Las juntas universales en los extremos de los ejes de toma de fuerza son las que más riesgo presentan de atrapar la ropa y producir una lesión por enrollamiento. Estas partes abultadas se extienden más allá del eje de toma de fuerza y pueden causar una lesión por enrollamiento incluso aunque se sea consciente del riesgo. Los ejes de toma de fuerza del tractor de la cosechadora de patatas deben ir provistos de carcasas protectoras. Nadie debe trabajar en condiciones poco seguras, como sería en ausencia de dichas carcasas.

Los puntos de cizallamiento son zonas en las que dos piezas se mueven describiendo un movimiento de corte. Si se coloca un dedo en la junta de dos barras o entre la correa de un ventilador y la polea, será rápidamente seccionado. La correa, que gira por acción del motor del ventilador, es un lugar con riesgo de amputación y otras lesiones corporales. También en este caso la instalación de las carcasas protectoras adecuadas en estas partes de la cosechadora de patatas reduce el peligro de una lesión por cizalladura.

Los puntos de aplastamiento son aquéllos en los que dos objetos se mueven uno hacia el otro, o un objeto móvil se desplaza hacia un objeto estacionario. En la recolección de la patata intervienen grandes camiones. Su movimiento en los campos y especialmente en recintos cerrados, como los edificios donde se almacenan los tubérculos, puede causar atropellos o aplastamiento de piernas y brazos.

Las lesiones por arrastre se producen cuando un trabajador es arrastrado hacia la maquinaria. Estas lesiones pueden ocurrir en cualquier momento cuando se intenta retirar algo de una cosechadora de patata cuando ésta está con el motor en marcha, aunque no esté en movimiento.
Las lesiones por objetos lanzados se producen cuando salen lanzados proyectiles. Las cosechadoras de patatas ayudadas por aire arrojan siempre tierra y pequeñas rocas en el proceso de separar los tubérculos de la tierra. La tierra y los residuos se arrojan con fuerza suficiente para causar lesiones oculares.

\section{Prevención}

Por fortuna, son muchas las medidas que pueden adoptarse para evitar accidentes. Las prendas adecuadas pueden suponer la diferencia entre quedar o no atrapado en un punto de pellizco o enrollado. El pelo largo y suelto puede quedar atrapado en puntos de enrollado o pellizco y tirar de la cabeza del trabajador hacia un punto peligroso. El pelo largo debe siempre llevarse recogido. Los zapatos con suelas antideslizantes ayudan a no resbalar mientras se permanece de pie en la plataforma de clasificación, que puede estar empapada de barro. Los guantes, si se utilizan durante el trabajo en la plataforma de clasificación, deben ajustar perfectamente, sino que queden bordes deshilachados ni partes sueltas.

La actitud, el estado de alerta y la prevención de situaciones peligrosas son un complemento de las prendas de seguridad. Nadie debe nunca montarse o bajarse en marcha de una cosechadora de patatas. El pasajero debe esperar siempre a que ésta se detenga. Muchos de los accidentes graves o discapacitantes ocurren cuando alguien se cae y es atropellado por intentar subir o bajar de una máquina en marcha. El trabajador debe estar en una posición estable antes de que el tractor empiece a tirar de la cosechadora. De esa forma se reduce la posibilidad de una caída cuando el tractor avance bruscamente. Nadie debe estar situado entre el tractor y la cosechadora cuando estén en movimiento o se ponga el motor en marcha. Ni el tractorista ni los trabajadores montados en la cosechadora deben situarse demasiado cerca del eje de toma de fuerza como para poder tocarlo mientras está moviéndose o con el motor en marcha. Las cosechadoras no deben nunca lubricarse, ajustarse o repararse en marcha. Tampoco se debe intentar sacar nada de las correas cuando se están moviendo.

\section{HORTALIZAS Y MELONES}

\section{B.H. Xu y Toshio Matsushita}

Una gran variedad de hortalizas (plantas herbáceas) se cultivan para obtener hojas, tallos, raíces, frutos y semillas comestibles. Entre estos productos se encuentran hojas utilizadas para ensaladas (como lechuga y espinacas), raíces (como zanahoria, remolacha y nabo), coles (como repollo, brócoli, coliflor) y muchas otras cultivadas por sus frutos o semillas (guisantes, judías, calabaza, melones, tomates).

Desde el decenio de 1949, el cultivo de hortalizas ha sufrido profundos cambios, sobre todo en América del Norte y Europa. En el pasado, la mayoría de las hortalizas se cultivaban cerca de las poblaciones en huertas y sólo se disponía de ellas durante o poco después de la recolección. La proliferación de los supermercados y la creación de grandes empresas dedicadas a la transformación de los alimentos creó una demanda de hortalizas durante todo el año. Al mismo tiempo se hizo posible la producción de hortalizas a gran escala en explotaciones comerciales alejadas de los centros de población gracias a la mejora de los sistemas de regadío, los insecticidas y el control de las malas hierbas, así como al desarrollo de maquinaria sofisticada para plantar, fumigar, cosechar y clasificar. En la actualidad, las principales fuentes de hortalizas frescas en Estados Unidos son las 
Figura 64.27 - Trabajo manual en una explotación de hortalizas cerca de Assam, Jordania.

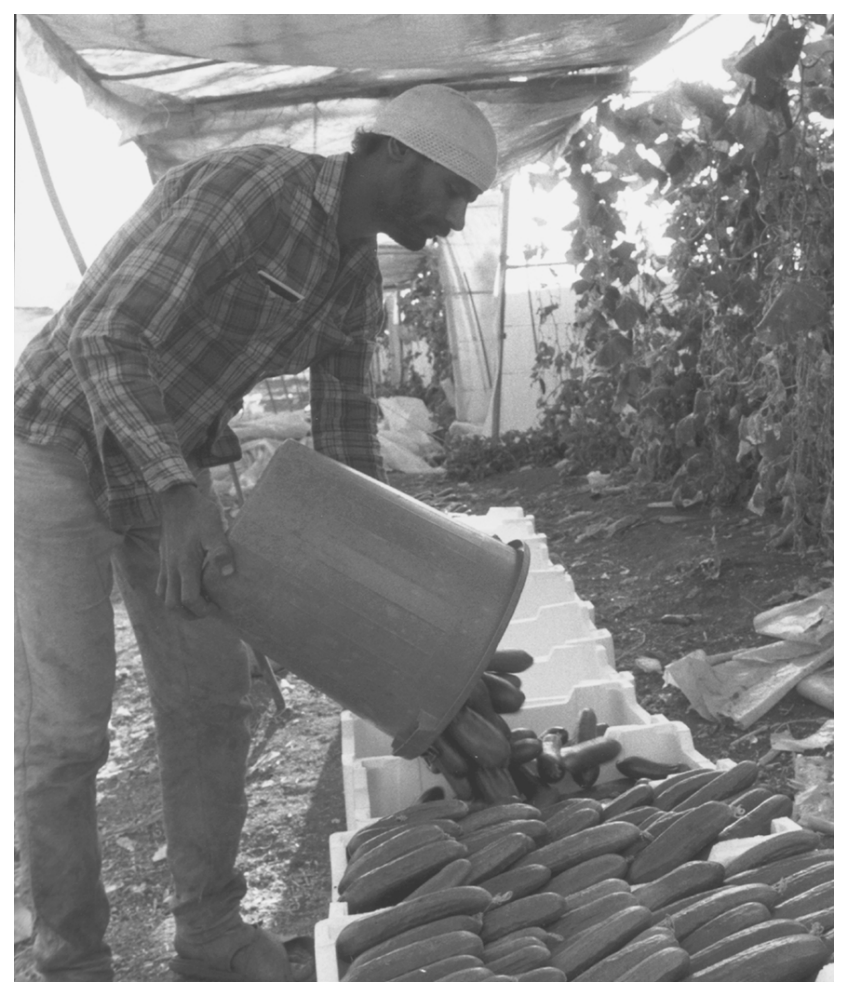

regiones con temporada larga, como los estados de California, Florida, Texas y México. Europa meridional y Africa del norte son las principales fuentes de hortalizas para Europa septentrional. Muchas hortalizas se cultivan también en invernadero. No obstante, los mercados en donde los agricultores venden productos locales siguen siendo los principales puntos de venta en gran parte del mundo, particularmente en Asia, Africa y América del Sur.

El cultivo de hortalizas exige unas destrezas y un cuidado considerables para asegurar la obtención de productos de alta calidad que puedan ser comercializados. Las operaciones necesarias para el cultivo de hortalizas son la preparación del suelo, la plantación y el crecimiento de los cultivos, la recolección, la transformación y el transporte. El control de malas hierbas y plagas y la gestión del agua son aspectos cruciales.

Los trabajadores de la producción de hortalizas y melones están expuestos a numerosos riegos profesionales en el ambiente de trabajo, entre ellos las plantas y sus productos, las productos fitosanitarios utilizadas para controlar las plagas y los aceites y detergentes utilizados para el mantenimiento y la reparación de la maquinaria. El trabajo manual o mecanizado obliga también a los trabajadores a adoptar posturas forzadas (véase la Figura 64.27). Los trastornos musculosqueléticos, como el dolor lumbar, son problemas importantes de salud en estos trabajadores. Las herramientas y la maquinaria agrícola utilizada para el cultivo de hortalizas y melones entraña un alto riesgo de lesiones traumáticas y algunos problemas de salud similares a los observados en otros trabajadores agrícolas. Además, las personas que trabajan al aire libre están expuestas a la radiación solar y al calor, mientras que la exposición a pólenes, endotoxinas y hongos debe tenerse en cuenta en el caso de los trabajadores de los invernaderos. Por consiguiente, en estas poblaciones puede encontrarse una gran variedad de trastornos relacionados con el trabajo.

Las alergias alimentarias a hortalizas y melones son bien conocidas. En su mayoría son provocadas por alergenos presentes en las hortalizas y pueden causar una reacción inmediata. Clínicamente, la mayoría de los pacientes presentan síntomas mucocutáneos y respiratorios. Las alergias de origen profesional en los trabajadores que cultivan hortalizas difiere de las alergias alimentarias en algunos aspectos. Los alergenos de origen profesional son diversos, pudiendo ser de origen vegetal, sustancias químicas o derivados biológicos. Se ha demostrado que hortalizas como la alcachofa, col de bruselas, repollo, zanahoria, apio, escarola, cebolleta, endivia, ajo, rábano, puerro, lechuga, ocra, cebolla, perejil y pastinaca contienen alergenos vegetales y sensibilizan a los trabajadores que los cultivan. En cambio, los casos de alergias al melón son muy raros. El número de alergenos de hortalizas y melones que se han aislado e identificado es muy reducido debido a la dificultad y complejidad de las técnicas de laboratorio requeridas. La mayoría de los alergenos, especialmente los de origen vegetal, son liposolubles, siendo muy pocos de ellos hidrosolubles. La capacidad de sensibilización varía también dependiendo de factores botánicos. Los alergenos pueden estar secuestrados en los canales de resina y liberarse sólo cuando la planta sufre daños. Pero en otros casos se liberan más fácilmente a través de pelos glandulares frágiles, o se excretan a la hoja, recubren los granos de polen o se diseminan ampliamente por acción del viento en los tricomas (estructuras parecidas a pelos que crecen sobre las plantas).

Clínicamente, las enfermedades alérgicas de origen profesional más comunes observadas en los trabajadores de las hortalizas son dermatitis alérgica, asma y rinitis. Se han dado algunos casos de alveolitis alérgica extrínseca, fotodermatitis alérgica y urticaria alérgica. Debe recordarse que las hortalizas, los melones, las frutas y los pólenes contienen algunos alergenos en común o alergenos de reacción cruzada. Esto significa que las personas atópicas y los individuos con alergia a algún alergeno pueden hacerse susceptibles a los otros cuando desarrollan alergias de origen profesional. Para detectar y diagnosticar estas alergias profesionales, en la actualidad se dispone de una serie de pruebas inmunológicas. En general, la prueba de punción, la prueba intradérmica, la medición del anticuerpo $\mathrm{IgE}$ específico del alergeno y la prueba de la provocación con alergeno in vivo son las más utilizadas en el caso de alergias agudas, mientras que la prueba de los parches es la preferida para las alergias diferidas. La prueba de proliferación de linfocitos específicos del alergeno y de producción de citoquina son útiles para diagnosticar ambos tipos de alergia. Estas pruebas pueden realizarse utilizando las propias hortalizas, sus extractos o sustancias químicas liberadas por ellas.

En los trabajadores que cultivan hortalizas se dan casos de dermatosis como paquilosis, hiperqueratosis, cromatosis con lesión de las uñas y dermatitis. La dermatitis por contacto, ya sea irritativa como alérgica, es la más frecuente. La dermatitis irritativa está causada por sustancias químicas y/o factores físicos. Algunas partes de las hortalizas, como tricomas, espículas, pelos hirsutos, rafidios y espinas son responsables de la mayor parte de las irritaciones. La dermatitis alérgica puede ser inmediata o diferida según su inmunopatogénesis. La primera está mediada por respuestas inmunológicas humorales, mientras que la segunda está mediada por respuestas inmunológicas.

Clínicamente, muchos pacientes con dermatitis alérgica experimentan síntomas como picor, eritema, sarpullido, edema y formación de vesículas. Estas lesiones aparecen principalmente en manos, brazos, cara y cuello. En un estudio de campo de los cultivadores japoneses de ocra (Nomura 1993), más del $50 \%$ de 
los trabajadores presentaban lesiones cutáneas, sobre todo en las manos y los brazos. Entre el 20 y el $30 \%$ de ellos presentaron una reacción positiva a la prueba de los parches de ocra y extractos de las hojas. Además, se ha demostrado que la actividad proteolítica de los extractos de ocra causa lesiones cutáneas.

Los productos fitosanitarios son también importantes alergenos responsables de la dermatitis alérgica. Entre ellos se encuentran los insecticidas (DDVP, diazinon, EPN, malation, naled, paration, etc.), fungicidas (benomilo, captafol, captan, maneb, manzeb, nitrofen, plondrel ${ }^{\circledR}$, tiram, zineb, ziram, etc.), herbicidas (carbine, randox, etc.) y fumigantes (D-D ${ }^{\circledR}$ mezcla de 1,3-dicloropropeno y 1,1,2-dicloropropano y compuestos relacionados). Además, bacterias oportunistas y Streptococcus pyogenes desempeñan un importante papel en la dermatitis alérgica y la urticaria de los trabajadores que cultivan hortalizas.

Estos trabajadores, especialmente cuando trabajan en invernaderos o espacios confinados, están expuestos a gran número de productos vegetales y compuestos como plaguicidas que son responsables de una mayor incidencia de enfermedades pulmonares. En un estudio nacional realizado entre los agricultores suizos, se demostró que la mortalidad proporcional ajustada por edades para todas las enfermedades pulmonares, bronquitis y asma, y asma sólo, era de 127, 140 y 137, respectivamente. Los productos de las hortalizas pueden causar directamente asma alérgica de origen profesional o proporcionar irritantes inespecíficos y/o el vehículo para otros alergenos, como pólenes, esporas, ácaros y otras sustancias. Los productos que pueden causar asma alérgica son la bromelina, cera y granos de ricino, freesia, goma guar, papaína, pimentón, lúpulo, ipecacuana, ácido plicático, ácido quillaico, saponina y polen de girasol.

Los hongos presentes en el ambiente de trabajo producen numerosas esporas, algunas de las cuales causan asma alérgica y/o alveolitis alérgica extrínseca. No obstante, es raro que el asma alérgica y la alveolitis alérgica intrínseca causadas por esos alergenos se den en una misma persona. En cuanto a los microorganismos causantes de alergias, se han identificado a Alternaria, Aspergillus niger, Cladosporium, el fango de los humidificadores, Merulius lacrymans, Micropolyspora faei, Paecilomyces y Verticillium. En la mayoría de los casos, los antígenos de origen fúngico están presentes en las esporas y los productos de degradación.

Los pacientes con asma profesional causada por productos de las hortalizas muestran siempre unos niveles plasmáticos elevados de anticuerpos $\mathrm{IgE}$, eosinofilia y resultados positivos a la prueba de punción, mientras que en los pacientes con alveolitis alérgica extrínseca se encuentran anticuerpos precipitantes específicos, resultados positivos a la prueba de punción y hallazgos radiológicos típicos. Además de la alergia pulmonar a productos de las hortalizas y esporas fúngicas, en pacientes atópicos se presentan síntomas nasales al manipular hortalizas como zanahorias y lechugas. En general no suelen producirse molestias gastrointestionales.

Los productos fitosanitarios se aplican con múltiples fines en el cultivo de hortalizas tanto a la intemperie como en invernaderos. Se ha demostrado que algunos de los productos químicos utilizados poseen potencial asmático, como ocurre con el captafol, clorotalonil, creosota, formaldehído, piretrina y estreptomicina. El uso inadecuado de plaguicidas puede contaminar el suelo y las hortalizas y la aplicación de plaguicidas sin equipos de protección personal puede tener efectos tóxicos agudos o crónicos.

\section{CULTIVO DE ARBOLES, ZARZAS Y VIDES}

\section{- BaYAS Y UVAS}

\section{William E. Steinke}

En este artículo se describen los métodos de prevención de accidentes y enfermedades contra los riesgos frecuentes en la producción de uvas (para consumo del producto fresco, vino, zumo o pasas) y bayas, entre ellas zarzas (por ejemplo, frambuesas), fresas y bayas de arbusto (por ejemplo, mirtillo y arándano americano).

Las vides son tallos que trepan sobre estructuras de apoyo. En los viñedos comerciales, suelen plantarse en primavera a partir de esquejes injertados o enraizados de un año de edad. En general se plantan dejando una distancia entre 2 y $3,5 \mathrm{~m}$. Todos los años los viñedos tienen que ser escardados y fertilizados, subdividiendo y podando las vides. El estilo de poda varía según las diferentes partes del mundo. En el sistema que predomina en Estados Unidos, se podan todos los vástagos menos los más fuertes; los restantes se cortan en 2 ó 3 yemas. La planta resultante desarrolla un tronco principal grueso que puede sostenerse sólo, antes de que se le permita dar fruto. Durante el crecimiento del tronco principal, la vid se ata firmemente a un soporte recto de $1,8 \mathrm{~m}$ o más de altura. Una vez alcanzada la etapa de producción de fruto, las vides se podan cuidadosamente para controlar el número de yemas.

Las fresas se plantan a principios de la primavera, a mediados de verano o más tarde, dependiendo de la latitud. Dan fruto en la primavera del año siguiente. Una variedad llamada fresa con fruto permanente produce una segunda cosecha más pequeña en el otoño. La mayoría de las fresas se propagan espontáneamente por medio de retoños que se forman aproximadamente unos dos meses después de la estación de la plantación. La fruta se encuentra a ras del suelo. Las zarzas, como las frambuesas, suelen ser arbustos de tallos espinosos (cañas) con frutos comestibles. Las partes subterráneas son perennes y las cañas, bienales; sólo las cañas del segundo año producen flores y frutos. Las zarzas producen frutos a alturas de $2 \mathrm{~m}$ o menos. $\mathrm{Al}$ igual que la vid, las bayas requieren una poda frecuente.

Los métodos de cultivo difieren según la especie, el tipo de suelo, el clima y los fertilizantes necesarias. El riguroso control de los insectos y las enfermedades es esencial, exigiendo a menudo la aplicación frecuente de plaguicidas. Algunos cultivadores modernos han optado por los controles biológicos y la estrecha vigilancia de las poblaciones de plagas, fumigando con sustancias químicas sólo en los momentos en que son más eficaces. La mayoría de las uvas y bayas se recolectan manualmente.

En un estudio de los accidentes no mortales ocurridos durante un período de 10 años, desde 1981 hasta 1990, en California, las lesiones más comunes dentro de esta categoría de cultivos fueron las dislocaciones y las distensiones, representando el $42 \%$ de todas las lesiones declaradas. Las laceraciones, las fracturas y las contusiones representaron otro $37 \%$ de las lesiones. La causa más frecuente de lesiones fueron: golpes recibidos por objetos (27\%), esfuerzos excesivos (23\%) y caídas (19\%) (AgSafe 1992). En un estudio realizado en 1991, Steinke (1991) observó que el $65 \%$ de las lesiones en explotaciones productoras de este tipo de cultivos en California fueron distensiones, dislocaciones, laceraciones, fracturas y contusiones. Las partes del cuerpo lesionadas 
con más frecuencia fueron los dedos (17\%), la espalda (15\%), los ojos $(14 \%)$ y las manos o muñecas $(11 \%)$. Según Villarejo (1995), en 1989 se concedieron 6.000 indemnizaciones por accidente por 100.000 equivalentes a trabajadores a tiempo completo en la producción de fresas en California. Puesto que la mayoría de estos trabajadores no encuentran empleo durante todo el año, el porcentaje de trabajadores con lesiones podría ser mucho mayor que la cifra del $6 \%$ declarada.

\section{Problemas musculosqueléticos}

El principal riesgo asociado a las lesiones musculosqueléticas en estos cultivos es el ritmo del trabajo. Si el propietario trabaja en los campos, lo suele hacer rápidamente para terminar una tarea y pasar a la siguiente. Los trabajadores contratados suelen ser retribuidos a destajo, es decir, en función del trabajo realizado (por ejemplo, kilogramos de bayas cosechadas o número de vides podadas). Este tipo de retribución suele imponer un ritmo tan rápido que el trabajador no dispone de tiempo para asegurarse de que sus dedos están fuera de las tijeras antes de cortar, o para caminar con cuidado desde o hacia el borde del campo para dejar las cestas llenas y recoger otras vacías durante la vendimia. Un elevado ritmo de trabajo puede favorecer que se adopten posturas forzadas, se corran riesgos innecesarios y no se respeten unas prácticas y procedimientos seguros.

La poda manual de bayas o vides exige una presión frecuente de la mano para agarrar las tijeras, o el uso frecuente de un cuchillo. Los riesgos que entrañan los cuchillos son evidentes, puesto que no existe ninguna superficie sólida en la que apoyar la vid, el retoño o el tallo y se producen cortes frecuentes en dedos, manos, brazos, piernas y pies. La poda con cuchillo sólo debe utilizarse como último recurso.

Aunque la mejor herramienta para la poda son las tijeras de podar, ya sea durante la estación inactiva o cuando las plantas o vides todavía tienen hojas, conlleva también ciertos riesgos. El principal de ellos es el peligro de corte por contacto con la cuchilla abierta cuando se coloca una vid o tallo entre las dos hojas, o por cortes inadvertidos de un dedo también al cortar una vid o tallo. El uso de gruesos guantes de cuero o tejido confiere una buena protección contra ambos riesgos y puede también proporcionar protección contra dermatitis por contacto, alergias, picaduras de insectos o abejas y cortes producidos con las espalderas.

La frecuencia y el grado del esfuerzo que tiene que realizarse para cortar determinan la probabilidad de que aparezcan lesiones traumáticas acumulativas. Aunque los casos notificados de lesiones no indican en la actualidad que estas lesiones se produzcan con frecuencia, según parece eso se debe a la frecuente rotación en el trabajo que se produce en la producción de estos cultivos. La fuerza necesaria para utilizar unas tijeras de podar normales supera los valores recomendados y la frecuencia del esfuerzo hace probable que se produzcan trastornos traumáticos acumulativos, según las directrices aceptadas (Miles 1996).

Para reducir la probabilidad de lesiones, las tijeras de podar deben mantenerse bien lubricadas y afiladas con frecuencia. Cuando se trata de vides de gran tamaño, como es el caso de las parras, el tamaño de las tijeras debe aumentar en consecuencia para no sobrecargar la muñeca ni dañar las propias tijeras. Con frecuencia tiene que recurrirse a cizallas o sierras de podar para cortar con seguridad grandes vides o plantas.

El levantamiento y transporte de cargas está típicamente asociado a la recolección de estos cultivos. Las bayas o frutos suelen recolectarse manualmente y se transportan en algún tipo de cesta o recipiente hasta el borde del campo, donde se depositan. Las cargas no suelen ser muy pesadas (10 kg o menos), pero en muchos casos tienen que transportarse a una distancia considerable y por terreno desigual, que puede estar húmedo o resbaladizo. Los trabajadores no deben correr por terreno desigual y han de pisar siempre en suelo firme.

La recolección suele exigir la adopción de posturas forzadas y un ritmo rápido de trabajo. La persona ha de girarse y doblarse, agachándose hacia el suelo sin doblar las rodillas y moviéndose rápidamente entre el arbusto o la vid y el recipiente. Los recipientes se colocan algunos veces sobre el suelo y el trabajador los va empujando o arrastrando. Los frutos y las bayas pueden encontrarse entre a ras de suelo y $2 \mathrm{~m}$ de altura, dependiendo del tipo de cultivo. Las zarzas se encuentran típicamente a alturas de $1 \mathrm{~m}$ o inferiores, obligando al trabajador a doblar casi siempre la espalda durante la recolección. Las fresas se encuentran a ras del suelo, pero los trabajadores están de pie y han de inclinarse para recogerlas.

Las uvas suelen también cortarse para extraer el vino durante la recolección manual. Este movimiento de corte es muy frecuente (centenares de veces a la hora) y exige un esfuerzo suficiente para entrañar riesgo de lesiones traumáticas acumulativas si la vendimia durara más de unas cuantas semanas.

El trabajo con espalderas o estructuras de soporte es frecuente en la producción de vides y bayas. Los trabajos de instalación o reparación suelen realizarse a alturas por encima de la cabeza y exigen estirar los músculos al mismo tiempo que se ejerce fuerza. Un esfuerzo sostenido de este tipo puede causar lesiones acumulativas. En cada ocasión existe el riesgo de una lesión por distensión o dislocación, especialmente en los hombros y los brazos, como resultado de ejercer una fuerza considerable al mismo tiempo que se trabaja en una postura forzada. La orientación de las plantas en las espalderas exige también ejercer una fuerza considerable que aumenta por el peso de las vides, las hojas y los frutos. Esta fuerza suele ejercerse a través de los brazos, los hombros y la espalda, todos los cuales son susceptibles a una lesión aguda o crónica por sobreesfuerzo.

\section{Plaguicidas y fertilizantes}

Las uvas y las bayas tienen que someterse a la aplicación frecuente de plaguicidas para el control de insectos y agentes patógenos. Los aplicadores, mezcladores, cargadores y demás personas presentes en los campos o que ayuden a la aplicación deben adoptar las precauciones que se indiquen en la etiqueta o los requisitos de las autoridades locales. La aplicación de plaguicidas en estos cultivos puede ser especialmente peligrosa por la naturaleza del depósito necesario para controlar las plagas. Con frecuencia deben rociarse todas las partes de la planta, incluido el envés de las hojas y todas las superficies de los frutos o bayas. Eso exige a menudo la aplicación de gotas muy pequeñas y la utilización de aire para facilitar la penetración entre las hojas y el depósito del plaguicida. Por ello se utilizan muchos aerosoles, que pueden ser peligrosos por inhalación y exposición ocular o dérmica

Los fungicidas suelen aplicarse en forma de polvo a las uvas y muchos tipos de bayas. El más común de ellos es el azufre, que puede utilizarse en la agricultura orgánica. El azufre puede ser irritante para la persona que lo aplica y para otras presentes en los campos. También se sabe que alcanza concentraciones atmosféricas suficientes para causar explosiones e incendios. Deben tomarse precauciones para evitar que se disperse en forma de una nube de polvo de azufre y alcance una posible fuente de ignición, como una máquina, un motor eléctrico $\mathrm{u}$ otro aparato que produzca chispas.

Muchos campos son fumigados con materiales muy tóxicos antes de plantar los cultivos para así reducir la población de plagas de nematodos, bacterias, hongos y virus que pueden atacar a las plantas jóvenes. La fumigación suele consistir en la inyección de un gas o líquido en el suelo, cubriéndolo luego 
con una lámina de plástico para evitar que el plaguicida se escape demasiado pronto. La fumigación es una práctica especializada que sólo debe ser realizada por personas debidamente formadas. En los campos fumigados debe colocarse un cartel de advertencia para que nadie entre hasta que se haya retirado la cubierta y disipado el fumigante.

La aplicación de fertilizantes conlleva ciertos riesgos. Puede producirse inhalación de polvo, dermatitis por contacto con la piel e irritación de los pulmones, la garganta y las vías respiratorias. El uso de una máscara con filtro de polvo puede ser útil para reducir la exposición hasta niveles no irritantes.

Los trabajadores pueden verse obligados a entrar en los campos para realizar operaciones de riego, poda o recolección poco después de la aplicación de plaguicidas. Cuando no pueda esperarse el tiempo indicado en la etiqueta del plaguicida o la normativa local, deberán utilizar prendas protectoras para evitar la exposición. La protección mínima consiste en una camisa de manga larga, pantalones largos, guantes, sombrero, zapatos y protección de los ojos. Dependiendo del plaguicida utilizado, el tiempo transcurrido desde su aplicación y la normativa local, es posible que se exija un mayor nivel de protección, con un respirador, un traje impermeable y botas de goma. Para determinar el nivel correcto de protección conviene consultar con las autoridades locales en materia de plaguicidas.

\section{Exposición a la maquinaria}

En la producción de estos cultivos suele utilizarse maquinaria para la preparación de la tierra, la plantación, la escarda, el cultivo y la recolección. Muchos de estos cultivos crecen en las laderas o en terrenos desiguales, aumentando el peligro de vuelco de tractores u otras máquinas. Siempre deben respetarse las normas generales de seguridad para evitar el vuelco de tractores y otras máquinas, al igual que la norma de no llevar pasajeros en esas máquinas salvo que sea necesaria la presencia de personal adicional para su correcto manejo y dispongan de una plataforma segura. En el artículo "Mecanización" de este mismo capítulo y en otros capítulos de esta Enciclopedia puede encontrarse más información sobre el uso correcto de la maquinaria.

Muchos de estos productos se cultivan en terrenos desiguales, como cauces u orillas de ríos o barrancos, lo que aumenta el peligro, sobre todo cuando se tornan fangosos y resbaladizos o se cubren de maleza. Las caídas delante de una máquina son muy peligrosas, como lo son también otras caídas que pueden causar distensiones y dislocaciones. Siempre deben tomarse precauciones especiales cuando los campos están húmedos o en la época de la recolección, cuando el suelo puede estar cubierto de restos de fruta.

La poda mecánica de las vides está generalizándose en todo el mundo. Suele exigir el uso de cuchillas giratorias o dedos que agarran las vides y las hacen pasar por cuchillas fijas. Este tipo de máquinas pueden ser peligrosas para cualquiera que se encuentre cerca del punto de entrada de las cuchillas y sólo deben ser manejadas por un operario debidamente instruido.

Para la recolección suelen utilizarse varias máquinas a la vez, siendo necesaria la coordinación y cooperación de los conductores de todas ellas. Estas operaciones, por su naturaleza, exigen la acumulación y transporte de la cosecha, lo que habitualmente se realiza utilizando rodillos o palas vibrátiles, dedos arrancadores, ventiladores, máquinas de corte o rebanado y rastrillo. Todas estas máquinas pueden causar grandes daños físicos a las personas que quedan atrapadas. Siempre debe evitarse la presencia de personas cerca del punto de entrada de esas máquinas cuando están en marcha. Las carcasas protectoras deben mantenerse siempre en su lugar y someterse al mantenimiento adecuado. Si se retiran para su lubricación, ajuste o limpieza, han de volverse a colocar en su sitio antes de volver a utilizar la máquina. Nunca deben abrirse o retirarse las carcasas de seguridad de una máquina en funcionamiento.

\section{Otros riesgos}

\section{Infecciones}

Entre los accidentes más comunes en los cultivadores de uvas y bayas destacan los cortes o pinchazos, ya sea por las espinas de las plantas, las herramientas o las espalderas o estructuras de apoyo. Este tipo de heridas abiertas pueden siempre ser infectadas por la gran cantidad de bacterias, virus o agentes patógenos presentes en los campos que en ocasiones causan graves complicaciones que pueden llevar a la amputación de una extremidad o incluso la muerte. Todos los trabajadores de los campos deben ser protegidos con una vacuna de recuerdo del tétanos. Los cortes deben lavarse y limpiarse, aplicando después un agente bactericida; cualquier infección que aparezca debe recibir tratamiento médico inmediato.

\section{Picaduras de insectos y abejas}

Los trabajadores agrícolas que realizan labores de cultivo y recolección corren un mayor riesgo de sufrir picaduras de insectos y abejas. $\mathrm{Al}$ introducir las manos y los dedos entre las hojas de las plantas para seleccionar y arrancar las bayas o frutas maduras, aumenta la exposición a abejas e insectos que pueden estar escondidos o descansando entre el follaje. Algunos insectos pueden estar también alimentándose de las bayas maduras, como también pueden hacerlo roedores y otros bichos. La mejor protección consiste en utilizar camisas de manga larga y guantes siempre que se trabaje entre las hojas.

\section{Radiación solar}

\section{Estrés térmico}

La exposición excesiva a la radiación solar y al calor puede causar fácilmente agotamiento por calor, golpe de calor o incluso la muerte. El calor añadido al cuerpo humano por la radiación solar, el esfuerzo del trabajo y la transferencia del calor ambiental tiene que liberarse del organismo a través del sudor o la pérdida sensible de calor. Cuando la temperatura ambiente supera los $37^{\circ} \mathrm{C}$ (es decir, la temperatura corporal normal), no puede haber pérdida sensible de calor, de manera que el cuerpo sólo puede recurrir a la sudoración para enfriarse.

La sudoración requiere agua. Las personas que trabajan bajo el sol o en un clima caluroso tienen que beber grandes cantidades de líquido durante todo el día. Deben tomar agua o bebidas para deportistas incluso antes de tener sensación de sed y evitar el consumo de alcohol y cafeína, puesto que estas sustancias tienen un efecto diurético y en realidad aceleran la pérdida de agua, interfiriendo con la transformación de regulación térmica del organismo. Suele recomendarse la ingestión de un litro de líquido por hora de trabajo al sol o en un clima caluroso. Un signo de deshidratación es la ausencia de necesidad de orinar.

Las enfermedades relacionadas con el calor pueden poner en peligro la vida de la persona y exigen atención inmediata. Las personas que sufren agotamiento por calor deben ser tumbadas a la sombra y beber abundantes líquidos. Todo aquel que sufra un golpe de calor se encuentra en grave peligro y necesita atención inmediata. Si no se tiene acceso a asistencia médica en cuestión de minutos, debe intentarse enfriar a la víctima sumergiéndola en agua fría. Si la víctima está inconsciente, debe conseguirse que siga respirando con técnicas de primeros auxilios. No debe ingerir líquidos por boca. 
Los síntomas de las enfermedades relacionadas con el calor son una sudoración excesiva, debilidad de los miembros, desorientación, cefalea, mareo y, en casos extremos, pérdida de la conciencia o de la capacidad de sudoración. Estos últimos síntomas advierten de un peligro de muerte inminente y exigen medidas urgentes.

El trabajo en los viñedos y los campos de arbustos con bayas pueden aumentar el riesgo de enfermedades relacionadas con el calor. La circulación de aire se reduce entre las filas, y se tiene la falsa sensación de estar trabajando a la sombra. Una elevada humedad relativa y un cielo nublado pueden también dar una falsa impresión de los efectos del sol. Siempre que se trabaja en los campos tienen que beberse abundantes líquidos.

\section{Enfermedades dermatológicas}

La exposición prolongada al sol puede causar envejecimiento prematuro de la piel y aumentar el riesgo de cáncer de piel. Las personas expuestas a los rayos directos del sol deben utilizan prendas de vestir o productos que actúen como pantalla solar para protegerse de ellos. En latitudes bajas, incluso unos cuantos minutos de exposición al sol pueden causar graves quemaduras, especialmente en personas de piel clara.

Los cánceres de piel pueden empezar en cualquier parte del cuerpo y cualquier sospecha de cáncer debe ser inmediatamente comprobada por un médico. Algunos de los síntomas más frecuentes de cáncer de piel o lesiones precancerosas son cambios en un lunar o una marca de nacimiento, un borde irregular, hemorragia o cambio de color, generalmente con un tono marrón o grisáceo. Las personas con antecedentes de exposición solar deben someterse a un examen anual para detectar cáncer de piel.

\section{Dermatitis por contacto y otras alergias}

El contacto frecuente y prolongado con las secreciones o los fragmentos de plantas pueden producir sensibilización y casos de alergias y dermatitis por contacto. El curso de actuación preferido es la prevención mediante el uso de camisas de manga larga, pantalones largos y guantes siempre que sea posible. Pueden utilizarse también ciertas cremas para crear una barrera que impida la transferencia de irritantes a la piel. Si la piel no puede protegerse de la exposición a las plantas, el lavado inmediato después del contacto con la planta puede reducir al mínimo los efectos. Los casos de dermatitis con erupciones cutáneas o que no cicatrizan deben ser vistos por un médico.

\section{CULTIVO DE ARBOLES FRUTALES}

\section{Melvin L. Myers}

Generalmente, los árboles frutales de las zonas templadas se cultivas en huertas, mientras que los árboles tropicales se cultivan en plantaciones o en huertas urbanas. Los árboles frutales que crecen espontáneamente han sido cultivados y seleccionados durante siglos para producir una gran diversidad de productos. Los cultivos frutales de las regiones templadas son la manzana, la pera, el melocotón, la nectarina, la ciruela, el albaricoque, la cereza, el caqui y la ciruela pasa. Los frutos secos que se cultivan en climas templados o semitropicales son la pacana, la almendra, la nuez, la avellana, la castaña y el pistacho. Algunos cultivos de árboles frutales semitropicales son la naranja, la uva, la mandarina, la lima, el limón, el higo, el kiwi, el tangelo, el kumquat, el calamondín (naranja de Panamá), la cidra, el pomelo javanés y el dátil.

\section{Sistemas de cultivo de árboles frutales}

El cultivo de árboles frutales consta de varios procesos. Los cultivadores pueden elegir entre propagar su propia población, ya sea plantando semillas o utilizando una o más técnicas de reproducción sexual con corte, injerto de yema, injertado o cultivo tisular. Los cultivadores aran la tierra, cavan agujeros, plantan los árboles, riegan y añaden fertilizante.

El cultivo de árboles exige fertilizar, controlar las malas hierbas, regar y proteger a los árboles contra las heladas de primavera. El fertilizante se aplica agresivamente durante los primeros años de crecimiento del árbol. Los componentes de las mezclas fertilizantes utilizadas son nitrato amónico y sulfato, fertilizante elemental (nitrógeno, fósforo y potasio), harina de semillas de algodón, harina de sangre, harina de pescado, fango de acantarillado esterilizado y formaldehído de urea (liberación lenta). Las malas hierbas se controlan mediante acolchado del suelo con sustancias orgánicas, arado, siega, cavado y aplicación de herbicidas. Los insecticidas y fungicidas se aplican con pulverizadores, que se instalan en los tractores en las grandes operaciones. Algunas plagas pueden dañar la corteza o comerse la fruta: ejemplos son las ardillas, conejos, mapaches, zarigüeyas, ratones, ratas y ciervos. Los controles consisten en redes, trampas, vallas electrificadas y escopetas, así como disuasivos visuales u olorosos.

Las heladas de primavera pueden destruir la floración en cuestión de horas. Se utilizan aspersores aéreos para mantener una mezcla de agua y hielo de manera que la temperatura no descienda por debajo del punto de congelación. Pueden aplicarse sustancias químicas anticongelantes especiales con el agua para controlar las bacterias que proliferan en el hielo y que pueden atacar a los tejidos dañados de los árboles. También pueden utilizarse calefactores en las huertas para evitar la congelación, bien de gasóleo o combustible en las zonas abiertas o bien con bombillas eléctricas incandescentes debajo de una lámina de plástico apoyada en una estructura de tubos de plástico.

Las herramientas de poda pueden transmitir enfermedades, razón por la cual deben sumergirse en una solución de agua con lejía clorada o frotarlas con alcohol después de podar cada árbol. Todas las ramas cortadas se retiran, despedazan y convierten en abono. El crecimiento de las ramas tiene que ser guiado, colocando para ello un andamiaje entre las ramas, construyendo espalderas, clavando estacas verticales en el suelo y atando las ramas a esas estructuras.

La abeja es el principal polinizador de los árboles frutales. La incisión anular parcial - cortes con cuchillo en la corteza del tronco- del melocotonero y el peral puede aumentar la producción. Para evitar un exceso de atrofia, la rotura de ramas y una producción irregular, los cultivadores entresacan la fruta manual o químicamente. El insecticida carbaril (Sevin), un fotoinhibidor, se utiliza para la entresaca química.

La recolección manual de la fruta exige trepar a una escalera, estirarse para alcanzar la fruta, colocarla en recipientes, bajar la escalera con los recipientes llenos y transportarlos hasta la zona de recogida. Las pacanas se golpean en los árboles con largas varas y se recogen manualmente o se utiliza una máquina especial que cubre y agita el tronco del árbol y recoge y vierte automáticamente las pacanas en un contenedor. Los camiones y remolques se utilizan habitualmente en el campo durante la recolección y para el transporte en las vías públicas.

\section{Riesgos del cultivo de árboles}

Los cultivadores utilizan una gran variedad de productos fitosanitarios, entre ellos fertilizantes, herbicidas, insecticidas y fungicidas. La exposición a plaguicidas puede ocurrir durante su aplicación, por contacto posterior con sus residuos al realizar una 
Tabla 64.8 • Medidas de seguridad en el empleo de segadoras giratorias, barrenadoras de postes e hincapostes.

Segadoras giratorias (cortadoras)

- No pasar cortando por encima de tocones de árboles, metales y piedras, que pueden convertirse en proyectiles lanzados por la segadora.

- Evitar la presencia de personas en la zona de trabajo, ya que podrían ser golpeadas por los objetos que salgan lanzados.

- Mantener las carcasas protectoras de las cadenas alrededor de la segadora para evitar que salgan proyectiles lanzados de la segadora.

- No permitir pasajeros en el tractor para prevenir caídas debajo de la segadora.

- Mantener en su lugar las carcasas protectoras de la toma de fuerza.

- Desenganchar la toma de fuerza antes de arrancar el tractor.

- Tener cuidado al tomar curvas cerradas y al remolcar una segadora para que ésta no quede atrapada por la rueda del tractor, ya que podría salir lanzada hacia el conductor.

- Utilizar contrapesos en las ruedas delanteras cuando se acople una segadora mediante el enganche de tres puntos, de manera que las ruedas delanteras se mantengan en el suelo y pueda controlarse la dirección.

- Siempre que sea posible, utilizar neumáticos anchos para aumentar la estabilidad del tractor.

- Bajar la segadora al suelo antes de dejarla desatendida.

Barrenadoras para postes (taladros acoplados a un tractor)

- Colocar la palanca de transmisión en aparcar o punto muerto antes de la operación.

- Frenar el tractor antes del barrenado.

- Manejar la barrenadora lentamente para mantener el control.

- Taladrar el agujero en pequeñas etapas.

- No llevar nunca el pelo suelto ni ropa floja o deshilachada durante el barrenado.
- Mantener a todo el mundo alejado del taladro y los ejes de toma de fuerza durante el barrenado.

- Detener el taladro y bajarlo hasta el suelo cuando no se esté barrenando.

- No conectar la máquina cuando se esté retirando un taladro. Retirar el taladro manualmente haciéndolo girar en sentido contrario a las agujas del reloj y seguidamente levantándolo mediante un mecanismo hidráulico con el tractor.

Hincapostes (sistema de percusión acoplado al tractor)

- Apagar el motor del tractor y bajar el martillo antes de su lubricación o ajuste.

- No colocar nunca las manos entre el extremo superior del poste y el martillo.

- No superar el número recomendado de golpes de martillo por minuto.

- Utilizar una guía para mantener el poste durante la conducción en caso de que éste se rompo.

- Mantener las manos fuera de los postes que están a punto de ser clavados.

- Colocar en su sitio todas las carcasas protectoras antes de la operación.

- Utilizar gafas de seguridad y protectores auditivos durante la operación.

Aplicación de fertilizantes (mecánica)

- Mantenerse alejado de la parte trasera de los aplicadores de fertilizantes.

- No desenchufar un aplicador cuando está funcionando.

- Trabajar en zonas bien ventiladas lejos de fuentes de ignición cuando se limpian los aplicadores con gasóleo.

- Evitar el contacto del polvo con la piel, utilizar camisas de manga larga y abrocharse el cuello de la camisa cuando se manipule fertilizante en polvo. Lavarse varias veces al día.

- Trabajar en una posición tal que el viento sople en dirección contraria al trabajo.

- Los tractoristas deben conducir con el viento de costado sobre el aplicador para evitar que el polvo sea arrastrado hacia ellos. serie de tareas, por su dispersión, durante el mezclado y la carga del plaguicida y durante la recolección. El melanoma maligno tiene una elevada incidencia entre los cultivadores de árboles, especialmente en el tronco, el cuero cabelludo y las manos, presumiblemente por acción de la radiación solar (exposición ultravioleta). La manipulación de algunos tipos de frutas, especialmente las cítricos, puede causar alergias u otros problemas de piel.

Las segadoras rotativas son máquinas utilizadas con frecuencia para cortar las malas hierbas. Estas segadoras se acoplan y son arrastradas por tractores. Los pasajeros de los tractores pueden caerse y resultar gravemente heridos o muertos por la segadora. Esta puede arrojar también residuos a centros de metros de distancia y causar lesiones.

La construcción de cercas, espalderas y postes verticales en las huertas puede exigir el uso de barrenadoras de postes o hincapostes acoplados a los tractores. Las barrenadoras de postes son grandes tornillos conectados al tractor que cavan agujeros de entre 15 y $30 \mathrm{~cm}$ de diámetro. Los hincapostes son un sistema de percusión conectado al tractor para clavar postes en el suelo. Estos dos máquinas son peligrosas si no se manejan correctamente.

Los fertilizantes deshidratados pueden causar quemaduras en la piel e irritación de la boca, la nariz y los ojos. El mecanismo giratorio en la parte trasera de una abonadora centrífuga es también una causa de lesiones. Estas abonadoras se limpian con gasóleo, con el consiguiente riesgo de incendio.

Los accidentes mortales entre los cultivadores de árboles frutales pueden ocurrir por colisiones entre vehículos, vuelco de tractores, incidentes con la maquinaria agrícola y electrocuciones al mover tuberías de riego o escaleras que entrar en contacto con tendidos eléctricos. Para el trabajo en las huertas suelen retirarse las estructuras de protección contra vuelcos porque interfieren con las ramas de los árboles.

La manipulación manual de las frutas y los frutos secos en las operaciones de recolección y transporte conllevan riesgo de distensiones y dislocaciones. Además, las herramientas manuales, como los cuchillos y tijeras de podar, pueden infligir cortes a los trabajadores, que también están expuestos a la caída de objetos desde los árboles durante la recolección y accidentes por caída de las escaleras.

\section{Control de riesgos}

En lo que se refiere al uso de plaguicidas, en primer lugar tiene que identificarse la plaga para seleccionar el método más eficaz y el momento más adecuado para el control. Siempre deben seguirse los procedimientos de seguridad que se indican en la etiqueta del plaguicida, entre ellos el uso de equipos de protección personal. El estrés por calor es un peligro cuando se utilizan prendas protectoras, exigiendo descansos frecuentes y la ingestión abundante de agua. Antes de volver a entrar en las huertas debe dejarse transcurrir el tiempo necesario para evitar exposiciones peligrosas a residuos de los plaguicidas. Asimismo, ha de evitarse la dispersión de los plaguicidas desde su lugar de aplicación a otros lugares. Deben existir unas instalaciones sanitarias adecuadas y el uso de guantes puede ser útil para evitar la exposición de la piel. En la Tabla 64.8 se indican algunas medidas de seguridad que pueden adoptarse cuando se manejan segadoras 
rotatorias, barrenadoras de postes, hincapostes y aplicadores de fertilizantes.

Cuando las estructuras de protección contra vuelcos interfieren con el trabajo en las huertas, deben instalarse estructuras plegables o telescópicas. El conductor no debe atarse con cinturón al asiento cuando maneja la máquina sin estas estructuras desplegadas. Tan pronto como lo permita la ausencia de ramas, estas estructuras deben desplegarse y el conductor abrocharse el cinturón de seguridad.

Para evitar caídas, no debe utilizarse el último peldaño de la escalera. Los peldaños deben estar provistos de superficies antideslizantes, y los trabajadores deben ser instruidos y orientados sobre el uso correcto de una escalera desde el primer momento. Han de utilizarse escaleras fabricadas con un material no conductor o escaleras con partes aislantes para evitar una posible descarga eléctrica si entran en contacto con un tendido eléctrico.

\section{- Cultivo de arboles TROPICALES Y PALMERAS}

Melvin L. Myers*

Aunque los estudios arqueológicos no permiten extraer conclusiones definitivas, parece ser que los árboles de los bosques tropicales trasplantados a los pueblos pudieron haber sido los primeros cultivos agrícolas domesticados. En los trópicos húmedos se han identificado más de 200 especies de árboles frutales. Algunos de esos árboles y palmeras, como el platanero y el cocotero, se cultivan en pequeñas propiedades, cooperativas o plantaciones. Aunque la palmera datilera está totalmente domesticada, otras especies, como la nuez de Brasil, se sigue recogiendo de árboles salvajes. En el mundo existen más de 150 variedades de plátanos y 2.500 especies de palmeras que proporcionan una gran variedad de productos utilizados por el hombre. La madera de la palmera de sagú alimenta a millones de personas en todo el mundo. La palmera cocotera se utiliza de más de 1.000 formas diferentes y la palmera palmira, de más de 800 formas. Unas 400.000 personas dependen del coco para su supervivencia. Algunos árboles, frutas y palmeras de las zonas tropicales y

* Una parte del texto ha sido adaptado de los artículos "Palmeras datileras", de D. Abed; "Rafia" y "Sisal", de E. Arreguin Velez; "Copra", de A.P. Bulengo; "Capok", de U. Egtasaeng; "Cultivo del coco", de L.V.R. Fernando; "Plátanos", de Y. Ko; "Bonote", de P.V.C. Pinnagoda, y "Aceite de palma", de G.O. Sofoluwe, de la $3^{\text {a }}$ edición de esta Enciclopedia.

Tabla 64.9 - Arboles, frutas y palmeras tropicales y subtropicales cultivados con fines comerciales.

\begin{tabular}{ll} 
Categorías & Especies \\
$\begin{array}{l}\text { Frutas tropicales y semitropicales } \\
\text { (salvo cítricos) }\end{array}$ & $\begin{array}{c}\text { Higos, plátano, palmera de jalea, níspero del Japón, papaya, guayaba, mango, kiwis, dátil, chirimoya, sapote blanco, durión, } \\
\text { fruto del pan, cereza de Surinam, lichis, aceituna, carambola, algarroba, chocolate, aguacate, sapotilla, japoticaba, granada, } \\
\text { piña }\end{array}$ \\
$\begin{array}{l}\text { Frutas cítricas semitropicales } \\
\text { Frutos secos tropicales }\end{array}$ & $\begin{array}{l}\text { Nuez de anacardo, nuez de Brasil, almendra, piñones, y nueces macadamia } \\
\text { Aceites }\end{array}$ \\
Alimento para insectos & Aceite de palma, oliva, coco \\
Fibras & Koja de morera (alimento para gusanos de seda), médula de palmera de sagú en descomposición (alimento para larvas) \\
Almidón & Kapok, sisal, cáñamo, coir (cáscara del coco), palmera de rafia, palmera de piasava, palmera de palmira, palmera de cola de pez \\
Granos de vainilla & Palmera de sagú \\
\hline
\end{tabular}

semitropicales del mundo aparecen en la Tabla 64.9. En la Tabla 64.10 se indican algunas palmeras o tipos de palmeras comerciales y sus productos.

\section{Procesos}

El cultivo de árboles y palmeras tropicales abarca los procesos de multiplicación, cultivo, recolección y transformación.

La multiplicación de los árboles y palmas tropicales puede ser sexual o asexual. Las técnicas sexuales son necesarias para producir frutos y la polinización es crítica. Las palmeras datileras son sexuadas. El polen de la palmera macho tiene que dispersarse para llegar a las flores de la palmera hembra. La polinización se realiza manual o mecánicamente. El proceso manual exige a los trabajadores trepar por el árbol agarrándose al tronco o utilizando altas escaleras para polinizar manualmasculinos en el centro de cada racimo femenino. El proceso mecánico utiliza un potente nebulizador para rociar el polen por encima de los racimos femeninos. Además de utilizarse para la producción de frutos, las técnicas sexuales se utilizan para producir semillas, que se planta y cultivan para obtener nuevas plantas. Un ejemplo de técnica asexual consiste en cortar esquejes de plantas maduras para replantarlos.

El cultivo puede ser manual o mecanizado. El cultivo del plátano es típicamente manual, aunque en terrenos llanos puede mecanizarse con grandes tractores. Las palas mecánicas pueden utilizarse para cavar zanjas de drenaje en los campos de plátanos. Todos los meses tienen que aplicarse fertilizantes a los plátanos, así como plaguicidas con pulverizadores para cultivos bajos o desde el aire. Las plantas se apoyan en postes de bambú para evitar daños de tormentas. Un platanero produce fruta al cabo de dos años.

La recolección se realiza fundamental a mano, aunque también se utilizan algunas máquinas. Los cosechadores cortan los racimos de plátanos del árbol con una cuchilla atada a un largo palo. El racimo cae sobre la espalda del trabajador y un segundo trabajador lo ata con una cuerda de nylon y lo cuelga de un cable elevado que transporta los racimos a un tractor con remolque. La sangría de la florescencia de los cocos para obtener jugo suele exigir el salto de árbol a árbol mediante cuerdas trenzadas a una gran altura del suelo. Los trabajadores trepan hasta la cima de los árboles para arrancar los cocos manualmente o cortan los cocos con un cuchillo atado a largas cañas de bambú. En la zona del sudoeste del Pacífico se deja que los cocos caigan espontáneamente y entonces se recogen. Los dátiles maduran en otoño y se recogen dos o tres cosechas, teniendo los recolectores que trepar a las palmeras o utilizar una mente las palmeras hembra colocando pequeños racimos 
Tabla 64.10 Productos de las palmeras.

\begin{tabular}{|c|c|c|}
\hline Grupos & Productos & Usos \\
\hline Coco & $\begin{array}{l}\text { Carne del fruto } \\
\text { Copra (carne deshidratada) } \\
\text { Agua del fruto } \\
\text { Cubiertas del fruto } \\
\text { Coir (cáscara) } \\
\text { Hojas } \\
\text { Madera } \\
\text { Inflorescencia con nectar } \\
\text { de flores }\end{array}$ & $\begin{array}{l}\text { Alimento, copra, pienso } \\
\text { Alimento, aceite, jabón de aceite, velas, aceite culinario, margarina, cosméticos, detergente, pai, } \\
\text { leche de coco, crema, mermelada } \\
\text { Combustible, carbón, cuencos, cucharas, copas } \\
\text { Esteras, cordeles, mezcla de barro para alfarería, cepillos, cuerdas, cordaje } \\
\text { Cubierta de tejados, teiidos } \\
\text { Construcción } \\
\text { Miel de palma } \\
\text { Azúcar de palma, alcohol, arrack (licor de palma) }\end{array}$ \\
\hline Dátil & $\begin{array}{l}\text { Fruta } \\
\text { Savia }\end{array}$ & $\begin{array}{l}\text { Dátiles secos } \\
\text { dulces y de excelente sabor }\end{array}$ \\
\hline Aceite africano & $\begin{array}{l}\text { Fruto (aceite de pulpa de } \\
\text { palma; similar al aceite } \\
\text { de oliva) } \\
\text { Semillas (aceite de pepitas } \\
\text { de palma) }\end{array}$ & $\begin{array}{l}\text { Cosméticos, margarina, aliño, combustible, lubricantes } \\
\text { Jabón, glicerina }\end{array}$ \\
\hline Palmira & $\begin{array}{l}\text { Hojas } \\
\text { Peciolos y vainas de las hojas } \\
\text { Tronco } \\
\text { Frutos y semillas } \\
\text { Savia, raíces }\end{array}$ & $\begin{array}{l}\text { Papel, cobiios, tejidos, ventiladores, cubos, gorras } \\
\text { Alfombras, cuerda, guita, escobas, cepillos } \\
\text { Madera, sagú, col } \\
\text { Alimento, pulpa del fruto, almidón, botones } \\
\text { Azúcar, vino, alcohol, vinagre, sura (bebida de savia no procesada) } \\
\text { Alimento, diurético }\end{array}$ \\
\hline $\begin{array}{l}\text { Sagú (médula de tronco } \\
\text { de distintas especies) }\end{array}$ & $\begin{array}{l}\text { Almidón } \\
\text { Alimento para insectos }\end{array}$ & $\begin{array}{l}\text { Harinas, engrudos, flanes, pan } \\
\text { Alimento (las larvas se alimentan de médula de sagú en descomposición) }\end{array}$ \\
\hline Coles (varias especies) & Yema apical (tronco superior) & Ensaladas, corazones de palma o palmito enlatados \\
\hline Rafia & Hojas & Trenzado, trabajo de cestería, material para atar \\
\hline Azúcar (varias especies) & Savia de palma & Azúcar de palma (gur, jaggery) \\
\hline Cera & Hojas & Velas, barras de labio, abrillantador de zapatos, abrillantador de coches, cera para suelos \\
\hline Junco de Indias & Tallos & Muebles \\
\hline Areca & Fruto (seco) & Estimulante (se masca) \\
\hline
\end{tabular}

escalera para llegar a los racimos de dátiles. El antiguo sistema de recolección con machete de los racimos de frutas ha sido sustituido por el uso de un gancho atado a un poste, si bien machete sigue utilizándose para recolectar muchos cultivos (por ejemplo, hojas de sisal).

Las operaciones posteriores a la recolección varían según se trate de árboles o palmeras y según el producto que se desee obtener. Después de la recolección, los recolectores de plátanos, la mayoría de los cuales son mujeres y jóvenes, lavan los plátanos, los envuelven en polietileno y los introducen en cajas de cartón ondulado para su transporte. Las hojas de sisal se secan, se atan y se transportan a la fábrica. La fruta del kapok se seca en los campos, con lo que se torna quebradiza, pudiendo romperse con un martillo o un tubo. Seguidamente, las fibras de kapok se desmotan en el campo para eliminar las semillas sacudiéndolas o agitándolas, se introducen en sacos de yute, se golpean dentro de los sacos para ablandar las fibras y se empacan. Después de la recolección, los dátiles se hidratan y maduran artificialmente, se exponen a calor seco (entre 100 y $110^{\circ} \mathrm{C}$ ) para abrillantar la piel, se semipasteurizan y se empacan.

El endosperma carnoso seco del coco se vende como copra, y las hojas preparadas del cocotero, una vez preparadas, se venden como coir. Las hojas fibrosas del coco se desprenden golpeándolas y haciendo palanca con unas estacas firmemente clavadas en el suelo. El coco, libre ya de las hojas, se divide por la mitad con un hacha y se seca al sol, en hornos o secadores de aire caliente. Una vez seco, la carne se separa de la cáscara leñosa dura. La copra se utiliza para producir aceite de coco, un residuo de la extracción del aceite llamado pasta de copra o poonac y alimento desecado. El coir se enría (putrefacción parcial) sumergiéndolo en agua durante tres o cuatro semanas. Los trabajadores retiran el coir enríado de hoyos con agua que les llega hasta la cintura y lo envían para su descortezado, blanqueado y transformación.

\section{Riesgos y su prevención}

Los riesgos en la producción de árboles frutales y palmeras son accidentes, exposiciones naturales, exposición a plaguicidas, problemas respiratorios y dermatitis. El cultivo de muchos árboles tropicales y palmeras exige trabajar a altitudes elevadas. El popular plátano de Guinea alcanza $5 \mathrm{~m}$ de altura, el kapok $15 \mathrm{~m}$, los cocoteros entre 20 y $30 \mathrm{~m}$ y la palmera datilera siempre verde $12 \mathrm{~m}$. Las caídas representan uno de los riesgos más graves en el cultivo de árboles tropicales, y lo mismo puede decirse de la caída de objetos. Siempre deben utilizarse arneses de seguridad y protectores para la cabeza y debe enseñarse a los trabajadores a utilizar esos equipos. El uso de variedades enanas de las palmeras puede ayudar a evitar las caídas de los árboles. Las caídas del árbol del kapok por rotura de las ramas y las pequeñas lesiones que se producen en las manos cuando se rompe la cáscara son también otros riesgos. 
Los trabajadores pueden sufrir un accidente durante su transporte en camiones o remolques tirados por tractores. Los trabajadores que trepan a las palmeras sufren cortes y abrasiones en las manos por el contacto con las espinas afiladas de la palmera datilera, el fruto de la palma de aceite o las hojas espinosas del sisal. Las dislocaciones por caídas en zanjas y agujeros constituyen otro problema. Los trabajadores pueden también sufrir graves heridas con los machetes. Los trabajadores, normalmente mujeres, que transportan las cajas de plátanos, tienen que alzar pesadas cargas. Los tractores deben disponer de cabinas de seguridad. A los trabajadores se les debe instruir sobre el manejo seguro de los aperos de labranza, las carcasas protectoras de la maquinaria y el manejo seguro de los tractores. Deben utilizar guantes que les proteja contra los pinchazos y utilizar siempre protectores de los brazos durante la recolección del fruto de la palma de aceite. La mecanización de la escarda y el cultivo reduce las dislocaciones por caídas en zanjas y agujeros. Siempre deben utilizarse unas prácticas de trabajo seguras y adecuadas, como métodos correctos para levantar pesos, solicitar ayuda para transportar cargas de manera que el peso se reparta entre un mayor número de personas y descansar cada cierto tiempo.

Entre los riesgos naturales figuran las serpientes - un problema cuando se despejan los bosques y en plantaciones nuevas-, los insectos y enfermedades como paludismo, anciclostomiasis, anemia e infecciones entéricas. La operación de enríado expone a los trabajadores a parásitos e infecciones cutáneas. El control de los mosquitos, la higiene y el acceso a agua potable son muy importantes.

La intoxicación por plaguicidas es un riesgo en la producción de árboles tropicales, puesto que en las huertas frutales se utilizan plaguicidas en cantidades importantes. Las palmeras tienen pocos problemas de plagas y éstas afectan exclusivamente a algunas partes del ciclo de vida, pudiendo identificarse para un control específico. La gestión integrada de plagas y, en el caso de aplicar plaguicidas, el seguimiento de las instrucciones del fabricante, son importantes medidas protectoras.

Las evaluaciones médicas han identificado casos de asma bronquial entre los trabajadores de los dátiles, probablemente por la exposición al polen. También se han dado en estos trabajadores casos de eczema seco crónico y "enfermedad de las uñas" (oniquia). Durante el proceso de polinización deben utilizar protectores respiratorios y cuando trabajan con árboles y dátiles deben protegerse las manos y lavárselas con frecuencia para evitar problemas dermatológicos.

\section{- Produccion de CORTEZa DE ARBOL Y SAVIA}

Melvin L. Myers*

El término corteza designa a una cubierta exterior protectora de los árboles, arbustos o vides, formada por varias capas. Alguna plantas herbáceas, como el cáñamo, se recolectan también por su corteza. Esta se compone de una capa exterior y una interior. La capa interior está formada por cambio vascular, donde las células se generan para formar el floema o tejido conjuntivo que transporta el azúcar de las hojas a las raíces y a otras partes de la planta y la madera con savia que existe por debajo de la corteza

* Una parte del texto ha sido adaptada de los artículos "Cáñamo", de A. Barbero-Carnicero; "Corcho", de C. de Abeu; "Cultivo del caucho", de The Dunlop Co. Ltd.; "Turpentina", de W. Grimm y H. Gries; "Taninos y acabado del cuero", de V.P. Gupta; "Industria de las especias", de S. Hruby; "Alcanfor", de Y. Ko; "Resinas", de J. Kubota; "Yute", de K.M. Myunt; y "Corteza de árbol", de F.J. Wenzel, de la $3^{\mathrm{a}}$ edición de esta Enciclopedia. para transportar agua (savia) de las raíces a la planta. El principal objetivo de la capa exterior es proteger al árbol contra las lesiones, el calor, el viento y las infecciones. De la corteza y la savia de los árboles se extraen una gran variedad de productos, según se indica en la Tabla 64.11.

Los productos derivados de la corteza y la savia pueden obtenerse de árboles cultivados o que crecen en estado salvaje. Las razones para esta elección son diversas. Los alcornocales ofrecen ventajas frente a los árboles salvajes, ya que estos están contaminados por arena y crecen irregularmente. El control de un hongo que crece en las hojas del árbol del caucho en Brasil es más eficaz en los árboles que crecen espontáneamente, ya que están más separados unos de otros. Sin embargo, en lugares libres de este hongo, como Asia, las plantaciones son muy eficaces para el cultivo de los árboles del caucho.

\section{Procesos}

Para la recolección de corteza y savia se utilizan tres procesos generales: incisión de la corteza en grandes láminas, descortezamiento para obtener corteza en bruto e ingredientes de la misma y extracción de fluidos del árbol practicando cortes o incisiones profundas.

\section{Láminas de corteza}

Arrancar láminas de corteza de los árboles vivos es más fácil cuando la savia está circulando o con la inyección de vapor entre la corteza y la madera. Seguidamente se describen dos técnicas utilizadas para el descortezamiento, una para el alcornoque y otra para el canelo.

El alcornoque se cultiva en la parte occidental de la cuenca mediterránea, siendo Portugal el mayor productor de corcho. El alcornoque, así como otros árboles como el baobab africano, comparten la importante característica de que su corteza exterior vuelve a crecer cuando se arranca. El corcho forma parte de la corteza exterior que crece por debajo de una capa exterior dura llamada ritidoma. El grosor de la capa de corcho aumenta año tras año. Tras el descortezado inicial, los cosechadores cortan el corcho recrecido cada 6 ó 10 años. El descortezado del corcho exige practicar dos incisiones circulares y uno o más cortes verticales sin dañar la corteza interior. Los trabajadores del corcho utilizan un hacha de mano biselada para arrancar las láminas. Seguidamente éstas se hierven, limpian y cortan en tamaños comercializables.

El cultivo del canelo se ha difundido de Sri Lanka a Indonesia, Africa Oriental y las Antillas. Sigue utilizándose una antigua técnica para el cultivo de esta especie (así como del olmo y el cascarillo): se llama plantación en tallar. En la era neolítica, el ser humano descubrió que, cuando un árbol se tala cerca del suelo, crecen una serie de ramas rectas similares a partir de la raíz alrededor del tocón y que esos troncos pueden regenerarse mediante un corte periódico justo por encima del suelo. El canelo puede alcanzar hasta $18 \mathrm{~m}$, pero se mantiene en brotes de 2 metros de altura. El tronco principal se corta cada tres años y los brotes que nacen de la cepa se cortan cada dos o tres años. Después de cortar y formar manojos con estos brotes, los recolectores de canela cortan los lados de la corteza con un cuchillo afilado y curvo. Seguidamente arrancan la corteza y después de uno o dos días separan la capa interior de la exterior. La capa exterior acorchada se arranca con un cuchillo grande y romo y se desecha. La capa interior (floema) se corta en longitudes de $1 \mathrm{~m}$ llamadas esquilas, que son los típicos palos de canela.

\section{Corteza en bruto e ingredientes}

Un segundo proceso consiste en arrancar la corteza de los árboles cortados utilizando grandes recipientes de metal giratorios que se llaman colectores descortezadores. La corteza, un subproducto de 
Tabla 64.11 - Productos y usos de la corteza y la savia de los árboles.

\begin{tabular}{|c|c|c|}
\hline Producto & Materia (árbol) & Uso \\
\hline Resinas (corteza interior) & $\begin{array}{l}\text { Resina de pino, copal, incienso franco, } \\
\text { mirra, resina roja (palmera trepadora) }\end{array}$ & $\begin{array}{l}\text { Barniz, goma, laca } \\
\text { Incienso, perfumes, tintes }\end{array}$ \\
\hline Resinas oleaginosas (albura) & $\begin{array}{l}\text { Trementina } \\
\text { Rosina } \\
\text { Benzoína } \\
\text { Alcanfor } \\
\text { (árbol del laurel del alcanfor) }\end{array}$ & $\begin{array}{l}\text { Disolvente, diluyente, aromatizante, desinfectante, pesticida } \\
\text { Tratamiento de los arcos de los violines, barniz, pintura, cera selladora, adhesivo, } \\
\text { cemento, jabón } \\
\text { Talco de los gimnastas } \\
\text { Perfume, incienso, plásticos y películas para la industria de la alimentación, lacas, explosivos } \\
\text { de pólvora fumífuga, perfumes, desinfectantes, repelentes de insectos }\end{array}$ \\
\hline Látex & $\begin{array}{l}\text { Caucho } \\
\text { Gutapercha }\end{array}$ & $\begin{array}{l}\text { Neumáticos, balones, juntas de culatas, preservativos, guantes } \\
\text { Aislantes, recubrimientos para cables subterráneos y marinos, pelotas de golf, instrumental } \\
\text { quirúrgico, algunos adhesivos, base de los chicles }\end{array}$ \\
\hline $\begin{array}{l}\text { Medicamentos y venenos } \\
\text { (corteza) }\end{array}$ & $\begin{array}{l}\text { Hamamelis } \\
\text { Cascara } \\
\text { Quinina (quino) } \\
\text { Cereza } \\
\text { Tejo del Pacífico } \\
\text { Curarina } \\
\text { Caféna (vid de yoco) } \\
\text { Vid de Lonchocarpus }\end{array}$ & $\begin{array}{l}\text { Lociones } \\
\text { Emetico } \\
\text { Medicamento contra el paludismo } \\
\text { Medicina para la tos } \\
\text { Tratamiento del cáncer de ovarios } \\
\text { Veneno de las flechas } \\
\text { Bebida amazónica sin alcohol } \\
\text { Asfixiante de peces }\end{array}$ \\
\hline Condimentos (corteza) & $\begin{array}{l}\text { Canela (canelo) } \\
\text { Amargos, nuez moscada y mace, clavo, } \\
\text { raíz de sasafrás }\end{array}$ & $\begin{array}{l}\text { Especias, condimentos } \\
\text { Cerveza de raíces (hasta que se asoció a cáncer de hígado) }\end{array}$ \\
\hline Taninos (corteza) & $\begin{array}{l}\text { Cicuta, encina, acacia, arce, } \\
\text { mangle, mimosa, quebracho, } \\
\text { zumaque, abedul }\end{array}$ & $\begin{array}{l}\text { Taninos vegetales para el endurecimiento de cueros, procesamiento de alimentos, maduración } \\
\text { de la fruta, procesamiento de bebidas (té, café, vino), ingrediente coloreado de las tintas, } \\
\text { colorantes con mordiente }\end{array}$ \\
\hline Corcho (corteza exterior) & $\begin{array}{l}\text { Corcho natural (alcornoque), } \\
\text { corcho reconstituido }\end{array}$ & $\begin{array}{l}\text { Boyas, corchos de botella, juntas de culatas, papel de corcho molido, tablero de corcho, } \\
\text { soleras, suela interior de zapato }\end{array}$ \\
\hline Fibra (corteza) & $\begin{array}{l}\text { Corteza (abedul, tapa, higuera, hibisco, } \\
\text { morera) } \\
\text { Corteza (interior) del árbol del baobab } \\
\text { Yute (familia del tilo) } \\
\text { Líber del lino, cáñamo (familia de la } \\
\text { morera), ramio (familia de la ortiga) }\end{array}$ & $\begin{array}{l}\text { Canoas, papel, taparrabos, faldas, telas, colgadores de pared, cuerdas, redes de pescar, } \\
\text { sacos, teiidos ásperos } \\
\text { Sombreros } \\
\text { Tela de yute, tela de saco, arpillera, guita, alfombras, teiidos } \\
\text { Cordaje, hilo }\end{array}$ \\
\hline Azúcar & $\begin{array}{l}\text { Jarabe de arce (albura) } \\
\text { Gur (muchas especies de palmeras) }\end{array}$ & $\begin{array}{l}\text { Jarabe de condimento } \\
\text { Azúcar de palma }\end{array}$ \\
\hline Residuos de corteza & Virutas de corteza, lascas & $\begin{array}{l}\text { Acondicionador del suelo, acolchado (virutas), cobertura de caminos en jardines, cartón de } \\
\text { pasta de madera, cartón de partículas de madera, cartón piedra, cartón gris ordinario, } \\
\text { combustible }\end{array}$ \\
\hline
\end{tabular}

la industria papelera, se utiliza como combustible, fibra, pajote y tanino. El tanino es uno de los principales productos derivados de la corteza y se utiliza para producir cuero con la piel de animales y la industria alimentaria (véase el capítulo Cuero, piel y calzado). Los taninos se obtienen de la corteza de algunos árboles en todo el mundo por difusión abierta o percolación.

Además del tanino, muchas cortezas se arrancan para obtener otros ingredientes, como hamamelis o alcanfor. La hamamelis es una loción que se extrae por destilación con vapor de las ramas del olmo escocés de América del Norte. Procesos similares se utilizan para obtener alcanfor de las ramas del laurel del alcanfor.

\section{Fluidos de los árboles}

El tercer proceso importante consiste en la obtención de resina y látex de la corteza interior y resinas oleaginosas y jarabes de la madera con savia. La resina se encuentra especialmente en el pino. Rezuma de las heridas producidas en la corteza para proteger al árbol contras las infecciones. Para obtener resina con fines comerciales, el trabajador debe herir al árbol pelando una delgada capa de la corteza o perforándola.

La mayoría de las resinas se espesan y endurecen cuando se exponen al aire, pero algunos árboles producen resinas líquidas u oleaginosas, como la trementina de las coníferas. Para obtener trementina se practican grandes heridas en un lado de la madera del árbol. La trementina se desliza por la herida, se recoge y transporta para almacenarla. La trementina se destila para obtener aceite de trementina con una colofonia o residuo de resina.

Cualquier savia lechosa exudada por las plantas se llama látex, que en los árboles del caucho se forma en la capa interior de la corteza. Los recolectores de látex practican en los árboles del caucho unos cortes espirales alrededor del tronco sin dañar la corteza interior y recogen el látex en un cuenco (véase el capítulo Industria del caucho). El endurecimiento del látex se evita mediante coagulación o con hidróxido amónico como fijador. 
En la Amazonia se utiliza humo ácido de madera o ácido fórmico para coagular el caucho en bruto. Este se transporta seguidamente para su transformación.

A principios de primavera, en las regiones frías de Estados Unidos, Canadá y Finlandia, se recoge un jarabe del árbol del azúcar de arce. Cuando la savia empieza a circular, se introducen unos tubos en los orificios practicados en el tronco a través de los cuales corre la savia hasta introducirse en recipientes o cubos de plástico para su transporte a los tanques de almacenaje. La savia se hierve hasta que se reduce a 1/40 de su volumen original para producir jarabe de arce. Para eliminar gran parte del agua antes de su evaporación puede utilizarse un proceso de ósmosis inversa. El jarabe concentrado se enfría y embotella.

\section{Riesgos y su prevención}

Los riesgos asociados a la producción de corteza y savia para su transformación son las exposiciones naturales, los accidentes, la exposición a plaguicidas, las alergias y la dermatitis. Entre los peligros naturales pueden citarse la mordeduras de serpientes, las picaduras de insectos y la posibilidad de contraer una infección en regiones con enfermedades endémicas transmitidas por vectores o por el agua. El control de los mosquitos es importante en las plantaciones y el acceso a agua potable y la higiene son cruciales en cualquier explotación, arboleda o plantación.

Gran parte del trabajo relacionado con el descortezado, el corte y la sangría conlleva el riesgo de sufrir cortes, que deben recibir cuidados inmediatos para prevenir una infección. Existen peligros en la tala manual de árboles, pero los métodos mecanizados para despejar los bosques y plantar han reducido el riesgo de accidentes. El uso del calor para "ahumar" el caucho y evaporar los aceites de la corteza, las resinas y la savia expone a los trabajadores al riesgo de sufrir quemaduras. El jarabe de arce caliente puede escaldar a los trabajadores cuando se hierve, produciéndoles lesiones. Otros riesgos especiales son el trabajo con animales o vehículos de tiro, accidentes relacionados con las herramientas y la elevación de pesadas cargas. Las máquinas descortezadoras exponen a los trabajadores a posibles lesiones graves, así como a un exceso de ruido. Los métodos de prevención de accidentes son siempre necesarios, entre ellos unas prácticas de trabajo seguras, equipos de protección personal y controles técnicos.

La exposición a plaguicidas, especialmente al herbicida arsenito sódico en las plantaciones de caucho, es especialmente peligrosa. Estas exposiciones pueden controlarse siguiendo las recomendaciones del fabricante para su almacenamiento, mezclado y aplicación.

En la savia natural del árbol del caucho se han identificado proteínas alérgicas que se han asociado con la alergia al látex (Makinen-Kiljunen y cols. 1992). Sustancias presentes en la resina y la savia del pino pueden causar reacciones alérgicas a personas sensibles al bálsamo de Perú, colofonia y trementina. Las resinas, los terpenos y los aceites pueden causar dermatitis alérgica por contacto en los trabajadores que manipulan madera no transformada. La exposición de la piel al látex, la savia y la resina debe evitarse mediante la adopción de unas prácticas de trabajo seguras y el uso de prendas protectoras.

La neumonitis por hipersensibilidad se conoce también como "pulmón del recolector de corteza de arce". Está causada por la exposición a esporas de Cryptostroma corticate, un moho negro que crece por debajo de la corteza, cuando se arranca la corteza de troncos de arce almacenados. La neumonitis progresiva se ha asociado también a la madera de secoya y alcornoque. Los controles consisten en eliminar la operación de aserrado, humedecer el material durante el descortezado con un detergente y ventilar la zona de descortezado.

\section{BAMBU Y CAÑA}

Melvin L. Myers y Y.C. Ko*

El bambú, pertenece a una subfamilia de las herbáceas, engloba más de mil especies diferentes, de las que sólo algunas se cultivan en plantaciones comerciales o viveros. Se trata de plantas con aspecto de árbol o arbusto de tallos leñosos. Las especies van desde pequeñas plantas con tallos de varios centímetros de grueso hasta especies subtropicales gigantes que alcanzan una altura de $30 \mathrm{~m}$ y un grosor de unos $30 \mathrm{~cm}$. Algunas especies de bambú crecen a una velocidad prodigiosa, hasta $16 \mathrm{~cm}$ al día. El bambú rara vez florece (y cuando lo hace quizá sea a intervalos de 120 años), pero puede cultivarse plantando sus tallos. La mayoría de las especies proceden de Asia, donde crecen en estado salvaje en áreas tropicales y subtropicales. Algunas se han exportado a climas templados, donde necesitan riego y cuidados especiales durante el invierno.

Varias especies de bambú se utilizan como alimento y pueden conservarse en salmuera. El bambú se ha utilizado como medicamento oral contra las intoxicaciones, puesto que contiene ácido silícico que absorbe el veneno en el estómago. (En la actualidad, el ácido silícico se produce sintéticamente.)

La caña del bambú se utiliza para sustituir a la madera con los más diversos fines. En algunos sitios, se emplea en construcción: las casas están construidas por completo con este material, los pilares con cañas y las paredes y el tejado con tallos en tiras o trenzados. También se pueden construir con bambú barcas, remos y balsas, vallas, muebles, contenedores y obras de artesanía, en especial mangos de paraguas y bastones. Otros usos son: tuberías de agua, ejes de carretillas de ruedas, flautas, cañas de pescar, andamios, persianas enrollables, cuerdas, rastrillos, escobas y armas como arcos y flechas. En algunos sitios se fabrica con la pulpa del bambú un papel de excelente calidad. El bambú se cultiva también en viveros y se planta en jardines con fines ornamentales, para cortar el viento y como seto (Recht y Wetterwald 1992).

A veces se confunde la caña con el bambú, pero botánicamente son diferentes, ya que aquélla proviene de algunas variedades de la palma de roten, que crece en estado salvaje en las regiones tropicales y subtropicales, especialmente en el sudeste de Asia. La caña se utiliza con fines decorativos, especialmente para fabricar sillas, canastas, cajones y otros productos de artesanía. Es muy popular por su vistosidad y por su elasticidad, para trabajarla es necesario hendir los tallos.

\section{Procesos de cultivo}

Los procesos del cultivo de bambú abarcan la multiplicación, plantación, riego y abono, poda y recolección. El bambú se multiplica de dos formas: plantando semillas o secciones del rizoma (el tallo que se encuentra bajo tierra). Algunas plantaciones dependen del resembrado natural. Puesto que hay especies de bambú que florecen con muy poca frecuencia y las semillas son viables sólo durante un par de semanas, la mayor parte de la multiplicación se realiza dividiendo una gran planta en trozos que incluyan rizoma y tallo. Para dividir la planta se utilizan palas, cuchillos, hachas o sierras.

El bambú se cultiva en plantaciones. Su plantación y replantación exigen cavar un agujero, introducir la planta en él y volverlo a cubrirlo de tierra tapando los rizomas y las raíces. Se necesitan unos 10 años para conseguir una buena plantación de bambú. Aunque el riego no es necesario en su hábitat natural, donde llueve con frecuencia, lo es cuando la

* Adaptado del artículo de Y.C. Ko's, "Bambú y caña" de la $3^{\text {a }}$ edición de la Enciclopedia de salud y seguridad en el trabajo. 
planta se cultiva en regiones más secas. Requiere el uso abundante de fertilizantes, particularmente nitrógeno. Se utilizan abonos tanto animales como comerciales. El sílice $\left(\mathrm{SiO}_{2}\right)$ es tan importante como el nitrógeno. Cuando crece en condiciones salvajes, el bambú consigue sílice suficiente reciclándolo naturalmente de las hojas caídas. En los viveros comerciales, las hojas caídas se dejan alrededor y en ocasiones se añaden minerales arcillosos ricos en sílice, como la bentonita. El bambú se poda para eliminar los tallos viejos o muertos y dejar espacio para que crezcan nuevos tallos. En las plantaciones asiáticas, los tallos muertos pueden cortarse en los campos para acelerar su descomposición y contribuir al humus del suelo.

El bambú se recolecta para utilizarse como alimento o por su madera o pulpa. Los tallos sirven como alimento. Se arrancan del suelo y se cortan con un cuchillo o con un hacha. El corte se hace cuando tienen entre 3 y 5 años de edad. La recolección debe realizarse en el momento oportuno, cuando los tallos no están ni demasiado blandos ni demasiado duros. Se cortan con hacha, con un cuchillo bien afilado o con una sierra, y la planta cortada puede calentarse para doblarla o cortarla con un cuchillo o mazo, dependiendo del uso al que se destine.

La recolección de la caña de palma de roten se realiza generalmente de los árboles salvajes que crecen en muchas zonas montañosas sin cultivar. Los tallos de la planta se cortan casi a nivel de la raíz, se limpian de maleza y se secan al sol. Se les quitan las hojas y la corteza, quedando los tallos listos para su transformación.

\section{Riesgos y su prevención}

Las serpientes venenosas constituyen un peligro en los bosques. Existe también el riesgo de caídas causadas por tropiezos con los tocones y cortes que pueden ocasionar tétanos. Los excrementos de aves y gallinas en las plantaciones de bambú pueden estar contaminados por Histoplasma capsulatum (Storch y cols. 1980). Cuando se trabaja con los tallos de bambú pueden producirse cortes con cuchillos, especialmente cuando se parten los tallos por la mitad. Los bordes afilados de la propia planta pueden también causar cortes o pinchazos. En los trabajadores que construyen cajas de bambú se ha observado hiperqueratosis de las palmas y los dedos de la mano. La exposición a plaguicidas es otro peligro más. Las mordeduras de serpiente exigen primeros auxilios y tratamiento médico. Asimismo, conviene utilizar vacunas y vacunas de recuerdo para prevenir el tétanos.

Todos los cuchillos y sierras con filos cortantes deben mantenerse en buen estado y utilizarse con cuidado. Cuando existen excrementos de aves, el trabajo debe realizarse en condiciones de humedad para prevenir la exposición a polvo o utilizar protección respiratoria.

En la recolección de la caña de palma, los trabajadores están expuestos a los peligros de los bosques alejados, entre ellos las serpientes y los insectos venenosos. La corteza del árbol tiene espinas que pueden desgarrar la piel y los trabajadores pueden cortarse con los cuchillos. Siempre que manejen los tallos deben utilizar guantes. Los cortes constituyen también un peligro durante la transformación y los trabajadores pueden desarrollar hiperqueratosis en las palmas y los dedos de la mano, probablemente por fricción con el material.

\section{CULTIVOS ESPECIALES}

\section{- Cultivo De TABACo}

\section{Gerald F. Peedin}

El tabaco (Nicotiana tabacum) es una planta singular que contiene en las hojas su componente comercial característico, la nicotina. Aunque el algodón ocupa una mayor superficie, el tabaco es el producto no alimenticio que más en cultiva en el mundo; se produce en aproximadamente 100 países y en todos los continentes. Se consume en todo el mundo en forma de cigarrillos, cigarros, tabaco de pipa y rapé. Sin embargo, más del $80 \%$ de la producción mundial, estimada actualmente en casi 5,6 billones anuales, se consume en forma de cigarrillos. China, Estados Unidos, Brasil y la India generaron en 1995 más del $60 \%$ de la producción mundial total, estimada en unos 6,8 millones de toneladas.

Los usos específicos del tabaco vienen determinados por las propiedades químicas y físicas de las hojas curadas, que a su vez dependen de interacciones entre factores genéticos, del suelo, climáticos y culturales. Por consiguiente, en el mundo se cultivan muchos tipos diferentes de tabaco, algunos con usos comerciales locales muy específicos. Sólo en Estados Unidos, el tabaco se clasifica en siete grandes clases que contienen un total de 25 tipos de tabaco. Las técnicas utilizadas para producir tabaco varían dentro y entre las distintas clases de tabaco según el país, pero la fertilización con nitrógeno, la densidad, la edad y la altura de las plantas, la recolección y la curación se manipulan para influir favorablemente para poder utilizar las hojas curadas con fines específicos. No obstante, la calidad de las hojas depende mucho de las condiciones climáticas de cada zona.
Los tabacos curados al humo, Burley y Oriental son los principales componentes del cada vez más popular tabaco rubio que actualmente se consume en todo el mundo, representando en 1995 el 57, el 11 y el $12 \%$, respectivamente, de la producción mundial. El comercio internacional de estos tabacos es muy intenso. Estados Unidos y Brasil son los principales exportadores de tabaco curado al humo y Burley, mientras que Turquía y Grecia son los grandes productores mundiales de tabaco Oriental. El mayor productor de tabaco y fabricante de cigarrillos de todo el mundo, China, consume actualmente la mayor parte de su producción internamente. Debido a la demanda cada vez mayor del tabaco rubio "americano", Estados Unidos se convirtió en el principal exportador de cigarrillos a principios del decenio de 1990

El tabaco es un cultivo de trasplante. En la mayoría de los países, los semilleros se inician a partir de diminutas semillas (unas 12.000 por gramo) que se siembran manualmente en lechos debidamente preparados y, cuando las plantas alcanzan una altura de 15 ó $20 \mathrm{~cm}$, se retiran manualmente para trasplantarlas en los campos. En los climas tropicales, los semilleros suelen cubrirse con material vegetal seco para conservar su humedad y reducir los daños que las fuertes lluvias producen en las semillas o semilleros. En climas más frescos los semilleros se protegen contra las heladas cubriéndolos con uno o varios materiales sintéticos o con tela de algodón durante varios días antes del trasplante. Los semilleros suelen tratarse antes del sembrado con metil bromuro o dazomet para eliminar la mayor parte de las malas hierbas, así como las enfermedades e insectos trasmitidos por la tierra. En algunos países se utilizan también herbicidas para ayudar a controlar las malas hierbas, pero en zonas 
donde la mano de obra es abundante y barata, la escarda suele realizarse manualmente. Los insectos y las enfermedades foliares se controlan mediante la aplicación periódica de los plaguicidas adecuados. En Estados Unidos y Canadá, los semilleros se producen principalmente en invernaderos cubiertos con plástico y cristal, respectivamente. Los semilleros suelen crecer en un medio de turba o mantillo, que en Canadá se esteriliza al vapor antes de sembrar las semillas. En Estados Unidos se utilizan principalmente bandejas de poliestireno que contienen el medio y que suelen tratarse con metil bromuro y/o solución de hipoclorito cálcico entre las sucesivas temporadas de producción y trasplante para conferir protección contra enfermedades fúngicas. Sin embargo, sólo unos cuantos plaguicidas está autorizados en Estados Unidos para su uso en los semilleros de tabaco, de manera que los agricultores dependen en gran medida de una ventilación adecuada, las corrientes de aire horizontales y la higiene para controlar la mayor parte de las enfermedades foliares.

Con independencia del método de producción y trasplante que se utilice, los semilleros se cortan o siegan periódicamente por encima de los meristemos apicales varias semanas antes del trasplantando para aumentar la uniformidad y la supervivencia en el campo. El corte se realiza mecánicamente en algunos países desarrollados, pero manualmente allí donde la mano de obra es abundante (véase la Figura 64.28).

Dependiendo de la disponibilidad y el coste de la mano de obra y los equipos, los semilleros se trasplantan mecánicamente a campos debidamente preparados y previamente tratados con uno o más plaguicidas para el control de los organismos patógenos del suelo y/o las hierbas (véase la Figura 64.29). Para proteger a los trabajadores de la exposición a plaguicidas, éstos rara vez se aplican durante la operación del trasplante, aunque con frecuencia se necesita un control adicional de las malas hierbas y las plagas foliares durante el crecimiento posterior y la recolección del tabaco. En muchos países se recurre con frecuencia a distintas variedades y a rotación cada 2-4 años entre el tabaco y otros cultivos (cuando se dispone de tierra suficiente) para reducir la necesidad de plaguicidas. En Zimbabwe, el gobierno exige la destrucción cada cierto tiempo de los lechos de siembra y de los tallos y raíces en los campos recolectados para reducir la incidencia y propagación de virus transmitidos por insectos.

Figura 64.28 - Corte manual de semilleros de tabaco con tijeras de podar en Zimbabwe.

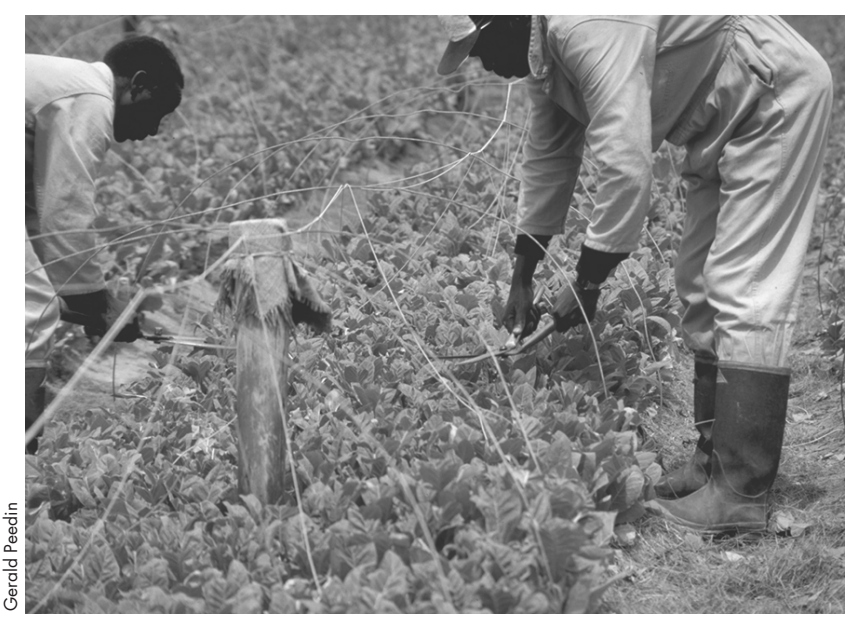

Figura 64.29 - Trasplante mecánico del tabaco curado al humo en Carolina del Norte (Estados Unidos).
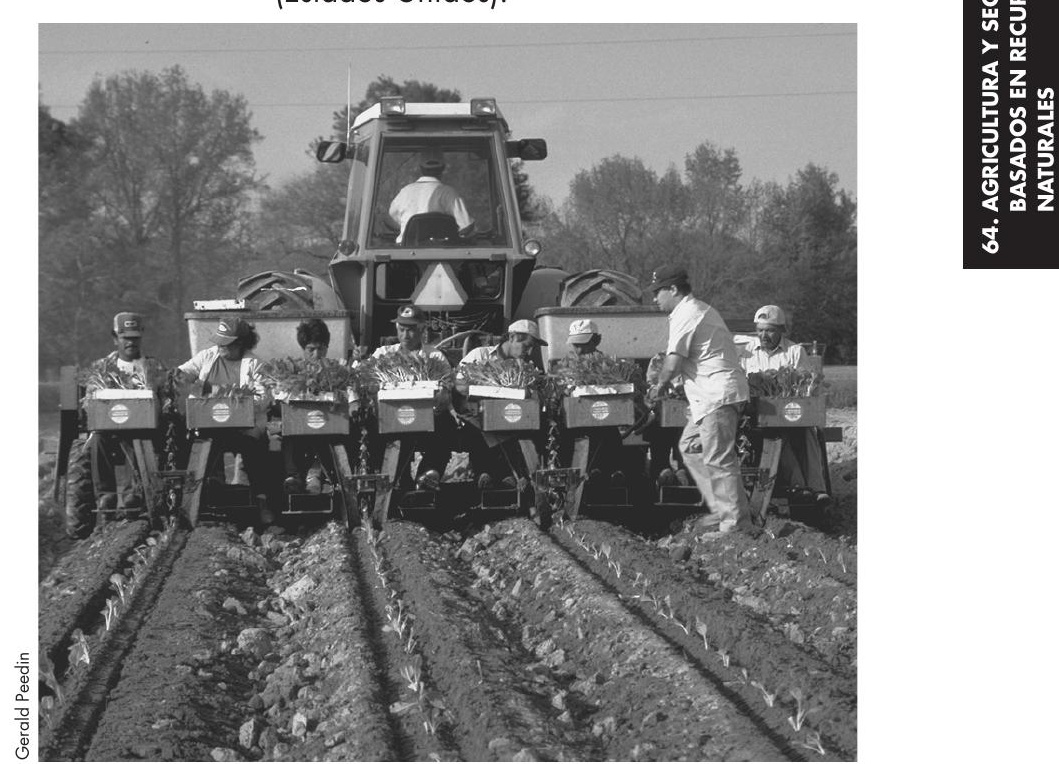

Con diez trabajadores y una trasplantadora de cuatro hileras pueden trasplantarse de 4 a 5 hectáreas diarias. Con una trasplantadora de dos hileras se necesitan seis trabajadores y con una de una hilera, cuatro trabajadores.

Dependiendo del tipo de tabaco, los campos reciben cantidades moderadas o altas de fertilizantes, que suelen aplicarse manualmente en los países en desarrollo. Para una buena maduración y curado del tabaco curado al humo, es necesario que la absorción de nitrógeno se reduzca rápidamente justo después de finalizar el crecimiento vegetativo. Por ello no se utilizan abonos naturales de forma rutinaria con estos cultivos y sólo se aplican entre 35 y $70 \mathrm{~kg}$ por hectárea de nitrógeno inorgánico presente en fertilizantes comerciales, dependiendo de las características del suelo y la pluviometría. El tabaco Burley y la mayor parte de los tabacos para mascar o para cigarro suelen cultivarse en suelos más fértiles que los utilizados para el tabaco curado al humo y reciben entre 3 y 4 veces más de nitrógeno para mejorar ciertas características deseables de estos tabacos.

El tabaco es un planta floreciente con un meristemo central que suprime el crecimiento de las yemas axilares (hijuelas) por acción hormonal hasta que el meristemo empieza a producir flores. En casi todos los tipos de tabaco, la eliminación de las flores (desbotonado) antes de la maduración de la semilla y el control del crecimiento posterior de las hijuelas son prácticas habituales para aumentar la producción desviando una mayor parte de los recursos del crecimiento a la producción de hojas. Las flores se arrancan manual o mecánicamente (principalmente en Estados Unidos) y el crecimiento de las hijuelas se retrasa en la mayoría de los países mediante la aplicación de reguladores del crecimiento por contacto y/o sistémicos. En Estados Unidos se recurre a la aplicación mecánica de sustancias químicas para suprimir las hijuelas del tabaco curado al humo, que tiene la temporada de recolección más larga de todos los tipos de tabaco producidos en ese país. En los países en desarrollo, estas sustancias suelen aplicarse manualmente. Sin embargo, con independencia de las sustancias químicas y los métodos de aplicación utilizados, rara vez se consigue un control completo y casi siempre se necesita una cierta mano de obra para eliminar las hijuelas que a pesar de todo han crecido. 
Figura 64.30 • Preparación del tabaco oriental para el curado al aire poco después de su recolección manual.

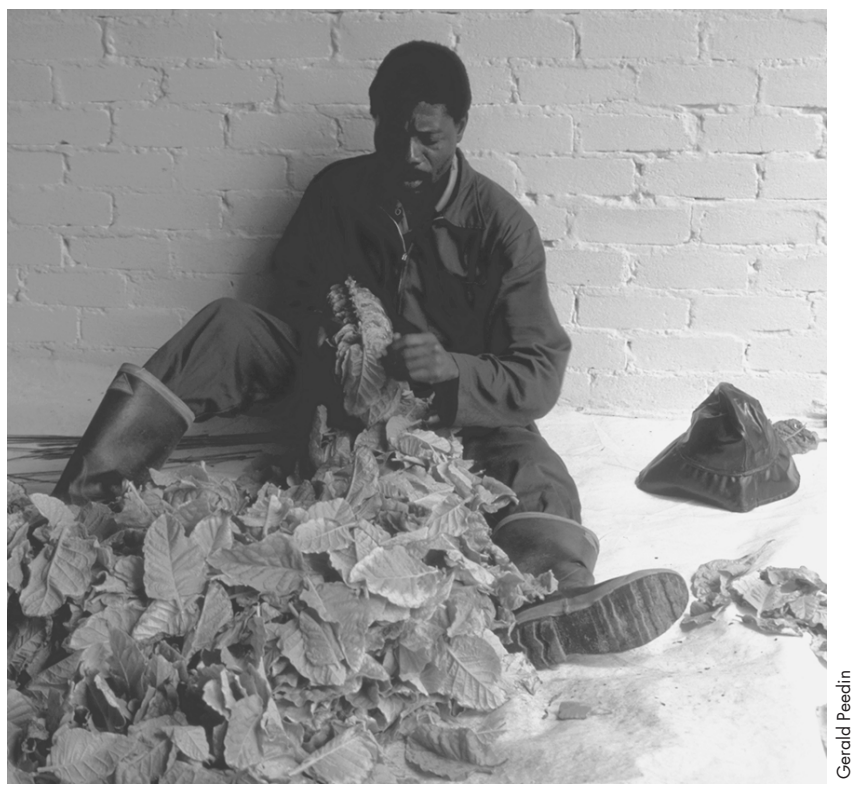

Las hojas pequeñas se insertan en una cuerda introduciendo una aguja a través del nervio central de cada hoja.

Las técnicas de recolección varían considerablemente según el tipo de tabaco. El tabaco curado al humo, el tabaco oriental y el tabaco para envolver cigarros son los únicos tipos cuyas hojas se recolectan siempre en secuencia a medida que maduran (senescencia) desde la parte inferior hasta la superior de la planta. Conforme maduran las hojas, se vuelven quebradizas y amarillentas al degradarse la clorofila. Durante un período que oscila entre 6 y 12 semanas después del desbotonado, se arrancan algunas hojas de cada planta cada vez que se visitan los campos, con una frecuencia que depende de la pluviometría, la temperatura, la fertilidad del suelo y la variedad. Otros tipos de tabaco, como el tabaco Burley, el tabaco Maryland, el tabaco para envolver y rellenar cigarros y los tabacos para mascar curados al fuego requieren un "corte del tallo", lo que significa que la planta entera se corta cerca del suelo cuando se considera que la mayoría de las hojas han madurado. Para algunos tipos de tabacos curados al aire, se seleccionan las hojas inferiores y el resto de la planta se corta por el tallo. Con independencia del tipo de tabaco, la recolección y la preparación de las hojas para su curado y comercialización son las tareas que más mano de obra requieren en la producción de tabaco (véase la Figura 64.30). La recolección suele realizarse manualmente, sobre todo cuando se cortan los tallos, una operación que todavía no ha podido mecanizarse del todo (véase la Figura 64.31). La recolección del tabaco curado al humo está ahora altamente mecanizada en la mayoría de los países desarrollados, donde la mano de obra es escasa y cara. En Estados Unidos, aproximadamente la mitad del tabaco curado al humo se recolecta con máquinas, lo que exige un control casi completo de las malas hierbas y las hijuelas para reducir al mínimo el contenido de estos materiales en las hojas curadas.

El curado de la mayoría de los distintos tipos de tabaco exige el control de la temperatura y el contenido de humedad en el interior del secadero para regular la velocidad de deshidratación de las hojas verdes. El curado al humo exige los sistemas más

\section{Figura 64.31 • Recolección manual del tabaco curado al humo por un pequeño agricultor en el sur de Brasil.}

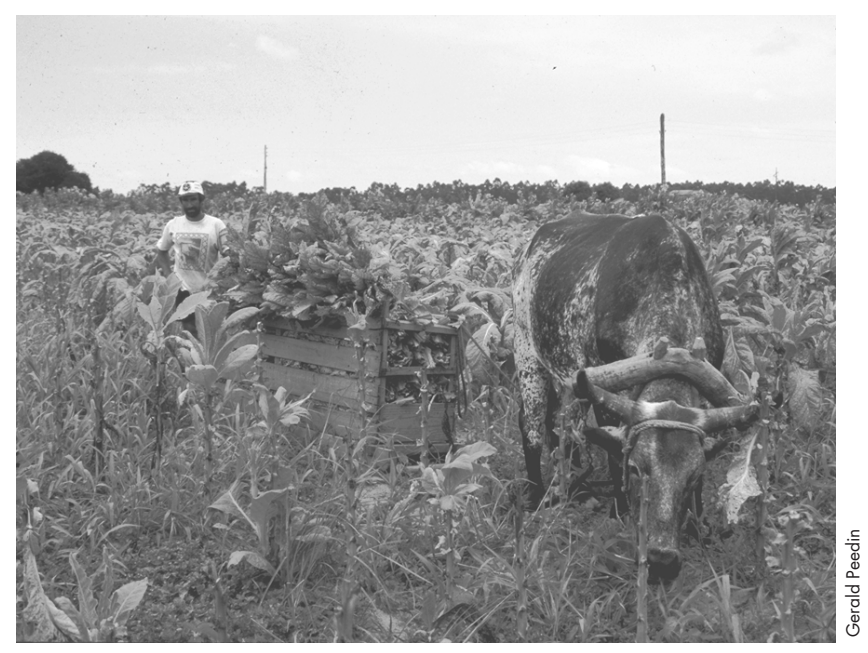

Algunos agricultores utilizan pequeños tractores en lugar de bueyes para tirar de las carretillas 0 remolques. Casi el $90 \%$ de la recolección y otras labores son realizadas por familiares y/o vecinos.

sofisticados, puesto que el control de la temperatura y la humedad siguen unos programas bastante específicos y las temperaturas alcanzan más de $70^{\circ} \mathrm{C}$ en las últimas etapas del proceso, que en total dura sólo de 5 a 8 días. En América del Norte y Europa Occidental, el curado al humo se realiza principalmente en trojes metálicos calentados con gas o petróleo y equipados con dispositivos automáticos o semiautomáticos para controlar la temperatura y la humedad. En la mayoría de los otros países, la atmósfera del troje se controla manualmente; los trojes se construyen de madera o ladrillo y suelen calentarse manualmente con madera (Brasil) o carbón (Zimbabwe). La etapa inicial y más importante del curado al humo se denomina amarilleado, durante la cual la clorofila se degrada y la mayoría de los hidratos de carbono se convierten en azúcares sencillos, dándoles a las hojas curadas un aroma dulce característico. A continuación, las células de las hojas se destruyen con aire caliente y seco para detener la pérdida respiratoria de

Figura 64.32 - Arranque manual de las hojas de los tallos del tabaco Burley curado.

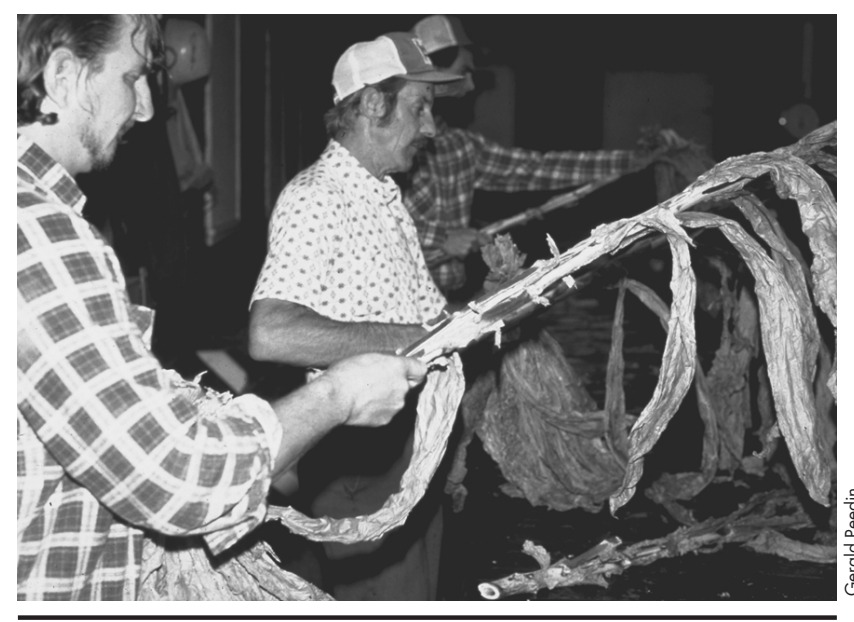


Figura 64.33 - Separación manual del tabaco curado al humo en clases homogéneas en Zimbabwe.

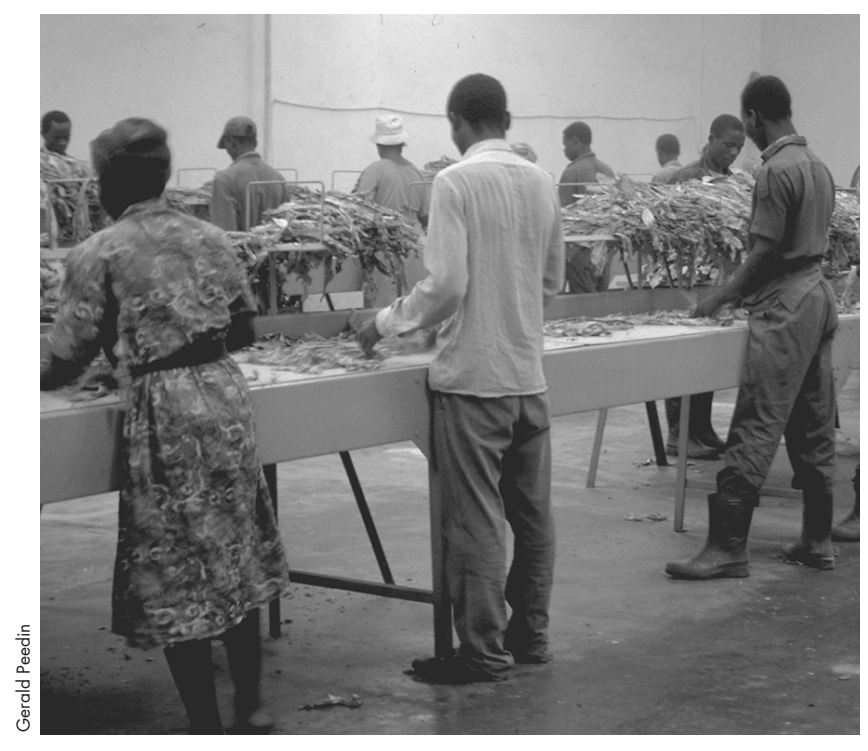

azúcares. Los productos de la combustión no entran en contacto con las hojas. Muchos otros tipos de tabaco se curan al aire en trojes o naves sin calentamiento, aunque normalmente con algún tipo de control manual de la ventilación. El proceso de curado al aire tarda entre 4 y 8 semanas, dependiendo de las condiciones ambientales existentes y la capacidad de controlar la humedad dentro del troje. Con este proceso más largo y gradual de curado se obtienen unas hojas con bajo contenido de azúcar. El tabaco curado al fuego, utilizado principalmente con productos para mascar o inhalar, se cura básicamente al aire, aunque también se utilizan pequeñas fogatas abiertas con madera de roble o nogal americano para "ahumar" periódicamente las hojas, dándoles un característico olor a madera y mejorando sus propiedades de conservación.

El color de las hojas curadas y su uniformidad dentro de un mismo lote son características importantes utilizadas por los compradores para seleccionar las hojas de tabaco con fines específicos. Por ello los cultivadores de tabaco suelen separar manualmente las hojas con colores no deseados (especialmente verde, negro y marrón) antes de poner el tabaco a la venta (véase la Figura 64.32). En la mayoría de los países, los tabacos curados se clasifican en lotes homogéneos en cuanto a color, tamaño, textura y otras características visuales de las hojas (véase la Figura 64.33). En algunos países del sur de Africa, donde la mano de obra es abundante y barata y la mayoría de la producción se exporta, una cosecha puede dividirse en 60 o más lotes (es decir, grupos) antes de venderse (Figura 64.33). La mayoría de los tipos de tabaco se empaquetan en balas que pesan entre 50 y $60 \mathrm{~kg}$ (100 kg en Zimbabwe) y se entregan al comprador ya curados (véase la Figura 64.34). En Estados Unidos, el tabaco curado al humo se vende en hojas de arpillera que pesan unos $100 \mathrm{Kg}$, aunque en la actualidad se está evaluando el uso de balas con un peso superior a $200 \mathrm{~kg}$. En la mayoría de los países, el tabaco se produce y vende de acuerdo con el contrato celebrado entre el productor y el comprador, con unos precios predeterminados para las distintas categorías. En algunos países que son grandes productores de tabaco, la producción anual está controlada por el gobierno o está sujeta a negociación entre el productor y el comprador, y el tabaco se vende mediante un sistema de subasta con (Estados Unidos y Canadá) o sin (Zimbabwe) precios mínimos establecidos para las distintas categorías. En Estados Unidos, el tabaco curado al humo o Burley que no consigue venderse es adquirido por cooperativas de los cultivadores para evitar que los precios se derrumben y vendido después a compradores nacionales o extranjeros. Aunque algunos sistemas de comercialización han sido mecanizados en su mayor parte, como en Zimbabwe (según se indica en la Figura 64.35), sigue necesitándose una cantidad considerable de mano de obra manual para descargar y presentar el tabaco en el punto de venta, retirarlo de allí y cargarlo y transportarlo hasta la planta de transformación del comprador.

\section{Riesgos y su prevención}

El trabajo manual necesario para producir y comercializar el tabaco varía mucho en todo el mundo, dependiendo principalmente del nivel de mecanización utilizado para el trasplante, la recolección y la preparación del producto para su venta. El trabajo manual entraña riesgos de problemas musculosqueléticos por actividades como trasplante de semilleros, aplicación de herbicidas para suprimir las hijuelas, recolección, clasificación del tabaco curado en categorías y carga de las balas de tabaco. Para evitar estos problemas, los trabajadores deben ser instruidos sobre unos métodos correctos de elevación de pesos y disponer de herramientas con diseño ergonómico. Durante las operaciones de cortado pueden producirse heridas de cuchillo, con el consiguiente riesgo de tétanos. La utilización de cuchillos bien afilados y diseñados y la instrucción sobre su uso pueden reducir el número de accidentes.

La mecanización puede reducir estos riesgos, pero conlleva a su vez riesgos de accidentes causados por la maquinaria, entre ellos accidentes durante el transporte. Los tractores correctamente diseñados con cabinas de seguridad, las carcasas protectoras en la maquinaria y una formación adecuada de los trabajadores pueden reducir el número de accidentes.

Figura 64.34 - Carga de balas de tabaco para su transporte a un centro comercial en el sur de Brasil.

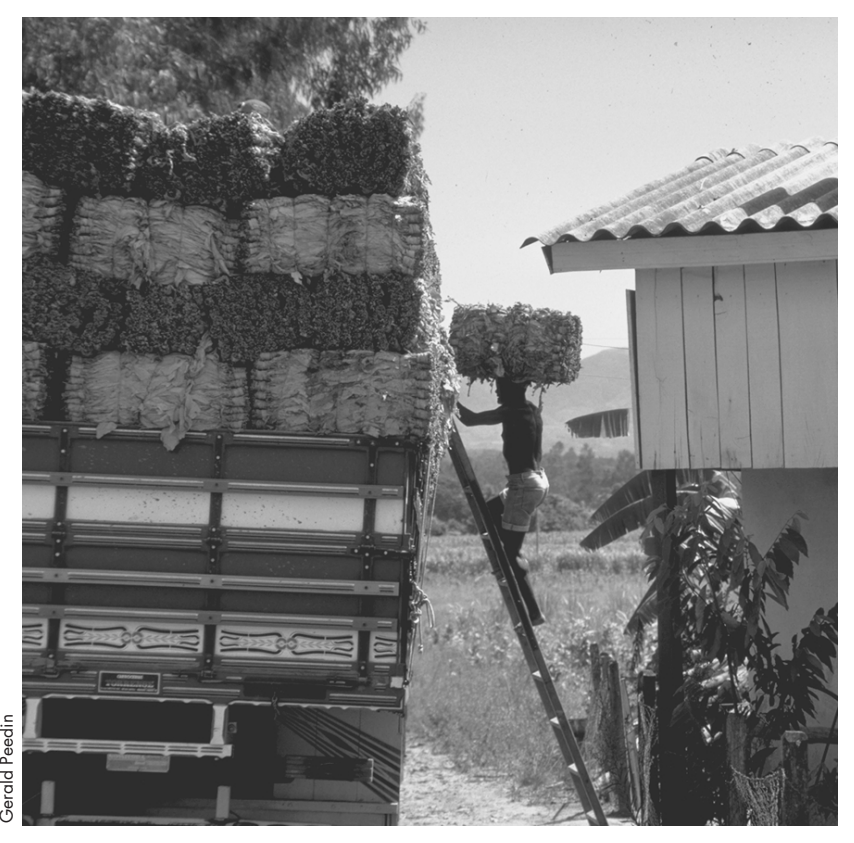


Figura 64.35 - Descarga de las balas de tabaco de un agricultor en el centro de subastas de Zimbabwe, que cuenta con el sistema de comercialización de tabaco curado al humo más mecanizado y eficiente del mundo.

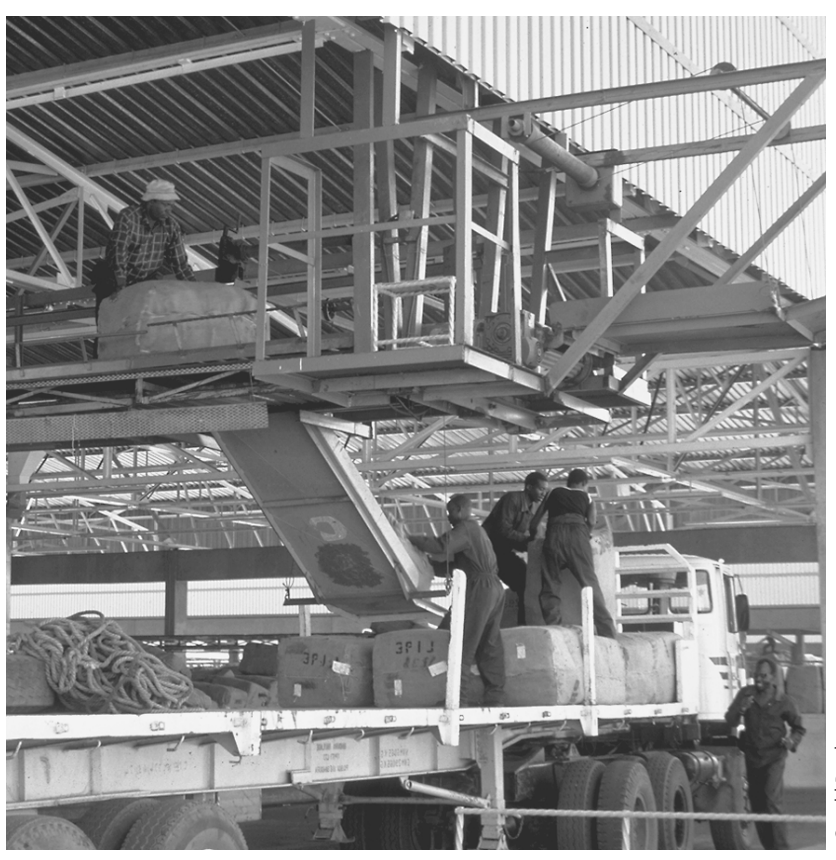

La aplicación de plaguicidas y fungicidas conlleva el riesgo de exposición a sustancias químicas. En Estados Unidos, la normativa sobre protección de los trabajadores de la Environmental Protection Administration (EPA) exige a los propietarios de las explotaciones agrícolas que protejan a los trabajadores contra enfermedades o lesiones causadas por plaguicidas mediante (1) su formación sobre el uso seguro de plaguicidas, específicamente de los plaguicidas utilizados en esa explotación; (2) la disponibilidad de equipos de protección personal y prendas protectoras, asumiendo la responsabilidad de un uso y limpieza correctos, además de asegurar que los trabajadores no entren en los campos fumigados durante un cierto período de tiempo después de la aplicación de los plaguicidas; y (3) la existencia de lugares de descontaminación y asistencia urgente en caso de exposición. En la medida de lo posible deben sustituirse los plaguicidas utilizados por otros menos peligrosos.

Algunos trabajadores de los campos, normalmente aquellos que no están acostumbrados a trabajar en tabacales, pueden sufrir náuseas o mareos poco después de tener contacto directo con las hojas verdes de tabaco durante la recolección, probablemente debido a la absorción a través de la piel de nicotina u otras sustancias. En Estados Unidos, este trastorno se denomina "enfermedad del tabaco verde" y afecta a un pequeño porcentaje de los trabajadores. Los síntomas se manifiestan sobre todo cuando personas sensibles recolectan tabaco húmedo y su ropa y/o piel desnuda están casi todo el tiempo en contacto con las hojas verdes del tabaco. Este trastorno es temporal y nunca grave, pero causa ciertas molestias durante las horas siguientes a la exposición. Los trabajadores sensibles deben reducir la exposición durante la época de la recolección y evitar otras tareas que exijan un contacto prolongado con las hojas verdes de tabaco. Deben esperar a que las hojas se hayan secado o utilizar imper- meables ligeros y guantes impermeables cuando las hojas están húmedas; deben utilizar también pantalones largos, camisas de manga larga y posiblemente guantes como precaución cuando trabajan con el tabaco seco; y deben abandonar los campos y lavarse inmediatamente si aparecen síntomas.

Las enfermedades cutáneas pueden afectar a los trabajadores que manipulan las hojas de tabaco en las naves o trojes. Algunos trabajadores que trabajan en estas zonas de almacenaje, sobre todo los nuevos trabajadores, pueden desarrollar conjuntivitis y laringitis.

Otras medidas preventivas consisten en unas buenas instalaciones sanitarias y de lavado, la prestación de primeros auxilios y asistencia médica y una formación adecuada.

\section{GINSENG, MENTA Y OTRAS HIERBAS CULINARIAS Y MEDICINALES}

LarryJ. Chapman

No existe una definición única del término hierba culinaria o hierba medicinal, y su distinción de las especias está poca clara. En este artículo se ofrece un resumen de los aspectos generales de algunas de estas plantas. Existen más de 200 hierbas culinarias y medicinales, que aquí se definen como aquellas plantas que se cultivan principalmente en climas templados y mediterráneos por las cualidades de sus hojas, tallos o flores. Su principal uso es como condimentos. Destacan la albahaca, el laurel, la semilla de apio, el perifollo, el eneldo, la mejorana, la menta, el orégano, el perejil, el romero, la salvia, la ajedrea, el estragón y el tomillo. La principal demanda de hierbas culinarias procede del sector minorista, seguido por los sectores de la transformación de alimentos y la hostelería. Estados Unidos es con diferencia el principal consumidor de hierbas culinarias, seguido por Reino Unido, Italia, Canadá, Francia y Japón. Las hierbas son también utilizadas con fines medicinales por la industria farmacéutica y en la práctica de la medicina natural.

\section{Ginseng}

Las raíces de ginseng se utilizan en medicina natural. China, la República de Corea y Estados Unidos son los principales productores. En China, la mayoría de las plantaciones han sido tradicionalmente gestionadas por el gobierno o son propiedad suya. En la República de Corea, el sector está formado por más de 20.000 explotaciones familiares, la mayoría de ellas de pequeño tamaño. En Estados Unidos, la mayoría de los productores trabajan en pequeñas explotaciones de menos de 1 ha. Sin embargo, la mayor proporción de la cosecha obtenida en Estados Unidos es producida por una minoría de cultivadores que contratan mano de obra y la mecanización les permite plantar hasta 25 ha al año. El ginseng suele cultivarse en terrenos abiertos cubiertos por estructuras que les dan sombra artificial y que simula el efecto de la cubierta vegetal de los bosques.

El ginseng se obtiene también con el cultivo intenso de terrenos forestales. Un cierto porcentaje de la producción mundial (y la mayor parte del ginseng orgánico) se recoge en zonas donde crece espontáneamente. Las raíces tardan entre 5 y 9 años en alcanzar un tamaño comercializable. En Estados Unidos, la preparación del lecho, tanto para los métodos de cultivo forestal como a campo abierto, suele realizarse con un arado tirado por un tractor. En algunos casos se necesita cierta mano de obra para limpiar las zanjas y dar a los lechos su forma final. Las plantadoras automáticas remolcadas por un tractor suelen utilizarse para la siembra, aunque en la República de Corea y China el trasplante de los semilleros a los lechos suele 
realizarse manualmente. La construcción de una estructura con postes de 2-2,5 metros de altura y una cubierta de madera o tela para dar sombra en los campos abiertos es una tarea intensiva en mano de obra que exige levantar pesos y trabajar con los brazos alzados. En Asia, estas estructuras se construyen con maderas, cañas o pajas localmente disponibles. En las operaciones mecanizadas de Estados Unidos, el acolchado se realiza con desmenuzadoras de paja adaptadas de las máquinas utilizadas por la industria de la fresa y remolcadas por un tractor.

Dependiendo de la idoneidad y estado de las defensas de la maquinaria, el contacto con el eje de toma de fuerza del tractor, la entrada de la desmenuzadora de paja y otras partes móviles de la maquinaria, puede existir riesgo de accidente. Todos los años, antes de la recolección se necesitan tres operaciones de escarda manual que obligan a los trabajadores a gatear, encorvarse y agacharse para trabajar a la altura del cultivo y que imponen grandes demandas al sistema musculosquelético. La escarda, especialmente en el caso de las plantas con uno o dos años de edad, es un trabajo intensivo. Un acre de ginseng cultivado en el campo puede necesitar en total más de 3.000 horas de escarda durante los entre 5 y 9 años anteriores a la recolección. Los métodos de control de las malas hierbas, ya sean o no químicos, entre ellos un mejor acolchado del suelo, pueden reducir las demandas sobre el sistema musculosquelético impuestas por la escarda. Las nuevas herramientas y la mecanización prometen también reducir las demandas del trabajo de escarda. En Wisconsin, Estados Unidos, algunos cultivadores de hierbas están probando un ciclopedal adaptado que permite la escarda estando sentado.

La sombra artificial crea una atmósfera húmeda especialmente propensa a la infestación por hongos y mohos. En Estados Unidos se aplican rutinariamente fungicidas al menos una vez al mes, utilizando para ello una máquina acoplada al tractor o fumigadores de jardín colgados a la espalda. Dependiendo de las necesidades, se aplican también insecticidas y raticidas. El uso de productos químicos menos tóxicos, las mejoras en los sistemas de fumigación y los métodos alternativas de gestión de plagas son estrategias para reducir las exposiciones repetidas de los trabajadores a pequeñas dosis de plaguicidas.

Cuando las raíces están ya listas para su recolección, las estructuras que dan sombra se desmontan y guardan. Las operaciones mecanizadas utilizan cavadoras adaptadas de la industria de la patata que se engancha detrás de un tractor. También en este caso unas pantallas protectoras inadecuadas del eje de toma de fuerza del tractor y de las partes móviles de la maquinaria pueden entrañar riesgo de accidente. La recogida, la última etapa en la recolección, tiene que realizarse manualmente y exige a los trabajadores agacharse y encorvarse para recoger las raíces del suelo.

En las pequeñas propiedades de Estados Unidos, China y la República de Corea, la mayoría de estas etapas en el proceso de producción suelen realizarse manualmente.

\section{Menta y otras hierbas culinarias y medicinales}

Existe una diversidad considerable en los métodos de producción de las hierbas culinarias y medicinales, su emplazamiento geográfico, los métodos de trabajo y los riesgos. Estas plantas pueden recogerse en zonas donde crecen espontáneamente o cultivarse. La producción de plantas cultivadas ofrece como ventajas una mayor eficiencia, una calidad y un suministro más constantes y la posibilidad de la mecanización. Gran parte de la producción de menta y otras hierbas en Estados Unidos está altamente mecanizada. La preparación del suelo, la plantación, el cultivo, el control de plagas y la recolección se realizan desde el asiento de un tractor que remolca la maquinaria necesaria en cada caso.
Los riesgos potenciales son similares a los de la producción mecanizada de otros cultivos, como las colisiones entre vehículos motorizados, los accidentes relacionados con tractores y maquinaria y las intoxicaciones y quemaduras producidas por productos fitosanitarios.

Los métodos de cultivo más intensivos en mano de obra son típicos de Asia, Africa del Norte, el Mediterráneo y otras regiones (por ejemplo, la producción de menta en China, India, Filipinas y Egipto). Las parcelas se aran, normalmente con la ayuda de animales de tiro, y seguidamente los lechos se preparan y fertilizan manualmente. Dependiendo del clima, se excava una red de zanjas de riego. Según la especie de que se trate, se plantan semillas, esquejes, plantas de semillero o rizomas. La escarda periódica es especialmente intensiva en mano de obra y las largas jornadas de un trabajo que exige encorvarse, agacharse y tirar imponen grandes demandas al sistema musculosquelético. A pesar del uso intensivo de mano de obra, el control de las malas hierbas es en ocasiones inadecuado. En algunos casos se recurre a la escarda química con herbicidas, seguido de la escarda manual, pero el uso de herbicidas no está generalizado, puesto que las hierbas cultivadas suelen ser también sensibles a los herbicidas. El acolchado puede reducir la necesidad de mano de obra para la escarda, además de contribuir a proteger el suelo y conservar su humedad. Este acolchado suele contribuir también al crecimiento y la productividad de la planta, puesto que añade materia orgánica al suelo cuando se descompone.

Además de la escarda, los métodos de preparación del suelo intensivos en mano de obra, la siembra, la construcción de las estructuras que dan sombra o sirven de apoyo, la recolección y otras operaciones pueden imponer también grandes demandas musculosqueléticas durante períodos prolongados de tiempo. La modificación de los métodos de producción, el uso de técnicas manuales y herramientas especiales y la mecanización son posibles medidas que pueden adoptarse para reducir las demandas musculosqueléticas y laborales.

El riesgo de quemaduras e intoxicaciones por plaguicidas y otros productos fitosanitarios puede ser un problema en las operaciones intensivas en mano de obra, puesto que la aplicación con fumigadores cargados a la espalda y otros métodos no siempre previenen las exposiciones nocivas a través de la piel, las membranas de las mucosas o el aire que se respira. El trabajo en los invernaderos entraña un riesgo especial debido a la atmósfera confinada que se respira. El uso de productos químicos menos tóxicos y estrategias alternativas para el control de las plagas, la mejora de los equipos y prácticas de aplicación y el uso de equipos de protección personal pueden reducir los riesgos.

La extracción de aceites volátiles de los productos cosechados es habitual en el caso de ciertas hierbas (por ejemplo, destilerías de menta). El material cortado y triturado se carga en un vagón cerrado u otro tipo de estructura. Existen unas calderas que producen vapor vivo, el cual se introduce en la estructura sellada a través de una tubería a baja presión. El aceite pasa al vapor y se extrae.

Los posibles riesgos asociados al proceso son quemaduras producidas por el vapor y, con menos frecuencia, explosiones de las calderas. Las medidas preventivas consisten en realizar inspecciones periódicas de las calderas y las tuberías de vapor para garantizar su integridad estructural.

La producción de hierbas con bajos niveles de mecanización puede exigir un contacto prolongado con la superficie de las plantas, los aceites y, con menos frecuencia, los polvos asociados. En la literatura médica se han publicado algunos casos de reacciones de sensibilización, dermatitis profesional, asma profesional y otros problemas respiratorios e inmunológicos asociados 
a una serie de hierbas y especias. No obstante, la literatura publicada es escasa y puede reflejar una notificación insuficiente, más que una menor probabilidad de problemas de salud.

La dermatitis profesional se ha asociado a hierbas como la menta, laurel, perejil, romero y tomillo, así como a la canela, achicoria, clavo, ajo, nuez moscada y vainilla. El asma profesional o los síntomas respiratorios se han asociado al polvo del ginseng brasileño y perejil, así como a la pimienta negra, canela, clavo, cilantro, ajo, jengibre, paprika y chile rojo (capsaicina), además de bacterias y endotoxinas presentes en los granos y las hierbas. Sin embargo, la mayoría de los casos se han producido en la industria de transformación, y sólo en algunos informes se alude a problemas derivados de exposiciones durante el cultivo de hierbas (por ejemplo, dermatitis después de la recogida de perejil, asma después de tocar las raíces de achicoria, reactividad inmunológica después del trabajo en invernaderos con plantas de la paprika). En la mayoría de los informes publicados, una parte de los trabajadores desarrollan problemas, mientras que otros se ven menos afectados o son asintomáticos.

\section{Transformación}

La transformación de las hierbas y especias conllevan la exposición a mayores riesgos que su cultivo. Por ejemplo, el molido, la trituración y el mezclado de hojas, semillas y otros materiales de las plantas pueden exponer a los trabajadores a ambientes ruidosos y extremadamente polvorientos. Los riesgos en las operaciones de transformación son pérdida auditiva, lesiones traumáticas por un apantallamiento inadecuado de las partes móviles de la maquinaria, exposición a polvo en el aire que se respira y explosiones de polvo. Los sistemas cerrados de transformación o las salas de máquinas cerradas pueden reducir el ruido. Las tolvas de entrada de las máquinas trituradoras no deben permitir la entrada de manos y dedos.

Los problemas de salud, como las enfermedades dermatológicas, la irritación de ojos, boca y tracto gastrointestinal, y los trastornos respiratorios e inmunológicos se han relacionado con polvo, hongos y otros contaminantes presentes en la atmósfera. Normalmente, durante las dos primeras semanas de trabajo se realiza una autoselección de los trabajadores que trituran estas especias, basada en la capacidad para tolerar sus efectos en la salud. La segregación del proceso, una ventilación aspirante local eficaz, una mejor recogida del polvo, la limpieza por aspiración de las zonas de trabajo cada cierto tiempo y el uso de equipos de protección personal pueden ayudar a reducir los riesgos de explosiones de polvo y contaminantes en el aire inhalado.

\section{SETAS}

\section{L.J.L.D. Van Griensven}

Los hongos comestibles más frecuentemente cultivados son: el champiñón, Agaricus bisporus, con una producción anual en 1991 de casi 1,6 millones de toneladas; la seta de cardo, especies Pleurotus (casi un millón de toneladas); y el shiitake, Lentinus edodes (unos 0,6 millones de toneladas) (Chang 1993). Agaricus se cultiva principalmente en el hemisferio occidental, mientras que la seta de cardo, el shiitake y algunos otros hongos de menor producción se producen principalmente en el este de Asia.

La producción de Agaricus y la preparación de su sustrato, el compost, están en gran parte mecanizadas. Este no suele ser el caso de otros hongos comestibles, con algunas excepciones.

\section{El champiñón}

El champiñón, Agaricus bisporus, se cultiva sobre compost formado por una mezcla fermentada de estiércol de caballo, paja de trigo, estiércol de ave y yeso. Estos materiales se humedecen, mezclan y colocan en grandes montones que se fermentan al aire libre, o se introducen en naves especiales de fermentación, llamadas túneles. El compost suele prepararse en cantidades de hasta varios cientos de toneladas por lote, y se utiliza equipos grandes y pesados para mezclar los montones y llenar y vaciar los túneles. La preparación del compost es un proceso biológico que depende del régimen de temperaturas y que exige una mezcla a fondo de los ingredientes. Antes de ser utilizado como substrato para el crecimiento, el compost debe pasteurizarse mediante tratamiento térmico y acondicionarse para eliminar el amoniaco. En este proceso se evapora una cantidad considerable de compuestos orgánicos volátiles azufrados que pueden causar problemas de mal olor en los alrededores. Cuando se utilizan túneles, el amoniaco liberado a la atmósfera puede eliminarse mediante lavado ácido y el escape de olores puede impedirse mediante oxidación biológica o química del aire (Gerrits y Van Griensven 1990).

Seguidamente, se siembra el abono libre de amoniaco (es decir, se inocula con un cultivo puro de Agaricus que ha crecido en grano esterilizado). El crecimiento de los micelios se produce durante un período de incubación de 2 semanas a $25^{\circ} \mathrm{C}$ en una nave especial o en un túnel, después del cual el compost enriquecido se traslada a naves de crecimiento en bandejas o estanterías (es decir, una estructura con 4 ó 6 lechos o niveles superpuestos a una distancia de entre 25 y $40 \mathrm{~cm}$ ) rellenas de una mezcla de turba y carbonato calcio. Después de otro período de incubación, la producción de champiñones se induce mediante un cambio de temperatura combinado con una intensa ventilación. Los champiñones aparecen en brotes a intervalos de semanas. Se recolectan manual o mecánicamente. Al cabo de 3 ó 6 brotes, la sala de crecimiento se esteriliza (es decir, se pasteuriza con vapor) y se vacía, limpia y desinfecta para poder iniciar el siguiente ciclo de crecimiento.

El éxito del cultivo de champiñones depende en gran medida de la higiene y la prevención de plagas y enfermedades. Aunque la gestión y la higiene son factores clave para la prevención de enfermedades, siguen utilizándose algunos desinfectantes y un número reducido de plaguicidas y fungicidas.

\section{Riesgos para la salud}

\section{Equipos eléctricos y mecánicos}

Uno de los grandes riesgos en la producción de champiñones es la exposición accidental a la electricidad. Con frecuencia se utilizan elevados voltajes y amperajes en ambientes húmedos. Los interruptores de circuitos con pérdida a tierra y otras precauciones eléctricas son siempre necesarios. La legislación laboral de cada país suele establecer normas para la protección de los trabajadores que deben seguirse estrictamente.

Los equipos mecánicos pueden entrañar algunos riesgos relacionados con su peso o su función. Las máquinas utilizadas para preparar el compost, con sus grandes piezas móviles, exigen cuidado y atención para prevenir accidentes. Los equipos utilizados para el cultivo y la recolección suelen estar provistos de partes giratorias utilizadas como palas excavadoras o cuchillas cosechadoras, cuyo uso y transporte exigen un gran cuidado. Lo mismo puede decirse de todas las máquinas que se mueven, ya sea autopropulsadas o remolcadas por encima de los lechos, estanterías o filas de bandejas. Todos estos equipos deben estar provistos de las defensas adecuadas. Todo los trabajadores que realicen tareas como el manejo de equipos eléctricos y mecánicos para el cultivo del champiñón deben ser debidamente instruidos antes de iniciar su trabajo y cumplir siempre las 
normas de seguridad. Las disposiciones relativas al mantenimiento de los equipos y las máquinas deben tomarse con gran seriedad. Un programa adecuado de bloqueo y puesta fuera de servicio es también necesario. Un mantenimiento defectuoso hace que los equipos mecánicos sean extremadamente peligrosos. Por ejemplo, la rotura de unas cadenas de transmisión han causado ya varias muertes entre los cultivadores de champiñón.

\section{Factores físicos}

Factores físicos como el clima, la iluminación, el ruido, el esfuerzo muscular y la postura tienen un gran efecto en la salud de los trabajadores. La diferencia entre la temperatura ambiente exterior y la de las naves de crecimiento puede ser considerable, sobre todo en invierno. Los trabajadores deben dejar siempre que su cuerpo se adapte a la nueva temperatura cuando cambien de lugar; de no hacerlo pueden contraer enfermedades de las vías respiratorias y, con el tiempo, aumentar su vulnerabilidad a infecciones bacterianas y víricas. Además, la exposición a cambios excesivos de temperatura puede hacer que los músculos y las articulaciones se vuelvan más rígidos y se inflamen, causando rigidez de cuello y espalda, un trastorno doloroso que puede incapacitar al trabajador.

Una iluminación insuficiente de las naves donde crecen los champiñones no sólo causa unas condiciones peligrosas de trabajo, sino que disminuye la velocidad de la recolección e impide a los recolectores detectar posibles síntomas de enfermedad en el cultivo. La intensidad de la luz debe ser como mínimo de 500 lux.

Los esfuerzos musculares y la postura determinan en gran medida la carga de trabajo. Las tareas manuales de cultivo y recolección suelen exigir posturas incómodas debido al reducido espacio de muchas naves de crecimiento. Esas posturas pueden dañar la articulaciones y producir sobrecarga muscular estática, causando con el tiempo la pérdida parcial o total de su función. Este riesgo puede prevenirse con descansos periódicos, ejercicios físicos y medidas ergonómicas (adaptación de las actividades a las dimensiones y posibilidades del cuerpo humano).

\section{Factores químicos}

Los factores químicos, como la exposición a sustancias peligrosas, crean posibles riesgos para la salud. La preparación a gran escala de compost consta de una serie de procesos que pueden entrañar riesgos mortales. Las fosas sépticas que recogen el agua recirculada y el drenaje del compost suelen crear atmósferas sin oxígeno y el agua contiene grandes concentraciones de ácidos sulfhídrico y amoniaco. Un cambio en la acidez $(\mathrm{pH})$ del agua puede causar una concentración letal de ácido sulfhídrico en las zonas que rodean la fosa. El amontonamiento de excrementos húmedos de aves o caballo en un recinto cerrado puede crear en él una atmósfera letal por la alta concentración de dióxido de carbono, ácido sulfhídrico y amoniaco que se genera. El ácido sulfhídrico, aunque produce un intenso olor a pequeñas concentraciones, es muy peligroso a elevadas concentraciones, ya que se vuelve inodoro al inactivar los nervios olfativos del ser humano. Los túneles cerrados con compost no tienen oxígeno suficiente para soportar la vida humana. Son espacios confinados y siempre es esencial determinar la concentración de oxígeno y gases tóxicos, utilizar los equipos adecuados de protección personal, disponer de un vigilante en el exterior e instruir debidamente al personal que acceda a su interior.

Los lavadores ácidos utilizados para eliminar el amoniaco del aire de los túneles con compost exigen un cuidado especial por las grandes cantidades de ácido sulfúrico y fosfórico que están presentes. Siempre debe existir un sistema de ventilación aspirante local.
La exposición a desinfectantes, fungicidas y plaguicidas puede tener lugar a través de la piel por contacto, a través de los pulmones por inhalación y a través de la boca por ingestión. Normalmente los fungicidas se aplican a gran escala utilizando camiones cisterna, pistolas pulverizadoras y remojado. Los plaguicidas se aplican con técnicas de bajo volumen como vaporizadores, dinanebulizadores, turbonebulizadores y por fumigación. Las pequeñas partículas que se crean permanecen en el aire durante horas. Es imprescindible utilizar unas prendas protectoras adecuadas y un respirador que haya sido certificado para las sustancias químicas aplicadas. Aunque los efectos de la intoxicación aguda son muy espectaculares, no debe olvidarse que los efectos de la exposición crónica, aunque menos espectaculares a primera vista, exigen también siempre la vigilancia médica en el lugar de trabajo.

\section{Factores biológicos}

Los agentes biológicos pueden causar enfermedades infecciosas, así como reacciones alérgicas severas (Pepys 1967). No se ha declarado ningún caso de enfermedad infecciosa causada por la presencia de patógenos humanos en el compost. Sin embargo, el pulmón del cultivador de champiñones es una enfermedad respiratoria grave que se asocia a la manipulación del compost utilizado para Agaricus (Bringhurst, Byrne y Gershon-Cohen 1959). Esta enfermedad, que pertenece al grupo de las llamadas alveolitis alérgicas extrínsecas (AAE), se produce por la exposición a esporas de los actinomicetos termofilicos Excellospora flexuosa, Thermomonospora alba, T. curvata y T. fusca que crecen durante la fase de acondicionamiento en el compost. Pueden estar presentes en altas concentraciones durante la siembra del compost de la fase 2 (es decir, más de $10^{9}$ unidades formadoras de colonias (UFC) por metro cúbico de aire) (Van den Bogart y cols. 1993); para causar los síntomas de la AAE basta con $10^{8}$ esporas por metro cúbico de aire (Rylander 1986). Los síntomas de la AAE y por tanto del pulmón del cultivador del champiñón son fiebre, dificultad respiratoria, tos, malestar, aumento del recuento leucocitario y cambios restrictivos en la función pulmonar, comenzando ya a las 3 ó 6 horas después de la exposición (Sakula 1967; Stolz, Arger y Benson 1976). Después de un período prolongado de exposición, se producen daños irreparables en el pulmón por inflamación y fibrosis reactiva. En un estudio realizado en los Países Bajos, se identificaron 19 casos de pulmón del cultivador de champiñón en un grupo de 1.122 trabajadores (Van den Bogart 1990). Todos los pacientes mostraron una respuesta positiva a la provocación por inhalación y poseían anticuerpos circulantes contra los antígenos de las esporas de uno o más de los actinomicetos mencionados antes. No se ha observado ninguna reacción alérgica a las esporas de Agaricus (Stewart 1974), lo que podría indicar una baja antigenicidad al propio champiñón o una baja exposición. El pulmón del cultivador de champiñón puede evitarse fácilmente proporcionando a los trabajadores respiradores potentes para purificar el aire inhalado equipados de un filtro para polvo fino como parte de su equipo habitual de trabajo durante la siembra del compost.

Algunos recolectores han sufrido lesiones cutáneas en las yemas de los dedos por contacto con las glucanasas y proteasas exógenas de Agaricus. El uso de guantes durante la recolección evita este problema.

\section{Estrés}

El cultivo de champiñones tiene un ciclo de crecimiento corto y complicado. Por ello, la gestión de un negocio de producción de champiñones plantea problemas y tensiones que pueden repercutir en los trabajadores. El estrés y su control se tratan en otros capítulos de esta Enciclopedia. 


\section{La seta de cardo}

Las setas de cardo, de la especie Pleurotus pueden cultivarse sobre una serie de substratos diferentes que contengan lignocelulosa o incluso celulosa. El substrato se humedece y generalmente se pasteuriza y acondiciona. Después de la siembra, el crecimiento de los micelios tiene lugar en bandejas, estanterías, contenedores especiales o bolsas de plástico. La fructificación se produce cuando la concentración ambiente de dióxido de carbono se reduce por ventilación o abriendo el contenedor o bolsa.

\section{Riesgos para la salud}

Los riesgos asociados al cultivo de setas de cardo son similares a los ya descritos para Agaricus, con una sola excepción. Todas las especies Pleurotus poseen laminillas desnudas (es decir, no cubiertas por un velo), que en seguida liberan un gran número de esporas. Sonnenberg, Van Loon y Van Griensven (1996) han realizado el recuento de la producción de esporas en especies Pleurotus y han observado que se producen miles de millones de esporas por gramos de tejido al día, dependiendo de las especies y la fase de desarrollo. Las variedades llamadas sin esporas de Pleurotus ostreatus producen hasta 100 millones de esporas. Muchos informes han descrito la aparición de síntomas de AAE después de la exposición a esporas de Pleurotus (Hausen, Schulz y Noster 1974; Horner y cols. 1988; Olson 1987). Cox, Folgering y Van Griensven (1988) han demostrado la relación causal entre la exposición a esporas de Pleurotus y la aparición de los síntomas de AAE causados por su inhalación. Debido a la naturaleza grave de la enfermedad y a la elevada sensibilidad del ser humano, todos los trabajadores deben protegerse con respiradores provistos de filtros contra el polvo. Las esporas presentes en las naves de crecimiento deben ser parcialmente eliminadas antes de que los trabajadores accedan a su interior. Esto puede lograrse dirigiendo una corriente de aire a través de un filtro húmedo o haciendo funcionar un ventilador a plena potencia 10 minutos antes de que los trabajadores entren en la nave. El pesado y envasado de los champiñones puede realizarse bajo una campana y durante su almacenamiento las bandejas deben cubrirse con una lámina que evite la liberación de esporas al ambiente de trabajo.

\section{Setas shiitake}

En Asia, esta deliciosa seta, Lentinus edodes, se ha cultivado en troncos de madera al aire libre durante siglos. El desarrollo de una técnica de cultivo de bajo coste sobre un substrato artificial en naves de crecimiento han hecho que este cultivo sea económicamente viable en el mundo occidental. Los substratos artificiales suelen consistir en una mezcla humedecida de serrín de maderas duras, paja de trigo y harina con alta concentración de proteínas, que se pasteuriza y esteriliza antes de la siembra. El crecimiento de los micelios se produce en bolsas, bandejas o estanterías, dependiendo del sistema utilizado. La fructificación suele inducirse por un cambio brusco de la temperatura o por inmersión en agua helada, como se hace para inducir la producción en los troncos de madera. Debido a su gran acidez (bajo $\mathrm{pH}$ ), el substrato es susceptible de infección por mohos verdes como las especies Penicillium y Trichoderma. La prevención del crecimiento de estos grandes esporuladores exige la esterilización del substrato o el uso de fungicidas.

\section{Riesgos para la salud}

Los riesgos para la salud asociados al cultivo de shiitake son similares a los de Agaricus y Pleurotus. Muchas cepas de shiitake esporulan fácilmente, produciendo concentraciones de más de 40 millones de esporas por metro cúbico de aire (Sastre y cols. 1990).

El cultivo de shiitake en interiores ha producido muchos casos de síntomas de AAE en los trabajadores (Cox, Folgering y Van
Griensven 1988, 1989; Nakazawa, Kanatani y Umegae 1981; Sastre y cols. 1990) por la inhalación de las esporas de shiitake (Cox, Folgering y Van Griensven 1989). Van Loon y cols. (1992) estudiaron a 5 pacientes y observaron que todos ellos tenían anticuerpos circulantes de tipo IgG contra antígenos de las esporas de shiitake. Pese al uso de máscaras protectoras, un grupo de 14 trabajadores experimentaron un aumento de los niveles de anticuerpos al aumentar la duración de su empleo, lo que indica la necesidad de una mejor prevención, como el uso de respiradores potentes que purifiquen el aire y controles técnicos adecuados.

Agradecimientos: las opiniones y resultados aquí presentados se han visto muy influidos por Jef Van Haaren, M.D., una excelente persona y un experto en medicina del trabajo, cuyo enfoque humano de los efectos en los trabajadores ha quedado reflejado sobre todo en Van Haaren (1988), el capítulo que escribió en mi libro y en el que me he basado para escribir el presente artículo.

\section{Plantas acuaticas}

Melvin L. Myers y J.W.G. Lund*

La producción mundial de hidrocultivos fue de 19,3 millones de toneladas en 1992, de las cuales 5,4 millones de toneladas fueron de plantas. Además, gran parte de los piensos utilizados en las piscifactorías son plantas acuáticas y algas, contribuyendo a su crecimiento como parte de la hidrocultura.

Las plantas acuáticas que se cultivan con fines comerciales son espinacas de agua, berros, castañas de agua, tallos de loto y diversas algas marinas que se utilizan como alimentos de bajo coste en Asia y Africa. Las plantas acuáticas flotantes que tienen potencial comercial son la lenteja de agua y el jacinto de agua (FAO 1995).

Las algas son un grupo diverso de organismos; si se incluyen las cianobacterias (algas azules-verdosas), su tamaño varía desde bacterias (entre 0,2 y 2 micras) hasta algas marinas gigantes $(40 \mathrm{~m})$. Toda las algas son capaces de realizar la fotosíntesis y liberar oxígeno.

Casi todas ellas son acuáticas, pero también pueden vivir como organismos simbióticos con hongos y líquenes sobre rocas secas o árboles. Las algas se encuentran donde quiera que haya humedad. El plancton vegetal está compuesto casi exclusivamente por algas. Las algas abundan en lagos, ríos y litorales. La viscosidad de algunas piedras y rocas resbaladizas, así como la cenagosidad, turbidez y decoloración del agua suelen obedecer a una acumulación de algas microscópicas. La algas se encuentran en fuentes de aguas termales, en campos nevados y en el hielo antártico. En las montañas forman a veces escurridizas vetas marrones (Tintenstriche) que son peligrosas para los escaladores.

No existe acuerdo unánime sobre la clasificación de las algas, aunque generalmente se dividen en 13 grupos principales, cuyos miembros pueden diferir de forma considerable, entre un grupo y otro, respecto de su color. Las algas azules-verdosas (Cyanophyta) son también consideradas por muchos microbiólogos bacterias (Cyanobacteria), dado que son procariotas, es decir, carecen de membrana nuclear y otros órganos de los organismos eucariotas. Probablemente son descendientes de los primeros organismos fotosintéticos y sus fósiles se han encontrado en rocas que datan de hace 2.000 millones de años. Las algas verdes (Chlorophyta), a cuyo grupo pertenece Chlorella, tienen muchas características de otras plantas verdes. Algunas son algas marinas, como es el caso de la mayoría de las algas

* Adaptado del artículo de J.W.G. Lund, "Algas" de la $3^{\text {a }}$ edición de la Enci clopedia de salud y seguridad en el trabajo. 
rojas (Rhodophyta) y marrones (Phaeophyta). Chrysophyta, generalmente de color amarillo o parduzco, es un grupo formado por las diatomeas, algas con paredes de dióxido de silicio polimerizado. Sus fósiles constituyen depósitos de interés desde el punto de vista industrial (Kielselguhr, diatomita, tierra de diatomeas). Las diatomeas constituyen la principal fuente de vida de los océanos y contribuyen en un 20-25\% a la producción mundial de plantas. Las algas dinoflageladas (Dinophyta) nadan libremente en los mares y son especialmente comunes. Algunas de ellas son tóxicas.

\section{Usos}

La hidrocultura puede variar considerablemente entre un ciclo de crecimiento de 2 meses hasta un año, que consta de distintas etapas: plantación, fertilizado, cuidado de las plantas, recolección, transformación, almacenamiento y venta. En algunas ocasiones el ciclo se comprime en un sólo día, como ocurre con el cultivo de lentejas de agua. La lenteja de agua es la planta con flor más pequeña que existe.

Algunas algas marinas son comercialmente valiosas como fuentes de alginatos, carragenina y agar. Estas sustancias se utilizan en la industria y en la medicina (fabricación textil, aditivos alimentarios, cosméticos, productos farmacéuticos, emulsionantes, etc.). El agar es el medio normal para el cultivo de bacterias y otros microorganismos. En el Extremo Oriente, especialmente en Japón, diversas algas marinas se utilizan como alimento humano. Las algas marinas son buenos fertilizantes, pero su uso se está reduciendo debido a los altos costes de preparación y la disponibilidad otros fertilizantes comerciales relativamente baratos. Las algas juegan un papel importante en las explotaciones tropicales pesqueras y en los campos de arroz. Estos últimos suelen ser ricos en cianofitas, algunas de cuyas especies utilizan gas nitrógeno como única fuente de alimento nitrogenado. Constituyendo el arroz la dieta principal de la mayoría de la raza humana, el cultivo de algas en los campos de arroz está siendo objeto de intenso estudio en países como la India y Japón. Ciertas algas han sido empleadas como fuentes de yodo y bromo.

En repetidas ocasiones se ha propuesto el cultivo industrial de algas microscópicas para alimento humano, ya que es teóricamente posible con elevadas producciones por área. Sin embargo, el coste de su deshidratación ha sido una barrera.

Si el clima es lo suficientemente bueno y la tierra es mala, las algas pueden utilizarse como parte del proceso de purificación de las aguas residuales y para alimentación animal. Si bien forman una parte útil de las reservas del mundo viviente, sin embargo, cuando existen en demasía, pueden dificultar seriamente o encarecer los suministros de agua. En las piscinas, el control del crecimiento de las algas puede efectuarse merced a los productos para luchar contra éstas (algicidas) pero, aparte del cobre en bajas concentraciones, estas sustancias no pueden añadirse a las aguas para uso doméstico. El enriquecimiento excesivo del agua con nutrientes, especialmente fósforo, con el consiguiente crecimiento de algas, constituye en algunas regiones un problema importante que ha llevado a la prohibición del uso de detergentes ricos en fósforo, aunque la mejor solución es eliminar el exceso de fósforo por procedimientos químicos en las plantas depuradoras.

Las lentejas de agua y los jacintos de agua pueden utilizarse como pienso animal, abono o combustible. Las plantas acuáticas se utilizan también como pienso para peces no carnívoros. Las piscifactorías producen tres productos principales: peces, gambas y moluscos. El $85 \%$ de los peces está constituido por especies no carnívoras, principalmente la carpa. Tanto las gambas como los moluscos dependen de las algas para su alimentación (FAO 1995).

\section{Riesgos}

El abundante crecimiento de algas en los cursos de agua dulce contienen con mucha frecuencia algas azules-verdosas potencialmente tóxicas. Tales "florecimientos acuáticos" difícilmente serán nocivos para el hombre, puesto que se trata de aguas muy desagradables de beber, por lo que la ingestión de una gran cantidad de algas, que sería lo peligroso, es poco menos que imposible. Por otro lado, pueden matar al ganado, especialmente en las zonas cálidas y secas, donde no existan otros manantiales. La intoxicación paralítica con moluscos está causada por algas (dinoflageladas) que sirven de alimento al molusco, concentrando éste en su organismo la poderosa toxina que para él es inocua. El hombre y otros animales marinos pueden enfermar o incluso morir por su causa.

Prymnesium (Chrysophyta) es muy tóxica para los peces y se desarrolla en la aguas ligera o moderadamente salinas. Constituyó una grave amenaza para las piscifactorías de Israel, hasta que la ciencia brindó un método práctico para detectar la presencia de la toxina antes de que llegara a alcanzar proporciones letales. De vez en cuando, un miembro no coloreado de las alga verdes (Prototheca) produce infecciones al hombre y otros mamíferos.

Se han registrado algunos casos de irritaciones cutáneas causadas por algas. Se sabe que la Oscillatoria nigroviridis causa dermatitis. En aguas dulces, Anaebaena, Lyngbya majuscula y Schizothrix pueden causar dermatitis por contacto. Las algas roja causan trastornos respiratorios. Las diatomeas contiene silicio, de manera que en forma de polvo pueden conllevar riesgo de silicosis. El ahogamiento es un peligro cuando se trabaja en aguas profundas para cultivar y recolectar plantas acuáticas y algas. El uso de algicidas entraña también riesgos y siempre deben seguirse las recomendaciones que aparezcan en la etiqueta del producto.

\section{CULTIVO DE PLANTAS PARA LA PRODUCCION DE BEBIDAS}

\section{- Cultivo de CAFE}

\section{Jorge da Rocha Gomes y Bernardo Bedrikow}

Se cree que la palabra café se deriva de Kaffa, un pueblo de Etiopía de donde parece que es originaria esta planta, si bien algunos piensan que se deriva de qahwa, que significa vino en árabe. El café se cultiva en todo el mundo, empezando por
Arabia (una especie se llama Coffea arabica, y una variedad es la Moka, que debe su nombre a un pueblo árabe) y pasando por muchos otros países, como Ceilán, Java, India, Filipinas, Hawaii y Viet Nam entre otros, algunos de los cuales son importantes productores en la actualidad. En América, el café se introdujo a partir de plantas previamente adaptadas al clima en Amsterdam y París y plantadas en Martinica, Surinam y la Guayana Francesa, desde donde se llevó a Brasil, el mayor productor mundial actual. 
La producción mundial puede estimarse a partir de la Figura 64.37. El valor de la cosecha de 1995-96 fue de 27 millones de dólares, lo que indica la importancia económica de este producto a escala mundial.

La tendencia a una economía mundial, la creciente competencia y la búsqueda de tecnologías de alta productividad han afectado también al cultivo de café. La mecanización está propagándose y modernizándose. Además, se están introduciendo nuevos métodos de cultivo, entre ellos el cultivo de alta densidad en los que la distancia entre las plantas se reduce. Este método moderno aumenta el número de plantas de café de 3.000 - 4.000 a 100.000 plantas por hectárea, con un aumento de la productividad cercano al $50 \%$ comparado con el método tradicional. Este procedimiento es importante para la salud de los trabajadores, puesto que entraña menores riesgos y una menor necesidad de utilizar herbicidas, especialmente a partir del tercer año. Por otra parte, las plantas tienen que podarse con más frecuencia y exigen un control más estricto de las enfermedades fúngicas.

El café es muy sensible a las fluctuaciones en el comercio internacional y muchos países están intentando sustituirlo por otros cultivos cuya rentabilidad pueda predecirse más fácilmente. En Brasil, por ejemplo, el café representó el $68 \%$ del volumen total de exportaciones en 1920, frente a un $4 \%$ en el decenio de 1990. El café está siendo sustituido por la soja, los frutos cítricos, el maíz, el látex y, especialmente, la caña de azúcar.

Es muy difícil realizar una estimación fiable del número total de personas que trabajan en el cultivo de café debido a que el número de trabajadores contratados es muy variable. Durante la recolección, se contrata a un elevado número de trabajadores

Figura 64.36 - Plantas de café mostrando los granos.

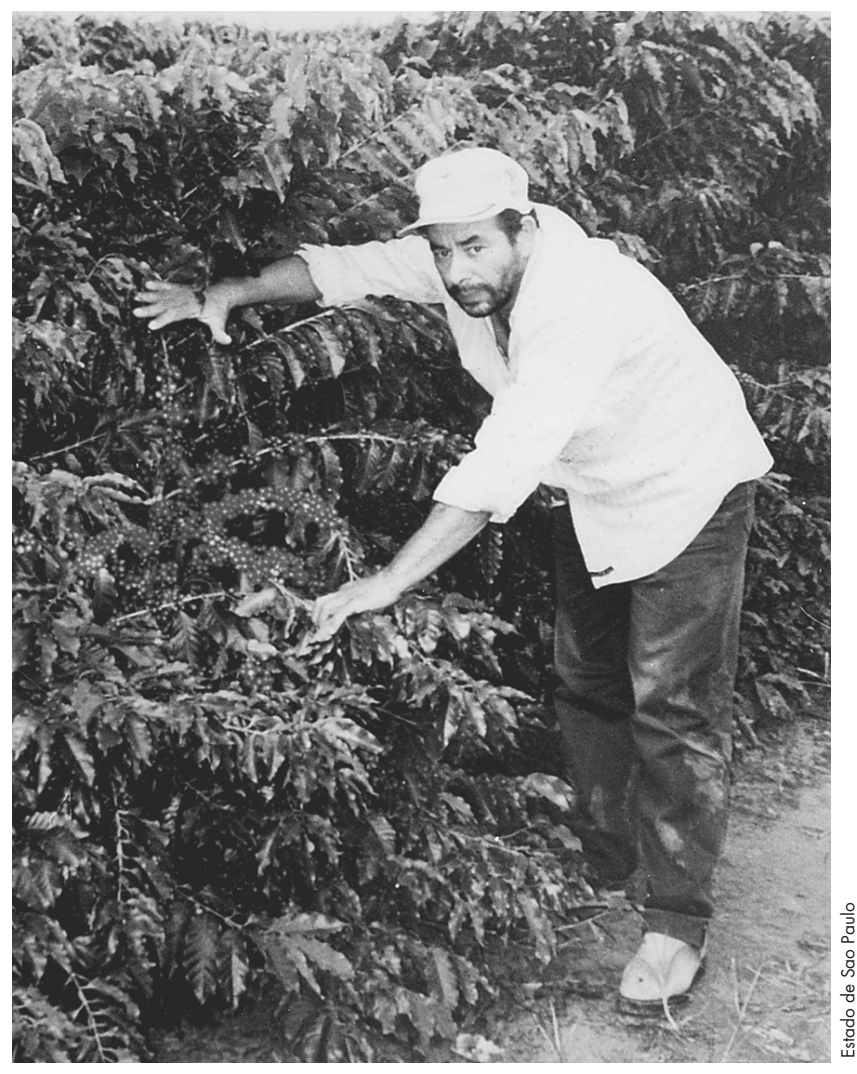

Figura 64.37 - Producción mundial de café en 1995-96.

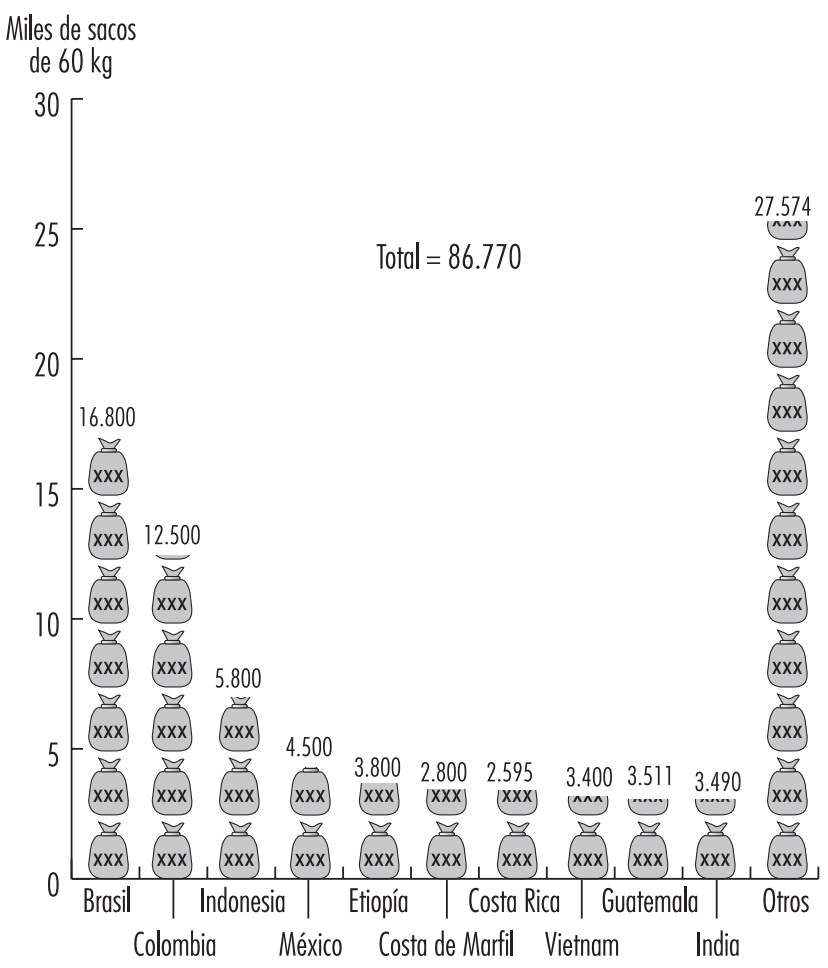

Fuente: USDA 1996

temporeros que se despiden en cuanto se termina aquélla. Además, en las pequeñas explotaciones es muy frecuente que los trabajadores no se registren legalmente, de manera que no aparecen en los informes oficiales. En 1993 se estimó que para una producción de 28,5 millones de sacos de café en Brasil, se necesitaban 1,1 millones de trabajadores en puestos de trabajo directos y entre 4 y 5 millones en puestos indirectos. Si se aplican los mismos parámetros a la producción mundial de ese mismo año, podría estimarse que el número de trabajadores del café en todo el mundo es de aproximadamente 3,6 millones.

Es igualmente difícil conocer el número medio de trabajadores por propiedad rural. En general predominan las propiedades de pequeño o mediano tamaño. La distribución por sexos y edades de la población trabajadora tampoco se conoce, aunque la proporción de mujeres está aumentando y se sabe que las plantaciones de café contratan mano de obra infantil. Las cifras correspondientes a los trabajadores afiliados a sindicatos varían según las políticas de trabajo en cada país, pero se sabe que constituyen una proporción relativamente pequeña.

\section{Operaciones}

El cultivo y el tratamiento de café comprenden los siguientes pasos: tala de los árboles, preparación del terreno; plantación (de plantas jóvenes previamente cultivadas en viveros en las mismas o en otras propiedades); tratamiento (corrección del suelo, fertilización, control de plagas y escarda manual o con herbicidas); recolección del fruto (los granos maduros de café suelen ser rojos y por ello se les llama bayas-véase la Figura 64.36) cribado para eliminar las impurezas; transporte; lavado para retirar la pulpa y las membranas; secado al sol, revolviendo los granos con un rastrillo, o secado mecánico mediante 
un chorro de aire caliente; separación a mano de los granos; almacenaje en silos; y embalaje en sacos.

\section{Posibles riesgos}

Los factores de riesgo que pueden afectar a la salud de los cultivadores de café son los mismos que para los trabajadores agrícolas en general.

Desde la tala de los árboles y la preparación del terreno hasta el almacenamiento final de los sacos de café, todas las etapas pueden entrañar algunos riesgos para la salud y la seguridad de los trabajadores. Los riesgos de accidente están principalmente asociados a procesos mecanizados, tala de árboles, preparación del terreno, recolección mecánica, transporte del café y de los trabajadores, tratamiento de los granos de café (incluido el riesgo de explosión de las calderas) y manejo de herramientas manuales (muchas veces de forma improvisada o sin el mantenimiento adecuado).

Los riesgos potenciales de enfermedades profesionales debido a condiciones físicas están relacionados con la exposición al calor en las operaciones de secado, la radiación solar, el ruido producido por la maquinaria, los problemas ergonómicos asociados a las herramientas manuales, la vibración de la maquinaria y los tractores, y el calor y la humedad de la exposición a la intemperie.

Los principales agentes químicos con riesgos potenciales para la salud de los trabajadores son los plaguicidas y los herbicidas. Los más utilizados son el glifosato como herbicida, las salas de cobre como fungicidas y los compuestos organofosforados para el control de otras plagas que suelen afectar a las plantas del café. El número de aplicaciones de plaguicidas varía según la edad de la planta, la composición del suelo, las especies o la variedad de la vegetación, el sistema de cultivo (por ejemplo, de baja o alta densidad) y otros factores. La fumigación suele realizarse individualmente cargando el equipo a la espalda, o desde tractores. En general se necesitan grandes cantidades y se dice que "sin fumigar no hay cosecha".

Los fertilizantes químicos pueden también suponer un riesgo para la salud. Se utilizan con frecuencia compuestos derivados de boro, zinc, nitrógeno, sodio, potasio, calcio, magnesio y azufre. La liberación de partículas durante la manipulación del fertilizante debe mantenerse bajo control.

Los agentes biológicos pueden representar importantes riesgos para la salud de los trabajadores. Entre ellos, cabe citar las mordeduras o picaduras de serpientes, arañas, abejas, mosquitos y ácaros, algunos de los cuales son importantes vectores de enfermedades. En algunas regiones, las enfermedades endémicas pueden ser graves riesgos para los trabajadores del café.

Seguidamente se describen los factores ergonómicos, psicosociales y organizacionales.

\section{Efectos sobre la salud}

Ejemplos de accidentes relacionados con el trabajo son los cortes producidos por herramientas manuales, las distensiones o fracturas producidas por máquinas y los accidentes con tractores. Los accidentes mortales, aunque poco frecuentes, pueden suceder como consecuencia del vuelco de un tractor o el uso de vehículos inadecuados para el transporte de los trabajadores. Cuando se recurre al secado artificial, las fuentes de calor pueden causar quemaduras y explosiones.

Las enfermedades profesionales pueden ser el resultado de la exposición a la radiación ultravioleta del sol; las enfermedades dermatológicas van desde un simple eritema hasta un cáncer de piel. La pérdida auditiva entre los operarios de las máquinas, las enfermedades pulmonares alérgicas, la intoxicación con herbicidas o plaguicidas, las callosidades, las enfermedades de pulmón, los trastornos óseos y circulatorios debido a posturas poco ergonómicas o la carga de pesos excesivos (un saco de café puede pesar $60 \mathrm{~kg}$ ) son otras de las enfermedades profesionales que pueden sufrir los cultivadores de café. Aunque sea un problema que afecta principalmente a los trabajadores que transforman los granos de café, los que manipulan los granos verdes se quejan también de problemas respiratorios y oculares. El polvo de los granos de café se ha asociado a enfermedades profesionales.

En algunas zonas de cultivo existe una elevada prevalencia de enfermedades tropicales como el paludismo, la fiebre amarilla, la filariasis, la tripanosomiasis, la leishmaniasis y la oncocercosis. El tétanos sigue siendo prevalente en muchas zonas rurales.

Otros problemas de salud más complejos relacionados con factores psicosociales y organizacionales pueden también afectar a los cultivadores de café. Puesto que durante la época de la recolección se precisa una abundante mano de obra y durante el resto del año apenas se necesitan trabajadores, los contratos temporales constituyen una práctica habitual que ocasiona con frecuencia complejos problemas de salud.

En muchos casos, los trabajadores abandonan a sus familias y permanecen durante la temporada de recolección en viviendas precarias con instalaciones sanitarias inadecuadas. Si la plantación está cerca de un pueblo, el dueño de la plantación contratará sólo a los cabezas de familia, si bien para aumentar su retribución, es posible que el propio trabajador lleve consigo a toda la familia para que le ayude, mujeres y niños incluidos. En algunas regiones, el número de niños que trabajan es tan alto que las escuelas cierran durante toda la temporada de recolección.

En este tipo de actividad estacional, los trabajadores pasan de un tipo de cultivo a otro, según cada período de recolección. Puesto que los hombres abandonan a sus familias, a las mujeres se las llama "viudas con maridos vivos". Se dan muchos casos de hombres que forman otra familia lejos de su pueblo.

El estricto cumplimiento de la legislación en materia de trabajo y seguridad social suele restringirse a las grandes plantaciones y las inspecciones del trabajo en las zonas rurales son por lo general poco eficaces. La asistencia sanitaria es muy limitada. Las jornadas de trabajo son prolongadas y rara vez se respetan los fines de semana y las vacaciones normales.

Estos factores psicosociales y organizacionales producen un marcado deterioro de la salud de los trabajadores, que se manifiesta en un envejecimiento prematuro, una menor esperanza de vida, una mayor prevalencia y duración de las enfermedades, malnutrición (la necesidad de comer en el campo alimentos fríos enlatados ha motivado que a los trabajadores se les apode-boias frias en portugués), anemia e hipovitaminosis que reducen la capacidad para el trabajo y producen confusión mental y otras manifestaciones.

\section{Prevención}

Las medidas preventivas con respecto al cultivo del café son las mismas que se aplican al trabajo agrícola en general. La protección colectiva consiste en instalar pantallas protectoras en la maquinaria, adoptar precauciones a la hora de aplicar plaguicidas y herbicidas, mecanizar las operaciones que exigen un excesivo esfuerzo y un elevado consumo energético, y transportar a los trabajadores en un vehículo apropiado. En plantaciones de alta densidad, la tala periódica no permite a los árboles crecer, eliminando así la necesidad de utilizar peligrosos e incómodas escaleras para la recolección manual. Cuando el secado del café exige el uso de calderas, es muy importante que éstas se sometan a un estricto mantenimiento preventivo. El control de plagas biológicas y la correcta selección de especies resistentes a las 
plagas son importantes medidas preventivas con respecto a los plaguicidas para evitar enfermedades a los trabajadores y daños al medio ambiente.

La vigilancia del uso de los equipos de protección personal recomendados plantea dificultades, puesto que dichos equipos no suelen estar adaptados a las condiciones climáticas o al biotipo de los trabajadores. Además, los trabajadores no suelen recibir formación son respecto al uso de estos equipos y la selección de los mismos no siempre es la correcta. Los equipos de uso generalizado se limitan a botas, sombreros y prendas para protegerse del clima, aunque también se requiera protección de las manos, los pulmones, los ojos y los oídos.

La prevención para controlar los factores psicosociales y organizacionales puede plantear también muchas dificultades. La concienciación de los trabajadores debe conseguirse mediante actividades educativas, especialmente a través de los sindicatos y otras organizaciones de los trabajadores, para convencerles de su derecho a unas mejores condiciones de vida y de trabajo; por su parte, los empleadores tienen que aprender a asumir sus responsabilidades sociales con la población trabajadora. El gobierno debe desarrollar una labor eficaz y constante de orientación y vigilancia y emprender las acciones judiciales que considere oportunas. En algunos países se han elaborado normas y reglamentos específicamente relativos al trabajo agrícola. En Brasil, por ejemplo, las Normas Reguladoras del Trabajo Rural establecen directivas generales relativas a la seguridad en las actividades rurales, la organización de los servicios de medicina del trabajo y los comités de seguridad en las plantaciones, el uso de equipos de protección personal y la manipulación de sustancias químicas (plaguicidas, fertilizantes y productos para corregir la composición del suelo).

El control de la salud a través de la medicina del trabajo debe abarcar la evaluación de los efectos en la salud de la exposición a plaguicidas, la radiación ultravioleta, el exceso de ruido y otros peligros. En muchos casos, el control de enfermedades parasitarias, anemia, hipertensión, problemas de conducta, defectos visuales y problemas similares es especialmente necesario por su alta prevalencia en las zonas rurales. Debe insistirse en la importancia de la educación sanitaria, así como de la vacunación contra el tétanos, especialmente de las trabajadoras embarazadas para prevenir el tétanos neonatal. En algunas regiones los trabajadores tienen que vacunarse contra la fiebre amarilla. La quimioprofilaxis está recomendada en zonas donde el paludismo es endémico, además del uso de repelentes e instrucciones para prevenir las picaduras de mosquito, hasta conseguir un nivel de higiene suficiente para controlar o suprimir los vectores del agente etiológico. Siempre debe disponerse de suero contra el veneno de serpientes.

Agradecimientos: Los autores desean agradecer la colaboración prestada por el Profesor Nelson Batista Martin, del Instituto de Economía Rural, Secretaría de Estado de Agricultura, São Paulo; Andre Nasser y Ricardo Luiz Zucas, de la Sociedad Rural Brasileña; y Mónica Levy Costa, del Centro de Salud Escolar de la Escuela de Salud Pública de la Universidad de São Paolo.

\section{Gultivo de TE}

\section{L.V.R. Fernando*}

El té (Camellia sinensis) fue originariamente cultivado en China, y la mayoría del té del mundo todavía procede de Asia, con pequeñas cantidades de Africa y América del Sur. Ceilán y la India son actualmente los mayores productores, pero se producen

* Adaptado de la $3^{a}$ edición de la Enciclopedia de salud y seguridad en el trabajo. también cantidades apreciables en China, Japón, la antigua URSS, Indonesia y Pakistán. La República Islámica de Irán, Turquía, Vietnam y Malasia son cultivadores a pequeña escala. Desde la segunda Guerra Mundial, la zona de cultivo de té en Africa se ha ido extendiendo rápidamente, sobre todo en Kenia, Mozambique, Congo, Malawi, Uganda y la República Unida de Tanzania. Mauritania, Ruanda, Camerún, Zambia y Zimbabwe cultivan también pequeñas cantidades. Los principales productores de América del Sur son Argentina, Brasil y Perú.

\section{Plantaciones}

El té se produce más eficaz y económicamente en grandes plantaciones, aunque también se cultiva en pequeñas propiedades. En el sudeste de Asia, la plantación de té es una unidad autónoma que facilita alojamiento y toda clase de instalaciones para sus trabajadores y familias, formando cada unidad una comunidad virtualmente cerrada. Las mujeres constituyen una gran proporción de los trabajadores en India y Ceilán, pero la situación es algo diferente en Africa, donde principalmente se emplea mano de obra emigrante masculina y temporal, con lo que no hay familias que alojar. Véase también el artículo "Plantaciones" en este mismo capítulo.

\section{Cultivo}

La tierra se desbroza y prepara para el cultivo nuevo, o el té viejo de mala calidad es arrancado, replantándose la zona con esquejes propagados vegetativamente de alta producción. Los campos nuevos necesitan un par de años para rendir plenamente. A lo largo de todo el año se llevan a cabo programas regulares de distribución de abonos, escarda y aplicación de plaguicidas.

La recolección de las hojas de té jóvenes - la famosa "dos hojas y un capullo" - tiene lugar durante todo el año en casi todo el sudeste de Asia, pero es restringida en regiones que tienen una marcada estación fría (véase la Figura 64.38). Después de un ciclo de recolección que dura de tres a cuatro años, las matas son podadas drásticamente y el campo

Figura 64.38 - Recolectores de hojas de té trabajando en una plantación de Uganda.

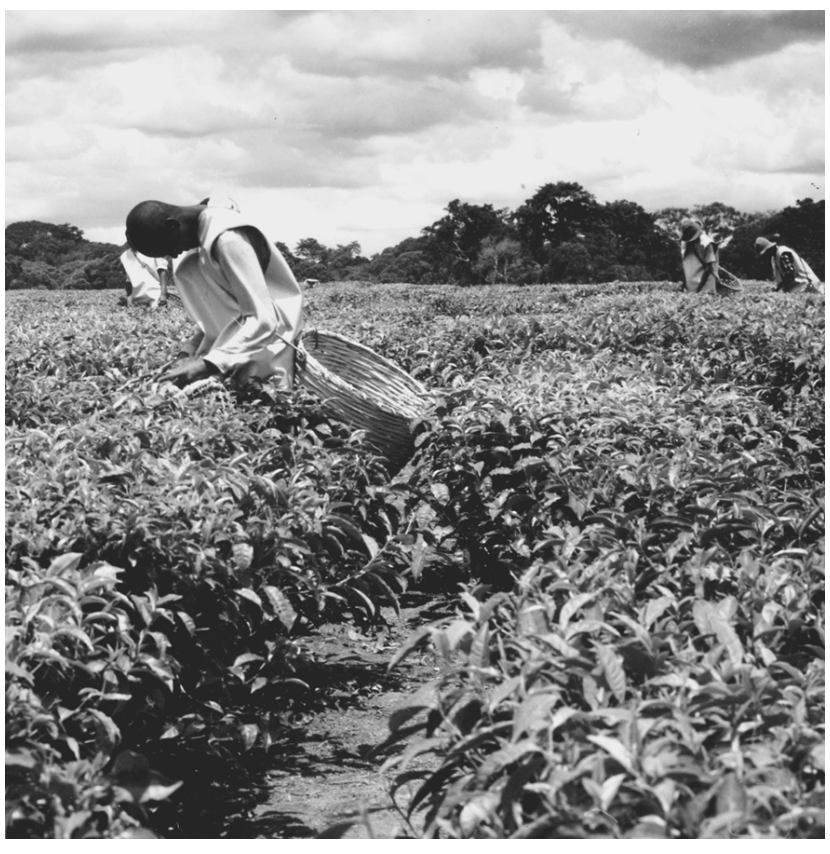


Figura 64.39 • Recolección manual en una plantación de té cerca del Mar Negro.

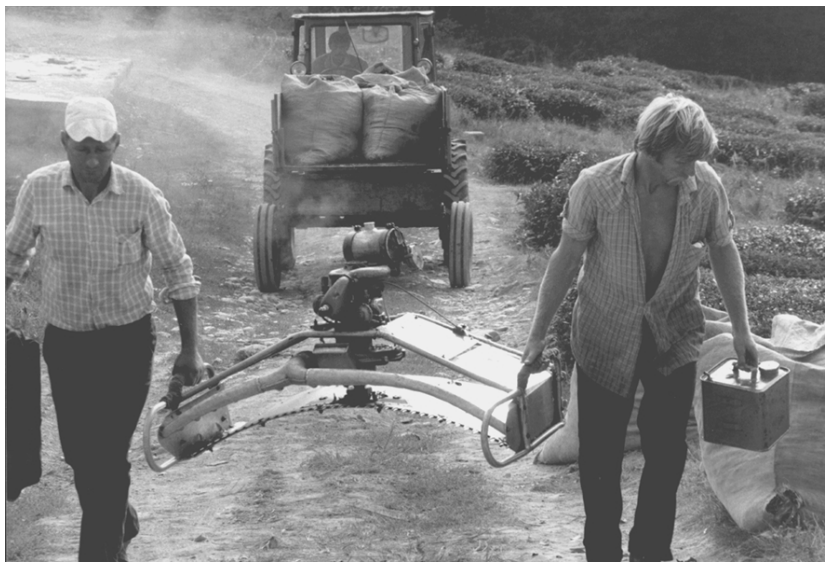

escardado. La escarda a mano está ahora dejando paso al uso de herbicidas químicos. El té cosechado se recoge en cestas que llevan a la espalda los cosecheros y se transporta a unos cobertizos céntricamente emplazados para pesarlos, siendo llevado desde allí a las fábricas para su elaboración. En algunos países, especialmente en el Japón y en la antigua URSS, se ha llevado a cabo con cierto éxito la recolección mecánica, pero ésta requiere un terreno bastante llano y arbustos plantados en hilera.

\section{Riesgos y su prevención}

Las caídas y lesiones causadas por herramientas agrícolas de tipo cortante y de cavado constituyen el género de accidentes más común. Esto no es de extrañar si se tienen en cuenta las inclinadas laderas en donde suele cultivarse el té y el tipo de trabajo implícito en los procesos de desbroce, extirpación y poda. Aparte de la exposición a riesgos naturales, como rayos, los trabajadores está expuestos a mordeduras de serpiente o picaduras de moscardones, arañas, avispas o abejas, aunque rara vez se encuentran serpientes muy venenosas a las elevadas altitudes en donde se cultiva el mejor té. Recientemente se ha registrado en Assam, India, una enfermedad alérgica causada por contacto con cierta especie de oruga.

La exposición de los trabajadores a cantidades cada vez mayores de plaguicidas altamente tóxicos requiere un cuidadoso control. La sustitución de estos plaguicidas por otros menos tóxicos y la atención a la higiene personal son medidas necesarias. La mecanización ha sido bastante lenta, pero está empezando a utilizarse un número creciente de tractores, vehículos motorizados y herramientas eléctricas, con el correspondiente aumento de accidentes por estas causas (véase la Figura 64.39). Muchos accidentes pueden eliminarse con tractores bien diseñados provistos de cabinas de seguridad y manejados por conductores entrenados y competentes.

En Asia, donde la población no trabajadora residente en los campos de té es casi tan elevada como la población trabajadora, el número total de accidentes en el hogar es casi igual al de los accidentes en los campos.

Las viviendas no suelen reunir buenas condiciones. Las enfermedades del sistema respiratorio, a las que siguen las enfermedades entéricas, anemia y desnutrición, son las causas más comunes de enfermedad. Las primeras obedecen principalmente a las condiciones de vida y de trabajo a elevadas altitudes y a la exposición a bajas temperaturas y a las inclemencias climáticas. Las enfermedades intestinales son debidas a la falta de instalaciones sanitarias y al bajo nivel de higiene existente entre los trabajadores. Estas son principalmente condiciones remediables que subrayan la necesidad de mejorar las instalaciones sanitarias y la educación higiénica. La anemia, especialmente entre las madres trabajadores pertenecientes a los grupos en edad gestante, es muy corriente; en parte es resultado de la anquilostomiasis, pero sobre todo tiene por origen una alimentación deficiente en proteínas. No obstante, las causas principales de la pérdida de horas laborales suelen ser dolencias leves, y no enfermedades graves. La vigilancia médica, tanto de las condiciones de habitabilidad como del trabajo, es una medida preventiva esencial, y la inspección oficial, ya sea a nivel local o nacional, es asimismo necesaria para garantizar el mantenimiento de las debidas condiciones sanitarias.

\section{LUPULO}

Thomas Karsky y William B. Symons

El lúpulo se utiliza para la fabricación de la cerveza y se cultiva principalmente en el norte de la costa oeste de Estados Unidos, Europa (especialmente Alemania y Reino Unido), Australia y Nueva Zelanda.

El lúpulo crece a partir de esquejes de rizomas de plantas hembras. Las vides de lúpulo alcanzan una altura de entre 4,5 y $7,5 \mathrm{~m}$ o más. A estas vides se les obliga a trepar por alambres o cuerdas pesadas a modo de espalderas. Las plantas del lúpulo suelen plantarse guardando una distancia de $2 \mathrm{~m}$ en todas las direcciones y se atan dos cuerdas por planta que van hasta los alambres de las espalderas formando un ángulo de unos $45^{\circ}$. Las espalderas tienen una altura de unos 5,5 m y están hechas con maderos o postes tratados a presión de $10 \times 10 \mathrm{~cm}$ que se entierran entre 0,6 y $1 \mathrm{~m}$ en el suelo.

El trabajo manual es necesario para guiar el crecimiento de las vides una vez que éstas alcanzan un longitud de casi $30 \mathrm{~cm}$; además, las plantas se podan hasta una altura de $1 \mathrm{~m}$ del suelo para permitir la circulación del aire y reducir la aparición de enfermedades.

Las vides de lúpulo se recolectan en otoño. En el Reino Unido algunas vides crecen en espalderas de $3 \mathrm{~m}$ de altura y se recolectan utilizando una cosechadora mecánica por encima de las hileras. En Estados Unidos existen cosechadoras de lúpulo para espalderas de 5,5 m de altura. Las zonas a las que no pueden llegar las cosechadoras (terrazas) se recolectan a mano con un machete. El lúpulo recién recogido se seca al horno para reducir su contenido de humedad del $80 \%$ al $10 \%$. El lúpulo se enfría, se embala y se mantiene refrigerado hasta su uso final.

\section{Problemas de seguridad}

Los trabajadores tienen que utilizar camisas de manga larga y guantes cuando trabajan cerca de las vides, puesto que los pelos curvados de las plantas pueden causar arañazos en la piel. Algunas personas son más sensibles a las vides que otras.

Una gran mayoría de los accidentes consisten en distensiones o dislocaciones debido a la elevación de materiales como tuberías de riego o balas o a estiramientos cuando se trabaja en las espalderas. Los trabajadores deben ser instruidos sobre la forma de elevar pesos o utilizar ayudas mecánicas.

Los trabajadores tienen que utilizar protectores en las rodillas y por debajo de ellas para proteger las piernas cuando cortan manualmente las vides. La protección de los ojos es imprescindible cuando se trabaja en las vides.

Muchos accidentes se producen cuando los trabajadores atan las cuerdas a los alambres de las espalderas. La mayor parte de 
este trabajo se realiza de pie en altos remolques o en las plataformas de los tractores. Los accidentes se han reducido como consecuencia del uso de cinturones de seguridad o barreras que previenen las caídas y el uso de protección ocular. Debido al intenso movimiento de las manos, el síndrome del túnel carpiano puede ser un problema.

Puesto que las plantas de lúpulo suelen tratarse con fungicidas durante la estación, es necesario colocar carteles advirtiendo del tiempo que debe transcurrir hasta volver a entrar de nuevo en los campos.

Las reclamaciones de indemnización de trabajadores en el Estado de Washington (Estados Unidos) indican que la incidencia de accidentes varía entre 30 y 40 por 100 personas año trabajado. Los cultivadores se han asociado y creado comités de seguridad que trabajan activamente para reducir las tasas de accidentes. Estas tasas son en Washington similares a las observadas en el sector de los árboles frutales o los productos lácteos. La mayor parte de los accidentes suceden en agosto y septiembre.

Las industrias de transformación del lúpulo utilizan métodos especiales y gran parte de la maquinaria y los equipos se fabrican localmente. Gracias a la labor de vigilancia de los comités de seguridad para asegurar la instalación de unas carcasas protectoras adecuadas en la maquinaria, se han podido reducir los accidentes por "quedar atrapados" durante las operaciones de recolección y transformación. La formación de los trabajadores debe centrarse en el uso correcto de los cuchillos, los equipos de protección personal y la prevención de caídas desde vehículos y otras máquinas.

\section{CUESTIONES DE SALUD Y AMBIENTALES}

\section{PROBLEMAS DE SALUd Y PAUTAS PATOLOGICAS EN LA AGRICULTURA}

\section{Melvin L. Myers}

A finales del siglo XX, menos del $5 \%$ de la población activa en los países industrializados trabaja en la agricultura, frente al $50 \%$ de la población activa mundial (Sullivan y cols. 1992). El trabajo puede ser altamente mecanizado o exigir una intensa mano de obra. Algunas agroindustrias han estado tradicionalmente orientadas al comercio internacional, como los cultivos de plantación o los cultivos para exportación. En la actualidad, la agroindustria es internacional y se organiza en torno a materias primas como el azúcar, el trigo y la carne vacuna. La agricultura abarca muchos entornos: propiedades familiares, incluida la agricultura de subsistencia; grandes explotaciones agrícolas y plantaciones; explotaciones urbanas, incluidas las empresas especializadas y la agricultura de subsistencia; y el trabajo migrante y estacional. Los cultivos varían desde alimentos básicos ampliamente utilizados, como el arroz y el trigo, hasta cultivos especiales, como café, fruta o algas marinas. Además, jóvenes y mayores trabajan en la agricultura más que en cualquier otro sector de la industria. En este artículo se describen los problemas de salud y las enfermedades más frecuentes entre los trabajadores agrícolas, exceptuando la ganadería, que se trata en otro capítulo.

\section{Perspectiva general}

La imagen del trabajo agrícola es la de una actividad saludable, lejos de las ciudades congestionadas y contaminadas, que ofrece la oportunidad de respirar aire puro y realizar ejercicio. En cierto sentido, eso es cierto. Los agricultores de Estados Unidos, por ejemplo, tienen una menor tasa de mortalidad por cardiopatías isquémicas y cáncer que otros trabajadores.

No obstante, el trabajo agrícola se asocia a una serie de problemas de salud. Los trabajadores agrícolas corren un mayor riesgo de sufrir ciertos tipos de cánceres, enfermedades respiratorias y lesiones (Sullivan y cols. 1992). Debido a los remotos lugares donde se realizar gran parte de este trabajo, no se tiene acceso a servicios médicos de urgencia y la agromedicina siempre se ha considerado una vocación que no permite alcanzar una buena posición social (véase el Recuadro y la Tabla 64.12). El ambiente de trabajo conlleva la exposición a riesgos físicos asociados al clima, el terreno, los incendios y la maquinaria, riesgos toxicológicos asociados a los plaguicidas, fertilizantes y combustibles; y daños para la salud causados por el polvo. Como se muestra en las Tablas 64.13 y 64.19 , la agricultura se asocia a una gran variedad de peligros para la salud. En estas tablas y en las correspondientes descripciones que siguen, se resumen seis categorías de riesgos: (1) respiratorios, (2) dermatológicos, (3) tóxicos y neoplásicos, (5) mecánicos y estrés térmico y (6) de conducta. En cada una de estas tablas se ofrece también un resumen de las intervenciones para prevenir y controlar el riesgo.

\section{Riesgos respiratorios}

Los trabajadores agrícolas pueden sufrir una serie de enfermedades pulmonares asociadas a exposiciones en el trabajo, tal

Tabla 64.12 • Comparación de dos tipos de programas de agromedicina.

\begin{tabular}{lll}
\hline Parámetro & Modelo A & Modelo B \\
Facultad & Medicina & Medicina y agronomía \\
Apoyo & Federal, fundación & Estatal, fundación \\
Investigación & Primaria (básica) & Secundaria (aplicada) \\
Educación de pacientes & Sí & Sí \\
$\begin{array}{c}\text { Educación de } \\
\text { productores/trabajadores }\end{array}$ & Sí & Sí \\
Educación de profesionales & Sí & \\
de la salud & & Sí \\
Educación avanzada & Electiva & Sí \\
Educación multidisciplinaria & Electiva & Sí \\
Servicios comunitarios & Intermitentes & Continuos \\
estatales & & (40 horas/semana) \\
Circunscripción: & Colegas académicos & Cultivadores, consumi- \\
sostenibilidad & Colegas nacionales & dores, profesionales \\
& Colegas & de la salud, médicos \\
& internacionales & rurales \\
Prestigio (académico) & Sí & Poco \\
Crecimiento (capital, & Sí & Poco \\
subvenciones) & & Dual (colaboradores) \\
Administración & Unica & Educación, servicios \\
Enfoque principal & Investigación, publica- & ción, recomendaciones \\
& de actuación & basada en el cliente \\
& &
\end{tabular}




\section{Agromedicina}

Desde que el ser humano inició sus actividades ganaderas y agrícolas, la agricultura y la medicina han estado interrelacionadas. Una explotación agrícola o ganadera saludable requiere unos trabajadores sanos. El hambre, la sequía o las plagas pueden destruir el bienestar de todas las especies interrelacionadas en la explotación, sobre todo en los países en desarrollo que dependen de la agricultura para su subsistencia. En la época colonial, los propietarios de las plantaciones tenían que prestar atención a las medidas higiénicas para proteger a sus trabajadores, animales y plantas. En la actualidad pueden citarse como ejemplos del trabajo agromédico en equipo la gestión integrada de plagas (un enfoque ecológico del problema de las plagas); la prevención y el control de la tuberculosis (TB) (trabajadores, ganado vacuno y productos lácteos), y la ingeniería agronómica (para reducir los traumatismos). La agricultura y la medicina tienen éxito cuando trabajan conjuntamente como una única disciplina.

\section{Definiciones}

Se utilizan indistintamente los términos siguientes, aunque posean connotaciones muy diferentes:

- Medicina agrícola: se denomina así una subdivisión de la salud pública y/o la medicina del trabajo que se incluye en la formación teórica y práctica de los profesionales de la salud.

- Agromedicina: término acuñado en el decenio de 1950 para poner de relieve los enfoques interdisciplinarios basados en la ampliación de la función de los profesionales agrícolas mediante la colaboración de dos disciplinas (la medicina y la agricultura).

En los últimos años, la medicina agrícola, entendida como una subespecialidad de la medicina del trabajo/medioambiental dentro de las ciencias de la salud, ha cedido terreno ante la agromedicina, entendida como el proceso de integración de los recursos agrícolas y sanitarios de un país o región al servicio de la población.

La unidad esencial de las ciencias biológicas es algo ya conocido para los químicos vegetales (nutrición), los químicos animales (nutrición) y los químicos humanos (nutrición); las áreas de superposición e integración rebasan los límites de una especialidad estrictamente definida.

\section{Campos de la agromedicina}

La agromedicina se ha centrado en tres campos principales:

1. lesiones traumáticas

2. exposiciones pulmonares

3. lesiones agroquímicas.
Otros campos, como las zoonosis, los servicios de salud rurales y otros servicios comunitarios, la seguridad de los alimentos (p. ej., la relación entre nutrición y cáncer), la educación sanitaria y la protección del medio ambiente, reciben una atención secundaria. También se han emprendido iniciativas relacionadas con la biotecnología, los problemas del crecimiento demográfico y la agricultura sostenible.

En los programas de investigación y estudios universitarios se hace más o menos hincapié en estos distintos campos dependiendo de los conocimientos del cuerpo docente, las becas e iniciativas de financiación, las necesidades de ampliación, las consultas de productores y empresas y las redes de cooperación entre universidades. Por ejemplo, los conocimientos sobre lesiones traumáticas pueden recibir una atención especial en una escuela de ingeniería agrícola que conceda un diploma en esta rama de la agronomía; las enfermedades pulmonares de los agricultores se examinarán en un programa de neumología para residentes de medicina del trabajo (especialización postuniversitaria) o medicina preventiva (master o doctorado en salud pública); un programa interuniversitario de seguridad de los alimentos puede integrar la ciencia veterinaria, la hematología y la especialidad médica de las enfermedades infecciosas. En la Tabla 64.T060ł2 se comparan dos tipos de programas.

En Estados Unidos, han establecido programas de agromedicina diversos estados: Alabama, California, Colorado, Georgia, lowa, Kansas, Kentucky, Minnesota, Mississippi, Nebraska, Nueva York, Oregon, Pensilvania, Carolina del Sur, Virginia y Wisconsin. En Michigan, Florida y Texas se han establecido programas que no utilizan los términos agromedicina o medicina agrícola o que se encuentran en sus primeras fases de desarrollo. En Saskatchewan (Canadá) existe también un programa de agromedicina.

\section{Conclusión}

Además de la colaboración interdisciplinaria en la denominada ciencia básica, se necesita una mayor coordinación de los expertos agrónomos y médicos. El trabajo en equipo es necesario para aplicar un enfoque preventivo y educativo que garantice la mejor ciencia y el mejor servicio que un sistema de universidades públicas puede poner a disposición de sus ciudadanos.

\section{Stanley H. Schuman y Jere A. Brittain}

como se indica en la Tabla 64.13. En varios países se ha observado una mayor incidencia de estas enfermedades.

El agravamiento del asma por alergenos específicos y causas inespecíficas se ha asociado al polvo atmosférico. La exposición a algunos antígenos presentes en el ambiente agrícola puede provocar asma, entre ellos polen, ácaros en los almacenes y polvo de los granos. La inflamación de las membranas mucosas es una reacción habitual al polvo atmosférico en personas con rinitis alérgica o antecedentes de atopia. Las partículas vegetales en el polvo de granos parecen causar irritación mecánica de los ojos, pero la exposición a endotoxinas y micotoxinas también puede asociarse a inflamación de los ojos, las fosas nasales y la garganta.

La bronquitis crónica es más frecuente entre los agricultores que en la población general. La mayoría de los agricultores con esta enfermedad tienen antecedentes de exposición a polvo de grano o trabajo en edificios confinados dedicados a la cría porcina. Se cree que el consumo de tabaco tiene un efecto aditivo y es una causa de esta enfermedad. Además, la bronquitis crónica ha sido descrita en los agricultores que cultivan cereales, especialmente en la época de recolección.

La neumonitis por hipersensibilidad está causada por la exposición repetida a antígenos procedentes de sustancias muy diversas, entre ellos los microorganismos presentes en el heno, los granos o el ensilaje descompuestos. Este problema se ha observado también en los trabajadores que limpian las naves de crecimiento de setas.

El síndrome tóxico del polvo orgánico se asoció en un principio a la exposición al ensilaje mohoso y fue, por consiguiente, denominado, sindrome del descargador de ensilaje. Una enfermedad parecida, llamada fiebre del grano, se asocia a la exposición al polvo del grano almacenado. Este síndrome se produce sin sensibilización previa, como en el caso de la neumonitis por hipersensibilidad y su epidemiología no se conoce bien.

Los agricultores pueden verse expuestos a diferentes sustancias que causan respuestas pulmonares agudas. El dióxido de 
Tabla 64.13 • Riesgos respiratorios.

\section{Exposiciones}

Polen de cereales, caspa del ganado, antígenos fúngicos en el polvo de los graneros

y sobre los cultivos, ácaros del polvo, insecticidas organofosforados

Polvo orgánico

Ciertos componentes de las plantas, endotoxinas, micotoxinas

Insecticidas, arsénico, polvo irritante, amoniaco, humos, polvo de los graneros (trigo, cebada)

Esporas de hongos 0 actinomicetos termofílicos liberados del grano o el heno mohosos,

antígenos con menos de $5 \mu \mathrm{m}$ de diámetro

Actinomicetos termofilicos: caña de azúcar mohosa

Esporas de setas (durante la limpieza de los lechos)

Heno mohoso, compost

Hongos: corteza de arce mohosa

Antrópodos: trigo infestado

Residuos vegetales, gránulos de almidón, mohos, endotoxinas, micotoxinas, esporas, hongos, bacterias gramnegativas, enzimas, alergenos, partes de insectos, partículas del suelo, residuos químicos

Polvo de los graneros

Ensilaje mohoso encima del silo

Gases de putrefacción: amoniaco, ácido sulfhídrico, monóxido de carbono, metano,

fosgenita, cloro, dióxido de azufre, ozono, paraquat (herbicida), anhídrido amónico (fertilizante), óxidos de nitrógeno

Dióxido de nitrógeno de la fermentación del ensilaje

Humos de soldadura

Falta de oxígeno en espacios confinados

Polvo del suelo en regiones áridas

Mycobacterium tuberculosis

\section{Efectos sobre la salud}

Asma y rinitis: Asma mediada por inmunoglobulina $\mathrm{E}$

Asma no inmunológica (asma por polvo de los graneros)

Inflamación de las mucosas

Broncoespasmo, bronquitis aguda y crónica

Neumonitis por hipersensibilidad

Bagazosis

Pulmón del cultivador de setas

Pulmón del agricultor

Enfermedad del descortezador del arce

Enfermedad del gorgojo del trigo

Síndrome tóxico del polvo orgánico

Fiebre del grano

Síndrome del descargador de silo

Respuestas pulmonares agudas

Enfermedad del cargador de silos

Fiebre por humo metálico

Asfixia

Fiebre del valle (coccidiomicosis)

Tuberculosis (trabajadores migrantes)

Intervenciones: ventilación, supresión o control del polvo, respiradores, prevención de mohos, abandono del tabaco.

Fuentes: Merchant y cols. 1986; Meridian Research, Inc. 1994; Sullivan y cols. 1992; Zejda, McDuffie y cols. 1994.

\section{Tabla 64.14 • Riesgos dermatológicos.}

\section{Exposiciones}

Amoniaco y fertilizantes secos, hortalizas, tubérculos, fumigantes, polvo de avena y cebada, distintos plaguicidas, jabones, productos derivados del petróleo, disolventes, hipoclorito, compuestos fenólicos, líquido amniótico, piensos, furazolidona, hidroquinona, halquinol

Acaros

Plantas sensibilizantes (hiedra venenosa), ciertos plaguicidas (ditiocarbamatos, piretrinas, tioatos, tiuramos, paration, y malation)

Manipulación de tulipanes y bulbos de tulipanes

Creosota, plantas que contienen furocumarinas

Radiación solar, radiación ultravioleta

Ambientes húmedos y calurosos

Contacto con hojas húmedas de tabaco

Incendios, electricidad, productos químicos ácidos o cáusticos, fertilizante seco (higroscópico), fricción, amoníaco anhidro líquido

Mordeduras y picaduras de avispas, niguas, abejas, ácaros del grano, avispones, hormigas carnívoras, arañas, escorpiones, ciempiés, otros artrópodos, serpientes

Punciones y pinchazos de espículas

\section{Efectos sobre la salud}

Dermatitis irritativa por contacto

Prurito producido por los granos

Dermatitis alérgica por contacto

Dedo del tulipán

Dermatitis por fotocontacto

Dermatitis inducida por el sol, melanoma, cáncer labial Dermatitis inducida por el calor

Intoxicación por nicotina (enfermedad del tabaco verde)

Quemaduras

Dermatitis inducida por artrópodos, envenenamiento, enfermedad de Lyme, paludismo

Tétanos

Intervenciones: control integrado de plagas, prendas protectoras, buena higiene, vacunación, control de insectos, cremas que actúen como barrera.

Fuentes: Estlander, Kanerva y Piirilä 1996; Meridian Research, Inc. 1994; Raffle y cols. 1994; Sullivan y cols. 1992. 
Tabla 64.15 • Riesgos tóxicos y neoplásicos.

Exposiciones
Disolventes, benceno, humos,
fumigantes, insecticidas (p. ei.,
organofosfatos, carbamatos,
organocloruros), herbicidas
(p. ej., ácidos fenoxialifáticos,
bipiridilos, triacinas, arsénicos,
acentanilidas, dinitro-toluidina),
fungicidas (p. ej., tiocarbamatos,
dicarboximidas)
Radiación solar
Dibromocloropropano (DBCP),
dibromuro de etileno

deficiencia de oxígeno en los espacios confinados es un problema continuo.

Muchos productos agrícolas son agentes etiológicos de enfermedades pulmonares cuando se transforman. Entre ellos cabe citar la neumonitis por hipersensibilidad causada por la malta mohosa (de cebada), el polvo de paprika y el polvo del café. La bisinosis está causada por polvo de algodón, lino oleaginoso y cáñamo. Algunos productos naturales se asocian también a asma profesional cuando se transforman: gomas vegetales, semillas de lino oleaginoso, granos de ricino, soja, granos de café, productos derivados de granos, harina, raíces de papaína y polvo de tabaco (Merchant y cols. 1986; Meridian Research, Inc. 1994; Sullivan y cols. 1992).

\section{Riesgos dermatológicos}

Los agricultores están expuestos a ciertos riesgos dermatológicos, según se indica en la Tabla64.14. El tipo más frecuente de enfermedad de la piel relacionada con la agricultura es la dermatitis por contacto irritante. Además, la dermatosis alérgica por contacto es una reacción a la exposición a sensibilizantes como ciertas plantas y plaguicidas. Otra enfermedades de la piel son las dermatosis por fotocontacto o las inducidas por el sol, el calor y los artrópodos.

La piel puede sufrir distintos tipos de quemaduras. Los fertilizantes secos que son higroscópicos y atraen la humedad pueden causar quemaduras (Deere \& Co. 1994). Cuando entran en contacto con la piel, puede atraer la humedad y causar quemaduras en la piel. El anhídrido amónico líquido se utiliza para inyectar nitrógeno en el suelo, donde se expande a gas y rápidamente se combina con la humedad. Si el líquido o gas contacta con el cuerpo - especialmente los ojos, la piel y el tracto respiratorio- puede provocar destrucción celular y quemaduras, causando lesiones permanentes si no se recibe tratamiento inmediato.

Los cultivadores y cosechadores de tabaco pueden experimentar la enfermedad del tabaco verde cuando trabajan con tabaco húmedo. El agua de la lluvia o las gotas de rocío sobre las hojas del tabaco probablemente disuelven la nicotina y facilitan su absorción a través de la piel. La enfermedad del tabaco verde se manifiesta con cefalea, palidez, náuseas, vómitos y postración después del contacto del trabajador con las hojas húmedas del tabaco. Otras agresiones a la piel pueden ser causadas por

Figura 64.40 - Tasas de mortalidad de los trabajadores agrícolas, Estados Unidos, 1980-89.

\section{Barrenas}

Electricidad

Maquinaria y vehículos, coces y ataques recibidos de animales de tiro, caídas Empacadoras

Aplastamiento del tórax, extravasación (salida de líquidos - p. ej., sangre y teiido circundante), estrangulación/ asfixia, ahogamiento

Hipovolemia (pérdida de sangre), sepsis y asfixia

Electrocución

Lesiones no fatales: infección de la herida (p. ej., tétanos)

Quemaduras por fricción, aplastamiento, lesiones neurovasculares, desgarros, fracturas, amputación

Tomas de fuerza

Desgarro o despellejado de la piel o el cuero cabelludo, amputación, heridas contusas múltiples

Desbrozadoras

Heridas en las manos (quemaduras por fricción, aplastamiento, desgarro 0 despellejado, amputación de dedos)

Incendios y explosiones

Quemaduras graves o fatales, inhalación de humos

Intervenciones: estructuras de protección contra vuelcos, carcasas protectoras, buenas prácticas, cableado eléctrico de seguridad, prevención de incendios, equipos protectores, buenas prácticas de limpieza.

Fuentes: Deere \& Co. 1994; Meridian Research, Inc. 1994; Meyers y Hard 1995.

Tasa de mortalidad por 100.000 trabajadores

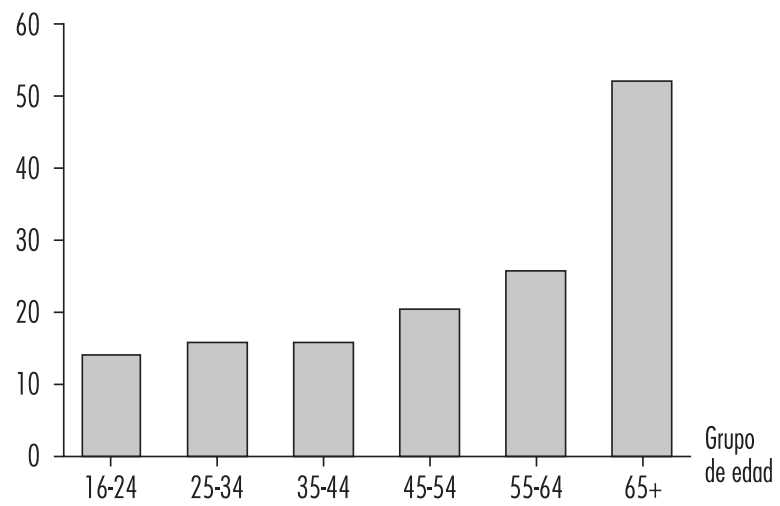


Tabla 64.17 • Porcentaje de accidentes con pérdida de horas de trabajo, clasificado por los orígenes de los accidentes, por naturaleza de éstos y por la actividad, en cuatro tipos de operaciones agrícolas, Estados Unidos, 1993.

\begin{tabular}{|c|c|c|c|c|}
\hline & Cereales & $\begin{array}{l}\text { Cultivo al } \\
\text { aire libre }\end{array}$ & $\begin{array}{l}\text { Hortalizas, } \\
\text { frutas, } \\
\text { frutos } \\
\text { secos }\end{array}$ & $\begin{array}{l}\text { Cultivo } \\
\text { en } \\
\text { vivero }\end{array}$ \\
\hline \multicolumn{5}{|l|}{ Origen del accidente } \\
\hline Tractores & 11,0 & 9,7 & - & 1,0 \\
\hline Maquinaria & 18,2 & 18,6 & 25,1 & 12,5 \\
\hline Ganado & 11,0 & 12,1 & 1,7 & - \\
\hline Herramientas manuales & 13,4 & 13,0 & 19,3 & 3,8 \\
\hline Herramientas eléctricas & 4,3 & 4,6 & 0,4 & 17,9 \\
\hline $\begin{array}{l}\text { Plaguicidas/productos } \\
\text { químicos }\end{array}$ & 1,3 & 2,8 & 0,4 & 0,5 \\
\hline Plantas o árboles & 2,2 & 3,1 & 7,4 & 4,6 \\
\hline Superficies de trabajo & 11,5 & 11,6 & 6,8 & 5,1 \\
\hline Camiones o automóviles & 4,7 & 1,4 & 1,5 & - \\
\hline Otros vehículos & 3,6 & - & 3,5 & - \\
\hline Líquidos & 3,1 & 1,0 & - & - \\
\hline Otros & 15,6 & 22,2 & 34,0 & 54,5 \\
\hline \multicolumn{5}{|l|}{ Naturaleza del accidente } \\
\hline Distorsión/dislocación & 20,5 & 23,5 & 39,3 & 38,0 \\
\hline Corte & 16,4 & 32,3 & 18,9 & 21,7 \\
\hline Fractura & 20,3 & 6,5 & 4,3 & 5,6 \\
\hline Contusión & 9,3 & 9,5 & 12,6 & 14,8 \\
\hline Aplastamiento & 10,4 & 2,6 & 2,4 & 1,0 \\
\hline Otras & 23,1 & 25,6 & 22,5 & 18,9 \\
\hline \multicolumn{5}{|l|}{ Actividad } \\
\hline $\begin{array}{l}\text { Mantenimiento de la } \\
\text { explotación agrícola }\end{array}$ & 23,8 & 19,1 & 10,8 & 33,3 \\
\hline Trabajo en el campo & 17,2 & 34,6 & 34,0 & 38,2 \\
\hline Cuidado de los cultivos & 14,1 & 13,8 & 9,4 & 7,7 \\
\hline Cuidado del ganado & 17,1 & 14,7 & 5,5 & 3,2 \\
\hline $\begin{array}{l}\text { Mantenimiento de la } \\
\text { maquinaria }\end{array}$ & 22,6 & 10,1 & 18,0 & - \\
\hline Otras & 5,1 & 7,5 & 22,3 & 17,6 \\
\hline
\end{tabular}

mordeduras o picaduras de artrópodos y reptiles o pinchazos de espinas que pueden transmitir enfermedades.

\section{Riesgos tóxicos y neoplásicos}

El riesgo de exposición a sustancias tóxicas en la agricultura es elevado, como puede observarse en la Tabla 64.15. Los productos químicos utilizados en la agricultura son fertilizantes, plaguicidas (insecticidas, fumigantes y herbicidas) y combustibles. Las exposiciones humanas a los plaguicidas son muy frecuentes en los países en desarrollo, así como en los desarrollados. En Estados Unidos existen más de 900 plaguicidas registrados, con más de 25.000 nombres comerciales distintos. Cerca del $65 \%$ de los usos registrados son agrícolas. Se utilizan principalmente para controlar los insectos y reducir la pérdida de cultivos. Las dos terceras partes (en peso) de los plaguicidas son herbicidas. Los plaguicidas pueden aplicarse a la semilla, el suelo, el cultivo o la cosecha, ya sea con equipos de fumigación o pulverizadores. Después de la aplicación, la exposición a los plaguicidas puede producirse por escape de gases, dispersión por acción del viento o contacto con las plantas a través de la piel o la ropa. El contacto con la piel es el tipo más frecuente de exposición profesional. Algunos efectos en la salud se han asociado a la exposición a plaguicidas, entre ellos efectos agudos, crónicos, carcinogénicos, inmunológicos, neurotóxicos y reproductivos.

Los agricultores experimentan un mayor riesgo de ciertos tipos de cánceres, como los que afectan al cerebro, el estómago, los sistemas linfático y hematopoyético, el labio, la próstata y la piel. La exposición a la radiación solar y a los plaguicidas (especialmente herbicidas) se ha relacionado con una mayor incidencia de cáncer en las poblaciones rurales (Meridian Research, Inc. 1994; Popendorf y Donham 1991; Sullivan y cols. 1992).

\section{Riesgo de accidentes}

Muchos estudios han demostrado que los trabajadores agrícolas corren un mayor riesgo de mortalidad por accidentes. En Estados Unidos, un estudio de la mortalidad relacionada con el trabajo entre 1980 y 1989 observó unas tasas en la producción agrícola de 22,9 muertes por 100.000 trabajadores, comparado con 7,0 muertes por 100.000 en el caso de todos los demás trabajadores. La tasa media de mortalidad para hombres y mujeres era, respectivamente, de 25,5 y 1,5 muertes por 100,000 trabajadores. Las principales causas de mortalidad en la producción agrícola son la maquinaria y los vehículos motorizados. Muchos estudios han demostrado que los tractores son el principal tipo de maquinaria implicada en accidentes mortales, generalmente por vuelcos. Otras causas importantes de mortalidad son las electrocuciones, los accidentes por quedar atrapado en la maquinaria, los golpes recibidos de objetos que salen lanzados por la maquinaria, las causas ambientales y los ahogamientos. La edad es un

Tabla 64.18 • Riesgos de estrés mecánico y térmico.

\begin{tabular}{|c|c|c|}
\hline Exposiciones & Efectos sobre la salud & Intervenciones \\
\hline $\begin{array}{l}\text { Sobrecarga de tendones, } \\
\text { estiramiento; fuerza } \\
\text { excesiva }\end{array}$ & $\begin{array}{l}\text { Trastornos tendinosos } \\
\text { (tendinitis, tendosinovitis) }\end{array}$ & $\begin{array}{l}\text { Diseño ergonómico, } \\
\text { amortigüación de las } \\
\text { vibraciones, prendas } \\
\text { de abrigo, períodos } \\
\text { de descanso }\end{array}$ \\
\hline $\begin{array}{l}\text { Movimientos repetitivos, } \\
\text { postura incómoda de la } \\
\text { muñeca }\end{array}$ & Síndrome del túnel carpiano & \\
\hline Vibración de las manos & Síndrome de Raynaud & \\
\hline $\begin{array}{l}\text { Repetición, fuerza } \\
\text { intensa, mala postura, } \\
\text { vibración del cuerpo } \\
\text { entero }\end{array}$ & $\begin{array}{l}\text { Cambios degenerativos, } \\
\text { dolor lumbar, hernia de } \\
\text { disco; lesiones en los } \\
\text { sistemas nervioso } \\
\text { periférico, vascular, } \\
\text { gastrointestinal y } \\
\text { vestibular }\end{array}$ & \\
\hline $\begin{array}{l}\text { Ruido de motores y } \\
\text { máquinas }\end{array}$ & Pérdida auditiva & $\begin{array}{l}\text { Control del ruido, } \\
\text { protectores auditivos }\end{array}$ \\
\hline $\begin{array}{l}\text { Metabolismo acelerado, } \\
\text { altas temperaturas y } \\
\text { humedad, reposición } \\
\text { limitada de agua y } \\
\text { electrolitos }\end{array}$ & $\begin{array}{l}\text { Calambres por calor, } \\
\text { agotamiento por calor, } \\
\text { golpe de calor }\end{array}$ & $\begin{array}{l}\text { Ingestión de agua, } \\
\text { períodos de } \\
\text { descanso, protección } \\
\text { contra la radiación } \\
\text { solar }\end{array}$ \\
\hline $\begin{array}{l}\text { Bajas temperaturas, } \\
\text { ausencia de prendas } \\
\text { secas }\end{array}$ & $\begin{array}{l}\text { Quemaduras por frío, } \\
\text { sabañones, congelación, } \\
\text { hipotermia sistémica }\end{array}$ & $\begin{array}{l}\text { Ropa seca de abrigo, } \\
\text { generación de calor } \\
\text { con la actividad }\end{array}$ \\
\hline
\end{tabular}

Fuente: Meridian Research, Inc. 1994 


\section{Tabla 64.19 • Riesgos derivados del comportamiento.}

\begin{tabular}{|c|c|c|}
\hline Exposiciones & Efectos sobre la salud & Intervenciones \\
\hline $\begin{array}{l}\text { Aislamiento, inseguridad } \\
\text { económica, problemas } \\
\text { intergeneracionales, } \\
\text { violencia, abuso de } \\
\text { sustancias, incesto, } \\
\text { plaguicidas, aceptación } \\
\text { de riesgos, actitudes } \\
\text { patriarcales, inestabilidad } \\
\text { climática, inmovilismo }\end{array}$ & $\begin{array}{l}\text { Depresión, ansiedad, } \\
\text { suicidio, escasa } \\
\text { capacidad para hacer } \\
\text { frente a los problemas }\end{array}$ & $\begin{array}{l}\text { Diagnóstico precoz, } \\
\text { asesoramiento, } \\
\text { habilitación, control } \\
\text { de plagas, apoyo } \\
\text { comunitario }\end{array}$ \\
\hline $\begin{array}{l}\text { Tuberculosis, enfermedades } \\
\text { de transmisión sexual } \\
\text { (trabajadores migrantes) }\end{array}$ & $\begin{array}{l}\text { Enfermedades } \\
\text { infecciosas }\end{array}$ & $\begin{array}{l}\text { Diagnóstico precoz, } \\
\text { vacunación, uso de } \\
\text { preservativos }\end{array}$ \\
\hline
\end{tabular}

Fuentes: Boxer, Burnett y Swanson 1995; Davies 1995; Meridian Research, Inc. 1994; Parrón, Hernández y Villanueva 1996.

importante factor de riesgo asociado a la mortalidad agrícola en el caso de los varones. Por ejemplo, la tasa de mortalidad de los trabajadores agrícolas mayores de 65 años en Estados Unidos excede 50 por 100.000 trabajadores, más del doble que la media global (Meyers y Hard 1995) (véase la Figura 64.40. En la Tabla 64.16 se indican las exposiciones a distintos riesgos de accidente, sus consecuencias y las intervenciones de eficacia demostrada.

Un estudio realizado en 1993 de los accidentes agrícolas en Estados Unidos demostró que las principales causas de accidentes estaban relacionadas con el ganado (18\%), la maquinaria $(17 \%)$ y las herramientas manuales (11\%). Los accidentes más frecuentes observados en este estudio fueron las distensiones y dislocaciones $(26 \%)$, los cortes $(18 \%)$ y las fracturas $(15 \%)$. El $95 \%$ de los accidentes se produjeron en varones, mientras que la mayor concentración se observó en trabajadores de 30 a 39 años de edad. En la Tabla 64.17 se indica la fuente y la naturaleza de los accidentes y la actividad que se estaba realizando cuando ocurrió el accidente para cuatro grandes categorías de trabajadores agrícolas. El National Safety Council de Estados Unidos ha estimado una tasa en este país de 13,2 lesiones y enfermedades profesionales por 100 trabajadores agrícolas en 1992. Más de la mitad de ellos causaron la baja del trabajador durante un período medio de 39 días. Por el contrario, los sectores de la fabricación y la construcción presentaron una tasa de incidencia de accidentes y enfermedades de 10,8 y 5,4 por 100 trabajadores. En otro estudio realizado también en Estados Unidos, los investigadores determinaron que el $65 \%$ de todos los accidentes agrícolas exigían asistencia médica y que otras máquinas distintas a los tractores causaron casi la mitad de los accidentes responsables de una discapacidad permanente (Meridian Research, Inc. 1994; Boxer, Burnett y Swanson 1995).

\section{Riesgos por estrés mecánico y térmico}

Como ya se ha señalado, las dislocaciones y distensiones constituyen un importante problema entre los trabajadores agrícolas. Según se indica en la Tabla 64.18, los trabajadores agrícolas están expuestos a distintos tipos de estrés mecánico y térmico que causan lesiones. Muchos de estos problemas son el resultado del manejo de cargas muy pesadas, movimientos repetitivos, malas posturas y movimientos dinámicos. Además, los operarios de vehículos agrícolas están expuestos a vibración de todo el cuerpo. En un estudio se determinó que la prevalencia de dolor en la parte inferior de la espalda era un $10 \%$ mayor entre los conductores de tractores.
La pérdida auditiva inducida por el ruido es también frecuente en los trabajadores agrícolas. Un estudio determinó que los agricultores mayores de 50 años registraban pérdidas auditivas incluso superiores al $55 \%$. Otro estudio demostró que los estudiantes rurales presentaban una incidencia dos veces mayor de pérdida auditiva que los estudiantes urbanos.

Los trabajadores agrícolas están expuestos a temperaturas extremas. Tienen que soportar ambientes calurosos y húmedos cuando trabajan en zonas tropicales y subtropicales y durante el verano en las zonas templadas. El estrés por calor y la apoplejía son un peligro en estas condiciones. También pueden verse expuestos a frío extremo durante el invierno en zonas templadas y posiblemente a congelación o muerte por hipotermia (Meridian Research, Inc. 1994).

\section{Riesgos de conducta}

Algunos aspectos del trabajo agrícola pueden causar estrés en los agricultores. Como puede observarse en la Tabla 64.19, estos factores son el aislamiento, la existencia de riesgos, las actitudes patriarcales, la exposición a plaguicidas, la inestabilidad económica y climática y la inmovilidad. Estas circunstancias generan problemas como relaciones disfuncionales, conflictos, abuso de sustancias, violencia doméstica y suicidio. La mayoría de los suicidios asociados a depresión en los agricultores de América del Norte corresponden a víctimas que están casadas y trabajan a tiempo completo en la agricultura, la mayoría de las cuales utilizan armas de fuego para cometer el suicidio. Los suicidios tienden a producirse en los períodos de máxima actividad agrícola (Boxer, Burnett y Swanson 1995).

Los trabajadores agrícolas migrantes corren un elevado riesgo de tuberculosis y cuando predominan los trabajadores varones, las enfermedades de transmisión sexual son un problema añadido. Las trabajadoras migrantes experimentan problemas perinatales, altas tasas de mortalidad infantil y baja percepción del riesgo profesional. En la actualidad se están investigación diversos aspectos de la conducta de los trabajadores migrantes, como maltratos y negligencia en el cuidado de los hijos, violencia doméstica, abuso de sustancias, trastornos mentales y trastornos relacionados con el estrés (OIT 1994).

\section{GUESTIONES AMBIENTALES Y DE SALUD PUBLICA EN LA AGRICULTURA}

Melvin L. Myers

Con el crecimiento de la población mundial está aumentando la demanda de alimentos y, por otro lado, la demanda de tierra cultivable para usos no agrícolas. Los ingenieros agrónomos tienen que buscar alternativas para alimentar a la creciente población mundial, como el aumento de la producción por hectárea, la conversión de tierra no utilizada en tierra de cultivo y la reducción o interrupción de la destrucción de las actuales tierras de labor. En los últimos 25 años el mundo ha sido testigo de una "revolución verde", sobre todo en América del Norte y Asia. Esta revolución ha dado lugar a un tremendo incremento de la producción de alimentos y ha sido estimulada por el desarrollo de variedades genéticas más productivas y un mayor uso de fertilizantes, plaguicidas y automatización. La ecuación para la producción de más alimentos se complica por la necesidad de abordar ciertos problemas de salud ambiental y pública, entre ellos la necesidad de prevenir la contaminación y el agotamiento del suelo, encontrar alternativas para el control de las plagas, lograr una agricultura sostenible, luchar contra la mano de obra infantil y erradicar el cultivo de drogas ilegales. 


\section{Agua y conservación}

Posiblemente la contaminación de las aguas sea el problema medioambiental más generalizado causado por la agricultura. La agricultura contribuye de manera importante a la contaminación de las aguas superficiales por fuentes dispersas, entre ellas sedimentos, sales, fertilizantes y plaguicidas. La escorrentía de los sedimentos produce erosión del suelo y la consiguiente disminución de la producción agrícola. La transformación natural de los 2,5 cm superiores de suelo a partir de la roca madre y el material superficial tarda entre 200 y 1.000 años, mucho tiempo comparado con la vida humana.

El contenido de sedimentos de los ríos, corrientes, lagos y estuarios aumenta la turbidez del agua, reduciendo la luz que llega a la vegetación subacuática. Las poblaciones de especies que dependen de esta vegetación pueden, por tanto, experimentar un descenso. Los sedimentos se depositan en los cursos y masas de agua, con el consiguiente aumento del coste del dragado y la menor capacidad de almacenamiento de las redes de abastecimiento de agua, los sistemas de regadío y las centrales hidroeléctricas. Los residuos de los fertilizantes, tanto sintéticos como naturales, contribuyen al contenido de fósforos y nitratos de las aguas. Una elevada concentración de nutrientes estimula el crecimiento de las algas, pudiendo ocasionar la eutrofización de los lagos y la consiguiente reducción en las poblaciones de peces. Los plaguicidas, especialmente los herbicidas, contaminan la aguas superficiales y los sistemas convencionales de tratamiento de la aguas no son eficaces para eliminarlos de los cursos de agua. Estas sustancias contaminan también los alimentos, las aguas y los piensos. Las aguas subterráneas son una fuente de agua potable para muchas personas y también pueden contaminarse con los plaguicidas y los nitratos presentes en los fertilizantes. Las aguas subterráneas se utilizan también para dar de beber a los animales y para riego.

$\mathrm{El}$ riego ha hecho posible la agricultura intensiva en lugares donde antes era imposible, pero también tiene sus consecuencias negativas. Los acuíferos están ya agotados en lugares donde el uso de las aguas subterráneas es mayor que la velocidad de recarga; el agotamiento de los acuíferos puede causar también al hundimiento de la tierra. En las regiones áridas, el riego se ha asociado a mineralización y salinización de los suelos y las aguas, y también ha sido la causa de que se sequen algunos ríos (NRG 1989).

\section{Control de plagas}

Después de la segunda Guerra Mundial, el uso de plaguicidas orgánicos sintéticos - fumigantes, insecticidas, herbicidas y fungicidas- aumentó rápidamente y el uso de estos compuestos químicos ha originado toda una serie de problemas. Los cultivadores vieron en la eficacia de los plaguicidas sintéticos de amplio espectro una solución a los problemas de la plagas que habían azotado a la agricultora desde siempre. No sólo aparecieron nuevos problemas por sus efectos en la salud humana, sino que los científicos medioambientales advirtieron del inmenso daño ecológico que podían causar. Por ejemplo, los hidrocarburos clorados permanecen en el suelo y se bioacumulan en peces, mariscos y aves. El contenido corporal de hidrocarburos ha disminuido en estos animales allí donde las comunidades han decidido eliminar o reducir el uso de estos compuestos.

El uso de plaguicidas ha tenido un efecto adverso en especies distintas a la que se pretendía eliminar. Además, las plagas se han hecho resistentes a los plaguicidas y existen muchos ejemplos de especies resistentes que se han convertido en predadores más virulentos de los cultivos. Por todo ello los agricultores tienen que buscar otras alternativas para el control de las plagas. La gestión integrada de plagas es una estrategia que tiene como finalidad el control de las plagas utilizando medios ecológicos.
Tabla 64.20 • Cultivos obtenidos mediante ingeniería genética.

$\begin{array}{ll}\text { Cultivo } & \text { Variedades } \\ \text { Algodón } & \text { Tres variedades, resistentes a insectos y herbicidas } \\ \text { Maíz } & \text { Dos variedades, resistentes a insectos } \\ \text { Soja } & \text { Una variedad, resistente a herbicidas } \\ \text { Patatas } & \text { Una variedad, resistente a insectos } \\ \text { Tomates } & \begin{array}{c}\text { Cinco variedades, con maduración retrasada y piel más } \\ \text { gruesa }\end{array} \\ \text { Sandía } & \text { Una variedad, resistente a dos viruses } \\ \text { Canola } & \text { Una variedad, modificada genética para producir aceite con } \\ & \text { alto contenido en ácido laúrico }\end{array}$

Fuente: Toner 1996

Integra el uso menos nocivo posible de las sustancias químicas con el control biológico. Su objetivo no es tanto eliminar las plagas, sino controlarlas a un nivel que evite pérdidas económicas (NRG 1989).

Los cultivos obtenidos mediante ingeniería genética cada vez se utilizan más (véase la Tabla 64.20, pero además de sus resultados positivos, tienen también consecuencias negativas. Un ejemplo de resultado positivo es la variedad obtenida mediante ingeniería genética de un algodón resistente a los insectos. Esta variedad, cultivada actualmente en Estados Unidos, requiere sólo una aplicación de insecticida, frente a las cinco o seis aplicaciones que se necesitarían normalmente. La planta genera su propio plaguicida y de esta forma se reduce el coste y la contaminación ambiental. La posible consecuencia negativa de esta tecnología es el desarrollo de resistencia al plaguicida. Cuando una plaga sobrevive al nuevo plaguicida, puede desarrollar resistencia al mismo. De esta forma, las plagas más virulentas son las que más probabilidades tienen de sobrevivir al plaguicida obtenido mediante ingeniería genética y a otros plaguicidas sintéticos similares. Por consiguiente, el problema puede extenderse de un cultivo a otros. En la actualidad, el picudo del algodonero se controla utilizando una variedad del algodón obtenida mediante ingeniería genética. Si aparece una plaga de picudo algodonero resistente, otros 200 cultivos pueden caer víctimas de esta plaga, que ya no será sensible al plaguicida (Toner 1996).

\section{Agricultura sostenible}

Debido a los problemas ambientales y económicos, los agricultores han empezado a utilizar métodos agrícolas alternativos para reducir el coste de las materias primas, preservar los recursos y proteger la salud humana. Estos sistemas alternativas hacen

Tabla 64.21 • Cultivo de drogas ilegales, 1987, 1991 y 1995.

\begin{tabular}{llrrr} 
Cultivo & Producto & \multicolumn{3}{l}{ Hectáreas cultivadas } \\
& & 1987 & \multicolumn{1}{l}{1991} & \multicolumn{1}{l}{1995} \\
\hline Amapola real & Opiáceos & 112.585 & 226.330 & 234.214 \\
Coca (hoja) & Cocaína & 175.210 & 206.240 & 214.800 \\
Cánamo de la India & Marihuana & 24.423 & 20.919 & 12.205
\end{tabular}

Fuente: Departamento de Estado de Estados Unidos 1996. 
hincapié en la gestión, las relaciones biológicas y los procesos naturales.

En 1987, la Comisión Mundial de Medio Ambiente y Desarrollo definió el desarrollo sostenible como aquel que satisface "las necesidades y aspiraciones del presente sin comprometer la capacidad de las futuras generaciones para satisfacer sus propias necesidades" (Myers 1992). Una agricultura sostenible, en su sentido más amplio, es aquella que produce grandes cantidades de alimentos de alta calidad, protege sus recursos, es rentable y no daña al medio ambiente. Reduce los riesgos para la salud humana utilizando una estrategia a escala de sistemas. El concepto de la agricultura sostenible incorpora el término seguridad agrícola en todo el ambiente de trabajo, abarcando la disponibilidad y uso correcto de todos los recursos, como el suelo, el agua, los fertilizantes, los plaguicidas, los edificios rurales, los animales, el capital y el crédito y la personas que forman parte de la comunidad agrícola.

\section{Mano de obra infantil y migrante}

Los niños trabajan en la agricultura en todo el mundo. El mundo industrializado no es una excepción. De los 2 millones de niños menores de 19 años que viven en las granjas y ranchos de Estados Unidos, se estima que 100.000 sufren accidentes todos los años relacionados con la producción agrícola. Generalmente son hijos de los propietarios de las granjas o de sus empleados (National Committee for Childhood Agricultural Injury Prevention 1996). La agricultura es uno de los pocos entornos laborales, tanto en los países desarrollados como en desarrollo, donde los niños pueden realizar trabajos que normalmente realizan los adultos. Los niños están también expuestos a peligros cuando acompañan a sus padres durante el trabajo o cuando visitan las granjas durante su tiempo libre. Los principales causantes de accidentes agrícolas son los tractores, otros tipos de maquinaria agrícola, el ganado, las estructuras de los edificios y las caídas. Los niños están también expuestos a plaguicidas, combustibles, gases nocivos, irritantes atmosféricos, ruido, vibración, zoonosis y estrés. En plantaciones de todo el mundo se emplea mano de obra infantil. Los niños ayudan a sus padres como miembros de un equipo que trabaja a destajo en las plantaciones y como trabajadores migrantes, o son contratados directamente para realizar ciertos tipos de trabajo en las plantaciones (OIT 1994).

Algunos de los problemas y enfermedades de los trabajadores migrantes y la mano de obra infantil se describen en otras secciones de este capítulo y en otros capítulos de esta Enciclopedia.

\section{Cultivo de drogas ilegales}

Algunos cultivos no aparecen en los registros oficiales porque son ilegales. Se trata de plantas cultivadas con el fin de obtener narcóticos para consumo humano que alteran el juicio, son adictivos y pueden causar la muerte. Además, contribuyen a la disminución de terreno productivo para la producción de alimentos. Estos cultivos son la amapola (de la que se obtiene opio y heroína), la hoja de coca (de la que se obtiene cocaína y crack) y el cáñamo de la India (del que se obtiene marihuana). Desde 1987, la producción mundial de amapola real y coca ha aumentando, mientras que el cultivo de cáñamo de la India se ha reducido, según se indica en la Tabla 64.21. En el tráfico de drogas ilegales, la cadena entre el agricultor y el usuario está formada por cinco eslabones: cultivo, transformación, tránsito, distribución mayorista y venta minorista. Para luchar contra el tráfico de drogas ilegales, los gobiernos intentan erradicar la producción de estas drogas. Por ejemplo, la destrucción de 200 hectáreas de coca puede evitar la entrada en el mercado de casi una tonelada métrica de cocaína durante un período de 2 años, puesto que ese es el tiempo que se tardaría es volver a disponer de plantas maduras. La forma más eficiente de destruir los cultivos es mediante la aplicación aérea de herbicidas, aunque algunos gobiernos se resisten a esta medida. La erradicación manual es otra posibilidad, pero expone al personal a la reacción violenta de los cultivadores (Departamento de Estado de Estados Unidos 1996). Algunos de estos cultivos tienen también un uso legal, como es la fabricación de morfina y codeína a partir del opio, y la exposición al polvo de estas sustancias puede ocasionar riesgos narcóticos en el lugar de trabajo (Klincewicz y cols. 1990).

\section{Referencias}

AgSafe Coalition for Health and Safety in Agriculture. 1992. Occupational Injuries in Califormia Agriculture 1981-1990. Berkeley, California: Universidad de California.

Alexandratos, N. 1995. World Agriculture: Towards 2010. An FAO Study. Nueva York: John Wiley \& Sons.

Bean, TL, TS Lawrence. 1992. Vehicles on Public Highways. National Institute for Farm Safety Paper No. 92-04. Myrtle Beach, Carolina del Sur: National Institute for Farm Safety.

Bonsall, JL. 1985. Measurement of occupational exposure to pesticides. En Occupational Hazards of Pesticide Use, dirigido por GJ Turnbull. Londres: Taylor and Francis.

Boxer PA, C Burnett, N Swanson. 1995. Suicide and occupation: A review of the literature. 7 Occup Med $37(4): 442-452$.

Bringhurst, LS, RN Byrne, J Gershon-Cohen. 1959. Respiratory disease of mushroom workers. Farmer's lung. fAMA 171:15-18.

Brown, LR, N Lenssen, H Kane. 1995. Vital Signs 1995: The Trends that Are Shaping Our Future. Nueva York: WW Norton \& Company.

Bull, D. 1982. A Growing Problem: Pesticides and the Third World Poor. Washington DC: Oxfam.

Campbell, WP. 1987. The Condition of Agricultural Driveline System Shielding and Its Impact on Injuries and Fatali- ties Tesis MS West Lafayette Indiana: Universidad de Purdue.

Chang, S. 1993. Mushroom biology: The impact on mushroom production and mushroom products. En Mushroom Biology and Mushroom Products, dirigido por S Chang, JA Buswell y S Chiu. Hong Kong: Chinese University Press.

Christiani, DC. 1990. Occupational health in developing countries: Review of research needs. Am $\mathcal{F}$ Ind Med 17:393-401.

Connally LB, PA Schulte, RJ Alderfer, LM Goldenhar, GM Calvert, KE Davis-King, WT Sanderson. 1996. Developing the National Institute for Occupational Safety and Health's cancer control demonstration projects for farm populations. Fournal of Rural Health sup.l 12(4):258-264.

Cox, A, HTM Folgering, LJLD Van Griensven. 1988. Extrinsic allergic alveolitis caused by the spores of the Oyster mushroom Pleurotus ostreatus. Eur Respir f 1:466-468.

1989. Allergische Alveolitis verursacht durch Einatmung von Sporen des Pilzes Shii-take (Lentinus edodes). Atemwegs Lungenkr 15:233-234.

Dankelman, I, J Davidson. 1988. Women and Environment in the Third World: Alliance for the Future. Londres: Earthscan Publications.

Davies DR. 1995. Organophosphates, affective disorders, and suicide. Fournal of Nutritional and Environmental Medicine 5:367-374.
Deere \& Co. 1994. Farm and Ranch Safety Management. Moline, Ilinois: Deere \& Company.

Dufaut, A. 1988. Women carrying water: How it affects their health. Waterlines 6:23-25.

Eicher, LC. 1993. State Codes for Road Travel of Agricultural Machinery. American Society of Agricultural Engineering (ASAE) Paper No. 931513. St. Joseph, Michigan: ASAE.

Estlander T, L Kanerva, P Pïrilä. 1996. Allergic dermatoses and respiratory diseases caused by decorative plants. Afr Neweslttr Occup Health Saf 6(1):11-13.

Etherton, JR, JR Myers, RC Jensen, JC Russell, RW Broddee. 1991. Agricultural machine-related deaths. Am F Public Health 81(6):776-768.

Forget, G. 1991. Pesticides and the third world. $f$ Toxicol Environ Health 32:11-31.

- 1992. Occupational health and development: An overview of the situation. IDRC Reports: Perils in the Workplace 20:4-7.

Franck MI, DM Brownstone. 1987. Harvesters. Nueva York: Facts on File Publications.

Freivalds, A. 1984. Evaluation of the lift angle in spade work. Ergonomics 27 supl.:128-133.

Gerrits, JPG, LJLD Van Griensven. 1990. New developments in indoor composting (tunnel process). Mushroom f 205:21-29.

Gite, LP, BG Yadav. 1990. Optimum handle height for a push-pull type manually operated dryland weeder. Ergonomics 33:1487-1494. 
Gite, LP. 1991. Optimum handle height for animal drawn mould board plough. Appl Ergon 22:21-28.

Glascock, LA, TL Bean, RK Wood, TG Carpenter, RG Holmes. 1993. Characteristics of SMV Accidents. American Society of Agricultural Engineering (ASAE) Paper No. 931618. St. Joseph, Michigan: ASAE

Griffin, GA. 1973. Combine Harvesting. Moline, Illinois: Deere \& Company.

Gunderson, PD. 1995. An analysis of suicides on the farm or ranch within five north central United States, 1980 to 1988. En Agricultural Health and Safety: Workplace, Environment, Sustainability, dirigido por HH McDuffie, JA Dosman, KM Semchuk, SA Olenchock y A Senthilselvan. Boca Raton, Florida: CRC Press.

Hanrahan, LP, HA Anderson, LK Haskins, J Olson, K Lappe, D Reding. 1996. Wisconsin farmer cancer mortality, 1981 to 1990 : Selected malignancies. fournal of Rural Health supl. 12(4):273-277.

Hausen, BM, KH Schulz, U Noster. 1974. Allergic disease caused by the spores of an edible fungu Pleurotus florida. Mushr Sci 9:219-225.

Horner, WE, MD Ibanez, V Liengswangwong, JE Salvaggio, SB Lehrer. 1988. Characterization of allergens from spores of the Oyster mushroom Pleurotus ostreatus. F Allergy Clin Immunol 82:978-986.

Jones, TH. 1978. How to Build Greenhouses, Garden Shelters, Sheds. Nueva York: Harper \& Row.

Kelley, KA. 1996. Characteristics of flowing grainrelated entrapments and suffocations with emphasis on grain transport vehicles. Fournal of Agricultural Safety and Health 96(3):143-151.

Klincewicz, S, AT Fidler, G Siwinski, A Fleeger. 1990. Health Hazard Report: Penick Corporation, Newark, New fersey. No. HETA -87-311-2087. Cincinnati, Ohio: $\mathrm{NIOSH}$.

Kundiev, YI. 1983. Condiciones de trabajo en la agricultura. En Enfermedades profesionales en los agricultores, dirigido por YI Kundiev y EP Krasnyu. Kiev: Zdorovye.

Loftas, T (dir.). 1995. Dimensions of Need: An Atlas of Food and Agriculture. Santa Barbara, California: ABCCLIO, Inc.

Makinen-Kiljunen, S, K Turjanmaa, T Palosuo, T Reunala. 1992. Characterization of latex antigens and allergens in surgical gloves and natural rubber by immunoelectrophoretic methods. Fournal Allergy Clin Immunol 90(2):230_235.

McDuffie, HH, JA Dosman, KM Semchuk, SA Olenchock, A Senthilselvan (dirs.). 1994. Agricultural Health and Safety: Workplace, Environment, Sustainability. Boca Raton, Florida: CRC Press.

Merchant. JP, BA Boehlecke, G Taylor, M PickettHarner (dirs.). 1986. Occupational Respiratory Diseases. DHHS (NIOSH) Publication No. 86-102. Washington, DC: GPO

Meridian Research, Inc. 1994. Occupational Safety and Health Hazards in Agriculture: A Review of the Literature. Silver Spring, Maryland: Meridian Research.

Meyers, JR, DL Hard. 1995. Work-related fatalities in the agricultural production and services sectors, 1980-1989. Am f Ind Med 27:51-63.

Meyers, JR. 1997. Injuries among Farm Workers in the United States, 1993. DHHS (NIOSH) Publication No. 97-115. Cincinnati, Ohio: NIOSH.

Miles, J. 1996. Personal communication.

Mines, R, PL Martin. 1986. A Profile of California Farmworkers. Giannini Information Series 86-2, Berkeley: Universidad de California, Departamento de agricultura y recursos naturales.

Mohan D, R Patel. 1992. Design of safer agricultura equipment: Application of ergonomics and epidemiology. Int 7 Ind Erg 10: 301-310.

Murphy, DJ, RC Williams. 1983. Safe Forage Harvesting. Agricultural Engineering Fact Sheet No. 21. State
College, Pensilvania: Pennsylvania State University Cooperative Extension Service.

Murphy, DJ. 1992. Safety and Health for Production Agriculture. St. Joseph, Michigan: American Society of Agricultural Engineering.

Myers, ML. 1992. Sustainable Agriculture as a Strategy in Agricultural Safety. American Society of Agricultural Engineers (ASAE) Paper No. 928510. St. Joseph, Michigan: ASAE

Nag, PK, A Goswami, SP Ashtekar, CK Pradhan. 1988. Ergonomics in sickle operation. Appl Ergon 19:233-239.

Nag, PK, CK Pradhan. 1992. Ergonomics in the hoeing operation. Int $\mathcal{f}$ Ind Erg 10:341-350.

Nag, PK, NG Sebastian, MG Marlankar. 1980. Occupational workload of Indian agricultural workers Ergonomics 23:91-102.

Nag, PK, P Dutt. 1979. Effectiveness of some simple agricultural weeders with reference to physiological responses. 7 Hum Ergol 8:13-21.

1980. Circulo-respiratory efficiency in some agricultural work. Appl Ergon 11:81-84.

Nag, PK, SK Chatterjeee. 1981. Physiological reactions of female workers in Indian agricultural work. Hum Factors 23:607-614

Nakazawa, T, K Kanatani,Y Umegae. 1981. Mushroom workers lung due to the inhalation of spores of Cortinus shii-take. Jpn $\mathcal{F}$ Chest Dis 40:934-938.

National Committee for Childhood Agricultural Injury Prevention. 1996. Children and Agriculture: Opportunities for Safety and Health. Marshfield, Wisconsin. Marshfield Clinic.

National Research Council (NRC). 1989. Alternative Ag riculture. Washington, DC: National Academy Press. 1993. Sustainable Agriculture and the Environment in the Humid Tropics. Washington, DC: National Academy Press.

National Safety Council (NSC). 1942. Accident Facts. Chicago, Illinois: NSC.

- 1986. Grain Harvest Safety. Chicago, Illinois: NSC. - 1993. Accident Facts. Chicago, Illinois: NSG. 1995. Accident Facts. Chicago, Illinois: NSC.

Nomura, S. 1993. Studies on the work load and health management in agricultural workers. Journal of Fapanese Association of Rural Medicine 42:1007-1011.

Olson, J.A. 1987. Pleurotus spores as allergens. Mushr f 172:115-117.

Organización de las Naciones Unidas para la Agricultura y la Alimentación (FAO). 1987. African Agriculture: The Next 25 rears. Roma: FAO.

1995. The State of World Fisheries and Aquaculture. Roma: FAO.

- 1997. FAOSTAT Statistics Database (http://apps.fao.org/Default.htm). Al 22 enero.

Organización Internacional de Normalización (ISO). 1985. ISO 263. Evaluation of Human Exposure to Whole-body Vibration: Part I: General Requirements. Ginebra: ISO.

Organización Internacional del Trabajo (OIT). 1994 Situación reciente del trabajo en las plantaciones. Ginebra: OIT

Organización para la Cooperación y el Desarrollo Económico (OCDE). 1994. Farm Employment and Economic Adjustment in OECD Countries. París: OCDE.

Parrón, T, AF Hernández, E Villanueva. 1996. Increased risk of suicide with exposure to pesticides in an intensive agricultural area: A 12-year retrospective study. Forensic Science International 79:53-63.

Partanen, T. 1996. Improving the work environment by means of risk surveys. Afr Neweslttr Occup Health Saf 6(2):28-29.

Pearce, N, JS Reif. 1990. Epidemiologic studies of cancer in agricultural workers. $\mathrm{Am}$ f Ind $\mathrm{Med}$ 18:133-148.
Pepys, J. 1967. Hypersensitivity against inhaled organic antigens. f Roy Coll Phys London 2:42-48.

Popendorf, W, KJ Donham. 1991. Agricultural hygiene. En Patty's Industrial Hygiene and Toxicology, $4^{\text {a }}$ edición, dirigido por GD Clayton y FE Clayton. Nueva York: John Wiley \& Sons, Inc.

Pradhan, CK, A Goswami, SK Ghosh, PK Nag. 1986. Evaluation of working with spade in agriculture. Indian F Med Res 84:424 429.

Raffle, PAB, PH Adams, PJ Baxter, WR Lee. 1994. Hunter's Diseases of Occupations, 8th edition, Londres: Edward Arnold.

Recht, C, MF Wetterwald. 1992. Bamboos. Portland, Oregón: Timber Press.

Rowntree, RA. 1987. Contemplating the urban forests. En Our American Land: 1987 Yearbook of Agriculture. Washington, DC: USDA.

Rylander, R. 1986. Lung diseases caused by organic dusts in the farm environment. Am 7 Ind Med 10:221-227.

Sakula, A. 1967. Mushroom-worker's lung. Brit Med 7 3:708-710

Sastre, J, MD Ibañez, M Lopez, SB Lehrer. 1990. Respiratory and immunological reactions among Shiitake (Lentinus edodes) workers. Clin Exp Allergy $20 \cdot 13-20$

Scherf, BD. 1995. World Watch List for Domestic Animal Diversity. Roma: FAO.

Sen, RN, PK Nag. 1975. Work organization of heavy load handling in India. 7 Hum Ergol 4:103-113.

Shutske, JM, WE Field, LD Gaultney, SD Parsons. 1991. Agricultural machinery fire losses: A preventative approach. Applied Engineering in Agriculture 6(5):575-581.

Skillicorn, P, W Spira, W Journet. 1993. Duckweed Aquaculture: A New Aquatic Farming System for Developing Countries. Washington, DC: World Bank.

Snyder, K T Bobick. 1995. Safe Grain and Silage Handling. DHHS (NIOSH) Publication No. 95-109. Cincinnati, Ohio: NIOSH

Sonnenberg, ASM, PCC Van Loon, LJLD Van Griensven. 1996. Het aantal sporen dat Pleurotus spp. in de lucht verspreidt (con un índice en inglés). $D e$ Champignoncultuur 40:269-272.

Steinke, WE. 1991. Farm Labor, Tractor Use, and Farm Work Injury Survey. Unpublished data. Davis, California: Universidad de California.

Stewart, CJ. 1974. Mushroom worker's lung-Two outbreaks. Thorax 29:252-257.

Stolz, JL, PH Arger, JM Benson. 1976. Mushroom worker's lung disease. Radiology 119:61-63.

Storch, G, JG Burford, RB George, L Kaufman, L Ajello. 1980. Acute histoplasmosis: Description of an outbreak in Northern Louisiana. Chest 77(1):38-42

Sullivan JB, M Gonzales, GR Krieger, CF Runge. 1992. Health-related hazards of agriculture. En Hazardous Material Toxicology: Clinical Principles of Environmental Health, dirigido por JB Sullivan y GR Kreiger. Londres: Williams \& Wilkins.

Tannahill, R. 1973. Food in History. Nueva York: Stein and Day.

Toner, M. 1996. Debugging king cotton. Atlanta foumal-Constitution 47(50):G1.

United Nations Development Programme (UNDP) 1996. Urban Agriculture: Food, Fobs, and Sustainable Cities. Nueva York: UNDP.

US Department of Agriculture (USDA). 1996. Foreign Agricultural Service Circular Series FTROP 2-96. Washington, DC: USDA.

US Department of Labor (DOL). 1968. Fair Labor Standards Act - The Hazardous Occupations Order for Agriculture. Washington, DC: US DOL.

US Department of State. 1996. International Narcotics Control Report. Washington, DC: US Department of State. 
Van den Bogart, HGG, G Van den Ende, PGG Van Loon, LJLD Van Griensven. 1993. Mushroom worker's lung: serologic reactions to thermophilic actinomycetes in the air of compost tunnels. Mycopathologia 122:21-28.

Van den Bogart, HGG. 1990. De champignonkwekerslong: een onderzoek naar voorkomen en etiologie in Nederland. Disertación doctoral. Nijmegen, Países Bajos: Universidad de Nijmegen.

Van Haaren, JPM. 1988. Occupational diseases. En The Cultivation of Mushrooms, dirigido por LJLD Van Griensven. Rustington, Reino Unido: Darlington Mushroom Laboratories.

Van Loon, PCC, AL Cox, OPJM Wuisman, SLGE Burgers, LJLD Van Griensven. 1992. Mushroom worker's lung. Detection of antibodies against shii take (Lentinus edodes) spore antigens in shii take workers. 7 Occup Med 34:1097-1101.

Villarejo, D. 1995. Issues for farm employees in the United States. En Agricultural Health and Safety: Workplace, Environment and Sustainability, dirigido por $\mathrm{HH}$ McDuffie, JA Dosman, KM Semchulk, SA Olenchock y A Senthilselvan. Boca Raton, Florida: CRC Press.

Viten VPh, EP Krashyyuh, OV Ilyna. 1994. Ergonomic and health aspects of pesticide exposure in greenhouses. En Health, Safety and Ergonomic Aspects in Use of Chemicals in Agriculture and Forestry: Proceedings of the XII foint GIGR; IAAMRH, IUFRP International Symposium, dirigido por Y Kundiev. Kiev: Instituto de Salud en el Trabajo.

Wallerstein N, M Weinger. 1992. Health and safety education for worker empowerment. Am $\mathcal{f}$ Ind Med 22:619-635.

Weinger, J, M Lyons. 1992. Problem-solving in the fields: An action-oriented approach to farmworke education about pesticides. Am $\mathcal{f}$ Ind $\mathrm{Med}$ 22:677-690.

Weinger, M, N Wallerstein. 1990. Education for action: An innovative approach to training hospital employees. En Essentials of Modern Hospital Safety, dirigido por W Charney y J Whirmer. Chelsea, Michigan: Lewis Publishers.

Zejda. JE, HH McDuffie, JA Dosman. 1993. Epidemiology of health and safety risks in agriculture and related industries: Practical applications for rural physicians. West f Med 158:56-63.

\section{Otras lecturas recomendadas}

Adams, WD, TR Leroy. 1992. Growing Fruits and Nuts in the South: The Definitive Guide. Dallas, Texas: Taylor Publishing Co.

Akehurst, BC. 1981. Tobacco. Nueva York: Humanities Press.

Ashworth J, FN Curry, IR White, RJG Rycroft. 1990 Occupationally allergic contact dermatitis in eas coast of England fisherman: Newly described hypersensitivities to marine organisms. Contact Dermat 22(3):185-186.

Atkin, M. 1992. The International Grain Trade. Cambridge: Woodhead Publishing Limited.

Atta, MV. 1991. Growing and Using Exotic Foods. Sarasota, Florida: Pineapple Press.

Australian Canegrowers Publication. Cane Farm Workers Guide. 1992. Brisbane, Australia: Australian Canegrowers Publication.

Borget, M. 1993. Spice Plants. Londres: Macmillan Press Ltd.

Brittain J, S Caldwell, S Schuman. 1992. Agriculture and Medicine: A Partnership. Videoconference Guide. Clemson, Carolina del Sur: Clemson University.

Cary, AE. 1991. Agriculture, agricultural chemicals, and water quality. En Agriculture and the Environment: The 1991 Yearbook of Agriculture. Washington, DC: USDA.
Chan, OY, CS Lee, KT Tan, T Thirumoorthy. 1990. Health problems among spice grinders. 7 Soc Occup Med 40:111-115.

Christiansson, C, C Folke, T Karberger (dirs.). 1991 Use and Impacts of Chemical Pesticides in Smallholder Agriculture in the Central Kenya Highlands. Dordrecht, Países Bajos: Kluwer Academic Publishers.

Clerc, J-M (dir.). 1985. Introducción a las condiciones y el medio ambiente de trabajo. Ginebra: OIT

Collins, WK, SN Hawks, Jr. (dirs.). 1993. Principles of Flue-cured Tobacco Production. Raleigh, Carolina del Norte: Universidad Estatal de Carolina del Norte.

Cordes, DH, DF Rea (dirs.). 1991. Health hazards of farming. Occup Med: State Art Rev 6(3).

Cotes, JE, J Steel. 1987. Work-related Lung Diseases. Oxford: Blackwell Scientific Publications.

Coumbis JJ. 1992. Musculoskeletal disorders and hazards. Papers and Proceedings of the Surgeon General's Conference on Agricultural Safety and Health. DHHS NIOSH) Publication No. 92-105. Washington, DC: GPO.

Coye MJ. 1985. The health effects of agricultural production: I. The health of agricultural workers. $\mathcal{F} P u b$ Hlth Policy 6:349-370.

Cullen M, Johnson L. 1992. The Urban/suburban Composter. Nueva York: St. Martin's Press.

Davies JE, RF Smith, V Freed. 1978. Agromedical approach to pesticide management. Ann Rev Entomol 23:353-366

Dawson, MW, JG Scott, LM Cox. 1996. The medical and epidemiologic effects on workers of the levels of airborne Thermoactinomyces spp. Spores present in Australian raw sugar mills. Am Ind Hyg Asso $\mathcal{J}$ 57:1002-1012.

Division of Workplace Safety and Health. 1991. Take Time for Safety: Sugar Industry. Queensland, Australia: Department of Employment, Vocational Education, Training and Industrial Relations, Division of Workplace Safety and Health.

Dosman, JA, DW Cockcroft. 1989. Principles of Health and Safety in Agriculture. Boca Raton, Florida: CRC Press.

El Batawi, MA. 1992. Migrant workers. En Occupational Health in Developing Countries, dirigido por J Jeyaratnam. Nueva York: Oxford University Press.

Fenske, R, NJ Simcox. 1995. Agricultural workers. En Occupational Health: Recognizing and Preventing Workrelated Diseases, dirigido por BS Levy y DH Wegman. Boston: Little, Brown \& Co.

Forsman S, GH Coppee. 1984. Occupational Health Problems of Young Workers. Ginebra: OIT.

Graber, DR, WJ Jones, JA Johnson. 1995. Human and ecosystem health: The environment-agricultural connection in developing countries. 7 Agromedicine $2: 47-64$.

Greenhalgh, P. 1972. The Market for Culinary Herbs. Londres: Tropical Products Institute.

Hay, A. 1991. Recent assessment of cocoa and pesticides in Brazil: An unhealthy blend for plantation workers. Sci Total Environ 106(1):97-109.

Hayes, WJJ, ERJ Laws. 1991. Handbook of Pesticide Toxicology. San Diego, California: Academic Press.

Heimlich, RE. 1987. Agriculture and urban areas in perspective. En Our American Land: 1987 Yearbook of Agriculture. Washington, DC: GPO.

Helmore, K, A Ratta. 1995. The surprising yields of urban agriculture. Choices 4(1):22-27.

James, ER. 1994. Onchocerciasis control by insecticides and chemotherapy stimulates agricultural development in Central West Africa. If Agromedicin $1: 3-17$.

James, PA: Agromedicine: What's in a name? 7 Agromedicine 1:81-87.

Jones, DL. 1995. Palms throughout the World. Washington, DC: Smithsonian Institution Press.
Karr, C, J Kalat, D Locke, E Atkinson, M Rohde. 1995. Farm worker occupational illness and injury in Washington State. En Agricultural Health and Safety: Workplace, Environment, Sustainability, dirigido por HH McDuffie, JA Dosman, KM Semchuk, SA Olenchock y A Senthilselvan. Boca Raton, Florida: CRC Press.

Kelley, WD. 1982. Agricultural Respiratory Hazards. Cincinnati, Ohio: Conferencia Americana de Higienistas Industriales del Gobierno.

Kelsey, TW. 1994. The agrarian myth and policy responses to farm safety. Am 7 Public Health 84(7):1171-1177.

Kidd, P, T Scharf, M Veazie. 1996. Linking stress and injury in the farming environment: A secondary analysis of qualitative data. Health Education Quarterly 23(2):224-237.

Levy, BS, DH Wegman. 1995. Occupational Health: Recognizing and Preventing Work-related Disease, $3^{\circ}$ edición. Boston: Little, Brown and Co.

Malmros, P, P Jonsson. 1994. Wastes management: Planning for recycling and workers' safety. Fournal of Waste Management and Resource Recovery 1(3):107-112.

Marotz-Baden, R, CB Hennon, TH Brubaker (dirs.) 1988. Families in Rural America: Stress, Adaptation, and Revitalization. St. Paul, Minnesota: National Council on Family Relations.

Martin, NB. 1995. Custos e rentabilidade de diferentes sistemas de producao de café. Informmacóes Econômicas (Sao Paulo) 5(8):35-47.

McCurdy, SA, TS Ferguson, DF Goldsmith, JE Parker, MB Schenker. 1996. Respiratory health of California rice farmers. Am 7 Respir Crit Care Med 153:1553-1559..

Merchant, JP, B Kross, K Donham, D Pratt. 1989. Agriculture at Risk: A Report to the Nation. Kansas City, Misuri: National Coalition for Agricultural Safety and Health, National Rural Health Association.

Meyers, JR, KA Snyder. 1995. Roll-over protective structure use and the cost of retrofitting tractors in the United States, 1993. Fournal of Agricultural Safety and Health 1(3):185-197.

Mikheev, M. 1994. Health and safety issues in the use of pesticides: An international perspective. En Health, Safety and Ergonomic Aspects in Use of Chemicals in Agriculture and Forestry: Proceedings of the XII Joint GIGR, IAAMRH, IUFRP International Symposium, dirigido por Y Kundiev. Kiev: Instituto para la Salud en el Trabajo.

Miller, RA. 1992. The Potential of Herbs as a Cash Crop. Berkeley, California: Ten Speed Press.

Mobed, K, E Cold, MB Schenker. 1992. Occupational health problems among migrant and seasonal farmworkers. West f Med 157:367-373.

Morrison, HI, RM Semenciw, D Morrison D, Y Mao. 1995. Mortality among Canadian fruit and vegetable farmers. Agricultural Health and Safety: Workplace, Environment, Sustainability, dirigido por $\mathrm{HH}$ McDuffie, JA Dosman, KM Semchuk, SA Olenchock y A Senthilselvan. Boca Raton, Florida: CRC Press.

Myers, ML, RF Herrick, SA Olenchock, JR Myers, JE Parker, DL Hard, K Wilson (dirs.). 1992. Papers and Proceedings of the Surgeon General's Conference on Agricultural Safety and Health. DHHS (NIOSH) Publication No. 92-105. Cincinnati, Ohio: NIOSH.

National Institute for Occupational Safety and Health (NIOSH). 1977. Occupational Diseases: A Guide to Their Recognition. Washington, DC: NIOSH.

1983. Musculoskeletal Diseases in Agricultural Workers. Cincinnati, Ohio: NIOSH

. 1993. Fatal Injuries to Workers in the United States, 1980-1989: A Decade of Surveillance. Cincinnati, Ohio: NIOSH.

1996. Ecologically Based Pest Management: New Solution for a New Century. Washington, DC: National Academy Press. 
Nelson, PV. 1981. Greenhouse Operation and Managemen, $2^{\text {a }}$ edición. Reston, Virgina: Reston Publishing Co.

Nogueira, DP. 1987. Prevention of accidents and injuries in Brazil. Ergonomics 30(2):387-393.

Norse, EA (dir.). 1993. Global Marine Biological Diversity: A Strategy for Building Conservation into Decision Making. Washington, DC: Island Press.

O'Toole, C. 1995. Alien Empire: An Exploration of the Lives of Insects. Nueva York: Harper Collins Publishers.

Organización Internacional del Trabajo (OIT). 1965 Safety and Health in Agricultural Work. Ginebra: OIT.

- 1979. Guide to Health and Hygiene in Agricultural Work Ginebra: OIT.

- 1988. Maximum Weights in Load Lifting and Carrying. Geneva: ILO.

Organización Mundial de la Salud (OMS). 1987. Detección precoz de enfermedades profesionales. Ginebra: OMS

- 1990. Public Health Impact of Pesticides Used in Agriculture. Ginebr: OMS.

Persons, WS. 1986. American Ginseng: Green Gold. Pompano Beach, Florida: Exposition Press of Florida.

Phoolchund, HN. 1991. Aspects of occupational health in the sugar cane industry. I Soc Occ Med 41(3):133-136.

Pinstrup-Andersen, P (dir.). 1993. The Political Economy of Food and Nutrition Policies. Johns Baltimore, Maryland: Johns Hopkins University Press.

Prosterman, RL, T Hanstad, L Ping. 1996. Can China feed itself? Sci Am 275(5):90-96.

Rastogi, SK, BN Gupta, T Husain, N Mathur, N Garg. 1989. Study of respiratory impairment among pesticide sprayers in mango plantations. $A m$ 7 Ind Med 16(5):529-538.

Rodríguez, E. 1993. Factores de riesgo psicoscociales en la organización laboral. Medellín, Colombia: Instituto de la Seguridad Social.
Rosenstock, L, M Cullen. 1986. Clinical Occupational Medicine. Filadelfia, Pensilvania: WB Saunder Company.

Rovell, CR. 1993. Plants and the Skin. Oxford: Blackwell Scientific Publications.

Rycroft, RJG, T Menné, PJ Frosch. 1995. Textbook of Contact Dermatitis. Berlín: Springer-Verlag.

Satterwaite, D. 1993. The impact on health of urban environments. Environment and Urbanization 5(2):87-111.

Schenker, MB, R López, G Wintemute. 1995. Farmrelated fatalities among children in California, 1980 to 1989. Am F Public Health 85(1):89-92.

Schuman, S (dir.). 1995. 1994 - A vintage year for agromedicine journals. $\mathcal{F}$ Agromedicine 2:1-2.

Schuman, SH, WM Simpson Jr. 1997. AG-MED: The Rural Practitioner's Guide to Agromedicine. Kansas City, Misuri: American Academy of Family Physicians.

Sekimpi, DK, EF Agaba, M Okot-Nwang, DA Orgaram. 1996. Occupational coffee dust allergies in Uganda. Afr Newslett Occup Health Saf 6(1):6.

Snyder, K, T Bobick. 1995. Safe Grain and Silage Handling. DHHS (NIOSH) Publication No. 95-109. Washington, DC: GPO.

Sobczak, PM, JA Johnson, WJ Jones, LG Lusby. 1994. Agromedicine: A delphi study of the field - present and future. F Agromedicine 1:69-79.

Stransky, L, S Transkov. 1980. Contact dermatitis from parsley. Contact Dermat 6:233-234.

Thrupp, LA. 1991. Sterilization of workers from pesticide exposure: The causes and consequences of DBCP-induced damage in Costa Rica and beyond. Int 7 Health Serv 21(4):731-757.

Thune, PO, YJ Solberg. 1980. Photosensitivity and allergy to aromatic lichen acids, compostae, oleoresins and other plant substances. Contact Dermatitis 6(2):81-87.
Toorenenbergen, AW, PH Dieges. 1984. Occupational allergy in horticulture: demonstration of immediate-type allergic reactivity to freesia and paprika plants. International Archives of Allergy and Applied Immunology 75:44-47.

Tso, TC. 1990. Production, Physiology, and Biochemistry of the Tobacco Plant. Beltsville, Maryland: Ideals, Inc.

US Department of Agriculture (USDA). 1985. U.S. Agriculture in a Global Economy: 1985 Yearbook of Agriculture. Washington, DC: GPO.

- 1988. Agricultural Statistics 1988. Washington, DC: GPO.

US Department of Labor. 1991. Findings from the $\mathrm{Na}$ tional Agricultural Workers Survey (NAWS) 1990: A Demographic and Employment Profile of Perishable Crop Farm Workers. Washington, DC: US Department of Labor.

US General Accounting Office (GAO). 1992. Report to Congressional Requestors: Hired Farmworkers: Health and Well-being at Risk. GAO/HRD-92-46. Washington, DC: GAO.

Vázquez-Castellanos, JC. 1991. El cultivo del café y la historia social de la oncocerciasis en Soconusco, Chiapas, México. Salud Pública de Mexico 33:(2):124-135

Wan, H. 1990. Pesticide exposure of applicators working in tea plantations. $B$ Environ Contam Tox 45(3):459-462.

Wheat, JR, MC Nagy, JT McKnight, RL Anderson. 1994. Alabama agrimedicine program: Rationale, proposal, and supportive study. If Agromedicine 1:63-82

Wilk, VA. 1986. The Occupational Health of Migrant and Seasonal farmworkers in the United States, $2^{\mathrm{a}}$ ed. Washington, DC: Farmworker Justice Fund, Inc.

- 1993. Health hazards to children in agriculture. $A m$ f Ind Med 24(3):283-90. 
Director del capítulo

Lance A. Ward

\section{Sumario}

Perfil general

David Franson. . . . . . . . . . . . . . . . . . . . 65.2

Fabricación de concentrados de bebidas refrescantes Zaida Colon . . . . . . . . . . . . . . . . . . . . 65.2

Embotellado y envasado de bebidas refrescantes

Mathew Hirsheimer . . . . . . . . . . . . . . . . . . . . . . . . . . 65.3

Industria del café

Forge da Rocha Gomes y Bernardo Bedrikow. . . . . . . . . . . . . . 65.7

Industria del té

Industria de licores destilados

R.G. Aldiy Rita Seguin . . . . . . . . . . . . . . . . . . . . . . 65.10

Industria del vino

Alvaro Durao . . . . . . . . . . . . . . . . . . 65.13

Industria de la cerveza

7.F. Eustace . . .

Cuestiones ambientales y de salud pública

Lance A. Ward . 
Perfil General

\section{David Franson}

\section{Descripción del sector}

La industria de las bebidas se compone de dos categorías principales y ocho subgrupos. La categoría de las bebidas sin alcohol comprende: la fabricación de jarabes de bebidas refrescantes; el embotellado y enlatado de agua y bebidas refrescantes; embotellado, enlatado y envasado en cajas de zumos de frutas; la industria del café; y la industria del té. La categoría de las bebidas alcohólicas incluye los licores destilados, el vino y la cerveza.

\section{Evolución de la industria.}

Aunque muchas de estas bebidas, incluida la cerveza, el vino y el té, han existido desde hace miles de años, su industria se ha desarrollado en los últimos siglos.

La industria de las bebidas, considerada desde un punto de vista global, aparece muy fragmentada, lo que resulta evidente por el gran número de fabricantes, de métodos de envasado, de procesos de producción y de productos finales. La industria de bebidas refrescantes constituye la excepción de la regla, pues está bastante concentrada. Aunque la industria de las bebidas esté fragmentada, sigue un proceso de consolidación desde el decenio de 1970, de modo que está cambiando la situación.

Desde principios de siglo, las compañías de bebidas han evolucionado desde las empresas regionales que producían artículos destinados principalmente a los mercados locales hasta las gigantescas empresas de hoy, que elaboran productos para mercados internacionales. Este cambio se inició cuando las compañías del sector adoptaron técnicas de producción en masa que les permitieron expansionarse. Además, durante este tiempo, se consiguieron avances en el envasado de productos y en los procesos que incrementaron enormemente el período de validez de los productos. Los envases herméticos para el té evitan la absorción de humedad, que representa la principal causa de pérdida del sabor, y la aparición de los aparatos de refrigeración permitió la elaboración de cerveza en los meses de verano.

\section{Importancia económica}

La industria de las bebidas emplea a varios millones de personas en todo el mundo, y cada tipo de bebida produce unos ingresos del orden de billones de dólares anuales. No cabe duda de que en algunos pequeños países en desarrollo la producción de café es el principal soporte de la economía global.

\section{Características de la población activa}

Aunque los ingredientes y los métodos de producción de las bebidas varíen, el personal empleado en esta industria suele presentar muchas características en común. En el proceso de recolección de las materias primas, ya sean granos de café, cebada, lúpulo o uvas, se emplea a individuos o familias de bajos ingresos, no cualificados. Además de constituir su principal fuente ingresos, la recolección determina en gran medida su cultura y estilo de vida.

En cambio, la elaboración del producto requiere operaciones automáticas y mecanizadas, y habitualmente da empleo a trabajadores manuales semicualificados. En las instalaciones de producción y en las áreas de almacenamiento, los puestos más comunes son los de operario de máquinas de envasado y llenado, operario de cinta transportadora y trabajadores mecánicos y manuales. La formación para estos puestos se realiza en el propio lugar y se completa con instrucción sobre el trabajo. A medida que avanzan la tecnología y la automatización, la plantilla se reduce en número y adquiere mayor importancia la formación técnica. Este personal de fabricación semicualificado suele contar con el apoyo de un grupo técnico altamente cualificado, integrado por ingenieros industriales, jefes de fabricación, contables y técnicos en garantía de calidad/seguridad de alimentos.

En general, las empresas de bebidas distribuyen sus productos a los mayoristas utilizando medios de transporte corrientes. Sin embargo, los fabricantes de bebidas refrescantes normalmente emplean conductores para entregar sus productos directamente a los detallistas. Estos conductores-comerciales representan alrededor de una séptima parte de los trabajadores de la industria de bebidas refrescantes.

El hecho de que en el decenio de 1990 exista una mayor preocupación por la salud en Europa y Norteamérica ha frenado el mercado de bebidas alcohólicas e incrementado la demanda de bebidas sin alcohol. Sin embargo, tanto las bebidas alcohólicas como las no alcohólicas están proliferando en los países en desarrollo de Asia, Suramérica y, en cierta medida, Africa. Como consecuencia de esta expansión, se están creando muchos puestos de trabajo para satisfacer las necesidades de producción y distribución.

\section{FABRICACION DE CONCENTRADOS DE BEBIDAS REFRESCANTES}

Zaida Colon

\section{Descripción del proceso}

La elaboración del concentrado representa la primera etapa en la producción de bebidas refrescantes. En los albores de la industria, en el siglo XIX, los concentrados y las bebidas refrescantes se fabricaban en las mismas instalaciones. En ocasiones, se vendía el concentrado a los consumidores, que preparaban sus propias bebidas refrescantes. El crecimiento del mercado de bebidas carbonatadas condujo a una especialización entre la fabricación de la bebida refrescante y el concentrado. Hoy en día, una planta de fabricación de concentrado vende su producto a varias empresas envasadoras.

Las plantas de concentrado están optimizando constantemente sus procedimientos mediante sistemas automáticos. Al aumentar la demanda de concentrado, la automatización permite al fabricante satisfacer las necesidades sin ampliar las dimensiones de la planta de fabricación. Los tamaños de los envases también se han ido incrementando. En el inicio de la industria, los envases de $1 / 2,1$ y 5 galones eran los más frecuentes. Hoy se utilizan bidones de 40 y 50 galones e incluso camiones cisterna con una capacidad de 3.000 y 4.000 galones. Las operaciones que se llevan a cabo en una planta de fabricación de concentrado se pueden dividir en cinco procesos básicos:

1. tratamiento del agua;

2. recepción de materias primas;

3. fabricación del concentrado;

4. llenado del concentrado y de los aditivos,

5. transporte de los productos terminados.

Cada uno de estos procesos entraña riesgos para la salud que pueden medirse y controlarse. El agua es un componente muy importante del concentrado y debe tener una calidad excelente. Cada planta de concentrado trata el agua hasta conseguir la calidad deseada y que esté exenta de microorganismos. El tratamiento del agua se controla durante todas las etapas.

Cuando la fábrica recibe los ingredientes, se procede a la inspección, toma de muestras y análisis de los mismos en el 


\section{Producción de zumos de fruta}

Los zumos de fruta se elaboran a partir de una amplia variedad de frutas, como naranjas y otros cítricos, manzanas, uvas, arándanos, piñas, mangos, etc. En muchos casos, se combinan varios zumos de frutas. La fruta suele convertirse en un concentrado casi en el lugar donde crece, enviándose después a un envasador de zumos de fruta. Los zumos de fruta se venden como concentrados, concentrados congelados lespecialmente el zumo de naranja) y zumos diluidos. Con frecuencia se añaden azúcar y conservantes.

Una vez que se reciben en la planta de procesamiento, se lavan las naranjas, se seleccionan para eliminar las dañadas, se separan por tamaños y se llevan a los extractores de zumo. Alli se extraen los aceites de la corteza y, a continuación, se extrae el zumo por aplastamiento. El zumo pulposo se tamiza para eliminar las semillas y la pulpa, que a menudo acaba siendo alimento para el ganado. Si el zumo de naranja está destinado a la venta como "no concentrado" se pasteuriza. De lo contrario, el zumo se introduce en máquinas evaporadoras, que eliminan la mayor parte del contenido de agua por calor y vacío; después se enfría para producir el concentrado de zumo de naranja congelado. En este proceso también se obtienen numerosos aceites y esencias, que se mezclan con el concentrado antes de enviarlo al envasador de zumos.

El concentrado congelado se envía al envasador en camiones o tanques refrigerados. Muchas industrias lácteas envasan zumo de naranja con el mismo equipo utilizado para la leche. (Véase el artículo "Industria de productos lácteos" en otra parte de este volumen.) El concentrado se diluye con agua filtrada, se pasteuriza y se envasa en condiciones estériles. Dependiendo de la cantidad de agua añadida, el producto final puede ser botes de conce ntrado de zumo de naranja congelado o de zumo de naranja listo para tomar.

Michael McCann

departamento de control de calidad. En el proceso de fabricación del concentrado sólo se utilizan materiales que hayan pasado las pruebas. Algunas materias primas se reciben en camiones cisterna y requieren una manipulación especial. También se recibe el material de envasado, que se evalúa y analiza de la misma forma que las materias primas.

Para la fabricación del concentrado, el agua tratada y los ingredientes líquidos y sólidos se bombean al interior de tanques de acero inoxidable, donde se mezclan, homogeneizan y/o se concentran según las instrucciones de fabricación. Los tanques tienen capacidad para 50 galones, 10.000 galones e incluso más. Deben estar completamente limpios y desinfectados en el momento del mezclado.

Una vez fabricado el concentrado, se llega a la etapa de llenado. Todos los productos son conducidos por tuberías a la sala de llenado. Antes de iniciar el proceso, las máquinas deben estar completamente limpias y desinfectadas. La mayoría de las máquinas llenadoras se utilizan para tamaños de recipientes específicos. Los productos se mantienen dentro de las tuberías y los tanques durante el proceso de llenado para evitar la contaminación. Cada recipiente debe llevar la etiqueta con el nombre del producto y los riesgos de manipulación (si procede). Los recipientes llenos se trasladan con máquinas transportadoras al área de envasado, se apilan en estantes y se envuelven con plástico o se atan antes de almacenarlos. Además de los concentrados, se envasan los aditivos que se utilizan para la preparación de bebidas carbonatadas. Muchos de estos aditivos se introducen en bolsas de plástico y se colocan en cajas.

Ya en el almacén, los productos se reparten y acondicionan para enviarlos a las distintas empresas embotelladoras. El etiquetado debe ajustarse a las normas gubernamentales. Si los productos se destinan a otro país, la etiqueta deberá cumplir los requisitos de etiquetado de dicho país.

\section{Prevención de riesgos}

Los riesgos existentes en una planta de fabricación de concentrados varían dependiendo de los productos fabricados y de las dimensiones de la fábrica.

Las fábricas de concentrados presentan una baja tasa de lesiones por el alto grado de mecanización y la manipulación automatizada. Los materiales se manejan con elevadoras de horquilla y los recipientes llenos se colocan en estantes mediante apiladoras automáticas. Aunque los trabajadores no tienen que emplear, en general, una fuerza excesiva para realizar su trabajo, las lesiones relacionadas con el levantamiento de pesos siguen siendo un motivo de preocupación. Los principales riesgos se derivan de los motores y equipos en movimiento, objetos que se caen de recipientes que están encima de la cabeza, riesgos eléctricos en operaciones de reparación y mantenimiento, riesgos en espacios confinados debido a las operaciones de limpieza de los tanques de mezclado, ruido, accidentes con las elevadoras y agentes químicos de limpieza peligrosos. Para más información sobre riesgos y precauciones, véase el artículo "Embotellado y envasado de bebidas refrescantes".

\section{EMBOTELLADO Y ENVASADO DE BEBIDAS REFRESCANTES}

\section{Matthew Hirsheimer}

En la mayoría de los mercados establecidos en todo el mundo, las bebidas refrescantes ocupan el primer lugar entre las bebidas fabricadas, superando incluso a la leche y el café en términos de consumo "per capita".

Entre productos envasados listos para beber y mezclas a granel para dispensar a chorro, se dispone de bebidas refrescantes en casi todos los tamaños y sabores imaginables y en prácticamente todos los canales de distribución a minoristas. Además de esta disponibilidad universal, el crecimiento de la categoría de bebidas refrescantes se puede atribuir, en buena medida, a un envasado conveniente. Dado que los consumidores cada vez tienen más movilidad, han optado por artículos envasados fáciles de transportar. Con la llegada de los botes de aluminio y, más recientemente, de las botellas de plástico con tapón de rosca, los envases de bebidas refrescantes se han hecho más ligeros y manejables.

Las rigurosas normas de control de calidad aplicadas a los procesos de tratamiento del agua y los avances tecnológicos en la materia también han aportado a la industria de bebidas refrescantes un alto grado de confianza sobre la pureza del producto. Además, las plantas de fabricación y embotellado que producen bebidas refrescantes se han transformado en instalaciones manipuladoras de alimentos altamente mecanizadas, eficientes y perfectamente limpias.

A comienzos del decenio de 1960, la mayoría de los embotelladores producían bebidas con maquinaria que procesaba 150 botellas por minuto. Dado que la demanda del producto ha aumentado vertiginosamente, los fabricantes de bebidas refrescantes han introducido maquinaria más rápida. Gracias a los 
Figura 65.1 - Panel de control de una planta automática de bebidas refrescantes en Novosibirsk, Rusia.

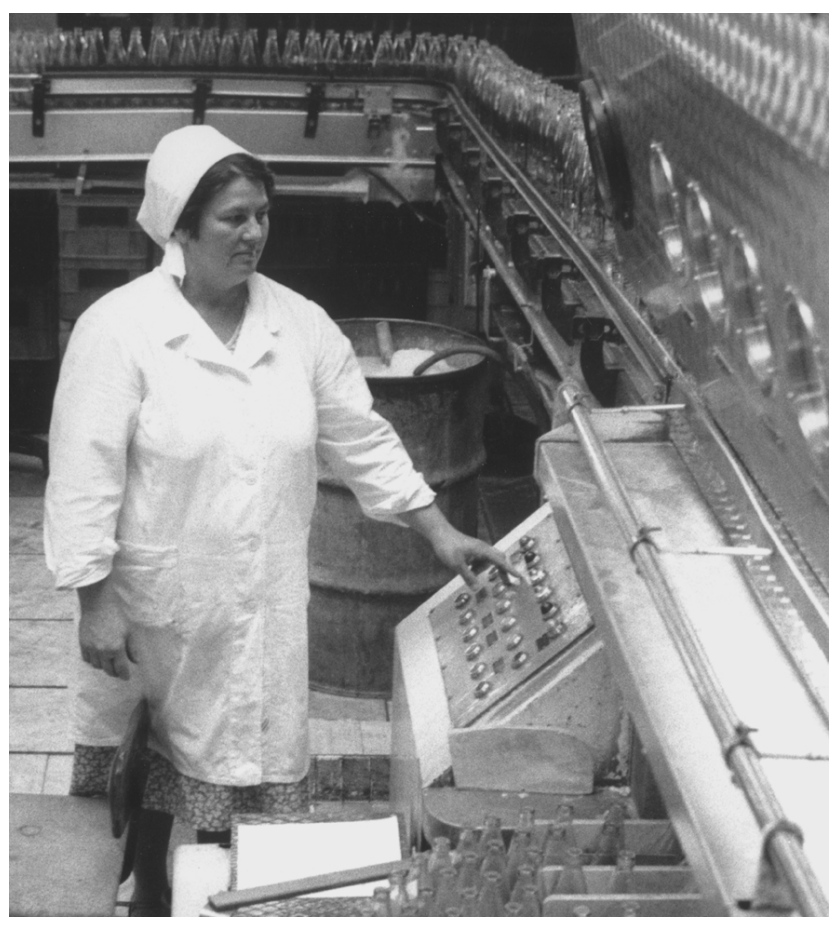

avances en la tecnología de producción, las líneas de llenado son capaces de procesar ahora más de 1.200 recipientes por minuto, con una pérdida de tiempo mínima, salvo para realizar los cambios de producto o de sabor. Este entorno altamente automatizado ha permitido a los fabricantes de bebidas refrescantes reducir el número de trabajadores necesarios en las cadenas de producción (véase la Figura 65.1). Con todo, y aun cuando haya aumentado considerablemente la eficiencia de producción, la seguridad de la fábrica sigue siendo un aspecto de importante consideración.

El embotellado o la fabricación de bebidas refrescantes comprende cinco procesos principales, cada uno de los cuales plantea aspectos de seguridad que deben ser evaluados y controlados:

1. tratamiento del agua;

2. ingredientes de la composición;

3. carbonatación de los productos;

4. llenado de los productos,

5. envasado.

\section{Véase la Figura 65.2.}

La fabricación de bebidas refrescantes empieza por el agua, que se trata y depura para cumplir rigurosamente las normas de control de calidad, que suelen estar por encima de la calidad del suministro local de agua. Este proceso es crítico para conseguir un producto de alta calidad y con características adecuadas de sabor.

A medida que los ingredientes se van combinando, el agua tratada se conduce a través de tuberías a grandes tanques de acero inoxidable. Esta es la etapa en que se añaden y mezclan varios ingredientes. Las bebidas dietéticas se mezclan con edulcorantes artificiales, no nutritivos, como aspartamo o sacarina, mientras que en las bebidas edulcoradas suelen utilizarse azúcares líquidos, como fructosa o sacarosa. Durante esta etapa del proceso de producción es cuando se añaden los colorantes alimentarios. Las aguas aromatizadas efervescentes reciben el aromatizante deseado y las aguas naturales se almacenan en los tanques de mezclado hasta que sean necesarias en las líneas de llenado. Una práctica común entre las empresas embotelladoras es adquirir el concentrado a otras compañías.

Para que se produzca la carbonatación [absorción de dióxido de carbono $\left.\left(\mathrm{CO}_{2}\right)\right]$, las bebidas refrescantes se enfrían en grandes sistemas de refrigeración basados en amoniaco. Esto es lo que confiere a los productos carbonatados su efervescencia y textura. $\mathrm{El} \mathrm{CO}_{2}$ se almacena en estado líquido y se transfiere a través de tuberías a las unidades de carbonatación a medida que se necesita. El proceso se puede manipular para controlar la velocidad de absorción exigida por cada tipo de bebida. Dependiendo del producto, las bebidas refrescantes pueden contener desde 15 a 75 psi de $\mathrm{CO}_{2}$. Las bebidas refrescantes con sabor a frutas tienden a tener menos carbonatación que las colas o el agua con gas. Una vez carbonatados, los productos están listos para ser envasados en botellas o botes.

La sala de llenado se encuentra normalmente separada del resto de la instalación, para proteger al producto abierto de cualquier posible contaminante. La operación de llenado, altamente automatizada, requiere un número mínimo de personal. Véase la Figura 65.3. Los operarios de la planta de llenado controlan la eficacia de la instalación, añadiendo tapas o tapones a granel si es preciso. Las botellas y botes vacíos son transportados automáticamente a la máquina llenadora por el equipo de manejo de material a granel.

A lo largo del proceso de producción se aplican estrictos procedimientos de control de calidad. Los técnicos miden numerosas variables, entre ellas el $\mathrm{CO}_{2}$, el contenido de azúcar y el sabor, para garantizar que los productos terminados cumplan las normas de calidad exigidas.

El envasado es la última etapa antes del almacenamiento y transporte. Este proceso también se ha automatizado en gran medida. En cumplimiento de ciertos requisitos de los mercados, las botellas o botes entran en la maquinaria de envasado y pueden ser envueltas con cartón para formar cajas o ser colocadas en bandejas o armazones de plástico recuperable. Los productos envasados entran entonces en la máquina apiladora, que los coloca automáticamente en los palés. (Véase la Figura 65.4). A continuación, se trasladan los palés cargados -normalmente con una elevadora de horquilla - al almacén, donde se almacenan.

\section{Prevención de riesgos}

Las lesiones relacionadas con la carga de peso - especialmente en la espalda y los hombros de los trabajadores - no son raras en la industria de las bebidas. Aunque con el tiempo se han logrado muchos avances tecnológicos en el manejo del material, la industria sigue buscando formas más seguras y eficientes de mover los productos pesados.

Naturalmente, se debe proporcionar a los trabajadores la formación necesaria sobre prácticas seguras de trabajo. También se pueden reducir al mínimo las lesiones limitando la exposición a la carga de pesos a través del diseño del puesto de trabajo. Por ejemplo, pueden utilizarse mesas ajustables para elevar o bajar material al nivel de la cintura, de manera que los trabajadores no tengan que girar y subir tanto. De este modo, la mayoría del estrés relacionado con el peso es transferido a una pieza del equipo en lugar de al cuerpo humano. Todos los fabricantes de bebidas están obligados a aplicar programas ergonómicos para identificar los riesgos relacionados con el trabajo y minimizarlos, bien a través de la modificación del equipo o bien desarrollando uno mejor. Una medida razonable para alcanzar 
Figura 65.2 - Diagrama de flujo de las operaciones básicas de embotellado.

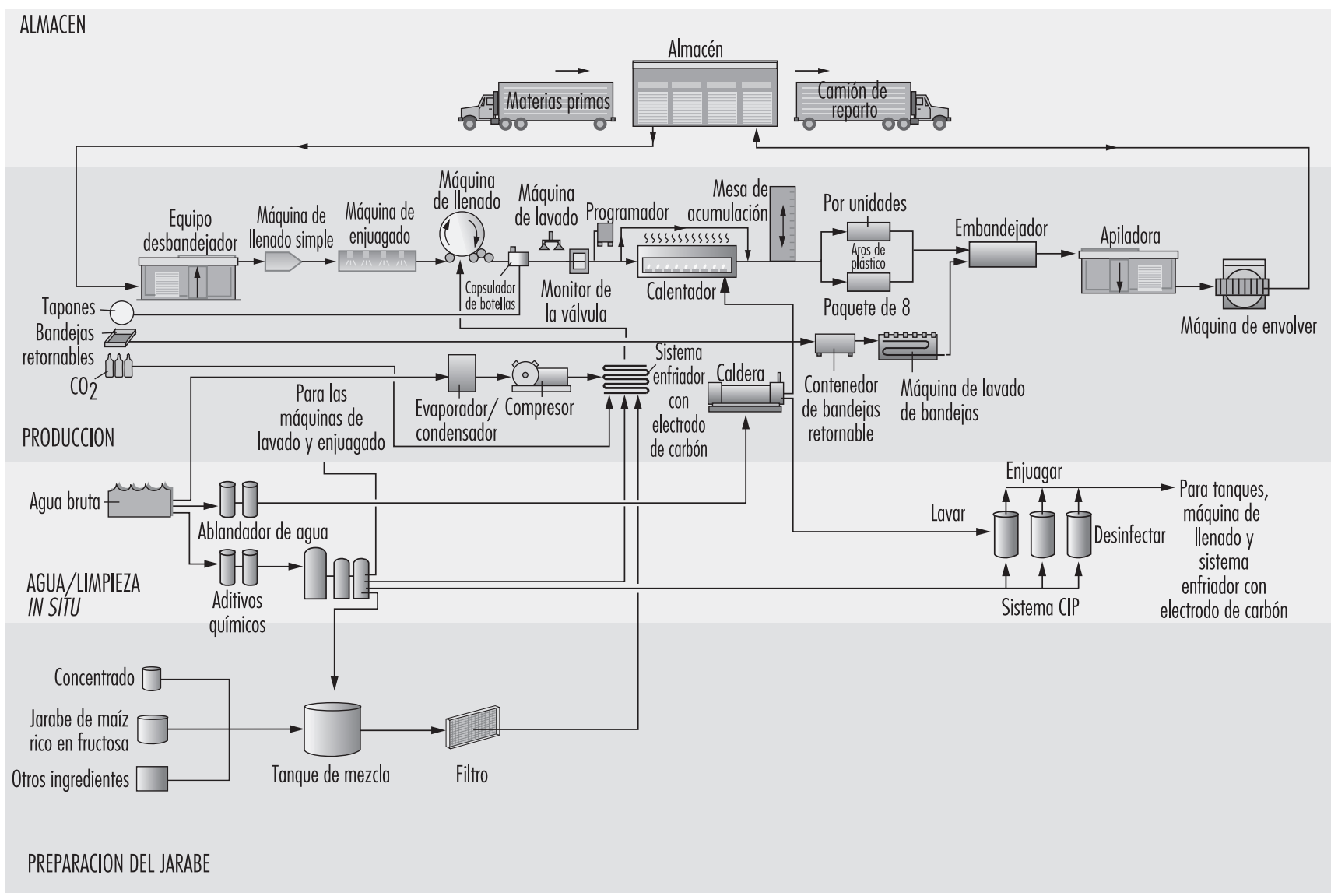

este objetivo es la rotación del trabajo, que reduce la exposición del trabajador a las tareas de alto riesgo.

El empleo de sistemas de protección de la maquinaria es otro componente crítico en la fabricación segura de bebidas. Equipos como las máquinas llenadoras y las cintas transportadoras se mueven a alta velocidad y, si carecen de protección, pueden enganchar la ropa o partes del cuerpo de los trabajadores, causando lesiones potencialmente graves. Las cintas

Figura 65.3 - Línea de enlatado de bebidas refrescantes que muestra las operaciones de llenado.

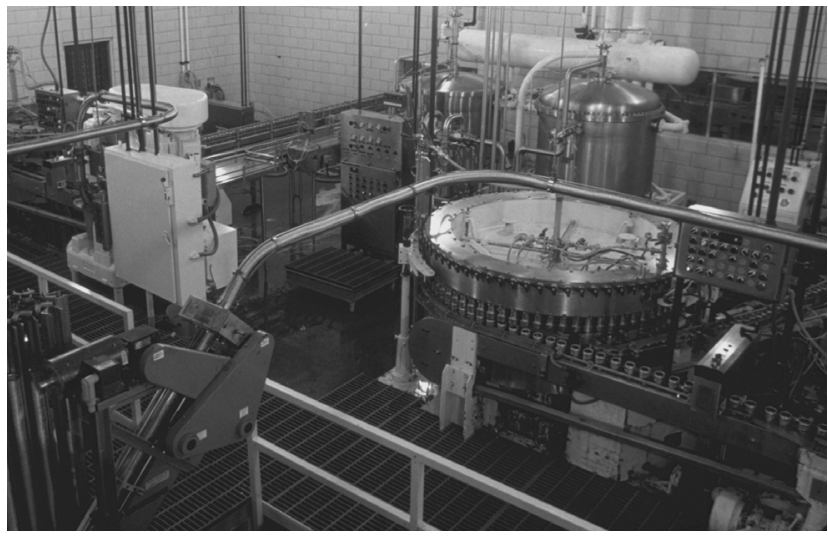

transportadoras, poleas, engranajes y ejes deben llevar cubiertas apropiadas para evitar el contacto del trabajador. Las transportadoras que se mueven sobre las cabezas pueden presentar un peligro adicional de caída de las cajas, por lo que conviene instalar redes o telas metálicas para evitar este peligro. Hay que implantar programas de mantenimiento para que todas las protecciones que se retiran cuando se necesita reparar el equipo sean repuestas tan pronto finalice el trabajo de reparación.

Figura 65.4 - Paquetes de 8 botellas de plástico de 2 litros de bebidas refrescantes de camino a un apilador automático.

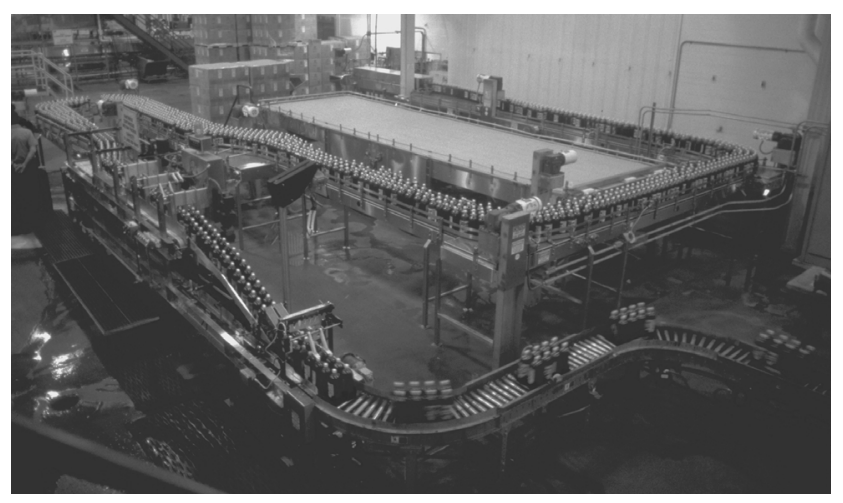


Dadas las condiciones de humedad permanente en la sala de llenado, es necesario un drenaje adecuado para evitar la acumulación de líquidos en los lugares de paso. Con objeto de evitar lesiones por resbalones y caídas, se debe procurar mantener los suelos lo más secos posible. Aunque no suele ser necesario llevar calzado con punta de acero en la planta de llenado, sí es altamente recomendable utilizar suelas antideslizantes. Se debe seleccionar el calzado teniendo en cuenta el coeficiente de deslizamiento. Como norma complementaria, todo el equipo eléctrico ha de ser conectado a tierra y protegido convenientemente de la humedad. Los trabajadores deben tomar la precaución de secar las zonas que rodean el equipo antes de iniciar el trabajo eléctrico.

Unas buenas prácticas de mantenimiento e inspecciones rutinarias son también medidas beneficiosas para mantener el lugar de trabajo libre de riesgos. Con la realización de estas operaciones relativamente sencillas, el personal directivo puede estar seguro de que todos los equipos funcionan correctamente y se conservan de forma adecuada. También se debe inspeccionar el correcto funcionamiento de los equipos de emergencia, como extintores de incendios o puestos de lavado ocular.

Aunque la mayoría de las sustancias químicas presentes en las fábricas de embotellado no son extremadamente peligrosas, en todas las operaciones se emplean sustancias inflamables, ácidas, cáusticas, corrosivas y oxidantes. Se deben emplear unas prácticas de trabajo adecuadas para que los trabajadores sepan cómo manipular de forma segura las sustancias químicas. Hay que enseñarles a conservar, manejar y eliminar las sustancias químicas y a utilizar el equipo protector. La formación consistirá en mostrarles la ubicación y funcionamiento del equipo de emergencia. Los puestos de lavado ocular y las duchas pueden reducir al mínimo las lesiones de cualquiera que se exponga accidentalmente a sustancias químicas peligrosas.

Es conveniente instalar barreras y diques químicos, así como material absorbente, para utilizarlos en caso de que se produzca un derrame. Un diseño idóneo de las instalaciones de almacenamiento de sustancias químicas también minimizará el riesgo de lesiones del trabajador. Los productos inflamables se deben separar de los corrosivos y oxidantes.

Los grandes tanques que se utilizan para mezclar los ingredientes, a los que hay que acceder y limpiar periódicamente, se consideran espacios confinados. Para más información sobre riesgos y precauciones relacionados con ellos, véase el recuadro sobre espacios confinados de este capítulo.

El equipo mecanizado es cada vez más complejo y a menudo funciona bajo control remoto por ordenador, líneas neumáticas o incluso por densidad. Los trabajadores deben asegurarse de que el equipo esté desconectado de la red eléctrica antes de repararlo. Es preciso desarrollar procedimientos de desconexión idóneos para garantizar la seguridad de los encargados de mantener y reparar el equipo. La corriente debe cortarse y separarse de su fuente de forma que la unidad que ha de ser reparada no pueda conectarse accidentalmente, ocasionando lesiones potencialmente fatales a los encargados del mantenimiento o a los trabajadores que estén próximos a la línea.

La formación sobre seguridad y los procedimientos escritos de desconexión eléctrica para cada pieza del equipo son importantísimos. En todos los equipos conviene colocar estratégicamente interruptores de parada para situaciones de emergencia. Se utilizan conmutadores de seguridad para parar el equipo automáticamente cuando se abren puertas o se interrumpen haces de luz. Sin embargo, se debe informar a los trabajadores de que estos mecanismos no desconectan el equipo de la red eléctrica, sino que sólo lo detienen en una emergencia. Los interruptores de emergencia no sustituyen a un procedimiento comprobado de desconexión para el mantenimiento del equipo.
El cloro, que se utiliza en el área de tratamiento del agua, puede ser peligroso en caso de liberación accidental. Normalmente, se recibe en recipientes de acero, que se almacenan en áreas aisladas y bien ventiladas y se sujetan para evitar su inclinación. Se debe formar a los trabajadores para seguir procedimientos seguros en el cambio de recipiente. También se les ha de enseñar cómo tomar decisiones rápidas si se produce una liberación accidental de cloro. A finales del decenio de 1990, nuevos compuestos de cloro van sustituyendo paulatinamente al cloro gaseoso. Aunque siguen siendo peligrosos, son mucho más seguros de manipular que el gas.

$\mathrm{El}$ amoniaco se utiliza como refrigerante en las operaciones de embotellado. Normalmente, los grandes sistemas de amoniaco pueden entrañar un riesgo para la salud en caso de fuga o derrame. En las instalaciones de embotellado deben desarrollarse procedimientos de respuesta en caso de emergencia en los que se indiquen claramente las responsabilidades del personal. Los encargados de responder a esas situaciones de urgencia serán formados sobre cómo atajar un derrame y sobre el empleo de respiradores. En caso de fuga o derrame, se debe disponer inmediatamente de los respiradores y evacuar a todo el personal que no sea esencial a zonas seguras hasta que la situación esté controlada.

El $\mathrm{CO}_{2}$ que se utiliza en la operación de llenado también puede causar problemas relacionados con la salud. Si las salas de llenado y las áreas adyacentes no están suficientemente ventiladas, la acumulación de $\mathrm{CO}_{2}$ puede desplazar al oxígeno en las zonas de respiración de los trabajadores. Las instalaciones deben controlarse periódicamente para evaluar los niveles de $\mathrm{CO}_{2}$ y, si se detectan anomalías, hay que inspeccionar los sistemas de ventilación para determinar sus causas. Para corregir la situación puede ser necesaria ventilación adicional.

Los avances tecnológicos han propiciado que se disponga de mejores materiales de absorción de ruido para aislar o silenciar los motores y engranajes de la mayoría de los equipos. Sin embargo, dada la función y el tamaño de la maquinaria de llenado, los niveles de ruido suelen superar los $90 \mathrm{dBA}$. Los trabajadores que estén expuestos a este nivel de ruido durante una media ponderada de 8 horas deben contar con protección. Un buen programa de protección del oído debe incluir la investigación de formas más adecuadas de control del ruido; la formación de los trabajadores sobre los efectos relacionados con la salud; la protección personal frente al ruido; y la formación sobre cómo utilizar los mecanismos protectores de oídos, que deben ser obligatorios en las áreas de alto nivel de ruido. Periódicamente conviene explorar el oído de los trabajadores.

Las elevadoras de horquilla se manejan en la planta de embotellado y es imperativo que su uso sea seguro. Además de demostrar su aptitud como conductor, los posibles operarios deben comprender los principios de seguridad de las elevadoras. Se suelen expedir licencias que acreditan un nivel mínimo de competencia. Los programas sobre seguridad de las elevadoras deben incluir un proceso de inspección previo al uso con el fin de comprobar los vehículos y garantizar que todo el equipo de seguridad esté en su sitio y funcione. Cualquier deficiencia debe ser inmediatamente notificada y corregida. Las elevadoras de gas o de petróleo líquido (PL) generan monóxido de carbono como subproducto de la combustión. Estas emisiones se pueden minimizar manteniendo los motores de las elevadoras con arreglo a las especificaciones de los fabricantes.

Es normal usar un equipo de protección personal (EPP) en la instalación de embotellado. Los trabajadores de la sala de llenado llevan protectores de ojos y oídos. El personal de desinfección lleva protección en cara, manos y pies adecuada para las sustancias químicas a que están expuestos. Aunque se recomienda el calzado antideslizante en la fábrica, los encargados de 
mantenimiento deben llevar también la protección añadida de calzado con punta de acero. La clave de un buen programa de EPP es identificar y evaluar los riesgos potenciales asociados a cada tarea y determinar si esos riesgos se pueden eliminar con modificaciones técnicas. Si no es así, se debe elegir un EPP adecuado para evitar el riesgo específico y tenerlo a mano.

El papel de los directivos es crítico en la identificación de los riesgos y en el desarrollo de unas prácticas y procedimientos tendentes a reducirlos al mínimo. Una vez desarrollados, se deben comunicar a los trabajadores para que puedan realizar su trabajo de forma segura.

Dado que la tecnología de las fábricas sigue avanzando - proporcionando mejor equipo, nuevos sistemas de protección de la maquinaria y nuevos equipos de protección - los embotelladores de bebidas refrescantes dispondrán aún de más medios para mantener la seguridad en los puestos de trabajo.

\section{INDUSTRIA DEL CAFE}

\section{Jorge da Rocha Gomes y} Bernardo Bedrikow

\section{Descripción general}

El café como bebida se introdujo en Europa en el siglo XVI. Desde Alemania se extendió en el siglo siguiente a todo el continente europeo, especialmente Francia y Holanda. Después se expandió por el resto del mundo.

Dado que el café no mantiene sus características de sabor y olor durante mucho tiempo después de tostado y molido, en las zonas en que se consume café se han implantado establecimientos industriales para tostar y moler café. Son plantas de tamaño pequeño o mediano, aunque existen grandes factorías, principalmente para producir café normal e instantáneo (soluble).

Es difícil estimar el número de trabajadores de la industria del café. Algunas de las plantas más pequeñas no llevan registros y las cifras no son muy fiables. Considerando un consumo total de unos 100 millones de bolsas de $60 \mathrm{~kg}$ de café en el año 1995, el volumen de negocios del café en el mundo representa unos 50 millones de dólares. La Tabla 65.1 muestra una lista de los principales países importadores de café, lo que da una idea del consumo actual en el mundo.

La fabricación del café es un proceso relativamente sencillo, que comprende la limpieza, el tostado, la molienda y el empaquetado, como se muestra en la Figura 65.5. Sin embargo, la tecnología moderna ha puesto en marcha procesos complejos con mayor velocidad de producción y necesidad de contar con laboratorios para pruebas de control de calidad del producto.

Tabla 65.1 - Principales importadores de café (en toneladas).

\begin{tabular}{lrrr} 
País & 1990 & 1991 & 1992 \\
\hline Estados Unidos & 1.186 .244 & 1.145 .916 & 1.311 .986 \\
Francia & 349.306 & 364.214 & 368.370 \\
Japón & 293.969 & 302.955 & 295.502 \\
España & 177.681 & 176.344 & 185.601 \\
Reino Unido & 129.924 & 119.020 & 128.702 \\
Austria & 108.797 & 118.935 & 125,245 \\
Canadá & 120.955 & 126.165 & 117.897 \\
Fuente: FA0 1992. & & & \\
\hline
\end{tabular}

Los granos de café llegan a las fábricas en bolsas de $60 \mathrm{~kg}$, que se descargan mecánica o manualmente. En el último caso, dos trabajadores sostienen una bolsa y la colocan en la cabeza de otro trabajador, que traslada la bolsa al almacén. Aun cuando el traslado se realice en cintas transportadoras, se requiere algo de esfuerzo físico con alto consumo energético.

El uso de café instantáneo no deja de aumentar y representa aproximadamente el $20 \%$ del consumo mundial. El café instantáneo se obtiene mediante un proceso complejo, en el que chorros de aire caliente pasan sobre los extractos de café, viniendo después la evaporación, el enfriamiento y la liofilización, con detalles variables de una fábrica a otra. En la fabricación del café descafeinado, que representa alrededor de un $10 \%$ del consumo en Estados Unidos y en Europa, algunas fábricas utilizan aún disolventes clorados (como el cloruro de metileno), que se elimina mediante un chorro de vapor de agua.

\section{Riesgos potenciales y efectos sobre la salud}

La elaboración del café comienza con la apertura de las bolsas con un pequeño cuchillo y el vertido de los granos en un recipiente para proceder a su limpieza. La zona de trabajo es ruidosa y gran cantidad de material residual en forma de partículas que se libera de las máquinas de limpieza permanece en suspensión.

El tostado expone a los trabajadores a riesgos de quemaduras y molestias producidas por el calor. La mezcla de los granos, o combinación, se realiza automáticamente, así como la molienda, en áreas en que la iluminación puede ser insuficiente debido al polvo de café en suspensión. La suciedad se acumula, los niveles de ruido pueden ser altos y la mecanización requiere trabajar a gran alta velocidad.

Figura 65.5 - Diagrama de flujo de la fabricación del café.

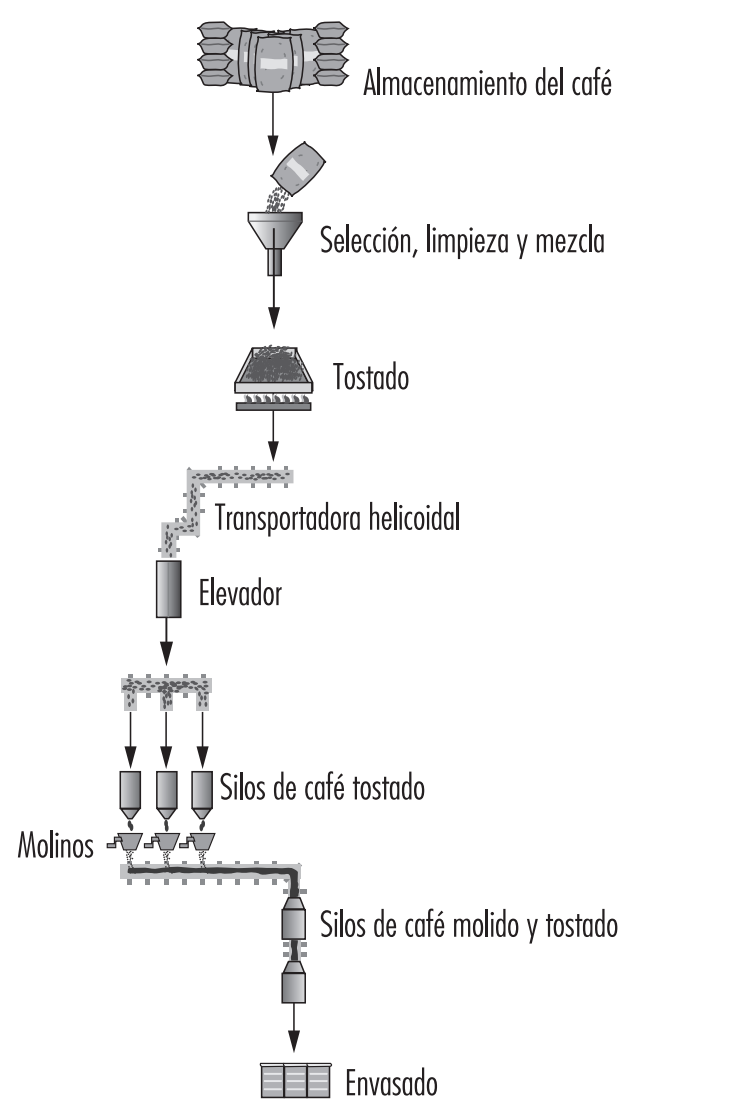


Después de la molienda, se llenan bolsas de distintos materiales y tamaños, y se embalan normalmente en cajas de cartón. Cuando estas operaciones se realizan manualmente, exigen movimientos repetitivos de manos y brazos a gran velocidad. Las cajas de cartón se transportan a las zonas de almacenamiento y después a su destino final.

El fuerte olor característico de la industria del café puede molestar a los trabajadores dentro de las fábricas, así como a las personas que viven en los alrededores. La importancia de este problema como riesgo potencial para la salud todavía no se ha aclarado. El olor del café se debe a una mezcla de varios productos, que se está investigando para identificar los efectos individuales de cada sustancia química. Se sabe que algunos componentes del polvo de café y algunas de las sustancias que producen olores son alérgenos.

Los riesgos potenciales en las fábricas de café instantáneo son similares a los existentes en la producción de café normal, pero a ellos se suman los derivados del vapor caliente y la explosión de las calderas. En la extracción de la cafeína, aun cuando se realiza automáticamente, existe un riesgo de exposición a los disolventes.

Otros posibles riesgos que pueden afectar a la salud de los trabajadores son similares a los encontrados en las industrias de alimentos en general. Los riesgos de accidentes por cortes producidos con los cuchillos al abrir las bolsas, quemaduras durante el tostado y aplastamiento en las operaciones de molienda, especialmente en la maquinaria antigua sin protección. Existe riesgo de incendio y explosión por las grandes cantidades de polvo existentes y la falta de seguridad de la red eléctrica y de gas utilizada para encender los tostadores.

Entre los diversos riesgos que se pueden encontrar en la industria del café hay que citar: la pérdida auditiva por exceso de ruido, estrés por calor durante el tostado, intoxicación por plaguicidas y trastornos musculosqueléticos, que afectan especialmente a la espalda de los trabajadores que levantan y llevan bolsas pesadas.

Pueden aparecer trastornos alérgicos en los ojos, la piel o el sistema respiratorio en cualquier área de la fábrica de café. El polvo de café se asocia a la bronquitis con insuficiencia de la función pulmonar; también se producen rinitis y conjuntivitis (Sekimpi y cols. 1996). Se han descrito además reacciones alérgicas a los contaminantes de bolsas usadas previamente para contener otros materiales, como las semillas de ricino (Romano y cols. 1995).

Los movimientos a gran velocidad que se realizan en las operaciones de empaquetado pueden ocasionar trastornos por movimientos repetitivos, especialmente si no se advierte a los trabajadores del riesgo.

En los países menos desarrollados, los efectos de los riesgos profesionales pueden aparecer antes debido a la inadecuación de las condiciones de trabajo y a otros factores de índole social y de salud pública. Entre esos factores cabe citar: bajos salarios, atención médica y seguridad social inadecuada, vivienda e higiene precarias, bajo nivel de educación, incultura, enfermedades endémicas y malnutrición.

\section{Medidas preventivas}

Sistemas de protección de las máquinas, ventilación general y sistemas locales de aspiración, atenuación del ruido, tareas de mantenimiento y limpieza, reducción del peso de las bolsas, sustitutos de los disolventes utilizados en la extracción de la cafeína, inspección periódica y mantenimiento preventivo de las calderas son ejemplos de medidas preventivas para garantizar unos niveles adecuados de higiene y seguridad industrial. La intensidad del olor se puede reducir modificando los procedimientos de tostado.
Es posible modificar la organización del trabajo para evitar los trastornos por movimiento repetitivo, alterando la posición y ritmo del trabajo, e introduciendo paradas sistemáticas y ejercicios regulares, entre otras prácticas.

La exploración médica periódica debe centrarse en la evaluación de la exposición a herbicidas y plaguicidas, los trastornos de la médula espinal y los síntomas precoces de trastornos por movimientos repetitivos. La realización de la prueba de escarificación con extractos de granos de café, aunque no esté universalmente aceptada como completamente fiable, puede ser un método útil para identificar a los individuos hipersensibles. Las pruebas de la función pulmonar sirven de ayuda para diagnosticar precozmente enfermedades respiratorias obstructivas.

La educación para la salud es un importante instrumento para conseguir que los trabajadores identifiquen los riesgos y sus consecuencias e informarles sobre su derecho a trabajar en un entorno saludable.

Los gobiernos deben adoptar medidas legislativas y hacer obligatorio su cumplimiento; la participación de los trabajadores es necesaria para establecer y mantener unas condiciones adecuadas de trabajo.

\section{INDUSTRIA DEL TE}

Lou Piombino

La leyenda cuenta que el té fue descubierto en China por el Emperador Shen-Nung, "El sanador divino". Al observar que la gente que bebía agua caliente gozaba de mejor salud, el sabio Emperador insistió en que se tomara esta precaución. Mientras se añadían ramas al fuego, una hoja de té cayó accidentalmente al agua. El Emperador aprobó su placentero aroma y su delicioso sabor y nació el té.

Desde China, el té se extendió por Asia, convirtiéndose muy pronto en la bebida nacional de China y Japón. No fue hasta el siglo XVI que Europa se familiarizó con la bebida. Poco tiempo después, el té se introdujo en Norteamérica. A principios de 1900, Thomas Sullivan, un mayorista de Nueva York, decidió empaquetar el té en pequeñas bolsas en lugar de en latas. La gente empezó a hervir el té en la bolsa de seda en vez de retirar su contenido. De este modo se introdujo por primera vez la bolsa de té

El té es la segunda bebida más popular en el mundo; solamente el agua se consume en mayor cantidad. Los consumidores pueden elegir entre una amplia variedad de productos de té - té instantáneo, mezclas de té helado, tés especiales y aromatizados, tés de hierbas, tés listos para beber, tés descafeinados y bolsas de té. El envase de los productos ha cambiado significativamente; la mayoría de las tiendas pequeñas que antes dispensaban el té pasándolo de cajones de madera a latas individuales han dado paso a sofisticadas cadenas de producción a alta velocidad que procesan, envasan y/o embotellan cientos de libras de té y mezclas listas para beber por hora.

\section{Breve descripción del proceso}

Para la producción de bolsas de té, se mezclan varias hojas de té cortadas y secas procedentes de numerosas regiones del mundo. Normalmente, el té se recibe en cajones de madera o bolsas grandes. Se mezcla y se transfiere a las máquinas envasadoras, donde se empaqueta como bolsas de té individuales o envases a granel. El té en polvo instantáneo se produce mezclando hojas cortadas y dejándolas fermentar en agua caliente. El concentrado de té líquido se seca entonces mediante pulverización pasando a ser un fino polvo que se introduce en barriles. El polvo de té se 
puede enviar a las cadenas de envasado en latas o tarros, o combinarlo con otros ingredientes como azúcar o sustitutos del azúcar. Durante la etapa de mezclado, antes de envasarlo, pueden añadirse sabores, de limón u otras frutas.

\section{Riesgos}

Existen numerosos riesgos de seguridad y salud asociados con el mezclado, procesado y envasado del té. Riesgos relacionados con las protecciones de las máquinas, el ruido, los resbalones y caídas y las lesiones debidas al levantamiento de pesos son bastante corrientes en la industria de bebidas. Otros riesgos, como el polvo en las áreas de mezclado y envasado, no se suelen encontrar en los procesos húmedos de las operaciones de embotellado y enlatado.

\section{Riesgos de la maquinaria}

La mezcla y envasado del té requiere un equipo y una maquinaria que expone a los trabajadores a cadenas y engranajes, correas y poleas, aspas giratorias, y máquinas y líneas de envasado que funcionan a gran velocidad y presentan numerosos puntos peligrosos. La mayoría de las lesiones son resultado de laceraciones y contusiones en dedos, manos y brazos. Las protecciones del equipo son críticas para evitar que los trabajadores queden enganchados bajo las partes móviles o entre ellas. Hay que instalar protecciones y/o conmutadores para proteger a los trabajadores de las partes móviles en que exista posibilidad de lesionarse.

Cuando se retire una protección (por ejemplo para el mantenimiento), se deben aislar todas las fuentes energéticas, y el mantenimiento y reparación del equipo realizarse siguiendo un programa vigente y eficaz de mecanismos de bloqueo y carteles de advertencia.

\section{Riesgos del polvo}

El polvo de té se genera en las operaciones de mezclado y envasado. También está presente en altas concentraciones durante las operaciones de limpieza o descardado con ventilador. Cuando tiene un diámetro superior a 10 micrómetros se puede calificar de "polvo molesto". El polvo molesto provoca efectos adversos leves en los pulmones y no debería producir ninguna enfermedad orgánica significativa ni efectos tóxicos si las exposiciones se mantienen por debajo de un nivel razonable. Sin embargo, una concentración excesiva en el aire de las zonas de trabajo puede hacer que se deposite polvo en los ojos, oídos y conductos nasales, lo que resulta incómodo. Una vez inhaladas, estas partículas quedan atrapadas en la región nasal y faríngea del sistema respiratorio, hasta que se expelen a través de los mecanismos limpiadores del propio organismo (p. ej., tos y estornudos).

Las partículas de polvo respirables son aquellas que tienen un diámetro menor de 10 micrómetros y, por tanto, son lo suficientemente pequeñas para atravesar las regiones nasal y faríngea y acceder al tracto respiratorio inferior. Una vez en los pulmones, se incrustan en la región alveolar, donde pueden llegar a producir escaras en el tejido. Las partículas respirables pueden ser irritantes respiratorios, especialmente en personas asmáticas. El empleo de sistemas de cierre eficaces puede ayudar a contener las partículas de polvo.

Se deben instalar sistemas de ventilación aspirante $u$ otro tipo de equipos de control del polvo en el lugar en que se produce para mantener unos niveles inferiores a los estándares generalmente reconocidos $\left(10 \mathrm{mg} / \mathrm{m}^{3}\right)$ o establecidos en la normativa gubernamental aplicable. Los trabajadores que sean muy sensibles al polvo y los expuestos a concentraciones elevadas en un determinado momento deben llevar máscaras antipolvo. Las personas con bronquitis crónica o asma constituyen un grupo de alto riesgo. Los que presentan hipersensibilidad al polvo de té no deben permanecer en el área en que se genera.
Aunque existe muy poca información real sobre las explosiones de polvo de té, los datos de los análisis indican que se trata de una explosión relativamente débil. Parece que el mayor potencial de explosión del polvo de té se da en las latas almacenadas y en los colectores de polvo, donde las concentraciones y el tamaño de las partículas son óptimos para que se produzca la explosión. Reduciendo al mínimo la concentración de polvo en una sala o en un proceso se reducirá el potencial de explosión. Para algunas operaciones puede ser deseable la utilización de equipo eléctrico diseñado para áreas con riesgo de generación de polvo.

Aunque el té y el polvo de té no suelen arder con llama, grandes cantidades de té casi siempre se queman poco a poco si se incendian. Se puede utilizar una gran cantidad de agua en una fina neblina para enfriar el té que se está quemando por debajo de su temperatura de ignición.

\section{Ruido}

$\mathrm{Al}$ igual que en las operaciones de envasado a alta velocidad, en la industria del té casi siempre se encuentran altos niveles de ruido. Pueden ser generados por los mezcladores vibratorios, las máquinas que trabajan con aire y otro tipo de máquinas de envasado, sistemas de convección de aire, colectores de polvo y cortadoras de cajas. Los niveles de ruido en muchas de estas áreas pueden oscilar entre $85 \mathrm{dBA}$ y más de $90 \mathrm{dBA}$. El principal riesgo potencial para la salud asociado a la exposición al ruido reside en la posibilidad de que se produzca una pérdida auditiva permanente. La gravedad de la pérdida de audición depende de los niveles de ruido en el lugar de trabajo, la duración de la exposición y la susceptibilidad personal del individuo. Los programas sobre ruido y conservación de la audición se comentan en otro capítulo de esta Enciclopedia.

\section{Riesgos químicos}

Aunque la mayoría de los procesos de producción y de las operaciones de envasado no exponen a los trabajadores a sustancias químicas peligrosas, en las operaciones de desinfección se emplean sustancias químicas para limpiar y desinfectar el equipo. Algunas de ellas se manejan a granel mediante sistemas fijos de tuberías, mientras que otras se aplican a mano utilizando mezclas predeterminadas. La exposición a estas sustancias puede ocasionar problemas respiratorios, dermatitis o irritación cutánea y quemaduras químicas en la piel. Las quemaduras graves de los ojos y/o pérdida de la visión son también riesgos asociados a la manipulación de sustancias químicas de limpieza. Es esencial evaluar los riesgos de las sustancias que se están utilizando. Como parte de los procedimientos de trabajo rutinarios se debe hacer una selección adecuada y utilizar EPP, como gafas de montura ajustada a prueba de salpicaduras o pantallas faciales, guantes resistentes a las sustancias químicas, delantales, botas y un respirador. Conviene instalar puestos de lavado ocular y corporal para casos de emergencia donde se almacenen, mezclen o utilicen sustancias químicas peligrosas.

\section{Manejo del material}

El té llega en bolsas o cajones sobre palés y se ubica en los almacenes en espera del mezclado o el envasado. Las bolsas y cajones se mueven a mano o utilizando sistemas de manejo de material, como elevadoras de horquilla o elevadoras de vacío. Una vez mezclado, el té se traslada mediante cintas transportadoras a vagones para su envasado. Las operaciones de envasado pueden variar desde la utilización de equipo altamente automatizado hasta operaciones de trabajo manual intensivo (Figura 65.6). Las lesiones lumbares resultantes de levantar pesos son bastante comunes cuando se manejan bolsas de 100 libras $(45,5 \mathrm{~kg})$ o más. Los movimientos repetitivos que se practican en las cadenas de 
Figura 65.6 - Envasado de té en la fábrica de té y café Brooke Bond en Dar-es-Salaam, Tanzania.

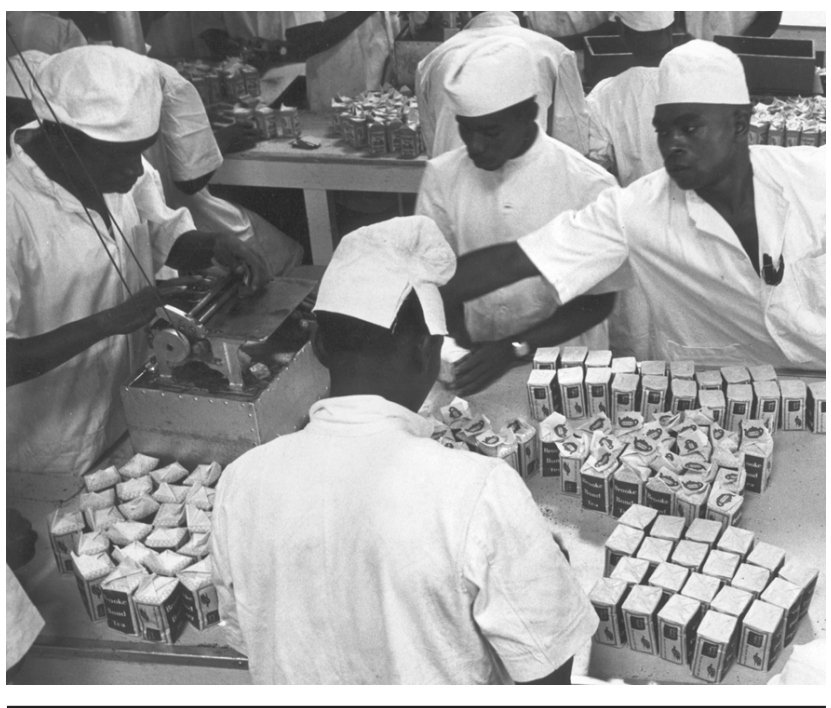

envasado pueden ocasionar trauma acumulado de cadera, brazos o zona de los hombros.

Sistemas mecánicos, como las elevadoras de vacío, ayudan a reducir las tareas de levantamiento de pesos. La asignación de dos trabajadores para cargar pesos puede contribuir a evitar la aparición de lesiones graves de espalda. La modificación de los puestos de trabajo para que sean ergonómicamente más correctos y/o la implantación de equipos automáticos en las cadenas de envasado reducen la exposición del trabajador a las tareas repetitivas. La rotación de los trabajadores a trabajos más ligeros también puede reducir la exposición del trabajador a este tipo de tareas.

Algunos trabajadores utilizan ayudas personales, como cinturones a la espalda y bandas en la cadera, que les facilitan las tareas de carga o les sirven de alivio temporal en pequeños esfuerzos. Ahora bien, estos sistemas no han demostrado su eficacia, pudiendo ser incluso contraproducentes.

La mayoría de las operaciones de almacén requieren el empleo de elevadoras-transportadoras de horquilla. La conducción a velocidades no seguras, los giros bruscos, la conducción con las horquillas levantadas, la falta de observación, la no cesión del paso a los peatones y los accidentes de carga/descarga constituyen las principales causas de lesión entre los operarios de las elevadoras de horquilla. Sólo se debe permitir que operarios entrenados y competentes conduzcan las elevadoras de horquilla. La formación consistirá en clases teóricas y exámenes de conducción en los que los trabajadores deberán demostrar su aptitud. Un mantenimiento adecuado y la revisión diaria antes de ponerlos en marcha pueden contribuir asimismo a un uso seguro de estos vehículos.

\section{Resbalones, tropezones y caídas}

Los resbalones, tropezones y caídas constituyen un problema importante. En las operaciones de mezclado y envasado en seco se acumula polvo de té fino en las superficies de paso y de trabajo. Es importante contar con un buen servicio de mantenimiento. Se debe barrer el polvo del suelo de forma regular. Los residuos y otros objetos que queden en el suelo se deben recoger inmediatamente. El calzado con suela de goma antideslizante parece que proporciona la mejor tracción. Las áreas de procesos húmedos también entrañan riesgos de resbalones y caídas, por lo que los suelos deben mantenerse lo más secos posible. Las zonas en que se realizan procesos húmedos han de contar con un drenaje adecuado. No se debe permitir la acumulación de agua estancada. Si hay agua estancada se deberá arrastrar hasta los drenajes del suelo.

\section{Exposición a temperaturas elevadas}

El contacto con agua caliente, conducciones de vapor y otros equipos de proceso puede ocasionar quemaduras graves. La mayoría de las quemaduras se producen en las manos, los brazos y la cara. El agua caliente utilizada para limpiar o lavar también puede causar quemaduras en pies y piernas.

Los selladores por calor y las operaciones de encolado en las cadenas de envasado son otra causa de quemaduras. Es importante recubrir los puntos calientes expuestos del equipo. Una correcta evaluación de los riesgos y la elección y uso del equipo de protección personal ayudará a reducir o eliminar la exposición del trabajador a temperaturas elevadas y quemaduras. El empleo de procedimientos de interrupción y cierre de tuberías protegerá a los trabajadores de la liberación fortuita de líquidos y vapores calientes.

\section{Prácticas seguras}

Un programa general de seguridad que se centre en el uso y elección del EPP, entrada en espacios confinados, aislamiento de fuentes de energía, identificación y comunicación de sustancias químicas peligrosas, programas de autoinspección, programas de conservación de la audición, control de materiales infecciosos, gestión de procesos y programas de respuesta ante una emergencia debería formar parte del proceso de trabajo. Es importante la formación de los trabajadores en prácticas seguras de trabajo para reducir la exposición del trabajador a situaciones peligrosas y lesiones.

\section{INDUSTRIA DE LICORES DESTILADOS}

\section{R.G. Aldi y Rita Seguin}

Se pueden obtener licores destilados a partir de muchos materiales, entre los que se encuentran las masas fermentadas de cereales, los zumos de fruta fermentados, jugo de azúcar de caña, melazas, miel y jugo de cactus. La fermentación para elaborar vino y cerveza data de los años 5000 y 6000 a.C.; sin embargo, la historia de la destilación es mucho más reciente. Aunque no está claro dónde se originó la destilación, se atribuye a los alquimistas, y su uso comenzó a extenderse en los siglos XIII y XIV. Los primeros usos fueron fundamentalmente farmacéuticos.

\section{Breve descripción del proceso}

Las bebidas alcohólicas se dividen en dos grupos dependiendo del modo de preparación: bebidas fermentadas, como el vino y la cerveza, y bebidas destiladas, como el whisky y el brandy. Los licores se preparan básicamente mezclando zumos o extractos de frutas, frutos secos u otros productos alimenticios. La elaboración del vino y la cerveza se comenta en otros artículos de este capítulo.

La producción de licores destilados comprende las siguientes fases: recepción de los cereales, molienda, cocción, fermentación, destilación, conservación, mezclado y embotellado (véase la Figura 65.7).

El elevador de cereales recibe y pesa el grano que le llega y lo coloca en los recipientes apropiados. La molienda consiste en moler el grano necesario para la cuba de bracear la cerveza, clave del proceso de fermentación. 
Figura 65.7 • Diagrama de flujo de la fabricación de licores destilados.

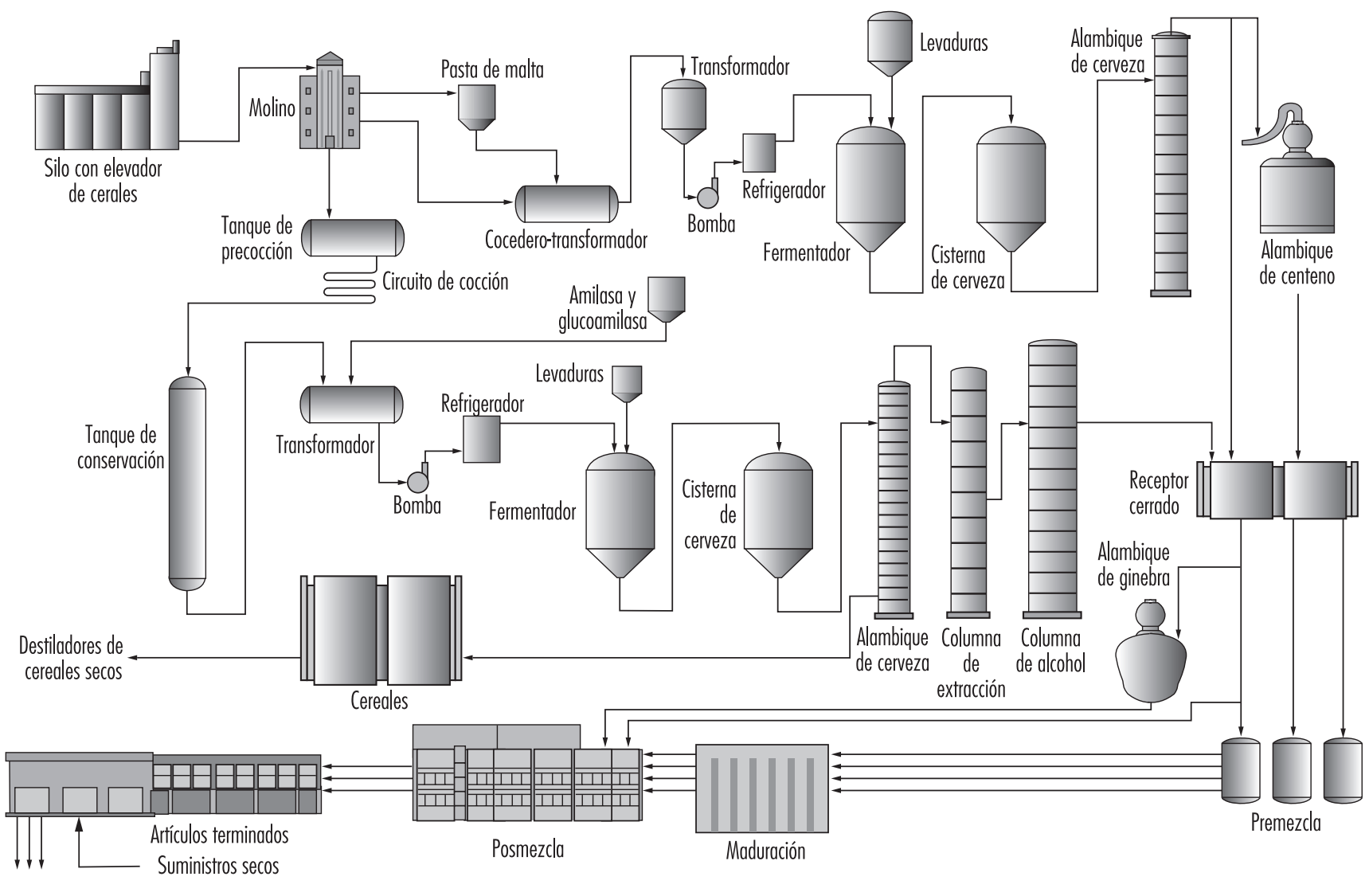

Los cocederos reciben harina del molino y pastas con restos de grano, agua y amoniaco de un $\mathrm{pH}$ (acidez) y temperatura determinados. El almidón se solubiliza utilizando cocinas de chorro de vapor. Se añaden enzimas para romper el almidón en moléculas más pequeñas, con lo que se reduce la viscosidad de la masa. La masa resultante se enfría a la temperatura de fermentación.

La fermentación es el proceso mediante el cual los azúcares se convierten en alcohol y dióxido de carbono por acción de las levaduras. Los fermentadores se enfrían a temperaturas óptimas para las levaduras, pues las reacciones que tienen lugar son de naturaleza exotérmica. Es importante la desinfección: los sistemas biológicos de fermentación están en constante competencia con las bacterias oportunistas que pueden producir componentes de sabor no deseados.

El tipo de destilación depende del licor que se desee obtener. Generalmente se utilizan alambiques de barro cuando se quiere dotar al producto de un "carácter" especial, como es el caso del coñac y el whisky, mientras que, en general, se emplea la destilación continua en multicolumna para producir licores más neutros, que se usan como mezclas o como licores neutros de cereales.

Un aspecto muy importante del funcionamiento de una destilería moderna es la recuperación de los subproductos. El grano residual (fermentado y desalcoholizado) es rico en proteínas, vitaminas, fibra y grasas y puede servir, una vez procesado convenientemente, como suplemento del pienso animal. Estos procesos consisten generalmente en centrifugación, evaporación, secado y mezclado.
Los distintos tipos de whisky, brandy y ron son envejecidos (madurados) en barriles de roble quemados. La maduración tiene lugar durante una serie de años hasta conseguir las características finales que distinguen a estos productos. Una vez que han madurado, se mezclan y filtran y, a continuación, se envasan como productos finales para el consumidor.

Las salas de embotellado están separadas del resto de las instalaciones, para proteger al producto de cualquier posible contaminante. La operación de llenado altamente automatizada exige un control de eficacia continuo. Las botellas vacías se transportan mediante cintas transportadoras a las máquinas de llenado.

El envasado es la etapa final antes del almacenamiento. Este proceso se ha automatizado, aunque existe una pequeña cantidad que se envasa manualmente, dependiendo del tamaño de la botella y el tipo de envase. A continuación, los productos envasados entran en la máquina apiladora, que apila automáticamente las cajas en palés, que son trasladados con elevadorastransportadoras de horquilla al almacén.

\section{Aspectos de salud y seguridad}

El problema de seguridad más evidente en las instalaciones donde se manejan granos es el peligro de incendio y explosión del polvo. Altas concentraciones de polvo de cereales pueden ser explosivas; por tanto, un buen servicio de mantenimiento es el factor más importante para reducir el riesgo de explosión del polvo de cereales. Ciertos cereales, si se humedecen o almacenan durante mucho tiempo, pueden generar calor, provocando así un 
riesgo de incendio. La rotación del cereal de un recipiente a otro o la adopción de un procedimiento de liberación del cereal "justo a tiempo" puede suprimir este riesgo.

La exposición a los vapores y gases liberados durante la producción de licores destilados representa un posible riesgo. Durante el proceso de fermentación, los gases refrigerantes pueden ser tóxicos y explosivos. Por consiguiente, son esenciales una ventilación adecuada y un mantenimiento estricto, incluido el empleo de un equipo intrínsecamente seguro como los respiradores. Especialmente significativos son los riesgos de asfixia debidos a los vapores de alcohol y al dióxido de carbono liberado en el proceso de fermentación, especialmente cuando los líquidos se transportan y decantan en depósitos y espacios confinados con una ventilación insuficiente. En este proceso, los trabajadores deben llevar respiradores. En el cuadro adjunto se describen algunos de los riesgos que presenta la entrada en espacios confinados, que se comentan también en otro apartado de esta Enciclopedia.

En toda la instalación se utilizan materiales peligrosos, como "varsol" (licor mineral), productos cáusticos, ácidos y muchos otros disolventes y agentes de limpieza. Los trabajadores deben recibir formación sobre el manejo seguro de estos productos. La revisión anual de un sistema de información sobre materiales peligrosos en el lugar de trabajo, como el Canadian WHMIS, puede aportar la ocasión para impartir este tipo de formación continua. Los trabajadores se deben acostumbrar a utilizar fichas técnicas de seguridad de los materiales (FTSM), que son hojas informativas que facilitan los proveedores y ofrecen información sobre los productos peligrosos y los riesgos para la salud relacionados con los mismos, acciones de emergencia, primeros auxilios, etc. Es obligatorio que todos los trabajadores expuestos o con posibilidad de estar expuestos a materiales peligrosos estén formados y se les imparta una revisión anual del manejo de materiales peligrosos. En muchos países se exige que las FTSM estén disponibles en cada lugar en que existan sustancias controladas y convendría que todos los trabajadores tuvieran acceso a ellas. Aparte de la formación de los trabajadores, se debe disponer de puestos de lavado ocular, duchas y puestos de primeros auxilios en toda la fábrica, con el fin de reducir al mínimo las lesiones de los trabajadores que resulten accidentalmente expuestos a sustancias químicas peligrosas.

En muchos procesos de la fábrica se utilizan elevadoras de horquilla. Los dos usos más comunes de éstas son el transporte a los barriles de maduración y el manejo del producto terminado. Debe existir un programa preventivo de mantenimiento "in situ" para las elevadoras, así como un programa de seguridad que garantice que todos los conductores comprenden los principios de seguridad de las elevadoras. Todos los conductores deben tener permiso para manejar una elevadora-transportadora de horquilla.

Los riesgos profesionales derivados de los procesos de embotellado son semejantes a los de la mayoría de las instalaciones de embotellado. Las lesiones producidas por esfuerzos repetitivos, como tendinitis y síndrome del túnel carpiano, son las más frecuentes, debido al trabajo repetitivo que exige el empaquetado de botellas y las operaciones de etiquetado. Sin embargo, la frecuencia de este tipo de lesiones profesionales ha disminuido, lo que se debe a los cambios tecnológicos introducidos en la fábrica, que hacen los trabajos menos intensivos, incluida la automatización del envasado y el empleo de soporte informático. El EPP es común en toda la instalación de embotellado. Es obligatorio para los trabajadores de la zona de embotellado llevar gafas de seguridad para protegerse los ojos y protectores de oídos en los lugares donde están expuestos a altos niveles de ruido. Se debe implantar un programa de seguridad relativo al calzado, para que los trabajadores lleven zapatos de punta de acero. Si no es posible eliminar el riesgo en su origen (a través de la técnica) o durante el camino (a través de barreras), se debe usar el EPP para seguridad del trabajador.

Existen muchos métodos para crear un ambiente de trabajo seguro. Una compañía debe contar con una política de salud y seguridad y transmitirla a través de un manual en el que se indiquen los procedimientos de seguridad. Asimismo, las inspecciones mensuales de la fábrica pueden prevenir riesgos y minimizar lesiones. La transmisión a los trabajadores de los principios de unas prácticas seguras es la parte más esencial de un programa de seguridad exitoso.

\section{Riesgos de entrada en espacios confinados en la industria de bebidas}

Un espacio confinado se define como aquel donde, por su construcción, localización, contenido o actividad de trabajo en su interior, puede producirse una acumulación de gases peligrosos, vapor, polvo o humo, o la creación de una atmósfera con escasez de oxígeno. Si se tiene que acceder a un espacio confinado, es obligatorio contar con un procedimiento de entrada en espacios confinados y que todos los trabajadores sean formados y educados en dicho procedimiento. Antes de acceder a un espacio confinado, se debe determinar la deficiencia de oxígeno y la presencia de gases combustibles y tóxicos. Los trabajadores han de llevar respiradores independientes de presión positiva u otros respiradores homologados al entrar en estos espacios. Es obligatorio llevar un control continuo mientras el personal está dentro del espacio confinado. Toda persona que entre debe ir provista del equipo de seguridad adecuado, con cuerdas en hombros y piernas. Se asignará un observador competente que mantendrá una vigilancia constante de los trabajadores que se encuentren en el espacio confinado, y se dispondrá de una persona bien entrenada en las técnicas de respiración artificial.

La industria de bebidas presenta muchas situaciones en que existe un riesgo de entrada en espacios confinados. Ejemplos de dichas situaciones son

- tinas de mezcla en la industria de bebidas refrescantes en las que están presentes vapores o gases nocivos;

- tanques de cereales en las industrias de la cerveza y de los licores destilados:

- tanques de fermentación en la elaboración de cerveza y vino,

- fermentadores y alambiques en la industria de licores destilados.

De vez en cuando, es preciso entrar en estos tanques de cereales, fermentadores, etc. para limpiarlos, repararlos, etc. Durante el proceso de fermentación, en particular, se produce un riesgo de asfixia por los vapores de alcohol y de dióxido de carbono liberados, si se accede a espacios confinados que no dispongan de una ventilación adecuada (Giullemin y Horisberger 1994).

R.G. Aldi y Rita Seguin 


\section{- INDUSTRIA DEL VINO}

\section{Alvaro Durao*}

El vino se produce a partir de la uva. Cuando se aplasta la uva madura se obtiene el mosto, que por fermentación normal, total o parcial, se transforma en vino. Durante la fermentación, al principio rápida y turbulenta y después más lenta, el azúcar se convierte en alcohol y dióxido de carbono, pero muchos de los elementos contenidos en las uvas permanecen en la bebida. Las distintas fases de actividad de la producción de vino a partir de la uva son: la elaboración del vino, el almacenamiento y el embotellado.

\section{Elaboración del vino}

La elaboración del vino comprende una serie de actividades en las que se emplean métodos que van desde la "producción de granja" tradicional hasta la moderna producción industrial. El antiguo método de prensar las uvas, en que los cosecheros pisaban durante la noche las uvas que habían recogido durante el día, cada vez se utiliza menos en la moderna elaboración del vino. En la actualidad, el vino se produce en instalaciones pertenecientes a grupos de viticultores o empresas comerciales, con técnicas que permiten producir un tipo de vino más uniforme y reducen el riesgo de maculatura y, en particular, la acidificación que transforma el vino en vinagre.

A la llegada a las bodegas, la uva se prensa en molinos sencillos o en grandes máquinas, como prensas centrífugas, rodillos u otros métodos. Estos procesos siempre entrañan riesgos mecánicos y de ruido durante todo el tiempo en que se manejan grandes cantidades de mosto. La materia triturada se transfiere entonces a grandes depósitos, por bombeo u otros procedimientos, donde se prensa para separar el jugo de las pieles y los tallos. A continuación, el mosto se traslada a los barriles de fermentación. Una vez completada la fermentación, el vino se extrae de la madre y se vierte en tinajas o tanques de almacenamiento. La materia extraña y las impurezas se eliminan con filtros. En algunos países, como Estados Unidos, la tierra de diatomeas ha sustituido al asbesto como agente filtrante. Los cuerpos extraños de mayor tamaño se eliminan con centrifugadoras.

La calidad del vino se puede mejorar mediante refrigeración en frigoríficos de flujo continuo y tanques de refrigeración de doble pared. En estas operaciones, hay que considerar la exposición a los vapores y los gases liberados durante las distintas etapas del proceso - especialmente la recolección, fermentación y el uso de desinfectantes y otros productos para garantizar las condiciones higiénicas del proceso y la calidad del vino-. Los gases refrigerantes, como el amoniaco, presentan riesgos de intoxicación y explosión, por lo que es esencial disponer de una ventilación adecuada y llevar a cabo un mantenimiento estricto para prevenir fugas. Se debe contar con sistemas automáticos de detección de fugas y equipos de protección respiratoria frecuentemente revisados para las emergencias. También existen los riesgos habituales debidos al suelo húmedo y resbaladizo, el desorden característico de las actividades estacionales y la calidad de la iluminación y la ventilación (los locales en que se prepara el vino a menudo se utilizan también como almacén y están diseñados para mantener una temperatura uniforme relativamente baja).

Particularmente significativos son los riesgos de asfixia derivados de los vapores de alcohol y de dióxido de carbono liberados en los procesos de fermentación, especialmente cuando se

* Adaptado de la $3^{\text {a }}$ edición, Enciclopedia de saludy seguridad en el trabajo. transportan y decantan los líquidos en cisternas o espacios confinados con ventilación insuficiente. Otras sustancias nocivas se utilizan en la elaboración del vino. El metabisulfito en solución concentrada es irritante cutáneo y de las membranas mucosas; el ácido tartárico, que no se considera tóxico, puede ocasionar una ligera irritación en soluciones muy concentradas; el dióxido de azufre provoca una intensa irritación en los ojos y el tracto respiratorio; los taninos secan la piel y provocan una pérdida de pigmentación; el uso de desinfectantes y detergentes para la limpieza de los tanques de almacenamiento ocasiona dermatitis; y el bitartrato potásico, ácido ascórbico, enzimas proteolíticas, etc., que se suelen utilizar en la preparación de bebidas alcohólicas, pueden dar lugar a la aparición de diarrea o reacciones alérgicas.

Cuando se modernizan los procesos de trabajo, los trabajadores suelen necesitar apoyo y asistencia para adaptarse a dicha modernización. Las grandes bodegas deben tener presentes los principios ergonómicos a la hora de elegir la maquinaria para sus instalaciones. Las trituradoras y prensas deben ser de fácil acceso para facilitar el vertido de las uvas y los residuos. Donde sea posible, se instalarán bombas adecuadas que faciliten su inspección y tengan una base sólida para no causar obstrucciones, niveles de ruido elevados ni vibraciones.

La disposición general de la bodega productora debe ser tal que no se creen riesgos innecesarios y que los riesgos existentes no se extiendan a otras áreas; la ventilación debe cumplir la normativa; hay que controlar la temperatura; se deben instalar compresores, condensadores, equipo eléctrico y demás para obviar todos los riesgos posibles. Como consecuencia de la humedad de varios procesos, es necesario proteger los equipos eléctricos y, si es posible, utilizar voltajes bajos, especialmente en equipos portátiles y lámparas de inspección. Cuando sea necesario, se instalarán interruptores de circuitos conectados a tierra para los casos de avería. El equipo eléctrico de las proximidades de las plantas de destilación debe ser de material no inflamable.

Las tinajas de madera se utilizan cada vez menos, aunque ocasionalmente se encuentran en pequeñas bodegas de "producción de granja". En la elaboración moderna del vino, las tinajas son de vidrio o de acero inoxidable por razones higiénicas o de control; también se utilizan las construidas con hormigón reforzado y, a veces, de plástico. Las tinajas deben ser de dimensiones adecuadas, resistentes a la fermentación y la decantación (separación de la madre), contar con un volumen de reserva tan grande como sea preciso y, en caso necesario, permitir el intercambio de contenidos con facilidad. La limpieza de los contenedores representa un alto riesgo y debe efectuarse siguiendo un programa para espacios confinados: el gas se extraerá mediante ventiladores móviles antes de acceder a los contenedores y se llevarán cinturones de seguridad, cuerdas salvavidas y equipo de protección respiratoria. Un trabajador competente debe colocarse en el exterior para vigilar y rescatar a los trabajadores del interior si fuera necesario. Para más información, véase el recuadro sobre espacios confinados.

\section{Conservación del vino}

El almacenamiento no sólo consiste en guardar grandes volúmenes de líquido, sino que comprende también numerosas actividades como la limpieza y desinfección de los tanques o cubas; su mantenimiento y conservación; la aplicación de dióxido de azufre, ácido ascórbico, ácido tartárico, gases inertes, taninos y albúminas; y otros procesos adicionales, como mezcla, aglutinación, filtrado, centrifugación, etc. Algunos tratamientos del vino requieren la utilización del calor y el frío para destruir levaduras y bacterias, el empleo de carbono y otros desodorizantes, la aplicación de $\mathrm{CO}_{2}$, etc. Como ejemplo de este tipo de instalación, puede citarse el sistema de refrigeración instantánea para 
estabilizar los vinos a una temperatura próxima al punto de congelación, lo que facilita la eliminación de coloides, microbios y otros productos como el bitartrato potásico, que provoca precipitación en las botellas. Es obvio que estas instalaciones entrañan riesgos que antiguamente no se planteaban en la fase del almacenamiento. La prevención se basa esencialmente en la planificación ergonómica y el buen mantenimiento.

\section{Embotellado del vino}

El vino se vende habitualmente en botellas de vidrio (de 1,0, 0,8, 0,75 ó 0,301 de capacidad); ocasionalmente, se utilizan envases de vidrio de 5 l. Los envases de plástico no son tan comunes. En las plantas de llenado, lo primero es limpiar las botellas y a continuación, llenarlas, cerrarlas y etiquetarlas.

Los riesgos del embotellado se derivan de la manipulación de objetos de vidrio y varían dependiendo de que las botellas que se van a lavar sean nuevas o recuperadas y de los productos utilizados (agua y detergentes) y las técnicas aplicadas (lavado a mano o mecánico o ambos). Los riesgos vienen determinados por: la forma de las botellas; el modo en que se han de llenar (desde métodos manuales hasta sofisticadas máquinas de llenado capaces de introducir también dióxido de carbono); el proceso de encorchado; el sistema más o menos complejo de apilamiento o la colocación en cajas o en portabotellas tras el etiquetado y otros retoques finales.

Se trata de los riesgos habituales del llenado de recipientes con líquidos. Las manos están constantemente húmedas; si las botellas se rompen, las partículas de vidrio y líquido despedidas pueden causar lesiones. El esfuerzo necesario para su transporte una vez empaquetadas en cajas (normalmente por docenas) se podría suprimir al menos parcialmente mediante la mecanización. Véase también el artículo "Embotellado y envasado de bebidas refrescantes".

Agradecimientos: El autor quiere agradecer a la Junta Nacional dos Vinhos (Lisboa) su asesoramiento en aspectos técnicos.

\section{INDUSTRIA DE LA CERVEZA}

\section{J.F. Eustace*}

La elaboración de la cerveza es una de las industrias más antiguas del mundo: la cerveza, en sus diferentes variedades, se bebía ya en la antigüedad y los romanos la introdujeron en todas sus colonias. Hoy en día se elabora y consume en casi todos los países, especialmente en Europa y en las áreas de dominio europeo.

\section{Breve descripción del proceso}

El cereal utilizado como materia prima suele ser la cebada, aunque también se emplea centeno, maíz, arroz y avena. En la primera etapa se maltea el cereal, bien haciéndolo germinar, bien por medios artificiales. Este proceso transforma los carbohidratos en dextrina y maltosa, azúcares que después se extraen del grano sumergiéndolo en una tina de mezcla (tinaja o barril) y agitándolo en un tanque de fermentación. El licor resultante, conocido como mosto dulce, se hierve en una caldera de cobre con lúpulo, lo que le confiere el sabor amargo y ayuda a conservar la cerveza. A continuación, el lúpulo se separa del mosto y se pasa a través de refrigeradores al interior de los recipientes de fermentación, donde se añaden las levaduras - un proceso conocido como cebado - y se lleva a cabo el proceso principal, que es la conversión del azúcar en alcohol (Véase el capítulo Industria farmacéutica para cuestiones de fermentación ). La cerveza se enfría entonces

* Adaptado de la $3^{\text {a }}$ edición, Enciclopedia de salud y seguridad en el trabajo. a $0{ }^{\circ} \mathrm{C}$, se centrifuga y se clarifica mediante filtración, con lo que queda preparada para su envío en barriles, botellas, botes de aluminio o a granel. En la Figura 65.8 se ofrece un diagrama de flujo del proceso de elaboración de la cerveza.

\section{Riesgos y prevención de los mismos}

\section{Trabajo manual}

El trabajo manual es la causa de la mayor parte de las lesiones que se producen en las fábricas cerveceras: manos aplastadas, cortadas o punzadas por aros dentados, astillas de madera y vidrios rotos. También se magullan y aplastan los pies con barriles que se caen o que ruedan. Se puede hacer mucho para evitar estos accidentes con una protección adecuada de manos y pies. El incremento de la automatización y la normalización del tamaño de los barriles (por ejemplo: 50 l) pueden reducir los riesgos derivados del levantamiento de pesos. El dolor de espalda provocado por el levantamiento y transporte de barriles se puede reducir radicalmente con una formación sobre técnicas sanas de levantamiento. El manejo mecánico de los palés también reduce los problemas ergonómicos. Las caídas en suelos húmedos y deslizantes son muy corrientes. La mejor precaución es disponer de superficies y calzado no deslizantes y un sistema regular de limpieza.

La manipulación del grano puede producir el llamado picor de la cebada, causado por un ácaro que infesta el cereal. Se ha descrito asma de los molineros, a veces llamada fiebre de malta, en personas que manipulan cereales y se ha demostrado que se trata de una respuesta alérgica al gorgojo del cereal (Sitophilus granarius). La manipulación del lúpulo puede producir dermatitis por la absorción de esencias resinosas a través de la piel cortada o agrietada. Entre las medidas preventivas se encuentran unas buenas instalaciones de aseo y sanitarias, una ventilación eficaz de los locales de trabajo y el reconocimiento médico de los trabajadores.

Cuando la cebada se maltea por el método tradicional de remojarla y extenderla en el suelo para que germine, se puede contaminar con Aspergillus clavatus, capaz de crecer y formar

Figura 65.8 • Diagrama de flujo del proceso de producción de cerveza.

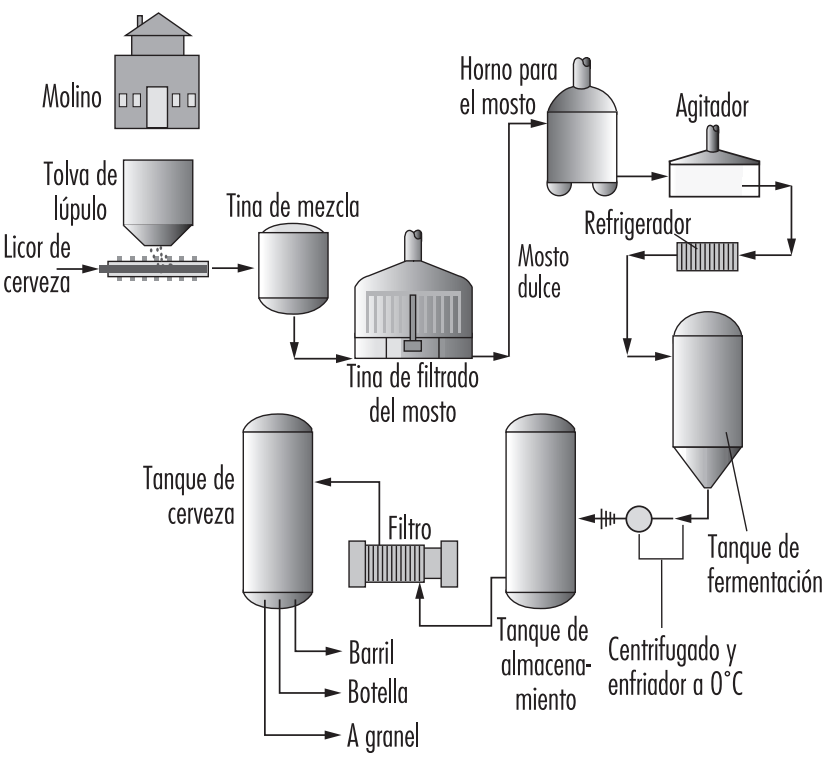


esporas. Guando se da la vuelta a la cebada para evitar que enraícen los vástagos o cuando se carga en el horno, los trabajadores pueden inhalar las esporas, lo que puede ocasionar una alveolitis alérgica extrínseca, cuya sintomatología no se distingue del pulmón del granjero; la exposición de un individuo sensibilizado va seguida de un aumento de la temperatura corporal y disnea. También se produce una disminución de la función pulmonar y del factor de transferencia del monóxido de carbono.

En un estudio llevado a cabo en dos cerveceras de Portugal con polvos orgánicos que contenían altos niveles de endotoxina se observó un predominio de los síntomas del síndrome tóxico del polvo orgánico, que es distinto de la alveolitis o de la neumonía hipersensible, en el $18 \%$ de los trabajadores. En un $39 \%$ de los trabajadores se encontró irritación de la membrana mucosa (Carveilheiro y cols. 1994).

En una población expuesta, la incidencia de la enfermedad es aproximadamente del $5 \%$ y la exposición continuada produce incapacidad respiratoria severa. Con la introducción del malteado automático, que evita la exposición del trabajador, esta enfermedad prácticamente ha desaparecido.

\section{Maquinaria}

Si la malta se almacena en silos, la abertura debe estar protegida y han de cumplirse obligatoriamente las normas en materia de entrada de personal, tal como se describe en el recuadro sobre espacios confinados de este capítulo. Las máquinas transportadoras se usan mucho en las plantas de embotellado; se puede evitar que los trabajadores queden enganchados entre las correas y tambores utilizando protecciones de maquinaria eficaces. Debe adoptarse un programa eficaz sobre bloqueo de máquinas y carteles de advertencia con fines de mantenimiento y reparación. Donde existan vías de paso a través o por encima de las cintas transportadoras, se deben instalar botones de parada. En el proceso de llenado, las botellas que estallan pueden ocasionar lesiones muy graves; protecciones adecuadas para la maquinaria y protectores faciales, guantes de goma, delantales de goma y botas antideslizantes para los trabajadores pueden prevenir las lesiones.

\section{Electricidad}

Debido a las condiciones de humedad reinantes, las instalaciones y el equipo eléctrico necesitan una protección especial, y esto se aplica sobre todo a los aparatos portátiles. Donde se precise, se deben instalar interruptores de circuitos conectados a tierra para las averías y, donde sea posible, utilizar voltajes bajos, especialmente en las lámparas portátiles de inspección. El vapor se utiliza mucho, por lo que son frecuentes las quemaduras y escaldaduras; se debe proporcionar aislamiento y protección a las tuberías y a los cierres de seguridad de las válvulas de vapor, que evitarán la liberación accidental de vapor.

\section{Dióxido de carbono}

El dióxido de carbono $\left(\mathrm{CO}_{2}\right)$ se forma durante la fermentación y está presente en los tanques de fermentación y en las tinajas y barriles que han contenido cerveza. Concentraciones del $10 \%$, aun cuando se respiren durante poco tiempo, producen inconsciencia, asfixia y, en su caso, la muerte. El dióxido de carbono es más pesado que el aire, por lo que es esencial una ventilación eficaz con extracción a bajo nivel en todas las cámaras de fermentación en que se empleen tinajas abiertas. Dado que el gas es imperceptible a los sentidos, debe instalarse un sistema acústico de alarma que se ponga en marcha inmediatamente si la ventilación falla. La limpieza de espacios confinados presenta serios riesgos: antes de permitir el acceso de los trabajadores, ha de expulsarse el gas por medio de ventiladores móviles; se debe disponer de cinturones de seguridad, cuerdas salvavidas y equipo de protección respiratoria del tipo de aire comprimido o de suministro de aire y otro trabajador debe hacer guardia para vigilar y, en caso necesario, rescatar al que está en el interior.

\section{Gas}

Se han dado casos de intoxicación por gas durante el revestimiento de tinajas con recubrimientos protectores que contenían sustancias tóxicas como tricloroetileno. Se deben tomar precauciones similares a las mencionadas anteriormente para el dióxido de carbono.

\section{Gases refrigerantes}

La refrigeración se utiliza para enfriar el mosto caliente antes de la fermentación y con fines de almacenamiento. Un vertido accidental de refrigerantes puede producir graves efectos tóxicos e irritantes. En el pasado, los más utilizados eran clorometano, bromoetano, dióxido de azufre y amoniaco, pero actualmente se utiliza sobre todo el amoniaco. Una ventilación adecuada y un mantenimiento cuidadoso evitarán la mayoría de los riesgos, pero se deben instalar detectores de fugas y aparatos respiradores de aire comprimido para emergencias, que serán probados con frecuencia. También puede ser necesario tomar precauciones contra los riesgos de explosión (por ejemplo, accesorios eléctricos a prueba de llama, eliminación de los que están expuestos al aire).

\section{Trabajo en condiciones de calor}

En algunos procesos, como la limpieza de tinas de mezcla, los trabajadores están expuestos al calor y a condiciones de humedad mientras realizan trabajos pesados; se han dado casos de congestión y calambres por calor, especialmente en los que son nuevos en el trabajo. Estas afecciones se pueden evitar incrementando la ingestión de sal, respetando unos períodos adecuados de reposo e instalando y usando duchas. La supervisión médica es necesaria para prevenir micosis en los pies (pie de atleta), que se propaga rápidamente en condiciones de humedad y temperaturas elevadas.

En todas las zonas de la fábrica, el control de la temperatura y la ventilación, con especial atención a la eliminación del vapor y la dotación de EPP son precauciones importantes, no sólo contra los accidentes y lesiones sino también contra los riesgos más generales de humedad, calor y frío (por ejemplo, ropa de abrigo para los trabajadores de locales fríos).

Se debe establecer un control para evitar que los trabajadores hagan un consumo excesivo del producto que se fabrica y disponer de bebidas calientes alternativas en las comidas.

\section{Ruido}

Cuando los barriles metálicos sustituyeron a las barricas de madera, las cerveceras se enfrentaron con un serio problema de ruido. Las barricas de madera apenas hacían ruido durante la carga, la manipulación o al rodarlas, pero los barriles metálicos cuando están vacíos generan altos niveles de ruido. Las modernas plantas de embotellado automático producen un volumen de ruido considerable. El ruido se puede reducir introduciendo la manipulación mecánica en los palés. En las plantas de embotellado, la sustitución de los tambores y guías metálicos por nylon o neopreno reduce substancialmente el nivel de ruido. 


\section{- Cuestiones AMBIENTALES Y DE SALUD PUBLICA}

Lance A. Ward

Las bebidas, tanto alcohólicas como no alcohólicas, se producen normalmente siguiendo unas directrices sanitarias estrictas establecidas por la legislación gubernamental. Para cumplir esas directrices, el equipo de las fábricas de bebidas tiene que estar constantemente limpio y desinfectado con agentes de limpieza agresivos. El empleo abusivo de agentes de limpieza puede, por sí solo, plantear problemas de salud a los trabajadores que se ven expuestos a ellos en sus obligaciones laborales. El contacto de la piel y los ojos con limpiadores cáusticos puede causar dermatitis severas. Otro problema es la inhalación de los humos o aerosoles producidos al utilizar los agentes de limpieza, que pueden dañar los pulmones, la nariz, la boca o la garganta. Es frecuente encontrar agua y otros líquidos en y alrededor del área de producción, haciendo de los resbalones y caídas una de las lesiones más comunes y ocasionando otros daños simplemente por la escasa tracción.

Los contenedores de vidrio, las máquinas de llenado de alta velocidad y las cintas transportadoras que van sobre la cabeza constituyen una combinación de elementos que pueden producir serios daños por el rebote de cristales. Cortes y lesiones oculares son frecuentes debido a la rotura de cristales. La mayor parte de la industria de bebidas ha evolucionado hacia una utilización cada vez mayor de los botes de aluminio y los envases de plástico, lo que ha reducido la incidencia de los daños causados por vidrios. Sin embargo, no ocurre así en determinados países y en industrias concretas, como las del vino y los licores.

Los sistemas eléctricos de cualquier industria poseen un alto grado de potencial lesivo. Cuando se mezclan con la siempre presente agua en la fabricación de bebidas, el peligro de electrocución se extrema. En las fábricas de bebidas, los sistemas eléctricos se están renovando constantemente a medida que la industria se moderniza con equipos de alta velocidad, lo que aumenta la exposición.

El proceso de fabricación en la industria de bebidas requiere el traslado de cantidades masivas de materias primas en bolsas y barriles, en palés de madera y de plástico; la carga de botellas y latas vacías; y de producto terminado en una gran variedad de envases. Las bebidas, que son líquidos, son por naturaleza pesadas. Con frecuencia se producen lesiones por movimiento repetitivo a causa de las tareas de distribución e inspección de las botellas de vidrio y en algunas operaciones de envasado. Este movimiento continuo de objetos ligeros y pesados plantea retos ergonómicos para la industria de bebidas, así como para otras industrias. Por ejemplo, la incidencia de torceduras de tejidos blandos y esguinces en Estados Unidos ha aumentado casi un $400 \%$ desde 1980. Las países se encuentran en diferentes fases de progreso en cuanto a la implantación de medidas preventivas que reduzcan este tipo de lesiones.

Los modernos equipos mecanizados han reducido radicalmente el número de personas necesarias para trabajar en las líneas de embotellado y envasado, lo que por sí mismo ha reducido la exposición a la lesión. Sin embargo, las cintas transportadoras de alta velocidad y el equipo automático de carga y descarga de palés pueden causar graves, aunque menos frecuentes, lesiones. El trabajador que quiere alcanzar un transportador móvil para colocar una botella o una lata, puede quedar enganchado por la ropa y ser arrastrado al interior del mecanismo. Las máquinas de carga y descarga de palés se pueden obstruir y un trabajador puede sufrir una rotura de miembros al tratar de limpiarlas.
En la mayoría de los casos, los equipos modernos de alta velocidad se han traducido en un aumento del nivel de ruido, especialmente a frecuencias elevadas. La pérdida de audición causada por el ruido en el lugar de trabajo se clasifica como enfermedad, pues se produce de forma insidiosa a lo largo del tiempo y es irreversible. Los índices de incidencia de pérdida de audición están aumentando. Se están utilizando y probando controles técnicos para reducir los niveles de ruido, pero la obligación de llevar una protección auditiva normalizada sigue siendo el método preferido por la mayoría de los trabajadores. Se abre un horizonte nuevo con la investigación del estrés en los trabajadores debido a la combinación de altos niveles de ruido, horarios de 24 horas y ritmo de trabajo.

Los espacios confinados, como tanques, barriles, tinajas, fosos de aguas residuales y tanques de almacenamiento o de mezcla, utilizados frecuentemente en las instalaciones de la industria de bebidas, pueden causar daños catastróficos. Este asunto no ha sido objeto de una atención suficiente por parte del personal directivo de la industria de bebidas, pues se considera que la mayor parte de los tanques están "limpios" y los accidentes ocurren con poca frecuencia. Aunque las lesiones en los distintos tipos de tanques utilizados en las fábricas de bebidas son raras, puede producirse un incidente grave al introducir materiales peligrosos durante las operaciones de limpieza o como consecuencia de anomalías atmosféricas, desencadenando un desenlace fatal. (Véase el recuadro sobre espacios confinados.)

La mayoría de las instalaciones de fabricación de bebidas tienen zonas de almacenamiento de materias primas y de producto terminado. El equipo de manipulación de material autopropulsado representa una seria amenaza tanto en las plantas de producción como en cualquier almacén. Las lesiones más comunes que producen las elevadoras-transportadoras de horquilla y equipo similar son el aplastamiento de peatones o del conductor si el vehículo se da la vuelta. Las plantas de producción con frecuencia se quedan pequeñas a medida que aumenta la capacidad de producción del equipo existente. Estas condiciones de espacio insuficiente conducen a accidentes graves con el equipo de manipulación del material.

La producción de bebidas requiere agua pura y sistemas de refrigeración. Las sustancias químicas más utilizadas para satisfacer estos requisitos son el cloro y el amoniaco líquido anhidro, respectivamente, y ambas se consideran sustancias extremadamente nocivas. Con frecuencia, el cloro se adquiere y se almacena en cilindros metálicos a presión de varios tamaños. El personal puede lesionarse al sustituir un cilindro por otro o por la existencia de fugas o válvulas defectuosas. La liberación accidental de amoniaco anhidro puede causar quemaduras en la piel y en el sistema respiratorio. Una liberación grande e incontrolada de amoniaco anhidro produce concentraciones en el aire suficientemente importantes para explotar violentamente. A menudo, se utilizan sistemas de emergencia para detectar fugas y mecanismos de ventilación automática, así como equipos barrera, junto con procedimientos de evacuación y respuesta. El cloro y el amoniaco anhidro son sustancias químicas de olor fuerte e identificable y se pueden detectar fácilmente en el aire. Se considera que estas propiedades son bastante perceptibles para alertar a los trabajadores de su presencia.

El dióxido de carbono, el más utilizado para la aplicación de presión y para la carbonatación, y el monóxido de carbono emitido por la combustión interna de los motores, están presentes en la mayor parte de las fábricas de bebidas. Las zonas de llenado suelen ser las más propensas a tener altos niveles de dióxido de carbono, especialmente durante los procedimientos de cambio del producto. Las compañías de bebidas han incrementado la gama de productos que ofrecen al público, de modo que los cambios son más frecuentes y aumenta la necesidad de 
ventilación aspirante del dióxido de carbono. El monóxido de carbono se encuentra en las elevadoras de horquilla o equipo similar. Se puede acumular una concentración peligrosa si los motores no trabajan de acuerdo con las especificaciones de los fabricantes.

En la industria de bebidas es frecuente el empleo estacional, sobre todo en zonas del mundo con distintas estaciones y en climas del norte. Una combinación de tendencias de fabricación que se observa en todo el mundo es el control del inventario "justo en el momento" y el contrato de personal temporal, lo que puede tener una gran repercusión sobre la seguridad y la salud. Es frecuente que a los trabajadores contratados por cortos períodos de tiempo no se les pueda proporcionar la misma formación en materia de seguridad que a los trabajadores fijos. En algunos casos, no es la empresa la que soporta los costes resultantes de las lesiones sufridas por el personal temporal sino que los asume la agencia que suministra el trabajador a la empresa. Esto ha creado una situación aparente de "sólo ganancia" para el empleador y el efecto opuesto para los trabajadores en situaciones como ésta. Los gobiernos, empresarios y sindicatos más interesados están comenzando a ocuparse exhaustivamente de este problema que va en aumento y están trabajando en métodos que mejoren la cantidad y la calidad de la formación en materia de seguridad impartida a los trabajadores de esta categoría.
No es habitual que la producción de bebidas dé lugar a problemas de medio ambiente, puesto que no se trata de una "industria chimenea". Si se excluye la emisión accidental de sustancias químicas peligrosas como el amoniaco anhidro o el cloro, la principal emisión nociva de la producción de bebidas es el agua residual. Normalmente, este agua residual se trata antes de entrar en los ríos, de ahí que sea rara la aparición de problemas. En ocasiones se ha tenido que desechar un lote de producto en malas condiciones, que, dependiendo de los ingredientes que formaban parte de la composición, se ha trasladado fuera para su tratamiento o bien se ha diluido con un gran volumen de agua antes de liberarlo al sistema de residuos. El vertido de una gran cantidad de bebida ácida a un río o un lago puede ocasionar la muerte de muchos peces, y esto debe evitarse.

El empleo creciente de aditivos químicos para potenciar el sabor, ampliar el período de validez o como sustitutos del azúcar representa un gran problema de salud pública. Determinadas sustancias químicas que se utilizan como edulcorantes artificiales están prohibidas en algunos países porque se ha observado que son cancerígenas. Sin embargo, la mayoría no presentan ningún riesgo aparente para la salud pública. La manipulación de estas sustancias y su presencia en el lugar de trabajo no han sido estudiadas con suficiente profundidad para determinar si entrañan riesgos de exposición para el trabajador.

\section{Referencias}

Carveilheiro, MF, MJM Gomes, O Santo, G Duarte, J Henriques, B Mendes, A Marques, R Avila. 1994. Symptoms and exposure to endotoxin among brewery employees. Am f Ind Med 25:113-115.

Giullemin, MP, B Horisberger. 1994. Fatal intoxication due to an unexpected presence of carbon dioxide. Ann Occ Hyg 38: 951-957.

Organización de las Naciones Unidas para la Agricultura y la Alimentación (FAO). 1992. FAO Year Book. Vol 46. Roma: FAO.

Romano, C, F Sulatto, G Piolatto, C Ciacco, E Capelaro, P Falagiani, DW Constabile, A Vaga, G Scor- cetti. 1995. Factors related to the development of sensitization on green coffee and castor bean allergens among coffee workers. Clin Exp Allergy $25: 643-650$

Sekimpi, DK, DF Agaba, M Okot-Mwang, DA Ogaram. 1996. Occupational coffee dust allergies in Uganda. Afr Newslett on Occup and Safety 6(1):6-9.

\section{Otras lecturas recomendadas}

Cartensen, JM, LO Bygren, T Hatschek. 1990. Cancer incidence among Swedish brewery workers. Int 7 Cancer 45:393-396.
Panzani, RC Palagiani, G Riva, P Mercier, Y Delord. 1995. Screening for atopy in a coffee processing factory. Allergol Imunopathol, Madr 23:29-34.

Reed, G, TW Nagodawithana. 1991. Yeast Technology, $2^{\mathrm{a}}$ edición. Nueva York: Van Nostrand Reinhold.

Sobolov, M, DM Booth, RG Aldi. 1985. Whisky. En Comprehensive Biotechnology, dirigido por $\mathrm{M}$ MooYoung. Oxford: Pergamon Press.

Tomoda, S. 1993. Evolución reciente de las industrias de la alimentación y de la bebida. Sectoral Activities Programme Working Paper. Ginebra: OIT.

Zuskin, E, B Kanceljak, TJ Vitek, Jr., and EN Schacter. 1991. Acute ventilatory response to green coffee dust extract. Annals of Allergy 66:219-224. 



\section{PESCA}

Directores del capítulo

Hulda Ólafsdóttir y Vilhjálmur Rafnsson

\section{Sumario}

Perfil general

Ragnar Arnason. . . . . . . . . . . . . . . . . . . . . . . . . . 66.2

Principales sectores y procesos

Hjálmar R. Bárdarson.

Características psicosociales de los trabajadores

en el mar

Eva Munk-Madsen

Características psicosociales de los trabajadores

del mar dedicados al procesamiento del pescado

en tierra

Marit Husmo . . . . . . . . . . . . . . . . . . . . . . . . . 66.13

Efectos sociales de la dependencia de una sola industria pesquera

Barbara Neis. . . . . . . . . . . . . . . . . . . . . . . . . . . . . . 66.14

Efectos sobre la salud y pautas patológicas

Vilhjálmur Rafnsson . . . . . . . . . . . . . . . . . . . 66.16

Afecciones musculosqueléticas: pesca y procesamiento

de pescado

Hulda Ólafsdóttir. .

Pesquerías comerciales: medio ambiente y

sanidad pública

Bruce McKay y Kieran Mulvaney. . . 


\section{Perfil General}

Ragnar Arnason

\section{Visión general}

La pesca es una de las actividades productivas más antiguas de la Humanidad. Las investigaciones arqueológicas e históricas nos indican que la pesca - tanto la de agua dulce como la marinaestaba muy extendida entre las civilizaciones antiguas. De hecho, parece ser que los asentamientos humanos se establecían a menudo en zonas con buena pesca. Estos descubrimientos sobre el papel de la pesca en el sustento humano se han visto confirmados por la investigación antropológica moderna de las sociedades primitivas.

Durante los últimos siglos, las pesquerías mundiales han sufrido una transformación radical. Los métodos tradicionales de pesca han sido sustituidos en gran medida por tecnología moderna derivada de la revolución industrial. Además se ha producido un drástico aumento del esfuerzo efectivo de pesca, un incremento mucho menor del nivel global de capturas y un grave deterioro de numerosas poblaciones de peces. La industrialización de la pesca global ha conducido asimismo a la desestabilización y el descenso de muchas pesquerías tradicionales. Por último, el aumento de la presión pesquera a escala mundial ha dado lugar a disputas internacionales sobre derechos de pesca.

En 1993, las capturas mundiales de pescado se aproximaron a 100 millones de toneladas métricas anuales (FAO 1995). De esta cantidad, la piscicultura (acuicultura y maricultura) representó unos 16 millones de toneladas. Así, las pesquerías mundiales produjeron unos 84 millones de toneladas anuales. Unos 77 millones proceden de las pesquerías marinas y el resto, en torno a 7 millones de toneladas, de pesquerías de aguas interiores. Para realizar estas capturas existía una flota pesquera de 3,5 millones de buques con un tonelaje bruto registrado de 30 millones de toneladas (FAO 1993, 1995). Hay pocos datos fiables sobre el número de pescadores que trabajaban en esta flota. La Organización de las Naciones Unidas para la Agricultura y la Alimentación (FAO 1993) estima que podían ascender a 13 millones. Menos información hay incluso sobre el número de trabajadores empleados en el procesamiento y la distribución de las capturas. Una cifra conservadora sería entre 1 y 2 veces el número de pescadores, lo que significa que entre 25 y 30 millones de personas pueden estar directamente empleados en la industria pesquera en todo el mundo. Asia es con mucho el mayor continente pesquero del mundo, con casi la mitad de las capturas totales anuales (FAO 1995). Vienen a continuación Norteamérica y Sudamérica juntas (30 \%), seguidas de Europa (15\%). En materia de pesca, los continentes de África y Oceanía son relativamente insignificantes, con una captura total conjunta del $5 \%$ de la captura global anual.

En 1993, la mayor nación pesquera del mundo en términos de capturas era China, con unos 10 millones de toneladas de capturas marinas, equivalentes al $12 \%$ de las capturas globales de pescado marino. El segundo y tercer lugar correspondían a Perú y Japón, con un 10 \% de las capturas cada uno. En 1993, 19 países realizaron capturas marinas superiores al millón de toneladas.

La captura mundial de pescado se distribuye entre un amplio número de especies y pesquerías. Muy pocas pesquerías tienen una producción anual superior al millón de toneladas. Las mayores en 1993 fueron la pesquería peruana de la anchoa (8,3 millones de toneladas), la pesquería de palero de Alaska (4,6 millones de toneladas) y la pesquería chilena de jurel (3,3 millones de toneladas). Conjuntamente, estas tres pesquerías representan aproximadamente el $20 \%$ del total de las capturas marinas mundiales.

\section{Evolución y estructura de la industria pesquera}

La combinación del crecimiento demográfico y los avances de la tecnología de pesca han conducido a una gran expansión de la actividad pesquera. Iniciada hace siglos en Europa, su expansión ha sido especialmente marcada a escala mundial en este siglo. Según estadísticas de la FAO (FAO 1992, 1995), la captura total mundial se ha cuadruplicado desde 1948, pasando de menos de 20 millones de toneladas al nivel actual de aproximadamente 80 millones de toneladas, lo que refleja un crecimiento anual de casi un $3 \%$. Ahora bien, en los últimos años, las capturas oceánicas se han estancado en 80 millones de toneladas anuales. Dado que el esfuerzo pesquero global ha seguido aumentado, ello significa que la explotación de las principales poblaciones ícteas del mundo ha alcanzado ya su producción máxima sostenible, o la ha superado. Por ello, a menos que se exploten nuevas poblaciones de peces, la captura de peces marinos no podrá aumentar en el futuro.

El procesamiento y la comercialización de la producción pesquera también han registrado una gran expansión. Gracias a las mejoras en el transporte y en la tecnología de la conservación y al estímulo generado por el aumento de las rentas reales per cápita, se procesan, embalan y comercializan cada vez más capturas en forma de productos alimenticios de elevado valor. Es probable que esta tendencia continúe a un ritmo incluso mayor en el futuro, lo que significa una plusvalía claramente superior por unidad de captura. Sin embargo, también conlleva una sustitución de las actividades tradicionales de procesamiento y distribución del pescado por métodos de producción industrial de alta tecnología. Y lo que es más grave, este proceso (al que a veces se denomina globalización de los mercados de la pesca) amenaza con despojar a las comunidades menos desarrolladas de su principal suministro de pescado debido a un exceso de oferta procedente del mundo industrializado.

En la actualidad, las pesquerías mundiales están formadas por dos sectores muy diferentes: las pesquerías artesanales y las pesquerías industriales. La mayoría de las pesquerías artesanales representan una continuación de las pesquerías tradicionales locales, que han cambiado muy poco a lo largo de los siglos. Se trata, por tanto, de pesquerías de mano de obra intensiva y baja tecnología, limitadas a caladeros de bajura o interiores (véase el recuadro "Buzos indígenas"). En cambio, las pesquerías industriales hacen un uso intensivo de capital y alta tecnología. Por lo general, los buques pesqueros industriales son grandes y están bien equipados, pudiendo navegar ampliamente a través de los océanos.

En cuanto al número de buques y al empleo, el sector artesanal domina las pesquerías mundiales. Casi un $85 \%$ de los buques pesqueros del mundo y un $75 \%$ de los pescadores son artesanales. A pesar de ello y debido a su baja tecnología y alcance limitado, la flota artesanal sólo disfruta de una pequeña parte de las capturas pesqueras mundiales. Además, por la baja productividad de la flota artesanal, la renta de los pescadores artesanales suele ser baja y sus condiciones de trabajo deficientes. El sector industrial de la pesca es económicamente mucho más eficiente. Aunque la flota industrial sólo comprende el $15 \%$ de los buques pesqueros del mundo y aproximadamente el $50 \%$ del tonelaje total de la flota pesquera mundial, absorbe más del $80 \%$ de las capturas marinas mundiales.

El desarrollo de la pesca durante este siglo se ha debido sobre todo a la expansión de las pesquerías industriales. La flota industrial ha mejorado la efectividad de las actividades pesqueras en las zonas tradicionales de pesca y ampliado el alcance geográfico de las pesquerías desde las zonas costeras relativamente 


\section{Buzos indígenas}

Durante siglos, los pueblos indígenas que viven en las zonas costeras han dependido del mar para sobrevivir. En las aguas más tropicales no sólo han pescado con embarcaciones tradicionales, sino que han pescado con lanzas y recolectado almejas, sumergiéndose desde la costa o desde barcos. En el pasado, las aguas eran generosas y no era necesario sumergirse profundamente durante mucho tiempo. La situación ha cambiado de unos años para acá. La pesca excesiva y la destrucción de las zonas de reproducción ha hecho imposible a los pueblos indígenas su propio sustento. Muchos han optado por sumergirse a mayor profundidad durante más tiempo para llevar a casa una captura suficiente. Puesto que la capacidad del ser humano para permanecer bajo el agua sin algún tipo de ayuda es sumamente limitada, los buzos indígenas de varias partes del mundo han empezado a usar compresores para obtener aire de la superficie o a usar aparatos de respiración submarina (SCUBA) para ampliar el tiempo que pueden permanecer bajo el agua (tiempo de fondo).

En el mundo en desarrollo existen buzos indígenas en Centroamérica y Sudamérica, el sudeste Asiático y el Pacífico. La iniciativa Ocean Conservation and Environmental Action Network (OCEAN) de la Facultad de Geografía de la Universidad de California en Berkeley calcula que puede haber hasta 30.000 buzos trabajando en Centroamérica, Sudamérica y el Caribe. ISe estima que entre los indios misquitos de América Central la población de buzos es de unas 450 personas.) Los investigadores del Divers Diseases Research Centre del Reino Unido calculan que en Filipinas puede haber entre 15.000 y 20.000 buzos indígenas; en Indonesia aún no se ha determinado su número, pero pueden llegar a 10.000.

En el sudeste Asiático, algunos buzos indígenas utilizan compresores situados en barcos a los que se conectan por líneas de aire o mangueras que llevan atadas. Normalmente, los compresores son de tipo comercial, como los usados en las gasolineras o compresores procedentes de grandes camiones con motor de gasolina 0 gasóleo. La profundidad puede superar los 90 m y la duración, más de 2 horas. Los buzos trabajan capturando peces y moluscos para el consumo humano, peces para acuarios, moluscos para el turismo, ostras perlíferas $y$, en determinadas épocas del año, esponjas. Sus técnicas de pesca incluyen el uso de trampas submarinas para peces, arpones y el golpeo de dos piedras una contra la otra para ahuyentar a los peces hacia una red situada corriente abajo. Las langostas, cangrejos y moluscos se capturan a mano (véase la Figura 66.1).

\section{Los buzos de Tailandia: los Gitanos del Mar}

En Tailandia viven unos 400 buzos que usan compresores y habitan en la costa occidental. Se les conoce como los Gitanos del Mar y antiguamente eran nómadas, si bien ahora se han asentado en 12 aldeas más o menos permanentes de tres provincias. Saben leer y escribir y casi todos ellos han completado la enseñanza obligatoria. Prácticamente todos los buzos hablan el tailandés y la mayoría también su propio idioma, Pasa Chaaw Lee, que es una lengua malaya ágrafa.

Sólo los hombres se sumergen, desde los 12 años hasta los 50, si llegan a esa edad. Se zambullen desde lanchas abiertas con una eslora que oscila entre los 3 y los $11 \mathrm{~m}$. Los compresores que usan son impulsados por motores de gasolina o gasóleo y son primitivos: ponen en circulación aire sin filtrar en un tanque de presión y a lo largo de una manguera de $100 \mathrm{~m}$ que llega hasta el buzo. El uso de compresores de aire ordinario sin filtración puede contaminar el aire que se respira con monóxido de carbono, dióxido de nitrógeno de los motores de gasóleo, plomo de la gasolina con plomo y partículas de combustión. La manguera se conecta a una máscara normal que cubre los ojos y la nariz. La inhalación y exhalación se realizan por la nariz, y el aire exhalado escapa por los bordes de la máscara. La única protección contra la vida marina y la temperatura del agua es un cuello elástico, una camisa de manga larga, un par de zapatos de plástico y un par de pantalones de estilo deportivo. Un par de guantes de malla de algodón ofrecen cierto grado de protección para las manos (véase la Figura 66.21.

En concertación con el Ministerio de Sanidad de Tailandia se llevó a cabo un proyecto de investigación para estudiar las prácticas submarinas de los Gitanos del Mar y desarrollar intervenciones educativas e informativas destinadas alertarlos de los riesgos que corren y de las medidas que pueden tomar para reducirlos. Como parte de ese proyecto, trabajadores sanitarios entrevistaron a 334 buzos en 1996 y 1997. El porcentaje de respuesta a los cuestionarios fue superior al $90 \%$. Aunque aún se están analizando los datos de esa encuesta, se han extraído ya algunas conclusiones.

Por lo que se refiere a las prácticas de submarinismo, se preguntó a un $54 \%$ de los buzos cuántas inmersiones habían realizado el último día. De los 310 que respondieron a esta pregunta, el $54 \%$ indicaron que habían hecho menos de 4 inmersiones; un $35 \%$ entre 4 y 6 , y un $11 \%$ habían realizado 7 o más.

Al preguntarles la profundidad de la primera inmersión del último día de trabajo, de los 307 buzos que respondieron a esta pregunta, un $51 \%$ indicaron $18 \mathrm{~m}$ o menos; un $38 \%$ entre $18 \mathrm{y}$ $30 \mathrm{~m}$; un $8 \%$ entre 30 y $40 \mathrm{~m}$; un $2 \%$ más de $40 \mathrm{~m}$, y un buzo señaló haberse sumergido a $80 \mathrm{~m}$. Un chico de 16 años de una aldea informó que había realizado 20 inmersiones en su último día de trabajo a profundidades de menos de $10 \mathrm{~m}$. Desde que empezó en este trabajo ha sufrido 3 episodios de descompresión.

Una alta frecuencia de inmersiones, grandes profundidades, tiempos prolongados de fondo e intervalos cortos en superficie son factores que pueden aumentar el riesgo de un episodio de descompresión.

\section{Riesgos}

Una muestra aleatoria tomada al principio de la encuesta puso de manifiesto que los tres riesgos más importantes son la interrupción del suministro de aire, que provoca un ascenso de emergencia, las lesiones ocasionadas por la vida marina y los episodios de descompresión.

A diferencia de los submarinistas deportivos o profesionales, los buzos indígenas no tienen suministro alternativo de aire. El corte, atascamiento o separación de la manguera de aire sólo deja dos opciones. La primera es encontrar a un compañero y compartir el aire de una sola máscara, cosa que es prácticamente desconocida por los Gitanos del Mar; y la segunda es nadar con urgencia hasta la superficie, lo que puede conducir y - a menudo lo hace- a un barotraumatismo llesión provocada por la rápida reducción de la presión) y un episodio de descompresión (causado por la expansión de burbujas de nitrógeno en la sangre y los tejidos a medida que el submarinista se acerca a la superficie). Cuando se les preguntó sobre la separación de sus compañeros durante el trabajo bajo el agua, de los 331 buzos que respondieron a la pregunta, 113 (34\%) señalaron que trabajaban a una distancia de $10 \mathrm{~m}$ o más de sus compañeros y otros 24 indicaron que no les preocupaba dónde se encontraban sus compañeros mientras estaban bajo el mar. Actualmente, este proyecto de investigación enseña a los buzos a compartir el aire de una sola máscara y los alienta a mantenerse unos cerca de los otros.

Puesto que los buzos indígenas suelen trabajar con vida marina muerta o lesionada siempre existe el peligro de que un depredador hambriento les ataque. También pueden manipular animales 
marinos venenosos, lo que aumenta el riesgo de lesión o enfermedad.

Por lo que respecta a los episodios de descompresión, el $83 \%$ de los buzos consideraban que el dolor era parte de su trabajo; un $34 \%$ señalaron que se habían recuperado de ellos y un $44 \%$ que habían tenido 3 o más episodios.

\section{Una intervención de salud laboral}

Para la aplicación de este proyecto se ha instruido a 16 asistentes sanitarios de la aldea y a 3 gitanos del mar para convertirse en formadores. Su tarea consiste en trabajar barco por barco con los buzos utilizando intervenciones breves (15 minutos) para alertarlos de los riesgos que corren; transmiten a los buzos sus conocimientos y técnicas para reducir los riesgos y desarrollan procedimientos de emergencia para asistir a los que caen enfermos o lesionados. En este taller de formación de formadores se desarrollan 9 normas, una lección breve sobre cada norma y una ficha de información que se entrega a los interesados. Las normas son las siguientes:

1. hacer primero la inmersión más profunda, cada una de las siguientes ha de ser menos profunda;
2. hacer primero la parte más profunda de la inmersión, seguida de trabajos en aguas menos profundas;

3. al ascender, es obligatorio hacer una parada de seguridad a $5 \mathrm{~m}$ tras una inmersión profunda;

4. subir lentamente en cada inmersión;

5. pasar un mínimo de una hora en superficie entre dos inmersiones profundas;

6. beber una gran cantidad de agua antes y después de cada inmersión;

7. mantenerse a distancia visual de otro buzo;

8. no aguantar nunca el aliento,

9. mostrar siempre la bandera internacional de inmersión cuando hay buzos bajo el agua.

Los Gitanos del Mar nacen y crecen junto al mar o en éste. Dependen del mar para su existencia. Aunque enferman y se lesionan como resultado de su prácticas submarinas siguen sumergiéndose. Las intervenciones antes mencionadas probablemente no harán que los Gitanos del Mar dejen de sumergirse, pero les harán tomar una mayor conciencia de los riesgos que corren y les proporcionarán los medios para reducirlos.

David Gold

Figura 66.1 - Buzo indígena pescando.

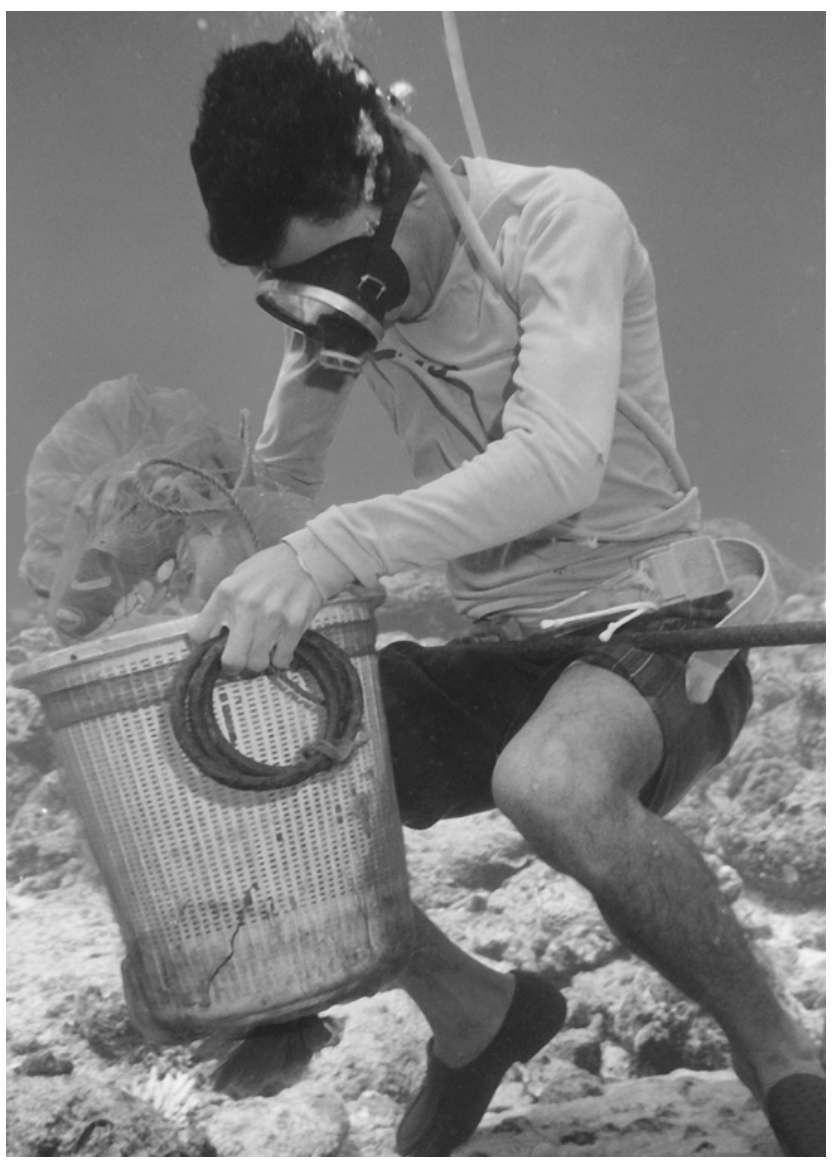

Figura 66.2 • Buzo en aguas de Phuket, Tailandia, preparándose para sumergirse desde una lancha abierta.

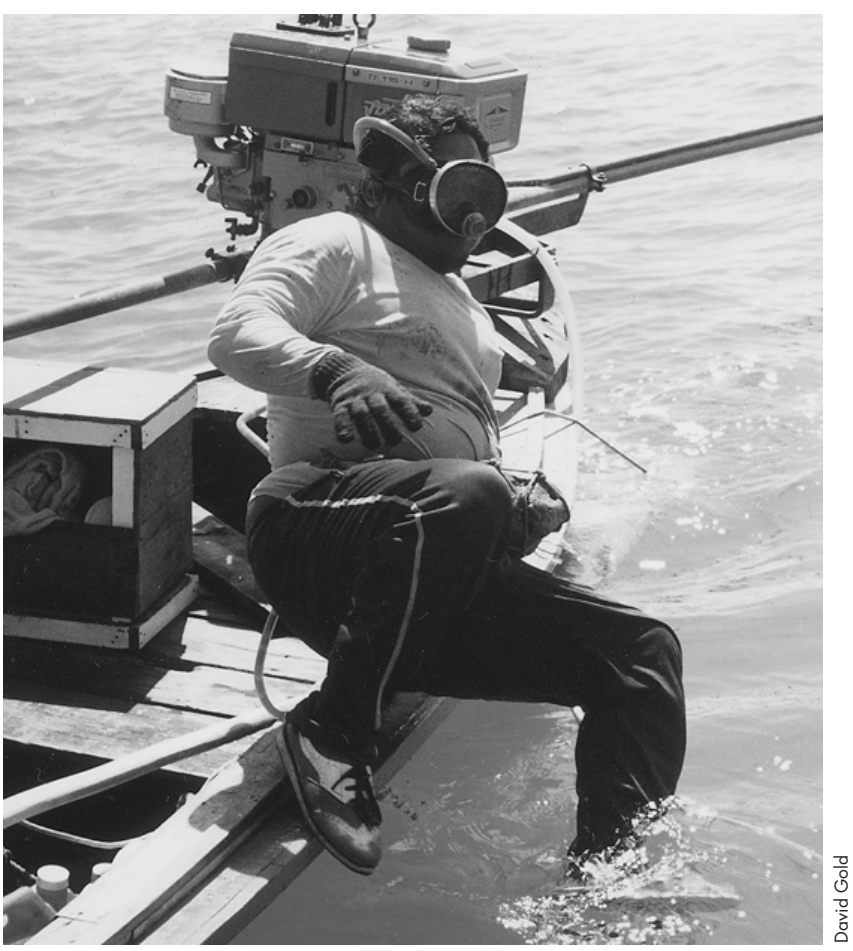

superficiales a casi cualquier lugar del océano donde puedan encontrarse peces. En cambio, la pesquería artesanal ha registrado un estancamiento relativo, aunque también se hayan producido progresos técnicos en este sector. 


\section{Importancia económica}

Se estima que el valor actual al desembarque de las capturas pesqueras mundiales es de 60.000-70.000 millones de dólares (FAO 1993, 1995). Aun cuando cabe suponer que el procesamiento y la distribución representan el doble o el triple de esta cifra, la pesca es una industria relativamente secundaria desde un punto de vista global, en particular si se compara con la agricultura, la principal industria de producción de alimentos del mundo. Ahora bien, para algunos países y regiones, la pesca tiene una gran importancia, como ocurre en muchas comunidades costeras del Atlántico del Norte y del Pacífico del Norte. Además, en muchas comunidades de África occidental, Sudamérica y el sudeste Asiático, la pesca es la principal fuente de proteína animal de la población y, por ende, muy importante económicamente.

\section{Gestión de las pesquerías}

El esfuerzo pesquero global ha aumentado de forma notable en este siglo, sobre todo después de la segunda Guerra Mundial. Como resultado, muchas de las poblaciones de peces más valiosas del globo se han visto reducidas hasta el punto de que un mayor esfuerzo pesquero conduciría de hecho a una disminución del nivel sostenible de capturas. La FAO estima que la mayoría de las principales poblaciones de peces del mundo se utilizan plenamente o son objeto de capturas excesivas (FAO 1995). El resultado es que la captura de muchas de las especies más importantes del mundo se ha reducido y que, a pesar de los continuos avances de la tecnología pesquera y del aumento de los precios reales del pescado, los rendimientos económicos de la actividad pesquera han disminuido.

Ante la reducción de las poblaciones de peces y de la rentabilidad de la industria pesquera, los países pesqueros del mundo han empezado a buscar medios para poner remedio a esta situación. Generalmente, estos esfuerzos han seguido dos vías: la ampliación de la jurisdicción nacional de las pesquerías a 200 millas náuticas y más, y la imposición de nuevos sistemas de gestión de las pesquerías dentro de las jurisdicciones nacionales.
Se han empleado muchos métodos de gestión de las pesquerías con el fin de mejorar la economía de la pesca. Considerando que la raíz del problema reside en el carácter de propiedad colectiva de las poblaciones de peces, los sistemas más avanzados de gestión de las pesquerías intentan resolver el problema mediante la definición de derechos de cuasipropiedad sobre ellas. Un método común consiste en establecer un total de capturas autorizadas para cada especie y a continuación asignar dicho total a diversas empresas pesqueras en forma de cuotas individuales de pesca. Dichas cuotas constituyen un derecho de propiedad en la pesquería. Si las cuotas pueden negociarse, la industria pesquera se beneficia de la limitación del esfuerzo pesquero al mínimo necesario para pescar la captura autorizada y, si las cuotas también son permanentes, del ajuste del tamaño de la flota al rendimiento sostenible a largo plazo de la pesquería. Este tipo de gestión de las pesquerías (generalmente denominado sistema de cuotas individuales negociables (CIT)) se está extendiendo rápidamente por el mundo y parece probable que se convierta en la norma de gestión para el futuro.

La ampliación de las jurisdicciones nacionales de pesca y los sistemas de gestión basados en derechos de propiedad que se están utilizando en ellas requieren una importante reestructuración de la pesca. La cobertura virtual de los océanos por parte de las jurisdicciones nacionales de pesca, que ya está en curso, no eliminará obviamente la pesca de altura. Los sistemas de gestión de las pesquerías basados en derechos de propiedad también representan una mayor invasión de las fuerzas del mercado en el ámbito de la pesca. La pesca industrial es económicamente más eficiente que la artesanal. Además, las empresas pesqueras industriales se encuentran mejor situadas para adaptarse a los nuevos sistemas de gestión de las pesquerías artesanales. Así, la actual evolución de la gestión de las pesquerías representa una nueva amenaza para la pesca artesanal. Por ello y por la necesidad de limitar el esfuerzo global de pesca, parece inevitable que el nivel de empleo en las pesquerías mundiales baje radicalmente en el futuro.

Figura 66.3 - Pesca con un arrastrero de fondo de popa.

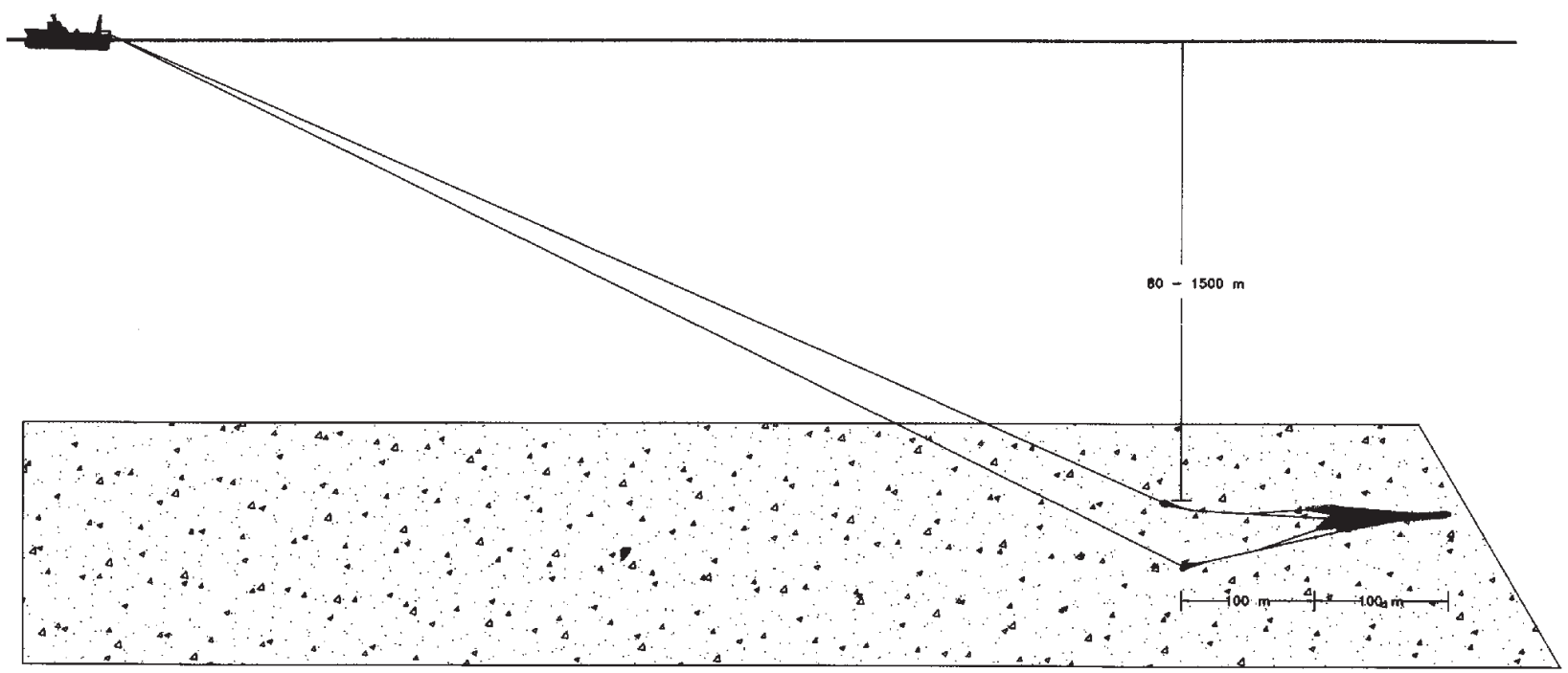

Fuente: Hampidjan Ltd. 


\section{PRINGIPALES SECTORES Y PROGESOS}

\section{Hjálmar R. Bárdarson}

\section{Características del trabajo en el mar}

El trabajo a bordo de buques de pesca difiere en varios aspectos del trabajo en buques mercantes, si bien la actividad relacionada con la navegación es similar o idéntica. La principal diferencia entre un buque mercante y un buque de pesca es que el primero embarca su cargamento en puerto. Tras la carga, las escotillas se cierran herméticamente y, normalmente, no se abren hasta llegar al siguiente puerto, donde se desembarca el cargamento.

En cambio, los buques de pesca capturan los peces en los caladeros, es decir embarcan su "cargamento" en el mar. Por ello, tienen que operar con cierta frecuencia con algunas escotillas abiertas en alta mar, lo que representa un peligro de inundación.

Otro aspecto es la captura en sí. A menudo se arrastra un elevado peso en artes de pesca, incluso en buques pequeños. Con frecuencia, la pesca se realiza en caladeros en alta mar desprovistos de protección. Además, en muchos buques pequeños la tripulación tiene que trabajar sin protección en cubiertas abiertas.

Por ello, los buques de pesca son más vulnerables que los mercantes, en particular con mar brava y requieren un diseño diferente e instrucciones para la educación y la formación de los pilotos y la tripulación.

\section{Métodos de pesca y tipos de buques de pesca}

La tipología de los buques de pesca suele estar determinada por los métodos de pesca utilizados. Algunos buques han sido diseñados únicamente para un método de pesca, pero otros son polivalentes y pueden usar dos o más tipos diferentes de artes de pesca. Los principales métodos de los buques en funcionamiento son los siguientes:

1. arrastre de fondo

2. arrastre de fondo a la pareja

3. pesca con red de cerco de jareta (arte de cerco)

4. pesca de palangre

5. pesca con redes de deriva

6. pesca a la línea en buques pequeños.

\section{Arrastre de fondo}

El método original de arrastre de fondo era el arrastre de costado. Un arrastrero de costado tiene dos pescantes: uno en proa y otro en popa, generalmente a estribor (lado derecho del buque de popa a proa). La tripulación arroja la red de arrastre por el costado y pasa los cables de arrastre por las pastecas que cuelgan de los pescantes. Las puertas, situadas a cada lado de la boca de la red, se colocan en ángulo, de forma que la red permanezca abierta mientras es arrastrada por el buque por el fondo (véase la Figura 66.3). Los peces se recogen en el denominado copo de la red. La superestructura de un arrastrero de costado se halla en la mitad de popa del buque, con una maquinilla de pesca de doble tambor generalmente instalada frente a ésta, en la cubierta de proa. Las capturas se cargan a bordo en esta última mediante una grúa instalada en el mástil de proa. Quedan muy pocos arrastreros de costado en funcionamiento, ya que la mayoría han sido sustituidos por arrastreros de popa. Éstos tienen el puente en la parte anterior y un amplio palo de popa de lado a lado en lugar de los pescantes (véase la Figura 66.4). Los arrastreros de popa de mayor tamaño poseen una cubierta de abrigo; la maquinilla principal de pesca se encuentra en el centro del buque y, generalmente, existen varias maquinillas de menor tamaño en la cubierta de popa para subir partes del arte de pesca. La red de arrastre sube por una rampa situada sobre la cubierta de abrigo, lugar donde se levanta el copo y se vacía su contenido a través de una escotilla en los buches situados en la cubierta principal, que en los grandes arrastreros de popa forman una cubierta de procesamiento.

\section{Arrastre de fondo a la pareja}

La finalidad de los arrastreros de fondo a la pareja es capturar especies pelágicas y otras especies ícteas en bancos a diversos niveles entre el fondo del mar y la superficie. El arrastre de fondo a la pareja es realizado por el mismo tipo de buques que el arrastre de fondo, aunque suelen estar equipados con un amplio tambor de red, capaz para redes mucho mayores. Estos arrastreros cuentan con puertas, pesos y flotadores especiales en los cables de arrastre para regular la profundidad del arrastre en relación con la superficie.

\section{Pesca con red de cerco de jareta (arte de cerco)}

Las redes con cerco de jareta sirven para capturar bancos de peces que nadan libremente, como el arenque, el capelán y la caballa. Las capturas pueden ser muy elevadas, por lo que es importante que el buque posea una gran capacidad de carga. La red de cerco de jareta está provista de flotadores en su parte superior y pesos en la inferior. Puesto que el buque debe tender la red en forma de aro alrededor de un banco de peces, es importante que éste posea una buena maniobrabilidad y una buena capacidad de giro. Existen dos tipos de buques con red de cerco de jareta. A uno de ellos se le denomina de tipo americano y al otro de tipo noreuropeo (o nórdico). Ambos utilizan accionamientos hidráulicos. Los buques de tipo americano tienen el puente y los camarotes en la parte de proa y el motor en un mástil situado hacia popa. Originalmente, los nórdicos eran arrastreros de costado con su caseta de cubierta, caseta de timón y camarotes en popa. Una vez cercado el banco de peces, la maquinilla situada en la cubierta cierra la red de cerco por su parte inferior tirando del cable de fondo; a continuación, los peces son bombeados a cubierta mediante un mecanismo separador de peces y agua.

Los buques de red de cerco de nuevo diseño (véase la Figura 66.5) suelen tener las mismas dimensiones que los grandes arrastreros de popa, con un entrepuente que va de proa a popa y un almacén de red separado en popa. La disposición de la sala de máquinas es similar al tipo original de buques.

\section{Pesca de palangre}

La pesca de palangre consiste en arrojar una línea larga a la que se han fijado varios fragmentos de línea con cebos

Figura 66.4 - Arrastrero de popa.

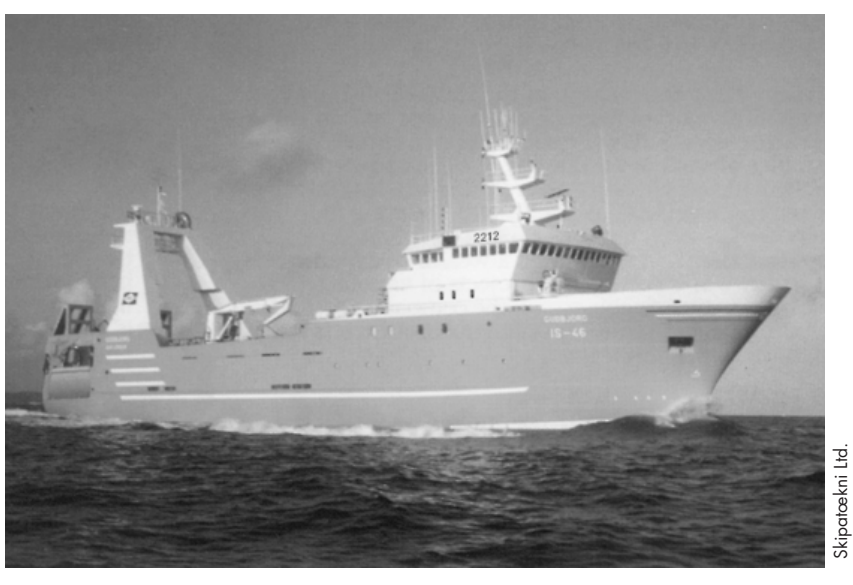


Figura 66.5 • Palangrero.

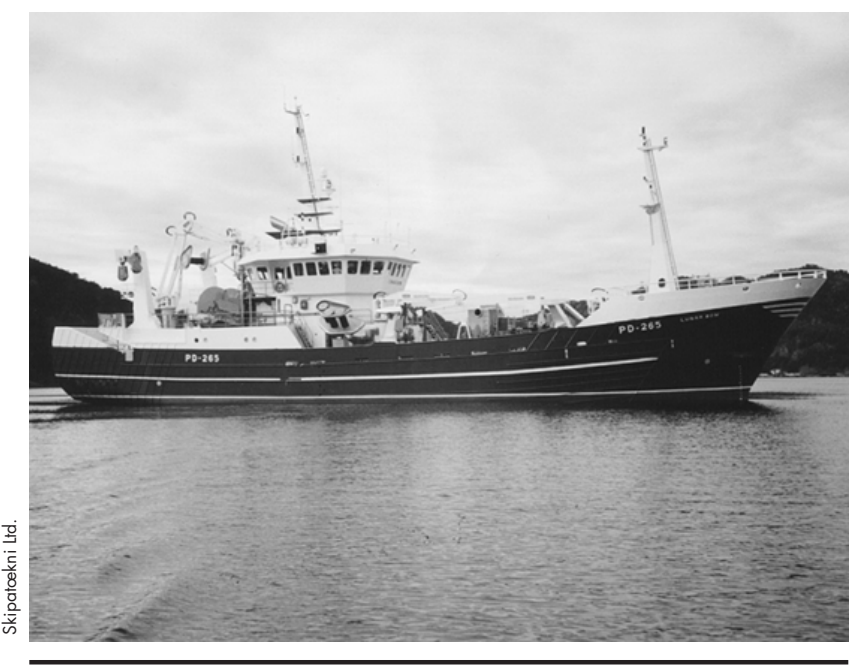

cada $1 \mathrm{~m}$ ó $2 \mathrm{~m}$. Transcurrido un tiempo determinado, se recoge la línea y se retiran los peces capturados de los anzuelos. Este método de pesca ha sido utilizado - y aún lo es - por buques de pesca de pequeño tamaño sin abrigo en la cubierta (véanse las Figuras 66.6 y 66.7). Por lo general, los cebos se colocan en tierra y se almacenan en tubos. El buque deja ir la línea por la popa y la recoge por estribor con un motor hidráulico.

Los buques palangreros modernos, equipados con línea automática, tienen una cubierta de abrigo, una apertura lateral para la recogida y una apertura en la roda para soltar la línea. Ambas aperturas pueden cerrarse herméticamente y están situadas a un ángulo que limita la inundación a una parte de la cubierta de trabajo en caso de que rompa una ola. Una vez recogida la línea, ésta pasa por un mecanismo automático en que se limpian los anzuelos y se cuelgan nuevos cebos, todo ello en una sola operación justo antes de volver a soltarla. Los palangreros pueden tener una longitud de $60 \mathrm{~m}$, pudiendo alojar entre 20 y 40 tripulantes. El sistema de línea automática cuenta con un máximo de 40.000-50.000 anzuelos en una línea de hasta $60 \mathrm{Km}$ de longitud. La línea se suelta a una velocidad de 7-8 nudos y el recogedor de línea tiene una potencia de unas $5 \mathrm{t}$. La zona de procesamiento se encuentra en el entrepuente, que está equipado con correas transportadoras, contenedores y mesas para la limpieza y el despiece manuales. En algunos casos, los buques están equipados para congelar el pescado.

Figura 66.6 - Pequeño palangrero de alta velocidad (parado).

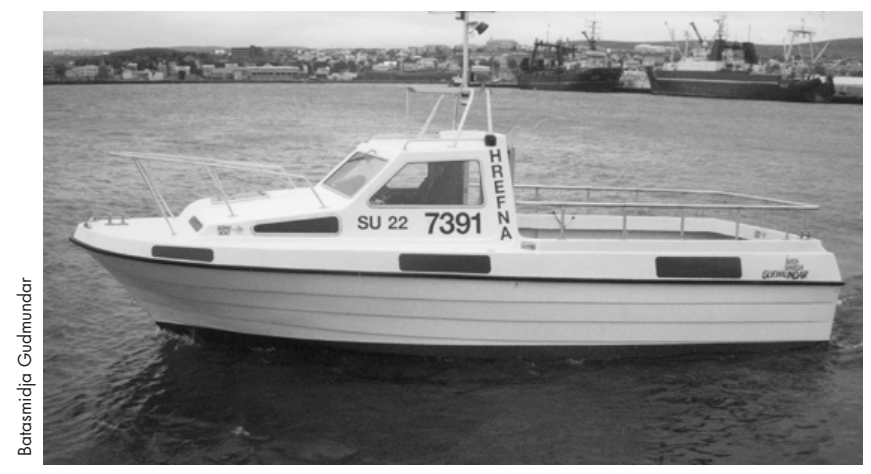

Figura 66.7 • Pequeño palangrero de alta velocidad (en funcionamiento).

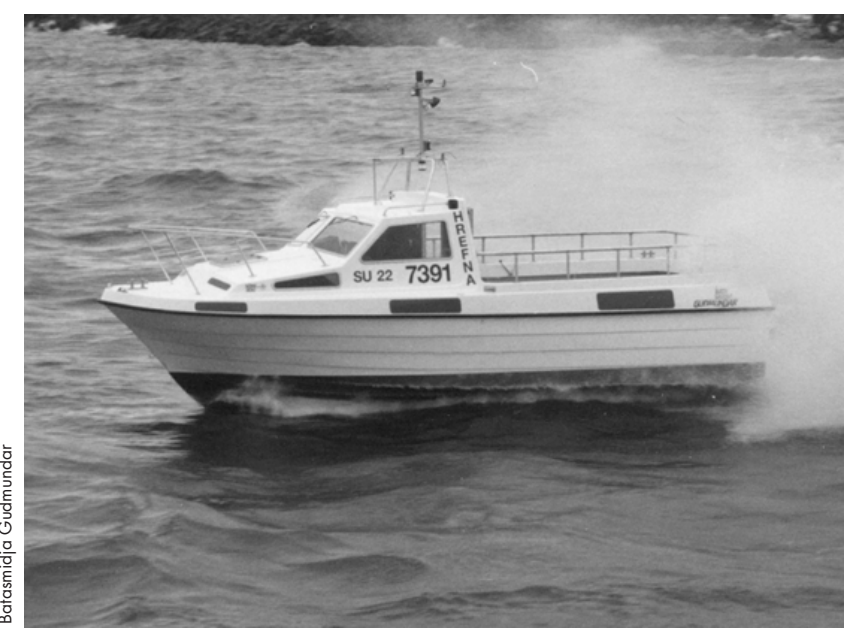

\section{Pesca con redes de deriva}

Las redes de deriva atrapan a los peces por las branquias. En los buques pesqueros con superestructura en popa y zona de trabajo en el centro del buque, se sueltan varias redes de deriva, unidas una a otra, por el costado. En el extremo libre de las redes se ata una boya y en la parte superior una serie de flotadores. El buque mantiene las redes extendidas. Actualmente, este tipo de pesca ha sido sustituido en muchos países por pesca de cerco y arrastreros de fondo a la pareja.

\section{Pesca a la línea en buques pequeños}

La pesca de bajura en pequeños buques todavía constituye una actividad importante en muchos países y ha registrado un considerable desarrollo. Las barcas de madera con motores fuera o dentro de borda han sido sustituidas en gran parte por buques de cubierta o media cubierta, en su mayoría de fibra de vidrio y con diseño de buques de alta velocidad que pueden llegar a caladeros a media distancia de la costa. Generalmente, la longitud de estos buques oscila entre 8 y $15 \mathrm{~m}$. Equipados con motores de 250 a 400 caballos de potencia, pueden alcanzar una velocidad crucero de hasta 24 nudos. Normalmente, la cabina tiene dos camarotes, un pasillo y un retrete. Algunas de estas embarcaciones están equipadas con carretes de pesca de accionamiento informatizado. El carrete suelta la línea y detecta cuando un lastre toca fondo, sitúa los anzuelos a la distancia deseada y efectúa acciones de tira y afloja. También detecta si pica un pez y, en tal caso, recoge la captura a la superficie.

\section{Procesamiento del pescado a bordo y en tierra}

Debido al aumento de tamaño de los buques pesqueros y a la extensión de la pesca a aguas profundas lejos de los puertos de amarre, también el procesamiento a bordo ha experimentado un considerable aumento. Como el espacio a bordo es más limitado que en las plantas de procesamiento en tierra, ha sido necesaria una distribución más compacta y el desarrollo de nuevas líneas automatizadas para el procesamiento tanto de pescado como de camarones. En el borde superior de la rampa de popa de un arrastrero moderno, el contenido del copo de la red de arrastre se vacía a través de escotillas hidráulicas hacia los contenedores de acero inoxidable situados en la cubierta de recepción, que se encuentra en la parte posterior de la zona de procesamiento. 
A través de cuatro escotillas hidráulicas situadas en el mamparo frontal de los contenedores de recepción, la línea de procesamiento recibe el pescado y lo transporta por las estaciones de la zona de procesamiento, con una superficie de $520 \mathrm{~m}^{2}$. El procesamiento esta diseñado para producir filetes, bloques, harina de pescado y pescado limpio. En la Figura 66.8 se ilustra este proceso.

La línea de procesamiento es lo más automática posible y está provista de cintas transportadoras, almacenes intermedios, funciones de circunvalación, etc. El trazado incluye los siguientes elementos:

- cinta de clasificación y desangrado;

- máquina de descabezado y limpieza;

- diez tanques intermedios con agua helada;

- dos cintas para transportar el pescado de los tanques intermedios a la zona de producción;

- una cinta para llevar los filetes de las dos máquinas de fileteado a la zona de recorte;

- una línea de recorte con ocho estaciones de trabajo,

- una línea de embalaje con estación automática de pesado (separación automática de porciones) y cinco estaciones de embalaje.

La línea de procesamiento también está dotada de una estación de fileteado a mano con cuatro puestos de trabajo. El sistema de congelación está conectado a tres congeladores horizontales automáticos de placa y un congelador manual. La capacidad de congelación es de unas 70 toneladas de filetes de pescado en 24 horas.

Figura 66.8 • Diagrama de pesca y procesamiento.

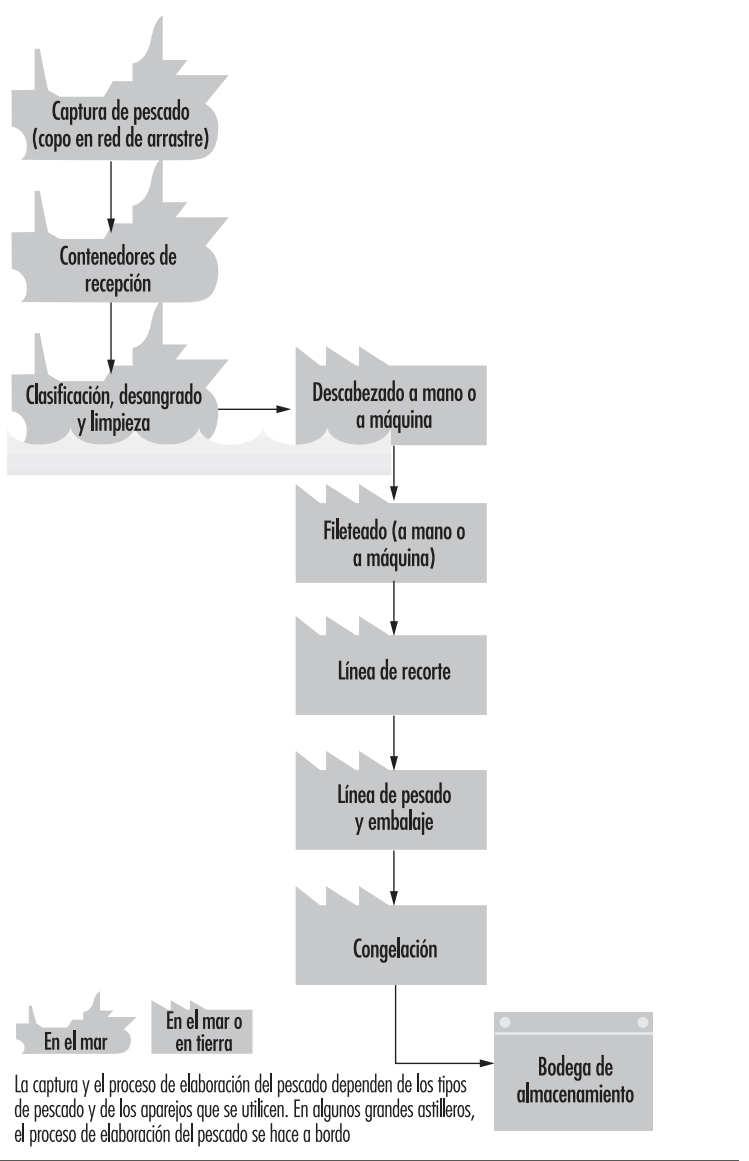

El tamaño de las cajas está normalizado y los filetes y bloques se embalan en pesos normalizados de bloques congelados. Se ha instalado un montacargas para el transporte desde la línea de procesamiento a la bodega. La bodega de pescado, con un volumen total de $925 \mathrm{~m}^{3}$, puede mantenerse a $-30{ }^{\circ} \mathrm{C}$, con una temperatura exterior de $30^{\circ} \mathrm{C}$ y una temperatura del agua de mar de $20^{\circ} \mathrm{C}$.

A estribor de la zona de procesamiento hay otra línea de procesamiento para camarones con cinta de clasificación, máquina de pelado, hervidor, báscula, túnel de congelación y embalaje. Parte del equipo de procesamiento para pescado blanco se utiliza también para el procesamiento del camarón. (p. ej., contenedores de recepción, congeladores de placa, embalaje, cintas transportadoras y almacenamiento en la bodega de pescado).

Algunos grandes arrastreros-congeladores están dotados de una fábrica de harina de pescado con capacidad para 50 ó 60 toneladas de materia prima y una producción de 7 a 9 toneladas de harina de pescado en 24 horas. La obtención de una buena calidad depende del vapor caliente del secador, procedente de una caldera mixta de evacuación/gasoil. La fábrica de harina de pescado consta de la siguiente maquinaria:

- un aparato de cocción indirecta con una camisa calentada por vapor, un rotor y boquillas para el suministro de vapor directamente sobre el pescado;

- una cinta transportadora y una prensa de dos tornillos;

- una cinta de desmenuzamiento para transportar el producto prensado a un secador de disco giratorio calentado por vapor;

- una bomba para transportar agua a presión desde fuera de borda,

- una tubería de succión para transportar la harina desde el receptor situado bajo la salida del secador a la planta de molido.

Por último, unos conductos conectan el molino con la estación de embalaje situada en la bodega de harina de pescado, y allí se embala y almacena la harina en bolsas de papel o yute de $35 \mathrm{Kg}$.

Las estaciones están dotadas de plataformas ajustables para los tripulantes que trabajan en la zona de procesamiento y que se ven obligados a permanecer en pie durante largo tiempo.

Las instalaciones de procesamiento de pescado blanco y otros productos del mar de los buques-factoría que no participan en las operaciones de pesca es casi idéntico al de los buques de pesca, como los arrastreros de popa que procesan su propias capturas. La principal diferencia es que los buques-factoría siguen a la flota de pesca a los caladeros y reciben las capturas para procesarlas y transportarlas a puerto.

El desarrollo de las líneas de congelación y del equipo de procesamiento de pescado de los buques ha tenido también una gran influencia en el equipamiento de las plantas procesadoras de pescado en tierra. Este sistema automático pero flexible cuenta con varias estaciones de trabajo donde se supervisa individualmente la calidad, el rendimiento, la capacidad y la producción para una gestión óptima del sistema. Los filetes son enviados a una máquina porcionadora y las porciones resultantes a estaciones en que son congeladas o embaladas. El sistema de cintas transportadoras de las líneas de procesamiento tanto de pescado como de camarón ofrece un flujo extraordinario con un esfuerzo mínimo, sin que los trabajadores tengan que levantar o arrojar el pescado.

\section{Códigos internacionales}

Tres organizaciones de Naciones Unidas - la FAO, la Organización Internacional del Trabajo (OIT) y la Organización Marítima Internacional (OMI) - celebraron un acuerdo de cooperación para llevar a cabo un proyecto consistente en 
elaborar un código de seguridad para los pescadores y buques de pesca, cada una de ellas en su correspondiente ámbito de competencia:

- FAO - pesquerías en general;

- OIT - el trabajo en la industria pesquera,

- OMI - seguridad de la vida, los buques y el equipo en el mar.

Un grupo de asesores de las tres organizaciones elaboró un Código de seguridad para los pescadores y buques de pesca que consta de dos partes: la Parte A, seguridad y prácticas sanitarias para patrones y tripulaciones de buques de pesca, contiene exigencias operativas y laborales; y la Parte B se dedica a la seguridad y los requisitos sanitarios para la construcción y equipamiento de los buques de pesca. La finalidad de esta guía es reducir los riesgos de lesión para los pescadores y, en la medida de lo posible, evitar accidentes, reduciendo así los peligros para el buque. La OMI coordinó las enmiendas propuestas, pero éstas fueron sometidas a la aprobación definitiva de las tres organizaciones. La OMI ha publicado las ediciones revisadas del código en nombre de la FAO, la OIT y la OMI.

En la Parte A se ofrece la información básica necesaria para realizar con seguridad las operaciones de pesca, como seguridad en la navegación, navegabilidad del buque y equipamiento adecuado. Otras medidas de precaución que deben tomarse incluyen el mantenimiento de una estabilidad adecuada del buque; precauciones contra las caídas fuera de borda; seguridad general en cubierta; seguridad en las salas de máquinas y equipo mecánico; conocimiento de los mecanismos de salvamento, prevención de incendios y equipo de primeros auxilios. También es fundamental el mantenimiento periódico de todos los mecanismos de seguridad del buque y su equipo.

Para la seguridad de un buque de pesca, la dirección y manejo del mismo son factores básicos. Los patrones de buques con $24 \mathrm{~m}$ de eslora o más que operen sin límites geográficos deben conocer todos los aspectos de la navegación, las maniobras y el manejo de un buque de pesca, su construcción y estabilidad. El patrón debe poder utilizar datos sobre estabilidad y evaluar la influencia de la carga de pescado, del contenido de los tanques de agua y carburante, del agua atrapada en la cubierta, del cierre de las escotillas del buque y de la tracción de las artes de pesca.

Para la seguridad de los buques de pesca y sus tripulantes es esencial que la educación, formación y certificación de todo el personal de a bordo se ajusten a normas reconocidas de alto nivel. A tal fin, se firmó en 1995 en la sede de la OMI de Londres un Convenio internacional sobre normas, titulación y guardia para la gente de mar. Aquellos Estados en que el Convenio ha entrado en vigor se han comprometido a adoptar todas disposiciones legales, reglamentarias y administrativas para garantizar que el personal de los buques marinos esté calificado y preparado para sus tareas desde el punto de vista de la seguridad de la vida y la propiedad en el mar y de la protección del medio ambiente marino. El convenio entrará en vigor 12 meses después de la fecha en que lo hayan ratificado al menos 15 Estados.

Los reglamentos anexos al Convenio estipulan las exigencias obligatorias mínimas en materia de certificación de patrones, oficiales, oficiales ingenieros y operadores de radio, así como la formación específica básica para todo el personal de los buques pesqueros y disposiciones sobre principios básicos que deben observarse durante la guardia de navegación a bordo de los buques de pesca.

Entre los elementos sobre los que deben examinarse los candidatos a los certificados de patrón de buque y oficiales de navegación de buques pesqueros sin limitación geográfica se encuentran los siguientes: navegación, guardia, determinación electrónica de la posición, meteorología, comunicación, prevención de incendios, salvamento, maniobras y manejo de un buque de pesca, construcción y estabilidad de buques de pesca (incluidos conocimientos sobre los efectos de las superficies libres y la adhesión de hielos), manejo y estiba de capturas, lengua inglesa, ayuda sanitaria, derecho marítimo, búsqueda y rescate, conocimiento de la Parte A del Código de seguridad para pescadores y buques de pesca de la FAO/OIT/OMI y prevención de la contaminación marina.

\section{Alojamiento y equipamiento para la tripulación en buques de pesca de altura}

En los mayores arrastreros-congeladores de popa, destinados a la pesca en alta mar y que a menudo permanecen durante meses lejos de su puerto de amarre, el alojamiento y equipamiento para la tripulación suele ser amplio. Por ejemplo, un arrastrero de popa islandés nuevo de $68 \mathrm{~m}$ de eslora botado en 1994 dispone de alojamiento para 37 personas. Cuenta con 13 camarotes individuales y 12 dobles, así como con una enfermería con 2 camas y un retrete y lavabo separados. La superficie total de alojamiento es de $625 \mathrm{~m}^{2}$. Todos los camarotes tienen acceso a un retrete, lavabo y ducha separados. El equipamiento de ocio incluye un televisor color estéreo de 28 pulgadas, dos grabadoras de vídeo, un equipo estéreo y receptores. Hay radios en cada camarote y 10 para la cubierta de procesamiento. En cubierta hay un retrete común, vestidores para la tripulación de cubierta, con casilleros, lavabos y lavadoras/secadoras, y una sala para chubasqueros con secadoras para botas altas, etc.

\section{Lugares de pesca}

Los lugares de pesca existentes en el mundo son muy diferentes, al igual que los tipos y tamaños de buques utilizados. Desde la más simple canoa de tronco de un lago interior a un complejo y bien equipado arrastrero-fábrica de alta mar tienen la misma finalidad: capturar peces. Con relación a la seguridad, en la Parte B del Código las zonas de pesca se dividen en tres categorías:

1. zonas sin límites geográficos;

2. zonas marinas hasta 200 millas náuticas del lugar de refugio,

3. zonas marinas hasta 50 millas náuticas del lugar de refugio.

Ahora bien, los lugares de pesca o caladeros se dividen generalmente en pesquerías de bajura y pesquerías de altura.

Las pesquerías de bajura están situadas en aguas costeras, pero la distancia de la costa varía dependiendo de las condiciones locales. En los fiordos u otras aguas resguardadas, se usan pequeñas lanchas motoras (incluso abiertas o de media cubierta) para travesías pesqueras de un día; para travesías más largas se emplean buques motorizados de muy diferentes tipos locales.

Las pesquerías de altura son actividades pesqueras más alejadas de la costa y no existen límites respecto de la distancia a la costa. Por lo general, los buques de pesca destinados a las pesquerías de altura han sido diseñados para zonas marinas no delimitadas, ya que en muchos países costeros la alta mar (u océano) se encuentra justo fuera de los fiordos o calas resguardadas de la costa.

\section{Buques de pesca}

Como ya se ha dicho, los buques de pesca utilizados para la pesca de altura son de tipos y tamaños muy variados : arrastreros de popa (buques para pescado fresco con líneas de procesamiento), buques con redes de cerco, palangreros, buques-fábrica, etc. Según la definición internacional, un buque de pesca es un buque usado para la captura comercial de pescado, ballenas, focas, morsas u otros recursos marinos vivos. Un buque de procesamiento es un buque utilizado exclusivamente para procesar las capturas. 
Las características de los buques de pesca son tan diferentes de las de otras embarcaciones marítimas que no pueden cubrirse individualmente en los convenios internacionales para la seguridad de la vida en el mar. En 1977, la Conferencia sobre seguridad de buques de pesca celebrada en Torremolinos, España, elaboró un Convenio internacional para la seguridad de los buques de pesca. Dicho convenio se basa en los trabajos técnicos realizados por la OMI durante varios años, en particular por el Subcomité sobre seguridad de los buques de pesca del Comité de seguridad marítima. Con anterioridad, ese Comité había adoptado unas recomendaciones sobre la estabilidad de los buques de pesca que fueron publicadas por la OMI e incluidas en el Convenio de 1977 sobre la seguridad de los buques de pesca. El Convenio estipula que sólo es aplicable a los buques de pesca nuevos de $24 \mathrm{~m}$ de eslora o más. Los buques pesqueros de menor tamaño no están cubiertos por este importante Convenio en materia de seguridad porque los tipos existentes en las flotas pesqueras nacionales son muy diversos y la información técnica disponible es sumamente limitada. Así pues, sólo por falta de información básica no pudieron establecerse disposiciones de seguridad para estos buques. Incluso entre aquellos que rebasan en poco la medida de $24 \mathrm{~m}$ existen grandes diferencias en la forma del casco y los métodos de pesca. Todas estas características tienen una influencia considerable sobre la estabilidad y la navegabilidad en general.

La información técnica en que se basan las disposiciones del Convenio fue proporcionada en su mayor parte por los países pesqueros industrializados de Europa y Norteamérica. Poco después de la Conferencia de 1977 se observó que algunos países de otras regiones del mundo tenían problemas para ratificar partes del Convenio relativas a los buques de menor tamaño dentro de los superiores a $24 \mathrm{~m}$ de eslora. Una conferencia celebrada en 1993 en Torremolinos dio como resultado el Protocolo de Torremolinos de 1993, que suavizó algunos capítulos del Convenio aplicables a determinados buques de pesca. El capítulo relativo a la maquinaria y las instalaciones eléctricas y a los espacios de máquinas desatendidos periódicamente sólo es aplicable, con arreglo al Protocolo de 1993, a los buques nuevos de $45 \mathrm{~m}$ de eslora o más. El capítulo relativo a la protección, detección y extinción de incendios se dividió en dos partes: la Parte A sólo es aplicable a los buques de pesca nuevos de $60 \mathrm{~m}$ de eslora o más, y la Parte B contiene exigencias menos estrictas para los buques comprendidos entre 45 y $60 \mathrm{~m}$. El capítulo sobre comunicaciones por radio se aplica a los buques tanto nuevos como en uso de $45 \mathrm{~m}$ de eslora o más. El Protocolo de 1993 del Convenio de Torremolinos de 1977 también actualiza dicho convenio y toma en consideración la evolución tecnológica desde 1977 a 1993. El Protocolo fue ampliado para incluir los buques que procesan sus propias capturas.

La Conferencia de Torremolinos de 1977 adoptó una Recomendación relativa al desarrollo de normas de seguridad para buques pesqueros con cubierta de menos de $24 \mathrm{~m}$ de eslora, dado que la gran mayoría de los buques de pesca de todo el mundo tienen una eslora inferior a $24 \mathrm{~m}$. Se recomendó a la OMI que continuase desarrollando normas de seguridad en materia de diseño, construcción y equipamiento para dichos buques a fin de promover la seguridad de los mismos y sus tripulaciones. Dichas directrices han sido desarrolladas por la OMI en cooperación con la FAO y la OIT.

\section{Seguridad de los buques de pesca}

\section{Construcción}

La seguridad de los buques, incluidos los pesqueros, depende de que la construcción y resistencia de la propia embarcación sean suficientes para el uso a que está destinada. Así, la resistencia y construcción de los cascos y superestructuras debe ser suficiente para resistir todas las condiciones previsibles del uso a que estén destinadas. Debe garantizarse la estanqueidad del buque y todas las aberturas por las que pueda entrar agua estarán provistas de mecanismos de cierre adecuados, incluidas las escotillas de cubiertas o costados que puedan permanecer abiertas durante las operaciones de pesca. Las falucheras son también de suma importancia para la seguridad, pues permiten que el agua salga de aquellos lugares en que las batayolas situadas a la intemperie en la cubierta de trabajo forman pozos que pueden atraparla. En los buques pequeños, la altura de estas batayolas se ha aumentado para proteger mejor a la tripulación que trabaja en la cubierta a la intemperie. El peso del agua sobre la cubierta puede llegar a ser considerable y constituir un grave peligro para la estabilidad en la zona de cubiertas si ésta no se libera rápidamente del agua. Por ello, es indispensable una zona mínima de falucheras para garantizar que el agua se achique rápida y eficazmente de la cubierta.

En diseños más recientes de buques pesqueros pequeños y medianos, la cubierta de trabajo se ha equipado con un cubierta de refugio. Si la doble cubierta de estos buques puede mantenerse completamente cerrada durante la mayor parte de las operaciones de pesca o si una apertura estanca de la doble cubierta se encuentra en un pequeño compartimento estanco, resulta razonable aceptar bombas de sentina de alta capacidad, en lugar de falucheras, para achicar el agua de la cubierta de trabajo. Este diseño ha aumentado la estabilidad de forma de los buques de pesca al utilizar un francobordo mucho más amplio.

\section{Estabilidad y navegabilidad de los buques de pesca}

Además de la resistencia y la estanqueidad, la estabilidad y la navegabilidad en general son los factores más importantes para la seguridad de un buque de pesca.

Los países miembros facilitaron al Subcomité sobre seguridad de los buques de pesca de la OMI valioso material sobre cálculos de estabilidad para buques existentes con un historial demostrado de funcionamiento y sobre condiciones reales de carga de buques de pesca que volcaron o sufrieron una amplia y peligrosa inclinación. Los criterios para la estabilidad mínima se desarrollaron a partir de dicho material.

Se pueden hacer cálculos de estabilidad estática, pero los movimientos de un navío en el mar están regidos por fuerzas dinámicas que resulta muy difícil, cuando no imposible, calcular, puesto que el viento y el estado del mar son sumamente irregulares. Por otra parte, un buque de pesca que ha sido utilizado sin un sólo accidente durante, digamos, 15 ó 20 años en operaciones de pesca en todas las condiciones normales meteorológicas y marinas puede considerarse razonablemente seguro. También se recomienda el uso de los denominados criterios meteorológicos, que toman en consideración la acción del viento y de las olas, así como el efecto del agua atrapada en cubierta para calcular la estabilidad. Todos estos cálculos y demás información pertinente sobre la estabilidad deben proporcionarse al patrón, que debe evaluar la estabilidad del buque en diversas condiciones de funcionamiento.

Como se indicó antes, en la estabilidad influye el francobordo del buque. La Conferencia sobre buques de pesca de 1977 consideró la imposición de líneas de carga a los buques de pesca, ya que la Convención internacional sobre líneas de carga sólo se aplica a los buques mercantes. Se llegó a la conclusión de que no sería práctico observar marcas de líneas de carga en los caladeros durante la carga. Sin embargo, el Convenio de Torremolinos sobre la seguridad de los buques de pesca exige la aprobación de un calado máximo por parte de la administración nacional y que éste satisfaga los criterios de estabilidad. 


\section{CARACTERISTICAS PSICOSOCIALES DE LOS TRABAJADORES EN EL MAR}

\section{Eva Munk-Madsen}

Dos aspectos revisten especial importancia en las características del trabajo de pesca en el mar. El primero es la cuestión de la escala y la tecnología. Las pesquerías pueden dividirse en: pesquerías de pequeña escala, artesanales, costeras o de aguas interiores; y pesquerías de gran escala, industriales, de altura, en aguas lejanas o profundas. Las condiciones psicosociales de trabajo y vida de los miembros de la tripulación en la pesca a pequeña escala difieren tremendamente de las condiciones a que se enfrentan las tripulaciones de los buques de gran escala.

El segundo aspecto es el sexo. Los buques de pesca suelen constituir entornos formados exclusivamente por tripulantes masculinos. Si bien existen excepciones tanto en la pesca a pequeña escala como en la de gran escala, las tripulaciones unisexuales son las más frecuentes a nivel mundial. La división entre mar y tierra a que se enfrentan los pescadores es, en gran parte, una división entre sexos.

\section{Buques pequeños de pesca}

A bordo de los buques pequeños de pesca, los miembros de la tripulación suelen estar emparentados de varias maneras. Una tripulación puede estar formada por padre e hijo, por hermanos o por una mezcla de parentescos más o menos cercanos. En la tripulación puede haber otros miembros de la comunidad. Dependiendo de la disponibilidad de parientes masculinos o de las costumbres locales, las mujeres forman parte de la tripulación. Las esposas pueden trabajar en un buque con sus maridos o una hija puede formar parte de la tripulación de su padre.

Una tripulación es algo más que un grupo de compañeros de trabajo. Puesto que a menudo les unen lazos de parentesco, de vecindad y la vida en comunidad, el buque y la tripulación están integrados socialmente con la familia y la vida comunitaria en tierra. Estos lazos tienen un efecto bidireccional. La cooperación en la pesca y la pertenencia a un buque también confirman y reafirman otras relaciones sociales. Cuando un grupo de parientes pesca conjuntamente, un miembro de la tripulación no puede ser sustituido por un extraño, aun cuando sea una persona más experimentada. Dentro de una red tan cerrada, los pescadores tienen seguridad en su puesto de trabajo. Por otra parte, esto también limita los cambios a otros buques por motivos de lealtad para con la propia familia.

Las polifacéticas relaciones sociales mitigan los conflictos a bordo. Los pescadores a pequeña escala comparten un reducido espacio físico y están sometidos a condiciones naturales impredecibles y a veces peligrosas. En circunstancias tan exigentes puede resultar necesario evitar los conflictos abiertos. La autoridad del patrón también se ve limitada por esta trama de relaciones.

En general, los buques de pequeña escala regresan a tierra cada día, lo que permite a los miembros de la tripulación interactuar con otras personas de forma periódica, aunque sus horarios de trabajo pueden ser prolongados. El aislamiento es poco frecuente, pero puede afectar a los pescadores que navegan solos en su embarcación. Sin embargo, la comunicación por radio en el mar y las transmisiones de los buques que pescan en las cercanías disminuyen el efecto de aislamiento que conlleva trabajar solo en la pesca moderna a pequeña escala. Los procesos de aprendizaje y la seguridad a bordo están marcadas por los lazos de parentesco y de localidad. Los miembros de la tripulación son responsable entre sí y dependen el uno del otro. Trabajar hábilmente y con responsabilidad puede ser de extrema importancia en situaciones imprevistas de mal tiempo o en caso de accidente. La gama de habilidades necesarias para la pesca a pequeña escala es muy amplia. Cuanto más reducida sea la tripulación, menor será el nivel de especialización, pues los trabajadores deben saber de todo y ser capaces de realizar diversas tareas.

La falta de atención o de voluntad en el trabajo se castiga severamente con la estigmatización. Cada miembro de la tripulación debe desempeñar las tareas necesarias de forma voluntaria, preferiblemente sin que nadie se lo pida. Se considera que las órdenes son innecesarias, salvo las relacionadas con el momento de realizar determinadas tareas. Así, la cooperación dentro del respeto mutuo es una capacidad importante. La muestra de interés y responsabilidad se ve fomentada por la socialización en una familia o aldea de pescadores. La diversidad del trabajo promueve el respeto a la experiencia en cualquier puesto a bordo y son habituales los valores igualitarios.

Un dominio eficaz de las exigencias de cooperación, oportunidad y habilidades necesarias para la pesca a pequeña escala en condiciones cambiantes de tiempo y temporada genera un elevado nivel de satisfacción laboral y una sólida identidad laboral que encuentra recompensa en la comunidad local. Las mujeres que trabajan en la pesca aprecian su ascenso de condición al participar con éxito en el trabajo de los hombres. No obstante, también tienen que afrontar el riesgo de perder atributos de femineidad. Por otra parte, los hombres que pescan con mujeres temen perder atributos de superioridad masculina cuando las mujeres muestran sus habilidades en la pesca.

\section{Grandes buques de pesca}

En la pesca a gran escala, los miembros de la tripulación se ven separados de su familia y su comunidad mientras están en el mar, y muchos de ellos sólo pasan breves períodos en tierra entre una travesía y otra. La duración de una travesía suele variar entre 10 días y 3 meses. La interacción social está limitada a los compañeros a bordo del buque. Este aislamiento es duro. La integración en la vida familiar y comunitaria en tierra puede resultar difícil y provoca una sensación de desarraigo. Los pescadores dependen en gran medida de sus esposas para mantener vivas sus relaciones sociales.

En una tripulación formada únicamente por hombres, la ausencia de mujeres y la falta de intimidad puede contribuir a conversaciones vulgares sobre sexo, alardeos sexistas y una concentración en las películas pornográficas. Esta cultura marítima puede dar lugar a una forma insana de exponer y confirmar la masculinidad. En parte para evitar que se desarrolle un ambiente crudo, sexista y deficitario, desde 1980 las compañías noruegas emplean hasta un $20 \%$ de mujeres en la tripulación de los buques-fábrica. Se dice que un entorno de trabajo con presencia de ambos sexos reduce le estrés psicológico y que las mujeres contribuyen a dar un tono más suave y una mayor intimidad a las relaciones sociales a bordo (MunkMadsen 1990).

La mecanización y la especialización del trabajo a bordo de los buques industrializados crea rutinas de trabajo repetitivas. El trabajo por turnos en dos guardias es habitual y la pesca continúa las 24 horas. La vida a bordo consiste de un ciclo de trabajo, comida y descanso. Si se realizan grandes capturas pueden reducirse las horas de sueño. El espacio físico está limitado, el trabajo es monótono y cansado y las interacciones sociales con personas distintas de los compañeros de trabajo resultan imposibles. Mientras el barco se encuentra en alta mar no hay forma de escapar a las tensiones entre los miembros de la tripulación, lo que es causa de estrés.

Los tripulantes de los buques de altura con una dotación de 20 a 80 trabajadores no pueden reclutarse dentro de una trama de estrechos lazos de parentesco y vecindad. Algunas compañías 


\section{Mujeres pescadoras}

The Entangling Net: Alaska's Commercial Fishing Women Tell Their Lives, de Leslie Leyland Fields (Urbana: University of Illinois Press, 1996), narra la historia, basada en entrevistas y en la propia experiencia de la autora, de algunas mujeres que trabajaron como pescadoras comerciales en aguas del Océano Pacífico y el Golfo de Alaska en torno a las islas Kodiak y las Aleutianas. Los extractos que se ofrecen a continuación transmiten algo del sabor de la experiencia de estas mujeres, por qué eligieron este oficio y qué significa.

\section{Theresa Peterson}

..La última temporada de fletán negro empezó el 15 de mayo. Eramos dos chicas y dos chicos. El patrón quería una tripulación que pudiera enganchar rápidamente la carnada en los aparejos; eso es lo que buscaba. ...Al principio, todo lo que intentábamos hacer era cambiar anzuelos. Es una cuestión de números. Lo ideal es hacer entre 18.000 y 20.000 anzuelos diarios. Así que éramos cuatro personas poniendo carnada en los anzuelos todo el tiempo y otra recogiendo el aparejo. Las que ponían el cebo se rotaban con la que enrollaba el aparejo. Habíamos vuelto a la forma tradicional de pescar. La mayoría de los barcos de las Kodiak van echando el aparejo en un cubo, tal como viene, luego se coge el cubo y se pone la carnada. En las antiguas goletas para pescar fletán todo se enrollaba a mano, para poder desenredar hasta el último anzuelo. Se trata de hacer una buena bobina para que, al desenrollarla, se pueda poner la cebo al doble de velocidad. Los primeros días vimos el tiempo que se tardaba en colocar la carnada en los sedales enredados (las largas líneas en las que se atan los anzuelos). Me negué a poner carnada a otro sedal en ese estado, así que todos empezamos a enrollar a mano, cada uno por su lado. Cuando lo haces, puedes salir de tu estación de carnada. Realmente, trabajábamos durante muchas horas, a menudo 24 horas, luego empezábamos al día siguiente y trabajábamos durante la noche hasta las dos de la mañana y al día siguiente otras 24 horas. Después nos tumbábamos unas tres horas y nos volvíamos a levantar para otra jornada de 24 horas y un par de horas de descanso. Calculamos que la primera semana dormimos un total de 10 horas. Así, íbamos haciendo bromas, veinticuatro horas trabajando y una de descanso.

Nunca antes había pescado con tanta intensidad. Cuando empezó la temporada, pescamos el sábado todo el día, todo el domingo y la mitad del lunes. Es decir, más de 46 horas sin dormir, trabajando con tanta fuerza, velocidad y ritmo como te daba el cuerpo. Luego nos echábamos durante tres horas. Te levantas y estás tiesa. Después desembarcamos la captura, algo más de 40.000 libras de pescado en cuatro días, de forma que prácticamente estuvimos de pie esos cuatro días. Era una buena carga, realmente te motivaba. Ganaba mil dólares diarios... Son las temporadas cortas, las temporadas cortas de palangre las que hacen que los buques hagan estos horarios... con una temporada de tres semanas casi te ves obligado a hacerlo, a menos que puedas rotar con otra persona [dejarlos dormir]. (pp. 3 1-33).

\section{Leslie Smith}

La razón por la que creo haber tenido suerte es por haber estado ahí, una mujer llevando un barco con una tripulación formada únicamente por mujeres y lo estábamos haciendo. Y lo hacíamos tan bien como cualquier otro de la flota, de forma que nunca pensé: "Una mujer no puede hacerlo, no puede resolverlo o no es capaz de hacerlo", porque el primer trabajo que tuve fue con mujeres y lo hacíamos bien. Así que tenía ese factor de confianza desde el principio de mi carrera de marinero... (p. 35).
Cuando estás en un barco, no tienes vida, careces de espacio físico, no tienes tiempo para ti misma. Todo es el barco, la pesca, durante cuatro meses seguidos...(p. 36)

Tengo poca protección de algunos vientos, pero la aprove charé toda... También hay mucha marea. Echas estas anclas; tienes quince $o$ veinte anclas, algunas de trescientas libras, para mantener la red en su lugar. $Y$ cada vez que vas, ves que la red se ha torcido y tienes que arrastrar las anclas de un lado a otro. La mayoría de las veces, el tiempo no es muy bueno. Siempre tienes que luchar contra el viento. Es un desafío, un desafío físico, no un desafío mental... (p. 37)

Recorrer los muelles [ir de barco en barco buscando trabajo] fue lo peor. Tras hacerlo durante un tiempo, me di cuenta de que sólo tienes posibilidades de ser contratada en un $15 \%$ de los barcos, porque los demás no contratan mujeres. Sobre todo porque sus esposas no los dejan o porque ya hay una mujer en el barco o simplemente porque son sexistas - no quieren mujeres. Pero entre esos tres factores, el número de barcos en que podías trabajar era tan reducido que resultaba desalentador. Había que descubrir qué barcos eran. Y eso significaba recorrer los muelles...(p. 81).

\section{Martha Sutro}

Estaba pensando en la pregunta que me hizo antes. Por qué las mujeres se sienten cada vez más atraídas por esto. No lo sé. Me pregunto si hay más mujeres en las minas o conduciendo un camión. No sé si tiene algo que ver con Alaska y todo ese aliciente de poder compartir algo que antes te estaba vedado o es un nuevo tipo de mujeres que han sido educadas así o que han llegado a comprender que ciertas barreras que supuestamente estaban ahí no eran legítimas. A pesar de todos los peligros, es una experiencia importante y es muy posible, muy... odio usar la palabra "satisfactoria", pero sí, es muy satisfactoria. Me encantaba, me encantaba soltar una tirada de nasas perfectamente sin tener que pedirle a nadie que me ayudase con las puertas y poner los montones de carnada que deslizas en el centro de la nasa... Hay cosas que no encuentras en ningún otro tipo de experiencia. Es casi como la agricultura. Es tan elemental. Requiere un proceso tan elemental. Desde los tiempos bíblicos se habla de esta gente. Está rodeada de unos valores que son muy antiguos. Y puedes hacerlo y aprovecharlos. Entrar en todo ese reino místico (p.44).

\section{Lisa Jakubowski}

Una se siente muy sola siendo la única mujer del barco. Nunca entré en relación con los chicos de forma romántica ni nada. Amigos. Siempre estoy dispuesta a hacer amigos, pero tienes que tener cuidado de que no vayan a creer que hay algo más. Mire, hay tantos tipos diferentes de hombres. No quiero ser amiga de los borrachos y cocainómanos. Pero sin duda he hecho amistad con las personas más respetables y he mantenido amistades masculinas y femeninas. Sin embargo, hay mucha soledad. He descubierto que la terapia de la risa ayuda. Me voy a la cubierta de popa y me río de mí misma hasta sentirme mejor (p. 61).

\section{Leslie Leyland Fields}

Las mujeres sólo pedían igualdad de trato y de oportunidades. Algo que no se da automáticamente en un trabajo en que necesitas la fuerza para subir una trampa de cangrejos de 130 libras que se balancea en el aire, la entereza para resistir 36 horas de trabajo seguidas sin dormir, la sangre fría para conducir un palangrero de 150 caballos a toda velocidad cerca de los arrecifes y la habilidad manual para realizar reparaciones en un motor de gasóleo, remendar redes, manejar aparatos hidráulicos. Es lo que se 
necesita para imponerse y sacar pescado; es lo que las mujeres deben demostrar a los hombres escépticos. Y por último, también hay resistencias procedentes de otra parte: de otras mujeres, las esposas de los pescadores (p 53).

Esto es parte de lo que, para mí, es ser patrón de buque...Tienes en tus manos la vida de dos, tres o cuatro personas. Tienes que pagar decenas de miles de dólares cada año por el barco y el seguro... tienes que pescar. Te las ves con una mezcla potencialmente explosiva de personalidades y costumbres de trabajo. Tienes que tener amplios conocimientos de navegación, meteorología, reglamentos de pesca; tienes que saber utilizar y reparar hasta cierto punto toda una gama de aparatos electrónicos de alta tecnología que constituyen el cerebro del barco... Y no se acaba ahí.

¿Por qué hay gente que se muestra dispuesta a cargar con todo este peso? Eso es otra cuestión, por supuesto. Por ponerlo de una forma positiva, está la independencia del patrón de barco, un grado de autonomía que raramente se encuentra en otras profesiones. Tú personalmente controlas la vida dentro de tu arca. Puedes decidir dónde vas a pescar, cuándo vas a salir, a qué velocidad vas a navegar, durante cuánto tiempo y cuán duramente debe trabajar la tripulación, cuánto tiempo ha de dormir cada uno, las condiciones meteorológicas en que vas a trabajar, el grado de riesgo que correrás, el tipo de comida que comerás... (p. 75).

In 1992 naufragaron 44 buques en Alaska, 87 personas fueron rescatadas y 35 fallecieron. En la primavera de 1988 fallecieron 44 personas con la llegada de una niebla helada que se tragó barcos y tripulación. Para poner estas cifras en perspectiva, el Instituto Nacional de Seguridad y Salud en el Trabajo informa que la tasa anual de mortalidad en todas las profesiones en EE. UU. es de un 7 por 100.000 trabajadores. En la pesca comercial en Alaska esta tasa se eleva a 200 por 100.000, lo que lo convierte en el trabajo con mayor riesgo de muerte del país. Entre los pescadores de cangrejo, cuya temporada transcurre en invierno, la tasa es de 660 por 100.000, es decir, casi 100 veces la media nacional (p. 98).

\section{Debra Nielsen}

Sólo mido 1,50 m y peso 45 kilos, de forma que los hombres sienten un instinto protector hacia mí. He tenido que luchar toda mi vida para que me aceptaran y poder hacer cosas. La única forma en que me he podido abrir camino es siendo más rápida y sabiendo lo que hacía. Es una cuestión de equilibrio... Tienes que bajar el ritmo. Tienes que usar la cabeza y el cuerpo de una forma diferente. Creo que es importante que se sepa lo pequeña que soy porque si yo puedo hacerlo, cualquier mujer puede... (p. 86)

\section{Christine Holmes}

Realmente creo en la North Pacific Vessel Owner's Association pues ofrecen unos cursos realmente buenos, como el de emergencias médicas en el mar. Creo que cada vez que asistes a un curso de marina técnica te haces un favor a ti misma. (p. 106).

\section{Rebecque Raigoza}

He desarrollado un sentido de la independencia y de la fuerza Aprendí que aquí haría cosas que nunca pensé que podía hacer. Simplemente, se me ha abierto todo un mundo nuevo como mujer joven, para convertirme en mujer. No lo sé. Ahora tengo tantas posibilidades porque sé que puedo hacer un "trabajo de hombre", ¿sabe? Eso da mucho poder (p. 129)

Copyright 1997 Junta de administración de la Universidad de Illinois. Usado con la autorización de University of Illinois Press.

japonesas han cambiado su política de contratación y prefieren alistar personal que se conozca por relaciones de parentesco o vecindad y que proceda de comunidades con tradición pesquera para resolver los problemas de conflictos violentos y excesos de alcohol. (Dyer 1988). También en el Atlántico Norte los armadores prefieren hasta cierto punto contratar pescadores de la misma comunidad para conseguir un mejor control social y crear un ambiente amistoso a bordo.

La mayor recompensa de la pesca de altura son los elevados salarios. Además, para las mujeres, representa una oportunidad de elevar su situación al efectuar un trabajo tradicionalmente masculino y considerado superior al femenino (Husmo y MunkMadsen 1994).

La flota internacional de pesca de altura que explota las aguas del globo puede dotar a sus buques con tripulaciones de distintas nacionalidades, como ocurre con la flota de Taiwan, la mayor flota de altura del mundo. También puede suceder en pesquerías conjuntas, en que buques de países industrializados operan en aguas de países en desarrollo. En las tripulaciones multinacionales, la comunicación a bordo puede resultar perjudicada por las dificultades lingüísticas y la jerarquía marítima intensificarse por esta dimensión étnica. Los pescadores de etnias y nacionalidades distintas del país de pabellón del buque pueden ser objeto de un trato considerablemente inferior al requerido, en particular si el buque opera en aguas de dicho país. Ello también puede repercutir en las condiciones salariales y en la alimentación y hospedaje a bordo. Este tipo de prácticas pueden crear entornos de trabajo racistas, aumentar las tensiones entre la tripulación y potenciar las relaciones de poder entre oficiales y tripulación.
La pobreza, la esperanza de un buen salario y la globalización de la pesca de altura han propiciado prácticas ilegales de contratación. Al parecer, las tripulaciones filipinas están endeudadas con agencias de contratación y trabajan en aguas extranjeras sin contrato ni seguridad de pago o medidas de seguridad. El trabajo en una flota de altura con elevada movilidad y sin apoyo de las autoridades produce una gran inseguridad, que puede ser mayor a los riesgos afrontados en una tormenta en pleno océano (Cura 1995; Vacher 1994).

\section{CARACTERISTICAS PSICOSOCIALES DE LOS TRABAJADORES DEL MAR DEDICADOS AL PROCESAMIENTO DEL PESCADO EN TIERRA}

\section{Marit Husmo}

El procesamiento del pescado en tierra comprende varias actividades, que van desde el procesamiento a pequeña escala y con poca tecnología, como el secado o ahumado de las capturas locales para el mercado local, hasta la gran fábrica moderna con alta tecnología que prepara productos altamente especializados en envases de consumo para un mercado internacional. Este artículo se limita al procesamiento industrial del pescado. El nivel tecnológico es un factor importante del entorno psicosocial de las plantas industriales de procesamiento de pescado, lo que influye en la organización de las tareas de trabajo, los sistemas de 
remuneración, los mecanismos de control y supervisión y las oportunidades del personal para intervenir en su trabajo y en las políticas de la empresa. Otro aspecto importante de las características psicosociales del personal en la industria de procesamiento en tierra es la división del trabajo por sexos, que se encuentra muy extendida en este sector, de modo que se asignan trabajos distintos a hombres y mujeres en función del sexo y no de su capacidad

En las plantas de procesamiento, algunos departamentos se caracterizan por su elevada tecnología y grado de especialización, mientras que otros emplean tecnologías menos avanzadas y tienen una organización más flexible. Por norma general, los departamentos con mayor nivel de especialización cuentan con personal predominantemente femenino, mientras que los departamentos en que las tareas son menos especializadas disponen de personal mayormente masculino. Se parte de la idea de que ciertas tareas son adecuadas sólo para hombres o sólo para mujeres. En consecuencia, los hombres se muestran renuentes a realizar "trabajos de mujer", mientras que la mayoría de las mujeres están ansiosas por efectuar "trabajos de hombre" si se les permite. Asimismo y como regla general, una situación más elevada significa un sueldo más alto y mayores oportunidades de ascenso (Husmo y Munk-Madsen 1994; Skaptadóttir 1995).

Un departamento típico de alta tecnología es el departamento de producción, en el que los trabajadores están situados a lo largo de la cinta transportadora, cortando o embalando filetes de pescado. Este entorno psicosocial se caracteriza por la monotonía y la repetición de las tareas y por un reducido nivel de interacción social entre los trabajadores. El sistema de remuneraciones se basa en el rendimiento personal (sistema de bonificaciones) y los trabajadores son supervisados por sistemas informatizados aparte del capataz, lo que provoca un alto nivel de estrés; este tipo de trabajo incrementa también el riesgo de desarrollar síndromes de esfuerzo entre los trabajadores. La circunscripción de los trabajadores a la cinta transportadora reduce sus posibilidades de comunicación informal con la dirección para influir en la política de la empresa y/o solicitar un aumento o ascenso. (Husmo y Munk-Madsen 1994). Puesto que los trabajadores de los departamentos altamente especializados sólo aprenden un número reducido de tareas, son los que más probabilidades tienen de ser despedidos cuando se reduce la producción por una falta temporal de materia prima o por problemas de mercado. También son quienes tienen más probabilidades de ser sustituidos por maquinaria o robots industriales a medida que se introducen nuevas tecnologías (Husmo y Søvik 1995).

Un ejemplo de departamento de baja tecnología es el departamento de materias primas, en el que los trabajadores conducen camiones y elevacargas en el muelle y descargan, clasifican y lavan el pescado. En él encontramos una gran flexibilidad en las tareas de trabajo y los trabajadores realizan diferentes funciones a lo largo del día. El sistema de remuneración se basa en tarifas horarias y el rendimiento personal no se mide con ordenadores, lo que reduce el estrés y contribuye a crear una atmósfera más relajada. La variación en las tareas laborales estimula el trabajo en equipo y mejora el entorno psicosocial de varios modos. Aumenta la interacción social y disminuye el riesgo de desarrollar síndromes de esfuerzo. Las posibilidades de promoción aumentan, ya que el aprendizaje de una mayor gama de tareas hace que los trabajadores estén mejor cualificados para ocupar puestos superiores. La flexibilidad permite una comunicación informal con la dirección o el supervisor para influir en la política de la empresa y promover el ascenso personal (Husmo 1993; Husmo y Munk-Madsen 1994).

La tendencia general consiste en un aumento del nivel tecnológico del procesamiento, lo que conduce a una mayor especia- lización y automatización del sector de procesamiento de pescado. Todo ello repercute en el entorno psicosocial de los trabajadores, como se indicó anteriormente. La división del trabajo por sexos significa que el entorno psicosocial es peor para la mayoría de las mujeres que para los hombres. El hecho de que las mujeres tengan que efectuar las tareas en que tienen más probabilidades de ser sustituidas por robots añade una nueva dimensión a este tema, pues limita las oportunidades de trabajo para las mujeres en general. En algunos casos, estas consecuencias no sólo son válidas para las trabajadoras sino también para las clases sociales más bajas de la población activa o incluso para distintas razas (Husmo 1995).

\section{EFECTOS SOCIALES DE LA DEPENDENCIA DE UNA SOLA INDUSTRIA PESQUERA}

Barbara Neis

Con el desarrollo del procesamiento industrial del pescado en los siglos XIX y XX, las esposas y las familias fueron quedándose desplazadas del procesamiento y la venta familiares y acabaron desempleadas o trabajando para empresas pesqueras. La introducción de arrastreros propiedad de empresas y, más recientemente, de cuotas de pesca propiedad de empresas (en forma de asignaciones a empresas y cuotas individuales negociables) ha desplazado a los pescadores masculinos. Cambios de esta naturaleza han transformado a muchas comunidades pesqueras en localidades dependientes de una sola industria. Hay varios tipos de localidades dependientes de la industria pesquera, pero todas ellas se caracterizan por una elevada dependencia de un solo empleador para obtener trabajo y una significativa influencia de la empresa en la comunidad y, en ocasiones, en la vida familiar de los trabajadores. En el caso más extremo, las poblaciones dependientes de la industria pesquera son en realidad aldeas de empresa, en las que una sola sociedad posee no sólo la planta y algunos buques, sino también las viviendas, las tiendas, los servicios sanitarios, etc. y ejerce un control importante sobre los representantes del gobierno local, los medios de comunicación y otras instituciones sociales.

Algo más frecuentes son las poblaciones en que el empleo local está en manos de una empresa, generalmente integrada en un grupo, que utiliza su control sobre el empleo y el mercado para influir indirectamente en la política local y en otras instituciones sociales relacionadas con la vida familiar y comunitaria de los trabajadores. La definición de aldea dependiente de una sola industria pesquera puede extenderse a las sociedades de procesamiento de pescado que, aun estando situadas en comunidades más amplias que no dependen de la pesca, operan con una considerable autonomía respecto de dichas comunidades. Esta estructura es frecuente en la industria de procesamiento del camarón en la India, que hace un uso extensivo de jóvenes trabajadoras migrantes, a menudo contratadas por agencias de Estados vecinos. Las trabajadoras suelen vivir en complejos propiedad de la empresa y se ven segregadas de la comunidad local por sus prolongados horarios laborales, la ausencia de lazos de parentesco y las barreras de lingüísticas. Estos lugares de trabajo son una especie de aldeas de empresa en las que las sociedades ejercen una influencia considerable sobre la vida extralaboral de sus trabajadores y éstos no pueden acudir con facilidad a las autoridades locales u otros miembros de la comunidad en busca de ayuda. 
La incertidumbre económica, el desempleo, la marginación de los procesos de toma de decisiones, una renta baja y un acceso y control limitados a los servicios son factores determinantes del estado de salud. $\mathrm{Y}$ estas son, en mayor o menor medida, las características de las aldeas dependientes de una sola industria pesquera. Las fluctuaciones en los mercados pesqueros y las fluctuaciones en la disponibilidad de recursos pesqueros, tanto naturales como derivadas de la pesca, constituyen una característica fundamental de las comunidades pesqueras. Estas fluctuaciones generan incertidumbres sociales y económicas. Los hogares y comunidades pesqueras a menudo han desarrollado instituciones que les ayudan a sobrevivir en los períodos de incertidumbre. Ahora bien, esas fluctuaciones parecen más frecuentes en los últimos años. En el actual contexto de pesca excesiva global de las poblaciones comerciales de peces, con el desplazamiento consiguiente del esfuerzo hacia nuevas especies y regiones, la globalización de los mercados y el desarrollo de productos de la acuicultura que compiten con los productos de la pesca silvestre aumentan la incertidumbre del empleo y han hecho frecuentes los cierres de plantas y las rentas bajas. Además, cuando se producen cierres, es más probable que sean permanentes al haber desaparecido el recurso y haberse marchado el trabajo a otros lugares.

La incertidumbre laboral y el desempleo son importantes fuentes de estrés psicológico que afectan de un modo diferente a hombres y mujeres. El trabajador/pescador desplazado debe afrontar una pérdida de autoestima, una pérdida de ingresos, estrés y, en casos extremos, una pérdida de patrimonio familiar. Los demás miembros de la familia se enfrentan a los efectos que el desplazamiento del trabajador tiene sobre su vida familiar y laboral. Por ejemplo, las estrategias familiares para paliar una ausencia masculina prolongada pueden convertirse en un problema cuando los trabajadores de un arrastrero se encuentran desempleados y sus mujeres descubren que la autonomía y las rutinas que les habían permitido sobrellevar la ausencia masculina se ven amenazadas por la presencia prolongada de los maridos desplazados. En familias dedicadas a la pesca a pequeña escala, las esposas deben adaptarse a prolongadas ausencias y al aislamiento social a medida que los miembros de la familia tienen que alejarse más y más en busca de peces y empleo. En los lugares en que las madres de familia también dependen de la pesca para obtener un empleo asalariado, es posible que tengan que luchar además con los efectos que el propio desempleo puede tener sobre su salud.

El estrés del desempleo puede ser mayor en las comunidades dependientes de una sola industria, en las que los cierres de plantas amenazan el futuro de comunidades enteras y el coste económico de la pérdida del empleo se ve incrementado por la caída en picado del valor de patrimonios personales como casas y chozas. Como sucede a menudo, si para encontrar empleo es necesario trasladarse a otro sitio, se produce un estrés adicional entre los trabajadores, sus cónyuges e hijos en relación con dicho desplazamiento. Cuando el cierre de plantas va acompañado de la transferencia de las cuotas de pesca a otras comunidades y la erosión de los servicios educativos, sanitarios y de otro tipo como respuesta a la migración y el colapso de la economía local, todavía son mayores las amenazas para la salud.

La dependencia de un sólo empleador puede hacer más difícil la participación de los trabajadores en los procesos de toma de decisiones. En la pesca, al igual que en otras industrias, algunas sociedades han utilizado esta estructura de dependencia para controlar a los trabajadores, oponerse a su sindicalización y manipular los consensos públicos dentro del lugar de trabajo y fuera de él. En el sector indio de procesamiento del camarón, las trabajadoras migrantes sufren unas condiciones de vida terribles, unos horarios extremadamente prolongados, horas extraordinarias obligatorias y la violación rutinaria de sus contratos laborales. En los países occidentales, las empresas suelen utilizar su papel de controladores de la elegibilidad de los trabajadores estacionales para programas como el seguro de desempleo en las negociaciones con los trabajadores sobre sindicalización y condiciones de trabajo. Los trabajadores de algunas poblaciones dependientes de una sola industria están sindicalizados, pero aún así su papel en los procesos de toma de decisiones se ve disminuido por la falta de alternativas de empleo, por un deseo de encontrar empleo en la localidad para sus esposas e hijos y por la incertidumbre ecológica y económica. Los trabajadores pueden sentirse indefensos y obligados a seguir trabajando a pesar de estar enfermos si sus posibilidades de acceder a un empleo, vivienda y programas sociales están controladas por un solo empleador.

Un acceso limitado a unos servicios sanitarios adecuados constituye una fuente adicional de estrés. En las ciudades de empresa, los profesionales de la salud pueden ser empleados de la compañía y, al igual que en la industria minera y otras, ello puede limitar el acceso de los trabajadores a un asesoramiento médico independiente. En todas las poblaciones dependientes, las diferencias culturales, de clase y de otro tipo entre el personal médico y los pescadores y la elevada rotación de dichos profesionales sanitarios puede limitar la calidad de los servicios médicos de la localidad. El personal médico raramente procede de comunidades pesqueras y, además, no suele estar familiarizado con los riesgos profesionales que deben afrontar los pescadores y con el estrés derivado de la vida en una población dependiente. La rotación puede ser muy elevada, por los ingresos profesionales relativamente bajos y la incomodidad inherente al estilo de vida rural y el desconocimiento de la cultura pesquera. Además, el personal médico tiende a asociarse más con las élites locales, como la dirección de la planta, que con los trabajadores y sus familias. Estos patrones de conducta pueden interferir en las relaciones entre médico y paciente, en la continuidad de la atención y en la competencia médica adecuada para el trabajo en la pesca. En estas comunidades, puede haber un acceso muy limitado a unos servicios de diagnóstico adecuado para enfermedades relacionadas con la pesca como las lesiones por esfuerzo repetitivo o el asma profesional. Además, la pérdida del trabajo puede repercutir en el acceso a los servicios médicos, al eliminar el acceso a los programas de medicación y otros servicios médicos asegurados.

Un apoyo social sólido puede contribuir a mitigar los efectos sobre la salud del desempleo, el desplazamiento y la incertidumbre económica. Las poblaciones dependientes pueden estimular el desarrollo de unos estrechos lazos sociales y de parentesco entre los trabajadores y, cuando las plantas sean propiedad de personas de la localidad, entre trabajadores y empresa. El apoyo social puede atenuar los efectos de la vulnerabilidad social, de unas condiciones de trabajo difíciles y de la incertidumbre ecológica. Los miembros de una misma familia pueden cuidar uno del otro en el lugar de trabajo y, en ocasiones, echar una mano cuando algún trabajador tiene problemas económicos. En los lugares en que los pescadores mantienen cierta independencia económica mediante actividades de subsistencia, pueden mantener un control sobre sus vidas y su trabajo mayor que cuando pierden el acceso a dichas actividades. Una mayor incertidumbre laboral, los cierres de plantas, la competencia local en la búsqueda de trabajo y los programas gubernamentales de ajuste pueden erosionar la fuerza de las redes locales, contribuyendo así a los conflictos y el aislamiento dentro de estas comunidades.

Si el cierre de plantas provoca un traslado, los trabajadores desplazados pueden perder el acceso a estas redes sociales de apoyo y a las fuentes de una subsistencia independiente. 


\section{EFECTOS SOBRE LA SALUD} Y PAUTAS PATOLOGICAS

Vilhjálmur Rafnsson

El trabajo en la pesca y en la industria de procesamiento de pescado es muy diferente según el sexo del trabajador, pues los hombres realizan tradicionalmente los trabajos de pesca y las mujeres trabajan en el procesamiento en tierra. Se puede considerar que muchas de las personas que trabajan en buques de pesca no están cualificadas, como los marineros, que reciben su formación a bordo. Los navegantes (capitán, patrón y oficial de cubierta), el personal de la sala de máquinas (ingeniero, maquinista y fogonero), los operadores de radio y los cocineros tienen unos antecedentes formativos distintos. La tarea principal es pescar; otras actividades son cargar el buque, lo que se hace en mar abierto, y el procesamiento del pescado, que se efectúa en varias fases. La única exposición común a estos grupos tiene lugar durante su estancia a bordo del buque y es el movimiento constante, tanto mientras trabajan como cuando descansan. Hablaremos del procesamiento en tierra más adelante.

\section{Accidentes}

Las tareas más peligrosas para el pescador son las relacionadas con el lanzamiento y la recogida de los aparejos de pesca. En la pesca de arrastre, por ejemplo, la red de arrastre se arroja en una secuencia de operaciones que requieren una compleja coordinación de distintos tipos de chigres (véase "Principales sectores y procesos" en el presente capítulo). Todas las operaciones se realizan a gran velocidad y el trabajo en equipo es indispensable. $\mathrm{Al}$ echar la red, la conexión de las puertas de la red al cable de arrastre constituye uno de los momentos más peligrosos, pues las puertas pesan varios cientos de kilos. Otras partes de las artes de pesca son demasiado pesadas para ser manejadas sin utilizar pescantes y chigres mientras se arroja la red (es decir, los aparejos pesados y diábolos se mueven libremente antes de ser elevados por encima de la borda).

Todo el proceso de arrojar y recoger las distintas redes se realiza con la ayuda de cables que a menudo pasan por la zona de trabajo. Los cables están muy tensos, pues suele existir una fuerte tracción de los aparejos de pesca en dirección contraria al avance del buque. Los pescadores corren un gran riesgo de enredarse en los aparejos o caer en ellos y verse arrastrados fuera de borda, o de caer al agua al arrojar los aparejos. Pueden producirse lesiones en los dedos, manos y brazos, y los aparejos de gran peso pueden caer o desplazarse y lesionar pies y piernas.

La limpieza y el desangrado de los peces a menudo se realiza a mano en cubierta o en una cubierta de abrigo. Los movimientos bruscos del barco hacen que sean frecuentes las lesiones en manos y dedos por cuchillos o espinas de pescado. La pesca con línea y con sedal manual entraña el riesgo de herirse dedos y manos con los anzuelos. Puesto que este tipo de pesca cada vez se automatiza más, el peligro lo constituyen los haladores de línea y los chigres.

El método de gestión de la pesca consistente en limitar las capturas en una zona delimitada de recursos naturales también influye en el índice de lesiones. En algunos lugares, las cuotas asignan a los buques determinados días para pescar y los pescadores creen que deben salir cualquiera que sea el tiempo.

\section{Accidentes mortales}

Los accidentes mortales en el mar pueden estudiarse fácilmente a través de los registros de mortalidad, pues en los certificados de defunción se codifican como accidentes de transporte marino
Tabla 66.1 - Cifras de mortalidad por lesiones mortales entre pescadores procedentes de estudios de varios países.

$\begin{array}{lll}\text { País } & \text { Período de estudio } & \text { Tasa por } 100.000 \\ \text { Reino Unido } & 1958-67 & 140-230 \\ \text { Reino Unido } & 1969 & 180 \\ \text { Reino Unido } & 1971-80 & 93 \\ \text { Canadá } & 1975-83 & 45,8 \\ \text { Nueva Zelandia } & 1975-84 & 260 \\ \text { Australia } & 1982-84 & 143 \\ \text { Alaska } & 1980-88 & 414,6 \\ \text { Alaska } & 1991-92 & 200 \\ \text { California } & 1983 & 84,4 \\ \text { Dinamarca } & 1982-85 & 156 \\ \text { Islandia } & 1966-86 & 89,4\end{array}$

según la Clasificación internacional de enfermedades y se indica si la lesión se sufrió mientras la víctima estaba empleada a bordo. Las tasas de mortalidad por accidente laboral de los trabajadores de la industria pesquera son altas, más altas que las de muchos otros grupos profesionales en tierra. En la Tabla 66.1 se muestra el índice de mortalidad por 100.000 por causa de accidente laboral en varios países. Las lesiones mortales se clasifican tradicionalmente en: 1) accidentes individuales (es decir, individuos que caen al mar, son barridos de cubierta por la mar brava o sufren lesiones mortales causadas por la maquinaria) y 2) individuos perdidos por accidentes del buque (naufragio, vuelco, buques perdidos, explosiones e incendios). Ambas categorías están relacionadas con las condiciones meteorológicas. El número de accidentes sufridos por individuos superan a los demás. La seguridad de un buque depende de su diseño, tamaño y tipo, así como de factores como la estabilidad, el francobordo, la estanqueidad y la protección estructural contra incendios. Una navegación negligente o errores de juicio pueden causar accidentes a los buques, y la fatiga producida por los turnos prolongados también desempeña un papel y es causa importante de accidentes personales.

La reducción de los accidentes en los buques más modernos puede deberse a una mayor eficiencia técnica y humana. La formación del personal, un mejor uso de los sistemas de flotación, una vestimenta adecuada y el empleo de monos de trabajo flotantes pueden aumentar las probabilidades de rescate en caso de accidente. En la industria pesquera en general, puede ser necesario un uso más extendido de otras medidas de seguridad, como líneas de seguridad, casco y calzado de seguridad, tal como se expone en otra sección de esta Enciclopedia.

\section{Lesiones no mortales}

Las lesiones no mortales son también bastante frecuentes en la industria pesquera (véase la Tabla 66.2). Las partes del cuerpo más afectadas son las manos, las extremidades inferiores, la cabeza y el cuello y las extremidades superiores, seguidas del pecho, la columna vertebral y el abdomen, en orden decreciente de frecuencia. Los tipos de traumatismos más comunes son heridas abiertas, fracturas, tensiones, esguinces y contusiones. Numerosas lesiones no mortales pueden ser graves, provocando, por ejemplo, la amputación de dedos, manos, brazos y piernas, así como lesiones en la cabeza y el cuello. Las infecciones, laceraciones y traumatismos menores de las manos y dedos son 
Tabla 66.2 • Trabajos o puestos más expuestos a riesgos de lesiones.

Tareas o trabajos
Arrojar y recoger la red de arrastre, de cerco y otras
artes de pesca

Conexión de puertas de la red de arrastre

Desangrado y limpieza

Palangres y sedales manuales

Levantamiento de cargas pesadas

Producción de filetes

Recorte de filetes

Trabajo en lugares cerrados, carga y desembarque
Lesiones a bordo de buques

Atrapado por artes de pesca o cables, aplastamientos, caídas fuera de borda

Aplastamientos, caídas fuera de borda

Cortes de cuchillos o máquinas, afecciones musculosqueléticas

Heridas de anzuelos, atrapado en la línea

Afecciones musculosqueléticas

Cortes, amputaciones al usar cuchillos o máquinas, afecciones musculosqueléticas

Cortes con cuchillos, afecciones musculosqueléticas

Intoxicación, asfixia
Lesiones en tierra

Cortes de cuchillos o máquinas, afecciones musculosqueléticas

Afecciones musculosqueléticas

Cortes, amputaciones al usar cuchillos o máquinas, afecciones musculosqueléticas

Cortes con cuchillos, afecciones musculosqueléticas

Intoxicación, asfixia sumamente frecuentes y a menudo el médico del barco recomienda el tratamiento con antibióticos en todos los casos.

\section{Morbilidad}

La información sobre la salud en general de los pescadores y sus perspectivas generales de enfermedad se obtiene principalmente de dos tipos de informes. Una fuente son las series de casos recopiladas por los médicos de a bordo y otra los informes de consejo médico, donde se indican las evacuaciones, hospitalizaciones y repatriaciones. Por desgracia, la mayoría de estos informes, si no todos, sólo mencionan el número de pacientes y porcentajes.

Los estados no traumáticos mencionados con más frecuencia y que requieren consulta y hospitalización son resultado de enfermedades dentales, gastrointestinales, musculosqueléticas, psiquiátrico-neurológicas, respiratorias, cardiológicas y dermatológicas. En una serie notificada por un médico de navío, las enfermedades psiquiátricas aparecían como la razón más frecuente de evacuación de los trabajadores de arrastreros en travesías prolongadas, ocupando las lesiones un segundo lugar. En otra serie, las enfermedades que con más frecuencia hicieron necesaria la repatriación fueron las cardiológicas y psiquiátricas.

\section{Asma profesional}

El asma profesional se observa con frecuencia entre los trabajadores de la industria pesquera. Está relacionada con diversos tipos de pescado, pero generalmente se asocia con la exposición a los crustáceos y moluscos; por ejemplo, camarones, cangrejos, almejas, etc. La producción de harina de pescado, al igual que procesos similares, como el pelado (en particular, el pelado de camarones), se han relacionado también con el asma.

\section{Pérdida de oído}

Se sabe que el ruido excesivo es causa de pérdida de agudeza auditiva entre los trabajadores de la industria de procesamiento de pescado. El personal de la sala de máquinas de los buques corre un grave riesgo, al igual que quienes trabajan con equipo antiguo en el procesamiento de pescado. Es necesario organizar programas para la conservación de las facultades auditivas.

\section{Suicidio}

Algunos estudios sobre pescadores y marinos de la flota mercante mencionan elevadas tasas de mortalidad por suicidio. También hay un gran número de muertes en que los médicos no pueden determinar si las lesiones fueron accidentales o voluntarias. Está ampliamente aceptado que no se notifican todos los suicidios y se rumorea que sobre todo es así en la industria pesquera. La literatura psiquiátrica recoge descripciones de calentura, un fenómeno de la conducta en que el síntoma predominante es un impulso irresistible de saltar al mar. Las causas subyacentes del riesgo de suicidio entre los pescadores no han sido objeto de ningún estudio en particular; sin embargo, la consideración de la situación psicosocial de los trabajadores en el mar, tal como se expone en otro artículo del presente capítulo, parece un buen punto de partida. Existen indicaciones de que el riesgo de suicidio aumenta si los trabajadores dejan de pescar y vuelven a tierra, tanto por un período breve como de forma definitiva.

\section{Intoxicaciones y asfixia mortales}

Las intoxicaciones mortales se producen en incendios a bordo de buques de pesca y se deben a la inhalación de humos tóxicos. También se conocen casos de intoxicaciones mortales y no mortales resultantes de la fuga de refrigerantes o el uso de productos químicos para conservar el camarón o el pescado, así como de gases tóxicos procedentes de la putrefacción anaeróbica de materias orgánicas en bodegas sin ventilación. Como refrigerantes se utilizan desde el altamente tóxico cloruro de metilo hasta el amoniaco. Algunas muertes pueden atribuirse a la exposición al bióxido de azufre en espacios cerrados, lo que recuerda la enfermedad de los trabajadores de silos, en que se produce una exposición a óxidos de nitrógeno. Las investigaciones han demostrado asimismo que existen mezclas de gases tóxicos (por ejemplo, bióxido de carbono, amoniaco, sulfuro de hidrógeno y monóxido de carbono) que, sumadas a una baja presión parcial del oxígeno en las bodegas de barcos y en tierra, han dado lugar a accidentes, tanto mortales como no mortales, relacionados a menudo con pescados industriales, como el arenque y el capelán. En la pesca comercial se conocen algunos informes de intoxicación al desembarcar el pescado atribuida a la trimetilamina y a las endotoxinas, que provocan síntomas similares a los de la influenza pero que pueden producir la muerte. Estos riesgos podrían reducirse con una formación mejor y modificaciones en los equipos.

\section{Enfermedades de la piel}

Las enfermedades de la piel de las manos son frecuentes y pueden deberse al contacto con proteínas de pescado o al uso de guantes de caucho. Si no se usan guantes, las manos están constantemente húmedas y algunos trabajadores pueden hacerse 
sensibles a ello. Así, la mayoría de las enfermedades de la piel son eczemas de contacto, ya sean de carácter alérgico o no, y estas afecciones a menudo tienen una presencia constante. Los forúnculos y abscesos en manos y dedos también son problemas frecuentes.

\section{Mortalidad}

Algunos estudios, aunque no todos, ponen de manifiesto una baja tasa de mortalidad por todas las causas entre los pescadores en comparación con la población general masculina. Este fenómeno de baja mortalidad en un grupo de trabajadores se denomina "efecto del trabajador sano" y se refiere a la tendencia constante entre las personas con trabajos activos a presentar una tasa de mortalidad inferior a la de la población en general. Sin embargo, debido a la alta tasa de mortalidad por accidentes en el mar, los resultados de muchos estudios sobre mortalidad entre pescadores arrojan una elevada tasa de fallecimiento por todas las causas.

En los estudios sobre pescadores la mortalidad debida a enfermedades cardiovasculares isquémicas tanto aumenta como disminuye. La mortalidad ocasionada por enfermedades cerebrovasculares y respiratorias entre los pescadores es equivalente a la media.

\section{Causas desconocidas}

En varios estudios, la mortalidad por causas desconocidas entre los pescadores es superior a la de otros hombres. Las causas desconocidas son números especiales de la Clasificación internacional de enfermedades que los médicos utilizan al cumplimentar el certificado de defunción cuando no pueden determinar una enfermedad o lesión como causa de la muerte. En ocasiones, las muertes registradas en la categoría de causas desconocidas se deben a accidentes en que no llega a encontrarse el cuerpo, y es muy probable que se trate de accidentes de transporte marítimo o suicidios cuando la muerte se produce en el mar. En todo caso, un número excesivo de muertes por causas desconocidas puede indicar no sólo que se trata de un trabajo peligroso, sino también de un estilo de vida peligroso.

\section{Accidentes ocurridos fuera del mar}

Entre los pescadores se ha observado un número excesivo de accidentes mortales de tráfico, intoxicaciones y otros accidentes, así como suicidios y homicidios (Rafnsson y Gunnarsdóttir 1993). A este respecto, se ha avanzado la hipótesis de que la gente del mar sufre la influencia de su peligrosa profesión, que les empuja a una conducta arriesgada o a un estilo de vida peligroso. Los propios pescadores señalan que ya no están acostumbrados al tráfico, lo que explicaría los accidentes. Otra explicación consiste en que los pescadores, al regresar de largas travesías que les han mantenido alejados de su familia y amigos, intentan ponerse al día en su vida social. A veces, pasan poco tiempo en tierra (un día o dos) entre dos travesías largas. El número excesivo de muertes por accidentes no ocurridos en el mar destaca este estilo de vida poco habitual.

\section{Cáncer}

La Agencia Internacional para la Investigación del Cáncer (IARC), que se dedica entre otras cosas a evaluar los posibles riesgos de cáncer entre los trabajadores de distintos sectores industriales, no ha incluido la pesca ni la industria de procesamiento del pescado entre las ramas industriales con signos evidentes de riesgo de cáncer. El riesgo de cáncer entre los pescadores se aborda en varios estudios de mortalidad y morbilidad del cáncer (Hagmar y cols. 1992; Rafnsson y Gunnarsdóttir 1994, 1995). Algunos de ellos han puesto de manifiesto la existencia de un riesgo incrementado de diversos cánceres entre los pescadores y las explicaciones sobre las posibles causas de ellos se refieren tanto a factores profesionales como de estilo de vida. Se trata de los cánceres de labios, de pulmón y de estómago.

\section{Cáncer de labios}

Tradicionalmente se ha relacionado la pesca con el cáncer de labios. Anteriormente se creía que ello se debía a la exposición a los alquitranes utilizados para la conservación de las redes, ya que los trabajadores utilizaban la boca como "tercera mano" al manipular las redes. Ahora se considera que la etiología del cáncer de labios entre los pescadores se debe al efecto conjunto de la exposición a los rayos ultravioleta durante el trabajo al exterior y del tabaco.

\section{Cáncer de pulmón}

Los estudios sobre cáncer de pulmón no coinciden. Algunos no señalan un mayor riesgo de cáncer de pulmón entre los pescadores. Estudios sobre pescadores suecos muestran una menor incidencia del cáncer de pulmón que en la población de referencia (Hagmar y cols. 1992). Un estudio italiano considera que el riesgo de cáncer de pulmón está relacionado con el tabaco y no con causas profesionales. Otros estudios sobre pescadores ponen de manifiesto la existencia de un mayor riesgo de cáncer de pulmón y otros no la confirman. Sin información sobre los hábitos de tabaquismo, es dificil evaluar el papel del tabaco en comparación con los factores profesionales en los posibles casos. Parece que es necesario estudiar por separado los distintos grupos profesionales de los buques de pesca, pues el personal de la sala de máquinas tiene un alto riesgo de cáncer de pulmón atribuido a la exposición al amianto o a los hidrocarburos policíclicos aromáticos. Así pues se requieren nuevos estudios para dilucidar la relación entre cáncer de pulmón y pesca.

\section{Cáncer de estómago}

Numerosos estudios han descubierto un alto riesgo de cáncer de estómago entre los pescadores. Los estudios suecos consideran que el riesgo de cáncer de estómago se debe a un elevado consumo de pez graso contaminado con compuestos de organoclorina (Svenson y cols. 1995). Actualmente, se desconoce el papel que desempeñan los factores dietéticos, profesionales y de estilo de vida en la relación entre cáncer de estómago y pesca.

\section{AFECGIONES MUSCULOSQUELETICAS: PESCA Y PROGESAMIENTO DE PESCADO}

\section{Hulda Ólafsdóttir}

El término afecciones musculosqueléticas se utiliza para una serie de síntomas y enfermedades de los músculos, tendones y/o articulaciones. A menudo, esas afecciones pueden no ser específicas y tener una duración variable. Los principales factores de riesgo de las afecciones musculosqueléticas relacionadas con el trabajo son el levantamiento de grandes pesos, posturas forzadas al trabajar, tareas repetitivas, estrés psicológico y una organización inadecuada del trabajo (véase la Figura 66.9).

En 1985, la Organización Mundial de la Salud (OMS 1994) realizó la siguiente declaración: "Las enfermedades relacionadas con el trabajo son de carácter multifactorial cuando el entorno de trabajo y la realización del mismo contribuyen a ellas de forma significativa, pero como uno de los varios factores que causan la enfermedad" (OMS 1985). Sin embargo, no existen criterios aceptados internacionalmente sobre las causas de las afecciones musculosqueléticas relacionadas con el trabajo. Aparecen tanto en los países en desarrollo como en los desarrollados. No han desaparecido a pesar del desarrollo de 
Figura 66.9 - Manipulación manual de pescado en una planta embaladora en Tailandia.

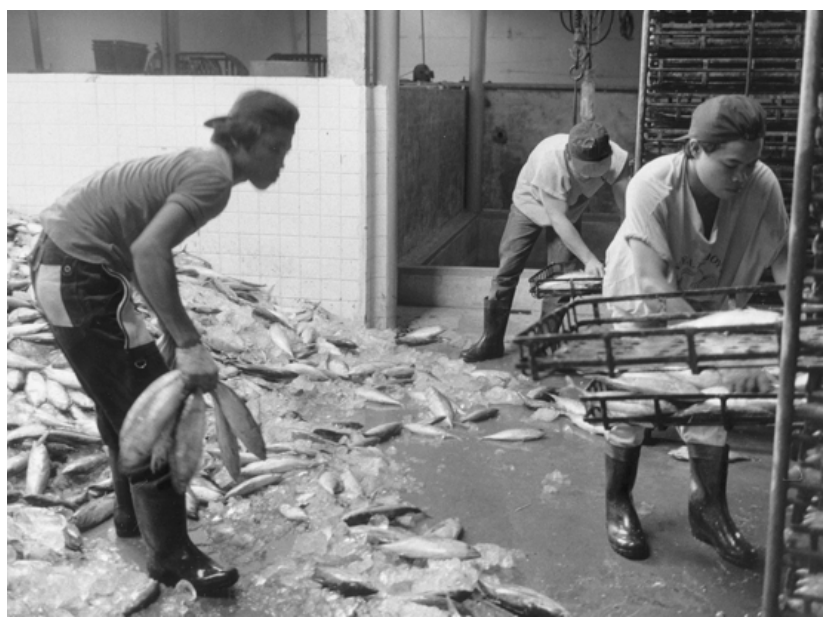

nuevas tecnologías que permiten que máquinas y ordenadores se hagan cargo de lo que anteriormente era trabajo manual (Kolare 1993).

El trabajo a bordo de buques es exigente tanto física como mentalmente. La mayoría de los factores de riesgo bien conocidos de las afecciones musculosqueléticas suelen darse en la situación y organización del trabajo de los pescadores.

Por tradición, la mayoría de los trabajadores de la pesca han sido hombres. Los estudios suecos sobre pescadores muestran que son frecuentes los síntomas del sistema musculosquelético y que siguen un patrón lógico dependiendo del tipo de tareas que se realicen a bordo. Un $74 \%$ de los pescadores habían experimentado síntomas del sistema musculosquelético durante los 12 meses anteriores. Un importante número de pescadores consideraban que el movimiento del buque representaba una gran tensión, no sólo para el sistema musculosquelético, sino para el individuo en su conjunto. (Törner y cols. 1988).

No se han publicado muchos estudios sobre las afecciones musculosqueléticas entre los trabajadores del procesamiento de pescado. Hay una larga tradición de predominio femenino en el corte y recorte de filetes en la industria de procesamiento de pescado. Los resultados de estudios islandeses, suecos y taiwaneses demuestran que las trabajadoras de la industria de procesamiento de pescado presentaban un mayor número de síntomas en el cuello o los hombros que las mujeres con trabajos más variados (Ólafsdóttir y Rafnsson 1997; Ohlsson y cols. 1994; Chiang y cols. 1993). Se considera que estos síntomas tienen una relación causal con la realización de tareas altamente repetitivas en un ciclo inferior a 30 segundos. El desempeño de tareas muy repetitivas sin posibilidad de rotar entre diferentes puestos representa un factor de alto riesgo. Chiang y sus colaboradores (1993) estudiaron a los trabajadores de la industria de procesamiento de pescado (hombres y mujeres) y descubrieron un predominio de síntomas en las extremidades superiores entre las personas cuyo trabajo requería una gran repetición o movimientos violentos en comparación con trabajadores de las mismas fábricas que desempeñaban tareas de poca repetición y movimientos con poca fuerza.

Como se ha dicho, las afecciones musculosqueléticas no han desaparecido a pesar del desarrollo de nuevas tecnologías. La línea de flujo es un ejemplo de nueva técnica introducida en la industria de procesamiento de pescado en tierra y a bordo de los grandes buques-fábrica. Consiste en un sistema de cintas transportadoras que transportan el pescado a través de maquinas descabezadoras y fileteadoras hasta los trabajadores que cogen cada filete y lo recortan con un cuchillo. Otras cintas transportan el pescado a la estación de embalaje, después de lo cual se congela el pescado. La línea de flujo ha modificado el predominio de los síntomas musculosqueléticos entre las trabajadoras de las plantas de producción de filetes de pescado. Desde la introducción de la línea de flujo, han aumentado los síntomas en las extremidades superiores al tiempo que disminuían los relativos a las extremidades inferiores (Ólafsdóttir y Rafnsson 1997).

Para desarrollar una estrategia de prevención es muy importante comprender las causas, mecanismos, prognosis y prevención de las afecciones musculosqueléticas (Kolare y cols. 1993). Estas afecciones no pueden prevenirse únicamente con la introducción de nuevas tecnologías. Hay que tomar en consideración todo el entorno de trabajo, incluida la organización del mismo.

\section{PESQUERIAS COMERCIALES: MEDIO AMBIENTE Y SANIDAD PUBLICA}

\section{Bruce McKay y Kieran Mulvaney}

\section{Capturas accesorias y descartes}

La captura de especies no deseadas - denominada captura accesoria (o en algunos casos mortandad accesoria) - constituye uno de los principales impactos medioambientales de la industria pesquera marina mundial. Las capturas accesorias, la mayoría de las cuales se "descarta" y arroja de vuelta al mar, incluyen:

- especies comercializables que son demasiado pequeñas o cuyo desembarque esta prohibido;

- especies no comercializables;

- especies comerciales que no corresponden a la especie específica de la pesquería,

- especies no relacionadas con la pesquería, como aves, tortugas y mamíferos marinos.

En un importante estudio realizado por la FAO (Alverson y cols. 1994) se estima, de forma provisional y conservadora, que cada año las operaciones de pesca comercial ocasionan la captura y descarte de 27 millones de toneladas de pescado y vida invertebrada (es decir, excluidos mamíferos, aves y tortugas marinos) - muchos de ellos muertos o a punto de morir. Esto equivale a más de una tercera parte del peso de todos los desembarques notificados de las pesquerías comerciales de todo el mundo, calculados en unos 77 millones de toneladas.

Aparte de las cuestiones éticas relacionadas con este derroche existe una gran preocupación pública por las repercusiones medioambientales de la mortalidad causada por el descarte, como una posible pérdida de la biodiversidad y la reducción de las poblaciones de peces. Es posible que hasta 200.000 mamíferos marinos mueran anualmente en los aparejos de pesca (Alverson y cols. 1994). La pesca con red de enmalle representa probablemente la más grave amenaza para muchas poblaciones de marsopas; al menos una especie (la yaquita del Golfo de California) y varias poblaciones de marsopas costeras están a punto de extinguirse por este tipo de pesca. La captura no intencional y la mortalidad de las tortugas marinas, en particular la provocada por los camaroneros y algunos palangreros, constituye un importante factor que pone continuamente en peligro diversas poblaciones en todos los océanos del mundo (Dayton y cols. 1995). También un gran número de aves marinas mueren en algunas pesquerías; los palangreros matan anualmente decenas de miles de albatros y están considerados la mayor 
amenaza para la supervivencia de muchas especies y poblaciones de albatros (Gales 1993).

La cuestión de las capturas accesorias es un factor importante en la negativa opinión que tiene el público de la pesca comercial marina. Para remediarlo, se han realizado amplias investigaciones en los últimos años con el fin de mejorar la selectividad de las artes y métodos de pesca. De hecho, la FAO (1995) estima que podría lograrse una reducción del $60 \%$ de los descartes para el año 2000 si los gobiernos y la industria realizaran un esfuerzo concertado.

\section{Desechos de pescado/marisco y eliminación de las capturas accesorias}

Los desechos de pescado y marisco pueden incluir los órganos internos (vísceras), cabezas, colas, sangre, escamas, aguas sucias y sedimentos (por ejemplo, jugos de cocción, coagulantes químicos utilizados en los sistemas de tratamiento primario, aceite, grasas, sólidos suspendidos, etc.). En muchas regiones, la mayoría de los restos del procesamiento de productos del mar procedentes de la industria situada en tierra se convierte en harina de pescado o fertilizantes y los desechos se arrojan al mar, se vacían en aguas costeras, se echan directamente al suelo o se entierran. Los desechos resultantes del procesamiento en buques (por ejemplo, limpieza del pescado) consisten en partes del pez (despojos) y siempre se vierten al mar.

El efecto de los restos de pescado procesado sobre los sistemas acuáticos puede variar ampliamente dependiendo del tipo de desecho, el porcentaje y la cantidad del vertido, la sensibilidad ecológica del entorno que lo recibe y factores físicos que ejercen una influencia sobre la mezcla y dispersión de los desechos. La mayor preocupación es el vertido de desechos por parte de las empresas procesadoras en los entornos costeros; en estas zonas, una cantidad excesiva de elementos nutritivos puede provocar eutrofia y, posteriormente, la pérdida de poblaciones locales de plantas y animales acuáticos.

El vertido de despojos y capturas accesorias desde buques de pesca puede provocar el agotamiento del oxígeno en los hábitats bentónicos (es decir, el fondo), si se acumulan cantidades suficientes en el fondo del mar. Sin embargo, los descartes y despojos se consideran factores que contribuyen al rápido crecimiento de algunas poblaciones de aves marinas, aunque ello pueda ir en detrimento de especies menos competitivas (Alverson y cols. 1994).

\section{Caza comercial de la ballena}

La caza comercial de la ballena continúa despertando una intensa atención pública y política debido a: 1) que se considera que las ballenas son seres únicos, 2) el carácter inhumano de las técnicas de caza y 3) el hecho de que la mayoría de las poblaciones de ballenas como la azul, el rocual o el cachalotehan sufrido un drástico descenso. Actualmente, la caza se concentra en la ballena hocicuda, que las flotas balleneras no cazaban anteriormente por su pequeño tamaño (7 a $10 \mathrm{~m})$ en comparación con otras mucho más grandes.

En 1982, La Comisión Ballenera Internacional (CBI) adoptó una moratoria global para la caza comercial de las ballenas que entró en vigor en la temporada ballenera 1985/1986 y se prevé que tenga una duración indefinida. Sin embargo, dos países - Noruega y Rusia - mantienen reservas oficiales a esta moratoria y Noruega la utiliza para proseguir la caza comercial de ballenas en el Atlántico nororiental. Aunque Japón no mantiene ninguna reserva a la moratoria, sigue cazando ballenas en el Pacífico norte y en los océanos meridionales amparándose en un artículo del Convenio internacional para la regulación de la pesca de la ballena que permite a los Estados parte matar ballenas con fines de investigación científica. Las flotas japonesa y noruega matan menos de 1.000 ballenas anuales y prácticamente toda la carne de ballena termina en el mercado japonés para consumo humano.

\section{Seguridad de los alimentos del mar: patógenos, productos contaminantes y toxinas naturales}

Se pueden producir enfermedades humanas por la ingestión de alimentos del mar contaminados a través de tres vías:

1. Pescado y moluscos crudos, faltos de cocción o mal procesados contaminados por patógenos que pueden causar enfermedades como hepatitis $A$, cólera o fiebre tifoidea. Las aguas domésticas residuales no tratadas o tratadas de forma deficiente constituyen la fuente principal de patógenos microbianos, como virus y bacterias, en los alimentos del mar; algunos organismos causantes de enfermedades pueden permanecer en el pescado o dentro de los conductos digestivos o escamas del pescado y el molusco. Los riesgos para la salud que plantean estos patógenos pueden eliminarse prácticamente con un tratamiento y eliminación adecuados de las aguas residuales, programas de vigilancia, un procesamiento y técnicas de preparación adecuadas de los alimentos y, lo que es más importante, mediante una cocción completa de los productos del mar (Food and Nutrition Board 1991).

2. Consumo de alimentos del mar contaminados por productos químicos industriales, como mercurio, plomo y pesticidas. El carácter global y la omnipresencia de la contaminación medioambiental significa que una amplia variedad de productos químicos industriales como los pesticidas y los metales pesados (p. ej., plomo y mercurio) - se encuentren en los alimentos del mar. Sin embargo, la extensión de la contaminación varía mucho de una región a otra y de una especie a otra. Son motivo de especial preocupación los productos químicos que pueden ser objeto de una acumulación biológica en los seres humanos, como los PCB, las dioxinas y el mercurio. En esos casos, la carga contaminante (procedente de diversas fuentes, incluidos los alimentos del mar) aumenta con el tiempo hasta llegar a niveles que pueden tener efectos tóxicos. Aunque queda mucho por saber sobre los efectos de una exposición crónica a los contaminantes en la salud humana, una enorme cantidad de información permite suponer que existe una clara posibilidad de aumento del riesgo de cáncer, inmunosupresión, consecuencias reproductivas y una sutil afección del desarrollo neurológico en los fetos y niños. En un importante informe sobre la seguridad de los alimentos del mar, el Institute of Medicine of the US Academy of Sciences (Food and Nutrition Board 1991) recomienda - al igual que numerosas organizaciones sanitarias y medioambientales - la creación de una instancia medioambiental activa destinada a prevenir la contaminación como el mejor medio de evitar los continuos problemas de salud humana y los desastres de contaminación producidos por los productos químicos industriales.

3. Consumo de alimentos del mar contaminados con toxinas procedentes de algas, como el ácido domoico, la ciguatoxina y la saxitoxina. Diversas especies de algas producen una amplia gama de toxinas que pueden acumularse en una serie de productos del mar, en particular los moluscos (salvo la ciguatoxina, que sólo se encuentra en los peces de roca). Entre las enfermedades resultantes se encuentran: la "intoxicación con moluscos" —ya sea paralítica (PSP), amnésica (ASP), diarréica (DSP) o neurótica (NSP) - y la ciguatera; no se conocen casos mortales de ASP desde su descubrimiento en 1987, en que murieron tres personas. Parece haberse producido un incremento en el florecimiento de algas tóxicas desde el decenio 
de 1970, así como cambios en la distribución e intensidad de la toxicidad del pescado y los moluscos. Si bien la aparición de algas es un suceso natural, existen serios indicios de que la contaminación de la costa con productos nutrientes - en particular procedentes de fertilizantes y aguas residuales- incrementa su formación o duración, aumentando las probabilidades de episodios de toxicidad de los productos del mar (Anderson 1994). Cabe señalar que, a diferencia de los patógenos, una cocción completa no reduce la toxicidad de los alimentos del mar contaminados con venenos naturales.

\section{Referencias}

Alverson, DL, MH Freeberg, SA Murawski, JG Pope. 1994. A Global Assessment of Fisheries Bycatch and Dis cards. Roma: FAO.

Anderson, DM. 1994. Red tides. Sci Am 271:62-68.

Chiang, H-C, Y-C Ko, S-S Chen, H-S Yu, T-N Wu, P-Y Chang. 1993. Prevalence of shoulder and upper-limb disorders among workers in the fishprocessing industry. Scand $\mathcal{f}$ Work Environment and Health 19:126-131.

Cura, NM. 1995. Treading on dangerous waters. Samudra 13:19-23.

Dayton, PK, SF Thrush, MT Agardy, RF Hofman. 1995. Environmental effects of marine fishing. Aquatic Conservation: Marine and Freshwater Ecosystem 5:205-232.

Dyer, CL. 1988. Social organization as a function of work. Organization aboard a Japanese surimi trawler. Fournal of the Society for Applied Anthropolog 47:76-81.

Food and Nutrition Board. 1991. Seafood Safety. Washington, DC: National Academy Press.

Gales, R. 1993. Co-operative Mechanisms for the Conservation of Albatross. Australia: Australian Nature Conservation Agency.

Hagmar, L, K Lindén, A Nilsson, B Norrving, B Åkesson, A Schütz, T Möller. 1992. Cancer incidence and mortality among Swedish Baltic Sea fishermen. Scand f Work Environ Health 18:217-224.

Husmo, M. 1993. Drommen om å bli fiskekjoper. Om rekruttering til ledelse og kvinners lederstil $i$ norsk fiskeindustri, Rap. $\quad \mathrm{N}^{\mathrm{o}}$ 8. Tromsø, Noruega: Fiskeriforskning/Norges fiskerihøgskole, Universidad de Tromsø.

1995. Institusjonell endring eller ferniss? Kvalitetsstyring sprosessen i noen norske fiskeindustribedrifter, Rap. $\mathrm{N}^{\circ} 1$. Tromsø, Noruega: Norges fiskerihøgskole/Seksjon for fiskeriorganisasjon.

Husmo, M , E Munk-Madsen. 1994. Kjønn som kvalifikasjon i fiskeindustrien. En Leve Kysten? Strandhogg i fiskeri-Norge, dirigido por O Otterstad y SJentoft. Noruega: Ad Notam Glydenal.

Husmo, M , G Søvik. 1995. Ledelsesstrukturen i norsk fiskeforedlingsindustri. Rap. $\mathrm{N}^{\circ}$ 2. Tromsø, Noruega: Norges fiskerihøgskole/Seksjon for fiskeriorganisasjon.

Kolare, S. 1993. Strategies for prevention of workrelated musculoskeletal disorders (documento de consenso). Int $\mathcal{f}$ of Ind Ergonomics 11:77-81.

Moore, SRW. 1969. The mortality and morbidity of deep sea fishermen sailing from Grimsby in one year. Br f Ind Med 26:25-46.

Munk-Madsen, E. 1990. Skibet er ladet med køn. En analyse af kønrelationer og kuinders vilkår i fabriksskibsfladen. Tromsø, Noruega: Colegio Noruego de Ciencias de la Pesca, Universidad de Tromsø.

Ohlsson, K, GA Hansson, I Balogh, U Strömberg, B Pålsson, C Nordander, L Rylander, S Skerfving. 1994. Disorders of the neck and upper limbs in women in the fish processing industry. Occup and Envir Med 51:826-32.

Ólafsdóttir, H , V Rafnsson. 1997. Increase in musculoskeletal symptoms of upper limbs among women after introduction of the flow-line in fish-fillet plants. Int $\mathcal{F}$ Ind Erg, en imprenta.

Organización de las Naciones Unidas para la Agricultura y la Alimentación (FAO). 1992. Review of the
State of World Fishery Resources. Part 1: Marine resources. Roma: FAO.

1993. Marine Fisheries and the Law of the Sea: A Decade of Change. Roma: FAO.

1995. The State of the World Fisheries and Aquaculture. Rome: FAO.

Organización Mundial de la Salud (OMS). 1985. Identification and Control of Work-related Diseases. Series de informes técnicos $\mathrm{N}^{\circ}$ 714. Ginebra: OMS.

Rafnsson, V , H Gunnarsdóttir. 1992. Fatal accidents among Icelandic seamen: 1966-1986. Br f Ind Med 49:694-699.

1993. Risk of fatal accidents occurring other than at sea among Icelandic seamen. $\mathrm{Br} \mathrm{Med} \mathcal{F}$ 306:1379-1381

- 1994. Mortality among Icelandic seamen. Int $\mathcal{f}$ Epidemiol 23:730-736.

- 1995. Cancer incidence among seamen in Iceland. Am f Ind Med 27:187-193.

Reilley, MSJ. 1985. Mortality from occupational accidents to United Kingdom fishermen 1961-1980. Br F Ind Med 42:806-814.

Skaptadóttir, UD. 1995. Fishermen's Wives and Fish Processors: Continuity and Change in Women's Position in Icelandic Fishing Villages, 1870-1990. Tesis doctoral. Nueva York: Universidad de Nueva York.

Stroud, C. 1996. The ethics and politics of whaling. En The Conservation of Whales and Dolphins: Science and Practice, dirigido por MP Simmons y JD Hutchinson. Chichester, Reino Unido: John Wiley \& Sons.

Svenson, B-G, Z Mikoczy, U Strömberg, L Hagmar. 1995. Mortality and cancer incidence among Swedish fishermen with a high dietary intake of persistent organochlorine compounds. Scand $\mathcal{J}$ Work Environ Health 21:106-115.

Törner, M, G Blide, H Eriksson, R Kadefors, R Karlsson, I Petersen. 1988. Musculo-skeletal symptoms as related to working conditions among Swedish professional fishermen. Applied Ergonomics 19: 191-201.

Vacher, J. 1994. Be strong by being together. Samudra 10 y 11 (suplemento especial).

\section{Otras lecturas recomendadas}

Andersen, R , C Wadel (dirs.). 1972. North Atlantic Fishermen: Anthropological Essays on Modern Fishing. Social and Economic Papers No. 5. St. John's, Terranova: Institute of Social and Economic Research, Universidad San Juan de Terranova.

Bárdarson, HR. 1969. Icing of ships. Presentado en la Segunda Conferencia Internacional sobre Ingeniería portuaria y oceánica en condiciones árticas, Universidad de Islandia, Departmento de Ingeniería y Ciencia, Reikiavik.

Barth, F. 1966. The Analytical Importance of Transactions. Models of Social Organization. Royal Anthropological Institute Occasional Paper No. 23. Londres: RAI.

Bennett, PB, DH Elliott (dirs.). 1993. The Physiology and Medicine of Diving. Londres: W.B. Saunders.

Bookspan, J 1995. Diving Physiology in Plain English. Kensington: Underseas and Hyperbaric Medical Society, Inc

Cross, T. 1985. The health of British trawlermen on the arctic fishing grounds. If Soc Occup $\mathrm{Med}$ $35: 55-61$
Dalgaard, JB, F Dencker, B Fallentin, B Hansen, B Kaempe, J Steensberg, P Wilhardt. 1972. Fatal poisoning and other health hazards connected with industrial fishing. Br f Ind Med 29:307-316.

Fields, LL. 1996. The Entangling Net: Alaska's Commercial Fishing Women Tell Their Lives. Urbana: University of Illinois Press.

Flemming, NC, MD Max. 1990. Scientific Diving: A General Code of Practice. París: UNESCO.

Gerrard, S. 1986. Kvinners makt og avmakt. Et kjonnsrolleperspektiv på forvaltning av faglige interesser i fiskeindustrien, Rap. $\mathrm{N}^{\mathrm{o}}$ 6. Tromsø, Noruega: Finmark Distriktshøgskole.

Hagland, K. 1995. Kvinner $i$ norsk fiskeindustri: deres arbeidsrettslige stilling ved permitteringer. Tromsø, Noruega: Institutt for Rettsvitenskap, Universidad de Tromsø.

Hale, AR, AI Glendon. 1987. Individual Behaviour in the Control of Danger. Amsterdam: Elsevier.

Hornsby, A (dir.). 1993. Encyclopaedia of Recreational Diving. Santa Ana, California: Professional Association of Diving Instructors.

Høst, L, C Wadel (dirs.). 1980. Fiske og Lokalsamfunn. Oslo, Noruega: Universitetsforlaget.

Kaplan, IM. 1988. Women who go to sea. Working in the commercial fishing industry. Fournal of Contemporary Ethnography 16: 491-514.

Larsen, M , E Munk-Madsen. 1989. Kjonnsmyter med konsekvenser. En analyse av skillet mellom kvinner og menn $i$ industriell fiskebearbeiding til lands og til vanns. Tromsø, Noruega: Norges fiskerihøgskole, Universidad de Tromsø.

Melamed, Y, A Shupak, H Bitterman. 1992. Medical problems associated with underwater diving. $\mathcal{N}$ Engl 7 Med 236(1).

Nadel-Klein, J, DL Davis (dirs) 1988. To Work and to Weep: Women in Fishing Economies. Social and Economic Papers No. 18. San Juan, Terranova: Institute of Social and Economic Research, Universidad de San Juan de Terranova.

Organización de las Naciones Unidas para la Agricultura y la Alimentación (FAO), Organización Internacional del Trabajo (OIT) y la Organización Marítima Internacional (OMI). 1980. Voluntary Guidelines for the Design, Construction and Equipment of Fishing Vessels (Roma: FAO; Ginebra: OIT; Londres: $\mathrm{OMI}$ ).

Organización Marítima Internacional (OMI) 1975. Code of Safety for Fishermen and Fishing Vessels. Part A. Safety and health practice for skippers and crew. Publicado en nombre de la FAO, la OIT y la OMI. Londres: OMI.

1987. Document for Guidance, 1985: An International Maritime Training Guide. Publicado en nombre de la OIT y la OMI. Londres: OMI.

Rafnsdottir, GL. 1995. Kvinnofack eller integrering som strategi mot underordning. Diskussion kring kvinnliga fackföreningar på Island. Lund, Suecia: Lund University Press.

Schilling, RSF. 1971. Hazards of deep-sea fishing. $B r \mathcal{F}$ Ind Med 28:27-35.

Wold, TM. 1995. Kvinner $i$ nord-norsk fiskeindustri likelonn. Tromsø, Noruega: Institutt for Rettsvitenskap, Universidad de Tromsø.

Zulaika, J. 1981. Terranova - The ethos and luck of deep sea fishermen. San Juan, Terranova: Universidad de San Juan de Terranova. 



\section{INDUSTRIA AUMENTARIA}

Directora del capítulo

D eborah E. B erkowitz

\section{Sumario}

VISION GENERAL Y EFECTOS SOBRE LA SALUD

Procesos de la industria alimentaria

M. M alagié, G. J ensen, J.C. G rahamy D onald L. Smith ...

Efectos sobre la salud y pautas patológicas

J ohn J. Svagr

Protección ambiental y cuestiones de salud pública

J erry Spiegel. ...

SECTORES DE LA PRODUCCION ALIMENTARIA

Industria cárnica

D eborah E. B erkowitz y M ichael J. Fagel . .

Industria avícola

Tony A shdown. . . .

Industria láctea

M arianne Smukowski y N orman B rusk. . . . . . . . . . . . . 67.26

Producción de cacao e industria del chocolate

Anaide Vilasboas de Andrade.

Cereales, elaboración de cereales y productos de consumo basados en cereales

Tomas E. H awkinson, J ames J . Collins y G ary W. O Imstead . . .

Panaderias

R.F. Villard . . . . . . . . . . . . . . . . . . . . . . . . . 67.30

Industria de la remolacha azucarera

Carol J. Lehtola .............................. 67.32

A ceites y grasas

N.M . Pant . . 


\section{- Pro Cesos de LA INDUSTRIA ALIMENTARIA}

\author{
M. M alagié, G. Jensen, J.C. G raham \\ y D onald L. Smith*
}

El término industrias alimentarias abarca un conjunto de actividades industriales dirigidas al tratamiento, la transformación, la preparación, la conservación y el envasado de productos alimenticios (véase la Tabla 67.1). En general, las materias primas utilizadas son de origen vegetal 0 animal y se producen en explotaciones agrarias, ganaderas y pesqueras. En el presente artículo se ofrece una visión general del complejo de industrias alimentarias. En otros artículos incluidos en este capítulo y en la Enciclopedia se abordan ramas del sector y riesgos específicos.

La industria alimentaria actual ha experimentado un intenso proceso de diversificación y comprende desde pequeñas empresas tradicionales de gestión familiar, caracterizadas por una utilización intensiva de mano de obra, a grandes procesos industriales altamente mecanizados basados en el empleo generalizado de capital. M uchas de las ramas de esta industria dependen totalmente de la agricultura o la pesca locales. En el pasado, esta dependencia daba lugar a una producción estacional y a la contratación de trabajadores por temporadas. Las mejoras de las tecnologías de tratamiento y conservación de los alimentos han atenuado parcialmente la presión afrontada por los trabajadores debida a la necesidad de procesar con rapidez para evitar el deterioro de los productos. De este modo, se han reducido las fluctuaciones estacionales en el empleo. Con todo, en ciertos sectores siguen desarrollándose este tipo de actividades de temporada, como en el tratamiento de la fruta fresca y las verduras 0 en la producción de pasteles y chocolates, que aumenta en períodos vacacionales. Mujeres y trabajadores extranjeros suelen engrosar sus filas.

La producción mundial de alimentos ha ido aumentando. Las exportaciones de este tipo de productos alcanzaron los 290.000 millones de dólares en 1989, lo que representa un crecimiento del $30 \%$ respecto a 1981 . Un $67 \%$ de estas exportaciones es generado por países industrializados de economía de mercado. Gran parte del aumento puede atribuirse a un incremento de la demanda de bebidas y alimentos elaborados, sobre todo en los países en desarrollo, donde el mercado aún no se ha saturado.

Con todo, este aumento de la producción alimentaria no ha generado un crecimiento del empleo debido a la intensificación de la competencia, que ha dado lugar a una reducción de la mano de obra utilizada en numerosas ramas del sector, en especial en los países industrializados. Las causas de esta tendencia consisten en una mejora de la productividad y la mecanización en gran parte de dichas ramas.

La presión demográfica, un reparto desigual de los recursos agrarios y la necesidad de asegurar la conservación de los productos alimenticios para facilitar una mejora de su distribución explican la rápida evolución técnica de estas industrias. Las presiones económicas y comerciales constantes llevan al sector a ofrecer productos nuevos y diferentes para el mercado, mientras que, en otras industrias, puede fabricarse el mismo producto del mismo modo durante decenios. Incluso en instalaciones muy industrializadas suele recurrirse a técnicas aparentemente

* Adaptado de los artículos "Industrias de la alimentación", de M . M alagié; "Industria de la congelación de alimentos", de G. Jensen, y "Conservación y preservación de alimentos" de J.C. Graham, incluidos en la 3a edición de la Enciclopedia de salud y seguridad en el trabajo, y revisado por D onald L. Smith. arcaicas al lanzar o iniciar nuevos productos y procesos. En la práctica, para satisfacer las demandas de la población, no se necesita únicamente una cantidad suficiente de alimentos, lo que exige un aumento de la producción, sino también un control estricto de la higiene con el fin de lograr la calidad indispensable para mantener la salud de la comunidad. Sólo la modernización de las técnicas justificada por la necesidad de obtener grandes volúmenes de producto en un entorno productivo estable eliminarán los riesgos de la manipulación manual. A pesar de la enorme diversidad de las industrias alimentarias, los procesos de fabricación pueden dividirse en la manipulación y el almacenamiento de materias primas, la extracción, la elaboración, la conservación y el envasado.

\section{Manipulación y almacenamiento}

La manipulación de las materias primas, los ingredientes utilizados en la elaboración y los productos terminados es varia y diversa. Actualmente se tiende a reducir al mínimo la manipulación manual mediante la mecanización, el "proceso continuo" y la automatización. La manipulación mecánica puede abarcar el transporte interior autopropulsado con o sin embandejación o la disposición en grandes sacos a granel (que contienen a menudo varios miles de kilogramos de material en polvo seco); cintas transportadoras (que portan, por ejemplo, remolacha, grano o fruta); montacargas de cubetas ( $p$. ej., con grano y pescado); transportadores de tornillo sin fin (p. ej., con dulces, harina, etc.); canal de descarga en alto (p. ej., para descargar grano, azúcar, o frutos secos y para el transporte de harinas).

El almacenamiento de materias primas es sumamente importante en una industria estacional ( $p$. ej., refinado de azúcar, elaboración de cerveza, moltura de harina y enlatado). Suele realizarse en silos, tanques, bodegas y cámaras frigoríficas. El almacenamiento de productos terminados varía en función de su naturaleza (líquidos o sólidos), y el método de conservación y envasado (suelto, en sacos de mayor o menor tamaño, en fardos, cajas o botellas); y el diseño de las instalaciones respectivas debe responder a las condiciones de manipulación y conservación (pasillos de tránsito, facilidad de acceso, temperatura y humedad adecuadas al producto, cámaras frigoríficas). Los productos pueden conservarse en atmósferas deficientes en oxígeno o fumigados durante su almacenamiento o justo antes de su envío.

\section{Extracción}

Para extraer un alimento específico de la fruta, los cereales o los líquidos, debe utilizarse uno de los métodos siguientes: trituración, machacado o molienda, extracción por calor (directa o indirecta), utilización de disolventes, secado y filtrado.

La trituración, el machacado y la molienda suelen ser operaciones preparatorias; por ejemplo, la trituración de los granos del cacao y el cortado en finas lonjas de la remolacha en la industria azucarera. En otros casos, pueden constituir el verdadero proceso de extracción, como en la molienda de harina.

El calor puede utilizarse directamente como medio de preparación por extracción, como en el caso del tostado (p. ej., del cacao, el café y la achicoria); en la fabricación suele aplicarse de modo directo o indirecto en forma de vapor (p. ej., extracción de aceites comestibles o del jugo dulce de finas lonjas de remolacha en la industria azucarera).

Los aceites pueden extraerse con igual eficacia mediante la combinación y la mezcla de la fruta triturada con disolventes, que serán eliminados con posterioridad a través de las operaciones de filtrado y recalentamiento. La separación de productos 
Tabla 67.1 • Las industrias alimentarias, sus materias primas y procesos.

\begin{tabular}{|c|c|c|c|c|c|}
\hline Industria & $\begin{array}{l}\text { Materiales } \\
\text { elaborados }\end{array}$ & $\begin{array}{l}\text { Requisitos de } \\
\text { almacenamiento }\end{array}$ & Técnicas de elaboración & Técnicas de preservación & $\begin{array}{l}\text { Empaquetado de productos } \\
\text { terminados }\end{array}$ \\
\hline $\begin{array}{l}\text { Elaboración y } \\
\text { conservación de la } \\
\text { carne }\end{array}$ & $\begin{array}{l}\text { Ganado vacuno, } \\
\text { ganado ovino, ganado } \\
\text { porcino, aves }\end{array}$ & Cámaras refrigeradas & $\begin{array}{l}\text { Sacrificio, trinchado, } \\
\text { deshuesado, triturado, } \\
\text { cocción }\end{array}$ & $\begin{array}{l}\text { Sazonado, ahumado, } \\
\text { refrigeración, ultracongela- } \\
\text { ción, esterilización }\end{array}$ & $\begin{array}{l}\text { A granel } 0 \text { en latas, caja de } \\
\text { cartón }\end{array}$ \\
\hline $\begin{array}{l}\text { Elaboración de } \\
\text { pescado }\end{array}$ & Todo tipo de pescado & $\begin{array}{l}\text { Cámaras frigoríficas, a granel } \\
\text { en salazón o en barriles }\end{array}$ & $\begin{array}{l}\text { Descabezamiento, } \\
\text { evisceración, fileteado, } \\
\text { cocción }\end{array}$ & $\begin{array}{l}\text { Ultracongelación, secado, } \\
\text { ahumado, esterilización }\end{array}$ & $\begin{array}{l}\text { A granel en contenedores } \\
\text { refrigerados } 0 \text { en latas }\end{array}$ \\
\hline $\begin{array}{l}\text { Conservación de } \\
\text { frutas y verduras }\end{array}$ & $\begin{array}{l}\text { Frutas y verduras } \\
\text { frescas }\end{array}$ & $\begin{array}{l}\text { Elaboración inmediata; las } \\
\text { frutas pueden estabilizarse } \\
\text { con dióxido de azufre }\end{array}$ & $\begin{array}{l}\text { Escaldado o cocción, } \\
\text { triturado, concentración } \\
\text { de zumos al vacío }\end{array}$ & $\begin{array}{l}\text { Esterilización, pasteurización, } \\
\text { secado, deshidratación, } \\
\text { liofilización ( secado por } \\
\text { congelación) }\end{array}$ & $\begin{array}{l}\text { Sacos, latas o botellas de } \\
\text { vidrio o plástico }\end{array}$ \\
\hline $\begin{array}{l}\text { Elaboración de } \\
\text { cereales }\end{array}$ & Cereales & $\begin{array}{l}\text { Fumigación de los cereales } \\
\text { almacenados en silos }\end{array}$ & $\begin{array}{l}\text { Trituración, cribado, } \\
\text { molienda, rodadura }\end{array}$ & $\begin{array}{l}\text { Cocción de secado u } \\
\text { horneado }\end{array}$ & $\begin{array}{l}\text { Silos (transportados } \\
\text { neumáticamente), sacos o } \\
\text { bolsas enviados a otros } \\
\text { procesos, o embalado en } \\
\text { cajas para el comercio } \\
\text { minorista }\end{array}$ \\
\hline Cocción en horno & $\begin{array}{l}\text { Harina y otros } \\
\text { productos secos, agua, } \\
\text { aceites }\end{array}$ & $\begin{array}{l}\text { Silos, sacos de grandes } \\
\text { dimensiones y bolsas }\end{array}$ & $\begin{array}{l}\text { Amasado, fermentación, } \\
\text { tratamientos de superficie de } \\
\text { laminación en el condimento }\end{array}$ & $\begin{array}{l}\text { Cocción en horno, } \\
\text { tratamientos de superficie } \\
\text { de corte y empaquetado }\end{array}$ & $\begin{array}{l}\text { Empaquetado para } \\
\text { establecimientos mayoristas, } \\
\text { restaurantes y mercados } \\
\text { minoristas }\end{array}$ \\
\hline $\begin{array}{l}\text { Elaboración de } \\
\text { galletas }\end{array}$ & $\begin{array}{l}\text { Harina, nata, } \\
\text { mantequilla, azúcar, } \\
\text { fruta y condimentos }\end{array}$ & $\begin{array}{l}\text { Silos, sacos de grandes } \\
\text { dimensiones y bolsas }\end{array}$ & $\begin{array}{l}\text { Mezcla, amasado, moldeo } \\
\text { de estratificado }\end{array}$ & $\begin{array}{l}\text { Cocción en horno, trata- } \\
\text { mientos de superficie de } \\
\text { corte y empaquetado }\end{array}$ & $\begin{array}{l}\text { Bolsas, cajas para } \\
\text { establecimientos } \\
\text { institucionales y minoristas }\end{array}$ \\
\hline $\begin{array}{l}\text { Fabricación de la } \\
\text { masa }\end{array}$ & Harina, huevos & Silos & $\begin{array}{l}\text { Amasado, molienda, corte, } \\
\text { extrusión o moldeo }\end{array}$ & Secado & Bolsas, paquetes \\
\hline $\begin{array}{l}\text { Elaboración y refino } \\
\text { de azúcar }\end{array}$ & $\begin{array}{l}\text { Remolacha azucarera, } \\
\text { caña de azúcar }\end{array}$ & Silos & $\begin{array}{l}\text { Trituración, maceración, } \\
\text { concentración al vació, } \\
\text { centrifugado, secado }\end{array}$ & Cocción al vacío & Bolsas, paquetes \\
\hline $\begin{array}{l}\text { Fabricación de } \\
\text { chocolate y } \\
\text { repostería }\end{array}$ & $\begin{array}{l}\text { Azúcar de cacao, } \\
\text { grasas }\end{array}$ & $\begin{array}{l}\text { Silos, sacos, Cámaras } \\
\text { acondicionadas }\end{array}$ & $\begin{array}{l}\text { Tostado, molienda, mezcla, } \\
\text { conchado, moldeo }\end{array}$ & - & Paquetes \\
\hline $\begin{array}{l}\text { Fabricación de } \\
\text { cerveza }\end{array}$ & Cebada, lúpulo & $\begin{array}{l}\text { Silos, depósitos, sótanos } \\
\text { acondicionados }\end{array}$ & $\begin{array}{l}\text { Molienda del cereal, } \\
\text { malteado, braceaje, filtrado } \\
\text { con filtro prensa, } \\
\text { fermentación }\end{array}$ & Pasteurización & Botellas, latas, barriles \\
\hline $\begin{array}{l}\text { Destilación y } \\
\text { fabricación de otras } \\
\text { bebidas }\end{array}$ & $\begin{array}{l}\text { Fruta, cereales, agua } \\
\text { carbonatada }\end{array}$ & Silos, depósitos, cubas & $\begin{array}{l}\text { Destilación, mezcla, } \\
\text { aireación }\end{array}$ & Pasteurización & Barriles, botellas, latas \\
\hline $\begin{array}{l}\text { Elaboración de leche } \\
\text { y productos lácteos }\end{array}$ & $\begin{array}{l}\text { Leche, azúcar, otros } \\
\text { ingredientes }\end{array}$ & $\begin{array}{l}\text { Elaboración inmediata; } \\
\text { elaboración posterior en } \\
\text { cubas de maduración, } \\
\text { cubas acondicionadas, } \\
\text { almacén refrigerado }\end{array}$ & $\begin{array}{l}\text { Desnatado, batido } \\
\text { (mantequilla), coagulación } \\
\text { (queso), maduración }\end{array}$ & $\begin{array}{l}\text { Pasteurización, esterilización } \\
\text { o concentración, desecación }\end{array}$ & $\begin{array}{l}\text { Botellas, envueltas de } \\
\text { plástico, cajas (queso) o } \\
\text { a granel }\end{array}$ \\
\hline $\begin{array}{l}\text { Elaboración de } \\
\text { aceites y grasas }\end{array}$ & $\begin{array}{l}\text { Cacahuetes, aceitunas, } \\
\text { dátiles, otras frutas y } \\
\text { cereales, grasas } \\
\text { animales o vegetales }\end{array}$ & $\begin{array}{l}\text { Silos, depósitos, almacenes } \\
\text { refrigerados }\end{array}$ & $\begin{array}{l}\text { Molienda, extracción con } \\
\text { disolventes o vapor, filtrado } \\
\text { con filtro prensa }\end{array}$ & $\begin{array}{l}\text { Pasteurización en caso } \\
\text { necesario }\end{array}$ & Botellas, paquetes, latas \\
\hline
\end{tabular}

líquidos se lleva a cabo mediante la centrifugación (turbinas en la industria azucarera) o el filtrado a través de filtros prensa en la elaboración de cerveza y la producción de aceites y grasas.

\section{Procesos de fabricación}

Las operaciones efectuadas al elaborar alimentos son muy diversas y quedan definidas únicamente tras el estudio individual de cada industria, si bien pueden mencionarse los siguientes procedimientos generales: fermentación, cocción, deshidratación y destilación.

La fermentación, que suele obtenerse mediante la adición de microorganismos a los productos previamente preparados, se utiliza en las tahonas, las fábricas de cerveza, la industria de vinos y bebidas alcohólicas y la fabricación de quesos (véase asimismo el capítulo $L$ a industria de las bebidas). 
La cocción interviene en muchos procesos de fabricación, como el enlatado y la conservación de carne, pescado, verduras y frutas, en los centros de producción de carne lista para servir (p. ej., piezas de pollo) y en la elaboración de pan, galletas, cerveza, etc. En otros casos, la cocción se realiza en recipientes de junta hermética y produce una concentración del producto (p. ej., refinado de azúcar y elaboración de pasta de tomate).

Además del secado de productos al sol, que se aplica a numerosas frutas tropicales, la deshidratación puede efectuarse mediante la utilización de aire caliente (secadores fijos o túneles de secado), por contacto (en un tambor secador calentado al vapor, como en la producción de café instantáneo y té), al vacío (a menudo combinada con filtrado) y liofilización (secado por congelación), en la que el producto se congela inicialmente en estado sólido y se seca con posterioridad al vacío en una cámara de calor

La destilación se utiliza en la fabricación de bebidas alcohólicas. El líquido fermentado, tratado para separar el grano o la fruta, es vaporizado en un alambique. El vapor condensado se recoge a continuación en forma de alcohol etílico.

\section{Procesos de conservación}

Es importante evitar el deterioro de los productos alimenticios, tanto por lo que se refiere a su calidad, como al riesgo, más grave, de contaminación o peligro para la salud de los consumidores.

$\mathrm{H}$ ay cinco métodos básicos de conservación de alimentos:

1. esterilización por radiación

2. esterilización antibiótica

3. acción química

4. deshidratación

5. refrigeración.

En resumen, los tres primeros métodos dan lugar a la destrucción de la vida microbiana, mientras que los dos últimos se limitan a inhibir su desarrollo. Los ingredientes crudos como el pescado, la carne, las frutas o las verduras se recogen frescos y se conservan mediante la utilización de uno de los métodos anteriores, o bien una mezcla de diversos alimentos se somete a determinados procesos para constituir un producto 0 un plato, que se conserva a continuación. En este último grupo se incluyen las sopas, los platos preparados de carne y los budines. L a conservación de alimentos se remonta a la última glaciación, en torno al 15.000 a.C . , cuando el hombre de Cromagnon descubrió una primera forma de preservar la comida en el ahumado. Las pruebas de este avance se encuentran en las cuevas de L es Eyzies en la Dordoña francesa, donde este modo de vida ha quedado fielmente reflejado en tallas, grabados y pinturas. D esde entonces hasta la fecha, aunque se ha recurrido a multitud de métodos, que siguen utilizándose, el calor constituye aún una de las piedras angulares de la conservación de alimentos.

Los procesos realizados a altas temperaturas pueden destruir las bacterias, dependiendo de los grados alcanzados en la cocción y de la duración de ésta. La esterilización (utilizada fundamentalmente en el enlatado) exige el sometimiento del producto previamente enlatado a la acción del vapor, generalmente en un recipiente cerrado, como un autoclave o un horno de cocción continua. La pasteurización (el término se aplica en particular al tratamiento de líquidos como el zumo de frutas, la cerveza, la leche y la nata) se lleva a cabo a una temperatura baja y durante un breve período de tiempo. El ahumado, que se aplica principalmente al pescado, el jamón y el tocino, asegura la deshidratación y da un sabor característico.

La esterilización por radiación ionizante se utiliza en gran medida en el caso de las especias en ciertos países, con el fin de reducir los desperdicios y las pérdidas. La "pasteurización por radiación", en la que se aplican dosis muy inferiores, facilita un aumento considerable de la vida útil de numerosos alimentos. No obstante, la esterilización de conservas mediante radiación exige la aplicación de dosis tan elevadas que se generan sabores y olores inaceptables.

La radiación ionizante se emplea con otros dos fines comúnmente aceptados en la industria alimentaria: el control de envases de alimentos realizados con materiales ajenos y la supervisión para detectar casos de llenado incompleto.

La esterilización por microondas es otro tipo de emisión electromagnética utilizada actualmente en la industria alimentaria. Se aplica en el descongelado rápido de ingredientes crudos congelados antes de proceder al resto de la elaboración, así como en el calentamiento de alimentos precocinados congelados en lapsos de 2 a 3 minutos. Es un método que, dada su baja pérdida de humedad, mantiene la apariencia y el sabor de los alimentos.

El secado en un proceso de conservación común. El realizado al sol es el método más antiguo y de empleo más generalizado con este fin. Los alimentos actuales pueden secarse al aire, con vapor sobrecalentado, al vacío, en gas inerte y mediante la aplicación directa de calor. Existen muchos tipos de agentes de secado, que se eligen en función de la naturaleza del material, la forma deseada del producto terminado, etc. La deshidratación es un proceso en el que se transfiere calor al agua presente en el alimento, que se evapora. EI vapor se elimina posteriormente.

Los procesos realizados a bajas temperaturas consisten en el almacenamiento en cámaras frigoríficas (la temperatura viene determinada por la naturaleza de los productos en cuestión), la congelación y la ultracongelación, que permite la conservación de los alimentos en su estado fresco natural mediante la aplicación de diversos métodos de congelación lenta o rápida.

En el secado por congelación, el material objeto del proceso se congela y se introduce en una cámara estanca. La presión en ésta se reduce y se mantiene a un valor inferior a $1 \mathrm{~mm} \mathrm{H} \mathrm{g}$. Se le aplica calor, el hielo de la superficie aumenta de temperatura y el vapor de agua resultante es evacuado por el sistema de vacío. A medida que la capa exterior de hielo se incrusta en el alimento, el hielo sublima in situ y el agua se filtra hacia la superficie a través de la estructura porosa del material.

Los alimentos de humedad intermedia contienen cantidades relativamente elevadas de agua (de un 5 a un $30 \%$ ) y, pese a ello, no presentan crecimiento microbiano. La tecnología, compleja, es un resultado del desarrollo de los viajes espaciales. La estabilidad en ambiente externo se consigue mediante un control adecuado de la acidez, el potencial de reducción-oxidación, los humectantes y los conservantes. La mayoría de los avances hasta la fecha se han concentrado en la gama de alimentos para animales domésticos.

Con independencia del proceso aplicado, el alimento que debe conservarse debe ser antes elaborado. La conservación de carne exige la actuación de un departamento de carnicería, el pescado requiere la ejecución de operaciones de limpieza y destripado, fileteado, curado, etc. Antes de que las frutas y verduras puedan conservarse, deben ser lavadas, limpiadas, peladas, quizá clasificadas, destronchadas, descortezadas y deshuesadas. Muchos de los ingredientes han de picarse, cortarse en rodajas, desmenuzarse o prensarse.

\section{Envasado}

Entre los numerosos métodos de envasado de alimentos se cuentan el enlatado, el envasado aséptico y el envasado por congelación.

\section{Enlatado}

El método convencional de enlatado se basa en el proceso original concebido por A ppert en Francia, por el que el gobierno 
francés le otorgó un premio de 12.000 francos en 1810. Ideó la conservación de alimentos en recipientes de cristal. En Dartford, Inglaterra, D onkin y $\mathrm{H}$ all crearon la primera fábrica de conservas basada en la utilización de envases de hojalata en 1812.

En la actualidad se emplean en el mundo varios millones de toneladas de plancha de hojalata al año en la industria conservera, y una cantidad sustancial de alimentos se conserva en recipientes de cristal. EI proceso de enlatado consiste en introducir alimentos limpios, crudos o cocinados en parte, pero no esterilizados intencionadamente, en una lata sellada con una tapa. C on posterioridad, la lata se calienta, normalmente mediante vapor a presión, a una temperatura y por un período de tiempo que permita la penetración del calor hasta el centro del recipiente, destruyendo la vida microbiana. D espués se enfría la lata al aire 0 en agua clorada, se etiqueta y se embala.

La elaboración se ha modificado con los años. Los esterilizadores continuos reducen los daños producidos en las latas debidos a impactos y permiten la refrigeración y el secado en una atmósfera cerrada. Asimismo, los alimentos pueden conservarse al calor en bolsas recalentables. Se trata de bolsas de sección limitada fabricadas con laminado de aluminio y plásticos sellables al calor. El proceso es el mismo que en el enlatado convencional, pero se mantienen mejor los sabores de los productos porque los tiempos de esterilización pueden reducirse. Es fundamental controlar exhaustivamente el proceso de recalentado para evitar dañar los sellos, lo que podría provocar una contaminación bacteriológica.

\section{Envasado aséptico}

Se han producido avances recientes en el envasado aséptico de alimentos. EI proceso difiere esencialmente del enlatado convencional. En el método aséptico, el contenedor del alimento y el dispositivo de cierre se esterilizan por separado, y las operaciones de llenado y cierre se realizan en una atmósfera estéril. La calidad de los productos es óptima, ya que el tratamiento por calor de los alimentos puede controlarse con precisión y es independiente del tamaño o del material del contenedor. Debe prestarse atención a la exposición de los trabajadores a los agentes esterilizantes. Es probable que la utilización del método se generalice, ya que, en conjunto, debe dar lugar a un ahorro de energía. $\mathrm{H}$ asta ahora, los mayores avances se han registrado en el tratamiento de líquidos y purés esterilizados mediante el denominado proceso HTST, en el que el producto se calienta a una temperatura elevada durante algunos segundos. A estas mejoras se añadirán las obtenidas respecto a los alimentos en partículas. Un beneficio probable en las fábricas de alimentos consistirá en la reducción del ruido gracias a la sustitución de recipientes metálicos rígidos. Además, estos recipientes pueden plantear problemas debidos a la contaminación con plomo y estaño de los alimentos conservados. Para su atenuación, pueden emplearse los nuevos tipos de recipientes de dos piezas realizados con hojalata laqueada y los recipientes de tres piezas de costuras soldadas en vez de estañadas.

\section{Envasado por congelación}

En la industria de la congelación de alimentos se utilizan el conjunto de métodos de ultracongelación de productos frescos a temperaturas por debajo de su punto de congelación, formando de este modo cristales de hielo en los tejidos acuosos. Los alimentos pueden procesarse crudos o parcialmente cocinados (p. ej., reses o platos de carne preparados, pescados o productos derivados de éste, verduras, frutas, aves, huevos, comidas listas para consumir, pan y pasteles). Los artículos perecederos congelados pueden transportarse a grandes distancias y almacenarse para su tratamiento y/ o venta cuando la demanda lo requiera, disponiendo en todo momento de productos de temporada.
Los alimentos que se van a congelar deben encontrarse en una condición excelente y elaborarse bajo un estricto control higiénico. Deben utilizarse materiales de envasado a prueba de vapores y olores y resistir bajas temperaturas. La calidad del producto depende del ritmo de la congelación: si es muy lenta, es posible que su estructura quede dañada por la formación de cristales de hielo de gran tamaño y que se destruyan sus propiedades encimáticas y microbiológicas. En algunos casos, como el de los camarones o los guisantes, puede congelarse con rapidez, ya que esta opción mejora la calidad.

Entre los diversos métodos de congelación figuran los que se realizan al aire, por chorro, por lecho fluidificado, por fluido, por contacto, por gas licuado y por deshidratación.

La congelación al aire en su forma más sencilla consiste en colocar los alimentos en bandejas o estantes de una cámara frigorífica a una temperatura aproximada de $-30{ }^{\circ} \mathrm{C}$ durante un período de tiempo que oscila entre unas pocas horas y 3 días, dependiendo del tamaño. En la congelación por chorro, que constituye una técnica más compleja, se utiliza una corriente de aire frío que circula con gran rapidez, en ocasiones combinado con serpentines fríos, que elimina el calor mediante la radiación. Las temperaturas oscilan entre los -40 y los $-50{ }^{\circ} \mathrm{C}$, y la velocidad máxima del aire es de $5 \mathrm{~m} / \mathrm{s}$. El proceso se lleva a cabo en congeladores en forma de túnel, a menudo equipados con dispositivos transportadores para trasladar los alimentos a las cámaras frigoríficas de almacenamiento. Cuando el congelador es adyacente a la cámara frigorífica, el túnel suele cerrarse con una cortina de aire en lugar de con puertas.

La congelación en lecho fluidificado se utiliza con verduras picadas o cortadas en tiras, guisantes, etc., que se colocan sobre una cinta perforada a través de la que fluye una corriente de aire. Cada elemento se cubre de hielo y, de este modo, conserva su forma y su individualidad. Las verduras congeladas pueden conservarse en grandes recipientes y volver a envasarse cuando se requieran en pequeñas unidades. En la congelación por fluido (uno de los métodos más antiguos conocidos), los alimentos, normalmente pescados, se sumergen en una solución concentrada de salmuera. La sal puede penetrar en los productos sin envoltorio e incluso en los envueltos, afectando al sabor y acelerando su rancidez. Aunque es un método que había caído en desuso, está ganando terreno en la actualidad gracias al desarrollo de envoltorios de plástico más eficaces. Las aves se congelan mediante una combinación de los métodos de fluido y al aire. Cada pieza, empaquetada en polietileno o un material similar, se rocía o sumerge en un fluido frío para congelar su capa exterior; la parte interior se trata después en un congelador por chorro de aire.

La congelación es el método que suele utilizarse con los alimentos empaquetados en cajas de cartón, que se colocan entre estantes huecos, a través de los cuáles se hace circular un fluido refrigerante; los estantes se presionan contra estas cajas, generalmente mediante presión hidráulica.

En la congelación por gas licuado, el producto se sitúa en una cinta transportadora que atraviesa un tanque de nitrógeno líquido (en ocasiones, de dióxido de carbono líquido) o un túnel en el que se pulveriza este gas licuado. La congelación se produce a la temperatura de $-196{ }^{\circ} \mathrm{C}$, y no todos los productos ni envoltorios pueden soportar ese frío. La congelación por deshidratación, en la que se elimina parte del agua antes de iniciar el proceso, se aplica a ciertas verduras y frutas. Se logra una reducción considerable de peso, lo que aminora los costes de transporte, almacenamiento y empaquetado.

Durante el almacenamiento en frío, el producto debe conservarse a una temperatura comprendida entre los -25 y los $-30{ }^{\circ} \mathrm{C}$ y debe mantenerse una circulación de aire adecuada. El transporte de artículos congelados debe realizarse en vagones, 
camiones, barcos y otros vehículos refrigerados y, en las operaciones de carga y descarga, los productos deben exponerse al menor calor posible. N ormalmente, las empresas que producen alimentos congelados también elaboran las materias primas, pero, en ocasiones, estos tratamientos se llevan a cabo en instalaciones diferentes. En las operaciones efectuadas con carne de vacuno y aves suele emplearse el dióxido de carbono para refrigerar y conservar el producto durante su transporte.

\section{Riesgos y su prevención}

\section{Riesgos de lesión}

Las lesiones en la industria alimentaria suelen estar causadas por lo común por las herramientas manuales, en especial los cuchiIlos; por la utilización de maquinaria; por los choques con objetos en movimiento o estáticos; por caídas y resbalones, y por quemaduras.

Las lesiones debidas al empleo de cuchillos en la elaboración de la carne y el pescado pueden reducirse al mínimo mediante el diseño y el adecuado mantenimiento de los mismos, la disposición de áreas de trabajo adecuadas, la selección del instrumento apropiado para cada tarea, la aplicación de guantes y delantales protectores resistentes y la correcta formación de trabajadores en el afilado y la utilización de estas herramientas. Los dispositivos de corte mecánico también constituyen una fuente de riesgo, y resultan esenciales para evitar las lesiones un mantenimiento conveniente y la capacitación óptima de los trabajadores (véase la Figura 67.1).

A unque los accidentes en los que interviene la maquinaria de transmisión son relativamente infrecuentes, pueden ser graves. Los riesgos asociados a los equipos y los sistemas de manipulación deben ser objeto de un estudio individualizado en cada industria. Los problemas en la manipulación pueden abordarse mediante un análisis pormenorizado del historial de accidentes en cada proceso y el empleo de protecciones personales adecuadas, como las aplicadas en pies, piernas, manos, brazos, ojos y cara. Los riesgos debidos a la maquinaria pueden prevenirse mediante la adopción de protecciones seguras. L os equipos

Figura 67.1 • Trinchado de carne de ballena congelada con una sierra de banda y sin protección adecuada de la maquinaria ni precauciones de carácter eléctrico. Japón, 1989.

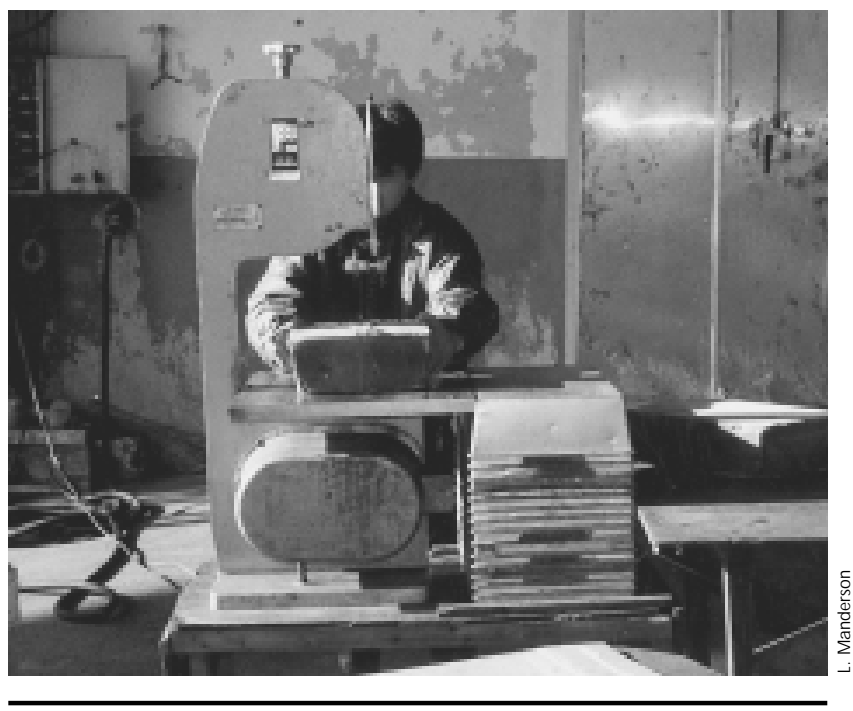

de manipulación mecánica, y en particular los transportadores, son muy utilizados y debe prestarse especial atención a los salientes que se desplazan en su movimiento. Las máquinas de llenado y sellado deben aislarse totalmente, a excepción de las tomas de entrada y descarga. Las entradas de cintas transportadoras, tambores, poleas y engranajes deben ser protegidas adecuadamente. Por ejemplo, para evitar el riesgo de corte al enlatar, deben emplearse dispositivos eficaces para la retirada de latas con bordes afilados o cristales rotos. Las lesiones graves debidas a la puesta en marcha involuntaria de la maquinaria de transmisión durante las operaciones de limpieza o de mantenimiento pueden prevenirse mediante la adopción estricta de procedimientos de bloqueo y carteles de advertencia.

L os accidentes por caída suelen deberse $a$ :

- El estado del suelo. Pueden ocurrir accidentes cuando los suelos son desiguales, están húmedos o resbaladizos debido al tipo de superficie, a la acción de ciertos productos, al vertido de residuos de grasa, aceite o polvo; o, en las cámaras frigoríficas, por la condensación del aire húmedo. Los suelos antideslizantes ayudan a prevenir los resbalones. L a elección de una superficie y de un régimen de limpieza adecuados, además de una buena conservación y el empleo del calzado apropiado, contribuyen a evitar numerosas caídas. Las máquinas con reborde circundante evitan la precipitación de agua al suelo. D ebe disponerse de un drenaje óptimo para eliminar con rapidez la acumulación o el derrame de líquidos.

- Pozos o canales de drenaje al descubierto. Es necesario mantenerlos cubiertos o vallados.

- Trabajo en altura. La utilización de medios seguros de acceso a los equipos y las áreas de almacenamiento, las escaleras sólidas y la protección contra caídas (incluidos los cinturones de seguridad y los cables salvavidas) puede evitar muchos riesgos.

- Vapor 0 polvo. Las operaciones que generan vapor 0 polvo, además de hacer resbaladizo el suelo, pueden impedir una buena visibilidad.

- Iluminación insuficiente o irregular. La iluminación debe ser suficiente para que los trabajadores sean capaces de observar el proceso en el que intervienen. La percepción de una iluminación inadecuada se produce cuando las áreas de almacenamiento parecen oscuras en comparación con las de producción y los ojos no se adaptan al paso de un nivel de luz a otro.

Las quemaduras y escaldaduras debidas a la acción de licores calientes y equipos de cocción son habituales y se producen lesiones similares cuando se utiliza vapor y agua caliente en la limpieza de equipos. Pueden ocurrir accidentes más graves como consecuencia de la explosión de calderas y autoclaves debida a la falta de controles regulares, una formación deficiente de los trabajadores, la adopción de procedimientos inadecuados o un mantenimiento poco apropiado. Todos los equipos que emplean vapor deben ser objeto de un mantenimiento periódico y a fondo con el fin de evitar grandes explosiones o fugas de menor importancia.

Las instalaciones eléctricas, en especial en lugares húmedos, requieren una toma de tierra adecuada y un buen mantenimiento para controlar el riesgo habitual de descarga eléctrica. A demás de estas precauciones, las tomas de corriente dotadas de interruptores de circuito de avería por puesta a tierra (IFT) son eficaces en la protección frente a las descargas eléctricas. U na clasificación eléctrica adecuada de los entornos peligrosos es esencial. Con frecuencia, los sazonadores, los extractos y los polvos inflamables, como los de cereales, almidón de maíz o azúcar (considerados como alimentos y no como productos químicos peligrosos) pueden requerir el empleo de equipo eléctrico catalogado para eliminar el riesgo de ignición durante los desajustes y las desviaciones de los procesos. A simismo, pueden 
producirse incendios si se llevan a cabo operaciones de soldadura en entornos con polvos orgánicos combustibles o explosivos en silos y centros de elaboración de cereales. También pueden tener lugar explosiones en hornos de gas o de fueloil 0 en procesos de cocción si éstos no se instalan, operan 0 mantienen correctamente, no se dotan de los dispositivos de seguridad esenciales 0 no se cumplen los procedimientos de seguridad pertinentes (sobre todo en operaciones con Ilama abierta).

Es esencial un estricto control de la higiene de los productos en todas las fases de la elaboración de los alimentos, incluidos los mataderos. Las prácticas de higiene industrial y personal son sumamente importantes en la protección contra la infección y la contaminación de las materias tratadas. Los locales y los equipos deben diseñarse para promover la higiene personal mediante la disposición de instalaciones sanitarias y lavabos adecuados y convenientemente situados, de duchas en caso necesario, de ropas protectoras adecuadas y de servicios de lavandería de las mismas, así como de cremas y lociones protectoras cuando resulte pertinente.

A demás, es imprescindible garantizar una higiene estricta de los equipos en todas las fases de la elaboración de los alimentos. En el funcionamiento ordinario de la mayoría de las instalaciones, las normas de seguridad son eficaces para controlar los riesgos vinculados a la maquinaria. En el ciclo de higiene, los equipos deben abrirse, deben desmontarse los dispositivos de protección e inabilitarse los sistemas de enclavamiento. R esulta frustrante que el diseño de las máquinas responda a su funcionamiento y que su limpieza ocupe por lo común un plano secundario, como lo demuestra la enorme proporción de lesiones graves producidas en esta fase del proceso. Sus causas más comunes son los puntos de atenazado para la introducción de material, el agua caliente, los productos químicos y las salpicaduras de ácidos o de bases, así como la limpieza de equipos en movimiento. Las mangas de aire comprimido que transportan agua caliente también constituyen un peligro. La falta de procedimientos específicos de cada equipo, la formación deficiente y el escaso nivel de experiencia de los trabajadores novatos que son obligados a realizar tareas de limpieza pueden agravar el problema. El riesgo aumenta cuando la maquinaria que debe limpiarse se sitúa en áreas de acceso difícil. Es esencial que exista un programa eficaz de procedimientos de bloqueo y carteles de advertencia. U na buena práctica actual que facilita la superación de este problema es el diseño de instalaciones para la limpieza en el lugar de ubicación del equipo. Algunas máquinas se diseñan para su autolimpieza mediante la utilización de esferas pulverizadoras a alta presión y de sistemas de autolavado, pero es muy frecuente que deba recurrirse a los servicios de trabajadores que se ocupan de puntos problemáticos. Por ejemplo, en las industrias de la carne y las aves, todas las operaciones de limpieza son manuales.

\section{Riesgos para la salud}

Las infecciones y las enfermedades infecciosas o parasitarias propagadas por animales o por los productos de desecho de éstos utilizados en la fabricación son problemas profesionales comunes en la industria alimentaria. Entre estas zoonosis se encuentran el ántrax, la brucelosis, la leptospirosis, la tularemia, la tuberculosis bovina, el muermo, la erisipela, la fiebre Q , la fiebre aftosa, la hidrofobia, etc. Algunos manipuladores de alimentos pueden contraer una amplia gama de infecciones de la piel, incluido el ántrax, la actinomicosis y la erisipela. Ciertos frutos secos están plagadas de ácaros que pueden afectar a los trabajadores en las operaciones de clasificación.

A parte de la vacunación profiláctica específica contra las enfermedades infecciosas, la utilización de guantes adecuados, una higiene personal apropiada y unas instalaciones sanitarias que permitan adoptar tales precauciones (que constituyen un requisito previo de toda industria alimentaria como protección del producto) son las medidas preventivas más importantes. U nos buenos servicios de lavado, que incluyan duchas, y la equipación con ropa protectora apropiada son esenciales. Es igualmente importante disponer de una asistencia médica eficaz, sobre todo en el tratamiento de lesiones menores.

Las dermatitis de contacto y las alergias de la piel o del sistema respiratorio provocadas por productos orgánicos, animales o vegetales, también son habituales. La dermatitis puede deberse a la acción de productos irritantes como ácidos, álcalis, detergentes y agua utilizados en las tareas de limpieza; la fricción producida en las operaciones de recogida y embalaje de fruta; y la manipulación del azúcar, muy utilizado en la elaboración de ciertos alimentos. La sensibilización secundaria se deriva de la manipulación de numerosas frutas y verduras. Asimismo, los polvos orgánicos generados por los cereales o la harina pueden causar enfermedades respiratorias (p. ej., el "asma del panadero") y deben controlarse. Con demasiada frecuencia, en la industria alimentaria se consideran los materiales utilizados como meros ingredientes, y no como productos químicos que pueden afectar a la salud cuando los trabajadores se exponen a fuerzas o cantidades industriales de ingredientes "normales" empleados en la cocina doméstica.

\section{Enfermedades por traumas acumulados}

En muchos de los centros de elaboración de carnes, pescados, aves y otros alimentos, se realizan tareas enérgicas y muy repetitivas. La propia naturaleza de los productos obliga con frecuencia a utilizar trabajadores para su manipulación al inspeccionar 0 cargar artículos frágiles en los embalajes o durante el proceso de ampliación de la producción antes de que se adquieran e instalen equipos de gran volumen. Además, el manejo de cajas para su traslado puede provocar lesiones de espalda. D eben vigilarse las tareas que exigen la adopción de posturas extremas, las fuerzas de gran intensidad y los niveles de repetición elevados. Las combinaciones de varios de estos factores agravan el problema. Es deseable una detección y un tratamiento precoz de los trabajadores afectados. El diseño ergonómico de los equipos y otras transformaciones analizadas en artículos específicos incluidos en el presente capítulo reducen la incidencia de estos riesgos.

Los refrigerantes como el amoníaco anhidro, el cloruro de metilo y otros hidrocarburos alifáticos halogenados utilizados en procesos de congelación y en cámaras frigoríficas plantean riesgos de intoxicación y quemaduras químicas. Es importante llevar a cabo una planificación de urgencias, además de la habitual relativa a incendios. $L$ a formación de los trabajadores en lo que respecta a procedimientos de evacuación también es necesaria. En la evacuación de ciertas áreas de las instalaciones puede requerirse una protección respiratoria como la utilizada en situaciones de evacuación. En el caso de algunos productos químicos, se utilizan sensores en los edificios para que los trabajadores sean advertidos desde un primer momento mediante un sistema de alarma central que señala la necesidad de evacuar el lugar. Las reacciones de los trabajadores a los aumentos del nivel de amoníaco deben considerarse detenidamente, y los que resulten afectados deben ser evacuados y tratados. Las fugas de esta sustancia requieren una atención estricta y una vigilancia continua. La evacuación puede ser imprescindible si los niveles comienzan a elevarse y antes de que se alcancen niveles peligrosos. D ebe seleccionarse un lugar común de reunión de forma que los evacuados no corran el peligro de situarse en la misma dirección de la fuga de refrigerante. $\mathrm{H}$ a de emplearse ropa de protección contra sustancias químicas para aproximarse con determinación al lugar de la fuga y contener el vertido. El 
amoníaco anhidro y otros refrigerantes utilizados con menor frecuencia, como el propano, el butano, el etano y el etileno, son asimismo inflamables y explosivos. Las fugas en los tubos de conducción suelen deberse a un mantenimiento inadecuado y pueden evitarse prestando la debida atención. D eben adoptarse las medidas oportunas para prevenir las explosiones y luchar contra los incendios.

Los plaguicidas, los productos fumigantes y otros materiales peligrosos deben someterse a un control estricto y utilizarse únicamente de acuerdo con las directrices de los fabricantes. Los plaguicidas organosfosfatados sólo deben emplearse si son objeto de un seguimiento biológico que asegure el control de la exposición.

La soldadura tradicional con aleaciones de estaño y plomo de las juntas de las latas de alimentos y la sensibilización respecto al problema de los niveles de este último elemento en los productos ha dado lugar a la realización de estudios sobre niveles de plomo ambiental en las unidades de fabricación de envases y niveles hemáticos de plomo de los trabajadores. Los datos recogidos indican un aumento de ambas magnitudes, pero no se ha superado en ningún caso el valor límite umbral (TLV) ni los niveles hemáticos aceptados en la actualidad. Por tanto, los resultados son coherentes con un proceso del plomo "de bajo riesgo".

El dióxido de carbono, utilizado en la refrigeración de productos que deben transportarse, ha de mantenerse asimismo bajo controles estrictos. Debe garantizarse una ventilación adecuada sobre los recipientes de hielo seco para evitar que el gas tenga efectos nocivos.

La exposición al frío puede ir desde la manipulación y el almacenamiento de materias primas en invierno, o en salas de elaboración y mantenimiento refrigeradas con "aire en calma", a extremos como la refrigeración de materias primas por chorro de aire, como en las industrias de fabricación de helados y de elaboración de alimentos congelados. L os trabajadores que desarrollan su labor en áreas de almacenamiento en frío pueden ver deteriorada su salud debido a la exposición a bajas temperaturas si no se les proporcionan ropas protectoras adecuadas. Tal exposición reviste gran importancia en el caso de los trabajadores con actividades sedentarias en entornos muy fríos. Deben instalarse barreras que desvíen las corrientes que afectan al personal situado cerca de los ventiladores utilizados para hacer circular el aire. Es aconsejable la rotación de puestos de trabajo que permita el desempeño de tareas en puestos de mayor actividad 0 en lugares más cálidos. En las instalaciones de congelación en grandes túneles, puede resultar letal para los trabajadores la exposición a corrientes de aire que se desplazan a gran velocidad, incluso con ropa polar. Es fundamental prohibir la entrada a los congeladores de túnel en funcionamiento y disponer de bloqueos eficaces o utilizar protocolos de acceso a espacios restringidos para garantizar que los congeladores no puedan ponerse en marcha cuando los trabajadores aún permanecen en los mismos. L os comedores con temperatura acondicionada y la provisión de bebidascalientesmitigan losefectosdel trabajo con frío.

El calor, combinado a menudo con una humedad elevada en las operaciones de cocción y esterilización, puede producir un entorno físico igualmente intolerable, en el que el golpe de calor y el agotamiento por las elevadas temperaturas constituyen un problema digno de consideración. Son condiciones especialmente habituales en las tareas que exigen la evaporación de soluciones, como la fabricación de pasta de tomate, sobre todo en países donde prevalece inicialmente la influencia del calor. Este predomina asimismo en las salas de sacrificio de los mataderos. La instalación de sistemas de ventilación eficaces es esencial, y debe prestarse especial atención a los problemas de condensación. El aire acondicionado puede ser necesario en algunas áreas.
Un riesgo grave para la salud en la mayoría de las fábricas modernas, y en especial en las conserveras, es la exposición al ruido. El aumento del número de máquinas de alta velocidad dispuestas en un espacio limitado eleva los niveles de ruido, a pesar del esfuerzo dedicado a mantenerlos por debajo de los $85 \mathrm{dBA}$. La fabricación, el transporte y el llenado de latas a velocidades de hasta 1.000 unidades por minuto da lugar a la exposición de los operarios a niveles de ruido en torno a los $100 \mathrm{dBA}$ a frecuencias que oscilan entre los 500 y los $4.000 \mathrm{~Hz}$, lo que constituye una dosis equivalente a unos $96 \mathrm{dBA}$, que, si no se controlan, provocan en muchos casos sorderas inducidas por el ruido a lo largo de la vida laboral. Ciertas técnicas de ingeniería, como el montaje de insonorización, los elevadores magnéticos, los cables recubiertos de nylon y los reguladores de velocidad en los sistemas transportadores, pueden atenuar el problema en cierta medida. No obstante, la adopción de cambios radicales en la industria, como la utilización de envases de plástico, constituye la única esperanza de lograr en el futuro un entorno razonablemente insonorizado. Actualmente, debe aplicarse un programa de conservación de la audición basado en los exámenes audiométricos, los equipos de protección sonora y la formación. Deben instalarse asimismo cabinas aislantes del ruido y equipos de protección personal.

En caso de utilización de radiación ionizante son necesarias todas las precauciones aplicables a este tipo de trabajo (p. ej., protección contra la radiación, control de los riesgos, exploración sanitaria selectiva y exámenes médicos periódicos).

La supervisión médica de los trabajadores es conveniente; muchos centros de producción alimentaria son pequeños y la afiliación a un servicio médico mancomunado puede constituir la forma más eficaz de garantizar esta prestación.

Los comités de salud y seguridad que consiguen la participación efectiva del conjunto de la organización, incluidos los trabajadores dedicados a las tareas de producción, en el desarrollo de programas aplicables en los centros de trabajo son esenciales para lograr la seguridad de las operaciones. Con demasiada frecuencia, la industria alimentaria no se considera especialmente peligrosa y se generaliza un sentimiento de complacencia. Suelen utilizarse materiales muy conocidos y, por esta razón, los trabajadores pueden no comprender los riesgos que se generan cuando se aplican fuerzas o cantidades industriales. Los miembros del personal que entienden que las normas y los procedimientos de seguridad se adoptan para proteger su salud y su seguridad y no simplemente para cumplir con los requisitos impuestos por la Administración son esenciales para el desarrollo de un programa de seguridad de calidad. La dirección debe establecer prácticas y políticas que permitan a los trabajadores consolidar estas creencias.

\section{EFECTOS SOBRE LA SALUD Y PAUTAS PAT O LOGICAS}

John J. Svagr

Los efectos de la elaboración de alimentos sobre la salud son similares a los registrados en otras actividades manufactureras. Trastornos respiratorios y musculosqueléticos, enfermedades de la piel y alergias de contacto y deterioro de la audición son algunos de los problemas de salud más comunes en la industria alimentaria (Tomoda 1993; BLS 1991; Caisse nationale d'assurance maladie des travailleurs salariés 1990). La exposición a temperaturas extremas constituye otra fuente de preocupación. En la Tabla 67.2 se ofrece una clasificación de las tres 
Tabla 67.2 • Enfermedades profesionales más habituales en las industrias alimentarias de varios países.

\begin{tabular}{|c|c|c|c|c|c|}
\hline \multirow[t]{2}{*}{ País } & \multirow[t]{2}{*}{ Año } & \multicolumn{2}{|c|}{ Enfermedades profesionales más comunes } & \multirow[b]{2}{*}{ Tercera } & \multirow[b]{2}{*}{ Otras } \\
\hline & & Primera & Segunda & & \\
\hline Austria & 1989 & Bronquitis, asma & Deficiencia auditiva & Enfermedades de la piel & $\begin{array}{l}\text { Infecciones transmitidas por } \\
\text { animales }\end{array}$ \\
\hline $\begin{array}{l}\text { Bélgica } \\
\text { (alimentación) }\end{array}$ & 1988 & $\begin{array}{l}\text { Enfermedades inducidas por } \\
\text { inhalación de sustancias }\end{array}$ & $\begin{array}{l}\text { Enfermedades inducidas por } \\
\text { agentes físicos }\end{array}$ & Enfermedades de la piel & $\begin{array}{l}\text { Infecciones o parásitos de } \\
\text { animales }\end{array}$ \\
\hline $\begin{array}{l}\text { Bélgica } \\
\text { (producción de } \\
\text { bebidas) }\end{array}$ & 1988 & $\begin{array}{l}\text { Enfermedades debidas a agentes } \\
\text { físicos }\end{array}$ & $\begin{array}{l}\text { Enfermedades inducidas por } \\
\text { agentes químicos }\end{array}$ & $\begin{array}{l}\text { Enfermedades inducidas por } \\
\text { inhalación de sustancias }\end{array}$ & - \\
\hline Colombia & 1989 & Deficiencia auditiva & Trastornos respiratorios (asma) & Trastornos musculosqueléticos & Enfermedades de la piel \\
\hline Checoslovaquia & 1988 & Trastornos respiratorios & Trastornos musculosqueléticos & Trastornos digestivos & $\begin{array}{l}\text { Trastornos circulatorios, } \\
\text { enfermedades de la piel }\end{array}$ \\
\hline Dinamarca & 1988 & Trastornos de coordinación física & Enfermedades de la piel & Deficiencia auditiva & Infecciones, alergias \\
\hline Francia & 1988 & $\begin{array}{l}\text { Asma y otros trastornos } \\
\text { respiratorios }\end{array}$ & $\begin{array}{l}\text { Tensiones en diversas partes } \\
\text { del cuerpo ( rodillas, codos) }\end{array}$ & $\begin{array}{l}\text { Septicemia (intoxicación } \\
\text { sanguínea) y otras infecciones }\end{array}$ & Deficiencia auditiva \\
\hline Polonia & 1989 & Trastornos respiratorios & Enfermedades de la piel & Infecciones & Deficiencia auditiva \\
\hline Suecia & 1989 & Trastornos musculosqueléticos & $\begin{array}{l}\text { Alergias (contacto con agentes } \\
\text { químicos) }\end{array}$ & Deficiencia auditiva & Infecciones \\
\hline Estados Unidos & 1989 & $\begin{array}{l}\text { Trastornos asociados a traumas } \\
\text { repetidos }\end{array}$ & Enfermedades de la piel & $\begin{array}{l}\text { Enfermedades debidas a agentes } \\
\text { físicos }\end{array}$ & $\begin{array}{l}\text { Trastornos respiratorios asociados } \\
\text { a la acción de agentes tóxicos }\end{array}$ \\
\hline
\end{tabular}

Fuente: Tomoda 1993.

enfermedades profesionales más habituales en este sector en ciertos países.

\section{Sistema respiratorio}

En general, los problemas respiratorios pueden dividirse en rinitis, que afecta a los conductos nasales; broncoconstricción de las vías respiratorias principales y la neumonitis, que consiste en el deterioro de las estructuras delicadas de los pulmones. La exposición al polvo en suspensión en el aire generado por diversas materias alimenticias, así como por productos químicos, puede provocar enfisemas y asma. En un estudio finlandés se observó que la rinitis crónica es habitual entre los trabajadores de mataderos y de centros de producción de alimentos precocinados (30\%), de fábricas de cereales y panaderías (26\%) y de centros de elaboración de alimentos ( $23 \%$ ). A simismo, los miembros del primer y el último grupo (11 \% y $14 \%$, respectivamente) sufren de toses crónicas. En las panaderías, el agente causante es el polvo de harina, mientras que, en otras ramas, se cree que diversos tipos de polvo (especias) producen las enfermedades.

En dos estudios realizados en la antigua Yugoslavia se detectó una prevalencia de síntomas respiratorios crónicos muy superior a la de un grupo de control. En un estudio de los trabajadores que deben utilizar especias, la dolencia más común $(57,6 \%)$ era la disnea o dificultad respiratoria, seguida por el catarro nasal $(37,0 \%)$, la sinusitis $(27,2 \%)$, la tos crónica $(22,8 \%$ ) y la flema crónica y la bronquitis (19,6 \%). U n estudio de los trabajadores dedicados a la elaboración de alimentos de origen animal puso de relieve que, además de a los ingredientes de los productos fabricados, estos trabajadores se veían expuestos al contacto con polvo de coriandro, ajo, canela, pimiento rojo y otras especias. Los no fumadores analizados mostraron una prevalencia significativamente superior de flema crónica y opresión torácica. En el caso de los fumadores, la prevalencia de toses, flemas y bronquitis crónicas y opresión torácica era superior a la del resto del grupo. $L$ a frecuencia de síntomas respiratorios agudos asociados a la jornada laboral era alta en el grupo expuesto y la capacidad de ventilación respiratoria de los fumadores era muy inferior a lo previsto. Por tanto, en el estudio se concluía que existe una relación entre la exposición al polvo procedente de alimentos de origen animal y el desarrollo de trastornos respiratorios.

En el régimen de indemnizaciones por accidentes laborales del Reino U nido, se reconoce el asma profesional debido al manejo de encimas, animales, cereales y harina. La exposición al aldehído cinámico derivado de la corteza de los árboles y al dióxido de azufre, un blanqueador y fumigante, causa una elevada prevalencia de asma en los trabajadores dedicados a la producción de canela en Sri Lanka. La exposición al polvo es mínima en el caso de los trabajadores que extraen la corteza, pero los que desarroIlan su actividad en los establecimientos de los compradores locales están en contacto con niveles de polvo y dióxido de azufre altos. En un estudio se comprobó que 35 de 40 de estos trabajadores padecían toses crónicas $(37,5 \%)$ o asma $(22,5 \%)$. 0 tros trastornos consistían en la pérdida de peso $(65 \%$ ), la irritación de la piel $(50 \%)$, pérdida de pelo $(37,5 \%)$, irritación de los ojos $(22,5 \%$ ) y erupciones cutáneas (12,5\%). En el caso de los trabajadores expuestos a concentraciones similares de polvo de origen vegetal en suspensión en el aire, la prevalencia del asma era superior en los que trabajan con la canela $(22,5 \%$ frente a un $6,4 \%$ en los dedicados al sector del té y un 2,5\% en los productores de capoc). Se cree que no existe una relación directa del tabaquismo con las toses, ya que se observaron síntomas semejantes en 8 mujeres no fumadoras y 5 hombres que consumían 7 cigarrillos al día. La irritación de las mucosas respiratorias debida al polvo de canela provoca la tos.

En otros estudios se analizó la relación entre los trastornos respiratorios y los alérgenos y los antígenos originados en los alimentos, como la proteína de huevo y los productos obtenidos en el mar. Aunque no pudo vincularse ningún polvo específico presente en lugares de trabajo con las diversas enfermedades respiratorias agudas y crónicas padecidas por los trabajadores expuestos, los resultados indican una fuerte asociación entre estos trastornos y el entorno laboral. 
Hace muchos años que la microbiología forma parte de la producción alimentaria. En general, la mayoría de los microorganismos utilizados en estas industrias se consideran inofensivos. En la elaboración del vino, el queso, el yogur y la pasta agria se emplean procesos microbiológicos para obtener productos consumibles. En la producción de proteínas y encimas se aplican cada vez más técnicas biotecnológicas. Ciertas especies de aspergilos y de bacilos generan amilasas que convierten la fécula en azúcar. L a levadura transforma la fécula en acetona. EI tricoderma y el penicillium producen celulasas que se descomponen en celulosa. Como resultado, las esporas de hongos y actinomicetos se encuentran en abundancia en los procesos de elaboración de alimentos. EI aspergillus y el penicillium suelen estar presentes en la atmósfera de las panaderías. EI segundo se encuentra asimismo en los centros de producción láctea y cárnica; en la maduración de quesos y salchichas puede existir un importante crecimiento en superficie. Las medidas de limpieza adoptadas con anterioridad a la venta dispersan estas sustancias en el aire, y los trabajadores pueden padecer alveolitis alérgica. Los casos de asma profesional se asocian a la acción de muchos de estos organismos, mientras que de algunos otros se sospecha que causan infecciones y transportan micotoxinas. Las encimas tripsina, quimotripsina y proteasa se vinculan a la hipersensibilidad y a los trastornos respiratorios, sobre todo en el caso de los trabajadores de laboratorio.

Además de las partículas en suspensión en el aire generadas en los alimentos y de los agentes microbianos, la inhalación de sustancias químicas peligrosas utilizadas como reactivos, refrigerantes, fumigantes y esterilizadores pueden provocar trastornos respiratorios y de otros tipos. Tales sustancias se encuentran en estado sólido, líquido o gaseoso y la exposición a ellas a niveles similares o superiores a los límites reconocidos suele dar lugar a irritación de la piel y de los ojos y a enfermedades respiratorias. Las migrañas, la salivación, la irritación de la garganta, la transpiración, las náuseas y los vómitos son síntomas de intoxicación debida a la sobreexposición.

El amoníaco es un refrigerante gaseoso incoloro, un agente limpiador y un fumigante utilizado en la elaboración de alimentos. La exposición a esta sustancia puede provocar quemaduras corrosivas o la formación de ampollas en la piel. Si esta exposición es intensa y se prolonga, puede producir bronquitis y neumonía.

El tricloroetileno, el hexano, el benceno, el monóxido de carbono ( $\mathrm{CO})$, el dióxido de carbono $\left(\mathrm{CO}_{2}\right)$ y el cloruro de polivinilo (PVC) suelen abundar en los centros de producción alimentaria. Las dos primeras sustancias se utilizan en la extracción de aceite de oliva.

EI CO, un gas incoloro e inodoro, es difícil de detectar. La exposición tiene lugar en fábricas de ahumados de ventilación deficiente, silos de cereales, bodegas para la fermentación del vino o almacenes de pescado. La congelación o refrigeración con hielo seco, los túneles de congelación por $\mathrm{CO}_{2}$ y los procesos de combustión ponen en contacto a los trabajadores con este gas. Los síntomas de intoxicación por sobreexposición al CO y el $\mathrm{CO}_{2}$ incluyen migrañas, mareos, somnolencia, náuseas, vómitos y, en casos extremos, llegan a producirse fallecimientos. Asimismo, el CO puede agravar los síntomas coronarios y respiratorios. En los límites de tolerancia aceptables establecidos por varios gobiernos se prevé una exposición al $\mathrm{CO}_{2} 100$ veces superior a la del CO para desencadenar la misma respuesta.

EI PVC se utiliza en los materiales de envasado y en los envoltorios de alimentos. Cuando se calienta una película de PVC, Ios productos de degradación térmica irritan los ojos, la nariz y la garganta. Además, los trabajadores declaran padecer dificultades al respirar, dolores en el pecho, náuseas, dolores de músculos, escalofríos y fiebre.
Los hipocloritos, ácidos (fosfórico, nítrico y sulfúrico), cáusticos y compuestos amónicos cuaternarios suelen utilizarse en las tareas de limpieza con productos líquidos. En los laboratorios de microbiología se emplean compuestos de mercurio y formaldehídos (gas y solución de formalina). Para la desinfección de los laboratorios se aplican fenólicos, hipocloritos y glutaraldehído. En caso de una exposición excesiva y de contacto, se produce irritación y corrosión de los ojos, la piel y los pulmones. Una manipulación inapropiada puede dar lugar a la emisión de sustancias altamente tóxicas, como el cloro y los óxidos de azufre.

El Instituto Nacional para la Salud y la Seguridad en el Trabajo (NIOSH) de Estados U nidos informó de que los trabajadores dedicados al lavado de aves con agua superclorada sufren dificultades respiratorias. Entre los síntomas figuran migrañas, irritación de garganta, opresión torácica y dificultad al respirar. Se sospecha que la cloramina es el agente causante. Las cloraminas pueden formarse cuando el agua tratada con amoníaco o el agua hirviendo tratada con aminas entra en contacto con soluciones de hipocloritos utilizadas en las tareas de higienización. En las ciudades se añade amoníaco al agua para evitar la formación de halometanos. No se dispone de métodos de toma de muestras del aire en el caso de las cloraminas. Los datos sobre cloro y amoníaco no son indicativos de la exposición, ya que en las pruebas se registraron niveles de estas sustancias muy por debajo de sus límites.

Los fumigantes previenen la aparición de plagas durante el almacenamiento y el transporte de materias primas alimentarias. Algunos ejemplos de estas sustancias son el amoníaco anhidro, la fostoxina (fosfina) y el bromuro de metilo. La escasa duración de este proceso convierte la protección respiratoria en la estrategia más eficaz en función del coste. Deben seguirse las prácticas adecuadas para lograr esta protección al manipular tales compuestos, hasta que las mediciones atmosféricas del área en cuestión se encuentren por debajo de los límites establecidos.

Las empresas han de adoptar las medidas necesarias para evaluar el nivel de contaminación tóxica en el lugar de trabajo y garantizar que los niveles de exposición no excedan los límites estipulados en las normativas sobre salud y seguridad. El grado de contaminación debe analizarse con frecuencia, sobre todo después de cambios en los métodos de elaboración o en los productos químicos utilizados.

L os controles técnicos concebidos para minimizar el riesgo de intoxicación o infección pueden aplicarse de acuerdo con dos planteamientos. En primer lugar, puede optarse por dejar de emplear ciertos materiales o sustituirlos por otros menos peligrosos. Tal posibilidad exige, por ejemplo, el cambio de una sustancia en polvo por un líquido de mayor o menor densidad. En segundo lugar, puede controlarse la exposición mediante la reducción del nivel de contaminación atmosférica. Los diseños de los lugares de trabajo comprenden los elementos siguientes: aislamiento total o parcial del proceso, aplicación de sistemas de ventilación adecuados y restricción del acceso (para reducir el número de personas expuestas). U n sistema de ventilación apropiado resulta esencial en la prevención de la dispersión de esporas o aerosoles en el lugar de trabajo. La sustitución de la aplicación de aire comprimido en los equipos por la limpieza al vacío o con productos líquidos es fundamental para evitar que ciertos materiales queden en suspensión en el aire durante la realización de estas tareas

Entre los controles administrativos se cuentan la rotación de trabajadores (para reducir el período de exposición) y la realización de tareas peligrosas en fines de semana y en períodos ajenos a los turnos habituales (para reducir el número de personas expuestas). La utilización de equipos de protección personal (EPP) es el método de control de la exposición menos favorecido 
debido a los elevados costes de mantenimiento, los problemas de disponibilidad en los países en desarrollo y la necesidad de que los trabajadores recuerden que deben emplearlos.

Un EPP consta de gafas contra salpicaduras, protectores faciales y respiradores para el personal encargado de mezclar productos químicos peligrosos. Los trabajadores deben recibir formación sobre la utilización, las limitaciones y la colocación de los equipos para que éstos sirvan adecuadamente a su propósito. Se emplean distintos tipos de respiradores (máscaras) en función de la naturaleza de la tarea efectuada y del nivel del riesgo: desde una sencilla máscara facial que cubre media cara y protege del polvo y el vapor, pasando por depuradores de aire de diversos tipos, hasta aparatos respiradores autónomos (ARA). U na selección adecuada (basada en el riesgo, en la adecuación a la cara y en el mantenimiento) y la formación aseguran la eficacia del respirador en la reducción de la exposición y de la incidencia de los trastornos respiratorios.

\section{Piel}

Los problemas dermatológicos asociados a las industrias alimentarias son la dermatitis y las alergias de contacto (p. ej., el eczema). D ebido a cuestiones de higiene, los trabajadores deben lavarse las manos con jabón muy a menudo, y lo hacen en recipientes que contienen compuestos amónicos cuaternarios. La constante humedad de las manos puede reducir el contenido de lípidos de la piel y dar lugar a la aparición de dermatitis, enfermedad por la que la piel se inflama como resultado del contacto con productos químicos y aditivos alimentarios. El trabajo con grasas y aceites puede obstruir los poros de la piel y generar síntomas acneícos. El $80 \%$ de las dermatitis de origen profesional están causadas por estos irritantes primarios.

Existe una preocupación cada vez mayor por la posibilidad de que aumente la sensibilización de los trabajadores respecto a las proteínas microbianas y los péptidos generados por la fermentación y la extracción, lo que puede dar lugar a eczemas y otras alergias. U na alergia es una respuesta hipersensible de cualquier tipo superior a la que se produce normalmente en presencia de antígenos (no propios) en el medio ambiente. La dermatitis por contacto alérgica no suele detectarse antes del quinto al séptimo día posterior al inicio de la exposición. La dermatitis de origen profesional por hipersensibilidad también se ha observado en trabajadores que están en contacto con encimas como la tripsina, la quimotripsina y la proteasa.

Los disolventes clorados (véase la sección "Sistema respiratorio" anterior) estimulan a las células de la epidermis para adoptar pautas de crecimiento peculiares, y tal estimulación queratínica puede dar lugar a la formación de tumores. 0 tros compuestos clorados presentes en los jabones con fines bactericidas pueden provocar dermatitis por fotosensibilidad.

La reducción de la exposición a los agentes causantes constituye el principal método preventivo de la dermatitis y las alergias de contacto. Un secado adecuado de los alimentos con anterioridad a su almacenamiento y el mantenimiento de la limpieza mientras dure éste pueden facilitar el control de las esporas en suspensión en el aire. LOS EPP, como guantes, máscaras y trajes especiales, previenen el contacto directo de los trabajadores con estas sustancias y reducen al mínimo el riesgo de dermatitis y otras alergias. Los materiales de los guantes de látex pueden provocar reacciones alérgicas en la piel y deben evitarse. Asimismo, una aplicación correcta de cremas protectoras, siempre que sea posible, puede minimizar el contacto con el irritante dérmico.

Las enfermedades infecciosas y parasitarias de origen animal son los trastornos profesionales más específicos de las industrias alimentarias. Son muy comunes en los trabajadores de los sectores cárnico y lácteo, como resultado del contacto directo con los animales infectados. Es un riesgo que corren también los agricultores y otros trabajadores que entran en contacto con animales. La prevención resulta especialmente compleja, ya que es posible que los animales no muestren síntomas de enfermedad. En la Tabla 67.3 se muestran los tipos de infecciones observadas.

El principio fundamental para prevenir la contracción y la difusión de las enfermedades dérmicas infecciosas y parasitarias

Tabla 67.3 - Tipos de infecciones registrados en las industrias alimentarias.

Infecciones
Brucelosis (Brucella melitensis)

Erisipela

Leptospirosis

Epidermicosis

Dematofitosis (tiña)

Toxoplasmosis

\section{Exposición}

Contacto con ganado bovino, caprino y ovino infectado

(Europa septentrional y central y América del norte)

Contacto de heridas abiertas con cerdos y pescado infectado (Checoslovaquia)

Contacto directo con animales infectados y su orina

Causada por un hongo parásito situado en la piel de los animales

Enfermedad micótica debida al contacto con la piel y el pelo de animales infectados

Contacto con ganado bovino, ovino, caprino, porcino y aves infectados

Cáncer de pulmón y papiloma viral Contacto regular con animales vivos o carne de animal combinado con exposición a hidrocarburos aromáticos policíclicos y nitritos

\section{Síntomas}

fiebre constante y recurrente, migrañas, debilidad, dolor de articulaciones, sudores nocturnos y pérdida de apetito; asimismo sintomas de artritis, gripe, astenia y espondilitis.

Enrojecimiento localizado, irritación, sensación de ardor, dolor en el área infectada. Puede propagarse a la corriente sanguínea y a los ganglios linfáticos

Migrañas, dolor muscular, infecciones oculares, fiebre, vómitos y escalofríos; en casos más graves, deterioro hepático y renal, y complicaciones cardiovasculares y neurológicas.

Eritema y aparición de ampollas en la piel.

Pérdida de pelo localizada y pequeñas costras en el cuero cabelludo.

Fase aguda: fiebre, dolor muscular, dolor de garganta, migrañas, hinchazón de los ganglios linfáticos y dilatación del bazo. La infección crónica da lugar al desarrollo de quistes en las células del cerebro y de los músculos. La transmisión fetal provoca abortos y partos prematuros. Los niños nacidos tras el período de gestación normal pueden presentar defectos en el cerebro y el corazón y fallecer.

Cáncer de pulmón en carniceros y trabajadores de mataderos estudiado en Inglaterra, Gales, Dinamarca y Suecia. 
es la higiene personal. Es necesario disponer de baños, lavabos y duchas limpios. Los uniformes, los equipos de protección personal y las toallas de mano deben lavarse y, en algunos casos, esterilizarse con frecuencia. Las heridas han de desinfectarse y vendarse, con independencia de su gravedad, así como cubrirse con un material protector hasta su curación. La limpieza y la higiene del lugar de trabajo son igualmente importantes. Se incluyen aquí un lavado exhaustivo de los equipos y las superficies en contacto con los tejidos animales después de cada jornada laboral, el control y la exterminación de roedores y la exclusión de perros, gatos y otros animales de los centros de trabajo.

La vacunación de animales y la inoculación de trabajadores son medidas adoptadas por numerosos países con el fin de prevenir las enfermedades infecciosas y parasitarias. La detección y el tratamiento precoces de las enfermedades con medicamentos antibacterianos y antiparasitarios son esenciales para contenerlas e, incluso, erradicarlas. Es necesario examinar a los trabajadores tan pronto como aparezca algún síntoma, como toses recurrentes, fiebre, migrañas, irritación de garganta y trastornos intestinales. En cualquier caso, deben someterse a exploraciones médicas con una periodicidad establecida, además de los reconocimientos básicos previos y posteriores a la ocupación de un determinado puesto. En algunos países es obligatorio informar a las autoridades de los casos en que se detecten en las exploraciones infecciones de origen profesional en los trabajadores.

\section{Ruido y audición}

El deterioro de la audición se produce como consecuencia de una exposición continua y prolongada al ruido por encima de los niveles umbral reconocidos, y constituye una enfermedad incurable que causa trastornos de la comunicación y resulta estresante si el trabajo exige concentración. Como resultado, el rendimiento psicológico y fisiológico puede reducirse. Asimismo, existe una asociación entre la exposición a un nivel de ruido elevado y las anomalías en la tensión arterial, la frecuencia cardíaca y el ritmo y el volumen de la respiración, así como la aparición de espasmos estomacales e intestinales y trastornos nerviosos. La susceptibilidad personal, la duración de la exposición y la frecuencia y la intensidad del ruido son factores que determinan el riesgo de la exposición.

Las normativas sobre salud y seguridad varían de un país a otro, pero la exposición de los trabajadores al ruido suele limitarse de 85 a $90 \mathrm{dBA}$ durante 8 horas, seguida de un período de recuperación de 16 horas con un nivel inferior a $80 \mathrm{dBA}$. A partir de $85 \mathrm{dBA}$ debe suministrarse protección auditiva, obligatoria en los casos de pérdida confirmada y en las exposiciones de 8 horas 0 más a niveles iguales o superiores a 90 dBA. Se recomienda la realización de pruebas audiométricas anuales en la población expuesta (en algunos países son obligatorias). Las mediciones del ruido efectuadas con instrumentos como el sonómetro tipo II del A merican National Standards I nstitute (ANSI) deben llevarse a cabo, al menos, cada dos años, y repetirse siempre que las modificaciones de los equipos o de los procesos puedan aumentar los niveles de ruido ambiental.

Garantizar que el grado de exposición al ruido no resulta peligroso constituye la estrategia fundamental de los controles sonoros. Las buenas prácticas de fabricación exigen que los dispositivos de control y sus superficies de contacto puedan limpiarse, no alberguen plagas y hayan recibido las autorizaciones necesarias para ponerse en contacto con alimentos 0 contribuir a la producción de éstos. Asimismo, los métodos adoptados dependen de la disponibilidad de recursos financieros, equipos, materiales y personal capacitado. Uno de los factores más importantes en la reducción del ruido es el diseño del lugar de trabajo. Los equipos deben concebirse para una generación mínima de ruido y vibración. La sustitución de los componentes metálicos por otros materiales más blandos, como el caucho, puede contribuir a la consecución de este objetivo. Al adquirir maquinarias nuevas o de sustitución, debe optarse por las menos ruidosas. Es necesario instalar silenciadores en las válvulas de aire y en los tubos de escape. Las máquinas y los procesos que generan ruido deben aislarse con el fin de reducir al mínimo el número de trabajadores expuestos a niveles de contaminación acústica elevados. Cuando sea posible, se instalarán tabiques y techos que atenúen y absorban el ruido, y el traslado y la limpieza de los mismos debe incluirse en los costes de mantenimiento. La mejor solución suele consistir en la combinación de estas medidas, adaptadas a las necesidades de cada lugar de trabajo.

Cuando los controles técnicos no sean viables o resulte imposible reducir el ruido a niveles no nocivos, deben utilizarse EPP para proteger los oídos. La disponibilidad de estos equipos y la sensibilización de los trabajadores son importantes para prevenir el deterioro auditivo. En general, una selección de los tapones y de otros dispositivos protectores facilitará una mayor aceptación y un uso más generalizado.

\section{Sistema musculosquelético}

En los datos de 1988-1989 también se reflejó la existencia de trastornos musculosqueléticos (véase la Tabla 67.2). En los correspondientes a principios del decenio de 1990 se señala que un número cada vez mayor de trabajadores declaraban padecer este tipo de dolencias. La automatización de los centros de producción y la regulación del ritmo de trabajo por parte de máquinas o cintas transportadoras afecta en la actualidad a una cantidad de trabajadores de la industria alimentaria sin precedentes. Las tareas en este tipo de centros suelen ser monótonas y los trabajadores realizan el mismo movimiento todo el día.

En un estudio finlandés se observó que casi el $40 \%$ de los participantes en el mismo realizaban trabajos repetitivos a lo largo de la jornada laboral. De este colectivo, el $60 \%$ utilizaba las manos, el $37 \%$, más de una parte del cuerpo y el $3 \%$, los pies. L os trabajadores de los siguientes grupos profesionales efectúan tareas repetitivas durante dos tercios o más de sus jornadas de trabajo: el $70 \%$ del personal de limpieza, el $67 \%$ de los trabajadores de mataderos y centros de elaboración de alimentos precocinados y envasado; el $56 \%$ de los trabajadores de almacenes y dedicados al transporte y el $54 \%$ de los trabajadores del sector lácteo.

Las tensiones ergonómicas se deben a que la mayoría de los productos alimentarios proceden de fuentes naturales y no son uniformes. La manipulación de la carne obliga a los trabajadores a tratar con reses de diversos tamaños. Con la introducción de la venta de aves en porciones en el decenio de 1960, un mayor número de éstas (un $40 \%$, frente a una proporción anterior inferior al $20 \%$ ) son troceadas. Así pues, los trabajadores deben realizar numerosos cortes con herramientas afiladas. La modificación de los procedimientos de inspección del Departamento de Agricultura de Estados U nidos (USDA) permiten en la actualidad aumentar la velocidad media de producción en cadena de 56 a 90 aves por minuto. Las operaciones de envasado pueden exigir la realización de movimientos de mano y muñeca repetitivos para colocar los productos terminados en bandejas o paquetes sin dañarlos. Así ocurre especialmente en el caso de los nuevos productos, ya que es posible que el mercado no justifique la adopción de operaciones de gran volumen. Las promociones especiales, incluidas las recetas y los cupones, pueden obligar a la introducción manual de productos en los paquetes. El envasado de ingredientes y la disposición del lugar de trabajo pueden exigir que los pesos que han de levantarse 
superen los límites de acción recomendados por los organismos competentes en materia de salud en el trabajo.

Entre las lesiones por effuerzo repetitivo (LER) figuran la inflamación de tendones (tendinitis) y de la envoltura del tendón (tenosinovitis). Son dolencias prevalentes en los trabajadores cuya tarea exige la realización de movimientos manuales repetitivos, como los de la industria cárnica. Las tareas que obligan reiteradamente a doblar la muñeca y a agarrar, apretar y girar pueden causar el síndrome del túnel carpiano (STC). Caracterizado por una sensación de hormigueo en los dedos pulgar, índice, medio y anular, es un trastorno que se debe a la inflamación de la articulación de la muñeca, que presiona al sistema nervioso de ésta. El diagnóstico erróneo del STC como artritis puede dar lugar a un entumecimiento permanente y al padecimiento de fuertes dolores en las manos, codos y hombros.

Los trastornos debidos a la vibración también se asocian a un aumento en el grado de mecanización. Los trabajadores de la industria alimentaria no son una excepción, aunque tal vez el problema no sea tan grave como en otros sectores. Los miembros de este colectivo que utilizan máquinas, como sierras de banda, mezcladores y cuchillas, están expuestos a las vibraciones. Además, las bajas temperaturas elevan la probabilidad de sufrir este tipo de trastornos en los dedos de la mano. Un $5 \%$ de los participantes en el estudio finlandés mencionado padecieron un nivel de vibración elevado, y un $9 \%$, intermedio.

Una exposición excesiva a la vibración provoca, entre otros problemas, trastornos musculosqueléticos en las muñecas, los codos y los hombros. El tipo y el grado de las dolencias dependen de la clase de máquina, del modo en que se emplee y del nivel de oscilación en cuestión. U na vibración elevada puede dar lugar al crecimiento de protuberancias en los huesos y la destrucción gradual del hueso en la articulación, lo que produce fuertes dolores y/ o una limitación de la movilidad.

La rotación de trabajadores como vía para evitar los movimientos repetitivos puede reducir el riesgo mediante el reparto de la tarea crítica entre los miembros de un grupo. El trabajo en equipo mediante la rotación de tareas o la manipulación de sacos de ingredientes pesados o incómodos por dos personas puede reducir el estrés soportado por un solo trabajador en el manejo de materiales. EI mantenimiento de herramientas, y en especial el afilado de cuchillos, desempeña asimismo un papel importante. Un equipo ergonómico de trabajadores de gestión y producción puede abordar mejor estas cuestiones a medida que se plantean.

Los controles técnicos se centran en la reducción o la eliminación de las tres causas principales de problemas musculosqueléticos: fuerza, posición y repetición. El lugar de trabajo debe ser analizado para detectar los cambios necesarios, incluido el diseño de los puestos de trabajo (favoreciendo la ajustabilidad), los métodos de trabajo, las ayudas automáticas o mecánicas a la realización de tareas y las herramientas de mano adecuadas desde el punto de vista ergonómico. D ebe impartirse una formación apropiada a los trabajadores que utilizan cuchillos sobre el afilado de estos instrumentos para minimizar la fuerza aplicada. Además, los centros de producción deben ofrecer instalaciones de afilado adecuadas y evitar el corte de carne congelada. La formación facilita a los trabajadores la comprensión de la causa y la prevención de los trastornos musculosqueléticos. R efuerza la necesidad de utilizar correctamente las herramientas y las máquinas específicas para cada tarea. A simismo, debe animar a los trabajadores a declarar los síntomas médicos que presenten a la mayor brevedad posible. La supresión de intervenciones médicas más invasivas mediante la restricción de tareas y otras medidas de atención moderadas es un método eficaz de tratamiento de estas dolencias.

\section{Frío y calor}

En las áreas de trabajo de las industrias alimentarias se registran temperaturas extremas. $\mathrm{H}$ ay personas que deben desarrollar su actividad en cámaras frigoríficas con temperaturas de $-18^{\circ} \mathrm{C} 0$ inferiores. Las ropas utilizadas en estos lugares ayudan a aislar al trabajador del frío, pero es necesario además disponer de salas de descanso acondicionadas en las que se puedan consumir bebidas calientes. L os centros de producción cárnica deben mantenerse a temperaturas que oscilan entre los 7 y los $10{ }^{\circ} \mathrm{C}$. Es una banda que se encuentra por debajo del umbral de comodidad y es posible que los trabajadores necesiten utilizar ropas adicionales.

Los hornos y los cocedores de vapor generan calor radiante y húmedo. El estrés por calor puede producirse durante los cambios de estación y las olas de calor. El consumo abundante de líquidos y la salazón de los alimentos pueden aliviar los síntomas hasta que el trabajador se aclimate, normalmente transcurridos de 5 a 10 días. Las pastillas de sal no son recomendables debido a las complicaciones asociadas a la hipertensión y los trastornos gastrointestinales.

\section{PROTECCION AMBIENTAL Y CUESTIONES DE SALUD PUBLICA}

Jerry Spiegel

\section{Visión general}

La industria alimentaria depende directamente del medio ambiente natural para garantizar un suministro de materias primas que permita obtener productos libres de contaminantes adecuados para el consumo humano. Debido al amplio proceso de elaboración de un gran volumen de materiales, la capacidad de repercutir en el medio ambiente es considerable. Lo mismo ocurre en la industria de la producción de bebidas

En un contexto ecológico, el interés respecto a la industria alimentaria se centra más en las cargas de contaminantes orgánicos que en el efecto de las sustancias tóxicas. Si estas cargas no se previenen o controlan adecuadamente, pondrán en apuros las infraestructuras comunitarias de supervisión de la contaminación o afectarán de manera negativa a los ecosistemas locales. Las técnicas de producción que controlan las pérdidas de producto cumplen la doble función de mejorar el rendimiento y la eficacia y, al mismo tiempo, reducir los residuos potenciales y atenuar los problemas de contaminación.

Aunque la disponibilidad de agua potable es esencial, la industria alimentaria también requiere grandes volúmenes de este elemento para diversos usos ajenos al consumo, como la limpieza inicial de las materias primas, el lavado en canaletas, el escaldado, la pasteurización, la limpieza de los equipos productivos y la refrigeración del producto terminado. Los usos del agua se determinan en función de criterios de calidad para diferentes aplicaciones, y los de calidad superior suelen exigir un tratamiento específico para asegurar una eliminación completa de olor y sabor y garantizar la existencia de condiciones uniformes.

EI tratamiento de grandes cantidades de material plantea un problema potencialmente grave, relativo a la gestión de los residuos sólidos en la fase de producción. Los residuos del envasado son objeto de una atención cada vez mayor en lo que se refiere a la fase posterior al consumo del ciclo vital de un producto. En ciertas ramas de la industria alimentaria las actividades de elaboración se vinculan asimismo a la posibilidad de emisiones atmosféricas y a problemas de control de olores.

A pesar de la considerable variación existente entre subsectores específicos de la industria, los planteamientos respecto a la 
prevención y al control de la contaminación comparten numerosas características generales.

\section{Control de la contaminación del agua}

La industria alimentaria genera un efluente de residuos antes de su tratamiento con un contenido extremadamente alto de materia orgánica soluble. Incluso las pequeñas fábricas estacionales producen cargas de residuos equiparables a las de poblaciones de 15.000 a 25.000 habitantes, mientras que las grandes generan cantidades de residuos comparables a las correspondientes a unas 250.000 personas. Si las corrientes o cursos de agua que reciben los efluentes son demasiados pequeños y el volumen de los residuos demasiado grande, éstos utilizarán el oxígeno disuelto en el proceso de estabilización y contaminarán o degradarán el agua mediante la reducción de los niveles de este elemento a cifras inferiores a las que requieren organismos acuáticos normales. En la mayoría de los casos, los residuos procedentes de los centros de producción alimentaria pueden someterse a tratamiento biológico.

La importancia de las aguas residuales varía considerablemente en función del tipo de fábrica, los procesos específicos aplicados y las características de las materias primas. D esde un punto de vista económico, suele resultar menos costoso tratar residuos de gran potencia y escaso volumen que los de índole inversa. Por esta razón, los efluentes con una elevada demanda biológica de oxígeno (DBO), como la sangre de los pollos o la carne, no deben verterse a las alcantarillas de los centros de producción avícola y cárnica para reducir la carga de contaminación y conservarse en recipientes para su evacuación individual en un centro de tratamiento de subproductos 0 de clasificación.

Los cursos de aguas residuales con valores de $\mathrm{pH}$ (acidez) extremos deben ser objeto de especial atención debido a su efecto sobre el tratamiento biológico. La combinación de cursos de agua con residuos ácidos y básicos puede dar lugar a la neutralización y, siempre que sea posible, la cooperación con industrias circundantes puede resultar muy beneficiosa.

La parte líquida de los residuos alimentarios suele tamizarse 0 separarse después de su asentamiento, como fase preliminar en todo proceso de tratamiento, con el fin de poder evacuar éstos como basura o combinados con otros sólidos en un programa de recuperación de subproductos.

El tratamiento de las aguas residuales puede llevarse a cabo siguiendo diversos métodos físicos, químicos y biológicos. Puesto que los procesos secundarios son más caros, la utilización al máximo del tratamiento primario es fundamental en la reducción de las cargas de contaminantes. En este tipo de tratamiento se incluyen procesos como el depósito o la sedimentación simple, la filtración (simple, doble y múltiple), la floculación, la flotación, el intercambio de iones por centrifugación, la ósmosis inversa, la absorción de carbono y la precipitación química. Las instalaciones de sedimentación van desde sencillos estanques a complejos depósitos de decantación diseñados de forma específica para las características de cada curso de aguas residuales.

La utilización de un tratamiento biológico secundario con posterioridad al primario suele constituir una necesidad si se trata de alcanzar ciertos niveles relativos a los efluentes líquidos. Como la mayoría de las aguas residuales de la industria alimentaria contienen principalmente contaminantes orgánicos biodegradables, los procesos biológicos utilizados como tratamiento secundario pretenden reducir la DBO del curso mezclando combinaciones superiores de organismos y oxígeno en el mismo para facilitar una rápida oxidación y su estabilización antes de su evacuación al medio ambiente.

Las técnicas y las combinaciones de éstas pueden adaptarse para hacer frente a condiciones específicas de los residuos. Por ejemplo, en el caso de los generados por la industria láctea, se ha comprobado la eficacia del tratamiento anaeróbico encaminado a eliminar la parte principal de la carga contaminante, unido a un tratamiento aeróbico posterior diseñado para reducir la DBO residual y la demanda química de oxígeno (DQ O) hasta alcanzar valores inferiores y separar los nutrientes biológicamente. La combinación biogaseosa de metano $\left(\mathrm{CH}_{4}\right)$ y $\mathrm{CO}_{2}$ resultante del tratamiento anaeróbico puede capturarse y emplearse como alternativa a los combustibles fósiles o como fuente generadora de energía eléctrica (normalmente, $0,30 \mathrm{~m}^{3}$ de biogás por kg de DQ 0 eliminada).

Son ejemplos de otros métodos secundarios de amplia utilización el proceso de cienos activos, los filtros aeróbicos percoladores, el riego por aspersión y la utilización de diversos estanques y lagunas. La existencia de malos olores se ha asociado al empleo de estanques de profundidad inadecuada. L os olores generados por los procesos anaeróbicos pueden eliminarse mediante la aplicación de filtros de suelo que oxiden los gases polares desagradables.

\section{Control de la contaminación atmosférica}

La contaminación atmosférica generada por la industria alimentaria suele centrarse en la cuestión de los olores desagradables más que en las emisiones tóxicas, con algunas excepciones. Por esta razón, por ejemplo, numerosas ciudades han regulado la ubicación de los mataderos en sus normativas sanitarias. El aislamiento es una forma obvia de reducir las quejas de la comunidad respecto a la producción de olores. Ahora bien, con ello no se elimina el problema. En ocasiones es necesario adoptar medidas de control, como la instalación de absorbentes o depuradores.

U n motivo de preocupación fundamental en el contexto de la salud en las industrias alimentarias es el de las fugas de gas amoníaco de las unidades de refrigeración. Es un elemento que irrita gravemente los ojos y el aparato respiratorio, y si el escape es importante, pueden exigir la evacuación de los habitantes de la zona. Es necesario disponer de un plan de control de fugas y de procedimientos de urgencia.

Los procesos alimentarios en los que se utilizan disolventes (p. ej., tratamiento del aceite para consumo humano) pueden emitir vapores de estas sustancias a la atmósfera. Los sistemas cerrados y el reciclado de los disolventes constituyen el método de control más eficaz. Industrias como las del refinado de la caña de azúcar, en las que se emplean el ácido sulfúrico y otros ácidos, pueden emitir a la atmósfera óxidos de azufre y otros contaminantes. Deben aplicarse dispositivos de control, como los depuradores.

\section{Gestión de residuos sólidos}

Los residuos sólidos pueden ser bastante importantes. Por ejemplo, los del tomate para enlatado constituyen de un 15 a un $30 \%$ de la cantidad total del producto elaborado; en el caso de los guisantes y el maíz, esta proporción supera el $75 \%$. M ediante el aislamiento de los residuos sólidos, la concentración de sustancias orgánicas solubles en las aguas residuales se reduce y aquéllos pueden emplearse con mayor facilidad como subproductos, alimentos o combustible.

La utilización de los subproductos de los procesos de un modo rentable reduce el coste global del tratamiento de residuos y, en última instancia, el coste del producto final. Los residuos sólidos deben evaluarse como fuentes de alimentación de plantas y animales. Cada vez se atiende más al desarrollo de mercados de subproductos y del abono producido mediante la transformación de los materiales orgánicos residuales en humus inocuo. En la Tabla 67.4 se ofrecen ejemplos de los usos de los subproductos generados por la industria alimentaria. 


\section{Reutilización del agua y reducción de los efluentes}

La gran dependencia respecto al agua de las industrias alimentarias ha fomentado el desarrollo de programas de conservación y reutilización, sobre todo en lugares donde este recurso escasea. La reutilización del agua empleada en los distintos procesos puede facilitar una reducción sustancial de su consumo y de la carga de residuos, y la adopción de esta medida en numerosas aplicaciones de calidad inferior no exige un tratamiento biológico. Con todo, la posibilidad de fermentación anaeróbica de los sólidos orgánicos debe evitarse, de forma que los productos de descomposición, olorosos y corrosivos, no afecten a los equipos, el medio ambiente de trabajo y la calidad de los productos. El crecimiento bacteriano puede controlarse mediante la desinfección y

Tabla 67.4 • Ejemplos de utilización de subproductos de las industrias alimentarias.

$\begin{array}{ll}\text { Método } & \text { Ejemplos } \\ \text { Digestión } & \text { Digestión mediante una población de bacterias combinada } \\ \text { anaeróbica } & \text { para producir metano y } \mathrm{CO}_{2} \\ & \text { - Tartas de prensa de manzana, fibra de albaricoque, residuos } \\ & \text { de melocotones y peras, piel de naranja } \\ \text { Alimentación } & \text { Directamente, después del prensado o el secado, como ensi- } \\ \text { animal } & \text { lado de pienso o como complemento } \\ & \text { - Amplia gama de residuos de elaboración de frutas y } \\ & \text { verduras } \\ & \text { - Paja de cereales con álcalis para mejorar la digestibilidad } \\ \text { Compostación } & \text { Proceso microbiológico natural en el que los componentes } \\ & \text { orgánicos se descomponen en condiciones aeróbicas } \\ & \text { controladas } \\ & \text { - Cieno deshidratado procedente de los residuos de braceaje } \\ & \text { - Amplia gama de residuos de frutas y verduras } \\ & \text { - Residuos gelatinosos }\end{array}$

Fibra comestible Método para utilizar sólidos orgánicos mediante el filtrado y la hidratación

- Fibras de pulpa de manzana y pera utilizadas para productos horneados, productos farmacéuticos

- Cáscaras de avena u otras semillas

Fermentación Combinación de almidón, azúcar, y sustancias con contenido alcohólico

- Biomasa (residuos agrarios, madera, basuras) para producir etanol

- Residuos de patata para producir metano

- Azúcar derivado del almidón de maíz para producir plásticos biodegradables

Incineración Quemado de biomasa como combustible

- Huesos de frutas, hojas

Pirólisis Transformación de cáscaras de frutos secos y huesos de frutas en briquetas de carbón vegetal

- Huesos de melocotón, albaricoque y aceituna; cáscaras de almendra y nuez

Enmienda del Fertilización de los suelos con escaso contenido de materia suelo orgánica y nutrientes

- Melocotones, peras, tomates

\section{Tratamiento de las aguas residuales en la industria láctea}

La industria láctea se caracteriza por la existencia de muchas fábricas relativamente pequeñas que ofrecen productos como leche, queso, requesón, nata, helados, suero y lactosa.

Desde hace tiempo, la industria láctea ha defendido el tratamiento aeróbico de las aguas residuales biológicas. $\mathrm{N}$ umerosos centros de producción han realizado grandes inversiones en sistemas de cienos activos, biotorres, reactor químico secuencial por cargas y tratamiento en paquetes. El interés por el agua y la conservación de la energía ha llevado a muchas instalaciones de producción láctea a reducir el consumo de este elemento. Esta tendencia, con la presencia en los centros productivos de cursos de aguas residuales, normalmente de gran potencia, ha dado lugar al diseño y construcción de numerosos sistemas anaeróbicos de tratamiento de aguas residuales.

la modificación de factores ambientales como el $\mathrm{pH}$ y la temperatura.

En la Tabla 67.5 se presentan coeficientes de reutilización del agua característicos. Factores como la localización de nebulizadores, la temperatura del agua y la presión son factores fundamentales que influyen en el volumen de este elemento requerido en las operaciones de elaboración. Por ejemplo, el agua utilizada como medio de refrigeración para enfriar latas o en el acondicionamiento del aire, puede emplearse con posterioridad en el lavado inicial de verduras y otros productos. Después, esa misma agua puede utilizarse para el material residual canalizado y, por último, una parte de ella puede servir para enfriar cenizas en las instalaciones suministradoras de energía.

Las técnicas de conservación del agua y de prevención de la acumulación de residuos comprenden la utilización de nebulizadores de alta presión en las tareas de limpieza, la eliminación del exceso de líquido de los tanques de lavado y remojo, la sustitución de transportadores mecánicos por cursos de agua, la aplicación de válvulas de cierre automático en mangueras, la separación del agua de refrigeración de envases del curso de agua residual mixta y la recirculación de aquélla.

Las cargas de contaminación en los centros de producción pueden reducirse mediante la modificación de los métodos de elaboración. Por ejemplo, la mayor parte de la contaminación generada en la elaboración de frutas y verduras tiene su origen en las operaciones de pelado y escaldado. Pasando del agua 0 el vapor convencionales utilizados en estas tareas a un proceso basado en la aplicación de gas caliente, las cargas de contaminación disminuirán en un 99,9\%. Del mismo modo,

Tabla 67.5 - Coeficientes de reutilización del agua habituales en diferentes subsectores de la industria.

$\begin{array}{ll}\text { Subsectores } & \text { Coeficientes de reutilización } \\ \text { Azúcar de remolacha } & 1,48 \\ \text { Azúcar de caña } & 1,26 \\ \text { Elaboración de maíz y trigo } & 1,22 \\ \text { Destilación } & 1,51 \\ \text { Elaboración alimentaria } & 1,19 \\ \text { Carne } & 4,03 \\ \text { Industria avícola } & 7,56\end{array}$


el pelado cáustico en seco puede reducir la DBO en más de un $90 \%$ en comparación con los procesos de pelado convencionales.

\section{Conservación de la energía}

Las necesidades energéticas han crecido a medida que la industria alimentaria ha ido ganando en complejidad. Son muchos los equipos a los que ha de suministrarse energía: hornos a gas; secadoras; calderas de vapor; motores eléctricos; unidades de refrigeración, y sistemas de calefacción, ventilación y aire acondicionado. Con la elevación del coste de la energía se ha tendido a instalar equipos de recuperación del calor para conservarla y a investigar la viabilidad de fuentes energéticas alternativas en diversas áreas de la elaboración de alimentos, como la producción de queso, la deshidratación de alimentos y el calentamiento de agua. La conservación de la energía, la minimización de los residuos y la conservación del agua son estrategias que se apoyan entre sí.

\section{Cuestiones relativas a la salud de los consumidores}

La separación cada vez mayor entre el consumidor y el sector de la producción alimentaria, que ha acompañado a la urbanización en todo el mundo, ha dado lugar a una pérdida de los medios tradicionales utilizados por el consumidor para garantizar la calidad y la seguridad de los alimentos y a la dependencia de éste respecto a una industria alimentaria funcional y responsable. Tal aumento de la dependencia ha posibilitado la exposición a alimentos contaminados por patógenos procedentes de centros productivos. Para garantizar la protección frente a esta amenaza, se han establecido normativas exhaustivas, sobre todo en los países industrializados, con el fin de velar por la salud pública y regular la utilización de aditivos y otros productos químicos. La armonización de reglamentos y normas a escala internacional se considera cada vez más como una cuestión que debe abordarse para asegurar el libre flujo de alimentos entre todos los países del mundo.

\section{SECTORES DE LA PRODUCCION AUMENTARIA}

\section{- IN DUSTRIA CAR NICA}

\section{Deborah E. Berkowitz y Michael J. Fagel}

Entre las fuentes de carne sacrificadas para consumo humano figuran el ganado vacuno, el porcino y el ovino $y$, en algunos países, los caballos y los camellos. El tamaño y la producción de los mataderos varía de manera considerable. Excepto en el caso de empresas muy pequeñas situadas en áreas rurales, los animales se sacrifican y tratan en grandes instalaciones productivas. Estos lugares de trabajo suelen someterse a controles de seguridad alimentaria llevados a cabo por parte de la Administración local con el fin de prevenir la contaminación bacteriana que puede provocar enfermedades en los consumidores. Son ejemplos de patógenos conocidos presentes en la carne la salmonella y el E scherichia coli . En estos centros de producción cárnica el trabajo está muy especializado y casi todas las tareas se realizan en cadenas de despiece en las que la carne se desplaza en cintas y transportadores y cada trabajador efectúa una sola operación. Casi todas las labores de corte y elaboración siguen siendo desempeñadas por trabajadores. L as tareas productivas pueden exigir entre 10.000 y 20.000 cortes diarios. Por ejemplo, en algunos grandes centros de Estados U nidos, algunas actividades, como la división de la res en canal y el corte del tocino en lonjas, se han automatizado.

\section{Proceso de sacrificio}

Los animales son conducidos en un redil al matadero (véase la Figura 67.2). D eben ser aturdidos antes de su sangrado, salvo que sean sacrificados de acuerdo con los ritos judío o musulmán. Normalmente, se les golpea para dejarles inconscientes con una pistola con pernos o con una de aire comprimido que introduce una punta en la cabeza (la médula oblongata). Tras el proceso de aturdimiento o "golpeo", una de las patas traseras del animal es bloqueada por una cadena enganchada a una cinta de transporte elevada que lo traslada a la siguiente sala, donde se le sangra mediante el corte de las arterias yugulares en el cuello con un cuchillo afilado. A continuación se procede al sangrado, cuyo producto resultante se filtra a través de tuberías para su tratamiento en salas inferiores.
La piel se retira mediante una serie de cortes a cuchillo (en las grandes instalaciones se utilizan al efecto nuevos cuchillos de aire comprimido) y el animal queda suspendido de las dos patas traseras en el sistema elevado de transporte. En algunas operaciones con ganado porcino, la piel no se elimina en esta fase. Por el contrario, se suprime el pelo pasando la res a través de depósitos de agua a $58{ }^{\circ} \mathrm{C}$ y, con posterioridad, por una máquina que lo elimina de la piel. El pelo restante se retira mediante chamuscado y, finalmente, rasurado.

\section{Figura 67.2 • Esquema de las fases del sacrificio de} ganado bovino.

Recepción y marcado del ganado

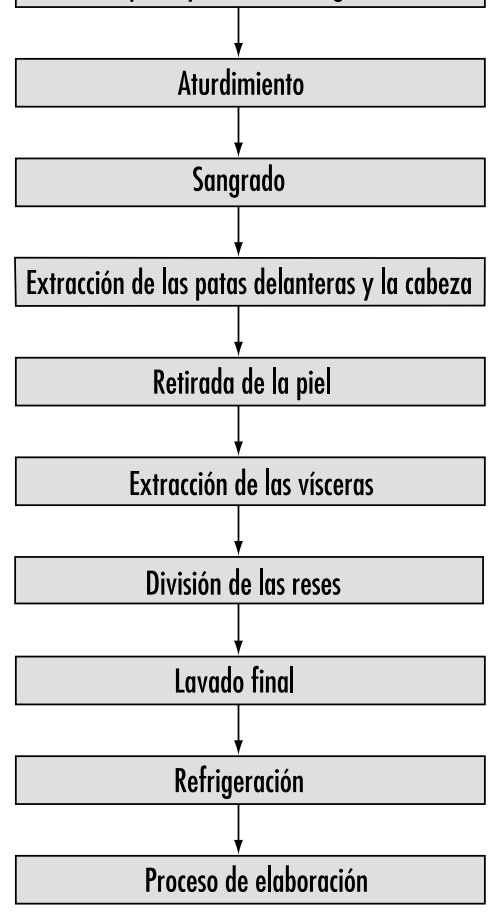


D espués se cortan las patas delanteras y se extraen las vísceras (intestinos). Se corta la cabeza y se separa del cuerpo, que se divide por la mitad verticalmente a lo largo de la columna vertebral. Para este trabajo suelen emplearse sierras de banda hidráulicas. U na vez dividida la res, se enjuaga en agua caliente y puede someterse a vacuovaporización o tratarse con un nuevo proceso de pasteurización de reciente introducción en algunos países.

Los inspectores de sanidad de la A dministración suelen supervisar la decapitación, la extracción de las vísceras, la división de la res en canal y el lavado final.

Después de estas operaciones, la canal, aún colgada del sistema elevado de transporte, se traslada a una cámara frigorífica para su refrigeración en el plazo de las 24 a 36 horas siguientes. La temperatura suele mantenerse en torno a los $2{ }^{\circ} \mathrm{C}$, con el fin de ralentizar el crecimiento bacteriano y evitar el deterioro de la carne

\section{Elaboración}

U na vez refrigeradas, las mitades de la canal se dividen en los cuartos delanteros y traseros. Después, estas piezas vuelven a subdividirse en piezas principales, de acuerdo con las especificaciones del cliente. Algunos cuartos se elaboran para su entrega como delanteros o traseros sin otras modificaciones significativas; pueden pesar de 75 a $125 \mathrm{~kg}$. M uchos centros de producción (en Estados U nidos, la mayoría) realizan más fases en la elaboración de la carne (otras sólo realizan esta parte del proceso y reciben la carne de los mataderos). Los productos de estos centros se transportan en cajas de unos $30 \mathrm{~kg}$ de peso.

Los cortes se realizan a mano o con sierras eléctricas en función de las necesidades, normalmente después de efectuar las operaciones oportunas para retirar la piel. Asimismo, muchos centros utilizan grandes trituradoras con el fin de obtener carne picada para hamburguesas, etcétera. La realización de otras tareas de elaboración pueden exigir el empleo de equipos como prensas para tocino, tambores giratorios para jamón cocido y extrusores, máquinas para rebanar tocino, dispositivos eléctricos para ablandar la carne y cámaras de ahumado. Las cintas transportadoras y las barrenas helicoidales suelen utilizarse para trasladar los productos. Las áreas de elaboración se mantienen a temperaturas que se sitúan en torno a los $4{ }^{\circ} \mathrm{C}$. Los despojos como el hígado, el corazón, las mollejas, la lengua y las glándulas se tratan en una zona independiente.

M uchos centros de producción llevan a cabo un tratamiento inicial de las pieles antes de enviarlas para su curtido.

\section{Riesgos y su prevención}

La elaboración de la carne registra una de las mayores tasas de accidentes de la industria en conjunto. Un trabajador puede lesionarse por el contacto con los animales en movimiento que son trasladados en el redil al centro de producción. Debe impartirse al personal una formación adecuada sobre la manipulación de animales vivos y se recomienda una exposición mínima del trabajador en esta parte del proceso. Las pistolas utilizadas para aturdir a los animales pueden dispararse de modo prematuro 0 involuntario mientras los trabajadores tratan de calmarlos. La caída y las reacciones debidas al sistema nervioso en los animales aturdidos que provocan sacudidas suponen un riesgo para los trabajadores próximos. Además, en numerosas operaciones se utilizan ganchos, cadenas y raíles de vagonetas de transporte para trasladar los productos de una fase a otra del proceso, lo que constituye un riesgo de caída de éstos y de las canales.

Es necesario un mantenimiento adecuado de todos los equipos (en especial de los utilizados para transportar la carne), que han de comprobarse con frecuencia y repararse cuando sea oportuno. Deben adoptarse dispositivos de protección en la armas de golpeo, como interruptores de seguridad y medidas que garanticen la imposibilidad de un retroceso. L os trabajadores que llevan a cabo las tareas de golpeo y degüello deben ser instruidos acerca de los peligros de su puesto y equipados con cuchillos protegidos y dispositivos de protección para evitar las lesiones. En las operaciones de degüello deben emplearse defensas de brazos, guantes de malla y cuchillos protegidos especiales.

Tanto en el sacrificio como en diversas fases de la elaboración, se utilizan cuchillos de mano y otros dispositivos cortantes. Entre los de carácter mecánico figuran las cuchillas para cabezas y huesos, los tiradores de hocicos, las sierras eléctricas de banda 0 circulares, los cuchillos de hoja circular eléctricos o de aire comprimido, las trituradoras y las máquinas elaboradoras de tocino. Son tareas que registran una tasa de lesiones elevada, desde los cortes con cuchillos hasta las amputaciones, debido a la velocidad a la que operan los trabajadores, el peligro inherente a las herramientas empleadas y la naturaleza con frecuencia resbaladiza del producto derivado de los procesos en que intervienen grasas o líquidos. Los trabajadores pueden cortarse con sus propios cuchillos o con los de sus compañeros durante el proceso de preparación de la carne (véase la Figura 67.3).

Las operaciones mencionadas exigen la utilización de equipos de protección que incluyan casco, calzado, guantes y delantales de malla, defensas de la muñeca y el antebrazo y delantales impermeables. Puede ser necesario el empleo de gafas protectoras en las actividades de deshuesado, preparación y corte, con el fin de evitar la entrada de cuerpos extraños en los ojos de los trabajadores. No deben utilizarse guantes de malla metálica al usar sierras motorizadas o eléctricas de cualquier tipo. Tanto éstas como otras herramientas motorizadas deben disponer de las salvaguardas pertinentes, como protectores de la hoja e interruptores de apagado. Las ruedas dentadas, cadenas, cintas transportadoras y otros dispositivos sin protección pueden constituir un riesgo. Todos ellos deben dotarse de los mecanismos de defensa oportunos. Asimismo, los cuchillos de mano también deben contar con protectores para evitar que la mano se deslice de la empuñadura a la hoja. La formación y la disposición del espacio suficiente entre trabajadores son necesarios para desempeñar las distintas tareas con seguridad.

Figura 67.3 - Trinchado y clasificación de carne sin equipo protector en un centro de producción cárnica thailandés.

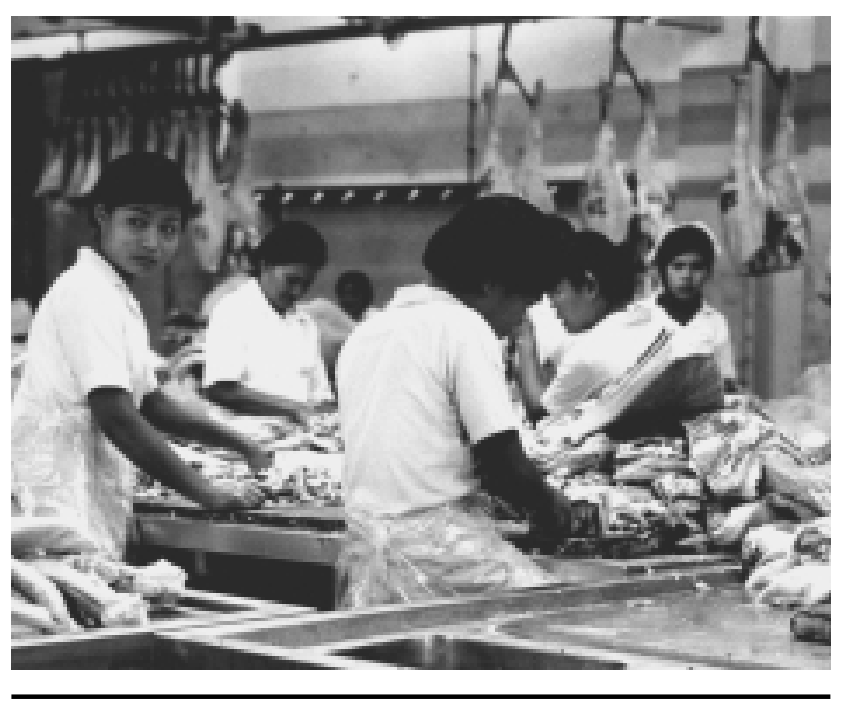


Figura 67.4 - Con cintas transportadoras situadas al lado de las mesas de trabajo, los trabajadores pueden arrojar los productos terminados a través de una abertura practicada en la mesa, en lugar de tener que lanzar la carne sobre su cabeza.

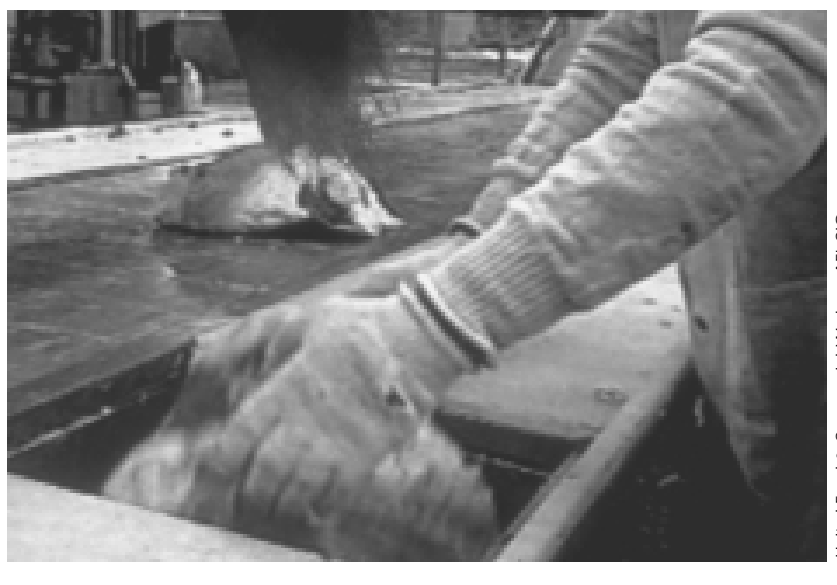

Los trabajadores que mantienen, limpian o desatascan equipos como cintas transportadoras, máquinas elaboradoras de tocino, picadoras y otros dispositivos, se exponen al riesgo de un arranque inadvertido de los equipos. Es un tipo de accidente que ha causado muertes y amputaciones. Algunas máquinas se limpian en funcionamiento, lo que expone a los trabajadores al peligro de quedar atrapados por las mismas.

Los trabajadores deben recibir formación sobre procedimientos de bloqueo y carteles de advertencia. La aplicación de procedimientos que impiden que el personal arregle, limpie 0 desatasque equipos hasta que éstos estén apagados y bloqueados evitará lesiones. Los trabajadores encargados del bloqueo de los distintos dispositivos deben ser instruidos acerca de los procedimientos de neutralización de todas las fuentes de energía.

Los suelos y escaleras mojados y resbaladizos en los centros de producción representan un grave riesgo para el personal. Las plataformas de trabajo elevadas también plantean riesgos de caídas. L os trabajadores deben utilizar calzado de seguridad con suelas antideslizantes. Las superficies antideslizantes y rugosas, aprobadas por los organismos sanitarios locales, pueden y deben emplearse en suelos y escaleras. $\mathrm{H}$ a de garantizarse un drenaje adecuado en las áreas húmedas y la conservación eficaz y oportuna de los suelos durante las horas de producción, con el fin de reducir al mínimo la existencia de superficies mojadas y resbaladizas. Asimismo, todas las superficies elevadas deben equiparse con barandillas de seguridad para evitar que entren en contacto con los trabajadores, que éstos sufran caídas accidentales y que caigan materiales de los transportadores. A demás, se utilizarán tablas de pie sobre estos andamios en caso necesario. Las barandillas deben instalarse asimismo en las escaleras de las instalaciones productivas para prevenir los resbalones.

La combinación en el lugar de trabajo de la humedad y de un cableado eléctrico complejo supone un riesgo de electrocución para los trabajadores. Todos los equipos deben dotarse de tomas de tierra adecuadas. Debe disponerse de cajas de toma de corriente eléctrica con tapas que protejan con eficacia contra los contactos accidentales. El cableado eléctrico ha de someterse a revisiones periódicas para examinar la existencia de grietas, signos de desgaste u otros defectos y todos los equipos deben ponerse a tierra. Se utilizarán siempre que sea posible interruptores de circuito de avería por puesta a tierra.
La carga de canales (que pueden llegar a pesar $140 \mathrm{~kg}$ ) y el levantamiento reiterado de cajas de carne de $30 \mathrm{~kg}$ preparadas para su transporte puede producir lesiones en la espalda. Los trastornos por traumatismos acumulados como el síndrome del túnel del carpo bilateral, la tendinitis y la tenosinovitis son comunes en este sector. En Estados U nidos, por ejemplo, las operaciones de elaboración de la carne registran tasas de estas dolencias superiores a las del resto de los sectores. $M$ uñecas, codos y hombros resultan afectados. La causa puede residir en la naturaleza forzada y altamente repetitiva del trabajo en las cadenas de montaje de los centros productivos, en la utilización de equipos vibratorios en algunas actividades, en el empleo de cuchillos romos, en el corte de carne congelada y en la aplicación de mangueras de aire comprimido en las tareas de limpieza. La prevención de estos trastornos se basa en el diseño ergonómico de los equipos, la utilización de ayudas mecánicas, el mantenimiento exhaustivo de los equipos que generan vibración para reducir ésta al mínimo y la mejora de la formación de los trabajadores y de los programas médicos. Entre las medidas de diseño ergonómico se cuentan:

- el descenso de los transportadores elevados para reducir los lanzamientos repetitivos por encima de la cabeza en las líneas de producción (véase la Figura 67.4);

- el desplazamiento de las plataformas horizontales para permitir a los trabajadores trocear los animales con un número mínimo de movimientos;

- la disponibilidad de cuchillos afilados con mangos de diseño renovado;

- la incorporación de ayudas mecánicas que reduzcan la fuerza aplicada en cada tarea (véase la Figura 67.5);

- el aumento del personal asignado a las actividades que requieren una gran fuerza, asegurando la disponibilidad de herramientas de mano del tamaño adecuado y de guantes y un diseño apropiado de las áreas de elaboración, con el fin de

Figura 67.5 • Extraer los huesos de las aletas mediante la fuerza de una cadena anexa, evitando la extracción manual, reduce los riesgos musculosqueléticos.

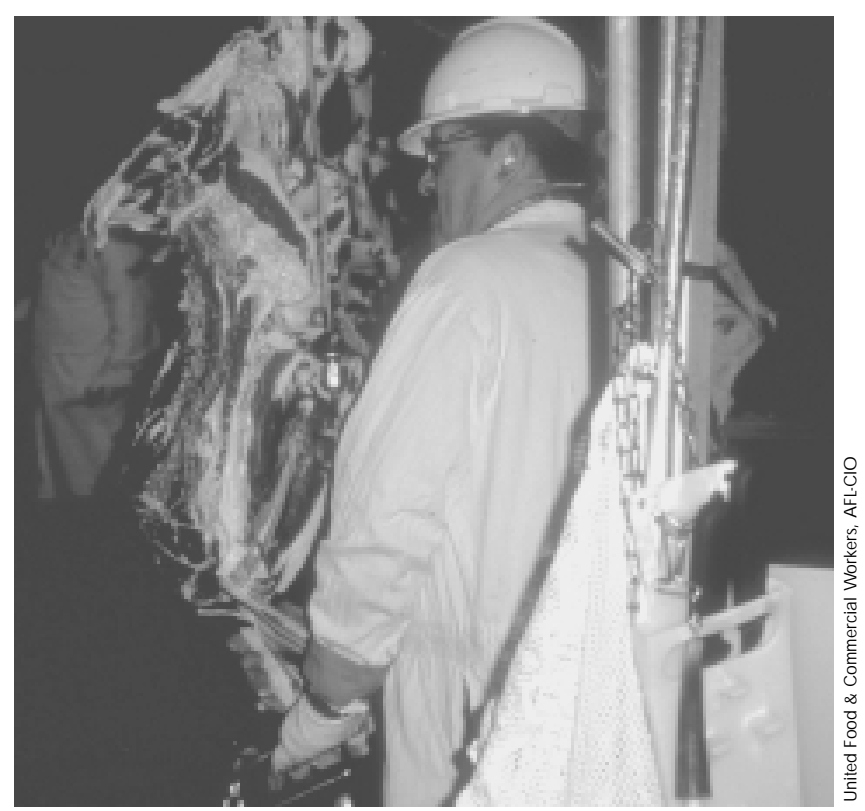


Figura 67.6 • La utilización de elevadores por vacío para levantar cajas permite a los trabajadores moverlas sin tener que cargarlas a mano.

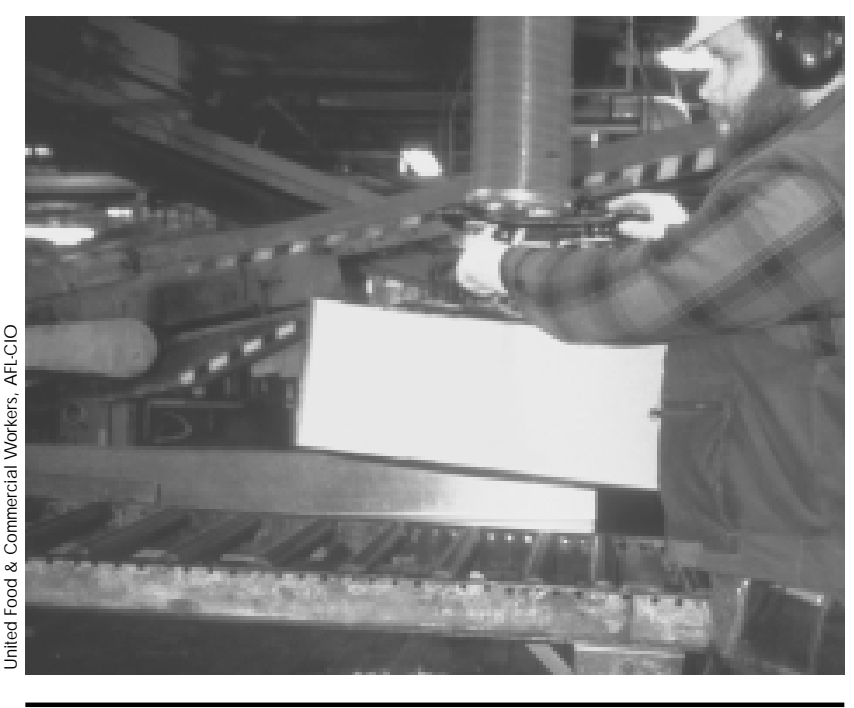

reducir al mínimo los giros al izar pesos y los levantamientos realizados desde debajo de las rodillas y por encima de los hombros,

- la dotación de elevadores por vacío y otros dispositivos de elevación mecánica para reducir el levantamiento de cajas (véase la Figura 67.6).

Los pasillos y pasarelas deben mantenerse secos y libres de obstáculos para garantizar la seguridad en el transporte de cargas pesadas.

Los trabajadores han de recibir formación sobre la utilización correcta de los cuchillos. El corte de carne congelada debe evitarse rigurosamente.

A simismo, es aconsejable una intervención y un tratamiento médicos precoces de los trabajadores sintomáticos. Debido al carácter similar de los factores de estrés en los trabajos de esta industria, la rotación de puestos debe emplearse con precaución. Deben efectuarse y revisarse análisis de los puestos de trabajo para conseguir que no se utilicen los mismos grupos de tendones en tareas diferentes. Además, los trabajadores deben ser instruidos pertinentemente en todos los puestos que formen parte de una rotación planificada.

La maquinaria y los equipos utilizados en los centros de producción cárnica genera un nivel de ruido elevado. $\mathrm{H}$ an de suministrarse a los trabajadores tapones para los oídos, y debe someterse a las plantillas a exploraciones médicas para determinar la posibilidad de pérdidas auditivas. Asimismo, siempre que sea posible, se aplicarán dispositivos de atenuación del ruido en la maquinaria. Un mantenimiento adecuado de los sistemas de transporte puede evitar la emisión de ruido innecesario.

Los trabajadores pueden verse expuestos al contacto con productos químicos tóxicos durante las operaciones de limpieza e higienización de los equipos. Entre los compuestos utilizados al efecto figuran los limpiadores alcalinos (cáusticos) y ácidos. Se trata de productos que pueden provocar sequedad, erupciones alérgicas y otros problemas dérmicos. Los líquidos pueden salpicar y producir quemaduras en los ojos. Dependiendo del tipo de compuesto limpiador aplicado, debe emplearse el EPP pertinente (incluidos los protectores de ojos, cara y brazos, delantales y calzado protector). Además, debe disponerse de instalaciones para el lavado de manos y ojos. Las mangas de aire comprimido utilizadas en el transporte de agua caliente para desinfectar los equipos también pueden causar quemaduras. Es importante impartir una formación adecuada al personal acerca de la utilización de estos instrumentos. Asimismo, el cloro presente en el agua empleada para lavar las canales puede irritar los ojos, la garganta y la piel. $\mathrm{H}$ an comenzado a aplicarse nuevos enjuagues antibacterianos en los mataderos para reducir las bacterias que pueden provocar enfermedades originadas en los alimentos. Es necesario garantizar una ventilación apropiada. D eben tomarse todas las precauciones necesarias para asegurar que la concentración de los productos químicos no exceda lo estipulado por los fabricantes en las instrucciones.

El amoníaco se utiliza como refrigerante en la industria, y las fugas de esta sustancia de los conductos que lo transportan son habituales. El gas amoníaco irrita los ojos y la piel. U na exposición de leve a moderada a este gas puede provocar migrañas, escozor en la garganta, transpiración, náuseas y vómitos. Si no es posible evitar su contacto, puede producirse una irritación grave del tracto respiratorio que genera tos, edema pulmonar 0 paro respiratorio. Un mantenimiento adecuado de los conductos de la refrigeración es esencial para prevenir estas fugas. Además, una vez detectado el escape de amoníaco, deben observarse los procedimientos de vigilancia y evacuación para evitar exposiciones peligrosas.

El dióxido de carbono $\left(\mathrm{CO}_{2}\right)$ en forma de hielo seco se utiliza en el área de envasado. En este proceso, el gas $\mathrm{CO}_{2}$ puede salir de su depósito y expandirse por toda la sala. La exposición al mismo puede producir migrañas, mareos, náuseas, vómitos y, en casos extremos, la muerte. Debe garantizarse una ventilación adecuada.

L os depósitos de sangre plantean riesgos asociados a los espacios restringidos si en el centro de producción en cuestión no se utiliza un sistema cerrado de tratamiento y conducción por tuberías de la misma. Las sustancias tóxicas emitidas por la sangre en descomposición y la falta de oxígeno constituyen un grave peligro para las personas que deben acceder y/ o limpiar los depósitos o trabajar en el área circundante. Antes de entrar, debe comprobarse la presencia en la atmósfera de productos químicos tóxicos y asegurarse la existencia de la cantidad de oxígeno apropiada.

Los trabajadores están expuestos a enfermedades infecciosas como la brucelosis, la erisipela, la leptospirosis, la dermatofitosis y la aparición de verrugas.

L a brucelosis está causada por una bacteria y se transmite por la manipulación de ganado vacuno o porcino infectado. Las personas infectadas por esta bacteria experimentan una fiebre constante o recurrente, migrañas, debilidad, dolor articular, sudores nocturnos y pérdida de apetito. La limitación del número de reses infectadas que son sacrificadas es una vía fundamental para la prevención de esta enfermedad.

La erisipela y la leptospirosis también tienen su causa en las bacterias. La primera se transmite mediante la infección de heridas, arañazos y abrasiones; produce enrojecimiento e irritación alrededor del lugar de la infección y puede extenderse a la corriente sanguínea y a los ganglios linfáticos.

La leptospirosis se transmite por contacto directo con animales infectados o con agua, tierra mojada o vegetales contaminados por la orina de los mismos. Pueden producirse dolores musculares, infecciones oculares, fiebre, vómitos, escalofríos y migrañas, y deteriorarse los riñones y el hígado.

La dermatofitosis, por su parte, es una enfermedad micótica y se transmite por el contacto con el pelo y la piel de personas o animales infectados. Conocida también como tiña, provoca la caída del pelo y el desarrollo de pequeñas costras amarillentas en forma de copa sobre el cuero cabelludo. 
La verruca vulgarias, verruga causada por un virus, puede ser propagada por los trabajadores infectados que hayan contaminado toallas, carne, cuchillos de pescado, mesas de trabajo u otros objetos.

0 tras enfermedades observadas en los centros de producción cárnica en algunos países son la fiebre Q y la tuberculosis. LoS principales portadores de la primera son el ganado bovino, ovino y caprino y las garrapatas. Los seres humanos suelen infectarse mediante la inhalación de partículas en suspensión en el aire procedentes de entornos contaminados. Los síntomas habituales son: fiebre, malestar, migrañas graves y dolores musculares y abdominales. La incidencia de anticuerpos de la toxoplasmosis entre los trabajadores de los mataderos es elevada en ciertos países.

La dermatitis también es común en los centros de producción de carne. La exposición a la sangre y a otros fluidos animales, a la humedad y a compuestos utilizados en la limpieza y la higienización de las instalaciones puede provocar la irritación de la piel.

Las enfermedades infecciosas y la dermatitis pueden prevenirse mediante la higiene personal, que comprende un acceso inmediato y sencillo a servicios de higiene y lavado de manos en los que se disponga de jabón y de toallas de mano desechables, el suministro del EPP adecuado (que puede incluir guantes de protección, así como protectores oculares y respiratorios cuando la exposición a fluidos corporales animales en suspensión en el aire es posible), la utilización de algunas cremas de barrera que proporcionen una protección limitada frente a elementos irritantes, la formación de los trabajadores y la asistencia médica precoz.

La humedad y el calor en la sala donde se realizan el sacrificio, el sangrado y la división de las reses pueden resultar especialmente elevados. D ebe utilizarse un sistema de ventilación en buenas condiciones de funcionamiento, que elimine el calor y el aire húmedo y prevenga el estrés por calor. Los ventiladores, preferiblemente elevados o colgados del techo, aumentan el movimiento del aire. D eben suministrarse bebidas para sustituir los fluidos y las sales perdidos al transpirar y han de establecerse períodos de descanso en áreas acondicionadas.

En los mataderos existe asimismo un olor característico, debido a la combinación de los generados por el cuero húmedo, la sangre, el vómito, la orina y las heces de los animales. Es un olor que se extiende a toda la sala de sacrificio y a las áreas de elaboración de despojos, clasificación y tratamiento de las pieles. La extracción es necesaria para eliminar estos olores.

Los entornos de trabajo refrigerados son esenciales en la industria cárnica. La elaboración y el transporte de los productos de la carne suelen exigir el mantenimiento de temperaturas iguales 0 inferiores a $9^{\circ} \mathrm{C}$. L as áreas como las cámaras de refrigeración pueden requerir temperaturas en torno a los $-40{ }^{\circ} \mathrm{C}$. Las lesiones más habituales relacionadas con el frío son las quemaduras por hielo, la congelación, el pie de inmersión y el pie de trinchera, que se producen en ciertas áreas localizadas del cuerpo. U na consecuencia grave del estrés por frío es la hipotermia. A simismo, los sistemas respiratorio, circulatorio y osteoarticular pueden verse afectados por una exposición excesiva al frío.

Para evitar las consecuencias del estrés por frío y reducir los riesgos del trabajo en condiciones de baja temperatura, los trabajadores deben utilizar ropas apropiadas y el lugar de trabajo debe dotarse de los equipos y los controles técnicos y administrativos pertinentes. El empleo de varias capas de ropa ofrece una mejor protección que la proporcionada por prendas únicas gruesas. Los equipos de refrigeración y los sistemas de distribución del aire deben minimizar la velocidad de éste. Los refrigeradores de las distintas unidades deben situarse tan alejados del personal como sea posible, y deben aplicarse pantallas y barreras deflectoras para proteger a los trabajadores del efecto enfriador del viento.

\section{INDUSTRIA AVICOLA}

Tony Ashdown

\section{Importancia económica}

La producción de pollos y pavos ha aumentado enormemente en Estados U nidos desde el decenio de 1980. De acuerdo con un informe del D epartamento de Trabajo de este país, la evolución se debe a un cambio en las pautas de alimentación de los consumidores (H etrick 1994). El paso de la carne roja y de cerdo a la de ave obedece en parte a la publicación de estudios médicos recientes.

La expansión del consumo, a su vez, ha fomentado un crecimiento del número de centros productivos y criadores y un gran aumento de los niveles de empleo. Por ejemplo, la industria avícola de Estados U nidos registró un incremento del empleo del $64 \%$ de 1980 a 1992.

La productividad, medida en función de los kilos producidos por cada trabajador, aumentó en un 3,1 \% debido a la mecanización y la automatización, así como a la aceleración de la velocidad en la cadena productiva, estimada en número de aves por hora de trabajo. Con todo, en comparación con la producción de carne roja, en la avícola sigue utilizándose intensivamente la mano de obra.

Se asiste asimismo a un proceso de mundialización. $\mathrm{H}$ ay centros de producción y elaboración de propiedad conjunta de China y de inversores de Estados U nidos, y los centros de cría, crecimiento y elaboración situados en China exportan su producción a Japón.

El trabajador medio de la industria avícola está relativamente poco cualificado, su formación es escasa, suele formar parte de grupos minoritarios y su remuneración es muy inferior a la del personal de los sectores de producción de carne roja y manufactureros. La rotación de plantilla es extraordinariamente elevada en ciertos aspectos del proceso. Las tareas de colgado de los animales vivos, de deshuesado y de higienización resultan muy estresantes y registran tasas de rotación altas. D ebido a su naturaleza, la elaboración de las aves es una industria basada en gran medida en el medio rural y habitual en áreas de economía deprimida, en las que existen excedentes de mano de obra. En Estados U nidos, muchos de los centros productivos cuentan con un número cada vez mayor de trabajadores de habla hispana. Se trata de personal temporal hasta cierto punto, ya que desarrolla su actividad en dichos centros parte del año. Cuando se acerca el momento de cosechar los cultivos de la región, una gran proporción de los trabajadores pasa a dedicarse a esta labor.

\section{Elaboración}

A lo largo del proceso de elaboración de los pollos deben cumplirse estrictos requisitos sanitarios. En concreto, lavar los suelos periódicamente y con frecuencia y eliminar los desechos, las partes sobrantes y la grasa. A simismo, los equipos de transporte y elaboración han de ser accesibles, lavados e higienizados. No debe permitirse la acumulación de vaho en los techos y los equipos situados sobre las aves; debe ser suprimido con mopas de esponja de mango largo. Se utilizarán ventiladores de techo, sin protectores y de palas radiales en las áreas de elaboración. 
Debido a estos requisitos sanitarios, es frecuente que los equipos rotatorios protegidos no puedan silenciarse para atenuar los ruidos. En consecuencia, la exposición a la contaminación acústica es elevada en la mayoría de las áreas productivas de los centros de elaboración. Es necesario formular programas de conservación de la audición adecuados y bien gestionados. Las medidas adoptadas para documentar la exposición no se limitarán a la realización de audiometrías iniciales y anuales, sino que incluirán asimismo dosimetrías periódicas. Los equipos de elaboración adquiridos emitirán durante su funcionamiento el menor nivel de ruido posible. D ebe prestarse especial atención a la educación y la formación del personal.

\section{Recepción y colgado en vivo}

El primer paso del proceso de elaboración consiste en la descarga de los módulos y colocación de las bandejas en un sistema de transporte que conduce al área de colgado en vivo. El trabajo en esta fase se lleva a cabo casi en completa oscuridad, puesto que esta medida tiene un efecto tranquilizador para las aves. La altura de la cinta transportadora con una bandeja encima es, aproximadamente, la de la cintura. U n colgador, enguantado, debe agarrar el ave por ambos muslos y colgarlo de las patas en las argollas de una cinta transportadora elevada que se desplaza en la dirección opuesta.

Los riesgos de esta operación son variables. A parte del nivel elevado de ruido habitual, la oscuridad y el efecto desorientador de las cintas de transporte que se mueven en direcciones opuestas, las aves, al aletear, generan polvo, pueden expulsar orina y heces hacia la cara del trabajador y existe la posibilidad de pillarse un dedo con una argolla. Las cintas transportadoras deben equiparse con interruptores de emergencia. L os colgadores se golpean constantemente la parte anterior de las manos con las argollas cercanas que pasan sobre su cabeza.

Lo habitual es que se exija a estos trabajadores colgar una media de 23 (o más) aves por minuto. (Algunos puestos en las líneas de producción de los colgadores requieren un mayor número de movimientos, quizá 26 aves por minuto). En general, siete colgadores en una cinta pueden colgar 38.640 aves en 4 horas antes de llegar a un período de descanso. Si cada ave pesa unos 1,9 kg, un colgador levanta un total de $1.057 \mathrm{~kg}$ en las 4 primeras horas de su turno. Es una labor extremadamente estresante desde un punto de vista fisiológico y psicológico. La reducción de la carga de trabajo podría atenuar este estrés. Las tareas de agarrar con ambas manos, sujetar y, de forma simultánea, levantar un ave que aletea y araña a la altura del hombro o de la cabeza pone en tensión la parte superior de los hombros y el cuello.

Las plumas y las patas de estos animales pueden arañar con facilidad los brazos de un colgador si no están protegidos. Estos trabajadores se ven obligados a permanecer de pie durante períodos prolongados sobre superficies duras, lo que puede dar lugar a molestias y dolores en la parte inferior de la espalda. Para proteger a los colgadores, debe disponerse de un calzado apropiado, posiblemente un lugar donde sentarse, gafas protectoras, protección respiratoria desechable de un solo uso, instalaciones para el lavado de ojos y protectores de brazos.

Un elemento muy importante para garantizar la salud del trabajador es la formulación de un programa de adaptación al puesto adecuado. Durante un período máximo de dos semanas, el nuevo colgador se acostumbrará a las condiciones de su actividad y comenzará a desarrollar su trabajo gradualmente hasta que realice un turno completo. 0 tro elemento fundamental es la rotación de puestos; después de dos horas colgando aves, este trabajador puede ser asignado a una tarea menos extenuante. La división del trabajo entre colgadores puede ser tal que la institución de descansos breves y frecuentes en áreas de aire acondicionado resulta esencial. En algunas fábricas se ha intentado duplicar las plantillas para que los trabajadores puedan desempeñar su labor durante 20 minutos y descansar otros 20 , reduciendo así los factores de estrés ergonómico.

Las condiciones de salud y comodidad de los colgadores dependen en cierta medida de las condiciones meteorológicas externas y de la situación de las aves. Si el tiempo es cálido y seco, las aves portan polvo y ácaros, que quedan en suspensión en el aire con facilidad. Si es húmedo, las aves resultan más difíciles de manipular, los guantes se humedecen de inmediato y los colgadores deben aumentar su esfuerzo para agarrarlas. Recientemente se ha avanzado en el desarrollo de guantes reutilizables con almohadillas.

El efecto de las partículas, las plumas, los ácaros y otros elementos en suspensión en el aire puede moderarse con un sistema eficaz de extracción localizada (VAL). U n sistema equilibrado en el que se aplique el principio de contrafase y se utilice la refrigeración o la calefacción de corriente descendente, resultará beneficioso para los trabajadores. 0 tros ventiladores distribuidos en el área en cuestión reducirían la eficacia de dicho sistema.

Una vez colgadas de las argollas, las aves son transportadas para su aturdimiento inicial con electricidad. El alto voltaje no las mata, pero las obliga a colgar flácidamente mientras una rueda rotante (neumático de bicicleta) dirige su cuello hacia una hoja cortante circular que gira en dirección contraria. El cuello se secciona parcialmente con el corazón del animal aún latiendo para que bombee al exterior el resto de la sangre, que ha de eliminarse totalmente del cuerpo. Un trabajador cualificado debe situarse para sacrificar las aves que la máquina no ha alcanzado. Debido al exceso de sangre, el trabajador ha de protegerse utilizando ropa impermeable y protectores oculares. A simismo, debe disponerse de instalaciones para el lavado de ojos.

\section{Preparación}

A continuación, la cinta transportadora de aves pasa a través de una serie de cubas o depósitos de agua caliente circulante. Se denominan escaldaderas. EI agua suele calentarse mediante serpentines de vapor y tratarse o clorarse para destruir las bacterias. Con ello se consigue una rápida eliminación de las plumas. Deben tomarse precauciones al trabajar alrededor de escaldaderas. Con frecuencia, los conductos y las válvulas no están protegidas, su aislamiento es deficiente y el contacto con los mismos provoca quemaduras.

Cuando las aves salen de estos depósitos, el cuerpo se pasa a través de un dispositivo en forma de $U$ que lo decapita. Estas piezas suelen transportarse en cubas de agua a un área de clasificación (o de tratamiento de subproductos).

La línea con el cuerpo de las aves pasa a través de máquinas dotadas de varios tambores rotatorios con una especie de dedos de caucho que retiran las plumas. Estas caen en un canal inferior con agua en circulación que se dirige al área de clasificación.

La homogeneidad en el peso de las aves es fundamental en todos los aspectos del proceso de elaboración. Si los pesos varían de una carga a otra, los departamentos productivos deben ajustar sus equipos convenientemente. Por ejemplo, si a aves de poco peso les siguen otras de peso superior en las desplumadoras, es posible que los tambores rotativos no consigan eliminar la totalidad de las plumas, lo cual provoca rechazos y repetición del trabajo. No sólo aumenta los costes de elaboración, sino que también provoca estrés ergonómico adicional de las manos, ya que alguien debe extraer las plumas utilizando unas tenazas.

U na vez superadas las desplumadoras, la línea de aves pasa a través de una chamuscadora. Se trata de un dispositivo a gas con 
tres quemadores a cada lado, utilizado para quemar los pelos y las plumas más pequeñas de las aves. D ebe tomarse precauciones para asegurar el mantenimiento de la integridad de los conductos de gas, debido a las condiciones corrosivas de las áreas de desplumado y preparación.

Posteriormente, las aves se someten a la acción de una máquina que les corta las patas. Estas pueden transportarse por separado a un área de elaboración independiente para su limpieza, clasificación por tamaño, selección, refrigeración y envasado para el mercado asiático.

Las aves deben volverse a colgar de otras argollas antes de entrar en la sección de extracción de vísceras de la fábrica. $L a$ forma de las argollas en esta fase es ligeramente diferente y suelen ser más largas. La automatización en esta parte del proceso puede aplicarse de inmediato (véase la Figura 67.7). No obstante, los trabajadores deben estar pendientes de los bloqueos de las máquinas, de volver a colgar las aves que se caen y de cortar manualmente las patas a tijera si la desjarretadora no corta adecuadamente. D esde el punto de vista de la elaboración y de los costes, es esencial que se utilicen todas las argollas. Volver a colgar las aves exige de los trabajadores la realización de movimientos muy repetitivos y la adopción de posturas incómodas (elevación de los codos y de los hombros), por lo que corren un mayor riesgo de sufrir trastornos por traumatismos acumulados (TTA).

En caso de avería o desajuste de la maquinaria, debe dedicarse un gran effuerzo a la restitución de las líneas, en ocasiones a costa de la seguridad de los trabajadores. Al tratar de acceder a los puntos pertinentes de los equipos, puede que los trabajadores de mantenimiento no se entretengan en conseguir una escalera y se suban a la parte superior de las máquinas húmedas y resbaladizas. Las caídas constituyen un riesgo. Cuando se adquieren e instalan estos equipos, debe preverse la disposición de un acceso y un mantenimiento sencillos. Es necesario instalar en cada máquina puntos de bloqueo e interruptores. El fabricante debe considerar el medio ambiente y las condiciones peligrosas en las que ha de llevarse a cabo el mantenimiento.

Figura 67.7 • Las máquinas de corte múltiple reducen el trabajo manual repetitivo; los trabajadores deben acabar el tratamiento de las aves que las máquinas dejan pasar.

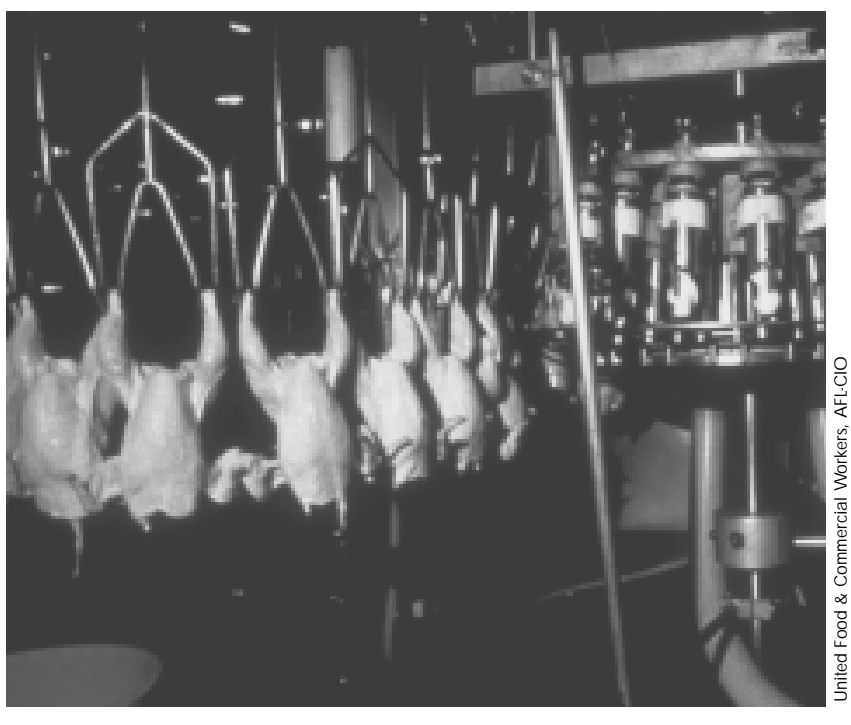

\section{Extracción de vísceras}

Cuando el transportador de aves sale del área de elaboración y accede a otra parte del proceso físicamente separada, éstas suelen pasar por otra chamuscadora y a través de un cuchilla circular rotativa que extrae la bolsa o glándula de aceite que presenta cada ave en su parte posterior en la base de la cola. A menudo, estas cuchillas giran libremente y deben ser equipadas con las defensas oportunas. De nuevo en este caso, si la máquina no se ajusta de acuerdo con el peso, deben asignarse trabajadores para la retirada de dicha glándula mediante su extracción con un cuchillo.

A continuación, la cinta transportadora de la aves pasa a través de un dispositivo automático que oprime ligeramente el abdomen hacia arriba mientras que una cuchilla abre el cuerpo del animal sin alterar las vísceras. En la siguiente máquina o fase del proceso se penetra en la cavidad y se extraen las vísceras inalteradas para su inspección. En Estados U nidos, las siguientes etapas de la elaboración pueden contar con la intervención de inspectores de la Administración que comprueban los engordes, las enfermedades de la bolsa de aire, la contaminación fecal y otras anomalías. Normalmente, cada inspector se ocupa de supervisar sólo dos o tres elementos. Si la tasa de anomalías es elevada, los inspectores ralentizan la cadena productiva. A menudo, estas deficiencias no provocan un rechazo completo del producto, y partes específicas de las aves pueden lavarse y separarse del resto del cuerpo para aumentar el rendimiento.

Cuantos más rechazos, más tareas manuales deben volver a efectuar los trabajadores, lo que exige la realización de movimientos repetitivos de corte, partición, etc. Los inspectores de la Administración suelen sentarse en puestos elevados ajustables previstos en la reglamentación, mientras que los trabajadores denominados ayudantes, situados a ambos lados, permanecen de pie sobre enrejados o utilizan un asiento ajustable si éste se encuentra disponible. Los dispositivos de apoyo para los pies, las plataformas de altura ajustable, los asientos y la rotación de puestos de trabajo contribuirá a aliviar el estrés físico y psicológico asociado a esta fase del proceso.

Después de las inspecciones, las vísceras se clasifican según pasan a través de un recogedor de hígados, corazones y demás despojos. Los intestinos, estómagos bazos, riñones y vesículas biliares se descartan y se arrojan a un canal de salida inferior. Los corazones y los hígados se separan y se colocan en otras cintas transportadoras de clasificación o se llevan a un área de elaboración independiente para ser envasadas a granel manualmente 0 recombinadas con posterioridad en un paquete de menudillos para su introducción a mano en la cavidad del cuerpo completo del ave puesta a la venta.

U na vez que el cuerpo pasa el recogedor, la cavidad del buche se comprueba a mano para extraer las mollejas y las vísceras restantes si es necesario. Los trabajadores aplican cada mano a un ave cuando pasa la cinta transportadora. Suele emplearse un dispositivo succionador para extraer los pulmones y riñones que permanezcan en el cuerpo del animal. Con frecuencia, debido a la costumbre de las aves de ingerir pequeñas piedras o elementos de la basura durante su crecimiento, los trabajadores sufren heridas punzantes dolorosas en la punta de los dedos o bajo las uñas al explorar las cavidades de los animales.

Estas pequeñas heridas, si no se tratan convenientemente, suponen un riesgo de infección grave, ya que la cavidad de las aves aún no se ha limpiado de bacterias. Puesto que la sensibilidad táctil es necesaria para el trabajo, en esta fase aún no se pueden utilizar guantes que prevengan estos incidentes habituales. Se ha probado con cierto éxito el empleo de guantes de cirujano. El ritmo de la cinta es tan rápido que no permite una inserción cuidadosa de las manos por parte del trabajador. 
Por último, el cuello es eliminado por un dispositivo al efecto y recogido. $L$ a aves pasan por un dispositivo específico de lavado que utiliza agua pulverizada y clorada para lavar las vísceras restantes dentro y fuera del cuerpo del animal

A lo largo de las fases de preparación y extracción de vísceras, los trabajadores se ven expuestos a niveles de ruido elevados, suelos resbaladizos e importantes factores de estrés ergonómico en las operaciones de sacrificio, corte y envasado. De acuerdo con un estudio del NIOSH, las tasas de TTA documentados en los centros de producción avícola pueden oscilar entre el 20 y el $30 \%$ de los trabajadores (N IO SH 1990).

\section{Refrigeración}

Dependiendo del proceso, los cuellos se envían a un depósito refrigerante de superficie abierta con aspas, paletas o hélices rotativas. Los depósitos de este tipo representan una grave amenaza para la seguridad de los trabajadores durante su funcionamiento y deben ser protegidos adecuadamente mediante cubiertas 0 enrejados desmontables. Las cubiertas deben permitir la inspección visual del depósito. Si una cubierta se retira o se levanta, debe disponerse de dispositivos de bloqueo para inmovilizar las aspas giratorias. L os cuellos refrigerados se envasan a granel para su elaboración posterior o se trasladan a un área de envasado de menudillos para su recombinación y empaquetado.

Tras superar la fase de extracción de vísceras, las cintas transportadoras acaban en grandes depósitos horizontales y abiertos de refrigeración 0 , en Europa, se someten a la acción de aire circulante refrigerado. Tales depósitos constan de paletas que giran lentamente, haciendo descender la temperatura corporal del ave. El agua refrigerada presenta una gran concentración de cloro (20 ppm o más) y se ventila por agitación. El tiempo de permanencia del ave en el depósito puede llegar a una hora.

Debido al elevado nivel de cloro libre vertido y puesto en circulación, los trabajadores están expuestos y pueden experimentar síntomas de irritación ocular y de garganta, toses y dificultad respiratoria. EI NIOSH ha realizado varios estudios acerca de la irritación de los ojos y de las vías respiratorias superiores en los centros de producción avícola, en los que se recomienda un control y un seguimiento exhaustivos de los niveles de cloro, la utilización de pantallas para retener el cloro liberado (o de un cerramiento de algún tipo que rodee la superficie abierta del depósito) y la instalación de un sistema de ventilación aspirante (Sanderson, Weber y Echt 1995).

El tiempo de permanencia es esencial y objeto de cierta controversia. Al salir de la fase de extracción de vísceras, el cuerpo no está limpio por completo y los poros de la piel y los folículos de las plumas están abiertos y albergan bacterias causantes de enfermedades. El objetivo principal del paso por el depósito de refrigeración es enfriar el ave con rapidez para evitar su deterioro. No se eliminan bacterias, y el riesgo de contaminación cruzada es una cuestión de salud pública grave. Los críticos han denominado al método de refrigeración por inmersión "sopa fecal". D esde la perspectiva de la rentabilidad, una ventaja complementaria consiste en que la carne absorbe el agua del refrigerador como una esponja. Aumenta en casi un $8 \%$ el peso de comercialización del producto (Linder 1996).

Al salir del depósito refrigerador, los cuerpos se depositan en una cinta transportadora o en una mesa vibratoria. U nos trabajadores especialmente capacitados, denominados clasificadores, inspeccionan las aves para detectar magulladuras, fracturas de la piel, etc. y vuelven a colgarlas en líneas de argollas separadas en movimiento delante de ellos. Las aves que no pasan la prueba se trasladan a otros procesos para la recuperación de ciertas piezas. Los clasificadores deben permanecer de pie durante períodos prolongados manipulando aves refrigeradas, lo que puede dar lugar a entumecimiento y dolor en las manos. Los guantes forrados se utilizan para proteger las manos no sólo de los residuos de cloro, sino también del frío.

\section{Trinchado}

Del área de clasificación, las aves pasan colgadas a diversos procesos, máquinas y líneas de producción en una zona de la fábrica denominada de elaboración secundaria o posterior. Algunas máquinas son alimentadas manualmente con operaciones en las que se han de utilizar las dos manos. 0 tros equipos europeos más modernos, situados en ubicaciones independientes, pueden separar los muslos y las alas y dividir la pechuga sin la intervención del trabajador. De nuevo en este caso, la homogeneidad del tamaño y del peso de las aves es esencial para un funcionamiento eficaz de estos equipos automáticos. Las hojas circulares rotatorias deben cambiarse todos los días.

Los técnicos y los operarios de mantenimiento cualificados deben permanecer atentos al comportamiento de los equipos. EI acceso a los mismos para su ajuste, mantenimiento e higiene debe ser frecuente, utilizando escaleras fijas, no de mano, y plataformas de trabajo considerables. Al cambiar las cuchillas, deben tomarse precauciones debido al carácter resbaladizo de las mismas por la presencia de grasa. Para proteger la mayor parte de la mano, deben utilizarse guantes especiales resistentes al corte y al deslizamiento, mientras que las puntas de los dedos pueden emplearse para manipular las herramientas, pernos y tuercas aplicados a la sustitución.

La evolución de los gustos de los consumidores han afectado al proceso productivo. En algunos casos, los productos (p. ej., muslos y pechuga) deben comercializarse sin piel. Se han desarrollado equipos para retirarla y evitar que los trabajadores deban realizar esta operación manualmente. No obstante, a medida que se incorporan equipos automatizados y se reestructuran las líneas de producción, empeoran las condiciones de espacio y comodidad a las que se enfrentan los trabajadores para maniobrar gatos, transportar cargas o contenedores de plástico de producto congelado con pesos superiores a $27 \mathrm{~kg}$ por suelos resbaladizos y húmedos.

En función de la demanda de los consumidores y de las ventas de combinaciones de productos, los trabajadores se sitúan de pie frente a transportadores de altura fija, seleccionando y disponiendo el producto en bandejas de plástico. El producto se desplaza en una dirección determinada o cae de una rampa. Las bandejas llegan sobre cintas transportadoras elevadas, que descienden para que los trabajadores puedan coger una pila de ellas y colocarlas en frente para facilitar su alcance. Los productos defectuosos pueden situarse en un transportador que se desplaza inferiormente en dirección contraria o colgarse de argollas que pasan en esta misma dirección por encima de la cabeza. Los trabajadores permanecen de pie durante períodos prolongados casi hombro con hombro, quizá separados únicamente por un contenedor en el que se acumulan los productos defectuosos y los residuos. EI personal debe equiparse con guantes, delantales y botas.

Algunos productos pueden envasarse a granel en cajas de cartón cubiertas de hielo. A este envase se le denomina paquete refrigerado. L os trabajadores llenan Ias cajas a mano, colocadas sobre una báscula, y las transfieren, también manualmente, a cintas transportadoras en movimiento. Después, en la sala de envasado con hielo, se añade éste, se recuperan las cajas y se apilan a mano en paletas listas para su transporte.

Algunos trabajadores que intervienen en las tareas de trinchado también se ven expuestos a niveles de ruido elevados.

\section{Deshuesado}

Si el cuerpo se destina al deshuesado, se deposita en grandes cubas de aluminio 0 en cajas de cartón situadas en paletas. La 
carne de pechuga debe conservarse durante un cierto número de horas antes de su elaboración mecánica o manual. El pollo fresco es difícil de cortar y preparar a mano. Desde un punto de vista ergonómico, el envejecimiento de la carne es un elemento esencial que contribuye a reducir las lesiones de la mano provocadas por la reiteración de movimientos.

$\mathrm{H}$ ay dos métodos utilizados en el deshuesado. En el manual, una vez preparados, los cuerpos de la aves en los que solo queda la carne de la pechuga se vierten en una tolva que va a parar a una transportador. L os trabajadores de esta sección de la cadena de producción deben manipular cada cuerpo de ave y sujetarlos contra dos rodillos desolladores horizontales texturados. EI cuerpo pasa a través de los dos rodillos y la piel es retirada y arrojada a un transportador inferior. Existe el riesgo de que los trabajadores se descuiden o se distraigan y metan los dedos entre los rodillos. Es necesario disponer de interruptores de parada de emergencia al alcance de la mano libre o de la rodilla. No pueden utilizarse guantes ni ropas sueltas en la cercanía de estos equipos. Deben emplearse delantales (perfectamente ajustados) y protectores oculares debido a la posibilidad de contacto con fragmentos de los huesos.

La fase siguiente es llevada a cabo por trabajadores denominados marcadores. Sostienen el cuerpo del ave en una mano y realizan un corte a lo largo de la quilla (o esternón) con la otra. Suelen emplearse cuchillos afilados de hoja corta. Normalmente, se utilizan guantes de malla de acero inoxidable sobre otros guantes de látex o de nitrilo que recubren la mano que sujeta el cuerpo. Los cuchillos aplicados en esta operación no necesitan tener una punta afilada. Es conveniente utilizar protectores oculares.

La tercera fase corre a cargo de los extractores de quillas. Su tarea puede efectuarse a mano o con un dispositivo en forma de " $Y$ " (realizado con una estructura de barras de acero inoxidable) en el que el trabajador sitúa el cuerpo del ave y tira de éste hacia sí. La altura de cada dispositivo debe ajustarse al trabajador. El método manual exige sencillamente al trabajador la utilización de unas tenazas con la mano enguantada para extraer la quilla. Como ya se ha descrito, deben emplearse protectores oculares.

La cuarta fase consiste en el cortado en filetes. Los trabajadores se sitúan de pie, hombro con hombro, y recogen la carne de pechuga transportada en bandejas de transmisión situadas en frente de ellos. Hay ciertas técnicas que deben aplicarse en esta parte del proceso. Es necesario impartir una instrucción adecuada al puesto y una corrección inmediata de los errores observados. Los trabajadores se protegen una mano con un guante de malla o con una cadena, mientras que con la otra sostienen un cuchillo muy afilado (con una punta que puede presentar esta misma condición).

El ritmo de la actividad es rápido, y los trabajadores que se retrasan se ven obligados a tomar atajos, como recoger la carne poniéndose delante de los compañeros cercanos o intentar llegar a una bandeja que se desplaza fuera de su alcance pinchando la carne con el cuchillo. El pinchazo no sólo reduce la calidad del producto, sino que también provoca graves lesiones a los trabajadores vecinos en forma de desgarrones, que se infectan a menudo. Pueden utilizarse protectores de plástico en los brazos para evitar este tipo de accidente frecuente.

La carne en filetes vuelve a colocarse en los recipientes de la cinta transportadora $y$, posteriormente, es recogida por el siguiente grupo de trabajadores, denominados recortadores. Son ellos los que eliminan de la carne la grasa, la piel y los huesos sobrantes utilizando unas tijeras afiladas y ajustadas. U na vez arreglado, el producto terminado se envasa en una bandeja a mano o se guarda en bolsas a granel y se coloca en cajas de cartón para su uso en restauración.
El segundo método de deshuesado requiere la intervención de un equipo de elaboración automático desarrollado en Europa. Como ocurre en el método manual, las cajas a granel o los depósitos con los cuerpos de las aves, en ocasiones aún con las alas, se cargan en una mesa vibratoria o en una rampa. A continuación, los cuerpos pueden recogerse manualmente y situarse en transportadores segmentados 0 colocarse individualmente, también a mano, en soportes de la máquina. Esta se mueve con rapidez, haciendo pasar el cuerpo a través de una especie de dedos (para eliminar la piel), hojas y cortadoras. EI resultado es un esqueleto sin carne que se apila y se utiliza en otras áreas. La mayoría de los puestos de la cadena de producción manual se suprimen, excepto el que ocupan los recortadores con las tijeras.

Los trabajadores dedicados al deshuesado están expuestos a graves riesgos ergonómicos derivados de la naturaleza forzada y repetitiva de su actividad. En cada uno de los puestos de la fase de deshuesado, y en especial los ocupados por los fileteadores y los recortadores, la rotación de tareas puede ser un elemento esencial en la reducción de los factores de estrés ergonómico. Debe entenderse que, en el nuevo puesto al que se asigna un trabajador, no debe utilizarse el mismo grupo muscular. Se ha argumentado sin mucho fundamento que los fileteadores y los recortadores pueden intercambiar sus posiciones, pero no debe permitirse, ya que se emplean los mismos métodos de agarrado, giro y volteo en la mano que no sostiene la herramienta (cuchillo o tijeras). Puede argüirse que los músculos que sostienen un cuchillo sin apretar para girar y voltear al realizar cortes para obtener filetes se utilizan de manera diferente al abrir y cerrar unas tijeras. No obstante, los giros y volteos de la mano siguen siendo necesarios. Las velocidades de la cadena productiva desempeñan un papel primordial en el planteamiento de trastornos ergonómicos en estos puestos de trabajo.

\section{E mpaquetado y refrigeración}

Una vez que el producto se ha situado en bandejas trinchado 0 deshuesado, éstas se trasladan a otra fase del proceso denominada empaquetado. Los trabajadores recogen los productos específicos en bandejas y las introducen en máquinas que aplican y extienden envueltas transparentes impresas alrededor de las mismas selladas en caliente. A continuación la bandeja pasa por un dispositivo de lavado, donde se recoge y se coloca en una cesta. La que contiene un determinado tipo de producto se sitúa en un transportador que la traslada al área de refrigeración. Allí las bandejas son clasificadas y apiladas de modo manual 0 automático.

L os trabajadores del área de empaquetado deben permanecer de pie durante períodos prolongados y sus puestos son objeto de rotación, con el fin de que las manos que utilizan para recoger el producto cambien de forma alternativa. Se trata de una zona que suele ser relativamente seca. Las esteras amortiguadoras pueden reducir la fatiga de piernas y espalda.

La demanda de los consumidores, las ventas y el marketing pueden crear riesgos ergonómicos especiales. En ciertas épocas del año, se empaquetan grandes bandejas con varios kilos de producto para "comodidad y ahorro de costes". Es un peso añadido que ha contribuido al aumento de las lesiones de la mano relacionadas con movimientos repetitivos debido, sencillamente, a que el proceso y el sistema de transporte están diseñados para la recogida con una sola mano. Un trabajador carece de la fuerza necesaria para realizar levantamientos de bandejas sobrecargadas con una sola mano.

El envoltorio de plástico transparente utilizado en el empaquetado puede liberar cantidades moderadas de monómeros y otros productos de descomposición al calentarse para su sellado. Si se plantean quejas respecto a los humos, el fabricante 0 el 
proveedor de la película plástica debe ser convocado para ayudar a evaluar el problema. Puede ser necesario aplicar sistemas de extracción localizada. El equipo de sellado por calor debe mantenerse adecuadamente y los interruptores de emergencia deben comprobarse para controlar su correcto funcionamiento al comienzo de cada turno.

EI área o las cámaras de refrigeración plantean otro tipo de riesgos de incendio, de salud y de seguridad. En cuanto a la prevención de incendios, el envoltorio del producto constituye un peligro, ya que suele fabricarse con poliestireno altamente combustible. El aislamiento de las paredes suele tener un núcleo de goma esponjosa de este material. Las cámaras frigoríficas deben protegerse adecuadamente con sistemas de pulverizadores en seco de acción preliminar diseñados para abordar riesgos extraordinarios. (En los sistemas de acción preliminar se emplean pulverizadores automáticos acoplados a los sistemas de conducción que contienen aire seco o nitrógeno, así como un sistema de detección complementario instalado en la misma área que los pulverizadores).

U na vez que las cestas de bandejas entran en la cámara frigorífica, los trabajadores deben recogerlas y levantarlas hasta la altura del hombro o superior para apilarlas en una plataforma móvil. Cuando las pilas de cestas ganan en altura, los trabajadores tienen que ayudarse entre sí para amontonarlas en niveles superiores.

L as temperaturas en estas cámaras pueden alcanzar los $-2{ }^{\circ} \mathrm{C}$. Los trabajadores deben recibir ropas de múltiples capas o "trajes anticongelación", además de calzado aislante con dispositivos de seguridad, y formación para utilizar estos equipos. Las plataformas móviles y las pilas de cestas deben ubicarse en diversas áreas de las cámaras frigoríficas hasta que sean reclamadas. A menudo, los trabajadores intentan ahorrar tiempo empujando varias pilas de bandejas al mismo tiempo, lo que puede dar lugar a lesiones musculares y de la parte inferior de la espalda.

La integridad de las cestas es un aspecto importante, tanto del control de la calidad del producto, como de la seguridad de los trabajadores. Si se acumulan rotas con otras completas apiladas en la parte superior, el conjunto de la carga se vuelve inestable y puede volcarse con facilidad. Los paquetes de producto caen sobre el suelo y se ensucian o deterioran, lo que obliga a repetir tareas y a realizar una manipulación extraordinaria a los trabajadores. Asimismo, las pilas pueden caer sobre otros miembros del personal.

Cuando se solicita una combinación de producto específica, las cestas pueden retirarse de la pila a mano. Las bandejas se cargan en un transportador con una balanza que las pesa y las marca con etiquetas en las que figuran el peso y los códigos de seguimiento. Las bandejas se embalan manualmente en cajas de cartón 0 de otros materiales, en ocasiones forradas con cubiertas impermeables. A menudo, los trabajadores deben coger las bandejas. Como en el caso del proceso de empaquetado, los paquetes de producto más grandes y pesados pueden provocar estrés en las manos, los brazos y los hombros. Los trabajadores se mantienen de pie durante mucho tiempo en una única ubicación. L as esteras antifatiga pueden reducir la tensión en las piernas y la parte inferior de la espalda.

A medida que las cajas de cartón con los paquetes se depositan en las cintas transportadoras, los envoltorios pueden sellarse con calor mientras se inyecta $\mathrm{CO}_{2}$. Tales operaciones, unidas a una refrigeración continua, prolonga la vida útil de almacenamiento del producto. A simismo, según avanzan las cajas, se añade una paleta de cápsulas de $\mathrm{CO}_{2}$ (hielo seco) para prolongar la vida útil del producto en su camino hacia el consumidor en un camión refrigerado. $\mathrm{No}$ obstante, el $\mathrm{CO}_{2}$ plantea riesgos inherentes en las áreas cerradas. Las cápsulas pueden dejarse caer desde una rampa o extraerse de un gran recipiente parcialmente cubierto. Aunque el límite de exposición (TLV) correspondiente al $\mathrm{CO}_{2}$ es relativamente alto y se dispone de controles continuos, los trabajadores también deben recibir formación sobre sus riesgos y síntomas y utilizar guantes y protectores oculares. Asimismo, deben colocarse en la zona signos de advertencia adecuados.

Las cajas con el producto dispuesto en bandejas suelen sellarse con material adhesivo termoimpregnado inyectado en el cartón. Pueden producirse quemaduras dolorosas por contacto si los ajustes, los sensores y las presiones no son adecuadas. LoS trabajadores deben utilizar protectores oculares con dispositivos laterales de defensa. Antes de realizar ajustes o reparaciones, los equipos de aplicación y sellado deben estar completamente desactivados y carentes de presión.

Después del sellado de las cajas, éstas pueden ser levantadas manualmente del transportador o ser trasladadas por una embandejadora automática u otro equipo accionado por control remoto. Debido a la elevada tasa productiva, existe la posibilidad de que se produzcan lesiones de espalda. Es un trabajo que suele desempeñarse en un medio ambiente frío, que tiende a provocar lesiones por tensión.

D esde un punto de vista ergonómico, la recuperación de cajas de cartón y el apilado puede automatizarse con facilidad, pero los costes de inversión y de mantenimiento son elevados.

\section{Deshuesado de muslos y pollo triturado}

En la industria avícola moderna no se desperdicia ninguna parte del pollo. Sus muslos se empaquetan a granel, se almacenan congelados 0 cuasicongelados y se elaboran o deshuesan, con tijeras $u$ otros instrumentos de mano accionados por aire comprimido. Al igual que en la operación de deshuesado de pechugas, los trabajadores dedicados a esta tarea deben eliminar el exceso de grasa y la piel con tijeras. Las temperaturas en el área de trabajo puede oscilar entre los 4 y los $7^{\circ} \mathrm{C}$. A pesar de que los recortadores pueden utilizar guantes forrados, el enfriamiento de las manos restringe la circulación sanguínea, aumentando así la acción de los agentes de estrés ergonómico.

U na vez refrigerada, la elaboración de la carne de los muslos puede continuar mediante el añadido de sazonadores y la trituración bajo una capa de $\mathrm{CO}_{2}$. Se comercializa como preparados de pollo o a granel.

\section{Elaboración de platos preparados}

Los cuellos, los cuartos traseros y el resto de los cuerpos resultantes del deshuesado de las pechugas no se desperdician y se depositan en grandes trituradores 0 mezcladores de paletas, transportados a través de mezcladores refrigerados y arrojados en recipientes de gran capacidad. El producto suele venderse 0 enviarse a otras fases de elaboración para obtener las denominadas "salchichas de pollo" o "salchichas de Francfort".

EI desarrollo reciente de alimentos preparados, que requieren una escasa elaboración en el hogar, ha dado lugar a la generación de productos de gran valor añadido en la industria avícola. Ciertas piezas seleccionadas de carne procedentes del deshuesado de pechuga se sitúan en recipientes giratorios; a continuación, se mezclan combinaciones de sazonadores y especias al vacío durante un período de tiempo determinado. La carne gana no sólo en sabor, sino también en peso, lo que mejora el margen de beneficio. Después, las piezas se empaquetan en bandejas individuales, que se sellan al vacío y se embalan en pequeñas cajas para su transporte. El proceso no depende del tiempo, por lo que los trabajadores no están sometidos a las mismas velocidades de la cadena productiva como otros que intervienen en la fase de trinchado. El producto final debe ser manipulado, inspeccionado y empaquetado con cuidado para lograr una presentación adecuada en los establecimientos de venta. 


\section{Resumen}

En todos los centros de producción avícola, la humedad de ciertos procesos y la grasa pueden dejar los suelos en condiciones muy peligrosas, con el consiguiente riesgo elevado de resbalones y caídas. U na limpieza adecuada de los pisos, un drenaje apropiado (situando barreras protectoras en todos los orificios del suelo), un calzado correcto (impermeable y antideslizante) suministrado a los trabajadores y unos suelos antideslizantes constituyen factores esenciales en la prevención de estos riesgos.

Además, los niveles de ruido elevados son habituales en los centros mencionados. Debe prestarse atención a las medidas técnicas adoptadas para reducirlos. Deben ofrecerse tapones para los oídos y repuestos y debe formularse un programa de conservación de la audición plena en el que se prevea la realización de exploraciones auditivas anuales.

La industria avícola constituye una combinación interesante de operaciones intensivas en la utilización de mano de obra y procesos de alta tecnología. El sudor y la angustia humanos aún caracterizan este sector. Las demandas de un aumento del rendimiento y de las velocidades de la cadena productiva eclipsan a menudo los esfuerzos dedicados a la formación y la protección adecuadas de los trabajadores. A medida que la tecnología mejora para contribuir a la eliminación de las lesiones o los trastornos debidos a la realización de movimientos repetitivos, es necesario que los equipos sean mantenidos y calibrados con cuidado por técnicos cualificados. En general, esta industria no atrae a técnicos altamente capacitados a causa de los mediocres niveles de remuneración, las condiciones de trabajo extremadamente estresantes y el carácter de la dirección, a menudo autocrática, que suele resistirse a los cambios positivos que pueden realizarse con una programación proactiva de la salud y la seguridad.

\section{IN DUSTRIA LACTEA}

\section{Marianne Smukowski y Norman Brusk}

Los productos lácteos constituyen un elemento importante de la alimentación humana desde tiempos remotos, cuando los animales comenzaron a domesticarse. En un principio, el trabajo se realizaba en el hogar o en las explotaciones agrarias e, incluso en la actualidad, gran parte de la producción se genera en pequeñas empresas, aunque la existencia de grandes industrias es habitual en numerosos países. Las cooperativas han tenido una gran importancia en el desarrollo de esta industria y la mejora de sus productos.

En muchos países, se han adoptado normativas estrictas que regulan la elaboración de productos lácteos y en las que se establece, por ejemplo, la obligación de pasteurizar todos los líquidos. En la mayoría de las industrias lácteas, la leche se pasteuriza; en ocasiones, se esteriliza o se homogeneiza. La obtención de productos lácteos seguros y de alta calidad es el objetivo de los centros productivos actuales. Aunque los recientes avances tecnológicos permiten una mayor sofisticación y automatización, la seguridad sigue siendo motivo de preocupación.

La leche líquida o fluida es la materia prima básica de la industria láctea. Se recibe en camiones cisterna (0, en ocasiones, en bidones) y se descarga. Los depósitos son revisados para comprobar la existencia de residuos de fármacos y la temperatura. La leche se filtra y se almacena en depósitos o silos. Su temperatura debe ser inferior a $7{ }^{\circ} \mathrm{C}$ y no debe mantenerse durante plazos superiores a 72 horas. Tras su almacenamiento, la leche es desnatada, la nata sin tratar se almacena en el mismo centro de producción o en otra ubicación y la leche restante se pasteuriza. La nata debe cumplir las mismas condiciones de temperatura y conservación referidas respecto a la leche. Antes 0 después de la pasteurización (calentamiento a $72{ }^{\circ} \mathrm{C}$ durante 15 segundos), pueden añadirse vitaminas. En el caso de que se agreguen, deben administrarse las concentraciones adecuadas. Tras la pasteurización, la leche se traslada a un depósito de almacenamiento. A continuación, se envasa, se refrigera y comienza su distribución.

En la producción de queso cheddar, la leche bruta recibida se filtra, se almacena y la nata se separa como se ha descrito. Antes de la pasteurización, los ingredientes secos y no lácteos se mezclan con la leche. El producto combinado se pasteuriza a una temperatura superior a $72{ }^{\circ} \mathrm{C}$ durante más de 15 segundos. Una vez superado este proceso, se añade el medio iniciador (previamente pasteurizado). La mezcla de queso y leche se introduce en una cuba preparada al efecto. En este momento, pueden agregarse los colorantes, la sal (CINa), el cuajo y el cloruro cálcico $\left(\mathrm{CaCl}_{2}\right)$. Posteriormente, el queso pasa a la mesa de desecado. Puede volver a añadirse sal en esta fase. Se elimina el suero y se deposita en un recipiente de almacenamiento. Antes del llenado puede utilizarse un detector de metales para comprobar la presencia de fragmentos metálicos en el queso. Después del Ilenado, el queso se prensa, se empaqueta, se almacena y se introduce en la cadena de distribución.

En cuanto a la producción de mantequilla, la nata sin tratar obtenida al desnatar la leche se almacena en el propio centro de elaboración 0 es recibida en camiones 0 bidones. La nata se pasteuriza a temperaturas superiores a $85{ }^{\circ} \mathrm{C}$ durante más de 25 segundos y se mantienen en depósitos de almacenamiento. La nata es precalentada y bombeada a la mantequera. Durante el batido de la leche, puede añadirse agua, colorantes, sal y el destilado iniciador. Tras esta operación, el suero producido se acumula en depósitos. La mantequilla se bombea a un silo y se empaqueta posteriormente. Puede utilizarse un detector de metales antes o después del empaquetado para comprobar la presencia de fragmentos metálicos en el producto. Una vez empaquetada, la mantequilla se dispone en paletas, se almacena y se introduce en la cadena de distribución.

En la producción de leche en polvo, la leche sin tratar se recibe, filtra y almacena como ya se ha descrito. Tras su almacenamiento, se precaliente y desnata. La nata en bruto se conserva en el centro de producción o se envía a otro lugar. La leche restante se pasteuriza. La temperatura de la nata y la leche desnatada sin tratar debe ser inferior a $7{ }^{\circ} \mathrm{C}$ y mantenerse durante un período no superior a 72 horas. La leche desnatada en bruto se pasteuriza a una temperatura superior a $72{ }^{\circ} \mathrm{C}$ durante 15 segundos, se evapora mediante secado entre cilindros calentados o deshidratación por aspersión y se almacena en depósitos. Después de su almacenamiento, el producto se introduce en un sistema de secado. Una vez concluida esta operación, se procede a su refrigeración. El aire utilizado, tanto caliente como frío, debe filtrarse. Tras el enfriamiento, el producto se traslada a un depósito de almacenamiento a granel, se tamiza y se envasa. Puede utilizarse un imán antes del envasado para detectar la presencia de fragmentos de metales ferrosos mayores de 0,5 mm en la leche en polvo. Asimismo, puede aplicarse un detector de metales antes o después del envasado. U na vez concluida esta operación, la leche en polvo se almacena y se distribuye.

\section{Buenas prácticas de fabricación}

L as buenas prácticas de fabricación (BPF) son directrices concebidas para facilitar el funcionamiento ordinario de los centros de producción láctea y garantizar la fabricación en condiciones de seguridad. Entre las áreas abordadas figuran las instalaciones, la recepción y el almacenamiento, el rendimiento y el 
mantenimiento de los equipos, los programas de formación del personal, la higiene y los programas de retirada de los productos.

La contaminación microbiológica, física y química de los productos lácteos constituye una gran preocupación en el sector. Son riesgos de carácter microbiológico los planteados por el brucella, el clostridium botulinum, el listeria monocytogenes, la hepatitis A y E, la salmonella, el escherichia coli 0157:H 7, el bacillus cereus, el staphylococcus aureus y diversos parásitos. Entre los riesgos químicos se cuentan las toxinas naturales, los metales, los residuos de fármacos, los aditivos alimentarios y los productos químicos inadvertidos. Como consecuencia, las industrias lácteas llevan a cabo numerosas pruebas farmacológicas, microbiológicas y de otros tipos para garantizar la pureza de sus productos. La limpieza por vapor y química de los equipos es necesaria para mantener las condiciones de higiene.

\section{Riesgos y su prevención}

Los riesgos para la seguridad consisten en los resbalones y las caídas causados por las superficies húmedas o jabonosas de suelos y escaleras; Ias exposiciones a máquinas desprotegidas como las que tengan puntos de mordedura, los transportadores, los dispositivos de empaquetado, los mecanismos de relleno, los cortadores, etc.; y las exposiciones a descargas eléctricas, sobre todo en áreas húmedas.

Los pasillos deben mantenerse despejados. Los materiales derramados deben limpiarse de inmediato. Los suelos deben cubrirse de material antideslizante. La maquinaria debe protegerse de manera adecuada y ponerse a tierra, y deben instalarse interruptores de circuito de tierra accidental en las áreas húmedas. Es necesario establecer los procedimientos de bloqueo y advertencia pertinentes para garantizar que la posibilidad de un arranque imprevisto de las máquinas y los equipos no provoque lesiones al personal de las fábricas.

Las quemaduras térmicas pueden producirse por el contacto con conductos de vapor y la limpieza con este elemento, así como por fugas o roturas de los conductos de equipos hidráulicos de alta presión. Las "quemaduras" criogénicas pueden sufrirse por la exposición a un refrigerante compuesto por amoníaco líquido. Un mantenimiento correcto, la formulación de procedimientos de actuación en caso de vertidos y fugas y la formación pueden reducir al mínimo el riesgo de quemaduras.

Incendios y explosiones. Las fugas en los sistemas de conducción de amoníaco (el límite explosivo inferior del amoníaco es del $16 \%$, y el superior, del $25 \%$ ), la leche en polvo y otros materiales inflamables y combustibles, las operaciones de soldeo y los escapes de los equipos hidráulicos de alta presión pueden dar lugar a incendios y explosiones. Es necesario instalar un detector de fugas de amoníaco en las áreas en que existen sistemas de refrigeración basados en esta sustancia. Los materiales inflamables y combustibles deben almacenarse en recipientes de metal cerrados. La pulverización de leche en polvo debe satisfacer los requisitos pertinentes en materia de prevención de explosiones. Las operaciones de soldadura sólo serán llevadas a cabo por personal autorizado. Las botellas de gas comprimido deben examinarse regularmente. Deben tomarse precauciones para evitar la mezcla de oxígeno con gases inflamables. Las botellas se mantendrán alejadas de las fuentes de calor.

La congelación y el estrés por frío pueden deberse a la exposición acaecida en congeladores y cámaras frigoríficas. Las precauciones recomendadas en este caso consisten en la utilización de ropas protectoras adecuadas, la rotación de puestos con áreas de mayor temperatura, la instalación de comedores acondicionados y la disposición de bebidas calientes.

Las exposiciones a niveles de ruido elevados pueden producirse en las operaciones de elaboración, empaquetado, trituración y moldeo por soplado de moldes de plástico. Entre las precauciones oportunas figuran el aislamiento de los equipos ruidosos, el mantenimiento apropiado, la utilización de protectores auditivos y la formulación de un programa de conservación de la audición.

Cuando se accede a espacios restringidos, como al entrar en pozos de desagüe o al limpiar depósitos, debe garantizarse la ventilación. El área debe quedar despejada de equipos, productos, gases y personal. Las ruedas de paletas, mezcladores y otros equipos deben bloquearse.

Levantar materias primas, arrastrar cajas de producto y empaquetar son actividades asociadas a problemas ergonómicos. Entre las soluciones figura la mecanización y la automatización de las operaciones manuales.

En la industria láctea puede producirse una amplia gama de exposiciones a sustancias químicas, como el contacto con:

- vapores de amoníaco debidos a fugas en los sistemas de refrigeración;

- productos químicos corrosivos (p. ej., el ácido fosfórico, utilizado en la fabricación de requesón, los compuestos de limpieza, los ácidos de bacterias, etc.);

- el gas cloro generado por la combinación involuntaria de productos higiénicos clorados con ácidos;

- el peróxido de hidrógeno generado en las operaciones de empaquetado realizadas a temperaturas muy altas;

- el ozono (y la radiación ultravioleta) derivados de la luz ultravioleta utilizada en las actividades de higienización;

- el monóxido de carbono producido por la acción de sustancias cáusticas que reaccionan con el azúcar lácteo en las operaciones de limpieza in situ en los vaporizadores de leche;

- el monóxido de carbono generado por los carros elevadores que funcionan con propano o gasolina, los calentadores a gas y los dispositivos a gas de sellado por calor,

- el cromo, el níquel y otros humos y gases de soldeo.

Los trabajadores deben recibir formación y conocer las prácticas de manipulación de productos químicos peligrosos, que han de etiquetarse convenientemente. D eben establecerse procedimientos operativos normalizados, que serán observados en la limpieza de vertidos. En caso necesario, se dispondrá de sistemas de extracción localizada. Se suministrarán ropas protectoras, gafas de seguridad, máscaras faciales, guantes, etc. y se velará por su mantenimiento. Cuando se trabaje con materiales corrosivos, podrá accederse a instalaciones para el lavado de ojos y duchas rápidas.

Riesgos biológicos. Los trabajadores pueden estar en contacto con diversas bacterias y otros factores de riesgo microbiológico asociados a la leche fresca y los quesos no tratados. Entre las precauciones que deben adoptarse figuran la utilización de guantes adecuados, una buena higiene personal y la disposición de instalaciones sanitarias apropiadas.

\section{PRODUCCION DE CACAO E IN DUST RIA DEL CHO COLATE}

\section{Anaide Vilasboas de Andrade}

El cacao es un producto originario de la región amazónica de América del Sur $y$, durante los primeros años del siglo $X X$, la parte meridional de Bahía ofrecía las condiciones perfectas para su crecimiento. Con Ilheus e I tabuna como núcleos principales, esta región, compuesta por 92 municipios, concentra el $87 \%$ de la producción nacional de cacao en Brasil, en la actualidad, el segundo mayor productor mundial de semillas de cacao. Se 
obtiene también en otros 50 países, de los que Nigeria y G hana son los mayores productores.

La gran mayoría de esta producción se exporta a países como Japón, Federación Rusa, Suiza y Estados Unidos; la mitad se vende en forma de productos elaborados (chocolate, grasa vegetal, licor de chocolate, cacao en polvo y manteca) y el resto se exporta como semillas de cacao.

\section{Visión general del proceso}

El método industrial de elaboración del cacao comprende varias fases. Comienza con el almacenamiento de la materia prima en los locales adecuados, donde es fumigada para evitar la proliferación de roedores e insectos. A continuación, se inicia el proceso de limpieza de los granos, con el fin de eliminar los objetos extraños y los residuos. Después, las semillas se secan para extraer el exceso de humedad hasta que se alcanza un nivel ideal. La fase siguiente consiste en la trituración de los granos encaminada a separar la cáscara del núcleo y, posteriormente, se procede al tostado, que consiste en el calentamiento de la parte interior del grano.

El producto resultante, que adopta la forma de pequeñas partículas, se somete al proceso de molienda, para convertirse en una pasta líquida que, a su vez, filtrada y solidificada en cámaras de refrigeración y vendida como pasta.

La mayoría de las empresas que realizan la molienda suelen separar el licor a través de un proceso de prensado, hasta que extraen la grasa y la convierten en dos productos finales: manteca de cacao y torta de cacao. La torta se empaqueta en piezas sólidas, mientras que la manteca se filtra, desodoriza, se enfría en cámaras de refrigeración y, por último, se envasa.

\section{Riesgos y su prevención}

Aunque la elaboración del cacao suele automatizarse de modo que requiere un escaso contacto manual y se mantiene un nivel de higiene elevado, la gran mayoría de los trabajadores de esta industria están expuestos de todos modos a diversos riesgos profesionales.

El ruido y la vibración excesiva son problemas observados en toda la cadena de producción, puesto que, con el fin de evitar un acceso sencillo al producto de roedores e insectos, los almacenes cerrados se construyen con la maquinaria suspendida sobre plataformas metálicas. Tales equipos deben someterse a rutinas de mantenimiento y ajuste apropiadas. D eben instalarse dispositivos antivibratorios. Es necesario aislar la maquinaria ruidosa 0 utilizar barreras para la atenuación del sonido.

En el proceso de fumigación, se utilizan pastillas de fosfato de aluminio; si éstas entran en contacto con aire húmedo, se libera fosfamina. Se recomienda que los granos permanezcan cubiertos de 48 a 72 horas durante y después de las sesiones de fumigación. D eben tomarse muestras del aire antes de volver a acceder al lugar de depósito.

El funcionamiento de las trituradoras, las prensas hidráulicas y los equipos de secado genera un nivel elevado de calor y ruido, y la intensidad del primero aumenta en función del tipo de construcción de los edificios. N o obstante, pueden adoptarse numerosas medidas de seguridad: utilización de barreras, aislamiento de las operaciones, aplicación de programas de horas de trabajo y descansos, disponibilidad de bebidas, utilización de ropas adecuadas y aclimatación apropiada de los trabajadores. En las áreas reservadas a los productos terminados, donde la temperatura media alcanza los $10^{\circ} \mathrm{C}$, los miembros del personal deben emplear una vestimenta adecuada y someterse a períodos de trabajo de 20 a 40 minutos. EI proceso de aclimatación también es importante. Es necesario establecer períodos de descanso en áreas acondicionadas.
En las tareas de recepción del producto, en las que se almacena las materias primas y la totalidad de productos terminados son envasados, la maquinaria y los procedimientos inadecuados desde un punto de vista ergonómico son habituales. L os equipos mecanizados deben sustituir a la manipulación manual siempre que sea posible, ya que el movimiento y transporte de cargas puede causar lesiones, los artículos pesados pueden golpear a los trabajadores y pueden producirse accidentes debido a la utilización de maquinaria desprovista de los protectores pertinentes.

Los procedimientos y los equipos deben evaluarse desde una perspectiva ergonómica. Las caídas debidas al estado resbaladizo de los suelos también constituyen un motivo de preocupación. Además, hay otras actividades, como la trituración de los granos y la molienda y la producción de polvo de cacao, en las que se genera un nivel elevado de polvo orgánico. Deben instalarse sistemas adecuados de ventilación por dilución o de extracción localizada y los procesos y las operaciones deben aislarse según convenga.

Se recomienda encarecidamente la formulación de un programa riguroso de prevención de riesgos ambientales, combinada con la aplicación de un sistema regular de prevención de incendios y seguridad, una protección adecuada de la maquinaria y el establecimiento de las normas de higiene apropiadas. Las señales y los folletos informativos que se determinen deben colocarse en lugares bien visibles y deben distribuirse a cada trabajador los equipos y los dispositivos de protección personal pertinentes. En cuanto al mantenimiento de la maquinaria, debe establecerse un programa de procedimientos de bloqueo y carteles de advertencia para evitar lesiones.

\section{Cereales, elaboracion de CEREALES Y PRODUCTOS DE CONSUMO BASADOS EN CEREALES}

\author{
Tomas E. H awkinson, James J. Collins \\ y G ary W. O Imstead
}

L os cereales pasan por numerosas fases y procesos en su elaboración para el consumo humano. Las etapas principales son: la recogida, la consolidación y el almacenamiento en silos, la obtención de un producto intermedio como la fécula o la harina y la conversión en productos terminados como el pan, los copos o los aperitivos.

\section{Recogida, consolidación y almacenamiento de cereales}

L os cereales se cultivan en explotaciones agrarias y se trasladan a silos con elevador. Son transportados en camión, por ferrocarril, en barcazas o buques en función de la ubicación de la explotación y del tamaño y el tipo de almacén. Los silos con elevador se utilizan para recoger, clasificar y almacenar productos agrarios. L os cereales se separan de acuerdo con su calidad, su contenido en proteínas, su humedad y otros factores. Los silos con elevador contienen depósitos, tanques y otros receptáculos con cintas transportadoras continuas verticales y horizontales. A mbas constan de cubetas; las primeras, para transportar el cereal hasta las bandejas de pesado y, las segundas, para la distribución del cereal en los depósitos. Estos disponen de salidas de descarga en su parte inferior para depositar el cereal en la cinta horizontal que lo traslada a la cinta vertical para su pesado y su transporte o devolución al almacén. Los silos con elevador pueden tener una capacidad que oscila entre miles de fanegas en el caso de los almacenes locales y 
millones de fanegas en el de los silos terminales. A medida que estos productos avanzan en su elaboración, pueden ser manipulados en numerosas ocasiones a través de silos con elevador de tamaño y capacidad cada vez mayor. Cuando están preparados para su transporte a otros silo o instalación productiva, se cargan en un camión, un vagón, una barcaza o un buque.

\section{Molienda}

La molienda consta de una serie de operaciones que consisten en la trituración de los cereales para obtener fécula o harina, normalmente del trigo, la avena, el maíz, el centeno, la cebada y el arroz. El producto en bruto se muele y se criba hasta que se alcanza el tamaño deseado. Habitualmente, la molienda comprende las fases siguientes: entrega del cereal en bruto en el silo de la fábrica, limpieza y preparación del cereal, molienda del cereal y clasificación por tamaño y parte, empaquetado de la harina, la fécula y los subproductos obtenidos para su distribución comercial o su transporte a granel destinado a la utilización en diversas aplicaciones industriales.

\section{Fabricación de productos para el consumo basados en cereales}

La producción de pan, copos de cereal y otros productos de panadería comprende las fases siguientes: combinación de los ingredientes primordiales, producción y tratamiento de la masa, formación del producto, horneado o tostado, refrigeración 0 congelación, empaquetado, introducción en cajas, paletización $y$ transporte final.

Las materias primas suelen almacenarse en depósitos y tanques. Algunas se manejan en grandes sacos u otro tipo de contenedores. L os materiales se transportan a las áreas de elaboración utilizando transportadores mecánicos, bombas o métodos de manipulación manual.

La elaboración de la masa es la fase en la que los ingredientes en bruto, incluida la harina, el azúcar, las grasas y los aceites y otros elementos de menor importancia, como los sazonadores, las especias y las vitaminas, se combinan en un recipiente de cocción. A estos ingredientes pueden añadirse otros como puré 0 pulpa de frutas. Los frutos secos suelen pelarse y cortarse al tamaño apropiado. Se utilizan hornos de cocción (de proceso continuo o por lotes). La elaboración de la masa para avanzar a fases de producción intermedias puede exigir la utilización de extrusores, moldes, granuladoras y sistemas de conformación. 0 tras operaciones posteriores pueden requerir la aplicación de sistemas de laminación, moldes, calentadores, secadoras y sistemas de fermentación.

En los sistemas de empaquetado se coloca el producto terminado en envueltas individuales de papel o de plástico, se depositan los artículos individuales en cajas y se apilan éstas en paletas preparadas para su envío. El apilado manual de paletas o manipulación del producto se utiliza junto con carretillas de horquilla elevadora.

\section{Cuestiones relativas a la seguridad mecánica}

Los riesgos relacionados con los equipos incluyen los puntos de funcionamiento capaces de desgastar, cortar, magullar, aplastar, fracturar y amputar. Los trabajadores pueden protegerse mediante la instalación de dispositivos de defensa o el aislamiento de los riesgos, desactivando las fuentes de energía antes de realizar tareas de mantenimiento 0 ajuste en los equipos e impartiendo formación a los trabajadores acerca de los procedimientos correctos que deben seguirse al trabajar con la maquinaria.

Las máquinas utilizadas para elaborar y transportar los productos pueden resultar especialmente peligrosas. EI sistema neumático y sus válvulas rotatorias pueden provocar graves amputaciones de dedos y manos. L os equipos deben bloquearse durante las operaciones de mantenimiento y limpieza. Todas las máquinas deben dotarse de los dispositivos de protección adecuados y los trabajadores deben ser instruidos acerca de los procedimientos operativos pertinentes.

Los sistemas de elaboración constan de componentes mecánicos en movimiento bajo un control automático que pueden producir lesiones importantes, sobre todo en dedos y manos. LoS hornos de cocción generan calor y ruido y suelen basarse en el calentamiento por vapor a presión. L os troqueles de extrusión pueden estar formados por componentes móviles peligrosos, incluidos cuchillos en movimiento a gran velocidad. Las máquinas mezcladoras pueden provocar lesiones graves y son especialmente peligrosas al efectuar la limpieza entre distintos lotes. Los procedimientos de bloqueo y carteles de advertencia reducen al mínimo el riesgo de los trabajadores. L as cuchillas rotatorias e hidráulicas pueden causar laceraciones importantes y son particularmente peligrosas en los procedimientos de modificación y ajuste. 0 tras actividades de elaboración pueden requerir la aplicación de sistemas de laminación, moldes, calentadores, secadoras y sistemas de fermentación, que plantean otros riesgos para las extremidades en forma de lesiones por aplastamiento y quemaduras. La manipulación y la apertura de sacos puede dar lugar a cortes y magulladuras.

L os sistemas de empaquetado constan de piezas móviles automatizadas capaces de provocar lesiones por aplastamiento y desgarro. Los procedimientos de mantenimiento y ajuste son extremadamente peligrosos. El apilado manual de las paletas - la manipulación de productos puede causar lesiones por esfuerzo repetitivo. Las carretillas de horquilla elevadora y los transportadores manuales de paletas también son peligrosos y las cargas apiladas 0 aseguradas deficientemente pueden caer sobre el personal circundante.

\section{Incendio y explosión}

Los incendios y las explosiones pueden destruir las instalaciones de manipulación de cereales y herir o acabar con la vida de trabajadores y de otras personas presentes en los centros productivos 0 en zonas cercanas en el momento de la explosión. Para que ésta se produzca, se requiere oxígeno (aire), combustible (polvo de cereales), una fuente de ignición de la energía y la duración suficiente (chispa, llama o superficie caliente) y un espacio limitado (para que aumente la presión). $\mathrm{H}$ abitualmente, cuando se produce una explosión en un centro de producción cerealista, éstas no es única, sino múltiple. La inicial, que puede ser pequeña y localizada, puede dejar polvo en suspensión en el aire en toda la instalación, en concentraciones suficientes para sostener explosiones secundarias de gran magnitud. El límite inferior de explosión en el caso del polvo de cereal es de unos $20.000 \mathrm{mg} / \mathrm{m}^{3}$.

La prevención de los riesgos de incendio y explosión puede asegurarse mediante el diseño de fábricas en las que se reduzcan al mínimo los espacios cerrados (salvo por lo que respecta a depósitos, tanques y silos), el control de las emisiones de polvo a la atmósfera y las acumulaciones sobre suelos y superficies de los equipos (aislamiento de corrientes de producto, extracción localizada, mantenimiento y utilización de aditivos como el agua o el aceite mineral para la alimentación), y el control de la explosión (sistemas de extinción de incendios y explosiones, ventilación de explosiones). Debe existir salidas de incendio u otros medios de huida adecuados. Los equipos de lucha contra incendios deben ubicarse de manera estratégica, y los trabajadores deben recibir formación sobre la actuación en caso de emergencia, aunque sólo debe intentarse la extinción de incendios muy limitados, debido a la posibilidad de explosión. 


\section{Riesgos para la salud}

Puede generarse polvo cuando el cereal se traslada 0 se remueve. Aunque en la mayoría de los casos, este polvo es un mero factor de irritación del tracto respiratorio, los polvos derivados de cereales no elaborados pueden contener mohos y otros contaminantes capaces de provocar fiebre y reacciones asmáticas alérgicas en personas sensibles. Los trabajadores tienden a evitar el desarrollo de su trabajo en áreas de generación de polvo durante períodos prolongados. $\mathrm{H}$ abitualmente, se utiliza protección respiratoria en los casos necesarios. Las mayores exposiciones al polvo se producen en las operaciones de carga y descarga y en las de limpieza general. En algunos estudios se han indicado la existencia de cambios en la función respiratoria relacionados con este tipo de exposición. EI TLV estipulado por la actual Conferencia Americana de $\mathrm{H}$ igienistas Industriales del Gobierno (ACGIH) respecto a la exposición en el trabajo al polvo de cereales es de $4 \mathrm{mg} / \mathrm{m}^{3}$ en el caso de la avena, el trigo y la cebada, y de $10 \mathrm{mg} / \mathrm{m}^{3}$ en otros casos (partículas, no clasificadas de otro modo).

Suelen utilizarse protectores respiratorios para reducir al mínimo la exposición. Los protectores de este tipo aprobados pueden ser muy eficaces si se emplean correctamente. L os trabajadores deben recibir formación sobre su uso correcto, su mantenimiento y sus limitaciones. La conservación de las instalaciones es esencial.

Los plaguicidas se utilizan en las industrias cerealistas para controlar la acción de insectos, roedores, pájaros, moho, etc. Algunos de los más comunes son la fosfamina, los organofosfatos, las piretrinas. Los efectos para la salud de estas sustancias pueden consistir en dermatitis, mareos, náuseas y problemas a largo plazo de hígado, riñón y de las funciones del sistema nervioso; sólo se producen si la exposición de los trabajadores es excesiva.

En la mayoría de los centros de producción cerealista se aplican plaguicidas en los períodos de inactividad, cuando la presencia de trabajadores en las instalaciones es mínima. El personal que lo lleve a cabo debe formar parte del equipo encargado de la aplicación de estas sustancias y recibir una formación especial. Deben observarse las normas de reentrada para prevenir la sobreexposición. En muchos lugares se calienta la estructura en su conjunto a temperaturas en torno a los $60{ }^{\circ} \mathrm{C}$ durante 24 a 48 horas, en lugar de utilizar plaguicidas químicos. Asimismo, los trabajadores pueden verse expuestos a los plaguicidas presentes en el cereal elaborado transportado a la terminal de carga y descarga en camiones o vagones.

El ruido es un problema común en la mayoría de estos centros de fabricación. Los niveles predominantes oscilan entre los 83 y los 95 dBA, pero pueden exceder los 100 dBA en ciertas áreas. La posibilidad de recurrir a la absorción acústica es limitada, debido a la necesidad de limpiar los equipos utilizados en estas instalaciones. La mayoría de los suelos están fabricados en cemento, loseta y acero inoxidable para facilitar las tareas de limpieza y evitar que el centro productivo se convierta en un refugio de insectos. Muchos trabajadores se desplazan de un área a otra y pasan poco tiempo desarrollando su actividad en las zonas más ruidosas. De este modo se reduce la exposición personal de manera considerable, si bien deben utilizarse protectores auditivos para lograr que el ruido percibido se sitúe en niveles aceptables.

El trabajo en un espacio cerrado como un depósito, un tanque 0 un silo puede plantear riesgos físicos y de salud a los trabajadores. La mayor preocupación se refiere a la deficiencia de oxígeno. Los recipientes de este tipo, cerrados herméticamente, pueden registrar carencias de oxígeno debido a la presencia de gases inertes (nitrógeno y dióxido de carbono para evitar la propagación de plagas) y a la acción biológica (proliferación de insectos y de moho). Antes de acceder a un depósito de este tipo u otros espacios cerrados, deben comprobarse las condiciones atmosféricas en el interior para determinar la existencia de oxígeno en una cantidad suficiente. Si la proporción de éste es inferior a 19,5\%, debe procederse a la ventilación. Asimismo, debe examinarse la aplicación reciente de plaguicidas u otros materiales tóxicos que puedan estar presentes. L os riesgos físicos en este tipo de espacios consisten en el hundimiento en el cereal y en la posibilidad de quedar atrapado debido a la configuración del lugar (paredes inclinadas hacia dentro y equipos instalados en el interior). No debe permitirse la presencia de trabajadores en silos, depósitos o tanques de cereal durante las operaciones de extracción del mismo. Pueden evitarse lesiones y muertes mediante la desactivación y el bloqueo de todos los equipos asociados al espacio limitado, garantizando que los miembros del personal utilizan arneses con cuerda salvavidas mientras permanezcan en el interior de estos recintos y manteniendo el suministro de aire respirable. Antes de la entrada, debe comprobarse la atmósfera para determinar la presencia de gases combustibles, vapores y agentes tóxicos, así como la suficiencia del oxígeno existente. Los trabajadores no deben acceder a estos depósitos y situarse debajo de una acumulación de cereal en forma de puente o en lugares donde el cereal amontonado a ambos lados pueda caer y cubrirlos totalmente.

\section{Exploración médica}

Los aspirantes a trabajar en este sector deben someterse a una exploración médica centrada en la detección de alergias preexistentes y en la comprobación de las funciones del hígado, los riñones y los pulmones. Pueden exigirse exploraciones especiales a los encargados de la aplicación de plaguicidas y a los trabajadores que utilizan protectores respiratorios. Es necesario llevar a cabo evaluaciones de la capacidad auditiva para valorar posibles pérdidas de la misma. En los seguimientos periódicos se tratará de establecer las modificaciones producidas.

\section{PANADERIAS}

\section{R.F. Villard*}

La fabricación de alimentos a partir de féculas y azúcares se realiza en las panaderías y en los centros de producción de galletas, pasteles y tartas. Los riesgos para la salud y la seguridad que plantean las materias primas, las instalaciones, los equipos y los procesos de fabricación en estos centros son similares. El artículo se centra en las pequeñas panaderías y se abordan las cuestiones relacionadas con la elaboración de pan y otros productos afines.

\section{Producción}

La fabricación de pan consta de tres fases principales: mezcla y moldeo, fermentación y cocción. Tales procesos se llevan a cabo en áreas de trabajo diferentes, como son el almacén de materias primas, la sala de mezcla y moldeo, las cámaras refrigeradas y fermentación, el horno, la sala de refrigeración y la zona de envolvimiento y empaquetado. Las instalaciones para la venta suelen encontrarse anexas a los lugares de fabricación.

Para elaborar la masa, se combinan harina, agua, sal y levadura. La mezcla a mano ha sido sustituida en buena medida por la utilización de mezcladoras mecánicas. Las batidoras se utilizan en la fabricación de otros productos. La masa se deja

\footnotetext{
* Adaptado de la 3a edición de la E nciclopedia de salud y seguridad en el trabajo.
} 
Figura 67.8 - Producción de pan para una cadena de supermercados en Suiza.

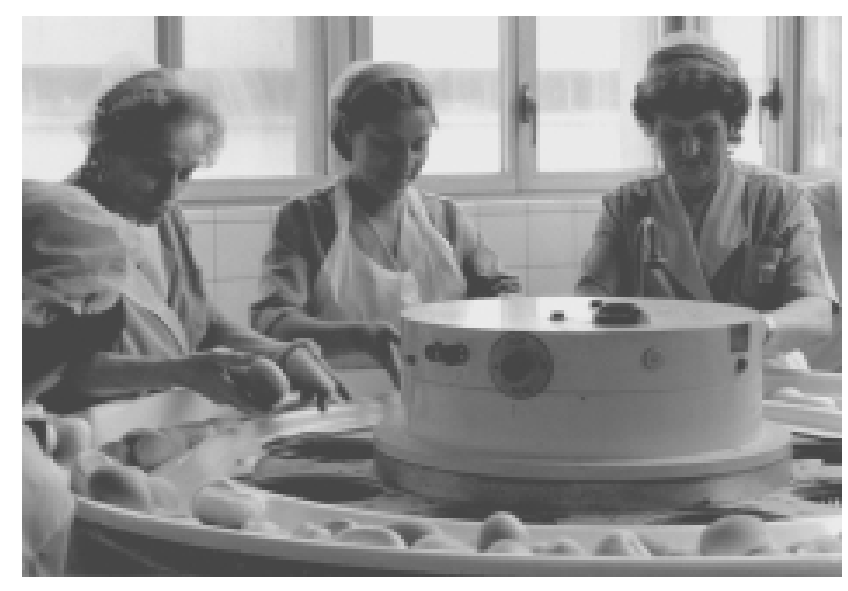

fermentar en una atmósfera cálida y húmeda y, posteriormente, se divide, pesa, moldea y cuece (véase la Figura 67.8).

Los hornos de producción a pequeña escala son del tipo de hogar fijo, con transferencia de calor directa o indirecta. En el primer caso, el revestimiento refractario se calienta de modo intermitente o continuo antes de cada carga. Los gases generados pasan a la chimenea a través de orificios ajustables situados en la parte posterior de la cámara. En el tipo indirecto, la cámara se calienta con el vapor que pasa por los conductos situados en la pared de la misma o mediante la circulación de aire caliente forzada. El horno puede ser alimentado con madera, carbón, petróleo, gas ciudad, gas de petróleo licuado 0 electricidad. En las áreas rurales, aún se encuentran hornos con hogares calentados directamente por hogueras de leña. EI pan se introduce en el horno con la ayuda de palas o bandejas. El interior puede iluminarse de forma que pueda observarse el pan en plena cocción a través de las ventanas de la cámara. D urante la cocción, el aire de la cámara se carga con el vapor de agua generado por el producto $y / 0$ introducido en forma de vaho. El exceso de este vapor suele perderse por la chimenea, aunque también puede dejarse abierta la puerta del horno.

\section{Riesgos y su prevención}

\section{Condiciones de trabajo}

Las condiciones de trabajo en las panaderías artesanales pueden presentar las características siguientes: trabajo nocturno que comienza a las 2 o las 3 de la madrugada, sobre todo en los países mediterráneos, donde la masa se prepara por la noche; instalaciones plagadas de parásitos como cucarachas, ratones y ratas, que pueden ser portadores de microorganismos patógenos (deben utilizarse materiales de construcción apropiados para garantizar que las instalaciones se mantienen en un estado de higiene adecuado); reparto del pan a domicilio, que no siempre se efectúa en las condiciones de higiene oportunas y que puede obligar a soportar un carga de trabajo excesiva; remuneración escasa complementada con la oferta de alojamiento y manutención.

\section{Instalaciones}

Las instalaciones suelen ser anticuadas, se encuentran en mal estado y plantean problemas de salud y seguridad considerables. La situación es especialmente grave en los locales alquilados, cuando ni el arrendatario ni el arrendador pueden permitirse el coste de la renovación. Las superficies del suelo pueden estar resbaladizas cuando están húmedas, aunque son razonablemente seguras en estado seco. Deben emplearse superficies antideslizantes siempre que sea posible. La higiene general se resiente debido a las deficiencias de los servicios sanitarios, el aumento de los riesgos de intoxicación, explosión e incendio y la dificultad de modernizar los equipos pesados de las fábricas de pan debido a las condiciones de arrendamiento. Las instalaciones de tamaño reducido no pueden dividirse adecuadamente; en consecuencia, los pasillos y las vías de paso se bloquean o se cubren de desechos, la disposición espacial de los equipos es inadecuada, la manipulación resulta difícil y el peligro de resbalones y caídas, choques con la maquinaria, quemaduras y lesiones debidas al agotamiento aumenta. Cuando las instalaciones se sitúan en dos o más pisos, existe el peligro de caída desde altura. Las ubicadas en sótanos suelen carecer de salidas de emergencia, tienen escaleras de acceso estrechas, en espiral o demasiado empinadas y están equipadas con una iluminación artificial deficiente. Su ventilación suele ser inadecuada y, en consecuencia, los niveles de temperatura y humedad son excesivos; la utilización de simples ventiladores de techo a la altura de la calle contribuye a la contaminación de la atmósfera de la panadería por el polvo del exterior y los gases de escape de los vehículos.

\section{Accidentes}

La utilización generalizada de cuchillos y agujas en las panaderías artesanales conlleva un riesgo de cortes y heridas por punción y de posterior infección; los objetos pesados y romos como pesas y bandejas pueden causar lesiones por aplastamiento si caen sobre los pies de los trabajadores.

L os hornos generan varios riesgos. Dependiendo del combustible utilizado, se corre el peligro de incendio y explosión. El retorno de la llama, el vapor, las cenizas, los productos horneados o los equipos no aislados pueden provocar quemaduras y escaldaduras. L os equipos de lucha contra incendios mal ajustados o que carecen de la potencia suficiente, así como las chimeneas defectuosas, pueden dar lugar a la acumulación de vapores o gases de combustible no consumido, 0 de productos de la combustión, como el monóxido de carbono, que pueden causar intoxicación o asfixia. Los equipos y las instalaciones eléctricas deficientes, sobre todo portátiles, pueden generar descargas eléctricas. El serrado y el corte de madera para los hornos alimentados por leña puede provocar cortes y abrasiones.

La harina se entrega en sacos con un peso de hasta $100 \mathrm{~kg}$ y, con frecuencia, éstos deben ser izados y transportados por trabajadores a lo largo de pasillos tortuosos (escaleras y cuestas empinadas) a las salas de almacenamiento. Existe el peligro de caída durante el transporte de cargas pesadas y estas arduas operaciones de manipulación pueden provocar dolores de espalda y lesiones de los discos intervertebrales. Los riesgos pueden evitarse mediante: la disposición de vías de acceso a las instalaciones adecuadas; la estipulación de un peso máximo de los sacos de harina, la utilización de equipos de manipulación mecánica de un tipo apropiado para su empleo en pequeñas empresas y a un precio asequible para la mayoría de los trabajadores artesanos; y la generalización en el uso del transporte de harina a granel que, sin embargo, sólo es conveniente cuando la facturación del productor es de una magnitud suficiente.

El polvo de harina constituye otro factor de riesgo de incendio y explosión, y deben tomarse las precauciones pertinentes al respecto, incluida la dotación de sistemas supresores de explosiones e incendios.

En las panaderías mecanizadas, la masa en un estado activo de fermentación puede emitir cantidades peligrosas de dióxido de carbono; por tanto, debe garantizarse una ventilación exhaustiva en espacios restringidos siempre que exista la 
probabilidad de acumulación de gas (canales de evacuación de la masa, etc.) Los trabajadores deben recibir formación sobre los procedimientos convenientes en espacios limitados.

En la fabricación de pan se utiliza una amplia gama de máquinas, sobre todo en las panaderías industriales. La mecanización puede tener como consecuencia el acaecimiento de accidentes graves. La moderna maquinaria de panadería suele venir equipada con dispositivos de protección incorporados cuya correcta operación depende a menudo del funcionamiento de interruptores eléctricos de seguridad y de bloqueos positivos. LoS dispositivos y conductos de alimentación presentan riesgos especiales que pueden eliminarse mediante la ampliación de la longitud de las aperturas de alimentación por encima de la longitud del brazo, con el fin de evitar que el trabajador pueda alcanzar los componentes móviles; en ocasiones, se utilizan puertas dobles de bisagra 0 aletas giratorias como dispositivos de alimentación para el mismo fin. Los salientes de las amasadoras pueden protegerse mediante mecanismos de defensa fijos o automáticos. Pueden utilizarse diversos protectores (cubiertas, enrejados, etc.) en las mezcladoras de la masa para prevenir el acceso a la zona, permitiendo simultáneamente la introducción de material adicional y la limpieza de la cubeta. Cada vez se utilizan más máquinas diseñadas para cortar el pan en rebanadas y envolver los productos, que constan de hojas de sierra alternativa o cuchillas rotatorias. Todos los componentes móviles deben aislarse completamente y debe disponerse de cubiertas de bloqueo cuando sea necesario el acceso. Debe formularse un programa de procedimientos de bloqueo y de carteles de advertencia respecto al mantenimiento y la reparación de la maquinaria.

\section{Riesgos para la salud}

Los trabajadores de las panadería suelen utilizar ropas ligeras y sudar con profusión; se ven expuestos a corriente y a variaciones acusadas de la temperatura ambiente al pasar, por ejemplo, de la tarea de carga del horno al trabajo de refrigeración. El polvo de harina en suspensión en el aire puede causar rinitis, dolencias de garganta, asma bronquial ("asma del panadero") y enfermedades oculares, mientras que el polvo de azúcar puede provocar caries dental. El polvo de vegetales en suspensión en el aire debe controlarse mediante una ventilación adecuada. La dermatitis alérgica puede darse en personas con una predisposición especial. Los riesgos para la salud mencionados y la elevada incidencia de tuberculosis pulmonar entre los trabajadores de panadería ponen de relieve la necesidad de una supervisión médica y de la realización de exploraciones periódicas y frecuentes; además, una higiene personal estricta es esencial en interés de los trabajadores y de la población en general.

\section{- INDUSTRIA DE LA REMOLACHA AZU CARERA}

\section{Carol J. Lehtola*}

\section{Elaboración}

El proceso de fabricación del azúcar de remolacha comprende numerosos pasos, que se han perfeccionado de forma continua a lo largo de más de un siglo de historia de esta industria. Las instalaciones productivas se han modernizado y se ha adoptado la

* Actualización del artículo preparado por el Comité Europeo de Fabricantes de Azúcar (CEFS) para la 3ạ edición de la E nciclopeda de salud y seguridad en el trabajo. tecnología y las medidas de seguridad actuales. Los trabajadores están capacitados para utilizar equipos modernos y sofisticados.

El contenido de azúcar de las remolachas oscila entre un 15 y un $18 \%$. Inicialmente, se limpian en un lavadero. Después, se cortan en las rebanadoras y las piezas obtenidas se transportan, pasando por una cuba de escaldar, a un difusor, donde la mayor parte del azúcar contenido en las remolachas se extrae en agua caliente. Las rebanadas desazucaradas, denominadas "pulpas", se prensan de forma mecánica y se secan, principalmente mediante calor. Contienen numerosos nutrientes y se utilizan en la alimentación animal.

El jugo en bruto obtenido en el difusor, además de azúcar, contiene impurezas que se precipitan (mediante la adición de cal y dióxido de carbono) y se filtran. De este modo el jugo se diluye, y presenta un contenido de azúcar del 12 al $14 \%$. Este jugo claro se concentra en evaporadores hasta obtener de un 65 a un $70 \%$ de sustancia seca. El jugo espeso resultante se calienta en un recipiente al vacío a una temperatura de unos $70^{\circ} \mathrm{C}$, hasta que se forman cristales. Esta masa cocida se descarga en los mezcladores y se separa el líquido que rodea a los cristales. El jarabe separado de este modo sigue conteniendo azúcar que puede cristalizar. El proceso de desazucarado continúa hasta que deja de resultar económico. El jarabe extraído tras la última cristalización se denomina melaza.

Después del secado y el enfriamiento, el azúcar se almacena en silos, donde puede conservarse indefinidamente si se acondiciona el aire de forma adecuada y se controla la humedad.

La melaza contiene en torno al $60 \%$ de azúcar y, junto con las impurezas carentes de azúcar, constituye un alimento valioso para el ganado y un medio idóneo para el cultivo de numerosos microorganismos. Parte de la melaza se añade a las pulpas de las que se ha extraído el azúcar antes de que se sequen y se emplea como alimento animal. La melaza se utiliza asimismo en la producción de levadura y alcohol.

Con la ayuda de otros microorganismos, pueden fabricarse otros productos como el ácido láctico, una materia prima importante para las industrias alimentarias y farmacéutica, o el ácido cítrico, requerido en el sector alimentario en grandes cantidades. Además, la melaza se aplica en la producción de antibióticos como la penicilina y la estreptomicina, así como del glutamato sódico.

\section{Condiciones de trabajo}

En la industria de la remolacha azucarera, altamente mecanizada, ésta se transforma en azúcar durante la denominada "temporada". En este período, que dura de tres a cuatro meses, las fábricas funcionan de manera continua. El personal trabaja en turnos rotatorios durante las 24 horas del día. Puede incorporarse trabajadores temporales en los períodos de mayor actividad. Al finalizar la elaboración de la remolacha, se llevan a cabo las tareas de reparación, mantenimiento y actualización en las instalaciones.

\section{Riesgos y su prevención}

En el proceso de elaboración de la remolacha azucarera no se producen gases tóxicos ni polvos en suspensión en el aire, ni debe trabajarse con ellos. Algunos componentes de las instalaciones productivas puede ser extremadamente ruidosos. En las áreas en que no pueden reducirse los niveles de ruido hasta alcanzar los valores umbral, es necesario suministrar protectores auditivos y formular un programa de conservación de la audición. No obstante, en general, las enfermedades profesionales son poco frecuentes en los centros de elaboración de la remolacha azucarera. Se debe en parte a que la duración de la temporada se limita a unos 3 o 4 meses al año. 
Como en la mayoría de las industrias alimentarias, las dermatitis de contacto y las alergias de la piel producidas por agentes empleados en la limpieza de cubas y otros equipos pueden constituir un problema que exige la utilización de guantes. Al acceder a las cubas para su limpieza o por otros motivos, deben observarse los procedimientos relativos a la actuación en espacios restringidos.

D eben tomarse precauciones al entrar en silos donde se almacene azúcar granulado, debido al riesgo de hundimiento, similar al planteado por los silos de cereales. (Para consultar recomendaciones más exhaustivas, véase el artículo "Cereales, elaboración de cereales y productos de consumo basados en cereales" en el presente capítulo.)

Las quemaduras producidas por los conductos de vapor y el agua caliente constituyen un motivo de preocupación. Un mantenimiento adecuado, la dotación de EPP y la formación de los trabajadores pueden ayudar a prevenir este tipo de lesión.

La mecanización y la automatización en la industria de la remolacha azucarera reduce al mínimo el riesgo de padecer trastornos ergonómicos.

La maquinaria debe someterse a controles regulares y a operaciones de mantenimiento rutinario y de reparación cuando sea necesaria. Deben instalarse protectores y mecanismos de seguridad. Los trabajadores deben disponer de acceso a equipos y dispositivos de protección. Asimismo, debe exigírseles la participación en la formación sobre seguridad.

\section{ACEITES Y GRASAS}

\section{N.M. Pant*}

El término "aceites y grasas" se aplica en general a los triglicéridos de los ácidos grasos presentes en las semillas vegetales y los tejidos animales. Los aceites y las grasas constituyen uno de los tres tipos fundamentales de materias orgánicas consideradas como los elementos que componen los organismos vivos; los otros dos son las proteínas y los hidratos de carbono.

M ás de 100 variedades de plantas y animales productores de aceite se aprovechan como fuentes para su obtención. Las fuentes vegetales más importantes son la aceituna, el coco, el cacahuete, la semilla de algodón, la soja, la colza, la semilla de mostaza, la semilla de lino, la palma, el sésamo, el girasol, el ricino, la semilla de cáñamo, la aleurita, el cacao, el mowrah, el maíz y el babassu.

Las principales fuentes animales son el ganado vacuno, porcino y ovino, las ballenas, el bacalao y el halibut.

L os aceites y grasas comestibles ofrecen una fuente concentrada de energía alimentaria, transportan las vitaminas solubles en grasa y suministran los ácidos grasos esenciales, de vital importancia para el metabolismo. Constituyen la materia prima principal de jabones y detergentes, pinturas, lacas y barnices, lubricantes, y dispositivos de iluminación como velas. Asimismo, se utilizan en la fabricación de linóleo y tejidos aceitados, así como de fijadores y mordientes para el curtido de pieles, y se emplean como productos iniciales para síntesis químicas.

\section{Elaboración}

La elaboración inicial depende de la materia prima; por ejemplo, las grasas animales se funden en recipientes dotados de camisas a vapor, las semillas se limpian, se muelen y se separan, y las semillas con carne se pelan. Las grasas y aceites se extraen mediante presión o tratamiento con disolventes, y el posterior proceso de

* Adaptado de la 3a edición de la E nciclopedia de salud y seguridad en el trabajo. fabricación depende del uso final que se asigne al producto. Las aceitunas pueden prensarse varias veces, pero no suele requerirse ningún otro tratamiento. En el caso de otros aceites y grasas comestibles, la elaboración puede comprender varias fases diferentes; a saber, refino, desodorización, hidrogenación, solidificación o emulsionado.

Las grasas y aceites crudos contienen impurezas que, en algunos casos, conviene eliminar ya que oscurecen el aceite, provocan la formación de espuma y humo al calentarse, producen un sabor 0 un olor desagradables 0 afectan al proceso de elaboración. El refino, que consiste en la neutralización y la lixiviación, elimina la mayoría de las impurezas. En la neutralización se suprimen los ácidos grasos y los fosfátidos resinosos mediante tratamiento con álcalis y de depuración.. Las materias primas se someten a lixiviación mediante absorción en tierras de blanquear naturales 0 activadas; no obstante, puede emplearse también la lixiviación por calor. Durante el refino, la temperatura del aceite no suele exceder de $100{ }^{\circ} \mathrm{C}$.

La desodorización elimina los compuestos odoríferos mediante la destilación por vapor a temperatura elevada y baja presión absoluta.

Las grasas blandas y los aceites líquidos se transforman en grasas plásticas firmes mediante la hidrogenación, lo que contribuye asimismo a evitar la ranciedad debida a la oxidación. En este proceso, se hace reaccionar el aceite con hidrógeno a una temperatura de $180{ }^{\circ} \mathrm{C}$ o superior en presencia de un catalizador, que generalmente es níquel dividido en piezas finas. El hidrógeno se alimenta a una presión comprendida entre dos y treinta atmósferas, según el producto final que se desee.

Si el aceite 0 la grasa se pretende comercializar en forma plástica o en emulsión, se precisa un tratamiento adicional. M uchos aceites y grasas de marcas registradas se mezclan y la combinación obtenida se solidifica para obtener gránulos mediante enfriamiento gradual controlado (destilación fraccionada) y separación de las fracciones cristalizadas a diversas temperaturas en función de sus puntos de fusión. Un método alternativo consiste en la obtención de un producto texturizado mediante enfriado rápido en un equipo especial denominado votador.

\section{Riesgos y su prevención}

EI hidrógeno plantea un elevado riesgo de explosión e incendio en el proceso de hidrogenación. Al arder, las grasas y los aceites pueden emitir humos altamente irritantes, como la acroleína. L os disolventes, como el hexano, utilizados para la extracción de aceites, son muy inflamables, aunque suelen utilizarse en sistemas cerrados. Las precauciones que deben adoptarse respecto a los incendios y las explosiones son:

- eliminación de todas las fuentes de ignición;

- utilización de equipos antideflagrantes y herramientas que no produzcan chispas.

- prohibición de fumar;

- garantía de que las salidas de incendios no están bloqueadas y de que su mantenimiento es correcto;

- disposición de extintores de incendios apropiados;

- desarrollo de procedimientos de actuación en caso de vertidos y fugas de hidrógeno y otros disolventes inflamables,

- formación del personal en los procedimientos de extinción de incendios.

Las instalaciones eléctricas presentan un cierto riesgo de descarga en condiciones de humedad y de vapor. Todos los equipos, conductos, etc. deberán protegerse adecuadamente, prestando especial atención a todo tipo de luz y dispositivo portátil. Deben instalarse interruptores de circuito de tierra 
accidental en el equipo eléctrico situado en áreas con presencia de humedad o de vapor.

Las lesiones producidas por componentes móviles de la maquinaria deben evitarse mediante la utilización de dispositivos de protección eficaces y adecuadamente mantenido. D ebe prestarse especial atención a la maquinaria de trituración, de llenado y cerrado de bidones, y a los puntos de contacto entre las correas, los tambores y las poleas de las cintas transportadoras. Deben utilizarse procedimientos de bloqueo y carteles de advertencia al mantener y reparar los equipos. Los riesgos de explosión y fugas en la planta de vapor deben prevenirse mediante la formulación de procedimientos periódicos de inspección y mantenimiento.

Siempre que sea posible, el ruido excesivo generado por los equipos debe reducirse al mínimo mediante la adopción de controles técnicos. Los trabajadores expuestos a este tipo de contaminación deben utilizar protectores auditivos adecuados y es necesario poner en práctica un programa de conservación de la audición.

La manipulación de los bidones puede causar tensiones y lesiones musculosqueléticas en las manos y los dedos de los pies. Cuando sea posible, deben utilizarse equipos de manipulación mecánicos. Debe impartirse formación acerca de los métodos correctos de manipulación y levantamiento, la protección de pies y manos, y la comprobación de los contenedores para determinar la existencia de algún canto vivo. Los bidones mal apilados pueden caer y causar lesiones graves; la supervisión y la formación sobre las operaciones de apilado y desapilado reducirán este riesgo.

Pueden producirse caídas en escaleras y pisos resbaladizos y es posible evitarlas manteniendo los suelos debidamente protegidos con antideslizantes, realizando una limpieza periódica y una buena conservación de las instalaciones y utilizando calzado antideslizante

Las quemaduras pueden ser causadas por el hidróxido de sodio durante la manipulación de los bidones para el refino, así como por las salpicaduras de sosa cáustica líquida cuando se abren aquéllos, o bien por el contacto con aceite caliente 0 el catalizador empleado en la limpieza de las prensas de filtro, con ácidos y con conductos o fugas de vapor. La utilización de ropa, botas, delantales y guantes protectores evitará muchas lesiones. Las máscaras faciales son necesarias para proteger los ojos de las salpicaduras de materiales corrosivos o calientes.

Los aceites, elaborados a temperaturas elevadas, pueden provocar molestias físicas, sobre todo en las zonas tropicales, a menos que se adopten medidas eficaces al respecto. Pueden producirse calambres musculares, agotamiento y golpes de calor. EI calor radiante debe reducirse mediante el revestimiento calorífugo y el aislamiento de los depósitos y los conductos de vapor. Una ventilación mecánica eficaz debe procurar una renovación frecuente del aire. Los trabajadores podrán acceder a menudo al consumo de bebidas y disfrutarán de descansos frecuentes en áreas acondicionadas.
El acceso a depósitos a granel para su reparación o limpieza puede constituir un riesgo relacionado con la presencia en espacios restringidos. Los trabajadores deben recibir formación sobre los procedimientos de actuación en estos casos, como la comprobación de la atmósfera de estos recintos y los métodos de rescate de emergencia. D eberá estar presente un mínimo de dos trabajadores.

Los disolventes empleados en la extracción de grasas y aceites pueden representar riesgos de carácter tóxico. No debe utilizarse el benceno y se aplicará el disolvente menos tóxico disponible (p. ej. se sustituirá el hexano por el heptano). La extracción localizada es necesaria para eliminar los vapores de disolvente en el lugar de origen, o se aplicarán sistemas cerrados.

La dermatitis puede deberse a la manipulación de aceites, grasas y disolventes. Es imprescindible disponer de instalaciones sanitarias y de lavado adecuadas y utilizarlas. Las cremas de barrera y las ropas protectoras contribuyen asimismo a la prevención.

En los centros de producción de aceite de cacahuete, en las condiciones adecuadas de humedad y temperatura, las tortas del filtro prensa pueden ser contaminadas por mohos de Aspergillus flavus, que contiene aflatoxinas. Se ha observado que los trabajadores expuestos a una considerable contaminación atmosférica de estas sustancias en su lugar de trabajo padecen afecciones hepáticas agudas o subagudas y registran una mayor prevalencia de tumores

La utilización de animales para producir grasas y piensos para el ganado puede conllevar asimismo riesgos biológicos Aunque la mayoría de animales y materias animales empleadas como fuente para la extracción de grasa son sanos o se han obtenido de animales sanos, un pequeño porcentaje procede de otros que han muerto en accidentes de tráfico o por otras causas desconocidas y, quizás, están enfermos. A lgunas enfermedades animales, como el ántrax o la brucelosis, también pueden afectar a los seres humanos. L os trabajadores de mataderos y centros de clasificación pueden correr peligro. En el Reino Unido, personas denominadas "matarifes" se ganan la vida recogiendo en el campo animales muertos y extrayéndoles la grasa en el patio de su casa. Pueden correr un gran riesgo, debido a la mayor probabilidad de que entren en contacto con animales enfermos y a las condiciones adversas en las que trabajan.

La utilización en el pasado de órganos de ovejas, incluidos los sesos, como fuente de pienso para el ganado ha dado lugar a la encefalopatía espongiforme bovina ("la enfermedad de las vacas locas") en algunas reses del R eino U nido cuando han consumido los sesos de ovejas con una enfermedad cerebral denominada "scrapie". Al parecer, algunas personas han contraído esta enfermedad al comer carne de vacas que padecían la encefalopatía espongiforme.

La exploración médica periódica de trabajadores, la selección, la formación y la supervisión son factores que contribuyen a la prevención de accidentes y enfermedades profesionales. 


\section{Referencias}

Bureau of Labor Statistics (BLS). 1991. O ccupational Injuries and IIInesses in the U nited States by Industry, 1989 Washington, DC: BLS.

Caisse nationale d'assurance maladie des travailleurs salariés. 1990. Statistiques nationales d'accidents du travail. París: Caisse Nationale d'assurance maladie des T ravailleurs Salariés.

H etrick, RL. 1994. Why did employment expand in poultry processing plants? M onthly Labor Review 117(6):31.

Linder, M. 1996. I gave my employer a chicken that had no bone: Joint firm-state responsibility for linespeed-related occupational injuries. Case W estern $\mathrm{Re}$ serve Law R eview 46:90.

M erlo, CA y WW Rose. 1992. Alternative methods for disposal/ utilization of organic by-products-From the literature". En P roceedings of the $1992 \mathrm{~F}$ ood Industry Environmental Conference. Atlanta, Georgia: Georgia T ech R esearch Institute.
National Institute for $\mathrm{O}$ ccupational Safety and $\mathrm{H}$ ealth (NIOSH ). 1990. H ealth H azard E valuation R eport: Perdue Farms, Inc. HETA 89-307-2009. Cincinnati, O hio: NIOSH.

Sanderson, WT , A Weber, A Echt. 1995. C ase reports: Epidemic eye and upper respiratory irritation in poultry processing plants. Appl O ccup Environ $\mathrm{H}$ yg 10(1): 43-49.

T omoda, S. 1993. E volución reciente de las industrias de la alimentación y de la bebida. Sectoral Activities Programme W orking Paper. Ginebra: OIT.

\section{0 tras lecturas recomendadas}

Erickson, DE. 1990. Proceedings of the W orld Conference on $E$ dible $F$ ats and Oils P rocessing: $B$ asic Principles and $M$ odern Practices. Champaign, Illinois: American $\mathrm{O}$ il Chemists' Society.

-. 1995. Practical $\mathrm{H}$ andbook of Soybean Processing and Utilization. Champaign, Illinois: American Oil
Chemists' Society; St. Louis, M isuri: U nited Soybean Board.

H ui, YH (dir.). 1996. Bailey's Industrial Oil and F at Products, 5a edición. Vol. 4. Nueva Y ork: John Wiley $\&$ Sons.

Institute of Shortening and Edible O ils. 1994. F ood Fats and Oils, 7a edición. Washington, DC: Institute of Shortening and Edible $\mathrm{O}$ ils.

National Fire Protection Association (NFPA). 1993. Solvent Extraction Plants. NFPA 36. Q uincy, M assachusetts: NFPA.

$O$ ccupational Safety and $\mathrm{H}$ ealth Administration (O SH A). 1992. OSH A H andbook for Small Businesses. Washington, DC: OSH A.

US Department of Agriculture (USDA). 1960. W ater Absorption by Eriscerated Broliers during $W$ ashing and Chilling. Marketing Research Report No 438. Washington, DC: USDA. 



\section{INDUSTRIA FORESTAL}

Director del capítulo

P eter Poschen

\section{Sumario}

Perfil general

Peter Poschen. .................................. 68.2

A provechamiento maderero

D ennis D ykstra y Peter Poschen.

Transporte de la madera

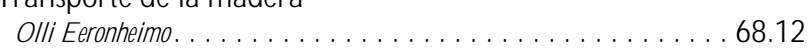

A provechamiento de productos forestales no madereros

Rudolf $\mathrm{H}$ einrich .......................... 68.14

Plantación de árboles

$D$ enis Giguère.

Tratamiento y control de incendios forestales

M ikej urvélius. . . . . . . . . . . . . . . . . . . . . 68.18

R iesgos para la seguridad física

B engt Pontén. . . . . . . . . . . . . . . . . . . . 68.21

Carga física

B engt Pontén

Factores psicosociales

Peter Poschen y $M$ arja-Liisa J untunen . . . . . . . . . . . . . 68.24

$R$ iesgos químicos

J uhani Kangas. . . . . . . . . . . . . . . . . . 68.26

$\mathrm{R}$ iesgos biológicos entre los trabajadores forestales

J. Augusta . . . . . . . . . . . . . . . . . . . 68.28

Normas, legislación, disposiciones y recomendaciones

0 thmar W ettmann . . . . . . . . . . . . . . . . . . . . 68.28

Equipos de protección personal

E ero Korhonen........................... 68.33

Condiciones de trabajo y seguridad en el trabajo forestal

L ucie L aflamme y E sther Cloutier . . . . . . . . . . . . . . . . . 68.36

Cualificación y formación

Peter Poschen. . . . . . . . . . . . . . . . . . . . . . . 68.39

Condiciones de vida

Elias A pud.......................... 68.40

Problemas para la salud del medio ambiente

Shane M cM ahon . . . . . . . . . . . . . . . . . . . . . 68.42 


\section{- Perfil general}

Peter Poschen

\section{La industria forestal: definición}

En el presente capítulo se entiende que de la industria forestal forman parte todas las tareas necesarias para establecer, repoblar, gestionar y proteger los bosques y aprovechar sus productos. El último paso de la cadena de producción del que nos ocupamos es el transporte de productos forestales en bruto, puesto que los procesos posteriores de transformación, como el aserrado de la madera o la fabricación de muebles o de papel, se tratan en los capítulos de la Enciclopedia titulados Industria de la madera, Carpintería e Industria del papel y la pasta de papel.

Los bosques pueden ser naturales, artificiales o plantaciones de árboles. En este capítulo se analizan tanto la madera como otros productos forestales, aunque se da prioridad a la primera, debido a su importancia para la seguridad y la salud.

\section{Evolución de los recursos forestales y del sector}

El aprovechamiento y la explotación de los bosques son tan antiguos como el ser humano. En un principio, los fines de la explotación de los bosques eran casi exclusivamente de subsistencia: alimentos, leña y materiales de construcción. Las primeras labores de explotación consistían sobre todo en incendios y talas para ganar espacio al bosque y destinar el terreno a otros usos (sobre todo, a la agricultura, aunque después también a asentamientos e infraestructuras). La presión ejercida sobre los bosques se agravó con la primera industrialización. El efecto conjunto de las conversiones y de la sobreexplotación fue una drástica reducción de la superficie forestal de Europa, O riente Próximo, India, China y, con posterioridad, algunas zonas de N orteamérica. En la actualidad, los bosques cubren aproximadamente una cuarta parte de la tierra firme del globo terráqueo.

El proceso de deforestación se ha detenido en los países industrializados, cuya superficie forestal está aumentando, aunque con lentitud. Con todo, en la mayoría de los países tropicales y subtropicales, las masas forestales se están reduciendo a un ritmo de 15 a 20 millones de hectáreas (ha), es decir, el 0,8\% anual. A pesar de la constante deforestación, los países en desarrollo siguen representando cerca del $60 \%$ de la superficie forestal mundial, como puede verse en la Tabla 68.1. Los países con

Tabla 68.1 • Superficie forestal por región (1990).

\begin{tabular}{lcc} 
Región & $\begin{array}{l}\text { Area (millones de } \\
\text { hectáreas) }\end{array}$ & $\%$ total \\
Africa & 536 & 16 \\
América del Norte/ Central & 531 & 16 \\
América del Sur & 898 & 26 \\
Asia & 463 & 13 \\
Oceanía & 88 & 3 \\
Europa & 140 & 4 \\
Antigua URSS & 755 & 22 \\
Industrializados (todos) & 1.432 & 42 \\
En desarrollo (todos) & 2.009 & 58 \\
Total mundial & 3.442 & 100 \\
Fuente: FA0 1995b. & & \\
\hline
\end{tabular}

mayores masas forestales son, con diferencia, Federación Rusa, Brasil, C anadá y Estados U nidos. EI menor porcentaje de superficie terrestre boscosa y hectáreas per cápita lo tiene Asia.

Los recursos forestales varían notablemente según las diferentes partes del mundo. Tales diferencias tienen un efecto directo en el entorno de trabajo, en la tecnología utilizada en las labores forestales y en el nivel de riesgo asociado a las mismas. Las selvas boreales de las partes septentrionales de Europa, Rusia y C anadá están formados sobre todo de coníferas y tienen un número relativamente pequeño de árboles por hectárea. La mayoría de estos bosques son naturales. Además, los propios árboles son de pequeño tamaño. D ebido a los largos inviernos, el crecimiento de los árboles es lento y el aumento de la superficie boscosa está comprendido entre 0,5 y $3 \mathrm{~m}^{3} / \mathrm{ha} /$ año.

Los bosques templados del Canadá meridional, Estados Unidos, Europa central, Rusia meridional, China y Japón se componen de una gran variedad de especies de coníferas y frondosas. La densidad de arbolado es alta y los árboles pueden ser muy grandes, de más de $1 \mathrm{~m}$ de diámetro y una altura superior a $50 \mathrm{~m}$. L os bosques pueden ser naturales 0 artificiales (es decir, explotados de forma intensiva con un menor número de especies de árboles de tamaño más uniforme). Los volúmenes en pie por hectárea y el incremento son elevados. Este último suele oscilar entre 5 y más de $20 \mathrm{~m}^{3} / \mathrm{ha}$ / año.

Las selvas tropicales y subtropicales se componen principalmente de frondosas. Los volúmenes de árboles en pie y sus tamaños varían bastante, pero los pies maderables tropicales cortados con fines industriales suelen ser grandes árboles con grandes copas. Es en los trópicos donde los árboles cortados alcanzan la media más alta en cuanto a dimensiones, con unos troncos que por lo común superan los $2 \mathrm{~m}^{3}$. L os árboles en pie con sus copas pesan por lo común más de 20 toneladas antes de su derribo y desramaje. EI denso sotobosque y las hiedras hacen que el trabajo sea aún más difícil y peligroso.

Un tipo de bosque cada vez más importante en términos de producción de madera y de puestos de trabajo es el constituido por las plantaciones de árboles. Se cree que las plantaciones tropicales cubren alrededor de 35 millones de hectáreas, que aumentan a razón de unos 2 millones de hectáreas anuales (FAO 1995). Suelen constar de una sola especie de muy rápido crecimiento. Por lo general aumentan a razón de 15 a $30 \mathrm{~m}^{3} / \mathrm{ha} /$ año. Varias especies de pinos (Pinus spp.) y eucaliptos (E ucalyptus spp.) son las más comunes entre las plantadas con fines industriales. Las plantaciones se explotan intensivamente y en breves rotaciones (de 6 a 30 años), aunque la mayoría de los bosques templados necesitan 80 y a veces hasta 200 años para madurar. Los árboles son bastante uniformes y de tamaño pequeño o mediano, con alrededor de 0,05 a $0,5 \mathrm{~m}^{3} /$ árbol. El sotobosque suele ser escaso.

A consecuencia de la escasez de la madera y de los desastres naturales, como corrimientos de tierras, inundaciones y avalanchas, la superficie boscosa sometida a alguna forma de gestión ha ido aumentando durante los últimos 500 años. La mayoría de los países industrializados aplican el "principio del rendimiento sostenido", por el que la explotación actual de los bosques no puede reducir su potencial para producir bienes y beneficios para generaciones posteriores. En casi todos ellos, los niveles de aprovechamiento forestal se encuentran por debajo de las velocidades de crecimiento. No sucede lo mismo en muchos países tropicales.

\section{Importancia económica}

A escala mundial, la madera es el producto forestal más importante con diferencia. La producción mundial de rollizos se aproxima a los 3,5 billones de $\mathrm{m}^{3}$ anuales. La producción de madera 
Figura 68.1 • Los nueve mayores productores de rollizos industriales, 1993 (antigua URSS 1991).

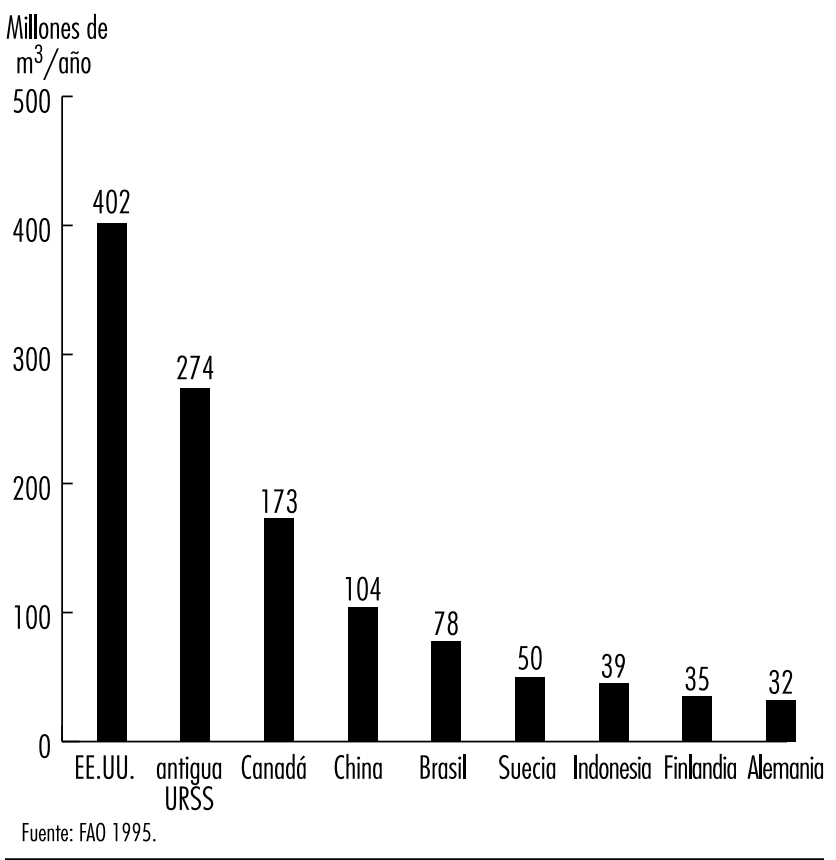

aumentó un 1,6\% anual en los decenios de 1960 y 1970 y un $1,8 \%$ anual en el decenio de 1980, y está previsto que aumente un $2,1 \%$ anual hasta bien entrado el siglo XXI, con porcentajes muy superiores en los países en desarrollo que en los países industrializados.

La cuota de producción mundial de rollizos de los países industrializados es del $42 \%$ (es decir, casi proporcional a la cuota de superficie forestal). En cambio, existe una diferencia importante en lo que respecta a la naturaleza de la madera cortada entre éstos y los países en desarrollo. M ientras en los primeros más del $85 \%$ consiste en rollizos industriales destinados al aserrado de madera, a la fabricación de tableros o a la elaboración de pasta, los segundos destinan el $80 \%$ a leña y a la fabricación de carbón vegetal. Por ese motivo sólo figuran cuatro países en desarrollo en la lista de los diez mayores productores de rollizos industriales enumerados en la Figura 68.1. Los productos forestales no madereros todavía son muy importantes para la subsistencia en muchos países. Sólo representan el 1,5\% del comercio de productos forestales no elaborados, pero las exportaciones de productos como el corcho, la rota, las resinas, las nueces y las gomas son muy importantes en algunos países.

El valor de la producción forestal a escala mundial fue de 96.000 millones de dólares en 1991, en comparación con los 322.000 millones de dólares de las industrias complementarias de transformación. La industria forestal por sí sola representó el $0,4 \%$ del PIB mundial. La cuota de la producción forestal en el PIB es muy superior en los países en desarrollo, con un promedio del 2,2 \%, con respecto a los industrializados, donde sólo representa el $0,14 \%$ del PIB. En varios países, la industria forestal es bastante más importante de lo que sugieren los promedios. $\mathrm{H}$ ay 51 países donde la silvicultura y las industrias complementarias de transformación generaron en conjunto un $5 \%$ o más del PIB respectivo en 1991 .

En varios países industrializados y países en desarrollo, la exportación de los productos forestales es importante. EI valor total de las exportaciones forestales de los países en desarrollo aumentó de alrededor de 7.000 millones de dólares en 1982 a más de 19.000 millones de dólares en 1993 (dólares de 1996). Entre los grandes exportadores de los países industrializados cabe citar a Canadá, Estados U nidos, Rusia, Suecia, Finlandia y Nueva Zelanda. Entre los países tropicales, Indonesia (5.000 millones de dólares), M alaisia (4.000 millones de dólares), C hile y Brasil (alrededor de 2.000 millones de dólares cada uno) son los más importantes.

Aunque no puede expresarse con facilidad en términos monetarios, el valor de los bienes y beneficios no comerciales generados por los bosques bien puede superar su rentabilidad comercial. Según algunos cálculos, entre 140 y 300 millones de personas habitan en bosques o dependen de ellos para subsistir. L os bosques son además el hogar de tres cuartas partes de todas las especies de seres vivos. D esempeñan una importante función como disipadores de dióxido de carbono y sirven para estabilizar climas y regímenes hidráulicos. Reducen la erosión, los corrimientos de tierras y las avalanchas, y producen agua potable limpia. También son fundamentales para el ocio y el turismo.

\section{Empleo}

Resulta difícil obtener cifras sobre el empleo en la industria forestal, que resultan poco fiables incluso las de los países industrializados. La razón está en el alto porcentaje de autónomos y granjeros entre sus trabajadores, quienes en muchos casos no están dados de alta, y en la estacionalidad de muchos puestos de trabajo. En la mayoría de los países en desarrollo, esas cifras pasan a integrar, simplemente, las estadísticas del sector agrícola, de mucha mayor envergadura, sin que se faciliten cifras independientes. Ahora bien, el principal problema es que la mayor parte del trabajo forestal no es remunerado, sino de subsistencia, y se basa sobre todo en la producción de leña, en especial en los países en desarrollo. Teniendo en cuenta estas limitaciones, la Figura 68.2 ofrece una estimación muy conservadora del empleo forestal a escala mundial.

La cifra de trabajadores forestales asalariados en todo el mundo es del orden de 2,6 millones, de los que alrededor de 1 millón trabajan en países industrializados. Es sólo una parte de los puestos de trabajo: las industrias madereras y la fabricación de pasta y papel emplean al menos a 12 millones de trabajadores en el sector formal. El grueso del empleo forestal es trabajo de subsistencia no remunerado: el equivalente a unos 12,8 millones

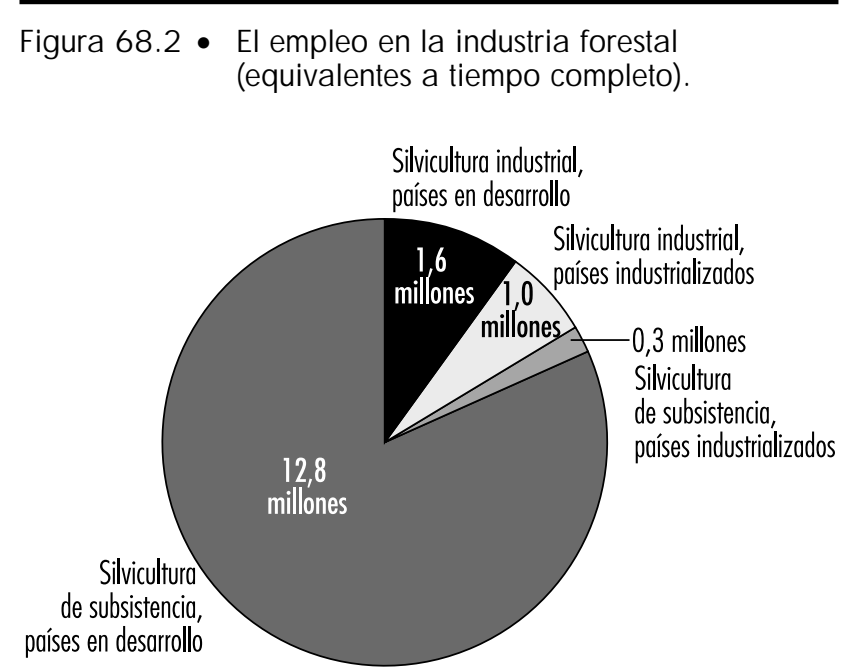

Fuente: Estimación de la OIT basada en los datos parciales de los países y en FAO/CEPE/OIT 1989. 
Figura 68.3 • Países con mayor nivel de empleo asalariado en la industria forestal y producción de rollizos industriales (desde finales del decenio de 1980 hasta principios del decenio de 1990).

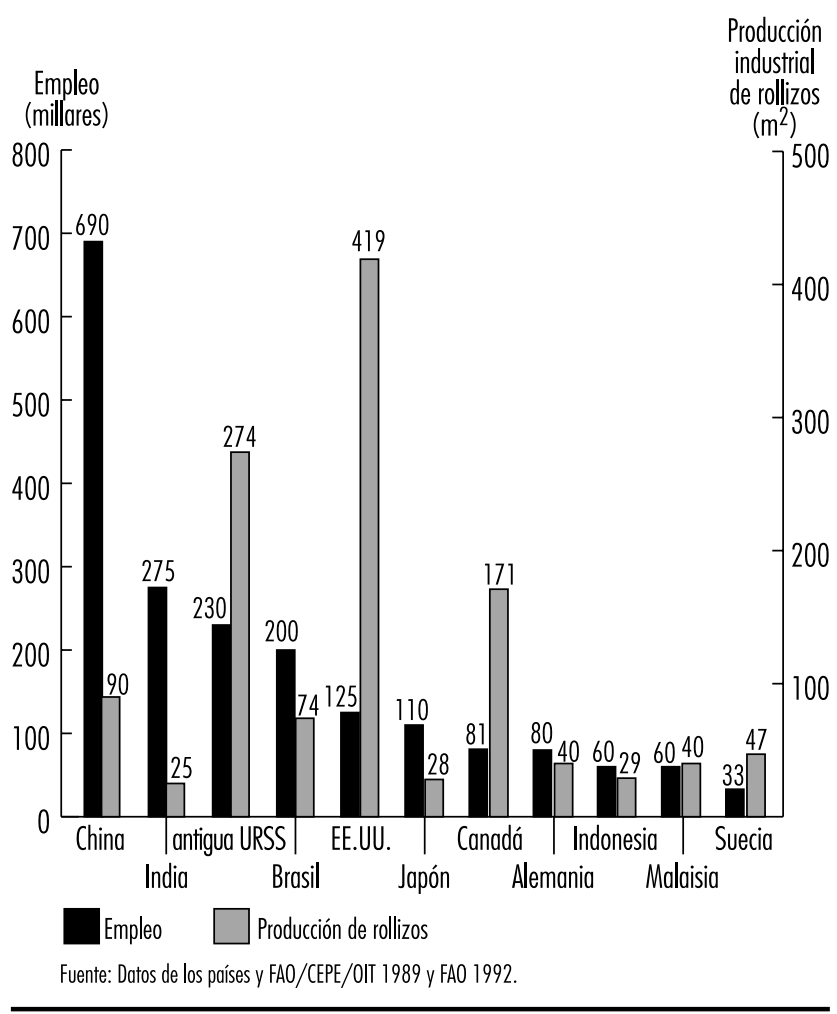

de puestos de trabajo a tiempo completo en los países en desarrollo y unos 0,3 millones en los países industrializados. A sí pues, se calcula que la industria forestal emplea en total a unos 16 millones de personas anuales, lo que supone aproximadamente un $3 \%$ del empleo agrícola mundial y un $1 \%$ del empleo mundial total.

En los países más industrializados el número de trabajadores forestales se ha ido reduciendo debido a la sustitución de los temporeros por profesionales contratados a tiempo completo, a lo que hay que añadir la rápida mecanización, en especial del aprovechamiento maderero. En la Figura 68.3 se observan las enormes diferencias de productividad entre los principales países productores, diferencias originadas en cierta medida por las condiciones naturales, los sistemas silvícolas y al error estadístico. Aun teniendo estos factores en cuenta, persisten desequilibrios significativos. Es probable que continúe la transformación de las plantillas: la mecanización se está extendiendo a un mayor número de países y la productividad se está viendo impulsada por nuevas formas de organización del trabajo, en concreto por los conceptos de trabajo en equipo, mientras que los niveles de aprovechamiento permanecen en general constantes. Es preciso indicar que en muchos países no se registran los puestos de trabajo de temporada y a tiempo parcial, pero son muy comunes entre los granjeros y los pequeños propietarios de bosques. Es probable que el número de trabajadores de la industria forestal aumente a consecuencia de la mayor intensidad de la explotación forestal y de las plantaciones de árboles. Por otra parte, cabe pensar que el empleo de subsistencia irá disminuyendo poco a poco, ya que la leña va sustituyéndose por otras formas de energía.

\section{Características de los trabajadores}

EI trabajo en la industria forestal ha sido casi siempre dominio masculino. La proporción de mujeres en las plantillas no supera por regla general el $10 \%$. Ahora bien, hay puestos de trabajo que desempeñados principalmente por mujeres, como la plantación o los cuidados de rodales jóvenes y el cultivo de plantones en viveros silvícolas. En el empleo de subsistencia, las mujeres son mayoría en muchos países en desarrollo, porque suelen ser las encargadas de recoger la leña.

La mayoría de los puestos de trabajo, tanto industriales como de subsistencia, en este sector están relacionados con el aprovechamiento de productos madereros. Incluso en los bosques artificiales y en las plantaciones, que requieren una importante actividad silvícola, el aprovechamiento representa más del $50 \%$ de los días de labor por hectárea. En el aprovechamiento hay un técnico o supervisor por cada tres capataces, y uno por cada 40 trabajadores. En la mayoría de los países industrializados estas proporciones son menores.

Por regla general, en la industria forestal existen dos grupos de puestos de trabajo: Ios relacionados con la silvicultura y los relacionados con el aprovechamiento. Entre las ocupaciones típicas de la silvicultura cabe citar la plantación de árboles, la fertilización, el control de plagas y malas hierbas y la poda. La plantación de árboles es muy estacional y en algunos países supone el empleo de otro grupo de trabajadores dedicados a esta actividad en exclusiva. En el aprovechamiento, los puestos más comunes son los de operarios de motosierras, que suelen tener un ayudante en los bosques tropicales; los bragadores, que fijan cables a los tractores o cables portantes para sacar los troncos a la carretera; los auxiliares, que se ocupan de medir, mover, cargar o desramar troncos; y los operarios de máquinas, que manejan tractores, cargadoras, cables-grúa, cosechadoras y camiones de saca.

Existen importantes diferencias entre los distintos segmentos de las plantillas forestales en cuanto a la forma de empleo, que tienen una repercusión directa en la exposición de los trabajadores a riesgos para la seguridad y la salud. EI porcentaje de trabajadores forestales empleados de forma directa por la industria o el propietario del bosque ha ido reduciéndose incluso en aquellos países en los que solía ser la norma. Cada vez se realizan más trabajos a través de contratistas (es decir, empresas de servicios relativamente pequeñas y con gran movilidad geográfica que se contratan para una obra en particular), que pueden ser operadores-propietarios (es decir, firmas unipersonales 0 empresas familiares) 0 tener cierto número de empleados. Tanto los empresarios como sus empleados suelen tener empleos muy inestables. Sometidos a la presión de reducir los costes en un mercado muy competitivo, recurren a veces a prácticas ilegales, como el pluriempleo y la contratación de inmigrantes clandestinos. Aunque la subcontratación ha contribuido en muchos casos a reducir costes, a aumentar la mecanización y la especialización y a ajustar las plantillas a los cambios de la demanda, algunos males tradicionales de la profesión se han visto agravados por la mayor dependencia de contratistas, entre cuyos trabajadores los accidentes y los problemas de salud suelen ser más frecuentes.

La subcontratación de trabajadores también ha contribuido a aumentar el alto porcentaje de rotación en las plantillas forestales. Algunos países declaran que, cada año, casi un $50 \%$ de los empleados cambian de empresa y más del $10 \%$ abandonan el sector forestal por completo, con lo que se agrava el problema de la cualificación, que ya está cobrando importancia entre gran parte de los trabajadores forestales. Casi todos ellos adquieren su cualificación por experiencia, lo que suele implicar un aprendizaje por tanteo. La falta de formación estructurada y la brevedad de los períodos de experiencia a consecuencia de la 
alta rotación laboral o del trabajo estacional son factores decisivos para los importantes problemas de salud y seguridad con los que se enfrenta el sector forestal (véase el artículo titulado "Cualificación y formación" en este mismo capítulo).

EI sistema salarial dominante en la industria forestal continúa siendo, con diferencia, la remuneración a destajo (es decir, basada exclusivamente en el rendimiento). Es un tipo de remuneración que tiende a estimular un ritmo de trabajo rápido, del que se piensa que aumenta el número de accidentes. Sin embargo, no hay pruebas científicas que respalden esta opinión. $U \mathrm{n}$ efecto secundario indiscutible es que los ingresos merman cuando los trabajadores alcanzan una determinada edad, ya que sus capacidades físicas disminuyen. En los países donde la mecanización tiene un papel importante, el sistema de jornales ha ido en aumento porque el ritmo de trabajo viene determinado en gran medida por la máquina. También se utilizan diversos sistemas salariales con gratificaciones.

Los salarios del sector forestal suelen ser muy inferiores a la media industrial de un país. Los trabajadores por cuenta ajena, los autónomos y los contratistas suelen intentar compensar este hecho trabajando 50 o incluso 60 horas semanales, lo que aumenta la tensión corporal y el riesgo de accidentes por fatiga.

Las organizaciones sindicales son bastante escasas en este sector. A los problemas tradicionales que comporta la organización de trabajadores geográficamente dispersos, móviles y a veces estacionales se suma su fragmentación en pequeñas empresas contratistas. Al mismo tiempo, el número de trabajadores en categorías que por lo común están afiliadas a sindicatos, como los empleados directamente por grandes empresas forestales, disminuye de manera constante. $L$ as inspecciones laborales que intentan cubrir la industria forestal se encuentran con problemas similares a los que tienen los sindicatos. En consecuencia, las inspecciones son muy escasas en la mayoría de los países. En ausencia de instituciones que velen por sus derechos, los trabajadores forestales no suelen conocerlos muy bien, entre ellos los que recogen las disposiciones existentes en materia de salud y seguridad, y tienen grandes dificultades para ejercerlos.

\section{Problemas de salud y seguridad}

La idea que popularmente se tiene en muchos países es que el trabajo forestal es sucio, difícil y peligroso. A esta reputación contribuyen toda una serie de factores naturales, técnicos y organizativos. EI trabajo forestal ha de realizarse al aire libre. De este modo, los trabajadores se ven expuestos a condiciones climáticas extremas: frío, calor, nieve, lluvia y radiación ultravioleta (UV). Se suele trabajar con mal tiempo y, en las operaciones mecanizadas, cada vez es más habitual continuar trabajando por la noche. Los trabajadores se ven expuestos a peligros naturales, como terrenos irregulares o fangosos, vegetación densa y a una serie de agentes biológicos.

Los lugares de trabajo suelen estar alejados y mal comunicados, lo que dificulta las labores de rescate y evacuación de los trabajadores si se presenta una emergencia. En muchos países todavía es normal que vivan durante largos períodos en campamentos aislados de sus familias y amigos.

Las dificultades se ven agravadas por la naturaleza del trabajo: pueden caer árboles de manera inesperada, se utilizan herramientas peligrosas y suele comportar un esfuerzo físico importante. 0 tros factores, como la organización del trabajo, las pautas de empleo y la formación también desempeñan un papel importante para aumentar o reducir los peligros asociados al trabajo forestal. En la mayoría de los países, estas influencias tienen como consecuencia clara un riesgo de accidentes muy alto y graves problemas de salud.

\section{Accidentes mortales en el trabajo forestal}

En la mayoría de los países, el trabajo forestal es una de las ocupaciones más peligrosas, con grandes pérdidas humanas y financieras. En Estados U nidos, los costes de los seguros de accidentes representan el $40 \%$ de las nóminas.

Una interpretación cautelosa de las pruebas disponibles revelaría que la tasa de accidentes tiende a aumentar más que a disminuir. Por ello resulta alentador que haya países con un largo historial de reducción de accidentes (p. ej., Suecia y Finlandia). En Suiza la situación sigue la pauta normal de aumento 0 , al menos, de estancamiento de los porcentajes de accidentes. Los escasos datos existentes sobre países en desarrollo revelan que las mejoras son escasas y los niveles de accidentes excesivamente altos por regla general. Un estudio, realizado en plantaciones de Nigeria, sobre la seguridad en las sacas de madera para pasta, demostró que, como promedio, cada trabajador sufría 2 accidentes al año. $Y$ en un determinado año, entre 1 de cada 4 y 1 de cada 10 trabajadores sufrieron un accidente grave (U do 1987).

U na inspección más minuciosa de los accidentes revela que la corta es mucho más peligrosa que otras operaciones forestales (O IT 1991). Dentro de la corta de árboles, el apeo y el tronzado son las faenas que causan mayor número de accidentes, sobre todo de carácter grave o mortal. En algunos países, como en los del área mediterránea, la extinción de incendios es causa también de muchos accidentes mortales: hasta 13 fallecimientos anuales en España en algunos años (Rodero 1987). El transporte por carretera contabiliza asimismo un gran número de accidentes graves, sobre todo en los países tropicales.

La sierra de cadena o motosierra es sin duda la herramienta por sí sola más peligrosa en la industria forestal y su operario, el trabajador más expuesto. La situación que se representa en la Figura 68.4, correspondiente a un territorio de Malaisia, se produce también en casi todos los demás países con pequeñas variaciones. A pesar del aumento de la mecanización, es probable que la motosierra continúe siendo el principal problema en los países industrializados. Es previsible que su uso siga extendiéndose en los países en desarrollo, ya que las plantaciones representan una parte cada vez mayor del aprovechamiento maderero.

Figura 68.4 • Distribución de fallecimientos entre los distintos trabajos de saca forestal, Malaisia (Sarawak), 1989.

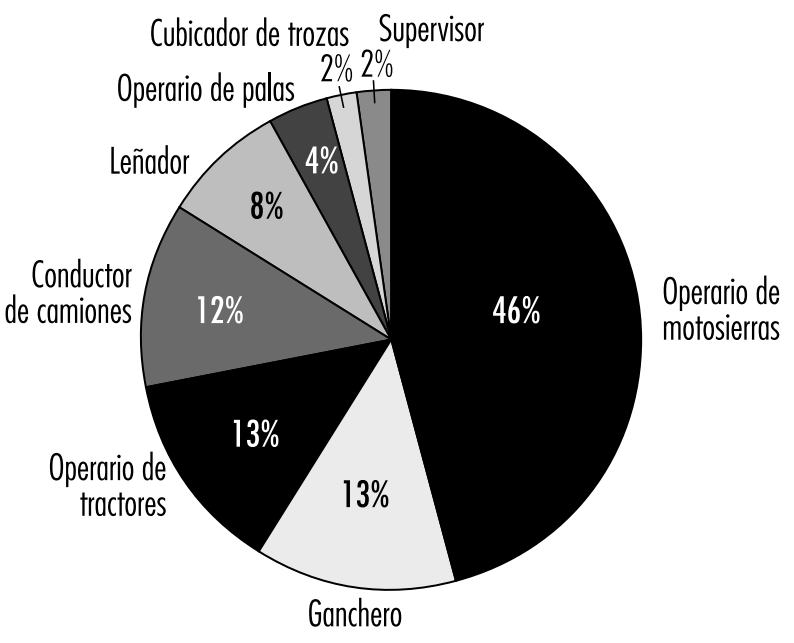

Fuente: Cheu 1990 
En el trabajo forestal pueden resultar heridas casi todas las partes del cuerpo, pero las lesiones suelen concentrarse en piernas, pies, espalda y manos, aproximadamente por ese orden. L os cortes y las heridas abiertas son el tipo de lesión más común en el trabajo con motosierras, mientras que en la saca por arrastre predominan las contusiones, aunque también se producen fracturas y dislocaciones.

Dos situaciones en las que se multiplica el ya alto riesgo de sufrir accidentes graves en el aprovechamiento forestal son los árboles "suspendidos" y los árboles derribados por el viento. La fuerza del viento somete a tensión los pies maderables, con lo que se precisan técnicas de corte adaptadas a esa función (véase FAO / CEPE / OIT 1996a; FAO / OIT 1980; y OIT 1998). L os árboles suspendidos son los que, una vez cortados por el pie, no han caído al suelo porque la copa se ha enredado con otros árboles. Son muy peligrosos, hasta el punto de que en algunos países se dice de ellos que "van dejando viudas" debido al gran número de fallecimientos que causan. Para bajar estos árboles con seguridad es preciso ayudarse de utillajes como cabrestantes y ganchos giratorios. En ningún caso debe permitirse el apeo de otros árboles sobre uno suspendido con la idea de tirarlo. Es una práctica conocida en algunos países como "arrastre", y resulta muy peligrosa.

Los riesgos de accidente están en función no sólo de la tecnología que se utilice y del grado de exposición que comporte el trabajo, sino también de otros factores. En casi todos los casos de los que se disponen datos, existe una diferencia muy significativa entre los segmentos de trabajadores. Los profesionales del trabajo forestal a tiempo completo empleados directamente por una empresa forestal se ven mucho menos afectados que los granjeros, los autónomos o los contratistas. En Austria, los granjeros que explotan los bosques estacionalmente sufren el doble de accidentes por millón de metros cúbicos cortados que los trabajadores profesionales (Sozialversicherung der Bauern 1990), mientras que en Suecia llegan a sufrir el cuádruple. En Suiza, los trabajadores empleados en los bosques públicos sólo sufren la mitad de accidentes que los empleados por empresas contratistas, sobre todo en el caso de la contratación de temporeros y de inmigrantes (Wettmann 1992).

La mayor mecanización del aprovechamiento forestal ha tenido consecuencias muy positivas para la seguridad laboral. Los operarios de las máquinas están bien protegidos en cabinas con defensas y los riesgos de accidente han disminuido de manera notable; sufren menos del $15 \%$ de los accidentes que afectan a los operarios de motosierras para obtener la misma cantidad de madera. En Suecia, estos trabajadores sufren una cuarta parte de los accidentes que afectan a los operarios profesionales de motosierras.

\section{Aumento de los problemas causados por enfermedades profesionales}

La otra cara de la moneda de la mecanización es la aparición en los operarios de las máquinas de lesiones de cuello y hombros, que pueden ser tan incapacitantes como los accidentes graves.

L os problemas citados se suman a los tradicionales problemas de salud de los operarios de motosierras: en concreto, lesiones de espalda y pérdida auditiva. El dolor de espalda provocado por el intenso esfuerzo físico y por la adopción de posturas de trabajo perjudiciales es muy común entre los operarios de motosierras y entre los trabajadores que realizan la descarga manual de los troncos. Existe una alta incidencia de pérdida prematura de la capacidad laboral, con la consiguiente jubilación anticipada entre los trabajadores forestales.
Figura 68.5 • Mujer transportando leña, Addis Abeba (Etiopía).

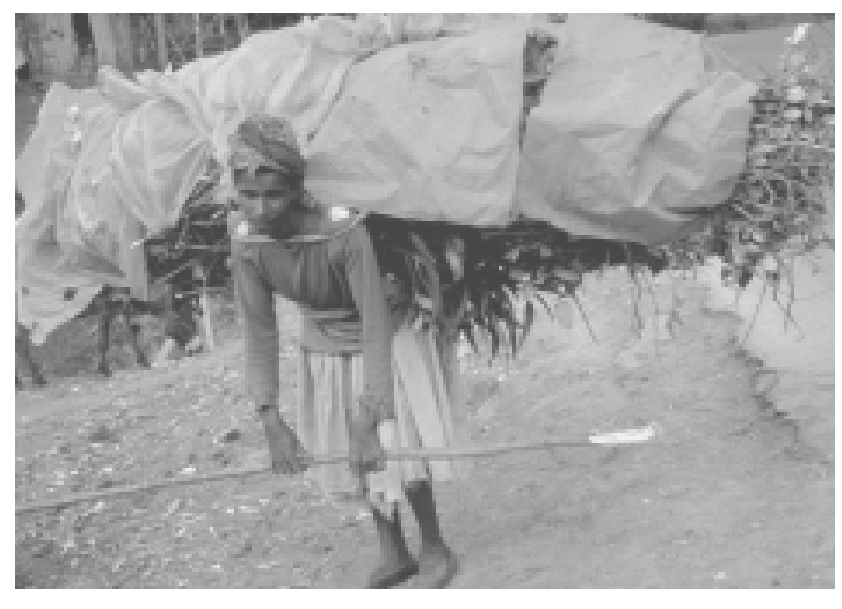

U n mal tradicional de los operarios de motosierras, al que en los últimos años se ha dado solución en gran medida mejorando el diseño de las sierras, es la enfermedad del "dedo blanco" provocada por la vibración.

En los siguientes artículos se tratan los riesgos físicos, químicos y biológicos que pueden causar problemas de salud en la industria forestal.

\section{Riesgos especiales para las mujeres}

En la industria forestal, hombres y mujeres están expuestos por lo general a los mismos riesgos para la seguridad. Las mujeres suelen participar en tareas de plantación y cuidados de mejora, entre ellas la aplicación de plaguicidas. C on todo, las mujeres que tienen el cuerpo, el corazón y los músculos más pequeños así como menor volumen pulmonar pueden tener, por término medio, una capacidad de trabajo aproximadamente un tercio inferior a la de los hombres. Por consiguiente, la legislación de muchos países limita el peso que deben levantar y transportar las mujeres a unos $20 \mathrm{~kg}$ (OIT 1988), aunque en muchos países es ilegal establecer tales diferencias por razón de sexo. Las mujeres que trabajan en los bosques suelen sobrepasar estos límites. L os estudios realizados entre trabajadores de plantación en la C olumbia Británica, donde las normas se aplican a ambos sexos, demostraron que hombres y mujeres transportaban cargas completas de plantas de 30,5 kg por término medio, a menudo en terrenos abruptos con un denso sotobosque (Smith 1987).

También es normal cargar pesos excesivos en muchos países en desarrollo, donde las mujeres trabajan como portadoras de leña. Por ejemplo, un estudio realizado en Addis Abeba, Etiopía, demostró que alrededor de 10.000 mujeres y niños se ganan la vida a duras penas llevando leña a la ciudad sobre sus espaldas (véase la Figura 68.5). Transportan fardos de $30 \mathrm{~kg}$ de peso por término medio a lo largo de $10 \mathrm{~km}$. Se trata de un trabajo que causa debilidad y numerosos problemas de salud graves, incluidos frecuentes abortos ( $\mathrm{H}$ aile 1991).

La relación entre las condiciones laborales específicas en la industria forestal, las características de los trabajadores, la forma de empleo, la formación y otros factores similares, así como la seguridad y la salud en el sector son los temas que nos han ocupado en este artículo de introducción. En la industria forestal, aún más que en otros sectores, la seguridad y la salud no pueden analizarse - y mucho menos fomentarse- independientemente. D e ello trata el resto del capítulo. 


\section{- APROVECHAMIENTO MADERERO}

\section{Dennis Dykstra y Peter Poschen*}

El aprovechamiento maderero es la preparación de los troncos en un bosque o plantación de acuerdo con las necesidades del usuario y la entrega de los mismos al consumidor. Comprende la corta de árboles, la preparación de los troncos y su extracción y transporte a larga distancia hasta el consumidor o los centros de elaboración. Los términos aprovechamiento forestal, aprovechamiento maderero o saca suelen utilizarse como sinónimos. Del transporte a larga distancia y el aprovechamiento de productos no madereros se ocupan otros artículos del presente capítulo.

\section{Operaciones}

Aunque se utilizan muchos métodos diferentes para el aprovechamiento maderero, todos ellos comportan operaciones similares:

- apeo: cortado de un árbol por el pie y derribo;

- desmochado y desramaje (escandalaje): eliminación de la zona inútil de la copa y de las ramas;

- descortezado: eliminación de la corteza del fuste; esta operación suele realizarse en el centro de elaboración más que en el bosque; en la corta de madera para leña no se realiza;

- extracción: traslado de los troncos o trozas desde el tocón hasta un lugar próximo a una carretera forestal en el que pueden clasificarse, apilarse y a menudo almacenarse temporalmente, en espera de su transporte a larga distancia;

- preparación de los troncos/ tronzado (troceado): corte del fuste a la longitud especificada por el destinatario de las trozas;

- cubicación: determinación de la cantidad de troncos obtenidos por lo común, midiendo el volumen (en maderos de pequeño tamaño, también por peso; esto último es normal en el caso de la madera para pasta; el pesaje se realiza en ese caso en el centro de elaboración);

- clasificación, apilamiento y almacenamiento temporal: los troncos suelen ser de dimensiones y calidades variables, por lo que se clasifican en surtidos según puedan destinarse a pasta, aserrado, etcétera, y se apilan hasta que se consigue una carga completa, por lo común la suficiente para llenar un camión; el área despejada donde se realizan estas operaciones, así como la cubicación y la carga, se denomina "cargadero",

- carga: traslado de los troncos al medio de transporte, normalmente un camión, y fijación de la carga.

No es preciso realizar estas operaciones en el orden citado. En función del tipo de bosque, del tipo de producto deseado y de la tecnología disponible, puede ser más conveniente realizar una operación antes (es decir, más cerca del tocón) o después (es decir, en el cargadero o incluso en el centro de elaboración. Una clasificación común de los métodos de aprovechamiento se basa en la distinción entre:

- saca de árboles enteros: los árboles se sacan al camino, cargadero o centro de elaboración enteros, incluida la copa;

- saca de trozas cortas: las operaciones de desmochado, desramaje y tronzado se realizan cerca del tocón (los troncos suelen medir entre 4 y $6 \mathrm{~m}$ ),

- saca de troncos enteros: antes de la saca sólo se quitan la copa y las ramas.

El grupo más importante de métodos de aprovechamiento de madera industrial se basa en la longitud del árbol. Los métodos

* El presente artículo se basa en buena medida en dos publicaciones: FAO 1996 y FAO / O IT 1980. La visión que en él se ofrece es de carácter general, aunque la bibliografía sobre esta cuestión es muy amplia. Para información más concreta sobre medidas preventivas: OIT 1998. de saca de trozas cortas son habituales en la Europa septentrional y también suelen aplicarse con maderos de pequeñas dimensiones y madera para leña en muchas otras partes del mundo; es probable que aumente su cuota. Los métodos de saca de árboles enteros son los menos comunes en el aprovechamiento de madera industrial y sólo se utilizan en un número limitado de países (p. ej., Canadá, Federación Rusa y Estados U nidos). En ellos representan menos del $10 \%$ del volumen. $L a$ importancia de este método está en declive.

A efectos de organización del trabajo, análisis de seguridad e inspección, resulta útil concebir tres áreas de trabajo distintas en una operación de aprovechamiento maderero:

1. el lugar de apeo o tocón;

2. el terreno forestal entre el tocón y la carretera forestal,

3. el cargadero.

También merece la pena analizar si las operaciones se realizan de manera independiente en el tiempo y el espacio o si están relacionadas estrechamente y son interdependientes. Esto último es lo que suele ocurrir en los métodos de aprovechamiento, donde todos los pasos están sincronizados y cualquier trastorno afecta a toda la cadena, desde el apeo hasta el transporte. Tales sistemas, llamados métodos de saca acelerada, pueden crear mayor presión y tensión si no se equilibran con cuidado.

La etapa del ciclo vital de un bosque durante la que se produce el aprovechamiento maderero, y la pauta de aprovechamiento, afectará tanto al proceso técnico como a los riesgos asociados. El aprovechamiento se realiza en forma de clareo 0 de corta final. El clareo es la eliminación de algunos árboles, por lo común inútiles, de un rodal joven para mejorar el desarrollo y la calidad de los árboles restantes. Suele ser selectivo (es decir, se eliminan árboles individuales sin crear calveros importantes). EI patrón espacial generado es parecido al de la corta final selectiva. A hora bien, en este último caso los árboles son maduros y, a menudo, de gran tamaño. Aun así, sólo se eliminan algunos de los árboles y permanece una cubierta forestal importante. En ambas circunstancias resulta difícil orientarse en el lugar de trabajo, porque el resto de los árboles y la vegetación bloquean la vista. Puede ser muy difícil derribar árboles, ya que las copas chocan con las de otros árboles. También existe un alto riesgo de que caigan despojos de las copas. En ambas situaciones la mecanización es difícil. Por consiguiente, el clareo y la corta selectiva requieren más planificación y cualificación para realizarse de manera segura.

La alternativa al apeo selectivo para el aprovechamiento final es la tala de todos los árboles de una zona, lo que se llama "corta a hecho". Pueden ser pequeñas, digamos de 1 a 5 hectáreas, 0 muy grandes, que abarquen varios kilómetros cuadrados. En muchos países se critican las grandes cortas a hecho por motivos ecológicos y paisajísticos. Cualquiera que sea el patrón de corta, el aprovechamiento de monte virgen y bosques naturales suele comportar mayor riesgo que el aprovechamiento de jóvenes rodales o bosques artificiales, porque los árboles son grandes y tienen una tremenda inercia al caer. Sus ramas pueden enredarse con las copas de otros árboles y hiedras, provocando la rotura de ramas de otros árboles. M uchos árboles están muertos o podridos en su interior, aunque esto no se aprecia hasta más adelante en el proceso de apeo; y durante esta fase su comportamiento suele ser imprevisible: pueden romperse y caer en direcciones inesperadas. A diferencia de los árboles verdes, los árboles muertos y secos caen con toda rapidez.

\section{Avances tecnológicos}

El progreso tecnológico en el aprovechamiento maderero ha sido muy rápido en la segunda mitad del siglo XX. El promedio de 
productividad ha ido aumentando vertiginosamente en el proceso. En la actualidad se utilizan muchos métodos diferentes de aprovechamiento, a veces de manera conjunta en el mismo país. Por ejemplo, en un estudio general de los sistemas aplicados en Alemania a mediados del decenio de 1980 se observan casi 40 variaciones de equipos y métodos (D ummel y Branz 1986).

Aunque algunos métodos de aprovechamiento son mucho más complejos que otros desde el punto de vista tecnológico, ninguno de ellos es superior a los demás. La elección suele depender de las especificaciones del cliente sobre los troncos, de las condiciones del bosque y del terreno, de consideraciones ecológicas y, a menudo, del coste que es la cuestión decisiva. Algunos métodos también están limitados desde el punto de vista técnico a los árboles de tamaño pequeño y mediano y a terrenos relativamente favorables, con no más de 15 a $20^{\circ}$ de pendiente.

El coste y el rendimiento de un sistema de aprovechamiento pueden variar mucho, en función de su adaptación a las condiciones del lugar y, lo que es igualmente importante, de la cualificación de los trabajadores y de la organización de las actividades. Por ejemplo, los utillajes de mano y la extracción manual resultan muy apropiados en términos sociales y económicos en países con un alto nivel de desempleo, bajos costes laborales y altos costes de inversión, o en operaciones a pequeña escala. Los métodos totalmente mecanizados pueden conseguir rendimientos diarios muy altos, pero requieren grandes inversiones de capital. En condiciones favorables, las modernas cosechadoras pueden producir más de $200 \mathrm{~m}^{3}$ de troncos por jornada de 8 horas. Es improbable que un operario de motosierras produzca más del $10 \%$ de esa cantidad. U na cosechadora 0 malacate de grandes dimensiones cuesta alrededor de 500.000 dólares en comparación con los 1.000 o 2.000 dólares que cuesta una motosierra y los 200 dólares que cuesta una tronzadora de mano de buena calidad.

\section{Métodos, equipos y riesgos comunes}

\section{Apeo y preparativos de extracción}

El apeo y la eliminación de la copa y las ramas se hacen en esta fase, que puede incluir también el descortezado, el tronzado y la cubicación. Es una de las ocupaciones industriales más peligrosas. Para derribar y desramar árboles y tronzarlos para convertirlos en trozas se utilizan herramientas de mano y motosierras o máquinas. Entre las herramientas de mano cabe citar las de corte, como hachas, martillos hendedores, ganchos y cuchillas trochadoras, y las sierras de mano, como tronzadoras y sierras de arco. Las motosierras se utilizan mucho en la mayoría de los países. A pesar de los esfuerzos y avances realizados por los que dictan las normas y los fabricantes para mejorar las motosierras, continúan siendo el tipo de máquina más peligroso en la industria forestal. Casi todos los accidentes graves y muchos problemas de salud están asociados a su uso.

Lo primero que se hace es el apeo, o corta del árbol por el pie lo más cerca posible del suelo. La parte inferior del fuste es por lo común la más valiosa, ya que representa un gran volumen, carece de nudos y su textura es uniforme. Por consiguiente, no debe rajarse y no debe desgarrarse ninguna fibra de la coz. Es importante controlar la dirección de caída, para proteger no sólo a ese árbol y a los que le rodean, sino también a los trabajadores y facilitar así la extracción. En el apeo manual, el control se consigue por medio de un orden y configuración de cortes especial.

EI método más común de apeo con motosierra es el representado en la Figura 68.6. Tras determinar la dirección de derribo (1) y despejar la base del árbol y las vías de escape, se empieza serrando la boca (2), que debe penetrar en el árbol entre una quinta y una cuarta parte de su diámetro. La boca debe abrirse a un ángulo aproximado de $45^{\circ}$. El corte oblicuo (3) se realiza antes del corte horizontal (4), que debe unirse con el oblicuo siguiendo una línea recta perpendicular a la dirección de derribo. Si los tocones pueden arrancar astillas del árbol, como suele ocurrir con las maderas más blandas, la boca deberá terminarse realizando pequeños cortes laterales (5) a ambos lados de la juntura (6). El corte posterior (7) también debe ser horizontal y ha de hacerse a una altura de entre 2,5 y $5 \mathrm{~cm}$ con respecto a la base de la boca. Si el diámetro del árbol es menor que el sable, el corte posterior puede realizarse en un solo

Figura 68.6 - Apeo con sierra mecánica: secuencia de cortes.

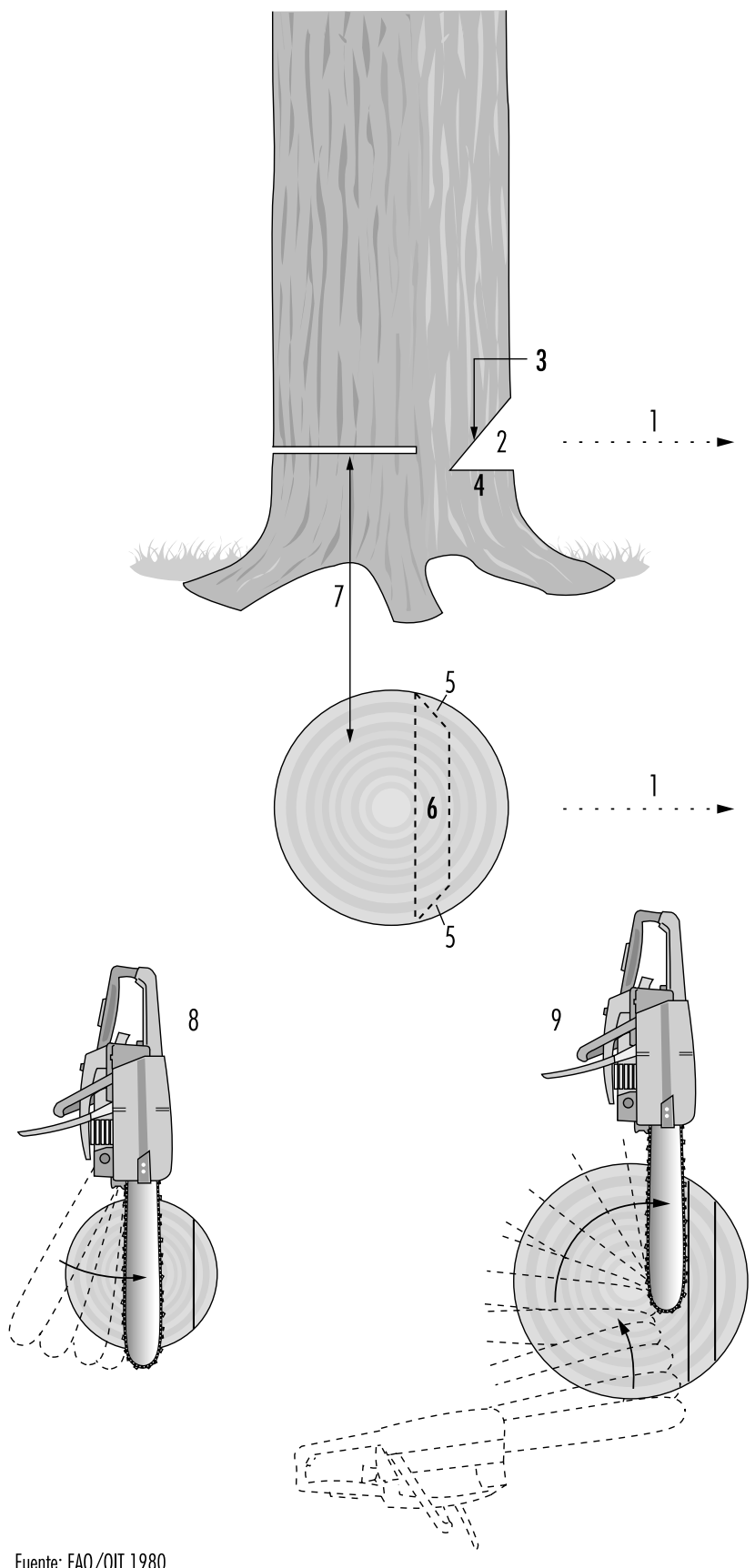

Fuente: FAO/OIT 1980. 
movimiento (8). En caso contrario, la sierra deberá moverse varias veces (9). EI método más generalizado se utiliza para apear árboles con raigales de más de $15 \mathrm{~cm}$ de diámetro. La técnica estándar se modifica si los árboles tienen copas de un solo lado, si están inclinados o si su diámetro supera el doble de la longitud de la hoja de la motosierra. En los manuales de formación de la FAO/OIT (1980), y en muchos otros dirigidos a operarios de motosierras, se incluyen instrucciones detalladas.

U nos trabajadores cualificados pueden apear un árbol con un alto grado de precisión siguiendo este método. Los árboles que tienen copas simétricas o que están ligeramente inclinados en una dirección que no es la óptima para la caída pueden desviarse de la dirección prevista al caer o no llegar a caer. En estos casos, es necesario emplear herramientas como palancas de apeo (para árboles pequeños) o martillos y cuñas (para árboles grandes) a fin de desplazar el centro de gravedad natural del árbol en la dirección deseada.

Excepto en el caso de árboles muy pequeños, las hachas no son adecuadas para las operaciones de apeo y tronzado. Con sierras de mano, el proceso es relativamente lento y los errores pueden detectarse y repararse; pero con motosierras, los cortes son rápidos y el ruido impide oír las señales que da el árbol, como el sonido de la fibra al romperse antes de caer. Si en su caída el árbol resulta interceptado por otros árboles, se queda "suspendido", situación muy peligrosa que debe solucionarse de modo inmediato y profesional. Para bajar los árboles suspendidos con seguridad y eficacia se utilizan palancas y ganchos giratorios (para árboles pequeños) y cabrestantes manuales 0 montados sobre tractor (para árboles grandes).

Entre los peligros que comporta el apeo cabe citar la caída o rodadura de árboles; la caída o rotura brusca de ramas; las herramientas de corte, y el ruido, la vibración y los gases de escape con las motosierras. Los vendavales son muy peligrosos, ya que las ramas y las raíces parcialmente cortadas se hallan en tensión; los árboles suspendidos suelen causar accidentes graves y mortales. Todos los trabajadores que participen en el apeo deberán haber recibido formación específica. Las herramientas para el apeo y para bajar árboles suspendidos tienen que encontrarse en el lugar donde se está trabajando. Entre los peligros asociados con el tronzado cabe citar las herramientas de corte, así como la rotura brusca de ramas y la rodadura de troncos 0 cachones, sobre todo en pendientes.

Una vez derribado el árbol, suele procederse al desmochado y desramaje. Por lo común, continúa haciéndose con herramientas de mano o motosierras a pie de tocón. Las hachas pueden ser muy eficaces para el desramaje. En lo posible, los árboles se derriban sobre un tronco previamente cruzado en el suelo, que sirve de banco de trabajo natural, ya que el árbol queda elevado a una altura más cómoda y pueden eliminarse todas las ramas sin necesidad de girar el árbol. Las ramas y la copa se cortan a ras del fuste y se dejan en el sitio. Si los árboles son grandes y frondosos, se cortan las copas en pequeños trozos o se retiran hacia un lado, pues pueden suponer un obstáculo para sacarlos al camino o cargadero.

Entre los peligros que entraña el desramaje cabe citar los cortes con herramientas o motosierras; el alto riesgo de retroceso de la motosierra (véase la Figura 68.7); la rotura brusca de ramas en tensión; la rodadura de troncos; los tropezones y las caídas; las posturas de trabajo forzadas, y un trabajo estático si la técnica utilizada no es la adecuada.

En las operaciones mecanizadas, la caída direccional se consigue sujetando el árbol con una pluma montada en una máquina base suficientemente pesada, y cortando el fuste con una cizalla, sierra circular o sierra de cadena integrada en la pluma. Para ello, la máquina ha de mantenerse bastante cerca

del árbol. A continuación se baja el árbol en la dirección deseada por medio de movimientos de la pluma o de la base de la máquina. Los tipos de máquinas más comunes son las cortadoras-atadoras y las cosechadoras.

Las cortadoras-atadoras se montan sobre todo en máquinas sobre orugas, pero también pueden equiparse con neumáticos. La pluma de apeo suele permitirles derribar y recoger varios árboles pequeños (un atado), que después depositan en una pista de arrastre. Algunas tienen una solera para recoger la carga. Cuando se utilizan cortadoras-atadoras, el desmochado y el desramaje suelen realizarse por medio de máquinas en el cargadero.

Con máquinas bien diseñadas y un manejo cuidadoso, el riesgo de accidentes con las cortadoras-atadoras es relativamente bajo, excepto cuando, además de la máquina, trabajan operarios de motosierras. Los riesgos para la salud, como la vibración, el ruido, el polvo y los vapores, son significativos, ya que las máquinas base no están fabricadas para el aprovechamiento forestal. Las cortadoras-atadoras no deben utilizarse si la pendiente es excesiva y la pluma no debe sobrecargarse, ya que resulta imposible controlar la dirección de apeo.

L as cosechadoras son máquinas que integran todas las operaciones de apeo, excepto el descortezado. Suelen tener seis u ocho ruedas, tracción y suspensión hidráulicas; dirección articulada, y plumas que alcanzan de 6 a $10 \mathrm{~m}$ una vez cargadas. Las hay de cabezal único y de cabezal doble. Las primeras llevan en la pluma un único cabezal cortador dotado de dispositivos de apeo, desramaje, desmochado y tronzado. Se utilizan con árboles pequeños de hasta $40 \mathrm{~cm}$ de diámetro en el raigal, sobre todo en clareos, aunque cada vez más en la corta final. Las segundas tienen dos cabezales independientes: uno de apeo y otro de transformación El último va montado en la máquina base en lugar de en la pluma. Manejan árboles de hasta $60 \mathrm{~cm}$ de diámetro en el tocón. Las cosechadoras modernas llevan incorporado un dispositivo de medición asistida por ordenador que

Figura 68.7 • Retroceso de una sierra mecánica.

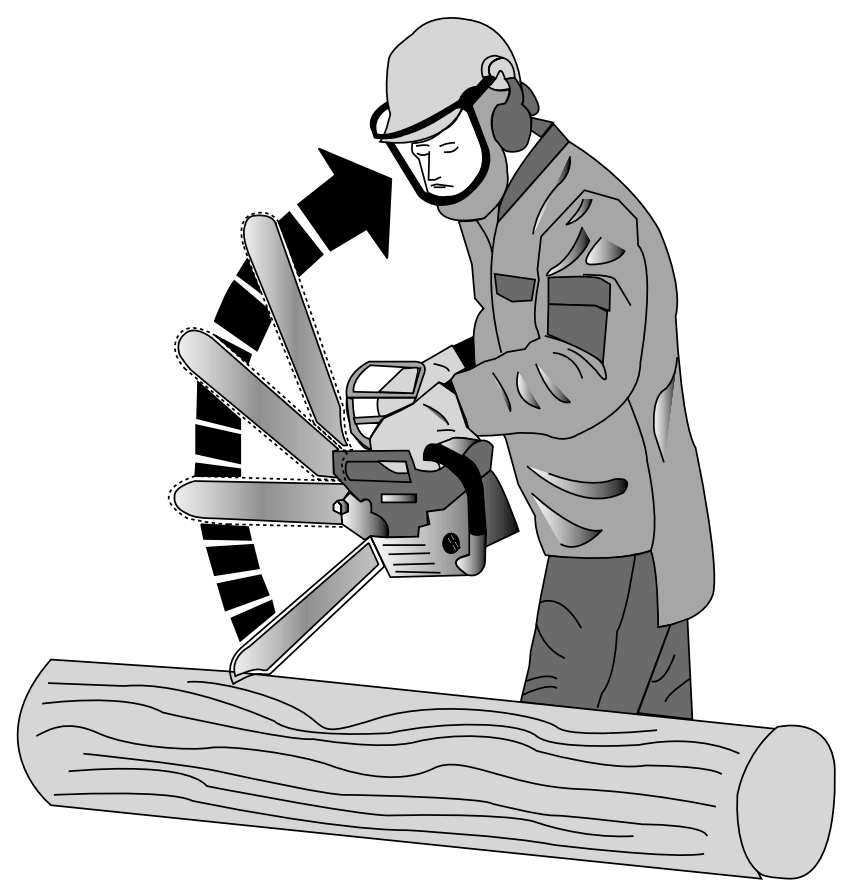


puede programarse para tomar decisiones sobre cómo conseguir el mejor tronzado en función de los surtidos necesarios.

Las cosechadoras son la tecnología dominante en el aprovechamiento a gran escala en Europa septentrional, pero en la actualidad representan un porcentaje bastante pequeño del aprovechamiento mundial. Con todo, es probable que su importancia aumente con rapidez, ya que las masas forestales de segunda formación, los bosques artificiales y las plantaciones son cada vez más importantes como fuentes de materias primas.

L as cifras de accidentes en el manejo de cosechadoras suelen ser bajas, aunque el riesgo aumenta cuando trabajan operarios de motosierras junto con las cosechadoras. EI mantenimiento de las cosechadoras es peligroso; las reparaciones siempre se realizan en situaciones de presión por la carga de trabajo; cada vez es más frecuente hacerlas durante la noche; existe un alto riesgo de resbalones y caídas, posturas de trabajo incómodas y difíciles, levantamiento de objetos pesados, contacto con aceites hidráulicos y aceites calientes bajo presión. Los mayores peligros son la tensión muscular estática y los esfuerzos repetitivos de manejo de controles y el estrés psicológico.

\section{Extracción}

La extracción implica el traslado de los troncos o trozas desde el tocón hasta un cargadero o camino donde pueden elaborarse 0 apilarse por surtidos. La extracción es una faena que puede resultar muy pesada y peligrosa, además de infligir notables daños ecológicos al bosque y a su regeneración, a los suelos y a las vías fluviales. Los principales tipos de sistemas de extracción comúnmente reconocidos son:

- sistemas de arrastre: los troncos o trozas se arrastran por el suelo por medio de máquinas, animales o personas;

- recogedores: los troncos o trozas se transportan con una máquina (en el caso de la leña, también por personas);

- sistemas de cables: las trozas se trasladan desde el tocón hasta el cargadero por medio de uno o más cables colgantes,

- sistemas aéreos: se utilizan helicópteros o globos para transportar las trozas.

El arrastre, con diferencia el sistema de extracción más importante tanto de madera industrial como de leña, suele realizarse por medio de arrastradores con ruedas especialmente diseñados para operaciones forestales. Los tractores de orugas y, sobre todo, los tractores agrícolas pueden ser rentables en pequeños bosques privados o para la extracción de pequeños árboles de plantaciones silvícolas, pero es necesario incorporarles adaptaciones que protejan tanto a los operarios como a las propias máquinas. L os tractores adolecen de la solidez, el equilibrio y la protección que ofrecen las máquinas construidas específicamente para estos fines. Al igual que con toda la maquinaria utilizada en la industria forestal, entre sus peligros se cuentan el de vuelco, caída y penetración de objetos, incendio, vibración de todo el cuerpo y ruido. Es preferible disponer de tracción a las cuatro ruedas y, durante el funcionamiento, como mínimo el $20 \%$ del peso de la máquina debe mantenerse como carga en el eje conducido, lo cual puede requerir la fijación de un peso adicional en la parte delantera de la máquina. Es posible que el motor y la transmisión necesiten protección mecánica adicional. El motor debe tener una potencia mínima de $35 \mathrm{~kW}$ para maderos de pequeñas dimensiones; $50 \mathrm{~kW}$ suelen ser suficientes para las trozas de tamaño normal.

Los arrastradores de garabato van directamente hasta cada tronco 0 atado, levantan el extremo delantero de la carga y la arrastran hasta el cargadero. Los arrastradores con cabrestantes pueden trabajar desde caminos de arrastre. Sus cargas suelen juntarse con bragas, correas, cadenas o cables cortos que se fijan a trozas individuales. Un bragador prepara las trozas para el enganche $y$, cuando el arrastrador vuelve del cargadero, fija varias bragas al cable principal y utiliza el cabrestante para llevarlas al arrastrador. La mayoría de los arrastradores tienen un arco sobre el que puede levantarse el extremo delantero de la carga para reducir el rozamiento durante el arrastre. Si se utilizan arrastradores con cabrestantes mecánicos, es esencial que los operarios mantengan una buena comunicación a través de radios bidireccionales o señales ópticas o acústicas. Es necesario acordar señales claras; cualquier señal que no se comprenda significará “ ¡Parar!”. En la Figura 68.8 se ofrecen las propuestas para el uso de arrastradores con tornos mecánicos.

Como regla práctica, los equipos de arrastre no deben utilizarse en pendientes de más de $15^{\circ}$. Los tractores de orugas pueden emplearse para extraer árboles grandes en terrenos relativamente abruptos, pero si no se hace con cuidado, los daños a

Figura 68.8 - Señales manuales convenidas internacionalmente para trabajar con arrastradores provistos de cabrestantes mecánicos.

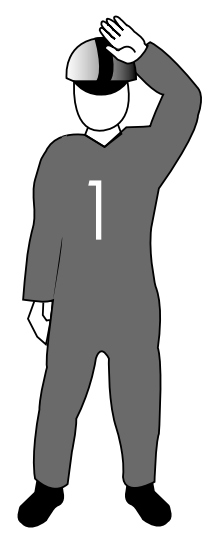

1. Avanzar tractor

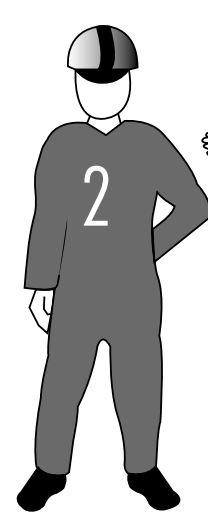

2. Tractor marcha atrás

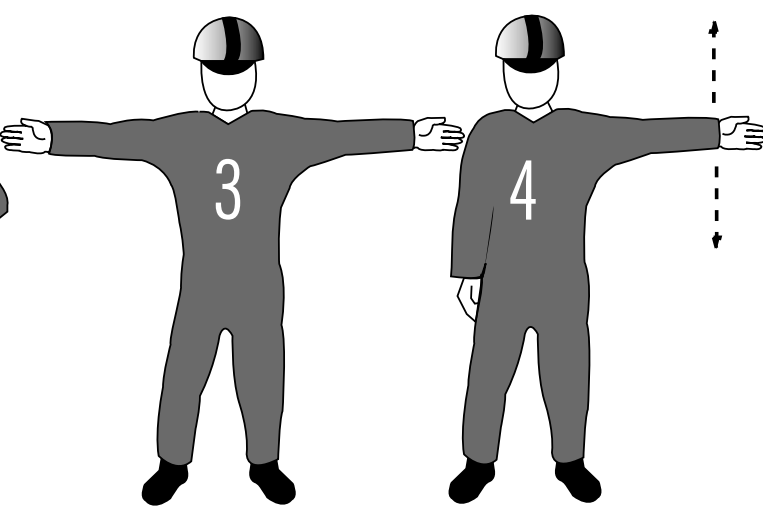

3. Detener tractor
4. Soltar cable

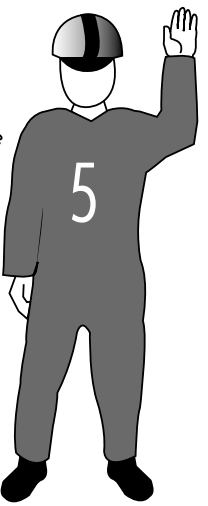

5. Recoger cable

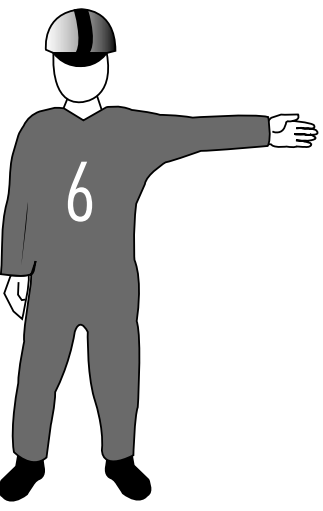

6. Detener cable

Toda seña que no se entienda significa "parar" 
los suelos pueden ser notables. Por motivos ecológicos y de seguridad, todas las operaciones de arrastre deben suspenderse en condiciones climatológicas muy lluviosas. La extracción con animales de tiro es una opción viable desde el punto de vista económico cuando se trata de pequeños troncos, sobre todo en operaciones de clareo. Las distancias de arrastre deben ser cortas (por lo común $200 \mathrm{~m}$ o menos) y las pendientes suaves. Es importante utilizar arneses adecuados que proporcionen la máxima potencia de tracción, y dispositivos como palas de arrastre, ruedas de saca o narrias que reduzcan la resistencia al arrastre.

El arrastre manual es cada vez más infrecuente en la saca industrial, pero continúa practicándose en la saca de subsistencia, sobre todo con leña. Aunque las trozas suelen ser pequeñas, esta faena es muy pesada y puede ser peligrosa en pendientes abruptas. A fin de mejorar la eficacia y la seguridad se utilizan ganchos, palancas y otras herramientas de mano para levantar y tirar de las trozas. Los deslizaderos, tradicionalmente hechos con maderos, aunque también los hay en forma de semitubos de polietileno, son una alternativa al arrastre manual de trozas cortas en terreno abrupto.

Los recogedores son máquinas de extracción que transportan una carga de trozas completamente separada del suelo, ya sea dentro de su propio bastidor o en un remolque. Suelen tener una grúa mecánica o hidráulica para realizar la autocarga y descarga de las trozas. T ienden a utilizarse en combinación con equipos de apeo y transformación mecanizados. La distancia de extracción económica es de 2 a 4 veces la de los arrastradores. Los recogedores funcionan mejor si el tamaño de las trozas es más o menos uniforme.

Los accidentes con recogedores son similares a los de los tractores y otras máquinas forestales: vuelco, penetración y caída de objetos, líneas de corriente eléctrica y problemas de mantenimiento. Entre los riesgos para la salud cabe citar la vibración, el ruido y los aceites hidráulicos.

El transporte de cargas de trozas cortas, como en el caso de la madera para pasta o puntales en ciertas operaciones de aprovechamiento industrial, lo realizan todavía personas, sobre todo en la recolección de leña. Las cargas transportadas suelen exceder todos los límites recomendados, sobre todo en el caso de las mujeres, que son las que lo hacen. Su carga se vería aliviada si recibieran formación acerca de las técnicas apropiadas para evitar tensiones extremas en la columna vertebral y pudieran utilizar mochilas y similares para distribuir mejor el peso.

Los sistemas de extracción por cable difieren básicamente de otros sistemas de extracción en que la máquina no cambia de sitio. Las trozas se transportan por medio de un carro que se traslada por cables colgantes. Los cables se accionan con un cabrestante motorizado, también llamado malacate o torno de cable. La máquina se instala en el cargadero o en el extremo opuesto de la vía de cable, a menudo en lo alto de un cerro. Los cables se cuelgan por encima del suelo de uno o más "mástiles de amarre", que pueden ser árboles o torres de acero. $\mathrm{H}$ ay muchos tipos diferentes de sistemas de cable: los portantes 0 cables-grúa llevan un carro que se traslada por la línea principal, pudiéndose soltar cable para permitir la introducción lateral de trozas en la línea, antes de levantarlas y transportarlas al cargadero. Si el sistema permite la total suspensión de la carga durante el acarreo, las consecuencias para el suelo son mínimas. Como la máquina está fija, los sistemas de cable pueden utilizarse en pendientes y en suelo mojado. L os sistemas de cable son en general bastante más caros que el arrastre y requieren una cuidadosa planificación y operarios cualificados.

EI montaje, el manejo y el desmontaje del sistema de cable entrañan riesgos, entre ellos, el impacto mecánico por deformación de la cabina o plataforma; la rotura de cables, anclajes, mástiles o soportes; los movimientos inadvertidos o incontrolados de cables, carros, bragas y cargas; y los aplastamientos, las rozaduras, etcétera, originados por las partes móviles. Entre los riesgos para la salud cabe citar el ruido, la vibración y las posturas de trabajo difíciles.

En los sistemas aéreos de extracción, las trozas quedan totalmente suspendidas en el aire durante todo el proceso. Los dos tipos que se utilizan en la actualidad son los sistemas de globos y los helicópteros, pero sólo está extendido el uso de los segundos. En el mercado existen helicópteros con capacidad para levantar alrededor de 11 toneladas. Las cargas van debajo del helicóptero, colgadas de un cable de entre 30 y 100 m de longitud, en función tanto de la topografía como de la altura de los árboles que debe sobrevolar el helicóptero. Las cargas se fijan con largas bragas y se llevan hasta el cargadero, donde se sueltan las bragas por control remoto desde la aeronave. Para sacar grandes trozas puede utilizarse un garabato accionado eléctricamente en lugar de las bragas. Por lo común, se tarda de dos a cinco minutos en cubrir el trayecto de ida y vuelta. Los helicópteros tienen un coste directo muy alto, pero también consiguen altas velocidades de producción y reducen o eliminan la necesidad de construir costosos caminos. Además, sus efectos en el medio ambiente son escasos. En la práctica, su uso está limitado a maderos de gran valor en regiones que de otro modo serían inaccesibles, o a otras circunstancias especiales.

D ebido a las altas velocidades de producción necesarias para que este equipo resulte económico, en las operaciones con helicópteros se emplean muchos más trabajadores que con otros sistemas. $Y$ se refiere tanto a los cargaderos como a las operaciones de corta. La saca forestal con helicópteros puede crear importantes problemas de seguridad, incluidos los accidentes mortales si no se toman precauciones y las plantillas no están bien preparadas.

\section{Preparación y carga de las trozas}

La preparación de las trozas, si se realiza en el cargadero, suele ser cometido de los operarios de motosierras. También puede hacerse con un procesador (es decir, una máquina que realiza el desramaje, el desmochado y corta a medida). La cubicación se hace por lo común a mano, con una cinta métrica. Para las operaciones de clasificación y apilamiento, las trozas se manipulan mecánicamente con arrastradores cuya pala frontal se emplea para empujar y levantar las trozas, o con cargadoras de garabato. Los operarios de las máquinas suelen contar con la ayuda de auxiliares que utilizan herramientas manuales, como palancas. La carga de leña o pequeñas trozas en camiones suele realizarse a mano 0 utilizando un pequeño cabrestante. La carga manual de grandes trozas es muy ardua y peligrosa; suelen manejarse por medio de cargadoras de garabato 0 de pluma articulada. En algunos países, los camiones de saca están equipados para autocarga. L as trozas se aseguran en el camión con soportes laterales y cables que pueden tensarse.

En la carga manual de madera, la tensión física y las cargas de trabajo son extremas. Tanto en la carga manual como en la mecanizada, existe el riesgo de recibir golpes de equipos o trozas en movimiento. Entre los peligros de la carga mecanizada cabe citar el ruido, el polvo, la vibración, la gran tensión mental debida al trabajo, el esfuerzo repetitivo, los vuelcos, la penetración o caída de objetos y los aceites hidráulicos.

\section{Normas y disposiciones}

En la actualidad, la mayoría de las normas internacionales en materia de seguridad aplicables a la maquinaria forestal tienen un carácter general: por ejemplo, la protección antivuelco. Ahora bien, la O rganización Internacional de N ormalización (ISO ) está 
elaborando normas especializadas (véase el artículo "Normas, legislación, disposiciones y recomendaciones en la práctica forestal" en este mismo capítulo).

Las motosierras son uno de los pocos equipos de aprovechamiento forestal para los que existen disposiciones específicas internacionales en materia de seguridad. $\mathrm{H}$ ay varias normas ISO de aplicación en este ámbito. Se incorporaron y complementaron en 1994 en la Norma Europea 608, titulada M aquinaria agrícola y forestal. M otosierras portátiles. Seguridad. Esta norma contiene indicaciones detalladas sobre características de diseño y. en ella se estipula que los fabricantes están obligados a proporcionar instrucciones completas e información sobre todos los aspectos del mantenimiento por parte de los operarios/ usuarios y la seguridad en la utilización de la sierra. Incluye asimismo requisitos en materia de ropa y equipos de protección personal así como la necesidad de formación. Todas las sierras vendidas en la Unión Europea deben llevar la leyenda: "Advertencia: véase el manual de instrucciones". La norma enumera las cuestiones que debe incluir el manual.

Las máquinas forestales no reciben tanta atención en las normas internacionales, y no suele existir disposiciones específica a escala nacional sobre los requisitos de seguridad. Las máquinas forestales pueden presentar también notables deficiencias ergonómicas que desempeñan un papel importante en la aparición de problemas graves de salud entre los operarios. En otros casos, las máquinas tienen un buen diseño para una determinada población de trabajadores, pero resultan menos adecuados cuando se importan a países donde los trabajadores tienen diferentes dimensiones corporales, rutinas de comunicación, etcétera. En el peor de los casos, se eliminan de las máquinas características esenciales para la salud y la seguridad con el fin de reducir los precios de exportación. Se han elaborado listas de control ergonómico especializadas en varios países destinadas a orientar a las organizaciones que realizan ensayos y a los responsables de la adquisición de máquinas. Las listas de control suelen ocuparse de las siguientes características de las máquinas:

- áreas de acceso y salida, como estribos, escaleras y puertas;

- espacio en la cabina y posición de los mandos;

- asiento, reposabrazos, respaldo y reposapiés del sillón del operario:

- visibilidad al realizar las principales operaciones;

- interfaz trabajador-máquina: tipo y disposición de los indicadores y mandos de las funciones de la máquina;

- entorno físico, incluidos el ruido de vibración, los gases y los factores climáticos;

- seguridad, incluidos los vuelcos, la penetración de objetos, los incendios y otros,

- mantenimiento.

En Golsse (1994) y en Apud y Valdés (1995) hay ejemplos específicos de estas listas de control. En OIT 1998 se incluyen recomendaciones para máquinas y equipos, así como una lista de las normas de la O IT que existen.

\section{- TRANSPORTE DE LA MADERA}

\section{Olli Eeronheimo}

El transporte de la madera es el eslabón entre el aprovechamiento forestal y la fábrica. Es una operación de gran importancia económica: en el hemisferio norte representa del 40 al $60 \%$ del coste total del abastecimiento de madera en la fábrica (excepto el canon por pie), y en los trópicos la proporción es todavía mayor.
He aquí los factores básicos que afectan al transporte de la madera: las dimensiones de la operación; la situación geográfica del bosque y de la fábrica, así como la distancia entre ellas; el surtido de madera para el que está proyectada la fábrica; y las clases de transporte disponibles y adecuadas. Los principales surtidos de madera los forman árboles completos con ramas, troncos escandalados, trozas largas (por lo común de 10 a $16 \mathrm{~m}$ de largo), trozas cortas (por lo común de 2 a $6 \mathrm{~m}$ ), astillas y leña para trizar. Muchas fábricas aceptan surtidos variados de madera, mientras que otras sólo aceptan determinados tipos: por ejemplo, trozas cortas por carretera. EI transporte se realiza por carretera, ferrocarril, barco, flotación por vía fluvial o, según la geografía y la distancia, varios de estos medios. Con todo, la forma principal de transporte de la madera es el transporte en camión por carretera.

En muchos casos, el transporte, sobre todo por carretera, es una parte integral de la operación de aprovechamiento, por lo que cualquier problema puede paralizar toda la operación de aprovechamiento. La urgencia puede dar lugar a una demanda de horas extraordinarias y a un deseo de economizar gastos que ponga en peligro la seguridad de los trabajadores.

Tanto el aprovechamiento forestal como el transporte de la madera suelen realizarse por contrata. En los casos en que hay muchos servicios contratados y subcontratados, pueden plantearse problemas respecto a la responsabilidad de proteger la seguridad y la salud de determinados trabajadores.

\section{Manipulación y carga de la madera}

Si las circunstancias lo permiten, la madera se carga directamente a pie de tocón, eliminando la necesidad de una fase adicional de transporte forestal. Si las distancias son cortas, los equipos de transporte forestal ( $p$. ej., un tractor agrícola con un remolque o semirremolque) pueden trasladar la madera directamente a la fábrica. En cambio, lo normal es llevar primero la madera al cargadero situado junto a la carretera forestal antes de transportarlo a larga distancia.

La carga manual suele practicarse en países en desarrollo y en operaciones con escaso capital. Las trozas pequeñas pueden levantarse y las grandes llevarse rodando con ayuda de rampas (véase la Figura 68.9). Ello puede implicar el uso de sencillas herramientas de mano, como ganchos, palancas, zapas, poleas, etcétera, así como de animales de tiro.

Con todo, en la mayoría de los casos la carga está mecanizada y suele hacerse con cargadoras de pluma giratoria, pluma articulada 0 de ataque frontal. Las cargadoras de pluma giratoria 0 articulada pueden ir montadas sobre transportes sobre ruedas $u$ orugas 0 en camiones, y suelen ir provistas de un garabato. Las cargadoras de ataque frontal suelen llevar horquillas o un garabato y van montadas sobre tractores de orugas o tractores articulados con tracción a las cuatro ruedas. En la carga semimecanizada, las trozas pueden levantarse o llevarse rodando sobre durmientes por medio de cables y diferentes clases de tractores y cabrestantes (véase la Figura 68.10). En la carga semimecanizada suele ser necesario que los trabajadores estén en el suelo fijando y soltando cables, guiando la carga, etcétera, para lo que suelen utilizar ganchos, palancas y otras herramientas de mano. En las operaciones de astillado, la máquina suele echar las astillas directamente al camión, remolque o semirremolque.

\section{Operaciones en cargadero}

Los cargaderos son lugares ajetreados y ruidosos donde se realizan muchas actividades diferentes al mismo tiempo. Según el sistema de aprovechamiento, pueden realizarse en ellos la carga y descarga, el escandalaje, el descortezado, el tronzado, la 
Figura 68.9 - Carga manual (con y sin rampas).
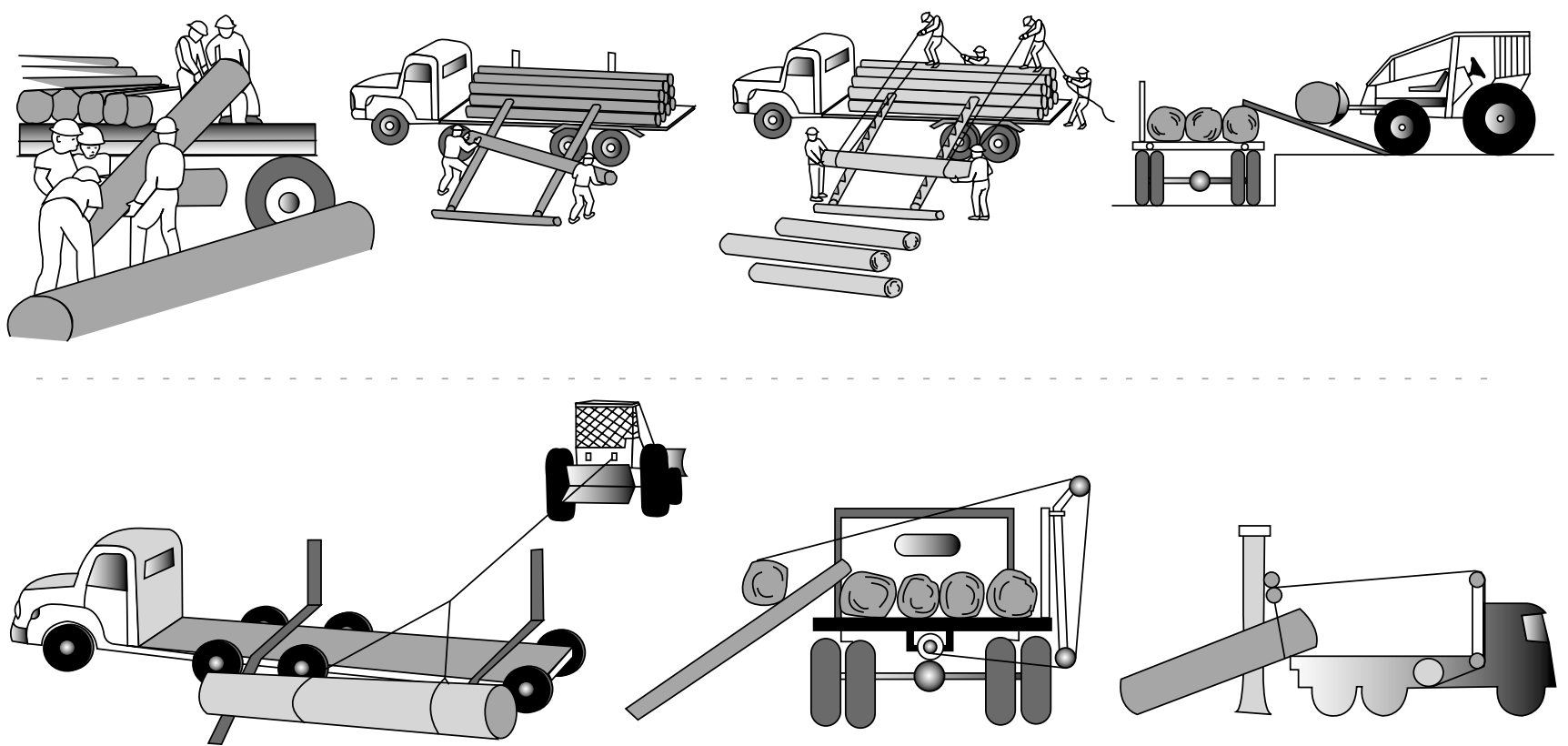

Fuente: Adaptado de Kantola y Harstela 1988.

clasificación, el almacenamiento y el astillado. Puede haber una o más máquinas grandes moviéndose y trabajando al mismo tiempo mientras se utilizan motosierras en las proximidades. Durante y después de las lluvias, las nieves y las heladas, los troncos están muy escurridizos y el suelo muy embarrado y resbaladizo. Y en tiempo seco, toda la zona está llena de detritos y muy polvorienta en tiempo seco. Los troncos pueden almacenarse en pilas sin amarrar de varios metros de alto. Todo ello convierte al cargadero en una de las áreas de trabajo más peligrosas de la industria forestal.

\section{Transporte por carretera}

El transporte de madera por carretera se realiza en vehículos cuyo tamaño depende de las dimensiones de los maderos, de las condiciones de la carretera y de las normas de tráfico, así como de la disponibilidad de capital para comprar o alquilar los equipos. En los países tropicales se utilizan camiones de dos o tres ejes, con una capacidad de carga de 5 a 6 toneladas. En Escandinavia, por ejemplo, el camión de saca forestal típico es un camión de 4 ejes con un remolque de 3 ejes o viceversa, con una capacidad de carga de 20 a 22 toneladas. En carreteras privadas de $\mathrm{N}$ orteamérica pueden encontrarse camiones con un peso total de 100 a 130 toneladas o más.

\section{Transporte acuático}

El uso de vías fluviales para el transporte de madera ha ido disminuyendo a medida que ha aumentaba el transporte por carretera, pero sigue siendo importante en Canadá, Estados Unidos, Finlandia y Rusia en el hemisferio norte, en las divisorias de los ríos Amazonas, Paraguay y Paraná en América Latina, en muchos ríos y lagos de Africa occidental y en la mayoría de los países del sureste asiático.

Figura 68.10 - Carga mecanizada y semimecanizada.
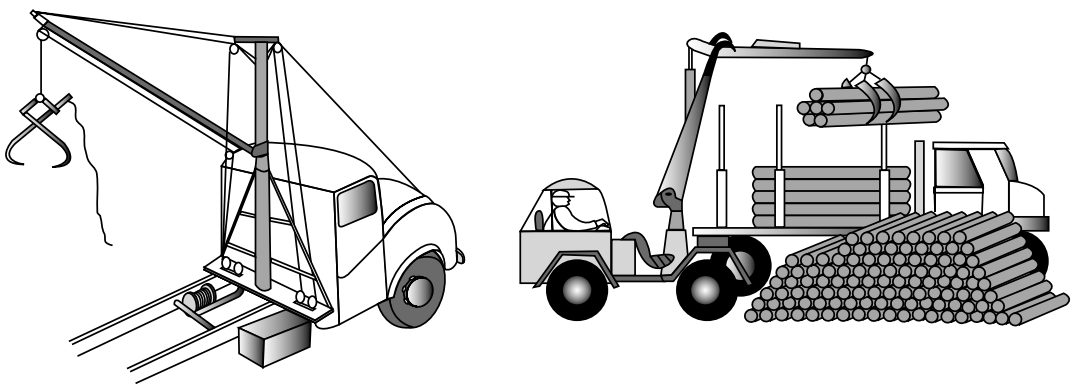

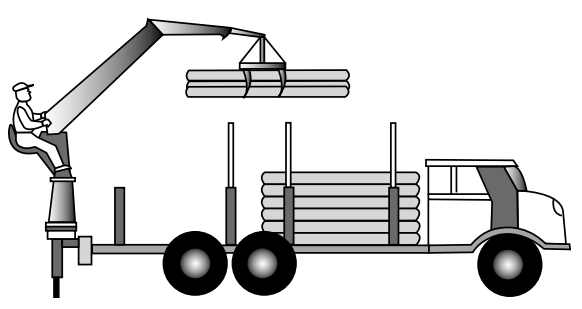

Fuente: Adaptado de Kantola y Harstela 1988. 
Figura 68.11 • O peraciones de saca en $\mathrm{N}$ igeria realizada por trabajadores sin protección.

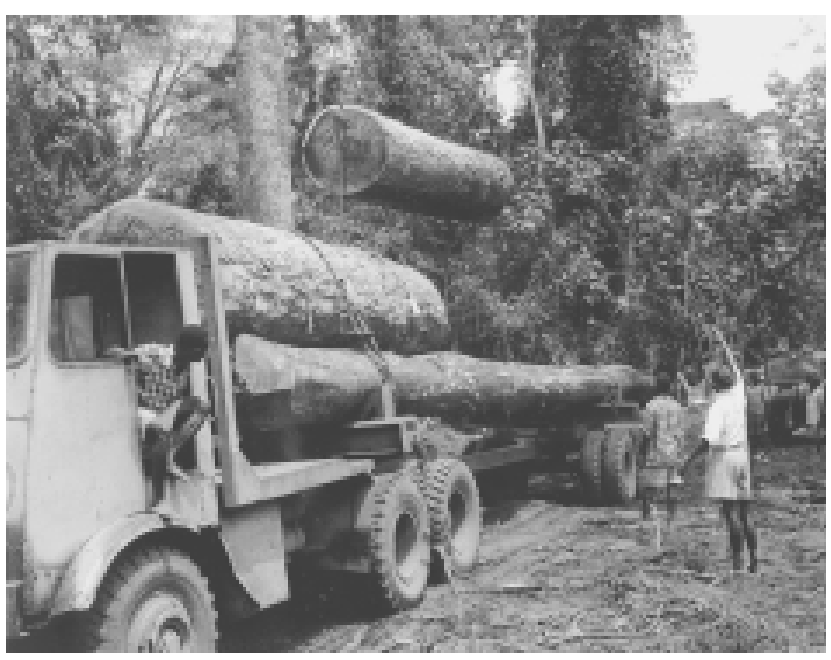

En los manglares y bosques estacionales, el transporte acuático suele empezar directamente desde el tocón; en los demás casos, los troncos han de transportarse hasta el muelle, por lo común en camión. Los troncos sueltos 0 atados pueden bajarse por el río a la deriva; o atarse formando balsas que se remolcan o se empujan por ríos, lagos y a lo largo de las costas; o cargarse en barcos y barcazas de diversos tamaños. L os barcos oceánicos desempeñan un importante papel en el comercio internacional de madera.

\section{Transporte ferroviario}

En Norteamérica y en los trópicos, el transporte ferroviario, al igual que el transporte acuático, está dejando paso al transporte por carretera. En cambio, sigue siendo muy importante en países como C anadá, Finlandia, Rusia y China, donde hay buenas redes ferroviarias con áreas intermedias de carga adecuadas. En algunas operaciones a gran escala, pueden utilizarse ferrocarriles temporales de vía estrecha. La madera se transporta en coches de mercancías estándar 0 en vagones especialmente fabricados para cargar madera. En algunas estaciones pueden utilizarse grandes grúas fijas para las operaciones de carga y descarga, pero, por lo general, se emplean los métodos de carga citados.

\section{Conclusión}

Las operaciones de carga y descarga, que a veces deben realizarse varias veces durante el recorrido de la madera desde el bosque hasta el lugar donde se utilizará, suelen ser muy peligrosas en la industria maderera. Aunque estén totalmente mecanizadas, es necesario a veces que los trabajadores vayan a pie y que utilicen herramientas de mano, lo cual entraña riesgos. Algunos de los más grandes operadores y contratistas, conocedores de ellos, someten sus equipos a un mantenimiento adecuado y proporcionan a sus trabajadores equipos de protección personal (EPP), como calzado, guantes, cascos, gafas y protectores contra el ruido. Aun así, se precisan supervisores avezados y diligentes que garanticen el cumplimiento de las medidas de seguridad. Es ésta una cuestión problemática en operaciones pequeñas, sobre todo en los países en desarrollo. (C omo ejemplo, véase la Figura 68.11, en la que aparecen trabajadores cargando troncos en Nigeria sin ningún tipo de equipos de protección personal.)

\section{APRO VECHAMIENTO DE PRODUCTOS FORESTALES NO MADEREROS}

\section{Rudolf H einrich}

\section{Entorno de trabajo}

Son muchos los riesgos asociados al aprovechamiento de productos forestales no madereros, debido a la gran diversidad de éstos. A fin de definir mejor los riesgos, los productos no madereros pueden agruparse por categorías, con algunos ejemplos representativos. Así pueden identificarse con más facilidad los riesgos asociados a su obtención (véase la Tabla 68.2).

La explotación de productos no madereros se realiza por varias razones (subsistencia, usos comerciales o de ocio) y para cubrir diversas necesidades, lo que a su vez afecta a los riesgos asociados a la recogida. Por ejemplo, el recolector de setas aficionado tiene muchas menos probabilidades de exponerse a condiciones climáticas severas por estar al aire libre que el recolector comercial, quien se gana la vida con esta actividad y compite por un producto limitado a una cierta temporada.

La escala de las operaciones de explotación no madereras es variable, con efectos positivos y negativos en términos de posibles riesgos. Por naturaleza, el aprovechamiento no maderero suele estar a cargo de pequeños empresarios o de personas que se ganan la vida con ello. La seguridad de un trabajador solitario en lugares remotos es más problemática que la del que no lo está. La experiencia individual influye en la situación. Puede ocurrir una emergencia u otro acontecimiento que exija la intervención directa de asesores externos en materia de seguridad y salud. Con todo, ciertos productos no madereros se han comercializado, prestándose incluso al cultivo en plantaciones, como es el caso del bambú, las setas, los pertrechos navales de goma, ciertos frutos secos y el caucho, por nombrar algunos. En teoría, es más probable que las operaciones sujetas a comercialización proporcionen información sistemática en materia de salud y seguridad en el curso del trabajo, prestándole mayor atención.

En conjunto, los productos enumerados, el entorno forestal en el que existen y los métodos necesarios para obtenerlos pueden ir ligados a ciertos riesgos inherentes para la salud y la seguridad. Tales riesgos son bastante elementales, porque se derivan de acciones muy comunes, como trepar, cortar con herramientas

Tabla 68.2 - Categorías de productos forestales no madereros y ejemplos.

$\begin{array}{ll}\text { Categorías } & \text { Ejemplos } \\ \text { Productos alimentarios } & \text { Productos animales, brotes de bambú, } \\ \text { bayas, bebidas, piensos, frutas, } \\ \text { hierbas, setas, frutos secos, aceites, } \\ \text { corazones de palma, raíces, semillas, } \\ \text { féculas }\end{array}$

Productos químicos y farmacológicos y Sustancias aromáticas, gomas y resinas, sus derivados látex y otros materiales exudados, extractos medicinales, taninos y tintes, toxinas

Materiales decorativos Corteza, follaje, flores, hierba, ambientadores florales

Fibra no maderera para trenzar, para Bambú, corteza, corcho, ceiba, hojas de usos estructurales, y para acolchar palma, rota, juncos, hierba para paja 
de mano, cavar, recolectar, seleccionar y transportar manualmente. Además, el aprovechamiento de un determinado producto alimentario puede incluir la exposición a agentes biológicos (plantas de superficie venenosa o serpientes venenosas), peligros biomécanicos (p. ej., debidos a movimientos repetitivos o al acarreo de cargas pesadas), condiciones climatológicas adversas, peligros para la seguridad derivados de las herramientas y técnicas utilizadas (como una laceración provocada por una técnica de corte negligente) y otros muchos que pueda entrañar un terreno abrupto, el atravesar un río o el trabajo a cierta altura del suelo).

Como los productos no madereros no suelen prestarse a la mecanización y su coste suele ser prohibitivo, la insistencia en su aprovechamiento manual o en el uso de animales de tiro para su aprovechamiento y transporte resulta desproporcionada en comparación con otras industrias.

\section{Control y prevención de riesgos}

Las operaciones de corta merecen una mención especial, ya que puede afirmarse que es la fuente más clara y común de riesgos asociados al aprovechamiento de productos forestales no madereros. Van ligados a la elección de las herramientas apropiadas y a la calidad de las mismas, al tamaño y al tipo de corte requerido, a la fuerza necesaria para realizar el corte, a la posición del trabajador y a su actitud.

En general, los riesgos de las operaciones de corta pueden reducirse 0 mitigarse mediante:

- formación directa sobre el trabajo: elección de herramientas apropiadas, mantenimiento y afilado de las herramientas y formación del trabajador con respecto a las técnicas biomecánicas apropiadas,

- formación en materia de organización de trabajo: planificación del trabajo, evaluación de riesgos y de seguridad, preparación de la zona y atención permanente del trabajador a la faena y a sus alrededores.

El objetivo de una buena formación con respecto a la técnica y los principios del trabajo debe ser: la planificación

Tabla 68.3 - Riesgos del aprovechamiento de productos no madereros y ejemplos.

\begin{tabular}{|c|c|}
\hline $\begin{array}{l}\text { Riesgos del aprove- } \\
\text { chamiento de } \\
\text { productos no } \\
\text { madereros }\end{array}$ & Ejemplos \\
\hline \multirow[t]{2}{*}{ Agentes biológicos } & $\begin{array}{l}\text { Mordeduras y picaduras (vector externo, venenos } \\
\text { sistémicos) }\end{array}$ \\
\hline & $\begin{array}{l}\text { Contacto con plantas (vector externo, venenos tópicos) } \\
\text { Ingestión (vector interno, venenos sistémicos) }\end{array}$ \\
\hline Acción biomecánica & $\begin{array}{l}\text { Lesión por emplear una técnica inadecuada o por } \\
\text { realizar movimientos repetitivos de encorvamiento, } \\
\text { acarreo, corta, levantamiento, carga }\end{array}$ \\
\hline $\begin{array}{l}\text { Condiciones } \\
\text { climatológicas }\end{array}$ & $\begin{array}{l}\text { Efectos del calor y el frío excesivos, ya sean inducidos } \\
\text { externamente (por el ambiente) o debidos al esfuerzo } \\
\text { físico del trabajo }\end{array}$ \\
\hline Herramientas y técnicas & $\begin{array}{l}\text { Cortes, peligros mecánicos, manejo de animales de tiro, } \\
\text { manejo de pequeños vehículos }\end{array}$ \\
\hline Otros & $\begin{array}{l}\text { Altercados, ataques de animales, dificultades del } \\
\text { terreno, fatiga, pérdida de orientación, trabajo en } \\
\text { altura, trabajo en lugares alejados, vadeo o trabajo en } \\
\text { vías fluviales }\end{array}$ \\
\hline
\end{tabular}

apropiada de éste, la implantación de medidas preventivas, el reconocimiento de los riesgos y medidas activas para evitarlos y la minimización de lesiones en caso de accidente.

\section{Factores relacionados con los riesgos del aprovechamiento}

Como el aprovechamiento no maderero, por naturaleza, se realiza al aire libre, está sujeto a condiciones meteorológicas variables y otros factores naturales, y es un trabajo que no está mecanizado por lo general, los trabajadores están especialmente sujetos a los efectos ambientales de la geografía, la topografía, el clima y la estación. D espués de considerables esfuerzos físicos, las condiciones climáticas pueden propiciar la aparición de problemas de salud y accidentes relacionados con el trabajo (véase la Tabla 68.3).

Las operaciones de aprovechamiento no maderero suelen realizarse en zonas alejadas, lo que implica una forma de riesgo debido a la falta de proximidad de atención médica en caso de accidente. No supone, desde luego, que aumente el número de accidentes, pero puede aumentar la gravedad de las posibles lesiones.

\section{Plantacion de arboles}

\section{Denis Giguère}

L os árboles se plantan colocando plantones o árboles jóvenes en la tierra. Se hace sobre todo para repoblar un bosque talado, crear un coto forestal o dar un nuevo uso a una parcela de terreno ( $p$. ej., de pasto a coto forestal, o bien para controlar la erosión en una pendiente abrupta). Los proyectos de plantación pueden ascender a varios millones de plantas, y ser ejecutados por contratistas privados al servicio de los propietarios de los bosques, por fabricantes de papel y pasta de papel, por servicios forestales estatales, por organizaciones no gubernamentales o por cooperativas. En algunos países, las plantaciones se han convertido en una verdadera industria. En este sentido, queda excluida la plantación de grandes árboles individuales, que se considera más bien una actividad paisajística que forestal.

Entre los trabajadores de este sector cabe citar a los propios plantadores; al personal encargado de los viveros; a los trabajadores dedicados al transporte y mantenimiento de las plantas, al apoyo y la logística (p. ej., gestión, cocina, conducción y mantenimiento de vehículos, etc.), y a los inspectores de control de calidad. L as mujeres representan del 10 al $15 \%$ de las plantillas de plantación. Como muestra de la importancia de esta industria y de la escala de sus actividades en regiones donde la silvicultura es un recurso importante, el gobierno provincial de Quebec, Canadá, se fijó en 1988 el objetivo de plantar 250 millones de plantones.

\section{Material de plantación}

Son varias las tecnologías aplicadas para producir plantones 0 árboles jóvenes, y de ellas depende la ergonomía de las plantaciones. En terreno plano puede realizarse con máquinas plantadoras; el papel del trabajador se limita entonces a alimentar la máquina manualmente 0 a un mero control de calidad. Ahora bien, en casi todos los países y situaciones, la preparación de la zona se hace de manera mecánica, aunque la plantación en sí sigue haciéndose a mano.

En la mayoría de los casos de reforestación (p. ej., tras un incendio o una corta a hecho) o de forestación se utilizan plantones de 25 a $50 \mathrm{~cm}$ de altura. Los plantones son de raíz desnuda 0 criados en envases. Los envases más comunes en los 
países tropicales tienen de 600 a $1.000 \mathrm{~cm}^{3}$ y pueden distribuirse en bandejas de plástico o espuma de estireno, en las que suelen caber de 40 a 70 unidades idénticas. Para algunos fines se requieren plantas más grandes, de 80 a $200 \mathrm{~cm}$, que suelen ser de raíz desnuda.

La plantación de árboles es estacional porque, ya que depende de que el clima sea lluvioso y/ o fresco. La estación dura de 30 a 90 días en la mayoría de las regiones. Aunque pueda parecer una ocupación estacional menor, la plantación de árboles debe considerarse una importante actividad estratégica a largo plazo donde los bosques son una industria importante, tanto por motivos ecológicos como económicos.

La información aquí presentada se basa sobre todo en el modelo canadiense, pero muchas de estas cuestiones pueden extrapolarse a otros países de características geográficas y económicas similares. Se abordan también prácticas específicas y consideraciones para la seguridad y la salud en países en desarrollo.

\section{Estrategia de plantación}

A fin de fijar unos objetivos de plantación adecuados, es importante realizar una evaluación minuciosa del terreno, ya que si ésta es superficial puede ocultar dificultades de carácter práctico que retrasan la plantación y sobrecargan de trabajo a los plantadores. Existen varias estrategias para plantar grandes superficies. Un método generalizado es disponer una hilera de 10015 plantadores separados por distancias iguales y hacer que avancen al mismo ritmo; un trabajador se encarga de proporcionar suficientes plantones a todo el equipo, por lo común mediante pequeños vehículos todo terreno. O tro método habitual es trabajar con varias parejas de plantadores, responsabilizándose cada pareja de ir a buscar y transportar sus propias plantas. Los plantadores experimentados saben distribuir el material para no perder tiempo llevando plantas de un lado a otro. No es recomendable plantar sin compañeros.

\section{Transporte de plantones}

El trabajo de plantación depende del suministro constante de plantones a los plantadores. Se traen de los viveros en tandas de varios millares, en camiones o furgonetas hasta donde llegue la carretera. Los plantones deben descargarse con toda rapidez y regarse con regularidad. Para transportarlos desde el almacén principal hasta los terrenos donde van a plantarse se utilizan pequeños vehículos todo terreno o maquinaria de saca forestal adaptada. Si los plantones han de ser transportados por los propios trabajadores, como sucede en muchos países en desarrollo, el trabajo resulta muy pesado. Deben emplearse mochilas adecuadas para reducir la fatiga y el riesgo de lesiones. Cada plantador lleva de cuatro a seis bandejas a su parcelas respectiva. Como a la mayoría se les paga a destajo, es importante para ellos minimizar los tiempos improductivos empleados en desplazarse 0 en ir a buscar y transportar plantones.

\section{Equipos y herramientas}

El equipamiento típico de un plantador silvícola comprende una pala 0 un almocafre (un bastón terminado en un cilindro metálico ligeramente cónico que se utiliza para hacer hoyos a la medida de los plantones envasados), dos o tres bandejas de envases de plantas transportadas por medio de un arnés, y equipos de seguridad como botas con puntera y guantes protectores. Para plantar plantones de raíz desnuda, en lugar del arnés se lleva en la mano un cubo con agua suficiente para cubrir las raíces del plantón. En Europa y N orteamérica también se utilizan diversos tipos de azadas para plantar plantones de raíces desnudas. Algunas herramientas de plantación son fabricadas por compañías especializadas, pero muchas de ellas se fabrican en tiendas locales o están concebidas para usos de jardinería y agricultura, y presentan algunas deficiencias en su diseño, como un exceso de peso y una longitud inadecuada. En la Tabla 68.4 se indican los pesos que se transportan normalmente.

\section{Ciclo de plantación}

Un ciclo de plantación silvícola se define como la serie de pasos necesarios para poner un plantón en la tierra. Las condiciones del lugar, como la pendiente, la tierra y el sotobosque, influyen de manera importante en la productividad. En Canadá, la producción de un plantador puede oscilar entre las 600 plantas diarias de un principiante hasta las 3.000 plantas diarias de un trabajador experimentado. El ciclo puede subdividirse de la forma siguiente:

E lección de una microestación. Este paso es fundamental para la supervivencia de los árboles jóvenes y depende de varios criterios que deben tener en cuenta los inspectores de control de calidad, entre los que cabe citar la distancia respecto a la planta precedente y su descendencia natural, la proximidad a materia orgánica, la ausencia de detritos en las proximidades y la evitación de lugares secos 0 inundados. El plantador debe aplicar todos estos criterios para cada uno de los árboles plantados, ya que su incumplimiento puede dar lugar a pérdidas económicas.

Perforación de la tierra. Se realiza un hoyo en el suelo con la herramienta de plantación. Se observan dos modalidades de trabajo, en función del tipo de mango y de la longitud de la barra. Una de ellas consiste en utilizar el peso del cuerpo aplicado a un estribo situado en el extremo inferior de la herramienta para hundirla a la fuerza en la tierra, mientras que la otra implica levantar la herramienta hasta donde alcance el brazo y hacerla caer con fuerza sobre el suelo. Para evitar que caigan partículas de tierra en el hoyo al retirar la herramienta, los plantadores tienen la costumbre de alisar sus paredes, bien haciendo girar la herramienta sobre sí misma con un movimiento de la mano o bien ensanchando el hoyo con un movimiento circular del brazo.

Introducción de la planta en el hoyo. Si el plantador todavía no tiene un plantón en su mano, coge uno del envase, lo dobla, lo introduce en el hoyo y lo endereza. La planta debe quedar recta, bien introducida en la tierra, y las raíces deben quedar cubiertas por completo. Es interesante observar aquí que la herramienta juega un importante papel secundario al servir de soporte al plantador en el momento de doblar y enderezar, aliviando así el esfuerzo de los músculos dorsales. Los movimientos pueden realizarse con la espalda recta o flexionada, en función de la longitud de la barra y del tipo de mango.

Compactación de la tierra. Alrededor del plantón recién colocado se compacta la tierra para afirmarlo en el hoyo y eliminar el aire, que podría secar las raíces. Aunque es recomendable pisotear la tierra, suele ser más habitual dar un fuerte golpe con el pie o talón.

Paso a la siguiente microestación. El plantador pasa a la siguiente microestación, generalmente a 1,8 m de distancia. Los plantadores experimentados suelen calcular esta distancia a ojo. En

Tabla 68.4 - Carga típica transportada durante el trabajo de plantación.

$\begin{array}{lc}\text { Elemento } & \text { Peso en kg } \\ \text { Arnés en el mercado } & 2,1 \\ \text { Tres bandejas de envases de } 45 \text { plantones, llenas } & 12,3 \\ \text { Herramienta típica de plantación (almocafre) } & 2,4 \\ \text { Total } & 16,8\end{array}$


Figura 68.12 • Plantadores trabajando en Canadá.

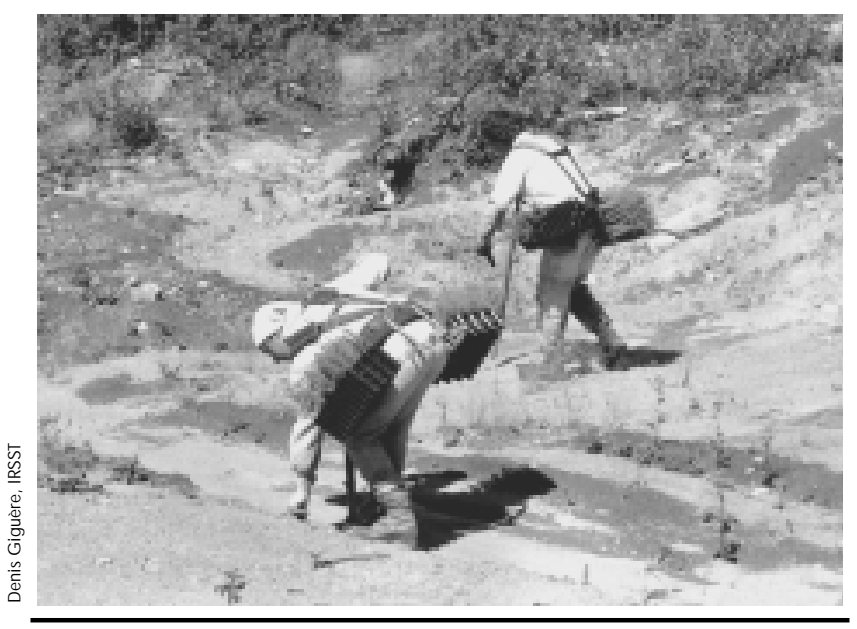

este momento, el plantador debe identificar los peligros del camino, pensar la forma de rodearlos o determinar otra estrategia evasiva. En la Figura 68.12, el plantador que se ve en primer término está a punto de introducir el plantón en el hoyo. El plantador que se ve en segundo término está a punto de realizar un hoyo con una herramienta de plantación de mango recto. A mbos transportan los plantones en envases sujetos a un arnés. Los plantones y los equipos pueden pesar hasta $16,8 \mathrm{~kg}$ (véase la Tabla 68.4). O bsérvese también que los plantadores van totalmente cubiertos por ropas que les protegen contra los insectos y el sol.

\section{Peligros, efectos y medidas preventivas}

Los estudios dedicados a la seguridad y la salud de los plantadores silvícolas son escasos en todo el mundo. La plantación de árboles a escala industrial, aunque aparentemente bucólica, es fatigosa y peligrosa. Un estudio pionero en este campo, realizado por Smith (1987) en la Columbia Británica, reveló que el $90 \%$ de los 65 plantadores entrevistados habían sufrido una enfermedad, lesión 0 accidente durante toda una vida de trabajo en plantaciones silvícolas. En un estudio similar realizado por el IRSST (Instituto para la Seguridad y la Salud en el Trabajo) de Q uebec (Giguère y cols. 1991, 1993), 24 de cada 48 plantadores silvícolas declararon haber sufrido una lesión relacionada con su trabajo a lo largo de su vida profesional en este campo. En Canadá, 15 plantadores silvícolas fallecieron entre 1987 y 1991 por las siguientes causas relacionadas con su trabajo: accidentes de tráfico (7), animales salvajes (3), rayos (2), incidentes durante el alojamiento (incendio, asfixia: 2) e insolación (1).

Aunque escasas y realizadas con un pequeño número de trabajadores, las pocas investigaciones de indicadores fisiológicos de esfuerzo físico (frecuencia cardíaca, parámetros de hematología sanguínea, elevada actividad de enzimas séricas) concluyeron todas ellas que la plantación de árboles es una ocupación muy fatigosa tanto en términos de esfuerzo cardiovascular como musculosquelético (Trites, Robinson y Banister 1993; Robinson Trites y Banister 1993; G iguère y cols. 1991; Smith 1987). Banister, Robinson y Trites (1990) definieron el "agotamiento del plantador", un síndrome derivado de una deficiencia hematológica y caracterizado por la presencia de somnolencia, debilidad y mareos, parecido al "síndrome de agotamiento suprarrenal" o "anemia deportiva" que desarrollan los atletas en sus entrenamientos. (Para conocer datos sobre cargas de trabajo en Chile, véase A pud y Valdés 1995; en Pakistán, véase Saarilahti y Asghar 1994).
Factores organizativos. Las largas jornadas laborales, los viajes y el estricto control de calidad, junto con el incentivo del trabajo a destajo (que es una práctica extendida entre los subcontratistas de plantaciones silvícolas), pueden perjudicar el equilibrio fisiológico y psicológico del trabajador y provocar fatiga crónica y estrés (Trites, R obinson y Banister 1993). La aplicación de una buena técnica de trabajo y la realización de breves pausas regulares contribuyen a mejorar el rendimiento diario y evitar el agotamiento.

Accidentes y lesiones. Los datos presentados en la Tabla 68.5 dan una indicación de la naturaleza y las causas de los accidentes y lesiones declarados por la población de plantadores que participó en el estudio de Q uebec. La importancia relativa de los accidentes declarados por parte corporal afectada demuestra que las lesiones en las extremidades inferiores son más frecuentes que en las superiores, si se suman los porcentajes de rodillas, pies, piernas y tobillos. El entorno de trabajo es propicio para sufrir caídas y tropezones. Las lesiones asociadas a movimientos enérgicos y las heridas provocadas por herramientas, desechos de la corta o detritos también tienen relevancia.

La correcta preparación de una zona de plantación, eliminando matorrales y obstáculos, agiliza las faenas de plantación y reduce los accidentes. Los desechos deben acumularse en pilas, en lugar de en surcos, para facilitar la circulación de los plantadores en la estación. Las herramientas deberán tener mangos rectos, para evitar lesiones, y colores fáciles de distinguir. Los zapatos 0 botas deben ser suficientemente robustos para proteger los pies durante el repetido contacto con la herramienta de plantación y mientras se pisotea la tierra; debe haber tallas disponibles para plantadores y plantadoras; y la suela, de talla apropiada para hombres y mujeres, debe tener un buen agarre en tocones o rocas húmedas. L os guantes son útiles para reducir la aparición de ampollas y la incidencia de cortes y magulladuras por la introducción del plantón en la tierra.

Tabla 68.5 • Clasificación de los accidentes más frecuentes de los plantadores según la parte corporal afectada (porcentaje de 122 informes relativos a 48 individuos en Q uebec).

\begin{tabular}{|c|c|c|c|}
\hline $\begin{array}{l}\text { Clasifi- } \\
\text { cación }\end{array}$ & $\begin{array}{l}\text { Parte del } \\
\text { cuerpo }\end{array}$ & $\%$ total & Causas relacionadas \\
\hline 1 & Rodillas & 14 & $\begin{array}{l}\text { Caídas, contacto con herramienta, } \\
\text { compactación del suelo }\end{array}$ \\
\hline 2 & Piel & 12 & $\begin{array}{l}\text { Contacto con el equipo, mordeduras y } \\
\text { picaduras de insectos, quemaduras } \\
\text { solares, agrietamiento }\end{array}$ \\
\hline 3 & 0jos & 11 & Insectos, repelentes de insectos, ramas \\
\hline 4 & Espalda & 10 & $\begin{array}{l}\text { Encorvarse frecuentemente, transportar } \\
\text { cargas }\end{array}$ \\
\hline 4 & Pies & 10 & Compactación del suelo, ampollas \\
\hline 5 & Manos & 8 & $\begin{array}{l}\text { Agrietamiento, arañazos por contacto } \\
\text { con el suelo }\end{array}$ \\
\hline 6 & Piernas & 7 & Caídas, contacto con herramienta \\
\hline 7 & Muñecas & 6 & Rocas ocultas \\
\hline 8 & Tobillos & 4 & $\begin{array}{l}\text { Tropezones y caídas, obstáculos } \\
\text { ocultos, contacto con herramienta }\end{array}$ \\
\hline 9 & Otros & 18 & - \\
\hline
\end{tabular}


También facilitan la manipulación de plantones espinosos o de coníferas.

Vida en los campamentos y trabajo al aire libre En Canadá y en otros países, los plantadores suelen tener que vivir en campamentos. Trabajar al aire libre requiere protección contra el sol (gafas de sol, sombreros, cremas con factor de protección) y contra los insectos. El estrés por calor también puede ser significativo y la prevención exige la posibilidad de ajustar el régimen trabajo-descanso y la disponibilidad de líquidos potables para evitar la deshidratación.

Es importante disponer de equipos de primeros auxilios y de personal con formación paramédica. Esta formación debe comprender el tratamiento de emergencia de la insolación y las alergias provocadas por el veneno de avispas o serpientes. LoS plantadores deben someterse a vacunación antitetánica y a alergodiagnósticos antes de desplazarse a estaciones remotas. Es esencial disponer de sistemas de comunicaciones de emergencia, procedimientos de evacuación y señales de reunión (en caso de incendio forestal, tormentas o vendavales repentinos o presencia de animales salvajes peligrosos y demás).

Peligros químicos. El uso de plaguicidas y fungicidas para proteger los plantones (durante su cultivo o almacenamiento) comporta un posible riesgo al manejar plantas recién rociadas (Robinson, Trites y Banister 1993). D ebido a la constante necesidad de aplicar lociones o aerosoles repelentes de insectos puede producirse irritación ocular.

Carga musculosquétética y fisiológica. Aunque no existe literatura epidemiológica específica que vincule la plantación de árboles con problemas musculosqueléticos, los movimientos enérgicos asociados al transporte de cargas, así como la variedad de posturas y de trabajo muscular que comporta el ciclo de plantación, constituyen sin duda factores de riesgo que se ven incrementados por la naturaleza repetitiva del trabajo.

Las flexiones y extensiones extremas de las muñecas - p. ej., para coger los plantones de las bandejas- y la transmisión a manos y brazos del impacto que se produce cuando la herramienta de plantación golpea una roca oculta, son algunos de los peligros biomecánicos a los que se ven expuestos los miembros superiores. El peso total acarreado, la frecuencia de levantamiento y la naturaleza física y repetitiva del trabajo - sobre todo el intenso effuerzo muscular necesario para hundir el almocafre en la tierra- son factores que contribuyen a la tensión muscular ejercida sobre los miembros superiores.

Los problemas lumbares están relacionados con la frecuencia con que los trabajadores encorvan la espalda. La manipulación de bandejas de plantones (de 3,0 a 4,1 kg cada una cuando están llenas) al descargar los camiones de reparto es también un riesgo potencial. El transporte de cargas con arneses también puede provocar molestias lumbares, sobre todo si el peso no está bien distribuido sobre los hombros y alrededor de la cintura.

Conviene no olvidar la carga muscular sobre los miembros inferiores: caminar varios kilómetros diarios transportando una carga sobre terreno irregular, a veces cuesta arriba, puede convertirse rápidamente en un trabajo agotador. Además, esta faena implica frecuentes flexiones de las rodillas y la constante utilización de los pies. La mayoría de los plantadores silvícolas se sirven de los pies para despejar los detritos con un movimiento lateral antes de realizar un hoyo, así como para aplicar peso sobre el estribo de la herramienta a fin de hundirla en el suelo y para compactar la tierra alrededor del plantón una vez insertado.

La prevención de la tensión musculosquelética depende de la minimización de las cargas transportadas, en términos de peso, frecuencia y distancia, junto con la optimización de las posturas de trabajo, lo que implica herramientas y prácticas de trabajo apropiadas.
Por ejemplo, si hay que llevar los plantones en un cubo, el agua puede reemplazarse por musgo turboso húmedo para reducir el peso transportado. En Chile, el rendimiento aumentó un $50 \%$ tras reemplazar las pesadas cajas de madera de transporte de plantones por otras de cartón más ligeras (A pud y Valdés 1995). Las herramientas también tienen que estar bien adaptadas a la faena. El cambio de pico y pala por una escarda especialmente diseñada redujo la carga de trabajo un $50 \%$ y mejoró el rendimiento hasta un $100 \%$ en la reforestación de Pakistán (Saarilahti y A sghar 1994). El peso de la herramienta de plantación también es crucial. Por ejemplo, en un estudio de campo de herramientas de plantación realizado en Q uebec, las variaciones oscilaban entre 1,7 y $3,1 \mathrm{~kg}$, lo que significa que la elección del modelo más ligero puede ahorrar el levantamiento de $1.400 \mathrm{~kg}$ diarios, sobre la base de 1.000 levantamientos diarios.

Las herramientas de plantación con mangos largos y rectos son preferibles porque si la herramienta golpea una roca oculta, la mano resbalará por el mango en lugar de absorber el choque. Un mango liso y conificado permite un agarre óptimo para un mayor porcentaje de la población. EI Instituto de Investigación de T écnica Forestal de Canadá (Forest Engineering Research Institute of $\mathrm{C}$ anada) recomienda utilizar herramientas ajustables con propiedades amortiguadoras, pero indica que en el momento de la realización de su estudio de 1988 no existía ninguna herramienta de este tipo (Stjernberg 1988).

Los plantadores también deben recibir formación relativa a las posturas óptimas de trabajo. Por ejemplo, utilizar el peso corporal para hundir el almocafre en lugar del esfuerzo muscular, evitar la torsión de la espalda o el esfuerzo excesivo de los brazos mientras se encuentran totalmente extendidos, evitar plantar cuesta abajo y utilizar la herramienta de plantación como soporte al encorvarse, todo ello puede contribuir a minimizar la tensión musculosquelética. A los plantadores principiantes no se les debe pagar a destajo hasta que estén bien entrenados.

\section{TRATAMIENTO Y CONTROL DE INCENDIOS FORESTALES}

M ike Jurvélius

\section{La importancia de los incendios forestales}

U na tarea importante para la ordenación forestal es la protección de los recursos forestales.

De los muchos tipos de ataques que puede sufrir el bosque, el fuego suele ser el más peligroso. Este peligro es también una amenaza real para las personas que viven en el interior o en las proximidades de la zona forestal. Cada año, miles de personas pierden sus hogares debido a los incendios descontrolados y cientos de personas fallecen en estos accidentes; además, decenas de miles de animales domésticos perecen. El fuego destruye las cosechas agrícolas y provoca la erosión del suelo, que a largo plazo es aún más desastrosa que los accidentes ya descritos. Cuando la tierra queda yerma tras el incendio, si caen fuertes lluvias se empapa y pueden ocurrir enormes corrimientos de tierras y fangos.

Se calcula que cada año:

- se queman de 10 a 15 millones de hectáreas de bosques templados o boreales;

- se queman de 20 a 40 millones de hectáreas de bosques pluviales tropicales, 
- se queman de 500 a 1.000 millones de hectáreas de sabanas tropicales y subtropicales, terrenos arbolados y bosques maderables.

M ás del $90 \%$ de todos estos incendios son provocados por la actividad humana. Por consiguiente, está bastante claro que la prevención y el control de incendios deben recibir la máxima prioridad entre las actividades de ordenación forestal.

\section{Factores de riesgo en los incendios forestales}

L os siguientes factores hacen del control de incendios un trabajo difícil y peligroso:

- el excesivo calor irradiado por el incendio (los incendios siempre se producen durante épocas de calor);

- la escasa visibilidad (a consecuencia del humo y del polvo);

- la dificultad del terreno (los incendios siempre siguen la dirección del viento y por lo común van cuesta arriba);

- las dificultades para obtener suministros para los bomberos (alimentos, agua, herramientas, combustible);

- la frecuente obligatoriedad de trabajar de noche (en las horas en que es más fácil "matar" el fuego);

- la imposibilidad de adelantar a un incendio durante fuertes vendavales (el fuego avanza con más rapidez que lo que pueda avanzar una persona);

- Ios repentinos cambios en la dirección del viento, de modo que nadie puede predecir con exactitud la extensión del incendio,

- el estrés y la fatiga, que da lugar a que las personas cometan errores de juicio desastrosos, a menudo con resultados fatales.

\section{Actividades en el tratamiento de incendios forestales}

Las actividades en el tratamiento de los incendios forestales pueden dividirse en tres categorías diferentes con diferentes objetivos:

- prevención de incendios (cómo evitar que ocurran incendios);

- detección de incendios (cómo dar parte de los incendios cuanto antes),

- la extinción de incendios (el trabajo realizado para apagar el fuego, la verdadera lucha contra incendios).

\section{Peligros profesionales}

El trabajo de prevención de incendios es por lo común una actividad muy segura.

La seguridad en la detección de incendios se basa sobre todo en conducir vehículos de manera segura, a menos que se utilicen aeronaves. Los aviones de ala fija son especialmente vulnerables a las fuertes corrientes de aire de elevación provocadas por el aire y los gases calientes. Cada año se pierden decenas de tripulaciones aéreas a consecuencia de errores de los pilotos, sobre todo en terrenos montañosos.

La extinción de incendios es una operación muy especializada. D ebe organizarse como una operación militar, porque la negligencia, la desobediencia y otros errores humanos no sólo pueden poner en peligro al bombero, sino provocar además la muerte de muchas otras personas, así como grandes daños materiales. Toda la organización ha de estructurarse de manera clara, con una buena coordinación entre el personal forestal, los servicios de emergencia, las brigadas contra incendios, la policía $y$, en los grandes incendios, las fuerzas armadas. D ebe haber una sola cadena de mando, centralizada y a pie de incendio.

La extinción de incendios comporta el establecimiento 0 mantenimiento de una red de cortafuegos, que suelen ser franjas de 10 a 20 metros de ancho despejadas de toda vegetación y material combustible. Los accidentes se deben sobre todo a las herramientas de corte.
Figura 68.13 • El triángulo del fuego.

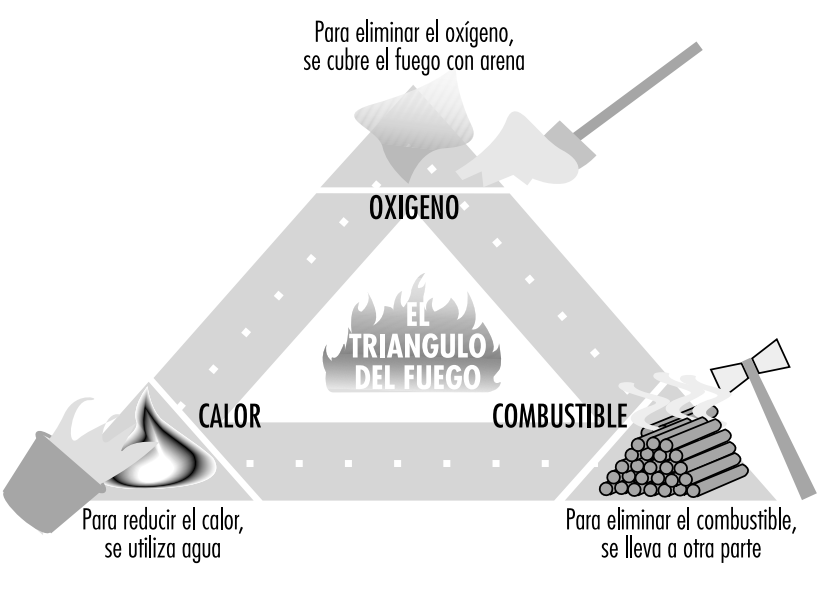

Por supuesto, los fuegos descontrolados importantes son los más peligrosos, pero surgen problemas similares con los incendios prescritos o "fuegos fríos", que es cuando se deja que fuegos leves reduzcan la cantidad de material inflamable sin dañar la vegetación. Se aplican las mismas precauciones en todos los casos.

\section{Intervención rápida}

Detectar el incendio cuando todavía es débil permite controlarlo con más facilidad y seguridad. Antes, la detección se basaba en observaciones a ras de suelo. En cambio, en la actualidad es posible detectar un fuego en su primera fase por medio de equipos de infrarrojos y microondas montados en un avión. La información se transmite a un ordenador en tierra, que puede procesarla e indicar la situación y temperatura exactas del incendio, aún cuando haya nubes. Así, el personal de tierra o los bomberos paracaidistas pueden atacar el fuego antes de que se extienda.

\section{Herramientas y equipos}

M uchas normas son aplicables a los bomberos, que pueden ser trabajadores forestales, voluntarios de la comunidad, empleados del gobierno o miembros de unidades militares destacadas en la zona. La más importante es: no ir jamás a apagar un incendio sin una herramienta de corte propia. La única manera de escapar al incendio puede ser utilizar la herramienta para eliminar uno de los componentes del "triángulo de fuego", ilustrado en la Figura 68.13. La calidad de esa herramienta también es crucial: dicho sin rodeos, si su parte metálica se rompe, el bombero puede perder su vida. La Figura 68.14 ilustra el equipamiento de seguridad de un bombero forestal.

\section{Extinción de incendios desde tierra}

La preparación de cortafuegos durante un incendio es especialmente peligrosa debido a lo urgente que es controlar el avance del fuego. El peligro puede multiplicarse por la escasa visibilidad y los cambios de dirección del viento. Para apagar incendios que producen humos muy densos (p. ej., incendios en turberas), entre las lecciones aprendidas de un incendio de este tipo ocurrido en Finlandia en 1995 cabe citar:

- En condiciones de humo muy denso sólo deberán enviarse personas experimentadas y en perfecta forma física.

- Cada persona deberá llevar una radio para recibir instrucciones desde un avión que sobrevuele el incendio. 
Figura 68.14 • Equipo de seguridad del bombero forestal.

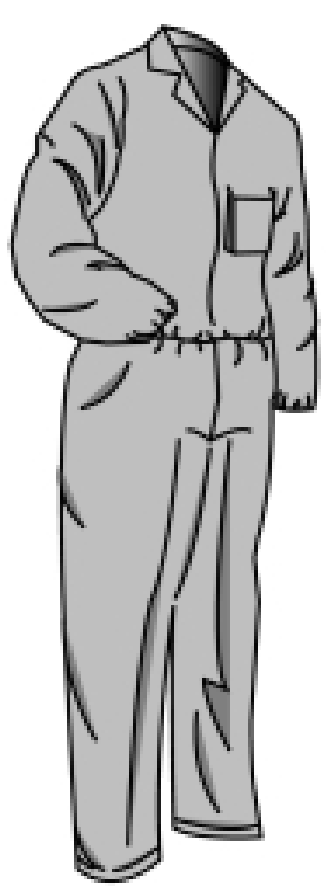

A

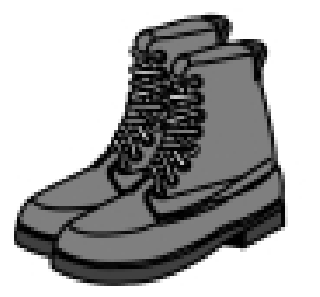

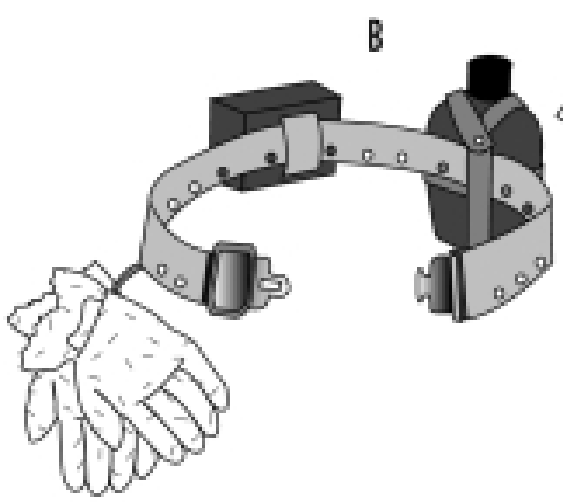

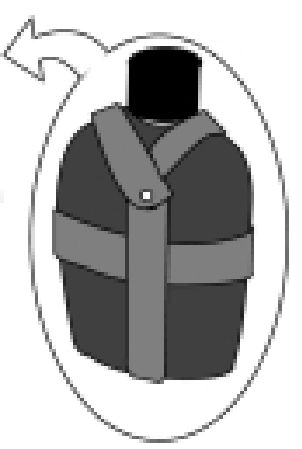

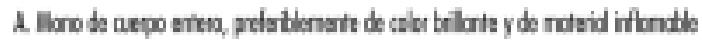

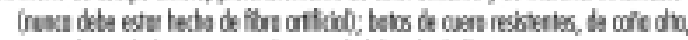

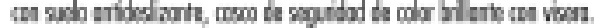

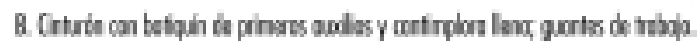

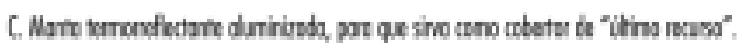
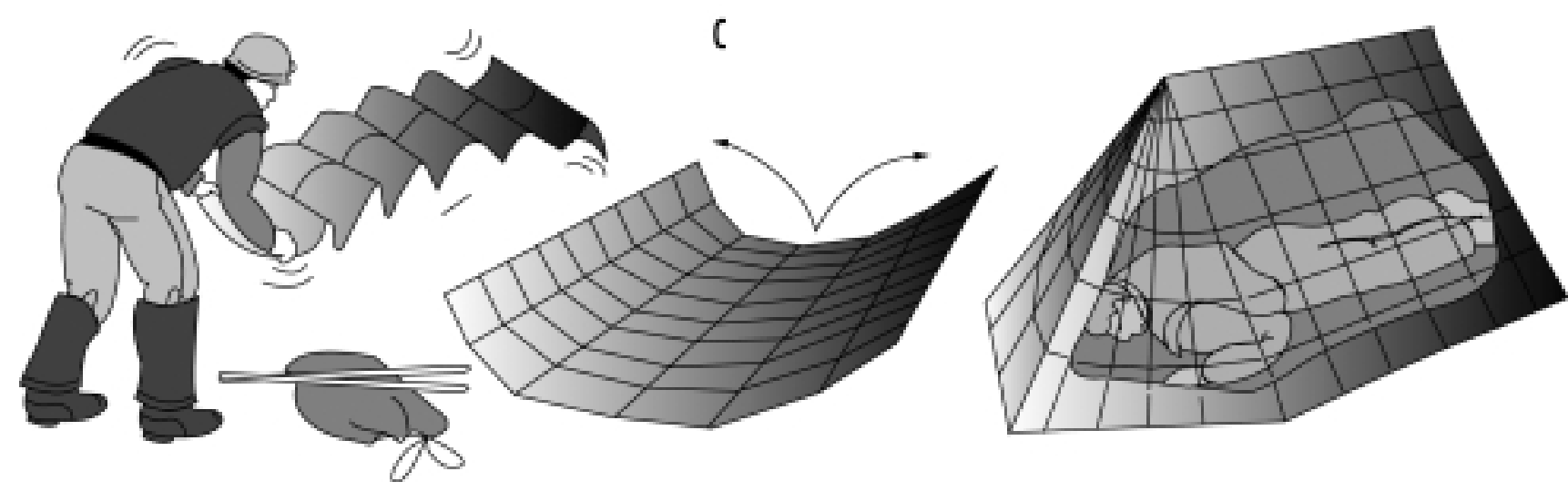

- Sólo deberán enviarse personas provistas de aparatos respiratorios o máscaras de gas.

Los problemas están relacionados con la escasa visibilidad y los cambios en la dirección del viento.

Si un incendio amenaza viviendas, puede que sea necesario evacuar a sus moradores, circunstancia propicia para la actuación de ladrones y vándalos, que exige actividades policiales diligentes.

La tarea más peligrosa es la creación de contrafuegos, que consiste en cortar la vegetación a toda prisa para formar una senda paralela a la línea de avance del incendio y prenderle fuego justo en el momento adecuado para provocar una fuerte corriente de aire que se dirija hacia el fuego en avance, de modo que se encuentren los dos incendios. La succión del incendio en avance es provocada por la necesidad que tiene éste de extraer oxígeno de todas las partes del fuego. Está muy claro que si falla la sincronización, todo el personal se verá envuelto por un fuerte humo y un calor agotador y sufrirá después falta de oxígeno. Sólo las personas más experimentadas deberán crear los contrafuegos y deberán preparar previamente vías de evacuación a ambos lados del fuego. Este sistema de contrafuegos siempre deberá practicarse antes de la temporada de incendios y preverá el uso de equipos, tales como sopletes, para encender el contrafuego. iL as cerillas normales son demasiado lentas!

Como último esfuerzo de autodefensa, el bombero puede eliminar todos los materiales combustibles en un diámetro de $5 \mathrm{~m}$, cavar un foso en el centro, cubrirse con tierra remojar su gorra o su chaqueta y ponérsela sobre la cabeza. Por lo común, sólo hay oxígeno a 1 ó $2 \mathrm{~cm}$ del suelo. 


\section{Descargas de agua desde aeronaves}

El uso de aeronaves en la extinción de incendios no es nuevo (los peligros de la aviación se describen en otros puntos de esta Enciclopedia). Sin embargo, existen algunas actividades que son muy peligrosas para el personal de tierra en un incendio forestal. La primera está relacionada con el lenguaje oficial de señas empleado en las operaciones aéreas, que ha de practicarse durante la formación.

La segunda es cómo marcar todas las áreas donde el avión va a cargar de agua sus depósitos. Para que esta operación sea lo más segura posible, estas áreas deberán marcarse con boyas flotantes para que el piloto no tenga que hacer conjeturas.

La tercera cuestión importante es que el personal de tierra y el avión mantengan contacto por radio constante cuando este último se prepare para descargar el agua. La descarga de pequeños helicubos de 500 a 800 litros no es tan peligrosa. Sin embargo, los grandes helicópteros, como el M I-6, transportan 2.500 litros, mientras que el avión C-120 lleva 8.000 litros y el IL-76 puede descargar 42.000 litros en una pasada. Si, por casualidad, una de estas grandes cargas de agua cae sobre personal de tierra, el impacto podría matarles.

\section{Formación y organización}

Un requisito esencial en la extinción de incendios es formar a todos los bomberos, lugareños y trabajadores forestales para organizar ejercicios conjuntos de extinción antes de que comience la temporada de incendios. Esta es la mejor manera de garantizar el éxito y la seguridad de los trabajos de extinción. Al mismo tiempo, todas las funciones de los diversos niveles de mando deberán practicarse sobre el terreno.

El jefe y los subjefes de bomberos deberán ser los que mejor conozcan las condiciones locales y las organizaciones gubernamentales y privadas. Es evidente que sería peligroso nombrar a personas situadas en niveles jerárquicos demasiado altos (sin ningún conocimiento de la localidad) o demasiado bajos (que suelen carecer de autoridad).

\section{RIESG OS PARA LA SE G URIDAD FISICA}

\section{Bengt Pontén}

El clima, el ruido y la vibración son riesgos físicos comunes en el trabajo forestal. La exposición a riesgos físicos varía en gran medida en función del tipo de trabajo y de equipo utilizado. El siguiente comentario se concentra en el aprovechamiento forestal y considera el trabajo manual y el trabajo motorizado (sobre todo motosierras) y las operaciones mecanizadas.

\section{Trabajo forestal manual}

\section{Clima}

El trabajo al aire libre, sujeto a condiciones climáticas, es tanto positivo como negativo para el trabajador forestal. El aire fresco en un clima agradable está muy bien, pero en condiciones desfavorables pueden surgir problemas.

Trabajar en un clima caliente pone presión al trabajador forestal que realiza trabajos pesados. Entre otras cosas, la frecuencia cardíaca aumenta para mantener la temperatura corporal baja. Sudar conlleva la pérdida de fluidos corporales. El trabajo pesado a altas temperaturas supone que un trabajador puede necesitar beber 1 litro de agua por hora para mantener el equilibrio de los fluidos corporales.

En un clima frío, los músculos no funcionan bien. Aumenta el riesgo de sufrir lesiones musculosqueléticas y accidentes.
A demás, el gasto energético aumenta notablemente, ya que sólo mantenerse caliente cuesta mucha energía.

Las condiciones lluviosas, sobre todo en combinación con el frío, entrañan un mayor riesgo de accidente, ya que es más difícil sujetar las herramientas. También suponen un enfriamiento del cuerpo aún mayor.

Para que el trabajador forestal se mantenga caliente y seco es esencial que disponga de ropa adecuada para diferentes condiciones climáticas. En climas calientes sólo se requiere ropa muy ligera. Entonces resulta bastante problemático utilizar calzado y ropa que le proteja suficientemente contra espinas, golpes de ramas y plantas irritantes. Los alojamientos deben disponer de instalaciones suficientes para lavar y secar la ropa. La mejora de las condiciones en los campamentos ha reducido mucho los problemas de los trabajadores en muchos países.

Establecer límites de condiciones climáticas aceptables para trabajar basándose exclusivamente en la temperatura es muy difícil. En primer lugar, la temperatura varía bastante de un lugar del bosque a otro. El efecto sobre la persona depende además de muchas otras cosas, como la humedad, el viento y la ropa.

\section{Riesgos relacionados con las her ramientas}

EI ruido, las vibraciones, los gases de escape, etcétera, no suelen causar problemas en el trabajo forestal manual. L os impactos que se producen al golpear nudos duros mientras se está escandalando un árbol con un hacha o al golpear piedras mientras se plantan árboles pueden provocar problemas en codos y manos.

\section{Trabajo forestal manual-motorizado}

El trabajador forestal manual-motorizado es aquel que trabaja con máquinas portátiles como motosierras o limpiatrochas mecánicos y está expuesto a las mismas condiciones climáticas que el trabajador manual. Por consiguiente, tiene la misma necesidad de ropa e instalaciones de alojamiento adecuadas. Un problema específico es el uso de equipos protectores personales en climas calientes. Pero el trabajador también está sujeto a otros riesgos específicos debidos a las máquinas con las que trabaja.

El ruido supone un problema cuando se trabaja con una motosierra, sierra limpiatrochas o aparato similar. EI nivel de ruido de la mayoría de las motosierras utilizadas en el trabajo forestal normal supera los $100 \mathrm{dBA}$. El operario está expuesto a este nivel de ruido durante entre 2 y 5 horas diarias. Es difícil reducir los niveles de ruido de estas máquinas sin que resulte demasiado pesado y difícil trabajar con ellas. Por consiguiente, es esencial utilizar protectores auditivos. Aun así, muchos operarios de motosierras sufren pérdidas auditivas. En Suecia, alrededor del $30 \%$ de los operarios de motosierras sufrían un grave deterioro auditivo. 0 tros países declaran cifras altas pero variables en función de cómo se defina el término "pérdida auditiva", de la duración de la exposición, del uso de protectores auditivos, etcétera.

La vibración inducida en las manos es otro problema con las motosierras. La enfermedad de los "dedos blancos" ha supuesto un problema importante para algunos trabajadores forestales que manejan motosierras. El problema se ha minimizado con las modernas motosierras. Por ejemplo, el uso de eficientes amortiguadores antivibración (que en climas fríos se combinan con mangos con calefacción) ha supuesto en Suecia que el número de operarios de motosierras que sufren de dedos blancos se haya reducido a un 7 u $8 \%$, que se corresponde con la cifra global de incidencia natural de los dedos blancos en todos los suecos. 0 tros países declaran un gran número de trabajadores con dedos blancos, pero es probable que no utilicen las modernas motosierras de vibración reducida. 
EI problema es semejante cuando se utilizan sierras trochadoras y sierras de podar. Son máquinas que no se han estudiado a fondo, ya que en la mayoría de los casos el tiempo de exposición es breve.

Las investigaciones recientes apuntan a un riesgo de pérdida de fuerza muscular debida a las vibraciones, a veces incluso sin que aparezcan los dedos blancos.

\section{Trabajo mecanizado}

La exposición a condiciones climáticas desfavorables es más fácil de resolver cuando las máquinas disponen de cabinas. La cabina puede disponer de aislamiento térmico, aire acondicionado, filtros antipolvo y demás. Estas mejoras cuestan dinero, de modo que en la mayoría de las máquinas antiguas y en muchas de las nuevas el operario sigue expuesto al frío, al calor, a la lluvia y al polvo en una cabina más o menos abierta.

Los problemas de ruido se resuelven de manera similar. Las máquinas utilizadas en climas fríos, como los países nórdicos, necesitan un aislamiento térmico eficiente. También es muy frecuente que dispongan de una buena protección acústica, con niveles de ruido de sólo 70 o 75 dBA. Pero las máquinas con cabinas abiertas suelen tener muy altos niveles de ruido (más de $100 \mathrm{dBA})$.

EI polvo es un problema especial en climas calientes y secos. Una cabina bien aislada contra el frío, el calor o el ruido también contribuye a evitar la entrada de polvo. U tilizando una ligera sobrepresión en la cabina, la situación puede mejorarse aún más.

En las máquinas forestales, todo el cuerpo puede sufrir vibraciones inducidas por el terreno por el que se desplaza la máquina, por el movimiento de la grúa y otras partes móviles de la máquina y por las vibraciones de la transmisión. U n problema concreto es el impacto para el operario cuando la máquina baja de un obstáculo como puede ser una roca. Los operarios de vehículos para transitar a campo traviesa, como arrastradores y recogedores, suelen tener molestias lumbares. Las vibraciones también aumentan el riesgo de sufrir lesiones por esfuerzos repetitivos (LER) en cuello, hombros, brazos o manos. Las vibraciones aumentan notablemente con la velocidad a la que el operario conduce la máquina.

A fin de reducir las vibraciones, la máquinas de los países nórdicos utilizan asientos con amortiguación de vibraciones. También se intenta reducir los impactos ocasionados por la grúa haciendo que funcione de manera más suave técnicamente y aplicando mejores técnicas de trabajo. De este modo también se consigue la máquina y la grúa duren más tiempo. U n nuevo e interesante concepto es la "cabina Pendo". Esta cabina va suspendida de sus "orejetas" y unida al resto de la máquina tan sólo por una plataforma. La cabina está aislada de las fuentes de ruido y es más fácil de proteger contra las vibraciones. Da buenos resultados.

0 tros métodos intentan reducir las repercusiones derivadas de la conducción sobre el terreno, mediante la utilización de una transmisión y ruedas "inteligentes". El objetivo es reducir el efecto ambiental, aunque también resulta positivo para el operario. Las máquinas menos costosas suelen reducir poco el ruido, el polvo y la vibración. La vibración también puede ser un problema en tiradores y mandos.

Si no se utilizan métodos técnicos para controlar los riesgos, la única solución disponible es reducirlos disminuyendo el tiempo de exposición, p. ej., por rotación del trabajo.

Existen listas de control ergonómico que han sido preparadas y utilizadas con éxito para evaluar maquinaria forestal, orientar al comprador y mejorar el diseño de las máquinas (véase A pud y Valdés 1995).

\section{Combinaciones de trabajo manual, manual-motorizado y mecanizado}

En muchos países, los trabajadores manuales trabajan junto con o cerca de los operarios de motosierras o máquinas. El operario se sienta en una cabina o utiliza protectores auditivos y buenos equipos protectores. Pero, en la mayoría de los casos, los trabajadores manuales no llevan protección. No se mantienen las distancias de seguridad con las máquinas, lo que provoca un riesgo muy alto de accidente y de deterioro auditivo para los trabajadores no protegidos.

\section{Rotación del trabajo}

Todos los riesgos citados aumentan con la duración de la exposición. La clave para reducir los problemas es la rotación del trabajo, pero conviene procurar no limitarse a cambiar las faenas manteniendo el mismo tipo de riesgos.

\section{CARGA FISICA}

Bengt Pontén

\section{Trabajo forestal manual}

Carga de trabajo. El trabajo forestal manual conlleva por lo común una gran carga de trabajo físico, lo que implica a su vez un alto consumo energético para el trabajador, que depende de la faena y del ritmo al que se realiza. EI trabajador forestal necesita ingerir alimentos en mucha mayor cantidad que el trabajador "normal" de oficina para afrontar las exigencias del trabajo.

En la Tabla 68.6 se ofrece una lista de trabajos característicos de la industria forestal, clasificados por categorías de carga de trabajo según el gasto energético requerido. Las cifras sólo son aproximadas, ya que dependen de la masa corporal, del sexo, de la edad, de la forma física y del ritmo de trabajo, así como de las herramientas y técnicas de trabajo. Sin embargo, sí dan idea de que el trabajo en los viveros es generalmente de ligero a moderado; el trabajo de plantación y corta con motosierra, de moderado a pesado; y la corta manual, de pesada a muy pesada (véanse casos prácticos y un comentario detallado del concepto de carga de trabajo aplicado a la industria forestal en Apud y cols. 1989; A pud y Valdés 1995; y FAO 1992.)

Tensión musculosquelética. El apilamiento manual comporta el repetido levantamiento de pesos. Si la técnica de trabajo no es perfecta y el ritmo es demasiado alto, el riesgo de sufrir lesiones musculosqueléticas será muy alto. Transportar cargas pesadas durante largos períodos de tiempo, como en la corta y transporte de madera para pasta o madera para leña, tiene efectos similares.

Un problema concreto es el uso de la máxima fuerza corporal, que puede provocar lesiones musculosqueléticas repentinas en ciertas situaciones. U n ejemplo puede ser echar abajo un árbol suspendido muy enredado utilizando una palanca de apeo. O tro ejemplo sería el "salvamento" de un tronco cayéndose de una pila.

El trabajo se realiza utilizando sólo la fuerza muscular y muy a menudo comporta el uso dinámico y no simplemente repetitivo de los mismos grupos musculares. No es estático. El riesgo de sufrir lesiones por esfuerzos repetitivos suele ser pequeño. Sin embargo, trabajar en posiciones corporales difíciles puede crear problemas, como p. ej., molestias lumbares. Un ejemplo sería el uso de un hacha para escandalar árboles tirados en el suelo, lo que supone trabajar encorvado durante largos períodos de tiempo, que se traduce en una gran tensión en la región lumbar y trabajo estático para los músculos de la espalda. El problema se reduce apeando los árboles de manera que queden 
Tabla 68.6 • Consumo energético en el trabajo forestal.

\begin{tabular}{|c|c|c|c|}
\hline & \multicolumn{2}{|c|}{$\mathrm{Kj} / \mathrm{min} / \mathrm{hombre}$ de $65 \mathrm{~kg}$} & \multirow{2}{*}{$\begin{array}{l}\text { Capacidad } \\
\text { de trabajo }\end{array}$} \\
\hline & Rango & Media & \\
\hline \multicolumn{4}{|l|}{ Trabajo en un vivero silvícola } \\
\hline Cultivo de plantas silvícolas & & 18,4 & $L$ \\
\hline Escardado & & 24,7 & M \\
\hline Desherbrado & & 19,7 & $\mathrm{~L}$ \\
\hline \multicolumn{4}{|l|}{ Plantado } \\
\hline $\begin{array}{l}\text { Despejar las zanjas de drenaje con } \\
\text { una pala }\end{array}$ & & 32,7 & I \\
\hline $\begin{array}{l}\text { Conducción de un tractor/ gradar } \\
\text { estando sentado }\end{array}$ & $14,2-22,6$ & 19,3 & L \\
\hline Plantado a mano & $23,0-46,9$ & 27,2 & M \\
\hline Plantado a máquina & & 11,7 & L \\
\hline \multicolumn{4}{|c|}{ Trabajo con hacha: golpes horizontales y perpendiculares } \\
\hline \multicolumn{4}{|c|}{$\begin{array}{ll}\text { Peso del destral } & \text { Ritmo } \\
& \text { (golpes/ min) }\end{array}$} \\
\hline $1,25 \mathrm{~kg}$ & & 23,0 & M \\
\hline $0,65-1,25 \mathrm{~kg} \quad 35$ & $38,0-44,4$ & 41,0 & MI \\
\hline \multicolumn{4}{|c|}{ Apeo, retestado, etc. con herramientas manuales } \\
\hline Apeado & $28,5-53,2$ & 36,0 & । \\
\hline Acarreo de troncos & $41,4-60,3$ & 50,7 & $\mathrm{El}$ \\
\hline Arrastre de troncos & $34,7-66,6$ & 50,7 & El \\
\hline \multicolumn{4}{|l|}{ Trabajo con sierra en el bosque } \\
\hline Acarreo de la sierra mecánica & & 27,2 & M \\
\hline Tronzado a mano & $26,8-44,0$ & 36,0 & I \\
\hline $\begin{array}{l}\text { Aserrado horizontal con motosierra } \\
\text { Saca mecanizada }\end{array}$ & $15,1--26,8$ & 22,6 & M \\
\hline $\begin{array}{l}\text { Manejo de cosechadora/ recogedor } \\
\text { Preparación de leña }\end{array}$ & $12-20$ & & L \\
\hline $\begin{array}{l}\text { Aserrado de pequeñas trozas a } \\
\text { mano }\end{array}$ & & 15,1 & L \\
\hline Rajado de madera & $36,0-38,1$ & 36,8 & I \\
\hline Arrastre de leña & $32,7-41,0$ & 36,8 & I \\
\hline Apilado de leña & $21,3-26,0$ & 23,9 & M \\
\hline
\end{tabular}

atravesados sobre un tronco ya tirado en el suelo para que sirva de banco de trabajo natural.

\section{Trabajo forestal manual-motorizado}

El manejo de máquinas portátiles, como las motosierras, puede requerir un gasto energético aún mayor que el trabajo manual, debido a su considerable peso. De hecho, las motosierras utilizadas suelen ser demasiado grandes para la faena, por lo que es mejor utilizar el modelo más ligero y con el sable más pequeño posible.

Siempre que un trabajador forestal que utiliza máquinas realiza además el apilamiento manualmente, se ve expuesto a los problemas anteriormente descritos. Es preciso instruir a los trabajadores para que mantengan la espalda recta y se apoyen en los grandes músculos de las piernas para levantar pesos.

El trabajo se realiza utilizando la potencia de la máquina y es más estático que el trabajo manual. El trabajo del operario consiste en elegir, mover y sujetar la máquina en la posición correcta.

M uchos de los problemas creados se deben a que se trabaja a poca altura. Escandalar un árbol tendido en el suelo significa trabajar encorvado. Este es un problema similar al descrito en el trabajo forestal manual. El problema se agrava si la motosierra que se maneja es pesada. La faena debe planificarse y organizarse de modo que el operario trabaje a una altura próxima a su cadera (p. ej., utilizando otros árboles como "bancos de trabajo" para el desramaje, como se ha descrito anteriormente). La sierra debe apoyarse en el tronco lo máximo posible.

$L$ as faenas manuales-motorizadas altamente especializadas crean un riesgo muy alto de lesiones musculosqueléticas ya que los ciclos de trabajo son cortos y los movimientos específicos se repiten muchas veces. Un ejemplo es el de los apeadores que trabajan con motosierras por delante de un procesador (desramaje y corta). L a mayoría de estos trabajadores forestales sometidos a estudio en Suecia sufrían molestias en cuello y hombros. Si se realiza la operación de saca forestal en su totalidad (apeo, desramaje, tronzado y ciertas faenas de apilamiento no demasiado pesadas), el trabajo resulta más variado y se reduce la exposición a determinados trabajos repetitivos y estáticos desfavorables. Incluso con la sierra apropiada y una buena técnica de trabajo, los operarios de motosierras no deben trabajar más de 5 horas diarias con la sierra en marcha.

\section{Trabajo mecanizado}

L as cargas de trabajo físico en la mayoría de las máquinas forestales con muy pequeñas en comparación con el trabajo manual 0 manual-motorizado. El operario o el mecánico sigue viéndose expuesto a veces al levantamiento de grandes pesos durante los trabajos de mantenimiento y reparación. EI trabajo del operario consiste en guiar los movimientos de la máquina, controlando la fuerza a ejercer por medio de tiradores, palancas, botones, etcé tera. Los ciclos de trabajo son muy cortos. La mayor parte del trabajo es repetitivo y estático, lo que puede comportar un alto riesgo de lesiones por esfuerzo repetitivo en cuello, hombros, brazos, manos o dedos.

En la maquinaria de los países nórdicos, el operario trabaja sólo con tensiones muy limitadas en los músculos, utilizando mini-joysticks, sentado en un asiento ergonómico con apoyabrazos. Pero las lesiones por esfuerzo repetitivo siguen siendo un problema importante. Los estudios realizados demuestran que entre el 50 y el $80 \%$ de los operarios de las máquinas tienen molestias en cuello $u$ hombros. Suele ser difícil realizar comparaciones de cifras porque las lesiones se desarrollan de forma gradual durante un largo período de tiempo. Los resultados dependen de cómo se definan los términos "lesión" o "molestias".

Las lesiones por esfuerzo repetitivo dependen de muchas cosas:

Grado de tensión en el músculo. U na alta tensión muscular estática o repetida y monótona puede deberse, por ejemplo, al uso de mandos pesados, al trabajo en posturas difíciles o los impactos y las vibraciones en todo el cuerpo, pero también a un fuerte estrés mental. El estrés puede deberse a una gran concentración, a la toma de decisiones complicadas o a la situación psicosocial, como p. ej., la falta de control sobre la situación en el trabajo y las relaciones con los supervisores o compañeros.

Tiempo de exposición al trabajo estático. Las continuas tensiones musculares estáticas sólo pueden interrumpirse realizando 
frecuentes pausas y micropausas, cambiando las faenas, rotando los trabajos, etcétera. U na larga exposición total a movimientos de trabajo monótonos durante años aumenta el riesgo de sufrir lesiones por esfuerzo repetitivo, que aparecen gradualmente y pueden ser irreversibles cuando se manifiestan.

Situación individual ("resistencia"). La "resistencia" del individuo cambia con el tiempo y depende de su predisposición heredada y de su estado físico y psicológico y situación social.

Las investigaciones realizadas en Suecia han demostrado que la única manera de reducir estos problemas es trabajar con todos estos factores, sobre todo por medio de la rotación y la ampliación del trabajo. Estas medidas disminuyen el tiempo de exposición y mejoran el bienestar y la situación psicosocial del trabajador.

Los mismos principios son válidos para todo el trabajo forestal: manual, manual-motorizado o mecanizado.

\section{Combinaciones de trabajo manual, manual-motorizado y mecanizado}

Las combinaciones de trabajo manual y mecanizado sin rotación del trabajo siempre significan que las faenas se especializan más. Un ejemplo sería el de los apeadores manuales-motorizados trabajando por delante de un procesador que realiza el desramaje y la corta. Los ciclos de trabajo de los apeadores son cortos y monótonos. El riesgo de sufrir lesiones musculosqueléticas y por esfuerzo repetitivo es muy alto.

En Suecia se realizó una comparación entre operarios de motosierras y de máquinas y se observó que los primeros tenían mayor riesgo de sufrir lesiones musculosqueléticas en la región lumbar, en rodillas y caderas, así como un alto riesgo de deterioro auditivo. Por otra parte, los operarios de máquinas estaban sujetos a peligros muy diferentes. Es probable que una comparación con el trabajo manual mostrase otro patrón de riesgos. Las combinaciones de diferentes tipos de faenas aplicando la rotación de trabajos y la ampliación del trabajo dan posibilidades de reducir el tiempo de exposición a muchos riesgos específicos.

\section{- FACTO RES PSICOSOCIALES}

\section{Peter Poschen y Marja $L$ iisa Juntunen}

Como se muestra en los artículos del presente capítulo, los riesgos físicos en el trabajo forestal están bastante bien documentados. En cambio, escasean las investigaciones sobre factores sociales y psicológicos (Slappendel y cols. 1993). En un contexto forestal, estos factores comprenden: satisfacción y seguridad laboral; carga de trabajo mental, susceptibilidad y respuesta al estrés; capacidad para enfrentarse a los riesgos percibidos; presión, horas extras y fatiga; necesidad de resistir condiciones ambientales adversas; aislamiento social en campamentos de trabajo con separación de las familias; organización del trabajo; y trabajo en equipo.

La situación en términos de salud y seguridad en el trabajo forestal depende de los diversos factores descritos en el presente capítulo: condiciones del rodal y del terreno; infraestructura; clima; tecnología; métodos de trabajo; organización del trabajo; situación económica; acuerdos contractuales; alojamiento del trabajador, y enseñanza y formación. Se sabe que estos factores interactúan y se combinan para crear un mayor riesgo o ambientes de trabajo más seguros (véase el artículo titulado "Condiciones laborales y seguridad en el trabajo forestal" en el presente capítulo).

Estos factores también interactúan con los sociales y psicológicos, en cuanto que influyen en la situación del trabajo forestal, la base de contratación y el conjunto de capacidades y habilidades disponibles para el sector. En una situación desfavorable, el resultado puede ser el círculo de problemas representado en la Figura 68.15. Por desgracia, esta situación es bastante común en los países en desarrollo y en ciertos segmentos de la población activa en el sector dasonómico de los países industrializados, en especial entre trabajadores inmigrantes.

Es probable que el perfil social y psicológico de la población activa en el sector forestal y el proceso de selección por el que atraviesan desempeñen un importante papel al determinar el efecto del estrés y de las situaciones de riesgo. Es probable que no hayan recibido suficiente atención en este ámbito. Tradicionalmente, los trabajadores forestales han procedido de áreas rurales y han considerado el trabajo en el bosque tanto una forma de vida como un trabajo. A menudo se han visto atraídos por la independencia del trabajo al aire libre. Las modernas operaciones forestales ya no satisfacen tales expectativas. Incluso para aquellos individuos cuyo perfil personal se ajustaba a las exigencias del trabajo bastante bien cuando empezaron, los rápidos cambios tecnológicos y estructurales que se han venido produciendo en el trabajo forestal desde los inicios del decenio de 1980 han creado importantes dificultades. L os trabajadores incapaces de adaptarse a la mecanización y a su posición de contratistas independientes suelen verse marginados. Para reducir la incidencia de tales inadaptaciones, el Laboratorio de Ergonomía de la Universidad de Concepción de Chile ha desarrollado una estrategia de selección de trabajadores forestales, teniendo en cuenta las necesidades de la industria, aspectos sociales y criterios psicológicos.

M ás aún, muchos de los principiantes continúan llegando mal preparados al trabajo. La formación en el tajo, que a menudo no es sino aprender por tanteo, sigue siendo normal. Incluso allí donde los sistemas de formación están bien desarrollados, puede que la mayoría de los trabajadores no reciban instrucción formal. En Finlandia, por ejemplo, los operarios de máquinas forestales han recibido formación durante casi 30 años y un total de más de 2.500 se han graduado. No obstante, a finales del

Figura 68.15 • Representación en círculo de los problemas que pueden encontrarse en el trabajo forestal.

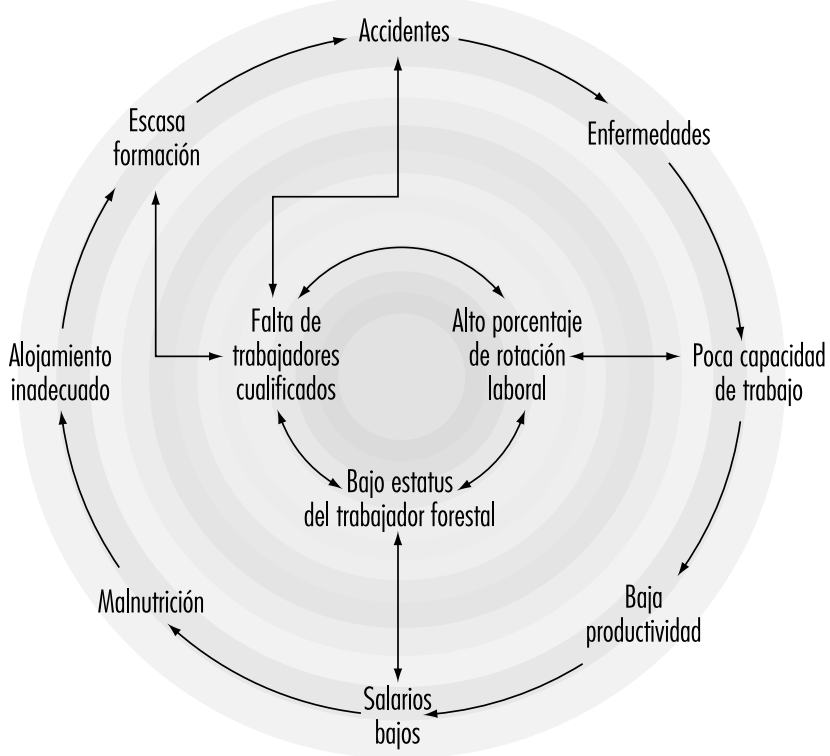


decenio de 1980 , el $90 \%$ de los contratistas y el $75 \%$ de los operarios no habían recibido instrucción formal.

Es probable que los factores sociales y psicológicos desempeñen un papel importante al determinar las repercusiones del riesgo y del estrés. Entre las causas de accidente apuntadas por los trabajadores alemanes destacaban los factores psicológicos. Alrededor de un $11 \%$ de los accidentes se atribuían al estrés y otro tercio a la fatiga, la rutina, la asunción de riesgos y la falta de experiencia. Los modelos cognoscitivos internos pueden desempeñar un papel significativo en la creación de situaciones de riesgo que dan lugar a accidentes en la saca forestal y cuyo estudio puede realizar una aportación importante a la prevención.

\section{Riesgo}

En Finlandia se han realizado trabajos prometedores sobre la percepción, evaluación y asunción de riesgos en la industria forestal. Sus hallazgos sugieren que los trabajadores desarrollan modelos internos acerca de sus trabajos que llevan al desarrollo de rutinas automáticas o semiautomáticas. La teoría de los modelos internos describe la actividad normal de un trabajador forestal, como el manejo de una motosierra o una máquina forestal, los cambios introducidos a través de la experiencia, las razones para dichos cambios y la creación de situaciones de riesgo (K anninen 1986). Ha contribuido a dar una explicación coherente para muchos accidentes y a efectuar propuestas de prevención.

De acuerdo con esta teoría, los modelos internos evolucionan a niveles sucesivos a través de la experiencia. K anninen (1986) ha sugerido que en el manejo de motosierras el modelo movimiento-control es el más bajo en la jerarquía de este tipo de modelos, seguido por el modelo de manipulación de árboles y el modelo del ambiente de trabajo. Según esta teoría, los riesgos aparecen cuando el modelo interno del trabajador forestal se desvía de las necesidades objetivas de la situación: puede no estar suficientemente desarrollado, o contener factores de riesgo inherentes, o no utilizarse en un momento determinado (p. ej., a causa de la fatiga) o no existir un modelo que encaje con una situación inusual (p. ej., un vendaval). Cuando se produce una de estas situaciones, es probable que provoque un accidente.
En el desarrollo y utilización de modelos influyen la experiencia y la formación, lo cual puede explicar los resultados contradictorios de los estudios realizados sobre percepción y evaluación de riesgos en la revisión de Slappendel y cols. (1993). Los trabajadores forestales consideran en general que la asunción de riesgos forma parte de su trabajo. Cuando esta tendencia es pronunciada, la compensación del riesgo puede minar los esfuerzos por mejorar la seguridad en el trabajo. En estas situaciones, los trabajadores ajustan su comportamiento y vuelven a lo que aceptan como nivel de riesgo. Por ejemplo, ésta puede ser parte de la explicación a la eficacia limitada de los equipos de protección personal (EPP). Sabiendo que están protegidos por botas y pantalones a prueba de cortes, los trabajadores van más aprisa, aproximan el cuerpo más a la máquina y siguen el camino más corto en algunas situaciones incumpliendo con ello los reglamentos en materia de seguridad porque "les llevan demasiado tiempo". Por lo común, la compensación del riesgo parece ser parcial. Es probable que existan diferencias entre trabajadores individuales y grupos, y que los factores de recompensa sean importantes para desencadenar la compensación del riesgo. Entre las recompensas cabría citar una menor incomodidad (como no llevar ropa protectora agobiante en un clima caluroso) 0 beneficios financieros (como en los sistemas de remuneración a destajo), pero el reconocimiento social en una cultura machista también es un motivo concebible. La selección y la instrucción de los trabajadores y la organización del trabajo deben intentar minimizar los incentivos a la compensación del riesgo.

\section{Carga de trabajo mental y estrés}

El estrés puede definirse como la presión psicológica sobre un individuo creada por la percepción de una inadaptación entre la capacidad de dicho individuo y las exigencias que percibe en el trabajo. Entre los factores estresantes normales en la industria forestal cabe citar el trabajo a gran velocidad; el trabajo repetitivo y aburrido; el calor; la falta o el exceso de trabajo en plantillas descompensadas; trabajadores jóvenes o viejos que intentan obtener suficientes ingresos con bajos precios de remuneración a destajo; el aislamiento de los compañeros de trabajo, la familia y los amigos; y la falta de intimidad en los campamentos. También

Figura 68.16 • Esquema simplificado de relaciones causa efecto en las operaciones subcontratadas.

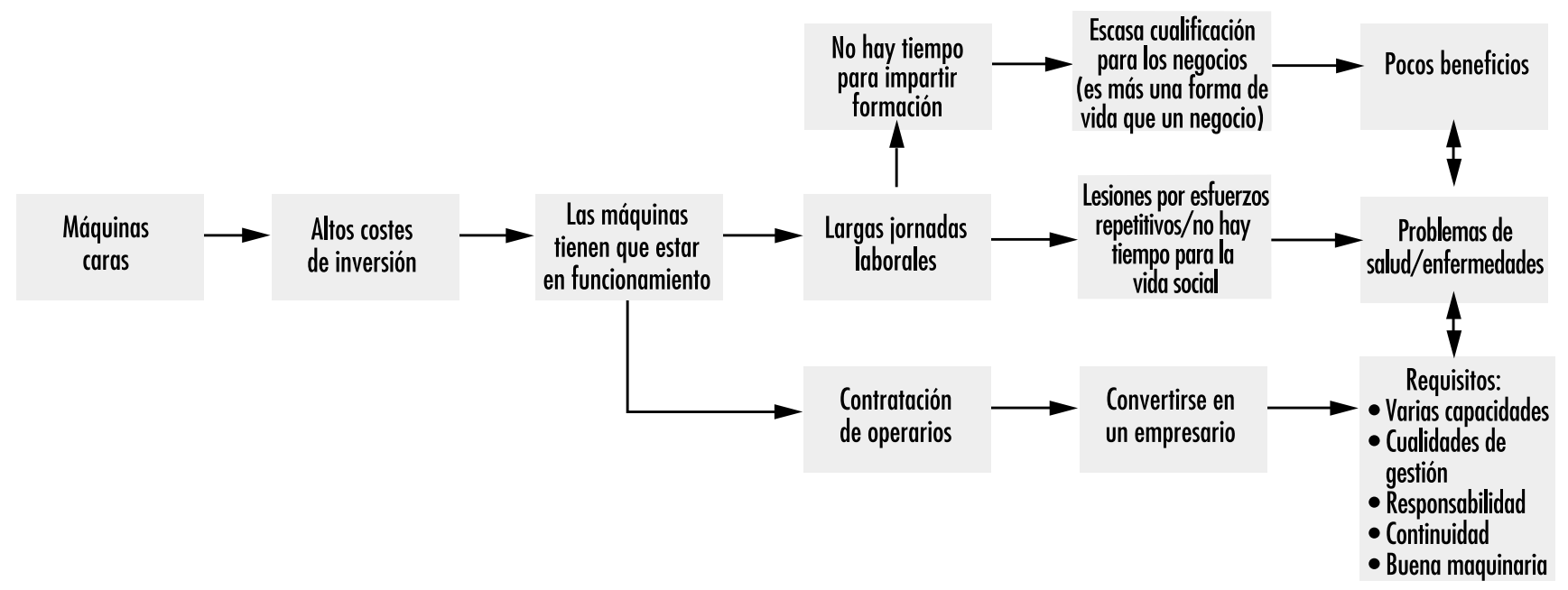


cabe citar un bajo estatus social general de los trabajadores forestales y los conflictos entre estos y la población local o los grupos ecologistas. M irándolo bien, la transformación del trabajo forestal que aumentó drásticamente la productividad también aumentó los niveles de estrés y redujo el bienestar general en el trabajo forestal (véase la Figura 68.16).

Dos tipos de trabajadores son propensos en especial al estrés: los operarios de cosechadoras y los contratistas. El operario de una sofisticada cosechadora está en una situación de estrés múltiple, debido a los cortos ciclos de trabajo, a la cantidad de información que tiene que absorber y al gran número de decisiones rápidas que debe tomar. Las cosechadoras son bastante más exigentes que las máquinas más tradicionales, como los arrastradores, las cargadoras y los recogedores. Además de manejar la máquina, el operario suele ser también responsable de su mantenimiento, de la planificación y del diseño de la pista de arrastre, así como del tronzado, de la cubicación y de otros aspectos de calidad que controla de cerca la empresa y que tienen una repercusión directa sobre la remuneración. Un ejemplo claro son los clareos, ya que el operario trabaja normalmente solo y toma decisiones que son irreversibles. En un estudio de clareos con cosechadoras, Gellerstedt (1993) analizó la carga mental y llegó a la conclusión de que la capacidad mental del operario es el factor limitador de la productividad. Los operarios que no podían afrontar dicha carga eran incapaces de realizar suficientes micropausas durante los ciclos de trabajo y, como consecuencia, desarrollaban problemas en cuello y hombros. La percepción de cuál es la más compleja de estas tareas y decisiones varía considerablemente, en función de factores como los antecedentes, la experiencia laboral previa y la formación (Juntunen 1993, 1995).

Es bastante normal que el operario sea también el propietario de la máquina y que trabaje en calidad de pequeño contratista, lo que añade tensión a la situación, como lo hace el alto riesgo económico que ello implica, pues suele traducirse en un préstamo de hasta 1 millón de dólares en el contexto de un mercado muy volátil y competitivo. Las semanas laborales suelen ser de más de 60 horas en este grupo. Los estudios realizados con estos contratistas demuestran que la capacidad de soportar el estrés es un factor importante (Lidén 1995). En uno de los estudios realizados por Lidén en Suecia, hasta el $54 \%$ de los contratistas mecanizados estaban pensando dejar el trabajo: primero, porque interfería en exceso en su vida familiar; segundo, por razones de salud; tercero, porque suponía demasiado trabajo; y, cuarto, porque no era rentable. Los investigadores y los propios contratistas consideran la flexibilidad ante el estrés un requisito esencial para que éstos puedan mantenerse en el negocio sin desarrollar graves problemas de salud.

Si el proceso de selección funciona, el grupo puede presentar pocos problemas de salud mental (Kanninen 1986). Sin embargo, en muchas situaciones - y no sólo en los países escandinavos - la falta de alternativas obliga a los contratistas a permanecer en este sector, donde están expuestos a mayores riesgos para su salud y seguridad que las personas cuyo perfil personal se corresponde más con el que requiere el trabajo. Con buenas cabinas y mejoras adicionales de diseño, sobre todo de los mandos, y adoptando medidas como tomarse breves descansos regulares y realizar ejercicios físicos, es posible reducir los problemas citados en cierto grado. La teoría de los modelos internos podría utilizarse para mejorar la formación y mejorar la disposición y capacidad del operario-contratista para afrontar las cada vez mayores exigencias del manejo de la máquina. Ello contribuiría a reducir el nivel de "estrés de fondo". Probablemente lo más difícil sea poner en práctica nuevas formas de organización del trabajo en equipo que comporten diversidad de tareas y rotación del trabajo, pero también es posible que sea la estrategia más eficaz.

\section{RIESG OS QUIMICOS}

Juhani Kangas

\section{Combustibles y aceites para máquinas portátiles}

Las máquinas forestales portátiles, como las motosierras, las sierras trochadoras y las máquinas móviles, emiten gases de escape derivados de la gasolina utilizada en las operaciones de saca. La gasolina contiene principalmente hidrocarburos aromáticos (hasta un $5 \%$ de benceno en algunos países) y alifáticos, aditivos y algunas impurezas. Durante la estación fría, la gasolina contiene hidrocarburos más ligeros y evaporables que durante la estación cálida. Los aditivos son compuestos de plomo orgánicos, alcoholes y éteres que se utilizan para aumentar el octanaje de la gasolina. En muchos casos, el plomo ha sido totalmente reemplazado por éteres y alcoholes.

Las máquinas portátiles utilizadas en la industria forestal son impulsadas por motores de dos tiempos, en los que se mezcla aceite lubricante con la gasolina. Los aceites lubricantes, así como los aceites para cadenas, son aceites minerales, sintéticos 0 vegetales. La exposición a la gasolina y a los aceites de lubricación puede producirse durante la mezcla de combustible y durante el repostaje, así como durante las operaciones de saca. Por supuesto, los combustibles también comportan un riesgo de incendio y tienen que ser almacenados y manipulados con cuidado.

Los aerosoles de aceite pueden crear riesgos para la salud, como la irritación de los ojos y de las vías respiratorias superiores, así como problemas cutáneos. Se realizó un estudio sobre la exposición de los leñadores a los aerosoles de aceite durante la saca manual. Se investigaron aceites minerales y vegetales. La exposición media de los trabajadores forestales a los aerosoles de aceite era de $0,3 \mathrm{mg} / \mathrm{m}^{3}$ en el caso del aceite mineral y aun menor en el caso del aceite vegetal.

La mecanización del trabajo forestal aumenta rápidamente. L as motores y los sistemas hidráulicos de las máquinas utilizadas en las operaciones de saca consumen grandes cantidades de gasóleo, lubricantes y aceites hidráulicos. Durante las actividades de mantenimiento y reparación, las manos de los operarios de las máquinas están expuestas a lubricantes, aceites hidráulicos y gasóleos, que pueden causar dermatitis irritantes. Los aceites minerales con hidrocarburos de cadena corta $\left(C_{14}-C_{21}\right)$ son los más irritantes. Para evitar la irritación, es preciso proteger la piel del contacto con el aceite por medio de guantes protectores y una buena higiene personal.

\section{Gases de escape}

EI principal componente de los gases de escape de las motosierras es gasolina sin quemar. Por lo común, alrededor de un $30 \%$ de la gasolina consumida por el motor de una motosierra se emite sin quemar. L os principales componentes de las emisiones de escape son hidrocarburos, que son componentes típicos de la gasolina. Entre ellos suelen identificarse hidrocarburos aromáticos, en especial el tolueno, pero se encuentra hasta benceno. Algunos de los gases de escape se forman durante la combustión y el principal producto tóxico de entre ellos es el monóxido de carbono. A consecuencia de la combustión también hay aldehídos, principalmente formaldehído, y óxidos de nitrógeno. 
Tabla 68.7 • Ejemplos de productos químicos utilizados en la industria forestal en Europa y

$\mathrm{N}$ orteamérica en el decenio de 1980.

\begin{tabular}{|c|c|}
\hline Funciones & Productos químicos \\
\hline Fungicidas & $\begin{array}{l}\text { Benomilo, Bórax, Carbendazim, Clorotalonilo, Dicropro- } \\
\text { peno, Endosulfanos, Gamma-HCH, Mancozeb, Maneb, } \\
\text { Metilbromuro, Metiram, Tiuram, Zineb }\end{array}$ \\
\hline $\begin{array}{l}\text { Control de animales } \\
\text { salvajes }\end{array}$ & Acetato polivinílico \\
\hline $\begin{array}{l}\text { Control de daños } \\
\text { provocados } \\
\text { por animales } \\
\text { salvajes }\end{array}$ & Tiram \\
\hline $\begin{array}{l}\text { Repelentes de } \\
\text { animales salvajes }\end{array}$ & Aceite de pescado, aceite de resina \\
\hline Herbicidas & $\begin{array}{l}\text { Alcohol alílico, Cianazin, Dachtal, Dalapon, Dicamba, Diclo-- } \\
\text { benilo, Diuron, Fosamina, Glifosato, Hexazinona, MCPA, } \\
\text { MCPB, Mecoprop (MCPP), MSMA, Oxifluorteno, Para- } \\
\text { quat, Fenoxiherbicidas (p. ej., 2,4,5-T*, 2,4-D), } \\
\text { Picloram, Pronoamida, Simazina, Azufre, TCA, Terbu- } \\
\text { tiuron, Terbutilazina, Triclopiro, Trifluralina }\end{array}$ \\
\hline Insecticidas & $\begin{array}{l}\text { Azinfos, Bacillus thuringiens, Bendiocarpanato, Carbarilo, } \\
\text { Cipermetrina, Deltametrina, Diflubenzuron, Dibromuro } \\
\text { de metileno, Fenitrotion, Fenvalerato, Lindane, } \\
\text { Lindane+promecarb, Malation, Paration, Parationmetilo, } \\
\text { Piretrina, Permetrina, Propoxuro, Propizamida, Tetraclor- } \\
\text { finos, Triclorfon }\end{array}$ \\
\hline Pesticidas & $\begin{array}{l}\text { Captan, Clorpirifos, Diazinona, Metalixilo, Napropamida, } \\
\text { Setoxidim, Traiadimefon, Cianuro sódico (conejos) }\end{array}$ \\
\hline Raticidas & $\begin{array}{l}\text { Fosfuro de aluminio, Estricnina, Warfarina, Fosfuro de } \\
\text { zinc, Ziram }\end{array}$ \\
\hline $\begin{array}{l}\text { Esterilizantes del } \\
\text { suelo }\end{array}$ & Dasomet \\
\hline Protección de tocones & Urea \\
\hline $\begin{array}{l}\text { Aceites y } \\
\text { combustibles }\end{array}$ & $\begin{array}{l}\text { Aceites minerales, aceites sintéticos, aceites vegetales, } \\
\text { gasolina, gasóleo }\end{array}$ \\
\hline $\begin{array}{l}\text { Otros productos } \\
\text { químicos }\end{array}$ & $\begin{array}{l}\text { Fertilizantes ( } p \text {. ej., urea), disolventes ( } p . \text { ej., éteres de } \\
\text { glicol, alcoholes de cadena larga), Desmetrina }\end{array}$ \\
\hline
\end{tabular}

En Suecia se ha estudiado la exposición de los trabajadores a los gases de escape de las motosierras. Se evaluó la exposición del operario a los escapes de la motosierra en varias situaciones de saca. Las mediciones no revelaron diferencias en los niveles medios de exposición en operaciones de saca con o sin nieve. Con todo, la operación de apeo produce altos niveles de exposición de corta duración, sobre todo si se realiza con una gruesa capa de nieve en el suelo. Se cree que ésta es la principal causa de la incomodidad experimentada por los leñadores. Los niveles medios de exposición de los leñadores que sólo realizaban operaciones de apeo eran el doble de altos que los de quienes también realizaban operaciones de desramaje, tronzado y arrastre manual de troncos. Estas últimas operaciones comportaban una exposición bastante menor. Los niveles medios típicos de exposición son los siguientes: hidrocarburos, $20 \mathrm{mg} / \mathrm{m}^{3}$; benceno, $0,6 \mathrm{mg} / \mathrm{m}^{3}$; formaldehído, $0,1 \mathrm{mg} / \mathrm{m}^{3}$; monóxido de carbono, $20 \mathrm{mg} / \mathrm{m}^{3}$.

Son valores muy inferiores a los límites de exposición profesional de 8 horas en los países industrializados. En cambio, los leñadores suelen quejarse de irritación de los ojos y de las vías respiratorias superiores, dolor de cabeza, náuseas y fatiga, lo cual puede explicarse al menos en parte por estos niveles de exposición.

\section{Plaguicidas y herbicidas}

Los plaguicidas se utilizan en bosques y en viveros silvícolas para controlar hongos, insectos y roedores. Las cantidades totales utilizadas son por lo común pequeñas en comparación con las empleadas en agricultura. En los bosques, los herbicidas se utilizan para controlar los arbustos de madera dura, la hierba y las malas hierbas en jóvenes rodales de brinzales de madera dulce. Para este fin se emplean herbicidas de fenóxidos, glifosatos o triazinas. Para necesidades ocasionales, también pueden utilizarse insecticidas, sobre todo compuestos organofosforados, compuestos organoclorados o piredroides sintéticos. En los viveros silvícolas se utilizan ditiocarbamatos regularmente para proteger los plantones de coníferas contra los hongos de los pinos. La Tabla 68.7 enumera algunos productos químicos utilizados en Europa y Norteamérica en el decenio de 1980. M uchos países han tomado medidas para encontrar alternativas a los plaguicidas o restringir su uso. La sección de esta E nciclopedia dedicada a los productos químicos contiene más detalles sobre la química, los síntomas químicos de intoxicación y su tratamiento.

Para aplicar los plaguicidas al objetivo previsto en bosques y viveros silvícolas se utilizan muy diversas técnicas. Algunos métodos comunes son el rociado aéreo, la aplicación desde equipos tractoreados, rociado desde alforjas, rociado ULV y pulverizadores conectados a sierras trochadoras.

El riesgo de exposición es parecido al de otras aplicaciones de plaguicidas. Para evitar la exposición a los plaguicidas, los trabajadores forestales deben utilizar equipos protectores personales (EPP) (p. ej., gorras, monos, botas y guantes). Si se aplican plaguicidas tóxicos, también deberá utilizarse un aparato respiratorio durante las aplicaciones. U n EPP eficaz suele comportar la acumulación de calor y un sudor excesivo. Es conveniente programar las aplicaciones para las horas más frescas del día y cuando no haya demasiado viento. También es importante lavar todos los derrames inmediatamente con agua y evitar fumar y comer durante las operaciones de rociado.

Los síntomas provocados por una exposición excesiva a los plaguicidas varían mucho en función del compuesto aplicado, pero muy a menudo la exposición laboral a los plaguicidas provoca trastornos cutáneos (véase un comentario más detallado de los plaguicidas utilizados en la industria forestal en Europa y N orteamérica en FAO / CEPE / O IT 1991.)

\section{Otros}

0 tros productos químicos utilizados en el trabajo forestal son los fertilizantes y los colorantes empleados para marcar los pies maderables. Estas marcas se realizan con un martillo marcador 0 con un bote pulverizador. Los colorantes contienen éteres de glicol, alcoholes y otros disolventes orgánicos, pero el nivel de exposición durante el trabajo es probablemente bajo. Los fertilizantes utilizados en la industria forestal son de baja toxicidad y su uso raramente constituye un problema con respecto a la higiene laboral. 


\section{- RIESG OS BIOLOGICOS ENTRE LOS TRABAJADO RES FO RESTALES}

\section{J. Augusta}

Las personas que trabajan al aire libre, sobre todo en la agricultura y el aprovechamiento forestal, están expuestas a peligros para la salud procedentes de animales, plantas, bacterias, virus, etcétera, en mayor medida que el resto de la población.

\section{Las plantas y la madera}

Son muy comunes las reacciones alérgicas a las plantas y a los productos madereros (madera, componentes de la corteza, serrín), especialmente al polen. Es posible que se produzcan lesiones en las operaciones de transformación (p. ej., por espinas, púas, corteza) y a causa de infecciones secundarias, que no siempre pueden evitarse y pueden provocar complicaciones adicionales. Por consiguiente, es decisivo disponer de prendas de protección adecuadas.

Es imposible dar una descripción completa de la toxicidad de las plantas y los productos madereros. El conocimiento de un determinado ámbito sólo puede adquirirse a través de la experiencia práctica, no sólo se aprende en los libros. Las posibles medidas sobre seguridad deben derivarse del conocimiento del ámbito específico.

\section{Los grandes mamíferos}

El empleo de caballos, bueyes, búfalos, elefantes, etcétera, como animales de trabajo puede dar lugar a situaciones peligrosas imprevistas, que pueden provocar lesiones de consecuencias graves. Las enfermedades que estos animales pueden transmitir a los seres humanos también plantean un peligro importante.

\section{Infecciones y enfermedades transmitidas por los animales}

Estas constituyen el peligro biológico más significativo. Su naturaleza e incidencia varía mucho de una región a otra. Por consiguiente no es posible una descripción completa. La Tabla 68.8 (en páginas 68.29 y 30 ) enumera las infecciones más comunes en la industria forestal.

\section{Serpientes venenosas}

Las mordeduras de serpientes venenosas siempre son emergencias médicas. Requieren un diagnóstico correcto y un tratamiento inmediato. I dentificar la serpiente tiene una importancia decisiva. Debido a la gran variedad de especies y particularidades territoriales, los conocimientos necesarios para ello sólo pueden adquirirse localmente, y por este motivo no puede realizarse una descripción general. Bloquear las venas y practicar incisiones locales (sólo por personas experimentadas) son medidas de primeros auxilios incuestionables. También es preciso prestar atención a la posibilidad de que se produzca una reacción alérgica general al antídoto que ponga en peligro la vida del afectado. Las personas heridas deberán transportarse tendidas. No deberá administrarse alcohol ni morfina.

\section{Arañas}

$H$ asta la fecha se han investigado pocos venenos. Es imprescindible intentar identificar la araña (conocimiento que sólo puede adquirirse localmente). No existen, pues, medidas generales de primeros auxilios (excepto, tal vez, administrar los antisueros disponibles). Además, también puede aplicarse en este caso lo que se ha afirmado acerca de las serpientes venenosas.

\section{Abejas, avispas, avispones, hormigas}

Los venenos de los insectos tienen efectos muy diferentes, según el lugar. M edidas recomendadas de primeros auxilios son retirar el aguijón de la piel (y tener cuidado de no introducir más veneno mientras se manipula) y el enfriamiento local. La complicación más temida es una reacción alérgica general que puede ser mortal. Por consiguiente, las personas alérgicas a los venenos de los insectos deberán llevar adrenalina y un antihistamínico inyectable.

\section{Escorpiones}

Tras la picadura, es imprescindible administrar una dosis de antídoto. Es necesario tener conocimientos locales de primeros auxilios.

\section{NORMAS, LEGISLACION, DISPOSICIONES Y RECOMENDACIONES}

Othmar Wettmann

En una profesión de alto riesgo como es la industria forestal, un elemento crucial de cualquier estrategia para reducir la frecuencia de los accidentes y los problemas para la salud es la existencia de disposiciones en materia de seguridad específicas de este trabajo. Por desgracia, elaborarlas y conseguir su cumplimiento es mucho más difícil en la industria forestal que en muchos otros sectores. La legislación en materia de seguridad laboral y las disposiciones de carácter general que se aplican no suelen ser específicas del sector. M ás aún, suelen resultar de difícil aplicación en un contexto como el del aprovechamiento forestal, muy variable y desarrollado al aire libre, porque por lo común se han concebido pensando en los ambientes de trabajo típicos de las fábricas.

Este artículo traza el camino desde la legislación general hasta las disposiciones específicas de la industria forestal y realiza algunas sugerencias sobre las aportaciones que los diversos protagonistas de este sector pueden realizar para mejorar su cumplimiento. Concluye con una breve presentación del concepto de los repertorios de recomendaciones prácticas en materia forestal, que resulta bastante prometedor como una especie de disposición o autodisposición.

\section{La ley perfila los principios}

La legislación en materia de seguridad suele limitarse a establecer algunos principios básicos, como los siguientes:

- La empresa es el principal responsable de la seguridad de sus empleados y debe tomar las medidas de protección necesarias.

- Los empleados deben participar en ello.

- Los empleados, a su vez, están obligados a respaldar los esfuerzos de la empresa.

- Las leyes se aplican a través de la inspección laboral, el servicio de salud u organismo análogo.

\section{Qué especifican las disposiciones generales}

Las que versan sobre prevención de accidentes y enfermedades profesionales suelen referirse a varios puntos:

- las obligaciones de las empresas y de los empleados;

- el asesoramiento de médicos y otros especialistas en materia de seguridad en el trabajo,

- Ias disposiciones en materia de seguridad para edificios y otras construcciones, para equipos y dispositivos técnicos, y las relativas al ambiente laboral y a la organización del trabajo. 
Tabla 68.8 • Infecciones más comunes en la industria forestal.

\begin{tabular}{|c|c|c|c|c|c|}
\hline & Causa & Transmisión & Lugares & Efectos & Prevención/ terapia \\
\hline Amebiasis & $\begin{array}{l}\text { Entamoeba } \\
\text { histolytica }\end{array}$ & $\begin{array}{l}\text { Entre personas, ingestión con } \\
\text { los alimentos (agua, fruta, } \\
\text { verdura); portadores frecuen- } \\
\text { temente asintomáticos }\end{array}$ & $\begin{array}{c}\text { Zonas tropicales } \\
\text { y templadas }\end{array}$ & $\begin{array}{l}\text { Frecuentes complicaciones del } \\
\text { tracto digestivo }\end{array}$ & $\begin{array}{l}\text { Higiene personal; } \\
\text { no es posible ni la quimiopro- } \\
\text { filaxis ni la inmunización. } \\
\text { Terapia: quimioterapia }\end{array}$ \\
\hline Dengue & Arbovirus & Picadura del mosquito Aedes & $\begin{array}{l}\text { Trópicos, subtrópicos, } \\
\text { Caribe }\end{array}$ & $\begin{array}{l}\text { La enfermedad produce inmu- } \\
\text { nidad durante un año o más, } \\
\text { no es letal }\end{array}$ & $\begin{array}{l}\text { Control y eliminación de } \\
\text { mosquitos portadores, } \\
\text { mosquiteras. } \\
\text { Terapia: sintomática }\end{array}$ \\
\hline $\begin{array}{l}\text { Meningoencefalitis } \\
\text { de principios de } \\
\text { verano }\end{array}$ & Flavivirus & $\begin{array}{l}\text { Vinculados a la presencia de la } \\
\text { garrapata ixodes ricinus, se } \\
\text { conoce su transmisión sin } \\
\text { vectores en casos individuales } \\
\text { (p. ej., leche) }\end{array}$ & $\begin{array}{l}\text { Reservorios naturales } \\
\text { limitados a ciertas } \\
\text { regiones, la mayoría } \\
\text { de las áreas endé- } \\
\text { micas se conocen }\end{array}$ & $\begin{array}{l}\text { Posibles complicaciones con } \\
\text { daños posteriores }\end{array}$ & $\begin{array}{l}\text { Posible inmunización } \\
\text { activa y pasiva } \\
\text { Terapia: sintomática }\end{array}$ \\
\hline Erisipeloide & $\begin{array}{l}\text { Erysipelotrix } \\
\text { rhusiopathiae }\end{array}$ & $\begin{array}{l}\text { Heridas profundas entre } \\
\text { personas que manipulan } \\
\text { tejidos de peces } 0 \text { animales }\end{array}$ & $\begin{array}{l}\text { Ubicua, infecta espe- } \\
\text { cialmente al cerdo }\end{array}$ & $\begin{array}{c}\text { Cura generalmente espontánea } \\
\text { a las } 2-3 \text { semanas, posible } \\
\text { bacteremia (artritis séptica, } \\
\text { válvula cardíaca afectada) }\end{array}$ & $\begin{array}{l}\text { Ropa protectora } \\
\text { Terapia: antibióticos }\end{array}$ \\
\hline Filariasis & $\begin{array}{l}\text { Wuchereria bancrofti, } \\
\text { Brugia malayi }\end{array}$ & $\begin{array}{l}\text { De animales a humanos, pero } \\
\text { también por algunos tipos de } \\
\text { mosquitos }\end{array}$ & $\begin{array}{l}\text { Trópicos y } \\
\text { subtrópicos }\end{array}$ & Muy variados & $\begin{array}{l}\text { Higiene personal, control de } \\
\text { mosquitos } \\
\text { Terapia: medicación posible }\end{array}$ \\
\hline Tenia del zorro & $\begin{array}{l}\text { Echinococcus } \\
\text { multilocularis }\end{array}$ & $\begin{array}{l}\text { Animales salvajes, esp. zorros, } \\
\text { menos comunmente también } \\
\text { animales domésticos (gatos, } \\
\text { perros) }\end{array}$ & $\begin{array}{l}\text { Es necesario conocer } \\
\text { las áreas endémicas }\end{array}$ & Afecta principalmente al hígado & $\begin{array}{l}\text { No consumir frutas silvestres } \\
\text { verdes; mojar los pellejos } \\
\text { al manipular zorros muertos; } \\
\text { guantes, protección bucal } \\
\text { Terapia: tratamiento clínico }\end{array}$ \\
\hline Gangrena gaseosa & $\begin{array}{l}\text { Varios tipos de } \\
\text { clostridium }\end{array}$ & $\begin{array}{l}\text { Al principio de la infección, } \\
\text { requiere un medio anaerobio } \\
\text { con bajo potencial redox y } \\
\text { tejido necrótico ( } p \text {. ej., partes } \\
\text { blandas machacadas abiertas) }\end{array}$ & $\begin{array}{l}\text { Ubicua, en el suelo, en } \\
\text { los intestinos de } \\
\text { humanos y animales }\end{array}$ & $\begin{array}{l}\text { Altamente letal, fatal sin trata- } \\
\text { miento (1-3 días) }\end{array}$ & $\begin{array}{l}\text { No se conoce una antitoxina } \\
\text { espećfica hasta la fecha, } \\
\text { existe controversia sobre el } \\
\text { suero de la gangrena gaseosa } \\
\text { Terapia: tratamiento clínico }\end{array}$ \\
\hline $\begin{array}{l}\text { Encefalitis } \\
\text { japonesa B }\end{array}$ & Arbovirus & $\begin{array}{l}\text { Por mosquitos (especie Culex); } \\
\text { entre personas; de mamíferos } \\
\text { a personas }\end{array}$ & $\begin{array}{l}\text { Endémica en China, } \\
\text { India, Japón, Corea } \\
\text { y países vecinos }\end{array}$ & $\begin{array}{l}\text { Mortalidad hasta del } 30 \% \text {; cura } \\
\text { parcial hasta del } 80 \%\end{array}$ & $\begin{array}{l}\text { Prevención antimosquitos, inmu- } \\
\text { nización activa posible; } \\
\text { Terapia: sintomática }\end{array}$ \\
\hline Leptospirosis & $\begin{array}{l}\text { Varios tipos de } \\
\text { leptospira }\end{array}$ & $\begin{array}{l}\text { Orina de animales salvajes y } \\
\text { domésticos infectados } \\
\text { (ratones, ratas, conejos de } \\
\text { campo, zorros, perros), } \\
\text { lesiones cutáneas, membrana } \\
\text { mucosa }\end{array}$ & $\begin{array}{l}\text { Areas endémicas en } \\
\text { todo el mundo }\end{array}$ & $\begin{array}{l}\text { Desde asintomática hasta infec- } \\
\text { ción de varios órganos }\end{array}$ & $\begin{array}{l}\text { Ropa protectora apropiada } \\
\text { cuando se está en las proximi- } \\
\text { dades de animales infectados, } \\
\text { inmunización imposible } \\
\text { Terapia: penicilina, tetraciclina }\end{array}$ \\
\hline Enfermedad de Lyme & Borrelia burgdorferi & $\begin{array}{l}\text { Garrapata ixodes ricinus, se } \\
\text { sospecha también de otros } \\
\text { insectos }\end{array}$ & $\begin{array}{l}\text { Europa, Norteamérica, } \\
\text { Australia, Japón, } \\
\text { China }\end{array}$ & $\begin{array}{l}\text { Numerosas formas de enfer- } \\
\text { medad, posible complicación } \\
\text { infecciosa de órganos }\end{array}$ & $\begin{array}{l}\text { Medidas de protección personal } \\
\text { antes de ser infectado por la } \\
\text { garrapata, inmunización } \\
\text { imposible } \\
\text { Terapia: antibióticos }\end{array}$ \\
\hline \multirow[t]{4}{*}{$\begin{array}{l}\text { Meningitis, meningo- } \\
\text { encefalitis }\end{array}$} & $\begin{array}{l}\text { Bacterias (meningo- } \\
\text { pneumoestafilo } \\
\text { cocos y otras) }\end{array}$ & $\begin{array}{l}\text { Infección transmitida principal- } \\
\text { mente por el aire }\end{array}$ & $\begin{array}{l}\text { Meningococos, menin- } \\
\text { gitis epidémica, por } \\
\text { lo demás ubicua }\end{array}$ & $\begin{array}{l}\text { Menos del } 10 \% \text { de mortalidad } \\
\text { con un diagnóstico temprano } \\
\text { y tratamiento específico }\end{array}$ & $\begin{array}{l}\text { Higiene personal, aislamiento } \\
\text { de las personas infectadas } \\
\text { Terapia: antibióticos }\end{array}$ \\
\hline & $\begin{array}{l}\text { Virus ( poliomielitis, } \\
\text { coxsackie, echo, } \\
\text { arbo, herpes y vari- } \\
\text { cela) }\end{array}$ & $\begin{array}{l}\text { Infección mucosa y transmitida } \\
\text { por el aire (vías respiratorias, } \\
\text { tejidos conectivos, piel lesio- } \\
\text { nada), los ratones son el } \\
\text { origen de la infección en un } \\
\text { alto porcentaje de los casos }\end{array}$ & Incidencia ubicua & $\begin{array}{l}\text { Alta mortalidad (70\%) con } \\
\text { infección de herpes }\end{array}$ & $\begin{array}{l}\text { Higiene personal; prevención } \\
\text { antirratones } \\
\text { Terapia: sintomática, entre los } \\
\text { virus de varicela es posible un } \\
\text { tratmiento específico eficaz }\end{array}$ \\
\hline & Setas & $\begin{array}{l}\text { Infecciones principalmente } \\
\text { sistémicas }\end{array}$ & Incidencia ubicua & Pronóstico incierto & $\begin{array}{l}\text { Terapia: antibióticos (trata- } \\
\text { miento prolongado) }\end{array}$ \\
\hline & $\begin{array}{l}\text { Micobacterias } \\
\text { (véase tubercu- } \\
\text { losis) } \\
\text { Leptospira } \\
\text { (véase leptospi- } \\
\text { rosis) }\end{array}$ & & & & \\
\hline
\end{tabular}




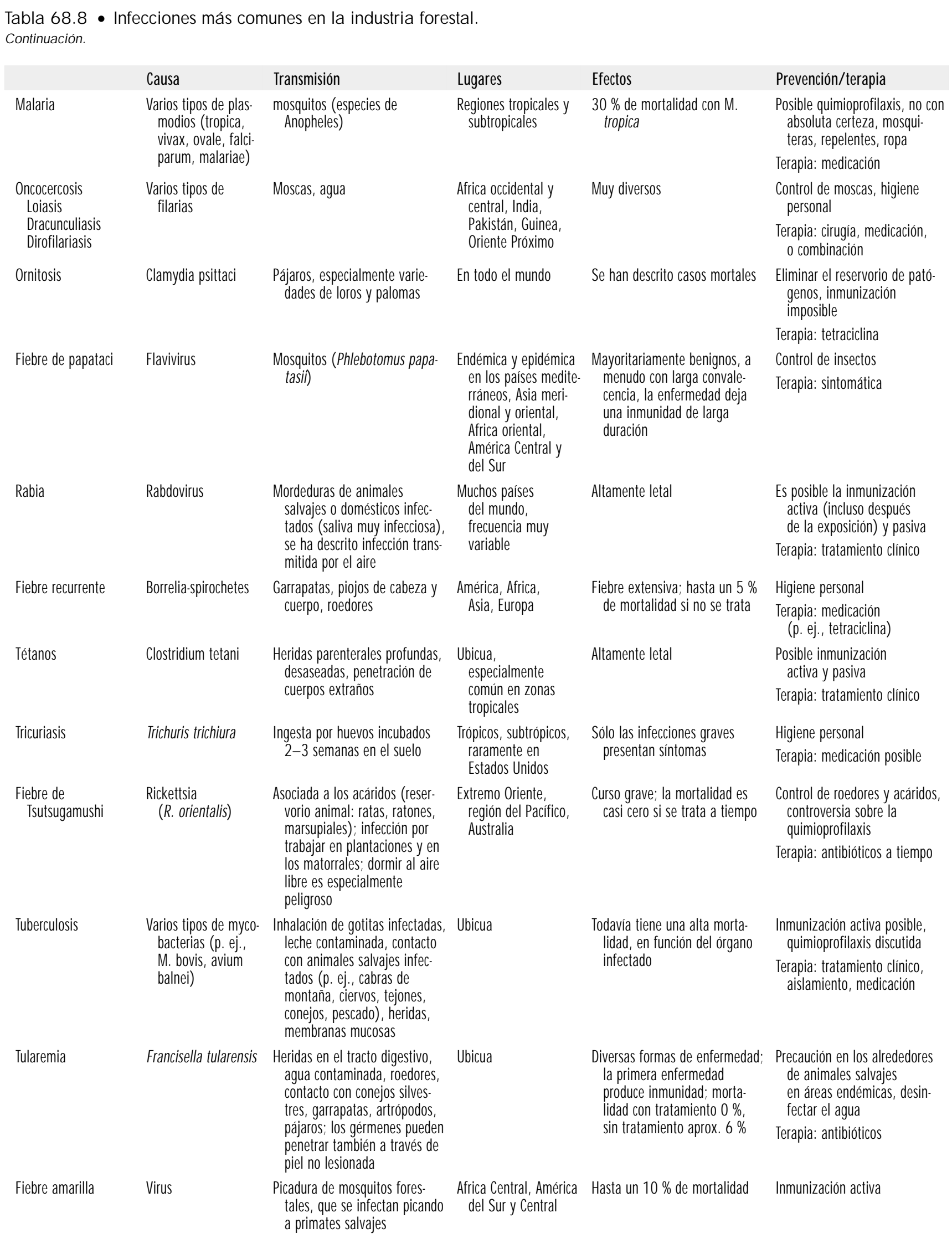


Las disposiciones contienen también instrucciones sobre:

- organización de la seguridad en el trabajo;

- implantación de las disposiciones en materia de seguridad en el trabajo;

- atención médica en el trabajo,

- financiación de la seguridad en el trabajo.

Como la legislación ha evolucionado con el tiempo, suele haber leyes para otros ámbitos y sectores que contienen también disposiciones aplicables a la seguridad en el trabajo forestal. En Suiza, por ejemplo, estas disposiciones incluyen el código laboral, la ley de explosivos, la ley de venenos y la legislación de tráfico. Sería beneficioso para los usuarios que todas estas estipulaciones y disposiciones asociadas se recopilaran para crear una sola ley.

\section{Disposiciones en materia de seguridad en la industria forestal: lo más concretas posible a la vez que flexibles}

En la mayoría de los casos, estas leyes y disposiciones son demasiado abstractas para su aplicación práctica al trabajo diario. No se corresponden con los riesgos y peligros que comporta el uso de máquinas, vehículos y materiales de trabajo en las diversas industrias y fábricas, sobre todo en un sector con condiciones de trabajo tan variadas y atípicas como la industria forestal. Por esta razón, las comisiones sectoriales elaboran disposiciones en materia de seguridad específicas para cada industria, sus puestos de trabajo específicos o sus equipos y dispositivos. En general, se procede consciente 0 inconscientemente de la forma siguiente:

En primer lugar, se analizan los peligros que pueden surgir en una actividad o sistema. Por ejemplo, una lesión frecuente entre los operarios de motosierras son los cortes en las piernas.

En segundo lugar, se enuncian objetivos de protección que se basan en los peligros identificados y que describen "Io que no debe ocurrir". Por ejemplo: "D eberán tomarse medidas apropiadas para evitar que el operario de motosierras se lesione la pierna".

Sólo en el tercer paso se buscan soluciones o medidas que, de acuerdo con el estado de la tecnología, reduzcan o eliminen los peligros. En el ejemplo citado, los pantalones a prueba de cortes son una de las medidas apropiadas. El estado de la tecnología para este elemento puede definirse exigiendo que los pantalones cumplan la N orma Europea (NE) 381-5, Ropa protectora para usuarios de motosierras accionadas a mano, Parte 5: Disposiciones para la protección de las piernas.

Este procedimiento ofrece las siguientes ventajas:

- Los objetivos de protección se basan en peligros concretos. Por lo tanto, los requisitos en materia de seguridad son eminentemente prácticos.

- Las disposiciones en forma de objetivos de protección permiten una mayor flexibilidad en la elección y desarrollo de soluciones que la prescripción de medidas concretas. Las medidas específicas también pueden ir adaptándose a los avances tecnológicos.

- Si aparecen nuevos peligros, tales disposiciones pueden completarse abordando el problema específico.

La creación de comisiones sectoriales bipartitas o tripartitas en las que participen la empresa interesada y las organizaciones de empleados ha demostrado ser una manera eficaz de mejorar la aceptación y la aplicación de las disposiciones en materia de seguridad en la práctica.

\section{Contenido de las normas en materia de seguridad}

Una vez analizados los peligros de ciertos trabajos o tipos de equipos y enunciados los objetivos de protección, pueden formularse medidas en los ámbitos de tecnologías, organización y personal (TOP).

\section{Cuestiones técnicas}

El estado de la tecnología en parte de los equipos y dispositivos forestales, como motosierras, limpiatrochas, protección para las piernas de los operarios de motosierras, etcétera, se establece en normas internacionales, tal como se trata en otras partes de este mismo capítulo. A largo plazo, deberán unificarse las EN y las normas de la O rganización Internacional de Normalización (ISO ). La adopción de estas normas por cada país contribuirá a la protección uniforme del empleado de la industria. La demostración del vendedor o fabricante de que un determinado equipo cumple estas normas garantiza al comprador que el equipo se corresponde con el estado de la tecnología. En los numerosos casos en los que no existen normas internacionales, es necesario que se definan requisitos nacionales mínimos por parte de grupos de expertos.

Además del estado de la tecnología, son importantes las siguientes cuestiones, entre otras cosas:

- disponibilidad de los equipos y materiales necesarios en el trabajo;

- estado fiable de los equipos y materiales,

- mantenimiento y reparación.

Las operaciones forestales suelen dejar mucho que desear en estos aspectos.

\section{Cuestiones de organización}

En la empresa y en el lugar de trabajo deben establecerse condiciones para que los trabajos individuales puedan realizarse con seguridad. Para que esto ocurra, deberán abordarse las siguientes cuestiones:

- clara definición de las tareas, autoridad y responsabilidades de todos los participantes;

- un sistema salarial que favorezca la seguridad;

- jornada laboral y descansos adaptados a las dificultades del trabajo;

- procedimientos de trabajo;

- planificación y organización del trabajo;

- alarmas y primeros auxilios,

- si los trabajadores han de vivir en campamentos, definición de requisitos mínimos para los dormitorios, saneamiento, nutrición, transporte y ocio.

\section{Cuestiones de personal}

L as cuestiones de personal pueden dividirse en:

Formación y enseñanza permanente. En algunos países, esto incluye a los empleados de las empresas forestales; por ejemplo, quienes trabajan con motosierras están obligados a asistir a cursos apropiados de formación y enseñanza permanente.

Orientación, bienestar y apoyo al empleado. Como ejemplos cabe citar enseñar a los empleados nuevos cómo se realiza el trabajo y supervisar a los empleados. La práctica demuestra que la situación de la seguridad en el trabajo en una empresa depende en gran medida de la manera en que la dirección mantenga la disciplina y desempeñe sus responsabilidades supervisoras. 


\section{Realizar el trabajo}

La mayoría de las disposiciones en materia de seguridad contienen normas de comportamiento que el empleado supuestamente debe cumplir al realizar el trabajo. En el trabajo forestal, estas normas están relacionadas sobre todo con operaciones cruciales, tales como:

- el apeo y el trabajo con los árboles;

- la extracción, el almacenaje y el transporte de madera;

- el trabajo con los árboles derribados por el viento,

- encaramarse a los árboles y trabajar en sus copas.

Además de las normas internacionales y de las disposiciones nacionales que han demostrado su eficacia en varios países, el Repertorio de recomendaciones prácticas de la O rganización Internacional del Trabajo (OIT) Seguridad y salud en el trabajo forestal, ofrece ejemplos y orientación sobre el diseño y la formulación de disposiciones a escala nacional 0 de empresa (OIT 1969, 1997, 1998).

Las disposiciones en materia de seguridad han de revisarse y adaptarse de manera constante a los cambios de las circunstancias o complementarse para que comprendan nuevas tecnologías o métodos de trabajo. Un sistema adecuado de información e investigación de accidentes puede ser de gran ayuda a estos efectos. Por desgracia, pocos países están haciendo uso de esta posibilidad. La OIT (1991) ofrece algunos buenos ejemplos. Incluso sistemas bastante sencillos pueden proporcionar buenos indicadores. (Para más información, véase Strehlke 1989.) Las causas de accidentes en la industria forestal son complejas. Si no se basan en una comprensión correcta y completa, las medidas preventivas y las disposiciones suelen no dar en el clavo. Un buen ejemplo es la frecuente pero a menudo errónea identificación de un "comportamiento poco seguro" como causa aparente. En la investigación de accidentes, deberá ponerse el mayor énfasis posible en comprender las causas de los accidentes, en lugar de en determinar quiénes son las personas responsables. El método del "árbol de causas" es demasiado oneroso para utilizarse de manera rutinaria, pero ha dado buenos resultados en casos complicados y como medio de aumentar la sensibilización sobre la importancia de la seguridad y de mejorar la comunicación en las empresas (véase un informe sobre la experiencia suiza en Pellet 1995.)

\section{Favorecer el cumplimiento}

Las disposiciones en materia de seguridad son papel mojado hasta que todos los participantes del sector forestal desempeñan su papel en la implantación. Jokulioma y Tapola (1993) dan una descripción de esta cooperación en Finlandia, que ha obtenido excelentes resultados. En la información, enseñanza y formación en materia de seguridad, incluidos los grupos a los que resulta difícil llegar, como los contratistas y los granjeros forestales, las asociaciones de contratistas y propietarios de bosques desempeñan un papel crucial.

Las disposiciones en materia de seguridad tienen que ponerse a disposición de los usuarios en una forma accesible. U na buena práctica es la publicación en formato de bolsillo de concisos extractos ilustrados pertinentes para determinados trabajos, como el manejo de motosierras o cables-grúa. En muchos países, un porcentaje importante de los trabajadores forestales son inmigrantes. Es necesario que las disposiciones y guías estén traducidas a sus idiomas respectivos. Los fabricantes de equipos forestales también deben estar obligados a incluir en el manual del propietario información e instrucciones completas sobre todos los aspectos de mantenimiento y la seguridad de uso del equipo.
La cooperación de trabajadores y empresa es fundamental, a escala sectorial y, sobre todo, empresarial. La OIT (1991) ha ofrecido algunos ejemplos de cooperación que fueron un éxito y resultaron muy rentables. La situación, por lo común insatisfactoria, de la seguridad en la industria forestal suele agravarse aun más cuando el trabajo es realizado por contratistas. En estos casos, los contratos ofrecidos por la parte contratante, el propietario del bosque o la industria deben siempre incluir una cláusula que exija el cumplimiento de los requisitos sobre seguridad, así como sanciones en caso de incumplimiento. Las disposiciones deben ser un anexo al contrato.

En algunos países, la legislación general dispone que la parte contratante - en este caso, la empresa o el propietario del bosque- y el contratista son responsables civiles solidarios 0 subsidiarios. Esta disposición puede ser muy útil para dejar a los contratistas irresponsables fuera de juego y favorecer el desarrollo de un sector de servicios cualificado.

U na medida más específica en la misma dirección es la acreditación de contratistas a través de las autoridades gubernamentales 0 de los administradores de indemnizaciones para trabajadores. En algunos países, los contratistas tienen que demostrar que están bien equipados, que son económicamente independientes y competentes desde el punto de vista técnico para realizar trabajos forestales. Las asociaciones de contratistas podrían desempeñar un papel similar, pero los programas voluntarios no han tenido mucho éxito.

La inspección laboral en la industria forestal es una tarea muy difícil, debido a que los puestos de trabajo son temporales y están dispersos, a menudo en lugares lejanos e inaccesibles. U na estrategia que motiva a los actores a adoptar prácticas seguras es más prometedora que la inspección aislada. En países donde predominan grandes compañías forestales o propietarios de bosques, la autoinspección de los contratistas por dichas empresas, controladas por la inspección laboral o la administración de indemnizaciones para trabajadores, es una manera de aumentar la cobertura. La inspección laboral directa deberá enfocarse en términos de problemas y geografía, para sacar el máximo partido al personal y al transporte. Como los inspectores laborales suelen no tener relación con el ámbito forestal, lo mejor es que la inspección se base en listas de control temáticas ("motosierras", "campamentos", etcétera), que los inspectores puedan utilizar después de uno o dos días de formación. La OIT dispone de un vídeo sobre inspección laboral en la industria forestal.

U no de los mayores retos es integrar las disposiciones en materia de seguridad en los procedimientos rutinarios. Si existen disposiciones específicas de la industria forestal como cuerpo normativo independiente, los supervisores y los operarios suelen percibirlas como una restricción adicional además de las técnicas, logísticas y otros factores. En consecuencia, suelen pasarse por alto. El resto de este artículo ofrece una posibilidad para superar este obstáculo.

\section{Repertorios de recomendaciones prácticas en la industria forestal}

Al contrario que las disposiciones generales en materia de salud y seguridad en el trabajo, los repertorios de recomendaciones prácticas son conjuntos de normas, prescripciones y recomendaciones específicas de la industria forestal, desde un punto de vista práctico, que comprenden todos los aspectos de una operación. Incluyen consideraciones sobre salud y seguridad. Las recomendaciones varían mucho en alcance y cobertura. Algunas son muy concisas, mientras que otras son complicadas y bastante detalladas. Pueden abarcar todo tipo de operaciones forestales 0 
limitarse a las consideradas más cruciales, como el aprovechamiento forestal.

Los repertorios de recomendaciones prácticas pueden ser un complemento muy interesante a las disposiciones en materia de seguridad generales 0 específicas de la industria forestal. Durante la última década, cada vez más países han adoptado o están desarrollando recomendaciones. Como ejemplos cabe citar Australia, Fiji, Nueva Zelanda, Suráfrica y numerosos estados de los Estados U nidos. En el momento de redactarse el presente artículo, se estaban realizando o planificando trabajos en varios países más, entre ellos Chile, Indonesia, M alaisia y Zimbabwe.

También existen repertorios de recomendaciones prácticas internacionales concebidos como directrices. El Código modelo de prácticas de aprovechamiento forestal de la FAO (1996) comprende todos los aspectos de las prácticas generales de aprovechamiento forestal. El Repertorio de recomendaciones prácticas Seguridad y salud en el trabajo forestal de la OIT, publicado en su primera edición en 1969 y que se volverá a editar revisado en 1998 [disponible en 1997 como documento de trabajo (O IT 1997)], trata exclusivamente de la salud y la seguridad en el trabajo.

L os nuevos repertorios se basan en inquietudes ecológicas más que en la seguridad. Sin embargo, existe un reconocimiento creciente de que en la industria forestal, la eficacia operativa, la protección ambiental y la seguridad son inseparables. Son la consecuencia de los mismos métodos y prácticas de planificación y trabajo. El apeo direccional para reducir el impacto sobre el resto del rodal o la regeneración y las normas de extracción en terreno abrupto son buenos ejemplos. Algunos repertorios, como los de la FAO y Fiji, se refieren de forma explícita a este vínculo y abordan simultáneamente la productividad, la protección ambiental y la seguridad en el trabajo. Lo ideal es que las recomendaciones no tengan capítulos especiales sobre seguridad, sino que las cuestiones de salud y seguridad en el trabajo estén incorporadas a sus disposiciones.

Las recomendaciones deben basarse en los métodos y tecnologías de trabajo disponibles más seguros, exigir que se considere la seguridad en la planificación, establecer requisitos en materia de seguridad para equipos, enumerar los equipos de protección personal necesarios y contener normas sobre prácticas de trabajo seguras. En caso necesario, también deberán incluir disposiciones relativas a los campamentos, la nutrición y el transporte de los trabajadores. $Y$ han de quedar reflejadas en las normas sobre supervisión y formación.

Los repertorios de recomendaciones pueden ser voluntarios y ser adoptados como obligatorios por grupos de empresas 0 por el sector forestal de un país en su conjunto. 0 ser legalmente vinculantes. En cualquier caso, su cumplimiento se exigirá siempre por medio de procedimientos o requerimientos legales.

Es el propio sector forestal el que elabora muchas recomendaciones, lo cual garantiza su carácter práctico y su oportunidad, además de reforzar el compromiso de cumplimiento. En el caso de Chile, se ha creado un comité tripartito para que elabore el repertorio de recomendaciones. En Fiji, fue elaborado en un principio con una importante participación de la industria y el M inisterio de Bosques le otorgó después carácter de vinculante.

L as características citadas y la experiencia con las recomendaciones existentes les convierten en una herramienta muy eficaz para la mejora de la seguridad en la industria forestal, así como para conseguir la cooperación entre los funcionarios de seguridad, los administradores de indemnizaciones para trabajadores, los inspectores laborales y los profesionales de la salud en el sector forestal.

\section{EQUIPOS DE PROTECCION PERSONAL}

E ero Korhonen

EI trabajo forestal es una de esas ocupaciones en las que siempre se necesitan equipos de protección personal (EPP). La mecanización ha reducido el número de trabajadores que utilizan motosierras portátiles, pero las demás faenas suelen realizarse en lugares difíciles a los que no pueden llegar las máquinas grandes.

La eficacia y la velocidad de la cadena de las motosierras portátiles han aumentado, mientras que ha disminuido la protección ofrecida por la ropa y el calzado diseñado para tal fin. La mayor necesidad de protección ha aumentado el peso del equipamiento. Especialmente en verano en los países nórdicos y todo el año en otros países, los dispositivos protectores añaden una carga más a la pesada faena de los trabajadores forestales. Este artículo está enfocado a los operarios de motosierras, pero en la mayoría de los trabajos forestales se necesita protección. La Tabla 68.9 contiene una descripción general de lo que se necesita normalmente.

\section{Mecanismo de protección y eficacia de los equipos de protección personal}

\section{Ropa protectora}

La ropa a prueba de cortes protege por medio de tres mecanismos principales diferentes. En la mayoría de los casos, los pantalones y los guantes contienen un acolchado de seguridad fabricado a base de tela de varias capas con fibras de alta resistencia a la tracción. Cuando la cadena en movimiento toca estas fibras, se estiran y resisten el movimiento de la cadena. En segundo lugar, estos materiales de acolchado pueden correr por la rueda motriz y el surco de la hoja y aumentar la fricción de la cadena contra la hoja hasta detener la cadena. En tercer lugar, el material también puede fabricarse de modo que la cadena resbale sobre la superficie y no pueda penetrarla con facilidad.

Cada faena requiere su propia cobertura de protección. Para las faenas forestales normales, el acolchado protector sólo cubre la parte delantera de los pantalones y la parte posterior de los guantes de seguridad. Las faenas especiales (p. ej., jardinería 0 cirugía silvícola) suelen requerir una mayor cobertura protectora. Los acolchados protectores cubren las piernas por completo, incluso la parte posterior. Si la sierra se sujeta por encima de la cabeza, puede ser necesario proteger la parte superior del cuerpo.

También es preciso recordar siempre que todos los EPP ofrecen una protección limitada, y deben utilizarse métodos de trabajo correctos y cuidadosos. Las nuevas motosierras portátiles son tan eficaces que la cadena puede atravesar con facilidad el mejor material protector si la cadena se mueve a gran velocidad o si entra en contacto con el material protector con gran fuerza. Los acolchados protectores a prueba de cortes fabricados con los mejores materiales actualmente conocidos serían tan gruesos que no se podrían utilizar en trabajos forestales pesados. El compromiso entre la eficacia de la protección y la comodidad se basa en los experimentos sobre el terreno. La reducción del nivel de protección para aumentar el confort de la ropa ha sido inevitable.

\section{Calzado protector}

El calzado protector de goma resiste bastante bien los cortes de las motosierras. El tipo de corte más frecuente se produce por el contacto de la cadena con la puntera del calzado. El calzado de 
Tabla 68.9 • Equipos de protección individual apropiados para operaciones forestales.

\begin{tabular}{|c|c|}
\hline Operaciones & EPP1 \\
\hline $\begin{array}{l}\text { Plantación } \\
\text { Manual } \\
\text { Mecanizada }\end{array}$ & $\begin{array}{l}\text { Botas } 0 \text { zapatos de seguridad } \\
\text { Botas } 0 \text { zapatos de seguridad, ropa ajustada, orejeras }{ }^{2}\end{array}$ \\
\hline $\begin{array}{l}\text { Desherbado/ limpieza } \\
\text { Herramientas de filo liso } \\
\text { Sierra manual } \\
\text { Motosierra }\end{array}$ & $\begin{array}{l}\text { Botas } 0 \text { zapatos de seguridad, guantes, gafas de montura ajustada } \\
\text { Botas o zapatos de seguridad, guantes } \\
\text { Botas o zapatos de seguridad, }{ }^{3} \text { pantalones de seguridad, ropa ajustada, guantes, }{ }^{4} \text { casco de seguridad, } \\
\text { gafas de montura ajustada, visera ( malla), orejeras }\end{array}$ \\
\hline $\begin{array}{l}\text { Sierra trochadora: } \\
\text { con hoja metálica } \\
\text { con filamento de nailon }\end{array}$ & $\begin{array}{l}\text { Botas o zapatos de seguridad }{ }^{3} \text { pantalones de seguridad, ropa ajustada, guantes, }{ }^{4} \text { casco de seguridad, } \\
\text { gafas de montura ajustada, visera (malla), orejeras } \\
\text { Botas } 0 \text { zapatos de seguridad, pantalones de seguridad, guantes, gafas de montura ajustada, orejeras }\end{array}$ \\
\hline Cuchilla giratoria/mayal & Botas o zapatos de seguridad, ropa ajustada, guantes, orejeras ${ }^{2}$ \\
\hline Aplicación de plaguicidas & Cumplir las especificaciones de la sustancia utilizada y de la técnica de aplicación \\
\hline $\begin{array}{l}\text { Poda } \\
\text { Herramientas manuales }\end{array}$ & Botas o zapatos de seguridad, guantes, casco de seguridad, ${ }^{6}$ gafas de montura ajustada, orejeras \\
\hline $\begin{array}{l}\text { Apeo }^{7} \\
\text { Herramientas manuales } \\
\text { Motosierra }\end{array}$ & $\begin{array}{l}\text { Botas o zapatos de seguridad, ropa ajustada, guantes, }{ }^{8} \text { casco de seguridad } \\
\text { Botas } 0 \text { zapatos de seguridad, pantalones de seguridad, ropa ajustada, guantes, }{ }^{4} \text { casco de seguridad, visera (malla), orejeras }\end{array}$ \\
\hline Mecanizado & Botas o zapatos de seguridad, ropa ajustada, casco de seguridad, orejeras \\
\hline $\begin{array}{l}\text { Descortezado } \\
\text { Manual } \\
\text { Mecanizado }\end{array}$ & $\begin{array}{l}\text { Botas o zapatos de seguridad, guantes } \\
\text { Botas o zapatos de seguridad, ropa ajustada, guantes, gafas de montura ajustada, orejeras² }\end{array}$ \\
\hline $\begin{array}{l}\text { Hendimiento } \\
\text { Manual } \\
\text { Mecanizado }\end{array}$ & $\begin{array}{l}\text { Botas o zapatos de seguridad, guantes, gafas de montura ajustada } \\
\text { Botas o zapatos de seguridad, ropa ajustada, guantes, gafas de montura ajustada, orejeras }\end{array}$ \\
\hline $\begin{array}{l}\text { Extracción } \\
\text { Manual, por medio de deslizaderos } \\
\text { y animales } \\
\text { Mecanizada } \\
\text { - arrastrador } \\
\text { - recogedor } \\
\text { - cable-grúa } \\
\text { - helicóptero }\end{array}$ & $\begin{array}{l}\text { Botas } 0 \text { zapatos de seguridad, ropa ajustada, guantes }{ }_{1}^{10} \text { casco de seguridad, orejeras }{ }^{2} \\
\text { Botas } 0 \text { zapatos de seguridad, ropa ajustada, casco de seguridad, orejeras }{ }^{2} \\
\text { Botas } 0 \text { zapatos de seguridad, ropa ajustada, guantes }{ }^{10} \text { casco de seguridad, orejeras } 2 \\
\text { Botas } 0 \text { zapatos de seguridad, ropa ajustada, }{ }_{1}^{11} \text { guantes, }{ }^{10} \text { casco de seguridad, gafas de montura ajustada, orejeras }\end{array}$ \\
\hline Apilamiento/ carga & Botas o zapatos de seguridad, ropa ajustada, guantes, casco de seguridad, orejeras² \\
\hline Astillado & Botas o zapatos de seguridad, ropa ajustada, guantes, casco de seguridad, visera (malla), orejeras² \\
\hline $\begin{array}{l}\text { Encaramarse a los árboles: } \\
\text { utilizando una motosierra } \\
\text { sin utilizar una motosierra }\end{array}$ & $\begin{array}{l}\text { Botas o zapatos de seguridad, }{ }^{3} \text { pantalones de seguridad, ropa ajustada, guantes, }{ }^{4} \text { casco de seguridad, }{ }^{13} \\
\text { gafas de montura ajustada, orejeras } \\
\text { Botas o zapatos de seguridad, casco de seguridad }\end{array}$ \\
\hline
\end{tabular}

1 Las botas 0 zapatos de seguridad deben llevar punteras de acero integradas para cargas medias o pesadas. Los pantalones de seguridad deben incorporar material oclusivo; en condiciones climáticas calurosas pueden utilizarse polainas o zahones para uso con sierras mecánicas. Los pantalones y zahones de seguridad contienen fibras inflamables que pueden derretirse; no deberá llevarse esta ropa durante trabajos de extinción de incendios. Los tapones y válvulas para las orejas no son adecuados en general para el aprovechamiento forestal debido al riesgo de infección.

2 Cuando el nivel de ruido en la posición de trabajo sobrepase los 85 dBA.

3 Las botas de uso con sierras mecánicas deben tener defensas de protección en la pala delantera y en el empeine.

4 Debe incorporarse material resistente a los cortes.

5 Si la poda implica encaramarse a los árboles a más de $3 \mathrm{~m}$ de altura, deberá utilizarse un dispositivo anticaídas. Deberán utilizarse EPP cuando sea probable que la caída de ramas provoque lesiones.

${ }^{6}$ Cuando se pode a una altura superior a $2,5 \mathrm{~m}$

7 El apeo incluye el desramaje y el tronzado.

8 Cuando se utilice una motosierra.

${ }^{9}$ Cuando la extracción se realice cerca de árboles inestables o leña de ramas

10 Sólo si se manipulan troncos; guantes con palmas para trabajos pesados si se manipulan guías o bragas de cable metálico.

11 Deberán utilizarse colores muy llamativos.

$12 \mathrm{El}$ casco debe estar provisto de barboquejo.

13 Son preferibles los cascos de escalada; si no se dispone de ellos, pueden utilizarse cascos de seguridad con barboquejos.

Fuente: 0 OIT 1997. 
seguridad debe tener un forro resistente a los cortes en la parte delantera y punteras metálicas; ésta es una muy buena protección contra estos cortes. Si hace calor resulta incómodo utilizar botas de goma y es mejor utilizar botas de cuero o zapatos de caña alta. Estos zapatos también deben estar provistos de punteras metálicas. La protección es por lo común bastante menor que la de las botas de goma y es preciso tener aún más cuidado si se utilizan zapatos o botas de cuero. Los métodos de trabajo deben planificarse de modo que se minimice la posibilidad de que la cadena entre en contacto con los pies.

Es esencial que la suela externa esté bien adaptada y fabricada para evitar resbalones y caídas, que son muy comunes. En zonas donde el suelo puede estar recubierto de hielo y nieve 0 donde los trabajadores andan sobre troncos resbaladizos, es preferible utilizar botas que puedan equiparse con púas.

\section{Casco protector}

L os cascos protegen contra la caída de ramas y árboles, así como contra el retroceso de una motosierra. El casco debe ser lo más ligero posible para minimizar la tensión del cuello. El ceñidor debe ajustarse de manera correcta para que el casco quede firmemente asentado sobre la cabeza. Los ceñidores de la mayoría de los cascos permiten también ajuste vertical. Es importante que el casco quede bajo sobre la frente para que su peso no cause excesiva incomodidad al trabajar cara abajo. En climas fríos, es necesario utilizar un gorro de tela o piel bajo el casco. Deberán utilizarse gorros especialmente diseñados para emplear con el casco. El gorro puede disminuir la eficacia de protección del casco al posibilitar su incorrecta colocación. La eficacia de los protectores auditivos puede aproximarse a cero si las orejeras quedan fuera del gorro. Los cascos forestales llevan dispositivos incorporados para montar una visera y orejeras de protección auditiva. Las orejeras de los protectores auditivos deben colocarse directamente en contacto con la cabeza insertándolas a través de ranuras practicadas en el gorro.

En climas calurosos, los cascos deberán llevar orificios de ventilación, que han de formar parte del diseño del casco. Bajo ninguna circunstancia deberán taladrarse en el casco, ya que ello podría reducir mucho su resistencia.

\section{Protección facial y ocular}

El protector o pantalla facial va normalmente montado en el casco y lo más común es que esté hecho de un material reticular. L as láminas de plástico se ensucian con facilidad tras un período de trabajo relativamente corto. Limpiarlas resulta difícil porque los plásticos no resisten bien a los disolventes. La malla reduce la luz que llega a los ojos del trabajador y los reflejos en la superficie de los hilos pueden dificultar la visión. L as gafas de montura ajustada que se llevan bajo los protectores faciales se empañan fácilmente y la visión suele distorsionarse mucho. Es preferible utilizar máscaras metálicas con un revestimiento negro y aberturas rectangulares en lugar de redondas.

\section{Protectores auditivos}

Los protectores auditivos sólo son eficaces si se colocan las orejeras bien apretadas contra la cabeza. Por consiguiente, deben utilizarse con cuidado. C ualquier separación entre la cabeza y los aros de las orejeras reducirá su eficacia notablemente. Por ejemplo, las patillas de unas gafas graduadas pueden producir tal separación. Los aros se inspeccionarán con frecuencia y deberán cambiarse siempre que se deterioren.

\section{Elección de los equipos de protección personal}

Antes de comenzar a trabajar en una nueva área, deberán evaluarse los posibles riesgos. Deberán evaluarse las herramientas, los métodos y el ambiente de trabajo, la cualificación de los trabajadores, etcétera, y deberán planificarse todas las medidas técnicas y organizativas. Si los riesgos no pueden eliminarse con estos métodos, pueden utilizarse EPP para mejorar la protección. Los EPP nunca pueden utilizarse como único método preventivo. Deben considerarse sólo como medio complementario. La sierra debe tener un freno en la cadena, el trabajador debe recibir formación, etcétera.

Sobre la base de este análisis de riesgos, es preciso definir los requisitos de los dispositivos de protección personal. Deberán tenerse en cuenta los factores ambientales a fin de minimizar el peso del equipo. Deberá evaluarse el peligro planteado por la sierra y definirse el área de protección y la eficacia de la ropa. Si los trabajadores no son profesionales, el área y el nivel de protección deberán ser mayores, pero este peso adicional deberá tenerse en cuenta al planificar los períodos de trabajo. U na vez definidos los requisitos de los EPP de acuerdo con los riesgos y tareas a realizar, se eligen los equipos apropiados de entre los que se han homologado. Los trabajadores deberán tener el privilegio de probar diferentes modelos y tallas para elegir los mejores para ellos. Elegir ropa inadecuada puede dar lugar a posturas y movimientos anómalos e incrementar así los riesgos de accidente y los peligros para la salud. La Figura 68.17 ilustra la elección del equipo.

\section{Determinación de las condiciones de uso}

Todos los trabajadores deberán ser instruidos y formados en el uso de los EPP. EI mecanismo de protección debe describirse de modo que los propios trabajadores puedan inspeccionar y evaluar el estado de los equipos a diario. D eberán dejarse bien claras las consecuencias de no utilizarlos y darse instrucciones precisas sobre su limpieza y reparación.

Los equipos protectores utilizados en trabajos forestales pueden constituir una carga adicional relativamente grande para el trabajador y habrá de tenerse en cuenta al planificar los períodos de trabajo y descanso.

U tilizar EPP suele dar una falsa sensación de seguridad. Los supervisores deben asegurarse de que no aumente la asunción de riesgos y de que los trabajadores conozcan bien los límites de eficacia de la protección.

\section{Conservación y mantenimiento}

Utilizar métodos de mantenimiento y reparación inadecuados puede privar de toda eficacia a los equipos de protección.

El casco debe limpiarse con soluciones detergentes diluidas. Las resinas no pueden eliminarse eficientemente sin utilizar disolventes, pero deberá evitarse su uso porque pueden dañar el casco. D eberán seguirse las instrucciones del fabricante, y tirar el casco si no puede limpiarse. Algunos materiales son más resistentes a los efectos de los disolventes y serán los que deberán elegirse para realizar trabajos forestales.

Los materiales del casco también pueden verse afectados por otros factores ambientales. L os materiales plásticos son sensibles a la radiación ultravioleta ( $U V$ ) del sol, que hace que el casco se haga más rígido, sobre todo a bajas temperaturas; este envejecimiento debilita el casco, que deja de ofrecer la protección esperada contra los impactos. El envejecimiento es difícil de apreciar, pero pueden ser síntoma de él las pequeñas fisuras y la pérdida de brillo. Además, si hay agrietamiento, apretándolo con suavidad se apreciarán ruidos. Los cascos han de inspeccionarse visualmente con atención al menos cada seis meses.

Si la cadena ha estado en contacto con los pantalones, la eficacia de la protección puede verse muy reducida 0 
Figura 68.17 • Localización corporal de las lesiones y equipos de protección individual recomendados para el trabajo forestal, Países Bajos, 1989.

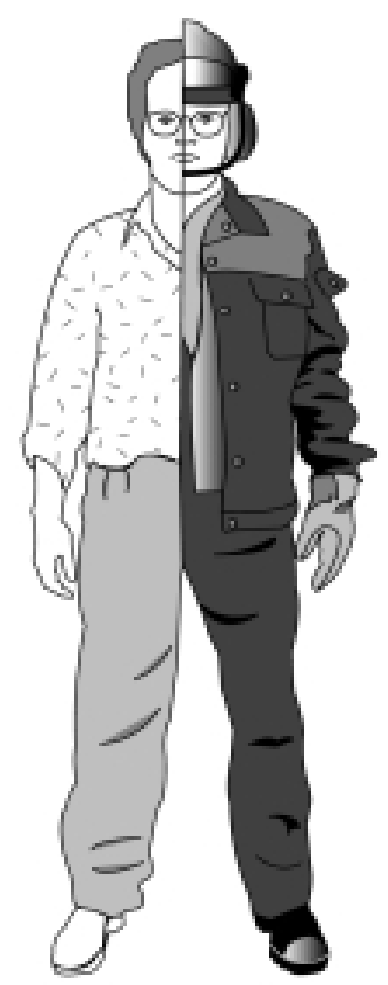

desaparecer por completo. Si se salen las fibras de acolchado de seguridad, deberán tirarse los pantalones y reemplazarse por otros nuevos. Si sólo se deteriora el material exterior, podrán repararse cuidadosamente sin coser a través del acolchado de seguridad. La eficacia de protección de los pantalones de seguridad se basa por lo común en las fibras resistentes, y si éstas se fijan muy tensas durante la reparación dejarán de dar la protección prevista.

El lavado debe realizarse ateniéndose a las instrucciones del fabricante. Se ha demostrado que utilizar métodos de lavado erróneos puede eliminar la eficacia de la protección. La ropa del trabajador forestal es difícil de limpiar y deberán elegirse productos que soporten los agresivos métodos de lavado necesarios.

\section{Cómo se marcan los equipos de protección homologados}

El diseño y la calidad de fabricación de los EPP debe cumplir exigentes normas. En el ámbito de la Comunidad Económica Europea, los equipos de protección personal deben ensayarse antes de salir al mercado. U na directiva describe los requisitos básicos en materia de seguridad y salud para los EPP. Para clarificar dichos requisitos, se han redactado normas europeas armonizadas. Estas normas son de cumplimiento voluntario, pero se considera que los equipos diseñados para cumplir los requisitos de las normas apropiadas cumplen los requisitos de la directiva.
La Organización de Normalización Internacional (ISO) y el Comité Europeo de Normalización (CEN) están trabajando conjuntamente en estas normas de conformidad con el Acuerdo de Viena. De modo que las normas NE y las normas ISO serán idénticas.

Los equipos se están ensayando en laboratorios de ensayo acreditados, que emitirán un certificado si cumplen los requisitos. Después, el fabricante podrá imponer la marca CE al producto, que demuestra que se ha realizado la evaluación de conformidad. En otros países, el procedimiento es similar y los productos reciben la marca de homologación nacional.

U na parte esencial del producto es el folleto que informa al usuario sobre la forma de utilizarlo correctamente, el grado de protección que puede proporcionar y las instrucciones para su limpieza, lavado y reparación.

\section{CONDICIONES DE TRABAJO Y SEGURIDAD EN EL TRABAJO FORESTAL}

Lucie Laflamme y E sther Cloutier

La seguridad en el sector forestal depende de adecuar las capacidades de trabajo individuales a las condiciones de trabajo. Cuanto más se aproximen los requisitos mentales y físicos del trabajo a las capacidades de los trabajadores (que, a su vez, varían con la edad, la experiencia y el estado de salud), menos probable será que se sacrifique la seguridad en un intento por cumplir los objetivos de producción. Si las capacidades individuales y las condiciones de trabajo tienen un equilibrio precario, es inevitable que se reduzca la seguridad individual y colectiva.

Como se ilustra en la Figura 68.18, existen tres clases de riesgos para la seguridad relacionados con las condiciones de trabajo: el ambiente físico (clima, iluminación, terreno, tipos de árboles), leyes y normas sobre seguridad deficientes (contenido o aplicación inadecuados) y organización inadecuada del trabajo (técnica y humanamente).

La organización técnica y humana del trabajo comporta posibles factores de riesgo que son distintos pero están muy ligados: distintos, porque se refieren a dos recursos intrínsecamente diferentes (es decir, los seres humanos y las máquinas); ligados, porque interactúan y se complementan durante el desempeño de las actividades laborales y porque su interacción permite cumplir los objetivos de producción de manera segura.

Este artículo detalla cómo los fallos en los componentes de la organización del trabajo enumerados en la Figura 68.18 pueden comprometer la seguridad. Es conveniente indicar que no es posible retroadaptar medidas de protección de la salud y la seguridad en un método de trabajo, máquina u organización ya existente. Es preciso que formen parte del diseño y de la planificación.

\section{Organización técnica del trabajo}

EI término organización técnica del trabajo se refiere a consideraciones operativas del trabajo forestal, incluidos el tipo de corta, la elección de la maquinaria y los equipos de producción, el diseño de los equipos, las prácticas de mantenimiento, la dimensión y composición de las plantillas y el tiempo asignado en el plan de producción.

\section{Tipo de corta}

En las operaciones forestales se utilizan sobre todo dos tipos de corta, que se diferencian por la tecnología utilizada para apear y desramar árboles: la corta convencional - por medio de motosierras - y la corta mecánica - por medio de máquinas manejadas 
Figura 68.18 • Factores determinantes de los riesgos para la seguridad en el trabajo forestal.

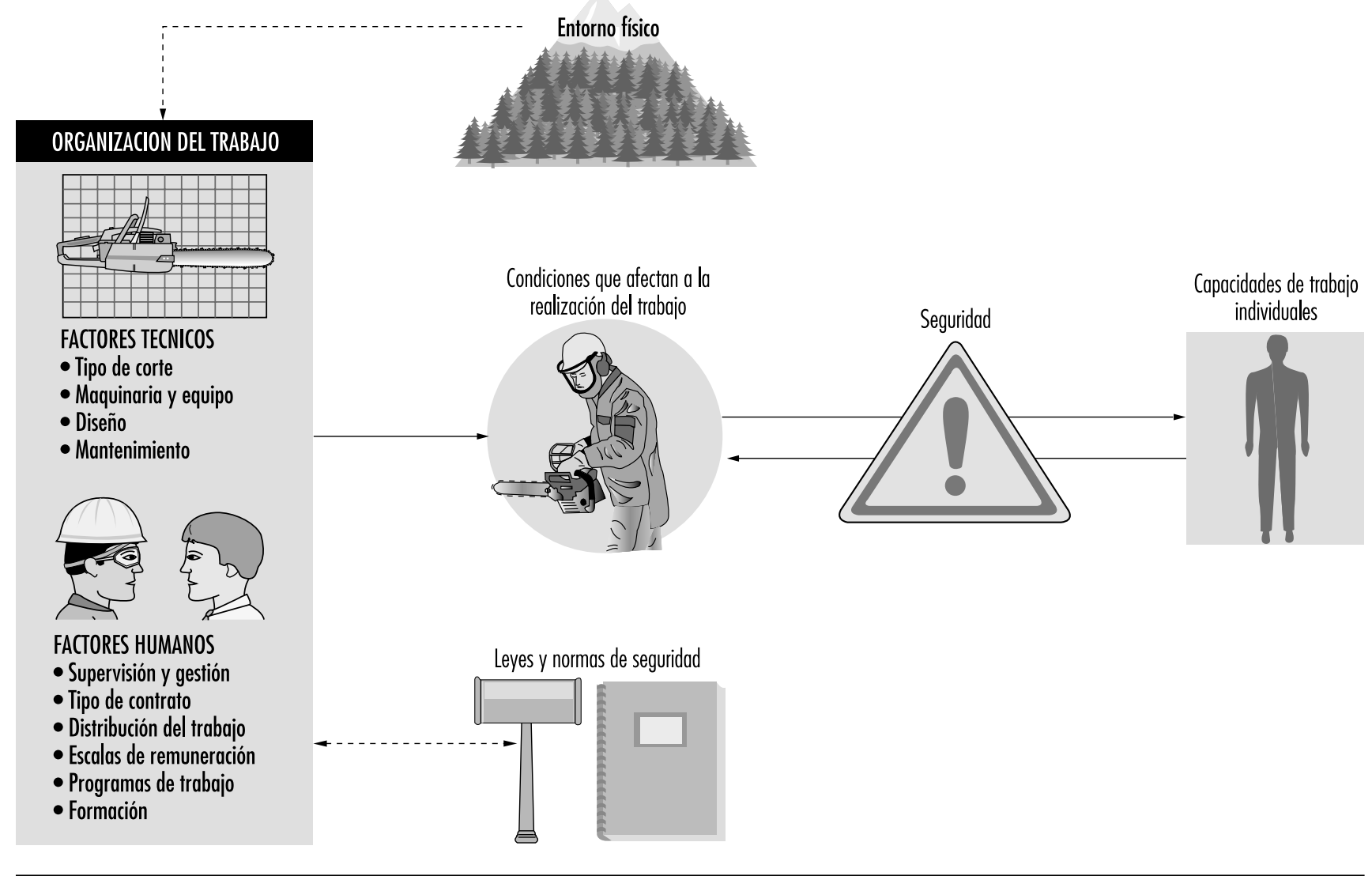

desde cabinas de maniobra y equipadas con plumas articuladas-. En ambos casos, los arrastradores, especialmente los propulsados por cadenas o garras, son los medios habituales de transporte de los árboles apeados junto a las carreteras o vías fluviales. La corta convencional es la más extendida y la más peligrosa de las dos.

Se sabe que la mecanización de la corta reduce considerablemente la frecuencia de los accidentes. Se ve con mayor claridad en el caso de los accidentes que ocurren durante las operaciones de producción, y se debe a la sustitución de las motosierras por máquinas manejadas desde cabinas de control remoto que aíslan a los operarios de los peligros. Sin embargo, la mecanización parece incrementar al mismo tiempo el riesgo de accidente durante el mantenimiento y la reparación de las máquinas. Este efecto se debe a factores tanto tecnológicos como humanos. Entre los factores tecnológicos cabe citar las deficiencias de las máquinas (véase a continuación) y las condiciones, a menudo improvisadas, cuando no francamente grotescas, en las que se realizan las operaciones de mantenimiento y reparación. Entre los factores humanos cabe citar la existencia de pluses de producción, que suelen provocar que se otorgue una baja prioridad a las operaciones de mantenimiento y reparación y que se tienda a realizarlas apresuradamente.

\section{Diseño de la máquina}

No existen reglas para el diseño de maquinaria forestal y son raros los manuales de mantenimiento completos. Las máquinas cortadoras, desramadoras y arrastradoras suelen ser una mezcla de componentes diversos ( $p$. ej., plumas, cabinas, máquinas base), algunos de los cuales están diseñados para otros sectores. Por estos motivos, la maquinaria utilizada en las operaciones forestales puede no ser adecuada para algunas condiciones ambientales, sobre todo las relacionadas con el estado del bosque y del terreno y con el funcionamiento constante. Por último, la máquina requiere frecuentes reparaciones que son muy difíciles de realizar.

\section{M antenimiento de máquinas y equipos}

Las prácticas de mantenimiento en el bosque suelen ser correctivas más que preventivas. Varias condiciones de trabajo - como urgencias de producción, la ausencia de estrictos programas y directrices de mantenimiento, la falta de lugares apropiados para realizar las operaciones de mantenimiento y reparación (garajes, resguardos), las difíciles condiciones en las que se realizan estas operaciones y la falta de herramientas adecuadas- pueden explicar esta situación. A demás, los talleres unipersonales 0 administrados por subcontratistas pueden sufrir limitaciones económicas

\section{Organización humana del trabajo}

EI término organización humana del trabajo se refiere a la manera en que se administran y organizan los esfuerzos humanos individuales o colectivos y a las políticas de formación concebidas para cumplir los requisitos de producción. 
Figura 68.19 • Los factores humanos repercuten en la seguridad del trabajo forestal.

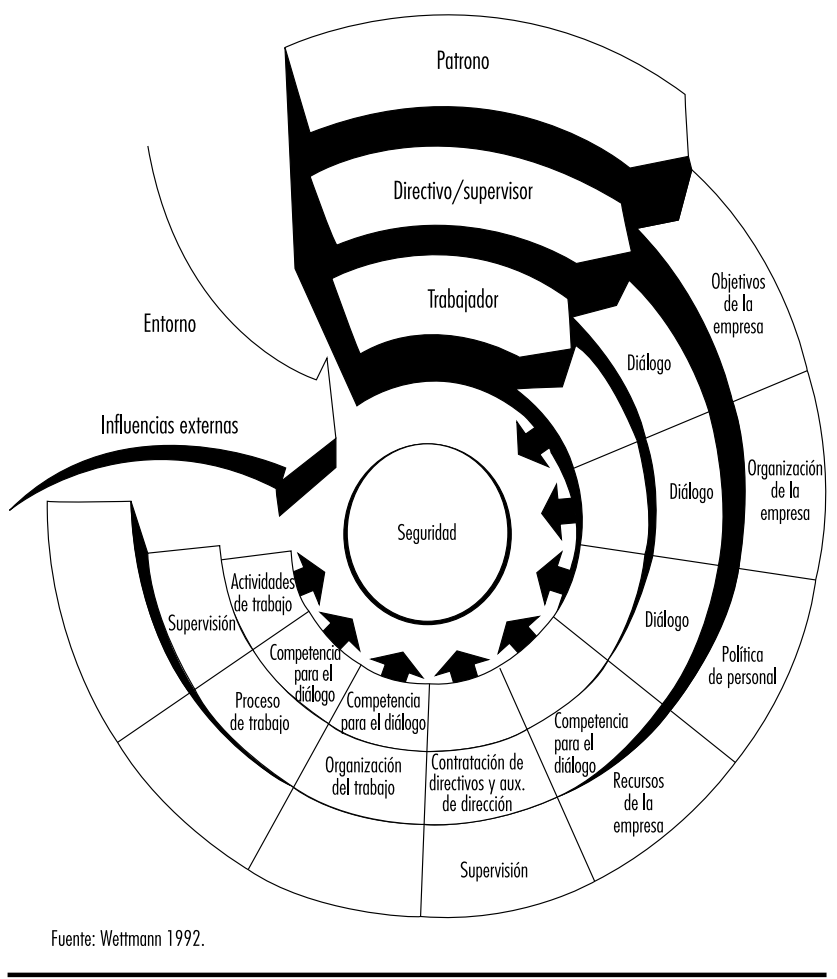

\section{Supervisión}

La supervisión del trabajo forestal no es fácil, debido al constante cambio de los lugares de trabajo y a la dispersión geográfica de los trabajadores en diversos lugares de trabajo. La producción se controla a través de estrategias indirectas, de las cuales los pluses de producción y el mantenimiento de situaciones de empleo precario son tal vez las más insidiosas. Este tipo de organización del trabajo no favorece una buena gestión de la seguridad, ya que es más fácil transmitir la información referente a las directrices y disposiciones en materia de seguridad que asegurarse de su aplicación y evaluar su valor práctico y la medida en que se entienden. Los directivos y supervisores deben tener claro que son los principales responsables de la seguridad. Como puede verse en la Figura 68.19, el trabajador controla muy pocos de los elementos que determinan el comportamiento en materia de seguridad.

\section{Tipo de contrato}

Con independencia del tipo de corta, los contratos laborales casi siempre se negocian de manera individual y suelen ser de duración fija o estacional. Es probable que esta precaria situación laboral provoque que se otorgue una baja prioridad a la seguridad personal, ya que es difícil favorecer la seguridad en el trabajo en ausencia de unas mínimas garantías de empleo. En términos concretos, a los leñadores u operarios les puede resultar difícil trabajar de manera segura si ello compromete los objetivos de producción de los que depende su empleo. Los contratos de larga duración con volúmenes mínimos anuales garantizados estabilizan el empleo y aumentan la seguridad.

\section{Subcontratación}

Subcontratar la responsabilidad (y los costes) para determinadas actividades de producción con propietarios-operarios es una práctica cada vez más extendida en el sector forestal, a causa de la mecanización y de su consecuencia: la especialización del trabajo (es decir, utilizar una máquina específica para faenas tales como el apeo, la poda, la corta-poda y el arrastre).

La subcontratación puede afectar a la seguridad de varias maneras. En primer lugar, debe reconocerse que la subcontratación no reduce los riesgos para la seguridad como tales, sino que simplemente los traslada del empresario al subcontratista. En segundo lugar, subcontratar también puede agravar ciertos peligros, ya que estimula la producción en lugar del comportamiento orientado a la seguridad. De hecho, se ha observado que los subcontratistas descuidan ciertas precauciones de seguridad, sobre todo las relacionadas con el mantenimiento preventivo, la formación de nuevos empleados, el suministro y el fomento del uso de los equipos de protección personal (EPP) y el cumplimiento de las normas en materia de seguridad. Por último, la responsabilidad de la gestión y el mantenimiento de la seguridad en los lugares de trabajo donde se practica la subcontratación es una zona gris en el ámbito judicial. Hasta puede ser difícil determinar de quién es la responsabilidad de declarar que los accidentes están relacionados con el trabajo. Los contratos laborales deben obligar al cumplimiento de las disposiciones en materia de seguridad, incluir sanciones por incumplimientos y asignar la responsabilidad de la supervisión.

\section{División del trabajo}

La división del trabajo en las estaciones forestales suele ser rígida y fomenta la especialización en lugar de la flexibilidad. La rotación de tareas es posible con la corta convencional, pero depende fundamentalmente de la dinámica del equipo. Por otra parte, la corta mecanizada fomenta la especialización, aunque la tecnología en sí (es decir, la especialización de la máquina) no es la única causa de este fenómeno. La especialización también se ve favorecida por factores organizativos (un operario por máquina, trabajo a turnos), por la dispersión geográfica (alejamiento de las máquinas y de las zonas de corta) y por el hecho de que los operarios sean por lo general propietarios de las máquinas.

Los problemas de aislamiento y comunicación resultantes de esta división del trabajo pueden tener graves consecuencias para la seguridad, sobre todo cuando obstaculizan la circulación eficaz de información relativa a peligros inminentes o a un incidente 0 accidente.

Es necesario equiparar correctamente las capacidades de trabajo de máquinas y trabajadores y componer las plantillas en consecuencia, a fin de evitar sobrecargar elementos de la cadena de producción. Pueden diseñarse programas de turnos que saquen el máximo partido a máquinas costosas, pero que proporcionen suficiente descanso y diversidad de tareas a los operarios.

\section{Sistemas de remuneración basados en la producción}

Los trabajadores forestales trabajan frecuentemente a destajo, lo que significa que su salario viene determinado por su producción (número de árboles apeados, podados o transportados, 0 algún otro índice de productividad), no por su duración. Por ejemplo, el precio que cobran los propietarios de las máquinas por el uso de las mismas es proporcional a su productividad. Este tipo de remuneración, aunque no controla directamente a los trabajadores, destaca por estimular la producción.

Los sistemas de remuneración basados en la producción pueden favorecer que se trabaje a gran velocidad y que se recurra a prácticas laborales poco seguras durante la producción y a buscar atajos en las operaciones de mantenimiento y reparación. Prácticas como estas persisten porque ahorran tiempo, aunque ignoren las directrices sobre seguridad establecidas y los riesgos que comportan. Cuanto mayor es el incentivo a la 
producción, en mayor medida se compromete la seguridad. Se ha observado que los trabajadores que cobran sobre la base de la producción sufren más accidentes, así como diferentes tipos de accidentes, que los trabajadores que cobran por horas por realizar las mismas faenas. La remuneración a destajo y los precios de los contratos tienen que ser adecuados para que se trabaje con seguridad en jornadas laborales aceptables. ( $V$ éase un reciente estudio empírico realizado en Alemania en K astenholz 1996.)

\section{Jornada laboral}

En el bosque, lo normal es que la jornada laboral diaria y semanal sea larga, ya que el aislamiento de los lugares de trabajo y las zonas de corta, la estacionalidad del trabajo y la frecuente dificultad de los factores climáticos y ambientales incitan a los trabajadores a faenar durante el mayor tiempo posible. 0 tros factores que favorecen la larga duración de la jornada laboral incluyen incentivos a la producción (remuneración por trabajo realizado, subcontratación) y la posibilidad de utilizar ciertas máquinas de manera constante (es decir, sin parar por la noche).

Las largas jornadas laborales suelen hacer que disminuya la atención y se pierda agudeza sensorial, efectos ambos que repercuten en la seguridad individual y colectiva. Tales problemas se ven agravados por la escasez y brevedad de los períodos de descanso. D eberán observarse los descansos previstos y los horarios laborales máximos: de este modo es posible, según las investigaciones ergonómicas, incrementar la producción.

\section{Formación}

No hay duda de que el trabajo forestal es física y mentalmente exigente. EI nivel de cualificación requerido aumenta de manera constante, a consecuencia de los avances tecnológicos y de la cada vez mayor complejidad de las máquinas. Por lo tanto, es muy importante que los trabajadores reciban formación previa y sobre el terreno. Los programas de formación deben basarse en objetivos claramente definidos y reflejar el trabajo que se va a realizar. Cuanto más se corresponda el contenido de los programas de formación con las condiciones reales de trabajo y cuanto mayor sea la integración de las cuestiones de seguridad y de producción, más útiles serán los programas, tanto individual como colectivamente. Los programas de formación eficaces no sólo reducen las pérdidas de materiales y los retrasos en la producción, sino que además evitan riesgos adicionales para la seguridad. Como orientación en materia de formación, véase el artículo titulado "Cualificación y formación" en este mismo capítulo.

\section{Conclusión}

La seguridad del trabajo forestal viene determinada por factores relacionados con la organización del trabajo, y los aspectos técnicos y humanos de la organización del trabajo pueden trastornar el equilibrio entre los objetivos de producción y la seguridad. Por supuesto, la influencia de cada factor sobre la seguridad en el trabajo varía de un escenario a otro, pero su efecto combinado siempre será significativo. A demás, su interacción será el principal determinante del grado de prevención posible.

También es conveniente observar que los avances tecnológicos no eliminan por sí solos todos los peligros. En los criterios de diseño de las máquinas deberá tenerse en cuenta la seguridad de su funcionamiento, mantenimiento y reparación. Por último, parece ser que algunas prácticas de gestión cada vez más extendidas, sobre todo la subcontratación, pueden agravar los peligros para la seguridad, en lugar de reducirlos.

\section{CUALIFICACION Y FORMACION}

\section{Peter Poschen}

\section{Cualificación, formación y exposición}

En muchas industrias, la atención a la seguridad en el diseño de los equipos, lugares y métodos de trabajo puede contribuir considerablemente a reducir los peligros para la salud y la seguridad en el trabajo. En la industria forestal, la exposición a los riesgos viene determinada en gran medida por los conocimientos técnicos, cualificación y experiencia del trabajador y del supervisor, y de su compromiso con un esfuerzo conjunto para planificar y realizar el trabajo. Por consiguiente, la formación es un factor crucial y determinante de la seguridad y la salud en la industria forestal.

Todos los estudios realizados en diferentes países y relativos a distintos trabajos forestales concuerdan en que tres grupos de trabajadores sufren accidentes con una frecuencia desproporcionadamente alta: los trabajadores no cualificados, a menudo temporeros; Ios jóvenes; y los recién llegados. En Suiza, por lo menos un $73 \%$ de los accidentes afectan a los trabajadores que llevan menos de un año en el sector forestal; asimismo, tres cuartas partes de las víctimas de accidentes no habían recibido formación o sólo de manera rudimentaria (Wettman 1992).

Los trabajadores sin formación suelen tener también una carga de trabajo mucho mayor y un mayor riesgo de sufrir lesiones en la espalda a consecuencia de una técnica inadecuada (véase ejemplo en el artículo titulado "Plantación de árboles" en este mismo capítulo). Si la formación es crucial tanto desde el punto de vista de la seguridad como de la productividad, es absolutamente indispensable en tareas de alto riesgo, como la recuperación de árboles derribados por el viento o la extinción de incendios. No deberá permitirse la participación en estas actividades de personas sin formación específica.

\section{Formación de los trabajadores forestales}

La formación en el tajo todavía es muy común en la industria forestal. Suele ser muy ineficaz, porque es un eufemismo para la imitación o sencillamente para el aprendizaje por tanteo. Toda formación tiene que basarse en objetivos establecidos de forma y en instructores bien preparados. Por ejemplo, la formación mínima exigible para nuevos operarios de motosierras es un curso de dos semanas seguido de adiestramiento sistemático en el lugar de trabajo.

Por suerte, se ha producido una tendencia a impartir una formación más larga y bien estructurada en los países industrializados, al menos para los empleados directos y la mayoría de los recién llegados. En varios países europeos, los trabajadores forestales tienen que pasar períodos de aprendizaje de 2 o 3 años. En FAO/CEPE/OIT 1996b se describe la estructura de los sistemas de formación y se enumeran los contactos con los colegios. Sin embargo, incluso en estos países existe una separación cada vez mayor entre lo anterior y los grupos problemáticos como los autónomos, contratistas y sus empleados, y los granjeros que trabajan en su propio bosque. Los programas piloto de formación para estos grupos han demostrado que pueden ser inversiones rentables, ya que su coste se ve más que compensado por el ahorro que se deriva de la menor frecuencia y gravedad de los accidentes. A pesar de sus ventajas demostradas y de algunos ejemplos alentadores, como la Escuela de A provechamiento Forestal de Fiji, la formación para los trabajadores forestales es prácticamente inexistente en la mayoría de los países tropicales y subtropicales.

La formación de los trabajadores forestales debe basarse en las necesidades prácticas de la industria y de la persona 
formada. Debe ser práctica en lugar de sólo teórica. Puede impartirse por medio de diversos mecanismos. En Europa se han utilizado mucho las escuelas o los centros de formación con excelentes resultados. Sin embargo, comportan un alto coste fijo, necesitan que se matriculen bastantes personas cada año para ser rentables y suelen estar alejados del lugar de trabajo. Por consiguiente, en muchos países se ha preferido la formación móvil. En su forma más simple, instructores especialmente preparados viajan a los lugares de trabajo y ofrecen cursos de acuerdo con programas que pueden ser estándar o modulares y adaptables a las necesidades locales. También ha resultado un éxito emplear como instructores a tiempo parcial a trabajadores cualificados con cierta formación adicional. Cuando la demanda de formación es mayor, se utilizan camiones o remolques especialmente equipados como aulas y talleres. Existen diseños y listas de posibles equipos para tales unidades (M oos y K vitzau 1988). La formación móvil puede ser la única manera de llegar a algunos grupos, como los contratistas y los granjeros.

Normas mínimas de competencia y certificación

En todos los países deben definirse normas mínimas de cualificación para todos los trabajos principales, al menos en el aprovechamiento forestal, la operación más peligrosa. Un método muy adecuado para garantizar que se definan y se cumplan unas normas mínimas es otorgar certificados de cualificación tras someter a los trabajadores a breves exámenes teóricos y prácticos. La mayoría de los programas dan mayor importancia a los conocimientos y capacidades demostrados en exámenes estandarizados que a los adquiridos a través de formación 0 una larga experiencia. Desde mediados del decenio de 1980 se han introducido varios programas de certificación. En muchos casos han sido promovidos por los fondos de indemnización de trabajadores o las direcciones de salud y seguridad, pero también ha habido iniciativas de la industria y de los grandes propietarios de bosques. Existen exámenes estándar para operarios de motosierras y arrastradores (N PTC y SSTS 1992, 1993; M inisterio de Desarrollo de Cualificaciones 1989). La experiencia demuestra que los exámenes son extrapolables tal cual o con pequeñas modificaciones. Por ejemplo, en 1995 la OIT y la Comisión Forestal de Zimbabwe lograron introducir el examen de motosierras desarrollado en un proyecto de formación de saca forestal de la OIT en Fiji.

\section{- CONDICIONES DE VIDA}

\section{Elias Apud}

Las operaciones forestales, sobre todo en los países en desarrollo, suelen ser temporales y estacionales. En general, este trabajo se realiza lejos de los centros urbanos y los trabajadores deben viajar largas distancias cada día o permanecer durante varios días o semanas en campamentos próximos a los lugares de trabajo. Cuando los trabajadores viajan desde sus casas todos los días, las condiciones de trabajo dependen en gran medida de su salario, del tamaño de su familia, de su nivel de educación y del acceso que tengan a los servicios de salud. Estas variables, que están relacionadas con el nivel de desarrollo alcanzado por una nación y con la organización del grupo familiar, son claves para garantizar la satisfacción de las necesidades básicas. Estas necesidades básicas incluyen una nutrición adecuada, que es decisiva dada la intensidad del esfuerzo exigido a los trabajadores forestales. En muchas regiones, incluso los trabajadores que viajan siguen necesitando protección contra a las condiciones climáticas adversas durante los descansos, sobre todo contra la lluvia y el frío. Existen refugios móviles especialmente diseñados y equipados para el aprovechamiento forestal. Si no se dispone de estos refugios forestales, los utilizados en las obras de construcción también pueden servir a estos fines. La situación en los campamentos es diferente, ya que su calidad depende de las instalaciones proporcionadas por la empresa en términos de infraestructuras y mantenimiento. Por consiguiente, a continuación se comentan las condiciones de vida en los campamentos forestales por lo que se refiere a la vivienda, el ocio y la alimentación.

\section{Infraestructura de los campamentos}

Los campamentos pueden definirse como hogares temporales para trabajadores forestales que trabajan en lugares alejados o de difícil acceso. Para cumplir sus fines, los campamentos deben proporcionar al menos niveles mínimos de higiene y confort. Por consiguiente, es importante plantear la pregunta: ¿cómo interpretan diferentes personas cuáles deben ser estos niveles mínimos? El concepto es subjetivo, pero es posible afirmar que, en el caso de un campamento, las condiciones mínimas necesarias son que la infraestructura proporcione instalaciones y servicios básicos coherentes con la dignidad humana, que cada trabajador pueda compartir con los demás de la plantilla sin tener que alterar significativamente sus costumbres 0 creencias personales.

Una cuestión que es necesario plantearse al planificar un campamento forestal es el tiempo que permanecerá en un lugar determinado. Como por lo común las faenas deben desplazarse de un lado a otro, los campamentos fijos, aunque más fáciles de montar y mantener, no suelen ser la mejor solución. En general, las estructuras móviles son las más prácticas y deben ser fáciles de desmontar y trasladar de un sitio a otro; lo cual, por otra parte, resulta problemático pues es fácil que hasta los módulos mejor construidos se deterioren con los traslados. Por consiguiente, las condiciones de los campos móviles suelen ser muy primitivas.

En términos de instalaciones, un campamento debe ofrecer un suministro de agua adecuado, suficientes dormitorios, cocina, cuartos de baño e instalaciones de recreo. Las dimensiones de cada sitio dependerán del número de personas que lo vayan a utilizar. A demás, deberá haber almacenes independientes para alimentos, combustibles, herramientas y materiales.

Los dormitorios deben permitir que los trabajadores mantengan su intimidad. Como esto no suele ser posible en un campamento, no deberá haber más de seis personas en cada dormitorio. Este número se ha establecido por experiencia, ya que se ha visto que una estructura plegable puede alojar a seis personas cómodamente, dejando espacio suficiente para instalar taquillas en las que puedan guardar sus pertenencias personales. En claro contraste con este ejemplo, un dormitorio abarrotado y sucio no es en absoluto adecuado para el uso humano. Lo correcto es que esté limpio, que la ventilación sea buena y el ambiente mínimamente agradable (p. ej., con cortinas y colchas del mismo color).

La cocina, por su parte, constituye una de instalaciones más importantes de un campamento. El primer requisito es que las personas encargadas de la cocina estén cualificadas en higiene y manipulación de alimentos. Deben tener licencia de una autoridad competente y ser supervisados periódicamente. La cocina debe ser fácil de limpiar y tener espacio adecuado para almacenar alimentos. Si se almacenan alimentos para una o dos semanas, la cocina deberá disponer de un frigorífico para conservar los alimentos perecederos. A los trabajadores les puede resultar incómodo y dilatorio tener que volver al campo para almorzar: es necesario disponer de medidas higiénicas para empaquetar los almuerzos a fin de que los trabajadores puedan Ilevárselos ellos mismos o para que alguien se los lleve al lugar de trabajo. 
Con respecto a las instalaciones de recreo, suelen utilizarse los comedores para este fin. Si los trabajadores están faenando todo el día y el único lugar para relajarse es el comedor, esta habitación debe tener una infraestructura suficiente para que los trabajadores se sientan cómodos y se recuperen física y mentalmente de su jornada laboral. D ebe existir ventilación adecuada $y$, si el clima lo requiere, calefacción. Las mesas de comedor deben servir para un máximo de seis personas y tener una superficie fácil de limpiar. Si el comedor también se utiliza con fines recreativos, deberá tener, si es posible, una televisión o radio que permita a los trabajadores mantenerse en contacto con el resto del mundo. También es aconsejable disponer de algunos juegos de mesa, como damas, cartas y dominós. Como entre los trabajadores forestales hay un contingente importante de trabajadores jóvenes, no es mala idea disponer una zona en la que puedan practicar deportes.

Un aspecto muy importante es la calidad de las instalaciones sanitarias, las duchas y las instalaciones para que los trabajadores laven y sequen sus pertenencias. $\mathrm{H}$ a de tenerse en cuenta que las heces y los desechos en general son una de las vías más comunes de transmisión de enfermedades. Por consiguiente, es mejor obtener agua de un pozo profundo que de uno poco profundo. Si pueden instalarse bombas eléctricas, podrá extraerse el agua del pozo a unos depósitos de los que pueda abastecerse el campamento. En cualquier caso, la eliminación de los desechos humanos y de otro tipo debe realizarse con cuidado, asegurándose sobre todo de no descargarlos en áreas próximas a los lugares donde se conservan los alimentos o donde se obtiene el agua potable.

\section{Nutrición}

L a nutrición es una necesidad básica para el mantenimiento de la vida y la salud de todos los seres humanos. La comida no sólo proporciona nutrientes sino la energía necesaria para realizar todas las actividades de la vida diaria. En el caso de los trabajadores forestales, el contenido calórico de los alimentos consumidos es especialmente importante porque la mayor parte de las actividades de aprovechamiento, manipulación y protección forestal exigen un gran esfuerzo físico (véanse datos sobre consumo de energía en el trabajo forestal en el artículo titulado "Carga física" en este mismo capítulo). Por consiguiente, los trabajadores forestales necesitan más nutrición que las personas que realizan trabajos menos exigentes. Si un trabajador no consume energía suficiente para compensar el gasto energético diario, al principio agotará las reservas acumuladas en la grasa corporal, perdiendo peso. Sin embargo, esto sólo puede hacerse durante un tiempo limitado. Se ha observado que, a medio plazo, los trabajadores que no obtienen en su dieta la energía equivalente a su gasto diario limitan su actividad y reducen su producción. En consecuencia, si trabajan a destajo, sus ingresos también disminuyen.

Antes de analizar la cantidad de energía que debe consumir un trabajador en su dieta, merece la pena mencionar que el trabajo en la moderna industria forestal se basa en tecnologías cada vez más sofisticadas, que reemplazan la energía humana por la de la maquinaria. En esas situaciones, los operarios corren el riesgo de consumir más energía de la que necesitan, acumulando el exceso en forma de grasa y arriesgándose a sufrir obesidad. En la sociedad moderna, la obesidad es una enfermedad que afecta a muchas personas, pero es rara en los trabajadores forestales que emplean métodos tradicionales. De acuerdo con los estudios realizados en Chile, es cada vez más común entre los maquinistas. La obesidad disminuye la calidad de vida porque se asocia a una menor forma física, predisponiendo a quienes la padecen a sufrir accidentes y enfermedades tales como las afecciones cardiovasculares y más lesiones en músculos y articulaciones.

Por este motivo, todos los trabajadores forestales, tanto si su actividad diaria es intensa o sedentaria, deberán tener acceso a una dieta equilibrada que les proporcione cantidades adecuadas de energía. L a clave es enseñarles a autorregular sus necesidades alimenticias. Por desgracia, es un problema de difícil solución; la tendencia observada en los estudios realizados en $C$ hile es que los trabajadores consumen todos los alimentos que les proporciona la empresa y, en general, su dieta les sigue pareciendo insuficiente aunque sus variaciones de peso indiquen lo contrario. Por tanto, la solución es enseñar a los trabajadores a que aprendan a comer en función de sus necesidades de energía.

Si a los trabajadores se les informa correctamente acerca de los problemas que provoca comer demasiado, los campamentos deben ofrecer dietas que tengan en cuenta a los trabajadores con mayor gasto energético. La ingesta y el gasto de energía del cuerpo humano se expresa por lo común en kilojulios. Sin embargo, la unidad más conocida es la kilocaloría. La cantidad de energía que necesita un trabajador forestal cuando el trabajo exige un intenso esfuerzo físico, como en el caso del operario de una motosierra o de un trabajador que utilice un hacha, puede llegar a 5.000 calorías diarias o incluso más. Sin embargo, para gastar tan grandes cantidades de energía, un trabajador debe estar en muy buena forma física y llegar al final de la jornada laboral sin sufrir una fatiga excesiva. Los estudios realizados en Chile han dado lugar a la recomendación de suministrar una media de 4.000 calorías diarias, distribuidas en tres comidas básicas: desayuno, almuerzo y cena. Ello permite tomar un tentempié a media mañana y otro a media tarde para obtener cantidades adicionales de energía. L os estudios realizados a lo largo de períodos de más de un año han demostrado que, con un sistema como el descrito, los trabajadores tienden a mantener su peso corporal y aumentar su rendimiento y sus ingresos cuando su remuneración va ligada a su producción.

U na buena dieta debe ser equilibrada y proporcionar, además de energía, nutrientes esenciales para el mantenimiento de la vida y la salud, como una cantidad adecuada de carbohidratos, proteínas, grasas, minerales y vitaminas. $L$ a tendencia existente en los países en desarrollo es que los grupos con menor renta consuman menos proteínas y grasas y mayores cantidades de carbohidratos. A demás, se ha observado una carencia de ciertas vitaminas y minerales debido al bajo consumo de alimentos de origen animal, frutas y verduras. En resumen, la dieta debe ser variada para equilibrar la ingesta de nutrientes esenciales. La opción más conveniente es pedir consejo a dietistas especializados que conozcan las demandas del trabajo intenso. Ellos pueden preparar dietas que sean razonablemente rentables y que tengan en cuenta los sabores, las tradiciones y las creencias de los consumidores y proporcionen las cantidades de energía que necesitan los trabajadores forestales para su labor diaria.

Un elemento muy importante es el suministro de líquidos de buena calidad, no contaminados y en cantidad suficiente. En el trabajo manual y con motosierras a muy altas temperaturas, un trabajador necesita aproximadamente 1 litro de líquido por hora. La deshidratación reduce drásticamente la capacidad de trabajo y de concentración, aumentando de este modo el riesgo de accidente. Por tanto, es necesario disponer de agua, té u otras bebidas adecuadas tanto en el lugar de trabajo como en el campamento.

El consumo de alcohol y drogas debe estar rigurosamente prohibido. Fumar tabaco, que constituye un peligro de incendio además de un peligro para la salud, sólo debe estar permitido en áreas restringidas y nunca en los dormitorios, áreas de recreo, comedores y lugares de trabajo. 


\section{Comentarios}

Este artículo ha tratado algunas de las medidas generales que pueden mejorar las condiciones de vida y la dieta de los campamentos forestales. Pero aunque estos dos aspectos son fundamentales, no son los únicos. También es importante diseñar el trabajo de manera ergonómicamente apropiada, porque los accidentes, enfermedades profesionales y la fatiga general que provocan estas actividades repercuten en la producción y, en consecuencia, en los ingresos. Este último aspecto del trabajo forestal es de vital importancia para los trabajadores y sus familias disfruten de una mejor calidad de vida.

\section{- Pro blemas para la SALU d del MEDIO AMBIENTE}

\section{Shane M cM ahon}

Las operaciones forestales afectan siempre al medio ambiente de un modo u otro. Algunos de estos efectos pueden ser beneficiosos, mientras que otros pueden ser perjudiciales. Son estos últimos, desde luego, los que tanto las autoridades reguladoras como la opinión pública miran con inquietud.

\section{El medio ambiente}

Cuando hablamos del medio ambiente, solemos pensar en los componentes físicos y biológicos del mismo: es decir, el suelo, la fauna y la flora y las vías fluviales. Cada vez más, los valores culturales, históricos y de ocio asociados con estos componentes más fundamentales se consideran parte del medio ambiente. El estudio del efecto de la ordenación y las operaciones forestales a nivel paisajístico, no sólo sobre los objetivos físicos y biológicos sino también sobre los valores sociales, ha comportado la evolución de conceptos tales como conservación de los ecosistemas y administración forestal. Por consiguiente, este comentario sobre la salud del medio ambiente también trata algunas de las repercusiones sociales.

\section{No todo son malas noticias}

Es comprensible que la atención tanto de los que dictan las normas como de la opinión pública con respecto a la industria forestal en todo el mundo se haya enfocado - y seguirá enfocándose- a los efectos negativos del medio ambiente para la salud.

Tabla $68.10 \bullet$ Posibles beneficios para la salud del medio a mbiente.

\begin{tabular}{|c|c|}
\hline $\begin{array}{l}\text { Operaciones } \\
\text { forestales }\end{array}$ & Posibles beneficios \\
\hline \multirow{5}{*}{$\begin{array}{l}\text { Plantación } \\
\text { (forestación) }\end{array}$} & Mayor absorción de carbono (efecto complejante) \\
\hline & Mayor estabilidad de la pendiente \\
\hline & $\begin{array}{l}\text { Mayores oportunidades de recreo (bosques de } \\
\text { esparcimiento) }\end{array}$ \\
\hline & Mayor biodiversidad paisajística \\
\hline & Control de inundaciones \\
\hline \multirow[t]{3}{*}{ Aprovechamiento } & Mayor acceso para el público \\
\hline & $\begin{array}{l}\text { Reducción del riesgo de enfermedades y de incendios } \\
\text { descontrolados }\end{array}$ \\
\hline & $\begin{array}{l}\text { Fomento del desarrollo por separado de los bosques } \\
\text { naturales }\end{array}$ \\
\hline
\end{tabular}

A pesar de ello, la industria forestal puede beneficiar al medio ambiente. La Tabla 68.10 destaca algunas de las posibles ventajas de la plantación de especies de árboles comerciales y del aprovechamiento tanto de bosques naturales como de plantaciones. Estas ventajas pueden utilizarse para contribuir a establecer el efecto neto (suma de efectos positivos y negativos) de la ordenación forestal para la salud del medio ambiente. El que dichas ventajas se acumulen, y en qué medida, dependerá de las prácticas adoptadas (p. ej., la biodiversidad depende de la combinación de especies, de la extensión de los monocultivos silvícolas y del tratamiento de los vestigios de la vegetación natural).

\section{Problemas para la salud del medio ambiente}

A pesar de que existen importantes diferencias en todo el mundo en cuanto a los recursos forestales, las disposiciones en materia ambiental y las inquietudes ecológicas, así como en las prácticas forestales, muchos de los problemas actuales para la salud del medio ambiente son genéricos en la industria forestal. Esta visión general se centra en los siguientes problemas:

- disminución de la calidad del suelo;

- erosión del suelo;

- cambios en la calidad y cantidad del agua (incluida la sedimentación);

- repercusiones sobre la biodiversidad;

- percepción negativa de la industria forestal por parte de la opinión pública,

- descarga de productos químicos (aceites y plaguicidas) al medio ambiente.

El grado de inquietud que estos problemas genéricos despierte en una zona determinada dependerá en gran medida de la sensibilidad de la zona forestal y de la naturaleza de los recursos hídricos y de los usuarios del agua situados corriente abajo 0 fuera del bosque.

Las actividades en las áreas forestales pueden afectar a otras áreas. Pueden hacerlo de manera directa (efectos visuales) o indirecta (efectos de la mayor cantidad de sedimentos suspendidos en actividades de explotación marítima). Por consiguiente, es importante reconocer las vías que enlazan a diferentes partes del medio ambiente. Por ejemplo: saca con arrastradores $\rightarrow$ tierras de las riberas $\rightarrow$ calidad de las aguas fluviales $\rightarrow$ usuarios del agua situados corriente abajo con fines recreativos.

\section{Disminución de la calidad del suelo}

La ordenación forestal puede afectar a la calidad del suelo (Powers y cols. 1990; FAO/CEPE/OIT 1989 1994). Donde se plantan bosques para rehabilitar suelos degradados, como suelos erosionados 0 que han sufrido sobreexplotación minera, este efecto neto puede ser un aumento de la calidad mejorando la fertilidad del suelo y el desarrollo estructural. A la inversa, las actividades forestales en suelos de alta calidad pueden reducir esta calidad. Las actividades que provocan el agotamiento de los nutrientes, la pérdida de materia orgánica y pérdida estructural por compactación son particularmente importantes.

Los nutrientes del suelo son utilizados por la vegetación durante el ciclo de crecimiento. Algunos de estos nutrientes pueden volver al suelo con la caída de hojarasca, los árboles muertos o los residuos de la saca forestal. Cuando todo el material vegetativo se elimina durante el aprovechamiento (es decir, durante la corta del árbol entero) estos nutrientes se eliminan del ciclo nutricional de la estación. Con los sucesivos ciclos de crecimiento y aprovechamiento, la reserva de nutrientes disponibles en el suelo puede disminuir hasta niveles que no pueden sostener los ritmos de crecimiento y la situación nutricional silvícola. 
La quema de los residuos de saca ha sido en el pasado el medio preferido para favorecer la regeneración o preparar una estación para plantar. Sin embargo, las investigaciones realizadas han demostrado que las quemas intensamente calientes pueden provocar la pérdida de nutrientes del suelo (carbón, nitrógeno, azufre y algo de fósforo, potasio y calcio). L as consecuencias del agotamiento de la reserva de nutrientes del suelo pueden ser la reducción del crecimiento de árboles y cambios en la composición de especies. La práctica de reemplazar los nutrientes perdidos por medio de fertilizantes inorgánicos puede resolver parte del problema. Sin embargo, esto no mitiga los efectos de la pérdida de materia orgánica, que es un medio importante para la fauna del suelo.

EI uso de maquinaria pesada para el aprovechamiento y los preparativos de plantación puede provocar la compactación del suelo. La compactación puede reducir la circulación de aire y agua en el suelo y aumentar la resistencia del mismo hasta el punto de que ya no puedan penetrarlo las raíces de los árboles. En consecuencia, la compactación de los suelos forestales puede reducir el crecimiento y la supervivencia de los árboles y aumentar las escorrentías pluviales y la erosión del suelo. Es importante observar que, sin cultivos, la compactación de los subsuelos puede persistir durante 20030 años después de la saca forestal. Cada vez se utilizan más los métodos de saca que reducen las áreas y el grado de compactación para reducir la disminución de la calidad del suelo. Los repertorios de recomendaciones prácticas en materia forestal adoptados en un número cada vez mayor de países y comentados en el artículo titulado "N ormas, legislación, disposiciones y recomendaciones en la práctica forestal" en este mismo capítulo ofrecen orientación sobre tales métodos.

\section{E rosión del suelo}

La erosión del suelo es un motivo de preocupación importante para todos los usuarios de terrenos, ya que puede provocar la pérdida irreversible de suelos productivos, repercutir negativamente en los valores visuales y de ocio y afectar a la calidad del agua (Brown 1985). Los bosques protegen a los suelos de la erosión:

- interceptando las lluvias;

- regulando los niveles de las aguas freáticas;

- aumentando la estabilidad de las pendientes con el crecimiento de las raíces

- protegiendo el suelo de los efectos de vientos y heladas.

Ahora bien, cuando se realiza el aprovechamiento de una superficie forestal, el nivel de protección del suelo se reduce significativamente, aumentando las posibilidades de erosión.

Es de dominio general que las operaciones forestales asociadas a las siguientes actividades contribuyen de manera importante a aumentar la erosión del suelo durante el ciclo de explotación forestal:

- construcción de carreteras;

- movimiento de tierras;

- corta;

- quema,

- cultivo.

Las actividades de construcción de carreteras, sobre todo en terrenos abruptos donde se utilizan terraplenes, producen superficies importantes de tierras sueltas sin consolidar que se ven expuestas a las lluvias y las escorrentías. Si no se mantiene el control del drenaje de carreteras y caminos, pueden canalizar las escorrentías pluviales, aumentando la posibilidad de que se erosione el suelo en la parte baja de las pendientes y en los bordes de las carreteras.
El aprovechamiento forestal aumenta la erosión del suelo de cuatro maneras:

- exponiendo la superficie del suelo a la lluvia;

- reduciendo el consumo de agua por parte de los rodales, aumentando así el contenido de agua del suelo y los niveles de las aguas freáticas;

- provocando el declive gradual de la estabilidad de las pendientes a medida que se descomponen los raigales,

- perturbando los suelos durante la extracción de madera.

La quema y el cultivo son dos técnicas que suelen utilizarse para preparar una estación para su regeneración o plantación. Estas prácticas pueden aumentar la erosión superficial exponiendo la superficie del suelo a los efectos erosivos de la lluvia.

El grado de aumento de la erosión del suelo, bien por erosión superficial o bien por consunción masiva, dependerá de muchos factores, entre ellos el tamaño de la superficie talada, los ángulos de las pendientes, la resistencia de los materiales de las pendientes y el tiempo transcurrido desde el aprovechamiento. Las grandes cortas a hecho (es decir, eliminación total de casi todos los árboles) pueden provocar una grave erosión.

El potencial de erosión del suelo puede ser muy alto durante el primer año después del aprovechamiento en comparación con antes de la construcción de una carretera y de un aprovechamiento. A medida que comienza a crecer el cultivo repoblado o regenerado, el riesgo de erosión del suelo disminuye a medida que aumenta la intercepción del agua (protección de la superficie del suelo) y la transpiración. $\mathrm{H}$ abitualmente, el potencial de aumento de la erosión disminuye hasta los niveles previos al aprovechamiento una vez que la cubierta forestal tapa la superficie del suelo (cierre de la cubierta).

Los encargados de la ordenación forestal intentan reducir el período de vulnerabilidad o el área de captación vulnerable en un momento dado. Dos posibles alternativas son la ejecución gradual del aprovechamiento para extenderlo a varias áreas de captación y reducir el tamaño de cada una de las áreas de aprovechamiento.

\section{Cambios en la calidad y cantidad del agua}

La calidad del agua descargada desde áreas forestales de captación no perturbadas suele ser muy alta, en comparación con las áreas de captación agrícolas y hortícolas. Ciertas actividades forestales pueden reducir la calidad del agua descargada aumentando el contenido de nutrientes y sedimentos, aumentando la temperatura del agua y disminuyendo los niveles de oxígeno disuelto.

Las mayores concentraciones y exportaciones de nutrientes de áreas forestales que se han incendiado, que han visto perturbado su suelo (escarificación) o en las que se han aplicado fertilizantes, pueden afectar negativamente al crecimiento de plantas acuáticas y provocar contaminación de las aguas corriente abajo. En particular, el nitrógeno y el fósforo son importantes debido a su asociación con el desarrollo de algas tóxicas. Asimismo, la mayor aportación de sedimentos a las vías fluviales puede afectar negativamente a la vida marina y de agua dulce, al potencial de inundaciones y a la utilización de agua para usos de boca 0 industriales.

La eliminación de la vegetación de las riberas y la introducción de material verde y leñoso en las vías fluviales durante las operaciones de clareo o aprovechamiento pueden afectar negativamente al ecosistema acuático al aumentar la temperatura del agua y los niveles de oxígeno disuelto en el agua, respectivamente.

La industria forestal también puede repercutir en el volumen estacional de agua que sale de un área de captación forestal (agua aflorada) y en los picos de descarga durante tormentas. La 
plantación de árboles (forestación) en áreas de captación que con anterioridad han estado bajo un régimen agrícola de pastoreo puede reducir el afloramiento de agua, algo que debe tenerse en cuenta si los recursos hídricos existentes debajo de una zona aforestada se utilizan con fines de riego.

A la inversa, la explotación en un bosque existente puede aumentar el afloramiento de agua debido a la pérdida de transpiración e intercepción de aguas, aumentando las posibilidades de inundación y erosión en las vías fluviales. Las dimensiones de un área de captación y la proporción aprovechada en un momento dado influirán en el nivel de aumento de un determinado afloramiento de agua. Cuando sólo se aprovechan pequeñas partes de un área de captación, como ocurre con las cortas de parcelas, los efectos sobre el afloramiento pueden ser mínimos.

\section{Repercusiones sobre la biodiversidad}

La biodiversidad de plantas y animales en áreas forestales se ha convertido en una cuestión importante para la industria forestal de todo el mundo. La diversidad es un concepto complejo, que no se limita exclusivamente a las diferentes especies de plantas y animales. La biodiversidad también se refiere a la diversidad funcional (la función de una especie determinada en el ecosistema), la diversidad estructural (acodadura dentro de la cubierta forestal) y diversidad genética (K immins 1992). Las operaciones forestales pueden afectar a la diversidad de las especies así como a la diversidad estructural y funcional.

Identificar la combinación óptima de especies, edades, estructuras y funciones es una cuestión subjetiva. La opinión más extendida es que un nivel bajo de diversidad estructural y de especies predispone a un bosque a un mayor riesgo de perturbación por el ataque de un patógeno o plaga. $\mathrm{H}$ asta cierto punto es cierto; sin embargo, cada una de las especies de un bosque natural mixto puede sufrir exclusivamente una determinada plaga. Un bajo nivel de biodiversidad no implica que una diversidad escasa sea un efecto antinatural e indeseable de la ordenación forestal. Por ejemplo, muchos bosques naturales con mezcla de especies que están sujetos de manera natural a fuegos incontrolados y plagas pasan por fases de baja diversidad estructural y de especies.

\section{Percepción negativa de la industria forestal por parte de la opinión pública}

La percepción y aceptación de la práctica forestal por parte de la opinión pública son dos cuestiones importantes para la industria forestal. M uchas áreas forestales constituyen un valor considerable en términos de ocio y recreo para los residentes y los visitantes. La opinión pública suele asociar las experiencias placenteras al aire libre, con paisajes forestales naturales y ordenados en su madurez. Si el aprovechamiento no se hace con cuidado, sobre todo si se trata de grandes cortas a hecho, la industria forestal puede modificar drásticamente el paisaje, y sus efectos son patentes durante muchos años, al contrario de lo que sucede con otros usos de la tierra, como la agricultura o la horticultura, donde los ciclos de cambio son menos evidentes.

Parte de la respuesta pública negativa a tales actividades procede de una escasa comprensión de los regímenes, prácticas y efectos de la ordenación forestal. Es evidente que la industria forestal tiene la responsabilidad de educar a la opinión pública, modificando al mismo tiempo sus propias prácticas para aumentar su aceptación. Las grandes cortas a hecho y la retención de los residuos de saca (ramas y árboles muertos en pie) son dos problemas que suelen provocar la reacción del público, debido a la asociación de estas prácticas con la percepción de una disminución de la sostenibilidad del ecosistema. Sin embargo, esta asociación puede no basarse en hechos, ya que lo que se valora en términos de calidad visual no implica beneficios para el medio ambiente. La retención de residuos, aunque parezca antiestética, sí proporciona hábitat y alimento a la fauna y permite que funcionen ciertos ciclos de nutrientes y materia orgánica.

\section{Aceites en el medio ambiente}

EI aceite puede llegar al medio ambiente forestal a través de vertidos de aceite y filtros de máquinas, por el uso de aceites para controlar el polvo en caminos sin pavimentar y por el uso las motosierras. Debido a la inquietud por la contaminación del suelo y el agua por aceites minerales, el vertido de aceite y su aplicación en carreteras se están convirtiendo en prácticas inaceptables.

Sin embargo, el uso de aceite mineral para lubricar los sables de las motosierras todavía es una práctica común en gran parte del mundo. Una motosierra utiliza aproximadamente 2 litros de aceite diarios, que suman cantidades de aceite considerables a lo largo de un año. Por ejemplo, se ha calculado que el consumo de aceite en motosierras fue de unos 8 a 11,5 millones de litros anuales en Alemania, de unos 4 millones de litros anuales en Suecia y de unos 2 millones de litros anuales en N ueva Zelanda.

El aceite mineral se ha vinculado con trastornos cutáneos (Lejhancova 1968) y problemas respiratorios (Skyber y cols. 1992) en trabajadores que están en contacto con el mismo. Además, la descarga de aceite al medio ambiente puede provocar contaminación del suelo y el agua. Skoupy y U Irich (1994) cuantificaron el destino del lubricante de los sables de las motosierras y hallaron que entre un 50 y un $85 \%$ se incorporaba al serrín, entre un 3 y un $15 \%$ permanecía en los árboles, menos del $33 \%$ se descargaba al suelo del bosque y el 0,5\% se pulverizaba sobre el operario.

Como respuesta a las preocupaciones de índole ecológica se ha hecho obligatorio el uso de aceites biodegradables en los bosques suecos y alemanes. Basados en la colza 0 en aceites sintéticos, estos aceites respetan más al medio ambiente y al trabajador, y también pueden rendir mejor que los lubricantes minerales, ya que ofrecen una mayor duración de la cabina y menor consumo de aceite y combustible.

\section{U so de herbicidas e insecticidas}

La industria forestal emplea herbicidas (productos químicos que matan plantas) para reducir la competición de las malas hierbas por el agua, la luz y los nutrientes con árboles en regeneración o jóvenes árboles recién plantados. Los herbicidas suelen ofrecer una alternativa rentable al control mecánico o manual de malas hierbas.

A pesar de la desconfianza generalizada con respecto a los hercibidas, posiblemente a consecuencia del uso del Agente $\mathrm{N}$ aranja durante la guerra del Vietnam, en realidad no está documentado que los herbicidas utilizados en el aprovechamiento forestal hayan repercutido negativamente en los suelos, la fauna y los seres humanos (K immins 1992). Ciertos estudios han hallado reducciones en las cifras de mamíferos después de un tratamiento con herbicidas. Sin embargo, estudiando también los efectos del control manual o mecánico de malas hierbas, se ha demostrado que estas disminuciones coinciden con la pérdida de vegetación más que con el propio herbicida. L os herbicidas rociados cerca de vías fluviales pueden entrar en el agua y ser transportados por ella, aunque las concentraciones de herbicidas suelen ser bajas y duran poco tiempo, ya que se diluyen (Brown 1985). 
Antes del decenio de 1960, el uso de insecticidas (productos químicos que matan insectos) por los sectores agrícolas, hortícolas y de salud pública estaba muy extendido, utilizándose cantidades menores en la industria forestal. U no de los insecticidas más utilizados durante esta época tal vez fuera el DDT. La reacción de la opinión pública a las cuestiones de salud ha refrenado en gran medida el uso indiscriminado de insecticidas, dando lugar al desarrollo de prácticas alternativas. Desde el decenio de 1970, se han dado pasos hacia el uso de organismos que provocan enfermedades en los insectos, la introducción de plagas y depredadores para los insectos y la modificación de los regímenes silvícolas para reducir el riesgo de ataque por insectos.

\section{Referencias}

Apud, E, L Bostrand, I Mobbs, B Strehlke. 1989. Guidelines on Ergonomic Study in Forestry. Ginebra: OIT.

Apud, E, S Valdés. 1995. E rgonomics in Forestry- The Chilean Case Ginebra: OIT

Banister, E, D R obinson, D T rites. 1990. E rgonomics of T ree Planting. Canada-British Columbia Forest Resources Development Agreement, FRDA Report 127. Victoria, Columbia Británica: FRDA.

Brown, GW. 1985. Forestry and W ater Quality. Corvallis, O regón: Universidad Estatal de O regón (OSU) Book Stores Inc.

Chen, K T. 1990. L ogging A ccidents- An E merging P roblem. Sarawak, Malaisia: O ccupational Health Unit, M edical D epartment.

Dummel, K, H Branz. 1986. "H olzernteverfahren," Schriften Re eihefdes B undesministers für $\mathrm{E}$ rnätrung, $\mathrm{H}$ andwirtschaft und $F$ orsten. R eihe $A$ : $L$ andwirtschafts verlag $M$ ünster-H iltrup.

Durnin, JVGA, R Passmore. 1967. Energy, W ork, Lèsure Londres: H einemann.

FAO/ECE/ILO . 1989. Impact of M echanization of Forest 0 perations on the Soil. Actas de un seminario, Louvain-la-neuve, Bélgica, 11-15 septiembre. Ginebra: Comité mixto FAO/CEE/OIT sobre T ecnología forestal, gestión y formación.

-.1991 . The U se of Pesticides in Forestry. Actas de un seminario, Sparsholt, R eino U nido, 10-14 septiem bre 1990.

- 1994. Soil, Tree M achine Interactions, FORSIT RISK Proceedings of an interactive workshop and seminar, Feldafiraf, Alemania, 4-8 julio. Ginebra: FAO/CEE/OIT Comité mixto sobre Tecnología forestal, gestión y formación.

- 1996a. M anual on Acute Forest Damage. NU/CEE/FAO documentos de debate CEE / TIM / DP / 7, N ueva Y ork y Ginebra: Comite mixto FAO/CEE/OIT sobre Tecnología forestal, gestión y formación.

- 1996b. Skills and Training in Forestry-Results of a Survey of ECE Member Countries. Ginebra: FAO/CEE/OIT Comité mixto sobre T ecnología forestal, gestión y formación.

FAO / O IT. 1980. Chainsaws in T ropical Forests. Forest T raining Series $\mathrm{N} \cong 2$. R oma: FAO

Gellerstedt, S. 1993. W ork and $\mathrm{H}$ ealth in Forest W ork. Göteborg: Universidad de Tecnología de Chalmers.

Giguère, $D, R$ Bélanger, J-M Gauthier, C Larue 1991. É tude préliminaire du travail de reboisement. R apport IR SST B-026. M ontreal: IR SST

-.1993 . Ergonomics aspects of tree planting using multi-pot technology. E rgonomics 36(8):963-972.

Golsse, JM. 1994. Revised FE RIC E rgonomic Checklist for Canadian F orest $M$ achinery. Pointe Claire: Forest Engineering $R$ esearch institute of $C$ anada.

H aile, F. 1991. W omen Fuelwood Carriers in Addis Ababa and the Peri-urban Forest. R esearch on women in fuelwood transport in Addis Ababa, Ethiopia ETH/88/MO1/IRDC y ETH/89/MO5/NOR. Project report. Ginebra: OIT.

$\mathrm{H}$ arstela, P. 1990. Work postures and strain of workers in N ordic forest work: A selective review. Int J Ind Erg 5:219-226.
Jokulioma, H , H T apola. 1993. Forest worker safety and health in Finland. U nasylva 4(175):57-63.

Juntunen, M L. 1993. T raining of harvester operations in Finland. Presentado en Seminar on the use of multifunctional machinery and equipment in logging operations. O lenino L ogging Enterprise, T vor R egion, Federación R usa 22-28 agosto.

- 1995. Professional harvester operator: Basic knowledge and skills from training-O perating skills from working life? Presentado en IUFRO XX World Congress, T ampre, Finlandia, 6-12 agosto.

K anninen, K. 1986. The occurrence of occupational accidents in logging operations and the aims of preventive measures. En las actas de un seminario sobre salud en el trabajo y rehabilitación de los trabajadores forestales, Kuopio, Finlandia, 3-7 junio 1985. FAO/CEE/OIT Comité mixto sobre Técnicas de trabajo forestal y formación de los trabajadores forestales

K antola, M , P H arstela. 1988. H andbook on A ppropriate $T$ echnology for $F$ orestry 0 perations in D eveloping Counties, Part 2. Forestry Training Programme Publication 19. Helsinki: National Board of V ocational Education.

K astenholz, E. 1996. Sicheres $\mathrm{H}$ andeln bei der $\mathrm{H}$ olzernteuntersuchung von Einflüssen auf das U nfallgeschehen bei der $W$ aldarbeit unter besonderer $B$ erücksichtigung der $L$ ohnform. Disertación doctoral. Friburgo, Alemania: U niversidad de Friburgo.

K immins, H . 1992. Balancing Act- E nvironmental I ssues in Forestry. V ancouver, Columbia Británica: U niversity of British Columbia Press.

Lejhancova, M. 1968. Skin damage caused by mineral oils. Procovni L ekarstvi 20(4):164-168.

Lidén, E. 1995. Forest M achine Contractors in Swedish Industrial Forestry: Significance and Conditions during 1986-1993. Department of O perational Efficiency R eport N o. 195. U niversidad Sueca de Ciencias de la Agricultura.

M inistry of Skills D evelopment. 1989. Cutter-skidder Oprator: Competency-based T raining Standards. O ntario: $M$ inistry of Skills D evelopment.

M oos, H, B K vitzau. 1988. R etraining of adult forest workers entering forestry from other occupation. En Proceedings of Seminar on the Employment of Contractors in F orestry, L oubières, F rance 26-30 September 1988. Loubiéres: FAO/CEE/OIT Comité mixto sobre T écnicas del trabajo forestal y formación de los trabajadores forestales

National Proficiency Test Council (NPTC) y Scottish Skill Testing Service (SST S). 1992. Schedule of Chainsaw Standards. Warwickshire, R eino U nido: NPT C y SST S.

-.1993 . Certificates of Competence in Chainsaw O peration. Warwickshire, Reino Unido: National Proficiency T ests C ouncil y Scottish Skills T esting Service.

O rganización de las $\mathrm{N}$ aciones U nidas para la Agricultura y la Alimentación (FAO). 1992. Introduction to E rgonomics in Forestry in Developing Countries. Forestry Paper 100. R oma:FAO

- .1995. F orestry- Statistics T oday for T omorrow. R oma: FAO

-.1996 . FAO M odel Code of $\mathrm{F}$ orest $\mathrm{H}$ arvesting Practice. Roma: FAO

O rganización Internacional de Normalización (ISO). 1986. E quipment for W orking the Soil: ROPS- Labora- tory Testing and Performance Specifications. ISO 3471-1. Ginebra: ISO

Organización Internacional del Trabajo (OIT) 1969. Seguridad e higiene en los trabajos forestales. Repertorio de recomendaciones prácticas de la OIT. Ginebra: OIT

- 1988. M aximum W eights in Load Lifting and Carrying. O ccupational Safety and Health Service, No. 59. Geneva: ILO.

- 1991. Salud e higiene en el trabajo forestal. Informe II Forestry and Wood Industries Committee, Sesión segunda. Ginebra: OIT.

- .1997. Repertorio de recomendaciones prácticas sobre Salud e higiene en los trabajos forestales. M EFW/ 1997/ 3. Ginebra: OIT.

- .1998. Repertorio de recomendaciones prácticas sobre Seguridad e higiene en los trabajos forestales. Ginebra: OIT.

Patosaari, P. 1987. Chemicals in Forestry: $\mathrm{H}$ ealth $\mathrm{H}$ azards and Protection. Report to the FAO/CEE/OIT Comité mixto sobre T écnicas del trabajo forestal y formación de los trabajadores forestales, H elsinki (mimeografía).

Pellet. 1995. Rapport d'étude: L'ánalyse de l'áccident par la méthode de l'arbre des causes. Lucerna: Schweizerische U nfallversicherungsanstalt (SUVA) (mimeografía).

Powers, RF, DH Alban, RE Miller, AE Tiarks, CG Wells, PE Avers, RG Cline, RO Fitzgerald, JNS Loftus. 1990. Sustaining site productivity in North American forests: Problems and prospects. En Sustained Productivity of F orest Soils, dirigido por SP Gessed, DS Lacate, GF Weetman y RF Powers. Vancouver, Columbia Británica: Faculty of Forestry Publication.

Robinson, DG, DG Trites, EW Banister. 1993. Physiological effects of work stress and pesticides exposure in tree planting by British Columbian silviculture workers. E rgonomics 36(8):951-961.

Rodero, F. 1987. Nota sobre siniestralidad en incendios forestales. M adrid, España: Instituto $\mathrm{N}$ acional para la Conservación de la Naturaleza.

Saarilahti, M , A Asghar. 1994. Study on winter planting of chir pine. Research paper 12, proyecto OIT, Pakistan.

Skoupy, A , R U Irich. 1994. Dispersal of chain lubrication oil in one-man chain-saws. Forsttechnische Information 11:121-123.

Skyberg, K, A Ronneberg, CC Christensen, CR Naess-Andersen, HE Refsum, A Borgelsen. 1992. Lung function and radiographic signs of pulmonary fibrosis in oil exposed workers in a cable manufacturing company: A follow up study. Brit J Ind M ed 49(5):309-315.

Slappendel, C, I Laird, I Kawachi, S M arshal, C Cryer. 1993. Factors affecting work-related injury among forestry workers: A review. I Saf Res 24:19-32.

Smith, TJ. 1987. O ccupational characteristics of treeplanting work. Sylviculture M agazine II (1):12-17.

Sozialversicherung der Bauern. 1990. Extractos de datos estadísticos oficiales austriacos presentados a la OIT (no publicado).

Staudt, F. 1990. E rgonomics 1990 . Proceedings P3.03 E rgonomics XIX W orld Congress IU FR O, M ontreal, Canada, August 1990. Países Bajos: D epartment of Forestry, Section Forest Technique and Woodscience, U niversidad de Agricultura de W ageningen. 
Stjernberg, EI. 1988. A Study of M anual T ree Planting 0 perations in Central and E astern Canada. FERIC technical report TR-79. M ontreal: Forest Engineering R esearch Institute of $C$ anada.

Stolk, T. 1989. Gebruiker mee laten kiezen uit persoonlijke beschermingsmiddelen. T uin \& Landschap 18.

Strehlke, B. 1989. The study of forest accidents. En Guidelines on Ergonomic Study in Forestry, dirigido por E Apud. Ginebra: OIT.

Trites, DG, DG Robinson, EW Banister. 1993. Cardiovascular and muscular strain during a tree planting season among British Columbian silviculture workers. E rgonomics 36(8):935-949.

U do, ES. 1987. W orking Conditions and Accidents in Nige rian Logging and Sawmilling Industries. Informe de la OIT (sin publicar).

Wettman, 0 . 1992. Securité au travail dans l'exploitation forestière en Suisse. En FAO / CEE / OIT Proceedings of Seminar on the Future of the Forestry W orkforce, dirigido por $\mathrm{FAO} / \mathrm{CEE} / \mathrm{OIT}$. Corvallis, O regón: $O$ regon State U niversity Press.

\section{0 tras lecturas recomendadas}

A pud, E , C Ilabaca. 1993. Diagnóstico del estado actual de la mano de obra en algunas empresas de servicio. En Actas III taller de producción forestal. Concepción: Fundación Chile.

Arteau, J, D T urcot, R Daigle, P D rouin. 1992. Findings from $T$ esting Chain-saw $L$ eg Protective $D$ evices and F ootwear. Actas de NOKOBETEF IV, K ittilä, Finlandia, 5-7 febrero.

Axelsson, S-Å, B Pontén. 1990. N ew ergonomic problems in mechanized logging. Int I Ind $\mathrm{Erg}$ 5:267-273.

Axelsson, S- $\AA$. 1995. Occupational Safety and $H$ ealth in Forestry- An International Study. R esearch Notes No. 280. Garpenberg: Department of O perational Efficiency, C ollege of Forestry, U niversidad Sueca de Ciencias de la Agricultura.

Böltz, K . 1988. Entwicklung der psycho-physischen B elastung und $B$ eanspruchung als $F$ olge der $M$ echanisierung und $T A$ lautomatisierung der $\mathrm{H}$ olsernte. Doktorwurde der Forstwissenschaftlichen Fakultät InauguralDissertation zur Erlangung, Albert-LudwigsU niversite Freiburg im Breisgau.

Bünte, H , W Domschke. 1993. Therapie $H$ andbuch [ $M$ anual de terapia]. M ünchen-W ien-Baltimore: U rban $\&$ Schearzenberg.

BV LB. 1995. Land-und-fortwirtschafitliche M aschinen, Allegemene Prüfliste. Munich: Bundesverband der Landwirtschaftlichen Berufsgenossenchaften.

Cloutier, E ,C Pelletier. 1993. La sécurité en forêt- M achinerie et conditions de travail. M ontreal: IR SST.

Comité conjunto FAO/CEE/OIT. 1994. Clothing and safety equipment in forestry. Proceedings of a Seminar, Kuopio, Finland 27 J une 1 J uly. Kuopio: Comité conjunto FAO/ CEE/OIT.

Comité Europeo de Normalización (CEN). 1994. Agricultural and Forest $M$ achinery: Portable Chainsaws- Safety. R ef. N o EN 608:1994. Bruselas: CEN.

FAO / CEE/ O IT . 1989. Proceedings of a Seminar, J ämsänkoski, Finland 22-26 M ay 1989. H elsinki: Comité conjunto FAO/CEE/OIT sobre Técnicas del trabajo forestal y formación de trabajadores forestales.

Fiji M inistry of Forests. 1990. Fiji National Code of Logging P ractice. Suva: M inistry of Forests.
Florian, H] ,E Stollenz. 1994. Arbeitsmedizin A ktuell [M e dicina de trabajo actual]. Stuttgart-Jena: Gustav Fischer V erlag.

Forest Engineering Working Group of South Africa (FESA). Sin fecha. South African $\mathrm{H}$ arvesting Code of Practice. M atieland: U niversidad de Stellenbosch.

Gäbler, H. 1957. W ildkrankheiten [E nfermedades silvestres] Berlín: D eutscher Landwirtschaftsverlag.

Gaskin, JE. 1989. Analysis of lost-time accidents 1988 (Accident reporting scheme statistics). L ogging Industry Research Association R eport 14 (6), R otorua, N ueva Zelanda: LIR A.

Golsse, JM , J Rickards. 1990. W oodlands equipment maintenance: An analysis of mechanical labour energy expenditure. Int J Ind E rg 5:243-253.

Guo, J. 1989. 0 ccupational Safety and $\mathrm{H}$ ealth in Chinese F orestry. Informe de la OIT (no publicado).

$H$ ansson, JE. 1990. Design of large forestry machines. Int J Ind E rg 5:255-266.

H eikkilä, T, R G rönquist, M Jurvélius. 1993. H andboo on $F$ orest Fire Control-A Guide for T rainers. Forestry Training Programme Publication 21. Helsinki: $\mathrm{Na}$ tional Board of Education.

H eilmeyer, L. 1955. Lehrbuch der Inneren M edizin [M anual de medicina interna]. Berlín: Springer-V erlag.

Juntunen, ML , HL Suomäki. 1992. Continuity in forest contracting companies-A follow up study of 74 Finnish forest contracting entrepreneurs, 1986 and 1991. Presentado en el seminario Future of the forestry workforce at Corvallis, O regón, 4-8 mayo.

K angas, J, A M anninen, J Liesivuori. 1995. O ccupational exposure to pesticides in Finland. International J ournal of Environmental Analytical Chemistry 58:423-429

K len, T , S V äyrynen. 1984. The role of personal protection in the prevention of accidental injuries in the logging work. J 0 ccup Acc 6:263-275.

K nopp, D , S G lass. 1991. Biological monitoring of the 2,4-dichlorphenoxyacetic acid-exposed workers in agriculture and forestry. Int Arch $\mathrm{O}$ ccup $\mathrm{E}$ nviron $\mathrm{H}$ ealth 63:329-333.

K uratorium für Waldarbeit und Forsttechnik (K WF). 1995. Prufliste: Fortspezialxchlepper, R ückezüge, Selbstfahrende Vollernter. Darmstadt: K uratorium für Waldarbeit und Forsttechnik/Deutsche Prüfstelle für Land- und Forttechnik.

Laflamme, L. 1988. M odèles et méthodes d'analyse de l'accident du travail, de l'organisation du travail aux stratégies de prévention. M ontréal, PQ : SyG eSa L tée.

- .1993. Technological improvement of the production process and accidents: An equivocal relation ship. Saf Sci 16:249-266.

Laflamme, L , A Arsenault. 1984. Rémunération postes de travail et accidents: une relation interactive. Relations I ndustrielles 39(3):509-524.

Laflamme, L , E Cloutier. 1988. M echanization and risk of occupational accidents in the logging industry. J 0 ccup Acc 10:191-198.

Lindsay, V, R V isser, M Smith. 1993. N ew Z ealand F orest Code of Practice. R otorua, Nueva Zelanda: Logging Industry R esearch O rganization (LIR O).

M arx, H H. 1987. M edizinische B egutachtung.5., N eubearb. U. E rw. Auflage [O pinión de los expertos médicos]. Stuttgart y N ueva Y ork: G eorg T hieme V erlag.

M SD Sharp \& Dohme. 1984. M SD - M anual der Diagnostik und Therapie. 3., Neubearb. A uflage [M anual of diagnosis and therapy]. M unich-V iena-Baltimore: U rban $\&$ Schwarzenberg.
National Board of Forestry. 1980. The Chain-saw: U se and $M$ aintenance. Suecia: Jönköping.

National Board of Labour Protection. 1988. Industrial Accidents. Labour M arket No. 23. Helsinki, Finlandia: NBLP.

Nilsson, C-A, R Lindahl,. A N orström. 1987. O ccupational exposure to chain-saw exhausts in logging operations. Am Ind H yg A ssoc 」 48:99-105.

O rganización de las $\mathrm{N}$ aciones U nidas para la Agricultura y la Alimentación (FAO). 1985. Logging and $T$ ransport in Steep T errain. R oma: FAO.

-.1986 . W ood Extraction with 0 xen and Agricultural T ractors. FAO Forestry Paper 49. R oma: FAO.

- 1986. Occupational $\mathrm{H}$ ealth and Rehabilitation of $\mathrm{F}$ orest W orkers. Actas del seminario sobre Salud en el trabajo y rehabilitación de los trabajadores forestales, K uopio, Finlandia, 3-7 junio 1985.

- .1987. Appropriate $\mathrm{W}$ ood $\mathrm{H}$ arvesting in Plantation Forests. FAO Forestry Paper 78. R oma: FAO.

- .1992. Introduction to $E$ rgonomics in F orestry in D eveloping Countries. R oma: FAO.

O rganización Internacional del Trabajo (O IT). 1980. Forestry Equipment Planning Guide for Vocational and T echnical training and education programmes. Ginebra: OIT.

- .1987. W ood $\mathrm{H}$ arvesting with $\mathrm{H}$ and T ools: An Illustrated Training $M$ anual. G inebra: OIT

-.1991 . The future of forestry workforce. En General Report of the Forestry and W ood Industries Committee Ginebra: OIT .

-.1992 . Fitting the J ob to the F orest W orker- An Illustrated $T$ raining $M$ anual on $E$ rgonomics. Ginebra: OIT.

Pontén, B. 1988. H ealth R isks in F orest- A Program for ACtion. R eport N o. 77.T esis. G arpenberg: D epartment of O perational Efficiency, SU AS.

Poschen, P. 1991. Forest worker training-A step child no longer? Actas del 10 World Forestry Congress, París 1991, R evue F orestière F rançaise H ors, série N 0. 8

Rummer, R , L Smith. 1990. Ergonomics applied to forest harvesting. Int J Ind E rg 5(3):195-302.

Rummer, RB. 1994. Labor for forestry operations-issues for the 1990s. Transactions of the ASAE 37(2):639-645

Schweizerische Unfallversicherungsanstalt (SUVA). 1986. Roll-over Protection (ROPS). (ISO 8082). Ginebra: ISO .

- .1989. Protection against $\mathrm{F}$ alling 0 bjects (F OPS). (ISO 8083). G inebra: ISO

- .1992. Forstliche Seilkrananlagen - N ormen, R egen, T abellen. Lucerna: SUVA.

Staal Wästerlund, D , F K ufakwandi. 1993. M ejoras de las condiciones de trabajo en ZAFFICO, industria paraestatal de Zambia. U nasylva 172:1.

Sturm, A. 1959. Grundbegriffe der Inneren M edizin. 9. E rg, $T$. N eubearb. Auflage [B ases de la medicina interna]. Jena: VEB G ustav Fischer V erlag.

Sundstrom-Frisk, C. 1984. Behavioural control through piece-rate wages. J 0 ccup Acc 6(1-6):49-59.

W ellburn, V . 1989. E rgonomics and T raining of $W$ orkers for M ountain L ogging. Actas del seminario sobre mecanización de las operaciones de siega en terrenos montañosos, Antalya, Turquía. Ginebra y Roma: FAO/CEE/OIT (no publicado).

Wolff, HP , TR W eihrauch. 1988. Internistische T herapie [T erapia interna]. M unich-V iena-Baltimore: U rban \& Scharzenberg. 
Director del capítulo

G eorge A. Conway

\section{Sumario}

Un perfil de la caza y de la caza con cepo en el decenio de 1990

J ohn N. T rent.

Enfermedades asociadas con la caza y la caza con cepo

M ary E. B rown. . . 


\section{- UN PERFIL DE LA CAZA Y DE LA CAZA CON CEPO EN EL DECENIO DE 1990}

John N. Trent

\section{Panorámica del sector}

La caza y la caza con cepo de animales silvestres son dos actividades muy antiguas del ser humano que persisten en el mundo actual en formas diversas, y que llevan aparejadas la captura y la muerte de especies que viven en hábitat silvestres o relativamente no urbanizados. En todo el mundo se cazan una gran variedad de especies, entre las que figuran mamíferos pequeños, como liebres, conejos y ardillas. Son ejemplos de especies de caza mayor perseguidas por los cazadores el ciervo, el antílope, los osos y los grandes felinos. Entre las aves cazadas con más frecuencia figuran las acuáticas y los faisanes. Por otro lado, la caza con cepo se limita a los animales de pelo que tienen valor comercial, o alguna utilidad práctica para el trampero. En las zonas templadas del hemisferio norte es frecuente la captura con cepos del castor, la rata almizclera, el visón, el lobo, el gato montés, el lince y el mapache.

La caza consiste en el acecho y muerte de animales silvestres individuales, generalmente para obtener alimento 0 vestido 0 por motivos recreativos. En los últimos tiempos, la caza se ha considerado en algunas situaciones como un medio de mantener la continuidad cultural de una cultura indígena. La caza de ballenas de subsistencia en el norte de Alaska es un ejemplo. Los cazadores suelen utilizar armas con proyectiles, como escopetas, rifles 0 arcos y flechas. Los tramperos están más especializados y tienen que capturar un número abundante de mamíferos de pelo sin dañar su piel. Los lazos y las trampas de doble suelo se utilizan desde hace miles de años. Para algunas especies todavía se usan con frecuencia los cepos de presa en la pata (acolchados y no acolchados, mientras que cepos como el "Conibear", que mata al animal al saltar, se utilizan más ampliamente para otras especies.

\section{Evolución y estructura del sector}

En algunas sociedades tradicionales de todo el mundo la caza sigue siendo una actividad de supervivencia individual, básicamente inalterada desde antes de que se produjera la evolución a la ganadería o la agricultura. Sin embargo, hoy en día la caza es para la mayoría de las personas una forma de actividad para ocupar el tiempo de ocio; algunos obtienen ingresos complementarios de su actividad como cazadores o tramperos profesionales, y un número relativamente escaso se dedica a tiempo completo a estas ocupaciones. El comercio relacionado con la caza y la caza con cepo se inició probablemente con el intercambio de las cantidades sobrantes de alimento y pieles de animales, y ha evolucionado gradualmente hasta originar profesiones especializadas pero relacionadas. Son ejemplos de ellas el curtido, la preparación de cueros y pieles, la fabricación de prendas, la producción de artículos destinados a la caza, la caza con cepo y la vida al aire libre, la existencia de guías profesionales y la regulación de las poblaciones de animales silvestres.

\section{Importancia económica}

En los últimos siglos, la búsqueda comercial de pieles influyó en el curso de la historia, al determinar las poblaciones de animales silvestres, el destino de pueblos indígenas y el carácter de numerosas naciones (por ejemplo, véase H innis 1973.) U na característica continua del comercio de pieles es que la demanda, y en consecuencia los precios, puede fluctuar ampliamente con el tiempo. Así, el cambio de la moda europea de los sombreros de fieltro de castor a los de seda en las primeras décadas del siglo XIX puso fin a la época de los tramperos de las M ontañas Rocosas de N orteamérica. Las repercusiones en las personas, que dependen de la recogida de pieles, pueden ser bruscas y graves. L as protestas públicas organizadas contra la matanza a palos de crías de foca en la parte occidental del Atlántico norte en el decenio de 1970 tuvieron efectos económicos y sociales graves en pequeñas comunidades de la costa de Terranova en Canadá.

La caza con cepo y la caza normal siguen teniendo importancia para numerosas economías rurales. Los gastos acumulados en estas actividades pueden ser considerables. Así, se calcula que en 1991 unos 10,7 millones de aficionados a la caza mayor de Estados U nidos se gastaron 5.100 millones de dólares en viajes y equipo de caza (Departamento del Interior de EE.UU., Servicio de pesca y vida silvestre, y Departamento de Comercio, O ficina del Censo 1993).

\section{Características de los trabajadores}

La caza profesional es poco frecuente en la actualidad (si se exceptúan las actividades de guía) en los países desarrollados, y se limita por lo general a operaciones de reducción de poblaciones excesivas ( $p$. ej., de predadores, de excedentes, etc.) o de control de animales molestos (p. ej., caimanes). Así pues, la caza se practica actualmente para la subsistencia 0 con fines recreativos, mientras que la caza con cepo sigue siendo una actividad que genera ingresos a algunos residentes en zonas rurales. La mayoría de los cazadores y tramperos son hombres: en 1991, el $92 \%$ de los 14,1 millones de personas (de 16 años o más) que cazaban en E stados U nidos eran varones. La caza normal y la caza con cepo atraen a personas independientes y vigorosas que disfrutan viviendo y trabajando al aire libre. Ambas son actividades tradicionales de numerosas familias rurales, en las que los jóvenes son instruidos por sus padres o mayores en la caza, al igual que en la preparación de alimentos, pieles y prendas de ropa. Se trata de trabajos estacionales utilizados para complementar las reservas de alimentos y, en el caso de la caza con cepo, para conseguir dinero en metálico. Su realización con éxito exige un conocimiento profundo de la vida silvestre y competencia en una gran variedad de destrezas necesarias cuando se trabaja al aire libre. También es un requisito importante la existencia de transporte eficiente a buenas zonas para la caza normal y la caza con cepo.

\section{Sectores y procesos principales}

La caza exige la localización y la aproximación estrecha a un animal silvestre, seguida de su aniquilación, bajo una combinación de reglas formales e informales (O rtega y Gasset 1985). El transporte a la zona de caza supone a menudo un gasto importante, sobre todo para los cazadores recreativos que viven en centros urbanos. También es una fuente primordial de riesgo laboral en forma de accidentes de automóvil, aeronaves ligeras y botes, así como contratiempos con caballos y vehículos todo terreno y para nieve. 0 tras fuentes de riesgo son el tiempo atmosférico, la exposición al aire libre y las dificultades del terreno. Perderse en una zona abrupta siempre supone un riesgo. LoS cazadores que buscan especies como osos, elefantes y búfalos siempre corren un riesgo de lesión por estos animales, peligrosos cuando están heridos. En cabañas reducidas o tiendas, el fuego, el monóxido de carbono y el gas propano constituyen riesgos potenciales. Tanto cazadores como tramperos tienen la posibilidad de autolesionarse con cuchillos y, en el caso de los cazadores con arco, con puntas de flecha anchas. Los accidentes con armas de fuego son igualmente una causa sobradamente conocida de 
heridas y muertes en cazadores, a pesar de los esfuerzos constantes por limitar el problema.

En líneas generales, los tramperos se exponen a los mismos riesgos que los cazadores. Los que trabajan en el círculo polar tienen más probabilidades de sufrir congelaciones y problemas de hipotermia. La posibilidad de que se rompa por su peso la capa de hielo que cubre lagos y ríos durante los meses de invierno es un problema grave. Algunos tramperos recorren largas distancias solos y tienen que manipular de modo seguro sus cepos, a menudo en condiciones difíciles que originan errores causantes de magulladuras o roturas de dedos, e incluso de un brazo. Las mordeduras de los animales atrapados vivos siempre son una amenaza potencial. Por otro lado, los ataques de zorros rabiosos o los problemas con animales grandes, como osos o alces, durante la época de celo son inusuales, pero no imposibles. El desollado y la manipulación de las pieles exponen a los tramperos a heridas con los cuchillos y, en ocasiones, enfermedades de los animales.

\section{Técnicas de caza}

\section{Armas de fuego}

Las armas de fuego son un equipo básico para la mayoría de los cazadores. L os rifles y las escopetas modernos son las más populares, pero desde el decenio de 1970 ha aumentado también en algunos países desarrollados la caza con pistolas y revólveres y con armas de fuego más primitivas que se cargan por la boca (de avancarga). Todas ellas son en esencia dispositivos para lanzar y apuntar un solo proyectil (una bala) o, en el caso de las escopetas, una carga de pequeños proyectiles de corto alcance (llamados perdigones). El alcance eficaz depende del tipo de arma de fuego utilizada y de la destreza del cazador. Puede variar desde unos pocos metros a varios centenares en la mayoría de las condiciones de caza. Las balas de rifle pueden recorrer miles de metros y seguir causando daño o herida.

La mayoría de los accidentes de caza en los que intervienen armas son disparos accidentales 0 accidentes relacionados con la visión, en los que la víctima no es identificada por quien dispara. Los fabricantes modernos de armas de fuego utilizadas para la caza normal y la caza con cepo han conseguido, con contadas excepciones, producir equipos mecánicamente seguros y fiables a precios competitivos. Se ha consagrado un enorme esfuerzo al perfeccionamiento de seguros mecánicos que impidan disparos accidentales, pero sigue siendo esencial la seguridad de manejo por el usuario. Fabricantes, gobiernos y grupos privados, como asociaciones de cazadores, han contribuido a promover la seguridad de las armas de fuego y del cazador, ocupándose sobre todo de la seguridad del almacenamiento, el uso y la manipulación de las armas de fuego.

La A sociación Internacional para la Educación de los Cazadores (IHEA) define un accidente de caza como "cualquier episodio que se atribuye directa o indirectamente a un arma de fuego 0 arco y que causa una lesión o la muerte a una persona 0 personas como resultado de las acciones de una persona mientras caza" (IHEA 1995). En 1995, 17 millones de personas compraron licencias de caza en Estados Unidos (excluida Alaska); la IHEA recibió informes de 107 muertes y 1.094 heridas por accidentes de caza ocurridos en ese mismo año en Estados U nidos. El tipo más común de accidente fue el originado por la no identificación de la víctima por el cazador. Se ha demostrado que el uso de prendas de colores llamativos reduce los problemas relacionados con la visibilidad en los Estados que las exigen, por lo que la IHEA recomienda la generalización de su uso. La utilización de prendas naranja reflectantes es obligatoria actualmente en 40 Estados de Estados U nidos, aunque en algunos de ellos está limitada a los terrenos de uso público o sólo para la caza mayor. La IHEA señala que las heridas autoinflingidas son las segunda causa más frecuente de accidentes cinegéticos por arma de fuego; en 1995 supusieron el 31 \% del total.

Los gobiernos se esfuerzan en mejorar la seguridad de la caza y de las armas de fuego por diversos medios. Así, en algunos países europeos los cazadores debe superar un examen escrito 0 demostrar su pericia para cazar una especie determinada. En Estados U nidos se insiste en la educación de los cazadores, que es competencia de los distintos Estados. En todos ellos, salvo en Alaska, se necesita alguna forma de tarjeta de educación del cazador obligatoria antes de permitir la caza en su territorio. Se exige un mínimo de 10 horas de enseñanza en materias como responsabilidad del cazador, conservación de la vida silvestre, armas de fuego, ética de la caza, caza especializada, destrezas de supervivencia y primeros auxilios.

\section{Otras técnicas de caza}

En las últimas décadas, el perfeccionamiento del arco compuesto ha puesto al alcance de millones de cazadores aficionados la caza con arco. El arco compuesto utiliza un sistema de poleas y cables para reducir al mínimo la fuerza y el entrenamiento antes necesarios para cazar con los arcos tradicionales. Los cazadores con arco utilizan puntas de flecha anchas muy afiladas, por lo que los cortes causados por ellas y las caídas sobre puntas de flecha no protegidas son dos tipos de accidente comunes a esta especialidad cinegética. La caza con arco eficaz exige conocimientos amplios de la vida natural y destreza para cazar al acecho, ya que por lo general la presa debe estar a 30 o menos metros del cazador para que el arma utilizada sea eficaz.

\section{Técnicas de caza con cepo}

La mayor parte de la producción de pieles de animales silvestres procede de dos zonas: Norteamérica y la antigua U nión Soviética. N ormalmente, los tramperos colocan una línea o serie de puestos, cada uno de ellos con uno o más dispositivos destinados a retener o matar a la especie que desean capturar sin dañar la piel. Casi siempre se utilizan lazos y trampas (incluidas las de caja, de presa en la pata y humanitarias que sujetan el cuerpo). Las líneas de cepos pueden variar desde unos pocos puestos en la zona de un río detrás de una cabaña hasta centenares tendidas a los largo de varios cientos de kilómetros de senda. EI M anual de tramperos de Alaska (ATA 1991) es una descripción reciente de las técnicas de los cepos que se utilizan actualmente en esa región.

\section{Técnicas de tratamiento de las pieles}

L os tramperos desuellan normalmente los animales que capturan y venden las pieles, una vez secadas, a un comprador de pieles 0 a una casa de subastas. Con el tiempo, se venderán a un fabricante que las adobará o curtirá, tras lo cual se convertirán en prendas de vestir. Los precios de las pieles de pelo varían considerablemente. El precio pagado por una piel original depende del tamaño, del color deseado, del estado del pelo, de la ausencia de defectos y de las condiciones del mercado. Los tramperos experimentados tienen que capturar animales de pelo, y preparar las pieles para la venta de forma que la totalidad del proceso sea lo bastante rentable para mantener su funcionamiento. Para una exposición detallada de la industria de pieles de animales silvestres véase N ovax y cols. (1987).

\section{Problemas ambientales y de salud pública}

Los avances tecnológicos realizados desde la Segunda Guerra $M$ undial han traído consigo numerosas mejoras para los cazadores y tramperos. Estas mejoras han mitigado, al menos en los países desarrollados, el aislamiento, el trabajo físico agotador y la 
desnutrición ocasional que antaño se sufrían. La mejoría de los métodos de orientación y búsqueda y rescate ha elevado los niveles de seguridad generales de estas profesiones. Por ejemplo, los cazadores de morsas y ballenas nativos de Alaska casi siempre vuelven ahora a sus hogares de la caza sanos y salvos.

En el siglo XX, dos problemas de importancia han supuesto una seria amenaza para estas profesiones: la necesidad continua de preservar los ecosistemas naturales y las cuestiones éticas derivadas de la forma en que cazadores y tramperos actúan sobre los animales silvestres. Las investigaciones y normativas patrocinadas por los gobiernos suelen ser el enfoque inicial para abordar el problema antiquísimo de la explotación por el hombre de la naturaleza. L a disciplina científica del naturalismo surgió a mediados del siglo y ha evolucionado continuamente hasta llegar al concepto más amplio de la biología de la conservación, cuyo objetivo es preservar la salud de los ecosistemas y la diversidad genética.

A principios del siglo XX, la destrucción de los hábitat y la explotación comercial en Estados U nidos habían contribuido al agotamiento de los recursos de pesca y animales de caza. Cazadores, tramperos y otros defensores de la naturaleza garantizaron la aprobación de legislación que creó la ley de ayuda federal para la recuperación de la fauna de Estados U nidos de 1937, que impone un impuesto del 10-11 \% sobre la venta de rifles, pistolas, escopetas, munición y equipo de arquería. El dinero así obtenido se suma a los ingresos por la venta de licencias, carnets o sellos estatales para la caza normal y la caza con cepo.

Desde finales del decenio de 1930, la ayuda federal de Estados U nidos ha canalizado millones de dólares hacia la investigación sobre la fauna, la conservación, la gestión y la educación de los cazadores. U no de los resultados de estos esfuerzos es que las poblaciones de animales silvestres utilizadas activamente por cazadores y tramperos gozan ahora de una relativa buena salud y son capaces de sostener los usos para consumo. La experiencia de la ayuda federal indica que cuando la fauna cuenta con el respaldo de una comunidad dispuesta a pagar los costes de investigación y gestión, el futuro de esas especies es relativamente brillante. Por desgracia, no ocurre así en el caso de numerosos ecosistemas y especies silvestres de todo el mundo. A medida que nos aproximamos a un nuevo siglo, la alteración de los hábitat y la extinción de las especies se nos aparecen como problemas de conservación muy evidentes.

El otro desafío pendiente es la controversia sobre los derechos de los animales. ¿Son la caza normal y la caza con cepo, sobre todo con fines recreativos 0 no de subsistencia, actividades socialmente aceptables en un mundo que entrará en el siglo $X X$ I con una población creciente y recursos cada vez más limitados? Este debate social se ha intensificado en las últimas décadas. Un aspecto positivo del diálogo es que quienes participan en estas actividades han tenido que esforzarse por mejorar la fundamentación de sus posturas y por mantener grados elevados de rendimiento de sus actividades de caza normal y caza con cepo. Las actividades que ofendían la sensibilidad del público en general, como la matanza a palos de las crías de foca en la costa de Terranova, se han suprimido en ocasiones, en este caso concreto con un enorme coste social y económico para los habitantes de Terranova, que han participado durante siglos en tales actividades. La amenaza reciente de las comunidades europeas de prohibir la importación de pieles capturadas por cepos de presa en la pata de acero ha intensificado la búsqueda de métodos prácticos y más humanitarios de matar a ciertos animales de pelo. Esa misma prohibición propuesta supone una amenaza para una forma de vida de subsistencia que ha existido durante mucho tiempo en la Norteamérica rural. (Para más detalles, véase $\mathrm{H}$ ercovici 1985).

\section{EN FERMEDADES ASO CIADAS CON LA CAZA Y LA CAZA CON CEPO}

Mary E. Brown

\section{Riesgos}

L os riesgos asociados con la caza normal y la caza con cepo son numerosos: caídas, ahogamiento por inmersión, congelación, heridas por cepos para animales, mordeduras de animales, reacciones a picaduras de insectos, heridas al cortar madera, deslumbramiento por el sol y muchos otros. Sin embargo, quienes sufren tales percances suelen ser los menos expertos. Los factores más importantes que influyen en la gravedad de estos riesgos profesionales son el aislamiento y la distancia. Cazadores y tramperos trabajan con frecuencia solos en zonas de terreno accidentado alejadas de cualquier centro de tratamiento médico, y es posible que su paradero sea desconocido por todos durante semanas. U na herida, mordedura de animal u otro accidente que de otro modo carecería de importancia pueden tener consecuencias graves en estas circunstancias.

\section{Accidentes}

D ado que los tramperos profesionales trabajan principalmente en la época invernal en climas norteños, el deslumbramiento solar por la nieve puede producir lesiones oculares, y las temperaturas frías causar congelaciones y un descenso peligroso de la temperatura corporal, llamado hipotermia; los síntomas de la hipotermia son euforia o letargo, y puede tener consecuencias fatales si no se reconoce a tiempo. Es necesaria una precaución extrema al atravesar lagos y ríos helados, ya que la rotura de una capa de hielo delgada originaría ahogamiento o hipotermia en cuestión de minutos. La exposición prolongada incluso a un tiempo moderadamente frío sin ropas adecuadas puede originar hipotermia. 0 tros accidentes posibles son heridas por arma de fuego, percances con vehículos para nieve, heridas al desollar las pieles 0 cortar madera, accionamiento accidental de cepos y mordeduras o heridas causadas por animales atrapados, serpientes u otros animales. Además del riesgo de que las heridas se infecten, también existe la posibilidad de contraer ciertas enfermedades de los animales.

\section{Enfermedades}

Los cazadores y los tramperos están potencialmente expuestos a gran variedad de agentes infecciosos capaces de causar enfermedades, incluidas las zoonosis, que son las transmitidas por los animales a las personas. Numerosos tipos de bacterias, virus, parásitos y hongos causan zoonosis. El riesgo de adquirir alguna de ellas varías según la región, la estación y las condiciones de vida. Una persona puede infectarse directamente (p. ej., por la mordedura de un animal o por contacto con sangre al desollar un animal) 0 indirectamente (p. ej., por la picadura de un insecto que transmite la enfermedad de otro animal a un ser humano).

La rabia es una de las enfermedades más graves que pueden contraerse de los animales silvestres, generalmente a causa de una herida por mordedura, debido a que, sin tratamiento médico, es prácticamente mortal en el $100 \%$ de los casos. La rabia es endémica en numerosas zonas, y puede infectar a la mayoría de los animales de sangre caliente, incluidos zorros, perros, gatos, murciélagos, mapaches, mofetas, lobos, osos y castores, así como a animales de mayor tamaño como caribúes, alces, ganado vacuno y caballos. El virus de la rabia afecta el cerebro, por lo que debe considerarse peligroso todo animal que parezca haber perdido el miedo al ser humano o que muestre 
cualquier comportamiento inusual. Como el virus de la rabia, al igual que varios otros virus y bacterias, se transmite con la saliva, todas las mordeduras de animales deben lavarse a conciencia con jabón y agua. Todo cazador o trampero que sea mordido por un animal que se sospeche que sufre la rabia debe buscar de inmediato asistencia médica, e intentar obtener la cabeza del animal para realizar pruebas.

La tularemia, también conocida como fiebre de ciervos volantes y fiebre de los conejos, es una enfermedad bacteriana que puede transmitirse de forma indirecta (por garrapatas, ciervos volantes y otras moscas picadoras) o directa (por mordeduras de los animales infectados). También puede infectar las fuentes de suministro de agua y contaminar la carne. Sus síntomas, semejantes a los de la fiebre de M alta y la peste, son fiebre, escalofríos, cansancio e hinchazón de los ganglios linfáticos. En las zonas en las que se sospeche la enfermedad, deben desinfectarse los suministros de agua. La caza debe cocinarse a conciencia antes de comerla. Los brazos y las manos han de mantenerse limpios y desinfectados. Deben utilizarse guantes de goma si existen cortes 0 arañazos. La zona en la que se manipulen canales, cueros y pieles de animales ha de mantenerse limpia y desinfectada.

El ántrax (carbunco) es otra enfermedad bacteriana que puede infectar a los tramperos y cazadores, puesto que es endémica en animales silvestres y domesticados en la mayor parte del mundo. Una infección de la piel por contacto con pieles y cueros contaminados es la forma más frecuente de ántrax; no obstante, las personas se infectan también por consumir carne contaminada. La enfermedad causada por inhalación es menos común. D ebe buscarse tratamiento de inmediato.

La tuberculosis supone un problema cada vez mayor en numerosas regiones. Son muchas las especies animales que pueden ser fuente de infección tuberculosa para los cazadores. Aunque la mayor parte de los casos de tuberculosis humana se deben a la exposición a toses y estornudos de seres humanos infectados, muchas especies de animales, incluidas aves y animales de sangre fría, pueden infectarse con el bacilo. También se transmite la tuberculosis por el consumo de productos lácteos no pasteurizados. Asimismo, es posible infectarse al inhalar gotitas respiratorias aerotransportadas 0 al comer carne de animales infectados. Las personas con depresión del sistema inmunitario (p. ej., por medicación o por infección con el virus de la inmunodeficiencia humana) corren un riesgo especial de contraer los agentes más comunes de la tuberculosis, así como los presentes en el suelo y el agua.

Los cazadores y los tramperos también pueden sufrir varias enfer medades micóticas transportadas tanto por animales como por los hongos del suelo. T richophyton ver rucosum y $T$. mentagrophytes son los principales agentes causales de la tiña en el hombre. Además, los perros actúan como reservorio de M icrosporum canis, la causa principal de tiña de origen animal en seres humanos. Cazadores y tramperos pueden verse expuestos a hongos que viven en el suelo y en vegetación en putrefacción, muy especialmente suelos contaminados con deyecciones de aves o murciélagos; estos hongos, que no causan zoonosis, viven en habitat específicos. Coccidioides immitis sólo es común en regiones áridas o semiáridas, mientras que $B$ lastomyces dermatitidis prefiere los suelos húmedos a lo largo de cursos de agua y las zonas apartadas. Cryptococcus neoformans e $\mathrm{H}$ istoplasma capsulatum son más frecuentes y viven en suelos enriquecidos con deyecciones de aves y murciélagos. C uando se inhalan, estos hongos pueden causar síntomas similares a los de la neumonía, así como enfermedades sistémicas graves tanto en personas como en animales.

EI tétanos es otra enfermedad grave que infecta tanto a seres humanos como a animales. L as bacterias que lo causan también son muy comunes en suelos y otras partes del medio ambiente, y son habitantes normales de los aparatos digestivos de numerosos animales. Las heridas, sobre todo las punzantes profundas, que se ensucian son las que tienen más probabilidades de infectarse. La prevención comprende el cuidado apropiado de la herida y la vacunación sistemática.

Garrapatas, mosquitos, pulgas y otros insectos picadores transmiten a menudo infecciones de los animales al hombre. Así, la peste bubónica es un ejemplo de enfermedad bacteriana transmitida por picaduras de pulga. Las pulgas se infectan cuando se alimentan de la sangre de un animal infectado, por lo general un roedor, conejo o liebre, pero también diversos carnívoros. La pulga transmite entonces la infección al siguiente animal del que se alimenta, incluido el hombre. Las personas también pueden infectarse al manipular tejidos de animales infectados, 0 al inhalar gotitas aerotransportadas procedentes de seres humanos 0 animales, por lo general gatos, con la forma neumónica de la peste. Los síntomas iniciales de la peste bubónica son inespecíficos y comprenden fiebre, escalofríos, náuseas y postración. Posteriormente, los ganglios linfáticos pueden hincharse e inflamarse (los bubones que dan el nombre a la enfermedad)

U na enfermedad más común transmitida por la picadura de un insecto es la enfermedad de L yme o borreliosis, que es una de las muchas que transmiten las garrapatas. El primer síntoma es a menudo una erupción de la piel en forma de diana, es decir, un círculo rojo con el centro claro en el lugar de la picadura. La erupción desaparece, pero si no se administra tratamiento la enfermedad puede evolucionar a la artritis y a complicaciones más graves.

Los hantavirus infectan a roedores en todo el mundo, y se han descrito desde hace décadas, que aparecen de modo característico en el riñón. En 1993, se reconoció inicialmente en Estados U nidos el síndrome pulmonar por hantavirus. Este virus causaba una insuficiencia respiratoria rápidamente fatal. Es probable que se transmita por medio de orina y heces de roedores en aerosol. Se cree que las personas infectadas se expusieron a ratones que contaminaban cabañas y casas.

Además, los cazadores y los tramperos pueden exponerse a una gran variedad de otras infecciones víricas, bacterianas, micóticas y parasitarias que se encuentran en ocasiones en animales silvestres (Tabla 69.1). Pueden consultarse las obras de referencia habituales para más detalles.

La mayoría de las zoonosis y de otros agentes infecciosos pueden evitarse si se utiliza el sentido común y se adoptan ciertas precauciones generales. El agua debe hervirse 0 tratarse químicamente. Todos los alimentos han de cocinarse adecuadamente, sobre todo los de origen animal. La carne de animales silvestres tiene que cocinarse a $71^{\circ} \mathrm{C}$. Los alimentos que se consuman crudos tienen que lavarse a conciencia. Hay que evitar mordeduras y picaduras de insectos metiendo los pantalones dentro de las botas, llevar camisas de manga larga y utilizar repelentes de insectos y mosquiteros si es necesario. D eben eliminarse las garrapatas lo antes posible. $\mathrm{H}$ ay que evitar el contracto con tejidos y líquidos orgánicos de animales. Se recomiendan utilizar guantes, sobre todo si existen grietas 0 abrasiones en las manos. $\mathrm{H}$ ay que lavarse las manos con agua y jabón después de manipular animales, y siempre antes de comer. Es preciso lavar mordeduras y heridas con agua y con jabón lo antes posible, con tratamiento médico de seguimiento sobre todo si se sospecha la exposición a un animal infectado de rabia. Los cazadores y tramperos deben estar vacunados contra enfermedades comunes en su lugar de residencia. La disponibilidad de un botiquín de primeros auxilios y un conocimiento básico de las técnicas de primeros auxilios pueden suponer la diferencia entre un incidente importante y otro sin trascendencia. 
Tabla 69.1 • Ejemplos de enfermedades de posible importancia para cazadores y tramperos.

\begin{tabular}{|c|c|c|c|c|}
\hline Agente & Enfermedad & Reservorio & Modo de transmissión & Ocurre en \\
\hline \multicolumn{5}{|l|}{ Enfermedades bacterianas } \\
\hline Bacillus anthracis & Antrax & $\begin{array}{l}\text { Animales, cueros, pelo, hueso, } \\
\text { suelo }\end{array}$ & $\begin{array}{l}\text { Contacto directo e indirecto, } \\
\text { picaduras de insectos, } \\
\text { inhalación, ingestión }\end{array}$ & América, Europa, Asia, Africa \\
\hline Borellia spp. & $\begin{array}{l}\text { Enfermedad de Lyme, fiebre } \\
\text { recurrente }\end{array}$ & $\begin{array}{l}\text { Roedores, mamíferos pequeños, } \\
\text { ciervo, garraptas }\end{array}$ & Picaduras de garrapatas y piojos & Todo el mundo, salvo Australia \\
\hline Brucella spp. & Brucelosis, fiebre de Malta & Animales & Contacto, ingestión, inhalación & Todo el mundo \\
\hline Campylobacter spp. & Enteritis & Animales & Ingestión & Todo el mundo \\
\hline Coxiella burnetii & Fiebre $Q$ & Animales & Inhalación, contacto & Todo el mundo \\
\hline Clostridium tetani & Tétanos & Suelo & Contacto & Todo el mundo \\
\hline Ehrlichia spp. & Ehrlichiosis & Desconocido & Picadura de garrapata & Norteamérica, Africa, Asia \\
\hline Francisella tularensis & Tularemia & Animales & $\begin{array}{l}\text { Picaduras de insectos, contacto, } \\
\text { ingestión, inhalación }\end{array}$ & Todo el mundo excepto Australia \\
\hline Leptospira spp. & Leptospirosis & Animales & Contacto, ingestión, inhalación & Todo el mundo \\
\hline Listeria monocytogenes & Listeriosis & Suelo, animales, humanos & Ingestión & EE UU \\
\hline Mycobacterium spp. & Tuberculosis & $\begin{array}{l}\text { Humanos, mamíferos, aves, } \\
\text { animales de sangre fría, } \\
\text { medio ambiente }\end{array}$ & $\begin{array}{l}\text { Inhalación, ingestión, contamina- } \\
\text { ción de heridas }\end{array}$ & Todo el mundo \\
\hline Rickettsia spp. & $\begin{array}{l}\text { Rickettsiosis por garrapatas (grupo } \\
\text { de fiebres maculosas) }\end{array}$ & Garrapatas, roedores & Picaduras de garrapatas y ácaros & Todo el mundo \\
\hline Salmonella spp. & Salmonelosis & $\begin{array}{l}\text { Mamíferos, aves, animales de } \\
\text { sangre fría }\end{array}$ & Ingestión & Todo el mundo \\
\hline Vibrio cholera & Cólera & Humanos & Ingestión & Todo el mundo \\
\hline Yersinia pestis & Peste, peste bubónica & $\begin{array}{l}\text { Roedores, liebres, conejos, } \\
\text { humanos, carnivoros }\end{array}$ & $\begin{array}{l}\text { Picaduras de pulgas, inhalación, } \\
\text { contacto }\end{array}$ & Todo el mundo \\
\hline \multicolumn{5}{|l|}{ Enfermedades víricas } \\
\hline $\begin{array}{l}\text { Arbovirus (más de } \\
100 \text { tipos) }\end{array}$ & $\begin{array}{l}\text { Fiebres, erupción, fiebres hemorrá- } \\
\text { gicas, encefalitis (incluye dengue, } \\
\text { Fiebre amarilla, encefalitis víricas, } \\
\text { fiebre del valle del Rift, fiebres } \\
\text { por garrapatas) }\end{array}$ & Humanos, animales, insectos & $\begin{array}{l}\text { Picaduras de insectos, garrapatas, } \\
\text { jejenes, moscas de arena, otros }\end{array}$ & Todo el mundo \\
\hline Virus Ebola/ Marburgo & Fiebres hemorrágicas & Desconocido & monos & $\begin{array}{l}\text { Desconocido, contacto con } \\
\text { líquidos corporal }\end{array}$ \\
\hline Hantavirus & $\begin{array}{l}\text { Fiebre hemorrágica, síndromes } \\
\text { renal y pulmonar }\end{array}$ & Roedores & Inhalación & $\begin{array}{l}\text { Asia, antigua Unión Soviética, } \\
\text { América }\end{array}$ \\
\hline Virua de Lassa & Fiebre de Lassa & Roedores & $\begin{array}{l}\text { Inhalación, contacto con líquido } \\
\text { corporal }\end{array}$ & Africa Occidental \\
\hline Virus de la rabia & Rabia & Mamíferos & $\begin{array}{l}\text { Virus en saliva, generalmente } \\
\text { una mordedura }\end{array}$ & $\begin{array}{l}\text { herida } 0 \text { arañazo, ocasional- } \\
\text { mente inhalación, trans- } \\
\text { plantes de órganos }\end{array}$ \\
\hline \multicolumn{5}{|l|}{ Enfermedades micóticas } \\
\hline Blastomyces dermatitidis & Blastomicosis & Suelo & Inhalación & $\begin{array}{l}\text { Africa, India, Israel, Norteáme- } \\
\text { rica, Arabia Saudí, Suráfrica }\end{array}$ \\
\hline Coccidioides immitis & $\begin{array}{l}\text { Coccidioidomicosis, fiebre del valle, } \\
\text { fiebre del desierto }\end{array}$ & Suelo & Inhalación & $\begin{array}{l}\text { Argentina, Paraguay, Colombia, } \\
\text { Venezuela, México, América } \\
\text { Central, EE UU }\end{array}$ \\
\hline Cryptococcus neoformans & Criptococosis & $\begin{array}{l}\text { Suelo, deyecciones de aves y } \\
\text { murciélagos }\end{array}$ & Inhalación & Todo el mundo \\
\hline Histoplasma capsulatum & Histoplasmosis & $\begin{array}{l}\text { Suelo, deyecciones de aves y } \\
\text { murciélagos }\end{array}$ & Inhalación & $\begin{array}{l}\text { América, Africa, este de Asia, } \\
\text { Australia }\end{array}$ \\
\hline $\begin{array}{l}\text { Microsporum spp., } \\
\text { Trichophyton spp. }\end{array}$ & Tiña & Humanos, animales, suelo & Contacto directo o indirecto & Todo el mundo \\
\hline
\end{tabular}


Tabla 69.1 • Ejemplos de enfermedades de posible importancia para cazadores y tramperos. Continuación.

\begin{tabular}{|c|c|c|c|c|}
\hline Agente & Enfermedad & Reservorio & Modo de transmissión & Ocurre en \\
\hline \multicolumn{5}{|c|}{ Enfermedades parasitarias } \\
\hline Babesia spp. & Babesiosis & Roedores, ganado vacuno & Picaduras de garrapatas & $\begin{array}{l}\text { Europa, México, Rusia, } \\
\text { Yugoslavia, EE UU }\end{array}$ \\
\hline Baylisascaris spp. & Larva migrans de Baylisascaris & $\begin{array}{l}\text { Mapaches, tejones, mofetas, } \\
\text { nutrias, martas, osos }\end{array}$ & Ingestión & Norteamérica \\
\hline Cryptosporidium parvum & Criptosporidiosis & $\begin{array}{l}\text { Humanos, ganado vacuno, } \\
\text { animales domésticos }\end{array}$ & Ingestión & Todo el mundo \\
\hline Diphyllobothrium latum & Infección por tenias & $\begin{array}{l}\text { Humanos, perros, osos, mamí- } \\
\text { feros que comen pescado }\end{array}$ & Ingestión & Regiones lacustres \\
\hline Echinococcus spp. & Equinococosis & Animales & Ingestión & Todo el mundo \\
\hline Giardia spp. & Giardiasis & Humanos, animales & Ingestión & Todo el mundo \\
\hline Leishmania spp. & Leishmaniasis & Humanos, animales & Picadura de moscas de arena & $\begin{array}{l}\text { Regiones tropicales y } \\
\text { subtropicales }\end{array}$ \\
\hline Trichinella spiralis & Triquinosis & Animales & Ingestión & Todo el mundo \\
\hline Trypanosoma spp. & Tripanosomiasis & Humanos, animales & Picaduras de insectos & Africa, América \\
\hline
\end{tabular}

\section{Referencias}

Alaska T rappers Association (AT A). 1991. Alaska T rappers $M$ anual. Fairbanks, Alaska: ATA.

Herscovici, A. 1985. Second Nature: The Animal Rights controversy. Toronto: CBC Enterprises.

H innis, H A. 1973. T he Fur T rade in Canada: An Introduction to E conomic H istory. Toronto: U niversity of T Oronto Press.

International Hunter Education Association (IHEA). 1995. $1995 \mathrm{H}$ unting Accident R eport. W ellington, CO IHEA.

Novak, M, JA Baker, ME O bbard, B M alloch (dirs.). 1987. W ild F urbearer $M$ anagementand $C$ onservation in $N$ orth A merica.T oronto:O ntarioT rappersA ssociation.

O rtega y G asset, J. 1985. M editations on $\mathrm{H}$ unting. Nueva Y ork: Scribner's
US D epartment of the Interior, Fish and Wildlife Service, $y$ U S D epartment of Commerce, Bureau of the Census. 1993. $1991 \mathrm{~N}$ ational Survey of Fishing, $\mathrm{H}$ unting and W ildlife associated Recreation. W ashington DC: US Government Printing 0 ffice.

\section{0 tras lecturas recomendadas}

Acha, PN, B Szyfres. 1987. Z oonoses and Communicable $D$ iseases Common to $M$ an and Animals, $2^{a}$ ed. Scientific publication No. 503. Washington, DC: PanAmerican $\mathrm{H}$ ealth $\mathrm{O}$ rganization.

American Public Health Association (APHA). 1995. Control of Communicable Diseases $M$ anual, 16 ed., dirigida por AS Beneson. Washington, DC: APH A.

American Veterinary Medical Association (AVMA). 1996. Z oonoses U pdates from the J ournal of the American
Veterinary M edical Association. Schaumberg, Illinois: AVMA.

Braid, P. 1977. Guide du trappeur (Guía del trampero). Bruselas: Les Editions de I'H omme. (en francés.)

Centers for Disease Control and Prevention (CDC). 1995. H ealth Information for International Travel. Atlanta, Georgia: CDC.

Docherty, D, J Eckerson, ML Collis, 」 H ayward. 1977. Changes in fitness level of humans attributable to hunting activities. J ournal of Sports M edicine and Physical Fitness 17(3):315-320.

T akeda, J. 1972. An ecological study of bear hunting activities of the $M$ atagi: Japanese traditional hunters. J ournal of $\mathrm{H}$ uman E rgology 2:167-187.

Winkler, WG (dir.). 1985. Rabies Concepts for M edical Professionals. M iami, Florida: M erieux Institute, Inc. 



\section{GANADERIA Y CRIA DE ANIMALES}

Director del capítulo

M edvin L. M yers

\section{Sumario}

Ganadería: ámbito y efectos sobre la salud

M elvin L. M yers.

Problemas de salud y pautas patológicas

Kendall T hu, Craig Z werling y Kelley D onham .

Problemas de salud en el trabajo relacionados con los artrópodos

D onald B arnard.

Cultivos forrajeros

L orann Stallones

Confinamiento del ganado

Kelley D onham

Cría de animales domésticos

D ean T. Stueland y Paul D. G underson. . .

Comportamiento de los animales

D avid L. H ard

Gestión del estiercol y de los excrementos

W illiam Popendorf . . . . . . . . . . . . . . . . . . . . . . . 70.18

Lista de comprobación de las prácticas de seguridad de la ganadería

M elvin L. M yers . .

Vaquerías

$$
\text { J ohn M ay . . }
$$

Vacuno, ovino y caprino

$M$ elvin $L$. M yers

Porcino

M elvin L. M yers

Producción de aves de corral y de huevos

Steven W. L enhart.

Captura, enjaulado y sacrificio de las aves de corral

Tony A shdown. ...
Caballos y otros équidos

L ynn B arroby . . . . . . . . . . . . . . . . . . . . . . . . . . . . 70.30

A nimales de tiro en Asia

D.D. Joshi ............................... 70.31

Elefantes

M elvin L. M yers . . . . . . . . . . . . . . . . . . . . . 70.32

Cría de toros

David L. H ard . . . . . . . . . . . . . . . . . . . . . . . . . 70.34

Producción de animales de compañía, de peleteria y de laboratorio

Christian E. N ewcomer . . . . . . . . . . . . . . . . . . . . . . . . 70.36

Piscifactorias y acuicultura

$G$ eorge A. Conway y Ray RaL onde . . . . . . . . . . . . . . . . 70.37

A picultura, cría de insectos y producción de seda

$M$ elvin $L$. M yers y $D$ onald $B$ arnard. . . . . . . . . . . . . . . . 70.38 


\section{- GANADERIA: AMBITO Y EFECTOS SOBRE LA SALUD}

\section{M elvin L. M yers}

\section{Generalidades}

Los seres humanos dependen de los animales para obtener de ellosalimentos y otros de sus productos, para trabajar y para diversos usos (véase la Tabla 70.1). Para satisfacer estas demandas, han domesticado o mantienen en cautividad a especies de mamíferos, aves, reptiles, peces y artrópodos. Estos animales reciben el nombre de ganado, y su cría tiene implicaciones para la seguridad y la salud en el trabajo. Un perfil general de este sector debe incluir su evolución y su estructura, la importancia económica de las diferentes instalaciones para el ganado y las características regionales del propio sector y de los trabajadores. Los artículos de este capítulo están organizados por procesos profesionales, sectores y consecuencias de la ganadería.

\section{Evolución y estructura del sector}

En los últimos 12.000 años, la ganadería ha evolucionado a través de la selección realizada por las comunidades humanas y la adaptación a nuevos entornos. Los historiadores creen que cabras y ovejas fueron las primeras especies animales en ser domesticadas por el ser humano. Con posterioridad, hace unos 9.000 años, se domesticó al cerdo. La vaca fue el último animal importante en ser domesticado, hace unos 8.000 años, en Turquía o en
M acedonia. Probablemente sólo entonces se descubrió la utilidad nutritiva de la leche. También se utilizaba la leche de cabra, de oveja, de cierva y de camella. Los habitantes del valle del Indo domesticaron a la gallina salvaje de la India debido fundamentalmente a su producción de huevos; más tarde se convertiría en el pollo que hay en todo el mundo, fuente de huevos y de carne. Los habitantes de M éxico, por su parte, habían domesticado al pavo (Tannahill 1973).

Los seres humanos utilizaban diversas especies de mamíferos y aves para obtener alimento, así como especies de anfibios y de peces y diversos artrópodos. Los insectos han aportado siempre una importante fuente de proteínas, y hoy en día forman parte de la dieta humana, principalmente en las culturas no occidentales (Defoliart 1992). La miel de las abejas fue uno de los primeros alimentos: hace ya 5.000 años los egipcios sabían cómo expulsar a las abejas de sus panales mediante el humo para recoger la miel. La pesca es también una antigua ocupación destinada a obtener alimento, si bien el agotamiento de las zonas de pesca naturales ha hecho de la acuicultura la fuente de contribución a la producción de pescado que con más rapidez ha crecido desde el principio del decenio de 1980, alcanzando en la actualidad el $14 \%$ del total (Platt 1995).

Los seres humanos han domesticado asimismo muchos mamíferos para usarlos como animales de tiro, como el caballo, el burro, el elefante, el perro, el búfalo, el camello y el ciervo. Probablemente el primer animal utilizado para tiro, quizás con la excepción del perro, fue la cabra, que al buscar alimento era capaz de eliminar la capa seca de tierra, permitiendo su cultivo.

Tabla 70.1 - Usos del ganado.

$\begin{array}{ll}\text { Producto } & \text { Alimentación } \\ \text { Vacas lecheras } & \text { Leche líquida y en polvo, mantequilla, queso y } \\ & \text { cuajada, caseína, leche evaporada, nata, yogur } \\ \text { y otros tipos de leche fermentada, helados, } \\ \text { suero de leche }\end{array}$

Vacuno para carne, búfalos, ovejas Carne (ternera, cordero), grasa comestible

Aves de corral

Carne, huevos, huevos de pato (en la India)

$\begin{array}{ll}\begin{array}{l}\text { Porcino } \\ \text { Pescado (acuicultura) } \\ \text { Caballos, otros équidos }\end{array} & \begin{array}{l}\text { Carne } \\ \text { Carne } \\ \text { Pequeños animales (conejos, cobayas), } \\ \text { perros, gatos }\end{array} \\ \begin{array}{l}\text { Toros } \\ \text { Insectos y otros invertebrados (p. ej., } \\ \text { vermicultura, apicultura) }\end{array} & \begin{array}{l}\text { Miel, } 500 \text { especies (saltamontes, hormigas, } \\ \text { grillos, termitas, langostas, larvas de } \\ \text { escarabajos, avispas y abejas, orugas de la } \\ \text { polilla) son una dieta habitual en muchas } \\ \text { sociedades no occidentales }\end{array}\end{array}$

Subproductos y otros usos

Terneros y vacas viejas vendidos en el mercado correspondiente; leche como fuente industrial de hidratos de carbono (lactosa como diluyente para fármacos), proteínas (empleadas como surfactante para estabilizar las emulsiones de alimentos) y grasas (los lípidos pueden usarse como emulsificantes, surfactantes y gel), despojos

Cueros y pieles (cuero, colágenos para piel de salchichas, cosméticos, vendajes para heridas, reparación de tejidos humanos), despojos, trabajo (tracción), lana, pelo, estiércol (como combustible y fertilizante), huesos, objetos religiosos, comida para animales de compañía, grasa para usos industriales lácidos grasos, barnices, sustancias de goma, jabones, aceite para lámparas, plásticos, lubricantes), sangre

Plumas, estiércol (como fertilizante), cuero, grasa, despojos, aceite de aves no voladoras (vehículo para productos farmacéuticos que se aplican en parches), control de semillas (gansos en campos de menta)

Cueros y pieles, pelo, manteca, estiércol, despojos

Carne de pescado, aceite, conchas, animales de acuario

Ocio (monta, carreras), trabajo (transporte, tracción), cola, alimento para perros, pelo

Animales de compañía, pieles, perros guardianes, perros lazarillos, perros de caza, experimentación, perros pastores, control de roedores (por gatos)

Ocio (corridas, rodeos), semen

Cera de abejas, seda, insectos depredadores (>hay 5.000 especies posibles y 400 conocidas que sirven para el control de plagas de las cosechas; las larvas del mosquito carnívoro (Toxorhynchites spp.) se alimentan del venctor de la fiebre del dengue, vermicompostaje, animal fodder, polinización, medicamentos (veneno de abeja de miel para tratar la artritis), productos de insectos (goma laca, colorante rojo para cocina, cochinilla) 
Tabla 70.2 - Producción ganadera internacional (en miles de toneladas).

\begin{tabular}{|c|c|c|}
\hline Producto & 1991 & 1992 \\
\hline Canales de terneros y terneras & 46.344 & 45.396 \\
\hline Canales de porcino & 63.114 & 64.738 \\
\hline Canales de corderos, ovejas, y cabras & 6.385 & 6.245 \\
\hline Pieles y cueros de ganado bovino & 4.076 & 3.983 \\
\hline Sebo y grasa & 6.538 & 6.677 \\
\hline Carne de aves de corral & 35.639 & 37.527 \\
\hline Leche de vaca & 385.197 & 379.379 \\
\hline Camarones & 815 & 884 \\
\hline Moluscos & 3.075 & 3.500 \\
\hline Salmonoides & 615 & 628 \\
\hline Peces de agua dulce & 7.271 & 7.981 \\
\hline Consumo de huevos (millones de unidades) & 529.080 & 541.369 \\
\hline \multicolumn{3}{|l|}{ Uentes: FAO 1995; USDA 1996a, $1996 b}$. \\
\hline \multicolumn{3}{|c|}{$\begin{array}{l}\text { os historiadores creen que los asiáticos domesticaron al lobo } \\
\text { jue se convertiría en el perro hace } 13.000 \text { años. El perr } \\
\text { lemostró ser útil para el cazador por su velocidad, su oído y s } \\
\text { entido del olfato, y las variedades de perros pastores colabc } \\
\text { aron a la domesticación de las ovejas (Tannahill 1973). Lo } \\
\text { labitantes de las estepas de Eurasia domesticaron al caball } \\
\text { lace unos } 4.000 \text { años. Su empleo para el trabajo (tracción) se vi } \\
\text { stimulado por el invento de la herradura, y del arnés y por I } \\
\text { limentación con avena. Aunque el tiro sigue siendo important } \\
\text { n gran parte del planeta, se va sustituyendo a los animales po } \\
\text { náquinas a medida que se mecanizan la agricultura y el tran } \\
\text { orte. Algunos mamíferos, como el gato, se emplean par } \\
\text { ontrolar a los roedores (Caras 1996). }\end{array}$} \\
\hline
\end{tabular}

Figura 70.1 • Producción mundial de carne y de pescado.

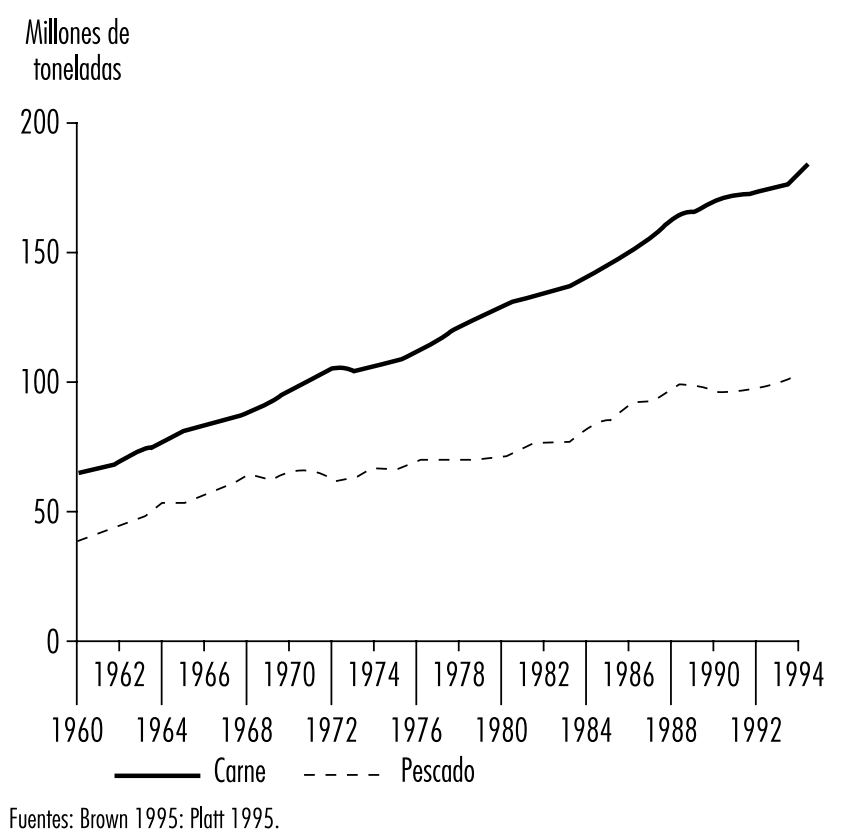

La estructura de la ganadería en la actualidad puede definirse por las mercancías, esto es, los productos animales que entran en el mercado. La Tabla 70.010 t2 muestra algunas de estas mercancías y la producción o el consumo mundiales respectivos.

\section{Importancia económica}

La creciente población mundial y el consumo per cápita cada vez mayor hacen que aumente la demanda global de carne y pescado, con los resultados que se ofrecen en la Figura 70.1. La producción global de carne casi se triplicó entre 1960 y 1994. En este período, el consumo per cápita pasó de 21 a 33 kilogramos por año. D ebido a las limitaciones de pasto disponible, la producción de ternera dejó de crecer en 1990. El resultado es que los animales más eficaces en la conversión del grano en carne, como el cerdo y el pollo, han obtenido una ventaja competitiva. De hecho, la producción de cerdo y de aves de corral ha aumentado de forma espectacular con respecto a la de ternera. La producción mundial de cerdo superó a la de ternera a finales del decenio de 1970 . Puede que pronto ocurra lo mismo con la producción de aves de corral. La producción de cordero permanece baja y estacionaria (USDA 1996a). En todo el mundo, el número de vacas lecheras desciende lentamente, a la vez que aumenta la producción de leche por animal (U SDA 1996b).

Entre 1984 y 1992, la producción de la acuicultura aumentó a una tasa anual del 9,1\%. La producción acuícola animal pasó de 14 millones de toneladas en todo el mundo en 1991 a 16 millones de toneladas en 1992, correspondiendo el $84 \%$ a Asia (Platt 1995). Los insectos son ricos en vitaminas, minerales y energía, y aportan entre el $5 \%$ y el $10 \%$ de las proteínas animales para muchas personas. También se convierten en fuente vital de proteínas en épocas de hambruna (D eFoliart 1992).

\section{Características regionales del sector y de los trabajadores}

R esulta difícil separar a los trabajadores dedicados a la ganadería de los que se ocupan de otras actividades de la agricultura. Las actividades de pastoreo, como las que se dan en gran parte de Africa, y las grandes operaciones realizadas en enormes instalaciones, como las de los Estados U nidos, han afirmado la diferencia entre la ganadería y la agricultura. No obstante, en 
Figura 70.2 • Población humana dedicada a la agricultura, por regiones del mundo, 1994.

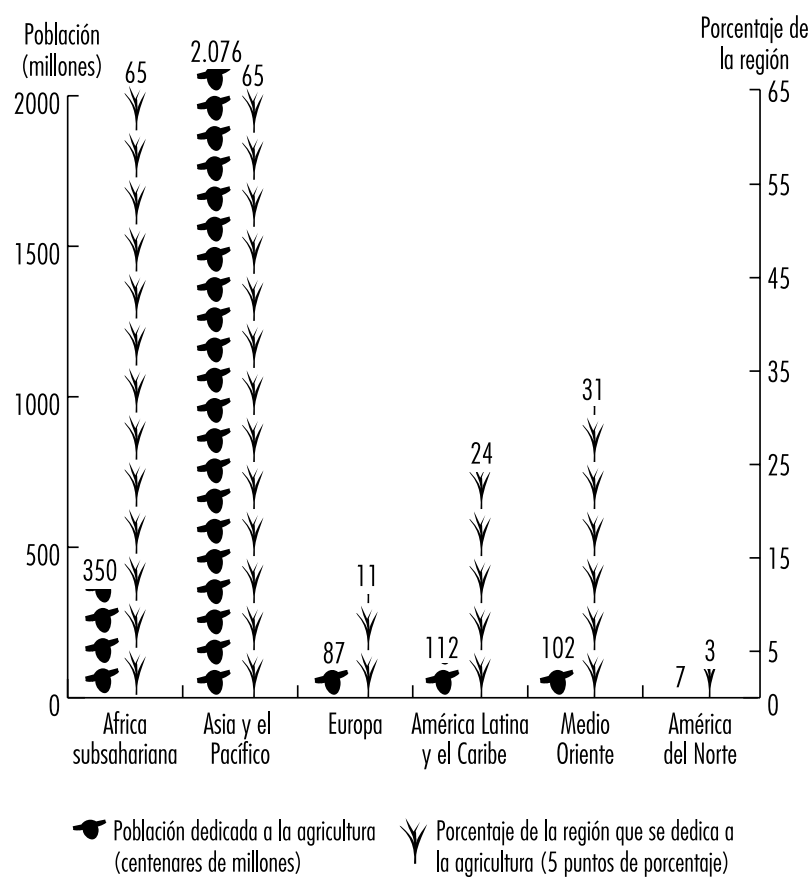

Fuente: Scherf 1995

muchas empresas aparecen integradas. En gran parte del mundo, siguen utilizándose animales de tiro en la agricultura. Además, el ganado y las aves de corral dependen del alimento y del forraje que genera la agricultura, por lo que las operaciones relacionadas con unos y con otros están frecuentemente integradas. La principal especie piscícola del mundo es la carpa, que se alimenta de algas. La producción de insectos también está directamente ligada a la agricultura. El gusano de seda se alimenta exclusivamente de hojas de morera; las abejas dependen del néctar de las flores; las plantas dependen de ellas para la polinización; y los humanos recolectan gusanos comestibles de diversos tipos de cosechas. En 1994, la población mundial ascendía a 5.623.500.000 personas, de las cuales 2.735.021.000 (el $49 \%$ de la población) se dedicaban a la agricultura (véase la Figura 70.2). La mayor contribución a esta masa laboral se encuentra en Asia, donde el $85 \%$ de la población agrícola cría animales de tiro. A continuación se exponen las características regionales de la ganadería.

\section{Africa subsahariana}

La cría de animales domésticos lleva más de 5.000 años practicándose en el Africa subsahariana. El nomadeo de los primeros rebaños ha hecho evolucionar a las especies que toleran la mala nutrición, las enfermedades infecciosas y las largas migraciones. A proximadamente el $65 \%$ de esta región , que es desierto en su mayor parte, sólo sirve pare criar ganado. En 1994, el $65 \%$ de los aproximadamente 539 millones de personas que vivían en el A frica subsahariana dependían de los ingresos procedentes de la agricultura, frente al $76 \%$ de 1975. Aunque su importancia ha aumentado desde la mitad del decenio de 1980, la acuicultura ha contribuido poco al suministro de alimentos a esta región: se basa en la producción de peces de agua dulce de la familia de los cíclidos, y algunas empresas de exportación han intentado dedicarse a la cría de camarones en el mar. Cabe esperar que se desarrolle la acuicultura para exportación, porque se espera que aumente la demanda asiática de pescado, alimentada por las inversiones asiáticas y por la tecnología traída a la región por un clima favorable y por la mano de obra africana.

\section{Asia y el Pacífico}

En Asia y en la región del Pacífico, casi el 76 \% de la población agrícola mundial vive en el $30 \%$ de la tierra cultivable de todo el mundo. A proximadamente el $85 \%$ de los labradores emplean bueyes y búfalos para cultivar y trillar las cosechas.

En esta región las actividades ganaderas se realizan en unidades a pequeña escala, aunque están empezando a operar grandes explotaciones comerciales cerca de las ciudades. En áreas rurales, millones de personas dependen del ganado para obtener carne, leche, huevos, cuero y pieles, animales de tiro y lana. China supera al resto del mundo con 400 millones de cerdos; en el resto del mundo hay un total de 340 millones de cerdos. India cuenta con más de un cuarto del total de ganado vacuno y búfalos del mundo, aunque, debido a las políticas religiosas que restringen el sacrificio de los animales, contribuye con menos del $1 \%$ a la producción mundial de ternera. En muchos países de esta región, la producción de leche forma parte de la agricultura tradicional. El pescado es un ingrediente frecuente en la dieta de la mayor parte de los habitantes de la región. A sia contribuye a la producción mundial de acuicultura con el $84 \%$. Con 6.856 .000 toneladas, China sola produce casi la mitad del total. Se espera que la demanda de pescado aumente rápidamente y que la acuicultura satisfaga esta demanda.

\section{Europa}

En esta región de 802 millones de habitantes, el 10,8 \% se dedicaba a la agricultura en 1994, lo cual supone un significativo descenso con respecto al 16,8 \% de 1975. El aumento de la urbanización y de la mecanización han sido responsables de este descenso. G ran parte de la superficie agrícola útil se encuentra en los climas húmedos y fríos del norte, que son apropiados para el crecimiento de pastos que sirven de alimento al ganado. El resultado es que la mayor parte de la cría de ganado se localiza en la zona septentrional de esta región. Europa contribuyó con el $8,5 \%$ de la producción mundial de acuicultura en 1992. La acuicultura se ha concentrado en especies de valor relativamente alto, tanto de pescado (288.500 toneladas) como de marisco (685.500 toneladas).

\section{América Latina y el Caribe}

La región de A mérica L atina y el Caribe difiere de las demás en muchos aspectos. Grandes extensiones de tierra permanecen sin ser explotadas, hay un importante censo de animales domésticos en la zona y buena parte de la agricultura se lleva a cabo en grandes explotaciones. La ganadería representa aproximadamente un tercio de la producción agrícola, lo que constituye una parte significativa del producto interior bruto. La carne de ternera aporta el mayor porcentaje, alcanzado el $20 \%$ de la producción mundial. La mayor parte de las especies que se crían son importadas. Entre las especies autóctonas que han sido domesticadas se encuentran cobayas, perros, llamas, alpacas, patos M uscovy, pavos y pollos negros. Esta región contribuyó sólo con el 2,3\% a la producción mundial de acuicultura.

\section{Medio Oriente}

En la actualidad, el $31 \%$ de la población de M edio O riente se dedica a la agricultura. Debido a la escasez de lluvias en la región, el único uso agrícola del $62 \%$ de estos terrenos son los pastos. La mayor parte de las especies de ganado fueron 
domesticadas en esta región (cabras, ovejas, cerdos y ganado bovino), en la confluencia de los ríos T igris y E ufrates. M ás tarde, en el norte de Africa, fueron domesticados los búfalos de agua, los dromedarios y los asnos. H oy en día persisten algunos sistemas de cría de ganado que hubo en la antigüedad. Se trata de sistemas de subsistencia que se practican en las sociedad tribales árabes y que se basan en la trashumancia a largas distancias en busca de comida y agua, con el cambio de estación. Se emplean sistema de agricultura intensiva en los países más desarrollados.

\section{América del Norte}

Aunque la agricultura es una actividad económica importante en Canadá y en Estados U nidos, la proporción de la población que se dedica a ella es inferior al 2,5\%. Desde el decenio de 1950, la agricultura se ha hecho más intensiva, de forma que las explotaciones son menos, pero más grandes. El ganado y los productos derivados de él constituyen una proporción fundamental de la dieta de la población, contribuyendo con un $40 \%$ al total de energía procedente de los alimentos. En esta región, el sector ganadero ha sido muy dinámico. Los animales introducidos han sido cruzados con razas autóctonas para formar otras nuevas. La demanda por parte de los consumidores de carnes más magras y huevos con menos colesterol influye actualmente sobre la política de cría. A finales del siglo X IX se utilizaban mucho los caballos, pero su número ha disminuido debido a la mecanización. En la actualidad se emplean en actividades deportivas (hipódromos) y de ocio. Estados Unidos ha importado unas 700 especies de insectos para controlar más de 50 plagas. La acuicultura está creciendo en esta región, y en 1992 constituyó el 3,7 \% de la producción mundial (FAO 1995; Scherf 1995).

\section{Cuestiones ambientales y de salud pública}

L os riesgos laborales de la ganadería pueden dar lugar a lesiones, asma 0 zoonosis. Además, la cría de ganado suscita diversas cuestiones ambientales y de salud pública. Un aspecto es el efecto de los excrementos de los animales sobre el entorno. 0 tros son la pérdida de diversidad biológica, los riesgos asociados con la importación de animales y de productos y la seguridad de los alimentos.

\section{Contaminación del aire y del agua}

Los excrementos de los animales tienen posibles consecuencias ambientales sobre la contaminación del agua y del aire. Según las cifras anuales sobre excrementos en Estados Unidos que se ofrecen en la Tabla 70.3, en 1994 las principales razas ganaderas fueron responsables de un total de 14.300 millones de toneladas de heces y orina en todo el mundo. De este total, al ganado bovino (leche y carne) le correspondió $87 \%$; al porcino, el $9 \%$; y a los pollos y pavos, el 3 \% (M eadows 1995). D ebido a su elevado factor de excreción anual de 9,76 toneladas de heces y orina por animal, el ganado bovino fue el máximo contribuyente a la emisión de excrementos en las seis regiones de la O rganización de las $\mathrm{N}$ aciones U nidas para la Agricultura y la Alimentación

Tabla 70.3 - Producción anual de heces y orina del ganado en EE.UU.

$\begin{array}{lrll}\text { Tipo de animal } & \text { Población } & \begin{array}{l}\text { Excrementos } \\ \text { (toneladas) }\end{array} & \begin{array}{l}\text { Toneladas } \\ \text { por animal }\end{array} \\ \text { Vacas (leche y carne) } & 46.500 .000 & 450.000 .000 & 9,76 \\ \text { Cerdos } & 60.000 .000 & 91.000 .000 & 1,51 \\ \text { Pollos y pavos } & 7.500 .000 .000 & 270.000 .000 & 0,04\end{array}$

Fuente: Meadows 1995.
(FAO), desde el $82 \%$ en Europa y en Asia hasta el $96 \%$ en el Africa subsahariana.

En los Estados U nidos, los granjeros que se especializan en la cría ganadera no se dedican a la agricultura, como ha sido la práctica histórica. El resultado es que los excrementos del ganado ya no se aplican sistemáticamente a las cosechas como abono. O tro problema de la moderna cría de ganado es la elevada concentración de animales en pequeñas zonas, como los edificios de confinamiento o establos. Las grandes explotaciones pueden tener encerrados entre 50.000 y 100.000 vacas, 10.000 cerdos o 400.000 pollos en una zona. A demás, tienden a agrupar las plantas de transformación, para acortar las distancia de transporte.

De la concentración de operaciones emanan diversos problemas ambientales, en particular los efectos sobre la salud de los vertidos a acuíferos, las filtraciones y aflujos crónicos y la contaminación atmosférica. El paso de nitritos al agua y los escapes procedentes de los campos y los establos contribuyen de forma fundamental a la contaminación del agua. El uso masivo de estabulaciones hace que el estiércol animal se concentre y aumenta el riesgo de que se contaminen las aguas freáticas. $\mathrm{H}$ abitualmente, los desechos de las explotaciones vacunas y porcinas se recogen en estanques, grandes excavaciones poco profundas hechas en el suelo. EI diseño de los estanques depende de la sedimentación de los elementos sólidos en el fondo, donde son digeridos de modo anaerobio, y los líquidos sobrantes se controlan esparciéndolos por los terrenos colindantes cuando rebosan (M eadows 1995).

La biodegradación de los excrementos de los animales emite, además, gases olorosos que contienen hasta 60 compuestos. Entre éstos se encuentran el amoníaco y aminas, sulfuros, ácidos grasos volátiles, alcoholes, aldehídos, mercaptanos, ésteres y carbonilos (Sweeten 1995). El olor de los concentrados de excrementos de las explotaciones puede producir náuseas, cefaleas, problemas respiratorios, trastornos del sueño, pérdida de apetito e irritación de ojos, oídos y garganta.

Se conocen peor los efectos adversos de los excrementos del ganado sobre el calentamiento global y la contaminación atmosférica. Su contribución al calentamiento global depende de su generación de los gases que provocan el efecto invernadero, dióxido de carbono y metano. El estiércol del ganado puede contribuir a la contaminación por nitrógeno, debido al amoníaco liberado por los estanques de desechos a la atmósfera. EI nitrógeno atmosférico vuelve a entrar en el ciclo hidrológico mediante la lluvia y pasa al agua de arroyos, ríos, lagos y costas. El nitrógeno del agua contribuye a que aumenten las algas que reducen el oxígeno disponible para los peces.

$\mathrm{H}$ ay dos formas de modificar la producción de ganado que ofrecen soluciones a algunos de los problemas de la contaminación. Se trata de confinar menos a los animales y de mejorar los sistemas de tratamiento de los desechos.

\section{Diversidad animal}

La posibilidad de que se pierdan rápidamente genes, especies y hábitat amenaza la adaptabilidad y los rasgos de determinadas razas de animales que son o podrían ser útiles. Los esfuerzos internacionales han hecho hincapié en la necesidad de preservar la diversidad biológica a tres niveles: genético, de la especie y del hábitat. U n ejemplo del declive de la diversidad genética lo constituye el limitado número de sementales que se emplea para cruzar artificialmente a las hembras de muchas especies (Scherf 1995).

Con el declive de muchas razas y la consiguiente reducción de la diversidad de especies, las razas dominantes han ido aumentando, favoreciendo la uniformidad de las razas más productivas. El problema de la falta de diversidad en el ganado 
productor de leche es particularmente agudo; a excepción de la raza $\mathrm{H}$ olstein, de alta producción, las poblaciones de vacas lecheras están desapareciendo. La acuicultura no ha reducido la presión sobre las poblaciones salvajes de peces. Por ejemplo, el empleo de redes de malla estrecha en la captura de gambas determina que se recojan alevines de especies salvajes valiosas, lo cual contribuye a su eliminación. Algunas especies, como el mero, el milkfish (especie comestible muy abundante en $\mathrm{H}$ awai) y la anguila, no puede ser criados en cautividad, por lo que sus alevines son capturados en estado salvaje y se crían en piscifactorías, lo que reduce aún más el conjunto de poblaciones salvajes.

Un ejemplo de la pérdida de diversidad del hábitat está representado por el impacto que el alimento para las piscifactorías tiene sobre las poblaciones salvajes. El pescado que se emplea como alimento en las zonas costeras afecta a la población salvaje de gambas y pescados porque destruye sus hábitat naturales, como son los manglares. Además, las heces de los peces y los alimentos pueden acumularse en el fondo y destruir a las comunidades bentónicas que filtran el agua (Safina 1995).

$L$ as especies animales que sobreviven en abundancia son las que se emplean básicamente para fines humanos, si bien ha surgido un movimiento de defensa de los animales que crea un problema social al afirmar que éstos, sobre todo los de sangre caliente, no deben emplearse para fines humanos. Precediendo a este movimiento a mediados del decenio de 1970 apareció otro encaminado a la defensa del bienestar de los animales. Sus defensores abogan por un trato humanitario para los animales que se emplean en investigación, alimentación, obtención de tejidos, deportes o compañía. Parece poco probable que la utilización de los animales por el hombre vaya a ser abolida. También es probable que la lucha por el bienestar de éstos persista como movimiento popular (NIH 1988).

\section{Importación de animales y de productos animales}

La historia de la ganadería está íntimamente ligada a la historia de la importación de ganado a nuevas zonas del mundo. Con la importación se difunden las enfermedades, al diseminarse el ganado importado y los productos derivados. Los animales pueden transportar enfermedades que infecten a otros animales 0 a los seres humanos, y de ahí que los países hayan establecido servicios de cuarentena para controlar la diseminación de las zoonosis. Entre estas se encuentran, la brucelosis, la fiebre $Q$ y el ántrax. La inspección del ganado y de los alimentos y las cuarentenas se han convertido en métodos de control de la importación de enfermedades (M acDiarmid 1993).

La preocupación pública por la posible infección de los seres humanos por la poco habitual enfermedad de CreutzfeldtJakob (ECJ) apareció entre las naciones importadoras de carne de ternera en 1996. Se sospecha que la ECJ surge por la ingestión de carne de ternera infectada por la encefalopatía espongiforme bovina (EEB), popularmente conocida como enfermedad de las vacas locas. Aunque no se ha demostrado, se piensa que esta última podría haber afectado al ganado alimentado con huesos y despojos de ovejas afectadas por la enfermedad similar correspondiente, la tembladera del ovino. $L$ as tres enfermedades, en seres humanos, vacas y ovejas, muestras síntomas comunes de lesiones cerebrales espongiformes. Las tres son mortales, tienen causas desconocidas y no hay pruebas para detectarlas. Los británicos decidieron el sacrificio preventivo de un tercio de su población de vacas en 1996 para controlar la EEB y devolver la confianza a los consumidores (Aldhous 1996).

La importación de abejas africanas en Brasil también se ha convertido en un asunto de salud pública. En Estados U nidos hay subespecies de abejas europeas que producen miel y cera y que polinizan los cultivos. R ara vez se tornan agresivas, lo que hace de la apicultura una ocupación segura. La subespecie africana ha emigrado desde Brasil a América Central, M éxico y los estados del sureste de Estados U nidos. Es agresiva y ataca en enjambres para defender la colonia. Se ha cruzado con la subespecie europea, lo que ha dado lugar a una abeja africanizada aún más agresiva. La amenaza para la salud pública consiste en que, cuando los enjambres de abejas africanizadas atacan, producen múltiples picotazos que dan lugar a graves reacciones tóxicas en el ser humano.

En la actualidad existen dos formas de controlar a la abeja africanizada. U na se basa en que no resisten bien los climas del norte y se quedan en climas más templados como los estados del sureste de Estados U nidos. La otra consiste en sustituir de forma rutinaria a la abeja reina de las colmenas por abejas reinas de la subespecie europea, aunque con este procedimiento no pueden controlarse las colonias salvajes (Schumacher y Egen 1995).

\section{Seguridad de los alimentos}

M uchas enfermedades que se contagian al ser humano a través de los alimentos son el resultado de bacterias patógenas de origen animal. Son ejemplos la listeria y la salmonela, que se encuentran en los productos lácteos, y la salmonela y campylobacter, que se encuentran en la carne y en las aves de corral. Los Centers for D isease Control and Prevention calculan que el $53 \%$ de los brotes de intoxicación alimentaria en Estados Unidos fueron causados por la contaminación bacteriana de productos de origen animal. Calculan que se produjeron 33 millones de intoxicaciones alimentarias al año, que produjeron 9.000 fallecimientos.

La adición de antibióticos en dosis subterapéuticas al alimento y el tratamiento con antibióticos de los animales enfermos son prácticas de salud animal actualmente en vigor. La posible disminución de la eficacia de estos medicamentos en el tratamiento de las enfermedades está suscitando preocupación debido a la frecuente aparición de resistencia a los antibióticos en los patógenos zoonóticos. M uchos antibióticos que se añaden al alimento de los animales se emplean también en medicina humana, y pueden aparecer resistencia en bacterias que causan infecciones a los animales y a los seres humanos.

Los residuos de fármacos procedentes de la medicación del ganado también presentan riesgos. En animales productores de alimento, como las vacas lecheras, se han encontrado residuos de los antibióticos utilizados para tratar sus enfermedades 0 como adición al alimento. Entre estos fármacos están el cloramfenicol y la sulfametazina. Las alternativas al empleo profiláctico de antibióticos en el alimento implican la modificación de los sistemas de producción. Consisten en reducir el confinamiento de los animales, mejorar la ventilación y mejorar los sistemas de tratamiento de los desechos.

La dieta se ha asociado con enfermedades crónicas. La evidencia de la relación existente entre el consumo de grasa y las cardiopatías ha estimulado los esfuerzos por producir derivados de los animales con un menor contenido graso. En estos esfuerzos se incluyen la selección de animales, la alimentación de machos intactos en lugar de castrados, y la ingeniería genética. También se considera el empleo de hormonas como forma de reducir el contenido graso de la carne. Las hormonas de crecimiento de porcino aumentan la tasa de crecimiento, la eficacia de la alimentación y la proporción entre músculo y grasa. La creciente popularidad de las especies con escasa grasa y colesterol, como los avestruces, constituye otra solución (NRC 1989). 


\section{Problemas de SALUd Y PAUTAS PAT O LO GICAS}

\section{Kendall Thu, Craig Zwerling} y Kelley D onham

La domesticación de animales tuvo lugar de modo independiente en varias zonas del Viejo y del Nuevo Mundo hace más de 10.000 años. H asta entonces, la caza y el acopio habían constituido el patrón predominante de subsistencia. El control por el ser humano de la producción de plantas y animales y de los procesos de reproducción implicó cambios revolucionarios en la estructura de las sociedades humanas y en sus relaciones con el entorno. La aparición de la agricultura marcó un aumento en la intensidad del trabajo y del tiempo empleado en actividades relacionadas con la obtención de alimentos. $L$ as pequeñas familias nucleares, que estaban adaptadas a la caza nómada y a los grupos de acopio, se transformaron en grandes unidades sociales ampliadas y sedentarias, adecuadas para la producción de alimento domesticado mediante explotaciones intensivas.

La domesticación de los animales aumentó la susceptibilidad de los seres humanos a las lesiones y enfermedades relacionadas con los animales. El hecho de que las poblaciones fueran mayores y sedentarias, y se asentaran en íntima proximidad de los animales, supuso un aumento de las probabilidades de transmisión de enfermedades entre los animales y los seres humanos. La aparición de grandes rebaños de ganado criado de modo más intensivo también aumentó la probabilidad de lesiones. En todo el mundo, las distintas formas de agricultura animal se asocian con riesgos diversos de lesiones y enfermedades. Por ejemplo, los 50 millones de habitantes que practican la agricultura de poda y quema en las regiones ecuatoriales afrontan problemas distintos que los 35 millones de pastores nómadas que hay en Escandinavia y en A sia central o que los 48 millones de productores de alimento que practican formas industrializadas de agricultura.

En este artículo se examinan algunos patrones de lesiones, enfermedades infecciosas, enfermedades respiratorias y enfermedades cutáneas que se asocian con la producción de ganado. EI tratamiento resulta desequilibrado en cuanto a los temas y las zonas geográficas a que se refiere, porque la mayor parte de la investigación ha sido realizada en países industrializados, en los que son habituales las formas intensivas de producción ganadera.

\section{Perspectiva general}

Los problemas de salud humanos y los patrones de enfermedad que se asocian con la producción de ganado pueden agruparse en función del tipo de contacto existente entre los animales y las personas (véase la Tabla 70.4). El contacto puede producirse por interacción física directa, o a través de un agente orgánico o inorgánico. L os problemas de salud que se asocian con todos los tipos de producción de ganado pueden agruparse en estos dos ámbitos.

El contacto humano directo con el ganado va desde la fuerza bruta de grandes animales como el búfalo chino hasta el contacto cutáneo indetectable con los pelos microscópicos de la lagarta oriental japonesa. Puede producirse una variedad paralela de problemas de salud, que van desde la irritación temporal hasta el golpe físicamente debilitante. Los problemas importantes son las lesiones traumáticas derivadas del manejo de animales grandes, la hipersensibilidad a venenos o las toxicosis por mordeduras y picaduras de artrópodos venenosos y las dermatitis cutáneas de contacto y alérgicas.

Ciertos agentes orgánicos emplean diversas vías para pasar del ganado a los seres humanos, dando lugar a distintos
Tabla 70.4 - Tipos de problemas de salud para el hombre relacionados con la producción ganadera.

Problemas de salud por contacto físico directo

Dermatitis alérgica de contacto

Rinitis alérgica

Mordiscos, coces, aplastamientos

Envenenamiento y posible hipersensibilidad

Asma

Arañazos

Lesión traumática

Problemas de salud por agentes orgánicos

Intoxicación por productos fitosanitarios

Resistencia a antibióticos

Bronquitis crónica

Dermatitis de contacto

Alergias por exposición a residuos de fármacos en los alimentos

Enfermedades transmitidas por los alimentos

"Pulmón de granjero"

Neumonitis por hipersensibilidad

Irritación de mucosas

Asma de origen profesional

Síndrome tóxico por polvo orgánico (STPO)

Alergias por exposición a fármacos

Zoonosis

Problemas de salud por agentes físicos

Sordera

Traumatismo relacionado con la maquinaria

Emisión de metano y efecto invernadero

Trastornos musculosqueléticos

Estrés

problemas de salud. Entre los más importantes desde el punto de vista global están las zoonosis. En todo el mundo se han identificado más de 150 zoonosis, de las cuales unas 40 son importantes para la salud humana (D onham 1985). La importancia de las zoonosis depende de factores regionales, como las prácticas agrícolas, el entorno y el status social y económico de la región. Sus consecuencias para la salud van desde síntomas gripales relativamente benignos por brucelosis hasta la tuberculosis debilitante 0 los efectos potencialmente letales de E scherichia coli o la rabia.

0 tros agentes orgánicos son los que se asocian con enfermedades respiratorias. Los sistemas intensivos de producción de ganado en edificios de confinamiento crean ambientes cerrados en los que el polvo, en el que se encuentran microbios y sus productos intermediarios, se concentran y aerosolizan junto con los gases que, a su vez, son respirados por las personas. A proximadamente el $33 \%$ de los trabajadores de explotaciones porcinas de Estados U nidos padecen el síndrome tóxico por polvo orgánico (ST PO) (T horne y cols. 1996). Existen problemas comparables en las explotaciones estabuladas de vacuno, donde el polvo que contiene endotoxinas y/o otros agentes biológicamente activos en el entorno contribuye a las bronquitis, al asma profesional y a la inflamación de mucosas. Aunque estos problemas son más llamativos en los países industrializados, en los que la agricultura está muy extendida, la creciente exportación de tecnologías de producción de ganado en confinamiento a las zonas en desarrollo como el sureste de A sia y América Central aumenta los riesgos para los trabajadores de esas regiones.

L os problemas de salud derivados de los agentes físicos suelen estar relacionados con las herramientas o con la maquinaria 
directa 0 indirectamente implicadas en la producción ganadera en el medio ambiente agrario. Los tractores son la principal causa de fallecimiento en explotaciones agrícolas en países desarrollados. Además, las elevadas tasas de sordera que se asocia con la maquinaria y los ruidos de la producción ganadera en confinamiento, y los trastornos musculosqueléticos causados por movimientos repetitivos, son otras tantas consecuencias de las formas industrializadas de agricultura animal. La industrialización agrícola, que se caracteriza por el empleo de tecnologías intensivas con grandes capitales que actúan como interfaz entre los seres humanos y el medio físico para producir alimento, está detrás del crecimiento de los agentes físicos como factores de salud importantes relacionados con la ganadería.

\section{Lesiones}

El contacto directo con el ganado es una de las causas principales de lesiones en muchas regiones industrializadas del mundo. En Estados Unidos, el Traumatic Injury Surveillance of Farmers (NIOSH 1993) indica que el ganado es la principal fuente de lesiones, de forma que el $18 \%$ de las lesiones relacionadas con la agricultura dependen de vacas, cerdos y ovejas, y suponen el mayor número de jornadas perdidas. Estos coinciden con un estudio realizado en 1980-81 por el Consejo de Seguridad Nacional de los Estados U nidos (N ational Safety C ouncil 1982).

Los estudios regionales realizados en Estados U nidos coinciden en señalar al ganado como la causa principal de lesión en el trabajo agrícola. Un trabajo antiguo realizado sobre consultas hospitalarias de los agricultores en Nueva York entre 1929 y 1948 reveló que el ganado era responsable del $17 \%$ de las lesiones relacionadas con la actividad agrícola, sólo detrás de la maquinaria (Calandruccio y Powers 1949). Esa tendencia se mantiene, puesto que las investigaciones indican que el ganado es responsable de un tercio al menos de las lesiones de origen agropecuario producidas en criadores de vacas de Vermont (Waller 1992), del $19 \%$ de las lesiones producidas en una muestra al azar de agricultores de Alabama (Zhou y Roseman 1995) y del $24 \%$ de las lesiones de los agricultores de lowa (Iowa Department of Public Health 1995). Uno de los escasos estudios dedicados a analizar los factores de riesgo de las lesiones específicamente derivadas de la ganadería indica que estas lesiones pueden estar relacionadas con la organización de la producción y con las características específicas del medio en el que se cría el ganado (L ayde y cols. 1996).

Datos procedentes de otras zonas agrícolas industrializadas del mundo muestran patrones similares. Investigaciones realizadas en Australia indican que los ganaderos tienen la segunda tasa de lesiones profesionales mortales del país (Erlich y cols. 1993). U n estudio de los registros de accidentes y de consultas a urgencias por parte de agricultores británicos de la parte occidental de Gales (Cameron y Bishop 1992) revela que el ganado fue la principal fuente de lesiones, habiendo causado el $35 \%$ de los accidentes relacionados con la actividad agrícola. En Dinamarca, un estudio de 257 lesiones de origen agrícola tratadas en hospitales situó al ganado en el segundo puesto, siendo la causa del $36 \%$ de las lesiones tratadas (Carstensen, Lauritsen y R asmussen 1995). Es necesario hacer más investigación de vigilancia para suplir la falta de datos sistemáticos sobre la tasa de lesiones relacionadas con el ganado en las zonas del mundo en desarrollo.

La prevención de las lesiones relacionadas con el ganado implica comprender su comportamiento y respetar los peligros, actuando adecuadamente y utilizando tecnologías de control apropiadas. Para reducir el riesgo de lesiones es fundamental entender los hábitos de los animales en relación a sus comportamientos alimentarios y a las fluctuaciones ambientales 0 a las relaciones sociales, como el aislamiento de su rebaño, el instinto de las hembras para alimentar y proteger a sus crías, y la variable naturaleza territorial y de los patrones alimentarios. $L a$ prevención de las lesiones depende también del empleo y mantenimiento de equipos de control del ganado, como cercas, corrales, establos y jaulas. El riesgo es especialmente alto para los niños, que deben mantenerse vigilados en zonas de juego diseñadas suficientemente alejadas de las zonas donde se cuida al ganado.

\section{Enfermedades infecciosas}

Las zoonosis se pueden clasificar por su forma de transmisión, la cual está ligada a su vez a las formas de la agricultura, a la organización social humana y al ecosistema. Las cuatro vías generales de transmisión son:

1. único huésped vertebrado directo

2. ciclo de múltiples huéspedes vertebrados

3. combinación de huéspedes vertebrados-invertebrados

4. reservorio inanimado intermedio.

Por lo general, las zoonosis pueden caracterizarse como sigue: no son mortales, a menudo quedan sin diagnosticar y son más esporádicas que epidémicas; remedan otras enfermedades; y los seres humanos suelen ser el último huésped. Puede consultarse la lista de zoonosis de la Tabla 70.5.

Las tasas de zoonosis en seres humanos son desconocidas en gran parte, debido a la falta de datos epidemiológicos y a los diagnósticos erróneos. H asta en países industrializados como los Estados Unidos, enfermedades como la leptospirosis se confunden a menudo con la gripe. Los síntomas son inespecíficos, los cual dificulta el diagnóstico y constituye una característica de muchas zoonosis.

La prevención de las zoonosis implica una combinación de actividades como la erradicación de enfermedades, las vacunaciones de animales, las vacunaciones de seres humanos, la higiene del medio de trabajo, la limpieza y protección de las heridas abiertas, el empleo de técnicas apropiadas de manipulación y preparación de alimentos (como la pasteurización de la leche y la cocción de la carne), la utilización de equipo de protección individual (como las botas en los campos de arroz) y el empleo prudente de los antibióticos para reducir el crecimiento de cepas resistentes. Las tecnologías de control y las conductas preventivas deben traducirse en términos de vías de contagio, agentes y huéspedes, y ser dirigidas específicamente a las cuatro vías de transmisión.

\section{Enfermedades respiratorias}

D ada la variedad y el grado de las exposiciones relacionadas con la producción ganadera, quizás las enfermedades respiratorias sean el principal problema de salud. Los estudios realizados en algunos sectores de la producción ganadera en zonas desarrolladas del mundo señalan que el $25 \%$ de los trabajadores de la ganadería padecen alguna forma de enfermedad respiratoria (Thorne y cols. 1996). Los tipos de trabajo que con más frecuencia se asocian con problemas respiratorios son la producción y manipulación de grano y el trabajo en unidades de confinamiento de animales y en explotaciones lácteas.

Las enfermedades respiratorias de origen agrícola pueden producirse como resultado de la exposición a diversos polvos, gases, productos químicos agrícolas y agentes infecciosos. Las exposiciones al polvo pueden dividirse según se trate de polvos formados fundamentalmente por componentes orgánicos o por componentes inorgánicos. La principal fuente de exposición a polvos inorgánicos es el polvo del campo. El polvo orgánico constituye la principal fuente de exposición respiratoria para trabajadores agrícolas. Las enfermedades correspondientes se producen como resultado de cortas exposiciones periódicas al 
Tabla 70.5 - Principales zoonosis, por regiones del mundo.

\begin{tabular}{|c|c|c|}
\hline Nombre común & Fuente principal & Región \\
\hline Antrax & Mamíferos & Mediterráneo oriental, Oeste y Sureste de Asia, América Latina \\
\hline Brucelosis & Cabras, ovejas, vacas, cerdos & Europa, Zona mediterránea, Estados Unidos \\
\hline $\begin{array}{l}\text { Encefalitis transmitida } \\
\text { por artrópodos }\end{array}$ & Aves, ovejas, roedores & Africa, Australia, Europa central, Lejano Oriente, América Latina, Rusia, Estados Unidos \\
\hline Hidatidosis & Perros, rumiantes, cerdos, carnívoros salvajes & $\begin{array}{l}\text { Mediterráneo Oriental, Sur de Sudamérica, Sur y Este de Africa, Nueva Zelanda, } \\
\text { Sur de Australia, Siberia }\end{array}$ \\
\hline Leptospirosis & $\begin{array}{l}\text { Roedores, vacas, cerdos, carnivoros salvajes, } \\
\text { caballos }\end{array}$ & Todo el mundo, mayor prevalencia en el Caribe \\
\hline Fiebre Q & Vacas, cabras, ovejas & Todo el mundo \\
\hline Rabia & Perros, gatos, carnívoros salvajes, murciélagos & Todo el mundo \\
\hline Salmonelosis & Aves, mamíferos & $\begin{array}{l}\text { Todo el mundo, mayor prevalencia en regiones con agricultura industrial y más } \\
\text { elevada utilización de antibióticos }\end{array}$ \\
\hline Triquinosis & Cerdos, carnívoros salvajes, animales árticos & Argentina, Brasil, Europa central, Chile, América del Norte, España \\
\hline Tuberculosis & Vacas, perros, cabras & Todo el mundo, mayor prevalencia en países en desarrollo \\
\hline
\end{tabular}

polvo orgánico agrícola, que contiene grandes cantidades de microbios.

Se denomina síndrome tóxico por polvo orgánico (ST PO ) una enfermedad aguda parecida a la gripe que se observa tras exposiciones cortas y periódicas a concentraciones de polvo elevadas (Donham 1986). Se trata de un síndrome con características muy similares a las del pulmón de granjero agudo, si bien no comporta el riesgo de deterioro pulmonar que se asocia con este último. Las bronquitis que afectan a los agricultores pueden ser agudas o crónicas (Rylander 1994). El asma, definida por una obstrucción reversible de las vías respiratorias asociada con inflamación de éstas, también puede ser producida por exposiciones agrícolas. En la mayor parte de los casos, este tipo de asma guarda relación con una inflamación crónica de las vías respiratorias, más que con una alergia específica.

La segunda fuente de exposición por orden de frecuencia es la relativa a un nivel algo más bajo de polvo orgánico. $\mathrm{H}$ abitualmente, los niveles de polvo están entre 2 y $9 \mathrm{mg} / \mathrm{m}^{3}$, las cifras de microbios están entre $10^{3}$ y $10^{5}$ microorganismos/ $\mathrm{m}^{3}$ y la concentración de endotoxinas está entre 50 y $900 \mathrm{UE} / \mathrm{m}^{3}$. Son ejemplos de estas exposiciones el trabajo en explotaciones porcinas, vacunas o de aves de corral. Los síntomas habituales son los de la bronquitis aguda y crónica, un síndrome de tipo asmático y síntomas de irritación de mucosas.

Los gases desempeñan un papel importante como causa de problemas pulmonares en el medio agrícola. En las instalaciones de confinamiento de cerdos y donde se crían aves de corral, los niveles de amoníaco suelen causar problemas respiratorios. La exposición al amoníaco anhidro, un fertilizante, tiene efectos agudos y a largo plazo sobre el tracto respiratorio. La intoxicación aguda por el ácido sulfhídrico que se libera en las instalaciones de depósito de estiércol en los establos de vacas y en las explotaciones de porcino puede producir fallecimientos. La inhalación de fumigantes insecticidas también puede producir muertes.

Es posible ayudar a prevenir las enfermedades respiratorias mediante el control de las fuentes de polvo y de otros agentes. En los edificios para el ganado, hay que disponer de un sistema de ventilación correctamente diseñado y de limpieza frecuente para impedir que se acumule el polvo. Con todo, los sistemas de control mecánicos son insuficientes. $\mathrm{H}$ ay que utilizar también mascarillas correctamente seleccionadas. Se pueden considerar alternativas tales como el pastoreo al aire libre y el confinamiento parcial, que pueden ser tan rentables como el confinamiento completo, sobre todo si se tienen en cuenta los costes en salud laboral.

\section{Problemas cutáneos}

Los problemas cutáneos pueden clasificarse en dermatitis de contacto, problemas relacionados con el sol, problemas infecciosos o inducidos por insectos. L os cálculos indican que los agricultores son los trabajadores que presentan un mayo rriesgo laboral de padecer ciertas dermatosis (M athias 1989). A falta de tasas de prevalencia, sobre todo en las regiones en desarrollo, los estudios realizados en Estados U nidos indican que las enfermedades cutáneas de origen profesional pueden significar hasta el $70 \%$ del total de enfermedades profesionales entre agricultores en ciertas regiones (H ogan y Lane 1986).

$\mathrm{H}$ ay tres tipos de dermatitis de contacto: dermatitis irritante, dermatitis alérgica y dermatitis por fotocontacto. La forma más común es la primera, mientras que la segunda es menos frecuente y las reacciones por fotocontacto son raras (Zuehlke, M utel y D onham 1980). En el campo, las fuentes habituales de dermatitis de contacto son los fertilizantes, las plantas y los plaguicidas. E s especialmente llamativa la dermatitis de contacto con el alimento del ganado. Los alimentos contienen aditivos, como antibióticos, que pueden dar lugar a dermatitis alérgicas.

Los agricultores de piel clara de ciertas zonas del mundo en desarrollo presentan un riesgo especial de padecer problemas cutáneos inducidos por el sol, como arrugas, queratitis actínica (lesiones escamosas no cancerosas) y cáncer de piel. L os dos tipos más frecuentes de cáncer de piel son el carcinoma de células basales y el carcinoma epidermoide. Un trabajo epidemiológico llevado a cabo en Canadá indica que los agricultores presentan un riesgo de padecer carcinoma epidermoide mayor que quienes se dedican a otras actividades (H ogan y Lane 1986). Los carcinomas epidermoides suelen derivar de queratitis actínicas. A proximadamente 2 de cada 100 casos dan metástasis, y la zona más frecuente son los labios. Los carcinomas de células basales son más frecuentes, y aparecen en la cara y en las orejas. Aunque localmente son destructivos, rara vez metastatizan.

L as dermatitis infecciosas más importantes para los ganaderos son la tiña (hongos dermatofíticos), la ectima contagiosa y los nódulos de los ordeñadores. La tiña es una infección cutánea 


\section{Problemas de salud en el trabajo relacionados con los artrópodos}

Los artrópodos comprenden más de 1 millón de especies de insectos y miles de especies de otros animales, como garrapatas, ácaros, arañas, escorpiones y ciempiés. Las abejas, hormigas, avispas y escorpiones pican e inyectan veneno; los mosquitos y las garrapatas chupan sangre y transmiten enfermedades; las escamas y pelos de los cuerpos de los insectos pueden irritar los ojos y la piel, así como los tejidos de la nariz, la boca y el sistema respiratorio. Casi todas las picaduras que reciben los seres humanos se deben a abejas sociales (abejorros, abejas de la miel). 0 tras picaduras se deben a avispas, avispones, tábanos y hormigas.

Los artrópodos pueden constituir un peligro para la salud en el centro de trabajo (véase la Tabla 70.6), pero los posibles peligros derivados de ellos no suelen ser exclusivos de ninguna ocupación concreta. Más bien, la exposición a artrópodos en el centro de trabajo depende de la localización geográfica, de las condiciones locales y de la estación del año. En la Tabla 70.7 figura una lista de algunos de estos peligros y sus correspondientes agentes. Para todos los peligros derivados de los artrópodos, la primera línea de defensa es la evitación 0 exclusión del agente agresor. La inmunoterapia puede aumentar la tolerancia de una persona al veneno de artrópodo, y se consigue inyectando dosis crecientes de veneno a lo largo de un período de tiempo. Es eficaz en el 90 al $100 \%$ de los individuos hipersensibles al veneno, pero comporta una ciclo indefinido de costosas inyecciones. En la Tabla 70.8 se recoge una lista de reacciones normales y alérgicas a las picaduras de insectos.

Tabla 70.6 - Diferentes ocupaciones y su potencial de contacto con artrópodos que pueden afectar de modo adverso a la salud y la seguridad.

\begin{tabular}{l} 
Ocupación \\
\hline Personal de construcción, especialistas en medio ambiente, agricultores, pesca- \\
dores, guardabosques, personas en contacto con animales salvajes, naturalistas, \\
transportistas, vigilantes de parques, trabajadores del agua, gas y electricidad \\
Fabricantes de cosméticos, trabajadores de los muelles, fabricantes de tintes, \\
trabajadores de fábricas, trabajadores de la industria alimentaria, trabajadores \\
con gramíneas, albañiles, molineros, trabajadores de restaurantes \\
Apicultores \\
Trabajadores de la producción de insectos, biólogos de laboratorio y de campo, \\
celadores de museos \\
Trabajadores de hospitales y otros trabajadores sanitarios, administradores de \\
centros escolares, profesores \\
Sericultores
\end{tabular}

Tabla 70.7 - Peligros potenciales derivados de los artrópodos en el lugar de trabajo y sus agentes causales.

\begin{tabular}{|c|c|}
\hline Peligro & Artrópodos \\
\hline $\begin{array}{l}\text { Envenenamiento por } \\
\text { picaduras }\end{array}$ & $\begin{array}{l}\text { Hormigas, moscas picadoras, ciempiés, ácaros, } \\
\text { arañas }\end{array}$ \\
\hline $\begin{array}{l}\text { Envenenamiento por } \\
\text { picadura, hipersensibi- } \\
\text { lidad al veneno }\end{array}$ & Hormigas, abejas, avispas, escorpiones \\
\hline $\begin{array}{l}\text { Toxicosis/ parálisis por } \\
\text { garrapatas }\end{array}$ & Garrapatas \\
\hline Asma & $\begin{array}{l}\text { Escarabajos, fríganos, orugas, cucarachas, grillos, } \\
\text { ácaros del polvo, larvas de moscas, ácaros de } \\
\text { las gramíneas, gorgojos del grano, saltamontes, } \\
\text { abejas de la miel, cachipollas, polillas, gusanos } \\
\text { de seda }\end{array}$ \\
\hline Dermatitis de contacto ${ }^{3}$ & $\begin{array}{l}\text { Abadejos, orugas, cucarachas, ácaros de la fruta } \\
\text { seca, ácaros del polvo, ácaros de las gramíneas, } \\
\text { ácaros de la paja, polillas, gusanos de seda, } \\
\text { arañas }\end{array}$ \\
\hline \multicolumn{2}{|c|}{$\begin{array}{l}{ }^{1} \text { Envenenamiento por veneno procedente de glándulas asociadas a las partes bucales. } \\
{ }^{2} \text { Envenenamiento por veneno procedente de glándulas no asociadas a las partes bucales. } \\
{ }^{3} \text { Incluye las dermatitis irritantes primarias y las alérgicas. }\end{array}$} \\
\hline
\end{tabular}

Artrópodos

Hormigas, abejas, moscas picadoras, orugas, chinches, ciempiés, fríganos, larvas de moscas, cachipollas, escorpiones, arañas, garrapatas, avispas

Hormigas; escarabajos; gorgojos de las judías, del grano y de los guisantes; ácaros; insectos con escamas; arañas

Hormigas, abejorros, abejas de la miel, avispas

Más de 500 especies de artrópodos se crían en laboratorios. Hormigas, escarabajos, ácaros, polillas, arañas y garrapatas son especialmente importantes. Hormigas, escarabajos, moscas picadoras, orugas, cucarachas, ácaros

Gusanos de seda
Tabla 70.8 • Reacciones normales y alérgicas a las picaduras de insectos.

\begin{tabular}{|c|c|}
\hline Tipo de respuesta & Reacción \\
\hline $\begin{array}{l}\text { I. Reacciones normales no } \\
\text { alérgicas en el momento } \\
\text { de la picadura }\end{array}$ & $\begin{array}{l}\text { Dolor, quemazón, picor, enrojecimiento, zona } \\
\text { blanca alrededor de la picadura, hinchazón, } \\
\text { dolor a la palpación }\end{array}$ \\
\hline $\begin{array}{l}\text { II. Reacciones normales no } \\
\text { alérgicas horas o días } \\
\text { después de la picadura }\end{array}$ & $\begin{array}{l}\text { Picor, enrojecimiento residual, pequeña mancha } \\
\text { parda o roja, hinchazón }\end{array}$ \\
\hline $\begin{array}{l}\text { III.Grandes reacciones } \\
\text { locales }\end{array}$ & $\begin{array}{l}\text { Hinchazón masiva que se extiende sobre una } \\
\text { superficie de } 10 \mathrm{~cm} \text { o más y que aumenta de } \\
\text { tamaño durante } 24 \text { a } 72 \text { horas, que a veces } \\
\text { dura una semana o más }\end{array}$ \\
\hline $\begin{array}{l}\text { IV. Reacciones alérgicas } \\
\text { cutáneas }\end{array}$ & $\begin{array}{l}\text { Urticaria en cualquier punto de la piel, hinchazón } \\
\text { masiva lejos del punto de la picadura, picor } \\
\text { generalizado de la piel, enrojecimiento genera- } \\
\text { lizado de la piel lejos del punto de la picadura }\end{array}$ \\
\hline $\begin{array}{l}\text { V. Reacciones alérgicas sisté- } \\
\text { micas que no ponen la } \\
\text { vida en peligro }\end{array}$ & $\begin{array}{l}\text { Rinitis alérgica, síntomas respiratorios menores, } \\
\text { calambres abdominales }\end{array}$ \\
\hline $\begin{array}{l}\text { VI. Reacciones alérgicas sisté- } \\
\text { micas que ponen la vida } \\
\text { en peligro }\end{array}$ & $\begin{array}{l}\text { Shock, pérdida de consciencia, hipotensión o } \\
\text { desmayo, dificultad para respirar, hinchazón } \\
\text { masiva de la garganta. }\end{array}$ \\
\hline
\end{tabular}

Donald Barnard 
superficial que se presenta como una serie de lesiones escamosas de color rojo que resultan del contacto con ganado infectado, sobre todo con vacas lecheras. Un estudio realizado en la India, donde las vacas suelen vagar libremente, reveló que más de $5 \%$ de la población rural padecía tiña (Chaterjee y cols. 1980). La ectima contagiosa, por el contrario, se debe a un poxvirus que suele contagiarse a partir de ovejas o cabras infectadas. Suele producir lesiones en el dorso de las manos o de los dedos de las manos, y habitualmente desaparece tras formar algunas cicatrices en unas 6 semanas. L os nódulos de los ordeñadores son el resultado de la infección por un poxvirus, el virus de la pseudoviruela, habitualmente por contacto con ubres 0 pezones de vacas lecheras infectadas. Estas lesiones son similares a las de la ectima contagiosa, aunque es más habitual que sean múltiples

Las dermatitis inducidas por insectos suelen deberse a mordeduras y picaduras. Las infecciones por los ácaros que parasitan al ganado o contaminan el grano son particularmente notables. Las picaduras de las chinches y del ácaro de la sarna son problemas cutáneos típicos causados por los ácaros, que producen diversas formas de irritaciones enrojecidas que suelen curar espontáneamente. M ás graves resultan las mordeduras y picaduras de diversos insectos, como abejas, avispas, avispones u hormigas, que dan lugar a reacciones anafilácticas. El shock anafiláctico es una rara reacción de hipersensibilidad que ocurre cuando las células de la sangre producen un exceso de sustancias químicas que dan lugar a constricción de las vías respiratorias y pueden provocar un paro cardiorrespiratorio.

Todos estos problemas cutáneos son previsibles en gran medida. Las dermatitis de contacto se pueden evitar reduciendo la exposición mediante el empleo de ropas protectoras, guantes y una higiene personal adecuada. Los problemas relacionados con los insectos se pueden prevenir llevando ropa de colores claros y sin dibujos de flores, y evitando aplicarse a la piel sustancias olorosas. EI riesgo de cáncer de piel puede reducirse espectacularmente usando la ropa adecuada para reducir al mínimo la exposición, como son los sombreros de ala ancha. El empleo de bronceadores adecuados puede ser útil, pero no debe confiarse en ellos como única medida.

\section{Conclusión}

El número de cabezas de ganado en todo el mundo ha crecido al mismo ritmo que la población humana. El total mundial es de unos 4.000 millones de cabezas de vacas, cerdos, ovejas, cabras, caballos, búfalos y camellos (Durning y Brough 1992). Sin embargo, hay una notable falta de datos sobre los problemas de salud humana relacionados con el ganado en regiones del mundo en desarrollo como C hina e India, donde vive la mayor parte del ganado en la actualidad y donde se espera que su crecimiento sea mayor. En todo caso, a la vista del crecimiento de la agricultura industrializada en todo el mundo, puede adelantarse que probablemente muchos de los problemas de salud documentados en la producción ganadera norteamericana y europea acompañarán a la producción ganadera industrializada en cualquier otra parte. También se prevé que los servicios sanitarios de esas zonas sean inadecuados para afrontar las consecuencias sanitarias y de seguridad de la producción industrializada de ganado que se han sido descritas aquí de modo general.

El crecimiento en todo el mundo de la producción industrializada de ganado, con sus consecuencias sanitarias para los cuidadores humanos, se acompañará de cambios fundamentales en el orden social, económico y político, comparables a los que se derivaron de la domesticación de los animales hace más de 10.000 años. La prevención de los problemas de salud de los seres humanos requerirá de una comprensión y una gestión apropiadas de estas nuevas formas de adaptación de los seres humanos, y del lugar que el ganado ha de ocupar en ellas.

\section{CULTIVOS FORRAJEROS}

\section{Lorann Stallones}

Al crecer la tendencia de las poblaciones a concentrarse y la necesidad en los países del norte de guardar alimento para el invierno, surgió la necesidad de recolectar, cuidar y cultivar heno para los animales domésticos. Aunque los pastos datan de la época de las primeras domesticaciones de animales, es posible que la primera planta cultivada para forraje fuese la alfalfa, sobre cuyo empleo ya existen registros en 490 a.C., en Persia y en Grecia.

El forraje es imprescindible para la cría de ganado. Se cultiva por su vegetación, no por sus granos ni sus semillas. Se emplean como pasto o se recolectan para alimentar al ganado los tallos, hojas e inflorescencias (agrupaciones de flores) de algunas leguminosas (p. ej., alfalfa y trébol) y de ciertas especies no leguminosas. Cuando cereales como el maíz o el sorgo se recolectan para aprovechar su vegetación, se consideran como cultivos forrajeros.

\section{Procesos de producción}

Los principales tipos de cultivos forrajeros son los pastos y praderas abiertas, el heno y el ensilaje. El forraje puede ser recolectado por el ganado (en los pastos) o por el hombre, a mano o mediante maquinaria. La cosecha puede utilizarse para alimentar al ganado o para venderla. En la producción de forraje, los tractores constituyen una fuente de tracción y de potencia transformadora y, en zonas secas, puede ser necesario el regadío.

El pasto se alimenta permitiendo al ganado que paste 0 ramonee. EI tipo de pasto, que suele ser hierba, varía en cuanto a su producción según la estación del año, y se gestiona para que los animales lo visiten en primavera, verano y otoño. La gestión de los pastos trata de evitar que se abuse de una zona, por lo que se rota al ganado de unas a otras. Los residuos de las mieses pueden formar parte de la dieta de pasto para el ganado.

La alfalfa, un cultivo popular, no es buena para pasto porque hincha el estómago de los rumiantes, formándose tal cantidad de gas en el rumen (la primera parte del estómago) que puede llegar a matar a la vaca. En climas templados, los pastos son ineficaces como fuente de alimento en invierno, por lo que resulta necesario almacenar alimento. Además, en las grandes explotaciones, se emplea forraje recolectado (heno y ensilaje) porque los pastos son impracticables para grandes concentraciones de animales.

El heno es el forraje que se cultiva y se deja secar antes de almacenarlo y que sirva de alimento. Una vez que ha crecido, se corta con una segadora o agavilladora (máquina que combina las operaciones de siega y rastrillado) y se rastrilla en largas hileras para el secado. Durante estos dos procesos se cura para el embalado. Históricamente, la recolección se ha hecho amontonando el heno suelto con horquillas, técnica que se sigue utilizando. U na vez curado, el heno es embalado. La embaladora toma el heno de la hilera, lo comprime y hace con él o bien una bala cuadrada y pequeña para ser manipuladas, 0 grandes balas cuadradas o redondas para ser manejadas por máquinas. La bala pequeña puede ser expulsada mecánicamente de la embaladora a un camión, o recogida a mano y colocada (faena que se conoce como apilado) en un camión para su transporte a la zona de almacenaje. Las balas se almacenan en almiares, generalmente protegidos de la lluvia por una 
cubierta (granero, cobertizo o plástico). EI heno húmedo fácilmente se estropea 0 entra en combustión debido al calor desprendido del proceso de descomposición. El heno puede ser transformado para su utilización comercial en pellets o cubos comprimidos. Se puede recoger varias veces en una estación, siendo tres veces lo más habitual. Cuando están curadas, las balas se ponen en el cebador del abrevadero, se abren y quedan a disposición de los animales. Esta parte de la operación suele hacerse a mano.

0 tro forraje que suele recolectarse para alimento del ganado es el maíz o el sorgo para ensilaje. La ventaja económica es que, cuando se recolecta como ensilaje, el maíz tiene un $50 \%$ más de energía que el grano. Se emplea una máquina para recolectar la mayor parte de la planta verde. Lo cosechado se corta, se aplasta, se reduce y se expulsa a un camión. Entonces puede utilizarse para alimento como planta verde o bien guardarse en un silo, donde sufre fermentación en las 2 primeras semanas. La fermentación produce una atmósfera que impide que se estropee. Al cabo de un año se vacía el silo y el ensilaje se emplea para alimentar al ganado. Este proceso de alimentación es fundamentalmente mecánico.

\section{Peligros y su prevención}

El almacenamiento del pienso presenta riesgos sanitarios para los trabajadores. Al principio del proceso de almacenamiento se produce dióxido de nitrógeno que puede producir graves lesiones respiratorias e incluso la muerte. El almacenamiento en lugares cerrados, como los silos, puede crear este peligro, que se evita no entrando en ellos ni en los espacios de almacenamiento anexos durante las primeras semanas. Posteriormente pueden producirse problemas si la alfalfa, el heno, la paja u otros forrajes estaban húmedos cuando se almacenaron, y se produce una acumulación de hongos y otros contaminantes microbianos. Pueden producirse así enfermedades respiratorias agudas ("enfermedad del descargador de silos", síndrome tóxico por polvo orgánico) y/ o enfermedades respiratorias crónicas ("pulmón de granjero"). El riesgo correspondiente puede reducirse mediante el empleo de mascarillas adecuadas. También deben seguirse procedimientos adecuados para poder entrar en el espacio de almacenamiento.

La paja y el heno que se usan para las camas de los animales suelen estar secos, pero pueden contener mohos y esporas causantes de síntomas respiratorios cuando el polvo pasa al aire. Las mascarillas para el polvo pueden reducir la exposición a este peligro.

Las máquinas cosechadoras y embaladoras y las cortadoras están diseñadas para tronchar, cortar y aplastar. Se han asociado con lesiones traumáticas, producidas en gran parte cuando los trabajadores intentan liberar piezas atascadas mientras el equipo está funcionando. $\mathrm{H}$ ay que desconectar el equipo antes de limpiar los atascos. Si hay más de una persona trabajando, debe aplicarse un programa de bloqueo/ desconexión. O tra fuente importante de lesiones y muertes son los vuelcos de tractores sin la adecuada protección antivuelcos para el conductor (D eere \& C o. 1994). En otra sección de esta E nciclopedia se ofrece más información sobre los peligros de la maquinaria agrícola.

Donde se utilicen animales para plantar, cosechar y almacenar alimento, existe la posibilidad de que se produzcan lesiones relacionadas con coces y mordiscos, que dan lugar a torceduras, luxaciones, lesiones por aplastamiento y laceraciones. La mejor forma de reducir la incidencia de estas lesiones es aplicar técnicas correctas en el manejo de los animales.

La manipulación de las balas de heno y paja puede producir problemas ergonómicos. Hay que enseñar a los trabajadores técnicas correctas de levantamiento, y se debe usar equipo mecánico siempre que sea posible.

EI forraje y las camas de heno son un riesgo de incendio. EI heno húmedo, como ya se ha mencionado, puede entrar espontáneamente en combustión. El heno, la paja y otros elementos parecidos arden muy bien cuando están secos, sobre todo si están sueltos. Pero incluso el forraje embalado es un estupendo combustible para el fuego. Es necesario aplicar normas básicas de prevención del fuego, como la prohibición de fumar, la eliminación de las fuentes de chispas y las medidas de lucha antiincendios.

\section{CONFINAMIENTO DEL GANADO}

\section{Kelley D onham}

Las fuerzas económicas globales han contribuido a la industrialización de la agricultura (Donham y Thu 1995). En los países desarrollados hay una tendencia al aumento de la especialización, la intensidad y la mecanización. El resultado de estas tendencias es el aumento de la producción de ganado en confinamiento. Muchos países en desarrollo han reconocido la necesidad de adoptar este tipo de producción, en un intento de transformar su agricultura de subsistencia en una actividad competitiva a nivel global. Al ir aumentando el número de organizaciones que obtienen la propiedad y el control de la industria, las explotaciones familiares son sustituidas por un menor número de explotaciones más grandes.

Desde el punto de vista conceptual, el sistema de confinamiento aplica los mismos principios de la producción industrial masiva a la producción de ganado. En general, este sistema implica la cría de animales en elevadas densidades aisladas del medio exterior y equipadas con sistemas mecánicos 0 automáticos de ventilación, control de residuos, alimentación y suministro de agua (D onham, Rubino y cols. 1977).

Varios países europeos utilizan sistemas de confinamiento desde principios del decenio de 1950. En Estados U nidos empezaron a utilizarse a finales de ese mismo decenio. Los productores de aves de corral fueron los primeros en adoptarlo. A principios del decenio siguiente, la industria porcina también empezó a adoptar esta técnica, seguida más recientemente por los productores de leche y de carne de ternera.

A compañando a esta industrialización han surgido diversas cuestiones sanitarias y sociales para los trabajadores. En la mayor parte de los países occidentales, cada vez hay menos explotaciones, pero cada vez más grandes. $\mathrm{H}$ ay menos explotaciones familiares (combinación de trabajo y gestión) y más estructuras empresariales (sobre todo en América del Norte). EI resultado es que hay más trabajadores contratados y relativamente menos miembros de una misma familia trabajando. Además, en América del Norte, cada vez son más los trabajadores procedentes de minorías y de grupos de inmigrantes. Por consiguiente, existe el riesgo de crear una nueva clase de trabajadores de segunda en algunos segmentos del sector.

Para el agricultor ha aparecido todo un nuevo grupo de exposiciones profesionales peligrosas, que se pueden clasificar en cuatro epígrafes principales:

1. gases tóxicos y asfixiantes

2. aerosoles bioactivos de partículas

3. enfermedades infecciosas

4. ruido

Los peligros respiratorios también tienen interés. 
Tabla 70.9 • Compuestos identificados en la atmósfera de los recintos confinados de explotaciones porcinas.

$\begin{array}{lll} & & \\ \text { 2-Propanol } & \text { Dimetil sulfuro } & \text { Isopropil acetato } \\ \text { 3-Pentanona } & \text { Dióxido de carbono } & \text { Isopropil propionato } \\ \text { Acetaldehído } & \text { Disulfuro } & \text { Metano } \\ \text { Acetona } & \text { Escatol } & \text { Metil acetato } \\ \text { Acido acético } & \text { Etanol } & \text { Metilamina } \\ \text { Acido butírico } & \text { Etil formato } & \text { Metilmercaptano } \\ \text { Acido isobutírico } & \text { Etilamina } & \text { Monóxido de carbono } \\ \text { Acido isovaleriánico } & \text { Formaldehído } & \text { n-Butanol } \\ \text { Acido propiónico } & \text { Heptaldehído } & \text { n-Butil } \\ \text { Acido sulfhídrico } & \text { Hexanal } & \text { n-Propanol } \\ \text { Amoníaco } & \text { Indol } & \text { Octaldehído } \\ \text { Compuesto de nitrógeno } & \text { Isobutanol } & \text { Propil propionato } \\ \text { heterocíclico } & \text { Isobutil acetato } & \text { Proponaldehído } \\ \text { Decaldehído } & \text { Isobutiraldehído } & \text { Trietilamina } \\ \text { Dietil sulfuro } & \text { Isopentanol } & \text { Trimetilamina } \\ & & \end{array}$

\section{Gases tóxicos y asfixiantes}

Diversos gases tóxicos y asfixiantes que resultan de la degradación microbiana de los excrementos de los animales (orina y heces) pueden asociarse con el confinamiento del ganado. Los excrementos suelen almacenarse en forma líquida debajo del edificio, sobre un suelo de listones o en un tanque o estanque en el exterior del edificio. Este sistema de almacenamiento suele ser anaerobio, lo que da lugar a la formación de algunos gases tóxicos (véase la Tabla 70.9) (D onham, Yeggy y Dauge 1988). V éase también el artículo "G estión del estiércol y de los excrementos" en este capítulo.

En casi todas la actividades en las que tiene lugar la digestión anaerobia de excrementos se producen sobre todo cuatro gases tóxicos o asfixiantes: dióxido de carbono $\left(\mathrm{CO}_{2}\right)$, amoníaco $\left(\mathrm{NH}_{3}\right)$, ácido sulfhídrico $\left(\mathrm{H}_{2} \mathrm{~S}\right)$ y metano $\left(\mathrm{CH}_{4}\right)$. En la descomposición de excrementos de animales también puede producirse una pequeña cantidad de monóxido de carbono ( $\mathrm{CO}$ ), pero la principal fuente de éste último son los hornos donde se queman los combustibles fósiles. Los niveles habituales de estos gases (también en forma de partículas) en el aire de los edificios destinados al confinamiento de porcino se muestran en la Tabla 70.10. También se incluye una lista de las exposiciones máximas recomendadas en explotaciones porcinas, según recientes investigaciones (Donham y Reynolds 1995; Reynolds y cols. 1996) y los valores umbrales límite (threshold limit values, T LV ) fijados por la Conferencia A mericana de H igienistas Industriales del Gobierno (ACGIH 1994). Estos TLV han sido adoptados por muchos países como límites legales. Puede verse cómo en muchas de las instalaciones hay al menos un gas, y a menudo varios, que sobrepasan los límites de exposición. $\mathrm{H}$ ay que destacar que la exposición simultánea a estas sustancias tóxicas puede ser aditiva o sinérgica, sobrepasándose el TLV de la mezcla aunque no se superen los TLV individuales. Las concentraciones suelen ser más altas en invierno que en verano, porque se reduce la ventilación para conservar el calor.

E stos gases han sido implicados en diversas afecciones agudas de los trabajadores. $\mathrm{EI} \mathrm{H}_{2} \mathrm{~S}$ ha sido implicado en muchas muertes súbitas de animales y en el fallecimiento de algunos seres humanos (D onham y K napp 1982). La mayor parte de los casos han ocurrido poco después de agitar o vaciar el depósito de estiércol, lo cual puede dar lugar a la repentina liberación de una gran volumen de $\mathrm{H}_{2} \mathrm{~S}$, que es tóxico de forma aguda. En otros casos mortales, los depósitos de estiércol acababan de ser vaciados, y los trabajadores que iban a inspeccionarlos, a repararlos 0 a recoger algún objeto caído se desmayaban sin previo aviso. EI único hallazgo notable entre los resultados disponibles de las autopsias de estos casos de intoxicación aguda fue un edema pulmonar masivo. Esta lesión, combinada con la historia, es compatible con la intoxicación por ácido sulfhídrico. Con frecuencia, los intentos de rescate por parte de los acompañantes han terminado con un balance de víctimas múltiples. Por consiguiente, los trabajadores de los confinamientos deben ser informados de los riesgos derivados de su trabajo y aconsejados para que nunca entren en un depósito de estiércol sin comprobar primero la presencia de gases tóxicos, ir equipados con una mascarilla (equipo autónomo) con su propio suministro de oxígeno, asegurarse de que la ventilación es adecuada e ir acompañados por dos compañeros por lo menos, unidos por una cuerda, de forma que puedan rescatarle sin ponerse ellos mismos en peligro. Debe existir un programa escrito para los espacios confinados.

EI CO también puede estar presente en concentraciones tóxicas. En sistemas de confinamiento de cerdos se ha documentado que las cerdas tienen abortos cuando la concentración atmosférica alcanza 200 a 400 ppm, así como síntomas subagudos en seres humanos, como cefalea crónica y náuseas. D eben tenerse en cuenta asimismo los posibles efectos sobre los fetos humanos. La principal fuente de CO son las unidades de calefacción que queman hidrocarburos y que están en mal estado. La gran acumulación de polvo que se produce en las instalaciones de confinamiento de cerdos dificulta la conservación de las calefacciones en buenas condiciones de funcionamiento. LoS sistemas de calor radiante a base de propano también son causa habitual de que disminuyan los niveles de CO (p. ej., de 100 a 300 ppm). 0 tra fuente son las limpiadoras de alta presión con motor de combustión interna funcionando en el interior de la instalación; hay que instalar alarmas de C 0 .

Cuando el sistema de ventilación falla, se producen otras situaciones causantes de un peligro agudo. En esas circunstancias, los niveles de gases pueden aumentar rápidamente hasta niveles críticos. En este caso, el principal problema es la sustitución del oxígeno por otros gases, fundamentalmente $\mathrm{CO}_{2}$ producido en el depósito o procedente de la actividad respiratoria de los animales que se encuentran en la instalación. Se pueden alcanzar condiciones letales en sólo 7 horas. Con respecto a la salud de los cerdos, el fallo de la ventilación en climas templados puede hacer que la temperatura y la humedad alcancen niveles letales en 3 horas. $\mathrm{H}$ ay que vigilar los sistemas de ventilación.

Un cuarto peligro potencial agudo procede de la acumulación de $\mathrm{CH}_{4}$, que es más ligero que el aire y que, cuando es emitido por el depósito de estiércol, tiende a acumularse en las partes altas de la instalación. $\mathrm{H}$ a habido varios casos de explosiones ocurridas cuando la acumulación de $\mathrm{CH}_{4}$ entraba en ignición por una luz de alarma o por la llama de soldadura de un trabajador.

\section{Aerosoles bioactivos de partículas}

Las fuentes de polvo en instalaciones de confinamiento son una combinación de alimentos, caspa y pelo de los animales, junto con materia fecal seca (D onham y Scallon 1985). Las partículas están formadas por un $24 \%$ aproximadamente de proteínas, por lo que tienen la posibilidad de iniciar no sólo una respuesta inflamatoria a una proteína extraña, sino también una reacción alérgica adversa. La mayor parte de las partículas 
Tabla 70.10 - Concentraciones atmosféricas de diversos gases en los recintos confinados de explotaciones porcinas.

\begin{tabular}{lllll} 
Gas & Límites (ppm) & $\begin{array}{l}\text { Concentraciones ambientales } \\
\text { típicas (ppm) }\end{array}$ & $\begin{array}{l}\text { Concentraciones de exposición } \\
\text { máximas recomendadas (ppm) }\end{array}$ & Valores umbral (ppm) \\
$\mathrm{CO}$ & 0 a 200 & 42 & 50 & 50 \\
$\mathrm{CO}_{2}$ & $1.000 \mathrm{a} 10.000$ & 8.000 & 1.500 & 5.000 \\
$\mathrm{NH}_{3}$ & 5 a 200 & 81 & 7 & 25 \\
$\mathrm{H}_{2} \mathrm{~S}$ & 0 a 1.500 & 4 & 5 & 10 \\
Polvo total & 2 a $15 \mathrm{mg} / \mathrm{m}^{3}$ & $4 \mathrm{mg} / \mathrm{m}^{3}$ & $2,5 \mathrm{mg} / \mathrm{m}^{3}$ & $10 \mathrm{mg} / \mathrm{m}^{3}$ \\
Polvo respirable & $0,10 \mathrm{a} 1,0 \mathrm{mg}^{3}$ & $0,4 \mathrm{mg} / \mathrm{m}^{3}$ & $0,23 \mathrm{mg} / \mathrm{m}^{3}$ & $3 \mathrm{mg} / \mathrm{m}^{3}$ \\
Endotoxinas & 50 a $500 \mathrm{ng} / \mathrm{m}^{3}$ & $200 \mathrm{ng} / \mathrm{m}^{3}$ & $100 \mathrm{ng} / \mathrm{m}^{3}$ & (ninguno establecido) \\
\hline
\end{tabular}

miden menos de 5 micras, lo que les permite ser aspiradas hasta las zonas más profundas de los pulmones, donde pueden producir un peligro mayor para la salud. Las partículas están cargadas de microbios (de $10^{4}$ a $10^{7} / \mathrm{m}^{3}$ de aire), que contribuyen con varias sustancias tóxicas/ inflamatorias, como endotoxinas (el peligro más documentado), glucanos, histamina y proteasas. Las concentraciones máximas recomendadas para los polvos se enumeran en la Tabla 70.10. L os gases presentes en la instalación y las bacterias de la atmósfera son adsorbidos en la superficie de las partículas de polvo. De esta forma, las partículas inhaladas tienen el efecto aun más peligroso de transportar hasta los pulmones gases irritantes o tóxicos, así como bacterias potencialmente infecciosas.

\section{Enfermedades infecciosas}

Unas 25 zoonosis tienen importancia para los agricultores $M$ uchas pueden ser transmitidas directa o indirectamente por el ganado. $L$ as condiciones de hacinamiento que suelen darse en los sistemas de confinamiento ofrecen un gran potencial para la transmisión de zoonosis del ganado al hombre. Los confinamientos de porcino implican un riesgo de transmisión a los trabajadores de la gripe porcina, leptospirosis, Streptococcus suis y salmonela, por ejemplo. Los confinamientos de aves de corral implican el riesgo de transmitir ornitosis, histoplasmosis, el virus de la enfermedad de $\mathrm{New}$ Castle y salmonela. Los confinamientos de ganado bovino pueden transmitir la fiebre $Q$, Trichophyton verrucosum (tiña de los animales) y leptospirosis.

También diversas sustancias biológicas y antibióticos han sido reconocidos como peligros potenciales para la salud. Las vacunas inyectables y ciertas sustancias biológicas se emplean habitualmente en programas médicos de prevención en veterinaria que se aplican en confinamientos de animales. Se ha observado que la inoculación accidental de vacunas de Brucella y de bacterias de Escherichia coli produce enfermedades en el hombre.

Se usan antibióticos por vía parenteral e incorporados al alimento de los animales. Como se sabe que el alimento es componente habitual del polvo presente en las instalaciones de confinamiento de animales, se supone que los antibióticos están también presentes en el aire. Por eso, la hipersensibilidad a los antibióticos y las infecciones resistentes a ellos implican peligros potenciales para los trabajadores.

\section{Ruido}

Se han medido niveles de ruido de 103 dBA en instalaciones de confinamiento de animales; esto supera el TLV, y constituye un riesgo de sordera inducida por el ruido (Donham, Yeggy y Dauge 1988).

\section{Síntomas respiratorios de los trabajadores de las instalaciones de confinamiento de ganado}

L os riesgos respiratorios generales de las instalaciones de confinamiento de animales son similares, independientemente de la especie de ganado de que se trate. Sin embargo, los confinamientos de porcino se asocian con un porcentaje mayor de efectos adversos para la salud (25 a $70 \%$ de los trabajadores activos), con síntomas más graves que los producidos en confinamientos de aves de corral o de vacuno (Rylander y cols. 1989). Los excrementos de los corrales suelen manejarse en forma sólida, y en este caso el amoníaco suele ser el principal problema gaseoso; no hay ácido sulfhídrico.

Se ha observado que los síntomas respiratorios crónicos o subagudos que con más frecuencia comunican los trabajadores de confinamientos se dan en los confinamientos de porcino. Los estudios realizados con trabajadores de confinamientos de cerdos han revelado que aproximadamente el $75 \%$ padece síntomas agudos adversos del tracto respiratorio superior. Estos síntomas pueden ser clasificados en tres grupos:

1. inflamación aguda o crónica de las vías respiratorias (manifestadas como bronquitis)

2. constricción adquirida (no alérgica) de las vías respiratorias (asma)

3. enfermedad febril tardía autolimitada con síntomas generalizados [síndrome tóxico por polvo orgánico (ST PO )].

Los síntomas que sugieren la presencia de una inflamación crónica del sistema respiratorio superior son comunes; se observan en el $70 \%$ aproximadamente de los trabajadores de explotaciones de porcino. Los más frecuentes son opresión en el tórax, tos, sibiliancias y exceso de producción de esputo.

En aproximadamente el $5 \%$ de los trabajadores, los síntomas aparecen con sólo unas semanas de trabajo en las instalaciones. Los síntomas consisten en opresión torácica, sibilancias y dificultad para respirar. $\mathrm{H}$ abitualmente estos trabajadores se ven $\tan$ afectados que tienen que buscar trabajo en otro sitio. $\mathrm{No}$ hay datos suficientes para indicar si esta reacción es una hipersensibilidad alérgica o una hipersensibilidad no alérgica al polvo y al gas. Lo más habitual es que los síntomas de bronquitis y asma aparezcan tras 5 años de exposición.

A proximadamente el $30 \%$ de los trabajadores experimentan de modo ocasional episodios de síntomas tardíos. Entre 4 y 6 horas después de trabajar en la instalación presentan una especie de gripe que se manifiesta por fiebre, cefalea, malestar, dolores musculares generalizados y dolor precordial. Suelen recuperarse de estos síntomas en 24 a 72 horas. Este síndrome se conoce como ST PO. 

Tabla 70.11 Enfermedades respiratorias asociadas a la
producción porcina.

\begin{tabular}{|c|c|}
\hline $\begin{array}{l}\text { Enfermedades de las vías } \\
\text { respiratorias superiores }\end{array}$ & $\begin{array}{l}\text { Sinusitis } \\
\text { Rinitis irritativa } \\
\text { Rinitis alérgica } \\
\text { Faringitis }\end{array}$ \\
\hline $\begin{array}{l}\text { Enfermedades de las vías } \\
\text { respiratorias inferiores }\end{array}$ & $\begin{array}{l}\text { Asma de origen profesional } \\
\text { Asma no alérgica, enfermedad por respuesta } \\
\text { excesiva de las vías respiratorias, o síndrome } \\
\text { de enfermedades reactivas de las vías } \\
\text { respiratorias ( } S E R V) \\
\text { Asma alérgica (mediada por lgE) } \\
\text { Bronquitis aguda o subaguda } \\
\text { Bronquitis crónica } \\
\text { Enfermedad pulmonar obstructiva crónica (EPOC) }\end{array}$ \\
\hline Enfermedades intersticiales & $\begin{array}{l}\text { Alveolitis } \\
\text { Infiltrado intersticial crónico } \\
\text { Edema pulmonar }\end{array}$ \\
\hline
\end{tabular}

Fuentes: Donham, Zavala y Merchant 1984; Dosman y cols. 1988; Haglind y Rylander 1987; Harries y Cromwell 1982; Heedrick y cols. 1991; Holness y cols. 1987; Iverson y cols. 1988; Jones y cols. 1984; Leistikow y cols. 1989; Lenhart 1984; Rylander y Essle 1990; Rylander, Peterson y Donham 1990; Turner y Nichols 1995

Ciertamente, la posibilidad de que se produzca una lesión pulmonar crónica parece real entre estos trabajadores. Sin embargo, hasta la fecha no ha sido documentada. Se recomienda que se sigan ciertos procedimientos para impedir la exposición crónica y aguda a materiales peligrosos en explotaciones porcinas. En la Tabla 70.11 se resumen las afecciones médicas que se observan en trabajadores de estas explotaciones.

\section{Protección de los trabajadores}

Exposición aguda al ácido sulfhídrico. $\mathrm{H}$ ay que tener cuidado para evitar la exposición al $\mathrm{H}_{2} \mathrm{~S}$ que puede producirse al agitar un tanque de depósito de estiércol líquido anaerobio. Si el depósito está debajo de la instalación, mientras dure el vaciado y en las horas siguientes es mejor permanecer fuera hasta que el análisis de una muestra de aire indique que es seguro. Durante este tiempo hay que poner la ventilación al máximo. Nunca se debe entrar en un depósito de estiércol líquido sin tomar las medidas mencionadas.

Exposición a partículas. Para controlar la exposición a partículas deben utilizarse procedimientos simples de gestión, como los equipos de alimentación automática diseñados para eliminar el máximo posible de polvo. La adición de grasa extra a la dieta, la limpieza frecuente y con máquinas de las instalaciones y la instalación de suelos de rejilla que se limpian con facilidad, son medidas de control de probada eficacia. En la actualidad se está estudiando un sistema de control del polvo mediante vaporización de aceite, que probablemente estará disponible en el futuro. A parte del control técnico, se debe llevar una mascarilla para el polvo que sea de buena calidad.

$\mathrm{R}$ uido. $\mathrm{H}$ ay que suministrar orejeras y lograr que los trabajadores se las pongan para trabajar en las instalaciones cuando se vaya a vacunar a los animales o vayan a practicarse otras maniobras. Debe ponerse en marcha un programa de conservación de la audición.

\section{CRIA DE ANIMALES DOMESTICOS}

\section{Dean T. Stueland y Paul D. G underson}

La cría de animales domésticos - y su utilización - abarca una amplia variedad de actividades, como la cría, la alimentación, el traslado de los animales de un sitio a otro, los cuidados básicos (p. ej. cuidado de las pezuñas, limpieza, vacunaciones), el cuidado de animales heridos (ya sea por lo ganaderos o por veterinarios) y las actividades asociadas con animales concretos (p. ej. ordeñar las vacas, esquilar a las ovejas, trabajar con animales de tiro).

Estas maniobras con el ganado se asocian con diversas lesiones y enfermedades en el hombre, debidas a la exposición directa o bien a la contaminación ambiental de origen animal. El riesgo de cada lesión y enfermedad depende mucho del comportamiento del animal concreto (véanse también los artículos de este capítulo sobre animales específicos). Además, a menudo las personas relacionadas con la cría de animales domésticos tienen más probabilidades de consumir productos derivados de éstos. Finalmente, la exposición específica depende de los métodos de manejo del ganado, influidos por factores geográficos y sociales que varían en la sociedad humana.

\section{Peligros y precauciones}

\section{Riesgos ergonómicos}

Con frecuencia, el personal que trabaja con ganado vacuno tiene que estar de pie, estirarse, inclinarse o hacer effuerzos físicos en posturas mantenidas o inusuales. Presenta un riesgo mayor de padecer lesiones articulares en la espalda, las caderas y las rodillas. $\mathrm{H}$ ay varias actividades que suponen un riesgo ergonómico. Por ejemplo, asistir al parto de un animal grande puede obligar a adoptar una postura forzada e inhabitual, mientras que, con un animal pequeño, el trabajador puede verse forzado a permanecer en un entorno inclemente. Además, el trabajador puede lesionarse al asistir a animales enfermos, cuyo comportamiento no es posible prever. Lo más frecuente es que se produzcan dolores articulares y de espalda debido a movimientos repetitivos, como el ordeño, durante el cual el trabajador puede verse obligado a ponerse en cuclillas o de rodillas repetidamente.

Se conocen otras enfermedades por acumulación de traumatismos, sobre todo en los responsables del ganado. Pueden deberse a un movimiento repetido 0 a frecuentes lesiones pequeñas.

Las soluciones para reducir el riesgo ergonómico radican en enseñar a manejar adecuadamente a los animales, así como en rediseñar el medio de trabajo y las tareas de acomodación de los factores animales y humanos.

\section{Lesiones}

Es frecuente que los estudios de lesiones asociadas con la agricultura señalen a los animales como agentes lesivos. Se han propuesto varias explicaciones para estas observaciones. La íntima asociación entre el trabajador y el animal, que a menudo tiene un comportamiento impredecible, supone un riesgo para el trabajador. M uchos animales les superan en tamaño y fuerza. A menudo las lesiones se deben a un traumatismo directo producido por una coz, un mordisco o el aplastamiento contra alguna estructura, siendo las extremidades inferiores las más frecuentemente afectadas. También el comportamiento de los trabajadores también puede contribuir al riesgo de lesión. Los trabajadores que penetran en el "radio de acción" del ganado o que se colocan en las "zonas ciegas" de los animales tienen mayor riesgo de resultar lesionados por reacciones de vuelo, embestidas, coces y aplastamientos. 


\section{Comportamiento de los animales}

Saber qué influye en el comportamiento de los animales puede ayudar a que resulte más seguro el medio de trabajo. En ese comportamiento influyen la genética y las respuestas aprendidas (condicionamiento operante). Ciertas razas de toros suelen ser más dóciles que otras (influencia genética). Un animal que se ha plantado o que se niega a entrar en una zona y se sale con la suya, probablemente se negará a hacerlo la próxima vez. En sucesivos intentos se irá tornando más agitado y peligroso. Los animales responden a la forma en que se les trata, y se basan en la experiencia cuando reaccionan ante una situación. Los que hayan sido perseguidos, golpeados, pateados, hayan recibido gritos o estén asustados tendrán miedo, naturalmente, cuando estén cerca de seres humanos. Por eso es importante tratar de mover a los a nimales al primer intento y con el mínimo estrés para ellos.

Los animales domesticados que viven en instalaciones muy uniformes adoptan hábitos que se basan en la repetición de 10 mismo todos los días a una hora específica. El confinamiento de toros en una dehesa y su alimentación allí permite que se acostumbren a los seres humanos, de forma que pueden utilizarse en sistemas de apareamiento en confinamiento. Los hábitos también son causados por los cambios regulares en el entorno, como las fluctuaciones de temperatura o de humedad al pasar del día a la noche. Los animales son más activos en el momento de máximo cambio, que es al atardecer 0 al amanecer, y menos activos al mediodía 0 a medianoche. Este factor puede ser una ventaja cuando hay que trasladar a los animales de trabajo.

Al igual que los animales salvajes, los animales domésticos pueden proteger sus territorios. Cuando está en juego la alimentación, esta protección puede adoptar la forma de un comportamiento agresivo. Ciertos estudios han demostrado que, si se distribuye el alimento en grandes bloques diseminados al azar, se elimina ese comportamiento territorial. Cuando se reparte el a limento de forma uniforme o previsible, pueden producirse luchas para tratar de asegurarlo y excluir a los demás. También puede haber un comportamiento de protección territorial cuando se le permite a un toro que permanezca en la manada. Este puede considerar que el rebaño y el pasto en que viven son su territorio, lo que significa que lo defenderá frente a amenazas supuestas y reales, procedentes de seres humanos, de perros o de otros animales. La introducción en la manada de un toro nuevo 0 extraño en edad de procrear casi siempre se traducirá en combates para determinar cuál es el macho dominante.

Los toros, al tener los ojos a los lados de la cabeza, tienen visión panorámica y muy poca sensación de profundidad. Esto quiere decir que pueden ver en unos 270 a su alrededor, quedando tan sólo una mancha ciega justo por detrás de ellos y por delante de sus narices (véase la Figura 70.3). Los movimientos repentinos 0 inesperados desde atrás pueden "espantarles" porque son incapaces de determinar la proximidad o la gravedad de la amenaza percibida. De ahí una posible respuesta de "lucha 0 huida". Debido a su escasa percepción de la profundidad, también pueden asustarse fácilmente con sombras y movimientos producidos fuera de la zona de trabajo o de recogida. Las sombras en la zona de trabajo pueden ser percibidas por el animal como agujeros, lo que hará que se plante. El ganado vacuno es daltónico, pero percibe los colores como diferentes intensidades de blanco y negro.

Muchos animales son muy sensibles al ruido (en comparación con los seres humanos), especialmente a frecuencias elevadas. Los ruidos fuertes e inesperados, como el de los portones metálicos al cerrarse, el de los golpes contra los pasadizos y/ o el de los gritos de los seres humanos, pueden producirles estrés.

David L Hard
Entre los cuidadores del ganado, las mujeres y los niños están abundantemente representados. Posiblemente se deba a determinados factores sociales que llevan a estos grupos a encargarse del trabajo relacionado con los animales, o a que las diferencias de tamaño entre el trabajador y el animal son en este caso exageradas 0 , en el caso de los niños, a que emplean técnicas de manejo del ganado a las que los animales no están habituados.

Las intervenciones específicas para evitar las lesiones correspondientes son la intensificación de los esfuerzos educativos, la selección de animales que sean más compatibles con los seres

Figura 70.3 • Visión panorámica del ganado vacuno.

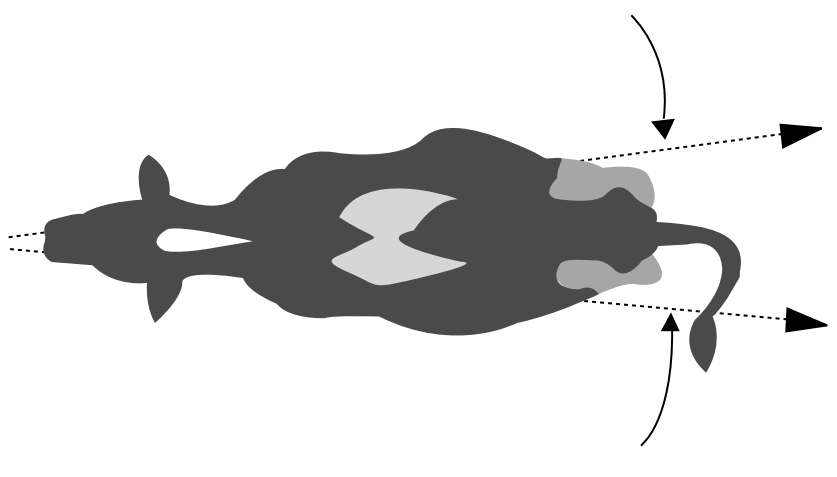

humanos, la selección de trabajadores que tengan menos probabilidades de poner nerviosos a los animales y la adopción de técnicas que disminuyan el riesgo de exposición para los seres humanos y los animales.

\section{Zoonosis}

La cría de animales exige un íntimo contacto entre trabajadores y animales. Los seres humanos pueden resultar infectados por microorganismos que están presentes normalmente en los animales, y que rara vez son patógenos humanos. Además, los tejidos de los animales infectados y los comportamientos asociados con ellos pueden exponer a trabajadores que apenas tendrían contacto con ellos si se ocupan de ganado sano o con los que ni siquiera entrarían en contacto.

Entre las zoonosis relevantes hay numerosos virus, bacterias, microbacterias, hongos y parásitos (véase la Tabla 70.12). Muchas zoonosis como el ántrax, la tinea capitis o la ectima contagiosa, se deben a contagio cutáneo. El contagio resultante de la exposición a animales enfermos es un factor de riesgo para la rabia y la tularemia. D ado que los ganaderos suelen tener más probabilidades de ingerir productos animales poco tratados, presentan riesgo de enfermedades como la infección por Campylobacter, criptosporidiosis, salmonelosis, triquinosis 0 tuberculosis.

El control de las zoonosis debe extenderse a la vía de contagio y la fuente del mismo. La eliminación de la fuente y/ o la interceptación de la vía son esenciales para controlar las enfermedades. Por ejemplo, debe haber una forma adecuada de 
Tabla 70.12 - Zoonosis de los manipuladores de ganado.

$\begin{array}{llll}\text { Enfermedad } & \text { Agente } & \text { Animal } & \text { Exposición } \\ \text { Antrax } & \text { Bacteria } & \text { Cabras, otros herbívoros } & \text { Manipulación del pelo, huesos u otros tejidos } \\ \text { Brucelosis } & \text { Bacteria } & \text { Vacas, cerdos, cabras, ovejas } & \text { Contacto con placentas y con otros tejidos contaminados } \\ \text { Campylobacter } & \text { Bacteria } & \text { Aves de corral, vacas } & \text { Ingestión de alimentos, agua, leche contaminados } \\ \text { Criptosporidiosis } & \text { Parásito } & \text { Aves de corral, vacas, ovejas, pequeños } & \text { Ingestión de heces de animales } \\ \text { mamíferos } & \\ \text { Ectima contagiosa } & \text { Virus } & \text { Ovejas, cabras } & \text { Contaminación directa de las mucosas } \\ \text { Fiebre Q } & \text { Rickettsia } & \text { Vacas, cabras, ovejas } & \text { Polvo inhalado de tejidos contaminados } \\ \text { Leptospirosis } & \text { Bacteria } & \text { Animales salvajes, cerdos, vacas, perros } & \text { Agua contaminada sobre piel herida } \\ \text { Psitacosis } & \text { Chlamydia } & \text { Periquitos, aves de corral, palomas } & \text { Inhalación de deyecciones desecadas } \\ \text { Rabia } & \text { Virus } & \text { Carnívoros salvajes, perros, gatos, ganado } & \text { Exposición de heridas de la piel a saliva cargada de virus } \\ \text { Salmonelosis } & \text { Bacteria } & \text { Aves de corral, cerdos, ganado } & \text { Ingestión de alimentos a partir de organismos contaminados } \\ \text { Tinea capitis } & \text { Hongos } & \text { Perros, gatos, vacas } & \text { Contacto directo } \\ \text { Triquinosis } & \text { Tenia } & \text { Cerdos, perros, gatos, caballos } & \text { Consumo de carne poco hecha } \\ \text { Tuberculosis bovina } & \text { Mycobacteria } & \text { Vacas, cerdos } & \text { Ingestión de leche sin pasteurizar; inhalación de gotículas del aire } \\ \text { Tularemia } & \text { Bacteria } & \text { Animales salvajes, cerdos, perros } & \text { Inoculación por agua o carne contaminada }\end{array}$

deshacerse de los animales enfermos que hayan muerto. A menudo, las enfermedades humanas pueden evitarse tratándolas en los animales. A demás, los productos o tejidos de origen animal deben ser adecuadamente transformados antes de utilizarlos en la cadena alimentaria humana. Algunas zoonosis se tratan en el trabajador con antibióticos. Sin embargo, el empleo rutinario de antibióticos profilácticos en el ganado puede hacer surgir microorganismos resistentes que se conviertan en un problema de salud pública.

\section{Herrería}

La herrería (trabajo de forja) produce fundamentalmente lesiones musculosqueléticas y ambientales. La manipulación del metal que ha usarse para atender a los animales, como es el caso de las herraduras, exige un trabajo duro, con intensa actividad muscular para preparar el metal y colocar las patas del animal. Además, la aplicación del producto creado en la forja al animal, como es el caso de una herradura, constituye una fuente adicional de lesiones (véase la Figura 70.4).

Con frecuencia, el calor necesario para doblar los metales implica una exposición a gases nocivos. Existe un síndrome, la fiebre por vapor de metales, cuyo cuadro clínico es similar al de una infección pulmonar y se produce por la inhalación de vapores de níquel, magnesio, cobre u otros metales.

Los efectos perjudiciales para la salud del trabajo de forja pueden aliviarse trabajando con una adecuada protección respiratoria. Se trata de mascarillas o respiradores purificadores de aire con cartuchos y filtros capaces de filtrar los vapores ácidos de gases/ orgánicos y los procedentes de metales. Si la forja se practica en un sitio fijo, la fragua debe contar con un sistema de ventilación por aspiración. Los controles de ingeniería, que ponen distancia o barreras entre el animal y el trabajador, reducirán el riesgo de lesión.

\section{Alergias a los animales}

Todos los animales tienen antígenos no humanos y que por eso pueden funcionar como alergenos potenciales. Además, el ganado suele albergar ácaros. Como hay muchas posibles alergias a animales, el reconocimiento de un alergeno específico exige una cuidadosa y exhaustiva historia de la enfermedad y de la ocupación. Incluso disponiendo de esos datos puede ser difícil reconocer un alergeno específico.

La expresión clínica de las alergias a los animales puede representar un cuadro de tipo anafiláctico, con urticaria, hinchazón, secreción nasal y asma. En algunos pacientes, los únicos síntomas son secreción nasal y picores.

El control de la exposición a alergias por animales es una tarea ingente. La mejora de las prácticas de cría de animales domésticos y la introducción de cambios en los sistemas de ventilación de las instalaciones para el ganado pueden reducir la posibilidad de que quien maneja el ganado se vea expuesto. Sin embargo, acaso haya poco más que hacer que la desensibilización para impedir que se formen alergenos específicos. En general sólo resulta posible desensibilizar a un trabajador cuando el alergeno específico ha quedado adecuadamente caracterizado.

Figura 70.4 • Herrado de un caballo en Suiza.

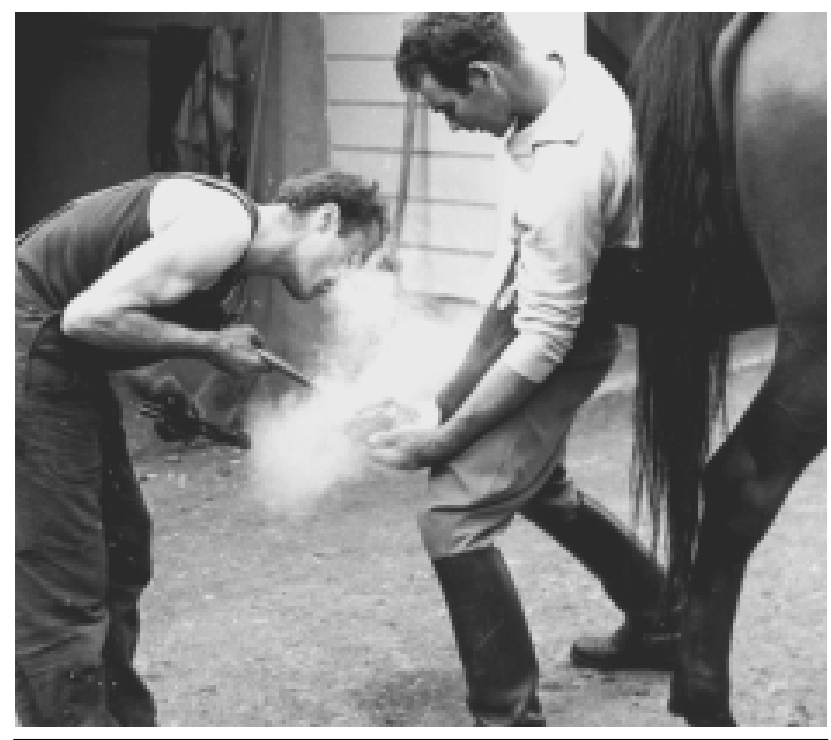




\section{- GESTION DEL ESTIERCOL Y DE LOSEXCREMENTOS}

William Popendorf

La importancia de la gestión de desechos ha ido creciendo a la vez que lo ha hecho la intensidad de la producción agrícola en las explotaciones. Los desechos de la producción ganadera están dominados por el estiércol, pero también se incluyen en este concepto las camas y mullidos, los alimentos y el agua no utilizados, y la tierra negra. En la Tabla 70.13 aparece una relación de características relevantes del estiércol; también se incluyen los desechos humanos para poder establecer una comparación, y porque en una explotación también resulta necesario tratarlos. El elevado contenido orgánico del estiércol proporciona un excelente medio de cultivo para las bacterias. La actividad metabólica de las bacterias consumirá el oxígeno y mantendrá los excrementos almacenados como estiércol en estado anaerobio. La actividad metabólica anaerobia puede producir ciertos productos intermediarios gaseosos bien conocidos, como el dióxido de carbono, el metano, el ácido sulfhídrico y el amoníaco.

\section{Procesos de gestión}

La gestión del estiércol implica su recogida, una o más operaciones de transferencia, almacenamiento $\mathrm{y} / 0$ tratamiento opcional y, finalmente, su utilización. La humedad que contiene el estiércol, según se recoge en la Tabla 70.13 determina su consistencia. LoS excrementos de diferentes consistencias requieren distintas técnicas de tratamiento y por eso pueden constituir diferentes peligros para la salud y para la seguridad (USDA 1992). EI reducido volumen de estiércol sólido o de escasa humedad suele permitir tratarlo con escasos gastos en equipo y menores necesidades energéticas, pero no es fácil automatizar los sistemas de procesamiento. La recogida, transferencia y tratamiento opcional de los excrementos líquidos son más fáciles de automatizar y requieren menos atención diaria. La exigencia de almacenar el estiércol es cada vez mayor, al ir aumentando la variabilidad estacional de las cosechas locales; el método de almacenamiento debe adaptarse para estar a la altura del ritmo al que se produce y al calendario de utilización a la vez que se preserva el medio ambiente, sobre todo en lo referente a vertidos de agua. L as posibilidades de utilización son como nutrientes para plantas, protección de plantas, alimento para animales, mullidos o como fuente de producción de energía.

\section{Producción de estiércol}

$\mathrm{H}$ abitualmente, las vacas lecheras se crían en pastos, excepto en áreas restringidas antes y después del ordeño y durante los extremos estacionales. El agua que se emplea en limpieza durante las operaciones de ordeño puede variar entre 20 a 40 litros por día y por vaca, allí donde no se practica el lavado a chorro

\section{Lista de comprobación de las prácticas de seguridad de la ganadería}

Alimentación

1. Use ventilación adecuada en edificios y silos.

2. Mantenga las entradas a los depósitos de grano, alimento y ensilaje cerradas y con llave.

3. Ponga señales de alarma en las zonas de almacenamiento de alimento y ensilaje que adviertan de los peligros de quedar atrapado en la corriente de grano o de alimento.

4. Mantenga las escaleras de silos y depósitos en buenas condiciones.

5. Cubra las entradas de los transportadores para impedir cualquier contacto con éstos.

6. Proteja con enrejados los cebadores situados sobre transportadores y elevadores.

7. Tenga precaución al cambiar de sitio los transportadores y elevadores; compruebe las líneas de tensión situadas por encima.

8. Asegúrese de que las protecciones están en su sitio en cualquier maniobra de cebado, molienda o de otro tipo.

9. Tenga en cuenta los efectos sobre la salud de respirar polvo orgánico, e informe a su médico sobre exposiciones recientes cuando acuda a la consulta por problemas respiratorios.

10. Use equipos automáticos o mecanizados cuando tenga que trasladar ma teria les podridos.

11. Haga uso del aislamiento de fuentes, la ventilación local por aspiración y los métodos húmedos para controlar el polvo orgánico.

12. Use protección respiratoria adecuada cuando la exposición al polvo sea inevitable.

Manipulación

1. Establezca buenos programas de sanidad, vacunación e inoculación.

2. Cuando trabaje con animales, prevea una salida de escape; disponga al menos de dos salidas.

3. Los manipuladores de ganado han de tener fuerza y experiencia suficientes para el trabajo.

4. Evite trabajar con animales cuando esté cansado.
5. Tenga cuidado al aproximarse a los animales para no a sustarlos.

6. Conozca a los animales y tenga paciencia con ellos

7. Descuerne a los animales peligrosos.

8. Ponga señales de advertencia donse se depositen sustancias químicas; guárdelas bajo llave en una habitación o trastero.

9. Haga las mezclas de sustancias químicas al aire libre 0 en una zona bien ventilada.

10. Tenga cuidado cuando conduzca animales

11. Leve guantes de goma cuando trate con animales enfermos.

12. Vacune a los animales y ponga en cuarentena a los que estén enfermos.

13. Lávese las manos tras el contacto con terneros que tengan diarrea.

Contención y alojamiento

1. Asegúrese de que todos los recintos, portalones, pasadizos y vallas están en buenas condiciones y son suficientemente fuertes para contener al a nimal.

2. Prohíba fumar en los alrededores de los edificios de la explotación y de las zonas de combustible y abastecimiento de combustible; ponga carteles de "prohibido fumar" en estas zonas.

3. Mantenga extintores cargados de tipo $A B C$ en los principales edificios de la explotación.

4. Retire la basura y los desechos de los alrededores de los edificios para impedir que se produzcan incendios y caídas.

5. Mantenga en buen estado las instalaciones.

6. Mantenga el cableado en buenas condiciones.

7. Use iluminación a decuada en todos los edificios.

8. Mantenga los suelos limpios y libres de hormigón roto y zonas resbaladizas.

Eliminación de desechos

1. Elimine correctamente los envases de sustancias químicas siguiendo las instrucciones de la etiqueta.

2. Instale conductos de ventilación y ventiladores en los depósitos de estiércol. 


\begin{tabular}{|c|c|c|c|c|c|}
\hline & Peso (lb) & Volumen & Volátiles & Humed & $\operatorname{ad}(\%)$ \\
\hline & & & & Excretados & Almacenados \\
\hline Vaca lechera & $80-85$ & 1,3 & $1,4-1,5$ & $85-90$ & $>98$ \\
\hline Ternera & $51-63$ & $0,8-1,0$ & $5,4-6,4$ & $87-89$ & $45-55$ \\
\hline $\begin{array}{l}\text { Cerdo (para } \\
\text { engorde) }\end{array}$ & 63 & 1,0 & 5,4 & 90 & 91 \\
\hline $\begin{array}{l}\text { Cerda } \\
\text { (gestación) }\end{array}$ & 27 & 0,44 & 2,1 & 91 & 97 \\
\hline $\begin{array}{l}\text { Cerdas y } \\
\text { lechones }\end{array}$ & 68 & 1,1 & 6,0 & 90 & 96 \\
\hline $\begin{array}{l}\text { Gallinas } \\
\text { ponedoras }\end{array}$ & 60 & 0,93 & 10,8 & 75 & 50 \\
\hline Pollos & 80 & 1,3 & 15. & 75 & 24 \\
\hline Pavos & 44 & 0,69 & 9,7 & 75 & 34 \\
\hline Corderos & 40 & 0,63 & 8,3 & 75 & - \\
\hline Seres humanos & 30 & 0,55 & 1,9 & 89 & 99,5 \\
\hline
\end{tabular}

y hasta 570 litros por día y por vaca, allí donde sí se practique. Por consiguiente, el método utilizado para limpiar influye mucho sobre el método elegido para el transporte, almacenamiento y utilización del estiércol. Debido a que la gestión de los animales para carne requiere menos agua, el estiércol de las terneras suele tratarse como sólido o semisólido. El compostaje es un método habitual de almacenamiento y tratamiento de dichos residuos secos. El patrón local de precipitaciones también afecta fuertemente al esquema elegido de gestión de residuos. Las estabulaciones excesivamente secas tienden a producir corrientes de polvo a favor del viento y problemas de olores.

Los principales problemas del porcino criado en pastos tradicionales son el control de los vertidos y de la erosión del suelo debidos a la naturaleza gregaria de estos animales. U na alternativa es la construcción de instalaciones de semiconfinamiento para cerdos con suelos pavimentados, que además facilitan la separación de los excrementos sólidos de los líquidos; los sólidos requieren algunas operaciones manuales de transferencia, pero para los líquidos basta con la acción de la gravedad. Los sistemas de gestión de residuos para instalaciones de producción en confinamiento total están diseñadas para recoger y almacenar residuos automáticamente en forma casi siempre líquida. Al jugar con las instalaciones de suministro de agua, los animales pueden hacer que aumente el volumen de excrementos porcinos. El estiércol suele almacenarse en zanjas o estanques anaerobios.

Las instalaciones para aves de corral suelen estar divididas, unas para las productoras de carne (pavos y pollos) y otras para huevos (gallinas ponedoras). Los primeros son criados directamente sobre lechos preparados, que mantienen el estiércol es un estado relativamente seco (humedad de 25 al $35 \%$ ); la única operación de transferencia es la retirada mecánica, generalmente sólo una vez al año, y el transporte directamente al campo. Las ponedoras se alojan en jaulas amontonadas sin lecho; puede dejarse que su estiércol se acumule en depósitos situados en el fondo para ser eliminados no muy a menudo, o se puede rascar o regar automáticamente en forma líquida, muy parecido a lo que se hace con el estiércol porcino.

La consistencia de los residuos de casi todos los demás animales, como ovejas, cabras y caballos, es fundamentalmente sólida; la principal excepción es la de las terneras, debido a su dieta líquida. El excremento de caballo contiene una alta proporción del lecho y puede llevar parásitos internos, lo cual limita su utilización para pastos. Los excrementos de pequeños animales, roedores y pájaros pueden contener microorganismos de enfermedades que pueden ser transmitidas al ser humano. Sin embargo, hay estudios que han demostrado que las bacterias fecales no sobreviven en el forraje (Bell, Wilson y D ew 1976).

\section{Peligros del almacenamiento}

En las instalaciones donde se almacenan los residuos sólidos debe mantenerse el control de los vertidos y escapes de agua a las aguas superficiales y subterráneas. Por eso deben ser instalaciones pavimentadas o forradas (que pueden funcionar como estanques estacionales) o cubiertas.

El almacenamiento líquido y de lechada se limita básicamente a estanques, lagunas, zanjas o tanques, subterráneos 0 no. El almacenamiento de larga duración coincide con el tratamiento in situ, habitualmente por digestión anaerobia. La digestión anaerobia reducirá la producción de sólidos volátiles que se indican en la Tabla 70.13, así como la emanación de olores por la ulterior utilización. Los depósitos subterráneos no vigilados pueden dar lugar a lesiones o fallecimientos por entradas y caídas accidentales (K noblauch y cols. 1996).

L a transferencia de estiércol líquido constituye un peligro muy variable debido a los mercaptanos producidos por la digestión anaerobia. Se ha demostrado que los mercaptanos (gases que contienen azufre) son los contribuyentes principales al olor del estiércol, y que todos son bastante tóxicos (Banwart y Brenner 1975). Q uizás el efecto más peligroso del $\mathrm{H}_{2} \mathrm{~S}$ de los que se citan en la Tabla 70.14 sea su insidiosa capacidad de paralizar el sentido del olfato en concentraciones de 50 a 100 ppm, eliminado la capacidad de los sentidos de detectar niveles mayores, cuya toxicidad es muy rápida. Basta con almacenar líquidos durante 1 semana para que se inicie la producción anaerobia de mercaptanos tóxicos. Se cree que las importantes diferencias en las tasas de generación de gas por el estiércol de larga duración se deben a las variaciones

Tabla 70.14 • Algunas características toxicológicas importantes del ácido sulfhídrico (H2S).

$\begin{array}{ll}\text { Propiedades fisiológicas o reguladoras } & \begin{array}{l}\text { Partes por } \\ \text { millón (ppm) }\end{array} \\ \text { Umbral de detección de olor (olor a huevos podridos) } & 0,01-0,1 \\ \text { Olor desagradable } & 3-5 \\ \text { TLV-TWA = límite recomendado de exposición } & 10 \\ \text { TLV-STEL = límite recomendado de exposición de 15 minutos } & 15 \\ \text { Parálisis olfatoria (incapacidad de oler) } & 50-100 \\ \text { Bronquitis (tos seca) } & 100-150 \\ \text { PIVS (neumonitis y edema pulmonar) } & 100 \\ \text { Paro respiratorio rápido (muerte en 1-3 respiraciones) } & 1.000-2.000\end{array}$

TLV-TWA = Valores umbral- Promedio ponderado por el tiempo;

STEL = Nivel de exposición de corta duración

PIVS = Peligro inmediato para la vida y la salud. 
incontroladas de las diferencias físicas y químicas del estiércol almacenado, como la temperatura, el pH y la carga orgánica y de amoníaco (D onham, Yeggy y D auge 1985).

La liberación de estos gases mientras están almacenados, que normalmente es lenta, aumenta mucho si se agita la lechada para disolver el barro acumulado en el fondo. Al agitar estiércol líquido se han comunicado concentraciones de $\mathrm{H}_{2} \mathrm{~S}$ de 300 ppm (Panti y Clark 1991), y se han medido hasta 1.500 ppm. Las cantidades de gas liberadas son demasiado altas para controlarlas por medio de la ventilación. Es fundamental percatarse de que la digestión anaerobia natural no tiene control, y por lo tanto es muy variable. Se puede predecir la frecuencia de exposiciones excesivas graves y fatales por métodos estadísticos, pero no en un lugar o momento concretos. U n estudio realizado entre vaqueros en Suiza comunicó una frecuencia de aproximadamente un accidente por gas de estiércol por cada 1.000 añospersona (K noblauch y cols. 1996). Es necesario tomar precauciones de seguridad cada vez que se prevea remover los desechos, para evitar los episodios inhabitualmente peligrosos. Si el operador no lo remueve, la lechada se irá acumulando hasta que sea necesario retirarla por medios mecánicos. $\mathrm{H}$ ay que dejar secar esta lechada antes de alguien entre físicamente en un depósito delimitado. Debe existir un programa escrito para la gestión del espacio confinado.

Entre las alternativas a los estanques anaerobios, aunque poco utilizadas, están el estanque aerobio, un estanque facultativo (a base de bacterias que pueden crecer en condiciones aerobias y anaerobias), el secado (desecado), el compostaje 0 un digestor anaerobio que produzca gas biológico (USDA 1992). Se pueden crear condiciones aerobias o bien impidiendo que el líquido alcance una profundidad superior a 60 a $150 \mathrm{~cm}$ o bien mediante aireación mecánica. $L$ a aireación natural necesita más espacio; la aireación mecánica es más cara, como ocurre con las bombas de circulación de un estanque facultativo. El compostaje puede hacerse en hileras de estiércol que deben ser dadas la vuelta cada 2 a 10 días, en pilas estáticas pero aireadas o en un depósito construido al efecto. $\mathrm{H}$ ay que reducir el elevado contenido en nitrógeno del estiércol mezclando una elevada dosis de carbono que respalde el crecimiento microbiano termófilo necesario para el compostaje, y así controlar los olores y retirar los patógenos. El compostaje es un método barato de tratar los cadáveres de animales pequeños, si las ordenanzas locales lo permiten. V éase también el artículo "O peraciones de eliminación de residuos" en otra parte de esta Enciclopedia. Si no se dispone de una planta de tratamiento de residuos, otras opciones son la incineración o el enterramiento. Es importante tratarlos cuanto antes para controlar las enfermedades de los animales 0 de los rebaños. Los excrementos de cerdos y aves son particularmente adecuados para la producción de metano, pero su técnica de utilización no ha sido masivamente adoptada.

En la superficie del estiércol líquido pueden formarse grandes costras que le dan aspecto de sólido. Puede que, al caminar sobre la costra, ésta se rompa y el trabajador se ahogue. Los trabajadores también pueden resbalar y caer en el estiércol líquido, y ahogarse. Es importante tener equipos de rescate cerca de los depósitos de estiércol líquido, y evitar trabajar a solas. Algunos gases del estiércol, como el metano, son explosivos, y hay que colocar señales de "no fumar" en el depósito de estiércol o en los alrededores (D eere \& C 0. 1994).

\section{Peligros de la aplicación}

La transferencia y utilización del estiércol seco puede hacerse a mano o con ayudas mecánicas como palas, excavadoras y esparcedoras de estiércol, cada una de las cuales constituye un peligro para la seguridad. El estiércol se esparce por el suelo como
Tabla 70.15 Procedimientos de seguridad relacionados con los distribuidores de estiércol.

1. La máquina debe ser manejada por una sola persona para evitar que cualquier otra la ponga en marcha sin darse cuenta.

2. Mantenga a los trabajadores alejados de los interruptores, pistones, transportadores y expeledores

3. Mantenga todas las protecciones y cubiertas.

4. Impida que haya personas en la parte de atrás 0 a los lados del distribuidor, que puede proyectar objetos pesados mezclados con el estiércol hasta una distancia de $30 \mathrm{~m}$.

5. Evite maniobras peligrosas impidiendo que se atasque el distribuidor:

- Retire las piedras, tablas y otros objetos del alcance de la máquina.

- Cuando la temperatura baje de cero, asegúrese de que las cuchillas y las cadenas están libres y descongeladas antes de poner la máquina en marcha.

- Mantenga las cadenas y las desbrozadoras en buenas condiciones, sustituyendo las cadenas que se han dado de sí y evitando que caigan trozos de estiércol congelado.

- No se meta nunca en un distribuidor en marcha para limpiarlo.

- Mantenga en buenas condiciones el transportador de descarga y el expeledor para que puedan funcionar libremente.

- Cuando haga frío, limpie el interior del distribuidor para que el estiércol húmedo no impida, al congelarse, que las piezas móviles se muevan.

6. Utilice buenas prácticas de seguridad para tractores e interruptores.

7. Asegúrese de que la válvula de liberación de los distribuidores de tanque cerrado funciona correctamente, para evitar presiones excesivas.

8. Al desenganchar el distribuidor del tractor, asegúrese de que el pivote que sujeta el peso de la placa está asegurado y bloqueado para impedir que se caiga.

9. Cuando el distribuidor emita polvo o aerosoles, utilice protección respiratoria.

Fuente: Deere \& Co. 1994

abono. Las esparcedoras de estiércol suelen ir remolcadas por un tractor y pueden ser puestas en marcha y desconectadas (sistema PTO ) desde el tractor. $\mathrm{H}$ ay cuatro tipos: de cajón con removedores traseros, desgranadora, tanque en $\mathrm{V}$ con expulsión lateral y tanque cerrado. Las dos primeras se emplean para aplicar estiércol sólido; la esparcedora con tanque en $\mathrm{V}$ se emplea para aplicar estiércol líquido, en lechada o sólido; y la esparcedora con tanque cerrado se emplea para aplicar estiércol líquido. Las esparcedoras esparcen el estiércol en grandes extensiones, por detrás o a los lados. Resultan peligrosos la maquinaria, los objetos que caen, el polvo y los aerosoles. En la Tabla 70.15 figuran diversas medidas de seguridad.

\section{VAQUERIAS}

John May

EI vaquero es un especialista cuyo objetivo es optimizar la salud, la nutrición y el ciclo reproductor de un rebaño de vacas con el empeño último de maximizar la producción de leche. Los principales determinantes de la exposición del vaquero a los peligros son el tamaño de la explotación y del rebaño, la acumulación de tareas, la geografía y el grado de mecanización. U na vaquería puede ser un pequeño negocio familiar en el que se ordeñan 20 vacas al día o menos, o bien una empresa con tres turnos de trabajadores para alimentar y ordeñar a miles de vacas las veinticuatro horas del día. En las zonas del mundo en las que el clima 
es muy suave, se puede alojar al ganado en cobertizos abiertos con tejados y paredes mínimos. Por el contrario, en otras regiones los establos han de estar bien cerrados a fin de que conserven calor suficiente para proteger a los animales y a los sistemas de suministro de agua y de ordeño. Todos estos factores contribuyen a la variabilidad del perfil de riesgo del vaquero. No obstante, existen algunos peligros que toda persona que trabaje en una vaquería en cualquier sitio del mundo encontrará en mayor o menor grado.

\section{Peligros y precauciones}

\section{Ruido}

Un peligro potencial claramente relacionado con el grado de mecanización es el del ruido. En las vaquerías es habitual que el ruido alcance niveles nocivos, siempre relacionados con algún tipo de aparato mecánico. Fuera del establo, las principales agresiones proceden de los tractores y de las sierras de cadena. Los niveles de ruido de estos aparatos superan a menudo los 90-100 dBA. Dentro del establo, otras fuentes de ruido son las cortadoras, las pequeñas cargadoras y las bombas de ordeño automático. También estos niveles de ruido pueden superar a los que se consideran nocivos para el oído. Aunque hay pocos estudios sobre sorderas por ruido en vaqueros, se combinan para mostrar un patrón convincente de déficit auditivos que afectan sobre todo a las frecuencias más altas. Estas pérdidas pueden ser muy importantes y se dan considerablemente más a menudo en granjeros de cualquier edad que en los controles que no son granjeros. En algunos de los estudios, las sorderas fueron más notables en el oído izquierdo que en el derecho, posiblemente porque los granjeros pasan mucho tiempo con el oído izquierdo vuelto hacia el motor y el silenciador cuando conducen algún vehículo. Puede lograrse prevenir estas sorderas mediante la reducción del ruido y el empleo de silenciadores, y mediante la implantación de un programa de reducción de ruidos. Ciertamente, el hábito de llevar dispositivos de protección de los oídos, ya sean orejeras 0 tapones, puede ayudar a reducir el riesgo de sorderas por ruido en la próxima generación.

\section{Productos químicos}

El vaquero tiene contacto con alguna sustancias químicas que suelen encontrarse en otros tipos de agricultura, y con otras que son específicas de la industria láctea, como las que se emplean para limpiar el sistema de ordeño automático al vacío. Este sistema de tubos ha de ser eficazmente limpiado antes y después de cada uso. Tal tarea suele hacerse irrigando el sistema primero con una solución de jabón muy alcalina (normalmente, hidróxido sódico al $35 \%$ ), y luego con una solución ácida como ácido fosfórico al 22,5\%. Se han observado algunas lesiones asociadas al empleo de estas sustancias. Los escapes producen quemaduras importantes. Las salpicaduras pueden lesionar la córnea o la conjuntiva si no se lleva protección en los ojos. Puede producirse la ingestión accidental con resultados trágicos (sobre todo por niños pequeños) cuando se pasan estas sustancias a envases que luego se descuidan durante un instante. La mejor forma de evitar estas situaciones consiste en utilizar un sistema de irrigación automático y cerrado. Si el sistema no es automático, hay que tomar precauciones para restringir el acceso a estas soluciones. Las unidades de medida deben ir cuidadosamente etiquetadas, deben reservarse sólo para este fin, nunca quedar desatendidas y deben aclararse bien después de cada uso.

Al igual que otros trabajadores del ganado, los vaqueros pueden verse expuestos a diversos agentes farmacéuticos, desde antibióticos y progestágenos hasta inhibidores de las prostaglandinas y hormonas. Dependiendo del país, los vaqueros también pueden utilizar fertilizantes, herbicidas e insecticidas con diversos grados de intensidad. En general, los vaqueros usan menos de estas sustancias químicas que las personas que se dedican a otras tareas agrícolas. Sin embargo, han de observarse las mismas precauciones al mezclar, aplicar y almacenar estas sustancias. Las correspondientes técnicas de aplicación y las ropas protectoras son tan importantes para el vaquero como para cualquier otra persona que trabaje con estos compuestos.

\section{Riesgos ergonómicos}

Aunque los datos actuales sobre la prevalencia del conjunto de problemas musculosqueléticos son incompletos, es evidente que los vaqueros tienen mayor riesgo de padecer artrosis de la cadera y de las rodillas. También, su riesgo de padecer problemas de espalda puede ser elevado. Aunque no está bien estudiada, hay pocas dudas de que la ergonomía es un problema importante. El trabajador puede cargar habitualmente pesos de más de $40 \mathrm{~kg}$, que a menudo se añaden a un peso corporal considerable. La conducción de tractores provoca abundantes vibraciones. Sin embargo, es la parte del trabajo dedicada al ordeño la que tiene más importancia ergonómica. U n ganadero puede agacharse 0 inclinarse de 4 a 6 veces para ordeñar a una sola vaca. Estos movimientos se repiten con cada vaca dos veces al día durante decenios. El acarreo del equipo de ordeño de establo a establo constituye una carga ergonómica adicional para las extremidades superiores. Puede que en países en los que el ordeño está poco mecanizado la carga ergonómica sobre el vaquero sea diferente, pero sigue teniendo probabilidades de reflejar una considerable tensión por repetición. En algunos países, una posible solución es utilizar salas de ordeño. En ellas el granjero puede ordeñar a varias vacas a la vez permaneciendo de pie varios centímetros por debajo de ellas, en el puesto central de la sala. De esta forma no es necesario agacharse e inclinarse, y se elimina el acarreo del equipo de establo a establo con las extremidades superiores. Este problema también puede abordarse mediante sistemas de transporte elevados que se están introduciendo en algunos países escandinavos. Sujetan el peso del equipo de ordeño mientras el granjero se mueve entre los establos, y hasta puede proporcionar un asiento adecuado para el ordeñador. Incluso con estas soluciones potenciales, queda mucho por aprender sobre los problemas ergonómicos y su solución en las vaquerías.

\section{Polvo}

Un problema estrechamente ligado es el del polvo orgánico. Se trata de un material complejo, a menudo alergénico y generalmente ubicuo, que se encuentra en las vaquerías. Con frecuencia, el polvo tiene elevadas concentraciones de endotoxinas y puede contener betaglucanos, histamina y otros materiales biológicamente activos (O lenchock y cols. 1990). L os niveles de polvo total y respirable pueden sobrepasar los $50 \mathrm{mg} / \mathrm{m}^{3}$ y los $5 \mathrm{mg} / \mathrm{m}^{3}$, respectivamente, con ciertas operaciones. Suele tratarse de trabajos con alimentos o lechos contaminados por microbios en un espacio cerrado como un establo, un pajar, un silo o un granero. La exposición a estos niveles de polvo puede producir problemas agudos, como el ST PO o la neumonitis por hipersensibilidad ("pulmón de granjero"). También la exposición crónica puede desempeñar un papel en el asma, el pulmón de granjero y la bronquitis crónica, que parecen darse con una frecuencia dos veces mayor que en una población no granjera (Rylander y Jacobs 1994). Las tasas de prevalencia de algunos de estos problemas son mayores allí donde es probable que los niveles de humedad sean elevados, y en zonas en las que los establos están más cerca debido a las necesidades climáticas. Diversas prácticas ganaderas como el secado del heno y el desempolvado del alimento de los animales a mano, así como del material de las camas, pueden ser determinantes principales de los niveles de 
polvo y de las enfermedades que se asocian con él. A menudo, los granjeros pueden poner en práctica algunas técnicas para reducir al mínimo la cantidad de sobrecrecimiento microbiano o su subsecuente aerosolización. Algunos ejemplos son el empleo de serrín, periódicos y otros materiales alternativos para las camas en lugar del heno, que está lleno de moho. Si se emplea heno, la adición de un litro de agua a la superficie de corte de la bala reduce al mínimo el polvo generado por una cortadora mecánica. Si se cubren los silos verticales con láminas de plástico o de alquitrán sin poner más alimento encima de esta capa, se reduce al mínimo el riesgo de producir polvo al retirar dicha cubierta. A menudo es posible utilizar pequeñas cantidades de humedad y/ o de ventilación en situaciones en las que es probable que se genere polvo. Finalmente, los granjeros deben prever las posibles exposiciones al polvo y utilizar la correspondiente protección respiratoria en estas situaciones.

\section{Alergenos}

Para algunos vaqueros, pueden representar un importante problema de salud. L os principales alergenos se encuentran en los establos, y suelen deberse a la caspa de los animales y a los "ácaros de almacén" que viven en el alimento que se almacena en los establos. Un estudio ha extendido el problema de los ácaros más allá del establo, encontrando considerables poblaciones de estas especies habitando también en las casas de los granjeros (van H age-H amsten, Johansson y H ogland 1985). Se ha confirmado que la alergia a los ácaros es un problema en diversas partes del mundo, a menudo con diferentes especies de ácaros. $L a$ reacción a estos ácaros, a la caspa de las vacas y a otros alergenos menos significativos produce diversas manifestaciones alérgicas (M arx y cols. 1993). Entre éstas se encuentra la aparición inmediata de irritación nasal y ocular, dermatitis alérgica y, lo que es más grave, asma profesional mediado por alergia. Puede tratarse de una reacción inmediata o tardía (hasta 12 horas) y puede aparecer en individuos de quienes no se sabía que eran asmáticos. Esto es preocupante porque el vaquero trabaja en los establos a diario, de modo intensivo y durante toda su vida. Sometidos de modo casi continuo a la estimulación alérgica, es probable que el asma sea cada vez más grave en algunos granjeros. La prevención consiste en evitar el polvo, que es la intervención más eficaz y, lamentablemente, la más difícil para la mayoría de los vaqueros. Los resultados de los tratamientos médicos, incluidas las vacunas, los esteroides tópicos y otros agentes antiinflamatorios, y el alivio sintomático mediante broncodilatadores, han sido variables.

\section{VACUNO, OVINO Y CAPRINO}

\section{M elvin L. M yers*}

Diversos animales convierten los alimentos ricos en fibra que se conocen como forraje (más del $18 \%$ en fibra) en alimentos comestibles para los seres humanos. Esta capacidad procede de su sistema de digestión, constituido por cuatro estómagos, entre ellos, el rumen (al que deben que se les llame rumiantes) (Gillespie 1997). La Tabla 70.16 muestra los diversos tipos de ganado rumiante que han sido domesticados y para qué se utilizan.

\section{Procesos de producción}

Los procesos de cría de rumiantes varían desde las explotaciones intensivas de elevada producción, como los grandes ranchos de

* Los pasajes sobre esquileo se han redactado tomando como base el artículo de J.F. Copplestone' sobre el tema incluido en la 3a edición de esta Enciclopedia.
Tabla 70.16 • Tipos de rumiantes domesticados.

\begin{tabular}{ll} 
Tipo de rumiante & Usos \\
Vacuno & Carne, leche, tiro \\
Ovino & Carne, lana \\
Caprino & Carne, leche, moer \\
$\begin{array}{l}\text { Camélidos (Ilama, alpaca, dromedario y } \\
\text { camellos) }\end{array}$ & Carne, leche, pelo, tiro \\
Búfalo (búfalo de agua) & Carne, tiro \\
Bisonte & Carne \\
Yaks & Carne, leche, lana \\
Ciervo & Carne, leche, tiro \\
\hline
\end{tabular}

terneras de $2,000 \mathrm{~km}^{2}$ en Texas hasta los pastos comunales que utilizan los pastores nómadas de Kenia y de Tanzania. Algunos granjeros emplean los bueyes como fuerza de tracción en tareas de ganadería como el arado. En zonas húmedas, el búfalo hace el mismo servicio (Ker 1995). La tendencia es favorable a los sistemas intensivos de elevada producción (G illespie 1997).

La producción intensiva de grandes cantidades de vacas depende de diversas operaciones interrelacionadas. U na es el sistema de vaca-ternera, que implica el mantenimiento de un rebaño de vacas. Estas son cubiertas por toros o por inseminación artificial para producir terneras que, una vez destetadas, son vendidas a los ganaderos correspondientes, que las crían para sacrificio. Los machos son castrados para el mercado de matanza; un ternero castrado recibe el nombre de novillo. Los criadores de razas puras mantienen los rebaños de animales de cría, incluidos los toros, que son animales muy peligrosos.

Las ovejas se cuidan en pastos o en granjas. En los pastos es frecuente que haya de 1.000 a 1.500 cabezas. En las granjas, la producción suele ser pequeña $y$, habitualmente, un negocio secundario. Las ovejas se crían por la lana o por los corderos. Estos no tienen cola, y la mayor parte de los machos son castrados. Algunas empresas se especializan en criar carneros para obtener razas puras.

Las cabras se crían en pastos 0 en pequeñas explotaciones para obtener su piel, leche y carne. Los criadores de razas puras tienen pequeñas explotaciones donde crían carneros con fines reproductivos. Existen razas específicas para cada uno de estos productos. A las cabras se les quitan los cuernos, y se castra a la mayor parte de los machos. Las cabras se alimentan de brotes, ramitas y hojas de arbustos, por lo que también pueden ser utilizadas para controlar los arbustos en un rancho o en una explotación.

0 tros procesos importantes que forman parte de la cría de vacuno, ovino y caprino son la alimentación, el control de enfermedades y parásitos, el esquilado de la lana y el trasquilado. EI proceso de ordeño y el de eliminación de residuos se abordan en otros artículos de este capítulo.

Las vacas, ovejas y cabras se alimentan de diversas maneras, como el pasto, el heno o el ensilaje. El pasto es la forma más barata de aportar forraje a los animales. Los animales suelen pacer en dehesas, campos sin cultivar o en los que se ha recolectado el maíz, y en los que quedan residuos, como los tallos de la planta. EI heno suele recolectarse en el campo y almacenarse suelto en balas. La operación de alimentación consiste en pasar el heno de los almiares a campo abierto o a comederos en los que se alimentan los animales. Algunos cultivos, como el maíz, se recolectan y se convierten en ensilaje. $\mathrm{H}$ abitualmente, el 
ensilaje es trasladado por medios mecánicos a los pesebres para que se alimenten los animales.

El control de enfermedades y parásitos en vacas, ovejas y cabras forma parte integral del proceso de cría de ganado y requiere estar en contacto con los animales. Las visitas de rutina de un veterinario al rebaño son una parte importante de este proceso, como lo es la observación de las constantes vitales. La vacunación periódica frente a determinadas enfermedades y la puesta en cuarentena de los animales enfermos también son importantes. Los parásitos externos son moscas, piojos, sarna, ácaros y garrapatas. U na forma de controlarlos son los productos químicos. Los plaguicidas se aplican por pulverización o mediante etiquetas impregnadas de insecticida que se aplican a las orejas. Las moscas ponen sus huevos en el pelo del ganado, y sus larvas, los gorgojos, se entierran en la piel. U na forma de controlar a los gorgojos son los plaguicidas sistémicos (que se pulverizan por el cuerpo con un aerosol, por inmersión o añadiéndolos a los alimentos). Los parásitos internos, como los nematelmintos y platelmintos, se controlan con medicamentos, antibióticos o purgantes (administración oral de un medicamento líquido). EI saneamiento también es una estrategia para el control de las enfermedades infecciosas y de las infestaciones parasitarias (G illespie 1997).

El esquilado de animales vivos ayuda a mantenerlos limpios o cómodos y los prepara para las exhibiciones en las ferias. Pero se puede retirar el pelo de los animales vivos para usarlo como producto, como la lana de las ovejas o el moer de las cabras. EI esquilador lleva al animal a un establo, lo sube a un altillo y los pone boca abajo para la operación de esquilado, sujetándolo por las patas. Los cortadores de pelo y los esquiladores de ovejas usan tijeras manuales o trasquiladoras a motor para cortar el pelo. $\mathrm{H}$ abitualmente, las trasquiladoras a motor son eléctricas. Antes de esquilar y también como parte de la preparación para la gestación, se marca y limpia a las ovejas (es decir, se elimina el pelo en el que han quedado heces incrustadas). La trasquiladora se ajusta a mano en función de la calidad y la hebra del pelo. L uego se comprime en balas para su transporte, mediante dispositivos manuales o con pistones hidráulicos.

Las instalaciones que se utilizan para criar vacas, ovejas y cabras suelen clasificarse en confinadas o no confinadas. Son instalaciones en confinamiento las cuadras, cobertizos, establos, corrales (zonas donde se guarda, clasifica y apiña el ganado), los vallados y los canalones de trabajo y carga. L as instalaciones no confinadas son los pastos $u$ operaciones en campo abierto. Las instalaciones para alimentar a los animales consisten en depósitos (silos verticales y horizontales), molinos y equipos de mezcla, almiares, equipo de transporte (como barrenas y grúas), tarimas para alimentación, fuentes de agua y suministradores de minerales y de sal. Además, puede proporcionarse protección contra el sol mediante sombrajos, árboles o enrejados. 0 tras instalaciones son los rascadores para el control de parásitos, los comederos muy bajos (para que coman los terneros o los corderos sin que lleguen los adultos), comederos individuales, los refugios para crías, los portalones para proteger al ganado y los establos para tratar a los animales. Pueden vallarse los pastos, incluso con alambrado de púas o con vallas eléctricas. Para guardar cabras pueden hacer falta mallas de alambrado. Los animales criados en libertad deben ir en rebaños para poder controlar sus movimientos; las cabras pueden estar atadas, pero han de tener sombra. Para el control de parásitos en grandes rebaños se emplean tanques de inmersión (Gillespie 1997).

\section{Peligros}

La Tabla 70.17 muestra otros procesos relacionados con el manejo del vacuno, ovino y caprino, y las exposiciones peligrosas con las que se asocian. En un estudio de Estados Unidos
(M eyers 1997), el manejo del ganado representó el $26 \%$ de las lesiones con absentismo. Este porcentaje fue mayor que el de cualquier otra actividad agrícola, como se muestra en la Figura 70.5. Cabe suponer que estas cifras sean representativas de la tasa de lesiones en otros países industrializados. En los países en los que los animales de tiro son habituales, lo lógico es que sean más elevadas. Las lesiones producidas por el ganado suelen producirse en dependencias de la explotación o en su vecindad. El ganado produce lesiones al dar coces o pisar a las personas 0 aplastarlas contra una superficie dura, como la pared del establo. Las personas también pueden resultar heridas al caerse mientras trabajan con vacas, ovejas y cabras. Los toros provocan las lesiones más graves. La mayor parte de los lesionados son miembros de la familia, no trabajadores contratados. El cansancio puede reducir la capacidad de juicio, de modo que aumenta la posibilidad de lesión (Fretz 1989).

El ganado adopta comportamientos que pueden producir lesiones a los trabajadores. El instinto gregario es fuerte en animales como las vacas o las ovejas, y la imposición de límites como son el aislamiento o el excesivo hacinamiento pueden dar lugar a patrones de comportamiento inhabituales. La respuesta refleja es un comportamiento defensivo habitual en los animales, y puede ser prevista. El territorialismo es otro comportamiento previsible. Cuando un animal es apartado de su dominio habitual y colocado en confinamiento, se resiste de modo reflejo. Los animales que han de pasar por pasillos para cargarlos en los

Tabla 70.17 • Procesos de la ganadería y peligros potenciales.

\begin{tabular}{|c|c|}
\hline Proceso & Exposiciones potencialmente peligrosas \\
\hline $\begin{array}{l}\text { Cruzamiento, inseminación } \\
\text { artificial }\end{array}$ & $\begin{array}{l}\text { Actos violentos de toros, carneros o machos } \\
\text { cabríos; resbalones y caídas; zoonosis; } \\
\text { polvo orgánico y caspa }\end{array}$ \\
\hline Alimentación & $\begin{array}{l}\text { Polvo orgánico; gas de silo; máquinas; } \\
\text { levantamientos; electricidad }\end{array}$ \\
\hline $\begin{array}{l}\text { Partos de vacas, ovejas, otros } \\
\text { animales }\end{array}$ & $\begin{array}{l}\text { Levantamiento y tracción; comportamiento } \\
\text { animal }\end{array}$ \\
\hline Castración, estabulación & $\begin{array}{l}\text { Comportamiento animal; levantamiento; cortes } \\
\text { por cuchillos }\end{array}$ \\
\hline Descuerne & $\begin{array}{l}\text { Comportamiento animal; cortes por los } \\
\text { utensilios; emplastos cáusticos; } \\
\text { quemaduras por planchas eléctricas }\end{array}$ \\
\hline Marcado & Quemaduras; comportamiento animal \\
\hline Vacunación & $\begin{array}{l}\text { Comportamiento animal; pinchazos con las } \\
\text { agujas }\end{array}$ \\
\hline $\begin{array}{l}\text { Formación de polvo y } \\
\text { aerosoles/ curtidos, } \\
\text { cría de gusanos }\end{array}$ & Organofosforados \\
\hline Cuidado de patas y cascos & $\begin{array}{l}\text { Comportamiento animal; cortes y pellizcos por } \\
\text { las herramientas correspondientes }\end{array}$ \\
\hline Esquileo, lavado y pelado & $\begin{array}{l}\text { Posturas antinaturales y levantamiento; } \\
\text { comportamiento animal; trasquiladoras } \\
\text { manuales; electricidad }\end{array}$ \\
\hline Carga y descarga & Comportamiento animal \\
\hline Manejo del estiércol & $\begin{array}{l}\text { Gases del estiércol; resbalones y caídas; } \\
\text { levantamientos; maquinaria }\end{array}$ \\
\hline
\end{tabular}

Fuentes: Deere \& Co. 1994; Fretz 1989; Gillespie 1997; NIOSH 1994. 


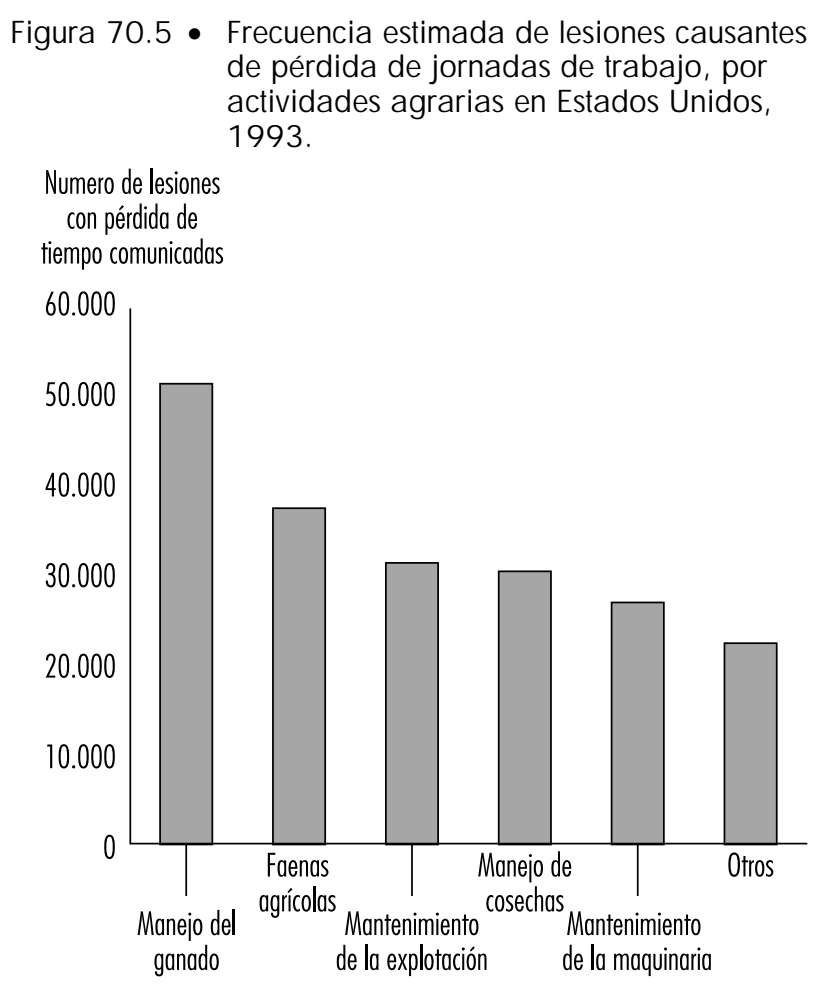

Actividad que realizaba el trabajador cuando se lesionó

Fuente: Meyers 1997.

medios de transporte mostrarán el reflejo que les lleva a resistirse con fuerza.

En las explotaciones de producción de vacuno, ovino y caprino son numerosas las zonas peligrosas. Se trata de los suelos resbaladizos, los depósitos de estiércol, los corrales, las zonas polvorientas donde se guarda el alimento, los silos, los equipos mecanizados para alimentación y las zonas de confinamiento de Ios animales. Estas últimas pueden tener depósitos de estiércol, que pueden emitir gases letales. (Gillespie 1997).

El golpe de calor y el ictus son peligros potenciales. La intensa actividad física, el estrés y la tensión, el calor, la elevada humedad y la deshidratación producida por la falta de agua potable contribuyen a estos peligros.

Q uienes tratan con ganado tienen el riesgo de presentar enfermedades respiratorias debido a la exposición a polvos inhalados. Una enfermedad habitual es el síndrome tóxico por polvo orgánico. Este síndrome puede aparecer tras la exposición a elevadas concentraciones de polvos orgánicos contaminados por microorganismos. A proximadamente el 30 al $40 \%$ de los trabajadores que se ven expuestos a polvos orgánicos presentará este síndrome, que incluye los trastornos que se muestran en la Tabla 70.18; en ella también figuran otras afecciones respiratorias (N I O SH 1994).

Los esquiladores y trasquiladores de ovejas afrontan diversos peligros. Durante el esquilado pueden producirse cortes y abrasiones. Las pezuñas y los cuernos de los animales también son peligros potenciales. Los resbalones y caídas son peligros siempre presentes cuando se manejan animales. A veces las baterías para las esquiladoras se llevan en cinturones, y hay que tomar precauciones. También hay peligros eléctricos. Los esquiladores tienen también peligros posturales, sobre todo en la espalda, como resultado de la maniobra de atrapar a la oveja y darle la vuelta. Si se sujeta al animal entre las piernas se tensa mucho la espalda, y los movimientos de torsión son frecuentes al esquilar. El esquilado manual suele producir tenosinovitis.

El control de los insectos de vacas, ovejas y cabras mediante plaguicidas en aerosol 0 en polvo puede exponer a los trabajadores al plaguicida. Cuando se sumerge a las ovejas en baños plaguicidas, el manejo del animal o el contacto con la solución del baño o con la lana contaminada también puede exponer a los trabajadores al plaguicida (Gillespie 1997).

Las zoonosis más habituales son la rabia, la brucelosis, la tuberculosis bovina, la triquinosis, la salmonelosis, la leptospirosis, la tiña, las tenias, la ectima contagiosa, la fiebre Q y la fiebre manchada. Las enfermedades que pueden contraerse tratando con el pelo o la lana son el tétanos, la salmonelosis producida al etiquetar y sujetar a los animales, la leptospirosis, el ántrax y las enfermedades por parásitos.

Las heces y la orina de los animales son también un mecanismo de infección para los trabajadores. El ganado constituye una reserva de criptosporidosis, enfermedad que puede ser transmitida del ganado a los seres humanos por la vía fecal-oral. Los terneros con diarrea pueden albergar esta enfermedad. La esquistosomiasis, una enfermedad producida por duelas hemáticas, se encuentra en las vacas, los búfalos de agua y otros animales, en diversas partes del mundo; su ciclo vital empieza en los huevos excretados por orina y heces que se convierten en larvas, entran en los caracoles, luego a pasan a cercarias que nadan en libertad y se adhieren a la piel de los seres humanos, atravesándola. La penetración puede producirse cuando los trabajadores vadean el agua.

A lgunas zoonosis son enfermedades virales transmitidas por artrópodos. Los vectores primarios de estas enfermedades son los mosquitos, las garrapatas y los flebotomos. Entre estas enfermedades se encuentras las encefalitis transmitidas por garrapatas y por la leche de oveja, las babesiosis transmitidas por las garrapatas de las vacas y la fiebre hemorrágica de CrimeaCongo (fiebre hemorrágica de Asia central) transmitida por mosquitos y garrapatas a partir de vacas, ovejas y cabras (como huéspedes intermediarios) cuando se producen epizootias (Benenson 1990; M ullan y M urthy 1991).

\section{Acción preventiva}

Los principales peligros profesionales que se producen en la cría de rumiantes son las lesiones, problemas respiratorios y zoonosis. (Véase el cuadro "Lista de comprobación de las prácticas de seguridad en la cría de animales").

Tabla 70.18 • Enfermedades respiratorias, por tipos de exposición en las explotaciones ganaderas.

Enfermedades del síndrome tóxico por polvo orgánico

Enfermedad del pulmón de granjero negativa a la precipitina

Micotoxicosis pulmonar

Síndrome del descargador de silos

Fiebre por gramíneas en trabajadores de elevadores de gramíneas

\section{Otras enfermedades respiratorias importantes}

"Enfermedad del rellenador de silos" (inflamación tóxica aguda del pulmón)

"Pulmón de granjero" (neumonitis por hipersensibilidad)

Bronquitis

Asfixia (ahogamiento)

Inhalación de gas tóxico (p. ej., depósitos de estiércol) 
$\mathrm{H}$ ay que mantener en buenas condiciones los escalones de las escaleras, y nivelar los suelos para reducir los riesgos de caídas. $\mathrm{H}$ ay que vigilar las correas de transmisión, las taladradoras, los arietes hidráulicos y los equipos de afilado de las esquiladoras. Los cables eléctricos han de estar en buenas condiciones para prevenir las descargas eléctricas. $\mathrm{H}$ ay que garantizar las ventilación siempre que se utilicen motores de combustión interna en los establos

La formación y la experiencia en el manejo adecuado de los animales ayuda a prevenir las lesiones relacionadas con el comportamiento de los animales. Para manejar los animales de forma segura hay que comprender los componentes innatos y adquiridos del comportamiento animal. Las instalaciones han de estar diseñadas de forma que los trabajadores no tengan que estar con los animales en zonas pequeñas o cerradas. La iluminación debe ser difusa, porque las luces intensas pueden confundir a los animales y hacer que se pierdan. L os ruidos o movimientos repentinos puede asustar a las vacas, haciendo que aplasten a una persona contra superficies duras. $\mathrm{H}$ asta el hecho de colgar ropa en las vallas de forma que ondee al viento puede asustar al ganado. $\mathrm{H}$ ay que acercarse a los animales de frente, para no asustarlos. Evite el uso de pinturas de contraste en las instalaciones para el ganado, porque los animales reducirán su marcha o se pararán las verlas. $H$ ay que evitar las sombras en el suelo, porque los animales pueden negarse a cruzarlas (G illespie 1997).

Los riesgos de exposición al polvo orgánico pueden evitarse de diversas maneras. Los trabajadores deben ser conscientes de los efectos sobre la salud de la respiración de polvo orgánico, y deben informar a su médico de las exposiciones recientes al polvo cuando consulten por problemas respiratorios. Si se evita que se estropeen los alimentos puede reducirse al mínimo la posibilidad de exposición a las esporas de hongos. Para evitar estos peligros, los trabajadores deben emplear equipos mecánicos para trasladar los materiales en descomposición. Los operadores de las explotaciones deben emplear sistemas de ventilación por aspiración y métodos de supresión de polvo por humedad para reducir al mínimo la exposición. $\mathrm{H}$ ay que llevar mascarillas adecuadas cuando no sea posible evitar la exposición al polvo orgánico (N IO SH 1994).

La prevención de las zoonosis depende de la limpieza de las instalaciones, la vacunación de los animales, la cuarentena de los animales enfermos y la evitación del contacto con animales enfermos. Al tratar animales enfermos hay que llevar guantes de goma para evitar los contagios por cortes en las manos. Los trabajadores que caigan enfermos tras el contacto con un animal enfermo deben acudir al médico (Gillespie 1997).

\section{- PORCINO}

M elvin L. M yers

EI cerdo fue domesticado fundamentalmente a partir de dos especies salvajes: el jabalí europeo y el cerdo de las Indias 0 rientales. L os chinos ya habían domesticado cerdos en 4.900 a.C., y hoy en día se crían en China más de 400 millones de cerdos, de una población mundial de 840 millones (Caras 1996).

Los cerdos se crían sobre todo para servir de alimento, y tienen muchas utilidades conocidas. C recen deprisa y alcanzan grandes tamaños, las camadas son grandes y los periodos de gestación cortos, de 100 a 110 días. Los cerdos son omnívoros y comen bayas, carroña, insectos y basura, aparte de maíz, ensilaje y el pasto de las grandes explotaciones. Convierten el $35 \%$ de lo que comen en carne y grasa, lo que les hace más eficaces que las especies de rumiantes, como las vacas (G illespie 1997).

\section{Procesos de producción}

Algunas explotaciones de cerdos son pequeñas: uno o dos ejemplares, por ejemplo, que pueden representar gran parte de los bienes de una familia (Scherf 1995). En las grandes explotaciones de porcinos tienen lugar dos procesos principales (G illespie 1997).

Uno es el de producción de razas puras, que consiste en criar y mejorar a los animales. En las instalaciones de raza pura prevalece la inseminación artificial. Los machos de raza pura suelen utilizarse para cubrir a las hembras del otro proceso de importancia, la producción comercial. Esta última implica la cría para matanza, y habitualmente sigue alguna de las dos diferentes formas de operar. U na consiste en un sistema en dos fases. La primera fase consiste en la producción de cerdos, que utiliza un rebaño de cerdas que alimenta entre 14 y 16 lechones por cerda. L os lechones son destetados y se venden a la siguiente fase del sistema, la empresa de compra y terminado, que los alimenta para la matanza. Los alimentos más utilizados son el maíz y el aceite de soja. Las gramíneas que comen las recogen del suelo.

La otra forma de operar, que es la más frecuente, es el sistema completo de cerda y camada. En estas explotaciones se cría una piara completa de cerdas y lechones, cuidando y engordando a los lechones para la matanza.

Algunas cerdas pueden parir más lechones que mamas tienen. Para alimentar a los lechones sobrantes, la práctica habitual consiste en pasar los lechones de las grandes camadas a cerdas que hayan tenido camadas pequeñas. Los cerdos nacen con dientes espiculares, que habitualmente se les cortan a la altura de la encía al cumplir los dos días. Se les practica una incisión en las orejas para poder identificarlos. Más o menos cuando cumplen 3 días se les recorta el rabo. Los cerdos macho criados para matanza son castrados cuando cumplen 3 semanas.

M antener sana a la piara es la faena más importante de la producción porcina. Las medidas higiénicas y la elección de animales sanos son importantes. Se emplean vacunas, sulfamidas y antibióticos para prevenir muchas enfermedades infecciosas. Se usan insecticidas para controlar piojos y ácaros. Las tenias y otros parásitos de los cerdos se controlan por medio de medidas higiénicas y de fármacos.

Entre las instalaciones que se emplean para la producción de porcino se encuentran los sistemas de pastos, una combinación de pastos y alojamientos baratos con sistemas de confinamiento total que requieren grandes inversiones. $\mathrm{H}$ ay una tendencia al aumento del número de alojamientos en confinamiento, porque la cría es más rápida que en los pastos. Pero el pasto es mejor para alimentar a la piara destinada a criar cerdos, porque impide que dicha piara engorde; puede utilizarse en todo el proceso de producción o sólo en parte, junto con el empleo de alojamientos y equipos portátiles.

Los edificios de confinamiento han de tener ventilación para controlar la temperatura y la humedad. Puede añadirse calefacción a las porqueras. En los confinamientos se instalan suelos acanalados porque exigen menos trabajo a la hora de gestionar el estiércol. Para la producción de cerdos es necesario acondicionar y gestionar los equipos de suministro de agua y alimento. Las instalaciones se limpian por lavado a presión y posterior desinfección de todas las camas, retirando el estiércol y la comida sobrante (G illespie 1997).

\section{Peligros}

Las lesiones producidas por el ganado porcino suelen producirse en los edificios de la explotación o en su vecindad. Resultan peligrosos los suelos resbaladizos, los depósitos de estiércol, los equipos automáticos de alimentación y los edificios de confinamiento. Estos edificios tienen un depósito de estiércol que emite gases que, si no se ventilan, pueden causar la muerte no sólo a los cerdos, sino también a los trabajadores. 
EI comportamiento de los cerdos puede constituir un peligro para los trabajadores. U na cerda atacará si sus lechones se ven amenazados. Los cerdos pueden morder, pisar o tirar a la gente al suelo. Tienden a permanecer o a regresar a las zonas familiares. Intentarán regresar a la piara cuando se trate de separarlos de ella. Es probable que se planten cuando se les traslade de una zona oscura a otra con luz, como cuando se les saca al exterior, a la luz del día. Por la noche, se resistirán a ser trasladados a zonas oscuras (G illespie 1997).

En un estudio canadiense sobre cuidadores de cerdos, el $71 \%$ comunicaron problemas crónicos de espalda. Los factores de riesgo son la presión sobre los discos intervertebrales derivada de los largos períodos de conducción y de estar sentando mientras se maneja equipo pesado. Este estudio también identifica las acciones de levantar, agacharse, girarse, empujar y tirar como factores de riesgo. Además, más del $35 \%$ de estos cuidadores comunicó problemas crónicos en las rodillas ( $\mathrm{H}$ olness y $\mathrm{N}$ ethercott 1994).

$\mathrm{H}$ ay tres tipos de exposiciones aéreas que constituyen peligro en las explotaciones de cerdos:

1. el polvo de los alimentos, del pelo de los animales y de la materia fecal

2. Ios plaguicidas que se usan para los cerdos y otras sustancias químicas, como los desinfectantes

3. amoníaco, ácido sulfhídrico, metano y monóxido de carbono de los depósitos de estiércol.

Los incendios de los edificios son otro peligro potencial, así como la electricidad.

Algunas zoonosis y parásitos pueden ser transmitidos por los cerdos a los trabajadores. Las zoonosis que suelen asociarse con los cerdos son la brucelosis y la leptospirosis (enfermedad del porquero).

\section{Medidas de prevención}

Se han recomendado diversas medidas de seguridad para el manejo seguro de los cerdos (G illespie 1997):

- Se debe evitar trabajar en el mismo recinto con los lechones y sus madres.

- Al manejar cerdos hay que utilizar algún obstáculo o protección sólida para evitar las mordeduras y el caer al suelo empujado por el animal.

- Se le puede dar la vuelta a un cerdo colocándole un cesto que le cubra la cabeza.

- Hay que mantener a los niños alejados de las porquerizas e impedirles que alimenten a los lechones a través de las vallas.

- Debido a sus instintos gregarios, resulta más fácil separar a un grupo de cerdos de la piara que a un animal solo.

- Es posible trasladar a los cerdos de zonas oscuras a otras iluminadas utilizando luz artificial. Cuando se les traslada de noche, ya sea usando pasillos o callejuelas, se debe colocar una luz en el punto de destino.

- Los pasillos de carga no han de tener más de 25 grados de inclinación.

Es posible disminuir el riesgo de lesión musculosquelética por medio de la reducción de la exposición a traumatismos repetidos (haciendo descansos frecuentes o variando el tipo de faenas), y mejorando la postura, reduciendo los pesos que se levantan (con la ayuda de un compañero o de máquinas) y evitando los movimientos rápidos y bruscos.

Para controlar el polvo hay que reducir la densidad de la piara, para que la concentración de polvo sea menor. Además, los sistemas de alimentación automáticos deben ir metidos protegidos para contener el polvo. Pueden emplearse humidificadores de agua, pero son ineficaces con el agua congelada y pueden contribuir a la supervivencia de bioaerosoles y a incrementar los niveles de toxinas. Los filtros y depuradoras de aire en el sistema de ventilación garantizan la limpieza de las partículas de polvo en el aire reciclado. Los respiradores son otra forma de controlar las exposiciones al polvo (Feddes y Barber 1994).

$\mathrm{H}$ ay que instalar troneras en los depósitos de estiércol para impedir que los gases peligrosos entren en los edificios de la explotación. Debe haber ventiladores eléctricos en los depósitos. L os trabajadores han de recibir formación sobre la forma segura de usar los plaguicidas y otras sustancias químicas, como los desinfectantes que se emplean en la producción de cerdos.

La limpieza, la vacunación, la cuarentena de los animales enfermos y la evitación de exposiciones son formas de controlar las zoonosis. Al tratar con cerdos enfermos, lleve guantes de goma. Toda persona que caiga enferma tras haber trabajado con cerdos debe acudir a un médico (Gillespie 1997).

\section{ProducCion de AVES DE CORRAL Y DE HUEVOS}

\section{Steven W. Lenhart}

La producción agrícola de aves que pesan $18 \mathrm{~kg}$ o menos incluye no sólo pollos, pavos, gansos y pintadas, sino también aves de caza, como perdices, codornices, urogallos y faisanes. Aunque algunas de estas aves se crían al aire libre, la mayor parte de la producción de aves de corral y huevos se produce en instalaciones de confinamiento o corrales especialmente diseñados. Las aves grandes que pesan entre 40 y $140 \mathrm{~kg}$, como casuarios, ñandúes y avestruces, también se crían en granjas por su carne, huevos, piel, plumas y grasa. Pero debido a su mayor tamaño la mayor parte de estas aves, que se conocen en conjunto como rátidas, suelen criarse al aire libre en zonas valladas que contienen refugios para ellas.

Los pollos y pavos constituyen la mayor parte de las aves de corral que se producen en el mundo. Los agricultores de Estados Unidos producen al año un tercio de los pollos del mundo, más que los seis siguientes países productores de pollos juntos (Brasil, C hina, Japón, Francia, Reino U nido y España). I gualmente, más de la mitad de la producción mundial de pavos tiene lugar en los Estados U nidos, seguidos por Francia, Italia, Reino U nido y Alemania.

Aunque en Estados U nidos ya había producción comercial de pollo en 1880, la producción se aves de corral y huevos no se consideró como industria a gran escala hasta 1950 aproximadamente. En 1900, un pollo pesaba un poco menos de un kilo a las 16 semanas. Antes de que la producción de aves de corral se convirtiera en industria, los pollos que se compraban para comer eran estacionales, y abundaban más al principio del verano. L as mejoras en las prácticas de alimentación, el uso del alimento para engorde, procesado y comercialización, el alojamiento y el control de las enfermedades contribuyeron al crecimiento de la industria de las aves de corral. La disponibilidad de vitamina $\mathrm{D}$ artificial también fue una contribución fundamental. Todas estas mejoras lograron que la producción de pollo durara todo el año, que los periodos de producción fueran más cortos y que aumentara el número de aves alojadas a la vez, de sólo unos pocos cientos a varios miles. La producción de pollos tiernos (pollos de 7 semanas que pesan unos $2 \mathrm{~kg}$ ) aumentó espectacularmente en Estados U nidos, de 143 millones de pollos en 1940, a 631 millones en 1950, a 1.800 millones en 1960 (N esheim, Austic y Card 1979). Los agricultores estadounidenses 
Figura 70.6 • Parte de un rebaño comercial de avestruces de 3 a 6 semanas de edad.

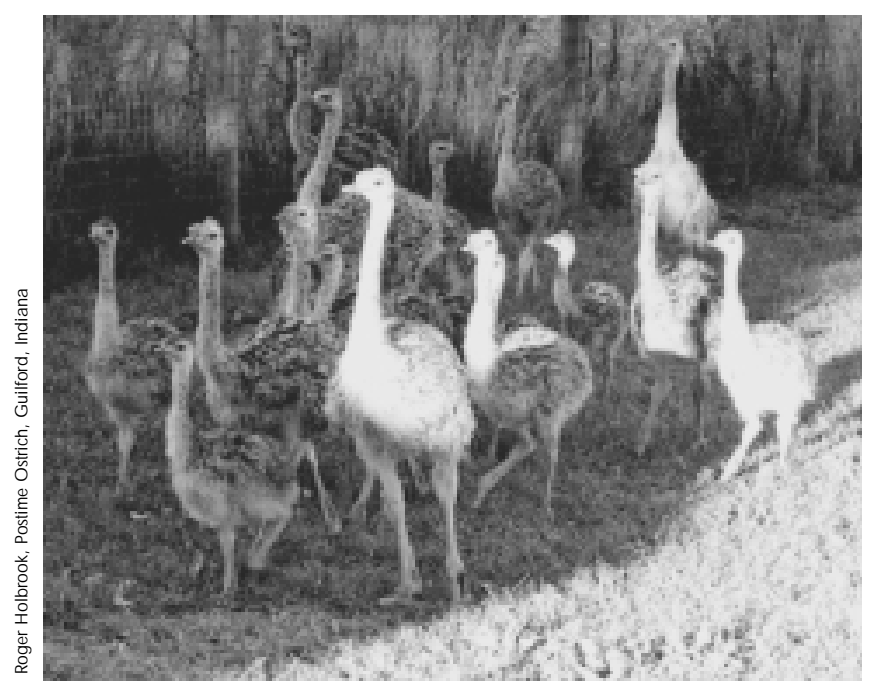

En el momento del sacrificio al cumplir los 12 meses, cada ave pesará unos $100 \mathrm{~kg}$, de los cuales $35 \mathrm{~kg}$ serán carne deshuesada. Un avestruz adulto puede pesar hasta $140 \mathrm{~kg}$.

produjeron unos 7.600 millones de pollos tiernos en 1996 (U SDA 1997).

La producción de huevos también ha sufrido un aumento espectacular, similar al de la producción de pollos tiernos. A comienzos del siglo $X X$, una ponedora producía unos 30 huevos al año, la mayor parte en primavera. Hoy en día, la media anual por ponedora está por encima de los 250 huevos.

La cría de rátidas se dedica sobre todo al avestruz africano, al emú y al casuario australianos y al ñandú suramericano. (La Figura 70.6 muestra un rebaño de avestruces, y la Figura 70.7, uno de emús). La cría de rátidas empezó en Sudáfrica al finales del siglo XIX, en respuesta a la moda del uso de las plumas de las alas y de la cola de los avestruces. Aunque las plumas de avestruz ya no decoran los sombreros ni la ropa, la producción comercial continúa no sólo en Sudáfrica, sino también en otros países africanos, como Namibia, Zimbabue y K enia. También se crían rátidas en Australia, Alemania, Reino U nido, Italia, China y Estados U nidos. La popularidad de la carne de estas aves está creciendo porque se trata de carne roja con textura y sabor de ternera, pero con una nivel de grasas saturadas muy inferior.

\section{Corrales de confinamiento para aves de corral}

En los Estados U nidos, un confinamiento típico es un corral largo (60 a $150 \mathrm{~m}$ ), estrecho (9 a $15 \mathrm{~m}$ ) de una sola planta con el suelo cubierto por un lecho (a base de una capa de viruta de madera, turba de musgo o serrín). Los dos extremos de la instalación tienen grandes puertas, y a los dos lados corren cortinas hasta media pared, cubriendo toda la longitud de la estructura. Los sistemas de aporte de agua (llamados bebederos) y los sistemas automáticos de alimentación se sitúan cerca del suelo y ocupan toda la longitud del corral. También hay grandes ventiladores de 1,2 m de diámetro para que las aves estén cómodas. U na de las faenas cotidianas del avicultor consiste en mantener condiciones ambientales aceptables para las aves, garantizando el continuo flujo de alimento y agua, y recogiendo y eliminando los animales muertos.
Figura 70.7 • Rebaño comercial de emús de 12 meses de edad.

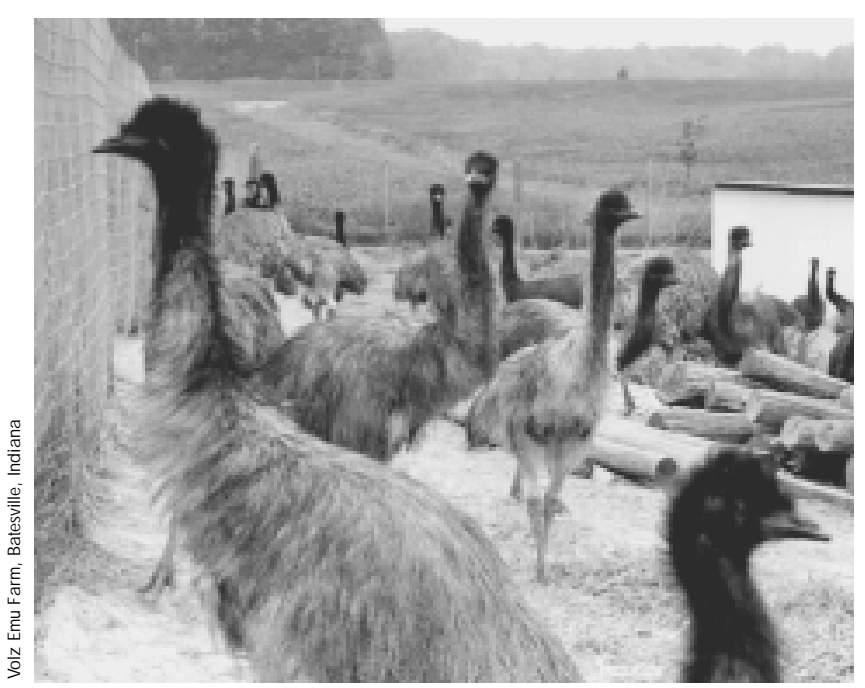

En el momento del sacrificio al cumplir los 14 meses, cada ave pesará entre 50 y 65 kilogramos, de los cuales unos 15 kilogramos serán carne y 15 kilogramos serán grasa para aceite y lociones.

Cuando las aves alcanzan la edad de ser procesadas los sistemas de alimentación y de bebida se suben a 2,5 a 3 metros del suelo para que sea más cómodo para el personal encargado de tomar a las aves para transportarlas a una planta de procesado avícola. Esta recogida suele hacerse a mano. Cada trabajador debe agacharse 0 encorvarse para tomar varias aves de una vez y ponerlas en canastas, jaulas o banastas. Cada trabajador repetirá este proceso varios cientos de veces por turno de trabajo (véase la Figura 70.8). Para otros tipos de aves (p. ej., patos y pavos), los trabajadores conducen a los rebaños a una zona de recolección. EI personal que separa a los pavos lleva palos con bolsas rojas atadas al extremo para separar a varios de

Figura 70.8 - O perarios capturando pollos y colocándolos en jaulas para trasladarlos a un matadero industrial.

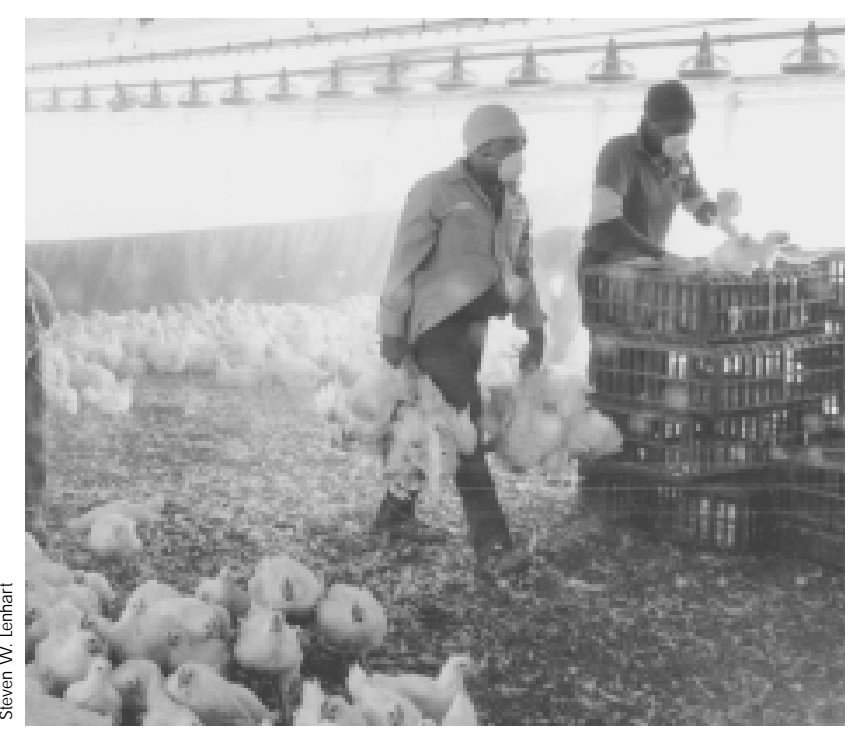


Figura 70.9 - O perarios capturando pavos para conducirlos al corral.

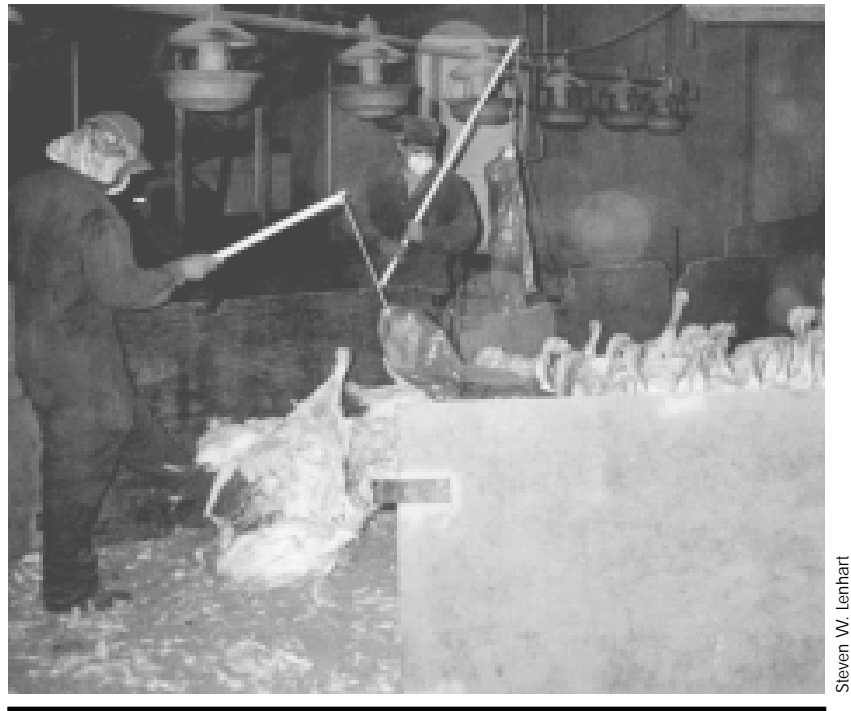

ellos a la vez, y conducirlos a un depósito a la entrada del corral (véase la Figura 70.9).

Los corrales de confinamiento varían con respecto a esta descripción general dependiendo sobre todo del tipo de aves alojadas. Por ejemplo, en la producción comercial de huevos, tradicionalmente se guarda a las gallinas adultas o ponedoras en jaulas dispuestas en estantes paralelos. L os sistemas de enjaulado de gallinas serán prohibidos en Suecia en 1999, serán sustituidos por sistemas en los que las gallinas vaguen en libertad. (En la Figura 70.10 puede verse uno de estos sistemas). 0 tra diferencia entre los corrales de confinamiento es que algunos no tienen el suelo cubierto por un lecho, sino que son acanalados o de plástico con sistemas de recogida del estiércol o de los excrementos líquidos situados bajo ellos. En Europa occidental, los corrales de confinamiento suelen ser más pequeños que en Estados Unidos, y se hacen con bloques de cemento para limpiar mejor la basura. Además, en Europa occidental se descontaminan y se limpian de basura los corrales después de cada camada.

Figura 70.10 • Sistema de estabulación libre.

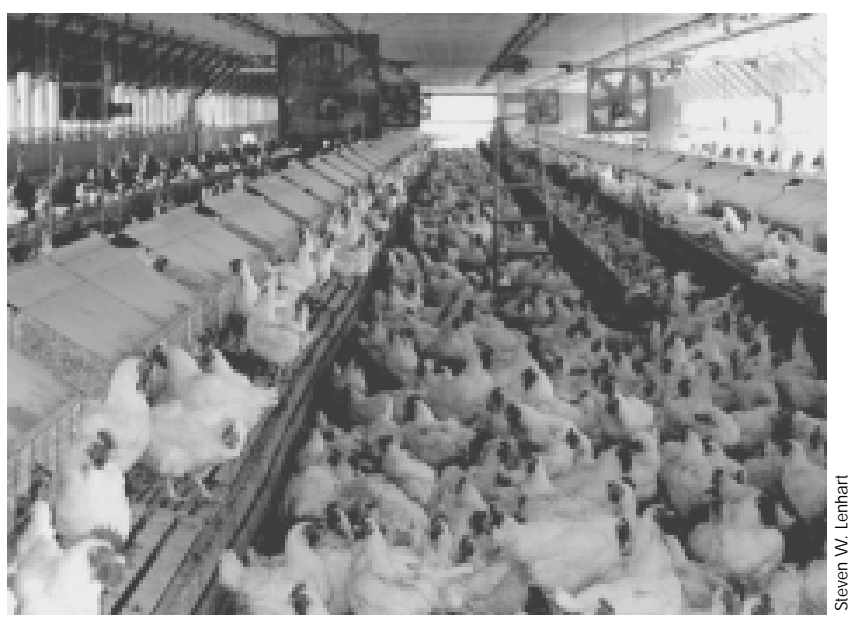

\section{Captura, enjaulado y sacrificio de las aves de corral}

La posibilidad de padecer lesiones de espalda y trastornos respiratorios es elevada para los operarios encargados de la captura de las aves de corral. Muchas empresas que se dedican a ello en Estados Unidos subcontratan la captura. Debido al carácter provisional de la relación de trabajo del personal dedicado a estas tareas, no hay datos sobre lesiones o pérdidas. Habitualmente se selecciona al personal y se le transporta al criadero en camiones de la empresa. Los trabajadores reciben 0 han de adquirir mascarillas individuales de un solo uso y guantes de algodón desechables para protegerse las manos. Las empresas deben asegurarse de que la protección respiratoria es llevada adecuadamente y de que el personal ha recibido la formación y la evaluación médica correspondientes.

Cada trabajador debe agacharse y agarrar varias aves combativas una tras otra, y quizá tenga que ocuparse de varias a la vez. Los pollos se colocan en una bandeja o cajón de un módulo de varios pisos. El módulo aloja varias bandejas, que se cargan mediante una excavadora en un camión de la empresa. El operador de la excavadora puede ser el mismo conductor de este camión o el jefe de la peonada contratada. En cualquier caso, deben garantizarse la adecuada formación y el desarrollo adecuado del trabajo. La velocidad y la coordinación son esenciales para el personal atrapador.

En Estados Unidos se han experimentado nuevos métodos de atrapamiento y carga. Uno de ellos se basa en la utilización de un recolector guiado con brazos que barren hacia adentro, guiando a los pollos hacia un sistema de vacío. Los intentos de automatización para reducir el estrés físico y la posibilidad de exposición respiratoria distan de alcanzar el éxito. Sólo los grandes empresas dedicadas a la cría de aves de corral, que son más eficaces, pueden permitirse los capitales necesarios para adquirir y mantener tales equipos.

La temperatura corporal normal de un pollo es de $42,2{ }^{\circ} \mathrm{C}$. En consecuencia, la tasa de mortalidad aumenta en invierno y en zonas en las que los veranos son cálidos y húmedos. Tanto en verano como en invierno, las aves deben ser transportadas cuanto antes al matadero. En verano, antes del sacrificio, los camiones con los módulos en los que van las aves deben ser apartados del sol y enfriados con grandes ventiladores. El resultado es que se levantan polvo, materia fecal seca y plumas de pollo.

En todas las fases del trabajo de un matadero, han de satisfacerse elevadas exigencias sanitarias. Esto significa que se deben fregar periódicamente y a menudo los suelos, y retirar las basuras, despojos y grasa. Las cintas sin fin y los equipos utilizados deben estar accesibles, y también deben ser lavados y sometidos a medidas sanitarias. $\mathrm{No}$ se debe permitir que la condensación se acumule en los techos y en el equipo situado por encima de los pollos. Deben ser limpiados con fregonas de mango largo.

En la mayor parte de la zonas de producción del matadero, la exposición al ruido es elevada. Hay ventiladores radiales en el techo que no se vigilan y que hacen circular el aire. Debido a las medidas sanitarias, no es posible silenciar el equipo de ventilación rotatoria para reducir el ruido. Es necesario implantar un programa apropiado de conservación de la audición, y ponerlo en práctica convenientemente. Para documentar la exposición deben practicarse audiometrías iniciales y anuales, así como sonometrías periódicas. Los equipos industriales adquiridos deben tener el más bajo nivel de ruido posible cuando están en funcionamiento.

Hay que prestar particular atención a las necesidades de la formación y educación de los trabajadores. Estos deben entender todas las implicaciones de la exposición al ruido y cómo llevar correctamente las protecciones auditivas. 


\section{Riesgos para la salud}

La salud y la seguridad de los avicultores, sus familiares (incluidos los niños) y otros trabajadores en explotaciones avícolas han mejorado al crecer la industria avícola. La cría de aves obliga al granjero a trabajar 7 días a la semana. En consecuencia, al contrario que la mayor parte de los trabajos, la exposición a los contaminantes se produce durante varios días consecutivos, siendo el periodo entre camadas (de sólo 2 días) el único en el que se libran de la exposición a los contaminantes del corral. El aire del corral puede contener agentes gaseosos como amoníaco de la basura, monóxido de carbono procedente de la calefacciones de gas mal ventiladas, y ácido sulfhídrico procedente del estiércol líquido. Además, el corral produce partículas de polvo orgánico o agrícola, que pasan al aire como aerosoles. La basura de los corrales contiene una selección de contaminantes como los excrementos de las aves, las plumas y la caspa; insectos (escarabajos y moscas), ácaros y partes de estos; microorganismos (virales, bacterianos y fúngicos); endotoxinas bacterianas; e histamina. El aire del corral puede tener mucho polvo, y para un visitante ocasional el olor del estiércol y del amoníaco puede llegar a ser insoportable. Sin embargo, aparentemente los granjeros desarrollan una tolerancia a los olores.

Debido a la inhalación, los trabajadores avícolas que no lleven protección corren el riesgo de padecer enfermedades respiratorias como rinitis alérgica, bronquitis, asma, neumonitis por hipersensibilidad o alveolitis alérgicas y síndrome tóxico por polvo orgánico. Los síntomas respiratorios agudos y crónicos que experimentan los trabajadores avícolas son tos, sibilancias, excesiva secreción de moco, disnea y dolor y sensación de opresión en el pecho. Las pruebas de función pulmonar realizadas a trabajadores avícolas han dado pruebas que sugieren no sólo el riesgo de padecer enfermedades obstructivas crónicas y asma, sino también enfermedades restrictivas como neumonitis crónicas por hipersensiblidad. Los síntomas no respiratorios más habituales son irritación ocular, náuseas, cefalea y fiebre. De las aproximadamente 40 zoonosis de importancia agrícola, seis (infección por M ycobacterium avium, erisipeloide, listeriosis, infección conjuntival de Newcastle, psitacosis y dermatofitosis) son importantes para los trabajadores avícolas, aunque sólo se producen raramente. Las enfermedades infecciosas no zoonósicas importantes son candidiasis, estafilococosis, salmonelosis, aspergilosis, histoplasmosis y criptococosis.

También hay cuestiones sanitarias que afectan a los trabajadores avícolas y que aún no han sido estudiadas o lo han sido poco. Por ejemplo, los granjeros avícolas y quienes se encargan de atrapar a los pollos padecen una afección cutánea a la que llaman galding. Esta afección tiene el aspecto de un exantema 0 de una dermatitis y afecta fundamentalmente a las manos, los antebrazos y la cara interna de los muslos de las personas. Tampoco se ha estudiado la ergonomía de los atrapadores. Para inclinarse para atrapar a varios miles de aves en cada turno de trabajo y transportar entre ocho y quince pollos de 1,8 a 2,3 de peso casa uno hace falta buena preparación física, pero se ignora cómo afecta esta tarea a la espalda y las extremidades superiores de los que la practican. También se ignora hasta qué grado afectan a la vida de los trabajadores avícolas y a la de sus familias los muchos factores psicosociales que se asocian con el trabajo de granja, pero muchos de ellos perciben que se produce un estrés problemático. 0 tro aspecto importante pero que no se ha estudiado es cómo afecta a los salud de los hijos de los trabajadores el hecho de trabajar en corrales.

\section{Medidas de protección de la salud respiratoria}

La mejor forma de proteger a un trabajador de la exposición a contaminantes aéreos es por medio de eficaces controles diseñados al efecto que capturan los posibles contaminantes allí donde se producen, antes de que puedan pasar al aire. En la mayor parte de los entornos industriales, es posible reducir los contaminantes del aire a niveles seguros en origen mediante la instalación de medidas de control adecuadas. Llevar mascarillas es el método menos deseable para reducir la exposición de los trabajadores a los contaminantes del aire, y su empleo sólo se recomienda cuando no es posible realizar controles más sofisticados, o mientras se instalan o reparan estos. No obstante, en la actualidad, llevar una mascarilla es probablemente el método más factible para reducir la exposición de los trabajadores avícolas a los contaminantes del aire. El principal objetivo de los sistemas de ventilación general de los corrales no es reducir la exposición de los trabajadores avícolas. Se está investigando para crear sistemas de ventilación adecuados capaces de reducir la contaminación del aire.

No todas las mascarillas proporcionan el mismo nivel de protección, y el tipo elegido para un corral de confinamiento puede variar según la edad de las aves, la antigüedad y el estado de las camas, el tipo de bebedero y la posición de las cortinas laterales (abiertas o cerradas). Todos estos factores afectan a las concentraciones aéreas de polvo agrícola y de amoníaco. LoS niveles de polvo en el aire son máximos durante las operaciones de atrapamiento de pollos, a veces hasta el punto de que no se alcanza a ver un extremo del corral desde el otro. Como protección mínima para los trabajadores avícolas se recomienda llevar mascarillas que cubran toda la cara con filtros de alto rendimiento, dado el nivel de endotoxinas bacterianas medidas durante el atrapamiento.

Cuando las concentraciones de amoníaco son elevadas, existen filtros combinados para llevar puestos que filtran el amoníaco y las partículas. También puede resultar conveniente un respirador purificador de aire a motor con mascarilla que cubra toda la cara y filtros de alto rendimiento, que son más caros. Estos dispositivos tienen la ventaja de que aportan aire filtrado constantemente a la mascarilla, con lo que la resistencia a la respiración es menor. $\mathrm{H}$ ay asimismo purificadores de aire en casco para trabajadores con barba. En ciertas situaciones laborales puede ser apropiado utilizar mascarillas que no cubran toda la cara o que no lleven purificadores de aire. Pero sólo se recomienda bajar el nivel de protección (como el empleo de mascarillas de media cara desechables) cuando mediante mediciones ambientales y monitorización médica se demuestre que el empleo de mascarillas menos protectoras reducirá la exposición a niveles seguros. La repetida exposición de los ojos al polvo de las aves aumenta el riesgo de lesiones y enfermedades oculares. Las mascarillas que cubren toda la cara y los cascos tienen la ventaja de que protegen asimismo los ojos. Los trabajadores avícolas que decidan llevar mascarillas de media cara deben llevar también gafas protectoras.

Para que una mascarilla proteja a quien la lleva debe usarse junto con una programa completo de protección respiratoria. Sin embargo, aunque los avicultores sufren exposiciones por inhalación que podrían reducirse con el empleo de mascarillas, la mayor parte no están preparados para poner en práctica una programa de protección respiratoria por su cuenta. Esto ha de ser organizado mediante programas de protección regionales o locales, en los que pueden participar las granjas avícolas.

Los depósitos de estiércol deben considerarse como espacios confinados. Si es obligatorio entrar en un depósito debe analizarse su atmósfera, y deben estar ventilados si tienen oxígeno insuficiente 0 si contienen niveles tóxicos de gases o de vapores. Para poder entrar con tranquilidad hay que llevar mascarilla. A demás, debe haber una persona de vigilancia que mantenga contacto visual o conversación con los trabajadores que estén en el interior de un depósito de estiércol. 


\section{Riesgos para la seguridad}

Los riesgos para la seguridad que se asocian con la producción de aves de corral y de huevos proceden de las cadenas, engranajes, cigüeñales, correas de transmisión y poleas desatendidos de los ventiladores, los equipos de alimentación y otros aparatos. Los arañazos, picotazos e incluso mordiscos producidos por los animales más grandes son también peligros. Un avestruz macho es especialmente protector de su nido durante la estación de apareamiento, y cuando se siente amenazado, intentará patear al intruso. El hecho de tener dedos largos con uñas afiladas añaden peligro a la potente coz del avestruz.

Los riesgos eléctricos creados por equipos mal situados o no resistentes a la corrosión, o por cables mal aislados en los corrales pueden dar lugar a electrocuciones, shocks eléctricos no mortales 0 incendios. EI polvo de las aves arderá y los trabajadores cuentan historias sobre explosiones de polvo acumulado en calefacciones de gas al diseminarse el polvo durante las faenas de limpieza. Los investigadores del US Bureau of M ines han provocado explosiones de polvo agrícola. Tras diseminarlo en una cámara de prueba de 20 litros de capacidad y prenderlo, se determinó que la concentración explosiva mínima del polvo recogido en las partes más altas de la cabina de la calefacción y en los alféizares de las ventanas de los corrales es de $170 \mathrm{~g} / \mathrm{m}^{3}$. No fue posible hacer explotar las muestras de basura avícola filtradas. Por el contrario, la concentración explosiva mínima del polvo de grano medido en las mismas condiciones de seguridad fue de $100 \mathrm{~g} / \mathrm{m}^{3}$.

\section{Medidas de seguridad}

Es posible tomar medidas para reducir los riesgos asociados a la producción de aves de corral y de huevos. Para protegerse de las partes móviles, toda la maquinaria debe estar protegida, así como los ventiladores. Para las faenas que implican contacto manual con las aves, hay que llevar guantes. $\mathrm{H}$ ay que mantener niveles elevados de higiene personal, y cualquier lesión producida por la maquinaria o por las aves, por muy pequeña que sea, debe ser tratada de inmediato para evitar la infección. Al acercarse a una rátida, ha de hacerse desde un lado o por detrás del animal, para que no dé coces. Cuando se revise el equipo eléctrico debe haber un sistema de desconexión. Los trabajadores avícolas deben limpiar con frecuencia el polvo depositado en las superficies pero siendo conscientes de que, en raras ocasiones, si se dispersan concentraciones elevadas de polvo acumulado en un medio cerrado y se encienden, pueden explotar.

\section{- CABALlos Y OTROSEQUIDOS}

L ynn Barroby

Los caballos pertenecen a la familia de los équidos, que incluye al asno salvaje africano, también conocido como burro. Los historiadores creen que la domesticación del caballo se inició en torno al año 6.000 a. C. y la del burro por los menos en el 2.600 a. C. El mulo, que se cría para trabajar, es un cruce entre burro macho y yegua; no puede reproducirse. Cuando se cruza un caballo macho (semental) con una burra, la cría, que también es estéril, recibe el nombre de burdégano. Caballos y burros han sido cruzados con otro équido, la cebra, y las crías reciben el nombre colectivo de zebroides. También son estériles, y su importancia económicas es escasa (Caras 1996).

\section{Procesos}

De los 10 millones de caballos que hay en los Estados U nidos, el $75 \%$ aproximadamente se emplean para montar por ocio.
O tros usos son las carreras, las actividades de las estancias, la cría y la monta comercial. El caballo se ha convertido en la figura de carreras, saltos, rodeos y muchos otros acontecimientos.

Las tres principales actividades con caballos son la cría, el entrenamiento y los establos para alojamiento. Las explotaciones de cría de caballos crían yeguas y venden las crías. Algunas explotaciones se especializan en entrenar caballos para exhibición o para carreras. Los establos los alimentan y cuidan para los clientes que no disponen de instalaciones en sus hogares. Las tres actividades son de trabajo intensivo.

La cría de caballos es un proceso cada vez más científico. Antes el pasto era habitual, pero ahora la alimentación suele controlarse en corrales. Aunque se emplea la inseminación artificial, es más frecuente que las yeguas estén junto al macho durante al cría. La yegua es examinada por un veterinario y, durante la cría, unos trabajadores especializados se ocupan del macho y de la hembra.

Después de parir, la yegua amamanta al potro hasta los 4 a 7 meses de edad; tras el destete se les separa de la madre. Algunos que no van a ser destinados a la cría son castrados en cuanto alcanzan los 10 meses de edad.

Cuando un caballo de carreras cumple dos años, los entrenadores y yóqueis profesionales empiezan a enseñarle. Se trata de un proceso gradual para acostumbrar al caballo al tacto humano, a llevar silla y bridas, y finalmente a ser montado. Los caballos que corren con remolques y los caballos de tiro empiezan a hacerlo hacia los dos años de edad, y los caballos de estancia hacia los tres años de edad, a veces mediante el poco sofisticado medio de la castración.

En las carreras de caballos, el mozo lleva al caballo al paddock, un entrenador y un ayudante le ponen la silla, y un yóquei lo monta. EI caballo es guiado por un poni y un jinete, calienta y se coloca en el cajón de salida. Los caballos de carreras pueden ponerse nerviosos, y el ruido de la carrera puede excitarlos y asustarlos aún más. El mozo lleva al caballo ganador a un establo para el control de dopaje, a base de muestras de sangre y de orina. Luego el mozo ha de enfriar al caballo con una baño, haciéndole caminar y dándole agua.

El mozo que cuida del caballo es responsable de cepillarlo y bañarlo, ponerle la silla, ponerle vendajes protectores 0 botas, limpiar el establo y hacerle la cama con paja, viruta, turba, cáscaras de cacahuete, tiras de papel de periódico o incluso cáscaras de arroz. El mozo u otra persona pasea al caballo; a veces se hace con máquinas. El mozo proporciona al caballo heno, grano y agua, rastrilla y barre, limpia la ropa del caballo y retira el estiércol con una carretilla. Se encarga de sujetar al caballo para el veterinario o el herrero (que es quien suele hacer el herraje). Todos los caballos requieren un control de parásitos, el cuidado de los cascos y el limado de los dientes.

Los caballos para exhibición suelen permanecer en el establo y practicar ejercicio a diario. Pero los caballos jóvenes y los dedicados al ocio suelen guardarse en establos por la noche y ser liberados durante el día, mientras que otros se guardan al aire libre en dehesas o pastos con cobertizos para guarecerse. LoS caballos de carreras reciben alimento tres o cuatro veces al día, mientras que los de exhibición, otros caballos de muestra y los destinados a cría comen dos veces al día. Los caballos de estancia sólo se alimentan una vez al día, dependiendo del forraje que haya.

Los caballos viajan por muchas razones: exhibiciones, carreras, cría o tiro. La mayoría va en camiones o remolques; pero algunos son transportados en tren o en avión para acontecimientos importantes. 
Tabla 70.19 • Zoonosis asociadas a los caballos.

Enfermedades virales

Rabia (incidencia muy baja)

Encefalomielitis equina oriental, occidental y algunos subtipos de la venezolana

Estomatitis vesiculosa

Influenza equina

Enfermedad equina por morbilivirus (documentada por primera vez en Australia en 1994)

Infecciones por hongos

Tiña (dermatomicosis)

Zoonosis parasitarias

Triquinosis (grandes brotes en Francia e Italia en los decenios de 1970 y 1980) Enfermedad hidatídica (equinococosis) (muy rara)

Enfermedades bacterianas

Salmonelosis

Muermo (muy rara en la actualidad, restringida a Medio Oriente y Asia) Brucelosis ( rara)

Antrax

Leptospirosis (relativamente rara; no está demostrado de forma definitiva el contagio directo a seres humanos)

Melioidosis (brotes en Francia en los decenios de 1970 y 1980; no se ha comunicado transmisión directa

Tuberculosis (muy rara)

Pasteurelosis

Actinobacillus lignieresii, A., A. suis (sospecha en la transmisión de la enfermedad de Lyme, Bélgica)

\section{Peligros y precauciones}

El trabajo con caballos se asocia con diversos peligros. El trabajo de mozo es físicamente muy exigente porque ha de rastrillar el estiércol, mover balas de heno y paja de 25 a $50 \mathrm{~kg}$ y manejar a los caballos activos. Los caballos asustados 0 amenazados pueden dar coces; por eso, los trabajadores deben evitar pasar por detrás de ellos. U n caballo asustado puede saltar y pisar a un trabajador; esto también puede ocurrir de modo accidental. Existen diversas sujeciones para caballos díscolos, como las cadenas para la nariz o para los belfos. El estrés de los caballos al ser trasladados puede hacer que se planten o que se lesionen los caballos y sus cuidadores.

EI mozo está potencialmente expuesto al polvo del heno y del grano, al polvo de las camas, a los mohos, a la caspa de los caballos y al amoníaco de la orina. L levar una mascarilla puede ser una protección. L os mozos hacen muchas tareas con las patas de los caballos, empleando a veces linimentos que contienen sustancias químicas peligrosas. Se recomienda llevar guantes. Algunos cuidados que se emplean en el cuidado de las tachuelas del cuero contienen disolventes peligrosos, que exigen ventilación y protección cutánea. Los cortes pueden dar lugar a infecciones graves, como el tétanos o la septicemia. $\mathrm{H}$ ay que mantener al día las vacunas del tétanos, debido sobre todo a la exposición al estiércol.

Al poner las herraduras, el herrero puede lesionarse. La tarea del mozo consiste en sujetar al caballo para que no dé coces al herrero e impedir que tire de la pata de forma que lesione la espalda del herrero o éste se corte con las herraduras y los clavos.

En la prueba de dopaje, la persona encargada se encierra en un establo con un caballo suelto, excitado y desconocido. Lleva un palo (con un recipiente para la orina) que puede asustar al caballo.
Al montar, es importante llevar unas buenas botas y un casco. Cualquier persona que monte debe llevar ropa adecuada al efecto ya sea correr, saltar, un rodeo o entrenar a caballos de carreras. Siempre existe el peligro de ser tirado por el caballo 0 que éste tropiece o se caiga.

Los sementales pueden ser impredecibles, muy fuertes, y pueden morder o patear con saña. Las yeguas defienden mucho a sus potros, y luchan si se sienten amenazadas. L os sementales se guardan en dehesas con vallas altas, mientras que otros caballos de cría se mantienen en grupos con su propia ley del más fuerte. L os caballos que intentan separarse de un caballo jefe 0 de un grupo de jóvenes jugando pueden arrollar a cualquiera que se ponga en su camino. Los potros, los recién destetados, los caballos jóvenes y los de dos años de edad pueden morder y pellizcar.

Algunos fármacos que se emplean en la cría (hormonas, p. ej.) se administran por vía oral y pueden ser nocivos para los seres humanos. Se recomienda llevar guantes. También son peligrosos los pinchazos con agujas. Para controlar al animal mientras se le administra la medicación es necesario usar buenas sujeciones, incluso con un potro. Es fácil que los aerosoles tópicos y los sistemas automáticos de aerosoles para eliminar las moscas de los establos se empleen en exceso. Estos insecticidas deben usarse con moderación, y se deben leer las etiquetas de advertencia y seguir las recomendaciones

Diversas zoonosis pueden ser transmitidas por los caballos a los seres humanos, especialmente infecciones cutáneas por secreciones infectadas. Las mordeduras de caballo pueden ser causa de algunas infecciones bacterianas. V éase en la T abla 70.19 una lista de zoonosis asociadas con los caballos.

\section{ANIMALES DE TIRO EN ASIA}

\section{D.D. Joshi}

El ganado contribuye en gran medida a la vida de pequeños granjeros, nómadas y silvicultores de todo el mundo, e incrementa su productividad, sus ingresos, su trabajo y su nutrición. Se espera que esta contribución crezca. La población mundial pasará de los 4.800 a 5.400 millones de personas a 10.000 millones por los menos en los próximos 100 años. En ese período cabe esperar que la población de Asia se duplique. La demanda de alimentos crecerá aún más, al ir aumentando también la calidad de vida. A la vez se producirá un aumento de la necesidad de fuerza de tiro para producir la cantidad de alimento necesaria. Según Ramaswami y Narasimhan (1982), 2.000 millones de personas en los países en vías de desarrollo dependen de los animales de tiro para la agricultura y el transporte rural. La fuerza de tiro suele quedarse corta al plantar las cosechas, y suele ser insuficiente para otros propósitos el resto del año. La fuerza de tiro seguirá siendo una fuente básica de energía para la agricultura en el futuro que se avecina, y su ausencia en algunos lugares puede ser la principal limitación para aumentar la producción de las cosechas.

Los animales de tiro fueron el primer complemento de la energía humana para la agricultura. La fuerza mecánica sólo se ha utilizado en el último siglo, más o menos. En Asia la proporción de granjeros que dependen de los animales de tiro es mayor que en ninguna otra parte del mundo. U na gran proporción de estos animales pertenecen a granjeros que tiene recursos limitados y cultivas pequeñas parcelas de terreno. En casi todas las partes de Asia, son los bueyes, búfalos y camellos quienes proporcionan la fuerza de tiro. Los bueyes seguirán siendo la fuente habitual de potencia ganadera, debido 


\section{Elefantes}

El mayor animal de tiro es el elefante, aunque su función como tal está convirtiéndose lentamente en una tradición más que en una necesidad. Hace dos decenios en Tailandia se empleaban 4.000 elefantes asiáticos para acarrear troncos, pero los bosques han sido despejados y la mecanización ha desplazado a estos animales. En cambio, aún se emplean en Myanmar, donde el acarreo con elefantes sigue siendo predominante. Con frecuencia, las compañías de transporte alquilan los elefantes en régimen de leasing a sus dueños, que suelen ser hombres de negocios de la ciudad.

El manipulador del elefante (o domador) recibe el nombre de oozie en Myanmar y de mahout en India y en Sri Lanka. Coloca una montura (una gruesa almohadilla a base de hojas y corteza de árbol) sobre el dorso del elefante para proteger su sensible columna del tack, que se emplea para acarrear troncos. Se sienta sobre el cuello del elefante mientras éste utiliza su tronco, patas, boca y frente para cumplir sus tareas diarias. Un elefante bien entrenado en el acarreo de troncos es capaz de responder a más de 30 órdenes vocales y a 90 puntos de presión sobre su cuerpo si lo maneja la persona adecuada. Se trabaja hasta las $2: 45$ de la tarde; a continuación el oozie lava al elefante en agua frotándolo con mitades de coco durante casi una hora. Después le alimenta con arroz cocido y salado y hobbles y lo deja suelto para pacer en el bosque por la noche. Hacia las 4:00 de la mañana, el oozie localiza al elefante por medio de los sonidos de una campana que lleva el a nimal (Schmidt 1997).

Raramente se mantiene en cautividad a los elefantes machos, y las hembras suelen pastar en libertad para ser cubiertas. También se emplea la inseminación artificial. Los machos donan semen a una hembra artificial de tamaño real. Es imposible detectar visualmente cuándo una elefanta está en celo (tres veces al año), por lo que se le extraen muestras de sangre semanalmente para medir los niveles de progesterona. Cuando una hembra está en celo, la cubrición se hace inyectándole el semen en la vagina con un tubo de inseminación neumático, flexible y largo.

El manejo de elefantes comporta varios tipos de peligro; son los debidos al tamaño del animal, al enorme tamaño de los objetos que mueven y a su comportamiento. La colocación del tack y la manipulación del mando expone al manipulador a riesgos de lesión. Además, éste puede caerse. La posibilidad de lesionarse se ve agravada por las operaciones de acarreo, que implican transportar, empujar, traccionar y amontonar; los troncos de teca pueden pesar hasta $1.360 \mathrm{~kg}$. El comportamiento del elefante puede ser impredecible y lesionar al domador. Los machos cautivos son muy peligrosos y difíciles de contener. Los machos en celo son particularmente peligrosos. Se ha comunicado que uno de Sri Lanka mató a nueve mahouts, si bien volvió al trabajo después de cada ataque, debido al valor que tenía para sus dueños (Schmidt 1997).

Algunos elefantes sólo responden a su domador. El método básico de control de elefantes imprevisibles se sustenta en el principio de que sólo su oozie se encargue de ellos. Los elefantes son animales de costumbres, por lo que los domadores deben respetar una rutina diaria. Se ha observado que el baño vespertino resulta decisivo para establecer un vínculo con el animal. $M$ antener el dominio del domador es otra garantía frente a posibles comportamientos peligrosos.

Los nadadores que transportan las muestras de sangre al laboratorio para los análisis de progesterona están expuestos a una tarea particularmente peligrosa. Cruzan a nado los ríos durante el monzón. Este peligro de ahogamiento puede corregirse aproximando los servicios de laboratorio a las zonas de trabajo de los elefantes.

Melvin L. Myers fundamentalmente a que son propicios y viven de los residuos. En algunos lugares también se emplean los elefantes.

\section{Producción}

En los países asiáticos, tres son las principales fuentes de fuerza: humana, mecánica y animal. En los países en vías de desarrollo, los seres humanos aportan la principal fuente de fuerza para cavar, escardar, trasplantar el arroz, esparcir las semillas y recolectar las cosechas. La potencia mecánica, con su versatilidad, se emplea para prácticamente todas las operaciones del campo, y la intensidad de su uso varía considerablemente de un país en vías de desarrollo a otro ( $K$ han 1983). La potencia animal suele utilizarse para operaciones de labranza, acarreo y funcionamiento de algunos dispositivos para sacar agua. U na vaca de tiro es un animal con múltiples funciones, pues proporciona fuerza, leche, estiércol, terneros y carne. La fuerza de tiro normal de diversos animales se recoge en la Tabla 70.20.

Para mejorar los animales de tiro, deben considerarse los siguientes aspectos:

Para que la gente que no es propietaria de tierra pueda devolver el crédito necesario para la adquisición de bueyes y alimentarlos, y ganar dinero suficiente para satisfacer los gastos diarios, deben trabajar con sus animales durante seis horas al día.

- Nutrición de los animales de tiro. La nutrición de los animales es un factor principal para aumentar la productividad de la potencia de los animales de tiro. Esto sólo es posible si se dispone de alimento suficiente. En algunas zonas se hacen más esfuerzos para garantizar el uso óptimo de los recursos disponibles, como tratar la paja con álcalis (bloque de urea de melaza (M UB)) para mejorar su disponibilidad de nutrientes. Dado que la disponibilidad de potencia de tiro limita en la actualidad la producción de cosechas de materias primas (se calcula que existe un déficit del $37 \%$ de las necesidades de animales de tiro en el momento de la recolección), el objetivo principal es producir animales de tiro y mejorar la eficacia de los mismos. La oportunidad de emplear tecnología nutricional mejorada (p. ej., MU B) puede colaborar al desarrollo de la fuerza de tiro mediante la mejora de la capacidad de trabajo de los animales y de las tasas de reproducción en las hembras, así como a que los animales jóvenes crezcan mejor, lo que hará que su tamaño corporal sea mayor.

- Cría y selección. Es necesario descartar a los toros improductivos y seleccionar a los mejores de la localidad. En la actualidad, los animales de tiro se seleccionan en función de su conformación, su temperamento y su salud; pero a menudo los granjeros se contentan con lo que tienen a mano.

Tabla 70.20 - Potencia de tiro normal de diversos animales.

$\begin{array}{lllll}\text { Animales } & \text { Peso }(\mathrm{kg}) & \begin{array}{l}\text { Carga de } \\ \text { tiro aprox. } \\ (\mathrm{kg})\end{array} & \begin{array}{l}\text { Promedio de } \\ \text { velocidad en } \\ \text { el trabajo } \\ (\mathrm{m} / \mathrm{seg})\end{array} & \begin{array}{l}\text { Potencia } \\ \text { desarrollada } \\ (\mathrm{CV} .)\end{array} \\ \text { Caballos pequeños } & 400-700 & 60-80 & 1,0 & 1,00 \\ \text { Bueyes } & 500-900 & 60-80 & 0,6-0,85 & 0,75 \\ \text { Búfalos } & 400-900 & 50-80 & 0,8-0,90 & 0,75 \\ \text { Vacas } & 400-600 & 50-60 & 0,7 & 0,45 \\ \text { Mulos } & 350-500 & 50-60 & 0,9-1,0 & 0,70 \\ \text { Asnos } & 200-300 & 30-40 & 0,7 & 0,35\end{array}$

Fuente: FAO 1966 
Determinadas razas muestran un aumento significativo no sólo de su capacidad de producción de leche y carne, sino también de la fuerza de tiro. En India, Pakistán y Australia se han hecho enormes effuerzos para mejorar las razas de búfalos, vacas, caballos (para producir mulas) y, en algunos sitios, camellos. Los resultados han sido muy estimulantes. En muchos otros países asiáticos, especialmente en países en vías de desarrollo, este trabajo de investigación para mejorar la fuerza de tiro y la producción de leche y carne es muy necesario.

- E quipo. La mayor parte del equipo de las granjas está anticuado y es improductivo. Gran parte del equipo que se emplea con los animales de tiro (arneses, aperos de labranza y remolques) es de tipo tradicional, cuyo diseño no ha variado en centenares de años. Además, los utensilios de la granja a menudo están mal diseñados y logran un escaso rendimiento.

- Salud. El estrés del trabajo puede alterar el equilibrio que a menudo existe entre los animales sanos y los parásitos.

\section{Gestión}

La alimentación diaria de los animales de tiro varía en función de la estación de trabajo. Tanto el ganado bovino como los búfalos que se emplean para tiro se alimentan en confinamiento (todo el año) mediante un sistema de corte y transporte, con escaso o nulo apacentamiento. Se le suministra caña de arroz todo el año, dependiendo de las preferencias del granjero, en cantidades de 8 a $10 \mathrm{~kg}$ al día, o según sea necesario. Cuando hay, se les alimenta con otros residuos de la cosecha como cáscaras de arroz, paja y puntas de caña. A demás de estos residuos de cosecha, durante la estación de lluvias (de abril a noviembre) se suministra hierba segada o comida por los animales en los bordes de los caminos y en los terraplenes, en cantidades de 5 a $7 \mathrm{~kg} /$ día y puede aumentarse cuando hay mucho trabajo hasta $10 \mathrm{~kg} /$ día.

La alimentación de los animales de tiro puede completarse con pequeñas cantidades de concentrados de subproductos como salvado, tortas de aceite, legumbres, cáscara de arroz y melaza. La forma predominante de proporcionar estos concentrados es la forma líquida, mezclando todos los ingredientes. Los tipos y cantidades de ingredientes varían según el trabajo diario del animal, la zona geográfica, y las preferencias y posibilidades del granjero. Durante las estaciones en las que hay más trabajo se incrementan las cantidades de concentrados que se suministran, y se reducen durante el monzón, que es cuando hay menos trabajo.

Los granjeros también eligen los ingredientes de la alimentación de los animales en función de su disponibilidad, su precio y la percepción y comprensión de su valor nutritivo. Por ejemplo, durante la estación de trabajo que va de noviembre a junio, la ración diaria puede consistir en: $200 \mathrm{~g}$ de torta de aceite de semilla de mostaza con $100 \mathrm{~g}$ (peso seco) de arroz hervido; $3 / 4 \mathrm{~g}$ de torta de aceite de semilla de mostaza, $100 \mathrm{~g}$ de arroz hervido $03 / 4 \mathrm{~g}$ de melaza; $02 \mathrm{~kg}$ en total de torta de aceite de sésamo, arroz pelado, salvado de trigo y arroz hervido a partes iguales, junto con sal. En los días de trabajo real de este período (163 días), los animales reciben un $50 \%$ de estas mismas raciones. Si los animales reciben algún tipo de concentrado en la estación en que no trabajan, la cantidad oscila entre 1/4 y $1 / 2$ kg.

\section{Animales de tiro en Australia}

El continente australiano fue colonizado por los europeos en 1788. Las vacas fueron introducidas a la vez que las primeras ovejas, pero escaparon a los bosques circundantes. En aquellos días el arado y otros preparativos de la tierra se hacía con bueyes pesados, y el cultivo menos pesado con bueyes normales o con caballos. El carro de bueyes se convirtió en el método estándar de transporte por tierra en Australia, y así siguió hasta que se inició y generalizó la construcción de carreteras y del ferrocarril siguiendo las rutas del oro desde 1851 en adelante.

En Australia, otros animales de tiro son el camello y el burro. Aunque se emplean mulas, nunca llegaron a ser populares en Australia (Auty 1983).

\section{Animales de tiro en Bangladesh}

En Bangladesh, el ganado vacuno desempeña un papel vital en la economía, aportando fuerza de tiro y leche, de forma que contribuye hasta al 6,5\% del producto interior bruto (PIB) (K han 1983). De los 22 millones de cabezas de ganado vacuno, el $90 \%$ se emplean para tiro y transporte. De este total, 8,2 millones cumplen los dos propósitos, pues aportan fuerza de tiro y productos lácteos, leche y carne (aunque en cantidades mínimas) para el consumo familiar y para el comercio. Si se suma el valor energético de la fuerza de tiro y del estiércol (fertilizante y combustible), el ganado contribuye al PIB en un $11,3 \%$.

Se ha observado que algunas vacas son utilizadas para tiro, a pesar de los problemas de fertilidad y de las complicaciones sanitarias, que dan como resultado una menor producción de leche y de terneros. Aunque las vacas no suelen trabajar durante la lactancia, contribuyen de modo significativo al aporte anual de fuerza de tiro en Bangladesh: 2.,4 millones (31 \%) de vacas adultas y $60.000(47 \%)$ búfalas adultas proporcionan fuerza bruta (Robertson y cols. 1994). Si se combina con el ganado trabajador macho, el $76 \%$ del ganado vacuno adulto (11,2 millones) y del 85 al $90 \%$ de los búfalos adultos $(0,41$ millones) se emplean para tiro ( $K$ han 1983).

En conjunto no hay déficit de animales de tiro. $M$ ás bien hay problemas con la calidad de los animales disponibles para tiro, dado que los malnutridos son muy poco productivos (O rlic y Leng 1992).

Se emplean varias razas con fines de tiro, como las vacas deshi puras y las deshi puras cruzadas con las razas Sahiwal, H aryana y Red Sindhi de vacas, y con las razas M anipuri, Nili-R avi y Murrah de búfalos. Los bueyes Deshi pesan $225 \mathrm{~kg}$ por término medio, los híbridos pesan un poco más, unos $275 \mathrm{~kg}$, y los búfalos pesan $400 \mathrm{~kg}$ por término medio. L os toros, las vacas, los novillos y los bueyes se utilizan como fuerza bruta, pero los bueyes constituyen la principal fuente de energía en ese sentido.

En Bangladesh, el mayor porcentaje de animales de tiro se emplea para preparar la tierra. Los investigadores recomiendan que se are la tierra de seis a siete veces antes de la siembra. Pero debido a la escasez de potencia de tiro, muchos productores sólo aran de cuatro a cinco veces para preparar cada cosecha. Todos los arados de Bangladesh requieren dos animales. Dos bueyes pueden arar 0,5 ha en 2,75 días (trabajando 6 horas al día) (O rlic y Leng 1992; R obertson y cols. 1994).

\section{Animales de tiro en China}

China tiene una larga tradición de cría de búfalos. L os animales se empleaban en el campo hace ya 2.500 años. El búfalo tiene un cuerpo más grande que las especies bovinas autóctonas. L os agricultores prefieren al búfalo debido a su mayor fuerza, su vida más duradera y su temperamento dócil. Un búfalo es capaz de proporcionar la fuerza necesaria para producir entre 7.500 y $12.500 \mathrm{~kg}$ de arroz (Yang 1995). La mayor parte se encuentra en explotaciones familiares para servir como animales de tiro. LoS búfalos lecheros importados, Murrah y Nili/ Ravi, y los cruces con estas dos razas, se crían principalmente en granjas estatales y en institutos de investigación. Durante siglos, los búfalos han 
sido criados para tiro fundamentalmente. Los animales sólo eran sacrificados para alimentación cuando envejecían o enfermaban. Era raro ordeñar a las búfalas. D espués de generaciones de selección y cría, el búfalo ha llegado a ser extremadamente adecuado para el trabajo, con tórax anchos y fuertes, patas fuertes, grandes pezuñas y un temperamento dócil.

En China, los búfalos se usan sobre todo en los arrozales y para acarreo de productos en el campo. También se emplean para sacar agua, remover la arcilla para hacer ladrillos, en los molinos y para exprimir el zumo de la caña de azúcar. La magnitud de esta utilización está descendiendo debido a la mecanización. El entrenamiento de los búfalos suele empezar a los dos años de edad. Empiezan a trabajar un año después. Su vida laboral es más larga que de las vacas, habitualmente más de 17 años. Es posible ver búfalos de más de 25 años que siguen trabajando en los campos. Trabajan entre 90 y 120 días al año en la zona de cultivo de arroz, con trabajo intensivo en primavera y en otoño, en que llegan a trabajar entre 7 y 8 horas al día. La capacidad de trabajo varía mucho con el tamaño, la edad y el sexo del animal. La potencia de tiro alcanza su máximo entre las edades de 5 y 12 años, sigue siendo alta entre los 13 y los 15 y empieza a declinar a partir de los 16. La mayor parte de los búfalos macho son castrados (Yang 1995).

El búfalo de Shanghai, uno de los más grandes de China, tiene una excelente capacidad de trabajo. Trabajando ocho horas al día, un animal puede arar de 0,27 a 0,4 hectáreas de arrozal o de 0,4 a 0,53 hectáreas de tierra de secano $(0,67$ hectáreas como máximo). Un búfalo puede arrastrar entre 800 y $1.000 \mathrm{~kg}$ en un carromato de ruedas de madera durante más de $24 \mathrm{~km}$ en una jornada. U n búfalo puede sacar agua suficiente como para regar 0,73 hectáreas de arrozal en 4 horas.

En algunas zonas productoras de azúcar, los búfalos se emplean para arrastrar las piedras que se emplean para aplastar la caña de azúcar. Seis búfalos trabajando en turnos pueden exprimir entre 7.500 y $9.000 \mathrm{~kg}$ de caña de azúcar, necesitando entre 15 y 20 minutos por cada $1.000 \mathrm{~kg}$.

\section{Animales de tiro en la India}

Según Ramaswami y Narasimhan (1982), 70 millones de búfalos y 8 millones de búfalos generan unos 30.000 millones de vatios de potencia, siguiendo el cálculo del Indian Council of Agricultural Research (ICAR), según el cual cada animal produce 0,5 CV. Para generar, transmitir y distribuir esta potencia en los mismos múltiples puntos en los que debe aplicarse haría falta una inversión de 3 billones de rupias. También se ha calculado que en el sistema de carros de bueyes de India se han invertido 30.000 millones de rupias, frente a los 45.000 millones invertidos en el ferrocarril.

El M inisterio de Transporte y M arina M ercante calculó que entre 11.700 y 15.000 millones de toneladas de carga son transportadas al año en las zonas urbanas mediante carros, frente a los 200.000 millones de toneladas que se transportan por ferrocarril. En las zonas rurales, a las que no llega el ferrocarril, los vehículos tirados por animales transportan unos 3.000 millones de toneladas de carga (G orhe 1983).

\section{Animales de tiro en Nepal}

En Nepal, los bueyes y los búfalos macho son la principal fuerza de tracción para labrar los campos. También se emplean para tirar de los carros, aplastar la caña de azúcar y las semillas de aceite y para arrastrar cargas. D ebido a la naturaleza topográfica del país y al elevado precio del carburante, hay pocas oportunidades para la mecanización del campo. Por consiguiente, la demanda de animales de tiro es elevada en este país (Joshi 1983).
En la producción de trigo, la contribución de los bueyes en términos de días de trabajo es de un $42 \%$ en el arado, un $3 \%$ en el transplante y un $55 \%$ en el trillado. En los arrozales, los porcentajes son del $63 \%$ en el arado, del $9 \%$ en el transplante y del $28 \%$ en el trillado (Joshi 1983; Stem, Joshi y O rlic 1995).

Dependiendo de la faena, los animales de tiro trabajan un buen número de horas al día durante un número predeterminado de días consecutivos antes de poder descansar. Por ejemplo, una jornada completa de arado es de 6 horas por término medio para un buey, y la jornada promedio para las vacas es de 4 a 5 días. Los animales que se utilizan para el arado siguen un ritmo de trabajo consistente en 6 a 8 días consecutivos de trabajo, seguidos por 2 días de descanso. En el caso de la trilla, las vacas $u$ otros animales menos pesados suelen trabajar de 6 a 8 horas al día. La duración y el patrón para la trilla y el transporte varían en función de las necesidades. $\mathrm{H}$ abitualmente, un buey trabajando a tiempo completo en el arado (máximo trabajo de labranza) trabaja 163 días al año.

\section{Animales de tiro en Sri Lanka}

Se calcula que la cifra total de cabezas de ganado en Sri Lanka es de 1,3 millones. Se emplean varias razas como animales de tiro. L as vacas se emplean para el transporte y el arado de campos de secano y de regadío, así como en tareas agrícolas. Los animales indígenas han sido utilizados por el pueblo para el transporte por los caminos durante decenios. Los cruces de razas indias con el ganado indígena han dado lugar a animales más grandes que se emplean mayoritariamente para el transporte por carretera. De la población total de 562.000 bueyes, el número que tiene una edad propicia para el trabajo, entre tres y doce años, es de unos 200.000 machos y 92.000 hembras.

\section{Peligros potenciales y su control}

En otros artículos de este capítulo se abordan los peligros y acciones preventivas que han de adoptarse con los animales de tiro que se comentan en este artículo. En los cuadros que sobre estos temas se encuentran en el capítulo "C ría de animales domésticos", puede encontrarse información general sobre el comportamiento animal y una lista de comprobación de prácticas de seguridad para la cría de ganado. Los caballos se abordan en el artículo "Caballos y otros équidos". El ganado vacuno (y por extensión, los bueyes y búfalos) se trata en el artículo "Vacas, ovejas y cabras". "Cría de toros" también ofrece información pertinente sobre los peligros potenciales y su control.

\section{CRIA DE TOROS}

David L. H ard

Aunque el término inglés bull se refiere al macho de diversas especies de animales (elefante, búfalo de agua y ganado vacuno) este artículo abordará específicamente la industria del ganado vacuno. Entre 1980 y 1992, el National Traumatic O ccupational Fatalities (NT OF) Surveillance System de Estados U nidos que se basa en los certificados de defunción y está mantenido por el Instituto Nacional para la Salud y la Seguridad en el Trabajo (NIO SH ), identificó 199 fallecimientos asociados con la industria de producción agrícola e infligidos por ganado. De estos, aproximadamente el $46 \%$ (92) fueron directamente atribuidos al manejo de reses para carne y productos lácteos. 
Durante siglos, los criadores de ganado se han servido de la castración de loa animales machos como forma de producir machos dóciles. Los machos castrados suelen ser pasivos, lo que indica que las hormonas (sobre todo la testosterona) están relacionadas con el comportamiento agresivo. Alguna culturas dan gran importancia al carácter luchador de los toros, que se emplean en los deportes y en acontecimientos sociales. En este caso, ciertas variedades son criadas de forma que dichas características de lucha se mantengan y se potencien. En Estados U nidos ha aumentado la demanda de toros para rodeos, al ir aumentando la popularidad de este entretenimiento. En E spaña, Portugal, zonas de Francia, M éxico y partes de Sudamérica, las corridas de toros son populares desde hace siglos (V éase el artículo "Corridas de toros y rodeos" en el capítulo Actividades artísticas, culturales y recreativas.)

La industria del ganado bovino se puede dividir en dos grupos principales (para leche y para carne) con algunas razas que sirven para las dos cosas. La mayor parte de las explotaciones comerciales para carne compran toros a los productores de razas puras, mientras que las explotaciones para leche se han pasado a la inseminación artificial (IA). Así, el ganadero de razas puras suele criar los toros que luego vende cuando están en edad de procrear (de 2 a 3 años de edad). Para cruzarlos existen tres sistemas en la actualidad. EI cruzamiento en el pasto consiste en permitir que el toro esté con la manada y cubra a las vacas cuando entran en celo (calor). Esto puede ocurrir todo el año (históricamente) o durante la estación específica correspondiente. Si se utilizan estaciones de cruce específicas, el toro debe ser separado de la manada durante ciertos períodos. El cruzamiento a mano consiste en mantener al toro aislado de las vacas, excepto cuando se le trae una vaca en celo para que la cubra. Generalmente sólo se permite un cubrimiento, tras el cual se retira a la vaca. Finalmente, la IA es el proceso de utilizar sementales probados, mediante la congelación de su semen, para que los técnicos de IA o el ganadero inseminen con él a muchas vacas. Esto tiene la ventaja de que no hay que tener al toro en la finca, con lo que disminuye el peligro para el ganadero. Pero sigue siendo posible una interacción entre el hombre y el animal en el momento de la recogida del semen.

Cuando se aparta a un toro de la manada para el cruzamiento a mano o se le mantiene aislado de la manada para establecer una estación de apareamiento, puede volverse agresivo al detectar a una hembra en celo. Como no puede responder de forma natural cubriendo a la hembra, puede producirse el complejo del "toro enfadado", que es un ejemplo de comportamiento anormal en los toros. El comportamiento antagonista o combativo típico del toro consiste en escarbar el suelo y mugir. Además, la disposición suele deteriorarse con la edad. Los animales viejos pueden ser pendencieros, traicioneros, impredecibles y suficientemente grandes como para ser peligrosos.

\section{Instalaciones}

Para garantizar el movimiento de los animales por las instalaciones, los pasillos deben ser curvados para que no se vea un extremo al entrar por el otro, y el corral debe estar diseñado de forma que tenga una discontinuidad a la derecha o a la izquierda, para que los animales no tengan la sensación de estar atrapados. La instalación de parachoques de goma sobre las piezas de metal que hagan mucho ruido al cerrarse pueden amortiguarlo y reducir el estrés en el animal. Lo ideal es que las instalaciones reduzcan al máximo los peligros debidos al contacto físico entre el toro y los seres humanos mediante el empleo de barreras, pasillos el evados y puertas que puedan ser manipuladas desde fuera del recinto. Es menos probable que los animales se planten en callejuelas hechas con paredes sólidas que con vallas, porque así el toro no se distrae con los movimientos del exterior. Los pasadizos y callejuelas deben ser suficientemente grandes como para que los animales puedan moverse por ellos, pero no tan anchos que puedan darse la vuelta.

\section{Directrices para el manejo}

L os machos deben ser considerados como peligros potenciales en todo momento. Cuando se guarda a los toros para el apareamiento, es posible evitar lesiones mediante instalaciones adecuadas de confinamiento y sujeción de los toros. Hay que extremar las precauciones al tratar con los animales macho. Los toros pueden no tener la intención de agredir a las personas, pero su tamaño y su masa les convierte en peligros potenciales. Todos los toriles, pasadizos, vallas y rampas de carga deben ser fuertes y funcionar bien. Para garantizar la seguridad hay que utilizar equipos e instalaciones adecuados. Lo ideal sería que, al trabajar con toros, el manipulador se halle físicamente separado del contacto con el toro (fuera del recinto y protegido por pasadizos, paredes, barreras y cosas así) lo cual reducirá mucho el riesgo de lesión. Cuando los manipuladores estén con el animal, deben disponer de vías de escape para casos de emergencia. No se puede azuzar a los animales cuando no tienen dónde ir. LoS manipuladores deben apartarse de los animales asustados 0 "espantados" y extremar los cuidados en torno a los animales desconocidos. Los pasillos con paredes en lugar de vallas logran que menos animales se planten en el corredor. Dado que los toros ven los colores como diferentes intensidades de blanco y negro, todas las instalaciones deben estar pintadas del mismo color. M ediante establos de tratamiento adecuadamente diseñados y equipos de sujeción de animales apropiados es posible reducir las lesiones producida durante las operaciones de exploración, medicación, recorte de cascos, descuerne y cruzamiento a mano.

Las personas que trabajan con animales reconocen que los animales pueden comunicarse aunque no puedan hablar. Los manipuladores deben ser sensibles a las advertencias que hacen los animales al levantar las orejas o ponerlas de punta, levantar el rabo, escarbar en la arena o mugir. En la lista de comprobación y en el cuadro sobre comportamiento animal del artículo "Cría de animales domésticos" de este capítulo se facilita información general y pautas para trabajar con toros.

\section{Zoonosis}

Los manipuladores también han de tener cuidado con las zoonosis. Un manipulador de ganado puede contraer zoonosis al manejar a un animal o productos animales infectados (cueros), al ingerir productos animales (leche, carne poco hecha) y al deshacerse de tejidos infectados. La leptospirosis, la rabia, la brucelosis (fiebre ondulante en seres humanos), la salmonelosis y la tiña son especialmente importantes. También deben tenerse en cuenta la tuberculosis, el ántrax, la fiebre $Q$ y la tularemia. Para reducir la exposición a las enfermedades hay que adoptar prácticas sanitarias e higiénicas básicas, que incluyen el tratamiento inmediato o apartamiento adecuado de animales infectados, adecuada eliminación de tejidos infectados, limpieza adecuada de las zonas contaminadas y empleo correcto del equipo protector del personal.

El método más higiénico de deshacerse de los cadáveres es quemarlos allí donde mueren, para evitar la contaminación del suelo circundante. $\mathrm{H}$ ay que hacer un agujero de tamaño conveniente, colocar en su interior materiales inflamables en cantidad suficiente y poner encima el cadáver para que se consuma por entero. Sin embargo, el método más habitual de eliminación de cadáveres es el enterramiento. El cadáver debe ser enterrado a una profundidad de $120 \mathrm{~cm}$ y cubierto con cal viva en un suelo que impida la contaminación por drenaje a corrientes de agua. 


\section{- ProducCION DE ANIMALES DE COMPAÑIA, DE PELETERIA Y DE LABO RATO RIO}

\section{Christian E. Newcomer}

\section{Procesos}

Los programas para animales en instituciones conllevan cuatro procesos principales:

1. recepción, cuarentena y separación de los animales

2. separación de especies o de animales para proyectos individuales, cuando es necesario

3. alojamiento, cuidados y sanidad

4. almacenamiento.

Las faenas de cría de animales domésticos son la alimentación, el aporte de agua, el suministro de lechos, el mantenimiento de la sanidad, la eliminación de residuos, incluidos los cadáveres, el control de las plagas y los cuidados veterinarios. EI manejo de materiales es significativo en la mayor parte de estas faenas; se trata de mover jaulas, comida, productos farmacéuticos, sustancias biológicas y otros suministros. El manejo y la manipulación de animales también son fundamentales en este trabajo. El cuidado sanitario consiste en cambiar las camas, limpiar y desinfectar, y lavar las jaulas es una importante tarea sanitaria.

L as instalaciones de reclusión de animales son las jaulas, cajas, corrales o establos dentro de una habitación, en una cuadra o en el exterior. Las instalaciones modernas proporcionan espacio, temperatura, humedad, alimento y agua, iluminación, control del ruido y ventilación adecuados. Las instalaciones están diseñadas para el tipo de animal que albergan. Los animales que suelen guardarse recluidos son los roedores por grupos (ratones, ratas, hámsters y cobayas), conejos, gatos, perros, visones, primates no humanos (monos, mandriles y chimpancés), aves (palomas, codornices y pollos) y animales de granja (ovejas y cabras, cerdos, vacas, caballos y ponis).

\section{Peligros y precauciones}

Las personas involucradas en la producción, cuidado y manejo de los animales de compañía, de peletería y de laboratorio están potencialmente expuestos a diversos peligros biológicos, físicos y químicos que pueden ser eficazmente controlados por medio de las prácticas de reducción del riesgo disponibles. Los peligros biológicos que son intrínsecos de las diversas especies animales de importancia para el personal son: mordiscos y arañazos; alergenos altamente sensibilizantes en las caspa, el suero, los tejidos, la orina o las secreciones salivares; y una gran variedad de agentes zoonóticos. Aunque los peligros biológicos son más diversos y potencialmente más devastadores en los medios de trabajo en los que se emplean estos animales, los peligros físicos y químicos son por lo general más penetrantes, como se refleja en su contribución a las enfer medades y a las lesiones en el centro de trabajo.

El personal dedicado a la producción de animales de compañía, de peletería o de laboratorio deben recibir una adecuada formación sobre técnicas de manejo y comportamiento de las especies animales en cuestión, porque el manejo inadecuado de un animal inestable suele ser la causa precipitante de un mordisco o de un arañazo. Estas lesiones pueden resultar contaminadas por microorganismos de la rica flora oral del animal y por la microflora de la piel o del entorno, por lo que es necesario desinfectar la herida de inmediato e instaurar de forma rápida y agresiva un tratamiento antimicrobiano y una profilaxis del tétanos para prevenir las graves complicaciones de la infección de la herida y la desfiguración. El personal debe ser consciente de que algunas infecciones zoonóticas por mordiscos pueden producir enfermedades generalizadas e incluso la muerte; son ejemplos de aquéllas la fiebre por arañazo de gato, la fiebre por mordedura de rata y la infección humana por ectima contagiosa; y ejemplos de éstas la rabia, y la infección por los virus de la hepatitis A y $B$.

Debido a estos riesgos extraordinarios, puede resultar beneficioso usar telas metálicas y guantes a prueba de mordiscos en algunas circunstancias, y en ocasiones la paralización química de los animales es obligatoria para facilitar la manipulación segura. EI personal también puede contraer zoonosis por la inhalación de aerosoles infecciosos, contacto de los microorganismos con la piel o las mucosas, ingestión de materiales infecciosos o transmisión por pulgas, garrapatas o ácaros específicos asociados con los animales.

Los animales de compañía, de peletería y de laboratorio pueden portar todo tipo de agentes zoonóticos, a saber, virus, bacterias, hongos y parásitos internos y externos. He aquí algunos ejemplos de zoonosis: giardiasis y campilobacterosis por animales de compañía; ántrax, tularemia y tiña por animales de peletería; y coriomeningitis linfocítica, virus de la hepatitis e infestación por tenia enana por roedores de laboratorio. La distribución de los agentes de zoonosis varía mucho según la especie de animal huésped, la localización y el aislamiento con respecto a otros reservorios de enfermedades, los métodos de alojamiento y de prestación de cuidados, y la historia y la intensidad de la asistencia veterinaria. Por ejemplo, algunas poblaciones de animales de laboratorio producidas comercialmente han sido sometidas a programas exhaustivos de erradicación de enfermedades y con posterioridad han sido sometidas a estrictas condiciones de control de calidad que impiden que vuelvan a aparecer las enfermedades. Sin embargo, no se han aplicados medidas comparables universalmente a los diversos medios de mantenimiento y producción de los animales de compañía, de peletería y de laboratorio, lo que permite que las zoonosis persistan en algunas circunstancias.

Las reacciones alérgicas, que van desde la irritación y secreción ocular y nasal hasta el asma o las manifestaciones cutáneas como la urticaria de contacto, son habituales en quienes trabajan con roedores, conejos, gatos y otras especies animales de laboratorio. Se calcula que entre un 10 y un $30 \%$ de los individuos que trabajan con estas especies de animales terminan por desarrollar reacciones alérgicas, y las personas con enfermedades alérgicas preexistentes tienen un riesgo mayor y un aumento de la incidencia de asma. En raras circunstancias, una exposición masiva de estas características al alergeno incitante por culpa de un mordisco de un animal, puede hacer que las personas sensibles presenten anafilaxia, una reacción alérgica generalizada y potencialmente peligrosa para la vida.

El personal debe observar buenas prácticas de higiene personal para reducir su probabilidad de exponerse a zoonosis y alergenos mientras trabajan con animales o con subproductos animales. Consisten en el empleo de ropa de trabajo al efecto, disponibilidad y uso de instalaciones para lavarse las manos y ducharse, y separación de las zonas de personal de las dedicadas a alojar a los animales. $\mathrm{H}$ ay que llevar ropa de trabajo 0 cubretodos que protejan la piel para impedir la exposición a mordiscos, arañazos y microbios y alergenos peligrosos. H ay que facilitar equipos de protección personal como guantes impermeables, gafas de seguridad, protectores oculares y dispositivos de protección respiratoria (p. ej., máscaras para partículas, respiradores o respiradores de presión positiva) adecuados a los posibles peligros y a la vulnerabilidad individual, que deben ser llevados para lograr condiciones de trabajo seguras. LoS controles de ingeniería y el diseño de los equipos también 
pueden reducir de forma eficaz la exposición del personal a alergenos peligrosos y zoonosis mediante la conducción del flujo de aire y el empleo de sistemas de jaulas de aislamiento que separen los entornos de los trabajadores de los ocupados por los animales.

L os trabajadores también afrontan peligros físicos y químicos significativos al cuidar de los animales. Las tareas rutinarias consisten en mover o levantar pesados equipos y suministros, y hacer tareas repetitivas, que dan al personal la ubicua oportunidad de hacerse cortes y lesiones por aplastamiento, tirones musculares y lesiones por movimientos repetitivos. Para poner freno a estos desfavorables resultados puede rediseñarse la práctica de trabajo, y utilizar equipo especializado y formación del personal. Con frecuencia, la limpieza de los equipos y de las instalaciones se hace con maquinaria que emplea vapor 0 agua muy caliente, lo que pone al personal en riesgo de padecer lesiones térmicas graves. $\mathrm{H}$ ay que asegurarse del correcto diseño, mantenimiento y utilización de estos aparatos para impedir que se produzcan lesiones personales y facilitar la dispersión del calor para que el medio de trabajo resulte cómodo. El personal que trabaja en torno a equipos grandes, 0 los dedicados a poblaciones de perros revoltosos o de primates no humanos, pueden verse expuestos a niveles de ruido extremadamente elevados, necesitando emplear protecciones auditivas. L os diversos productos químicos que se emplean para limpiar las jaulas y las instalaciones y para el control de parásitos externos de los animales deben ser cuidadosamente revisados con el personal, para garantizar el estricto cumplimiento de las prácticas implantadas para reducir al mínimo la exposición a estas sustancias potencialmente irritantes, corrosivas o tóxicas.

\section{- PISCIFACTORIAS Y ACUICULTURA}

\section{George A. Conway y Ray RaL onde}

\section{Fundamentos}

La cría de organismos marinos para obtener alimento ha sido una práctica extendida desde la antigüedad. Sin embargo, la producción a gran escala de moluscos, crustáceos y teleósteos ha ganado popularidad con rapidez desde principios del decenio de 1980, de forma que el $20 \%$ de los alimentos procedentes del mar proceden hoy día del cultivo, está previsto que aumente hasta el 25 \% para el año 2.000 (D ouglas 1995; Crowley 1995). La expansión de los mercados mundiales, contemporánea de la depleción de los reservorios salvajes, ha dado lugar a un crecimiento muy rápido de esta industria.

La acuicultura de base terrestre tiene lugar en tanques y estanques, mientras que los sistemas de base acuática suelen emplear jaulas con alambradas o recintos limitados por redes ancladas con muy diversos diseños (K uo y Beveridge 1990) en agua salada (maricultura) o dulce.

La acuicultura puede ser extensiva o intensiva. La acuicultura intensiva implica alguna forma de mejora ambiental para la producción natural de especies de pescado, marisco o plantas acuáticas. U n ejemplo sería el depositar conchas de ostras para que las ostras jóvenes las usen como sustrato de fijación. La acuicultura intensiva incorpora una tecnología más compleja y la inversión de capital en el cultivos de organismos acuáticos. Un ejemplo sería un criadero de salmones que utiliza un tanque de cemento con agua aportada por algún sistema se suministro. La acuicultura intensiva también requiere mayor dedicación de trabajo a la explotación

EI proceso de acuicultura intensiva consiste en la adquisición de razas adultos que se emplean para la producción de gametos, recogida y fecundación de los gametos, incubación de los huevos y cría de los alevines; puede incluir la cría de adultos hasta que alcancen el tamaño necesario para venderlos o para liberarlos al entorno. Aquí radica la diferencia entre las piscifactorías y la acuicultura extensiva. Las piscifactorías crían los organismos hasta que alcanzan tamaño de mercado, generalmente en un sistema cerrado. La acuicultura extensiva obliga a liberar al organismo al medio natural para ser pescado más adelante. EI papel esencial de la intensificación es producir un organismo específico para suplementar la producción natural, no para sustituirla. La acuicultura también puede practicarse mediante la mitigación de la pérdida de producción anual causada por acciones naturales o humanas; por ejemplo, la construcción de un criadero de salmones para sustituir la pérdida de producción natural causada al cegar una corriente para la producción de potencia hidroeléctrica.

La acuicultura puede practicarse en instalaciones terrestres, en el fondo del mar, en agua dulce y en estructuras flotantes. Para la cría de pescado se utilizan recintos flotantes delimitados por redes, y para el marisco se emplean jaulas suspendidas de balsas o de boyas de flotación.

Las explotaciones terrestres requieren la construcción de diques y/o la excavación de agujeros para los estanques y de canales para que fluya el agua. La maricultura puede implicar la construcción y mantenimiento de complejas estructuras en medios adversos. La gestión del esguín (para teleósteos) o de pequeños invertebrados, el alimento, los tratamientos químicos del agua y de los animales que se crean y de los excrementos han evolucionado hasta convertirse en actividades altamente especializadas según se ha ido desarrollando la industria.

\section{Peligros y controles}

\section{Lesiones}

Las operaciones de cría de pescado pueden dar lugar a muchas lesiones, que combinan las comunes a todas las operaciones agrícolas modernas (p. ej., atrapamiento en maquinaria pesada, sordera por exposición prolongada a motores ruidosos) con otras exclusivas de estas explotaciones. Los resbalones y caídas pueden tener resultados particularmente malos si ocurren cerca de los canales o de los estanques, pues se dan los riesgos añadidos de ahogarse 0 de contaminación biológica 0 química por agua contaminada.

Pueden producirse laceraciones graves o incluso amputaciones en las operaciones de recogida de huevas, descuartizamiento del pescado y despojamiento de las conchas de los moluscos, que pueden ser evitadas mediante el empleo de protecciones, guantes y equipos diseñados específicamente para cada faena. Las laceraciones contaminadas por la baba y la sangre de los peces pueden dar lugar a graves infecciones locales e incluso sistémicas ("intoxicación por pescado"). En estas lesiones resulta esencial desinfectar y desbridar con rapidez.

La pesca eléctrica (que se emplea para aturdir a los peces en los recuentos de investigación, y cada vez más para recoger los animales en los criaderos) comporta un elevado riesgo de shock eléctrico para los operadores y las personas que estén alrededor (National Safety Council 1985) y sólo debe ser realizada por operadores entrenados, con personal preparado para hacer reanimación cardiopulmonar $(\mathrm{RCP})$ in situ. Sólo debe utilizarse equipo específicamente diseñado para operaciones de pesca con electricidad en agua, y se debe prestar una escrupulosa atención al establecimiento y mantenimiento de un buen aislamiento y unas buenas fijaciones.

El agua siempre comporta el peligro de ahogarse, y las aguas frías añaden el peligro de la hipotermia. $\mathrm{H}$ ay que prevenir las inmersiones accidentales debido a caídas por la borda, igual que 
la posibilidad de enredarse o quedar atrapado en las redes. Todos los trabajadores deben llevar dispositivos de flotación personal verificados siempre que estén en el agua o en su vecindad, y cuando se trabaje en aguas frías debe añadirse alguna protección térmica (Lincoln y K latt 1994). El personal de maricultura debe recibir formación sobre supervivencia en el mar y técnicas de rescate, así como sobre RCP.

Se pueden producir lesiones por movimientos repetitivos en explotaciones de descuartizamiento y manipulación, que pueden ser evitadas en gran medida prestando atención a la ergonomía (mediante el análisis de las faenas y las modificaciones del equipo que sean necesarias) y con frecuentes rotaciones de los trabajadores manuales. L os trabajadores que presenten lesiones por movimientos repetitivos deben ser evaluados y tratados de inmediato, y cambiados de trabajo cuando sea posible.

La deprivación de sueño puede ser una factor de riesgo en las instalaciones de acuicultura que requieran trabajo intensivo durante un corto periodo de tiempo (p. ej., la recogida de huevas en criaderos de salmón).

\section{Peligros para la salud}

Con frecuencia es necesario bucear para construir y mantener los recintos para peces. Como cabría esperar, se ha observado la enfermedad por descompresión en los buceadores que no respetan escrupulosamente los límites de profundidad/tiempo ("tablas de buceo"). También se han comunicado casos de enfermedad por descompresión en buceadores que sí los respetan pero que hacen muchas inmersiones cortas; hay que crear métodos alternativos (sin buceadores) para retirar los peces muertos y mantener los recintos (D ouglas y M ilne 1991). C uando bucear sea estrictamente necesario, deben ser prácticas habituales la observación de las tablas de buceo publicadas, el evitar las inmersiones repetidas, bucear siempre con un segundo buceador y evaluar con rapidez las enfermedades parecidas a la descompresión, para instaurar el correspondiente tratamiento con oxígeno hiperbárico.

Se han producido intoxicaciones graves por organofosforados en trabajadores accidentalmente expuestos al tratamiento con plaguicidas del piojo marino del salmón (Douglas 1995). Los alguicidas que se emplean para controlar las plagas pueden ser tóxicos para los trabajadores, y las propias algas marinas y de agua dulce tóxicas pueden ser peligrosas (Baxter 1991). Los tratamientos por baño de infecciones fúngicas de los peces pueden emplear formaldehído y otros agentes tóxicos (D ouglas 1995). Los trabajadores deben recibir la formación adecuada y tener asignado el tiempo necesario para manejar sin peligro todos los productos químicos que se emplean, y sobre las prácticas higiénicas en entornos de aguas contaminadas.

Se han producido enfermedades respiratorias que van desde la rinitis hasta el broncoespasmo grave (síntomas de tipo asmático) debido a la sensibilización a posibles endotoxinas de bacterias gramnegativas que contaminan la trucha de piscifactoría en operaciones de destripamiento (Sherson, $\mathrm{H}$ ansen y Sigsgaard 1989), y puede producirse una sensibilización respiratoria a los antibióticos que se ponen en el alimento para peces. La cuidadosa observancia de la limpieza personal, mantener limpio el pescado al descuartizarlo y manipularlo y el empleo de protección respiratoria ayudarán a garantizar la seguridad frente a estos problemas. Los trabajadores que se sensibilicen deben evitar subsiguientes exposiciones a los antígenos implicados. La constante inmersión de las manos puede facilitar la sensibilización cutánea a sustancias químicas y a proteínas extrañas (del pescado). Las prácticas higiénicas y el empleo de guantes adecuados para la tarea correspondiente (como los de neopreno con puño, flocados e impermeables en las operaciones de descuartizado) reducirán este riesgo.

La exposición al sol puede dar lugar a quemaduras y a lesiones cutáneas queratósicas (crónicas). El empleo de sombreros, ropa adecuada y bronceadores ha de ser obligatorio para todos los trabajadores al aire libre

El pescado almacenado en grandes cantidades suele ser atacado o infestado por ratas y otros roedores, constituyendo un peligro de leptospirosis (enfermedad de Weil). Los trabajadores que manipulan pescado deben vigilar los almacenes, controlar los roedores y proteger la piel y mucosas erosionadas del contacto con aguas estancadas y alimentos contaminados. Los alimentos contaminados por orina de rata deben ser manipulados como potencialmente infecciosos, y eliminados rápidamente (Ferguson y Path 1993; Benenson 1995; Robertson y cols. 1981).

A partir de la inflamación cutánea de la piel macerada por el constante contacto con el agua pueden producirse eccemas y dermatitis. Además, esta inflamación y estas condiciones de humedad pueden estimular la reproducción de papilomavirus humanos, dando lugar a una rápida diseminación de verrugas cutáneas (Verruca vulgaris). La mejor forma de prevenirlas es mantener las manos lo más secas posible y utilizar guantes adecuados. Los emolientes tiene algún valor para tratar las pequeñas irritaciones debidas al contacto con el agua, pero puede ser necesario el tratamiento tópico con cremas de corticosteroides o de antibióticos (tras la evaluación realizada por un médico) si el tratamiento inicial resulta infructuoso.

\section{Impactos ambientales}

En todos estos sistemas la demanda de agua potable puede ser extremadamente elevada, calculándose en 40.000 litros por cada $0,5 \mathrm{~kg}$ de pez teleósteo criado hasta la madurez (Crowley 1995). La recirculación y la filtración pueden reducir mucho la demanda, pero requieren la aplicación intensiva de nuevas tecnologías (p. ej., zeolitos para atraer el amoníaco).

Los vertidos de las piscifactorías pueden llevar tantos residuos fecales como los de las ciudades pequeñas, y están proliferando con rapidez las regulaciones para controlarlos (Crowley 1995).

El consumo de plancton y de krill, y los efectos secundarios de la acuicultura, como las plagas de algas, pueden producir grandes desequilibrios entre las especies de los ecosistemas locales que rodean a las instalaciones.

\section{APICULTURA, CRIA DE INSECTOSY PRODUCCION DE SEDA}

\section{M elvin L. M yers y D onald Barnard*}

Hay en el mundo más de un millón de especies de insectos, y la masa global de estos individuos supera al total de masa de los demás animales terrestres. Los grillos, saltamontes, langostas, termitas, larvas de escarabajos, avispas, abejas y orugas de la polilla son algunas de las 500 especies que forman parte de la dieta habitual de personas en todo el mundo. Habitualmente, los seres humanos capturan o recolectan los insectos que les han de servir de alimento, en lugar de criarlos y cuidarlos de modo intencionado.

A parte de como alimento, los seres humanos emplean a los insectos como fuente de polinización, de control biológico de plagas y de fibra. L os distintos usos dependen de las cuatro fases

* Parte de la información sobre la industria de la seda ha sido adaptada del artículo de J. K ubota incluido la 3a edición de esta E nciclopedia. 
del ciclo vital de los insectos, que son el huevo, la larva, la crisálida y el adulto. Son ejemplos de utilización comercial de los insectos la apicultura (casi mil millones de toneladas de miel producidas al año y polinización de frutas y cosechas), la cría de insectos (más de 500 especies en cultivo, incluidas las utilizadas para control biológico), la producción de goma laca (36.000 toneladas al año) y la producción de seda (180.000 toneladas al año).

\section{Apicultura}

Los apicultores crían la abeja de la miel en colonias de colmenas. La abeja de la miel es fuente de polinización para las flores, de miel y de cera. Se trata de un importante polinizador, efectuando más de 46.430 viajes de aprovisionamiento por individuo y por kilo de miel que producen. En cada viaje de aprovisionamiento, la abeja de la miel visitará 500 flores en un período de 25 minutos. El origen de la miel de la abeja de la miel es el néctar de las flores. La abeja utiliza la enzima invertasa para convertir la sacarosa del néctar en glucosa y fructosa y, al evaporarse el agua, se produce la miel. Además se crían abejorros y avispones para la polinización de tomates y alfalfa, respectivamente.

La colonia se agrupa en torno a una sola abeja reina, y se aloja en cajones (colmenas artificiales). Los apicultores establecen una colonia de crías de unas 10.000 abejas en el fondo de la colmena, lo que se conoce como cámara de incubación. C ada cámara contiene diez paneles con celdillas que se emplean para almacenar la miel o para poner huevos. La reina pone unos 1.500 huevos al día. A continuación el apicultor añade el alza, una cámara de alimentación (una caja situada encima de la de incubación) que se convierte en la cámara de almacenamiento de la miel, de la cual vivirán las abejas en invierno. La colonia sigue multiplicándose, y se considera madura cuando llega a unas 60.000 abejas. El apicultor añade un separador para la reina (un panel plano que la reina no puede atravesar por ser de mayor tamaño) encima del alza de alimentación para impedir que ponga huevos en los huecos adicionales que se amontonan encima del separador. Estas alzas adicionales están diseñadas para recoger sólo miel sin huevos.

El apicultor traslada la colmena allí donde florecen las flores. Un colonia de abejas de la miel puede buscar en una zona de 48 hectáreas, y una hectárea puede mantener unas dos colmenas. La miel se recoge en verano de los agujeros del alza, que pueden amontonarse en siete alturas al crecer la colonia e ir llenando las abejas los paneles con miel. Las alzas con paneles cargados de miel son transportados a la "casa" de las abejas para su extracción. M ediante un cuchillo afilado y caliente que se conoce como cuchillo de desmielar, se retiran las cubiertas de cera que las abejas han colocado sobre las brescas de los paneles. A continuación se extrae la miel de los paneles mediante una centrifugadora. Se recoge la miel y se envasa para la venta (Vivian 1986).

Al final de la estación, el apicultor acondiciona las colmenas para el invierno, envolviéndolas en papel de alquitrán para proteger las colonias del viento y absorber el calor del sol. También proporciona a las abejas almíbar de azúcar con medicación para su consumo invernal. En primavera se abren las colmenas para que empiecen a producir como colonias adultas. Si la colonia alcanza un número excesivo de miembros, creará otra reina mediante una alimentación especial, y la vieja reina tendrá que irse con la mitad aproximadamente de la colonia, en busca de un nuevo alojamiento. El apicultor puede capturar el enjambre y tratarlo como si fuera una colonia de crías.

Los apicultores están expuestos a dos peligros relacionados con las picaduras de las abejas. U no es el envenenamiento por la picadura. El otro es la reacción de hipersensibilidad al veneno, y el posible shock anafiláctico. Los varones de 40 años de edad 0 más tienen más riesgo de presentar reacciones mortales. Se cree que el $2 \%$ aproximadamente de la población general es alérgica al veneno, pero se calcula que se producen reacciones sistémicas en el 8,9\% de los apicultores y sus parientes inmediatos. La incidencia de reacciones es inversamente proporcional al número de picaduras recibidas. Las reacciones anafilácticas al veneno de los abejorros son raras excepto entre quienes se dedican a criarlos, y el riesgo es mayor si han sido sensibilizados al veneno de la abeja de la miel.

Si una abeja pica al apicultor hay que sacar el aguijón y limpiar el picotazo. D ebe aplicarse hielo o un emplasto de bicarbonato y agua en el picotazo. Hay que vigilar los síntomas de reacción sistémica en la víctima, que pueden constituir una urgencia médica. Para las reacciones anafilácticas, se administra epinefrina por vía subcutánea a la primera señal de síntomas. Para trabajar con seguridad, el apicultor debe usar humo en la colmena para neutralizar el comportamiento protector de las abejas, y ha de llevar una capucha y un velo, guantes delgados y mangas largas o sobretodos. Las abejas se sienten atraídas por la humedad del sudor, por lo que los apicultores no deben llevar muñequeras ni cinturones, en los que se acumula el sudor. Al sacar la miel, el apicultor debe mantener el pulgar y los demás dedos de la mano alejados del movimiento de corte del cuchillo de desmielar.

\section{Cría de insectos en masa}

En los laboratorios se crían más de 500 especies de artrópodos, como hormigas, escarabajos, ácaros, moscas, polillas, arañas y garrapatas. Un uso importante de estos artrópodos es para el control biológico de otras especies animales. Por ejemplo, hace 2.000 años, en los mercados de China se vendían nidos de hormigas tejedoras para colocarlos en los huertos de cítricos y así apresar a las plagas de las cosechas. $\mathrm{H}$ oy día se han identificado más de 5.000 especies de insecto que pueden servir como posibles controladores biológicos de las plagas, y 300 se usan con éxito habitualmente en 80 países. Los vectores de las enfermedades también se han convertido en objeto de control biológico. Por ejemplo, el mosquito carnívoro del sureste de Asia, Toxorhynchites spp., también conocido como mosquito "tox", tiene una larva que se alimenta de las larvas del mosquito tigre Aedes spp., que transmite enfermedades como la fiebre del dengue a los seres humanos (O 'Toole 1995).

Se han creado instalaciones de cría masiva para criar insectos estériles como herramienta no química de supresión de plagas. U na de esas instalaciones en Egipto cría mil millones de moscas de la fruta (unas 7 toneladas) por semana. Esta industria de cría tiene dos ciclos principales. Uno es la conversión de alimento o ciclo de incubación de las larvas, y el otro es la propagación 0 ciclo de producción de huevos. La técnica de los insectos estériles se usó por vez primera para eliminar al gusano tornillo, que ataca al ganado vacuno. La esterilización se logra radiando a las crisálidas justo antes de que salga el adulto del capullo con rayos $X$ o con rayos gamma $E$ sta técnica consiste en tomar enormes cantidades de insectos criados y estériles y liberarlas en las zonas infestadas donde los machos estériles copulan con las hembras salvajes, que son fértiles. Al romper el ciclo vital del insecto se reduce espectacularmente la tasa de fertilidad de estas plagas. Esta técnica se emplea con los gusanos tornillo, las lagartas, el gorgojo del algodón y la mosca de la fruta (Kok, Lomaliza y Shivhara 1988).

U na típica instalación estéril de insectos tiene un sistema de aire estanco para impedir que entren insectos no deseados y que escapen los fértiles. Las tareas de cría consisten en fregar y barrer, apilar los huevos, lavar las bandejas, preparar la dieta, inocular (colocar los huevos en agar), teñir las crisálidas, asistir a 
la salida del capullo, empaquetar, poner en cuarentena, irradiar, hacer la selección y pesar. En la sala de crisálidas se mezcla la vermiculita con agua, y se pone en las bandejas. Se apilan las bandejas y se barre el polvo de vermiculita con una escoba. Se separan las crisálidas de la vermiculita mediante un cedazo. Las crisálidas elegidas para la técnica de esterilización de insectos son transportadas en bandejas apiladas sobre enrejados hasta la cámara de irradiación, que se encuentra en una zona o dependencia diferente, donde son irradiadas y quedan esterilizadas (Froehlich 1995; K iefer 1996).

Q uienes trabajan con insectos, incluidos los criadores de gusanos de seda, pueden presentar una reacción alérgica a alergenos de los artrópodos (escamas, pelos u otras partes del cuerpo). Los síntomas iniciales son picor de ojos e irritación nasal, seguidos por episodios intermitentes de estornudos, tos y disnea. En adelante, la exposición al alergeno desencadenará crisis de asma. Los entomólogos y quienes trabajan en dependencias de moscas estériles están expuestos a diversos agentes potencialmente peligrosos e inflamables. Son los siguientes: en los laboratorios de entomología, alcohol isopropilo, etil alcohol y xileno; en la sala de preparación de la dieta se usa el alcohol isopropilo disuelto en agua para esterilizar las paredes y los techos mediante un pulverizador. El polvo de vermiculita comporta problemas respiratorios. Algunas vermiculitas están contaminadas por asbesto. Las unidades de manipulación en estas instalaciones emiten ruido que puede ser nocivo para la audición de los empleados. En las dependencias puede utilizarse una adecuada ventilación y protección respiratoria personal para controlar la exposición a alergenos y polvos del aire. D eben usarse materiales de trabajo que no produzcan polvo. El aire acondicionado y el recambio frecuente de los filtros puede ayudar a reducir las concentraciones atmosféricas de púas y pelos. Los rayos $X$ o gamma (radiación ionizante) pueden dañar al material genético. En las dependencias de irradiación es necesario usar protección frente a los rayos $X$ y gamma y sus fuentes (Froehlich 1995; K iefer 1996).

\section{Cría de gusanos de seda}

La vermicultura, la cría de gusanos, tiene una larga historia en algunas culturas. Los gusanos, sobre todo el gusano de la harina (que es una larva, no un auténtico gusano del escarabajo nocturno), se crían en miles de millones para servir de alimento a los animales de laboratorio y de compañía. Los gusanos también se emplean en operaciones de compostaje (vermi-compostaje).

Sericultura es el término que se emplea para la producción de capullos del gusano de seda, que consiste en la alimentación del gusano de seda y la formación de capullos. El cultivo del gusano de seda y de la oruga de la polilla de la seda se remonta a al 3.000 a. de C. en C hina. Los criadores de gusanos de seda han domesticado a la polilla correspondiente; no quedan poblaciones salvajes. Los gusanos de seda sólo comen hojas de morera. Por eso, la producción de la fibra ha dependido siempre de la estación de floración del árbol de la morera. Se han creado alimentos artificiales para el gusano seda, de forma que la producción pueda mantenerse todo el año. Los gusanos de seda se crían en bandejas que a veces se apilan. Los gusanos tardan unos 42 días en alimentarse a una temperatura constante de $25^{\circ} \mathrm{C}$. Puede ser necesario usar calefacción artificial. La seda es una secreción de la boca del gusano que se solidifica al entrar en contacto con el aire. El gusano de seda segrega unos $2 \mathrm{~km}$ de hilo de seda para formar un capullo en la fase de crisálida (Johnson 1982). U na vez formado el capullo, el sericultor mata las crisálidas en un horno, y envía los capullos a una fábrica. En la fábrica se recoge la seda del capullo y se convierte en hilos y madejas.

El nueve por ciento de los sericultores manifiesta asma en respuesta a las escamas de la mariposa del gusano de seda, aunque casi todos los casos de asma en sericultores se atribuyen a la inhalación de heces del gusano. Además, el contacto de la piel con los pelos de la oruga del gusano puede producir una importante dermatitis de contacto irritante. El contacto con la seda pura también puede producir reacciones cutáneas de tipo alérgico. Para la producción de mariposas del gusano de seda, el tratamiento por hiposensibilización (para las escamas de la mariposa y las heces) logra mejorías en el 79,4\% de los tratados. Los corticosteroides pueden revertir los efectos de los antígenos inhalados. Las lesiones cutáneas pueden responder a las lociones y cremas a base de corticosteroides tópicos. Los antihistamínicos tópicos alivian el picor y la quemazón. Se han identificado casos de intoxicación por monóxido de carbono en algunos sericultores en sus casas, donde mantienen el calor con las chimeneas de carbón con que crían a los gusanos. Las chimeneas de carbón y los calefactores de queroseno deben ser sustituidos por calefacciones eléctricas para evitar la exposición al monóxido de carbono.

\section{Referencias}

Ahlgren, GH. 1956. Forage Crops. Nueva York: $\mathrm{M}$ CG raw-H ill Book Co.

Aldhous, P. 1996. Scrapie theory fed BSE complacency, now fears grow for unborn babies. N ew Scientist 150:4-5.

Auty, JH. 1983. Draught animal power in Australia. Asian Livestock V III:83-84.

Banwart, WC, JM Brenner. 1975. Identification of sulfur gases evolved from animal manures. J Environ Q ual 4:363-366.

Baxter, PJ. 1991. Toxic marine and freshwater algae: An occupational hazard? Br J Ind M ed 48(8):505506

Bell, RG, DB Wilson, EJ Dew. 1976. Feedlot manure top dressing for irrigated pasture: Good agricultural practice or a health hazard? B Environ Contam T ox 16:536-540.

Benenson, AS. 1990. Control of Communicable Diseases in $\mathrm{M}$ an. Washington, DC: American Public $\mathrm{H}$ ealth Association.

-. 1995. C ontrol of Communicable D iseases M anual. Washington, DC: A merican Public H ealth Association.
Brown, LR. 1995. M eat production takes a leap. En $V$ ital Signs 1995: T he T rends that are Shaping our Future, dirigido por LR Brown, $\mathrm{N}$ Lenssen y $\mathrm{H}$ Kane. Nueva Y ork: WW N orton \& Company.

Bursey, R G. 1992. N ew uses of dairy products. En N ew Crops, N ew U ses, N ew M arkets: Industrial and Commercial Products from U.S. Agriculture: 1992 Yearbook of Agriculture Washington, DC: USDA.

Calandruccio, RA, JH Powers. 1949. Farm accidents: A clinical and statistical study covering twenty years. Am Surg (N oviembre):652-660.

Cameron, D, C Bishop. 1992. Farm accidents in adults. B R M ed J 305:25-26.

Caras, RA. 1996. A P erfect $H$ armony: T he Intertwining Lives of A nimals and $\mathrm{H}$ umans throughout $\mathrm{H}$ istory. N ueva $\mathrm{Y}$ ork: Simon \& Schuster

Carstensen, O , J Lauritsen, K R asmussen. 1995. The West-Justland study on prevention of farm accidens, Phase 1: A study of work specific factors in 257 hospital-treated agricultural injuries. J ournal of A gricultural Safety and $H$ ealth 1:231-239.

Chatteriee, A, D Chattopadhyay, D Bhattacharya, Ak Dutta, DN Sen Gupta. 1980. Some epidemiologic aspects of zoophilic dermatophytosis. International ournal of Z oonoses 7(1):19-33.

Cherry, JP, SH Fearirheller, TA Foglis, GJ Piazza, G M aerker, JH Woychik, M K omanowski. 1992 Innovative uses of animal byproducts. En N ew Crops, New U ses, New M arkets: Industrial and Commercial Products from U.S. A griculture: 1992 Yearbook of Agriculture Washington, DC: USDA.

Conferencia Americana de $\mathrm{H}$ igienistas Industriales de Gobierno (ACGIH). 1994. Threshold Limit Values for Chemical Substances and Physical Agents and Biological Exposure Indices. Cincinnati, O hio: ACGIH .

Crowley, M. 1995. Aquaculture trends and technology. National Fisherman 76:18-19.

Deere \& Co. 1994. Farm and Ranch Safety M anagement. M oline, Illinois: Deere $\&$ C 0 .

Defoliart, GR. 1992. Insects as human foods. Crop Protection 11:395-399.

Donham, KJ, DC Zavala, JA M erchant. 1984. Acute effects of work environment on pulmonary functions of swine confinement workers. Am J Ind M ed 5:367-375 
Donham, KJ, J Y eggy, RR Dauge. 1985. Chemical and physical parameters of liquid manure from swine confinement facilities: $\mathrm{H}$ ealth implications for workers, swine and the environment. Agricultural W astes 14:97-113.

- 1988. Production rates of toxic gases from liquid manure: $\mathrm{H}$ ealth implications for workers and animals in swine buildings. B io W astes 24:161-173.

Donham, KJ, KM Thu. 1995. Agriculture medicine and enivronmental health: The missing component of the sustainable agricultural movement. En Agricultural health and safety: W orkplace, E nvironment, Sustainability, dirigido por $\mathrm{HH}$ MCDuffie, JA Dosman, KM Semchuk, SA Olenchock y A Senthilselvan. Boca R atón, Florida: CRC Press.

Donham, KJ, L Scallon. 1985. Characterization of dusts collected from swine confinement buildings. A m Ind H yg Assoc I 46:658-661.

Donham, KJ, LW K napp. 1982. A cute toxic exposure to gases from liquid manure. I 0 ccup M ed 24:142-145

Donham, KJ, MJ Rubino, TD Thedell, J Kammenmeyer. 1977. Potential health hazards of workers in swineconfinementbuildings.J 0 ccupM ed19:383-387.

Donham, KJ, SJ R eynolds. 1995. R espiratory dysfunc tion in swine production workers: D ose-response relationship of environmental exposures and pulmonary function. Am I Ind M ed 27:405-418.

Donham, KJ. 1985. Zoonotic diseases of occupational significance in agriculture: A review. International J ournal of Z oonoses 12:163-191.

-. 1986. H azardous agents in agricultural dusts and methods of evaluation. Am J Ind M ed 10:205-220.

Dosman, JA, BL Graham, D Hall, P Pahwa H M cD uffie, M Lucewicz, T To. 1988. Respiratory symptoms and alterations in pulmonary function tests in swine producers in Saskatchewan: R esults of a survey of farmers. J 0 cc M ed 30:715-720.

Douglas, JDM , AH M ilne. 1991. Decompression sick ness in fish farm workers: A new occupational hazard. B r M ed J 302:1244-1245.

Douglas, JDM . 1995. Salmon farming: 0 ccupational health in a new rural industry. 0 ccup $M$ ed 45:89-92.

Durning, AT, HB Brough. 1992. Reforming the livestock economy. En State of the W orld, dirigido por LR Brown. Londres: WW N orton \& Company.

Erlich, SM, TR Driscoll, JE Harrison, M S Frommer J Leight. 1993. Work-related agricultural fatalities in Australia, 1982-1984. Scand I W ork E nviron H ealth 19:162-167.

Feddes, JJR, EM Barber. 1994. A gricultural engineering solutions to problems of air contaminants in farm silos and animal buildings. En Agricultura $H$ ealth and Safety: W orkplace, E nvironment, Sustainability, dirigido por H H M CD uffie, JA Dosman, K M Semchuk, SA Olenchock y A Senthilselvan. Boca R atón, Florida: CRC Press.

Ferguson, IR, LRC Path. 1993. Rats, fish and Weil's disease. Safety and $\mathrm{H}$ ealth Practitioner :12-16.

Fretz, P. 1989. Injuries from farm animals. En Principles of $\mathrm{H}$ ealth and Safety in Agriculture, dirigido por JA D OSman y DW Crockcroft. Boca Ratón, Florida: CRC Press.

Froehlich, PA. 1995. Engineering Control Observations and Recommendations for Insect R earing F acilities. Cincinnati, O hio: NIOSH

Gillespie, JR. 1997. M odern Livestock and Poultry Production. Nueva Y ork: D elmar Publishers.

Gorhe, DS. 1983. Draught animal power vs mechanization. Asian Livestock VIII:90-91.

$\mathrm{H}$ aglind, M, R Rylander. 1987. O ccupational exposure and lung function measurements among workers in swine confinement buildings. I O ccup M ed 29:904-907

H arries, M G, O Cromwell. 1982.0 ccupational allergy caused by allergy to pig's urine. B r M ed J 284:867.

Heederick, D, R Brouwer, K Biersteker, J. Boleij. Relationship of airborne endotoxin and bacteria levels in pig farms with lung function and respiratory symptoms of farmers. Intl Arch 0 ccup $H$ ealth 62:595601.

Hogan, DJ, P Lane. 1986. Dermatologic disorders in agriculture. $O$ ccup M ed: State Art R ev 1:285-300.

H olness, DL, EL O 'G lenis, A Sass-K ortsak, C Pilger, J N ethercott. 1987. R espiratory effects and dust exposures in hog confinement farming. Am J Ind $\mathrm{M}$ ed 11:571-580.

H olness, DL, JR Nethercott. 1994. Acute and chronic trauma in hog farmers. En Agricultural $\mathrm{H}$ ealth and Safety: W orkplace, Environment, Sustainability, dirigido por HH McDuffie, JA Dosman, KM Semchuk, SA O lenchock, y A Senthilselvan. Boca Ratón, Florida: CRC Press

I owa Department of Public H ealth. 1995. Sentinel Project Research Agricultural Injury Notification System. Des M oines, I owa: I owa D epartment of Public $\mathrm{H}$ ealth.

I verson, M, R Dahl, J. K orsgaard, T H allas, EJ Jensen. 1988. R espiratory symptoms in Danish farmers: An epidemiological study of risk factors. Thorax 48:872-877.

Johnson, SA. 1982. Silkworms. M inneapolis, M innesota: Lerner Publications

Jones, W, K M orring, SA O lenchock, T Williams, J. H ickey. 1984. Environmental study of poultry confinement buildings. Am Ind $\mathrm{H}$ yg A ssoc $\mid 45: 760-766$.

Joshi, DD. 1983. Draught animal power for food production in N epal. Asian Livestock VIII:86-87.

K er, A. 1995. Farming Systems in the African Savanna. Ottawa,C anadá: IDR C Books.

$\mathrm{K}$ han, M H. 1983. Animal as power source in Asian agriculture. Asian L ivestock VIII:78-79.

K iefer, M. 1996. F lorida D epartment of A griculture and C onsumer Services Division of Plant Industry, Gainesville, Florida. Cincinnati, O hio: NIOSH

K noblauch, A, B Steiner, S Bachmann, G Trachsler, R Burgheer, J O sterwalder. 1996. Accidents related to manure in eastern Switzerland: An epidemiological study. 0 ccup E nviron M ed 53:577-582.

K ok, R, K Lomaliza, US Shivhare. 1988. The design and performance of an insect farm/ chemical reactor for human food production. Canadian Agricultural E ngineering 30:307-317.

K uo, C, M CM Beveridge. 1990. M ariculture: Biological and management problems, and possible engineering solutions. En Engineering for Offshore $\mathrm{F}$ ish Farming. Londres: Thomas T elford.

Layde, PM , DL N ordstrom, D Stueland, LB Wittman, M A Follen, K A O Isen. 1996. Animal-related occupational injuries in farm residents. J ournal of Agricultural Safety and $\mathrm{H}$ ealth 2:27-37.

Leistikow, B D onham, JA M erchant, S L eonard. 1989. Assessment of U.S. poultry worker respiratory risk. Am J Ind M ed 17:73-74.

Lenhart, SW. 1984. Sources of respiratory insult in the poultry processing industry. Am J Ind M ed 6:89-96.

Lincoln, JM, M L K latt. 1994. Preventing D rownings of Commercial F ishermen. Anchorage, Alaska: NIO SH.

M acD iarmid, SC. 1993. Risk analysis and the importation of animals and animal products. Rev Sci T ech 12:1093-1107.

M arx, J, J T wiggs, B Ault, J M erchant, E FernándezCaldas. 1993. Inhaled aeroallergen and storage mite reactivity in a Wisconsin farmer nested casecontrol study. Am R ev R espir D is 147:354-358.

$M$ athias, CGT. 1989. Epidemiology of occupational skin disease in agriculture. En Principles of $\mathrm{H}$ ealth and Safety in Agriculture, dirigido por JA Dosman y DW Cockroft. Boca R atón, Florida: CR C Press.

M eadows, R. 1995. Livestock legacy. Environ $H$ ealth Persp 103:1096-1100.

Meyers, JR. 1997. Injuries among Farm W orkers in the U nited States, 1993. DHHS (NIOSH) Publication No. 97-115. Cincinnati, O hio: NIOSH.

M ullan, RJ, LI M urthy. 1991. O ccupational sentinel health events: An up-dated list for physician recognition and public health surveillance. Am J Ind M ed 19:775-799.
$\mathrm{N}$ ational Institute for $\mathrm{O}$ ccupational Safety and $\mathrm{H}$ ealth (NIOSH ). 1993. Injuries among Farm W orkers in the U nited states. Cincinnati, O hio: NIOSH

-. 1994. Request for Assistance in Preventing Organic Dust T oxic Syndrome. W ashington, D C : G PO

National Institutes of $\mathrm{H}$ ealth (NIH). 1988. Institutional Administrator's M anual for Laboratory Animal $C$ are and $U$ se. W ashington, DC: GPO .

N ational Research Council (N R C). 1989. Alternative Agriculture: Committee on the Role of Alternative Farming $M$ ethods in M odern Production Agriculture. Washington, DC: N ational Academy Press.

National Safety Council. 1982. Accident Facts. Chicago, Illinois: N ational Safety Council.

-. 1985. Electrofishing. NSC data sheet I-696-85. Chicago, Ilinois: N ational Safety Council.

Nesheim, M C, RE Austic, LE Card. 1979. Poultry Production. Philadelphia, Pensilvania: Lea and Febiger.

O 'T oole, C. 1995. Alien Empire. Nueva Y ork: Harper Collins Publishers.

O lenchock, S, J M ay, D Pratt, L Piacitelli, J Parker. 1990. Presence of endotoxins in different agricultural environments. Am J Ind M ed 18:279-284.

O rganización de las $\mathrm{N}$ aciones U nidas para la Agricultura y la Alimentación (FAO ). 1965. F arm Implements for A rid and T ropical R egions. R oma: FAO

-. 1995. The State of the W orld Fisheries and Aquaculture. R oma: FAO

O rlic, M, RA Leng. 1992. Preliminary Proposal to Assist $B$ angladesh to I mprove R uminant Livestock Productivity and Reduce $M$ ethane $E$ missions. Washington, DC: US Environmental Protection Agency, Global Change Division.

Panti, NK, SP Clark. 1991. T ransient hazardous conditions in animal building due to manure gas release during slurry mixing. Applied Engineering in A griculture 7:478-484.

Platt, AE. 1995. Aquaculture boosts fish catch. En Vital Signs 1995: T he T rends that A re Shaping our Future, dirigido por LR Brown, $\mathrm{N}$ Lenssen, and $\mathrm{H} \mathrm{K}$ ane. $\mathrm{New}$ Y ork: WW N orton \& Company.

Programa de las Naciones U nidas para el Desarrollo (PN U D). 1996. U rban Agriculture: Food, I obs, and Sustainable Cities. Nueva Y ork: PNUD.

Pursel, VG, CE Rexroad, RJ Wall. 1992. Barnyard biotechnology may soon produce new medical therapeutics. En N ew Crops, N ew U ses, New M arkets: Industrial and Commercial Products from U.S. Agriculture: 1992 Y earbook of A griculture W ashington, DC : U SD A.

Ramaswami, NS, GL Narasimhan. 1982. A case for building up draught animal power. Kurushetra (India's $\mathrm{J}$ ournal for R ural $\mathrm{D}$ evelopment) 30:4

Reynolds, SI, KJ Donham, P Whitten, JA M erchant, LF Burmeister, WJ Popendorf. 1996. A longitudinal evaluation of dose-response relationships for environmental exposures and pulmonary function in swine production workers. Am I Ind M ed 29:33-40.

Robertson, MH, IR Clarke, JD Coghlan, ON Gill. 1981. Leptospirosis in trout farmers. Lancet: 2(8247)626-627.

Robertson, TD, SA Ribeiro, S Zodrow, JV Breman. 1994. Assessment of Strategic Livestock F eed Supplementation as an 0 pportunity for $G$ enerating Income for Small Scale $D$ airy Producers and $R$ educing $M$ ethane $E$ missions in $B$ angladesh. Washington, DC: US Environmental Protection Agency.

Rylander, R, KJ Donham, C H jort, R Brouwer, D Heederik. 1989. Effects of exposure to dust in swine confinement buildings: A working group report. Scand J W ork E nviron H ealth 15:309-312.

Rylander, R, N Essle. 1990. Bronchial hyperactivity among pigand dairy farmers. AmJ Ind M ed 17:66-69.

R ylander, R, R Jacobs. 1994. O rganic D usts: Exposure, E ffects and P revention. C hicago, Illinois: L ewisPublishing.

R ylander, R, Y Peterson, KJ D onman. 1990. Q uestionnaire evaluating organic dust exposure. Am J Ind M ed 17:121-128. 
Rylander, R. 1994. Symptoms and mechanisms: Inflammation of the lung. Am J Ind M ed 25:19-24.

Safina, C. 1995. The world's imperiled fish. Sci Am 272:46-53.

Scherf, BD. 1995. W orld W atch List for Domestic Animal Diversity. R oma: FAO .

Schmidt, JO. 1992. Allergy to venomous insects. En $T$ he $H$ ive and the $H$ oney $B e$, dirigido por JM Graham. $H$ amilton: $\mathrm{D}$ aD ant $\&$ Sons.

Schmidt, M J. 1997. Working elephants. Sci Am 279:82-87.

Sherson, D, I H ansen, T Sigsgaard. 1989. O ccupationally related respiratory symptoms in troutprocessing workers. Allergy 44:336-341.

Shumacher, M J, NB Egen. 1995. Significance of Africanized bees on public health. Arch Int M ed 155:2038-2043.

Stem, C, DD Joshi, and M O rlic. 1995. Reducing M ethane $E$ missions from R uminant L ivestock: N epal prefeasibility Study. Washington, DC: U S Environmental Protection Agency, G lobal Change Division.

Sweeten, JM. 1995. O dor measurement technology and applications: A state-of-the-art review. En Seventh International Symposium on Agricultural and Food P rocessing $W$ astes: P roceedings of the 7 th I nternational Symposium, dirigido por CC R oss. American Society of Agricultural Engineering.

T annahill, R. 1973. Food in H istory. Nueva York: Stein and Day.

Thorne, PS, KJ Donham, 」 Dosman, P Jagielo, JA Merchant, S Von Essen. 1996. O ccupational health. En U nderstanding the I mpacts of $L$ arge scale Swine Production, dirigido por KM Thu, D Mcmillan, J V enzke. I owa City, I owa: U niversidad de I owa.

T urner, F, PJ Nichols. 1995. R ole of the epithelium in the response of the airways. Abstract for the 19th Cotton and $O$ ther O rganic Dust R esearch Conference, 6-7 January, San antonio, T exas.

US Department of Agriculture (USDA). 1992. Agricultural $W$ aste $M$ anagement $F$ ield $H$ andbook. Washington, DC : U SDA Soil Conservation Service.

- . 1996a. Livestock and Poultry: W orld M arkets and T rade Circular Series FL\&P 1-96. Washington DC: USDA Foreign Agricultural Service.

- . 1996b. D airy: W orld M arkets and T rade. Circular Se ries FD 1-96. Washington DC: USDA Foreign Agricultural Service.

-. 1997. Poultry Production and Value, 1996 Summary. Washington, DC: National Agricultural Statistics Service.

van $\mathrm{H}$ age-Hamsten, $\mathrm{M}, \mathrm{S}$ Johansson, S Hogland. 1985. Storage mite allergy is common in a farming population. Clin Allergy 15:555-564.

Vivian, J. 1986. Keeping Bees. Charlotte, VT: Williamson Publishing.

Waller, JA. 1992. Injuries to farmers and farm families in a dairy state. J 0 ccup M ed 34:414-421.

Yang, N. 1995. R esearch and development of buffalo draught power for farming in China. Asian Livestock $X X: 20-24$

Zhou, C, JM Roseman. 1995. Agriculture-related residual injuries: Prevalence, type, and associated factors among Alabama farm operators, 1990. J ournal of $R$ ural $H$ ealth 11:251-258.

Zuehlke, RL, CF M utel, KJ D onham. 1980. Diseases of Agricultural W orkers. I owa City, I owa: D epartment of Preventive Medicine and Environmental $\mathrm{H}$ ealth, U niversity of I owa.

\section{0 tras lecturas recomendadas}

Alexander, JO . 1984. Arthropods and H uman Skin. Berlín: Springer-V erlag.
Baker, D, R Lee. 1993. Animal $\mathrm{H}$ andling Safety Considerations. Columbia, M isuri: M issouri State U niversity Extension.

Bauer, M A, DP Coppolo. 1993. Agriculture lung disease: Prevention. Semin Respir M ed 14:83-89.

Bean, T. 1992. W orking Safely with Livestock. Columbus: O hio State U niversity Extension.

Beno, J, C Schwab, L M iller. 1992: Know Your Livestock and Be Safe. Fact sheet PM-1265b. Ames, Iowa: I owa State U niversity Extension.

Bottcher, RW, RL Langley, R M cLymore. 1994. Improving the $\mathrm{H}$ ealth and Safety of Poultry Facility W orkers. Raleigh: North Carolina Cooperative Extension Service.

Centers for Disease Control and Prevention (CDC) 1984. Work-related allergies in insect-raising facilities. M orb M ortal W eekly R ep 33:448, 453-454.

Cole, WC 1996. Physical hazards in research anima facilities. Proceedings of the 4 th $N$ ational Symposium on Safety: W orking Safely with R esearch Animals. 27-31 enero Atlanta, Georgia.

Cotes, JE, J Steel. 1987. W ork-related L ung D isorders. O Xford: Blackwell Scientific Publications.

Crane, E. 1990. B ees and B eckeeping: Science, Practice and W orld R esources. O xford: $\mathrm{H}$ einemann $\mathrm{N}$ ewnes

-. 1994. Health hazards of pork producers in livestock confinement building: From recognition to control. En Agricultural $\mathrm{H}$ ealth and Safety: W orkplace, Environment, Sustainability, dirigido por $\mathrm{HH}$ M CD uffie, JA Dosman, KM Semchuk, SA O lenchock y A Senthilselvan. Boca R atón, Florida: CR C Press.

Donham, KJ, LW K napp, R M onoson, Gustafon. 1982. Acutely toxic exposure to gases from liquid manure. J 0 ccup M ed 24:142-145.

Ebert, K, M Dennis. 1993a. Cattle Safety. M anhattan, $K$ ansas: $K$ ansas State $U$ niversity Extension.

- . 1993b. Proper $\mathrm{H}$ andling/ facilities C ritical to $\mathrm{G}$ ood W orking Relationship. $M$ anhattan, $K$ ansas: $K$ ansas State University Extension.

Ellis, JL, PR G ordon. 1991. Farm family mental health issues. 0 ccup M ed: State Art R ev 6:493-502.

Ensminger, ME. 1991. Animal Science. Danville, Illinois: Interstate Publishers.

Fox, JG, CE N ewcomer, H R ozmiarek. 1984. Selected zoonoses and other health hazards. Laboratory A nimal $M$ edicine, dirigido por JG Fox, BJ Cohen FM Loew. N ueva Y ork: A cademic Press.

Frazier, CA, FK Brown. 1980. Insects and Allergy and $W$ hat to $D 0$ about Them. N orman, $O$ klahoma: U niversity of O klahoma Press.

Frazier, CA. 1980. Occupational Asthma. Nueva York: $\checkmark$ an $N$ ostrand R einhold Company.

Gill, ON, JD Coghlan, IM Calder. 1985. The risk of leptospirosis in U nited $\mathrm{K}$ ingdom fish farm workers. J $\mathrm{H}$ yg Camb 94:81-86.

Goddard, J. 1993. Physician's Guide to Arthropods of M edical Importance. Boca R atón, Florida: CR C Press.

Gordon, JS. 1996. The chicken story. American H eritage 47:52-67.

Graham, JM (dir. ). 1992. The $H$ ive and the $H$ oney $B$ ee. $\mathrm{H}$ amilton: $\mathrm{DaD}$ ant $\&$ Sons.

King, M. 1993. Environmental hazards and your horse. H orse Illustrated :26-35.

K ochuyt, AM, E V an-H oeyveld, EAM Stevens. 1993. 0 ccupational allergy to bumble-bee venom. Clin Exp Allergy 23:190-195.

Langley, RL, RL M CLymore, WJ M eggs, GT Roberson. 1997. Safety and $\mathrm{H}$ ealth in Agriculture, Forestry, and Fisheries. Rockville, Maryland: Government Institutes.

Layde, PM, DL N ordstrom, D Stueland, LB Wittman, M A Follen KA O Ison. 1996. A nimal-related occupational injuries in farm residents. I ournal of A gricultural Safety and $\mathrm{H}$ ealth 2:27-37.
Lenhart, SW, LD Reed. 1989. R espiratory protection for use against organic dust. En Principles of $\mathrm{H}$ ealth and Safety in Agriculture, dirigido por JA Dosman y DW Cockcroft. Boca R atón, Florida: CR C Press.

Lenhart, SW, PD M orris, RE Akin, SA Olenchock, WS Service, WP Boone. 1990. O rganic dust, endotoxin, and ammonia exposures in the North Carolina poultry processing industry. Appl 0 ccup Environ H yg 5:611-618.

Lenhart, SW, SA O lenchock. 1984. Sources of respiratory insult in the poultry processing industry. Am J Ind $M$ ed 6:89-96.

Levine, M L, RF Lockey. 1986. M onograph on Insect Allergy. M ilwaukee, W isconsin: American Academy of Allergy Immunology.

Lipman, NS, CE N ewcomer. 1989. H azard control in the animal research facility. En Biohazards $M$ anage ment $H$ andbook, dirigido por DF Liberman y JG G ordon. N ueva Y ork: M arcel D ekker.

Loftas, T. 1995. Dimensions of $\mathrm{N}$ ed: An Atlas of Food and Agriculture R oma: FAO .

M organ, WK, A Seaton. 1995. O ccupational Lung D iseases. Philadelphia: W B Saunders.

M orris, PD, SW Lenhart, WS Service. 1991. R espiratory symptoms and pulmonary function in chicken catchers in poultry confinement units. Am I Ind M ed 19:195-204.

M urphy, D. Animal H andling T ips. Safety Fact Sheet 14. State College, Pensilvania: Pennsylvania State U niversity Extension.

National Research Council (NRC). 1996. Guide for the Care and $U$ se of $L$ aboratory Animals. Washington, DC: $N$ ational A cademy Press.

N ational T echnical Information Service (NTIS). 1995. $\mathrm{H}$ ealth, Safety and Injury Prevention in Agriculture. $\mathrm{Na}$ tional Ag Safety Database CD-R O M \#95-503777. Springfield, V irginia: NTIS.

- 1997. O ccupational $\mathrm{H}$ ealth and Safety in the $\mathrm{C}$ are of $\mathrm{Re}$ search A nimals. Washington, DC: National Academy Press.

O rkin, M, HI M aibach. 1985. Cutaneous Infestations and Insect B ites. N ueva Y ork: M arcel D ekker.

Parkes, WR. 1981. O ccupational L ung D isorders. L ondres: Butterworths.

Proctor, M , P Y eo, A Lack. 1996. The Natural H istory of Pollination. Portland, 0 regón: T imber Press.

Reynolds, SJ, D Parker, D Vesley, D Smith, R Woellner. 1993. Cross-sectional epidemiological study of respiratory disease in turkey farmers. Am J Ind M ed 24:713-722.

Reynolds, SJ, D Parker, D V esley, K Janni, C M cjilton. 1994. O ccupational exposure to organic dusts and gases in the turkey growing industry. A ppl 0 ccup Environ $\mathrm{H}$ yg 9:493-502.

Rosenman, K. 1992. Zoonoses- Animals Can M ake You Sick. East Lansing, M ichigan: M ichigan State U niversity Extension.

Rylander, R. 1986. Lung diseases caused by organic dusts in the farm enivronment. $\mathrm{Am}$ I Ind $\mathrm{Med}$ 10:221-227.

Schenker, M, T Ferguson, T Gamsky. 1991. Respiratory risks associated with agriculture. 0 ccup $M$ ed: State A rt R ev 6:415-428.

Siegel, M . 1996. B ook of H orses. Davis, California: Davis School of Veterinary Medicine-Universidad de California.

Tu, AT. 1984. Handbook of Natural Toxins. Vol. 2. N ueva Y ork: M arcel Dekker.

Wagstaff, H . 1987. H usbandry methods and farm systems in industrial countries which use lower levels of external inputs: A review. Agric $E$ cosyst \& E nviron 19:1-27.

Wilkinson, $\mathrm{R}, \mathrm{A}$ Tilma. 1992. Livestock $\mathrm{H}$ andling and Confinement Safety. East Lansing, M ichigan: M ichigan State U niversity Extension. 
Directores del capítulo

Paul D emers y Kay T eschke

\section{Sumario}

Perfil general

Paul Demers............................. 71.2

Principales sectores y procesos: riesgos profesionales y controles

$H$ ugh D avies, Paul D emers, T imo Kauppinen y Kay Teschke. . .

Lesiones y enfermedades

Paul Demers............................ 71.10

Cuestiones ambientales y de salud pública

Kay Teschke y Anya K efe. 


\section{- Perfil general}

Paul Demers

La industria maderera es una de las más importantes en todo el mundo dentro del ámbito del aprovechamiento de los recursos naturales. En la mayoría de los países se cortan árboles para diversos fines. Este capítulo se centra en la transformación de la madera para la producción de tableros de madera maciza y tableros manufacturados en serrerías y lugares afines. Se denominan tableros manufacturados los compuestos por elementos de madera de varios tamaños, desde chapas hasta fibras, que se mantienen unidos por medio de adhesivos químicos añadidos 0 por enlaces químicos "naturales". La Figura 71.1 ofrece datos de la producción mundial. Sobre la base de las diferencias entre los procesos aplicados y los riesgos asociados, se distinguen en los tableros manufacturados tres grandes categorías: tableros de contrachapado, tableros de partículas y tableros de fibra. Se agrupan bajo el término tableros de partículas los materiales laminares fabricados a partir de pequeños trozos de madera, como astillas, escamas, hebras o tiras, y bajo el término tableros de fibra los paneles fabricados con fibras de madera, incluidos los tableros duros, los tableros de fibras de densidad media (FDM) y los tableros aislantes. A parte de la producción de tableros, el otro uso industrial importante de la madera es la fabricación de papel y productos relacionados, que se expone en el capítulo Industria del papel y pasta de papel.

La industria del aserrado ha existido en formas sencillas desde hace siglos, aunque ha sido estas últimas décadas cuando se han producido importantes avances tecnológicos con la introducción de la electricidad, la mejora en el diseño de las sierras y, más recientemente, la automatización de la clasificación y otras operaciones. También las técnicas básicas de fabricación de contrachapado se conocen desde hace muchos siglos, aunque el término contrachapado no vino a ser de uso común hasta el decenio de 1920 y su fabricación no adquirió importancia comercial hasta este siglo. Las industrias de fabricación de tableros manufacturados, incluidos los tableros de partículas, los de obleas, lo de hebras orientadas, los tableros aislantes, los de fibras de densidad media y los tableros duros, son todas ellas relativamente nuevas y sólo comenzaron a ser importantes desde el punto de vista comercial después de la segunda Guerra $M$ undial.

Los tableros manufacturados y de madera maciza pueden elaborarse a partir de una gran variedad de especies arbóreas. La elección se hace según la forma y el tamaño del árbol, las características físicas de la madera en sí, como su solidez o resistencia al deterioro, y sus propiedades estéticas. Se denomina madera dura la procedente de especies frondosas o de hojas anchas, clasificadas botánicamente como angiospermas, mientras que se conoce como madera blanda la que se obtiene de las coníferas o árboles de hojas aciculares, clasificados botánicamente como gimnospermas. M uchas maderas duras y algunas blandas que crecen en las regiones tropicales suelen recibir el nombre de maderas tropicales o exóticas. Aunque la mayoría de la madera cortada en todo el mundo (el $58 \%$ del volumen) se obtiene de árboles no integrados en el grupo de las coníferas, gran parte de ella se consume como combustible, de modo que la mayoría de la que se destina a usos industriales (el $69 \%$ ) procede de coníferas (FAO, 1993). Esto puede reflejar en parte la distribución de los bosques en relación con el desarrollo industrial. L os mayores bosques de coníferas están emplazados en las regiones septentrionales de N orteamérica, Europa y A sia, mientras que los principales bosques de frondosas están situados tanto en regiones tropicales como templadas.
Tabla 71.1 • Estimación de la producción de madera en 1990 (miles de $\mathrm{m}^{3}$ ).

\begin{tabular}{|c|c|c|c|}
\hline & $\begin{array}{l}\text { Madera } \\
\text { destinada a } \\
\text { combustible } \\
\text { o carbón } \\
\text { vegetal }\end{array}$ & $\begin{array}{l}\text { Total de } \\
\text { madera } \\
\text { destinada } \\
\text { a usos } \\
\text { industriales }\end{array}$ & $\begin{array}{l}\text { Troncos } \\
\text { para el } \\
\text { aserrado } \\
\text { de chapa }\end{array}$ \\
\hline NORTEAMERICA & 137.450 & 613.790 & 408.174 \\
\hline Estados Unidos & 82.900 & 426.900 & 249.200 \\
\hline Canadá & 6.834 & 174.415 & 123.400 \\
\hline México & 22.619 & 7.886 & 5.793 \\
\hline EUROPA & 49.393 & 345.111 & 202.617 \\
\hline Alemania & 4.366 & 80.341 & 21.655 \\
\hline Suecia & 4.400 & 49.071 & 22.600 \\
\hline Finlandia & 2.984 & 40.571 & 18.679 \\
\hline Francia & 9.800 & 34.932 & 23.300 \\
\hline Austria & 2.770 & 14.811 & 10.751 \\
\hline Noruega & 549 & 10.898 & 5.322 \\
\hline Reino Unido & 250 & 6.310 & 3.750 \\
\hline ANTIGUA URSS & 81.100 & 304.300 & 137.300 \\
\hline ASIA & 796.258 & 251.971 & 166.508 \\
\hline China & 188.477 & 91.538 & 45.303 \\
\hline Malasia & 6.902 & 40.388 & 39.066 \\
\hline Indonesia & 136.615 & 29.315 & 26.199 \\
\hline Japón & 103 & 29.300 & 18.377 \\
\hline India & 238.268 & 24.420 & 18.350 \\
\hline SUDAMERICA & 192.996 & 105.533 & 58.592 \\
\hline Brasil & 150.826 & 74.478 & 37.968 \\
\hline Chile & 6.374 & 12.060 & 7.401 \\
\hline Colombia & 13.507 & 2.673 & 1.960 \\
\hline AFRICA & 392.597 & 58.412 & 23.971 \\
\hline Suráfrica & 7.000 & 13.008 & 5.193 \\
\hline Nigeria & 90.882 & 7.868 & 5.589 \\
\hline Camerún & 10.085 & 3.160 & 2.363 \\
\hline Costa de Marfil & 8.509 & 2.903 & 2.146 \\
\hline OCEANIA & 8.552 & 32.514 & 18.534 \\
\hline Australia & 7.153 & 17.213 & 8.516 \\
\hline Nueva Zelanda & 50 & 11.948 & 6.848 \\
\hline Papua-Nueva Guinea & 5.533 & 2.655 & 2.480 \\
\hline MUNDIAL & 1.658 .297 & 1.711 .629 & 935.668 \\
\hline
\end{tabular}

1 Incluye madera utilizada para obtener chapa, pasta, astillas, partículas y residuos. Fuente: FAO 1993.

C asi todos los árboles destinados a la fabricación de productos y estructuras de madera se transforman primero en las serrerías. Por consiguiente, en todas las regiones del mundo donde se utiliza madera con fines industriales existen serrerías. La Tabla 71.1 presenta las estadísticas de 1990 relativas al volumen de madera cortada para combustible y usos industriales 
Figura 71.1 - Clasificación de los tableros manufacturados por el tamaño de las partículas, la densidad y el tipo de proceso.

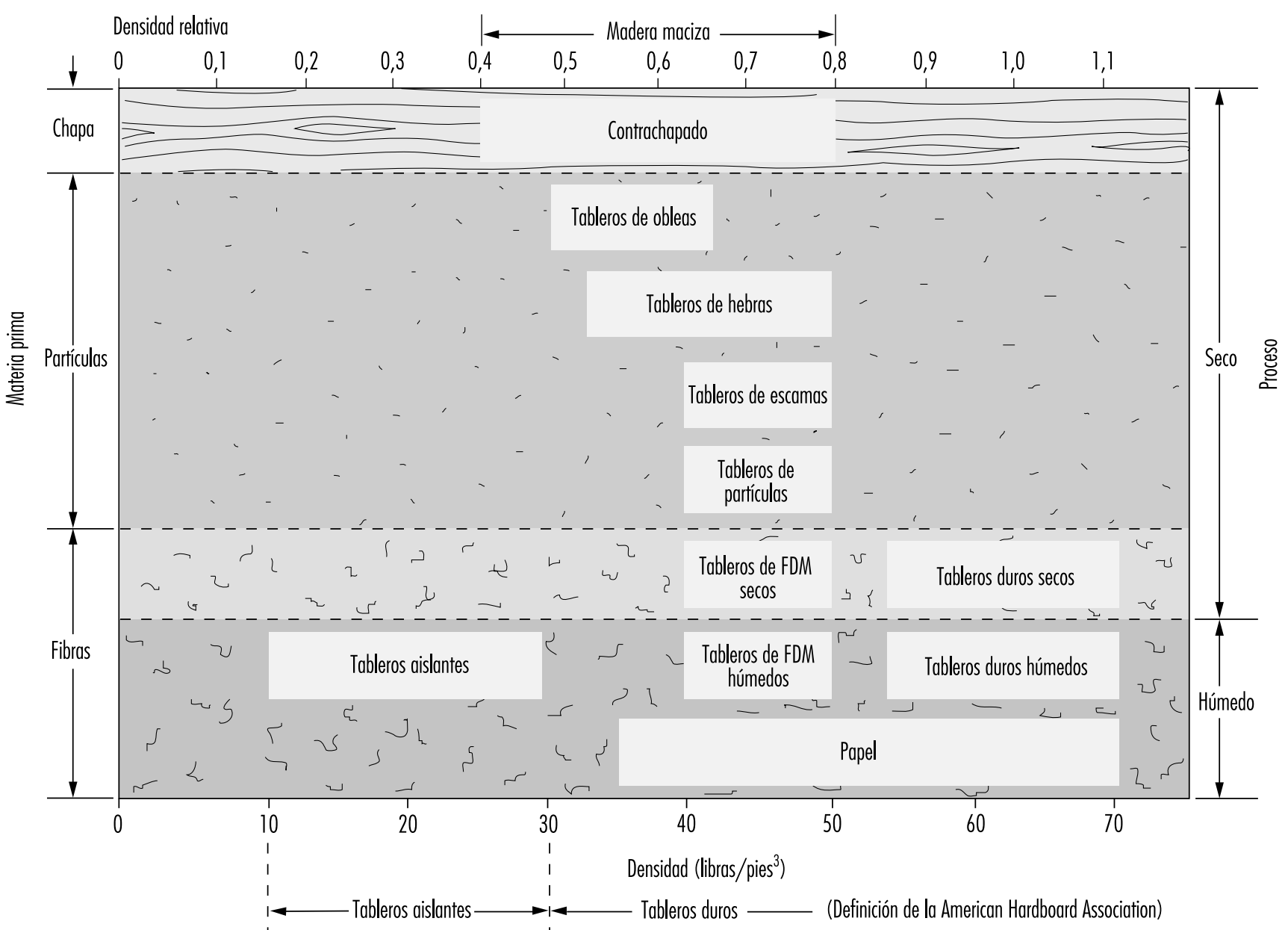

en los principales países productores de cada continente, así como los volúmenes cortados en troncos para el aserrado de chapa, que es una subcategoría de madera industrial y constituye una materia prima para las industrias descritas en el presente capítulo. En los países desarrollados, la mayoría de la madera cortada se destina a usos industriales: se incluyen aquí los troncos para el aserrado de chapa, pasta de madera, astillas, partículas y residuos. En 1990, tres países - Estados U nidos, la antigua URSS y Canadá- produjeron más de la mitad del total de la madera industrial del mundo, así como más de la mitad de los troncos destinados a aserraderos de chapa. En cambio, en muchos de los países en desarrollo de Asia, Africa y Sudamérica, la mayoría de la madera cortada se utiliza para combustible.

La Tabla 71.2 indica los principales productores mundiales de madera maciza elaborada, contrachapado, tableros de partículas y tableros de fibra. Los tres mayores productores de madera industrial también representan en total más de la mitad de la producción mundial de tableros de madera maciza y se cuentan entre los cinco primeros en cada una de las categorías de tableros manufacturados. El volumen de tableros manufacturados en todo el mundo es relativamente pequeño en comparación con el de tableros de madera maciza, pero las industrias de tableros manufacturados crecen a mayor velocidad. M ientras que la producción de tableros de madera maciza aumentó un
$13 \%$ entre 1980 y 1990, los volúmenes de contrachapado, tableros de partículas y tableros de fibra crecieron el $21 \%, 25 \%$ y $19 \%$ respectivamente.

La proporción de trabajadores de la población activa empleados en las industrias de productos de la madera es generalmente de un $1 \%$ o menos, incluso en países con una gran industria forestal, como Estados Unidos $(0,6 \%)$, Canadá $(0,9 \%)$, Suecia $(0,8 \%)$, Finlandia $(1,2 \%)$, M alasia $(0,4 \%)$, Indonesia $(1,4 \%)$ y Brasil $(0,4 \%)(0 I T, 1993)$. Aunque puede haber algunas serrerías situadas cerca de áreas urbanas, la mayoría tienden a situarse cerca de los bosques de los que obtienen sus troncos, y muchas se emplazan en comunidades pequeñas y a menudo aisladas, donde en ocasiones son la única fuente importante de empleo y el componente más importante de la economía local.

La industria maderera emplea a centenares de miles de trabajadores en todo el mundo, aunque resulta difícil calcular cifras exactas a escala internacional. En 1987 había en Estados U nidos 180.000 personas trabajando en serrerías y talleres de cepillado, 59.000 en la fabricación de contrachapado y 18.000 en la fabricación de tableros de partículas y de fibra (O ficina del Censo, 1987). En 1991 había en Canadá 68.400 personas trabajando en serrerías y talleres de cepillado y 8.500 en la fabricación de contrachapado (Statistics Canada, 1993). Aunque la 
Tabla 71.2 - Estimación de la producción de madera por sectores en los 10 mayores productores del mundo (miles de $\mathrm{m}^{3}$ ).

\begin{tabular}{|c|c|c|c|c|c|c|c|}
\hline \multicolumn{2}{|c|}{ Tableros de madera maciza } & \multicolumn{2}{|c|}{ Tableros de contrachapado } & \multicolumn{2}{|c|}{ Tableros de partículas } & \multicolumn{2}{|c|}{ Tableros de fibras } \\
\hline País & Volumen & País & Volumen & País & Volumen & País & Volumen \\
\hline EE.UU. & 109.800 & EE.UU. & 18.771 & Alemania & 7.109 & EE.UU. & 6.438 \\
\hline Antigua URSS & 105.000 & Indonesia & 7.435 & EE.UU. & 6.877 & Antigua URSS & 4.160 \\
\hline Canadá & 54.906 & Japón & 6.415 & Antigua URSS & 6.397 & China & 1.209 \\
\hline Japón & 29.781 & Canadá & 1.971 & Canadá & 3.112 & Japón & 923 \\
\hline China & 23.160 & Antigua URSS & 1.744 & Italia & 3.050 & Canadá & 774 \\
\hline India & 17.460 & Malasia & 1.363 & Francia & 2.464 & Brasil & 698 \\
\hline Brasil & 17.179 & Brasil & 1.300 & Bélgica-Luxemburgo & 2.222 & Polonia & 501 \\
\hline Alemania & 14.726 & China & 1.272 & España & 1.790 & Alemania & 499 \\
\hline Suecia & 12.018 & Corea & 1.124 & Austria & 1.529 & Nueva Zelanda & 443 \\
\hline Francia & 10.960 & Finlandia & 643 & Reino Unido & 1.517 & España & 430 \\
\hline Mundial & 505.468 & Mundial & 47.814 & Mundial & 50.388 & Mundial & 20.248 \\
\hline
\end{tabular}

Fuente: FAO 1993.

producción de madera aumenta, el número de trabajadores de serrerías disminuye a consecuencia de la mecanización y la automatización. El número de trabajadores de serrerías y talleres de mecanizado en Estados U nidos era un $17 \%$ mayor en 1977 que en 1987, y en Canadá era un $13 \%$ mayor en 1986 que en 1991. Se han observado reducciones similares en otros países, como Suecia, donde se están eliminando las operaciones más pequeñas y menos eficientes en favor del trabajo en talleres de mucha mayor capacidad y provistos de modernos equipos. La mayoría de los puestos de trabajo eliminados correspondían a tareas de baja cualificación, como las de clasificación o avance de la madera.

\section{PRINCIPALES SECT ORES Y PRO CESO S: RIESG OS PROFESIONALES Y CONTROLES}

\author{
H ugh Davies, Paul Demers, \\ Timo Kauppinen y Kay Teschke
}

\section{Proceso de aserrado}

Las serrerías pueden ser de muy diversos tamaños. Las más pequeñas son unidades fijas o portátiles constituidas por una sierra principal circular, un sencillo carro portatroncos y una canteadora doble (véanse descripciones a continuación) accionadas por un motor de gasolina o diesel y manejadas por uno 0 dos trabajadores. Las más grandes son estructuras permanentes, disponen de equipos mucho más elaborados y especializados y pueden emplear a más de 1.000 trabajadores. En función del tamaño de la fábrica y del clima de la región, las operaciones pueden realizarse en el interior 0 al aire libre. Aunque el tipo y el tamaño de los troncos determinan en gran medida el tipo de equipos necesarios, éstos varían también considerablemente en función de la antigüedad y las dimensiones de la instalación, así como del tipo y la calidad de los tableros fabricados. A continuación se describen algunos de los procesos que tienen lugar en una serrería típica.

U na vez transportados a la serrería, los troncos se almacenan en tierra, en masas de agua próximas a la fábrica o en estanques construidos para tal fin (véanse las Figuras 71.2 y 71.3). Para ello se clasifican según su calidad, especie u otras características. En las áreas de almacenamiento en tierra suelen utilizarse fungicidas e insecticidas si los troncos van a permanecer almacenados mucho tiempo hasta su transformación. Primero se nivelan los extremos de los troncos con una sierra tronzadora ya sea antes 0 después del descortezado y como paso previo a la elaboración posterior. El descortezado puede realizarse por varios métodos. Entre los mecánicos cabe citar el desenrollo periférico, en el que se hacen girar los troncos presionándolos contra cuchillas; el descortezado anular, en el que se presionan puntas de herramientas contra el tronco; la abrasión por rozamiento de la madera, que se consigue batiendo los troncos entre sí en un tambor giratorio; y la utilización de cadenas para arrancar la corteza. El descortezado puede realizarse también por medios hidráulicos, utilizando chorros de agua de alta presión. LoS troncos y tableros obtenidos tras el descortezado y demás operaciones de la serrería se trasladan de una operación a la siguiente

\section{Figura 71.2 • Carga de astillas con almacenamiento acuático de troncos al fondo.}

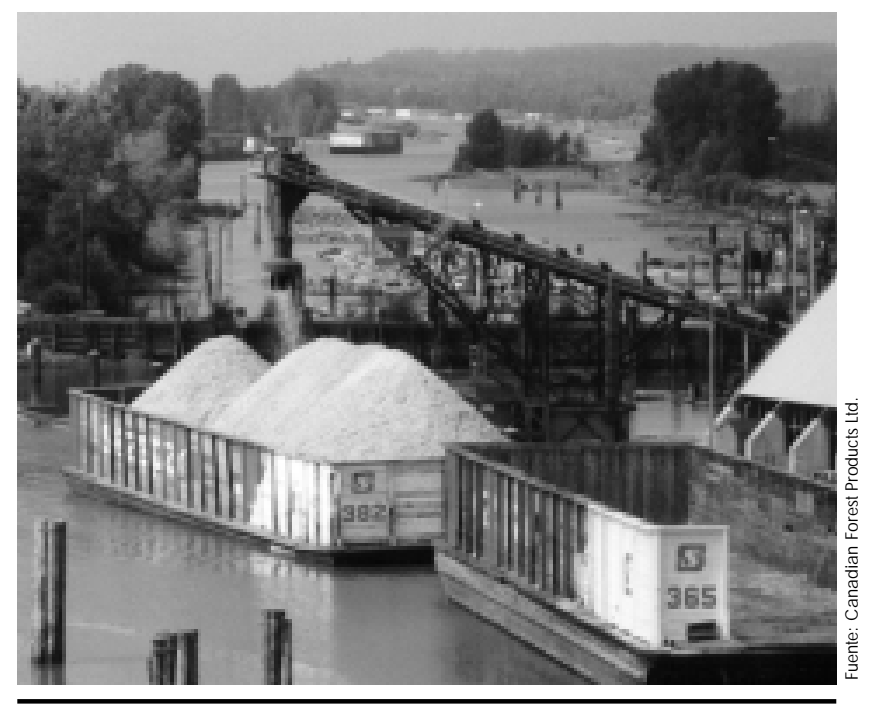


Figura 71.3 • Troncos entrando a una serrería; almacenes y secaderos al fondo.

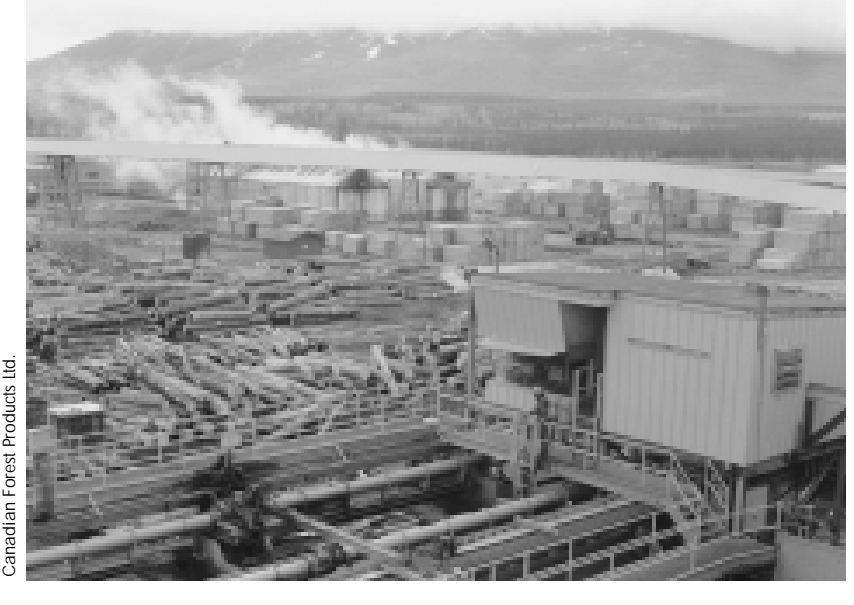

por medio de un sistema de transportadores, cintas y rodillos. En las serrerías grandes, estos sistemas pueden ser bastante complejos (véase la Figura 71.4).

La primera fase del aserrado, también conocida como troceado primario, se realiza en la sierra principal o sierra de cabecera. Esta es una sierra de cinta o sierra circular estacionaria de gran tamaño que se utiliza para cortar el tronco longitudinalmente. El tronco avanza y retrocede a través de ella mediante un carro móvil que puede hacerlo girar para obtener el corte óptimo. 0 tras veces se emplean varias sierras de cinta, especialmente con los troncos más pequeños. Los productos de la sierra de cabecera son un cuerpo de troza (el centro cuadrado del tronco), una serie de costeros (los bordes externos redondeados del tronco) y, en algunos casos, grandes tableros. En las serrerías es cada vez más normal utilizar rayos láser y rayos $X$ como guías visuales y de corte a fin de optimizar el aprovechamiento de la madera y el tamaño y tipo de tableros producidos.

En el troceado secundario, el cuerpo de troza y los grandes tableros o costeros se transforman en productos de dimensiones funcionales. Para estas operaciones suelen utilizarse sierras de varias hojas paralelas: por ejemplo, sierras circulares cuádruples o una batería de sierras, circulares o de guillotina. Para cortar los tableros a un ancho prefijado se utilizan canteadoras, compuestas al menos por dos sierras paralelas, y para cortar a un largo prefijado se utilizan retestadoras. El canteado y retestado suelen realizarse utilizando sierras circulares, aunque las canteadoras son a veces sierras de cinta. En las serrerías se suele disponer de sierras de cadena manuales para liberar la madera atrapada en el sistema por estar curvada o ensanchada. En las serrerías modernas, cada operación (por ej., sierra de cabecera, canteadora) suele ser responsabilidad de un solo operario, por lo general encerrado en una cabina. Además, es posible situar trabajadores entre las distintas operaciones en fases posteriores del troceado secundario para garantizar manualmente el correcto posicionamiento de los tableros para las siguientes operaciones.

Tras su elaboración en la serrería, los tableros se clasifican y seleccionan según sus dimensiones y calidad y se apilan manual o mecánicamente (véase la Figura 71.5). Si la madera se manipula manualmente, el área correspondiente recibe el nombre de "cadena verde". En muchas fábricas modernas se han instalado cajones de clasificación automáticos que sustituyen a la laboriosa clasificación manual. A fin de aumentar la circulación del aire
Figura 71.4 • Interior de la fábrica; cintas y rodillos de transporte de madera.

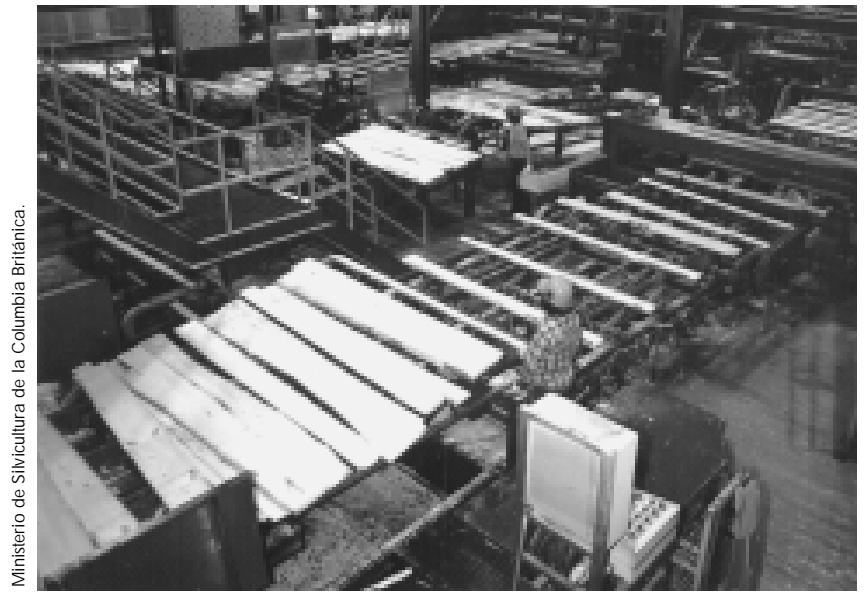

para acelerar el secado, pueden colocarse pequeños trozos de madera entre los tableros en el momento de apilarlos.

La madera de construcción puede secarse al aire libre o en cámaras de secado, en función de las condiciones climáticas locales y de la humedad de la madera verde, pero la madera de acabado se seca normalmente en cámara. $\mathrm{H}$ ay muchos tipos de secaderos. L os de compartimiento y los de alta temperatura son secaderos en serie. En los secaderos continuos, las pilas atadas pueden circular por el secadero en posición perpendicular 0 paralela, y la dirección de movimiento del aire puede ser perpendicular o paralela a los tableros. Como material aislante para los tubos de vapor de los secaderos se ha venido utilizando amianto.

Antes de almacenar madera verde, especialmente en lugares húmedos, pueden aplicarse fungicidas para evitar el desarrollo de hongos que produzcan coloraciones azules o negras en la madera (manchas). La aplicación de fungicidas puede hacerse también en la cadena de producción (habitualmente por rociado) o después de atar la madera (generalmente en tanques de inmersión). En el decenio de 1940 se introdujo la sal sódica del pentaclorofenol para controlar las manchas, aunque se reemplazó en el decenio de 1960 por el tetraclorofenato, más soluble en agua. El clorofenato se ha dejado de utilizar en gran parte debido a la preocupación por sus efectos para la salud y la

Figura 71.5 - Carretilla elevadora cargada.

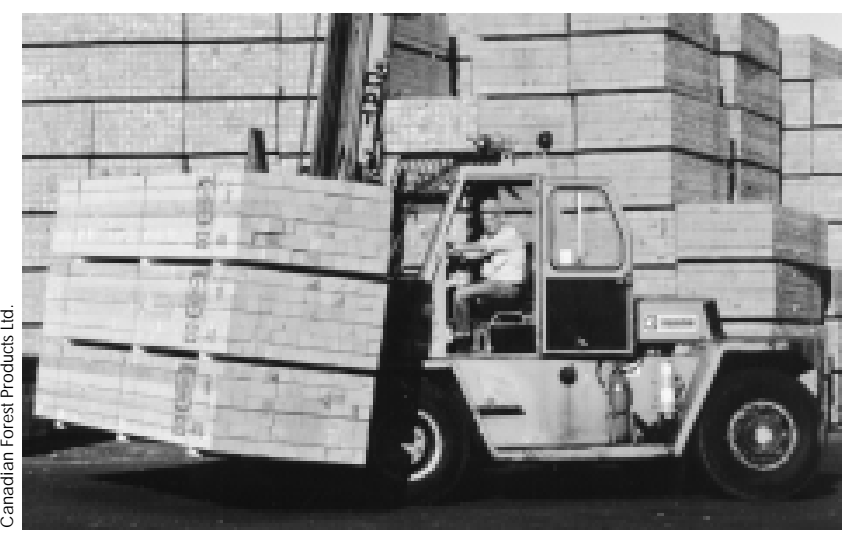


contaminación con dibenzo-p-dioxinas policloradas. Como sustitutivos cabe citar el cloruro de amonio didecildimetílico, el 3-yodo-2-propinil-butil-carbamato, el azaconazol, el bórax y el 2-(tiocianometiltio)benzotiazol, la mayoría de los cuales se han estudiado poco entre los trabajadores usuarios. A menudo no es necesario tratar la madera, especialmente la que se ha secado en cámara. La procedente de algunas especies, como el cedro rojo occidental, no presenta nunca manchas.

Antes o después del secado, la madera puede comercializarse como madera verde o basta; sin embargo, para la mayoría de los usos industriales debe someterse a elaboración adicional. La madera se corta a la medida definitiva y se labra en un taller de cepillado. Las cepilladoras se utilizan para reducir la madera a medidas estándar comercializables y para alisar la superficie. El cabezal de cepillado está formado por una serie de hojas de corte montadas sobre un cilindro que gira a alta velocidad. La operación suele realizarse con alimentación automática y en paralelo al grano de la madera. El cepillado suele realizarse simultáneamente por ambos lados del tablero. Las cepilladoras que trabajan los cuatro lados se denominan machihembradoras. A veces se utilizan molduradoras para redondear los bordes de la madera.

Tras la elaboración definitiva, la madera ha de clasificarse, apilarse y atarse con vistas al transporte. Estas operaciones están cada vez más automatizadas. En algunos talleres especializados, la madera se trata adicionalmente con agentes químicos utilizados como conservantes o ignífugos, o para proteger su superficie del desgaste mecánico o de la intemperie. Por ejemplo, las traviesas de vías férreas, pilotes, postes de cercados, postes telefónicos u otros artículos de madera que hayan de estar en contacto con el suelo o el agua se tratan a presión con arseniato de cobre amoniacal o de cromatos, pentaclorofenol o creosota en aceite derivado del petróleo. También se utilizan tinturas y colorantes para mejorar su comercialización, y pinturas para sellar los extremos de los tableros o para añadir marcas de empresa.

El serrado y demás operaciones de transformación de la madera de las serrerías producen grandes cantidades de serrín y residuos. En muchas serrerías, los costeros y otras grandes piezas de madera se reducen a astillas. Las astilladoras suelen ser grandes discos giratorios con hojas rectas empotradas en la superficie y provistos de ranuras para que pasen las astillas. Estas se producen cuando se pasan los troncos o los desechos de mecanizado por las hojas utilizando alimentación inclinada por gravedad, autoalimentación horizontal o alimentación automática controlada. La acción de corte de la astilladora suele ser perpendicular a las hojas. Para los troncos enteros se utilizan diseños diferentes que para los costeros, cantos y otros trozos de madera residual. Es normal que la astilladora esté integrada en la sierra de cabecera para astillar los costeros inservibles. También se utilizan astilladoras independientes para los desechos del resto del taller. El serrín y las astillas de madera pueden venderse para fabricar pasta, tableros reconstituidos, para elementos de paisajismo, como combustible o para otros usos. La corteza, las astillas, el serrín y otros materiales también pueden quemarse, bien como combustible o como residuos.

L as grandes serrerías modernas suelen disponer de una considerable plantilla de técnicos de mantenimiento: operarios de limpieza, montadores (mecánica industrial), carpinteros, electricistas y otros trabajadores cualificados. Si no se dispone de ventilación por aspiración localizada o los equipos no funcionan correctamente, puede acumularse material residual en la maquinaria, transportadores y suelos. Las correspondientes operaciones de limpieza suelen realizarse con aire comprimido para eliminar el polvo depositado en las máquinas, suelos y otras superficies. Es preciso inspeccionar las sierras periódicamente en busca de dientes rotos, grietas u otros defectos, y equilibrarlas correctamente para evitar vibraciones. De esto se ocupan unos profesionales típicos de la industria maderera: los afiladores, que son responsables de afilar, reconstruir los dientes y otras tareas de mantenimiento de sierras circulares y sierras de cinta.

\section{Riesgos para la seguridad y la salud en las serrerías}

La Tabla 71.3 indica los principales tipos de riesgos para la seguridad y la salud en el trabajo en una serrería típica. Son muchos los peligros graves. Es necesario instalar defensas en el punto de manejo de sierras y otros aparatos de corte, así como de engranajes, correas, cadenas, piñones y puntos de atrapamiento de transportadores, correas y rodillos. En muchas operaciones, como las relacionadas con las sierras circulares, hay que instalar dispositivos antirretroceso para evitar que las piezas de madera atascadas salgan disparadas de la máquina. Se han de instalar barandillas en pasillos que discurren junto a las operaciones 0 pasarelas que atraviesan transportadores y otras líneas de producción. Es necesario mantener el orden y la limpieza para evitar la acumulación peligrosa de serrín y residuos de la madera, que puedan provocar caídas y comporten un riesgo de incendio y explosión. M uchas de las áreas que requieren limpieza y mantenimiento rutinario están situadas en zonas peligrosas que normalmente permanecen inaccesibles mientras la serrería está en funcionamiento. El correcto cumplimiento de los procedimientos de bloqueo de maquinaria es de suma importancia durante las operaciones de mantenimiento, reparación y limpieza. Los equipos móviles deben dotarse de señales luminosas y acústicas de advertencia. Los caminos peatonales y las vías de tránsito rodado deben quedar claramente señalizados. También es necesario utilizar chalecos reflectantes para aumentar la visibilidad de los peatones.

La clasificación, selección y otras operaciones pueden implicar la manipulación manual de tableros y otras piezas pesadas de madera. Deben utilizarse transportadores y cajones de recepción de diseño ergonómico y técnicas apropiadas de manipulación de materiales que contribuyan a evitar lesiones de espalda y de las extremidades superiores. Es necesario utilizar guantes para evitar clavarse astillas, pincharse y el contacto con los productos conservantes. Entre los operarios y los puntos de trabajo deben colocarse pantallas de cristal de seguridad o materiales similares, debido al riesgo de que el serrín, las astillas y otros residuos expulsados por las sierras provoquen lesiones oculares y de otro tipo. Los rayos láser también presentan riesgos oculares y han de identificarse las áreas en las que se utilicen aparatos láser de las clases II, III o IV, colocando letreros de advertencia. En la mayoría de las operaciones de la serrería, los operarios deben llevar equipos de protección individual, como gafas de seguridad, cascos y botas de punta de acero.

En la mayoría de las zonas de las serrerías existe un nivel de ruido peligroso producido por las operaciones de descortezado, serrado, canteado, retestado, cepillado y astillado, así como por el golpeo de los troncos en los transportadores, rodillos y clasificadoras. Entre los controles técnicos viables para reducir los niveles de ruido cabe citar las cabinas insonorizadas para operarios, el encerramiento de las máquinas cortadoras con material insonorizante en las entradas y salidas, y la construcción de barreras insonorizantes. También es posible utilizar otros controles técnicos. Por ejemplo, el ruido de funcionamiento de las sierras circulares en vacío puede reducirse utilizando sierras cuyos dientes sean de forma adecuada 0 ajustando la velocidad de rotación. $L a$ instalación de material insonorizante en paredes y techos puede contribuir a reducir el ruido reflejado por toda la fábrica, aunque será necesario un control en la fuente cuando la exposición al mismo sea directa. 
Tabla 71.3 • Riesgos para la seguridad y la salud en el trabajo, por procesos industriales.

\begin{tabular}{|c|c|c|c|c|}
\hline Proceso & Riesgos para la seguridad & Riesgos físicos & $\begin{array}{l}\text { Riesgos por polvol } \\
\text { productos químicos }\end{array}$ & $\begin{array}{l}\text { Riesgos } \\
\text { biológicos }\end{array}$ \\
\hline Patio y estanque & $\begin{array}{l}\text { Equipos móviles;* maderas/ troncos sueltos;* cintas } \\
\text { transportadoras }\end{array}$ & $\begin{array}{l}\text { Ruido; temperaturas } \\
\text { extremas }\end{array}$ & $\begin{array}{l}\text { Polvo del camino, otras } \\
\text { partículas; pesticidas }\end{array}$ & $\begin{array}{l}\text { Mohos y } \\
\text { bacterias* }\end{array}$ \\
\hline Descortezado & $\begin{array}{l}\text { Pasos elevados; retroceso de máquinas; maderas/ troncos sueltos;* } \\
\text { cintas transportadoras; sierras/ equipos de corte; residuos } \\
\text { volantes;" no bloquear la maquinaria }\end{array}$ & Ruido & $\begin{array}{l}\text { Polvo de madera; polvo del } \\
\text { camino; otras partículas; } \\
\text { componentes volátiles de } \\
\text { la madera }\end{array}$ & $\begin{array}{l}\text { Mohos y } \\
\text { bacterias* }\end{array}$ \\
\hline $\begin{array}{l}\text { Aserrado, } \\
\text { retestado, } \\
\text { canteado }\end{array}$ & $\begin{array}{l}\text { Pasos elevados; retroceso de máquinas;* maderas/ troncos sueltos; } \\
\text { cintas transportadoras;* sierras/ equipos de corte;* residuos } \\
\text { volantes; astillas; no bloquear la maquinaria* }\end{array}$ & $\begin{array}{l}\text { Ruido; lesiones por esfuerzos } \\
\text { repetitivos }\end{array}$ & $\begin{array}{l}\text { Polvo de madera;* compo- } \\
\text { nentes volátiles de la } \\
\text { madera* }\end{array}$ & $\begin{array}{l}\text { Mohos y } \\
\text { bacterias }\end{array}$ \\
\hline Secado en cámara & Equipos móviles & Extremos de temperatura & $\begin{array}{l}\text { Componentes volátiles } \\
\text { de la madera, amianto }\end{array}$ & $\begin{array}{l}\text { Mohos y } \\
\text { bacterias }\end{array}$ \\
\hline Cepillado & $\begin{array}{l}\text { Pasos elevados; retroceso de máquinas;* maderas/ troncos sueltos; } \\
\text { cintas transportadoras;* sierras/ equipos de corte;* residuos } \\
\text { volantes; astillas; no bloquear la maquinaria }\end{array}$ & $\begin{array}{l}\text { Ruido;* lesiones por } \\
\text { esfuerzos repetitivos }\end{array}$ & $\begin{array}{l}\text { Polvo de madera; compo- } \\
\text { nentes volátiles de la } \\
\text { madera; pesticidas }\end{array}$ & \\
\hline Clasificación & $\begin{array}{l}\text { Pasos elevados; maderas/ troncos sueltos; cintas transportadoras;" } \\
\text { astillas; no bloquear la maquinaria }\end{array}$ & $\begin{array}{l}\text { Ruido; lesiones por } \\
\text { esfuerzos repetitivos* }\end{array}$ & Polvo de madera; pesticidas & \\
\hline $\begin{array}{l}\text { Astillados y } \\
\text { operaciones } \\
\text { relacionadas }\end{array}$ & $\begin{array}{l}\text { Pasos elevados; retroceso de máquinas; cintas transportadoras; } \\
\text { sierras/ equipos de corte; * residuos volátiles; }{ }^{*} \text { no bloquear la } \\
\text { maquinaria }\end{array}$ & Ruido* & $\begin{array}{l}\text { Polvo de madera;* compo- } \\
\text { nentes volátiles de la } \\
\text { madera }\end{array}$ & $\begin{array}{l}\text { Mohos y } \\
\text { bacterias* }\end{array}$ \\
\hline Corte de chapa & $\begin{array}{l}\text { Pasos elevados; equipos móviles; cintas transportadoras; } \\
\text { sierras/ equipos de corte; astillas; no bloquear la maquinaria }\end{array}$ & Ruido* & $\begin{array}{l}\text { Polvo de madera; compo- } \\
\text { nentes volátiles de la } \\
\text { madera }\end{array}$ & $\begin{array}{l}\text { Mohos y } \\
\text { bacterias* }\end{array}$ \\
\hline Secado de chapa & Equipos móviles; astillas & $\begin{array}{l}\text { Temperaturas extremas; } \\
\text { lesiones por esfuerzos } \\
\text { repetitivos }\end{array}$ & $\begin{array}{l}\text { Componentes volátiles de la } \\
\text { madera; amianto }\end{array}$ & $\begin{array}{l}\text { Mohos y } \\
\text { bacterias }\end{array}$ \\
\hline $\begin{array}{l}\text { Mezcla de colas y } \\
\text { parcheado }\end{array}$ & & $\begin{array}{l}\text { Lesiones por esfuerzos } \\
\text { repetitivos }\end{array}$ & $\begin{array}{l}\text { Formaldehido:* otros } \\
\text { componentes de las } \\
\text { resinas* }\end{array}$ & \\
\hline $\begin{array}{l}\text { Operaciones de } \\
\text { prensado } \\
\text { en caliente }\end{array}$ & Equipos móviles; astillas; no bloquear la maquinaria* & $\begin{array}{l}\text { Ruido; lesiones por esfuerzos } \\
\text { repetitivos }\end{array}$ & $\begin{array}{l}\text { Componentes volátiles de la } \\
\text { madera; formaldehido; }{ }^{*} \\
\text { otros componentes de las } \\
\text { resinas* }\end{array}$ & \\
\hline $\begin{array}{l}\text { Lijado y acabado } \\
\text { de paneles }\end{array}$ & $\begin{array}{l}\text { Equipos móviles; sierras/ equipos de corte; residuos volantes; } \\
\text { astillas; no bloquear la maquinaria }\end{array}$ & $\begin{array}{l}\text { Ruido; * lesiones por esfuerzos } \\
\text { repetitivos }\end{array}$ & $\begin{array}{l}\text { Polvo de madera; formal- } \\
\text { dehido; otros compo- } \\
\text { nentes de las resinas }\end{array}$ & \\
\hline $\begin{array}{l}\text { Operaciones } \\
\text { de limpieza }\end{array}$ & $\begin{array}{l}\text { Pasos elevados; cintas transportadoras; }{ }^{*} \text { residuos volantes;* asti- } \\
\text { Ilas; no bloquear la maquinaria* }\end{array}$ & Ruido & $\begin{array}{l}\text { Polvo de madera; } * \text { formal- } \\
\text { dehido; otros compo- } \\
\text { nentes de las resinas; } \\
\text { amianto }\end{array}$ & $\begin{array}{l}\text { Mohos y } \\
\text { bacterias* }\end{array}$ \\
\hline Afilado de sierras & $\begin{array}{l}\text { Pasos elevados; sierras/ equipos de corte; residuos volantes; } \\
\text { no bloquear la maquinaria }\end{array}$ & Ruido & Humos metálicos* & \\
\hline $\begin{array}{l}\text { Otras tareas de } \\
\text { mantenimiento }\end{array}$ & $\begin{array}{l}\text { Pasos elevados; equipos móviles; * no bloquear } \\
\text { la maquinaria* }\end{array}$ & & $\begin{array}{l}\text { Polvo de madera; amianto; } \\
\text { humos metálicos }\end{array}$ & \\
\hline $\begin{array}{l}\text { Embalaje y } \\
\text { envío }\end{array}$ & $\begin{array}{l}\text { Pasos elevados; equipos móviles;* maderas/ troncos sueltos; } \\
\text { cintas transportadoras; astillas; no bloquear la maquinaria }\end{array}$ & $\begin{array}{l}\text { Ruido; temperaturas } \\
\text { extremas; lesiones por } \\
\text { esfuerzos repetitivos }\end{array}$ & $\begin{array}{l}\text { Polvo del camino, otras } \\
\text { partículas; pesticidas }\end{array}$ & \\
\hline
\end{tabular}

Los trabajadores de casi todas las áreas de la serrería pueden verse expuestos a la proyección de material en partículas. Las operaciones de descortezado prácticamente no producen serrín, ya que el objetivo es dejar la madera intacta, pero sí es posible que el aire contenga tierra, cortezas y agentes biológicos en suspensión, tales como bacterias y hongos. Los trabajadores de casi todas las áreas de aserrado, astillado y cepillado pueden verse expuestos al polvo de madera. El calor generado por estas operaciones puede provocar exposición a los elementos volátiles de la madera, como los monoterpenos, aldehídos, cetonas y otros, que varían en función de la especie de árbol y de la temperatura. Algunos de los trabajadores más expuestos al serrín son los que utilizan aire comprimido para limpiar. Los que trabajan cerca de los secaderos se ven expuestos a los elementos volátiles de la madera. Además, pueden darse exposiciones a bacterias y hongos patógenos, que se desarrollan a 
temperaturas inferiores a $70^{\circ} \mathrm{C}$. Existe también el peligro de exposición a bacterias y hongos durante la manipulación de astillas y desechos de la madera, y durante el transporte de los troncos en el patio del almacén.

Existen controles técnicos viables, como una ventilación por aspiración localizada, para controlar los niveles de contaminantes suspendidos en el aire, y es posible combinar medidas para controlar el ruido y el polvo. Así, las cabinas cerradas reducen la exposición tanto al ruido como al serrín (y previenen lesiones oculares y de otro tipo). Sin embargo, sólo protegen al operario encerrado en ellas, y es preferible controlar la exposición en origen aislando las operaciones, sobre todo las de cepillado. En algunas fábricas se aplican métodos de limpieza por aspiración y mojado, habitualmente por los contratistas de limpieza, pero no son de uso general. La exposición a hongos y bacterias puede controlarse reduciendo 0 aumentando las temperaturas de los secaderos y tomando otras medidas para eliminar las condiciones propicias al desarrollo de estos microorganismos.

En las serrerías existen otras exposiciones potencialmente peligrosas. Es posible quedar expuesto a frío y calor extremos cerca de los puntos por donde los materiales entran o salen de la nave, y el calor es también un riesgo en las zonas de secaderos. 0 tro factor de riesgo es el alto nivel de humedad al serrar troncos mojados. La exposición a los fungicidas se produce principalmente por vía cutánea y puede darse si se manejan los tableros mientras todavía están mojados durante la clasificación y otras operaciones. Al manejar tableros mojados con fungicidas, deben utilizarse guantes y delantales apropiados. En las operaciones de pulverizado debe utilizarse ventilación por aspiración localizada con cortinas de pulverización y eliminadores de aerosoles y nieblas. Los equipos móviles utilizados para trasladar troncos y madera de un almacén a otro y para cargar los semirremolques o vagones de ferrocarril pueden provocar exposición al monóxido de carbono y a otros productos de la combustión. Los afiladores de sierras pueden verse expuestos a niveles peligrosos de humos y polvos, como los de cobalto, cromo y plomo procedente de las operaciones de amolado y soldadura. Es necesario instalar defensas en la maquinaria y ventilación por aspiración localizada.

\section{Procesos de elaboración de chapa y contrachapado}

Se llama contrachapado al panel constituido por tres o más chapas pegadas con cola. EI término se aplica asimismo a los paneles con un núcleo compuesto por listones de madera maciza y a los tableros de partículas revestido de chapa por ambos lados. El contrachapado puede fabricarse con madera de diversos árboles, incluidas coníferas y otras especies.

L as chapas suelen elaborarse directamente, a partir de troncos enteros descortezados, en un torno de desenrollado. Para ello se hace girar el tronco contra una barra de presión al mismo tiempo que toca una cuchilla que produce una fina lámina de entre 0,25 y $5 \mathrm{~mm}$ de grosor. Los troncos utilizados en este proceso pueden remojarse en agua caliente o vapor para ablandarlos antes del proceso de corte. L os bordes de la lámina suelen ser recortados por las cuchillas unidas a la barra de presión. Pueden obtenerse chapas decorativas rebanando un cuerpo de troza (el centro cuadrado del tronco) utilizando un brazo de presión y una hoja de corte de manera similar a la obtención de chapas. Tras el laminado o rebanado, las chapas se recogen en largas bandejas planas o se enrollan en carretes. Se cortan a medidas funcionales utilizando una máquina tipo guillotina y se secan utilizando calefacción artificial o ventilación natural. Los paneles secos son inspeccionados y, si es necesario, parcheados con pequeños trozos o listones de madera y resinas a base de formaldehído. Si las chapas secas son más pequeñas que un panel de medidas estándar, pueden empalmarse, aplicando en los bordes un adhesivo líquido a base de formaldehído, uniendo los bordes a presión y aplicando calor para curar la resina.

Para producir los paneles, se forma una chapa, se le aplica una capa de resina a base de formaldehído por medio de un rodillo o pulverizador, y se coloca entre dos chapas sin encolar con su grano en dirección perpendicular. El conjunto pasa después a una prensa caliente, donde se somete a presión y calor para solidificar la resina. Los adhesivos a base de resina fenólica son muy utilizados para fabricar contrachapado de madera blanda destinada a soportar duras condiciones de servicio, como es el caso de la construcción de edificios y barcos. L os adhesivos a base de resinas de urea se utilizan mucho para fabricar contrachapado de madera dura para muebles y paneles interiores; estos pueden reforzarse con resina melamínica para aumentar su resistencia. Las fábricas de contrachapado llevan más de 30 años utilizando colas para ensamblado a base de formaldehído. Antes de la introducción de estas resinas en el decenio de 1940, se empleaban adhesivos a base de soja y albúmina animal, y era habitual el prensado en frío de los paneles. Puede que estos métodos todavía se utilicen, pero son cada vez más raros.

L os paneles se cortan a la medida adecuada utilizando sierras circulares y se alisan utilizando grandes lijadoras de cinta o rotativas. También puede realizarse un mecanizado adicional para dar al contrachapado características especiales. En algunos casos, se añaden a las colas plaguicidas tales como clorofenoles, lindano, aldrín, heptacloro, cloronaftalenos y óxido de tributilzina, o se trata con ellos la superficie de los paneles. 0 tros tratamientos superficiales implican la aplicación de aceites ligeros derivados del petróleo (para paneles de encofrado), pinturas, tinturas, lacas y barnices. Todos ellos pueden aplicarse en lugares separados. Las chapas y los paneles suelen transportarse de una operación a otra por medio de equipos móviles.

\section{Riesgos derivados de la elaboración de chapas y contrachapado}

La Tabla 71.3 indica los principales tipos de riesgos para la seguridad y la salud en el trabajo en una fábrica típica de contrachapado. Muchos de ellos son parecidos a los existentes en las serrerías, y las medidas de control también son semejantes. En esta sección sólo se tratan las cuestiones que difieren de las operaciones de aserrado.

Los obreros que trabajan en las operaciones de preparación de colas, empalme, parcheado, lijado y prensado en caliente, y los que trabajan en las proximidades, pueden verse expuestos por vía cutánea y respiratoria al formaldehído y a otros componentes de las colas, resinas y adhesivos. Las resinas de urea liberan formaldehído durante el curado más fácilmente que las fenólicas; con todo, las mejoras logradas en la formulación de resinas han reducido estas exposiciones. Es necesario disponer de una ventilación por aspiración localizada y utilizar guantes y otros equipos protectores apropiados para reducir la exposición cutánea y respiratoria al formaldehído y otros componentes de las resinas.

La madera utilizada para producir chapas está mojada, y las operaciones de desenrollado y corte no suelen producir mucho polvo. Las operaciones de producción de contrachapado que más exposición al polvo producen son las de lijado, mecanizado y aserrado necesarias para el acabado. En particular, el lijado produce grandes cantidades de polvo fino porque durante el labrado puede eliminarse entre un 10 y un $15 \%$ del tablero. Estos procesos deben estar encerrados y tener ventilación por aspiración localizada; las lijadoras manuales deben disponer de aspiración integrada mediante una bolsa de recogida del polvo. $\mathrm{Si}$ no se dispone de ventilación localizada o no funciona 
correctamente, la exposición al polvo de madera puede ser importante. En las fábricas de contrachapado es muy normal utilizar métodos de limpieza húmedos y por aspiración, porque el pequeño tamaño de las partículas de polvo resta eficacia a otros métodos. Si no existen medidas de control del ruido, los niveles de ruido producidos por las operaciones de lijado, aserrado y mecanizado pueden superar los $90 \mathrm{dBA}$.

Una vez secas las chapas, pueden liberarse varios componentes químicos de la madera, tales como monoterpenos, ácidos de las resinas, aldehídos y cetonas. Los tipos y cantidades de los productos químicos liberados dependen de la especie del árbol y de la temperatura del secador de chapa. Es necesario disponer de una ventilación por aspiración adecuada y reparar inmediatamente las fugas del secador de chapa. L os trabajadores pueden verse expuestos a los humos de escape de los motores de las carretillas elevadoras en toda la fábrica, y los equipos móviles también presentan un riesgo para la seguridad. Los plaguicidas mezclados con las colas apenas son volátiles y no deberían ser detectables en el aire ambiental del lugar de trabajo, con la excepción de los cloronaftalenos, que se evaporan notablemente. La exposición a los plaguicidas puede producirse por vía cutánea.

\section{Otras industrias de manufactura de tableros}

Este grupo de industrias, en el que se incluyen la manufactura de tableros de partículas, de tableros de obleas, tableros de hebras, tableros aislantes, tableros de fibra y tableros duros, produce tableros compuestos por elementos de madera de varios tamaños, desde grandes escamas u obleas hasta fibras, unidas por colas resinosas 0 , en el caso de los tableros de fibra elaborados por procesos húmedos, por la unión "natural" entre las fibras. En el proceso más sencillo, los tableros se fabrican en dos fases. La primera fase es la producción de los elementos, bien directamente a partir de los troncos enteros o bien como subproducto residual de otros ámbitos de la industria maderera, como las serrerías. La segunda fase es su recombinación en forma de planchas o paneles utilizando adhesivos químicos.

Los tableros de partículas, de escamas, de hebras y de obleas se elaboran con astillas de madera de varios tamaños y formas utilizando procesos similares. Los de partículas y de escamas se elaboran con pequeños elementos de madera y se destinan en general a la elaboración de paneles de chapa de madera o laminados de plástico para la fabricación de muebles, armarios y otros productos de madera. La mayoría de los elementos se obtienen directamente de los desechos de la madera. Los tableros de obleas y de hebras se elaboran con partículas muy grandes - virutas y hebras de madera, respectivamente- y se utilizan principalmente para aplicaciones estructurales. Por lo general, los elementos se obtienen directamente de los troncos, utilizando una máquina provista de una serie de cuchillas giratorias que cortan finas obleas. El diseño puede ser parecido al de una astilladora, excepto que la madera debe alimentarse a la cortadora con el grano orientado en paralelo a las cuchillas. También pueden utilizarse diseños de desarrollo periférico. En estos procesos es mejor utilizar madera saturada de agua y, como la madera debe estar orientada, suelen utilizarse troncos cortos.

A ntes de elaborar las planchas o paneles, es preciso clasificar los elementos por su tamaño y calidad, y después secarlos por medios artificiales controlando estrictamente la humedad. Los elementos secos se mezclan con un adhesivo y se extienden en mantas. Se utilizan tanto resinas de formaldehído fenólico como de formaldehído ureico. Como ocurre con el contrachapado, las resinas fenólicas se utilizan más con paneles destinados a aplicaciones que requieren durabilidad en condiciones adversas, mientras que las de urea-formaldehído se emplean para aplicaciones interiores, menos exigentes. Las resinas de melamina-formal- dehído también aumentan la durabilidad, pero son más caras. En las últimas décadas, ha surgido una nueva industria de producción de madera reconstituida para varios usos estructurales, como vigas, soportes y otros elementos de apoyo de cargas. Aunque los procesos de fabricación pueden ser parecidos a los utilizados para los tableros de partículas, se utilizan resinas a base de isocianatos, debido a la mayor resistencia que se precisa.

Las mantas se dividen en secciones a la medida del panel, utilizando generalmente un equipo automático de aire comprimido o una hoja recta. Esta operación se realiza en un recinto cerrado, de modo que pueda reciclarse el material sobrante de la manta. Los paneles se unen para formar planchas por medio de una resina termoestable que se solidifica en una prensa caliente en un proceso similar a la elaboración del contrachapado. Posteriormente los paneles se enfrían y se recortan a medida. En caso necesario, se utilizan lijadoras para el acabado superficial. Por ejemplo, los tableros reconstituidos que han de recubrirse con una chapa de madera o laminado plástico deben lijarse para obtener una superficie relativamente lisa y uniforme. Aunque antes se utilizaban en esta industria lijadoras rotativas, en la actualidad se utilizan generalmente lijadoras de cinta. También pueden aplicarse revestimientos superficiales.

Los tableros de fibra (incluidos los tableros aislantes, los de fibra de densidad media (FDM ) y los tableros duros) son paneles compuestos por fibras de madera enlazadas. Su producción es algo distinta de la de los tableros de partículas y otros tableros manufacturados. (véase la Figura 71.1). Para producir las fibras, se reducen (a pasta) pequeños troncos 0 astillas de madera de forma similar a lo que se hace para producir pasta para la industria papelera (véase el capítulo Industria del papel y la pasta de papel). En general, se utiliza un proceso de desfibrado mecánico por el que se remojan las astillas en agua caliente y después se trituran mecánicamente. L os tableros de fibra pueden ser de muy diversa densidad, desde tableros aislantes de baja densidad hasta tableros duros, y se elaboran con madera de coníferas u otras especies. Para fabricar tableros duros es mejor utilizar otras especies, mientras que las coníferas son mejores para los tableros aislantes. L os procesos que intervienen en el desfibrado tienen un efecto químico menor sobre la madera triturada, eliminando una pequeña cantidad de lignina y otros materiales extraíbles.

Pueden utilizarse dos procesos diferentes, húmedo y seco, para unir las fibras y producir los paneles. Los tableros duros (tableros de fibra de alta densidad) y FDM pueden elaborarse por medio de procesos "húmedos" o "secos", mientras que los tableros aislantes (tableros de fibra de baja densidad) se han de elaborar por medio del proceso húmedo. Fue éste el que se desarrolló en primer lugar, y procede de la producción de papel, mientras que el proceso seco se desarrolló posteriormente y se deriva de las técnicas de elaboración de tableros de partículas. En el proceso húmedo, se distribuye una lechada de pasta y agua sobre un tamiz para formar una manta que después se prensa, se seca, se corta y se labra. Los tableros elaborados por procesos húmedos unen gracias a componentes de la madera parecidos a los adhesivos y a la formación de enlaces de hidrógeno. El proceso seco es similar, excepto en que las fibras se distribuyen sobre la manta tras la adición de un ligante (ya sea una resina termoestable, una resina termoplástica o un aceite secante) para que se unan las fibras. Por lo general, se utilizan resinas de fenol-formaldehído o urea-folmaldehído. A veces se emplean otros productos químicos diversos como aditivos, incluyendo sales inorgánicas como agentes ignífugos y fungicidas como agentes conservantes.

En general, los riesgos para la seguridad y la salud en las fábricas de tableros de partículas y otros tableros manufacturados son bastante parecidos a los existentes en las fábricas de 
contrachapado, con la excepción de las operaciones de desfibrado para la producción de tableros de fibra (véase la Tabla 71.3). La elaboración de los elementos puede implicar una exposición al polvo de madera, que varía mucho en función de la humedad de la madera y de la naturaleza de los procesos. Las operaciones de corte y acabado de los paneles, especialmente el lijado, son las que suponen una mayor exposición al polvo de madera si no existen controles técnicos o no funcionan correctamente. La mayoría de las lijadoras son sistemas cerrados, y se necesitan sistemas de aire de gran capacidad para eliminar el polvo generado. Los trabajadores que realizan las operaciones de astillado y trituración de madera secada y los que intervienen en el transporte de las astillas desde los almacenes hasta las áreas de proceso también pueden verse expuestos al polvo, así como a hongos y bacterias. Es posible quedar expuesto a niveles muy altos de ruido cerca de las operaciones de lijado, astillado, trituración y otras operaciones de transformación de la madera. Es posible quedar expuesto al formaldehído y a otros componentes de las resinas durante las operaciones de mezcla de colas, preparación de las mantas y prensado en caliente. Las medidas de control para limitar la exposición a los riesgos para la seguridad, al polvo de madera, al ruido y al formaldehído aplicadas en las fábricas de tableros son parecidas a las aplicables a las fábricas de contrachapado y serrerías.

\section{LESIONES Y ENFERMEDADES}

Paul Demers

\section{Lesiones}

Las serrerías y otros talleres de transformación de la madera son ambientes de trabajo extremadamente peligrosos debido a la naturaleza del proceso, que comporta el movimiento y corte de trozos de madera muy grandes y pesados a velocidades relativamente altas. Aunque se disponga de buenos controles técnicos, es preciso cumplir estrictamente normas y procedimientos de seguridad. Existen varios factores generales que pueden contribuir al riesgo de lesiones. No mantener el orden y la limpieza adecuadamente aumenta el riesgo de resbalones, tropezones y caídas, y el polvo de madera puede plantear un peligro de incendio o explosión. Los altos niveles de ruido han provocado lesiones debido a la menor capacidad de los trabajadores para comunicarse y oír las señales acústicas de advertencia. M uchas fábricas grandes trabajan en varios turnos, y las horas de trabajo, en especial los cambios de turno, pueden aumentar las probabilidades de accidente.

Entre los accidentes más comunes con riesgo de que se produzcan heridas muy graves o mortales hay que citar los golpes por los equipos móviles; las caídas de plataformas y pasos elevados; la no desconexión o bloqueo de los equipos mientras se realizan tareas de mantenimiento o se intenta eliminar atascos; los golpes por el retroceso de sierras, canteadoras y cepilladoras; y el ahogamiento en vías fluviales de conducción de troncos 0 estanques de almacenamiento. Los trabajadores de reciente contratación corren un riesgo mayor. Por ejemplo, en un análisis de las causas de 37 fallecimientos ocurridos en serrerías entre 1985 y 1994 en la Columbia Británica, Canadá, 13 (el 35 \%) de ellas ocurrieron durante el primer año de empleo, y 5 de estas últimas durante la primera semana de empleo (4 el primer día) (H oward, 1995).

También existe un alto riesgo de lesiones no mortales. Las partículas y pequeños trozos de madera 0 residuos expulsados por la maquinaria pueden provocar lesiones oculares. EI contacto entre la madera y la piel sin proteger puede dar lugar a pinchazos, cortes y astillas clavadas. Intentar empujar 0 levantar materiales pesados durante la clasificación y selección u otras operaciones implica riesgo de torceduras, esguinces y otras lesiones musculoesqueléticas.

\section{Enfermedades no malignas}

Los trabajadores de serrerías e industrias relacionadas están expuestos a diversos riesgos para el sistema respiratorio, causados por el polvo de madera, los componentes volátiles de la madera, los mohos y bacterias en suspensión y el formaldehído. Varios estudios han examinado la salud respiratoria entre los trabajadores de serrerías y fábricas de contrachapado, tableros de partículas y tableros de hebras. EI interés de los estudios en las serrerías se ha centrado generalmente en el polvo, mientras que los estudios de las fábricas de contrachapado y tableros de partículas se han centrado principalmente en la exposición al formaldehído.

La exposición laboral al serrín se ha relacionado con una gran variedad de efectos para el sistema respiratorio superior e inferior. D ebido al tamaño de las partículas generadas por las operaciones de las industrias madereras, la nariz es el destino natural de los efectos de la exposición al polvo de madera. Se han documentado muy diversos efectos en los senos nasales, como rinitis, sinusitis, obstrucción nasal, hipersecreción nasal y eliminación mucociliar deficiente. La exposición al polvo de madera se ha relacionado también con efectos para el tracto respiratorio inferior como el asma, la bronquitis crónica y la obstrucción respiratoria crónica. Las especies de coníferas y frondosas, maderas duras y blandas, procedentes de climas tropicales y templados se han asociado a efectos tanto para el tracto respiratorio superior como para el inferior. Por ejemplo, se ha asociado el asma, como enfermedad profesional, a la exposición al polvo de arce africano, roble gateado africano, fresno, sequoia californiana, cedro del Líbano, nogal centroamericano, cedro blanco oriental, ébano, iroko, caoba, roble, ramin y cedro rojo occidental, entre otras especies.

La madera se compone principalmente de celulosa, poliosas y lignina, pero también contiene diversos compuestos orgánicos biológicamente activos, como monoterpenos, tropolones, ácidos resínicos (diterpenos), ácidos grasos, fenoles, taninos, flavonoides, quinonas, lígnanos y estilbenos. Como se ha demostrado que los efectos para la salud varían según la especie de árbol, se sospecha que puedan deberse a estos productos químicos naturales, conocidos como extractivos, que también varían según la especie. En algunos casos, se han identificado extractivos específicos como la causa de los efectos para la salud asociados a la exposición a la madera. Por ejemplo, el ácido plicático, que aparece naturalmente en el cedro rojo occidental y en el cedro blanco oriental, produce asma y otros efectos alergénicos en los humanos. $M$ ientras que los extractivos de mayor peso molecular permanecen en el polvo durante las operaciones de transformación de la madera, otros, los extractivos más ligeros, tales como los monoterpenos, se volatilizan fácilmente durante las operaciones de secado en cámara, aserrado y retestado. Los monoterpenos (como el oxpineno, el $\beta$-pineno, el $\delta^{3}$-careno y el limoneno) son componentes importantes de la resina de muchas coníferas comunes y están relacionados con la irritación de boca y garganta, la disnea y la afectación de la función pulmonar.

Los mohos que se desarrollan en la madera son otro riesgo natural con posibles efectos perjudiciales. La exposición a ellos parece ser común entre los trabajadores de serrerías ubicadas en regiones de clima suficientemente húmedo y cálido para su desarrollo. Entre los trabajadores de las serrerías de los países escandinavos, Reino Unido y Norteamérica se han registrado casos de alveolitis alérgica extrínseca, también conocida como 
neumonitis por hipersensibilidad (Halpin y cols. 1994). Un efecto mucho más común, aunque menos grave de la exposición a mohos, es la fiebre por inhalación, también conocida como síndrome tóxico del polvo orgánico, caracterizada por crisis agudas de fiebre, malestar, dolores musculares y tos. Se ha calculado que la prevalencia de la fiebre por inhalación entre los desramadores suecos oscila entre un 5 y un $20 \%$, aunque es probable que estos porcentajes sean mucho menores en la actualidad, debido a la introducción de medidas preventivas.

La exposición a los productos químicos utilizados como adhesivos en la industria maderera puede tener asimismo efectos en el sistema respiratorio. El formaldehído es un irritante y puede provocar inflamación de nariz y garganta. Se han observado efectos agudos en los pulmones y se sospechan efectos crónicos. También se ha documentado que esta exposición provoca asma y bronquitis crónica.

Los efectos irritantes o alergénicos del polvo de madera, el formaldehído y otros materiales no se limitan al sistema respiratorio. Por ejemplo, los estudios que comunican síntomas nasales suelen indicar una mayor incidencia de irritación ocular. Se ha demostrado la relación de las dermatitis con el polvo de más de 100 especies diferentes de árboles, algunas de ellas especies comunes de maderas duras, maderas blandas y especies tropicales. El formaldehído es además un irritante cutáneo y puede provocar dermatitis alérgica por contacto. También se ha demostrado que algunos fungicidas antimanchas utilizados en la madera de maderas blandas provocan irritación ocular y cutánea.

Los trabajadores de las serrerías y otras industrias madereras tienen un alto riesgo de pérdida auditiva por ruido. Por ejemplo, en un reciente estudio realizado en una serrería de Estados Unidos, el 72,5 \% de los trabajadores presentaban algún grado de deterioro auditivo a una o más frecuencias en las pruebas audiométricas (T harr, 1991). Las personas que trabajan en las proximidades de sierras y otras máquinas de transformación de la madera suelen verse expuestas a niveles superiores a 900 $95 \mathrm{dBA}$. A pesar de este riesgo perfectamente conocido, los intentos de reducir los niveles de ruido son relativamente escasos (con la excepción de los encerramientos de las cepilladoras) y continúan produciéndose nuevos casos de pérdida auditiva inducida por ruido.

\section{Cáncer}

El trabajo en las industrias madereras puede comportar la exposición a cancerígenos conocidos y sospechosos. El polvo de madera, el elemento más presente en las industrias madereras, se ha clasificado como cancerígeno para los humanos (Agencia Internacional para la Investigación sobre el Cáncer (IARC): Grupo 1). Se han observado riesgos relativos muy altos de cáncer sinonasal, especialmente de adenocarcinoma sinonasal, entre los trabajadores expuestos a altos niveles de polvo de maderas duras, como el haya, el roble y la caoba, en la industria del mueble. Las pruebas relativas al polvo de maderas blandas son menos concluyentes y se han observado riesgos relativos menores. Existen pruebas de un riesgo excesivo entre los trabajadores de las serrerías e industrias relacionadas, sobre la base de un reanálisis conjunto de los datos originales de 12 estudios de casos-control de cáncer sinonasal (IARC, 1995). El cáncer sinonasal es relativamente raro en casi todas las regiones del mundo, con una tasa bruta de incidencia anual de aproximadamente 1 caso por cada 100.000 personas. Se considera que el $10 \%$ de todos los cánceres sinonasales son adenocarcinomas. Aunque se han observado asociaciones entre el polvo de madera y otros cánceres más comunes en algunos estudios, los resultados han sido mucho menos sólidos que en lo que se refiere al cáncer sinonasal.
El formaldehído, un elemento al que se ven muy expuestos los trabajadores de las fábricas de contrachapado, tableros de partículas y demás, se ha clasificado como probable cancerígeno para el ser humano (IARC: Grupo 2A). Se ha demostrado que produce cáncer en animales y se han observado cifras de cáncer nasofaríngeo y sinonasal superiores a lo normal en algunos estudios en seres humanos, aunque sin resultados concluyentes. Se sabe que los plaguicidas a base de pentaclorofenol y tetraclorofenol, hasta hace poco muy utilizados en las industrias madereras, están contaminados por furanos y dioxinas. El pentaclorofenol y la 2,3,7,8-tetraclorodibenzo-para-dioxina han sido clasificados como posibles cancerígenos para el ser humano (IARC: Grupo 2B). Algunos estudios han hallado una relación entre los clorofenoles y el riesgo de linfoma, no $\mathrm{H}$ odgkin, y de sarcoma de los tejidos blandos. Los resultados relativos al linfoma no Hodgkin han sido más consistentes, sólidos que los relativos al sarcoma de los tejidos blandos. Entre otras posibles exposiciones a elementos cancerígenos para algunos trabajadores de las industrias madereras cabe citar el amianto (IARC: Grupo 1), que se utiliza como aislante en hornos y tuberías de vapor, los humos de escape de los motores diesel (IARC: Grupo 2A) utilizados en equipos móviles, y la creosota (IARC: G rupo $2 A$ ), que se utiliza como conservante de la madera en traviesas de vías férreas y postes telefónicos.

Se han realizado relativamente pocos estudios de cáncer entre trabajadores específicamente empleados en serrerías, fábricas de contrachapado o fábricas de tableros. El mayor de ellos fue un estudio sobre un grupo humano de más de 26.000 trabajadores de serrerías canadienses realizado por Hertzman y colegas (1997) para examinar el riesgo de cáncer asociado con la exposición a plaguicidas a base de clorofenol. Se observó un aumento del doble de cáncer sinonasal y un aumento menor de linfoma no Hodgkin. El aumento de linfoma no Hodgkin pareció estar asociado con la exposición a los clorofenatos. Los demás estudios realizados han sido de mucha menor envergadura. Jäppinen, Pukkala y Tola (1989) estudiaron a 1.223 trabajadores de serrerías finlandesas y observaron aumento de cánceres cutáneos, bucales y faríngeos, y de linfomas y leucemias.

Blair, Stewart y Hoover (1990) y Robinson y colegas (1986) estudiaron respectivamente a 2.309 y 2.283 trabajadores de fábricas de contrachapado estadounidenses. En un análisis conjunto de los datos de los dos grupos humanos, se observaron aumentos de cáncer nasofaríngeo, mieloma múltiple, enfermedad de $\mathrm{H}$ odgkin y linfoma no $\mathrm{H}$ odgkin. Los resultados no aclaran si tales aumentos pueden deberse a la exposición a riesgos profesionales $\mathrm{ni}$, de ser así, a cuáles. Los estudios de menor envergadura han carecido de capacidad para examinar el riesgo de cánceres raros y muchos de los excesos observados se basaron en cifras muy pequeñas. Por ejemplo, no se observaron cánceres sinonasales, pero sólo se esperaba un 0,3 en el estudio de serrerías más pequeño, y 0,3 y 0,1 en los estudios de las fábricas de contrachapado.

\section{CUESTIONES AMBIENTALES Y DE SALUD PUBLICA}

Kay Teschke y Anya Keefe

\section{Aprovechamiento y eliminación de residuos de la madera}

Entre los subproductos de la industria maderera que pueden provocar problemas ambientales cabe citar las emisiones aéreas, los efluentes líquidos y los residuos sólidos. La mayoría de estos 
problemas se derivan de los residuos resultantes: astillas o serrín de las operaciones de tranfformación, corteza de las operaciones de descortezado y residuos de troncos en las vías fluviales de almacenamiento de troncos.

El serrín y otros productos pulverulentos del proceso plantean un peligro de incendio y explosión en los talleres. Para minimizar este peligro, el polvo puede eliminarse por medios manuales 0 , preferiblemente, recolectarse por medio de sistemas de ventilación por aspiración localizada y recogerse en filtros de mangas o ciclones. Los residuos de la madera de mayor tamaño revisten la forma de astillas. La mayor parte del serrín y de las astillas se utilizan precisamente en otros productos de madera (p. ej. tableros de partículas, pasta de madera y papel): cada vez es más normal este tipo de aprovechamiento a medida que aumentan los costes de eliminación de los residuos y aumenta la integración vertical de las compañías forestales. Sin embargo, el polvo fino y la corteza, por ejemplo, no son tan fácilmente aprovechables, por lo que es preciso buscar otros medios de eliminación.

La corteza representa a veces una buena parte del volumen del árbol, especialmente en regiones donde los troncos cortados son de pequeño diámetro. La corteza y el serrín fino y, en algunas operaciones, todos los residuos de la madera, incluidas las astillas, pueden quemarse (véase la Figura 71.6). Las operaciones tradicionales con técnicas ineficaces ( $p$. ej. hornos con forma de colmena) producen diversos productos orgánicos derivados de una combustión incompleta. La contaminación del aire por partículas, que pueden producir "niebla", es una queja común en las proximidades de estos quemadores. En las serrerías donde se utilizan clorofenoles, también existe preocupación por la producción de dioxina y furano. Algunas serrerías modernas utilizan calderas cerradas de temperatura controlada para producir vapor para secaderos o electricidad para la fábrica o para otros usuarios. 0 tras venden sus residuos a fábricas de pasta de papel y papel, donde se quema para satisfacer sus grandes necesidades de energía (véase el capítulo Industria del papel y pasta de papel). Las calderas y otros quemadores suelen cumplir las normas de control de emisiones de partículas utilizando sistemas tales como precipitadores electrostáticos o depuradores húmedos. Para minimizar la quema de residuos de la madera, pueden encontrarse otros usos para la corteza y el serrín fino, como el compost o el pajuzo en paisajismo, agricultura, reforestación y repoblación de vegetación en minas a cielo abierto, o el empleo como modificante de productos comerciales. Además, el uso de sierras de corte fino en el taller puede suponer una reducción drástica de la producción de serrín.

En ocasiones, la corteza, los troncos y otros residuos de madera se hunden en las áreas acuáticas de almacenamiento de troncos, recubriendo el fondo y matando a los microorganismos bentónicos. Para minimizar este problema, los troncos en remojo se atan juntos y se deshacen los atados en tierra, donde los residuos pueden recogerse fácilmente. Incluso con esta modificación, es preciso dragar los residuos hundidos periódicamente. L os troncos recuperados pueden utilizarse para madera, pero los demás desechos han de eliminarse. En la industria se ha utilizado tanto el vertido en tierra como en aguas profundas. LoS efluentes del descortezado hidráulico pueden dar lugar a problemas similares; de ahí la tendencia al empleo de sistemas mecánicos.

Las pilas de astillas pueden crear problemas de escorrentías debidas a la lluvia, ya que la lixiviación de la madera incluye ácidos de las resinas, ácidos grasos y productos fenólicos que son muy tóxicos para los peces. El enterramiento de los desechos de la madera también produce lixiviación, que requiere medidas de mitigación para proteger las aguas subterráneas y superficiales.

\section{Figura 71.6 • Cintas de transporte de desechos a un} quemador tipo colmena.

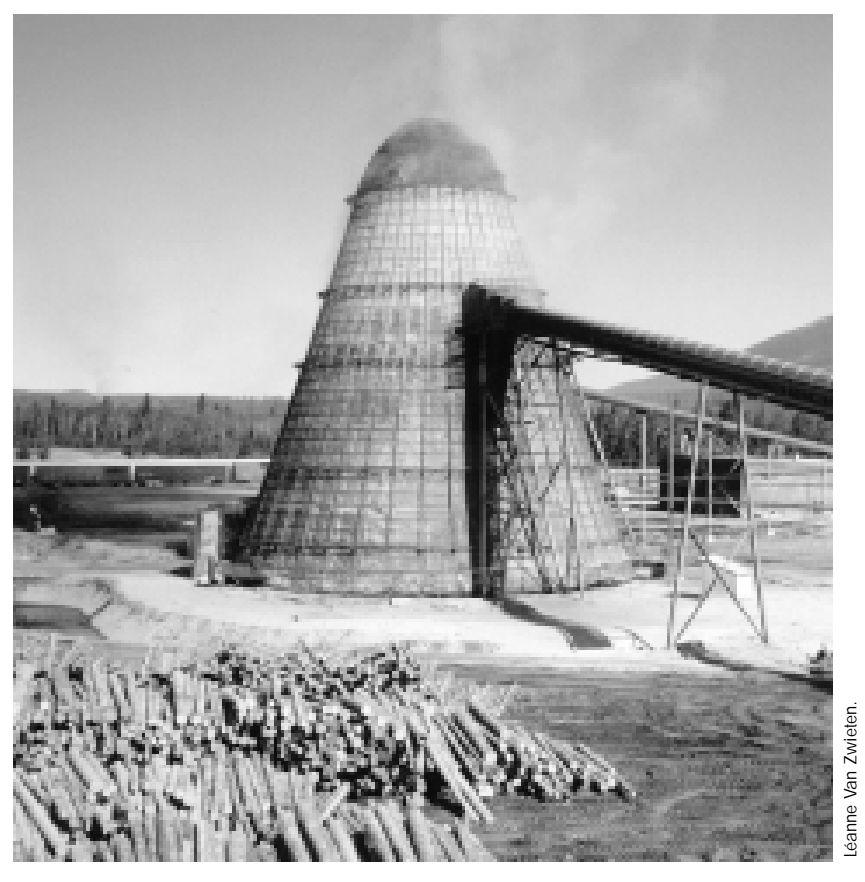

\section{Agentes antimanchas y fungicidas para la conservación de la madera}

EI tratamiento de la madera con fungicidas para evitar el desarrollo de manchas de origen fúngico ha dado lugar a la contaminación de las vías fluviales cercanas (a veces con gran mortandad de peces), así como a la contaminación del suelo. L os sistemas de tratamiento que implican el acarreo de madera atada a través de grandes tanques de inmersión descubiertos para desaguar en el patio de la serrería dan lugar a desbordamientos por aguas de Iluvia y a escorrentías de largo recorrido. Los tanques de inmersión cubiertos con elevadores automáticos, cabinas de pulverizado en la línea de producción y zanjas o taludes de contención alrededor del sistema de tratamiento y de las áreas de secado de madera reducen en gran medida la posibilidad de que se produzcan derrames y sus repercusiones. Sin embargo, aunque las cabinas de pulverizado de agentes antimanchas reducen el potencial de exposición ambiental, pueden suponer una mayor exposición del trabajador situado aguas abajo que los tanques de inmersión que tratan la madera atada terminada.

La nueva generación de fungicidas que ha sustituido a los clorofenoles parece haber reducido los impactos ambientales. Aunque la toxicidad para los microorganismos acuáticos puede ser la misma, ciertos fungicidas sustitutivos se fijan más firmemente a la madera, con lo que quedan menos biodisponibles y se degradan más fácilmente en el medio ambiente. Además, el mayor coste de muchos de los sustitutivos y el coste del vertido han fomentado el reciclaje de los residuos líquidos y otros procedimientos para minimizar los residuos.

Los tratamientos por presión y temperatura a los que se somete la madera para proporcionarle una resistencia duradera a hongos e insectos se han aplicado tradicionalmente en instalaciones más cerradas que los tratamientos antimanchas y, por consiguiente, no tienden a producir los mismos problemas de residuos líquidos. El vertido de los residuos sólidos, incluidos los 
lodos derivados de los tanques de tratamiento y almacenamiento, presenta problemas similares para los procesos en cabina. Entre las opciones posibles cabe citar el almacenamiento en contenedores estancos en taludes o zanjas impermeables, el enterramiento en un vertedero seguro y aislado hidrogeológicamente para residuos peligrosos o la incineración a altas temperaturas (p. ej., $1.000^{\circ} \mathrm{C}$ ) con tiempos de residencia especificados (p. ej., 2 segundos).

\section{Problemas especiales de las operaciones de elaboración de contrachapado y tableros de partículas}

Los secaderos de chapas en las fábricas de contrachapado pueden producir una neblina azul característica, compuesta por productos extractivos volátiles de la madera, como los terpenos y los ácidos de las resinas. Este problema tiende a aumentar en el interior de las fábricas, pero también puede darse en los penachos de vapor de agua de los secadores. L as fábricas de contrachapado y tableros de partículas suelen quemar los residuos de la madera para obtener calor para las prensas. Es posible utilizar métodos para el control de vapor y partículas, respectivamente, en estas emisiones aéreas.

Las aguas de lavado y otros efluentes líquidos de las fábricas de contrachapado y tableros de partículas pueden contener las resinas de formaldehído utilizadas como colas; sin embargo, actualmente es práctica habitual reciclar las aguas residuales para preparar las mezclas de colas.

\section{Referencias}

Blair, A, PA Stewart, RN Hoover. 1990. Mortality from lung cancer among workers employed in formaldehyde industries. Am J Ind M ed 17:683699.

Bureau of the Census. 1987. 1987 Census of M anufacturers. Washington, DC: US Department of Commerce.

Demers, PA, P Bofetta, M Kogevinas, A Blair, $B$ Miller, C Robinson, $R$ Roscoe, $P$ Winter, D Colin, E M atos, H Vainio. 1995. A pooled re-analysis of cancer mortality among five cohorts of workers in wood-related industries. Scand J W ork Environ H ealth 21(3):179-190.

Grupo de trabajo de la Agencia Internacional para la Investigación sobre el Cáncer (IARC). 1995. W ood Dust and Formaldehyde. Vol. 62. Lyon: IARC.

-.1981. W ood, Leather, and Associated Industries. Vol. 25. Lyon: IARC.

Halpin, DMG, BJ Graneek, M Turner-Warwick, A) Newman-Taylor. 1994. Extrinsic allergic alveolitis and asthma in a sawmill worker: Case report and review of the literature. Occup Environ $M$ ed 1(3):160-164.

Hertzman, C., K Teschke, A O stry, R Herschler, $H$ Dimich-Ward, S K elly, If Spinelli, $R$ Gallagher, M M cBride, SA M arion. 1997. M ortality and cancer incidence among a cohort of sawmill workers exposed to chlorophenol pesticides. Am Public H ealth 87(1):71-79.

Howard, B. 1995. Fatal Claims in Sawmills. Analysis of Causes and Costs from 1985-1994. Vancouver:
Prevention Division, Workers Compensation Board of British Columbia.

Jagels, R. 1985. Health hazards of natural and introduced chemical components of boatbuilding woods. Am J Ind M ed 8:241-251.

Jäppinen, P, E Pukkala, S T ola. 1989. Cancer incidence of workers in a Finnish sawmill. Scand I W ork Environ $\mathrm{H}$ ealth 15:18-23.

Organización Internacional del Trabajo (OIT). 1993. Yearbook of Labour Statistics. Ginebra: OIT.

O rganización de las Naciones Unidas para la Agricultura y la Alimentación (FAO). 1993. Yearbook of Forest Products 1980-1991. FAO Statistical Series $\mathrm{P} 6, \mathrm{~N}$ ㅇ110. R oma: FAO.

Robinson, C, D Fowler, DP Brown, RA Lemen. 1986. Plywood M ill Workers M ortality Patterns 1945-1977.(NTIS Report PB-86 221694). Cincinnati, O hio: US NIOSH.

Statistics Canada. 1993. Industry and the Class of W orker: The Nation. O ttawa: Statistics Canada.

Suchsland, O, GE Woodson. 1987. Fiberboard M anufacturing Practices in the U nited States. Agricultural handbook No. 640. Washington, DC: US Department of Agriculture, Forest Service

Tharr, D. 1991. A sawmill environment: Noise levels, controls and audiometric test results. Appl 0 ccup Environ $H$ yg 6(12):1000

\section{O tras lecturas recomendadas}

Chan-Y eung, M, JL M alo. 1995. O ccupational respiratory diseases associated with forest products industries. En Occupational and Environment Respiratory Diseases, dirigido por $\mathrm{P} \mathrm{H}$ arber, $\mathrm{M}$ Schenker y J Balmes. St. Louis: Mosby.

Hausen, B. 1981. W oods Injurious to H uman H ealth- A M anual. Berlin: Walter de Gryter $\&$ Co.

Koch, P. 1964. W ood M achining Processes. Nueva York: Ronald Press Company.

Maloney, TM. 1977. M odern Particleboard and Dryprocess Fiberboard $M$ anufacturing. San Francisco: M iller Freeman Publications.

National Institute for O ccupational Safety and Health. (NIOSH). 1977. H ealth and Safety Guide for Sawmills and Planing M ills. NIOSH Publication No. 78-102. Cincinnati, O hio: US NIOSH.

-.1977 . H ealth and safety guide for plywood and veneer mills. NIOSH Publication No. 77-186. Cincinnati, O hio: US NIOSH.

Tatken, RL, CA Browning. 1987. H ealth Effects of Exposure to W ood D ust: A Summary of the Literature Cincinnati, Ohio: US NIOSH

Timber Industry Ergonomics Group. 1977. B ette W orking Environment in Sawmills- T oday's Problems, Tomorrow's Environment. Estocolmo: Sagverksindustrins kommitte for arbetsmiliofragor.

Williston, EM . 1988. Lumber M anufacturing, the Design and Operation of Sawmills and Planer Mills. San Francisco, California: Miller Freeman Publications.

Woods, B, CD Calnan. 1976. Toxic Woods. Brit I Dermatol 94 Supl. 13:1-98. 



\section{INDUSTRIA DEL PAPEL \\ Y DE LA PASTA DE PAPEL}

Directores del capítulo

Kay Teschke y Paul Demers

\section{Sumario}

Perfil general

Kay Teschke. . .

PRINCIPALES SECTORES Y PROCESOS

Fuentes de fibra para la fabricación de pasta y de papel Anya Keefe y Kay Teschke . . . . . . . . . . . . . . . . . . . . 72.5

Manipulación de la madera

Anya Keefe y Kay Teschke . . . . . . . . . . . . . . . . . . 72.6

Elaboración de la pasta

Anya Keefe, George Astrakianakis y fudith Anderson . . . . . . . . . . 72.6

Blanqueo

George Astrakianakis y fudith Anderson. . . . . . . . . . . . . . 72.8

Fábricas de papel reciclado

Dick Heederik . . . . . . . . . . . . . . . . . . . . . . . . . . 72.9

Producción de papel y transformados:

pasta papelera, papel, y cartón

George Astrakianakis y fudith Anderson. . . . . . . . . . . . . . . . . . 72.9

Generación de energía y tratamiento de las aguas

George Astrakianakis y fudith Anderson. . . . . . . . . . . . . . 72.11

Producción de productos químicos y de subproductos

George Astrakianakis y fudith Anderson. . . . . . . . . . . . . . . . 72.11

Riesgos profesionales y controles

Kay Teschke, George Astrakianakis, Judith Anderson,

Anya Keefey Dick Heederik. . . . . . . . . . . . . . . . . . . . . . 72.12

PAUTAS DE ENFERMEDADES Y LESIONES

Lesiones y enfermedades no malignas

Susan Kennedy y Kjell Torén . . . . . . . . . . . . . . . . . 72.15

Cáncer

Kjell Torén y Kay Teschke.

Cuestiones de salud pública y ambiental

Anya Keefe y Kay Teschke. 


\section{Perfil General}

Kay Teschke

\section{Evolución y estructura de la industria}

Se cree que la fabricación de papel tiene su origen en China hacia el año 100 d.C.: se utilizaban trapos, cáñamo, paja y hierba como materias primas y se golpeaban contra morteros de piedra para separar la fibra original. Aunque con el tiempo ganó terreno la mecanización, hasta el siglo XIX siguieron utilizándose los métodos de producción por lotes y las fuentes de fibra agrícolas. Las primeras máquinas continuas de papel se patentaron en los años de cambio del siglo XIX al XX. Entre 1844 y 1884 se desarrollaron los primeros métodos para la obtención de pasta de madera, una fuente de fibra más abundante que los trapos o las hierbas; estos métodos implicaban la abrasión mecánica y la aplicación de procedimientos químicos a base de sosa cáustica, sulfitos y sulfatos (Celulosa al sulfato). Con estos cambios se inició la era moderna de la fabricación de pasta y de papel.

La Figura 72.1 ilustra el procedimiento más completo de fabricación de pasta y papel de la época actual: elaboración de la mecánica de la pasta; elaboración de la química de la pasta; reciclado del papel usado; fabricación de papel, y procesos de transformación. Hoy día, la industria se puede dividir en dos grandes sectores de acuerdo con los tipos de productos fabricados. La pasta se elabora generalmente en grandes fábricas situadas en las mismas zonas donde se recolecta la fibra (es decir, las principales regiones forestales). Muchas de estas instalaciones también fabrican papel (p. ej., papel prensa, papel de escribir, papel para imprenta o papel de seda) o cartón. La Figura 72.2 muestra el esquema de una fábrica que produce pasta blanqueada al sulfato, pasta termomecánica y papel prensa. Obsérvense los andenes y el muelle de embarque, la zona de almacenamiento de astillas, la cinta transportadora de astillas hacia el digestor, la caldera lejiadora de recuperación (edificio blanco alto) y los estanques de clarificación de los efluentes. Las distintas operaciones de transformación se realizan habitualmente cerca de los centros de consumo y utilizan papel o pasta comercial para fabricar bolsas, cartones, contenedores, papel de seda, papel de envolver, papelería decorativa, material de oficina y otros semejantes.

En los últimos años se ha acentuado la tendencia a que las empresas fabricantes de pasta y de papel pasen a formar parte de grandes compañías integradas de productos forestales. Estas compañías controlan las operaciones de recolección forestal (véase el capítulo Silvicultura), las serrerías (véase el capítulo Industria de la madera), la fabricación de pasta y de papel, y los

Figura 72.1 • Ilustración de la secuencia de procesos en las operaciones de fabricación de pasta y de papel.

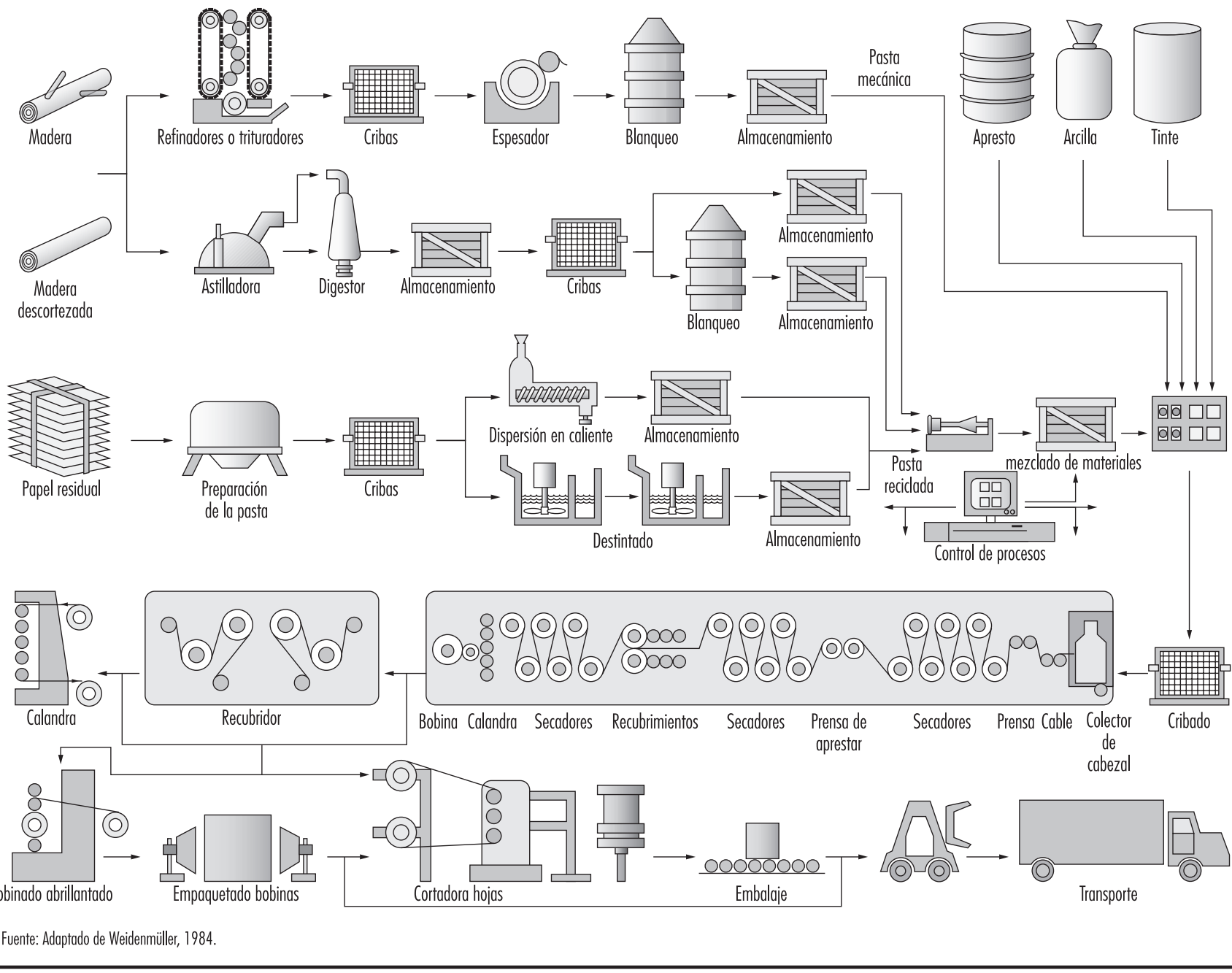


Figura 72.2 • Moderno complejo fabril de pasta y papel situado en la ribera de un río navegable.

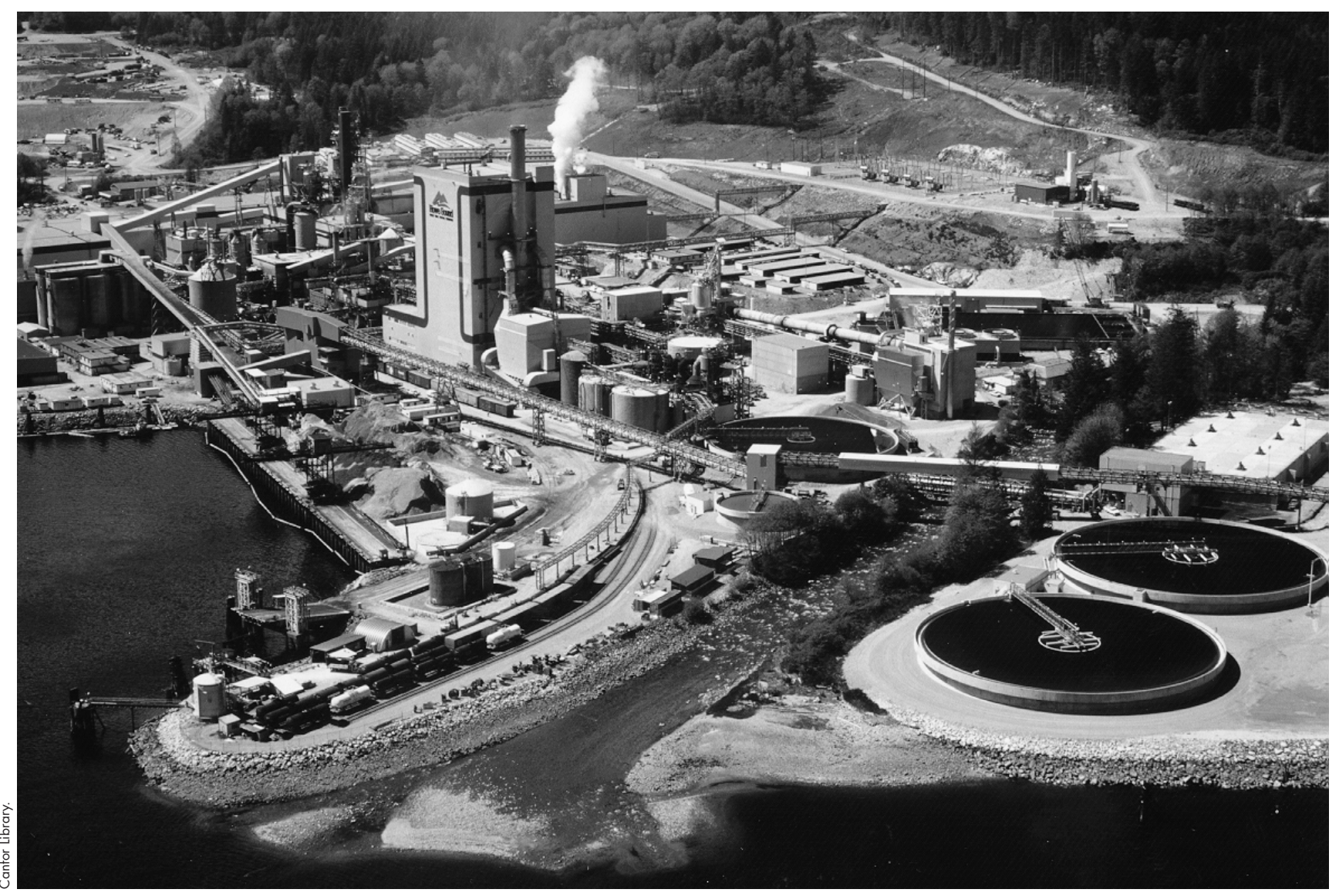

Figura 72.3 • Producción mundial de pasta y de papel, 1980 a 1993

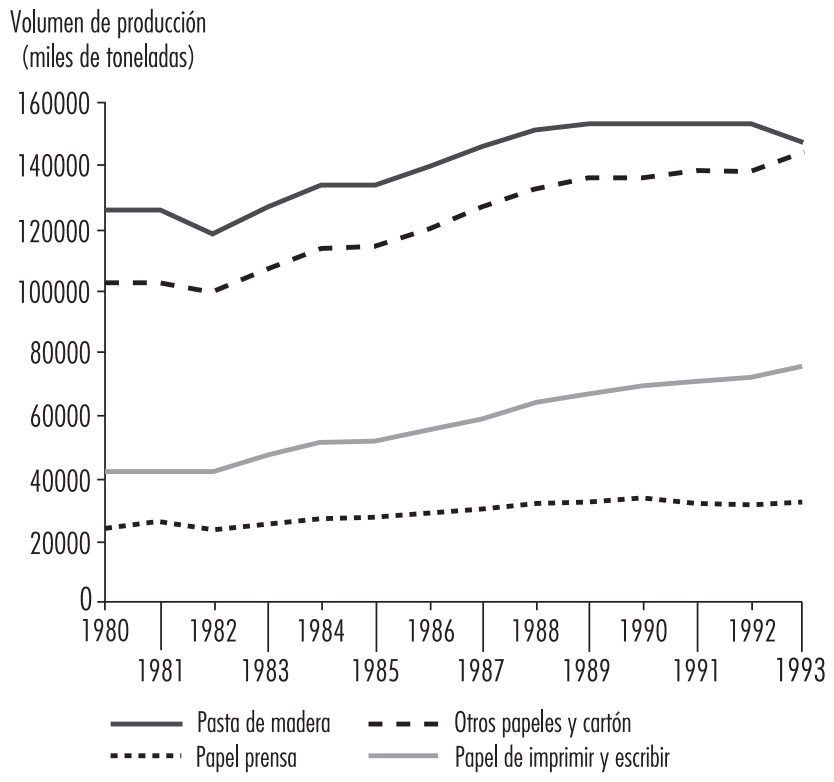

Fuente: Canadian Pulp and Paper Association 1995.
Figura 72.4 - Consumo de papel y cartón como indicador del desarrollo económico.

Consumo de papel

per capita (kg)

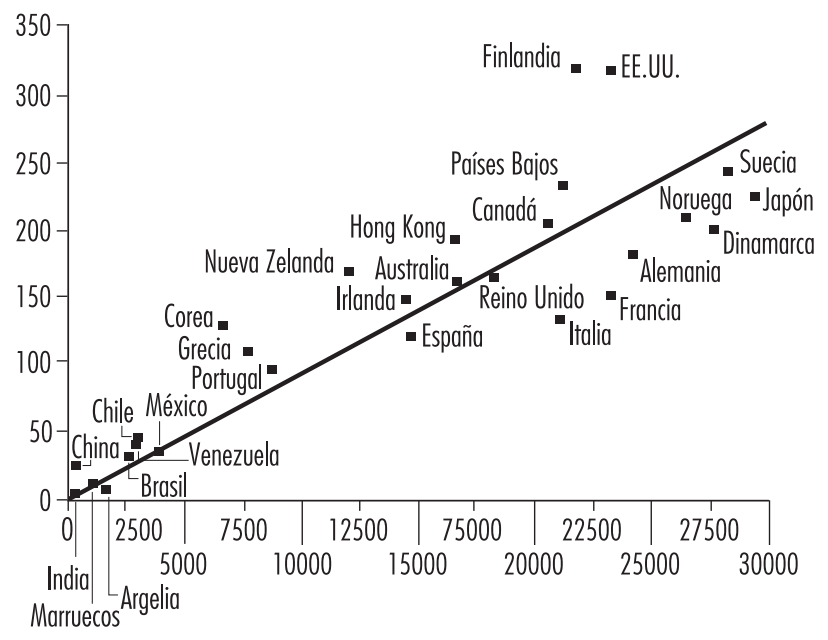

Producto interior bruto per capita (EE.UU.), 1992 
procedimientos de transformación. Una estructura así planteada les garantiza una continua fuente de fibra, una utilización eficaz de los residuos de la madera y unos compradores asegurados, todo lo cual favorece un aumento de su cuota de mercado. La integración se ha desarrollado en conjunción con la creciente concentración y mundialización, derivadas de la orientación de las empresas hacia las inversiones internacionales. La carga financiera derivada del establecimiento de plantas industriales estimula esta tendencia para permitir economías de escala. Algunas empresas han alcanzado ya niveles de producción de 10 millones de toneladas, semejantes a la capacidad total de países con la máxima producción. Muchas son multinacionales, y algunas tienen fábricas en 20 o más países de todo el mundo. Con todo, aun cuando muchas de las empresas y fábricas más pequeñas estén desapareciendo, la industria aún cuenta con centenares de miembros. A manera de ilustración, baste decir que las 150 primeras empresas suman las dos terceras partes de la producción de pasta y papel, y con solamente una tercera parte de los empleados.

\section{Importancia económica}

La fabricación de pasta, papel y derivados del papel alcanza cifras que sitúan esta industria entre las más grandes del mundo. Hay fábricas en más de 100 países repartidos por todo el mundo, con más de 3,5 millones de personas directamente empleadas. Los mayores productores de pasta y papel son Estados Unidos, Canadá, Japón, China, Finlandia, Suecia, Alemania, Brasil y Francia (todos ellos con cifras superiores a 10 millones de toneladas en 1994; véase la Tabla 72.1).

Todos los países son consumidores. La producción mundial de pasta, papel y cartón fue de unos 400 millones de toneladas en 1993. A pesar de las predicciones de disminución del consumo de papel ante el auge de la era electrónica, desde 1980 se observa un crecimiento razonablemente constante de la tasa anual de producción del 2,5\%. (Figura 72.3). Además de sus ventajas económicas, el consumo de papel tiene el valor cultural inherente a la función que desempeña en el registro y difusión de la información. Por esta razón, la tasa de consumo de pasta y papel se ha utilizado como indicador del desarrollo socioeconómico de una nación (Figura 72.4).

La principal fuente de fibra para la producción de pasta en este siglo ha sido la madera procedente de los bosques de coníferas, aunque más recientemente ha aumentado la utilización de bosques tropicales y boreales (véase el capítulo Industria de la madera para tener datos sobre recolección industrial de la madera en el mundo). Como las regiones forestales tienen generalmente una baja densidad de población, tiende a producirse en el mundo una dicotomía entre las zonas de producción y las de utilización. La presión ejercida por los grupos ecologistas para la conservación de los recursos forestales, manifestada en la defensa del empleo de papel reciclado, de cultivos agrícolas y de bosques de plantación de rápida rotación como fuentes de la materia prima, puede modificar la distribución de las instalaciones de producción de pasta y papel en todo el mundo en las próximas décadas. Otras necesidades, como el incremento del consumo de papel en los países desarrollados y la globalización, también influirán en la redistribución de la industria.

\section{Características de la población empleada}

La Tabla 72.1 indica la magnitud de la población empleada directamente en operaciones de producción de pasta y de papel y de transformación en 27 países, que en conjunto representan un $85 \%$ del empleo en esta industria y el $90 \%$ de las fábricas y de la producción. En países que consumen la mayor parte de lo que producen (p. ej., Estados Unidos, Alemania, Francia), por cada
Tabla 72.1 • Empleo y producción en operaciones de fabricación de pasta y de papel, en 1994, paises seleccionados. *

\begin{tabular}{|c|c|c|c|c|c|}
\hline \multirow[t]{2}{*}{ País } & \multirow[t]{2}{*}{$\begin{array}{l}\text { Número } \\
\text { de trabaja- } \\
\text { dores en la } \\
\text { industria }\end{array}$} & \multicolumn{2}{|c|}{ Pasta } & \multicolumn{2}{|c|}{ Papel y cartón } \\
\hline & & $\begin{array}{l}\text { Número } \\
\text { de } \\
\text { fábricas }\end{array}$ & $\begin{array}{l}\text { Producción } \\
(1.000 \\
\text { toneladas })\end{array}$ & $\begin{array}{l}\text { Número } \\
\text { de } \\
\text { fábricas }\end{array}$ & $\begin{array}{c}\text { Producción } \\
\text { (1.000 } \\
\text { toneladas) }\end{array}$ \\
\hline Austria & 10.000 & 11 & 1.595 & 28 & 3.603 \\
\hline Bangladesh & 15.000 & 7 & 84 & 17 & 160 \\
\hline Brasil & 70.000 & 35 & 6.106 & 182 & 5.698 \\
\hline Canadá & 64.000 & 39 & 24.547 & 117 & 18.316 \\
\hline China & 1.500 .000 & 8.000 & 17.054 & 10.000 & 21.354 \\
\hline $\begin{array}{l}\text { República } \\
\text { Checa }\end{array}$ & 18.000 & 9 & 516 & 32 & 662 \\
\hline Finlandia & 37.000 & 43 & 9.962 & 44 & 10.910 \\
\hline $\begin{array}{l}\text { Antigua } \\
\text { URSS** }\end{array}$ & 178.000 & 50 & 3.313 & 161 & 4.826 \\
\hline Francia & 48.000 & 20 & 2.787 & 146 & 8.678 \\
\hline Alemania & 48.000 & 19 & 1.934 & 222 & 14.458 \\
\hline India & 300.000 & 245 & 1.400 & 380 & 2.300 \\
\hline Italia & 26.000 & 19 & 535 & 295 & 6.689 \\
\hline Japón & 55.000 & 49 & 10.579 & 442 & 28.527 \\
\hline $\begin{array}{l}\text { República } \\
\text { de Corea }\end{array}$ & 60.000 & 5 & 531 & 136 & 6.345 \\
\hline México & 26.000 & 10 & 276 & 59 & 2.860 \\
\hline Pakistán & 65.000 & 2 & 138 & 68 & 235 \\
\hline Polonia ${ }^{\star \star}$ & 46.000 & 5 & 893 & 27 & 1.343 \\
\hline Rumania & 25.000 & 17 & 202 & 15 & 288 \\
\hline Eslovaquia & 14.000 & 3 & 304 & 6 & 422 \\
\hline Sudáfrica & 19.000 & 9 & 2.165 & 20 & 1.684 \\
\hline España & 20.180 & 21 & 626 & 141 & 5.528 \\
\hline Suecia & 32.000 & 49 & 10.867 & 50 & 9.354 \\
\hline Taiwan & 18.000 & 2 & 326 & 156 & 4.199 \\
\hline Tailandia & 12.000 & 3 & 240 & 45 & 1.664 \\
\hline Turquía & 12.000 & 11 & 416 & 34 & 1.102 \\
\hline $\begin{array}{l}\text { Reino } \\
\text { Unido }\end{array}$ & 25.000 & 5 & 626 & 99 & 5.528 \\
\hline $\begin{array}{l}\text { Estados } \\
\text { Unidos }\end{array}$ & 230.000 & 190 & 58.724 & 534 & 80.656 \\
\hline $\begin{array}{l}\text { Total } \\
\text { mundial }\end{array}$ & $\approx 3.500 .000$ & 9.100 & 171.479 & 14.260 & 268.551 \\
\hline $\begin{array}{l}\text { Se incluyen país } \\
\text { * Datos de } 198 \\
\text { vente: Datos par }\end{array}$ & $\begin{array}{l}\text { Ses con más de 10. } \\
\text { 9/90 (0IT 1992). } \\
\text { ra la tabla adaptado }\end{array}$ & $\begin{array}{l}\text { personas en } \\
\text { PPI } 1995 .\end{array}$ & pleadas en la ind & & \\
\hline
\end{tabular}


empleo dedicado a la producción de pasta y de papel hay dos dedicados a las operaciones de transformación.

La población empleada en la industria de la pasta y el papel trabaja fundamentalmente a tiempo completo en estructuras de gestión tradicionales, aunque algunas fábricas de Finlandia, Estados Unidos y de algún otro país han ensayado con éxito horarios de trabajo flexible y equipos de rotación de tareas autogestionados. A causa del alto coste de la inversión, muchas operaciones de la fabricación de pasta funcionan sin interrupción y requieren el trabajo por turnos; no ocurre así en las plantas de transformación. El horario laboral varía según los modelos de empleo existentes en cada país, con una gama que va de 1.500 a más de 2.000 horas al año. En 1991, los salarios anuales iban de 1.300 dólares (trabajadores no cualificados en Kenia) a 70.000 dólares (personal cualificado en los Estados Unidos) (OIT 1992). Predominan los trabajadores masculinos, ya que las mujeres representan únicamente del 10 al $20 \%$ de la población empleada en esta industria. China e India representan los dos extremos, con un $35 \%$ y un $5 \%$ de mujeres, respectivamente.

Los directivos y técnicos de una fábrica de pasta de papel suelen tener titulación universitaria. En los países europeos, la mayoría de los trabajadores cualificados y muchos de los no cualificados han recibido una formación en su oficio durante varios años. En Japón es común la formación informal dentro de la propia empresa y el ascenso ulterior, planteamiento que están adoptando algunas compañías latinoamericanas y norteamericanas. En cambio, en muchas empresas de Norteamérica y de los países en desarrollo sigue siendo frecuente la formación informal en el puesto. Algunos estudios ponen de manifiesto que, en ciertas actividades, muchos trabajadores tienen problemas educativos y están escasamente preparados para el aprendizaje permanente exigido por el entorno de esta industria, dinámico y potencialmente peligroso.

Los costes de construcción de una moderna planta de fabricación de pasta y papel son extremadamente altos (p. ej., la construcción de una fábrica de pasta kraft con 750 puestos de trabajo puede costar 1.500 millones de dólares; la de una fábrica de pasta termomecano-química con 100 personas, 400 millones de dólares), de forma que las instalaciones de alta capacidad implican grandes economías de escala. Las plantas nuevas y modernizadas emplean generalmente procesos mecanizados y continuos, con un seguimiento electrónico y controles informatizados. Necesitan, en términos relativos, pocos empleados por unidad de producción (por ejemplo, de 1 a 1,2 horas de trabajo por tonelada de pasta en las nuevas factorías indonesias, finlandesas y chilenas). En los últimos 10 a 20 años, la producción por empleado ha aumentado, por tanto, como consecuencia de los avances tecnológicos. Los equipos más modernos permiten una más fácil conmutación entre series de productos, menores existencias en almacén y una producción garantizada en todo momento. Las mejoras de productividad se han traducido en pérdida de empleo en muchas naciones productoras del mundo desarrollado. En cambio, ha aumentado el empleo en países en desarrollo, donde se construyen nuevas factorías que, aunque con dotaciones de personal escasas, representan nuevas salidas en la industria.

Desde el decenio de 1970 al de 1990 se produjo una disminución del $10 \%$ en la proporción de puestos de trabajo manuales en las empresas europeas y norteamericanas, de forma que estos puestos representan ahora entre el 70 y el $80 \%$ del total (OIT 1992). Ha aumentado la utilización de la subcontratación para la construcción de fábricas, el mantenimiento y la recolección de madera; muchas empresas informan de que del 10 al $15 \%$ de su plantilla está formada por personal subcontratado.

PRINCIPALES SECTORES Y PROCESOS

\section{- FUENTES DE FIBRA PARA LA FABRICACION DE PASTA Y DE PAPEL}

\section{Anya Keefe y Kay Teschke}

La estructura básica de la pasta y el papel es un entramado de fibras de celulosa (un polisacárido con 600 a 1.000 unidades de sacarosa) unidas mediante enlaces de hidrógeno. Una vez separadas del resto de componentes no celulósicos, mediante el proceso de elaboración de la pasta de papel, estas fibras tienen alta resistencia a la tracción, absorben los aditivos empleados para transformar la pasta en papel y cartón, y son flexibles, químicamente estables y blancas. Esos componentes no celulósicos son, en el caso de la madera, principalmente hemicelulosas (con 15 a 90 unidades iguales de sacarosa), ligninas (altamente polimerizadas y complejas, fundamentalmente monómeros de fenil-propano; actúan como aglutinante de las fibras), extractos (grasas, ceras, alcoholes, fenoles, ácidos aromáticos, aceites esenciales, oleorresinas, esteroles, alcaloides y pigmentos colorantes), y minerales y otros compuestos inorgánicos. En la Tabla 72.2 se muestra cómo varía la proporción relativa de estos componentes según la fuente de la fibra.

La principal fuente de fibra para la fabricación de pasta y de papel es la madera de coníferas y de especies arbóreas de hoja caduca. Fuentes secundarias son la paja de trigo, el centeno y el arroz; cañas, como el bagazo; los tallos leñosos del bambú, lino y cáñamo, y fibras de semillas, hojas y cortezas, como las del algodón, el abacá y el henequén o sisal. La mayor parte de la pasta se hace de fibra virgen, aunque la producción de papel reciclado es cada vez mayor, habiendo pasado del $20 \%$ en 1970 al $33 \%$ en 1991. La producción a partir de la madera supuso un $88 \%$ de la producción mundial de pasta en 1994 (176 millones de toneladas, Figura 72.5); en consecuencia, la descripción de los procesos de elaboración de la pasta y del papel del siguiente artículo se centra en la producción basada en la madera. Los principios básicos se aplican también a otras fibras.

Tabla 72.2 - Componentes químicos de las fuentes de pasta y de papel $(\%)$.

\begin{tabular}{lccccc} 
& $\begin{array}{c}\text { Maderas } \\
\text { blandas }\end{array}$ & $\begin{array}{l}\text { Maderas } \\
\text { duras }\end{array}$ & Paja & Bambú & Algodón \\
$\begin{array}{l}\text { Carbohidratos } \\
\alpha \text {-celulosa }\end{array}$ & $38-46$ & $38-49$ & $28-42$ & $26-43$ & $80-85$ \\
$\quad$ Hemicelulosa & $23-31$ & $20-40$ & $23-38$ & $15-26$ & n.d. \\
Lignina & $22-34$ & $16-30$ & $12-21$ & $20-32$ & n.d. \\
$\begin{array}{l}\text { Extraíbles } \\
\text { Minerales y otros }\end{array}$ & $1-5$ & $2-8$ & $1-2$ & $0.2-5$ & n.d. \\
$\begin{array}{l}\text { compuestos } \\
\text { inorgánicos }\end{array}$ & $0,1-7$ & $0,1-11$ & $3-20$ & $1-10$ & $0,8-2$ \\
\begin{tabular}{l} 
n.d. = sin datos disponibles. \\
\hline
\end{tabular} & & & & & \\
\hline
\end{tabular}




\section{MANIPULACION DE LA MADERA}

\section{Anya Keefe y Kay Teschke}

La madera llega a la fábrica de pasta en forma de troncos en bruto o como astillas de una planta de cortado de tablones. En ocasiones, la propia fábrica dispone de serrerías que producen tanto tablones comercializables como materia para la fábrica de pulpa. No obstante, la actividad de la serrería se estudia con detalle en el capítulo Industria de la madera. Aquí se examinan aquellos elementos de la preparación de la madera que son específicos de una fábrica de pasta de papel.

En la zona de preparación de la madera se llevan a cabo varias tareas básicas: recepción y cubicaje de la madera al ritmo requerido por la factoría; preparación de la madera para que responda a las especificaciones de aprovisionamiento por especies, limpieza y dimensiones de la fábrica; y recogida de todos los materiales desechados en las operaciones anteriores y envío para su eliminación final. La madera se transforma en astillas o troncos adecuados para la transformación en pasta mediante una serie de pasos, entre los que figuran el descortezado, el aserrado, el astillado y el tamizado.

Los troncos se descortezan porque la corteza contiene poca fibra, presenta un alto contenido de sustancias extractivas, es oscura y con frecuencia acarrea grandes cantidades de tierra. El descortezado se puede realizar hidráulicamente, mediante chorros de agua a alta presión, o mecánicamente, rozando los troncos unos con otros o con herramientas metálicas de corte. Las descortezadoras hidráulicas se pueden utilizar en zonas costeras; sin embargo, las aguas residuales producidas no son fáciles de tratar y contribuyen a la contaminación del agua.

Los troncos descortezados pueden serrarse en segmentos pequeños (1 a 6 metros) para la obtención de pasta mecánica a la piedra, o astillarse para los métodos de refinado mecánico o químico de obtención de pasta. Las astilladoras producen astillas de una amplia gama de tamaños, pero la preparación de la pasta requiere que éstas sean de dimensiones muy específicas para asegurar un flujo constante a través de los refinadores y un nivel de reacción uniforme en los digestores. En consecuencia, las astillas se hacen pasar por una serie de cribas cuya misión consiste en clasificarlas por longitud y grosor. Las astillas

Figura 72.5 • Producción mundial de pasta, por tipos.

Semiquímica
Termomecánica
Mecánica
Fuente: FAO 1995 .

Figura 72.6 - Zona de almacenaje de astillas con alas cargadoras frontales.

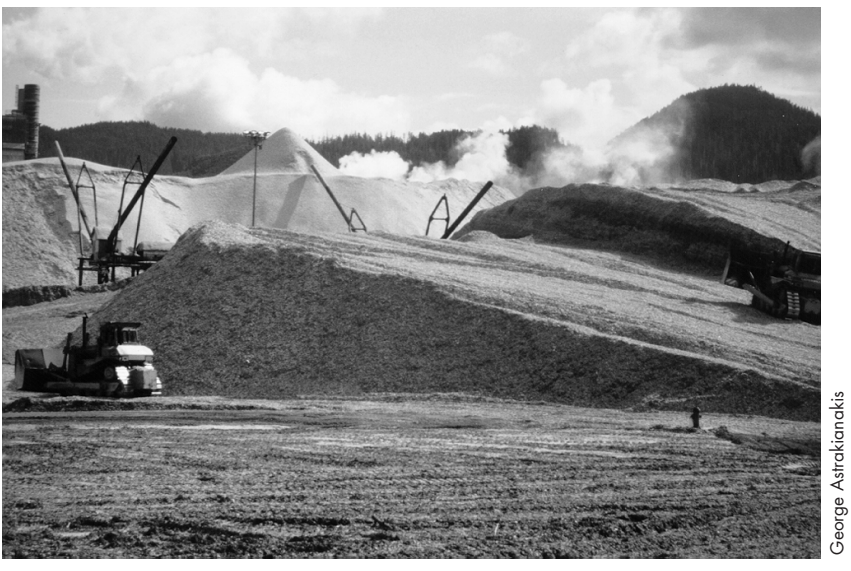

demasiado grandes se vuelven a pasar por la astilladora, y las menores se utilizan como residuos combustibles o se vuelven a introducir en el flujo de astillas.

Los requisitos de un proceso concreto de obtención de pasta y las condiciones de las astillas determinarán la duración de las astillas almacenadas (Figura 72.6; nótense los diferentes tipos de astillas disponibles para la preparación de pasta). Dependiendo del suministro de fibra y de la demanda de la fábrica, ésta puede mantener una reserva de astillas sin tamizar para un período de 2 a 6 semanas, normalmente apiladas al aire libre. Las astillas se pueden degradar como consecuencia de reacciones de autooxidación y de hidrólisis, o de la acción de los hongos sobre los componentes de la madera. Para evitar la contaminación, los almacenamientos a corto plazo (de horas a días) se realizan en silos o arcones. Las astillas destinadas a pasta al sulfito se almacenan al aire libre durante varios meses para permitir la evaporación de los productos extractivos que pueden crear problemas en las operaciones subsiguientes. Las astillas utilizadas en fábricas de celulosa al sulfato (papel kraft), donde la trementina y el aceite resinoso se recuperan como productos comerciales, se envían directamente a la producción de pasta.

\section{ELABORACION DE LA PASTA}

\section{Anya Keefe, George Astrakianakis y Judith Anderson}

$\mathrm{Al}$ elaborarse la pasta, los enlaces dentro de la estructura de la madera se rompen mecánica o químicamente. Las pastas químicas se pueden producir en medio alcalino (por ejemplo, sulfato o kraft) o en medio ácido (por ejemplo, sulfito). La mayor parte de la pasta se obtiene por el procedimiento al sulfato, seguida por los métodos mecánicos (semiquímico, termomecánico y mecánico) y por el procedimiento al sulfito (Figura 72.5). Los procesos de elaboración de la pasta difieren en el rendimiento y la calidad del producto, y en los métodos químicos, en los productos químicos utilizados y en la proporción que puede recuperarse para reutilización.

\section{Pasta mecánica}

Las pastas mecánicas se producen triturando la madera contra una piedra o entre placas metálicas, para que se separen las fibras. La acción de las máquinas rompe estas fibras de celulosa, por lo que la pasta resultante es más débil que la separada 
Figura 72.7 • Depurador de pasta mecánica.

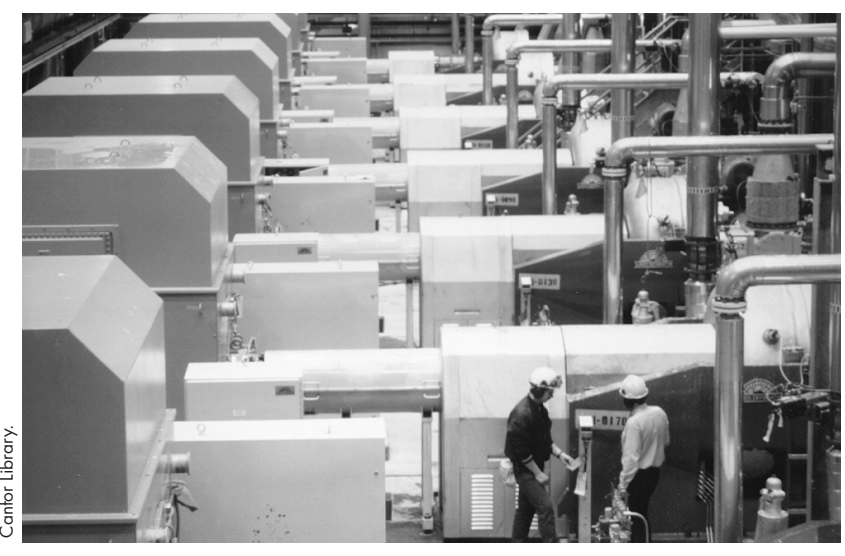

químicamente. La lignina que une la celulosa a la hemicelulosa no se disuelve, simplemente se ablanda, permitiendo que las fibras se asienten fuera de la estructura de la madera. El rendimiento (proporción de la madera inicial en la pasta) suele ser superior al $85 \%$. Algunos métodos mecánicos de formación de pasta utilizan también productos químicos (por ejemplo, las pastas quimiomecánicas); sus rendimientos son más bajos porque eliminan más cantidad de materiales no celulósicos.

En la elaboración de la pasta por raspado de la madera sobre una muela de piedra, el método mecánico más antiguo e históricamente el más usual, las fibras se extraen de trozos cortos de tronco presionados contra un cilindro rotatorio abrasivo. En la refinadora de pasta mecánica (Figura 72.7), que ganó popularidad al hacerse comercialmente viable en el decenio de 1960, se introducen astillas de madera o serrín a través del centro de un disco de la refinadora, donde se desmenuzan en trozos más pequeños al presionarlos a través de rejas y ranuras cada vez más estrechas. (En la Figura 72.7, las refinadoras se encuentran en el centro de la fotografía y sus grandes motores están a la izquierda. Las astillas se introducen a través de las tuberías de gran diámetro y la pulpa sale por las más estrechas.) Una variante de esta técnica es la elaboración de pasta termomecánica, en la que las astillas se cuecen al vapor antes y durante el refino, normalmente bajo presión.

Uno de los primeros métodos de producción de pasta mecano-química implica la precocción de los troncos con vapor antes de hervirlos en licores de pasta química, y su paso posterior a través de molinos con muelas de piedra para obtener pastas de "madera quimiomolida". El tratamiento moderno de pasta mecánico-química emplea discos refinadores con tratamiento químico (p. ej., bisulfato sódico, hidróxido sódico), durante o después del refinado. Las pastas así producidas se denominan mecano-químicas o termomecano-químicas, según el refino se haya producido a presión atmosférica o a alta presión. Muchas organizaciones han hecho modificaciones especializadas de estas últimas, desarrollándolas y patentándolas.

\section{Pasta química y recuperación}

La pasta química se produce disolviendo químicamente la lignina dispuesta entre las fibras de la madera, con lo cual se separan éstas sin dañarse de forma sustancial. Como en estos procesos se eliminan muchos de los componentes no fibrosos de la madera, los rendimientos son normalmente del 40 al $55 \%$.

El procedimiento implica la cocción de las astillas y los reactivos en solución acuosa en un reactor (digestor, Figura 72.8) que puede funcionar por lotes o de forma continua. En la cocción discontinua, el digestor se carga de astillas a través de una abertura superior, se añaden los digestores químicos, y el contenido se cuece a temperatura y presión elevadas. Una vez se termina la cocción, se libera la presión "soplando" fuera del digestor la pasta delignificada hacia un tanque de contención. Entonces se repite la secuencia. En la digestión continua, las astillas precocidas con vapor se introducen en el digestor a un ritmo constante. Las astillas y los reactivos se mezclan en la zona de impregnación, en la parte superior del digestor, y entonces se van desplazando desde la zona superior de cocción a la inferior y a la zona de lavado, antes de soplarlas al tanque.

Hoy día, en muchas de las operaciones de preparación de pasta, los digestores químicos se recuperan. De este modo pueden reconstituirse a partir del licor de cocción empleado, y además se recupera energía calorífica quemando los componentes orgánicos de la madera disueltos. La electricidad y el vapor resultantes suministran parte, si no la totalidad, de las necesidades energéticas de la fábrica.

\section{Procedimiento al sulfato y recuperación}

El procedimiento al sulfato produce una pasta más fuerte y oscura, y requiere la recuperación química para poder competir económicamente. Su punto de partida está en el procedimiento a la sosa (que utiliza únicamente hidróxido sódico para la digestión) y comenzó a adquirir importancia en la industria del decenio de 1930 al de 1950 con el desarrollo del blanqueo por dióxido de cloro y la implantación de procedimientos químicos de recuperación, que también producen vapor y energía para la fábrica. También desempeñó un papel importante el desarrollo de los

Figura 72.8 • Digestor continuo de kraft, con transportador de astillas en construcción.

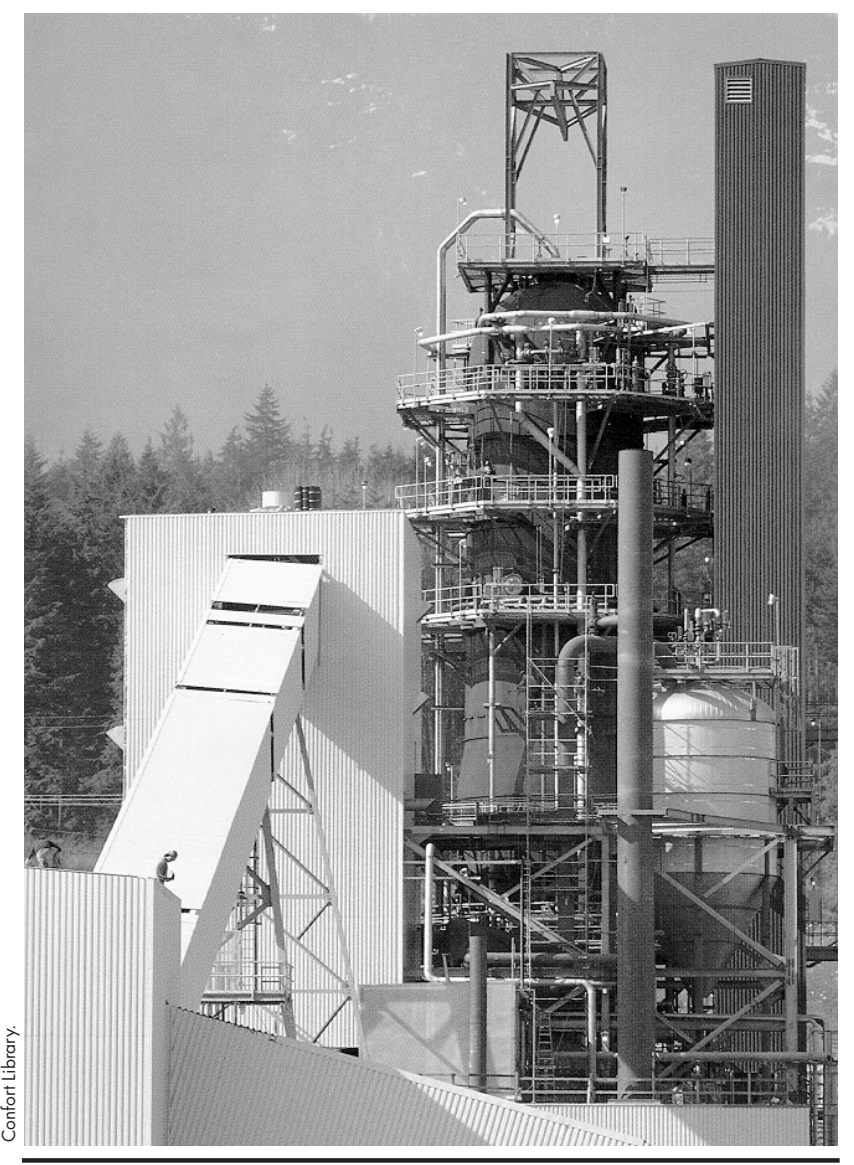


metales anticorrosión, como el acero inoxidable, para manejar el entorno ambiental de las fábricas de pasta ácida y de pasta alcalina.

La mezcla de cocción (licor blanco) es hidróxido sódico $(\mathrm{NaOH})$ y sulfuro de sodio $\left(\mathrm{Na}_{2} \mathrm{~S}\right)$. La moderna pasta kraft se transporta generalmente en digestores continuos con frecuencia revestidos de acero inoxidable (Figura 72.8). La temperatura del digestor se sube lentamente hasta unos $170^{\circ} \mathrm{C}$ y se mantiene a ese nivel durante 3 ó 4 horas. La pasta (llamada "parda", por su color) se tamiza para separar los trozos de madera que hayan quedado sin digerir, se lava para separar la mezcla de cocción utilizada (ahora licor negro) y se envía o a la nave de blanqueado o a la de la máquina de producción de pasta. La madera sin digerir se devuelve al digestor o a la caldera para quemarla y producir energía.

El licor negro recogido del digestor y el "papel pardo" de los lavaderos contienen sustancias orgánicas disueltas cuya composición química exacta depende de las características de la especie de la madera y de las condiciones de la cocción. El licor se concentra por evaporación hasta que su contenido en agua es inferior al $40 \%$, y se pulveriza en la caldera de recuperación. La parte orgánica se consume como combustible, generando calor que se recupera en la parte superior del horno en forma de vapor a elevada temperatura. La parte inorgánica no quemada se recoge en el fondo de la caldera como una mezcla fundida. El fundido fluye fuera del horno y se disuelve en una solución cáustica débil, obteniéndose un "licor verde" que contiene principalmente $\mathrm{Na}_{2} \mathrm{~S}$ disuelto y carbonato sódico $\left(\mathrm{Na}_{2} \mathrm{CO}_{3}\right)$. Este licor se bombea a una planta de recaustificación, donde se clarifica y entonces reacciona con cal apagada $\left(\mathrm{Ca}(\mathrm{OH})_{2}\right)$, formando $\mathrm{NaOH}$ y carbonato cálcico $\left(\mathrm{CaCO}_{3}\right)$. El licor blanco se filtra y se

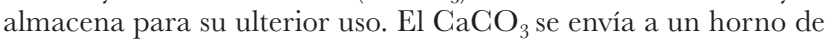
cal, donde se calienta para regenerar cal viva $(\mathrm{CaO})$.

\section{Procedimiento al sulfito y recuperación}

El procedimiento al sulfito dominó la industria papelera desde finales del siglo XIX hasta mediados del XX, si bien estaba limitado por los tipos de madera utilizables y por la contaminación creada al eliminar el licor residual sin tratar en los cauces. Procedimientos posteriores soslayaron muchos de aquellos problemas, pero la pasta elaborada al sulfito representa actualmente tan sólo un pequeño segmento del mercado de la pasta. Aunque suele utilizarse la digestión en medio ácido, existen variantes en las que se emplean un medio neutro o un medio básico.

El licor de cocción de ácido sulfuroso $\left(\mathrm{H}_{2} \mathrm{SO}_{3}\right)$ e ion bisulfito $\left(\mathrm{HSO}_{3}^{-}\right)$, se prepara in situ. Se quema azufre elemental para producir dióxido de azufre $\left(\mathrm{SO}_{2}\right)$, que se hace pasar a través de una torre de absorción que contiene agua y una de las cuatro bases alcalinas $\left(\mathrm{CaCO}_{3}\right.$, el sulfito original, $\mathrm{Na}_{2} \mathrm{CO}_{3}$, hidróxido de magnesio $\left(\mathrm{Mg}(\mathrm{OH})_{2}\right)$ o hidróxido amónico $\left(\mathrm{NH}_{4} \mathrm{OH}\right)$ que producen el ácido y el ion y controlan sus proporciones. Normalmente, la pasta al sulfito se carga en digestores discontínuos revestidos de ladrillos. Para evitar reacciones no deseadas, los digestores se calientan lentamente hasta una temperatura máxima de 130 a $140{ }^{\circ} \mathrm{C}$, y las astillas se cuecen durante mucho tiempo (6 a 8 horas). Al aumentar la presión del digestor, el dióxido de azufre gaseoso $\left(\mathrm{SO}_{2}\right)$ se purga y se vuelve a mezclar con el ácido de la cocción. Cuando quedan aproximadamente de 1 a 1,5 horas de cocción, se interrumpe la calefacción y se disminuye la presión extrayendo gas y vapor de agua. La pasta se descarga en un tanque, se lava y criba.

La mezcla usada en la digestión, llamada licor rojo, se puede utilizar para recuperar calor y productos químicos en todos los procedimientos menos en el que tiene como base bisulfito sódico. Para la pasta al sulfito amónico, el licor rojo diluido se deja primero para eliminar el $\mathrm{SO}_{2}$ residual, y se concentra y se quema. El gas que sale contiene $\mathrm{SO}_{2}$ se enfría y se pasa a través de una torre de absorción en la que se combina con amoniaco para regenerar el licor de cocción. Finalmente, el licor se filtra, se refuerza con $\mathrm{SO}_{2}$ y se almacena. El amoniaco no se puede recuperar porque se transforma en nitrógeno y agua en la caldera de recuperación.

En la pasta al sulfito de magnesio, al quemar el licor concentrado se obtiene óxido de magnesio $(\mathrm{MgO})$ y $\mathrm{SO}_{2}$, que se recuperan fácilmente. No se produce fusión en este proceso; se recoge bastante $\mathrm{MgO}$ del escape de gas y se apaga con agua para producir hidróxido de magnesio $\left(\mathrm{Mg}(\mathrm{OH})_{2}\right)$. El $\mathrm{SO}_{2}$ se enfría y se combina con el $\mathrm{Mg}(\mathrm{OH})_{2}$ en una torre de absorción para reconstituir el licor de cocción. El bisulfito de magnesio $\left(\mathrm{Mg}\left(\mathrm{HSO}_{3}\right)_{2}\right)$ se refuerza con $\mathrm{SO}_{2}$ y se almacena. Es posible una recuperación del 80 al $90 \%$ de los reactivos de cocción.

La recuperación del licor de cocción de la base de sulfito sódico es más complicada. Se incinera el licor de cocción concentrado utilizado y aproximadamente el $50 \%$ del azufre se transforma en $\mathrm{SO}_{2}$. El resto de azufre y de sodio se recoge del fondo de la caldera de recuperación como una fusión de $\mathrm{Na}_{2} \mathrm{~S}$ y $\mathrm{Na}_{2} \mathrm{CO}_{3}$. Esta se disuelve para producir licor verde, que se transforma en bisulfito sódico $\left(\mathrm{NaHSO}_{3}\right)$ en varios pasos. $\mathrm{El} \mathrm{NaHSO}_{3}$ se refuerza y se almacena. El proceso de recuperación produce algunos gases sulfurados, en particular sulfuro de hidrógeno $\left(\mathrm{H}_{2} \mathrm{~S}\right)$.

\section{BLANQUeO}

George Astrakianakis y Judith Anderson

El blanqueo es un proceso dirigido en varias etapas mediante el cual se refina y aclara la pasta en bruto. El objetivo es disolver (pasta química) o modificar (pasta mecánica) la lignina parda que no se eliminó durante los procesos de elaboración de la pasta, manteniendo la integridad de las fibras. Una fábrica produce pasta por encargo variando el orden, la concentración y el tiempo de reacción de los agentes blanqueantes.

Cada etapa del blanqueo se define por su agente blanqueante, el pH (acidez), la temperatura y la duración (Tabla 72.3). Después de cada una de ellas, la pasta se debe lavar con agentes cáusticos para eliminar los agentes blanqueadores y disolver la lignina antes de pasar a la siguiente. Finalizada la última etapa, la pasta se bombea a través de series de tamices y limpiadores para eliminar cualquier contaminante, como basura o plásticos. Entonces se concentra y transporta al almacenamiento.

Históricamente, la secuencia de blanqueo más comúnmente utilizada para producir pasta kraft blanqueada para el mercado se basaba en las cinco etapas del procedimiento GEDED (véase en la Tabla 72.3 la definición de los símbolos). Las dos primeras etapas completan el proceso de deslignificación y se consideran una prolongación de la obtención de pasta. A causa de los condicionantes ambientales referentes a las sustancias organocloradas en los vertidos de las fábricas de pasta de papel, muchas veces se sustituye el dióxido de cloro $\left(\mathrm{ClO}_{2}\right)$ por una parte de cloro $\left(\mathrm{Cl}_{2}\right)$, utilizado en la primera etapa del blanqueo $\left(\mathrm{C}_{\mathrm{D}} \mathrm{EDED}\right)$ y se utiliza un tratamiento previo con oxígeno $\left(\mathrm{O}_{2}\right)$ durante la primera extracción cáustica $\left(\mathrm{C}_{\mathrm{D}} \mathrm{E}_{\mathrm{O}} \mathrm{DED}\right)$. La tendencia actual en Europa y en Norteamérica apunta a la completa sustitución del $\mathrm{ClO}_{2}$ o eliminación de ambos, $\mathrm{Cl}_{2}$ y $\mathrm{ClO}_{2}$. En lugar de $\mathrm{ClO}_{2}$ se utiliza dióxido de azufre $\left(\mathrm{SO}_{2}\right)$ que se añade durante la etapa final de lavado, como un "anticloro", para detener la reacción del $\mathrm{ClO}_{2}$ y controlar el $\mathrm{pH}$. Se han desarrollado nuevas secuencias de blanqueo sin cloro (por ejemplo, OAZQP, OQPZP, donde $Q=$ quelación) que 
Tabla 72.3 - Agentes blanqueantes y condiciones para su empleo.

\begin{tabular}{|c|c|c|c|c|c|c|}
\hline & $\begin{array}{l}\text { Sim- } \\
\text { bolo }\end{array}$ & $\begin{array}{l}\text { Concen- } \\
\text { tración del } \\
\text { agente (\%) }\end{array}$ & $\mathrm{pH}$ & $\begin{array}{l}\text { Consis- } \\
\text { tencia* } \\
(\%)\end{array}$ & $\begin{array}{l}\text { Tempera- } \\
\text { tura }\left({ }^{\circ} \mathrm{C}\right)\end{array}$ & $\begin{array}{l}\text { Tiempo } \\
\text { (h) }\end{array}$ \\
\hline Cloro $\left(\mathrm{Cl}_{2}\right)$ & C & $2,5-8$ & 2 & 3 & $20-60$ & $0,5-1,5$ \\
\hline $\begin{array}{l}\text { Hidróxido } \\
\text { sódico } \\
(\mathrm{NaOH})\end{array}$ & $E$ & $1,5-4,2$ & 11 & $10-12$ & $<80$ & $1-2$ \\
\hline $\begin{array}{l}\text { Dióxido } \\
\text { de cloro } \\
\left(\mathrm{ClO}_{2}\right)\end{array}$ & D & $\approx 1$ & $0-6$ & $10-12$ & $60-75$ & $2-5$ \\
\hline $\begin{array}{l}\text { Hipoclorito } \\
\text { sódico } \\
(\mathrm{NaOCl})\end{array}$ & $H$ & $1-2$ & $9-11$ & $10-12$ & $30-50$ & $0,5-3$ \\
\hline Oxígeno $\left(\mathrm{O}_{2}\right)$ & 0 & $1,2-1,9$ & $7-8$ & $25-33$ & $90-130$ & $0,3-1$ \\
\hline $\begin{array}{l}\text { Peróxido de } \\
\text { hidrógeno } \\
\left(\mathrm{H}_{2} \mathrm{O}_{2}\right)\end{array}$ & $P$ & 0,25 & 10 & 12 & $35-80$ & 4 \\
\hline Ozono $\left(0_{3}\right)$ & Z & $0,5-3,5$ & $2-3$ & $35-55$ & $20-40$ & $<0,1$ \\
\hline $\begin{array}{l}\text { Dióxido de } \\
\text { azufre } \\
\left(\mathrm{SO}_{2}\right)\end{array}$ & A & $4-6$ & $1,8-5$ & 1,5 & $30-50$ & 0,25 \\
\hline $\begin{array}{l}\text { Ditiosulfato } \\
\text { sódico } \\
\left(\mathrm{NaS}_{2} \mathrm{O}_{4}\right)\end{array}$ & Y & $1-2$ & $5,5-8$ & $4-8$ & $60-65$ & $1-2$ \\
\hline
\end{tabular}

utilizan enzimas, $\mathrm{O}_{2}$, ozono $\left(\mathrm{O}_{3}\right)$, peróxido de hidrógeno $\left(\mathrm{H}_{2} \mathrm{O}_{2}\right)$, perácidos y agentes quelantes, como el ácido etilén-diamino tetracético (AETA). En 1993, ocho fábricas en todo el mundo habían adoptado procedimientos de blanqueo totalmente exentos de cloro. Como estos nuevos métodos eliminan las fases ácidas del blanqueo, se ha de añadir un lavado ácido para permitir la remoción de los metales enlazados a la celulosa.

Las pastas al sulfito son generalmente más fáciles de blanquear que las pastas kraft por su menor contenido de lignina. Para muchas calidades de papel se pueden utilizar diversas secuencias de blanqueo cortas (por ejemplo, GEH, DGEHD, P, HP, EPOP). Para pastas al sulfito de calidad disolvente, utilizadas en la producción de rayón, celofán y similares, hay que eliminar la lignina y la hemicelulosa, requiriéndose secuencias de blanqueo más complejas (por ejemplo, $\mathrm{C}_{1} \mathrm{C}_{2} \mathrm{ECHDA}$ ). $\mathrm{El}$ lavado final ácido se realiza tanto para controlar los metales como para la acción anti-cloro. La carga de vertido para pastas al sulfito de calidad disolvente es mucho mayor porque se consume mucha madera en bruto (rendimiento típico del $50 \%$ ) y se emplea más agua.

Se denomina abrillantado el blanqueo de pastas mecánicas o de otras pastas de alto rendimiento, porque la operación se realiza destruyendo los grupos cromóforos sin disolver la lignina. Entre los abrillantadores están el $\mathrm{H}_{2} \mathrm{O}_{2}$ y/o el hidrosulfito sódico. Antes se utilizaba generalmente el hidrosulfito de zinc $\left(\mathrm{ZnS}_{2} \mathrm{O}_{4}\right)$, pero se ha eliminado por completo a causa de la toxicidad de su vertido. Antes del blanqueo, se añaden agentes quelantes para neutralizar cualquier ion metálico, aquí presentes para evitar la formación de sales coloreadas o la descomposición del peróxido de hidrógeno $\mathrm{H}_{2} \mathrm{O}_{2}$. La eficacia del blanqueo de la pasta mecánica depende de las especies de procedencia de la madera. Las maderas duras (por ejemplo, el álamo y el chopo) y las blandas (por ejemplo, el abeto y el bálsamo de Judea) con más bajo contenido en lignina y en sustancias extractivas se blanquean con más alto nivel de abrillantado que las maderas más resinosas, como el pino y el cedro.

\section{FABRICAS DE PAPEL RECICLADO}

\section{Dick Heederik}

El uso de residuos o de papel reciclado como materia prima para la preparación de pasta ha aumentado en el transcurso de las últimas décadas, hasta el punto de que algunas papeleras dependen casi completamente del papel de desecho. En algunos países, este último se separa del resto de los residuos domésticos, en origen, antes de su recogida. En otros se realiza una separación por clases (por ejemplo, cartón ondulado, papel prensa, papel de calidad, papel mezclado) en plantas especiales de reciclaje.

El papel reciclado se puede retransformar en pasta en un proceso relativamente suave, que utiliza agua y a veces $\mathrm{NaOH}$. Los pequeños trozos de metal y de plástico se separan durante o después de la reconversión en pulpa, utilizando detritus sedimentados, ciclones o centrifugación. Las sustancias de relleno, colas y resinas se eliminan en la fase de lavado por corriente de aire a través de los lodos de la pasta, en ocasiones con la adición de agentes floculantes. La espuma contiene sustancias químicas indeseables y se retira. La pulpa se destinta empleando una serie de lavados que pueden incluir o no el uso de reactivos químicos (por ejemplo, detergentes tensioactivos) para disolver las impurezas restantes, y agentes blanqueantes que aclaran la pulpa. El blanqueo tiene la desventaja de que puede reducir la longitud de la fibra y, por consiguiente, disminuir la calidad final del papel. Los agentes blanqueantes utilizados en la producción de pasta reciclada son en general similares a los empleados en las operaciones de abrillantado de la pasta mecánica. Después de las operaciones de rebatido de la pasta y de destintado, la producción de hojas de papel continúa de una forma muy semejante a la utilizada empleando pasta de fibra virgen.

\section{PRODUCCION DE PAPEL Y TRANSFORMADOS: PASTA PAPELERA, PAPEL, Y CARTON}

\section{George Astrakianakis y Judith Anderson}

Los productos finales de la fábrica de pasta y de papel dependen del proceso de preparación de la pasta, pero pueden incluir pasta papelera y varios tipos de productos de papel y cartón. Por ejemplo, la pasta mecánica, relativamente frágil, se transforma en productos de un solo uso, como papel prensa y papel de seda. La pasta kraft se transforma en productos de papel de uso múltiple, como papel de escritorio de alta calidad, libros o bolsas para comestibles. La pulpa al sulfito, que es celulosa fundamentalmente, se puede utilizar en diversos productos finales, tales como papeles especiales, rayón, película fotográfica, TNT, plásticos, adhesivos y hasta componentes para helados y dulces. Las pastas mecano-químicas son excepcionalmente consistentes, ideales para la estructura necesaria para los recipientes de cartón ondulado. Las fibras de la pasta de papel reciclado son generalmente más cortas, menos flexibles y menos permeables; por consiguiente, no pueden utilizarse en productos de papel de alta calidad. El papel reciclado se utiliza, por tanto, para fabricar 
Figura 72.9 • Extremo húmedo de una máquina de papel mostrando fieltro de fibra sobre la rejilla.

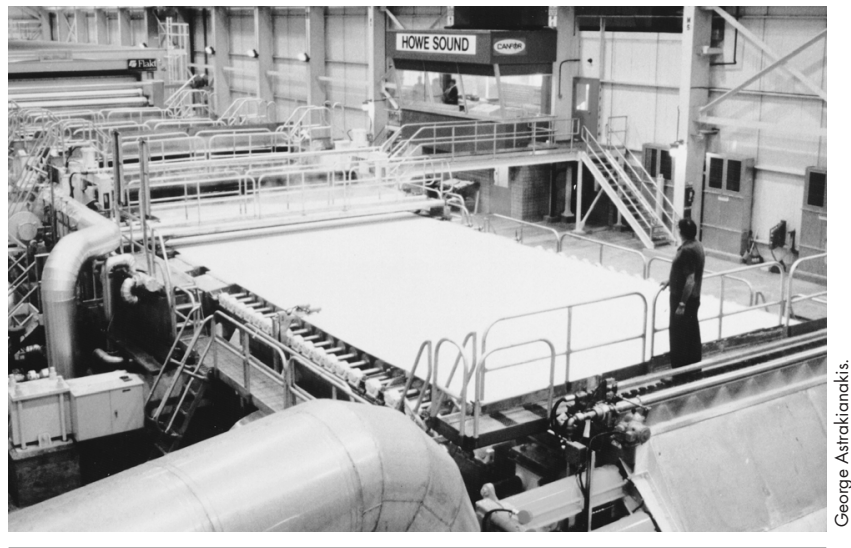

productos suaves y blandos, como el papel de seda, el papel higiénico, las toallitas y las servilletas de papel.

Para producir pasta papelera, la suspensión de pasta se tamiza una vez más y se ajusta su consistencia (4 al $10 \%$ ) antes de que esté preparada para la máquina. Entonces se extiende en una tela metálica móvil o malla de plástico (conocida como "rejilla") en el "extremo húmedo" de la máquina de pasta, donde los operadores vigilan la velocidad de la cinta en movimiento y el contenido en agua (Figura 72.9; las prensas y la tapa del secador pueden verse en la zona superior izquierda; en las fábricas modernas, los trabajadores emplean gran parte del tiempo salas de control). El agua y el filtrado se extraen a través de la cinta eliminando la humedad de la fibra. La hoja de pasta pasa a través de una serie de rodillos rotatorios ("prensas") que escurren el agua y el aire hasta que la consistencia es del 40 al $45 \%$. Se hace entonces flotar la hoja a través de una serie de pisos de secadores de aire caliente hasta que la consistencia sea del $90 \mathrm{al}$ $95 \%$. Finalmente, la lámina continua se corta en pliegos y se apila en balas. Las balas de pasta se comprimen, se embalan y se empaquetan en resmas para su almacenamiento y transporte.

Aunque a primera vista parece bastante similar a la producción de hojas de pasta papelera, la fabricación de papel es bastante más compleja. Algunas papeleras emplean un surtido de diferentes pastas para optimizar la calidad del papel (p. ej., una mezcla de madera dura, madera blanda, kraft, sulfito, pasta mecánica o reciclada). Dependiendo del tipo de pasta utilizada, hay que seguir una serie de pasos para obtener la hoja de papel. Generalmente, la pasta papelera seca se rehidrata, al tiempo que se diluye la pasta de alta consistencia almacenada. Las fibras de la pasta se pueden sacudir para aumentar la zona de enlaces entre fibras para así mejorar la persistencia de la hoja. La pasta se mezcla con aditivos del "extremo húmedo" (Tabla 72.4) y se pasa a través de un conjunto final de cribas y lavaderos. Entonces la pasta queda preparada para la máquina de papel.

El esparcidor de la pasta y el cabezal distribuyen una suspensión fina (1 a $3 \%$ ) de pasta depurada, en una rejilla móvil (semejante a la de la máquina de pasta, sólo que a una velocidad mucho mayor, en ocasiones a más de $55 \mathrm{~km} / \mathrm{h}$ ) que forma con las fibras una fina lámina afieltrada. La lámina se desplaza a través de una serie de rodillos de prensado a la sección de secado, donde unos rodillos calentados con vapor evaporan gran parte del agua restante. En esta etapa se han desarrollado por completo los enlaces de hidrógeno entre las fibras. Finalmente, el papel se pasa por la calandria y se enrolla en bobinas. El calandrado es el proceso por el cual se alisa la superficie del papel y se reduce su espesor. El papel seco alisado así obtenido
Tabla 72.4 • Aditivos en la fabricación de papel.

\begin{tabular}{|c|c|c|}
\hline Aditivo & Aplicado en & $\begin{array}{l}\text { Finalidad y/o ejemplos de agentes } \\
\text { específicos }\end{array}$ \\
\hline \multicolumn{3}{|c|}{ Aditivos más comúnmente utilizados } \\
\hline Talco & $\begin{array}{l}\text { Extremo } \\
\text { húmedo }\end{array}$ & $\begin{array}{l}\text { Control de la mezcla extráble* (evita la deposi- } \\
\text { ción y acumulación de la mezcla extraible) } \\
\text { Apresto (confiere más brillantez, más alisado, } \\
\text { más opaco) }\end{array}$ \\
\hline Dióxido de titanio & $\begin{array}{l}\text { Extremo } \\
\text { húmedo }\end{array}$ & $\begin{array}{l}\text { Pigmento (hoja brillante, mejora impresión) } \\
\text { Apresto (confiere más brillantez, más alisado, } \\
\text { más opaco) }\end{array}$ \\
\hline $\begin{array}{l}\text { "Alumbre" } \\
\left(\mathrm{Al}_{2}\left(\mathrm{SO}_{4}\right)_{3}\right)\end{array}$ & $\begin{array}{l}\text { Extremo } \\
\text { húmedo }\end{array}$ & $\begin{array}{l}\text { Precipita resina al encolar sobre las fibras } \\
\text { Ayuda a la retención (fija aditivos a las fibras, } \\
\text { mejora la retención de las fibras de la pasta) }\end{array}$ \\
\hline Resina & $\begin{array}{l}\text { Extremo } \\
\text { húmedo }\end{array}$ & $\begin{array}{l}\text { Encolado interno (resistencia penetración } \\
\text { líquidos) }\end{array}$ \\
\hline Arcilla (caolín) & Húmedo/seco & $\begin{array}{l}\text { Apresto (confiere más brillantez, más alisado, } \\
\text { más opaco) } \\
\text { Pigmento o satinado de superficie (imparte } \\
\text { color) }\end{array}$ \\
\hline Almidón & Húmedo/seco & $\begin{array}{l}\text { Encolado interno (resistencia a la penetración de } \\
\text { líquidos) } \\
\text { Aditivo de resistencia por vía seca (aumenta la } \\
\text { resistencia, reduce el polvo superficie) } \\
\text { Ayuda a la retención (aditivos para encuaderna- } \\
\text { ción del papel, mejora la retención de la fibra } \\
\text { de la pasta) }\end{array}$ \\
\hline $\begin{array}{l}\text { Tintes y } \\
\text { pigmentos }\end{array}$ & Húmedo/seco & $\begin{array}{l}\text { p. ej, tintes ácidos, básicos o directos, lacas de } \\
\text { color, } \mathrm{CO}_{3} \mathrm{Ca} \text {, puede incluir disolventes. }\end{array}$ \\
\hline Latex & Extremo seco & $\begin{array}{l}\text { Adhesivo (refuerza la hoja), aditivos para } \\
\text { encuadernación del papel, tapado de poros) } \\
\text { Impermeabilización (resistencia a la penetración } \\
\text { de líquidos) }\end{array}$ \\
\hline \multicolumn{3}{|l|}{ Otros aditivos } \\
\hline Antimohos & Extremo seco & $\begin{array}{l}\text { p. ej., tiones, tiazoles, tiocianates, tio- } \\
\text { carbamatos, tioles, isotiazolinonas, } \\
\text { formaldehído, glutaraldehído, glicoles, naftol, } \\
\text { organoclorados y organobromados, } \\
\text { compuestos organomercúricos }\end{array}$ \\
\hline
\end{tabular}

Desespumadores Extremo seco p. ej., aceite de pino, fuel oil, aceites reciclados, silicona, alcoholes

\begin{tabular}{|c|c|c|}
\hline $\begin{array}{l}\text { Agentes } \\
\text { tratamiento de } \\
\text { la rejilla }\end{array}$ & Extremo seco & $\begin{array}{l}\text { p. ej., imidazoles, butildiglicol, acetona, } \\
\text { trementina, ácido fosfórico }\end{array}$ \\
\hline $\begin{array}{l}\text { Húmedo y seco } \\
\text { aditivos para } \\
\text { consistencia }\end{array}$ & Extremo seco & $\begin{array}{l}\text { p. ej., resinas de formaldehído, epiclorhidrina, } \\
\text { glioxal, gomas, poliaminas, fenólicos, poli- } \\
\text { acrilamidas, poliamidas, derivados de celulosa }\end{array}$ \\
\hline $\begin{array}{l}\text { Adhesivos } \\
\text { cubrientes, y } \\
\text { plastificantes }\end{array}$ & Extremo seco & $\begin{array}{l}\text { p. ej., hidróxido de aluminio, acetato de polivi- } \\
\text { nilo, acrílicos, aceite de linaza, gomas, colas } \\
\text { proteicas, emulsiones de cera, papel metali- } \\
\text { zado, acita, glioxal, estearatos, disolventes, } \\
\text { polietileno, derivados de celulosa, derivados } \\
\text { del caucho, poliaminas, poliésteres, polímeros } \\
\text { de butadieno-estireno }\end{array}$ \\
\hline Otros & Húmedo/seco & $\begin{array}{l}\text { Inhibidores de la corrosión, dispersantes, ignifu- } \\
\text { gantes, agentes antivaho, ayuda al goteo, } \\
\text { defloculantes, agentes para control del pH, } \\
\text { conservantes }\end{array}$ \\
\hline
\end{tabular}


Figura 72.10 • Extremo seco de una máquina de papel mostrando la bobina de papel y al trabajador utilizando la cizalla de aire para cortar el extremo.

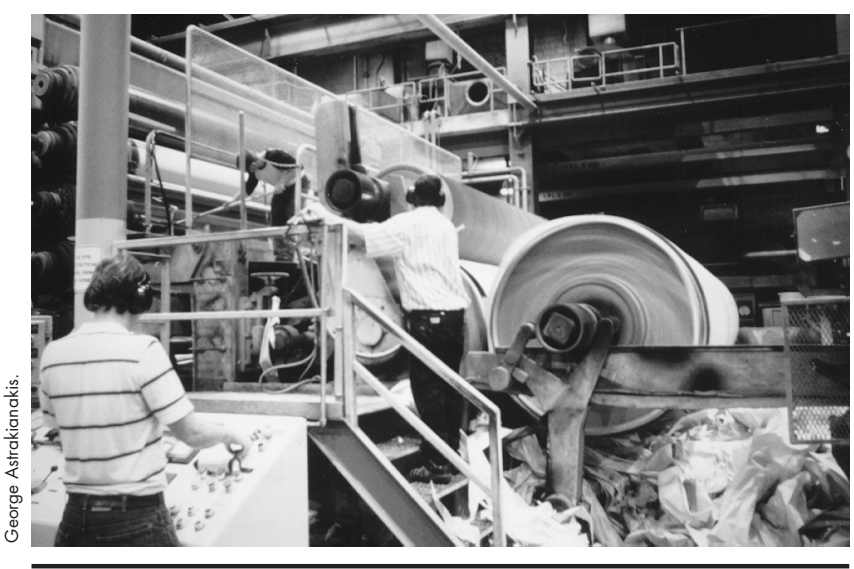

se enrolla en una bobina, se etiqueta y se transporta al almacén (Figura 72.10; nótense el papel residual bajo la bobina y el trabajador en el panel de control abierto). Los aditivos del "extremo seco" se pueden añadir antes del calandrado sobre la máquina, o en las operaciones de preparación, "fuera de máquina", en el sector de transformación de la industria.

En los procesos de fabricación de papel se utilizan distintos productos químicos para dar a éste características específicas en la superficie y propiedades de la hoja. Los aditivos más corrientes (Tabla 72.4) son normalmente empleados en la proporción adecuada, aunque algunos, como la arcilla o caotín y el talco, pueden aumentar hasta más del $40 \%$ el peso en seco de algunos papeles. La Tabla 72.4 también indica la variedad de aditivos químicos que se pueden utilizar para productos y fines específicos; algunos de ellos se emplean en concentraciones muy bajas (p. ej., los bactericidas antimoho se agregan al agua de la operación en partes por millón).

El proceso de fabricación de cartón se asemeja a los de producción de pasta o de papel. Se dispersa sobre una rejilla metálica móvil una suspensión de pasta papelera y agua, se extrae el agua, y la hoja se seca y se almacena como una bobina. El procedimiento difiere en cuanto al modo en que se forma la hoja para darle grosor, en la combinación de múltiples capas y en los procesos de secado. El cartón se puede fabricar en hojas formadas por una o por varias capas, con núcleo o sin él. Generalmente, las hojas son de pasta papelera kraft (o kraft y GTMP mezcladas) de alta calidad, mientras que el núcleo se produce o con una mezcla de pasta semi-química y pasta reciclada barata, o totalmente de pasta reciclada y otros materiales de desecho. Los satinados o estucados, las cortinas de vapor y capas múltiples se añaden de acuerdo con la finalidad, para proteger el contenido del agua y de los golpes.

\section{- GENERACION DE ENERGIA Y TRATAMIENTO DE LAS AGUAS}

\section{George Astrakianakis y Judith Anderson}

Además de la recuperación del licor, las fábricas de pasta recuperan una significativa cantidad de energía quemando materiales de residuos y subproductos del proceso en calderas de vapor. Materiales tales como cortezas, residuos de madera y lodo seco, recogidos de los sistemas de tratamiento de vertidos, se pueden quemar para proporcionar vapor a los generadores de energía eléctrica.

Las fábricas de pasta y de papel consumen grandes cantidades de agua. Una fábrica de blanqueo de pasta kraft con una producción de 1.000 toneladas al día consume más de 150 millones de litros de agua al día; una fábrica de papel aun más. Para prevenir los efectos adversos sobre la maquinaria de la fábrica y mantener la calidad del producto, el agua de entrada debe ser tratada para eliminar contaminantes, bacterias y minerales. Dependiendo de su calidad, se aplican varios tratamientos: lechos de sedimentación, filtros, floculantes, cloro o resinas de cambio iónico antes de ser usada en el proceso. El agua empleada en las calderas de vapor y de recuperación es posteriormente tratada con depuradores de oxígeno e inhibidores de la corrosión, como hidracina y morfolina, para evitar que se formen depósitos en los conductos de la caldera, reducir la corrosión de los metales y evitar el paso del agua a la turbina de vapor.

\section{PRODUCGION DE PRODUCTOS QUIMICOS Y DE SUBPRODUCTOS}

\section{George Astrakianakis y Judith Anderson}

Como muchos blanqueantes químicos son reactivos y peligrosos de transportar, se producen in situ o en las cercanías. El dióxido de cloro $\left(\mathrm{ClO}_{2}\right)$, el hipoclorito sódico $(\mathrm{NaOCl})$ y los perácidos se producen siempre in situ o en las proximidades, mientras que el cloro $\left(\mathrm{Cl}_{2}\right)$ y el hidróxido sódico o sosa cáustica $(\mathrm{NaOH})$ se producen generalmente fuera de la factoría. El aceite de resina, un producto derivado de la resina y los ácidos grasos que se extraen durante la cocción de kraft, se puede refinar tanto dentro como fuera. La trementina, una fracción ligera como subproducto de la obtención de la pasta kraft, a menudo se recoge y se concentra in situ, refinándose en otra parte.

\section{Dióxido de cloro}

El dióxido de cloro $\left(\mathrm{ClO}_{2}\right)$ es un gas amarillo verdoso extremadamente reactivo. Tóxico y corrosivo, explota en concentraciones altas $(10 \%)$ y en presencia de luz ultravioleta rápidamente se reduce a $\mathrm{Cl}_{2} \mathrm{y} \mathrm{O}_{2}$. Se debe preparar en forma de gas diluido y almacenar como disolución diluida, lo que impide su transporte en vehículo.

$\mathrm{El} \mathrm{ClO}_{2}$ se produce reduciendo clorato sódico $\left(\mathrm{Na}_{2} \mathrm{ClO}_{3}\right)$ con $\mathrm{SO}_{2}$, metanol, y masal del ácido hidroclórico. El gas que sale del reactor se condensa y se almacena como disolución acuosa al $10 \%$. Los generadores modernos de $\mathrm{ClO}_{2}$ operan con una eficacia del $95 \%$ o más, y la pequeña cantidad de $\mathrm{Cl}_{2}$ que se produce se recoge o se depura del gas de salida. Dependiendo de la pureza de los productos químicos empleados, de la temperatura y de otras variables del proceso, pueden tener lugar otras reacciones secundarias. Los subproductos se reincorporan al proceso y los reactivos consumidos se neutralizan y se mandan al alcantarillado.

\section{Hipoclorito sódico}

El hipoclorito sódico $(\mathrm{NaOCl})$ se obtiene haciendo reaccionar $\mathrm{Cl}_{2}$ con una solución diluida de $\mathrm{NaOH}$. Es un proceso sencillo y automático que apenas requiere intervención. Se controla manteniendo la concentración de sosa de forma que la cantidad de $\mathrm{Cl}_{2}$ residual en el reactor sea mínima. 


\section{Cloro y sosa cáustica}

El cloro $\left(\mathrm{Cl}_{2}\right)$, utilizado como agente blanqueante desde el principio del siglo XIX, es muy reactivo y tóxico; se trata de un gas de color verdoso que se vuelve corrosivo en presencia de humedad. Generalmente se fabrica por electrólisis de la salmuera ( $\mathrm{NaCl}$ ), que produce $\mathrm{Cl}_{2}$ y $\mathrm{NaOH}$, en instalaciones regionales, y se transporta hasta el cliente como líquido puro. Se utilizan tres métodos para la producción de $\mathrm{Cl}_{2}$ a escala industrial: la célula de mercurio, la célula de diafragma y la más reciente célula de membrana. $\mathrm{El} \mathrm{Cl}_{2}$ se produce siempre en el ánodo. Se enfría, se purifica, se seca, se licúa y se transporta a la fábrica. Si ésta es muy grande o se encuentra a larga distancia, se pueden construir instalaciones locales, desde las que el $\mathrm{Cl}_{2}$ se puede transportar en estado gaseoso.

La calidad del $\mathrm{NaOH}$ depende del procedimiento que se emplee. En el más antiguo, el de la célula de mercurio, el sodio y el mercurio se combinan, formando una amalgama que se descompone con el agua. El $\mathrm{NaOH}$ resultante es casi puro. Uno de los inconvenientes de este método es que el mercurio contamina el lugar del trabajo y ha dado lugar a serios problemas ambientales. El NaOH producido en la célula de diafragma se extrae con los restos de salmuera y se concentra para permitir que la sal cristalice y se separe. En el diafragma se emplea amianto. El $\mathrm{NaOH}$ más puro se produce en las células de membrana. Una membrana semipermeable de material resinoso permite el paso de los iones sodio, sin la salmuera ni los iones cloro, y se combina con el agua añadida a la cámara catódica para formar $\mathrm{NaOH}$ puro. El gas hidrógeno es un subproducto de cada uno de estos procesos. Normalmente se trata y se utiliza en otros procesos o como combustible.

\section{Producción de aceite de resina}

La producción de pasta kraft a partir de especies muy resinosas, como el pino, produce un jabón sódico de resina y ácidos grasos. El jabón se recoge de los tanques de almacenaje del licor negro y de los tanques de espumado del jabón que se encuentran localizados en el tren de evaporación del proceso de recuperación de productos químicos. El jabón refinado o el aceite de resina se utiliza como aditivo del combustible, agente de control del polvo, estabilizador de firmes de carretera, aglutinante del pavimento y material bituminoso para tejados.

En la planta del proceso, el jabón se almacena en los tanques primarios para dejar que el licor negro se asiente sobre el fondo. En un segundo tanque de almacenamiento, el jabón sube y flota. El jabón decantado y ácido sulfúrico se introducen en el reactor, se calientan hasta $100^{\circ} \mathrm{C}$, se agitan y se dejan sedimentar. Después de sedimentar toda la noche, el aceite de resina en bruto se decanta en el recipiente de almacenamiento y se le deja reposar durante otro día. La fracción superior se considera aceite de resina crudo seco y se bombea para su almacenamiento, listo para su envío. La lignina cocida de la fracción inferior es parte del lote siguiente. El ácido sulfúrico usado se bombea al tanque de almacenamiento dejando que la lignina arrastrada se sedimente en el fondo. La lignina que queda en el reactor se concentra durante varias cocciones, se disuelve en solución de sosa cáustica al $20 \%$ y se reenvía al primer tanque de jabón. Periódicamente, el licor negro recogido y la lignina residual de todas las procedencias se concentran y se queman como combustible.

\section{Recuperación de la trementina}

Los gases de los digestores y los condensados de los evaporadores de licor negro se recogen para recuperar la trementina. Los gases se condensan, se combinan, y entonces se recupera la trementina, que se recondensa, se recoge y se envía al decantador. La fracción superior del decantador se extrae y se envía al almacenamiento mientras que la fracción inferior se recicla en el recuperador. La trementina cruda se almacena separadamente del resto del sistema de recogida porque es nociva e inflamable, y se suele procesar fuera. Todos los gases no condensables se recogen y se incineran bien en las calderas de vapor, en el horno de cal o en un horno dedicado a este fin. La trementina se procesa para su empleo en alcanfor, resinas sintéticas, disolventes, agentes de flotación e insecticidas.

\section{RIESGOS PROFESIONALES Y CONTROLES}

\author{
Kay Teschke, George Astrakianakis, \\ Judith Anderson, Anya Keefe y \\ Dick Heederik
}

La Tabla 72.5 ofrece una visión general de los tipos de riesgos que cabe esperar en cada zona de las fábricas de pasta y de papel. Aunque hay riesgos que se pueden considerar específicos de ciertos procesos de producción, los que afectan a trabajadores de las demás áreas pueden tener lugar dependiendo de las condiciones meteorológicas, la proximidad a las fuentes del riesgo, o el hecho de trabajar en más de un área de proceso (p. ej., control de calidad, servicios de personal generales, personal de mantenimiento).

La exposición a los riesgos relacionados en la Tabla 72.5 puede depender del nivel de automatización de la planta. Antes, la producción industrial de pasta y de papel era un proceso semiautomático que requería una parte importante de intervención manual. En tales instalaciones, los trabajadores permanecían en paneles situados junto a los procesos para observar el efecto de sus acciones. Las válvulas en las partes superior e inferior del digestor de cocción se abrían manualmente, y durante las etapas de llenado, los gases en el digestor podían ser desplazados por las astillas introducidas (Figura 72.11). La adición de productos químicos se establecía de acuerdo con la experiencia, en vez de muestrear, y en el proceso dependían de la destreza y los conocimientos del trabajador, quien a veces es el que causaba el trastorno. Por ejemplo, la sobrecloración de la pasta puede exponer a los operarios de la zona inferior a elevados niveles de agentes blanqueantes. En las fábricas más modernas, Figura 72.11 - Trabajador levantando la tapa del digestor
discontinuo controlado manualmente.

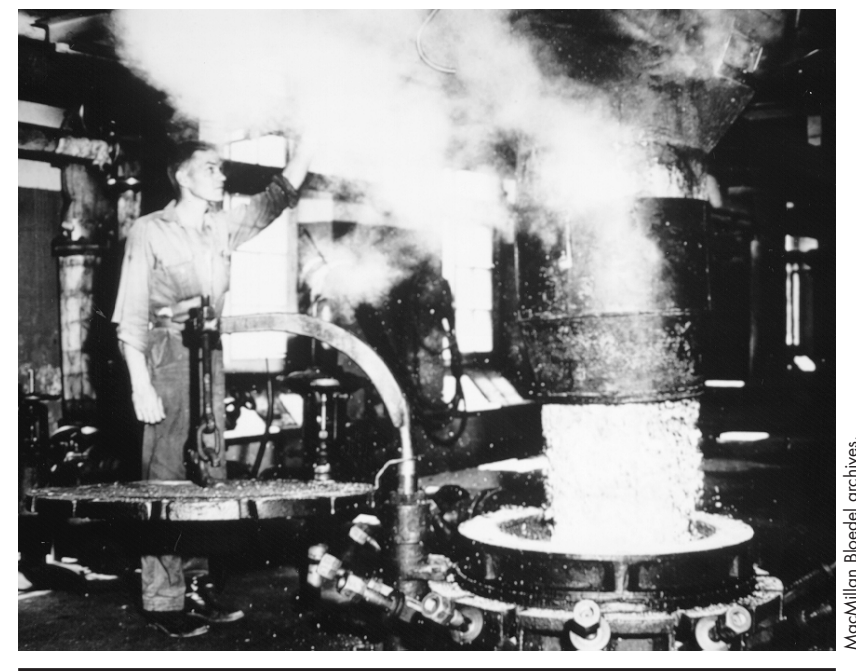


Tabla 72.5 • Riesgos potenciales de salud y seguridad en la producción de pasta y de papel, por áreas de proceso.

\begin{tabular}{|c|c|c|c|c|}
\hline Area de proceso & Riesgos de seguridad & Riesgos físicos & Riesgos químicos & Riesgos biológicos \\
\hline \multicolumn{5}{|c|}{ Preparación de la madera } \\
\hline $\begin{array}{l}\text { Desembarque } \\
\text { troncos }\end{array}$ & $\begin{array}{l}\text { Inmersión; equipo móvil; } \\
\text { deslizamiento, caída }\end{array}$ & Ruido; vibración; frío; calor & Escape motores & \\
\hline Sala de madera & $\begin{array}{l}\text { Puntos de atrapamiento; } \\
\text { deslizamiento, caída }\end{array}$ & Ruido; vibración & Terpenos y otros extractos de madera; polvo de madera & Bacterias; hongos \\
\hline Cribado de astillas & $\begin{array}{l}\text { Puntos de atrapamiento; } \\
\text { deslizamiento, caida }\end{array}$ & Ruido; vibración & Terpenos y otros extractos de madera; polvo de madera & Bacterias; hongos \\
\hline Patio de astillas & $\begin{array}{l}\text { Puntos de atrapamiento; } \\
\text { equipo móvil }\end{array}$ & Ruido; vibración; frío; calor & $\begin{array}{l}\text { Escape de motores; terpenos y otros extractos de madera; } \\
\text { polvo de madera }\end{array}$ & Bacterias; hongos \\
\hline \multicolumn{5}{|c|}{ Preparación de la pasta } \\
\hline Pasta papelera & Deslizamiento, caida & $\begin{array}{l}\text { Ruido; campos eléctricos y } \\
\text { magnéticos; elevada humedad }\end{array}$ & & \\
\hline REF, MQ, TMQ & Deslizamiento, caída & $\begin{array}{l}\text { Ruido; campos eléctricos y } \\
\text { magnéticos; elevada humedad }\end{array}$ & $\begin{array}{l}\text { Productos químicos y subproductos de cocción; terpenos y } \\
\text { otros extractos de madera; polvo de madera }\end{array}$ & \\
\hline Pasta al sulfato & Deslizamiento, caída & Ruido; elevada humedad; calor & $\begin{array}{l}\text { Acidos y alcalis; productos químicos y subproductos de la } \\
\text { cocción; gases de azufre reducido; terpenos y otros } \\
\text { extractos de madera; polvo de madera }\end{array}$ & \\
\hline $\begin{array}{l}\text { Recuperación de } \\
\text { sulfato }\end{array}$ & $\begin{array}{l}\text { Explosiones; Puntos de atrapa- } \\
\text { miento; deslizamientos, caída }\end{array}$ & Ruido; calor; vapor & $\begin{array}{l}\text { Acidos y álcalis; amianto; cenizas; productos químicos y } \\
\text { subproductos de la cocción; combustibles; gases de } \\
\text { azufre reducido; dióxido de azufre }\end{array}$ & \\
\hline Pasta al sulfito & Deslizamiento, caída & Ruido; elevada humedad; calor & $\begin{array}{l}\text { Acidos y álcalis; productos químicos y subproductos de la } \\
\text { cocción; dióxido de azufre; terpenos y otros extractos } \\
\text { de madera; polvo de madera }\end{array}$ & \\
\hline $\begin{array}{l}\text { Recuperación de } \\
\text { sulfito }\end{array}$ & $\begin{array}{l}\text { Explosiones; Puntos de atrapa- } \\
\text { miento; deslizamientos, caída }\end{array}$ & Ruido; calor; vapor & $\begin{array}{l}\text { Acidos y álcalis; amianto; cenizas; productos químicos y } \\
\text { subproductos de la cocción; combustible; dióxido de } \\
\text { azufre }\end{array}$ & \\
\hline $\begin{array}{l}\text { Recuperación de } \\
\text { pasta/ } \\
\text { destintado }\end{array}$ & Deslizamiento, caída & & $\begin{array}{l}\text { Acidos y álcalis; productos químicos y subproductos del } \\
\text { blanqueo; tintes y tintas; polvo de pasta/papel; anti- } \\
\text { moho; disolventes }\end{array}$ & Bacterias \\
\hline Blanqueo & Deslizamiento „caída & Ruido; elevada humedad; calor & $\begin{array}{l}\text { Productos y subproductos del blanqueo; antimohos; } \\
\text { terpenos y otros extractos de madera }\end{array}$ & \\
\hline \multicolumn{5}{|c|}{ Formación de hojas y transformación } \\
\hline Máquina de pasta & $\begin{array}{l}\text { Puntos de atrapamiento; desliza- } \\
\text { miento, caída }\end{array}$ & $\begin{array}{l}\text { Ruido; vibración; elevada } \\
\text { humedad; calor; vapor }\end{array}$ & $\begin{array}{l}\text { Acidos y álcalis; productos químicos y subproductos del } \\
\text { blanqueo; floculante; polvo de pasta/papel; antimohos; } \\
\text { disolventes }\end{array}$ & Bacterias \\
\hline Máquina de papel & $\begin{array}{l}\text { Puntos de atrapamiento; desliza- } \\
\text { miento, caída }\end{array}$ & $\begin{array}{l}\text { Ruido; vibración; elevada } \\
\text { humedad; calor; vapor }\end{array}$ & $\begin{array}{l}\text { Acidos y álcalis; productos químicos y subproductos del } \\
\text { blanqueo; tintes y tintas; floculante; polvo de } \\
\text { pasta/papel; aditivos de papel; antimohos; disolventes }\end{array}$ & Bacterias \\
\hline Acabado & $\begin{array}{l}\text { Puntos de atrapamiento; equipo } \\
\text { móvil }\end{array}$ & Ruido & $\begin{array}{l}\text { Acidos y álcalis; tintes y tintas; floculante; polvo de } \\
\text { pasta/papel; aditivos de papel;antimohos; disolventes }\end{array}$ & \\
\hline Almacén & Equipo móvil & & Combustibles; escape de motores; polvo de pasta/papel & \\
\hline \multicolumn{5}{|c|}{ Otras operaciones } \\
\hline $\begin{array}{l}\text { Generación de } \\
\text { energía }\end{array}$ & $\begin{array}{l}\text { Puntos de atrapamiento; desliza- } \\
\text { miento, caída }\end{array}$ & $\begin{array}{l}\text { Ruido; vibración; campos eléc- } \\
\text { tricos y magnéticos; calor; } \\
\text { vapor }\end{array}$ & $\begin{array}{l}\text { Amianto; cenizas; combustibles; terpenos y otros } \\
\text { extractos de madera; polvo de madera }\end{array}$ & Bacterias; hongos \\
\hline $\begin{array}{l}\text { Tratamiento de } \\
\text { aguas }\end{array}$ & Inmersión & & Productos químicos y subproductos del blanqueo & Bacterias \\
\hline $\begin{array}{l}\text { Tratamiento de } \\
\text { efluentes }\end{array}$ & Inmersión & & $\begin{array}{l}\text { Productos químicos y subproductos del blanqueo; flocu- } \\
\text { lante; gases de azufre reducido }\end{array}$ & Bacterias \\
\hline $\begin{array}{l}\text { Generación de } \\
\text { dióxido de cloro }\end{array}$ & $\begin{array}{l}\text { Explosiones; deslizamiento, } \\
\text { caída }\end{array}$ & & Productos químicos y subproductos del blanqueo & Bacterias \\
\hline $\begin{array}{l}\text { Recuperación } \\
\text { trementina }\end{array}$ & Deslizamiento, caída & & $\begin{array}{l}\text { Productos y subproductos de la cocción; gases de azufre } \\
\text { reducido; terpenos y otros extractos de madera }\end{array}$ & \\
\hline $\begin{array}{l}\text { Producción de } \\
\text { aceite de resina }\end{array}$ & & & $\begin{array}{l}\text { Acidos y álcalis; productos químicos y subproductos de la } \\
\text { cocción; gases de azufre reducido; terpenos y otros } \\
\text { extractos de madera }\end{array}$ & \\
\hline
\end{tabular}


la sustitución de las válvulas y bombas controladas manualmente por otras dotadas de control electrónico permite los procesos con control remoto. La necesidad de un control de los procesos dentro de tolerancias mínimas ha requerido el empleo de la informática y de avanzadas estrategias de ingeniería. Se establecen salas de control independientes para aislar los equipos electrónicos del entorno ambiental de la producción de pasta y de papel. Consecuentemente, los operarios trabajan habitualmente en salas de control con aire acondicionado que ofrecen refugio contra el ruido, las vibraciones, la temperatura, la humedad y la exposición a los agentes químicos inherentes a las operaciones fabriles. Otros controles que han mejorado el entorno laboral se describen seguidamente.

Los riesgos vinculados a los puntos de atrapamiento, las superficies mojadas, la maquinaria en movimiento y los puntos elevados son normales en las operaciones de una fábrica de pasta y de papel. Son esenciales las defensas de las cintas transportadoras y de las partes móviles de las máquinas, la rápida limpieza de los derrames, la disponibilidad de superficies de paso que permitan un rápido drenaje y la dotación de barandillas en los pasillos adyacentes a las líneas de producción y en las alturas. Deben establecerse mecanismos de bloqueo para el mantenimiento de las cintas transportadoras de astillas y de los rodillos de las máquinas de papel y de cualquier maquinaria con partes móviles. En relación con el equipo móvil utilizado en el almacenamiento de astillas, así como en los muelles y zonas de embarque, durante el almacenamiento y en otras operaciones debe haber una protección contra vuelcos, una buena visibilidad y señales acústicas; las zonas de paso para vehículos y peatones deben estar claramente marcadas y señalizadas.

El ruido y el calor son también riesgos ubicuos. Como se ha descrito, el mayor avance técnico es el aislamiento del trabajador, normalmente posible en las zonas de preparación de la madera, de preparación de la pasta, de blanqueo y de producción de papel. También existen cabinas aisladas con aire acondicionado para el equipo móvil utilizado en el apilamiento de astillas y en otras operaciones al aire libre. Fuera de estos lugares, los trabajadores han de utilizar equipo de protección auditiva. En el trabajo en los procesos de elevadas temperaturas o en zonas al aire libre y en las operaciones de mantenimiento de reactores, los trabajadores deben tener la formación precisa para reconocer los síntomas del estrés ocasionado por el calor; en estas zonas, la planificación del trabajo debe contemplar períodos de aclimatación y de descanso. El tiempo frío provoca riesgos de congelación en tareas al aire libre, aparte de producir neblina cerca de los apilamientos de astillas, que se mantienen templadas.

En los primeros pasos de la preparación de la pasta y en las operaciones de preparación de la madera hay que contar con los riesgos vinculados a la madera, a sus extractos y a los microorganismos asociados. La prevención dependerá de cada operación concreta y puede consistir en la instalación de cabinas para los operarios, el cerramiento y ventilación de las sierras y las cintas transportadoras, y de los depósitos de astillas así como un stock bajo de astillas. El empleo de aire comprimido para eliminar el polvo de la madera propicia exposiciones considerables que deben evitarse.

Las operaciones de preparación de la pasta química dan lugar a la exposición a los productos químicos de la digestión, así como a los subproductos gaseosos del proceso de cocción, entre ellos compuestos de azufre reducido (pasta kraft) y oxidado (pasta al sulfito), y compuestos orgánicos volátiles. La formación de gases depende de determinadas condiciones de la operación: la especie de la madera utilizada; la cantidad de madera transformada en pasta; la cantidad y la concentración del licor blanco aplicado; el tiempo requerido para la formación de la pasta; y la temperatura máxima alcanzada. Además del cierre automático de las válvulas del digestor y de las salas de control para los operarios, otras precauciones para estas zonas son la ventilación localizada de los escapes en la batería de digestores discontinuos y en los tanques de soplado, capaces de ventilar a la misma velocidad a la que los reactores liberan los gases; la aplicación de presión negativa, para evitar los escapes en las calderas de recuperación y en las torres ácidas de sulfito- $\mathrm{SO}_{2}$, la ventilación total o parcial de los lavaderos después de la digestión; la instalación de detectores continuos con alarmas en los lugares donde pueden producirse escapes, y los planes de formación de respuesta para emergencias. Los trabajadores que recogen muestras y realizan pruebas deben tomar precauciones ante las potenciales exposiciones a los ácidos y cáusticos reaccionantes y a los vapores residuales, y ante la posibilidad de reacciones secundarias debidas a la producción de sulfuro de hidrógeno $\left(\mathrm{H}_{2} \mathrm{~S}\right)$ gaseoso si el licor negro de la pasta kraft entra en contacto con los ácidos (por ejemplo, en las aguas de alcantarillado).

En las zonas de recuperación de reactivos químicos, por encima de $800^{\circ} \mathrm{C}$, puede haber productos y subproductos químicos resultantes de reacciones ácidas y básicas. Las obligaciones del puesto de trabajo pueden requerir que los trabajadores entren en contacto directo con estos agentes químicos, lo cual exige llevar la ropa de trabajo adecuada. Por ejemplo, hay que recoger la mezcla fundida que queda en la base de las calderas, y que, al salpicar entraña el consiguiente riesgo de quemaduras, térmicas y químicas. Asimismo se produce polvo cuando se añade sulfato sódico al licor negro concentrado, y cualquier fisura o abertura libera gases sulfurosos muy nocivos (y potencialmente letales). La posibilidad de una explosión de la solución acuosa siempre existe en las inmediaciones de la caldera de recuperación. Escapes de agua en las paredes de la caldera han dado lugar a muchas explosiones fatales. Los calderas de recuperación deben pararse al menor síntoma de escape, y es preciso tener previstos procedimientos para el traslado del material fundido. La carga de cal y otras sustancias cáusticas se debe hacer con transportadores cerrados y ventilados, elevadores y arcones de almacenaje.

En las plantas de blanqueo, los trabajadores están expuestos a los agentes blanqueantes y a las sustancias organocloradas y otros subproductos. Las variables del proceso, como la fuerza de los productos blanqueantes, el contenido de lignina, la temperatura y la consistencia de la pasta, se vigilan constantemente, y es preciso recoger muestras y hacer pruebas de laboratorio. A causa del peligro que encierran muchos de los agentes blanqueantes utilizados, los detectores continuos con alarma deben estar siempre dispuestos y hay que dotar de máscaras de emergencia a todos los trabajadores, que deben ensayar los procedimientos de respuesta en caso de emergencia. La instalación de campanas cerradas con salida de gases propia es una medida de control normal en la zona superior de cada torre de blanqueo y en cada fase de lavado.

La exposición a los agentes químicos en la sala de máquinas de una fábrica de pasta o de papel incluye el transporte de los productos de la planta de blanqueo, de los aditivos utilizados en la fabricación de papel y de la mezcla química a las aguas residuales. Hay polvos (celulosa, aprestos, revestimientos) y gases de escape del equipo móvil en el "extremo seco" y en la operaciones finales. La limpieza entre series sucesivas de producción debe realizarse con disolventes, ácidos y álcalis. Los controles en esta zona deben incluir el cerramiento total del área de secado de hojas, el cerramiento ventilado de las zonas donde los aditivos se descargan, pesan y mezclan; el empleo de los aditivos en solución líquida, mejor que en forma de polvo; la utilización de tintas y colorantes disueltos en agua, mejor que en disolventes, y la eliminación del uso de aire comprimido para barrer los recortes de papel y el papel de desecho. 
La producción de papel en fábricas de papel reciclado produce generalmente más polvo que en las de papel convencional que utilizan pasta recién producida. La exposición a los microorganismos tiene lugar desde el comienzo(recogida y clasificación del papel) hasta el final (producción de papel) de la cadena de producción, pero, en cambio, la exposición a los agentes químicos no es tan importante.

Las fábricas de pasta y de papel emplean un numeroso personal de mantenimiento al servicio de su equipo de fabricación: carpinteros, mecánicos de instrumentos, electricistas, aisladores, maquinistas, instrumentistas, albañiles, mecánicos, reparadores de máquinas, pintores, especialistas en tuberías, mecánicos de refrigeración, estañadores, soldadores, etc. Además de las exposiciones específicas de sus tareas (véanse los capítulos Metalurgia y metalistería y Guía de profesiones), estos profesionales están expuestos a cualquiera de los peligros relacionados con las operaciones antes descritas. Como los procedimientos se han automatizado y compartimentado más, las operaciones de mantenimiento, limpieza y control de calidad se han convertido en las más expuestas. Las paradas totales de la fábrica, para limpiar los reactores y las máquinas, son tema de una gran relevancia. Dependiendo de la organización establecida, estas operaciones se llevan a cabo por el personal de mantenimiento o de producción, aunque es normal la subcontratación de personal ajeno a la fábrica, que es común que tengan menos servicios de apoyo de salud y seguridad en el trabajo.

Además de las exposiciones propias del proceso, las operaciones de las fábricas de pasta y de papel implican algunos riesgos notables para el personal de mantenimiento. Como las operaciones de producción de elaboración de la pasta, las de recuperación y de las calderas, implican la generación de un alto grado de calor, se utiliza ampliamente el amianto para aislar conducciones y reactores. El acero inoxidable es de uso común en los reactores y conducciones de las operaciones de producción de pasta, recuperación y blanqueo, extendiéndose en algunas a la fabricación de papel. Sabido es que la soldadura de este metal genera humos de cromo y níquel.

En las paradas de mantenimiento, se aplican pulverizaciones con componentes de cromo para proteger contra la corrosión el fondo y las paredes de las calderas de recuperación durante las operaciones de arranque. A menudo se han realizado medidas de control de calidad en la línea de producción, utilizando medidores de infrarrojos y de radioisótopos. Aunque los medidores están normalmente bien protegidos, los instrumentistas que los manejan pueden estar expuestos a radiaciones.

También pueden darse ciertas exposiciones especiales entre los operarios en otras operaciones de apoyo de la fábrica. Los operarios de las calderas de vapor manejan cortezas, residuos de madera y lodos, todo ello procedente de los sistemas de tratamiento de los residuos.

En fábricas más antiguas, los operarios sacan la ceniza del fondo de las calderas y vuelven a precintarlas aplicando una mezcla de cemento y amianto alrededor de la parrilla. En las calderas modernas, este proceso está automatizado. Cuando la caldera se alimenta de material a un nivel demasiado elevado de humedad, los trabajadores están expuestos a bocanadas de productos parcialmente quemados. Los trabajadores responsables del tratamiento de aguas pueden quedar expuestos a productos químicos como el cloro, la hidracina y resinas varias. A causa de la reactividad del $\mathrm{ClO}_{2}$, el generador de $\mathrm{ClO}_{2}$ se sitúa habitualmente en un área restringida y el operario se coloca en una sala de control remoto, desplazándose para recoger muestras y dar servicio al filtro. El clorato sódico (un oxidante fuerte) utilizado para generar $\mathrm{ClO}_{2}$ se puede volver peligrosamente inflamable si se derrama sobre cualquier material orgánico o inflamable y se seca. Cualquier vertido debe ser humedecido antes de proceder a la labor de mantenimiento, y todo el equipo debe ser limpiado a fondo con posterioridad. Las ropas mojadas deben mantenerse así, y separadas de la ropa de calle, hasta su lavado.

\section{PAUTAS DE ENFERMEDADES Y LESIONES}

\section{LESIONES Y ENFERMEDADES NO MALIGNAS}

\section{Susan Kennedy y Kjell Torén}

\section{Lesiones}

En general, en esta industria se dispone de estadísticas limitadas sobre las tasas de accidentes. En Finlandia, esta tasa fue en 1990 inferior a la media; en Canadá, las tasas de 1990 a 1994 fueron semejantes a las de otras industrias; en Estados Unidos, la tasa de 1988 fue ligeramente superior a la media; en Suecia y Alemania las tasas fueron del $25 \%$ y del $70 \%$ por encima de la media (OIT 1992; Worker's Compensation Board of British Columbia 1995).

Los factores de riesgo más corrientemente encontrados en accidentes graves o mortales de la industria del papel y la pasta de papel son el propio equipo de fabricación utilizado, y el tamaño y peso extremadamente elevados de las balas o bobinas de pasta y de papel. Seguía un estudio oficial realizado en Estados Unidos, en 1993, sobre accidentes de trabajo mortales desde 1979 a 1984 en fábricas de pasta, papel y cartón (Departamento de Comercio 1993), el 28 \% correspondieron a operarios atrapados entre los rodillos giratorios o en otro equipo ("puntos de atrapamiento") y el $18 \%$ a trabajadores arrollados por objetos en caída o rodantes, especialmente balas y bobinas. Otras causas son la electrocución, la inhalación de sulfuro de hidrógeno y de otros gases tóxicos, las quemaduras masivas térmicas/químicas y, en un caso, un golpe de calor. Se observa que el número de accidentes graves relacionados con las máquinas ha disminuido con la instalación de equipo nuevo en algunos países. En el sector de transformación, el trabajo monótono y repetitivo y el empleo de equipo mecanizado, con velocidad y fuerza más elevadas, es cada vez más corriente. Aunque no se dispone de datos específicos del sector, se espera que aumentarán las tasas de lesiones por sobreesfuerzos relacionados con el trabajo repetitivo.

\section{Enfermedades no malignas}

Los trastornos respiratorios agudos y crónicos son los problemas sanitarios mejor documentados entre los trabajadores de las fábricas de pasta y de papel (Torén, Hagberg y Westberg 1996). La exposición a concentraciones extremadamente altas de cloro, dióxido de cloro o dióxido de azufre pueden deberse a escapes de gas o a fallos en otros procesos. En los trabajadores expuestos se desarrollan lesiones agudas de pulmón producidas por los productos químicos, con inflamación de las vías respiratorias y encharcamiento de los pulmones, que requieren hospitalización. La gravedad del daño depende de la duración y de la intensidad de la exposición y del gas implicado. Si el trabajador supera el 
episodio agudo, puede recuperarse totalmente. Sin embargo, en incidentes de exposición menos intensa (también como resultado de una serie de escapes o de fugas), la exposición aguda al cloro o al dióxido de cloro puede producir el desarrollo ulterior de asma. Este asma causada por la irritación, según se ha informado en numerosos casos y en recientes estudios epidemiológicos, y tal como la evidencia actual indica, persiste muchos años después de la exposición. Trabajadores igualmente expuestos en incidentes de menor intensidad, que no han desarrollado asma, pueden sufrir de forma persistentemente irritación nasal creciente, tos, sibilancias y disminución de la capacidad pulmonar. Los trabajadores que más riesgo corren con estos incidentes de exposición son los de mantenimiento, plantas de blanqueo y construcción de las propias fábricas de pulpa. La exposición a altos niveles de dióxido de cloro causa también irritación ocular y sensación de halo alrededor de las luces.

Algunos estudios de mortalidad indican que ha aumentado el riesgo de muerte por enfermedades respiratorias entre los trabajadores de las fábricas de pasta expuestos al dióxido de azufre y al polvo de papel (Jäppinen y Tola 1990; Torén, Järvholm y Morgan 1989). También se informa del aumento de los síntomas respiratorios en trabajadores de fábricas de sulfito, permanentemente expuestos a niveles bajos de dióxido de azufre (Skalpe 1964), aunque normalmente no se informa de obstrucción de las vías respiratorias entre los colectivos de trabajadores de fábricas de pasta en general. Se registran asimismo síntomas de irritación respiratoria en los trabajadores expuestos a altas concentraciones de terpenos en el aire en los procesos de recuperación de trementina, frecuentes en las fábricas de pasta. El polvo de papel blando, según se informa, está asociado con el aumento del asma y de las enfermedades obstructivas pulmonares crónicas (Torén, Hagberg y Westberg 1996).

La exposición a los microorganismos, sobre todo en las inmediaciones de pilas de astillas de madera, descortezados y lodos prensados, aumenta el riesgo de hipersensibilidad pulmonar. Parece que la evidencia se limita a casos aislados de neumonitis por hipersensibilidad, que puede derivar en cicatrices pulmonares. La bagazosis, o neumonitis por hipersensibilidad, relacionada con la exposición a microorganismos termofilicos y al bagazo (un subproducto de la caña de azúcar), se observa todavía en fábricas que utilizan bagazo para obtener fibra.

Otros peligros respiratorios típicos de esta industria son los relacionados con humos de la soldadura del acero inoxidable y del amianto (véanse "Amianto", Níquel" y "Cromo" y otros en esta misma Enciclopedia). Los trabajadores de mantenimiento son el grupo más proclive al riesgo de estas exposiciones.

Los compuestos de azufre reducido (como el sulfuro de hidrógeno, dimetil bisulfuros y mercaptanos) son fuertes irritantes oculares y pueden producir dolores de cabeza y náuseas en algunos trabajadores. Estos compuestos presentan muy bajo umbral olfativo (a niveles de parte por mil millones) para quienes no han estado expuestos previamente; en cambio, entre los trabajadores más antiguos, los umbrales olfativos son considerablemente más altos. Concentraciones del orden de 50 a 200 ppm producen fatiga olfativa e impiden percibir el característico olor a "huevos podridos". La exposición a concentraciones más altas puede producir pérdida del conocimiento, parálisis respiratoria y muerte. En las fábricas de pasta se han producido accidentes mortales relacionados con la exposición a compuestos de azufre reducido.

Se informa que la mortalidad cardiovascular ha aumentado entre los trabajadores de esta industria con indicios de una posible relación con la exposición a compuestos de azufre reducido (Jäppinen, 1987; Jäppinen y Tola, 1990). Sin embargo, otras causas de tal incremento de la mortalidad pueden ser la exposición al ruido y el trabajo por turnos, habiéndose relacionado ambos con el aumento del riesgo de cardiopatía isquémica en otras industrias.

Entre las alteraciones cutáneas observadas en los trabajadores de las fábricas de pasta y papel figuran las quemaduras graves, químicas y térmicas, y la dermatitis de contacto (ambas irritantes y alérgicas). Los trabajadores de las fábricas de pasta kraft sufren frecuentemente quemaduras con álcalis como consecuencia del contacto con los licores calientes de la producción y con las lechadas de hidróxido cálcico del proceso de recuperación. La dermatitis de contacto es más frecuente entre los trabajadores de las fábricas de transformados de papel, porque muchos de los aditivos, desespumantes, biocidas, tintas y colas utilizados en la fabricación del papel y productos de papel son irritantes y sensibilizantes cutáneos. La dermatitis puede producirse por el contacto directo con los propios aditivos o por el manejo del papel o productos del papel recién tratados.

El ruido es un peligro significativo en la totalidad de la industria de pasta y papel. El Departamento de Trabajo de Estados Unidos estima que hay niveles de ruido superiores a $85 \mathrm{dBA}$ en más del $75 \%$ de las fábricas de papel e industrias de productos afines, en comparación con el $49 \%$ del sector manufacturero en general, y que más del $40 \%$ de los trabajadores están regularmente expuestos a niveles de ruido superiores a 85 dBA (Departamento de Comercio 1993). Los niveles de ruido en las inmediaciones de las máquinas de papel, astilladoras y calderas de recuperación tienden a superar sobradamente los $90 \mathrm{dBA}$. Las operaciones de transformación también tienden a generar niveles altos de ruido. El empleo de cabinas de control cerradas permite reducir la exposición cerca de las máquinas de papel. En la transformación, donde el operador ha de situarse habitualmente cerca de la máquina, se utiliza rara vez este tipo de medidas. Sin embargo, donde se han aislado las máquinas transformadoras, ha decrecido la exposición tanto al polvo del papel como al ruido.

Se observa una excesiva exposición al calor en los trabajadores adscritos a las zonas de las máquinas de papel, donde se registran temperaturas de $60^{\circ} \mathrm{C}$, aunque en la literatura científica publicada no hay estudios sobre los efectos de esta exposición al calor.

\section{CANCER}

Kjell Torén y Kay Teschke

En la fabricación de pasta y de papel pueden producirse exposiciones a numerosas sustancias citadas por la Agencia Internacional para la Investigación sobre el Cáncer (IARC) como conocidos, probables y posibles agentes cancerígenos. El amianto, del que se sabe que causa el cáncer de pulmón y el mesotelioma, se utiliza para aislar conducciones y calderas. El talco, que se utiliza ampliamente como aditivo del papel, puede estar contaminado por amianto. Otros aditivos del papel, como las colas con bencidina, formaldehído y epiclorhidrina, se consideran probables cancerígenos para el hombre. Los compuestos de cromo hexavalente y de níquel generados por la soldadura del acero inoxidable son conocidos cancerígenos pulmonares y nasales. Recientemente, la IARC ha catalogado como cancerígeno el polvo de madera, basándose fundamentalmente en la evidencia de cáncer nasal entre los trabajadores expuestos al polvo de maderas duras (IARC, 1995). Los gases de escape de los motores diesel, la hidracina, el estireno, los aceites minerales, los fenoles clorados y las dioxinas, y las radiaciones ionizantes son otros de los posibles y probables cancerígenos.

Se han realizado pocos estudios epidemiológicos específicos sobre las operaciones de fabricación de pasta y de papel, y de 
ellos se desprenden pocos resultados sólidos. En la clasificación de las exposiciones utilizadas en estos estudios se emplea con frecuencia la amplia categoría industrial "pasta y papel", y aun las clasificaciones más específicas agrupan a los trabajadores por tipos de producción de pasta o por grandes áreas industriales. Los tres estudios de cohortes que se pueden localizar en la literatura abarcan menos de 4.000 trabajadores cada uno. Están actualmente en marcha varios estudios de grandes cohortes y la IARC está coordinando un estudio multicéntrico internacional que probablemente incluirá datos de más de 150.000 trabajadores de la pasta y el papel, y que permitirá hacer análisis con exposiciones mucho más específicas. En este artículo se revisan los conocimientos disponibles de los estudios publicados hasta la fecha. Se puede obtener información más detallada en las anteriores reseñas publicadas por la IARC (1980, 1987, y 1995) y por Torén, Persson y Wingren (1996). Los resultados de las enfermedades malignas de pulmón, estómago y hematológicas se resumen en la Tabla 72.6.

Tabla 72.6 • Resumen de los estudios sobre cáncer de pulmón, cáncer de estómago, linfoma y leucemia en trabajadores de la pasta y el papel.

\begin{tabular}{|c|c|c|c|c|c|c|}
\hline Descripción del proceso & $\begin{array}{l}\text { Localización del } \\
\text { estudio }\end{array}$ & Tipo de estudio & Cáncer de pulmón & $\begin{array}{l}\text { Cáncer de } \\
\text { estómago }\end{array}$ & $\begin{array}{l}\text { Linfoma } \\
\text { LNH/EH }\end{array}$ & Leucemia \\
\hline Sulfite & Finlandia & C & 0,9 & 1,3 & $x / x$ & $x$ \\
\hline Sulfito & USA & C & 1,1 & 0,7 & - & 0,9 \\
\hline Sulfito & USA & C & 0,8 & 1,5 & $1,3 / x$ & 0,7 \\
\hline Sulfito & USA & PM & 0,9 & $2,2^{*}$ & $2,7^{*} / x$ & 1,3 \\
\hline Sulfato & Finland & $c$ & 0,9 & 0,9 & $0 / 0$ & $x$ \\
\hline Sulfato & USA & $c$ & 0.8 & 1,0 & $2,1 / 0$ & 0,2 \\
\hline Sulfato & USA & PM & 1,1 & 1,9 & $1,1 / 4,1^{\star}$ & 1,7 \\
\hline Cloro & Finlandia & $C$ & $3,0^{*}$ & - & - & - \\
\hline Sulfito/papel & Suecia & $C R$ & - & $2,8^{\star}$ & - & - \\
\hline Polvo de papel & Canadá & $C R$ & $2,0^{\star}$ & - & - & - \\
\hline Fábricas de papel & Finlandia & $C$ & $2,0^{\star}$ & 1,7 & $x / x$ & - \\
\hline Fábricas de papel & Suecia & c & $0,7^{\star}$ & - & - & - \\
\hline Fábricas de papel & USA & c & 0,8 & 2,0 & - & 2,4 \\
\hline Fábricas de papel & Suecia & $C R$ & 1,6 & - & - & - \\
\hline Fábricas de papel & USA & PM & 1,3 & 0,9 & $x / 1,4$ & 1,4 \\
\hline Fábricas de cartón & Finlandia & $c$ & $2,2^{\star}$ & 0,6 & $x / x$ & $x$ \\
\hline Central de energía & Finlandia & c & 0,5 & 2,1 & - & - \\
\hline Mantenimiento & Finlandia & C & 1,3 & $0,3^{\star}$ & $1,0 / x$ & 1,5 \\
\hline Mantenimiento & Suecia & $C R$ & $2,1^{*}$ & 0,8 & - & - \\
\hline Pasta y papel & USA & $c$ & 0,9 & 1,2 & $0,7 / X$ & 1,8 \\
\hline Pasta y papel & USA & $c$ & 0,8 & 1,2 & $1,7 / x$ & 0,5 \\
\hline Pasta y papel & Suecia & $C R$ & 0,8 & 1,3 & 1,8 & 1,1 \\
\hline Pasta y papel & Suecia & $C R$ & - & - & $2,2 / 0$ & - \\
\hline Pasta y papel & Suecia & $C R$ & 1,1 & 0,6 & - & - \\
\hline Pasta y papel & USA & $C R$ & $1,2^{\star}$ & - & - & - \\
\hline Pasta y papel & USA & $C R$ & 1,1 & - & - & - \\
\hline Pasta y papel & USA & $C R$ & - & - & $-/ 4,0$ & - \\
\hline Pasta y papel & Canadá & PM & - & 1,2 & $3,8^{\star} /-$ & - \\
\hline Pasta y papel & USA & PM & $1,5^{\star}$ & 0,5 & $4,4 / 4,5$ & 2,3 \\
\hline Pasta y papel & USA & PM & 0,9 & $1,7^{\star}$ & $1,6 / 1,0$ & 1,1 \\
\hline Pasta y papel & USA & PM & 0,9 & 1,2 & $1,5 / 1,9^{*}$ & 1,4 \\
\hline Pasta y papel & USA & PM & - & $1,7^{\star}$ & 1,4 & $1,6^{*}$ \\
\hline
\end{tabular}

$C=$ estudio de cohorte, $C R=$ estudio de casos-referencias, $\mathrm{PM}=$ estudio proporcionado de mortalidad. * Estadísticamente significativo. $\S=$ Se informan por separado, LNH $=$ linfoma no Hodgkin y EH $=$ enfermedad de Hodgkin. $X=001$ caso informado, riesgo estimado no calculado. $-=$ No se informa sobre datos.

Un riesgo estimado superior a 1,0 indica riesgo incrementado, y un riesgo estimado por debajo de 1,0 indica riesgo disminuido.

Fuente: Adaptado de Torén, Persson y Wingren 1996. 


\section{Cánceres del sistema respiratorio}

Los trabajadores de mantenimiento de las fábricas de pasta y de papel experimentan un creciente riesgo de cáncer de pulmón y de mesotelioma maligno debido probablemente a su exposición al amianto. Un estudio sueco revela un incremento del triple del riesgo del mesotelioma de pleura entre los trabajadores de la pasta y el papel (Malker y cols. 1985). Cuando se analizaron después las exposiciones, el $71 \%$ de los casos habían estado expuestos al amianto, la mayoría en el sector de mantenimiento de la fábrica. Se han registrado también aumentos en el riesgo de cáncer de pulmón entre los trabajadores de mantenimiento en fábricas de Suecia y de Finlandia (Torén, Sällsten y Järvholm 1991; Jäppinen y cols. 1987). En el mismo estudio finlandés, se observó un incremento del doble del cáncer de pulmón entre trabajadores de fábricas de papel y de cartón. Los investigadores realizaron un estudio posterior, restringido a los trabajadores de fábricas de pasta expuestos a compuestos de cloro, y hallaron un incremento del triple del riesgo de cáncer de pulmón.

Otros pocos estudios sobre los trabajadores de la pasta y el papel han mostrado incrementos de riesgo de cáncer de pulmón. Un estudio canadiense muestra un aumento del riesgo entre los operarios expuestos al polvo de papel (Siemiatycki y col. 1986), y estudios suecos y estadounidenses muestran incrementos del riesgo entre los trabajadores de las papeleras (Milham y Demers 1984; Torén, Järvholm y Morgan 1989).

\section{Cánceres gastrointestinales}

Se ha indicado un incremento del riesgo de cáncer de estómago en muchos estudios, pero sin asociarlo con ningún área concreta; por consiguiente, se desconoce cuál es la exposición más relevante. El nivel socio-económico y los hábitos dietéticos son también factores de riesgo del cáncer de estómago, y podrían confundir los resultados. Estos factores no se han tenido en cuenta en ninguno de los estudios reseñados.

La relación entre el cáncer de estómago y el trabajo en las fábricas de pasta y de papel fue señalado por primera vez en un estudio realizado en Estados Unidos en el decenio de los 1970 (Milham y Demers 1984). Se encontró que el riesgo era aún más alto, casi el doble, cuando se examinó por separado a los trabajadores ocupados en operaciones al sulfito. También aparecen los trabajadores ocupados en tareas al sulfito y de pasta papelera en un estudio posterior en el que se registró un incremento del riesgo de cáncer de estómago (Robinson, Waxweiller y Fowler 1986). Un riesgo de la misma magnitud se halló en un estudio sueco realizado entre trabajadores de las fábricas de pasta y papel de un área en la que únicamente se utilizaba el procedimiento al sulfito (Wingren y cols. 1991). Trabajadores norteamericanos de fábricas de pasta, papel y cartón de New Hampshire y del estado de Washington presentaron un incremento de la mortalidad por cáncer de estómago (Schwartz 1988; Milham 1976). Los individuos de la muestra eran probablemente una mezcla de trabajadores ocupados en fábricas al sulfito, al sulfato y papeleras. En un estudio sueco, se observó un aumento al triple de la mortalidad por cáncer de estómago en un grupo de trabajadores de fábricas al sulfito y papeleras (Wingren, Kling y Axelson 1985). La mayoría de los estudios, aunque no todos, indican una mayor incidencia del cáncer de estómago en esta industria.

Debido al pequeño número de casos considerados, muchos estudios de otros cánceres gastrointestinales no son concluyentes. Se observa un incremento del riesgo de cáncer de colon entre los trabajadores en el procedimiento al sulfato y en la producción de cartón en un estudio finlandés (Jäppinen y col., 1987), así como entre trabajadores de Estados Unidos del sector de la pasta y el papel (Solet y cols. 1989). La incidencia de cáncer de vesícula en
Suecia entre 1961 y 1979 se puso en relación con los datos profesionales del Censo Nacional de 1960 (Malker y col., 1986). Se constató un incremento de dicha incidencia entre los trabajadores masculinos de las fábricas de papel. Se han observado incrementos del riesgo de cáncer de páncreas en algunos estudios de trabajadores de fábricas de papel y al sulfito (Milham y Demers 1984; Henneberger, Ferris y Monson 1989), así como en un amplio grupo de trabajadores de la pasta y el papel (Pickle y Gottlieb, 1980; Wingren y cols. 1991). Estos hallazgos no se han verificado en otros estudios.

\section{Cánceres hematológicos}

La cuestión de la presencia de linfomas entre los trabajadores de las fábricas de pasta y de papel fue planteada inicialmente en un estudio realizado en Estados Unidos en el decenio de 1960, en el que se halló un incremento del cuádruplo de la enfermedad de Hodgkin (Milham y Hesser 1967). En un estudio posterior, se estudió la mortalidad entre los trabajadores de las fábricas de pasta y de papel del estado de Washington entre 1950 y 1971, observándose un aumento al doble del riesgo tanto de la enfermedad de Hodgkin como de mieloma múltiple (Milham 1976). Este estudio fue seguido de otro en el que se analizó la mortalidad entre miembros de sindicatos de la pasta y el papel de Estados Unidos y Canadá (Milham y Demers, 1984). Se apreció un incremento al triple del riesgo de linfosarcoma y sarcoma reticular entre los trabajadores ocupados en operaciones al sulfito, mientras que en los trabajadores al sulfato había un riesgo cuatro veces mayor de enfermedad de Hodgkin. En un estudio de cohortes, se observó que los trabajadores al sulfato tenían un riesgo del doble de linfosarcoma y retículosarcoma (Robinson, Waxweiller y Fowler 1986).

En muchos de los estudios en los que se pudo investigar la existencia de linfomas malignos, se observó un incremento del riesgo (Wingren y col., 1991; Persson y cols. 1993). Puesto que este incremento del riesgo sucede tanto entre los trabajadores de fábricas que utilizan el procedimiento al sulfito, como el procedimiento al sulfato, todo apunta a una fuente de exposición común. En los departamentos de clasificación y astillado, las exposiciones son bastante similares. El personal está expuesto al polvo de la madera, terpenos y otros compuestos extraíbles de la madera. Además, ambos procesos blanquean con cloro, que puede generar subproductos orgánicos clorados, incluidas pequeñas cantidades de dioxinas.

Comparados con los estudios sobre linfomas, los estudios sobre leucemias presentan pautas menos consistentes, y los riesgos estimados son menores.

\section{Otros cánceres}

Entre los trabajadores de las fábricas de papel de Estados Unidos con presunta exposición al formaldehído, se encontraron cuatro casos de cáncer de vías urinarias, después de 30 años de estado latente, cuando solamente se esperaba uno (Robinson, Waxweiller y Fowler, 1986). Todas estas personas habían trabajado en las áreas de secado de papel de diversas papeleras.

En un estudio de casos-controles de Massachusetts, los tumores del sistema nervioso central en la infancia se relacionaron con la ocupación del padre, sin especificar, en una fábrica de pasta o de papel (Kwa y Fine 1980). Los autores consideran esta observación como un caso fortuito. Sin embargo, también se han encontrado incrementos del riesgo en tres estudios posteriores (Johnson y cols. 1987; Nasca y cols. 1988; Kuijten, Bunin y Nass 1992). En estudios de Suecia y Finlandia, se han observado incrementos de dos a tres veces del riesgo de tumores cerebrales entre los trabajadores de fábricas de pasta y de papel. 


\section{GUESTIONES DE SALUd PUBLICA Y AMBIENTAL}

\section{Anya Keefe y Kay Teschke}

Como la industria del papel y la pasta de papel consume grandes cantidades de recursos naturales (p. ej., madera, agua y energía), puede ser un gran contribuyente a los problemas de contaminación del agua, del aire y del suelo, por lo que está siendo sometida a una estrecha vigilancia en los últimos años. Esta preocupación es legítima considerando la cantidad de contaminantes del agua generados por tonelada de pasta (p. ej., demanda de DBO, $55 \mathrm{~kg}$ de oxígeno biológico, $70 \mathrm{~kg}$ de sólidos en suspensión , y hasta $8 \mathrm{~kg}$ de compuestos organoclorados) y la cantidad total de pasta producida mundialmente (180 millones de toneladas en 1994). Además, tan sólo alrededor del $35 \%$ del papel utilizado es reciclado, por lo que el papel residual es un contribuyente fundamental a los desperdicios sólidos mundiales (alrededor de 150 millones de un total de 500 millones de toneladas anuales).

Históricamente, el control de la contaminación no se tenía en cuenta al proyectar las fábricas de pasta y de papel. Muchos de los procesos empleados en la industria fueron desarrollados con muy poca atención para minimizar el volumen de residuos y la concentración de contaminantes. Desde el decenio de 1970, las tecnologías de reducción de la contaminación son un componente integrante del proyecto de las fábricas en Europa, Norteamérica y otras partes del mundo. La Figura 72.12 ilustra las tendencias en el período 1980 a 1994 en las fabricas canadienses en respuesta a algunos de estos aspectos ambientales: incremento del empleo de productos residuales de la madera y del papel reciclable como fuente de fibra, y disminución de la demanda de oxígeno y de compuestos organoclorados en las aguas residuales.

En este artículo se abordan los principales aspectos ambientales relacionados con los procesos de fabricación de pasta y de

\section{Figura $72.12 \bullet$ Indicadores ambientales en fábricas canadienses de pasta y de papel, 1980 a 1994, mostrando el uso de residuos de madera y de papel reciclado en la producción, y la demanda biológica de oxígeno (DBO) y compuestos organoclorados (AOX) en las aguas residuales efluentes.}

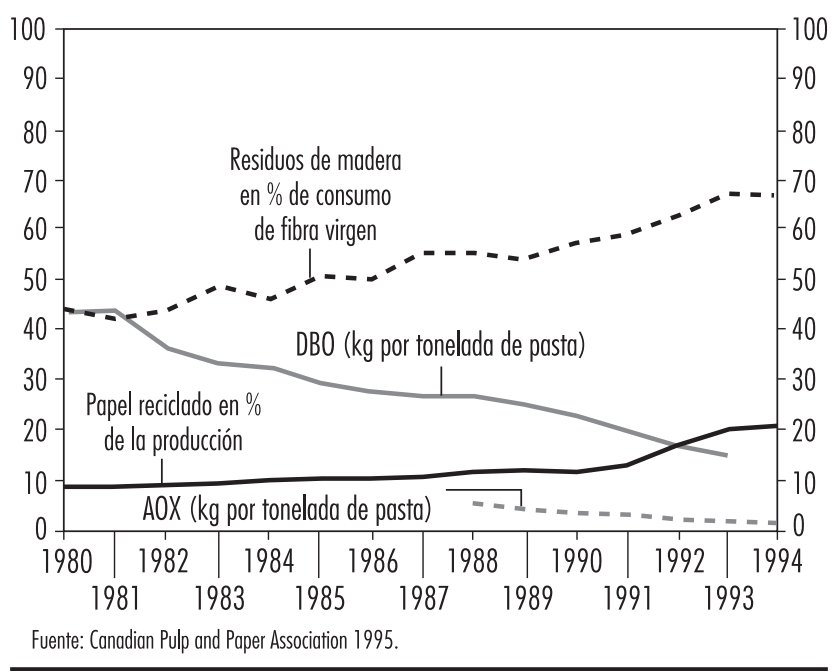

papel, se identifican las fuentes de contaminación en cada proceso y se describen brevemente las tecnologías de control, incluidos los tratamientos externos y las modificaciones en la planta. Los aspectos inherentes a los residuos de la madera y a los fungicidas se tratan más detalladamente en el capítulo Industria de la madera.

\section{Guestiones sobre la contaminación del aire}

Las emisiones al aire de compuestos de azufre oxidado por las fábricas de pasta y de papel han causado daños a la vegetación, y las de compuestos de azufre reducido suscitan quejas por el olor a "huevos podridos". Estudios entre habitantes de comunidades cercanas a estas fábricas, en particular niños, han mostrado problemas respiratorios relacionados con emisiones concretas, e irritación de la mucosa y cefaleas, se cree que vinculados a los compuestos de azufre reducido. De los procesos de producción de pasta, los que potencialmente más contaminación pueden producir son los métodos químicos, en particular los de producción de pasta kraft.

Las máximas tasas de emisión de óxidos de azufre provienen de las operaciones al sulfito, especialmente las que emplean bases de calcio o de magnesio. Las mayores fuentes son los vapores de los digestores, evaporadores y la preparación del licor; las operaciones de lavado, cribado y recuperación contribuyen en menor medida. Los hornos de recuperación kraft también son una fuente de dióxido de azufre, al igual que las calderas de vapor que utilizan como combustible carbón con alto contenido de azufre o petróleo.

Los compuestos de azufre reducido, como el sulfuro de hidrógeno, el metil mercaptano, el dimetil sulfuro y el dimetil disulfuro, están relacionados casi exclusivamente con la producción de pasta kraft, y confieren a estas fábricas su característico olor. Las fuentes principales son el horno de recuperación, los vapores del digestor, las válvulas de seguridad del digestor y los respiraderos de los lavaderos, aunque también contribuyen los evaporadores, tanques de fundido, apagadores de cal, el horno de cal y el agua residual. Algunas operaciones al sulfito emplean ambientes reductores en sus hornos de recuperación y pueden generar problemas con el olor del azufre reducido.

La mejor manera de controlar los gases sulfurosos emitidos por la caldera de recuperación es reducir las emisiones en su origen. Los controles implican la oxidación del licor negro, la reducción del licor sulfuroso y el empleo de calderas de recuperación de bajo olor y de operaciones adecuadas del horno de recuperación. Los gases sulfurosos del vapor del digestor, de las válvulas de seguridad del digestor y de la evaporación del licor se pueden recoger e incinerar, por ejemplo, en el horno de cal. Los gases de combustión del carburante se pueden recoger utilizando lavadores de gases.

Se producen óxidos de nitrógeno como consecuencia de la combustión a altas temperaturas, y pueden producirse en cualquier fábrica con caldera de recuperación, caldera de vapor $\mathrm{u}$ horno de cal, dependiendo de las condiciones de la operación. La formación de óxidos de nitrógeno puede controlarse regulando la temperatura, la relación aire/combustible y el tiempo de permanencia en la zona de combustión. Otros compuestos gaseosos contribuyen menos a la contaminación de la atmósfera de la fábrica (p. ej., el monóxido de carbono de la combustión incompleta, el cloroformo de las operaciones de blanqueo, y los compuestos orgánicos volátiles de la descompresión del digestor y de la evaporación del licor).

Se producen partículas principalmente en las operaciones de combustión, aunque los tanques de disolución del fundido también pueden ser una fuente menor. Más del $50 \%$ de las partículas de una fábrica de pasta son muy finas (menos de $1 \mu \mathrm{m}$ de diámetro). Este fino material consta de sulfato sódico 
$\left(\mathrm{Na}_{2} \mathrm{SO}_{4}\right)$ y carbonato sódico $\left(\mathrm{Na}_{2} \mathrm{CO}_{3}\right)$ de los hornos de recuperación, hornos de cal y tanques de disolución del fundido, y $\mathrm{NaCl}$ de la combustión de subproductos de los troncos que han estado almacenados en agua salada. Las emisiones del horno de cal incluyen una cantidad significativa de partículas gruesas debido al arrastre de sales de calcio y a la sublimación de compuestos de sodio. Las partículas gruesas pueden incluir cenizas en suspensión y productos de la combustión de sustancias orgánicas, sobre todo de las calderas de vapor. La reducción de las concentraciones de partículas puede lograrse haciendo pasar un flujo de gases a través de precipitadores electrostáticos o de lavadores de gases. Recientes innovaciones en la tecnología de las calderas de vapor incluyen un incinerador de lecho fluido que quema a muy alta temperatura, permitiendo una más eficaz conversión de la energía y la combustión de la madera residual menos uniforme.

\section{Cuestiones sobre la contaminación del agua}

$\mathrm{El}$ agua residual contaminada de las fábricas de pasta y de papel puede causar la muerte de organismos acuáticos, permite la bioacumulación de compuestos tóxicos en los peces y afecta al sabor del agua potable corriente abajo. Los vertidos de las aguas residuales de pasta y papel se caracterizan, según criterios físicos, químicos o biológicos, por ser los más importantes en contenido en sólidos, demanda de oxígeno y toxicidad.

El contenido en sólidos se clasifica típicamente sobre las bases de la fracción en suspensión (no disuelta), la fracción de sólidos en suspensión que es sedimentable y las fracciones respectivas que son volátiles. La fracción sedimentable es la más nociva, porque puede formar una densa capa de cieno junto al punto de desagüe, que rápidamente reduce el oxígeno del agua recibida y permite la proliferación de bacterias anaerobias que generan metano y gases de azufre reducido. Aunque los sólidos no sedimentables generalmente se diluyen en las aguas circulantes y son, por consiguiente, de menos relevancia, pueden transportar compuestos orgánicos tóxicos para los organismos acuáticos. Los sólidos en suspensión vertidos por las fábricas de pasta y de papel contienen partículas de corteza, fibras de madera, arena, granos de los molinos de pasta mecánica, aditivos de la fabricación de papel, sedimentos del licor, subproductos de los procesos de tratamiento de aguas y células microbianas de las operaciones del tratamiento secundario.

Los derivados de la madera disueltos en los licores de la preparación de la pasta, como oligosacáridos, azúcares simples, derivados de la lignina de bajo peso molecular, ácido acético y fibras de celulosa solubilizadas, son los principales contribuyentes tanto a la demanda biológica de oxígeno (DBO) como a la demanda de oxígeno químico (DQO). Los compuestos que son tóxicos para los organismos acuáticos son los organoclorados (AOX; separación del blanqueo, especialmente de pasta kraft); ácidos de resina; ácidos grasos insaturados; alcoholes diterpénicos (especialmente del descortezado y pasta mecánica); productos de la degradación de la lignina (especiales de la pasta de sulfito); orgánicos sintéticos, como los limicidas, aceites y grasas; y productos químicos de los procesos, aditivos de la fabricación del papel y metales oxidados. Los organoclorados tienen una especial incidencia, porque son muy tóxicos para los microorganismos marinos y pueden bioacumularse. Este grupo de compuestos, como las dibenzo-p-dioxinas policloradas, han sido los principales motivos para disminuir al máximo el uso del cloro en el blanqueo de la pasta.

La cantidad y las fuentes de sólidos en suspensión, la demanda de oxígeno y el vertido de tóxicos dependen del proceso (Tabla 72.7). Debido a la solubilización de los extractivos de la madera con pocos o ningún producto químico y a la recuperación del ácido de resina, tanto la pasta al sulfito como la termomecano-química producen residuos altamente tóxicos con alta DBO. Las fábricas de pasta kraft usaban más cloro para el blanqueo, y sus residuos eran más tóxicos; sin embargo, los residuos de las fábricas kraft que han eliminado el $\mathrm{Cl}_{2}$ en el blanqueo y utilizan el tratamiento secundario suelen presentar poca o ninguna toxicidad aguda, y la toxicidad sub-aguda ha sido enormemente reducida.

Los sólidos en suspensión han dejado de ser un problema porque muchas fábricas utilizan la clasificación primaria (p. ej., sedimentación por gravedad o flotación por aire disuelto), que elimina del 80 al $95 \%$ de los sólidos sedimentables. Se utilizan tecnologías del tratamiento secundario de las aguas residuales, tales como lagunas de aireación, sistemas de lodos activados y filtración biológica, para reducir la DBO, la DQO y la presencia de organoclorados en el vertido.

Las modificaciones de los procesos en planta para reducir los sólidos sedimentables, la DQO y la toxicidad incluyen el descortezado en seco y la conducción de troncos, la mejora del cribado de astillas para permitir una cocción uniforme, la deslignificación prolongada durante la producción de pasta, la introducción de cambios en las operaciones de recuperación química de la digestión, el empleo de tecnologías alternativas de blanqueo, el lavado de la pasta de alta eficacia, la recuperación de fibra del agua de vertido y la mejora de la contención de astillas. Sin embargo, fallos en el proceso (particularmente si de ellos resulta un vertido intencionado de licores) y cambios operativos (particularmente el empleo de madera sin esperar a su total desarrollo, con alto porcentaje de extraíbles) todavía pueden causar rupturas de toxicidad periódicas.

Una estrategia relativamente reciente para la eliminación completa de la contaminación del agua es la conocida como "fábrica cerrada". Tales fábricas son una alternativa atractiva en localidades con falta de grandes fuentes de agua que actúen como suministradoras en el proceso o como caudal receptor de residuos. Se han aplicado con éxito sistemas cerrados en fábricas de pasta termomecano-química y al sulfito con base sódica. Lo que diferencia a las fábricas cerradas es que el líquido residual se evapora y el condensado se trata, filtra, y entonces se reutiliza. Otras características son las salas de cribado cerradas, el lavado en contracorriente en la planta de blanqueo, y los sistemas de control salino. Aunque este avance es eficaz para reducir al mínimo la contaminación del agua, no está claro cómo las exposiciones de los trabajadores se verán afectadas por la concentración de todas las corrientes contaminantes dentro de la fábrica. La corrosión, un aspecto fundamental a tener en

Tabla 72.7 • Total de sólidos en suspensión y DBO asociados con los efluentes no tratados, en varios procesos de la formación de pasta.

\begin{tabular}{lcc}
$\begin{array}{l}\text { Proceso de formación de } \\
\text { pasta }\end{array}$ & $\begin{array}{l}\text { Total sólidos en } \\
\text { suspensión }(\mathrm{kg} / \mathrm{t})\end{array}$ & $\begin{array}{l}\text { DBO } \\
(\mathrm{kg} / \text { tonelada })\end{array}$ \\
Pasta papelera & $50-70$ & $10-20$ \\
Termomecánica & $45-50$ & $25-50$ \\
Termomecano-química & $50-55$ & $40-95$ \\
Kraft, sin blanquear & $20-25$ & $15-30$ \\
Kraft, blanqueada & $70-85$ & $20-50$ \\
Sulfito, bajo rendimiento & $30-90$ & $40-125$ \\
Sulfito, alto rendimiento & $90-95$ & $140-250$ \\
Destintado, no papel fino & $175-180$ & $10-80$ \\
Papel de residuos & $110-115$ & $5-15$ \\
\hline
\end{tabular}


cuenta en las fábricas que usan sistemas cerrados, y las concentraciones de bacterias y de endotoxinas aumentan en los procesos de reciclaje del agua.

\section{Tratamiento de sólidos}

La composición de los sólidos (lodos) separados por los sistemas de tratamiento del residuo líquido varían con la fuente. Los sólidos del tratamiento primario constan principalmente de fibras de celulosa. El principal componente de los sólidos del tratamiento secundario son células microbianas. Si la fábrica emplea agentes blanqueantes clorados, los sólidos tanto primarios como secundarios pueden contener también compuestos orgánicos clorados, un factor importante al determinar la amplitud del tratamiento requerido.

Antes de la eliminación, los lodos se espesan en unidades de sedimentación por gravedad y se secan en centrifugadoras, filtros de vacío o prensas de banda o de tornillo. Los lodos del tratamiento primario son relativamente fáciles de secar. Los del tratamiento secundario contienen una gran cantidad de agua intracelular y en la sustancia intercelular del légamo; por consiguiente, requieren la adición de floculantes químicos. Una vez suficientemente secado, el lodo se prepara para aplicaciones basadas en la tierra (p. ej., esparcido en tierra de labor o forestal, como compost o como acondicionador del suelo) o se incinera. Aunque la incineración es más costosa, y puede contribuir a los problemas de contaminación del aire, puede ser ventajosa porque destruye o reduce materiales tóxicos (p. ej., organoclorados) que podrían crear serios problemas ambientales si se filtraran en las aguas subterráneas como consecuencia de aplicaciones en la tierra.

En otras operaciones fabriles se pueden también generar residuos sólidos. Las cenizas de las calderas de vapor se pueden utilizar como lecho en la construcción de carreteras, como material de construcción y para eliminar el polvo. Residuos de los hornos de cal se utilizan para modificar la acidez del suelo y para mejorar su composición química.

\section{Referencias}

Agencia Internacional para la Investigación sobre el Cáncer (IARC). 1980. Monographs on the Evaluation of Carcinogenic Risks to Humans: Wood, Leather and Som Associated Industries. Vol. 25. Lyon: IARC.

-1987. Monographs on the Evaluation of Carcinogenic Risk to Humans, Overall Evaluations of Carcinogenicity: An Up dating of LARC Monographs. Vol. 1-42 (suplemento 7). Lyon: IARC.

-1995. Monographs on the Evaluation of Carcinogenic Risk to Humans: Wood Dust and Formaldehyde. Vol. 62 Lyon: IARC.

Canadian Pulp and Paper Association. 1995. Reference Tables 1995. Montreal, Quebec: CPPA.

Henneberger, PK, JR Ferris, RR Monson. 1989. Mortality among pulp and paper workers in Berlin. $\mathrm{Br} F$ Ind Med 46:658-664.

Jäppinen, P, S Tola. 1990. Cardiovascular mortality among pulp mill workers. $\mathrm{Br}$ f Ind Med 47:259-261.

Jäppinen, $\mathrm{P}, \mathrm{T}$ Hakulinen, E Pukkala, S Tola, K Kurppa. 1987. Cancer incidence of workers in the Finnish pulp and paper industry. Scand $\mathcal{f}$ Work Environ Health 13:197-202.

Jäppinen, P. 1987. Exposure to Compounds, Cancer Incidence and Mortality in the Finnish Pulp and Paper Industry. Tesis, Helsingfors, Finlandia.

Johnson, CC, JF Annegers, RF Frankowski, MR Spitz, PA Buffler. 1987. Childhood nervous system tumors - An evaluation of the association with paternal occupational exposure to hydrocarbons. $A m \mathcal{F}$ Epidemiol 126:605-613.

Kuijten, R, GR Bunin, CG Nass. 1992. Parental occupation and childhood astrocytoma: Results of a case-control study. Cancer Res 52:782-786.

Kwa, SL, IJ Fine. 1980. The association between parental occupation and childhood malignancy. $\mathcal{F} O c$ cup Med 22:792-794.

Malker, HSR, JK McLaughlin, BK Malker, NJ Stone, JA Weiner, JLE Ericsson, WJ Blot. 1985. Occupational risks for pleural mesothelioma in Sweden, 1961-1979. J Natl Cancer Inst 74:61-66.

1986. Biliary tract cancer and occupation in Sweden. Br f Ind Med 43:257-262.

Milham, SJ, J Hesser. 1967. Hodgkin's disease in woodworkers. Lancet 2:136-137.

Milham, SJ, P Demers. 1984. Mortality among pulp and paper workers. 7 Occup Med 26:844-846.

Milham, SJ. 1976. Neoplasias in the wood and pulp in dustry. Ann NY Acad Sci 271:294-300.

Nasca, P, MS Baptiste, PA MacCubbin, BB Metzger, $\mathrm{K}$ Carton, P Greenwald, VW Armbrustmacher.
1988. An epidemiologic case-control study of central nervous system tumors in children and parental occupational exposures. Am f Epidemiol 128:1256-1265.

Organización de las Naciones Unidas para la Agricultura y la Alimentación (FAO). 1995. Pulp and Paper Capacities, Survey 1994-1999. Roma: FAO.

Organización Internacional del Trabajo (OIT). 1992. Social and Labour Issues in the Pulp and Paper Industry. Ginebra: OIT.

Persson, B, M Fredriksson, K Olsen, B Boeryd, O Axelson. 1993. Some occupational exposures as risk factors for malignant melanomas. Cancer 72:17731778

Pickle, L, M Gottlieb. 1980. Pancreatic cancer mortality in Louisiana. Am f Public Health 70:256-259.

Pulp and Paper International (PPI). 1995. Vol. 37. Bruselas: Miller Freeman.

Robinson, C, J Waxweiller, D Fowler. 1986. Mortality among production workers in pulp and paper mills. Scand 7 Work Environ Health 12:552-560.

Schwartz, B. 1988. A proportionate mortality ratio analysis of pulp and paper mill workers in New Hampshire. Br f Ind Med 45:234-238.

Siemiatycki, J, L Richardson, M Gérin, M Goldberg, R Dewar, M Désy, S Campell, S Wacholder. 1986. Association between several sites of cancer and nine organic dusts: Results from an hypothesisgenerating case control study in Montreal, 19791983. Am J Epidemiol 123:235-249.

Skalpe, IO. 1964. Long-term effects of sulfur dioxide exposure in pulp mills. Br F Ind Med 21:69-73.

Solet, D, R Zoloth, G Sullivan, J Jewett, DM Michaels. 1989. Patterns of mortality in pulp and paper workers. 7 Occup Med 31:627-630.

Torén, K, B Järvholm, U Morgan. 1989. Mortality from asthma and chronic obstructive pulmonary diseases among workers in a soft paper mill: A case referent study. Br f Ind Med 46:192-195.

Torén, K, B Persson, G Wingren. 1996. Health effects of working in pulp and paper mills: Malignant diseases. Am J Ind Med 29:123-130.

Torén, K, G. Sällsten, B Järvholm. 1991. Mortality from asthma, chronic obstructive pulmonary disease, respiratory system cancer among paper mill workers: A case referent study. Am 7 Ind Med 19:729-737.

Torén, K, S Hagberg, H Westberg. 1996. Health effects of working in pulp and paper mills: Exposure, obstructive airways diseases, hypersensitivity reactions, and cardiovascular diseases. Am 7 Ind Med 29:111-122.
US Department of Commerce. 1983. Pulp and Paper Mills. (PB 83-115766). Washington, DC: US Department of Commerce.

-1993. Selected Occupational Fatalities Related to Pulp Paper and Paperboard Mills as Found in Reports of OSHA Fatality/Catastrophe Investigations. (PB93-213502). Washington, DC: US Department of Commerce.

Weidenmüller, R. 1984. Papermaking, the Art and Craft of Handmade Paper. San Diego, California: Thorfinn International Marketing Consultants Inc.

Wingren, G, B Persson, K Torén, O Axelson. 1991. Mortality patterns among pulp and paper mill workers in Sweden: A case-referent study. Am J Ind Med 20:769-774.

Wingren, G, H Kling, O Axelson. 1985. Gastric cancer among paper mill workers. f Occup Med 27:715.

Workers' Compensation Board of British Columbia. 1995. Comunicación personal.

\section{Otras lecturas recomendadas}

Bascom, R, P Raford. 1994. Upper airways disorders. En Textbook of Clinical Occupational and Environmental Medicine, dirigido por L Rosenstock y MR Cullen. Filadelfia: WB Saunders Co.

Bernhart, S. 1994. Irritant bronchitis. En Textbook of Clinical Occupational and Environmental Medicine, dirigido por L Rosenstock y MR Cullen. Filadelfia: WB Saunders Co.

Chan-Yeung, M, J Malo. 1995. Forestry products. En Occupational and Environmental Respiratory Disease, dirigido por P Harber, MB Schenker y JR Balmes. St. Louis: Mosby-Yearbook Inc.

Naciones Unidas. 1995. Statistical Yearbook, 1993. Nueva York: NU.

Organización de las Naciones Unidas para la Agricultura y la Alimentación (FAO). 1994. 1993 rearbook of Forest Products. Roma: FAO.

Rix, BA, E Lynge. 1996. Industrial hygiene measurements in a new industry: The repulping and deinking of paper waste. Am f Ind Med 30:142-147.

Schwartz, DA. 1994. Acute inhalational injury. En Textbook of Clinical Occupational and Environmental Medicine, dirigido por L Rosenstock y MR Cullen. Filadelfia: WB Saunders Co.

Smook, GA. 1989. Handbook for Pulp and Paper Technologists. Atlanta, GA: Technical Association for the Pulp and Paper Industry.

Springer, AM. 1986. Industrial Environmental Control Pulp and Paper Industry. Nueva York: John Wiley and Sons. 



\section{HIERRO Y ACERO}

Directora del capítulo

Augustine Moffit

\section{Sumario}

La industria del hierro y el acero

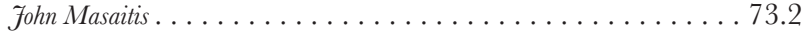

Trenes de laminación

Problemas y pautas de seguridad y salud. . . . . . . . . . 73.13

Cuestiones ambientales y de salud pública . . . . . . . . 73.15 


\section{LA INDUSTRIA DEL HIERRO} Y EL ACERO

John Masaitis

El hierro se encuentra en grandes cantidades en la corteza terrestre formando parte de diversos minerales (óxidos, minerales hidratados, carbonatos, sulfuros, silicatos, etc.). Desde tiempos prehistóricos, el hombre ha aprendido a preparar y procesar estos minerales por medio de operaciones de lavado, triturado y clasificado, separación de la ganga, calcinado, sinterizado y granulado, para fundir los minerales y obtener hierro y acero. A lo largo de la historia, muchos países han desarrollado una próspera industria siderúrgica basada en los suministros locales de mineral y en la proximidad de bosques para obtener carbón vegetal como combustible. A comienzos del siglo XVIII, el descubrimiento de que se podía utilizar coque en lugar de carbón vegetal revolucionó la industria, hizo posible un rápido desarrollo de la misma y sentó las bases para los demás avances de la Revolución Industrial. Los países que poseían yacimientos naturales de carbón próximos a yacimientos de mineral de hierro disfrutaron de grandes ventajas.

La fabricación de acero se desarrolló básicamente en el siglo XIX, al inventarse los procesos de fusión; el Bessemer (1855), el horno de hogar abierto, normalmente calentado a base de gas pobre (1864); y el horno eléctrico (1900). Desde mediados del siglo XX, el tratamiento con oxígeno - principalmente el proceso Linz-Donowitz (LD) de lanza de oxígenohizo posible la fabricación de aceros de alta calidad con unos costes de producción relativamente bajos.

Hoy en día, la producción de acero es indicativa de la prosperidad de una nación y constituye la base para la producción en serie de muchas otras industrias, como la construcción naval, la construcción de edificios y la fabricación de automóviles, maquinaria, herramientas y equipamiento doméstico. El desarrollo de los transportes, especialmente del marítimo, ha hecho económicamente rentable el intercambio internacional de las materias

Figura 73.1 • Producción mundial de arrabio en 1995, por regiones.

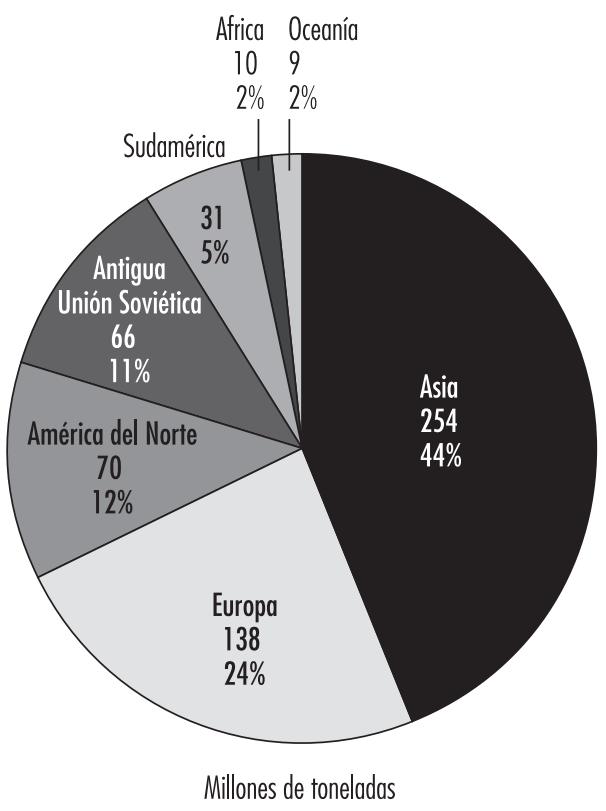

Figura 73.2 • Producción mundial de acero en bruto en 1995, por regiones.

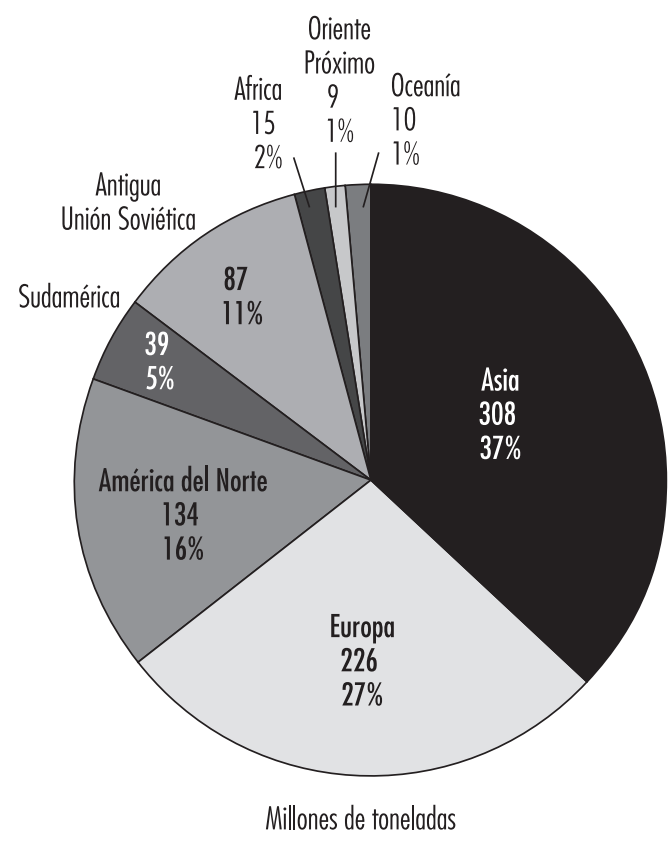

Figura 73.3 - Cargas de chatarra para hornos eléctricos.

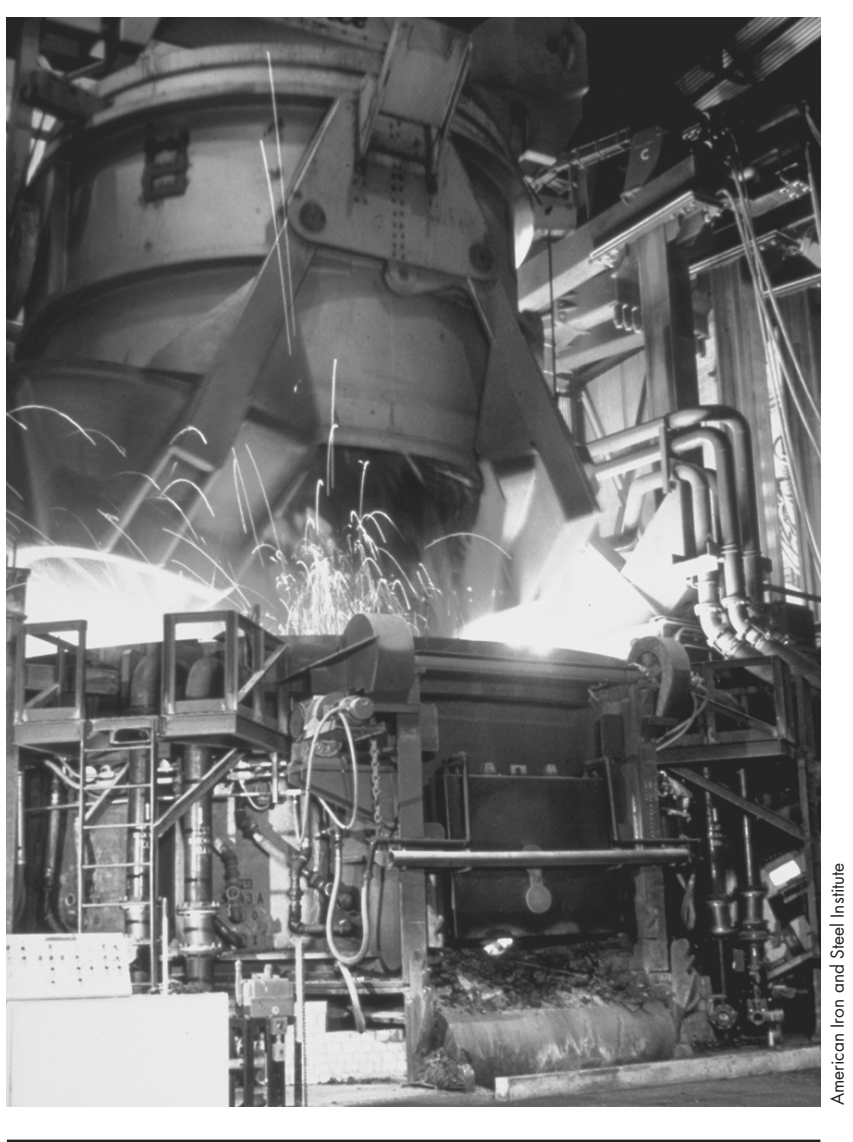


Figura 73.4 • Proceso de fabricación del acero.

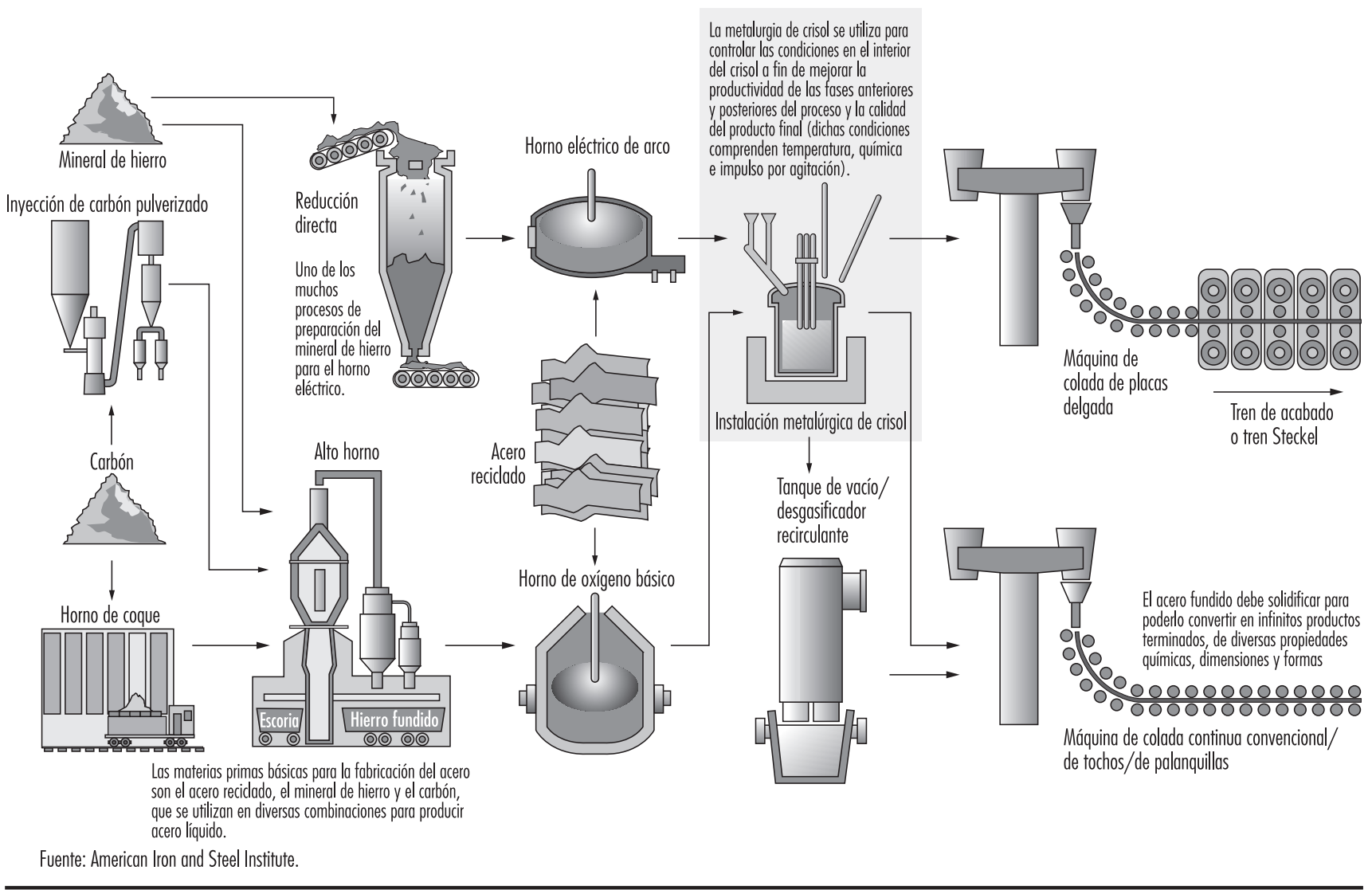

primas necesarias (mineral de hierro, carbón, gasóleo, chatarra y aditivos). Así pues, los países que poseen yacimientos de mineral de hierro cerca de yacimientos de carbón ya no gozan de ventaja, y se han construido grandes fundiciones y acerías en las regiones costeras de los principales países industrializados, que se abastecen de las materias primas de los países exportadores capaces de satisfacer las actuales exigencias de materiales de ley alta.

Durante los últimos decenios, se han desarrollado y alcanzado el éxito los procesos conocidos como de reducción directa. Los minerales de hierro, en especial los de ley alta o los enriquecidos, se reducen a hierro esponjoso por extracción del oxígeno que contienen, obteniéndose de este modo un material ferroso que sustituye a la chatarra.

\section{Producción de hierro y acero}

En 1995, la producción mundial de arrabio fue de 578 millones de toneladas (véase la Figura 73.1).

Ese mismo año, la producción mundial de lingote de acero alcanzó los 828 millones de toneladas (véase la Figura 73.2).

La industria del acero ha experimentado una revolución tecnológica que ha favorecido la creación de nuevas capacidades de producción mediante la instalación de hornos eléctricos de arco (EAF, electric arc furnace) alimentados con chatarra de acero reciclada en pequeñas acerías (véase la Figura 73.3). Aunque las acerías integradas que producen acero a partir de mineral de hierro están logrando altas cotas de eficiencia, las acerías EAF con capacidades de producción inferiores a 1 millón de toneladas anuales son cada vez más habituales en los principales países productores de acero de todo el mundo.

\section{Fabricación de hierro}

La Figura 73.4 ilustra todo el proceso de fabricación de hierro y acero.

La principal peculiaridad de la fabricación de hierro es el alto horno, en el cual se funde (reduce) el mineral de hierro para

Figura 73.5 - Control de temperatura del metal fundido en un alto horno.

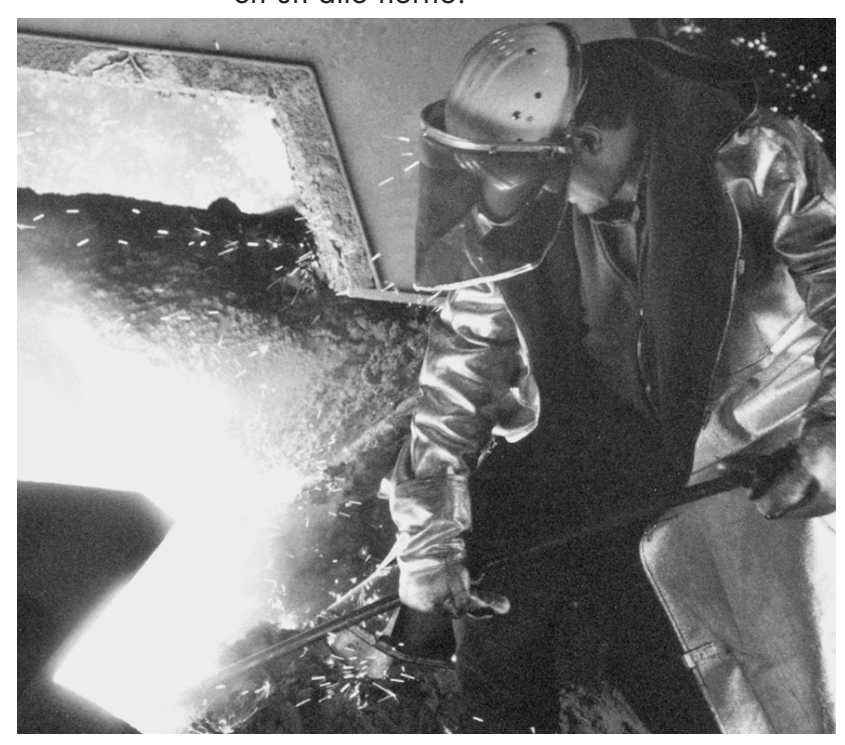


Figura 73.6 - Carga de metal caliente para un convertidor.

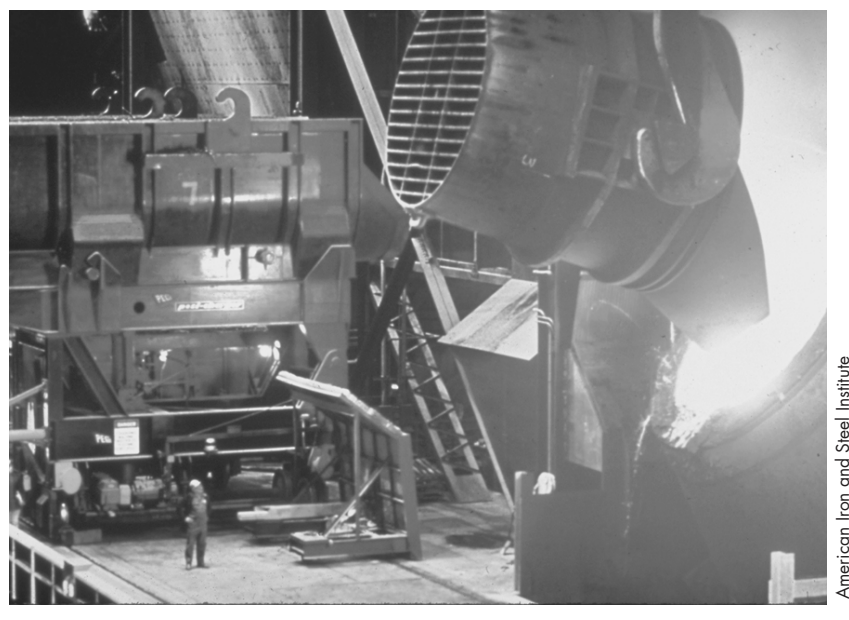

producir el arrabio. El horno se carga por la parte superior con mineral de hierro, coque y caliza; por la solera se inyecta aire caliente, a menudo enriquecido con oxígeno; y el monóxido de carbono producido a partir del coque transforma el mineral de hierro en un arrabio con carbono. La caliza actúa como fundente. A la temperatura de $1.600^{\circ} \mathrm{C}$ (véase la Figura 73.5) el arrabio se funde y se acumula en la solera, y la caliza se combina con la tierra formando escoria. El horno se sangra (es decir, se retira el arrabio) periódicamente, y entonces el arrabio puede moldearse en forma de lingotes para su uso posterior (p. ej., en fundiciones), o se recoge en crisoles en los que se traslada, todavía fundido, a la acería.

Figura 73.7 • Vista general de la fundición en horno eléctrico.

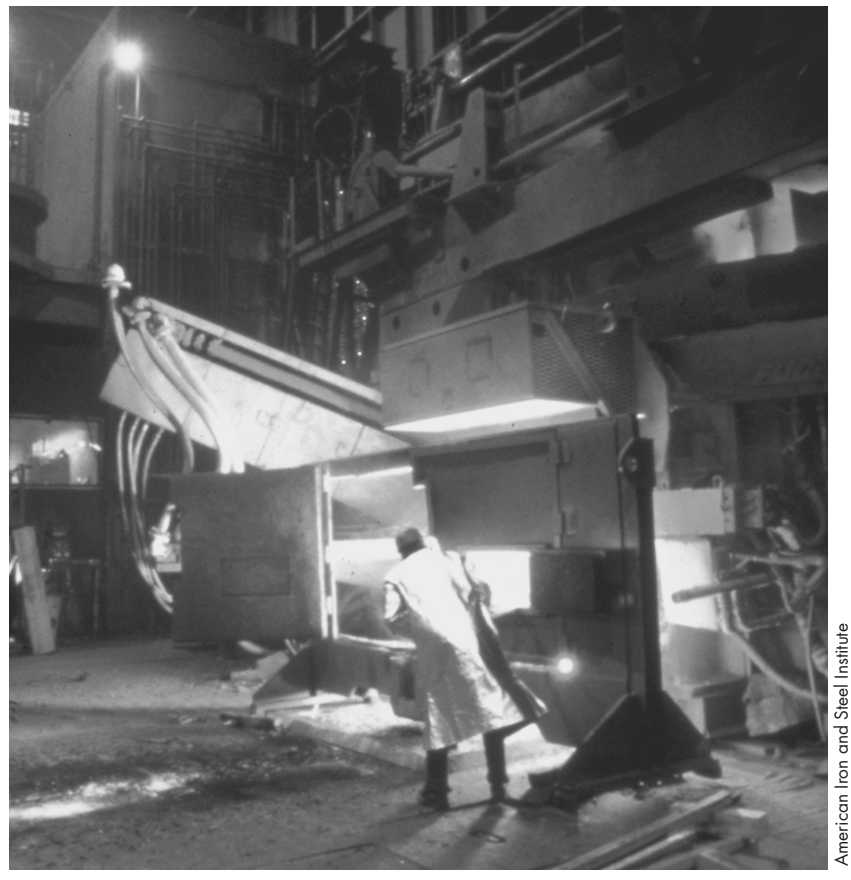

Figura 73.8 - Parte posterior de la carga de metal caliente.

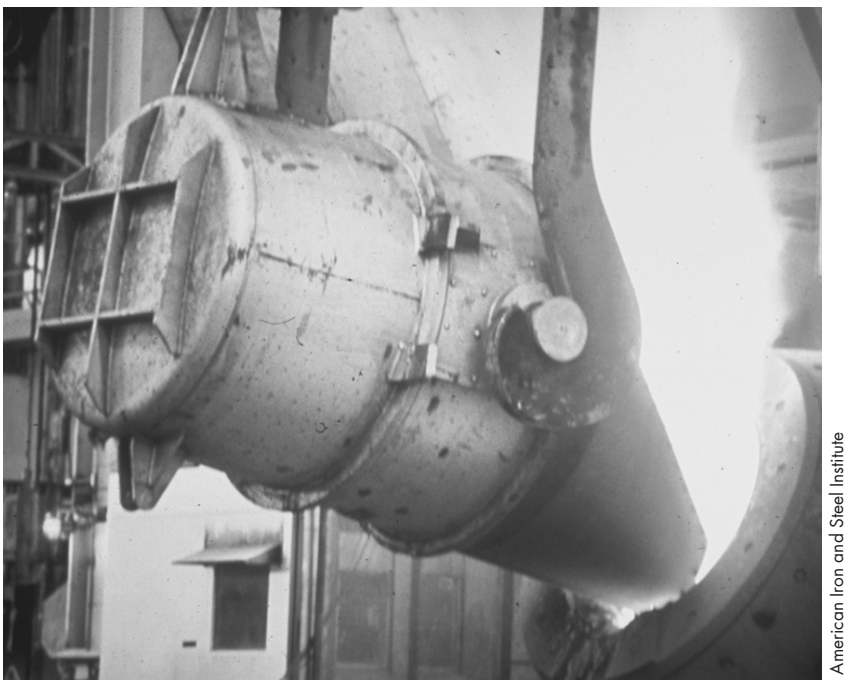

Algunas grandes plantas disponen de hornos de coque en la misma instalación. Generalmente, los minerales de hierro se someten a procesos especiales de preparación antes de ser cargados en el alto horno (lavado, reducción a un tamaño óptimo por triturado y cribado, separación del mineral menudo para sinterizarlo y granularlo, clasificación mecánica para separar la ganga, calcinado, sinterizado y granulado). La escoria retirada del horno puede transformarse en la planta para otros usos, en especial para fabricar cemento.

\section{Fabricación de acero}

$\mathrm{El}$ arrabio contiene grandes cantidades de carbono y otras impurezas (principalmente azufre y fósforo). Por consiguiente, debe ser refinado. Es preciso reducir el contenido de carbono, oxidar y eliminar las impurezas y convertir el hierro en un metal de alta

Figura 73.9 - Crisol de colada continua.

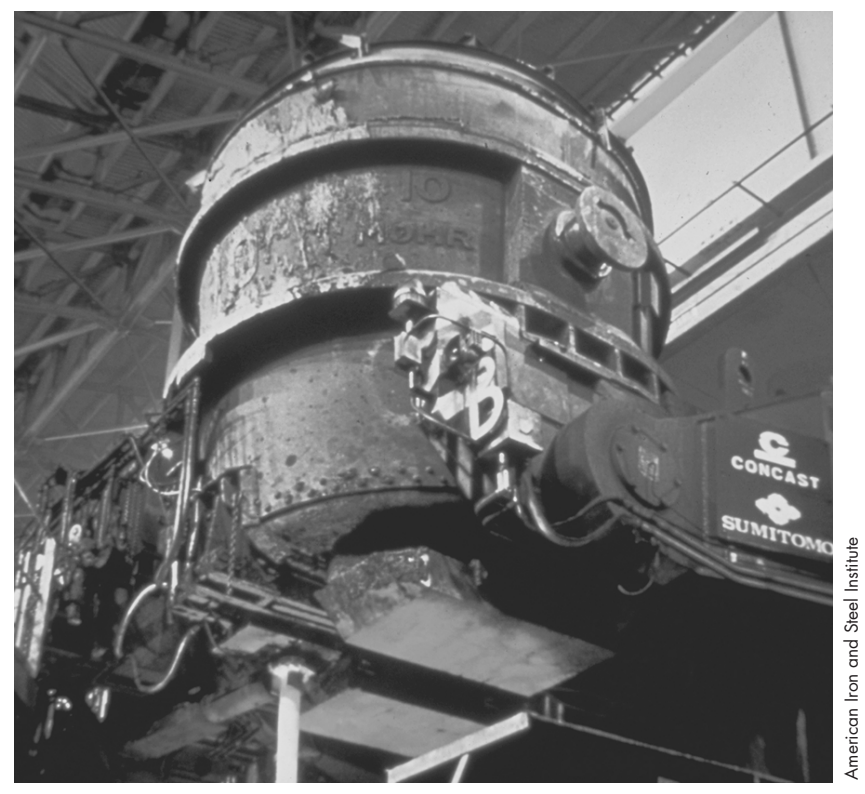


Figura 73.10 Palanquilla de colada continua.

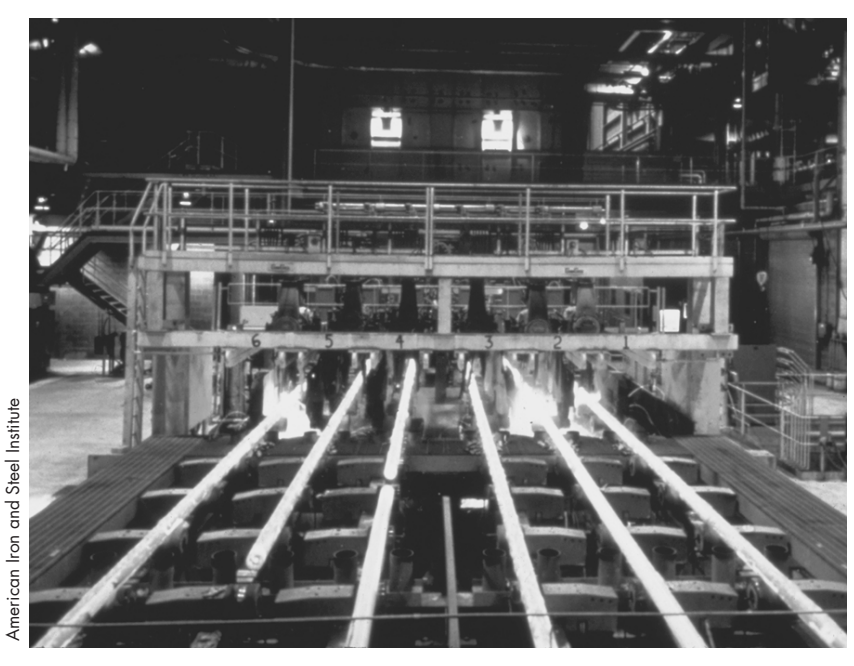

elasticidad que pueda ser forjado y trabajado. Este es el objeto de las operaciones de fabricación de acero. Existen tres tipos de hornos para la fabricación de acero: el horno de hogar abierto, el convertidor (véase la Figura 73.6) y el horno eléctrico de arco (véase la Figura 73.7). La mayoría de los hornos de hogar abierto han sido sustituidos por convertidores (que fabrican acero inyectando aire u oxígeno en el hierro fundido) y hornos eléctricos de arco (que fabrican acero a partir de chatarra de hierro y gránulos de hierro esponjoso).

Los aceros especiales son aleaciones a las que se incorporan otros elementos metálicos que les confieren características especiales para usos específicos (p. ej. se les añade cromo para evitar la oxidación, tungsteno para darles dureza y tenacidad a altas temperaturas, níquel para mejorar su resistencia, ductilidad y resistencia a la corrosión). Estos componentes de aleación pueden añadirse a la carga del alto horno (véase la Figura 73.8) o al acero fundido (en el horno o en el crisol) (véase la Figura 73.9). El metal fundido del proceso de fabricación de acero se vierte a máquinas de colada continua para obtener palanquillas (véase la Figura 73.10), tochos (véase la Figura 73.11) o placas. El metal fundido también puede moldearse en lingoteras. La mayoría del acero se obtiene por el método de la colada (véase la Figura 73.12). Las ventajas de la

Figura 73.11 - Tocho de colada continua.

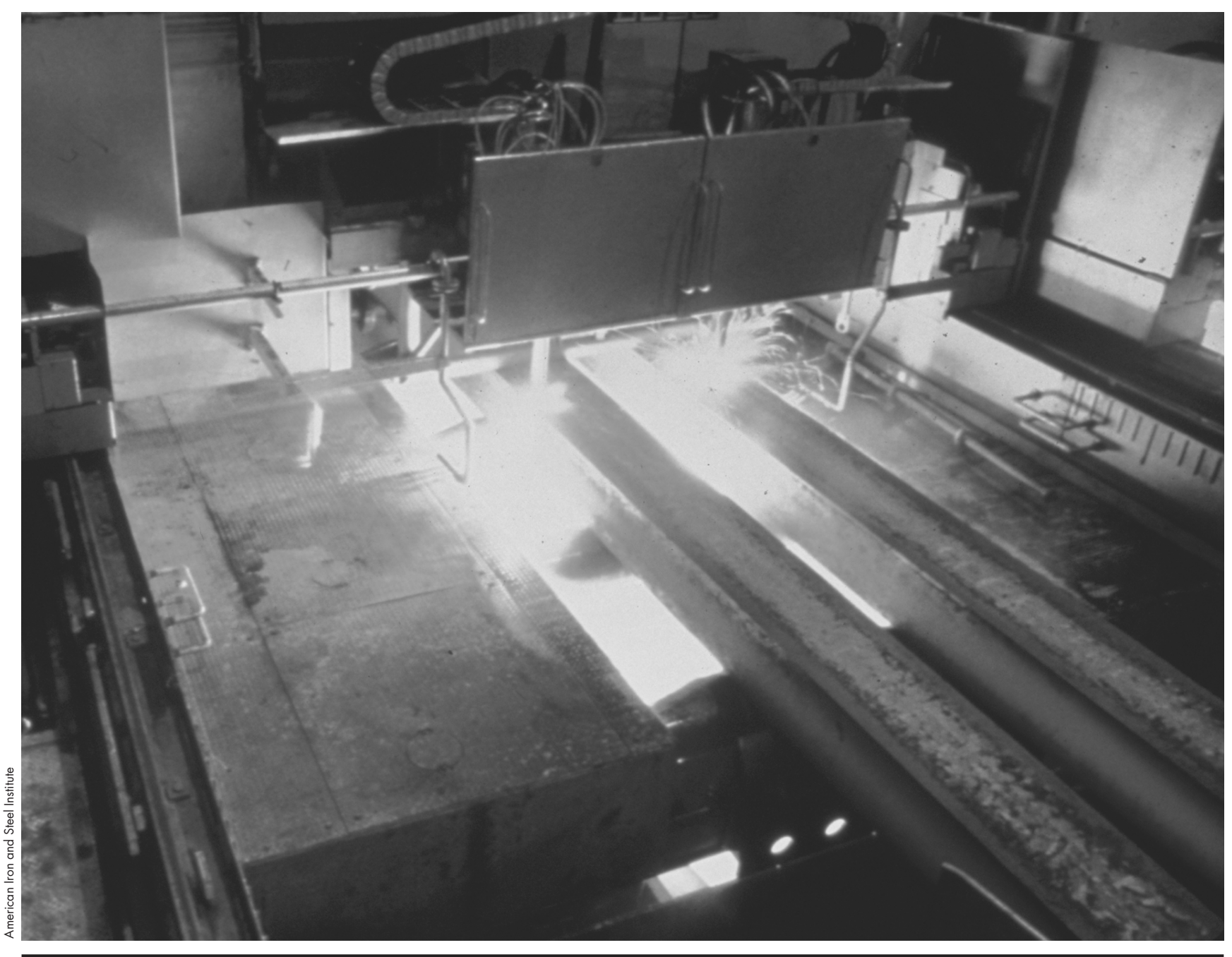


Figura 73.12 • Sala de control del proceso de colada continua.

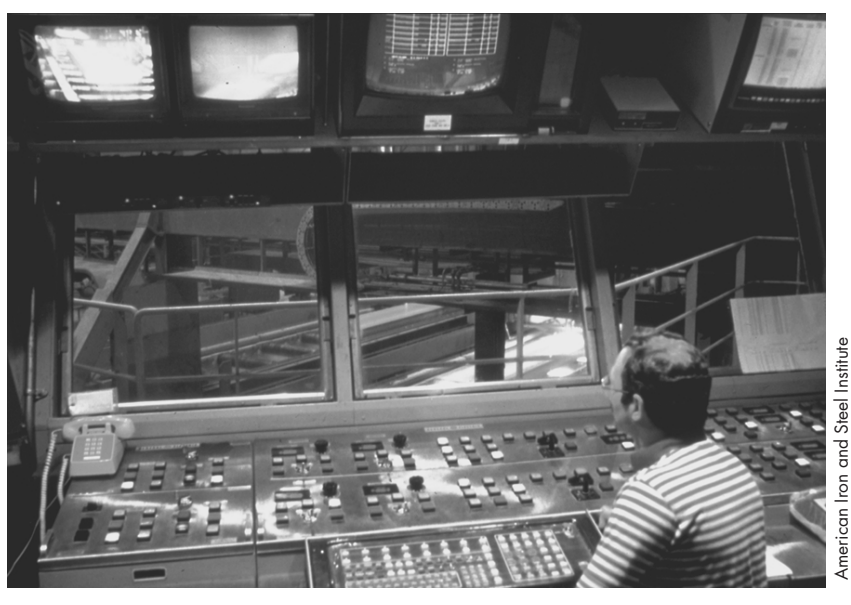

colada continua son su mayor rendimiento, calidad, ahorro de energía y reducción de los costes de inversión y explotación. Las lingoteras se almacenan en hornos de termodifusión (es decir, hornos subterráneos con puertas), donde pueden recalentarse los lingotes antes de pasar a los trenes de laminación u otros procesos posteriores (véase la Figura 73.4). Recientemente, las empresas han comenzado a fabricar acero con máquinas de colada continua. Los trenes de laminación se tratan en otros artículos de este capítulo; la fundición, la forja y la estampación son el objeto del capítulo titulado Metalurgia y metalistería.

\section{Riesgos}

\section{Accidentes}

En la industria del hierro y el acero, se transforman y transportan grandes cantidades de material utilizando enormes equipos que dejan pequeños a los de la mayoría de las industrias. Normalmente, las acerías aplican complejos programas de salud y seguridad para reducir los riesgos en un entorno que puede resultar implacable. Para controlar los riesgos suele ser necesario un enfoque integrado que combine prácticas técnicas y de mantenimiento adecuadas, procedimientos de trabajo seguros, formación laboral y el empleo de equipos de protección personal (EPP).

En muchos puntos del proceso de fabricación del acero pueden producirse quemaduras: delante del horno, durante el sangrado, por metal fundido o escoria; por derrames, salpicaduras o explosiones de metal caliente de crisoles o cubas durante su transformación, colada (vertido) o transporte; y por contacto con el metal caliente mientras se está formando el producto final.

El agua retenida por el metal fundido o la escoria puede generar fuerzas explosivas que hagan saltar metal o material caliente en una amplia zona. Introducir una herramienta húmeda en el metal fundido también puede provocar violentas explosiones.

El transporte mecánico es fundamental en la fabricación de hierro y acero, pero expone a los trabajadores a un riesgo de atropello o aplastamiento. En casi todas las zonas de las acerías hay puentes-grúa. Además, en la mayoría de las grandes plantas se utilizan mucho los equipos de vía fija y grandes tractores industriales para el transporte de materiales.

Un aspecto fundamental de los programas de seguridad de uso de grúas es impartir una formación que garantice el correcto manejo de la grúa y una fijación segura de las cargas; una buena comunicación y utilización de las señas manuales normalizadas entre los conductores de las grúas y quienes preparan la carga para evitar heridas provocadas por movimientos inesperados de las grúas; programas de inspección y mantenimiento de piezas de grúas, aparejos, eslingas y ganchos para evitar que se caigan las cargas; y medios seguros de acceso a las grúas para evitar caídas y accidentes en las vías transversales.

Los programas de seguridad para vías férreas también requieren una buena comunicación, especialmente durante las operaciones de desvío y acoplamiento, a fin de evitar que algún trabajador quede atrapado entre vagones.

Es fundamental mantener una distancia de seguridad adecuada para el paso de grandes tractores industriales y otros equipos y evitar arranques y movimientos inesperados a fin de eliminar los riesgos de atropello y aplastamiento de los operarios de los equipos, los peatones y los operarios de otros vehículos. También es necesario implantar programas de inspección y mantenimiento de las zonas de paso y de los aparatos de seguridad de los equipos.

El orden y la limpieza son la piedra angular de la seguridad en las plantas siderúrgicas y las acerías. Los suelos y zonas de paso pueden quedar rápidamente obstruidos por materiales y útiles capaces de provocar tropiezos. Se utilizan grandes cantidades de grasas, aceites y lubricantes que, si se derraman, pueden provocar fácilmente resbalones en las superficies de paso o de trabajo.

Las herramientas sufren un desgaste muy grande y se deterioran rápidamente, lo que hace peligroso su uso. Aunque la mecanización ha disminuido notablemente el número de operaciones manuales en esta industria, todavía se producen en muchas ocasiones problemas de carácter ergonómico.

Las partes afiladas de los motores o las rebabas de los productos de acero o bandas metálicas pueden provocar laceraciones y pinchazos a los trabajadores encargados de las operaciones de acabado, expedición y manipulación de chatarra. A fin de eliminar el riesgo de este tipo de lesiones se suelen utilizar muñequeras y guantes anticortes.

Los programas de protección ocular son especialmente importantes en las acerías y plantas siderúrgicas. En muchas zonas existe el riesgo de que entren cuerpos extraños en los ojos, especialmente en las operaciones de manipulación de materias primas y acabado del acero, que comprende labores de amolado, soldadura y quema.

El mantenimiento programado es especialmente importante para prevenir accidentes. Su finalidad es garantizar la eficiencia de los equipos y mantener las defensas en perfecto estado, porque un fallo puede provocar accidentes. También es muy importante atenerse a las prácticas y normas de seguridad por la complejidad, dimensiones y velocidad de los equipos y maquinaria de proceso.

\section{Intoxicación por monóxido de carbono}

Los altos hornos, los convertidores y los hornos de coque producen grandes cantidades de gases durante la fabricación de hierro y acero. Una vez separado el polvo, estos gases se emplean como combustible en las distintas instalaciones, y una parte se suministra a industrias químicas para su utilización como materia prima. Estos gases contienen una gran cantidad de monóxido de carbono (el gas de altos hornos del 22 al $30 \%$; el gas de hornos de coque del 5 al $10 \%$; y el gas de convertidores del 68 al $70 \%$ ).

A veces se producen emanaciones o fugas de monóxido de carbono por los tragantes o las cubas de los altos hornos o por las muchas tuberías de gas existentes en el interior de las instalaciones, provocando de forma accidental intoxicaciones agudas 
por monóxido de carbono. La mayoría de las intoxicaciones se producen mientras se trabaja en las inmediaciones de los altos hornos, especialmente durante las reparaciones. Otros casos se registran cuando se realizan trabajos cerca de los hogares encendidos, visitas de inspección a las cubas de los hornos o trabajos cerca de los tragantes, de las bigoteras de escorias o de los orificios de sangrado. En las acerías o plantas de laminación también pueden producirse intoxicaciones por gases desprendidos de válvulas o depósitos estancos; por la parada repentina de equipos soplantes, cuartos de calderas o ventiladores; por fugas; por no ventilar o purgar correctamente las cubas, tuberías o equipos de proceso antes de empezar a trabajar; y durante el cierre de válvulas de tuberías.

\section{Polvo y vapores}

Durante la fabricación de hierro y acero se generan polvo y vapores en muchos puntos. Se encuentran en los procesos de preparación, especialmente la sinterización, delante de los altos hornos y hornos acereros y en la fabricación de lingotes. El polvo y los vapores derivados del mineral de hierro o de metales ferrosos no provocan fácilmente fibrosis pulmonar y la neumoconiosis es infrecuente. Se cree que algunos tipos de cáncer de pulmón están relacionados con los productos cancerígenos que contienen las emisiones de los hornos de coque. Los densos vapores emitidos por las lanzas de oxígeno y por el uso de oxígeno en los hornos de hogar abierto pueden afectar especialmente a los operarios de grúas.

La exposición a sílice representa un riesgo para los trabajadores encargados de la colocación y reparación de los revestimientos de altos hornos y hornos acereros y sus cubas, compuestos de materiales refractarios que pueden contener hasta un $80 \%$ de sílice. Los crisoles van revestidos de ladrillos refractarios o de sílice triturada y aglomerada, y estos revestimientos requieren una reparación frecuente. La sílice de los materiales refractarios está parcialmente presente en forma de silicatos, que no causan silicosis, sino más bien neumoconiosis. Los trabajadores rara vez se ven expuestos a nubes densas de polvo.

Los aditivos de aleación para los hornos de fabricación de aceros especiales conllevan a veces posibles riesgos de exposición al cromo, manganeso, plomo y cadmio.

\section{Riesgos diversos.}

Las tareas que se realizan en la batería de retortas y en el tragante como parte de las operaciones de coquización, delante de los altos hornos como parte del proceso siderúrgico y las operaciones de moldeo de lingotes y de colada continua que se realizan delante del horno como parte de la fabricación del acero requieren todas ellas intensas actividades en un ambiente caluroso. Deberán implantarse programas de prevención de las indisposiciones debidas al calor.

Los hornos pueden producir resplandores que pueden lesionar los ojos a menos que se disponga de una protección ocular adecuada. Las operaciones manuales, como el revestimiento del horno con ladrillos y la vibración de manos y brazos que produce el uso de desbarbadoras y rectificadoras, pueden provocar problemas ergonómicos.

Las instalaciones de soplado, las de oxígeno, los ventiladores para descarga de gases y los hornos eléctricos de alta potencia pueden ocasionar un deterioro auditivo. Hay que proteger a los operarios de los hornos aislándolos del foco de ruido por medio de material insonorizante o facilitándoles cabinas insonorizadas. También puede resultar eficaz reducir el tiempo de exposición. En zonas con mucho ruido suele ser necesario utilizar protectores auditivos (orejeras o tapones) dada la imposibilidad de lograr una reducción adecuada del ruido por otros medios.

\section{Medidas de salud y seguridad}

\section{Organización de la seguridad}

La organización de la seguridad es de primordial importancia en la industria del hierro y el acero, ya que en ella la seguridad depende en gran medida de la reacción de los trabajadores ante los posibles peligros. La primera responsabilidad de la dirección es crear unas condiciones físicas lo más seguras posible, pero suele ser necesario conseguir la cooperación de todos en los programas de seguridad. Los comités de prevención de accidentes, los delegados de seguridad de los trabajadores, los incentivos a la seguridad, los concursos, los programas de sugerencias, y los lemas y letreros de advertencia pueden desempeñar un importante papel en los programas de seguridad. Hacer que todo el personal participe en ejercicios de evaluación de riesgos, observación de comportamientos y retroinformación puede favorecer actitudes positivas ante la seguridad y orientar las actividades de los grupos de trabajo dedicados a evitar lesiones y enfermedades.

Las estadísticas de accidentes ponen de relieve las áreas de peligro y la necesidad de mejorar la protección física e insistir más en el orden, la limpieza y el mantenimiento. Permiten determinar la validez de las distintas prendas de protección y comunicar sus ventajas a los trabajadores afectados.

\section{Formación}

La formación debe comprender información sobre riesgos, métodos de trabajo más seguros, evitación de riesgos y utilización de EPP. Si se introducen nuevos métodos o procesos, puede ser necesario readiestrar incluso a aquellos trabajadores con mayor experiencia en los tipos de hornos más antiguos. Los cursos de formación y perfeccionamiento para todos los niveles de personal son especialmente valiosos. Dichos cursos deberán servir para familiarizar al personal con los métodos de trabajo más seguros, los actos inseguros que es preciso evitar, las normas de seguridad y las principales disposiciones legales en materia de prevención de accidentes. Los cursos de formación deberán estar dirigidos por especialistas y utilizar medios audiovisuales eficaces. Se organizarán contactos o reuniones periódicas de seguridad para que todo el personal refuerce su formación y concienciación en la materia.

\section{Medidas técnicas y administrativas}

Todas las partes peligrosas de la maquinaria y los equipos, incluidos los ascensores, transportadores, árboles de largo recorrido y engranajes de puentes-grúa, deberán estar bien protegidas. Es necesario organizar un sistema regular de inspección, comprobación y mantenimiento para todas las máquinas y equipos de la instalación, especialmente grúas, aparejos, cadenas y ganchos. Deberá existir un programa eficaz de identificación y bloqueo de las máquinas y equipos que precisen mantenimiento o reparación. Los aparejos defectuosos deberán desecharse. Se marcarán claramente las cargas de trabajo seguras y se guardarán ordenadamente los aparejos que no se utilicen. Siempre que sea posible, se accederá a los puentes-grúa por una escalera. Si es preciso utilizar una escalerilla, se zunchará a intervalos. Se tomarán medidas eficaces para limitar el recorrido de los puentes-grúa cuando haya personas trabajando en sus inmediaciones. Puede que sea necesario, tal como exige la ley en ciertos países, instalar un aparellaje adecuado para evitar colisiones si dos o más grúas se desplazan por los mismos carriles.

Las locomotoras, vías, vagonetas, bogies y enganches deberán ser de diseño adecuado y mantenerse en buen estado, y se dispondrá de un sistema eficaz de señalización y alarma. Estará prohibido subirse a los enganches o pasar entre vagones. No deberá realizarse tarea alguna sobre las vías de equipos 
ferroviarios si no se han tomado medidas para restringir el acceso o el movimiento de los equipos.

Es necesario actuar con mucho cuidado en las instalaciones de almacenamiento de oxígeno. El suministro a las distintas dependencias de la planta deberá realizarse por tuberías e identificarse claramente. Todas las lanzas se mantendrán limpias.

Existe una necesidad continua de orden y limpieza. Las caídas y tropiezos en zonas obstruidas o provocados por dejar útiles y herramientas tirados de forma descuidada no sólo pueden producir lesiones, sino que pueden hacer caer a una persona contra material caliente o fundido. Hay que apilar todos los materiales cuidadosamente y disponer estanterías, adecuadamente situadas, para guardar las herramientas. Todo derrame de grasa o aceite deberá limpiarse inmediatamente. La iluminación de todas las zonas de los talleres y las defensas de las máquinas deberán ser de la mejor calidad.

\section{Higiene industrial}

Es necesaria una buena ventilación general en toda la planta y ventilación por extracción localizada (VEL) en las zonas en que se generen cantidades importantes de polvo y vapores o puedan producirse desprendimientos de gases, todo ello con el máximo nivel posible de orden y limpieza. Los equipos de gas deberán inspeccionarse periódicamente y estar bien conservados para evitar posibles fugas. Siempre que haya que realizar un trabajo en un ambiente que pueda contener gases, se utilizarán detectores de monóxido de carbono para garantizar la seguridad. Cuando sea imprescindible trabajar en una zona peligrosa, se emplearán respiradores independientes o con alimentación de aire. Es necesario que las botellas de oxígeno se encuentren siempre en perfectas condiciones de uso y los operarios estén perfectamente adiestrados para utilizarlas.

A fin de mejorar el ambiente de trabajo, se instalará ventilación forzada que suministre aire fresco. Pueden emplazarse ventiladores locales para aliviar a los trabajadores, especialmente en lugares de trabajo calurosos. Es posible conseguir una buena protección contra el calor instalando pantallas aislantes entre los trabajadores y los focos de calor, como los hornos o el metal caliente, disponiendo cortinas de agua o de aire delante de los hornos o colocando telas metálicas termorresistentes. La mejor protección para los trabajadores de los hornos es un traje de material termorresistente provisto de capucha y de un aparato de respiración con conducciones de oxígeno. Como el trabajo en los hornos es sumamente caluroso, también pueden conectarse al traje conducciones de enfriamiento. Es esencial establecer mecanismos que proporcionen un tiempo de enfriamiento antes de entrar en los hornos.

La aclimatación comprende el ajuste natural del contenido de sal del sudor corporal. La incidencia de las afecciones debidas al calor puede reducirse mucho ajustando la carga de trabajo y estableciendo períodos de descanso bien espaciados, especialmente si estos últimos se pasan en una habitación fría, con aire acondicionado si es necesario. Como paliativo, deberá proporcionarse agua en abundancia y otras bebidas adecuadas y garantizar la posibilidad de ingerir comidas ligeras. Las bebidas no deberán estar excesivamente frías y se indicará a los trabajadores que no beban demasiado líquido frío de una sola vez; durante las horas de trabajo es preferible consumir comidas ligeras. En los trabajos que provocan mucho sudor es necesario reponer la sal perdida y la mejor manera de conseguirlo es aumentar la ingestión de sal con las comidas normales. En climas fríos, hay que evitar los efectos perjudiciales de una exposición prolongada al frío o a cambios de temperatura repentinos y violentos. Es preferible que la cantina, los aseos y los sanitarios estén cerca. Las instalaciones de aseo deberán disponer de duchas y de vestuarios y armarios en condiciones de limpieza e higiene.

Siempre que sea posible, se aislarán los focos de ruido. Los cuadros centrales de mando a distancia permiten reducir el número de operarios en las zonas ruidosas; en las peores zonas será necesario utilizar protecciones auditivas. Además de cerrar la maquinaria ruidosa con material insonorizante o proteger a los trabajadores con barreras antirruido, los programas de protección auditiva han demostrado ser medios eficaces para controlar las pérdidas auditivas.

\section{Equipos de protección personal}

En la mayoría de los trabajos, todas las partes del cuerpo están expuestas a riesgos, pero el tipo de prendas protectoras necesarias será distinto según el lugar. Quienes trabajen en los hornos necesitarán ropa que les proteja de las quemaduras: monos de material ignífugo, botines de paño, botas, guantes, cascos con pantallas faciales o gafas antichispas y también antideslumbrantes. En casi todos los puestos de trabajo es obligado utilizar botas, gafas y cascos de seguridad y son muy necesarios los guantes. En la ropa de protección deben tenerse en cuenta los riesgos para la salud y la comodidad derivados de un calor excesivo; por ejemplo, una capucha ignífuga con una visera de tela metálica ofrece una buena protección contra las chispas y es resistente al calor; hay varios tipos de fibras sintéticas que también han demostrado su eficacia para resistir el calor. Es necesaria una estricta vigilancia y una propaganda continua a fin de asegurar la correcta utilización y mantenimiento de los equipos de protección personal.

\section{Ergonomía}

El enfoque ergonómico (es decir, la investigación de la relación trabajador-máquina-ambiente) es de especial importancia en determinadas operaciones de la industria del hierro y el acero. Hay que realizar un estudio ergonómico adecuado no sólo para investigar las condiciones existentes mientras un trabajador está realizando diversas operaciones, sino también para explorar el efecto de las condiciones ambientales sobre el trabajador y el diseño funcional de la maquinaria utilizada.

\section{Vigilancia médica}

Los reconocimientos médicos previos a la contratación son de gran importancia para seleccionar a personas adecuadas para las duras tareas que requiere la fabricación de hierro y acero. Para la mayoría de los trabajos, es imprescindible una buena condición fisica: la hipertensión, las enfermedades coronarias, la obesidad y la gastroenteritis crónica descalifican a quienes las sufren para trabajar en ambientes calurosos. Hay que prestar especial cuidado al seleccionar a los conductores de las grúas, tanto por su capacidad fisica como psíquica.

Se debe proporcionar una vigilancia médica especial a quienes estén expuestos al estrés por calor, reconocimientos del sistema respiratorio periódicos a quienes estén expuestos al polvo, y reconocimientos audiométricos a quienes estén expuestos al ruido; los operarios de equipos móviles también deberán someterse a reconocimientos médicos periódicos para garantizar su idoneidad continuada para este trabajo.

Es necesario inspeccionar constantemente todos los aparatos de reanimación y adiestrar a los trabajadores en las técnicas correspondientes.

También deberá disponerse de un puesto central de primeros auxilios con el equipo médico necesario para prestar asistencia de emergencia. Si es posible, se contará con una ambulancia para el transporte de personas gravemente heridas al hospital más próximo al cuidado de una persona cualificada. En las fábricas más grandes, los puestos o botiquines de primeros auxilios deberán estar situados en varios puntos céntricos. 


\section{Operaciones de producción de coque}

\section{Preparación del carbón}

El factor más importante por sí solo para la producción de coque metalúrgico es la selección de carbones. Los mejores son los carbones con un bajo contenido de cenizas y azufre. El carbón de baja volatilidad suele mezclarse en cantidades de hasta un $40 \%$ con carbón de alta volatilidad para lograr las características deseadas. La propiedad física más importante del coque metalúrgico es su resistencia y capacidad para soportar la rotura y la abrasión durante su manipulación y empleo en el alto horno. Las operaciones de manipulación de carbón consisten en la descarga de los coches ferroviarios, barcazas marinas o camiones; la mezcla del carbón; la dosificación; la pulverización; el control de la densidad volumétrica con aceite de grado diesel o similar; y el transporte a la batería de coquización.

\section{Coquización}

En su mayoría, el coque se produce en retortas de coquización diseñadas para acumular el material volátil del carbón. Las retortas constan de tres partes principales: las cámaras de coquización, los conductos de caldeo y la cámara de regeneración. Aparte del soporte estructural de acero y hormigón, estas retortas se construyen con ladrillo refractario. Normalmente, cada batería contiene aproximadamente 45 retortas independientes. Las cámaras de coquización suelen tener de 1,82 a 6,7 metros de altura, 9,14 a 15,5 metros de longitud y alcanzan una temperatura de $1.535^{\circ} \mathrm{C}$ en la base de los conductos de caldeo. El tiempo necesario para la coquización varía dependiendo de las dimensiones de la retorta, pero suele oscilar entre 16 y 20 horas.

En los grandes hornos verticales, el carbón se carga por unas toberas situadas en el tragante utilizando una vagoneta sobre raíles que lo transporta desde la carbonera. Una vez convertido el carbón en coque, se extrae del horno por un lateral empleando un émbolo automático llamado "deshornador". Las dimensiones de este émbolo son ligeramente inferiores a las del horno para evitar que entre en contacto con las superficies interiores de éste. El coque se recoge en una vagoneta sobre raíles o en un lateral de la batería situada frente al deshornador y se transporta a la instalación de templado. El coque caliente se templa mojándolo con agua antes de descargarlo en el muelle de coque. En algunas baterías, el coque caliente se templa en seco para recuperar el calor sensible para la generación de vapor.

Las reacciones que tienen lugar durante la carbonización del carbón para la producción de coque son complejas. Entre los productos de descomposición se encuentran inicialmente agua, óxidos de carbono, sulfuro de hidrógeno, compuestos hidroaromáticos, parafinas, olefinas, compuestos fenólicos y compuestos

\section{Tabla 73.1 - Subproductos recuperables de los hornos de coque.}

\begin{tabular}{|c|c|}
\hline Subproducto & Componentes recuperables \\
\hline $\begin{array}{l}\text { Gases de los hornos } \\
\text { de coque }\end{array}$ & $\begin{array}{l}\text { Hidrógeno, metano, etano, monóxido de carbono, dióxido } \\
\text { de carbono, etileno, propileno, butileno, acetileno, } \\
\text { sulfuro de hidrógeno, amoníaco, oxígeno y nitrógeno }\end{array}$ \\
\hline Aguas amoniacales & Amoníaco libre y estable \\
\hline Alquitrán & $\begin{array}{l}\text { Piridina, ácidos de alquitrán, naftaleno, aceite de creosot } \\
\text { y pez de alquitrán de hulla }\end{array}$ \\
\hline Aceites ligeros & $\begin{array}{l}\text { Cantidades variables de productos gaseosos del carbón } \\
\text { con puntos de ebullición de alrededor de } 40^{\circ} \mathrm{C} \text { a } \\
200^{\circ} \mathrm{C} \text {, y benceno, tolueno, xileno y nafta disolvente }\end{array}$ \\
\hline
\end{tabular}
Los productos primarios experimentan procesos hidrógeno, metano e hidrocarburos aromáticos. La posterior descomposición de los complejos compuestos nitrogenados da lugar a amoniaco, cianuro de hidrógeno, bases de piridina y nitrógeno. La continua extracción de hidrógeno de los residuos que permanecen en el horno produce coque duro.

Las retortas de coquización que disponen de equipos para recuperar y procesar los productos químicos del carbón producen los materiales enumerados en la Tabla 73.1.

Tras un enfriamiento suficiente para que la cinta transportadora no sufra daños, el coque se traslada al puesto de clasificación y trituración, donde se separan los tamaños adecuados para el alto horno.

\section{Riesgos}

\section{Riesgos físicos}

Durante las operaciones de descarga, preparación y manipulación del carbón, se manejan miles de toneladas de carbón, produciéndose polvo, ruido y vibraciones. La presencia de grandes cantidades de polvo acumulado puede representar un peligro de explosión añadido al riesgo de inhalación.

Durante la coquización, el calor ambiental y radiante constituye el principal problema físico, particularmente en los tragantes de las baterías, donde se sitúan la mayoría de los trabajadores. El ruido puede constituir un problema en los equipos móviles, debido principalmente a un mantenimiento inadecuado de los mecanismos de transmisión y los componentes vibratorios. A efectos de alineación de los equipos móviles puede utilizarse radiación ionizante y/o aparatos de láser.

\section{Riesgos químicos}

Suele utilizarse aceite mineral para controlar la densidad volumétrica y suprimir el polvo. Antes de llevar el carbón a la carbonera se le pueden aplicar sustancias que minimicen la acumulación y faciliten el vertido de desechos peligrosos derivados de las operaciones con subproductos.

El principal problema para la salud asociado a las operaciones de coquización son las emisiones de las retortas durante la carga del carbón, la coquización y el deshornado del coque. Estas emisiones contienen numerosos hidrocarburos aromáticos policíclicos (HAP), algunos de los cuales son cancerígenos. Los materiales utilizados para sellar tapas y puertas también pueden constituir un problema durante la mezcla y al quitar las tapas y puertas. Puede haber amianto y filtros cerámicos refractarios en forma de juntas y materiales aislantes, aunque se han venido utilizando sustitutos adecuados para productos que anteriormente contenían amianto.

\section{Riesgos mecánicos}

Es preciso reconocer los riesgos de la producción de carbón asociados a los coches ferroviarios, las barcazas marinas y el tráfico de vehículos, así como al movimiento de las cintas transportadoras. La mayoría de los accidentes se producen por atropello, aplastamiento, arrastre, enganche o caída de los trabajadores, o por no dejar estos equipos bloqueados (también eléctricamente).

Los riesgos mecánicos más problemáticos son los planteados por los equipos móviles del lado del deshornador, del coque y de la vagoneta en el tragante de la batería. Estos equipos se mantienen en funcionamiento prácticamente durante todo el turno de trabajo y se deja poco espacio entre los mismos y las operaciones. Los accidentes por atropello y aplastamiento asociados a equipos móviles sobre raíles representan la cifra más alta de incidentes fatales en la producción de coque. Las 
quemaduras cutáneas superficiales provocadas por materiales y superficies calientes y la irritación ocular ocasionada por partículas de polvo son las responsables de incidentes más numerosos, pero menos graves.

\section{Medidas de salud y seguridad}

Para mantener la concentración de polvo a un nivel aceptable durante la producción de carbón, hay que confinar y encerrar los sistemas de clasificación, trituración y transporte. También puede ser necesario disponer de ventilación por extracción localizada además de aplicar agentes humectantes al carbón. Se deben implantar programas adecuados de mantenimiento y limpieza para minimizar los derrames y mantener libres de carbón las zonas de paso junto a los equipos de proceso y transporte. En el sistema de transportadores se utilizarán componentes conocidos por su eficacia para la reducción de derrames y el mantenimiento del confinamiento, como limpiadores de cintas, rodapiés, una correcta tensión de las cintas, etc.

Debido a los riesgos para la salud asociados con los PAH liberados durante las operaciones de coquización, es importante contener y recoger estas emisiones. La mejor forma de conseguirlo es combinar controles técnicos, prácticas laborales y un programa de mantenimiento. También es necesario disponer de un programa de respiradores efectivo. Entre los controles deben incluirse los siguientes:

- diseñar y ejecutar un procedimiento de carga para eliminar las emisiones controlando el volumen de la carga de carbón, alineando correctamente la vagoneta sobre el horno, apretando bien los manguitos de carga y cargando el carbón de acuerdo con una secuencia que permita mantener un canal adecuado por encima del carbón para los flujos de emisiones al colector y recolocar la tapa nada más realizada la carga;

- disponer tubos de tiro en dos o más puntos del horno cargado y diseñar y emplear un sistema de aspiración para mantener suficiente flujo y presión negativa;

- disponer juntas de obturación de aire en las barras de nivel de la máquina deshornadora para controlar la infiltración durante la carga y reductores de carbono para evitar la acumulación de carbono;

- mantener en el colector una presión uniforme adecuada para transportar las emisiones;

- disponer las juntas y puertas de plato necesarias para mantener la estanqueidad y velar por una adecuada limpieza y mantenimiento de los bordes de cierre del lado del coque y del lado del deshornador;

- sellar tapas y puertas y mantener los burletes de las puertas del modo necesario para controlar las emisiones tras la carga;

- minimizar el deshornado prematuro calentando el carbón uniformemente durante un período de tiempo adecuado;

- instalar grandes cerramientos que cubran toda la zona del lado del coque para controlar las emisiones durante el deshornado del coque, o utilizar campanas móviles que puedan trasladarse de una retorta a otra a la hora de deshornar.

- inspección, mantenimiento y reparaciones de rutina para una adecuada contención de las emisiones;

- instalar cabinas de presión positiva y temperatura controlada para los operarios de los equipos móviles a fin de controlar los niveles de exposición de los trabajadores. Para conseguir la presión positiva en la cabina, es obligada su integración estructural, con puertas y ventanillas de montaje ajustado, eliminando las separaciones en la obra estructural.

También es necesario adiestrar a los trabajadores para que utilicen unas buenas prácticas laborales y comprendan la importancia de los procedimientos adecuados para minimizar las emisiones.
Se practicará un control rutinario de la exposición de los trabajadores para determinar qué niveles son aceptables. Se adoptarán programas de control de gases y de rescate, principalmente por presencia de monóxido de carbono en los hornos de gases de coque. Asimismo, deberá implantarse un programa de vigilancia médica.

\section{TRENES DE LAMINACION}

\section{H. Schneider*}

Las placas calientes de acero se convierten en largas bobinas de delgada chapa en los trenes de laminación continua de flejes en caliente. Estas bobinas pueden enviarse directamente a los clientes o bien limpiarse y laminarse en frío para elaborar productos. Véase la cadena de procesos en la Figura 73.13.

\section{Laminación continua en caliente}

Un tren de laminación continua en caliente puede contar con un transportador de más de un kilómetro de longitud. La placa de acero sale de un horno de recocido de placas y entra en el transportador. Se elimina la cascarilla superficial de la placa caliente, que se alarga y adelgaza al ser aplastada por los rodillos horizontales de cada uno de los laminadores, que normalmente reciben el nombre de trenes de desbastado. Los rodillos verticales de los extremos contribuyen a controlar la anchura. Después, el acero entra en los trenes de acabado para su reducción final, desplazándose a velocidades de hasta 80 kilómetros por hora al cruzar la mesa de enfriamiento y enrollarse.

Normalmente, la chapa de acero se limpia o se decapa en un baño de ácido sulfúrico o hidroclórico para eliminar el óxido superficial (cascarilla) que se forma durante la laminación en caliente. Un decapador moderno trabaja de manera continua. Cuando ya casi se ha limpiado una bobina de acero, se corta recto el extremo y se suelda al inicio de una nueva bobina. En el decapador, un laminador endurecedor contribuye a romper la cascarilla antes de que la chapa entre en la sección de decapado o limpieza de la cadena.

Se sitúa un acumulador bajo los tanques de decapado revestidos de caucho, los lavadores y los secadores. La chapa acumulada en el sistema pasa a los tanques de decapado cuando se para el extremo de entrada de la cadena para soldar una nueva bobina. De este modo es posible limpiar una chapa continuamente a una velocidad de $360 \mathrm{~m}$ por minuto. Un pequeño sistema de enlazado situado en el extremo de salida de la cadena permite que ésta funcione de forma continua durante las interrupciones para el bobinado.

\section{Laminación en frío}

Las bobinas de chapa de acero laminada en caliente y ya limpia pueden laminarse en frío para obtener un producto más fino y liso. Este proceso da lugar a un acero con una mejor relación resistencia/peso que la que puede obtenerse con un tren de laminación en caliente. Un moderno tren continuo de laminación en frío de cinco cajas puede recibir una chapa de un grosor aproximado de $1 / 10$ de pulgada $(0,25 \mathrm{~cm})$ y una longitud de $1,2 \mathrm{~km} ; 2$ minutos más tarde, esa chapa se habrá laminado a 0,03 pulgadas $(75 \mathrm{~mm})$ de grosor y tendrá más de $3,2 \mathrm{~km}$ de longitud.

El proceso de laminado en frío endurece la chapa de acero, de modo que suele ser necesario calentarla en un horno de recocido para que moldearla mejor. Las bobinas de chapa laminada en frío se apilan sobre una base. Se colocan cubiertas sobre las pilas

\footnotetext{
* Adaptado de la $3^{\text {a }}$ edición, Enciclopedia de seguridad y salud en el trabajo.
} 
Figura 73.13 • Proceso de laminación de chapa en frío y en caliente.

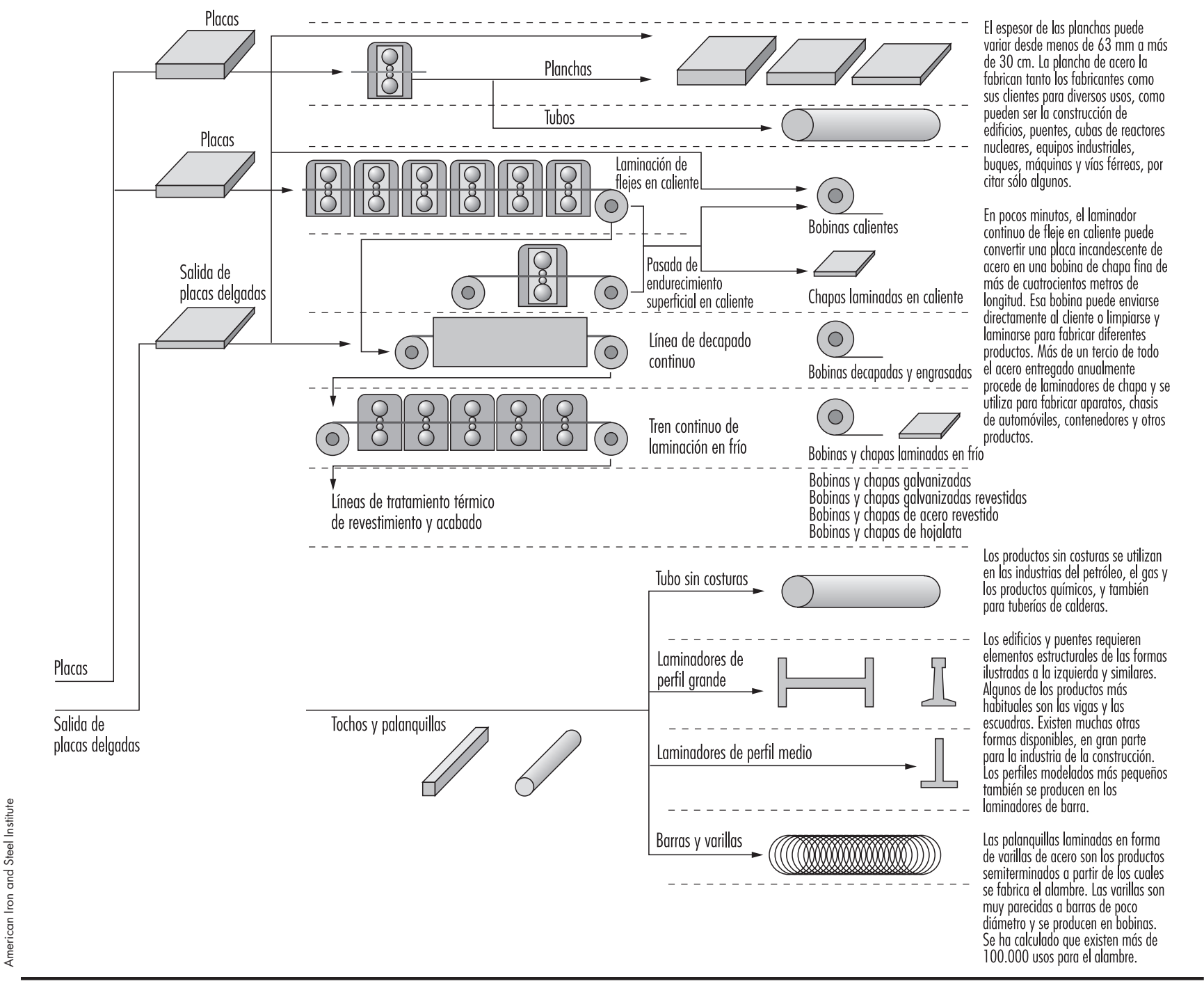

para controlar el recocido y después se baja el horno sobre las pilas así cubiertas. El calentamiento y posterior enfriamiento de la chapa de acero puede llevar de 5 a 6 días.

Una vez ablandado el acero en el proceso de recocido, se utiliza un laminador endurecedor para dar al acero la planeidad, las propiedades metalúrgicas y el acabado superficial deseados. El producto puede enviarse a los clientes en forma de bobinas, recortarse lateralmente o cortarse en largos a medida.

\section{Riesgos y su prevención}

Accidentes. La mecanización ha reducido el número de puntos de atrapamiento en la maquinaría, pero todavía existen, especialmente en los talleres de laminación en frío y en los departamentos de acabado.

La laminación en frío presenta un riesgo atrapamiento entre rodillos, especialmente si se intenta limpiarlos en funcionamiento; las zonas de contacto de los rodillos deben protegerse eficazmente y se ha de ejercer una supervisión estricta para evitar su limpieza en funcionamiento. Si no se instalan defensas seguras en las partes peligrosas de las máquinas de corte, despuntado, rebabado y guillotinas, pueden producirse lesiones graves. Es esencial implantar un programa eficaz de bloqueo/identificación para realizar los trabajos de mantenimiento y reparación.

Si los trabajadores intentan atravesar los transportadores de rodillos por puntos no autorizados, pueden producirse lesiones graves, especialmente en la laminación en caliente; deberá instalarse un número adecuado de puentes de uso obligado. Las soldaduras de enlazado de rollos pueden provocar extensas lesiones y quemaduras, incluso la amputación de los miembros inferiores; cuando no se elimine este riesgo con una mecanización completa, será necesario utilizar puntales protectores u otros mecanismos.

Deberá prestarse especial atención al riesgo de que los trabajadores se corten en los trenes de laminación de chapa y fleje. Estas heridas no sólo se producen con el metal finalmente laminado, sino también con las cinchas metálicas utilizadas en las bobinas, que pueden romperse durante la manipulación y constituyen un serio peligro.

La utilización de grandes cantidades de aceites, antioxidantes, etc., que generalmente se aplican por pulverización, es otro riesgo habitual en los trenes de laminación de chapa. A pesar de las medidas protectoras que se toman para confinar los productos pulverizados, suelen acumularse en el suelo y en las 
vías de paso, donde pueden provocar resbalones y caídas. Por consiguiente, además de limpiar con regularidad los suelos, hay que cubrirlos con rejillas y materiales absorbentes y utilizar botas de suela antideslizante.

Incluso en plantas automatizadas, pueden producirse accidentes en los trabajos de conversión al cambiar los pesados rodillos en las cajas. A menudo, una buena planificación reducirá la necesidad de cambiar los rodillos; es importante que estos trabajos se realicen sin prisas y con herramientas adecuadas.

La automatización de las plantas modernas da lugar a numerosas averías menores que a menudo son reparadas sin detener la planta ni partes de la misma. En esos casos, se puede olvidar la necesidad de utilizar las defensas mecánicas, lo que puede provocar graves accidentes. Frecuentemente se menosprecia el peligro de incendio que comporta la reparación de los sistemas hidráulicos. En las plantas equipadas con maquinaria hidráulica hay que planificar y organizar la protección contra incendios con especial cuidado.

Las tenazas utilizadas para asir el material caliente pueden entrechocar; las llaves cuadradas utilizadas para mover a mano los pesados perfiles laminados pueden provocar graves lesiones en la cabeza o en la parte superior del torso como consecuencia de movimientos no deseados. Todas las herramientas manuales deben diseñarse y mantenerse correctamente, e inspeccionarse con frecuencia. Los roblones de las tenazas deberán renovarse periódicamente; el personal encargado de cambiar los rodillos debe disponer de llaves redondas y llaves de percusión; no deberán utilizarse llaves de boca curvadas. Los trabajadores deben recibir una formación adecuada sobre el manejo de todas las herramientas manuales y se cuidará el correcto almacenamiento de las mismas.

Muchos accidentes pueden tener su origen en operaciones de izado y manipulación incorrectas y en grúas y aparejos defectuosos. Todas las grúas y aparejos deberán inspeccionarse regularmente; se prestará especial cuidado al almacenamiento y uso de las eslingas. Los procedimientos de selección y formación de los conductores de grúas y embragadores serán particularmente estrictos. Siempre existe el riesgo de que se produzcan accidentes debidos al transporte mecánico: las locomotoras, vagones y bogies deberán mantenerse en buen estado y será obligatorio el cumplimiento de un sistema claramente comprensible de advertencias y señalización; se mantendrán vías libres de paso para carretillas elevadoras y otros vehículos.

Muchos otros accidentes pueden producirse a consecuencia de caídas y tropiezos o de suelos mal conservados, materiales mal apilados, palanquillas que sobresalen, rodillos fracturados, etc. Estos riesgos pueden eliminarse con un buen mantenimiento de todos los suelos y medios de acceso, vías de paso claramente definidas, un correcto apilamiento de los materiales y una limpieza periódica de los residuos. Una buena limpieza y conservación es esencial en todas las zonas de la planta, incluidos los patios. Deberá mantenerse un nivel adecuado de iluminación en toda la planta.

En la laminación en caliente, los ojos pueden sufrir quemaduras y lesiones provocadas por la cascarilla desprendida; las defensas antisalpicaduras pueden reducir de forma efectiva la proyección de cascarilla y agua caliente. Otras causas de lesiones oculares son las partículas de polvo o los latigazos de las eslingas; los ojos también pueden verse afectados por el deslumbramiento.

La utilización de equipos de protección personal (EPP) es de gran importancia para prevenir los accidentes en los trenes de laminación. Deberán llevarse cascos, zapatos de seguridad, polainas, protecciones en los brazos, guantes, viseras y gafas de seguridad para protegerse de los riesgos correspondientes. Es esencial contar con la cooperación de los empleados para el uso de los mecanismos y prendas de protección. A tal fin, es importante la formación, así como una eficaz organización para la prevención de accidentes en la que participen los trabajadores o sus representantes.

Calor. Se han registrado niveles de calor radiante de hasta $1.000 \mathrm{kcal} / \mathrm{m}^{2}$ en algunos puestos de trabajo de trenes de laminación. Las enfermedades debidas al estrés por calor son un problema, pero los trabajadores de los modernos trenes de laminación suelen protegerse utilizando salas de control con aire acondicionado. Véase el artículo titulado "La fabricación de hierro y acero" para más información en materia de prevención.

Ruido. En toda la zona de laminación existe un ruido considerable producido por los reductores de los rodillos y enderezadoras, las bombas de agua a presión, las cizallas y sierras, los productos terminados que se arrojan a un foso y las paradas del movimiento del material con planchas metálicas. El nivel general de ruidos de trabajo puede alcanzar alrededor de 84-90 dBA, no siendo inhabituales picos de hasta $115 \mathrm{dBA}$ o más. Véase el artículo titulado "Fabricación de hierro y acero" para más información sobre prevención.

Vibración. La limpieza de los productos terminados con herramientas de percusión de alta velocidad puede dar lugar a alteraciones artríticas de los codos, hombros, clavícula, unión distal del cúbito y el radio, así como a lesiones de los huesos escafoide y semilunar.

Los trabajadores de los trenes de laminación pueden sufrir defectos en las articulaciones de manos y brazos a consecuencia del efecto de retroceso y rebote del material introducido en el espacio entre rodillos.

Gases y vapores perjudiciales. Si se lamina acero aleado con plomo o se utilizan discos de corte que contienen plomo, pueden inhalarse partículas tóxicas. Por consiguiente, es necesario controlar constantemente la concentración de plomo existente en el lugar de trabajo y someter a revisiones médicas periódicas a los trabajadores que puedan verse expuestos. También se puede inhalar plomo por el uso de escarpadores de llama y sopletes de oxicorte, que provocan al mismo tiempo la exposición a óxidos de nitrógeno $\left(\mathrm{NO}_{\mathrm{x}}\right)$, a cromo, níquel y óxido de hierro.

La soldadura a tope va asociada a la formación de ozono, que puede provocar, si se inhala, una irritación similar a la producida por el $\mathrm{NO}_{\mathrm{x}}$. Los operarios de hornos de cuba y de recocido pueden verse expuestos a gases nocivos, cuya composición dependerá del combustible utilizado (gases de altos hornos, gases de hornos de coque, petróleo) y generalmente incluye monóxido de carbono y dióxido de azufre. A veces, es necesario instalar sistemas de ventilación por extracción localizada o utilizar protecciones respiratorias.

Los trabajadores que lubrican los equipos de los trenes de laminación con aceites nebulizados pueden sufrir un deterioro de su salud provocado por los aceites utilizados y los aditivos que contienen. Si se utilizan aceites o emulsiones para el enfriamiento o la lubricación, habrá que garantizar que la proporción de aceite y aditivos sea la correcta para evitar no sólo la irritación de las mucosas, sino también las dermatitis agudas en los trabajadores expuestos. Véase el artículo "Lubricantes industriales, líquidos metalúrgicos y aceites de automoción" incluido en el capítulo titulado La industria metalúrgica.

En las operaciones de acabado se emplean grandes cantidades de agentes desengrasantes. Dichos agentes se evaporan y pueden inhalarse; su acción no es únicamente tóxica, sino que además, si no se manipulan correctamente los disolventes, la piel puede desgrasarse con el consiguiente deterioro. Deberán utilizarse guantes y sistemas de ventilación por extracción localizada.

Acidos. Los fuertes ácidos utilizados en los talleres de decapado son corrosivos para la piel y las membranas mucosas. Deberán utilizarse sistemas locales de ventilación de extracción y equipos de protección personal adecuados. 
Radiación ionizante. Pueden utilizarse equipos de rayos $\mathrm{X}$ y otras radiaciones ionizantes en calibrados e inspecciones; se tomarán precauciones estrictas de acuerdo con la reglamentación local.

Reconocimientos: la descripción de las operaciones de laminado en frío y en caliente se ha utilizado con autorización del American Iron and Steel Institute.

\section{- PROblemas y PaUtas de SEGURIDAD Y SALUD*}

La industria del hierro y el acero es una "industria pesada": además de los riesgos para la seguridad inherentes a las grandes plantas, a los enormes equipos y al movimiento de grandes masas de materiales, los trabajadores están expuestos al calor del metal fundido y de la escoria a temperaturas de hasta $1.800{ }^{\circ} \mathrm{C}$, a sustancias tóxicas o corrosivas, a contaminantes atmosféricos inhalables y al ruido. Espoleada por los sindicatos, por las presiones económicas para obtener una mayor eficiencia y por las normativas gubernamentales, la industria ha dado grandes pasos adelante en la introducción de equipos más modernos y mejores procesos que ofrecen mayor seguridad y permiten controlar mejor los riesgos físicos y químicos. Los accidentes con resultado de muerte o baja laboral se han reducido significativamente, pero siguen constituyendo un problema importante (OIT 1992). La fabricación de acero continúa siendo una profesión peligrosa, en la que no siempre pueden evitarse todos los posibles peligros con un perfecto diseño. En consecuencia, es éste un reto formidable para la gestión diaria de la planta. Exige una investigación continua, un control constante, una supervisión responsable y una formación actualizada de los trabajadores a todos los niveles.

\section{Riesgos físicos}

\section{Problemas ergonómicos}

Las lesiones musculosqueléticas son corrientes en la fabricación de acero. A pesar de la introducción de sistemas de mecanización y auxiliares, sigue siendo necesario manipular manualmente objetos grandes, voluminosos y/o pesados con frecuencia. Hay que prestar una atención constante al orden y la limpieza con el fin de reducir el número de resbalones y caídas. Se ha demostrado que los operarios encargados del revestimiento de los hornos son los más expuestos a sufrir problemas en la región lumbar y en la parte superior de los brazos. La introducción de la ergonomía en el diseño de los equipos y de sus mandos (p. ej., las cabinas de los conductores de grúas), sobre la base del estudio de las necesidades físicas y psíquicas del trabajo, junto con innovaciones tales como la rotación del trabajo y el trabajo en equipo, son avances recientes dirigidos a mejorar la seguridad, el bienestar y el rendimiento de los trabajadores del acero.

\section{Ruido}

La fabricación de acero es una de las industrias más ruidosas, aunque los programas de conservación de la capacidad auditiva están reduciendo el riesgo de sufrir pérdidas de oído. Entre los principales focos de ruido cabe citar: los sistemas de extracción de humos, los sistemas de aspiración con eyectores de vapor, los transformadores eléctricos y el proceso de arco en los hornos

* Adaptado en parte de un artículo no publicado de Simon Pickvance. eléctricos, los trenes de laminación y los grandes ventiladores. Al menos la mitad de los trabajadores expuestos sufrirán pérdidas auditivas incapacitantes debidas al ruido al cabo de no más de 10 o 15 años en este trabajo. Los programas de conservación de la capacidad auditiva, descritos en detalle en otros puntos de esta Enciclopedia, incluyen evaluaciones periódicas de ruido y oído, técnicas de control del ruido y de mantenimiento de máquinas y equipos, protección personal y formación del trabajador.

Entre las causas de pérdida auditiva distintas del ruido cabe citar las quemaduras en el tímpano producidas por partículas de escoria, cascarilla o metal fundido, la perforación del tímpano por un ruido impulsivo intenso y traumas provocados por objetos en su caída o movimiento. Un estudio de las reclamaciones de indemnización presentadas por los trabajadores canadienses del acero reveló que la mitad de los que sufrían pérdidas auditivas de origen laboral también sufrían acufeno (McShane, Hyde y Alberti 1988).

\section{Vibración}

Los movimientos mecánicos oscilantes producen vibraciones potencialmente peligrosas, la mayoría de las veces cuando no se han equilibrado los movimientos de las máquinas, cuando se manejan máquinas en la planta y cuando se utilizan herramientas portátiles como martillos y taladros neumáticos, sierras y esmeriladoras. Varios estudios de operarios de puentes-grúa atribuyen daños en los discos vertebrales, dolores lumbares y degeneración de la columna vertebral a la vibración de todo el cuerpo (Pauline y cols. 1988).

La vibración de todo el cuerpo puede provocar diversos síntomas (p. ej., mal del movimiento, visión borrosa y pérdida de agudeza visual) que pueden dar lugar a accidentes. La vibración del brazo y de la mano se ha asociado al síndrome del túnel carpiano, alteraciones degenerativas de las articulaciones y el fenómeno de Reynaud en las puntas de los dedos ("enfermedad de los dedos blancos"), que puede provocar incapacidad permanente. Un estudio de astilladores y esmeriladores demostró que su probabilidad de desarrollar la contractura de Dupuytren era más del doble que la de un grupo comparativo de trabajadores (Thomas y Clarke 1992).

\section{Exposición al calor}

La exposición al calor es un problema en toda la industria del hierro y el acero, especialmente en plantas ubicadas en climas calurosos. Recientes investigaciones han demostrado que, contrariamente a lo que se creía, las mayores exposiciones tienen lugar durante el forjado, cuando los trabajadores deben vigilar el acero caliente constantemente, y no durante la fusión, cuando, aunque las temperaturas son más altas, son intermitentes y sus efectos se ven limitados por el intenso calentamiento de la piel expuesta y por la utilización de protección ocular (Lydahl y Philipson 1984). El peligro del estrés por calor se reduce con una adecuada ingesta de líquidos, ventilación adecuada, el uso de pantallas antitérmicas y ropa protectora, e interrupciones periódicas para descansar o trabajar en tareas menos calurosas.

\section{Rayos láser}

Los rayos láser tienen una gran variedad de aplicaciones en la fabricación del acero y pueden provocar daños en la retina a niveles de potencia muy inferiores a los necesarios para producir efectos en la piel. Los operadores de láser pueden protegerse enfocando el haz con precisión y utilizando gafas de seguridad, pero otros trabajadores pueden sufrir lesiones si entran en el radio de acción del haz sin saberlo o si éste se refleja inadvertidamente hacia ellos. 


\section{Nucleidos radiactivos}

Muchos aparatos de medición emplean nucleidos radiactivos. En general, es posible controlar las exposiciones colocando letreros de aviso y pantallas. Es mucho más peligrosa la inclusión accidental o negligente de materiales radiactivos en la chatarra de acero reciclada. Para evitarlo, muchas plantas controlan toda la chatarra con detectores sensibles a la radiación antes de introducirla en el proceso.

\section{Contaminantes atmosféricos}

Los trabajadores pueden verse expuestos a una gran variedad de contaminantes dependiendo del proceso, de los materiales y de la eficacia de las medidas de vigilancia y control. Los efectos perjudiciales vienen determinados por el estado físico y las propensiones del contaminante, la intensidad y duración de la exposición, el grado de acumulación en el cuerpo y la sensibilidad del individuo a sus efectos. Algunos efectos son inmediatos, mientras que otros pueden tardar años e incluso decenios en aparecer. Los cambios en los procesos y equipos, junto con la mejora de las medidas para mantener las exposiciones por debajo de los niveles tóxicos, han reducido los riesgos para los trabajadores. Pero también se han introducido nuevas combinaciones de contaminantes, y siempre existe el peligro de que se produzcan accidentes, incendios y explosiones.

\section{Polvo y vapores}

Las emisiones de vapores y partículas representan un importante problema potencial para los empleados que trabajan con metales fundidos, que fabrican y manipulan coque y que cargan y sangran los hornos. También pueden resultar expuestos los trabajadores asignados al mantenimiento de los equipos, la limpieza de las conducciones y las operaciones de demolición de revestimientos refractarios. Sus efectos para la salud dependen del tamaño de las partículas (es decir, de la proporción que es inhalable) y de los metales y aerosoles adsorbidos en sus superficies. Hay evidencias de que la exposición a polvo y vapores irritantes puede hacer a los trabajadores del acero más susceptibles a un estrechamiento reversible de las vías respiratorias (asma), que con el tiempo puede hacerse permanente (Johnson y cols. 1985).

\section{Sílice}

Las exposiciones a sílice, con las consiguientes silicosis, antes bastante frecuentes en los trabajadores encargados del mantenimiento de los hornos en las plantas de fundición y en los altos hornos, se han reducido gracias al uso de revestimientos en los hornos y a la automatización, que ha reducido el número de trabajadores presentes en estos procesos.

\section{Amianto}

El amianto, que se utilizó mucho como aislante térmico e insonorizante, sólo se encuentra ya en actividades de mantenimiento y construcción cuando se remueven materiales con amianto y se generan fibras en suspensión. Los efectos a largo plazo de la exposición al amianto, descritos detalladamente en otras secciones de la presente Enciclopedia, comprenden la asbestosis, el mesotelioma y otros cánceres. En un reciente estudio de secciones transversales se detectó patología pleural en 20 de cada 900 trabajadores del acero (un 2 \%), diagnosticada en la mayoría de los casos como enfermedad pulmonar restrictiva, característica de la asbestosis (Kronenberg y cols. 1991).

\section{Metales pesados}

Las emisiones generadas en la fabricación de acero pueden contener metales pesados (p. ej., plomo, cromo, zinc, níquel y manganeso) en forma de vapores, partículas y adsorbatos en partículas de polvo inerte. Suelen estar presentes en la chatarra de acero y también se introducen en la fabricación de tipos especiales de productos de acero. Las investigaciones realizadas entre los trabajadores encargados de fundir aleaciones de manganeso han demostrado deterioros en el rendimiento físico y psíquico y otros síntomas de manganismo a niveles de exposición significativamente inferiores a los límites actualmente admisibles en la mayoría de los países (Wennberg y cols. 1991). La exposición a corto plazo a altos niveles de zinc y otros metales vaporizados puede provocar la "fiebre de los vapores metálicos", que se caracteriza por fiebre, escalofríos, náuseas, dificultades respiratorias y fatiga. En otras secciones de la presente Enciclopedia se ofrecen detalles de los demás efectos tóxicos producidos por los metales pesados.

\section{Nieblas de ácido}

Las nieblas de ácido de las áreas de decapado pueden provocar irritación cutánea, ocular y respiratoria. Además, un estudio asocia la exposición a nieblas de ácido hidroclórico y ácido sulfúrico procedentes de los baños de decapado con una casi duplicación del cáncer de laringe (Steenland y cols. 1988).

\section{Compuestos de azufre}

La fuente predominante de emisiones sulfúricas en la fabricación de acero es la utilización de combustibles fósiles con alto contenido de azufre y escoria de altos hornos. El sulfuro de hidrógeno tiene un característico olor desagradable y entre los efectos a corto plazo de las exposiciones de bajo nivel cabe citar la sequedad e irritación de los conductos nasales y del tracto respiratorio superior, tos, disnea y neumonía. Exposiciones prolongadas de bajo nivel pueden provocar irritación ocular, y si son de alto nivel, daños oculares permanentes. A niveles altos, también puede producirse una pérdida temporal del olfato que induzca a los trabajadores a creer erróneamente que ya no están expuestos.

\section{Nieblas de aceite}

Las nieblas de aceite generadas en la laminación de acero en frío pueden provocar irritación de la piel, de las membranas mucosas y del tracto respiratorio superior y ocasionar náuseas, vómitos y dolores de cabeza. En un estudio se documentan casos de neumonía lipoide en trabajadores de trenes de laminación sometidos a una exposición de larga duración (Cullen y cols. 1981).

\section{Hidrocarburos aromáticos policíclicos}

Los hidrocarburos HAP se producen en la mayoría de los procesos de combustión; en las acerías, la fabricación de coque es la causa principal. Cuando se quema carbón parcialmente para producir coque, se destilan gran número de compuestos volátiles, como los volátiles de la pez, incluidos HAP. Estos últimos pueden estar presentes en forma de vapores, aerosoles o adsorbatos en partículas finas. Las exposiciones a corto plazo pueden provocar irritación de la piel y las membranas mucosas, mareos, dolores de cabeza y náuseas, mientras que las exposiciones a largo plazo se han asociado con la carcinogénesis. Los estudios realizados demuestran que la tasa de mortalidad por cáncer de pulmón de los trabajadores de los hornos de coque es el doble de la de la población general. Los más expuestos a los volátiles de la pez son quienes corren mayor riesgo. Entre ellos cabe citar a los trabajadores del tragante del horno y a los trabajadores con un período más largo de exposición (IARC 1984; Constantino, Redmond y Bearden 1995). En algunos países los controles técnicos han reducido el número de trabajadores en situación de riesgo.

\section{Otros productos químicos}

En la fabricación de acero se utilizan o encuentran más de 1.000 productos químicos, ya sea como materias primas o como contaminantes de la chatarra y/o de los combustibles; como 
aditivos en procesos especiales; como refractarios; y como fluidos hidráulicos y disolventes utilizados en el funcionamiento y mantenimiento de la planta. La fabricación de coque genera subproductos como el alquitrán, el benceno y el amoníaco; otros se producen en los distintos procesos de fabricación del acero. Todos ellos pueden ser potencialmente tóxicos, dependiendo de la naturaleza de los productos químicos, del tipo, nivel y duración de las exposiciones, de su reactividad con otros productos químicos y de la susceptibilidad del trabajador expuesto. Exposiciones intensas accidentales a vapores con dióxido de azufre y óxidos de nitrógeno han producido casos de neumonitis química. El vanadio y otros aditivos de aleación pueden provocar neumonitis química. El monóxido de carbono, que se libera en todos los procesos de combustión, puede ser peligroso cuando el mantenimiento de los equipos y sus mandos es inadecuado. El benceno, junto con el tolueno y el xileno, está presente en los gases de los hornos de coque y produce síntomas respiratorios y en el sistema nervioso central si la exposición es grave; las exposiciones a largo plazo pueden dar lugar a deterioros del tuétano de los huesos, anemia aplástica y leucemia.

\section{Estrés}

En la industria del acero se encuentran elevados niveles de estrés laboral. Las exposiciones al calor radiante y al ruido se ven agravadas por la necesidad de una vigilancia constante para evitar accidentes y exposiciones potencialmente peligrosas. Como muchos procesos no paran nunca, el trabajo por turnos constituye una necesidad; su repercusión sobre el bienestar y el apoyo social esencial para los trabajadores se detalla en otras secciones de la presente Enciclopedia. Finalmente, un factor de estrés muy fuerte es la posible pérdida del puesto de trabajo como consecuencia de la automatización y los cambios en los procesos, la reubicación de las plantas y las reducciones de plantilla.

\section{Programas preventivos}

Proteger a los trabajadores del acero de una posible toxicidad requiere la asignación de los recursos necesarios para la aplicación de un programa continuado, completo y coordinado, que deberá incluir los siguientes elementos:

- evaluación de todas las materias primas y combustibles y, cuando sea posible, sustitución de los productos peligrosos por otros más seguros;

- controles efectivos para la seguridad de almacenamiento y manipulación de materias primas, productos, subproductos y desechos;

- control constante del ambiente de trabajo en que se desenvuelve cada trabajador y de la calidad del aire ambiental, realizando controles biológicos si fuera necesario, y revisiones médicas periódicas de los trabajadores para detectar efectos más sutiles sobre la salud y comprobar su aptitud física para el puesto de trabajo;

- sistemas técnicos para controlar posibles exposiciones (p. ej., cerramientos para equipos y sistemas de extracción y ventilación adecuados) completados con equipos de protección personal (p. ej., pantallas, guantes, gafas de seguridad, protectores auditivos, respiradores, protecciones corporales y para los pies, etc.) cuando no sean suficientes los controles técnicos;

- aplicación de principios ergonómicos al diseño de los equipos, mandos de las máquinas y herramientas, y análisis de la estructura y contenido del trabajo como orientación para intervenciones con el fin de prevenir lesiones y mejorar el bienestar de los trabajadores;

- mantenimiento de una información actualizada y fácilmente disponible sobre posibles riesgos, que debe difundirse entre los trabajadores y supervisores como parte de un programa de formación laboral continua;

- instalación y mantenimiento de sistemas para el almacenamiento y la recuperación de un gran volumen de datos sobre salud y seguridad, así como de los análisis e informes de los expedientes sobre resultados de inspecciones, accidentes y lesiones y enfermedades de los trabajadores.

\section{CUESTIONES AMBIENTALES Y DE SALUD PUBLICA*}

Debido al gran volumen y complejidad de las operaciones y al elevado consumo de energía y materias primas, la industria del hierro y el acero, al igual que otras industrias "pesadas", puede tener importantes repercusiones para el medio ambiente y la población de las comunidades vecinas. En la Figura 73.14 se resumen los contaminantes y desechos generados por los principales procesos productivos, que se clasifican en tres categorías principales: contaminantes atmosféricos, contaminantes de aguas residuales y residuos sólidos.

Históricamente, las investigaciones sobre las repercusiones de la industria del hierro y el acero para la salud pública se han centrado en los efectos localizados en áreas densamente pobladas, y especialmente en regiones concretas donde se registraron episodios graves de contaminación del aire, como en los valles de Donora y Meuse y en el triángulo comprendido por Polonia, la antigua Checoslovaquia y la antigua República Democrática Alemana (OMS 1992).

\section{Contaminantes atmosféricos}

Los contaminantes procedentes de las operaciones de fabricación de hierro y acero han constituido un problema ecológico desde siempre. Entre ellos se encuentran sustancias gaseosas como óxidos de azufre, dióxido de nitrógeno y monóxido de carbono. Además, las partículas de hollín y polvo, que pueden contener óxidos de hierro, han sido el principal objeto de control. Las emisiones de los hornos de coque y de las plantas de recuperación de los subproductos de hornos de coque han sido problemáticas, pero las constantes mejoras en la tecnología de fabricación del acero y en el control de las emisiones durante los dos últimos decenios, junto con reglamentaciones gubernamentales más restrictivas, han reducido significativamente su volumen en Norteamérica, Europa occidental y Japón. Se ha estimado que los costes totales del control de la contaminación, más de la mitad de los cuales están relacionados con las emisiones atmosféricas, oscilan entre el 1 y el $3 \%$ de los costes totales de producción; las instalaciones de control de la contaminación atmosférica constituyen aproximadamente de un 10 a un $20 \%$ de las inversiones totales de las plantas. Estos costes representan una barrera para la aplicación global de controles de tecnología punta en los países en desarrollo y en las empresas más antiguas, económicamente marginales.

Los contaminantes atmosféricos varían dependiendo del proceso, el diseño técnico y la construcción de la planta, de las materias primas empleadas, de las fuentes y las cantidades de energía necesarias, del grado de reciclaje de los productos de desecho dentro del proceso y de la eficiencia de los controles anticontaminantes. Por ejemplo, la introducción de la fabricación de acero con inyección de oxígeno ha permitido recuperar y reciclar los gases residuales de forma controlada, reduciendo

* Adaptado de PNUMA e IISI 1997 y de un artículo no publicado de Jerry Spiegel. 
Figura 73.14 Diagrama de flujos de contaminantes y residuos generados por diferentes procesos.

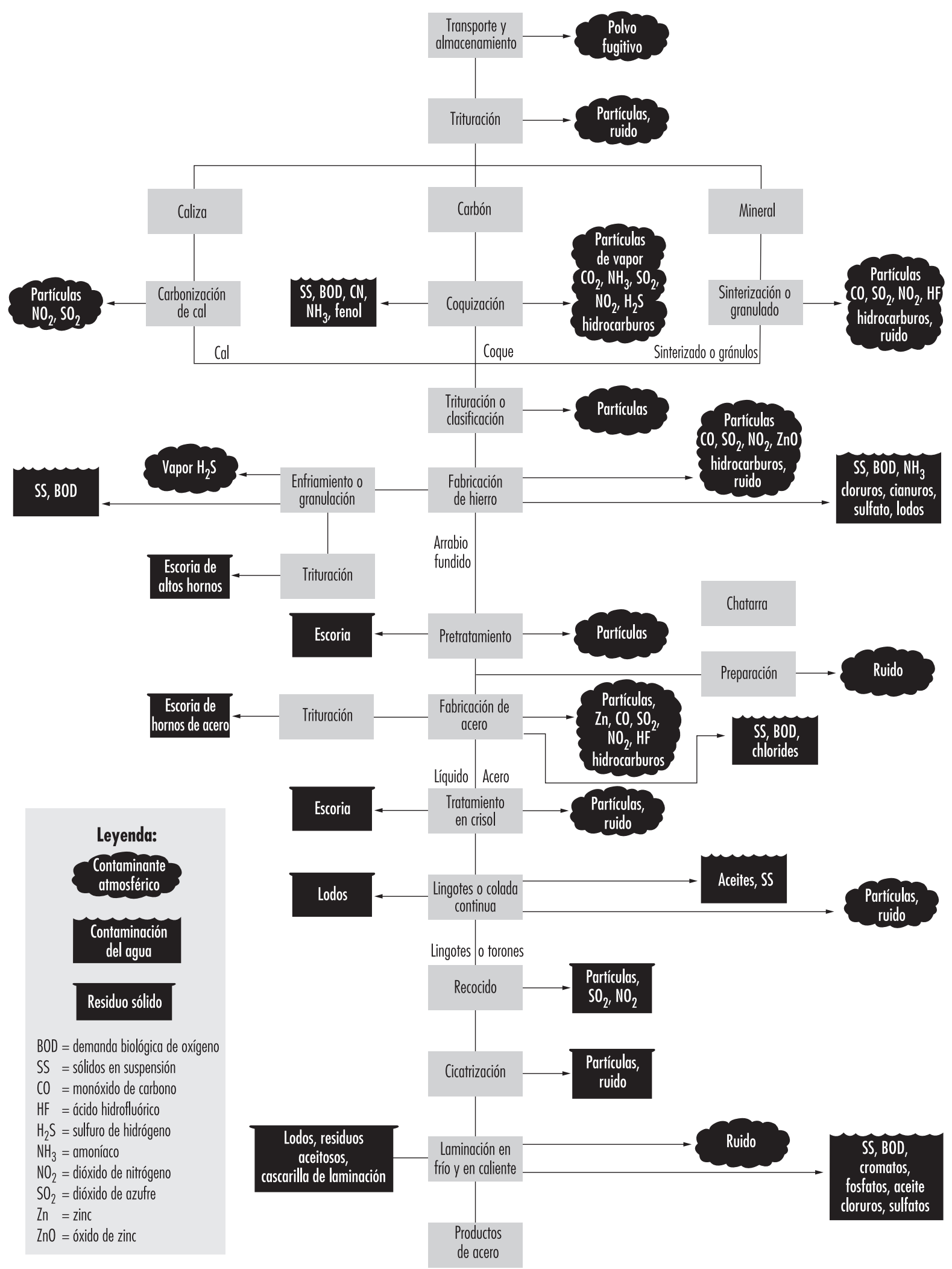

Fuente: PNUMA 1986 
las cantidades aspiradas al exterior, mientras que el proceso de colada continua ha disminuido el consumo de energía y, por tanto, las emisiones. De este modo, se ha aumentado el rendimiento del producto y mejorado la calidad.

\section{Dióxido de azufre}

La cantidad de dióxido de azufre, que se forma principalmente en los procesos de combustión, depende fundamentalmente del contenido de azufre del combustible fósil empleado. Tanto el coque como los gases de los hornos de coque utilizados como combustibles son importantes focos de dióxido de azufre. En el ambiente, el dióxido de azufre puede reaccionar con los radicales del oxígeno y con el agua para formar un aerosol de ácido sulfúrico $\mathrm{y}$, en combinación con amoníaco, puede formar un aerosol de sulfato de amonio. Los efectos para la salud atribuidos a los óxidos de azufre no sólo se deben al dióxido de azufre sino también a su tendencia a formar estos aerosoles respirables. Además, el dióxido de azufre puede adsorberse en partículas, muchas de las cuales se encuentran en el rango respirable. Es posible reducir las exposiciones no sólo empleando combustibles con un bajo contenido en azufre sino también reduciendo la concentración de las partículas. El uso de los hornos eléctricos ha reducido las emisiones de óxidos de azufre al eliminar la necesidad del coque, pero no se ha hecho más que pasar la responsabilidad del control de la contaminación a las plantas generadoras de electricidad. La desulfuración de los gases de los hornos de coque se consigue eliminando los compuestos de azufre reducidos, principalmente el sulfuro de hidrógeno, antes de la combustión.

\section{Oxidos de nitrógeno}

$\mathrm{Al}$ igual que los óxidos de azufre, los óxidos de nitrógeno, principalmente el óxido de nitrógeno y el dióxido de nitrógeno, se forman en procesos de combustión de combustible. Reaccionan con el oxígeno y con los compuestos orgánicos volátiles (COV) en presencia de radiación ultravioleta (UV) para formar ozono. También se combinan con el agua para formar ácido nítrico, que a su vez se combina con el amoníaco para formar nitrato de amonio. Pueden formar aerosoles respirables que se eliminan del ambiente mediante deposición húmeda o seca

\section{Partículas}

Las partículas, la forma más visible de contaminación, constituyen una mezcla compleja y variable de materiales orgánicos e inorgánicos. El polvo puede ser aventado de montones de mineral de hierro, carbón, coque y caliza, o puede pasar al aire durante su carga y transporte. Los materiales gruesos generan polvo por frotamiento o al ser machacados por vehículos. Las partículas finas se generan en los procesos de sinterización, fundición y licuefacción, especialmente cuando el hierro fundido entra en contacto con el aire para formar óxido de hierro. Los hornos de coque producen emisiones de finas partículas de coque y alquitrán. Sus posibles efectos para la salud dependen del número de partículas que se encuentren en el rango respirable, de la composición química del polvo y de la duración y concentración de la exposición.

Se han registrado importantes logros en la reducción de los niveles de contaminación por partículas. Por ejemplo, una acería alemana instaló precipitadores electrostáticos para limpiar los gases residuales secos producidos en la fabricación de acero con inyección de oxígeno y consiguió bajar el nivel de polvo emitido de $9,3 \mathrm{~kg} / \mathrm{t}$ de acero en bruto en 1960 a $5,3 \mathrm{~kg} / \mathrm{t}$ en 1975 y algo menos de $1 \mathrm{~kg} / \mathrm{t}$ en 1990. Sin embargo, el coste fue un claro aumento del consumo de energía. Otros métodos de control de la contaminación por partículas comprenden el empleo de depuradores por humedad, precipitadores de polvos y ciclones (que sólo son eficaces contra las partículas más grandes).

\section{Metales pesados}

Un horno puede emitir metales como cadmio, plomo, zinc, mercurio, manganeso, níquel y cromo en forma de polvo, humos o vapores, o pueden ser adsorbidos por partículas. Los efectos para la salud, descritos en otras secciones de la presente Enciclopedia, dependen del nivel y duración de la exposición.

\section{Emisiones orgánicas}

Las emisiones orgánicas de las principales operaciones de fabricación del acero incluyen: benceno, tolueno, xileno, disolventes, hidrocarburos PAH, dioxinas y fenoles. La chatarra de acero utilizada como materia prima puede contener varias de estas sustancias, dependiendo de su origen y de la forma en que se utilizase (p. ej., pintura y otros revestimientos, otros metales y lubricantes). No todos estos contaminantes orgánicos son capturados por los sistemas depuradores de gases convencionales.

\section{Radiactividad}

En los últimos años, se han registrado casos de inclusión inadvertida de materiales radiactivos en la chatarra de acero. Las propiedades fisicoquímicas de los nucleidos (p. ej., temperaturas de fusión y ebullición y afinidad al oxígeno) determinarán lo que ocurrirá en el proceso de fabricación del acero. Su cantidad puede ser suficiente para contaminar los productos de acero, los subproductos y los distintos tipos de desechos, por lo que se requieren costosos métodos de limpieza y vertido. También existe la posibilidad de que se contaminen los equipos de fabricación, lo que acarrearía la exposición de los trabajadores. Sin embargo, en muchas operaciones se han instalado detectores sensibles a la radiación para inspeccionar toda la chatarra de acero que se compra.

\section{Dióxido de carbono}

Aunque no produce efecto alguno sobre la salud humana ni los ecosistemas a los niveles atmosféricos normales, el dióxido de carbono es importante por su contribución al "efecto invernadero", que se asocia al calentamiento global. La industria del acero es una importante generadora de dióxido de carbono, más por el empleo del carbón como agente reductor en la producción de hierro a partir de mineral de hierro que por su uso como fuente de energía. En 1990, las emisiones de dióxido de carbono de la industria del hierro y el acero se habían reducido al $47 \%$ de los niveles existentes en 1960 gracias a diversas medidas encaminadas a reducir el porcentaje de coque en los altos hornos, recuperar el calor residual y ahorrar energía.

\section{Ozono}

El ozono, un importante componente del "smog" atmosférico cerca de la superficie de la tierra, es un contaminante secundario formado en el aire por la reacción fotoquímica de la luz del sol sobre los óxidos de nitrógeno, facilitada en distinta medida, en función de su estructura y reactividad, por diversos COV. La principal fuente de precursores del ozono la constituyen los escapes de los automóviles, pero algunos también son generados por las plantas de hierro y acero, así como por otras industrias. A consecuencia de las condiciones topográficas y atmosféricas, la reacción del ozono puede tener lugar a gran distancia de la fuente.

\section{Contaminantes de las aguas residuales}

Las plantas de acero descargan un gran volumen de agua a ríos, arroyos y lagos, vaporizándose volúmenes adicionales durante el enfriamiento del coque o del acero. Las aguas 
residuales almacenadas en estanques no herméticos o con fugas pueden filtrarse y contaminar la capa freática y las corrientes subterráneas. Éstas también pueden contaminarse por la lixiviación de las aguas pluviales a través de pilas de materias primas o acumulaciones de residuos sólidos. Entre los contaminantes cabe citar los sólidos en suspensión, los metales pesados y los aceites y grasas. Los cambios de temperatura en las aguas naturales como consecuencia del vertido de aguas de proceso a mayor temperatura (el $70 \%$ de las aguas de proceso se utilizan como medio de enfriamiento) pueden afectar a los ecosistemas. En consecuencia, es esencial aplicar un tratamiento de enfriamiento antes del vertido, lo que puede conseguirse con la tecnología disponible.

\section{Sólidos en suspensión}

Los sólidos en suspensión (SS) son los principales contaminantes del agua que se descargan durante la producción de acero. Comprenden principalmente óxidos de hierro procedentes de la formación de cascarilla durante el proceso; también puede haber carbón, lodos biológicos, hidróxidos metálicos y otros sólidos. $\mathrm{Su}$ presencia a mayores niveles puede dar lugar a la decoloración de las corrientes, la desoxigenación y la sedimentación.

\section{Metales pesados}

Las aguas de proceso de la fabricación de acero pueden contener altos niveles de zinc y manganeso, mientras que los vertidos de las áreas de laminación en frío y revestimientos pueden contener zinc, cadmio, aluminio, cobre y cromo. Estos metales están presentes naturalmente en el entorno acuático, pero su presencia a concentraciones superiores a las normales es preocupante por los posibles efectos para el hombre y los ecosistemas. Esta preocupación se ve aumentada por el hecho de que, a diferencia de muchos contaminantes orgánicos, los metales pesados no se biodegradan en productos finales inocuos y pueden concentrarse en sedimentos y en los tejidos de los peces y demás vida acuática. Además, al combinarse con otros contaminantes (p. ej., amoníaco, compuestos orgánicos, aceites, cianuros, álcalis, disolventes y ácidos), aumenta su toxicidad potencial.

\section{Aceites y grasas}

Las aguas residuales pueden contener aceites y grasas en formas solubles e insolubles. La mayoría de los aceites y grasas pesados son insolubles y relativamente fáciles de eliminar. Sin embargo, pueden emulsionarse por contacto con detergentes o álcalis o por agitación. Los aceites emulsionados se utilizan como parte del proceso de laminación en frío. Excepto porque provocan decoloración de la superficie del agua, la mayoría de los compuestos oleaginosos alifáticos son inocuos en pequeñas cantidades. Sin embargo, los compuestos oleaginosos aromáticos pueden ser tóxicos. Además, los componentes de los aceites pueden contener sustancias tóxicas como PCB, plomo y otros metales pesados. Aparte de la cuestión de la toxicidad, la demanda biológica y química de oxígeno (BOD y COD) de los aceites y de otros compuestos orgánicos puede reducir el contenido de oxígeno del agua, afectando de este modo a la viabilidad de la vida acuática.

\section{Residuos sólidos}

Es posible reutilizar la mayoría de los residuos sólidos producidos en la fabricación de acero. Por ejemplo, el proceso de producción de coque da lugar a derivados del carbón que son materias primas importantes en la industria química. Muchos subproductos (p. ej., coque pulverizado) pueden realimentarse en los procesos productivos. La escoria que se produce cuando las impurezas presentes en el carbón y el mineral de hierro se funden y se
Tabla 73.2 • Residuos generados y reciclados por la industria acerera de Japón.

\begin{tabular}{|c|c|c|c|}
\hline & $\begin{array}{l}\text { Generación (A) } \\
(1.000 \\
\text { toneladas) }\end{array}$ & $\begin{array}{l}\text { Tierras (B) } \\
(1.000 \\
\text { toneladas) }\end{array}$ & $\begin{array}{l}\text { Reutilización } \\
\text { (A-B/A) \% }\end{array}$ \\
\hline \multicolumn{4}{|l|}{ Escoria } \\
\hline $\begin{array}{l}\text { Altos hornos } \\
\text { Convertidores } \\
\text { Hornos eléctricos de arco } \\
\text { Subtotal }\end{array}$ & $\begin{array}{r}24.717 \\
9.236 \\
2.203 \\
36.156\end{array}$ & $\begin{array}{r}712 \\
1.663 \\
753 \\
3.128\end{array}$ & $\begin{array}{l}97,1 \\
82,0 \\
65,8 \\
91,3\end{array}$ \\
\hline Polvo & 4.763 & 238 & 95,0 \\
\hline Lodos & 519 & 204 & 60,7 \\
\hline Aceites residuales & 81 & & \\
\hline Total & 41.519 & 3.570 & 91.4 \\
\hline
\end{tabular}

Fuente: IISI 1992

mezclan con la cal utilizada como fundente en los procesos de fundición pueden utilizarse de varias maneras: como material de fertilización de suelos áridos, con grava para carreteras y como materia prima para plantas de sinterización para el suministro de altos hornos. El acero, con independencia de su calidad, tamaño, uso o permanencia en servicio, es completamente reciclable, y puede reciclarse repetidamente sin que se degraden en modo alguno sus propiedades mecánicas, físicas o metalúrgicas. Se calcula que el porcentaje de reciclaje es del $90 \%$. En la Tabla 73.2 se ilustra el nivel alcanzado por la industria acerera japonesa en el reciclaje de materiales residuales.

\section{Conservación de la energía}

La conservación de la energía es aconsejable no sólo por motivos económicos, sino también para reducir la contaminación provocada por las instalaciones suministradoras de energía, como las centrales eléctricas. La cantidad de energía consumida para la producción de acero varía mucho dependiendo del proceso utilizado y de la mezcla de chatarra metálica y mineral de hierro empleada como material de alimentación. En 1988, el consumo energético de las plantas estadounidenses alimentadas con chatarra alcanzó un promedio de 21,1 gigajulios, mientras que las plantas japonesas consumieron alrededor de un $25 \%$ menos. Un prototipo de planta alimentada con chatarra puesto en marcha por el Instituto Internacional del Hierro y el Acero (IISI, International Iron and Steel Institute) sólo utilizaba 10,1 gigajulios por tonelada (IISI 1992).

El aumento del coste de la energía ha estimulado el desarrollo de tecnologías de ahorro de energía y materiales. Los gases de baja energía, como los subproductos gaseosos producidos por los altos hornos y hornos de coque, se recuperan, se limpian y se reutilizan como combustible. El consumo de coque y combustibles auxiliares en la industria acerera alemana, que alcanzó una media de $830 \mathrm{~kg} / \mathrm{t}$ en 1960, se redujo a $510 \mathrm{~kg} / \mathrm{t}$ en 1990 . La industria acerera japonesa fue capaz de reducir su porcentaje de consumo total de energía del 20,5\% en 1973 a alrededor de un $7 \%$ en 1988. La estadounidense ha realizado importantes inversiones en conservación de la energía. La planta media ha reducido el consumo alrededor de un $45 \%$ desde 1975, por medio de modificaciones en los procesos, nuevas tecnologías y reestructuraciones (las emisiones de dióxido de carbono han disminuido proporcionalmente). 


\section{De cara al futuro}

Tradicionalmente, los gobiernos, las asociaciones comerciales y las industrias han abordado las cuestiones medioambientales según el medio, tratando por separado, por ejemplo, los problemas del aire, del agua y el vertido de residuos. Aunque útil, este planteamiento sólo ha servido en ocasiones para desviar el problema de un ámbito ecológico a otro, como ocurre con los costosos tratamientos de las aguas residuales, que dejan sin resolver el problema del vertido de los lodos de tratamiento, capaces de contaminar gravemente las aguas subterráneas.

En los últimos años, sin embargo, la industria acerera internacional ha abordado este problema mediante un control integrado de la contaminación, que ha dado lugar al concepto de gestión total de los riesgos ambientales, un programa que considera todos los impactos ecológicos de forma simultánea y aborda los ámbitos prioritarios de forma sistemática. Un segundo avance igualmente importante ha sido la insistencia en las medidas preventivas, en vez de en la reparación. Este enfoque aborda cuestiones como el emplazamiento de la planta, la preparación del emplazamiento, la distribución y equipamiento de la planta, la especificación de las responsabilidades diarias de gestión y la incorporación de plantillas y recursos adecuados para controlar el cumplimiento de las reglamentaciones ambientales y comunicar los resultados a las autoridades competentes.

El Centro de la Industria y el Medio Ambiente, creado en 1975 por el Programa de las Naciones Unidades para el Medio
Ambiente (PNUMA), tiene por objeto favorecer la cooperación entre las industrias y los gobiernos con el fin de promover un desarrollo industrial respetuoso con el medio ambiente. Entre sus objetivos cabe citar:

- fomento de la incorporación de criterios ecológicos en los planes de desarrollo industrial;

- facilitación de la implantación de procedimientos y principios para la protección del medio ambiente;

- promoción del uso de técnicas limpias y seguras;

- estímulo al intercambio de información y experiencias en todo el mundo.

El PNUMA trabaja en estrecha colaboración con el IISI, la primera asociación industrial internacional dedicada a una sola industria. Entre los miembros del IISI se encuentran empresas productoras de acero de propiedad pública y privada, así como asociaciones, federaciones e institutos de investigación de industrias acereras de los 51 países que engloban más del $70 \%$ de la producción mundial total de acero. El IISI, a menudo de concierto con el PNUMA, adopta declaraciones de política y principios ambientales e informes técnicos como el que ha servido en gran parte de base al presente artículo (PNUMA e IISI 1997). Ambos trabajan conjuntamente para abordar los factores económicos, sociales, morales, personales, de gestión y tecnológicos que afectan al cumplimiento de los principios, políticas y reglamentaciones ambientales.

\section{Referencias}

Agencia Internacional para la Investigación sobre el Cáncer (IARG). 1984. Monographs 1984. 34:101-131

Constantino, JP, CK Redmond, A Bearden. 1995. Occupationally related cancer risk among coke oven workers: 30 years of follow-up. $f$ Occup Env Med 37:597-603

Cullen, MR, JR Balmes, JM Robins, GJ Walker Smith. 1981. Lipoid pneumonia caused by oil mist exposure from a steel rolling tandem mill. Am f Ind Med 2:51-58.

International Iron and Steel Institute (IISI). 1992. Environmental Control in the Steel Industry. Documentos preparados para la Conferencia Mundial 1991 ENCOSTEEL, Bruselas.

Johnson, A, CY Moira, L MacLean, E Atkins, A Dybuncio, F Cheng, D Enarson. 1985. Respiratory abnormalities amongst workers in iron and steel industry. Br f Ind Med 42:94-100.

Kronenberg, RS, JC Levin, RF Dodson, JGN Garcia DE Grifith. 1991. Asbestos-related disease in employees of a steel mill and a glass bottle manufacturing plant. Ann NY Acad Sci 643:397-403.

Lydahl, E, B Philipson. 1984. Infrared radiation and cataract. 1. Epidemiologic investigation of iron and steel workers. Acta Ophthalmol 62:961-975.

McShane, DP, ML Hyde, PW Alberti. 1988. Tinnitus prevalence in industrial hearing loss compensation claimants. Clinical Otolaryngology 13:323-330.

Organización Internacional del Trabajo (OIT). 1992. Recent Developments in the Iron and Steel Industry. Informe l. Ginebra: OIT.
Organización Mundial de la Salud (OMS) Comisión sobre la Salud. 1992. Report of the Panel on Industry and Health. Ginebra: OMS.

Pauline, MB, CB Hendriek, TJH Carel, PK Agaath. 1988. Back disorders in crane operators exposed to whole body vibration. Int Arch Occup Environ Health 1988:129-137.

Programa de las Naciones Unidas para el Medio Ambiente (UNEP). 1986. Guidelines for Environmental Management of Iron and Steel Works. Paris: UNEP.

Steenland, K, T Schnoor, J Beaumont, W Halperin, T Bloom. 1988. Incidence of laryngeal cancer and exposure to acid mists. Br f Ind Med 45:766-776.

Thomas, PR, D Clarke. 1992. Vibration, White Finger and Dupuytren's Contracture: Are they related? Occup Med 42(3): 155-158.

United Nations Environment Programme (PNUMA) y Steel Institute (IISI). 1997. Steel Industry and the Environment: Technical and Management Issues. Technical Report No. 38. París y Bruselas: PNUMA y IISI.

Wennberg, A, A Iregren, G Strich, G Cizinsky, M Hagman, L Johansson. Manganese exposure in steel smelters, a health hazard to the nervous system. Scand 7 Work Environ Health 17: 255-62.

\section{Otras lecturas recomendadas}

American Iron and Steel Institute (AISI). 1995. Steel Processing Flow Lines. Washington: AISI.

Dasgupta, AK. 1989. Photodermatitis and photoaggravated dermatitis in an Indian steel plant. Contact Dermat 21:118-119.

Finkelstein, MN, N Wilk. 1990. Investigation of a lung cancer cluster in the melt shop of an Ontario steel producer. Am f Ind Med 17:483-491.
Fletcher, AC, A Ades. 1984. Lung cancer mortality in a cohort of English foundary workers. Scan $\mathcal{J}$ Work Environ Health 10:7-16.

International Iron and Steel Institute (IISI). 1997. Steel for Sustainable Development. Bruselas: IISI.

Kusiak, R, GM Liss, MM Galitis. 1993. Cor pulmonale and pneumoconiotic lung disease: An investigation using hospital discharge data. Am 7 Ind Med 24:161-173.

Moinov, S. 1995. Falling employment, the trend in steel. $M B M$ abril 1995:40-45.

Muldoon, SR, DJ Tollerud. 1996. Industries associated with respiratory disease: Foundaries and Steel making. En Occupational and Environmental Respiratory Disease, dirigido por P Harber, MB Schenker, JR Balmes. St. Louis, Misuri: Mosby.

Office of Population Censuses and Surveys. 1995. Occupational Health: Decennial Supplement. Series DS No. 10. Londres: Her Majesty's Stationery Office.

Porcq, F. 1977. Storage and handling of coils in the metal trades (Le stockage et la manutention des bobines dans les entreprises métallurgiques). Prevention et securite du travail (Lille) 114:29-38.

Radford, EP. 1976. Cancer mortality in the steel industry. Ann NY Acad Sci 271:228-238.

Rochette, HE, CK Redmond. 1985. Selection, followup and analysis in the coke oven study. National Cancer Institute Monographs 67:89-94.

Schnauber, H, U Kern. 1980. Ergonomic Design of Tongs for Rotating Billets (Ergonomische und sicherheitstechnische Optimierung von Kantwerkzeugen). Dortmund: Bundesanstalt für Arbeitsschutz und Unfallforschung. 

Directores del capítulo

Fames R. Amstrongy Raji Menon

\section{Sumario}

Visión general de la minería

Norman S. Fennings . . . . . . . . . . . . . . . . . . . 74.2

Prospección

William S. Mitchell y Courtney S. Mitchell . . . . . . . . . . . . . . 74.4

Tipos de minería de carbón

Fred W. Hermann . . . . . . . . . . . . . . . . . . . . . . . . 74.8

Técnicas de minería subterránea

Hans Hamrin . . . . . . . . . . . . . . . . . . . . . . . . . 74.9

Minas subterráneas

Simon Walker.

Minas a cielo abierto

Thomas A. Hethmon y Kyle B. Dotson . . . . . . . . . . . . . . . . . . 74.20

Control de la minería del carbón a cielo abierto

Paul Westcott . . . . . . . . . . . . . . . . . . . . . 74.24

Procesamiento del mineral

Sydney Allison . . . . . . . . . . . . . . . . . . . . . . . . 74.25

Preparación del carbón

Anthony D. Walters. . . . . . . . . . . . . . . . . . . . . 74.28

Control del terreno en las minas subterráneas

Luc Beauchamp . . . . . . . . . . . . . . . . . . . . . 74.32

Ventilación y refrigeración en las minas subterráneas M.7. Howes . . . . . . . . . . . . . . . . . . . . . . . . . . . . . . 74.35

Iluminación en las minas subterráneas

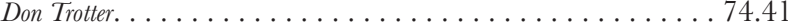

Equipos de protección individual en las minas

Peter W. Pickerill . . . . . . . . . . . . . . . . . . . . . 74.42

Incendios y explosiones en minas

Casey C. Grant . . . . . . . . . . . . . . . . . . . . . . . . . . . . 74.44

Detección de gases

Paul Mackenzie-Wood . . . . . . . . . . . . . . . . . . . . . . . . . 74.47

Preparación de emergencias

Gary A. Gibson . . . . . . . . . . . . . . . . . . . . . . . . . 74.52

Peligros para la salud en la minería y las canteras 


\section{VISION GENERAL DE LA MINERIA}

\section{Norman S. Jennings}

Los minerales constituyen el elemento base de la mayoría de las industrias. En prácticamente todos los países del mundo se realiza algún tipo de explotación minera. Esta actividad tiene importantes repercusiones económicas, ambientales, laborales y sociales, tanto en los países o regiones en que se practica como a escala global. Para muchos países en desarrollo la minería representa una parte significativa del PIB y, en muchos casos, la partida de entrada de divisas y de inversiones extranjeras más importante.

El impacto de la minería sobre el medio ambiente puede ser considerable y tener consecuencias a largo plazo. Hay muchos ejemplos de buenas y malas prácticas en la gestión y rehabilitación de áreas mineras. El efecto ambiental de las prácticas mineras es una cuestión cada vez más importante para la industria y sus trabajadores. Así, por ejemplo, el debate sobre el calentamiento global puede repercutir en el empleo del carbón en determinadas zonas, el reciclaje de productos reduce la cantidad de nuevos materiales necesarios y el uso creciente de materiales no minerales como los plásticos está afectando al consumo de metales y minerales por unidad del PIB.

La competencia, la disminución de la calidad de los minerales, el aumento de los costes de producción, la privatización y la reestructuración del mercado están obligando a las empresas mineras a reducir los costes y aumentar la productividad. Las elevadas inversiones que requiere la industria minera obliga a estas empresas a utilizar al máximo sus equipos y aplicar procesos más flexibles y a menudo más intensos. El empleo está disminuyendo en muchas áreas mineras debido a factores como el aumento de la productividad, la reestructuración radical y la privatización. Estos cambios afectan a los trabajadores despedidos, que se ven obligados a buscar otro empleo, y también a los que permanecen en la industria, que tienen que demostrar mayores habilidades y flexibilidad en el puesto de trabajo. La búsqueda de un equilibrio entre el deseo de las empresas mineras de reducir costes y el de los trabajadores de mantener sus puestos de trabajo es un tema clave en el mundo de la minería. Las comunidades mineras se están enfrentando a nuevas prácticas, a la reducción del empleo e incluso al cierre de las empresas.

La minería se considera una industria especial con comunidades muy interrelacionadas y trabajadores que realizan un trabajo sucio y peligroso. La minería es también un sector en que muchas de las personas que ocupan los niveles más altos de dirección y muchos trabajadores son ingenieros de minas o antiguos mineros con una amplia experiencia directa en las cuestiones que afectan a la empresa y los trabajadores. Además, los mineros han sido a menudo la élite de los trabajadores industriales y con frecuencia han desempeñado un papel decisivo en la sociedad ante los cambios políticos y sociales.

Cada año se producen cerca de 23 billones de toneladas de minerales. En el caso de los minerales preciosos, la cantidad de residuos generada supera ampliamente la de producto final. Así, por ejemplo, para obtener una onza de oro es necesario tratar unas 12 toneladas de mineral. Con los minerales de menos valor (arena, grava, arcilla, etc.), que representan la mayor parte del material extraído de las minas, la cantidad de material residual tolerable es mínima. Sin embargo, hay que partir del principio de que las minas deben producir como mínimo el doble de la cantidad final necesaria (excluyendo el material de recubrimiento superficial que es posteriormente reubicado y, por tanto, tratado dos veces). Así pues, de forma general, puede decirse que cada año se tratan 50 billones de toneladas de mineral, lo que equivale a perforar cada año un espacio de 1,5 metros de profundidad del tamaño de Suiza.

\section{Empleo}

La minería no es un importante generador de empleo, pues sólo absorbe el $1 \%$ de la mano de obra mundial, es decir, unos 30 millones de personas, de los cuales 10 trabajan en minas de carbón. Sin embargo, por cada puesto de trabajo en la minería existe como mínimo otro que depende directamente de ésta. Además, se estima que al menos otros 6 millones de personas trabajan en minas pequeñas. Por lo tanto, y considerando la población total relacionada con la minería, puede decirse que el número de personas que viven de la minería se acerca a los 300 millones.

\section{Seguridad y salud}

Los mineros tienen que trabajar en un entorno laboral en constante transformación. Algunos trabajan sin luz natural o ventilación, excavando la tierra, extrayendo material y, al mismo tiempo, tomando medidas para evitar que se produzca una reacción inmediata de los estratos adyacentes. A pesar de los importantes esfuerzos realizados en muchos países, la tasa mundial de víctimas mortales, lesiones y enfermedades entre los mineros demuestra que, en la mayoría de ellos, la minería sigue siendo el trabajo más peligroso en relación con el número total de trabajadores dedicados a esta actividad. En efecto, aunque la minería sólo emplea al $1 \%$ del total de trabajadores, es responsable de cerca del $8 \%$ de los accidentes laborales mortales (15.000 al año aproximadamente). A pesar de no disponer de datos fiables sobre accidentes, sí resulta significativo su número así como el de trabajadores afectados por enfermedades profesionales (pneumoconiosis, pérdida de audición y lesiones causadas por vibraciones), cuya incapacitación prematura e incluso fallecimiento son directamente atribuibles al trabajo.

\section{La OIT y la minería}

La Organización Internacional del Trabajo (OIT) viene estudiando desde su creación los problemas profesionales y sociales de la industria minera y ha realizado considerables esfuerzos para mejorar el trabajo y la vida de los trabajadores de dicha industria desde la adopción del Convenio sobre las horas de trabajo en la minería (No. 31) en 1931 hasta el Convenio sobre salud y seguridad en la minería (No. 176) adoptado por la Conferencia Internacional del Trabajo en 1995. Durante 50 años, en las reuniones tripartitas sobre minería se han estudiado numerosas cuestiones, que van desde el empleo, las condiciones de trabajo y la formación hasta la salud y la seguridad y las relaciones laborales. Los resultados se resumen en más de 140 conclusiones y resoluciones consensuadas, algunas de las cuales han sido aplicadas a escala nacional, mientras que otras han dado lugar a una actuación de la OIT, como programas de formación y asistencia en Estados miembros, o han permitido desarrollar códigos de prácticas de seguridad y, recientemente, el nuevo estándar de trabajo.

En 1996 se acordó un sistema de reuniones tripartitas más breves y específicas que permitirán identificar y debatir temas concretos relacionados con la minería y, al mismo tiempo, desarrollar los temas de forma práctica en los países y regiones afectados, tanto a escala nacional como por la OIT. En la primera de estas reuniones, que se celebrará en 1999, se abordarán los temas sociales y laborales relacionados con las minas pequeñas.

Los aspectos laborales y sociales de la minería no pueden disociarse de otras consideraciones, ya sean económicas, políticas, técnicas o ambientales. Aunque no existe un modelo que permita garantizar un desarrollo de la industria minera beneficioso para todos los interesados, éste debería de ser el ideal. La OIT está haciendo todo lo posible para contribuir al desarrollo 
laboral y social de esta importante industria. Pero no puede realizar su trabajo en solitario, sino que debe contar con una participación activa de los agentes sociales para maximizar su repercusión. La OIT trabaja asimismo con otras organizaciones internacionales atrayendo su atención hacia la dimensión social y laboral de la minería y colaborando con ellas del modo más adecuado.

Dada la naturaleza peligrosa de la minería, la OIT siempre ha estado profundamente preocupada por mejorar la salud y la seguridad profesional en la misma. La Clasificación Internacional de Radiografias de Pneumoconiosis de la OIT es una herramienta reconocida internacionalmente para registrar de forma sistemática anomalías radiográficas pulmonares provocadas por la inhalación de polvos. Dos códigos de prácticas de salud y seguridad tratan exclusivamente de las minas subterráneas y a cielo abierto, mientras que otros se refieren a la industria minera en general.

La adopción en 1995 del Convenio sobre salud y seguridad en la minería, que ha sentado las bases para la actuación a escala nacional en materia de mejora de las condiciones laborales en la industria minera, es importante porque:

- los mineros se enfrentan a peligros especiales;

- en muchos países, la industria minera está cobrando cada vez más auge,

- las normas anteriores de la OIT sobre salud y seguridad profesional y la legislación existente en muchos países resultaban inadecuadas para afrontar las necesidades específicas de la minería.

Las dos primeras ratificaciones del Convenio tuvieron lugar a mediados de 1997 y entrarán en vigor a mediados de 1998.

\section{Formación}

En los últimos años, la OIT ha llevado a cabo diversos proyectos de formación para mejorar la salud y la seguridad de los mineros a través de una mayor concienciación, una mejor inspección y una formación en primeros auxilios para casos de accidente. Hasta el momento, las actividades de la OIT han contribuido al progreso de muchos países al adaptar las legislaciones nacionales a las normas de trabajo internacionales y aumentar el nivel de salud y seguridad profesional en la industria minera.

\section{Relaciones laborales y empleo}

La presión, cada vez más fuerte, para la mejora de la productividad en un entorno competitivo puede poner en peligro los principios básicos de libertad de asociación y negociación colectiva cuando las empresas ven amenazada su rentabilidad o incluso su supervivencia. Pero unas buenas relaciones laborales basadas en la aplicación constructiva de estos principios pueden contribuir de forma considerable a mejorar la productividad. Este tema se examinó con detalle en la reunión de 1995 y se concluyó que un punto importante es la necesidad de consultar a los interlocutores sociales sobre cualquier reestructuración que resulte necesaria para que tenga éxito y sobre la industria minera en su conjunto para obtener beneficios duraderos. Se convino asimismo que el hecho de flexibilizar tanto la organización como los métodos de trabajo no debería poner en peligro los derechos de los trabajadores ni afectar de forma negativa a la salud y la seguridad de los mismos.

\section{Minas pequeñas}

Las minas pequeñas pueden dividirse en dos categorías. La primera abarca minas y canteras pequeñas de materiales industriales y de construcción, operaciones que en su mayoría están dirigidas a mercados locales y que existen en casi todos los países (véase la Figura 74.1). A menudo, este tipo de minas están controladas por una normativa legal, pero, al igual que en las pequeñas plantas de fabricación, la falta de inspección y de un control riguroso favorecen la existencia de operaciones ilegales.

La segunda categoría es la minería de minerales valiosos, especialmente oro y piedras preciosas (véase la Figura 74.2). Los productos se exportan, por lo general, a través de organismos legales o ilegales. Dado su tamaño y carácter, las leyes resultan inadecuadas e imposibles de aplicar en este tipo de minas.

Las minas pequeñas emplean una gran cantidad de mano de obra, especialmente en las áreas rurales. En algunos países, trabajan muchas más personas en minas pequeñas que en el sector minero establecido. Los datos existentes indican que más de seis millones de personas trabajan en minas pequeñas. Sin embargo y por desgraciada, muchos de estos trabajos son precarios y no cumplen la normativa internacional y nacional de trabajo. La tasa de accidentes en las minas pequeñas es, por lo general, seis o siete veces más elevada que en las grandes explotaciones, incluso en los países industrializados. Las enfermedades, provocadas muchas veces por unas condiciones de trabajo poco higiénicas, son muy comunes. Aunque esta es la tónica general en las minas pequeñas, existen también algunas seguras y limpias.

Un problema especial es la utilización de mano de obra infantil. Como parte de su Programa Internacional para la Erradicación del Trabajo Infantil, la OIT está desarrollando proyectos en varios países de Africa, Asia y América Latina para proporcionar oportunidades educativas y formas alternativas de generación de ingresos y eliminar la mano de obra infantil en las minas de carbón, oro y piedras preciosas en tres regiones de estos países. Estos proyectos están siendo realizados en colaboración con el Sindicato Internacional de Mineros (ICEM) y con organizaciones locales no gubernamentales $(\mathrm{ONG})$ y organismos gubernamentales.

Las ONG también han trabajado con interés y efectividad a escala local para introducir tecnologías adecuadas que mejoren la eficiencia y reduzcan el impacto sobre la salud y el medio ambiente de las minas pequeñas. Algunas organizaciones gubernamentales internacionales (OGI) han realizado estudios y elaborado directrices y programas de acción sobre el trabajo infantil, el papel de la mujer y de los indígenas, la tributación, la reforma catastral y el impacto ambiental, pero hasta el momento

Figura 74.1 • Pequeña cantera en Bengala occidental.

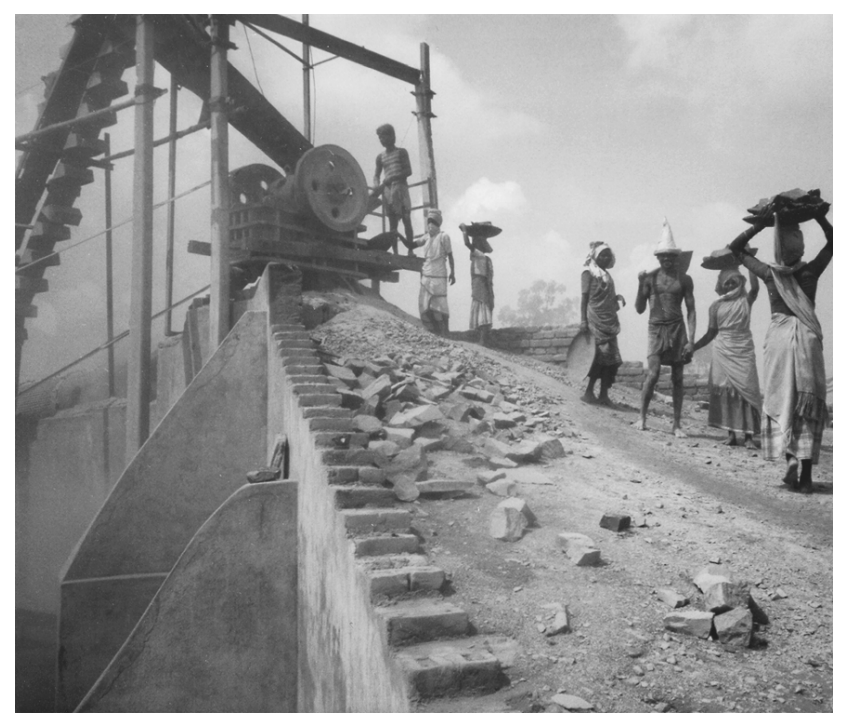


Figura 74.2 • Pequeña mina de oro en Zimbabwe.

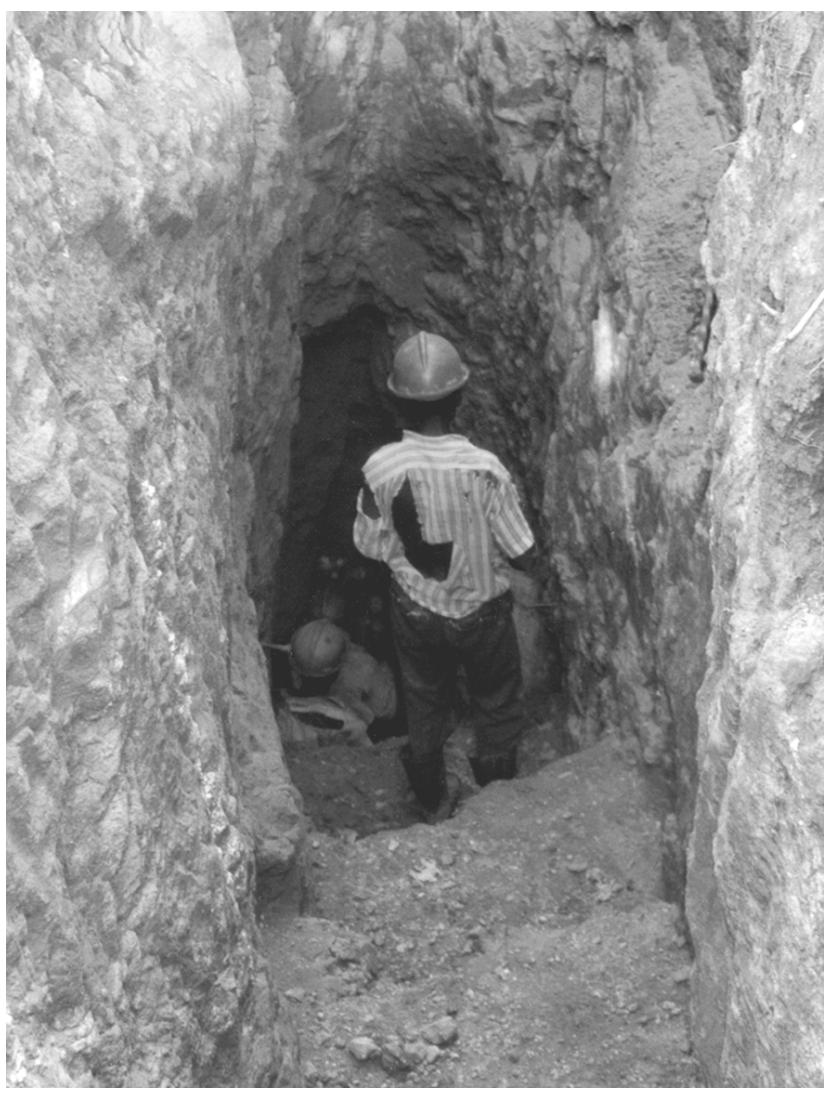

parece que su repercusión es reducida. Sin embargo, hay que destacar que, sin el apoyo activo y la participación de los gobiernos, estos esfuerzos difícilmente pueden tener éxito.

Parece que los trabajadores de las minas pequeñas tienen poco interés en utilizar una tecnología barata, disponible y efectiva que mitigue los impactos sobre la salud y el medio ambiente, como los alambiques para recuperar el mercurio. A menudo no existen incentivos para ello, dado que el coste del mercurio no es una restricción. Además, y especialmente en el caso de los mineros itinerantes, no suelen tener interés por rehabilitar la tierra a largo plazo para su uso después de finalizados los trabajos de minería. El reto es demostrar a estos mineros que existen mejores formas de practicar la minería que no limitan sus actividades y que además supondrían un beneficio para su salud y su riqueza y para la tierra, redundando finalmente en beneficio del país. Las "Directrices Harare", desarrolladas en 1993 durante el Seminario Interregional de las Naciones Unidas sobre Directrices para el desarrollo de la minería a pequeña y mediana escala, sirven de guía a los gobiernos y los organismos de desarrollo a la hora de abordar los distintos aspectos de una forma global y coordinada. La falta de participación de las organizaciones de empleadores y de trabajadores en la mayoría de las minas pequeñas confiere una especial responsabilidad a los gobiernos para su incorporación al sector establecido, acción que mejoraría la vida de todos los trabajadores y aumentaría considerablemente los beneficios económicos y sociales de este tipo de minería. Asimismo, en una mesa redonda internacional celebrada en 1995 y organizada por el Banco Mundial, se desarrolló una estrategia para la minería artesanal dirigida a minimizar los efectos secundarios negativos, como las deficientes condiciones de salud y seguridad de esta actividad y maximizar los beneficios socioeconómicos.

El Convenio sobre salud y seguridad en la minería y su correspondiente Recomendación (núm. 183) fijan con detalle un punto de referencia internacional que sirve de base al elaborar la legislación y las prácticas nacionales. Este punto de referencia, aplicable de forma general a las minas, establece los requisitos mínimos de seguridad que deben presidir cualquier cambio en una operación de minería. Las disposiciones del Convenio ya están siendo incluidas en nuevas legislaciones de minería y en acuerdos colectivos de varios países y las normativas de salud y seguridad promulgadas en muchos otros países superan incluso estas normas mínimas. La futura ratificación del Convenio por parte de todos los países (al conferirle rango de ley) permitirá a las autoridades competentes disponer del personal necesario para supervisar la aplicación de la normativa en todos los sectores de la industria minera. También la OIT supervisará la aplicación del Convenio en los países que lo hayan ratificado.

\section{Prospeccion}

William S. Mitchell y Courtney S. Mitchell

La prospección es la fase anterior a la explotación. La prospección es un negocio de alto coste y riesgo que, en el mejor de los casos, da como resultado el descubrimiento de un filón explotable de forma rentable. En 1992 se invirtieron en todo el mundo 1,2 billones de dólares de EE.UU. en tareas de prospección, cifra que en 1995 casi alcanzó los 2,7 billones. Muchos países promocionan la inversión en prospecciones y existe una gran competencia para sondear áreas de gran potencial. Casi sin excepción, la prospección de minerales es realizada actualmente por equipos interdisciplinares de prospectores, geólogos, geofísicos y geoquímicos cuya misión es detectar filones en todo el mundo.

La prospección del mineral comienza con un reconocimiento o fase generativa y continúa con una fase de evaluación de objetivos que, en caso favorable, conduce a una prospección más detallada. A medida que un proyecto va pasando por las diferentes fases de prospección, va variando también el tipo de trabajo y los aspectos de salud y seguridad.

El trabajo de campo de la fase de reconocimiento suele correr a cargo de pequeños grupos de geocientíficos que disponen de un apoyo limitado en un terreno poco familiar. El reconocimiento puede incluir labores de prospección, sondeo, muestreo geológico, muestreo geoquímico general y preliminar y estudios geofísicos. La prospección más detallada comienza después de la fase de evaluación de objetivos, una vez que se han adquirido los derechos sobre el terreno con los correspondientes permisos, concesiones o alquiler. El trabajo de campo detallado, que comprende operaciones de sondeo geológico, muestreo y estudios geofísicos y geoquímicos, requiere un modelo de control de los estudios. Este trabajo exige con frecuencia la realización de pruebas con utilización de zanjas o perforaciones y equipos pesados como retroexcavadoras, palas eléctricas, aplanadoras, barrenas y, en algunos casos, explosivos. Los equipos de perforación con trépanos de diamantes, giratorios o de percusión pueden estar montados sobre camiones o ser transportados hasta el lugar adecuado sobre plataformas rodantes. En algunas ocasiones se utilizan helicópteros para transportar los equipos de perforación hasta los mismos pozos.

Los resultados de algunos proyectos de prospección son suficientemente alentadores para justificar una prospección más detallada con recogida de grandes muestras o de material a 
granel que permitan evaluar las posibilidades económicas del filón. Esta operación puede realizarse mediante perforaciones intensivas, aunque en muchos filones puede ser necesario realizar muestreos subterráneos o con zanjas. A veces, se excavan pozos de prospección, rampas o galerías para acceder al filón. Aunque el trabajo lo realizan los mineros, la mayoría de las empresas encargan a un geólogo el plan previo de muestreo subterráneo.

\section{Salud y seguridad}

Antiguamente, las empresas no solían adoptar planes ni métodos para la seguridad en la prospección. Incluso actualmente, los trabajadores de la prospección muestran a menudo una actitud desdeñosa hacia los temas de salud y seguridad, por lo que a veces quedan en un segundo plano y no son considerados parte integrante del trabajo del prospector. Afortunadamente, en la actualidad muchas empresas de prospección minera intentan cambiar este aspecto de la cultura de prospección y exigen que trabajadores y contratistas respeten los procedimientos de seguridad establecidos.

Los trabajos de prospección suelen ser de tipo temporal, por lo que son normales las presiones para finalizar el trabajo en un tiempo limitado, a veces a costa de la seguridad. Además, a medida que los trabajos de prospección avanzan hacia fases posteriores, aumentan el número y los tipos de riesgos y peligros. El trabajo de campo de reconocimiento inicial sólo requiere un pequeño equipo de campo y un campamento reducido. Los trabajos de prospección más detallada exigen, por lo general, campamentos más amplios para acomodar a un mayor número de trabajadores y contratistas. Los aspectos de seguridad (en especial, formación en temas de salud personal, riesgos en el campamento y en el lugar de trabajo, uso seguro de los equipos y seguridad de las vías de paso) son muy importantes para los geocientíficos que no tienen experiencia en el trabajo de campo.

Dado que el trabajo de prospección se realiza a menudo en áreas alejadas, la posible evacuación a un centro de atención sanitaria puede ser dificultosa y depender de las condiciones atmosféricas o de la luz. Por lo tanto, antes de comenzar el trabajo de campo es necesario planificar este aspecto cuidadosamente y comprobar los procedimientos y las comunicaciones de emergencia.

Aunque la seguridad al aire libre puede considerarse una cuestión de sentido común, no hay que olvidar que lo que en una cultura se considera de sentido común, en otra puede no serlo. Las empresas mineras deben suministrar a los trabajadores de prospección un manual de seguridad para la región en que trabajan. Un manual detallado de seguridad puede servir de base para reuniones de orientación en el campamento y sesiones de formación y seguridad rutinaria durante todo el período de trabajo de campo.

\section{Prevención de riesgos para la salud personal}

Las tareas de prospección imponen a los trabajadores un duro trabajo físico que puede incluir la realización de difíciles travesías, el levantamiento de objetos pesados, el empleo de equipos potencialmente peligrosos y la exposición al calor, el frío, las lluvias y tal vez alturas elevadas (véase la Figura 74.3). Resulta fundamental que, al comenzar el trabajo de campo, los trabajadores se encuentren en buenas condiciones físicas y gocen de buena salud. Deben haber sido vacunados recientemente y no sufrir enfermedades infecciosas (hepatitis, tuberculosis, etc.) que puedan propagarse rápidamente por el campamento. De forma ideal, todos los trabajadores de prospección deberían estar formados y disponer de un certificado de primeros auxilios y de técnicas de supervivencia. Los campamentos o lugares de trabajo más

\section{Figura 74.3 - Perforación en las montañas de la Columbia Británica (Canadá) con un equipo ligero Winkie.}

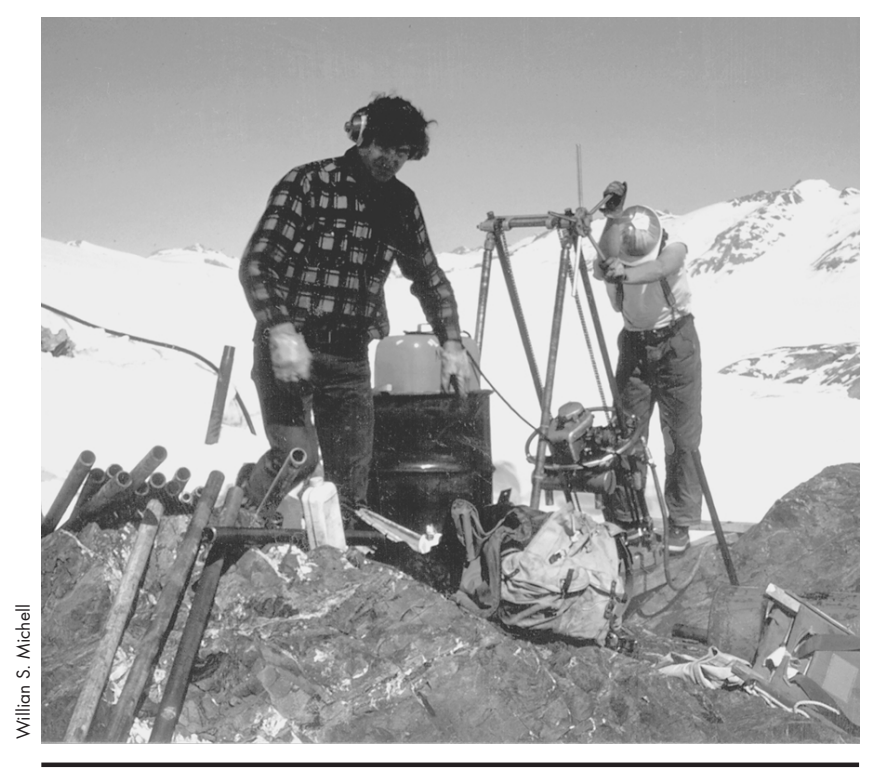

grandes deberían disponer como mínimo de un trabajador con formación y certificado de primeros auxilios de nivel avanzado o industrial.

Los trabajadores al aire libre deben llevar ropa adecuada que les proteja de los rigores atmosféricos como calor, frío, lluvia y nieve. En las regiones con un alto índice de rayos UV, deberían cubrirse con un sombrero de seguridad de ala ancha y utilizar cremas protectoras para la piel de factor de protección alto (SPF). Cuando sea necesario el uso de repelentes contra los insectos, se utilizará un producto que contenga DEET (N,N-dietilmetatoluamida) que es el compuesto más eficaz para evitar las picaduras de mosquitos. Asimismo, la ropa tratada con permetrin protege contra las garrapatas.

Formación. Todos los trabajadores de campo deben recibir formación en temas como manipulación de grandes pesos, uso adecuado de equipos de seguridad homologados (gafas y botas de seguridad, respiradores, guantes protectores, etc.) y medidas para evitar accidentes por insolación, congelación, deshidratación, exposición a rayos UV, protección contra picaduras de insectos o exposiciones a cualquier enfermedad endémica. Cuando trabajen en países en desarrollo, deberían informarse sobre los problemas locales de salud y seguridad, incluida la posibilidad de secuestros, robos y asaltos.

\section{Medidas preventivas en el campamento}

Los aspectos de salud y seguridad varían en función del lugar y el tipo de trabajo que se realiza en el campamento. En la instalación de un campamento debe tenerse en cuenta la normativa local sobre incendios, salud y seguridad. Un campamento limpio y ordenado ayuda a reducir el número de accidentes.

Localización. El campamento se montará lo más cerca posible del lugar de trabajo y respetando las normas de seguridad, con el fin de minimizar los desplazamientos y la exposición a los peligros derivados del transporte. Un campamento debe estar situado lejos de cualquier peligro natural, teniendo en cuenta asimismo las costumbres y el hábitat de los animales salvajes próximos al campamento (insectos, osos, reptiles, etc.). Siempre que sea posible, debería situarse cerca de una fuente 
de agua potable (véase la Figura 74.4). Cuando se trabaje a gran altura, el campamento debe estar situado a un nivel inferior con el fin de evitar el mal de altura.

Control de incendios y manipulación de combustibles. Los campamentos deberían situarse de forma que las tiendas o estructuras estén relativamente alejadas entre sí para evitar o reducir el peligro de propagación de incendios. El equipo contra incendios debe conservarse en un depósito central, aunque han de existir extintores en las cocinas y edificios de oficinas. La normativa para fumadores contribuye a evitar incendios tanto en el campamento como en el lugar de trabajo. Todos los trabajadores deben participar en los simulacros de incendios y conocer los planes de evacuación en caso de un incendio real. Los combustibles deben estar etiquetados de forma clara para garantizar que se utiliza el correcto para las linternas, estufas, generadores, etc. Los depósitos de combustible deben estar situados como mínimo a $100 \mathrm{~m}$ del campamento y a una altura superior al nivel potencial de inundación o marea alta.

Medidas sanitarias. El campamento debe contar con un suministro de agua potable segura. En caso necesario, se comprobará la pureza de la fuente. Si fuera asimismo necesario se almacenará el agua potable en recipientes limpios y etiquetados separados del agua no potable. Los suministros de alimentos deben examinarse a su llegada para comprobar su calidad e introducirse inmediatamente en un refrigerador o almacenarse en depósitos para evitar que puedan acceder a ellos insectos, roedores u otro tipo de animales. Los lavabos deben estar situados cerca de las zonas de comedores y de las letrinas. Estas últimas deben cumplir las normas de salud pública y
Figura 74.4 - Campamento de verano en los Territorios del Noroeste (Canadá).

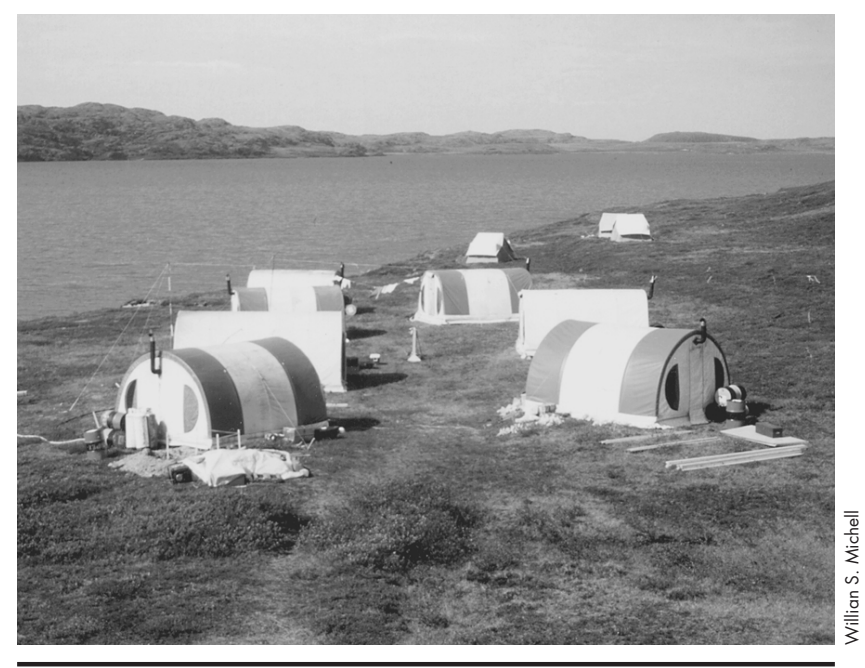

estar situadas como mínimo a 100 m de cualquier corriente de agua o costa.

Equipo de campamento, equipo de campo y maquinaria. Todos los equipos (sierras de cadena, hachas, martillos neumáticos, machetes, radios, estufas, linternas, equipos geofísicos y geoquímicos) deben mantenerse en buenas condiciones. Cuando, a efectos de seguridad personal, sea necesario utilizar armas de

Figura 74.5 • Perforadora montada sobre un camión en Australia.

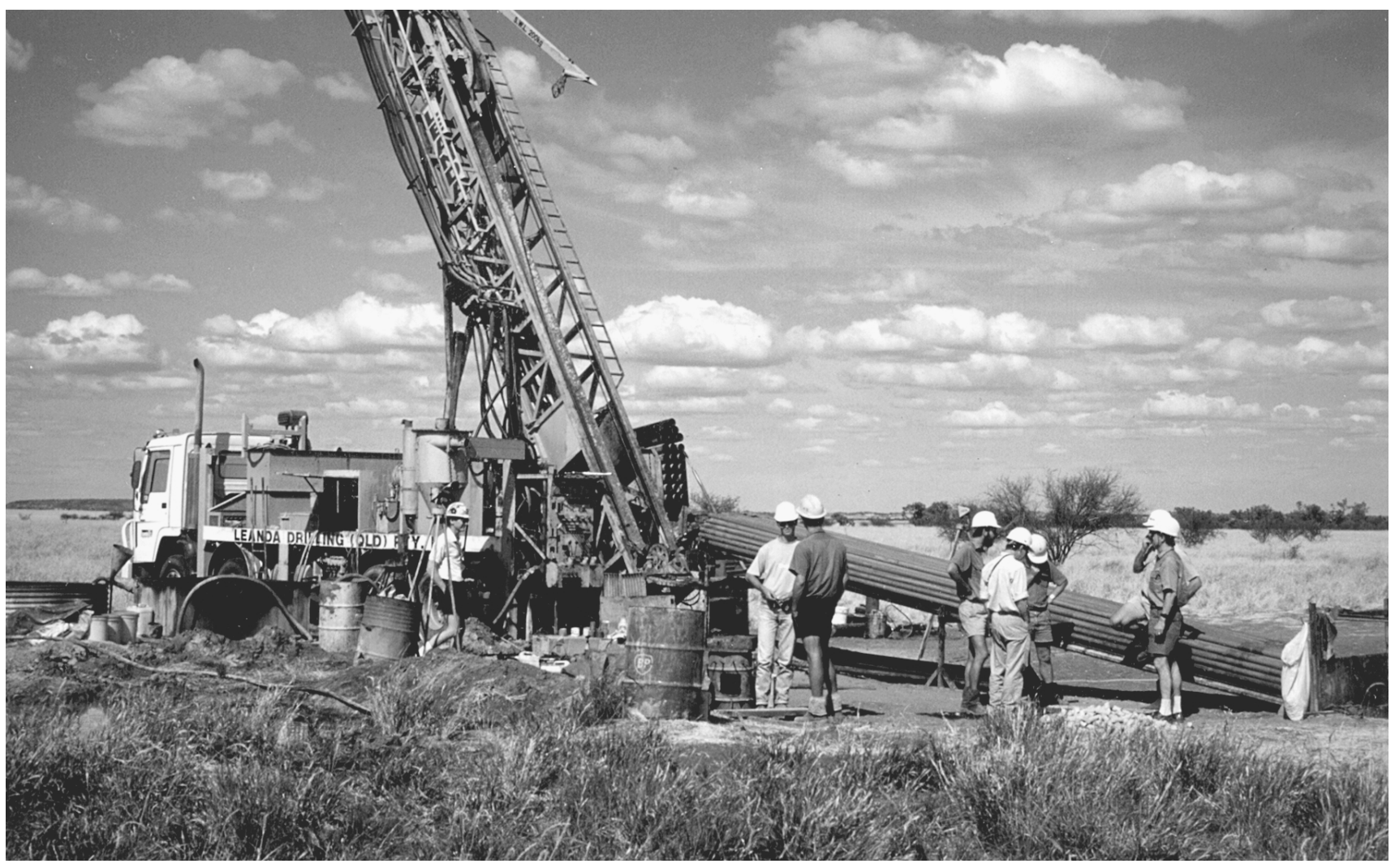


Figura 74.6 • Perforación de circulación inversa en un lago helado de Canadá.

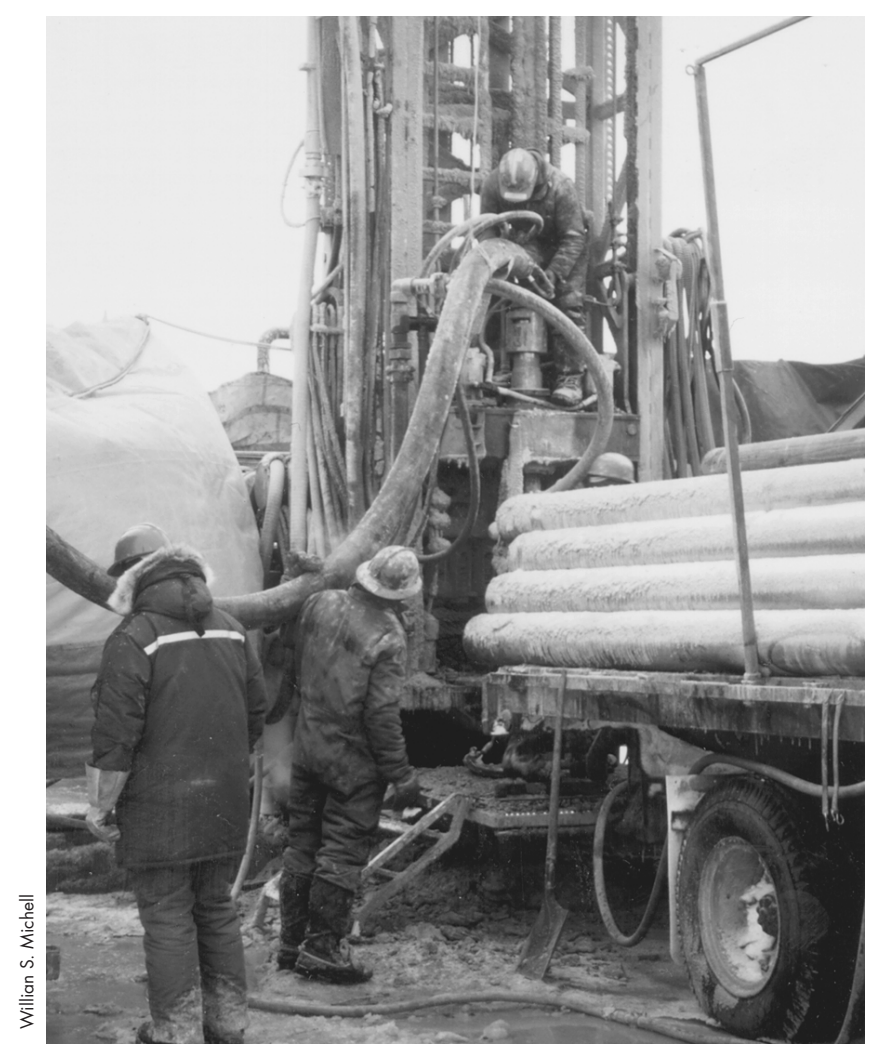

fuego contra animales (osos, etc.), su uso estará estrictamente controlado y supervisado.

Comunicación. Es importante establecer planes de comunicación. Una buena comunicación aumenta la moral y la seguridad y es la base de un plan de acción de emergencia.

Formación. Los trabajadores deben estar formados en el uso seguro de todo el equipo. Todos los geofísicos y auxiliares deben recibir formación sobre el uso de los equipos geofísicos de tierra que funcionen con alto voltaje. Otros temas de formación podrían ser la prevención de incendios, los simulacros de incendios y la manipulación de combustibles o de armas de fuego.

\section{Medidas preventivas en el lugar de trabajo}

La fase de evaluación de objetivos y la de prospección más detallada requieren la instalación de campamentos de mayor tamaño y el empleo de equipos pesados en el lugar de trabajo. Cuando se utilice maquinaria pesada sólo se permitirá el acceso al lugar de trabajo a los trabajadores con experiencia o a los visitantes autorizados.

Equipos pesados. Unicamente podrá manejar equipos pesados el personal debidamente autorizado y formado. Los trabajadores deben estar siempre alerta y no acercarse nunca a los equipos pesados salvo que estén seguros de que el conductor sabe dónde están, qué quieren hacer y a dónde pretenden dirigirse.

Perforadoras montadas sobre soporte. El personal que maneja este tipo de máquinas debe tener una formación adecuada para este trabajo, llevar el equipo de protección personal adecuado (casco, botas con puntera de acero, protección para los oídos, guantes, gafas ajustadas y mascarillas contra el polvo) y evitar llevar ropa suelta que pueda engancharse en la máquina. Las perforadoras montadas sobre carrillo deben cumplir todos los requisitos de seguridad (protecciones que cubran todas las partes móviles de la máquina y mangueras de aire de alta presión con fijaciones y cadenas de seguridad) (véase la Figura 74.5). Los trabajadores deben ser conscientes de las condiciones del suelo (escurridizo, húmedo, grasiento o helado) y el área de perforación debe mantenerse lo más ordenada posible (véase la Figura 74.6).

Excavaciones. Los pozos y zanjas se construirán de acuerdo con las normas de seguridad, utilizando sistemas de soporte o con los laterales cortados hacia atrás en un ángulo de $45^{\circ}$ para evitar un posible hundimiento. Los trabajadores no deben trabajar o permanecer nunca solos en un pozo o zanja, ni siquiera durante un corto período de tiempo, dado que estas obras se derrumban fácilmente y pueden enterrar a los trabajadores.

Explosivos. Los explosivos sólo deben ser manejados por personal formado y autorizado. Se observará cuidadosamente la normativa sobre manejo, almacenamiento y transporte de explosivos y detonantes.

\section{Medidas preventivas para la estancia sobre el terreno}

Los trabajadores de prospección deben estar preparados para trabajar en las condiciones de terreno y clima de su zona de trabajo. El terreno puede ser un desierto, una zona pantanosa, una selva, un terreno montañoso, un glaciar o un campo de nieve. El clima puede ser cálido, frío, seco o húmedo. Entre los peligros naturales pueden encontrarse rayos, incendios forestales, avalanchas, deslizamientos de lodos, inundaciones por riadas, etc. Los insectos, reptiles y/o animales de mayor tamaño pueden representar un peligro para los trabajadores, que no deben arriesgarse o poner en peligro sus vidas por obtener una muestra. Los trabajadores deben recibir formación sobre métodos seguros de afrontar las condiciones del terreno y atmosféricas en que trabajan, así como sobre prácticas de supervivencia para reconocer y combatir la hipotermia, la hipertermia y la deshidratación. Deben trabajar por parejas y llevar suficiente equipo, alimentos y agua (o poder acceder a un depósito de emergencia) que les permita pasar una o dos noches en el campo en caso de necesidad. Las trabajadores de campo deben aplicar un plan de comunicación de rutina con el campamento base. Todos los campamentos móviles deben adoptar y comprobar planes de emergencia por si hubiese que rescatar a trabajadores.

\section{Medidas preventivas de transporte}

Muchos accidentes tienen lugar durante los desplazamientos entre el campamento y el lugar de prospección. La conducción de vehículos o barcos a excesiva velocidad y/o después de haber consumido alcohol son aspectos importantes de seguridad.

Vehículos. Entre las causas más habituales de accidentes de vehículos se encuentran las condiciones atmosféricas extremas, unas carreteras peligrosas, la sobrecarga o carga incorrecta del vehículo, unas prácticas no seguras de remolque, la fatiga del conductor, la inexperiencia del conductor, y el cruce de la carretera por animales o personas, especialmente durante la noche. Entre las medidas preventivas para todos los tipos de vehículos se encuentran la utilización de los cinturones de seguridad por parte del conductor y los ocupantes de coches y camiones y la utilización de métodos de carga y remolque seguros; sólo deben utilizarse vehículos adaptados a las condiciones atmosféricas y de terreno de la zona, p. ej., vehículos con tracción a las cuatro ruedas, motos de dos ruedas, vehículos todoterreno o motos de nieve (véase la Figura 74.7). Se procederá a un mantenimiento adecuado y periódico y se les dotará de las correspondientes piezas de repuesto. Para conducir vehículos todoterreno o motos de dos ruedas se utilizará ropa de protección y casco.

Aviones. Para acceder a lugares remotos a menudo es necesario utilizar aviones o helicópteros (véase la Figura 74.8). En este caso, sólo deben contratarse compañías de vuelos chárter que 
Figura 74.7 • Transporte de campo en pleno invierno en Canadá.

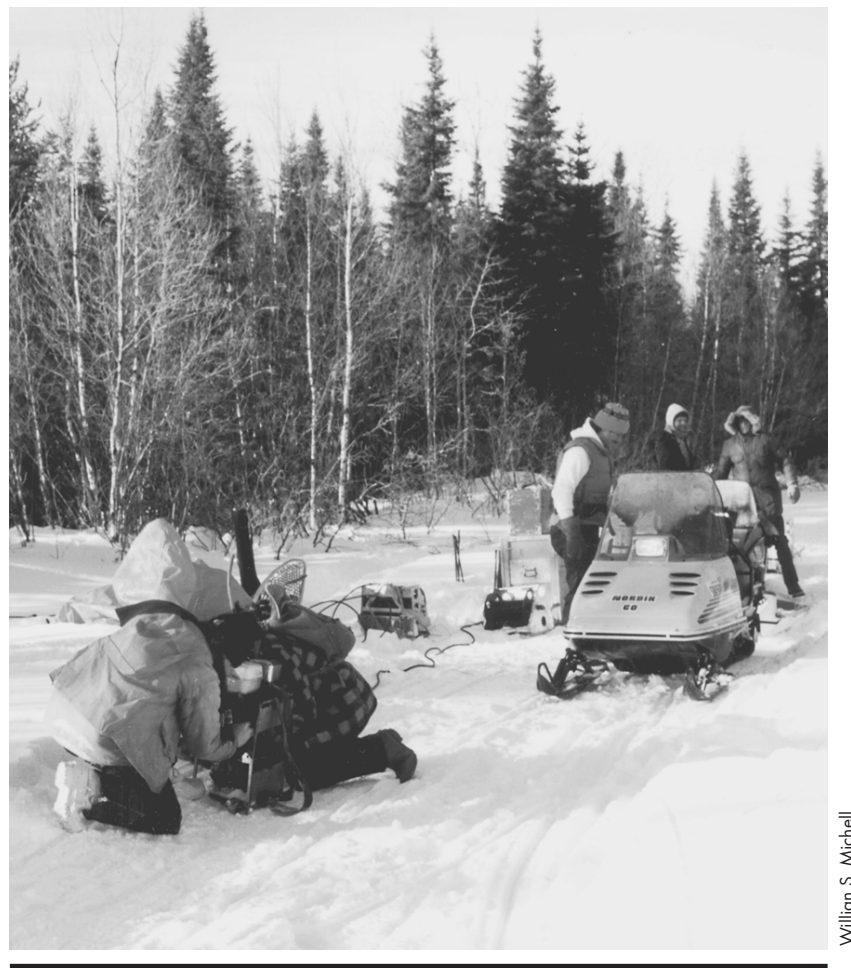

dispongan de equipos bien mantenidos y un buen nivel de seguridad. Se recomiendan los aviones con motores de turbina. Los pilotos nunca deben rebasar el número legal de horas de vuelo autorizadas ni volar si están cansados o las condiciones atmosféricas no son las adecuadas. Los pilotos deben supervisar la estiba de la carga y cumplir las limitaciones de la carga de pago. Para evitar accidentes, los trabajadores de prospección estarán formados en las técnicas de seguridad en el trabajo en las proximidades del avión y en las operaciones de carga y embarque, evitando situarse en las proximidades de las hélices o de las palas de los rotores, que resultan invisibles cuando están en movimiento. Las zonas de aterrizaje para helicópteros deben mantenerse despejadas, sin objetos que puedan salir proyectados por efecto de las palas de los rotores.

Eslingaje. Los helicópteros se utilizan a menudo para transportar suministros, combustible, perforadoras o equipos del campamento. Entre los principales peligros de esta operación se encuentran la sobrecarga, el uso incorrecto y el mantenimiento deficiente de las eslingas de a bordo y la suciedad de las zonas de trabajo, con restos o equipos que puedan ser lanzados al aire por efecto de las palas, una vegetación excesiva u objetos en los que pueda quedar enganchada la carga. Además, la fatiga de los pilotos, la falta de formación del personal, la deficiente comunicación entre las partes (especialmente entre pilotos y personal de tierra) y las condiciones atmosféricas extremas aumentan los riesgos de la operación de eslingaje. Para un eslingaje seguro y con el fin de evitar accidentes, todas las partes deben aplicar unos métodos de operación seguros y estar totalmente alerta, siendo conscientes de las responsabilidades mutuas. El peso de la carga eslingada no debe exceder de la capacidad de izada del helicóptero. Las cargas deben situarse de tal forma que estén seguras y no puedan deslizarse fuera de la red de carga.

Cuando se realiza una operación de eslingaje con un cable demasiado largo (p. ej., en la jungla o en lugares montañosos con árboles muy altos), deberían utilizarse maderos o piedras grandes para lastrar el cable durante el viaje de vuelta y no volar nunca con redes vacías ni con cables colgando del gancho de eslingaje. Se han producido accidentes fatales al engancharse en las palas o en el rotor de cola cables colgantes durante el vuelo.

Embarcaciones. Los trabajadores que utilizan embarcaciones para transportar equipos en aguas costeras, lagos de montaña, corrientes o ríos pueden enfrentarse a peligros derivados del viento, la niebla y la existencia de rápidos, bajíos u objetos sumergidos o semisumergidos. Para evitar este tipo de accidentes, los técnicos deben conocer y cumplir los requisitos de la embarcación y el motor y respetar su capacidad de navegación. Debería utilizarse la embarcación mayor y más segura disponible. Los trabajadores deben ir provistos de un sistema de flotación personal (PFD) de calidad siempre que viajen y/o trabajen en embarcaciones pequeñas. Además, todos los botes deben disponer del equipo reglamentario, piezas de repuesto, herramientas, equipos de supervivencia y de primeros auxilios así como cartas actualizadas de navegación y de mareas.

\section{TIPOS DE MINERIA DE CARBON}

\section{Fred W. Hermann}

La elección del método de extracción del carbón de una mina depende de factores como la topografía, la forma del filón, la geología de las rocas de las capas superiores y los requisitos o limitaciones ambientales. Pero, por encima de todos ellos, son decisivos los factores económicos, como disponibilidad, calidad y coste de la mano de obra necesaria (incluidos supervisores y gestores debidamente formados), idoneidad de las instalaciones de alojamiento, comedores y de ocio para los trabajadores (especialmente si la mina está alejada de un centro de población), disponibilidad de los equipos y la maquinaria necesarios y de trabajadores con experiencia en su manejo, medios y costes de transporte de los trabajadores, suministros necesarios y forma de enviar el carbón al usuario o comprador, existencia del capital necesario para financiar la operación (en moneda del país) y del mercado para el tipo especial de carbón que se va a extraer

Figura 74.8 - Descarga de suministros de campo desde un De Havilland DHC-6 Twin Otter, Territorios del Noroeste (Canadá).

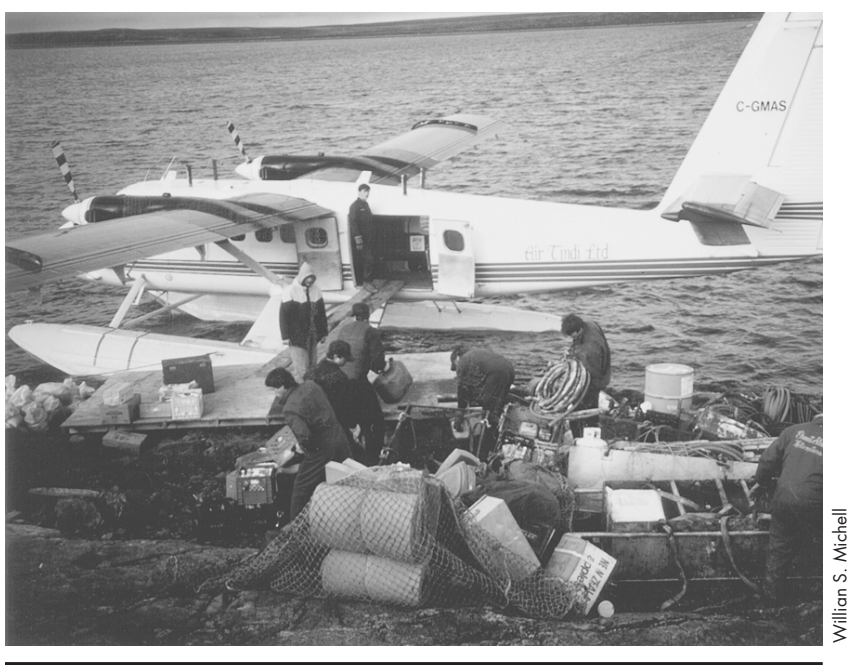


(p. ej., precio al que puede venderse). Un factor fundamental es la relación de "extracción", es decir, la cantidad de capa de cobertura que hay que eliminar con respecto a la cantidad de carbón que puede extraerse. Cuanto más alta es esta relación, menos rentable resulta la explotación de la mina. Un factor importante, especialmente en las minas a cielo abierto, y que por desgracia no suele tenerse en cuenta en la planificación, es el coste necesario para rehabilitar el terreno y el medio ambiente cuando se cierre la mina.

\section{Salud y seguridad}

Otro factor crítico es el coste de la protección de la salud y la seguridad de los mineros. Lamentablemente, y en especial en operaciones a pequeña escala, cuando se decide la viabilidad de la explotación de carbón o la forma de llevarla a cabo, se ignoran o subestiman con frecuencia las medidas de protección necesarias.

En realidad, y aunque siempre pueden surgir riesgos imprevistos (en general debido a factores ajenos a las operaciones de minería), todas las operaciones pueden ser seguras siempre que todas las partes se comprometan a operar de un modo también seguro.

\section{Minas de carbón a cielo abierto}

La explotación de las minas a cielo abierto de carbón puede realizarse con diferentes técnicas según la topografía, el área de extracción y los factores ambientales. Todos los métodos incluyen la eliminación de la capa de cobertura para poder extraer el carbón. La operaciones a cielo abierto, aunque suelen ser más seguras que las de las minas subterráneas, presentan algunos riesgos específicos que deben tenerse en cuenta. El principal es el uso de equipos pesados que, además de causar posibles accidentes, suponen una exposición a gases de escape y ruidos y el contacto con combustibles, lubricantes y disolventes. Las condiciones climáticas, como lluvias torrenciales, nieve o hielo, la escasa visibilidad o el calor o el frío excesivos pueden representar un riesgo adicional. Si se utilizan barrenos para romper la roca, hay que tomar precauciones especiales durante el almacenamiento, el manejo y el uso de los explosivos.

Las operaciones a cielo abierto requieren inmensas escombreras para almacenar los productos de la capa de cobertura. Se debe proceder a los controles necesarios para evitar fallos en el escombrado y proteger tanto a los trabajadores como a la población en general y el entorno.

\section{Minas subterráneas}

En este tipo de minería también pueden aplicarse diferentes técnicas, aunque el común denominador es la perforación de galerías que van desde la superficie al filón de carbón, así como el uso de máquinas y/o explosivos para extraer el carbón. En las operaciones dentro de las minas subterráneas, además de la alta tasa de accidentes (la minería del carbón ocupa en todas la estadísticas uno de los primeros lugares en cuanto a puestos de trabajo peligrosos), siempre existe la posibilidad de que se produzca un accidente grave con pérdida de vidas humanas. Las dos principales causas de este tipo de catástrofes son los hundimientos por un entibado deficiente de las galerías y las explosiones e incendios debidos a la acumulación de metano y/o de niveles inflamables de polvo de carbón presentes en el aire.

\section{Metano}

El metano es altamente deflagrante en concentraciones del 5 al $15 \%$ y ha sido la causa de muchos accidentes graves en las minas. La mejor forma de controlarlo es introduciendo un flujo de aire que diluya el gas a un nivel por debajo de su punto de deflagración y aspirarlo rápidamente fuera de la zona de trabajo.
En cualquier caso, hay que supervisar continuamente los niveles de metano y establecer una normativa para interrumpir el trabajo cuando la concentración alcance niveles entre 1 y 1,5 \% y evacuar la mina rápidamente cuando los niveles se encuentren entre 2 y $2,5 \%$.

\section{Polvo de carbón}

Además de provocar la enfermedad pulmonar denominada antracosis cuando es inhalado, el polvo de carbón es deflagrante al contacto con el aire y en combustión. El polvo de carbón transportado por el aire puede controlarse mediante pulverización con agua y aspiración. Se puede recoger filtrando el aire de recirculación o neutralizar añadiendo polvo de piedra en cantidad suficiente para inertizar la mezcla de polvo de carbón y aire.

\section{TECNICAS DE MINERIA SUBTERRANEA}

\section{Hans Hamrin}

En todo el mundo existen minas subterráneas que trabajan con los métodos y equipos más variados. Se cuentan aproximadamente 650 minas subterráneas con una producción anual superior a las 150.000 toneladas, lo que representa el $90 \%$ de la producción minera del mundo occidental. Además, se estima que hay 6.000 minas de menor tamaño con una producción inferior a las 150.000 toneladas. Cada mina es diferente en cuanto a ubicación, instalaciones y operaciones subterráneas, todo ello dependiendo del tipo de mineral que se extrae, la localización y las formaciones geológicas, así como de aspectos económicos como el mercado del mineral y la disponibilidad de capital. Algunas minas llevan en funcionamiento ininterrumpido desde hace más de un siglo, mientras que en otras acaba de iniciarse la explotación

Las minas son lugares peligrosos y la mayoría de los trabajos son duros. Los riesgos para los trabajadores van desde catástrofes como hundimientos, explosiones e incendios hasta accidentes, exposición al polvo, ruido, calor, etc. La protección de la salud y la seguridad de los trabajadores es una cuestión fundamental en las minas correctamente gestionadas y, en la mayoría de los países, esta normativa es de obligado cumplimiento.

\section{La mina subterránea}

La mina subterránea es una fábrica situada en el interior de la tierra en la que trabajan los mineros para extraer minerales ocultos en los estratos rocosos. Los mineros pican, arrancan y barrenan para poder acceder y extraer el mineral, es decir, la roca que contiene una mezcla de minerales de los cuales como mínimo uno es procesable y convertible en un producto comercializable. El mineral se transporta a la superficie para refinarlo y obtener un concentrado de alta calidad.

El trabajo en el interior del estrato rocoso y a gran profundidad requiere un tipo de infraestructura especial: una red de pozos, galerías y cámaras conectados con la superficie que permitan el movimiento de los trabajadores, las máquinas y el mineral dentro de la mina. El pozo es el acceso hacia el interior y de él salen las galerías laterales que conectan la estación del pozo con los frentes de explotación. La rampa interna es una galería inclinada que conecta los niveles subterráneos a distintas cotas (o profundidades). Todas las galerías deben disponer de servicios tales como ventilación y aire fresco, electricidad, agua y aire comprimido, desagües y bombas para el agua subterránea que se filtra así como un sistema de comunicación. 


\section{Planta y sistemas de extracción}

El castillete identifica la mina en superficie. Se encuentra situado justo encima del pozo, la arteria principal de la mina a través de la cual entran y salen los mineros, se bajan los suministros y equipos y se suben a la superficie el mineral y los materiales residuales. El pozo y las instalaciones de extracción varían según las necesidades de capacidad, profundidad, etc. Cada mina debe disponer como mínimo de un segundo pozo como salida de emergencia.

Las instalaciones de extracción y los pozos deben cumplir una normativa estricta. El equipo de extracción (p. ej., máquina de extracción, frenos y soga) ha de estar diseñado con un amplio margen de seguridad y ser revisado periódicamente. También el interior del pozo debe ser inspeccionado regularmente por personal situado sobre el montacargas. En caso necesario, los botones de parada situados en todas las paradas permiten activar el freno de emergencia.

En cada parada las puertas de la verja del pozo impiden la entrada al montacargas si éste no se encuentra en la misma. Cuando el montacargas se detiene en una parada, una señal abre la puerta. Una vez que los mineros han entrado en el montacargas y se ha cerrado la puerta, otra señal permite que el mismo suba o baje por el . Según los casos, es el operador del montacargas quien activa la señal o, siguiendo las instrucciones situadas en cada parada, son los propios mineros quienes marcan la detención. Por lo general, los mineros son muy conscientes de los riesgos que corren durante los desplazamientos por el pozo y las galerías de extracción, lo que limita el número de accidentes.

\section{Perforación con trépano de diamantes}

Antes de comenzar la explotación se localiza el filón en la roca y se define su anchura, longitud y profundidad para obtener una visión tridimensional del mismo.

La perforación con trépano de diamantes se utiliza para explorar un estrato rocoso y puede iniciarse desde la superficie o desde una galería de la mina. En esta técnica, un trépano provisto de pequeños diamantes corta un núcleo cilíndrico que es recogido en los tubos adyacentes. A continuación, se analiza el núcleo para determinar el contenido de la roca. Se inspeccionan las muestras y se dividen en porciones para analizar su contenido en metales. Para localizar los filones, hay que desarrollar amplios programas de perforación, efectuando barrenos a intervalos regulares en sentido horizontal y vertical para identificar las dimensiones del yacimiento (véase la Figura 74.9).

\section{Trazado de las minas}

El trazado de una mina incluye las excavaciones necesarias para instalar las infraestructuras con que trabajar en los tajos y preparar la continuidad futura de las operaciones. Entre los elementos rutinarios, realizados todos con técnicas de perforación-voladura-excavación, se encuentran las galerías horizontales, las rampas inclinadas y los pozos verticales o inclinados.

\section{Creación de pozos}

Para crear un pozo se excava la roca avanzando en sentido vertical. Normalmente, esta operación, que suele asignarse a contratistas, requiere personal especializado y equipos específicos, como un marco de superficie para excavación de pozos, un sistema de elevación con un gran cangilón de draga al final de un cable y un sistema especial de desescombro del pozo.

El personal de excavación de pozos se expone a muchos riesgos, pues trabaja en el fondo de una excavación profunda y vertical, y comparte el mismo cangilón de draga con el material y la roca barrenada. Además, los trabajadores que se encuentran en el fondo del pozo no disponen de espacio para

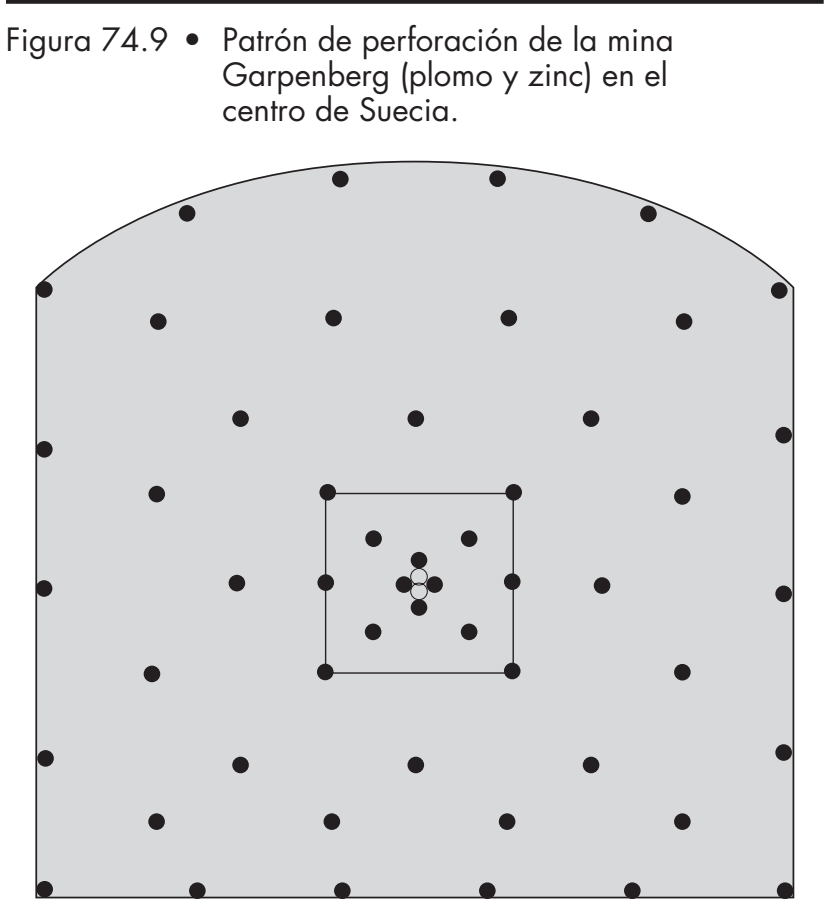

resguardarse de los objetos que puedan caerles encima; en resumen, puede decirse que la excavación de pozos no es un trabajo para novatos.

\section{Galerías y rampas}

Una galería es un túnel horizontal de acceso que se utiliza para transportar roca y mineral. La excavación de una galería es una actividad rutinaria dentro del trazado de una mina. En minas mecanizadas, se utilizan trenes electrohidráulicos perforadores múltiples de doble brazo para perforar los frentes. Una galería típica presenta un perfil de $16,0 \mathrm{~m}^{2}$ de sección y el frente se perfora a una profundidad de 4,0 m. Los barrenos se cargan de forma neumática con un explosivo (normalmente fueloil de nitrato amónico (ANFO) a granel) que se transporta en un camión especial. Se utilizan detonadores no eléctricos (Nonel) de retardo breve.

Figura 74.10 - Cargador CLV.

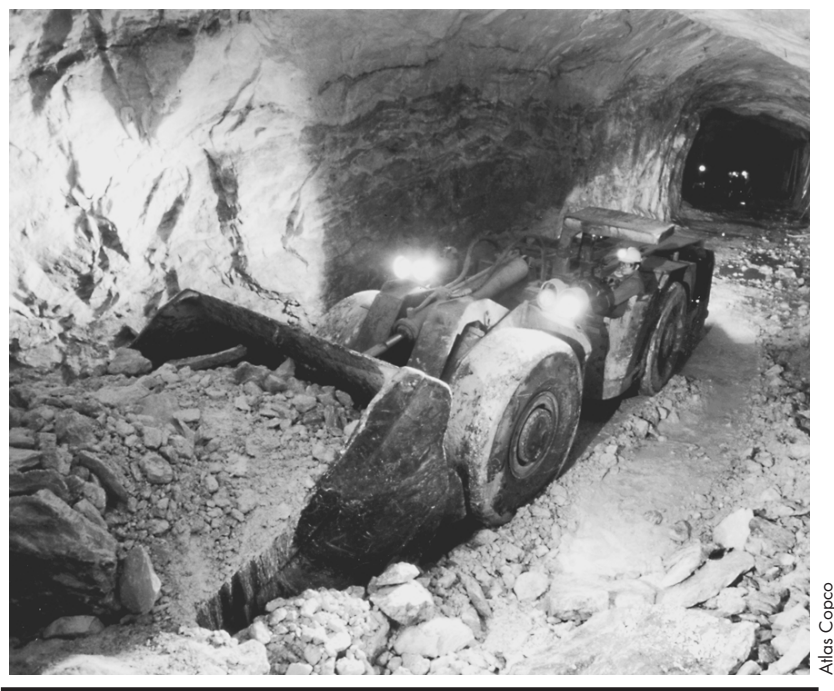


Figura 74.11 • Métodos de perforación de pozos.

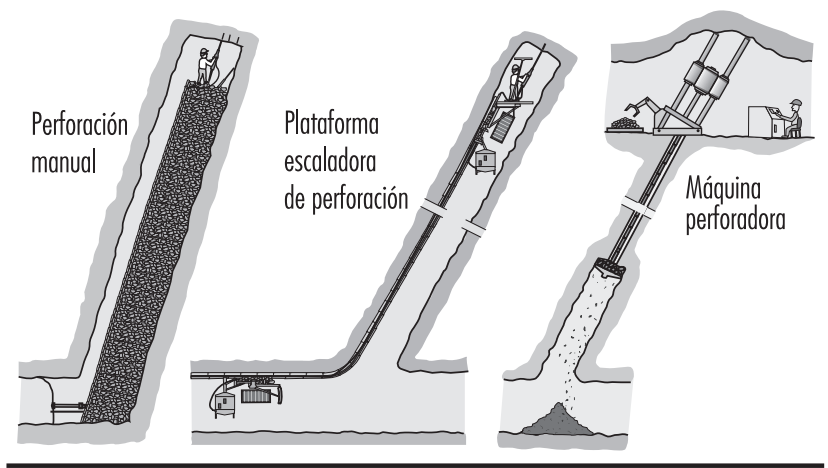

Las labores de desescombro se realizan con vehículos CLV (cargar, levantar, volcar) (véase la Figura 74.10) con palas de cerca de $3,0 \mathrm{~m}^{3}$ de capacidad. Los escombros se transportan directamente al sistema de paso de mineral, donde se transfieren a camiones de mayor tonelaje. Las rampas son pasajes con desniveles entre 1:7 y 1:10 (muy superiores a los de las carreteras normales), que conectan uno o más niveles y permiten una tracción adecuada para los equipos pesados de autopropulsión. Tienen a menudo forma de espiral. La excavación de las rampas, que se realiza con el mismo equipo utilizado en las galerías, es un trabajo de rutina dentro del trazado de una mina.

\section{Excavación de pozos}

Un pozo es una abertura vertical o muy inclinada que conecta diferentes niveles en una mina y puede servir como escalera para acceder al tajo, como paso del mineral o como parte del sistema de ventilación de la mina. La excavación de pozos es una tarea difícil y peligrosa pero necesaria. Los métodos utilizados van desde la simple perforación y voladura manuales hasta la excavación mecánica de la roca con maquinaria especializada (véase la Figura 74.11).

\section{Excavación manual de pozos}

La excavación manual es un trabajo difícil, peligroso y físicamente duro que exige una gran agilidad, fuerza y resistencia y sólo puede ser realizado por mineros expertos y en buenas condiciones físicas. Por regla general, la sección del pozo se divide mediante un muro de largueros de madera en dos compartimientos, uno de los cuales se mantiene expedito para la escalera de acceso al frente, a las conducciones de aire, etc. y el otro se va llenando con la roca procedente de la voladura formando una plataforma de perforación para el minero. La división con largueros de madera se va ampliando progresivamente. Este trabajo, que exige subir por la escalera, montar los andamiajes de madera, perforar la roca y realizar el barrenado, es realizado en un espacio escaso y mal ventilado por un solo minero, pues no hay espacio para un ayudante. En las explotaciones mineras se sigue buscando alternativas viables a estos métodos peligrosos y duros de excavación manual de pozos.

Vehículo de cremallera

El vehículo de cremallera para excavación de pozos evita el uso de la escalera y facilita considerablemente el método manual. Es un vehículo que sube por el pozo sobre unos raíles anclados en la roca y proporciona una plataforma sólida de trabajo desde la cual el minero puede picar la roca. Con este vehículo pueden perforarse pozos muy profundos con una seguridad mucho mayor que la que ofrece el método manual. Con todo, la excavación de pozos sigue siendo un trabajo muy peligroso.

\section{Perforadora}

La perforadora $(\mathrm{RBM})$ es una máquina potente que rompe la roca de forma mecánica (véase la Figura 74.12). Se instala encima del punto planificado para el pozo y con ella se perfora un barreno piloto de unos $300 \mathrm{~mm}$ de diámetro hasta alcanzar un objetivo de nivel inferior. La perforación piloto se sustituye por un cabezal de trépano del diámetro del pozo previsto y se coloca la máquina de forma invertida, de forma que el cabezal de trépano gira y se eleva para crear un pozo circular del tamaño deseado.

\section{Control de tierras}

El control de tierras es crucial para las personas que trabajan en el interior de un estrato rocoso y de especial interés en minas mecanizadas, donde se utilizan equipos con ruedas de neumáticos en secciones de galería de $25,0 \mathrm{~m}^{2}$, frente a las minas con equipos sobre raíles donde la sección suele ser de sólo $10,0 \mathrm{~m}^{2}$. En estos casos, la altura del techo de 5,0 m es excesiva para que el minero pueda utilizar una barra de saneamiento del techo y comprobar los posibles desprendimientos de rocas.

En las galerías subterráneas se utilizan varios modos de asegurar el techo. En los volados suaves se perforan barrenos muy juntos y se cargan con un explosivo de baja potencia. La voladura produce una perforación sin llegar a fragmentar la roca exterior.

Sin embargo, a menudo se producen grietas en el estrato rocoso que no resultan visibles en superficie, por lo que los

Figura 74.12 Máquina perforadora de pozos.

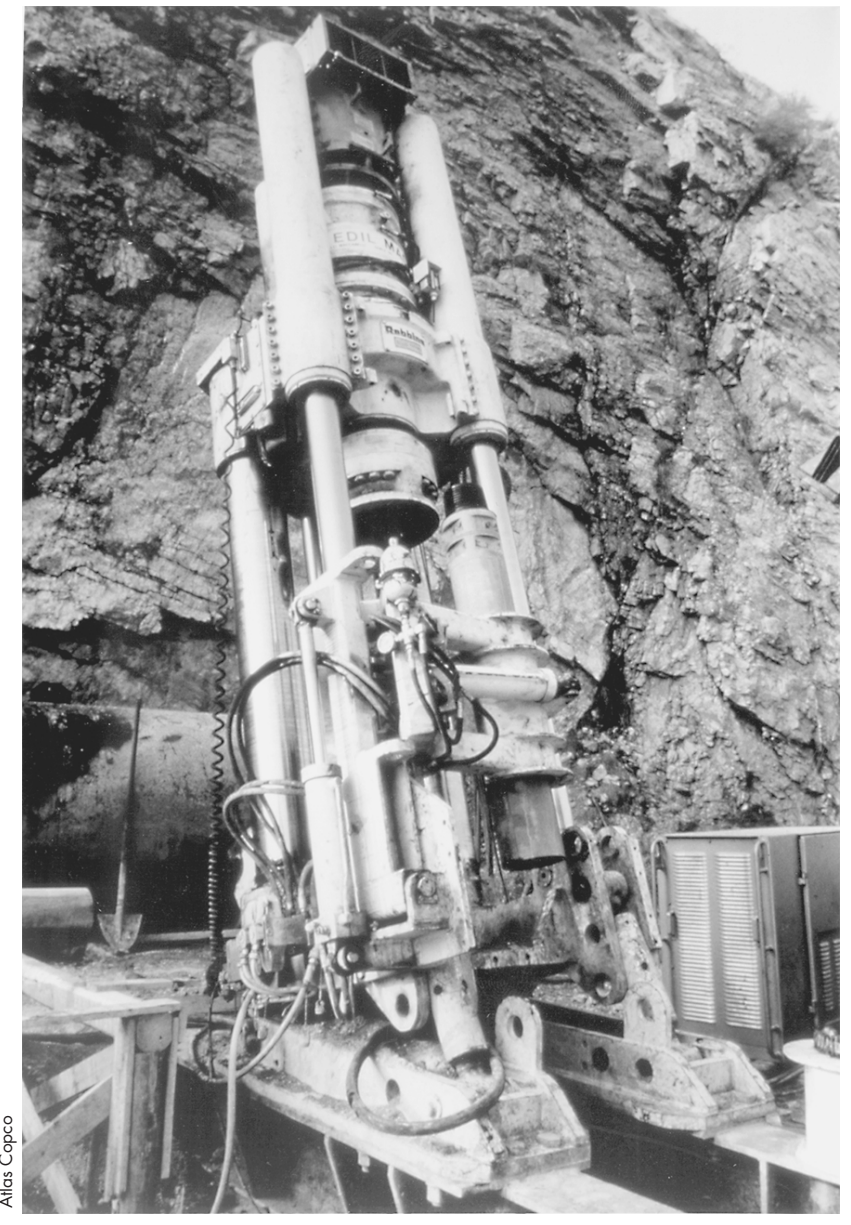


desprendimientos de rocas es un riesgo siempre presente. Este riesgo puede reducirse mediante el anclaje de las rocas, es decir, insertando y sujetando varillas de acero en los taladros. Los anclajes sujetan el estrato rocoso, evitan que las grietas aumenten de tamaño, ayudan a estabilizar el estrato rocoso y dan mayor seguridad al entorno subterráneo.

\section{Métodos de minería subterránea}

En las minas subterráneas la elección del método de explotación depende de la forma y el tamaño del filón, el valor de los minerales contenidos, la composición, estabilidad y fuerza del estrato rocoso, así como de la demanda de producción y las condiciones de seguridad del trabajo (aspectos que a veces son casi incompatibles). Aunque las técnicas de minería han avanzado con el paso del tiempo, el presente artículo se centra en las utilizadas en las minas total o parcialmente mecanizadas de finales del siglo XX. Aunque cada mina es diferente, en todas se intenta conseguir un entorno de trabajo seguro y un funcionamiento rentable.

\section{Filones planos con cámaras y pilares}

Este sistema se aplica a la extracción en suelo horizontal o ligeramente inclinado sin exceder los $20^{\circ}$ (véase la Figura 74.13). Los filones suelen ser de tipo sedimentario y la roca es resistente tanto para el techo como para la explotación (concepto relativo ya que los mineros tienen la opción de instalar anclajes de roca para reforzar el techo cuando su estabilidad es dudosa). El sistema de pilares es uno de los métodos más utilizados en las minas de carbón subterráneas.

Con esta técnica, el mineral se extrae perforando horizontalmente y avanzando a lo largo de un frente de explotación múltiple dejando espacios vacíos o cámaras detrás de él. Los pilares (secciones de roca) se van dejando entre las cámaras para evitar el hundimiento del techo. El resultado suele ser un diseño regular de cámaras y pilares con un tamaño que depende de la estabilidad del estrato rocoso pero con el objetivo de extraer la mayor cantidad posible de mineral. A tal fin, es necesario un cuidadoso análisis previo de factores como la resistencia de los pilares o la resistencia de los estratos del techo. Los anclajes en la roca se utilizan habitualmente para aumentar la resistencia de la roca en los pilares. Las cámaras entre pilares sirven de paso para los camiones que transportan el mineral al almacén de la mina.

El frente en este tipo de minas se perfora como en el caso de las galerías. La anchura y altura del tajo dependen del tamaño de la galería, que puede ser bastante grande. En las minas de altura normal se utilizan grandes trenes perforadores y máquinas compactas cuando el mineral presenta un grosor inferior a $3,0 \mathrm{~m}$. El yacimiento se va explotando gradualmente desde la parte superior, lo que permite asegurar el techo a una altura adecuada para los mineros. Las secciones inferiores se extraen en estratos horizontales perforando barrenos planos y realizando la voladura contra el espacio superior. El mineral se carga en camiones en el frente. Normalmente, se utilizan retroexcavadoras y volquetes convencionales. En las minas de poca altura se utilizan camiones y vehículos CLV especiales.

El sistema de pilares resulta muy eficaz. La seguridad depende de la altura de las cámaras y de las normas de control de suelos. Los principales riesgos son los accidentes causados por hundimiento de rocas y equipos en movimiento.

\section{Filones inclinados con pilares}

Esta técnica se aplica a la extracción en suelo liso con una inclinación comprendida entre $15^{\circ}$ y $30^{\circ}$ sobre el plano horizontal. Se trata de una inclinación excesiva para los vehículos con neumáticos e insuficiente para la caída de la roca por la fuerza de gravedad.

Figura 74.13 - Mina de cámaras y pilares en un filón plano.

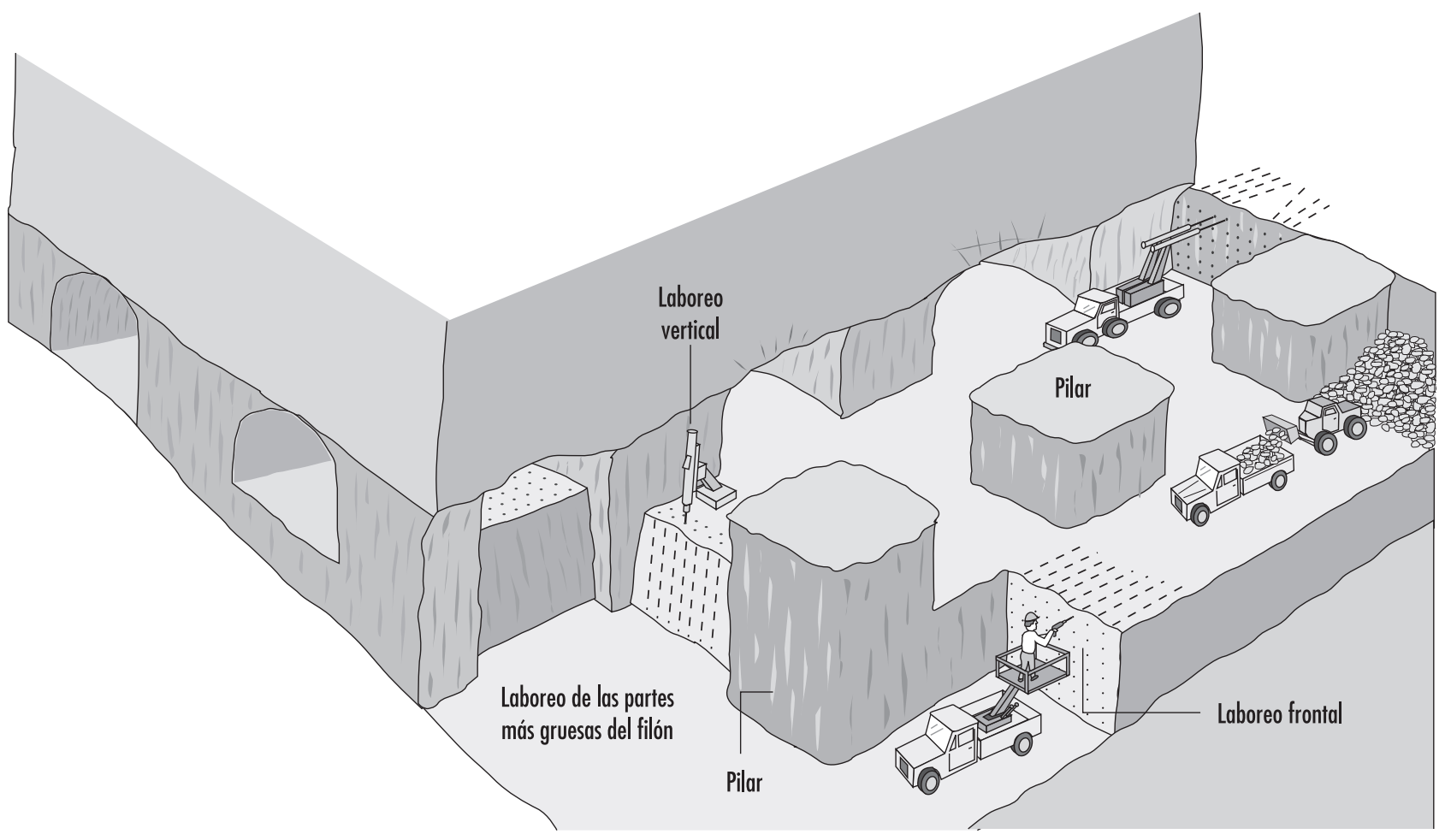


El enfoque tradicional del yacimiento inclinado se basa en el trabajo manual. Los mineros realizan perforaciones en el frente con máquinas sostenidas por ellos mismos. El frente se limpia con palas de arrastre.

El trabajo en el frente inclinado es difícil. Los mineros tienen que trepar por encima de los montones de rocas arrancadas cargando con las perforadoras, las poleas y los cables de acero. A los riesgos de caída de rocas y de accidentes, hay que añadir los debidos al ruido, el polvo, la ventilación inadecuada y el calor.

Cuando es posible introducir la mecanización en los filones inclinados de mineral, se utiliza la técnica de la "extracción en escalón", convirtiendo la galería de "fuerte inclinación" en una "escalera" con peldaños con un ángulo adecuado para que puedan subir las máquinas sin raíl. Los peldaños se moldean en forma de diamante con tajos y vías de carga con el ángulo elegido para todo el yacimiento.

La extracción del mineral se inicia con perforaciones horizontales a partir de una galería combinada de acceso y carga. El tajo inicial es horizontal en la dirección del techo. El siguiente tajo comienza a una pequeña distancia del anterior y en la misma dirección. Este procedimiento se repite desplazándose hacia abajo para crear una serie de peldaños y poder extraer el mineral.

Para soportar el techo se mantienen secciones de la explotación. Esta operación se realiza perforando dos o tres barrenos adyacentes en toda su longitud y comenzando el siguiente un paso más abajo, dejando un pilar alargado entre ellos. Las secciones de estos pilares pueden recuperarse posteriormente perforando y barrenando desde el tajo inferior.

Los modernos equipos sin raíles se adaptan bien a este tipo de minería. La extracción puede mecanizarse totalmente utilizando equipos móviles estándar. El mineral extraído es recogido en el tajo por vehículos CLV que lo trasladan a camiones para su transporte al pozo. Si el tajo no tiene altura suficiente para cargar el mineral en camiones, puede cargarse en espacios especialmente excavados en la vía de acarreo.

\section{Explotación por franjas-almacenes}

La explotación por franjas-almacenes puede considerarse el método "clásico" de minería, y fue muy utilizado durante el siglo pasado. Actualmente, esta técnica ha sido sustituida en gran medida por métodos mecanizados, aunque todavía se sigue utilizando en muchas minas pequeñas de todo el mundo. Se aplica a filones con límites regulares y fuerte inclinación situados dentro de un estrato rocoso resistente. También el mineral extraído debe resistir el almacenamiento en las laderas (p. ej., los minerales con sulfuros tienden a oxidarse y descomponerse en contacto con el aire). Su principal característica es el uso de la fuerza de gravedad para el tratamiento del mineral: el mineral extraído del tajo cae directamente a vagonetas a través de canaletas, lo que evita la carga manual, tradicionalmente la tarea más común y menos agradable de las minas. Hasta la aparición de la pala oscilante neumática en el decenio de 1950, no existía una máquina adecuada para cargar la roca en las minas subterráneas.

La extracción del mineral se realiza en planchas horizontales, comenzando por la base del tajo y avanzando hacia arriba. La mayor parte de la roca barrenada permanece en el tajo formando una plataforma de trabajo que permite al minero perforar los barrenos en el techo y asegurar los muros del tajo. Cuando la roca barrenada aumenta en un $60 \%$, se retira el $40 \%$ del mineral en la base para mantener un espacio de trabajo libre entre la parte superior del escombro y el techo. El mineral restante se retira cuando la voladura alcanza el límite superior del tajo.

$\mathrm{Al}$ tener que trabajar encima del montón de escombros y desde el acceso a la escalera resulta imposible utilizar equipos mecanizados. Sólo son útiles los equipos ligeros que pueda utilizar el propio minero. La perforadora neumática, de unos $45 \mathrm{~kg}$ de peso, es la herramienta habitual utilizada en este tipo de tajos. El minero, situado sobre la parte superior del montón de escombros, coloca la broca de acero de la perforadora contra el techo y comienza a trabajar. No es un trabajo fácil.

\section{Sistema de corte y relleno}

El sistema de cortar y llenar está indicado para filones de gran inclinación dentro de un estrato rocoso de estabilidad buena o media. El mineral se extrae en planchas horizontales comenzando desde un corte en la base y avanzando hacia arriba, dejando que los límites del tajo se ajusten a la explotación irregular. Así, se pueden extraer de forma selectiva secciones ricas y dejar intactas las de menor calidad.

Una vez que se ha desescombrado el tajo, el espacio limpio se vuelve a rellenar para formar una plataforma de trabajo que permita extraer la siguiente plancha y mejorar la estabilidad de los muros del tajo.

Este tipo de explotación en un entorno de trabajo sin equipos de raíles comprende una galería de acarreo a lo largo del yacimiento en el nivel principal, una roza en el tajo con desagües para el rellenado hidráulico, una rampa en espiral excavada en el suelo con salidas de acceso al tajo y un pozo desde el tajo hasta el nivel superior para la ventilación y el transporte del relleno.

El rebaje de cabeza se utiliza en el sistema de corte y relleno con roca seca y arena hidráulica como material de relleno. En este sistema, el tajo se perfora desde abajo barrenando una plancha de 3,0 m a 4,0 m de grosor. Así, se extrae toda el área de explotación y se barrena todo el tajo sin interrupción. Los barrenos "superiores" se perforan con simples perforadoras de vagoneta.

Este sistema deja una superficie de roca basta en el techo; después del desescombro, su altura puede ser de unos 7,0 m. Antes de que los mineros puedan entrar en esa zona, hay que asegurar el techo alisándolo con un barrenado suave y eliminando las rocas sueltas. Esta operación la realizan los mineros con equipos manuales y trabajando desde el montón de escombros.

En el sistema frontal, se utilizan equipos sin raíles para la extracción del mineral. Para rellenar se emplean relaves de arena que se distribuyen en los tajos subterráneos a través de conducciones de plástico. Los tajos se rellenan casi en su totalidad, lo que crea una superficie suficientemente dura para ser atravesada por equipos con neumáticos. La explotación en los tajos está totalmente mecanizada con trenes y vehículos CLV. El frente es un muro vertical de 5,0 $\mathrm{m}$ a lo largo del tajo con una abertura de $0,5 \mathrm{~m}$ por debajo de él. Se perforan en el frente barrenos horizontales de cinco metros de longitud y se barrena el mineral contra la abertura inferior.

El volumen producido en una voladura depende del área frontal y no es comparable al que se consigue con el sistema anterior de rebaje de cabeza. Sin embargo, la producción del equipo sin raíl es muy superior al método manual y el control del techo puede realizarse con el tren perforador, que realiza un barrenado ligero junto con la voladura del tajo. El vehículo GLV, equipado con un inmenso cangilón de carga y grandes ruedas, es una herramienta versátil para el desescombro y el acarreo y se desplaza con facilidad por la superficie de relleno. En un tajo de doble frente, el tren perforador trabaja en un lateral mientras el CLV trabaja en el montón de escombros en el otro extremo, haciendo un uso eficiente del equipo y mejorando el rendimiento.

En el sistema por subniveles se extrae el mineral en tajos abiertos. El relleno del tajo con un material consolidado después de la extracción permite a los mineros volver posteriormente a 
Figura 74.14 • Explotación por subniveles con perforadora circular y carga en galerías cruzadas.

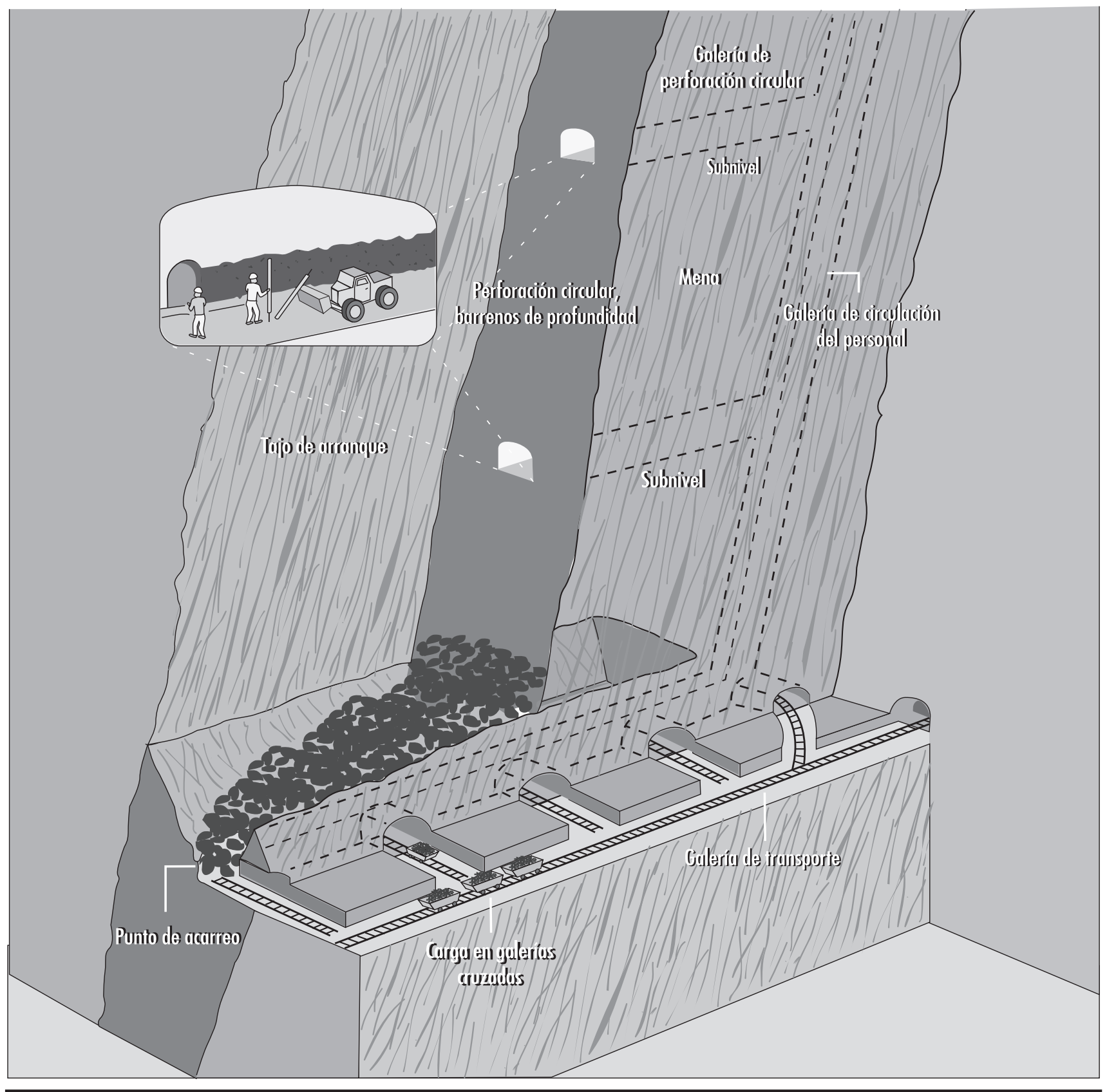

recuperar los pilares entre los tajos, obteniéndose una tasa de recuperación muy alta del filón.

El desarrollo del sistema por subniveles es complejo. El yacimiento se divide en secciones de una altura vertical de unos $100 \mathrm{~m}$ en la que se preparan subniveles conectados a través de una rampa inclinada. Las secciones del yacimiento se dividen a su vez lateralmente en tajos y pilares y se crea una galería de arrastre en el suelo con salidas para la carga en puntos de vaciado.

Una vez arrancado el mineral, el tajo por subniveles será una abertura rectangular a lo largo del yacimiento. La base del tajo es un embudo en forma de $\mathrm{V}$ que permite enviar el material barrenado a los puntos de vaciado. Las galerías de perforación para los equipos de pozos profundos se preparan en los subniveles superiores (véase la Figura 74.14).

El barrenado requiere un espacio para que la roca se expanda en volumen, por lo que es necesario preparar una abertura de unos metros de anchura antes de iniciar la voladura de pozos profundos. Esto se consigue aumentando el tamaño de un coladero de abajo a arriba hasta obtener la abertura completa.

Una vez realizada esta operación, el equipo de pozos profundos (véase la Figura 74.15) comienza la extracción en galerías por subniveles siguiendo con precisión un plan diseñado por expertos en voladuras especificando la posición de los barrenos, la posición de laminado circular, la profundidad y la dirección de los barrenos. El equipo de perforación continúa 
Figura 74.15 Equipo de perforación de pozos profundos.

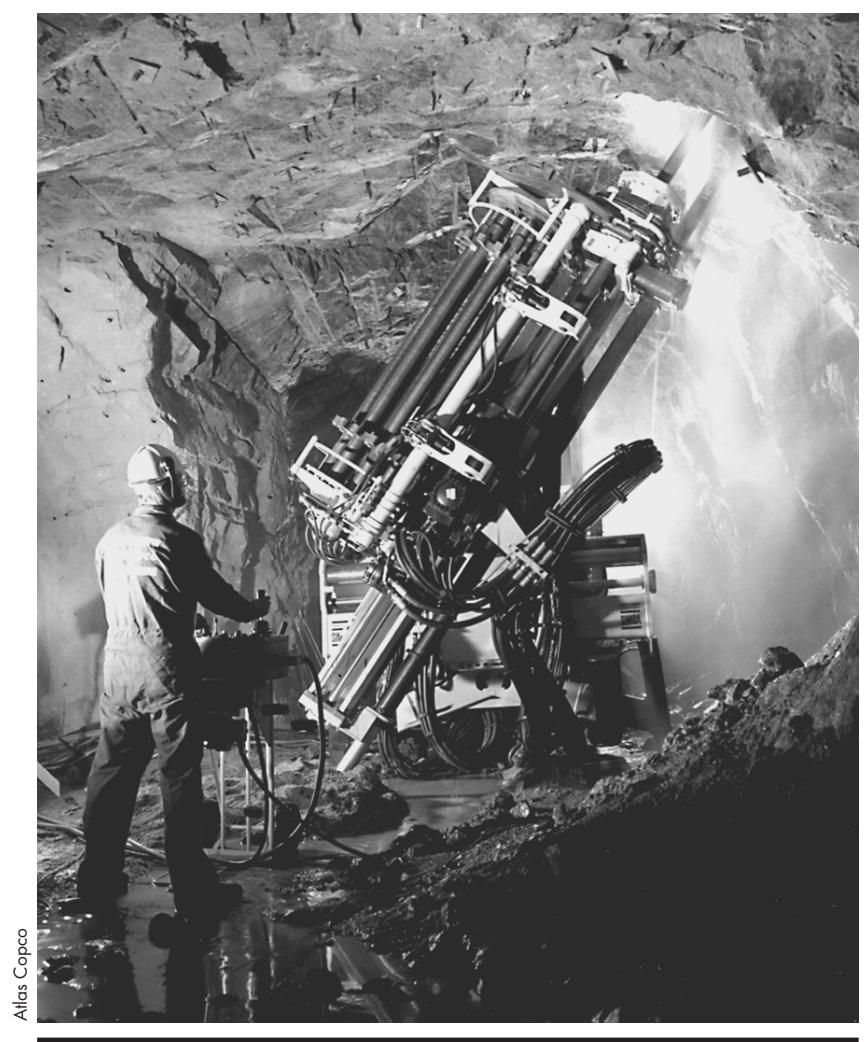

hasta finalizar todos los círculos de un nivel. A continuación, se desplaza al siguiente subnivel para continuar la perforación. Entretanto, los barrenos se cargan y un sistema de voladura que cubre un área extensa dentro del tajo hace saltar un gran volumen de mineral de una sola vez. El mineral barrenado cae al fondo del tajo y es recuperado por vehículos CLV que están desescombrando en el punto de vaciado por debajo del tajo. Normalmente, la perforación de pozos profundos precede a la carga y la voladura, lo que proporciona una reserva de mineral listo para barrenar y permite una explotación efectiva.

El sistema por subniveles es un método de extracción productivo. La eficiencia se mejora utilizando para la perforación de pozos profundos equipos totalmente mecanizados y de funcionamiento continuo. Esta técnica resulta además relativamente segura, pues al realizar la operación de perforación dentro de galerías de subnivel y la de desescombro a través de puntos de vaciado se elimina el riesgo potencial de desprendimiento de rocas.

\section{Sistema de retirada mediante cráteres verticales}

$\mathrm{Al}$ igual que el sistema por subniveles y el de franjas-almacenes, el sistema de retirada mediante cráteres verticales (RCV) se aplica a la extracción en estratos de gran inclinación aunque utilizando una técnica de voladura diferente: la roca se rompe con cargas pesadas concentradas en barrenos ("cráteres") de gran diámetro (unos $165 \mathrm{~mm}$ ) a una distancia de $3 \mathrm{~m}$ de la superficie rocosa libre. La voladura rompe una abertura en forma de cono en el estrato rocoso alrededor del barreno y permite que el material barrenado permanezca en el tajo durante la fase de explotación, de forma que el relleno de roca ayuda a soportar los muros del tajo. En este caso, el requisito de estabilidad de la roca es menor que en el sistema por subniveles.

El desarrollo del sistema RCV es similar al de subniveles salvo que se requieren excavaciones superiores e inferiores. La talla superior es necesaria en la primera fase para instalar el equipo de perforación de los barrenos de gran diámetro y para acceder mientras se cargan los barrenos. La talla inferior proporciona la superficie libre necesaria para la voladura RCV. También permite el acceso a un vehículo CLV (manejado por control remoto por un operario que permanece fuera del tajo) para cargar el mineral barrenado en los puntos de vaciado bajo el tajo.

En la voladura RCV normal se utilizan barrenos en patrón de $4,0 \mathrm{~m} \times 4,0 \mathrm{~m}$ dirigido en sentido vertical o inclinado con las cargas cuidadosamente situadas a distancias calculadas para liberar la superficie inferior. Las cargas permiten romper una abertura horizontal en la roca de unos 3,0 m de grosor. La roca barrenada cae al tajo inferior. Controlando la velocidad de desescombro, se mantiene el tajo parcialmente lleno de forma que el relleno de roca ayuda a estabilizar los muros durante la fase de explotación. La última voladura rompe la talla superior, que cae al tajo; después, se desescombra el tajo y se prepara para el relleno.

El sistema RCV utiliza a menudo un sistema de tajos primarios y secundarios en el yacimiento. Los primarios se extraen en la primera fase, se rellenan con material cementado y se dejan compactar. A continuación, los mineros recuperan el mineral de los pilares entre tajos primarios y de los tajos secundarios. Este sistema, junto con el relleno cementado, permite obtener casi el $100 \%$ de la reserva de mineral.

\section{Sistema de hundimiento de subniveles}

El sistema de hundimiento de subniveles se aplica a filones con una inclinación importante o moderada y una gran profundidad. El mineral se fractura en bloques manejables mediante voladura. El techo se hunde al extraer el mineral y el suelo en la superficie del yacimiento también lo hace (debe acordonarse la zona para evitar el acceso de personal a este área).

El hundimiento de subniveles está basado en la fuerza de la gravedad dentro de un estrato rocoso fracturado que contiene mineral y roca. El estrato rocoso se fractura mediante perforación y voladura y, a continuación, se desescombra a través de galerías por debajo del estrato rocoso hundido. Es un método seguro, porque los mineros siempre trabajan en el interior de aberturas del tamaño de una galería.

En este sistema, se abren subniveles con galerías de forma regular preparadas dentro del yacimiento con una separación vertical bastante pequeña (entre $10,0 \mathrm{~m}$ y $20,0 \mathrm{~m}$ ). El diseño de la galería es el mismo en todos los subniveles (es decir, galerías paralelas a través del yacimiento desde la galería de transporte de base hasta la de techo) pero ligeramente desplazadas en cada subnivel con respecto al anterior de forma que las galerías del nivel inferior están situadas entre las galerías del subnivel superior. Una sección transversal de las mismas mostraría un esquema en diamante con galerías verticales y horizontales espaciadas de forma regular, lo que da idea de la complejidad del sistema de hundimiento de subniveles. Sin embargo, la excavación de galerías es una tarea fácilmente mecanizable. La posibilidad de trabajar en frentes múltiples a diferentes subniveles favorece un elevada tasa de utilización de los equipos.

Cuando se ha completado el trazado de un subnivel, el equipo de perforación de pozos profundos pasa a perforar barrenos en forma de abanico en la roca superior. Cuando todos los barrenos están listos, el equipo se desplaza al subnivel inferior.

La voladura de pozos profundos fractura el estrato rocoso por encima de la galería del subnivel, iniciando un hundimiento que 
comienza en contacto con el techo y va retrocediendo hacia el suelo siguiendo un frente recto a través del yacimiento en el subnivel. Una sección vertical mostraría una escalera en donde cada subnivel superior se encuentra avanzado respecto al subnivel inferior.

La voladura rellena el frente del subnivel con una mezcla de mineral y desechos. Cuando llega el vehículo CLV, el hundimiento contiene un $100 \%$ de mineral. A medida que avanza la carga, la proporción de roca residual irá aumentando gradualmente hasta que el operario decida que la dilución es excesiva y detenga la carga. Cuando el vehículo se desplaza a la siguiente galería para continuar el desescombro, el técnico en voladuras prepara el siguiente círculo de barrenos.

El trabajo de desescombro en los subniveles es una aplicación ideal para el vehículo CLV. Este vehículo, disponible en diferentes tamaños, rellena el cangilón, se desplaza unos $200 \mathrm{~m}$, vacía el cangilón en el rumbadero y vuelve por otra carga.

El sistema de hundimiento de subniveles consta de tareas repetitivas (excavación de galerías, perforación de pozos profundos, barrenado y voladura, carga y transporte) que se realizan de forma independiente. Así, el personal y los equipos pueden trasladarse continuamente de un subnivel a otro, lo que permite un uso muy eficiente de los mismos. Realmente, la mina es como una fábrica con departamentos. Sin embargo, el sistema de subniveles es menos selectivo que otros métodos y no proporciona unas tasas de extracción especialmente eficientes. El hundimiento genera un 20-40\% de residuos y una pérdida de mineral de entre el $15 \%$ y el $25 \%$.

\section{Sistema de hundimiento en bloque}

Este sistema es aplicable a explotaciones del orden de 100 millones de toneladas distribuidas en todas las direcciones del estrato rocoso con posibilidad de hundimiento (p. ej., con tensiones internas que, al extraer los elementos de soporte del estrato rocoso, ayudan a fragmentar el bloque barrenado). El rendimiento anual previsto tiene que situarse entre $10 \mathrm{y}$ 30 millones de toneladas. Estos requisitos hacen que el sistema de hundimiento en bloque sólo pueda aplicarse en algunos filones específicos. Se utiliza en todo el mundo en minas de cobre, hierro, molibdeno y diamantes.

El término bloque se refiere al diseño de la mina. El yacimiento se divide en grandes secciones o bloques con un tonelaje suficiente para muchos años de explotación. El hundimiento se induce eliminando el soporte del estrato rocoso directamente debajo del bloque mediante la realización de un corte, una sección de roca de $15 \mathrm{~m}$ de alto fracturada mediante perforación de pozos profundos y voladura. Las tensiones creadas por fuerzas tectónicas naturales de considerable magnitud, similares a las que provocan los movimientos continentales, agrietan el estrato rocoso y fracturan los bloques en trozos de un tamaño que les permite pasar por las aberturas de los puntos de vaciado en la mina. A veces, sin embargo, es necesaria la ayuda de los mineros para manejar bloques demasiado grandes.

El sistema de hundimiento de bloques requiere una gran planificación y un trazado inicial detallado, que incluye un complejo sistema de excavaciones bajo el bloque. Aunque éstas pueden variar según el lugar, por lo general incluyen rozas, aberturas cónicas, cribones para separar las rocas de tamaño excesivo y rumbaderos que envían el mineral al vagón de carga.

Las aberturas cónicas excavadas por debajo de una roza recogen el mineral de un área mayor y lo envían a un punto de vaciado en el nivel de explotación inferior. Allí, el mineral es recogido en vehículos CLV y trasladado a rumbaderos. Los bloques demasiado grandes que no caben en el cangilón se barrenan en puntos de vaciado, mientras que los más pequeños son tratados en el cribón. Los cribones, conjunto de barras de hierro paralelas para clasificar las rocas, se utilizan por lo general en minas de hundimiento de bloques aunque para esta tarea cada vez se emplean más los equipos hidráulicos.

Las brechas en una mina de hundimiento de bloques están sometidas a una elevada presión por la roca, de modo que las galerías y demás aberturas se excavan con la sección mínima posible. Es necesario realizar un cuidadoso anclaje de las rocas y un recubrimiento con hormigón para mantener las aberturas en buen estado.

Adecuadamente aplicado, el sistema de hundimiento de bloques es un método de minería barato y rentable. Sin embargo, no siempre se puede prever la capacidad de hundimiento de un estrato rocoso. Además, el extenso trazado necesario requiere una larga fase previa antes de comenzar la explotación de la mina, y el retraso en la entrada de ingresos puede influir negativamente en las previsiones económicas que sirvan para justificar la inversión.

\section{Sistema por tajos largos}

El sistema por tajos largos se aplica a filones de forma uniforme, grosor limitado y extensión horizontal amplia (p. ej., vetas de carbón, capa de potasa o estrato de material de cuarzo explotado en las minas de oro de Sudáfrica) y es uno de los principales métodos utilizados en las minas de carbón. Con este sistema, se extrae el mineral en láminas a lo largo de una línea que se repite para extraer el material en un área más extensa. El espacio más cercano al frente se mantiene abierto mientras que el techo se deja hundir a una distancia segura detrás de los mineros y de su equipo.

El sistema de tajos largos incluye la realización de una red de galerías para acceder al área de explotación y para acarrear el producto extraído hasta el pozo. Dado que la explotación se realiza en forma de una plancha que se extiende a lo largo de una extensión amplia, normalmente pueden diseñarse las galerías en forma de red. Las galerías de arrastre se realizan en la propia veta de carbón. La distancia entre dos galerías de arrastre adyacentes determina la longitud del frente por tajos largos.

\section{Relleno}

El relleno de los tajos impide que la roca se hunda, manteniendo la estabilidad del estrato rocoso y permitiendo una extracción más completa del mineral. Tradicionalmente, el relleno se ha utilizado en operaciones de corte y relleno pero también se utiliza en los sistemas de subniveles y RCV.

Por norma general, los mineros vuelcan los residuos de roca en tajos vacíos en lugar de llevarlos a la superficie. Así, por ejemplo, en las minas de corte y relleno la roca residual es distribuida por el tajo vacío con palas de carga o aplanadoras.

En el sistema de relleno hidráulico se utilizan relaves de la instalación de preparación mecánica de la mina que se distribuyen en el subsuelo a través de barrenos y tubos de plástico. Los relaves primero se desenlodan y sólo se utiliza la fracción gruesa para el relleno. El relleno es una mezcla de arena y agua, con aproximadamente un $65 \%$ de materia sólida. Al mezclar el cemento en el último vertido, la superficie del relleno se endurece formando un lecho firme para los equipos de ruedas neumáticas.

El relleno también se utiliza en los sistemas de subniveles y $\mathrm{RCV}$, en donde se introduce roca machacada como complemento al relleno de arena. La roca machacada y cribada, obtenida de una cantera cercana, se envía al subsuelo a través de pozos especiales de relleno, donde es cargada en camiones y transportada al tajo, para ser volcada en pozos de relleno especiales. Los tajos primarios se rellenan con roca cementada que se obtiene vaporizando sobre el relleno una mezcla de polvo de cenizas y cemento antes de distribuirlo a los tajos. Este relleno se endurece formando un pilar artificial para explotar el tajo 
secundario. Por lo general, no es necesaria la mezcla de cemento cuando se rellenan los tajos secundarios, salvo en los últimos vertidos para obtener un suelo de desescombro firme.

\section{Equipos para la minería subterránea}

Las minas subterráneas disponen de un grado de mecanización cada vez mayor. Características comunes a todas las máquinas de funcionamiento subterráneo son la articulación sobre ruedas de goma, el uso de motores diesel y la tracción a las cuatro ruedas (véase la Figura 74.16).

\section{Tren perforador de frentes}

Este vehículo, dotado de uno o dos brazos con perforadores hidráulicos, es un elemento indispensable en las minas y se utiliza para todos los trabajos de excavación de rocas. Dirigido por un trabajador desde un panel de control, puede realizar 60 perforaciones de 4,0 $\mathrm{m}$ de profundidad en pocas horas.

\section{Perforadora de profundidad para pozos}

Este equipo (véase la Figura 74.15) perfora barrenos de forma radial alrededor de la galería cubriendo una gran área de roca y rompiendo grandes volúmenes de mineral. Se utiliza en los sistemas de subnivel, hundimiento de subniveles, hundimiento de bloques y RCV. El operario utiliza un potente perforador hidráulico y almacenamiento en carrusel con brazos extensibles de control remoto para perforar la roca desde una posición segura.

\section{Camión de carga}

El camión de carga es un complemento necesario del tren perforador. Sobre el transportador se monta una plataforma de servicio hidráulica, un contenedor a presión de explosivos ANFO y una manguera de carga que permite al operario llenar los barrenos en todo el frente en un plazo muy breve de tiempo. Simultáneamente, pueden introducirse detonadores Nonel para controlar las voladuras individuales.

\section{Vehículo CLV}

El vehículo versátil de carga-levantamiento-volcado (véase la Figura 74.10) se utiliza para una serie de operaciones, como la explotación del mineral y el manejo de materiales. Existe en varios tamaños, de forma que el minero puede seleccionar el modelo más adecuado para cada tarea y situación. A diferencia

Figura 74.16 • Equipo para frentes de pequeño tamaño.

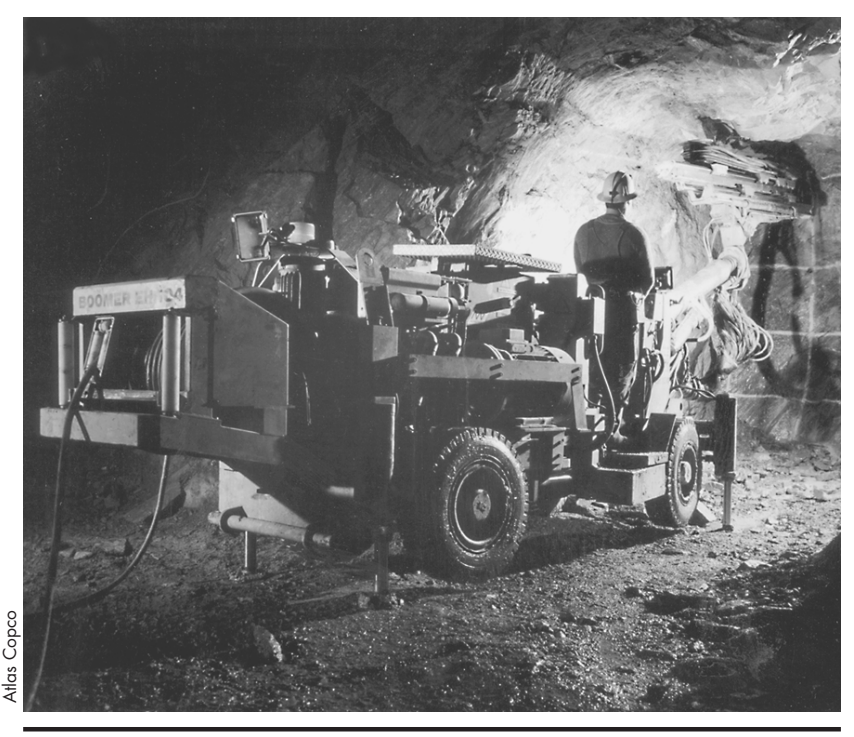

de otros vehículos diesel utilizados en las minas, el vehículo CLV se usa a la máxima potencia durante largos períodos de tiempo por lo que genera un gran volumen de humo y gases de escape. Un sistema de ventilación capaz de diluir y aspirar estos humos es esencial para mantener unos niveles de aire aceptables en el área de carga.

\section{Carga subterránea}

El mineral arrancado en los tajos de todo el yacimiento se acarrea hasta un vertedero situado cerca del pozo de extracción. Se abren galerías especiales de acarreo para un transporte lateral más amplio que normalmente están formadas por instalaciones de trenes con vagonetas. El acarreo sobre raíles ha demostrado ser un sistema de transporte eficiente para volúmenes y distancias importantes y está provisto de locomotoras eléctricas que no contaminan el ambiente subterráneo como los camiones diesel utilizados en las minas sin raíles.

\section{Manejo del mineral}

En el trayecto desde el tajo al pozo de extracción, el mineral pasa por varias estaciones en las que el mineral recibe diversos tratamientos.

La excavadora de carga, que utiliza un cangilón de acarreo para transportar el mineral del tajo al rumbadero, está equipada con tambores giratorios, cables y poleas y puede producir un movimiento de carga de vaivén. La excavadora de carga no requiere que el piso del tajo esté acondicionado y puede cargar el mineral almacenado en montones irregulares de escombros.

El vehículo $C L V$, con motor diesel y ruedas neumáticas, transporta la carga contenida en su cangilón (de tamaño variable) desde el montón de escombros al rumbadero.

El rumbadero es una abertura vertical o muy inclinada a través de la cual la roca cae por el peso de la gravedad desde un nivel superior a otro inferior. Los rumbaderos a veces están situados en una secuencia vertical para recoger el mineral de los niveles superiores en un punto común en la galería de arrastre.

La canaleta es la trampilla situada en el fondo del rumbadero. Los rumbaderos normalmente finalizan cerca de la galería de arrastre de forma que, cuando se abre la canaleta, el mineral cae llenando los camiones situados debajo de la misma.

Gerca del pozo, los trenes con mineral pasan por una estación de volcado donde puede descargarse el material en un depósito. Un cribón en la estación de volcado impide que caigan en el depósito rocas grandes. Estas últimas se parten mediante volado o con martillos hidráulicos; también puede instalarse una machacadora debajo del cribón para un control posterior de tamaño. Debajo del depósito se encuentra un calibrador que comprueba automáticamente que el volumen y el peso de la carga no exceden de las capacidades del eskip y del elevador. Cuando un eskip vacío, que es un contenedor para desplazamiento vertical, llega a la estación de llenado, se abre una canaleta en el fondo del calibrador que lo llena con la carga adecuada. Cuando el elevador levanta el eskip cargado hasta el marco de superficie, se abre una canaleta para descargar material en el depósito de superficie. La elevación del eskip puede realizarse de forma automática utilizando un circuito cerrado de televisión para supervisar el proceso.

\section{MINAS SUBTERRANEAS}

\section{Simon Walker}

En un principio, la explotación de las minas de carbón subterráneas se realizaba excavando túneles de acceso, o bocaminas, en las vetas de carbón a partir de su afloramiento superficial. Sin embargo, los problemas derivados de unos medios de transporte 
inadecuados para llevar el carbón a la superficie y el riesgo creciente de combustión de las bolsas de metano por velas y otras llamas abiertas limitaron la profundidad a que podían trabajarse las primeras minas subterráneas.

El aumento de la demanda de carbón durante la Revolución Industrial propició la excavación de pozos para poder acceder a reservas de carbón más profundas. Así, a mediados del siglo XX, la mayor parte de la producción de carbón del mundo procedía de minas subterráneas. Durante los decenios de 1970 y 1980 se produjo un amplio desarrollo de la capacidad de las minas de carbón a cielo abierto, especialmente en países como Estados Unidos, Sudáfrica, Australia e India. En el decenio de 1990, sin embargo, un renovado interés por las minas subterráneas hizo que se abrieran algunas nuevas (p. ej., en Queensland, Australia) a partir de la máxima profundidad anteriormente alcanzada por las minas a cielo abierto. A mediados del decenio de 1990, casi el $45 \%$ del total de carbón extraído en el mundo procedía de minas subterráneas. La proporción actual varía ampliamente, siendo, por ejemplo, del $30 \%$ en Australia e India y del $95 \%$ en China. Por razones económicas, no se suele explotar en minas subterráneas el lignito y el carbón bituminoso.

Una mina subterránea de carbón está formada básicamente por tres elementos: área de explotación, acarreo del carbón a pie de pozo o rampa y transporte del carbón a la superficie. La explotación comprende asimismo el trabajo previo necesario para permitir el acceso a futuras áreas de explotación de la mina, que presenta el máximo nivel de riesgo personal.

\section{Trazado de la mina}

La forma más sencilla de acceder a una veta de carbón es seguirla desde su afloramiento superficial, técnica todavía muy utilizada en áreas donde la topografía es inclinada y las vetas de carbón son relativamente horizontales. Un ejemplo son las minas de los Apalaches en Virginia del Sur (EE.UU.). Realmente, el método no es determinante, lo importante es que se pueda explotar la mina de forma económica y con un mínimo esfuerzo de infraestructura. Las bocaminas se suelen utilizar también en áreas mineras con escasa tecnología, en las que se amortizan los costes de trazado con el carbón que se va extrayendo de la bocamina.

Otros medios de acceso pueden ser las rampas y los pozos verticales. La elección depende normalmente de la profundidad de la veta de carbón: cuanto más profunda sea, más caro resultará perforar una rampa escalonada que permita el funcionamiento de los vehículos o las cintas transportadoras.

La construcción de un pozo vertical desde la superficie exige mucho tiempo y dinero, e impone el paso de un mayor lapso de tiempo entre el inicio de la construcción y la primera extracción de carbón. Cuando las vetas de carbón se encuentran a gran profundidad, como suele ocurrir en la mayor parte de los países europeos y China, a menudo hay que construir pozos que atraviesan capas freáticas. En tal caso, para evitar que el agua caiga al pozo hay que recurrir a técnicas especiales como la congelación o cementación del terreno y, a continuación, recubrir el pozo con anillos de acero u hormigón armado para su aislamiento definitivo.

Las rampas se utilizan normalmente para acceder a vetas de carbón que se encuentran a demasiada profundidad como para ser explotadas a cielo abierto, pero que están cerca de la superficie. Así, por ejemplo, en las minas de Mpumalanga (Transvaal oriental), Sudáfrica, las vetas de carbón se encuentran a menos de $150 \mathrm{~m}$. En algunas zonas se explotan a cielo abierto y en otras se utiliza la explotación subterránea con rampas para introducir el equipo necesario e instalar las cintas transportadoras con las que se saca el carbón arrancado fuera de la mina.

Las rampas se diferencian de las galerías en que normalmente se excavan en la roca, no en el carbón (salvo que la inclinación de la veta de carbón sea constante), y presentan una inclinación constante para facilitar el acceso de vehículos y medios de transporte. Una innovación introducida en el decenio de 1970 ha sido el uso de cintas transportadoras instaladas en rampas para la explotación de minas profundas, un sistema que presenta ventajas sobre la extracción tradicional por pozos en términos de capacidad y fiabilidad.

\section{Métodos de explotación}

Para la explotación de minas subterráneas se utilizan básicamente dos sistemas, a partir de los cuales se han desarrollado múltiples variantes que mejoran condiciones específicas de funcionamiento. Con el sistema de cámaras y pilares se excavan galerías (o vías) dispuestas de forma regular, dejando a menudo pilares de roca para soportar el techo. Con el sistema por tajos largos se consigue la extracción total de grandes zonas de una veta de carbón, dejando que las rocas del techo se hundan en la zona ya explotada.

\section{Sistema de cámaras y pilares}

Este sistema, el más antiguo en las minas subterráneas de carbón, fue el primero en que se previó un soporte del techo para proteger a los mineros. Su nombre se debe a los pilares de carbón que se dejan de forma regular como soporte in situ del techo. Este sistema se ha ido desarrollando hasta convertirse en un método mecanizado de alta explotación con el que, en algunos países, se obtiene una parte importante del total de la producción de minas subterráneas. Así, por ejemplo, en Estados Unidos el 60 \% de la producción en minas subterráneas de carbón procede de minas explotadas con el sistema de cámaras y pilares. Algunas minas en Sudáfrica están obteniendo una producción de más de 10 millones de toneladas anuales en operaciones de multiproducción en vetas de carbón de hasta 6 m de espesor. En cambio, en Estados Unidos, muchas de las minas en que se aplica este sistema son pequeñas, operan con grosores de veta de sólo $1 \mathrm{~m} \mathrm{y}$ tienen capacidad para detener y reanudar rápidamente la explotación en función de la demanda del mercado.

Normalmente, el sistema de cámaras y pilares se utiliza en vetas delgadas de carbón, donde la presión ejercida por las rocas superiores sobre los pilares de soporte no es excesiva. Este sistema presenta dos ventajas clave sobre el método de tajos largos: su flexibilidad y su seguridad. La principal desventaja es que la recuperación de los recursos de carbón sólo es parcial y depende de factores como la profundidad de la veta bajo la superficie y su grosor, llegando a conseguirse recuperaciones de hasta un $60 \%$ o incluso un $90 \%$ si se explotan los pilares en una segunda fase del proceso de extracción.

Este sistema también presenta varios niveles de complejidad técnica, que van desde técnicas de trabajo intensivo (como el sistema "de cestos", en el que la mayoría de las fases de explotación, incluido el acarreo, son manuales) hasta técnicas de alta mecanización. El carbón puede arrancarse desde el frente del túnel utilizando explosivos o máquinas de funcionamiento continuo. Para su acarreo se emplean vehículos o cintas transportadoras . Para soportar el techo de las vías y de sus intersecciones, donde el vano es mayor, se utilizan pernos de consolidación del techos y sujeción con puntales metálicos o de madera.

Un equipo de funcionamiento continuo, con un cabezal cortador y un sistema de carga del carbón montado sobre orugas pesa, por lo general, entre 50 y 100 toneladas, según la altura de operación, la potencia y la anchura de corte necesaria. Algunos de estos equipos llevan máquinas de instalación de pernos de consolidación de la roca y realizan la operación de sujetar el techo al mismo tiempo que cortan el carbón; en otros casos, el funcionamiento de los equipos continuos y de las 
máquinas de instalación de pernos de consolidación es de tipo secuencial.

Las vagonetas de transporte de carbón pueden estar movidas por electricidad a partir de un cable umbilical o funcionar con baterías o motores diesel, de más flexibilidad. El carbón se carga desde la parte trasera de la máquina de extracción continua al vagón, que acarrea una carga de entre 5 y 20 toneladas durante una pequeña distancia, hasta un alimentador de tolva que, a su vez, lo trasvasa al sistema de cinta transportadora principal. El alimentador de tolva puede ir provisto de una trituradora para romper los trozos grandes de carbón o roca capaces de bloquear las canaletas o dañar las cintas transportadoras en algún punto del sistema de acarreo.

Una alternativa al acarreo en vehículos es el sistema de carga continua, que consiste en un transportador montado sobre una oruga de sección flexible que traslada el carbón arrancado directamente desde el equipo continuo a la tolva. El uso de estos equipos, que presentan ventajas en términos de seguridad personal y capacidad de producción, se está extendiendo también al sistema por tajos largos.

Las vías se excavan con una anchura de hasta $6,0 \mathrm{~m}$ y generalmente con la altura total de la veta de carbón. El tamaño de los pilares depende de la profundidad desde la superficie; lo normal en minas de carbón poco profundas de filón delgado son pilares cuadrados de 15,0 m separados unos 21,0 m.

\section{Sistema por tajos largos}

Aunque se cree que este sistema es un desarrollo del siglo XX, parece que ya existía hace 200 años. El principal avance registrado es que antiguamente las operaciones eran en su mayoría manuales, mientras que desde el decenio de 1950 el nivel de mecanización ha aumentado hasta el punto de que un frente extraído por tajos largos es ahora una unidad de alta productividad que requiere un grupo muy reducido de trabajadores.

El sistema de tajos largos presenta una gran ventaja en comparación con el de cámaras y pilares: permite la extracción total del panel en una pasada, recuperando una proporción mayor de la reserva total de carbón. Sin embargo, es un método relativamente poco flexible y requiere la existencia de una gran reserva explotable y que la venta esté garantizada, dadas las fuertes inversiones necesarias para su trazado y equipamiento (en algunos casos más de 20 millones de dólares).

Si antiguamente lo habitual era que la extracción se realizase de forma simultánea en varios frentes (en países como Polonia, más de 10 frentes por mina en muchos casos), la tendencia actual es efectuar una extracción intensiva en menos unidades, lo que reduce las necesidades de mano de obra, así como el trazado y el mantenimiento de la infraestructura subterránea necesaria.

En el sistema por tajos largos se hunde deliberadamente el techo a medida que se va agotando la veta de carbón; sólo las principales rutas de acceso subterráneas se mantienen con pilares. El techo a lo largo del tajo se entiba mediante soportes de accionamiento hidráulico de doble o cuádruple cadena que soportan la carga inmediata del techo y permiten que se distribuya parcialmente al frente sin explotar y a los pilares a ambos lados del panel, protegiendo asimismo al equipo y al personal del techo hundido detrás de la línea de soportes. El carbón se corta con una rozadora eléctrica, normalmente equipada con dos tambores de corte de carbón, que extrae una tira de carbón de hasta 1,1 m de grosor en cada pase. La rozadora se desplaza cargando el carbón arrancado en un transportador blindado que se desliza hacia delante después de cada corte mediante un movimiento secuencial de los soportes del frente.

En el extremo del frente, el carbón cortado se carga en una cinta transportadora para su acarreo hasta la superficie.
A medida que se avanza en el frente hay que ir ampliando la cinta, al contrario de lo que sucede con el sistema de retirada de tajos largos.

Durante los últimos 40 años se ha producido un importante aumento tanto en la longitud del frente explotado por tajos largos como en la longitud de los paneles (bloque de carbón a través del cual progresa el frente) trabajados con este sistema. A título ilustrativo valga citar que en Estados Unidos la longitud media del frente trabajado con este sistema aumentó de $150 \mathrm{~m}$ en 1980 a 227 m en 1993. En Alemania, la media en el decenio de 1990 era de 270 m y están previstas longitudes de frente de más de $300 \mathrm{~m}$. En el Reino Unido y Polonia, los frentes típicos son de más de $300 \mathrm{~m}$ de longitud. La longitud del panel viene determinada por factores geológicos como las fallas o la extensión de la mina, pero en condiciones normales suele ser de más de 2,5 km. En Estados Unidos se está estudiando la posibilidad de explotar paneles de hasta 6,7 km de longitud.

El sistema de explotación en retirada se está convirtiendo en el más habitual, aunque requiere una mayor inversión inicial para el trazado de vías hasta el límite de cada panel antes de poder comenzar la extracción por tajos largos. Actualmente, siempre que resulta viable, se excavan las vías en la veta de carbón, utilizando turnos continuos de mineros y sustituyendo los arcos de acero y los refuerzos anteriormente utilizados para soportar las rocas superiores por pernos de consolidación, en lugar de limitarse a reaccionar de forma pasiva ante los movimientos de rocas. Sin embargo, su aplicación está supeditada a la existencia de rocas resistentes en el techo.

\section{Precauciones de seguridad}

Las estadísticas de la OIT (1994) indican que existe una gran variación en la tasa de accidentes mortales en las minas de carbón de todo el mundo, aunque en estos datos hay que tener en cuenta el nivel de complejidad del trabajo y el número de trabajadores empleados en cada país. En muchos países industrializados las condiciones han mejorado considerablemente.

En la actualidad, son relativamente infrecuentes los accidentes graves en las minas gracias a la mejora de los estándares de ingeniería y a la incorporación de la lucha contra incendios a materiales como las cintas transportadoras y los fluidos hidráulicos utilizados en las minas subterráneas. Sin embargo, sigue existiendo el riesgo de que se produzcan accidentes con daños personales o materiales. Igualmente, se siguen produciendo explosiones de gas metano y de polvo de carbón, a pesar de la mejora de las prácticas de ventilación, y los hundimientos de techos son los causantes de la mayor parte de los accidentes graves en todo el mundo. Los incendios, bien de equipos o como resultado de una combustión espontánea, representan un peligro especial.

Para las dos opciones extremas, funcionamiento prácticamente manual y altamente mecanizado, las tasas y los tipos de accidentes difieren mucho. Los trabajadores empleados en pequeñas minas de explotación manual están más expuestos a accidentes por caídas de rocas o carbón del techo o de las paredes. También están más expuestos al polvo y a los gases inflamables si los sistemas de ventilación no son los adecuados.

Tanto el sistema de cámaras y pilares como el trazado de vías para acceder a los paneles de explotación por tajos largos requieren un soporte del techo y de los muros laterales. El tipo y la distancia entre soportes varía dependiendo, entre otras cosas, del grosor de la veta de carbón, de la solidez de la roca superior y de la profundidad de la veta. El lugar más peligroso de una mina es debajo de un techo sin soportes, y la mayoría de los países imponen serias limitaciones legales a la longitud de vía que puede desarrollarse antes de instalar los soportes adecuados. La recuperación de pilares en el sistema de cámaras y pilares 
presenta un riesgo específico por la posibilidad de que el techo se hunda de forma inesperada, lo que hace necesaria una planificación cuidadosa para evitar un riesgo mayor para los trabajadores.

El sistema moderno de extracción de frentes por tajos largos, de alta productividad, requiere un equipo reducido de seis a ocho trabajadores, de forma que el número de personas expuestas a riesgos potenciales es ahora mucho menor. El problema principal es el polvo generado por la rozadora de tajos largos. Para que el flujo de ventilación arrastre el polvo lejos de los trabajadores de la rozadora, el corte de carbón a veces se limita a una sola dirección a lo largo del frente. El calor generado por las máquinas eléctricas cada vez más potentes que se emplean en las proximidades del frente tiene asimismo efectos nocivos sobre los trabajadores, especialmente a medida que se va profundizando en la mina.

También está aumentando la velocidad de trabajo de las rozadoras. A finales del decenio de 1990, la velocidad de corte ha llegado a alcanzar los $45 \mathrm{~m} /$ minuto. Se duda que los trabajadores puedan resistir físicamente un turno entero de trabajo manejando una rozadora que se desplaza constantemente a esa velocidad a lo largo de un frente de $300 \mathrm{~m}$. En consecuencia, este factor será un motivo importante para introducir de forma masiva sistemas de automatización de las máquinas en los que los mineros actuarían como simples supervisores y no como operarios directos.

La recogida de los equipos empleados en el frente y su traslado a un nuevo lugar de trabajo representa un riesgo especial para los trabajadores. Se han desarrollado métodos innovadores para asegurar el techo y las paredes del frente de carbón de forma que se minimice el riesgo de caída de rocas durante las operaciones de traslado. Sin embargo, la maquinaria utilizada es extremadamente pesada (más de 20 toneladas para un equipo acarreador de frente largo y bastante más en el caso de una rozadora) y a pesar del uso de herramientas específicas, en estas operaciones de traslado sigue existiendo el riesgo de aplastamiento de personas o de lesiones por manejo de grandes pesos.

\section{- Minas A CIELO ABIERTO}

Thomas A. Hethmon y Kyle B. Dotson

\section{Trazado de las minas}

\section{Planificación y diseño de la mina}

El principal objetivo económico de las minas a cielo abierto es extraer la cantidad mínima de material y obtener una máxima recuperación de la inversión procesando el producto mineral más comercializable. Cuanto mejor sea la calidad del filón, mayor será su valor. Para minimizar las inversiones de capital y acceder al mismo tiempo al material de mayor valor dentro de un filón, hay que desarrollar un plan de explotación que detalle de forma precisa el método de extracción y de tratamiento del mineral. Dado que muchos yacimientos no presentan una disposición uniforme, antes de elaborar el plan de explotación de la mina es necesario emprender amplias perforaciones exploratorias para perfilar la geología y localización del mineral. La forma del filón definirá el tamaño y el diseño de la mina. El diseño depende de la mineralogía y la geología de la zona. La mayoría de las minas a cielo abierto son de forma cónica, aunque ésta puede variar dependiendo de la forma del filón. Se construyen con una serie de mantos o antepechos concéntricos divididos por el acceso a la mina y las vías de acarreo que descienden desde el borde de la mina hasta el fondo en forma de espiral o zigzag.
Independientemente de su tamaño, el plan de la mina incluye disposiciones sobre el trazado, las infraestructuras (de almacenamiento, oficinas, mantenimiento, etc.), el transporte, los equipos y el ritmo de explotación que repercuten en el período de vida útil de la mina, que concluye con el agotamiento del mineral o con el cumplimiento de un límite económico.

Las minas a cielo abierto actuales pueden consistir en pequeñas empresas privadas que procesan unos cientos de toneladas de mineral al día hasta grandes complejos industriales estatales o empresas multinacionales que extraen más de un millón de toneladas de material diario. Las operaciones de mayor envergadura pueden realizarse en superficies de muchos kilómetros cuadrados.

\section{Capa de cobertura de extracción a cielo abierto}

La capa de cobertura es la roca residual formada por material consolidado y no consolidado que debe eliminarse para dejar al descubierto el mineral subyacente. Es aconsejable eliminar la menor cantidad posible de capa de cobertura para acceder al mineral de interés, pero si el filón es profundo será necesario excavar un volumen mayor de roca residual. La mayoría de las técnicas de eliminación son cíclicas, con interrupción de las fases de extracción (perforación, voladura y carga) y transporte. Esto es especialmente válido en terrenos de recubrimiento de roca dura que deben ser previamente perforados y barrenados. Una excepción a este carácter cíclico la constituyen las dragas utilizadas en la minería de superficie con equipos hidráulicos y en algunos tipos de minería de material suelto con excavadoras de ruedas y cangilones. La relación de extracción a cielo abierto define la relación entre la parte de roca residual y la parte de mineral excavado. En operaciones importantes de minería esta relación suele estar comprendida entre 2:1 y 4:1. Las relaciones superiores a 6:1 tienden a ser menos viables desde el punto de vista económico, aunque depende del mineral extraído. La capa de cobertura, una vez extraída, puede utilizarse para la construcción de carreteras y para relaves o comercializarse como material de relleno.

\section{Selección del equipo de minería}

La selección del equipo de minería aparece definida en el plan de la mina. Algunos de los factores que deben tenerse en cuenta a tal fin son la topografía de la mina y del área circundante, la cantidad de mineral que va a extraerse, la velocidad y distancia a que debe transportarse el mineral para su procesamiento y la vida útil estimada de la mina. Por lo general, la mayoría de las operaciones en las minas a cielo abierto se efectúan con equipos de perforación móviles, palas hidráulicas, palas cargadoras de ataque frontal, cucharas de carga y camiones para extraer el mineral e iniciar su procesamiento. Cuanto mayor sea el volumen de operación de la mina, mayor capacidad deberá tener el equipo para poder mantener el plan de la mina. Por lo general, se elige el mayor equipo disponible de acuerdo con la economía de escala de la mina a cielo abierto y la capacidad necesaria. Así, por ejemplo, una pequeña pala cargadora de ataque frontal puede llenar un gran camión de transporte pero la operación no resultaría eficiente. De forma análoga, una pala de gran capacidad puede cargar camiones más pequeños pero obligaría a los camiones a reducir sus tiempos de ciclo y no se optimizaría la utilización de la pala, pues su cangilón puede contener mineral para cargar más de un camión. Si se intenta cargar sólo medio cangilón o cargar un camión en exceso se reduce el nivel de seguridad. El tamaño del equipo elegido debe estar de acuerdo también con las instalaciones de mantenimiento disponibles. A menudo se producen problemas con grandes equipos debido a las dificultades logísticas para transportarlos a las instalaciones de mantenimiento adecuadas. Siempre que sea posible, las instalaciones de mantenimiento de la mina deben corresponderse con el 
tamaño y la cantidad de los equipos de la mina. Por tanto, cada vez que se introduzcan en el plan de la mina nuevos equipos de mayor tamaño, deberá ajustarse asimismo la infraestructura de apoyo (tamaño y calidad de las vías de acarreo, herramientas, instalaciones de mantenimiento, etc.).

\section{Métodos convencionales de la minería a cielo abierto}

Las dos categorías principales de la minería superficial son la minería a cielo abierto y la minería de extracción a cielo abierto, que representan más del $90 \%$ de la explotación minera mundial a cielo abierto. Las principales diferencias entre ambos métodos son la localización del mineral y la forma de extracción mecánica. En la tecnología para roca suelta, el proceso en serie de arrancado y carga es básicamente continuo. La tecnología para roca consolidada requiere un proceso discontinuo de fases de perforación y voladura y fases de carga y acarreo. Con las técnicas de minería de extracción a cielo abierto (o minería a cielo abierto) se extrae el mineral que se encuentra próximo a la superficie y que se presenta en vetas relativamente planas o tabulares. Se utiliza maquinaria como palas, camiones, dragalinas, excavadoras de ruedas de cangilones y cucharas de carga. La mayoría de las minas de descortezado procesan yacimientos de roca no consolidada. El carbón es el mineral que se extrae de forma más habitual con técnicas de descortezamiento de filones superficiales. Por el contrario, la minería a cielo abierto se utiliza para extraer mineral consolidado que se encuentra diseminado o en vetas profundas utilizando, por lo general, palas y camiones. Muchos metales, como oro, plata y cobre, se extraen con la técnica de cielo abierto.

La explotación en canteras es un término que se utiliza para describir una técnica especial de minería a cielo abierto que consiste en la extracción de roca con un alto grado de compactación y densidad de yacimientos localizados. La piedra que se extrae en las canteras puede ser machacada o fracturada para producir agregados o piedra para construcción, como la dolomita y la piedra caliza, o combinarse con otros productos químicos para producir cemento y cal viva. Los materiales de construcción se obtienen en canteras situadas en las proximidades del lugar de utilización del material con el fin de reducir los costes de transporte. Otra clase de material extraído de las canteras son las piedras para construcción, como placas, granito, piedra caliza, mármol, arenisca y pizarra. Este tipo de canteras se localizan en zonas con las características minerales deseadas, que pueden estar o no geográficamente alejadas y hacer necesario el transporte a los correspondientes mercados.

Muchos yacimientos son demasiado irregulares, demasiado pequeños o demasiado profundos para ser explotados mediante métodos de descortezado o a cielo abierto y deben extraerse con un enfoque de minería subterránea. Para determinar cuándo es aplicable la minería a cielo abierto hay que considerar factores como el terreno y la altitud del lugar y la región, la lejanía, el clima, la infraestructura de carreteras, el suministro de electricidad y agua, los requisitos legales y ambientales, la estabilidad de la ladera, la eliminación de la capa de cobertura y el transporte del producto.

Terreno y altitud: La topografía y la altitud del terreno desempeñan un papel importante, pues definen la viabilidad y el alcance del proyecto de minería. En general, cuanto mayor sea la altitud y más irregular el terreno, más difícil será el trazado y la explotación de la mina. Un mineral de mayor calidad en un lugar montañoso de difícil acceso puede extraerse con menos eficiencia que un mineral de menor calidad pero situado en una planicie. Las minas situadas a menor altura presentan, por lo general, menos problemas derivados de las inclemencias atmosféricas durante las fases de prospección, trazado y explotación de la mina. Por tanto, la topografía y la localización repercuten en la técnica de minería y en la viabilidad económica.

La decisión de explotar una mina se toma después de definir el yacimiento de mineral durante la fase de prospección y determinar las opciones de extracción y procesamiento del mineral en los estudios de viabilidad. Entre la información necesaria para elaborar un plan de trazado se encuentran la forma, el tamaño y la calidad de los minerales del yacimiento, el volumen total o tonelaje de material, incluida la capa de cobertura, además de otros factores como la hidrología, el acceso a una fuente de agua de procesamiento, la disponibilidad de una fuente de electricidad, de lugares de almacenamiento de la roca residual, los requisitos de transporte y las características de la infraestructura, incluida la localización de centros de población con mano de obra o la necesidad de crear un centro de población. Los requisitos de transporte pueden incluir carreteras, autovías, conducciones, aeropuertos, ferrocarriles, vías fluviales y puertos.

Las minas a cielo abierto requieren, por lo general, grandes extensiones de terreno en las que puede no existir la infraestructura necesaria. En este caso, primero hay que construir carreteras, instalaciones y centros habitables. La mina se desarrolla en función de otros elementos de procesamiento, como áreas de almacenamiento de la roca residual, machacadoras, concentradores, hornos de fusión y refinerías, dependiendo del grado de integración necesario. Debido al gran volumen de inversión necesario para financiar estas operaciones, el trazado puede realizarse en fases que permitan ir comercializando lo antes posible el mineral inicial extraído y seguir financiando el resto del trazado.

\section{Explotación y equipos}

\section{Perforación y voladura}

En la mayoría de las minas a cielo abierto las operaciones de perforación y voladura son las primeras que se realizan para extraer el mineral, y suelen ser el método más utilizado para eliminar la capa de cobertura de roca dura. Aunque existen muchos sistemas mecánicos para fragmentar la roca dura, los explosivos son el método más habitual, dado que no existe ningún sistema mecánico que pueda igualar la capacidad de fragmentación de la energía de una carga explosiva. Para volar rocas suele emplearse nitrato amónico. El equipo de perforación se elige en función de la naturaleza del mineral y de la velocidad y profundidad de los barrenos necesarios para fragmentar un volumen específico de mineral diario. Por ejemplo, para extraer un antepecho de $15 \mathrm{~m}$ de mineral, es necesario perforar más de 60 barrenos, según la longitud del antepecho, a $15 \mathrm{~m}$ por detrás del frente de desescombro. En este proceso hay que tener en cuenta el tiempo necesario para preparar el lugar para las actividades de carga y arrastre posteriores.

\section{Carga}

Actualmente, en la minería de superficie se utilizan palas de mesa, cargadoras de ataque frontal o hidráulicas. En las minas a cielo abierto el equipo de carga se selecciona de forma que los camiones puedan cargarse en tres a cinco ciclos o pases de la pala; sin embargo, existen otros factores que determinan el tipo de equipo de carga. Para rocas duras o climas húmedos son preferibles las palas sobre orugas. En cambio, para cargar material de pequeño volumen y fácil extracción resultan mucho más económicas e indicadas las cargadoras sobre neumáticos. Además, por su movilidad, las cargadoras son adecuadas en lugares en que se requieran desplazamientos rápidos de una zona a otra o para operaciones de mezclado de mineral. Las cargadoras también se utilizan con frecuencia para cargar, transportar 
y volcar en las machacadoras los montones de mineral de mezclado depositados por los camiones.

Las palas hidráulicas y las de cable presentan ventajas y limitaciones similares. Las primeras no son adecuadas para la extracción de minerales duros y las segundas suelen ser de mayor tamaño, por lo que en minas donde la producción es superior a 200.000 toneladas al día los equipos adecuados son las grandes palas de cable con capacidades superiores a 50 metros cúbicos. Por el contrario, las palas hidráulicas son más versátiles en el frente de la mina y permiten al operario una mayor selectividad de la carga del mineral desde el fondo o la mitad superior del frente de la mina. Esta ventaja es importante cuando en la zona de carga es posible separar el mineral de la roca residual, optimizando así la calidad del mineral que se carga y procesa.

\section{Acarreo}

El acarreo en las minas a cielo abierto y de extracción se realiza, por lo general, con camiones. El papel de los camiones en muchas minas a cielo abierto se limita al traslado del material entre la zona de carga y puntos de transferencia, como la estación interna de machaqueo o el sistema de transporte. Los camiones tienen una mayor flexibilidad de funcionamiento que el ferrocarril, método de transporte predominante hasta el decenio de 1960. El coste del transporte en las minas de superficie metálicas y no metálicas suele ser superior al $50 \%$ del coste total de operación de la mina. La trituración dentro de la mina y el transporte mediante sistemas de cintas ha contribuido de forma decisiva a reducir este elevado coste de transporte. Las innovaciones introducidas en los camiones, como los motores diesel o la transmisión eléctrica, han permitido aumentar la capacidad de los vehículos. Actualmente, algunos fabricantes construyen camiones de más de 240 toneladas y en un futuro próximo se espera llegar hasta las 300 toneladas. Además, el uso de sistemas informáticos de gestión de cargas y la tecnología de posicionamiento por satélite permiten el seguimiento y la planificación de los vehículos con una mayor eficiencia y productividad.

$\mathrm{El}$ acarreo puede realizarse en vías de dirección única o doble. La conducción puede ser por la derecha o por la izquierda; esta última se utiliza más porque permite al operario ver mejor la posición de las ruedas en camiones muy grandes. La circulación por la izquierda ha permitido asimismo mejorar la seguridad al reducir la posibilidad de colisión en el lateral del conductor. Las pendientes en las vías de transporte suelen estar limitadas al 8-15\% para transportes sostenidos, situándose el valor óptimo entre el $7 \%$ y el $8 \%$. La seguridad y el drenaje de las aguas requieren pendientes fuertes con secciones mínimas de $45 \mathrm{~m}$ y un gradiente máximo del $2 \%$ cada $460 \mathrm{~m}$ de pendiente. Las bermas (bordes elevados) entre la carretera y la excavación constituyen una norma de seguridad en las minas de superficie, aunque también pueden estar situadas en el centro de la carretera para separar las dos direcciones del tráfico. En las carreteras alternadas?? pueden instalarse vías de escape de elevación creciente al final de las pendientes prolongadas. Las barreras de limitación como las bermas deben utilizarse de forma normalizada entre la carretera y las excavaciones adyacentes. Unas carreteras de alta calidad mejoran la productividad al aumentar la velocidad de seguridad de los camiones y reducir el tiempo muerto de mantenimiento y la fatiga del conductor. El buen mantenimiento de las carreteras para el tránsito de camiones contribuye a reducir los costes de funcionamiento gracias a un menor consumo de combustible, una mayor vida útil de los neumáticos y menores costes de reparación.

El transporte por ferrocarril es el más indicado para acarrear el mineral a gran distancia de la mina, pero ya no suele utilizarse en las minas a cielo abierto desde la aparición de los camiones de motor eléctrico y diesel. El acarreo por ferrocarril dentro de las minas se ha abandonado por la mayor versatilidad y flexibilidad de los camiones de carga y los sistemas de transporte. El ferrocarril sólo puede desplazarse por pendientes muy suaves del $0,5 \%$ al $3 \%$ y la inversión en máquinas e infraestructuras es muy elevada, sólo justificada en minas con una vida útil muy larga y grandes volúmenes de explotación que permitan amortizar la inversión.

\section{Tratamiento del mineral}

La trituración y el acarreo dentro del pozo es un método que ha ido ganando popularidad desde que se inició a mediados del decenio de 1950. La instalación de una trituradora semimóvil en el pozo de la mina y el posterior arrastre del mineral fuera del mismo mediante un sistema de transporte aporta importantes ventajas de explotación y un ahorro de costes frente al transporte tradicional en vehículos, pues reduce los gastos de construcción y mantenimiento de carreteras de alto coste y minimiza el consumo de combustible y los costes de mano de obra asociados al manejo y el mantenimiento de los camiones.

La razón de instalar el sistema de trituración dentro del pozo es básicamente permitir el transporte del mineral con una cinta transportadora. Estos sistemas pueden ser permanentes o móviles, aunque su diseño suele ser de tipo modular, lo que facilita su transporte dentro de la mina. La operación de traslado de una trituradora (transcurridos de 1 a 10 años) puede requerir horas, días o meses dependiendo del tamaño, la complejidad de la unidad y la distancia de desplazamiento. Las ventajas de las cintas transportadoras frente a los camiones son la puesta en marcha instantánea, el funcionamiento automático y continuo y un alto grado de fiabilidad con una disponibilidad de hasta el 90-95 \%. Estos equipos no se ven afectados, por lo general, por las inclemencias atmosféricas. Las cintas transportadoras también presentan unas exigencias de funcionamiento muy inferiores a las de los camiones; el funcionamiento y el mantenimiento de una flota de camiones puede requerir diez veces más personal que un sistema de acarreo de capacidad equivalente. Además, las cintas transportadoras pueden trabajar con pendientes de hasta el $30 \%$, mientras que los camiones sólo pueden hacerlo con pendientes del $10 \%$. Al utilizar pendientes más pronunciadas se evita eliminar la capa de cobertura de baja calidad e incluso puede que no sea necesario construir carreteras de alto coste. Los sistemas de cintas transportadoras también pueden integrarse en palas de cangilones de carga para muchas operaciones de extracción de carbón en minas a cielo abierto, lo que evita el uso de camiones.

\section{Sistemas de minería por disolución}

El sistema por disolución, que es el más habitual de los dos utilizados en la minería con agua, se aplica para la extracción de mineral soluble allí donde los métodos de minería convencionales resultan menos eficientes y/o menos económicos. Esta técnica, que también recibe el nombre de lixiviación o lixiviación superficial, constituye en ocasiones el método básico de explotación, como ocurre en los yacimientos de oro y plata, mientras que en otras se utiliza para completar las fases pirometalúrgicas convencionales de fundido y refinado, como en los yacimientos de óxidos de baja calidad. En cualquier caso, los métodos por disolución superficial presentan dos características comunes: 1) el mineral se extrae de la forma habitual y se apila en montones y 2) se vierte una solución acuosa en la parte superior del montón que reacciona químicamente con el metal de que se trate y, cuando éste escurre por el montón, se recoge y procesa. La aplicación del sistema de disolución superficial depende del volumen, de la metalurgia de los minerales de interés y del tipo de roca hospedante, así como del espacio y el drenaje disponible para 


\section{Aspectos ambientales de la minería a cielo abierto}

Las importantes repercusiones ambientales de las minas a cielo abierto son claramente visibles sea cual sea su ubicación. La alteración del terreno, la destrucción de la flora y los efectos negativos sobre la fauna autóctona son sus consecuencias inevitables. La contaminación de la superficie y de las aguas subterráneas a menudo constituye un problema, especialmente a causa de los lixiviantes en la minería por disolución y de los derrumbes en la minería hidráulica

Gracias al trabajo de los ecologistas y al uso de aviones y de fotografías aéreas, las empresas de minería ya no pueden "cavar e irse" una vez concluida la extracción del mineral. En la mayoría de los países desarrollados se han adoptado leyes y normativas, que las organizaciones internacionales están promoviendo en los países en que todavía no existen. Esas normativas establecen un programa de gestión medioambiental como parte integrante de todo proyecto de minería al tiempo que exigen estudios preliminares de impacto ambiental, programas de rehabilitación progresiva (con recuperación del aspecto del terreno, reforestación, restauración de la fauna y de la flora autóctona, etc.), así como una auditoría de cumplimiento durante la explotación y a largo plazo (UNEP 1991, UN 1992, Environmental Protection Agency (Australia) 1996, ICME 1996). Es fundamental que este programa no se quede en meras afirmaciones en la documentación necesaria para obtener la licencia gubernamental. Los gestores de campo deben aceptar y poner en la práctica los principios básicos, que han de comunicarse asimismo a los trabajadores de todos los niveles.

crear vertederos de lixiviación suficientemente amplios como para que la operación sea rentable.

El trazado de los vertederos de lixiviación de una mina de superficie en que la disolución constituya el método básico de explotación es similar a los de las minas a cielo abierto, salvo que el mineral se destina únicamente al vertedero y no al procesamiento. En minas con métodos de procesamiento y de disolución, el mineral se separa en una parte procesada y otra lixiviada. Así, por ejemplo, la mayor parte del mineral de sulfuro de cobre se procesa y purifica hasta conseguir una calidad comercial aceptable mediante fundición y refinado. El mineral de óxido de cobre, que generalmente no admite el tratamiento pirometalúrgico, se somete a operaciones de lixiviación. Una vez creado el vertedero, la disolución lixivia el metal soluble de la roca adyacente a la velocidad deseada, controlable a través de los parámetros de diseño del vertedero, de la naturaleza y el volumen de la disolución aplicada así como de la concentración y la mineralogía del metal contenido en el mineral. La disolución que se utiliza para extraer el metal soluble se denomina lixiviante. Los lixiviantes más habituales en este sector de la minería son disoluciones diluidas de cianuro sódico alcalino para el oro, ácido sulfúrico para el cobre, dióxido de azufre acuoso para el manganeso y ácido sulfúrico-sulfato férrico para el mineral de uranio. Sin embargo, la mayor parte del uranio y de las sales solubles lixiviadas se recogen in-situ inyectando el lixiviante directamente en el mineral del yacimiento, sin realizar una extracción mecánica previa. Esta técnica permite procesar minerales de calidad baja sin necesidad de extraer previamente el mineral del filón.

\section{Salud y seguridad}

Los riesgos profesionales de salud y seguridad relacionados con la extracción mecánica del mineral utilizando sistemas por disolución son básicamente los mismos que en las minas de superficie convencionales. La única diferencia es que en las minas de superficie el mineral que no se va a lixiviar se somete a un trituración antes de ser enviado a fábrica para su procesamiento convencional, mientras que en el sistema de disolución el mineral suele transportarse en camiones directamente del lugar de extracción al vertedero de lixiviación. Los trabajadores de este tipo de minas están, por lo tanto, menos expuestos a peligros como polvo, ruido y accidentes físicos. Las principales causas de accidente en minas de superficie son el manejo de materiales, los resbalones y caídas, el uso de maquinaria, el uso de herramientas manuales o equipos eléctricos y el contacto con fuentes eléctricas. Sin embargo, un peligro específico del sistema por disolución es la exposición a los lixiviantes químicos durante las operaciones de transporte y lixiviación y los procesos químicos y electrolíticos. En los tanques de extracción electrolítica de metales puede existir cierta exposición a la niebla ácida, mientras que en la minería del uranio hay un riesgo de radiación ionizante, que aumenta desde la extracción a la clasificación.

\section{Métodos hidráulicos en minería}

En la minería hidráulica, para extraer el material suelto consolidado o no consolidado y formar una mezcla que es procesada posteriormente, se utiliza una vaporización con agua a alta presión. Los métodos hidráulicos se aplican básicamente a yacimientos de metales y de agregados, aunque el carbón, la arenisca y los relaves metálicos también pueden tratarse con este método. Su aplicación más común es el sistema de aluvión, que consiste en lavar metales como oro, titanio, plata, estaño o tungsteno en un depósito de aluvión. Para realizar el trazado de una instalación de minería hidráulica hay que tener en cuenta factores tan importantes como el suministro y la presión de agua, la pendiente del terreno de escorrentía, la distancia desde el frente de la mina a las instalaciones de procesamiento, el grado de consolidación del material extraíble y la disponibilidad de áreas de vertido. Al igual que en otros sistemas de minería superficial, su aplicación depende específicamente del lugar. Entre las principales ventajas de este método se encuentran unos costes relativamente bajos y una gran flexibilidad, derivados del uso de equipos sencillos, resistentes y móviles, por lo que muchas operaciones hidráulicas se desarrollan en áreas mineras remotas donde los requisitos de infraestructura no constituyen una limitación.

A diferencia de otros tipos de minería superficial, los sistemas hidráulicos utilizan el agua como medio tanto de extracción como de transporte del mineral extraído ("lavado a gran agua"). Con monitores o cañones de agua se envían al banco de aluvión o filón vaporizaciones de agua a alta presión que desintegran la grava y el material no consolidado, que una vez lavado pasa a las instalaciones de recogida y procesamiento. La presión del agua puede ser desde la propia de un flujo de caída para materiales finos muy sueltos hasta miles de kilogramos por centímetro cuadrado en yacimientos no consolidados. A veces se utilizan aplanadoras y máquinas niveladoras $u$ otro equipo móvil de excavación para facilitar la extracción de los materiales más compactos. Tanto en el pasado como actualmente en operaciones a pequeña escala, la recogida de la mezcla o escorrentía se realiza con cajas y trampillas de pequeño volumen. Para operaciones a escala comercial, se utilizan bombas, estanques de contención y de sedimentación y equipos de separación que pueden procesar grandes volúmenes de lodos de lavado por hora. Dependiendo del tamaño del yacimiento, el control del agua puede realizarse de forma manual, por control remoto o por ordenador.

El método de minería hidráulica para tratar mineral situado bajo el agua se denomina dragado. Se utiliza una estación de 
tratamiento por flotación para extraer depósitos sueltos, como arcilla, fango, arena, grava y otros minerales asociados, utilizando una línea de cangilones de draga, dragalinas y/o chorros bajo el agua. El material extraído se transporta por métodos hidráulicos o mecánicos hasta una estación de lavado integrada en el propio equipo de dragado o que puede estar físicamente separada y contener las fases posteriores de procesamiento para separar y completar el tratamiento. Aunque el dragado se utiliza para extraer minerales comerciales y agregados, es más conocido como técnica de limpieza y profundización de canales de agua y terrenos inundables.

\section{Salud y seguridad}

Los riesgos físicos de la minería hidráulica difieren de los de la minería superficial. Al haber una utilización mínima de operaciones de perforación, voladura, transporte y reducción, los riesgos se derivan principalmente de los sistemas de agua a presión, los movimientos manuales de equipos móviles, el suministro de energía y agua, los hundimientos de frentes de mineral y el mantenimiento de los equipos. Los riesgos para la salud están básicamente relacionados con la exposición al ruido y el polvo y los riesgos ergonómicos se concentran en el manejo de los equipos. La exposición al polvo es un problema menos importante que en la minería de superficie tradicional gracias al uso del agua como medio de tratamiento. Las actividades de mantenimiento como la soldadura incontrolada también pueden ser un riesgo para los trabajadores.

\section{- ConTrol de la Mineria DEL CARBON A CIELO ABIERTO}

\section{Paul Westcott}

Las características geológicas diferenciadoras de las minas de carbón a cielo abierto de otros tipos de minas a cielo abierto son la naturaleza de la formación y su valor relativamente bajo, lo que a menudo hace necesario mover grandes volúmenes de capa de cobertura en una amplia zona (es decir, una alta relación de descortezado). Por esta razón, para la minería del carbón a cielo abierto se han desarrollado equipos y técnicas específicos, como un sistema de extracción a cielo abierto mediante dragalinas que extraen tiras de un ancho de 30 a $60 \mathrm{~m}$ y vierte el material en galerías de hasta $50 \mathrm{~km}$ de longitud. La rehabilitación del entorno es una parte fundamental del ciclo de una mina debido al importante deterioro de estas áreas.

La producción de las minas de carbón a cielo abierto puede ser pequeña (inferior a 1 millón de toneladas al año) o de gran volumen (más de 10 millones de toneladas al año). La mano de obra necesaria depende de la extensión y el tipo de la mina, del tamaño y la cantidad de equipos utilizados y del volumen de carbón y de la capa de cobertura que deben extraerse. Existen algunos indicadores típicos que definen la productividad y el volumen de mano de obra, como:

1. producción por minero (toneladas $\mathrm{x}$ minero $\mathrm{x}$ año), con valores que oscilan entre 5.000 toneladas por minero y año y 40.000 toneladas por minero y año;

2. material total movido (toneladas $\mathrm{x}$ minero $\mathrm{x}$ año). Este indicador de productividad comprende el material de carbón y de capa de cobertura, con valores que oscilan entre 100.000 toneladas por minero y año, que se considera una productividad baja, y 400.000 toneladas por minero y año, que se considera una productividad muy alta.
Debido a la gran inversión de capital necesaria, muchas minas de carbón operan con turnos continuos 7 días a la semana, lo que requiere disponer de cuatro equipos: tres turnos de ocho horas y un cuarto turno que cubre los días de descanso.

\section{Planificación de una mina}

La planificación de las minas de carbón a cielo abierto es un proceso rutinario que puede resumirse en una lista de comprobación. El ciclo comienza con los estudios geológicos y de comercialización y finaliza con una evaluación económica. El nivel de detalle (y el coste) de la planificación aumenta a medida que el proyecto pasa por las diferentes fases de homologación y trazado. Antes de comenzar el trazado se realizan los estudios de viabilidad. La misma lista de comprobación es válida cuando el equipo de explotación comienza a desarrollar los planes anuales y quinquenales o los planes para cerrar la mina y rehabilitar la zona una vez extraído todo el carbón.

La planificación es un proceso continuo, con frecuentes actualizaciones derivadas de los cambios de mercado, tecnológicos y legislativos, así como de la información sobre el yacimiento que se va obteniendo a medida que avanza la explotación.

\section{Influencias geológicas}

Las características geológicas influyen en gran medida en la elección del método de minería y del equipo que se van a utilizar en una determinada mina de superficie de carbón.

La inclinación de la veta de carbón, o pendiente, representa el ángulo entre la veta de carbón y el plano horizontal. Cuanto mayor es la inclinación, más difícil resulta su explotación. La inclinación también afecta a la estabilidad de la mina; la inclinación límite para operaciones de dragalina es de unos $7^{\circ}$.

La dureza del carbón y de la roca residual determina el tipo de equipo que puede utilizarse y si es necesario aplicar técnicas de voladura al material . Los equipos de minería continua, como las excavadoras de rueda de cangilones utilizadas habitualmente en Europa oriental y Alemania, sólo sirven para material de una dureza muy baja que no requiera la aplicación de sistemas de voladura. La capa de cobertura suele ser demasiado dura para ser excavada sin realizar operaciones de voladura que fragmenten la roca en trozos más pequeños, que a continuación se cargan con palas y equipos mecánicos.

A medida que aumenta la profundidad de las vetas de carbón, va aumentando también el coste del transporte de los residuos y del carbón hasta la superficie o el vertedero. Alcanzada una determinada profundidad resulta más económico aplicar métodos de minería subterránea que de cielo abierto.

Es posible extraer vetas de carbón delgadas de hasta $50 \mathrm{~mm}$ de espesor, pero la recuperación del carbón se hace más difícil y costosa a medida que disminuye el grosor de la veta de carbón.

El término hidrología se refiere a la cantidad de agua presente en el carbón y en la capa de cobertura. Cantidades importantes de agua afectan a la estabilidad, y la necesidad de bombeo aumenta los costes.

El volumen de las reservas de carbón y la magnitud de la explotación influye en el tipo de equipo que debe utilizarse. Las minas pequeñas requieren equipos más reducidos y relativamente más caros, mientras que las minas grandes permiten las economías de escala y presentan costes menores por unidad de explotación.

Por características ambientales se entiende el comportamiento de la capa de cobertura una vez explotada. Algunas capas de cobertura son "acidificantes", lo que significa que, cuando quedan expuestas al aire y al agua, producen ácido que daña el medio ambiente, por lo que requieren un tratamiento especial. 
Los factores anteriores, además otros no mencionados, determinan el método de minería y el equipo adecuados para una determinada mina de carbón a cielo abierto.

\section{El ciclo de la mina}

La metodología de las minas de carbón a cielo abierto puede dividirse en las fases siguientes:

La eliminación de la capa superficial del suelo y su almacenamiento o vertido en zonas de rehabilitación es una parte importante del ciclo, ya que el objetivo es devolver el terreno a una situación como mínimo equivalente a la que existía antes de iniciar la explotación. La capa superficial del suelo es un elemento importante pues contiene nutrientes para las plantas.

En la preparación del terreno pueden utilizarse explosivos para fragmentar las rocas de gran tamaño. En algunos casos esta operación la realizan aplanadoras con disgregadores mecánicos para fragmentar la roca en elementos más pequeños. En minas donde la dureza de la roca es baja no es necesario preparar el terreno, ya que la excavadora puede trabajar directamente en el frente de ataque.

La eliminación de residuos consiste en arrancar la roca situada encima de la veta de carbón y transportarla al vertedero. En una mina a cielo abierto que tenga el vertedero en las proximidades, esta operación es secundaria. Sin embargo, en algunas minas, el vertedero puede encontrarse a varios kilómetros de distancia debido a la estructura de la veta de carbón, por lo que resulta necesario acarrear hasta allí el material en camiones o cintas transportadoras.

La extracción del carbón consiste en arrancar el carbón del frente de la mina y acarrearlo fuera del pozo. El siguiente paso depende de la situación del mercado del carbón y de su uso final. Si hay que enviarlo a una estación eléctrica en la propia mina, se machaca y envía directamente a la caldera. Si el carbón es de baja calidad, puede mejorarse con un "lavado" en una planta de preparación, donde se separa el carbón de la capa de cobertura para obtener un producto de mayor calidad. Antes de enviarlo al mercado suele ser necesario triturarlo para que su tamaño sea uniforme y mezclarlo para controlar la calidad. El carbón puede acarrearse en camión, cinta transportadora, tren o barco.

La rehabilitación es la operación que se realiza en el vertedero para restaurar el terreno y cumplir los criterios de drenaje, volviendo a colocar la capa superficial de suelo y la vegetación para devolver al terreno su aspecto original. Otras consideraciones de tipo ambiental pueden ser:

- control del agua: desviación de cursos existentes de agua y control del agua de la mina mediante construcción de presas de sedimentación y reciclado de forma que no se vierta agua contaminada;

- planificación visual: para garantizar que el impacto visual sea mínimo;

- flora y fauna: para recuperar árboles y vegetación y devolver al terreno su fauna autóctona;

- arqueología: conservación y/o restauración de posibles lugares de interés cultural;

- vacío final: dar una utilidad al vacío resultante una vez cerrada la mina (p. ej., volverlo a llenar o convertirlo en un lago);

- explosiones de aire y vibraciones causadas por las voladuras, que deben realizarse con técnicas específicas si existen edificios en las proximidades,

- ruido y polvo, que han de controlarse para evitar molestias a los habitantes de las comunidades vecinas.

El impacto ambiental de las minas de carbón a cielo abierto puede ser importante, pero con una planificación y un control adecuados durante todas las fases de la explotación, es posible cumplir todos los requisitos.

\section{Métodos y equipos de minería}

Existen tres métodos básicos para explotar las minas de carbón a cielo abierto : el sistema de camiones y palas, el sistema de dragalinas y el sistema basado en cintas transportadoras (p. ej., excavadoras de rueda de cangilones o trituradoras dentro de la mina), aunque en muchas minas se utilizan combinados. Hay también técnicas especiales, como la de barrenado y la de pared continua, que sólo representan una pequeña parte de la explotación total de las minas a cielo abierto de carbón. Los sistemas de dragalina y de rueda de cangilones de draga fueron desarrollados específicamente para las minas de carbón a cielo abierto, mientras que los sistemas de camiones y palas se utilizan en toda la industria minera.

El método de minería de camiones y palas requiere una excavadora (pala de cable eléctrico, excavadora hidráulica o pala cargadora de ataque frontal) para cargar en los camiones la capa de cobertura. La capacidad de éstos puede oscilar entre 35 y 220 toneladas. El camión transporta la capa de cobertura desde el frente del tajo hasta la zona de vertidos, donde un aplanadora arrastra y amontona la roca de acuerdo con el esquema previsto de rehabilitación. La gran flexibilidad del método de camión y pala hace que sea el más utilizado en la mayoría de los países del mundo.

El método de dragalinas es uno de los más económicos para arrancar la capa de cobertura, pero su funcionamiento está limitado por el aguilón. La dragalina se balancea sobre un eje central, pudiendo arrojar el material al vertedero a una distancia aproximada de $100 \mathrm{~m}$ de su posición. Para su utilización es necesario que la mina esté diseñada con franjas de extracción largas y estrechas.

La principal limitación de la dragalina es que sólo puede extraer la capa de cobertura hasta una profundidad de unos $60 \mathrm{~m}$; para profundidades mayores hay que utilizar un sistema suplementario, como una flota de camiones y palas.

Los sistemas de minería basados en cintas transportadoras utilizan, como su nombre indica, cintas transportadoras en lugar de camiones para acarrear la capa de cobertura. Si ésta es de baja dureza puede arrancarse directamente en el frente con una excavadora de rueda de cangilones. Este método se dice que es "continuo" porque arranca la capa de cobertura y el carbón de forma ininterrumpida, mientras que las dragalinas y las palas operan de forma cíclica, cargando cada cangilón en 30-60 segundos. Las capas de cobertura más duras hay que tratarlas con una combinación de técnicas de voladura o trituración dentro de la mina y de carga con palas para introducir el material en la cinta transportadora. Este tipo de sistema está especialmente indicado cuando la capa de cobertura debe transportarse a grandes distancias o a gran altura.

\section{Conclusión}

La minería superficial del carbón requiere la utilización de equipos y técnicas especiales para arrancar grandes volúmenes de residuos y de carbón en zonas amplias. La rehabilitación de las minas es una parte fundamental del proceso global.

\section{PROCESAMIENTO DEL MINERAL}

Sydney Allison

Casi todos los metales y algunos materiales inorgánicos explotados en minas están integrados en compuestos que forman la 
corteza terrestre. Los procesos que han conformado la superficie terrestre han ido concentrando estos minerales en cantidades muy diferentes. Cuando su concentración es suficientemente importante y permite que el mineral sea explotado y recuperado de forma rentable, el depósito se denomina yacimiento. Sin embargo, aun en este caso, los minerales no suelen encontrarse con la pureza necesaria para que su procesamiento sea inmediato y se pueda obtener el producto final deseado. En su obra sobre la minería en el siglo XVI, Agricola afirmaba que: "La naturaleza normalmente crea metales en un estado impuro, mezclados con tierra, piedras y líquidos solidificados, por lo que resulta necesario separar al máximo el mineral de estas impurezas antes de fundirlos".

Primero, hay que separar los minerales valiosos de los que no tienen valor comercial, que reciben el nombre de ganga. Por procesamiento del mineral se entiende este tratamiento inicial del material extraído con el fin de obtener un mineral concentrado de una calidad suficientemente alta para que pueda ser procesado satisfactoriamente hasta obtener el metal puro u otro producto final. Las diferentes características de los minerales presentes permiten separarlos utilizando métodos físicos que no modifican, por lo general, la composición química del mineral (el procesamiento del carbón se estudia de forma específica en el artículo "Preparación del carbón".)

\section{Trituración y molienda}

El tamaño de partícula del material que llega a la planta de procesamiento dependerá del método utilizado y del tipo de mineral de que se trate, pero en cualquier caso siempre será relativamente grande. La conminución o reducción progresiva del tamaño de partícula del mineral se realiza por dos razones: para reducir el material a un tamaño más adecuado y para separar el componente valioso del material residual como primer paso hacia su recuperación efectiva. En la práctica, la conminución va seguida de la trituración del material en tambores giratorios de acero hasta obtener partículas más finas.

\section{Trituración}

No es posible pasar de trozos muy grandes a partículas finas en una sola operación o utilizando una única máquina. La trituración es normalmente una operación en seco que se suele realizar en fases (primaria, secundaria y terciaria).

En la trituración primario se reducen los trozos de mineral de 1,5 m a 100-200 mm. Las máquinas, como las trituradoras de mandíbulas y las trituradoras giratorias, aplican una fuerza de fragmentación a las partículas de mayor tamaño que rompe el mineral por compresión.

En una trituradora de mandíbulas el mineral cae en un espacio en forma de cuña entre una placa fija y otra móvil. El material que entra se comprime hasta que se rompe. La operación se vuelve a repetir abriendo y cerrando las mandíbulas hasta que finalmente el material puede escapar por la abertura del fondo.

En la trituradora giratoria, un largo vástago soporta un elemento cónico de acero de gran peso que se mueve de forma excéntrica mediante un casquillo inferior de cojinete dentro de la cámara de la trituradora y que realiza la función de fragmentación. El movimiento relativo de los planos de trituración se produce mediante el giro del cono excéntrico contra la cámara externa. Normalmente, esta máquina se utiliza en minas de gran capacidad de producción.

En la trituración secundario se reduce el tamaño de las partículas hasta 5-20 mm. Los principales tipos de trituradoras son la de conos, la de cilindros y la de martillos. La trituradora de conos es una máquina giratoria con un vástago más corto que no está suspendido sino apoyado sobre un soporte debajo del cabezal. La trituradora de cilindros consta de dos cilindros horizontales que giran en sentido inverso, arrastran el mineral hacia su estrechamiento y después de una sola pasada descargan el producto. La trituradora de martillos es un dispositivo típico de impacto. La conminución se realiza mediante el impacto de los martillos, que están sujetos a un rotor dentro del espacio de trabajo y que golpean el material a gran velocidad.

\section{Molienda}

La molienda, última fase de la conminución, se realiza en recipientes giratorios cilíndricos de acero denominados tambores. Estos aparatos reducen las partículas de mineral a un tamaño de 10 a $300 \mathrm{~mm}$. A los tambores se añade un agente de molienda, que pueden ser bolas de acero, varillas o trozos de mineral de tamaño prefijado y mucho más grandes que el material a granel alimentado, de forma que el mineral se va partiendo hasta alcanzar el tamaño deseado y en este caso el proceso recibe el nombre de molienda autógena. A veces se utiliza la molienda directa en la mina (ROM), que es una forma de molienda autógena en la que el mineral pasa directamente de la mina al equipo de molienda sin realizar un trituración previo, pues los trozos grandes de mineral actúan como agente de molienda.

El molino se carga, por lo general, hasta la mitad de su capacidad con mineral machacado y un agente de molienda. Estudios realizados han demostrado que este tipo de trituración es una combinación de sistemas de impacto y abrasión. En estos equipos se utilizan recubrimientos para evitar el desgaste de la cubeta, reducir el deslizamiento de los agentes de molienda y mejorar la relación entre la elevación y el impacto de la operación.

Existe un tamaño óptimo hasta el cual es necesario triturar el material para conseguir una separación y una recuperación efectiva del componente valioso, pues una trituración deficiente daría lugar a una liberación incompleta y a una recuperación baja, mientras que una molienda excesiva dificultaría la separación además de suponer un gasto excesivo de energía.

\section{Separación por tamaños}

Después de realizadas las operaciones de trituración y molienda, los productos se separan por tamaños con el fin de obtener un material de tamaño adecuado para su tratamiento posterior. El material demasiado grande se recicla hasta alcanzar una reducción mayor.

\section{Cribado}

El cribado se aplica, por lo general, para separar materiales bastante gruesos. También puede utilizarse para conseguir un tamaño uniforme del material para un tratamiento posterior. El cribón está formado por una serie de pesadas barras paralelas sujetas por un marco para cribar materiales muy gruesos. El tromel es una criba cilíndrica inclinada giratoria. Utilizando cribas con secciones de diferente tamaño pueden obtenerse simultáneamente productos de varios tamaños.

\section{Clasificadores}

La clasificación es la separación de partículas de acuerdo con su velocidad de sedimentación en un fluido, para lo que se utilizan de forma efectiva las diferencias de densidad, tamaño y forma. Los clasificadores se utilizan para separar el material grueso del fino, obteniendo una gran distribución de tamaños. Los clasificadores se suelen emplear en operaciones de molienda de circuito cerrado. Aunque el objetivo principal es la separación por tamaños, normalmente se produce al mismo tiempo cierta separación por tipos de minerales a causa de la diferencia de densidad. 
En los clasificadores de espiral, un mecanismo de rastrillo levanta las arenas más gruesas de un estanque de fangos de lavado para obtener un producto desenfangado.

En el hidrociclón se utiliza la fuerza centrífuga para acelerar la velocidad de sedimentación y producir una separación eficiente de las partículas finas. Los fangos de lavado se introducen en un recipiente cónico que gira a gran velocidad tangencial. Debido al movimiento de giro, el sedimento más rápido, es decir, las partículas mayores y más pesadas se desplazan hacia la pared exterior donde la velocidad es menor y se sedimentan, mientras que las partículas más ligeras y pequeñas se desplazan hacia la zona de baja presión a lo largo del eje, donde son arrastradas hacia arriba.

\section{Separación por concentración}

Se trata de separar las partículas del mineral valioso de las partículas de ganga para obtener como resultado un concentrado y un producto residual. El objetivo es conseguir una recuperación máxima del mineral valioso con una calidad aceptable para su posterior procesamiento o venta.

\section{Clasificación del mineral}

El método más antiguo y sencillo de separación por concentración es la selección visual y la separación manual de las partículas. La clasificación manual ha sido sustituida por una serie de métodos electrónicos. En los métodos fotométricos, las partículas se separan por la diferente reflectancia de los minerales. A continuación, una explosión de aire comprimido sirve para sacar el material de la cinta móvil. Un proceso análogo puede aplicarse teniendo en cuenta las diferentes conductividades de los minerales.

\section{Separación en medio pesado}

La separación en medio pesado o denso es un proceso que depende exclusivamente de la diferente densidad de los minerales. Se introduce la mezcla de minerales en un líquido cuya densidad se encuentre entre las de los dos minerales que se desea separar. El material más ligero flotará y el más pesado se sedimentará. En algunos procesos se utiliza este método para la clasificación previa de los minerales antes de la trituración final y se emplea con frecuencia como una fase de lavado en la preparación del carbón.

En ciertas aplicaciones, se utilizan fluidos orgánicos pesados como el tetrabromoetano, con una densidad relativa de 2,96, pero a escala comercial se usan normalmente suspensiones de sólidos finamente triturados que se comportan como simples fluidos newtonianos, como la magnetita y la ferrosilicona, que forman "fluidos" estables, inertes y de baja viscosidad y son fácilmente separables de la suspensión por medios magnéticos.

\section{Fuerza de gravedad}

Los procesos de separación natural, como los sistemas fluviales, producen depósitos de aluvión en donde las partículas mayores y más pesadas se separan de las más pequeñas y ligeras. Las técnicas basadas en la fuerza de la gravedad imitan a estos procesos naturales. La separación se consigue por el equilibrio entre el peso de la partícula y la resistencia ejercida por el fluido en el que tiene lugar la separación.

A lo largo de los años se han ido desarrollando diversos tipos de separadores por gravedad, cuyo uso continuo refleja la buena relación coste/efectividad de este tipo de separación.

En una criba hidráulica se suspende ("fluidifica") un lecho de partículas de mineral mediante una corriente pulsante de agua. A medida que el agua drena entre cada ciclo, las partículas más densas caen por debajo de las menos densas y, durante un período de drenaje, las partículas pequeñas (y especialmente las partículas más densas y más pequeñas) penetran en los espacios entre las partículas más grandes y se sedimentan en el lecho. $\mathrm{Al}$ repetir el ciclo, aumenta el grado de separación.

En las mesas de agitación se trata material más fino que en las cribas hidráulicas. La mesa consta de una superficie plana que se balancea ligeramente en sentido longitudinal y transversal. Unos separadores de madera dividen la mesa en sentido longitudinal en ángulo recto. El mineral entra a lo largo del extremo superior y las partículas son arrastradas hacia abajo por el flujo de agua al tiempo que se someten a vibraciones asimétricas a lo largo del eje longitudinal u horizontal. Las partículas más densas, que tienden a quedar atrapadas detrás del separador, se distribuyen por la mesa a causa de las vibraciones.

\section{Separación magnética}

Todos los materiales se ven afectados por los campos magnéticos, aunque en la mayoría de los casos su efecto es demasiado débil para detectarse. Ahora bien, si uno de los componentes minerales de una mezcla presenta una susceptibilidad magnética fuerte, puede utilizarse para separarlo de los demás. Los separadores magnéticos se clasifican en aparatos de baja o alta intensidad y en separadores secos o húmedos.

Un separador de tipo tambor consta de un tambor giratorio no magnético que en su interior contiene imanes estacionarios de polaridad alternante. Las partículas magnéticas al ser atraídas por los imanes se adhieren al tambor y son lanzadas fuera del campo magnético. Un separador húmedo de alta intensidad (WHIMS) tipo carrusel consta de una matriz concéntrica giratoria de bolas de hierro que pasa a través de un fuerte electroimán. Los residuos de fango de lavado se vierten en la matriz donde actúa el electroimán y seguidamente las partículas magnéticas son atraídas hacia la matriz imantada mientras que el grueso de la mezcla pasa y sale por una rejilla de base. Justo después del electroimán, el campo se invierte y mediante una corriente de agua se elimina la fracción magnética.

\section{Separación electrostática}

La separación electrostática, que se utilizaba antiguamente de forma habitual, ha sido sustituida en gran medida por el sistema de flotación (véase más adelante). Sin embargo, se aplica con éxito a algunos minerales (rutilo, etc.) a los que resulta dificil aplicar otros métodos pero cuya conductividad permite la separación electrostática.

Este método se basa en las diferencias de conductividad eléctrica de los minerales. Se introduce mineral seco en el campo de un electrodo ionizante y se cargan las partículas mediante bombardeo de iones. Las partículas conductoras pierden rápidamente esta carga pasándola a un rotor con toma de tierra y son despedidas por la fuerza centrífuga. Las partículas no conductoras pierden su carga más lentamente, permaneciendo adheridas a la toma de tierra por la fuerza electrostática, para ser enviadas a un punto de recogida.

\section{Flotación}

La flotación es un proceso de separación que se basa en las diferencias en las propiedades superficiales físicoquímicas de los minerales.

En este proceso se añaden a la pulpa unos reactivos químicos denominados colectores que reaccionan de forma selectiva con la superficie de las partículas del mineral valioso. Los productos de reacción que se forman convierten la superficie del mineral en hidrófoba o impermeable, de forma que se adhiere fácilmente a una burbuja de aire.

En cada celda de un circuito de flotación se agita la pulpa; así, el aire que se ha introducido se dispersa en el sistema. Las partículas de mineral hidrófobo se adhieren a las burbujas de aire y, si 
hay presente un agente espumante adecuado, forman una espuma estable en la superficie que rebasa continuamente los laterales de la celda de flotación arrastrando consigo la carga de mineral.

Una planta de flotación está formada por bancos de celdas interconectadas. El concentrado obtenido en el primer banco se puede seguir limpiando de los componentes indeseados de ganga en un segundo banco más limpio e incluso, en caso necesario, en un tercer banco de celdas. El mineral valioso puede ser depurado en un cuarto banco y reciclado en bancos más limpios antes del descarte final de los residuos.

\section{Deshidratación}

Tras la mayoría de las operaciones suele ser necesario eliminar el agua utilizada en los procesos de separación del concentrado de la ganga residual. En entornos secos, esta operación resulta de especial interés porque permite reciclar el agua.

Un tanque de sedimentación consta de un recipiente cilíndrico donde se alimenta la pulpa en el centro a través de un alimentador que se coloca por debajo de la superficie para interferir al mínimo con los sólidos sedimentados. El líquido aclarado rebasa por los laterales del tanque y cae en una artesa. Unas aspas radiales con cuchillas rastrillan los sólidos sedimentados hacia el centro, donde son retirados. Pueden añadirse a la suspensión floculantes para acelerar la velocidad de sedimentación de los sólidos.

El proceso de filtración consiste en separar las partículas sólidas del fluido y obtener una pasta de concentrado que pueda ser secada y transportada. Para ello se suele utilizar un filtro de vacío continuo, como el filtro de tambor. En este aparato, un tambor cilíndrico horizontal gira en un tanque abierto con su sección inferior sumergida en la pulpa. La parte exterior del tambor consta de una serie de compartimientos cubiertos por un filtro y la parte interior de doble pared está conectada a un mecanismo de válvula en el eje central que permite aplicar el vacío o una determinada presión. Cuando se aplica el vacío a la sección sumergida en la pulpa pasa agua a través del filtro y se forma una pasta de concentrado en el tejido. El vacío deshidrata la pasta una vez que está fuera de los fangos de lavado. Justo antes de que la sección vuelva a entrar en estos fangos, se aplica presión para extraer la pasta. Los filtros de disco, formados por una serie de discos sujetos al eje central, funcionan con el mismo principio.

\section{Eliminación de los relaves}

Sólo una pequeña parte del mineral extraído contiene mineral valioso. El resto es la ganga que después del procesamiento da lugar a los relaves que hay que eliminar.

Los dos aspectos principales en la eliminación de los relaves son la seguridad y la economía. Con respecto a la seguridad, hay que tener en cuenta dos aspectos: las consideraciones físicas relativas al vertedero o presa donde se van a verter los relaves y la contaminación causada por el material residual, que puede afectar a la salud humana y causar daños al medio ambiente. Los relaves deben eliminarse de la forma más rentable posible pero respetando siempre las normas de seguridad.

Por lo general, los relaves se clasifican por tamaños, y la fracción arenosa gruesa se utiliza para construir la presa en el lugar elegido. La parte fina o fango se bombea en el embalse formado por el muro de la presa.

Cuando las aguas residuales contienen productos químicos tóxicos como cianuro, hay que acondicionar especialmente la base de la presa (p. ej., recubriéndola con un laminado plástico) para evitar la posible contaminación de las aguas subterráneas.

Siempre que sea posible, el agua de la presa se reciclará para un uso posterior, operación que puede ser de gran importancia en las regiones secas y que cada vez es más exigida por las legislaciones para evitar la contaminación de las aguas subterráneas y superficiales a causa de sustancias químicas.

\section{Lixiviación en montón y lixiviación in situ}

Gran parte del concentrado obtenido tras el procesamiento del mineral se sigue procesando con métodos hidrometalúrgicos. La parte de metal valioso se separa del mineral mediante lixiviación o disolución y después se separan entre sí los diferentes metales. Las soluciones obtenidas se concentran y el metal se recupera con métodos como la precipitación o la deposición electrolítica o química.

Muchos minerales presentan una calidad demasiado baja para justificar su concentración previa. El material residual también puede contener cierta cantidad de metal valioso, por lo que en algunos casos se reprocesa de forma rentable mediante un método hidrometalúrgico conocido como lixiviación en montón, que ya se utilizaba en las minas de Río Tinto en España hace más de 300 años. En estas minas, el agua que se filtraba lentamente a través de montones de mineral de baja calidad adquiría un color azulado por las sales de cobre en disolución procedentes de la oxidación del mineral. El cobre se recuperaba de la solución mediante precipitación sobre recortes de hierro.

Este proceso básico se utiliza actualmente en todo el mundo para la lixiviación en montón de óxidos y sulfuros de baja calidad y de material residual. Una vez creado un montón o un vertedero de material, se aplica el agente solubilizante adecuado (p. ej., una solución ácida) mediante rociado o inundación de la parte superior del montón y seguidamente se recupera la solución que se filtra por la base del mismo.

Aunque hace ya tiempo que se viene practicando con éxito la lixiviación en montón, hasta hace poco no se conocía el importante papel que desempeñan ciertas bacterias en este proceso. Las bacterias identificadas han sido la especie oxidante del hierro Thiobacillus ferrooxidans y la oxidante del azufre Thiobacillus thiooxidans. En el primer caso, la energía procede de la oxidación de los iones ferrosos a férricos y, en el segundo, de la oxidación de sulfuros a sulfatos. Estas reacciones catalizan de forma efectiva la oxidación acelerada de los sulfuros metálicos a los sulfatos metálicos solubles.

La lixiviación in situ, denominada a veces minería por disolución, es una variante de la lixiviación en montón y consiste en bombear la solución a minas abandonadas, obras hundidas, áreas remotas abandonadas o incluso yacimientos enteros en los que se ha comprobado su permeabilidad a la solución. Las formaciones rocosas tienen que permitir el contacto con la solución de lixiviación, y también es necesario disponer de oxígeno.

\section{PREPARACION DEL CARbON}

Anthony D. Walters

La preparación del carbón es el proceso por el cual el carbón en bruto extraído de la mina se convierte en un producto limpio y comercializable de tamaño coherente y calidad especificada por el consumidor. Los usos finales del carbón se agrupan en las siguientes categorías generales:

- generación de electricidad: el carbón se quema para suministrar el calor necesario y mover turbinas generadoras de electricidad;

- fabricación de hierro y acero: el carbón se somete a combustión en hornos, en ausencia de aire, con emisión de gases (materia volátil) para producir coque que se utiliza en los altos hornos en la fabricación de hierro y acero. También puede añadirse 
directamente el carbón a los altos hornos como en el proceso de inyección de carbón triturado (PIC);

- fines industriales: el carbón se utiliza en la industria metalúrgica como reductor, y su contenido en carbono se utiliza para eliminar el oxígeno (reducción) en los procesos metalúrgicos;

- calefacción: el carbón puede utilizarse en los hogares y en la industria como combustible para calentar recintos. También se utiliza como combustible en hornos de secado para fabricar cemento.

\section{Trituración y fragmentación}

El carbón extraído de la mina debe triturarse hasta alcanzar un tamaño máximo aceptable para su tratamiento en la planta de preparación. Para ello, se utilizan los mecanismos siguientes:

- fracturador de alimentación: consta de un tambor giratorio provisto de picos para fragmentar el carbón. Un transportador de cuchara se encarga de la alimentación de carbón y el tambor gira en la misma dirección que el flujo de éste. Se utiliza, por lo general, en el interior de la mina y a veces también en la superficie como parte del circuito de preparación del carbón;

- fracturador giratorio: es un circuito de fragmentación que consta de una cubeta externa fija y un tambor interno giratorio con placas perforadas. La velocidad típica de rotación del tambor es de 12-18 rpm. Unas placas elevadoras recogen el carbón extraído de la mina para descargarlo en la sección del tambor. $\mathrm{Al}$ caer, el carbón más blando se rompe y pasa a través de las perforaciones mientras que la roca más dura es enviada a la salida. Este equipo realiza dos funciones: reducción del tamaño y limpieza mediante la eliminación del material de roca;

- trituradora de cilindros: puede estar formada por un solo tambor giratorio y una placa fija o por dos cilindros que giran a la misma velocidad y en sentidos opuestos. Las superficies de los cilindros están normalmente dentadas o acanaladas. Una forma habitual de trituradora es el equipo de dos fases o trituradora de cuatro cilindros; aquí, el producto que sale de la primera trituradora cae a una segunda que presenta una abertura menor, lográndose así una reducción a gran escala en una sola máquina, como la trituración del material extraído de la mina a $50 \mathrm{~mm}$.

La trituración se utiliza a veces después del proceso de lavado del carbón para fragmentar las piezas de gran tamaño y ajustarlas a los requisitos del mercado. Las trituradoras de cilindros o de martillo son las más utilizadas y están formadas por una serie de martillos que se balancean y giran libremente en un pozo golpeando el carbón y lanzándolo contra una placa fija.

\section{Clasificación por tamaños}

El carbón se clasifica por tamaños antes y después del proceso de lavado. Para ello, se utilizan diferentes procedimientos dependiendo del tamaño del carbón; así, el carbón en bruto al entrar en la planta de preparación pasa por cribas de tres o cuatro tamaños antes de llegar al proceso de lavado adecuado. El cribado se realiza, por lo general, con cribas vibratorias rectangulares que disponen de una malla o una placa perforada. Para tamaños inferiores a $6 \mathrm{~mm}$ se emplea el cribado húmedo, que resulta más eficiente, y, para tamaños inferiores a $0,5 \mathrm{~mm}$, se coloca una criba curva estática (criba de barras curvadas) antes de la pantalla vibratoria, también con el fin de aumentar la eficiencia.

Después del proceso de limpieza, a veces se clasifica el carbón mediante separación de determinados productos para los mercados industriales y domésticos. La clasificación por tamaños casi no se utiliza para el carbón destinado a la generación de electricidad (carbón térmico) o a la fabricación de acero (carbón metalúrgico).

\section{Almacenamiento}

Por lo general, el carbón se almacena en tres puntos de la cadena de preparación y tratamiento:

1. almacenamiento del carbón bruto entre la mina y la planta de preparación;

2. almacenamiento del carbón lavado entre la planta de preparación y el punto de carga en vagonetas o camiones,

3. almacenamiento del carbón lavado en puertos que pueden estar o no controlados por la mina.

Habitualmente, después de la trituración, el almacenamiento del carbón bruto se realiza en montones a la intemperie (cónicos, alargados o circulares), silos (cilíndricos) o carboneras. En esta fase, se suele realizar el mezclado de capas de carbón para suministrar un producto homogéneo a la planta de preparación. El mezclado puede ser una operación tan sencilla como depositar de forma secuencial distintos carbones en un montón cónico o una operación más compleja, en la que intervengan transportadores apiladores y equipos de rueda de cangilones de carga.

El carbón lavado puede almacenarse en montones a la intemperie o en silos. El sistema de almacenamiento del carbón lavado debe permitir una carga rápida de los vagones o camiones. Los silos de carbón lavado se construyen normalmente junto a una vía férrea, de forma que trenes de hasta 100 vagones puedan pasar lentamente por debajo del silo para ir cargando los vagones hasta un peso determinado. Normalmente, el pesaje se realiza en movimiento para mantener un funcionamiento continuo.

Existen diferentes peligros derivados del almacenamiento del carbón. Al ser los montones inestables, debería estar prohibido andar sobre los mismos por el peligro de hundimiento interno y, además, porque los trabajos de recogida pueden iniciarse sin previo aviso. Los atascos o bloqueos en la limpieza en las carboneras o silos deben tratarse con el máximo cuidado, ya que el carbón aparentemente estable puede resbalar de forma imprevista.

\section{Lavado del carbón}

El carbón bruto contiene materiales que van desde el carbón "puro" hasta roca con variadas incrustaciones de densidades relativas comprendidas entre 1,30 y 2,5. El carbón se limpia separando el material de baja densidad (producto comercial) del de alta densidad (residuo). La densidad de separación depende de la naturaleza del carbón y de los requisitos de calidad del carbón lavado. Es imposible separar el carbón fino sobre la base de su densidad; para separar el carbón bruto de $0,5 \mathrm{~mm}$, se emplean procesos basados en las distintas propiedades superficiales del carbón y la roca. El método más habitual es el de flotación por espuma.

\section{Separación sobre la base de la densidad}

Existen dos métodos básicos. En el primero, se mueve el carbón bruto en el agua de forma que el carbón más ligero presenta una mayor aceleración que la roca más pesada. El segundo método consiste en introducir el carbón bruto en un líquido con una densidad intermedia entre la del carbón y la de la roca, de forma que el carbón flota y la roca se hunde.

Los sistemas basados en el agua son los siguientes:

- cribas hidráulicas: el carbón bruto se introduce en un baño pulsante de agua y se desplaza a través de una placa perforada con agua pulsante a través de ella, formándose un lecho estratificado de material con la roca más pesada en el fondo y el carbón más ligero en la parte superior. En el extremo de descarga se retira el residuo del carbón lavado. Los tamaños de 
material que se suelen tratar con una criba hidráulica oscilan entre $75 \mathrm{~mm}$ y $12 \mathrm{~mm}$. Existen cribas hidráulicas especiales que utilizan un lecho artificial de roca de feldespato;

- mesas concéntricas: constan de una placa de goma con separadores sobre un soporte conectado a un mecanismo de cabeza que origina un movimiento rápido alternativo en dirección paralela a los separadores. La pendiente lateral de la mesa es ajustable. A continuación, se produce un flujo cruzado de agua mediante una artesa montada en la parte superior de la placa y, al entrar el carbón justo delante del agua, es distribuido por toda la placa de la mesa por un movimiento diferencial y por la fuerza de la gravedad. Las partículas de carbón bruto se estratifican en capas. El carbón lavado rebasa el lateral inferior de la mesa y el residuo es extraído por el extremo opuesto. El sistema de mesas se utiliza para una gama de tamaños de $5 \times 0,5 \mathrm{~mm}$;

- espirales: las partículas finas de carbón bajan por una espiral en una corriente de agua y la fuerza centrífuga empuja a las partículas más ligeras de carbón hacia el exterior de la corriente y a las partículas más pesadas hacia el interior de la misma. Un mecanismo en el extremo de descarga separa el carbón fino del residuo. Las espirales se utilizan para lavar fracciones de $2 \mathrm{~mm}$ '0,1 mm;

- ciclones sólo de agua: el carbón bruto transportado por el agua se envía tangencialmente bajo presión a un ciclón, donde el efecto de remolino y la fuerza centrífuga desplazan el material más pesado hacia el lateral del ciclón, desde donde es transportado al flujo inferior en el ápice (o espiga). Las partículas más ligeras (carbón) permanecen en el centro del vórtice del remolino y son extraídas por la parte superior a través de un tubo (visor del vórtice) al flujo superior. La densidad exacta puede ajustarse variando la presión, la longitud y el diámetro del visor del vórtice y el diámetro del ápice. El ciclón sólo de agua se utiliza con materiales de una gama de tamaños de $0,5 \mathrm{~mm}$ '0,1 mm y habitualmente su funcionamiento se realiza en dos fases para mejorar la eficiencia de separación.

El segundo tipo de separación por densidad utiliza un medio pesado. En un líquido pesado (medio denso), las partículas con una densidad inferior a la del líquido (carbón) flotarán y las que presentan una densidad superior (roca) se hundirán. El medio denso más utilizado a escala industrial es una suspensión finamente molida de magnetita en agua, que presenta muchas ventajas como el que:

- la mezcla sea inofensiva, en comparación con los fluidos inorgánicos y orgánicos;

- la densidad pueda ajustarse rápidamente variando la relación magnetita/agua,

- la magnetita pueda reciclarse fácilmente mediante separación magnética.

Existen dos tipos de separadores de medio denso: el separador tipo baño para carbón grueso de una gama de tamaños de $75 \mathrm{~mm}$ ' $12 \mathrm{~mm}$, y el separador tipo ciclón para tamaños de carbón de $5 \mathrm{~mm} \times 0,5 \mathrm{~mm}$.

En los separadores tipo baño, que pueden ser profundos o poco profundos, el material flotante se extrae por el lateral del baño y el material hundido se retira del fondo mediante una cadena de palas de carga o una rueda de paletas.

El separador tipo ciclón suma la fuerza centrífuga a la de la gravedad. La aceleración centrífuga es unas 20 veces superior a la de la gravedad y actúa sobre las partículas en el separador de baño (esta aceleración es unas 200 veces superior a la aceleración de la gravedad en el ápice del ciclón). Estas fuerzas confieren al ciclón su alto rendimiento y su capacidad para tratar trozos de carbón pequeños.
Los productos obtenidos en los separadores de medio denso, es decir, el carbón lavado y los residuos, pasan a través de rejillas de desagüe y de enjuague donde se elimina el medio magnético, que se devuelve a los separadores. La magnetita diluida de las pantallas de enjuague se pasa por unos separadores magnéticos para su recuperación y uso posterior. Los separadores magnéticos constan de cilindros giratorios de acero inoxidable con imanes cerámicos fijos montados sobre el eje del tambor estacionario. El tambor se sumerge en un tanque de acero inoxidable que contiene la suspensión de magnetita diluida. Al girar el tambor, la magnetita se adhiere a la zona próxima a los imanes internos fijos. La magnetita se traslada fuera del baño y del campo magnético y es retirada de la superficie del tambor con una pala de carga y enviada a un tanque de almacenamiento.

En las plantas de preparación de carbón se utilizan calibradores nucleares de densidad y analizadores nucleares de corriente. Por ello, deben observarse las precauciones aplicables a los equipos emisores de radiaciones.

\section{Flotación por espuma}

La flotación por espuma es un proceso físico-químico basado en la adherencia selectiva de las burbujas de aire a la superficie de las partículas de carbón y en la no adherencia a las partículas de desecho. Este proceso requiere la utilización de reactivos adecuados para formar una superficie hidrófoba (repelente del agua) en los sólidos que flotan. Las burbujas de aire se generan dentro de un tanque (o celda) y a medida que van subiendo a la superficie, las partículas finas de carbón recubiertas con reactivo se adhieren a la burbuja, permaneciendo los residuos en el fondo de la celda. La espuma de carbón se elimina de la superficie mediante paletas y seguidamente se deshidrata mediante filtración o centrifugado. Los desechos (o relaves) pasan a un depósito de descarga y se espesan antes de bombearlos a un estanque de embalsado de relaves.

Los reactivos más utilizados en la flotación por espuma del carbón son los espumantes y los reactivos de adherencia. Los espumantes se emplean para facilitar la creación de una espuma estable (es decir, que no se deshace). Hay productos químicos que reducen la tensión superficial del agua. El espumante más utilizado para la flotación del carbón es el metilisobutilcarbinol (MIBC). Por otro lado, la función de un reactivo de adherencia es mejorar el contacto entre las partículas de carbón y las burbujas de aire formando una capa fina alrededor de las partículas que tienen que flotar, impermeabilizándolas. Al mismo tiempo, el reactivo de adherencia debe ser selectivo, es decir, no debe recubrir las partículas que no tienen que flotar (residuos). El reactivo de adherencia más utilizado para la flotación del carbón es el fueloil.

\section{Briquetado}

La historia de la briquetado del carbón es larga. A finales del decenio de 1800 se comprimió el carbón fino relativamente poco valioso obteniéndose una briqueta. Este producto fue aceptado tanto por el mercado doméstico como por el industrial. Para formar una briqueta estable había que utilizar un aglutinante y se recurrió a los alquitranes minerales y las breas. Ultimamente, la industria de briquetado del carbón para el mercado doméstico está en declive, aunque se han producido avances en su tecnología y aplicación.

Los carbones de alto contenido en humedad y baja calidad pueden mejorarse por secado térmico y eliminación de una parte de la humedad inherente o "incrustada". Sin embargo, el producto que se obtiene con este proceso es friable y tiende a reabsorber la humedad y a la combustión espontánea. El briquetado del carbón de baja calidad permite obtener un producto 
estable y transportable. Esta técnica se utiliza también en la industria de la antracita, donde los productos de mayor tamaño tienen un precio de venta bastante superior.

Las economías en desarrollo recurren a la briquetación del carbón para proporcionar combustible de uso doméstico a las áreas rurales. El proceso de fabricación de las briquetas comprende, por lo general, una fase de desvolatilización en la que se elimina el exceso de gas o de materia volátil antes de proceder a la briquetación y obtener un combustible doméstico que no produzca humo.

\section{El proceso de briquetación comprende las siguientes fases:}

- secado del carbón: el contenido de humedad es fundamental, ya que influye en el grado de dureza de la briqueta. Entre los métodos utilizados para el secado se encuentran el secado directo (secadora instantánea con gas caliente) y el secado indirecto (secador de disco con vapor caliente);

- desvolatilización: sólo es aplicable a carbones altamente volátiles y de baja calidad. El equipo utilizado es un alambique o una estufa de coque tipo colmena;

- trituración: a menudo se tritura el carbón porque con un tamaño de partícula menor se obtiene una briqueta más dura;

- aglutinantes: los aglutinantes son necesarios para proporcionar a la briqueta la dureza adecuada para resistir el manejo normal. Los tipos de aglutinantes más comunes son la brea de horno de coque, el asfalto de petróleo, el lignosulforato amónico y el almidón, y la cantidad que suele añadirse es la equivalente al 5-15 \% del peso. El carbón fino y el aglutinante se mezclan en un mezclador de arcillas o de paletas a alta temperatura;

- fabricación de briquetas: la mezcla carbón-aglutinante se introduce en una prensa de doble cilindro con superficie dentada. Puede variar la forma de las briquetas en función del tipo de indentación de los cilindros, aunque la forma más habitual es de tipo almohada. La presión aumenta la densidad aparente de la mezcla carbón-aglutinante en 1,5-3 veces;

- recubrimiento y endurecimiento: cuando se utilizan aglutinantes como el lignosulforato amónico o petróleo asfáltico es necesario realizar un tratamiento térmico a $300^{\circ} \mathrm{C}$ para endurecer las briquetas. La estufa para el tratamiento térmico es un aparato cerrado y calentado mediante gases calientes;

- enfriamiento y extinción con agua: la estufa de enfriamiento es un aparato cerrado con recirculación de aire para reducir la temperatura de la briqueta a las condiciones ambientales. Los gases desprendidos se recogen, depuran y descargan a la atmósfera. A veces se utiliza la extinción con agua para enfriar las briquetas.

La briquetación del carbón bituminoso blando con un alto contenido de humedad (60-70 \%) es un proceso algo diferente del descrito. La calidad de este tipo de carbón puede mejorarse mediante la briquetación, que comprende operaciones de trituración, cribado, secado del carbón hasta reducir la humedad a aproximadamente un $15 \%$ y compresión sin aglutinantes para formar un producto compacto. Con este método se tratan actualmente grandes cantidades de carbón en Alemania, India, Polonia y Australia. El secador utilizado es un sistema de tubo giratorio calentado por vapor. Después de la compresión por extrusión, el carbón compactado se corta y enfría antes de ser trasladado por cintas transportadoras a vagones, camiones o almacenes.

Las plantas de briquetación manejan grandes cantidades de material altamente combustible con mezclas potencialmente explosivas de polvo de carbón y aire. El control, la aspiración y el manejo del polvo así como un buen mantenimiento son factores fundamentales para un funcionamiento seguro.

\section{Eliminación de residuos y relaves}

La eliminación de residuos es un aspecto fundamental en las plantas modernas de preparación de carbón. Tanto los residuos gruesos como los relaves finos en forma de fangos de lavado deben ser transportados y eliminados de una forma ecológicamente responsable.

\section{Residuos gruesos}

Los residuos gruesos se transportan en camiones, cintas transportadoras o aviones hasta el vertedero de productos sólidos y con ellos se construyen normalmente los muros del embalse de relaves. Los residuos también pueden devolverse a la mina abierta.

Actualmente, se están utilizando formas innovadoras y rentables para transportar los residuos gruesos, como los procesos de trituración o el transporte mediante bombeo en forma de fangos de lavado hasta un embalse de vertidos o el sistema de transporte neumático hasta un almacén subterráneo.

El lugar de vertido debe disponer de una superficie de exposición mínima y, al mismo tiempo, de una buena estabilidad. Una estructura abierta por todos los laterales produce un mayor drenaje superficial, tiene más tendencia a formar fango en los cursos de agua próximos y presenta un mayor peligro de combustión espontánea. Para minimizar estos riesgos se necesita una mayor cantidad de material de recubrimiento, así como un mayor compactado y sellado. La opción ideal de vertido de residuos es la operación de llenado de valles.

Los embalses de residuos de las plantas de preparación pueden fallar por alguna de las razones siguientes:

- cimientos débiles;

- pendiente excesiva de la ladera por exceso de altura;

- control deficiente del agua y filtración del material fino a través del vertedero,

- control inadecuado del agua durante lluvias torrenciales.

Para reducir considerablemente los riesgos ambientales asociados al vertido de residuos de carbón pueden utilizarse las técnicas siguientes:

- drenaje desde el interior del montón de residuos;

- desviación del drenaje superficial;

- compactación de los residuos para minimizar la combustión espontánea,

- estabilización del montón de residuos.

\section{Relaves}

Los relaves (residuos sólidos finos en agua) suelen ser transportados a través de conducciones hasta una zona de embalse. Ahora bien, en algunos casos, esta operación no resulta aceptable desde el punto de vista ecológico y hay que realizar un tratamiento alternativo, como deshidratar los relaves en una prensa hidráulica o en una centrifugadora de alta velocidad para enviar el producto deshidratado en cintas transportadoras o camiones a la zona de vertidos gruesos.

En los embalses de relaves éstos se sedimentan en el fondo y el agua aclarada resultante se devuelve mediante bombeo a la planta para su posterior reutilización. La altura del embalse se mantiene reteniendo el agua de las tormentas y extrayéndola posteriormente por bombeo o con pequeños sistemas de trasvase. Periódicamente, puede ser necesario extraer el sedimento de los embalses más pequeños para ampliar su vida útil. El muro de contención del embalse se suele construir con residuos gruesos. Un diseño deficiente del muro o la liquefacción de los relaves por un drenaje deficiente pueden producir situaciones de riesgo. Para obtener un efecto de cementación se han utilizado agentes estabilizantes, como derivados químicos del calcio. 
Los embalses de relaves suelen ir cambiando a lo largo de la vida de la mina. Por esta razón, hay que supervisar de forma cuidadosa y continua la estabilidad de la estructura del embalse.

\section{- Control Del TERRENO EN LAS MINAS SUBTERRANEAS}

\section{Luc Beauchamp}

El principal objetivo del control del terreno es mantener la seguridad en las excavaciones de rocas y suelo (en las minas subterráneas y en las explotaciones a cielo abierto se utilizan los términos control de estratos y control de laderas, respectivamente). El control del terreno, que también se aplica mucho en proyectos de ingeniería civil como túneles, plantas hidroeléctricas y repositorios de residuos nucleares, se define como la aplicación práctica de la mecánica de rocas a la minería cotidiana. El US National Committee on Rock Mechanics ha propuesto la definición siguiente: "La mecánica de rocas es la ciencia teórica y práctica del comportamiento mecánico de las rocas y los estratos rocosos y es la rama de la mecánica que estudia la respuesta de rocas y lechos rocosos a los campos de fuerza de su entorno físico".

Los estratos rocosos muestran un comportamiento extremadamente complejo, por lo que desde el decenio de 1950 la mecánica de rocas y el control del terreno han sido objeto de numerosas investigaciones teóricas y prácticas en todo el mundo. En cierto modo, el control del terreno es más un arte que una ciencia. Requiere la comprensión de la geología estructural, de las propiedades de las rocas, de las aguas subterráneas y de los regímenes de tensión del terreno, así como de la forma en que interaccionan estos factores. Entre las herramientas disponibles a tal fin se encuentran los métodos de investigación del terreno y de prueba de rocas, las medidas para minimizar el daño causado al estrato rocoso por las voladuras, la aplicación de técnicas de diseño, y la supervisión y soporte del terreno. Ultimamente se han realizado importantes desarrollos relacionados con la mecánica de rocas y el control del terreno, como técnicas de diseño empírico y análisis por ordenador del trazado de minas, introducción y uso generalizado de instrumentos de supervisión del terreno y desarrollo de herramientas y técnicas especializadas de soporte al terreno. Muchas explotaciones mineras disponen de departamentos de control del terreno formados por ingenieros y técnicos especialistas.

Las minas subterráneas son más difíciles de abrir y mantener que las explotaciones a cielo abierto, por lo que es necesario dedicarles más recursos y esfuerzos de diseño para el control del terreno que a las segundas. En los métodos tradicionales de minería subterránea, como el de franjas-almacenes y el de corte y relleno, los trabajadores están directamente expuestos a un terreno potencialmente inestable en la zona de explotación. Cuando se utilizan métodos de minería no selectivos, como el barrenado, los trabajadores no entran a la zona de explotación. En las últimas décadas se aprecia una tendencia a sustituir los métodos selectivos por los no selectivos.

\section{Tipos de fallos del terreno}

Los principales factores de inestabilidad de las minas son su estructura y la tensión de la roca.

Un estrato rocoso está formado por roca intacta y por ciertas estructuras rocosas o discontinuidades estructurales. Entre los principales tipos de estructuras rocosas se encuentran los planos de estratificación (planos divisorios que separan los distintos estratos), los pliegues (de los estratos de roca), las fallas (fracturas por desplazamiento), las contravetas (intrusiones horizontales de roca ígnea) y las fisuraciones (fracturas de origen geológico a lo largo de las cuales no se ha producido un desplazamiento visible). Las propiedades de las discontinuidades estructurales que se enumeran a continuación afectan al comportamiento de los lechos rocosos: orientación, espaciado, persistencia, dureza, apertura y presencia de material de relleno. En una explotación minera, la recogida de la información estructural por parte de los ingenieros y geólogos es un elemento importante del programa de control del terreno. Actualmente, complejos programas informáticos permiten analizar los datos estructurales y la forma y estabilidad de las cuñas en minas a cielo abierto o subterráneas.

La tensión de la roca también puede ser una causa de inestabilidad en las minas, por lo que el conocimiento de la relación tensión-deformación de los lechos rocosos resulta fundamental para realizar un diseño de ingeniería adecuado. Las pruebas de laboratorio sobre muestras cilíndricas de roca procedentes de un núcleo de perforación pueden proporcionar información útil sobre la dureza y la deformabilidad de la roca intacta; cada tipo de roca se comporta de un modo diferente, desde la plasticidad de la sal hasta la elasticidad y la fragilidad de muchas rocas duras. La existencia de fisuras influirá de forma considerable en la dureza y la deformabilidad de todo el estrato rocoso.

Existen algunos tipos comunes de fallos de la ladera rocosa tanto en las minas a cielo abierto como en las canteras. El fallo de un bloque deslizante se produce cuando hay un desplazamiento a lo largo de una o más estructuras rocosas (fallos de corte de plano, paso escalonado, cuña, cuña escalonada o placa); el fallo de corte rotacional puede producirse en un suelo o en una ladera frágil del estrato rocoso; otros fallos pueden ser el vuelco de bloques formados por estructuras muy inclinadas y desmoronables (p. ej., desalojamiento de bloques por heladas o lluvias). Los principales fallos de ladera pueden tener consecuencias catastróficas, aunque la inestabilidad de la ladera no significa necesariamente un fallo de ladera desde un punto de vista operativo. Para el funcionamiento, la estabilidad de los antepechos suele ser un motivo de preocupación más inmediato, dado que los accidentes pueden producirse de forma súbita con pérdidas de equipos y de vidas humanas.

En las minas subterráneas pueden producirse fenómenos de inestabilidad resultantes de movimientos o hundimientos de bloques a causa de una inestabilidad estructural, de un fallo de la roca cerca de la entrada de la mina por condiciones de alta tensión de la roca o de una combinación de fallos de la roca causados por tensiones, inestabilidad estructural o inestabilidad debida a estalladuras por presión. La estructura de la roca puede influir en la elección del método de minería subterránea y en el diseño de las instalaciones mineras, ya que determina el tamaño de los vanos de excavación estables y los requisitos de capacidad y asentamiento. La roca profunda está sometida a las tensiones resultantes del peso de los estratos superiores y a tensiones de origen tectónico, siendo las horizontales a menudo superiores a las verticales. Hay instrumentos para determinar el nivel de tensión del terreno antes de iniciar la explotación. Cuando se excava la boca de una mina, el campo de tensión alrededor de ésta cambia, superando posiblemente la fuerza del estrato rocoso y dando lugar a una inestabilidad.

Existen varios tipos de fallos en las minas subterráneas de roca dura. Cuando los niveles de tensión son bajos, los fallos son controlados en gran medida por la estructura, apareciendo cuñas o bloques que caen del techo o resbalan de las paredes de las aberturas. Estas cuñas o bloques están formados por la intersección de discontinuidades estructurales. Salvo que se sujeten las cuñas o los bloques sueltos, el fallo puede proseguirse hasta el arqueado natural de la abertura. En depósitos estratificados, la separación y el fallo del lecho puede producirse a lo largo de los 
planos de estratificación. Cuando los niveles de tensión son altos, los fallos incluyen desde fisuras debidas a la fragilidad y desprendimientos de lajas en estratos rocosos masivos de escasa fisuración hasta un tipo de fallo más dúctil en los estratos rocosos muy fisurados.

Un estallido rocoso debido a la presión se define como un daño que se produce en una excavación de forma imprevista o violenta y que está relacionado con un movimiento sísmico. Se han identificado diferentes tipos de estallido por presión, como la expansión o el pandeo de la roca a causa de una fractura alrededor de la boca de la mina, desprendimientos de rocas provocados por un movimiento sísmico y lanzamiento de rocas a causa de una transferencia de energía desde una fuente sísmica remota. En algunas minas de carbón, sal u otros minerales se producen explosiones de rocas y de gases con consecuencias catastróficas debido a las altas tensiones de las rocas y los grandes volúmenes de metano o de dióxido de carbono comprimidos. En las canteras y las minas a cielo abierto también se han producido pandeos y proyecciones repentinas de suelos de roca. En varios países se han estudiado ampliamente las causas y la posible atenuación de los estallidos debidos a la presión. Entre las técnicas actuales para minimizarlas se encuentran el cambio de forma, orientación y secuencia de la extracción, el empleo de una técnica conocida como voladura a baja presión, el relleno de las minas y el uso de sistemas de soporte especializados. Complejos sistemas de supervisión sísmica a escala local o global de la mina pueden ayudar a identificar y analizar los mecanismos de origen, aunque la predicción de los estallidos debidos a la presión todavía no es fiable.

En la provincia canadiense de Ontario, casi un tercio de los accidentes mortales en minas subterráneas, en el marco de una industria minera altamente mecanizada, está causado por desprendimientos de rocas y estallidos debidos a la presión y su frecuencia durante el período comprendido entre 1986 y 1995 fue de 0,014 en 200.000 horas de trabajo subterráneo. En las industrias mineras subterráneas menos mecanizadas o donde el soporte del terreno no es práctica habitual, esta frecuencia puede ser mucho mayor. El registro de seguridad del control del terreno en las minas a cielo abierto y en las canteras es, por lo general, más completo que en las minas subterráneas.

\section{Métodos de diseño}

El diseño de las excavaciones subterráneas exige la toma de decisiones de ingeniería en materias como localización, tamaño y forma de las excavaciones y pilares rocosos, secuencia de explotación y aplicación de sistemas de soporte. En las minas a cielo abierto, además de elegir un ángulo de ladera óptimo para cada sección de la mina, hay que tener en cuenta otros aspectos de diseño y soporte de las laderas. El diseño de una mina es un proceso dinámico que se va actualizando y refinando a medida que se dispone de más información a partir de la observación y la supervisión de los trabajos. Por lo general, los métodos de diseño utilizados son analíticos, de tipo empírico y de observación.

Los métodos empíricos suelen basarse en un sistema de clasificación del estrato rocoso (existen numerosos esquemas de este tipo, como el Sistema de estrato rocoso y el Indice de calidad de túneles en roca) junto con recomendaciones de diseño basadas en prácticas aceptadas. En la práctica, se han aplicado con éxito varias técnicas de diseño empírico, como el Método gráfico de estabilidad para el diseño de tajos abiertos.

Los métodos de observación se basan en la supervisión de los movimientos del terreno durante la excavación para medir la inestabilidad y en el análisis de la interacción terreno-soporte. Como ejemplos de este tipo de métodos cabe citar el nuevo método austríaco de túneles y el método de convergencia-confinamiento.
Los métodos analíticos se basan en el análisis de las tensiones y deformaciones en la proximidad de las bocas. Las primeras técnicas de análisis de tensiones utilizaban soluciones matemáticas cerradas o modelos fotoelásticos, pero su aplicación práctica era limitada debido a la compleja forma tridimensional de la mayoría de las excavaciones subterráneas. Ultimamente se han desarrollado varios métodos numéricos basados en ordenador que permiten obtener soluciones aproximadas para problemas de tensiones, fallas y fallos en la roca alrededor de la bocamina.

Entre los últimos avances se encuentra la utilización de modelos tridimensionales, los modelos con discontinuidades estructurales e interacciones roca-soporte y la disponibilidad de interfaces gráficas orientadas al usuario. A pesar de sus limitaciones, estos modelos numéricos proporcionan una visión realista del complejo comportamiento de las rocas.

Las tres metodologías descritas deben considerarse más como un enfoque unificado de diseño de las excavaciones subterráneas que como técnicas independientes. El ingeniero de diseño debe saber utilizar una serie de herramientas y estar dispuesto a reevaluar la estrategia de diseño siempre que sea necesario, tomando como base la cantidad y la calidad de la información disponible.

\section{Controles de perforación y de voladura}

Un problema especial de la voladura de rocas es su efecto sobre la roca de las proximidades, ya que puede producir una intensa fragmentación y disrupción de la integridad de la roca de la zona circundante si la voladura o los sistemas de perforación son incorrectos. El daño sería mayor si la energía de la voladura se transmitiese a una zona más remota, lo que desestabilizaría las estructuras de la mina.

Los resultados de una voladura dependen de factores como el tipo de roca, el régimen de tensión, la geología estructural y la presencia de agua. Entre las medidas adecuadas para minimizar el daño producido por una voladura se encuentran: una elección adecuada del explosivo, el uso de técnicas de voladura perimétrica, como la voladura de predivisión (barrenos paralelos y muy juntos que definen el perímetro de la excavación), las cargas de desacople (el diámetro del explosivo es menor que el del barreno de voladura), tiempo de retardo y taladros de tope. La forma de los taladros influye en el éxito de una voladura de control de pared, por lo que hay que controlar cuidadosamente su disposición y alineamiento.

En las voladuras se realiza a menudo el seguimiento de las vibraciones para optimizar la disposición de los barrenos y no dañar el estrato rocoso. Hay criterios empíricos para evitar los daños producidos por voladuras. El equipo para el seguimiento de voladuras consta de transductores montados en la superficie o en el barreno, cables conectados a un sistema de amplificación y un grabador digital. El desarrollo de modelos informáticos ha permitido mejorar el diseño de las voladuras y predecir su rendimiento, incluida la fragmentación, el perfil de desescombro y la penetración de grietas causadas por los barrenos de voladura. Entre los datos de entrada de estos modelos figuran la forma de la excavación y de los barrenos perforados y cargados, las características de detonación de los explosivos y las propiedades dinámicas de la roca.

\section{Saneamiento del techo y de las paredes de la excavación}

El saneamiento es la eliminación de las placas sueltas de roca en techos y paredes de la excavación. Esta operación puede realizarse manualmente con una barra de acero o aluminio, o con una máquina de saneamiento. En el saneamiento manual, el minero comprueba la solidez de la roca golpeando el techo; un 
sonido hueco indica, por lo general, que la roca está suelta y debe eliminarse con la barra. El minero debe seguir unas normas estrictas para evitar accidentes durante la operación de saneamiento (p. ej., avanzar desde terrenos sólidos a otros desconocidos, mantener un buen apoyo en los pies, asegurarse una zona libre para retroceder y hacer que la roca golpeada caiga en el lugar adecuado). El saneamiento manual requiere un esfuerzo físico considerable y puede ser una actividad de alto riesgo. Así, por ejemplo, en Ontario (Canadá) un tercio de los accidentes causados por caídas de roca se producen durante operaciones de saneamiento.

El uso de plataformas sobre brazos extensibles para que mineros montados sobre ellas puedan sanear manualmente paredes altas entraña nuevos riesgos, como el que la plataforma de saneamiento sea golpeada y volcada por las rocas al desprenderse. En la mayoría de las explotaciones mineras de grandes dimensiones se suelen utilizar equipos de saneamiento mecánico compuestos por un potente fracturador hidráulico, una pala de carga o un martillo de neumático montado sobre un brazo pivotante y, a su vez, sujeto a un chasis móvil.

\section{Soporte del terreno}

El principal objetivo del soporte del terreno es contribuir a la estabilidad del estrato rocoso. Para reforzar las rocas se instalan pernos de consolidación en su interior, mientras que para el soporte exterior se utilizan piezas de acero o madera. Las técnicas de soporte del terreno no han sido muy utilizadas en la minería de superficie y en la cantería, en parte debido al desconocimiento de la forma real de la mina y en parte por problemas de corrosión. Para elegir un sistema en concreto hay que tener en cuenta factores como las condiciones del terreno, la vida útil planificada de la excavación, la facilidad de instalación, la disponibilidad y el coste. Actualmente, existen en el mercado una gran variedad de sistemas de pernos de consolidación, algunos de los cuales se describen a continuación.

Los pernos de anclaje mecánico constan de una cubierta de expansión (hay varios diseños según el tipo de roca), pernos de acero (roscado o de cabeza forjada) y chapa frontal. La cubierta de expansión suele estar formada por hojas dentadas de hierro fundido maleable con una cuña cónica roscada en un extremo del perno. Cuando el perno se gira dentro del barreno, el cono se introduce a presión dentro de las hojas y las comprime contra las paredes del barreno. La cubierta de expansión aumenta su agarre a la roca a medida que aumenta la tensión en el perno. Hay pernos de diferentes longitudes con sus correspondientes accesorios. Los pernos de consolidación de rocas anclados mecánicamente son relativamente económicos y, por tanto, se utilizan mucho en las minas subterráneas para soportes a corto plazo.

La clavija enlechada consta de una barra de refuerzo nervada que se inserta en la perforación y se sujeta a la roca en toda su longitud, lo que refuerza el estrato rocoso de forma prolongada. Hay diferentes tipos de lechadas de cemento y de resina de poliéster. La lechada puede colocarse en la perforación mediante bombeo o utilizando cartuchos, una operación que resulta rápida y sencilla. Las clavijas son de acero y de fibra de vidrio de diferentes diámetros y los pernos pueden ser tensionados o no tensionados.

El estabilizador por fricción consta normalmente de un tubo de acero abierto en sentido longitudinal que, cuando se introduce en una perforación de tamaño algo menor, presiona y produce una fricción entre el tubo y la roca. Para que este perno sea efectivo debe medirse el diámetro de la perforación con una tolerancia muy reducida.

Los pernos de consolidación de roca Swellex van provistos de un tubo de acero de evolvente circular que se introduce en una perforación y se expande mediante presión hidráulica utilizando una bomba portátil. Hay diferentes tipos y longitudes de tubos Swellex.

El perno de cable enlechado suele instalarse para controlar los hundimientos y estabilizar los techos y paredes en los tajos subterráneos. Se utiliza una lechada de cemento Portland, aunque las formas del cable y los métodos de instalación pueden variar. También se emplean en las minas barras de refuerzo y anclajes de roca de gran capacidad junto con otros tipos de pernos, como los tubulares enlechables de anclaje mecánico.

Los flejes o mallas de acero fabricados con alambre tejido o soldado se instalan a menudo en techos o paredes de la boca de la mina para soportar la roca entre los pernos.

Las explotaciones mineras deben disponer de un programa de control de calidad con variadas pruebas de campo que garanticen que el aguante del terreno es efectivo. Un aguante deficiente en las instalaciones puede deberse a un diseño inadecuado (incorrecta elección del tipo de soporte del terreno, de la longitud o la disposición de las condiciones del terreno), a materiales de aguante del terreno de calidad inferior a la estándar (por envío incorrecto del fabricante, por daños durante su manejo o por las condiciones de almacenamiento en la mina), a deficiencias de instalación (equipo defectuoso, planificación incorrecta de la instalación, preparación inadecuada de la superficie rocosa, formación deficiente del personal o incumplimiento de los procedimientos especificados), a efectos resultantes de los trabajos de minería no previstos en la fase de diseño (variaciones de tensión, fracturas o fisuras causadas por tensiones o voladuras, aflojamiento de las grietas o estallido debido a la presión) o a cambios en el diseño de la mina (cambios en la forma de excavación o prolongación de la vida útil prevista de la mina).

El comportamiento de los lechos rocosos reforzados o soportados todavía no está bien estudiado. Aunque se han establecido algunos principios básicos, directrices empíricas de diseño basadas en sistemas de clasificación de lechos rocosos y programas informáticos, el éxito de un determinado diseño depende en gran medida del conocimiento y la experiencia del técnico que controla el terreno. Un estrato rocoso de buena calidad con pocas discontinuidades estructurales y aberturas pequeñas, y con una vida de servicio limitada, puede no requerir prácticamente ningún soporte, aunque deben instalarse pernos para consolidación de rocas en determinados puntos para estabilizar los bloques que se identifiquen como potencialmente inestables. En muchas minas es obligatorio instalar en todas las excavaciones anclajes patrón o pernos de consolidación de rocas dispuestos de forma regular para estabilizar techos o paredes. En cualquier caso, los mineros y los supervisores deben tener suficiente experiencia para reconocer las zonas en que pueda ser necesario instalar un soporte adicional.

La forma más antigua y sencilla de soporte es el entibado mediantes vigas de madera, que todavía se instalan cuando se trabaja en terreno inestable. Los arcos y puntales de acero son elementos con una gran capacidad de aguante de carga y se utilizan para entibar galerías y vías. En las minas subterráneas, se utiliza como material de entibado adicional el relleno, que puede ser de roca residual, arena o relaves junto con un agente de cementación. El relleno cubre los vacíos creados en las excavaciones subterráneas y sirve, entre muchas otras cosas, para evitar fallos a gran escala, para encerrar y por tanto proporcionar fuerza adicional a los pilares de roca, para permitir la transferencia de tensiones de la roca, para reducir el asentamiento superficial, para obtener una recuperación máxima del mineral y para proporcionar una plataforma de trabajo en algunos métodos de minería.

Una innovación relativamente reciente en muchas minas ha sido el uso del hormigón vaporizado en un frente de roca que puede 
aplicarse directamente a ésta sin necesidad de ninguna otra forma de soporte o que puede vaporizarse a través de mallas y pernos de consolidación de rocas formando parte de un sistema de soporte integrado. A este tipo de hormigón se le pueden añadir fibras de acero junto con otras mezclas para conferirle propiedades específicas. Los dos procesos actuales de utilización del hormigón vaporizado son con mezcla seca y con mezcla húmeda. El hormigón vaporizado se ha aplicado para distintos fines en las minas, como, por ejemplo, para estabilizar frentes de roca que de otra forma se desmoronarían por su estrecha fisuración. En las minas a cielo abierto también se ha utilizado el hormigón vaporizado con éxito para estabilizar fallos de desmoronamiento progresivo. Otra de las últimas novedades es el uso de recubrimientos de poliuretano vaporizado en las minas subterráneas.

Para que los sistemas de entibado reaccionen de forma efectiva en caso de estallido debido a la presión, es necesario que tengan determinadas propiedades, como capacidad de deformación y de absorción de energía. Actualmente, se está estudiando en diferentes países el tema de la elección de soportes resistentes a las estallidos debidos a la presión y existen ya nuevas recomendaciones de diseño al respecto.

En las aberturas subterráneas pequeñas la instalación del entibado manual del terreno suele realizarse con una perforadora. En excavaciones de mayor tamaño se utilizan equipos semimecanizados (equipos de perforación mecanizados y equipo manual para la instalación de los pernos de consolidación), así como equipos totalmente mecanizados (perforación mecanizada e instalación de pernos de consolidación controlada desde un panel de operación situado bajo un techo soportado con pernos). La instalación manual del soporte del terreno es una actividad de alto riesgo. Así, en Ontario (Canadá), un tercio de los accidentes causados por caída de rocas durante el período de 1986 1995 y el 8 \% de los accidentes en minas subterráneas se produjeron durante la instalación de pernos de consolidación.

Otros posibles peligros son las salpicaduras de lechada de cemento o de resina en los ojos, las reacciones alérgicas producidas por derrames de productos químicos y la fatiga. Cuando se utilizan equipos mecanizados resulta más segura y eficiente la instalación de grandes cantidades de pernos de consolidación.

\section{Supervisión de las condiciones del terreno}

La supervisión de las condiciones del terreno en la mina puede realizarse por diversas razones, entre las que se encuentran: obtener los datos necesarios (deformabilidad del estrato rocoso, tensiones de la roca, etc.) para diseñar la mina; comprobar los datos y los supuestos del diseño mediante el calibrado de modelos informáticos y el ajuste de los métodos de minería para mejorar la estabilidad; estudiar la efectividad del entibado del terreno existente y, tal vez, decidir la instalación de entibados adicionales; o detectar a tiempo fallos potenciales del terreno.

La supervisión de las condiciones del terreno puede hacerse visualmente o con la ayuda de instrumentos especializados. La inspección de la superficie y del subsuelo debe ser cuidadosa, utilizando en caso necesario focos de luz de alta intensidad; tanto los mineros como los supervisores, los técnicos y los geólogos tienen un importante papel que desempeñar en la realización periódica de las inspecciones. Entre las señales visuales o audibles de cambio en las condiciones del terreno se encuentran, entre otras, el estado del núcleo del trépano de diamantes, contactos entre tipos de rocas, terreno con sonido hueco, presencia de características estructurales, carga obvia de entibado del terreno, pandeo del suelo, nuevas fisuras en paredes o techos, aguas subterráneas y fallos de los pilares. Los mineros a menudo utilizan instrumentos sencillos (p. ej., cuñas de madera en una grieta) para detectar movimientos del techo.
La planificación y la implantación de un sistema de supervisión incluye la definición del objetivo del programa y de las variables a supervisar, la determinación de la precisión necesaria en las medidas, la selección e instalación del equipo, así como la definición de la frecuencia de observación y la forma de presentación de los datos. El equipo de supervisión debe ser instalado por personal experimentado. Son aspectos importantes del mismo un fácil manejo de los instrumentos, la redundancia y la fiabilidad. El diseñador debe definir las posibles amenazas para la seguridad o la estabilidad e incluir la elaboración de planes de emergencia en caso de que se superen determinados niveles de señal.

Un sistema de supervisión consta de un sensor que registra los cambios de la variable supervisada, un sistema de transmisión constituido por indicadores, cables eléctricos y líneas hidráulicas o radiotelemétricas para enviar la señal del sensor al punto de lectura, una unidad de lectura (p. ej., dial, calibrador de presión, multímetro o pantalla digital), así como una unidad de registro/procesamiento (p. ej., grabador de cinta, registrador de datos o microordenador).

El modo de funcionamiento de un instrumento puede ser:

- mecánico: suelen ser los instrumentos más sencillos, baratos y fiables en cuanto a detección, transmisión y lectura. Los detectores mecánicos utilizan una varilla o cinta de acero que por un extremo está fijada a la roca y por el otro está en contacto con un indicador graduado o un sistema eléctrico. El principal inconveniente de los sistemas mecánicos es que no permiten una lectura remota o una grabación continua;

- óptico: se utilizan en métodos de supervisión convencionales, precisos y fotogramétricos para establecer los perfiles de excavación, medir movimientos de límites de excavación y supervisar el asentamiento superficial;

- hidráulico y neumático: los transductores de diafragma se emplean para medir las presiones de agua, las cargas de soporte, etc. La cantidad medida es una presión de fluido que actúa en un extremo de un diafragma flexible de metal, goma o plástico;

- eléctrico: es el modo de funcionamiento más común en los instrumentos de minería, aunque los sistemas mecánicos todavía se utilizan mucho en la supervisión de fallas. Los sistemas eléctricos están provistos de un indicador de variación de la resistencia eléctrica, un cable vibratorio o una autoinducción.

Entre las variables más supervisadas en las minas se encuentran el movimiento (mediante métodos de supervisión, mecanismos de superficie como indicadores de grietas y extensómetros de cinta, mecanismos de voladura como extensómetros de varilla o inclinómetros), las tensiones de la roca (tensión absoluta o cambio de tensión en dispositivos de barreno), la presión, la carga y la deformación de los sistemas de soporte del terreno (p. ej., celdas de carga), así como los seísmos y las vibraciones por voladura.

\section{VENTILACION Y REFRIGERACION EN LAS MINAS SUBTERRANEAS}

M.J. Howes

El principal objetivo de la ventilación en las minas es suministrar una cantidad suficiente de aire a todos los puestos de trabajo y galerías de una mina subterránea para diluir hasta un nivel aceptable los productos contaminantes que no pueden ser controlados por otros medios. Cuando la profundidad y la temperatura de la roca es tal que la temperatura del aire resulta excesiva, se pueden 
utilizar sistemas mecánicos de refrigeración para mejorar la ventilación.

\section{El ambiente dentro de una mina}

La composición de la capa gaseosa que envuelve la Tierra varía en menos de un $0,01 \%$ de un lugar a otro. El aire "seco" suele estar compuesto por un 78,09 \% de nitrógeno, un 20,95 \% de oxígeno, un $0,93 \%$ de argón y un $0,03 \%$ de dióxido de carbono. El vapor de agua también está presente en la atmósfera en cantidad variable dependiendo de la temperatura y la presión del aire y de la existencia de superficies de agua. A medida que el aire de ventilación va pasando por la mina, la concentración del vapor de agua puede ir cambiando de forma importante. Esta variación es estudiada por una ciencia denominada psicometría. Para definir el estado de una mezcla de vapor de agua y aire seco en un punto determinado hay que conocer tres propiedades independientes: la presión barométrica, la temperatura de termómetro seco y la temperatura de termómetro húmedo.

\section{Requisitos de ventilación}

Las sustancias contaminantes que deben controlarse mediante la ventilación de dilución son básicamente los gases y el polvo, aunque las radiaciones ionizantes relacionadas con el radón natural pueden ocasionar problemas, especialmente en las minas de uranio y cuando las concentraciones de uranio de la roca principal o de las adyacentes son elevadas. La cantidad de aire necesaria para una ventilación de dilución depende de la fuerza de la fuente de contaminación y de la efectividad de otras medidas de control, como el agua para la supresión del polvo o los sistemas de drenaje de metano en las minas de carbón. El flujo mínimo de aire de dilución viene determinado por el contaminante que requiera mayor dilución, una vez estudiados los posibles efectos resultantes de mezclas y sinergias que hacen que un contaminante pueda potenciar el efecto de otro. En cualquier caso, la velocidad mínima del aire debe ser de $0,25 \mathrm{~m} / \mathrm{s}$, aumentando a medida que sube la temperatura del aire.

\section{Ventilación de equipos con motor diesel}

En las minas mecanizadas que utilizan equipos móviles con motor diesel y no se supervisa el gas de forma continua, se utiliza la dilución del gas de escape para determinar los requisitos mínimos de ventilación. La cantidad de aire normalmente necesaria oscila entre 0,03 y $0,06 \mathrm{~m}^{3} / \mathrm{s}$ por $\mathrm{kW}$ de potencia media en el punto de funcionamiento, dependiendo del tipo de motor y de si se utiliza acondicionamiento de gas de escape. Las continuas innovaciones en combustibles y motores están consiguiendo reducir las emisiones, al tiempo que los convertidores catalíticos, las depuradoras húmedas y los filtros cerámicos también ayudan a reducir las concentraciones de monóxido de carbono/aldehídos, óxidos de nitrógeno y partículas diesel, respectivamente. De este modo, se podrían cumplir límites de contaminantes cada vez más rigurosos sin necesidad de aumentar en gran medida el caudal de dilución de los gases de escape. El límite mínimo posible de dilución $\left(0,02 \mathrm{~m}^{3} / \mathrm{s}\right.$ por $\left.\mathrm{kW}\right)$ viene determinado por las emisiones de dióxido de carbono que son proporcionales a la potencia del motor e independientes del acondicionamiento del gas de escape.

Los motores diesel convierten aproximadamente un tercio de la energía disponible en el combustible en potencia útil, que en su mayor parte se utiliza para contrarrestar la fricción, dando lugar a una emisión de calor que es aproximadamente tres veces la potencia. Incluso cuando se transporta roca en un camión por una rampa, el trabajo útil realizado sólo es del $10 \%$ de la energía disponible en el combustible. Los equipos móviles de mayor tamaño necesarios para un funcionamiento seguro en
Tabla 74.1 • Factores nominales de cantidad de aire.

\begin{tabular}{lc} 
Método de explotación & $\begin{array}{c}\alpha \text { (factor de cantidad } \\
\text { de aire } \mathrm{m} 3 / \mathrm{s} / \text { Mtpa) }\end{array}$ \\
\hline Por socavación y derrumbe & 50 \\
Por cámaras y pilares (potasa) & 75 \\
Por socavación en subniveles & 120 \\
Por escalones a cielo abierto & \\
$>0,5$ Mtpa & 160 \\
$<0,5$ Mtpa & 240 \\
Por excavación y relleno mecanizados & 320 \\
Por explotaciónno mecanizada & 400
\end{tabular}

grandes excavaciones utilizan motores diesel de mayor potencia. Si se toman los valores normales del vehículo y un caudal típico de dilución de gases diesel de $0,04 \mathrm{~m}^{3} / \mathrm{s}$ por $\mathrm{kW}$, la velocidad de aire mínima necesaria en lugares donde operan motores diesel es de aproximadamente $0,5 \mathrm{~m} / \mathrm{s}$.

\section{Ventilación de diferentes métodos de minería}

Aunque no es conveniente establecer unos requisitos generales de cantidad de aire cuando se dispone o se puede disponer de información detallada sobre la planificación de la mina y su ventilación, al menos sirven para apoyar los criterios empleados en el diseño. Por lo general, en las minas con problemas causados por calor o por la presencia de radón se explican y justifican desviaciones de los valores normales. La ecuación general es:

$$
\text { cantidad de aire en la mina }=\alpha t+\beta
$$

siendo t la velocidad de producción anual en millones de toneladas por año (Mtpa), $\alpha$ es un factor variable de cantidad de aire que está directamente relacionado con la velocidad de producción y $\beta$ es la constante del aire necesario para ventilar la infraestructura de la mina así como el sistema de tratamiento del mineral. En la Tabla 74.1 se muestran valores típicos de a.

La constante del aire $B$ depende principalmente del sistema de tratamiento del mineral y, hasta cierto punto, de la velocidad de producción global de la mina. En minas en que la roca se acarrea por rampas con camiones de motor diesel y no existe fase de trituración de la roca arrancada, un valor adecuado de $\beta$ es $50 \mathrm{~m}^{3} / \mathrm{s}$. Este valor suele aumentar a $100 \mathrm{~m}^{3} / \mathrm{s}$ cuando se utilizan trituradoras subterráneas y extracción mediante eskip con zonas de mantenimiento subterráneo. Si se amplía el sistema de manejo de mineral (p. ej., con cintas transportadoras $\mathrm{u}$ otros sistemas de transporte del mineral), 8 puede aumentar en un $50 \%$. En minas de gran volumen donde se utilizan sistemas de pozos múltiples, la constante del aire $\beta$ también es múltiplo del número de sistemas de pozos necesarios.

\section{Requisitos de refrigeración}

\section{Condiciones térmicas nominales}

La definición de unas condiciones térmicas adecuadas para minimizar los peligros y los efectos negativos de la fatiga calorífica puede hacer necesaria la instalación de refrigeración mecánica además de la ventilación destinada a controlar los contaminantes. Aunque la fatiga calorífica aplicada es una función compleja de variables climáticas y respuestas fisiológicas a ellas, en términos de minería práctica los factores que más influyen son la velocidad del aire y la temperatura del termómetro húmedo. Así se observa en las potencias de refrigeración de aire con corrección de ropa 
Tabla 74.2 • Potencias de refrigeración de aire con corrección de ropa (W/m2).

\begin{tabular}{lrrrrrr}
$\begin{array}{l}\text { Velocidad del aire } \\
\text { (m/s) }\end{array}$ & \multicolumn{5}{c}{ Temperatura de bola mojada $\left(^{\circ} \mathrm{C}\right)$} \\
& 20,0 & 22,5 & 25,0 & 27,5 & 30,0 & 32,5 \\
0,1 & 176 & 153 & 128 & 100 & 70 & 37 \\
0,25 & 238 & 210 & 179 & 145 & 107 & 64 \\
0,5 & 284 & 254 & 220 & 181 & 137 & 87 \\
1,0 & 321 & 290 & 254 & 212 & 163 & 104 \\
\hline
\end{tabular}

$\left(\mathrm{W} / \mathrm{m}^{2}\right)$ de la Tabla 74.2. A escala subterránea la temperatura radiante se considera igual a la temperatura del termómetro seco y $10^{\circ} \mathrm{C}$ más que la temperatura del termómetro húmedo. La presión barométrica y el régimen de ropa son típicos del trabajo subterráneo (p. ej., $110 \mathrm{kPa}$ y 0,52 unidades de ropa).

Una velocidad del aire de $0,1 \mathrm{~m} / \mathrm{s}$ refleja el efecto de la convección natural (p. ej., no se percibe ningún flujo de aire). Una velocidad del aire de $0,25 \mathrm{~m} / \mathrm{s}$ es la mínima permitida normalmente, y es necesaria una de $0,5 \mathrm{~m} / \mathrm{s}$ cuando la temperatura del termómetro húmedo excede de $25^{\circ} \mathrm{C}$. Para conseguir un equilibrio térmico, el calor metabólico resultante de velocidades de trabajo típicas debe ser: reposo, $50 \mathrm{~W} / \mathrm{m}^{2}$; trabajo ligero, 115 a $125 \mathrm{~W} / \mathrm{m}^{2}$; trabajo intermedio, 150 a $175 \mathrm{~W} / \mathrm{m}^{2}$; y trabajo duro, 200 a $300 \mathrm{~W} / \mathrm{m}^{2}$. Las condiciones nominales para una aplicación minera específica requerirían un estudio detallado de optimización. Por lo general, las temperaturas óptimas de termómetro húmedo se encuentran entre $27,5^{\circ} \mathrm{C}$ y $28,5^{\circ} \mathrm{C}$, siendo las inferiores aplicables a operaciones menos mecanizadas. Cuando la temperatura del termómetro húmedo excede de $30,0^{\circ} \mathrm{C}$, disminuye el rendimiento y aumenta de forma considerable el riesgo de enfermedades relacionadas con el calor. Normalmente, debería interrumpirse el trabajo cuando la temperatura del termómetro húmedo supere los $32,5^{\circ} \mathrm{C}$.

\section{Cargas de calor en las minas}

La carga de refrigeración de una mina es igual a la carga de calor de la misma menos la capacidad de refrigeración del aire de ventilación. La carga de calor es función de la autocompresión del aire en las vías de entrada de aire (conversión de la energía potencial en entalpía cuando el aire entra en la mina), del flujo de calor en la mina procedente de la roca circundante, del calor desprendido de las rocas fracturadas o del agua procedente de fisuras antes de ser eliminada de las entradas o secciones de trabajo y del calor resultante del funcionamiento de los equipos utilizados en los procesos de extracción y transporte del mineral. La capacidad de refrigeración del aire de ventilación depende de las condiciones ambientales térmicas del diseño en los puestos de trabajo y de las condiciones climáticas reales en superficie.

Aunque la contribución relativa de cada fuente de calor al valor total depende del lugar, la autocompresión suele ser el factor principal (35-50 \% del total). Cuando aumenta la profundidad de la mina, puede llegar un punto en que la autocompresión convierta en negativa la capacidad de refrigeración del aire y, si se suministra más aire, aumenta la carga de refrigeración de la mina. En este caso, la cantidad de ventilación suministrada debe ser la mínima para el control de los contaminantes, siendo necesario incrementar la refrigeración para garantizar unas condiciones de trabajo productivas y seguras. La profundidad de la mina a la que empieza a ser necesario suministrar refrigeración depende fundamentalmente de las condiciones climáticas en superficie, de la distancia que tiene que recorrer el aire antes de ser utilizado y de la cantidad de maquinaria pesada (diesel o eléctrica) que se emplee.

\section{Sistemas de ventilación primaria}

\section{Redes}

Los sistemas de ventilación primaria son redes que garantizan el flujo de aire a través de aberturas interconectadas. La red general de ventilación consta de puntos de conexión en los que se cruzan tres o más vías de aire, ramales entre estos puntos de conexión y mallas, que son pasos cerrados en la red. Aunque la mayoría de las redes de ventilación de minas son de tipo ramificado con cientos e incluso miles de ramales, el número de vías principales de entrada (ramal entre la superficie y los lugares de trabajo de la mina) y de retorno o escape (ramal entre los lugares de trabajo y la superficie) normalmente es inferior a diez.

Cuando en una red existe un gran número de ramales, no es fácil fijar un patrón de flujo y establecer la pérdida global de presión. Aunque muchas secciones suelen estar dispuestas en serie o en paralelo y pueden calcularse con precisión con métodos algebraicos, pueden existir otras más complejas que requieran métodos iterativos con convergencia a una tolerancia aceptable. Para el análisis de las redes se han utilizado ordenadores analógicos, que posteriormente han sido sustituidos por sistemas digitales más rápidos basados en la técnica de aproximación de Hardy Cross para redes de flujo de agua.

\section{Resistencia en las vías y pérdidas por choque}

La resistencia al flujo de aire de un túnel o de la bocamina es función de su tamaño y de las irregularidades de la superficie, dependiendo la pérdida de presión resultante de dicha resistencia y del cuadrado de la velocidad del aire. Al añadir energía al sistema puede generarse una presión para compensar esta pérdida. La energía puede tener un origen natural, como la energía procedente del calor de la roca o de otras fuentes (ventilación natural), que ha sido el método más utilizado para producir ventilación, aunque sólo convierte el 2-3 \% de la energía y en los veranos cálidos la roca puede llegar a enfriar el aire entrante dando lugar incluso a inversiones de flujo. En las minas modernas, para suministrar energía a la corriente de aire se suele utilizar un ventilador que restaura la pérdida de presión, aunque los efectos de la ventilación natural pueden favorecer o dificultar esta operación en función de la época del año.

Cuando el aire pasa por encima de una superficie, las moléculas de aire en contacto directo con ésta se encuentran en reposo y las adyacentes resbalan sobre ellas con una resistencia que depende de la viscosidad del aire, formándose un gradiente de velocidad en el que la velocidad aumenta a medida que aumenta la distancia a la superficie. La capa límite creada como resultado de este fenómeno y la subcapa laminar que se va formando a medida que se desarrolla la capa límite influyen considerablemente en la cantidad de energía necesaria para favorecer el flujo. Por lo general, las rugosidades de la superficie de las vías de aire de la mina son suficientemente significativas para que los "baches" se extiendan a través de la subcapa límite. Desde el punto de vista hidráulico, la vía de aire es irregular y la resistencia es función de la irregularidad relativa, es decir la relación entre la altura de la irregularidad y el diámetro de la vía de aire.

La mayoría de las vías de aire construidas con técnicas convencionales de perforación y voladura presentan alturas de rugosidad comprendidas entre 100 y $200 \mathrm{~mm}$ y, ni siquiera en un terreno muy "rugoso", la altura media de las rugosidades supera los $300 \mathrm{~mm}$. Cuando las vías de aire se construyen utilizando máquinas de barrenar, la altura de las rugosidades se sitúa entre 5 y $10 \mathrm{~mm}$, valor que todavía se considera irregular desde 
el punto de vista hidráulico. Las rugosidades de las vías de aire pueden reducirse con un recubrimiento, aunque esta operación se justifica más por el entibado del terreno que por la reducción de la energía necesaria para hacer circular el aire de ventilación. Así, por ejemplo, un pozo recubierto con cemento con irregularidades de $1 \mathrm{~mm}$ sería considerado transitoriamente irregular y el índice de Reynolds (relación entre inercia y viscosidad) también afectaría a la resistencia al flujo de aire. En la práctica, las dificultades para ir recubriendo de forma regular con hormigón un pozo profundo a medida que es excavado hace que las irregularidades y resistencias sean crecientes, pudiendo llegar a aumentar casi en un $50 \%$ al final del pozo con respecto a los valores de superficie.

El número de vías de aire de entrada y de salida entre los lugares de trabajo y la superficie es limitado, y gran parte de la pérdida total de presión en la mina (70-90 \%) tiene lugar en ellas. Esta pérdida de presión en las vías de aire también depende de si existen discontinuidades que puedan causar pérdidas por choque, como curvas, contracciones, expansiones u obstrucciones en las vías de aire. Las pérdidas resultantes de estas discontinuidades (curvas de entrada o de salida de las vías de aire, etc.), expresadas en términos de pérdidas en longitudes equivalentes de vías de aire rectas, pueden representar un porcentaje importante del total y deben ser cuidadosamente valoradas, especialmente cuando se estudian las entradas y salidas de aire principales. Las pérdidas por discontinuidades dependen de la distancia de separación de la capa límite, que puede minimizarse evitando alteraciones repentinas en la zona.

\section{Resistencia de las vías de aire con obstrucciones}

La pérdida de presión por obstrucciones depende de su coeficiente de frenado y del coeficiente de relleno, que es la relación entre el área de bloqueo del objeto y el área de la sección transversal de la vía de aire. Las pérdidas causadas por obstrucciones pueden reducirse minimizando la separación de la capa límite laminando el objeto para reducir la amplitud de cualquier estela turbulenta. Los coeficientes de frenado son función de la forma y disposición de las obstrucciones en el pozo (valores comparativos: viga I, 2,7; cuadrada, 2,0; cilíndrica, 1,2; hexagonal alargada, $0,6$ y totalmente laminada, 0,4$)$.

Incluso con coeficientes de relleno pequeños y coeficientes de frenado bajos, si la obstrucción se repite de forma periódica, como ocurre con las vigas que separan los compartimientos de extracción en un pozo, el efecto acumulativo sobre la pérdida de presión es importante. Así, la resistencia de un pozo equipado con vigas hexagonales alargadas semilaminadas y con un coeficiente de relleno de 0,08 sería aproximadamente cuatro veces superior a la del pozo recubierto de hormigón. Aunque el coste de las estructuras de acero de sección rectangular hueca más comunes en el mercado es superior al de las vigas I, los coeficientes de frenado son aproximadamente la tercera parte y justifican fácilmente su utilización.

\section{Ventiladores principales y ventiladores de refuerzo}

Para mejorar la circulación del aire en los sistemas de ventilación de las minas se utilizan ventiladores axiales y centrífugos que permiten alcanzar eficiencias de ventilación superiores al $80 \%$. En los ventiladores principales de una mina la elección entre flujo axial o centrífugo depende de factores tales como el coste, el tamaño, la presión, la robustez y la eficiencia. En las minas en que un fallo de ventilación puede causar acumulaciones peligrosas de grisú, hay que instalar un sistema adicional de ventilación. Cuando el caso no sea tan crítico y se disponga de una instalación de doble ventilación, aunque deje de funcionar uno de los ventiladores se seguirá disponiendo de casi dos terceras partes del flujo de aire de la mina. Los ventiladores de flujo axial instalados en las vías de aire resultan económicos pero su capacidad se limita a $300 \mathrm{~m}^{3} / \mathrm{s}$. Para flujos mayores, hay que instalar ventiladores múltiples, que se conectan a la aspiración mediante conducciones y secciones curvas.

Para obtener la máxima eficiencia a un coste razonable, se utilizan ventiladores de flujo axial para las aplicaciones de baja presión (inferior a $1,0 \mathrm{kPa}$ ) y ventiladores centrífugos para los sistemas de alta presión (superior a 3,0 kPa). Cualquiera de las dos opciones resulta adecuada para presiones intermedias. Cuando se requiere robustez, como en el caso de aspiraciones con velocidades de aire por encima del rango crítico, y además por el sistema circulan gotículas de agua, la opción más aconsejable es un ventilador centrífugo. El rango crítico de velocidad del aire se sitúa entre 7,5 m/s y 12,5 m/s, donde las gotículas de agua pueden mantenerse en suspensión según su tamaño. Dentro de este rango, la cantidad de agua suspendida puede aumentar e ir incrementando la presión del sistema hasta que el ventilador se detiene. Esta es la región de fluctuación de flujo en la que parte del aire recircula alrededor de las paletas y el funcionamiento del ventilador se hace inestable. Aunque esta situación no es deseable para ningún tipo de ventilador, en esta región la posibilidad de un fallo de las paletas del ventilador centrífugo es bastante menor que en un ventilador axial.

Es raro que un ventilador principal se utilice siempre en el mismo punto durante toda la vida útil de la mina y, por tanto, es aconsejable disponer de métodos efectivos que permitan variar el rendimiento de la ventilación. Aunque poder variar la velocidad hace más eficiente el funcionamiento tanto de los ventiladores axiales como de los centrífugos, el aumento del coste es significativo, especialmente en ventiladores de gran tamaño. Es posible variar el rendimiento de un ventilador de flujo axial ajustando el ángulo de la paleta, operación que puede realizarse cuando el ventilador está parado o, a un coste bastante más alto, cuando está girando. Para variar el rendimiento de un ventilador centrífugo en funcionamiento se aplica una turbulencia al aire que entra en el ventilador aplicando paletas de entrada variables. La eficiencia del ventilador centrífugo fuera de su punto de diseño disminuye más rápidamente que la de un ventilador de flujo axial; así, cuando se necesita obtener un alto rendimiento en un amplio rango de puntos de operación y las presiones lo permiten, es aconsejable utilizar el ventilador de flujo axial.

\section{Sistemas de ventilación}

En el sistema general, el ventilador principal suele estar instalado a nivel de la superficie en la vía de salida del aire. Las principales razones para ello son, por un lado, la facilidad de instalación, ya que la entrada de aire suele ser un pozo de extracción y la salida de aire una vía independiente, y, por otro, la minimización de la carga de calor al estar los ventiladores separados de las vías de aire de entrada. Los ventiladores pueden instalarse en los pozos de extracción en modo impelente o aspirante instalando un castillete de extracción hermético. Sin embargo, si el pozo se utiliza asimismo para la entrada o salida de trabajadores, materiales o roca, pueden producirse fugas de aire.

Los sistemas de retorno que tienen instalados ventiladores de entrada y de salida de aire se utilizan para repartir la presión máxima en el sistema o para mantener una diferencia de presión mínima entre el lugar de trabajo y la superficie. Estos sistemas están indicados para minas con métodos por hundimiento, en donde la fuga de aire por la zona hundida puede ser indeseable. $\mathrm{Al}$ existir grandes diferencias de presión, y aunque la fuga de aire por una zona hundida normalmente es pequeña, pueden producirse problemas en los puestos de trabajo a causa del calor, la radiación o la oxidación. 
Por las limitaciones de espacio, los ventiladores reforzadores subterráneos son casi siempre de flujo axial y se utilizan para reforzar el flujo en las secciones más profundas o alejadas de la mina. Su principal inconveniente es la posibilidad de recirculación entre las vías de salida de aire y las de entrada del ventilador reforzador. Si sólo se suministra un refuerzo a los flujos de aire más pequeños en caso necesario, puede reducirse la presión de ventilación principal en todo el flujo de aire de la mina, con la consiguiente reducción de potencia total de ventilación necesaria.

\section{Ventilación secundaria}

\section{Sistemas auxiliares}

Los sistemas de ventilación secundaria se instalan cuando la ventilación general resulta impracticable, como en los frentes en explotación. Hay cuatro tipos de sistemas, que presentan sus ventajas e inconvenientes específicos.

El sistema de función forzada produce el aire más natural y frío en el frente y permite utilizar tubos flexibles y más económicos. La alta velocidad del aire que sale del extremo del tubo de suministro produce un chorro que introduce aire adicional, y por efecto inductor del frente los contaminantes y proporciona una velocidad aceptable. Su principal desventaja es que el resto del frente se ventila con aire que está contaminado con los gases y el polvo producidos en las operaciones de minería. Este es un problema especialmente importante después de las voladuras, cuando los tiempos de reentrada segura son mayores.

El sistema de aspiración permite eliminar todos los contaminantes del frente y mantiene el resto del mismo con aire de entrada. Los inconvenientes son que el flujo de calor procedente de la roca circundante y la evaporación de la humedad dan lugar a un aumento de la temperatura del aire en el frente, las operaciones en la parte posterior del frente (eliminación de rocas con equipos diesel, etc.) contaminan el aire de entrada, no se produce chorro de aire que barra el frente y además es necesario utilizar conducciones más costosas que pueden mantener una presión negativa.

En el sistema de aspiración-solapamiento se ha solucionado el problema de limpiar el frente con un chorro de aire instalando un ventilador y conducciones más pequeñas (solapamiento). Además del coste adicional, presenta el inconveniente de que es necesario hacer avanzar el solapamiento a medida que lo hace el frente.

En el sistema de inversión se utiliza la ventilación forzada, salvo durante la voladura y en la fase de reentrada posterior a la voladura, cuando se invierte el flujo de aire. Su principal aplicación es en la construcción de pozos, donde los tiempos de reentrada para pozos profundos pueden ser prohibitivos si sólo se ha utilizado un sistema de forzado. La inversión del aire puede realizarse utilizando reguladores a la entrada y la salida del ventilador o aprovechando la característica de los ventiladores de flujo axial que hace que, al cambiar la dirección de giro de la paleta, se invierta el flujo obteniéndose un rendimiento del $60 \%$ de la normal.

\section{Ventiladores y conducciones}

Los ventiladores utilizados para la ventilación secundaria son casi exclusivamente de flujo axial. Para conseguir las altas presiones necesarias para que el flujo logre pasar a través de conducciones de gran longitud, pueden utilizarse ventiladores múltiples con sistemas de impulsión de contrarrotación o corrotación. El mayor problema en los sistemas de ventilación auxiliar y de conducciones son las fugas de aire, especialmente en grandes distancias. Cuando las conducciones rígidas de acero galvanizado o fibra de vidrio se instalan con juntas dan lugar a fugas reducidas y pueden utilizarse en frentes de hasta varios kilómetros de longitud.

Las conducciones flexibles son bastante más económicas y fáciles de instalar, pero las fugas en los acoplamientos y la facilidad con que se rompen al contacto con equipos móviles da lugar a pérdidas de aire mucho mayores. El límite práctico de utilización de conducciones flexibles raramente supera un 1,0 km, aunque puede ampliarse utilizando conducciones de mayor longitud y dejando amplios espacios de seguridad entre las conducciones y el equipo móvil.

\section{Controles de ventilación}

Tanto la ventilación general como los sistemas auxiliares de ventilación y las conducciones sirven para proporcionar aire de ventilación a los lugares de trabajo. Los controles de ventilación tienen el cometido de dirigir el aire al puesto de trabajo y de minimizar el cortocircuito o pérdida de aire entre las vías de entrada y salida de aire.

Para interrumpir el aire que fluye a través de un túnel de conexión se utilizan tabiques. Los materiales de construcción de estos tabiques dependen de la diferencia de presión existente y de la probabilidad de sufrir ondas de choque procedentes de voladuras. Las cortinas flexibles sujetas a las superficies de roca circundantes están indicadas para aplicaciones de baja presión, como la separación de las vías de aire de entrada y de salida en un panel de sala y pilares extraído con un equipo continuo. Los tabiques de madera y de hormigón están indicados para soportar presiones mayores y pueden incorporar una faldilla de goma pesada que, al abrirse en caso de voladura, minimiza los posibles daños.

Hay que disponer de una puerta de ventilación en los lugares de paso de personas o vehículos. El material de construcción, el mecanismo de apertura y el grado de automatización de estas puertas dependerán de la diferencia de presión existente y de la frecuencia de la operación de apertura/cierre. Para aplicaciones a alta presión pueden instalarse dos o incluso tres puertas para crear bloqueos de aire y reducir las fugas y las pérdidas de aire de entrada. A fin de facilitar la apertura de las puertas de bloqueo de aire, suelen disponer de una pequeña sección deslizante que se abre primero para equilibrar la presión a ambos lados de la puerta.

Los reguladores se utilizan cuando sólo se desea reducir y no interrumpir totalmente la cantidad de aire que pasa por un túnel y también cuando los accesos son innecesarios. El regulador dispone de un orificio variable, de modo que al variar el área varía la cantidad de aire que pasa a través de él. El panel abatible es uno de los tipos más sencillos y consta de un marco de hormigón con canales en los que se pueden colocar (abatir) diferentes paneles de madera, variando así el área de paso. Otros tipos, como los registros de ventilación con persiana, pueden automatizarse y controlarse de forma remota. En los niveles superiores de algunos sistemas de frentes abiertos puede ser necesario el paso esporádico de aire a través de los reguladores, para lo cual basta levantar o bajar los paneles flexibles pero rígidos horizontalmente que permiten el acceso del aire al tiempo que minimizan los daños por voladura. Para aumentar la resistencia en secciones de un nivel donde temporalmente no existe actividad minera a veces se utilizan montones de roca partida.

\section{Sistemas de refrigeración}

El primer sistema de refrigeración de minas se instaló en 1919 en Morro Velho (Brasil). Desde entonces, esas instalaciones fueron en aumento, pasando de los 3 megavatios de refrigeración (MWR) por año de la primera instalación hasta cerca de 100 MWR en 1965. A partir de ese momento, el aumento de la capacidad ha sido exponencial, duplicándose el valor cada seis o 
siete años. En la evolución de la refrigeración de las minas ha influido el desarrollo de la industria del aire acondicionado y las dificultades derivadas de un sistema de minería dinámico en el que las incrustaciones de las superficies del intercambiador de calor pueden afectar profundamente a la cantidad de refrigeración suministrada.

En un principio, las plantas de refrigeración estaban instaladas en la superficie y se enfriaba el aire que entraba en la mina. A medida que fue aumentando la distancia entre la superficie y el fondo de la mina se fue reduciendo el efecto refrigerante y hubo que trasladar las plantas de refrigeración al interior de las minas, más cerca de los puestos de trabajo. Sin embargo, la dificultad para combatir el calor subterráneo, así como la sencillez de funcionamiento y mantenimiento de las plantas de superficie, ha provocado una vuelta a ellas. Actualmente, además de enfriar el aire de entrada, también se suministra agua fría al interior de la mina para su uso en los sistemas de enfriamiento de aire próximos a los puestos de trabajo o como agua de servicio en perforaciones y para la eliminación del polvo.

\section{Equipo de la planta de refrigeración}

Los equipos generadores están formados por bombas de calor situadas en la planta de superficie. La capacidad de una planta puede oscilar entre 5 MWR y 100 MWR y, por lo general, son necesarios sistemas de compresores múltiples con mecanismos de desplazamiento centrífugo o positivo. El frigorígeno suele ser amoniaco en las plantas al nivel de superficie y un hidrocarburo halogenado para las plantas a nivel subterráneo.

El calor necesario para condensar el refrigerante después de la compresión se libera a la atmósfera y, para minimizar la potencia necesaria de refrigeración de la mina, se reduce al mínimo. La temperatura del termómetro húmedo siempre es inferior o igual a la temperatura del termómetro seco y, por lo tanto, siempre se seleccionan sistemas de rechazo de calor húmedo. Se suelen utilizar condensadores por agua y forma de separación. También pueden combinarse ambos procesos utilizando un condensador evaporativo en el que el frigorígeno circula por tubos por los que pasa el aire y se vaporiza el agua. Si la planta de refrigeración se instala dentro de la mina, se utiliza el aire de aspiración de ésta para rechazar el calor, salvo que se bombee a la superficie el agua del condensador. El funcionamiento de la planta subterránea está limitado por la cantidad de aire disponible y por su humedad relativa ya que dentro de la mina es mayor que en la superficie.

La producción de aire frío se realiza mediante un sistema de evaporador por agua que se suministra a intercambiadores agua-aire, climatizadores y también suministra agua fría de servicio para la mina. La calidad del agua de mina produce incrustaciones en el intercambiador de calor, aumentando la resistencia al flujo de calor. Siempre que sea posible, debe minimizarse este efecto seleccionando equipos que presenten grandes áreas superficiales de contacto con el agua y que sean fáciles de limpiar. Tanto a nivel superficial como subterráneo se utilizan cámaras de vaporización y torres de refrigeración que proporcionan un intercambio de calor más efectivo por contacto directo entre el aire en proceso de enfriamiento y el agua fría. Los serpentines de refrigeración que separan el aire y las corrientes de agua se van obstruyendo con el polvo y las partículas diesel y su efectividad disminuye rápidamente.

Los sistemas de recuperación de energía pueden utilizarse para amortizar los costes producidos por el bombeo del agua al exterior de la mina, aplicación para la que están muy indicadas las ruedas Pelton. El uso del agua fría como agua de servicio ha permitido disponer de refrigeración en todas las actividades de la mina y su uso ha mejorado considerablemente la efectividad de los sistemas de refrigeración de las minas.

\section{Sistemas de hielo y refrigeradores locales}

La capacidad de refrigeración de 1,0 l/s de agua fría suministrada dentro de la mina oscila entre 100 y 120 kWR. En minas en que es necesaria una gran potencia de refrigeración a profundidades superiores a $2.500 \mathrm{~m}$, el coste de la recirculación del agua fría puede justificar su sustitución por hielo. Si se tiene en cuenta el calor latente de fusión del hielo, la capacidad de refrigeración de un 1,0 l/s se cuadriplica aproximadamente, reduciendo así la cantidad de agua que es necesario bombear desde el interior de la mina a la superficie. La utilización del hielo para transportar el frío reduce la potencia de bombeo necesaria, pero esta ventaja se compensa con la energía empleada en la producción del hielo y por la imposibilidad de recuperar la energía.

El trazado de la mina es, por lo general, la actividad que genera una mayor carga de calor en relación con la cantidad de aire disponible para ventilación. Esto suele generar unas temperaturas en el puesto de trabajo muy superiores a las que se encuentran en otras actividades en la misma mina. Cuando la instalación de la refrigeración en la mina sea una cuestión compleja, podrán utilizarse temporalmente refrigeradores locales especialmente dirigidos a las operaciones de trazado. Un refrigerador local es básicamente una planta de refrigeración subterránea en miniatura con condensadores por aire, el cual es conducido a los circuitos de retorno desde la explotación, y sus valores típicos se encuentran entre 250 y $500 \mathrm{~kW}$ de refrigeración.

\section{Supervisión y emergencias}

Para cumplir los requisitos legales y supervisar de forma continuada la efectividad de los métodos de control de la ventilación, se efectúan estudios rutinarios de la ventilación que incluyen mediciones del flujo de aire, de los contaminantes y de la temperatura. Siempre que sea posible, se supervisarán de forma continua los parámetros del sistema, tanto de los equipos como de la calidad de aire. Cuando se supervisa continuamente un contaminante crítico, puede realizarse un control automático que, al superar un límite prefijado, active la acción correctora correspondiente.

Estudios más detallados de presión barométrica y temperatura son menos frecuentes y se utilizan para confirmar la resistencia de las vías de aire y planificar ampliaciones de operaciones existentes. Esta información puede utilizarse para ajustar las resistencias de simulación de la red y reflejar la distribución real del flujo de aire. Para determinar el rendimiento real del equipo y supervisar cualquier posible variación pueden utilizarse asimismo modelos de sistemas de refrigeración y análisis de mediciones de flujo y temperatura.

En las minas, las emergencias relacionadas con el sistema de ventilación pueden ser incendios, explosiones de gas y fallos en la corriente de ventilación. Los dos primeros casos se estudian en otra sección de este capítulo y el tercero sólo representa un problema en las minas profundas, donde las temperaturas del aire pueden aumentar hasta niveles peligrosos. En esos casos se suele instalar un ventilador de refuerzo con motor diesel para disponer de un flujo reducido de aire a través de la mina. Por lo general, cuando se produce una emergencia, como un incendio dentro de la mina, es mejor no modificar la ventilación mientras quede dentro de la mina personal familiarizado con el tipo normal de ventilación. 


\section{ILUMINACION EN LAS MINAS SUBTERRANEAS}

Don Trotter

\section{Fuentes de iluminación en las minas}

En 1879 se patentó la lámpara de filamento incandescente, y a partir de entonces la iluminación dejó de depender de una fuente de combustible. Desde el descubrimiento de Edison se han producido numerosos e importantes avances en el conocimiento de la luz, entre ellos algunas aplicaciones para las minas subterráneas que presentan ventajas e inconvenientes específicos. En la Tabla 74.3 se muestran varios tipos de fuentes de iluminación y algunos de los parámetros correspondientes.

La corriente para alimentar fuentes de iluminación puede ser de tipo alterno $(\mathrm{CA})$ o continuo $(\mathrm{CG})$. Las fuentes de iluminación fijas utilizan casi siempre corriente alterna mientras que las portátiles, como las lámparas de casco y los faros de los vehículos subterráneos, se sirven de baterías de corriente continua. No todos los tipos de fuentes de iluminación resultan adecuados para corriente continua.

\section{Fuentes de iluminación fijas}

Las lámparas de filamento de tungsteno son las más habituales y a menudo están provistas de una bombilla esmerilada y una protección para reducir el deslumbramiento. La lámpara fluorescente es la segunda fuente de iluminación más utilizada y se distingue fácilmente por su diseño tubular. En las minas, donde suele escasear el espacio, se emplean diseños compactos de tipo circular y en forma de U. En las minas subterráneas las fuentes de filamento de tungsteno y fluorescentes se utilizan para iluminar estaciones de pozo, acarreadores, galerías, comedores, estaciones de carga, depósitos de combustibles, instalaciones de reparación, almacenes, cuartos de herramientas y estaciones de trituración.

La tendencia en materia de iluminación de minas es utilizar fuentes de iluminación más eficientes, del tipo de las de descarga de alta intensidad (HID), vapor de mercurio, haluro metálico, y sodio a alta presión y a baja presión. Estas fuentes requieren algunos minutos (1-7) para alcanzar su capacidad lumínica total y, si se interrumpe el suministro de energía a la lámpara, el tubo de arco debe enfriarse antes de poder encenderse de nuevo (salvo en las lámparas de sodio a baja presión (Sox), de reencendido casi instantáneo). La distribución espectral es diferente a la de la luz natural. Las lámparas de vapor de mercurio producen una luz blancoazulada mientras que las de sodio a alta presión producen una luz amarillenta. Dado que en el trabajo subterráneo es importante distinguir bien los colores (p. ej., para utilizar botellas de gas con diferentes códigos de color en los trabajos de soldadura, para reconocer señales con códigos de color, para conectar cables eléctricos o para clasificar minerales por su color), hay que tener en cuenta la apreciación de color que permite cada fuente. Los objetos, al ser iluminados por una lámpara de sodio a baja presión, presentan un color superficial distorsionado. En la Tabla 74.3 se indica la apreciación de color de las diferentes fuentes.

\section{Fuentes de iluminación móviles}

Cuando los puestos de trabajo están diseminados tanto en sentido horizontal como vertical y se realizan operaciones continuas de voladura en ellos, las instalaciones permanentes resultan impracticables por su alto coste de instalación y mantenimiento. En muchas minas, la lámpara de baterías en el casco del minero es la principal fuente de iluminación. Aunque a veces se utilizan lámparas de casco fluorescentes, en su mayoría son de filamento de tungsteno alimentadas con batería (bien de tipo ácido de plomo o bien de níquel-cadmio). En ocasiones también se utiliza una minibombilla halógena de tungsteno; la minibombilla permite enfocar fácilmente el rayo y el gas halógeno alrededor del filamento evita que éste hierva y ennegrezca las paredes de la lámpara. La bombilla también puede arder con más calor y, por tanto, con más luz.

Para los vehículos móviles, el método de iluminación más utilizado son las lámparas incandescentes, que no requieren mecanismos especiales, resultan económicas y son fáciles de sustituir. En los faros de los vehículos se utilizan lámparas parabólicas de reflector aluminizado (PAR).

\section{Normas de iluminación en las minas}

En los países con una industria minera subterránea fuerte existen, por lo general, requisitos muy específicos de seguridad de iluminación en las minas y, en especial, en aquellas en que se desprende gas metano, generalmente minas de carbón. El gas metano puede entrar en combustión y ocasionar explosiones subterráneas de efectos devastadores. Por lo tanto, el diseño de la iluminación debe ser "intrínsecamente seguro" o "antideflagración". Una fuente luminosa intrínsecamente segura es aquella que dispone de una corriente de alimentación de baja energía, de forma que un cortocircuito no puede producir chispas que den lugar a la combustión del gas metano. En una lámpara antideflagración cualquier explosión causada por la electricidad de la

Tabla 74.3 • Comparación de fuentes de iluminación en minería.

\begin{tabular}{|c|c|c|c|c|c|}
\hline $\begin{array}{l}\text { Tipo de fuente de } \\
\text { iluminación }\end{array}$ & $\begin{array}{l}\text { Luminancia aproximada } \mathrm{cd} / \mathrm{m}^{2} \\
\text { (bombilla transparente) }\end{array}$ & Vida nominal media (h) & Fuente CC & $\begin{array}{l}\text { Eficacia inicial } \\
\text { aproximada } \mathrm{Im} \cdot \mathrm{W}^{-1}\end{array}$ & Apreciación de color \\
\hline Filamento de tungsteno & 105 a 107 & 750 a 1.000 & Sí & 5 a 30 & Excelente \\
\hline Incandescente & $2 \times 107$ & 5 a 2.000 & Sí & 28 & Excelente \\
\hline Fluorescente & $5 \times 104$ a $2 \times 105$ & 500 a 30.000 & Sí & 100 & Excelente \\
\hline Vapor de mercurio & 105 a 106 & 16.000 a 24.000 & Sí, con limitaciones & 63 & Media \\
\hline Halogenuro metálico & $5 \times 106$ & 10.000 a 20.000 & Sí, con limitaciones & 125 & Buena \\
\hline Sodio a alta presión & 107 & 12.000 a 24.000 & No recomendada & 140 & Regular \\
\hline Sodio a baja presión & 105 & 10.000 a 18.000 & No recomendada & 183 & Mala \\
\hline
\end{tabular}

$\mathrm{cd}=$ bujías, $\mathrm{CC}=$ corriente continua; $\mathrm{Im}=$ lúmenes. 
lámpara debe quedar contenida dentro de la misma, y no debe generar calor suficiente para causar una explosión. Este tipo de lámparas son más caras y más pesadas, pues contienen piezas de metal fundido. Los gobiernos suelen disponer de instalaciones de prueba para certificar las lámparas clasificadas como válidas para su uso en minas con emisiones de gas. Una lámpara de sodio a baja presión no podría ser certificada como tal, ya que en caso de rotura el sodio de su interior ardería en contacto con el agua.

Los Estados han adoptado asimismo normas que establecen la cantidad de luz necesaria para cada tarea; según las diferentes legislaciones, la cantidad de luz para cada puesto de trabajo varía considerablemente.

Las organizaciones internacionales que se ocupan de la iluminación, como la Sociedad de Ingeniería de la Iluminación (IES) y la Comisión Internacional de la Iluminación (CIE), también elaboran directrices de iluminación para minas. Según la CIE, la calidad de la luz recibida por el ojo es tan importante como la cantidad y ha establecido fórmulas para evitar que el deslumbramiento afecte al rendimiento visual.

\section{Repercusión de la iluminación en los accidentes, la producción y la salud}

Cabría esperar que una mejor iluminación permitiría reducir el número de accidentes, aumentar la producción y reducir los riesgos para la salud, pero esto no resulta fácil de justificar. En una mina, es difícil medir el efecto directo de la iluminación sobre la eficiencia y la seguridad, porque la iluminación es sólo uno de los muchos factores que inciden en la producción y la seguridad. Está bien documentado el hecho de que los accidentes en las autopistas disminuyen cuando se mejora la iluminación. También en las fábricas se ha observado una correlación similar. Sin embargo, en la minería, las zonas de trabajo experimentan un cambio continuo y hay muy pocos informes que relacionen los accidentes en las minas con la iluminación, por lo que ésta sigue siendo un campo de investigación muy poco explorado. Las investigaciones sobre accidentes demuestran que una iluminación deficiente rara vez es la causa primera de los accidentes subterráneos, aunque sí un factor adicional. Las condiciones de iluminación influyen en muchos accidentes en las minas y de forma especial en los producidos por caídas, ya que una mala iluminación dificulta la observación de situaciones peligrosas que podrían haberse evitado.

Hasta comienzos del siglo XX los mineros sufrían, por lo general, de una afección ocular denominada nistagmus, para la que no existía curación. Esta enfermedad producía un movimiento incontrolado de los globos oculares, dolor de cabeza, vértigos y pérdida de la visión nocturna y estaba causada por el trabajo con niveles de luz muy bajos durante largos períodos de tiempo. Los mineros del carbón eran especialmente susceptibles a esta enfermedad, dado que el carbón refleja muy poca luz. Además, a menudo tenían que tumbarse de lado para poder trabajar en los filones de carbón más bajos, lo que también parece haber contribuido a esta enfermedad. Con la introducción en las minas de las lámparas eléctricas de casco esta enfermedad ha desaparecido y se ha eliminado el mayor riesgo para la salud asociado a la iluminación de las minas.

Con los últimos avances tecnológicos en materia de fuentes de iluminación se ha reavivado el interés por la iluminación y la salud. En la actualidad, es posible disponer en las minas de niveles de iluminación que hubieran sido extremadamente difíciles de alcanzar hace tiempo. Ahora, el principal problema es el deslumbramiento, aunque también existe cierta preocupación por la energía radiométrica que emiten las luces, que puede afectar a los trabajadores al actuar directamente sobre las células de la piel o activar ciertas respuestas, como los ritmos biológicos que influyen en la salud física y mental. Una fuente de iluminación HID puede seguir funcionando aunque la parte exterior de vidrio que contiene la fuente esté rajada o rota, dando lugar a que los trabajadores reciban dosis superiores a los valores límite umbral, especialmente porque estas fuentes de iluminación a menudo tienen que instalarse a baja altura.

\section{EQUIPOS DE PROTECCION INDIVIDUAL EN LAS MINAS}

Peter W. Pickerill

\section{Protección para la cabeza}

En la mayoría de los países, los mineros deben tener y llevar cascos o sombreros de seguridad homologados por la jurisdicción en que opere la mina. Los sombreros se diferencian de los cascos en que tienen un ala completa en lugar de sólo la parte frontal, de forma que el agua escurre por ella cuando se trabaja en minas muy húmedas; por otro lado, al no llevar ranuras laterales, no se pueden montar en él los protectores de oídos, linternas, caretas para trabajos de soldadura, corte, molienda, picado y saneamiento u otros accesorios. En las minas, los sombreros de seguridad sólo se utilizan raramente para proteger la cabeza.

El casco o el sombrero de seguridad va equipado en la mayoría de los casos con una abrazadera y una cuerda para sujetar la lámpara.

El casco tradicional es de perfil muy bajo para reducir la posibilidad de golpearse la cabeza en las minas de carbón de capas bajas. Sin embargo, en las minas en que el espacio para la cabeza es suficiente, un perfil bajo del casco no tiene mucha utilidad. Además, el perfil bajo se consigue a costa de reducir el espacio libre entre la parte alta del casco y el cráneo del minero, de forma que estos tipos de casco rara vez cumplen las normas de seguridad industrial para impacto superior en la cabeza. En las jurisdicciones en que las normas son de obligado cumplimiento, el casco tradicional del minero está siendo sustituido por un protector industrial convencional para la cabeza.

Las normas de seguridad industrial para la cabeza han variado muy poco desde el decenio de 1960, aunque en el de 1990 el auge en el deporte de los protectores de cabeza (cascos para jugar al hockey, montar en bicicleta, etc.) ha permitido detectar los defectos de los mecanismos de seguridad industrial para la cabeza, especialmente la falta de protección frente a impactos laterales y la falta de sujeción en caso de impacto. Estos beneficios han servido de presión para actualizar las normas de los protectores industriales de cabeza, que en algunas jurisdicciones ya ha dado sus frutos. Actualmente, están apareciendo en el mercado industrial cascos de seguridad con relleno de espuma, suspensiones de trinquete y mentoneras, aunque su aceptación por los usuarios todavía no es muy amplia a causa de su alto coste y peso y su incomodidad de uso. Sin embargo, a medida que las nuevas normas vayan siendo incorporadas a la legislación del trabajo, este nuevo tipo de casco seguramente se irá abriendo paso en la industria minera.

\section{Lámparas de casco}

En las zonas de las minas en que no hay instalada una iluminación permanente, la lámpara de casco de los mineros es fundamental para poder moverse y trabajar de forma efectiva y segura. Los requisitos clave de una lámpara de casco es que sea resistente, de fácil manejo con los guantes puestos, que proporcione luz suficiente durante todo un turno de trabajo (con el nivel de 
iluminación especificado por la normativa local) y sea lo más ligera posible sin sacrificar ninguno de los parámetros de rendimiento anteriores.

Recientemente, las bombillas halógenas están sustituyendo en gran medida a las de filamento incandescente de tungsteno. De este modo, se ha podido triplicar y hasta cuadruplicar el nivel de iluminación, cumpliendo las normas mínimas de iluminación especificadas en la legislación incluso al final de un turno prolongado de trabajo. Las baterías también son un factor importante en el rendimiento de una lámpara. En la mayoría de las aplicaciones mineras todavía predomina la batería ácida de plomo, aunque algunos fabricantes están introduciendo con éxito baterías de níquel-cadmio (nicad), con el mismo rendimiento y menor peso. Sin embargo, los aspectos de fiabilidad, duración y mantenimiento siguen siendo favorables a la batería ácida de plomo, razón por la que probablemente siguen dominando el mercado.

Ultimamente, las lámparas de casco, además de para iluminar, también se utilizan como sistemas de comunicación de seguridad en las minas. Los receptores de radio y la circuitería integrada en la cubierta de la batería permiten a los mineros recibir mensajes, avisos o instrucciones de evacuación a través de un transmisor de radio de muy baja frecuencia (VLF), con aviso de los mensajes entrantes mediante parpadeo de la lámpara del casco. Estos sistemas todavía se encuentran en su fase inicial de desarrollo, pero su potencial como sistema de alarma hace pensar que van a desplazar a los sistemas tradicionales de gas fétido en las minas en que sea posible instalar un sistema de comunicación por radio VLF.

\section{Protección para ojos y cara}

La mayoría de las explotaciones mineras disponen de programas de protección para los ojos, siendo obligatorio el uso de gafas de seguridad, mascarillas protectoras o escafandras autónomas, dependiendo de las operaciones que realice y los riesgos a los que esté expuesto el minero. En la mayoría de las operaciones mineras las gafas de seguridad con protectores laterales aportan una protección adecuada. El polvo y la suciedad en muchos entornos mineros, especialmente en la minería de roca dura, pueden ser muy abrasivos y causar rayaduras y un desgaste rápido en las gafas de seguridad con cristales de plástico (policarbonato). Por esta razón, en muchas minas todavía está permitido el uso de cristales de vidrio, aunque no tengan la misma resistencia a impactos y fracturas de los cristales de policarbonato e incluso a veces puedan incumplir la normativa local vigente en materia de protección ocular. En las gafas con cristales de plástico se sigue mejorando el tratamiento antiniebla y el endurecimiento de la superficie, tratamientos que al cambiar la estructura molecular de la superficie de la lente en lugar de aplicar simplemente una película o un recubrimiento, suelen ser más efectivos y duraderos y permiten sustituir el cristal en entornos de minería de efecto abrasivo.

La gafas ajustadas no se suelen utilizar dentro de la mina salvo cuando la operación de que se trate conlleve un peligro de salpicadura de productos químicos.

La careta se suele utilizar cuando el minero necesita protegerse la cara de salpicaduras de metal fundido, residuos de molienda u otras partículas grandes que puedan saltar en operaciones de corte, picado o saneamiento. La careta puede ser de material especial, como en el caso de las soldaduras, o ser acrílica transparente o de policarbonato. Aunque puede llevar su propia sujeción de cabeza, en las minas normalmente se monta en las ranuras del casco de seguridad del minero. Las caretas están diseñadas de forma que puedan levantarse de forma rápida y fácil para observar el trabajo y bajarse por delante de la cara para seguir realizando el trabajo.

Cuando se necesita también una protección respiratoria frente a una sustancia irritante de los ojos puede utilizarse una escafandra autónoma que aporte protección total a la cara. En las minas, este tipo de trabajo suele ser más común en el procesamiento a nivel de superficie que en la propia operación subterránea.

\section{Protección respiratoria}

La protección respiratoria más habitual en las operaciones mineras es la protección contra el polvo. El polvo de carbón, como la mayoría de los polvos ambientales, puede filtrarse de forma efectiva utilizando una mascarilla convencional. Entre las escafandras autónomas disponibles resulta eficaz el tipo que utiliza una protección elástica de nariz y boca y filtros desechables, mientras que el tipo de copa de fibra desechable se considera ineficaz.

Por ejemplo, las operaciones de soldadura, uso de disolventes, manejo de combustibles o voladura pueden producir contaminantes transportados por el aire que hagan necesario el uso de respiradores dobles de cartucho para eliminar las combinaciones de polvo, niebla, humos, vapores orgánicos y gases ácidos. En estos casos, el nivel de protección del minero vendrá dado por la medida de los contaminantes, realizada habitualmente de forma local con tubos de detección o instrumentos portátiles. El minero utilizará la escafandra hasta que el sistema de ventilación de la mina hava eliminado o reducido los contaminantes a un nivel aceptable.

Ciertos tipos de partículas habituales en las minas, como las fibras de amianto en las minas de este mineral, el polvo de carbón en las minas por tajos largos y los radionucleidos en las minas de uranio, pueden obligar a utilizar una escafandra de presión equipado con un filtro absoluto de alta eficiencia para partículas (HEPA), como las escafandras eléctricas de purificación del aire (PAPR) que envían el aire filtrado a una campana, a una mascarilla ajustada o a una mascarilla integrada en el casco.

\section{Protección para los oídos}

Los vehículos, la maquinaria y las herramientas eléctricas que se utilizan en el interior de las minas generan niveles elevados de ruido ambiental que a largo plazo pueden dañar la salud de las personas. Para evitarlo, se suelen utilizar protectores tipo orejeras que se montan en las ranuras del casco del minero y, como protección adicional, tapones de espuma. Los tapones de oídos, ya sean desechables de espuma o elastoméricos reutilizables, pueden utilizarse directamente en los oídos bien porque así se desee o porque las ranuras laterales del casco se hayan utilizado ya para una mascarilla facial o para otro accesorio.

\section{Protección para la piel}

Algunas operaciones mineras pueden causar irritación de la piel. Siempre que sea posible, se utilizarán guantes de trabajo en estas operaciones. Como protección adicional se utilizarán cremas barrera, especialmente cuando no se puedan utilizar guantes.

\section{Protección para los pies}

Las botas de trabajo en las minas pueden ser de piel o de goma, dependiendo de si la mina es seca o húmeda. Los requisitos mínimos que deben cumplir las botas incluyen una suela gruesa totalmente resistente a la perforación con una capa exterior 
reforzada para evitar deslizamientos, una puntera de acero y con protección para el empeine. Aunque estos requisitos básicos no han variado a lo largo de los años, sí se ha conseguido que la estructura de las botas sea mucho menos pesada e incómoda que la de las utilizadas hace algunos años. Así, en lugar de las anillas y los antiguos enganches de acero, en la actualidad se utiliza la protección de empeine en fibra moldeada, que proporciona una protección equivalente pero más ligera y con menor riesgo de tropiezos. La forma de la bota de los mineros se ha hecho más anatómica y se han adoptado del calzado deportivo las suelas intermedias, que absorben energía, las barreras totales para la humedad y los materiales aislantes modernos.

\section{Ropa}

Los monos de algodón normal o ignífugo son de uso habitual en las minas. Por lo general, se les añaden tiras de material reflectante para que el minero sea más visible para los conductores de vehículos que trabajen en el interior de las minas. Los mineros que trabajan con trenes perforadores u otro tipo de equipo pesado pueden llevar impermeables encima de los monos para protegerse de líquidos ácidos o aceites hidráulicos o lubricantes que puedan gotear o salpicarles desde los equipos.

Como protección para las manos se utilizan guantes de trabajo. Los de uso universal están fabricados en lona de algodón reforzada con piel. Para funciones especiales pueden utilizarse guantes de otros tipos.

\section{Cinturones y sujeciones}

En la mayoría de las jurisdicciones, el cinturón de minero ya no se considera adecuado ni está homologado como protección frente a caídas. Sin embargo, todavía se sigue utilizando un cinturón de cincha o piel con o sin mecanismos de suspensión y con o sin soporte lumbar para llevar la batería de la lámpara y un autorrescatador con filtro o de tipo autocontenido (con generador de oxígeno), en caso necesario.

Actualmente en las minas, el único sistema recomendado de protección frente a caídas es un arnés de cuerpo completo con una anilla en D entre los homóplatos. Los mineros que trabajan en pozos, sobre trituradoras o cerca de aberturas o pozos abiertos deben llevar este arnés junto con una cuerda adecuada y un mecanismo amortiguador de choques. También pueden añadirse mosquetones al arnés o al cinturón del minero para permitir el posicionamiento en el trabajo o limitar sus movimientos dentro de unos márgenes seguros.

\section{Protección contra el frío y el calor}

En las minas a cielo abierto de regiones de clima frío, los mineros llevarán ropa de invierno con calcetines, ropa interior y guantes térmicos, calzoncillos o calzones resistentes al viento, un chaquetón guateado con capucha y un gorro de lana para debajo del casco de seguridad.

En las minas subterráneas suele ser más problemático el calor que el frío. La temperatura ambiente puede ser alta debido a la profundidad o por estar situada la mina en una región de clima cálido. Para protegerse de la fatiga calorífica y de un posible golpe de calor, se utilizarán trajes o ropa interior especiales en los que puedan introducirse paquetes de gel congelado o fabricados con una red de tubos de refrigeración con líquido refrigerante que circule por la superficie del cuerpo y después a través de un intercambiador de calor externo. Cuando la propia roca está caliente se utilizarán guantes, calcetines y botas resistentes al calor. Deberá disponerse de agua potable, preferentemente con electrolitos, que se consumirá para sustituir los fluidos corporales eliminados.

\section{Otros equipos de protección}

Algunas normativas locales y algunos tipos de minas exigen la utilización por los mineros de un mecanismo de autorrescate, que es una protección respiratoria que ayuda al minero a escapar de la mina en caso de incendio o explosión y cuando la atmósfera resulte irrespirable por monóxido de carbono, humo u otros contaminantes tóxicos. El autorrescatador puede ser un mecanismo de tipo filtro con un catalizador para el monóxido de carbono o de tipo autocontenido, es decir, un respirador de circuito cerrado que regenera químicamente el oxígeno exhalado.

En las minas, los instrumentos portátiles para detectar y medir los gases y combustibles tóxicos (como tubos y bombas de tubo de detección) sólo son utilizados por los responsables de seguridad de la mina o por las personas designadas en los procedimientos de funcionamiento estándar, que comprueban la atmósfera de la mina periódicamente o antes de la entrada de los mineros.

Se ha comprobado que la comunicación con el personal que trabaja en las minas subterráneas produce enormes beneficios en materia de seguridad, por lo que cada vez se están implantando más en las explotaciones mineras modernas los sistemas de comunicación bidireccional, los buscapersonas y los mecanismos de localización.

\section{INCENDIOS Y EXPLOSIONES EN MINAS}

Casey C. Grant

Los incendios y las explosiones representan una amenaza constante para la seguridad de los mineros y para la capacidad productiva de las explotaciones mineras y figuran tradicionalmente entre las catástrofes industriales más devastadoras.

A finales del siglo pasado, los incendios y explosiones en la minería ocasionaron una cantidad de pérdidas personales y materiales no igualada por ningún otro sector industrial. En la actualidad, se ha avanzado notablemente en el control de estos peligros, como refleja la reducción del número de incendios y explosiones registradas en los últimos decenios en las minas.

En el presente artículo se describen los peligros básicos que presentan los incendios y las explosiones en la minería subterránea y las precauciones que deben observarse para minimizarlos. La información sobre la protección contra incendios de los mineros en explotaciones a cielo abierto puede encontrarse en esta misma Enciclopedia y en las normativas publicadas por organizaciones tales como la Asociación Nacional de Protección contra Incendios (National Fire Protection Association) de Estados Unidos (p. ej., NFPA 1996a).

\section{Areas de servicio permanente}

Por su propia naturaleza, las áreas de servicio permanente requieren ciertas actividades peligrosas ante las que deben adoptarse precauciones especiales. Los talleres de mantenimiento subterráneos y demás instalaciones afines constituyen un peligro especial en la minería subterránea.

Los equipos móviles de los talleres de mantenimiento suelen ser una fuente frecuente de incendios. Los incendios en las máquinas con motor diesel suelen estar causados por pérdidas 
en las conducciones hidráulicas a alta presión que vierten una mezcla caliente de líquido altamente combustible sobre un punto de ignición, como puede ser un colector caliente de escape o un turbosobrealimentador (Bickel 1987). Los incendios en este tipo de equipos se propagan rápidamente.

Gran parte de los equipos móviles empleados en las minas subterráneas no sólo cuentan con fuentes de combustible (p. ej., diesel y mecanismos hidráulicos), sino también con fuentes de ignición (p. ej., motores diesel y equipos eléctricos), por lo que representan en sí mismos un riesgo notable de incendio. Aparte de estos equipos, los talleres de mantenimiento disponen generalmente de numerosas herramientas, materiales y aparatos (p. ej., equipos para desengrasar) que constituyen un peligro en cualquier entorno de taller mecánico.

Las operaciones de soldadura y corte, sumamente habituales en cualquier zona de mantenimiento, son una causa primaria de incendios en la minería. Es preciso adoptar precauciones especiales para garantizar que estas actividades no constituyan una fuente potencial de ignición de incendios o explosiones. En esta misma Enciclopedia y en documentos como el NFPA 1994a puede encontrarse información sobre protección contra incendios y explosiones en relación con una práctica segura de la soldadura.

Hay que considerar la posibilidad de construir toda la zona de taller como una estructura totalmente cerrada y edificada con materiales ignífugos, aspecto que tiene especial interés en talleres con una vida prevista superior a los 6 meses. Cuando no resulte posible utilizar estos materiales, la zona deberá protegerse con un sistema automático de extinción de incendios. Esta medida resulta especialmente importante en la minería del carbón, donde es fundamental reducir al mínimo cualquier fuente potencial de incendio.

Otra consideración importante para cualquier zona de taller es que la ventilación esté conectada al retorno de aire, lo que reduce la propagación de los productos resultantes de la combustión en caso de incendio. Los requisitos para este tipo de instalaciones se encuentran claramente descritos en documentos tales como NFPA 122, Normativa para la prevención y el control de incendios en minas subterráneas dedicadas a la extracción de minerales metálicos y no metálicos, y NFPA 123, Normativa para la prevención y control de incendios en minas subterráneas de carbón bituminoso (NFPA 1995a, 1995b).

\section{Depósitos y áreas de almacenamiento de combustibles}

El almacenamiento, la manipulación y la utilización de líquidos inflamables y combustibles presentan un peligro especial de incendio en todos los sectores de la industria minera.

En muchas minas subterráneas los equipos móviles trabajan con motores diesel, y en un gran porcentaje de los incendios que se producen interviene el combustible utilizado por estas máquinas. En las minas de carbón, estos peligros de incendio se ven agravados por la presencia de carbón, polvo de carbón o metano.

El almacenamiento de líquidos inflamables y combustibles es un problema especialmente importante, pues estas sustancias entran en combustión con más facilidad y propagan el fuego con más rapidez que los combustibles ordinarios. En las minas de carbón, tanto los líquidos inflamables como los combustibles se suelen almacenar bajo tierra y en cantidades variables. En algunas minas, las instalaciones principales de almacenamiento de gasóleo, lubricantes, líquidos de engrase y fluidos hidráulicos se encuentran bajo tierra. La gravedad de un incendio potencial en una zona subterránea de depósito de líquidos inflamables y combustibles exige un cuidado extremo a la hora de diseñar las áreas de almacenamiento, además de la implantación y estricta observancia de procedimientos operativos de seguridad.

Todos los aspectos relativos a la utilización de líquidos inflamables y combustibles, incluido su transporte, almacenamiento, repostaje y utilización final en los equipos, constituyen un reto importante en materia de protección contra incendios. Los peligros y métodos de protección para los líquidos inflamables y combustibles en las minas subterráneas se recogen en esta Enciclopedia y en la normativa NFPA (p. ej., NFPA 1995a, 1995b, 1996b).

\section{Prevención de incendios}

La seguridad frente a incendios y explosiones en las minas subterráneas se basa en el principio general de prevención. Normalmente, esto requiere la aplicación de técnicas de seguridad de sentido común, como la prohibición de fumar, y la implantación de medidas intrínsecas de protección contra incendios a fin de evitar su propagación, como la instalación de extintores portátiles o sistemas de detección precoz de incendios.

Las técnicas de prevención de incendios y explosiones en la minería están basadas en la limitación de las fuentes de ignición, la limitación de las fuentes de combustible y la limitación de los contactos entre el combustible y la fuente de ignición.

La limitación de las fuentes de ignición tal vez sea la forma más elemental de prevenir incendios y explosiones. Las fuentes de ignición que no resulten esenciales para el proceso minero deberían eliminarse. Así, debería estar totalmente prohibido fumar o hacer fuego, especialmente en las minas subterráneas de carbón. Cualquier equipo automático o mecánico que pueda sufrir un aumento indeseado de calor, como las cintas transportadoras, debería disponer de conmutadores de goteo y de secuencia y disruptores térmicos en los motores eléctricos. Los explosivos constituyen un peligro evidente, pero también pueden actuar como fuentes de ignición del polvo en suspensión de gases peligrosos y sólo deberían utilizarse observando estrictamente la normativa especial sobre voladuras.

La eliminación de las fuentes eléctricas de ignición es una medida preventiva esencial contra explosiones. Cualquier equipo eléctrico que vaya a funcionar en lugares donde pueda existir metano, polvo de azufre o cualquier otro peligro de incendio debería estar diseñado, construido, comprobado e instalado de forma que su funcionamiento no pueda provocar incendios o explosiones en la mina. En las zonas de peligro se deberían usar cerramientos a prueba de explosiones, por ejemplo, para fusibles, cajetines e interruptores de circuitos. La utilización de equipos eléctricos intrínsecamente seguros se describe con más detalle en esta Enciclopedia y en documentos como NFPA 70, Código eléctrico nacional (NFPA 1996c).

La limitación de las fuentes de combustible empieza por un buen mantenimiento interno para evitar una acumulación peligrosa de basuras, trapos con aceite, polvo de carbón y demás materiales combustibles.

Siempre que sea posible, ciertas sustancias combustibles como pueden ser los fluidos hidráulicos, las bandas transportadoras, las mangueras hidráulicas y las conducciones de ventilación se sustituirán por otras más inocuas (Bureau of Mines 1978). La combustión de determinados materiales que desprenden productos altamente tóxicos se produce a menudo a partir de la combustión de otros considerados como menos peligrosos. Por ejemplo, muchos países han prohibido recientemente la espuma de poliuretano, que hasta hace poco se utilizaba mucho en las explotaciones subterráneas para sellar las instalaciones de ventilación.

Las explosiones en las minas subterráneas de carbón se deben, por lo general, a combustibles como el polvo de carbón 
y el metano. También puede aparecer metano en minas no carboníferas, y normalmente se combate rebajándolo con aire de ventilación y aspirándolo de la mina (Timmons, Vinson y Kissell 1979). En cuanto al polvo de carbón, en los procesos de minería se hace todo lo posible por reducir al mínimo la producción de polvo, pero resulta casi imposible evitar cantidades tan pequeñas como las que bastan para provocar una explosión de polvo de carbón. Una capa de polvo sobre el suelo de apenas 0,012 $\mathrm{mm}$ de grosor es capaz de provocar una explosión si se halla en suspensión en el aire. Por consiguiente, para prevenir las explosiones de polvo de carbón, hay que pulverizar la roca con alguna sustancia inerte, como la caliza, la dolomita o el yeso.

Con la limitación del contacto entre el combustible y la fuente de ignición se trata de evitar la proximidad entre dichas fuentes y el combustible. Por ejemplo, si no es posible efectuar las operaciones de soldadura y corte en recintos a prueba de incendios, es conveniente humedecer bien la zona y cubrir los combustibles próximos con materiales ignífugos o cambiar su ubicación. Los extintores deberán estar fácilmente accesibles y habrá que vigilar los posibles fuegos latentes durante el tiempo que sea preciso.

Las zonas con gran densidad de materiales combustibles, como talleres y almacenes de vigas, explosivos o líquidos inflamables y combustibles, deberán diseñarse intentando minimizar las posibles fuentes de ignición. En los equipos móviles deberán reubicarse las conducciones de fluido hidráulico, combustible y lubricantes lejos de cualquier superficie caliente, equipo eléctrico o fuente de ignición. Se deberán instalar protectores contra salpicaduras para evitar que las salpicaduras de líquido combustible procedentes de conducciones defectuosas puedan alcanzar posibles fuentes de ignición.

Los requisitos de prevención de incendios y de explosiones en la minería están perfectamente descritos en los documentos NFPA (p. ej., NFPA 1992a, 1995a, 1995b).

\section{Detección de incendios y sistemas de alarma}

El tiempo transcurrido entre el comienzo de un incendio y su detección es crítico, ya que puede aumentar rápidamente en magnitud e intensidad. La forma más rápida y fiable de detectar un fuego es mediante sistemas de detección y de alarma que utilicen sensores de calor, llamas, humos y gases (Griffin 1979).

La detección de gases o humos es el planteamiento más económico de protección contra incendios en áreas extensas o en toda la mina (Morrow y Litton 1992). Los sistemas de detección térmica de incendios se instalan normalmente en equipos sin operador, como las cintas transportadoras. En zonas de mayor peligro, como almacenes de líquidos inflamables y combustibles, zonas de repostaje o talleres, es aconsejable instalar mecanismos de detección de incendios con mayor capacidad de reacción. En esas zonas a menudo se utilizan detectores ópticos de llamas capaces de percibir la radiación ultravioleta o infrarroja emitida por el fuego.

Una vez detectado un incendio, hay que alertar inmediatamente a todos los mineros. A veces se utilizan teléfonos o mensajeros, pero a menudo los mineros se encuentran lejos de los teléfonos o dispersos por la mina. En las minas de carbón, la forma más común de alertar de un incendio es cortar el suministro eléctrico y comunicarse después por teléfono y mensajeros. Esta medida no es aplicable a minas no carboníferas, en las que muy pocos equipos utilizan motor eléctrico. La notificación mediante olor fétido es un método muy común de aviso de emergencias en las minas subterráneas no carboníferas (Pomroy y Muldoon 1983). También se han utilizado de forma satisfactoria sistemas especiales de comunicación por radiofrecuencia en explotaciones mineras de carbón y otros minerales (Bureau of Mines 1988).

La máxima preocupación en caso de incendio subterráneo debe ser la seguridad del personal dentro de la mina. Una detección y una alarma precoces permiten poner en marcha el plan de emergencia, que debe garantizar el desarrollo de las actividades necesarias, como la evacuación y la extinción del incendio. Para asegurar una ejecución fluida del plan de emergencia, los mineros deben recibir una formación exhaustiva y recordatorios periódicos de los procedimientos de emergencia. Han de realizarse simulacros de incendio con cierta periodicidad, activando incluso el sistema de alarma de la mina para reforzar el adiestramiento, así como para detectar fallos del plan de emergencia.

Más información sobre la detección de incendios y los sistemas de alarma puede encontrarse en esta Enciclopedia y en documentos NFPA (p. ej., NFPA 1995a, 1995b, 1996d).

\section{Extinción de incendios}

Los equipos de extinción de incendios de uso más común en las minas subterráneas son los extintores portátiles, las mangueras de agua, los sistemas de aspersores, el polvo de roca (aplicado manualmente o con una máquina especial) y los lanzadores de espuma. El tipo más usual de extintor portátil es el que emplea productos químicos secos de uso múltiple.

Los sistemas de extinción de incendios, ya sean manuales o automáticos, se utilizan cada vez más en equipos móviles, zonas de almacenamiento de líquidos combustibles, cintas transportadoras e instalaciones eléctricas (Grannes, Ackerson y Green 1990). La extinción automática de incendios es especialmente importante en equipos sin operador, automáticos o de control remoto, en los que no hay nadie para detectar el fuego, activar el sistema automático de extinción o poner en marcha el procedimiento de extinción.

La eliminación de explosiones constituye una variante de la extinción de incendios. En algunas minas de carbón europeas se utiliza a pequeña escala esta tecnología en forma de barreras pasivas o activas. Las barreras pasivas están formadas por una serie de filas de grandes recipientes llenos de agua o polvo de roca suspendidos del techo a la entrada de la mina. En caso de explosión, el frente de presión que precede la llegada del frente de llamas activa el vertido del contenido de los recipientes. La sustancia extintora vertida sofoca las llamas en el momento de atravesar la entrada protegida por el sistema de barrera. Las barreras activas disponen de un mecanismo de disparo eléctrico o neumático que es activado por el calor, las llamas o la presión de la explosión, liberando los agentes extintores almacenados en los recipientes a presión (Hertzberg 1982).

Los incendios de cierta magnitud sólo deben ser combatidos por equipos de extinción altamente adiestrados y dotados de material especial. Deberán adoptarse medidas especiales siempre que ardan grandes extensiones de carbón o madera en minas subterráneas o cuando la extinción del incendio se vea dificultada por grandes desprendimientos del techo, fallos de ventilación o acumulación de gases explosivos. Las únicas alternativas prácticas pueden ser inertizar con nitrógeno o dióxido de carbono los productos de combustión de un generador de gas inerte, inundar con agua o cerrar parte o toda la mina (Ramaswatny y Katiyar 1988).

Más información acerca de la extinción de incendios puede encontrarse en esta Enciclopedia y en diversos documentos NFPA (p. ej., NFPA 1994b, 1994c, 1994d, 1995a, 1995b, 1996e, 1996f, 1996g). 


\section{Contención de incendios}

La contención de incendios constituye un mecanismo fundamental de control en cualquier tipo de instalación industrial. La contención o limitación de un incendio en una mina subterránea puede garantizar una evacuación más segura y reducir los peligros de extinción del incendio.

En las minas de carbón subterráneas, el gasóleo y los aceites deberán almacenarse en recipientes cerrados e ignífugos y la construcción de las zonas de almacenamiento debe ser resistente al fuego. Las estaciones transformadoras, las estaciones de carga de baterías, los compresores de aire, las subestaciones, los talleres y demás instalaciones deberán estar alojados en zonas ignífugas o con estructuras a prueba de incendios. Los equipos eléctricos sin operario deberán ir montados sobre superficies no combustibles y separados del carbón o de cualquier otro combustible, o protegidos mediante un sistema de extinción de incendios.

Los materiales para construir tabiques y cierres, como maderas, telas, sierras, clavos, martillos, yeso o cemento y polvo de roca deben estar fácilmente accesibles en todas las zonas de trabajo. En las minas de carbón subterráneas, los aceites, las grasas y los combustibles diesel deberán almacenarse en recipientes herméticamente cerrados y en zonas ignífugas a una distancia de seguridad de los depósitos de explosivos, las instalaciones eléctricas y las estaciones de pozos. En determinadas áreas son necesarias barreras de control de ventilación y puertas cortafuegos para evitar la propagación de las llamas, el humo o los gases tóxicos (Ng y Lazzara 1990).

\section{Almacenamiento de reactivos}

Ciertas operaciones del tratamiento a que se somete el mineral extraído de la mina pueden provocar situaciones de peligro, como explosiones de polvo e incendios en operaciones de transporte.

El calor generado por la fricción entre la cinta transportadora y los rodillos motrices o de tensión puede constituir un problema; para atajarlo, se utilizarán conmutadores de goteo y de secuencia, que también pueden emplearse satisfactoriamente junto con los disyuntores térmicos en los motores eléctricos.

El peligro de explosión puede prevenirse eliminando las fuentes eléctricas de ignición. Los equipos eléctricos que funcionan en entornos en que puede existir metano, polvo de azufre o cualquier otra sustancia peligrosa se deben diseñar, construir, comprobar e instalar de forma que su funcionamiento no ocasione incendios ni explosiones.

Las reacciones de oxidación exotérmicas pueden producirse tanto en el mineral de carbón como en el de sulfuro metálico (Smith y Thompson 1991). Si no se disipa el calor generado en tales reacciones, aumentará la temperatura del estrato rocoso o del montón de mineral. Cuando la temperatura alcance un valor suficientemente elevado, puede producirse la combustión rápida del carbón, de los minerales sulfurosos y de otras sustancias combustibles (Ninteman 1978).

Aunque los incendios por ignición espontánea se producen con una frecuencia relativamente baja, suelen causar daños considerables a la explotación y además son difíciles de extinguir.

El procesamiento del carbón presenta problemas especiales, pues por su naturaleza constituye una fuente de combustible. Más información sobre la protección contra incendios y explosiones en relación con una manipulación segura del carbón puede encontrarse en esta Enciclopedia y en diversos documentos NFPA (p. ej., NFPA 1992b, 1994e, 1996h).

\section{DETECGION DE GASES}

\section{Paul MacKenzie-Wood}

Todo el personal que trabaje en explotaciones mineras subterráneas debe tener conocimiento de las características de los gases de la mina y ser consciente de los peligros que pueden causar. De igual forma, es necesario que tenga un conocimiento básico de los instrumentos y sistemas para la detección de gases. Los encargados de la utilización de dichos instrumentos han de conocer en detalle sus limitaciones y los tipos de gases para los que están indicados.

El ser humano es capaz de detectar, incluso sin instrumento alguno, la aparición progresiva de los fenómenos químicos y físicos asociados a la combustión espontánea. El calor eleva la temperatura del aire de ventilación y lo satura de humedad superficial e integral por efecto del calentamiento. Cuando este aire entra en contacto con otro más frío en el ramal de ventilación, se produce una condensación que da lugar a una neblina y a la aparición de gotas en las superficies de las conducciones de retorno. El síntoma es la presencia de un característico olor a aceite o a petróleo, seguido a veces de humo y, finalmente, de llamas visibles.

El monóxido de carbono ( $\mathrm{CO}$ ), que es un gas inodoro, aparece en concentraciones medibles alrededor de $50-60^{\circ} \mathrm{C}$ antes de que se manifieste el característico olor de la combustión espontánea. Por consiguiente, la mayoría de los sistemas de detección de incendios se basan en el reconocimiento de este aumento de la concentración del monóxido de carbono por encima del nivel normal en una zona concreta de la mina.

A veces, un foco de calor es detectado por una persona capaz de percibir un ligero olor durante un breve instante. Otras, es necesario repetir la inspección exhaustiva de la zona varias veces antes de detectar un aumento notable y medible de la concentración de monóxido de carbono. Por consiguiente, el personal de la mina nunca debe descuidar la vigilancia y ha de poner en marcha el proceso de intervención preestablecido tan pronto como sospeche o detecte y notifique la presencia de cualquiera de los indicadores. Afortunadamente, gracias al notable avance de la tecnología de detección y control de incendios registrado desde el decenio de 1970 (válvulas detectoras, detectores electrónicos de bolsillo, sistemas informáticos fijos, etc.), ya no hay que depender exclusivamente de los sentidos humanos.

\section{Instrumentos portátiles para la detección de gases}

El detector de gases está diseñado para detectar y controlar la presencia de un amplio campo de tipos y concentraciones de gas resultantes de incendios, explosiones o cualquier ambiente deficitario de oxígeno, así como para alertar de forma inmediata sobre la aparición de una combustión espontánea. Entre los gases para los que utilizan estos detectores se encuentran: el $\mathrm{CO}$, el dióxido de carbono $\left(\mathrm{CO}_{2}\right)$, el dióxido de nitrógeno $\left(\mathrm{NO}_{2}\right)$, el sulfuro de hidrógeno $\left(\mathrm{H}_{2} \mathrm{~S}\right)$ y el dióxido de azufre $\left(\mathrm{SO}_{2}\right)$. Existen varios tipos de instrumentos, y la elección de cuál se ha de utilizar en una situación concreta dependerá de la respuesta a las siguientes preguntas:

- ¿Por qué se precisa detectar un gas o gases concretos?

- ¿Cuáles son las propiedades de dichos gases?

- ¿Dónde y en qué circunstancias se producen?

- ¿Qué instrumento o mecanismo de detección de gases resulta más adecuado para tales circunstancias? 
- ¿Cómo funciona dicho instrumento?

- ¿Cuáles son sus limitaciones?

- ¿Cómo deben interpretarse los resultados obtenidos?

Los trabajadores deben estar adiestrados en la utilización correcta de los detectores portátiles de gas, que deberán conservarse siguiendo las indicaciones del fabricante.

\section{Equipos universales de detección}

El equipo de detección está compuesto por una bomba de tipo pistón o fuelle accionada por un muelle y un juego de tubos indicadores de cristal que contienen las sustancias químicas específicas para cada gas. La bomba tiene una capacidad de 100 cc y puede accionarse con una sola mano, de modo que pase una muestra de ese volumen a través del tubo indicador antes de pasar al fuelle. El indicador de alarma en la escala graduada corresponde al nivel mínimo de decoloración general y no al punto más profundo de penetración del color.

El aparato es fácil de manejar y no necesita calibrado. Sin embargo, hay que adoptar ciertas precauciones:

- los tubos indicadores (que deben estar fechados) suelen tener una vida de almacenamiento de dos años;

- un tubo indicador puede reutilizarse unas diez veces mientras no sufra ninguna decoloración;

- la precisión general de cada medida suele situarse en torno a $\pm 20 \%$;

- los tubos para hidrógeno no pueden utilizarse en instalaciones subterráneas por el intenso calor generado;

- hay que utilizar un "tubo previo" relleno de carbón vegetal activado cuando se observen niveles bajos de monóxido de carbono en presencia de gases de escape diesel o de hidrocarburos superiores que pueden existir después de una explosión;

- los gases de escape deben pasar por un sistema de refrigeración para enfriarlos por debajo de $40^{\circ} \mathrm{C}$ antes de pasar por el tubo indicador;

- los tubos para oxígeno y metano no se deben utilizar en instalaciones subterráneas por su falta de precisión.

\section{Metanómetros de tipo catalítico}

El metanómetro de tipo catalítico se utiliza en explotaciones mineras subterráneas para medir la concentración de metano en el aire. Este aparato consta de un sensor basado en el principio de una red de cuatro arrollamientos espirales equilibrados en cuanto a resistencia, generalmente filamentos catalíticos, dispuestos de una forma simétrica conocida con el nombre de puente de Wheatstone. Normalmente, dos de los filamentos son activos y los otros dos pasivos. Los filamentos activos suelen ir recubiertos con un catalizador de óxido de paladio para provocar la oxidación del gas inflamable a temperaturas más bajas.

El metano flotante en la atmósfera llega a la cámara de muestreo bien por difusión a través de un disco sinterizado o bien siendo arrastrado por un aspirador o una bomba interna. $\mathrm{Al}$ pulsar el botón de funcionamiento del metanómetro se cierra el circuito y la corriente que fluye por el puente de Wheatstone produce la oxidación del metano en los filamentos catalíticos (activos) de la cámara de muestreo. El calor de esta reacción eleva la temperatura de los filamentos catalíticos, aumentando su resistencia eléctrica y provocando el desequilibrio del puente. La corriente eléctrica que circula es proporcional a la resistencia del elemento y, por consiguiente, a la cantidad de metano existente. El resultado se muestra en un indicador de salida graduado como porcentaje de metano presente. Los elementos de referencia del circuito del puente de Wheatstone sirven para compensar las variaciones de las condiciones del entorno, como la temperatura ambiente y la presión barométrica.

Este instrumento presenta una serie de limitaciones importantes:

- para que el aparato funcione, tiene que haber presencia tanto de metano como de oxígeno. Si el nivel de oxígeno en la cámara de muestreo es inferior al $10 \%$, no se oxidará la totalidad del metano que llegue al detector y se obtendrá una lectura anormalmente baja. Por esta razón, no debe utilizarse para medir niveles de metano después de una explosión o en zonas estancas en las que la concentración de oxígeno sea reducida. Si la cámara contiene metano puro no se producirá ningún tipo de lectura. De forma similar, hay que pulsar el botón de funcionamiento antes de introducir el instrumento en una previsible capa de metano para que penetre en la cámara aire rico en oxígeno. La presencia de dicha capa se verá confirmada por una lectura superior a la de la escala completa, seguida de un retorno a los límites de ésta a medida que se consuma el oxígeno;

- el metanómetro catalítico responde a gases inflamables distintos del metano, como el hidrógeno o el monóxido de carbono. Por consiguiente, pueden producirse lecturas ambiguas de gases existentes aún después de producirse incendios o explosiones;

- los instrumentos dotados de cabezales de difusión deberán protegerse de las corrientes fuertes de aire para evitar lecturas falsas, cubriéndolos con la mano o con cualquier otro objeto;

- los instrumentos con filamentos catalíticos pueden no responder al metano si el filamento entra en contacto con vapores de gases tóxicos en el momento de su calibrado o de su utilización (p. ej., siliconas de barnices de muebles, barnices y pinturas para suelos, ésteres de fosfato existentes en fluidos hidráulicos y carbonos fluorados empleados como impulsores en los vaporizadores de aerosol);

- los metanómetros basados en el principio del puente de Wheatstone pueden arrojar lecturas erróneas con distintos ángulos de inclinación. Esta imprecisión se puede minimizar sosteniendo el instrumento en un ángulo de $45^{\circ}$ en el momento de su calibrado y de su uso;

- los metanómetros pueden arrojar lecturas erróneas a distintas temperaturas ambiente. Esta imprecisión puede reducirse al mínimo calibrando el instrumento en condiciones de temperatura similares a las existentes en la explotación subterránea.

\section{Células electroquímicas}

En las minas subterráneas se utilizan instrumentos con células electroquímicas para medir la concentración de oxígeno y de monóxido de carbono. Existen dos versiones: la célula de composición, que sólo responde a variaciones en la concentración de oxígeno, y la célula de presión parcial, que responde a los cambios de presión parcial del oxígeno en la atmósfera y, por tanto, del número de moléculas de oxígeno por unidad de volumen.

La célula de composición emplea una barrera de difusión capilar que frena la difusión del oxígeno a través de la célula de combustible de forma que la velocidad a la que el oxígeno puede alcanzar el electrodo depende únicamente del contenido de oxígeno de la muestra. La célula no se ve afectada por las variaciones de altitud (es decir, de presión barométrica), temperatura y humedad relativa. Sin embargo, la presencia de $\mathrm{CO}_{2}$ en la mezcla altera la velocidad de difusión del oxígeno y provoca lecturas erróneas por exceso. Por ejemplo, la presencia de un 
$1 \%$ de $\mathrm{CO}_{2}$ llega a incrementar la lectura del oxígeno hasta en un $0,1 \%$. Aunque pequeño, este incremento puede resultar significativo e invalidar la lectura. Es particularmente importante tener en cuenta esta limitación siempre que el instrumento vaya a utilizarse después de una explosión o en ambientes donde se sepa qué contienen $\mathrm{CO}_{2}$.

La célula de presión parcial está basada en el mismo principio electroquímico que la célula de concentración, aunque carece de barrera de difusión y sólo responde al número de moléculas de oxígeno por unidad de volumen, dependiendo, por tanto, de la presión. Las concentraciones de $\mathrm{CO}_{2}$ inferiores al $10 \%$ no provocan ningún efecto a corto plazo sobre la lectura, pero a la larga, el dióxido de carbono destruye el electrolito y acorta la vida de la célula.

La fiabilidad de las lecturas de oxígeno de la célula de presión parcial se ve afectada por las siguientes circunstancias:

- altitud y presión barométrica: el desplazamiento desde la superficie hasta el fondo del pozo incrementa la lectura de oxígeno en un $0,1 \%$ cada $40 \mathrm{~m}$ descendidos. Lo mismo vale para la inclinación, presente en las explotaciones subterráneas. Además, los 5 milibares de variación normal diaria en la presión barométrica pueden alterar la lectura de oxígeno hasta en un $0,1 \%$. La actividad tormentosa puede provocar una disminución de unos 30 milibares en la presión, lo que causaría una reducción del $0,4 \%$ en la lectura de oxígeno;

- ventilación: la variación máxima de presión en el ventilador debería ser de unas 6-8 pulgadas de altura manométrica de agua o bien 10 milibares. Esto ocasionaría una caída de un $0,4 \%$ en la lectura del oxígeno desde la entrada hasta el retorno del ventilador y una disminución del $0,2 \%$ desde el frente más alejado del fondo del pozo;

- temperatura: la mayoría de los detectores disponen de un circuito electrónico que mide la temperatura de la célula e introduce la corrección pertinente debida al efecto de la misma sobre la medida del sensor;

- humedad relativa: un aumento de la humedad relativa desde la condición de sequedad hasta la saturación a $20^{\circ} \mathrm{C}$ ocasionaría aproximadamente una disminución de un $0,3 \%$ en la lectura de oxígeno.

\section{Otras células electroquímicas}

Se han construido células electroquímicas capaces de medir concentraciones de $\mathrm{CO}$ desde $1 \mathrm{ppm}$ hasta $4.000 \mathrm{ppm}$. Su funcionamiento se basa en la medida de la corriente eléctrica existente entre los cátodos sumergidos en un electrolítico acidificado. El CO se oxida en el ánodo para formar $\mathrm{CO}_{2}$ y la reacción libera electrones en proporción directa a la concentración de $\mathrm{CO}$.

También existen células electroquímicas para el hidrógeno, el sulfuro de hidrógeno, el óxido nítrico, el dióxido de nitrógeno y el dióxido de azufre, aunque adolecen de sensibilidad cruzada.

No existe en el mercado ninguna célula electroquímica para $\mathrm{CO}_{2}$. Esta carencia se ha subsanado con el desarrollo de un instrumento portátil que contiene una minicélula de rayos infrarrojos sensible al dióxido de carbono en concentraciones por encima del $5 \%$.

\section{Detectores de radiación infrarroja no dispersiva}

Los detectores de radiación infrarroja no dispersiva son capaces de medir cualquier gas que contenga radicales químicos del tipo $-\mathrm{CO},-\mathrm{CO}_{2} \mathrm{y}-\mathrm{CH}_{3}$, los cuales absorben las frecuencias infrarrojas que son específicas de su configuración molecular. Tales sensores son caros pero proporcionan una lectura precisa para gases tales como $\mathrm{CO}, \mathrm{CO}_{2}$ y metano en un contexto variable de otros gases y con bajos niveles de oxígeno resultando, por consiguiente, idóneos para controlar gases en reductos confinados. $\mathrm{El} \mathrm{O}_{2}, \mathrm{~N}_{2}$ y $\mathrm{H}_{2}$ no absorben la radiación infrarroja por lo que no pueden detectarse con este método.

Otros sistemas portátiles con detectores basados en propiedades de conducción térmica y en el índice de refracción resultan de utilidad limitada en la minería del carbón.

\section{Limitaciones de los instrumentos portátiles de detección de gases}

La eficacia de los instrumentos portátiles de detección de gases está limitada por una serie de factores:

- Es necesario calibrarlos. Esto significa normalmente una puesta a cero y una comprobación del voltaje diarios, una comprobación semanal de la escala y una prueba de calibrado cada 6 meses a cargo de un organismo externo autorizado;

- Los sensores tienen una vida limitada. Si no vienen fechados por el fabricante, es aconsejable registrar la fecha de adquisición;

- Los sensores pueden llegar a contaminarse;

- Los sensores pueden verse afectados por sensibilidades cruzadas;

- Una exposición excesiva puede saturar el sensor y provocar una recuperación más lenta;

- La inclinación puede afectar a la lectura;

- Las baterías deben cargarse y descargarse periódicamente.

\section{Sistemas centralizados de control}

Con las inspecciones, la ventilación y los análisis con instrumentos portátiles se consigue a menudo detectar y localizar pequeños focos de calor que provocan cantidades reducidas de $\mathrm{CO}$ antes de que éste se propague por el sistema de ventilación o de que su nivel supere los límites permitidos. Sin embargo, estos controles no resultan adecuados en aquellos lugares en que exista un riesgo notable de combustión, cuando los niveles de metano en las galerías de retorno sobrepasen el $1 \%$ o cuando se sospeche la posibilidad de ciertos peligros. En tales circunstancias, es necesario un control continuo en puntos estratégicos. Hay varios tipos de sistemas centralizados de supervisión continua.

\section{Sistemas de grupos de tubos}

El sistema de grupos de tubos, desarrollado en Alemania en el decenio de 1960 para detectar y controlar la evolución de combustiones espontáneas, consta de una serie de hasta 20 tubos de plástico fabricados en naylon o en polietileno con un diámetro de $1 / 4$ o $3 / 8$ de pulgada que se extienden desde un banco de analizadores en la superficie hasta puntos seleccionados en las galerías subterráneas. Los tubos van equipados con filtros, drenajes y parallamas; los analizadores suelen ser de tipo infrarrojo para el $\mathrm{CO}, \mathrm{CO}_{2}$ y metano, y paramagnéticos para el oxígeno. Una bomba de barrido impulsa el paso simultáneo de una muestra a través de cada tubo y un temporizador secuencial va dirigiendo sucesivamente la muestra de cada tubo a través de los analizadores. El registro de datos recoge la concentración de cada gas en cada una de las ubicaciones y activa una alarma automática en cuanto se sobrepasan ciertos niveles fijados.

Este sistema presenta las siguientes ventajas:

- No se precisa instrumentación antideflagración;

- El mantenimiento es relativamente sencillo;

- No necesita alimentación eléctrica en áreas subterráneas;

- Cubre una amplia gama de gases; 
- Los analizadores por infrarrojos suelen ser bastante estables y fiables; conservan sus características específicas en entornos cambiantes de gases procedentes de combustión y en atmósferas pobres en oxígeno (una elevada concentración de metano y/o de dióxido de carbono puede presentar sensibilidad cruzada a la lectura de monóxido de carbono en los bajos valores de ppm);

- Los instrumentos pueden calibrarse a la intemperie, aunque las muestras para calibrado deberían enviarse por los tubos para comprobar la integridad del sistema de recogida así como el sistema de identificación de las ubicaciones de donde proceden las diferentes muestras.

El sistema presenta asimismo algunos inconvenientes:

- Los resultados no se obtienen en tiempo real;

- Las fugas no se detectan de forma inmediata;

- Puede producirse condensación en los tubos;

- Los defectos del sistema no siempre se manifiestan de manera inmediata y su identificación puede entrañar ciertas dificultades;

- Los tubos pueden sufrir daños a causa de voladuras, incendios o explosiones.

\section{Sistema telemétrico (electrónico)}

El sistema telemétrico automático de supervisión de gases consta de un módulo de control en la superficie y una serie de cabezas sensoras de seguridad intrínseca colocadas en las áreas subterráneas y conectadas por línea telefónica o cables de fibra óptica. Hay sensores para metano, CO y velocidad del aire. El sensor para CO es similar al sensor electroquímico utilizado en los instrumentos portátiles y adolece de las mismas limitaciones. El sensor para metano se basa en la combustión catalítica del metano sobre los elementos activos de un circuito de un puente de Wheatstone que pueden estar contaminados por compuestos de azufre, ésteres fosfáticos o compuestos de silicio y que no funcionará a bajas concentraciones de oxígeno.

Entre las ventajas específicas de este sistema se encuentran:

- Los resultados se obtienen en tiempo real (es decir, existe una indicación inmediata de la existencia de fuego o de la aparición de metano);

- Permite trabajar con distancias apreciables entre las cabezas sensoras y la unidad de control sin afectar al comportamiento del sistema;

- Los fallos de los sensores se detectan inmediatamente.

Este sistema también presenta algunos inconvenientes:

- Precisa un alto nivel de mantenimiento:

- La gama del sensor para CO es limitada $(0,4 \%)$;

- La variedad de sensores es limitada; no existen para $\mathrm{CO}_{2}$ ni para hidrógeno;

- El sensor para metano puede sufrir contaminación;

- Es necesario un calibrado in situ;

- La sensibilidad cruzada puede constituir un problema;

- Puede producirse una pérdida de potencia (p. ej., 1,25 \% para el metano);

- La vida de los sensores está limitada entre 1 y 2 años;

- El sistema no resulta adecuado para ambientes pobres en oxígeno (p. ej., zonas estancas).

\section{Cromatógrafo de gases}

El cromatógrafo de gases es un equipo muy complejo capaz de analizar muestras con un elevado grado de precisión y que, hasta ahora, sólo podía ser utilizado por químicos o técnicos especialmente cualificados y adiestrados. Las muestras de gas procedentes de un tubo o de un grupo de tubos se inyectan automáticamente en el cromatógrafo de gases o se introducen manualmente a partir de muestras embolsadas extraídas de la mina. Una columna con relleno especial sirve para separar los distintos gases y, con el correspondiente detector, normalmente de conductividad térmica o de ionización de llama, se mide cada gas a medida que sale de la columna. El proceso de separación proporciona un elevado grado de especificidad.

El cromatógrafo de gases presenta ventajas concretas:

- No tiene lugar la sensibilidad cruzada con otros gases;

- Es capaz de medir hidrógeno;

- Es capaz de medir el etileno y otros hidrocarburos superiores;

- Es capaz de medir con precisión concentraciones desde muy bajas hasta muy altas de la mayoría de los gases presentes o que puedan generarse en el interior a causa de un foco de calor o de un fuego;

- Está generalmente aceptado que los sistemas modernos contra incendios y focos de calor en las minas de carbón deben basarse en el análisis de gases procedentes de ubicaciones estratégicas de la mina. La obtención de resultados precisos, fiables y exhaustivos requiere un cromatógrafo de gases, y su interpretación, por personal cualificado, experto y perfectamente adiestrado.

Entre los inconvenientes cabe citar:

- Los análisis son relativamente lentos;

- Exigen un elevado grado de mantenimiento;

- El equipamiento y los controles son complejos;

- Se precisa una atención periódica esmerada;

- El calibrado debe realizarse con cierta frecuencia;

- Una elevada concentración de metano interfiere con la medida de niveles bajos de company

\section{Elección del sistema}

Los sistemas de grupos de tubos son los más indicados para controlar zonas en que no se esperan variaciones rápidas de la concentración del gas o, como en el caso de las zonas mal ventiladas, con un bajo nivel de oxígeno.

Los sistemas telemétricos resultan adecuados en lugares como las instalaciones de cintas transportadoras o el frente, donde pueden producirse cambios rápidos en la concentración del gas significativos.

La cromatografía de gases no sustituye los sistemas actuales de control, sino que viene a completar la amplitud, precisión y fiabilidad de los análisis. Este aspecto es especialmente importante cuando se trata de evaluar un riesgo de explosión o cuando un foco de calor está alcanzando una fase avanzada.

\section{Consideraciones acerca del muestreo}

- La ubicación de los puntos de muestreo en lugares estratégicos es de la máxima importancia. La información procedente de un punto aislado de muestreo alejado de la fuente sólo es indicativa $\mathrm{y}$, sin una confirmación de otras ubicaciones, puede conducir a una valoración excesiva o deficiente de la gravedad de una situación. En consecuencia, los puntos de muestreo para detectar la aparición de una combustión espontánea deben ubicarse allí donde exista mayor probabilidad de que surjan focos de calor. Apenas debe existir disminución de los flujos entre el foco de calor y los detectores. Deberá tenerse en cuenta la posibilidad de formación de capas de metano y de gases de combustión calientes que pueden incrementar la inclinación en zonas mal ventiladas. 
Preferiblemente, los puntos de muestreo deberán ubicarse en los entrantes de los paneles, detrás de los tabiques de ventilación y en los diques de cierre, así como en la corriente principal del circuito de ventilación. Deberán tenerse en cuenta las siguientes consideraciones:

- El lugar de muestreo ha de situarse como mínimo a $5 \mathrm{~m}$ de una puerta de cierre, ya que éstos presentan un efecto de aspiración al aumentar la presión atmosférica;

- Las muestras deben extraerse de las perforaciones sólo cuando están expulsando el aire y pueda garantizarse que no hay fugas;

- Las muestras deben tomarse a una distancia superior a los $50 \mathrm{~m}$ corriente abajo de un fuego para garantizar la mezcla (Mitchell y Burns 1979);

- Las muestras deben tomarse en la parte ascendente del gradiente de un fuego cerca del techo, habida cuenta del ascenso de los gases calientes;

- Las muestras deben tomarse frente a una puerta de ventilación para evitar las fugas;

- Todos los puntos de muestreo deberán estar claramente indicados en los mapas esquemáticos del sistema de ventilación de la mina. La toma de muestras de gases para su análisis en cualquier otra ubicación de áreas subterráneas o de perforaciones de superficie es dificultosa y está sujeta a errores. La muestra contenida en la bolsa o en el envase debe representar fielmente la atmósfera en el punto de muestreo.

Actualmente, en la industria se están utilizando de forma generalizada las bolsas de plástico para la toma de muestras. El plástico minimiza los escapes y puede mantener adecuadamente una muestra durante 5 días. Si hay hidrógeno presente en la bolsa, se irá degradando con una pérdida diaria de un $1,5 \%$ de su concentración original. Una muestra dentro de la cámara de un balón de fútbol cambia de concentración en media hora. Las bolsas son fáciles de llenar y la muestra puede expulsarse al interior de un instrumento de análisis o extraerse con una bomba.

En los tubos metálicos que se llenan a presión por medio de una bomba pueden almacenarse muestras durante largos períodos de tiempo, pero el tamaño de la muestra es limitado y es habitual que se produzcan pérdidas por fugas. El cristal es inerte a los gases, pero los recipientes de cristal son frágiles y es difícil extraer de ellos la muestra sin que se diluya.

Antes de recoger la muestra, hay que esterilizar el recipiente al menos tres veces para eliminar totalmente los restos de la muestra anterior. Cada recipiente debe llevar una etiqueta con información de interés, tal como la fecha y hora de recogida, la ubicación exacta, el nombre de la persona responsable de la recogida de la muestra, etc.

\section{Interpretación de los datos de muestreo}

La interpretación y el análisis de los resultados del muestreo de gases constituye una ciencia compleja y sólo debe ser practicada por personas con formación y experiencia específicas. Estos datos son vitales en muchas emergencias, pues proporcionan información sobre lo que está ocurriendo dentro de la mina, que son datos necesarios para planificar e implantar las acciones correctoras y preventivas oportunas. Durante un calentamiento, incendio o explosión subterráneos o inmediatamente después de ellos, deberán controlarse en tiempo real todos los parámetros ambientales posibles para que los responsables puedan evaluar con exactitud el estado de la situación y medir su evolución, a fin de poner rápidamente en marcha cualquier actuación de rescate necesaria.
Los resultados de los análisis de gases deben cumplir los siguientes criterios:

- Precisión: los instrumentos deben estar correctamente calibrados;

- Fiabilidad: hay que conocer la posibilidad de sensibilidades cruzadas;

- Carácter global: deben medirse todos los gases, incluidos el hidrógeno y el nitrógeno;

- Atemporalidad: si no existe la posibilidad de trabajar en tiempo real deberá efectuarse un análisis de tendencias;

- Validez: los puntos de muestreo deben situarse dentro y en torno al lugar del incidente.

$\mathrm{Al}$ interpretar los resultados de los análisis de gases hay que respetar las siguientes reglas:

- Deberán seleccionarse cuidadosamente algunos puntos de muestreo y reseñarse sobre plano. Para el análisis de tendencias, es más adecuado hacer ésto que tomar muestras de muchos puntos;

- Si un resultado se desvía de la tendencia, deberá confirmarse el valor repitiendo el muestreo o comprobarse el calibrado del instrumento antes de adoptar ninguna decisión. Las variaciones de las influencias externas, tales como ventilación, presión barométrica y temperatura o el funcionamiento de un motor diesel en la zona, suelen provocar desviaciones en los resultados;

- Deberá conocerse la composición o mezcla del gas en circunstancias ajenas a la minería y tenerlo en cuenta al efectuar los cálculos;

- No deberá aceptarse sin más ningún resultado de los análisis; los resultados deben ser válidos y comprobables;

- Hay que tener presente que las cifras aisladas no indican evolución; las tendencias proporcionan una imagen más exacta.

\section{Cálculo de los resultados en aire libre}

Los resultados en aire libre se obtienen eliminando en los cálculos el aire atmosférico de la muestra (Mackenzie-Wood y Strang 1990) para poder comparar adecuadamente muestras de una zona similar una vez eliminado el efecto de dilución del escape del aire.

La fórmula es como sigue:

$$
\text { Resultado en aire libre }=\frac{\text { Resultado analizado }}{100-4,776 \mathrm{O}_{2}}
$$

que se obtiene de la siguiente forma:

$$
\begin{aligned}
\text { Aire atmosférico } & =O_{2}+\mathcal{N}_{2}= \\
& =O_{2}+\frac{79,1 O_{2}}{20,9}= \\
& =4,776 O_{2}
\end{aligned}
$$

Los resultados en aire libre son útiles cuando se necesita determinar la tendencia y ha existido riesgo de dilución del aire entre el punto de muestreo y la fuente, se ha producido un escape de aire en las líneas de muestreo o ha penetrado aire en las muestras de las bolsas. Por ejemplo, si se trata de hallar la tendencia de la concentración de monóxido de carbono en un incendio, una dilución del aire debida a un aumento de la ventilación podría ser interpretada erróneamente como una disminución del monóxido de carbono de la fuente. El cálculo de la tendencia de las concentraciones en aire libre proporcionaría un resultado correcto. 
Un cálculo similar se necesita cuando en la zona de muestreo se esté generando metano: el aumento de la concentración de metano rebajaría la concentración de cualquier otro gas que estuviera presente. Por consiguiente, un nivel creciente de óxido de carbono puede presentarse como decreciente.

Los resultados en aire libre para el metano se calculan de la siguiente manera:

$$
\text { Resultados libre de metano }=\frac{\text { Resultado analizado }}{100-\mathrm{CH}_{4} \%}
$$

\section{Combustión espontánea}

La combustión espontánea es un proceso por el cual una sustancia arde debido a su calor interno, que surge de forma espontánea a causa de ciertas reacciones que liberan calor a mayor velocidad de la que puede disiparse en la atmósfera. La combustión espontánea del carbón suele ser lenta hasta que la temperatura alcanza los $70^{\circ} \mathrm{C}$, lo que se conoce como "temperatura de transición". Por encima de dicha temperatura, la reacción suele acelerarse. Pasados los $300^{\circ} \mathrm{C}$ se liberan gases volátiles también denominados "gas de hulla" o "gas de craquin". Estos gases (hidrógeno, metano y monóxido de carbono) entran en combustión de forma espontánea a temperaturas próximas a los $650^{\circ} \mathrm{C}$ (se ha observado que la presencia de radicales libres puede dar lugar a la aparición de llamas en el carbón a unos $400{ }^{\circ} \mathrm{C}$ ). En la Tabla 74.4 se ofrece el proceso de un caso típico de combustión espontánea (los resultados pueden variar según el tipo de carbón).

\section{Monóxido de carbono}

$\mathrm{El} \mathrm{CO}$ se libera realmente unos $50^{\circ} \mathrm{C}$ antes de que pueda percibirse el olor característico de la combustión. La mayoría de los sistemas diseñados para detectar la aparición de una combustión espontánea se basan en la detección del monóxido de carbono en concentraciones superiores a las normales en una determinada zona de la mina.

Una vez detectado un foco de calor, debe controlarse para determinar su estado (es decir, su temperatura y magnitud), el ritmo de aceleración, las emisiones tóxicas y la posibilidad de explosión de la atmósfera.

\section{Control de focos de calor}

Hay una serie de índices y parámetros que ayudan a los planificadores a determinar la extensión, la temperatura y el ritmo de progreso de un foco de calor y que generalmente están basados en las variaciones de la composición del aire que pasa por una zona en estudio. Son muchos los indicadores que se han descrito en la bibliografía publicada a lo largo de los años y la mayoría ofrecen un ámbito muy limitado de aplicación y son de escaso valor. Todos ellos son específicos de la ubicación y varían con los distintos tipos de carbón y las circunstancias concretas. Entre los más populares cabe citar: tendencias del monóxido de carbono; mezcla de monóxido de carbono (Funkemeyer y Kock 1989); coeficiente de Graham (Graham 1921); gases de traza (Chamberlain 1970); coeficiente de Morris (Morris 1988) y coeficiente de monóxido de carbono/dióxido de carbono. A partir del cerramiento de seguridad es difícil utilizar indicadores debido a la ausencia de un flujo definido de aire.

Ningún indicador proporciona un método preciso y seguro para medir el progreso de un incendio. Las decisiones han de basarse en la recogida, tabulación, comparación y análisis de toda la información y en su interpretación a la luz de la formación y la experiencia.

\section{Explosiones}

Las explosiones constituyen el mayor peligro en la minería del carbón, ya que tienen potencial suficiente para acabar con la vida de todos los trabajadores de una galería, destruir el equipamiento y los servicios e impedir la explotación posterior de la mina, y todo ello tal vez en sólo 2 o 3 segundos.

En todo momento deberá controlarse el potencial deflagrante de la atmósfera de la mina, especialmente cuando los trabajadores están realizando tareas de rescate en una mina saturada de gases.

Como en el caso de los indicadores para evaluar un incendio, hay diferentes sistemas para calcular el potencial deflagrante de la atmósfera en una mina subterránea, entre los que se encuentran: el triángulo de Coward (Greuer 1974), el triángulo de Hughes y Raybold (Hughes y Raybold 1960), el diagrama de Elicott (Elicott 1981) y el coeficiente de Trickett (Jones y Trickett 1955).

Debido a la complejidad y variabilidad de las condiciones y circunstancias concretas, no existe una fórmula única a la que atenerse como garantía de que no se vaya a producir una explosión en un determinado momento y en una mina concreta. Hay que confiar en un nivel elevado e ininterrumpido de supervisión, un alto índice de sospecha y una puesta en marcha decidida de las acciones pertinentes en cuanto se aprecie el más mínimo indicio de posibilidad de explosión. Una interrupción temporal de la producción es un precio relativamente pequeño a cambio de evitar una deflagración.

\section{Conclusión}

En este artículo se ha ofrecido un resumen de la detección de los gases que pueden aparecer en incendios y deflagraciones en las minas subterráneas.

Otros aspectos de la salud y la seguridad relativos a la presencia de gases en la minas (p. ej., enfermedades producidas por el polvo, asfixia, efectos tóxicos, etc.) son objeto de estudio en otros artículos de este mismo capítulo y en otros apartados de esta Enciclopedia.

Tabla 74.4 • Calentamiento del carbón - jerarquía de temperaturas.

Temperatura a la cual el carbón absorbe $0_{2}$ para formar un compuesto y producir calor

$30^{\circ} \mathrm{C}$ El compuesto se descompone produciendo $\mathrm{CO} / \mathrm{CO2}$

$45^{\circ} \mathrm{C} \quad$ Oxidación real del carbón para formar $\mathrm{CO}$ y $\mathrm{CO2}$

$70^{\circ} \mathrm{C}$ Temperatura de transición, aceleración del calentamiento

$110^{\circ} \mathrm{C}$ Humedad, liberación de $\mathrm{H} 2$ y del olor característico

$150^{\circ} \mathrm{C}$ Desorción de $\mathrm{CH} 4$, liberación de hidrocarburos no saturados

$300{ }^{\circ} \mathrm{C}$ Liberación de gases de cracking ( $\mathrm{H} 2, \mathrm{CO}, \mathrm{CH} 4$, etc.)

$400^{\circ} \mathrm{C} \quad$ Llama abierta

Fuente: Chamberlain y cols. 1970. 


\section{- Preparacion de EMERgencias}

\section{Gary A. Gibson}

Las emergencias en las minas se producen con frecuencia debido a la ausencia de sistemas destinados a limitar, controlar o prevenir situaciones que, gestionadas de forma ineficaz, desembocan en catástrofes, o bien a fallos en los sistemas existentes. Así pues, una emergencia podría definirse como un suceso imprevisto que afecta a la seguridad y la salud de los individuos o a la continuidad de la explotación y que exige una respuesta eficaz y puntual para afrontar, controlar o aliviar la situación.

Todas las formas de explotación minera entrañan peligros y riesgos concretos capaces de provocar una situación de emergencia. Entre los riesgos de la minería subterránea del carbón se encuentran la liberación de metano, la generación de polvo de carbón, los sistemas de minería de gran potencia y la tendencia del carbón a la combustión espontánea. En las minas subterráneas dedicadas a la explotación de minerales metálicos pueden producirse emergencias por fallas de los estratos (estallidos debidos a la presión, desprendimientos de rocas, fallos del techo o de los pilares), detonaciones imprevistas de explosivos y presencia de polvo de mineral de azufre. Las explotaciones mineras a cielo abierto presentan riesgos relacionados con los equipos móviles de gran tamaño y alta velocidad, las detonaciones imprevistas de explosivos y la estabilidad de las rampas. En el procesamiento de los minerales, hay que considerar la exposición a sustancias químicas peligrosas, los vertidos o salpicaduras de éstas y los fallos de los embalses de relaves.

Con el tiempo, se han ido desarrollando buenas prácticas de minería y de explotación que incorporan medidas encaminadas a controlar o reducir estos riesgos. Sin embargo, en todo el mundo siguen produciéndose catástrofes mineras, aun cuando en algunos países se hayan adoptado técnicas concretas de gestión de riesgos, como estrategias preventivas para mejorar la seguridad en la mina y reducir la probabilidad y las consecuencias de las emergencias.

Las investigaciones y el análisis de los accidentes siguen poniendo de manifiesto la existencia de fallos a la hora de aplicar las enseñanzas del pasado y fallos en la confección de barreras y medidas de control eficaces para combatir determinados peligros y riesgos. Estos fallos a menudo se ven agravados por la ausencia de medidas adecuadas para atajar, controlar y gestionar la situación de emergencia.

En el presente artículo se expone un sistema de preparación de emergencias que puede utilizarse como referencia tanto para controlar y reducir los peligros y riesgos en la minería como para desarrollar medidas eficaces que garanticen el control de las emergencias y la continuidad de la explotación minera.

\section{Sistema de gestión de prevención de emergencias} El sistema propuesto integra diversos sistemas de prevención y gestión de las emergencias, y comprende los puntos siguientes:

- propósito y compromiso por parte de la organización (política corporativa, compromiso y dirección por parte del equipo de gestión);

- gestión del riesgo (identificación, valoración y control de peligros y riesgos);

- definición de medidas para gestionar cualquier imprevisto, incidencia o emergencia;

- definición de la organización de emergencias (estrategias, estructura, personal, técnicas, sistemas y procedimientos);

- dotación de instalaciones, equipos, suministros y materiales;
- formación del personal en materia de identificación, contención y notificación de incidentes y papel del mismo en las actividades de movilización y despliegue, y durante la fase posterior al incidente;

- evaluación y perfeccionamiento del sistema global mediante la aplicación de procedimientos regulares de revisión y prueba;

- revisión periódica de riesgos y funcionalidades;

- crítica y evaluación de la capacidad de respuesta en caso de emergencia, junto a la necesaria mejora del sistema.

La integración de la preparación de emergencias en el esquema del sistema de gestión de calidad ISO 9000 aporta un enfoque estructurado para afrontar y controlar las situaciones de emergencia de forma precisa, eficaz y segura.

\section{Propósito y compromiso por parte de la organización}

Por lo general, sólo se considera necesario estar preparado ante una emergencia si alguna vez se ha detectado un peligro potencial o existe una amenaza directa, altamente probable y con posibilidad de ocurrir a corto plazo. Sin embargo, la naturaleza de las emergencias es tal que, por lo general, no existe posibilidad de reconocimiento previo o se las considera inofensivas. La ausencia de sistemas adecuados o los fallos en los existentes se traducen en accidentes o situaciones de emergencia.

El compromiso y la inversión en una preparación de emergencias eficaz aporta a la organización la facultad, la experiencia y los sistemas para crear un entorno seguro de trabajo, cumplir las obligaciones éticas y legales, y mejorar las expectativas de continuidad del negocio en caso de emergencia. Los incendios y explosiones en la minería, aun cuando no se trate de incidentes fatales, provocan unas pérdidas significativas por interrupción de la explotación dado el tipo y la naturaleza de las medidas de control utilizadas y el alcance de los daños, que puede llegar incluso a la destrucción de la mina. Las labores de investigación también tienen una repercusión notable. La ausencia de medidas para gestionar y controlar adecuadamente cualquier incidente puede incrementar el daño económico total.

El desarrollo y la puesta en marcha de un sistema eficaz de preparación de emergencias exige la dirección, el compromiso y el apoyo del equipo gestor. Por consiguiente, resulta necesario:

- asumir y garantizar el liderazgo, el compromiso y el apoyo ininterrumpidos por parte del equipo gestor;

- establecer unos objetivos y una finalidad a largo plazo;

- garantizar el apoyo económico;

- garantizar la disponibilidad de las personas, así como su acceso y participación en el proceso de formación;

- proporcionar los recursos organizativos apropiados para desarrollar, implantar y mantener el sistema.

El liderazgo y el compromiso necesarios pueden demostrarse mediante el nombramiento de un profesional experto, capaz y generalmente respetado como Coordinador de preparación de emergencias, con autoridad para promover la participación y la cooperación a todos los niveles y en todas las unidades de la organización. La creación de un Comité de planificación de la preparación de emergencias, sometido a la autoridad del Coordinador, facilitará la dotación de los recursos necesarios para planificar, organizar y poner en marcha un programa integrado y eficaz contra las emergencias en toda la organización. 


\section{Gestión del riesgo}

El proceso de gestión del riesgo consiste en identificar y analizar los distintos tipos de riesgos que tiene que afrontar la organización para determinar su probabilidad y las posibles consecuencias si llegan a producirse. Se evalúan los riesgos tomando como base determinados criterios y se concluye si resultan aceptables o, en caso contrario, la forma de tratamiento que debe aplicarse para reducirlos (p. ej., reduciendo la probabilidad de que se produzcan, disminuyendo las consecuencias, transfiriendo la totalidad o parte de los riesgos o evitándolos). Después, será necesario desarrollar, implantar y gestionar planes concretos para controlar los riesgos identificados.

Tabla 74.5 • Elementos y subelementos críticos de preparación de emergencias.

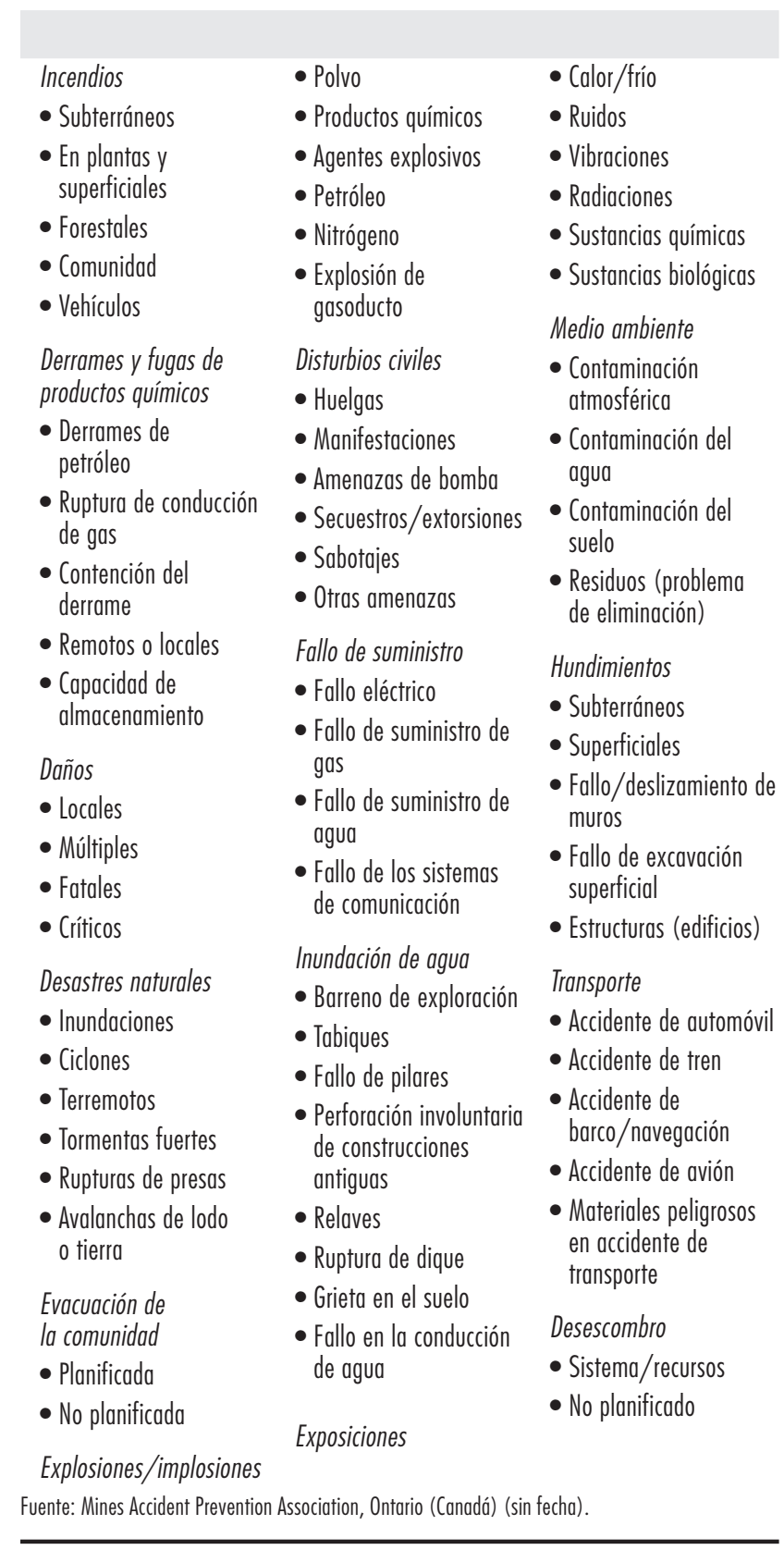

Este enfoque puede aplicarse asimismo para desarrollar planes de emergencia que contemplen la aplicación de controles eficaces llegado el caso. La identificación y análisis de los riesgos permite predecir situaciones análogas con un alto grado de precisión. Pueden determinarse así las medidas de control necesarias para afrontar cada una de las situaciones de emergencia detectadas, lo que constituye la base de una estrategia de preparación de emergencias.

Las situaciones más probables contendrán algunos o todos los factores enumerados en la Tabla 74.5 Por otra parte, ciertas normativas nacionales, como la norma australiana AS/NZS 4360: 1995 - Gestión del riesgo, incluyen una enumeración de fuentes genéricas de riesgo y distintas clasificaciones del mismo, así como las áreas de impacto de los riesgos; se dispone así de un esquema exhaustivo para el análisis de peligros en la preparación de emergencias.

\section{Medidas y estrategias para el control de emergencias}

Dentro del sistema de preparación de emergencias hay que identificar, evaluar y desarrollar tres niveles de acciones de respuesta. La respuesta individual o primaria comprende las acciones de cada individuo una vez identificada una situación de peligro o un incidente, e incluye:

- la notificación a los supervisores, controladores o personal de gestión de la situación, de las circunstancias o del incidente;

- la contención (tareas básicas de extinción, primeros auxilios o despeje de la zona);

- la evacuación, huida o refugio.

La respuesta secundaria abarca las acciones posteriores a la notificación del incidente por parte de los responsables adiestrados, como equipos de bomberos, equipos de búsqueda y rescate y equipos especiales de intervención en accidentes (SCAT), cada uno de los cuales con sus conocimientos, facultades y equipos específicos.

La respuesta terciaria corresponde al despliegue de sistemas, equipos y tecnologías especializadas en situaciones en las que no pueden utilizarse de forma segura o eficaz las respuestas primaria y secundaria, e incluye:

- sistemas de localización de personas y detectores de fenómenos sísmicos;

- rescate mediante perforaciones de gran diámetro;

- inertización, precintado remoto o inundación

- vehículos y sistemas de vigilancia/exploración (p. ej., cámaras de perforación y muestreo atmosférico).

\section{Definición de la organización de emergencias}

Las condiciones de emergencia se hacen más críticas cuanto más se prolonga la situación. El personal en el lugar del siniestro debe estar en condiciones de responder de forma adecuada a cualquier emergencia y son muchas las actividades que hay que coordinar y gestionar para garantizar un control rápido y eficaz de la situación.

La organización de emergencias de acuerdo con un enfoque estructurado define e integra las estrategias de emergencia, la estructura de gestión (o cadena de mando), los recursos personales, las funciones y responsabilidades, los equipos e instalaciones y los sistemas y procedimientos, abarcando todas las fases de la emergencia, desde la identificación inicial y las actividades de contención hasta la notificación, movilización, despliegue y recuperación (restablecimiento del funcionamiento normal). 
La organización de emergencias debe contemplar una serie de elementos clave, como:

- la capacidad de respuesta primaria y secundaria ante una emergencia;

- la capacidad de gestionar y controlar una emergencia;

- la coordinación y las comunicaciones, incluida la recogida, comprobación y evaluación de datos, la toma de decisiones y su puesta en práctica;

- la magnitud de los procedimientos necesarios para un control eficaz, incluida la identificación, la contención, la notificación y la información inmediata, la declaración de emergencia, los procedimientos específicos de operación, la extinción, la evacuación, el despeje y los primeros auxilios, la supervisión y la revisión;

- la identificación y asignación de responsabilidades clave;

- los servicios de control, asesoría, técnicos, de administración y apoyo;

- el tránsito de un funcionamiento normal a otro de emergencia en cuanto a líneas de comunicación, niveles de autoridad, responsabilidad, cumplimiento, coordinación y política;

- la disponibilidad y capacidad para mantener el procedimiento de emergencia durante un período prolongado y la gestión de los cambios de turno;

- la repercusión de los cambios organizativos en una situación de emergencia, incluida la supervisión y el control del personal, la reubicación o reasignación de trabajadores, la motivación, el compromiso y la disciplina, las funciones de los expertos y los especialistas, los organismos externos y los mandos corporativos;

- las medidas de emergencia para afrontar situaciones como las que pueden surgir al cabo de algunas horas o cuando ciertos miembros clave de la organización no están disponibles o se han visto afectados por la propia emergencia;

- la integración y el despliegue de los sistemas, equipos y tecnologías de respuesta terciaria.

\section{Instalaciones, equipos y materiales de emergencia}

La naturaleza, dimensiones y alcance de las instalaciones, equipos y materiales necesarios para controlar y mitigar las emergencias se determinarán durante la aplicación y ampliación del proceso de gestión de riesgos y la definición de las estrategias de control de emergencias. Por ejemplo, un elevado riesgo de incendio exige una dotación y un equipo de extinción de incendios adecuados. La distribución se efectuará de acuerdo con el perfil del riesgo. La dotación, equipo y material necesarios para cubrir de forma eficaz tareas de salvamento y primeros auxilios o de evacuación, escape y rescate se muestran en la Tabla 74.6.

Otras medidas y equipos que pueden resultar necesarios en caso de emergencia son: gestión de incidentes e instalaciones de control, zonas de reunión para trabajadores, zonas de rescate, seguridad de los edificios y controles de acceso, instalaciones para los familiares y los medios de información, materiales y consumibles, transporte y logística. La dotación de estas instalaciones y equipos debe realizarse previamente a cualquier incidente. Las últimas emergencias en la minería han venido a destacar la necesidad de centrarse en tres aspectos concretos de la infraestructura: refugios, comunicaciones y control atmosférico.

\section{Refugios}

Los refugios se están utilizando cada vez más como medio para mejorar la escapatoria y rescate de los trabajadores en la mina. Algunos de estos refugios están diseñados de forma que los individuos pueden ponerse a salvo por sí solos y comunicarse con la superficie con total seguridad; otros pretenden servir de refugio eficaz durante cierto tiempo para permitir el rescate desde el exterior.

La decisión de instalar refugios depende de los sistemas globales de escape y refugio de la mina. A la hora de ponderar la necesidad y el diseño de los refugios hay que evaluar los siguientes factores:

- la probabilidad de quedar atrapado;

- el tiempo que se tarda en evacuar a las personas que se encuentren bajo tierra por las vías normales de salida, y que puede resultar excesivo en explotaciones mineras con largas galerías o en condiciones difíciles tales como techos bajos o pendientes pronunciadas;

- la capacidad de las personas que se encuentren bajo tierra para escapar por sí mismas (considerando, p. ej., enfermedades o problemas previos y daños sufridos durante el incidente);

Tabla 74.6 - Instalaciones, equipos y materiales de emergencia.

\section{Emergencia}

Incendio

Salvamento y primeros auxilios

Evacuación, escape y rescate

\section{Nivel de respuesta}

Primario

Extintores, tomas de agua y mangueras instaladas cerca de las zonas de alto riesgo, como cintas transportadoras, estaciones de repostaje, transformadores y subestaciones eléctricas, y en equipos móviles

Salvamento, respiración y circulación

Medios de sistemas de alarma 0 notificación, salidas de emergencia seguras, autorrescatadores con oxígeno, cuerdas de seguridad y sistemas de comunicación, disponibilidad de vehículos de transporte

\section{Secundario}

Escafandras autónomas y ropa de protección almacenados en lugares centralizados para permitir la respuesta por parte de un "equipo contraincendios" con aparatos especiales, como generadores de espuma y mangueras múltiples

Primeros auxilios, clasificación, estabilización y desescombro

Disponibilidadde refugios convenientemente equipados, equipos de rescate minero debidamente entrenados y equipados, sistemas de localización de personas

\section{Terciario}

Medios de sellado o inertización distancia.

Paramédica, forense y legal

Sistemas de rescate mediante perforación de gran diámetro, inertización, vehículos especiales para rescate 
- la disciplina necesaria para mantener y utilizar refugios;

- los medios de que disponen las personas para encontrar los refugios en situaciones de visibilidad extremadamente baja y/o de obstrucción;

- la resistencia necesaria para hacer frente a explosiones e incendios;

- el tamaño y la capacidad necesarios;

- los servicios previstos (p. ej., ventilación/renovación del aire, refrigeración, comunicaciones, medidas sanitarias y de supervivencia);

- la aplicación potencial de la inertización como estrategia de control;

- las opciones para el rescate final de las personas (p. ej., equipos de rescate en la mina y perforaciones de gran diámetro).

\section{Comunicaciones}

En todas las minas suele existir una infraestructura de comunicaciones para facilitar la gestión y el control de las operaciones, así como para contribuir a la seguridad de la explotación minera al hacer posible las llamadas de ayuda. Por desgracia, la infraestructura no suele ser suficientemente sólida para resistir un incendio o una explosión importantes, interrumpiéndose las comunicaciones cuando más necesarias son. Además, los sistemas tradicionales incorporan auriculares que no pueden utilizarse de manera segura con la mayoría de las máscaras de respiración y que además suelen estar instalados en las vías principales de entrada de aire próximas a la planta fija, en vez de en los pasillos de escape.

La necesidad de disponer de comunicaciones después de un incidente debe evaluarse con detenimiento. Aunque es preferible que el sistema de comunicaciones tras el incidente forme parte del sistema anterior al mismo con el fin de mejorar el mantenimiento, el coste y la fiabilidad, debería instalarse un sistema independiente de comunicaciones de emergencia como parte de la estrategia global de gestión de escape, rescate y emergencia.

\section{Supervisión atmosférica}

El conocimiento de las condiciones en el interior de la mina después de cualquier incidente es esencial para identificar y aplicar las medidas más adecuadas con el fin de controlar la situación, así como para ayudar a evacuar a los trabajadores y proteger al equipo de salvamento. La necesidad de una supervisión atmosférica posterior al incidente deberá evaluarse con detenimiento, habilitándose sistemas que cubran las necesidades específicas de la explotación minera, entre los que se encuentran:

- la ubicación y el diseño de puntos de muestreo atmosféricos y de ventilación para situaciones atmosféricas normales y potencialmente anormales;

- el mantenimiento de equipos para analizar, detectar e interpretar la atmósfera de la mina, concretamente allí donde puedan existir mezclas explosivas tras un incidente;

- la disposición modular de sistemas de grupos de tubos alrededor de las perforaciones a fin de reducir al mínimo los retrasos en el muestreo y mejorar la solidez del sistema;

- la dotación de mecanismos para comprobar la integridad de los sistemas de grupos de tubos después de un incidente;

- la utilización de la cromatografía de gases en los lugares en que puedan existir mezclas explosivas tras un incidente y cuando sea preciso que el equipo de rescate penetre en la mina.

\section{Facultades, competencias y formación para la preparación de emergencias}

Las facultades y competencias necesarias para hacer frente con eficacia a una emergencia pueden determinarse rápidamente mediante el reconocimiento de los riesgos básicos y de las medidas de control de emergencias, el desarrollo de la organización y los procedimientos de emergencia, así como la identificación de la dotación y el equipamiento necesarios.

Las facultades y competencias para la preparación de emergencias no sólo comprenden la planificación y gestión de una emergencia, sino también una amplia gama de funciones básicas asociadas a las iniciativas de respuesta primaria y secundaria que deben incorporarse en una estrategia exhaustiva de formación y que incluyen:

- la identificación y contención del incidente (p. ej., extinción, salvamento, evacuación y desescombro);

- notificación (p. ej. por radio o teléfono);

- actividades de movilización y despliegue (p. ej., equipos de búsqueda y rescate, extinción, gestión de accidentes y recuperación).

El sistema de preparación de emergencias proporciona una estructura para el desarrollo de una estrategia eficaz de formación al identificar la necesidad, la magnitud y el alcance de consecuencias específicas, predecibles y fiables en un lugar de trabajo y de las competencias complementarias subyacentes. El sistema incluye:

- una declaración de intenciones, en la que se exponga la razón por la que deben desarrollarse la experiencia, las facultades y las competencias necesarias y que representa el compromiso y la dirección de la organización para una puesta en práctica satisfactoria;

- la gestión del riesgo y las medidas para gestionar emergencias que identifiquen los elementos clave (p. ej., incendios, deflagraciones, materiales peligrosos, movimientos y descargas no planificados, sabotaje, amenazas de bomba, fallos de seguridad, etc.);

- una definición de la organización de emergencias (estrategias, estructura, personal, conocimientos, sistemas y procedimientos) que identifique las personas que deben formarse, su función en caso de emergencia y los conocimientos y facultades necesarios;

- la identificación de los recursos de formación para determinar la ayuda, equipos, instalaciones y personas necesarios;

- la formación de personas en las actividades de identificación, contención, notificación, movilización, despliegue y actividades posteriores al incidente, para desarrollar la base necesaria de facultades y competencias;

- la comprobación, evaluación y mejora rutinarias del sistema global, junto con la comprobación periódica de riesgos y capacidad de respuesta para completar el proceso de aprendizaje y garantizar la existencia de un sistema eficaz de preparación de emergencias.

La formación para la preparación de emergencias puede estructurarse en una serie de categorías (véase la Tabla 74.7).

\section{Auditoría, revisión y evaluación}

Para comprobar y evaluar la eficacia global de los sistemas, procedimientos, instalaciones, programas de mantenimiento, equipos, formación y competencias individuales de emergencia es necesario incorporar procesos de auditoría y revisión. La realización de una auditoría, o una simulación de la misma, brinda, sin excepciones, una oportunidad para la mejora, la crítica constructiva y la comprobación del nivel de prestaciones de las actividades clave.

Toda organización debería comprobar su plan global de emergencia al menos una vez al año para cada turno de trabajo. Los elementos críticos del plan, como los sistemas de 
Tabla 74.7 • Matriz de formación para preparación de emergencias.

\section{Nivel de respuesta de formación Educación/primario \\ Diseñado para que los trabajadores comprendan la naturaleza de las emergencias en las minas y la forma en que aspectos específicos del plan global de emergencia pueden requerir su participación 0 afectarles, incluidas las medidas de respuesta primaria.}

Elementos de conocimiento y competencia

- Conocimiento de los indicadores clave de los accidentes en las minas

- Condiciones ambientales posteriores a un accidente (p. ej., temperatura, visibilidad y gases)

- Capacidad de respuesta ante un cambio adverso de las condiciones ambientales (p. ej., humo, interrupción de la ventilación)

- Capacidad para proceder a la notificación y las comunicaciones necesarias tras un accidente

- Conocimiento de las opciones de respuesta adecuadas ante una emergencia ambiental

- Conciencia del uso y las limitaciones de aparatos, rutas y sistemas de escape

- Conocimiento de las funciones y responsabilidades del personal de la mina en el marco del plan de respuesta de emergencia, incluidas sus funciones y responsabilidades específicas

- Posesión de habilidades y competencias de respuesto primaria para situaciones específicas de emergencia (p. ej., extinción, salvamento, escape y refugio a nivel básico)

- Conocimientos sobre salvamento y otros servicios de emergencia en minas

- Participación en simulacros de emergencia.

\section{Procedimientos/secundario}

Habilidades y competencias para aplicar satisfactoriamente procedimientos específicos definidos en los planes de respuesta a emergencias y las medidas de respuesta secundaria para situaciones de emergencia específicas.

- Conocimiento de los indicadores clave de los accidentes en las minas

- Capacidad para detectar, supervisar y evaluar las condiciones ambientales después de un accidente (p. ej., gases en la mina, ventilación, humo)

- Capacidad para analizar e interpretar cambios en los sistemas de ventilación de la mina (p. ej., destrucción de tabiques de ventilación, obturaciones y cruces de ventilación, daños en los ventiladores principales)

- Conocimiento de las medidas de respuesta utilizables para controlar y mitigar la situación de emergencia (p. ej., extinción, búsqueda y rescate, restablecimiento de la ventilación, primeros auxilios, clasificación y desescombro)

- Conocimiento de las funciones y responsabilidades del personal de la mina en el marco de los planes de respuesta de emergencia y de su capacidad para desempeñar el cometido asignado

- Conciencia del uso y la limitación de aparatos, rutas y sistemas de escape (p. ei., autorrescate, refugios, escafandras autónomas)

- Capacidad para establecer comunicaciones y protocolos internos de emergencio

- Conciencia del uso y limitaciones de aparatos y sistemas de escape y rescate (p. ej., autorrescate, refugios, respiradores)

- Capacidad de rescate y otros servicios de emergencia en minas

- Iniciación en los esquemas de petición de ayuda y asistencia mutua

- Participación en simulacros de ejercicios y emergencias

\section{Funciones/terciario}

Desarrollo de las habilidades y competencias necesarias para gestionar y controlar una emergencia.
- Conocimiento de los indicadores clave de las emergencias en las minas y conocimiento detallado de los sucesos que activan una respuesta ante una emergencia

- Conocimiento detallado del diseño y la ventilación de la mina y de los sistema de supervisión

- Capacidad para analizar e interpretar los sistemas de información de la mina (p. ej., datos de control de la ventilación y ambientales)

- Conciencia de las medidas de control utilizables para gestionar y mitigar una situación de emergencia

- Capacidad para cumplir y controlar los planes y procedimientos de respuesta de emergencia mediante la realización de emergencias simuladas

- Capacidad para establecer comunicaciones y protocolos de emergencia,, tanto en el plano interno como en el externo

- Capacidad de los servicios de rescate de la mina y de otros servicios de emergencia, apoyo de acceso por parte de estos servicios

- Capacidad para crear y apoyar equipos de trabajo para accidentes críticos

- Conocimiento de la capacidad de los sistemas de respuesta terciaria y despliegue de los mismos (p. ej., sistemas de localización, inertización, sellado a distancia, rescate mediante perforaciones de gran diámetro, laboratorios móviles)

- Capacidad para utilizar recursos de especialistas (p. ej., paramédicos, forenses, legales, tecnológicos, declaraciones tras accidentes críticos)

- Gestión y dirección de situaciones críticas alimentación de emergencias o de alarma remota, deberían comprobarse individualmente y con mayor frecuencia.

Hay dos formas básicas de auditoría. La auditoría horizontal consiste en la comprobación de pequeños elementos concretos del plan global de emergencia para detectar deficiencias. Deficiencias aparentemente sin importancia pueden ser críticas en caso de emergencia real. En la Tabla 74.8 se ofrecen algunos ejemplos de este tipo de elementos. En una auditoría vertical se comprueban simultáneamente un conjunto de elementos del plan mediante la simulación de una emergencia. De esta forma, pueden auditarse actividades como la activación del plan, los procedimientos de búsqueda y rescate, salvamento y extinción de incendios, así como la logística relacionada con una respuesta de emergencia en una mina o explotación remota.

En los simulacros pueden participar trabajadores de más de un departamento, personas de otras empresas o de organizaciones de ayuda mutua o incluso servicios de emergencia, como el cuerpo de policía y el parque de bomberos. La intervención 
Tabla 74.8 • Ejemplos de auditoría horizontal de planes de emergencia.

Elemento
Indicadores de alerta de accidente 0
incidente
Procedimientos de alerta/evacuación
Colocación de escafandras autónomas
de emergencia

Equipos de extinción de incendios

Alarmas de emergencia

Instrumentos de comprobación de presencia de gases

\section{Fallo} alerta de accidente 0 incidente

Los trabajadores no están familiarizados con los procedimientos de evacuación

Los trabajadores no están familiarizados con las escafandras autónomas

Los extintores están descargados, los aspersores están recubiertos de pintura, las tomas de agua están ocultas 0 enterradas

Se hace caso omiso de las alarmas

No se efectúa de forma regular su mantenimiento, servicio o calibración
No se reconocen los indicadores de

de organizaciones externas proporciona a todos los participantes una oportunidad inestimable para mejorar e integrar operaciones, procedimientos y equipos de preparación de emergencias y adecuar la capacidad de respuesta ante riesgos o peligros de mayor envergadura en determinadas instalaciones.

Tan pronto se pueda, se procederá a una crítica formal, si es posible inmediatamente después de la auditoría o el simulacro. Es importante hacer público el reconocimiento a aquellas personas y equipos que hayan tenido un comportamiento destacado. Los puntos débiles deberán describirse con la mayor concreción posible y será necesario revisar los procedimientos para incorporar las mejoras necesarias. Se introducirán asimismo los cambios pertinentes y se supervisará el funcionamiento a fin de perfeccionarlo.

Un programa que haga especial hincapié en los elementos de planificación, práctica, disciplina y trabajo en equipo es un elemento necesario de cualquier simulacro y entrenamiento bien diseñados. La experiencia demuestra una y otra vez que cualquier simulacro es bueno y positivo, y ofrece la oportunidad de demostrar los puntos fuertes y de identificar los aspectos mejorables.

\section{Revisión periódica de riesgos y capacidades de respuesta}

Pocos son los riesgos que permanecen invariables. En consecuencia, hay que supervisar y controlar los riesgos y la funcionalidad de las medidas de control y de preparación de emergencias para garantizar que circunstancias cambiantes (individuos, sistemas, procesos, instalaciones, equipos, etc.) no alteren la prioridad de los riesgos ni reduzcan la capacidad del sistema.

\section{Conclusiones}

A menudo, las emergencias se consideran sucesos imprevistos. Sin embargo, en esta época de comunicaciones y tecnologías tan avanzadas, son pocos los sucesos que realmente pueden calificarse de imprevistos y muy pocas las desgracias que no hayan ocurrido ya alguna vez. Los periódicos, las alertas de peligro, las estadísticas de accidentes y los informes técnicos proporcionan una sólida base histórica de datos e imágenes sobre lo que el futuro puede deparar a quienes no estén bien preparados.

En cualquier caso, la naturaleza de las emergencias cambia a medida que lo hace la industria. Confiar en técnicas y medidas

de emergencia adoptadas sobre la base de experiencias del pasado no ofrece el mismo grado de seguridad para sucesos futuros.

La gestión de riesgos aporta un enfoque amplio y estructurado para comprender los peligros y riesgos de la minería y desarrollar capacidades y sistemas eficaces de respuesta ante las emergencias. Hay que entender y aplicar de forma continua el proceso de gestión de riesgos, sobre todo cuando se envía personal de rescate a entornos potencialmente peligrosos o explosivos.

El sistema de preparación de emergencias debe apuntalarse en la formación de todo el personal de la mina acerca de la detección de peligros básicos, el reconocimiento y la rápida notificación de cualquier inicio de incidente o sucesos desencadenantes, la respuesta primaria y las habilidades de escape. También es crítica la formación preventiva sobre condiciones de calor, humedad, humo o escasa visibilidad. A menudo, la formación en estas disciplinas básicas marca la diferencia entre un accidente y una catástrofe.

De la formación depende la operatividad de la organización y la planificación de emergencias. La integración de la preparación de emergencias en un entorno de sistemas de calidad, junto con la práctica rutinaria de auditorías y simulacros, constituye el mecanismo para su permanente mejora y perfeccionamiento.

El Convenio sobre salud y seguridad en la minería de la OIT, 1955 ( $\left.\mathrm{N}^{\circ} 176\right)$, y la posterior Recomendación, 1995 ( $\mathrm{N}^{\circ} 183$ ), proporcionan un marco global para la mejora de la seguridad y la salud en la minería. El sistema propuesto de preparación de emergencias aporta una metodología para alcanzar los objetivos descritos en el Convenio y en la Recomendación.

Agradecimiento: Deseamos agradecer sinceramente el apoyo prestado por Paul MacKenzie-Wood, Director de los Servicios técnicos de la minería del carbón (Mines Rescue Service NSW, Australia) en la elaboración y crítica de este artículo.

\section{Peligros PaRa la SALUd EN LA MINERIA Y LAS CANTERAS}

James L. Weeks

Entre los principales riesgos de transmisión a través del aire que presenta la industria minera se encuentran varios tipos de partículas, los gases libres, los escapes de motores y ciertos vapores químicos, y entre los principales riesgos físicos, el ruido, la vibración por segmentos, el calor, los cambios de presión barométrica y la radiación ionizante. Todos ellos se producen en distintas proporciones dependiendo de la mina o de la cantera, de su profundidad, de la composición del mineral y de las rocas circundantes y del método de explotación. Los grupos de personas que viven juntas en lugares aislados corren también un riesgo de transmisión de algunas enfermedades infecciosas, como la tuberculosis, la hepatitis (B y E) y el virus del SIDA. La exposición de cada individuo depende de su trabajo, su proximidad a la fuente del peligro y la efectividad de los métodos de control.

\section{Peligros de las partículas transmitidas por el aire}

La sílice cristalina libre es el compuesto más abundante en la superficie terrestre y, por consiguiente, el polvo más común transportado por el aire al que están expuestos los mineros y los trabajadores de las canteras. La sílice libre es dióxido de silicio que no está unido químicamente a ningún otro compuesto en forma de silicato. La forma más común de sílice es el cuarzo, 
aunque también puede presentarse como tridimita o cristobalita. Las partículas respirables se forman al someter rocas que contienen sílice a procesos de perforación, voladura, trituración o molienda o por cualquier otra técnica, dando lugar a partículas muy finas. La proporción de sílice en las distintas variedades de roca es variable, pero no constituye un indicador fiable de la cantidad de polvo de sílice que puede contener una muestra del aire respirable. No es extraño, por ejemplo, hallar un $30 \%$ de sílice libre en una roca y sólo un $10 \%$ en la muestra, y viceversa. La arenisca puede contener hasta un $100 \%$ de sílice, el granito hasta un $40 \%$ y la pizarra un $30 \%$, siendo menor esta proporción en otros minerales. El peligro de exposición puede producirse en cualquier explotación minera, ya sea a cielo abierto o subterránea, pues puede haber sílice en la capa de cobertura de una mina a cielo abierto o en el techo, el suelo o el yacimiento de mineral de una explotación subterránea. La dispersión del sílice puede estar producida por el viento, el tráfico rodado o las máquinas de movimiento de tierras.

Debido a una exposición excesiva, la sílice produce silicosis, una neumoconiosis típica que se desarrolla internamente tras muchos años de exposición. Un grado excepcionalmente elevado de exposición puede causar silicosis aguda o acelerada en el plazo de algunos meses, provocando un deterioro significativo o incluso la muerte en el transcurso de pocos años. La exposición a la sílice también va asociada a un riesgo mayor de tuberculosis, cáncer de pulmón y determinadas enfermedades de autoinmunidad, incluido el escleroderma, el lupus sistémico eritematoso y la artritis reumática. El polvo de sílice recién triturado parece más activo y perjudicial que el formado hace tiempo, lo que puede deberse a que las partículas recién formadas presentan una carga superficial relativamente mayor.

Los procesos más habituales que generan polvo respirable de sílice en las minas y canteras son la perforación, la voladura y el corte de rocas que contienen sílice. La mayoría de los barrenos que se taladran para las voladuras están hechos con máquinas de aire comprimido montadas sobre una oruga. El barreno se taladra mediante una combinación de movimientos de rotación, percusión y empuje del trépano. A medida que va profundizando el taladro, se van añadiendo barras de acero que conectan el trépano con la parte motriz. El aire comprimido no sólo actúa de fuerza motriz de la perforadora, sino que va expulsando las partículas y el polvo de la vía perforada, lo cual, si no se controla, supone la proyección de una gran cantidad de polvo a la atmósfera. El martillo o la taladradora manual funcionan de forma análoga, aunque a menor escala. Esta herramienta transmite una cantidad considerable de vibración al operario, con el consiguiente riesgo de falta de riego en las manos (dedos blancos). Esta dolencia se ha detectado en mineros de India, Japón, Canadá y otros países. La perforadora de oruga y el martillo de picar también se utilizan en proyectos de obra civil en los que hay que taladrar o volar rocas para construir una carretera, triturar rocas para cimientos, efectuar reparaciones o cualquier otro tipo de trabajo.

Para estas operaciones de perforación se han desarrollado controles eficaces del polvo. Uno de ellos consiste en inyectar vapor de agua, a veces mezclado con una sustancia detergente, en el aire comprimido, lo que produce la coalescencia de las partículas de polvo y su desprendimiento. Un exceso de agua provoca la formación de un puente o collar entre la varilla de acero de la perforadora y la pared del taladro, que a menudo es necesario romper para sacar el trépano, mientras que un defecto de agua resulta ineficaz. Los problemas que presenta este tipo de control son la reducción de la velocidad de perforación, la ausencia de un suministro fiable de agua y la sustitución del aceite, que origina un desgaste mayor de las piezas lubricadas.
Otro sistema de control del polvo en las perforadoras consiste en la ventilación local de los gases de escape. Un flujo inverso de aire que atraviesa la varilla de acero de la perforadora extrae parte del polvo, y un collar alrededor del trépano dotado de conducciones y un ventilador eliminan el polvo. Este sistema es más funcional que el húmedo anteriormente descrito, ya que los trépanos duran más y la velocidad de perforación es mayor, aunque, por otro lado, es más costoso y exige un mantenimiento mayor.

Otros controles de protección son cabinas con filtrado de aire y, a veces, aire acondicionado para los operarios de perforadoras y máquinas oruga así como para los conductores de vehículos. Puede utilizarse una máscara de protección, debidamente ajustada, como solución temporal o en caso de que todas las demás opciones resulten ineficaces.

La exposición al sílice también se produce en las canteras de piedra donde se cortan rocas de determinadas dimensiones. La técnica más común en la actualidad consiste en utilizar un soplete de chorros múltiples alimentado con gasoil y aire comprimido, lo que da lugar a la difusión de partículas de sílice. El problema más significativo de este tipo de sopletes es el ruido: en el momento del encendido inicial y al extraerlo del corte, el nivel de ruido puede superar los 120 dBA y cuando está introducido en el corte el nivel es de unos 115 dBA. Una técnica alternativa de corte de la piedra es mediante inyección de agua a alta presión.

Junto a la cantera o en sus proximidades suele existir una instalación para tallar los bloques y darles el acabado. A menos que dispongan de una ventilación local de calidad, en estas instalaciones la exposición suele ser elevada, ya que para tallar la piedra se utilizan herramientas manuales con mecanismos de vibración o rotación que dispersan el polvo.

El polvo que se respira en una mina de carbón constituye un peligro tanto en las minas subterráneas como en las explotaciones a cielo abierto y en las instalaciones de procesamiento del carbón. Es una mezcla compuesta en su mayor parte por carbón, pero también puede contener sílice, arcilla, piedra caliza y otros polvos minerales. La composición del polvo de una mina de carbón varía dependiendo del filón, de la composición de los estratos adyacentes y de los métodos de extracción. El polvo de carbón se genera en las operaciones de voladura, perforación, tallado y acarreo del mineral.

En la minería mecanizada se produce mayor cantidad de polvo que en la manual y algunos métodos de la primera generan más cantidad de polvo que otros. Las máquinas de cortar que arrancan el carbón con tambores rotatorios dentados, que pueden ser, entre otros, de tipo continuo o de tajos largos, son la fuente principal de polvo en las operaciones mineras mecanizadas. Las máquinas de tajos largos son normalmente las que más polvo generan. En la minería por tajos largos la dispersión del polvo puede deberse también al movimiento de los escudos, así como al trasvase del carbón desde los vehículos o cintas transportadoras a otras formas de transporte.

El polvo de las minas de carbón provoca la enfermedad denominada neumoconiosis minera y contribuye a la aparición de dolencias crónicas en las vías respiratorias, como bronquitis crónica o enfisemas pulmonares. El carbón de alta calidad (con alto contenido en carbono, como la antracita) presenta un riesgo más elevado de neumoconiosis. Además, el polvo de carbón provoca reacciones de tipo reumático.

Puede reducirse la producción de polvo de carbón modificando las técnicas de cortado, y controlar su dispersión mediante una ventilación adecuada y agua vaporizada. Si se disminuye la velocidad de rotación de los tambores de extracción y se aumenta la velocidad a que el tambor va penetrando en la veta de carbón, es posible reducir la generación de polvo 
sin pérdida de productividad. En la minería de tajos largos, el polvo disminuye si se corta el carbón en una sola pasada (en lugar de dos) a lo largo del frente, retrocediendo sin cortar o realizando un corte de rectificación. La dispersión del polvo en secciones de tajos largos puede reducirse mediante la minería homotrópica (es decir, el transportador de cinta en el frente y el cabezal cortador y la corriente de aire desplazándose en la misma dirección). Una nueva forma de cortar carbón, que consiste en utilizar un cabezal excéntrico que trabaja de forma continua en sentido perpendicular al grano de la veta, parece generar menos cantidad de polvo que el tradicional cabezal cortador circular.

La instalación de una ventilación mecánica, que primero pase por las personas y después en dirección hacia y a lo largo del frente, reduce la exposición. Una ventilación auxiliar local en el frente de trabajo, compuesta por ventilador, conducciones y depuradora, es otro factor reductor del grado de exposición al proporcionar una ventilación local de aspiración.

La colocación estratégica de vaporizadores de agua, dispuestos cerca de los cabezales cortadores para alejar el polvo de los mineros impulsándolo hacia el frente, también ayudan a reducir el grado de exposición. Los tensioactivos contribuyen asimismo a reducir la concentración de polvo de carbón.

La exposición al amianto se produce entre los mineros que trabajan en minas de este mineral y en explotaciones de minerales que contienen amianto. Entre la población minera, la exposición al amianto ha incrementado el riesgo de cáncer de pulmón y de mesotelioma, así como de asbestosis (otro tipo de neumoconiosis) y dolencias de las vías respiratorias.

Los gases de escape de los motores diesel están formados por una mezcla compleja de gases, vapores y partículas. Los más peligrosos son el monóxido de carbono, el monóxido de nitrógeno, el dióxido de nitrógeno y el dióxido de azufre. Hay numerosos compuestos orgánicos volátiles (COV), como los aldehídos y los hidrocarburos, los hidrocarburos aromáticos policíclicos (HAP) y los compuestos HAP nitrogenados (N-HAP). Los compuestos HAP y N-HAP también se encuentran absorbidos en las partículas diesel. Los óxidos de nitrógeno, el dióxido de azufre y los aldehídos son agentes irritantes agudos de las vías respiratorias. Muchos de los compuestos HAP y N-HAP son cancerígenos.

Las partículas diesel están formadas por partículas de carbono de pequeño diámetro $(<1 \mathrm{~mm}$ de diámetro) que se condensan de los gases de escape y que a menudo se agrupan en el aire formando aglomerados o cadenas. Estas partículas son respirables. Las partículas diesel y otras partículas de diámetro similar son cancerígenas en animales de laboratorio y parece que aumentan el riesgo de cáncer de pulmón en los trabajadores expuestos a concentraciones superiores a $0,1 \mathrm{mg} / \mathrm{m}^{3}$. Los mineros de explotaciones subterráneas se exponen a estas partículas en concentraciones notablemente más altas. La Agencia Internacional para la Investigación sobre el Cáncer (IARC) tiene catalogadas las partículas diesel como posible agente cancerígeno.

La generación de los escapes diesel puede reducirse mediante un diseño adecuado de los motores y la utilización de combustible de alta calidad, limpio y con bajo contenido en azufre. Los motores con reducción de potencia y el combustible de bajo índice de cetano y bajo contenido en azufre producen muchas menos partículas. El consumo de combustible de bajo contenido en azufre reduce la generación de $\mathrm{SO}_{2}$ y partículas. El empleo de filtros es eficaz y práctico, y permite eliminar más del $90 \%$ de las partículas diesel del flujo de escape. Hay filtros para motores sin depuración y para motores con depuración húmeda o seca. El monóxido de carbono puede reducirse de manera notable utilizando convertidores catalíticos. Los óxidos de nitrógeno se forman cuando el nitrógeno y el oxígeno se encuentran en condiciones de alta presión y temperatura (p. ej., en el interior del cilindro diesel) y, por consiguiente, resultan más difíciles de eliminar

Es posible reducir la concentración de partículas diesel dispersas en las minas subterráneas mediante una adecuada ventilación mecánica y la restricción del uso de equipos diesel. Cualquier vehículo u otro tipo de máquina con motor diesel exige un mínimo de ventilación para diluir y eliminar los productos de escape. La intensidad de la ventilación dependerá del tamaño de la máquina y de su utilización. Si se utiliza más de un equipo con motor diesel en una corriente de aire, habrá que aumentar la ventilación para diluir y eliminar los escapes.

Los equipos con motor diesel pueden aumentar el riesgo de incendio o de deflagración ya que expulsan gas de escape caliente mezclado con llamas y chispas, y su elevada temperatura superficial es capaz de iniciar la combustión del polvo de carbón acumulado o de cualquier otra sustancia combustible. La temperatura superficial de los motores diesel debe mantenerse por debajo de los $305^{\circ} \mathrm{F}\left(150^{\circ} \mathrm{C}\right)$ en el interior de las minas de carbón con el fin de evitar la combustión del mismo. Las llamas y chispas de los gases de escape pueden controlarse mediante un depurador para evitar la combustión del polvo de carbón o del metano.

\section{Gases y vapores}

En la Tabla 74.9 se indican los gases que se encuentran normalmente en las explotaciones mineras. Los más importantes que aparecen de forma natural son el metano y el sulfuro de hidrógeno en las minas de carbón, y el radón en las de uranio y otros metales. En ambos casos puede existir escasez de oxígeno. El metano es un gas combustible y la mayoría de las deflagraciones en minas de carbón se deben a su inflamación, que a menudo va seguida de deflagraciones de carácter aún más violento provocadas por el polvo de carbón que queda en suspensión debido a la onda expansiva de la primera deflagraciones. Durante toda la historia de la minería del carbón, los incendios y las deflagraciones han ocasionado la muerte de miles de mineros. Puede reducirse el riesgo de deflagración diluyendo el metano por debajo de su límite inferior de deflagración y mediante la erradicación de posibles fuentes de incendio en las zonas del frente, donde suele darse la máxima concentración. Las deflagraciones pueden prevenirse espolvoreando las paredes, el suelo y los techos de la mina con

Tabla 74.9 • Denominación común de los gases nocivos existentes en las minas de carbón y sus efectos sobre la salud.

\begin{tabular}{|c|c|c|}
\hline Gas & Nombre común & Efectos sobre la salud \\
\hline Metano (CH4) & Grisú & $\begin{array}{l}\text { Inflamable, explosivo; asfixia } \\
\text { simple }\end{array}$ \\
\hline $\begin{array}{l}\text { Monóxido de carbono } \\
\text { (CO) }\end{array}$ & Gas metífico & Asfixia química \\
\hline $\begin{array}{l}\text { Sulfuro de hidrógeno } \\
\text { (H2S) }\end{array}$ & Sulfuro de hidrógeno & $\begin{array}{l}\text { Irritación de ojos, nariz, } \\
\text { garganta; depresión } \\
\text { respiratoria aguda }\end{array}$ \\
\hline Falta de oxígeno & Mofeta & Anoxia \\
\hline $\begin{array}{l}\text { Productos secundarios } \\
\text { de voladura }\end{array}$ & Gases deletéreos & Irritación respiratoria \\
\hline $\begin{array}{l}\text { Gases de escape de } \\
\text { motores diesel }\end{array}$ & Idem & $\begin{array}{l}\text { Irritación respiratoria; cáncer } \\
\text { de pulmón }\end{array}$ \\
\hline
\end{tabular}


piedra caliza incombustible (o con cualquier otro polvo de roca incombustible que no contenga sílice); si el polvo que queda en suspensión a causa de una deflagración de metano no es combustible no se originará una segunda deflagración.

El radón es un gas radioactivo de aparición espontánea que existe en las minas de uranio, estaño y otros minerales aunque no se ha detectado en las minas de carbón. El principal peligro asociado al radón es que constituye un foco de radiación ionizante, tal como se describe más adelante.

Entre los gases peligrosos cabe citar los agentes irritantes de las vías respiratorias que se encuentran en los escapes de los motores diesel y en los subproductos de las explosiones. El monóxido de carbono aparece no sólo en los escapes de los motores sino también como consecuencia de los incendios en las minas, durante los cuales el CO puede alcanzar concentraciones letales, además de convertirse en un peligro potencial de deflagración.

Los óxidos de nitrógeno $\left(\mathrm{NO}_{\mathrm{x}}\right)$, principalmente el $\mathrm{NO}$ y el $\mathrm{NO}_{2}$, proceden de los escapes de los motores diesel y de las voladuras. En los primeros, el $\mathrm{NO}_{\mathrm{x}}$ se genera como subproducto implícito al someter el aire, formado en un $79 \%$ por nitrógeno y un $20 \%$ por oxígeno, a condiciones de temperatura y presión elevadas, condiciones necesarias para el funcionamiento de cualquier motor diesel. La producción de $\mathrm{NO}_{\mathrm{x}}$ puede reducirse hasta cierto punto manteniendo refrigerado el motor en la medida de lo posible y aumentando la ventilación para diluir y eliminar los gases de escape.

El $\mathrm{NO}_{x}$ es también un subproducto de las voladuras, durante las cuales se procura alejar a los trabajadores de la zona afectada. Como norma general, a fin de evitar una exposición excesiva a los óxidos de nitrógeno, conviene esperar hasta que la ventilación de la mina haya eliminado un volumen suficiente de subproductos de la voladura antes de volver a entrar en una zona de entrada de aire.

La escasez de oxígeno puede originarse de diversas formas. El oxígeno puede ser desplazado por otro gas, como el metano, o ser consumido por combustión o por microbios en un espacio carente de ventilación.

Hay numerosos peligros derivados de las materias transportadas por el aire a los que pueden verse expuestos determinados grupos de mineros. Los mineros de explotaciones auríferas y de mercurio corren un riesgo de exposición al vapor de mercurio, y por tanto de envenenamiento por este metal. Los trabajadores de las minas de oro y de plomo pueden verse expuestos al arsénico y sufrir cáncer de pulmón. En las minas de níquel la exposición a este mineral conlleva un riesgo de cáncer de pulmón y alergias de piel.

También se han comenzado a utilizar en las minas determinados plásticos como los formaldehídos ureicos y las espumas de poliuretano, que se fabrican in situ y sirven para taponar agujeros y mejorar la ventilación, así como para proporcionar un mejor anclaje para los soportes del techo. Los formaldehídos y los isocianatos, dos materiales básicos de estas espumas, son agentes irritantes de las vías respiratorias y pueden causar reacciones alérgicas que lleguen incluso a impedir a los trabajadores afectados trabajar en contacto con tales sustancias. El formaldehído es un agente cancerígeno (IARC Grupo 1).

\section{Peligros físicos}

El ruido es un fenómeno omnipresente en la minería debido al uso de potentes máquinas y ventiladores, y a las voladuras y el transporte del mineral. Por lo general, las explotaciones subterráneas disponen de un espacio limitado que crea un campo de reverberación. La exposición al ruido en un recinto cerrado es mayor que en un espacio abierto.

La exposición al ruido puede reducirse utilizando los medios tradicionales de control de ruidos en la maquinaria minera. Las transmisiones pueden ser más silenciosas, los motores pueden protegerse y la maquinaria hidráulica también puede hacerse menos ruidosa. Es posible aislar o proteger las chimeneas con material absorbente del ruido. A menudo resultan necesarios los protectores de oídos, junto con un muestreo audiométrico regular, para proteger la facultad auditiva de los mineros.

La radiación ionizante constituye un peligro en la industria minera. El radón puede liberarse de las rocas durante el proceso de voladura, pero también puede penetrar en la mina a través de corrientes subterráneas. Es un gas y, por tanto, se transporta por el aire. El radón y los productos resultantes de su desintegración emiten radiación ionizante, parte de la cual posee suficiente energía para producir células cancerígenas en los pulmones. Por consiguiente, las tasas de mortalidad por cáncer de pulmón entre los mineros de uranio son elevadas y entre los mineros fumadores aún mucho más.

El calor constituye un peligro tanto para los trabajadores de minas subterráneas como para los de explotaciones a cielo abierto. En las minas subterráneas la principal fuente de calor es la propia roca. La temperatura de la roca aumenta aproximadamente en $1^{\circ} \mathrm{C}$ por cada $100 \mathrm{~m}$ de profundidad. Otros factores que influyen en la cantidad de calor son la actividad física que desarrollan los trabajadores, la cantidad de aire en circulación, la temperatura y la humedad del aire ambiente y el calor generado por los equipos de minería, sobre todo las máquinas con motores diesel. Las explotaciones muy profundas (superiores a los $1.000 \mathrm{~m}$ ) pueden presentar importantes problemas de calor, con temperaturas en las galerías próximas a los $40^{\circ} \mathrm{C}$. Las principales fuentes de calor en las minas a cielo abierto son la actividad física, la proximidad a máquinas calientes, la temperatura del aire, la humedad y la radiación solar.

La presión térmica puede rebajarse refrigerando las máquinas, limitando la actividad física de los mineros y suministrándoles cantidad suficiente de agua potable, protección solar y una ventilación adecuada. En el caso de la maquinaria a cielo abierto, las cabinas con aire acondicionado proporcionan protección a los operadores. En algunas minas profundas de Sudáfrica, por ejemplo, se utilizan equipos subterráneos de aire acondicionado para aliviar el calor y existen equipos de primeros auxilios para combatir el calor.

Muchas explotaciones mineras trabajan a gran altitud (p. ej., a más de $4.600 \mathrm{~m}$ ), por lo que los mineros pueden padecer el mal de altura; esta enfermedad se agrava si los mineros tienen que desplazarse entre la mina a una gran altitud y un lugar con presión atmosférica más baja. 


\section{Referencias}

Agricola, G. 1950. De Re Metallica, traducido por HC Hoover y LH Hoover. Nueva York: Dover Publications.

Bickel, KL. 1987. Analysis of diesel-powered mine equipment. En Proceedings of the Bureau of Mines Technology Transfer Seminar: Diesels in Underground Mines. Information Circular 9141. Washington, DC: Bureau of Mines.

Bureau of Mines. 1978. Coal Mine Fire and Explosion Prevention. Information Circular 8768. Washington, DC: Bureau of Mines.

- 1988. Recent Developments in Metal and Nonmetal Fire Protection. Information Circular 9206. Washington, DC: Bureau of Mines.

Chamberlain, EAC. 1970. The ambient temperature oxidisation of coal in relation to the early detection of spontaneous heating. Mining Engineer (octubre) 130(121):1-6.

Ellicott, CW. 1981. Assessment of the explosibility of gas mixtures and monitoring of sample-time trends. Proceeding of the Symposium on Ignitions, Explosions and Fires. Illawara: Australian Institute of Mining and Metallurgy.

Environmental Protection Agency (Australia). 1996. Best Practice Environmental Management in Mining. Canberra: Environmental Protection Agency.

Funkemeyer, M, FJ Kock. 1989. Fire prevention in working rider seams prone to spontaneous combustion. Gluckauf 9-12.

Graham, JI. 1921. The normal production of carbon monoxide in coal mines. Transactions of the Institute of Mining Engineers 60:222-234.

Grannes, SG, MA Ackerson, GR Green. 1990. Preventing Automatic Fire Suppression Systems Failure on $\mathrm{Un}$ derground Mining Belt Conveyers. Information Circular 9264. Washington, DC: Bureau of Mines.

Greuer, RE. 1974. Study of Mine Fire Fighting Using Inert Gases. USBM Contract Report No. S0231075. Washington, DC: Bureau of Mines.

Griffin, RE. 1979. In-mine Evaluation of Smoke Detectors. Information Circular 8808. Washington, DC: Bureau of Mines.

Hartman, HL (ed.). 1992. SME Mining Engineering Handbook, $2^{a}$ edición. Baltimore, MD: Society for Mining, Metallurgy, and Exploration.

Hertzberg, M. 1982. Inhibition and Extinction of Coal Dust and Methane Explosions. Report of Investigations 8708. Washington, DC: Bureau of Mines.

Hoek, E, PK Kaiser, WF Bawden. 1995. Design of Support for Underground Hard Rock Mines. Rotterdam: AA Balkema

Hughes, AJ, WE Raybold. 1960. The rapid determination of the explosibility of mine fire gases. Mining Engineer 29:37-53.

International Council on Metals and the Environment (ICME). 1996. Case Studies Illustrating Environmental Practices in Mining and Metallurgical Processes. Ottawa: ICME.

Jones, JE, JC Trickett. 1955. Some observations on the examination of gases resulting from explosions in collieries. Transactions of the Institute of Mining Engineers 114: 768-790.

Mackenzie-Wood P, J Strang. 1990. Fire gases and their interpretation. Mining Engineer 149(345):470478

Mines Accident Prevention Association Ontario. Sin fecha. Emergency Preparedness Guidelines. Technical Standing Committee Report. North Bay: Mines Accident Prevention Association Ontario.
Mitchell, D, F Burns. 1979. Interpreting the State of a Mine Fire. Washington, DC: US Department of Labor.

Morris, RM. 1988. A new fire ratio for determining conditions in sealed areas. Mining Engineer 147(317):369-375.

Morrow, GS, GD Litton. 1992. In-mine Evaluation of Smoke Detectors. Information Circular 9311. Washington, DC: Bureau of Mines.

Naciones Unidas (NU) Departmento de Cooperación Técnica para el Desarrollo y la German Foundation for International Development. 1992. Mining and the Environment: The Berlin Guidelines. Londres: Mining Journal Books.

National Fire Protection Association (NFPA). 1992a. Fire Prevention Code. NFPA 1. Quincy, Massachusetts: NFPA.

. 1992b. Standard on Pulverized Fuel Systems. NFPA 8503. Quincy, Massachusetts: NFPA.

- 1994a. Standard for Fire Prevention in Use of Cutting and Welding Processes. NFPA 51B. Quincy, Massachusetts: NFPA

- 1994b. Standard for Portable Fire Extinguishers. NFPA 10. Quincy, Massachusetts: NFPA.

-. 1994c. Standard for Medium and High Expansion Foam Systems. NFPA 11A. Quncy, Maryland: NFPA.

1994d. Standard for Dry Chemical Extinguishing Systems. NFPA 17. Quincy, Massachusetts: NFPA.

. 1994e. Standard for Coal Preparation Plants. NFPA 120. Quincy, Massachusetts: NFPA.

- 1995a. Standard for Fire Prevention and Control in Underground Metal and Nonmetal Mines. NFPA 122. Quincy, Massachusetts: NFPA.

- 1995b. Standard for Fire Prevention and Control in Underground Bituminious Coal Mines. NFPA 123. Quincy, Massachusetts: NFPA.

1996a. Standard on Fire Protection for Self-propelled and Mobile Surface Mining Equipment. NFPA 121. Quincy, Massachusetts: NFPA.

1996b. Flammable and Combustible Liquids Code. NFPA 30. Quincy, Massachusetts: NFPA.

1996c. National Electrical Code. NFPA 70. Quincy, Massachusetts: NFPA.

1996d. National Fire Alarm Code. NFPA 72. Quincy, Massachusetts: NFPA.

1996e. Standard for the Installation of Sprinkler Systems. NFPA 13. Quincy, Massachusetts: NFPA.

1996f. Standard for the Installation of Water Spray Systems. NFPA 15. Quincy, Massachusetts: NFPA

- 1996g. Standard on Clean Agent Fire Extinguishing Systems. NFPA 2001. Quincy, Massachusetts: NFPA.

1996h. Recommended Practice for Fire Protection in Electric Generating Plants and High Voltage DC Converter Stations. NFPA 850. Quincy, Massachusetts: NFPA.

Ng, D, CP Lazzara. 1990. Performance of concrete block and steel panel stoppings in a simulated mine fire. Fire Technology 26(1):51-76.

Ninteman, DJ. 1978. Spontaneous Oxidation and Combustion of Sulfide Ores in Underground Mines. Information Circular 8775. Washington, DC: Bureau of Mines.

Organización Internacional del Trabajo (OIT). 1994 Recent Developments in the Coalmining Industry. Ginebra: OIT.

Pomroy, WH, TL Muldoon. 1983. A new stench gas fire warning system. En Proceedings of the 1983 MAPAO Annual General Meeting and Technical Sessions. North Bay: Mines Accident Prevention Association Ontario.

Programa de las Naciones Unidas para el Medio Ambiente (PNUMA). 1991. Environmental Aspects of Se- lected Non-ferrous Metals (Cu, $\mathrm{Ni}, \mathrm{Pb}, \mathrm{Zn}, \mathrm{Au})$ in Ore Mining. París: PNUMA.

Ramaswatny, A, PS Katiyar. 1988. Experiences with liquid nitrogen in combating coal fires underground. Journal of Mines Metals and Fuels 36(9):415424.

Smith, AC, CN Thompson. 1991. Development and application of a method for predicting the spontaneous combustion potential of bituminous coals. Presentado en la 24th International Conference of Safety in Mines Research Institutes, Makeevka State Research Institute for Safety in the Coal Industry, Makeevka, Federación Rusa.

Timmons, ED, RP Vinson, FN Kissel. 1979. Forecasting Methane Hazards in Metal and Nonmetal Mines. Report of Investigations 8392. Washington, DC: Bureau of Mines.

\section{Otras lecturas recomendadas}

Agencia Internacional para la Investigación sobre el Cáncer (IARC). 1989. Diesel and Gasoline Engine Exhausts and Some Nitroarenes. IARC Monographs on the Evaluation of Carcinogenic Risks to Humans. Vol. 46. Lyon: IARC.

American Geological Institute. 1992. Planning for Field Safery. Alexandria, Virginia: American Geological Institute.

Banks, DE (dir.). 1993. The mining industry. Occ Med: State Art Rev 8(1).

Bieniawski, YT. 1984. Rock Mechanics Design in Mining and Tunnelling. Rotterdam: AA Balkema.

Brady, BHG, ET Brown. 1993. Rock Mechanics for Underground Mining, $2^{\mathrm{a}}$ edición. Londres: Chapman \& Hall.

British Columbia and Yukon Chamber of Mines Safety Committee. Safety Manual: Mineral Exploration in Western Canada. Vancouver, Columbia Británica: British Columbia and Yukon Chamber of Mines.

Dunnicliff, J, GE Green. 1988. Geotechnical Instrumentation for Monitoring Field Performance. Nueva York: John Wiley \& Sons.

Franklin, J (dir.). 1990. Mine Monitoring Manual. Vol. 42. Etobocoke, Ontario: Canadian Institute of Mining and Metallurgy.

Franklin, JA, MB Dusseault. 1989. Rock Engineering. Nueva York: McGraw-Hill.

Garcia, MM. 1989. Mining and Milling: In-plant Practices for Fob-related Health Hazards Control, Volume 1: Production Processes. Nueva York: John Wiley \& Sons.

Gilchrist, JD. 1989. Extraction Metallugry, 3a edición. Oxford: Pergamon Press.

Hedley, DGF. 1992. Rockburst Handbook for Ontario Hardrock Mines. CANMET Special Report SP921E. Ottawa: Supply and Services Canada.

Jennings, NS. 1995. Productivity, Employment and Industrial Relations in Coal Mines: Three Case Studies from China, India and Zimbabwe. Ginebra: OIT.

1995. Productivity, Employment and Industrial Relations in Coal Mines: Three Case Studies from Australia, United Kingdom, United States. Ginebra: OIT.

1995. Productivity, Employment and Industrial Relations in Coal Mines: Two Case Studies from the Czech Republic and the Russian Federation. Ginebra: OIT.

Kaiser, PK, DR McCreath, DD Tannant. 1996. Canadian Rockburst Support Handbook. Sudbury, Ontario: Geomechanics Research Centre.

Kelly, EG, DJ Spottiswood. 1982. Introduction to Mineral Processing. Nueva York: John Wiley \& Sons.

Keystone, JS (dir.). 1995. Don't Drink the Water. Toronto: Canadian Public Health Association. 
Kural, O. (dir.) 1994 Coal: Resources, Properties, Utilization, Pollution. Estambul: Istanbul Technical University.

Laskowski, JS, AD Walters. 1987. Encyclopedia of Physical Science and Technology. Nueva York: Academic Press.

Merry, W. 1994. The official Wilderness First Aid Guide. Toronto: McClelland \& Stewart.
Organización Internacional (OIT). 1990. Coal Mineworkers' Charter: Collection of Conclusions and Resolutions. Ginebra: OIT.

- 1991. Safety and Health in Opencast Mines: A Code of Practice. Ginebra: OIT.

- 1994. Productvity and Its Impact on Employment and Labour Relations in the Coalmining Industry. Ginebra: OIT.
- 1995. Note on the Proceedings of the 13th Session of the ILO's Coal Mines Committee, 1995.

Osborne, DG. 1988. Coal Preparation Technology. Londres: Graham \& Trottman.

Peters, WC. 1987. Exploration and Mining Geology, $2^{\mathrm{a}}$ edición. Nueva York: John Wiley \& Sons.

Reedman, JH. 1979. Techniques in Mineral Exploration. Nueva York: Applied Science Publishers. 



\section{PETROLEO:}

PROSPECCION Y PERFORACION

Director del capítulo

Richard S. Kraus

\section{Sumario}

Prospección, perforación y producción de petróleo

y gas natural

Richard S. Kraus . . 


\section{ProspecGION, PERFORACION Y PRODUCGION DE PETROLEO Y GAS NATURAL}

Richard S. Kraus

\section{Perfil general}

Los crudos de petróleo y los gases naturales son mezclas de moléculas de hidrocarburos (compuestos orgánicos de átomos de carbono e hidrógeno) que contienen de 1 a 60 átomos de carbono. Las propiedades de estos hidrocarburos dependen del número y de la disposición de los átomos de carbono e hidrógeno en sus moléculas. La molécula básica de hidrocarburo consta de 1 átomo de carbono unido a 4 átomos de hidrógeno (metano). Todas las demás variedades de hidrocarburos de petróleo se forman a partir de esta molécula. Los hidrocarburos que tienen hasta 4 átomos de carbono suelen ser gases; si tienen entre 5 y 19, son generalmente líquidos, y cuanto tienen 20 o más, son sólidos. Además de hidrocarburos, los crudos de petróleo y los gases naturales contienen compuestos de azufre, nitrógeno y oxígeno, junto con trazas de metales y otros elementos.

Se cree que el petróleo y el gas natural se formaron a lo largo de millones de años por la descomposición de la vegetación y de organismos marinos, comprimidos bajo el peso de la sedimentación. Al ser el petróleo y el gas más ligeros que el agua, ascendieron y llenaron los huecos creados en estas formaciones superpuestas. El movimiento ascendente cesó cuando el petróleo y el gas alcanzaron estratos densos e impermeables superpuestos o roca no porosa. El petróleo y el gas llenaron los huecos de los mantos de roca porosa y los yacimientos subterráneos naturales, como las arenas saturadas, situándose debajo petróleo, más pesado, y encima el gas, más ligero. Originalmente, estos huecos eran horizontales, pero el desplazamiento de la corteza terrestre creó bolsas, denominadas fallas, anticlinales, domos salinos y trampas estratigráficas, donde el petróleo y el gas se acumularon en yacimientos.

Figura 75.1 • Producción mundial de crudo para 1995.

Producción mundial (miles de barriles diarios) $=57.037$

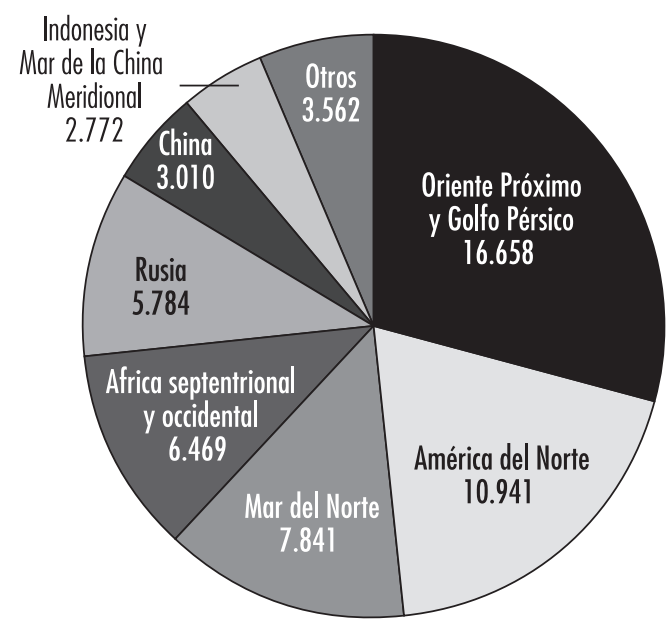

Fuente: Adaptado de Energy Information Administration 1996.
Figura 75.2 • Producción mundial de líquidos de plantas de gas natural para 1995.

Producción mundial (miles de barriles diarios) $=5.470$

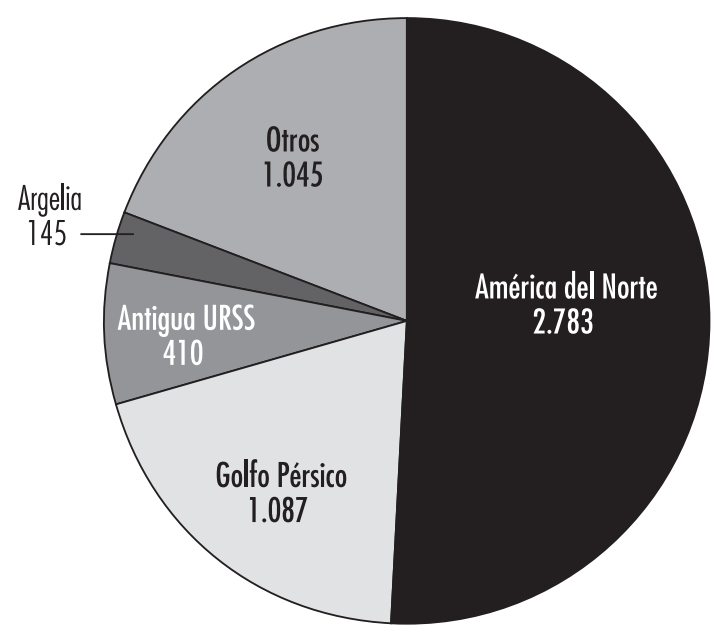

Fuente: Adaptado de Energy Information Administration 1996

\section{Petróleo de pizarras bituminosas}

El petróleo de pizarras bituminosas, o querógeno, es una mezcla de hidrocarburos sólidos y otros compuestos orgánicos que contiene nitrógeno, oxígeno y azufre. Se extrae, por calentamiento, de una roca llamada pizarra bituminosa, con un rendimiento de entre 68 y 227 litros de petróleo por tonelada de roca.

Prospección y producción son los términos comúnmente aplicados a la parte de la industria del petróleo que se ocupa de la exploración para descubrir nuevos yacimientos de petróleo y gas natural, la perforación de pozos y la extracción de los productos a la superficie. En el pasado, el petróleo que rezumaba de forma natural a la superficie se recogía para utilizarlo en medicina, revestimientos protectores y como combustible para lámparas. Hay noticias de incendios en la superficie terrestre producidos por emanaciones de gas natural. Hasta 1859 no se desarrollaron métodos de perforación y obtención de petróleo en grandes cantidades con fines comerciales.

El petróleo y el gas natural se encuentran en todo el mundo, tanto bajo tierra como bajo el agua, según se indica a continuación:

- Cuenca intercontinental del hemisferio occidental (Costa del Golfo de Estados Unidos, México, Venezuela);

- Oriente Próximo (península arábiga, Golfo Pérsico, Mar Negro y Mar Caspio);

- Indonesia y Mar de la China Meridional;

- Africa septentrional y occidental (Sahara y Nigeria);

- América del Norte (Alaska, Terranova, California y región centrocontinental de Estados Unidos y Canadá);

- Extremo Oriente (Siberia y China),

- Mar del Norte.

En las Figuras 75.1 y 75.2 se muestra la producción mundial de petróleo y gas natural de 1995.

Los nombres de los crudos de petróleo suelen indicar tanto los tipos de crudo como las zonas donde se descubrieron originalmente. Por ejemplo, el primer petróleo comercial, el "Pennsylvania Crude", lleva el nombre de su lugar de origen en Estados Unidos. Otros ejemplos son el "Saudi Light" y el "Venezuelan 
Tabla 75.1 - Características y propiedades usuales aproximadas y potencial de gasolina de varios crudos de petróleo comunes. *

\begin{tabular}{llllllll} 
Origen y denominación del crudo & $\begin{array}{l}\text { Parafinas } \\
\% \text { vol }\end{array}$ & $\begin{array}{l}\text { Aromáticos } \\
\% \text { vol }\end{array}$ & $\begin{array}{l}\text { Naftenos } \\
\% \text { vol }\end{array}$ & $\begin{array}{l}\text { Azufre } \\
\% \text { peso }\end{array}$ & $\begin{array}{l}\text { Densidad API } \\
\text { (aprox.) }\end{array}$ & $\begin{array}{l}\text { Rendimiento en } \\
\text { naftenos \% vol }\end{array}$ & $\begin{array}{l}\text { Indice de octano } \\
\text { (característico) }\end{array}$ \\
\hline Nigerian Light & 37 & 9 & 54 & 0.2 & 36 & 28 & 60 \\
Saudi Light & 63 & 19 & 18 & 2 & 34 & 22 & 40 \\
Saudi Heavy & 60 & 15 & 25 & 2.1 & 28 & 23 & 35 \\
Venezuela Heavy & 35 & 12 & 53 & 2.3 & 30 & 2 & 60 \\
Venezuela Light & 52 & 14 & 34 & 1.5 & 24 & 18 & 50 \\
USA Midcontinental Sweet & - & - & - & 0.4 & 40 & - & - \\
USA West Texas Sour & 46 & 22 & 32 & 1.9 & 32 & 33 & 55 \\
North Sea Brent & 50 & 16 & 34 & 0.4 & 37 & 31 & 50
\end{tabular}

* Valores medios representativos.

Heavy". Dos crudos de referencia que se utilizan para fijar los precios mundiales de los crudos son el "Texas Light Sweet" y el "North Sea Brent".

\section{Clasificación de los crudos de petróleo}

Los crudos de petróleo son mezclas complejas que contienen muchos compuestos de hidrocarburos diferentes, cuyo aspecto y composición es distinto de unos yacimientos a otros, a veces incluso entre pozos relativamente próximos. La consistencia de los crudos es variable (desde acuosos hasta sólidos con aspecto de alquitrán), como lo es su color (desde transparente a negro). Un crudo "medio" contiene alrededor de $84 \%$ de carbono, $14 \%$ de hidrógeno, de 1 a $3 \%$ de azufre y menos de $1 \%$ de nitrógeno, oxígeno, metales y sales (véanse las Tablas 75.1 y 75.2).

Los crudos se clasifican en parafínicos, nafténicos, aromáticos o mixtos mediante análisis relativamente simples, de acuerdo con la proporción predominante de moléculas de hidrocarburos similares. Los crudos de base mixta tienen cantidades variables de cada tipo de hidrocarburo. Uno de los métodos de análisis (el del Departamento de Minas de Estados Unidos) se basa en la destilación, y otro (el del factor "K" de la UOP) en la densidad y en los puntos de ebullición. Para determinar el valor del crudo (es decir, su rendimiento y la calidad de sus productos útiles) y los parámetros de procesado, se llevan a cabo análisis más completos. Los crudos de petróleo suelen agruparse por su estructura de rendimiento, y entre sus productos, el preferido es la gasolina de alto octanaje. Los crudos utilizados como materia prima en las refinerías suelen consistir en mezclas de dos o más crudos diferentes.

También se definen según la densidad API (específica). Por ejemplo, los crudos pesados tienen bajas densidades API (y altas densidades específicas). Un crudo de baja densidad API puede tener un punto de inflamabilidad alto o bajo, dependiendo de sus componentes más ligeros (constituyentes más volátiles). Dada la importancia de la temperatura y la presión en el proceso de refino, los crudos se clasifican además por su viscosidad, puntos de fluidez y rangos de destilación. También se tienen en cuenta otras características físicas y químicas, como el color y el contenido de carbono residual. Los crudos de petróleo con alto contenido de carbono, bajo contenido de hidrógeno y baja densidad API suelen ser ricos en aromáticos, mientras que los de bajo contenido de carbono, alto contenido de hidrógeno y alta densidad API, son por lo general ricos en parafinas.

Los crudos de petróleo que contienen cantidades apreciables de ácido sulfhídrico u otros compuestos de azufre reactivos se denominan "agrios"; a los de menor contenido de azufre se les llama "dulces". Algunas excepciones a esta regla son los crudos "West Texas" (que siempre se consideran "agrios" independientemente de su contenido de $\mathrm{H}_{2} \mathrm{~S}$ ) y los crudos árabes altamente sulfurosos (que no se consideran "agrios" porque sus compuestos de azufre no son muy reactivos).

\section{Gas natural comprimido y gases de hidrocarburos licuados}

La composición de los gases de hidrocarburos de origen natural es similar a la de los crudos de petróleo, en el sentido de que contienen una mezcla de diferentes moléculas de hidrocarburos que depende de su origen. Pueden extraerse como gas natural (casi libre de líquidos) de los yacimientos de gas; como gas asociado a petróleo, que se extrae junto con petróleo de los yacimientos de gas y petróleo, y en forma de gas de los campos de condensado de gas, donde algunos componentes líquidos del petróleo se convierten al estado gaseoso cuando la presión es alta (10 a $70 \mathrm{mPa}$ ). Cuando disminuye la presión (a un valor de entre 4 y $8 \mathrm{mPa}$ ) el condensado que contiene hidrocarburos pesados se separa del gas por condensación. El gas se extrae de pozos que alcanzan hasta 6,4 $\mathrm{km}$ o más de profundidad, con presiones de manto que van desde $3 \mathrm{mPa}$ hasta $70 \mathrm{mPa}$ (véase la Figura 75.3.)

El gas natural contiene entre 90 y $99 \%$ de hidrocarburos, principalmente metano (el hidrocarburo más sencillo) junto con cantidades menores de etano, propano y butano. Asimismo, tiene trazas de nitrógeno, vapor de agua, dióxido de carbono, ácido sulfhídrico y a veces gases inertes, como argón o helio. Los gases naturales que contienen más de $50 \mathrm{~g} / \mathrm{m}^{3}$ de hidrocarburos con moléculas de tres o más átomos de carbono $\left(\mathrm{C}_{3}\right.$ o superiores $)$ se clasifican como gases "pobres".

En función del uso que se le dé como combustible, el gas natural se comprime o se licúa. El procedente de yacimientos de gas y condensado de gas se prepara en el mismo yacimiento para que cumpla unos criterios de transporte específicos antes de comprimirlo y conducirlo a los gasoductos. La preparación incluye la eliminación del agua con desecadores (deshidratadores, separadores y calentadores), del petróleo con filtros de coalescencia, y de sólidos mediante filtración. También se eliminan del gas natural el ácido sulfhídrico y el dióxido de carbono, para que no corroan los gasoductos y el equipo de transporte y de compresión. Antes de la transmisión se eliminan igualmente el propano, el butano y el pentano presentes en el gas natural, para evitar que se condensen y formen líquidos en 
Tabla 75.2 • Composición del petróleo y el gas natural.

\section{Hidrocarburos \\ Parafinas: Las moléculas de hidrocarburos de cadena saturada parafínica (alifá- ticos) del crudo tienen como fórmula $\mathrm{C}_{n} \mathrm{H}_{2 n+2}$ y pueden ser cadenas rectas (normales) o ramificadas (isómeros) de átomos de carbono. Las moléculas de parafina de cadena normal, más ligeras, se encuentran en los gases y en las ceras parafínicas. Las parafinas de cadena ramificada suelen encontrarse en frac- ciones pesadas del crudo y tienen mayores índices de octano que las parafinas normales.}

Aromáticos: Son compuestos de hidrocarburos de anillo insaturado (cíclicos). Los naftalenos son compuestos aromáticos de doble anillo fusionado. Los aromáticos más complejos, los polinucleares (tres o más anillos aromáticos fusionados), se encuentran en fracciones pesadas del crudo.

Naftenos: Son grupos de hidrocarburos de anillo saturado, de fórmula $\mathrm{C}_{n} \mathrm{H}_{2 n}$ dispuestos en forma de anillos cerrados (cíclicos), que se encuentran en todas las fracciones del crudo excepto en las más ligeras. Predominan los naftenos de un solo anillo (parafinas monocíclicas) con 5 y 6 átomos de carbono, encontrándose los naftenos de dos anillos (parafinas dicíclicas) en los componentes más pesados de la nafta.

\section{No hidrocarburos}

Azufre y sus compuestos: El azufre está presente en el gas natural y el petróleo crudo en forma de ácido sulfhídrico $\left(\mathrm{H}_{2} \mathrm{~S}\right)$, formando compuestos (tioles, mercaptanos, sulfuros, polisulfuros, etc.) o como azufre elemental. Cada gas y cada crudo tienen distintos tipos y cantidades de compuestos de azufre, pero por lo general la proporción, estabilidad y complejidad de los compuestos son mayores en las fracciones pesadas del crudo.

Los compuestos de azufre denominados mercaptanos, que tienen olores característicos, detectables incluso a muy bajas concentraciones, se encuentran en el gas, en los crudos de petróleo y en los destilados. Los más comunes son los metilmercaptanos y los etilmercaptanos. Los mercaptanos se añaden con frecuencia al gas comercial (GNL y GPL) para odorizarlo con miras a la detección de fugas.

Existe riesgo de exposición a niveles tóxicos de $\mathrm{H}_{2} \mathrm{~S}$ cuando se realizan trabajos de perforación, producción, transporte y procesado de petróleo y de gas natural. La combustión de hidrocarburos de petróleo que contienen azufre produce compuestos indeseables, como el ácido sulfúrico y el dióxido de azufre.

Compuestos de oxígeno: En los crudos de petróleo se encuentran compuestos de oxígeno, como fenoles, cetonas y ácidos carboxílicos en cantidades variables.

Compuestos de nitrógeno: El nitrógeno se encuentra en las fracciones ligeras del crudo formando parte de compuestos básicos, y con mayor frecuencia en las fracciones pesadas, en compuestos no básicos que también pueden contener trazas metálicas.

Trazas metálicas: En los crudos de petróleo se encuentran con frecuencia cantidades muy pequeñas de metales como cobre, níquel, hierro, arsénico y vanadio.

Sales inorgánicas: A menudo, los crudos de petróleo contienen sales inorgánicas, como el cloruro sódico, el cloruro de magnesio y el cloruro cálcico, suspendidas en el crudo o disueltas en el agua retenida (salmuera).

Dióxido de carbono: Puede proceder de la descomposición de bicarbonatos presentes en el crudo 0 añadidos al mismo, 0 del vapor utilizado en el proceso de destilación.

Acidos nafténicos: Algunos crudos de petróleo contienen ácios nafténicos (orgánicos), que pueden volverse corrosivos a temperaturas superiores a $232^{\circ} \mathrm{C}$ cuando la acidez del crudo supera cierto nivel.

Materiales radiactivos naturales: Los crudos de petróleo y los depósitos y lodos de perforación contienen a menudo materiales radiactivos naturales (NORM) cuyos bajos niveles de radiactividad pueden suponer un riesgo.
Figura 75.3 - Plataforma marina de producción de gas natural instalada en aguas de 87,5 metros de profundidad en la zona de Pitas Point del Canal de Santa Bárbara, en el sur de California.

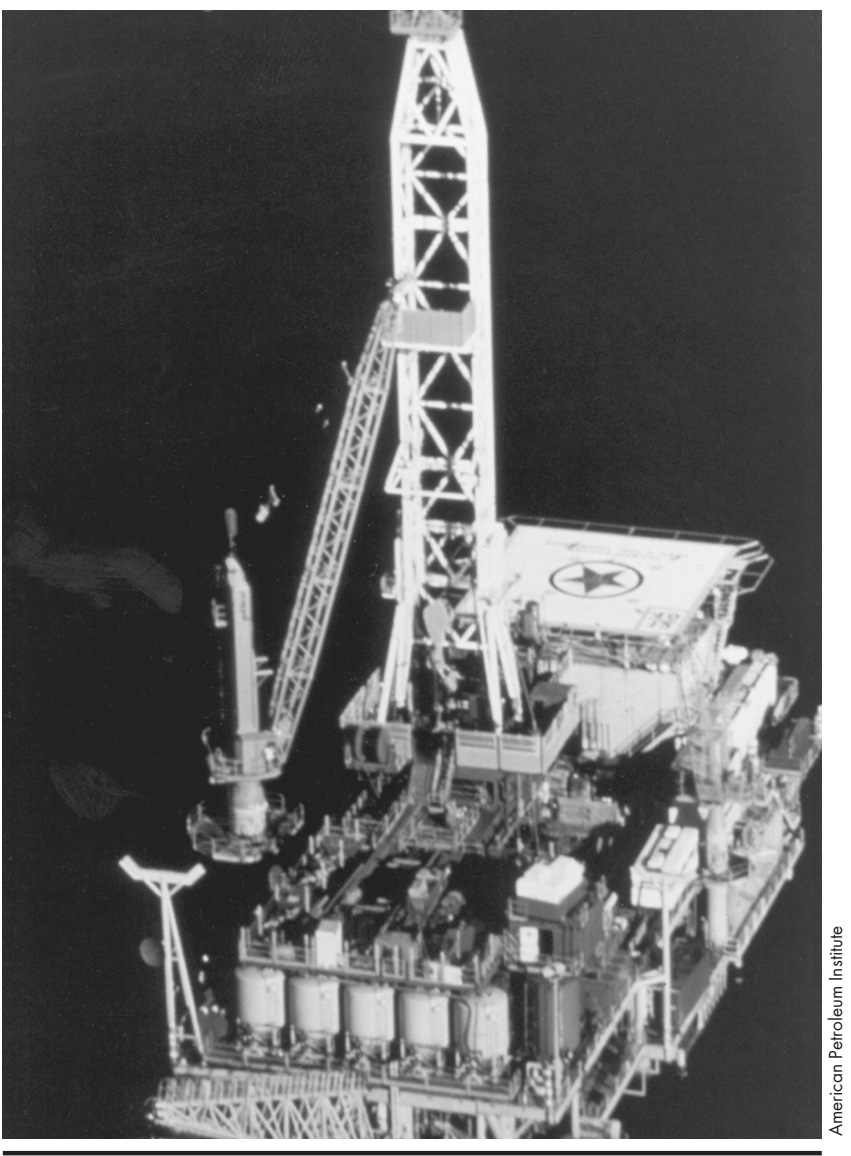

el sistema (véase la sección "Operaciones de producción y procesado de gas natural").

El gas natural se transporta por gasoductos desde los campos de extracción hasta las plantas de licuefacción, donde se comprime y se enfría hasta aproximadamente $-162{ }^{\circ} \mathrm{C}$ para producir gas natural licuado (GNL) (véase la Figura 75.4). La composición del GNL es distinta de la del gas natural debido a la eliminación de algunas impurezas y componentes durante el proceso de licuefacción. El GNL se utiliza sobre todo para aumentar la provisión de gas natural durante los períodos de fuerte demanda y para abastecer gas a zonas alejadas de los principales gasoductos. Se regasifica añadiendo nitrógeno y aire para hacerlo equivalente al gas natural antes de introducirlo en las tuberías de suministro. El GNL se utiliza también como combustible para automóviles como alternativa a la gasolina.

Los gases asociados al petróleo y los gases de condensado se clasifican como "ricos" porque contienen cantidades considerables de etano, propano, butano y otros hidrocarburos saturados. Los gases asociados al petróleo y los gases de condensado se separan y licúan para producir gas de petróleo licuado (GPL) por compresión, adsorción, absorción y enfriamiento en plantas de procesado de gas y petróleo. En esas plantas se produce también gasolina natural y otras fracciones de hidrocarburos.

A diferencia del gas natural, el gas asociado al petróleo y el gas de condensado, los obtenidos del procesado del petróleo 
Figura 75.4 • La planta de GNL más grande del mundo, en Arzew, Argelia.

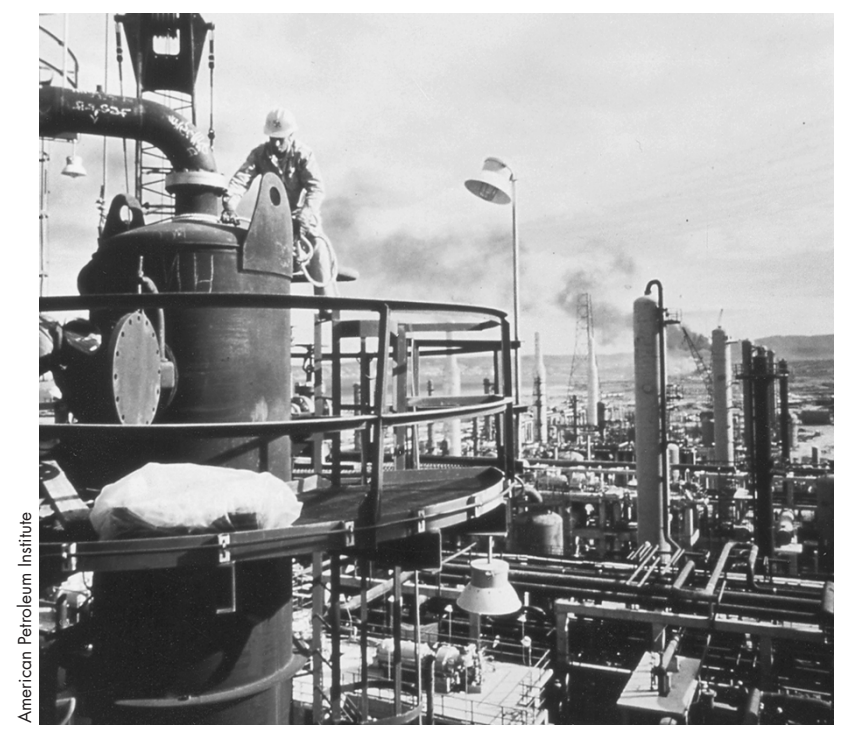

(producidos como subproductos de procesado en las refinerías) contienen cantidades considerables de hidrógeno e hidrocarburos insaturados (etileno, propileno, etc.). La composición de los gases obtenidos del procesado del petróleo depende de cada proceso específico y de los crudos de petróleo utilizados. Por ejemplo, los gases obtenidos mediante craqueo térmico suelen contener cantidades considerables de olefinas, mientras que los obtenidos por craqueo catalítico tienen más isobutanos. Los gases de pirólisis contienen etileno e hidrógeno. La composición de los gases naturales y de los principales gases de procesado del petróleo se indica en la Tabla 75.3.

El gas natural combustible, con un poder calorífico de entre 35,7 y $41,9 \mathrm{MJ} / \mathrm{m}^{3}\left(8.500\right.$ a $\left.10.000 \mathrm{kcal} / \mathrm{m}^{3}\right)$, se usa principalmente como combustible para proporcionar calor en el ámbito doméstico, agrícola, comercial e industrial. El hidrocarburo del gas natural se utiliza también como materia prima para procesos petroquímicos y químicos. El gas de síntesis $\left(\mathrm{CO}+\mathrm{H}_{2}\right)$ se obtiene del metano por oxigenación o mediante conversión de vapor de agua, y se utiliza para preparar amoníaco, alcohol y otros productos químicos orgánicos. El gas natural comprimido (GNC) y el gas natural licuado (GNL) se usan como combustible para motores de combustión interna. Los gases de petróleo licuado (GPL) obtenidos del procesado del petróleo tienen valores caloríficos más altos: $93,7 \mathrm{MJ} / \mathrm{m}^{3}$ (propano) $\left(22.400 \mathrm{kcal} / \mathrm{m}^{3}\right.$ ) y $122,9 \mathrm{MJ} / \mathrm{m}^{3}$ ) (butano) $\left(29.900 \mathrm{kcal} / \mathrm{m}^{3}\right)$, y se utilizan como combustible en el ámbito doméstico y en la industria, aparte de en automóviles (NFPA 1991). Es posible convertir los hidrocarburos insaturados (etileno, propileno, etc.) derivados de los gases obtenidos del procesado del petróleo en gasolina de alto octanaje, o bien utilizarse como materias primas en las industrias de procesos químicos y petroquímicos.

\section{Propiedades de los gases de hidrocarburos}

Según la National Fire Protection Association de Estados Unidos, son gases inflamables (combustibles) los que arden a las concentraciones de oxígeno normalmente presentes en el aire. La combustión de gases inflamables es similar a la de vapores de líquidos de hidrocarburos inflamables, ya que se requiere una temperatura de ignición específica para iniciar la reacción de combustión y cada uno de ellos arde únicamente dentro de una cierta gama definida de mezclas de gas y aire. Los líquidos inflamables tienen un determinado punto de inflamabilidad [temperatura (siempre inferior al punto de ebullición) a la que desprenden vapores suficientes para la combustión]. Los gases inflamables no parecen tener punto de inflamabilidad, ya que normalmente se encuentran a temperaturas superiores a sus puntos de ebullición, incluso estando licuados, y por lo tanto se hallan siempre a temperaturas muy por encima de sus puntos de inflamabilidad.

La National Fire Protection Association de Estados Unidos (1976) define los gases comprimidos y licuados como sigue:

- "Son gases comprimidos los que a todas las temperaturas atmosféricas normales en el interior de los recipientes que los contienen se encuentran únicamente en estado gaseoso a presión".

- "Son gases licuados los que a las temperaturas atmosféricas normales en el interior de los recipientes que los contienen se encuentran en parte en estado líquido y en parte en estado gaseoso, y están a presión mientras queda líquido en el recipiente".

El principal factor que determina la presión en el interior del recipiente es la temperatura del líquido contenido en él. Cuando se le expone a la atmósfera, el gas licuado se vaporiza con gran rapidez y se desplaza por el suelo o la superficie del agua a menos que se disperse en el aire por efecto del viento o del movimiento mecánico del aire. A temperaturas atmosféricas normales, aproximadamente la tercera parte del líquido contenido en el recipiente se vaporiza.

Los gases inflamables se clasifican asimismo como combustibles e industriales. Los primeros, incluidos el gas natural y los gases de petróleo licuados (propano y butano), arden en presencia de aire para producir calor en estufas, hornos, calentadores de agua y calderas. Los segundos, como el acetileno, se utilizan en operaciones de transformación, soldadura, corte y termotratamiento. Las diferencias entre las propiedades del gas natural licuado (GNL) y de los gases de petróleo licuados (GPL) se indican en la Tabla 75.3.

Tabla 75.3 • Composición normal aproximada de los gases naturales y gases de procesado del petróleo (porcentaje en volumen).

$\begin{array}{lcccccccccc}\text { Tipo de gas } & \mathrm{H}_{2} & \mathrm{CH}_{4} & \mathrm{C}_{2} \mathrm{H}_{6} & \mathrm{C}_{3} \mathrm{H}_{4} & \mathrm{C}_{3} \mathrm{H}_{8} & \mathrm{C}_{3} \mathrm{H}_{6} & \mathrm{C}_{4} \mathrm{H}_{10} & \mathrm{C}_{4} \mathrm{H}_{8} & \mathrm{~N}_{2+} \mathrm{CO}_{2} & \mathrm{C}_{5+} \\ \text { Gas natural } & \mathrm{NA} & 98 & 0,4 & \mathrm{NA} & 0,15 & \mathrm{NA} & 0,05 & \mathrm{NA} & 1,4 & \mathrm{NA} \\ \begin{array}{l}\text { Gas asociado al petróleo } \\ \text { Gases de procesado del petróleo }\end{array} & \mathrm{NA} & 42 & 20 & \mathrm{NA} & 17 & \mathrm{NA} & 8 & \mathrm{NA} & 10 & 3 \\ \quad \begin{array}{l}\text { Craqueo catalítico } \\ \text { Pirólisis }\end{array} & 5-6 & 10 & 3-5 & 3 & 16-20 & 6-11 & 42-46 & 5-6 & \mathrm{NA} & 5-12 \\ & 12 & 5-7 & 5-7 & 16-18 & 0,5 & 7-8 & 0,2 & 4-5 & \mathrm{NA} & 2-3 \\ \end{array}$




\section{En busca de petróleo y gas natural}

La búsqueda de petróleo y gas natural requiere conocimientos de geografía, geología y geofísica. El petróleo suele encontrarse en ciertos tipos de estructuras geológicas, como anticlinales, trampas por falla y domos salinos, que se hallan bajo algunos terrenos y en muy distintos climas. Tras seleccionar una zona de interés, se llevan a cabo numerosos tipos diferentes de prospecciones geofisicas y se realizan mediciones a fin de obtener una evaluación precisa de las formaciones del subsuelo, a saber:

- Prospecciones magnetométricas. Las variaciones del campo magnético terrestre se miden con magnetómetros suspendidos de un aeroplano, a fin de localizar formaciones de rocas sedimentarias cuyas propiedades magnéticas son generalmente débiles en comparación con las de otras rocas.

- Prospecciones fotogramétricas aéreas. Las fotografías tomadas con cámaras especiales desde aeroplanos proporcionan vistas tridimensionales de la tierra, que se utilizan para determinar formaciones geológicas en las que puede haber yacimientos de petróleo y gas natural.

- Prospecciones gravimétricas. Como las grandes masas de roca densa aumentan la atracción de la gravedad, se utilizan gravímetros para obtener información sobre formaciones subyacentes midiendo pequeñísimas diferencias de gravedad.

- Prospecciones sísmicas. Las prospecciones sísmicas proporcionan información sobre las características generales de la estructura del subsuelo (véase la Figura 75.5). Las medidas se obtienen a partir de ondas de choque generadas por detonación de cargas

Figura 75.5 • Arabia Saudí, operaciones sísmicas.

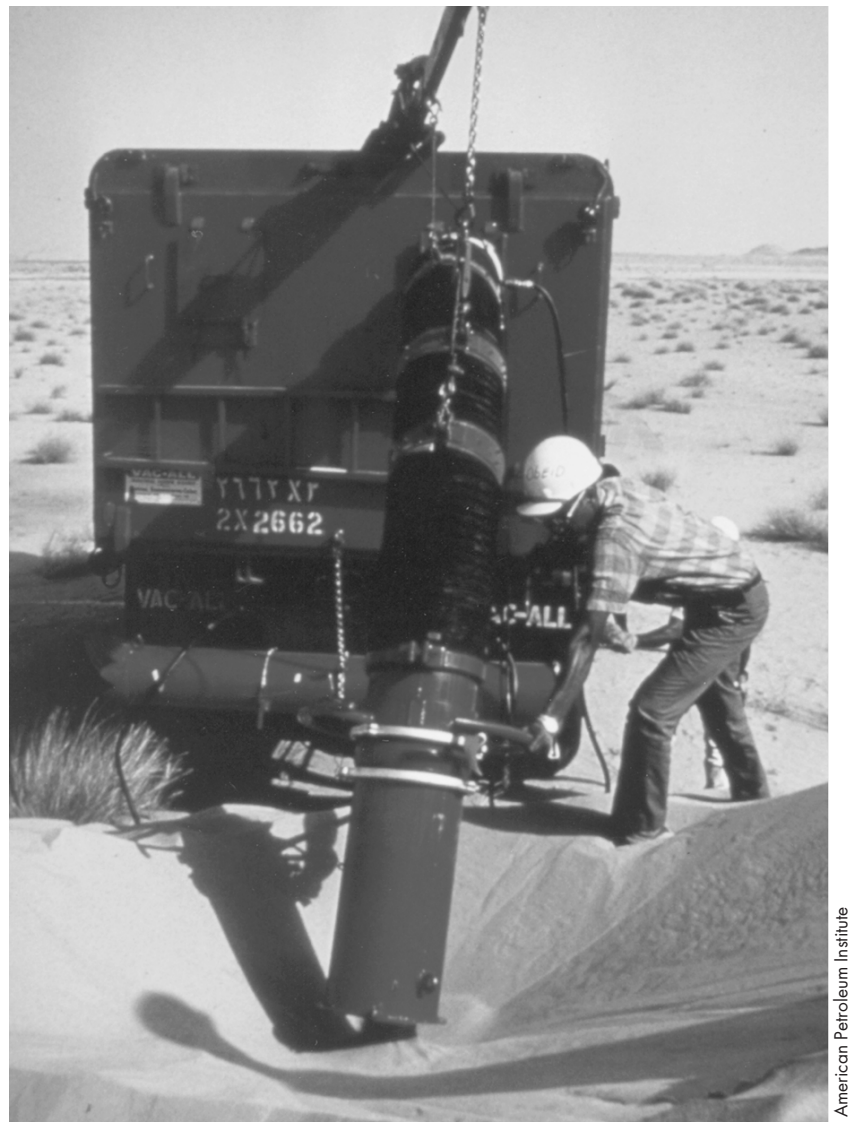

explosivas en agujeros de pequeño diámetro; mediante dispositivos vibrantes o de percusión tanto en tierra como en el agua, y mediante descargas explosivas subacuáticas de aire comprimido. El tiempo transcurrido entre el comienzo de la onda de choque y el retorno del eco se utiliza para determinar la profundidad de los sustratos reflectores. Gracias al uso reciente de superordenadores para generar imágenes tridimensionales, la evaluación de los resultados de las pruebas sísmicas ha mejorado notablemente.

- Prospecciones radiográficas. La radiografía consiste en el uso de ondas de radio para obtener información similar a la que proporcionan las prospecciones sísmicas.

- Prospecciones estratigráficas. El muestreo estratigráfico es el análisis de testigos extraídos de estratos rocosos del subsuelo para ver si contienen trazas de gas y petróleo. Se corta con una barrena hueca un trozo cilíndrico de roca, denominado testigo, y se empuja hacia arriba por un tubo (sacatestigos) unido a la barrena. El tubo sacatestigos se sube a la superficie y se extrae el testigo para su análisis.

Cuando las prospecciones y mediciones indican la presencia de formaciones de estratos que pueden contener petróleo, se perforan pozos de exploración para determinar si existe o no petróleo o gas y, en caso de que exista, si es asequible y puede obtenerse en cantidades comercialmente viables.

\section{Operaciones en alta mar}

Aunque la perforación del primer pozo petrolífero en alta mar se llevó a cabo a principios del decenio de 1900 en las costas de California, el comienzo de las modernas perforaciones submarinas tuvo lugar en 1938, con un descubrimiento en el Golfo de México, a 1,6 km de la costa de Estados Unidos. Después de la segunda Guerra Mundial, la perforación submarina tuvo una rápida expansión, primero en aguas poco profundas cercanas a zonas de producción conocidas de tierra firme, y más tarde en otras zonas de aguas poco profundas o profundas de todo el mundo y en los climas más diversos, desde el Artico al Golfo Pérsico. Al principio, la perforación submarina sólo era posible en aguas de hasta $91 \mathrm{~m}$ de profundidad aproximadamente; en cambio, las plataformas modernas superan los $3,2 \mathrm{~km}$. Las actividades petrolíferas en alta mar comprenden la exploración, perforación, producción, procesado, construcción submarina, mantenimiento, reparación y el transporte a tierra del petróleo y el gas, por barco o mediante oleoductos y gasoductos.

\section{Plataformas marinas}

Las plataformas de perforación sirven de soporte a las torres de perforación, los utensilios y el equipo para las operaciones en alta mar o en aguas interiores, y las hay de distintos tipos, desde barcos y barcazas flotantes o sumergibles hasta plataformas fijas sobre soportes de acero utilizadas en aguas poco profundas y plataformas de gravedad grandes, flotantes, de hormigón armado, que se utilizan en aguas profundas. Una vez completada la perforación, las plataformas marinas se usan como soporte del equipo de producción. Las más grandes tienen capacidad para más de 250 operarios y demás personal de apoyo, para helipuertos y plantas de procesado, además de capacidad de almacenamiento de petróleo crudo y condensado de gas (véase la Figura 75.6).

Por lo común, para la perforación con plataforma flotante en aguas profundas, el equipo de la cabeza del pozo se baja hasta el fondo del océano y se conecta de forma estanca a la entubación o tubería de revestimiento del pozo. La tecnología de fibra óptica permite controlar a distancia una plataforma central grande y trabajar con plataformas satélite más pequeñas y plataformas submarinas. Las instalaciones de producción de la 
Figura 75.6 - Embarcaciones de perforación; buque perforador Ben Ocean Laneer.

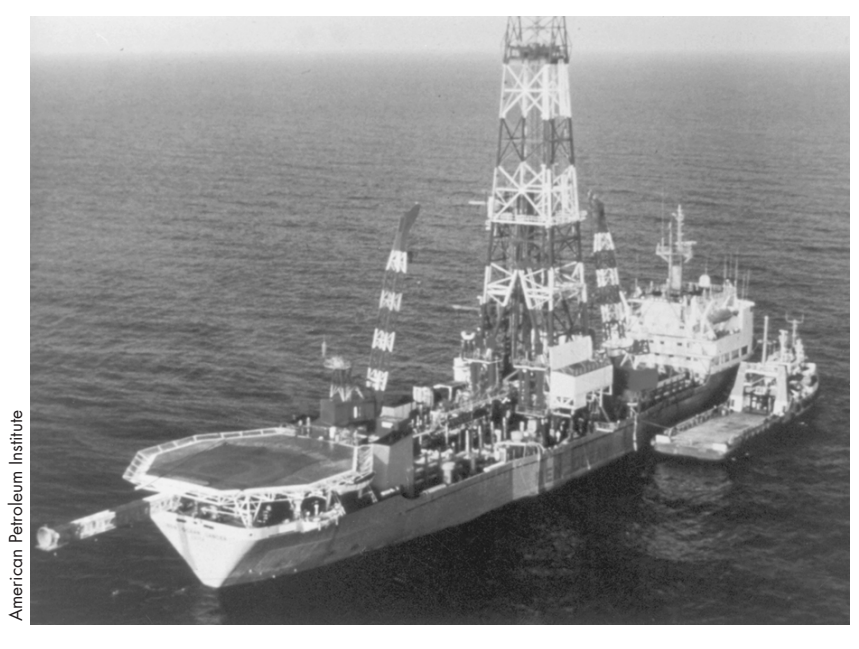

plataforma grande procesan el crudo, el gas y el condensado de las instalaciones satélite antes de su embarque en tierra.

El tipo de plataforma utilizado en la perforación submarina suele estar determinado por el tipo de pozo que se va a perforar (de exploración o de producción) y por la profundidad del agua (véase la Tabla 75.4).

\section{Tipos de pozos}

Pozos de exploración. Después del análisis de los datos geológicos y de las prospecciones geofísicas se perforan pozos de exploración, en tierra firme o en el mar. Los pozos de este tipo que se perforan en zonas donde no se había encontrado antes petróleo ni gas se denominan pozos experimentales o de cateo. Los pozos donde se encuentra petróleo o gas reciben el nombre de "pozos de descubrimiento". Otros pozos de exploración, conocidos como "pozos de delimitación" o "de valoración", se perforan para determinar los límites de un yacimiento después del descubrimiento, o para buscar nuevas formaciones que contengan petróleo o gas, situadas cerca o debajo de las que ya se sabe que contienen el producto. A un pozo donde no se encuentra petróleo ni gas, o sólo en cantidades demasiado escasas para una producción económica, se le llama "pozo seco".

Pozos de desarrollo. Después de un descubrimiento se determina de forma aproximada la extensión del yacimiento mediante una serie de pozos de delimitación o de valoración. Acto seguido se perforan pozos de desarrollo para producir gas y petróleo, cuyo número depende de la definición esperada del nuevo yacimiento, tanto en tamaño como en productividad. Debido a la incertidumbre acerca de la forma o el confinamiento de los yacimientos, algunos pozos de desarrollo pueden resultar pozos secos. A veces, la perforación y la producción se realizan simultáneamente.

Pozos de geopresión y geotérmicos. Son pozos que producen agua a una presión (7.000 psi) y una temperatura $\left(149^{\circ} \mathrm{C}\right)$ extremadamente elevadas, la cual puede contener hidrocarburos. El agua se convierte en una nube de vapor caliente y gases que se expande rápidamente al ser liberada a la atmósfera debido a una fuga o una rotura.

Pozos mermados o casi agotados. Son los que producen menos de diez barriles de petróleo diarios en un yacimiento.

Pozos de múltiples zonas. Cuando se descubren múltiples formaciones productivas al perforar un solo pozo, puede introducirse una columna de tubos en un mismo pozo para cada una de las formaciones. El petróleo y el gas de cada formación se dirigen a su respectiva tubería y se aíslan de los demás mediante obturadores, que sellan los espacios anulares entre la columna de tubos y el revestimiento. Son los denominados pozos "de múltiples zonas".

Pozos de inyección. Bombean aire, agua, gas o productos químicos a los yacimientos de los campos de producción, ya sea para mantener la presión o para desplazar el petróleo hacia pozos de producción mediante fuerza hidráulica o un aumento de la presión.

Tabla 75.4 • Tipos de plataformas de perforación submarina.

$\begin{array}{lcl}\begin{array}{l}\text { Tipo de plataforma } \\ \text { Barcazas y plataformas } \\ \text { sumergibles }\end{array} & \text { Profundidad (m) } & \begin{array}{c}\text { Descripción } \\ \text { Con gato (sobre soportes) }\end{array} \\ \begin{array}{c}\text { Barcazas o plataformas que se remolcan hasta el lugar de la perforación y se hunden y apoyan en el fondo. } \\ \text { Columna inferior con capacidad de flotación para mantener la torre de perforación a flote cuando se mueve. }\end{array} & \begin{array}{c}\text { Plataformas móviles flotantes autoelevadoras, cuyos soportes se elevan para poder remolcarlas. Una vez en el } \\ \text { lugar de la perforación, se bajan los soportes hasta el fondo y después se extienden para elevar la plataforma } \\ \text { por encima del nivel del agua. }\end{array}\end{array}$

Plataformas flotantes $\quad 100-3,000+$

Estructuras de gravedad de hormigón armado de grandes dimensiones, autónomas, con varios niveles, que se remolcan hasta el lugar de la perforación, se sumergen con lastre de agua hasta una profundidad predeterminada, para que las columnas y los dispositivos estabilizadores contrarresten el oleaje, y se anclan. Con frecuencia, el crudo se almacena en las columnas hasta su descarga.

Plataformas flotantes más pequeñas, suspendidas de la misma forma, que soportan únicamente el equipo de perforación y son atendidas por una embarcación de servicio

Barcazas de perforación $\quad 30-300 \quad$ Barcazas autopropulsadas, flotantes o semisumergibles.

Barcos de perforación $\quad 120-3,500+\quad$ Barcos flotantes 0 semisumergibles muy avanzados, de diseño especial.

Plataformas fijas $\quad 0-250$

Plataformas construidas sobre soportes de acero (blindajes) que se hunden y fijan en el lugar de la perforación, e islas artificiales utilizadas como plataformas.

Plataformas submarinas NDStalaciones de producción subacuáticas. 
Figura 75.7 - Equipo de perforación en Ellef Ringnes Island, en el Artico canadiense.

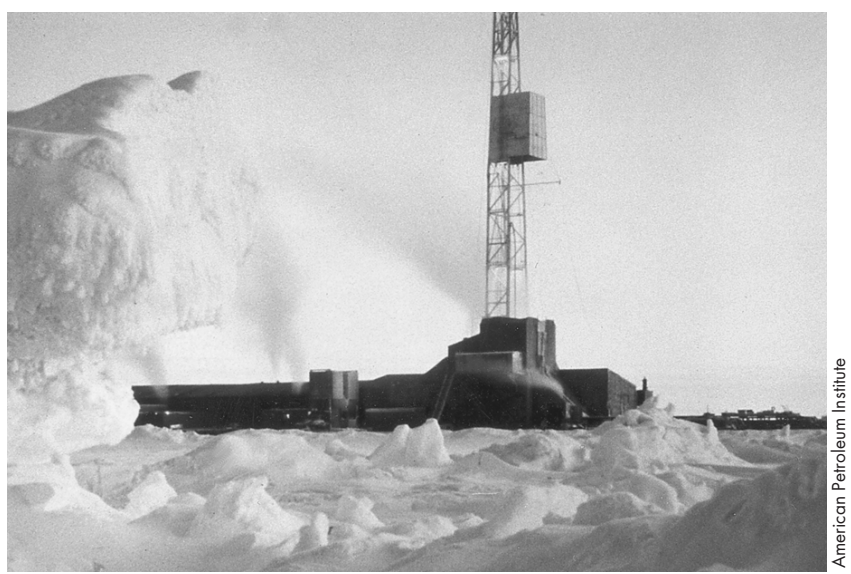

Pozos de servicio. Son los que se utilizan para operaciones de pesca de tubos o accesorios y operaciones con cable de acero, colocación de obturadores o tapones, o retirada y rehabilitación. Asimismo se perforan para la evacuación subterránea del agua salada que se separa del crudo y el gas.

\section{Métodos de perforación}

Equipos de perforación. Los equipos de perforación básicos contienen una torre, una tubería de perforación, un cabrestante de gran capacidad para bajar y subir la tubería de perforación, una mesa o plataforma que hace girar la tubería y la barrena, una mezcladora y una bomba de lodos, y un motor para el accionamiento de la plataforma giratoria y el cabrestante (véase la Figura 75.7). Se pueden montar sobre camiones sondas o perforadoras pequeñas que se utilizan para perforar pozos de exploración o de prospección sísmica, con objeto de trasladarlas de un lugar a otro. Las perforadoras grandes se instalan en el lugar de la perforación o tienen torres portátiles articuladas (plegables) para facilitar la manipulación e instalación.

Perforación por percusión o con cable. El método de perforación más antiguo es el que se realiza por percusión o con cable. Es un método lento y de profundidad limitada, que rara vez se utiliza. Se basa en triturar la roca elevando y dejando caer una pesada barrena cincel con vástago sujeta al extremo de un cable. Cada cierto tiempo se extrae la barrena y los fragmentos de roca triturada se suspenden en agua y se eliminan sacándolos a la superficie mediante lavado a presión o bombeo. A medida que el agujero va adquiriendo mayor profundidad, se le reviste con tubería de acero para evitar su derrumbe y como protección contra la contaminación de las aguas subterráneas. La perforación, incluso de un pozo de escasa profundidad, representa un trabajo considerable y al encontrar petróleo o gas no hay modo de controlar el flujo inmediato de producto a la superficie.

Perforación rotativa. La perforación rotativa es el método más común y se utiliza para perforar pozos tanto de exploración como de producción, hasta profundidades superiores a $7.000 \mathrm{~m}$. Para perforar en tierra pozos sísmicos de poca profundidad se utilizan perforadoras ligeras montadas sobre camiones. Para abrir los pozos de exploración y de producción se utilizan perforadoras rotativas móviles y flotantes, semipesadas y pesadas. El equipo de perforación rotativa se monta sobre una plataforma de perforación con una torre de 30 a $40 \mathrm{~m}$ de altura, y comprende una plataforma giratoria, motor, mezcladora de lodo y bomba de inyección, un cabrestante o malacate con cable metálico, y numerosos tubos, de $27 \mathrm{~m}$ de longitud cada uno aproximadamente. La plataforma hace girar un vástago de transmisión cuadrado conectado a la tubería de perforación. El vástago cuadrado tiene en la parte superior una lanzadera de lodo conectada a unas válvulas de seguridad antirreventones. La tubería de perforación gira a una velocidad de entre 40 y $250 \mathrm{rpm}$ y hace girar una barrena de fricción de bordes cortantes fijos, tipo cincel, o una barrena de rodillos con cuchillas rotativas de dientes endurecidos.

Perforación rotopercutante. La perforación rotopercutante, o por rotación y percusión, es un método combinado en el que una barrena rotativa utiliza un líquido hidráulico circulante para accionar un mecanismo tipo martillo, creando así una serie de rápidos golpes de percusión que permiten que la barrena perfore y simultáneamente triture la tierra.

Electroperforación y turboperforación. La mayoría de las plataformas giratorias, cabrestantes y bombas de los equipos de perforación pesados suelen ser accionados por motores eléctricos o turbinas, lo que permite mayor flexibilidad en las operaciones y la perforación telecontrolada. La electroperforación y la turboperforación son nuevos métodos que proporcionan a la barrena una potencia más directa al conectar el motor de perforación justo por encima de la barrena, en el fondo del agujero.

Perforación direccional. La perforación direccional es una técnica de perforación rotativa que guía la columna de perforación siguiendo una trayectoria curva a medida que el agujero se hace más profundo. Este método se utiliza para llegar hasta yacimientos que son innacesibles mediante la perforación vertical. Asimismo reduce los costes, ya que permite perforar varios pozos en distintas direcciones desde una sola plataforma. Este mayor alcance de perforación permite penetrar en yacimientos submarinos desde la costa. Muchos de estos métodos son posibles gracias al empleo de ordenadores para guiar perforadoras automáticas y tubería flexible (espiral), que se sube y baja sin tener que conectar y desconectar secciones.

Otros métodos de perforación. La perforación abrasiva es un método en el que se utiliza un material abrasivo a presión (en lugar de una barra con barrena) para atravesar los sustratos. Otros métodos son la perforación con explosivos y la perforacón con llama.

Abandono. Cuando los yacimientos de petróleo y gas natural dejan de ser productivos, normalmente se taponan los pozos con cemento para evitar flujos o fugas a la superficie y proteger los estratos y el agua subterráneos. Se retira el equipo y los emplazamientos de los pozos abandonados se limpian y se devuelven a la normalidad.

\section{Operaciones de perforación}

\section{Técnicas de perforación}

La plataforma de perforación sirve de base para que los operarios acoplen y desacoplen las secciones de tubería de perforación que se utilizan para aumentar la profundidad de perforación. A medida que aumenta la profundidad del orificio se va alargando el tubo y se suspende de la torre la columna de perforación. Cuando hay que cambiar una barrena, se extrae del pozo toda la columna del tubo de perforación, separando cada una de las secciones que la integran y disponiéndolas verticalmente 
dentro de la torre. Una vez colocada la nueva barrena, el proceso se invierte y el tubo vuelve a situarse en el agujero para proseguir con la perforación. Ha de prestarse mucha atención a que el tubo de la columna de perforación no se disgregue y caiga en el interior del orificio, ya que sería difícil y muy costoso recuperarlo y podría dar lugar, incluso, a que el pozo tuviera que abandonarse. Otro problema que puede plantearse es que las herramientas de perforación se atasquen en el agujero al detener la perforación. Por ello, una vez que se inicia ésta normalmente se continúa sin interrupción hasta terminar el pozo.

\section{Lodo de perforación}

El lodo de perforación es un líquido compuesto de agua o petróleo y arcilla con aditivos químicos (por ejemplo, formaldehído, cal, hidracida sódica, baritina). A menudo se añade sosa cáustica para controlar el $\mathrm{pH}$ (acidez) del lodo de perforación y neutralizar aditivos del lodo y líquidos de terminación potencialmente peligrosos. El lodo de perforación se inyecta en el pozo bajo presión desde el tanque de mezcla en la plataforma de perforación, por el interior de la tubería de perforación hasta la barrena. Después, el lodo asciende por entre la superficie exterior de la tubería de perforación y las paredes del agujero y vuelve a la superficie, donde se filtra y recicla.

El lodo de perforación se utiliza para refrigerar y lubricar la barrena, lubricar la tubería y expulsar del agujero de perforación los fragmentos de roca triturados. El lodo de perforación se utiliza también para controlar el flujo que sale del pozo, al revestir las paredes del agujero y oponer resistencia a la presión del gas, petróleo o agua que encuentre la barrena. Se pueden inyectar chorros de lodo a presión en el fondo del agujero para facilitar la perforación.

\section{Revestimiento y cementación}

El revestimento es una tubería pesada de acero especial que reviste el agujero del pozo. Se utiliza para evitar el derrumbe de las paredes del agujero de la perforación y proteger los estratos de agua dulce previniendo fugas del flujo de retorno de lodo durante las operaciones de perforación. El revestimiento sella también las arenas impregnadas de agua y las zonas de gas a alta presión. Inicialmente se utiliza cerca de la superficie y se cementa para guiar la tubería de perforación. Para ello se bombea una lechada de cemento a la tubería y se la fuerza a subir por el espacio comprendido entre el revestimiento y las paredes del pozo. Una vez fraguado el cemento y colocado el revestimiento, se continúa con la perforación utilizando una barrena de menor diámetro.

Después de colocar en el pozo el revestimiento superficial, se montan en la parte superior de éste dispositivos antirreventones (grandes válvulas, sacos o empaquetaduras), en lo que se denomina un árbol. Cuando se descubre petróleo o gas, se entuba el fondo del pozo, es decir, se reviste para evitar que penetren en el agujero de perforación tierra, rocas, agua salada y otros contaminantes, y también con objeto de crear un conducto para las tuberías de extracción de crudo y gas.

\section{Operaciones de terminación, recuperación optimizada y rehabilitación}

\section{Terminación}

La terminación es el proceso de poner un pozo en producción una vez perforado hasta la profundidad a que se espera encontrar petróleo o gas. Comprende varias operaciones, entre ellas la penetración de la tubería de revestimiento y la limpieza del oleoducto para expulsar el agua y el sedimento a fin de que no obstaculicen el flujo de producción. Durante la perforación se utilizan barrenas sacatestigos especiales para extraer muestras de hasta
$50 \mathrm{~m}$ de longitud con el fin de analizarlas para determinar cuándo debe efectuarse la penetración. Primero se extraen la tubería de perforación y la barrena, y se cementa el tramo final de revestimiento; después se introduce en el pozo una pistola de perforación consistente en un tubo metálico con casquillos que contienen balas o cargas explosivas huecas. Las cargas se detonan por medio de impulsos eléctricos para que atraviesen la entubación y penetren en el yacimiento, creando así aberturas para que el petróleo y el gas fluyan al pozo y, a través de éste, lleguen a la superficie.

El flujo de petróleo crudo y gas natural se controla mediante una serie de válvulas, denominadas "árboles de navidad", que se colocan en la parte superior de la cabeza del pozo. Se instalan monitores y controles para accionar de forma automática o manual las válvulas de seguridad de superficie y subterráneas, en caso de cambio de presión, incendio u otra situación peligrosa. Una vez obtenidos el petróleo y el gas natural, se separan y se eliminan del petróleo crudo el agua y el sedimento.

\section{Producción y conservación de petróleo crudo y gas natural} La producción de petróleo se lleva a cabo básicamente por desplazamiento mediante agua o gas. Al iniciarse la perforación, casi todo el crudo está a presión. Esta presión natural disminuye a medida que se van extrayendo petróleo y gas del yacimiento, durante las tres fases de la vida de éste.

- Durante la primera fase, llamada de producción emergente, el flujo lo controla la presión natural del yacimiento, debida al gas disuelto en el petróleo, al gas a presión atrapado encima del petróleo y a la presión hidráulica del agua atrapada debajo de este último.

- La segunda fase, la de producción por presión artificial, se realiza inyectando gas a presión en el yacimiento cuando se ha agotado la presión natural.

- La fase tres, denominada de agotamiento o de producción marginal, tiene lugar cuando los pozos sólo producen intermitentemente.

$\mathrm{Al}$ principio no se conocían bien las fuerzas que afectaban a la producción de petróleo y gas natural. El estudio del comportamiento de los yacimientos de petróleo y gas natural se inició al comienzo del siglo XX, cuando se descubrió que bombeando agua en un yacimiento aumentaba la producción. En aquel entonces, la industria recuperaba entre el 10 y el $20 \%$ de la capacidad de los yacimientos, frente a unas tasas de recuperación actuales que superan el $60 \%$ antes de que los pozos se vuelvan improductivos. El concepto de control se basa en que una tasa de producción rápida disipa la presión del yacimiento con mayor rapidez, reduciendo por tanto la cantidad total de petróleo recuperable. Dos de las medidas que se utilizan para conservar los yacimientos petrolíferos son la unificación y el espaciado de los pozos.

- La unificación consiste en explotar un campo como una sola unidad a fin de aplicar métodos de recuperación secundarios y mantener la presión, aunque para ello sea necesaria la intervención de varias compañías diferentes. La producción total se distribuye equitativamente entre las distintas compañías.

- El espaciado de los pozos es la delimitación y el correcto emplazamiento de los pozos para conseguir la máxima producción sin disipar un campo por exceso de perforaciones.

\section{Métodos de recuperación de producto adicional}

La productividad de los yacimientos de petróleo y gas natural mejora con diversos métodos de recuperación. Uno de ellos consiste en abrir pasos en los estratos por procedimientos químicos o físicos para que el petróleo y el gas puedan moverse 
con mayor libertad por los yacimientos hasta el pozo. Se inyecta agua y gas en los yacimientos para mantener la presión de trabajo por desplazamiento natural. Métodos de recuperación secundarios, entre los que se incluyen el desplazamiento por presión, la producción por presión artificial y la inyección de agua, mejoran y restauran la presión del yacimiento. La recuperación optimizada consiste en el empleo de diversos métodos de recuperación secundarios en múltiples combinaciones diferentes. Asimismo incluye métodos más avanzados para obtener producto adicional de yacimientos agotados, como la recuperación térmica, que utiliza calor en lugar de agua o gas para forzar la salida de mayor cantidad de petróleo crudo de los yacimientos.

\section{Acidificación}

La acidificación es un método para aumentar el rendimiento de un pozo bombeando ácido directamente en un yacimiento productor con objeto de abrir canales de flujo mediante la reacción de los productos químicos y los minerales. Al principio se utilizaba ácido clorhídrico (normal) para disolver las formaciones calizas. Este ácido es aún muy utilizado, pero ahora se le añaden diversas sustancias químicas para controlar su reacción y evitar la corrosión y la formación de emulsiones.

Junto al ácido clorhídrico se emplean también ácido fluorhídrico, ácido fórmico y ácido acético, dependiendo del tipo de roca o de los minerales del yacimiento. El ácido fluorhídrico siempre se combina con uno de los otros tres ácidos y originalmente se usaba para disolver la arenisca. Suele llamársele "ácido antilodo", dado que actualmente se utiliza para limpiar perforaciones taponadas con lodo de perforación y restaurar la permeabilidad dañada en las inmediaciones del agujero del pozo. Los ácidos fórmico y acético se utilizan en yacimientos profundos, muy calientes, de caliza y dolomita, y como ácidos de descomposición antes de la perforación. El ácido acético también se añade a los pozos como agente tampón neutralizante para controlar el $\mathrm{pH}$ de los líquidos de estimulación del pozo. Casi todos los ácidos llevan aditivos, como inhibidores para evitar la reacción con los revestimientos metálicos, y tensoactivos para prevenir la formación de lodos y emulsiones.

\section{Fracturación}

La fracturación es el método utilizado para aumentar el flujo de petróleo o gas natural a los pozos a través de un yacimiento mediante fuerza o presión. La producción puede disminuir porque la formación del yacimiento no sea lo bastante permeable para que el petróleo pueda fluir libremente hacia el pozo. La fracturación fuerza la apertura de canales subterráneos bombeando al yacimiento, a alta presión, un líquido con materiales o productos de entibación especiales (como arena, metal, bolas químicas y conchas) para producir fisuras. Se puede añadir nitrógeno al líquido para estimular la expansión. Cuando se suprime la presión, el líquido se retira y los materiales de entibación permanecen, manteniendo así las fisuras abiertas para que el petróleo pueda circular más fácilmente.

La fracturación masiva consiste en bombear grandes cantidades de líquido a los pozos para crear hidráulicamente fisuras de miles de pies de longitud. La fracturación masiva se utiliza normalmente para abrir pozos de gas donde las formaciones de los yacimientos son tan densas que ni siquiera el gas puede atravesarlas.

\section{Mantenimiento de la presión}

Dos métodos comunes de mantenimiento de la presión son la inyección de agua o gas (aire, nitrógeno, dióxido de carbono y gas natural) en yacimientos donde las presiones naturales son reducidas o insuficientes para la producción. Ambos métodos exigen perforar pozos de inyección auxiliares en determinados lugares para conseguir los mejores resultados. La inyección de agua o gas para la presión de trabajo del pozo se denomina desplazamiento natural. El empleo de gas a presión para aumentar la presión del yacimiento recibe el nombre de producción o extracción por presión artificial (con gas).

\section{Inyección de agua}

El método secundario de recuperación optimizada utilizado con más frecuencia es el bombeo de agua a un yacimiento de petróleo para empujar el producto hacia los pozos de producción. En el método inyección de agua "five spot" (cinco puntos), se perforan cuatro pozos de inyección para formar un cuadrado con el pozo de producción en el centro. Se controla la inyección para mantener un avance uniforme del frente de agua hacia el pozo productor a través del yacimiento. Una parte del agua que se utiliza es agua salada, obtenida del petróleo crudo. En la inyección de agua con baja tensión superficial, se añade al agua un tensoactivo para facilitar la circulación del petróleo por el yacimiento reduciendo su adherencia a la roca.

\section{Inyección miscible}

La inyección de líquido miscible y de polímero miscible son métodos de recuperación optimizados que se utilizan para mejorar la inyección de agua reduciendo la tensión superficial del petróleo crudo. Primero se inyecta en un yacimiento un líquido miscible (es decir, soluble en el crudo). Después, se inyecta otro líquido que empuja la mezcla de crudo y líquido miscible hacia el pozo de producción. La invección de polímero miscible consiste en utilizar un detergente para separar el crudo de los estratos mediante lavado. Detrás del detergente se inyecta un gel o agua espesada para desplazar el crudo hacia el pozo productor.

\section{Inyección de fuego}

La inyección de fuego, o combustión in situ (en el yacimiento), es un método de recuperación térmica de elevado coste consistente en inyectar en el yacimiento grandes cantidades de aire o de un gas que contenga oxígeno e inflamar una parte del petróeo crudo. El calor producido por el fuego reduce la viscosidad del crudo denso y permite que éste fluya más fácilmente. Los gases calientes producidos por el fuego elevan la presión del yacimiento y crean un estrecho frente de combustión que empuja al crudo menos denso desde el pozo de inyección hacia el de producción. El crudo denso permanece donde se encuentra y aporta combustible adicional a medida que el frente de llama avanza lentamente. El proceso de combustión se vigila y controla cuidadosamente regulando el aire o el gas inyectado.

\section{Inyección de vapor}

La inyección de vapor es un método de recuperación térmica consistente en calentar el petróleo crudo denso y reducir su viscosidad inyectando vapor a muy alta temperatura en el estrato más bajo de un yacimiento relativamente poco profundo. El vapor se inyecta a lo largo de un período de 10 a 14 días y después se cierra el pozo más o menos durante otra semana para permitir que el vapor caliente completamente el yacimiento. Al mismo tiempo, el aumento de temperatura expande los gases del yacimiento, elevando así la presión de éste. Entonces se reabre el pozo y el crudo calentado, ahora menos viscoso, fluye por el pozo. Un método más reciente consiste en inyectar vapor no muy caliente y a baja presión en secciones mayores de dos, tres o más zonas simultáneamente, creando de ese modo una "cámara de vapor" que comprime el petróleo en cada una de las zonas. Esto permite obtener un mayor flujo de petróleo hacia la superficie utilizando menos vapor. 


\section{Operaciones de producción y procesado de gas natural}

Hay dos tipos de pozos que producen gas natural. Los pozos de gas húmedo producen gas que contiene líquidos disueltos y los de gas seco producen gas que no puede licuarse fácilmente.

Una vez extraído de los pozos de producción, el gas natural se envía a las plantas de procesado. El procesado del gas natural exige conocer cómo interactúan la temperatura y la presión y cómo afectan a las propiedades de los líquidos y gases. Casi todas las plantas de procesado de gas trabajan con gases que son mezclas de diversas moléculas de hidrocarburos. El procesado del gas tiene por finalidad separar estos gases en constituyentes de composición similar mediante diferentes procesos, como absorción, fraccionamiento y reciclado, para que puedan transportarse y ser utilizados por los consumidores.

\section{Procesos de absorción}

La absorción es un proceso de tres fases: recuperación, extracción y separación.

Recuperación. Elimina los gases residuales indeseables y algo de metano absorbiéndolos del gas natural. La absorción se lleva a cabo en una torre de contracorriente, donde el gas del pozo entra por el fondo y asciende a través del petróleo de absorción, que circula hacia abajo. El petróleo de absorción es "pobre" cuando entra en el recipiente por la parte superior y "rico" cuando sale por el fondo, ya que ha absorbido los hidrocarburos deseables del gas. El gas que sale por la parte superior de la unidad se denomina "gas residual."

La absorción también puede realizarse mediante refrigeración. El gas residual se utiliza para enfriar previamente el gas de admisión, el cual pasa a continuación por una enfriadora de gas a temperaturas de $0 \mathrm{a}-40^{\circ} \mathrm{C}$. El petróleo de absorción pobre se bombea a través de una enfriadora antes de entrar en contacto con el gas frío de la unidad de absorción. En las unidades enfriadoras de la mayoría de las plantas se utiliza propano como refrigerante. Se inyecta glicol directamente en la corriente de gas de admisión para que se mezcle con el agua contenida en el gas, a fin de prevenir la congelación y la formación de hidratos. La mezcla de glicol y agua se separa del hidrocarburo gaseoso y líquido en el separador de glicol y después se reconcentra evaporando el agua en una unidad de regeneración.

Extracción. El siguiente paso del proceso de absorción es la extracción, o desmetanización. El metano remanente se extrae del petróleo rico en plantas de recuperación de etano. Normalmente, el proceso se divide en dos fases. En la primera, se extrae al menos la mitad del metano del petróleo rico reduciendo la presión y aumentando la temperatura. El petróleo rico restante suele contener suficiente etano y propano para hacer deseable la reabsorción. Si no se vende, el gas de evaporación se utiliza como combustible en la planta o como presaturador, o se recicla incorporándolo al gas de admisión en la torre de absorción principal.

Separación. En la fase final del proceso de absorción, la destilación, se utilizan vapores para separar los hidrocarburos deseables del petróleo de absorción rico. En los alambiques húmedos se utiliza como medio de separación vapor de agua, y en los alambiques secos vapores de hidrocarburos obtenidos de la vaporización parcial del petróleo caliente bombeado a través del alambique rehervidor. Este controla el punto de ebullición final y el peso molecular del petróleo pobre, y el punto de ebullición de la mezcla de hidrocarburos obtenidos como producto final.

\section{Otros procesos}

Fraccionamiento. Es la separación de la mezcla de hidrocarburos deseables procedentes de las plantas de absorción en productos individuales específicos, relativamente puros. El fraccionamiento es posible cuando los dos líquidos, denominados producto superior y producto de fondo, tienen distinto punto de ebullición. El proceso de fraccionamiento consta de tres partes: una torre para separar los productos, un rehervidor para calentar el producto a tratar y un condensador para eliminar el calor. La torre tiene numerosas bandejas, por lo que se produce un amplio contacto entre vapor y líquido. La temperatura del rehervidor determina la composición del producto de fondo.

Recuperación de azufre. Antes de enviar el gas para su venta es necesario separar de él el ácido sulfhídrico. Esto se lleva a cabo en plantas de recuperación de azufre.

Reciclado del gas. El reciclado del gas no es un medio de mantener la presión ni un método de recuperación secundario, sino un método de recuperación optimizada que se utiliza para aumentar la producción de líquidos derivados del gas natural extraído de yacimientos de "gas húmedo". Después de extraer los líquidos del "gas húmedo" en plantas de reciclado, el "gas seco" restante se devuelve al yacimiento a través de pozos de inyección. $\mathrm{Al}$ recircular por el yacimiento, el "gas seco" absorbe más líquidos. Los ciclos de producción, procesado y recirculación se repiten hasta que se han extraído del yacimiento todos los líquidos recuperables y sólo queda "gas seco".

\section{Preparación de los campos de producción de petróleo y gas natural}

Poner en producción un nuevo campo de petróleo o gas natural exige amplios trabajos de preparación. El acceso al emplazamiento puede estar limitado o dificultado por condiciones climáticas o geográficas. Entre los requisitos necesarios se incluyen instalaciones de transporte, construcción, mantenimiento, alojamiento y administración; equipos de separación de petróleo, gas y agua; transporte de petróleo crudo y gas natural; instalaciones de abastecimiento de agua y evacuación de residuos, y muchos otros servicios, instalaciones y equipos de diversa índole. La mayoría de ellos no están disponibles en el emplazamiento y deben aportarlos la compañía perforadora o productora o contratistas externos.

\section{Actividades de los contratistas}

Las compañías de prospección y producción de petróleo y gas natural suelen utilizar los servicios de contratistas para que provean algunos o la totalidad de los siguientes servicios de soporte necesarios para perforar y poner en explotación campos productores:

- Preparación del emplazamiento: desmonte, construcción de carreteras, rampas y pasarelas, puentes, campos de aterrizaje, puertos marítimos, muelles, embarcaderos y plataformas de carga y descarga.

- Montaje e instalación: equipo de perforación, energía y servicios, tanques y oleoducto, alojamientos, edificios de mantenimiento, garajes, soportes, edificios de servicio y administración.

- Trabajos bajo el agua: instalación, inspección, reparación y mantenimiento de equipos y estructuras subacuáticos.

- Mantenimiento y reparación: mantenimiento preventivo de equipos de perforación y producción, vehículos y embarcaciones, maquinaria y edificios.

- Contratas: servicio de comidas; servicios de conservación; protección y seguridad de las instalaciones y del perímetro; 
conserjería, actividades recreativas y de soporte; almacenamiento y distribución de equipo de protección, repuestos y suministros desechables.

- Ingeniería y trabajos técnicos: pruebas y análisis, servicios informáticos, inspecciones, laboratorios, análisis no destructivos, almacenamiento y manipulación de explosivos, protección contra incendios, permisos, protección ambiental, medicina y salud, higiene industrial y medidas de seguridad y frente a vertidos.

- Servicios externos: teléfono, radio y televisión, alcantarillado y recogida de basuras.

- Equipos de transporte y manutención: aviones y helicópteros, servicios marítimos, maquinaria pesada de construcción y maquinaria de manutención.

\section{Servicios}

Tanto si las operaciones de exploración, perforación y producción se llevan a cabo en tierra firme o en el mar, se necesita energía eléctrica de fuerza y alumbrado y otros servicios de soporte, como los siguientes:

- Generación de energía: gas, electricidad y vapor;

- Agua: abastecimiento, depuración y tratamiento de agua dulce, y agua de procesado;

- Alcantarillado y drenaje: aguas pluviales, tratamiento sanitario y tratamiento y evacuación de aguas residuales (con petróleo);

- Comunicaciones: teléfono, radio y televisión, comunicaciones por ordenador y vía satélite,

- Servicios: luz, calefacción, ventilación y refrigeración.

\section{Condiciones de trabajo, salud y seguridad}

El trabajo en torres de perforación requiere normalmente un equipo mínimo de 6 personas (el perforista y su segundo, tres ayudantes o auxiliares de perforación (perforistas asistentes ) y un cabrestantero) bajo las órdenes de un jefe de obra o capataz (manipulador de la herramienta ) que es responsable del correcto avance del trabajo de perforación. El primer y segundo perforistas tienen la responsabilidad general de las operaciones de perforación y la supervisión del equipo de perforación durante sus turnos respectivos. Los perforistas deben conocer la capacidad y las limitaciones de sus equipos, ya que el trabajo sólo puede avanzar al ritmo del miembro más lento del equipo.

Los ayudantes de perforación se sitúan en la plataforma para manejar el equipo, leer los instrumentos y realizar trabajos generales de mantenimiento y reparación. El cabrestantero tiene que trepar casi hasta la cima de la torre de perforación cuando se está introduciendo o extrayendo del pozo la tubería de perforación y ayuda a introducir y extraer los tubos en el árbol de válvulas. Durante la perforación, maneja también la bomba de lodo y también ayuda a la cuadrilla de perforación.

El personal encargado de montar, colocar, disparar y recuperar las pistolas de perforación, debe estar correctamente adiestrado, conocer los riesgos de los explosivos y estar cualificado para manipular explosivos, cables de cebo y cápsulas detonadoras. Otros miembros del personal que trabajan en los campos petrolíferos o los frecuentan son los geólogos, ingenieros, mecánicos, conductores, personal de mantenimiento, electricistas, operarios de oleoductos y peones.

Los pozos se perforan las veinticuatro horas del día, en turnos de 8 o 12 horas, y los trabajadores deben poseer considerable experiencia, destreza y energía para afrontar las duras exigencias físicas y mentales de su trabajo. Prolongar el horario de trabajo de una cuadrilla puede acarrear graves accidentes o lesiones. La perforación requiere un estrecho trabajo en equipo y una gran coordinación para poder realizar las tareas de forma segura y en el momento oportuno. Debido a estos y otros requisitos, es necesario prestar atención al estado de ánimo y a la salud y seguridad de los trabajadores. Períodos adecuados de descanso y relajación, alimentación nutritiva e higiene y alojamientos apropiados, con aire acondicionado en climas húmedos y calurosos, y calefacción en zonas de clima frío, son aspectos esenciales.

Los principales riesgos profesionales relacionados con las operaciones de prospección y producción, son las enfermedades por exposición a elementos geográficos y climáticos, el estrés producido por tener que recorrer largas distancias por el agua o por terreno difícil, y las lesiones personales. El aislamiento físico de los lugares de prospección y su lejanía de los campamentos base, y los largos períodos de trabajo necesarios en las plataformas de perforación marinas y en lugares remotos en tierra, pueden acarrear problemas psicológicos. En otros apartados de esta Enciclopedia se tratan asimismo muchos otros riesgos específicos de las operaciones en alta mar, como el buceo.

El trabajo en alta mar es peligroso en todo momento, tanto en el puesto de trabajo como fuera de él. Algunos trabajadores no pueden soportar el estrés del trabajo en alta mar a un ritmo exigente, durante largos períodos de tiempo, en un relativo confinamiento y sometidos a condiciones ambientales continuamente cambiantes. Entre los síntomas de estrés de los trabajadores están la irritabilidad inusual, otros síntomas de angustia mental, beber o fumar en exceso y el consumo de drogas. Trabajadores de plataformas han descrito problemas de insomnio, que pueden agravarse por altos niveles de vibración y ruido. La confraternización entre trabajadores y los permisos frecuentes para ir a tierra pueden reducir el estrés. El mareo y el ahogamiento, así como la exposición a condiciones climáticas rigurosas, son otros riesgos del trabajo en alta mar.

La exposición a climas rigurosos, infecciones o enfermedades parasitarias en zonas donde éstas son endémicas, provoca patologías (como enfermedades del tracto respiratorio). Aunque muchas de estas enfermedades requieren todavía estudios epidemiológicos en trabajadores de la perforación, se sabe que trabajadores del petróleo han experimentado periartritis del hombro y del omoplato, epicondilitis humeral, artrosis de la columna cervical y polineuritis de las extremidades superiores. En las operaciones de perforación también existe la posibilidad de padecer enfermedades por exposición al ruido y las vibraciones. La gravedad y frecuencia de estas enfermedades relacionadas con la perforación parece ser proporcional al tiempo de servicio y exposición a las condiciones de trabajo adversas (Duck 1983; Ghosh 1983; Montillier 1983).

Mientras se realizan actividades de perforación y producción pueden sufrirse lesiones por muchas causas, como resbalones y caídas, manipulación de tubos, elevación de tuberías y equipos, uso inadecuado de herramientas y manipulación incorrecta de explosivos. Se pueden producir quemaduras por vapor, fuego, ácido o lodo que contenga sustancias químicas, como el hidróxido sódico. La exposición al petróleo crudo y a productos químicos puede provocar dermatitis y lesiones de la piel.

Existe la posibilidad de exposición aguda y crónica a una gran variedad de materiales y sustancias químicas insalubres presentes en las actividades de perforación y producción para la obtención de petróleo y gas natural. En la Tabla 75.2 se relacionan algunas sustancias químicas y materiales que pueden estar presentes en cantidades potencialmente peligrosas, entre ellos los siguientes:

- Petróleo crudo, gas natural y ácido sulfhídrico durante la perforación y los reventones.

- Metales pesados, benceno y otros contaminantes presentes en el crudo. 
- Amianto, formaldehído, ácido clorhídrico y otras sustancias químicas y materiales peligrosos.

- Materiales radiactivos naturales (NORM) y equipos con fuentes radiactivas.

\section{Seguridad}

La perforación y la producción se realizan en todo tipo de climas y en condiciones meteorológicas variables, desde selvas tropicales y desiertos hasta los hielos del Artico y desde tierra firme hasta el Mar del Norte. Las cuadrillas de perforación tienen que trabajar en condiciones difíciles, expuestas a ruido, vibración, mal tiempo, riesgos físicos y averías mecánicas. La plataforma de perforación, la plataforma giratoria, y el equipo suelen estar resbaladizos y vibran debido al funcionamiento del motor y a la perforación, por lo que los trabajadores han de realizar movimientos precisos y cuidadosos.. Existe el riesgo de resbalones y caídas desde lugares altos al trepar por la perforadora y la torre, y riesgo de exposición a petróleo crudo, gas, lodo y humos de escape del motor. La operación de acoplar y desacoplar rápidamente los tubos de perforación requiere entrenamiento, destreza y precisión por parte de los trabajadores para realizarlo de forma segura una y otra vez.

Las cuadrillas de construcción, perforación y producción que trabajan en alta mar tienen que enfrentarse a los mismos riesgos que las que trabajan en tierra, más los riesgos adicionales específicos del trabajo en alta mar, como la posibilidad de desplome de la plataforma en el mar y la previsión de procedimientos de evacuación especializada y equipo de supervivencia en caso de emergencia. Otra consideración importante cuando se trabaja en alta mar es la necesidad de bucear a mucha o poca profundidad para instalar, mantener e inspeccionar el equipo.

\section{Incendio y explosión}

Siempre existe riesgo de reventón cuando se perfora un pozo, con la consiguiente formación de una nube de gas o vapor, seguida de explosión e incendio. Además, existe un potencial adicional de riesgo de incendio y explosión en las operaciones de procesado de gas.

Los trabajadores de plataformas marinas y sondas de perforación deben ser evaluados cuidadosamente después de ser sometidos a un reconocimiento físico exhaustivo. La selección de personal de plataforma marina con historial o síntomas evidentes de enfermedades pulmonares, cardiovasculares o neurológicas, epilepsia, diabetes, alteraciones psicológicas y adicción a las drogas o al alcohol, debe sopesarse cuidadosamente. Dado que los tabajadores tendrán que utilizar previsiblemente equipo de protección respiratoria, en particular los que estén entrenados y equipados para la extinción de incendios, deberá evaluárseles física y mentalmente en cuanto a su capacidad para desempeñar estas tareas. El reconocimiento médico deberá incluir una evaluación psicológica acorde con los requisitos particulares del trabajo a realizar.

Entre los servicios médicos de urgencia de los equipos de perforación y plataformas de producción marinos deberá incluirse el equipamiento necesario para un pequeño dispensario o clínica, atendido por un médico cualificado que esté a bordo permanentemente. El tipo de servicio médico prestado se determinará en función de la disponibilidad, distancia y calidad de los servicios disponibles en tierra. La evacuación puede realizarse por barco o helicóptero, o un médico puede viajar hasta la plataforma o facilitar asesoramiento médico por radio al médico de a bordo cuando sea necesario. Cuando varias plataformas grandes operen en una zona de reducida extensión, como por ejemplo el Mar del Norte, se puede estacionar un barco médico en la zona para contar con mayor disponibilidad y poder atender con más rapidez a un trabajador enfermo o lesionado.
También el personal que no trabaja directamente en torres o plataformas de perforación debe ser sometido a reconocimiento médico previo al empleo y periódicamente, sobre todo si va a ser contratado para trabajar en climas inusuales o en condiciones rigurosas. En estos reconocimientos deberán tenerse en cuenta las especiales exigencias físicas y psicológicas del trabajo.

\section{Protección personal}

Deberá ejecutarse un programa de supervisión y muestreo de higiene industrial, junto a un programa de vigilancia médica, para evaluar sistemáticamente el alcance y efecto de las exposiciones peligrosas para los trabajadores. Asimismo deberá establecerse un plan de vigilancia para detección de vapores inflamables y exposiciones tóxicas, por ejemplo a ácido sulfhídrico, durante las operaciones de exploración, perforación y producción. No se deberá permitir prácticamente ninguna exposición a $\mathrm{H}_{2} \mathrm{~S}$, especialmente en plataformas marinas. Un método eficaz para controlar la exposición es utilizar lodo de perforación debidamente ponderado para evitar la entrada de $\mathrm{H}_{2} \mathrm{~S}$ en el pozo y añadir sustancias químicas al lodo para neutralizar el $\mathrm{H}_{2} \mathrm{~S}$ eventualmente retenido. Se deberá enseñar a todos los trabajadores a detectar la presencia de $\mathrm{H}_{2} \mathrm{~S}$ y a adoptar medidas preventivas inmediatas para reducir la posibilidad de exposición tóxica y explosiones.

El personal que realice actividades de exploración y producción deberá tener y utilizar equipo de protección personal apropiado, como por ejemplo:

- Protección para la cabeza (cascos con forro interior resistente a la intemperie).

- Guantes (guantes de trabajo antideslizantes, resistentes al petróleo, ignífugos o térmicos cuando sea necesario).

- Protección para los brazos (mangas largas o guanteletes resistentes al petróleo).

- Protección para los pies y las piernas (botas de seguridad protegidas contra la intemperie, botas de seguridad impermeables al petróleo con puntera de acero y suela antideslizante).

- Protección ocular y facial (gafas de seguridad, gafas de montura ajustada y pantalla facial para manipulación de ácidos).

- Protección de la piel contra el calor y el frío (crema con filtro solar y máscaras faciales contra el frío).

- Ropa climatizada y protegida contra la intemperie [parkas (cazadoras con capucha), prendas de lluvia].

- Cuando se requiera, equipo antifuego, ropa ignífuga y delantales o trajes resistentes a los ácidos.

Las salas de control, alojamientos y otras dependencias de las plataformas marinas grandes suelen estar presurizados para impedir la entrada de atmósferas nocivas, como por ejemplo ácido sulfhídrico gaseoso, que pueden desprenderse al penetrar el yacimiento o en situaciones de emergencia. Puede necesitarse protección respiratoria en caso de fallo de la presurización y cuando exista posibilidad de exposición a gases tóxicos (ácido sulfhídrico), asfixiantes (nitrógeno, dióxido de carbono), ácidos (ácido fluorhídrico) u otros contaminantes atmosféricos al trabajar fuera de las zonas presurizadas.

Cuando se trabaje cerca de pozos de geopresión o geotérmicos, deberá considerarse la necesidad de utilizar guantes aislados y trajes completos de protección contra el calor y el vapor, con suministro de aire para la respiración, ya que el contacto con vapor y gases calientes puede producir quemaduras en la piel y los pulmones.

Se utilizarán arneses de seguridad y cabos salvavidas cuando se esté en pasillos y pasarelas, especialmente en plataformas marinas y con mal tiempo. Al trepar a perforadoras y torres de 
perforación, se usarán arneses y cabos salvavidas enganchados a un contrapeso. Con frecuencia se utilizan cestas de personal que transportan cuatro o cinco trabajadores provistos de equipo de flotación personal, para transbordar cuadrillas entre embarcaciones y plataformas o torres de perforación marinas. Otros medios de transferencia son los "cables de transbordo." Los utilizados para transbordos desde embarcaciones a plataformas marinas se enganchan justo encima del borde de las plataformas de desembarque de las embarcaciones, mientras que los utilizados para transbordos desde plataformas a embarcaciones deben engancharse aproximadamente a un metro del borde exterior.

Proveer instalaciones para el aseo de los trabajadores y el lavado de la ropa, y observar unas prácticas de higiene adecuadas, son medidas fundamentales para controlar la dermatitis y otras enfermedades de la piel. Cuando proceda, se deberá considerar la conveniencia de proveer puestos de lavado ocular de emergencia y duchas de seguridad.

\section{Medidas de protección y seguridad}

En los sistemas de cierre de seguridad de las plataformas petrolíferas y de gas natural, se utilizan diversos dispositivos y monitores para detectar fugas, incendios, roturas y otras situaciones de peligro, activar alarmas y parar operaciones siguiendo una secuencia lógica y planificada. Cuando la naturaleza del gas o el crudo lo aconsejen, se utilizarán métodos de ensayo no destructivos, por ejemplo ultrasónicos, radiográficos, de partículas magnéticas, colorantes líquidos penetrantes o inspecciones visuales, para determinar el grado de corrosión de las tuberías, tubos de calentadores, unidades de tratamiento y recipientes empleados en la produción y procesado de petróleo crudo, condensado y gas natural.

Válvulas de cierre temporal superficiales y subsuperficiales protegen instalaciones terrestres, pozos individuales en aguas de poca profundidad y plataformas multipozo de perforación y producción en alta mar, y se activan automáticamente (o manualmente) en caso de incendio, variaciones críticas de presión, rotura catastrófica en la cabeza del pozo u otra emergencia. También se utilizan para proteger pequeños pozos de inyección y pozos de producción por presión artificial con gas.

La inspección y conservación de grúas, cabrestantes, tambores, cable de acero y material conexo, es un aspecto importante de la seguridad en perforación. La caída de una columna de perforación en el interior de un pozo es un grave incidente que puede acarrear la pérdida del pozo. Pueden producirse lesiones, y a veces muertes, cuando el personal es golpeado por un cable de acero al romperse estando tenso. El funcionamiento seguro del equipo de perforación depende también de la marcha suave y el correcto mantenimiento del cabrestante, que deberá estar correctamente mantenido, con los tornos auxiliares y los sistemas de freno bien ajustados. Cuando se trabaje en tierra firme, deberán mantenerse las grúas a una distancia segura de las líneas de tendido eléctrico.

La manipulación de explosivos durante las operaciones de exploración y perforación se realizará bajo el control de una persona expresamente cualificada. A continuación se indican algunas precauciones de seguridad que deben tenerse en cuenta al utilizar una pistola de perforación:

- No golpear o dejar caer nunca una pistola cargada, ni dejar caer tubos u otros materiales sobre una pistola cargada.

- Despejar la línea de fuego y evacuar al personal innecesario de la plataforma y de la planta baja de la torre de perforación cuando se baje la pistola al pozo y se recupere de él.

- Controlar el trabajo que se realice en la cabeza del pozo y en sus inmediaciones mientras la pistola esté en el pozo.
- Restringir el uso de radios y prohibir la soldadura al arco mientras la pistola esté conectada al cable para prevenir su disparo por un impulso eléctrico inadvertido.

La planificación de procedimientos y los simulacros para situaciones de emergencia son importantes para la seguridad de los trabajadores de plataformas marinas y de torres de perforación y producción de petróleo y gas natural. Debe evaluarse cada tipo de emergencia posible (por ejemplo, incendio o explosión, emanaciones de gases tóxicos o inflamables, condiciones meteorológicas inusuales, caída de trabajadores por la borda, o la necesidad de abandonar una plataforma) y trazar planes de reacción específicos. Es necesario que los trabajadores estén entrenados en las acciones correctas que deben llevar a cabo en las emergencias y conozcan perfectamente el equipo a utilizar.

La seguridad y la supervivencia en caso de caída de helicópteros al agua son consideraciones importantes en relación con las operaciones de las plataformas marinas y los procedimientos para situaciones de emergencia. Los pilotos y pasajeros deben llevar cinturones de seguridad y, en caso necesario, equipo de supervivencia durante el vuelo. Deberán llevarse puestos chalecos salvavidas en todo momento, tanto durante el vuelo como durante el transbordo desde el helicóptero a la plataforma o al barco. Al subir y bajar de un helicóptero o trabajar en sus inmediaciones, se deberá tener cuidado de mantener el cuerpo y los materiales por debajo de la trayectoria de las palas del rotor.

La formación, tanto de los trabajadores de tierra como de los de alta mar, es esencial para la seguridad de la operación. Se deberá pedir a los trabajadores que asistan a reuniones periódicas programadas de seguridad sobre requisitos obligatorios y otras cuestiones. Se han dictado normas legales por organismos gubernamentales, como la Occupational Safety and Health Administration, el Servicio de Guardacostas de Estados Unidos para operaciones en alta mar y sus equivalentes en el Reino Unido, Noruega y otros países, que regulan la seguridad y la salud de los trabajadores de exploración y producción, tanto en tierra como en el mar. El Repertorio de recomendaciones prácticas de la Organización Internacional del Trabajo Safety and Health in the Construction of Fixed Offshore Installations in the Petroleum Industry (Seguridad y salud en la construcción de instalaciones fijas en alta mar en la industria del petróleo) (1982) ofrece asesoramiento en este sentido. El American Petroleum Institute tiene varias normas y métodos recomendados sobre seguridad y salud en relación con las actividades de exploración y producción.

\section{Medidas de protección y prevención de incendios}

La prevención y protección contra incendios, especialmente en plataformas marinas de perforación y producción, es un elemento importante para la seguridad de los trabajadores y la continuidad de las operaciones. Se debe entrenar y enseñar a los trabajadores a reconocer el triángulo de fuego, como se explica en el capítulo Fuego, en lo concerniente a líquidos, gases y vapores de hidrocarburos inflamables y combustibles y a los posibles riesgos de incendio y explosión. Es esencial una sensibilización respecto a la prevención de incendios, que incluya el conocimiento de las fuentes de ignición, como soldadura, llamas libres, altas temperaturas, energía eléctrica, chispas de electricidad estática, explosivos, oxidantes y materiales incompatibles.

Tanto en tierra como en alta mar se utilizan sistemas de protección contra el fuego activos y pasivos.

- Los sistemas pasivos comprenden el ignifugado, disposición y espaciado, diseño de equipos, clasificación eléctrica y drenaje.

- Se instalan detectores y sensores que activan alarmas y pueden activar también sistemas de protección automáticos, al detectar calor, llamas, humo, gas o vapores. 
- La protección activa contra el fuego incluye sistemas de agua contra incendios, suministro de agua de extinción, bombas, hidrantes, mangueras y sistemas de aspersores fijos; sistemas automáticos de extinción con productos químicos en polvo y extintores manuales; sistemas de halón y de dióxido de carbono para zonas confinadas o cerradas, como salas de control, salas de ordenadores y laboratorios, y sistemas de espuma y agua.

Los empleados que deban combatir incendios, desde pequeños incendios en las fases incipientes hasta grandes incendios en espacios cerrados, como por ejemplo en plataformas marinas, deberán estar correctamente entrenados y equipados. Los trabajadores designados como jefes de bomberos y jefes de operaciones en caso de incidente, necesitan dotes de mando y formación especializada adicional en técnicas avanzadas de lucha contra incendios y de control de incendios.

\section{Protección del medio ambiente}

Las principales fuentes de contaminación del aire, el agua y el suelo en la producción de petróleo y gas natural son los vertidos de petróleo y las emanaciones de gas en tierra o en el mar, ácido sulfhídrico presente en el petróleo y emanaciones de gas a la atmósfera, productos químicos peligrosos presentes en el lodo de perforación que contaminan el agua o la tierra, y productos de la combustión de los incendios de pozos de petróleo. Los posibles efectos para la salud pública derivados de la inhalación de partículas de humo procedentes de incendios de grandes proporciones en campos petrolíferos, ha sido causa de gran preocupación desde los incendios de campos de petróleo que se produjeron en Kuwait durante la guerra del Golfo Pérsico en 1991.

Entre las medidas de control de la contaminación se incluyen normalmente las siguientes:

- Separadores de API y otras instalaciones de tratamiento de residuos y de aguas residuales.

- Control de vertidos, incluyendo barreras de contención para vertidos en agua.

- Contención de vertidos, diques y drenajes para controlar vertidos de petróleo y desviar el agua contaminada con petróleo hacia instalaciones de tratamiento.

Se crean modelos de dispersión de gas para determinar la zona que probablemente resultaría afectada por una nube de gas o vapor tóxico o inflamable originada por un escape. Se realizan estudios de capas freáticas para proyectar el alcance máximo que tendría la contaminación del agua en caso de contaminación por petróleo.

Los trabajadores deberán estar entrenados y cualificados para aplicar medidas de urgencia en respuesta a vertidos y emanaciones. Normalmente se encarga a contratistas especializados en reparación de contaminaciones el control de los grandes vertidos y el diseño de los proyectos de reparación.

\section{Referencias}

Duck, BW. 1983. Petróleo, extracción y transporte marítimo. En Enciclopedia de salud y seguridad en el trabajo, $3^{\mathrm{a}}$ edición. Ginebra: OIT.

Energy Information Administration. 1996. International Petroleum Statistics Report: Fanuary 1996. Washington, DC: US Department of Energy

Ghosh, PK. 1983. Petróleo, plataformas marinas. En Enciclopedia de salud y seguridad en el trabajo, $3^{\mathrm{a}}$ edición. Ginebra: OIT: 1559-1563.

Montillier, J. 1983. Perforación, petróleo y agua. En Enciclopedia de salud y seguridad en el trabajo, $3^{\mathrm{a}}$ edición. Ginebra: OIT.
National Fire Protection Association (NFPA). 1976. Fire Protection Handbook, 14 edición. Quincy, Massachusetts:NFPA.

-. 1991. Fire Protection Handbook, 17 edición. Quincy, Massachusetts:NFPA.

Organización Internacional del Trabajo (OIT). 1982. Safety and Health in the Construction of Fixed Offshore Installations in the Petroleum Industry. Repertorio de Recomendaciones prácticas de la OIT. Ginebra: OIT.

\section{Otras lecturas recomendadas}

American Petroleum Institute. 1980. Facts about Oil. Manual 4200-10/80-25m, octubre 1980. Washington, DC: American Petroleum Institute.
Nabieva, GV. 1976. Occupational disease in oil rig workers. Gigiene truda $i$ proffesional'nye zabolevanija 8:22-24

National Safety Council. 1995. Petroleum Section Safety and Health Fact Sheet. Itasca, Illinois: National Safety Council.

Panov, GE y cols. 1977. Ergonomic assessment of work posture on drilling rigs. Besopasnost' truda v promyslennosti 3:49.

Salpukas, A. 1995. New ideas for US oil. New York Times, 16 noviembre. 

Director del capítulo

M ichad Crane

\section{Sumario}

Perfil general

M ichael Crane. . . . . . . . . . . . . . . . . . . . . . . . 76.2

Generación de energía hidroeléctrica

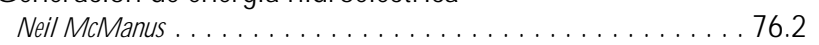

Generación de energía a partir de combustibles fósiles

Anthony W. J ackson . ....................... 76.3

Generación de energía nuclear

W.G. M orison . . . . . . . . . . . . . . . . . . . 76.8

Seguridad en la generación, transmisión y distribución de energía eléctrica: un ejemplo de Estados U nidos

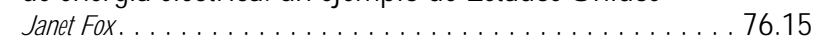

$\mathrm{R}$ iesgos

M ichael Crane. . . . . . . . . . . . . . . . . . . . . . 76.17

Problemas para la salud pública y el medio ambiente

Alexander C. Pittman, J r. . . . . . . . . . . . . . . . . . . . 76.17 


\section{- Perfil general}

\section{Michael Crane}

En 1993, la producción mundial de electricidad alcanzó los 12,3 trillones de kilovatios-hora (Naciones Unidas 1995). (Un kilovatio-hora es la cantidad de electricidad necesaria para encender diez bombillas de 100 vatios durante 1 hora.) L os datos de Estados Unidos, país que produjo por sí solo el $25 \%$ de la energía total, nos dan la medida de este esfuerzo. La industria eléctrica norteamericana, que combina entidades de propiedad pública y privada, generó 3,1 trillones de kilovatios-hora en 1993 a partir de más de 10.000 generadores (Departamento de Energía de EE.UU., 1995). La p+arte de esta industria que está en manos de inversores privados emplea a 430.000 personas en operaciones eléctricas y de mantenimiento, con unos ingresos anuales de 200 billones de dólares.

La electricidad se genera en centrales que utilizan combustibles fósiles (petróleo, gas natural o carbón), energía nuclear 0 energía hidráulica. En 1990, por ejemplo, el $75 \%$ de la energía eléctrica de Francia se obtuvo de centrales nucleares. En 1993, el $62 \%$ de la electricidad generada en todo el mundo procedió de combustibles fósiles, el $19 \%$ de la energía hidráulica y el $18 \%$ de la energía nuclear. 0 tras energías renovables, como la eólica, la solar, la geotérmica o la biomasa, representan sólo una pequeña parte de la producción eléctrica mundial. Desde las centrales que la generan, la electricidad se transmite a través de redes interconectadas a los sistemas locales de distribución y, de ahí, a los consumidores.

Los trabajadores que hacen posible todo esto son principalmente varones y poseen un alto grado de cualificación técnica y de conocimiento del "sistema". Las tareas que desempeñan son bastante variadas y presentan elementos en común con la construcción, la fabricación, la manipulación de materiales, el transporte y las comunicaciones. En los artículos siguientes se describen con detalle algunas de estas operaciones. En los artículos dedicados a las normas de mantenimiento eléctrico y a los problemas ambientales se destacan también importantes iniciativas normativas del G obierno norteamericano que afectan a la industria eléctrica.

\section{- GENERACION DE ENERGIA HIDROELECTRICA}

\section{Neil McM anus}

Los seres humanos aprendieron a aprovechar la energía del agua corriente hace muchos milenios. D urante más de un siglo, la electricidad se ha generado utilizando la energía hidráulica. La mayoría de la gente asocia el aprovechamiento de la energía hidráulica al represado de ríos, pero también puede generarse energía hidroeléctrica aprovechando las mareas.

Las operaciones de generación de energía hidroeléctrica cubren una extensión inmensa y muchos climas, desde el permafrost ártico hasta los bosques pluviales ecuatoriales. La ubicación geográfica de las centrales eléctricas influye en las situaciones peligrosas que puedan darse, ya que riesgos laborales como insectos 0 animales agresivos 0 incluso plantas venenosas varían dependiendo del lugar.

Una central hidroeléctrica consta generalmente de una presa que almacena una gran cantidad de agua, un aliviadero que libera el agua sobrante de forma controlada y una casa de máquinas. La central hidroeléctrica también puede contar con diques y otras estructuras de control y contención del agua, que no participan directamente en la generación de electricidad. La casa de máquinas contiene canales de conducción que hacen pasar el agua a través de unas turbinas que convierten el caudal lineal en caudal rotativo. El agua cae por las palas de la turbina o fluye horizontalmente a través de ellas. La turbina y el generador están interconectados. De este modo, la rotación de la turbina hace girar el rotor del generador.

El potencial de energía eléctrica del caudal de agua es el producto de la masa de agua por la altura de caída y la aceleración gravitatoria. La masa depende de la cantidad de agua disponible y de su caudal. El diseño de la central eléctrica determina la altura de caída. En la mayoría de los diseños se introduce el agua desde un punto situado cerca de la parte superior de la presa y se descarga por la parte inferior al cauce fluvial existente aguas abajo. De este modo, se optimiza la altura mientras se mantiene un caudal razonable y controlable.

En la mayoría de las centrales hidroeléctricas modernas, los turbogeneradores están orientados verticalmente (son las conocidas estructuras que sobresalen del piso principal de las centrales). Sin embargo, casi toda la estructura está situada por debajo de lo que puede verse en el piso principal. Se trata del foso del generador y, por debajo de éste, del foso de la turbina y las tuberías de alimentación y descarga. A estas estructuras y a los canales de conducción de agua sólo se entra ocasionalmente.

En las centrales más antiguas, el turbogenerador es de orientación horizontal. El eje de la turbina sobresale de una pared hacia el interior de la casa de máquinas, donde se conecta al generador. Este último se parece a un enorme y anticuado motor eléctrico de carcasa abierta. Como testimonio de la calidad de diseño y construcción de estos equipos, algunas instalaciones de fin de siglo todavía continúan en funcionamiento. En ciertas centrales modernas se han incorporado versiones actualizadas de los diseños antiguos. En ellas, el canal de agua rodea completamente el turbogenerador y el acceso tiene lugar a través de una camisa tubular que atraviesa el canal.

En los devanados del rotor del generador se genera un campo magnético. La energía de este campo procede de baterias ácidas de plomo 0 alcalinas de níquel cadmio. El movimiento del rotor y el campo magnético presente en sus devanados inducen un campo electromagnético en los devanados del estator. El campo electromagnético inducido crea la energía eléctrica que se suministra a la red. La tensión eléctrica es la presión eléctrica originada por el caudal de agua. Para mantener la presión eléctrica - es decir, la tensión - a un nivel constante, hay que modificar el caudal de agua que pasa por la turbina en función de la demanda o de cambio de condiciones.

El flujo de electricidad puede producir un chisporroteo, por ejemplo en el conjunto excitador del rotor, que puede generar ozono, el cual, incluso a niveles bajos, resulta perjudicial para la goma de las mangueras contra incendios y otros materiales.

Los generadores de energía hidroeléctrica producen altas tensiones e intensidades muy altas. Los conductores de los generadores se conectan al transformador de la unidad y desde éste a un transformador de potencia. El transformador de potencia incrementa la tensión y reduce la intensidad para su transmisión a larga distancia. U na baja intensidad minimiza la pérdida de energía por calentamiento durante la transmisión. En algunos sistemas se emplea como aislante el gas hexafluoruro de azufre en lugar de los aceites convencionales. El chisporroteo eléctrico puede descomponer este aislante en productos notablemente más peligrosos que el compuesto original.

Los circuitos eléctricos contienen disyuntores que pueden desconectar el generador de la red eléctrica de forma rápida e impredecible. En algunas unidades se emplea un chorro de aire comprimido para romper la conexión. Cuando actúa una unidad de este tipo, se produce un altísimo ruido de impacto. 


\section{Administración y operaciones de la central}

La mayoría de la gente está familiarizada con los aspectos administrativos y operativos de la generación de energía hidroeléctrica, que suelen dar el perfil público de la organización. La administración de la central eléctrica trabaja para garantizar la prestación de un servicio fiable. Entre el personal administrativo se encuentran los empleados de oficina, que desempeñan funciones comerciales y técnicas, y la dirección. Entre el personal de operaciones se cuentan los gerentes y supervisores de planta y los operadores de proceso.

La generación de energía hidroeléctrica es una operación de proceso pero, a diferencia de otras, como las existentes en la industria química, muchas centrales hidroeléctricas carecen de personal de operaciones. Los equipos se manejan por control remoto, a veces a gran distancia. Casi toda la actividad laboral se centra en el mantenimiento, reparación, modificación y mejora de la central y los equipos. Esta forma de funcionamiento exige sistemas eficaces que permitan pasar el control de producción a mantenimiento para evitar una puesta en marcha inesperada.

\section{Riesgos y estructura de gestión}

Las compañías eléctricas se han dirigido tradicionalmente como organizaciones jerárquicas de "ascenso". Es decir, la estructura organizativa ha creado tradicionalmente una vía de movilidad ascendente que comienza en los puestos de acceso y conduce a la alta dirección. Son relativamente pocas las personas que acceden a la organización lateralmente. Esto significa que muy probablemente los supervisores y directivos de una compañía eléctrica han experimentado las mismas condiciones de trabajo que las personas que ocupan actualmente los puestos de acceso. E ste tipo de estructura puede repercutir en la posible exposición de los trabajadores a los agentes peligrosos, especialmente a los que tienen efectos acumulativos crónicos. Por ejemplo, analicemos el ruido. Los empleados que actualmente ocupan cargos de dirección pueden haber sufrido graves pérdidas auditivas cuando ocupaban puestos de trabajo expuestos a ruido. Estas pérdidas podrían pasar inadvertidas para los programas de pruebas audiométricas de la empresa, ya que este tipo de programas sólo se aplica en general a empleados actualmente expuestos a elevados niveles de ruido en el trabajo.

\section{Mantenimiento de los equipos generadores}

El mantenimiento de los equipos generadores se divide en dos tipos principales de actividad: el mantenimiento eléctrico y el mantenimiento mecánico. Aunque ambos tipos de trabajos pueden realizarse simultáneamente y uno junto a otro, los conocimientos y tareas necesarios son completamente diferentes.

Para realizar tareas de mantenimiento puede ser necesario parar y desmantelar una unidad. El caudal de agua se controla mediante compuertas, es decir, estructuras de acero que permiten bloquear el canal de alimentación para desaguar los canales interiores. El nivel de agua en reposo a la salida de la turbina (tubo de aspiración) está por debajo del nivel del caracol y de las palas del rodete de la turbina, lo que permite acceder a estas estructuras. EI caracol es una estructura cónica con forma de espiral que distribuye el caudal de agua por el rodete de la turbina de modo uniforme. El agua pasa desde el caracol a través de paletas fijas que dirigen la corriente de agua, y de paletas móviles (compuertas de mariposa) que regulan su volumen.

Si es necesario, es posible desmontar la turbina y el generador de su ubicación normal para colocarlos en el piso principal de la casa de máquinas, por ejemplo para repintar o desengrasar y para reparar y sustituir devanados, rodamientos, frenos 0 sistemas hidráulicos.
A veces, las palas del rodete, así como las compuertas de mariposa, las paletas fijas y las estructuras de conducción de agua del caracol y del tubo de aspiración, sufren daños debidos a la cavitación. La cavitación se produce cuando la presión del agua es inferior a la presión de su vapor. Cuando esto ocurre, se forman burbujas de gas y la turbulencia provocada por éstas erosiona los materiales que entran en contacto con el agua. Puede ser necesario reparar los materiales deteriorados por medio de soldaduras o mediante reparación y reaplicación de los revestimientos de las superficies de acero y hormigón.

Si las estructuras de acero sufren corrosión también puede ser necesaria su reparación y la reaplicación de los revestimientos.

\section{Riesgos}

$\mathrm{H}$ ay varios riesgos asociados a la generación de energía hidroeléctrica. Algunos de ellos son compartidos por todos los empleados que trabajan en la industria, mientras que otros sólo afectan a los que participan en actividades de mantenimiento eléctrico o mecánico. La mayoría de los riesgos que pueden producirse se resumen en las Tablas 76.1 y 76.2, donde también se indican las precauciones que deben tomarse.

\section{Efectos medioambientales}

La generación de energía hidroeléctrica está considerada respetuosa con el medio ambiente. Por supuesto, las ventajas que ofrece a la sociedad en términos de suministro de energía y estabilización de los caudales de agua son muy importantes. Pero no deja de tener un coste ecológico, que en los últimos años ha sido objeto de un reconocimiento y una atención cada vez mayores por parte de la opinión pública. Por ejemplo, ahora se sabe que la inundación de grandes áreas de tierra y roca con agua ácida produce la lixiviación de los metales contenidos en las mismas. Se ha observado bioacumulación de mercurio en los peces capturados en aguas de estas áreas inundadas.

La inundación también modifica los patrones de turbulencia del agua así como el nivel de oxigenación. A mbas cosas pueden tener graves efectos ecológicos. Por ejemplo, en los ríos represados no puede tener lugar la migración de los salmones. Esta desaparición se debe, en parte, a que los peces no pueden localizar 0 atravesar el camino al nivel de agua superior. Además, el agua se parece más a la de un lago que a la de un río, y el agua estancada de un lago no es compatible con la migración del salmón.

La inundación también destruye el hábitat de los peces y puede desmantelar las zonas de cría de los insectos que sirven de alimento a los peces y otros organismos. En algunos casos, la inundación anega productivos terrenos agrícolas y forestales. La inundación de grandes áreas también ha provocado inquietud por el cambio climático y otros cambios del equilibrio ecológico. La retención de agua dulce cuyo destino era mezclarse con una masa de agua salada también plantea el problema de los posibles cambios de salinidad.

\section{GENERACION DE ENERGIA A PARTIR DE COMBUSTIBLES FOSILES}

Anthony W. Jackson

El funcionamiento de las centrales termoeléctricas alimentadas con carbón comprende una serie de operaciones que pueden exponer a los trabajadores a lesiones traumáticas y a peligrosos agentes físicos y químicos. Es posible controlar estos riesgos con un buen diseño, una buena información de los trabajadores y la planificación del trabajo. Un buen diseño es la garantía de que 
Tabla 76.1 • Control de las exposiciones a determinados riesgos químicos y biológicos en la generación de energía hidroeléctrica.

$\begin{array}{ll}\text { Exposición } & \text { Dónde puede producirse } \\ \begin{array}{l}\text { Polvo abrasivo } \\ \text { (chorreo) }\end{array} & \begin{array}{l}\text { El polvo puede contener material de chorreo y polvo de } \\ \text { pintura. La pintura aplicada antes de } 1971 \text { puede } \\ \text { contener PCB. }\end{array}\end{array}$

Amianto

Puede haber amianto en los frenos de los generadores, en los aislantes de tuberías y materiales eléctricos, revestimientos aplicables por rociado, cemento amiantado y otros productos; la exposición depende de la friabilidad y la proximidad de la fuente.

Productos susceptibles de explosión en baterías

Productos de descomposición de revestimientos

Cloro

Disolventes desengrasantes

Humos de motores diesel

Restos de insectos

Aceites y
lubricantes

Ozono
Un cortocircuito e nlos bornes de los bancos de baterías puede provocar explosión e incendio y exposición al líquido y los aerosoles del electrolito.

Pueden producirse emisiones de: monóxido de carbono, pigmentos inorgánicos que contengan plomo y otros cromatos y productos de descomposición de las resinas de pintura. LOS PCB se utilizaban como plastificantes antes de 1971. Los PCB pueden formar furanos y dioxinas, si se calientan.

Puede producirse exposición al cloro durante la conexión/ desconexión de los cilindros de cloro de sistemas de tratamiento de aguas y aguas residuales.

El desengrase de los equipos eléctricos requiere disolventes con propiedades específicas de inflamabilidad, disolución y evaporación rápida sin dejar residuos; los disolventes con esas características son volátiles y pueden crear riesgos de inhalación.

Se trata principalmente de emisiones de: dióxido de nitrógeno, óxido nítrico, monóxido de carbono, dióxido de carbono, dióxido de azufre y partículas que contienen hidrocarburos policíclicos (PAH) de los vehículos 0 motores que trabajan en la casa de máquinas.

En las rápidas aguas que rodean la central se crían algunos insectos; tras el acoplamiento, los adultos mueren y los cadáveres se corrompen y secan; algunas personas desarrollan sensibilidad respiratoria alérgica a las sustancias que contiene el polvo.

Tras el desagüe, las larvas de insectos que viven en los canales de agua pueden intentar asentarse en el agua restante bajando por una especie de hilo que producen; algunas personas pueden desarrollar sensibilidad respiratoria alérgica al polvo resultante de la desecación de estos materiales.

Los devanados del rotor y del estator están cubiertos por aceites y fluidos hidráulicos; la descomposición de los hidrocarburos en contacto con superficies calientes puede producir hidrocarburos aromáticos policíclicos (PAH). La exposición puede producirse por inhalación y contacto cutáneo. Este último puede provocar dermatitis.

El ozono generado por chisporroteo en el rotor y otros equipos eléctricos puede plantear un problema de exposición dependiendo de la proximidad de la fuente.
Trabajadores Control

afectados

Trabajadores de mante- Sistema de control del polvo

nimiento mecánico Equipos de protección personal

Protección respiratoria

Medidas de higiene personal

Vigilancia médica (según las circunstancias)

Trabajadores de mantenimiento eléctrico,

trabajadores de mantenimiento mecánico

Adoptar las mejores prácticas actuales para tareas que requieran la utilización de productos con amianto.

Equipos de protección personal

Protección respiratoria

Medidas de higiene personal

Vigilancia médica (según las circunstancias)

Trabajadores de mantenimiento eléctrico

Blindaje de los bornes de las baterías y de los conductores no aislados

Prácticas y procedimientos que garanticen unas condiciones de trabajo seguras en torno a estos equipos

Trabajadores de mante- Ventilación de extracción localizada nimiento mecánico Protección respiratoria

Medidas de higiene personal

Vigilancia médica (según la composición del revestimiento)

Operadores

Seguir las directrices de la industria del cloro durante el trabajo con cilindros de cloro Mascarilla para escapes

Trabajadores de mantenimiento eléctrico

Ventilación de extracción localizada

Equipos de protección personal

Protección respiratoria

Todos los trabajadores

Prohibir la circulación de automóviles y camiones en las naves.

Sistema de extracción localizada para aspirar los humos en origen

Convertidores catalíticos en los sistemas de escape

Todos los trabajadores

Los insectos que pasan parte de su vida en aguas rápidas pierden su hábitat como consecuencia de la construcción de la central hidroeléctrica. Estos organismos pueden utilizar los canales de agua de la central como hábitat sustitutivo. El polvo de los restos secos puede provocar sensibilización alérgica.

Trabajadores de mantenimiento

Entre las medidas de control cabría citar:

Iluminación que no atraiga a insectos voladores

Pantallas en ventanas, puertas y aberturas de la envolvente del edificio

Limpieza por aspiración para eliminar los cadáveres

Trabajadores de mante- Equipos de protección personal (según las circunstancias) nimiento eléctrico, trabajadores de mantenimiento mecánico

Todos los trabajadores Evitar el chisporroteo de los equipos eléctricos con un correcto mantenimiento.

Continúa en la página siguiente. 


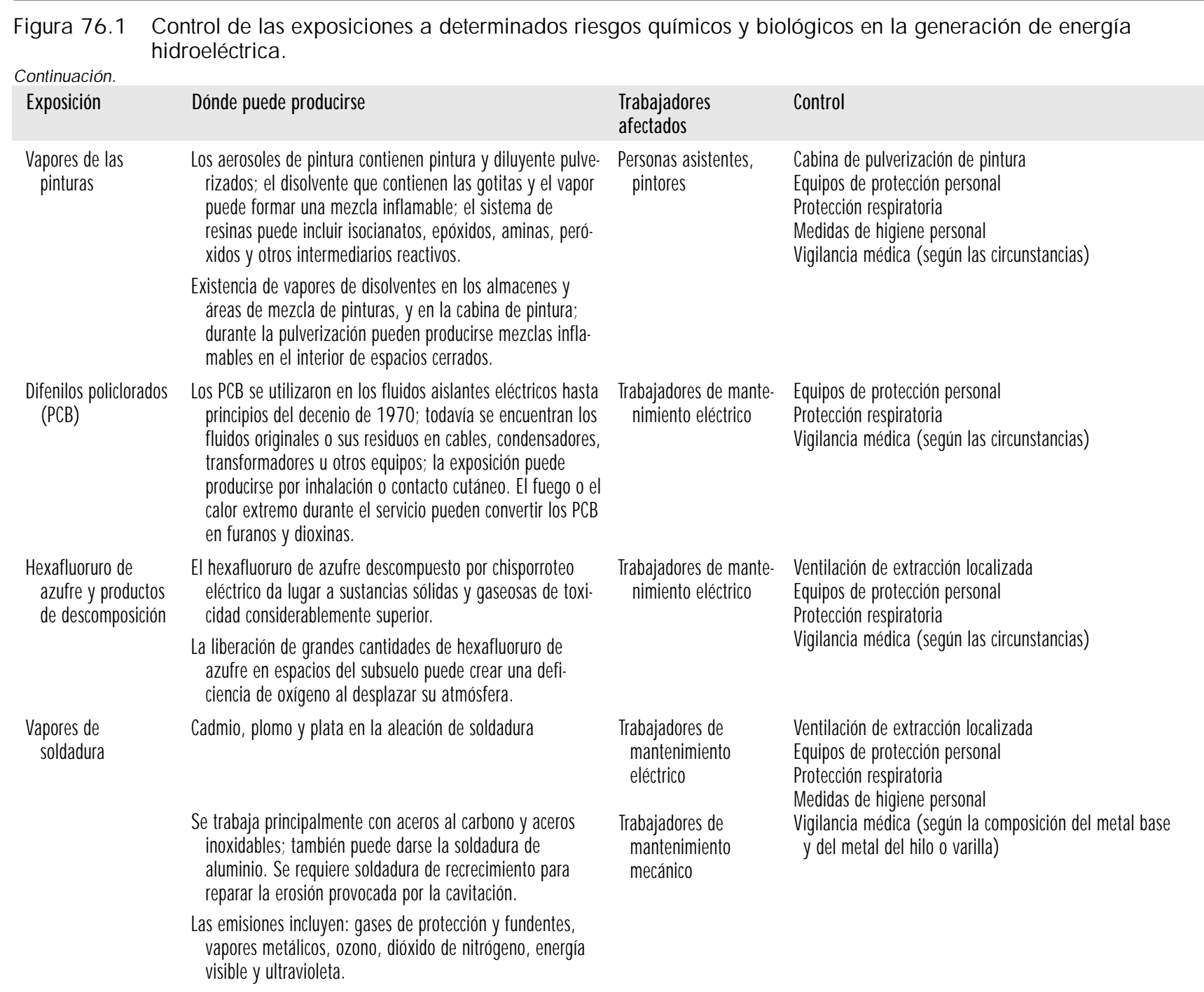

todos los componentes cumplen las normativas pertinentes de integridad y seguridad de funcionamiento. También de que la distribución de los equipos permite un manejo y mantenimiento de los mismos con seguridad gracias a un fácil acceso. U nos trabajadores bien informados son conscientes de los riesgos que pueden correr en el lugar de trabajo, lo que les permite elaborar planes para atajar los riesgos efectivamente encontrados. Dichos planes comprenden la identificación de los riesgos y la aplicación de los controles convenientes, que pueden consistir en una combinación de cortes de corriente, barreras físicas y equipos de protección personal. El análisis de la experiencia adquirida en materia de accidentes demuestra que las centrales modernas tienen un funcionamiento seguro en comparación con otras industrias mecánicas pesadas. Del personal que trabaja en las centrales, los empleados que sufren el mayor número de accidentes con baja laboral son los operarios de mantenimiento. Entre las lesiones más frecuentes se encuentran los esguinces y torceduras de los tejidos blandos del cuerpo, siendo las lesiones de espalda las más corrientes. También se observan enfermedades laborales asociadas a la exposición crónica al ruido y, ocasionalmente, al amianto.

El funcionamiento de una central eléctrica moderna puede dividirse en una serie de operaciones.

\section{Manipulación del carbón}

Comprende la recepción del carbón (por transporte ferroviario 0 acuático) y su almacenamiento y posterior recuperación para alimentar los turbogeneradores. Para compactar las pilas de almacenamiento, operación necesaria para evitar incendios por combustión espontánea, se utiliza maquinaria pesada (traíllas mecánicas y explanadoras). La manipulación posterior se realiza por medio de cintas transportadoras que van hasta la casa de máquinas. La exposición al polvo de carbón (que puede provocar neumoconiosis) se controla pulverizando agua sobre la pila de carbón y utilizando cabinas de control cerradas provistas de filtros para el polvo. Ciertas tareas en que se producen altos niveles de polvo de carbón requieren el uso de protección respiratoria de gran eficacia en la absorción de partículas. La mayoría de los trabajadores de este ámbito laboral se ven expuestos a niveles de ruido superiores a 85 dBA (capaces de provocar pérdidas auditivas), que deben controlarse con orejeras y tapones para los oídos y aplicando un programa de conservación de la capacidad auditiva.

En esta parte de la planta se producen varios riesgos convencionales en materia de seguridad. EI trabajo cerca del agua exige una cuidadosa atención a los procedimientos y el empleo de chalecos salvavidas. La conducción nocturna de maquinaria 
Tabla 76.2 - Control de las exposiciones a determinados riesgos físicos y en materia de seguridad en la generación de energía hidroeléctrica.

\begin{tabular}{|c|c|c|c|}
\hline Exposición & Dónde puede producirse & $\begin{array}{l}\text { Trabajadores } \\
\text { afectados }\end{array}$ & Control \\
\hline $\begin{array}{l}\text { Posturas de } \\
\text { trabajo } \\
\text { incómodas }\end{array}$ & $\begin{array}{l}\text { El trabajo prolongado en una postura incómoda puede } \\
\text { provocar lesiones musculosqueléticas. } \\
\text { Hay peligro de caída alrededor de fosos y aberturas en estruc- } \\
\text { turas. }\end{array}$ & Todos los trabajadores & $\begin{array}{l}\text { Equipos diseñados de acuerdo con principios ergonómicos } \\
\text { Formación en acondicionamiento muscular, levantamiento } \\
\text { de pesos y atención lumbar } \\
\text { Elección de prácticas laborales que minimicen la incidencia } \\
\text { de las lesiones musculosqueléticas }\end{array}$ \\
\hline $\begin{array}{l}\text { Espacios } \\
\text { confinados }\end{array}$ & $\begin{array}{l}\text { La presa, las estructuras de control, las compuertas de control, } \\
\text { los canales de conducción de aguas y la maquinaria de } \\
\text { turbinas y generadores contienen muchos fosos, sumideros, } \\
\text { tanques y otros espacios parcialmente cerrados que pueden } \\
\text { tener deficiencia de oxígeno, encerrar ambientes peligrosos, } \\
\text { o crear otras condiciones peligrosas. }\end{array}$ & Todos los trabajadores & $\begin{array}{l}\text { Sistemas analizadores del aire } \\
\text { Sistemas de ventilación portátiles } \\
\text { Equipos de protección personal } \\
\text { Protección respiratoria }\end{array}$ \\
\hline Ahogamiento & $\begin{array}{l}\text { Pueden producirse ahogamientos por caída a las rápidas aguas } \\
\text { del depósito de carga (zona de admisión) o del canal de } \\
\text { desague (zona de descarga) u otra zona. En las latitudes } \\
\text { más altas el agua está extremadamente fría durante los } \\
\text { meses de primavera, otoño e invierno. }\end{array}$ & Todos los trabajadores & $\begin{array}{l}\text { Barreras de seguridad personal } \\
\text { Sistemas anticaídas } \\
\text { Chalecos salvavidas }\end{array}$ \\
\hline Electrocución & $\begin{array}{l}\text { Ciertas zonas de la central contienen conductores con tensión } \\
\text { y sin aislar; los equipos que contienen conductores aislados } \\
\text { pueden activarse al quitar el aislamiento. La entrada delibe- } \\
\text { rada en zonas no autorizadas o el fallo accidental de los } \\
\text { sistemas de protección colleva un riesgo de electrocución. }\end{array}$ & Todos los trabajadores & $\begin{array}{l}\text { Adoptar prácticas y procedimientos que garanticen determi- } \\
\text { nadas condiciones de seguridad en el trabajo con equipos } \\
\text { eléctricos. }\end{array}$ \\
\hline $\begin{array}{l}\text { Campos electro- } \\
\text { magnéticos } \\
\text { (incluidas } \\
\text { radiofrecuen- } \\
\text { cias) }\end{array}$ & $\begin{array}{l}\text { Los generadores y otros equipos eléctricos producen campos } \\
\text { de C.A. de } 60 \mathrm{~Hz} \text { (o más) y C.C.; la exposición depende de } \\
\text { la proximidad de la fuente y del aislamiento que ofrezcan } \\
\text { las estructuras. Los campos magnéticos son especialmente } \\
\text { difíciles de atenuar con aislamiento. Todavía no se ha esta- } \\
\text { blecido la importancia de laexposición. } \\
\text { Radiofrecuencias: no se han establecido plenamente sus } \\
\text { efectos sobre los seres humanos. }\end{array}$ & Todos los trabajadores & $\begin{array}{l}\text { No se ha determinado el riesgo por debajo de los límites } \\
\text { actuales }\end{array}$ \\
\hline Calor & $\begin{array}{l}\text { Los generadores producen un calor considerable; los genera- } \\
\text { dores e intercambiadores de calor pueden descargar el aire } \\
\text { caliente a la casa de máquinas; la estructura de la casa de } \\
\text { máquinas puede absorber e irradiar la energía solar al inte- } \\
\text { rior del edificio; pueden producirse lesiones por calor durante } \\
\text { los meses más cálidos, en función del clima y del esfuerzo } \\
\text { realizado. }\end{array}$ & $\begin{array}{l}\text { Trabajadores de } \\
\text { interiores }\end{array}$ & $\begin{array}{l}\text { Desvío del aire caliente hacia el techo, aislamiento, } \\
\text { controles técnicos } \\
\text { Bebidas de reposición del electrolito } \\
\text { Equipos de protección personal }\end{array}$ \\
\hline Ruido & $\begin{array}{l}\text { El ruido constante de los generadores y otros equipos y activi- } \\
\text { dades puede rebasar los límites legales; los disyuntores de } \\
\text { aire comprimido producen muy altos niveles de ruido de } \\
\text { impacto y pueden descargar en cualquier momento. }\end{array}$ & Todos los trabajadores & $\begin{array}{l}\text { Aplicar tecnologías de control del ruido. } \\
\text { Protección auditiva personal }\end{array}$ \\
\hline Turnos de trabajo & $\begin{array}{l}\text { El trabajo por turnos puede provocar estrés fisiológico y psico- } \\
\text { social; éste último puede ser especialmente grave para las } \\
\text { pequeñas plantillas empleadas en las comunidades } \\
\text { pequeñas y aisladas donde tienden a ubicarse estas opera- } \\
\text { ciones. }\end{array}$ & Operadores & $\begin{array}{l}\text { Adoptar planes de trabajo que reflejen los conocimientos } \\
\text { actuales sobre los ritmos circadianos. }\end{array}$ \\
\hline $\begin{array}{l}\text { Vibración, manos } \\
\text { y brazos }\end{array}$ & $\begin{array}{l}\text { La vibración producida por las herramientas mecánicas de } \\
\text { mano y las máquinas portátiles se transmite a través de las } \\
\text { empuñaduras. }\end{array}$ & $\begin{array}{l}\text { Trabajadores de mante- } \\
\text { nimiento eléctrico, } \\
\text { trabajadores de } \\
\text { mantenimiento } \\
\text { mecánico }\end{array}$ & $\begin{array}{l}\text { Utilizar herramientas que cumplan las normas vigentes } \\
\text { sobre vibración en manos y brazos. } \\
\text { Guantes antivibración. }\end{array}$ \\
\hline $\begin{array}{l}\text { Vibración, todo el } \\
\text { cuerpo }\end{array}$ & $\begin{array}{l}\text { La vibración soportada por las estructuras y originada por el } \\
\text { movimiento giratorio de los generadores y la turbulencia de } \\
\text { las aguas se transmite a través de paredes y suelos. }\end{array}$ & Todos los trabajadores & $\begin{array}{l}\text { Supervisar y mantener los equipos giratorios para minimizar la } \\
\text { vibración. }\end{array}$ \\
\hline $\begin{array}{l}\text { Aparatos de } \\
\text { visualización }\end{array}$ & $\begin{array}{l}\text { La eficacia de los puestos de trabajo informatizados depende } \\
\text { de la aplicación de principios ergonómicos visuales y ofimá- } \\
\text { ticos. }\end{array}$ & $\begin{array}{l}\text { Trabajadores de oficinas } \\
\text { (personal directivo, } \\
\text { administrativo y } \\
\text { técnico) }\end{array}$ & $\begin{array}{l}\text { Aplicar los principios ergonómicos ofimáticos a la selección y } \\
\text { utilización de los aparatos de vídeo }\end{array}$ \\
\hline $\begin{array}{l}\text { Problemas relacio- } \\
\text { nados con el } \\
\text { clima }\end{array}$ & $\begin{array}{l}\text { La energía ultravioleta puede provocar quemaduras solares, } \\
\text { cáncer de piel y cataratas. } \\
\text { El frío puede producir estrés por frío y congelación. } \\
\text { El calor puede producir estrés por calor. }\end{array}$ & $\begin{array}{l}\text { Trabajadores al aire } \\
\text { libre }\end{array}$ & $\begin{array}{l}\text { Ropa de trabajo que proteja contra el frío } \\
\text { Ropa de trabajo que proteja contra la radiación solar } \\
\text { Protección ocular contra la radiación solar } \\
\text { Lociones de protección solar (bajo asesoramiento médico } \\
\text { para uso prolongado) }\end{array}$ \\
\hline
\end{tabular}


pesada por encima de pilas de almacenamiento irregulares requiere un buen alumbrado, mientras que la mejor manera de controlar los riesgos derivados de las tareas manuales de despeje de las rampas de carbón (que tienden a bloquearse, especialmente en inviernos duros) es instalar cubiertas desmontables en las rampas, que permiten un fácil acceso. El manejo y mantenimiento de amplios sistemas transportadores exige la instalación de defensas en las poleas motrices y poleas de retorno, tensores y otros puntos donde es fácil engancharse.

\section{Funcionamiento de una turbina-caldera}

El funcionamiento de una turbina-caldera de alta presión requiere una rigurosa serie de controles que garanticen la seguridad de su manejo. Dichos controles abarcan la integridad física del equipo y la habilidad, conocimientos y experiencia de los operarios. Para asegurar la integridad de los componentes de alta presión se combinan las especificaciones de las modernas normas técnicas con inspecciones rutinarias de las juntas soldadas por medio de técnicas visuales y técnicas no destructivas de formación de imágenes (rayos $X$ y métodos fluoroscópicos). Además, las válvulas de seguridad, que se comprueban regularmente, impiden la acumulación de un exceso de presión en la caldera. Para proporcionar al personal los conocimientos y cualificaciones necesarios puede establecerse un proceso interno de formación, unido a la acreditación gubernativa, a lo largo de varios años.

El entorno de la casa de máquinas consiste en un conjunto de complejos sistemas diseñados técnicamente para transportar combustible, aire de combustión, agua de calderas desmineralizada y agua de enfriamiento para la caldera. Además de los riesgos derivados del vapor a alta presión, existen otros riesgos convencionales y físicos/químicos que deben conocerse y controlarse. Durante el funcionamiento, el riesgo más generalizado es el ruido. Los estudios demuestran que todo el personal de operación y mantenimiento soporta una exposición media ponderada en el tiempo de más de $85 \mathrm{dBA}$, que requiere el empleo de protecciones auditivas (tapones u orejeras) en gran parte de la casa de máquinas y la realización de exámenes audiométricos periódicos para evitar el deterioro del oído. Entre las principales fuentes de ruido cabe citar los pulverizadores de carbón, el turbogenerador y los compresores de aire para servicio de la central. Los niveles de polvo existentes en la casa de máquinas durante el funcionamiento dependen del estado de conservación del aislamiento térmico. Esto es especialmente importante por cuanto los aislantes antiguos contienen altos niveles de amianto. Con un cuidadoso mantenimiento de los controles (principalmente mediante encolado y retención del aislamiento deteriorado) se consigue que las concentraciones de amianto en el aire sean indetectables $\left(<0,01\right.$ fibras $\left./ \mathrm{cm}^{3}\right)$.

La fase final del proceso operativo que crea posibles riesgos es la recogida y manipulación de las cenizas. Para recoger las cenizas se utilizan grandes precipitadores electrostáticos, habitualmente situados fuera de la casa de máquinas, aunque en los últimos años cada vez se utilizan más los filtros textiles. En ambos casos, las cenizas se extraen de los gases de combustión y se conservan en silos de almacenamiento. El polvo es inherente a todos los procesos de manipulación posteriores, a pesar de los esfuerzos de diseño técnico realizados para controlar su nivel. Este tipo de ceniza (que son cenizas volantes, frente a las cenizas de sedimentación acumuladas en el fondo de la caldera) contiene una parte significativa (entre un 30 y un $50 \%$ ) de partículas respirables y constituye por tanto un posible problema por sus efectos para la salud de los trabajadores expuestos. Dos de los componentes de estas cenizas pueden ser relevantes: la sílice cristalina, asociada a la silicosis y posiblemente al cáncer de pulmón, y el arsénico, asociado al cáncer de piel y de pulmón. En ambos casos es necesario realizar evaluaciones de exposición para determinar si se sobrepasan los límites normativos y si se precisan programas de control específicos. Dichas evaluaciones, que incluirán la realización de estudios con muestreos personales, deberán abarcar a todos los trabajadores que puedan verse afectados, incluidos los que queden expuestos durante las inspecciones de los sistemas de acumulación de polvo y de las superficies de rectificado y calentamiento de la caldera, donde es sabido que se deposita arsénico. Los programas de control, en caso necesario, deberán comprender la información a los trabajadores sobre la importancia de evitar la ingestión de cenizas (no comer, beber ni fumar en las zonas de manipulación de cenizas) y la necesidad de lavarse minuciosamente después de estar en contacto con ellas. Los niveles de polvo encontrados en estos estudios suelen indicar la existencia de unas buenas prácticas de seguridad y de un programa de control respiratorio de la exposición al polvo peligroso. Por ejemplo, la base de datos de mortalidad laboral que mantiene el Instituto $\mathrm{N}$ acional para la Salud y la Seguridad en el Trabajo (NIOSH) no tiene registrados fallecimientos imputables a la exposición a sílice 0 arsénico en la industria eléctrica norteamericana.

\section{Mantenimiento}

Durante la fase de mantenimiento es cuando se produce la máxima exposición a los agentes convencionales y físicos/ químicos. D ada la complejidad de las modernas centrales eléctricas, es crucial disponer de un proceso eficaz de aislamiento de los equipos, de modo que no reciban corriente eléctrica mientras se estén realizando reparaciones. N ormalmente, se aplica un sistema controlado de bloqueos y etiquetas identificativas.

Durante el mantenimiento puede producirse un amplio abanico de riesgos convencionales, entre los que cabe citar:

- trabajos de altura (protección anticaídas);

- estrés térmico;

- grúas y aparejos (seguridad de carga);

- trabajo en espacios confinados (riesgos ambientales y convencionales);

- excavaciones (desplome de zanjas);

- trabajos/levantamiento de objetos en lugares estrechos (esguinces y torceduras).

En todos los casos, es posible controlar los riesgos aplicando un proceso de análisis gradual que identifique los mismos y los controles correspondientes.

En las actividades rutinarias de mantenimiento se utilizan muchos productos comerciales peligrosos. El amianto es corriente, pues ha sido muy utilizado como aislante térmico y es un componente de numerosos productos comerciales. Hay que implantar procesos de control que garanticen una correcta identificación de todos los materiales que incorporen amianto por medio de un análisis microscópico (la posibilidad de efectuar este análisis en el propio lugar mejora enormemente el tiempo de respuesta). L os métodos específicos de control utilizados para este fin dependerán de la escala de la actividad. En operaciones a gran escala, será necesario construir recintos de trabajo a presión ligeramente reducida (para evitar fugas), equipar a los trabajadores con protecciones respiratorias y seguir cuidadosos procedimientos que eviten la contaminación exterior. En todos los casos, los materiales que contengan amianto deberán mojarse por completo e introducirse en bolsas etiquetadas para su eliminación. Hay que realizar atentas inspecciones para eliminar todo el amianto antes de seguir adelante. Deberán registrarse las exposiciones de los trabajadores y se realizarán radiografías pectorales periódicas junto con pruebas de capacidad pulmonar para detectar el inicio de cualquier enfermedad. Si los exámenes dan positivo, el trabajador deberá ser inmediatamente apartado de nuevas exposiciones. L as prácticas actuales 
reflejan una gran preocupación por la exposición al amianto en la industria eléctrica.

Con respecto a la gran mayoría de los demás materiales peligrosos que se utilizan en el lugar de trabajo, las cantidades presentes son pequeñas y su uso infrecuente, de modo que su repercusión total es insignificante. Las exposiciones más importantes a materiales peligrosos se asocian más a operaciones concretas que a productos determinados.

Por ejemplo, la soldadura es una actividad corriente que puede dar lugar a una serie de posibles efectos perjudiciales para la salud. La exposición a la luz ultravioleta del arco provoca ceguera temporal y grave irritación ocular ("ojo de arco"); la inhalación de vapores de óxidos metálicos puede causar la "fiebre de los vapores metálicos"; y los óxidos de nitrógeno y el ozono formados a las altas temperaturas del arco pueden ocasionar neumonía química y posibles problemas respiratorios crónicos. Entre los controles aplicables cabe citar las viseras de protección contra la luz dispersa para los trabajadores que se encuentren en las proximidades, la ventilación de extracción localizada o la protección respiratoria (por medio de una mascarilla con filtro de aire).

U na actividad corriente parecida es el rectificado y el chorreo abrasivo, donde lo preocupante es la inhalación de óxido metálico respirable y de partículas abrasivas. Tal posibilidad suele controlarse mediante la elección del agente abrasivo (actualmente se ha abandonado la arena en favor de agentes más benignos, como las cáscaras vegetales) y la instalación de una ventilación de extracción localizada de la potencia adecuada.

0 tra actividad que da lugar a exposiciones significativas es la aplicación de revestimientos protectores a superficies metálicas. Dichos revestimientos pueden contener disolventes que se liberan a la atmósfera de trabajo. La exposición de los trabajadores puede controlarse por medio de una ventilación de extracción localizada o bien, si eso no fuera práctico, por medio de una protección respiratoria.

\section{- Generacion DE ENERgIA NUCLEAR}

\section{W.G. Morison}

En todos los reactores nucleares, la energía se libera por fisión de los núcleos de los átomos del combustible en una reacción en cadena. El combustible nuclear más habitual es el uranio 235. Cada átomo de combustible fisionado da lugar a dos nuevos átomos - productos de fisión- y los neutrones expulsados de su núcleo provocan nuevas fisiones de átomos. Los productos de fisión transportan la mayor parte de la energía liberada por ésta, que se transforma a su vez en energía térmica cuando los átomos de combustible adyacentes reducen la gran velocidad de los productos de fisión y absorben su radiación. Los neutrones transportan alrededor del $3 \%$ de la energía de fisión.

Para evitar que el núcleo del reactor se caliente demasiado, se utiliza un refrigerante líquido o gaseoso, que también produce el vapor (ya sea directa o indirectamente) que impulsa la turbina. A fin de mantener la reacción de fisión a la velocidad deseada por el operador de la central eléctrica, se insertan en el núcleo del reactor barras de control fabricadas con materiales capaces de absorber neutrones. En los reactores de agua a presión, los materiales absorbentes pueden colocarse disueltos en el refrigerante.

La mayoría de los productos de fisión son inestables y, por consiguiente, radiactivos. Estos productos se desintegran, liberando una radiación a una velocidad característica del elemento de cada producto de fisión, así como un nuevo producto que también puede ser radiactivo. Esta secuencia de desintegración continúa hasta que se liberan productos estables (no radiactivos). En el reactor se forman otros productos radiactivos por absorción de neutrones en el núcleo de los átomos de materiales no fisibles, como el uranio 238, y materiales estructurales, como guías, soportes y camisas de combustible.

En reactores que han estado en funcionamiento durante cierto tiempo, la desintegración de los productos de fisión y la creación de nuevos productos de fisión alcanza un cuasiequilibrio. En este punto, la radiación y la producción de energía resultante de la desintegración de los productos radiactivos es casi una décima parte de toda la que se produce en el reactor.

De esta gran cantidad de material radiactivo se derivan los riesgos específicos de las centrales nucleares. En condiciones de funcionamiento, la mayoría de los materiales radiactivos se comportan como sólidos, pero algunos lo hacen como gases, o se volatilizan a la alta temperatura del reactor. Así, podrían ser fácilmente absorbidos por los organismos vivos y afectar a sus procesos biológicos. Son peligrosos, por tanto, si se liberan o se dispersan en el medio ambiente.

\section{Tipos de centrales nucleares y características}

Los reactores térmicos utilizan materiales llamados moderadores para controlar la producción rápida de neutrones producidos por la fisión, de modo que puedan ser capturados más fácilmente por los átomos del uranio 235. El moderador más utilizado es el agua normal. O tros son el grafito y el deuterio, un isótopo del hidrógeno, que se emplea en forma de óxido de deuterio, también llamado agua pesada. El principal componente del agua normal es óxido de hidrógeno y contiene una pequeña proporción $(0,015 \%)$ de agua pesada.

El combustible se enfría por medio de un refrigerante, que directa 0 indirectamente produce el vapor que impulsa la turbina y controla además la temperatura del núcleo del reactor, evitando que se caliente en exceso y se deteriore el combustible - los materiales estructurales. Entre los refrigerantes de uso corriente en los reactores térmicos cabe citar el agua normal, el agua pesada y el dióxido de carbono. El agua tiene buenas características de transferencia térmica (alto calor específico, baja viscosidad, fácil bombeo) y es el refrigerante más utilizado en las centrales nucleares. La refrigeración de un reactor con agua a presión 0 en ebullición permite alcanzar importantes densidades de energía en el núcleo, de modo que pueden construirse grandes unidades de potencia en reactores de vasija relativamente pequeña. Sin embargo, si el sistema refrigerante del reactor utiliza agua, debe funcionar a alta presión para que el vapor alcance presiones y temperaturas útiles para el eficiente funcionamiento del turbogenerador de vapor. Por consiguiente, la integridad del contorno del sistema refrigerante del reactor es muy importante en todas las centrales nucleares refrigeradas con agua, ya que constituye una barrera de seguridad que protege a los trabajadores, a la población y al medio ambiente

El combustible utilizado en todos los reactores refrigerados por agua, y en la mayoría de los demás, es dióxido de uranio cerámico con camisa metálica (de acero inoxidable o de una aleación de zirconio). El dióxido de uranio sinterizado es un combustible ininflamable que puede rendir durante largos períodos de tiempo y conservar sus productos de fisión a altas temperaturas sin deformarse significativamente ni romperse. Los únicos reactores térmicos operativos que utilizan un combustible distinto del dióxido de uranio son las centrales M agnox (refrigeradas con dióxido de carbono), y están siendo gradualmente retiradas de servicio a medida que alcanzan el final de su vida útil.

Los materiales absorbentes de neutrones (como el boro, el cadmio, el hafnio y el gadolinio) utilizados en varias formas, como barras de control con camisa de acero o disueltos en los 
refrigerantes o moderadores, pueden introducirse y retirarse del núcleo del reactor para controlar la velocidad de la reacción de fisión. Contrariamente a lo que ocurre con la generación de energía a partir de combustibles fósiles, no es necesario aumentar la cantidad de combustible para aumentar la energía producida en una reacción de fisión en cadena.

Una vez iniciado un aumento en el ritmo de producción de energía por fisión, se mantendrá hasta que se detenga insertando en el núcleo la cantidad apropiada de materiales absorbentes de neutrones y de moderador. Este aumento de potencia se debe a un exceso de neutrones en la reacción de fisión en cadena con respecto a los necesarios para conseguir una reacción en cadena crítica. Por consiguiente, la velocidad de fisión y la consiguiente producción de energía pueden controlarse agregando o retirando cantidades muy pequeñas de materiales absorbentes de neutrones. Si se requiere una reducción brusca de la potencia, se inyecta en el núcleo una cantidad relativamente importante de material absorbente de neutrones. $\mathrm{C}$ ada tipo de reactor tiene sus propias características de reactividad, que determinan el diseño de los mecanismos absorbentes de neutrones que permitirán controlar eficazmente la potencia y parar el reactor de forma rápida y segura cuando sea necesario. Sin embargo, los mismos principios básicos de control y seguridad son aplicables a todos ellos.

En la Figura 76.1 se ilustran los tipos de reactores térmicos actualmente en servicio, y en la Tabla 76.3, sus principales características. En las ilustraciones simplificadas de la Figura 76.1, se representan blindajes de hormigón en torno a los reactores y los sistemas refrigerantes primarios. Estos blindajes, que adoptan diversos diseños, protegen de la radiación directa del reactor y también actúan como contención de posibles fugas de los sistemas moderadores o refrigerantes; en general, están diseñados para soportar las elevadas presiones que se generarían si se produjese una avería grave en los sistemas refrigerantes.

En una central nuclear con reactor de agua a presión (PW R: pressurized water reactor), el moderador y el refrigerante primario son el mismo material - agua normal depurad-a, que está separada del circuito secundario de vapor/ agua de alimentación por un contorno metálico en generadores de vapor (a veces llamados calderas), a través del cual se transfiere el calor por conducción. Por consiguiente, el vapor alimentado al turbogenerador no es radiactivo y el turbogenerador de vapor puede funcionar como una central eléctrica convencional. Como el hidrógeno del agua moderadora/ refrigerante primaria absorbe una parte importante de los neutrones, es necesario someter el combustible al proceso denominado enriquecimiento isotópico, que consiste en incrementar el contenido del isótopo fisible (uranio 235) hasta alcanzar entre un $2 \%$ y un $5 \%$, a fin de mantener una reacción en cadena práctica para la producción de energía a largo plazo.

En todas las centrales nucleares dotadas de reactores de agua pesada a presión (PH W R: pressurized heavy water reactors), el moderador y el refrigerante primario son agua pesada con un contenido isotópico de deuterio muy alto $(>99 \%)$. En el PHWR CANDU, que es prácticamente el único tipo de PHWR en funcionamiento, el moderador está separado del refrigerante primario y se mantiene a una temperatura y presión relativamente bajas, siendo éste un ambiente adecuado para ubicar la instrumentación de control y vigilancia, así como una instalación refrigerante de reserva integrada por si se produce una avería en las tuberías de refrigerante primario. En el CANDU, el combustible y el refrigerante primario circulan por tuberías de presión horizontales en el núcleo del reactor. Al igual que en los PWR, el circuito de refrigerante primario está separado del circuito secundario de vapor/agua de alimentación por un

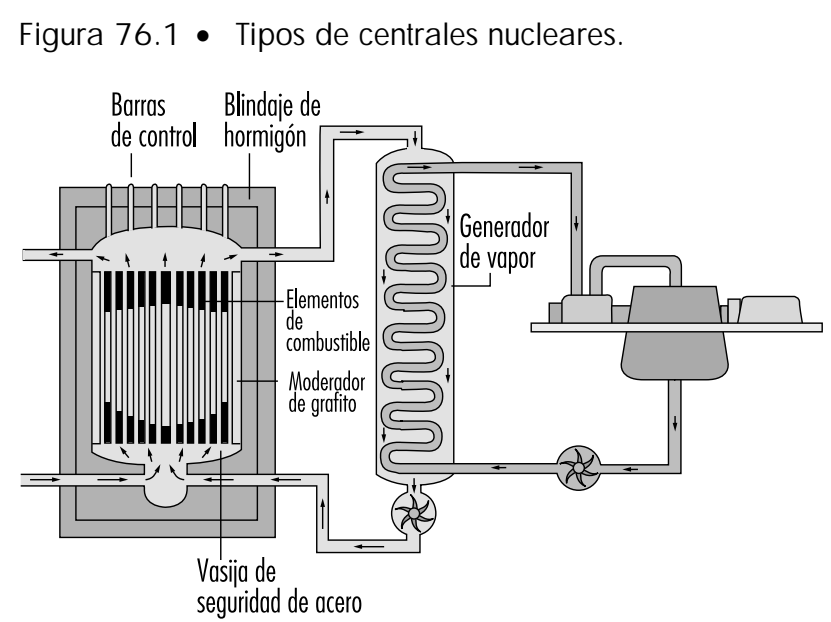

Reactor básico enfriado por gas (MAGNOX)

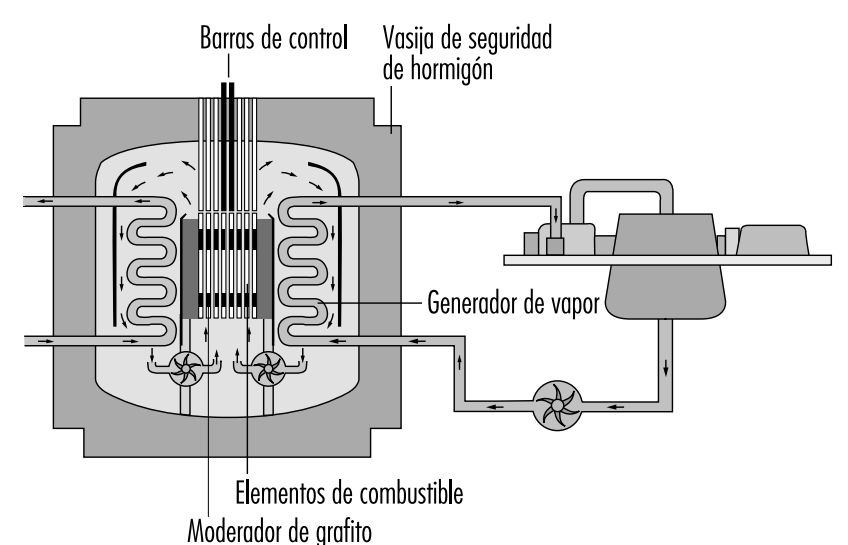

Moderador de grafito

Reactor avanzado enfriado por gas (AGR)

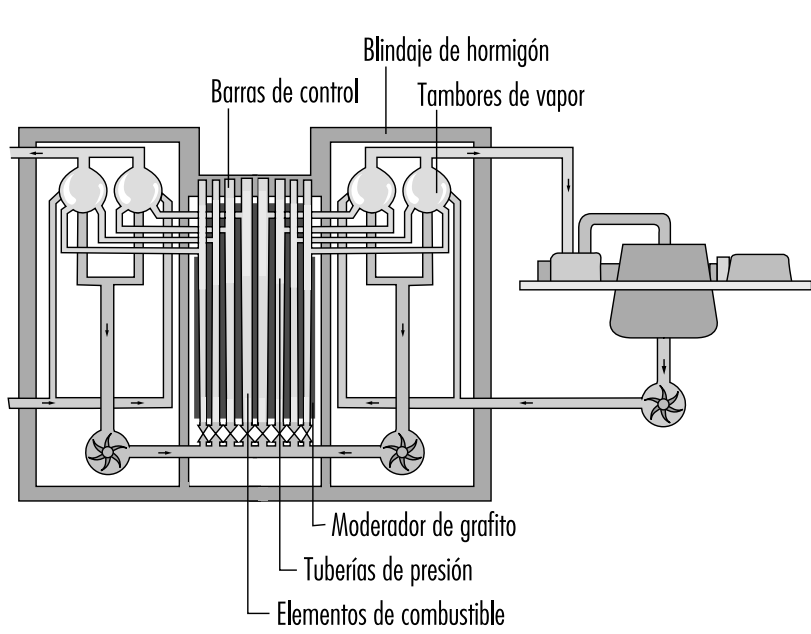

Reactor de agua ligera en ebullición moderado con grafito (RBMK)

Fuente: Uranium Institute 1988

contorno metálico en generadores de vapor, a través del cual se transfiere el calor desde el agua pesada primaria al sistema de vapor/agua de alimentación de agua normal. Por consiguiente, 
Tabla 76.3 • Características de las centrales nucleares (1997).

\begin{tabular}{|c|c|c|c|c|c|c|}
\hline Tipo de reactor & Combustible & Moderador & $\begin{array}{l}\text { Refrigerante y } \\
\text { presión aprox. } \\
\text { (en bar) }\end{array}$ & Generación de vapor & $\begin{array}{l}\text { №de } \\
\text { unidades } \\
\text { operativas }\end{array}$ & $\begin{array}{l}\text { Producción } \\
\text { neta } \\
\text { (MWe) }\end{array}$ \\
\hline PWR & $\begin{array}{l}\text { Dióxido de uranio enriquecido } \\
\text { (2 \% a } 5 \% \text { U } 235 \text { ) }\end{array}$ & Agua ligera & $\begin{array}{l}\text { Agua ligera } \\
\text { (160 bar) }\end{array}$ & Indirecta & 251 & 223.717 \\
\hline $\begin{array}{l}\text { PHWR (tipo } \\
\text { CANDU) }\end{array}$ & $\begin{array}{l}\text { Dióxido de uranio no enriquecido } \\
(0,71 \% \text { U } 235)\end{array}$ & Agua pesada & $\begin{array}{l}\text { Agua pesada } \\
\text { (90 bar) }\end{array}$ & Indirecta & 34 & 18.927 \\
\hline BWR & $\begin{array}{l}\text { Dióxido de uranio enriquecido } \\
\text { (2 \% a } 3 \% \text { U 235) }\end{array}$ & Agua ligera & $\begin{array}{l}\text { El agua ligera } \\
\text { hierve en el núcleo } \\
\text { ( } 70 \text { bar) }\end{array}$ & Directa & 93 & 78.549 \\
\hline $\begin{array}{l}\text { GCR (tipo } \\
\text { MAGNOX) }\end{array}$ & $\begin{array}{l}\text { Metal de uranio no enriquecido } \\
(0,71 \% \text { U 235) }\end{array}$ & Grafito & $\begin{array}{l}\text { Dióxido de carbono } \\
\text { (20 bar) }\end{array}$ & Indirecta & 21 & 3.519 \\
\hline AGR & $\begin{array}{l}\text { Dióxido de uranio enriquecido } \\
(2,3 \% \text { U 235) }\end{array}$ & Grafito & $\begin{array}{l}\text { Dióxido de carbono } \\
\text { (40 bar) }\end{array}$ & Indirecta & 14 & 8.448 \\
\hline $\begin{array}{l}\text { LWGR (tipo } \\
\text { RBMK) }\end{array}$ & $\begin{array}{l}\text { Dióxido de uranio enriquecido } \\
\text { (2 \% a 2,5 \% U 235) }\end{array}$ & Grafito & $\begin{array}{l}\text { El agua ligera } \\
\text { hierve en el núcleo } \\
\text { ( } 70 \text { bar) }\end{array}$ & Directa & 18 & 13.644 \\
\hline FBR & Oxidos de plutonio & Ninguno & $\begin{array}{l}\text { Sodio } \\
\text { (10 bar) }\end{array}$ & Indirecta & 3 & 928 \\
\hline
\end{tabular}

el vapor alimentado al turbogenerador es de agua normal, no radiactivo (excepto por pequeñas fugas) y el turbogenerador puede funcionar como una central térmica convencional. EI agua pesada moderadora y refrigerante absorbe sólo una parte muy pequeña de los neutrones generados durante la fisión, lo que permite mantener una reacción en cadena práctica para la producción de energía a largo plazo utilizando uranio natural $(0,071 \%$ de uranio 235). LoS PHWR existentes pueden funcionar con combustible de uranio 235 ligeramente enriquecido, con lo que se consigue que la energía total extraída del combustible sea proporcionalmente mayor.

En una central nuclear con reactor de agua en ebullición (BW R: boiling water reactor), el agua refrigerante primaria se evapora parcialmente en el propio núcleo del reactor, y el vapor generado se alimenta directamente al turbogenerador. La presión de trabajo en el reactor es inferior a la existente en los PWR, pero la presión del vapor alimentado a la turbina es similar. Este último es ligeramente radiactivo, lo que impone algunas precauciones por la posibilidad de que se produzca una contaminación de bajo nivel en el sistema de agua de alimentación o en la turbina. Sin embargo, no se ha demostrado que sea un factor importante a tener en cuenta en el funcionamiento y el mantenimiento de los BWR. En la potencia de estos reactores influye la cantidad de vapor existente en el núcleo, lo que ha de compensarse mediante un control adecuado del caudal de refrigerante 0 inserciones de reactividad al modificar el nivel de potencia del reactor.

Los reactores $M$ agnox, también conocidos como reactores refrige rados con gas (GCR: gas cooled reactors), son alimentados con uranio natural con camisa de magnesio. Se refrigeran con dióxido de carbono a presión moderada, pero generan vapor a temperatura relativamente alta, con lo que se obtiene una buena eficiencia térmica. Tienen grandes núcleos con baja densidad de energía, de modo que las vasijas, que actúan además como única estructura de seguridad, también son grandes. Las de los primeros reactores M agnox eran de acero; las de los últimos, de hormigón pretensado, y contenían tanto el núcleo del reactor como los intercambiadores de calor generadores de vapor.

$L$ os reactores avanzados refrigerados con gas (AGR : advanced gas-cooled reactors) utilizan combustible de óxido de uranio enriquecido $\left(2,3 \%{ }^{235} \mathrm{U}\right)$. Se refrigeran con dióxido de carbono a una presión más elevada que en los reactores Magnox y presentan una eficiencia y transferencia térmica mejores. La mayor densidad de energía en el núcleo de estos reactores en comparación con los $M$ agnox permite que el reactor $A G R$ sea más pequeño y potente. La vasija de hormigón pretensado, que contiene tanto el núcleo del reactor como los intercambiadores de calor que generan el vapor, actúa además como estructura de seguridad.

Los reactores refrigerados con agua ligera y moderados con grafito (LW GR: light water graphite reactors) son un híbrido de varios sistemas de energía nuclear. Las únicas centrales eléctricas de este tipo que funcionan en la actualidad son los reactores RBM K ubicados en la antigua U nión Soviética, en concreto en Rusia, U crania y Lituania. En los reactores RBMK, el agua refrigerante normal asciende por canales (tuberías) de refrigeración verticales que contienen el combustible y entra en ebullición en el interior del núcleo. El vapor producido en el núcleo se alimenta directamente al turbogenerador, igual que en un BWR . El grafito moderador que rodea los canales de refrigeración se encuentra a una temperatura de trabajo suficientemente superior a la del refrigerante, de modo que el calor generado en el grafito por la moderación de los neutrones es eliminado por los canales de refrigeración. Los reactores RBMK son de gran tamaño y tienen muchos canales de refrigeración (>1.500).

$L$ os reactores reproductores de neutrones rápidos (F BR : fast-breeder reactors) necesitan material fisible enriquecido del orden de un $20 \%$ y mantienen la reacción de fisión en cadena principalmente absorbiendo los neutrones rápidos producidos en el proceso de fisión. Estos reactores no necesitan un moderador para lentificar los neutrones y pueden utilizar los neutrones sobrantes para criar plutonio 239, potencialmente útil como combustible para reactores. Pueden producir más combustible del que consumen. Aunque se han construido varios reactores de este tipo para producir electricidad en nueve países de todo el mundo, las dificultades técnicas y prácticas relacionadas con el uso de refrigerantes metálicos líquidos (sodio) y con su altísimo consumo calorífico han provocado una pérdida de interés. Actualmente, sólo hay tres o cuatro reactores de neutrones rápidos refrige rados con metal líquido (LM FBR: liquid metal fast breeder reactors) en 
funcionamiento en todo el mundo, que producen en total menos de 1.000 megawatios de electricidad (M We), y que se están poniendo fuera de servicio gradualmente. Sin embargo, el desarrollo de la tecnología de los reactores de neutrones rápidos ha sido considerable y la documentación existente permitiría utilizarlos en el futuro si fuera necesario.

\section{Los combustibles y su manipulación}

EI proceso que comienza con la extracción del mineral de uranio y termina con la eliminación final del combustible usado y todos sus residuos se conoce con el nombre de ciclo de combustible nuclear. $\mathrm{H}$ ay muchas variaciones en los ciclos de combustible dependiendo del tipo de reactor de que se trate y del diseño de las medidas de eliminación del calor en el núcleo.

Los ciclos de combustible básicos de los reactores PWR y BWR son casi idénticos, diferenciándose solamente por los niveles de enriquecimiento y por el diseño detallado de los elementos combustibles. Las etapas que comprende, habitualmente en diferentes lugares e instalaciones, son las siguientes:

- extracción y trituración del uranio para producir un óxido de uranio $\left(\mathrm{U}_{3} \mathrm{O}_{8}\right)$;

- transformación del uranio en hexafluoruro de uranio $\left(\mathrm{UF}_{6}\right)$;

- enriquecimiento;

- fabricación del combustible, que comporta la transformación del uranio en dióxido de uranio $\left(\mathrm{UO}_{2}\right)$, la producción de gránulos de combustible, la fabricación de barras de combustible de longitud igual a la altura del núcleo del reactor, y la fabricación de montajes de combustible compuestos de unas 200 barras de combustible por montaje dispuestas en cuadro;

- instalación y servicio en una central nuclear;

- reprocesado o almacenamiento temporal;

- envío del combustible usado o de los residuos del enriquecimiento a un depósito federal/ centralizado;

- eliminación eventual, que todavía está en fase de desarrollo.

Durante estos procesos hay que tomar precauciones para asegurarse de que la cantidad de combustible enriquecido presente en un determinado lugar sea inferior a la que podría provocar una reacción de fisión en cadena importante, excepto, por supuesto, en el reactor. Esto impone restricciones de espacio para los materiales en las fases de fabricación, expedición y almacenamiento.

En cambio, el reactor CANDU utiliza uranio natural y su ciclo de combustible desde la extracción del mineral hasta la eliminación del combustible es muy sencillo, ya que no incluye fases de enriquecimiento y reprocesado. El combustible para el CANDU se fabrica de forma semiautomática en mazos redondos y de medio metro de largo integrados por 28 ó 37 barras de combustible que contienen gránulos de $\mathrm{UO}_{2}$. No hay limitaciones de espacio para la fabricación de combustible de uranio natural ni para el envío o almacenamiento de combustible nuevo o usado. La inmovilización y eliminación de combustible usado del CANDU se está desarrollando desde hace 17 años en Canadá, y en la actualidad se encuentra en fase de aprobación del concepto.

En todos los reactores de potencia operativos, con excepción del M agnox, el componente básico del combustible del reactor es el gránulo cilíndrico de combustible, compuesto de dióxido de uranio $\left(\mathrm{UO}_{2}\right)$ en polvo compactado y sinterizado para obtener las características cerámicas y de densidad necesarias. Estos gránulos sinterizados, que van sellados en tubos sin costuras de acero inoxidable o de una aleación de zirconio formando los elementos 0 barras de combustible, son químicamente inertes con respecto a su material de encamisado a las temperaturas y presiones normales en el reactor. Aunque la camisa se deteriore
0 se raje y el refrigerante entre en contacto con el $\mathrm{UO}_{2}$, este material cerámico retendrá la mayoría de los productos de fisión radiactivos y resistirá el deterioro provocado por el agua a elevada temperatura.

Los reactores $M$ agnox utilizan combustible de uranio natural con camisa de magnesio y trabajan perfectamente a temperaturas relativamente altas, porque el refrigerante (dióxido de carbono) no reacciona con estos metales en seco.

El objetivo básico del diseño de las barras de combustible de un reactor nuclear es transferir el calor generado por la fisión al refrigerante, manteniendo al mismo tiempo la integridad de las barras incluso en las condiciones transitorias más severas. La realización de vastas pruebas de laboratorio en materia de transferencia térmica con combustible simulado para aplicaciones en todo tipo de reactores operativos ha demostrado que un combustible de diseño específico y autorizado puede resistir con márgenes de seguridad adecuados a la máximas condiciones previstas de calor transitorio en el reactor.

El combustible nuevo que llega a la central eléctrica procedente de la fábrica productora no es significativamente radiactivo y puede manipularse manualmente 0 con herramientas de elevación/ manipulación de manejo manual, sin necesidad de protección. U n montaje de combustible típico para un reactor PWR o BWR consiste en unas 200 barras de combustible dispuestas en cuadro, de unos $4 \mathrm{~m}$ de largo, con un peso aproximado de $450 \mathrm{~kg}$. Un reactor PWR o BWR de gran tamaño necesita alrededor de 200 montajes de estos. EI combustible se manipula por medio de un puente-grúa y se coloca en estanterías verticales en seco en el almacén de combustible nuevo. Todas las operaciones de instalación de combustible nuevo en un reactor de agua ligera en servicio, como un PWR o BWR, se realizan bajo el agua, a profundidad suficiente para proteger a cualquier persona que pueda encontrarse por encima del reactor. Primero debe quitarse la tapa embridada de la vasija del reactor y retirar parte del combustible usado (en general, entre un tercio y la mitad del núcleo del reactor) usando el puente-grúa y el montacargas de manipulación de combustible. El combustible usado se deposita en bahías de almacenamiento llenas de agua. Puede ser necesario reorganizar los demás montajes de combustible usado del núcleo (generalmente moviéndolos hacia el centro del núcleo) para conformar la producción de energía en el reactor. D espués, se instalan los montajes nuevos en los lugares vacantes. La recarga de un reactor de gran tamaño puede requerir de 2 a 6 semanas, dependiendo de los trabajadores disponibles y de la cantidad de combustible que haya que reemplazar.

EI reactor CANDU y algunos reactores refrigerados con gas se recargan en funcionamiento utilizando equipos con control remoto que retiran el combustible usado e introducen los mazos o elementos de combustible nuevo. En el caso del CANDU, el combustible consiste en mazos de barras de combustible de medio metro de largo, aproximadamente $10 \mathrm{~cm}$ de diámetro y alrededor de $24 \mathrm{~kg}$ de peso. El combustible se recibe de fábrica en cajas de embalaje de cartón y se deposita en el almacén de combustible nuevo, listo para cargarlo al reactor. L os reactores en servicio suelen recargarse diariamente para mantener su reactividad. En un reactor CANDU de gran tamaño, la recarga normal es de 12 mazos diarios. Los mazos se colocan manualmente en un mecanismo de carga de combustible que, a su vez, los introduce en una máquina de recarga manejada a distancia desde la sala de control de la central. Para cargar combustible nuevo en el reactor, se maniobran dos máquinas de recarga controladas a distancia y conectadas a los extremos del canal horizontal de combustible que se va a recargar. Las máquinas abren el canal por ambos extremos, con el sistema refrigerante a presión y temperatura de trabajo, e introducen el combustible nuevo por un extremo y retiran el usado por el otro. U na vez 
instalados los mazos de combustible necesarios, vuelven a colocar los cierres de los canales y pasan a recargar otro canal o a descargar el combustible usado en la bahía llena de agua.

EI combustible usado descargado de todos los reactores operativos es muy radiactivo y precisa refrigeración para no sobrecalentarse y un blindaje que evite la irradiación directa de equipos $u$ organismos vivos sensibles que se encuentren en las proximidades. Lo que suele hacerse es descargar el combustible usado en una piscina de almacenamiento donde el combustible quede cubierto por al menos $4 \mathrm{~m}$ de agua. Esto permite observar el combustible a través del agua con total seguridad y acceder al mismo para moverlo bajo el agua hasta un lugar de almacenamiento más duradero.

$L$ a radiactividad y el calor total generados por el combustible descargado disminuyen hasta alrededor de un $1 \%$ de su valor inicial en un año, y hasta un $0,1 \%$ en 10 . Pasados de 5 a 10 años desde la descarga, la producción de calor habrá disminuido hasta el punto de que podrá retirarse el combustible de la piscina y almacenarse en seco en un contenedor, sólo con la circulación natural de aire alrededor del mismo. Sin embargo, seguirá siendo bastante radiactivo y necesitará un blindaje antirradiación durante muchos decenios. H abrá que evitar la ingestión del material combustible por parte de organismos vivos durante mucho más tiempo.

La eliminación efectiva del combustible usado de los reactores de potencia todavía se encuentra en fase de desarrollo y aprobación. En varios países se está estudiando activamente su eliminación, pero todavía no se ha aprobado en ninguna parte del mundo. El concepto de almacenamiento subterráneo a gran profundidad en estructuras de roca estable se encuentra en fase de aprobación en Canadá, como método práctico y seguro de deshacerse de forma definitiva de estos residuos radiactivos de alto nivel. Sin embargo, parece que, aun cuando se apruebe este sistema hacia el año 2000, la eliminación real del combustible usado no se producirá hasta alrededor del 2025.

\section{Operaciones en planta}

En los 33 países que tienen programas de energía nuclear, existen organismos reguladores que elaboran y aplican normas de seguridad para el funcionamiento de las instalaciones nucleares. Sin embargo, generalmente se responsabiliza a la compañía eléctrica propietaria y operadora de las instalaciones de la seguridad de funcionamiento de sus centrales nucleares. La función del operador es, en realidad, una tarea directiva de recopilación de información, planificación y toma de decisiones, y sólo incluye un control más activo ocasionalmente, cuando se trastorna el servicio rutinario. El operador no es el principal sistema protector.

Todas las centrales nucleares modernas disponen de sistemas de control y seguridad automáticos muy fiables y sensibles, que protegen constantemente el reactor y demás componentes de la planta, y que generalmente tienen un diseño a prueba de fallos si se produce un corte de corriente. No es de esperar que el operador duplique o sustituya estos sistemas automáticos de control y protección. Sin embargo, sí debe ser capaz de parar el reactor casi instantáneamente si es necesario, así como de reconocer cualquier problema relacionado con el funcionamiento de la planta y responder al mismo, aumentando así la diversidad de la protección. El operador tiene que ser capaz de comprender, diagnosticar y prever la evolución de la situación global a partir de todos los datos suministrados por los sistemas automáticos de información y proceso de datos.

Se espera del operador que:

- comprenda cuáles son las condiciones normales de todos los sistemas importantes para el estado global de la planta;
- reconozca, con ayuda de los sistemas automáticos o de los mecanismos especiales de control, cuándo se dan condiciones anómalas y cuál es su importancia;

- sepa cómo responder correctamente para restaurar el funcionamiento normal de la planta o detener la planta en condiciones de seguridad.

La capacidad del operador para hacer esto dependerá tanto del diseño de la máquina como de su propia competencia y formación.

En todas las centrales nucleares debe haber en todo momento operadores competentes, estables y bien adiestrados en el servicio. Los candidatos a operadores nucleares siguen un completo programa de formación, que suele incluir formación teórica y práctica en ciencia, equipos y sistemas de potencia, protección antirradiación y políticas y principios de funcionamiento. En las centrales nucleares norteamericanas siempre se utilizan simuladores para proporcionar al operador experiencia práctica en las operaciones de la planta, en situaciones difíciles y condiciones inusuales. EI vínculo entre el operador y los sistemas de potencia es el instrumental de la sala de control. Un instrumental bien diseñado puede facilitar la comprensión y la capacidad de respuesta de los operadores.

Es habitual la designación del personal de operación clave de una central nuclear ya durante su construcción, para que pueda aportar asesoramiento desde el punto de vista del funcionamiento y seleccionar al personal que se encargará de la puesta en servicio y el trabajo de la central. También se ocupará de preparar un completo conjunto de procedimientos de operación antes de que la central entre en funcionamiento. Los expertos en materia de diseño y el personal del organismo regulador inspeccionarán dichos procedimientos para garantizar la coherencia del diseño con las prácticas de operación.

Es de esperar que el personal gestione la central sistemáticamente y con rigor, de acuerdo con los procedimientos de operación y autorizaciones de trabajo. El personal de operación trabaja constantemente para garantizar la seguridad pública llevando a cabo un completo programa de pruebas y controles de los sistemas de seguridad y barreras protectoras y manteniendo la capacidad para afrontar cualquier emergencia en la planta. Si los operadores tienen que tomar medidas en respuesta a una alteración en el estado de la planta, disponen de procedimientos sistemáticos escritos que les guiarán y les proporcionarán la información necesaria para controlar la planta. Dichos procedimientos son revisados por los comités de seguridad de la central y del organismo regulador.

U n programa de gestión de seguridad bien elaborado incluye:

- el conocimiento detallado de las áreas cruciales para la seguridad;

- normas y objetivos para un funcionamiento aceptable;

- un programa de control del funcionamiento que responda a los problemas y documente los resultados;

- un programa de estudio de experiencias para establecer tendencias y definir el grado de cumplimiento de las normas y la causa de cualquier funcionamiento inaceptable 0 degenerativo;

- un medio de evaluación de las repercusiones de los cambios propuestos en los equipos físicos o en los procedimientos de operación y de implantación de cambios coherentes con la norma aceptada.

Además de los procedimientos de operación normal, cada central nuclear dispone de un sistema de notificación de incidentes con el que se investiga y registra cualquier fallo o deterioro de los equipos, deficiencias en el diseño o la construcción y 
errores de funcionamiento detectados por los sistemas de vigilancia o por pruebas e inspecciones periódicas. Se determina la causa fundamental de cada incidente de modo que pueda adoptarse una medida preventiva o correctiva apropiada. Los informes de incidentes, incluidos los resultados de los análisis y las recomendaciones, son analizados por la dirección de la central y por expertos en materia de seguridad y factores humanos que no suelen estar radicados en la central.

El sistema de notificación de incidentes del 0 rganismo Internacional de Energía Atómica (OIEA) funciona en todo el mundo como complemento de los sistemas nacionales para garantizar el intercambio de información entre todos los países participantes. La A sociación $\mathrm{M}$ undial de $\mathrm{O}$ peradores $\mathrm{N}$ ucleares (WANO, World Association of Nuclear 0 perators) también facilita el intercambio de información detallada en el plano operativo.

L os reactores nucleares y todos los sistemas auxiliares y relacionados con la seguridad se mantienen y se prueban periódicamente obedeciendo a unos requisitos de garantía de calidad con el fin de asegurar su fiabilidad durante toda su vida de servicio. Además de la vigilancia automática, se realizan pruebas e investigaciones manuales sistemáticas en busca de evidencias de deterioros o fallos. Entre ellas cabe citar una vigilancia de campo constante, el mantenimiento preventivo, las pruebas periódicas y el estudio de los cambios registrados en las condiciones de la planta.

Se establecen objetivos de funcionamiento muy exigentes para los sistemas de proceso y seguridad a fin de que el riesgo para el personal y la población se mantenga dentro de unos límites aceptablemente reducidos. Para los sistemas de proceso, que funcionan activamente mientras se genera electricidad, los porcentajes de fallo se comparan con los objetivos de funcionamiento y, si éste se encuentra por debajo de lo exigido, se pueden introducir cambios en el diseño. Para los sistemas de seguridad el planteamiento es diferente, ya que sólo entran en funcionamiento si fallan los sistemas de proceso. Se controlan por medio de completos programas de pruebas, y los resultados se utilizan para determinar cuánto tiempo podría quedar fuera de servicio cada uno de ellos. EI tiempo total calculado se compara con una norma de funcionamiento muy exigente. Si se detecta una deficiencia en un sistema de seguridad se corrige inmediatamente 0 se para el reactor.

También se aplican vastos programas de pruebas y mantenimiento durante las paradas periódicas programadas. Por ejemplo, todas las vasijas y componentes a presión y sus soldaduras se inspeccionan sistemáticamente con métodos no destructivos y siguiendo las normas de seguridad.

\section{Principios de seguridad y características de diseño relacionadas con la seguridad}

$\mathrm{H}$ ay cuatro aspectos de la reacción de fisión en cadena que pueden resultar peligrosos y que no es posible separar del aprovechamiento de la energía nuclear para la producción de electricidad, lo que hace necesario la adopción de medidas de seguridad:

1. la fisión produce radiación ionizante, que impone una protección frente a la exposición directa a la radiación;

2. se crean productos de fisión altamente radiactivos, que requieren recintos estancos para evitar la contaminación del medio ambiente exterior y una posible ingestión;

3. la reacción de fisión en cadena es un proceso dinámico que requiere un control constante;

4. la producción de calor no puede detenerse instantáneamente, ya que la desintegración radiactiva continúa produciendo calor una vez terminada la reacción de fisión en cadena, por lo que se requiere una refrigeración de larga duración.

Los requisitos de seguridad derivados de estas características marcan las principales diferencias en cuanto a equipos de seguridad y estrategia de funcionamiento entre una central nuclear y las centrales eléctricas que utilizan combustibles fósiles. Su cumplimiento es diferente en los distintos tipos de centrales nucleares, pero los principios fundamentales de seguridad son los mismos en todas ellas.

Durante el procedimiento de concesión de licencias, cada instalación nuclear debe demostrar que la liberación de radiactividad será inferior a los límites reglamentados, tanto en condiciones normales de servicio como en caso de avería o accidente. La prioridad es evitar los fallos y no limitarse a mitigar sus consecuencias, pero el diseño tiene que ser capaz de resolver los fallos si llegan a producirse a pesar de todas las precauciones. Ello exige la aplicación del más alto grado de control y de garantía de calidad a todos los equipos, funciones de construcción y operaciones. Las características de seguridad inherentes y las medidas técnicas de seguridad están diseñadas para evitar y controlar los accidentes y contener y minimizar la liberación de materiales radiactivos.

En especial, la generación de calor y la capacidad de enfriamiento deben corresponderse en todo momento. En funcionamiento, el reactor se enfría bombeando refrigerante a través de unas tuberías conectadas al mismo, que lo hacen circular por la superficie de la camisa del combustible. Si se corta la corriente de las bombas o se produce una avería repentina en las tuberías de conexión, se interrumpirá el enfriamiento del combustible, lo que podría dar lugar a un rápido aumento de la temperatura del combustible, un posible fallo de la camisa del combustible y el escape de material radiactivo del combustible a la vasija del reactor. Una rápida parada de la reacción de fisión en cadena, junto con la posible activación de sistemas de refrigeración auxiliares o de emergencia, evitará que se deteriore el combustible. Estas medidas de seguridad existen en todas las centrales nucleares.

Aun cuando se pare el reactor, la pérdida de la refrigeración y una avería en la instalación de refrigeración auxiliar o de emergencia podrían provocar el sobrecalentamiento del combustible debido a la producción constante de calor ocasionada por la desintegración de los productos de fisión en el combustible, como se indica en la Figura 76.2. A unque el calor de desintegración es sólo del $1 \%$ o el $2 \%$ de la producción de calor a plena potencia, si no se elimina, la temperatura del combustible puede alcanzar niveles de fallo en cuestión de minutos desde el momento de la pérdida total de la refrigeración. El principio de seguridad en materia de diseño de centrales nucleares exige que se evalúen minuciosamente todas las circunstancias que puedan provocar sobrecalentamiento y deterioro del combustible y la liberación de materiales radiactivos del mismo y que se eviten por medio de sistemas técnicos de control y protección.

Para proteger una central nuclear, hay tres tipos de sistemas de seguridad: las características inherentes, los sistemas pasivos y los sistemas activos, que se utilizan en distintas combinaciones en las centrales nucleares operativas.

L as características de seguridad inherentes se basan en las leyes de la naturaleza para mantener la seguridad en la central eléctrica. $\mathrm{H}$ ay características de seguridad inherentes a ciertos combustibles nucleares, de modo que, a medida que se eleva su temperatura, disminuye la velocidad de la reacción de fisión en cadena. $\mathrm{H}$ ay características de seguridad inherentes a algunos diseños de sistemas refrigerantes, por las que el refrigerante circula sobre el combustible de forma natural para eliminar adecuadamente el calor de la desintegración sin necesidad de bombeo. Hay 
Figura 76.2 • Descenso del calor tras la parada del reactor.

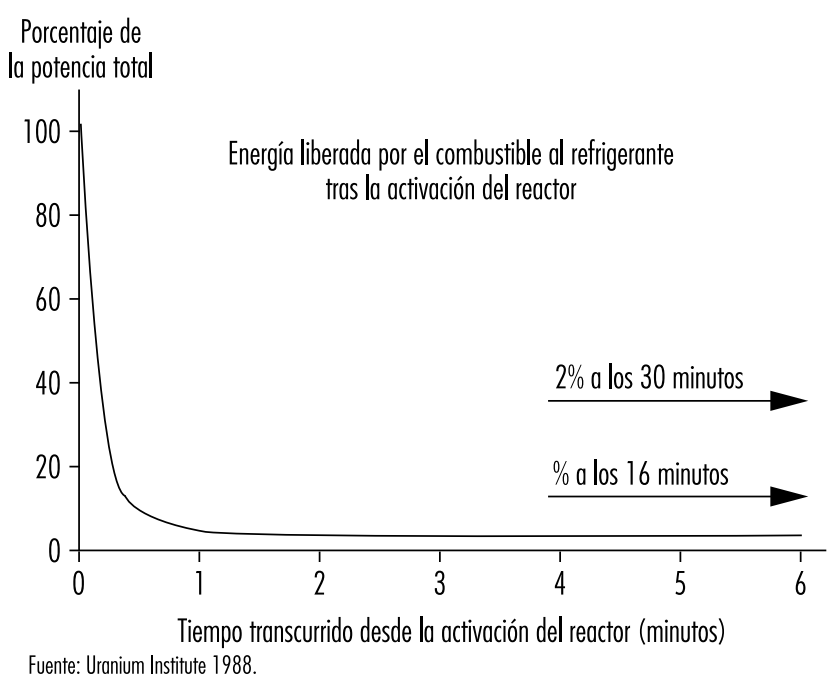

características de seguridad inherentes a la mayoría de las estructuras metálicas, de modo que bajo una carga fuerte reaccionan con elasticidad o estiramiento en lugar de con rotura 0 reventazón.

Las características de seguridad pasivas incluyen el levantamiento de válvulas de seguridad de contrapeso (gravedad) por la presión del líquido que descargan, o el uso de energía almacenada en sistemas de inyección de refrigerante de emergencia, o algunas vasijas de seguridad diseñadas para amortiguar la energía liberada por la avería de las tuberías y el consiguiente calor por desintegración.

Los sistemas de seguridad activos comprenden todos los sistemas que precisan señales de activación y una alimentación eléctrica de algún tipo. Los sistemas activos suelen controlar un mayor abanico de circunstancias que los sistemas inherentes y pasivos, y pueden comprobarse sin restricciones durante el funcionamiento del reactor.

L a seguridad de diseño de las centrales nucleares se basa en la elección de una combinación de sistemas inherentes, pasivos y activos para cumplir los requisitos legales de seguridad de la jurisdicción en que esté ubicada la central. Se necesita un alto grado de automatización de los sistemas de seguridad para evitar en la medida de lo posible que el personal de operaciones tenga que tomar decisiones y medidas rápidas bajo tensión. Los sistemas de los reactores nucleares están diseñados para adaptarse automáticamente a los cambios en la demanda de potencia, que generalmente son graduales. Es especialmente importante que los sistemas relacionados con la seguridad estén en condiciones de responder en todo momento de forma inmediata, efectiva y fiable. Para alcanzar ese elevado nivel de rendimiento, deben cumplir los más estrictos criterios de garantía de calidad y diseñarse siguiendo principios reconocidos de seguridad en el diseño, como son la redundancia, la diversidad y la separación física.

La redundancia es la instalación de más componentes o subsistemas de los estrictamente necesarios para que el sistema funcione: por ejemplo, instalar tres o cuatro componentes donde sólo se necesitan dos para que el sistema funcione correctamente.

La diversidad es la instalación de dos o más sistemas basados en principios funcionales 0 de diseño diferentes para desempeñar una misma función de seguridad.
La separación física de componentes o sistemas diseñados para desempeñar la misma función de seguridad, protege de daños locales que de otro modo podrían afectar al funcionamiento de los sistemas de seguridad.

Un buen ejemplo de aplicación de estos principios de seguridad en el diseño es la alimentación eléctrica de las centrales nucleares, que consta de más de una conexión al sistema de alimentación principal, con el apoyo in situ de varios motores diesel de arranque automático y/o turbinas de combustión y de bancos de baterías y grupos electrógenos que garantizan la fiabilidad del suministro eléctrico a los sistemas vitales en materia de seguridad.

La medida preventiva básica contra la liberación de materiales radiactivos es muy sencilla en principio: instalar una serie de barreras estancas entre los materiales radiactivos y el medio ambiente para conseguir protección contra la radiación directa y contención de los materiales radiactivos. La primera barrera interna es el propio combustible cerámico o metálico, que aglomera la mayoría de los materiales radiactivos dentro de la matriz. La segunda barrera es la camisa estanca y resistente a la corrosión. La tercera es el contorno a presión del sistema refrigerante primario. Finalmente, la mayoría de los sistemas de energía nuclear están encerrados en una estructura de contención resistente a la presión y diseñada para resistir el fallo de las tuberías mayores del interior y contener la liberación de materiales radiactivos al medio ambiente.

El objetivo básico del diseño de seguridad de una central nuclear es mantener la integridad de estas barreras aplicando un enfoque de defensa en profundidad, que puede caracterizarse por tres niveles de medidas de seguridad: preventivas, protectoras y atenuantes.

Entre las medidas preventivas cabe citar: alcanzar el máximo nivel de garantía de calidad durante el diseño, la construcción y el funcionamiento; emplear operadores con un alto nivel de formación que se sometan a un readiestramiento periódico; utilizar características de seguridad inherentes; crear márgenes de diseño apropiados; llevar a cabo un cuidadoso mantenimiento preventivo, pruebas e inspecciones constantes y corrección de deficiencias; vigilancia constante; evaluaciones y reevaluaciones de seguridad minuciosas cuando sea necesario; y evaluación y análisis causal de incidentes y averías, introduciendo las modificaciones pertinentes.

Las medidas de protección incluyen: sistemas de parada de acción rápida; sistemas/ válvulas de seguridad sensibles y automáticas; circuitos de bloqueo como protección contra un falso accionamiento; control automático de las funciones vitales de seguridad; y medición y control constante de los niveles de radiactividad y de la radiactividad efluente de modo que no se rebasen los límites admisibles.

Entre las medidas atenuantes cabe citar: los sistemas refrigerantes de emergencia; sistemas de agua de alimentación altamente fiables; sistemas de alimentación de emergencia diversos y redundantes; contención para evitar cualquier fuga de materiales radiactivos de la central, diseñada para soportar diversas tensiones naturales y artificiales, como terremotos, fuertes vientos, inundaciones o impactos de aeronaves; y, finalmente, la planificación de emergencias y el tratamiento de accidentes, que incluye la vigilancia de la radiación, la información a las autoridades competentes en materia de seguridad y los avisos públicos, el control de la contaminación y la distribución de materiales atenuantes.

La seguridad nuclear no sólo depende de factores técnicos y científicos; el factor humano desempeña un papel muy importante. El control normativo aporta una comprobación independiente de todos los aspectos de seguridad de las centrales nucleares. Ahora bien, la seguridad nuclear no se garantiza 
principalmente con leyes y reglamentos, sino con un diseño, un funcionamiento y una gestión responsables por parte de las compañías eléctricas, que deberán aplicar las revisiones y autorizaciones pertinentes de quienes tienen los conocimientos y la autoridad.

El único accidente nuclear que ha tenido consecuencias muy graves para la población se produjo durante una prueba de refrigeración en una configuración inusual de una central nuclear RBM K en Chernobil, U crania, en 1986. En este grave accidente, el reactor quedó destruido y gran cantidad de materiales radiactivos escaparon al medio ambiente. Después se descubrió que el reactor no disponía de un sistema de parada adecuado y que era inestable a baja potencia. Las deficiencias de diseño, el error humano y la falta de una gestión apropiada confluyeron para que se produjese el accidente. En los reactores RBMK todavía en servicio se han realizado modificaciones para eliminar graves deficiencias de diseño y se han mejorado las instrucciones de operación para evitar que se repita un incidente tan lamentable.

Se ha aprendido mucho del accidente del RBMK, de otros accidentes nucleares menos graves (como el acaecido en Three M ile Island en Estados U nidos en 1978) y de muchos accidentes e incidentes menores durante más de 30 años de funcionamiento de las centrales nucleares. El objetivo de la comunidad nuclear es garantizar que ningún accidente nuclear ponga en peligro a los trabajadores, la población o el medio ambiente. La estrecha cooperación entre programas, como los sistemas de notificación de incidentes de la OIEA y la WANO, las investigaciones de las agencias reguladoras y de grupos industriales y la vigilancia de los propietarios y operadores de las centrales nucleares, aumentan las posibilidades de que pueda cumplirse este objetivo.

\section{- SEgURIDAD EN LA GENERACION, TRANSMISION Y DISTRIBUCION DE ENERGIA ELECTRICA: U N EJEMPLO DE ESTADOS UNIDOS}

Janet Fox

\section{Generación, transmisión y distribución}

El suministro de energía eléctrica consta de tres fases: generación, transmisión y distribución. Cada una de ellas conlleva distintos procesos productivos, actividades laborales y riesgos.

La mayor parte de la electricidad se genera a niveles de 13.200 a 24.000 voltios. Entre los riesgos presentes en el proceso de generación de energía eléctrica se incluyen las explosiones y quemaduras derivadas de averías inesperadas de los equipos. También pueden producirse accidentes por no seguir unos procedimientos apropiados de bloqueo e identificación, que se implantan con el fin de controlar las fuentes de energía. Antes de realizar tareas de mantenimiento en equipos que puedan recibir excitación eléctrica, ponerse en funcionamiento o liberar energía almacenada de forma inesperada y provocar lesiones, deberá procederse a su aislamiento de la fuente de energía y dejarse inoperativos. Si no se aíslan correctamente las fuentes de energía (bloqueo/identificación) pueden producirse graves lesiones o fallecimientos.

U na vez generada, la energía eléctrica se envía a distancia a través de líneas de transmisión tendidas entre subestaciones de transmisión ubicadas en centrales generadoras. La instalación de las líneas puede ir elevada, por medio de torres de sustentación,
- subterránea. Las líneas de alta tensión transmiten grandes cantidades de energía eléctrica y se despliegan a lo largo de distancias considerables. Cuando la electricidad sale de una central generadora, la subestación de transmisión allí ubicada aumenta la tensión hasta niveles de 138.000 a 765.000 voltios. Dentro del área operativa, las subestaciones de transmisión reducen la tensión transmitida a niveles de 34.500 a 138.000 voltios. Esta energía se transporta después a través de líneas a los sistemas de distribución situados en el territorio de servicio local. Los principales riesgos presentes durante el proceso de transmisión son eléctricos. Si no se mantienen las distancias de seguridad apropiadas o no se utilizan equipos de protección adecuados (guantes y manguitos de goma) pueden producirse graves lesiones o fallecimientos. Las caídas también dan lugar a accidentes graves durante la realización de trabajos de mantenimiento en líneas elevadas y mientras se trabaja desde postes o camiones de cangilón.

El sistema de distribución conecta el sistema de transmisión al equipo del cliente. La subestación distribuidora reduce la tensión eléctrica transmitida a niveles de 2.400 a 19.920 voltios. Un transformador distribuidor reduce todavía más la tensión. Los riesgos relacionados con el trabajo de distribución también son de naturaleza eléctrica. Sin embargo, existe el riesgo adicional de trabajar en espacios cerrados (registros y bóvedas) cuando se trata de sistemas de distribución subterráneos.

En las subestaciones de transmisión y distribución se cambia la tensión, la fase u otras características de la energía eléctrica como parte del proceso de distribución final. La electrocución representa el principal riesgo para la seguridad. Este tipo de accidentes suelen producirse por no mantener las distancias de seguridad con los equipos eléctricos activos o no utilizar equipos de protección personal adecuados, incluidos guantes y manguitos aislantes de goma.

\section{Riesgos para la seguridad en los procesos de generación, transmisión y distribución}

La norma de generación, transmisión y distribución de energía eléctrica, también conocida como norma de mantenimiento eléctrico, codificada como 29 CFR 1910.269, fue promulgada por la Administración para la Salud y la Seguridad en el Trabajo de Estados Unidos (OSHA, US Occupational Safety and Health Administration) el 31 de Enero de 1994. La norma es aplicable a todos los trabajadores de compañías eléctricas que se ocupan del funcionamiento y el mantenimiento de equipos de generación, transmisión y distribución de energía eléctrica y equipos afines. Además, las disposiciones de la norma 1910.269 también se aplican a los operarios de líneas contratadas, los trabajadores encargados del desramaje de árboles para despejar el paso a las líneas contratadas y los productores de energía independientes. 0 tros países y regiones tienen normas similares.

Los riesgos que contempla directamente la norma de la O SH A son los de naturaleza eléctrica que pueden provocar electrocución y lesiones por choque eléctrico. Entrar inadvertidamente en contacto con electricidad de alta tensión suele tener como consecuencia la muerte o lesiones graves, como quemaduras de segundo y tercer grado, amputación de miembros, daños en órganos internos y daños neurológicos.

La norma también contempla los fallecimientos y lesiones debidos a otros cuatro tipos de accidentes: golpes; caídas desde escaleras, andamios, postes u otras alturas; aplastamiento por activación accidental de maquinaria durante las tareas rutinarias de mantenimiento; y contacto con temperaturas extremas debido a la liberación inadvertida de vapor a alta presión durante el mantenimiento de las calderas. EI Eastern R esearch Group (ERG), que preparó el estudio de impacto económico para la propuesta de norma de la OSHA, informó que 
"se producen más accidentes asociados a las líneas de transmisión y distribución que a las subestaciones o instalaciones de generación de electricidad". EI ERG comunicó que en la categoría de líneas de transmisión y distribución, los operarios, aprendices y supervisores son quienes sufren la mayoría de los accidentes mortales o graves con baja laboral. En la categoría de subestaciones y generación de potencia, los electricistas de las subestaciones y los mecánicos de las compañías eléctricas son quienes sufren la mayoría de los accidentes.

\section{Reducción de accidentes}

La OSHA ha estimado que en Estados U nidos los trabajadores de las compañías de generación, transmisión y distribución de electricidad sufren anualmente una media de 12.976 lesiones con baja, ascendiendo el número de fallecidos a 86. Asimismo, ha calculado que podrían evitarse 1.633 lesiones con baja y 61 accidentes mortales anuales si se cumplieran las disposiciones de la norma y de otras normas mencionadas en la disposición final. La OSHA desglosa dicha reducción en dos categorías. Se espera que las más beneficiadas sean las compañías eléctricas, que representan aproximadamente el $80 \%$ de los accidentes mortales. Los contratistas - incluidos contratistas eléctricos y operarios desramadores - y los establecimientos no relacionados con las compañías eléctricas absorben el $20 \%$ restante. La OSHA también espera que sean las compañías eléctricas quienes experimenten una mayor reducción en la incidencia de las lesiones con baja. La segunda categoría de reducción se relaciona con las referencias que hace la norma 190.269 a otras normas existentes. Por ejemplo, la OSH A espera que los empleadores proporcionen servicios médicos y primeros auxilios con arreglo a la norma 1910.151.

Las operaciones de excavación deben ajustarse a la subsección P de la norma 1926; los equipos de protección personal, a los requisitos de la subsección I de la norma 1910; los equipos anticaídas, a los requisitos de la subsección E de la norma 1926; y las escaleras, a la subsección D de la norma 1910. Son algunos ejemplos del gran número de referencias a otras normas O SH A que se incluyen en la norma de generación, transmisión y distribución de energía eléctrica. La O SH A cree que estas referencias fomentarán un mayor reconocimiento de las distintas normas de seguridad aplicables y, junto con la formación de los empleados y el reconocimiento de los riesgos por medio de sesiones informativas sobre tareas, se evitarán cada año otros 2 accidentes mortales y 1.310 lesiones con baja.

\section{Disposiciones generales}

La norma de generación, transmisión y distribución de energía eléctrica constituye un enfoque completo del control de los riesgos existentes en la industria eléctrica. Está basada en el funcionamiento, y da al empleador la oportunidad de implantar programas alternativos siempre que demuestre que el nivel de seguridad obtenido es equivalente al especificado por la norma. En sus disposiciones generales se contemplan: requisitos de formación, procedimientos de control (bloqueo/identificación) de energía peligrosa durante la generación, transmisión y distribución de electricidad; procedimientos de entrada en espacios cerrados y de trabajo seguro en instalaciones subterráneas; requisitos para trabajar con o cerca de piezas eléctricamente activas y expuestas; requisitos para trabajar en líneas elevadas; requisitos de toma a tierra; desramaje de árboles para despejar el paso de las líneas; procedimientos para trabajar en subestaciones; y requisitos para herramientas de líneas con tensión, herramientas de mano y portátiles, escaleras y equipos de protección personal. La norma es completa y abarca todos los aspectos del funcionamiento y el mantenimiento de los equipos de generación, transmisión y distribución de electricidad.

\section{Disposiciones importantes}

Algunas de las disposiciones más importantes de la norma incluyen: requisitos para que los empleados reciban formación en materia de primeros auxilios, sesiones informativas sobre tareas y formación en prácticas laborales relacionadas con la seguridad, procedimientos de seguridad y procedimientos de emergencia, incluidos rescates en registros y en lo alto de postes. También se establecen requisitos específicos sobre la ropa que debe llevarse para trabajar en equipos con tensión eléctrica y los requisitos para entrar en estructuras subterráneas, así como para el control de fuentes de energía peligrosas. 0 tro elemento importante de la norma exige a los empleadores que certifiquen que los empleados han recibido una formación adecuada y tienen pericia en las prácticas laborales especificadas en la norma. Algunos de estos elementos se comentan a continuación con más detalle.

La OSHA exige que los empleados que realizan trabajos en líneas y equipos expuestos y activos a 50 o más voltios deben recibir formación en primeros auxilios y reanimación cardiopulmonar (RCP). Para trabajos de campo que requieran dos o más empleados en un determinado lugar, se impartirá formación al menos a dos de ellos. En lugares de trabajo fijos, como una central eléctrica, deberá impartirse formación a un número suficiente de trabajadores para asegurar que un trabajador expuesto a un choque eléctrico pueda recibir auxilio en 4 minutos.

El empleado jefe de un grupo de trabajo debe celebrar una sesión informativa con los participantes en un trabajo antes de iniciar cada tarea. En dicha sesión se explicarán los riesgos asociados a la tarea, los procedimientos de trabajo necesarios, las precauciones especiales, el control de las fuentes de energía y los equipos de protección personal. Para tareas repetitivas y parecidas se celebrará una sesión informativa antes de iniciar la primera de cada jornada o turno. Si se producen cambios importantes, se celebrará otra sesión. El estudio de la tarea que va a realizarse requiere planificación, lo que contribuye a reducir los accidentes.

La OSHA también exige que el empleador certifique que cada empleado ha recibido la formación necesaria para su cualificación y competencia. La certificación se emitirá cuando el empleado demuestre pericia en las prácticas laborales y se mantendrá durante todo el tiempo que permanezca empleado. La formación por sí sola es inadecuada. Debe demostrarse la pericia, generalmente examinando al empleado de sus conocimientos sobre el tema de que se trate. De este modo se contribuye a asegurar que los equipos eléctricamente activos sólo sean manipulados por trabajadores cualificados.

$\mathrm{H}$ ay requisitos en cuanto a la ropa que deben llevar los trabajadores expuestos a riesgos derivados de llamas o arcos eléctricos. En esta sección se exige al empleador que se asegure de que los trabajadores expuestos a estos riesgos no lleven ropa que, en contacto con llamas o arcos eléctricos, puedan aumentar el alcance de una posible lesión. Las ropas de acetato, nailon, poliéster o rayón, solos o mezclados, están prohibidas a menos que el empleador demuestre que han sido tratadas para soportar las condiciones que puedan darse. Los trabajadores pueden elegir entre algodón, lana o ropa ignífuga, pero el empleador deberá determinar, basándose en la exposición, si es aceptable utilizar fibras naturales como el algodón o la lana; estas fibras pueden arder en ciertas circunstancias. Aunque esta sección de la norma ha provocado una gran controversia en la industria, la prohibición del uso de materiales sintéticos es un paso importante para reducir las lesiones que sufren los trabajadores de la industria eléctrica. 


\section{RIESG OS}

\section{Michael Crane}

La O SH A, en su preámbulo a la norma de generación, transmisión y distribución de energía eléctrica (29 CFR parte 1910.269), establece que "el índice de siniestralidad total de la industria de servicios eléctricos (es decir, de la industria suministradora de electricidad, SIC-491) es ligeramente menor que el correspondiente al sector privado en su conjunto" y que "excepto por los riesgos de tipo eléctrico y de caídas, los empleados de las compañías eléctricas afrontan riesgos de naturaleza y grado similar a los que se encuentran en muchas otras industrias" (OSH A 1994). El preámbulo continúa citando los archivos del D epartamento de Estadística Laboral de Estados U nidos (BLS), en los que se identifican las principales causas de lesión en las compañías eléctricas:

- caídas;

- sobreesfuerzo;

- golpes, que provocan esguinces y torceduras, cortes, laceraciones y contusiones/ magulladuras.

En el preámbulo se indica expresamente que el choque eléctrico no constituye una categoría de lesiones importante (o que se describa con frecuencia). Sin embargo, los archivos laborales, industriales y de la OSH A revelan que los accidentes eléctricos son el tipo más frecuente de lesiones mortales o graves en la industria eléctrica, seguidos de los accidentes de automóvil, las caídas y los "golpes/ aplastamientos".

L os trabajadores de las compañías eléctricas afrontan muchos otros peligros para realizar las diversas tareas les corresponden. Los autores de los artículos del presente capítulo abordan muchas de ellas con detalle; yo me limitaré a mencionar algunas de las exposiciones peligrosas.

Las lesiones musculosqueléticas son las lesiones más habituales de los trabajadores físicamente activos, y comprenden:

- dedos blancos por vibración, debido al uso de martillos neumáticos;

- lesiones de latigazo en el cuello provocadas por accidentes de automóvil;

- distensiones lumbares

- lesiones en la cabeza;

- traumas en pies y tobillos

- desgarro del menisco medial.

Los trabajadores de la industria eléctrica pueden trabajar en muy diversos ambientes: trepan hasta lo más alto de las torres rurales de transmisión y empalman cables en registros situados bajo las ajetreadas calles de las ciudades; sudan a mares en los pisos superiores de las centrales eléctricas en verano y tiritan de frío cuando reparan líneas de distribución elevadas derribadas por un temporal. Las fuerzas físicas a las que se enfrentan son enormes. U na central eléctrica, por ejemplo, impulsa vapor a tal presión que la rotura de una tubería puede escaldarles y sofocarles. Entre los peligros físicos existentes en las centrales, además del calor, cabe citar el ruido, los campos electromagnéticos (CEM ), la radiación ionizante de las instalaciones nucleares y la asfixia en espacios cerrados. La exposición al amianto ha sido un motivo importante de morbilidad y polémica, y está surgiendo la preocupación por otros materiales aislantes. Se utilizan mucho productos químicos cáusticos, corrosivos y disolventes. L as centrales también emplean trabajadores para desempeñar tareas especializadas como la extinción de incendios o el buceo (para inspeccionar sistemas de admisión y descarga de agua), que se ven expuestos a riesgos específicos e intrínsecos de dichas tareas.
Aunque las modernas centrales nucleares han reducido la exposición de los trabajadores a la radiación durante los períodos normales de servicio, puede producirse una exposición importante durante las paradas de mantenimiento y recarga. Se precisan excelentes capacidades de control de la radiación para proteger adecuadamente a los trabajadores que acceden a las áreas de radiación durante estos períodos. Como muchos trabajadores contratados pueden entrar en una central nuclear durante una parada y desplazarse después a otra central, es necesario mantener una estrecha coordinación entre las autoridades reguladoras e industriales para controlar la exposición total anual de un trabajador determinado.

L os sistemas de transmisión y distribución comparten algunos de los peligros de la central nuclear, pero se caracterizan además por exposiciones laborales exclusivas. Las enormes tensiones e intensidades intrínsecas del sistema crean una predisposición a choques eléctricos y quemaduras mortales cuando los trabajadores ignoran los procedimientos de seguridad o están inadecuadamente protegidos. Si los transformadores se sobrecalientan, pueden incendiarse y explotar, liberando aceite y posiblemente PCB y sus productos de descomposición.

Las subestaciones eléctricas comparten con las centrales nucleares la posibilidad de una exposición a materiales aislantes, a los CEM y a los riesgos de los espacios cerrados. En el sistema de distribución, las operaciones de corte, quema y empalme de cables eléctricos exponen a los trabajadores al plomo y a otros metales tanto en forma de polvo como de humos. Las estructuras subterráneas que soportan el sistema también deben considerarse espacios cerrados con posibles riesgos. EI pentaclofenol, un pesticida utilizado para la conservación de los postes de madera de las líneas eléctricas, representa un riesgo exclusivo del sistema de distribución.

Finalmente, los lectores de contadores y los trabajadores al aire libre pueden verse expuestos a la violencia callejera; este conjunto de trabajadores se han visto afectados por muertes producidas en intentos de robo.

\section{Problemas para la SALUd PUBLICA YEL MEDIO AMBIENTE}

Alexander C. Pittman, Jr.

Toda actividad humana repercute en el medio ambiente. La magnitud y las consecuencias de tal repercusión son variables y se han creado leyes medioambientales para regularlas y minimizarlas.

La generación de energía eléctrica ocasiona varios riesgos importantes, posibles y reales, para el medio ambiente, incluidas emisiones a la atmósfera y contaminación del agua y del suelo (véase la Tabla 76.4). Las centrales que se alimentan de combustibles fósiles presentan un problema específico por las emisiones atmosféricas de óxidos de nitrógeno (véase "O zono" más adelante), óxidos de azufre y la cuestión de la "lluvia ácida", dióxido de carbono (véase "Cambio global del clima", más adelante) y partículas, de las que se ha afirmado recientemente que contribuyen a provocar problemas respiratorios.

Las centrales nucleares han despertado preocupación por el almacenamiento a largo plazo de sus residuos y la posibilidad de que se produzcan accidentes catastróficos que acarreen la liberación de contaminantes radiactivos a la atmósfera. El accidente ocurrido en 1986 en Chernobil, U crania, es un ejemplo clásico de lo que puede ocurrir si no se toman las precauciones adecuadas en las centrales nucleares. 
Tabla 76.4 - Principales riesgos ambientales por la generación de energía.

$\begin{array}{ll}\text { Tipo de central } & \text { Aire } \\ \text { Combustible fósil } & \mathrm{NO}_{2} \\ & \mathrm{SO}_{2} \\ & \text { Partículas } \\ & \mathrm{CO} \\ & \mathrm{CO}_{2} \\ & \text { Compuestos orgánicos } \\ & \text { volátiles } \\ & \\ & \\ & \\ \text { Nuclear } & \text { Como la anterior más las } \\ & \text { emisiones radiactivas } \\ \text { Hidroeléctricas } & \text { Principalmente los } \\ & \text { lixiviados del suelo al } \\ & \text { agua detrás de las } \\ & \text { presas } \\ & \text { Perturbación del hábitat } \\ & \text { de la fauna }\end{array}$

* Debe incluir efectos "locales", como aumento de la temperatura de la masa de agua que recibe las descargas de la central y reducción en la población de peces como consecuencia de los efectos mecánicos de los sistemas de alimentación de agua.

Con respecto a las centrales hidroeléctricas, las principales inquietudes han sido la lixiviación de metales y la perturbación de los hábitats de la fauna acuática y terrestre, aspectos que se tratan en el artículo "Generación de energía hidroeléctrica" de este mismo capítulo.

\section{Campos electromagnéticos}

Los esfuerzos de investigación sobre campos electromagnéticos (CEM) se han incrementado en todo el mundo desde que se publicó el estudio de Wertheimer y Leeper en 1979. Dicho estudio sugería la existencia de una relación entre el cáncer infantil y los cables eléctricos situados cerca de las viviendas. Los estudios publicados desde entonces no han sido concluyentes y no han confirmado la causalidad. D e hecho, los estudios epidemiológicos posteriores han apuntado posibilidades que requieren más conocimientos y datos para empezar a extraer conclusiones razonables. Algunas de las dificultades encontradas para realizar un buen estudio epidemiológico se deben a los problemas de evaluación (es decir, la medición de la exposición, la caracterización de la fuente y los niveles de los campos magnéticos en las residencias). Aunque el estudio más reciente publicado por el Consejo Nacional de Investigación de la A cademia Nacional de Ciencias (1996) determinó que no había suficientes evidencias para considerar que los campos eléctricos y magnéticos puedan suponer una amenaza para la salud humana, es probable que este asunto siga siendo objeto de la atención pública hasta que la ansiedad propagada sea mitigada por futuros estudios e investigaciones que demuestren la ausencia de efecto alguno.

\section{Cambio global del clima}

Durante los últimos años ha aumentado el conocimiento público del impacto de los seres humanos sobre el clima global. Se considera que aproximadamente la mitad de todas las emisiones derivadas de la actividad humana que repercuten en el efecto invernadero son de dióxido de carbono $\left(\mathrm{CO}_{2}\right)$. Se han realizado y continúan realizándose muchas investigaciones sobre esta cuestión a escala nacional e internacional. Dado que el funcionamiento de las compañías eléctricas contribuye en gran medida a la liberación de $\mathrm{CO}_{2}$ a la atmósfera, toda legislación encaminada a controlar las emisiones de $\mathrm{CO}_{2}$ puede afectar a la industria de generación de energía de varios modos. El convenio marco de Naciones U nidas sobre el cambio climático, el plan de acción estadounidense sobre cambio climático y la ley de política energética de 1992 han hecho comprender a la industria energética cuál ha de ser su respuesta a la futura legislación.

En la actualidad, algunos ejemplos de los ámbitos que se están estudiando son: la creación de modelos matemáticos de emisiones, la determinación de los efectos del cambio climático, la determinación de los costes asociados a cualquier plan de tratamiento del cambio climático, beneficios para los seres humanos de la reducción de las emisiones gaseosas que repercuten en el efecto invernadero, y predicción del cambio climático.

Un importante motivo de preocupación sobre el cambio climático es el posible impacto negativo para los sistemas ecológicos. Se cree que los sistemas no ordenados son los más sensibles y tienen más probabilidades de verse afectados de un modo importante a escala global.

\section{Contaminantes atmosféricos peligrosos}

La US Environmental Protection Administration (EPA) ha enviado al Congreso de Estados Unidos un informe provisional sobre contaminantes atmosféricos peligrosos de las compañías eléctricas, tal como exigían las enmiendas de 1990 a la ley de aire limpio. La EPA debía analizar los riesgos de las instalaciones generadoras de electricidad a partir del vapor obtenido de los combustibles fósiles. La conclusión fue que dichas emisiones no constituyen ningún riesgo para la salud pública. Las conclusiones acerca del mercurio se han retrasado en espera de estudios adicionales. Un completo estudio realizado por el Electric Power Research Institute en centrales eléctricas alimentadas por combustibles fósiles indica que más del 99,5\% de las centrales de este tipo no presentan riesgos de cáncer superiores al umbral de 1 caso por millón (Lamarre 1995), en comparación con el riesgo inducido por todas las fuentes de emisión, que se estima en 2.700 casos anuales.

\section{Ozono}

La reducción de los niveles de ozono atmosférico constituye una preocupación importante en muchos países. Los óxidos de nitrógeno $\left(\mathrm{N} \mathrm{O}_{\mathrm{x}}\right.$ ) y los compuestos orgánicos volátiles (C OV) producen ozono. Como las centrales eléctricas alimentadas por combustibles fósiles liberan gran parte de todas las emisiones de $\mathrm{NO}_{x}$ del mundo, son de esperar medidas de control más rigurosas a medida que los países adopten normas medioambientales más exigentes. Así se seguirá hasta que se definan con más precisión los datos de partida para la realización de los modelos de cuadrícula fotoquímica utilizados para modelar el transporte de ozono troposférico.

\section{Protección del emplazamiento}

L as compañías eléctricas se ven obligadas a aceptar los costes de reparación de los emplazamientos en que se asientan las plantas de gas manufacturado (PGM ). Dichos emplazamientos se crearon originariamente para la producción de gas de carbón, coque 0 petróleo, lo que dio lugar al vertido en obra de alquitrán de carbón y otros subproductos en grandes lagunas o estanques, 0 al vertido terrestre fuera de obra. Los vertidos de este tipo pueden contaminar las aguas freáticas y el suelo. Esta cuestión permanecerá sin resolver durante algún tiempo, hasta que se determine el nivel de contaminación de las aguas freáticas y el suelo de estos emplazamientos y los medios para reducirla de manera rentable. 


\section{Referencias}

Lamarre, L. 1995. Assessing the risks of utility hazardous air pollutants. EPRI J ournal 20(1):6.

Naciones U nidas. 1995. 1993 E nergy Statistics Yearbook. Nueva Y ork: N aciones U nidas.

$\mathrm{N}$ ational Research Council of the National Academy of Sciences. 1996. Possible $H$ ealth $E$ ffects of Exposure to Residential Electric and M agnetic Fields. Washington, DC: N ational A cademy Press.
U ranium Institute. 1988. The Safety of Nuclear Power Plants. Londres: U ranium Institute.

US Department of Energy. 1995. E lectric Power Annual 1994. V ol. 1. Washington, DC: US D epartment of Energy, Energy Information Administration, O ffice of C oal, N uclear, Electric and Alternate Fuels.

US Department of Labor, O ccupational Safety and Health Administration (OSHA). 1994. 29 CFR Part 1910.269, Electric Power Generation, Trans- mission and Distribution: Electrical Protective Equipment; Final R ule. F ederal R egister, V ol. 59.

US Environmental Protection Administration (EPA). Interim R eport on $U$ tility $\mathrm{H}$ azardous Air Pollutants. Washington, DC: EPA.

Wertheimer, N, E Leeper. 1979. Electrical wiring configurations and childhood cancer. Am J Epidemiol 109:273-284 



\section{PROCESADO QUIMICO}

Directores del capítulo

Jeanne Mager Stellman y

Michael McCann

\section{Sumario}

Industria química

L. De Boer . . . . . . . . . . . . . . . 77.2

Elaboración de un programa de gestión de seguridad de procesos

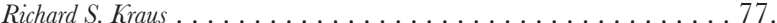

Operaciones y actividades principales de las unidades

de proceso: visión general

Sydney Lipton . . . . . . . . . . . . . . . . . . . . . . . . . 77.9

EJEMPLOS DE OPERACIONES DE TRATAMIENTO DE

PRODUCTOS QUIMICOS

Producción de cloro y cáusticos

The Chlorine Institute, Inc. . .

Fabricación de pinturas y revestimientos

Michael McCann . . . . . . . . . . . . . . . . . . . . . 77.22

Industria del plástico

P.K. Law y T.F. Britton . . . . . . . . . . . . . . . . . . . . . 77.25

Industria de la biotecnología

Susan B. Lee y Linda B. Wolfe . . . . . . . . . . . . . . . . . . . . 77.32

Industria pirotécnica

7. Kroeger. . . . . . . . . . . . . . . . . . . . . . . . . . . . 77.38 


\section{INDUSTRIA QUIMICA}

\section{De Boer*}

La industria química se ocupa de cambiar la estructura química de los materiales naturales con el fin de obtener productos útiles para otras industrias o para la vida cotidiana. Los productos químicos se obtienen a partir del procesamiento, en una serie de etapas, de esas materias primas (minerales, metales e hidrocarburos, sobre todo), que suelen requerir tratamientos ulteriores, como el mezclado, para conseguir el producto final (p. ej., pinturas, adhesivos, medicamentos y cosméticos). Así pues, la industria química no se limita exclusivamente a los denominados "productos químicos", sino que abarca otros productos, como las fibras artificiales, las resinas, los jabones, las pinturas, las películas fotográficas y otros.

Hay dos tipos principales de productos químicos: orgánicos e inorgánicos. Los primeros tienen una estructura básica de átomos de carbono, a la que se añaden hidrógeno y otros elementos. Actualmente, las fuentes del $90 \%$ de la producción mundial de productos químicos orgánicos son el petróleo y el gas, que han sustituido, con diferencia, al carbón y las sustancias vegetales y animales, anteriores materias primas. Los productos químicos inorgánicos proceden principalmente de fuentes minerales. Algunos ejemplos son el azufre, que se extrae como tal o de otros minerales, y el cloro, que se obtiene de la sal común.

Los productos de la industria química se clasifican, a grandes rasgos, en tres grupos, que corresponden a las principales etapas de fabricación: productos químicos básicos (orgánicos e inorgánicos), producidos normalmente a gran escala y convertidos en otros productos químicos; productos intermedios, obtenidos a partir de los productos químicos básicos, en su mayoría requieren un tratamiento posterior en la industria química, aunque algunos, como los disolventes, se utilizan sin procesar; y productos químicos terminados, que requieren tratamientos químicos ulteriores. Algunos de ellos (fármacos, cosméticos, jabones) se consumen tal cual; otros, como las fibras, los plásticos, los colorantes y los pigmentos deben someterse aún a otros tratamientos.

Los principales sectores de la industria química son los siguientes:

1. productos inorgánicos básicos: ácidos, álcalis y sales, utilizados sobre todo en otros sectores industriales, y gases industriales, como el oxígeno, el nitrógeno y el acetileno;

2. productos orgánicos básicos: materias primas para plásticos, resinas, cauchos sintéticos y fibras sintéticas; disolventes y materias primas de detergentes; colorantes y pigmentos;

3. fertilizantes y plaguicidas (incluidos herbicidas, fungicidas e insecticidas);

4. plásticos, resinas, cauchos sintéticos, fibras sintéticas y celulósicas;

5. productos farmacéuticos (fármacos y medicamentos);

6. pinturas, barnices y lacas;

7. jabones, detergentes, productos limpiadores, perfumes, cosméticos y otros productos de perfumería;

8. productos químicos diversos, como líquidos para abrillantar, explosivos, adhesivos, tintas, películas fotográficas y productos para revelado.

En la CIIU (Clasificación Industrial Internacional Uniforme de todas las Actividades Económicas), sistema utilizado por las Naciones Unidas para clasificar las actividades económicas en diez grupos principales, la industria química figura como División 35, una de las nueve subdivisiones de la División principal 3: Fabricación. La división 35 comprende a su vez

*Adaptado de la tercera edición, Enciclopedia de salud y seguridad en el trabajo productos químicos industriales (351), otros productos químicos (352), refinerías de petróleo (353), productos diversos derivados del carbón y del petróleo, por ejemplo el asfalto (354), productos de caucho, incluidos los neumáticos (355) y tratamiento de plásticos (356).

Cada país suele seguir su propio sistema de clasificación al elaborar las estadísticas de la industria química, lo que puede crear cierta confusión. Por esta razón, la comparación entre los distintos países en cuanto a la actividad de la industria química no puede basarse en fuentes nacionales. En todo caso, los organismos internacionales como la Organización para la Cooperación y el Desarrollo Económico (OCDE) y las Naciones Unidas, ofrecen datos basados en la CIIU, aunque con un retraso de aproximadamente dos años.

Las estadísticas comerciales del sector se publican a nivel internacional a través de la CUCI (Clasificación Uniforme para el Comercio Internacional), que difiere del sistema CIIU; las de cada país se refieren casi siempre a la sección 5 de la CUCI, que comprende aproximadamente el $90 \%$ de todos los productos químicos existentes en el sistema de CIIU.

En la última mitad del siglo, la industria química ha crecido con mucha más rapidez que el resto del sector privado en conjunto. Aunque a principios del decenio de 1990 se produjo una crisis económica en el sector químico, mediado el decenio la producción aumentó, sobre todo en el sureste asiático. En la Figura 77.1 se muestra el cambio porcentual de la producción química de algunos países en el período 1992-1995.

En la mayor parte de la industria química el capital está muy concentrado y depende en gran medida de la investigación y el desarrollo (por ejemplo, los productos farmacéuticos). Como resultado de ambos factores, es un sector donde el número de trabajadores manuales sin cualificar es sorprendentemente bajo para su tamaño, en comparación con la industria manufacturera en general. El empleo total en la industria aumentó ligeramente durante el período de crecimiento rápido anterior a 1970, pero desde entonces, el aumento de la productividad ha provocado

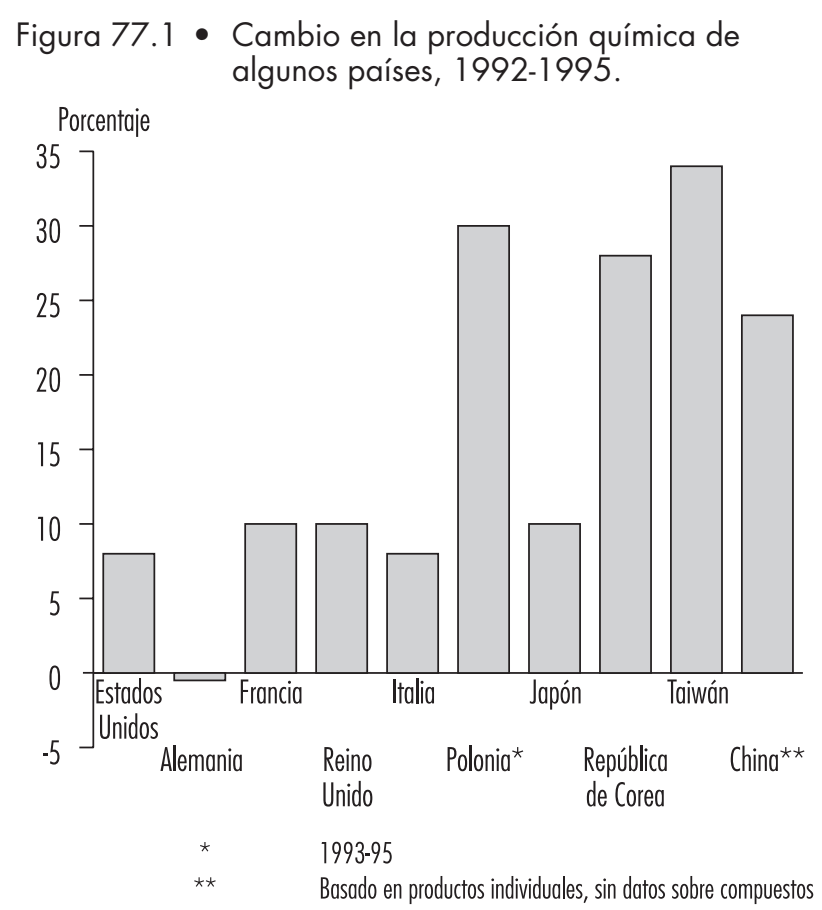

Fuente: Chemical and Engineering News 1996 
Tabla 77.1 • Número de trabajadores de la industria química en algunos países (1995).

$\begin{array}{lc}\text { País } & \text { Número de empleados } \\ \text { Estados Unidos } & 1.045 .000 \\ \text { Alemania } & 538.000 \\ \text { Francia } & 248.000 \\ \text { Reino Unido } & 236.000 \\ \text { Italia } & 191.000 \\ \text { Polonia } & 140.000 \\ \text { España } & 122.000\end{array}$

Fuente: Chemical and Engineering News 1996.

un descenso en el empleo en la industria química de los países más desarrollados. En la Tabla 77.1 se ofrecen las cifras de empleo en este sector en Estados Unidos y en varios países europeos durante 1995 .

\section{- ELABORACION DE UN PROGRAMA DE GESTION DE SEGURIDAD DE PROCESOS}

\section{Richard S. Kraus}

Siempre que existan procesos en los que se utilicen la temperatura y la presión para modificar la estructura molecular o crear nuevos productos a partir de productos químicos, existe la posibilidad de incendio, explosión o emisión de líquidos, vapores, gases u otros productos químicos intermedios tóxicos e inflamables. El ontrol de estos sucesos no deseados requiere la aplicación de una ciencia especial llamada gestión de seguridad de procesos. Se utilizan los términos seguridad de procesos y gestión de seguridad de procesos para referirse a la protección de los trabajadores, el público y el medio ambiente contra las consecuencias de incidentes indeseables graves en los que intervienen líquidos inflamables y materiales muy peligrosos. Según la Chemical ManufacturersAssociation (CMA) de Estados Unidos, "la seguridad de los procesos es el control de los riesgos causados por errores en la operación o en el funcionamiento de los procesos aplicados para transformar materias primas en productos terminados, que puede provocar la emisión imprevista de materiales peligrosos" (CMA 1985).

En la identificación y evaluación sistemática de los riesgos deben considerarse el diseño y la tecnología del proceso, los cambios en el mismo, los materiales y los cambios en los materiales, los procedimientos y las prácticas de operación y de mantenimiento, la formación, la preparación ante emergencias y otros elementos que afectan al proceso, con el fin de determinar si tienen o no el potencial de provocar una catástrofe en el lugar de trabajo y en la comunidad circundante.

Desde principios del decenio de 1980 ocurrieron una serie de accidentes muy graves en las industrias químicas y del petróleo, en los que intervinieron materiales muy peligrosos, que causaron un gran número de víctimas mortales y heridos, así como cuantiosas pérdidas materiales. Los accidentes sirvieron como impulso para que los organismos oficiales, los sindicatos y las asociaciones privadas de todo el mundo elaboraran y aplicaran códigos, reglamentos, procedimientos y prácticas de trabajo seguras, encaminados a eliminar o mitigar estos acontecimientos indeseables mediante la aplicación de los principios de gestión de seguridad de procesos. De ello se trata en profundidad en Desastres naturales y tecnológicos y en otros capítulos de esta Enciclopedia.

En respuesta a la preocupación pública sobre los peligros potenciales de los productos químicos, los gobiernos y las instituciones legislativas de todo el mundo iniciaron programas que exigían a los fabricantes y los usuarios la identificación de los materiales peligrosos en el lugar de trabajo, y la información a los empleados y consumidores de los peligros que entrañan su fabricación, uso, almacenamiento y manipulación. Estos programas, que abarcaban la preparación y la respuesta en casos de emergencia, el reconocimiento de los riesgos, el conocimiento de los productos, el control de los productos químicos peligrosos y la notificación de las emisiones tóxicas, incluían el procesado de hidrocarburos.

\section{Requisitos para la gestión de la seguridad de procesos}

La gestión de la seguridad de los procesos forma parte del programa general de seguridad de las instalaciones de procesos de productos químicos. Un programa eficaz de gestión de seguridad de procesos requiere el liderazgo, el apoyo y la participación activa de los directivos, los gestores de las instalaciones, los supervisores, los trabajadores, los contratistas y los empleados de éstos últimos.

$\mathrm{Al}$ desarrollar un programa de gestión de seguridad de procesos deben considerarse los aspectos siguientes:

- Continuidad interdependiente de operaciones, sistemas y organización

- Gestión de la información. El programa de gestión de seguridad de procesos se basa en proporcionar disponibilidad y acceso a buenos registros y documentos.

- Control de la calidad del proceso, desviaciones y excepciones y métodos alternativos

- Accesibilidad a los directores y supervisores, y comunicación. Debido a que la gestión de la seguridad de los procesos es la base de todos los esfuerzos para la seguridad en la instalación, para que el programa funcione se deben delimitar con claridad, comunicar y comprender las responsabilidades y competencias de los gestores, supervisores y trabajadores.

- Fines y objetivos, auditorías de cumplimiento y medición de los resultados. Antes de su aplicación es importante establecer fines y objetivos a corto y largo plazo para cada uno de los elementos del programa de gestión de seguridad de procesos.

\section{Elementos del programa de gestión de la seguridad de procesos}

Todos los programas de gestión de seguridad de procesos de la instalación abarcan los mismos requisitos básicos, aunque el número de elementos del programa varía en función de los criterios utilizados. Con independencia de que se utilice como guía un documento gubernamental, de una empresa o de una asociación, todo programa de gestión de seguridad de procesos químicos debe incluir unos requisitos básicos:

- información sobre seguridad de los procesos;

- participación de los trabajadores;

- análisis de los riesgos del proceso;

- gestión de los cambios;

- procedimientos de trabajo;

- prácticas de trabajo seguras y autorizaciones;

- información y formación de los trabajadores;

- personal del contratista;

- revisiones de seguridad antes de la puesta en marcha;

- garantía de calidad del diseño;

- mantenimiento e integridad mecánica; 


\section{La industria y la seguridad de los procesos de trabajo}

La tecnología de la seguridad de los procesos ha desempeñado un papel muy importante en las industrias de proceso químico, de forma que se pueden manipular líquidos inflamables y combustibles sin consecuencias adversas. Durante el decenio de 1980, las industrias del petróleo, por ejemplo, reconocieron que la tecnología de la seguridad de los procesos por sí sola, sin una gestión de la seguridad, no era válida para prevenir incidentes catastróficos. Habida cuenta de ello, varias asociaciones industriales, como el Center for Chemical Process Safety (CCPS), el American Petroleum Institute (API) y el Chemical Manufacturers' Association (CMA), todos ellos en Estados Unidos, iniciaron programas para elaborar y proporcionar normas de gestión de la seguridad de los procesos a sus miembros. Como ha establecido la CCPS, "La evolución de la seguridad de los procesos desde un aspecto puramente técnico a otro que exige planteamientos de gestión era esencial para la mejora continua de la seguridad de los procesos".

La CCPS se fundó en 1985 para promover la mejora de las técnicas de gestión de seguridad de los procesos entre aquellas que almacenan, manipulan, procesan y utilizan productos y sustancias químicas peligrosas. En 1988, la Chemical Manufacturer's Association (CMA) inició su programa Responsible Care $\AA$ que destaca el compromiso de cada compañía miembro con respecto a sus responsabilidades con el medio ambiente, la salud y la seguridad en la manipulación de productos químicos.

En 1990, la API inició un programa industrial titulado STEP-Strategies for Today's Environmental Partnership, cuya intención era mejorar las repercusiones sobre el medio ambiente, la salud y la seguridad de la industria del petróleo y del gas. Uno de los siete elementos estratégicos del programa STEP cubre la seguridad de los procesos y operaciones con petróleo. Los documentos siguientes son ejemplos de algunos de los materiales desarrollados como resultado del programa STEP, que proporcionan normas para la industria del petróleo y del gas con objeto de prevenir la aparición - minimizar las consecuencias de emisiones catastróficas de líquidos inflamables y vapores o sustancias peligrosas de los procesos.
- Management of Process Hazards (RP 750)

RP 750 cubre la gestión de los riesgos de los procesos con hidrocar buros en el diseño, la construcción, la puesta en marcha, las operaciones, la inspección, el mantenimiento y las modificaciones de las instalaciones. Se aplica específicamente a refinerías, plantas de petróleo e instalaciones principales de proceso que utilizan producen, manipulan o almacenan líquidos inflamables y productos químicos tóxicos en cantidades superiores a ciertas cantidades peligrosas (como se han definido).

- Management of Hazards Associated with Location of Process Plant Buildings (RP 752)

RP 752, desarrollado conjuntamente por API y CMA, pretende ayudar a identificar los edificios de interés de las plantas de procesado, a comprender los riesgos potenciales relacionados con su situación en la instalación de proceso y a gestionar el riesgo de incendio, explosión y emisiones tóxicas

- Management Practices, Self-assessment Process, and Resource Materials (RP 9000)

RP 9000 proporciona recursos y métodos de autoevaluación para medir el progreso en la aplicación de elementos de gestión de seguridad de procesos.

Otros ejemplos de organizaciones que han desarrollado materiales y programas con directrices que abarcan la gestión de la seguridad de los procesos químicos son:

- Informe de Organizations Resource Counselors' (ORC), Process Hazards Management of Substances with Catastrophic Potential

- Programa National Petroleum Refiners Association (NPRA), BEST (Building Environmental Stewardship Tools)

- Organización Internacional del Trabajo (ILO), Convenio sobre la prevención de accidentes industriales mayores

- Cámara de Comercio Internacional (CCI), Charter for Sustainable Development.
- respuesta ante emergencias;

- auditorías de seguridad periódicas;

- investigación de los incidentes durante el proceso;

- normas y reglamentos,

- secretos comerciales.

\section{Información sobre seguridad de los procesos}

La información sobre seguridad de los procesos se utiliza en la industria para definir los procesos, los materiales y los equipos fundamentales. En ella está incluida toda la información escrita disponible relativa a la tecnología del proceso, los equipos utilizados, las materias primas y los productos y su peligrosidad antes de realizar un análisis de riesgos del proceso. Otra información crucial en cuanto a seguridad de los procesos es la documentación relativa a las revisiones de proyectos importantes y criterios básicos de diseño.

La información química incluye no solamente las propiedades químicas y físicas, los datos de reactividad y corrosión y la estabilidad térmica y química de productos químicos como los hidrocarburos y materiales altamente peligrosos del proceso, sino también los efectos peligrosos resultantes de mezclar inadvertidamente diferentes sustancias incompatibles. La información química incluye también los aspectos necesarios para realizar una evaluación del riesgo ambiental de emisiones tóxicas e inflamables y límites de exposición permisibles.

Información sobre la tecnología del proceso: incluye diagramas de flujo generales y/o simples, así como las descripciones de los aspectos químicos de cada proceso específico con los límites de seguridad superiores e inferiores para temperaturas, presiones, flujos, composiciones y, cuando estén disponibles, materiales de diseño del proceso y balances energéticos. También se determinan las consecuencias de las desviaciones en los procesos y materiales, entre ellas su efecto sobre la seguridad y la salud de los trabajadores. Siempre que se modifiquen los procesos o los materiales se actualiza la información y se evalúa nuevamente de acuerdo con el sistema de gestión establecido para cambios de la instalación.

Información sobre los equipos del proceso y el diseño mecánico: incluye la documentación sobre las normas de construcción utilizadas y si el equipo cumple o no las prácticas técnicas reconocidas. Se determina si el equipo del que se dispone, que fue diseñado y fabricado conforme a códigos, normas y prácticas ya en desuso, se mantiene, utiliza, inspecciona y comprueba para asegurar un funcionamiento seguro en todo momento. Cuando se producen modificaciones se actualiza y evalúa de nuevo la información sobre los materiales de construcción, los diagramas de tuberías e 
instrumentos, el diseño de los sistemas de emergencia, la clasificación eléctrica, el diseño de la ventilación y los sistemas de seguridad.

\section{Participación de los trabajadores}

Los programas de gestión de la seguridad de procesos deben incluir la participación del trabajador en la elaboración y dirección de los análisis de seguridad de procesos y otros elementos del programa. Normalmente se proporciona a todos los trabajadores y empleados de los contratistas que trabajan en el área en cuestión, el acceso a la información sobre seguridad de procesos, los informes de investigación de incidentes y los análisis de riesgos de los procesos. Los países más industrializados exigen que los trabajadores sean instruidos sistemáticamente en la identificación, naturaleza y manipulación segura de todos los productos químicos a los que pueden estar expuestos.

\section{Análisis de los riesgos de los procesos}

Una vez recopilada la información sobre seguridad de procesos, se realiza un análisis de los riesgos de los procesos interdisciplinar, concienzudo y sistemático, adaptado a la complejidad del proceso, con el fin de identificar, evaluar y controlar los riesgos. Las personas que realicen el análisis de los riesgos de los procesos deben ser conocedores y expertos en los aspectos de importancia relativos a química, ingeniería y operaciones del proceso. Por lo común, en cualquier equipo de análisis hay una persona (como mínimo) muy familiarizada con el proceso que se somete a análisis, y otra competente en la metodología de análisis de riesgos empleada.

El orden de prioridades seguido para determinar dónde empezar el análisis de los riesgos de los procesos en la instalación se basa en los criterios siguientes:

- extensión y naturaleza de los riesgos de los procesos;

- número de trabajadores potencialmente afectados;

- historia del funcionamiento y los incidentes del proceso,

- edad del proceso.

En la industria química se utilizan varios métodos para realizar el análisis de seguridad del proceso.

El método "Qué ocurriría si...?", en el que se plantean una serie de preguntas para revisar las situaciones de riesgo potencial y las posibles consecuencias. Suele emplearse cuando se examinan las modificaciones o cambios propuestos al proceso, los materiales, el equipo o la instalación.

El método "Lista de control" es similar al método "¿Qué ocurriría si...?", a excepción de que en éste se utiliza una lista de control previamente elaborada y específica para la operación, los materiales, el proceso y el equipo en cuestión. Es un método útil cuando se realizan las revisiones previas a la puesta en marcha una vez finalizada la construcción inicial o después de importantes ciclos de parada o adiciones a la unidad de procesado. Cuando se analizan unidades idénticas en su construcción, materiales, equipos y procesos, se emplea por lo común una combinación de los métodos “QQué ocurriría si...?” y "Lista de control".

El método Estudio de riesgos y análisis funcional de operabilidad (HAZOP) se utiliza normalmente en las industrias química y petrolífera. Requiere un equipo interdisciplinar dirigido por un experto. El equipo utiliza palabras guía específicas que le sirven de directriz, tales como "no", "aumento", "disminución" e "inverso", que se aplican sistemáticamente junto a las variables clave (presión, temperatura, flujo, etc.) para identificar las consecuencias de las desviaciones con respecto al diseño previsto para los procesos, equipos y operaciones en análisis.
Los análisis de árboles de fallos y errores/árboles de sucesos son técnicas similares deductivas utilizadas para entre otros aspectos estimar la probabilidad cuantitativa de que ocurra un suceso. En la primera se analizan los acontecimientos previos a un potencial accidente o incidente para identificar y presentar la combinación de errores operativos y fallos del equipo implicados en él. El análisis de árboles de sucesos es el proceso contrario: se trabaja a partir de sucesos, o secuencias de sucesos, específicos con el fin de detectar los que entrañan daños, para calcular entonces la probabilidad de que tales secuencias de sucesos y daños se materialicen.

El método de análisis de modos de fallos y efectos tabula cada sistema de proceso o unidad de equipo con sus modos de fallos, el efecto de cada fallo potencial sobre el sistema o unidad y la relevancia de cada fallo para la integridad del sistema. A continuación, los modos de fallos se clasifican según su importancia para determinar cuál es el que tiene más probabilidades de causar un incidente grave. Independientemente del método utilizado, los análisis de riesgos de los procesos químicos consideran lo siguiente:

- posición, localización y riesgos del proceso;

- identificación de cualquier incidente previo o cuasierror con consecuencias potencialmente catastróficas;

- controles técnicos y administrativos aplicables a los riesgos;

- interrelaciones de los controles y la adecuada aplicación de los métodos de detección para advertir el peligro con prontitud;

- consecuencias de los fallos humanos, la situación de la instalación y el fallo de los controles,

- consecuencias de los efectos sobre la salud y la seguridad de los trabajadores en áreas con posibilidad de que ocurran fallos.

\section{Gestión de cambios o modificaciones}

En las instalaciones de procesos químicos se deben elaborar y aplicar programas de revisión de la información sobre seguridad de procesos, de los procedimientos y de las prácticas al producirse los cambios. Tales programas incluyen un sistema de autorización de gestión y documentación escrita para los cambios de materiales, productos químicos, tecnología, equipos, procedimientos, personal e instalaciones que afecten a cada proceso.

La gestión de los programas de cambio en la industria química, por ejemplo, comprende las áreas siguientes:

- Cambio de la tecnología de tratamiento de hidrocarburos.

- Cambios en las instalaciones, los equipos o los materiales (p. ej., catalizadores o aditivos).

- Gestión del personal encargado del cambio y cambios organizativos y de personal.

- Cambios temporales, variaciones y cambios permanentes.

- Ampliación de los conocimientos sobre la seguridad de los procesos, que incluye:

- base técnica para el cambio propuesto;

- impacto del cambio sobre la seguridad, la salud y el medio ambiente;

- modificaciones de los procedimientos de trabajo y las prácticas de trabajo seguras;

- modificaciones requeridas para otros procesos;

- tiempo necesario para el cambio;

- requisitos para la autorización del cambio propuesto;

- actualización de la documentación relativa a la información del proceso, los procedimientos de trabajo y las prácticas de seguridad;

- necesidad de formación o educación a consecuencia del cambio;

- Gestión de modificaciones pequeñas o sutiles (cualquiera que no sea realmente una sustitución).

- Cambios no rutinarios. 
La gestión del sistema de cambio incluye prestar información a los trabajadores que participan en el proceso y al personal de mantenimiento y del contratista cuyas tareas se ven afectadas por cualquier modificación de los cambios, así como proporcionar procedimientos de trabajo actualizados, información sobre la seguridad del proceso, prácticas de trabajo seguras y formación, según las necesidades, antes de poner en marcha el proceso o la parte del proceso en cuestión.

\section{Procedimientos de trabajo}

En las instalaciones de procesos químicos se deben elaborar y facilitar a los trabajadores instrucciones de trabajo y procedimientos detallados. Se comprobará regularmente que las instrucciones sean completas y precisas (actualizándose o corrigiéndose cuando se produzcan cambios) y cubren los límites de operatividad de las unidades de proceso, incluidas las tres áreas siguientes:

1. consecuencias de las desviaciones

2. medidas para evitar o corregir las desviaciones

3. funciones de los sistemas de seguridad relacionados con los límites operativos.

Los trabajadores que intervienen en el proceso tienen acceso a las instrucciones de trabajo de las áreas siguientes:

- puesta en marcha inicial (puesta en marcha después de ciclos de parada, emergencias y operaciones temporales);

- puesta en marcha normal (operaciones normales y temporales y parada normal);

- operaciones de parada y cierre de emergencia;

- condiciones en las que se requiere la parada de emergencia y la asignación de las responsabilidades del cierre a operarios cualificados;

- trabajo no rutinario;

- interfaz operador-proceso y operador-equipo,

- controles administrativos frente a controles automatizados.

\section{Prácticas de trabajo seguro}

En las instalaciones de procesos químicos se deben aplicar autorizaciones de trabajo en operaciones con aporte de altas temperaturas y control de trabajo seguro, así como programas de ordenación de trabajo para controlar las actividades realizadas en o cerca de las áreas de proceso. Los supervisores, los trabajadores y el personal del contratista deben estar familiarizados con los requisitos de los distintos procedimientos de autorización, entre ellos, la expedición y la expiración de mismo, así como con las medidas adecuadas de seguridad, manipulación de materiales y prevención y protección contra incendios.

He aquí los tipos de trabajo incluidos normalmente en los procedimientos de autorización de una instalación de productos químicos:

- trabajo a altas temperaturas (soldadura, derivación sobre tubería en carga, motores de combustión interna, etc.);

- bloqueo/advertencia de equipos con energía eléctrica, mecánica, neumática y presión;

- entrada a espacios confinados y utilización de gases inertes;

- recipientes, tanques, equipos y circuitos de procesos de venteo, apertura y limpieza,

- control de la entrada de personal no asignado a las áreas de proceso.

En las instalaciones de tratamiento químico se deben elaborar y aplicar prácticas de trabajo seguras para controlar los riesgos potenciales durante las operaciones del proceso que incluyan los siguientes aspectos:
- propiedades y factores de riesgo de materiales, catalizadores y productos químicos utilizados en el proceso;

- controles de protección técnica, administrativa y personal para prevenir las exposiciones;

- medidas que deben adoptarse en caso de contacto físico o exposición a productos químicos peligrosos;

- control de calidad de las materias primas, los catalizadores y control de existencias de productos químicos peligrosos;

- funciones de los sistemas de seguridad y de protección (bloqueo, supresión, detección, etc.),

- riesgos especiales o únicos en el lugar de trabajo.

\section{Información y formación de los trabajadores}

En las instalaciones de procesos químicos se debe contar con programas de formación en materia de seguridad de los procesos, con los que se proporcione formación y educación al personal que corresponda, al recientemente asignado a un puesto y a los nuevos supervisores y trabajadores. La formación impartida a los supervisores y trabajadores en operaciones y mantenimiento de procesos químicos abarcará las áreas siguientes:

- formación, conocimientos y cualificaciones que se exigen a los trabajadores;

- selección y desarrollo de programas de formación relacionados con el proceso;

- medición y documentación del rendimiento y la eficacia de los trabajadores;

- diseño de procedimientos de trabajo y mantenimiento del proceso;

- revisión de las operaciones y los riesgos del proceso;

- disponibilidad y adecuación de los materiales y piezas de repuesto a los procesos en los que se emplean;

- procedimientos de puesta en marcha, funcionamiento, parada y emergencia del proceso;

- riesgos para la seguridad y la salud relacionados con el proceso, los catalizadores y los materiales,

- prácticas y procedimientos de trabajo seguros en la planta y la zona del proceso.

\section{Personal de empresas contratistas}

En las instalaciones de procesos químicos es habitual acudir a contratistas, para lo cual la planta debe instituir procedimientos que garanticen que los empleados del contratista encargados de mantenimiento, reparaciones, ciclos de parada, renovaciones esenciales o trabajos especializados, conoce los riesgos, los materiales, los procesos, los procedimientos de trabajo y de seguridad y los equipos. La eficiencia de estos trabajadores ha de evaluarse periódicamente para garantizar que están formados, cualificados, que cumplen todas las reglas y procedimientos de seguridad y que son conscientes de:

- los posibles riesgos de incendios, explosiones y emisión de materiales tóxicos relacionados con su trabajo;

- los procedimientos de seguridad de la planta y las prácticas de trabajo seguras del contratista;

- el plan de emergencia y las acciones del personal del contratista,

- los controles de entrada, salida y presencia del personal del contratista en las áreas de proceso.

\section{Revisiones de seguridad antes de la puesta en marcha}

En las plantas químicas, las revisiones de la seguridad del proceso previas a la puesta en marcha se realizan antes de poner en marcha nuevas instalaciones de proceso o introducir nuevos materiales o productos químicos peligrosos en las instalaciones, después de un ciclo de parada importante o de modificaciones significativas de los procesos. 
Las revisiones de seguridad previas a la puesta en marcha garantizan que se ha realizado lo siguiente:

- se han verificado la construcción y montaje, los materiales y el equipo conforme a los criterios de diseño;

- se han inspeccionado, comprobado y certificado los sistemas del proceso y el hardware, incluido el programa de control del ordenador;

- se han inspeccionado, probado y certificado las alarmas e instrumentos;

- se han inspeccionado, probado y certificado los dispositivos de emergencia y seguridad y los sistemas de señales;

- se han inspeccionado, probado y certificado los sistemas de protección y prevención de incendios;

- se han desarrollado y revisado los procedimientos de seguridad, prevención de incendios y respuesta de emergencia, que han de estar en su sitio y ser los adecuados;

- los procedimientos de puesta en marcha están instalados y se han iniciado las acciones adecuadas;

- se han analizado los riesgos del proceso; abordado, aplicado o resuelto todas las recomendaciones, y documentado las acciones;

- se ha completado toda la formación inicial y/o de recuerdo exigida al personal de funcionamiento y mantenimiento, incluidas la respuesta de emergencia, los riesgos del proceso y los riesgos para la salud;

- están completos y en su sitio todos los procedimientos de trabajo (normal y de cambio de estado), los manuales de funcionamiento, los procedimientos de los equipos y los de mantenimiento,

- se cumplen los requisitos de gestión de cambio para nuevos procesos y modificación de los ya existentes.

\section{Garantías de calidad de diseño}

Cuando se inician nuevos procesos o cambios esenciales de los ya existentes, suelen realizarse una serie de revisiones del diseño de la seguridad de los procesos antes y durante la construcción (antes de la revisión previa a la puesta en marcha). La revisión del control del diseño, realizada inmediatamente antes de la fase en que se consideran los planes y especificaciones como "representaciones definitivas del diseño", abarca las áreas siguientes:

- planos, situación, espacio, clasificación eléctrica y drenajes;

- análisis de riesgos y diseño del proceso desde el punto de vista químico;

- requisitos y cualificaciones para la gestión del proyecto

- diseño e integridad de los equipos de proceso y mecánicos;

- planos de conducciones e instrumentos;

- dispositivos técnicos fiables de seguridad, de emergencia, de alarma y de bloqueo,

- materiales de construcción y compatibilidad.

Normalmente se realiza otra revisión antes del inicio de la construcción en la que se consideran los aspectos siguientes:

- procedimientos de demolición y excavación;

- control de las materias primas;

- control del personal de construcción y equipamiento en la instalación y en el lugar donde ésta se halle.

- procedimientos de fabricación, construcción e instalación, e inspección de los mismos.

Por lo común, se realizan una o más revisiones en el curso de la construcción o modificación para garantizar que se cumplen las especificaciones del diseño y los requisitos de la instalación en los ámbitos siguientes:
- los materiales de construcción se suministran y se utilizan de la forma especificada;

- las técnicas, inspecciones, verificaciones y certificaciones de montaje y soldadura son las correctas;

- se tienen en cuenta los riesgos químicos y de salud profesional durante la construcción;

- se tienen en cuenta los riesgos físicos, mecánicos y de seguridad en el trabajo durante la construcción; además de la observancia de autorizaciones y prácticas de seguridad en la instalación,

- se dispone de sistemas de protección provisionales y de respuesta a emergencias, y se hallan en funcionamiento.

\section{Mantenimiento e integridad mecánica}

Las instalaciones de proceso tienen programas para mantener la integridad continua del equipo utilizado en el proceso, que incluyen inspecciones periódicas, pruebas, mantenimiento del rendimiento, acciones correctoras y garantía de calidad. Lo que se pretende con estos programas es garantizar que la integridad mecánica del equipo y los materiales se revisa y certifica, y que se corrigen los defectos antes de la puesta en marcha, o se toman las medidas de seguridad adecuadas.

Los programas de integridad mecánica se aplican a los equipos y sistemas siguientes:

- recipientes a presión y tanques de almacenamiento;

- sistemas de parada de emergencia y de protección contra incendios;

- defensas del proceso, como los sistemas y dispositivos de alivio de presión y venteos, los controles, los bloqueos, los sensores y las alarmas;

- sistemas de bombas y de conducción (incluidos componentes como las válvulas);

- garantía de calidad, materiales de construcción y técnicas de seguridad,

- mantenimiento y programas preventivos de mantenimiento.

Los programas de integridad mecánica abarcan también la inspección y prueba de materiales de mantenimiento, piezas de repuesto y equipos, con el fin de asegurar la instalación adecuada para la aplicación del proceso en cuestión. Los criterios de aceptación y la frecuencia de las inspecciones y pruebas debe adaptarse a las recomendaciones de los fabricantes, las buenas prácticas técnicas, los requisitos legales, las prácticas industriales, la política de la instalación o la experiencia previa.

\section{Respuesta ante emergencias}

Para cubrir una instalación completa de proceso y facilitar la identificación y la evaluación de los riesgos del mismo se elaboran programas de preparación y respuesta ante emergencias. En ellos se incluyen la formación y educación de los trabajadores y de los empleados de los contratistas en materia de procedimientos de notificación, respuesta y evacuación de emergencia.

Un programa típico de preparación para emergencias en las instalaciones de proceso debe cumplir los correspondientes requisitos legales y de la propia compañía, e incluye lo siguiente:

- sistema de alarma o notificación a los trabajadores y la comunidad;

- método preferente para la comunicación interna de incendios, vertidos, escapes y emergencias;

- requisitos para la notificación de incidentes relacionados con el proceso a los organismos oficiales correspondientes; 
- parada de emergencia, evacuación, procedimientos para control del personal, procedimientos de escape de emergencia, retirada de vehículos y equipos y asignaciones de rutas;

- procedimientos de respuesta y rescate de emergencia, obligaciones y capacidades que incluyan trabajadores, seguridad pública, contratistas y organizaciones de ayuda mutua;

- procedimientos para manipular pequeños vertidos o emisiones de productos químicos peligrosos;

- procedimientos para facilitar y proteger los servicios y fuentes de energía de emergencia;

- planes de continuidad de actividades, dotación y aporte de personal y equipos,

- conservación de documentos y registros, seguridad, limpieza, recuperación y restauración de la instalación.

\section{Auditorías periódicas de seguridad}

En muchas instalaciones de proceso se realizan auditorías de autoevaluación de la gestión de seguridad de procesos para medir el rendimiento de la planta y garantizar el cumplimiento de los requisitos internos y externos (legales, de la empresa y de la industria) sobre seguridad de los procesos. Los dos principios básicos de estas auditorías son: recopilación de toda la documentación relevante acerca de los requisitos de gestión de seguridad de procesos en una instalación específica y determinación de la puesta en práctica y eficacia del programa mediante el seguimiento de su aplicación en uno o más procesos determinados. Se elabora un informe de los hallazgos y recomendaciones de la auditoría; el departamento de gestión de la instalación documenta cómo se han corregido o mitigado las deficiencias y, en caso contrario, la causa de que no se haya realizado la corrección correspondiente.

Los programas de auditorías de cumplimiento de las plantas de procesado de hidrocarburos incluyen los aspectos siguientes:

- establecimiento de objetivos, programa y métodos de verificación de los hallazgos antes de la auditoría;

- determinación de la metodología (o formato) que va a utilizarse al realizar la auditoría, y elaboración de listas de comprobación o formularios de informe de auditoría;

- disponibilidad para certificar el cumplimiento de los requisitos del gobierno, la empresa y la industria;

- asignación de equipos de auditoría con los conocimientos prácticos adecuados (expertos internos y/o externos);

- respuestas rápidas a todos los hallazgos y recomendaciones y documentación de las acciones llevadas a cabo;

- conservación de una copia del último (como mínimo) informe de auditoría de cumplimiento.

Las listas de comprobación específicas de la instalación y las unidades de procesado suelen elaborarse para su utilización cuando se realizan auditorías de seguridad de procesos que contemplen los aspectos siguientes:

- revisión del programa de orientación y gestión de la seguridad de procesos;

- visita preliminar a la refinería o instalación de tratamiento de gas;

- revisión de la documentación de la instalación de proceso;

- "incidentes previos" y cuasierrores (en la instalación o en una unidad específica);

- determinación y revisión de las unidades de procesado seleccionadas para someterlas a auditoría;

- construcción de unidades de procesado (iniciales y modificaciones posteriores);

- riesgos químicos de la unidad (materias primas, catalizadores, productos químicos, etc.);

- operaciones de las unidades de procesado;
- controles de la unidad, sistemas de emergencia y de seguridad;

- mantenimiento, reparación, prueba e inspección de las unidades;

- formación y participación de los trabajadores relacionados con la unidad;

- programa de cambios y modificaciones: gestión, aplicación y eficacia,

- protección contra incendios en el proceso y procedimientos de notificación y respuesta ante emergencias.

Dado que los objetivos y el alcance de las auditorías es variable, en el equipo de auditoría de cumplimiento debe haber al menos una persona con conocimientos sobre el proceso auditado, una persona con experiencia en las normas y reglamentos aplicables y otra persona con la formación y la cualificación necesaria para dirigir la auditoría. El departamento de gestión decide la inclusión de uno o más expertos externos en el equipo, si la instalación no cuenta con el suficiente personal o carece de expertos, o si los requisitos legales así lo exigen.

\section{Investigación de los accidentes-incidentes durante el proceso}

Las instalaciones de proceso debieran tener establecido procedimientos para investigar y analizar a fondo los accidentes-incidentes y los cuasiaccidentes relacionados con el proceso, aplicar y resolver rápidamente lo averiguado y las recomendaciones y revisar los resultados con los trabajadores y los subcontratistas con puestos relevantes respecto a las causas del accidente. Los accidentes-incidentes (o cuasiaccidentes) son investigados a fondo lo más pronto posible por un equipo que incluye al menos una persona que conozca la operación del proceso implicada y otras con los conocimientos y experiencia adecuados.

\section{Normas y reglamentos}

Las instalaciones de proceso están sometidas a dos formas distintas e independientes de normas y reglamentos.

1. Los códigos, normas y reglamentos externos aplicables al diseño, el funcionamiento y la protección de las instalaciones y los trabajadores del proceso, incluyen por lo común los reglamentos oficiales y las normas y prácticas de las asociaciones empresariales y de la industria.

2. Los principios, las directrices y los procedimientos internos, elaborados o adoptados por la empresa o instalación como complemento a los requisitos externos y para cubrir procesos diferentes o únicos, se revisan periódicamente y se modifican cuando es necesario, de acuerdo con la gestión del sistema de cambios de la instalación.

\section{Secretos comerciales}

Independientemente de los posibles secretos comerciales o acuerdos confidenciales, los responsables de la gestión de la instalación deben facilitar información sobre el proceso a las personas que:

- sean responsables de reunir y recopilar información sobre la seguridad de los procesos;

- estén realizando análisis de riesgos de los procesos y auditorías de control de cumplimiento;

- estén elaborando procedimientos de mantenimiento, funcionamiento y trabajo seguros;

- participen en investigaciones sobre accidentes-incidentes,

- sean responsable de los planes y respuestas de emergencia.

Por regla general, las instalaciones exigen que las personas a las que se facilitan datos sobre el proceso se comprometan por escrito a no revelar la información. 
OPERACIONES Y ACTIVIDADES PRINCIPALES DE LAS UNIDADES DE PROCESO: VISION GENERAL

\section{Sydney Lipton}

En este artículo se ofrece información sobre los equipos básicos de proceso, el almacenamiento, la disposición de la planta y algunas consideraciones sobre las operaciones, en el ámbito de las industrias de procesos químicos, incluidos los principales temas y conceptos aplicables a todo el sector. Ahora bien, gran parte de los equipos que precisan los procesos químicos son muy especializados y no aceptan generalizaciones. En otros puntos de esta Enciclopedia se atiende con más detalle a la toxicidad, los materiales peligrosos y la seguridad del proceso.

Existen dos categorías básicas en cuanto a la disposición de las instalaciones de tratamiento químico: disposición de la planta (que comprende todas las unidades de proceso, servicios, zonas de almacenamiento, zonas de carga y descarga, edificios, áreas comerciales y almacenes) y disposición de la unidad o proceso (que comprende solamente la localización del equipo para un proceso específico, denominado también área de proceso.

\section{Disposición de la planta}

\section{Situación}

La localización o situación de una planta completa depende, como se expone en la Tabla 77.2 (CCPS 1993), de varios factores generales, que varían considerablemente en función de los lugares, los gobiernos y las políticas económicas. Entre estos distintos factores, las consideraciones en materia de seguridad ocupan un lugar destacado, y en algunos lugares constituyen el factor principal que rige la situación de la planta.

Un aspecto importante de la seguridad de la instalación en cuanto a su localización es contar con una separación o zona de amortiguación entre la planta donde se realicen procesos peligrosos y otras plantas, viviendas, colegios, hospitales, carreteras, cursos de agua y pistas de aterrizaje cercanos. En la Tabla 77.3 se presentan algunas consideraciones generales de seguridad. La importancia de la zona de amortiguación radica en que la distancia tiende a reducir o mitigar las exposiciones potenciales debidas a distintos accidentes. La distancia necesaria para

Tabla 77.2 • Algunos factores para la selección de los emplazamientos de las fábricas.

- Densidad de población en torno a la fábrica

- Frecuencia de desastres naturales (terremotos)

- Vientos predominantes y datos meteorológicos

- Disponibilidad de energía

- Aspectos relacionados con la seguridad

- Normas en materia de agua

- Accesibilidad a las materias primas y a los mercados

- Transporte

- Permisos de instalación y dificultad para obtenerlos

- Requisitos de interacción en los avances industriales

- Disponibilidad y coste de la mano de obra

- Incentivos para la inversión
Tabla 77.3 • Aspectos en la seguridad del emplazamiento de la planta.

- Zona de separación

- Localización de otras instalaciones peligrosas próximas

- Existencias de materiales tóxicos y peligrosos

- Idoneidad del suministro de agua para combatir incendios

- Acceso al equipo de emergencia

- Disponibilidad de apoyo en la respuesta de emergencia de las industrias adyacentes y la comunidad

- Condiciones atmosféricas extremas y vientos predominantes

- Presencia de autopistas

- Restricciones medioambientales y de eliminación de residuos durante las emergencias

- Drenaje y pendiente

- Mantenimiento e inspección

reducir las concentraciones tóxicas a niveles aceptables a través de la interacción atmosférica y la dispersión de materiales tóxicos de una emisión accidental es algo que puede definirse. Asimismo, el lapso de tiempo entre una emisión tóxica y la exposición del público (mientras atraviesa la zona de amortiguación) se utiliza para advertir a la población mediante programas de respuesta de emergencia planeados previamente. Debido a que las plantas tienen distintos tipos de instalaciones con materiales tóxicos, se deben realizar análisis de dispersión sobre los sistemas peligrosos para asegurar que la zona de amortiguación es adecuada en todas las áreas que rodean el perímetro de la planta.

El fuego es un riesgo potencial en las plantas e instalaciones de proceso. Los grandes incendios causan a veces radiación térmica que puede mitigarse también con la distancia. Los dispositivos de recogida de gases y vapores situados en lugares elevados son también una fuente de radiación térmica durante una operación de emergencia o de puesta en marcha/parada. Lo que hacen es quemar automáticamente gases de escape o emisiones de vapor en posiciones elevadas o en lugares especiales sobre el suelo; deben estar emplazados fuera del perímetro de la planta (para proteger a las comunidades cercanas) y debe prohibirse a los trabajadores el acceso a una determinada zona alrededor de su base. Si no se manipula correctamente, el sobrante del líquido que entra en estos dispositivos puede originar gotas de líquido en combustión. Además del fuego, es posible que se produzcan explosiones en el equipo o una nube de vapor que cause al inflamarse ondas explosivas. La distancia que ocupe la zona de amortiguación reducirá los efectos de la explosión; aún así, ésta afectará a la comunidad vecina.

Asimismo deben considerarse posibles emisiones o incendios accidentales en las instalaciones existentes cercanas al lugar en cuestión. Se deben prever y evaluar los eventuales incidentes para determinar el posible efecto sobre la disposición propuesta para la planta y las respuestas de emergencia a un suceso externo, coordinando estas respuestas con las de otras plantas y comunidades afectadas.

\section{Otras consideraciones}

Dow Chemical Company ha elaborado otro planteamiento de disposición de plantas basado en un nivel aceptable de daño máximo probable para la propiedad (MPPD) y en un riesgo de interrupción de la actividad (B1) (Dow Chemical Company 1994a). Se trata de consideraciones de importancia 
Tabla 77.4 - Instalaciones que suelen situarse separadas en la disposición general de las plantas.

- Unidades de proceso

- Parque de tanques

- Instalaciones de carga y descarga

- Antorchas

- Generadores, calentadores e incineradores

- Torres de refrigeración

- Subestaciones, grandes centros de conmutación eléctrica

- Edificios centrales de control

- Almacenes

tanto para las plantas nuevas como para las ya existentes. El índice Dow de incendios y explosiones es útil al trazar nuevas disposiciones de plantas o al añadir equipos a las existentes. Si los riesgos calculados a partir del índice son inaceptables, deben aumentarse las distancias de separación. A su vez, los cambios en la disposición reducen a veces el riesgo.

\section{Disposición general}

Al trazar la disposición general de una planta es importante considerar los vientos dominantes. Las fuentes de ignición deben estar situadas en contra del viento con respecto a las posibles fugas. En esta categoría se incluyen los calentadores, hervidores, incineradores y dispositivos de recogida de vapor (CCPS 1993). Otra recomendación (CCPS 1993) es la colocación de los tanques de almacenamiento a favor del viento con respecto a las unidades y servicios de procesado. La legislación ambiental ha reducido significativamente las fugas de los tanques (Lipton y Linch 1994).

En varias publicaciones se han señalado las distancias mínimas de separación para unidades de procesado, equipos y diferentes funciones de las plantas (CCPS 1993; Dow Chemical Company 1994a; IRI 1991). En la Tabla 77.4 figuran una serie de instalaciones generales sobre las que suele recomendarse la existencia de una distancia de separación en las disposiciones generales de las plantas. Las recomendaciones reales para distancias deben definirse cuidadosamente. Aunque los calentadores expuestos al fuego y los hornos de proceso no aparecen en la Tabla 77.4, tienen importancia, y la distancia de separación recomendada debe incluirse en la disposición de una unidad de proceso.

Asimismo son necesarias carreteras para emergencias y acceso de vehículos o equipos de mantenimiento; requieren un cuidado emplazamiento entre las unidades de proceso y a través de las distintas secciones de la planta. Deben dejarse espacios libres para tuberías y otros equipos elevados, además de los requeridos en los laterales de cruces y entradas a todas las instalaciones.

Los requisitos de disposición se basan en distancias de separación mínimas recomendadas (CCPS 1993; NFPA 1990; IRI 1991; Mecklenburgh 1985) o determinadas mediante un análisis de riesgos (Dow Chemical Company 1994a).

\section{Disposición de unidades de proceso}

La Tabla 77.4 contiene un resumen de la disposición general de las separaciones de la planta. Las unidades de proceso están incluidas en el bloque específico presentado en la disposición general. El proceso químico aparece, por lo común, detallado en los diagramas de proceso y ejecución. La disposición de un proceso requiere tener en cuenta algunos aspectos, además de las distancias específicas de separación entre equipos, algunas de las cuales se presentan en la Tabla 77.5

El ensamblaje del equipo en cualquier unidad de procesado variará considerablemente en función del proceso. La toxicidad y las características de peligro de las corrientes y materiales en las unidades presentan también grandes variaciones. A pesar de estas diferencias, se han desarrollado normas de distancias mínimas para muchos equipos (CCPS 1993; NFPA 1990; IRI 1991; Mecklenburgh 1985). Se dispone de procedimientos para calcular las posibles fugas y las exposiciones tóxicas procedentes del equipo de procesado que también pueden afectar a la separación (Dow Chemical Company 1994b). Asimismo se aplican análisis de dispersión cuando se hayan estimado las fugas.

\section{Equipos y distancia de separación}

Es posible utilizar una técnica de matriz para calcular el espacio de separación necesario entre los equipos (CCPS 1993; IRI 1991). En los cálculos basados en las condiciones específicas del proceso y en una evaluación de los riesgos en los mismos se pueden obtener distancias de separación diferentes a las de una matriz normalizada.

Es posible elaborar listas muy amplias para una matriz mediante la depuración de las categorías individuales y la adición de equipo. Por ejemplo, los compresores se pueden dividir en varios tipos, como aquellos que manipulan gases inertes, aire y gases peligrosos. Las distancias de separación para compresores de motor difieren de las de las máquinas de motor o de vapor. Las distancias de separación en las instalaciones de almacenamiento que albergan gases licuados deben ser analizadas sobre la base de la naturaleza inerte del gas.

Deben definirse cuidadosamente los límites de los acumuladores del proceso, que son las líneas limítrofes o límites del terreno para una unidad de proceso (el nombre procede de la utilización, en un principio, de una batería de hornos en el proceso). Otras unidades, carreteras, servicios, conducciones, zanjas, etc., se disponen en función de los límites de los acumuladores. Aunque la situación del equipo de una unidad no llegue a los límites de acumuladores, deben definirse distancias de separación entre ambos.

Tabla 77.5 • Consideraciones generales en la disposición de una unidad de proceso.

- Definición del área para expansión y accesibilidad a la unidad

- Accesibilidad al equipo de reparaciones para mantenimientos frecuentes

- Requisitos espaciales para reparaciones de equipos (p. ej., área necesaria para empujar el haz del intercambiador de calor 0 accesibilidad para la válvula de control)

- Barreras para equipos de alta presión o reactores con potencial explosivo

- Requisitos espaciales y mecánicos para carga y descarga de reactores o torres rellenas de sólidos

- Espacio para venteo de explosiones de polvo

- Separación entre los equipos abiertos o inspeccionados con frecuencia y las tuberías, los recipientes, etc. a altas temperaturas.

- Edificios o estructuras especiales y espacio libre necesario (p. ej., cabina del compresor con puente grúa interno o grúa externa) 


\section{Salas o edificios de control}

En el pasado, el diseño de cada unidad de procesado incluía una sala desde donde se llevaba el control operativo del proceso. Con la aparición de la instrumentación electrónica y el proceso controlado informáticamente, las salas individuales de control han sido sustituidas por una sala central que controla varias unidades de proceso en muchas operaciones. La sala de control centralizado es económicamente rentable debido a la optimización del proceso y los aumentos en la eficacia del personal. Aún existen unidades individuales de proceso, y en algunas plantas especializadas los antiguos edificios de control sustituidos por salas de control centralizado aún pueden utilizarse para el seguimiento de procesos locales y controles de emergencia. Aunque las funciones y el emplazamiento de la sala de control están condicionados generalmente por cuestiones económicas, el diseño de la sala o edificio de control es muy importante para mantener el control de emergencia y para la protección del trabajador. He aquí algunas consideraciones para los edificios de control central y local:

- presurización del edificio de control para prevenir la entrada de vapores tóxicos y peligrosos;

- diseño del edificio de control de forma que sea resistente a explosiones y estallidos;

- establecimiento de un lugar con un riesgo mínimo (basado en la distancia de separación y la probabilidad de escapes de gases);

- purificación de todo el aire de entrada e instalación de un bloque de entrada que minimice la entrada de vapores peligrosos o tóxicos;

- sellado de todas las salidas de desagües procedentes del edifico de control,

- instalación de un sistema de extinción de incendios.

\section{Reducción de existencias}

Un aspecto importante en las disposiciones del proceso y de las plantas es la cantidad de materiales tóxicos y peligrosos en existencia, incluido el equipo. Las consecuencias de una fuga son más graves al aumentar el volumen del material. Por consiguiente, deben reducirse las existencias al mínimo posible. Las mejoras del proceso que reducen el número y el tamaño de las piezas

Tabla 77.6 • Medidas para limitar las existencias.

- Reducción de las existencias en tanques de almacenamiento mediante mejora de los controles del proceso y control puntual de las operaciones y existencias

- Eliminación o minimización de existencias en tanques en planta mediante integración de los procesos

- Utilización de análisis y desarrollo de las variables de las reacciones para reducir el volumen del reactor

- Sustitución de los reactores discontinuos por reactores continuos, lo que reduce también las retenciones aguas abajo

- Disminución de las retenciones de la columna de destilación mediante reducciones del volumen de residuos y retención de bandejas empleando bandejas 0 empaquetamientos más avanzados

- Sustitución de calderinas por termosifones

- Minimización de los volúmenes de los depósitos elevados y de los depósitos de compensación

- Mejora de la disposición y el tamaño de las tuberías para minimizar las retenciones

- Donde se produzcan materiales tóxicos, minimizar su retención.
Figura 77.2 - Tanques típicos de almacenamiento sobre el suelo.

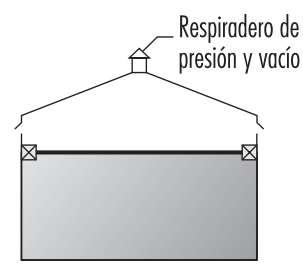

TANQUE DE TECHO FIIO

(TTF)

TANQUE DE TECHO FLOTANTE INTERNO (TTFI)

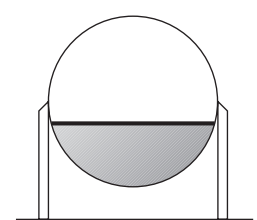

ESFERA

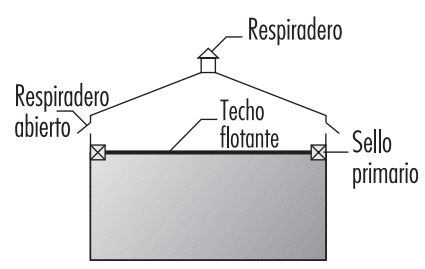

Sello

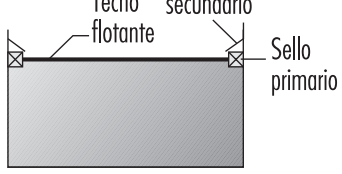

TANQUE DE TECHO FLOTANTE EXTERNO (TTFE)

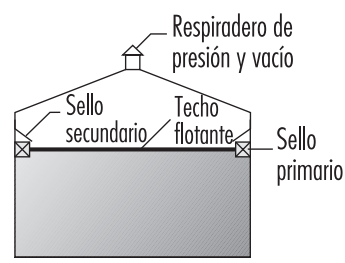

TANQUE DE TECHO FLOTANTE CONVERTIDO 0 CERRADO (TTFC)

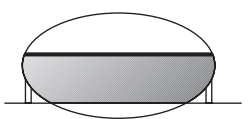

ESFEROIDE del equipo reducen las existencias, disminuyen el riesgo y la inversión y mejoran también la eficacia.

En la Tabla 77.6 se mencionan algunas consideraciones para la reducción de las existencias. Al construir una nueva instalación, el proceso debe optimizarse atendiendo a los objetivos de la Tabla 77.6.

\section{Almacenes}

Los almacenes de una planta de tratamiento de productos químicos pueden albergar sustancias sólidas y líquidas, productos intermedios, subproductos y productos del proceso. Los productos almacenados en muchas instalaciones son intermediarios o precursores de otros procesos. Es posible también que se almacenen diluyentes, disolventes u otros materiales del proceso. Todos estos materiales se almacenan por regla general en tanques sobre el suelo (TSS). En algunas instalaciones se utilizan aún los tanques subterráneos (TS), pero su uso está muy limitado debido a los problemas de acceso que plantean y a su capacidad limitada. Además, las posibles fugas de dichos tanques subterráneos presentan problemas ambientales cuando las fugas contaminan el agua subterránea. La contaminación de la tierra puede provocar exposiciones atmosféricas por evaporaciones de materiales de elevada presión de vapor. Las fugas o evaporaciones de materiales entrañan un problema de exposición durante los trabajos de descontaminación del suelo. En muchos países, las fugas de los TS han provocado la elaboración de estrictas normas ambientales, como los requisitos para los tanques de doble pared y el control del subsuelo.

En la Figura 77.2 se representan tanques típicos de almacenamiento sobre el suelo. Los TSS verticales son tanques con techo en forma de cono o de bóveda; tanques de techo flotante que pueden estar cubiertos o no cubiertos, o tanques de techos flotantes externos (TTFE). Los tanques de techos cerrados o 
Tabla 77.7 • Separación de tanques y consideraciones sobre la localización.

- La separación según las distancias de un contenedor a otro puede basarse en referencias, y es posible calcular la distancia de radiación térmica en caso de incendio en un tanque adyacente.

- Se deben separar los tanques de las unidades de proceso.

- La localización del tanque, a ser posible a sotavento de otras áreas, minimiza los problemas de ignición en caso de que el tanque emita una cantidad importante de vapor.

- Los tanques de almacenamiento deben tener cubetos, exigidos por la ley en algunos países.

- Se pueden agrupar los tanques para la utilización de cubetos y equipos contra incendios comunes.

- Los cubetos deben tener capacidad de aislamiento en una emergencia.

convertidos son TTFE con cubiertas instaladas sobre los tanques, normalmente bóvedas de tipo geodésico. Debido a que con el tiempo los TTFE no mantienen una forma perfectamente circular, es difícil sellar el techo flotante, por lo que se instala una cubierta sobre el tanque. Un diseño de bóveda geodésica elimina los armazones necesarios para tanques de techo cónico (TTC). La bóveda geodésica es más económica que el techo cónico y además reduce la emisión de materiales al medio ambiente.

Normalmente los tanques están limitados al almacenamiento de líquidos cuando la presión del vapor del líquido no supera los $77 \mathrm{kPa}$. Cuando no es así, se utilizan esferas o esferoides diseñados para operaciones con presión. Los esferoides pueden ser muy amplios, pero no se instalan donde la presión supere ciertos límites definidos por el diseño mecánico. En la mayor parte de las aplicaciones de almacenamiento de elevada presión de vapor, las esferas suelen ser el recipiente de almacenamiento y están equipadas con válvulas limitadoras de presión para prevenir el exceso de ésta. Un aspecto preocupante en cuanto a la seguridad de las esferas es la posibilidad de rotura o de vuelco, al generarse sobrecargas y sobrepresiones, provocando la descarga de la válvula de seguridad y llegando en casos extremos a la ruptura de la pared de la esfera (CCPS 1993). En general, el contenido líquido se estratifica, y si el material caliente (menos denso) se carga en el fondo de la esfera, sube a la superficie con el material de superficie frío de mayor densidad vertido sobre el fondo. El material caliente de superficie se evapora, aumentando la presión, lo que puede provocar la descarga de la válvula de seguridad o la sobrepresión de la esfera.

\section{Disposición del tanque}

La disposición del tanque requiere una cuidadosa planificación. Existen recomendaciones para las distancias de separación de tanques y otros aspectos (CCPS 1988; 1993). En muchas instalaciones, las distancias de separación no están especificadas, pero las mínimas (OSHA 1994) pueden obtenerse de diversas decisiones aplicables a las distancias de separación. Algunas de estas consideraciones se exponen en la Tabla 77.7. Por otra parte, el mantenimiento del tanque es un factor que ha de tenerse en cuenta en la separación de tanques a presión, refrigerados y atmosféricos (CGPS 1993).

Se necesitan cubetos de retención con un volumen nominal suficiente para el contenido del tanque. Cuando dentro de un cubeto hay varios tanques, la capacidad mínima volumétrica del mismo es equivalente a la capacidad del mayor (OSHA 1994). Las paredes del cubeto pueden estar construidas de tierra, acero, hormigón o mampostería sólida. No obstante, los cubetos de tierra deben ser impermeables y tener una parte superior lisa con una anchura mínima de 0,61 m. Además, el suelo dentro del área de los cubetos debe tener también una capa impermeable para prevenir la fuga de productos químicos o aceites al suelo.

\section{Fugas de los tanques}

Un problema que va agravándose con el transcurso de los años son las fugas de los tanques debidas a la corrosión de la parte inferior. Los tanques suelen tener capas de agua en el fondo que pueden contribuir a la corrosión, y existe la posibilidad de que se produzca corrosión electrolítica debido al contacto con la tierra. Así pues, se han establecido requisitos legales en distintas zonas para controlar las fugas del fondo de los tanques y la contaminación del subsuelo y del agua subterránea con contaminantes del agua. Se han elaborado varios procedimientos de diseño para controlar las fugas (Hagen y Rials 1994), a lo que se añade la instalación de fondos dobles y la protección catódica, empleada en algunas instalaciones para controlar mejor el deterioro de los metales (Barletta, Bayle y Kennelley 1995).

\section{Extracción de agua}

La descarga manual periódica de agua desde el fondo del tanque entraña riesgo de exposición a sustancias peligrosas. La observación visual para determinar el interfaz mediante un drenaje abierto manual puede exponer al trabajador. Para minimizarlo, se instala una descarga cerrada con un sensor de interfaz y una válvula de control (Lipton y Lynch 1994). A estos efectos se dispone en el mercado de distintos sensores.

\section{Exceso de llenado de los tanques}

Con frecuencia los tanques se llenan en exceso, lo que entraña riesgos para la seguridad, exponiendo a los trabajadores. Una manera de prevenirlo es la utilización de instrumentos de doble nivel que controlen las válvulas de bloqueo de entrada o las bombas de alimentación (Bahner 1996). Durante muchos años se instalaron tubos de rebose en los tanques de productos químicos, pero terminaban a una corta distancia sobre la abertura del drenaje para así permitir la observación visual de la descarga del sobrante. Por otra parte, el drenaje debía tener capacidad para acoger la tasa máxima de llenado y garantizar un drenaje adecuado. No obstante, este sistema es una fuente potencial de exposición, que se elimina conectando el tubo de rebose directamente al drenaje con un indicador de flujo en el tubo para mostrar el exceso de llenado. Aunque funcionara correctamente, dicha solución produce una sobrecarga del sistema de drenaje con un volumen de contaminantes muy alto y posibles problemas de salud y seguridad.

\section{Inspección y limpieza de los tanques}

Los tanques se retiran del servicio periódicamente para su inspección y limpieza, labores que han de controlarse cuidadosamente para prevenir la exposición del trabajador y reducir al mínimo los riesgos. Después del drenaje, los tanques se lavan con un chorro de agua para eliminar los restos de líquido del proceso. Antiguamente solían limpiarse manual o mecánicamente donde fuera necesario. Al drenar un tanque, se llena de vapor que puede generar una atmósfera tóxica e incluso combustible. Es posible que el lavado con un chorro de agua no afecte significativamente a la toxicidad de la atmósfera interior, pero reduce los problemas de combustión. Con techos flotantes, el material que se halla por debajo de ellos puede rociarse o drenarse, aunque en algunas ocasiones quedan materiales en el sumidero que deben eliminarse manualmente, con los consiguientes problemas de exposición. El personal debe en esos casos llevar equipos de protección personal (EPP). 
Por lo común, los tanques cerrados y cualquier volumen que se halle por debajo de los techos flotantes se purgan con aire hasta conseguir una concentración determinada de oxígeno antes de permitir la entrada. Ahora bien, debe medirse continuamente la concentración para asegurar que la concentración de tóxicos no excede el nivel adecuado ni varía.

\section{Purga de vapor y control de emisiones}

En el caso de tanques con techos fijos o con techos flotantes convertidos (TTFC), el purgado a la atmósfera no resulta aceptable en muchas situaciones. $\mathrm{Al}$ eliminar estos tanques, el respiradero de presión y vacío (PV) (representado en la Figura 77.2), los vapores fluyen a través de un conducto cerrado a un dispositivo de control en el que los contaminantes se destruyen o recuperan. Con ambos tanques se puede inyectar una purga inerte (p. ej., nitrógeno) para eliminar el efecto de vacío diurno y mantener una presión positiva para el dispositivo de recuperación. En el tanque TTFC, el nitrógeno elimina el efecto diurno y reduce los vapores enviados a la atmósfera mediante un respiradero de PV. No obstante, las emisiones de vapor no se eliminan. Entre los numerosos dispositivos y técnicas de control que existen, están la combustión, los absorbentes y los condensadores (Moretti y Mukhopadhyay 1993; Carroll y Ruddy 1993; Basta 1994; Pennington 1996; Siegall 1996). La elección de un sistema de control está en función de los objetivos que se tengan en cuanto a emisiones y de los costes de operación e inversión.

En los tanques con techo flotante, tanto internos como externos, los precintos y los controles de ajuste auxiliar reducen al mínimo las pérdidas de vapor.

\section{Riesgos para la seguridad}

La inflamabilidad es uno de los mayores motivos de preocupación del almacenamiento en tanques; se requieren sistemas de lucha contra incendios para el control y la protección de las zonas de propagación de incendios. Existen recomendaciones en este sentido, sobre sistemas e instalaciones de agua para incendios (CCPS 1993; Dow Chemical Company 1994a; NFPA 1990). Es posible pulverizar el agua directamente sobre un fuego en ciertas condiciones, siendo esencial para enfriar el tanque o el equipo contiguo y prevenir el sobrecalentamiento. Por otra parte, la espuma es un agente eficaz para combatir incendios, de modo que se pueden instalar equipos permanentes de espuma en los tanques. Si se instalan en un equipo móvil contra incendios, debe revisarlo el fabricante. Actualmente se dispone de espumas relativamente ecológicas y de baja toxicidad, además de eficaces y comparables a otras espumas en la extinción rápida de los incendios.

\section{Equipos de proceso}

En el tratamiento de productos químicos se utiliza una gran variedad de equipos, debido a los numerosos procesos, los requisitos especiales para cada uno de ellos y las variaciones de los productos. Así pues, es imposible revisar todos los equipos químicos utilizados hoy en día, por lo que en esta sección nos ocuparemos de los equipos más aplicados, según la secuencia del proceso.

\section{Reactores}

En la industria química existen muchos tipos de reactores. La selección del reactor depende de algunas variables, entre las cuales está si la reacción es discontinua o continua. Con frecuencia las reacciones discontinuas se convierten en continuas cuando se tiene más experiencia con las reacciones y mejoran algunas circunstancias, como disponer mejores catalizadores. El proceso de reacción continua es generalmente más eficaz y da lugar a un producto más consistente, lo cual favorece el cumplimiento de los objetivos en cuanto a la calidad del producto. No obstante, aún existe un gran número de operaciones discontinuas.

\section{Reacción}

En todas las reacciones es necesaria su clasificación en base a cuestiones como las siguientes: Para definir los requisitos de calentamiento o enfriamiento precisos para controlar una reacción es necesario clasificarla como exotérmica o endotérmica (que produce o consume calor). Además, deben establecerse criterios sobre reacciones incontroladas para instalar sensores y controles que lo impidan. Antes de poner en funcionamiento un reactor a pleno rendimiento, se deben investigar y elaborar procedimientos de emergencia que garanticen la contención segura de la reacción incontrolada. Algunas de las posibles soluciones son: disponer de un equipo de control de emergencia que se active automáticamente, inyectar productos químicos que detengan la reacción y contar con dispositivos de purga que puedan adaptar y controlar el contenido del reactor. Las válvulas de seguridad y la purga son de gran importancia, y requieren equipos bien cuidados y en funcionamiento permanente. En consecuencia, suelen instalarase varias válvulas de seguridad con dispositivos de enclavamiento para permitir que no se reduzca la capacidad de protección requerida durante el mantenimiento de una válvula.

$\mathrm{Si}$, debido a un fallo en el funcionamiento, hay escapes por una válvula o boquilla de seguridad, el efluente de descarga debe ser contenido en prácticamente todos los casos para reducir al mínimo los riesgos para la seguridad y la salud. Así pues, deben estudiarse cuidadosamente el método de contención de las descargas de emergencia mediante tuberías y la disposición final de la descarga del reactor. En general, deben separase los vapores de los líquidos: los primeros se envían a un dispositivo de despresurización o recuperación, y los segundos se reciclan siempre que sea posible. La retirada de los sólidos requiere un estudio más complejo.

\section{Discontinua}

En los reactores donde se producen reacciones exotérmicas, un aspecto importante es la obstrucción de las paredes o los tubos internos causada por el refrigerante utilizado para mantener la temperatura. El método de eliminación de los materiales atascados se realiza de distintas formas, y está en función de sus características: con un disolvente, un chorro a alta presión o, en algunos casos, manualmente. En cualquier caso, deben controlarse cuidadosamente la seguridad y la exposición. El movimiento de los materiales dentro y fuera del reactor no debe permitir la entrada de aire, que puede formar una mezcla de vapor inflamable. El vacío debe romperse con un gas inerte (p. ej., nitrógeno). La entrada al recipiente para inspección y otros trabajos debe considerarse como entrada en un espacio confinado, debiéndose observar las normas y procedimientos para esta operación. Deben conocerse la toxicidad cutánea y por inhalación, y los técnicos deben conocer los riesgos para la salud.

\section{Continua}

Los reactores de flujo se pueden llenar con líquido o con vapor y líquido. Algunas reacciones producen lodos en los reactores. Asimismo, algunos reactores contienen catalizadores sólidos. El fluido de reacción puede ser un líquido, un gas o una mezcla de ambos. Los catalizadores sólidos, que facilitan la reacción sin participar en ella, suelen estar contenidos en rejillas y se denominan lechos fijos. Los reactores de lecho fijo tienen lechos sencillos y múltiples, mientras que las reacciones que en ellos se producen pueden ser exotérmicas o endotérmicas, y en su mayor parte requieren una temperatura constante (isoterma) en cada 
lecho. Ello exige, por regla general, la inyección de flujos de alimentación o un diluyente en distintos lugares entre los lechos para controlar la temperatura. Con estos sistemas de reacción, la indicación de temperatura y la localización de los sensores en los lechos son muy importantes para prevenir una reacción incontrolada y cambios en el rendimiento o la calidad del producto.

Los lechos fijos normalmente pierden su actividad y deben ser regenerados o sustituidos. Para su regeneración, los depósitos del lecho deben ser eliminados mediante combustión, disueltos en un disolvente $\mathrm{o}$, en algunos casos, regenerados mediante la inyección de un producto químico en un fluido interno en el lecho, restableciendo así la actividad catalítica. La aplicación de una u otra técnica está en función del catalizador. Cuando se queman los depósitos, el reactor se vacía y purga de todos los fluidos del proceso, y después se llena con un gas inerte (por lo común, nitrógeno) que se calienta y recircula, aumentado el lecho a un nivel de temperatura determinado. En este punto se añade un volumen muy pequeño de oxígeno al flujo de entrada para iniciar un frente de llama que se mueve gradualmente a través de todo el lecho y controla el aumento de la temperatura. El exceso de oxígeno tiene un efecto perjudicial sobre el catalizador.

\section{Retirada del catalizador de lecho fijo}

La retirada de los catalizadores de lecho fijo debe controlarse cuidadosamente. Se drenan los fluidos del proceso de los reactores y a continuación el fluido remanente se desplaza con un chorro de líquido o se purga con un gas hasta que se haya eliminado todo el fluido del proceso. Es posible que el purgado final requiera otras técnicas antes de que el recipiente se pueda purgar con un gas inerte o aire, tras lo cual se abre el recipiente o se descarga el catalizador del recipiente bajo una capa inerte. Si en este proceso se utiliza agua, ésta se drena a través de tuberías cerradas hasta un desagüe. Algunos catalizadores son sensibles al aire o al oxígeno, haciéndose pirofóricos o tóxicos. Estos requieren procedimientos especiales para eliminar el aire durante el llenado o vaciado de los envases. Se deben definir cuidadosamente los procedimientos de protección personal y de manipulación para reducir al mínimo las exposiciones y proteger al personal.

La eliminación del catalizador consumido puede requerir otros tratamientos antes de enviarlo al fabricante para su reciclado o someterlo a un procedimiento de eliminación ecológico.

\section{Otros sistemas de catalizadores}

El flujo de gas a través de un lecho de catalizador sólido suelto expande el lecho y forma una suspensión similar a un líquido, denominada lecho fluido. Este tipo de reacción se emplea en distintos procesos. Los catalizadores utilizados se eliminan como flujos laterales gas-sólido para su regeneración y después vuelven al proceso a través de un sistema cerrado. En otras reacciones, la actividad del catalizador llega a ser muy alta y, aunque el catalizador se descarga en el producto, la concentración es muy baja y no plantea ningún problema. Cuando no conviene que se produzca una concentración elevada de sólidos de catalizador en el gas del producto, el arrastre de impurezas de los sólidos debe eliminarse antes de la purificación. Aún así, quedarán restos sólidos que se retiran eliminándolos en uno de los flujos de productos secundarios, que a su vez debe ser clarificado.

En casos en que el catalizador agotado se regenera mediante combustión, se requieren instalaciones de recuperación de sólidos en sistemas de lecho fluido para cumplir las restricciones ambientales. La recuperación consiste en varias combinaciones de ciclones, precipitadores eléctricos, filtros de bolsa o purificadores. Si la combustión se produce en lechos fijos, el principal motivo de preocupación es el control de la temperatura.
Debido a que los catalizadores de lecho fluido suelen ser susceptibles de ser respirados, los sólidos se deben manipular con cuidado para asegurar la protección del trabajador, tanto con catalizadores recientes como recuperados.

En algunas ocasiones se utiliza vacío para eliminar distintos componentes de un lecho fijo. El generador de vacío suele ser un chorro de vacío por vapor, lo que produce una descarga de vapor que contiene por regla general materiales tóxicos, aunque en concentración muy baja en la corriente de gases. No obstante, debe revisarse con atención la descarga del chorro de vapor para determinar las cantidades contaminantes, la toxicidad y la posible dispersión si se descarga directamente a la atmósfera. Si esto no es satisfactorio, la descarga puede requerir la condensación en un sumidero donde se controlen todos los vapores y el agua se envíe al sistema de desagüe cerrado; a tal efecto se utiliza una bomba de vacío rotativa. Cabe la posibilidad de que no se permita que una bomba de vacío oscilante descargue directamente a la atmósfera, pero en algunos casos se hace a un tubo de descarga, a un incinerador o a un calentador del proceso.

\section{Seguridad}

En todos los reactores los aumentos de presión constituyen un motivo de preocupación importante, ya que no debe superarse la presión del recipiente. Esos aumentos pueden deberse a un control deficiente del proceso, a un fallo en el funcionamiento o a una reacción incontrolada. En consecuencia, se necesitan sistemas limitadores de presión para mantener la integridad del recipiente, de manera que impidan la sobrepresión del reactor. Las descargas de las válvulas limitadoras deben estar cuidadosamente diseñadas para mantener una protección adecuada en todas las condiciones, incluido su mantenimiento. Es posible que ello requiera muchas válvulas. Si una válvula limitadora está diseñada para descargar en la atmósfera, el punto de descarga debe situarse por encima de todas las estructuras próximas y debe realizarse un análisis de dispersión para asegurar una protección adecuada de los trabajadores y las comunidades vecinas.

Si se instala un disco de ruptura con una válvula de seguridad, la descarga debe ser cerrada, diseñándose la descarga final de la forma anteriormente descrita. La ruptura de un disco no significa rectificación, por lo que un disco sin válvula de seguridad liberará probablemente la mayor parte del contenido de un reactor y al final del proceso de liberación podrá entrar aire en el reactor. Esto requiere un análisis cuidadoso para asegurar que no exista peligro de inflamación y que no se producen reacciones indeseables. Además, la descarga de un disco libera a veces líquido; el sistema de ventilación debe diseñarse para contener todos los líquidos con el vapor descargado, como se ha descrito antes. Las emisiones de emergencia a la atmósfera deben estar aprobadas por las autoridades legislativas antes de su instalación.

Los agitadores de mezcla instalados en los reactores se sellan, ya que las fugas pueden ser peligrosas; si se producen, el sello debe repararse, lo que requiere la parada del reactor. Tal vez sea necesaria una manipulación o tomar precauciones especiales para el contenido del reactor; la parada de emergencia debe incluir la finalización de la reacción y la disposición del contenido del reactor. La inflamabilidad y el control de la exposición deben revisarse cuidadosamente en cada etapa, incluida la disposición final de la mezcla del reactor. Dado que una parada resulta costosa y supone pérdidas de producción, se han introducido mezcladores magnéticos y sistemas de sellado más modernos para reducir el mantenimiento y las paradas del reactor.

La entrada a todos los reactores exige el cumplimiento de los métodos seguros de entrada a espacios confinados. 


\section{Torres de fraccionamiento o destilación}

La destilación es un proceso en el que las sustancias químicas se separan mediante métodos que aprovechan las diferencias de sus puntos de ebullición. Las torres más comunes en las plantas químicas y refinerías son las de destilación.

La destilación en sus distintas modalidades es una etapa de procesado presente en la mayor parte de los procesos químicos. Es posible encontrar el fraccionamiento o la destilación en las etapas de purificación, separación, lavado, azeotrópicas y de extracción. Estas aplicaciones incluyen ahora la destilación de los reactivos, en la que se produce una reacción en una sección independiente de la torre de destilación.

La destilación se realiza con una serie de bandejas en una torre, o en una torre con un material de relleno. Los rellenos tienen configuraciones especiales que permiten rápidamente el paso de líquido y de gases, pero proporcionan un área suficiente para el contacto líquido-gas y un fraccionamiento eficaz.

\section{Funcionamiento}

Normalmente se aporta calor a una torre mediante un hervidor, aunque el contenido de calor de los flujos específicos puede ser suficiente para prescindir de él. Con el calor del hervidor se produce una separación vapor-líquido de varias etapas en las bandejas, y los materiales más ligeros ascienden a través de la torre. Los vapores de la bandeja superior se condensan total o parcialmente en el condensador superior. El líquido condensado se recoge en el tambor de recuperación del destilado, en el que parte del líquido se recicla a la torre y otra parte se retira y envía a un lugar específico. Los vapores no condensados se recuperan en otro lugar o se envían a un dispositivo de control que puede ser un quemador o un sistema de recuperación.

\section{Presión}

Las torres funcionan, por regla general, a presiones superiores a la atmosférica. No obstante, suelen hacerlo en condiciones de vacío para así minimizar las temperaturas del líquido que puedan afectar a la calidad del producto, o bien en situaciones en las que los materiales de la torre suponen un problema mecánico y económico debido al nivel de temperatura, que a veces es difícil de conseguir. Asimismo, las elevadas temperaturas pueden afectar al fluido. En las fracciones pesadas del petróleo, las temperaturas elevadas de los fondos de las torres dan lugar frecuentemente a problemas de coquificado.

El vacío se consigue normalmente con eyectores o bombas de vacío. En las unidades de procesado, las cargas de vacío comprenden varios materiales gaseosos ligeros, elementos inertes que tal vez hayan estado en el flujo de alimentación de la torre, y aire de las fugas. Por lo común, el sistema de vacío se instala detrás de un condensador para reducir la carga orgánica al sistema de vacío. El tamaño del sistema de vacío depende de la carga estimada del vapor, con eyectores que manipulan grandes cargas de vapor. En algunos sistemas se conecta directamente una bomba de vacío a una salida del condensador. Lo normal en un sistema eyector es la combinación de eyectores y condensadores barométricos directos en los que los vapores del eyector tienen contacto directo con el agua refrigerante. Los condensadores barométricos son grandes consumidores de agua, y la mezcla agua-vapor produce altas temperaturas del agua de salida, que tienden a evaporar todas las trazas de compuestos orgánicos en el sumidero barométrico atmosférico, con lo que aumentan las posibilidades de exposición en el área de trabajo. Asimismo se añade una gran carga de efluente al sistema de eliminación de agua.

Se consigue una gran reducción de agua junto a una reducción importante en el consumo de vapor en los sistemas de vacío modificados. La bomba de vacío no trabaja con una gran carga de vapor, por lo que se utiliza un eyector de vapor en la primera etapa en combinación con un condensador de superficie para reducir la carga de la bomba de vacío. Igualmente, se instala un tambor sumidero para las operaciones en superficie. El sistema más simple reduce la carga de agua residual y mantiene un sistema cerrado que elimina las posibles exposiciones de vapor.

\section{Seguridad}

Todas las torres y tambores deben estar protegidos de las sobrepresiones que pueden causar los fallos en el funcionamiento, los incendios (Mowrer 1995) o los defectos en los servicios. Es necesaria una evaluación de los riesgos, exigida por la ley en algunos países. Disponer de un planteamiento de gestión general de seguridad de procesos aplicable al funcionamiento de la planta y del proceso mejora la seguridad, minimiza las pérdidas y protege la salud del trabajador (Auger 1995; Murphy 1994; Sutton 1995). Una válvula limitadora de presión (VLP) actúa descargando a la atmósfera o a un sistema cerrado. Suele estar instalada en la parte superior de la torre para eliminar la gran carga de vapor, aunque en algunas instalaciones están en otros puntos de la torre. En ocasiones se encuentran en el tambor elevado de recuperación del destilado, siempre que las válvulas no estén situadas entre la VLP y la parte superior de la torre. Si las válvulas de bloqueo están instaladas en los tubos del proceso que llegan al condensador, la VLP debe instalarse sobre la torre.

Cuando se libera la sobrepresión de la torre de destilación, en ciertas circunstancias de emergencia, la descarga de la VLP puede ser extremadamente grande. Una carga muy elevada en un tubo de ventilación de sistema cerrado puede ser la mayor carga en el sistema. Dado que una descarga de VLP puede ser repentina y el tiempo total de evacuación muy corto (menos de 15 minutos), esta carga de vapor extremadamente grande debe analizarse cuidadosamente (Bewanger y Krecter 1995; Boicurt 1995). Debido a que esta gran carga rápida es difícil de procesar en dispositivos de control, como los absorbentes, los adsorbentes, los hornos, etc., en la mayor parte de las situaciones el dispositivo de control preferido para la eliminación del vapor es una antorcha. Normalmente, hay varias VLP conectadas a una sola antorcha. No obstante, tanto éste como todo el sistema deben estar diseñados cuidadosamente para cubrir las posibles contingencias (Boicourt 1995).

\section{Riesgos para la salud}

En el caso de la eliminación directa a la atmósfera debe realizarse un análisis de dispersión detallado de los vapores de descarga de la válvula, para asegurar que los trabajadores no están expuestos y que las concentraciones en la comunidad circundante están dentro de los límites permitidos. Al controlar la dispersión, los tubos de descarga de la válvula de seguridad a la atmósfera se pueden elevar para prevenir concentraciones excesivas en las estructuras próximas. Tal vez sea necesaria una chimenea alta semejante a una antorcha para controlar la dispersión.

Otro motivo de preocupación es la entrada a una torre para mantenimiento o para realizar cambios mecánicos durante una parada. Al tratarse de un espacio confinado, los trabajadores están expuestos a los riesgos que ello lleva asociados. El método de rociado a chorro y purga antes de abrir debe aplicarse cuidadosamente para asegurar unas exposiciones mínimas mediante la reducción de las concentraciones tóxicas por debajo de los niveles recomendados. Antes de comenzar las operaciones de rociado a chorro y purga debe reducirse la presión de la torre y cegar todas las conexiones de tuberías que llegan a ella (es decir, deben colocarse discos ciegos de metal entre los bordes de la torre y los bordes de la tubería de conexión). Son labores que deben llevarse a cabo con gran precaución para minimizar las exposiciones. En los diferentes procesos varían los métodos de 
Figura 77.3 • Intercambiadores de calor típicos.

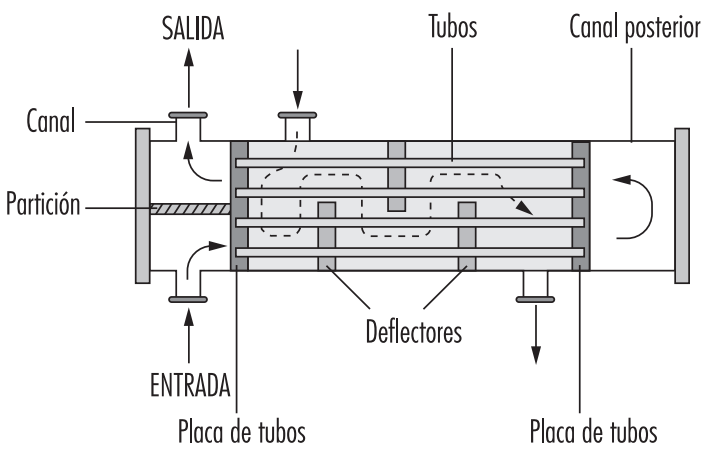

INTERCAMBIADOR DE TUBOS Y CARCASA PLACA DE TUBOS FIJA

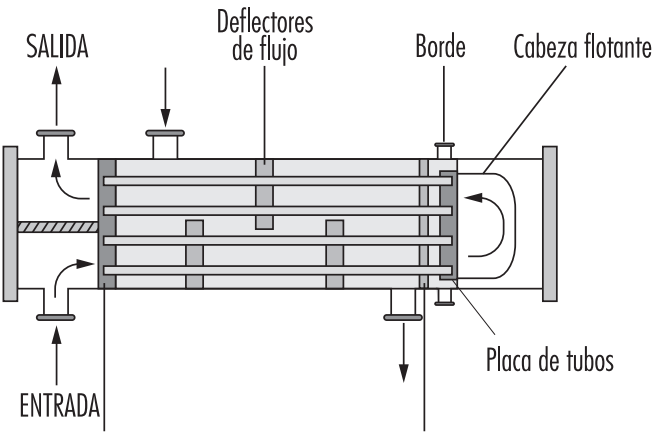

Placa de tubos

CARCASA DE CABEZA FLOTANTE E INTERCAMBIADOR DE TUBO

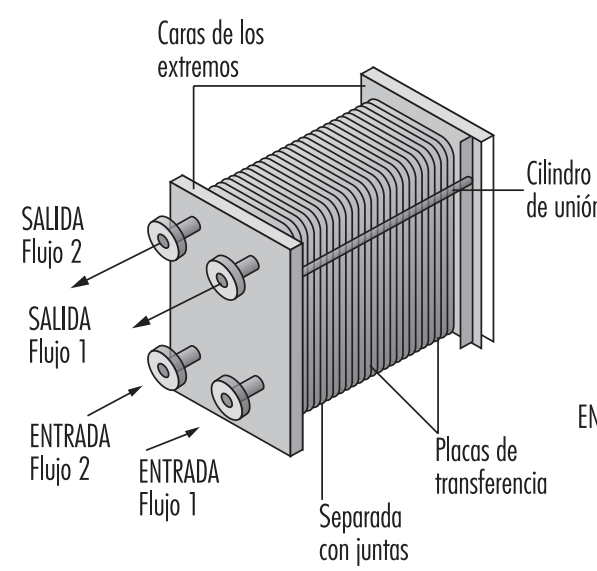

INTERCAMBIADOR DE PLACA Y CUADRO

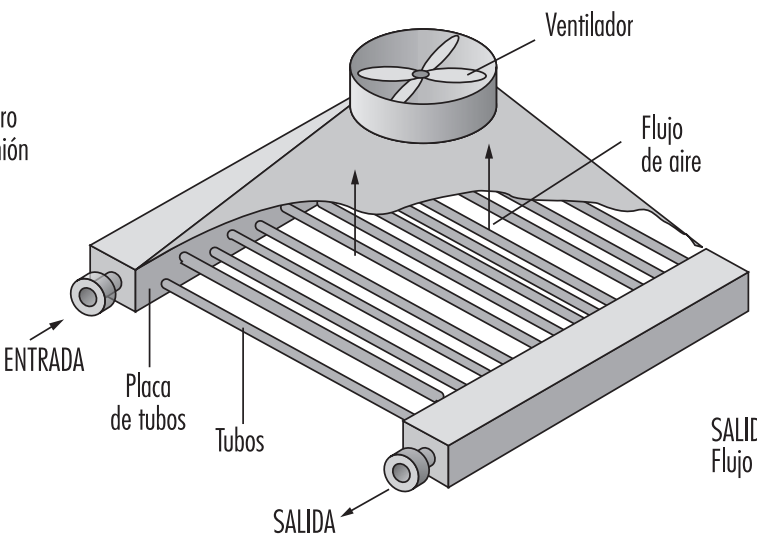

INTERCAMBIADOR AEROREFRIGERANTE

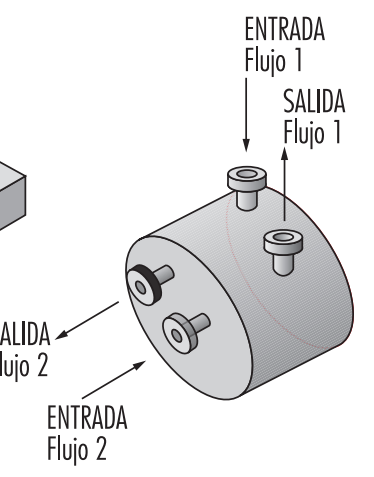

INTERCAMBIADOR ESPIRAL clarificación de fluidos tóxicos de la torre. Por lo común, el fluido de la torre es desplazado con un fluido que tiene una toxicidad muy baja y que posteriormente se drena y bombea a un lugar determinado. La capa y las gotas de líquido remanentes se vaporizan a la atmósfera a través de una brida superior que tiene un separador de soporte especial con una abertura entre el separador y la brida de la torre. Después de la vaporización, el aire entra en la torre a través de la abertura del separador especial, conforme va enfriándose la torre. Se abre una cámara en el fondo de la torre, y otra en la parte superior de la misma que permiten el flujo de aire en la torre. Cuando la concentración interna de la torre alcanza un nivel determinado, se puede pasar al interior.

\section{Intercambiadores de calor}

En la industria de procesos químicos existe una gran variedad de intercambiadores de calor. Son dispositivos mecánicos para la transferencia de calor a o desde un flujo del proceso. Se seleccionan conforme a las condiciones del proceso y el diseño del intercambiador. En la Figura 77.3 se presentan algunos de los tipos habituales de intercambiadores. La elección del más conveniente para un proceso es complicada y requiere una investigación detallada (Woods 1995). En muchas situaciones algunos tipos no son adecuados debido a la presión, la temperatura, la concentración de sólidos, la viscosidad, la cantidad de flujo y otros factores. Por otra parte, el diseño de un intercambiador individual de calor varía considerablemente; se dispone de varios tipos de tubos de cabeza flotante e intercambiadores de chapas (Green, Maloney y Perry 1984). Suele preferirse la cabeza flotante cuando hay posibilidad de que las temperaturas provoquen una expansión excesiva del tubo que de otra forma no podría mantener la integridad en un intercambiador de chapas de tubo fijo. En el intercambiador de cabeza flotante simplificado de la Figura 77.3, la cabeza flotante está inserta completamente en el intercambiador y no tiene ninguna conexión con la cubierta. En otros modelos de cabeza flotante puede haber empaquetamiento en torno a la chapa de la tubería flotante (Green, Maloney y Perry 1984).

\section{Fugas}

El empaquetamiento de las chapas de tuberías flotantes está en contacto con la atmósfera y puede ser una fuente de fugas y exposición. Otros intercambiadores a veces tienen también fuentes de fugas, y por lo tanto deben ser examinados atentamente. Debido a sus características de transferencia de calor, los intercambiadores de placa y cuadro son frecuentes en la industria química. Las placas tienen distintas ondulaciones y configuraciones; están separadas por juntas que previenen la mezcla de los flujos y proporcionan un sellado externo. No obstante, los precintos limitan las aplicaciones de temperatura a unos $180{ }^{\circ} \mathrm{C}$, aunque las mejoras en el sellado pueden superar esta limitación. Dado 
que existen distintas placas, éstas se deben comprimir adecuadamente para asegurar un sellado correcto entre ellas. En consecuencia, es necesaria una instalación mecánica cuidadosa para prevenir las fugas y los posibles riesgos. La abundancia de precintos exige un control cuidadoso para minimizar las posibilidades de exposición.

Los intercambiadores refrigerados por aire resultan rentables económicamente, por lo que se encuentran en numerosas aplicaciones de procesos y en diversas partes de las unidades de proceso. Para ahorrar espacio, estos intercambiadores suelen instalarse apilados y sobre tuberías. La selección del material es importante, por lo que existe una gran variedad en la industria química. Estos tubos se conectan a la chapa del tubo, lo que requiere el uso de materiales compatibles. Las fugas a través de una fractura del tubo o en la chapa del tubo son un motivo de preocupación, ya que si el ventilador hace circular los vapores de la fuga, su dispersión entraña riesgo de exposición. La dilución del aire puede reducir significativamente el riesgo. Ahora bien, en ciertas condiciones atmosféricas los ventiladores se detienen, por lo que las concentraciones de las fugas aumentan, incrementando así las posibilidades de exposición. Asimismo, si no se reparan los tubos con fugas, la rotura puede agrandarse. Con líquidos tóxicos que no se evaporan rápidamente cabe la posibilidad de que se produzca un goteo y, en consecuencia, una exposición cutánea.

Los intercambiadores de calor acorazados y de tubo a veces desarrollan fugas a través de cualquiera de las bridas (Green, Maloney; Perry 1984). Ya que su tamaño varía enormemente y cuentan con superficies desde muy pequeñas a muy amplias, el diámetro de las bridas exteriores suele ser mucho mayor que las de las tuberías normales. Con estas anchas bridas, las juntas no sólo deben resistir las condiciones del proceso, sino proporcionar hermeticidad en las variaciones de carga de los pernos. Existen varios modelos de juntas. Mantener tensiones constantes de carga en todos los pernos de las bridas es difícil, lo que provoca fugas en muchos intercambiadores. La fuga de la brida puede controlarse con anillos obturadores (Lipton y Lynch 1994).

Las fugas se producen en los tubos de cualquiera de los intercambiadores que hay en el mercado, a excepción de los de placa y otros especiales. No obstante, estos últimos presentan otros problemas: cuando la fuga de los tubos va hacia un sistema de refrigeración por agua, el agua refrigerante descarga el contaminante en una torre refrigerante que puede ser una fuente de exposición para los trabajadores y la comunidad próxima y, por lo tanto, debe controlarse.

La dispersión de los vapores de la torre refrigerante se extiende a veces a causa de los ventiladores de las torres refrigerantes de tiro por aspiración (inducida o forzada). Además, las torres de convección natural descargan los vapores a la atmósfera, que después los dispersa. Ahora bien, la dispersión varía considerablemente según las condiciones meteorológicas y la elevación de la descarga. Los materiales tóxicos menos volátiles permanecen en el agua refrigerante y en el flujo de vaciado de la torre refrigerante, que debe tener la suficiente capacidad de tratamiento como para destruir los contaminantes. La torre refrigerante y el recipiente de la torre deben limpiarse periódicamente. Los contaminantes se suman a los posibles riesgos del recipiente y del relleno de la torre. Para la mayor parte de este trabajo es necesario llevar equipo de protección personal.

\section{Limpieza del intercambiador}

Un problema que se plantea con los tubos en la actividad de refrigeración del agua es la formación de sustancias en los mismos como resultado de la corrosión, los organismos biológicos y los depósitos sólidos. Como se ha afirmado antes, es posible que los tubos tengan fugas porque haya fracturas, o porque estén enrollados en estrías sobre la chapa del tubo. Cuando se da cualquiera de estas condiciones, es preciso reparar el intercambiador y eliminar los fluidos del proceso del intercambiador, mediante una operación completamente controlada, necesaria para cumplir los objetivos en cuanto a exposición ambiental, seguridad y salud.

Generalmente, el fluido del proceso se drena hacia un recipiente, y el material restante se rocía a chorro fuera del intercambiador con un disolvente o material inerte. Este último se envía también a un recipiente para material contaminado drenando o presurizando con nitrógeno. En los casos en que haya material tóxico en el intercambiador, debe controlarse la presencia de restos de material tóxico. Si los resultados de los ensayos no son satisfactorios, el intercambiador se puede vaporizar para eliminar todas las trazas de material. No obstante, el orificio de escape de vapor se debe conectar a un sistema cerrado para prevenir el escape a la atmósfera. Mientras que el escape a un recinto cerrado puede no ser absolutamente necesario, en ocasiones hay más material contaminante en el intercambiador, lo que requiere la ventilación del vapor cerrado en todo momento para controlar los posibles riesgos. Después de la vaporización, la ventilación a la atmósfera admite aire. Este método general es aplicable al lado o lados del intercambiador que tienen material tóxico.

Los productos químicos utilizados después para la limpieza de los tubos o la coraza deben circular en un sistema cerrado. Normalmente, la solución de limpieza circula desde un camión cisterna, y la solución contaminada en el sistema se drena a un camión para su eliminación.

\section{Bombas}

Una de las funciones más importantes del proceso es el movimiento de líquidos, para lo cual existen en la industria química todo tipo de bombas. Las bombas herméticas y magnéticas son bombas centrífugas sin precintos. Existen accionadores de bombas magnéticas para su instalación en otros tipos de bombas para prevenir fugas. En la Tabla 77.8 se citan los tipos de bombas utilizados en la industria de procesos químicos.

\section{Sellado}

Desde el punto de vista de la salud y la seguridad, el sellado y la reparación de las bombas centrífugas son los principales motivos de preocupación. Los precintos mecánicos, que constituyen los principales sistemas de sellado, pueden presentar fugas $y$, en ocasiones, hincharse. No obstante, se han producido avances importantes en la tecnología del sellado desde el decenio de 1970, que han dado lugar a una reducción significativa de las fugas y han ampliado la vida útil de la bomba. Algunas de estas mejoras son: precintos de fuelle, precintos de cartucho, diseños externos mejorados, mejores materiales externos y mejoras en el control de las variables de la bomba. La continua investigación en la tecnología del sellado permitirá otras mejoras tecnológicas.

\section{Tabla 77.8 • Bombas en la industria de proceso de} productos químicos.

$\begin{array}{ll}\text { - Centrífugas } & \text { - De membrana } \\ \text { - Alternativas (pistón) } & \text { - De flujo axial } \\ \text { - Herméticas } & \text { - De hélice } \\ \text { - Magnéticas } & \text { - De cavidad móvil } \\ \text { - De turbina } & \text { - De lóbulos } \\ \text { - De engranajes } & \text { - De paletas }\end{array}$


En caso de fluidos altamente tóxicos se instalan con frecuencia bombas sin fugas o sin precintos, herméticas o magnéticas. El período de servicio operativo o el tiempo medio entre operaciones de mantenimiento ha mejorado notablemente y, en general, varía entre tres y cinco años. En estas bombas, el fluido del proceso es el fluido lubricante para los cojinetes del rotor. La vaporización del fluido interno afecta adversamente a los cojinetes, y a menudo hace necesaria su sustitución. Las condiciones del líquido en las bombas pueden mantenerse siempre que la presión interna en el sistema de cojinetes sea mayor que la presión de vapor del líquido a la temperatura de trabajo. Al reparar una bomba sin sellado, es importante drenar por completo un material de volatilidad relativamente pequeña bajo la supervisión del proveedor.

En las bombas centrífugas típicas el empaquetamiento se ha sustituido por precintos mecánicos, que se clasifican en general en sencillos y duales, y entre éstos últimos, tándem o dobles. Existen otras combinaciones de precintos duales, pero no se utilizan tanto. En general, los precintos mecánicos tándem o dobles con fluidos amortiguadores de líquido entre los precintos se instalan para reducir las fugas del precinto. El American Petroleum Institute (API 1994) publicó normas en materia de precintos mecánicos para las bombas centrífugas y rotativas, en las que se incluían la especificación e instalación de precintos mecánicos simples y duales. Actualmente existe una guía de aplicaciones de precintos mecánicos muy útil para evaluar los distintos tipos de precinto (STLE 1994).

A fin de prevenir un exceso de fugas o hinchamientos a causa del fallo de un precinto, se instala un casquillo prensaestopas detrás del precinto. Puede haber un fluido de chorro del prensaestopas para trasladar la fuga a un sistema de drenaje cerrado (API 1994). El sistema prensaestopas no es un precinto completo, por lo que se dispone de sistemas de sellado auxiliar, como manguitos aisladores. Estos están instalados en el casquillo que controla las fugas excesivas a la atmósfera o el hinchamiento del precinto (Liton y Lynch 1994). El diseño de estos precintos no está pensado para un funcionamiento continuo; tras su activación funcionan durante dos semanas, dando tiempo para cambiar las bombas o realizar ajustes en el proceso.

Existe un sistema de sellado mecánico más reciente que reduce esencialmente las emisiones a cero. Se trata de un sistema mecánico doble con un sistema amortiguador de gas que sustituye el amortiguador líquido del sistema de sellado mecánico dual (Fone 1995; Netzel 1996; Adams, Dingman y Parker 1995). En los sistemas de amortiguación líquidos, las caras del precinto están separadas por una película lubricante extremadamente delgada de fluido amortiguador ,que también enfría las caras del precinto. Aunque están ligeramente separados, existe cierto contacto frontal que da lugar al deterioro del precinto y al calentamiento de la cara del precinto. Los precintos de gas se llaman precintos sin contacto, ya que una cara del precinto con muescas curvas bombea gas a través de las caras del precinto y forma una capa o dique de gas que separa completamente dichas caras. Esta falta de contacto concede una vida muy larga al precinto al par que reduce la pérdida por fricción, lo que hace que disminuya considerablemente el consumo de energía. Debido a que el precinto bombea gas, el flujo al proceso y a la atmósfera es muy pequeño.

\section{Riesgos para la salud}

Un motivo de inquietud importante con respecto a las bombas es el drenaje y rociado de la bomba para su mantenimiento o reparación. El drenaje o purgado y la retirada incluyen el fluido del proceso y del amortiguador. Estos procedimientos requieren la descarga de todos los fluidos en un sistema de drenaje de conexión cerrada. En el manguito prensaestopas de la bomba en el
Tabla 77.9 • Posibles fuentes de explosión en los equipos.

$\begin{array}{ll}\text { Equipo de transporte } & \text { Almacenamiento } \\ \text { - Conducciones neumáticas } & \text { - Contenedores } \\ \text { - Transportadores mecánicos } & \text { - Tolvas } \\ & \text { - Válvulas rotativas } \\ \text { Equipo de proceso } & \text { - Trituradores } \\ \text { - Colectores de polvo en filtros } & \text { - Molinos de bolas } \\ \text { - Secadores de lecho fluido } & \text { - Mezclado de polvos } \\ \text { - Secadores de banda } & \text { - Ciclones }\end{array}$

que el manguito aislador separa el propulsor del prensaestopas, el manguito actúa como un aliviadero, ya que recoge parte del líquido. Las salidas de alivio del manguito o del drenaje del prensaestopas permiten la eliminación completa del líquido del proceso mediante drenaje y rociado. En el caso de fluidos amortiguadores, debería existir un método para drenar todo el fluido del área de sellado dual. El mantenimiento requiere la eliminación del precinto y, si el volumen no se drena y rocía completamente, los precintos pueden suponer una fuente de exposición durante la reparación.

\section{Polvos}

La manipulación de polvos en el equipo de procesado de sólidos constituye un motivo de preocupación debido a la posibilidad de incendio o explosiones. La explosión de un equipo puede hacerlo traspasar una pared o cierre como resultado de la presión generada, y enviar una onda de presión y fuego al área de trabajo. Los trabajadores pueden correr peligro, y el equipo adyacente recibir impactos fuertes con efectos drásticos. El polvo suspendido en el aire o en un gas con oxígeno y en un espacio confinado en ocasiones explota si hay presente una fuente de ignición con energía suficiente. En la Tabla 77.9 se presentan algunos ambientes explosivos típicos de los equipos.

Una explosión produce calor y la expansión rápida del gas (aumento de presión) y generalmente produce deflagración, que es un frente de llama que se desplaza rápidamente pero a una velocidad menor que la del sonido para estas condiciones. Cuando la velocidad del frente de la llama es mayor que la velocidad del sonido o es una velocidad supersónica, la condición se denomina detonación, que es más destructiva que la deflagración. La explosión y la expansión del frente de la llama ocurren en milisegundos y no dan tiempo suficiente para las respuestas estándar del proceso. En consecuencia, deben definirse las características de los posibles incendios y explosiones para determinar los riesgos que existen en las distintas etapas del tratamiento (CCPS 1993; Ebadat 1994; Bartknecht 1989; Cesana y Siwek 1995). Así pues, esta información puede servir de base para la instalación de controles y la prevención de explosiones.

\section{Cuantificación del riesgo de explosión}

Las explosiones se producen generalmente en equipo cerrado, por lo que se han realizado varios ensayos en equipos de laboratorio diseñados especialmente. Aunque los polvos parezcan similares, no deberían utilizarse los resultados publicados, ya que unas pequeñas diferencias entre ellos pueden significar que poseen características distintas de explosión.

Es posible definir el riesgo de explosión mediante diversas pruebas realizadas con polvos; entre éstas se hallan las descritas a continuación. 
La prueba de clasificación determina si una nube de polvo puede iniciar y propagar llamas (Ebadat 1994). Los polvos con estas características se consideran polvos de Clase A; los que no arden, se incluyen en la Clase B. Los polvos de Clase A necesitan después más ensayos para evaluar su potencial de explosión y riesgo.

La prueba de energía mínima de ignición define la energía de chispa mínima necesaria para la ignición de una nube de polvo (Bartknecht 1989; Garzia y Senecal 1996).

En el análisis de la gravedad de la explosión, los polvos del Grupo A se someten a una prueba posterior en la que se introducen en forma de nube de polvo en una esfera, donde la presión se mide durante una explosión de ensayo basada en la energía mínima de ignición. Se define la presión máxima de explosión junto con el gradiente de presión (variación de la presión por unidad de tiempo). A partir de esta información se determina el valor característico específico de la explosión (Kst) en bar metros por segundo y se define la clase de explosión (Bartknecht 1989; Garzia y Senecal 1996):

$\begin{array}{lll}\text { Kst (bar } \cdot \mathrm{m} / \mathrm{s}) & \text { Clase de explosión de polvo } & \text { Intensidad relativa } \\ 1-200 & \text { St } 1 & \text { Moderada } \\ 201-300 & \text { St } 2 & \text { Fuerte } \\ 300+ & \text { St } 3 & \text { Muy fuerte }\end{array}$

Se ha ensayado con muchos polvos, y la mayoría fueron de clase ST 1 (Bartknecht 1989; Garzia y Senecal 1996).

En la evaluación de los polvos que no forman nubes, la prueba se hace para determinar las condiciones y los procedimientos seguros de trabajo.

\section{Pruebas de prevención de explosiones}

Resultan útiles cuando no pueden instalarse sistemas de supresión de explosiones. Proporcionan información sobre las condiciones deseables de trabajo (Ebadat 1994).

La prueba de oxígeno mínimo define el nivel de oxígeno por debajo del cual el polvo no arderá (Fone 1995). Un gas inerte del proceso impedirá la ignición si el gas es aceptable.

Se determina la concentración mínima de polvo con el fin de establecer el nivel de trabajo por debajo del cual no puede producirse la ignición.

\section{Pruebas de riesgo electrostático}

Muchas explosiones son el resultado de combustiones electrostáticas y los posibles riesgos los determinan las diferentes pruebas. Algunas de ellas incluyen la energía mínima de ignición, las características de la carga eléctrica del polvo y la resistividad del volumen. A partir de los resultados de las pruebas es posible tomar ciertas medidas en la prevención de las explosiones, como el aumento de la humedad, la modificación de los materiales de construcción, las instrucciones adecuadas, el control de determinados aspectos del diseño del equipo y la prevención de chispas (Bartknecht 1989; Cesana y Siwek 1995).

\section{Control de la explosión}

Básicamente, son dos los métodos para controlar las explosiones o frentes de forma que no se propaguen de un lugar a otro o para contener las explosiones en un aparato: supresores químicos y válvulas de aislamiento (Bartknecht 1989; Cesana y Siwek 1995; Garzia y Senecal 1996). Sobre la base de los datos de la presión de la explosión obtenidos en las pruebas de gravedad de la explosión, se dispone de sensores de respuesta rápida que activarán un supresor químico o válvulas barrera de aislamiento de cierre rápido. Los supresores se encuentran en el mercado, pero conviene recordar que el diseño del inyector del supresor es muy importante.

\section{Parámetros débiles o discos de ruptura}

En los equipos en los que existe un peligro de explosión se instalan con frecuencia orificios de liberación de las sobrepresiones explosivas que se activan a presiones específicas. Estos deben diseñarse cuidadosamente y debe definirse la vía de escape del equipo para prevenir la presencia del operario en esta zona. Asimismo, debe analizarse qué equipos van a verse afectados en el recorrido de la explosión, con el fin garantizar su seguridad. Tal vez sea necesaria una barrera.

\section{Carga y descarga}

Los productos finales, los intermedios y los subproductos se cargan en camiones cisterna y vagones. (En algunos casos, en función de la situación de las instalaciones y los requisitos del muelle, se utilizan camiones tanque y remolques). Es importante la situación de las instalaciones de carga y descarga. Aunque los materiales cargados y descargados son habitualmente líquidos y gases, también se cargan y descargan sólidos en lugares preferentes en función del tipo de sólidos desplazados, el riesgo potencial de explosión y el grado de dificultad de la transferencia.

\section{Escotillas abiertas.}

Durante la carga de vagones cisterna o vagones a través de escotillas superiores abiertas, un aspecto muy importante es minimizar las salpicaduras al llenar el contenedor. Si la tubería de llenado se encuentra mucho más arriba del fondo del recipiente, se producen muchas salpicaduras y vapor o mezclas de líquido y vapor. Las salpicaduras y la generación de vapor pueden reducirse situando la salida de la tubería de llenado muy por debajo del nivel de líquido. La tubería de llenado normalmente se extiende a través del recipiente a una distancia mínima del fondo. Debido a que el llenado de líquido también desplaza vapor, los vapores tóxicos pueden entrañar un riesgo para la salud y suscitar preocupación en cuanto a la seguridad, por lo que deben recogerse. Se comercializan unos brazos de llenado con tuberías de llenado profundas y que se extienden a través de una cubierta especial que cierra la abertura de la escotilla (Lipton y Lynch 1994). Asimismo, una tubería de recolección de vapor se extiende a escasa distancia por debajo de la cubierta especial de la escotilla. En el extremo del brazo que recoge el flujo, la salida de vapor se conecta a un dispositivo de recuperación (p. ej., un absorbente o un condensador), o bien el vapor puede volver al tanque de almacenamiento como una transferencia de vapor de equilibrio (Lipton y Lynch 1994).

En el sistema de escotilla abierta del camión cisterna, el brazo se eleva para permitir el drenaje en el camión cisterna y parte del líquido del brazo puede presurizarse con nitrógeno al retirar el brazo, pero durante esta operación las tuberías de llenado deben permanecer dentro de la abertura de la escotilla. Cuando el brazo de llenado deja la escotilla, debe colocarse un cubo sobre la salida para recoger el goteo del brazo.

\section{Vagones}

Muchos vagones tienen escotillas cerradas con cañas de llenado muy próximas al fondo del recipiente y una salida independiente de recogida de vapor. El líquido se carga a través de un brazo que se extiende hacia la escotilla cerrada, y el vapor se recoge de forma similar al método del brazo de la escotilla abierta. En los sistemas de carga de vagones, después del cierre de la válvula en la entrada del brazo, se inyecta nitrógeno en la parte del recipiente de los brazos para impulsar el líquido remanente en el brazo dentro del vagón antes de que se cierre la válvula de llenado del vagón (Lipton y Lynch 1994). 


\section{Camiones cisterna}

Muchos camiones cisterna se llenan a través del fondo para minimizar la generación de vapor (Lipton y Lynch 1994). Los conductos de llenado pueden ser mangueras especiales o brazos maniobrables. En su extremo y en las conexiones del fondo del camión cisterna se colocan acoplamientos secos. Cuando el vagón cisterna está lleno y el conducto se bloquea automáticamente, el brazo o la manguera se desconecta del acoplamiento, que automáticamente se cierra. Existen unos acoplamientos nuevos que se desconectan sin apenas fugas.

En la carga de fondo, el vapor se recoge mediante una válvula de vapor superior y se conduce a través de una línea externa que termina cerca del fondo del recipiente (Lipton y Lynch 1994). Esto permite que los trabajadores accedan a las conexiones del vapor. El vapor recogido, a una presión ligeramente superior a la atmosférica, debe ser recogido y enviado a un dispositivo de recuperación (Lipton y Lynch 1994). Estos dispositivos se eligen en función del coste inicial, la eficacia, el mantenimiento y la capacidad operativa. En general, es preferible el sistema de recuperación a una antorcha, que destruye los vapores recuperados.

\section{Control de carga}

En los camiones cisterna hay sensores de nivel instalados permanentemente en el cuerpo del camión que indican cuándo se ha alcanzado el nivel de llenado y envían una señal a una válvula de bloqueo de control remoto que detiene el flujo al camión. (Lipton y Lynch 1994). Puede haber más de un sensor en el camión cisterna para asegurar que éste no se ha llenado en exceso, ya que podría dar lugar a graves problemas de exposición para la salud y la seguridad.

Los vagones de los servicios químicos tienen a veces sensores de nivel montados internamente en el vehículo. En otros vagones, un medidor de flujo controla la cantidad de líquido enviada al vagón y automáticamente cierra la válvula de bloqueo de control remoto en un lugar determinado (Lipton y Lynch 1994). Deben investigarse ambos tipos de contenedores para determinar si permanece líquido en el contenedor antes del llenado. Muchos vagones tienen indicadores de nivel manuales que se utilizan con este fin. No obstante, en los casos en que se indica el nivel mediante la apertura de un escape recto a la atmósfera, este procedimiento debe realizarse sólo en condiciones correctamente controladas y aprobadas debido a la toxicidad de algunas de las sustancias químicas cargadas.

\section{Descarga}

Si los productos químicos tienen una presión de vapor muy alta y el vagón o el camión cisterna tienen una presión relativamente alta, el producto químico se descarga por debajo de su propia presión de vapor. Si la presión de vapor cae hasta un nivel que dificulte el procedimiento de descarga, se inyecta gas nitrógeno para mantener una presión satisfactoria. Asimismo se puede comprimir e inyectar el vapor de un tanque del mismo producto químico para aumentar la temperatura.

En el caso de productos químicos tóxicos con una presión de vapor relativamente baja, como el benceno, el líquido se descarga bajo presión de nitrógeno, lo que elimina el bombeo y simplifica el sistema (Lipton y Lynch 1994). Los camiones cisterna y los vagones para este servicio están diseñados para resistir las presiones y variaciones soportadas. No obstante, después de descargar un contenedor se mantienen presiones más bajas hasta que el camión cisterna o el vagón se vuelve a llenar; la presión se crea de nuevo durante la carga. Se puede añadir nitrógeno si no se ha conseguido una suficiente presión durante la carga.

Uno de los problemas de las operaciones de carga y descarga es las líneas de drenaje y de purga y el equipo en las instalaciones de carga y descarga. Se necesitan drenajes cerrados y en particular drenajes de punto bajo con purgas de nitrógeno para eliminar todas las trazas de productos químicos tóxicos. Estos materiales pueden recogerse en un tambor y trasladarse a una instalación receptora o de recuperación (Lipton y Lynch 1994).

\section{EJEMPLOS DE OPERACIONES DE TRATAMIENTO DE PRODUCTOS QUIMICOS}

\section{- PRODUCCION DE GLORO Y CAUSTICOS}

\section{The Chlorine Institute, Inc.}

La electrólisis de sal da lugar a la formación de cloro y un hidróxido. El cloruro sódico $(\mathrm{NaCl})$ es la principal sal utilizada; produce sosa cáustica $(\mathrm{NaOH})$. No obstante, si se utiliza cloruro potásico $(\mathrm{KCl})$ se obtiene potasa cáustica $(\mathrm{KOH})$.

$$
2 \mathrm{NaCl}+2 \mathrm{H}_{2} \mathrm{O} \rightarrow \mathrm{Cl}_{2} \uparrow+2 \mathrm{NaOH}+\mathrm{H}_{2} \uparrow
$$

sal + agua $\rightarrow$ cloro (gas) + hidróxido + hidrógeno (gas)

Actualmente, el proceso en celda de diafragma es el más utilizado para la producción comercial de cloro, seguido del proceso en celda de mercurio y del proceso en celda de membrana. Debido a aspectos económicos, ambientales y de calidad del producto, los fabricantes prefieren ahora el de membrana para las nuevas instalaciones de producción.

\section{El proceso en celda de diafragma}

En la celda de diafragma (véase Figura 77.4) se introduce una solución saturada de sal en un compartimiento que contiene un ánodo de titanio revestido de sales de rutenio u otros metales. Un colector de plástico recoge el gas cloro húmedo caliente producido en este ánodo. La succión por un compresor lleva el cloro a un colector para su posterior tratamiento, consistente en enfriado, secado y compresión. El agua y la sal sin reaccionar percolan a través de un separador de diafragma poroso en el compartimiento del cátodo en el que el agua reacciona en un cátodo de acero y produce hidróxido sódico (sosa cáustica) e hidrógeno. El diafragma mantiene separados el cloro producido en el ánodo del hidróxido sódico y el hidrógeno producidos en el cátodo. Si estos productos se combinan, el resultado es hipoclorito sódico (lejía) o clorato sódico. Los productores comerciales de clorato sódico utilizan celdas que no tienen separadores. El diafragma más habitual es un compuesto de amianto y un polímero fluorocarbonado. Las plantas modernas de celdas de diafragma no presentan los problemas de salud y ambientales asociados tradicionalmente al uso de los diafragmas de amianto. Algunas plantas emplean diafragmas sin amianto, comercializados ahora. El proceso en celda de diafragma produce una solución diluida de hidróxido sódico que contiene sal sin reaccionar. Un proceso de evaporación adicional concentra el hidróxido y elimina la mayor parte de la sal para preparar un hidróxido de calidad comercial. 
Figura 77.4 • Tipos de procesos en celdas de cloruros alcalinos.

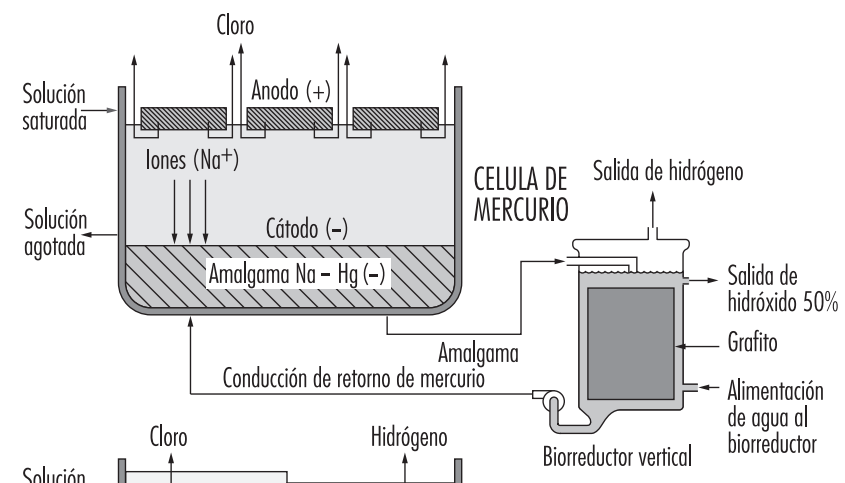

de intercambio de cationes en lugar del diafragma poroso (véase Figura 77.4). Esta membrana previene la migración de los iones cloruro hacia el cátodo, produciendo así esencialmente hidróxido del 30 al $35 \%$ exento de sal, directamente en la celda. La eliminación de la necesidad de retirar la sal hace que la evaporación de la solución alcalina para llegar a la concentración comercial del $50 \%$ sea más sencilla, y requiere menos inversiones y energía. En la celda de membrana se utiliza como cátodo níquel, muy caro, debido a la mayor agresividad del álcali.

\section{Riesgos para la seguridad y la salud}

A temperaturas ordinarias el cloro seco, en forma de líquido o de gas, no corroe el acero. El cloro húmedo es altamente corrosivo debido a que forma ácidos clorhídrico e hipocloroso. Deben adoptarse precauciones para mantener seco el cloro y el equipo que lo contiene. Deben cerrarse o taparse tuberías, válvulas y recipientes cuando no se utilicen, para protegerlos de la humedad atmosférica. Si se utiliza agua en una fuga de cloro las condiciones corrosivas resultantes empeorarán dicha fuga.

El volumen de cloro líquido aumenta con la temperatura. Deben adoptarse precauciones para evitar la ruptura hidrostática de las tuberías, los recipientes, los contenedores u otros equipos llenos de cloro líquido.

El hidrógeno es un producto secundario de todo proceso de fabricación de cloro mediante la electrólisis de soluciones acuosas de sal. En un intervalo de concentraciones las mezclas de cloro e hidrógeno son inflamables y potencialmente explosivas. La reacción de cloro e hidrógeno puede iniciarse por luz solar directa, otras fuentes de luz ultravioleta, electricidad estática o un impacto fuerte.

En la fabricación de cloro es posible que se produzcan pequeñas cantidades de tricloruro de nitrógeno, un compuesto inestable y altamente explosivo. Cuando se evapora el cloro líquido que contiene tricloruro de nitrógeno, éste puede alcanzar concentraciones peligrosas en el cloro líquido remanente.

El cloro reacciona, a veces explosivamente, con diversos materiales orgánicos, como aceite o grasa, procedentes de compresores de aire, válvulas, bombas e instrumentos de diafragma con aceite, así como madera y alfombrillas usadas en los trabajos de mantenimiento.

En cuanto exista alguna indicación de escape de cloro, deben tomarse ciertas medidas inmediatas para corregir la situación. Las fugas de cloro siempre empeoran si no se corrigen rápidamente. Cuando se produce una fuga de cloro, el personal autorizado y capacitado, equipado con equipo de protección personal (EPP) respiratorio y de otro tipo, debe investigar y adoptar las medidas oportunas. Estas personas no deben entrar en atmósferas que contengan concentraciones de cloro superiores a la concentración inmediatamente peligrosa para la vida y la salud (IPVS) $(10 \mathrm{ppm}) \sin$ un equipo de protección personal adecuado y personal de apoyo. El personal innecesario debe mantenerse apartado y el área de riesgo aislarse. Las personas posiblemente afectadas por un escape de cloro deben ser evacuadas o protegidas en el lugar, según lo requieran las circunstancias.

Los monitores de cloro y los indicadores de dirección del viento del área pueden proporcionar información oportuna (p. ej., vías de escape) para ayudar a determinar si el personal debe ser evacuado o protegido en el lugar.

En caso de evacuación, las personas con riesgo de exposición deben situarse en un lugar en dirección opuesta a la fuga. Dado que el cloro es más pesado que el aire, es preferible que el lugar esté alto. Para escapar cuanto antes, las personas que ya se encuentren en el área contaminada deben avanzar con el viento de costado. 
Si se opta por permanecer y protegerse en el mismo edificio, se cerrarán todas las ventanas, puertas y otras aberturas, así como los acondicionadores de aire y los sistemas de entrada de aire. El personal debe situarse en la parte del edificio más lejana al escape y siempre con una vía de escape cercana. Conviene recordar, igualmente, que es posible que cualquier posición segura pase a ser peligrosa si cambia la dirección del viento, o en caso de que se produzcan nuevas fugas o que la ya existente aumente.

Si existe fuego o éste es inminente, los contenedores de cloro y el equipo deben alejarse del fuego, si es posible. Si un contenedor o equipo sin fugas no puede moverse, debe mantenerse frío aplicando agua. No debe utilizarse directamente agua sobre una fuga de cloro. El agua y el cloro reaccionan formando ácidos, y la fuga empeorará rápidamente. No obstante, en los casos en que se vean implicados varios contenedores y algunos tengan fugas, tal vez convenga utilizar un pulverizador de agua para prevenir la sobrepresión de los contenedores sin fugas.

Siempre que los contenedores hayan estado expuestos a llamas, debe aplicarse agua fría hasta mucho después de que el incendio se haya extinguido y los contenedores se hayan enfriado. Los contenedores expuestos al fuego deben aislarse, y se informará cuanto antes al proveedor.

Las soluciones de hidróxido sódico son corrosivas, sobre todo si son concentradas. Los trabajadores con riesgo de exposición a vertidos y fugas deben llevar guantes, mascarillas y gafas y otras ropas protectoras.

Agradecimientos: Agradecemos al Dr. R.G. Smerko su colaboración al haber puesto a nuestra disposición los recursos del Chlorine Institute, Inc.

\section{- FABRICACION DE PINTURAS Y REVESTIMIENTOS}

\section{Michael McCann*}

Se agrupan bajo los términos pinturas y revestimientos a las pinturas, barnices, lacas, colorantes, tintas para impresión y otros productos. Las pinturas tradicionales consisten en una dispersión de partículas de pigmentos en un vehículo formado por un agente reticulante o un secante (un aceite o una resina, por lo común) y un diluyente (por lo general, un disolvente volátil). Asimismo puede contener una gran variedad de cargas y otros aditivos. Un barniz es una solución de aceite y resina natural en un disolvente orgánico. También se utilizan resinas sintéticas. Las lacas son revestimientos en los que la película se seca o endurece completamente por evaporación del disolvente.

Las pinturas tradicionales constaban de menos de un $70 \%$ de sólidos y el resto eran en su mayor parte disolventes. A raíz de las normas sobre contaminación atmosférica que limitan la cantidad de disolventes que pueden ser emitidos a la atmósfera, se han elaborado múltiples tipos de pinturas con poco o ningún disolvente orgánico. Entre éstas se encuentran: pinturas de látex a base de agua; pinturas catalizadas mixtas (p. ej., sistemas epoxi y uretano); pinturas con alto contenido en sólidos (más del $70 \%$ de sólidos), incluidas las pinturas plastisol formadas principalmente por pigmentos y plastificantes; pinturas curadas con radiaciones; y revestimientos de pintura en polvo.

Según el National Institute for Occupational Safety and Health (NIOSH 1984), de Estados Unidos, aproximadamente el $60 \%$ de los fabricantes de pinturas empleaban menos de 20 trabajadores, y solamente un $3 \%$ tenía más de 250 trabajadores. Es posible que estas estadísticas sean representativas de

*Adaptado de NIOSH 1984. los fabricantes de pinturas en todo el mundo. Esto indica el predominio de las pequeñas empresas, muchas de las cuales no disponen de expertos internos en salud y seguridad.

\section{Procesos de fabricación}

En general, la fabricación de pinturas y otros revestimientos consiste en una serie de operaciones unitarias en las que se emplean procesos discontinuos. Las reacciones químicas son pocas o ninguna; las operaciones son en su mayoría mecánicas. La fabricación implica la reunión de las materias primas, el mezclado, la dispersión, la dilución y el afinado, llenado de recipientes y almacenamiento.

\section{Pinturas}

Las materias primas utilizadas para fabricar pinturas se encuentran en forma de líquidos, sólidos, polvos, pastas y suspensiones. Se pesan manualmente y se mezclan. Las partículas aglomeradas de pigmento deben disgregarse al tamaño original, y humectarse con aglutinante para asegurar la dispersión en la matriz líquida. Este proceso de dispersión, llamado molienda, se realiza con distintos tipos de equipos, incluidos dispersadores con eje motriz de alta velocidad, mezcladores de sólidos, molinos de bolas, molinos de arena, molinos de tres rodillos, trituradores, etc. Después de un tratamiento inicial, que puede durar hasta 48 horas, se añade resina a la pasta y se repite el proceso de molienda durante un período más corto. El material disperso se transfiere después por gravedad a un tanque de decantación en el que se pueden añadir otros materiales como colorantes. En el caso de pinturas a base de agua el aglutinante se añade en esta etapa. Después se diluye la pasta con resina o disolvente, se filtra y se transfiere de nuevo por gravedad al área de llenado de envases, que se realiza manual o mecánicamente.

Después del proceso de dispersión puede ser necesario limpiar los tanques y los molinos antes de introducir un nuevo lote. En esta etapa se utilizan herramientas manuales y eléctricas, así como limpiadores alcalinos y disolventes.

\section{Lacas}

La producción de lacas se realiza habitualmente en equipos cerrados como tanques y mezcladores, con el fin de minimizar la evaporación del disolvente, lo que podría causar el depósito de una película de laca seca sobre el equipo de procesado. Por lo demás, la producción de laca tiene lugar de la misma forma que la producción de pintura.

\section{Barnices}

En la fabricación de barnices de oleorresinas se calientan el aceite y la resina para hacerlos más compatibles, desarrollar moléculas o polímeros de alto peso molecular y aumentar la solubilidad en el disolvente. Las plantas antiguas utilizan recipientes portátiles y abiertos para el calentamiento. Se añaden a éstos la resina y el aceite o la resina sola y después se calientan a aproximadamente $316^{\circ} \mathrm{C}$. Las resinas naturales se deben calentar antes de añadir los aceites. Los materiales se vacian por la parte superior del recipiente. Durante el calentamiento, se cubren con campanas de extracción refractarias. Después se trasladan a salas en las que se enfrían rápidamente, a menudo por rociado con agua, y después se añaden el diluyente y los secantes.

En las plantas modernas se utilizan grandes reactores cerrados con capacidades de 500 a 8.000 galones. Estos reactores son similares a los utilizados en la industria de procesos químicos. Están provistos de agitadores, mirillas, tuberías para llenar y vaciar los reactores, condensadores, dispositivos de medición de la temperatura, fuentes de calor, etc.

Tanto en las plantas antiguas como en las modernas, la resina diluida se filtra en una etapa final antes del envasado. Esto se 
Figura 77.5 • Diagrama de flujo para la fabricación de revestimientos de polvo por el método de fusión y extrusión-mezcla.

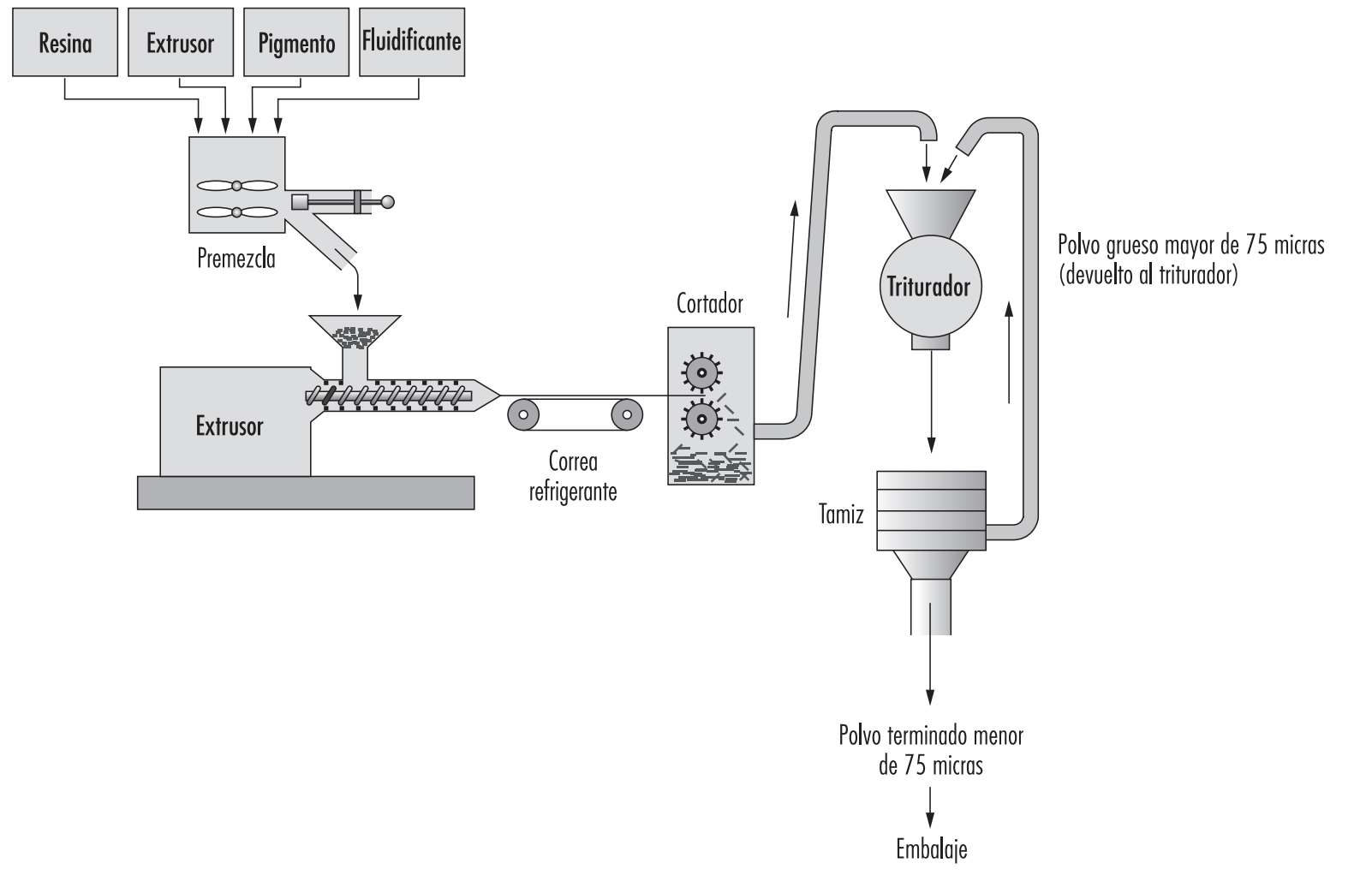

realiza normalmente cuando la resina aún está caliente, utilizando un filtro prensa.

\section{Revestimientos en polvo}

Los revestimientos en polvo son productos sin disolventes basados en la fusión de resinas y otras partículas de aditivos sobre las superficies de objetos calientes. Los revestimientos en polvo pueden ser termoestables o termoplásticos e incluyen resinas de tipo epoxi, polietileno, poliéster, cloruro de polivinilo y acrílicas.

El método más habitual de fabricación consiste en la mezcla en seco de los ingredientes pulverulentos y el mezclado por fusión y extrusión (véase Figura 77.5). Se pesan la resina seca o el aglutinante, el pigmento, el material de carga y los aditivos y se transfieren a un mezclador. Este proceso es similar a las operaciones de mezclado en seco en la fabricación de caucho. Después del mezclado, el material se coloca en un extrusor y se calienta hasta que se funde. El material fundido se extruye sobre una correa transportadora refrigerante y después se transfiere a un granulador. El granulado se pasa a través de un molino fino y se tamiza para obtener el tamaño de partícula deseado. Por último el revestimiento en polvo se envasa.

\section{Riesgos y su prevención}

En general, los principales riesgos asociados con la fabricación de pintura y revestimientos supone la manipulación de materiales, que pueden ser sustancias tóxicas, inflamables o explosivas; y agentes físicos como descargas eléctricas, ruido, calor y frío.

La manipulación manual de cajas, barriles, recipientes, etc., que contienen las materias primas y los productos terminados, es la principal fuente de lesiones debido a la elevación incorrecta, deslizamientos, caídas, goteo de recipientes, etc. Las precauciones incluyen controles técnicos y ergonómicos tales como medios auxiliares para manipulación de materiales (rodillos, gatos y plataformas) y equipos mecánicos (transportadores, montacargas y elevadores-transportadores de horquilla), suelos antideslizantes, equipo de protección personal (EPP) como zapatos de seguridad y la formación adecuada en la elevación manual y otras técnicas de manipulación de materiales.

Los riegos químicos incluyen la exposición a polvos tóxicos como pigmento de cromato de plomo, que puede presentarse durante la pesada, el llenado del mezclador y las tolvas del molino, las operaciones con equipos abiertos, el llenado de recipientes de pinturas en polvo y la limpieza del equipo y de los vertidos de los recipientes. La fabricación de revestimientos en polvo ocasiona a veces altas exposiciones al polvo. Las precauciones a adoptar son la sustitución de polvo por pasta o suspensiones; la ventilación por extracción localizada (LEV) para la abertura de bolsas y sacos (véase Figura 77.6) y para el equipo de proceso, el cierre del equipo, los procedimientos de limpieza de vertidos y la protección respiratoria cuando sea necesaria.

En la fabricación de pinturas y revestimientos se utilizan diversos disolventes volátiles, entre ellos hidrocarburos alifáticos y aromáticos, alcoholes, cetonas, etc. Los disolventes más volátiles se encuentran normalmente en lacas y barnices. La exposición a los vapores de disolvente se puede producir durante la dilución en la fabricación de pinturas a base de disolventes; mientras se cargan los recipientes de reacción (especialmente los tipos más antiguos de recipientes) en la fabricación de barnices; durante el llenado de los envases con cualquier revestimiento a base de disolventes; y durante la limpieza manual del equipo de proceso con disolventes. El cerramiento de equipos como los reactores de barnices y los mezcladores de lacas normalmente implica menos exposición a los disolventes, excepto en caso de fugas. Las protecciones son el cerramiento de los equipos de 
Figura 77.6 - Sistema de control de polvo.

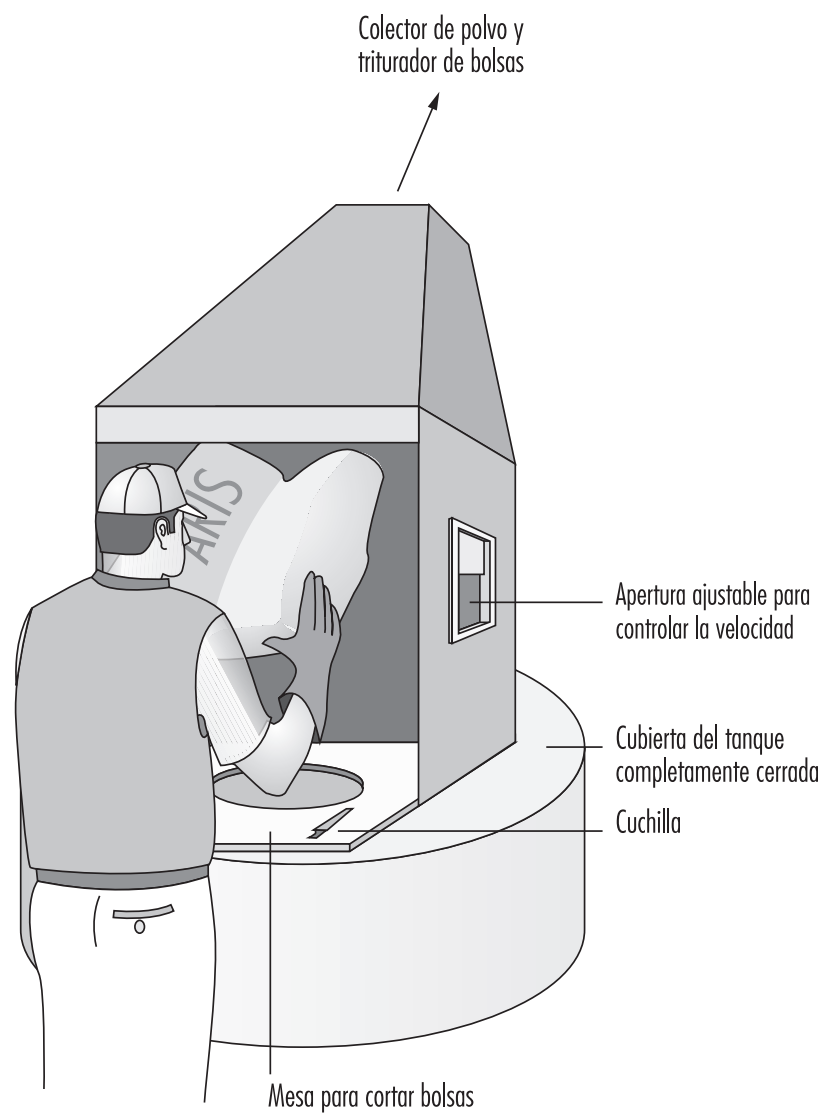

Fuente: adaptado de NIOSH 1984.

proceso, LEV para la dilución y el llenado de los envases y protección respiratoria y procedimientos de trabajo en espacios confinados aplicables a la limpieza de reactores.

Otros riesgos para la salud incluyen la inhalación o contacto de la piel con isocianatos, utilizados en la fabricación de pinturas y revestimientos de poliuretano; con acrilatos, otros monómeros y fotoiniciadores utilizados en la fabricación de revestimientos curados por radicación; con acroleína y otras emisiones gaseosas del calentamiento de los barnices; y con agentes endurecedores y otros aditivos en los revestimientos en polvo. Algunas protecciones son el cerramiento, LEV, guantes y otras ropas y equipos de protección personal, formación respecto a materiales peligrosos y buenas prácticas de trabajo.

Los disolventes inflamables, los polvos combustibles (especialmente nitrocelulosa utilizada en la producción de lacas) y los aceites tienen riesgo de explosión o incendio si se inflaman por una chispa o altas temperaturas. Las fuentes de ignición pueden ser un equipo eléctrico defectuoso, fumar, fricciones, llamas abiertas, electricidad estática, etc. Las alfombrillas empapadas de aceite originan a veces combustiones espontáneas. Las precauciones recomendadas son la conexión a tierra de los recipientes al transferir líquidos inflamables, y de equipos como molinos de bolas que contienen polvos combustibles, la ventilación para mantener la concentración de vapor por debajo del límite inferior de inflamabilidad, la cobertura de los contenedores fuera de uso, la eliminación de las fuentes de ignición, la utilización de herramientas antichispa de metales no ferrosos en proximidad de materiales inflamables o combustibles y las buenas practicas en las operaciones de mantenimiento.

Los riesgos de ruido se pueden asociar al uso de molinos de bolas y martillos, dispersadores de alta velocidad, tamices vibradores utilizados para el filtrado, etc. Las medidas de precaución son aislantes de vibración y otros controles técnicos, la sustitución del equipo ruidoso, un buen mantenimiento del equipo, el aislamiento de la fuente de ruido y un programa de conservación de audición cuando el ruido sea excesivo.

Entre otros riesgos se encuentra la protección inadecuada de las máquinas, que es una causa frecuente de lesiones ocasionadas por la maquinaria. Los riesgos eléctricos son un problema particular si no existe un programa de enclavamiento y desconexión para el mantenimiento y la reparación del equipo. Se pueden producir quemaduras debido a los recipientes de

Figura 77.7 • Secuencia de producción en el proceso de plásticos.

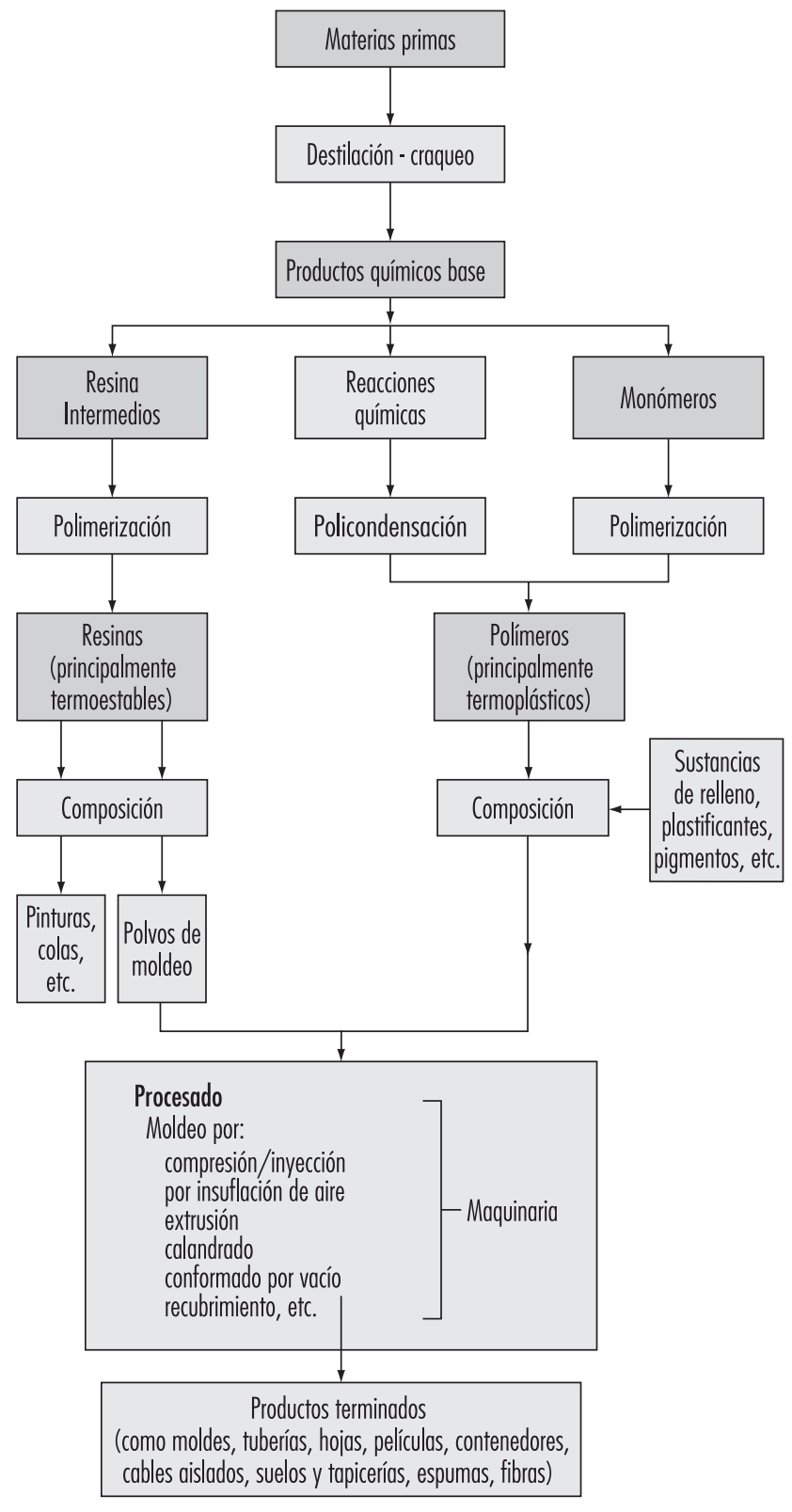


calentamiento de los barnices y a las salpicaduras de los materiales y a causa de las colas fundidas calientes utilizadas para envases y etiquetas.

\section{- INDUSTRIA DEL PLASTICO}

\section{P.K. Law y T.J. Britton*}

La industria del plástico se divide en dos sectores principales, cuya relación se representa en la Figura 77.7. El primer sector incluye los proveedores de materias primas que fabrican polímeros y compuestos de moldeo a partir de productos intermedios que ellos mismos pueden haber producido. En términos de capital invertido este es normalmente el mayor de los dos sectores. El segundo sector consta de manipuladores que convierten las materias primas en artículos vendibles utilizando diversos procesos como moldeo por extrusión e inyección. Otros sectores incluyen los fabricantes de maquinaria que proporcionan equipos a los manipuladores y proveedores de aditivos especiales para el uso en la industria.

\section{Fabricación de polímeros}

Los materiales plásticos se clasifican en dos grandes categorías: materiales termoplásticos, que se pueden ablandar repetidamente mediante la aplicación de calor y materiales termoestables, que experimentan un cambio químico cuando se calientan y moldean y no se pueden transformar posteriormente mediante la aplicación de calor. Es posible fabricar varios cientos de polímeros individuales con propiedades muy variables, pero menos de 20 tipos constituyen el $90 \%$ de toda la producción mundial. El mayor grupo es el de los termoplásticos, aumentando su producción a una velocidad mayor que la de los termoestables. En términos de cantidad de producción los termoplásticos más importantes son polietileno y polipropileno de alta y baja densidad (las poliolefinas), el cloruro de polivinilo (PVC) y el poliestireno.

Algunas resinas importantes del grupo termoestable son fenol-formaldehído y urea-formaldehído, ambas en forma de resinas y polvo para moldeo. También son destacables las resinas epoxi, los poliésteres insaturados y los poliuretanos. Un volumen menor de "plásticos técnicos", por ejemplo poliacetatos, poliamidas y policarbonatos, tienen un gran valor en aplicaciones específicas.

La considerable expansión de la industria de los plásticos después de la Segunda Guerra Mundial estuvo facilitada por el aumento en la oferta de materias primas básicas disponibles; esta disponibilidad y el precio de las materias primas son decisivos para cualquier industria en rápido crecimiento. Las materias primas tradicionales no podrían haber proporcionado productos químicos intermedios en cantidades suficientes a un coste aceptable para facilitar la producción comercial económica de toneladas de materiales plásticos; fue el desarrollo de la industria petroquímica lo que hizo posible este desarrollo. El petróleo, como materia prima, es abundante, fácil de transportar y manipular y hasta la crisis del decenio de 1970 era relativamente barato. Por consiguiente, en todo el mundo la industria de los plásticos está vinculada en primer lugar a la utilización de productos intermedios obtenidos del craqueo del petróleo y a partir del gas natural. Las materias primas no convencionales como biomasa y carbón aún no han tenido un impacto importante en el suministro a la industria de los plásticos.

El diagrama de flujo de la Figura 77.8 ilustra la versatilidad del petróleo crudo y del gas natural como puntos de partida

Adaptado de la tercera edición, Enciclopedia de salud y seguridad en el trabajo. para los importantes materiales termoestables y termoplásticos. Después de los primeros procesos de destilación del petróleo crudo, la materia prima nafta se craquea o reforma para obtener productos intermedios útiles. El etileno producido por el proceso de craqueo tiene aplicación inmediata en la fabricación de polietileno o en otro proceso del que se obtiene un monómero, el cloruro de vinilo, la base del PVC. El propileno, también obtenido durante el proceso de craqueo, se utiliza vía cumeno o vía isopropilalcohol para la fabricación de acetona, necesaria para el polimetilmetacrilato; también se utiliza en la fabricación de óxido de propileno para resinas de poliéster o poliéter y de nuevo puede polimerizarse directamente a polipropileno. Los butenos se utilizan en la fabricación de plastificantes y el 1,3-butadieno se utiliza directamente para la fabricación de caucho sintético. Los hidrocarburos aromáticos como benceno, tolueno y xileno se producen ahora principalmente a partir de derivados de la destilación del petróleo, en lugar de obtenerse a partir de procesos de coquificado de carbón; como se observa en el diagrama de flujo, estos son productos intermedios en la fabricación de los materiales plásticos más importantes y de los productos auxiliares como los plastificantes. Los hidrocarburos aromáticos son también un punto de partida para muchos polímeros requeridos por la industria de las fibras sintéticas, algunas de las cuales se comentan en otros lugares de esta Enciclopedia.

Son muchos, y muy diferentes entre sí, los procesos que contribuyen a la producción final de un artículo terminado hecho total o parcialmente de plástico. Unos procesos son puramente químicos, algunos implican procedimientos de mezclado puramente mecánicos mientras que otros, en particular aquellos hacia el extremo inferior del diagrama, implican el uso de maquinaria especializada. Algunas de estas máquinas son semejantes a las utilizadas en las industrias de caucho, vidrio, papel y textiles; las restantes son específicas de la industria de los plásticos.

\section{Procesado de plásticos}

La industria de proceso de plásticos convierte material polimérico a granel en artículos terminados.

\section{Materias primas}

La unidad de proceso de la industria del plástico recibe sus materias primas para la producción en las formas siguientes:

- material polimérico completamente formulado, en forma de pellets, gránulos o polvo, que se introduce directamente en las máquinas para su procesamiento

- polímeros no formulados, en forma de gránulos o polvo, que deben ser mezclados con aditivos antes de introducirlos en la maquinaria

- materiales en forma de hojas, rodillos, tubos y láminas poliméricos, que son sometidos a posteriores procesos en la industria

- otros materiales, que pueden ser totalmente polimerizados en forma de suspensiones o emulsiones (conocidos generalmente como dispersiones poliméricas) o líquidos o sólidos que pueden polimerizarse, o sustancias en un estado intermedio entre las materias primas reactivas y el polímero final. Algunos de estos son líquidos y algunos soluciones verdaderas de materiales parcialmente polimerizados en agua de acidez controlada $(\mathrm{pH})$ o en disolventes inorgánicos.

\section{Formulación}

La fabricación de compuestos a partir de polímeros implica la mezcla del polímero con aditivos. A pesar de la gran variedad de maquinaria utilizada con este fin, cuando se manejan polvos, los molinos de bolas o los agitadores de paletas de alta velocidad son los más habituales, y al mezclar masas de plástico normalmente 
Figura 77.8 • Esquema que ilustra la versatilidad de la producción, a partir de fracciones del petróleo, de materias primas en la fabricación de diversos tipos de plástico.

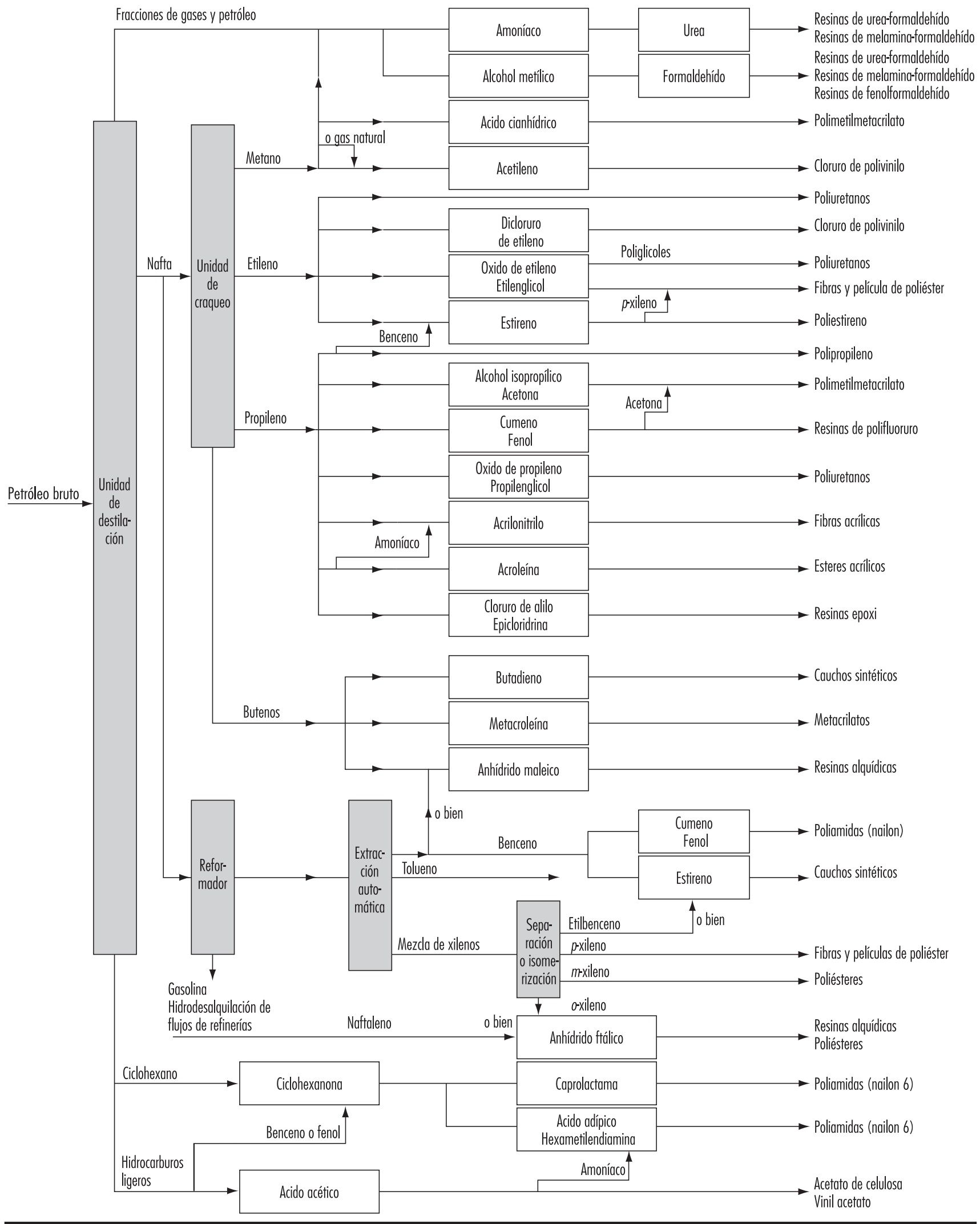




\section{Figura 77.9 • Técnico sacando un recipiente de polipropileno de una máquina de moldeo por inyección.}

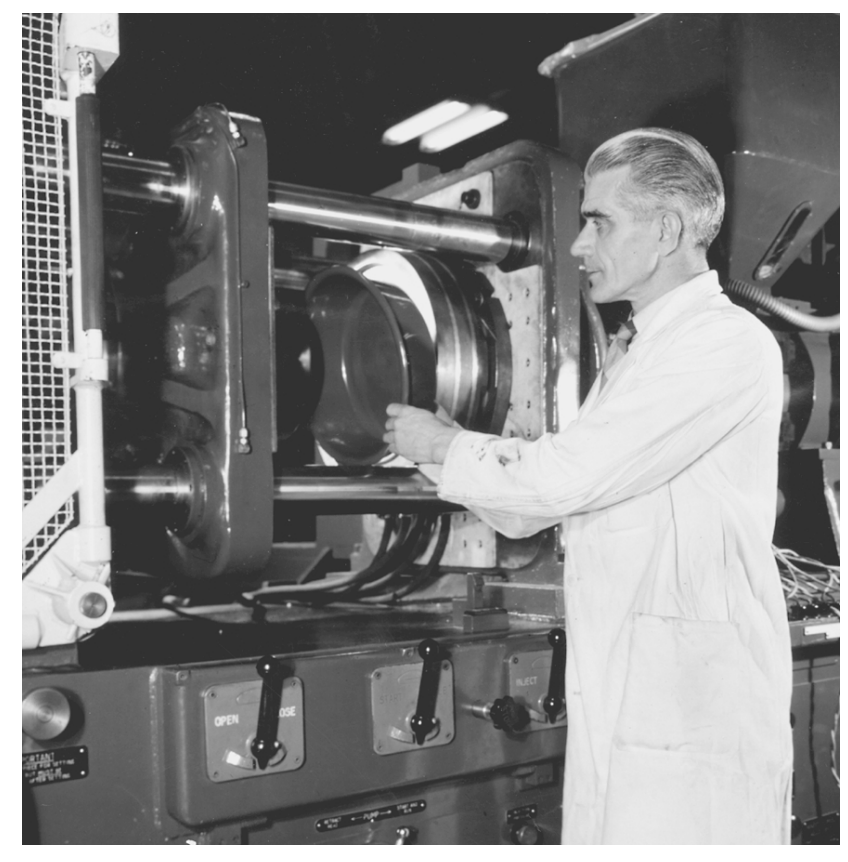

se utilizan máquinas mezcladoras tales como los de cilindros o mezcladores de tipo Banbury, o extrusores.

Los aditivos requeridos por la industria son muchos y de tipos químicos muy variados. De unas 20 clases, los más importantes son:

- plastificantes, generalmente ésteres de baja volatilidad

- antioxidantes, productos químicos orgánicos para proteger frente a la descomposición térmica durante el tratamiento

- estabilizantes, productos químicos inorgánicos u orgánicos para proteger frente a la descomposición térmica y frente a la degradación por energía radiante

- lubricantes

- materiales de carga, sustancias baratas que dan propiedades especiales o abaratan las composiciones

- colorantes, sustancias orgánicas o inorgánicas para teñir los compuestos

- agentes de espumación, gases o productos químicos que emiten gases para producir espumas plásticas

\section{Procesos de conversión}

Todos los procesos de conversión se basan en el fenómeno "plástico" de los materiales poliméricos y se clasifican en dos tipos. En primer lugar, aquellos en los que el polímero se lleva mediante calentamiento a un estado plástico en el que se aplica una constricción mecánica que da lugar a una forma que retiene al consolidarse y enfriarse. En segundo lugar, aquellos en los que un material polimerizable, que puede estar parcialmente polimerizado, se polimeriza totalmente por la acción del calor, de un catalizador o de ambos conjuntamente, bajo una constricción mecánica que permite obtener una forma que retiene cuando está completamente polimerizado y frío. La tecnología de los plásticos se ha desarrollado para explotar estas propiedades y producir artículos muy consistentes con un esfuerzo humano mínimo. Los procesos siguientes se utilizan habitualmente.

\section{Moldeo por compresión}

Consiste en calentar el material plástico, que puede estar en forma de gránulos o polvo, en un molde sostenido en una prensa. Cuando el material se hace "plástico", la presión lo fuerza a adoptar la forma del molde. Si el plástico es del tipo que se endurece al calentar, el artículo formado se retira después de un corto período de calentamiento abriendo la prensa. Si el plástico no se endurece al calentar, debe enfriarse antes de abrir la prensa. Algunos artículos fabricados mediante moldeo por compresión son tapones de botellas, cierres de jarras, clavijas y enchufes eléctricos, asientos de sanitarios, bandejas y artículos de fantasía. El moldeo por compresión se utiliza también para fabricar láminas para su moldeo subsiguiente en el proceso de conformado por vacío o para la fabricación de tanques y grandes contenedores mediante soldadura o revestimiento de los tanques de metal existentes.

\section{Moldeo a presión}

Es una modificación del moldeo por compresión. El material termoestable se calienta en una cavidad y después se introduce mediante un pistón en un molde que está físicamente separado y calentado independientemente de la cavidad de calefacción. Este método se prefiere al moldeo por compresión cuando el artículo final tiene que llevar insertos metálicos delicados, como un pequeño conmutador eléctrico o cuando, como en los objetos muy gruesos, la reacción química no se completa mediante el moldeo por compresión normal.

\section{Moldeo por inyección}

En este proceso los gránulos o polvos de plástico se calientan en un cilindro (conocido como husillo) que está separado del molde. El material se calienta hasta que se hace fluido mientras se transporta por el husillo mediante un tornillo helicoidal y después se empuja al molde donde se enfría y endurece. Después el molde se abre mecánicamente y se sacan los artículos formados (véase la Figura 77.9). Este proceso es uno de los más importantes en la

Figura 77.10 • Extrusión de plástico: la cinta se parte con el fin de hacer pastillas para las máquinas de moldeo por inyección.

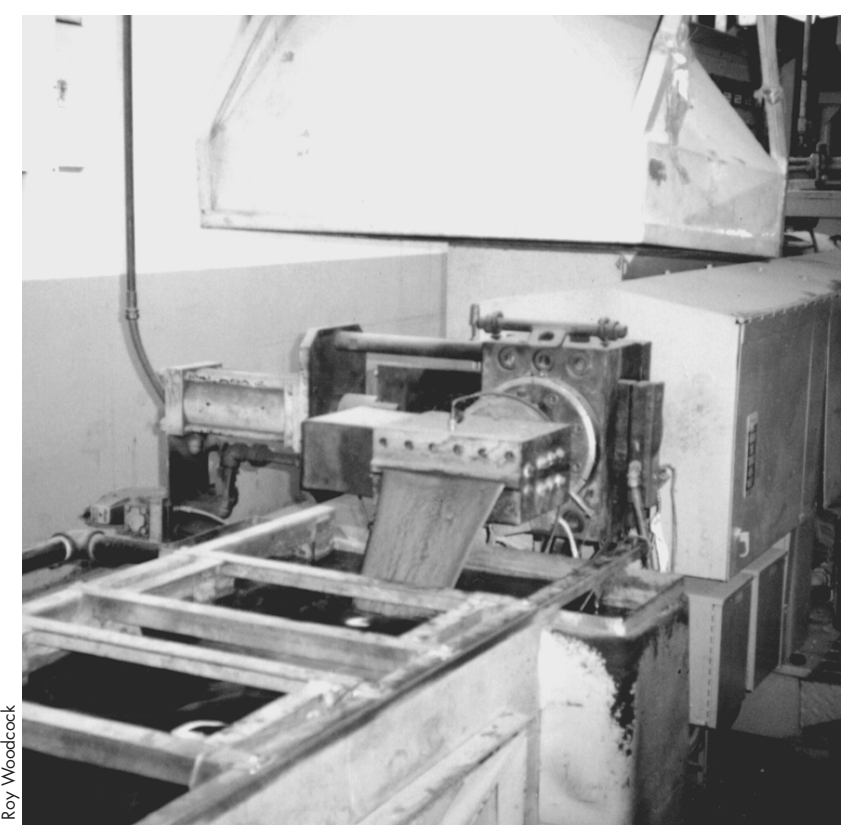


Figura 77.11 - Extrusión de plástico con campana de extracción local y baño de agua en el cabezal del extrusor.

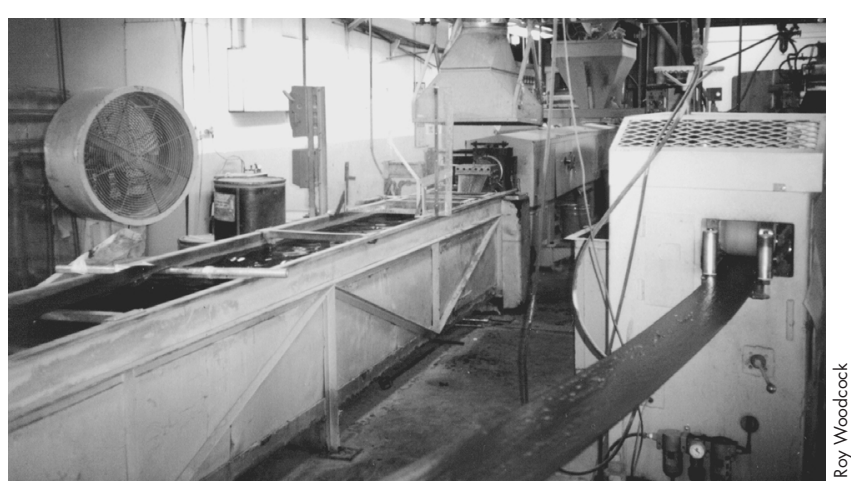

industria de plásticos. Se ha desarrollado extensamente y ha conseguido fabricar artículos muy complejos a un coste muy bajo.

Aunque el moldeo a presión y por inyección son en principio idénticos, la maquinaria empleada es muy diferente. El moldeo a presión está restringido normalmente a materiales termoendurecidos y el moldeo por inyección a termoplásticos.

\section{Extrusión}

Este es un proceso en el que una máquina ablanda un plástico y lo hace pasar a través de un troquel que le da la forma que retiene al enfriarse. Los productos de la extrusión son tubos o rodillos que pueden tener secciones transversales con prácticamente cualquier configuración (véase la Figura 77.10). Los tubos para usos industriales o domésticos se producen de esta forma, pero es posible preparar otros artículos mediante procesos secundarios. Por ejemplo, se pueden preparar bolsitas cortando tubos y sellando ambos extremos, y bolsas a partir de tubos flexibles de pared fina cortando y sellando un extremo.

El proceso de extrusión es de dos tipos. En uno se produce una hoja plana. Esta hoja se puede convertir en artículos útiles mediante otros procesos, como el conformado por vacío.

El segundo es un proceso en el que se forma el tubo extruido y cuando aún está caliente se expande mediante una presión de aire mantenida dentro del tubo. Esto da lugar a un tubo de varios $\mathrm{dm}$ de diámetro con una pared muy fina. $\mathrm{Al}$ cortar este tubo se obtiene una película muy utilizada en la industria de envasado para obtener envoltorios. Alternativamente, el tubo puede plegarse y obtenerse una hoja de doble capa que se puede utilizar para hacer bolsas sencillas cortando y sellando. La Figura 77.11 muestra un ejemplo de una extracción localizada adecuada en un proceso de extrusión.

\section{Galandrado}

En este proceso se introduce un plástico entre dos o más rodillos calentados y se convierte en una hoja pasándolo entre ellos y enfriando a continuación. De esta forma se preparan hojas más gruesas que una película, utilizadas en aplicaciones industriales y domésticas y como materia prima en la fabricación de ropa y artículos hinchados como muñecos (véase la Figura 77.12).

\section{Moldeo por insuflación de aire comprimido}

Este proceso se puede considerar una combinación del proceso de extrusión y de termomoldeado. Se extruye un tubo en un molde abierto; cuando alcanza el fondo el molde se cierra en torno a él y se expande el tubo por presión de aíre. De esta forma se fuerza el plástico a los lados del molde y se sellan la parte superior y la inferior. Una vez frío se extrae el artículo del molde. En este proceso se obtienen artículos huecos, de los cuales las botellas son los más importantes.

La resistencia a la compresión e impacto de ciertos productos de plástico fabricados por moldeo por insuflación de aire comprimido se puede mejorar considerablemente utilizando técnicas de moldeado por estirado y soplado. Para ello se produce primero una preforma que después se expande mediante presión de aire y se estira biaxialmente. Con este método se ha mejorado tanto la resistencia a la presión de rotura de las botellas de PVC que se utilizan para bebidas carbónicas.

\section{Moldeo por rotación}

Este proceso se utiliza para la producción de artículos moldeados calentando y enfriando una forma hueca que se rota para que la fuerza de la gravedad distribuya polvo finamente dividido o líquido sobre la superficie interna de dicha forma. Algunos artículos fabricados mediante este método son balones de fútbol, muñecas y otros artículos similares.

\section{Colada de películas}

Además de por extrusión, se pueden formar películas mediante extrusión de un polímero caliente en un tambor de metal muy pulido, o bien pulverizando una solución de polímero en una correa en movimiento.

Una aplicación importante de algunos plásticos es el revestimiento de papel. Para ello, se extruye una película de plástico fundido sobre papel en condiciones que favorecen la adherencia del plástico al papel. Igualmente se puede revestir cartón. El papel y el cartón así revestidos se pueden utilizar en envasado, y este tipo de cartón se utiliza para hacer cajas.

\section{Termoformado}

Bajo este epígrafe se agrupan varios procesos en los que una hoja de un material plástico, con más frecuencia termoplástico, se calienta, por lo general en un horno, y después de sujetar el perímetro se moldea en una forma determinada mediante presión de pistones mecánicos o de aire o vapor comprimidos. En el caso de artículos muy grandes la hoja caliente "gomosa" se sujeta con pinzas sobre los moldes. Algunos productos así obtenidos son accesorios para lámparas, señales de tráfico, carteles publicitarios, baños y otros artículos de tocador y lentes de contacto.

Figura 77.12 - Campanas para captar las emisiones calientes de molinos de calentamiento en un proceso de calandrado.

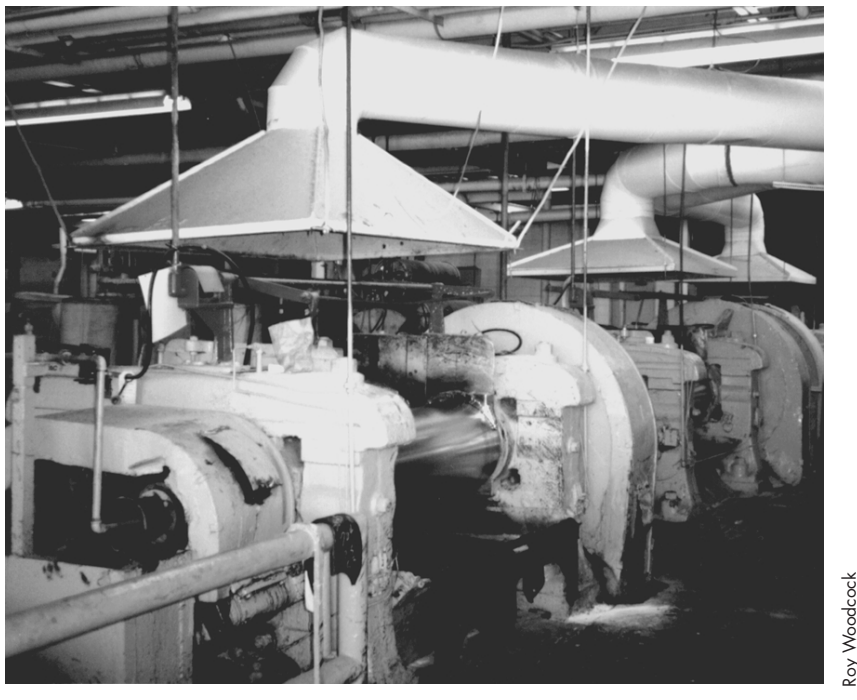




\section{Conformado por vacío}

Bajo esta denominación general se incluyen muchos procesos, todos ellos de moldeado térmico, y con la característica común de que se calienta una hoja de plástico en una máquina sobre un cavidad, alrededor de cuyo borde se sujeta, y cuando está flexible se fuerza por succión dentro de la cavidad, en la que adopta una forma específica y se enfría. En una operación posterior el artículo se pule sin la hoja. En estos procesos se obtienen recipientes de paredes finas muy baratos y de todos los tipos, así como artículos de publicidad y exhibición, bandejas y similares, y materiales absorbentes de choques para envasar artículos como pasteles de fantasía, frutas blandas y carne troceada.

\section{Laminado}

En todos los procesos de laminado se comprimen dos o más materiales en forma de hojas para obtener una hoja o un panel con propiedades especiales. El caso más sencillo son laminados decorativos fabricados con resinas fenólicas y amínicas; en el otro extremo se encuentran las películas complejas utilizadas en el envasado y formadas, por ejemplo, por celulosa, polietileno y láminas de metal.

\section{Procesos de la tecnología de resinas}

Entre estos se incluye la fabricación de madera contrachapada y muebles y la construcción de artículos grandes y complicados como carrocerías de coches y cascos de barcos de fibra de vidrio impregnada con resinas de poliéster o epoxi. En todos estos procesos se polimeriza una resina líquida bajo la acción del calor o de un catalizador y de esta forma se unen partículas discretas o fibras, o películas u hojas mecánicamente débiles, obteniéndose un panel robusto de construcción rígida. Estas resinas se pueden utilizar mediante técnicas de aplicación manuales, como pintado e inmersión o mediante pulverizado.

También se pueden preparar por moldeo objetos pequeños como recuerdos y bisutería de plástico, mezclando la resina líquida y el catalizador e introduciéndolos en un molde.

\section{Procesos de acabado}

Aquí se incluyen diversos procesos comunes a muchas industrias, por ejemplo el uso de pinturas y adhesivos. No obstante, existen varias técnicas específicas utilizadas para la soldadura de plásticos. Una de ellas es el uso de disolventes, como hidrocarburos clorados, metiletilcetona (MEG) y tolueno, para unir hojas de plástico rígido en la fabricación general, carteles publicitarios y obras similares. La radiación de radiofrecuencia $(\mathrm{RF})$ utiliza una combinación de presión mecánica y radiación electromagnética con frecuencias en general en el intervalo de 10 a $100 \mathrm{MHz}$. Este método se utiliza a menudo para soldar material plástico flexible en la fabricación de carteras, portafolios y coches para niños (ver el recuadro). Asimismo se utilizan ultrasonidos en combinación con presión mecánica para artículos semejantes.

\section{Riesgos y su prevención}

\section{Fabricación de polímeros}

Los riesgos especiales de la industria de los polímeros están estrechamente relacionados con los de la industria petroquímica y dependen en gran parte de las sustancias utilizadas. Los riesgos para la salud de las materias primas individuales se comentan en otro apartado de esta Enciclopedia. Un riesgo general importante es el peligro de incendios y explosiones. Muchos procesos de polímeros/resinas tienen riesgo de incendio y explosión debido a la naturaleza de las materias primas utilizadas. Si no se toman las medidas de protección adecuadas existe a veces el riesgo de que durante la reacción, en general dentro de edificios parcialmente confinados, escapen gases o líquidos inflamables a temperaturas superiores a sus puntos de ignición. Si las presiones son muy elevadas, se deben prever venteos a la atmósfera. Se puede crear una presión excesiva debido a reacciones exotérmicas inesperadamente rápidas; la manipulación de algunos aditivos y la preparación de ciertos catalizadores puede aumentar el riesgo de incendio o explosión. La industria ha abordado ya estos problemas; en particular, en la fabricación de resinas fenólicas ha elaborado notas técnicas sobre diseño de las plantas y procedimientos seguros de trabajo.

\section{Procesado de plásticos}

La industria de procesado de plásticos presenta riesgos de lesiones debido a la maquinaria utilizada, riesgos de incendio debido a la capacidad de combustión de los plásticos y su polvo y riesgos para la salud debido a los numerosos productos químicos utilizados.

\section{Lesiones}

La principal área de esta industria en la que se producen lesiones es la de manufactura de productos plásticos. La mayor parte de los procesos de conversión de plástico depende casi por completo del uso de maquinaria. En consecuencia, los principales riesgos son los asociados al uso de dicha maquinaria, no sólo durante el funcionamiento normal sino también durante su limpieza, instalación y mantenimiento.

Las máquinas de moldeo por compresión, presión, inyección y soplado de aire tienen platos de prensa con una fuerza de cierre de muchas toneladas por centímetro cuadrado. Debe existir una protección adecuada para evitar amputaciones o lesiones por aplastamiento. Esto se consigue generalmente cerrando las zonas peligrosas y bloqueando las protecciones móviles con los controles de la máquina. Una protección de bloqueo no debe permitir movimientos peligrosos dentro del área protegida y debe hacer que las piezas peligrosas paren o inviertan el movimiento peligroso cuando se abra la protección durante el funcionamiento de la máquina.

Cuando exista un riesgo grave de lesión en la maquinaria como en las placas de máquinas de moldeo, y un acceso normal al área de peligro, se requiere un bloqueo mayor; puede consistir en un segundo dispositivo de bloqueo independiente en la protección que interrumpe el suministro de energía y previene el movimiento peligroso cuando está abierta.

En el caso de procesos con hojas de plástico, un riesgo habitual son los atrapamientos entre los rodillos en funcionamiento y durante el tratamiento de la hoja. Esto se produce en los rodillos tensores y dispositivos de arrastre en la planta de extrusión y calandrados. Se puede conseguir la protección utilizando un dispositivo de desenganche localizado adecuadamente que inmediatamente pare o invierta el movimiento peligroso de los rodillos.

Muchas de las máquinas de tratamiento de plástico funcionan a temperaturas muy altas; se pueden producir quemaduras graves si el cuerpo entra en contacto con metal o plásticos calientes. Si es posible, éstas partes se deben proteger cuando la temperatura sea superior a $50{ }^{\circ} \mathrm{C}$. Por otra parte, los bloqueos que se producen en las máquinas de moldeo por inyección y los extrusores se pueden liberar violentamente. Debe seguirse un sistema seguro de trabajo cuando se intenten liberar obstrucciones de plástico, en el que se incluye el uso de guantes y protección facial adecuados.

La mayor parte de las funciones de las máquinas modernas están controladas por sistemas informáticos o de control electrónico programado, que también pueden controlar los dispositivos de desmontaje mecánico o estar unidos a robots. Con las nuevas máquinas no existe la necesidad de que el operario se acerque a las áreas de peligro, de lo que resulta que la seguridad en la maquinaria debería mejorar. No obstante es necesario que 


\section{Calentadores y selladores dieléctricos de RF}

Los calentadores y selladores de radiofrecuencia (RF) se utilizan en muchas industrias para calentar, fundir o endurecer materiales dieléctricos, como plástico, caucho y cola, que son aislantes eléctricos y térmicos difíciles de calentar con los métodos habituales. Los calentadores de RF se aplican en el sellado de cloruro de polivinilo (p. ej., fabricación de productos de plástico, como impermeables, fundas para asientos y materiales de envasado); el endurecimiento de colas utilizadas en la industria maderera; el estampado y secado de tejidos, papel, piel y plásticos; y el endurecimiento de muchos materiales que contienen resinas plásticas.

Los calentadores de RF utilizan radiación de RF en el intervalo de frecuencia de 10 a $100 \mathrm{MHz}$ con una potencia de salida desde menos de $1 \mathrm{~kW}$ a aproximadamente $100 \mathrm{~kW}$ para producir calor. Se sitúa el material a calentar comprimido entre dos electrodos y se aplica la potencia RF durante períodos que varían entre pocos segundos a aproximadamente un minuto, en función del uso. Los calentadores de RF pueden producir campos eléctricos y magnéticos de RF de alta dispersión en el medio ambiente circundante, especialmente si los electrodos no están apantallados.

La absorción de la energía de RF por el cuerpo humano puede provocar calentamiento de parte o todo el cuerpo, con efectos adversos para la salud. Si la temperatura corporal aumenta $1^{\circ} \mathrm{C}$ o más, es posible que se produzcan efectos cardiovasculares, como taquicardia y aumento del gasto cardíaco. Algunos efectos localizados son: cataratas, recuentos bajos de espermatozoides en el sistema reproductor masculino y efectos teratogénicos en el feto en desarrollo.

Los riesgos indirectos incluyen quemaduras por radiofrecuencia debido al contacto directo con piezas metálicas del calentador, dolorosas, profundas y de curación lenta; parálisis en las manos y efectos neurológicos como el síndrome del túnel carpiano, y efectos sobre el sistema nervioso periférico.

\section{Controles}

Los dos tipos básicos de controles que se utilizan para reducir los riesgos derivados de los calentadores de RF son las prácticas de trabajo y el apantallamiento; por supuesto, es preferible este último, pero unos procedimientos adecuados de mantenimiento y otras prácticas de trabajo pueden reducir también la exposición. También se aplica la limitación del tiempo que el operario está expuesto, esto es, un control administrativo.

Los métodos de reparación y un correcto mantenimiento son aspectos importantes, debido a que el fallo en la reinstalación adecuada de pantallas, dispositivos de enclavamiento, paneles $y$ cierres puede provocar fugas excesivas de RF. Por otra parte, se debe desconectar y bloquear o cerrar la toma de corriente del calentador para proteger al personal de mantenimiento.

Si se mantienen las manos y la parte superior del cuerpo lo más lejos posible del calentador de RF se reducen los niveles de exposición del operario. Los paneles de control del operario para algunos calentadores automatizados se colocan a cierta distancia de los electrodos del calentador utilizando bandejas deslizantes, mesas giratorias o correas transportadoras para alimentar el calentador.

La exposición del personal operativo y no operativo se reduce midiendo los niveles de RF. Debido a que estos niveles disminuyen al aumentar la distancia del calentador, es posible establecer un "área de riesgo de RF" en torno a cada calentador. Se advertirá a los trabajadores para que no ocupen estas áreas peligrosas cuando funciona el calentador de RF. Si es posible, deben utilizarse barreras físicas no conductoras para mantener a las personas a una distancia segura

Lo más conveniente es que los calentadores de RF tengan una pantalla en torno al aplicador, que impida la radiación de RF. La pantalla y todas las juntas deben tener una conductividad alta para las corrientes eléctricas interiores que fluyen en las paredes. E número de aberturas en la pantalla será el mínimo posible, y tan pequeñas como lo permita una operación práctica. Deberán estar orientadas en dirección opuesta a donde se encuentre el operario. Se pueden minimizar las corrientes en las pantallas mediante conductores separados en la cabina que conduzcan corrientes altas. El calentador debe tener la toma de tierra adecuada, con el cable de tierra en la misma tubería que la línea de corriente, así como dispositivos de enclavamiento adecuados para prevenir la exposición a altos voltajes y elevadas emisiones de RF.

Es mucho más sencillo que el fabricante incorpore esta pantalla a los nuevos modelos de calentadores de RF, que actualizar el material. Los confinamientos en cajas pueden ser eficaces, como lo es una toma de tierra correcta para reducir las emisiones de RF. Después debe medirse cuidadosamente la RF para garantizar que las emisiones se han reducido realmente. La práctica de confinar el calentador en un sala con pantalla de metal puede aumentar la exposición si el operario también se encuentra en dicha sala aunque reduce las exposiciones fuera de la sala.

Fuente: ICNIRP; en prensa. preparadores y técnicos se aproximen a estas áreas. Por consiguiente es esencial instalar un programa adecuado de bloqueo y cierre antes de realizar este tipo de trabajo, particularmente cuando no se puede conseguir una protección completa mediante los dispositivos de seguridad de la máquina. Por otra parte, los sistemas de emergencia o de socorro deben estar diseñados y señalizados de tal forma que actúen en situaciones en las que el control programado falle por cualquier motivo, por ejemplo durante una interrupción del suministro de energía.

Es importante que las máquinas estén adecuadamente dispuestas en el taller, con espacios libres de trabajo para cada una. Esto contribuye al mantenimiento de altos estándares de limpieza y orden. Las máquinas se deben mantener correctamente, comprobándose regularmente los dispositivos de seguridad.

Es esencial un buen servicio de mantenimiento, debiéndose prestar una atención especial a la limpieza de los suelos. Sin una limpieza regular, los suelos se contaminan con aceite de las máquinas o con gránulos de plástico derramados. Se debe contar con métodos de trabajo que incluyan medios seguros de acceso a las áreas sobre el nivel del suelo.

Debe disponerse de espacio suficiente para el almacenamiento de materias primas y productos terminados; estas áreas deben estar claramente señalizadas.

Los plásticos son buenos aislantes eléctricos; como consecuencia se pueden crear cargas estáticas en la maquinaria sobre la que se desplazan hojas o películas. Estas cargas pueden tener un potencial suficiente para provocar accidentes graves o actuar como fuentes de ignición. Se deben utilizar eliminadores de electricidad para reducir estas cargas y aplicar tomas de tierra a las piezas metálicas.

Existe una tendencia creciente al retratamiento de los residuos plásticos utilizando granuladores y mezclado con nuevos materiales. Los granuladores se deben confinar completamente para prevenir cualquier posibilidad de alcanzar los rotores a través de las aberturas de descarga y alimentación. El diseño de éstas 
Tabla 77.10 • Productos volátiles en la descomposición de los plásticos (componentes de referencia).

En muchos sectores industriales, los plásticos están sometidos a estrés térmico Las temperaturas varían de valores relativamente bajos en el procesado de plásticos (p. ej., 150 a $250^{\circ} \mathrm{C}$ ), a casos extremos (p. ej.. cuando se sueldan metal laminado en punta o tubos revestidos de plástico). Es en tales circunstancias cuando se plantea siempre la duda de si en las áreas de trabajo se alcanzan concentraciones tóxicas de productos volátiles procedentes de la pirólisis.

Para responder a esto, en primer lugar se deben determinar las sustancias liberadas, y después medir sus concentraciones. Mientras que el segundo paso es en principio factible, no suele ser posible la determinación de los productos de la pirólisis sobre el terreno. El Berufsgenossenschaftliches Institut für Arbeitssicherheit (BIA) ha estudiado el problema durante años, y en el curso de muchos ensayos de laboratorio ha determinado los productos de descomposición de plásticos. Los resultados de los ensayos para los distintos tipos de plásticos están publicados(Lichtenstein y Quellmalz 1984, 1986a, 1986b, 1986c).

\begin{tabular}{|c|c|c|}
\hline Plástico & Abreviatura & Sustancias volátiles \\
\hline Polioximetileno & POM & Formaldehído \\
\hline Resinas epoxi a base de bisfenol A & & Fenol \\
\hline Caucho cloropreno & $C R$ & Cloropreno (2-clorobuto-1,3-dieno), cloruro de hidrógeno \\
\hline Poliestireno & PS & Estireno \\
\hline Copolímero de acrilonitrilo -butadieno-estireno & $A B S$ & Estireno, 1,3-butadieno, acrilonitrilo \\
\hline Copolímero estireno-acrilonitrilo & SAN & Acrilonitrilo, estireno \\
\hline Policarbonatos & $P C$ & Fenol \\
\hline Cloruro de polivinilo & PVC & $\begin{array}{l}\text { Cloruro de hidrógeno, plastificantes (por lo común, ésteres del ácido ftálico como dioctil ftalato, } \\
\text { dibutil ftalato) }\end{array}$ \\
\hline Poliamida 6 & PA 6 & $\varepsilon$-caprolactama \\
\hline Poliamida 66 & PA 66 & Ciclopentanona, hexametilendiamina \\
\hline Polietileno & HDPE, LDPE & Hidrocarburos alifáticos insaturados, aldehídos alifáticos \\
\hline Politetrafluoroetileno & PTFE & $\begin{array}{l}\text { Hidrocarburos insaturados polifluorados (p. ei., tetrafluoroetileno, hexafluoropropeno, } \\
\text { octafluorobuteno) }\end{array}$ \\
\hline Polimetil metacrilato & PMMA & Metil metacrilato \\
\hline Poliuretano & PUR & $\begin{array}{l}\text { Según el tipo, productos de descomposición muy variables (p. ej., CFCl como agentes espumantes, } \\
\text { éter y éter glicólico, diisocianatos, , cianuro de hidrógeno }{ }^{2} \text {, aminas aromáticas, ésteres de ácidos } \\
\text { fosfóricos clorados como agentes protectores contra las llamas) }\end{array}$ \\
\hline Polipropileno & $\mathrm{PP}$ & Hidrocarburos alifáticos saturados e insaturados \\
\hline Polibutilo entereftalato (poliéster) & PBTP & 1,3-butadieno, benceno \\
\hline Poliacrilonitrilo & PAN & Acrilonitrilo, cianuro de hidrógeno ${ }^{2}$ \\
\hline Celulosa acetato & CA & Acido acético \\
\hline
\end{tabular}

En la siguiente tabla se resumen los resultados obtenidos hasta la fecha; su finalidad es ayudar a todos aquellos que se enfrentan a la labor de medir concentraciones de sustancias peligrosas en determinadas áreas de trabajo. Los productos de descomposición citados para los distintos plásticos pueden servir de "componentes de referencia". No obstante, debe recordarse que la pirólisis puede dar lugar a mezclas muy complejas de sustancias, cuyas composiciones dependen de muchos factores.

La tabla no es completa en lo que respecta a los productos de pirólisis citados como componentes de referencia (todos ellos determinados en experimentos de laboratorio). No se puede excluir la aparición de otras sustancias que presenten riesgos para la salud; registrarlas todas resultaría imposible.

Norbert Lichtenstein

\footnotetext{
1 Utilización discontinua.

2 No pudo detectarse con la técnica analítica empleada (CG/EM), pero se conoce por los datos publicados.

* Reimpresión de BIA 1997, autorizada.
}

últimas debe impedir el paso de un cuerpo entero. Los rotores se mueven a alta velocidad, no debiéndose retirar las cubiertas hasta que se hayan detenido. Cuando existan protecciones de bloqueo, éstas deben evitar el contacto con las hojas hasta que se hayan parado por completo.

\section{Riesgos de incendio y explosión.}

Los plásticos son materiales combustibles, aunque no todos los polímeros soportan la combustión. En forma de polvo finamente dividido pueden alcanzar concentraciones explosivas en el aire. Cuando exista este riesgo se debe controlar el polvo, preferentemente en un sistema cerrado, con discos de ruptura suficientes con venteo a baja presión (aproximadamente 0,05 bar) a un lugar seguro. Es esencial una limpieza escrupulosa para prevenir acumulaciones de polvo en las salas de trabajo que pueden transportarse por el aire y provocar una explosión secundaria.

Los polímeros pueden estar sometidos a degradación térmica y pirólisis a temperaturas no muy superiores a las del tratamiento normal. En estas circunstancias se pueden crear presiones suficientes en el husillo o el extrusor para, por ejemplo, expulsar el plástico fundido y cualquier tapón sólido de plástico que provoque un bloqueo inicial.

En esta industria es frecuente el uso de líquidos inflamables, tales como pinturas, adhesivos, agentes limpiadores y disolventes 
para soldadura. Las resinas de fibra de vidrio (poliéster) también emiten vapores inflamables de estireno. Deben reducirse al mínimo las existencias de estos líquidos en las salas de trabajo y almacenarse en un lugar seguro cuando no se utilicen. Las áreas de almacenamiento deben incluir lugares seguros al aire libre o un almacén resistente al fuego.

Los peróxidos utilizados en la fabricación de resinas de plástico reforzado con vidrio (PRV) se deben almacenar aparte de los líquidos inflamables y otros materiales combustibles, sin someterse a temperaturas extremas, ya que son explosivos al calentarse.

\section{Riesgos para la salud}

Existen numerosos riesgos para la salud asociados al proceso de plásticos. Raramente se utilizan los plásticos brutos, debiéndose adoptar las precauciones adecuadas frente a los aditivos utilizados en las distintas formulaciones. Los aditivos utilizados incluyen jabones de plomo en PVC y ciertos colorantes orgánicos y de cadmio.

Es importante el riesgo de dermatitis a causa de los líquidos y polvos de "productos químicos reactivos", como resinas de fenol formaldehído (antes de formar enlaces cruzados), uretanos y resinas de poliéster insaturado utilizados en la fabricación de productos de PRV. Se debe llevar la ropa protectora adecuada.

Es posible la generación de humos en la degradación térmica de polímeros durante los procesos en caliente. Este problema se puede minimizar con controles técnicos. No obstante, debe evitarse la inhalación de productos de la pirólisis en condiciones adversas, por ejemplo, el purgado del husillo extrusor. Pueden ser necesarias unas condiciones de buena LEV. Han surgido problemas, por ejemplo cuando los trabajadores han quedado envueltos por ácido clorhídrico gas y han sufrido "fiebre del humo de polímeros" después del sobrecalentamiento de PVG y politetrafluoroetileno (PTFE), respectivamente. El cuadro adjunto detalla algunos productos de la descomposición química de los plásticos.

También existe el peligro de inhalación de vapores tóxicos procedentes de ciertas resinas termoendurecidas. La inhalación de isocianatos utilizados con las resinas de poliuretano puede provocar neumonía química y asma grave; una vez sensibilizadas, estas personas deben ser trasladadas a un trabajo alternativo. El problema es similar con las resinas de formaldehído. En ambos ejemplos es necesaria una buena LEV. En la fabricación de artículos PRV se desprenden cantidades significativas de vapores de estireno, de forma que este trabajo debe realizarse en condiciones de buena ventilación general en las salas de trabajo.

Otros riesgos son comunes a varias industrias. Entre ellos se incluye el uso de disolventes para dilución u otros fines antes descritos. Se utilizan habitualmente hidrocarburos clorados para la limpieza; sin una ventilación por extracción adecuada las personas pueden sufrir narcosis.

La eliminación de residuos de plásticos mediante incineración se debe realizar en condiciones cuidadosamente controladas; por ejemplo, el PTFE y los uretanos deben estar en un área en la que los gases se ventilen hacia un lugar seguro.

Durante el uso de los granuladores se pueden alcanzar niveles de ruido muy altos, que pueden causar pérdidas auditivas en los operarios y personas que trabajan en las proximidades. Este riesgo puede controlarse separando este equipo de otras áreas de trabajo. Preferiblemente los niveles de ruido se deben reducir en su origen. Esto se ha conseguido cubriendo el granulador con material insonorizante y acoplando pantallas de separación en la boca de alimentación. Otro riesgo para la audición procede del sonido audible generado por las máquinas soldadoras por ultrasonido. Se pueden diseñar cerramientos adecuados para reducir el nivel de ruido percibido, que se interbloqueen para prevenir un riesgo mecánico. Como norma mínima, las personas que trabajan en áreas muy ruidosas deben llevar protección auditiva adecuada y debe existir un programa de conservación de la audición que incluya controles audiométricos y formación.

Las quemaduras son otro riesgo. Algunos aditivos y catalizadores para la producción y procesado de plásticos pueden ser muy reactivos al contacto del aire o el agua y pueden causar rápidamente quemaduras químicas. Siempre que se manipulen o transporten termoplásticos fundidos existe el riesgo de vertidos de material caliente y por consiguiente de quemaduras y escaldados. La gravedad de estas quemaduras puede aumentar por la tendencia de termoplásticos calientes a adherirse a la piel como la cera caliente.

Los peróxidos orgánicos son irritantes y pueden provocar ceguera si salpican a los ojos. Debe llevarse protección ocular apropiada.

\section{INDUSTRIA DE LA BIOTEGNOLOGIA}

\section{Susan B. Lee y Linda B. Wolfe}

\section{Evolución y perfil}

Se puede definir la biotecnología como la aplicación de sistemas biológicos a procesos técnicos e industriales. Comprende tanto los organismos tradicionales como los modificados por ingeniería genética. La biotecnología tradicional es el resultado de hibridaciones clásicas, apareamientos o cruzamientos de varios organismos para crear nuevos organismos utilizados durante siglos para producir pan, cerveza, queso, soja, saki, vitaminas, plantas híbridas y antibióticos. Más recientemente se han utilizado también algunos microorganismos para tratar aguas residuales, residuos humanos y residuos tóxicos industriales.

La biotecnología moderna combina los principios de la química y la ciencia biológica (biología molecular y celular, genética, inmunología) con disciplinas tecnológicas (ingeniería, informática) para producir artículos y servicios y para la gestión ambiental. La biotecnología moderna utiliza enzimas de restricción para aislar y añadir información genética, $\mathrm{ADN}$, de un organismo a otro fuera de células vivas. El ADN compuesto se introduce después en células hospedadoras para determinar si se expresa el carácter deseado. La célula resultante se denomina clon, un organismo recombinante o manipulado genéticamente (OMG). La "moderna" industria de la biotecnología nació entre 1961 y 1965 al descifrarse el código genético y ha crecido rápidamente desde los primeros experimentos de clonación de ADN con éxito en 1972.

Desde principios del decenio de 1970 los científicos han comprendido que la ingeniería genética es una tecnología muy poderosa y prometedora, pero existen algunos riesgos que es necesario considerar. Ya en 1974 los científicos solicitaron una moratoria a nivel mundial sobre tipos específicos de experimentos con el fin de evaluar los riesgos y establecer unas normas adecuadas para evitar riesgos biológicos y ecológicos (Committee on Recombinant DNA Molecules, National Research Council, National Academy of Sciences 1974). Algunas de las preocupaciones entonces expresadas incluían el potencial "escape de vectores que podrían iniciar un proceso irreversible, y crear problemas muchas veces mayores que los surgidos de multitud de recombinaciones genéticas que tienen lugar espontáneamente en la naturaleza". También se expresó la preocupación de que "microorganismos con genes transplantados pudieran ser peligrosos para el hombre u otras formas de vida. Puede producirse un daño si la célula huésped alterada tiene una ventaja competitiva que pueda favorecer su supervivencia 
en un nicho del ecosistema “(NIH 1976). También se reconoció que los trabajadores se encontrarían en un entorno peligroso y que se debería intentar proteger a los trabajadores y al medio ambiente de los riesgos desconocidos y potencialmente graves.

El informe de una conferencia internacional celebrada en Asilomar, California, en febrero de 1975, contenía las primeras directrices por consenso basadas en estrategias de confinamiento físico y biológico para controlar los posibles riesgos previstos con la nueva tecnología. Se juzgó que algunos experimentos presentaban tales peligros que la conferencia recomendó que no se realizaran (NIH 1976). En un principio se prohibieron los trabajos siguientes:

- experimentos con ADN de organismos patógenos y oncogenes

- formación de recombinantes que incorporan genes de toxinas

- trabajos que puedan extender la gama de hospedadores de patógenos de plantas

- introducción de genes de resistencia a fármacos en organismos que no los adquieran naturalmente y cuando el tratamiento estuviera comprometido

- liberación deliberada al medio ambiente (Freifelder 1978).

Las primeras National Institutes of Health Guidelines (NIHG) se publicaron en Estados Unidos en 1976, sustituyendo a las directrices de Asilomar. Estas directrices permitían la investigación clasificando los experimentos según clases de peligros en base a los riesgos asociados a las células hospedadoras, sistemas de vectores que transportan genes a las células e inserciones de genes, permitiendo o restringiendo así la realización de los experimentos según la evaluación del riesgo. La premisa básica de las directrices NIHG (ofrecer protección a los trabajadores, y por extensión, seguridad a la comunidad) sigue vigente hoy (NIH 1996). Las NIHG se actualizan regularmente y han evolucionado hasta convertirse en una norma aceptada ampliamente para las prácticas de biotecnología en los Estados Unidos. Las instituciones que reciben subvenciones federales deben cumplirlas, además de muchas ordenanzas locales. Las NIHG proporcionan una base para la legislación en otros países, incluidos Suiza (SCBS 1995) y Japón (Instituto Nacional de Salud 1996).

Desde 1976 se han ampliado las NIHG con objeto de incorporar consideraciones de confinamiento y aprobación para nuevas tecnologías, incluidas instalaciones para la producción a gran escala y propuestas de terapias génicas para plantas, animales y el ser humano. Algunos de los experimentos que en principio fueron prohibidos están ahora autorizados con la aprobación específica del NIH o con prácticas específicas de confinamiento.

En 1986 la Office of Science and Technology Policy (OSTP) de Estados Unidos publicó su Coordinated Framework for Biotechnology Regulation. En él se abordaba la cuestión política subyacente de si la legislación existente era adecuada para evaluar productos derivados de las nuevas tecnologías y si los procesos de revisión para investigación eran suficientes para proteger el público y el medio ambiente. Los organismos legislativos y de investigación de Estados Unidos (Environmental Protection Agency (EPA), Food and Drug Administration (FDA), Occupational Safety and Health Administration (OSHA), NIH, US Department of Agriculture (USDA) y National Science Foundation (NSF)) acordaron regular los productos, no los procesos, y que no eran necesarias leyes especiales para proteger a los trabajadores, el público o el medio ambiente. Se estableció la política de aplicar programas legislativos de forma integrada y coordinada, minimizando la superposición, y en la medida de lo posible, la responsabilidad para la aprobación de un producto recaería en un organismo. Los organismos coordinarían sus esfuerzos adoptando definiciones consistentes y utilizando revisiones científicas (evaluación de riesgos) de rigor científico comparable (OSHA 1984; OSTP 1986).

Las NIHG y el Coordinated Framework han proporcionado un grado adecuado de debate científico objetivo y de participación pública que se han traducido en el crecimiento de la biotecnología en los Estados Unidos en una industria de muchos millones de dólares. Antes de 1970 existían menos de 100 compañías implicadas en todos los aspectos de la biotecnología moderna. En 1977, se unían otras 125 empresas; en 1983 otras 381 empresas llevaron el nivel de inversión de capital privado a más de 1.000 millones de dólares. En 1994 la industria había crecido a más de 1.230 empresas (Massachusetts Biotechnology Council Community Relations Committee 1993), y la capitalización en el mercado es superior a 6.000 millones de dólares.

En 1980 el número de empleados en empresas de biotecnología era de unos 700; en 1994 unas 1.300 empresas empleaban a más de 100.000 trabajadores (Massachusetts Biotechnology Council Community Relations Committee 1993). Por otra parte existe una completa industria de apoyo que provee reactivos (productos químicos, componentes de los medios, líneas celulares), equipos, instrumentos y servicios (bancos de células, validación, calibración) necesarios para garantizar la integridad de la investigación y la producción.

En todo el mundo existe una gran preocupación y escepticismo acerca de la seguridad de la ciencia y de sus productos. El Consejo de las Comunidades Europeas (Parlamento de las Comunidades Europeas 1987) elaboró directivas para proteger a los trabajadores de los riesgos asociados con la exposición a productos biológicos (Consejo de las Comunidades Europeas 1990a) y aplicar controles ambientales en las actividades experimentales y comerciales, incluida la liberación deliberada. (p. ej., de productos de marketing que utilizan OMG (Consejo de las Comunidades Europeas 1990b); Van Houten y Flemming 1993). Se han elaborado normas y directrices relativas a los productos biotecnológicos en organizaciones internacionales y multinacionales, como la Organización Mundial de la Salud (OMS), la Asociación Internacional de Normalización (ISO), la Comisión de las Comunidades Europeas, la Organización para la Agricultura y la Alimentación (FAO) y la Microbial Strains Data Network (OSTP 1986).

La moderna industria de la biotecnología se puede desglosar en cuatro grandes sectores, cada uno con investigación y desarrollo $(\mathrm{I}+\mathrm{D})$ de laboratorio, de campo y clínico que apoyan la producción real de bienes y servicios.

- productos biomédicos-farmacéuticos, biológicos y dispositivos médicos;

- alimentos agrícolas, peces y animales transgénicos, plantas resistentes a las enfermedades y a las plagas;

- productos industriales mejorados genéticamente, como ácido cítrico, butanol, acetona, etanol y enzimas detergentes (véase la Tabla 77.11),

- tratamiento de aguas residuales y del medio ambiente, descontaminación de residuos industriales.

\section{Trabajadores en biotecnología}

La biotecnología comienza en el laboratorio de investigación y es una ciencia interdisciplinar. Los biólogos moleculares y celulares, los inmunólogos, los genetistas, los químicos de proteínas y péptidos, los bioquímicos y los ingenieros bioquímicos están expuestos más directamente a los riesgos reales y potenciales de la tecnología del $\mathrm{ADN}$ recombinante $(\mathrm{ADNr})$. Otros trabajadores también expuestos, pero menos directamente, a los riesgos biológicos del ADNr son el personal de servicio y apoyo, como los 
Tabla 77.11 • Microorganismos de importancia industrial.

\begin{tabular}{|c|c|c|}
\hline Nombre & Organismo hospedador & Usos \\
\hline Acetobacter aceti & Bacterias aerobias & Fermenta la fruta \\
\hline Aspirgillus niger & Hongos asexuados & $\begin{array}{l}\text { Degrada la materia orgánica } \\
\text { Uso seguro en la producción de ácido cítrico y enzimas }\end{array}$ \\
\hline Aspirgillus oryzae & Hongos asexuados & Se utiliza en la producción de miso, salsa de soja y sake \\
\hline Bacillis licheniformis & Bacterias, & Productos químicos y enzimas industriales \\
\hline Bacillis subtilis & Bacterias & $\begin{array}{l}\text { Productos químicos, enzimas, fuente de proteínas de células únicas para consumo } \\
\text { humano en Asia }\end{array}$ \\
\hline Células de ovario de hámster chino $(\mathrm{CHO})^{\star}$ & Cultivo de células de mamíferos & Fabricación de productos biofarmacéuticos \\
\hline Clostridium acetobutylicum & Bacterias & Butanol, producción de acetona \\
\hline Escherichia coli K-12* & Cepa bacteriana & Clonación para fermentación, obtención de productos farmacéuticos y biológicos \\
\hline Penicillium roqueforti & Hongos asexuados & Producción de queso azul \\
\hline Saccharomyces cerevisiae ${ }^{\star}$ & Levaduras & Clonación para la producción de cerveza \\
\hline Saccharomyces uvarum ${ }^{\star}$ & Levaduras & Clonación para bebidas alcohólicas y producción de alcohol industrial \\
\hline
\end{tabular}

técnicos de ventilación y refrigeración, los proveedores de servicios de calibración y el personal de mantenimiento. En una revisión reciente de los profesionales de la salud y seguridad en la industria se encontró que los trabajadores expuestos directa e indirectamente constituyen cerca del 30 al $40 \%$ de toda la mano de obra en una empresa de biotecnología comercial típica (Lee y Ryan 1996). La investigación biotecnológica no está limitada a la "industria"; también se realiza en instituciones universitarias, médicas y oficiales.

Los trabajadores de los laboratorios de biotecnología están expuestos a muchos y diversos productos químicos peligrosos y tóxicos, a riesgos biológicos recombinantes o no recombinantes o de "tipo salvaje", a patógenos humanos transmitidos por la sangre y a zoonosis, así como a materiales radiactivos utilizados en experimentos de marcado. Por otra parte, cada vez es mayor el reconocimiento de que las alteraciones musculosqueléticas y las lesiones repetitivas por tensiones son posibles riesgos para los trabajadores de investigación debido al uso continuado de ordenadores y micropipetas manuales.

Los operarios de la fabricación biotecnológica están también expuestos a productos químicos peligrosos, aunque no son tan variados como en el caso de la investigación. En función del producto y del proceso, en el curso de la fabricación pueden producirse exposiciones a radionúclidos. Incluso al nivel de riesgo biológico más bajo, los procesos de fabricación biotecnológica son sistemas cerrados y la posibilidad de exposición a los cultivos recombinantes es baja, excepto en el caso de accidentes. En las instalaciones de producción biomédica, la aplicación de las buenas prácticas de fabricación actuales complementa las directrices de seguridad biológica para proteger a los trabajadores en la planta. Los principales riesgos para los trabajadores de fabricación en las operaciones con buenas prácticas a gran escala en las que se utilizan organismos recombinantes no peligrosos incluyen lesiones traumáticas músculosqueléticas (p. ej., tensión y dolor de espalda), quemaduras térmicas por las líneas de vapor y quemaduras químicas por ácidos y cáusticos (ácido fosfórico, hidróxido sódico y potásico) utilizados en el proceso.

Los trabajadores de la asistencia sanitaria, incluidos los técnicos del laboratorio clínico, están expuestos a vectores de terapia génica, excreta y muestras de excreciones y de laboratorio durante la administración de fármacos y atención de los pacientes implicados en estos procedimientos experimentales. También puede estar expuesto el personal del servicio de mantenimiento. $\mathrm{Al}$ presentar una solicitud al NIH para experimentos de terapia génica humana, dos puntos experimentales que han de considerarse son la protección del trabajador y del medio ambiente (NIH 1996).

Los trabajadores agrícolas pueden sufrir una exposición elevada a productos, plantas o animales recombinantes durante las operaciones de aplicación de plaguicidas, plantado, cosechado y procesado. Independientemente del posible riesgo biológico por la exposición a plantas y animales modificados genéticamente, están presentes también los riesgos físicos tradicionales provocados por el equipo agrícola y los animales. Para prevenir estos riesgos se utilizan controles técnicos, EPP, formación y supervisión médica (Legaspi y Zenz 1994; Pratt y May 1994). Durante la aplicación, cultivo y cosechado de plantas u organismos del suelo modificados genéticamente, son importantes los EPP, entre ellos los trajes de protección total, los equipos de protección respiratoria, los guantes, las gafas y las capuchas.

\section{Procesos y riesgos}

En los procesos biotecnológicos del sector biomédico se cultivan células u organismos, modificados de formas específicas para obtener productos deseados, en biorreactores de monocultivos. En los cultivos de células de mamíferos, el producto de las proteínas se escreta de las células al medio nutritivo, utilizándose diversos métodos de separación química (cromatografia de exclusión o afinidad, electroforesis) para capturar y purificar el producto. En los casos en que se utilicen organismos hospedadores Escherichia coli en fermentaciones, el producto deseado se encuentra dentro de la membrana celular y la células se deben romper fisicamente a fin de recoger el producto. La exposición a endotoxinas es un posible riesgo de este proceso. A menudo se añaden antibióticos a los medios de producción para aumentar la producción del producto deseado o mantener una presión selectiva sobre elementos de producción genética que de otra forma serían inestables (plásmidos). Es posible la sensibilización alérgica a estos materiales. En general estos son riesgos por exposición a aerosoles. 
Son posibles las fugas y escapes de aerosoles; los medios de control de las posibles exposiciones son varios. Es necesario entrar en los recipientes de reacción para suministrar nutrientes y oxígeno, desgasificar el dióxido de carbono $\left(\mathrm{CO}_{2}\right)$ y vigilar y controlar el sistema. Cada entrada debe sellarse o filtrarse (0,2 micras) para prevenir la contaminación del cultivo. La filtración de los gases de escape también protege a los trabajadores y al medio ambiente en el área de trabajo de aerosoles generados durante el cultivo o la fermentación. En función del riesgo biológico potencial del sistema, la inactivación biológica validada de los efluentes líquidos (normalmente por calor, vapor o métodos químicos) es una práctica normalizada. Otros posibles riesgos en la fabricación biotecnológica son similares a los de otras industrias: ruido, protección mecánica, quemaduras por vapor o calor, contacto con productos corrosivos, etc.

Los enzimas y la fermentación industrial se comentan en otros apartados de esta Enciclopedia e implican procesos, riesgos y controles similares para los sistemas de producción por ingeniería genética.

La agricultura tradicional depende del desarrollo de cepas utilizando el cruzamiento tradicional de especies de plantas relacionadas. La gran ventaja de las plantas modificadas por ingeniería genética es que el tiempo entre las generaciones y el número de cruzamientos necesario para obtener el carácter deseado se reduce considerablemente. Asimismo, la dependencia, actualmente muy impopular, de los plaguicidas y fertilizantes químicos (que contribuyen a la contaminación por arrastre) está favoreciendo una tecnología que posiblemente hará innecesarias estas aplicaciones.

La biotecnología de plantas implica la elección de especies vegetales adaptables genéticamente o económicamente significativas para las modificaciones. Debido a que las células vegetales tienen paredes celulares rígidas de celulosa, los métodos utilizados para transferir ADN en células vegetales difiere del utilizado para bacterias y líneas celulares de mamíferos en el sector biomédico. Los métodos primarios utilizados para introducir ADN extraño modificado por ingeniería genética en células vegetales son dos (Watrud, Metz y Fishoff 1996):

- una pistola de partículas dispara ADN en la célula de interés

- un virus de Agrobacterium tumefaciens no tumorígeno e inactivado introduce genes en el material genético de la célula.

El Agrobacterium tumefaciens salvaje es un patógeno natural de las plantas que causa tumores de agalla del roble en las plantas afectadas. Estas cepas inactivadas del vector modificado no causan la formación de tumores.

Después del tratamiento por cualquiera de los métodos, las células vegetales se diluyen y cultivan en medios selectivos de cultivo de tejidos durante un período relativamente largo (en comparación a la velocidad del crecimiento bacteriano) en cámaras o incubadores. Las plantas regeneradas de los tejidos tratados se transplantan al suelo en cámaras de crecimiento cerradas para su desarrollo posterior. Una vez alcanzada una edad adecuada se examina la expresión de los caracteres deseados y después se cultivan en invernaderos. Se necesitan varias generaciones de experimentos en invernaderos para evaluar la estabilidad genética del carácter de interés y generar la cantidad de semillas necesaria para estudios posteriores. Asimismo, en el curso de esta fase se recopilan datos de impacto ambiental, que se envían junto a proposiciones a los organismos legislativos para la aprobación de ensayos de campo abiertos.

\section{Controles: el caso de los Estados Unidos}

Las NIHG (NIH 1996) describen un planteamiento sistemático para prevenir la exposición de los trabajadores y la liberación al medio ambiente de organismos recombinantes. Cada institución (p. ej., universidad, hospital o laboratorio comercial) es responsable de la realización de la investigación sobre $\mathrm{ADNr}$ en condiciones seguras y cumpliendo las NIHG. Este se consigue mediante un sistema administrativo que define las responsabilidades y requiere evaluaciones completas de los riesgos por científicos expertos y funcionarios de seguridad biológica, la aplicación de controles de exposición, programas de vigilancia médica y planes de emergencia. Un Institutional Biosafety Committee (IBC) facilita los mecanismos para la revisión y aprobación de los experimentos en la institución. En algunos casos se requiere la aprobación del NIH Recombinant Advisory Committee (RAC)

El grado de control depende de la gravedad del riesgo y se describe en términos de Biosafety Level (BF) (niveles de seguridad biológica) 1-4: BL1 es el menos restrictivo y BL4 el que más. Se establecen directrices de confinamiento para investigación, I\&D a gran escala (más de 10 litros de cultivo), producción a gran escala y experimentos con animales y plantas a gran y pequeña escala.

El apéndice G de las NIHG (NIH 1996) describe el confinamiento físico a escala de laboratorio. El nivel BLl es adecuado para el trabajo con organismos sin riesgos o con riesgos mínimos para el personal del laboratorio o el medio ambiente. El laboratorio no está separado de las zonas de ocupación generales del edificio. El trabajo se realiza en mesas abiertas. No son necesarios ni se utilizan dispositivos especiales de confinamiento. El personal del laboratorio está formado en los métodos de laboratorio y supervisado por científicos con formación general en microbiología o una ciencia relacionada.

El nivel BL2 es adecuado para trabajar con productos de riesgo moderado para el personal y el medio ambiente. El acceso al laboratorio está limitado cuando se realiza el trabajo, los trabajadores reciben formación específica en la manipulación de agentes patógenos y son dirigidos por científicos competentes; el trabajo que genera aerosoles se realiza en cabinas de seguridad biológica $u$ otros equipos de confinamiento. Este trabajo puede requerir seguimiento médico o vacunaciones según determine el IBC.

El nivel BL3 se aplica cuando el trabajo se realiza con agentes indígenas o exóticos que pueden causar enfermedades graves o potencialmente letales como resultado de una exposición por inhalación. Los trabajadores reciben una formación específica y son supervisados por científicos competentes experimentados en la manipulación de estos agentes peligrosos. Todos los procedimientos se realizan en condiciones de confinamiento que requieren medidas técnicas especiales y EPP.

El nivel BL4 se reserva para los agentes más peligrosos y exóticos que presentan un alto riesgo individual y comunitario de enfermedad mortal. Sólo existen unos pocos laboratorios BL4 en el mundo.

$\mathrm{El}$ apéndice $\mathrm{K}$ aborda el confinamiento físico para las actividades de investigación o producción en volúmenes mayores de 101 (gran escala). Como en las directrices para pequeña escala, existe una jerarquía de requisitos de confinamiento del menor al mayor potencial de riesgo: GLSP a BL gran escala (BL3-LS).

Las NIHG, en el apéndice P, incluyen el trabajo con plantas en las mesas, las cámaras de cultivo y los invernaderos. Como indica la introducción: "El objetivo principal del confinamiento de plantas es evitar la transmisión involuntaria de un genoma vegetal que contiene $\mathrm{ADN}$ recombinante, incluido material hereditario nuclear o de orgánulos o liberación de ADN recombinante derivado de organismos asociados con plantas. En general estos organismos no suponen una amenaza para la salud humana ni de animales superiores, a no ser que se modifiquen intencionadamente con este fin. Con todo, son posibles la diseminación inadvertida de un patógeno serio desde un invernadero a un cultivo agrícola local o la introducción y el 
establecimiento no intencionado de un organismo en un nuevo ecosistema". (NIH 1996). En Estados Unidos, la EPA y el Animal and Plant Health Inspection Service (APHIS) de la USDA son responsables conjuntamente de la evaluación de riesgos y la revisión de los datos generados antes de aprobar los ensayos de campo (EPA 1996; Foudin y Gay 1995). A menudo se evalúan primero en los invernaderos aspectos como la persistencia y la diseminación en agua, aire y suelo, por insectos y especies animales; la presencia de otros cultivos similares en la zona; la estabilidad ambiental (sensibilidad a la congelación o al calor) y la competencia con las especies nativas. (Liberman y cols. 1996).

Los niveles de confinamiento de plantas para las instalaciones y prácticas también varían de BL1 a BL4. Los experimentos típicos BL1 implican el autoclonado. Los BL2 pueden implicar la transferencia de caracteres de un patógeno a una planta hospedadora, y los BL3 la expresión de toxinas o agentes ambientalmente peligrosos. Se consigue la protección del trabajador en los distintos niveles mediante EPP y controles técnicos como invernaderos y casetas con flujo de aire direccional y filtros de partículas en aire de alta eficacia (HEPA) para prevenir la liberación de polen. En función del riesgo se puede conseguir una protección ambiental y comunitaria de agentes potencialmente peligrosos mediante controles biológicos. Algunos ejemplos son los caracteres sensibles a la temperatura o a fármacos y requisitos nutricionales no presentes en la naturaleza.

Con los avances científicos y tecnológicos era de esperar que las NIHG necesitaran una revisión. En los últimos 20 años el RAC se ha reunido para considerar y aprobar las propuestas de cambios. Por ejemplo, las NIHG ya no publican prohibiciones sobre la liberación deliberada de organismos modificados genéticamente; se permiten las liberaciones en ensayos de campo de productos agrícolas y los experimentos de terapia génica humana en circunstancias apropiadas y después de una evaluación adecuada de los riesgos. Una modificación muy significativa de las NIHG fue la creación de una categoría de confinamiento GLSP. Esta relaja los requisitos de confinamiento para las "cepas recombinantes no patógenas, no toxigénicas derivadas de organismos hospedadores con una larga historia de uso seguro a gran escala, o que se han formado en condiciones ambientales que permiten el crecimiento óptimo a gran escala pero una supervivencia limitada sin consecuencias adversas para el medio ambiente" (NIH 1991). Este mecanismo ha permitido el progreso de la tecnología sin dejar de considerar las necesidades de seguridad.

\section{Controles: el caso de la Comunidad Europea}

En abril de 1990 la Comunidad Europea (CE) elaboró dos directivas sobre el uso confinado y la liberación deliberada al medio ambiente de OMG. Ambas directivas exigen que los Estados miembros garanticen la adopción de todas las medidas adecuadas para evitar los efectos adversos sobre la salud humana y el medio ambiente, en particular haciendo que el usuario prevea todos los riesgos. En Alemania se aprobó el Acta de Ingeniería Genética en 1990, en parte como respuesta a las Directivas de la CE, y también ante la necesidad de autorización legal para construir una instalación de producción de insulina recombinante (Reutsch y Broderick 1996). En Suiza, las leyes se basan en las NIHG de Estados Unidos, en las Directivas del Consejo de la CE y en las leyes alemanas sobre ingeniería genética. La ley suiza requiere el registro anual y actualizaciones de los experimentos ante el gobierno. En general, las normas relativas a ADNr en Europa son más restrictivas que en Estados Unidos, y esto ha contribuido a que muchas empresas farmacéuticas europeas trasladen su investigación sobre ADNr de sus países de origen. Con todo, las leyes suizas permiten una categoría de nivel 4 de seguridad a gran escala, no permitido en las NIHG (SCBS 1995).

\section{Productos de biotecnología}

Algunos de los productos biológicos y farmacéuticos preparados con éxito por biotecnologías de $\mathrm{ADN}$ recombinante son: insulina humana; hormona del crecimiento humana; vacunas contra la hepatitis; interferón alfa, beta y gamma; factor estimulante de colonias de granulocitos; activador del plasminógeno tisular; factor estimulante de colonias de granulocitos-macrófagos; IL2; eritropoyetina; Crymax, un insecticida para el control de orugas en hortalizas; cultivos de avellanos y viñas; tomate Flavr Savr (TM); quimogen, una enzima para la preparación de queso; ATIII (antitrombina III), derivada de leche de cabra transgénica utilizada para prevenir los coágulos de sangre en cirugía; BST y PST (somatotropina bovina y porcina) utilizada para estimular la producción de leche y carne.

\section{Problemas de salud y patrones de enfermedad}

Son cinco los principales riesgos para la salud derivados de la exposición a microorganismos o sus productos en biotecnología a escala industrial.

- infección

- reacción a endotoxinas

- alergia a los microorganismos

- reacción alérgica a un producto

- reacción tóxica a un producto.

La infección es poco probable, ya que en la mayor parte de los procesos industriales se utilizan organismos no patógenos. No obstante, es posible que microorganismos considerados inocuos como especies de Pseudomonas y Aspergillus puedan causar infecciones a individuos inmunocomprometidos (Bennett 1990). La exposición a endotoxina, un componente de la capa de lipopolisacáridos de la pared celular de todas las bacterias gram negativas a concentraciones mayores de unos $300 \mathrm{ng} / \mathrm{m}^{3}$ provocan síntomas transitorios semejantes a los de la gripe (Balzer 1994). Los trabajadores de muchas industrias, incluidas la agricultura tradicional y la biotecnología, han experimentado los efectos de la exposición a endotoxinas. En muchas industrias se producen también reacciones alérgicas a los microorganismos o productos. Se ha diagnosticado asma profesional en la industria de la biotecnología para un gran abanico de microorganismos y productos, entre los que se incluyen Aspergillus niger, Penicillium spp. y proteasas; algunas compañías han observado una incidencia en más del $12 \%$ del personal. Las reacciones tóxicas pueden ser tan variadas como los organismos y productos. Se ha demostrado que la exposición a antibióticos causa desplazamientos de la flora intestinal. Se sabe que algunos hongos pueden producir toxinas y productos cancerígenos en determinadas condiciones de cultivo (Bennett 1990).

Para hacer frente a la preocupación de que los trabajadores expuestos serían los primeros en desarrollar los efectos adversos para la salud resultantes de las nuevas tecnologías, el seguimiento médico de los trabajadores con $\mathrm{ADNr}$ ha sido parte de las directrices NIHG desde sus comienzos. Los Institutional Biosafety Committees, con el asesoramiento de los médicos de empresa, son responsables de determinar, proyecto a proyecto, la vigilancia médica apropiada. En función de la identidad del agente específico, la naturaleza del riesgo biológico, las vías potenciales de exposición y la disponibilidad de vacunas, el programa de vigilancia médica puede incluir exámenes físicos antes de la asignación de un puesto, exámenes periódicos de seguimiento, vacunas específicas, evaluaciones de alergia y enfermedades, sueros anteriores a la exposición y análisis epidemiológicos. 
En opinión de Bennett (1990), es poco probable que los microorganismos modificados genéticamente planteen un riesgo mayor de infección o alergia que los organismos originales, pero podrían existir riesgos adicionales por el nuevo producto o el ADNr. Un informe reciente señala que la expresión de un alergeno de nuez del Brasil en soja transgénica puede causar efectos inesperados sobre la salud entre trabajadores y consumidores (Nordlee y cols. 1996). Otros riesgos nuevos son el uso de líneas celulares animales con oncogenes desconocidos o no detectados, o virus potencialmente peligrosos para el ser humano.

Es importante señalar que no se han materializado los primeros temores sobre la creación de especies mutantes genéticamente peligrosas o supertoxinas. La OMS ha encontrado que la biotecnología no plantea riesgos distintos a los de otras industrias de proceso (Miller 1983), y, según Liberman, Ducatman y Fink (1990), "actualmente existe consenso en relación con que los riesgos potenciales del $\mathrm{ADNr}$ fueron exagerados inicialmente y que los riesgos asociados con esta investigación son similares a los asociados con el organismo, el vector, el ADN, los disolventes y los aparatos utilizados". La conclusión a la que llegan es que los organismos modificados por ingeniería genética tienen riesgos; con todo, se puede aplicar un confinamiento que minimice la exposición.

Es muy difícil identificar las exposiciones profesionales específicas de la biotecnología, ya que no es una industria separada con un código por la Standard Industrial Classification (SIC); por el contrario, se considera un proceso o conjunto de herramientas utilizadas en muchas aplicaciones industriales. En consecuencia, cuando se informa de accidentes y exposiciones, los datos sobre los casos en los que se ven envueltos trabajadores de la biotecnología quedan incluidos entre los datos de todos los demás del sector de las industrias principales (p. ej., agricultura, industria farmacéutica o atención sanitaria). Por otra parte, se sabe que no se comunican muchos de los incidentes y accidentes de laboratorio.

Se han comunicado pocas enfermedades debidas específicamente a ADN alterado genéticamente; no obstante, éstas no son desconocidas. Al menos se ha documentado una infección local con seroconversión cuando un trabajador sufrió un pinchazo con una aguja contaminada con un vector de vacuna recombinante (Openshaw y cols. 1991).

\section{Aspectos relativos a las políticas}

En el decenio de 1980 aparecieron los primeros productos de biotecnología en Estados Unidos y Europa. El uso de la insulina obtenida por ingeniería genética fue aprobado en 1982, al igual que una vacuna contra la disentería porcina (Sattelle 1991). Se ha demostrado que la somatotropina bovina recombinante (BST) aumenta la producción de la leche de cabra y el peso del ganado bovino. Entonces surgieron preocupaciones sobre la salud pública y la seguridad del producto y sobre si las leyes existentes eran adecuadas para hacer frente a estas preocupaciones en todas las distintas áreas en que los productos de biotecnología podrían comercializarse. Las NIHG proporcionan protección para los trabajadores y el medio ambiente durante las etapas de investigación y desarrollo. La seguridad y la eficacia del producto no son competencia de las NIHG. En Estados Unidos, a través del Coordinated Framework, los posibles riesgos de los productos de biotecnología son evaluados por el organismo más apropiado (FDA, EPA o USDA).

Aún continua el debate sobre la seguridad de la ingeniería genética y los productos de biotecnología (Thomas y Myers 1993), sobre todo con respecto a las aplicaciones agrícolas y los alimentos para consumo humano. Los consumidores de algunos países desean que se etiqueten los productos de manera que se identifiquen los híbridos tradicionales y los derivados de la biotecnología. Algunos fabricantes de derivados lácteos rechazan el uso de la leche de cabras que reciben BST, prohibida en algunos países (p. ej., en Suiza). La FDA estima que los productos son seguros, pero existen también aspectos económicos y sociales tal vez inaceptables para el público. La BST puede suponer un inconveniente para las granjas más pequeñas, la mayor parte de las cuales son familiares. A diferencia de las aplicaciones médicas en donde puede no existir una alternativa al tratamiento obtenido por ingeniería genética, cuando se dispone de alimentos tradicionales en cantidad suficiente, el público prefiere hibridaciones tradicionales a los alimentos recombinantes. Con todo, los medios hostiles y la carestía actual de alimentos a nivel mundial pueden cambiar esta actitud.

Las aplicaciones más recientes de la tecnología a la salud humana y a las enfermedades hereditarias ha reavivado las preocupaciones y creado nuevos aspectos éticos y sociales. El proyecto Genoma Humano, que comenzó en el decenio de 1980, dará lugar a un mapa físico y genético del material genético humano. Este mapa facilitará a los investigadores información para comparar la expresión de genes "sanos o normales" y "enfermos", con objeto de comprender, predecir y buscar curación a los defectos genéticos básicos. Las tecnologías del Genoma Humano han desarrollado nuevas pruebas diagnósticas para la enfermedad de Huntington, la fibrosis quística y los cánceres de mama y colon. Se espera que la terapia génica humana somática corrija o mejore los tratamientos para enfermedades hereditarias. La obtención de la "huella dactilar" de ADN por cartografía de fragmentos de restricción de material genético se utiliza como prueba forense en casos de violación, secuestro y homicidio. Se puede utilizar para probar (o descartar técnicamente) la paternidad. Asimismo se aplica a otras áreas controvertidas, como la evaluación de las posibilidades de desarrollo de cáncer y enfermedades coronarias para la cobertura de seguros y tratamientos preventivos o como prueba en tribunales de guerra y "chapa de identificación" genética en el ejército.

A pesar de que es técnicamente factible, en Estados Unidos no se ha considerado la aprobación de los experimentos con líneas germinativas humanas (transmisibles de generación en generación) debido a consideraciones sociales y éticas graves. No obstante, en dicho país se han programado conferencias públicas para reabrir el debate sobre terapia de líneas germinativas humanas y la expresión de caracteres deseados no asociados con enfermedades.

Por último, además de los aspectos de seguridad, sociales y éticos, aún evolucionan las teorías legales sobre la posesión de genes y ADN y la responsabilidad sobre su buen o mal uso.

Es necesario seguir las implicaciones a largo plazo de la liberación al ambiente de distintos agentes. El nuevo confinamiento biológico y el número limitado de hospedadores contribuirán a un trabajo cuidadosa y apropiadamente controlado en el medio ambiente del laboratorio, para el que sin embargo no se conocen todas las posibilidades ambientales. Los países en desarrollo, en los que pueden no existir expertos científicos adecuados ni organismos reguladores, pueden estar poco dispuestos o ser incapaces de realizar la evaluación del riesgo para su medio ambiente particular. Esto podría originar restricciones innecesarias o una política de "puertas abiertas" imprudente; cualquiera de las dos opciones perjudicaría a largo plazo al país (Ho 1996).

Por otra parte, es importante tener precaución cuando se introducen agentes agrícolas modificados por ingeniería genética en nuevos entornos en los que no existen las heladas ni otros controles naturales de confinamiento. ¿Será posible que las poblaciones indígenas o los intercambiadores naturales de información genética se apareen con agentes recombinantes causando la transferencia de caracteres modificados por 
ingeniería genética? ¿Serán estos caracteres nocivos en otros agentes? ¿Cuál será el efecto sobre los administradores de tratamientos? ¿Las reacciones inmunes limitarán la diseminación? ¿Los agentes vivos modificados por ingeniería genética son capaces de cruzar las barreras de las especies? ¿Persisten en desiertos, montañas, llanuras y ciudades?

\section{Resumen}

En Estados Unidos la moderna biotecnología se ha elaborado desde principios del decenio de 1970 al amparo de las directrices de consenso y ordenanzas locales. Los estudios detallados no han demostrado aspectos inesperados e incontrolables en organismos recombinantes. Es una tecnología útil, sin la cual no hubieran sido posibles numerosos avances médicos basados en proteínas terapéuticas naturales. En muchos países desarrollados la biotecnología es una fuerza económica de primer orden, debido a la industria que se ha desarrollado en torno a la revolución biotecnológica.

Los problemas médicos para los trabajadores de la biotecnología están relacionados con los riesgos del hospedador específico, el vector y el ADN, y las operaciones físicas realizadas. Hasta ahora las enfermedades de los trabajadores se han prevenido mediante mejoras técnicas, prácticas de trabajo, vacunas y controles de confinamiento biológico, específicos para el riesgo y evaluados caso por caso. También se cuenta con la infraestructura administrativa para realizar evaluaciones prospectivas de riesgos para cada nuevo protocolo experimental. Mantener la seguridad en la liberación al medio ambiente de materiales viables, depende de la evaluación continua de la posible persistencia de los riesgos ambientales, la dispersión, los intercambiadores naturales, las características de la célula hospedadora, la especificidad del rango de hospedadores para los agentes de transferencia utilizados, la naturaleza del gen insertado, etc. Es importante considerar todos los entornos posibles y las especies afectadas con objeto de minimizar las sorpresas que a menudo nos ofrece la naturaleza.

\section{INDUSTRIA PIROTECNICA}

\section{J. Kroeger*}

La industria pirotécnica puede definirse como la fabricación de artículos pirotécnicos (fuegos artificiales) para entretenimiento, uso técnico y militar en señalización e iluminación, aplicación como plaguicida y para otros fines. Estos artículos contienen sustancias pirotécnicas compuestas de polvos o pastas conformadas, compactadas o comprimidas. Cuando se encienden, la energía que contienen se libera provocando unos efectos específicos, como iluminación, detonación, silbidos, ruidos, formación de humo, combustión lenta, propulsión, ignición, cebado, disparo y disgregación. La sustancia pirotécnica más importante es aún la pólvora negra (pólvora, formada por carbón vegetal, azufre y nitrato potásico), y se puede utilizar suelta o para detonación, compactada para propulsión o disparo, o amortiguada con carbón vegetal como cebo.

\section{Procesos}

Las materias primas utilizadas en la fabricación de artículos pirotécnicos deben ser muy puras, exentas de impurezas mecánicas y (sobre todo) de ingredientes ácidos. Esto se aplica también a los materiales auxiliares, como papel, cartón y cola. La Tabla 77.12

ofrece una relación de materias primas comunes utilizadas en la fabricación de artículos pirotécnicos.

Una vez secas, trituradas y tamizadas, las materias primas se pesan y mezclan en un edificio especial. Antes se mezclaban siempre a mano, pero en las plantas modernas se utilizan a menudo mezcladores mecánicos. Después de la mezcla, las sustancias se deben guardar en almacenes especiales con objeto de evitar la acumulación en el lugar de trabajo. Solamente se introducirán las cantidades necesarias para las operaciones de proceso.

Los estuches para los artículos pirotécnicos deben ser de papel, cartón, material sintético o metal. El método de envasado varía. Por ejemplo, para la detonación, la mezcla se introduce suelta en un estuche y se sella, mientras que para la propulsión, iluminación, ruido o silbido se introduce suelta en el estuche y después se compacta o comprime y se sella.

La compresión o compactación se realizaban mediante golpes de mazo sobre una herramienta de "asentamiento" de madera, pero este método se emplea poco en las instalaciones modernas; en su lugar se utilizan prensas hidráulicas o prensas de grageas rotativas. Las prensas hidráulicas permiten comprimir la composición simultáneamente en varios estuches.

Las sustancias para la iluminación suelen conformarse en húmedo para formar estrellas, que se secan e introducen en estuches para cohetes, bombas, etc. Estas sustancias preparadas en húmedo deben secarse bien o corren peligro de inflamarse espontáneamente.

Dado que es difícil encender muchas sustancias pirotécnicas cuando están comprimidas, los artículos pirotécnicos en cuestión se presentan con un ingrediente intermediario o cebador para garantizar la ignición; entonces el estuche se sella. El artículo se enciende desde el exterior mediante una cerilla, un fusible, un rascador o una cápsula fulminante.

Tabla 77.12 - Materias primas utilizadas en la fabricación de productos pirotécnicos.

\section{Productos \\ Explosivos}

Materiales combustibles

Materiales oxidantes

Colorantes de llamas

Materiales inertes

\section{Materias primas}

Nitrocelulosa (lana de colodión), fulminante de plata, pólvora negra (nitrato de potasio, azufre y carbón vegetal).

Resina acaroide, dextrina, ácido gálico, goma arábiga, madera, carbón vegetal, colofonia, lactosa, cloruro de polivinilo(PVC), goma laca, metilcelulosa, sulfuro de antimonio, aluminio, magnesio, silicio, zinc, fósforo, azufre.

Clorato potásico, clorato de bario, potasio, perclorato, nitrato de bario, nitrato potásico, nitrato sódico, nitrato de estroncio, peróxido de bario, dióxido de plomo, óxido de cromo.

Carbonato de bario (verde), criolita (amarillo), cobre, sulfato amónico (azul), oxalato sódico (amarillo), carbonato de cobre (azul) arsenito acetato de cobre(azul), carbonato de estroncio (rojo), oxalato de estroncio (rojo). Se utilizan colorantes para producir humo coloreado, y cloruro amónico para producir humo blanco.

Triestearato de glicerilo, parafina, tierra de diatomeas, cal, creta. 


\section{Riesgos}

Los riesgos más importantes en la industria pirotécnica son, evidentemente, el fuego y las explosiones. Debido al pequeño número de máquinas implicadas, los riesgos mecánicos son menos importantes; son similares a los de otras industrias.

La sensibilidad de la mayor parte de las sustancias pirotécnicas es tal que en forma suelta se pueden encender fácilmente mediante golpes, fricción, chispas y calor. Presentan riesgos de incendio y explosión y se consideran explosivos. Muchas sustancias pirotécnicas tienen el efecto explosivo de los explosivos ordinarios, de forma que los trabajadores pueden quemarse el cuerpo o la ropa con las llamas.

En el curso del tratamiento de sustancias tóxicas utilizadas en productos pirotécnicos (p. ej., compuestos de plomo y bario y arsenito de acetato de cobre), existe el riesgo de inhalación del polvo durante la pesada y el mezclado.

\section{Medidas de seguridad y salud}

En la fabricación de sustancias pirotécnicas solamente se podrán emplear personas mayores de 18 años. Es necesario dar las instrucciones adecuadas y supervisar a los trabajadores.

Antes de iniciar un proceso de fabricación es importante evaluar la sensibilidad de las sustancias pirotécnicas a la fricción, el impacto y el calor, y también su acción explosiva. La naturaleza del proceso de fabricación y las cantidades permisibles en las salas de trabajo y los edificios de secado y almacenamiento dependerán de estas propiedades.

En la fabricación de sustancias y artículos pirotécnicos se deben adoptar las precauciones fundamentales siguientes:

- Los edificios de la parte no peligrosa (oficinas, talleres, áreas de descanso, etc.) deben estar situadas a distancia de las áreas peligrosas.

- Deben existir edificios separados de fabricación, procesado y almacenamiento para los distintos procesos de fabricación en las áreas peligrosas; estos edificios deben encontrase bien separados.

- Los edificios de procesado se deben dividir en salas separadas.

- Deben limitarse las cantidades de sustancias pirotécnicas en los edificios de mezclado, procesado, almacenamiento y secado.

- Debe limitarse el número de trabajadores en las distintas salas.

Se recomiendan las distancias siguientes:

- entre los edificios de las áreas peligrosas y los de las áreas no peligrosas, al menos $30 \mathrm{~m}$;

- entre los distintos edificios de procesado, $15 \mathrm{~m}$;

- entre los edificios de mezclado, secado y almacenamiento y otros edificios, 20 a $40 \mathrm{~m}$ en función de la construcción y el número de trabajadores afectados,

- entre los distintos edificios de mezclado, secado y almacenamiento, de 15 a $20 \mathrm{~m}$.

En circunstancias favorables, se pueden reducir las distancias entre los lugares de trabajo, también si entre ellos se construyen paredes protectoras.

Se debe disponer de edificios separados para las funciones siguientes: almacenamiento y preparación de las materias primas, mezclado, almacenamiento de composiciones, procesado (envasado, compactado o compresión) secado, acabado, (encolado, barnizado, envasado, parafinado, etc.), secado y almacenado de los artículos terminados y almacenamiento de pólvora.

Se deben almacenar en salas aisladas las materias primas siguientes: cloratos y percloratos, perclorato amónico; nitratos, peróxidos y otras sustancias oxidantes; metales ligeros; sustancias combustibles; líquidos inflamables; fósforo rojo; nitrocelulosa.
Esta se debe guardar húmeda. Los polvos metálicos deben protegerse contra la humedad, los aceites grasos y la grasa. Los oxidantes se deben almacenar por separado.

\section{Diseño de los edificios}

En el caso del mezclado, los más adecuados son los edificios con venteo contra explosión (tres paredes y tejado resistentes y una pared de venteo contra explosiones con revestimiento de plástico). Se recomienda una pared protectora delante de la pared de venteo contra explosiones. No deben utilizarse las salas de mezclado de sustancias con cloratos para sustancias con metales o sulfuro de antimonio.

En cuanto al secado, los edificios con un área de venteo contra explosiones y los edificios cubiertos con tierra y provistos de una pared de venteo contra explosiones son satisfactorios. Deben estar rodeados por un muro. En los edificios de secado se recomienda una temperatura ambiente controlada de $50{ }^{\circ} \mathrm{C}$.

En los edificios de manipulación debe haber salas independientes para: llenado; compresión o compactación; cortado, engarzado y cierre de los estuches; lavado de sustancias pirotécnicas conformadas y comprimidas; cebado de sustancias pirotécnicas; almacenamiento de sustancias pirotécnicas y productos intermedios; envasado y almacenamiento de sustancias envasadas. Se ha encontrado que la disposición más adecuada es una hilera de edificios con áreas de venteo contra explosiones. La resistencia de las paredes intermedias debe adecuarse a la naturaleza y cantidad de las sustancias manipuladas.

He aquí algunas reglas básicas para edificios en los que pueden estar presentes o utilizarse materiales explosivos:

- Los edificios deben tener un solo piso y no tener sótanos.

- Las superficies de los tejados deben permitir una protección suficiente contra la dispersión del fuego.

- Las paredes de las salas deben ser lisas y lavables.

- Los suelos deben tener una superficie lisa y plana sin orificios. Debe ser de un material blando como xilotita, asfalto exento de arena y materiales sintéticos. No deben utilizarse suelos de madera ordinarios. Los suelos de las salas peligrosas deben ser conductores eléctricos, y los trabajadores llevarán zapatos con suelas conductoras de la electricidad.

- Las puertas y las ventanas de todos los edificios deben tener salida al exterior. Durante las horas de trabajo no se cerrarán las puertas con llave.

- No se permite la calefacción de los edificios con llamas abiertas. Para la calefacción de los edificios peligrosos solamente se utilizarán agua caliente, vapor a baja presión o sistemas eléctricos estancos al polvo. Los radiadores deben ser lisos y fáciles de limpiar; no se deben utilizar radiadores con tuberías finas. Se recomienda una temperatura de $115^{\circ} \mathrm{C}$ para calentar superficies y tuberías.

- Las mesas y estanterías deben ser de materiales resistentes al fuego o madera dura.

- Las salas de trabajo, almacenamiento y secado y sus equipos se deben limpiar regularmente mediante aspiración en húmedo.

- Los lugares de trabajo, las entradas y salidas de emergencia deben diseñarse de tal forma que las salas puedan evacuarse rápidamente.

- En la medida de lo posible, se deben separar los lugares de trabajo mediante paredes protectoras.

- Las materias primas necesarias deben guardarse en lugar seguro.

- Todos los edificios deben estar equipados con pararrayos.

- Se debe prohibir fumar, las llamas abiertas y llevar cerillas y encendedores en las instalaciones. 


\section{Equipos}

Las prensas mecánicas deben tener pantallas o paredes protectoras, de forma que si se declara un incendio los trabajadores no estén en peligro y el fuego no se pueda extender a los lugares de trabajo contiguos. Si se manipulan grandes cantidades de material, las prensas deben estar en salas aisladas y manejarse desde el exterior, sin que nadie permanezca en el interior de la sala.

Se debe disponer de suficientes extintores de incendios, marcados y revisados regularmente, y adecuados a la naturaleza de los materiales presentes. Se utilizarán extintores de clase D sobre polvo metálico en combustión, no agua, espuma, productos químicos secos o dióxido de carbono. Se recomiendan duchas, mantas de lana y mantas retardantes del fuego para apagar las ropas en llamas.

Las personas que entren en contacto con sustancias pirotécnicas o puedan estar amenazadas por las llamas deben llevar ropas protectoras resistentes al fuego y al calor. La ropa se desempolvará diariamente en un lugar previsto para la eliminación de contaminantes.

Se adoptarán medidas para proporcionar primeros auxilios en caso de accidentes.

\section{Materiales}

Se deben recoger por separado los residuos peligrosos con propiedades diferentes, y vaciar diariamente los contenedores de residuos. Hasta su destrucción, los residuos recogidos se guardarán en un lugar protegido al menos a $15 \mathrm{~m}$ de cualquier edificio. Los productos defectuosos e intermedios se deben tratar como residuos. Solamente serán reprocesados si ello no implica riesgos.

Se evitará el contacto directo con materiales nocivos para la salud cuando se manipulen. Se deben eliminar con eficacia y seguridad los gases, vapores y polvos nocivos. Si los sistemas de ventilación no son adecuados, deben llevarse equipos de protección respiratoria y ropa protectora adecuada.

\section{Referencias}

Adams, WV, RR Dingman, JC Parker. 1995. Dual gas sealing technology for pumps. Actas del 12 International Pump Users Symposium. March, College Station, TX.

American Petroleum Institute (API). 1994. Shaft Sealing Systems for Centrifugal Pumps. API Standard 682 Washington, DC: API

Auger, JE. 1995. Build a proper PSM program from the ground-up. Chemical Engineering Progress 91:47-53.

Bahner, M. 1996. Level-measurement tools keep tank contents where they belong. Environmental Engineering World 2:27-31.

Balzer, K. 1994. Strategies for developing biosafety programs in biotechnology facilities. Presentado en el 3 Simposio Nacional sobre la Biosfera, 1 marzo, Atlanta, Georgia.

Barletta, T, R Bayle, K Kennelley. 1995. TAPS storage tank bottom: Fitted with improved connection Oil \& Gas fournal 93:89-94.

Bartknecht, W. 1989. Dust Explosions. Nueva York: Springer-Verlag.

Basta, N. 1994. Technology lifts the VOC cloud Chemical Engineering 101:43-48.

Bennett, AM. 1990. Health Hazards in Biotechnology. Salisbury, Wiltshire, Reino Unido: Division of Biologics, Public Health Laboratory Service, Centre for Applied Microbiology and Research.

Berufsgenossenschaftlices Institut für Arbeitssicherheit (BIA). 1997. Measurement of Hazardous Substances: Determination of Exposure to Chemical and Biological Agents. BIA Working Folder. Bielefeld: Erich Schmidt Verlag.

Bewanger, PC, RA Krecter. 1995. Making safety data "safe". Chemical Engineering 102:62-66.

Boicourt, GW. 1995. Emergency relief system (ERS design: An integrated approach using DIERS methodology. Process Safety Progress 14:93-106.

Carroll, LA, EN Ruddy. 1993. Select the best VOC control strategy. Chemical Engineering Progress 89:28-35.

Center for Chemical Process Safety (CCPS). 1988. Guidelines for Safe Storage and Handling of High Toxic Hazard Materials. Nueva York: American Institute of Chemical Engineers.

- 1993. Guidelines for Engineering Design for Process Safetv. Nueva York: American Institute of Chemical Engineers.

Cesana, G, R Siwek. 1995. Ignition behavior of dusts meaning and interpretation. Process Safety Progress 14:107-119.
Chemical and Engineering News. 1996. Facts and figures for the chemical industry. $C \mathcal{E}^{2} E N$ (24 junio):38-79.

Chemical Manufacturers Association (CMA). 1985. Process Safety Management (Control of Acute Hazards). Washington, DC: CMA.

Comisión Internacional de Protección contra la Radiación no Ionizante (ICNIRP). En imprenta. Practical Guide for Safety in the Use of RF Dielectric Heaters and Sealers. Ginebra: OIT

Committee on Recombinant DNA Molecules, Assembly of Life Sciences, National Research Council, National Academy of Sciences. 1974. Cartas al director. Science 185:303.

Consejo de la Comunidad Europea. 1990a. Directiva del Consejo de 26 de noviembre 1990 sobre protección de los trabajadores contra los riesgos relacionados con la exposición a agentes biológicos durante el trabajo. 90/679/CCE. Diario Oficial de las Comunidades Europeas 50(374):1-12.

- 1990b. Directiva del Consejo de 23 abril 1990 sobre liberación intencional en el medio ambiente de organismos modificados genéticamente. 90/220/CEE. Diario Oficial de las Comunidades Euro peas 50(117): 15-27.

Dow Chemical Company. 1994a. Dow's Fire E Explo sion Index Hazard Classification Guide, $7^{\mathrm{a}}$ edición. Nueva York: American Institute of Chemical Engineers.

1994b. Dow's Chemical Exposure Index Guide. Nueva York: American Institute of Chemical Engineers.

Ebadat, V. 1994. Testing to assess your powder's fire and explosion hazards. Powder and Bulk Engineering $14: 19-26$

Environmental Protection Agency (EPA). 1996. Proposed guidelines for ecological risk assessment. Federal Register 61.

Fone, CJ. 1995. The application of innovation and technology to the containment of shaft seals. Presentado en la First European Conference on Controlling Fugitive Emissions from Valves, Pumps, and Flanges, 18-19 octubre, Amberes.

Foudin, AS, C Gay. 1995. Introduction of genetically engineered microorganisms into the environment: Review under USDA, APHIS regulatory authority. En Engineered Organisms in Environmental Settings: Biotechnological and Agricultural Applications, dirigido por MA Levin y E Israeli. Boca Ratón, Florida:CRC Press.

Freifelder, D (dir.). 1978. The controversy. En Recombi nant DNA. San Francisco, California: WH Freeman.

Garzia, HW, JA Senecal. 1996. Explosion protection of pipe systems conveying combustible dusts or flammable gases. Presentado en el 30 Loss Preven- tion Symposium, 27 febrero, Nueva Orleans, Los Ángeles.

Green, DW, JO Maloney, RH Perry (dirs.). 1984. Perry's Chemical Engineer's Handbook, $6^{\text {a }}$ edición. Nueva York: McGraw-Hill.

Hagen, T, R Rials. 1994. Leak-detection method ensures integrity of double bottom storage tanks. Oil $\&$ Gas foumal (14 noviembre).

Ho, M-W. 1996. Are current transgenic technologies safe? Presentado en el Workshop on Capacity Building in Biosafety for Developing Countries, 22-23 mayo, Estocolmo.

Industrial Biotechnology Association. 1990. Biotechnology in Perspective. Cambridge, Reino Unido: Hobsons Publishing plc.

Industrial Risk Insurers (IRI). 1991. Plant Layout and Spacing for Oil and Chemical Plants. IRI Information Manual 2.5.2. Hartford, Connecticut: IRI.

Lee, SB, LP Ryan. 1996. Occupational health and safety in the biotechnology industry: A survey of practicing professionals. Am Ind Hyg Assoc $\vec{f}$ 57:381-386.

Legaspi, JA, C Zenz. 1994. Occupational health aspects of pesticides: Clinical and hygienic principles. En Occupational Medicine, $3^{\mathrm{a}}$ edición, dirigido por C Zenz, OB Dickerson y EP Horvath. St. Louis: Mosby-Year Book, Inc.

Liberman, DF, AM Ducatman, R Fink. 1990. Biotechnology: Is there a role for medical surveillance? En Bioprocessing Safety: Worker and Community Safety and Health Considerations. Filadelfia, Pensilvania: American Society for Testing and Materials.

Liberman, DF, L Wolfe, R Fink, E Gilman. 1996. Biological safety considerations for environmental release of transgenic organisms and plants. En Engineered Organisms in Environmental Settings: Biotechnological and Agricultural Applications, dirigido por MA Levin y E Israeli. Boca Ratón, Florida: CRC Press.

Lichtenstein, N, K Quellmalz. 1984. Flüchtige Zersetzungsprodukte von Kunststoffen I: ABSPolymere. Staub-Reinhalt 44(1):472-474.

1986a. Flüchtige Zersetzungsprodukte von Kunststoffen II: Polyethylen. Staub-Reinhalt 46(1):11-13.

1986b. Flüchtige Zersetzungsprodukte von Kunststoffen III: Polyamide. Staub-Reinhalt 46(1):197-198.

1986c. Flüchtige Zersetzungsprodukte von Kunststoffen IV: Polycarbonate. Staub-Reinhalt 46(7/8):348-350.

Lipton, S, JR Lynch. 1994. Handbook of Health Hazard Control in the Chemical Process Industry. Nueva York: John Wiley \& Sons. 
Massachusetts Biotechnology Council Community Relations Committee. 1993. Estadísticas no publicadas.

Mecklenburgh, JC. 1985. Process Plant Layout. Nueva York: John Wiley \& Sons.

Miller, H. 1983. Informe sobre el Grupo de Trabajo de la Organización Mundial de la Salud sobre Implicaciones de la Biotecnología en la Salud. Recombinant DNA Technical Bulletin 6:65-66.

Miller, HI, MA Tart, TS Bozzo. 1994. Manufacturing new biotech products: Gains and growing pains. f Chem Technol Biotechnol 59:3-7.

Moretti, EC, N Mukhopadhyay. 1993. VOC control: Current practices and future trends. Chemical Engineering Progress 89:20-26.

Mowrer, DS. 1995. Use quantitative analysis to manage fire risk. Hydrocarbon Processing 74:52-56.

Murphy, MR. 1994. Prepare for EPA's risk management program rule. Chemical Engineering Progress 90:77-82.

National Fire Protection Association (NFPA). 1990. Flammable and Combustible Liquid. NFPA 30. Quincy, Massachussets: NFPA.

National Institute for Occupational Safety and Health (NIOSH). 1984. Recommendations for Control of Occupational Safety and Health Hazards. Manufacture of Paint and Allied Coating Products. DHSS (NIOSH) Publication No. 84-115. Cincinnati, OH: NIOSH.

National Institute of Health (Japan). 1996. Personal communication.

National Institutes of Health (NIH). 1976. Recombinant DNA research. Federal Register 41:2790227905

-. 1991. Recombinant DNA research actions under the guidelines. Federal Register 56:138.

—. 1996. Guidelines for research involving recombinant DNA molecules. Federal Register 61:10004.

Netzel, JP. 1996. Seal technology: A control for industrial pollution. Presentado en los 45th Society of Tribologists and Lubrication Engineers Annual Meetings. 7-10 May, Denver.

Nordlee, JA, SL Taylor, JA Townsend, LA Thomas, and RK Bush. 1996. Identification of a Brazil-nut allergen in transgenic soybeans. New Engl f Med 334 (11):688-692.
Occupational Safety and Health Administration (OSHA). 1984. 50 FR 14468. Washington, DC: OSHA.

-. 1994. CFR 1910.06. Washington, DC:OSHA

Office of Science and Technology Policy (OSTP). 1986. Coordinated Framework for Biotechnology Regulation. FR 23303. Washington, DC: OSTP.

Openshaw, PJ, WH Alwan, AH Cherrie, FM Record. 1991. Accidental infection of laboratory worker with recombinant vaccinia virus. Lancet 338.(8764):459.

Parlamento de las Comunidades Europeas. 1987. Tratado por el que se establece una Consejo Unico y una Comisión Unica de las Comunidades Europeas. Diario Oficial de las Comunidades Europeas 50(152):2.

Pennington, RL. 1996. VOC and HAP control operations. Separations and Filtration Systems Magazine 2:18-

Pratt, D, J May. 1994. Agricultural occupational medicine. En Occupational Medicine, $3^{\text {a }}$ edición, dirigida por C Zenz, OB Dickerson y EP Horvath. St. Louis: Mosby-Year Book, Inc.

Reutsch, C-J, TR Broderick. 1996. New biotechnology legislation in the European Community and Federal Republic of Germany. Biotechnology.

Sattelle, D. 1991. Biotechnology in perspective. Lancet 338:9,28.

Scheff, PA, RA Wadden. 1987. Engineering Design for Control of Workplace Hazards. Nueva York: McGrawHill.

Siegell, JH. 1996. Exploring VOC control options. Chemical Engineering 103:92-96.

Society of Tribologists and Lubrication Engineer (STLE). 1994. Guidelines for Meeting Emission Regulations for Rotating Machinery with Mechanical Seals. STLE Special Publication SP-30. Park Ridge, Illinois: STLE.

Sutton, IS. 1995. Integrated management systems improve plant reliability. Hydrocarbon Processing 74:63-66.

Swiss Interdisciplinary Committee for Biosafety in Research and Technology (SCBS). 1995. Guidelines for Work with Genetically Modified Organisms. Zurich: SCBS.
Thomas, JA, LA Myers (dirs.). 1993. Biotechnology and Safety Assessment. Nueva York: Raven Press.

Van Houten, J, DO Flemming. 1993. Comparative analysis of current US and EC biosafety regulations and their impact on the industry. Fournal of Industrial Microbiology 11:209-215.

Watrud, LS, SG Metz, DA Fishoff. 1996. Engineered plants in the environment. En Engineered Organisms in Environmental Settings: Biotechnological and Agricultural Applications, edited by M Levin and E Israeli. Boca Ratón, Florida: CRC Press.

Woods, DR. 1995. Process Design and Engineering Practice. Englewood Cliffs, Nueva Jersey: Prentice Hall.

\section{Otras lecturas recomendadas}

American Petroleum Institute (API). 1990. Management of Process Hazards. RP 750. Washington, DC: API.

- 1992. Management Practices, Self-assessment Process, and Resource Materials. RP 9000. Washington, DC: API

- 1995. Management of Hazards Associated with Location of Process Plant Buildings. RP 752. Washington, DC: API.

Burgess, WA. 1995. Recognition of Health Hazards in Industry, $2^{\mathrm{a}}$ edición. Nueva York: John Wiley \& Sons.

Center for Chemical Process Safety (CCPS). 1985. Guidelines for Hazard Evaluation Procedures. Nueva York: American Institute of Chemical Engineers.

- 1989. Guidelines for Technical Management of Chemical Process Safety. Nueva York: American Institute of Chemical Engineers.

Comisión Ecónomica para Europa- Naciones Unidas (CEPE). 1993. The Chemical Industry in 1992: Annual Review-Production and Trade Statistics, 1989-1991. Ginebra: CEPE.

National Institute for Occupational Safety and Health. 1981. Control Technology in the Plastics and Resin Industry. DHHS (NIOSH) Publication No. 81-107. Washington, DC: GPO.

Occupational Safety and Health Administration (OSHA). 1992. 29 CFR Part 1910, Process Safety Management of Highly Hazardous Chemicals, Explosives and Blasting Agents, Final Rule. Washington, DC: OSHA.

Society of the Plastics Industry and National Safety Council. 1981. Plastics Industry Safety Handbook. Boston: Society of the Plastics Industry. 



\section{PETROLEO Y GAS NATURAL}

Director del capítulo

Richard S. Kraus

\section{Sumario}

Proceso de refino del petróleo

Richard S. Kraus . . . . . . . . . . . . . . . . . . . . . . 78.2 


\section{PROCESO DE REFINO DEL PETROLEO}

Richard S. Kraus

\section{Perfil general}

El refino del petróleo comienza con la destilación, o fraccionamiento, de los crudos en grupos de hidrocarburos separados. Los productos resultantes están directamente relacionados con las características del petróleo crudo que se procesa. La mayoría de estos productos de la destilación se convierten a su vez en productos más útiles cambiando sus estructuras físicas y moleculares mediante craqueo, reforma y otros procesos de conversión. A continuación, estos productos se someten a diversos procesos de tratamiento y separación (extracción, hidrotratamiento y desmercaptanización), para obtener productos terminados. Mientras que las refinerías más sencillas se limitan generalmente a la destilación atmosférica y al vacío, en las refinerías integradas se hace fraccionamiento, conversión, tratamiento y mezcla con lubricante, combustibles pesados y fabricación de asfalto, y, en ocasiones, procesado petroquímico.

La primera refinería, inaugurada en 1861, producía queroseno mediante destilación atmosférica simple. Entre los subproductos había alquitrán y nafta. Pronto se descubrió que podían producirse aceites lubricantes de alta calidad destilando petróleo al vacío. Con todo, durante los 30 años siguientes el queroseno fue el producto de mayor demanda. Los dos acontecimientos más significativos en el cambio de esta situación fueron:

- la invención de la luz eléctrica, que redujo la demanda de queroseno,

- la invención del motor de combustión interna, al que siguió una demanda de gasóleo diesel y gasolina (nafta).

Con la llegada de la producción a gran escala y la primera Guerra Mundial, el número de vehículos propulsados por gasolina aumentó de manera espectacular, como lo hizo la demanda de gasolina. Con todo, los procesos de destilación atmosférica y al vacío sólo permitían obtener del petróleo crudo cierta cantidad de gasolina. El primer proceso de craqueo térmico se aplicó en 1913. El craqueo térmico sometía los combustibles pesados a presión y calor intenso, descomponiendo así físicamente sus grandes moléculas en otras más pequeñas, con lo que producía más gasolina y combustibles de destilación. A fines del decenio de 1930 se aplicó una forma más elaborada de craqueo térmico, la ruptura de la viscosidad, que permitía obtener productos más valiosos y apreciables.

$\mathrm{Al}$ elaborarse motores de gasolina de compresión más elevada, se produjo una demanda de gasolina de mayor octanaje, con mejores cualidades antidetonantes. La introducción del craqueo catalítico y de los procesos de polimerización en la segunda mitad del decenio de 1930, satisfizo esta demanda al proporcionar gasolina de mayor rendimiento y octanajes más

Tabla 78.1 • Cronología resumida del proceso de refino.

\begin{tabular}{|c|c|c|c|}
\hline Año & Nombre del proceso & Finalidad del proceso & Subproductos del proceso \\
\hline 1862 & Destilación atmosférica & Producir queroseno & Nafta, alquitrán, etc. \\
\hline 1870 & Destilación al vacío & $\begin{array}{l}\text { Lubricantes (originales) } \\
\text { Cargas de craqueo (decenio 1930) }\end{array}$ & $\begin{array}{l}\text { Asfalto, residuo } \\
\text { Cargas de coquificador }\end{array}$ \\
\hline 1913 & Craqueo térmico & Aumentar gasolina & Residuo, combustible para barcos \\
\hline 1916 & Desmercaptanización & Reducir azufre y olor & Azufre \\
\hline 1930 & Reforma térmica & Mejorar índice de octano & Residuo \\
\hline 1932 & Hidrogenación & Eliminar azufre & Azufre \\
\hline 1932 & Coquización & Producir materiales base para gasolina & Coque \\
\hline 1933 & Extracción de disolventes & Mejorar índice viscosidad del lubricante & Aromáticos \\
\hline 1935 & Desparafinado de disolventes & Mejorar punto de goteo & Ceras \\
\hline 1935 & Polimerización catalítica & Mejorar rendimiento gasolina e índice de octano & Cargas petroquímicas \\
\hline 1937 & Craqueo catalítico & Gasolina de mayor octanaje & Cargas petroquímicas \\
\hline 1939 & Ruptura de la viscosidad & Reducir la viscosidad & Más destilado, alquitrán \\
\hline 1940 & Alquilación & Aumentar octanaje y rendimiento de la gasolina & Gasolina de aviación de alto octanaje \\
\hline 1940 & Isomerización & Producir carga de alquilación & Nafta \\
\hline 1942 & Craqueo catalítico de líquidos & Aumentar rendimiento y octanaje de la gasolina & Cargas petroquímicas \\
\hline 1950 & Desasfaltado & Aumentar la carga de craqueo & Asfalto \\
\hline 1952 & Reforma catalítica & Convertir nafta de baja calidad & Aromáticos \\
\hline 1954 & Hidrodesulfuración & Eliminar azufre & Azufre \\
\hline 1956 & Desmercaptanización con inhibidores & Eliminar mercaptano & Disulfuros \\
\hline 1957 & Isomerización catalítica & Convertir en moléculas de alto índice de octano & Cargas de alquilación \\
\hline 1960 & Hidrocraqueo & Mejorar calidad y reducir azufre & Cargas de alquilación \\
\hline 1974 & Desparafinado catalítico & Mejorar punto de goteo & Cera \\
\hline 1975 & Hidrocraqueo de residuos & Aumentar rendimiento en gasolina de los residuos & Residuos pesados \\
\hline
\end{tabular}


Figura 78.1 • Organigrama del proceso de una refinería.

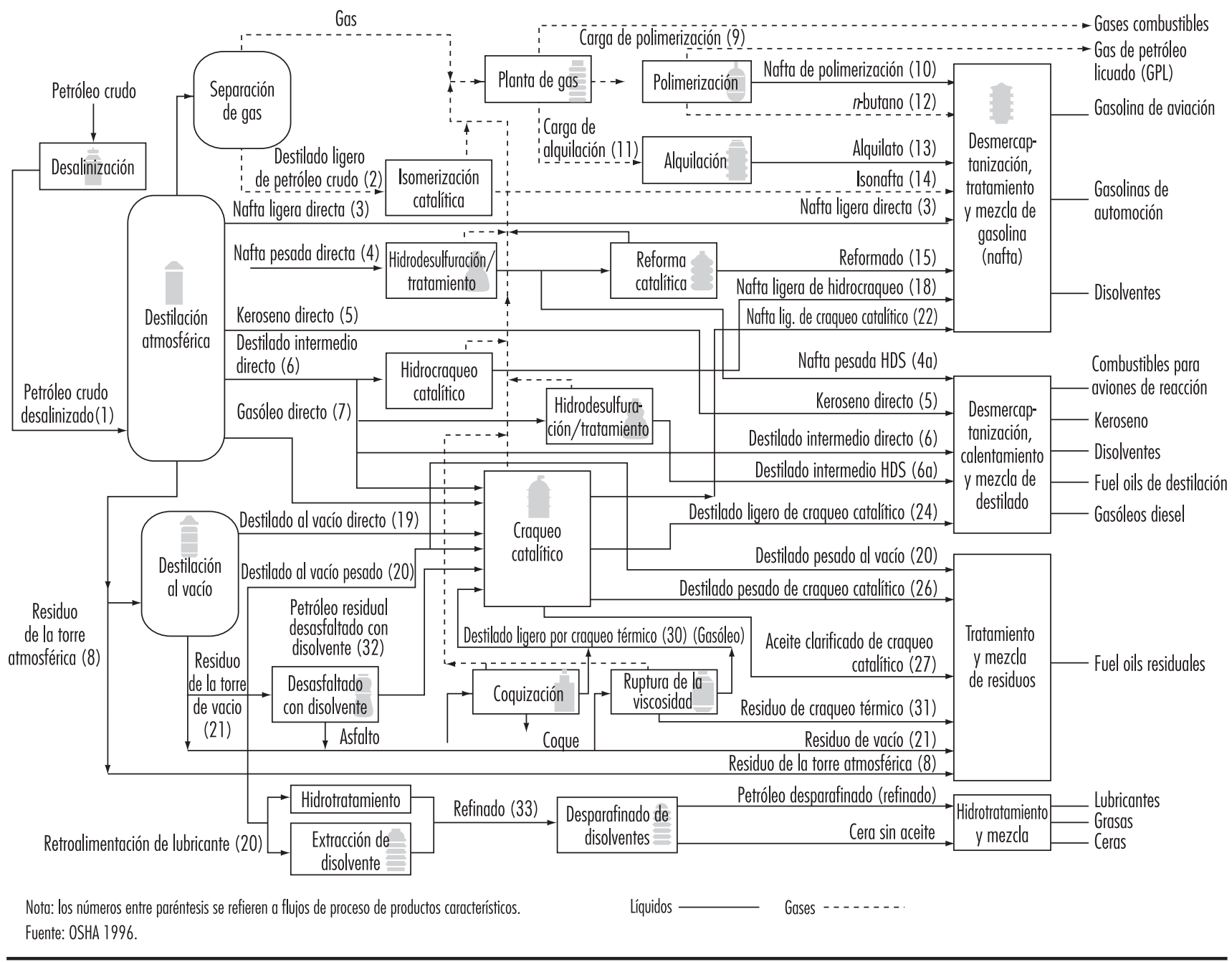

elevados. Al comienzo del decenio de 1940 se desarrolló la alquilación, otro proceso catalítico, para producir más gasolina destinada al campo de la aviación de alto octanaje y cargas petroquímicas para la fabricación de explosivos y caucho sintético. Le siguió la isomerización catalítica, cuyo objeto era convertir los hidrocarburos para producir mayores cantidades de materias primas para la alquilación.

Después de la segunda Guerra Mundial se introdujeron diversos procesos de reforma que mejoraron la calidad y el rendimiento de la gasolina, y proporcionaron productos de mayor calidad. Algunos de ellos requerían el empleo de catalizadores y/o de hidrógeno para cambiar las moléculas y eliminar el azufre. Durante el decenio de 1960 se introdujeron mejoras en los catalizadores y se elaboraron métodos de proceso, como el hidrocraqueo y la reforma, para aumentar los rendimientos de la gasolina y mejorar las cualidades antidetonantes. Tales procesos catalíticos produjeron también moléculas de doble enlace (alquenos), base de la moderna industria petroquímica.

El número y tipo de los diferentes procesos utilizados en las modernas refinerías dependen principalmente de la naturaleza de los crudos empleados como materia prima y de los requisitos de los productos finales. También influyen en los procesos factores económicos: costes de los crudos, valores de los productos, disponibilidad de servicios básicos y transporte. La cronología de la introducción de los diversos procesos se recoge en la Tabla 78.1.

\section{Procesos y operaciones básicos de refino}

Los procesos y operaciones de refino de petróleo se clasifican básicamente en: separación, conversión, tratamiento, formulación y mezcla, operaciones auxiliares y operaciones fuera de proceso (véase el organigrama simplificado de la Figura 78.1).

Separación. El petróleo crudo se separa físicamente, mediante fraccionamiento en torres de destilación atmosféricas y de vacío, en grupos de moléculas de hidrocarburos con diferentes intervalos de temperaturas de ebullición, denominados "fracciones".

Conversión. Los procesos de conversión más utilizados para modificar el tamaño y/o la estructura de las moléculas de hidrocarburos, son los siguientes:

- descomposición (división) mediante hidrocraqueo, craqueo térmico y catalítico, coquización y ruptura de la viscosidad;

- unificación (combinación) mediante alquilación y polimerización;

- alteración (rectificación) con isomerización y reforma catalítica,

- tratamiento. 


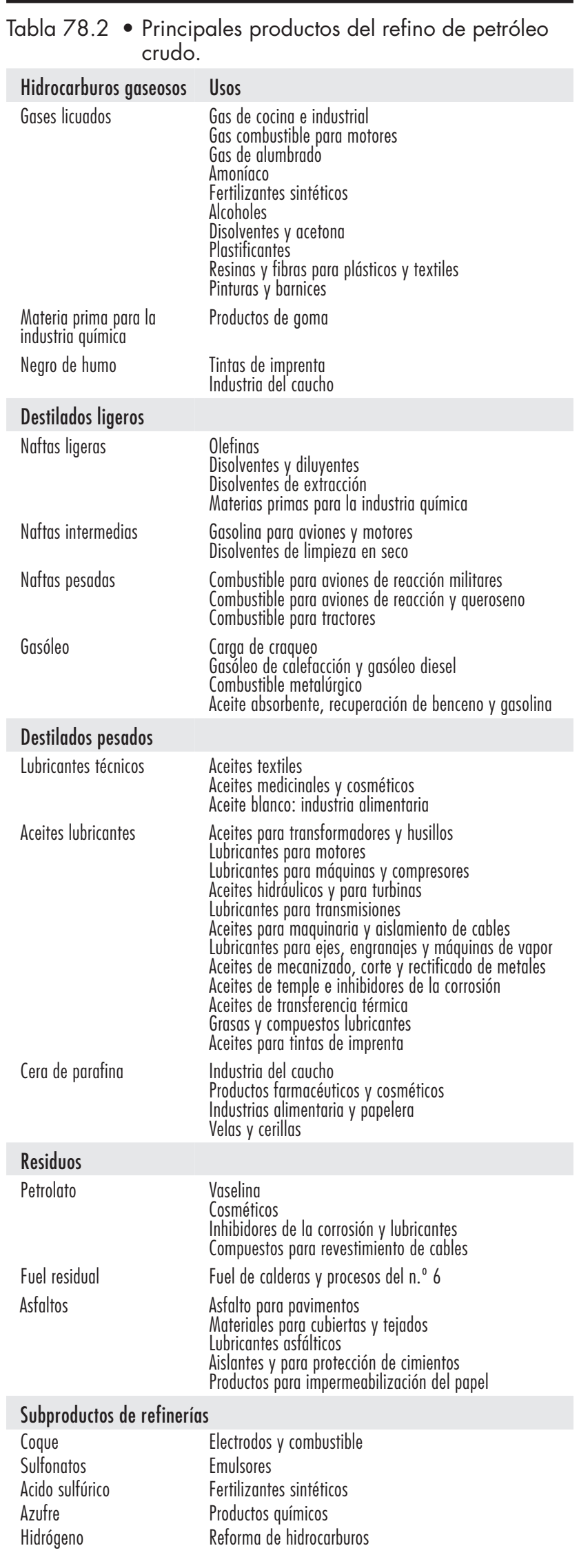

Desde los comienzos del refino se han utilizado diversos métodos de tratamiento para eliminar no hidrocarburos, impurezas y otros constituyentes que afectan negativamente a las propiedades de rendimiento de los productos acabados o reducen la eficacia de los procesos de conversión. El tratamiento implica reacciones químicas y separación física, como disolución, absorción o precipitación, mediante varios procesos y combinaciones de procesos. Entre los métodos de tratamiento se cuentan la eliminación o separación de componentes aromáticos y naftenos, y la eliminación de impurezas y contaminantes indeseables. Se utilizan compuestos desmercaptanizantes y ácidos para desulfurar el petróleo crudo antes del procesado, y para tratar los productos durante y después de éste. Otros métodos de tratamiento son la desalinización del crudo, la extracción química de mercaptanos, el tratamiento con ácidos, el contacto con arcilla, la hidrodesulfuración, el refino de disolventes, el lavado cáustico, el hidrotratamiento, el secado, y la extracción y el desparafinado de disolventes.

La formulación y mezcla es el proceso consistente en mezclar y combinar fracciones de hidrocarburos, aditivos y otros componentes para obtener productos acabados con unas propiedades específicas de rendimiento idóneo.

Operaciones auxiliares de refino. Otras operaciones de las refinerías necesarias para dar soporte al procesado de los hidrocarburos son la recuperación de residuos ligeros; la eliminación del agua amarga; el tratamiento y refrigeración de residuos sólidos, aguas residuales y agua de proceso; la producción de hidrógeno; la recuperación de azufre, y el tratamiento de gases ácidos y gas residual. Otras funciones del proceso son la provisión de catalizadores, reactivos, vapor, aire, nitrógeno, oxígeno, hidrógeno y gases combustibles.

Instalaciones de las refinerías que no forman parte del proceso. Todas las refinerías tienen multitud de instalaciones, funciones, equipos y sistemas que dan soporte a las operaciones de procesado de los hidrocarburos. Las operaciones de soporte habituales son la generación de calor y energía; el movimiento de productos; el almacenamiento en depósitos; la expedición y manipulación; las llamas y sistemas de descarga de presión; los hornos y calentadores; las alarmas y sensores, y el muestreo, la verificación y la inspección. Entre las instalaciones y sistemas que no forman parte del proceso están los sistemas de lucha contra incendios, de abastecimiento de agua y de protección, controles de ruido y contaminación, laboratorios, salas de control, almacenes, e instalaciones de mantenimiento y administrativas.

\section{Principales productos del refino de petróleo crudo}

El refino de petróleo ha evolucionado continuamente en respuesta a la demanda de productos mejores y diferentes por parte de los consumidores. El requisito original del proceso era producir queroseno como fuente de combustible para el alumbrado más barata y mejor que el aceite de ballena. La elaboración del motor de combustión interna condujo a la producción de benceno, gasolina y gasóleos diesel. La evolución del aeroplano hizo necesarios la gasolina de aviación de alto octanaje y el combustible para aviones de reacción, que es una forma más elaborada del producto original de las refinerías, el queroseno. Las refinerías actuales producen varios productos, muchos de los cuales se utilizan como materia prima para procesos de craqueo y fabricación de lubricantes, y para la industria petroquímica. Se clasifican en términos generales como combustibles, cargas petroquímicas, disolventes, aceites de proceso, lubricantes y productos especiales, como cera, asfalto y coque (véase la Tabla 78.2).

En el procesado de hidrocarburos se utilizan, o se forman como resultado del mismo, varios productos químicos. A 
continuación figura una breve descripción de aquéllos que son específicos y característicos del refino:

\section{Dióxido de azufre}

El gas procedente de la combustión de combustibles de alto contenido en azufre suele tener niveles altos de dióxido de azufre, que se elimina por lo común mediante lavado con agua.

\section{Cáusticos}

Se añaden cáusticos al agua de desalinización para neutralizar ácidos y reducir la corrosión. Se añaden también al crudo desalinizado con el fin de reducir la cantidad de cloruros corrosivos de los productos de las zonas superiores de la torre. Se utilizan en procesos de tratamiento de las refinerías para eliminar contaminantes de las corrientes de hidrocarburos.

\section{Oxidos de nitrógeno y monóxido de carbono}

El gas de chimenea contiene hasta 200 ppm de óxido nítrico, que reacciona lentamente con el oxígeno y forma dióxido de nitrógeno. El óxido nítrico no se elimina mediante el lavado con agua, por lo que el dióxido de nitrógeno puede disolverse en el agua y formar ácido nitroso y nítrico. Por lo común, el gas de chimenea sólo contiene una pequeña cantidad de monóxido de carbono, a menos que la combustión sea anómala.

\section{Acido sulfhídrico}

El ácido sulfhídrico se encuentra de modo natural en la mayoría de los crudos de petróleo y se forma también durante el procesado debido a la descomposición de compuestos de azufre inestables. El ácido sulfhídrico es un gas extremadamente tóxico, incoloro e inflamable, más pesado que el aire y soluble en agua. Tiene un olor a huevos podridos que se percibe a concentraciones muy por debajo de su límite de exposición, que es muy bajo. Aun así, no ha de confiarse en ese olor como señal de alerta, pues los sentidos se desensibilizan casi de forma inmediata al producirse la exposición. Se necesitan detectores especiales para alertar a los trabajadores de la presencia de ácido sulfhídrico, y en presencia del gas debe utilizarse protección respiratoria adecuada. La exposición a niveles bajos de ácido sulfhídrico causa irritación, mareos y cefaleas, mientras que la exposición a niveles por encima de los límites prescritos causa depresión del sistema nervioso e incluso la muerte.

\section{Agua amarga}

El agua amarga es agua de proceso que contiene ácido sulfhídrico, amoníaco, fenoles, hidrocarburos y compuestos de azufre de bajo peso molecular. Se produce al absorber el vapor fracciones de hidrocarburos durante la destilación, en la regeneración de catalizador o al absorber el vapor ácido sulfhídrico durante el hidrotratamiento y el hidroacabado. También se genera por la adición de agua a procesos para absorber ácido sulfhídrico y amoníaco.

\section{Acido sulfúrico y ácido fluorhídrico}

Ambos se utilizan como catalizadores en los procesos de alquilación. El ácido sulfúrico se emplea también en algunos de los procesos de tratamiento.

\section{Catalizadores sólidos}

En los procesos de refino se utilizan varios catalizadores sólidos diferentes, de numerosas formas distintas, desde pastillas hasta cuentas granulares o polvos, constituidos por diversos materiales y con diversas composiciones. En unidades de lecho móvil y fijo se emplean catalizadores de pastillas extruidas, mientras que en procesos de lecho fluido se usan catalizadores de partículas esféricas finas. Los catalizadores utilizados en procesos que eliminan el azufre están impregnados de cobalto, níquel o molibdeno. En las unidades de craqueo se emplean catalizadores de función ácida: arcilla natural, alúmina-silíce y zeolitas. En la isomerización y la reforma se emplean catalizadores de función ácida impregnados de platino u otros metales nobles. Los catalizadores agotados requieren medidas especiales de manipulación y protección frente a las exposiciones, dado que a veces contienen metales, aceites aromáticos, compuestos aromáticos policíclicos cancerígenos u otros materiales peligrosos, y también pueden ser pirofóricos.

\section{Combustibles}

Los principales productos combustibles son el gas de petróleo licuado, la gasolina, el queroseno, el combustible para motores de reacción, el gasóleo diesel, el gasóleo para calefacción y el fuel residual.

El gas de petróleo licuado (GLP), constituido por mezclas de hidrocarburos parafínicos y olefínicos, como el propano y el butano, se produce para utilizarlo como combustible, y se almacena y manipula en fase líquida a presión. El GPL tiene puntos de ebullición que van desde aproximadamente $74{ }^{\circ} \mathrm{C}$ hasta $+38{ }^{\circ} \mathrm{C}$, es incoloro y sus vapores son más pesados que el aire y extremadamente inflamables. Las cualidades importantes del GPL desde la perspectiva de la salud y seguridad en el trabajo, son la presión de vapor y el control de los contaminantes.

Gasolina. El producto más importante de las refinerías es la gasolina para motores, una mezcla de fracciones de hidrocarburos con puntos de ebullición relativamente bajos, incluida la gasolina reformada, de alquilato, nafta alifática (nafta ligera de destilación directa), nafta aromática (nafta de craqueo térmico y catalítico) y aditivos. Las mezclas de gasolina tienen puntos de ebullición que van desde temperaturas ambiente hasta unos $204^{\circ} \mathrm{C}$, y un punto de inflamación inferior a $-40^{\circ} \mathrm{C}$. Las cualidades críticas de la gasolina son el índice de octano (cualidad antidetonante), la volatilidad (arranque y tapón de vapor) y la presión de vapor (control ambiental). Los aditivos se utilizan para mejorar el rendimiento de la gasolina y proporcionar protección frente a la oxidación y la corrosión. La gasolina empleada en aviación es un producto de alto índice de octano, una mezcla especialmente estudiada para ofrecer buen rendimiento a grandes altitudes.

El plomo tetraetílico (PTE) y el plomo tetrametílico (PTM) son aditivos de la gasolina que mejoran los índices de octano y las cualidades antidetonantes. En un esfuerzo por reducir la presencia de plomo en las emisiones de escape de los automóviles, estos aditivos ya no se utilizan de modo habitual, excepto en la gasolina empleada en aviación.

Para mejorar las cualidades antidetonantes de la gasolina sin plomo y reducir las emisiones de monóxido de carbono, en lugar de PTE y PTM se utilizan etilbutiléter terciario (EBET), metilbutiléter terciario (MBET), amilmetiléter terciario (AMET) y otros compuestos oxigenados.

Combustible para motores de reacción y queroseno. El queroseno es una mezcla de parafinas y naftenos, generalmente con menos de un $20 \%$ de componentes aromáticos. Tiene un punto de inflamación superior a $38{ }^{\circ} \mathrm{C}$ y un intervalo de temperaturas de ebullición de $160{ }^{\circ} \mathrm{C}$ a $288^{\circ} \mathrm{C}$, y se utiliza para alumbrado, calefacción, disolventes y para mezclarlo con gasóleo diesel. El combustible para motores de reacción es un destilado intermedio de queroseno cuyas cualidades críticas son el punto de congelación, el punto de inflamación y el punto de humo. El combustible comercial para motores de reacción tiene un rango de ebullición de aproximadamente $191^{\circ} \mathrm{C}$ a $274{ }^{\circ} \mathrm{C}$, y el combustible para motores de reacción de uso militar, un rango de $55^{\circ} \mathrm{C}$ a $288^{\circ} \mathrm{C}$. 
Combustibles de destilación. Los gasóleos diesel y los de calefacción doméstica son mezclas de color claro de parafinas, naftenos y componentes aromáticos, que a veces contienen cantidades moderadas de olefinas. Los combustibles de destilación tienen puntos de inflamación superiores a $60{ }^{\circ} \mathrm{C}$ y rangos de ebullición de $163{ }^{\circ} \mathrm{C}$ a $371{ }^{\circ} \mathrm{C}$ aproximadamente, y con frecuencia se someten a hidrodesulfuración para mejorar la estabilidad. Al ser combustibles, cuando se tratan emiten vapores que forman mezclas inflamables con el aire. Entre las cualidades idóneas de los combustibles de destilación están los puntos de inflamación y de goteo controlados, la combustión limpia, la ausencia de formación de depósitos en los tanques de almacenamiento y un índice de cetano de los gasóleos diesel adecuado para un buen arranque y una combustión satisfactoria.

Combustibles residuales. Muchos barcos e instalaciones comerciales e industriales utilizan combustibles residuales o combinaciones de combustibles residuales y de destilación, para generación de energía y calor y para procesado. Los combustibles residuales son mezclas líquidas de color oscuro y alta viscosidad de moléculas grandes de hidrocarburos, con puntos de inflamación superiores a $121^{\circ} \mathrm{C}$ y altos puntos de ebullición. Las especificaciones críticas de los combustibles residuales son la viscosidad y el bajo contenido de azufre (para el control ambiental).

\section{Salud y seguridad}

El riesgo más importante del GPL y la gasolina para la seguridad, es el fuego. La alta volatilidad e inflamabilidad de los productos de bajo punto de ebullición permite que los vapores se difundan fácilmente en el aire y formen mezclas inflamables que entran en ignición con facilidad. Se trata de un riesgo reconocido, que hace que aquéllos requieran almacenamiento específico, confinamiento y precauciones de manipulación, así como medidas de seguridad para garantizar que las emanaciones de vapores y las fuentes de ignición están controlados a fin de que no puedan producirse incendios. Los combustibles menos volátiles (queroseno y gasóleo diesel) deben manipularse con cuidado para evitar derrames y su posible ignición, ya que sus vapores también son combustibles cuando se mezclan con aire en el rango de inflamabilidad. Cuando se trabaja en atmósferas que contienen vapores de combustible, las concentraciones en el aire de vapores de productos inflamables muy volátiles, suelen estar restringidas a no más del $10 \%$ de los límites inferiores de inflamabilidad (LII), y las concentraciones de los vapores de productos combustibles menos volátiles, a no más del $20 \%$ de los LII, en función de la normativa que aplique la empresa y el gobierno en cuestión, a fin de reducir el riesgo de ignición.

Aunque los niveles de vapores de gasolina en las mezclas con aire se mantienen normalmente por debajo del $10 \%$ de los LII por motivos de seguridad, esta concentración es bastante superior a los límites de exposición que deben observarse por razones de salud. La inhalación de pequeñas cantidades de vapor de gasolina en el aire, muy por debajo del límite inferior de inflamabilidad, causa irritación, cefaleas y mareos, mientras que la inhalación de mayores concentraciones puede provocar pérdida del conocimiento e incluso la muerte. Es posible que se produzcan también efectos de larga duración para la salud. La gasolina contiene, por ejemplo, benceno, un conocido cancerígeno con límites de exposición permisibles de sólo algunas partes por millón. Así pues, incluso trabajar en atmósferas con vapores de gasolina a niveles inferiores al $10 \%$ de los LII exige la adopción de precauciones apropiadas de higiene industrial: protección respiratoria o ventilación aspirante local.

Antes, muchas gasolinas contenían los aditivos antidetonantes a base de plomo alquídico tetraetílico o tetrametílico, que son tóxicos y presentan graves riesgos de absorción de plomo por contacto con la piel o por inhalación. Los depósitos o recipientes que han contenido gasolina con plomo en algún momento durante su utilización, deben ventilarse, limpiarse a fondo, comprobarse con un dispositivo de ensayo especial de "plomo en aire" y certificar que carecen de plomo para garantizar que los trabajadores puedan entrar en ellos sin utilizar respiradores autónomos ni equipos con admisión de aire puro, aunque los niveles de oxígeno sean normales y los depósitos contengan ahora gasolina sin plomo u otros productos.

Las fracciones de petróleo gaseosas y los productos combustibles, más volátiles, tienen un ligero efecto anestésico, por lo general inversamente proporcional al peso molecular. La inhalación de combustibles de bajo punto de ebullición, como la gasolina y el queroseno, causa una grave neumonía química, y debe evitarse su aspiración por efecto sifón con la boca así como su ingestión accidental. Es posible que las concentraciones de gases y vapores sean lo bastante elevadas para desplazar el oxígeno (del aire) hasta reducirlo por debajo de los niveles normales para la respiración. Por lo común, se consigue mantener las concentraciones de vapor por debajo de los límites de exposición y los niveles de oxígeno dentro de los rangos respiratorios normales, mediante purga o ventilación.

Los destilados de craqueo contienen pequeñas cantidades de hidrocarburos aromáticos policíclicos (HAP) cancerígenos; así pues, deberá limitarse la exposición. En ocasiones originan también dermatitis por exposición a gasolina, queroseno y combustibles de destilación, ya que tienen tendencia a desgrasar la piel, cuya prevención se consigue utilizando equipos de protección personal y cremas barrera; reduciendo el contacto y observando buenas prácticas higiénicas, como lavarse con agua tibia y jabón en lugar de limpiarse las manos con gasolina, queroseno o disolventes. Algunas personas tienen sensibilidad cutánea a los tintes utilizados para colorear la gasolina y otros productos de la destilación.

Los fueles residuales contienen trazas de metales y a veces retienen ácido sulfhídrico, que es extremadamente tóxico. Los combustibles residuales, cuyos componentes de craqueo tienen puntos de ebullición superiores a $370{ }^{\circ} \mathrm{C}$ contienen hidrocarburos aromáticos policíclicos (HAP) cancerígenos. Debe evitarse la exposición repetida a combustibles residuales sin la debida protección personal, sobre todo al abrir depósitos y recipientes, ya que puede desprenderse ácido sulfhídrico gaseoso.

\section{Cargas petroquímicas}

Muchos productos derivados del refino de crudos de petróleo, como el etileno, propileno y butadieno, son hidrocarburos olefínicos derivados de procesos de craqueo de refinerías, y están destinados a su utilización en la industria petroquímica como materias primas para la producción de plásticos, amoníaco, caucho sintético, glicol, etc.

\section{Disolventes derivados del petróleo}

Varios compuestos puros, entre ellos el benceno, el tolueno, el xileno, el hexano y el heptano, cuyos puntos de ebullición y composición en cuanto a hidrocarburos están estrictamente controlados, se obtienen para utilizarlos como disolventes. Los disolventes se clasifican en aromáticos y no aromáticos, según su composición. Su empleo como diluyentes de pintura, líquidos de limpieza en seco, desengrasantes, disolventes industriales y de plaguicidas, etc., suele estar determinado por su punto de inflamación, que varía desde bastante menos de $-18^{\circ} \mathrm{C}$ hasta más de $60{ }^{\circ} \mathrm{C}$.

Los riesgos asociados con los disolventes son semejantes a los de los combustibles, ya que los disolventes con un punto de inflamación más bajo son inflamables, y sus vapores, cuando se mezclan con aire que está dentro del rango de inflamabilidad, 
pueden entrar en ignición. Por lo común, los disolventes aromáticos tienen mayor toxicidad que los no aromáticos.

\section{Aceites de proceso}

Los aceites de proceso comprenden el rango de alto punto de ebullición, los productos de destilación directa atmosférica o al vacío, y los que se obtienen por craqueo térmico o catalítico. Se trata de mezclas complejas que contienen grandes moléculas de hidrocarburos parafínicos, nafténicos y aromáticos con más de 15 átomos de carbono; se utilizan como cargas para craqueo o fabricación de lubricantes. Los aceites de proceso tienen viscosidades bastante altas, puntos de ebullición comprendidos entre $260{ }^{\circ} \mathrm{C}$ y $538^{\circ} \mathrm{C}$ y puntos de inflamación superiores a $121^{\circ} \mathrm{C}$.

Los aceites de proceso son irritantes para la piel y contienen altas concentraciones de HAP, así como compuestos de azufre, nitrógeno y oxígeno. Debe evitarse la inhalación de vapores y nieblas, y la exposición cutánea debe controlarse con medios de protección personal y buenas prácticas higiénicas.

\section{Lubricantes y grasas}

Los aceites lubricantes básicos se obtienen mediante procesos de refino especiales de acuerdo con requisitos específicos de los clientes. Son mezclas de color claro a intermedio, baja volatilidad, y viscosidad entre intermedia y alta, de aceites parafinicos, nafténicos y aromáticos, con rangos de ebullición entre $371{ }^{\circ} \mathrm{C}$ y $538{ }^{\circ} \mathrm{C}$. Con los aceites lubricantes base se mezclan aditivos (desemulsificantes, antioxidantes y elementos que mejoran de la viscosidad) a fin de proporcionarles las características exigidas a los aceites de motor, aceites hidráulicos y para turbinas, grasas industriales, lubricantes, aceites para engranajes y aceites de corte. La cualidad más crítica de un aceite lubricante base es un alto índice de viscosidad, lo que, a temperaturas variables, proporciona menores cambios en viscosidad. Tal característica la tiene el petróleo crudo utilizado como carga o se consigue por medio de aditivos que mejoren el índice de viscosidad. Se añaden detergentes para mantener en suspensión cualquier lodo formado durante el uso del aceite.

Las grasas son mezclas de aceites lubricantes y jabones metálicos, a los que se añaden materiales de función específica, como amianto, grafito, molibdeno, siliconas y talco para proporcionar aislamiento o lubricidad. Los aceites de corte y los aceites de transformación de metales son aceites lubricantes con aditivos especiales, como cloro, azufre y ácidos grasos, que reaccionan bajo la acción del calor, proporcionando así lubricación y protección a las herramientas de corte. A los aceites de corte solubles en agua se les añaden emulsificantes y agentes antibacterianos.

Aunque los aceites lubricantes no son irritantes por sí mismos y tienen baja toxicidad, los aditivos presenta ciertos riesgos. Los usuarios deben consultar los datos de seguridad de los materiales que figuran en la información facilitada por el proveedor, para determinar los riesgos de ciertos aditivos, lubricantes, aceites de corte y grasas específicos. El principal riesgo de los lubricantes es la dermatitis, que normalmente se controla con equipos de protección personal y unas prácticas higiénicas adecuadas. De forma aislada, en algunos trabajadores aparece sensibilidad a los aceites de corte o lubricantes, lo que hará necesario asignarles a un puesto de trabajo en que no pueda producirse el contacto. Existe cierta preocupación por la exposición cancerígena a vapores de aceites de corte y aceites ligeros para husillos, de base nafténica, que se controla mediante sustitución, medidas de control técnico o protección personal. Los riesgos de exposición a la grasa son similares a los del aceite lubricante, con los riesgos añadidos que presentan los materiales o aditivos de las grasas. La mayoría de estos riesgos se tratan en otra sección de esta Enciclopedia.

\section{Productos especiales}

La cera se utiliza para proteger productos alimenticios, en revestimientos, como ingrediente de otros productos (cosméticos y cremas limpiadoras de calzado) y para velas.

El azufre se produce como resultado del refino del petróleo. Se almacena unas veces en fase líquida, calentado y fundido, en depósitos cerrados, y otras en fase sólida, en recipientes o a la intemperie.

El coque es carbono casi puro y tiene diversos usos, desde electrodos hasta pastillas combustibles para barbacoas, dependiendo de sus características físicas, que son resultado del proceso de coquización.

El asfalto, que se utiliza principalmente para pavimentar carreteras y fabricar materiales para cubiertas y tejados, debe ser inerte a la mayoría de las sustancias químicas y condiciones meteorológicas.

Las ceras y asfaltos son sólidos a temperatura ambiente, si bien para su almacenamiento, manipulación y transporte se requieren temperaturas más elevadas, con el consiguiente riesgo de que se produzcan quemaduras. La cera de petróleo está tan refinada que, por lo común, no presenta ningún riesgo. El contacto de la piel con la cera puede causar taponamiento de los poros, que se controla con las prácticas higiénicas adecuadas. Para evitar la exposición al ácido sulfhídrico al abrir depósitos de asfalto y de azufre fundido basta con utilizar medidas adecuadas de control técnico o protección respiratoria. El azufre es también fácilmente inflamable a temperaturas elevadas. El asfalto se trata en otra parte de esta Enciclopedia.

\section{Procesos de refino del petróleo}

El refino de hidrocarburos consiste en el empleo de sustancias químicas, catalizadores, calor y presión para separar y combinar los tipos básicos de moléculas de hidrocarburos que se hallan de forma natural en el petróleo crudo, transformándolos en grupos de moléculas similares. Es decir: se reorganizan las estructuras y los modelos de enlaces de las moléculas básicas y se convierten en moléculas y compuestos de hidrocarburos con más valor. El factor más significativo del proceso de refino no son los compuestos químicos que intervienen, sino el tipo de hidrocarburo (parafínico, nafténico o aromático).

Es necesario utilizar en toda la refinería procedimientos operativos, métodos de trabajo seguros y prendas y equipos de protección personal, entre ellos: protección respiratoria homologada, contra la exposición al fuego, las sustancias químicas, las partículas, el calor y el ruido, así como durante las operaciones de proceso y las actividades de toma de muestras, inspección, revisión general y mantenimiento. Como la mayoría de los procesos de la refinería son continuos y las corrientes de proceso están confinadas en recipientes y tuberías cerrados, el potencial de exposición es limitado. Ahora bien, aunque las operaciones de la refinería son procesos cerrados, el riesgo de incendio existe, pues si se produce una fuga o emanación de líquido, vapor o gas de hidrocarburos, hay fuentes de ignición como los calentadores, los hornos y los intercambiadores de calor de las distintas unidades de proceso.

\section{Tratamiento previo del petróleo crudo}

\section{Desalinización}

El petróleo crudo suele contener agua, sales inorgánicas, sólidos en suspensión y trazas metálicas solubles en agua. El primer paso del proceso de refino consiste en eliminar estos contaminantes mediante desalinización (deshidratación), a fin de reducir la corrosión, el taponamiento y la formación de incrustaciones en el equipo, y evitar el envenenamiento de los catalizadores en las unidades de proceso. Tres métodos usuales de desalinización del 
petróleo crudo son la desalinización química, la separación electrostática y el filtrado. En la desalinización química se añaden al crudo agua y surfactantes químicos (desemulsificantes), se calientan para que las sales y otras impurezas se disuelvan en el agua o se unan a ella, y después se dejan reposar en un tanque, donde se decantan. En la desalinización eléctrica se aplican cargas electrostáticas de alto potencial para concentrar los glóbulos de agua suspendidos en la parte del fondo del tanque de decantación. Los surfactantes se añaden sólo cuando el crudo contiene gran cantidad de sólidos en suspensión. Un tercer proceso, menos común, consiste en filtrar el petróleo crudo calentado utilizando tierra de diatomeas como medio filtrante.

En la desalinización química y electrostática, el crudo utilizado como carga se calienta a una temperatura entre $66^{\circ} \mathrm{C}$ y $177^{\circ} \mathrm{C}$, para reducir la viscosidad y la tensión superficial con objeto de facilitar la mezcla y la separación del agua. La temperatura está limitada por la presión de vapor del crudo que sirve de materia prima. Ambos métodos de desalinización son continuos. Puede añadirse un cáustico o un ácido para ajustar el pH del baño de agua, y amoníaco para reducir la corrosión. El agua residual, junto con los contaminantes, se descarga por el fondo del tanque de decantación a la instalación de tratamiento de agua residual. El petróleo crudo desalinizado se extrae continuamente de la parte superior de los tanques de decantación y se envía a una torre de destilación atmosférica (fraccionamiento) de crudo (véase la Figura 78.2) .

Una desalinización inadecuada origina incrustaciones en los tubos de los calentadores y de los intercambiadores de calor de todas las unidades de proceso de la refinería, lo que restringe el flujo de producto y la transferencia térmica, y origina averías debido al aumento de presiones y temperaturas. La presurización excesiva de la unidad de desalinización provocará averías.

También causa averías la corrosión, que se produce debido a la presencia de ácido sulfhídrico, cloruro de hidrógeno, ácidos nafténicos (orgánicos) y otros contaminantes del petróleo crudo. La corrosión tiene lugar cuando las sales neutralizadas (cloruros y sulfuros de amonio) se mojan por el agua condensada. Al ser la desalinización un proceso cerrado, existe poco riesgo potencial de exposición al petróleo crudo o las sustancias químicas de proceso, a menos que se produzca una fuga o emanación. Es posible que se origine un incendio a causa de una fuga en los calentadores, lo que permitiría la liberación de componentes del crudo con bajo punto de ebullición.

Durante la desalinización hay posibilidad de exposición a amoníaco, desemulsificantes químicos secos, sustancias cáusticas y/o ácidos. Cuando se utilizan temperaturas elevadas en las operaciones de desalinización de crudos de petróleo agrios (sulfurosos), hay ácido sulfhídrico. Dependiendo del crudo utilizado como carga y de los productos químicos de tratamiento empleados, el agua residual contendrá cantidades variables de cloruros, sulfuros, bicarbonatos, amoníaco, hidrocarburos, fenol y sólidos en suspensión. Si se utiliza tierra de diatomeas en la filtración, deberán minimizarse o controlarse las exposiciones, ya que la tierra de diatomeas puede contener sílice con partículas de granulometría muy fina, por lo que presenta un riesgo respiratorio potencial.

\section{Procesos de separación del petróleo crudo}

El primer paso en el refino de petróleo es el fraccionamiento del crudo en torres de destilación atmosférica y al vacío. El petróleo crudo calentado se separa fisicamente en distintas fracciones de destilación directa, diferenciadas por puntos de ebullición específicos y clasificadas, por orden decreciente de volatilidad, en gases, destilados ligeros, destilados intermedios, gasóleos y residuo. El fraccionamiento funciona porque la gradación de temperatura desde el fondo al extremo superior de la torre de destilación hace que los componentes con punto de ebullición más alto se condensen primero, en tanto que las fracciones con punto de ebullición más bajo alcanzan mayor altura en la torre antes de condensarse. En el interior de la torre, los vapores ascendentes y los líquidos descendentes (reflujo) se mezclan a niveles en los que sus composiciones respectivas están equilibradas entre sí. En dichos niveles (o fases) están dispuestos unos platos especiales que extraen una fracción del líquido que se condensa en cada nivel. En una unidad ordinaria de destilación de crudo en dos fases, la torre atmosférica, que produce fracciones y destilado ligeros, va seguida inmediatamente de una torre de destilación al vacío que procesa los productos residuales atmosféricos. Después de la destilación, sólo unos pocos hidrocarburos son adecuados para utilizarlos como productos acabados sin necesidad de un proceso ulterior.

\section{Destilación atmosférica}

En las torres de destilación atmosférica, el crudo desalinizado se precalienta utilizando calor recuperado del proceso. Después pasa a un calentador de carga de crudo de caldeo directo, y desde allí a la columna de destilación vertical, justo por encima del fondo, a presiones ligeramente superiores a la atmosférica y a temperaturas comprendidas entre $343^{\circ} \mathrm{C}$ y $371^{\circ} \mathrm{C}$, para evitar el craqueo térmico que se produciría a temperaturas superiores. Las fracciones ligeras (de bajo punto de ebullición) se difunden en la parte superior de la torre, de donde son extraídas continuamente y enviadas a otras unidades para su ulterior proceso, tratamiento, mezcla y distribución.

Figura 78.2 • Proceso de desalinización (tratamiento previo).
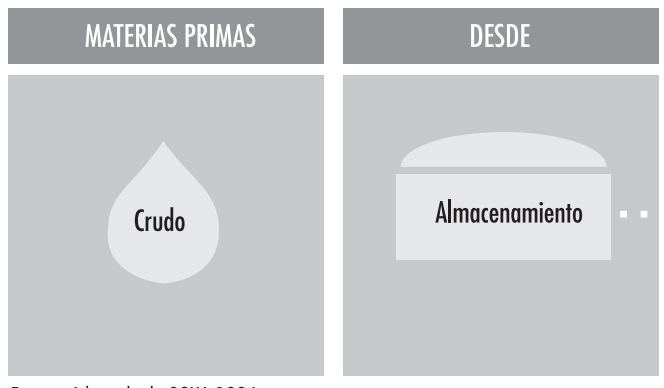

Fuente: Adaptado de OSHA 1996
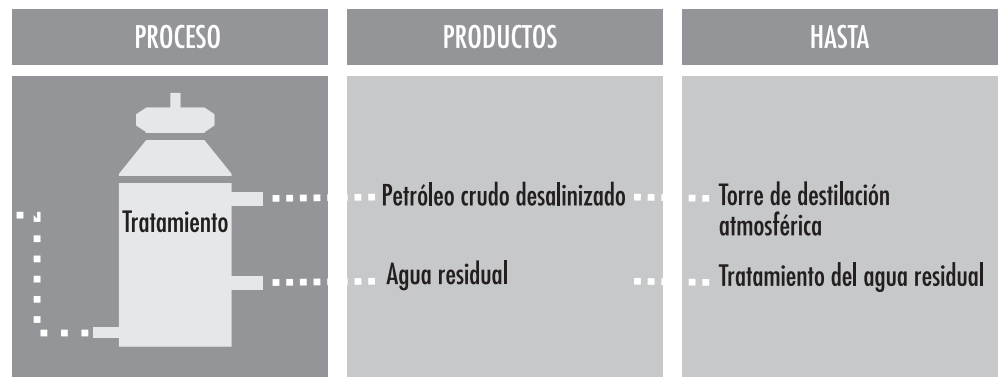
Figura 78.3 • Proceso de destilación atmosférica.
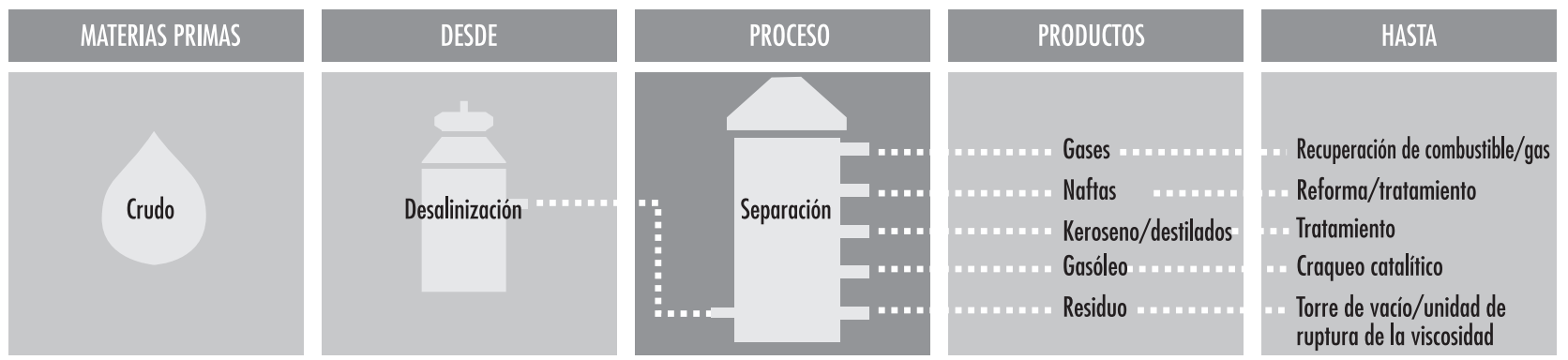

Fuente: Adaptado de OSHA 1996.

Las fracciones con los puntos de ebullición más bajos (el gas combustible y la nafta ligera) se extraen de la parte superior de la torre por una tubería en forma de vapores. La nafta, o gasolina de destilación directa, se toma de la sección superior de la torre como corriente de productos de evaporación. Tales productos se utilizan como cargas petroquímicas y de reforma, material para mezclas de gasolina, disolventes y GPL.

Las fracciones del rango de ebullición intermedio (gasóleo, nafta pesada y destilados) se extraen de la sección intermedia de la torre como corrientes laterales y se envían a las operaciones de acabado para su empleo como queroseno, gasóleo diesel, fuel, combustible para aviones de reacción, material de craqueo catalítico y productos para mezclas. Algunas de estas fracciones líquidas se separan de sus residuos ligeros, que se devuelven a la torre como corrientes de reflujo descendentes.

Las fracciones pesadas, de alto punto de ebullición (denominadas residuos o crudo reducido), que se condensan o permanecen en el fondo de la torre, se utilizan como fuel, para fabricar betún o como carga de craqueo, o bien se conducen a un calentador y a la torre de destilación al vacío para su ulterior fraccionamiento (véanse las Figuras 78.3 y 78.4).

Figura 78.4 • Esquema del proceso de destilación atmosférica.

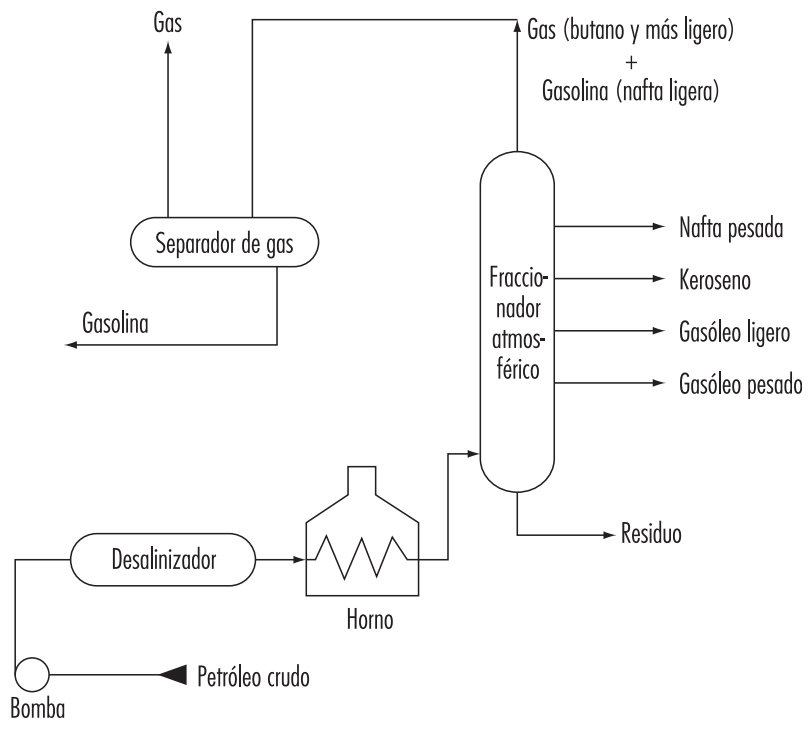

Fuente: OSHA 1996

\section{Destilación al vacío}

Las torres de destilación al vacío proporcionan la presión reducida necesaria para evitar el craqueo térmico al destilar el residuo, o crudo reducido, que llega de la torre atmosférica a mayores temperaturas. Los diseños internos de algunas torres de vacío se diferencian de los de las torres atmosféricas en que en lugar de platos se utiliza relleno al azar y pastillas separadoras de partículas aéreas. A veces se emplean también torres de mayor diámetro para reducir las velocidades. Una torre de vacío ordinaria de primera fase produce gasóleos, material base para aceites lubricantes y residuos pesados para desasfaltación de propano. Una torre de segunda fase, que trabaja con un nivel menor de vacío, destila el excedente de residuo de la torre atmosférica que no se utiliza para procesado de lubricantes, y el residuo sobrante de la primera torre de vacío no utilizado para la desasfaltación.

Por lo común, las torres de vacío se usan para separar productos de craqueo catalítico del residuo sobrante. Asimismo, los residuos de las torres de vacío pueden enviarse a un coquificador, utilizarse como material para lubricantes o asfalto, o desulfurarse y mezclarse para obtener fuel bajo en azufre (véanse las Figuras 78.5 y 78.6).

\section{Columnas de destilación}

En las refinerías hay muchas otras torres de destilación más pequeñas, denominadas columnas, diseñadas para separar productos específicos y exclusivos, todas las cuales trabajan según los mismos principios que las torres atmosféricas. Por ejemplo, un despropanizador es una columna pequeña diseñada para separar el propano del isobutano y otros componentes más pesados. Para separar el etilbenceno y el xileno se utiliza otra columna más grande. Una torres pequeñas de "burbujeo", llamadas torres rectificadoras, utilizan vapor para eliminar vestigios de productos ligeros (gasolina) de corrientes de productos más pesados.

Las temperaturas, presiones y reflujo de control deben mantenerse dentro de los parámetros operacionales para evitar que se produzca craqueo térmico dentro de las torres de destilación. Se utilizan sistemas de descarga dado que pueden producirse desviaciones de presión, temperatura o niveles de líquidos si fallan los dispositivos de control automático. Se vigilan las operaciones para evitar la entrada de crudo en la carga de la unidad de reforma. Los crudos utilizados como materia prima contienen a veces cantidades apreciables de agua en suspensión que se separa al principio del proceso y que, junto con el agua procedente de la purga de vapor que queda en la torre, se deposita en el fondo de ésta. Es posible que esta agua se caliente hasta alcanzar el punto de ebullición, originando una explosión por vaporización instantánea al entrar en contacto con el aceite de la unidad. 
Figura 78.5 • Proceso de destilación al vacío.

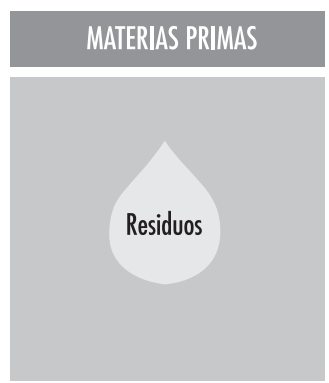

Fuente: Adaptado de OSHA 1996.
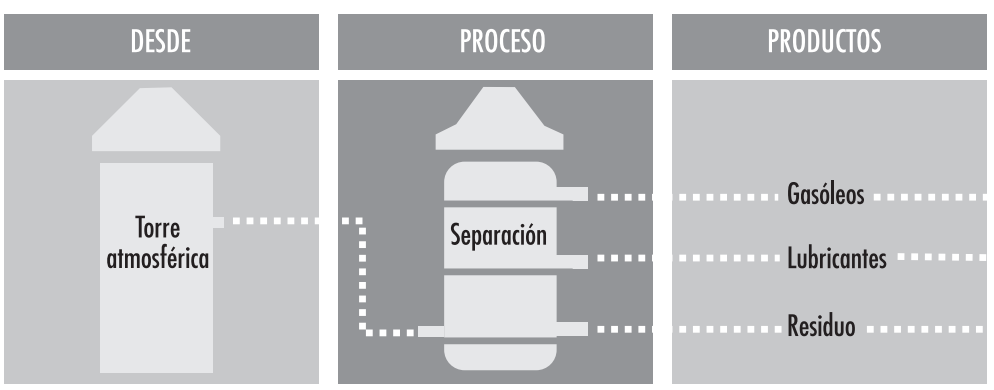

El intercambiador de precalentamiento, el horno de precalentamiento, el intercambiador de calor de residuos, la torre atmosférica, el horno de vacío, la torre de vacío y la sección superior de evaporación sufren corrosión por efecto del ácido clorhídrico ( $\mathrm{HCl})$, el ácido sulfhídrico $\left(\mathrm{H}_{2} \mathrm{~S}\right)$, el agua, los compuestos de azufre y los ácidos orgánicos. Cuando se procesan crudos sulfurosos es posible que la corrosión sea intensa tanto en las torres atmosféricas como en las de vacío si la temperatura de las partes metálicas excede de $232{ }^{\circ} \mathrm{C}$, y en los tubos de los hornos. El $\mathrm{H}_{2} \mathrm{~S}$ húmedo también produce grietas en el acero. $\mathrm{Al}$ procesar crudos con alto contenido de nitrógeno se forman, en los gases de combustión de los hornos, óxidos de nitrógeno, que son corrosivos para el acero cuando se enfrían a bajas temperaturas en presencia de agua.

Se utilizan productos químicos para controlar la corrosión por ácido clorhídrico producida en las unidades de destilación. Puede inyectarse amoníaco en la corriente de la sección superior antes de la condensación inicial, y/o inyectarse con mucho

Figura 78.6 • Esquema del proceso de destilación al vacío.

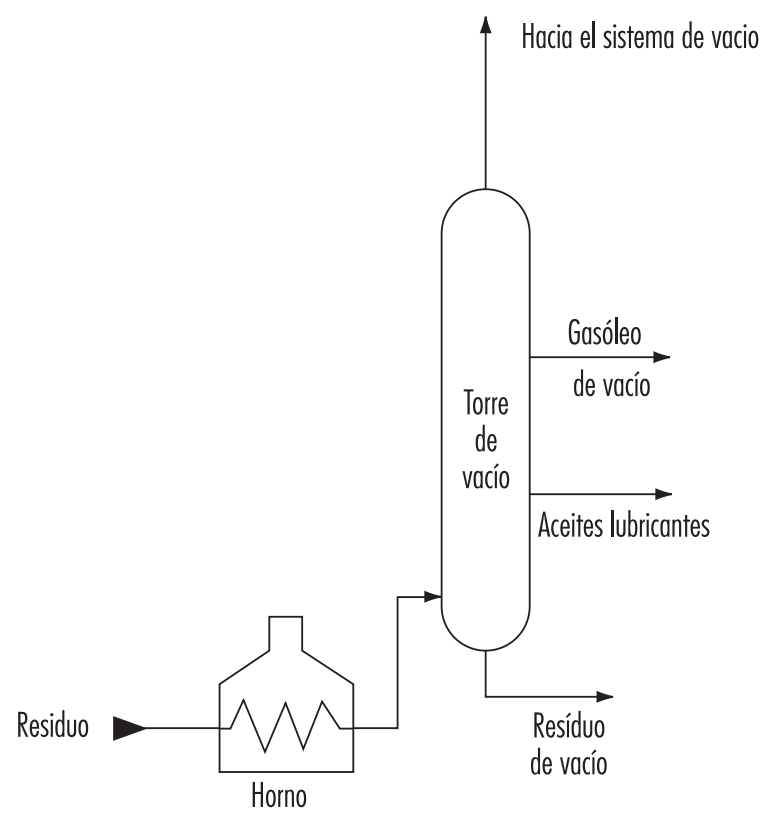

Fuente: OSHA 1996 cuidado una solución alcalina en la alimentación de petróleo crudo caliente. Si no se inyecta suficiente agua de lavado, se forman depósitos de cloruro de amonio y se produce una intensa corrosión.

La destilación atmosférica y al vacío son procesos cerrados, por lo que las exposiciones son mínimas. Cuando se procesan crudos agrios (con alto contenido de azufre) se produce exposición al ácido sulfhídrico en el intercambiador y el horno de precalentamiento, la zona de destilación instantánea y el sistema de evaporación superior de la torre, el horno y la torre de vacío, y el intercambiador de calor de residuos. Todos los crudos de petróleo y los productos de destilación contienen compuestos aromáticos de alto punto de ebullición, como los HAP cancerígenos. La exposición de corta duración a altas concentraciones de vapor de nafta causa cefaleas, náuseas y mareos, y la de larga duración, pérdida del conocimiento. Las naftas aromáticas contienen benceno, por lo que debe limitarse la exposición a las mismas. Es posible que los productos de evaporación del deshexanizador contengan grandes cantidades de hexano normal que afecten al sistema nervioso. En el intercambiador de precalentamiento, en zonas superiores de la torre y en productos de evaporación a veces hay cloruro de hidrógeno. El agua residual contiene a veces sulfuros hidrosolubles en altas concentraciones y otros compuestos hidrosolubles, como amoníaco, cloruros, fenol y mercaptano, dependiendo del crudo de partida y de los productos químicos de tratamiento.

\section{Procesos de conversión del petróleo crudo}

Los procesos de conversión, como el craqueo, la combinación y la rectificación, modifican el tamaño y la estructura de las moléculas de hidrocarburos para convertir las fracciones en productos de más valor (véase la Tabla 78.3).

Como resultado de la conversión se crean varias moléculas de hidrocarburos que no suelen encontrarse en el petróleo crudo, aunque son importantes para el proceso de refino. Las olefinas (alquenos, olefinas dicíclicas y alquinos) son moléculas de hidrocarburos de cadena o anillo insaturados con un enlace doble como mínimo. Por lo común, se forman por craqueo térmico y catalítico, y rara vez se encuentran de modo natural en el petróleo crudo sin procesar.

Los alquenos son moléculas de cadena recta y fórmula $\mathrm{C}_{\mathrm{n}} \mathrm{H}_{\mathrm{n}}$, que contienen al menos un enlace doble (insaturado) en la cadena. La molécula de alqueno más sencilla es el etileno de olefina monocíclica, con dos átomos de carbono unidos por un doble enlace, y cuatro átomos de hidrógeno. Las olefinas dicíclicas (que contienen dos dobles enlaces), como el 1,2-butadieno y el 1,3-butadieno, y los alquinos (con un triple enlace), como el acetileno, se encuentran en el $\mathrm{C}_{5}$ y las fracciones más ligeras procedentes del craqueo. Las olefinas son más reactivas que las 
Tabla 78.3 • Resumen de los procesos de refino del petróleo.

\begin{tabular}{|c|c|c|c|c|c|}
\hline Nombre del proceso & Acción & Método & Finalidad & Materia prima & Productos \\
\hline \multicolumn{6}{|l|}{ Procesos de fraccionamiento } \\
\hline Destilación atmosférica & Separación & Térmico & Separar fracciones & Petróleo crudo desalinizado & Gas, gasóleo, destilado, residuo \\
\hline Destilación al vacío & Separación & Térmico & Separar sin craqueo & Residuo de torre atmosférica & $\begin{array}{l}\text { Gasóleo, materia prima para } \\
\text { lubricantes, residuo }\end{array}$ \\
\hline \multicolumn{6}{|c|}{ Procesos de conversión - Descomposición } \\
\hline Craqueo catalítico & Alteración & Catalíico & Mejorar gasolina & Gasóleo, destilado de coque & $\begin{array}{l}\text { Gasolina, materia prima } \\
\text { petroquímica }\end{array}$ \\
\hline Coquización & Polimerización & Térmico & Convertir residuos de vacío & $\begin{array}{l}\text { Residuo, aceite pesado, } \\
\text { alquitrán }\end{array}$ & Nafta, gasóleo, coque \\
\hline Hidrocraqueo & Hidrógenoación & Catalíico & $\begin{array}{l}\text { Convertir en hidrocarburos más } \\
\text { ligeros }\end{array}$ & $\begin{array}{l}\text { Gasóleo, aceite de craqueo, } \\
\text { residuos }\end{array}$ & $\begin{array}{l}\text { productos más ligeros, de mayor } \\
\text { calidad }\end{array}$ \\
\hline $\begin{array}{l}\text { Reforma de hidrógeno al } \\
\text { vapor }\end{array}$ & Descomposición & Térmico/catalítico & Producir hidrógeno & Gas desulfurado, $0_{2}$, vapor & Hidrógeno, $\mathrm{CO}, \mathrm{CO}_{2}$ \\
\hline Craqueo al vapor & Descomposición & Térmico & Craqueo de moléculas grandes & $\begin{array}{l}\text { Combustible pesado/destilado } \\
\text { de torre atmosférica }\end{array}$ & $\begin{array}{l}\text { Nafta de craqueo, coque, } \\
\text { residuos }\end{array}$ \\
\hline Ruptura de la viscosidad & Descomposición & Térmico & Reducir la viscosidad & Residuo de torre atmosférica & Destilado, alquitrán \\
\hline \multicolumn{6}{|c|}{ Procesosde conversión - Unificación } \\
\hline Alquilación & Combinación & Catalíico & Unir olefinas e isoparafinas & $\begin{array}{l}\text { Isobutano de torre/olefina de } \\
\text { craqueo }\end{array}$ & Isooctano (alquilato) \\
\hline Composición de grasas & Combinación & Térmico & Combinar jabones y aceites & $\begin{array}{l}\text { Aceite lubricante, ácido graso, } \\
\text { metal alcalino }\end{array}$ & Grasa lubricante \\
\hline Polimerización & Polimerización & Catalíicico & Unir dos o más olefinas & Olefinas de craqueo & $\begin{array}{l}\text { Nafta de alto índice de octano, } \\
\text { materias primas petroquímicas }\end{array}$ \\
\hline \multicolumn{6}{|c|}{ Procesos de conversión -Alteración/rectificación } \\
\hline Reforma catalítica & $\begin{array}{l}\text { Alteración/ } \\
\text { deshidrogenación }\end{array}$ & Catalítico & $\begin{array}{l}\text { Mejorar nafta de bajo índice de } \\
\text { octano }\end{array}$ & $\begin{array}{l}\text { Nafta de } \\
\text { coquificador/hidrocraqueo }\end{array}$ & $\begin{array}{l}\text { Reformado/aromático de alto } \\
\text { índice de octano }\end{array}$ \\
\hline Isomerización & Rectificación & Catalíico & $\begin{array}{l}\text { Convertir cadena recta en } \\
\text { ramificada }\end{array}$ & Butano, pentano, hexano & $\begin{array}{l}\text { Isobutano/pentano/ } \\
\text { hexano }\end{array}$ \\
\hline \multicolumn{6}{|l|}{ Procesos de tratamiento } \\
\hline Tratamiento de aminas & Tratamiento & Absorción & Eliminar contaminantes acídicos & $\begin{array}{l}\text { Gas ácido, hidrocarburos con } \\
\mathrm{CO}_{2} \text { y }_{2} \mathrm{~S}\end{array}$ & $\begin{array}{l}\text { Gases sin ácidos e hidrocar- } \\
\text { buros líquidos }\end{array}$ \\
\hline $\begin{array}{l}\text { Desalinización } \\
\text { (pretratamiento) }\end{array}$ & Deshidratación & Absorción & Eliminar contaminantes & Petróleo crudo & Petróleo crudo desalinizado \\
\hline $\begin{array}{l}\text { Secado y } \\
\text { desmercaptanización }\end{array}$ & Tratamiento & Absorción/térmico & $\begin{array}{l}\text { Eliminar } \mathrm{H} 2 \mathrm{O} \text { y compuestos de } \\
\text { azufre }\end{array}$ & $\begin{array}{l}\text { Hidrocarburo líquido, GPL, } \\
\text { materia prima alquilada }\end{array}$ & $\begin{array}{l}\text { hidrocarburos desmercaptani- } \\
\text { zados y secos }\end{array}$ \\
\hline Extracción de furfural & $\begin{array}{l}\text { Extracción de } \\
\text { disolvente }\end{array}$ & Absorción & $\begin{array}{l}\text { Mejorar destilado intermedio y } \\
\text { lubricantes }\end{array}$ & $\begin{array}{l}\text { Aceites reciclados y materia } \\
\text { prima para lubricantes }\end{array}$ & $\begin{array}{l}\text { Gasóleo diesel y lubricante } \\
\text { de alta calidad }\end{array}$ \\
\hline Hidrodesulfuración & Tratamiento & Catalíicico & Eliminar azufre, contaminantes & Residuo/gasóleo alto en azufre & Olefinas desulfuradas \\
\hline Hidrotratamiento & Hidrogenación & Catalíitico & $\begin{array}{l}\text { Eliminar impurezas/saturar } \\
\text { hidrocarburos }\end{array}$ & $\begin{array}{l}\text { Residuos, hidrocarburos de } \\
\text { craqueo }\end{array}$ & $\begin{array}{l}\text { Carga de craqueo, destilado, } \\
\text { lubricante }\end{array}$ \\
\hline Extracción de fenol & $\begin{array}{l}\text { Extracción de } \\
\text { disolvente }\end{array}$ & Absorción/térmico & $\begin{array}{l}\text { Mejorar índice de viscosidad del } \\
\text { lubricante, color }\end{array}$ & $\begin{array}{l}\text { Materiales básicos para aceites } \\
\text { lubricantes }\end{array}$ & $\begin{array}{l}\text { Aceites lubricantes de alta } \\
\text { calidad }\end{array}$ \\
\hline Desasfaltado de disolventes & Tratamiento & Absorción & Eliminar asfalto & $\begin{array}{l}\text { Residuo de torre de vacío, } \\
\text { propano }\end{array}$ & $\begin{array}{l}\text { Aceite lubricante pesado, } \\
\text { asfalto }\end{array}$ \\
\hline $\begin{array}{l}\text { Desparafinado de } \\
\text { disolventes }\end{array}$ & Tratamiento & $\begin{array}{l}\text { Refrigeración/ } \\
\text { filtración }\end{array}$ & $\begin{array}{l}\text { Eliminar cera de las cargas de } \\
\text { lubricante }\end{array}$ & $\begin{array}{l}\text { Aceites lubricantes de torre } \\
\text { de vacío }\end{array}$ & $\begin{array}{l}\text { Material básico para lubricantes } \\
\text { desparafinados }\end{array}$ \\
\hline Extracción de disolvente & $\begin{array}{l}\text { Extracción de } \\
\text { disolvente }\end{array}$ & $\begin{array}{l}\text { Absorción/ } \\
\text { precipitación }\end{array}$ & Separar aromáticos insaturados & Gasóleo, reformado, destilado & $\begin{array}{l}\text { Gasolina de alto índice de } \\
\text { octano }\end{array}$ \\
\hline Desmercaptanización & Tratamiento & Catalíitico & $\begin{array}{l}\text { Eliminar } \mathrm{H}_{2} \mathrm{~S} \text {, convertir } \\
\text { mercaptano }\end{array}$ & Destilado/gasolina sin tratar & $\begin{array}{l}\text { Destilado/gasolina de alta } \\
\text { calidad }\end{array}$ \\
\hline
\end{tabular}


Figura 78.7 • Proceso de ruptura de la viscosidad.

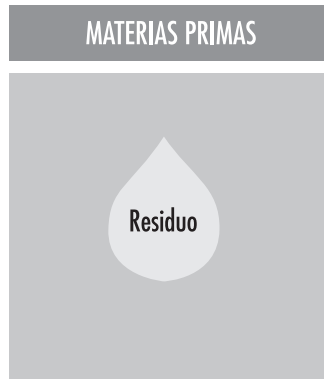

Fuente: Adaptado de OSHA 1996
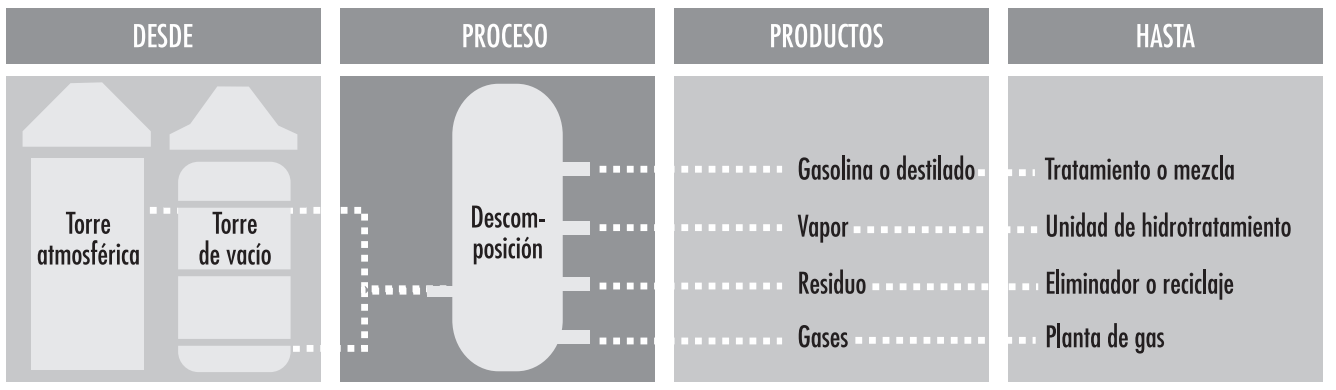

parafinas o los naftenos, y se combinan fácilmente con otros elementos, como el hidrógeno, el cloro y el bromo.

\section{Procesos de craqueo}

Después de la destilación se utilizan otros procesos de refino para alterar las estructuras moleculares de las fracciones con el fin de crear más productos de valor. Uno de estos procesos, el conocido como craqueo, descompone (rompe) fracciones de petróleo pesadas, de alto punto de ebullición, y los convierte en productos más valiosos: hidrocarburos gaseosos, materiales para mezclas de gasolina, gasóleo y fuel. Durante el proceso, algunas de las moléculas se combinan (polimerizan) para formar moléculas mayores. Los tipos básicos de craqueo son el craqueo térmico, el craqueo catalítico y el hidrocraqueo.

\section{Procesos de craqueo térmico}

Los procesos de craqueo térmico, desarrollados en 1913, se basan en la destilación por calor de combustibles y aceites pesados, bajo presión, en grandes tambores, hasta que se rompen (dividen) en moléculas más pequeñas con mejores cualidades antidetonantes. El primer método, que producía grandes cantidades de coque sólido, sin valor, ha evolucionado hasta los modernos procesos de craqueo térmico, entre los que se cuentan la ruptura de la viscosidad, el craqueo en fase de vapor y la coquización.

\section{Ruptura de la viscosidad}

La ruptura de la viscosidad es una forma suave de craqueo térmico que rebaja el punto de goteo de los residuos parafinicos y reduce bastante la viscosidad de la carga sin afectar a su límite de ebullición. El residuo de la torre de destilación atmosférica se descompone suavemente en un calentador a la presión atmosférica. Después se enfría con gasóleo refrigerante para controlar el exceso de craqueo y se destila por expansión instantánea en una torre de destilación. El alquitrán residual del craqueo térmico, que se acumula en el fondo de la torre de fraccionamiento, se somete a expansión instantánea al vacío en una torre rectificadora, y el destilado se recicla (véase la Figura 78.7).

\section{Craqueo en fase de vapor}

El craqueo en fase de vapor produce olefinas mediante craqueo térmico de materiales con moléculas de hidrocarburos grandes, a presiones ligeramente superiores a la atmosférica y a muy altas temperaturas. El residuo del craqueo se mezcla para obtener combustibles pesados. Normalmente, la nafta producida por este método contiene benceno, que se extrae antes del hidrotratamiento.

\section{Coquización}

La coquización es una forma enérgica de craqueo térmico utilizada para obtener gasolina de destilación directa (nafta de coquificador) y diversas fracciones de destilación intermedia, que se utilizan como materiales para craqueo catalítico. Por este proceso, el hidrógeno de la molécula de hidrocarburo se reduce de forma tan completa, que el residuo es una forma de carbono casi puro, denominado coque. Los dos procesos de coquización más comunes son la retardada y la continua (por contacto o líquida), que, dependiendo del mecanismo de reacción, el tiempo, la temperatura y el crudo de partida, producen tres tipos de coque: esponjoso, alveolar y cristalizado en agujas (véase la Figura 78.8).

- Coquización retardada. En la coquización retardada, primero se carga el material en un fraccionador para separar los hidrocarburos más ligeros y después se combina con el petróleo pesado reciclado. El material pesado pasa al horno de coquización y se

Figura 78.8 • Proceso de coquización.
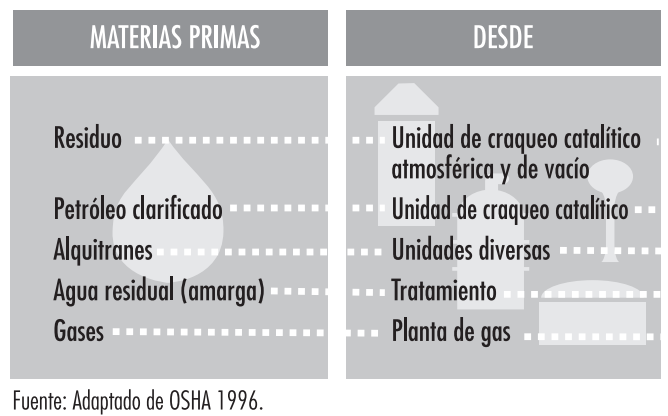

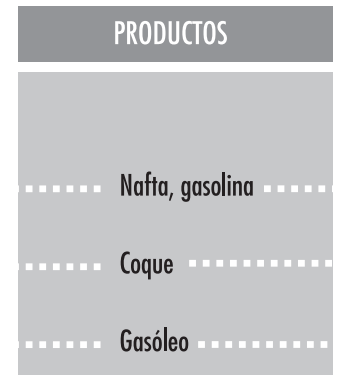

HASTA
- Columna de destilación,
mezcla
Expedición, reciclaje
Craqueo catalíitico


Figura 78.9 • Proceso de craqueo catalítico.

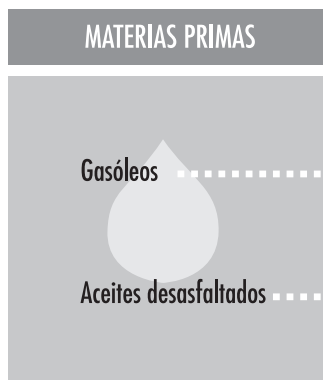

Fuente: Adaptado de OSHA 1996.
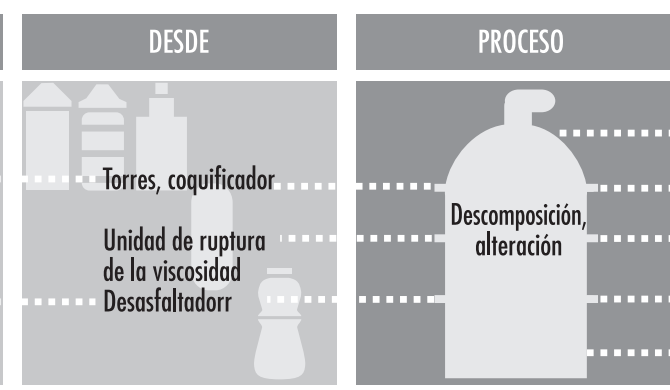

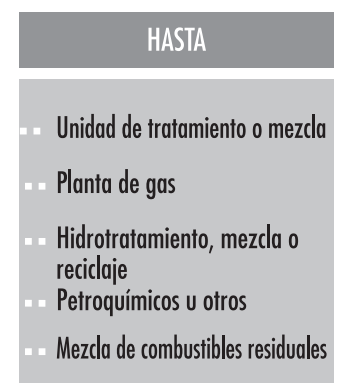

calienta hasta altas temperaturas a bajas presiones para evitar la coquización prematura en los tubos del calentador, produciendo así una vaporización parcial y un craqueo suave. La mezcla de líquido y vapor se bombea desde el calentador a uno o más tambores de coque, donde el material caliente permanece aproximadamente 24 horas (retardo) a bajas presiones hasta que se descompone en productos más ligeros. Cuando el coque alcanza un nivel predeterminado en un tambor, el flujo se desvía a otro tambor para mantener la continuidad de la operación. El vapor procedente de los tambores se devuelve al fraccionador para separar el gas, la nafta y los gasóleos, y reciclar los hidrocarburos más pesados a través del horno. El tambor lleno se trata con vapor para eliminar los hidrocarburos no craqueados, se enfría mediante inyección de agua y se decoquiza mecánicamente por medio de un tornillo sin fin que asciende desde el fondo del tambor, o hidráulicamente, rompiendo el lecho de coque con agua a alta presión proyectada desde un cortador rotativo.

- Coquización continua. La coquización continua (por contacto o líquida) es un proceso de lecho móvil que opera a presiones menores y temperaturas más altas que la coquización retardada. En la coquización continua se efectúa un craqueo térmico utilizando calor transferido de las partículas de coque calientes recicladas a la carga situada en un mezclador radial, llamado reactor. Se toman los gases y vapores del reactor, se enfrían para impedir que continúe la reacción y se fraccionan. El coque de la reacción entra en un tambor de compensación y se eleva hasta un alimentador y clasificador donde se separan las partículas de coque más grandes. El coque restante cae en el precalentador del reactor para ser reciclado con la carga. El proceso es automático, dado que hay un flujo continuo de coque y carga, y la coquización tiene lugar tanto en el reactor como en el tambor de compensación.

\section{Salud y seguridad}

En la coquización, la temperatura debe mantenerse controlada dentro de un estrecho margen, ya que las temperaturas altas producen un coque demasiado duro para cortarlo y extraerlo del tambor y las temperaturas demasiado bajas provocan la formación de lodos de alto contenido asfáltico. Si se descontrolasen las temperaturas de coquización, podría producirse una reacción exotérmica.

En el craqueo térmico, cuando se procesan crudos sulfurosos, se produce corrosión a temperaturas del metal comprendidas entre $232{ }^{\circ} \mathrm{C}$ y $482{ }^{\circ} \mathrm{C}$. Al parecer, por encima de $482{ }^{\circ} \mathrm{C}$ el coque forma una capa protectora sobre el metal. En cambio, cuando las temperaturas no están debidamente controladas por encima de los $482{ }^{\circ} \mathrm{C}$ se produce corrosión por ácido sulfhídrico.
La parte inferior de la torre, los intercambiadores de alta temperatura, el horno y los tambores de reacción están sujetos a corrosión. Los continuos cambios térmicos hacen que las carcasas de los tambores de coque se hinchen y agrieten.

Para evitar la acumulación de coque en los tubos de los hornos de coquización retardada, se inyecta agua o vapor. Debe drenarse completamente el agua del coquificador para no provocar una explosión al recargarlo con coque caliente. En caso de urgencia, se requieren medios alternativos de escape de la plataforma de trabajo situada en la parte superior de los tambores de coque.

Pueden producirse quemaduras al manipular coque caliente, por vapor en caso de fuga de una tubería de vapor, o por expulsión violenta de agua, coque o lodo calientes al abrir los coquificadores. Existe riesgo potencial de exposición a naftas aromáticas que contienen benceno, ácido sulfhídrico y monóxido de carbono, y a trazas de HAP cancerígenos asociados a las operaciones de coquización. El agua amarga residual puede ser altamente alcalina y contener petróleo, sulfuros, amoníaco y fenol. Cuando se mueve coque en forma de lodo en espacios confinados, como los silos de almacenamiento, cabe la posibilidad de que se agote el oxígeno, puesto que es absorbido por el carbono húmedo.

\section{Procesos de craqueo catalítico}

El craqueo catalítico descompone los hidrocarburos complejos en moléculas más simples para aumentar la calidad y cantidad de otros productos más ligeros y valiosos para este fin y reducir la cantidad de residuos. Los hidrocarburos pesados se exponen, a alta temperatura y baja presión, a catalizadores que favorecen las reacciones químicas. Este proceso reorganiza la estructura molecular, convirtiendo las cargas de hidrocarburos pesados en fracciones más ligeras, como queroseno, gasolina, GPL, gasóleo para calefacción y cargas petroquímicas (véanse las Figuras 78.9 y 78.10). La selección de un catalizador depende de una combinación de la mayor reactividad posible con la máxima resistencia al desgaste. Los catalizadores utilizados en las unidades de craqueo de las refinerías son normalmente materiales sólidos (zeolita, hidrosilicato de aluminio, arcilla bentonítica tratada, tierra de batán, bauxita y alúmina-sílice) en forma de polvos, cuentas, gránulos o materiales perfilados denominados pastillas extruidas.

En todo proceso de craqueo catalítico hay tres funciones básicas:

- Reacción: la carga reacciona con el catalizador y se descompone en diferentes hidrocarburos.

- Regeneración: el catalizador se reactiva quemando el coque.

- Fraccionamiento: la corriente de hidrocarburos craqueados se separa en diversos productos. 
Figura 78.10 Esquema del proceso de craqueo catalítico.

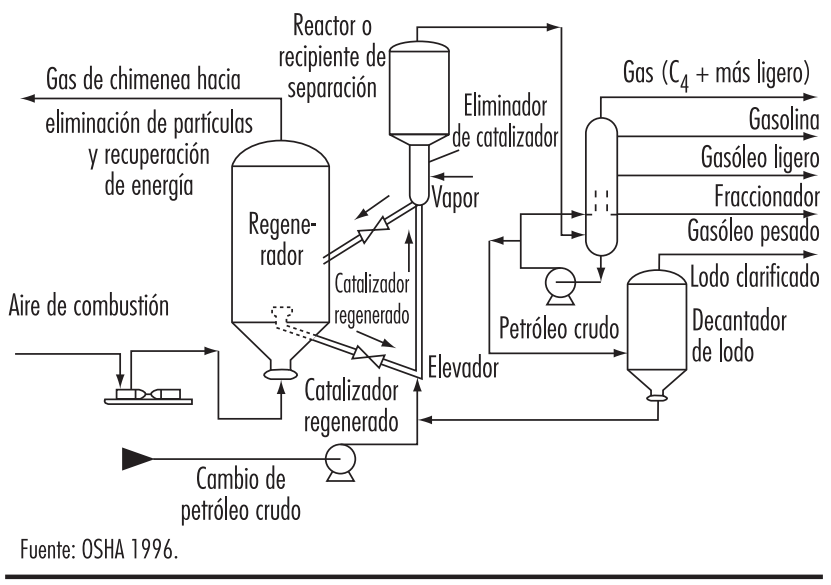

Los procesos de craqueo catalítico son muy flexibles, por lo que los parámetros de operación se ajustan según la demanda de productos. Los tres tipos básicos de procesos de craqueo catalítico son los siguientes:

- craqueo catalítico de líquidos (CCL);

- craqueo catalítico de lecho móvil,

- craqueo catalítico termofor (CGT).

\section{Craqueo catalítico de líquidos}

Las unidades de craqueo catalítico de lecho fluido tienen una sección de catálisis (elevador, reactor y regenerador) y una sección de fraccionamiento, las cuales trabajan conjuntamente como una unidad de proceso integrada. El CCL utiliza un catalizador finamente pulverizado, suspendido en vapor o gas de petróleo, que actúa como un líquido. El craqueo tiene lugar en la tubería de alimentación (elevador), por la que la mezcla de catalizador e hidrocarburos fluye a través del reactor.

El proceso de CCL mezcla una carga de hidrocarburos precalentada con catalizador regenerado caliente al entrar aquélla en el elevador que conduce al reactor. La carga se combina con aceite reciclado dentro del elevador, se vaporiza y es calentada por el catalizador caliente hasta alcanzar la temperatura del reactor. Mientras la mezcla asciende por el reactor, la carga se craquea a baja presión. El craqueo continúa hasta que los vapores de petróleo se separan del catalizador en los ciclones del reactor. La corriente de producto resultante entra en una columna donde se separa en fracciones, volviendo parte del aceite pesado al elevador como aceite reciclado.

El catalizador agotado se regenera para separar el coque que se acumula en el catalizador durante el proceso. Para ello circula por la torre rectificadora de catalizador hacia el regenerador, donde se mezcla con el aire precalentado y quema la mayor parte de los depósitos de coque. Se añade catalizador fresco y se extrae catalizador agotado para optimizar el proceso de craqueo.

\section{Graqueo catalítico de lecho móvil}

Es similar al craqueo catalítico de líquidos, pero el catalizador está en forma de pastillas en lugar de polvo fino. Las pastillas se transfieren continuamente mediante una cinta transportadora o tubos elevadores neumáticos a una tolva de almacenamiento situada en la parte superior de la unidad, y después desciende por gravedad a través del reactor hasta un regenerador. El regenerador y la tolva están aislados del reactor por sellos de vapor. El producto craqueado se separa en gas reciclado, aceite, aceite clarificado, destilado, nafta y gas húmedo.

\section{Craqueo catalítico termofor}

En el craqueo catalítico termofor, la carga precalentada circula por gravedad por el lecho del reactor catalítico. Los vapores se separan del catalizador y se envían a una torre de fraccionamiento. El catalizador agotado se regenera, enfría y recicla, y el gas de chimenea de la regeneración se envía a una caldera de monóxido de carbono para recuperar calor.

\section{Salud y seguridad}

Deben realizarse tomas de muestras y verificaciones periódicas de la carga y de las corrientes de producto y de reciclaje para asegurarse de que el proceso de craqueo funciona como estaba previsto $y$ de que no han entrado contaminantes en la corriente de proceso. Si hay sustancias corrosivas o depósitos en la carga, pueden ensuciar los compresores de gas. Cuando se procesa crudo sulfuroso, es de prever que se produzca corrosión a temperaturas inferiores a $482{ }^{\circ} \mathrm{C}$. La corrosión se produce donde hay fases líquidas y de vapor, y en las zonas sometidas a refrigeración local, como por ejemplo, toberas y soportes de plataformas. Cuando se procesan cargas con alto contenido de nitrógeno, la exposición a amoníaco y cianuro somete el equipo de acero al carbono del sistema superior de CGL a corrosión, agrietamiento o vesiculación por hidrógeno, efectos que se reducen al mínimo mediante lavado con agua o el empleo de inhibidores de la corrosión. Se utiliza lavado con agua para proteger los condensadores superiores de la columna principal sujetos a contaminación por bisulfuro amónico.

Deberá inspeccionarse el equipo crítico: bombas, compresores, hornos e intercambiadores de calor. Entre las inspecciones deberá incluirse la comprobación de fugas por erosión u otras anomalías de funcionamiento: acumulación de catalizador en los expansores, coquización de las tuberías de alimentación superiores por residuos de la carga y otras condiciones de funcionamiento inusuales.

La presencia de hidrocarburos líquidos en el catalizador o su entrada en la corriente de aire de combustión calentado provocan reacciones exotérmicas. En algunos procesos deben adoptarse precauciones para asegurarse de que no hay concentraciones explosivas de catalizador en polvo durante la recarga o eliminación. $\mathrm{Al}$ descargar catalizador coquizado, existe riesgo de incendio por sulfuro de hierro. El sulfuro de hierro se inflama espontáneamente al ser expuesto al aire, por lo que es necesario humedecerlo con agua para evitar que se convierta en una fuente de ignición de vapores. El catalizador coquizado se enfría hasta una temperatura inferior a $49^{\circ} \mathrm{C}$ antes de descargarlo del reactor, o bien se vacía en recipientes purgados con nitrógeno inerte y después se enfría antes de someterlo a ulterior manipulación.

Al tomar muestras durante el proceso, así como en caso de fugas o emanaciones, existe riesgo de exposición a líquidos o vapores de hidrocarburos extremadamente calientes. Igualmente, durante un escape de producto o vapor hay exposición a HPA cancerígenos, nafta aromática que contenga benceno, gas ácido (gas combustible derivado de procesos como craqueo catalítico e hidrotratamiento, que contiene ácido sulfhídrico y dióxido de carbono), ácido sulfhídrico y/o monóxido de carbono. Es posible también que en procesos de craqueo en los que se utilizan catalizadores de níquel, se produzca, de forma inadvertida, níquel carbonilo, compuesto altamente tóxico, con el consiguiente riesgo de exposiciones peligrosas.

La regeneración del catalizador implica absorción por vapor y descoquización, con el consiguiente riesgo de exposición a corrientes de residuos líquidos con cantidades variables de agua amarga, hidrocarburo, fenol, amoníaco, ácido sulfhídrico, mercaptano y otros materiales, dependiendo de las cargas, crudos y procesos. $\mathrm{Al}$ manipular catalizador agotado o recargar 
Figura 78.11 • Proceso de hidrocraqueo.
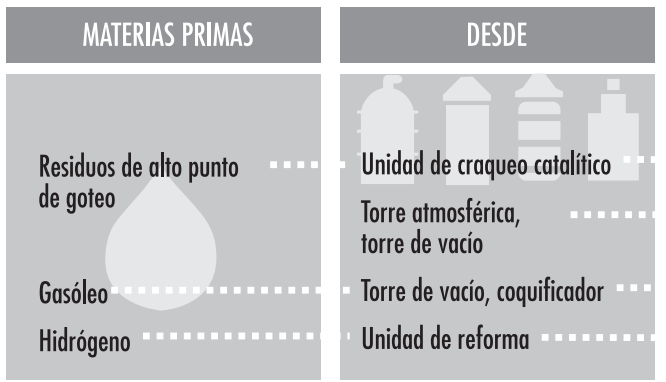
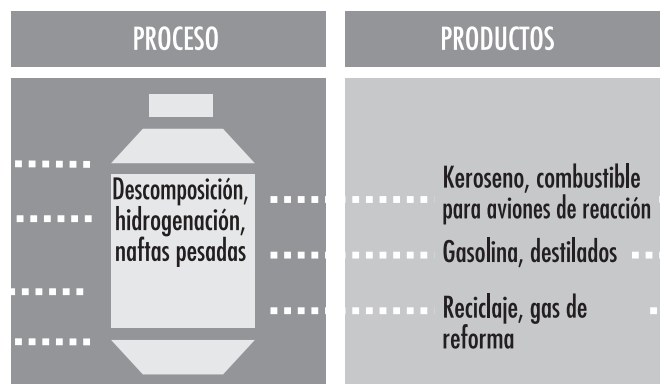

Fuente: Adaptado de OSHA 1996

catalizador, y en caso de fugas o emanaciones, es preciso adoptar prácticas de trabajo seguras y utilizar equipos de protección personal adecuados.

\section{Proceso de hidocraqueo}

El hidrocraqueo es un proceso en dos fases que combina el craqueo catalítico y la hidrogenación, y por medio del cual las fracciones de destilado se descomponen en presencia de hidrógeno y catalizadores especiales dando lugar a productos de más valor. En comparación con el craqueo catalítico, el hidrocraqueo tiene la ventaja de que se procesan cargas con alto contenido de azufre sin desulfuración previa. En el proceso, la carga de productos aromáticos pesados se convierte en productos más ligeros, a muy altas presiones y temperaturas bastante elevadas. Cuando la carga tiene un alto contenido parafínico, el hidrógeno impide la formación de HAP, reduce la formación de alquitrán y previene la acumulación de coque en el catalizador. El hidrocraqueo produce cantidades relativamente grandes de isobutano para cargas de alquilación, así como isomerización para control del punto de goteo y del punto de humo, dos características importantes en el combustible de alta calidad para aviones de reacción.

En la primera fase, la carga se mezcla con hidrógeno reciclado, se calienta y se envía al reactor primario, donde gran parte de ella se convierte en destilados intermedios. Los compuestos de azufre y nitrógeno se convierten en ácido sulfhídrico y amoníaco en el reactor de la fase primaria por medio de un catalizador. El residuo se calienta y se envía a un separador de alta presión, donde se extraen y reciclan los gases ricos en hidrógeno. Los restantes hidrocarburos se rectifican o purifican para extraer el ácido sulfhídrico, el amoníaco y los gases ligeros, que se recogen en un acumulador, donde la gasolina se separa del gas ácido.
Los hidrocarburos líquidos rectificados procedentes del reactor primario se mezclan con hidrógeno y se envían al reactor de la segunda fase, donde se descomponen en gasolina de alta calidad, combustible para aviones de reacción y materiales de destilación para mezclas. Tales productos pasan por una serie de separadores de alta y baja presión para extraer de ellos los gases, los cuales se reciclan. Los hidrocarburos líquidos se estabilizan, dividen y rectifican, y las naftas ligeras producidas en la unidad de hidrocraqueo se utilizan para mezclas de gasolina mientras que las naftas pesadas se reciclan o se envían a una unidad de reforma catalítica (véase la Figura 78.11).

\section{Salud y seguridad}

La inspección y verificación de los dispositivos de seguridad son importantes debido a las muy altas presiones que se producen en este proceso. Es necesario un control adecuado del mismo como protección contra el taponamiento de los lechos del reactor. Debido a las temperaturas de la operación y a la presencia de hidrógeno, hay que reducir estrictamente al mínimo el contenido de ácido sulfhídrico de la carga para reducir el riesgo de que se produzca una corrosión intensa. También deberá tenerse en cuenta la posibilidad de corrosión por dióxido de carbono húmedo en las zonas de condensación. Cuando se procesan cargas con alto contenido de nitrógeno, el amoníaco y el ácido sulfhídrico forman bisulfuro amónico, que provoca fuerte corrosión a temperaturas inferiores al punto de rocío del agua. El bisulfuro amónico también se encuentra en la eliminación del agua amarga. Como la unidad de hidrocraqueo trabaja a presiones y temperaturas muy elevadas, es importante el control de fugas de hidrocarburos y de emanaciones de hidrógeno para evitar incendios.

Al tratarse de un proceso cerrado, en condiciones de trabajo normales las exposiciones son mínimas. Existe riesgo de exposición a nafta alifática que contenga benceno, HAP cancerígenos,

Figura 78.12 • Proceso de polimerización.

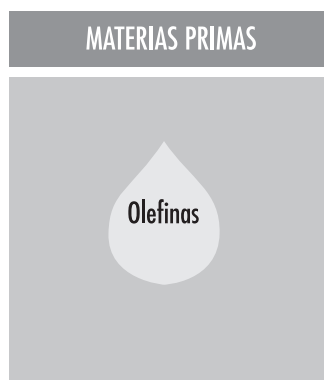

Fuente: Adaptado de OSHA 1996
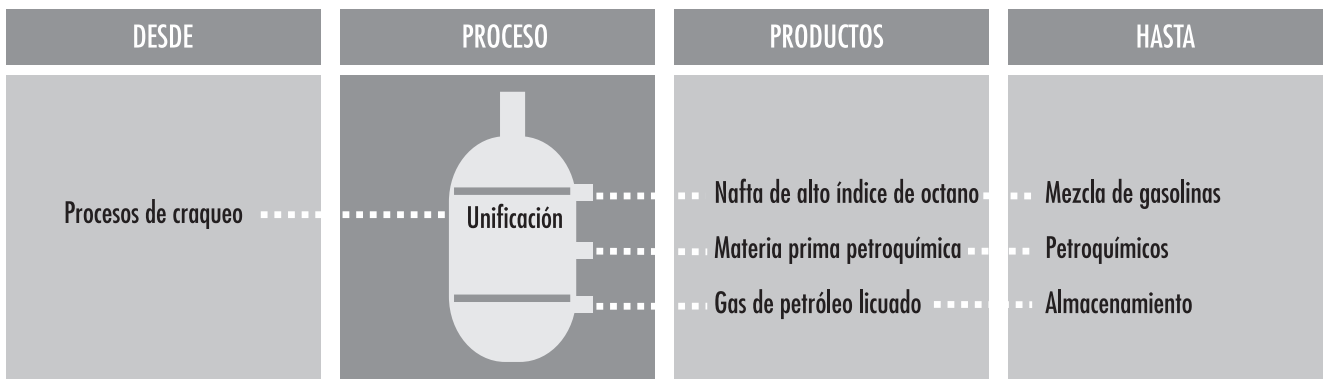
emisiones de gases y vapores de hidrocarburos, gas rico en hidrógeno y ácido sulfhídrico, como consecuencia de fugas a alta presión. Durante la regeneración y el cambio de catalizador se desprenden grandes cantidades de monóxido de carbono. La absorción y regeneración de catalizador con vapor crea corrientes de residuos que contienen agua amarga y amoníaco. Al manipular catalizador agotado deben utilizarse métodos de trabajo seguros y equipos de protección personal adecuados. En algunos procesos, se requiere actuar con precaución para que no se formen concentraciones explosivas de polvo catalítico durante la recarga. La descarga de catalizador coquizado requiere precauciones especiales para evitar incendios inducidos por sulfuro de hierro. El catalizador coquizado debe enfriarse hasta una temperatura inferior a $49^{\circ} \mathrm{C}$ antes de su descarga, o colocarse en recipientes inertizados con nitrógeno hasta que se le enfríe.

\section{Procesos de combinación}

Se utilizan dos procesos de combinación, la polimerización y la alquilación, para unir entre sí pequeñas moléculas deficitarias en hidrógeno, denominadas olefinas, recuperadas del craqueo térmico y catalítico, con el fin crear materiales de mezcla de gasolinas de más valor.

\section{Polimerización}

La polimerización es el proceso que consiste en combinar dos o más moléculas orgánicas insaturadas (olefinas) para formar un sola, más pesada, con los mismos elementos y en la misma proporción que en la molécula original. Convierte las olefinas gaseosas, como el etileno, el propileno y el butileno convertidos por unidades de craqueo térmico y de líquidos, en moléculas más pesadas y complejas, de mayor índice de octano, como la nafta y las cargas petroquímicas. La carga de olefinas se trata previamente para eliminar los compuestos de azufre y otros constituyentes sin valor, y después se hace pasar sobre un catalizador fosforoso, generalmente un catalizador sólido o ácido fosfórico líquido, donde tiene lugar una reacción polimérica exotérmica. Para ello se requiere el empleo de agua refrigerante y la inyección de una carga fría en el reactor con el fin de controlar las temperaturas a distintas presiones. Se elimina el ácido de los líquidos mediante un lavado cáustico, se fraccionan los líquidos y se recicla el catalizador ácido. El vapor se fracciona para extraer los butanos y se neutraliza para eliminar trazas de ácido (véase la Figura 78.12).

Si entra agua en contacto con el ácido fosfórico, por ejemplo durante el lavado con agua en las paradas, se producirá una intensa corrosión que acarreará la avería del equipo. La corrosión alcanza también a las tubuladuras, rehervidores, intercambiadores de calor y otros puntos donde pueda depositarse ácido.
Existe riesgo de exposición a solución de lavado cáustico (hidróxido sódico), al ácido fosfórico utilizado en el proceso o eliminado mediante lavado durante las revisiones generales, y al catalizador en polvo. Es posible que se produzca asimismo una reacción exotérmica incontrolada en caso de pérdida de agua refrigerante.

\section{Alquilación}

La alquilación combina las moléculas de las olefinas producidas en el craqueo catalítico con las de isoparafinas para aumentar el volumen y octanaje de las mezclas de gasolina. Las olefinas reaccionan con las isoparafinas en presencia de un catalizador muy activo, por lo general ácido sulfúrico o ácido fluorhídrico (o cloruro de aluminio) para crear una molécula parafínica de cadena ramificada larga, denominada alquilato (isooctano), con excepcionales cualidades antidetonantes. A continuación, el alquilato se separa y se fracciona. Las temperaturas de reacción, relativamente bajas, de $10^{\circ} \mathrm{C}$ a $16^{\circ} \mathrm{C}$ para el ácido sulfúrico, $27{ }^{\circ} \mathrm{C}$ a $0{ }^{\circ} \mathrm{C}$ para el ácido fluorhídrico y $0{ }^{\circ} \mathrm{C}$ para el cloruro de aluminio, se controlan y mantienen mediante refrigeración (véase la Figura 78.13).

Alquilación del ácido sulfúrico. En las unidades de alquilación de ácido sulfúrico en cascada, , penetran en el reactor cargas de propileno, butileno, amileno e isobutano fresco, entre otras, y allí entran en contacto con el catalizador de ácido sulfúrico. El reactor está dividido en zonas; las olefinas se introducen en cada zona mediante distribuidores, y el ácido sulfúrico y los isobutanos circulan sobre deflectores de una zona a otra. El calor de la reacción se elimina por evaporación del isobutano. El isobutano gaseoso se extrae de la parte superior del reactor, se enfría y se recicla, enviándose una parte del mismo a la torre despropanizadora. El residuo del reactor se decanta y el ácido sulfúrico se extrae del fondo del recipiente y se recicla. Se utilizan lavadores cáusticos o de agua para eliminar pequeñas cantidades de ácido de la corriente de proceso, que a continuación pasa a una torre desisobutanizadora. El isobutano obtenido en la sección superior del desbutanizador se recicla, y los restantes hidrocarburos se separan en una torre de redestilación y/o se envían a la operación de mezcla.

Alquilación del ácido fluorhídrico. Hay dos tipos de procesos de alquilación del ácido fluorhídrico: Phillips y UOP. En el proceso Phillips, la carga de olefina e isobutano se seca y pasa a una unidad combinada de reacción y decantación. El hidrocarburo procedente de la zona de decantación se carga en el fraccionador principal. El producto de evaporación de la sección superior del fraccionador principal pasa a un despropanizador. El propano, que contiene trazas de ácido fluorhídrico (HF), pasa a una torre rectificadora de HF, y después se desfluora catalíticamente, se trata y se almacena. El isobutano se extrae del

Figura 78.13• Proceso de alquilación.

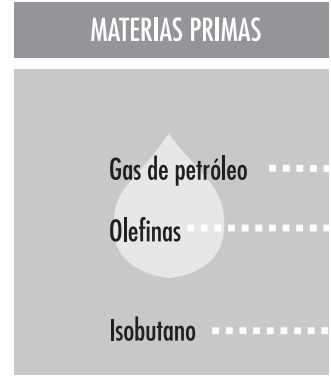

Fuente: Adaptado de OSHA 1996.
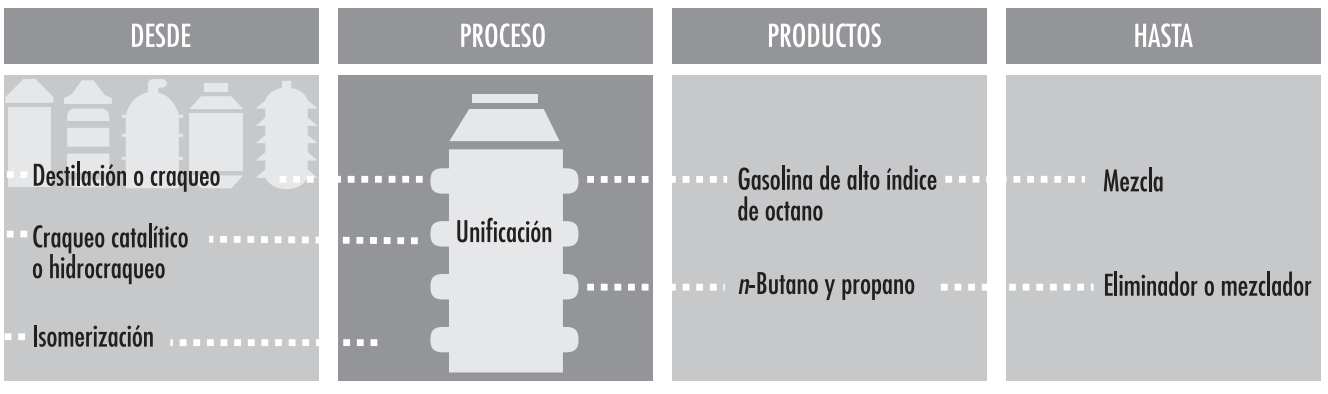
fraccionador principal y se recicla en el reactor/decantador, y el alquilato del fondo del fraccionador principal se envía a un divisor.

El proceso UOP utiliza dos reactores con divisores separados. La mitad del material seco se carga en el primer reactor, junto con isobutano reciclado y de relleno, y después en su decantador, donde se recicla el ácido y se carga el hidrocarburo en el segundo reactor. La otra mitad del material va al segundo reactor; el ácido del decantador se recicla y los hidrocarburos se cargan en el fraccionador principal. El proceso subsiguiente es similar al Phillips en que el producto de la sección superior del fraccionador principal pasa a un despropanizador, se recicla el isobutano y se envía el alquilato a un divisor.

\section{Salud y seguridad}

El ácido sulfúrico y el ácido fluorhídrico son productos químicos peligrosos, por lo que es esencial proceder con precaución durante la entrega y descarga del ácido. Para trabajar con del ácido sulfúrico de forma satisfactoria y evitar la corrosión, es necesario mantener su concentración entre el 85 y el 95 \%; para evitar la corrosión por ácido fluorhídrico la concentración de éste en la unidad de proceso debe mantenerse por encima del $65 \%$, y la humedad por debajo del $4 \%$. En las unidades de ácido sulfúrico se origina corrosión e incrustaciones debido a la descomposición de los ésteres del ácido sulfúrico, o cuando se añade un cáustico con fines de neutralización. Los ésteres se eliminan mediante tratamiento con ácido fresco y lavado con agua caliente.

En el caso de que haya pérdida del agua refrigerante, necesaria para mantener las temperaturas, a veces se producen descompensaciones. Para evitar la contaminación por agua, la presión se mantiene en el lado del agua refrigerante y del vapor de los intercambiadores de calor por debajo de la presión mínima del lado de servicio del ácido. Para neutralizar el fluoruro de hidrógeno gaseoso o los vapores de ácido fluorhídrico antes de su descarga, se conectan los tubos de ventilación a lavadores de ceniza de sosa. Se proporcionarán bordillos, drenajes y aislamiento para la contención de la unidad de proceso a fin de que pueda neutralizarse el efluente antes de verterlo al alcantarillado.

Las unidades de ácido fluorhídrico deben drenarse y limpiarse a fondo químicamente antes de las revisiones generales y de la entrada en dichas unidades, para eliminar cualquier resto de fluoruro de hierro y ácido fluorhídrico. Después de la parada, si se ha utilizado agua se deberá secar por completo la unidad antes de introducir en ella ácido fluorhídrico. Las fugas, las emisiones o los derrames contaminados con ácido fluorhídrico, así como los hidrocarburos que contienen dicho ácido, son extremadamente peligrosos. Es necesario adoptar precauciones para asegurarse de que el equipo y los materiales que han estado en contacto con ácido se manipulen con cuidado y se limpien perfectamente antes de que abandonen el área de proceso o la refinería. Con frecuencia se prevén tanques de lavado por inmersión para neutralizar el equipo que ha estado en contacto con ácido fluorhídrico.

Existe riesgo de exposiciones tóxicas y gravemente peligrosas en caso de fugas, derrames o emanaciones. El contacto directo con ácido sulfúrico o ácido fluorhídrico provoca graves lesiones cutáneas y oculares, y la inhalación de vahos ácidos o de vapores de hidrocarburos que contienen ácido causa fuerte irritación y graves daños en el sistema respiratorio. Deberán utilizarse medidas especiales de precaución para situaciones de emergencia, y proveerse una protección acorde con el potencial de riesgo y las zonas que pueden resultar afectadas. Será necesario utilizar métodos de trabajo seguros y equipos de protección personal apropiados para proteger la piel y el aparato respiratorio cuando haya riesgo de exposición a ácidos fluorhídrico y sulfúrico durante las operaciones normales, como lectura de manómetros, inspección y toma de muestras de proceso, así como durante las actividades de respuesta a emergencias, mantenimiento y revisión general. Deberán existir procedimientos que aseguren que el equipo y las prendas de protección utilizados en actividades en que intervengan el ácido sulfúrico o el ácido fluorhídrico (trajes de protección química, fundas para la cabeza y el calzado, guantes, protección facial y ocular, y equipo de protección respiratoria) se limpien y descontaminen perfectamente antes de su reutilización.

\section{Procesos de rectificación}

La reforma catalitica y la isomerización son procesos que reorganizan las moléculas de hidrocarburos para obtener productos con diferentes características. Después del craqueo algunas corrientes de gasolina, aunque tienen el tamaño molecular correcto, requieren un proceso ulterior para mejorar su rendimiento, por ser deficitarias en algunas cualidades, como el índice de octano o el contenido de azufre. La reforma de hidrógeno (al vapor) produce hidrógeno adicional para utilizarlo en el proceso de hidrogenación.

\section{Reforma catalítica}

Los procesos de reforma catalítica convierten las naftas pesadas de bajo octanaje en hidrocarburos aromáticos para cargas petroquímicas y componentes de gasolina de alto índice de octano, que reciben el nombre de reformados, mediante reorganización molecular o deshidrogenación. Dependiendo de la carga y de los catalizadores, se producen reformados con concentraciones muy altas de tolueno, benceno, xileno y otros aromáticos útiles para la mezcla de gasolinas y el procesado petroquímico. El hidrógeno, un subproducto importante, se separa del reformado para reciclarlo y utilizarlo en otros procesos. El producto resultante depende de la temperatura y presión del reactor, el catalizador utilizado y la velocidad de reciclaje del hidrógeno. Algunas unidades de reforma catalítica trabajan a baja presión y otras a alta presión. Algunos sistemas de reforma catalítica regeneran continuamente el catalizador; algunas instalaciones regeneran todos los reactores durante las revisiones generales, y otras sacan los reactores de la corriente por turno, de uno en uno, para la regeneración del catalizador.

En la reforma catalítica, la carga de nafta se trata previamente con hidrógeno para eliminar contaminantes tales como los compuestos de cloro, azufre y nitrógeno, que podrían envenenar el catalizador. El producto se somete a vaporización instantánea y se fracciona en unas torres, donde se eliminan el resto de gases y contaminantes. La carga de nafta desulfurada se envía a la unidad de reforma catalítica, donde se calienta hasta la evaporación y se hace pasar por un reactor con un lecho estacionario de catalizador bimetálico o metálico que contiene una pequeña cantidad de platino, molibdeno, renio u otros metales nobles. Las dos reacciones primarias que tienen lugar son la producción de aromáticos de alto índice de octano mediante extracción del hidrógeno de las moléculas de la carga de partida, y la conversión de las parafinas normales en parafinas de cadena ramificada o en isoparafinas.

En la platformación, otro proceso de reforma catalítica, la carga que no ha sido hidrodesulfurada se combina con gas reciclado y se hace pasar primero sobre un catalizador de bajo coste. Cualquier impureza remanente se convierte en ácido sulfhídrico y amoníaco, y se elimina antes de que la corriente pase sobre el catalizador de platino. El vapor rico en hidrógeno se recicla para inhibir reacciones que podrían envenenar el catalizador. El producto de salida del reactor se separa en reformado líquido, 
Figura 78.14 • Proceso de reforma catalítica.

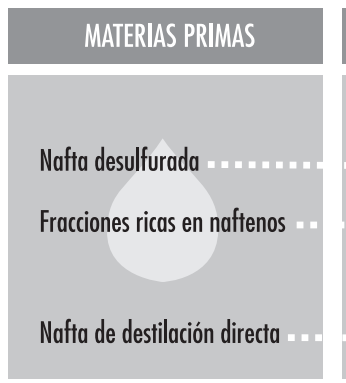

Fuente: Adaptada de OSHA 1996
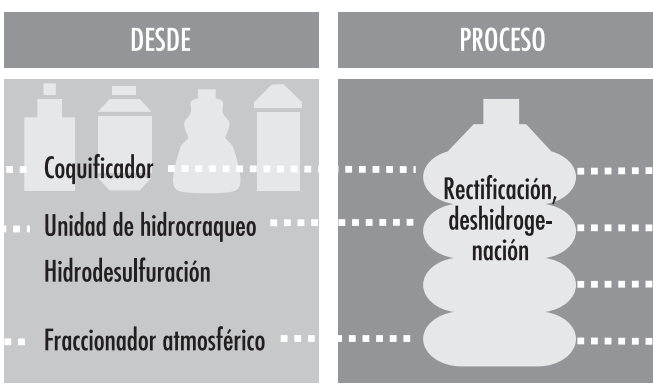

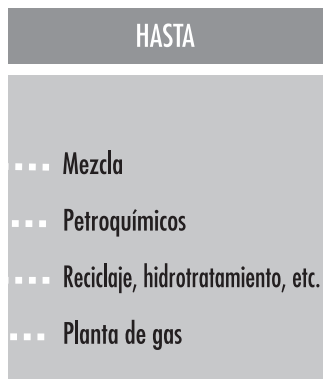

que se envía a una torre rectificadora, y gas, que se comprime y recicla (véase la Figura 78.14).

Se necesitan procedimientos operativos para controlar los puntos calientes durante el arranque. Hay que actuar con cuidado para no romper o aplastar el catalizador al cargar las cuentas, ya que el polvo menudo obturará las rejillas de la unidad de reforma. Es preciso adoptar precauciones contra el polvo al regenerar o sustituir el catalizador. Es posible que durante la regeneración del catalizador se originen pequeñas emisiones de monóxido de carbono y ácido sulfhídrico.

Si se ha ensuciado el estabilizador en las unidades de reforma debido a la formación de cloruro amónico y sales de hierro deberá considerarse la conveniencia de un lavado con agua. En ocasiones se forma cloruro amónico en los intercambiadores de calor de la unidad de tratamiento previo y origina corrosión e incrustaciones. El cloruro de hidrógeno formado por hidrogenación de compuestos de cloro puede formar ácidos o sales de cloruro amónico. En caso de fugas o emanaciones existe riesgo de exposición a naftas alifáticas y aromáticas, gas de proceso rico en hidrógeno, ácido sulfhídrico y benceno.

\section{Isomerización}

La isomerización convierte el $n$-butano, $n$-pentano y $n$-hexano en sus respectivas isoparafinas. Algunos de los componentes parafínicos normales de cadena recta de la nafta ligera de destilación directa tienen un bajo índice de octano. Tales componentes se convierten en isómeros de cadena ramificada y alto octanaje reorganizando los enlaces entre átomos, sin cambiar el número o la clase de átomos. La isomerización se asemeja a la reforma catalítica en que reorganiza las moléculas de hidrocarburo, pero sólo convierte parafinas normales en isoparafinas. La isomerización utiliza un catalizador distinto al de la reforma catalítica.

Los dos procesos de isomerización claramente diferenciados son el de butano $\left(\mathrm{C}_{4}\right)$ y el de pentano/hexano. $\left(\mathrm{C}_{5} / \mathrm{C}_{6}\right)$.

$\mathrm{La}$ isomerización de butano $\left(\mathrm{C}_{4}\right)$ produce materia prima para la alquilación. Un proceso de baja temperatura utiliza un catalizador muy activo de cloruro de aluminio o cloruro de hidrógeno sin calentadores caldeados para isomerizar $n$-butano. La carga tratada y precalentada se añade a la corriente de reciclaje, se mezcla con $\mathrm{HCl}$ y se hace pasar por el reactor (véase la Figura 78.15).

Figura 78.15• Isomerización de C4.

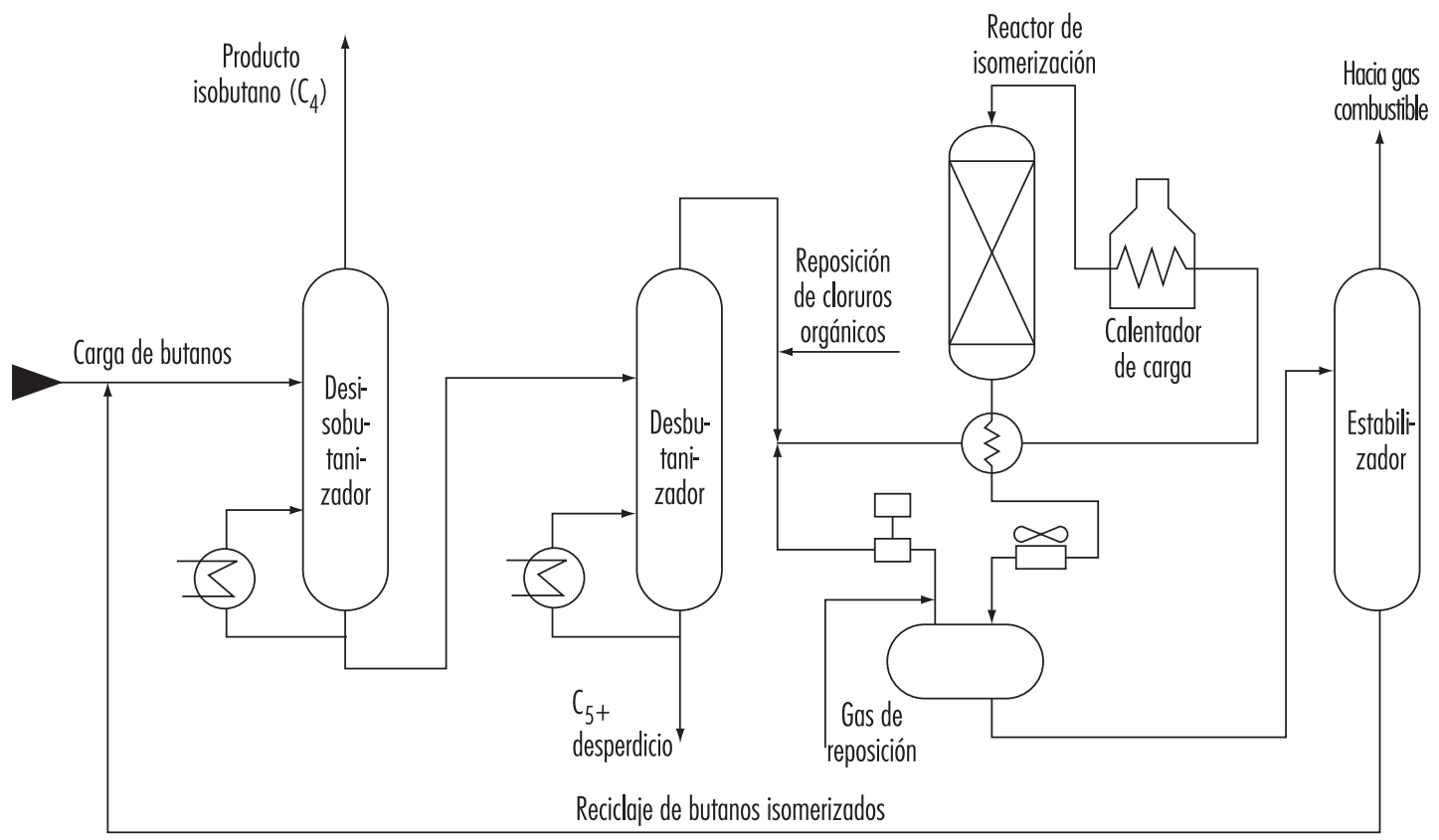

Fuente: OSHA 1996. 
Figura 78.16 • Proceso de isomerización.

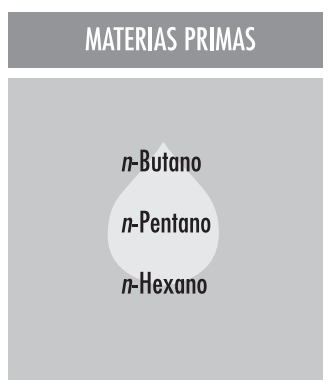

Fuente: Adaptado de OSHA 1996.
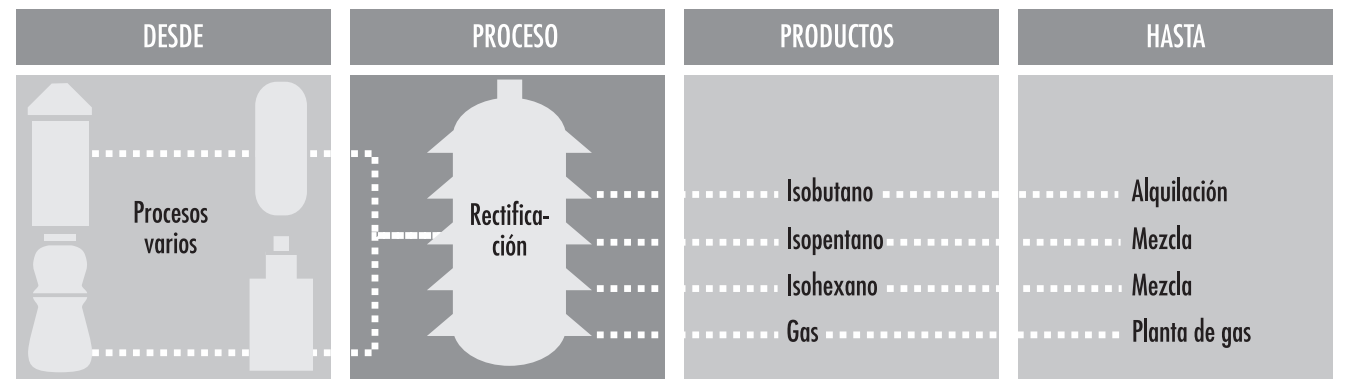

La isomerización de pentano/hexano se utiliza para elevar el índice de octano convirtiendo $n$-pentano y $n$-hexano. En un proceso normal de isomerización de pentano/hexano, la carga desecada y desulfurada se mezcla con una pequeña cantidad de cloruro orgánico e hidrógeno reciclado, y se calienta a la temperatura del reactor. A continuación se hace pasar sobre un catalizador metálico soportado (de contacto) en el primer reactor, donde se hidrogenan el benceno y las olefinas. Seguidamente, el material pasa al reactor de isomerización, donde las parafinas se isomerizan catalíticamente en isoparafinas, se enfrían y pasan a un separador. El gas y el hidrógeno del separador, con hidrógeno de reposición, se reciclan. El líquido se neutraliza con materiales alcalinos y se envía a una columna rectificadora, donde el cloruro de hidrógeno se recupera y recicla (véase la Figura 78.16).

Si la carga no está completamente seca y desulfurada, existe riesgo de formación de ácido, con el consiguiente envenenamiento del catalizador y corrosión del metal. No se debe permitir que entre agua o vapor en zonas donde haya cloruro de hidrógeno. Es preciso adoptar precauciones para evitar que penetre $\mathrm{HCl}$ en las alcantarillas y drenajes. Cuando se utiliza catalizador sólido hay riesgo de exposición a isopentano y nafta alifática en fase de vapor y líquida, así como a gas de proceso rico en hidrógeno, ácido clorhídrico y cloruro de hidrógeno, y también a polvo.

\section{Producción de hidrógeno (reforma al vapor)}

Para los procesos de hidrodesulfuración, hidrogenación e hidrocraqueo, y para los procesos petroquímicos, se necesita hidrógeno de alta pureza (95 a $99 \%$ ). Si no se produce suficiente hidrógeno como subproducto de los procesos de la refinería para satisfacer totalmente la demanda de ésta, será necesario fabricar hidrógeno adicional.
En la reforma de hidrógeno al vapor, los gases desulfurados se mezclan con vapor sobrecalentado y se reforman en tubos que contienen un catalizador de base níquel. El gas reformado, compuesto de vapor, hidrógeno, monóxido de carbono y dióxido de carbono, se enfría y se hace pasar por convertidores en los que el monóxido de carbono reacciona con el vapor y forma hidrógeno y dióxido de carbono. El dióxido de carbono se lava con disoluciones de aminas y se ventila a la atmósfera cuando las soluciones se reactivan mediante calentamiento. Gualquier resto de monóxido de carbono que quede en la corriente de producto se convierte en metano (véase la Figura 78.17).

Se realizarán inspecciones y comprobaciones si existe la posibilidad de que se averíen las válvulas debido a la presencia de contaminantes en el hidrógeno. Deben controlarse los arrastres desde los lavadores cáusticos para prevenir la corrosión en los precalentadores e impedirse que entren en los tubos de la unidad de reforma cloruros procedentes de la carga o del sistema de vapor y contaminen el catalizador. A veces se producen exposiciones por contaminación del condensado con materiales de proceso (cáusticos y compuestos de aminas), así como por exceso de hidrógeno, monóxido de carbono y dióxido de carbono. Existe riesgo de quemaduras por gases calientes y vapor sobrecalentado en caso de fuga.

\section{Procesos diversos de las refinerías}

\section{Procesos de material base para lubricantes y ceras}

Los aceites lubricantes y las ceras se refinan a partir de diversas fracciones obtenidas por destilación atmosférica y al vacío. $\mathrm{Al}$ inventarse la destilación al vacío se descubrió que el residuo ceroso era mejor lubricante que cualquiera de las grasas animales utilizadas por aquel entonces, y ello dio origen a la moderna tecnología de refino de lubricantes a partir de hidrocarburos,

Figura 78.17 Proceso de reforma al vapor.

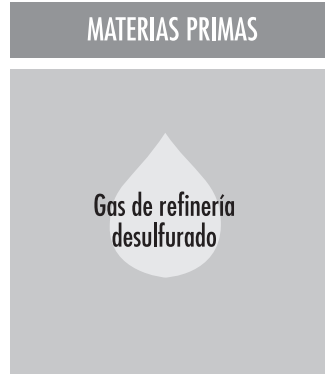

Fuente: Adaptado de OSHA 1996.
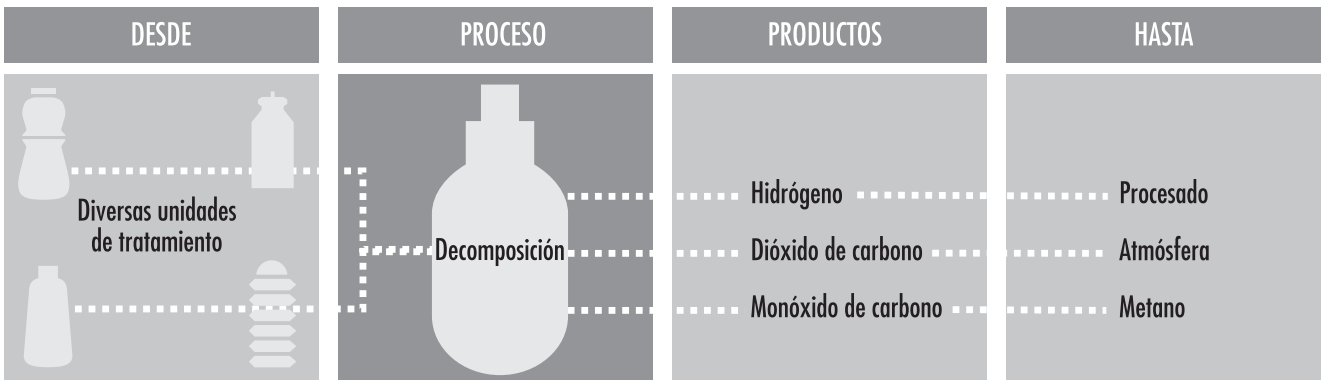
Figura 78.18 • Proceso de fabricación de aceite lubricante y cera.

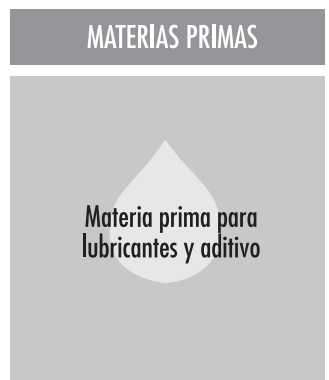

Fuente: Adaptado de OSHA 1996.
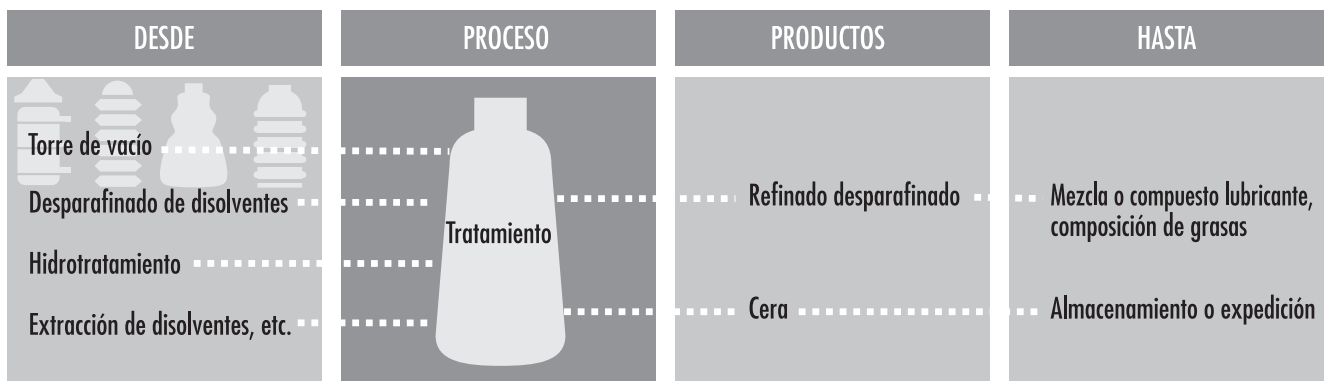

cuyo principal objetivo es eliminar los productos sin valor, como asfaltos, aromáticos sulfonados y ceras parafínicas e isoparafinicas de las fracciones residuales, a fin de producir lubricantes de alta calidad. Se lleva a cabo mediante una serie de procesos, entre los que se incluyen el desasfaltado, la extracción de disolventes y procesos de separación y tratamiento, como el desparafinado y el hidroacabado (véase la Figura 78.18).

En el procesado por extracción, el crudo reducido procedente de la unidad de vacío se desasfalta con propano y se combina con una carga de aceite lubricante de destilación directa, se precalienta y se le extrae el disolvente para producir una materia prima denominada refinado. En el proceso normal de extracción, en el que se utiliza fenol como disolvente, la carga se mezcla con fenol en la sección de tratamiento a temperaturas inferiores a $204^{\circ} \mathrm{C}$. Después, se separa el fenol del refinado y se recicla. A continuación, el refinado se somete a otro proceso de extracción en el que se utiliza furfural para separar los compuestos aromáticos de los hidrocarburos no aromáticos, con lo que se obtiene un refinado de color más claro con mejor índice de viscosidad, resistencia a la oxidación y estabilidad térmica.

El refinado desparafinado puede someterse también a un proceso ulterior para mejorar las cualidades del material base. Se utilizan adsorbentes de arcilla para eliminar las moléculas inestables, de color oscuro, de los materiales base para aceites lubricantes. En un proceso alternativo, denominado hidroacabado de lubricante, se hace pasar refinado desparafinado caliente e hidrógeno por un catalizador que modifica ligeramente la estructura molecular, produciendo con ello un aceite de color más claro y mejores características. Después, los materiales base de aceite lubricante tratados se mezclan y/o forman compuestos con aditivos para darles las características físicas y químicas que se exigen a los aceites de motor, lubricantes industriales y aceites para el trabajo de metales.

Los dos tipos de ceras distintos derivados del petróleo crudo son la parafina, producida a partir de materiales destilados, y la cera microcristalina, fabricada con materiales residuales. El refinado procedente de la unidad de extracción contiene una cantidad considerable de cera, que se separa mediante extracción de disolventes y cristalización. Se mezcla el refinado con un disolvente (propano, una mezcla de metiletilcetona (MEG) y tolueno o metilisobutilcetona (MIBC), y se preenfría en intercambiadores de calor. La temperatura de cristalización se alcanza por evaporación del propano en la enfriadora y en los tanques de alimentación con filtros. La cera se extrae continuamente mediante filtros y se lava con disolvente frío para recuperar el aceite retenido. El disolvente se recupera del refinado desparafinado mediante destilación instantánea y absorción con vapor, y se recicla.
La cera se calienta con disolvente caliente, se enfría, se filtra y se somete a un lavado final para eliminar todo vestigio de aceite. Antes de utilizarla, puede aplicársele un hidroacabado para mejorar su olor y eliminar todo rastro de aromáticos a fin de poder usarla en la elaboración de productos alimenticios. Si se desea utilizar el refinado desparafinado (que contiene pequeñas cantidades de parafinas, naftenos y algunos aromáticos).como material base para aceites lubricantes, se le somete a un proceso ulterior.

Es importante controlar la temperatura de la unidad de tratamiento para prevenir la corrosión por fenol. La cera puede obstruir los sistemas de alcantarillado y drenaje de aceite y perturbar el tratamiento de las aguas residuales. Existe riesgo de exposición a disolventes de proceso, como fenol, propano, mezcla de metiletilcetona y tolueno o metilisobutilcetona. La inhalación de gases y vapores de hidrocarburos, nafta aromática conteniendo benceno, ácido sulfhídrico y gas de proceso rico en hidrógeno, supone un riesgo.

\section{Procesado de asfalto}

El asfalto es una parte de la materia residual de las operaciones de destilación primaria, que requiere un proceso ulterior para impartirle las características que se le exigen en su utilización final. El asfalto para materiales de cubiertas y tejados se obtiene mediante soplado con aire. El residuo se calienta en una columna de fraccionamiento casi hasta su punto de inflamación y se carga en una torre de soplado donde se inyecta aire caliente durante un tiempo predeterminado. La deshidrogenación del asfalto forma ácido sulfhídrico, y la oxidación crea dióxido de azufre. Se utiliza vapor para cubrir la zona superior de la torre con objeto de separar los contaminantes, y se hace pasar por un lavador para condensar los hidrocarburos.

Generalmente se utiliza destilación al vacío para producir asfalto de alquitrán para carreteras. El residuo se calienta y se carga en una columna donde se aplica vacío para prevenir el craqueo.

El vapor condensado procedente de los diversos procesos del asfalto contiene trazas de hidrocarburos. Cualquier alteración del vacío puede determinar la entrada de aire atmosférico, con el consiguiente incendio. Si se eleva la temperatura del fondo de la torre de vacío para mejorar el rendimiento en la producción de asfalto, se genera metano por craqueo térmico, lo que origina vapores en los depósitos de almacenamiento de asfalto, que están en el rango de inflamabilidad pero no son detectables mediante pruebas de temperatura de inflamación. El soplado con aire puede crear algunos aromáticos polinucleares (es decir, HAP). Es posible asimismo que el vapor condensado procedente del proceso de asfalto con soplado de aire contenga diversos contaminantes. 
Figura 78.19• Proceso de extracción de disolvente.

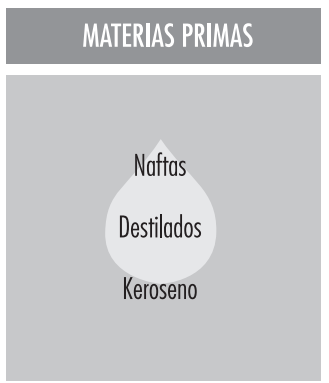

Fuente: Adaptado de OSHA 1996
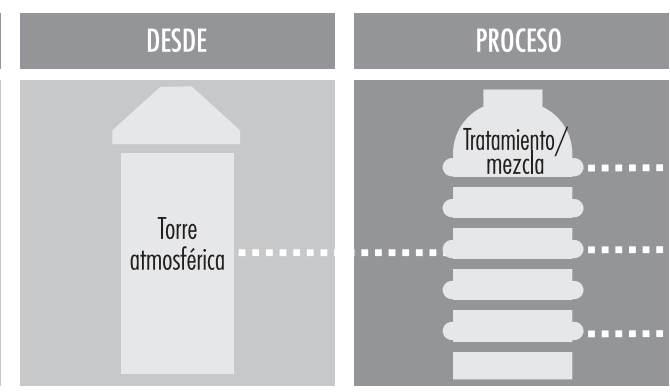

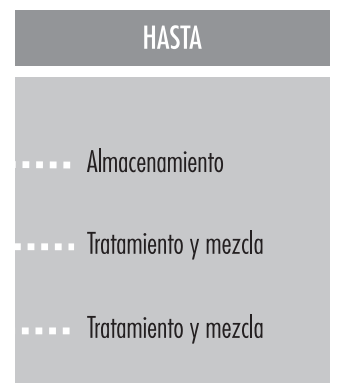

\section{Procesos de desmercaptanización y tratamiento de \\ hidrocarburos}

Hay muchos productos que requieren tratamiento para utilizarlos en mezclas de gasolina y de fuel: tal es el caso de las naftas térmicas obtenidas mediante ruptura de la viscosidad, coquización o craqueo térmico, y de las naftas y destilados de alto contenido de azufre procedentes de la destilación del petróleo crudo. Es posible que los productos de la destilación, como el queroseno y otros destilados, contengan trazas de aromáticos, y los naftenos y materiales base para aceites lubricantes, cera. Tales componentes se eliminan en fases de refino intermedias o justo antes de enviar los productos para su mezcla y almacenamiento, mediante procesos de refino, como la extracción y el desparafinado de disolventes. Una serie de productos intermedios y acabados (los destilados intermedios, la gasolina, el queroseno, el combustible para aviones de reacción y los gases sulfurosos) requieren secado y desmercaptanización.

El tratamiento se lleva a cabo en una fase intermedia del proceso de refino o justo antes de enviar los productos acabados para su mezcla y almacenamiento. El tratamiento elimina los contaminantes del petróleo, tales como compuestos orgánicos que contienen azufre, nitrógeno y oxígeno, metales disueltos, sales inorgánicas y sales solubles disueltas en agua emulsionada. Entre los materiales de tratamiento hay ácidos, disolventes, álcalis y oxidantes y adsorbentes. Los tratamientos con ácido se utilizan para mejorar el olor, color y otras propiedades de los materiales base para lubricantes, prevenir la corrosión y la contaminación de los catalizadores, y mejorar la estabilidad de los producto. El ácido sulfhídrico que se extrae del gas ácido "seco" por medio de un absorbente (dietanolamina) se quema, se utiliza como combustible o se convierte en azufre. El tipo de tratamiento y de agentes utilizados depende de la carga de crudo, de los procesos intermedios y de las especificaciones del producto final.

\section{Procesos de tratamiento con disolventes}

La extracción de disolventes separa los aromáticos, naftenos e impurezas de las corrientes de productos mediante disolución o precipitación. La extracción de disolventes previene la corrosión, protege el catalizador en procesos subsiguientes y mejora los productos terminados eliminando hidrocarburos aromáticos insaturados de los materiales base para grasas y lubricantes.

La carga se seca y se somete a un tratamiento continuo con disolvente a contracorriente. En uno de los procesos, se lava con un líquido en el que las sustancias que se eliminan son más solubles que en el producto resultante. En otro proceso, se añaden disolventes seleccionados con los que las impurezas se precipitan y se separan del producto. El disolvente se separa de la corriente de producto por calentamiento, evaporación o fraccionamiento, eliminándose a continuación las trazas residuales del refinado mediante separación al vapor o vaporización instantánea al vacío. Para separar los compuestos inorgánicos se utiliza la precipitación eléctrica. Después se regenera el disolvente para emplearlo de nuevo en el proceso.

Entre los productos químicos normalmente utilizados en el proceso de extracción están una gran variedad de ácidos, álcalis y disolventes, como fenol y furfural, así como oxidantes y adsorbentes. En el proceso de adsorción, materiales sólidos altamente porosos recogen moléculas de líquido en su superficie. La selección de procesos específicos y agentes químicos depende de la naturaleza de la carga tratada, de los contaminantes y de los requisitos del producto acabado (véase la Figura 78.19).

El desparafinado de disolventes elimina la cera del destilado o de los materiales base residuales, y se aplica en cualquier fase del

Figura 78.20 • Proceso de desparafinado de disolvente.

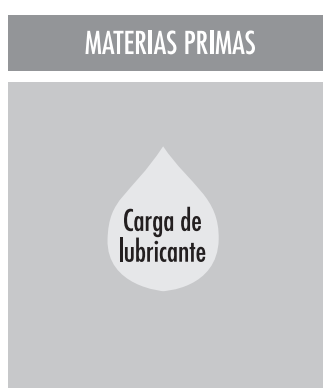

Fuente: Adaptado de OSHA 1996.
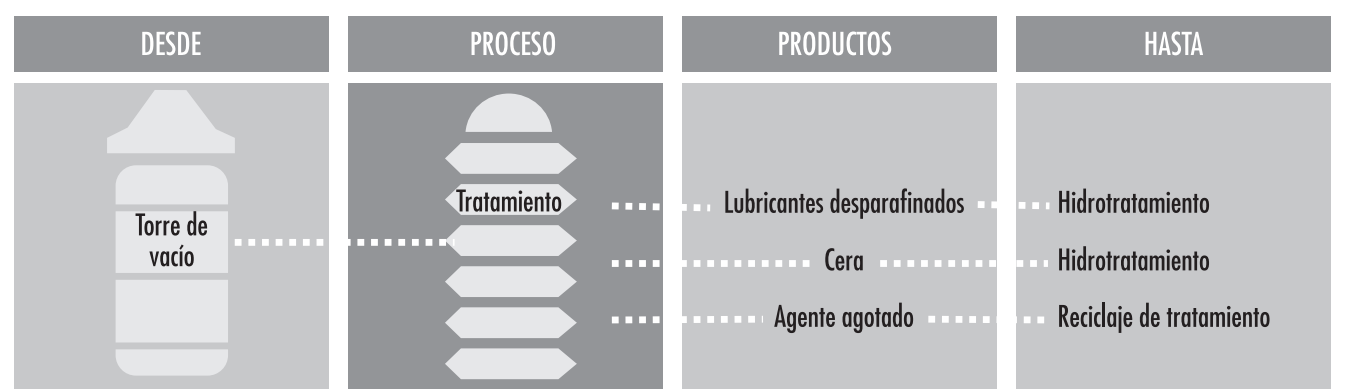
Figura 78.21 - Proceso de desasfaltado de disolvente.
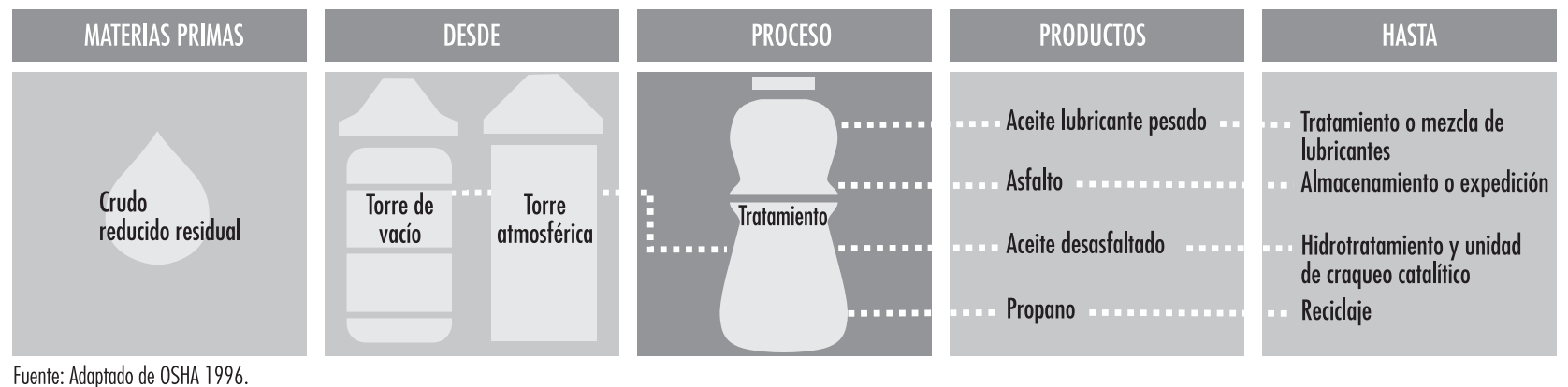

proceso de refino. En el desparafinado de disolventes, las cargas parafínicas se enfrían mediante intercambiadores de calor y refrigeración, y se añade disolvente para facilitar el crecimiento de cristales, que se eliminan mediante filtración al vacío. El petróleo desparafinado y el disolvente se vaporizan instantáneamente y se separan, y la cera pasa por un decantador de agua, un fraccionador de disolvente y una torre de destilación instantánea (véase la Figura 78.20).

El desasfaltado de disolventes separa las fracciones de aceite pesado para producir aceite lubricante pesado, carga de craqueo catalítico y asfalto. La carga y el propano (o hexano) líquido se bombean a una torre de extracción en mezclas y a temperaturas y presiones controladas con exactitud. La separación tiene lugar en un contactor de disco giratorio, en función de las diferencias de solubilidad. Después los productos se evaporan y se separan al vapor para recuperar el propano con el fin de reciclarlo. El desasfaltado de disolventes elimina también de la carga compuestos de azufre y de nitrógeno, metales, residuos de carbono y parafinas (véase la Figura 78.21).

\section{Salud y seguridad.}

En el desparafinado de disolventes, la ruptura del vacío crea un riesgo potencial de incendio al permitir la entrada de aire en la unidad. Existe riesgo de exposición a vapores del disolvente de desparafinado, una mezcla de MEC y tolueno. Aunque la extracción de disolventes es un proceso cerrado, hay riesgo de exposición a HAP cancerígenos en los aceites de proceso y a disolventes de extracción tales como fenol, furfural, glicol, MEC, aminas y otros productos químicos de proceso durante la manipulación y las operaciones.

El desasfaltado requiere un control exacto de las temperaturas y presiones para evitar la descompensación. Además, puede crearse espuma por humedad, exceso de disolvente o descenso de la temperatura de la operación, lo que afecta al control de la temperatura del producto y origina una descompensación. El contacto con corrientes de aceite caliente provoca quemaduras de la piel. Existe riesgo de exposición a corrientes de aceite caliente que contienen compuestos aromáticos policíclicos cancerígenos, propano licuado y vapores de propano, ácido sulfhídrico y dióxido de azufre.

\section{Procesos de hidrotratamiento}

El hidrotratamiento se utiliza para eliminar alrededor del $90 \%$ de los contaminantes, como nitrógeno, azufre, metales e hidrocarburos insaturados (olefinas), de las fracciones de petróleo líquidas, como la gasolina de destilación directa. El hidrotratamiento es similar al hidrocraqueo en que tanto el hidrógeno como el catalizador se utilizan para enriquecer el contenido de hidrógeno de la carga de olefinas. En cambio, el grado de saturación no es tan elevado como el que se consigue en el hidrocraqueo. Normalmente, el hidrotratamiento se realiza antes que otros procesos (como la reforma catalítica), para que el catalizador no se contamine con la carga de material no tratado. El hidrotratamiento se utiliza también antes del craqueo catalítico para reducir el azufre y mejorar el rendimiento de producción, así como para mejorar las fracciones intermedias de petróleo destilado convirtiéndolas en queroseno, gasóleo diesel y gasóleos de calefacción.

Los procesos de hidrotratamiento difieren en función de las cargas y los catalizadores. La hidrodesulfuración elimina el azufre del queroseno, reduce los aromáticos y las características que favorecen la formación de gomas, y satura cualquier olefina. La hidroformación es un proceso de deshidrogenación que se utiliza para recuperar el exceso de hidrógeno y producir gasolina de alto índice de octano. Los productos hidrotratados se mezclan o se utilizan como material de carga para la reforma catalítica.

En la hidrodesulfuración catalítica, la carga se desairea, se mezcla con hidrógeno, se precalienta y se hace pasar a alta presión por un reactor catalítico de lecho fijo. El hidrógeno se separa y recicla y el producto se estabiliza en una columna de destilación primaria donde se eliminan los residuos ligeros.

Durante este proceso, los compuestos de azufre y nitrógeno que hay en la carga se convierten en ácido sulfhídrico $\left(\mathrm{H}_{2} \mathrm{~S}\right)$ y amoníaco $\left(\mathrm{NH}_{3}\right)$. El ácido sulfhídrico y el amoníaco residuales se eliminan por separación al vapor, mediante un separador combinado de alta y baja presión o por medio de un lavado con aminas que recupera el ácido sulfhídrico en una corriente altamente concentrada, apta para conversión en azufre elemental (véanse las Figuras 78.22 y 78.23).

En el hidrotratamiento debe controlarse el ácido sulfhídrico que contiene la carga para mantenerlo en un nivel mínimo con objeto de reducir la corrosión. A veces se forma cloruro de hidrógeno y se condensa en forma de ácido clorhídrico en las secciones de baja temperatura de la unidad. En las unidades de alta presión y temperatura se forma bisulfuro amónico. En caso de fuga se produce exposición a vapores de naftas aromáticas que contienen benceno, a ácido sulfhídrico o hidrógeno gaseoso, o a amoníaco si se origina una fuga o derrame de agua amarga. También puede haber fenol si se procesan cargas con alto punto de ebullición.

Un tiempo de contacto y/o una temperatura excesivos provocarán coquización en la unidad. Se han de tomar precauciones al descargar el catalizador coquizado de la unidad para prevenir incendios por sulfuro de hierro. El catalizador coquizado deberá enfriarse hasta una temperatura inferior a $49{ }^{\circ} \mathrm{C}$ antes de extraerlo, o vaciarse en recipientes inertizados con nitrógeno donde pueda enfriarse antes de su ulterior manipulación. Para 
Figura 78.22 • Proceso de hidrodesulfuración.

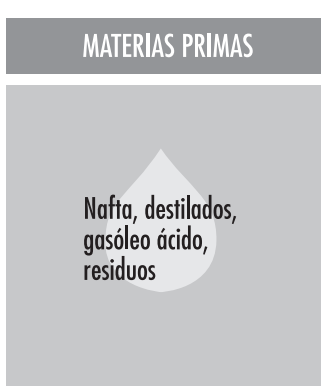

Fuente: Adaptado de OSHA 1996.
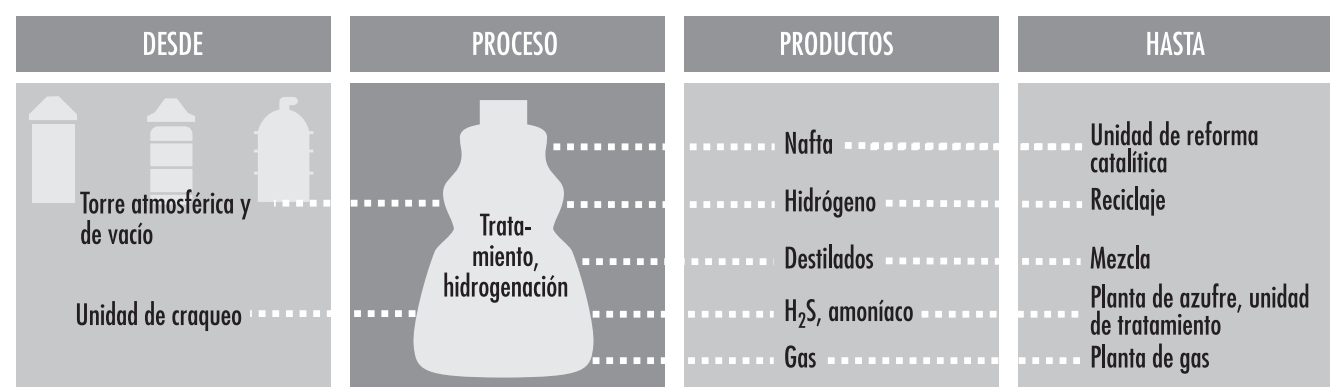

prevenir el envenenamiento del catalizador por arrastre de silicona en la carga del coquificador se emplean aditivos antiespumantes especiales.

\section{Otros procesos de desmercaptanización y tratamiento}

Para eliminar impurezas de los materiales de mezcla se utilizan procesos de tratamiento, secado y desmercaptanización (véase la Figura 78.24).

En los procesos de desmercaptanización se emplea aire u oxígeno. Si entra una cantidad excesiva de oxígeno en estos procesos, puede producirse un incendio en el decantador debido a la generación de electricidad estática. Existe riesgo de exposición a ácido sulfhídrico, dióxido de azufre, líquido cáustico (hidróxido sódico), cáustico agotado, catalizador agotado (Merox), catalizador en polvo y desmercaptanizadores (carbonato sódico y bicarbonato sódico).

Plantas de aminas (tratamiento de gas ácido)

El gas ácido (gas combustible derivado de procesos como el craqueo catalítico y el hidrotratamiento, que contiene ácido sulfhídrico y dióxido de carbono) debe tratarse para poder usarlo como combustible de refinería. Las plantas de aminas eliminan los contaminantes ácidos del gas ácido y de las corrientes de hidrocarburos. En dichas plantas, las corrientes de hidrocarburos líquidos y gaseosos que contienen dióxido de carbono y/o ácido sulfhídrico se cargan en una torre de absorción de gas o en un contactor de líquidos, donde los contaminantes ácidos son absorbidos por disoluciones de aminas que circulan a contracorriente: monoetanolamina (MEA), dietanolamina (DEA) o metildietanolamina (MDEA). El gas o el líquido separados se eliminan por la parte superior, y la amina se envía a un regenerador, donde los componentes ácidos se separan mediante calor y rehervido, y se evacuan, en tanto que la amina se recicla.

A fin de minimizar la corrosión, deben establecerse métodos de operación adecuados y controlarse las temperaturas del fondo del regenerador y del rehervidor. Es necesario impedir que entre oxígeno en el sistema para prevenir la oxidación de la amina. Hay riesgo de exposición a compuestos de aminas (es decir, MEA, DEA, MDEA), ácido sulfhídrico y dióxido de carbono.

\section{Desmercaptanización y secado}

En la desmercaptanización (eliminación del mercaptanos) se tratan los compuestos de azufre (ácido sulfhídrico, tiofeno y mercaptano) para mejorar el color, el olor y la estabilidad a la oxidación, y se reducen las concentraciones de dióxido de

Figura 78.23• Esquema del proceso de hidrodesulfuración.

Reactor

Separador de alta presión

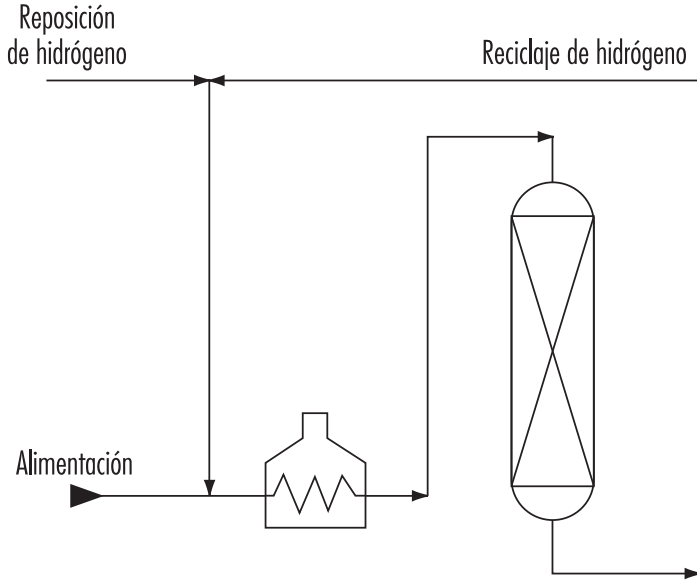

Eliminador

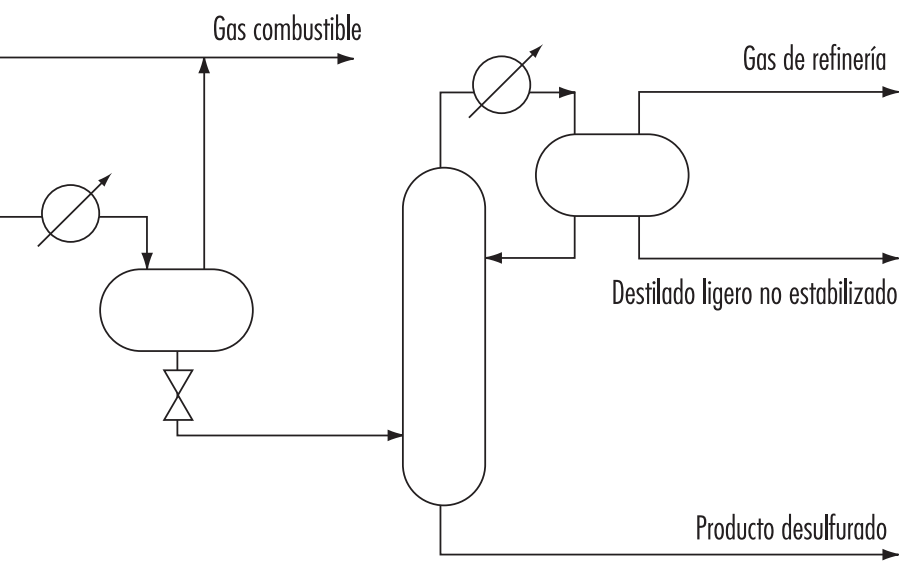


Figura 78.24 • Procesos de desmercaptanización y tratamiento.

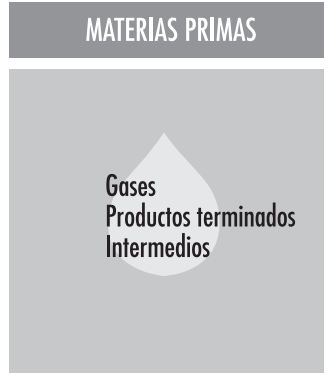

Fuente: Adaptado de OSHA 1996
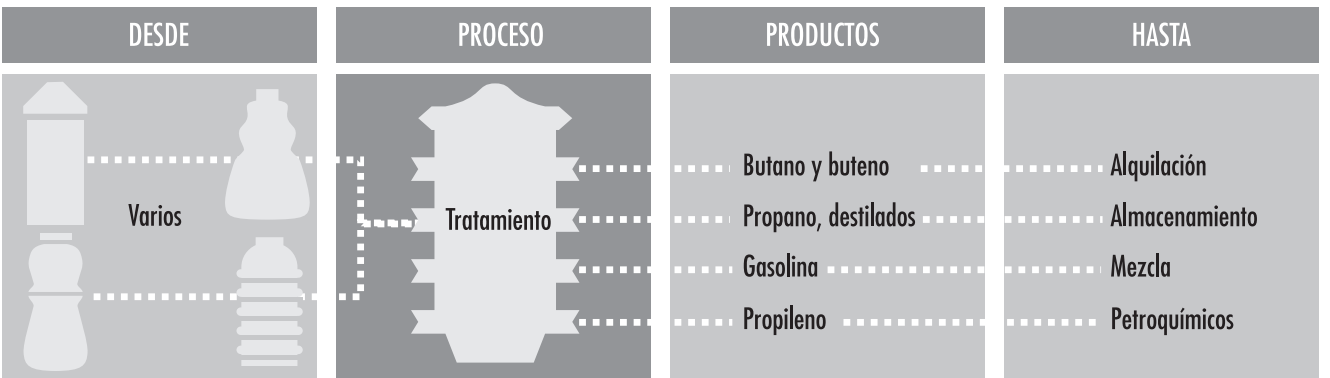

carbono en la gasolina. Algunos mercaptanos se eliminan poniendo el producto en contacto con compuestos químicos hidrosolubles (por ejemplo, ácido sulfúrico) que reaccionan con los mercaptanos. Para convertir los mercaptanos en disulfuros más aceptables se utiliza líquido cáustico (hidróxido sódico), compuestos de aminas (dietanolamina) o desmercaptanización con catalizador de lecho fijo.

El secado del producto (eliminación del agua) se realiza por absorción de agua, con o sin adsorbentes. Algunos procesos secan y desmercaptanizan simultáneamente por adsorción en tamices moleculares.

\section{Recuperación de azufre}

En la recuperación de azufre se elimina ácido sulfhídrico de los gases ácidos y las corrientes de hidrocarburos. El proceso Clause convierte el ácido sulfhídrico en azufre elemental mediante reacciones térmicas y catalíticas. Después de quemar ácido sulfhídrico en condiciones controladas, los deshidratadores eliminan el agua y los hidrocarburos de las corrientes de carga de gas, las cuales se exponen seguidamente al catalizador para recuperar azufre adicional. El vapor de azufre de la combustión y la conversión se condensa y recupera.

\section{Tratamiento del gas residual}

Para tratar el gas residual procedente de las unidades de recuperación de azufre se utilizan la oxidación y la reducción, dependiendo de la composición del gas y de los planteamientos económicos de la refinería. Los procesos de oxidación queman gas residual para convertir todos los compuestos de azufre en dióxido de azufre, y los procesos de reducción convierten los compuestos de azufre en ácido sulfhídrico.

\section{Lavado del ácido sulfhídrico}

El lavado del ácido sulfhídrico es un importante proceso de tratamiento primario de la carga de hidrocarburos, utilizado para prevenir el envenenamiento del catalizador. Dependiendo del tipo de carga y de la naturaleza de los contaminantes, los métodos de desulfuración varían desde la absorción de carbón activada a temperatura ambiente hasta la hidrogenación catalítica a alta temperatura seguida de tratamiento con óxido de zinc.

\section{Plantas de gas saturado e insaturado}

Las cargas procedentes de diversas unidades de la refinería se envían a plantas de tratamiento de gas, donde se extraen los butanos y butenos para utilizarlos como carga de alquilación, los componentes pesados se envían a la mezcla de gasolinas, se recupera el propano para GPL y se extrae el propileno para usarlo en productos petroquímicos.
Las Plantas de gas saturado separan los componentes de los gases de la refinería, como butanos para alquilación, pentanos para mezcla de gasolinas, gases de petróleo licuados para usarlos como combustible y etano para productos petroquímicos. Hay dos procesos diferentes de gas saturado: absorción-fraccionamiento o fraccionamiento directo. En el de absorción-fraccionamiento, los gases y líquidos procedentes de las diversas unidades se envían a un absorbedor/desetanizador donde el $\mathrm{C}_{2}$ y las fracciones ligeras se separan por absorción de aceite pobre y se extraen para utilizarlos como gas combustible o material de carga para procesos petroquímicos. La restantes fracciones, más pesadas, se separan y envían a un desbutanizador, y el aceite pobre se recicla y vuelve al absorbedor/ desetanizador. $\mathrm{El}_{3} / \mathrm{C}_{4}$ se separa de los pentanos en el desbutanizador, se lava para eliminar el ácido sulfhídrico, y se pasa a un divisor para separar el propano y el butano. En las plantas de fraccionamiento se prescinde de la fase de absorción. Los procesos de gas saturado dependen de la carga y de la demanda del producto.

Se produce corrosión debido a la presencia de ácido sulfhídrico, dióxido de carbono y otros compuestos procedentes del tratamiento anterior. Las corrientes que contienen amoníaco deben secarse antes del procesado. En el aceite de absorción se utilizan aditivos antiincrustaciones para proteger los intercambiadores de calor. En los sistemas superiores se utilizan inhibidores de la corrosión para controlar ésta. Existe riesgo de exposición a ácido sulfhídrico, dióxido de carbono, hidróxido sódico, MEA, DEA y MDEA arrastrados del tratamiento anterior.

Las plantas de gas insaturado recuperan hidrocarburos ligeros de las corrientes de gas húmedo procedentes de las unidades de craqueo catalítico y los acumuladores superiores de los coquizadores retardados o los receptores de fraccionamiento. En un proceso normal, los gases húmedos se comprimen y se tratan con amina para eliminar el ácido sulfhídrico antes o después de su entrada en un absorbedor de fraccionamiento, donde se mezclan con un flujo concurrente de gasolina desbutanizada. Las fracciones ligeras se separan por calor en un rehervidor, enviándose el gas de la descarga a un absorbedor de esponja y el residuo a un desbutanizador. Una parte del hidrocarburo desbutanizado se recicla y el resto pasa a un divisor para la separación. Los gases de la parte superior van a un despropanizador para utilizarlos como carga en la unidad de alquilación (véase la Figura 78.25).

En las plantas de gas insaturado que manejan cargas de CFC puede producirse corrosión por ácido sulfhídrico y cianuros húmedos, además de por ácido sulfhídrico y depósitos en las secciones de alta presión de los compresores de gas, debido a los compuestos de amonio, cuando las cargas proceden del 
Figura 78.25 - Proceso de una planta de gas insaturado.
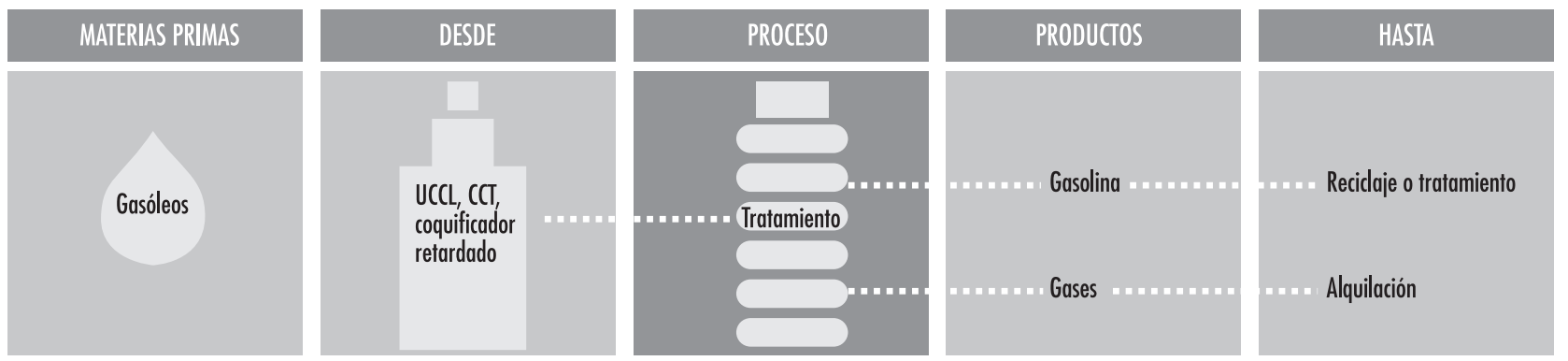

Fuente: Adaptado de OSHA 1996

coquificador retardado o del TCG. Existe riesgo de exposición a ácido sulfhídrico y a compuestos de aminas, como MEA, DEA y MDEA.

\section{Procesos de mezcla de gasolina, combustible de destilación y material base para lubricantes}

La mezcla es la combinación física de varias fracciones de hidrocarburos líquidos diferentes para obtener productos acabados con unas características específicas. Los productos se mezclan dentro del proceso por medio de un sistema de distribuidores, o bien fuera del proceso en tanques y recipientes. La mezcla de gasolina, destilados, combustible para aviones de reacción y materiales base para lubricantes dentro del proceso, se realiza inyectando cantidades proporcionales adecuadas de cada componente en la corriente principal, cuya turbulencia favorece una mezcla perfecta.

- Las gasolinas son mezclas de reformados, alquilatos, gasolina de destilación directa, gasolinas de craqueo térmico y catalítico, gasolina de coquificador, butano y aditivos apropiados.

- El fuel y el gasóleo diesel son mezclas de destilados y aceites reciclados, y el combustible para aviones de reacción puede ser un producto de destilación directa o estar mezclado con nafta.

- Los aceites lubricantes son mezclas de materiales base refinados.

- El asfalto es una mezcla de distintos materiales residuales, según el uso a que se destine.

A menudo se incorporan aditivos a la gasolina y los combustibles de automoción durante o después de la mezcla, para conferirles propiedades específicas no inherentes a los hidrocarburos de petróleo. Entre estos aditivos están los que mejoran el índice de octano, los antidetonantes, los antioxidantes, los inhibidores de goma, los antiespumantes, los inhibidores de la corrosión, los limpiadores de carburadores (anticarbonilla), los detergentes de limpieza de inyectores, los odorizantes de gasóleo diesel, los colorantes, los antiestáticos para destilados, los oxidantes de gasolina (metanol, etanol y metilbutiléter terciario), los desactivadores de metales y otros.

Las operaciones de mezcla, tanto dentro como fuera del proceso, requieren estrictos controles para mantener la calidad del producto. Deben limpiarse los derrames y repararse las fugas para evitar resbalones y caídas. Los aditivos, tanto en bidones como en sacos, deben manipularse correctamente para evitar fatiga y exposiciones. Durante la mezcla existe riesgo de contacto con aditivos, productos químicos, benceno y otros materiales peligrosos, por lo que se requieren controles técnicos apropiados, equipo de protección personal y una higiene adecuada para reducir al mínimo las exposiciones.

\section{Operaciones auxiliares de las refinerías}

Entre las operaciones auxiliares que sirven de soporte a los procesos de la refinería, están las que proporcionan calor y refrigeración de proceso, el alivio de presiones, el control de emisiones a la atmósfera, la recogida y tratamiento de las aguas residuales, el suministro de servicios básicos (energía, vapor, aire y gases para la planta), y el bombeo, almacenamiento, tratamiento y refrigeración del agua de proceso.

\section{Tratamiento de las aguas residuales}

Las aguas residuales de las refinerías comprenden el vapor condensado, el agua de separación, disoluciones cáusticas agotadas, descarga procedente de la purga de torres de refrigeración y calderas, agua de lavado, agua de neutralización de residuos ácidos y alcalinos, y otras aguas relacionadas con los procesos. Normalmente, las aguas residuales contienen hidrocarburos, materiales disueltos, sólidos en suspensión, fenoles, amoníaco, sulfuros y otros compuestos. El tratamiento de aguas residuales se aplica al agua de proceso, al agua de derrames y a las aguas cloacales antes de su descarga. En ocasiones, estos tratamientos requieren la obtención de permisos o exigen un reciclaje.

Existe riesgo de incendio si vapores procedentes de aguas residuales que contienen hidrocarburos entran en contacto con una fuente de ignición durante el proceso de tratamiento. Existe riesgo de exposición a los diversos productos químicos y residuales durante las operaciones de toma de muestras de proceso, inspección, mantenimiento y revisiones generales.

\section{Tratamiento previo}

El tratamiento previo consiste en la separación inicial de los hidrocarburos y sólidos contenidos en las aguas residuales. Se utilizan separadores API, placas interceptoras y estanques de decantación para eliminar los hidrocarburos, lodos oleosos y sólidos en suspensión mediante separación por gravedad, despumación y filtración. El agua residual ácida se neutraliza con amoníaco, cal o ceniza de sosa. El agua residual alcalina se trata con ácido sulfúrico, ácido clorhídrico, gas de chimenea rico en dióxido de carbono o con azufre. Algunas emulsiones de aceite en agua se calientan primero para facilitar la separación del aceite del agua. La separación por gravedad se basa en la diferencia entre la densidad del agua y la de los glóbulos de aceite inmiscibles, que permite eliminar el aceite libre despumándolo de la superficie del agua residual.

\section{Eliminación del agua amarga}

En los procesos de craqueo catalítico e hidrotratamiento, y siempre que se condensa vapor en presencia de gases que contienen ácido sulfhídrico, se produce agua que contiene sulfuros, conocida como agua amarga. 
Con el agua residual que contiene sulfuros y/o amoníaco se utiliza un proceso de separación, y para eliminar los fenoles del agua residual se utiliza la extracción de disolventes. Tal vez sea necesaria la refrigeración del agua residual que se va a reciclar, con objeto de extraer el calor, y/o la oxidación mediante pulverización o separación con aire para eliminar los fenoles, nitratos y amoníaco que hayan quedado.

\section{Tratamiento secundario}

Después del tratamiento previo se eliminan los sólidos en suspensión por decantación o mediante flotación del aire disuelto. El agua residual con bajos niveles de sólidos se tamiza o se filtra, pudiendo añadirse floculantes para facilitar la separación. Se utilizan materiales de altas propiedades de adsorción en filtros de lecho fijo o se añaden al agua residual para formar un lodo que se elimina por decantación o filtración. Los procesos de tratamiento secundario degradan y oxidan biológicamente la materia orgánica soluble utilizando lodo activado, estanques no aireados o aireados, métodos de percolación o tratamientos anaerobios. Se utilizan otros métodos de tratamiento adicionales para eliminar aceites y productos químicos del agua residual.

\section{Tratamiento terciario}

Los tratamientos terciarios eliminan contaminantes específicos a fin de cumplir los requisitos de descarga exigidos por la normativa. Entre ellos están la cloración, la ozonización, el intercambio iónico, la ósmosis inversa, la adsorción por carbono activado y otros. Se puede difundir oxígeno comprimido en las corrientes de agua residual para oxidar ciertas sustancias químicas o satisfacer requisitos reglamentarios sobre contenido de oxígeno.

\section{Torres de refrigeración}

Las torres de refrigeración extraen calor del agua de proceso por evaporación y transferencia de calor latente entre el agua caliente y el aire. Hay dos tipos de torres, de contraflujo y de flujo cruzado.

- En la refrigeración por contraflujo, el agua de proceso caliente se bombea a la cámara situada en la parte más alta y se permite que caiga por la torre. A todo lo largo de ésta hay numerosos listones, o boquillas rociadoras, para dispersar el flujo de agua y facilitar la refrigeración. Simultáneamente, entra aire por la parte inferior de la torre, creándose así un flujo de aire concurrente en sentido contrario al del agua. Las torres de tiro inducido tienen los ventiladores en la salida de aire. Las torres de tiro forzado tienen los ventiladores o soplantes en la entrada de aire.

- Las torres de flujo cruzado introducen el flujo de aire en sentido perpendicular al flujo de agua por toda la estructura.

$\mathrm{El}$ agua refrigerante recirculada debe tratarse para eliminar las impurezas y cualquier hidrocarburo disuelto. Las impurezas del agua refrigerante corroen y se incrustan en las tuberías y en los intercambiadores de calor; las sales disueltas se incrustan en las tuberías, y las torres de refrigeración de madera resultan dañadas por microorganismos.

$\mathrm{El}$ agua de las torres de refrigeración pueden contaminarla los materiales y subproductos de proceso, como el dióxido de azufre, el ácido sulfhídrico y el dióxido de carbono, con las consiguientes exposiciones. Existe riesgo de exposición a productos químicos de tratamiento del agua o a ácido sulfhídrico cuando se tratan aguas residuales y se utilizan conjuntamente torres de refrigeración. $\mathrm{Al}$ estar el agua saturada de oxígeno por haber sido refrigerada con aire, las posibilidades de corrosión son mayores. Un medio de prevenir la corrosión es añadir al agua refrigerante un material que forme una película protectora sobre las tuberías y otras superficies metálicas.
Cuando el agua refrigerante está contaminada con hidrocarburos, se desprenden vapores inflamables y se mezclan con el aire de descarga. Si hay una fuente de ignición o se produce una chispa eléctrica, existe la posibilidad de que se declare un incendio. También se corre este riesgo cuando hay zonas relativamente secas en torres de refrigeración de tiro inducido de estructura combustible. La interrupción de la alimentación eléctrica a los ventiladores de las torres de refrigeración o a las bombas de agua puede tener graves consecuencias en las operaciones de proceso.

\section{Generación de vapor}

El vapor se produce por medio de operaciones con calentadores y calderas en centrales generadoras de vapor y en diversas unidades de proceso, utilizando calor producido por gas de chimenea u otras fuentes. Ente los sistemas de generación de vapor están los siguientes:

- calentadores (hornos), con sus quemadores y un sistema de aire de combustión;

- sistemas de tiro o de presión para extraer del horno el gas de chimenea, sopladores de hollín, y sistemas de aire comprimido que sellan las aberturas para impedir que escape el gas de chimenea;

- calderas, formadas por varios tubos que transportan la mezcla de agua y vapor a través del horno propiciando la máxima transferencia térmica (estos tubos pasan entre colectores de distribución de vapor situados en la parte superior de la caldera y colectores de agua situados en el fondo de la misma),

- colectores de vapor que recogen éste y lo envían al sobrecalentador antes de que entre en el sistema de distribución de vapor.

En la generación de vapor, la operación con mayor potencial de riesgo es la puesta en marcha del calentador. Cabe la posibilidad de que se forme una mezcla inflamable de gas y aire por pérdida de la llama en uno o más quemadores durante el encendido. Para cada tipo de unidad se requieren procedimientos de arranque específicos, como purga antes del encendido y procedimientos de urgencia en caso de fallo de encendido o pérdida de la llama del quemador. Si disminuye el caudal de agua de caldera y se secan las calderas, los tubos se sobrecalientan y se averían. El exceso de agua pasa al sistema de distribución de vapor y daña las turbinas. Las calderas deben tener sistemas de purga continua o intermitente para extraer el agua de los colectores de vapor y limitar la formación de incrustaciones en los álabes de la turbina y en los tubos del sobrecalentador. Se han de tomar precauciones para no calentar en exceso el sobrecalentador durante el arranque y la parada. Deberán proveerse fuentes de combustible alternativas por si se perdiese el suministro de gas combustible debido a una parada o una emergencia de la unidad de la refinería

\section{Combustible para los calentadores}

En los calentadores se utiliza cualquier combustible o combinación de combustibles, como gas de refinería, gas natural, fuel y carbón en polvo. El gas de descarga de la refinería se recoge de las unidades de proceso y se combina con gas natural y GPL en un colector de compensación de gas combustible. Dicho colector proporciona una presión constante en el sistema, combustible con un contenido energético en $\mathrm{Kcal} / \mathrm{h}$ bastante estable y separación automática de los líquidos en suspensión en el gas, al tiempo que previene el arrastre de grandes cúmulos de condensado al sistema de distribución.

Normalmente, el fuel es una mezcla de petróleo crudo de refinería y residuos de destilación directa y de craqueo, mezclados con otros productos. El sistema de fuel suministra combustible a los calentadores y generadores de vapor de las unidades de 
proceso a las temperaturas y presiones necesarias. El fuel se calienta hasta la temperatura de bombeo, se aspira a través de un tamiz de malla gruesa, se bombea a un calentador de temperatura controlada y después se hace pasar por un tamiz de malla fina antes de quemarlo. Antes de quemar el gas combustible se extraen de él los líquidos utilizando deshidratadores previstos en las unidades de proceso.

En uno de los procedimientos de generación de calor a partir de las unidades de proceso, calderas de monóxido de carbono (CO) recuperan el calor de las unidades de craqueo catalítico quemando totalmente el monóxido de carbono contenido en el gas de chimenea. En otros procesos, unidades de recuperación de calor residual utilizan el calor del gas de chimenea para producir vapor.

\section{Distribución del vapor}

Normalmente, el vapor se genera en calentadores y calderas combinados en una sola unidad. El vapor sale de las calderas a la máxima presión requerida por las unidades de proceso o el grupo electrógeno. A continuación, la presión del vapor se reduce en turbinas que accionan bombas y compresores de proceso. Cuando el vapor de la refinería se emplea también para accionar generadores de turbina de vapor para producir electricidad, el vapor debe producirse a una presión muy superior de la que se requiere para el vapor de proceso. El sistema de distribución de vapor se compone de válvulas, racores, tuberías y conexiones adecuados para la presión del vapor que se transporta. La mayor parte del vapor que se utiliza en la refinería se transforma en agua por condensación en los intercambiadores de calor y se reutiliza como agua de caldera o se descarga al sistema de tratamiento de aguas residuales.

\section{Agua de caldera procedente de vapor}

El suministro de agua de caldera es una parte importante de la generación de vapor. El peso del agua que entra en el sistema de generación de vapor debe ser siempre igual al del vapor que sale de ella. El agua utilizada para generar vapor ha de estar libre de contaminantes, como minerales e impurezas disueltas que dañan el sistema o afectan a la operación. Los materiales en suspensión (limo, materias cloacales y petróleo), que forman lodos e incrustaciones, se extraen del agua por coagulación o filtración. Los gases disueltos, en especial el dióxido de carbono y el oxígeno, que provocan corrosión de las calderas, se eliminan mediante desaireación y tratamiento. Los minerales disueltos, como sales metálicas, calcio y carbonatos, que producen incrustaciones y corrosión, y depósitos en los álabes de las turbinas, se tratan con cal o ceniza de sosa para extraerlos del agua por precipitación. Dependiendo de sus características, el agua bruta de caldera se trata por clarificación, decantación, filtración, intercambio iónico, desaireación o tratamiento interno. También debe tratarse el agua de refrigeración recirculada, para eliminar hidrocarburos y otros contaminantes.

\section{Calentadores, intercambiadores de calor y enfriadores de proceso}

Los calentadores e intercambiadores de calor de proceso precalientan las cargas de las torres de destilación y de los procesos de la refinería hasta las temperaturas de reacción. La mayor parte del calor suministrado a las unidades de proceso proviene de los calentadores caldeados situados en los precalentadores de crudo y de unidades de reforma, calentadores de coquificador y rehervidores de columna grande, alimentados con gas de refinería o gas natural, destilado y aceites residuales. Los calentadores suelen estar diseñados para operaciones de proceso específicas, y la mayoría son cilíndricos y verticales o en forma de cajón. Los intercambiadores utilizan como fuente de calor vapor o hidrocarburo caliente, transferido desde alguna otra sección del proceso.

También se extrae calor de algunos procesos por medio de intercambiadores de aire y agua, haces de tubos con aletas refrigerados por ventilador, enfriadores de gas y de líquido y condensadores superiores, o transfiriendo el calor a otros sistemas. El sistema básico de refrigeración por compresión mecánica de vapor está diseñado para dar servicio a una o más unidades de proceso, y comprende evaporador, compresor, condensador, elementos de control y tuberías. Los refrigerantes normalmente utilizados son el agua, una mezcla de alcohol y agua o diversas disoluciones de glicol.

Para reducir el riesgo de explosiones al encender hornos calentadores se requiere un medio que permita un tiro o una purga de vapor adecuados. Cada tipo de unidad requiere unos procedimientos específicos de arranque y de emergencia. Si el fuego llega a los haces de tubos con aletas refrigerados por ventiladores, puede producirse una avería por exceso de calor. Si se produce un escape de producto inflamable de un intercambiador de calor o de un enfriador a causa de una fuga, hay peligro de incendio.

Antes de desmontar un cabezal o de colocar tapones hay que asegurarse de que la presión de los tubos del calentador se ha anulado por completo. Debe considerarse la provisión de un dispositivo de descarga de presión en los sistemas de tuberías de los intercambiadores de calor por si se bloqueasen estando llenos de líquido. Si fallan los elementos de control, pueden producirse variaciones de presión y temperatura en uno u otro lado del intercambiador. Si fallan los tubos de éste y la presión de proceso es mayor que la del calentador, es posible que entre producto en el calentador con las lógicas consecuencias corriente abajo. Si la presión es menor, la corriente del calentador podría entrar en la de fluido de proceso. Si se produce una pérdida de circulación en enfriadores de líquido o de gas, el aumento de temperatura del producto podría afectar a las operaciones corriente abajo y sería necesaria una descarga de presión.

Dependiendo del combustible, de la operación del proceso y del diseño de la unidad, existe riesgo de exposición a ácido sulfhídrico, monóxido de carbono, hidrocarburos, lodos de agua de caldera de vapor y productos químicos de tratamiento del agua. Debe evitarse el contacto de la piel con la descarga de la caldera, que puede contener compuestos fenólicos. Existe riesgo de exposición a calor radiante, vapor sobrecalentado e hidrocarburos calientes.

\section{Sistemas de descarga de presión y de llama}

Entre los controles técnicos incorporados a los procesos están la reducción de las concentraciones de vapores inflamables mediante ventilación, dilución e inertización. Se recurre a la presurización para mantener las salas de control a una presión superior a la atmosférica, a fin de reducir la posibilidad de entrada de vapores. Se utilizan sistemas de descarga de presión para controlar los vapores y líquidos liberados por dispositivos limitadores de presión y por las purgas. La descarga de presión es una operación automática y prevista, que se produce cuando la presión de la operación alcanza un nivel predeterminado. Por purga se entiende la descarga intencionada de material; es el caso de las purgas de arranque de unidades de proceso, purgas de hornos paradas y emergencias. La despresurización de vapores es la extracción rápida de los vapores de recipientes de presión en caso de emergencia. Para ello se utiliza un disco de ruptura, cuya presión suele ser más alta que la de la válvula de descarga.

\section{Válvulas de seguridad}

Las válvulas de seguridad, utilizadas para controlar presiones de aire, vapor, gas e hidrocarburos en fase de vapor y en fase líquida, 
abren en función del aumento proporcional de presión por encima de la presión normal de trabajo. Diseñadas principalmente para liberar grandes volúmenes de vapor, suelen abrir instantáneamente a su máxima capacidad. La sobrepresión necesaria para abrir las válvulas de descarga de líquido, en la que no se requiere la descarga de grandes volúmenes, aumenta a medida que la válvula abre debido a la creciente resistencia del muelle. Cuando se requiere mayor estanqueidad y descargas de mayor volumen, se utilizan válvulas de seguridad pilotadas, con una capacidad hasta seis veces mayor que la de las válvulas de seguridad normales. Generalmente, los líquidos no volátiles se bombean a sistemas de separación y recuperación de aceite y agua, y los volátiles se envían a unidades que trabajan a menor presión.

\section{Llamas}

Un sistema cerrado característico de descarga de presión y llama, está constituido por válvulas de seguridad y conductos procedentes de las unidades de proceso para recogida de las descargas, colectores de separación para separar vapores y líquidos, sellos y/o gas de purga para protección contra retroceso de llama, y un sistema de llama y encendedor que quema los vapores si no está permitida la descarga directa a la atmósfera. Es posible inyectar vapor en la punta de la llama para reducir el humo visible.

No debe permitirse la descarga de líquidos a un sistema de evacuación de vapor. Los colectores de llama y las llamas han de ser lo bastante grandes para hacer frente a purgas de emergencia, y los colectores deben estar provistos de dispositivos de descarga contra sobrepresiones. Se utilizarán válvulas de descarga de presión cuando exista riesgo de sobrepresión en procesos de refinería, como la producida por las siguientes causas:

- pérdida de agua refrigerante, lo que provoca un gran aumento de la pérdida de carga en los condensadores con el consiguiente aumento de presión en la unidad de proceso;

- rápida vaporización y aumento de presión por inyección de un líquido de bajo punto de ebullición (agua, por ejemplo) en un recipiente de proceso que trabaja a mayores temperaturas;

- expansión del vapor y sobrepresión consiguiente por excesiva temperatura del vapor de proceso, mal funcionamiento de los calentadores o incendio;

- fallo de controles automáticos, bocas de salida cerradas, avería de intercambiadores de calor, etc.;

- explosión interna, reacción química, expansión térmica, gases acumulados, etc.,

- pérdida de reflujo, con el resultado de un aumento de presión en las torres de destilación.

Como la cantidad de reflujo afecta al volumen de vapores que salen de la torre de destilación la pérdida de volumen provoca una pérdida de carga en los condensadores y un aumento de la presión en las torres de destilación.

El mantenimiento es importante, ya que es necesario que las válvulas funcionen correctamente. Entre los problemas de funcionamiento más comunes de las válvulas están los siguientes:

- no abrir a la presión de tarado por taponamiento de la entrada o la salida de la válvula o por corrosión, lo que impide el correcto funcionamiento del portadisco y las guías;

- no cerrar después de la apertura debido a la presencia de suciedad, corrosión o depósitos en el asiento o las piezas móviles, o de sólidos en la corriente de gas que cortan el disco de la válvula,

- vibración y apertura prematura por ser la presión de trabajo demasiado próxima al punto de consigna del tarado de la válvula.

\section{Servicios básicos}

Water. Dependiendo de la localización y de los recursos comunes, las refinerías utilizan la red pública de abastecimiento de agua para sus necesidades de agua potable y de proceso, o bien han de bombear y tratar su propia agua potable. El tratamiento requiere varias operaciones, desde desalinización hasta filtrado, cloración y análisis.

Aguas cloacales. Asimismo, dependiendo de la disponibilidad de plantas depuradoras externas comunes o privadas, las refinerías tienen que encargarse de la obtención de permisos, recogida, depuración y descarga de sus aguas cloacales.

Energía eléctrica. Las refinerías reciben electricidad de fuentes externas o producen su propia energía eléctrica, utilizando grupos electrógenos accionados por turbinas de vapor o motores de combustión interna. Las distintas zonas se clasifican en función del tipo de protección eléctrica necesaria para evitar la inflamación de vapores a causa de una chispa o confinar una explosión dentro del equipo eléctrico. Las subcentrales eléctricas, situadas normalmente en zonas no clasificadas, lejos de las fuentes de vapores de hidrocarburos inflamables o del agua rociada en las torres de refrigeración, contienen transformadores, disyuntores e interruptores de circuitos de alimentación. Las subcentrales suministran energía a estaciones de distribución situadas en las zonas de las unidades de proceso. Las estaciones de distribución pueden estar ubicadas en zonas clasificadas siempre que cumplan los requisitos de clasificación eléctrica. Normalmente, utilizan un transformador lleno de líquido provisto de un seccionador lleno de aceite o de desconexión al aire.

Deberán adoptarse las precauciones de seguridad eléctrica normales, es decir, pisar en seco, letreros de aviso de "alta tensión" y cubiertas anticontacto, como protección contra la electrocución. Los empleados deberán conocer perfectamente los procedimientos de trabajo correctos en relación con la seguridad eléctrica en la refinería. Se utilizarán medios de bloqueo, etiquetas de advertencia y otras prácticas seguras de trabajo para evitar la conexión imprevista de equipos eléctricos de alta tensión mientras se trabaja en los mismos. Pueden producirse exposiciones peligrosas al trabajar en transformadores e interruptores que contienen un líquido dieléctrico que requiere precauciones de manipulación especiales. De estas cuestiones se ocupa con mayor amplitud otra sección de la Enciclopedia.

\section{Operaciones con turbinas y compresores de gas y de aire}

\section{Compresores de aire y de gas}

Los sistemas de extracción, ventilación y abastecimiento de aire de las refinerías están diseñados para capturar o diluir los gases, humos, polvos y vapores que contaminan los espacios de trabajo o la atmósfera exterior. Los contaminantes capturados se recuperan, si es posible, o se conducen a sistemas de evacuación después de limpiarlos o incinerarlos. Entre los sistemas de abastecimiento de aire se incluyen: compresores, enfriadores, calderines, deshumidificadores, elementos de control y tuberías de distribución. También se emplean soplantes para suministrar aire a determinados procesos. Se utiliza aire comprimido de la planta para el funcionamiento de herramientas neumáticas, regeneración de catalizadores, calentadores de proceso, descoquización con vapor y aire, oxidación de agua amarga, desmercaptanización de gasolinas, soplado de asfalto y otras aplicaciones. También se provee aire comprimido de instrumentación para utilizarlo en instrumentos y controles neumáticos, motores neumáticos y conexiones de purga, y gas de planta (por ejemplo, nitrógeno) para la inertización de recipientes y otros usos. Para la producción de gas y aire comprimidos se utilizan compresores alternativos y centrífugos. 
Los compresores de aire deben ubicarse de manera que la aspiración no absorba vapores inflamables o gases corrosivos. Existe riesgo de incendio si se produce una fuga en los compresores de gas. Se necesitan colectores de separación para evitar que penetren oleadas de líquido en estos compresores. Si los gases están contaminados con materiales sólidos, deberán utilizarse tamices. La avería de los controles de los compresores automáticos afecta a los procesos. Si existe la posibilidad de que la presión máxima supere la presión de diseño de un compresor o equipo de proceso, deberán montarse dispositivos de descarga de presión. Es necesario cubrir con protecciones adecuadas las piezas móviles expuestas de los compresores. Los edificios donde estén instalados los compresores deberán tener la correspondiente clasificación eléctrica, y medios para su adecuada ventilación.

Guando se utilice aire de planta como complemento del aire de instrumentación, las interconexiones deberán estar antes del sistema de deshumidificación del aire de instrumentación para prevenir la contaminación de los instrumentos con humedad. Tal vez sean necesarias fuentes alternativas para el aire de instrumentación (por ejemplo, nitrógeno), por si se producen cortes de energía o averías de compresores. Se adoptarán medidas de seguridad que garanticen que el gas, el aire de planta y el aire de instrumentación no puedan utilizarse como fuente de aire para respiración o para la presurización de sistemas de agua potable.

\section{Turbinas}

Generalmente, las turbinas son impulsadas por gas o vapor y se utilizan para accionar bombas, compresores, soplantes y otros equipos de proceso de las refinerías. El vapor entra en las turbinas a altas temperaturas y presiones, se expande y es guiado por álabes fijos para impulsar los álabes giratorios.

Las turbinas de vapor utilizadas en sistemas de escape que trabajan al vacío necesitan una válvula de seguridad en el lado de descarga con fines de protección y para mantener el vapor en caso de fallo del vacío. Si existe la posibilidad de que la presión máxima en funcionamiento supere la presión de diseño, las turbinas de vapor necesitan dispositivos de descarga de presión. Debe considerarse el empleo de reguladores de velocidad y moderadores de sobrevelocidad en las turbinas.

\section{Bombas, tuberías y válvulas}

Para impulsar los hidrocarburos, el agua de proceso, el agua para extinción de incendios y las aguas residuales a través de la refinería, se utilizan bombas centrífugas y volumétricas (de movimiento alternativo). Las bombas son accionadas por motores eléctricos, turbinas de vapor o motores de combustión interna.

Los hidrocarburos, el vapor, el agua y otros productos se distribuyen por las instalaciones a través de sistemas de tuberías de fluidos básicos y de proceso. Los sistemas están dimensionados y construidos con materiales que dependen del tipo de servicio, presión, temperatura y naturaleza de los productos. Las tuberías tienen conexiones de purga, drenaje y toma de muestras, así como dispositivos de corte y obturación. En función de su cometido se utilizan diferentes tipos de válvulas: de compuerta, de bypass, esféricas y de bola, obturadoras, de bloqueo y de purga, y de retención, y pueden accionarse manual o automáticamente.

Las válvulas y la instrumentación que requieren mantenimiento $\mathrm{u}$ otras intervenciones, han de ser accesibles desde el suelo o desde una plataforma de trabajo. Pueden utilizarse válvulas telecontroladas, válvulas contra incendios y válvulas de incomunicación para limitar la pérdida de producto en las tuberías de aspiración de las bombas en caso de fuga o incendio. Como protección contra escapes las conexiones activas de purga y drenaje se dotan de una doble válvula de bloqueo o de una válvula de bloqueo y un tapón o una brida ciega. Dependiendo del producto y el tipo de servicio, se necesitan medidas para evitar el reflujo desde el conducto de descarga. Es posible adoptar medidas preventivas para evitar la rotura de las tuberías por dilatación, movimiento y cambios de temperatura. Si las bombas funcionan con flujo reducido o sin flujo pueden calentarse en exceso y romperse. La avería de los controles automáticos de las bombas puede provocar desviaciones de la presión y la temperatura de proceso. Si las bombas quedan expuestas a presiones excesivas deben preverse dispositivos de alivio de presión en las tuberías de descarga.

\section{Almacenamiento en depósitos}

En toda la refinería se utilizan depósitos atmosféricos y a presión para el almacenamiento de crudos, hidrocarburos intermedios (los que se utilizan para proceso) y productos terminados, tanto en fase líquida como gaseosa. También hay depósitos para agua contra incendios, agua de proceso y de tratamiento, ácidos, aire e hidrógeno, aditivos y otros productos químicos. El tipo, estructura, capacidad y ubicación de los depósitos depende de su uso y de la naturaleza, presión de vapor, punto de inflamación y punto de goteo de los materiales almacenados. En las refinerías se utilizan muchos tipos de depósitos, siendo los más sencillos los depósitos de superficie al exterior, de techo cónico, para el almacenamiento de líquidos combustibles (no volátiles), como gasóleo diesel, fuel y aceite lubricante. Los depósitos abiertos por arriba y los depósitos cubiertos (interiores), de techo flotante, en los que se almacenan líquidos inflamables (volátiles) como gasolina y petróleo crudo, restringen el espacio disponible entre la superficie superior del producto y el techo del depósito, con el fin de mantener una atmósfera rica en vapor que excluya la ignición.

Existe riesgo de incendio si los depósitos de almacenamiento de hidrocarburos se llenan en exceso o presentan fugas de líquido y vapores que permiten que estos entren en contacto con fuentes de ignición. En las refinerías se deben establecer procedimientos de aforo y recepción de productos para controlar los llenados excesivos, o prever sistemas automáticos de control y señalización de reboses en los depósitos. Estos últimos se dotan de sistemas fijos o semifijos de protección contra incendios por medio de espuma y agua.

Pueden montarse en los depósitos válvulas telecontroladas, válvulas de incomunicación y válvulas contra incendios, para cierre o bombeo al exterior en caso de incendio en el interior del depósito o en el dique o zona de almacenamiento del mismo. Se utilizan programas de ventilación, limpieza y entrada en espacios confinados para controlar el trabajo en el interior de los depósitos, y sistemas de autorización de trabajos con empleo de calor para controlar las fuentes de ignición en los depósitos de almacenamiento y a su alrededor.

\section{Manipulación, expedición y transporte}

Las operaciones finales de la refinería consisten en la canalización de gases e hidrocarburos líquidos en oleoductos y gasoductos, y su carga en vagones y camiones cisterna, y barcos y barcazas para su transporte a las terminales y consumidores. Las características de los productos, necesidades de distribución, requisitos de embarque y prevención de incendios, criterios de protección medioambiental y procedimientos operativos, son importantes al diseñar muelles marítimos, llenaderas y conectores múltiples de oleoductos. Deben establecerse y convenirse procedimientos operativos entre remitente y destinatario, y mantenerse las comunicaciones durante la transferencia del producto. Los camiones y vagones cisterna se cargan por la parte superior o inferior. La carga y descarga de gas licuado de petróleo (GLP) requiere consideraciones especiales además de las necesarias para los 
hidrocarburos líquidos. Cuando proceda, deberán preverse sistemas de recuperación de vapores en las llenaderas y en los muelles marítimos.

Unas prácticas seguras de trabajo y unos equipos de protección personal adecuados son necesarios durante la carga y la descarga, limpieza de derrames por fugas, o al realizar tareas de aforo, inspección, toma de muestras o mantenimiento en instalaciones de carga o sistemas de recuperación de vapores. En caso de emergencia como, por ejemplo, el rebose del compartimiento de un camión o vagón cisterna, deberá detenerse o desviarse la carga.

En las refinerías se utilizan varios productos químicos tóxicos y peligrosos diferentes, desde las pequeñas cantidades de reactivos de análisis que se emplean en los laboratorios hasta las grandes cantidades de ácido sulfúrico y ácido fluorhídrico utilizadas en el procesado alcalino. Tales productos químicos deben recibirse, almacenarse y manipularse correctamente. Los fabricantes de productos químicos facilitan información sobre la seguridad del material, utilizada por las refinerías para aplicar procedimientos de seguridad, controles técnicos, requisitos de protección personal y procedimientos de manipulación de productos químicos en respuesta a emergencias.

La naturaleza del riesgo en las instalaciones de carga y descarga depende de los productos que se carguen y de los que se hayan transportado anteriormente en el vagón o camión cisterna, o en el barco. El interconectado iguala la carga eléctrica entre la llenadera y el camión o vagón cisterna. La puesta a tierra previene la circulación de corrientes parásitas en las instalaciones de llenado de camiones y vagones cisterna. En las conexiones de tuberías de los muelles marítimos se utilizan bridas aislantes para prevenir la acumulación y las descargas de electricidad estática. En los conductos de recuperación de vapores de las llenaderas y los muelles de carga marítimos se instalan apagallamas para impedir el retroceso de llama. Siempre que se permita la carga con conmutación, deberán establecerse y seguirse procedimientos de seguridad.

Se deberán prever sistemas de corte automáticos o manuales en los tubos de carga superiores e inferiores de las llenaderas y muelles marítimos, para el caso de que se produzcan fugas o reboses. En los muelles y en las llenaderas de carga superior a veces es necesario instalar medios de protección anticaídas, como barandillas. Pueden preverse sistemas de drenaje y recuperación en las llenaderas, para el desagüe de aguas pluviales, en los muelles y para la recogida de vertidos por fugas o derrames. En las instalaciones de carga de GLP es preciso adoptar precauciones para no sobrecargar o sobrepresurizar los vagones y camiones cisterna.

\section{Actividades e instalaciones de soporte de las refinerías}

Como soporte de los procesos de las refinerías se requieren diversas instalaciones, actividades y programas diferentes, cada uno con sus propios requisitos específicos en cuanto a salud y seguridad, dependiendo de la ubicación de la refinería y de los recursos disponibles en la misma.

\section{Actividades administrativas}

Según la filosofía de la empresa de refino y la disponibilidad de servicios comunitarios, son necesarias una gran variedad de actividades administrativas de soporte para asegurar la continuidad de las operaciones de la refinería. La función que regula los movimientos de entrada y salida (así como internos) del petróleo de la refinería es exclusiva de estas instalaciones. Las funciones administrativas pueden desglosarse como sigue. El funcionamiento diario de las unidades de proceso corresponde a la función de operaciones. Otra función es la de las gestiones necesarias para asegurar la continuidad del abastecimiento de petróleo crudo. Entre otras actividades funcionales se incluyen los servicios médicos (tanto de urgencia como de asistencia sanitaria continuada), comidas, servicios técnicos, servicios de conserjería y las funciones generales de administración y dirección comunes a la mayoría de las industrias: contabilidad, compras, relaciones humanas, etc. La función de formación de la refinería se ocupa de la cualificación de supervisores y empleados, y de la formación profesional del personal, en la que se incluyen la formación inicial, la de repaso y la de corrección, así como de la orientación y formación de empleados y contratistas en procedimientos para situaciones de emergencia y en prácticas y procedimientos de trabajo seguros.

\section{Construcción y mantenimiento}

La continuidad y seguridad de las operaciones de las refinerías depende del establecimiento y puesta en práctica de programas y procedimientos de mantenimiento periódico y preventivo, y de la posibilidad de efectuar sustituciones en caso necesario. Las revisiones generales, en las que se para la totalidad de la refinería o unidades de proceso completas para la revisión general y sustitución de todo el equipo a la vez, es un tipo de programa de mantenimiento preventivo exclusivo de las industrias de transformación. Las actividades de integridad mecánica (revisión, reparación, prueba y certificación de válvulas y dispositivos de descarga), que forman parte del programa de gestión de la seguridad de proceso, son importantes para la continuidad y seguridad de las operaciones de una refinería, al igual que lo son las órdenes de trabajo de mantenimiento para asegurar la eficacia continuada del programa de "gestión de cambios" de la refinería. Los programas de permisos para trabajar controlan los trabajos térmicos y las medidas de seguridad de trabajo, tales como el aislamiento y bloqueo, y la entrada en espacios confinados. Los talleres de mantenimiento e instrumentación tienen, entre otros, los siguientes cometidos:

- trabajos delicados y de precisión para la comprobación, mantenimiento y calibración de controles, instrumentos y ordenadores de la refinería;

- soldadura;

- reparación y revisión de equipos:

- mantenimiento de vehículos,

- carpintería, etc.

La salud y la seguridad en la construcción y el mantenimiento dependen de algunos de los siguientes programas.

\section{Aislamiento}

La seguridad en el mantenimiento, reparación y sustitución de equipos en unidades de proceso, exige con frecuencia aislar los depósitos, recipientes y conductos para excluir la posibilidad de entrada de líquidos o vapores inflamables en una zona donde se estén realizando trabajos térmicos. Generalmente, el aislamiento se consigue desconectando y cerrando todas las tuberías que desembocan o parten del recipiente; taponando u obturando la tubería en una conexión próxima al depósito o recipiente; o cerrando un doble juego de válvulas de bloqueo en la tubería, si lo hay, y abriendo una válvula de purga entre dos válvulas cerradas.

\section{Bloqueo/etiquetado}

Los programas de bloqueo y etiquetado evitan la activación inadvertida de equipos eléctricos, mecánicos, hidráulicos o neumáticos durante su reparación o mantenimiento. Antes de empezar a trabajar en cualquier equipo de funcionamiento eléctrico, se deberá bloquear o etiquetar el interruptor automático o el 
interruptor general del mismo y se deberá comprobar que no es posible accionarlo. Los equipos mecánicos, hidráulicos y neumáticos deberán desactivarse y su fuente de alimentación bloquearse o etiquetarse antes de empezar a trabajar en ellos. También deberán bloquearse o etiquetarse las válvulas que cierren conductos en los que se esté trabajando, para evitar su apertura no autorizada.

\section{Metalurgia}

La metalurgia se utiliza para asegurarse de la resistencia e integridad continuadas de los conductos, recipientes, depósitos y reactores sujetos a corrosión por los ácidos, las sustancias corrosivas, el agua amarga, los gases y otros productos químicos creados y utilizados en el procesado de petróleo crudo. En toda la refinería se utilizan métodos de ensayo no destructivos para detectar corrosiones y desgastes excesivos antes de que se produzca el fallo. Es necesario adoptar precauciones de seguridad especiales para evitar exposiciones excesivas a los trabajadores que manipulan o están expuestos a equipos de ensayo, colorantes y productos químicos radiactivos.

\begin{abstract}
Almacenes
En los almacenes se guardan no sólo las piezas, materiales y equipo necesarios para la continuidad de las operaciones de la refinería, sino también productos químicos y aditivos envasados que se utilizan en el mantenimiento, procesado y mezcla. En los almacenes se guardan asimismo suministros de las ropas y equipos de protección personal necesarios, como cascos, guantes, delantales, protección ocular y facial, protección respiratoria, calzado de seguridad e impermeable, ropas ignífugas y ropas protectoras contra los ácidos. Es necesario un correcto almacenamiento y separación de los líquidos inflamables y combustibles y de los productos químicos peligrosos, para evitar derrames, incendios y la mezcla de productos incompatibles.
\end{abstract}

\section{Laboratorios}

Los laboratorios se encargan de determinar el valor y consistencia de los crudos de petróleo antes del procesado, así como de realizar las pruebas necesarias para el control de calidad de los productos acabados. El personal de laboratorio debe tener la formación necesaria para detectar los riesgos inherentes a la manipulación y mezcla de productos químicos tóxicos y líquidos inflamables, y protegerse a sí mismos y a los demás.

\section{Seguridad e higiene ambiental e industrial}

Otras actividades importantes de soporte de las refinerías son la seguridad, prevención y protección contra incendios, protección del medio ambiente e higiene industrial. Pueden realizarse como funciones independientes o integradas en las operaciones de la refinería. Con frecuencia, las actividades de seguridad, medidas especiales de precaución y reacción para situaciones de emergencia y prevención y protección contra incendios suelen formar parte de la misma función dentro de una refinería. La función de seguridad está integrada en programas de gestión de la seguridad de procesos como parte de los equipos de revisión de diseño, revisión antes y durante la construcción, y revisión previa a la puesta en marcha. La función de seguridad suele ser de ayuda en el proceso de calificación de contratistas, en el de revisión de las actividades de éstos y el de investigación de incidentes en los que intervienen empleados y contratistas. El personal de seguridad puede encargarse de supervisar actividades que requieren permisos, como la entrada en espacios confinados y los trabajos con empleo de calor, y de comprobar la disponibilidad y operatividad de los extintores de incendios portátiles, instalaciones de descontaminación, duchas de seguridad, puestos de lavados oculares, dispositivos de detección y alarmas fijos, y aparatos respiradores autónomos de emergencia colocados en lugares estratégicos para utilizarlos en caso de un escape de gas tóxico.

Programas de seguridad. La función de seguridad de la refinería suele incluir la elaboración y administración de diversos programas de seguridad y prevención de incidentes, entre ellos los siguientes:

- revisiones de diseño, construcción y antes de la puesta en marcha;

- investigación e informes de accidentes, incidentes y cuasierrores;

- planes de precaución y programas de reacción para situaciones de emergencia;

- programa de seguridad de contratistas;

- prácticas y procedimientos seguros de trabajo;

- bloqueo/etiquetado;

- entrada en espacios confinados e inertes;

- andamiajes;

- programa de seguridad eléctrica, puesta a tierra de equipos y protección frente a averías;

- colocación de cubiertas de protección en máquinas;

- señales y rótulos de seguridad,

- sistemas de permisos para trabajos térmicos, trabajo seguro y entrada.

Brigadas de bomberos. Las brigadas de bomberos y el personal especializado en emergencias de las refinerías están formados por equipos a tiempo completo; empleados de la refinería designados al efecto (operarios y personal de mantenimiento con formación y designados para responder ante emergencias, además de sus quehaceres normales) o una combinación de ambas cosas. Además de incendios, tradicionalmente estos equipos responden a otros incidentes en la refinerías, como escapes de ácidos o gases, salvamentos en recipientes o depósitos, derrames, etc. La función de protección contra incendios puede encargarse de la inspección y comprobación de detectores y señales de incendio, así como de los sistemas y equipos de protección contra incendios fijos y portátiles (autobombas, bombas de incendios, tuberías de agua de extinción, hidrantes, mangueras y lanzas).

La lucha contra incendios en las refinerías se diferencia de la normal en que suele ser preferible permitir que ciertos incendios continúen en lugar de extinguirlos. Además, cada tipo de líquido, gas o vapor de hidrocarburo tiene unas características únicas en cuanto a la química de los incendios, que es preciso conocer a la perfección para controlar óptimamente los incendios respectivos. Por ejemplo, la extinción de un incendio de vapores de hidrocarburo sin detener primero la emisión de los vapores, lo único que haría sería crear continuamente una nube de gases, con probable reignición y explosión. Los incendios en depósitos que contienen petróleo crudo y residuos pesados deben combatirse con métodos específicos de lucha contra incendios para evitar la posibilidad de una explosión o de la ebullición del contenido del depósito.

Normalmente, los incendios de hidrocarburos se extinguen deteniendo el flujo de producto y permitiendo que el fuego continúe mientras se lanza agua refrigerante para proteger los equipos, depósitos y recipientes cercanos de la exposición al calor. Muchos sistemas fijos de protección contra incendios están diseñados con este fin específico. La lucha contra incendios en unidades de proceso a presión requiere una consideración y formación especiales, sobre todo cuando intervienen catalizadores como el ácido fluorhídrico. Para extinguir incendios de hidrocarburos y controlar emisiones de vapor se utilizan ciertos productos químicos antifuego especiales: polvo seco y disoluciones de espuma y agua. 
Preparación para emergencias. Las refinerías necesitan desarrollar y ejecutar planes de respuesta a emergencia ante situaciones potenciales de explosión, incendio, emisiones y salvamentos. Los planes de emergencia deberían incluir la utilización de ayuda externa (contratistas, ayudas del gobierno y ayuda mutua), así como la disponibilidad de suministros y equipos especiales, como espuma extintora y materiales de contención y absorción de derrames.

\section{Análisis de gases y vapores}

En las refinerías se realizan actividades de vigilancia, toma de muestras y análisis de gases, partículas y vapores para asegurarse de que es posible trabajar con seguridad y de que es posible llevar a cabo los procesos sin exposiciones tóxicas o peligrosas, explosiones o incendios. Se realizan pruebas atmosféricas utilizando diversos métodos e instrumentos para medir el contenido de oxígeno y los vapores y gases de hidrocarburos, y determinar si existen niveles de exposición tóxicos y peligrosos. Antes de utilizarlos, los instrumentos deben ser correctamente calibrados y ajustados por personas cualificadas, para garantizar la fiabilidad y exactitud de las mediciones. Dependiendo de la ubicación del lugar de trabajo, el potencial de riesgo y el tipo de trabajo que se realiza, las pruebas, tomas de muestras y controles de vigilancia pueden llevarse a cabo antes del inicio del trabajo, a intervalos predeterminados durante el trabajo o continuamente mientras se realiza éste.

$\mathrm{Al}$ establecer procedimientos de toma de muestras y análisis de atmósferas inflamables, inertes y tóxicas en las refinerías, debe considerarse el empleo de equipo de protección personal, incluida la protección respiratoria adecuada. Hay que señalar que los respiradores de cartucho son inadecuados para atmósferas deficitarias en oxígeno. Los requisitos de comprobación y análisis deberán depender del grado de riesgo que existiría en caso de avería de los instrumentos.

Las siguientes sustancias se analizan utilizando equipo portátil o instrumentación fija:

Oxígeno. Los medidores de gases combustibles trabajan quemando una pequeña muestra de la atmósfera que se analiza. Para obtener una lectura precisa de gas combustible, es necesario que haya entre un mínimo del $10 \%$ y un máximo del $25 \%$ de oxígeno en la atmósfera. La cantidad de oxígeno en la atmósfera se determina utilizando un medidor de oxígeno antes de usar el medidor de gas combustible o simultáneamente con éste. La medición de oxígeno es esencial cuando se trabaja en espacios confinados o cerrados, ya que para la entrada sin protección respiratoria (siempre que no haya exposiciones tóxicas) se requieren concentraciones normales de oxígeno en el aire respirable del $21 \%$ aproximadamente. También se utilizan medidores de oxígeno para medir la cantidad de oxígeno presente en espacios inertizados, a fin de garantizar que no hay suficiente oxígeno para permitir la combustión durante los trabajos térmicos u otras operaciones.

Vapores y gases de hidrocarburos. Se denomina "trabajo térmico" al que genera una fuente de ignición (por ejemplo, la soldadura, el corte, el esmerilado, la limpieza con chorro abrasivo, el uso de un motor de combustión interna, etc.), en una zona con potencial de riesgo de exposición a vapores y gases inflamables. Para que el trabajo térmico pueda realizarse con seguridad, se comprueba si la atmósfera contiene vapores de hidrocarburos utilizando unos instrumentos denominados medidores de gases combustibles. Los vapores o gases de hidrocarburos sólo arden cuando se mezclan con aire (oxígeno) en determinadas proporciones y son inflamados por una fuente de ignición. Si no hay suficiente vapor en el aire, se dice que la mezcla es "demasiado pobre para arder", y si hay demasiado (demasiado poco oxígeno), que la mezcla es "demasiado rica para arder". Las proporciones límite se denominan "límite superior e inferior de inflamabilidad" y se expresan como porcentaje de volumen de vapor en el aire. Cada molécula o mezcla de hidrocarburo tiene diferentes límites de inflamabilidad, por lo general del 1 al $10 \%$ de vapor en aire aproximadamente. El vapor de gasolina, por ejemplo, tiene un límite inferior de inflamabilidad del 1,4\% y un límite superior del 7,6\%.

Atmósferas tóxicas. Se utilizan instrumentos especiales para medir los niveles de gases, vapores y partículas tóxicos y peligrosos que haya en la atmósfera donde trabaja el personal. Son medidas utilizadas para determinar el nivel y el tipo de protección necesario, que varía desde la ventilación y renovación completa de la atmósfera hasta el uso de equipo de protección respiratoria y personal por quienes trabajan en la zona. Entre los ejemplos de exposiciones tóxicas y peligrosas que se pueden existir en las refinerías están el amianto, benceno, ácido sulfhídrico, cloro, dióxido de carbono, ácido sulfúrico y fluorhídrico, aminas, fenol y otros.

\section{Programas de salud y seguridad}

La base de la higiene industrial en las refinerías es un programa de controles técnicos y administrativos que contemple la exposición a productos químicos tóxicos y peligrosos en las instalaciones, higiene y seguridad en los laboratorios, ergonomía y vigilancia médica.

Los organismos y entidades reguladores establecen límites de exposición a diversos productos químicos tóxicos y peligrosos. De la función de higiene industrial forman parte los controles y la toma de muestras para medir la exposición de los empleados a sustancias y productos químicos tóxicos y peligrosos. Los higienistas industriales elaboran o recomiendan controles técnicos, prácticas preventivas de trabajo, sustitución de productos, ropa y equipo de protección personal o medidas de protección alternativas para reducir la exposición.

Programas médicos. Normalmente, las refinerías exigen exploraciones médicas previas y periódicas para determinar la aptitud del empleado para realizar el trabajo tanto al principio como posteriormente, y asegurarse de que las continuas exigencias y exposiciones del trabajo no pondrán en peligro su salud o su seguridad.

Protección personal. Los programas de protección personal deben contemplar las exposiciones habituales en las refinerías: por ejemplo, al ruido, al amianto, al aislamiento, a los residuos peligrosos, al ácido sulfhídrico, al benceno y a productos químicos de proceso, como cáusticos, fluoruro de hidrógeno, ácido sulfúrico, etc. Higiene industrial puede designar el equipo de protección personal adecuado que deberá utilizarse para las diversas exposiciones, incluidos los respiradores de presión negativa y con admisión de aire puro, así como las protecciones auditiva, ocular y cutánea.

Seguridad de los productos. El conocimiento de la seguridad de los productos implica conocer los riesgos de los productos químicos y materiales a los que existe riesgo de exposición en el lugar de trabajo, y las medidas a adoptar en caso de exposición por ingestión, inhalación o contacto con la piel. Se llevan a cabo estudios toxicológicos del petróleo crudo, corrientes de las refinerías, productos químicos de proceso, productos acabados y nuevos productos propuestos, a fin de determinar los posibles efectos de la exposición tanto para los empleados como para los consumidores. Los datos se utilizan para elaborar información sobre la salud en relación con los límites de exposición permisibles o las cantidades de materiales peligrosos en los productos. Normalmente, esta información se distribuye mediante fichas técnicas de seguridad (FTS) u otros documentos similares, y se forma o educa a los empleados en relación con los riesgos de los materiales en el lugar de trabajo. 


\section{Protección del medio ambiente}

La protección del medio ambiente es una consideración importante en las operaciones de las refinerías debido a los requisitos de obligado cumplimiento y a la necesidad de conservación a medida que aumentan los precios y los costes. Las refinerías de petróleo producen una gran variedad de emisiones aéreas y acuosas peligrosas para el medio ambiente; algunos de estos contaminantes se hallaban en el crudo original, mientras que otros son resultado de los procesos y operaciones que se llevan a cabo en las refinerías. Entre las emisiones aéreas están el ácido sulfhídrico, dióxido de azufre, óxidos de nitrógeno y monóxido de carbono (véase la Tabla 78.2). Las aguas residuales contienen normalmente hidrocarburos, materiales disueltos, sólidos en suspensión, fenoles, amoníaco, sulfuros, ácidos, álcalis y otros contaminantes. También existe riesgo de derrames y fugas accidentales de una gran variedad de productos químicos tóxicos y/o inflamables.

Entre los controles establecidos para contener las emisiones de líquidos y vapores y reducir los costes de explotación, están los siguientes:

- Conservación de la energía. Los controles incluyen programas de control de fugas de vapor y recuperación de condensado para conservar la energía y aumentar la eficiencia.

- Contaminación del agua. Los controles incluyen el tratamiento de las aguas residuales en separadores API e instalaciones de tratamiento subsiguientes, recogida de aguas pluviales, programas de retención y tratamiento, y de prevención, contención y control de derrames.
- Contaminación atmosférica. Dado que las refinerías operan continuamente, es importante la detección de fugas, sobre todo en las válvulas y en las conexiones de las tuberías. Entre los controles se incluyen la reducción de emisiones y emanaciones de vapores de hidrocarburos a la atmósfera, programas de estanqueidad de las válvulas y racores de la refinería, programas de sellado de depósitos de techo flotante y de contención de vapores, y recuperación de vapores para instalaciones de carga y descarga y ventilación de depósitos y recipientes.

- Contaminación del suelo. La prevención de la contaminación del suelo y las aguas subterráneas por derrames de petróleo se consigue mediante el empleo de diques y la provisión de drenajes a zonas de contención protegidas específicas. La contaminación por derrames en el interior de las zonas de diques se evita utilizando medidas de contención secundarias, como revestimientos impermeables de plástico o de arcilla para los diques.

- Respuesta a los derrames. Las refinerías deben elaborar y ejecutar programas de respuesta a los derrames de petróleo crudo, productos químicos y productos acabados, tanto en tierra como en el agua. De su ejecución se encargan empleados con formación específica o entidades y contratistas externos que respondan a la emergencia. El plan de preparación deberá incluir el tipo, la cantidad necesaria y la disponibilidad de suministros y equipos de limpieza de derrames y de restauración, ya sea in situ o a demanda.

\section{Referencias}

Occupational Safety and Health Administration (OSHA), 1996. OSHA Instruction TED $1.15 \mathrm{CH}-1$. Washington, DC: OSHA, US Department of Labor.

\section{Otras lecturas recomendadas}

American Petroleum Institute. 1971. Chemistry and Pe troleum for Classroom Use in Chemistry Courses. Washington, DC: American Petroleum Institute.

- 1973. Industrial Hygiene Monitoring Manual for Petroleum Refineries and Selected Petrochemical Operations. Manual 2700-1/79-1M. Washington, DC: American Petroleum Institue.

1980. Facts about Oil. Manual 4200-10/80-25m Washington, DC: American Petroleum Institute.

1990. RP574, Inspection of Piping, Tubing, Valves and Fittings. Washington, DC: American Petroleum Institute.

C. 1990. RP750, Management of Process Hazard. Washington, DC: American Petroleum Institute.

1991. RP 573, Inspection of Fired Boilers and Heaters. Washington, DC: American Petroleum Institute.

- 1992. RP 572, Inspection of Pressure Vessels. Washington, DC: American Petroleum Institute.

- 1992. RP576, Inspection of Pressure Relieving Devices. Washington, DC: American Petroleum Institute.
- 1994. RP2001, Fire Protection in Refineries. Washington, DC: American Petroleum Institute.

Armistead, GJ. 1950. Safety in Petroleum Refining and Re lated Industries. Nueva York: John G. Simmons \& Co., Inc.

Exxon Company. 1987. Encyclopedia for the User of Petroleum Products. Houston, Texas: Exxon Company, USA, Marketing Technical Services.

Kutler, AA. 1969. Crude distillation. En Petro/chem Engineering. Nueva York: John G. Simmonds \& Co.

Mobil Oil Corporation. 1972. Light Products Refining, Fuels Manufacture (Mobil Technical Bulletin). Fairfax, Virginia: Mobil Oil Corporation.

- 1993. A Mobil Guide to Health Effects of Refinery Streams. Princeton, Nueva Jersey: Mobil Oil Corporation.

Nabieva, GV. 1976. CIS 77-1451. Occupational disease in oil rig workers. Gigiene truda i proffesional'nye zabolevanija 8:22-24.

Organización Internacional del Trabajo (OIT). 1992. Labour Inspection in the Oil Refining and Large-Scale Petrochemical Industries. Ginebra: OIT.

Ostrowski, R. 1991. Oil quenching. En Industrial Fire Hazards Handbook. Quincy, Massachusetts: National Fire Protection Association.

Parkes, KR. 1992. Mental health in the oil industry: A comparative study of onshore and offshore employees. Psych Med 22:997-1009.
Rom, WN, JS Lee, BF Craft. 1981. Occupational and environmental health problems of the developing oil shale industry: A review. Am $f$ Ind Med 2:247-260.

Salpukas, A. 1995. New ideas for U.S. oil. New York Times, 16 noviembre.

Skoupy, A, R Ulrich. 1994. Dispersal of chain lubrication oil in one-man chain-saws. Forsttechnische Information 11:121-123.

Skyberg, K, A Ronneberg, CG Christensen, CR Naess-Andersen, HE Refsum, A Borgelsen. 1992. Lung function and radiographic signs of pulmonary fibrosis in oil exposed workers in a cable manufacturing company: A follow up study. Brit 7 Ind Med 49(5):309-315.

Sutherland, VJ, CL Cooper. 1986. Man and Accidents Offshore: The Costs of Stress among Workers on Oil and Gas Rigs. Londres, Bélgica: Dietsmann International $\mathrm{NV}$, Lloyd's List.

Vervalin, CH (dir.). 1985. Fire Protection Manual for Hydrocarbon Processing Plants, Vol. 1, $3^{\mathrm{a}}$ ed. Houston, Texas: Gulf Publishing Co.

Wagenaar, W, J Groeneweg, PTW Hudson, JT Reason. 1994. Promoting safety in the oil industry. Ergonomics 37(12):1999-2013.

Woods, GM. 1984. Oil quenching. In Industrial Fire Hazards Handbook. Quincy, Massachusetts: National Fire Protection Association. 



\section{INDUSTRIA FARMACEUTICA}

Director del capítulo Keith Tait

\section{Sumario}

Industria farmacéutica

Efectos de los estrógenos sintéticos sobre los trabajadores de la industria farmacéutica: un ejemplo de Estados Unidos

Dennis D. Zaebst. 
INDUSTRIA FARMACEUTICA

Keith Tait

La industria farmacéutica es un importante elemento de los sistemas de asistencia sanitaria de todo el mundo; está constituida por numerosas organizaciones públicas y privadas dedicadas al descubrimiento, desarrollo, fabricación y comercialización de medicamentos para la salud humana y animal (Gennaro 1990). $\mathrm{Su}$ fundamento es la investigación y desarrollo $(\mathrm{I}+\mathrm{D})$ de medicamentos para prevenir o tratar las diversas enfermedades y alteraciones. Los principios activos que se utilizan en los medicamentos presentan una gran variedad de actividades farmacológicas y propiedades toxicológicas (Hardman, Gilman y Limbird 1996; Reynolds 1989). Los modernos avances científicos y tecnológicos aceleran el descubrimiento y desarrollo de productos farmacéuticos innovadores dotados de mejor actividad terapéutica y menos efectos secundarios. En este sentido los biólogos moleculares, químicos y farmacéuticos mejoran los beneficios de los fármacos aumentando la actividad y la especificidad. Estos avances suscitan, a su vez, una nueva preocupación por la protección de la salud y la seguridad de los trabajadores en la industria farmacéutica (Agius 1989; Naumann y cols. 1996; Sargent y Kirk 1988; Teichman, Fallon y Brandt-Rauf 1988).

Son muchos los factores dinámicos científicos, sociales y económicos que configuran la industria farmacéutica. Algunas compañías farmacéuticas trabajan tanto en los mercados nacionales como en los multinacionales. En todo caso, sus actividades están sometidas a leyes, reglamentos y políticas aplicables al desarrollo y aprobación de fármacos, la fabricación y control de calidad, la comercialización y las ventas (Spilker 1994). Investigadores, tanto de instituciones públicas como del sector privado, médicos y farmacéuticos, así como la opinión pública, influyen en la industria farmacéutica. Los proveedores de asistencia sanitaria (p. ej., médicos, odontólogos, enfermeras, farmacéuticos y veterinarios) de hospitales, clínicas, farmacias y consultas privadas pueden prescribir fármacos o recomendar cómo dispensarlos. Los reglamentos y las políticas de asistencia sanitaria aplicables a los productos farmacéuticos son sensibles intereses públicos, de grupos de defensa y privados. La interacción de todos estos complejos factores influye en el descubrimiento, desarrollo, fabricación, comercialización y venta de fármacos.
La industria farmacéutica avanza impulsada por los descubrimientos científicos y por la experiencia toxicológica y clínica (véase la Figura 79.1). Existen diferencias fundamentales entre las grandes organizaciones dedicadas a un amplio espectro de actividades de descubrimiento y desarrollo de fármacos, fabricación y control de calidad, comercialización y ventas, y otras organizaciones más pequeñas que se centran en algún aspecto específico. Aunque la mayor parte de las compañías farmacéuticas multinacionales participan en todas esas actividades, suelen especializarse en algún aspecto en función de diversos factores del mercado nacional. El descubrimiento y desarrollo de nuevos fármacos está en manos de organizaciones universitarias, públicas y privadas. En este sentido, la industria de la biotecnología se ha convertido en un sector fundamental de la investigación farmacéutica innovadora (Swarbick y Boylan 1996). A menudo se establecen acuerdos de colaboración entre organizaciones de investigación y grandes compañías farmacéuticas para explorar el potencial de nuevos principios activos.

Muchos países tienen sistemas específicos de protección de los fármacos y los procesos de fabricación en el marco del sistema general de protección de los derechos de propiedad intelectual. En los casos en los que esta protección legal es limitada o no existe, hay compañías especializadas en la fabricación y comercialización de medicamentos genéricos (Medical Economics Co. 1995). La industria farmacéutica requiere la inversión de grandes capitales debido a los gastos asociados a la I+D, la autorización de comercialización, la fabricación, la garantía y el control de calidad, la comercialización y las ventas (Spilker 1994). Numerosos países han adoptado reglamentos aplicables al desarrollo y la autorización de comercialización de los fármacos. En ellos se establecen requisitos estrictos de buenas prácticas de fabricación que garantizan la integridad de las operaciones industriales y la calidad, seguridad y eficacia de los productos farmacéuticos (Gennaro 1990).

El comercio internacional y nacional, así como las políticas y prácticas en materia de impuestos y de finanzas, afectan a la forma en que la industria farmacéutica trabaja en un país (Swarbick y Boylan 1996). Existen diferencias significativas entre los países desarrollados y en desarrollo con respecto a sus necesidades de sustancias farmacéuticas. En los países en desarrollo, en los que prevalecen la malnutrición y las enfermedades infecciosas, los fármacos más necesarios son los suplementos

Figura 79.1 • Desarrollo de fármacos en la industria farmacéutica.

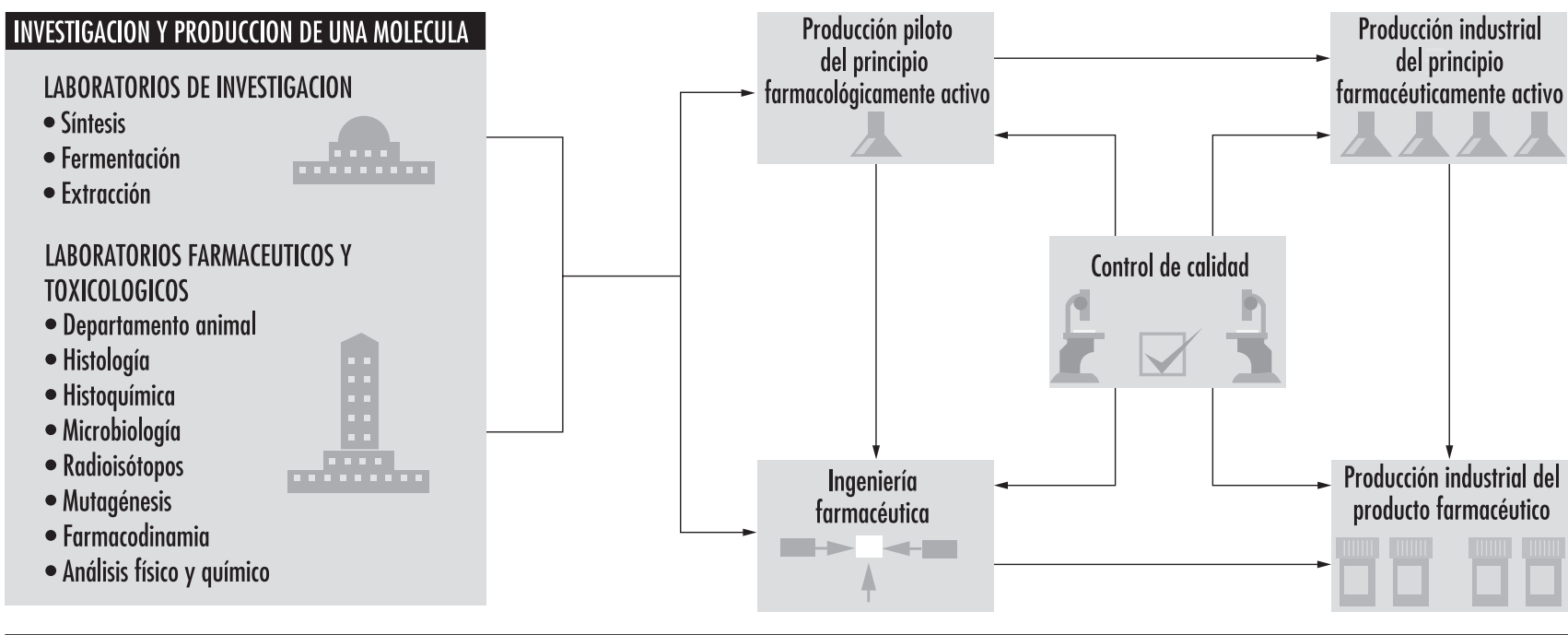


nutricionales, las vitaminas y los antiinfecciosos. En los países desarrollados, en los que las enfermedades asociadas con el envejecimiento y dolencias específicas son las principales preocupaciones sanitarias, los fármacos más demandados son los que actúan sobre el sistema cardiovascular, el sistema nervioso central, el sistema gastrointestinal, los antiinfecciosos, los antidiabéticos y los quimioterápicos.

Los fármacos para la salud humana y veterinaria comparten actividades de $\mathrm{I}+\mathrm{D}$ y procesos de fabricación similares; no obstante, tienen beneficios terapéuticos y se ajustan a mecanismos de autorización: distribución, comercialización y venta diferentes (Swarbick y Boylan 1996). Los productos veterinarios ayudan a controlar enfermedades infecciosas y parásitos en los animales para la agricultura y de compañía; normalmente se trata de vacunas y de agentes antiparasitarios y antiinfecciosos. Los suplementos nutricionales, los antibióticos y las hormonas son productos de amplio uso en la agricultura moderna para promover el crecimiento y la salud de los animales de explotaciones ganaderas. La $\mathrm{I}+\mathrm{D}$ de los medicamentos para la salud humana y animal se realiza a menudo en colaboradores, debido al interés común en controlar enfermedades y agentes infecciosos.

\section{Productos químicos industriales peligrosos y sustancias relacionadas con fármacos}

Son muchos los agentes biológicos y químicos que se han descubierto, desarrollado y utilizado en la industria farmacéutica (Hardman, Gilman y Limbird 1996; Reynolds 1989). Por otra parte, las industrias farmacéutica, bioquímica y de productos químicos orgánicos sintéticos comparten numerosos procesos de fabricación; no obstante, la industria farmacéutica destaca por la mayor diversidad, la menor escala y la especificidad de sus aplicaciones. Debido a que su objetivo primario es producir sustancias con actividad farmacológica, muchos agentes utilizados en la I+D y fabricación farmacéutica son peligrosos para los trabajadores. En consecuencia, deben establecerse medidas de control adecuadas para proteger a los trabajadores de los productos químicos industriales y los principios activos durante las operaciones de I+D, fabricación y control de calidad (OIT 1983; Naumann y cols. 1996; Teichman, Fallon y Brandt-Rauf 1988).

La industria farmacéutica utiliza agentes biológicos (p. ej., bacterias y virus) en muchas aplicaciones especiales, como la producción de vacunas, los procesos de fermentación, la obtención de productos hemoderivados y la biotecnología. Estos agentes no se consideran en el presente artículo debido a sus aplicaciones farmacéuticas singulares, si bien se dispone de referencias adecuadas (Swarbick y Boylan 1996). Por su parte, los agentes químicos se pueden clasificar en dos grupos: productos químicos industriales y sustancias relacionadas con fármacos (Gennaro 1990), que pueden ser materias primas, productos intermedios o productos terminados. Se presentan situaciones especiales cuando los productos químicos industriales o los principios activos se utilizan en laboratorios de $\mathrm{I}+\mathrm{D}$, ensayos de control y garantía de calidad, ingeniería y mantenimiento, o cuando se generan como subproductos o residuos.

\section{Productos químicos industriales}

Se utilizan productos químicos industriales en la investigación y desarrollo de principios activos y en la fabricación de sustancias base y de productos farmacéuticos terminados. Se trata de materias primas que sirven de reactivos, catalizadores y disolventes. Su utilización está determinada por los procesos y las operaciones específicas de fabricación. Muchos de ellos pueden ser peligrosos para los trabajadores. Por este motivo, las organizaciones

\section{Definiciones}

Son de uso frecuente en la industria farmacéutica los términos siguientes:

Los productos biológicos son vacunas bacterianas y virales, antígenos, antitoxinas y productos análogos, sueros, plasmas y otros productos hemoderivados para la protección o tratamiento terapéutico de humanos y animales.

Los principios activos son las sustancias activas utilizadas para fabricar formas galénicas, procesar piensos animales medicados o preparar tratamientos recetados.

Los productos de diagnóstico ayudan a diagnosticar enfermedades y alteraciones en humanos y animales. Puede tratarse de productos químicos inorgánicos para examinar el tracto gastrointestinal, productos químicos orgánicos para visualizar el sistema circulatorio y el hígado, a compuestos radiactivos para medir las función de un sistema orgánico.

Los fármacos son sustancias dotadas de propiedades farmacológicas en humanos y animales. Se mezclan con otras sustancias, como los excipientes farmacéuticos, para obtener medicamentos.

Los productos farmacéuticos de venta con receta son agentes biológicos y químicos para la prevención, diagnóstico y tratamiento de enfermedades y alteraciones de humanos y animales. Se dispensan por prescripción de un médico, farmacéutico o veterinario

Los excipientes son componentes inertes que se combinan con principios activos para obtener una forma galénica. Pueden afectar a la velocidad de absorción, disolución, metabolismo y distribución en humanos y animales.

Las especialidades farmacéuticas publicitarias son fármacos, de venta en farmacias o en estos establecimientos, que no requieren la prescripción de un médico, farmacéutico o veterinario

Se denomina farmacia la ciencia que estudia el modo de preparar y dispensar fármacos para prevenir, diagnosticar o tratar enfermedades o alteraciones en humanos y animales.

La farmacocinética es el estudio de los procesos metabólicos relacionados con la absorción, distribución, biotransformación y eliminación de un fármaco en humanos y animales.

La farmacodinamia es el estudio de la acción de un fármaco en relación con su estructura química, su lugar de acción y sus consecuencias bioquímicas y fisiológicas en humanos y animales.

gubernamentales, técnicas y profesionales (ACGIH) han establecido límites de exposición profesional, como el Valor Límite Umbral (TLV).

\section{Sustancias relacionadas con los fármacos}

Los principios farmacológicamente activos pueden clasificarse en dos grupos: productos naturales y fármacos sintéticos. Los primarios derivan de fuentes vegetales y animales, mientras que los segundos son producidos mediante técnicas microbiológicas y químicas. Los antibióticos, las hormonas esteroideas y peptídicas, las vitaminas, las enzimas, las prostaglandinas y las feromonas son productos naturales importantes. La investigación científica se centra cada vez más en los fármacos sintéticos debido a los últimos avances en biología molecular, bioquímica, farmacología e informática. La Tabla 79.1 recoge las principales clases de fármacos.

Durante la fabricación farmacéutica se combinan principios activos y materiales inertes para producir diferentes formas galénicas (p. ej., comprimidos, cápsulas, líquidos, polvos, cremas y pomadas) (Gennaro 1990). Los fármacos se pueden clasificar 
Tabla 79.1 • Principales categorías farmacológicas.

\begin{tabular}{|c|c|c|c|c|c|c|c|}
\hline $\begin{array}{l}\text { Sistema nervioso } \\
\text { central }\end{array}$ & $\begin{array}{l}\text { Sistema renal y } \\
\text { cardiovascular }\end{array}$ & $\begin{array}{l}\text { Sistema } \\
\text { gastrointestinal }\end{array}$ & $\begin{array}{l}\text { Antiinfecciosos y } \\
\text { órganos diana }\end{array}$ & $\begin{array}{l}\text { Sistema } \\
\text { inmunitario }\end{array}$ & Quimioterapia & $\begin{array}{l}\text { Sangre y órganos } \\
\text { hematopoyéticos }\end{array}$ & $\begin{array}{l}\text { Sistema } \\
\text { endocrino }\end{array}$ \\
\hline $\begin{array}{l}\text { Analgésicos } \\
\text { - Paracetamol } \\
\text { - Salicilatos } \\
\text { Anestésicos } \\
\text { - Generales y } \\
\text { locales } \\
\text { Anticonvulsionantes } \\
\text { - Barbitúricos } \\
\text { - Benzodiazepinas } \\
\text { Preparados } \\
\text { antimigrañosos } \\
\text { - Agentes } \\
\text { bloqueantes } \\
\text { beta adrenérgicos } \\
\text { - Antagonistas de } \\
\text { los receptores de } \\
\text { serotonina } \\
\text { Narcóticos } \\
\text { - Opiáceos } \\
\text { Psicoterapéuticos } \\
\text { - Ansiolíticos } \\
\text { - Antidepresivos } \\
\text { Sedantes e } \\
\text { hipnóticos } \\
\text { - Barbitúricos } \\
\text { Benzodiazepinas }\end{array}$ & $\begin{array}{l}\text { Antidiabéticos } \\
\text { - Biguanidas } \\
\text { - Inhibidores de } \\
\text { la glucosidasa } \\
\text { - Insulinas } \\
\text { - Sulfotriforeas } \\
\text { Agentes cardiopro- } \\
\text { tectores } \\
\text { - Bloqueantes } \\
\text { - adrenérgicos } \\
\text { - Estimulantes } \\
\text { - Inhibidores de la } \\
\text { angiotensina } \\
\text { - Antiarrítmicos } \\
\text { - Bloqueadores de } \\
\text { los canales de } \\
\text { calcio } \\
\text { - Diuréticos } \\
\text { - Vasodilatores } \\
\text { - Vasodepresores }\end{array}$ & $\begin{array}{l}\text { Fármacos que actúan } \\
\text { en el sistema } \\
\text { gastrointestinal } \\
\text { - Antiácidos } \\
\text { - Antiflatulentos } \\
\text { - Antidiarreicos } \\
\text { - Antieméticos } \\
\text { - Antiespasmódicos } \\
\text { - Laxantes } \\
\text { - Prostaglandinas }\end{array}$ & $\begin{array}{l}\text { Antiinfecciosos } \\
\text { sistémicos } \\
\text { - Tratamientos } \\
\text { del SIDA } \\
\text { - Amebicidas } \\
\text { - Antihelmínticos } \\
\text { - Antibióticos } \\
\text { - Antifúngicos } \\
\text { - Antipalúdicos } \\
\text { - Sulfamidas } \\
\text { - Cefalosporinas, } \\
\text { penicilinas, tetra- } \\
\text { ciclinas, etc. } \\
\text { Fármacos que } \\
\text { actúan en el } \\
\text { aparato respira- } \\
\text { torio } \\
\text { - Antitusígenos } \\
\text { - Broncodilatadores } \\
\text { - Descongestio } \\
\text { nantes } \\
\text { - Expectorantes } \\
\text { Fármacos que } \\
\text { actúan sobre la piel } \\
\text { y las mucosas } \\
\text { - Preparados contra } \\
\text { Preparados } \\
\text { vaginales } \\
\text { - Antifúngicos } \\
\text { - Alergenos } \\
\text { - Antiinfecciosos } \\
\text { - Preparados para } \\
\text { - Anemaduras } \\
\text { Fármacos que } \\
\text { actúan en el } \\
\text { tracto urinario } \\
\text { - Antiinfecciosos } \\
\text { - Antiespasmódicos } \\
\text { - }\end{array}$ & $\begin{array}{l}\text { Analgésicos } \\
\text { - Agentes } \\
\text { antiinflamatorios } \\
\text { no esteroideos. } \\
\text { (AINE) } \\
\text { Modificadores } \\
\text { de la respuesta } \\
\text { biológica } \\
\text { - Inhibidores de la } \\
\text { alfa proteinasa } \\
\text { - Antitoxinas } \\
\text { - Sueros inmunes } \\
\text { - Toxoides } \\
\text { - Vacunas } \\
\text { Tratamiento } \\
\text { antifibrosis } \\
\text { Inmunoreguladores } \\
\text { e inmunosupresores } \\
\text { Tratamiento de la } \\
\text { esclerosis múltiple }\end{array}$ & $\begin{array}{l}\text { Antineoplásicos } \\
\text { - Tratamiento } \\
\text { coadyuvante } \\
\text { - Agentes } \\
\text { alquilantes } \\
\text { - Antibióticos } \\
\text { - Antimetabolitos } \\
\text { - Hormonas } \\
\text { - Inmuno } \\
\text { moduladores }\end{array}$ & $\begin{array}{l}\text { Modificadores de la } \\
\text { sangre } \\
\text { - Anticoagulantes } \\
\text { - Antiplaquetarios } \\
\text { - Factores } \\
\text { estimulantes } \\
\text { de colonias } \\
\text { - Antianémicos } \\
\text { - Hemostásicos } \\
\text { - Fracciones } \\
\text { del plasma }\end{array}$ & $\begin{array}{l}\text { Productos para } \\
\text { diagnóstico } \\
\text { - Esteroides de } \\
\text { la corteza } \\
\text { suprarrenal } \\
\text { - Glucocorticoides } \\
\text { - Gonadotropinas } \\
\text { - Disfunción } \\
\text { hipotalámica } \\
\text { - Pruebas de } \\
\text { función tiroidea } \\
\text { Hormonas } \\
\text { - Inhibidores de } \\
\text { los esteroides } \\
\text { de la corteza } \\
\text { suprarrenal } \\
\text { - Esteroides } \\
\text { anabolizantes } \\
\text { - Andrógenos } \\
\text { - Estrógenos } \\
\text { - Gonadotropinas } \\
\text { - Hormona del } \\
\text { crecimiento } \\
\text { - Progesterona } \\
\text { - Somatostatina } \\
\text { Prostaglandinas }\end{array}$ \\
\hline
\end{tabular}

según su proceso de fabricación y los beneficios terapéuticos (EPA 1995), y se administran por vías (p. ej., vía oral, inyección, vía dérmica) y a dosis prescritas estrictamente. Los trabajadores pueden estar expuestos a los principios activos a través de la inspiración inadvertida de polvo transportado por el aire o vapores o la ingestión accidental de alimentos o bebidas contaminados. Toxicólogos e higienistas industriales han desarrollado límites de exposición profesional (OEL) para limitar las exposiciones de los trabajadores a los principios activos (Naumann y cols. 1996; Sargent y Kirk 1988).

Los excipientes farmacéuticos (p. ej., aglutinantes, sustancias de carga, aromatizantes y diluyentes, conservantes y antioxidantes) se mezclan con los principios activos para dar a las formas galénicas las propiedades físicas y farmacológicas deseadas (Gennaro 1990). Muchos excipientes farmacéuticos tienen un valor terapéutico bajo o nulo y son relativamente inocuos para los trabajadores durante el desarrollo y la fabricación del fármaco. Se trata de antioxidantes, conservantes, colorantes, aromatizantes y diluyentes, agentes emulsionantes y de suspensión, bases de pomadas, disolventes y excipientes farmacéuticos.

\section{Operaciones farmacéuticas, riesgos relacionados} y medidas de control del lugar de trabajo

Dentro de las operaciones de fabricación farmacéutica se puede distinguir entre la producción básica de principios activos a granel y la fabricación farmacéutica de formas galénicas. La Figura 79.2 esquematiza el proceso de fabricación.

En él se aplican tres tipos de procesos: fermentación, sintesis de productos químicos orgánicos y extracción biológica y natural (Theodore y McGuinn 1992). Estas operaciones pueden ser discontinuas, continuas o una combinación de ambas. Los antibióticos, los esteroides y las vitaminas se producen por fermentación, mientras que muchos principios activos nuevos se producen por 


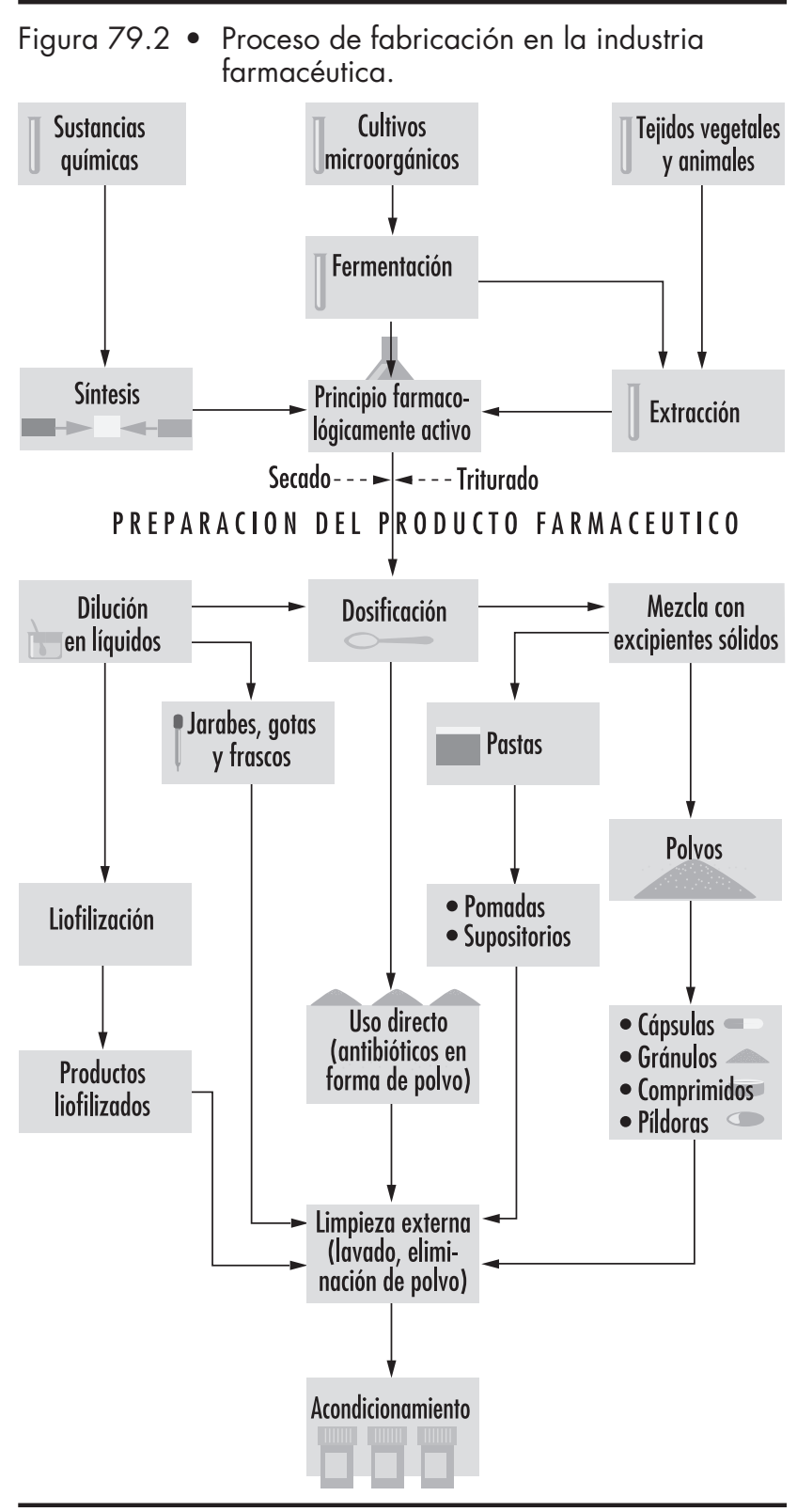

síntesis orgánica. Históricamente, la mayor parte de los principios activos derivan de fuentes naturales, como plantas, animales, hongos y otros organismos. Las medicinas naturales son farmacológicamente muy diversas y difíciles de producir comercialmente debido a su complejidad química y actividad limitada.

\section{Fermentación}

La fermentación es un proceso bioquímico en el que se utilizan microorganismos seleccionados y técnicas microbiológicas para obtener un producto químico. Los procesos de fermentación discontinua comprenden tres etapas básicas: preparación del inóculo y siembra, fermentación y recuperación o aislamiento del producto (Theodore y McGuinn 1992). En la Figura 79.3 se presenta un esquema del proceso. La preparación del inóculo comienza con una muestra de esporas de una cepa microbiana. La cepa se cultiva selectivamente, se purifica y se desarrolla utilizando una batería de técnicas microbiológicas para obtener el producto deseado. Se activan las esporas de la cepa microbiana con agua y nutrientes en condiciones de temperaturas elevadas y se desarrollan las células del cultivo en una serie de placas de agar, tubos y matraces de ensayo en condiciones ambientales controladas, obteniéndose una suspensión densa.

Las células se transfieren después a un tanque de siembra para su crecimiento. El tanque de siembra es un recipiente pequeño de fermentación diseñado para optimizar el crecimiento del inóculo. En él, las células se cargan en un fermentador de producción esterilizado por vapor. Se añaden nutrientes esterilizados y agua purificada al recipiente para comenzar la fermentación. Durante la fermentación aerobia, el contenido del fermentador se calienta, agita y ventila mediante una tubería perforada o tubo burbujeador, manteniendo un flujo de aire y una temperatura óptimos. Una vez terminada la reacción bioquímica, se filtra el caldo de fermentación para retirar los microorganismos, o micelios. El fármaco, que puede estar presente en el filtrado o en el micelio, se recupera en varias etapas, como las de extracción en disolventes, precipitación, intercambio iónico y absorción.

En general se pueden recuperar los disolventes utilizados para la extracción del producto (Tabla 79.2); no obstante, en el agua residual pueden quedar pequeñas porciones en función de su solubilidad y del diseño del equipo. La precipitación es un método para separar el fármaco del caldo acuoso. El producto se separa del caldo por filtración y se extrae de los residuos sólidos; el cobre y el zinc son agentes precipitantes comunes en este proceso. El intercambio iónico y la adsorción retiran el producto del caldo mediante una reacción química con materiales sólidos, como resinas o carbón activado. El principio activo se recupera de la fase sólida mediante un disolvente que se puede recuperar por evaporación.

Salud y seguridad de los trabajadores

Las piezas móviles de las máquinas y el equipo presentan riesgos para la seguridad del trabajador; otros factores de riesgo son el vapor a alta presión, el agua y las superficies calientes y los ambientes calurosos en el lugar de trabajo; los productos químicos corrosivos e irritantes; la manipulación manual de materiales y equipos, y los niveles altos de ruido. Pueden producirse exposiciones a vapores de disolventes al recuperar o aislar los productos, y a los disolventes como consecuencia de la falta de confinamiento de los equipos de filtración y las emisiones fugitivas de bombas, válvulas y estaciones colectoras durante los procesos de extracción y purificación. Dado que el aislamiento y el crecimiento de microorganismos son esenciales para la fermentación, los riesgos biológicos se reducen utilizando microbios no patógenos, manteniendo los equipos cerrados y tratando el caldo utilizado antes de su vertido.

Generalmente, la preocupación por la seguridad del proceso es menor durante la fermentación que durante las operaciones de síntesis orgánica, ya que la fermentación se basa en técnicas de química acuosa y requiere el confinamiento del proceso durante la preparación de la siembra y la fermentación. Durante las extracciones de disolventes hay riesgos de incendio y explosión; no obstante, la inflamabilidad de los disolventes se reduce por dilución con agua en etapas de filtración y recuperación. Los grandes volúmenes de vapor a presión y de agua caliente asociados a las operaciones de fermentación plantean riesgos de seguridad (p. ej., quemaduras térmicas y escaldado).

\section{Síntesis química}

Los procesos de síntesis química utilizan productos químicos orgánicos e inorgánicos en operaciones discontinuas para producir principios activos dotados de determinadas propiedades físicas y farmacológicas. Por lo general se realiza una serie de reacciones químicas, aislándose los productos por extracción, 
Figura 79.3 • Diagrama de un proceso de fermentación.

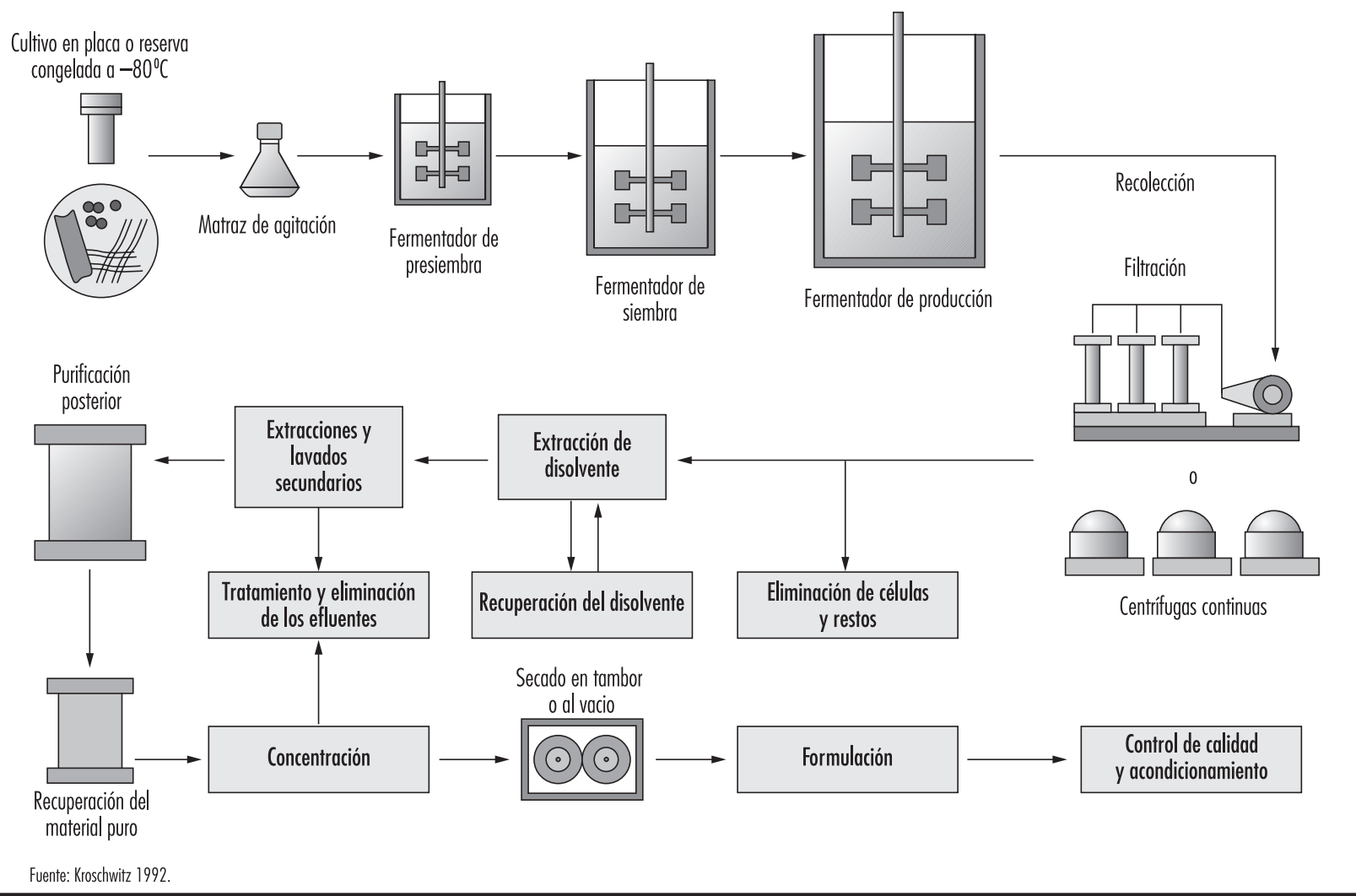

Figura 79.4 • Diagrama de un proceso de síntesis orgánica.

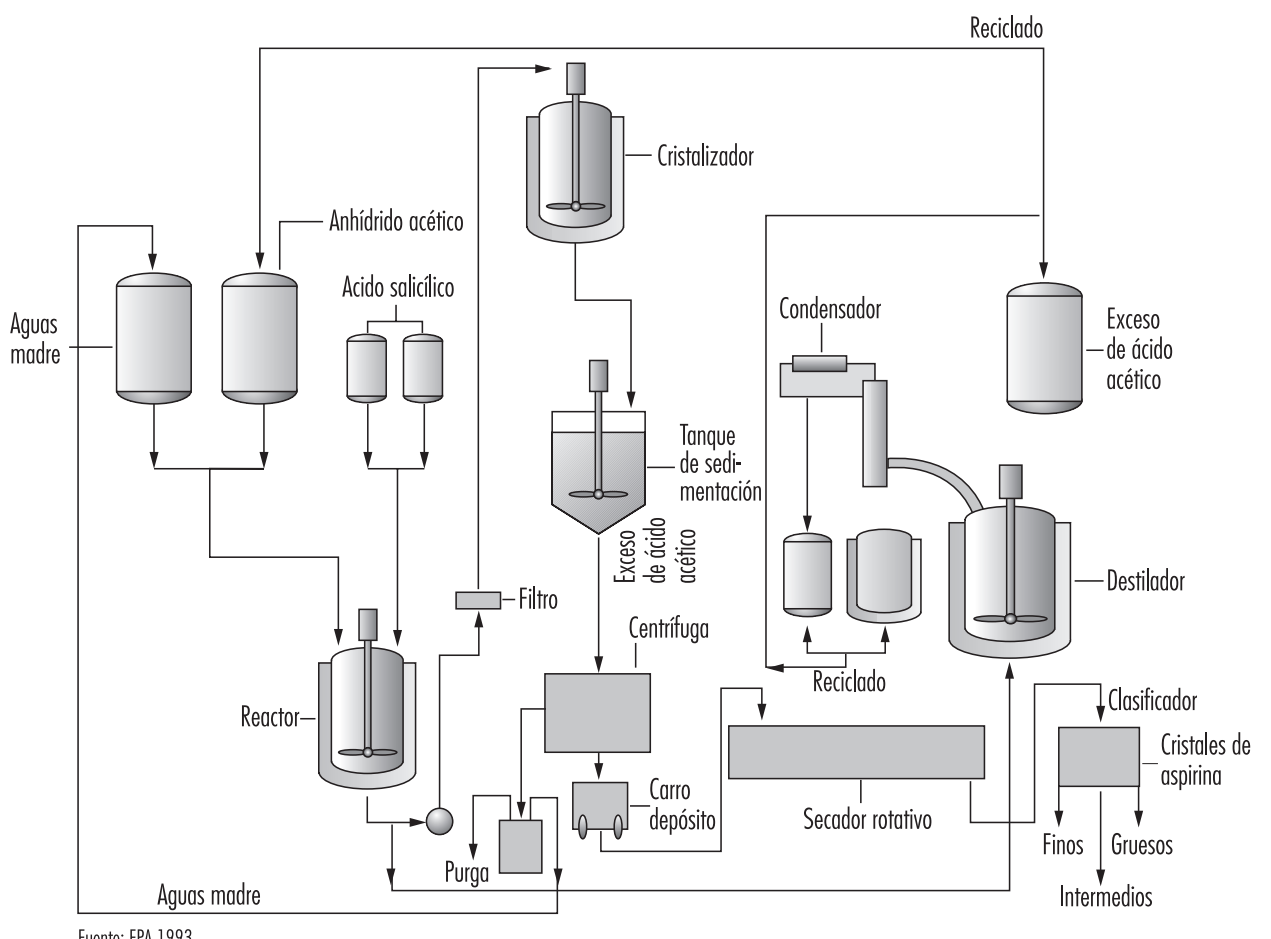


Tabla 79.2 • Disolventes utilizados en la industria farmacéutica.

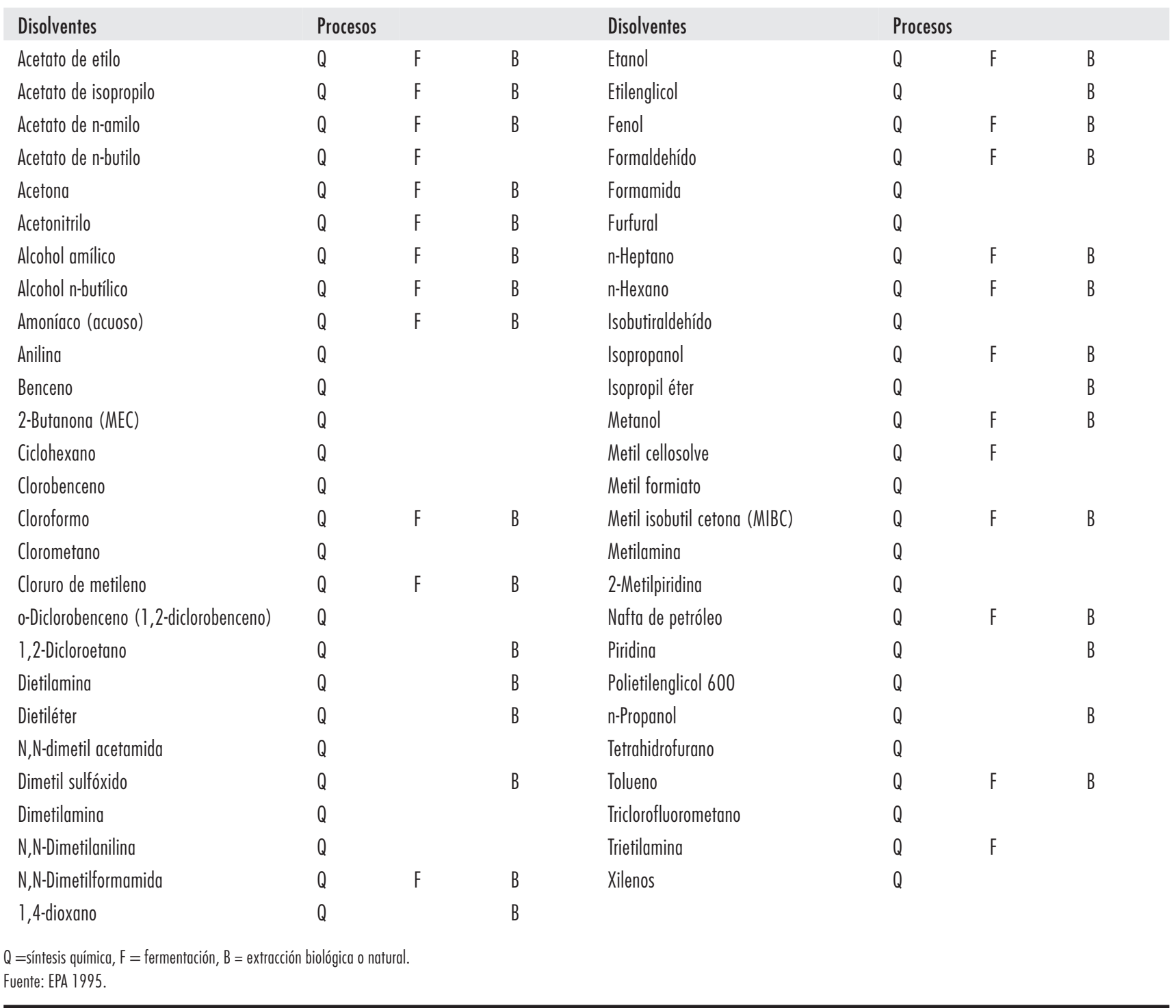

cristalización y filtración (Kroschwitz 1992). Los productos terminados se secan, trituran y mezclan. Las plantas de síntesis orgánica, los equipos de procesado y los servicios son comparables en industria farmacéutica y en la de productos químicos muy puros. En la Figura 79.4 se presenta un esquema de un proceso de síntesis orgánica.

La química farmacéutica es cada vez más compleja, caracterizándose por el empleo de procesos de varias etapas en los que el producto de una etapa es el material de partida de la siguiente, hasta que se sintetiza el principio activo terminado. Se pueden transferir productos químicos base intermedios entre distintas plantas de síntesis orgánica por varios motivos técnicos, económicos y jurídicos. La mayoría de los productos intermedios y terminados se obtienen en una serie de reacciones discontinuas. Los procesos de fabricación funcionan durante períodos de tiempo limitados, antes de modificar los materiales, el equipo y los servicios para preparar un nuevo proceso. Muchas plantas de síntesis orgánica de la industria farmacéutica están diseñadas para aumentar al máximo sus posibilidades, debido a la diversidad y complejidad de la química médica moderna. Esto se consigue construyendo centros e instalando equipos de procesado que se pueden modificar y adaptar a nuevos procesos de fabricación, además de sus requisitos de servicios.

Los reactores son el equipo principal de procesado en las operaciones de síntesis química (véase Figura 79.5). Se trata de recipientes a presión reforzada con revestimiento inoxidable de vidrio o aleaciones de metales. La naturaleza de las reacciones químicas y las propiedades físicas de los materiales (p. ej., reactivos, corrosivos, inflamables) determinan el diseño, las características y la construcción de los reactores. Estos tienen cubierta externa y serpentines internos rellenos de agua fría, vapor o productos químicos con propiedades especiales de transferencia de calor. La cubierta se calienta o enfría según los requisitos de las reacciones químicas. Agitadores, compuertas y diferentes entradas y salidas permiten la conexión con otros recipientes, equipos y suministros de productos químicos a granel. Se instalan además sensores de temperatura, presión y peso, para medir y controlar los procesos químicos. Los reactores pueden funcionar a presiones elevadas o al vacío, en función del diseño, las características técnicas y los requisitos de la química del proceso. 
Figura 79.5 • Diagrama de un reactor químico en síntesis orgánica.

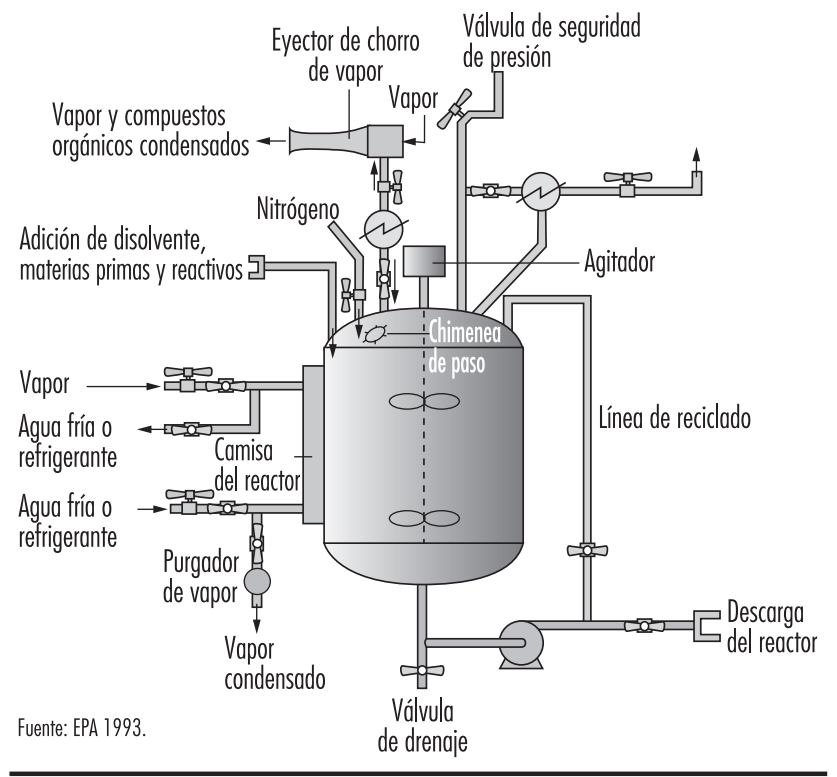

Los intercambiadores de calor están conectados a los reactores y se utilizan para calentar o enfriar la reacción y condensar los vapores de disolventes cuando se calientan por encima de su punto de ebullición, creando un reflujo o reciclado de los vapores condensados. Se pueden conectar dispositivos de control de la contaminación del aire (p. ej., purificadores de aire e impactores) a las salidas de escape de los recipientes de procesado, reduciendo las emisiones de gas, vapor y polvo (EPA 1993). Se pueden liberar al lugar de trabajo o a la atmósfera disolventes volátiles y productos químicos tóxicos, a menos que estén
Figura 79.6 • Ejemplos de estructuras de estrógenos esteroideos y no esteroideos.<smiles>CC(C)C1CCC2C1CCC1C3CCCCC3CCC12</smiles>

17a- etinilestradiol<smiles>O=C1CCC2C1CC1c3ccc(O)cc3CCC12</smiles>

Estrona $\left(E_{1}\right)$
Estrógenos esteroideos<smiles>CC/C(=C(\CC)c1ccc(O)cc1)c1ccc(O)cc1</smiles>

Dietilestilbestrol (DES)<smiles>CCC(=C(CC)c1ccc(O)cc1)c1ccc(O)cc1</smiles>

Dienestrol
Estrógenos no esteroideos

controlados durante la reacción por intercambiadores de calor o dispositivos de control de aire. Es difícil condensar, absorber o adsorber en dispositivos de control de aire algunos disolventes (véase Tabla 79.2) y reactivos (p. ej., cloruro de metileno y cloroformo), debido a sus propiedades químicas y físicas.

Los productos químicos se recuperan o aíslan mediante separación, purificación y filtración. Estos productos están contenidos en las aguas madre como sólidos disueltos o suspendidos en una mezcla de disolventes. Las aguas madre pueden transferirse entre recipientes o equipos del proceso a través de tuberías o montacargas temporales o permanentes, mediante bombas, gases inertes a presión, vacío o gravedad. La transferencia de

Figura 79.7 • Flujo del proceso de fabricación de una píldora anticonceptiva oral típica.

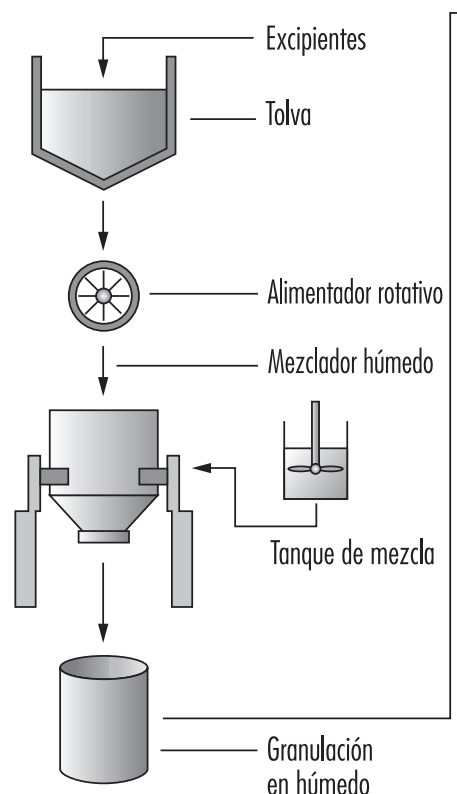

Fuente: Adaptado de Anastas 1984
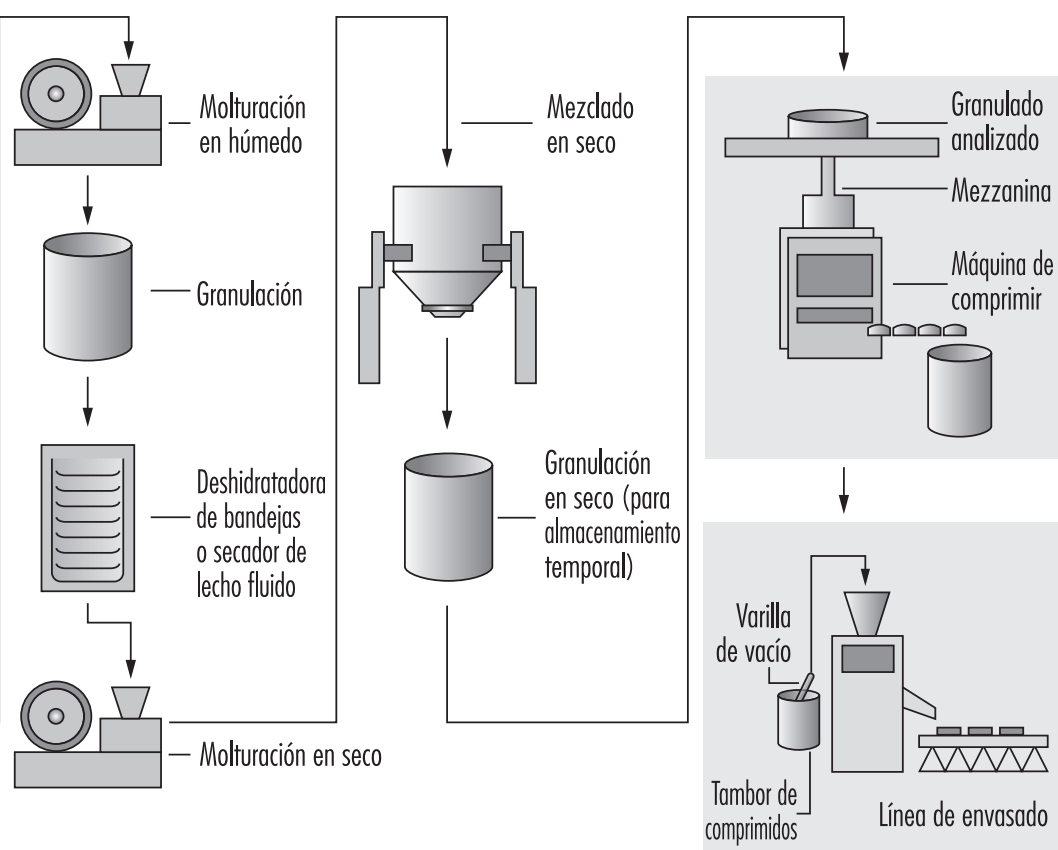
Efectos de los estrógenos sintéticos sobre los trabajadores de la industria farmacéutica: un ejemplo de Estados Unidos

\section{Antecedentes}

Los estrógenos utilizados en la industria farmacéutica se pueden clasificar en general como naturales o sintéticos, y asimismo como esteroideos o no esteroideos. Todos los estrógenos esteroideos, tanto naturales (p. ej., estrona) como sintéticos (p. ej., dietilestilbestrol y dienestrol), tienen una estructura típica de varios anillos, como se representa en la Figura 79.6. El dietilestillbestrol (DES) y dienestrol son ejemplos de estrógenos no esteroideos. Los compuestos estrogénicos se utilizan principalmente para comprimidos de anticonceptivos orales y comprimidos para el tratamiento sustitutivo con estrógenos. Los compuestos puros /derivados naturales o de síntesis) han dejado de fabricarse en Estados Unidos, pero se importan.

\section{Procesos de fabricación}

Seguidamente se hace una descripción general y combinada de los procesos de fabricación utilizados en muchas compañías farmacéuticas de Estados Unidos. Es posible que algunos procesos específicos no sigan el flujo exactamente como se describe: ciertas etapas pueden estar ausentes en algunos procesos, y en otros casos pueden existir etapas adicionales que no se describen aquí.

Como con la mayor parte de los fármacos obtenidos por vía seca, los productos farmacéuticos a base de compuestos estrogénicos se fabrican mediante un procedimiento discontinuo de varias etapas (Figura 79.7). Estas etapas comienzan con la recogida y pesada previa de los principios activos y excipientes (componentes inactivos) en una sala aislada por aspiración local. Cuando es necesario, los componentes se transfieren a una sala de mezclado equipada con mezcladores mecánicos. Por lo general, los excipientes se cargan mediante una tolva situada sobre el mezclador. Casi siempre se disuelven los principios activos primero en un alcohol, y se añaden manualmente o se introducen a través de un tubo por una parte lateral del mezclador. La mezcla inicial de los componentes se realiza en húmedo. Al final de este proceso de mezcla en húmedo, el granulado se transfiere a un molino en húmedo, en el que las partículas de la mezcla se reducen a un tamaño específico. El granulado molido se seca con un secador de lecho fluido o se deshidrata en bandejas en hornos especiales. Se puede añadir o no al granulado un lubricante seco antes del secado-mezcla o secado-molturación, en función del producto y el proceso. El granulado final, listo para la preparación de comprimidos, se almacena después en recipientes sellados. Se extraen muestras de las materias primas y el granulado, y a veces de los productos intermedios, que son analizadas por el personal de control de calidad antes de pasar a la siguiente etapa del proceso.

En su caso, se lleva el granulado a la sala de compresión, donde se preparan los comprimidos mediante una máquina de comprimir. El granulado se introduce desde el recipiente de almacenamiento (un tambor de fibra revestido de plástico o un recipiente revestido de acero inoxidable) en la tolva de la máquina de comprimir por gravedad o neumáticamente mediante una varilla de vacío. Los comprimidos formados salen de la máquina a través de un tubo lateral, y caen en tambores revestidos de plástico. Cuando están llenos, se toman muestras de los tambores y se inspeccionan. Después de su análisis por el personal de control de calidad, los tambores se sellan, se almacenan y se colocan para las operaciones de envasado. Algunos comprimidos se someten también a un proceso de recubrimiento, en el que se utilizan capas de cera comestible y a veces azúcares para recubrir el comprimido.

Los comprimidos se envasan en blisters o en frascos, en función de la naturaleza del producto. En este proceso los recipientes de comprimidos se llevan al área de envasado los recipientes de comprimidos, vertiéndose éstos manualmente en la tolva de la máquina envasadora $\circ$ introduciéndose mediante una varilla de vacío. A continuación los comprimidos se sellan entre capas de lámina de aluminio y películas de plástico (envasado en blister) o se introducen en frascos. Después los blisters o los frascos se transportan por una línea, en la que se inspeccionan y se colocan en bolsas o cajas con los prospectos adecuados.

Efectos sobre la salud de los varones y mujeres que trabajan en la industria farmacéutica.

Existen pocos informes acerca de la exposición profesional y los efectos sobre los varones, en comparación con la abundante bibliografía acerca de los efectos agudos y crónicos de los estrógenos en las mujeres como resultado de exposiciones no profesionales. Esta última bibliografía procede ante todo del uso extendido como anticonceptivos y para otros fines médicos de distintos fármacos estrogénicos (pero también contaminantes medioambientales con propiedades estrogénicas, como los organoclorados) y se centra en especial en las relaciones entre dicha exposición y diversos cánceres humanos, como el de endometrio, cérvix y mama en mujeres (Hoover 1980; Houghton y Ritter 1995). En la bibliografía sobre enfermedades profesionales, el síndrome hiperestrogénico en varones y mujeres se ha asociado a exposiciones a DES y sus derivados, estrógenos naturales o conjugados, hexoestrol y sus derivados y productos sintéticos esteroideos como etinilestradiol y dienestrol. Poco después del inicio de la producción comercial de estrógenos comenzaron a publicarse informes sobre sus efectos, como ginecomastia (aumento anormal de las mamas en varones) y disminución de la líbido en los varones, y trastornos menstruales (aumento del flujo o manchado intermenstrual) en las mujeres (Scarff y Smith 1942; Fitzsimons 1944; Klavis 1953; Pagani 1953; Watrous 1947; Watrous y Olsen 1959; Pacynski y cols. 1971; Burton y Shumnes 1973; Meyer, Peteet y Harrington 1978; KatzeneIlenbogen 1956; Dunn 1940; Stoppleman y van Valkenburg 1955; Goldzieher y Goldzieher 1949; Fisk 1950). Hay asimismo informes de síndrome tóxico asociado a algunos progestágenos, como la acetoxiprogesterona (Suciu y cols. 1973), y la viniloestrenolona en combinación con etinilestradiol (Gambini, Farine y Arbosti 1976).

Se registraron en total 181 casos de hiperestrogenismo en varones y mujeres (durante el período de 1940-1978), informados por médicos de empresa de 10 compañías farmacéuticas (con 13 plantas) de Estados Unidos (Zaebst, Tanaka y Haring 1980). De estas 13 plantas, 9 fabricaban principalmente anticonceptivos orales con distintos estrógenos y progestágenos sintéticos, otra fabricaba medicamentos para el tratamiento sustitutivo con estrógenos a partir de estrógenos naturales conjugados, y otra fabricaba productos farmacéuticos a partir de DES (en años anteriores había sintetizado también DES).

Algunos investigadores del National Institute for Occupational Safety and Health (NIOSH) de Estados Unidos realizaron un estudio piloto médico y de higiene industrial en 1984 con varones y mujeres que trabajaban en dos plantas (Tanaka y Zaebst 1984). Se documentaron exposiciones mensurables a dienestrol y estrógenos naturales conjugados, dentro y fuera del equipo de protección respiratoria utilizado. No obstante, no se observaron cambios estadísticamente significativos en las neurofisinas estimuladas con estrógenos (NEE), las globulinas unidas a corticosteroides (GVC), la testosterona, la función tiroidea, los factores de coagulación sanguínea, la función hepática, la glucosa, los lípidos sanguíneos ni las hormonas gonadotrópicas. Tampoco se apreciaron en la 
exploración médica cambios físicos adversos en varones ni en mujeres. No obstante, en la planta en la que se utilizaban dienestrol y noretindrona para fabricar comprimidos anticonceptivos orales, los niveles de etinilestradiol indicaban exposición a estrógenos y su absorción a pesar del uso de respiradores. Las muestras de aire obtenidas dentro del respirador sugerían una protección en el lugar de trabajo menos efectiva de lo esperado.

Los síntomas hiperestrogénicos en varones comunicados en estos estudios fueron, entre otros, sensibilidad de los pezones (manifestada como comezón o sensibilidad) o sensación de opresión torácica, aparte de algunos casos de hiperplasia de mamas y ginecomastia. Se comunicó asimismo disminución de la líbido o la potencia sexual. En mujeres se observaron menstruación irregular, náuseas, cefaleas, dolor de pecho, leucorrea (descargas espesas y blanquecinas de la vagina o el canal vaginall y edema de tobillo. No se han realizado estudios de seguimiento a largo plazo de personas expuestas profesionalmente a estrógenos o progestágenos.

\section{Riesgos y control de la exposición}

Uno de los riesgos más graves en la fabricación de productos farmacéuticos estrogénicos es la inhalación ly en cierta medida la ingestión oral) del compuesto estrogénico activo puro durante la pesada, la mezcla o los controles de garantía de calidad. No obstante, los trabajadores también pueden inhalar polvo seco y mezclado (con un bajo porcentaje de principio activo) durante la granulación, compresión y envasado. Puede producirse asimismo absorción por la piel, en particular durante las fases por vía húmeda de la granulación, ya que se utilizan soluciones alcohólicas. El personal de control de calidad y de laboratorio tiene igualmente riesgo de exposición durante la siembra, ensayo o cualquier otra manipulación de sustancias estrogénicas puras, granulado o comprimidos. El personal de mantenimiento puede estar expuesto durante la limpieza, reparación o inspección de mezcladores, tolvas, molinos, líneas de vacío y sistemas de ventilación, o al cambiar los filtros. Los investigadores del NIOSH han evaluado en profundidad los controles técnicos utilizados durante la fabricación de anticonceptivos orales (Anastas 1984). Su informe ofrece una revisión detallada de los controles y una evaluación de su eficacia para la granulación, molturación, transferencias de material, equipo de alimentación de polvo y comprimidos, y sistemas de ventilación por aspiración general y local.

Los cuatro elementos principales de control de riesgos empleados en las plantas en que se manejan derivados estrogénicos son:

1. Controles técnicos. Entre ellos figuran el aislamiento del equipo de proceso, el control del flujo de aire desde las áreas menos contaminadas a las más contaminadas, la ventilación por aspiración local en todos los puntos de transferencia abiertos, el cierre de las máquinas, el cierre de los flujos y el cierre de los sistemas de alimentación de polvo. La aplicación de controles técnicos como la ventilación por aspiración general y local se complica cuando las normas de buena fabricación (como las exigidas por la Food and Drug Administration de Estados Unidos), diseñadas para garantizar un producto seguro y eficaz, entran en conflicto con las mejores prácticas de salud y seguridad. Por ejemplo, las diferencias de presión causadas por los sistemas de ventilación general, diseñadas para proteger a los trabajadores fuera del proceso peligroso, chocan con los requisitos legales para prevenir la contaminación del producto por polvos o contaminantes externos al proceso. Considerando que elimina el contacto directo entre las personas y los contaminantes peligrosos, el confinamiento del equipo o del proceso es a menudo la mejor opción.

2. Buenas prácticas de trabajo. Entre éstas se incluyen la separación de vestuarios limpios y contaminados mediante duchas, los cambios de ropa, los lavados o duchas antes de salir de las áreas contaminadas $y$, cuando sea factible y apropiado, las rotaciones sistemáticas de todos los trabajadores entre las áreas expuestas y las no expuestas. Una parte importante de un programa efectivo de protección de los trabajadores está constituida por la educación y la formación adecuadas sobre los riesgos de los estrógenos y las buenas prácticas de trabajo. Los mejores controles técnicos y el equipo de protección personal son inútiles si los trabajadores no conocen los riesgos y los controles, y si no están formados adecuadamente para beneficiarse de estos últimos y para utilizar el equipo de protección proporcionado.

3. Seguimiento exhaustivo medioambiental y médico de los trabajadores expuestos. Además de las exploraciones normales, los controles de rutina deben incluir como mínimo una revisión de los síntomas (sensibilidad torácica, cambios de la líbido, etc.), las exploraciones de mamas y nódulos axilares y la medida de las areolas. La frecuencia de estos controles variará en función de la gravedad del riesgo de exposición. Los controles y el seguimiento médico (p. ej., exámenes físicos, cuestionarios de salud o análisis de líquidos corporales) deben completarse con la mayor sensibilidad al bienestar de los trabajadores, su salud y su intimidad, ya que su cooperación y ayuda en este programa son críticos para el éxito. El seguimiento de la exposición de los trabajadores a principios activos estrogénicos y progestágenos se debe realizar regularmente e incluir no sólo el muestreo de contaminantes atmosféricos en la zona de respiración, sino también evaluaciones de la contaminación de la piel y la eficacia del equipo de protección personal.

4. Uso del equipo de protección personal adecuado. El equipo de protección personal incluye trajes de trabajo desechables o lavables; zapatos, calcetines, ropa interior y guantes de goma para el área de esteroides y respiradores eficaces adecuados al grado de riesgo. En las áreas más peligrosas pueden ser necesarios equipos de protección respiratoria con aporte de aire y trajes impermeables (a polvos o disolventes orgánicos).

5. Debido a la actividad de las sustancias estrogénicas, en particular las sintéticas como el dienestrol y el etinilestradiol, todas estas medidas son necesarias para controlar adecuadamente las exposiciones. El uso solamente de equipo de protección personal puede no conferir una protección completa. La primera medida a adoptar debe ser el control de las exposiciones en su origen mediante el confinamiento del proceso y el aislamiento.

\section{Métodos de seguimiento}

Se han utilizado los métodos de análisis por cromatografía líquida de alta resolución y radioinmunoensayo para determinar los estrógenos y progestágenos en muestras del medio ambiente. En las muestras de suero se analizan el compuesto activo exógeno, su metabolito (p. ej., el etinilestradiol es el metabolito principal del dienestrol), las neurofisinas estimuladas con estrógenos $u$ otras hormonas (p. ej., hormonas gonadotrópicas y GVC) consideradas adecuadas para el proceso y el riesgo específico. El seguimiento de las partículas en suspensión en el aire incluye el seguimiento del personal de la zona de respiración, si bien el muestreo del área puede ser útil para detectar desviaciones de los valores esperados con el tiempo. El seguimiento personal tiene la ventaja de que permite identificar averías o problemas del equipo de proceso, el equipo de protección personal o los sistemas de ventilación, y proporcionar una primera señal de alarma de exposición. Por su parte, el seguimiento biológico puede detectar exposiciones que han escapado al seguimiento del medio ambiente (p. ej., absorción por la piel o ingestión). En general, las buenas prácticas combinan el muestreo medioambiental y biológico para proteger a los trabajadores.

Dennis D. Zaebst 
materiales puede crear problemas debido a las velocidades de reacción, las temperaturas o las presiones críticas, las características del equipo de procesado y la posibilidad de fugas y vertidos. Se requieren precauciones especiales para minimizar la electricidad estática cuando los procesos utilizan o generan gases y líquidos inflamables. La carga de los líquidos inflamables mediante tubos de inmersión, la unión a tierra y eléctrica de los materiales conductores y el mantenimiento de atmósferas inertes dentro del equipo del proceso reducen el riesgo de incendio o explosión (Crowl y Louvar 1990).

\section{Salud y seguridad de los trabajadores}

Las operaciones de síntesis plantean muchos riesgos para la salud y seguridad de los trabajadores; algunos como consecuencia de las piezas móviles de las máquinas, equipos y tuberías a presión, manipulación manual de materiales y equipos, vapor, líquidos y superficies calientes y ambientes calurosos en el lugar de trabajo; espacios confinados y fuentes de energía peligrosas (p. ej., electricidad), y altos niveles de ruido.

Los riesgos agudos y crónicos para la salud son resultado de la exposición del trabajador a productos químicos peligrosos durante las operaciones de síntesis. Los productos químicos con efectos agudos sobre la salud pueden dañar los ojos y la piel, ser corrosivos o irritantes para los tejidos corporales, provocar sensibilización o reacciones alérgicas o ser asfixiantes, provocando asfixia o deficiencia de oxígeno. Los productos químicos con efectos crónicos sobre la salud pueden provocar cáncer, alteraciones hepáticas, renales o pulmonares o afectar los sistemas nervioso, endocrino, reproductor $u$ otros órganos. Los riesgos para la salud y la seguridad se pueden controlar aplicando las medidas de control adecuadas (p. ej., modificaciones del proceso, controles técnicos, prácticas administrativas, equipo de protección personal y respiratoria).

Las reacciones de síntesis orgánica pueden provocar riesgos importantes que comprometen la seguridad del proceso debido a los materiales altamente peligrosos, el fuego, las explosiones o las reacciones químicas incontroladas que afectan a la población establecida en los alrededores de la planta. La seguridad del proceso puede ser muy complicada en la síntesis orgánica, por lo que se adoptan distintas técnicas de enfoque: examen de la dinámica de las reacciones químicas y de las propiedades de los materiales altamente peligrosos, diseño, funcionamiento y mantenimiento de los equipos y servicios, formación del personal técnico y operativo, y preparación y respuestas de emergencia de la instalación y la comunidad local. Se dispone de normas técnicas sobre el análisis de riesgos del proceso y las actividades de gestión para reducir los riesgos de las operaciones de síntesis química (Crowl y Louvar 1990; Kroschwitz 1992).

\section{Extracción biológica y natural}

Se procesan grandes volúmenes de materiales naturales, tales como sustancias vegetales y animales, para extraer sustancias farmacológicamente activas (Gennaro 1990; Swarbick y Boylan 1996). En cada etapa se reducen los volúmenes mediante una serie de procesos discontinuos, hasta obtener el fármaco final. Los procesos se suelen realizar en campañas de algunas semanas de duración, hasta conseguir la cantidad deseada de producto terminado. Los disolventes se utilizan para eliminar grasas y aceites insolubles, extrayendo así el principio activo terminado. El pH (acidez) de la solución de extracción y los productos de desecho se puede ajustar neutralizándolos con ácidos y bases fuertes. Los compuestos metálicos sirven con frecuencia de agentes precipitantes, y los compuestos fenólicos como desinfectantes.
Salud y seguridad de los trabajadores.

Algunos trabajadores desarrollan reacciones alérgicas o irritaciones cutáneas al manipular ciertas plantas. Las sustancias de origen animal pueden estar contaminadas con organismos infecciosos a menos que se adopten las precauciones adecuadas. Los trabajadores pueden estar expuestos a disolventes y productos químicos corrosivos durante las operaciones de extracción biológica y natural. El almacenamiento, la manipulación, el procesado y la recuperación de líquidos inflamables presentan riesgos de incendio y explosión. La seguridad de los trabajadores está amenazada por las piezas móviles mecánicas; el vapor, el agua y las superficies calientes y los lugares de trabajo calurosos, y los elevados niveles de ruido.

Los problemas de la seguridad del proceso están a menudo atenuados por los grandes volúmenes de materiales vegetales y animales, y por las actividades de extracción de disolventes a menor escala. Durante las operaciones de extracción y recuperación puede existir peligro de incendio y explosión y producirse exposiciones de los trabajadores a disolventes o productos químicos corrosivos o irritantes, en función de la química específica y el confinamiento del equipo de procesado.

\section{Figura 79.8 • Fabricación farmacéutica de formas galénicas.}

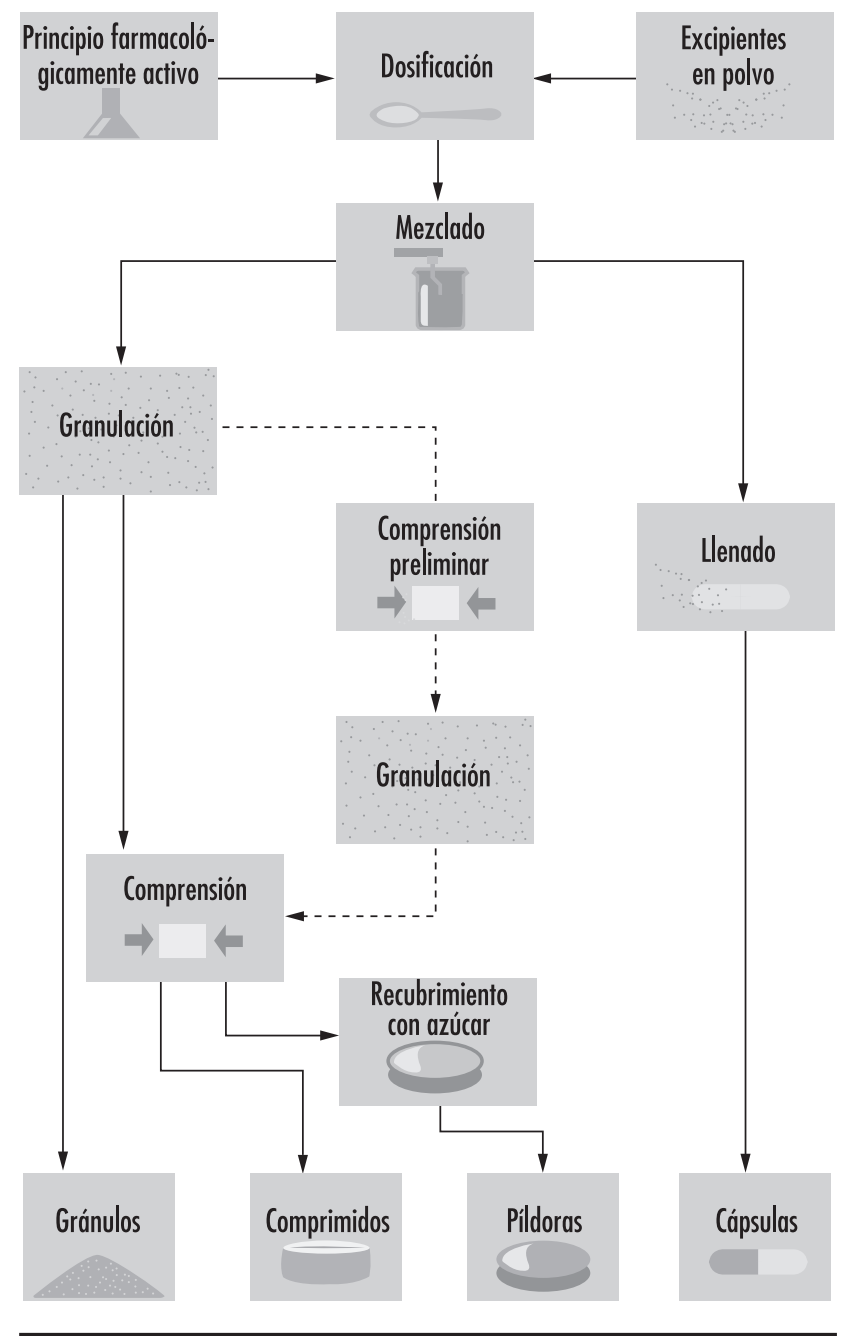




\section{Fabricación farmacéutica de formas galénicas}

Los principios activos se transforman en formas galénicas antes de su dispensación o administración a humanos o animales. Para ello se mezclan con excipientes farmacéuticos, como aglutinantes, sustancias de carga, aromatizantes, diluyentes, conservantes y antioxidantes. Estos ingredientes se secan, trituran, mezclan, comprimen o granulan para obtener las propiedades deseadas antes de su fabricación como una formulación final. Los comprimidos y las cápsulas son formas orales muy comunes; otra forma habitual son los líquidos estériles para inyección o aplicación oftálmica. La Figura 79.8 muestra las operaciones unitarias típicas en la fabricación de formas galénicas.

Las mezclas farmacéuticas se pueden comprimir mediante granulación húmeda, compresión directa o golpeo para obtener las propiedades físicas deseadas antes de su formulación como un fármaco terminado. En la granulación húmeda, los principios activos y los excipientes se humedecen con soluciones acuosas o disolventes, obteniéndose gránulos groseros con mayor tamaño de partícula. Se secan los gránulos, se mezclan con lubricantes (p. ej., estearato de magnesio), disgregantes o aglutinantes, y después se comprimen a comprimidos. Durante la compresión directa, una matriz de metal sostiene una cantidad medida de la mezcla mientras un punzón comprime el comprimido. Los fármacos que no son lo suficientemente estables para la granulación húmeda o no pueden ser comprimidos directamente son golpeados. El golpeo o granulación seca mezcla y comprime comprimidos relativamente grandes que son triturados y tamizados a un tamaño de partícula determinado, y después se vuelven a comprimir en el comprimido final. Los materiales mezclados y granulados se pueden producir también en forma de cápsulas. Las cápsulas de gelatina dura se secan, pulen, rellenan y unen en máquinas llenadoras de cápsulas.

Las formas líquidas se utilizan en forma de soluciones estériles para inyección en el organismo o administración ocular; se fabrican también líquidos, suspensiones y jarabes para ingestión oral, y tinturas para su aplicación sobre la piel (Gennaro 1990). Para la fabricación de líquidos estériles y la prevención de contaminación microbiológica y de partículas se requieren condiciones medioambientales muy controladas, la utilización de equipos de procesado confinados y el empleo de materias primas purificadas (Cole 1990; Swarbick y Boylan 1996). Se deben limpiar y mantener los servicios de la instalación (p. ej., ventilación, vapor y agua), el equipo de procesado y las superficies del lugar de trabajo de forma que se prevenga y minimice la contaminación. Se utiliza agua a presión y temperatura elevada para destruir y filtrar bacterias y otros contaminantes del suministro de agua estéril cuando se preparan soluciones para inyección. Los líquidos parenterales se inyectan en el organismo mediante administración intradérmica, intramuscular e intravenosa. Se esterilizan por calor seco o húmedo a presiones elevadas con filtros bacterianos. No es necesario esterilizar las soluciones para administración oral y tópica, pero sí las soluciones oftálmicas. Los líquidos orales se preparan mezclando los principios activos con un disolvente o conservante para inhibir el crecimiento de bacterias y hongos. Las suspensiones líquidas y las emulsiones se preparan mediante molinos coloidales y homogeneizadores, respectivamente, y las cremas y pomadas mezclando principios activos con vaselina, grasas consistentes o emolientes, envasándolas después en tubos de plástico o metal.

\section{Salud y seguridad de los trabajadores}

Los riesgos para la salud y seguridad de los trabajadores durante la fabricación farmacéutica son causados por las piezas móviles de las máquinas (p. ej., engranajes, correas y ejes expuestos) y las fuentes de energía peligrosas (p. ej., eléctricas, neumáticas, térmicas, etc.); la manipulación manual de materiales y equipos; el vapor a alta presión, el agua y las superficies calientes; los líquidos inflamables y corrosivos; y los altos niveles de ruido. Se pueden producir exposiciones a polvos transportados por el aire durante la dispensación, el secado, la molturación y la mezcla. Es especialmente preocupante la exposición a los productos farmacéuticos cuando se manipulan o procesan mezclas que contienen grandes proporciones de principios activos. La granulación húmeda, la composición y el recubrimiento pueden exponer al trabajador a vapores de disolventes.

Los aspectos de la seguridad del proceso están relacionados en primer lugar con los riesgos de incendio o explosión durante la fabricación de las formas galénicas. Muchas de estas operaciones (p. ej., granulación, mezcla, composición y secado) utilizan líquidos inflamables que pueden crear atmósferas inflamables o explosivas. Algunos polvos farmacéuticos son altamente explosivos; por lo tanto, se deben examinar sus propiedades físicas antes de su procesado. El secado en lecho fluido, la molturación y el golpeo pueden ser peligrosos cuando se utilizan materiales potencialmente explosivos. Las medidas técnicas y las prácticas seguras de trabajo reducen los riesgos de polvos explosivos y líquidos inflamables (p. ej., equipos y servicios eléctricos estancos al vapor y al polvo, conexión a tierra de los equipos, contenedores sellados con protección antipresión y atmósferas inertes).

\section{Medidas de control}

He aquí algunas medidas de control del lugar de trabajo aplicables durante todas las operaciones farmacéuticas que se describen a continuación: prevención y protección contra incendios y explosiones; confinamiento de sustancias peligrosas, riesgos de la maquinaria y altos niveles de ruido; dilución y ventilación por aspiración local (VAL); uso de respiradores (p. ej., mascarillas protectoras frente a polvos y vapores orgánicos y en algunos casos respiradores purificadores de aire o mascarillas y trajes con inyección de aire) y equipo de protección personal (EPP); y formación de los trabajadores sobre los riesgos del lugar de trabajo y prácticas seguras de trabajo. Otras medidas específicas implican la sustitución de material menos peligrosa cuando sea posible durante el desarrollo y la fabricación de fármacos. Asimismo, si se reducen al mínimo las transferencias de material, los procesos abiertos o no sellados y los muestreos, se reduce la posibilidad de exposiciones de los trabajadores.

El diseño técnico y las características de las instalaciones, servicios y equipos de procesado pueden prevenir la contaminación medioambiental y reducir las exposiciones de los trabajadores a las sustancias peligrosas. Las instalaciones modernas de fabricación de productos farmacéuticos y sus equipos de procesado reducen los riesgos para el medio ambiente, la salud y la seguridad impidiendo la contaminación y mejorando el confinamiento de los riesgos. Los objetivos de control de calidad y de salud y seguridad de los trabajadores se alcanzan mejorando el aislamiento, el confinamiento y la limpieza de las instalaciones y equipos de procesado. La prevención de las exposiciones de los trabajadores a sustancias peligrosas y productos farmacéuticos es completamente compatible con la necesidad de prevenir a los trabajadores de la contaminación accidental de materias primas y productos terminados. Otras actividades complementarias son unos métodos seguros de trabajo y unas buenas prácticas de fabricación.

\section{Aspectos técnicos del diseño de la instalación y del proceso}

El diseño técnico y las características de las instalaciones y equipos de procesado farmacéuticos influyen en la salud y la seguridad de los trabajadores. Los materiales de construcción, los equipos de procesado y las actividades de mantenimiento afectan considerablemente a la limpieza del lugar de trabajo. Los sistemas de dilución y VAL controlan las fugas de vapor y las 
emisiones de polvo durante las operaciones de fabricación. Las medidas de prevención y protección frente a incendios y explosiones (p. ej., equipos y servicios eléctricos estancos al vapor y al polvo, sistemas de extinción, detectores de incendios y humos y alarmas de emergencia) son necesarios cuando están presentes líquidos y vapores inflamables. Se instalan sistemas de almacenamiento y manipulación (p. ej., recipientes de almacenamiento, contenedores portátiles, bombas y tuberías) para trasladar líquidos dentro de las instalaciones de fabricación farmacéutica. Los sólidos peligrosos se pueden manipular y procesar en equipos y recipientes cerrados, contenedores de granel individuales y tambores y bolsas sellados. El aislamiento o confinamiento de las instalaciones, los equipos de procesado y los materiales peligrosos promueven la salud y seguridad del trabajador. Los riesgos mecánicos se controlan instalando defensas en las piezas móviles de las máquinas.

Los equipos y servicios se pueden controlar manual o automáticamente. En las plantas manuales, los operarios químicos leen los instrumentos y controlan los equipos y servicios cercanos. En las plantas automatizadas, los equipos, servicios y dispositivos de control se controlan mediante sistemas distribuidos, permitiendo su operación desde un lugar remoto como una sala de control. A menudo se realizan operaciones manuales cuando se cargan o transfieren materiales, se descargan y envasan productos y cuando se realiza el mantenimiento o se presentan condiciones no habituales. Se deben redactar instrucciones que describan los procedimientos normalizados de trabajo, así como los riesgos para la salud y la seguridad de los trabajadores y las medidas de control.

\section{Verificación de los controles del lugar de trabajo}

Las medidas de control del lugar de trabajo se evalúan periódicamente para proteger a los trabajadores de los riesgos para la salud y la seguridad y reducir la contaminación medioambiental. Muchos procesos de fabricación y piezas del equipo son validados en la industria farmacéutica con el fin de asegurar la calidad de los productos (Cole 1990; Gennaro 1990; Swarbick y Boylan 1996). Pueden aplicarse prácticas similares de validación en las medidas de control del lugar de trabajo, para asegurar que son eficaces y fiables. Periódicamente se revisan las instrucciones del proceso y las prácticas seguras de trabajo. Las actividades de mantenimiento preventivo identifican cuando pueden fallar los equipos de procesado e ingeniería, evitando de esta forma algunos problemas. En el curso de la formación y la supervisión se informa y educa a los trabajadores acerca de los riesgos para el medio ambiente, la salud y la seguridad, reforzándose las prácticas seguras de trabajo y el uso de respiradores y equipo de protección personal. Los programas de inspección examinan si se mantienen condiciones seguras en el lugar de trabajo y las prácticas seguras de trabajo. Para ello se inspeccionan los respiradores y se comprueba que son elegidos, llevados y mantenidos adecuadamente por los trabajadores. Los programas de auditoría revisan los sistemas de gestión para identificar, evaluar y controlar los riesgos para el medio ambiente, la salud y la seguridad.

\section{Operaciones farmacéuticas}

\section{Pesada y dispensación}

La pesada y la dispensación de sólidos y líquidos son actividades muy comunes en toda la industria farmacéutica (Gennaro 1990). Por lo general, los trabajadores dispensan los materiales vaciando a mano los sólidos y vertiendo o bombeando los líquidos. La pesada y la dispensación se realizan a menudo en un almacén durante la producción de productos químicos o en una farmacia durante la preparación de formas galénicas. La probabilidad de vertidos, fugas y emisiones en el curso de estas operaciones hace necesaria la adopción de medidas de control en el lugar de trabajo. La pesada y la dispensación deben realizarse en un área de trabajo separada físicamente con buena ventilación de dilución. Las superficies de trabajo en las áreas donde se pesan y dispensan los materiales deben ser lisas y herméticas, de forma que permitan una limpieza adecuada. La VAL con campanas de extracción lateral o posterior previenen la liberación de contaminantes atmosféricos cuando se pesan y dispensan sólidos pulvurulentos o líquidos volátiles (Cole 1990). La pesada y dispensación de materiales altamente tóxicos puede requerir medidas de control adicional. como campanas de ventilación laminar o dispositivos de aislamiento (p. ej., cajas o bolsas de manipulación con guantes) (Naumann y cols. 1996).

\section{Carga y descarga de sólidos y líquidos}

Los sólidos y líquidos se cargan y descargan con frecuencia de los recipientes y equipos en las operaciones de fabricación farmacéutica (Gennaro 1990). Estas operaciones se realizan a menudo manualmente; no obstante se utilizan también otros métodos (p. ej., gravedad, sistemas de transferencia mecánicos o neumáticos). Un equipo de procesado confinado, los sistemas de transferencia y los controles técnicos previenen las exposiciones de los trabajadores durante la carga y descarga de materiales altamente peligrosos. La carga por gravedad desde recipientes cerrados y los sistemas de vacío, presión y bombeo eliminan emisiones fugitivas durante las operaciones de carga y descarga. La VAL con entradas laterales captura polvos y vapores fugitivos liberados en los puntos de transferencia abierta.

\section{Separaciones de líquidos}

Los líquidos se separan sobre la base de sus propiedades físicas (p. ej., densidad, solubilidad y miscibilidad) (Kroschwitz 1992). En general se realizan separaciones de líquidos durante la producción de productos químicos a granel y las operaciones de fabricación farmacéutica. Los líquidos peligrosos se deben transferir, procesar y separar en recipientes cerrados y sistemas de tuberías para reducir las exposiciones de los trabajadores a los vertidos de líquidos y vapores del aire. Cerca de las operaciones de transferencia, procesado o separación de líquidos se deben disponer coliriros y duchas de seguridad. Si se utilizan líquidos inflamables son necesarias medidas de control de vertidos y prevención y protección contra incendios y explosiones.

\section{Transferencia de líquidos}

A menudo se transfieren líquidos entre los recipientes de almacenamiento, contenedores y equipo de procesado en el curso de las operaciones de fabricación farmacéutica. Idealmente, las instalaciones y procesos de fabricación están diseñados para minimizar la necesidad de transferir materiales peligrosos, disminuyendo de esta forma la posibilidad de vertidos y exposiciones. Se pueden transferir líquidos entre los recipientes y los equipos del proceso a través de estaciones de admisión, áreas dotadas de bridas de tubos muy próximas (Kroschwitz 1992). Esto permite realizar conexiones temporales entre los sistemas de conducción. En las estaciones de admisión se pueden producir vertidos, fugas y emisiones de vapor; por lo tanto se necesitan juntas adecuadas y sellados herméticos en mangueras y tuberías para prevenir la contaminación medioambiental y las emisiones en el lugar de trabajo. Los sistemas de drenaje con tanques o sumideros cerrados capturan los líquidos vertidos, que pueden así ser recuperados. Cuando se transfieren grandes volúmenes de líquido se prefieren recipientes y contenedores cerrados y sistemas de tuberías. Se deben adoptar precauciones especiales cuando se utilizan gases inertes para presurizar las líneas de transferencia o el equipo de procesado, ya que esto puede aumentar la liberación de compuestos orgánicos volátiles $(\mathrm{COV})$ y contaminantes atmosféricos peligrosos. El 
reciclado o condensación de los gases y vapores de ventilación reduce la contaminación del aire.

\section{Filtración}

Durante las operaciones de filtración se separan sólidos y líquidos. Los filtros tienen distintos diseños y características, variando el confinamiento y el control de líquidos y vapores (Kroschwitz 1992: Perry 1984). Cuando se utilizan filtros abiertos para materiales peligrosos, los trabajadores pueden estar expuestos a líquidos, sólidos húmedos, vapores y aerosoles durante las operaciones de carga y descarga. Se puede utilizar equipo cerrado de procesado para filtrar materiales altamente peligrosos, reducir las emisiones de vapor y prevenir las exposiciones (véase Figura 79.9). La filtración se debe realizar en áreas con control de vertidos y buena dilución y VAL. Se pueden eliminar los vapores de disolventes volátiles mediante salidas en los equipos cerrados, controlándose mediante dispositivos de emisión de aire (p. ej., condensadores, purificadores, adsorbentes).

\section{Composición}

En las operaciones de composición se mezclan sólidos y líquidos para producir soluciones, suspensiones, jarabes, pomadas y pastas. Se recomienda el empleo de equipos de procesado confinados y de sistemas de transferencia cuando se utilizan materiales altamente peligrosos (Kroschwitz 1992; Perry 1984). Los agentes amortiguadores, detergentes y germicidas que actúan como neutralizantes, limpiadores y biocidas pueden ser peligrosos para los trabajadores. Los colirios y las duchas de seguridad reducen las lesiones si los trabajadores entran en contacto accidentalmente con sustancias corrosivas o irritantes. Las superficies húmedas de las áreas de composición exigen la protección de los peligros eléctricos de los equipos y servicios. El vapor y el agua caliente plantean riesgos térmicos durante las actividades de composición y limpieza. Las lesiones de los trabajadores debido a quemaduras y caídas se previenen instalando aislamientos sobre las superficies calientes y manteniendo suelos secos antideslizantes.

\section{Granulación}

Se granulan sólidos secos y húmedos para modificar sus propiedades físicas. Los granuladores tienen distintos diseños y características con confinamiento y control variables de los riesgos mecánicos y los polvos y vapores transportados por el aire (Perry 1984; Swarbick y Boylan 1996). Los granuladores cerrados

Figura 79.9 - Filtro.

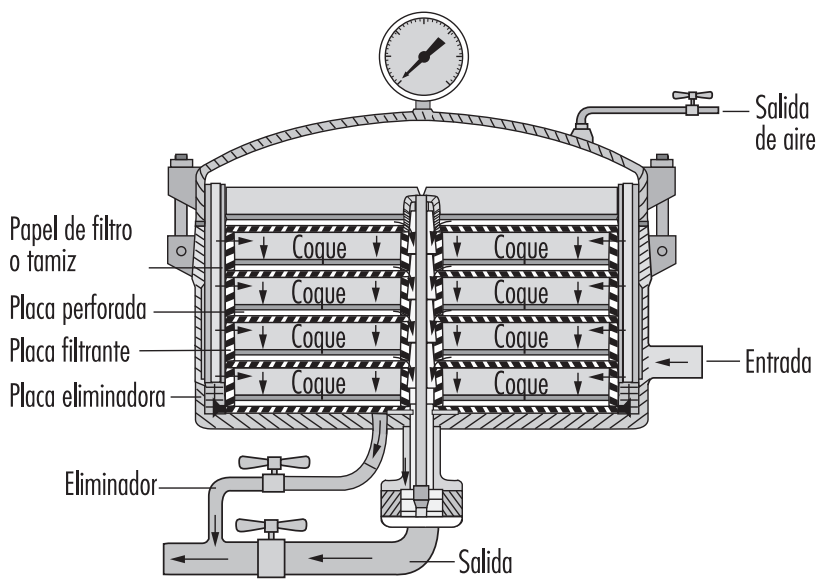

Fuente: Perry 1984
Figura 79.10 - Granulador de vapor.

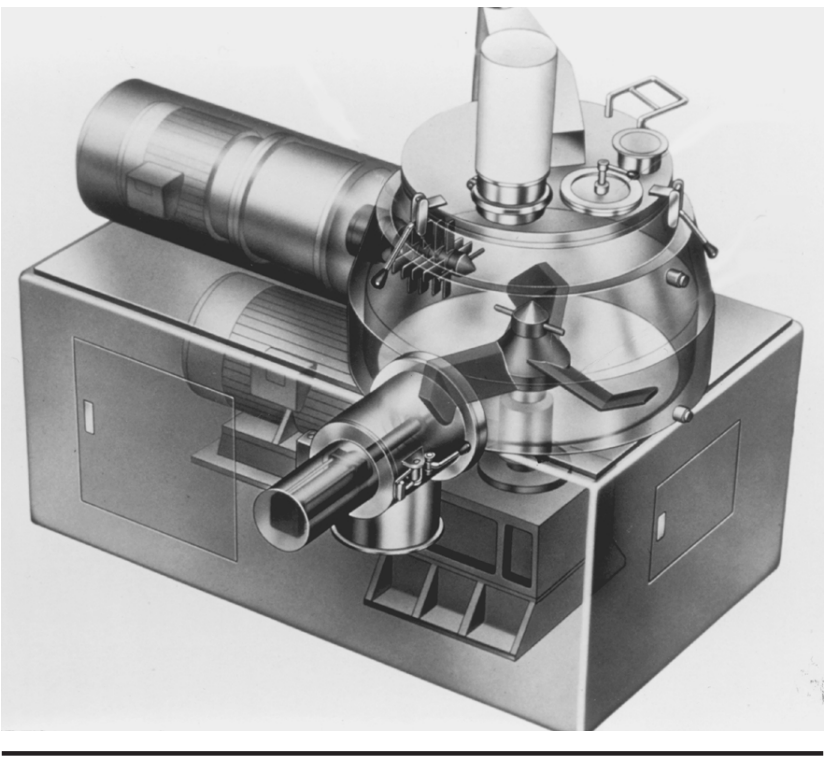

pueden ventilarse hacia dispositivos de control de aire, reduciéndose así las emisiones de vapores de disolventes o de polvos al lugar de trabajo y atmósfera (véase Figura 79.10). Durante la carga y descarga de los granuladores la manipulación del material puede ser problemática. El equipo mecánico (p. ej., plataformas elevadas, mesas elevadoras y gatos) sirve de ayuda en la realización de las tareas manuales pesadas. Se necesitan colirios y duchas de seguridad si los trabajadores entran en contacto accidentalmente con disolventes o polvos irritantes.

\section{Secado}

Se secan sólidos humedecidos con agua o disolventes durante muchas operaciones de fabricación farmacéutica. Los secadores tienen distintos diseños y características con confinamiento y control variables de vapores y polvos (véase Figura 79.11). Los vapores de disolventes inflamables y los polvos explosivos transportados por el aire pueden crear atmósferas inflamables o explosivas; la ventilación de seguridad contra explosiones es particularmente importante en los secadores confinados. La dilución y la VAL reducen el riesgo de incendios o explosiones, además de controlar las exposiciones de los trabajadores a los vapores de disolventes cuando se manipulan tortas húmedas, o a los polvos transportados por el aire al descargar los productos secos. La carga o descarga de bandejas, recipientes o contenedores de secadores implica la manipulación de materiales pesados (véase Figura 79.12). En estas tareas manuales se utilizan equipos mecánicos (p. ej., gatos de tambor, elevadores y plataformas de trabajo). Se debe disponer de colirios y duchas de seguridad próximos al lugar de trabajo para el caso de accidente de los trabajadores que entren en contacto con disolventes y polvos.

\section{Molturación}

Se muelen sólidos secos para modificar las características de sus partículas y producir polvos de flujo libre. Los molinos tienen distintos diseños y características, con confinamiento y control variables de los riesgos mecánicos y los polvos transportados por el aire (Kroschwitz 1992; Perry 1984). Antes de moler los materiales, se deben revisar y ensayar sus propiedades físicas y riesgos. Las medidas de prevención y protección contra las explosiones implican la instalación de equipos y servicios eléctricos estancos 
Figura 79.11 - Secador rotativo vacio.

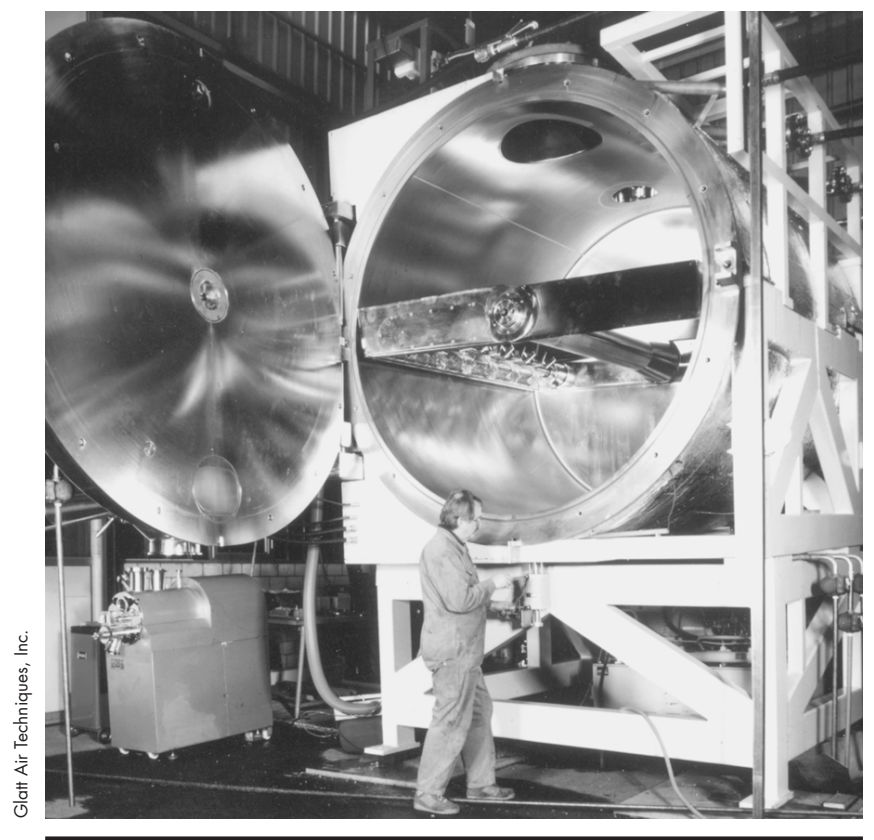

al polvo, la conexión a tierra de los equipos y accesorios para eliminar las descargas electrostáticas, la instalación de válvulas de seguridad en los molinos cerrados, y la construcción de paneles de seguridad contra explosiones en las paredes. Estas medidas pueden ser necesarias debido a la explosividad de algunos principios activos y excipientes, las altas concentraciones de polvo y las energías asociadas a las operaciones de molturación.

\section{Mezclado}

Se mezclan sólidos secos para producir mezclas homogéneas. Los mezcladores tienen distintos diseños y características, con confinamiento y control variables de los riesgos mecánicos y los polvos transportados por el aire (Kroschwitz 1992; Perry 1984). Los

Figura 79.12 • Autosecador de vacío.

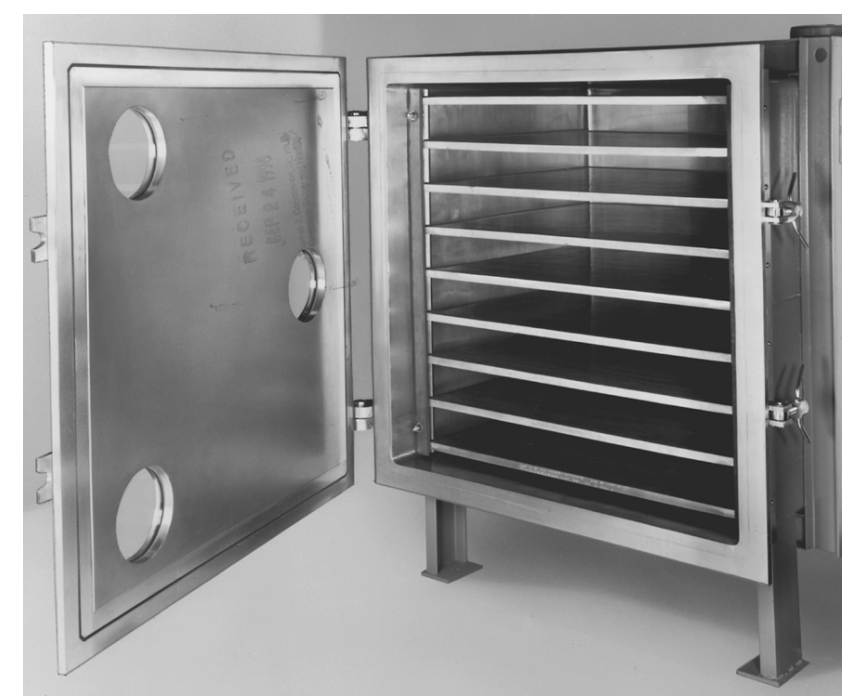

Fuente: EPA 1993. trabajadores pueden quedar expuestos a principios activos, excipientes y mezclas al cargar y descargar el equipo de mezcla. La VAL con entradas laterales reduce las emisiones fugitivas de polvo durante el mezclado. Puede ser necesaria la manipulación de material pesado cuando se cargan y descargan sólidos de los mezcladores. El equipo mecánico (p. ej., plataformas de trabajo, montacargas y gatos de tambor y bandeja) reduce el trabajo físico necesario para la manipulación de material pesado.

\section{Compresión}

Se comprimen sólidos secos, o bien se golpean para compactarlos, cambiando las propiedades de sus partículas. Los equipos de compresión tienen distintos diseños y características, con confinamiento y control variables de los riesgos mecánicos y los polvos transportados por el aire (Gennaro 1990; Swarbick y Boylan 1996), y graves riesgos mecánicos cuando se protegen inadecuadamente. La compresión y el golpeo producen asimismo altos niveles de ruido. El cierre de las fuentes de impacto, el aislamiento del equipo vibrante, la rotación de los trabajadores y el uso de dispositivos de protección auditiva (p. ej., tapones para los oídos) reducen el impacto de las exposiciones al ruido.

\section{Fabricación de formas galénicas sólidas}

Las formas galénicas orales más frecuentes son los comprimidos y las cápsulas. Los comprimidos contienen mezclas de principios activos y excipientes. Estos comprimidos pueden ser recubiertos con mezclas de disolventes o soluciones acuosas, o no recubrirse. Las cápsulas llevan una cubierta de gelatina dura o blanda. Las

Figura 79.13 - Máquina de comprimir con tolva de carga y recogida espiral de polvo para la recuperación del producto.

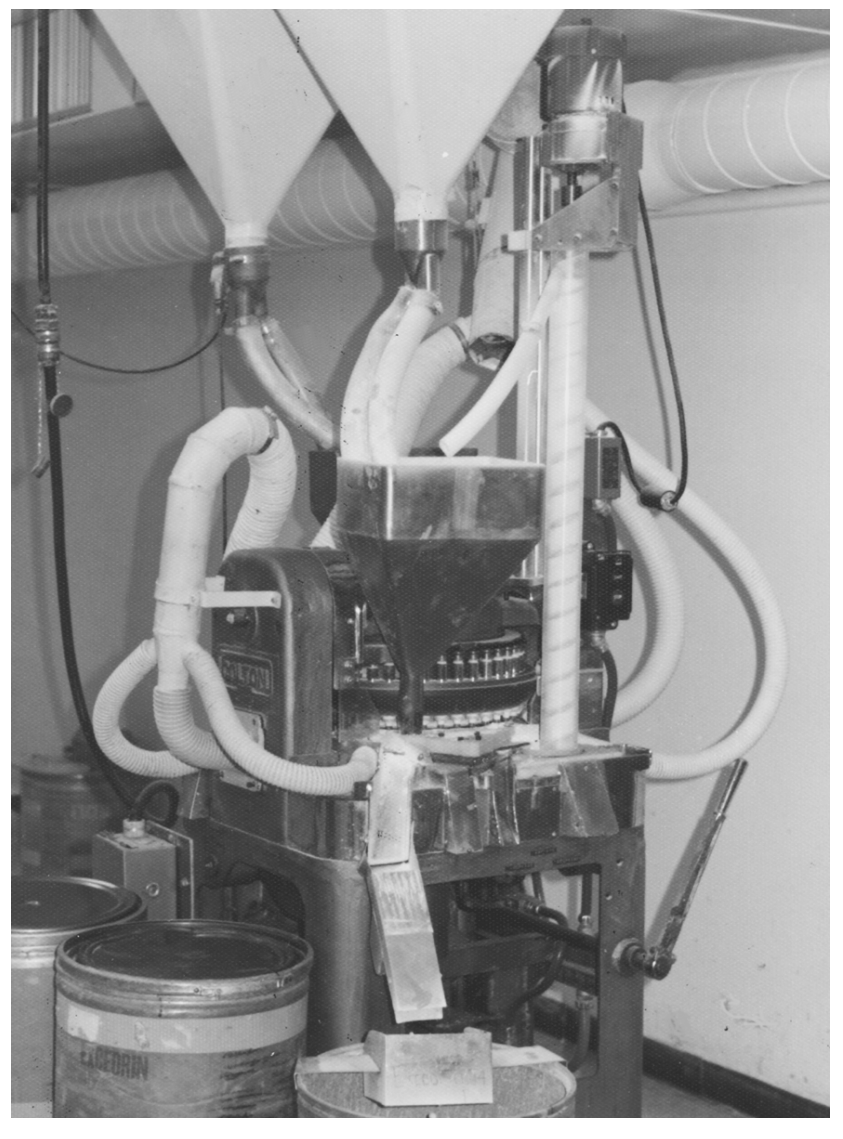


Figura 79.14 Máquina de recubrimiento de comprimidos.

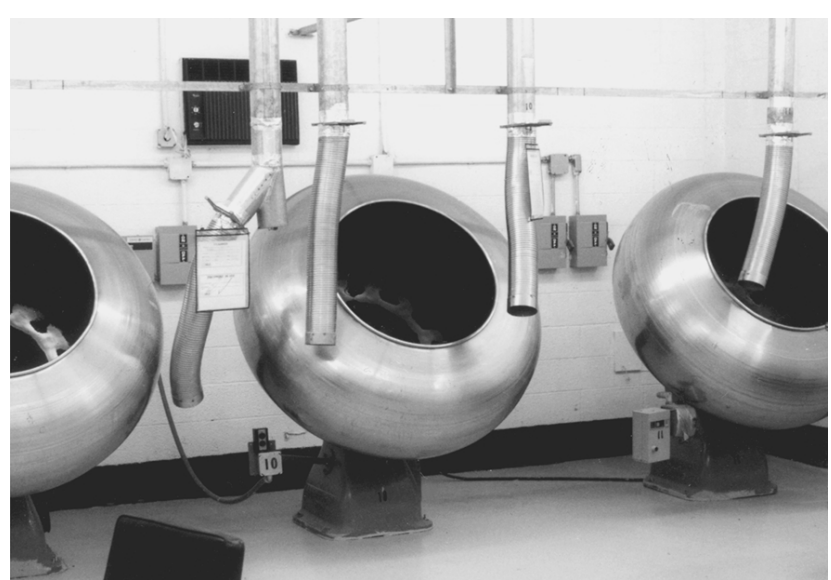

Fuente: Perry 1984

máquinas de comprimir (véase Figura 79.13), los aparatos de recubrimiento de comprimidos y las máquinas de llenado de cápsulas tienen distintos diseños y características, con confinamiento y control variables de los riesgos mecánicos y los polvos transportados por el aire (Cole 1990). Durante el recubrimiento por rociado de los comprimidos, los trabajadores pueden estar expuestos a vapores de disolventes. Los modernos aparatos de recubrimiento están muy confinados; no obstante, se puede instalar VAL en recipientes antiguos y abiertos de recubrimiento para controlar los vapores fugitivos de disolvente. Los aparatos de recubrimiento de comprimidos se pueden ventilar a dispositivos de emisión de aire para controlar los COV del proceso (véase Figura 79.14). Cuando sea posible, se utilizarán de nuevo en el proceso los disolventes recuperados o se sustituirán las mezclas de disolventes por mezclas acuosas para el recubrimiento de comprimidos. Las modernas máquinas de comprimir y de llenado de cápsulas están encerradas en paneles interbloqueados, lo que reduce los riesgos de las piezas con movimiento rápido, los niveles altos de ruido y las emisiones de polvo durante su operación. Los dispositivos de protección auditiva pueden reducir la exposición de los trabajadores al ruido durante las operaciones de compresión y encapsulado.

\section{Fabricación estéril}

Se fabrican productos estériles en plantas de fabricación farmacéutica con diseño modular (véase Figura 79.15), lugares de trabajo limpios y superficies limpias de equipos, y sistemas de ventilación con filtros de aire particulado de alta eficacia (HEPA) (Cole 1990; Gennaro 1990). Los principios y prácticas que controlan la contaminación en la fabricación de líquidos estériles son similares a los de la industria microelectrónica. Los trabajadores llevan ropa protectora frente a los productos contaminantes. Las técnicas farmacéuticas estériles para controlar la contaminación implican la liofilización de los productos, el empleo de germicidas líquidos y gases esterilizantes, la instalación de ventilación de flujo laminar, el aislamiento de módulos con presiones diferenciales de aire y el confinamiento de los equipos de fabricación y llenado.

Los germicidas tóxicos (p. ej., formaldehído y glutaraldehído) y los gases esterilizantes (p. ej., óxido de etileno) presentan riesgos químicos. Cuando sea posible, se seleccionarán agentes menos peligrosos (p. ej., alcoholes, compuestos de amonio). Las materias primas y los equipos se pueden esterilizar por vapor a alta presión o gases tóxicos (p. ej., mezclas de gases con óxido de etileno diluido) (Swarbick y Boylan 1996). Se pueden situar recipientes de esterilización en áreas separadas con sistemas de instrumentos y control remotos, aire no recirculado y VAL para extraer las emisiones de gases tóxicos. Los trabajadores deberán recibir formación sobre procedimientos normalizados de trabajo, prácticas seguras de trabajo y respuestas de emergencia adecuadas. Las cámaras de esterilización por gases se deben evacuar completamente al vacío y purgar con aire para minimizar las emisiones al lugar de trabajo antes de retirar los artículos esterilizados. Las emisiones de gases procedentes de las cámaras de esterilización se pueden eliminar a dispositivos de control de aire (p. ej., adsorción en carbón o convertidores catalíticos) para reducir las emisiones atmosféricas. En el seguimiento de la higiene industrial se miden las exposiciones de los trabajadores a germicidas químicos y gases esterilizantes, contribuyendo a evaluar la adecuación de las medidas de control. Los riesgos para la seguridad proceden del vapor a alta presión y el agua caliente, las piezas móviles de las máquinas en los instrumentos de lavado, llenado, encapsulado y envasado, los niveles altos de ruido y las actividades manuales repetitivas.

\section{Actividades de limpieza y mantenimiento}

Durante la limpieza, reparación y mantenimiento de los equipos, servicios y áreas de trabajo se realizan tareas no rutinarias. Los riesgos que surgen durante estas actividades son pocos, pero amenazan siempre la salud y la seguridad. El lugar de trabajo y las superficies del equipo pueden estar contaminados por materiales peligrosos y principios activos, por lo que se requiere su limpieza previa. Esta se realiza lavando o recogiendo los líquidos y barriendo o aspirando los polvos. No se recomienda el barrido en seco ni la aspiración de sólidos con aire comprimido, ya que implican la exposición a polvos transportados por el aire. El fregado en húmedo y la aspiración reducen las exposiciones de los trabajadores a los polvos durante la limpieza. Puede ser necesario el empleo de limpiadores de vacío con filtros HEPA al limpiar sustancias peligrosas y fármacos de alta actividad. En los sistemas de vacío para polvos explosivos se requieren equipos resistentes a explosiones y materiales conductores. Los colirios, las duchas de seguridad y el EPP reducen el efecto del contacto accidental de los trabajadores con detergentes corrosivos e irritantes y líquidos limpiadores.

Antes de la revisión, reparación o mantenimiento de los equipos y servicios puede ser necesario liberar o controlar la

Figura 79.15 • Diagrama de una instalación de fabricación de líquidos estériles.

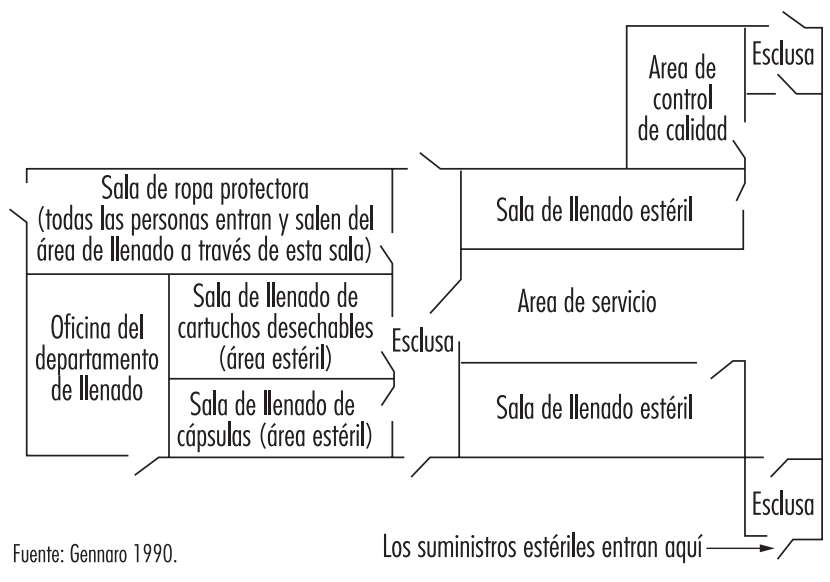


energía mecánica, eléctrica, neumática o térmica. Es posible que trabajadores subcontratados realicen actividades especiales de producción e ingeniería en las plantas farmacéuticas sin una formación adecuada sobre seguridad. Es importante una supervisión cuidadosa de estos trabajadores, de forma que no infrinjan las normas de seguridad ni realicen trabajos que provoquen incendios, explosiones $\mathrm{u}$ otros riesgos graves para la salud y la seguridad. Se han de impartir programas especiales de seguridad a los subcontratistas cuando se trabaje con materiales (p. ej., tóxicos, reactivos, inflamables o explosivos) y procesos (p. ej., exotérmicos o de alta presión) altamente peligrosos en las instalaciones de fabricación de productos farmacéuticos a granel y formas galénicas.

\section{Acondicionamiento}

Las operaciones de acondicionamiento farmacéutico se realizan con una serie de máquinas integradas y tareas manuales repetitivas (Gennaro 1990; Swarbick y Boylan 1996). Las formas galénicas terminadas se acondicionan en distintos tipos de recipientes (p. ej., frascos de vidrio o plástico, blisters de aluminio, bolsas o sobres, tubos y viales estériles). Los aparatos llenan, tapan, etiquetan, embalan en cajas de cartón y acondicionan los productos terminados en recipientes para el transporte. La proximidad del trabajador a los equipos de acondicionamiento requiere la instalación de protecciones de barrera en las piezas móviles de las máquinas, en los interruptores de control accesibles y en los cables de parada de emergencia, así como la formación de los trabajadores sobre los riesgos de la maquinaria y prácticas seguras de trabajo. El cierre y el aislamiento del equipo reducen los niveles de vibraciones y ruidos. El uso de dispositivos de protección auditiva (p. ej., tapones para los oídos) reduce las exposiciones a los ruidos. Un buen diseño industrial promueve la productividad, la comodidad y la seguridad de los trabajadores considerando los riesgos ergonómicos originados por las malas posturas, la manipulación del material y las tareas muy repetitivas.

\section{Operaciones en los laboratorios}

En la industria farmacéutica se realizan diversas operaciones en los laboratorios. Puede haber riesgos biológicos, químicos y físicos, en función de los agentes, operaciones, equipos y prácticas de trabajo aplicados. Existen diferencias fundamentales entre los laboratorios que llevan a cabo investigación científica y desarrollo de productos y procesos y los que evalúan las actividades de control y garantía de calidad (Swarbick y Boylan 1996). Los trabajadores de los laboratorios orientan su investigación científica al descubrimiento de principios activos, el desarrollo de procesos de fabricación para productos químicos a granel y formas galénicas o el análisis de materias primas, productos intermedios y productos terminados. Las actividades de los laboratorios se deben evaluar individualmente, aunque en muchas ocasiones se aplican las buenas prácticas de laboratorio (National Research Council 1981). La definición clara de las responsabilidades, la formación y la información, las prácticas seguras de trabajo, las medidas de control y los planes de respuesta de emergencia son medios importantes para controlar con eficacia los riesgos para el medio ambiente, la salud y la seguridad.

Los riesgos para la salud y la seguridad derivados de los materiales inflamables y tóxicos se reducen minimizando sus existencias en laboratorios y almacenándolos en salas separadas. Se pueden realizar ensayos y operaciones de laboratorio que emitan contaminantes atmosféricos en campanas extractoras, con objeto de proteger a los trabajadores. Las campanas de seguridad biológica suministran un flujo laminar descendente y hacia dentro, previniendo la emisión de microorganismos (Gennaro 1990; Swarbick y Boylan 1996). La formación y la información al trabajador describen los riesgos del trabajo en el laboratorio, las prácticas seguras de trabajo y las respuestas de emergencia adecuadas a incendios y vertidos. No se deben consumir alimentos ni bebidas en el recinto del laboratorio. La seguridad de éste aumenta si se pide a los supervisores que aprueben y dirijan las operaciones altamente peligrosas. Las buenas prácticas de laboratorio separan, tratan y eliminan los residuos biológicos y químicos. Con frecuencia se certifican y comprueban los riesgos físicos (p. ej., fuentes de radiación y de energía electromagnética) conforme a reglamentos específicos.

\section{Riesgos generales para la salud y la seguridad}

\section{Ergonomía y manipulación del material}

Los materiales transportados, almacenados, manipulados, procesados y envasados en la industria farmacéutica varían desde grandes cantidades de materias primas a pequeños envases con productos farmacéuticos. Las materias primas para los productos químicos a granel se transportan en grandes contenedores (p. ej., camiones cisterna, vagones), tambores de metal y fibra, papel reforzado y bolsas de plástico. En la industria farmacéutica se utilizan cantidades menores de materias primas, debido a la escala reducida de las operaciones. Se utilizan diversos dispositivos de manipulación del material (p. ej., carretillas elevadoras, paletas, montacargas de vacío y gatos de tambor) para la manipulación del material durante las operaciones de producción y almacenamiento. Pueden producirse riesgos ergonómicos al desplazar materiales y equipos sin disponer de dichos aparatos. Las buenas prácticas de ingeniería industrial y de gestión de las instalaciones reducen las lesiones causadas por la manipulación del material mejorando el diseño y las características del equipo y el lugar de trabajo y disminuyendo el tamaño y peso de los contenedores (Cole 1990). Las medidas de control técnico (p. ej., diseño ergonómico de herramientas, materiales y equipo) y administrativo (p. ej., rotación de los trabajadores, formación) reducen los riesgos de traumatismos durante las operaciones repetitivas de producción y envasado.

\section{Protección de las máquinas y control de la energía peligrosa}

Las piezas móviles sin protección de los equipos de fabricación y envasado farmacéuticos presentan riesgos mecánicos. Los "puntos de choque y contacto" expuestos de los equipos abiertos pueden causar lesiones graves. Los riesgos mecánicos son mayores debido al número y a la variedad del diseño de los equipos, a la masificación en el lugar de trabajo y a las frecuentes interacciones entre trabajadores y equipo. Las protecciones de bloqueo, los interruptores de control, los dispositivos de parada de emergencia y la formación de los operarios son medios importantes de reducción de los riesgos mecánicos. El pelo suelto, la ropa de manga larga, las joyas u otros objetos pueden quedar atrapados en el equipo. La inspección de rutina y las actividades de reparación identifican y controlan los riesgos mecánicos durante las operaciones de producción y envasado. Se debe liberar o controlar la energía peligrosa eléctrica, neumática y térmica antes de trabajar con el equipo y los servicios activos. Los trabajadores se protegen de las fuentes de energía peligrosa aplicando procedimientos de bloqueo/cierre.

\section{Exposiciones al ruido}

Los equipos y servicios de fabricación (p. ej., aire comprimido, fuentes de vacío y sistemas de ventilación) pueden generar altos niveles de ruido. Debido al diseño en módulos cerrados de los lugares de trabajo, los trabajadores se encuentran a menudo próximos a las máquinas durante las operaciones de fabricación y envasado. De hecho, observan e interactúan con el equipo de 
producción y envasado, aumentando de esta forma su exposición al ruido. Los métodos de ingeniería reducen los niveles de ruido modificando, cerrando y amortiguando las fuentes de ruido. La rotación de los trabajadores y el uso de dispositivos de protección auditiva (p. ej., tapones para los oídos) reducen la exposición individual a altos niveles de ruido. Los programas de conservación de la audición identifican las fuentes de ruido, reducen los niveles de sonido en los lugares de trabajo y forman a los trabajadores acerca de los riesgos de la exposición al ruido y el uso adecuado de dispositivos de protección auditiva. El control del ruido y el seguimiento médico (p. ej., con audiometrías) evalúan las exposiciones del trabajador al ruido y las pérdidas de audición resultantes. Esto ayuda a identificar los problemas de ruido y a evaluar la adecuación de las medidas correctoras.

\section{Exposiciones a vapores de disolventes y fármacos potentes}

La exposición de los trabajadores a vapores tóxicos de disolventes y fármacos potentes, como los polvos transportados por el aire, puede ser objeto de preocupación. Esta exposición se puede producir durante distintas operaciones de fabricación, que necesitan ser identificadas, evaluadas y controladas para garantizar la protección de los trabajadores. Los controles técnicos son los medios de control preferidos, debido a su eficacia y fiabilidad (Cole 1990; Naumann y cols. 1996). Los equipos cerrados de procesado y los sistemas de manipulación de materiales previenen las exposiciones de los trabajadores, mientras que la VAL y el EEP sirven de medidas complementarias. Es necesario aumentar el confinamiento de las instalaciones y del proceso para controlar los disolventes altamente tóxicos (p. ej., benceno, hidrocarburos clorados, cetonas) y los compuestos potentes, y el uso de respiradores de presión positiva (p. ej., de purificación por corriente de aire y admisión de aire) y de EPP cuando se manipulan y procesan disolventes muy tóxicos y fármacos potentes. Son preocupantes las operaciones en las que se generan altos niveles de vapores de disolventes (p. ej., composición, granulación y recubrimiento de comprimidos) y polvos (p. ej., secado, molturación y mezclado). Las salas estanco y de duchas, las prácticas de descontaminación y las buenas prácticas sanitarias (p. ej., lavado y duchas) son necesarias para prevenir o minimizar los efectos de las exposiciones de los trabajadores dentro y fuera del lugar de trabajo.

\section{Gestión de seguridad de los procesos}

En la industria farmacéutica se aplican programas de seguridad de los procesos debido a la complejidad de la química, la peligrosidad de los materiales y las operaciones en la fabricación de productos químicos a granel (Crowl y Louvar 1990). En ocasiones se utilizan materiales y procesos altamente peligrosos en reacciones de síntesis orgánica en varias etapas para producir el principio activo deseado. Deben evaluarse la termodinámica y la cinética de estas reacciones químicas, ya que pueden participar materiales altamente tóxicos y reactivos y compuestos lacrimógenos e inflamables o explosivos. La gestión de la seguridad de los procesos implica la realización de ensayos de los riesgos físicos de los materiales y reacciones, la organización de estudios de análisis de riesgos para revisar la química del proceso y las prácticas técnicas, el examen del mantenimiento preventivo y la integridad mecánica del equipo y servicios del proceso, la formación de los trabajadores y la elaboración de instrucciones de trabajo y procedimientos de respuesta de emergencia. Las características técnicas especiales para la seguridad del proceso incluyen la selección de recipientes a presión adecuados, los sistemas de aislamiento y supresión y la ventilación de seguridad para amortiguar la presión con tanques de captación. Las prácticas de gestión de la seguridad de los procesos son similares en las industrias farmacéutica y química cuando se fabrican productos farmacéuticos como productos químicos orgánicos (Crowl y Louvar 1990; Kroschwitz 1992).

\section{Aspectos medioambientales}

Cada uno de los procesos de fabricación farmacéutica tiene sus propios aspectos medioambientales, que se discuten a continuación.

\section{Fermentación}

La fermentación genera grandes volúmenes de residuos sólidos que contienen micelios y tortas de filtro (EPA 1995; Theodore y McGuinn 1992). Las tortas de filtro contienen micelios, medios filtrantes y cantidades pequeñas de nutrientes, productos intermedios y residuos. Estos residuos sólidos no son peligrosos, pero pueden contener disolventes y pequeñas cantidades de productos químicos residuales, en función de la química específica del proceso de fermentación. Se pueden producir problemas medioambientales si los lotes de fermentación son infectados por un fago viral que ataque los microorganismos en el proceso de fermentación. Aunque las infecciones por fagos son poco frecuentes, crean un problema medioambiental significativo al generar grandes cantidades de caldo residual.

El caldo de fermentación utilizado contiene azúcares, almidones, proteínas, nitrógeno, fosfatos y otros nutrientes con demanda bioquímica de oxígeno (DBO), demanda química de oxígeno (DQO) y sólidos totales suspendidos (STS) altos y valores de $\mathrm{pH}$ entre 4 y 8 . Se pueden tratar los caldos de fermentación mediante sistemas microbiológicos de aguas residuales después de homogeneizar el efluente para promover la operación estable del sistema de tratamiento. El vapor y pequeñas cantidades de productos químicos industriales (p. ej., fenoles, detergentes y desinfectantes) mantienen la esterilidad del equipo y de los productos durante la fermentación. Se extraen grandes volúmenes de aire húmedo de los fermentadores que contiene dióxido de carbono y olores que se pueden tratar antes de su emisión a la atmósfera.

\section{Síntesis orgánica}

Los residuos procedentes de la síntesis química son complejos debido a la variedad de materiales, reacciones y operaciones peligrosas (Kroschwitz 1992; Theodore y McGuinn 1992). Los procesos de síntesis orgánica pueden generar ácidos, bases, licores acuosos o de disolventes, cianuros y residuos metálicos en forma líquida o de suspensión. Los residuos sólidos pueden incluir tortas de filtro con sales inorgánicas, subproductos orgánicos y complejos metálicos. Los disolventes residuales de la síntesis orgánica se recuperan por destilación y extracción. De esta forma se pueden reutilizar en otros procesos y se reduce el volumen de residuos líquidos peligrosos a eliminar. Los residuos de la destilación (residuos de alambique) requieren un tratamiento antes de su eliminación. Uno de los sistemas típicos de tratamiento es el burbujeo de vapor para eliminar los disolventes, seguido del tratamiento microbiológico de otras sustancias orgánicas. Se deben controlar las emisiones de sustancias volátiles orgánicas y peligrosas durante las operaciones de síntesis orgánica mediante dispositivos de control de la contaminación del aire (p. ej., condensadores, purificadores, impactadores venturi).

El agua residual de las operaciones de síntesis puede contener licores acuosos, aguas de lavado, descargas de bombas, purificadores y sistemas de refrigeración, y fugas y vertidos (EPA 1995); esto es, muchas sustancias orgánicas e inorgánicas con distintas composiciones químicas, toxicidad y biodegradabilidad. En las aguas madre acuosas de cristalizaciones y aguas de lavado de las extracciones y de la limpieza del equipo pueden estar presentes cantidades traza de materias primas, disolventes y subproductos. 
Estas aguas residuales contienen DBO, DQO y STS altos, con acidez o alcalinidad variables y valores de $\mathrm{pH}$ de 1 a 11 .

\section{Extracción biológica y natural}

Las materias primas y los disolventes utilizados, las aguas de lavado y los vertidos son las fuentes principales de residuos sólidos y líquidos (Theodore y MacGuinn 1992). En estos flujos residuales pueden estar presentes como residuos productos químicos orgánicos e inorgánicos. En general, las aguas residuales tienen DBO, DQO y STS bajos, con valores de $\mathrm{pH}$ entre 6 y 8.

\section{Fabricación de formas galénicas}

La fabricación de formas galénicas genera residuos sólidos y líquidos durante la limpieza y la esterilización, y a partir de fugas, vertidos y productos rechazados (Theodore y McGuinn 1992). Las operaciones de secado, molturación y mezclado generan emisiones de polvo atmosférico, que pueden ser controladas y recicladas a la fabricación de formas galénicas; no obstante, las prácticas de control de calidad pueden prevenirlo si están presentes otros residuos. Cuando se utilizan disolventes durante la granulación húmeda, la composición y el recubrimiento de los comprimidos, se pueden liberar COV y contaminantes atmosféricos peligrosos a la atmósfera o en el lugar de trabajo como emisiones del proceso o fugas. Las aguas residuales pueden contener sales inorgánicas, azúcares, jarabes y trazas de principios activos y en general tienen DBO, DQO y STS bajos, con valores de $\mathrm{pH}$ neutros. Algunos fármacos antiparasitarios o antiinfecciosos para humanos y animales pueden ser tóxicos para los organismos acuáticos, siendo necesario un tratamiento especial de los residuos líquidos.

\section{Prevención de la contaminación medioambiental}

Minimización de los residuos y prevención de la contaminación Las buenas prácticas técnicas y administrativas minimizan el impacto medioambiental de la producción de productos químicos a granel y las operaciones de fabricación farmacéutica. Para prevenir la polución se modifican los procesos y equipos, se reciclan y recuperan los materiales y se mantienen buenas prácticas de servicio y trabajo (Theodore y McGuinn 1992). Estas actividades estimulan la gestión de los aspectos medioambientales, así como la salud y la seguridad de los trabajadores.

\section{Modificaciones de los procesos}

Se pueden modificar los procesos con objeto de formular nuevamente los productos utilizando materiales menos peligrosos o persistentes o modificando las operaciones de fabricación para reducir las emisiones a la atmósfera, los efluentes líquidos y los residuos sólidos. La reducción de la cantidad y la toxicidad de residuos es prudente, ya que mejora la eficiencia de los procesos de fabricación y reduce los costes y el impacto de la eliminación de residuos. Las disposiciones sobre autorización de fármacos pueden limitar la capacidad de los fabricantes farmacéuticos para modificar los materiales peligrosos, los procesos de fabricación, los equipos y las instalaciones (Spilker 1994). En una primera etapa, los fabricantes de medicamentos deben prever los impactos sobre el medio ambiente, la salud y la seguridad de la selección de materiales peligrosos y el diseño de procesos de fabricación. Cada vez es más difícil introducir modificaciones durante las últimas etapas del desarrollo de los fármacos, sin pérdidas de tiempo y gastos considerables.

Sería deseable desarrollar procesos de fabricación con disolventes menos peligrosos. Se prefieren el acetato de etilo, los alcoholes y la acetona a disolventes altamente tóxicos como el benceno, el cloroformo y el tricloroetileno. En la medida de lo posible, deben evitarse algunas sustancias debido a sus propiedades físicas, ecotoxicidad o persistencia en el medio ambiente (p. ej., metales pesados, cloruro de metileno) (Crowl y Louvar 1990). La sustitución de disolventes por lavados acuosos durante las filtraciones en la fabricación de productos químicos a granel reduce los residuos líquidos y las emisiones de vapor. Asimismo, la sustitución de soluciones de disolventes por soluciones acuosas durante el recubrimiento de los comprimidos reduce el impacto sobre el medio ambiente, la salud y la seguridad. La contaminación se previene mediante la mejora y automatización del equipo de procesado, así como mediante calibraciones, revisiones y un mantenimiento preventivo regulares. La optimización de las reacciones de síntesis orgánica aumenta los rendimientos del producto, disminuyendo a menudo la generación de residuos. Unos sistemas incorrectos o ineficaces de control de la temperatura, la presión y los materiales provocan reacciones químicas ineficaces, generando residuos sólidos, líquidos y gaseosos adicionales.

Algunos ejemplos de modificaciones de procesos en la producción farmacéutica a granel son los siguientes (Theodore y McGuinn 1992):

- Minimizar las cantidades de materiales peligrosos utilizadas y seleccionar materiales cuyos residuos se puedan controlar, recuperar y reciclar, cuando sea posible.

- Desarrollar e instalar sistemas de reciclado de materias primas (p. ej., disolventes), productos intermedios, residuos y materiales de servicio (p. ej., agua refrigerante, líquidos de transferencia de calor, lubricantes, vapores condensados).

- Examinar reactivos, disolventes y catalizadores para optimizar la eficacia de las reacciones químicas.

- Modificar el diseño y las características del equipo de procesado para minimizar la contaminación y los residuos.

- Mejorar los procesos para optimizar los rendimientos del producto y propiedades deseadas, eliminando el procesado adicional (p. ej., recristalización, secado y molturación).

- Considerar la utilización de equipos universales (p. ej., reactores, filtros y secadores) para reducir la contaminación y los residuos durante las transferencias, la limpieza y otras etapas del proceso.

- Utilización de instrumentos adecuados, sistemas de control automatizados y programas informáticos para maximizar la eficiencia de los procesos y reducir la contaminación y los residuos.

\section{Recuperación de recursos y reciclado}

La recuperación de recursos utiliza productos de desecho y regenera materiales durante el procesado separando las impurezas de los residuos de los materiales deseados. Se pueden añadir residuos sólidos de la fermentación (p. ej., micelios) a piensos animales como suplemento nutricional o como acondicionantes y fertilizantes del suelo. Asimismo se pueden recuperar sales inorgánicas de licores químicos producidos durante las operaciones de síntesis orgánica. A menudo se reciclan mediante separación y destilación los disolventes consumidos. Los dispositivos de control de las emisiones a la atmósfera (p. ej., condensadores, equipo de compresión y refrigeración) reducen las emisiones de compuestos orgánicos volátiles (EPA 1993). Estos dispositivos capturan vapores de disolventes mediante condensación, permitiendo la reutilización de disolventes como materias primas o para la limpieza de recipientes y equipos. Los purificadores neutralizan o absorben gases y vapores ácidos, cáusticos y solubles, descargado sus efluentes en los sistemas de tratamiento de residuos.

Los disolventes reciclados se pueden reutilizar como medios para reacciones y extracciones y para operaciones de limpieza. No deben mezclarse diferentes tipos de disolventes, ya que esto reduce la posibilidad de reciclado. Algunos disolventes deben 
separarse durante el procesado (p. ej., disolventes clorados y no clorados, alifáticos y aromáticos, acuosos e inflamables). Los sólidos disueltos y suspendidos se extraen o separan de los disolventes antes de recuperar éstos. Se identifican la composición y las propiedades de los disolventes residuales y las materias primas recicladas mediante análisis de laboratorio. Actualmente se desarrollan muchas nuevas tecnologías de prevención y control de residuos sólidos, líquidos y gaseosos.

\section{Prácticas generales de servicio y trabajo}

Los procedimientos de trabajo escritos, las instrucciones sobre manipulación del material y las prácticas de gestión de residuos reducen la generación de residuos y mejoran su tratamiento (Theodore y McGuinn 1992). Las buenas prácticas de trabajo y servicio identifican las responsabilidades específicas respecto a la generación, manipulación y tratamiento de residuos. Mediante la formación y supervisión del personal se aumenta su capacidad para mejorar y mantener operaciones eficientes de fabricación y gestión de residuos. Se debe formar a los trabajadores sobre los riesgos de las prácticas de gestión de residuos y los medios apropiados para responder a los vertidos, fugas y emisiones. Esta formación debe abordar la manipulación de materiales, la limpieza o neutralización de residuos y la utilización de respiradores y EPP. Los dispositivos de detección de vertidos y fugas previenen la contaminación controlando regularmente el equipo y los servicios de producción, identificando y controlando las emisiones y las fugas. Estas actividades deben integrarse en prácticas de mantenimiento preventivo para limpiar, calibrar, sustituir y reparar el equipo contaminante.

Mediante instrucciones escritas que describan los procedimientos normales de trabajo, así como los procedimientos de puesta en marcha, parada y emergencia, se previene la contaminación y se reducen los riesgos para la salud y la seguridad de los trabajadores. Una gestión cuidadosa de las existencias de materiales disminuye los excesos en la adquisición de materias primas y generación de residuos; la aplicación de sistemas informáticos mejora la gestión eficaz de las operaciones de la planta, las prácticas de mantenimiento y los inventarios de material. Se pueden instalar sistemas de pesada automática, control y alarma para mejorar la gestión de materiales y equipos (p. ej., tanques de almacenamiento, equipos de procesado y sistemas de tratamiento de residuos). Los instrumentos y sistemas de control modernos aumentan a menudo la productividad de las operaciones, reduciendo la contaminación y los riesgos para la salud y la seguridad. Los programas de prevención de la contaminación examinan todos los residuos generados en una instalación y las opciones para eliminarlos, reducirlos o tratarlos. Las auditorías medioambientales estudian los puntos fuertes y débiles de los programas de prevención de la contaminación y gestión de residuos, con vistas a optimizar sus resultados.

\section{Referencias}

Agius, R. 1989. Occupational exposure limits for therapeutic substances. Ann. Occ. Hyg. 33: 555-562.

Anastas, MY. 1984. Engineering and Other Health Hazard Controls in Oral Contraceptive Tablet-Making Operations. NIOSH, NTIS Pub. No. PB-85-220739. Cincinnati, Ohio: NIOSH.

Burton, DJ, E Shumnes. 1973. Health Hazard Evaluation USDHEW (NIOSH) Report 71-9-50. Cincinnati, Ohio: NIOSH.

Cole, G. 1990. Pharmaceutical Production Facilities: Design and Applications. Chichester, West Sussex: Ellis Horwood Ltd.

Conferencia Americana de Higienistas Industriales del Gobierno (ACGIH). 1995. Threshold Limit Values (TLVs) for Chemical Substances and Physical Agents and Biological Exposure Indices (BEIs). Cincinnati, Ohio: ACGIH

Crowl, D, J Louvar. 1990. Chemical Process Safety: Fundamentals with Applications. Englewood Cliffs, Nueva Jersey: Prentice Hall

Dunn, CW. 1940. Stilbestrol-induced gynecomastia in the male. JAMA 115:2263.

Environmental Protection Agency (EPA). 1993. Control of Volatile Organic Compound Emissions from Batch Processes. EPA453/R-93-017. Washington, DC: US EPA, Office of Air Quality.

- 1995. Development Document for Proposed Effluent Limi tations Guidelines and Standards for the Pharmaceutical Manufacturing Point Source Category. EPA-821-R-95019. Washington, DC: US EPA, Office of Water.

Fisk, GH. 1950. Oestrogen absorption and toxicity in male workers in a chemical plant. Can Med Assoc f 62:285

Fitzsimons, MP. 1944. Gynecomastia in Stilbestrol Workers. Brit f Ind Med 1:235.

Gambini, G, G Farine, G Arbosti. 1976. Estroprogestin syndrome in a worker engaged in the production of a contraceptive drug. Medicine Lavoro 67(2): 152-157.

Gennaro, A. 1990. Remington's Pharmaceutical Sciences, 18 edición. Easton, Pensilvania: Mack Publishing Company.
Goldzieher, MA, JW Goldzieher. 1949. Toxic effect of percutaneously absorbed estrogens. FAMA 140:1156.

Hardman, JA Gilman, L Limbird. 1996. Goodman and Gilman's The Pharmacologic Basis of Therapeutics. Nueva York: McGraw Hill Co.

Hoover, RH. 1980. Association of exogenous estrogen and cancer in humans. En Estrogens in the Environment, dirigido por JA McLachlan. Nueva York. Elsevier/North-Holland.

Houghton, DL, L Ritter. 1995. Organochlorine residues and risk of breast cancer. $7 \mathrm{Am}$ College of Toxic 14(2):71-89.

Katzenellenbogen, I. 1956. A dermatoendocrinological syndrome and problems connected with the production and use of stilbestrol. Harefuah 50:239.

Klavis, G. 1953. Casuistic report concerning deficiency symptoms of working with stilbestrol. 7 of Occup Med And Occup Safety 4:46-47.

Kroschwitz, J. (dir.). 1992. Kirk-Othmer Encyclopedia of Chemical Technology. Nueva York: Wiley Interscience.

Medical Economics Co. 1995. Physician's Desk Reference, 49 edición. Montvale, Nueva Jersey: Medical Economics Co.

Meyer, CR, D Peteet, M. Harrington, 1978. Health Hazard Evaluation Determination. USDHEW (NIOSH) HE 77-75-494. Cincinnati, Ohio: NIOSH

National Research Council. 1981. Prudent Practices for Handling Hazardous Chemicals in Laboratories. Washington, DC: National Academy Press.

Naumann, B, EV Sargent, BS Starkman, WJ Fraser, GT Becker, GD Kirk. 1996. Performance-based exposure control limits for pharmaceutical active ingredients Am Ind Hyg Assoc 7 57: 33-42. 1996.

Organización Internacional del Trabajo (OIT). 1983 Enciclopedia de salud y seguridad en el trabajo, $3^{a}$ edición. Ginebra. OIT.

Pacynski, A, A Budzynska, S Przylecki, J Robaczynski. 1971. Hyperestrogenism in workers in a pharmaceutical establishment and their children and occupational disease. Polish Endocrinology 22:125.
Pagani, C. 1953. Hyperestrinic syndromes of exogenic origin. Annali di Ostetrica e Gynecologia 75:1173-1188.

Perry, R. 1984. Perry's Chemical Engineers' Handbook. McGraw- Hill Inc. Nueva York, Nueva York. 1984.

Reynolds, J. 1989. Martindale's: The Extra Pharmacopoeias, 29 edición. Londres: Pharmaceutical Press.

Sargent, E, G Kirk. 1988. Establishing airborne exposure control limits in the pharmaceutical industry. Am Ind Hyg Assoc f 49:309-313.

Scarff, RW, CP Smith. 1942. Proliferative and other lesions of the male breast. Brit f Surg 29:393.

Spilker, B. 1994. Multinational Pharmaceutical Companies: Principles and Practices, $2^{\mathrm{a}}$ edición. Nueva York: Raven Press.

Stoppleman, MRH, RA van Valkenburg. 1955. Pigmentation and gynecomastia in children caused by hair lotion containing stilbestrol. Dutch ff Med 99:2935-2936

Suciu, I, V Lazar, I Visinescu, A Cocirla, O Zegreanu, A Sin, Z Lorintz, G Resu, A Papp. 1973. Concerning certain neuro-endocrine modifications during the preparation of acetoxyprogesterone. Arch mal prof méd trav sécur soc. 34:137-142.

Swarbick, J, J Boylan (dirs.). 1996. Encyclopedia of Phar maceutical Technology. Nueva York: Marcel Dekker, Inc.

Tanaka, S, D Zaebst. 1984. Occupational Exposure to Estrogens: A Report of Two Pilot Medical and Industrial Hygiene Surveys. Cincinnati, Ohio: NIOSH.

Teichman, R, F Fallon, P Brandt-Rauf. 1988. Health effects on workers in the pharmaceutical industry: A review. 7 Soc Occ Med 38: 55-57.

Theodore, L, Y McGuinn. 1992. Pollution Prevention. Nueva York: Van Nostrand Reinhold.

Watrous, RM, RT Olsen. 1959. Diethylstilbestrol absorption in industry: A test for early detection as an aid in prevention. Am Ind Hyg Assoc 7 20:469.

Watrous, RM. 1947. Health hazards of the pharmaceutical industry. Brit f Ind Med 4:111.

Zaebst, D, S Tanaka, M Haring. 1980. Occupational exposure to estrogens: Problems and approaches. En Estrogens in the Environment, dirigido por JA McLachlan. Nueva York: Elsevier/North-Holland. 
Directores del capítulo

Louis D. Beliczky y John Fajen

\section{Sumario}

Perfil general

Louis S. Beliczky y fohn Fajen . . . . . . . . . . . . . . . . . 80.2

Gultivo del árbol del caucho

Alan Echt ...............

Fabricación de neumáticos

Fames S. Frederick . . . . . . . . . . . . . . . . . . . . . 80.4

Otros productos industriales

Ray C. Woodcock . . . . . . . . . . . . . . . . . . 80.8

1,3-butadieno

Ronald L. Melnick . . . . . . . . . . . . . . . . . . . 80.9

Controles de ingeniería

Ray C. Woodcock . . . . . . . . . . . . . . . . . . . . . . . 80.10

Seguridad

Fames $R$. Townhill . . . . . . . . . . . . . . . . 80.13

Estudios epidemiológicos

Robert Harris . . . . . . . . . . . . . . . . . . . . . . . . . . . . . 80.15

Dermatitis por contacto con caucho y alergia al látex

Fames S. Taylor y Yung Hian Leow . . . . . . . . . . . . . . . . 80.16

Ergonomía

William S. Marras. . . . . . . . . . . . . . . . . . . . . 80.17

Cuestiones ambientales y de salud pública

Thomas Rhodarmer ........................ 80.17 
PERfIL GENERAL

\section{Louis S. Beliczky y John Fajen}

En la industria del caucho se utilizan básicamente dos tipos de caucho: el natural y el sintético. Este último, obtenido a través de diferentes polímeros, sirve para la fabricación de una gran variedad de productos (véase la Tabla 80.1). El caucho natural se produce principalmente en el sudeste asiático, mientras que el sintético procede en su mayoría de países industrializados como Estados Unidos, Japón, Europa occidental y Europa oriental. Brasil es el único país en desarrollo que posee una industria importante de caucho sintético.

El $60 \%$ del caucho sintético y el $75 \%$ del caucho natural (Greek 1991) se destina a la fabricación de neumáticos y productos afines, que da empleo a casi medio millón de trabajadores en todo el mundo. Otras aplicaciones importantes del

Tabla 80.1 • Principales polímeros del caucho.

\begin{tabular}{|c|c|c|}
\hline $\begin{array}{l}\text { Tipo de caucho/ } \\
\text { Elastómero }\end{array}$ & \multicolumn{2}{|c|}{$\begin{array}{l}\text { Producción } \\
\text { (en miles de toneladas en } 19\end{array}$} \\
\hline Caucho natural & $\begin{array}{l}\text { Tailandia } \\
\text { Indonesia } \\
\text { Malasia } \\
\text { India }\end{array}$ & $\begin{array}{r}1.501 \\
1.353 \\
923 \\
426\end{array}$ \\
\hline Polisopreno (IR) & $\begin{array}{l}\text { EE.UU. } \\
\text { Europa occidental } \\
\text { Japón }\end{array}$ & $\begin{array}{l}47 \\
15 \\
52\end{array}$ \\
\hline Estireno-butadieno (SBR) & $\begin{array}{l}\text { EE.UU. } \\
\text { Europa occidental } \\
\text { Japón }\end{array}$ & $\begin{array}{r}920 \\
1.117 \\
620\end{array}$ \\
\hline Polibutadieno (BR) & $\begin{array}{l}\text { EE.UU. } \\
\text { Europa occidental } \\
\text { Japón } \\
\text { Europa oriental }\end{array}$ & $\begin{array}{r}465 \\
297 \\
215 \\
62\end{array}$ \\
\hline Butilo (IIR) & $\begin{array}{l}\text { EE.UU. } \\
\text { Europa occidental } \\
\text { Europa oriental } \\
\text { Japón }\end{array}$ & $\begin{array}{r}130 \\
168 \\
90 \\
83\end{array}$ \\
\hline $\begin{array}{l}\text { Etilenpropileno/ } \\
\text { Etilen- } \\
\text { propilen- } \\
\text { dieno }\end{array}$ & $\begin{array}{l}\text { EE.UU. } \\
\text { Europa occidental } \\
\text { Japón }\end{array}$ & $\begin{array}{l}261 \\
201 \\
124\end{array}$ \\
\hline $\begin{array}{l}\text { Policloropreno (CR) } \\
\text { (neopreno) }\end{array}$ & $\begin{array}{l}\text { EE.UU. } \\
\text { Europa occidental } \\
\text { Japón }\end{array}$ & $\begin{array}{r}105 \\
102 \\
74\end{array}$ \\
\hline
\end{tabular}

Propiedades Usos comunes

Usos generales; no resistente al aceite, se hincha con los disolventes; no resistente al oxígeno, ozono y luz UV

426

\begin{tabular}{|c|}
\hline $\begin{array}{l}\text { Usos generales; no resistente al aceite, se } \\
\text { hincha con los disolventes; no resistente al } \\
\text { oxígeno, ozono y luz UV }\end{array}$ \\
\hline
\end{tabular}

$\begin{array}{llr}\text { Nitrilo (NBR) } & \text { EE.UU. } & 64 \\ & \text { Europa occidental } & 108 \\ & \text { Japón } & 70 \\ & \text { Europa oriental } & 30\end{array}$

$\begin{array}{llr}\text { Silicona (MQ) } & \text { EE.UU. } & 95 \\ & \text { Europa occidental } & 107 \\ & \text { Japón } & 59 \\ & & \\ \text { Polisulfuros (OT) } & \text { EE.UU. } & 20 \\ & \text { Europa occidental } & 0 \\ & \text { Japón } & 3\end{array}$

Caucho reciclado

\section{Usos generales; caucho natural sintético, propiedades similares}

Usos generales; sustituyó al caucho natural durante la segunda Guerra Mundial; baja resistencia al aceite y disolventes

Baja resistencia al aceite y disolventes; no resistente a la intemperie, alta resiliencia, resistencia a la abrasión y flexibilidad a baja temperatura

Baja permeabilidad al gas; resistente a calor, ácidos y líquidos polares; no resistente al aceite y disolventes; resistencia moderada a la intemperie

Flexibilidad a baja temperatura; resistente o la intemperie y al calor pero no al aceite, o a los disolventes; excelentes propiedades eléctricas

Resistente al aceite, llamas, calor e intemperie

Resistente al aceite, disolventes y aceite vegetal; se hincha con disolventes polares como las cetonas

Estable a temperaturas altas y bajas; resistente al aceite, disolventes e intemperie; fisiológica y químicamente inerte

Resistente al aceite, disolventes, bajas temperaturas e intemperie; baja permeabilidad al gas

Cadenas poliméricas más cortas; mayor facilidad de procesamiento; menor tiempo de mezclado y menor consumo de energía; menor resistencia a la tracción y menor coste
Neumáticos, soportes elásticos, burletes, acoplamientos, soportes de puentes y para la construcción , calzado, mangueras, correas transportadoras, productos moldeados, revestimientos, rodillos, guantes, preservativos, dispositivos sanitarios, pegamentos, tejidos de fondo para alfombras, hilos, espuma

Véase Caucho natural (párrafo anterior).

Neumáticos (75\%), correas transportadoras, esponjas, productos moldeados, calzado, mangueras, recubrimientos de rodillos, pegamentos, productos impermeables, forros de alfombra de látex, productos de espuma

Neumáticos, calzado, correas transportadoras, correas de transmisión, pelotas de juguete.

Interior de tubos, cámaras de vulcanizado de neumáticos, calafateo y selladores, aislamiento de cables, aisladores vibracionales, revestimiento protector de estanques y membranas para tejados, correas transportadoras y mangueras para alta temperatura

Recubrimientos de cables; desfibradores y burletes extruidos; productos moldeados; juntas aislantes; recubrimientos para silos, tejados, estanques, zanjas y vertederos controlados

Recubrimientos de cables, mangueras, correas transportadoras, calzado, ropa impermeable, teijdos recubiertos y productos inflables, extruídos, pegamentos, soportes de puente y raíl, revestimientos, juntas de esponja, productos de espuma de látex

Sustancias taponadoras, recubrimientos y juntas para mangueras resistentes a combustibles, camisas de rodillos, correas transportadoras, suelas de zapatos, guantes, pegamentos, equipos de perforación para pozos petrolíferos

Aislamiento de cables, burletes, pegamentos, juntas, productos moldeados y extruídos, mascarillas de gas y respiradores, tubos para alimentación y sanitarios, implantes quirúrgicos

Camisas de rodillos, revestimientos de mangueras, juntas, productos moldeados, taponadores, diafragmas para gasómetros, selladores de vidrio, aglomerante sólido de combustible para cohetes

Neumáticos, interior de tubos, felpudos, productos mecánicos, pegamentos, asfalto cauchutado 
Tabla 80.2 • Consumo mundial de caucho en 1993.

\begin{tabular}{lcc}
\hline Región & $\begin{array}{c}\text { Caucho sintético } \\
(1.000 \text { toneladas) }\end{array}$ & $\begin{array}{c}\text { Caucho natural } \\
\text { (1.000 toneladas }\end{array}$ \\
\hline Norteamérica & 2.749 & 999 \\
Europa occidental & 2.137 & 930 \\
Asia y Oceanía & 1.849 & 2.043 \\
América Latina & 575 & 260 \\
Centroeuropa & 215 & 65 \\
Commonwealth de & 1.665 & 100 \\
$\quad$ Estados Independientes & & \\
Oriente Próximo y Africa & 124 & 162 \\
China y Asia* & 453 & 750 \\
Total & 9.767 & 5.309
\end{tabular}

*Incluye China, Corea del Norte y Vietnam.

Fuente: Instituto Internacional de Fabricantes de Caucho Sintético 1994.

caucho son la fabricación de correas y manguitos para vehículos, guantes, preservativos y calzado de goma.

En los últimos tiempos, la industria del caucho ha experimentado un proceso de mundialización. Al tratarse de una industria que utiliza un gran volumen de mano de obra, se encuentra en expansión en los países en desarrollo. En la Tabla 80.2 se muestra el consumo mundial de caucho natural y sintético en 1993.

\section{- Gultivo Del ARbol Del GaUGHo}

Alan Echt

El caucho natural (cis-1,4-polisopreno) es un producto vegetal procesado que se obtiene de la savia de varios centenares de especies de árboles y plantas existentes en distintas partes del mundo, en especial en el Africa ecuatorial, el sudeste asiático y Sudamérica. La savia de aspecto lechoso o látex que se obtiene del árbol Hevea brasiliensis cubre más del $99 \%$ del consumo mundial de caucho natural. Este producto también puede obtenerse del Ficus elastica y de otras plantas africanas que se cultivan en Costa del Marfil, Madagascar, Senegal y Sierra Leona. El trans-1,4-polisopreno natural, que se conoce como gutapercha o balata y se obtiene de árboles de Sudamérica e Indonesia, proporciona un caucho menos puro que el isómero cis. Otra fuente de caucho natural comercial es el arbusto Parthenium argentatum o guayule, que crece en regiones cálidas y áridas, como los Estados del suroeste de Estados Unidos.

El caucho procedente de la Hevea se cultiva en plantaciones de más de 100 acres pero también en pequeñas granjas de menos de 10. La productividad de los árboles del caucho comercial ha ido aumentando progresivamente desde el decenio de 1970, debido principalmente a la reforestación con árboles de crecimiento más rápido y mayor rendimiento, así como al uso de fertilizantes químicos y al control de las enfermedades del árbol del caucho. La adopción de medidas estrictas para controlar los riesgos de los herbicidas y pesticidas durante las operaciones de almacenamiento, mezclado y pulverización, el uso de ropa de protección adecuada y cremas barrera, la instalación de vestuarios, y una supervisión médica adecuada han permitido controlar de forma efectiva los riesgos asociados al uso de los productos químicos agrícolas.

El látex se obtiene practicando en la corteza del árbol del caucho una incisión en espiral en días alternos, aunque la frecuencia y el método pueden variar. El látex se recoge en vasos colgados del árbol, bajo la incisión, y a continuación se transfiere a cubos que se transportan a las estaciones de procesamiento. Por lo general, se añade amoníaco como conservante. El amoníaco rompe las partículas de caucho y produce un producto que forma dos fases con un 30 - $40 \%$ de parte sólida. Este producto se concentra hasta obtener un $60 \%$ de parte sólida, obteniéndose así un concentrado de látex amoniacal con un 1,6\% de amoníaco en peso. También existe un concentrado de látex con bajo contenido en amoníaco $(0,15-0,25 \%)$. Con el fin de evitar la coagulación y la contaminación, se añade a este concentrado un conservante secundario, como el pentaclorofenato sódico, el disulfuro de tetrametiltiuram, el dimetilditiocarbamato sódico o el óxido de zinc.

Los principales riesgos para los trabajadores de las plantaciones son la exposición a los elementos atmosféricos, las mordeduras de animales, las picaduras de insectos y los riesgos asociados al uso de las herramientas cortantes que se utilizan para hacer la incisión en el árbol. Las posibles heridas deben tratarse rápidamente para minimizar el riesgo de infección. Los riesgos atmosféricos y de plagas pueden reducirse con medidas preventivas y terapéuticas. En las plantaciones modernas se ha limitado la incidencia de enfermedades como la malaria o la gastroenteritis mediante la profilaxis, el control de los mosquitos y las medidas sanitarias.

Figura 80.1 • Un trabajador del caucho coagula el látex recogido colocándolo sobre un palo y manteniéndolo sobre el humo que emana de un recipiente.

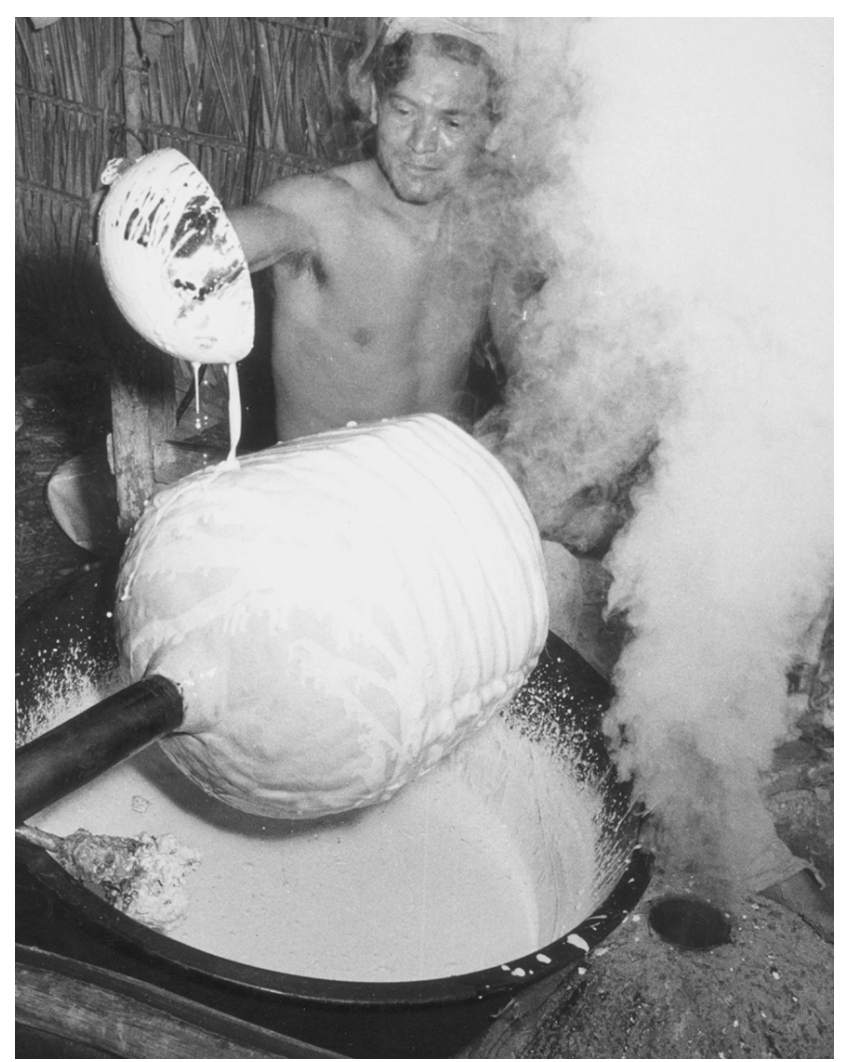


El arbusto denominado guayule, planta nativa del sur de Texas y del centro y norte de México, contiene caucho natural en sus tallos y raíces, por lo que se recoge toda la planta.

El caucho extraído del guayule es prácticamente idéntico al de la Hevea, aunque con menor potencia clorofilica. Actualmente, el caucho extraído del guayule no representa una alternativa comercial viable al de la Hevea.

\section{Tipos de caucho natural}

Entre los diferentes tipos de caucho natural que se producen actualmente se encuentran las planchas estriadas ahumadas, el caucho de especificación técnica, los crepés, el látex, el caucho natural epoxidizado y el caucho natural termoplástico. Tailandia es el principal proveedor de planchas estriadas ahumadas, con casi la mitad de la producción mundial de caucho natural. El caucho de especificación técnica (que debe su nombre al hecho de que su calidad, especialmente su pureza y elasticidad, se determina mediante especificaciones técnicas, en vez de las especificaciones visuales convencionales) o caucho natural en bloque fue introducido en Malasia a mediados del decenio de 1960 y representa casi el 40-45 \% de la producción de caucho natural, siendo Indonesia, Malasia y Tailandia los principales proveedores de este tipo de caucho. En la actualidad, el caucho de crepé sólo representa una pequeña parte del mercado mundial de caucho natural. Ultimamente ha crecido el consumo mundial del látex de caucho natural, a causa principalmente de la mayor demanda de este tipo de productos como protección frente al virus del SIDA y a otros agentes patógenos transmitidos por la sangre. Los concentrados de látex se utilizan para la producción de pegamentos, tejidos de fondo de alfombras, espumas y productos como globos, guantes y preservativos. El caucho natural epoxidizado se obtiene tratando el caucho natural con perácidos y se utiliza como alternativa a algunos cauchos sintéticos. El caucho natural termoplástico, que se encuentra todavía en la fase inicial de desarrollo comercial, es resultado de la vulcanización dinámica parcial de mezclas de poliolefinas y caucho natural.

\section{Figura 80.2 • Procesamiento del caucho en una} plantación de Camerún oriental.

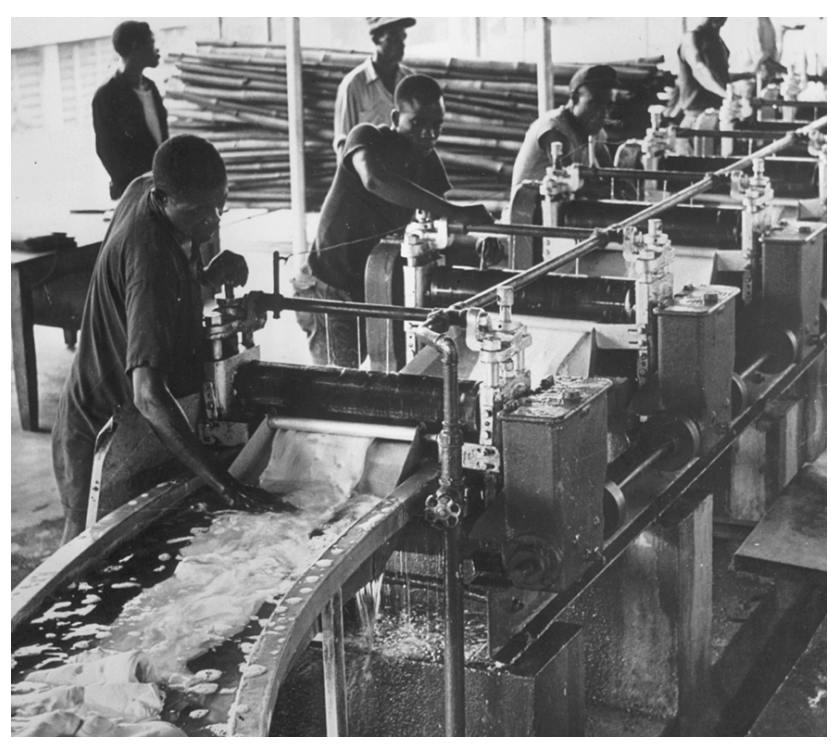

\section{Procesos de producción}

El látex obtenido del árbol puede comercializarse directamente en forma de concentrado o bien procesarse para obtener caucho seco (véanse las Figuras 80.1 y 80.2). Un método de fabricación del caucho de especificación técnica consiste en coagular el látex bruto con ácido y pasarlo después por las máquinas de cortado y por una serie de cilindros de crepado; a continuación, con una trituradora de martillos o un granulador, se convierte el producto en grumos de caucho que son tamizados, lavados, secados, embalados y acondicionados. Otro método de producción de caucho de especificación técnica consiste en añadir un agente disgregante antes de la coagulación, seguido de la trituración con cilindros de crepado.

Las planchas estriadas ahumadas se obtienen pasando el látex coagulado a través de una serie de cilindros, de los que salen planchas finas que se estampan con un patrón estriado para aumentar la superficie del material y mejorar su secado. Las planchas se tratan en un ahumador a 60 C durante una semana y a continuación se clasifican visualmente y se acondicionan en balas.

Las fórmulas de las mezclas de los compuestos que se utilizan en los cauchos naturales son básicamente las mismas que las que se emplean para la mayoría de los cauchos sintéticos no saturados. La presencia de aceleradores, activadores, antioxidantes, materiales de relleno, agentes plastificantes o vulcanizantes depende de las propiedades que se deseen obtener del compuesto final.

Para minimizar los riesgos derivados del empleo de métodos de producción mecanizados (cilindros, centrifugadoras, etc.), es necesario establecer un riguroso control de seguridad durante la instalación, funcionamiento y mantenimiento de las máquinas. Cuando se procesen productos químicos, deberán tomarse las precauciones adecuadas. Asimismo, se dedicará especial atención al calzado y a los suelos de las áreas de trabajo para evitar resbalones, tropezones y caídas. Los trabajadores deberán recibir una formación sobre técnicas de seguridad en el trabajo. Además, será necesaria una estricta supervisión para evitar accidentes al aplicar calor durante el proceso de vulcanización del caucho.

\section{FABRICAGION DE NEUMATICOS}

\section{James S. Frederick}

\section{Proceso de fabricación}

En la Figura 80.3 se ofrece un esquema del proceso de fabricación de neumáticos.

\section{Mezclado de compuestos y malaxador Banbury}

En el malaxador Banbury se introduce la mezcla de caucho, negro de humo y otros productos químicos para obtener un material de caucho homogéneo. El tiempo, el calor y las materias primas utilizadas son los factores decisivos en la composición del producto final. Por lo general, los ingredientes llegan a la planta en paquetes ya pesados o en cantidades a granel que son preparadas y pesadas allí por el técnico encargado del malaxador Banbury. Los ingredientes pesados se colocan en un transportador que los carga en el malaxador Banbury para iniciar el proceso de mezclado.

Para obtener el caucho para fabricar neumáticos se combinan cientos de componentes como, por ejemplo, activadores, antioxidantes, antiozonizantes, ceras para facilitar la extensión del caucho, vulcanizadores, pigmentos, plastificantes, arcillas para refuerzo y resinas. La mayoría de estos elementos no están 
Figura 80.3 • Proceso de fabricación de neumáticos.

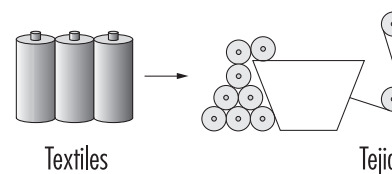

Tejido

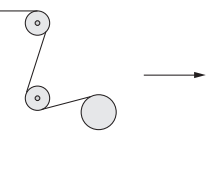

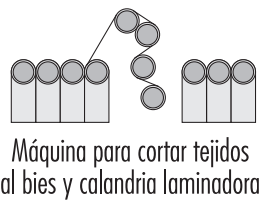

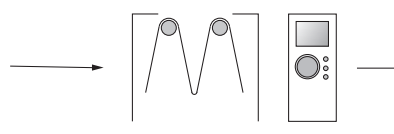

Máquina de moldeado de neumáticos

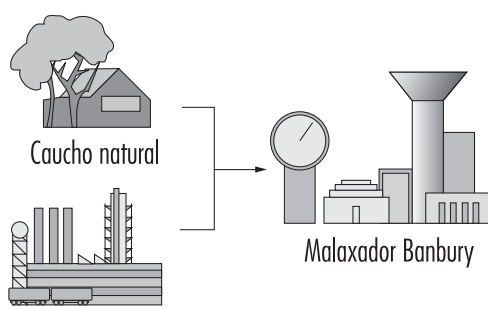

Productos químicos

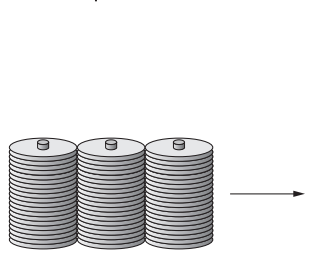

Acero
Talón, cinta, hilo metálico de refuerzo

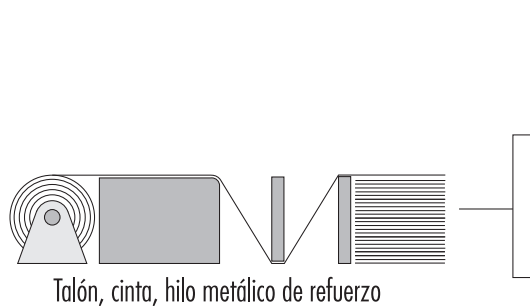

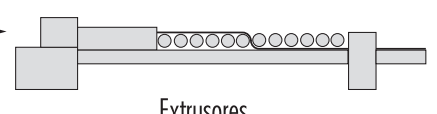

Extrusores

regulados y pueden no haber pasado unas evaluaciones toxicológicas serias. En general, las mejoras introducidas en el control legal y en el control de ingeniería han reducido los riesgos laborales asociados a las materias primas para los operarios de este tipo de malaxadores Banbury. Sin embargo, persisten ciertos riesgos derivados de la naturaleza y el volumen de los componentes utilizados.

Figura 80.4 - Laminador antiguo con una barra de seguridad situada a una altura excesiva para que resulte efectiva. Sin embargo, el operario lleva guantes de gran tamaño que protegerían sus manos en caso de que quedaran atrapadas entre los cilindros.

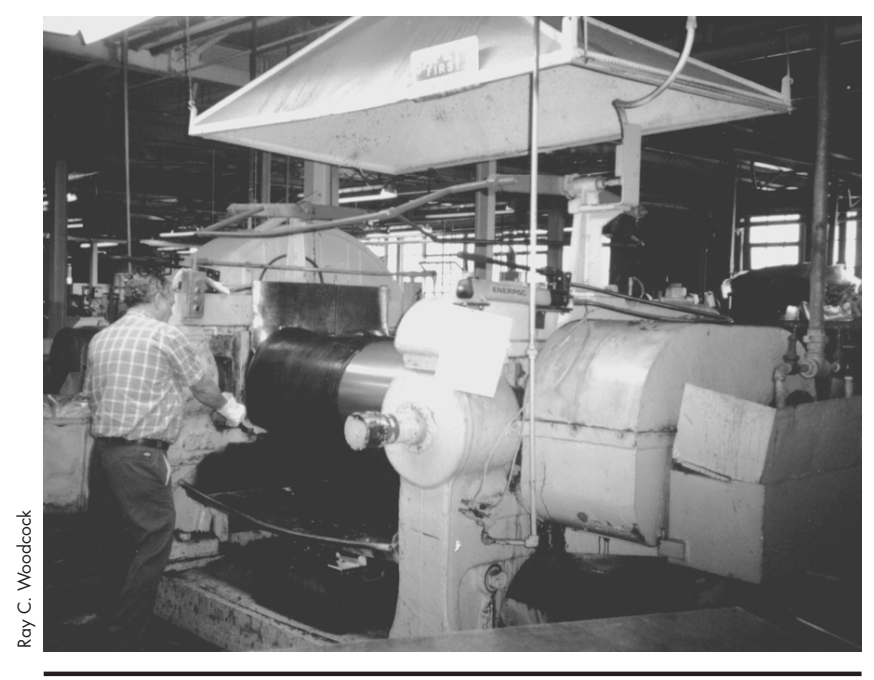

\section{Masticación}

El laminado del caucho comienza con el proceso de masticación. Una vez finalizado el ciclo de mezclado con el equipo Banbury, el caucho se coloca en un laminador. Este proceso transforma las placas de caucho en largas láminas al pasar a través de dos cilindros que giran en dirección opuesta y a diferentes velocidades.

Durante esta operación, los trabajadores están expuestos a los riesgos derivados del funcionamiento sin protección de los cilindros giratorios. Los laminadores más antiguos solían disponer de cables o barras que eran accionados por el operario si quedaba atrapado en el laminador (véase la Figura 80.4); los laminadores modernos disponen de barras a la altura de la rodilla que se activan automáticamente en caso de que un operario quede atrapado entre los cilindros (véase la Figura 80.5).

La mayoría de las instalaciones disponen de medidas de emergencia para los operarios que sufren accidentes en los laminadores. Estos trabajadores están expuestos al calor y al ruido, así como a las sustancias que se forman durante el calentamiento del caucho o que se desprenden de él (véase la campana de aspiración sobre un laminador en la Figura 80.6).

\section{Extrusores y calandrias}

Las calandrias, que se utilizan para producir láminas y perfiles a partir de las planchas de caucho, constan de uno o varios (a menudo cuatro) cilindros a través de los cuales se fuerzan las planchas de caucho (véase la Figura 80.5).

La calandria realiza las funciones siguientes:

- formar, a partir de la mezcla de caucho, una lámina uniforme, de grosor y anchura definidos;

- aplicar un recubrimiento fino de caucho sobre un tejido ("recubrimiento" o "nivelado"),

- introducir el caucho en los intersticios del tejido mediante fricción ("friccionamiento"). 
Figura 80.5 • Laminador de una línea de calandrias con una barra de seguridad a nivel del cuerpo que desconecta el equipo al ser accionada por el operario.

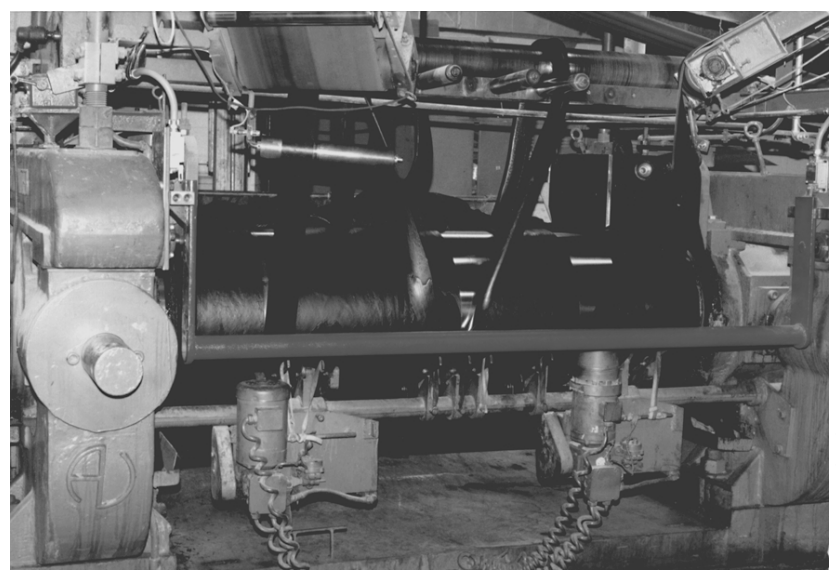

Las láminas de caucho que salen de la calandria se acondicionan en tambores con espaciadores denominados "separadores", que evitan que se adhieran entre sí.

El extrusor produce piezas de caucho en forma de tubo forzando su paso a través de una matriz del tamaño adecuado. El extrusor consta de tolva, cilindro, émbolo y matriz, y para formar la parte hueca del interior del tubo se utiliza un eje. El extrusor moldea la sección larga y plana de la banda de rodadura de los neumáticos.

Los operarios de extrusores y calandrias están expuestos al talco y a los disolventes que se utilizan en el proceso. Además, al final de la operación de extrusión, tienen que realizar la tarea altamente repetitiva de colocar las bandas de rodadura en carros de varios pisos. Esta operación recibe a menudo el nombre de 'encuadernar' las bandas de rodadura, porque el carro parece un libro y las bandejas las páginas. Tanto el diseño del extrusor como el peso y el volumen de las bandas de rodadura influyen

Figura 80.6 • Laminador y secador con campana de aspiración y cables de seguridad.

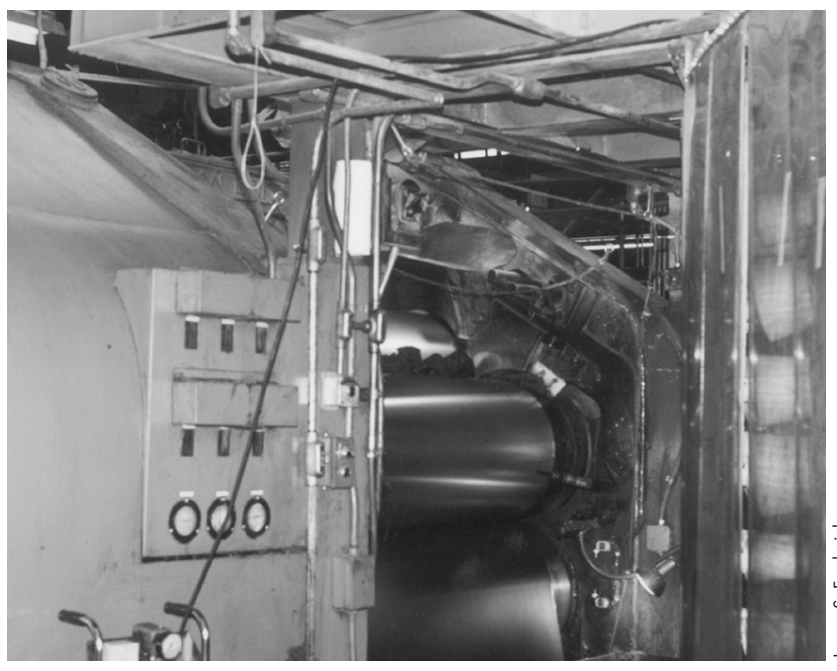

Figura 80.7 • Operario montando un neumático en una máquina monofase.

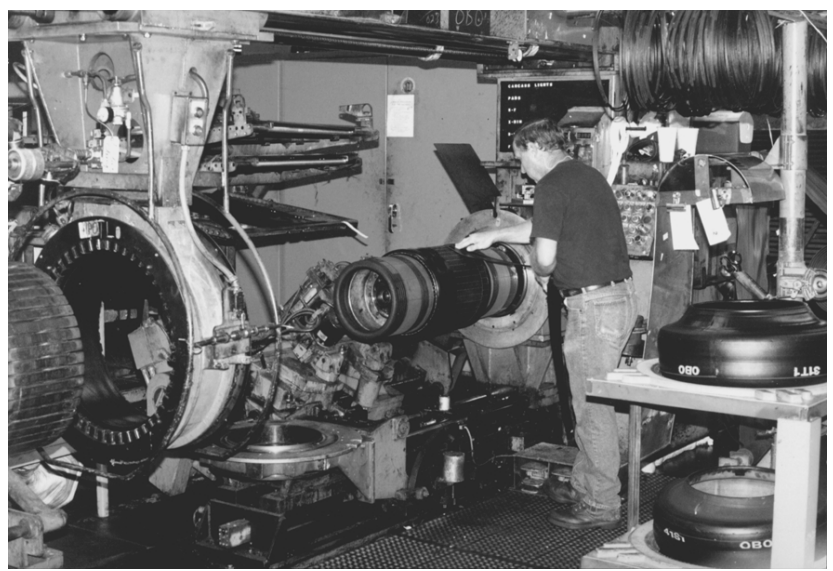

en el impacto ergonómico de esta operación. Para reducir dicho impacto se han realizado numerosas modificaciones e incluso se han automatizado algunas operaciones.

\section{Montaje de los componentes y moldeo}

El montaje de los neumáticos puede automatizarse en gran parte. La máquina de montaje de neumáticos consta de un tambor rotatorio donde se montan los componentes y de mecanismos que suministran al montador los componentes necesarios (talones, tejidos, flancos y bandas de rodadura) (véase la Figura 80.7). Una vez montado, el neumático recibe a menudo el nombre de "neumático verde".

Los montadores de neumáticos y otros operarios de esta fase del proceso tienen que realizar una serie de operaciones repetitivas. Los componentes, a menudo suministrados en rollos muy pesados, se colocan en la zona de alimentación del equipo de montaje, lo que exige el levantamiento y manejo de esos

Figura 80.8 - Prensa de vulcanizado con ventilador de techo Bag-o-matic McNeal para neumáticos de vehículos ligeros y camionetas Akron, Ohio (EE.UU.).

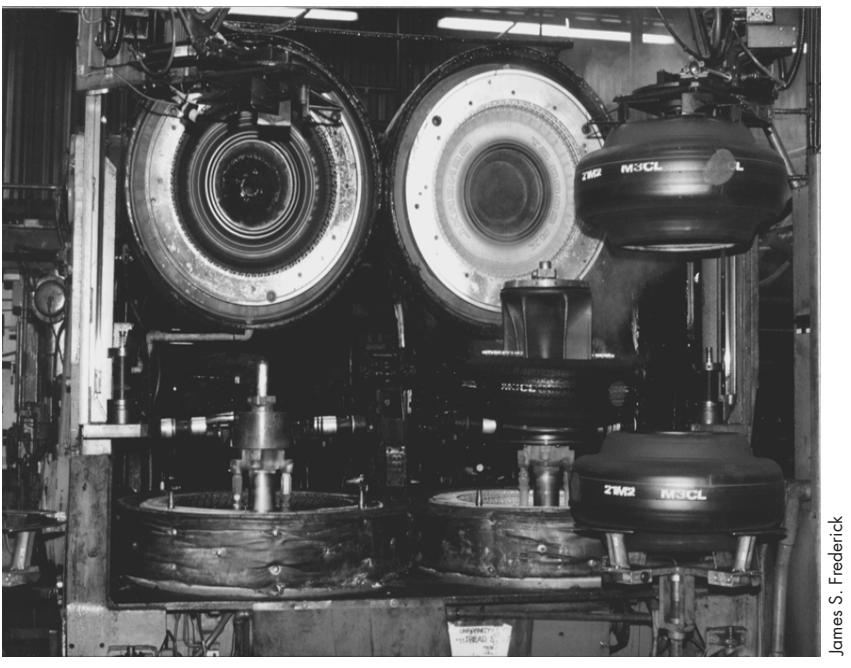


Figura 80.9 - Un colector de polvo de una muela abrasiva recoge el polvo de caucho.

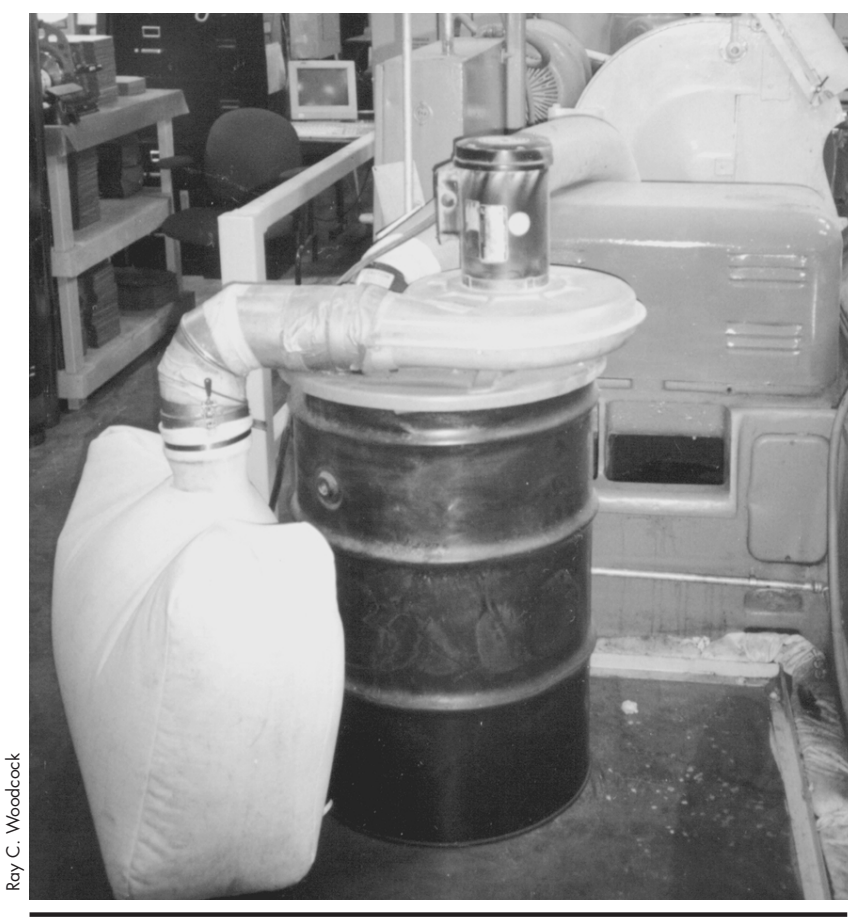

pesados rollos en un espacio limitado. La naturaleza de la operación requiere asimismo que el montador realice en cada montaje una serie de movimientos similares o idénticos. Los montadores de neumáticos utilizan disolventes como el hexano para pegar la banda de rodadura y el tejido de caucho. Uno de los factores de riesgo es la exposición a los disolventes.

Una vez montado, el neumático verde se rocía con un disolvente o un material soluble en agua para evitar que se adhiera al molde de vulcanización. Los disolventes representan un riesgo potencial para los operarios que realizan el rociado y que manejan el material y la prensa de vulcanización. Actualmente, los materiales más utilizados para este fin son los solubles en agua.

\section{Vulcanización}

El operario de la prensa de vulcanización coloca los neumáticos verdes en la prensa o en el cargador de la prensa. En Norteamérica existen prensas de vulcanización de distintas características, antigüedad y nivel de automatización (véase la Figura 80.8). En la prensa se utiliza vapor para calentar o vulcanizar el neumático verde. La vulcanización del caucho transforma un material pegajoso y flexible en otro no pegajoso, menos flexible y de larga duración.

Cuando se calienta el caucho durante la vulcanización o en fases anteriores del proceso, se forman $\mathrm{N}$-nitrosaminas carcinogénicas. Por ello, debe controlarse cualquier nivel de exposición a las N-nitrosaminas e intentar limitar al máximo el riesgo de exposición. Además, los polvos, gases, vapores y humos que se utilizan o se producen cuando se calienta o vulcaniza el caucho contaminan el entorno de trabajo.

\section{Inspección y acabado}

Después de la vulcanización y antes de que el neumático sea almacenado o expedido, se realizan las operaciones de acabado y de inspección. En la operación de acabado se recortan las rebabas de caucho del neumático procedentes de los orificios de ventilación del molde de vulcanización. Además, a veces es necesario pulir los sobrantes de caucho en los flancos o en las inscripciones del neumático.

Uno de los principales riesgos a que están expuestos los trabajadores cuando manipulan un neumático vulcanizado son los movimientos repetitivos. Además, en las operaciones de acabado o pulido de los neumáticos, los trabajadores se ven expuestos al polvo de caucho o a partículas (véase la Figura 80.9), que pueden causar enfermedades respiratorias. Un riesgo adicional reside en los disolventes de la pintura protectora que a menudo se utiliza para proteger los flancos o las inscripciones del neumático.

Una vez acabado, el neumático está listo para ser almacenado o expedido a su destino.

\section{Problemas de salud y seguridad}

Los problemas de salud y seguridad en las instalaciones de fabricación de neumáticos siempre han sido y siguen siendo de la mayor importancia. A menudo, el impacto de los accidentes graves puede encubrir enfermedades asociadas a las exposiciones en el puesto de trabajo. A causa de los prolongados períodos de latencia, algunas enfermedades no son evidentes hasta después de que el trabajador ha abandonado su trabajo. Ocurre que muchas enfermedades ocasionadas por exposiciones laborales en plantas de fabricación de neumáticos no llegan a relacionarse jamás con el trabajo realizado. Pero enfermedades como el cáncer siguen siendo frecuentes entre los trabajadores de plantas de caucho.

Se han realizado numerosos estudios científicos con trabajadores de fábricas de neumáticos. En algunos de ellos se ha identificado un incremento de la mortalidad por cáncer de vejiga, estómago, pulmón, hematopoyético o de otros tipos. Dicho incremento no suele atribuirse a un producto químico concreto, sino a exposiciones prolongadas a diferentes sustancias químicas y/o a una combinación simultánea de varias de ellas. A menudo se producen cambios en la formulación de los materiales utilizados en la fabricación de neumáticos. Estos cambios en el tipo y la cantidad de los componentes constituyen una dificultad adicional para la detección de los agentes causales.

Otro problema de los trabajadores de las plantas de fabricación de neumáticos son las enfermedades o irritaciones respiratorias (opresión en el pecho, disnea, reducción de la función pulmonar y otros síntomas respiratorios). El enfisema es una de las causas más comunes de jubilación anticipada. Estos problemas son más comunes en las áreas de vulcanización, procesamiento (premezclado, pesado, mezclado y calentamiento de materias primas) y acabado final (inspección). En las zonas de procesamiento y vulcanización las exposiciones químicas se deben a menudo a una gran cantidad de elementos a niveles de exposición relativamente bajos. Muchos de los componentes individuales a que están expuestos los trabajadores no están regulados por los organismos gubernamentales y en muchos casos ni siquiera se ha investigado adecuadamente su toxicidad o carcinogenicidad. En los Estados Unidos, los trabajadores de estas áreas de las fábricas de neumáticos no suelen estar obligados a utilizar protección respiratoria. Hasta el momento no ha sido identificada una causa evidente de estos problemas respiratorios.

Muchos trabajadores en este tipo de plantas sufren dermatitis de contacto, sin que muchas veces este hecho se haya podido relacionar con una sustancia en particular. Algunos de los productos químicos relacionados con la dermatitis han dejado de utilizarse en la fabricación de neumáticos en Norteamérica, pero muchos de los productos químicos sustitutivos no están evaluados completamente.

Otros problemas identificados en la fabricación de neumáticos son los trastornos crónicos o acumulativos, como la 
Figura 80.10 - Un elevador por vacío coloca las bolsas en el transportador de carga de un malaxador Banbury, evitando el dolor de espalda causado por la manipulación manual.

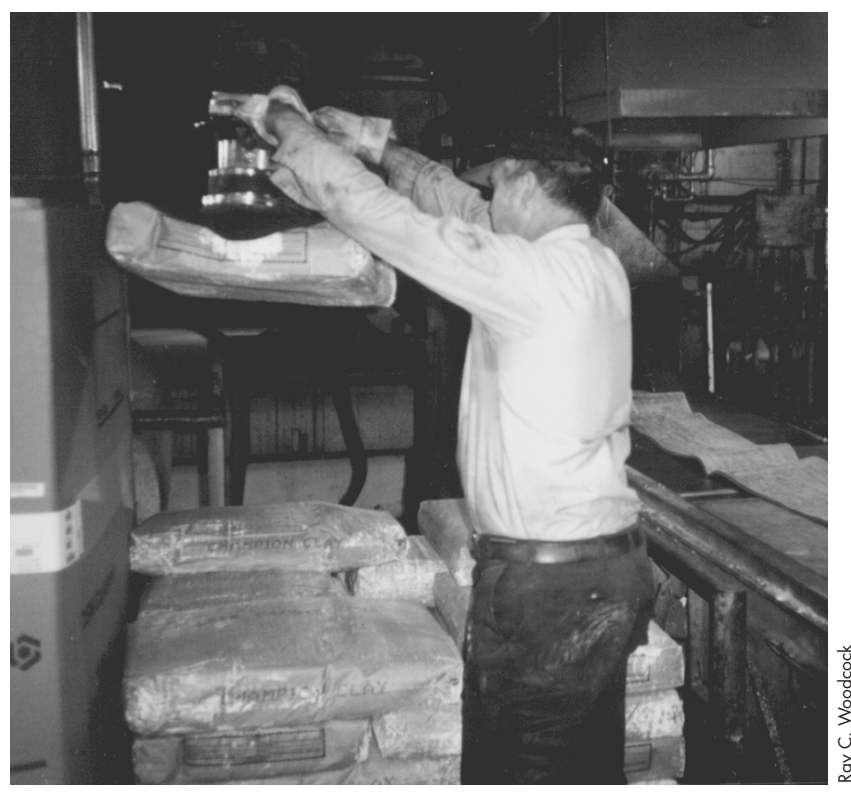

tenosinovitis, el síndrome del túnel carpiano, la sinovitis, la pérdida de audición por ruido y otros trastornos causados por movimientos, vibraciones o presiones repetitivos. El proceso de fabricación de neumáticos conlleva, intrínsecamente, que gran parte de los trabajadores de producción tengan que efectuar excesivas y múltiples manipulaciones de material y productos. En algunos países ya se han introducido y se siguen introduciendo numerosas mejoras para solucionar este problema. Muchas de ellas han sido iniciativa de los trabajadores o de comités conjuntos empresa-trabajadores. En algunos casos se han introducido controles de ingeniería para la manipulación de materiales y productos (véase la Figura 80.10).

Debido en parte a la reestructuración de las plantillas, en muchas plantas de fabricación de neumáticos la edad media de los trabajadores va en aumento. También hay cada vez más plantas de fabricación de este tipo que operan de forma continua. En muchas instalaciones se realizan turnos de 12 horas y/o turnos rotativos. Se está estudiando la posible relación entre turnos de trabajo ampliados, edad y trastornos acumulativos.

\section{OTROS PRODUGTOS INDUSTRIALES}

\section{Ray C. Woodcock}

El caucho tiene numerosas aplicaciones y en su producción intervienen procesos similares a los descritos para la fabricación de neumáticos. Sin embargo, en la fabricación de los productos industriales del caucho distintos de los neumáticos se utiliza una mayor variedad de polímeros y productos químicos que les confiere las propiedades necesarias (véase la Tabla 80.1). Los compuestos se diseñan cuidadosamente para reducir riesgos como la dermatitis y las nitrosaminas tanto durante la fabricación como en los productos que se utilizan en contacto directo con el cuerpo (material quirúrgico, respiradores, tetinas de biberones, etc.). A menudo se utilizan equipos de procesamiento de menor escala que en la fabricación de neumáticos y con un mayor recurso al mezclado de compuestos. Las cubiertas de tejado y las membranas para vertederos controlados se fabrican en las calandrias de mayor tamaño del mundo. Algunas empresas están especializadas en el mezclado de compuestos de caucho siguiendo las especificaciones de otras empresas, que después lo procesan para fabricar diferentes productos.

Los productos reforzados, como correas de transmisión, pastillas para frenos o calzado, se fabrican a partir de caucho tratado en calandrias o tejidos o cuerdas recubiertos en un tambor giratorio o en un molde estático. Normalmente, para darle la forma final, se somete a vulcanización en un molde a presión utilizando en algunos casos presión de vapor y una cámara de aire como para los neumáticos. En los productos industriales distintos de los neumáticos, se emplean polímeros sintéticos que no son tan pegajosos como el caucho natural, por lo que se utiliza más disolvente para limpiar y conferir adherencia a las capas compuestas. En algunos casos, no se requiere el proceso de masticación, el paso por las calandrias ni la aplicación de disolventes o adhesivos, sino que se pasa directamente del mezclador a un extrusor de émbolo cruzado para dar forma al producto.

Los productos no reforzados se tratan y vulcanizan mediante moldeo a presión o inyección. Después, se tratan por extrusión, se vulcanizan en una estufa de aire caliente y se les da forma en un molde de compresión a partir de un tocho precortado. El caucho para esponja se fabrica añadiendo al compuesto agentes que liberan gases al ser calentados.

Las mangueras de caucho se fabrican trenzando, tejiendo o enrollando cuerda o alambre reforzado sobre un tubo extruido ayudado por presión neumática o un mandril sólido, y extruyendo después encima un tubo de recubrimiento. A continuación, se coloca una cubierta de plomo extruido o un revestimiento cruzado de nylon sobre la manguera para el moldeo por compresión, que se elimina después de la vulcanización, o bien la manguera se coloca en la parte descubierta del vulcanizador con vapor a presión. Cada vez se está sustituyendo más el plomo por un revestimiento cruzado de nylon o plástico extruido. La manguera curva para automóviles se corta y se introduce en mandriles moldeadores para su vulcanización; en algunos casos se están utilizando robots para realizar este pesado trabajo manual. También existe un proceso en el que se emplean virutas de fibra como refuerzo y una matriz móvil en el extrusor para moldear la manguera.

Los adhesivos mezcla de caucho y disolvente se utilizan como recubrimiento de tejidos en una gran cantidad de productos. Entre los disolventes habituales se encuentran el tolueno, el acetato de etilo y el ciclohexano. En algunos casos, el tejido se sumerge en adhesivo fino y, en otros, se puede formar el caucho en capas de varias micras aplicando adhesivo de mayor espesor bajo el filo de una cuchilla por encima de un cilindro. La vulcanización se realiza en equipos de rotación continua o en estufas de aire caliente protegidas contra la explosión. En la actualidad se están desarrollando procesos de látex para sustituir a los adhesivos en el recubrimiento de tejidos.

Los adhesivos de caucho también se utilizan como pegamentos. Disolventes habituales para estos productos son el hexano, el heptano, la nafta y el 1,1,1-tricloroetano, aunque el hexano está siendo progresivamente sustituido por su toxicidad.

El látex es una suspensión muy alcalina de caucho natural o sintético en agua. Con él pueden moldearse guantes y globos o también puede esponjarse el compuesto de látex para fabricar tejidos de fondo para alfombras, extruirse en solución coagulante de ácido acético y lavarse para fabricar hilos o bien extender sobre los tejidos. El producto se seca y se vulcaniza en 


\section{Vulcanización en baño de sales}

El tratamiento en baño de sales es un método de vulcanizado líquido (MVL) dentro de los métodos habituales de vulcanización continua (VC) que se utilizan para la fabricación de productos como tubos, mangueras y burletes. El empleo de sales permite disponer de unidades de vulcanización de duración relativamente corta, presenta buenas propiedades de intercambio de calor y puede utilizarse a altas temperaturas (entre 177 y $260^{\circ} \mathrm{C}$ ). Además, la sal no produce oxidación superficial y es fácil de limpiar con agua. La vulcanización en baño de sales consta, como mínimo, de cuatro fases: alimentación del caucho a través de un extrusor refrigerado (o al vacío), paso por el baño de sales, aclarado/enfriado y, finalmente, cortado y procesado según la especificación correspondiente. En la primera fase, el extruído se sumerge en sal molida o se pulveriza con ella. La sal molida es una mezcla eutéctica (fácilmente fusible) de sales de nitrato y nitrito, con un $53 \%$ de nitrato potásico, un $40 \%$ de nitrito sódico y un $7 \%$ de nitrato sódico. Por lo general, el baño de sales se encuentra en un recinto cerrado con las puertas de acceso en un lateral y resistencias eléctricas en el otro.

La principal desventaja del baño de sales MVL es que forma nitrosaminas, sustancias supuestamente cancerígenas. Estas sustancias químicas se forman cuando un nitrógeno $(\mathrm{N})$ y un oxígeno $(\mathrm{O})$ de un compuesto "nitrosificante" se unen al grupo nitrógeno $(\mathrm{N})$ del grupo amino del compuesto aminado. Las sales de nitrato y nitrito utilizadas en el baño de sales actúan como agentes nitrosificantes y se unen con las aminas del compuesto de caucho para formar nitrosaminas. Entre los compuestos de caucho precursores de la nitrosamina se encuentran las sulfenamidas, las sulfenamidas secundarias, los ditiocarbamatos, los tiuramos y las dietilhidroxilaminas. Algunos compuestos del caucho contienen una nitrosamina como la nitrosodifenilamina (NDPhA), que actúa como retardante, o la dinitrosopentametilenetetramina (DNPT), que actúa como agente insuflante.
Estas nitrosaminas son ligeramente cancerígenas, pero pueden "trans-nitrosificarse", es decir, transferir sus grupos nitrosos a otras aminas para formar más nitrosaminas cancerígenas. Entre las nitrosaminas detectadas en operaciones de baño de sales se encuentran la nitrosodimetilamina (NDMA), la nitrosopiperidina (NPIP), la nitrosomorfolina (NMOR), la nitrosodietilamina (NDEA) y la nitrosopirrolidina (NPYR).

En Estados Unidos, tanto la Occupational Safety and Health Administration (OSHA) como la NIOSH consideran que la NDMA es un producto cancerígeno ocupacional, aunque ninguna de ellas ha fijado un límite de exposición. En Alemania existe una estricta normativa para la exposición profesional a las nitrosaminas: en la industria en general la exposición total a la nitrosamina no debe ser superior a $1 \mu \mathrm{g} / \mathrm{m}^{3}$. En determinados procesos, como la vulcanización del caucho, la exposición total a la nitrosamina no puede ser superior a $2,5 \mu \mathrm{g} / \mathrm{m}^{3}$

En operaciones de VC es posible evitar la formación de nitrosaminas reformulando los compuestos de caucho o utilizando un método de VC distinto del baño de sales, como aire caliente con perlas de vidrio o vulcanizado con microondas. Estas opciones requieren todavía una fase de investigación y desarrollo para poder garantizar que el producto final dispone de las mismas propiedades que el producto de caucho anterior. Otra forma de reducir la exposición es proceder a la aspiración local. No sólo el baño de sales tiene que estar cerrado y ventilado correctamente, sino que también otras áreas a lo largo de la línea, como las zonas de corte o estampado del producto, requieren controles que garanticen que la exposición del trabajador se mantiene a niveles bajos.

Beth Donovan Reh una estufa. El látex de caucho natural se utiliza de forma generalizada para fabricar guantes y otros materiales sanitarios. Para conseguir una superficie antiadherente se empolvan los guantes con almidón de trigo o se tratan con una solución de cloro, pues sin este tratamiento podrían entrar en combustión espontánea si se almacenasen en grandes cantidades en un lugar caliente.

\section{Riesgos y precauciones}

Entre los riesgos inherentes al procesamiento del caucho se encuentran la exposición a superficies calientes, el vapor a presión, los disolventes, los agentes adyuvantes del proceso, los humos de vulcanización y los ruidos. Entre los agentes productores de polvo se encuentran los estearatos, el talco, la mica y el almidón de trigo. Los polvos orgánicos son explosivos. Durante el proceso de acabado se originan numerosos riesgos debidos a las operaciones de troquelado, cortado, trituración, adición de disolventes para tinta de impresión y lavados alcalinos o ácidos para el tratamiento de las superficies.

En cuanto a las precauciones que deben tomarse, se recomienda consultar los artículos "Controles de ingeniería" y "Seguridad" del presente capítulo.

Actualmente se encuentra en fase de desarrollo la vulcanización por microondas, láser y ultrasonido, con la intención de generar calor directamente dentro del caucho en lugar de transferir el calor de una forma ineficaz desde el exterior. La industria está intentando eliminar o encontrar alternativas menos peligrosas al plomo, los agentes empolvantes y los disolventes orgánicos volátiles, así como conseguir compuestos con propiedades mejores y más seguras durante su procesamiento y utilización.

\section{1,3-BUTADIENO}

\section{Ronald L. Melnick}

El 1,3-butadieno, gas incoloro que se obtiene como producto secundario de la fabricación del etileno, es muy utilizado como materia prima para la fabricación de caucho sintético (p. ej., caucho de estireno-butadieno (SBR) y caucho de polibutadieno) y de resinas termoplásticas.

\section{Efectos sobre la salud}

Estudios en animales. El butadieno inhalado produce cáncer en diferentes lugares del organismo de las ratas y de los ratones. En las ratas expuestas al butadieno en dosis de $0,1.000 \mathrm{u} 8.000 \mathrm{ppm}$ durante 2 años se observó un aumento de la incidencia tumoral y/o de la tendencia dosis-respuesta en el páncreas exocrino, los genitales y el cerebro en los machos y en las glándulas mamarias, la tiroides, el útero y la glándula Zymbal en las hembras. Se han realizado estudios de inhalación de butadieno en ratones utilizando dosis entre 6,25 y 1.250 ppm. En los ratones resultó especialmente interesante la inducción de linfomas malignos y hemangiosarcomas de corazón. Se indujeron asimismo tumores malignos de pulmón a todas las concentraciones de exposición y 
tumores en el hígado, el estómago, la glándula de Harder, los ovarios, las glándulas mamarias y la glándula prepucial. Entre los efectos no neoplásticos de la exposición al butadieno en ratones se encuentran la toxicidad de la médula espinal, la atrofia testicular, la atrofia de ovarios y la toxicidad de desarrollo.

El butadieno es genotóxico para las células de la médula espinal de los ratones, aunque no de las ratas, produciéndose un aumento del intercambio de cromátidas hermanas, de los micronúcleos y de las aberraciones cromosómicas. El butadieno es asimismo mutagénico a la Salmonella typhimurium en presencia de sistemas de activación metabólica. La actividad mutagénica del butadieno se ha atribuido a su metabolismo para dar productos intermedios epóxidos mutagénicos (y carcinogénicos).

Estudios en personas. Los estudios epidemiológicos realizados en personas han puesto de manifiesto un incremento de la mortalidad por cánceres linfático y hematopoyético asociado a exposiciones a butadieno en el trabajo. En la industria de producción de butadieno, se detectó un aumento de linfosarcomas en trabajadores que habían comenzado a trabajar antes de 1946. En un estudio de caso sobre el control de los cánceres linfático y hematopoyético en ocho fábricas de SBR se identificó una estrecha relación entre la mortalidad por leucemia y la exposición al butadieno. Entre las características comunes de estos casos de leucemia se encontraba el hecho de que la mayoría de los pacientes habían comenzado a trabajar antes de 1960, habían trabajado en tres plantas y durante un mínimo de 10 años. La Agencia Internacional para la Investigación sobre el Cáncer (IARC) ha clasificado el 1,3-butadieno como presunto agente cancerígeno para el hombre (IARG 1992).

Un estudio epidemiológico reciente ha aportado datos que confirman el incremento de la mortalidad por leucemia entre trabajadores de SBR expuestos al butadieno (Delzell y cols. 1996). Resulta especialmente significativa la correspondencia entre los linfomas inducidos en ratones expuestos al butadieno y los cánceres linfático y hematopoyético asociados a la exposición laboral al butadieno. Además, las estimaciones de riesgo de cáncer en el hombre obtenidas tomando como base los datos sobre los linfomas inducidos por butadieno en ratones son similares a las estimaciones de riesgo de leucemia determinadas a partir de los nuevos datos epidemiológicos.

\section{Riesgo industrial y medidas de control}

A mediados del decenio de 1980, el US National Institute for Occupational Safety and Health (NIOSH) realizó un estudio sobre la exposición en las industrias en que se produce y se utiliza el butadieno. Los valores obtenidos eran superiores a $10 \mathrm{ppm}$ en el $4 \%$ de las muestras e inferiores a $1 \mathrm{ppm}$ en el $81 \%$ de las mismas. Los riesgos no eran homogéneos dentro de cada categoría específica de trabajo y se obtuvieron desviaciones de hasta $370 \mathrm{ppm}$. La exposición al butadieno fue probablemente muy superior durante la segunda Guerra Mundial, momento en que la industria del caucho estaba en rápido crecimiento. Sin embargo, un muestreo limitado a las plantas de fabricación de neumáticos de caucho y mangueras arrojó resultados por debajo del límite de detección (0,005 ppm) (Fajen, Lunsford y Roberts 1993).

Las exposiciones al butadieno pueden reducirse comprobando que los componentes de los sistemas de circuito cerrado no estén gastados o incorrectamente conectados. Otras medidas para controlar riesgos potenciales pueden ser el uso de sistemas de circuito cerrado para el muestreo de cilindros, el uso de juntas mecánicas duales para controlar escapes de bombas con fugas, el uso de indicadores magnéticos para supervisar las operaciones de llenado de vagones y el uso de una campana de laboratorio para el vaciado de cilindros.

\section{Controles DE INGENIERIA}

\section{Ray C. Woodcock}

En la fabricación de neumáticos y otros productos de caucho los trabajadores están expuestos a numerosos productos químicos, como polvos, sólidos, aceites y polímeros utilizados en la mezcla de compuestos, polvos antiadherentes, neblinas, humos y vapores generados al calentar y vulcanizar los compuestos de caucho y disolventes utilizados para los adhesivos y agentes adyuvantes de proceso. En la mayoría de los casos todavía se desconocen sus efectos sobre la salud, excepto que suelen ser de naturaleza crónica y no aguda a los niveles típicos de exposición. Normalmente, los controles de ingeniería tienen por objetivo reducir de forma general el nivel de polvo, las emisiones del caucho calentado o los humos de vulcanización. Cuando el trabajador está expuesto a productos químicos, a disolventes o a agentes (ruido) localizados y reconocidos como dañinos, los esfuerzos de control pueden dirigirse de forma más específica, llegando en muchos casos a eliminar por completo la exposición.

En la fabricación del caucho tal vez la forma más efectiva de controlar los riesgos sea eliminar o sustituir los materiales nocivos. Así, por ejemplo, en el decenio de 1950 se detectó que la -naftilamina contenida como impureza en un antioxidante provocaba cáncer de vejiga, por lo que se prohibió su uso. El benceno era antiguamente un disolvente habitual, pero en el decenio de 1950 fue sustituido por la nafta, o gasolina blanca, con un contenido de benceno reducido (del 4-7 \% a menos del $0,1 \%$ de la mezcla). El heptano se ha utilizado para sustituir al hexano, obteniéndose rendimientos iguales o incluso superiores. En el vulcanizado de mangueras el revestimiento de plomo está siendo sustituido por otros materiales. En el diseño de los compuestos del caucho se está intentando reducir los efectos de la dermatitis debida a la manipulación de los productos, así como la formación de nitrosaminas durante la vulcanización. Los talcos utilizados como antiadherentes se seleccionan atendiendo a un bajo contenido en amianto y sílice.

\section{Mezclado de los compuestos del caucho}

Se recurre a la aspiración localizada para controlar el polvo, la neblina y los humos que se producen durante la preparación y el mezclado de los compuestos del caucho y en los procesos de acabado, que comprenden el pulido y esmerilado de los productos del caucho (véase la Figura 80.11). Con prácticas operativas y diseños de ventilación adecuados, la exposición al polvo es, por lo general, inferior a $2 \mathrm{mg} / \mathrm{m}^{3}$. El mantenimiento efectivo de filtros, campanas y equipos mecánicos es un factor esencial del control de ingeniería. Los manuales sobre ventilación de la American Conference of Governmental Industrial Hygienists y del Rubber and the Plastics Research Association of Great Britain (ACGIH 1995) incluyen diseños específicos de campanas.

Tradicionalmente, los productos químicos para el mezclado se vierten desde las tolvas a pequeñas bolsas colocadas sobre la balanza de pesada, que, a continuación, se sitúan en un transportador y se vierten en el mezclador o laminador. La exposición al polvo se controla mediante una campana de aspiración con ranuras situada detrás de la balanza (véase la Figura 80.12) y en algunos casos mediante campanas con ranuras junto a las tolvas de mezcla. El control del polvo en este proceso se mejora sustituyendo los polvos por partículas de mayor tamaño o gránulos, mezclando los ingredientes en una sola bolsa (a menudo termosellada) y suministrando los compuestos de forma automática desde la tolva de almacenamiento a la bolsa o directamente al mezclador. Las prácticas de trabajo del operario 
Figura 80.11 • Una campana de aspiración controla los humos producidos durante el acabado de un tubo en una fábrica industrial de caucho en Italia.

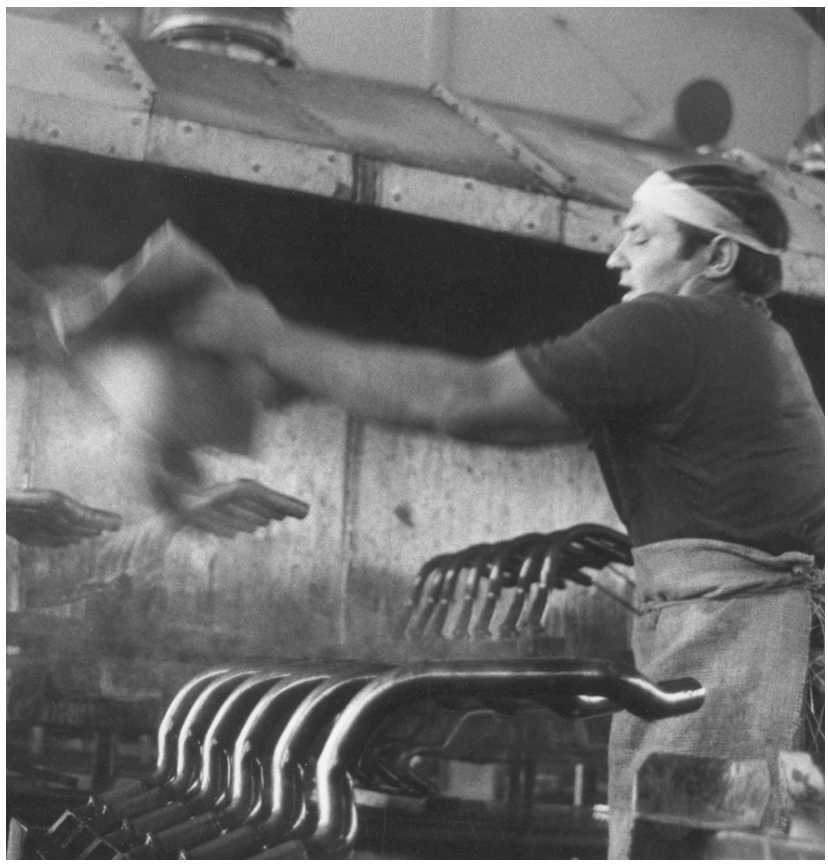

también influyen considerablemente en el nivel de exposición al polvo.

El malaxador Banbury requiere una amplia y eficaz campana para apresar el polvo de la carga y los humos y la neblina de aceite procedentes de la mezcla de caucho caliente. Campanas bien diseñadas pueden verse afectadas por corrientes procedentes de los ventiladores de pie utilizados por el operario. Para transportar bolsas desde la carretilla al transportador de carga a veces se utilizan equipos eléctricos.

Figura 80.12 • Aspiración local en una estación de pesado de compuestos.

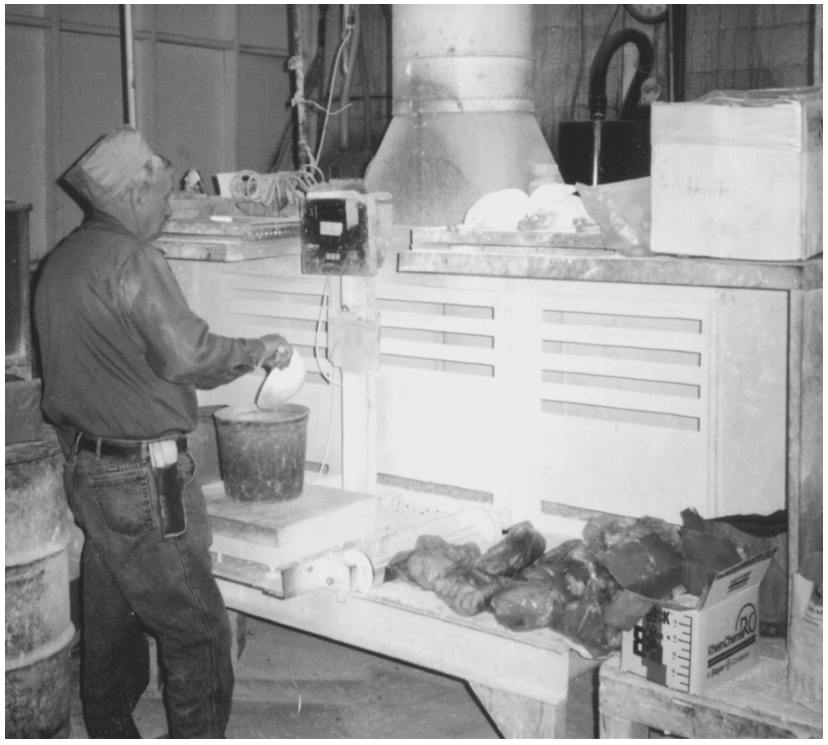

Los laminadores disponen de campanas de aspiración que recogen las emisiones de neblina aceite, vapores y humos procedentes del caucho caliente. En estas campanas, salvo que estén dotadas de un cerramiento adicional, la recogida de polvo resulta menos efectiva cuando se mezclan compuestos en el laminador o éste se empolva con polvos antiadherentes (véase la Figura 80.13). También estas campanas son sensibles a las corrientes procedentes de ventiladores de pie o al aire generado por una ventilación general mal direccionada. En ocasiones, se recurre a un sistema de empuje y arrastre que genera una cortina de aire delante del operario dirigida hacia la campana. A menudo, los laminadores se elevan para situar el estrechamiento entre cilindros fuera del alcance del operario y disponen de un cable o una barra delante del operario que interrumpe el funcionamiento del laminador en caso de emergencia. Los operarios utilizan guantes gruesos, que protegen los dedos si la mano queda atrapada en el estrechamiento entre cilindros.

Las placas de caucho procedentes de laminadores y calandrias se recubren para evitar que se adhieran entre sí. Esta operación se realiza a veces empolvando el caucho, aunque actualmente se suele hacer mediante inmersión en un baño de agua con un compuesto antiadherente (véase la Figura 80.14), lo que reduce considerablemente la exposición al polvo y mejora el mantenimiento.

El polvo y los humos se conducen a un precipitador de polvos o a colectores de polvo tipo cartucho. En las grandes instalaciones se dispone de un circuito de retorno de aire, en cuyo caso hay que disponer de equipos de detección de fugas que garanticen la eliminación de los contaminantes presentes en el aire. En algunos casos, los olores de ingredientes como la cola animal hacen desaconsejable la recirculación del aire. Debido a que el polvo de caucho es fácilmente combustible, es importante tener en cuenta la protección contra incendios y explosiones en las tuberías y en los colectores de polvo. Los polvos sulfúricos y explosivos, como el almidón de trigo, también exigen medidas especiales de seguridad contra incendios.

Figura 80.13 • Una cortina colocada alrededor de una campana de aspiración sobre un laminador ayuda a controlar el polvo.

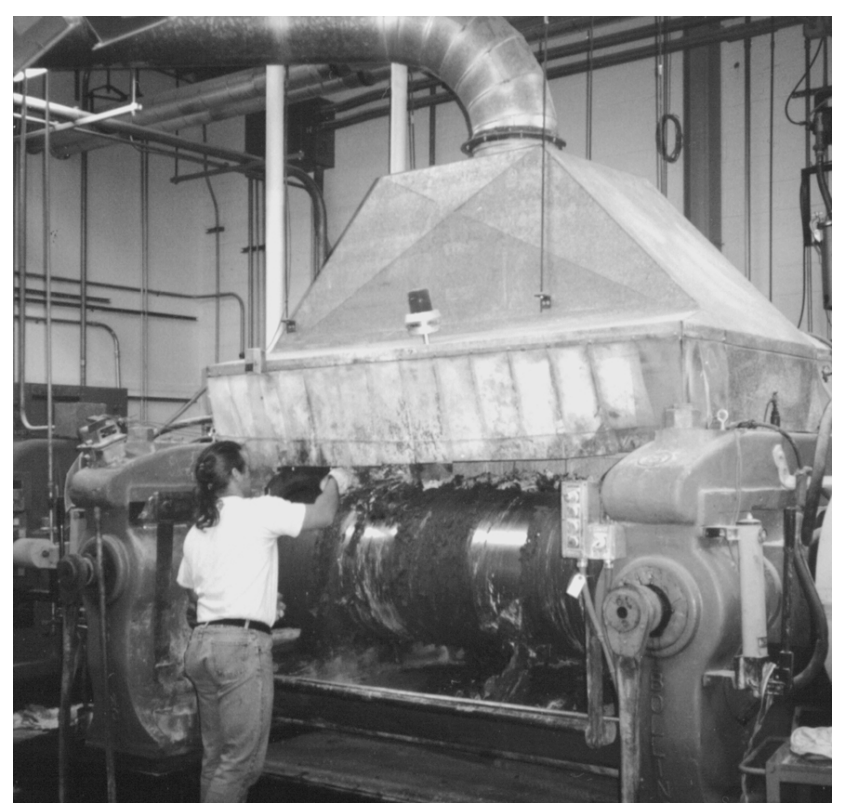


Figura 80.14 - Una plancha de caucho procedente de un laminador Banbury pasa por un baño de agua donde se le aplica un compuesto antiadherente.

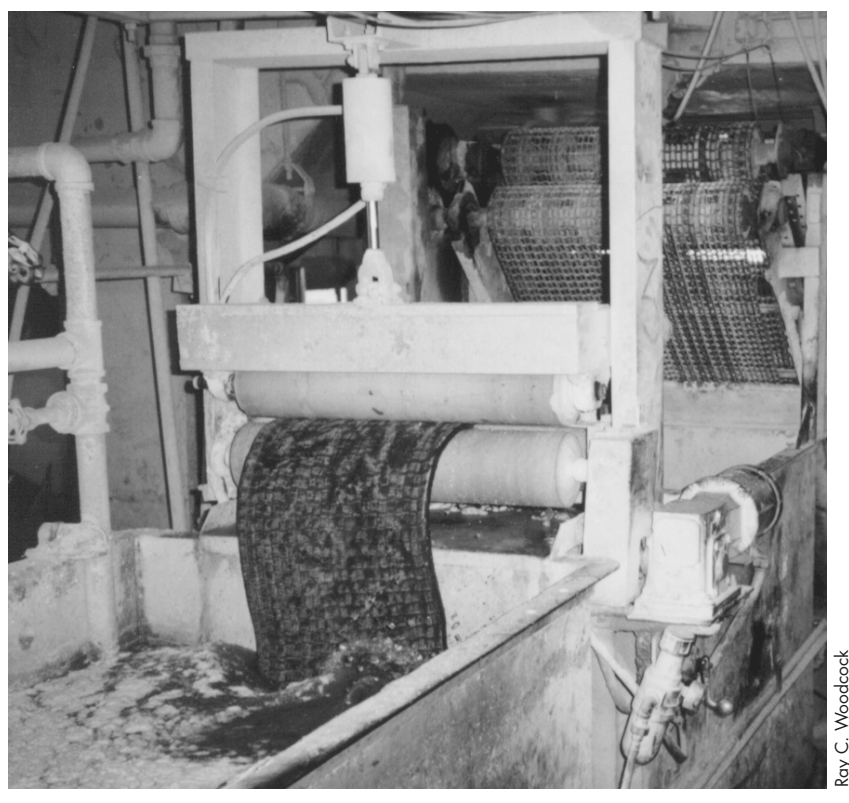

\section{Procesamiento del caucho}

Sobre los émbolos de extrusión se suelen utilizar aspiradores locales para recoger la neblina y los vapores procedentes de la extrusión en caliente, que a continuación pueden enfriarse en un baño de agua para eliminar así las emisiones. Las campanas de aspiración también se utilizan en las fábricas en otros muchos puntos de emisión, como pulidores, tanques de inmersión y equipos de pruebas de laboratorio, donde resulta fácil apresar en la fuente los contaminantes atmosféricos.

El diseño de las estaciones de moldeo de neumáticos y otros productos dificulta, por lo general, la instalación de aspiradores localizados. Para mantener un nivel bajo de riesgo es importante guardar los disolventes en depósitos cerrados, respetar unas prácticas operativas cuidadosas y mantener un volumen de aire de dilución adecuado en el área de trabajo. Para reducir al mínimo el contacto de los productos con la piel se deben utilizar guantes y herramientas auxiliares.

$\mathrm{Al}$ abrir los vulcanizadores, se libera una gran cantidad de humo caliente. La parte más visible de la emisión es neblina de aceite, aunque la mezcla contiene otros muchos compuestos orgánicos. Actualmente, la ventilación de dilución es la medida de control más utilizada y a menudo se combina con campanas de aspiración o cerramientos de cortinas sobre el vulcanizador o los grupos de prensas. Esta ventilación requiere un gran volumen de aire por lo que, si no se aporta suficiente aire auxiliar, puede interrumpirse su funcionamiento y el de las campanas de aspiración conectadas entre edificios o secciones. Los trabajadores deben trabajar fuera de la campana o del cerramiento. En caso de que tengan que colocarse debajo de la propia campana, pueden disponerse ventiladores de corriente descendente encima del puesto de trabajo o introducirse por los laterales de los cerramientos aire que no vaya dirigido a la campana de aspiración. En Gran Bretaña, la exposición laboral a los humos de la vulcanización del caucho está limitada a $0,6 \mathrm{mg} / \mathrm{m}^{3}$ de material soluble en ciclohexano, nivel fácil de conseguir con unas buenas prácticas y un diseño de ventilación adecuado.

En la fabricación y aplicación de adhesivo de caucho, los disolventes deben cumplir unos requisitos especiales de control de ingeniería. Los agitadores de mezclado deben estar cerrados y conectados a un sistema de recuperación de disolventes y, mediante la ventilación de dilución, se deben controlar los niveles de vapor en el área de trabajo. La máxima exposición para el operario se produce cuando limpia los agitadores. Durante la aplicación del adhesivo de caucho al tejido, la exposición depende de factores como la aspiración localizada en los puntos de emisión, el cierre de los depósitos, la ventilación general en el lugar de trabajo y una ventilación auxiliar dirigida de forma adecuada. Las estufas de secado disponen de aspiración directa y en algunos casos se introduce aire en ellas antes de la aspiración.

Los sistemas de recuperación de disolventes mediante adsorción por carbono son los dispositivos de limpieza de aire más habituales. El disolvente así recuperado se devuelve al proceso. La normativa de protección contra incendios exige que la concentración de vapor inflamable en la estufa se mantenga por debajo del $25 \%$ del límite inferior de explosión (LIE), salvo que se disponga de controles automáticos de seguimiento continuo que garanticen que la concentración de vapor no excede el $50 \%$ del LIE (NFPA 1995).

$\mathrm{Al}$ automatizar los procesos y los equipos se reduce la exposición del operario a los agentes físicos y a los contaminantes transportados por el aire, ya que puede situarse éste a mayor distancia, confinarse la fuente o reducir la generación del riesgo. Otra de las ventajas importantes de la automatización de los procesos y de la manipulación de materiales es la reducción del esfuerzo físico.

\section{Control de ruidos}

Las exposiciones significativas a ruidos suelen proceder de equipos como trenzadoras y trituradoras de correa, salidas de aspiración de aire y fugas de aire comprimido o de vapor. Los cerramientos acústicos resultan efectivos para trenzadoras y trituradoras. En cuanto a las salidas de aspiración de aire, son muy útiles los silenciadores disponibles en el mercado. En algunos casos, las salidas confluyen en un colector común que realiza la evacuación total al lugar adecuado. El ruido emitido por las fugas de aire puede reducirse mejorando el mantenimiento, el cerramiento, el diseño o las buenas prácticas, con lo que se limita el ciclo de ruido.

\section{Prácticas operativas}

Para evitar las dermatitis y las alergias al caucho es necesario evitar el contacto con los productos químicos del caucho y con los lotes de caucho en bruto. Si los controles de ingeniería son insuficientes, deben utilizarse guantes largos, o guantes normales con camisas de manga larga, para que los polvos y las planchas de caucho no entren en contacto con la piel. La ropa de trabajo no debe mezclarse con la de calle. Para eliminar de la piel posibles contaminantes residuales se recomienda ducharse al quitarse la ropa de trabajo.

Con el fin de reducir las exposiciones peligrosas en el lugar de trabajo puede ser necesario en algunos casos utilizar protectores para oídos y vías respiratorias. Sin embargo, según recomiendan las buenas prácticas, es conveniente dar siempre prioridad a la sustitución o la adopción de nuevas soluciones de ingeniería frente a estas opciones, para reducir las exposiciones peligrosas en el lugar de trabajo. 


\section{- SEgURIDAD}

James R. Townhill

\section{Seguridad en los laminadores}

Los laminadores y las calandrias se utilizan de forma generalizada en toda la industria del caucho. Los accidentes por atrapamiento entre los cilindros giratorios representan el principal peligro durante el funcionamiento de estas máquinas, aunque también existe un peligro potencial de accidente durante la reparación y el mantenimiento de éstas y otras máquinas utilizadas en la industria del caucho. En el presente artículo se analizan estos riesgos.

En 1973 en Estados Unidos, el National Joint Industrial Council for the Rubber Manufacturing Industry concluyó que la instalación de un mecanismo de seguridad que tenga que ser activado por el trabajador no puede considerarse una solución efectiva para evitar los accidentes por atrapamiento en la línea de estrechamiento entre cilindros. Esto es especialmente cierto en el caso de los laminadores de la industria del caucho. Por desgracia, se ha hecho poco por modificar la normativa. Actualmente, sólo existe un tipo de mecanismo de seguridad que no es activado por el propio operario: la barra de cuerpo, que es el único mecanismo automático de amplia aceptación que resulta efectivo para evitar los accidentes en los laminadores. Sin embargo, incluso la barra de cuerpo presenta limitaciones y no puede utilizarse en todos los casos, salvo que se realicen las modificaciones oportunas en el equipo y en las prácticas operativas.

El problema de la seguridad en los laminadores no es fácil de resolver, ya que en él intervienen factores como:

- la altura del laminador

- la estatura del operario

- el equipo auxiliar

- el modo de funcionamiento del laminador

- la adherencia o pegajosidad de la mezcla

- la distancia de parada.

La altura del laminador determina la colocación del operario en la zona de trabajo. En laminadores de menos de 1,27 m de altura, y si la estatura del operario es superior a $1,68 \mathrm{~m}$, se tiende a trabajar demasiado alto en el laminador o demasiado cerca del estrechamiento entre cilindros, por lo que el mecanismo automático de seguridad dispone de un tiempo de reacción muy corto para interrumpir el funcionamiento del equipo.

La estatura del operario determina asimismo la distancia a la que éste tiene que acercarse al laminador para hacerle funcionar. En un mismo laminador pueden trabajar operarios de muy diferente estatura y en la mayoría de los casos no se realizan los ajustes necesarios en el mecanismo de seguridad de la máquina.

Los equipos auxiliares de transporte o de carga interfieren con frecuencia con los cables o las cuerdas de seguridad. A pesar de que la normativa lo prohibe, a menudo se desplazan estas cuerdas o cables de seguridad para permitir el funcionamiento de los equipos auxiliares, llegando a darse el caso de que el operario esté trabajando en el laminador con el cable de seguridad por detrás de su cabeza.

Además de la altura del laminador y de los equipos auxiliares, existen otros factores que influyen en el funcionamiento de un laminador. Cuando no existe un cilindro de mezclado debajo del mezclador para distribuir el caucho de forma uniforme en el laminador, el operario tiene que mover manualmente el caucho de un lado a otro del laminador. El operario, además del riesgo de atrapamiento en el estrechamiento entre los cilindros del laminador, está expuesto a un riesgo de sobreesfuerzo y de esguinces en las operaciones de mezclado y desplazamiento del caucho.

La viscosidad o pegajosidad de la mezcla representa un riesgo adicional. Si el caucho se adhiere al cilindro del laminador y el operario tiene que separarlo, la barra de seguridad de cuerpo se convierte en un peligro para la seguridad. Los operarios de laminadores con caucho caliente están obligados a llevar guantes y además utilizan cuchillas. La mezcla pegajosa puede adherirse a una cuchilla, a un guante o a la mano y arrastrarlo hacia el estrechamiento.

Tampoco será efectivo el mecanismo automático de seguridad si no es posible detener el laminador antes de que el cuerpo del operario llegue al estrechamiento. Deben comprobarse las distancias de parada semanalmente como mínimo y los frenos al comienzo de cada turno. Los frenos eléctricos dinámicos deben comprobarse de forma regular. Si el conmutador cero no está ajustado adecuadamente, el laminador se balanceará y se estropeará. En algunas situaciones son preferibles los frenos de disco. En el caso de los frenos eléctricos pueden surgir problemas si el operario activa el botón de parada del laminador y a continuación intenta una parada de emergencia del mismo. En algunos laminadores, la parada de emergencia no funciona si se ha activado antes el botón de parada.

Algunas medidas han mejorado la seguridad en los laminadores, y las que se indican a continuación, en especial, han reducido considerablemente el riesgo por atrapamiento en el estrechamiento entre los cilindros del laminador:

- utilizar una barra de seguridad al nivel de cuerpo en el frente de trabajo del laminador, pero sólo si ésta es ajustable en altura y distancia con respecto al operario;

- los frenos de un laminador pueden ser mecánicos o eléctricos, pero deben comprobarse después de cada turno. La distancia de parada se comprobará semanalmente y debe cumplir las recomendaciones de la American National Standards Institute (ANSI);

- si en los laminadores de mezclado se trabaja con una mezcla pegajosa caliente, el sistema de laminador único se sustituirá por uno doble. Esto reduce la exposición del operario y mejora el mezclado;

- si el operario tiene que desplazar la mezcla de un lado a otro del laminador, se añadirá un cilindro de mezclado para reducir la exposición del operario;

- se han revisado las prácticas actuales de trabajo en los laminadores para garantizar que el operario no trabaje demasiado cerca del estrechamiento entre cilindros. Esto incluye la instalación de pequeños laminadores de laboratorio, especialmente si la muestra debe pasar varias veces a través de los cilindros;

- en los laminadores se han añadido cargadores de mezcla. Esto ha eliminado la práctica de cargar los laminadores utilizando una carretilla elevadora y mejorado la efectividad de la barra de seguridad.

Actualmente, la tecnología permite mejorar la seguridad en los laminadores. En Canadá, por ejemplo, está prohibido manejar un laminador de caucho si no dispone de una barra de seguridad en el área de trabajo o en el frente del laminador. Los países que compran equipos usados a otros países deben ajustarlos para adecuarlos a las características de sus trabajadores.

\section{Seguridad en las calandrias}

Las calandrias y el equipo auxiliar presentan diseños muy diferentes, lo que dificulta los estudios específicos de seguridad. Para un estudio más detallado se recomienda consultar el National Joint Industrial Council for the Rubber Manufacturing Industry $(1959,1967)$. 
Por desgracia, cuando se traslada una calandria o cualquier otro equipo de una empresa a otra o de un país a otro no suele incluirse un registro de los accidentes ocurridos con el mismo. Esto da lugar a la supresión de mecanismos de protección y a la adopción de prácticas operativas que habían sido modificadas a causa de un accidente anterior, por lo que vuelven a repetirse accidentes que ya habían tenido lugar anteriormente. Otro problema es el idioma. Las máquinas con controles e instrucciones en un idioma extranjero hacen más difícil una práctica de seguridad.

Ha aumentado la velocidad de funcionamiento de las calandrias, pero su capacidad de frenado no siempre ha seguido el mismo ritmo de avance, lo que resulta especialmente cierto por lo que se refiere a los cilindros de estos equipos. Cuando éstos no puedan detenerse a la distancia recomendada, será necesario utilizar un mecanismo adicional para proteger al operario. En caso necesario, las calandrias deben disponer de un sensor que reduzca la velocidad de la máquina cuando una persona se acerque a los cilindros. Este mecanismo ha resultado muy efectivo para mantener a los empleados a cierta distancia de los cilindros durante el funcionamiento de la máquina.

El National Joint Industrial Council ha identificado otros puntos importantes que siguen siendo causa de accidentes:

- eliminación de atascos y ajustes de material;

- atrapamiento en el estrechamiento entre cilindros, especialmente al despegar las planchas de caucho;

- introducción del tocho,

- comunicación.

Un programa efectivo de interrupción (véase más adelante) ayuda mucho a reducir o eliminar los accidentes que se producen al eliminar atascos o ajustar el material mientras la máquina está en funcionamiento. Los sensores que reducen la velocidad de los cilindros cuando el operario se acerca a ellos pueden disuadirle de intentar ajustar el material.

Los accidentes por atrapamiento en el estrechamiento siguen siendo un problema, especialmente al despegar las planchas de caucho. La velocidad de despegue de las planchas de caucho debe poder ajustarse para permitir una puesta en marcha progresiva del cilindro y han de existir mecanismos de seguridad para casos de emergencia. Un mecanismo que reduzca la velocidad del cilindro cuando alguien se aproxima a él tenderá a disuadir al operario en su intento de ajustar un calce de separación o un tejido durante el despegue de las planchas de caucho. Los cilindros telescópicos constituyen una tentación especial, incluso para operarios con experiencia.

Los accidentes durante la introducción del tocho han aumentado al aumentar también la velocidad y la complejidad del tren de las calandrias y la cantidad de equipo auxiliar. Aquí resulta fundamental la existencia de un control de línea y una buena comunicación. El operario puede no estar en situación de ver a todo el equipo. Sin embargo, hay que tener en cuenta a todas las personas, y la comunicación entre ellas debe ser fluida.

La necesidad de una buena comunicación entre los miembros de un equipo es fundamental para un funcionamiento seguro. Los momentos críticos tienen lugar cuando se realizan los ajustes y cuando se pone en marcha la máquina al comienzo de un proceso o después de una interrupción debida a un problema.

Para resolver estos problemas son necesarios: un buen trabajo en equipo, cuyos miembros sean conscientes de los problemas operativos de las calandrias; un sistema de mantenimiento de los mecanismos de seguridad en condiciones operativas; y un sistema de supervisión de ambos.

\section{Sistema de interrupción de las máquinas}

El concepto de interrupción del funcionamiento de las máquinas no es nuevo. Aunque está generalmente aceptado en los programas de mantenimiento, poco se ha hecho para mejorar su introducción en el área operativa. Un primer paso es reconocer que hay riesgo. Una norma típica de interrupción de funcionamiento exige que "cuando se sospeche que un movimiento del equipo o una liberación de energía imprevistos pueden ocasionar una lesión a un trabajador, se interrumpirá el funcionamiento del equipo". El concepto de interrupción no se refiere exclusivamente a la energía eléctrica, y tampoco es posible a veces cortar toda la energía; en algunos casos, basta con bloquear la posición de algunas piezas y, en otros, con desconectar y cerrar las tuberías, liberando la presión acumulada. Aunque en algunas industrias el concepto de interrupción está considerado como algo normal, en otras no ha sido aceptado a causa de su alto coste.

En las interrupciones resulta básico el control. Cuando una persona corre un peligro al realizar un movimiento, deben desactivarse las fuentes de energía y socorrer a la persona en cuestión. No es fácil identificar las situaciones que requieren una interrupción e, incluso una vez identificadas, no es sencillo modificar las prácticas operativas.

Otra de las claves, a menudo olvidada, de un programa de interrupción es la facilidad con que puede interrumpirse una máquina, una línea o toda la energía. Los equipos antiguos no se diseñaron o instalaron teniendo en cuenta esta posibilidad. Algunas máquinas instaladas disponen de un solo freno para un grupo de ellas. Otras disponen de varias fuentes de energía, lo que complica la interrupción de su funcionamiento. A esto hay que añadir que a menudo se modifican los frenos de los cuartos de control de máquinas o se añaden equipos nuevos, y la documentación de estos cambios no siempre se mantiene actualizada.

En la industria del caucho está generalmente aceptada la práctica de la interrupción del funcionamiento. Aunque el concepto de protección ante los peligros de un movimiento imprevisto no es nuevo, el uso generalizado de la interrupción sí lo es. En el pasado, el personal de mantenimiento aplicaba formas de protección diferentes, que debido a presiones de producción no siempre resultaban coherentes y, por tanto, eficaces. En algunos equipos industriales la práctica de un programa de interrupción es compleja y no siempre resulta fácilmente comprensible.

La prensa de moldeo de neumáticos es un ejemplo de falta de consenso sobre el momento y el método de interrupción. Si bien se admite la interrupción completa de una prensa para una reparación importante, no hay consenso, en cambio, sobre la interrupción de su funcionamiento en caso de cambio y limpieza de moldes, cambio de cámaras de aire o eliminación de atascos.

La máquina de fabricación de neumáticos es otro ejemplo. Muchos de los accidentes en esta área de trabajo no son sufridos por el personal de mantenimiento, sino por operarios y técnicos que realizan operaciones de ajuste, cambio de tambores, carga o descarga de mezclas, eliminación de atascos o limpieza de los equipos.

Es difícil disponer de un programa de interrupción adecuado cuando se trata de una operación compleja y tiene un alto coste en tiempo. Siempre que sea posible, los dispositivos de desconexión deben estar situados en el mismo equipo, lo que facilita su identificación y elimina o reduce la posibilidad de que algún operario se encuentre en la zona de peligro cuando se vuelve a conectar la energía del equipo. Aun cuando se hayan realizado cambios para facilitar su identificación, no puede considerarse nunca una interrupción como completa hasta que no se ha comprobado que se han utilizado los dispositivos de aislamiento de energía correctos. Cuando se utilicen cables 
eléctricos, debería comprobarse después de la desconexión que realmente toda la energía ha sido desconectada.

En un programa efectivo de interrupción se deben cumplir las premisas siguientes:

- el diseño del equipo ha de facilitar una interrupción de todas las fuentes de energía;

- las fuentes de interrupción deben ser fácilmente identificables;

- deben identificarse las prácticas operativas que requieren una interrupción;

- todos los trabajadores afectados por una interrupción deben recibir formación en esta práctica;

- los trabajadores encargados de realizar la interrupción deben disponer de la formación adecuada y ser avisados cuando se va a producir la interrupción. El incumplimiento de estas medidas es inaceptable bajo cualquier circunstancia;

- el programa debe ser auditado de forma regular para garantizar su efectividad.

\section{- ESTUDIOS EPIDEMIOLOGICOS}

\section{Robert Harris}

En los decenios de 1920 y 1930, algunos estudios realizados en el Reino Unido demostraron que los trabajadores del caucho presentaban unas tasas de mortalidad más altas que la población general, y que ese incremento de la mortalidad era producido por el cáncer. Dado que en la fabricación de los productos del caucho se utilizan miles de materiales diferentes era difícil saber cuáles podían estar relacionados con el aumento de la mortalidad. Una seria preocupación por la salud de los trabajadores de la industria del caucho llevó al establecimiento de programas conjuntos entre empresas y sindicatos con el fin de investigar la salud laboral en la industria norteamericana del caucho. Dichos programas fueron puestos en práctica por las Universidades de Harvard y Carolina del Norte. Los programas de investigación se prolongaron durante el decenio de 1970 para, a continuación, ser sustituidos por programas, patrocinados conjuntamente por empresas y sindicatos, de mantenimiento y supervisión de la salud, basados, al menos en parte, en los resultados obtenidos en estas investigaciones.

El trabajo de investigación realizado por la Universidad de Harvard se centró básicamente en la mortalidad en la industria del caucho (Monson y Nakano 1976a, 1976b; Delzell y Monson 1981a, 1981b; Monson y Fine 1978) y en la morbilidad respiratoria entre los trabajadores de esta industria (Fine y Peters 1976a, 1976b, 1976c; Fine y cols. 1976). Los resultados de los trabajos de investigación fueron publicados por Peters y cols. en 1976.

El grupo de la Universidad de Carolina del Norte se centró en una investigación de tipo epidemiológico y medioambiental. Los estudios iniciales fueron básicamente de carácter descriptivo sobre la mortalidad y las condiciones de trabajo de los trabajadores del caucho (McMichael, Spirtas y Kupper 1974; McMichael y cols. 1975; Andjelkovich, Taulbee y Symons 1976; Gamble y Spirtas 1976; Williams y cols. 1980; Van Ert y cols. 1980). Sin embargo, el centro de la investigación lo constituyeron los estudios analíticos sobre la relación entre riesgo laboral y enfermedad (McMichael y cols. 1976a; McMichael y cols. 1976b; McMichael, Andjelkovich y Tyroler 1976; Lednar y cols. 1977; Blum y cols. 1979; Goldsmith, Smith y McMichael 1980; Wolf y cols. 1981; Checkoway y cols. 1981; Symons y cols. 1982; Delzell, Andjelkovich y Tyroler 1982; Arp, Wolf y Checkoway 1983; Checkoway y cols. 1984; Andjelkovich y cols. 1988). Especialmente interesantes fueron los resultados obtenidos al estudiar la relación entre la exposición a vapores de disolventes de hidrocarburos y el cáncer (McMichael y cols. 1975; McMichael y cols. 1976b; Wolf y cols. 1981; Arp, Wolf y Checkoway 1983; Checkoway y cols. 1984) y la relación entre la exposición a partículas transportadas por el aire y las enfermedades pulmonares (McMichael, Andjelkovich y Tyroler 1976; Lednar y cols. 1977).

En la Universidad de Carolina del Norte, los estudios analíticos iniciales sobre la leucemia entre los trabajadores del caucho pusieron de manifiesto la existencia de una tasa más elevada de presencia entre los trabajadores con un historial de trabajo con disolventes (McMichael y cols. 1975). La exposición al benceno, disolvente antiguamente habitual en la industria del caucho, fue reconocida rápidamente como causa de la leucemia. Sin embargo, un análisis más detallado demostró que los casos de leucemia eran, por lo general, de tipo linfocítico, mientras que la exposición al benceno se había relacionado normalmente con la de tipo mieloblástico (Wolf y cols. 1981). Se sospechó entonces que en este proceso podía intervenir tal vez otro agente distinto del benceno. Una investigación detallada del empleo de los disolventes y de las fuentes de suministro en una conocida empresa demostró que los disolventes extraídos del carbón, incluido el benceno y el xileno, estaban mucho más relacionados con la leucemia linfocítica que los extraídos del petróleo (Arp, Wolf y Checkoway 1983). Los disolventes extraídos del carbón están, por lo general, contaminados con hidrocarburos aromáticos polinucleares, incluidos los compuestos que se ha demostrado que causan leucemia linfocítica en animales de experimentación. Otros análisis de este estudio pusieron de manifiesto que la leucemia linfocítica estaba mucho más relacionada con la exposición al disulfuro de carbono y al tetracloruro de carbono que con la exposición del benceno (Checkoway y cols. 1984). La exposición al benceno es peligrosa y debe ser eliminada o minimizada al máximo en el puesto de trabajo. Sin embargo, concluir que suprimiendo el uso del benceno en los procesos del caucho se eliminará el exceso de leucemia, especialmente la de tipo linfocítico, entre los trabajadores de esta industria quizá no sea correcto.

Estudios realizados por la Universidad de Carolina del Norte sobre trabajadores del caucho jubilados por incapacidad demostró que los que tenían un historial de trabajo en tareas de vulcanización, preparación de la vulcanización, acabado e inspección tenían más tendencia a padecer enfermedades pulmonares invalidantes, como el enfisema, que los trabajadores de otras áreas (Lednar y cols. 1977). Las áreas de trabajo mencionadas presentan una exposición a polvos y humos que pueden ser inhalados. En estos estudios se encontró que en las personas fumadoras se duplicaba, por lo general, el riesgo de invalidación por enfermedad pulmonar, incluso en las tareas con polvo que ya de por sí estaban relacionadas con la invalidez.

Por esta época se realizaron asimismo estudios epidemiológicos en la industria del caucho en Europa y Asia (Fox, Lindars y Owen 1974; Fox y Collier 1976; Nutt 1976; Parkes y cols. 1982; Sorahan y cols. 1986; Sorahan y cols. 1989; Kilpikari y cols. 1982; Kilpikari 1982; Bernardinelli, Marco y Tinelli 1987; Negri y cols. 1989; Norseth, Anderson y Giltvedt 1983; Szeszenia-Daborowaska y cols. 1991; Solionova y Smulevich 1991; Gustavsson, Hogstedt y Holmberg 1986; Wang y cols. 1984; Zhang y cols. 1989), que se prolongaron después de haberse concluido los de las Universidades de Harvard y Carolina del Norte (Estados Unidos) y que pusieron de manifiesto un incremento de la mortalidad por cáncer en distintos puntos y algunos de ellos específicamente por cáncer de pulmón (Fox, Lindars y Owen 1974; Fox y Collier 1976; Sorahan y cols. 1989; Szeszenia-Daborowaska y cols. 1991; Solionova y Smulevich 1991; Gustavsson, Hogstedt y Holmberg 1986; Wang y cols. 1984), relacionados en algunos casos con trabajos de vulcanización. 
Este resultado se vio confirmado por algunos estudios en Estados Unidos (Monson y Nakano 1976a; Monson y Fine 1978), aunque no por otros (Delzell, Andjelkovich y Tyroler 1982; Andjelkovich y cols. 1988).

En Alemania se estudió una cohorte de trabajadores de la industria alemana del caucho (Weiland y cols. 1996) que presentaba una mortalidad debida a todo tipo de causas y a cualquier tipo de cáncer muy elevada. Se identificó una tasa estadísticamente significativa de mortalidad por cáncer de pulmón y pleura. Sin embargo, la mortalidad por leucemia entre los trabajadores alemanes de la industria del caucho era estadísticamente poco significativa.

En un estudio de caso de cáncer linfático y de cáncer hematopoyético en ocho fábricas de caucho de estireno-butadieno (SBR) se observó una importante relación entre la mortalidad por leucemia y la exposición al butadieno. El IARC ha incluido el 1,3-butadieno entre las posibles sustancias cancerígenas para el hombre (IARG 1992). En un estudio epidemiológico más reciente se han obtenido datos que confirman una mayor tasa de mortalidad por leucemia entre los trabajadores SBR expuestos al butadieno (Delzell y cols. 1996).

Con el paso de los años, los estudios epidemiológicos entre los trabajadores de la industria del caucho han permitido identificar los riesgos en el puesto de trabajo y mejorar así su control. Se están realizando notables progresos tanto en las técnicas de investigación como en las bases de datos. El área de investigación epidemiológica profesional que actualmente requiere más atención es el de la valoración de las exposiciones pasadas de los sujetos en estudio. Aunque todavía quedan sin resolver cuestiones de relaciones causales, el continuo progreso epidemiológico conducirá seguramente a una mejora continua del control de las exposiciones en la industria del caucho y, por tanto, a una mejora continua de la salud de los trabajadores de esta industria.

Reconocimiento: me gustaría reconocer aquí los esfuerzos del pionero Peter Bommarito, ex presidente de la United Rubber Workers Union, primer responsable de la investigación causal sobre la salud de los trabajadores del caucho realizada en EE.UU. en los decenios de 1970 y 1980.

\section{- DERMATITIS POR GONTACTO GON GAUGHO Y ALERGIA AL LATEX}

\section{James S. Taylor y Yung Hian Leow}

\section{Dermatitis por contacto}

Entre los trabajadores que están en contacto directo con el caucho y con los cientos de productos químicos utilizados en esta industria se han registrado frecuentes reacciones adversas en la piel. Entre estas reacciones se encuentran dermatitis irritativa de contacto, dermatitis alérgica de contacto, urticaria de contacto (erupciones), agravamiento de enfermedades preexistentes de la piel y otros trastornos menos habituales de la piel como foliculitis, xerosis (piel seca), miliaria y despigmentación debidos a ciertos derivados del fenol.

La dermatitis irritativa de contacto es la reacción más frecuente y está causada por una exposición intensa a productos químicos fuertes o por una exposición acumulada a productos irritantes más débiles, como los utilizados en trabajos con líquidos o disolventes. La dermatitis alérgica de contacto es un tipo de reacción alérgica retardada causada por productos químicos como aceleradores, vulcanizadores, antioxidantes y antiozonizantes que se añaden durante la fabricación del caucho. Estos productos suelen estar presentes en el producto final y pueden causar dermatitis de contacto tanto a los usuarios de los productos finales como a los trabajadores del caucho, y en especial en los operarios de malaxadores Banbury, calandrias y extrusores, así como en los montadores.

Algunos trabajadores sufren dermatitis de contacto por realizar tareas que no permiten el empleo de ropa de protección frente a los productos químicos (PPQ). Algunos trabajadores desarrollan alergia a la propia ropa PPQ, y en especial a los guantes de goma. Una prueba de parche válida para detectar el alérgeno es la que se utiliza para diferenciar la dermatitis alérgica por contacto de la irritativa. Es importante recordar que el primer tipo de dermatitis puede coexistir con el segundo así como con otros trastornos de la piel.

La dermatitis puede evitarse realizando el mezclado de los productos químicos de forma automática, instalando sistemas de aspiración, sustituyendo los alérgenos de contacto conocidos por productos químicos alternativos y optimizando la manipulación de los materiales para reducir el contacto con la piel.

\section{Alergia al látex del caucho natural (LCN)}

La alergia LCN es una reacción alérgica inmediata del tipo I con mediación de inmunoglobulina $\mathrm{E}$, causada, en la mayoría de los casos, por proteínas LCN presentes en el material sanitario y no sanitario a base de látex. La gama de síntomas clínicos va desde la urticaria por contacto, la urticaria generalizada, la rinitis alérgica (inflamación de la mucosa nasal), la conjuntivitis alérgica, el angioedema (hinchamiento grave) y el asma hasta la anafilaxis (reacción alérgica grave que puede poner en peligro la vida del paciente). Los individuos con mayor riesgo son los pacientes con espina bífida, los trabajadores del sector sanitario y otros trabajadores con exposición LCN significativa. Los factores que favorecen esta reacción son los eczemas en las manos, la rinitis alérgica, la conjuntivitis alérgica o el asma en personas que llevan guantes con frecuencia, cuyas mucosas están expuestas al LCN o que han sufrido procesos quirúrgicos múltiples. En la US Food and Drug Administration se han registrado quince fallecimientos debidos a la exposición a LCN durante los reconocimientos con enemas de bario. Así la ruta de la exposición a las proteínas LCN es importante e incluye el contacto directo de la piel intacta o inflamada y la exposición de las mucosas, incluida la inhalación, a polvos de guantes que contengan LCN, especialmente en instalaciones sanitarias y quirófanos. Puede decirse que en todo el mundo la alergia LCN constituye un problema grave en los ámbitos sanitario, de salud laboral, de salud pública y normativo, con una incidencia que sigue aumentando de forma clara desde mediados del decenio de 1980.

El diagnóstico de la alergia LCN está especialmente recomendado si existen antecedentes de angioedema de labios al soplar globos y/o de picor, quemazón, urticaria o anafilaxis cuando la persona lleva guantes, se somete a procesos quirúrgicos, sanitarios u odontológicos o después de una exposición a preservativos o a otros productos LCN. El diagnóstico puede confirmarse con una prueba positiva de uso de guantes LCN, una prueba positiva intracutánea al LCN o un análisis de sangre positivo RAST (prueba radioalergosorbente) de alergia al látex. Se han observado reacciones alérgicas graves durante estas pruebas, por lo que al realizarlas debe tenerse disponible epinefrina y un equipo de reanimación que no contenga LCN.

La alergia al LCN puede estar relacionada con reacciones alérgicas a la fruta, especialmente plátanos, castañas y aguacates. Todavía no es posible realizar una hiposensibilización al LGN, por lo que de momento resulta fundamental evitar y sustituir el LCN. Para la prevención y el control de la alergia al LCN los trabajadores y pacientes afectados evitarán utilizar látex en centros sanitarios. Debería disponerse de guantes sintéticos sin LCN y en muchos casos los demás colaboradores deberían llevar guantes con bajo contenido en alérgenos LCN que no afecten a 
los que tengan alergia al LCN, con el fin de minimizar los síntomas y reducir la inducción de alergias LCN. Es necesaria una continua cooperación entre gobiernos, industrias y profesionales sanitarios para controlar la alergia al látex, como se describe en el capítulo Instalaciones sanitarias

\section{- ERgonOMia}

\section{William S. Marras}

La ergonomía es la ciencia que estudia la relación entre el trabajador y su entorno de trabajo. Esta ciencia no sólo comprende el estudio del riesgo para el sistema óseo y muscular debido al tipo de trabajo, sino también una consideración de los procesos cognitivos del trabajo que pueden ser causa de errores humanos.

En la industria del caucho y los neumáticos se han identificado las tareas que provocan un riesgo mayor de sufrir determinados tipos de trastornos en el sistema óseo y muscular, observándose un predominio de las lesiones de espalda. Un muestreo realizado en la industria del caucho y los neumáticos sobre las tareas de manipulación de materiales ha demostrado que las tareas de alto riesgo presentan un índice de lesiones en la parte inferior de la espalda que es aproximadamente un $50 \%$ más alto que el observado en la industria en general. Un estudio de esas tareas revela que los problemas suelen surgir en los trabajos que requieren el transporte manual de los productos de caucho, como en las operaciones de procesamiento del caucho (malaxadores Banbury), de montaje, de acabado y de transporte de los neumáticos, tanto en la fábrica como en el almacén. Las lesiones de muñeca, como el síndrome del túnel carpiano y la tenosinovitis parecen ser también un problema común en las fábricas de neumáticos. Un estudio de las operaciones de fabricación de neumáticos sugiere que deberían observarse también problemas en los hombros. Sin embargo, los registros de lesiones tienden a subestimar el riesgo de las lesiones de hombro debido a una falta de sensibilización hacia este problema. Finalmente, parecen existir algunos problemas del proceso cognitivo dentro de la industria del neumático, que resultan más evidentes en las tareas de inspección y que a menudo se ven agravados por una escasa iluminación.

Algunos factores de riesgo relacionados con el puesto de trabajo parecen ser responsables de estos problemas a nivel de sistema óseo y muscular en la industria del caucho, como posturas estáticas e incómodas de espalda, hombros y muñecas, movimientos rápidos de muñecas y espalda, manejo de grandes pesos y grandes tensiones del tronco al manejar piezas voluminosas de caucho. Un estudio de los factores asociados a los problemas de la parte inferior de la espalda indica que en la industria del neumático los trabajadores mueven pesos superiores a otros sectores y, además, esas cargas se manejan a distancias del cuerpo superiores a la media. A esto hay que sumar que esas tensiones y pesos se imponen al cuerpo durante movimientos asimétricos del tronco, por ejemplo, en posición curvada. La duración de la aplicación de la fuerza en este tipo de trabajo también es problemática. A menudo, en una operación de fabricación de neumáticos se requieren aplicaciones de fuerza prolongadas en las que la fuerza del trabajador va disminuyendo con el tiempo. Finalmente, la temperatura en los puestos de trabajo de la industria del caucho suele ser alta y, además, los puestos de trabajo están expuestos a la suciedad y al polvo. El calor tiende a aumentar la demanda calorífica de la tarea, incrementando así la demanda de energía. Las resinas y el polvo del puesto de trabajo aumentan la probabilidad de que los trabajadores tengan que llevar guantes para realizar su trabajo, lo que incrementa la tensión de los músculos del antebrazo que controlan los dedos. Además, cuando los trabajadores llevan guantes, realizan un mayor esfuerzo para sujetar las piezas, pues no perciben fácilmente cuándo un objeto está a punto de resbalarse de las manos. Entre las soluciones a estos problemas ergonómicos se encuentra la reorganización del puesto de trabajo (p. ej., levantando o bajando el objeto o desplazando el puesto de trabajo para suprimir grandes torsiones o curvaturas laterales del tronco, lo que puede conseguirse reorientando el origen y destino de las tareas de elevación, pasando de giros de 180 a giros de 90 ). A menudo es necesario realizar cambios más importantes, que pueden ir desde la instalación de puestos de trabajo ajustables, por ejemplo con mesas de altura variable, hasta la incorporación de mecanismos elevadores, como ascensores o grúas, o incluso la automatización total del puesto. Lógicamente, algunas de estas soluciones conllevan un alto coste. Por tanto, la clave para un diseño ergonómico adecuado es hacer exclusivamente los cambios necesarios y determinar el efecto del cambio en términos de modificación del riesgo a nivel del sistema óseo y muscular. Afortunadamente, existen en el mercado nuevos métodos que permiten cuantificar la dimensión del riesgo asociado con un determinado diseño del puesto de trabajo. Así, por ejemplo, existe un modelo que estudia el riesgo de trastornos ocupacionales de la parte inferior de la espalda en función de las exigencias del trabajo (Marras y cols. 1993; 1995). Se han desarrollado asimismo modelos que analizan la carga sobre la columna vertebral debida a actividades dinámicas del tronco (Marras y Sommerich 1991; Granata y Marras 1993). Cada vez existen más modelos en el mercado para estudiar el diseño del puesto de trabajo en la industria y el nivel de exposición.

\section{GUESTIONES AMBIENTALES Y DE SALUD PUBLICA}

\section{Thomas Rhodarmer}

Todos los productos del caucho se fabrican a partir de un "compuesto de caucho", que, a su vez, está formado por un polímero de caucho (natural o sintético) y otras sustancias como material de relleno, plastificantes, antioxidantes, agentes adyuvantes, activadores aceleradores o agentes de vulcanización. Muchos de los ingredientes químicos están clasificados como sustancias peligrosas o tóxicas e incluso algunos como cancerígenos. La manipulación y procesamiento de estos productos químicos presentan problemas ambientales y de seguridad.

\section{Residuos peligrosos}

Los sistemas de ventilación y los colectores de polvo son indispensables para los trabajadores que manipulan y pesan los productos químicos y para los encargados de mezclar y procesar el compuesto de caucho sin vulcanizar. En ocasiones, deben llevar además equipos de protección. El material recogido en los colectores de polvo debe ser examinado para determinar si se trata de un residuo peligroso, es decir reactivo, corrosivo o inflamable, o si contiene sustancias químicas consideradas peligrosas.

Los residuos peligrosos, después de quedar registrados en un informe, deben ser enviados para su eliminación a un vertedero adecuado. Los residuos no peligrosos pueden enviarse a un vertedero controlado local o a uno industrial, según la normativa ambiental vigente. 


\section{Contaminación atmosférica}

Durante el proceso de fabricación, algunos productos de caucho requieren la aplicación de adhesivo de caucho. Los adhesivos de caucho se fabrican mezclando el compuesto de caucho sin vulcanizar con un disolvente. Los disolventes utilizados para este proceso se clasifican normalmente como compuestos orgánicos volátiles $(\mathrm{COV})$. Los procesos que utilizan $\mathrm{COV}$ deben disponer de algún tipo de equipo de control de emisiones, como un sistema de recuperación de disolventes o un oxidante térmico, que es un sistema de incineración que destruye los COV mediante combustión y que requiere normalmente un combustible adicional, como el gas natural. Si no se dispone de este tipo de control de emisiones, los COV pueden llegar a causar problemas de salud en la fábrica y en la comunidad. Si los COV son fotoquímicamente reactivos, afectarán a la capa de ozono.

Al vulcanizar piezas de caucho y abrir el depósito, se escapan emisiones en forma de humo, vapor o ambos. Los vapores del proceso de vulcanización pueden arrastrar a la atmósfera sustancias químicas sin reaccionar, plastificantes, lubrificantes y otros materiales, lo que obliga a realizar controles de emisiones.

\section{Contaminación del suelo y del agua}

El almacenamiento y el manejo de los COV debe realizarse con extremo cuidado. Antes, los COV se almacenaban en tanques subterráneos, donde a veces se producían fugas y derramamientos que contaminaban el suelo y las aguas subterráneas, lo que obligaba a costosas reparaciones. La mejor opción de almacenamiento son los tanques sobre el nivel del suelo con un buen confinamiento secundario para prevenir los derramamientos.

\section{Caucho residual}

En todos los procesos de fabricación se producen desechos, tanto durante el proceso como en el acabado del producto. Parte de esos desechos pueden ser reciclados para el mismo proceso o para otros procesos diferentes. Sin embargo, una vez que el caucho está vulcanizado, ya no puede ser reciclado y todos los desechos del proceso de vulcanización y de acabado se convierten en material residual. La eliminación de los productos residuales del caucho se ha convertido en un problema mundial.

En todos los hogares y empresas del mundo se utiliza algún tipo de producto de caucho. La mayor parte de estos productos están clasificados como material no peligroso y, por lo tanto, sus residuos tampoco son peligrosos. Sin embargo, la eliminación después de su vida útil de productos de caucho como los neumáticos, las mangueras y otros productos tubulares ocasiona un problema ambiental. En efecto, no pueden ser enterrados en un vertedero controlado porque sus zonas huecas atrapan aire y hacen que el producto emerja a la superficie al cabo de cierto tiempo. La trituración de estos productos resuelve este problema, pero requiere equipos especiales y resulta muy costosa.

La combustión sin llama de los neumáticos puede generar una gran cantidad de humo irritante que contiene numerosas sustancias químicas y partículas tóxicas.

\section{Incineración de los residuos de caucho}

Una de las opciones para eliminar los desechos de caucho y los residuos del proceso de fabricación es la incineración. En principio, parece también la mejor solución para deshacerse de los numerosos productos de caucho "obsoletos" que existen actualmente en el mundo. Algunas empresas de fabricación de caucho utilizan la incineración para eliminar los desechos de caucho y los residuos de caucho vulcanizado y no vulcanizado. En teoría, el caucho, al quemarse, genera un vapor que podría reutilizarse en la fábrica. Pero, por desgracia, esto no resulta tan sencillo en la práctica. El incinerador debe disponer de un control de las emisiones de aire y probablemente necesitaría depuradores para eliminar las sustancias contaminantes como el cloro. Las emisiones de cloro, por lo general, proceden de los productos y residuos en combustión que contienen polímeros de cloropreno. Los depuradores generan una descarga ácida que tal vez debería neutralizarse antes de proceder a la descarga.

Casi todos los compuestos de caucho contienen algún tipo de agentes de relleno, como negro de humo, arcillas, carbonatos cálcicos o compuestos hidratados de sílice. La combustión de estos compuestos produce cenizas equivalentes a la cantidad de agentes de relleno presentes en el compuesto de caucho. Las cenizas se recogen en depuradores húmedos o secos. En ambos casos, es necesario analizar el contenido en metales pesados antes de su eliminación. Los depuradores húmedos probablemente generarán unas aguas residuales con un contenido de 10 a 50 ppm de zinc, que al ser vertidas a un sistema de alcantarillado darán problemas en la planta de tratamiento y obligarán a instalar un sistema de eliminación del zinc. Este sistema de tratamiento produce un lodo de zinc que debe transportarse a un lugar adecuado para su eliminación.

Los depuradores secos generan unas cenizas que deben recogerse para su eliminación. Tanto las cenizas húmedas como las secas son difíciles de manejar, y su eliminación puede ser problemática dado que la mayoría de los vertederos controlados no aceptan este tipo de residuos. Ambos tipos de cenizas pueden ser muy alcalinas si los compuestos de caucho que entran en combustión presentan un alto contenido de carbonato cálcico.

Finalmente, la cantidad de vapor generada sería inferior a la necesaria para el funcionamiento de una fábrica de caucho. En la actualidad, la cantidad total de desechos de caucho es excesiva y se están realizando esfuerzos para reducirla, lo que a su vez disminuiría el suministro necesario de combustible. El coste de mantenimiento de un incinerador diseñado para quemar desechos y productos de caucho es también muy alto.

Si se optimizaran todos estos costes, la incineración de los residuos de caucho podría ser un método rentable de eliminación.

\section{Conclusión}

Tal vez la mejor solución para los problemas ambientales y de salud relacionados con la fabricación de productos de caucho sería disponer de un buen control de ingeniería para producir y mezclar los productos químicos en polvo utilizados en los compuestos del caucho, así como de programas de reciclado para todos los desechos y productos de caucho vulcanizados y sin vulcanizar. Los productos químicos en polvo recogidos mediante sistemas adecuados podrían añadirse de nuevo a los compuestos de caucho, con los controles de ingeniería adecuados, lo que suprimiría el vertedero de estos productos.

El control de los problemas ambientales y de salud en la industria del caucho aunque es viable, no resulta fácil ni económico y habría que sumar su coste al de los propios productos de caucho. 


\section{Referencias}

Agencia Internacional para la Investigación sobre el Cáncer (IARC). 1992. 1,3-Butadiene. En IARC Monographs on the Evaluation of Carcinogenic Risks to $\mathrm{Hu}$ mans: Occupational Exposures to Mists and Vapours from Strong Inorganic Acids and Other Industrial Chemicals. Lyon: IARC.

Andjelkovich, D, H Abdelghany, RM Mathew, S Blum. 1988. Lung cancer case-control study in a rubber manufacturing plant. Am $f$ Ind Med 14:559-574.

Andjelkovich, D, JD Taulbee, MJ Symons. 1976. Mortality experience in a cohort of rubber workers, 1964-1973. J Occup Med 18:386-394.

Arp, EW, PH Wolf, H Checkoway. 1983. Lymphocytic leukemia and exposures to benzene and other solvents in the rubber industry. If Occup Med 25:598-602

Bernardinelli, L, RD Marco, C Tinelli. 1987. Cancer mortality in an Italian rubber factory. $\mathrm{Br} \mathcal{F}$ Ind $\mathrm{Med}$ 44:187-191.

Blum, S, EW Arp, AH Smith, HA Tyroler. 1979. Stomach cancer among rubber workers: An epidemiologic investigation. En Dusts and Disease. Park Forest, Illinois: SOEH, Pathotox Publishers.

Checkoway, H, AH Smith, AJ McMichael, FS Jones, RR Monson, HA Tyroler. 1981. A case-control study of bladder cancer in the U.S. tire industry. Br f Ind Med 38:240-246.

Checkoway, H, T Wilcosky, P Wolf, H Tyroler. 1984 An evaluation of the associations of leukemia and rubber industry solvent exposures. Am 7 Ind $\mathrm{Med}$ 5:239-249

Conferencia Americana de Higienistas Industriales del Gobierno (ACGIH), 1995. Industrial Ventilation: A Manual of Recommended Practice, 22 ed. Cincinnati: Ohio: ACGIH.

Delzell, E, D Andjelkovich, HA Tyroler. 1982 A case-control study of employment experience and lung cancer among rubber workers. Am $\mathcal{F}$ Ind Med 3:393-404.

Delzell, E, N Sathiakumar, M Hovinga, M Macaluso, J Julian, R Larson, P Cole, DCF Muir. 1996. A follow-up study of synthetic rubber workers Toxicology 113:182-189.

Delzell, E, RR Monson. 1981a. Mortality among rubber workers. III. Cause-specific mortality 1940-1978. f Occup Med 23:677-684.

-. 1981b. Mortality among rubber workers. IV. General mortality patterns. F Occup Med 23:850-856.

Fajen, J, RA Lunsford, DR Roberts. 1993. Industrial exposure to 1,3-butadiene in monomer, polymer and end-user industries. En Butadiene and Styrene: Assessment of Health Hazards, dirigido por M Sorsa, K Peltonen, H Vainio y K Hemminki. Lyon: IARC Scientific Publications.

Fine, LJ, JM Peters, WA Burgess, LJ DiBerardinis. 1976. Studies of respiratory morbidity in rubber workers. IV. Respiratory morbidity in talc workers. Arch Environ Health 31:195-200.

Fine, LJ, JM Peters. 1976a. Respiratory morbidity in rubber workers. I. Prevalence of respiratory symptoms and disease in curing workers. Arch Environ Health 31:5-9.

1976b. Respiratory morbidity in rubber workers. II. Pulmonary function in curing workers. Arch Environ Health 31:10-14.

- 1976c. Studies of respiratory morbidity in rubber workers. III. Respiratory morbidity in processing workers. Arch Environ Health 31:136-140.

Fox, AJ, DC Lindars, R Owen. 1974. A survey of occupational cancer in the rubber and cablemaking industries: Results of a five-year analysis, 1967-71. Br f Ind Med 31:140-151.
Fox, AJ, PF Collier. 1976. A survey of occupational cancer in the rubber and cablemaking industries: Analysis of deaths occurring in 1972-74. Br 7 Ind Med 33:249-264.

Gamble, JF, R Spirtas. 1976. Job classification and utilization of complete work histories in occupational epidemiology. F Occup Med 18:399-404.

Goldsmith, D, AH Smith, AJ McMichael. 1980. A case-control study of prostate cancer within a cohort of rubber and tire workers. $f$ Occup Med 22:533-541.

Granata, KP, WS Marras. 1993. An EMG-assisted model of loads on the lumbar spine during asymmetric trunk extensions. F Biomech 26:1429-1438.

Greek, BF. 1991. Rubber demand is expected to grow after 1991. $C \& E \mathcal{N}$ (13 mayo): 37-54.

Gustavsson, P, C Hogstedt, B Holmberg. 1986. Mortality and incidence of cancer among Swedish rubber workers. Scand 7 Work Environ Health 12:538-544.

Instituto Internacional de Fabricantes de Caucho Sintético (IISRP). 1994. Worldwide Rubber Statistics. Houston, Texas: Instituto Internacional de Fabricantes de Caucho Sintético.

Kilpikari, I, E Pukkala, M Lehtonen, M Hakama. 1982. Cancer incidence among Finnish rubber workers. Int Arch Occup Environ Health 51:65-71.

Kilpikari, I. 1982. Mortality among male rubber workers in Finland. Arch Environ Health 37:295-299.

Lednar, WM, HA Tyroler, AJ McMichael, CM Shy. 1977. The occupational determinants of chronic disabling pulmonary disease in rubber workers. f Occup Med 19:263-268.

Marras, WS, CM Sommerich. 1991. A three dimensional motion model of loads on the lumbar spine, Part I: Model structure. Hum Factors 33:123-137.

Marras, WS, SA Lavender, S Leurgans, F Fathallah, WG Allread, SA Ferguson, S Rajulu. 1995. Biomechanical risk factors for occupationally related low back disorder risk. Ergonomics 35:377-410.

Marras, WS, SA Lavender, S Leurgans, S Rajulu, WG Allread, F Fathallah, SA Ferguson. 1993. The role of dynamic three dimensional trunk motion in occupationally-related low back disorders: The effects of workplace factors, trunk position and trunk motion characteristics on injury. Spine 18:617-628.

McMichael, AJ, DA Andjelkovich, HA Tyroler. 1976. Cancer mortality among rubber workers: An epidemiologic study. Ann NY Acad Sci 271:125-137.

McMichael, AJ, R Spirtas, JF Gamble, PM Tousey. 1976a. Mortality among rubber workers: Relationship to specific jobs. 7 Occup Med 18:178-185.

McMichael, AJ, R Spirtas, LL Kupper, JF Gamble. 1975. Solvent exposures and leukemia among rubber workers: An epidemiologic study. 7 Occup Med 17:234-239.

McMichael, AJ, R Spirtas, LL Kupper. 1974. An epidemiologic study of mortality within a cohort of rubber workers, 1964-72. 7 Occup Med 16:458-464.

McMichael, AJ, WS Gerber, JF Gamble, WM Lednar. 1976b. Chronic respiratory symptoms and job type within the rubber industry. 7 Occup Med 18:611-617.

Monson, RR, KK Nakano. 1976a. Mortality among rubber workers. I. White male union employees in Akron, Ohio. Am 7 Epidemiol 103:284-296.

- 1976b. Mortality among rubber workers. II. Other employees. Am f Epidemiol 103:297-303.

Monson, RR, LJ Fine. 1978. Cancer mortality and morbidity among rubber workers. 7 Natl Cancer Inst 61:1047-1053.

National Fire Protection Association (NFPA). 1995. Standard for Ovens and Furnaces. NFPA 86. Quincy, Massachusetts: NFPA.
National Joint Industrial Council for the Rubber Manufacturing Industry. 1959. Running Nip Accidents. Londres: National Joint Industrial Council for the Rubber Manufacturing Industry.

.1967. Safe Working of Calenders. Londres: National Joint Industrial Council for the Rubber Manufacturing Industry.

Negri, E, G Piolatto, E Pira, A Decarli, J Kaldor, C LaVecchia. 1989. Cancer mortality in a northern Italian cohort of rubber workers. $\mathrm{Br} f \mathrm{Ind} \mathrm{Med}$ 46:624-628.

Norseth, T, A Anderson, J Giltvedt. 1983. Cancer incidence in the rubber industry in Norway. Scand $\mathcal{F}$ Work Environ Health 9:69-71.

Nutt, A. 1976. Measurement of some potentially hazardous materials in the atmosphere of rubber factories. Environ Health Persp 17:117-123.

Parkes, HG, CA Veys, JAH Waterhouse, A Peters. 1982. Cancer mortality in the British rubber industry. Brf Ind Med 39:209-220.

Peters, JM, RR Monson, WA Burgess, LJ Fine. 1976. Occupational disease in the rubber industry. Environ Health Persp 17:31-34.

Solionova, LG, VB Smulevich. 1991. Mortality and cancer incidence in a cohort of rubber workers in Moscow. Scand J Work Environ Health 19:96-101.

Sorahan, R, HG Parkes, CA Veys, JAH Waterhouse, JK Straughan, A Nutt. 1989. Mortality in the British rubber industry 1946-85. Br F Ind Med 46:1-11.

Sorahan, R, HG Parkes, CA Veys, JAH Waterhouse. 1986. Cancer mortality in the British rubber industry 1946-80. Br f Ind Med 43:363-373.

Szeszenia-Daborowaska, N, U Wilezynska, T Kaczmarek, W Szymezak. 1991. Cancer mortality among male workers in the Polish rubber industry. Polish Fournal of Occupational Medicine and Environmental Health 4:149-157.

Van Ert, MD, EW Arp, RL Harris, MJ Symons, TM Williams. 1980. Worker exposures to chemical agents in the manufacture of rubber tires: Solvent vapor studies. Am Ind Hyg Assoc f 41:212-219.

Wang, HW, XJ You, YH Qu, WF Wang, DA Wang, YM Long, JA Ni. 1984. Investigation of cancer epidemiology and study of carcinogenic agents in the Shanghai rubber industry. Cancer Res 44:3101-3105.

Weiland, SK, KA Mundt, U Keil, B Kraemer, T Birk, M Person, AM Bucher, K Straif, J Schumann, L Chambless. 1996. Cancer mortality among workers in the German rubber industry. Occup Environ Med 53:289-298.

Williams, TM, RL Harris, EW Arp, MJ Symons, MD Van Ert. 1980. Worker exposure to chemical agents in the manufacture of rubber tires and tubes: Particulates. Am Ind Hyg Assoc f 41:204-211.

Wolf, PH, D Andjelkovich, A Smith, H Tyroler, 1981. A case-control study of leukemia in the U.S. rubber industry. F Occup Med 23:103-108.

Zhang, ZF, SZ Yu, WX Li, BCK Choi. 1989. Smoking, occupational exposure to rubber and lung cancer. Br f Ind Med 46:12-15.

\section{Otras lecturas recomendadas}

Auchter, JF, R Mulach, S Mori. 1992. CEH Marketing Research Report: Natural Rubber. Menlo Park, California: SRI International.

Bhowmick, AK, MM Hall, HA Benarey (dirs.). 1994. Rubber Products Manufacturing Technology. Nueva York: Marcel Dekker, Inc.

British Rubber Manufacturers' Association (BRMA). 1990. Toxicity and Safe Handling of Rubber Chemicals: Code of Practice, $3^{\text {a }}$ edición. Birmingham: BRMA. 
Burgess, WA. 1995. Rubber products. In Recognition of Health Hazards in Industry, $3^{\text {a }}$ ed. Nueva York: John Wiley \& Sons.

Dunlop Co. Ltd. 1983. Caucho, cultivo. En Enciclopedia de salud y seguridad en el trabajo, $3^{\mathrm{a}}$ ed., Vol. 2. Ginebra: OIT.

Feinman, SE. 1987. Sensitivity to rubber chemicals. fournal of Toxicology - Cutaneous and Ocular Toxicology 6:117-153.

Fenoglio, S, G Meo, A Bonzanino. 1968. Manufacturing Risks in the Rubber Industry and Their Prevention I: Some Technical Aspects. Turín, Italia: Universidad de Turín, Instituto de Medicina Clínica General y Terapia Médica.

Fink JN. 1995. Latex allergy. Immunology and Allergy Clinics of North America 15:1-175.
International Federation of Chemical, Energy and General Workers' Unions (ICEF). 1990. Change and Concentration in the World Rubber Industry. Bruselas: ICEF.

McKinnery, WN, Jr, WA Heitbrink. 1984. Control of Air Contaminants in Tire Manufacturing. Research Report DHHS (NIOSH), Núms. 84-111. Cincinnati, Ohio: NIOSH.

Morton, M (dir.). 1987. Rubber Technology, $3^{\text {a }}$ edición. Nueva York: Van Nostrand Reinhold.

Reisch, MS. 1993. Rubber: Slow growth ahead. $C$ E EN (10 May): 24-33.

Slater, JE. 1994. Latex allergy. I Allergy Clin Immunol 94:139-149.

Symons, MJ, DA Andjelkovich, R Spirtas, DR Herman. 1982. Brain and central nervous system can- cer mortality in U.S. rubber workers. Ann NY Acad Sci 381:146-159.

Taylor, JS, P Praditsuwan. 1996. Latex allergy: Review of 44 cases including outcome and frequent association with allergic hand eczema. Archives of Dermatology 132:265-271.

Taylor, JS. 1986. Rubber. En Contact Dermatitis, $3^{\text {a }}$ de., dirigido por AA Fisher. Filadelfia: Lea \& Febiger.

UK Health and Safety Commission (HSC). 1994. Control of Fume at Extruders, Calendars and Vulcanising Operations. Londres: HSC Rubber Industry Advisory Committee/Health and Safety Executive.

- 1996. Dust and Fume Control in Rubber Mixing and Milling. Londres: HSC Rubber Industry Advisory Committee/Health and Safety Execu- 


\section{APARATOS Y EQUIPOS ELECTRICOS}

Director del capítulo

N. A. Smith

\section{Sumario}

Perfil general

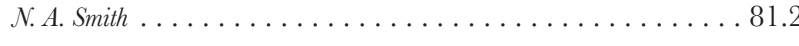

Fabricación de acumuladores de plomo

Barry P. Kelley . . . . . . . . . . . . . . . . . . . . 81.2

Pilas y baterías

N. A. Smith . . . . . . . . . . . . . . . . . . . . . . . 81.4

Fabricación de cables eléctricos

David A. O'Malley. . . . . . . . . . . . . . . . . . . . 81.8

Fabricación de lámparas eléctricas Albert M. Zielinski.

Fabricación de aparatos electrodomésticos

$\mathcal{N} . A$. Smith y $W$. Klost $\ldots \ldots \ldots \ldots \ldots \ldots \ldots$
Cuestiones ambientales y de salud pública

N. A. Smith 


\section{Perfil General}

\section{N. A. Smith}

\section{Visión general del sector}

Los equipos eléctricos comprenden muy diversos tipos de aparatos. Sería imposible ofrecer información sobre cada uno de ellos, por lo que en este capítulo sólo se tratan ciertos productos de algunas de las principales industrias. En la fabricación de los equipos intervienen muchos procesos. En este capítulo se explican los posibles riesgos a los que se exponen las personas que trabajan en la fabricación de baterías, pilas, lámparas y cables eléctricos, y electrodomésticos en general. El capítulo se ocupa sobre todo de los equipos eléctricos, ya que los electrónicos se estudian más a fondo en el capítulo titulado "Microelectrónica y semiconductores".

\section{Evolución de la industria}

El innovador descubrimiento de la inducción electromagnética contribuyó al desarrollo de la vasta industria eléctrica actual. El descubrimiento del efecto electroquímico dio lugar al desarrollo de las baterías como fuentes portátiles de alimentación de equipos eléctricos utilizando sistemas de corriente continua. Cuando se inventaron aparatos que recibían la alimentación eléctrica de una red, se hizo necesario un sistema de transmisión y distribución de electricidad, lo que dio lugar a la introducción de los conductores eléctricos flexibles (cables).

Las primeras formas de iluminación artificial (es decir, la iluminación de gas y de arco con electrodos de carbono) fueron sustituidas por la lámpara de filamento (en la lámpara exhibida en Inglaterra por Joseph Swan en enero de 1879, el filamento era de carbono). La lámpara de filamento había de disfrutar de un monopolio sin precedentes en aplicaciones domésticas, comerciales e industriales hasta el estallido de la Segunda Guerra Mundial, momento en el que se introdujo la lámpara fluorescente. Con posterioridad se han desarrollado otras formas de iluminación por descarga (basadas todas ellas en el paso de una corriente eléctrica a través de un gas o un vapor), con muy diversas aplicaciones comerciales e industriales.

El abanico de aparatos eléctricos que se desarrollan en muchos campos (p. ej., en aplicaciones audiovisuales, de calefacción, cocina y refrigeración) aumenta de manera constante. Basta citar como ejemplo la introducción de la televisión por satélite y el horno de microondas.

Aunque la disponibilidad y accesibilidad de las materias primas ha tenido un efecto importante en la evolución de las industrias, la ubicación de éstas no ha estado necesariamente determinada por la situación de aquéllas. Las materias primas suelen ser transformadas por terceros antes de su utilización en el montaje de aparatos y equipos eléctricos.

\section{Garacterísticas de los trabajadores}

La cualificación y los conocimientos prácticos que poseen quienes trabajan en este sector en la actualidad son diferentes de los que poseían los trabajadores hace años. Los equipos utilizados en la producción y fabricación de baterías, pilas, cables, lámparas y aparatos electrodomésticos están muy automatizados.

En muchos casos, pues, estos trabajadores requieren formación especializada para poder realizar su labor. El trabajo en equipo es un factor importante en este sector, ya que muchas operaciones responden a un sistema de producción en cadena, donde el trabajo de cada persona depende del trabajo de las demás.

Cada vez son más los procesos de fabricación de aparatos eléctricos que están informatizados de uno u otro modo. Por consiguiente, es necesario que el trabajador esté familiarizado con las técnicas informáticas, lo cual tal vez no plantee problema alguno a los más jóvenes, pero es posible que los de más edad no hayan trabajado nunca con ordenadores y requieran un reciclaje.

\section{Importancia económica de este sector}

La industria de aparatos y equipos eléctricos beneficia a unos países más que otros: es importante desde el punto de vista económico para los países donde se obtienen las materias primas y para aquellos en los que se montan y/o fabrican los productos finales. Estas dos operaciones tienen lugar en países muy diferentes.

Las materias primas no son infinitas. Los equipos desechados deben reutilizarse siempre que sea posible. Ahora bien, los costes que ocasiona la recuperación de la piezas reutilizables de los equipos desechados pueden resultar prohibitivos.

\section{FABRICACION DE ACUMULADORES DE PLOMO}

Barry P. Kelley

La primera batería viable a base de plomo-ácido fue diseñada por Gaston Planté en 1860 y su fabricación ha ido aumentando constantemente desde entonces. Es en las baterías de automoción donde más se utiliza esta tecnología, seguidas de las baterías industriales (energía auxiliar y tracción). Más de la mitad de la producción mundial de plomo se destina a la fabricación de baterías.

Es probable que la demanda de baterías de plomo-ácido continúe en el futuro gracias a su bajo coste y a la sencillez de estos sistemas en comparación con otros pares electroquímicos.

Este tipo de batería, también conocido por el nombre de "acumulador de plomo", tiene un electrodo positivo de peróxido de plomo $\left(\mathrm{PbO}_{2}\right)$ y un electrodo negativo de plomo esponjoso $(\mathrm{Pb})$ de amplia superficie. El electrólito es una disolución de ácido sulfúrico con una densidad relativa de entre 1,21 y 1,30 (28 a $39 \%$ del peso). En el momento de la descarga, ambos electrodos se convierten en sulfato de plomo, como se demuestra a continuación:

$$
\mathrm{PbO}_{2}+\mathrm{Pb}+2 \mathrm{H}_{2} \mathrm{SO}_{4} \underset{\text { descarga }}{\stackrel{\text { carga }}{\rightleftharpoons}} 2 \mathrm{PbSO}_{4}+2 \mathrm{H}_{2} \mathrm{O}
$$

\section{Proceso de fabricación}

A continuación se describe el proceso de fabricación, ilustrado en el diagrama de flujos de la Figura 81.1).

Fabricación del óxido: existen dos métodos de fabricar óxido de plomo a partir de lingotes (masas de plomo obtenidas en hornos de fundición): la vasija de Barton y el proceso de trituración. En el primero, se hace pasar aire sobre el plomo fundido para producir una fina corriente de gotitas de plomo. Estas reaccionan con el oxígeno del aire y forman el óxido, que consta de un núcleo de plomo revestido de óxido de plomo $(\mathrm{PbO})$.

En el proceso de trituración, se introduce el plomo sólido (cuyo tamaño varía de pequeñas bolitas hasta lingotes completos) en un molinillo giratorio. El movimiento del tambor genera calor, con lo que la superficie del plomo se oxida. Además, el movimiento de las partículas en el interior del tambor, hace que las capas superficiales de óxido vayan cayendo y dejando más plomo expuesto a la oxidación. La corriente de aire lleva el polvo a una bolsa filtrante, donde queda recogido. 


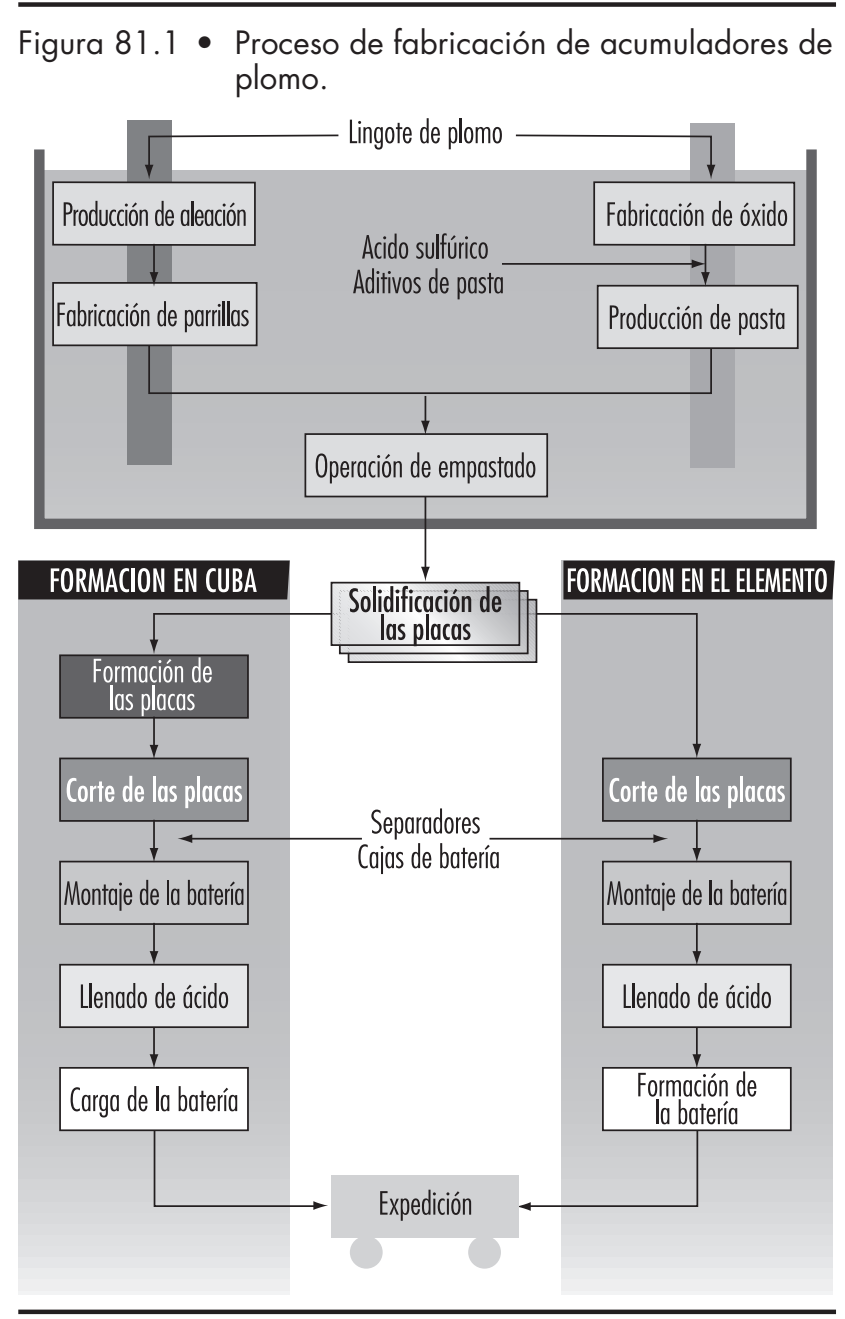

Fabricación de parrillas: las parrillas se fabrican principalmente por moldeo (tanto manual como automático) o bien, sobre todo en el caso de las baterías de automoción, por expansión a partir de una aleación de plomo de forja o fundición.

Empastado: la pasta de la batería se elabora mezclando el óxido con agua, ácido sulfúrico y varios aditivos especiales. Después se introduce a presión por los intersticios de la parrilla por medios mecánicos o manuales, y las placas obtenidas suelen secarse al instante por evaporación en un horno de alta temperatura.

Las placas obtenidas por empastado se curan en hornos bajo condiciones de temperatura, humedad y tiempo perfectamente controladas. El plomo libre presente en la pasta se convierte en óxido de plomo.

Formación eléctrica, corte y montaje de las placas: son dos los procesos de formación eléctrica a los que se someten las placas de las baterías: la formación en cuba y la formación en el elemento. En el primero de ellos, las placas se introducen en grandes baños de ácido sulfúrico diluido y se pasa una corriente continua para formar las placas positivas y negativas. Una vez secas, las placas se cortan y se montan, separadas por tabiques, en la caja de la batería. Las placas de igual polaridad se conectan soldando sus orejetas.

En el segundo proceso, las placas se forman eléctricamente dentro de los elementos acumuladores ya montados en la caja de la batería.

\section{Riesgos para la salud en el trabajo y controles}

\section{Plomo}

El plomo es el principal riesgo para la salud asociado a la fabricación de baterías. La principal vía de exposición es la inhalación, pero la ingestión también plantea problemas si no se presta atención suficiente a la higiene personal. En todas las fases de la producción hay posibilidad de exposición.

La fabricación de óxido de plomo puede ser muy peligrosa. Las exposiciones se controlan automatizando el proceso, apartando así a los trabajadores del riesgo. En muchas fábricas, el proceso lo lleva a cabo una sola persona.

En el moldeo de parrillas, la exposición a los humos de plomo se minimiza con ventilación aspirante local (VAL) y con el control termostático de los tanques de plomo (las emisiones de humos de plomo aumentan bastante por encima de $\operatorname{los} 500{ }^{\circ} \mathrm{C}$ ). La escoria plumbosa que se forma sobre el plomo fundido también puede causar problemas, ya que contiene una gran cantidad de polvo muy fino y es preciso tener gran cuidado al eliminarla.

Las zonas de empastado son lugares donde tradicionalmente existe una alta exposición al plomo. El método de fabricación suele dar lugar a que las máquinas, suelos, delantales y botas reciban salpicaduras de fangos de plomo. Estas salpicaduras se secan y producen polvo de plomo que queda en suspensión en el aire. Como método de control, se mantienen los suelos permanentemente mojados y se friegan a menudo los delantales.

La exposición al plomo en otros departamentos (formación eléctrica, corte de placas y montaje) es consecuencia de la manipulación de placas secas y polvorientas, y se reduce al mínimo por medio de sistemas de VAL y con el uso apropiado de equipos de protección individual.

Muchos países tienen leyes que limitan el grado de exposición en el trabajo y existen normas numéricas de niveles de plomo en aire y de plomo en sangre.

Por lo común se emplea a un profesional de la salud en el trabajo para tomar muestras de sangre a los trabajadores expuestos. La periodicidad de los análisis puede ser anual para los trabajadores de bajo riesgo y trimestral para quienes trabajan en departamentos de alto riesgo (p. ej., empastado). Si el nivel de plomo en sangre de un trabajador supera el límite legalmente establecido, será preciso apartarlo de cualquier exposición hasta que el nivel disminuya y alcance un valor aceptable para el asesor médico.

La toma de muestras de aire es complementaria a los análisis de sangre. Es preferible el muestreo personal que el estático. Debido a la variabilidad inherente a los resultados, suele ser necesario tomar un gran número de muestras de plomo en aire. Utilizando procedimientos estadísticos correctos en el análisis, los datos obtenidos ofrecen información sobre posibles fuentes de plomo y constituyen una base a partir de la cual realizar mejoras en el diseño técnico. Es posible utilizar muestreos de aire periódicos a fin de evaluar la eficacia continuada de los sistemas de control.

Las concentraciones admisibles de plomo en aire y en sangre varían según el país, y en la actualidad oscilan entre 0,05 y $0,20 \mathrm{mg} / \mathrm{m}^{3}$ y entre 50 y $80 \mathrm{mg} / \mathrm{dl}$ respectivamente. La tendencia a la baja de estos límites es constante.

Además de los controles técnicos normales, son necesarias otras medidas para minimizar las exposiciones al plomo. En ninguna zona de producción deberá permitirse comer, fumar, beber ni mascar chicle.

Deberán existir instalaciones adecuadas donde los trabajadores se laven y se cambien, guardando la ropa de trabajo separada de la ropa y el calzado personales. Las duchas y los lavabos deberán estar ubicados entre las zonas limpias y sucias. 


\section{Acido sulfúrico}

Durante el proceso de formación eléctrica, el material activo de las placas se convierte en $\mathrm{PbO}_{2}$ en el electrodo positivo y en $\mathrm{Pb}$ en el negativo. A medida que las placas van cargándose totalmente, la corriente de formación comienza a disociar el agua del electrólito en hidrógeno y oxígeno:

$\begin{array}{ll}\text { Positivo: } & \mathrm{H}_{2} \mathrm{O}-2 \mathrm{H}^{+}+1 / 2 \mathrm{O}_{2}+2 \mathrm{e}^{-} \\ \text {Negativo: } & \frac{2 \mathrm{H}^{+}+2 \mathrm{e}^{-}-\mathrm{H}_{2}}{\mathrm{H}_{2} \mathrm{O}-\mathrm{H}_{2}+1 / 2 \mathrm{O}_{2}}\end{array}$

El desprendimiento de gases genera una niebla de ácido sulfúrico. En otra época, era corriente que los trabajadores de las zonas de formación sufriesen erosión dental. Las empresas fabricantes de baterías han empleado tradicionalmente los servicios de un dentista y muchas de ellas continúan haciéndolo.

En estudios recientes (IARC 1992) se ha observado una posible relación entre las exposiciones a las nieblas de ácidos inorgánicos (incluido el ácido sulfúrico) y el cáncer de laringe. Las investigaciones en este sentido continúan.

La norma establecida de exposición laboral a la niebla de ácido sulfúrico en el Reino Unido es de $1 \mathrm{mg} / \mathrm{m}^{3}$. Es posible mantener la exposición por debajo de este nivel instalando sistemas de VAL sobre los circuitos donde se forma.

La exposición al corrosivo ácido sulfúrico líquido es también motivo de preocupación. Como precauciones cabe citar los equipos de protección individual, los surtidores de lavado ocular y las duchas de emergencia.

\section{Talco}

El talco se utiliza en ciertas operaciones de moldeo manual como agente de desmoldeo. La exposición prolongada al polvo de talco puede provocar neumoconiosis, y es importante controlarlo con ventilación adecuada y medidas de control de proceso.

\section{Fibras minerales artificiales (FMA)}

En los acumuladores de plomo se utilizan tabiques para aislar eléctricamente las placas positivas de las negativas. A lo largo de los años se han venido utilizando varios tipos de materiales [p. ej., caucho, celulosa, cloruro de polivinilo (PVC), polietileno], pero cada vez se utilizan más los separadores de fibra de vidrio, fabricados con FMA.

En los inicios de la industria de la lana mineral se demostró un mayor riesgo de cáncer de pulmón entre sus trabajadores (HSE 1990). Ahora bien, tal vez la causa estaba en otros materiales cancerígenos que se utilizaban entonces. No obstante, es prudente asegurarse de minimizar toda exposición a las FMA bien por medio de un encerramiento total o por medio de sistemas de VAL.

\section{La estibina y la arsina}

$\mathrm{El}$ antimonio y el arsénico son materiales muy utilizados en las aleaciones de plomo, por lo que puede producirse estibina $\left(\mathrm{SbH}_{3}\right)$ $\mathrm{o}$ arsina $\left(\mathrm{AsH}_{3}\right)$ en ciertas circunstancias:

- cuando un elemento acumulador se sobrecarga en exceso;

- cuando se mezcla una aleación de plomo-calcio con escoria de una aleación de plomo-antimonio o plomo-arsénico. La reacción química de ambas escorias forma antimonio cálcico o arseniuro cálcico, los cuales, al mojarse después, pueden generar $\mathrm{SbH}_{3}$ o $\mathrm{AsH}_{3}$.

La estibina y la arsina son gases muy tóxicos, cuyo efecto es la destrucción de los glóbulos rojos. Para evitar cualquier riesgo de exposición a estos gases es preciso mantener rigurosos controles de proceso durante la fabricación de baterías.

\section{Riesgos físicos}

En la fabricación de baterías también existen diversos riesgos físicos (p. ej., ruido, salpicaduras de ácido y metal fundido, riesgos eléctricos y manipulaciones manuales), aunque se reducen por medio de los adecuados controles técnicos y de proceso.

\section{Cuestiones ambientales}

Los efectos del plomo en la salud de los niños han sido objeto de amplios estudios. Es fundamental, pues, mantener la liberación de plomo al medio ambiente en niveles mínimos. En las fábricas de baterías deben filtrarse las emisiones atmosféricas más contaminantes. Todos los desechos de proceso (fangos plumbosos ácidos, por lo común) han de llevarse a una planta de tratamiento de efluentes para neutralizar el ácido y separar el plomo de la suspensión.

\section{Tendencias futuras}

Es probable que el uso de plomo se vea cada vez más restringido en el futuro. En el ámbito laboral, esto dará lugar a una mayor automatización de los procesos, de modo que se aparte al trabajador del peligro.

\section{Pillas y Baterias}

N. A. Smith

Se denomina batería a una serie de elementos individuales o pilas (nombre éste que se da a muchos tipos de baterías), que generan electricidad por medio de reacciones químicas. Los elementos pueden ser primarios o secundarios. En los primarios, las reacciones químicas que producen el flujo de electrones no son reversibles y, por consiguiente, no se recargan con facilidad. Por el contrario, los elementos secundarios deben cargarse antes de su utilización, lo que se consigue haciendo pasar por ellos una corriente eléctrica. Tales elementos (llamados también acumuladores) tienen la ventaja de que suelen poder recargarse y descargarse repetidamente durante su uso.

La pila primaria clásica de uso diario es la pila seca Leclanché, llamada de este modo porque el electrólito es una pasta, no un líquido. La pila Leclanché es la típica pila cilíndrica utilizada en linternas, radios portátiles, calculadoras, juguetes eléctricos y similares. En los últimos años, las pilas alcalinas, como las de zinc-dióxido de manganeso, han ganado terreno en este tipo de usos. Las pilas en miniatura o pilas "de botón" han hallado aplicaciones en audífonos, ordenadores, relojes, cámaras y otros equipos electrónicos. Las pilas de zinc-óxido de plata, de mercurio, de zinc-aire y de litio-dióxido de manganeso son algunos ejemplos. En la Figura 81.2 se ofrece el corte de una típica pila alcalina de botón.

La batería secundaria clásica es la de acumuladores de plomo, que se emplea mucho en la industria del transporte, así como en las centrales eléctricas y en la industria. Linternas, cepillos de dientes, herramientas recargables a pilas y similares constituyen un nuevo mercado para este tipo de pila. Las secundarias de níquel-cadmio están adquiriendo mayor popularidad, sobre todo como pilas de bolsillo para iluminación de emergencia, arranques de motores diesel y aplicaciones estacionarias y de tracción, en las que las características de fiabilidad, larga duración, frecuente recargabilidad y rendimiento a baja temperatura compensan su coste adicional.

Las baterías recargables que se están elaborando para su aplicación en vehículos eléctricos utilizan litio-sulfuro ferroso, zinccloro y sodio-azufre. 
Figura 81.2 - Corte de una pila alcalina de botón.

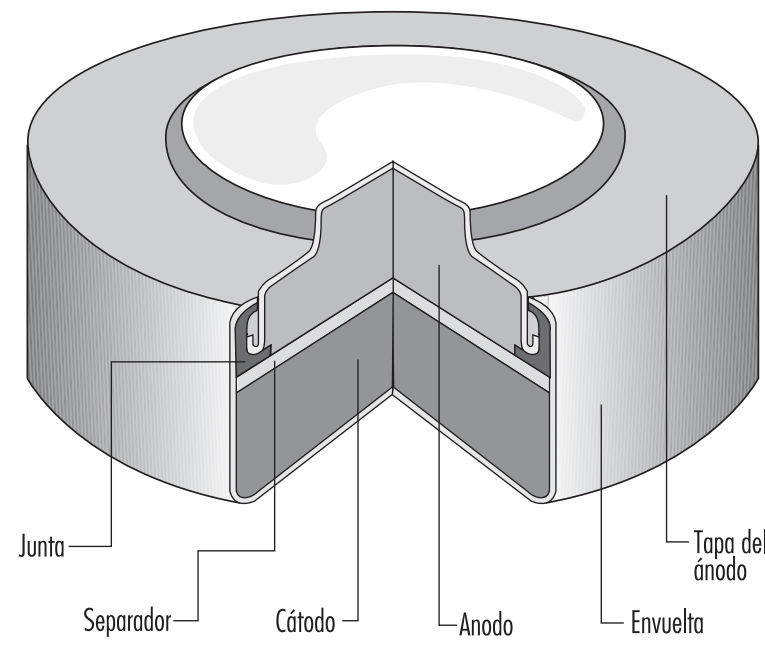

Fuente: Eveready Battery Co.

En la Tabla 81.1 se indica la composición de muchas baterías corrientes.

\section{Procesos de fabricación}

Aunque existen claras diferencias en la fabricación de los diferentes tipos de baterías, tienen en común los procesos de pesaje, trituración, mezcla, compresión y secado de los ingredientes. En las modernas fábricas de baterías, muchas de estas operaciones se hacen en recintos aislados (con equipos herméticos) y están muy automatizadas. Por consiguiente, puede producirse exposición de los trabajadores a los diversos ingredientes durante su pesaje y carga y durante la limpieza de los equipos.

En las fábricas más antiguas, muchas de las operaciones de trituración, mezcla y otras, o bien el paso de los ingredientes de una etapa a otra del proceso, se realizan manualmente. En estos casos, el riesgo de inhalación de polvo o de contacto cutáneo con sustancias corrosivas es alto. Entre las precauciones que deben tomarse en las operaciones que producen polvo cabe citar el aislamiento total y la mecanización de la manipulación y el pesaje de los distintos tipos de polvo, el empleo de ventilación aspirante local, la limpieza diaria (fregar y/o aspirar) de los suelos y la utilización de mascarillas respiratorias y otros equipos de protección individual durante las operaciones de mantenimiento.

El ruido también supone un riesgo, ya que las máquinas de compresión y empaquetado lo producen. Es esencial que existan métodos de control del ruido y programas de conservación de la capacidad auditiva.

Los electrólitos que se utilizan en muchas baterías contienen hidróxido de potasio, que es un material corrosivo. El aislamiento y la protección cutánea y ocular son precauciones convenientes. También puede haber exposición a las partículas de metales tóxicos, como el óxido de cadmio, el mercurio, el óxido de mercurio, el níquel y sus compuestos y el litio y sus compuestos, que se utilizan como ánodos o cátodos en determinados tipos de baterías. La batería de acumuladores de plomo-ácido, también conocida como "acumulador de plomo", entraña riesgos considerables de exposición al plomo y se trata específicamente en el artículo titulado "Fabricación de acumuladores de plomo".

El litio es un metal muy reactivo, por lo que el montaje de pilas de litio ha de realizarse en un ambiente seco a fin de evitar que el litio reaccione con el vapor de agua. El dióxido de azufre y el cloruro de tionilo, utilizados en algunas pilas de litio, comportan riesgos respiratorios. El hidrógeno, gas utilizado en las pilas de níquel-hidrógeno, comporta riesgos de incendio y explosión. Estos materiales, así como los que se utilicen en las pilas de nuevo diseño, requerirán precauciones especiales.

\section{Pilas Leclanché}

La Figura 81.3 ilustra la producción de las pilas secas Leclanché. El electrodo positivo o la mezcla catódica contiene entre 60 y $70 \%$ de dióxido de manganeso, y el resto es grafito, negro de

Tabla 81.1 • Composición de las pilas y baterías más comunes.

$\begin{array}{llll}\text { Tipo de pila o batería } & \text { Electrodo negativo } & \text { Electrodo positivo } & \text { Electrólito } \\ \begin{array}{l}\text { Elementos primarios } \\ \text { Pila seca Leclanché }\end{array} & \text { Zinc } & \text { Dióxido de manganeso } & \text { Agua, cloruro de zinc, cloruro de amonio } \\ \text { Alcalina } & \text { Zinc } & \text { Dióxido de manganeso } & \text { Hidróxido de potasio } \\ \text { Mercurio (pila de Ruben) } & \text { Zinc } & \text { Oxido mercúrico } & \text { Hidróxido de potasio, óxido de zinc, agua } \\ \text { Plata } & \text { Zinc } & \text { Oxido de plata } & \text { Hidróxido de potasio, óxido de zinc, agua } \\ \text { Litio } & \text { Litio } & \text { Dióxido de manganeso } & \text { Clorato de litio, LiCF } \mathrm{SO}_{3} \\ \text { Litio } & \text { Litio } & \text { Dióxido de azufre } & \text { Dióxido de azufre, acetonitrilo, bromuro de litio } \\ & & \text { Cloruro de tionilo } & \text { Cloruro de litio y aluminio } \\ \text { Zinc en aire } & \text { Zinc } & \text { Oxígeno } & \text { Oxido de zinc, hidróxido de potasio } \\ \text { Elementos secundarios } & & & \\ \text { Plomo-ácido } & \text { Plomo } & \text { Dióxido de plomo } & \text { Acido sulfúrico diluido } \\ \text { Níquel-hierro (batería de Edison) } & \text { Hierro } & \text { Oxido de níquel } & \text { Hidróxido de potasio } \\ \text { Níquel-cadmio } & \text { Hidróxido de cadmio } & \text { Hidróxido de níquel } & \text { Hidróxido de potasio, posiblemente hidróxido de } \\ & & \text { litio }\end{array}$


Figura 81.3 • Diagrama de flujo de la producción de pilas Leclanché.

\begin{tabular}{|c|}
\hline PREPARACION DEL CATODO \\
\hline Pesaje de la mezcla catódica \\
\hline 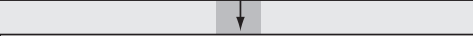 \\
\hline Alimentación de la mezcla catódica al molinillo mezclado \\
\hline$\downarrow$ \\
\hline Adición del electrólito \\
\hline$\checkmark$ \\
\hline Secado al horno \\
\hline$\checkmark$ \\
\hline Tamizado \\
\hline$\downarrow$ \\
\hline Remojado \\
\hline$\checkmark$ \\
\hline Prensado en tabletas \\
\hline$\checkmark$ \\
\hline Inspección y empaquetado \\
\hline$\checkmark$ \\
\hline Endurecimiento \\
\hline$\checkmark$ \\
\hline Remojo en el electrólito \\
\hline
\end{tabular}
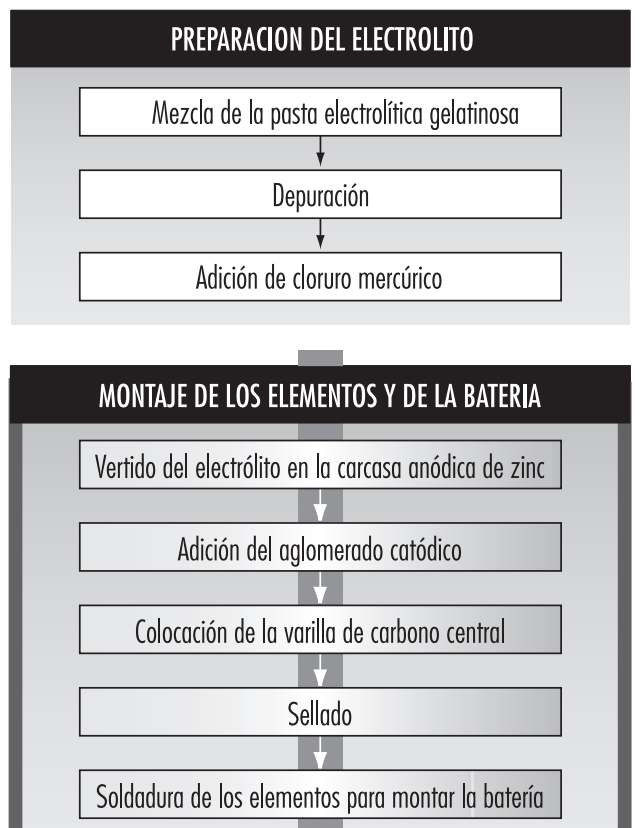

acetileno, sales amónicas, cloruro de zinc y agua. Se pesa el polvo fino y seco de dióxido de manganeso, grafito y negro de acetileno y se introduce en un molinillo mezclador; se agrega el electrólito compuesto de agua, cloruro de zinc y cloruro de amonio, y la mezcla así preparada se comprime con una prensa de alimentación manual para formar aglomerados o tabletas. En ciertos casos, la mezcla se seca al horno, se tamiza y se vuelve a humedecer antes de producir las tabletas. Estas se inspeccionan y se empaquetan con máquinas de alimentación manual tras dejar que se endurezcan durante algunos días. Los aglomerados se colocan después en bandejas y se remojan en el electrólito, quedando así listos para el montaje.

El ánodo es la carcasa de zinc, que se elabora a partir de tochos de zinc en una prensa caliente (o bien doblando y soldando chapas de zinc a la carcasa). En grandes tinas se mezcla una pasta orgánica gelatinosa que consta de almidones de harina y maíz remojados en electrólito. Los ingredientes suelen verterse directamente de los sacos, sin pesarlos. La mezcla se depura después con astillas de zinc y dióxido de manganeso. Se agrega cloruro mercúrico al electrólito para formar una amalgama con el interior del envase de zinc. Esta pasta constituirá el medio conductor o electrólito.

El montaje de los elementos se realiza vertiendo automáticamente la cantidad necesaria de pasta gelatinosa en las carcasas de zinc para formar un recubrimiento interior en el envase de zinc. En algunos casos, las carcasas cuentan con un acabado cromado debido a la introducción y al vaciado de una mezcla de ácido crómico e hidroclórico antes de agregar la pasta gelatinosa. Entonces se coloca el aglomerado catódico en el centro de la carcasa. Se sitúa una varilla de carbono en el centro del cátodo para que actúe como colector de corriente.

Después se sella el elemento de zinc con parafina o cera fundida y se calienta con una llama para obtener una mejor estanquidad. Por último, se sueldan los elementos para formar la pila. La reacción de la pila es la siguiente:

$$
2 \mathrm{MnO}_{2}+2 \mathrm{NH}_{4} \mathrm{Cl}+\mathrm{Zn}-\mathrm{ZnCl}_{2}+\mathrm{H}_{2} \mathrm{O}_{2}+\mathrm{Mn}_{2} \mathrm{O}_{3}
$$

Los trabajadores pueden quedar expuestos al dióxido de manganeso durante las operaciones de pesaje, carga de la mezcladora, trituración, limpieza del horno, tamizado, prensado y empaquetado manual, en función del grado de automatización, de la estanquidad del recinto y de la ventilación aspirante local. En el prensado y empaquetado manual de la mezcla húmeda, el trabajador está expuesto a la misma, que puede secarse y producir polvo inhalable; la exposición al electrólito, ligeramente corrosivo, puede provocar dermatitis. Estos riesgos se reducen con medidas de higiene personal, con el uso de guantes y protección respiratoria en las operaciones de limpieza y mantenimiento, y con duchas y taquillas separadas para la ropa de calle y de trabajo. Como ya se ha dicho, el empaquetado y la formación de tabletas son operaciones que entrañan riesgo de ruido.

Durante la fabricación de la pasta gelatinosa, la mezcla es automática y el trabajador sólo puede quedar expuesto durante la adición de los materiales. La adición de cloruro mercúrico a la pasta gelatinosa comporta el riesgo de inhalación y absorción cutánea y posible intoxicación por mercurio. Es necesario disponer de sistemas de VAL o de equipos de protección individual.

También es posible la exposición a derrames de ácido crómico y ácido hidroclórico durante el cromado, y a los humos de soldadura y del calentamiento del compuesto sellador. La mecanización del proceso de cromado, el uso de guantes y de sistemas de VAL para las operaciones de soldadura y sellado térmico son precauciones adecuadas.

\section{Acumuladores de níquel-cadmio}

El método de fabricación de electrodos de níquel-cadmio más corriente en la actualidad es depositar el material activo del electrodo directamente sobre una placa o sustrato poroso de níquel sinterizado (véase la Figura 81.4.) La placa se elabora prensando una pasta de polvo de níquel sinterizado (que suele fabricarse por descomposición de carbonilo de níquel) a través de una chapa perforada de acero niquelado (o tamiz de níquel o de acero niquelado) y sinterizándola o secándola al horno. Posteriormente, para determinados usos las placas se cortan, se pesan y se acuñan 
Figura 81.4 • Diagrama de flujo de la producción de pilas de níquel-cadmio utilizando níquel sinterizado.

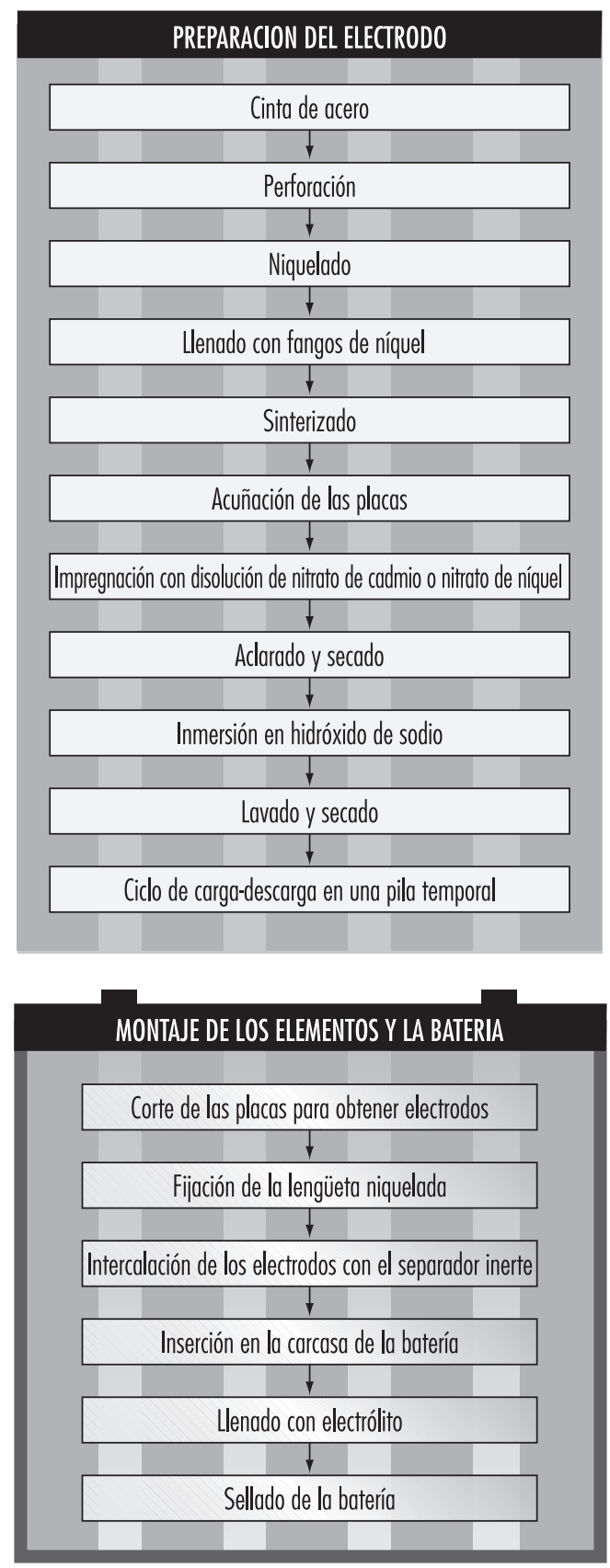

(comprimen), o se laminan en forma de espiral para pilas de tipo doméstico.

La placa sinterizada se impregna después con una disolución de nitrato de níquel para el electrodo positivo o de nitrato de cadmio para el negativo. Estas placas se lavan y se secan, se sumergen en hidróxido de sodio para formar hidróxido de níquel o hidróxido de cadmio y se vuelven a lavar y secar. Habitualmente, el paso siguiente es sumergir los electrodos positivo y negativo en una gran batería temporal con un 20 o $30 \%$ de hidróxido de sodio. Se realizan ciclos de carga y descarga para eliminar impurezas y después se retiran, lavan y secan los electrodos.
Otro modo de fabricar electrodos de cadmio es preparar una pasta de óxido de cadmio mezclada con grafito, óxido de hierro y parafina, que se tritura y se compacta finalmente por medio de rodillos para conformar el material activo. Este se prensa para formar un fleje de acero perforado móvil que se seca, a veces se comprime, y se corta en placas. En esta fase pueden agregarse orejetas.

En los pasos siguientes se hace el montaje de los elementos y de la pila. En las pilas de gran tamaño, los electrodos individuales se montan formando grupos de electrodos con placas de polaridad opuesta intercaladas con separadores de plástico. Los grupos pueden atornillarse o soldarse y se colocan en una carcasa de acero niquelado. Las carcasas de plástico son de introducción más reciente. Los elementos se llenan con una disolución electrolítica de hidróxido de potasio, que también puede contener hidróxido de litio. Después se montan las baterías atornillando los elementos. Las pilas de plástico se unen con cemento o cinta. Cada elemento se conecta al adyacente por medio de un puente de plomo para formar un borne positivo y otro negativo, uno en cada extremo de la batería.

En las pilas cilíndricas, las placas impregnadas se montan en grupos de electrodos enrollando los electrodos positivo y negativo, separados por un material inerte, para formar un cilindro apretado. El electrodo cilíndrico se coloca entonces en una carcasa metálica niquelada, se agrega electrólito de hidróxido de potasio y se sella el elemento por soldadura.

La reacción química que se produce en la carga y descarga de las pilas de níquel-cadmio es la siguiente:

$2 \mathrm{Ni}(\mathrm{OH})_{2}+\mathrm{Cd}(\mathrm{OH})_{2} \underset{\text { descarga }}{\stackrel{\text { carga }}{\rightleftharpoons}} \mathrm{Cd}^{\circ}+2 \mathrm{HO}_{2} \mathrm{O}+2 \mathrm{NiOOH}$

La exposición más importante al cadmio es la que se produce en la manipulación del nitrato de cadmio y su disolución durante la fabricación de pasta a partir de óxido de cadmio en polvo y en la manipulación del polvo activo seco. Es posible asimismo la exposición durante el reciclaje del cadmio de las placas de desecho. El encerramiento y la automatización de las operaciones de pesaje y mezcla pueden reducir estos riesgos durante las primeras fases.

La exposición a los compuestos del níquel puede controlarse con medidas parecidas. La producción de níquel sinterizado a partir de carbonilo de níquel, aunque se realiza en maquinaria hermética, comporta una posible exposición al carbonilo de níquel y al monóxido de carbono, ambos extremadamente tóxicos. Este proceso requiere una constante vigilancia de las fugas de gas.

La manipulación de hidróxido de potasio o de hidróxido de litio cáusticos requiere ventilación adecuada y protección individual. La soldadura genera humos y requiere sistemas de VAL.

\section{Efectos sobre la salud y pautas patológicas}

Los riesgos más graves para la salud en la fabricación tradicional de baterías son las exposiciones a plomo, cadmio, mercurio y dióxido de manganeso. Los riesgos del plomo son objeto de análisis en otros apartados de este mismo capítulo y de la presente Enciclopedia. El cadmio puede provocar enfermedades renales y es cancerígeno. La exposición al cadmio resultó estar muy extendida en las fábricas de pilas de níquel-cadmio de Estados Unidos, y muchos trabajadores tuvieron que ser apartados por motivos médicos, de conformidad con las disposiciones de la norma de la OSHA sobre el cadmio, debido a los altos niveles del mismo hallados en sangre y orina (McDiarmid y cols. 1996). El mercurio afecta a los riñones y al sistema nervioso. Los estudios realizados en varias fábricas de pilas de mercurio han demostrado la existencia de una excesiva exposición al vapor de mercurio (Telesca 1983). Se ha demostrado que la exposición al 
dióxido de manganeso es alta en las operaciones de manipulación y mezcla de polvo para la fabricación de pilas secas alcalinas (Wallis, Menke y Chelton 1993). Esto puede provocar deficiencias neurofuncionales en los trabajadores (Roels y cols. 1992). El polvo de manganeso absorbido en cantidades excesivas causa trastornos del sistema nervioso central parecidos al síndrome de Parkinson. También son metales problemáticos, entre otros, el níquel, el litio, la plata y el cobalto.

La exposición a las disoluciones de cloruro de zinc, hidróxido de potasio, hidróxido de sodio e hidróxido de litio utilizadas en los electrólitos de las baterías pueden provocar quemaduras en la piel.

\section{FABRICACION DE CABLES ELECTRICOS}

\section{David A. O'Malley}

Los cables se comercializan en muy diversos tamaños para usos diferentes, desde los cables de tensión muy alta, que transmiten energía eléctrica a más de 100 kilovoltios, hasta los cables de telecomunicaciones. Estos últimos utilizaban en el pasado conductores de cobre, pero han sido reemplazados por los de fibra óptica, que permite transmitir más información con un cable mucho más pequeño. Entre ambos se hallan los cables generales para conexiones domésticas, otros cables flexibles y los cables eléctricos de tensión inferior a los de tensión muy alta. Además, existen cables más especializados, como los cables de aislante mineral (que se utilizan cuando resulta crucial su inherente resistencia al fuego: por ejemplo, en una fábrica, en un hotel o a bordo de un barco), los hilos esmaltados (que se utilizan como devanados eléctricos de motores), el hilo de oropel o hilo tinsel (utilizado en la conexión espiral de un microteléfono), los cables de cocina (cuyo aislamiento ha sido históricamente de asbesto, aunque en la actualidad es de otros materiales), etcétera.

\section{Materiales y procesos}

\section{Conductores}

El material más utilizado como conductor en cables siempre ha sido el cobre, debido a su conductividad eléctrica. El cobre ha de refinarse en un estado de gran pureza antes de su utilización para fabricar conductores. El refinado del cobre a partir del mineral o de la chatarra es un proceso de dos fases:

1. el refinado al fuego en un gran horno para eliminar impurezas indeseadas y moldear un ánodo de cobre; y

2. el refinado electrolítico en una pila eléctrica de ácido sulfúrico, en cuyo cátodo se deposita cobre muy puro.

En las fábricas modernas, primero se funden los cátodos de cobre en un horno de cuba y después se fabrican las barras de cobre por colada continua y por laminación. Estas barras se reducen a los diámetros necesarios en una trefiladora haciéndolas pasar por una hilera de precisos troqueles. La operación de trefilado se ha realizado tradicionalmente en un lugar central, rodeado de muchas máquinas que producían alambres de diferentes medidas. Recientemente, las pequeñas fábricas autónomas ya hacen sus propias operaciones de trefilado. Para algunas aplicaciones especializadas, se recubre el conductor de cobre con un revestimiento metálico, como el estaño, la plata o el zinc.

En los cables eléctricos elevados se utilizan conductores de aluminio, cuya inferior conductividad en comparación con el cobre se ve más que compensada por su menor peso. Los conductores de aluminio se fabrican haciendo pasar una palanquilla de aluminio caliente por un troquel mediante una prensa de extrusión.

Otros conductores metálicos más especializados utilizan aleaciones especiales para una determinada aplicación. Se han empleado aleaciones de cadmio y cobre para fabricar catenarias (el conductor aéreo utilizado en las vías férreas) e hilos tinsel para microteléfonos. El cadmio aumenta la resistencia a la tracción en comparación con el cobre puro, y se utiliza para que la catenaria no se combe entre soportes. También se utilizan aleaciones de berilio y cobre en ciertas aplicaciones.

Las fibras ópticas, que consisten en un filamento continuo de vidrio de alta calidad óptica para la transmisión en el campo de las telecomunicaciones, se inventaron a principios del decenio de 1980. Exigieron desarrollar una tecnología de fabricación totalmente nueva. Dentro de un torno se quema tetracloruro de silicio para depositar dióxido de silicio sobre un tocho. El dióxido de silicio se convierte en vidrio por calentamiento en una atmósfera de cloro; después se trefila a medida y se le aplica un revestimiento protector.

\section{Aislamiento}

Se han utilizado muchos materiales aislantes en diferentes tipos de cables. Los tipos más corrientes son los materiales plásticos, como el PVC, el polietileno, el politetrafluoretileno (PTFE) y las poliamidas. En cada caso, el plástico se elabora para que cumpla una especificación técnica y se aplica a la parte externa del conductor utilizando una máquina de extrusión. A veces se añaden otros materiales al compuesto plástico para una aplicación determinada; por ejemplo, algunos cables eléctricos incorporan un compuesto de silano para vulcanizar el plástico. Si el cable va a enterrarse en el suelo, se añade un plaguicida para evitar que las termitas devoren el aislante.

Algunos cables flexibles, sobre todo los que se instalan en minas subterráneas, utilizan aislante de caucho. Se necesitan cientos de compuestos de caucho para cumplir diferentes especificaciones, y se requieren unas instalaciones especializadas para su fabricación. El caucho es extrusionado sobre el conductor. También debe vulcanizarse pasando por un baño de sales de nitrito calientes o de un líquido presurizado. Para evitar que los conductores con aislante de caucho se queden pegados unos con otros, se les hace pasar a través de polvos de talco.

$\mathrm{El}$ conductor del interior del cable va envuelto en un aislante, como el papel (previamente remojado en un aceite sintético o mineral) o la mica. Después se aplica una vaina externa, normalmente por extrusión de plástico.

Se han desarrollado dos métodos de fabricación de cables de aislante mineral (AM). En el primero, un tubo de cobre lleva en su interior varios conductores sólidos de cobre y el espacio entre estos se rellena con polvo de óxido de magnesio. Después se pasa todo el conjunto por una hilera de troqueles para reducirlo al tamaño necesario. La otra técnica comporta la soldadura continua de una espiral de cobre alrededor de conductores separados por polvo. En uso, la vaina exterior de cobre de un cable $\mathrm{AM}$ es la conexión a tierra y los conductores interiores transmiten la corriente. Aunque no se necesita una capa exterior, algunos clientes especifican una vaina de PVC por motivos de estética. Esto resulta contraproducente, ya que la principal ventaja del cable AM es que no se quema, y la vaina de PVC le priva en parte de esta ventaja.

En los últimos años se ha prestado mayor atención al comportamiento de los cables en los incendios por dos motivos:

1. La mayoría de los cauchos y plásticos, materiales aislantes tradicionales, emiten ingentes cantidades de humos y gases tóxicos al arder, y en varios incendios de importancia ésta ha sido la principal causa de muerte. 
2. Una vez que el fuego alcanza el interior del cable, los conductores se tocan y se funde el circuito, cortándose la corriente eléctrica. Como consecuencia, se han desarrollado compuestos fumífugos e ignífugos (FI), tanto para materiales de plástico como de caucho. Con todo, las mejores prestaciones en caso de incendio las proporcionan los cables de aislante mineral.

Para ciertos cables se utilizan varios materiales especializados: los cables de tensión muy alta se llenan de aceite por sus propiedades aislantes y refrigerantes; otros cables utilizan una grasa de hidrocarburos conocida como MIND, vaselina o una vaina de plomo. La fabricación de hilos esmaltados comporta por lo común su revestimiento con un esmalte de poliuretano disuelto en cresol.

\section{Fabricación de cables}

Muchos cables se fabrican retorciendo los conductores aislados para formar una determinada configuración. Los conductores salen de sendos carretes que giran alrededor de su eje y van pasando por la máquina que forma el cable, en las operaciones conocidas como trenzado y estratificado.

Algunos cables han de ser protegidos contra posibles daños mecánicos. Suele hacerse por entrelazado, es decir, entretejiendo un material con el aislamiento externo de un cable flexible de modo que cada hilo se cruce con el otro una y otra vez en forma helicoidal. Un ejemplo de este tipo de cable entrelazado (al menos en el Reino Unido) es el que se utiliza en las planchas eléctricas, donde se utiliza hilo textil como material de entrelazado. En otros casos se utiliza hilo de acero, y entonces la operación se denomina armado.

\section{Operaciones auxiliares}

Los cables más grandes se suministran en tambores de varios metros de diámetro. Tradicionalmente, los tambores eran de madera, pero también se han utilizado de acero. Un tambor de madera se fabrica remachando piezas de madera aserrada con una máquina o pistola remachadora neumática. Se utiliza un conservante de cobre-cromo-arsénico para evitar que se pudra la madera. Los cables más pequeños suelen suministrarse en carretes de cartón.

Es posible que la operación de conexión de los dos extremos de los cables, conocida como empalme, haya de ser realizada en un lugar alejado. El empalme no sólo ha de contar con una buena conexión eléctrica, sino que además debe ser capaz de soportar las futuras condiciones ambientales. Los compuestos de empalme utilizados suelen ser resinas acrílicas e incorporan compuestos de isocianato y sílice en polvo.

Los conectores de los cables suelen fabricarse en tornos automáticos a partir de barras de latón. Las máquinas se refrigeran y lubrican utilizando una emulsión de aceite en agua. Las abrazaderas de los cables se fabrican con máquinas de moldeo por inyección de plástico.

\section{Riesgos y su prevención}

El riesgo más extendido para la salud en toda la industria del cable es el ruido. Las operaciones más ruidosas son las siguientes:

- el trefilado;

- el entrelazado;

- el refinado del cobre al fuego;

- la colada continua de barras de cobre,

- la fabricación de tambores de cable.

En estas zonas son corrientes los niveles de ruido superiores a los $90 \mathrm{dBA}$. En las operaciones de trefilado y entrelazado, el nivel de ruido total depende del número y la ubicación de las máquinas y del ambiente acústico. Es preciso planificar la distribución de las máquinas para minimizar la exposición al ruido. El medio más eficaz de controlar el ruido es la instalación de recintos acústicos bien diseñados, pero resulta caro. En el refinado de cobre al fuego y en la colada continua de barras de cobre, los principales focos de ruido son los quemadores, que deben diseñarse para ser poco ruidosos. En el caso de la fabricación de tambores de cable, las pistolas remachadoras neumáticas son el principal foco de ruido, que se reduce bajando la presión de la conducción de aire e instalando silenciadores de escape. Sin embargo, en la mayoría de los casos la norma de la industria es facilitar protección auditiva a los trabajadores de las áreas afectadas, aunque la protección resulta más incómoda en este caso debido al calor ambiental existente en las operaciones de refinado de cobre al fuego y de colada continua de barras de cobre. También se precisa la realización de audiometrías periódicas para controlar el oído de cada persona.

Muchos de los riesgos para la seguridad y su prevención son iguales que en otras industrias de fabricación. Sin embargo, algunas máquinas de fabricación de cables presentan riesgos especiales, ya que cuentan con numerosos carretes de conductores girando alrededor de dos ejes al mismo tiempo. Es esencial asegurarse de que las defensas de las máquinas tengan dispositivos de enclavamiento que impidan que la máquina funcione si no están colocadas, para evitar el acceso a cilindros en marcha y otras piezas giratorias, como los grandes tambores de cable. Durante el enhebrado inicial de la máquina, cuando puede ser preciso que el operario pase al interior de la defensa de la máquina, es obligado que ésta sólo pueda moverse algunos centímetros cada vez. Los dispositivos de enclavamiento pueden instalarse de modo que con una sola llave se abra la defensa o bien se inserte en la consola de control para que pueda funcionar.

Deberá realizarse una evaluación del riesgo que presentan las partículas que puedan salir proyectadas: por ejemplo, si un hilo se rompe y da un latigazo.

Es esencial que el diseño de las defensas impida físicamente que dichas partículas alcancen al operario. Cuando esto no sea posible, los trabajadores recibirán y llevarán protecciones oculares adecuadas. En las operaciones de trefilado suele ser necesaria la utilización de protectores oculares.

\section{Conductores}

En cualquier proceso de metal caliente, como el refinado de cobre al fuego o el moldeo de barras de cobre, debe impedirse que el agua entre en contacto con el metal fundido para evitar una explosión. Al cargar el horno es posible que se produzcan escapes de humos de óxido metálico en el lugar de trabajo, por lo que es preciso contar con un sistema de ventilación aspirante local eficaz sobre la puerta de carga. De manera similar, conviene controlar adecuadamente los canales por los que pasa el metal fundido desde el horno hasta la máquina de colada, así como la propia máquina de colada.

El principal riesgo existente en la refinería electrolítica es la niebla de ácido sulfúrico que emanan las pilas. Las concentraciones atmosféricas deben mantenerse por debajo de $1 \mathrm{mg} / \mathrm{m}^{3}$ por medio de una ventilación adecuada, a fin de evitar irritaciones.

El moldeo de barras de cobre entraña un riesgo adicional por el uso de mantas o planchas aislantes para conservar el calor alrededor de la rueda de colada. Los materiales cerámicos pueden haber reemplazado al asbesto en estas aplicaciones, pero las propias fibras cerámicas deben manipularse con gran cuidado para evitar la exposición a ellas. Estos materiales resultan más friables (es decir, se rompen con más facilidad) tras su uso, cuando han sido afectados por el calor, y su manipulación ha provocado exposición a fibras respirables en suspensión. 
Un riesgo inusual es el que presenta la fabricación de cables eléctricos de aluminio. Se aplica al émbolo de la prensa de extrusión una suspensión de grafito en un aceite pesado para evitar que la palanquilla de aluminio se quede pegada al émbolo. Cuando éste está caliente, parte del material se quema y se eleva hasta el techo. Siempre que no haya operarios de puentes-grúa en las proximidades y que haya ventiladores en funcionamiento en el techo, no ha de constituir un riesgo para la salud de los trabajadores.

La fabricación de aleaciones de cobre-cadmio o de cobre-berilio puede presentar graves riesgos para los trabajadores que intervienen. Como el cadmio hierve muy por debajo del punto de fusión del cobre, se generan humos de óxido de cadmio siempre que se agrega cadmio al cobre fundido (como debe hacerse para fabricar la aleación). Esta operación sólo resulta segura con una cuidada ventilación aspirante local. De manera similar, la fabricación de la aleación de cobre-berilio requiere prestar una gran atención, ya que el berilio es el más tóxico de todos los metales tóxicos y los límites de exposición al mismo son los más estrictos.

La fabricación de fibras ópticas es una operación de alta tecnología, muy especializada. Los productos químicos utilizados tienen sus propios riesgos específicos y el control del ambiente de trabajo requiere el diseño, la instalación y el mantenimiento de complejos sistemas de VAL y de ventilación de proceso. Estos sistemas se controlan por medio de humidificadores de control supervisados por ordenador. Los principales riesgos químicos proceden del cloro, del cloruro de hidrógeno y del ozono. Además, los disolventes utilizados para limpiar los troqueles deben manipularse en cabinas con extracción de humos y ha de evitarse el contacto de la piel con las resinas a base de acrilatos que se utilizan para revestir las fibras.

\section{Aislamiento}

Las operaciones de elaboración de compuestos de plástico y de caucho presentan riesgos específicos que deben controlarse adecuadamente (véase el capítulo titulado La industria del caucho). Aunque en la industria del cable se utilizan compuestos distintos a los de otros sectores, las técnicas de control son las mismas.

Cuando se calientan, los compuestos de plástico desprenden una compleja mezcla de productos procedentes de la degradación térmica, cuya composición depende del compuesto plástico original y de la temperatura a la que se someta. A la temperatura normal de proceso de los extrusores de plástico, los contaminantes atmosféricos suelen constituir un problema relativamente pequeño, pero es prudente instalar un sistema de ventilación sobre la zona de separación entre el cabezal extrusor y la artesa de agua utilizada para enfriar el producto, sobre todo para controlar la exposición a los ftalatos plastificantes que suelen emplearse en el PVC. La fase de la operación que tal vez precise nuevas investigaciones es el cambio de material. El operario ha de subirse al cabezal extrusor para retirar el compuesto plástico todavía caliente e introducir el nuevo compuesto hasta que sólo salga el nuevo color y el cable quede centrado en el cabezal extrusor. El diseño de sistemas de VAL eficaces para esta fase del trabajo en la que el operario está tan cerca del cabezal extrusor, tal vez resulte difícil.

El politetrafluoretileno (PTFE) entraña un riesgo específico: puede provocar la fiebre de los humos poliméricos, cuyos síntomas son parecidos a los de la gripe. Es una afección temporal, pero debe evitarse controlando adecuadamente la exposición al compuesto caliente.

El uso de caucho en la fabricación de cables ha presentado un menor nivel de riesgo que otros usos del mismo, como en la industria del neumático. En ambas industrias, el empleo de un antioxidante (Nonox S) que contenía $\beta$-naftilamina, hasta su retirada en 1949, provocó casos de cáncer de vejiga hasta 30 años más tarde en quienes habían estado expuestos con anterioridad a la fecha de retirada, pero ninguno en los empleados sólo con posterioridad a 1949. Sin embargo, en la industria del cable no se ha experimentado la mayor incidencia de otros cánceres - en especial, los de pulmón y estómago - aparecidos en la industria del neumático. La razón es, casi con toda seguridad, que en la fabricación de cables, las máquinas de extrusión y vulcanización están aisladas, y la exposición de los trabajadores a los humos y al polvo de caucho era por lo común mucho menor que en la industria del neumático. El empleo de talco puede ser peligroso en las fábricas de cables de caucho. Es importante asegurarse de que se utilice solamente la forma no fibrosa del talco (es decir, la que no contiene tremolita fibrosa) y de que el talco se aplique en una cabina cerrada con ventilación aspirante local.

En muchos cables se estampan marcas de identificación. Si se utilizan las modernas videoimpresoras a chorro, el riesgo para la salud es casi con toda seguridad despreciable, debido a las pequeñísimas cantidades de disolvente que se utilizan. Sin embargo, otras técnicas de impresión pueden dar lugar a exposiciones importantes a disolventes, ya sea durante la producción normal o, lo que es más habitual, durante las operaciones de limpieza. Por consiguiente, es preciso emplear sistemas de extracción adecuados para controlar tales exposiciones.

Los principales riesgos de la fabricación de cables AM son la exposición al polvo, al ruido y a las vibraciones. Los dos primeros se controlan por medio de técnicas estándar de las que se trata en otros artículos. La exposición a la vibración solía ocurrir en el pasado durante la conificación, por la que se formaba una punta al final del tubo montado por inserción manual en una máquina con martillos giratorios, de modo que la punta pudiera introducirse en la máquina trefiladora. Más recientemente, este tipo de conificadora ha sido reemplazada por máquinas neumáticas, lo que ha eliminado tanto la vibración como el ruido generado por el método antiguo.

La exposición al plomo durante el envainado debe controlarse por medio de sistemas de VAL adecuados y prohibiendo comer, beber y fumar en áreas susceptibles de contaminación por plomo. Es preciso realizar controles biológicos periódicos analizando el contenido de plomo en muestras de sangre en un laboratorio cualificado.

El cresol utilizado en la fabricación de hilos esmaltados es corrosivo y tiene un olor distintivo a concentraciones muy bajas. Parte del poliuretano se degrada térmicamente en los hornos de esmaltado y libera tolueno diisocianato (TDI), un potente sensibilizador respiratorio. Es preciso instalar un buen sistema de VAL alrededor de los hornos provistos de dispositivos catalíticos de poscombustión para asegurarse de que el TDI no contamine el área circundante.

\section{Operaciones auxiliares}

Las operaciones de empalme presentan riesgos para dos grupos distintos de trabajadores: quienes los fabrican y quienes los utilizan. La fabricación comporta la manipulación de un polvo fibrogénico (sílice), un sensibilizador respiratorio (isocianato) y un sensibilizador cutáneo (resina acrílica). Debe utilizarse un sistema de VAL eficaz para controlar adecuadamente la exposición de los empleados, quienes han de llevar guantes adecuados para evitar que la resina entre en contacto con su piel. El principal riesgo para los usuarios de los compuestos es la sensibilización cutánea a la resina, lo cual es difícil de controlar, ya que es posible que el empalmador no pueda evitar el contacto cutáneo del todo y es probable que se encuentre en un lugar alejado y desprovisto de agua para limpiarse. Por tanto, es esencial disponer de un limpiador de manos sin agua. 


\section{Riesgos ambientales y su prevención}

Por regla general, la fabricación de cables no genera emisiones significativas al exterior de la fábrica. Existen tres excepciones, no obstante. La primera es que la exposición a los vapores de los disolventes utilizados para imprimir y para otros fines se controlan utilizando sistemas de VAL que descargan a la atmósfera. Los compuestos orgánicos volátiles (COV) de dichas emisiones son uno de los componentes necesarios para formar "esmog" fotoquímico, por lo que están sufriendo una presión cada vez mayor por parte de las autoridades reguladoras de varios países. La segunda excepción es la posible liberación de TDI procedente de la fabricación de hilos esmaltados. La tercera es que, en varios casos, la fabricación de las materias primas que se utilizan en los cables puede dar lugar a emisiones al medio ambiente si no se toman medidas de control. Las emisiones de partículas metálicas de las refinerías de cobre y de la fabricación de aleaciones de cobre-cadmio o cobre-berilio deberán canalizarse hacia sistemas filtrantes adecuados. Asimismo, todas las emisiones de partículas procedentes de la elaboración de compuestos de caucho lo harán a su vez hacia un sistema filtrante. Las emisiones de partículas, cloruro de hidrógeno y cloro procedentes de la fabricación de fibras ópticas deberán canalizarse hacia un sistema filtrante seguido de un depurador de sosa cáustica.

\section{- FABRICACION DE LAMPARAS ELECTRICAS}

\section{Albert M. Zielinski}

Las lámparas son de dos tipos básicos: de filamento (o incandescentes) y de descarga. Los componentes básicos de ambos tipos de lámparas son el vidrio, varias piezas de hilo metálico, un gas de relleno y, por lo común, una base. Algunos fabricantes producen estos materiales en sus instalaciones y otros los obtienen de proveedores externos. Lo normal es que fabriquen sus propios globos de vidrio, comprando otros componentes y tipos de vidrio a fabricantes especializados u otras empresas del ramo.

En función del tipo de lámpara, se utilizan diversas clases de vidrio. En las lámparas incandescentes y fluorescentes suele utilizarse un vidrio de sosa y cal. En las lámparas de mayor temperatura se utilizan vidrios de borosilicatos, mientras que en las lámparas de descarga de alta presión se utilizan materiales cerámicos o cuarzo para el tubo de descarga y vidrios de borosilicatos para la ampolla exterior. Para sellar los extremos de las bombillas suele utilizarse vidrio plumboso (que contiene entre un 20 y un $30 \%$ de plomo).

Los hilos metálicos utilizados como soportes o conectores en la fabricación de las lámparas pueden ser de diversos materiales: acero, níquel, cobre, magnesio y hierro, mientras que los filamentos son de tungsteno o de una aleación de tungsteno y torio. Un requisito crucial para el hilo soporte es que sus características de dilatación coincidan con las del vidrio si el hilo penetra en el vidrio para conducir la corriente eléctrica de la lámpara. Es frecuente utilizar para este fin hilos conductores compuestos de varios materiales.

Las bases (o casquillos) suelen ser de latón o aluminio, siendo el latón el material preferido para aplicaciones al aire libre.

\section{Lámparas de filamento o incandescentes}

Son las lámparas más antiguas y todavía hoy siguen fabricándose. Toman su nombre del modo en que producen la luz: por calentamiento de un filamento metálico a temperatura suficiente para que se ponga al rojo. Aunque es posible fabricar una lámpara incandescente casi con cualquier tipo de filamento (en las primeras lámparas se utilizaba carbono), hoy en día la mayoría de ellas utilizan un filamento de tungsteno.

Lámparas de tungsteno. La versión más común de estas lámparas para uso doméstico consiste en un globo de vidrio que encierra un filamento de tungsteno. La electricidad llega al filamento conducida por hilos metálicos que lo sustentan y que atraviesan la montura de vidrio que va sellada al globo. Los hilos se conectan después a la base metálica, uno soldado al ojal central de la base y el otro conectado al cuerpo roscado. Los hilos de soporte tienen una composición especial, de modo que tengan las mismas características de dilatación que el vidrio, lo que evita que se produzcan fugas cuando se calientan las lámparas. El globo suele ser de vidrio de cal, mientras que la montura es de vidrio plumboso. Para preparar la montura suele emplearse dióxido de azufre, que actúa como lubricante durante el montaje de las lámparas a alta velocidad. En función del diseño de la lámpara, el globo se cierra al vacío o se llena de argón o de otro gas no reactivo.

Las lámparas de este tipo se venden con globos transparentes, globos translúcidos y globos revestidos con diversos materiales. Los globos translúcidos y los revestidos con un material blanco (por regla general, arcilla o sílice amorfa) se utilizan para reducir el brillo que produce el filamento con los globos transparentes. También se aplican a los globos, por la parte externa, diversos revestimientos decorativos, como cerámicas y lacas de colores, mientras que la parte interna puede decorarse con otros colores, como el amarillo o el rosa.

Aunque la forma doméstica típica es la más corriente, las lámparas incandescentes pueden fabricarse con globos de muchas formas (tubulares, redondos y reflectores), así como en muchos tamaños y vatajes, desde las lámparas en miniatura hasta los grandes focos de estudio o escenario.

Lámparas halógenas de tungsteno. Un problema del diseño de la lámpara de filamento de tungsteno normal es que el tungsteno se evapora en servicio y se condensa en la pared de vidrio, más fría, oscureciéndola y reduciendo la transmisión de luz. Este problema se elimina añadiendo al gas interior un halógeno, como el bromuro de hidrógeno o el bromuro metílico. El halógeno reacciona con el tungsteno, impidiendo que se condense en la pared de vidrio. Cuando la lámpara se enfría, el tungsteno vuelve a depositarse sobre el filamento. Como esta reacción funciona mejor a mayor presión, las lámparas halógenas de tungsteno suelen contener gas a varias atmósferas de presión. Normalmente, el halógeno se añade integrado en el gas interior de la lámpara, habitualmente a concentraciones del $2 \%$ o menos.

En las lámparas halógenas de tungsteno también se utilizan globos de cuarzo en lugar de vidrio. Los primeros soportan mayores presiones; ahora bien, el cuarzo entraña un posible riesgo, ya que es transparente a la luz ultravioleta. Aunque el filamento de tungsteno produce relativamente poca radiación ultravioleta, la exposición prolongada a corta distancia puede causar enrojecimiento de la piel e irritación ocular. Filtrando la luz por una cubierta de vidrio se reduce en gran medida la cantidad de radiación ultravioleta, al tiempo que se ofrece protección contra el cuarzo caliente en el caso de que la lámpara se rompa mientras está en funcionamiento.

\section{Riesgos y precauciones}

En general, los mayores riesgos que presenta la fabricación de lámparas, con independencia del tipo de producto, son los que presentan los equipos automáticos y la manipulación de lámparas y globos de vidrio y otros materiales. Los cortes producidos al manipular el vidrio y al introducir las manos en los equipos en funcionamiento son las causas más corrientes de accidente; los 
problemas derivados de la manipulación de materiales, como los movimientos repetitivos o las lesiones de espalda, son especialmente preocupantes.

Es frecuente emplear pasta de soldadura plumbosa en las lámparas. En las utilizadas en aplicaciones de alta temperatura, se emplean pastas de soldadura con cadmio. En las operaciones automáticas de montaje de lámparas, la exposición a estas pastas de soldadura es mínima. Si se realizan soldaduras manuales, como en las operaciones semiautomáticas o en reparaciones, deberá vigilarse la exposición al plomo o al cadmio.

Las posibilidades de quedar expuesto a materiales peligrosos durante la fabricación de lámparas han ido disminuyendo constantemente desde mediados del siglo XX. En la fabricación de lámparas incandescentes, a una gran cantidad de ellas se les solía aplicar una solución de ácido hidrofluórico o sales bifluóricas para darles un acabado translúcido. Esto se ha sustituido en gran medida por un revestimiento arcilloso de baja toxicidad. Aunque no se ha reemplazado por completo, el uso de ácido hidrofluórico se ha reducido mucho. Este cambio ha reducido el riesgo de sufrir quemaduras en la piel e irritación pulmonar a causa del ácido. Los revestimientos cerámicos de colores utilizados en la parte externa de algunas lámparas solían contener pigmentos de metales pesados, como el plomo, el cadmio, el cobalto y otros, además de integrar una frita de vidrio de silicato de plomo en su composición. En los últimos años, muchos de estos pigmentos metálicos han sido reemplazados por colorantes menos tóxicos. En los casos en los que todavía se utilizan los metales pesados, pueden aplicarse los de menor toxicidad (p. ej., cromo III en lugar de cromo VI).

Los filamentos de tungsteno helicoidales continúan fabricándose enrollando el tungsteno alrededor de un mandril de acero o molibdeno. Una vez formada y sinterizada la espiral, los mandriles se disuelven utilizando ácido hidroclórico (para el acero) o una mezcla de ácido nítrico y sulfúrico para el molibdeno. Dado que existe la posibilidad de exposición al ácido, este trabajo se realiza por regla general dentro de sistemas con cubierta y, más recientemente, en recintos de disolución totalmente aislados (sobre todo si se utiliza la mezcla de ácido nítrico y sulfúrico).

Los gases de relleno para las lámparas halógenas de tungsteno se introducen en ellas dentro de sistemas totalmente cerrados con escasa exposición o pérdida. El uso del bromuro de hidrógeno plantea sus propios problemas debido a su naturaleza corrosiva. Es preciso disponer de VAL y de una canalización resistente a la corrosión para los sistemas de suministro de gases. El hilo de tungsteno toriado (por lo común, entre un 1 y un $2 \%$ de torio) sigue utilizándose en algunos tipos de lámparas. Sin embargo, el riesgo que entraña el torio en forma de hilo es escaso.

El dióxido de azufre debe controlarse cuidadosamente. En todos los lugares donde se añada este material al proceso es preciso utilizar sistemas de VAL. También es útil la instalación de detectores de fugas en los almacenes. Las bombonas de gas de $75 \mathrm{~kg}$ son preferibles a los grandes contenedores de $1.000 \mathrm{~kg}$, debido a las posibles consecuencias catastróficas de una liberación en cantidades elevadas.

La irritación cutánea es un riesgo que entrañan los fundentes de soldadura o de las resinas utilizadas en el cemento de sustentación. En algunos cementos de sustentación se utiliza paraformaldehído en lugar de resinas naturales, que da lugar a una posible exposición al formaldehído durante la solidificación del cemento de sustentación.

Todas las lámparas utilizan un sistema de "adsorción" química, por el que el filamento se reviste de un determinado material antes del montaje. La finalidad del material adsorbente (getter) es reaccionar con cualquier residuo de humedad $\mathrm{u}$ oxígeno que haya quedado en la lámpara una vez sellada, y eliminarlo. Entre los adsorbentes típicos cabe citar el nitruro de fósforo y las mezclas de polvos metálicos de aluminio y zirconio. Aunque el adsorbente de nitruro de fósforo es bastante benigno mientras actúa, la manipulación de los polvos metálicos de aluminio y zirconio puede constituir un riesgo por su inflamabilidad. Los adsorbentes se aplican en estado húmedo a un disolvente orgánico, pero si se derrama el material, los polvos metálicos secos pueden arder por fricción. Las llamas de metal deben apagarse con extintores de incendios especiales de clase D, y no con agua, espuma ni otros materiales habituales. Un tercer tipo de adsorbente incluye el uso de fosfamina o silano. Es posible incluir estos materiales a baja concentración en el relleno de gas de la lámpara, o añadirlos a la lámpara, a alta concentración y durante un instante, antes de introducir el último relleno de gas. Ambos materiales son muy tóxicos; si se utilizan en concentraciones altas, la fábrica contará con sistemas cerrados por completo con detectores de fugas y alarmas.

\section{Lámparas de descarga}

Las lámparas de descarga, tanto los modelos de alta como de baja presión, son más eficaces que las lámparas incandescentes en cuanto a proporción luz/vatio. Las lámparas fluorescentes se han utilizado durante muchos años en edificios comerciales y cada vez se utilizan más en los hogares. Hace poco se han desarrollado versiones reducidas de las lámparas fluorescentes específicamente pensadas para sustituir a las lámparas incandescentes.

Las lámparas de descarga de alta presión se han destinado durante mucho tiempo al alumbrado de calles y grandes superficies. También se están desarrollando versiones de menor vataje de estos productos.

\section{Lámparas fluorescentes}

Toman su nombre del polvo fluorescente utilizado para revestir la parte interna del tubo de vidrio. Este polvo absorbe la luz ultravioleta producida por el vapor de mercurio utilizado en la lámpara y la transforma y vuelve a emitir en forma de luz visible.

El vidrio utilizado en estas lámparas es parecido al de las incandescentes, empleándose vidrio de cal para el tubo, y vidrio plumboso para las monturas de cada extremo. Actualmente se utilizan dos familias diferentes de revestimientos fosfóricos. Los halofosfatos, a base de clorofluorofosfato de calcio o estroncio, son los más antiguos, cuyo uso se extendió a principios del decenio de 1950, año en que reemplazaron a los revestimientos fosfóricos a base de silicato de berilio. La segunda familia de revestimientos fosfóricos incluye los fabricados a partir de tierras raras, entre los que están el itrio, el lantano y otros. Este tipo de revestimientos fosfóricos suelen tener un espectro de emisión de banda estrecha y se utilizan combinados: por lo común, uno rojo, uno azul y uno verde.

Los revestimientos fosfóricos se mezclan con un aglomerante y quedan en suspensión en una mezcla orgánica o en una mezcla de agua y amoníaco, y se aplican al interior del tubo de vidrio. La suspensión orgánica utiliza acetato butílico, nafta/acetato butílico o xileno. Debido a las normativas en materia ambiental, las suspensiones a base de agua están reemplazando a las de base orgánica. Una vez aplicado el revestimiento, se seca en el tubo y se calienta éste a alta temperatura para eliminar el aglomerante.

En cada extremo de la lámpara se fija una montura. A continuación se introduce mercurio en la lámpara, lo cual se hace de varias maneras: aunque en algunas zonas el mercurio se añade de forma manual, lo normal es hacerlo automáticamente, con la lámpara montada en vertical o en horizontal. En las máquinas verticales, se cierra la montura del extremo inferior de la lámpara. Después se vierte el mercurio por arriba, se introduce 
argón a baja presión y se cierra la montura superior, quedando la lámpara sellada por completo. En las máquinas horizontales, el mercurio se introduce por un lado mientras por el otro se hace el vacío en la lámpara. Se añade el argón a la presión adecuada y se sellan ambos extremos de la lámpara. Una vez sellada, se agregan los casquillos o bases en los extremos y se sueldan los hilos conductores a los contactos eléctricos.

Existen otros dos métodos para introducir el vapor de mercurio. En el primero, el mercurio va en un fleje impregnado, que lo libera al primer encendido de la lámpara. En el segundo, se utiliza mercurio líquido, pero dentro de una cápsula de vidrio fijada a la montura. La cápsula se rompe una vez sellada y vaciada la lámpara, liberando el mercurio.

Las lámparas fluorescentes compactas son versiones reducidas de la lámpara fluorescente normal; a veces se incluyen los circuitos electrónicos como componente integrado de la lámpara. Los fluorescentes compactos utilizan por lo común una mezcla de materiales fosfóricos a base de tierras raras. Algunos incorporan un cebador de descarga que contiene pequeñas cantidades de materiales radiactivos para ayudar al encendido de la lámpara. Estos cebadores de descarga suelen utilizar criptón-85, hidrógeno-3, promecio-147 o torio natural para suministrar lo que se denomina una corriente oscura, que ayuda a que la lámpara se encienda con mayor rapidez. Desde el punto de vista del consumidor resulta útil, ya que la lámpara se enciende de inmediato, sin parpadear.

\section{Riesgos y precauciones}

La fabricación de lámparas fluorescentes ha sufrido considerables cambios. El primer revestimiento fosfórico con berilio dejó de utilizarse en 1949, lo que eliminó un importante riesgo respiratorio durante la producción y utilización de estos materiales. En muchas operaciones, las suspensiones fosfóricas acuosas han reemplazado a las suspensiones orgánicas en el revestimiento de las lámparas fluorescentes, reduciendo la exposición de los trabajadores, así como la emisión de COV al medio ambiente. Las suspensiones acuosas sí comportan cierta exposición mínima al amoníaco, sobre todo durante la mezcla de las suspensiones.

El mercurio continúa siendo el material más problemático durante la fabricación de lámparas fluorescentes. Aunque las exposiciones son relativamente bajas excepto alrededor de las máquinas de extracción, existe la posibilidad de que los trabajadores situados alrededor de estas máquinas, los mecánicos que trabajan con ellas y los encargados de su limpieza sufran exposiciones significativas. Deberán utilizarse equipos de protección individual, como monos y guantes de trabajo, para evitar o limitar la exposición y, cuando sea necesario, protección respiratoria, sobre todo durante las actividades de mantenimiento y limpieza. Es esencial el establecimiento de un programa de control biológico (que incluya análisis de mercurio en orina) en las fábricas de lámparas fluorescentes.

Los dos sistemas fosfóricos que se producen en la actualidad emplean materiales que se consideran de toxicidad relativamente baja. Aunque diversos organismos públicos han establecido límites de exposición a algunos de los aditivos de los materiales fosfóricos base (como el bario, el plomo y el manganeso), estos componentes suelen presentarse en las composiciones en porcentajes relativamente bajos.

En los casquillos de las lámparas se utilizan resinas de fenolformaldehído como aislantes eléctricos. El cemento suele contener resinas naturales y sintéticas, en las que es posible que haya irritantes cutáneos como el hexametileno-tetramina. Los equipos de mezcla y manipulación automatizados limitan las posibilidades de que estos materiales entren en contacto con la piel, limitando así la posibilidad de que se produzca irritación cutánea.

\section{Lámparas de mercurio de alta presión}

Existen dos tipos similares: los que sólo utilizan mercurio y los que mezclan éste con diversos haluros metálicos. El diseño básico de las lámparas es parecido. Ambos tipos utilizan un tubo de descarga de cuarzo que contiene el mercurio o la mezcla de mercurio/haluro. Este tubo de descarga va encerrado en una dura cubierta exterior de vidrio de borosilicatos, y se añade una base metálica para los contactos eléctricos. La cubierta exterior puede ser transparente o revestirse de un material difusor o fosfórico para modificar el color de la luz.

Las lámparas de mercurio sólo contienen mercurio y argón en el tubo de descarga. El mercurio, a alta presión, genera luz con un alto contenido de azul y ultravioleta. El tubo de descarga de cuarzo es totalmente transparente a la luz UV y, en el caso de que se rompa o se quite la cubierta exterior, constituye un potente foco de luz UV que puede producir quemaduras en la piel y en los ojos de las personas expuestas. Aunque la lámpara de mercurio típica continúa funcionando aunque se retire la cubierta, los fabricantes ofrecen también algunos modelos que dejan de funcionar en tal caso. Durante el servicio normal, el vidrio de borosilicatos de la cubierta exterior absorbe un alto porcentaje de la luz UV, de modo que la lámpara intacta no presente riesgos.

Debido al alto contenido de azul del espectro de la lámpara de mercurio, es frecuente revestir el interior de la cubierta con un material fosfórico intensificador del rojo, como el fosfato vanadato de itrio o un material similar.

Las lámparas de haluros metálicos contienen también mercurio y argón en el tubo de descarga, pero agregan haluros metálicos (por regla general, una mezcla de sodio y escandio, posiblemente con otros materiales). La adición de los haluros metálicos intensifica la luminosidad roja de la lámpara, lo que equilibra su espectro luminoso.

\section{Riesgos y precauciones}

Aparte del mercurio, como materiales posiblemente peligrosos empleados en la fabricación de lámparas de mercurio de alta presión cabe citar los revestimientos aplicados a las carcasas exteriores y los haluros añadidos a las lámparas de haluros metálicos. En algunos casos se trata de un sencillo difusor, igual que los utilizados en las lámparas incandescentes, y en otros, de un material fosfórico corrector del color, como el vanadato de itrio o el fosfato vanadato de itrio. Aunque parecido al pentóxido de vanadio, el vanadato se considera menos tóxico. Normalmente, la exposición a los haluros no es importante porque los haluros reaccionan a la humedad del aire y deben mantenerse en seco y en una atmósfera inerte durante su manipulación y mientras están en funcionamiento. Asimismo, aunque el sodio es un metal altamente reactivo, también necesita manipularse bajo una atmósfera inerte para evitar que se oxide el metal.

\section{Lámparas de sodio}

Actualmente se producen dos tipos de lámparas de sodio. Las lámparas de baja presión sólo contienen sodio metálico como fuente luminosa y producen una luz de un amarillo intenso. Las lámparas de sodio de alta presión utilizan mercurio y sodio para generar luz más blanca.

Las lámparas de sodio de baja presión tienen un tubo de vidrio, que contiene el sodio metálico, encerrado en un segundo tubo de vidrio.

Las lámparas de sodio de alta presión contienen una mezcla de mercurio y sodio dentro de un tubo de descarga de alúmina cerámica de gran pureza. Aparte de la composición del tubo de descarga, la construcción de la lámpara de sodio de alta presión es básicamente igual a la utilizada para las lámparas de mercurio y haluros metálicos. 


\section{Riesgos y precauciones}

Existen algunos riesgos exclusivos de la fabricación de lámparas de sodio de alta o baja presión. En ambos tipos de lámparas, el sodio debe permanecer seco. El sodio metálico puro reacciona violentamente con el agua, produciendo hidrógeno y calor suficiente para arder. Si se deja el sodio metálico al descubierto, reaccionará con la humedad del aire, produciendo una capa de óxido en el metal. Para evitarlo, el sodio suele manipularse en cámaras con guantes bajo una atmósfera de nitrógeno seco o de argón. En fábricas de lámparas de alta presión, es necesario tomar precauciones adicionales para manipular el mercurio, parecidas a las que exigen las fábricas de lámparas de mercurio de alta presión.

\section{Problemas ambientales y de salud pública}

La eliminación de residuos y/o el reciclaje de lámparas de mercurio es un problema que ha sido objeto de gran atención en muchas zonas del mundo durante los últimos años. Aunque en el mejor de los casos se trata de una operación "equilibrada" desde el punto de vista de su coste, hoy día existen medios tecnológicos que permiten recuperar el mercurio de las lámparas fluorescentes y de las lámparas de descarga de alta presión. El término que más exactamente describe el reciclaje de los materiales de las lámparas en la actualidad es "recuperación", ya que estos materiales raramente se reprocesan y se utilizan en la fabricación de nuevas lámparas. Por lo común, las piezas metálicas se emplean como chatarra. El vidrio recuperado se utiliza para fabricar fibra de vidrio o bloques de vidrio o como árido de pavimentación con cemento o asfalto. Tal vez el reciclaje sea la alternativa más económica, en función del lugar en el que se lleve a cabo y de su disponibilidad, así como de las opciones de vertido de residuos peligrosos o especiales.

Los estabilizadores utilizados en las instalaciones de lámparas fluorescentes contenían anteriormente condensadores que utilizan PCB como dieléctrico. Aunque se ha abandonado la fabricación de estabilizadores con PCB, es posible que muchos de los antiguos estabilizadores continúen en servicio debido a su larga esperanza de duración. Puede que se regule la eliminación de los estabilizadores con $\mathrm{PCB}$ como residuo peligroso o especial.

La fabricación de vidrio, en especial los vidrios de borosilicatos, constituye un foco importante de emisión de $\mathrm{NO}_{\mathrm{x}}$ a la atmósfera. Recientemente, se ha utilizado oxígeno puro en lugar de aire con quemadores de gas como medio para reducir las emisiones de $\mathrm{NO}_{\mathrm{x}}$

\section{- FABRICACION DE APARATOS ELECTRODOMESTICOS}

\section{N. A. Smith y W. Klost*}

La industria de los electrodomésticos se ocupa de la fabricación de muchos equipos para distintas aplicaciones: audiovisual, cocina, calefacción y preparación y almacenamiento (refrigeración) de alimentos. La producción y fabricación de tales aparatos comprende muchos procesos muy automatizados, con sus correspondientes riesgos para la salud y pautas patológicas.

\footnotetext{
* Adaptado de la $3^{\text {a }}$ edición, Enciclopedia de salud y seguridad en el trabajo.
}

\section{Procesos de fabricación}

Los materiales utilizados en la fabricación de aparatos electrodomésticos se dividen en las siguientes categorías:

1. metales utilizados por lo común para fabricar los conductores eléctricos de los cables y de la estructura y/o armazón de los aparatos;

2. materiales aislantes o dieléctricos utilizados para la prevención del contacto accidental con equipos eléctricamente activos;

3. pinturas y acabados;

4. productos químicos.

En la Tabla 81.2 se ofrecen ejemplos de materiales pertenecientes a las cuatro categorías mencionadas.

A los materiales utilizados en la industria de los electrodomésticos se les exige el cumplimiento estricto de ciertos requisitos, como la capacidad de soportar la manipulación que posiblemente se produzca durante su normal funcionamiento, la capacidad de soportar la fatiga de los metales y la capacidad de no verse afectados por ningún otro proceso o tratamiento que pueda hacer peligroso el empleo del aparato inmediatamente o después de un período prolongado de tiempo.

Los materiales utilizados en la industria suelen recibirse en la fase de montaje de los aparatos, una vez pasados varios procesos de fabricación, cada uno de los cuales probablemente tenga sus propios riesgos y problemas para la salud. De ello se ocupan a fondo los capítulos correspondientes de la presente Enciclopedia.

Los procesos de fabricación varían según el producto, pero en general siguen los flujos de producción ilustrados en la Figura 81.5. Este gráfico también ilustra los riesgos asociados a los diferentes procesos.

\section{Problemas de salud y seguridad}

\section{Incendio y explosión}

Muchos de los disolventes, las pinturas y los aceites aislantes utilizados en la industria son sustancias inflamables, por lo que deben almacenarse en locales adecuados, frescos y secos, a ser posible en un edificio a prueba de incendios independiente de la instalación de producción. Los contenedores han de estar claramente etiquetados, y las diferentes sustancias separadas o almacenadas de forma independiente, según lo requieran sus temperaturas de inflamabilidad y su clase de riesgo. En el caso de los materiales aislantes y plásticos, es importante obtener información sobre la combustibilidad o características en caso de incendio de cada nueva sustancia utilizada. El zirconio en polvo, que se emplea en

Tabla 81.2 • Ejemplos de materiales utilizados en la fabricación de aparatos electrodomésticos.

\begin{tabular}{|c|c|c|c|}
\hline Metales & Dieléctricos & Pinturas/acabados & $\begin{array}{l}\text { Productos } \\
\text { químicos }\end{array}$ \\
\hline Acero & $\begin{array}{l}\text { Materiales inorgánicos } \\
\text { (p. ej., mica) }\end{array}$ & Pinturas & Acidos \\
\hline Aluminio & Plásticos (p. ej., PVC) & Lacas & Alcalis \\
\hline Plomo & Caucho & Barnices & Disolventes \\
\hline Cadmio & Materiales silicoorgánicos & $\begin{array}{l}\text { Tratamientos } \\
\text { anticorrosión }\end{array}$ & \\
\hline Mercurio & $\begin{array}{l}\text { Otros polímeros } \\
\text { (p. ej., nailón) }\end{array}$ & & \\
\hline
\end{tabular}


Figura 81.5 - Orden habitual de los procesos de fabricación y riesgos probables.

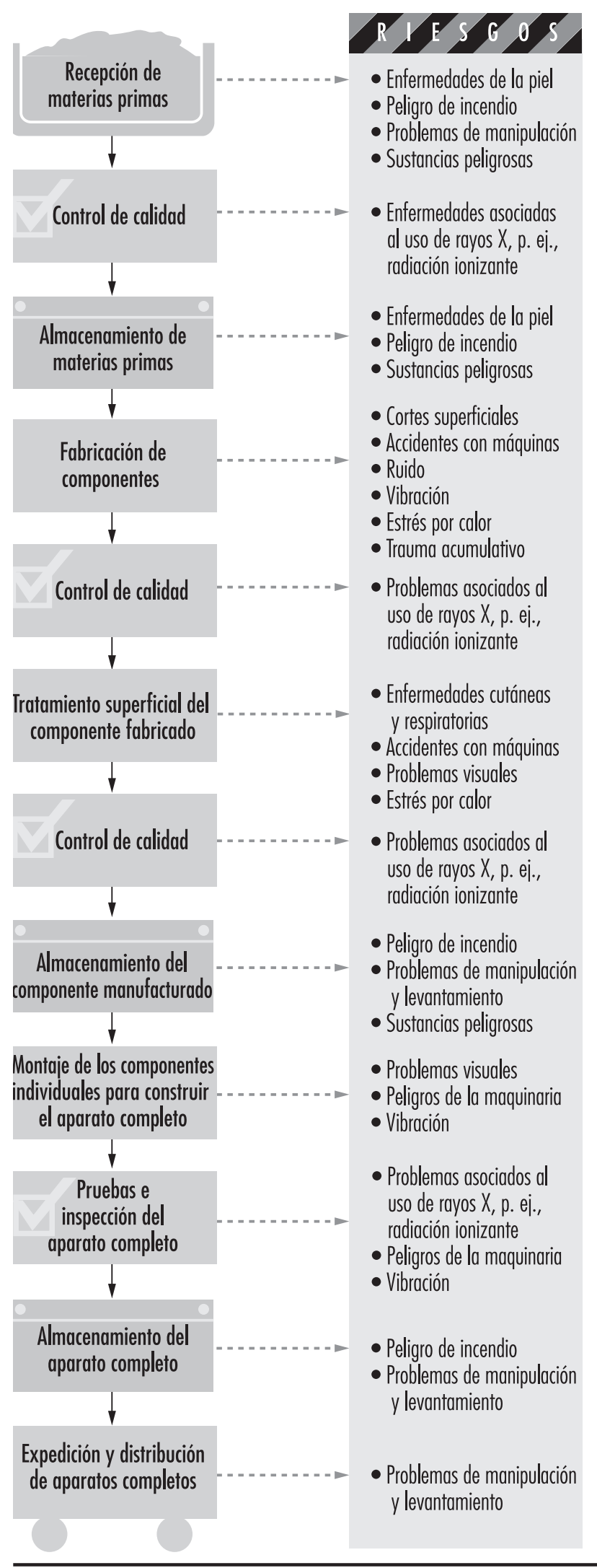

cantidades importantes en la industria actual, entraña también un riesgo de incendio.

La cantidad de sustancias inflamables que sale de los almacenes ha de ser la mínima necesaria para la producción. Cuando se decantan líquidos inflamables pueden formarse cargas de electricidad estática y, por consiguiente, todos los contenedores deben tener toma de tierra. Es esencial que se cuente con aparatos de extinción de incendios y que el personal del almacén reciba formación sobre su utilización.

Los componentes suelen pintarse en cabinas construidas al efecto, que deben disponer de equipos de ventilación y extracción adecuados para proporcionar, en combinación con los equipos de protección individual (EPI), un ambiente de trabajo seguro.

Las operaciones de soldadura requieren precauciones especiales contra incendios.

\section{Accidentes}

La recepción, el almacenamiento y la expedición de materias primas, componentes y productos terminados puede dar lugar a accidentes por tropezones y caídas, desplomes de objetos, carretillas elevadoras, etcétera. La manipulación manual de materiales causa también problemas ergonómicos, que se evitan automatizándola siempre que sea posible.

Como en la industria se emplean numerosos procesos diferentes, los riesgos de accidente varían de un taller a otro de la fábrica. Durante la producción de componentes, el uso de máquinas-herramientas, prensas automáticas, máquinas de moldeo de plásticos por inyección, etcétera, puede comportar riesgos y es esencial instalar defensas eficaces en la maquinaria. Durante las operaciones de galvanoplastia deben tomarse precauciones contra las salpicaduras de materiales corrosivos. Durante el montaje de componentes, el constante movimiento de éstos de un proceso a otro entraña un alto riesgo de accidentes debidos a los equipos mecánicos de manipulación y transporte en planta.

Las pruebas de control de calidad no comportan problemas especiales de seguridad. Sin embargo, las pruebas de funcionamiento requieren precauciones especiales, ya que suelen realizarse con aparatos semiterminados o sin aislar. Es preciso proteger todos los componentes, conductores, bornes e instrumentos de medición con tensión eléctrica durante la realización de pruebas eléctricas, para evitar así contactos accidentales. El lugar de trabajo deberá protegerse mediante pantallas, se prohibirá la entrada de personas no autorizadas y se colocarán letreros de advertencia. En las zonas de pruebas eléctricas, es especialmente aconsejable instalar interruptores de emergencia, situados en una posición destacada para que todos los equipos puedan desexcitarse de inmediato en caso de emergencia.

Existen normas de protección radiológica para los aparatos de pruebas que emiten rayos $\mathrm{X}$ o que contienen sustancias radiactivas. Un supervisor competente deberá responsabilizarse del cumplimiento de estas normas.

Existen riesgos especiales en el uso de gases comprimidos, equipos de soldadura, aparatos de rayos láser, plantas de impregnación, equipos de pulverización de pinturas, hornos de recocido y revenido e instalaciones eléctricas de alta tensión.

Es esencial aplicar programas adecuados de bloqueo y de colocación de carteles de advertencia durante todas las actividades de reparación y mantenimiento.

\section{Riesgos para la salud}

Las enfermedades profesionales asociadas a la fabricación de electrodomésticos son relativamente escasas y no suelen estar 
consideradas como graves. Los problemas que plantea este sector vienen tipificados por:

- el desarrollo de enfermedades cutáneas debido al uso de disolventes, aceites de corte, endurecedores utilizados con resinas epoxídicas y bifenilos policlorados (PCB);

- el principio de silicosis debida a la inhalación de sílice y arena de chorreo (aunque la arena está siendo paulatinamente reemplazada por agentes de chorreo menos tóxicos, como el corindón o gránulos o bolitas de acero);

- los problemas de salud provocados por la inhalación de vapores de disolventes en las operaciones de pintura y desengrasado, y la intoxicación por plomo derivada del uso de esmaltes y pigmentos de plomo, etc.;

- diversos niveles de ruido producidos durante los procesos.

Siempre que sea posible, los compuestos clorados y los disolventes altamente tóxicos se reemplazarán por sustancias menos peligrosas; bajo ninguna circunstancia deberán emplearse el benceno ni el tetracloruro de carbono como disolventes. La intoxicación por plomo se evita utilizando materiales o técnicas que ofrezcan mayor seguridad y con la estricta aplicación de procedimientos de trabajo seguros, higiene personal y vigilancia médica. Si existe peligro de exposición a concentraciones peligrosas de contaminantes atmosféricos, deberá controlarse con periodicidad el aire interior del lugar de trabajo, y tomar medidas como la instalación de un sistema de extracción cuando sea necesario. El peligro del ruido se reduce encerrando los focos de ruido, utilizando materiales insonorizantes en los cuartos de trabajo o utilizando protecciones auditivas personales.

En las fases de diseño y planificación de nuevas plantas u operaciones deberá contarse con los técnicos de seguridad y médicos industriales, así como eliminarse los riesgos de los procesos o máquinas antes de ponerlos en marcha, tras lo cual ha de hacerse una inspección periódica de máquinas, herramientas, equipos de transporte, aparatos de extinción de incendios, talleres y zonas de pruebas, etcétera.

La participación de los trabajadores en el programa de seguridad es esencial, y los supervisores deberán cerciorarse de que disponen de equipos de protección individual y de que los emplean siempre que sea necesario. Especial atención merece la formación de los trabajadores nuevos en materia de seguridad, ya que la tasa de accidentes es relativamente alta en su caso.

Los trabajadores deben pasar un examen médico previo a la colocación y, si existe la posibilidad de una exposición peligrosa, los exámenes periódicos que sean necesarios.

Muchos procesos de producción de componentes individuales comportan el rechazo de material de desecho (p. ej., la viruta de rectificado de chapas o barras metálicas) y la eliminación de dichos materiales ha de realizarse de acuerdo con los requisitos de seguridad. Además, si no es posible devolver dichos residuos de proceso al productor o fabricante para su reciclaje, entonces su eliminación deberá realizarse siguiendo procesos autorizados a fin de evitar la contaminación del medio ambiente.

\section{- CUESTIONES AMBIENTALES Y DE SALUD PUBLICA}

N. A. Smith

Los principales problemas ambientales asociados a la fabricación de equipos y aparatos eléctricos comprenden la contaminación y el tratamiento de los materiales desechados durante los procesos de fabricación, junto con el reciclaje, siempre que sea posible, del producto completo una vez alcanzado el final de su vida útil.

\section{Pilas y baterías}

Debe evitarse en la medida de lo posible la emisión a la atmósfera de aire contaminado con ácidos, álcalis, plomo, cadmio y otros materiales potencialmente nocivos, así como la contaminación provocada por el agua procedente de la fabricación de pilas y baterías y, cuando esto no sea posible, se precisan controles que garanticen el cumplimiento de la legislación vigente.

El empleo de pilas y baterías implica problemas para la salud pública. Las pilas alcalinas o acumuladores de plomo abiertos puede provocar quemaduras a causa del electrólito. La recarga de grandes acumuladores de plomo produce hidrógeno, que entraña riesgo de incendio y explosión en recintos cerrados. La liberación de cloruro de tionilo o dióxido de azufre de las grandes pilas de litio puede comportar exposición al dióxido de azufre, a nieblas de ácido hidroclórico, a litio inflamado, etcétera, y ha provocado al menos un fallecimiento (Ducatman, Ducatman y Barnes 1988). La fabricación de estas pilas también entraña riesgos.

Los fabricantes de pilas y baterías se han sensibilizado con respecto al problema cada vez mayor que constituye para el medio ambiente el vertido y la incineración de pilas con metales pesados tóxicos. Las fugas de metales tóxicos procedentes de vertederos o de las chimeneas de las incineradoras de residuos pueden contaminar el aire y las aguas. Por consiguiente, los fabricantes han reconocido la necesidad de reducir, en especial, el contenido de mercurio de las pilas hasta los límites admisibles por la tecnología moderna. La campaña de eliminación del mercurio fue anterior a la legislación de la Unión Europea, la Directiva comunitaria en materia de pilas y baterías.

El reciclaje es otro modo de abordar la contaminación ambiental. Las pilas de níquel-cadmio pueden reciclarse con relativa facilidad. La recuperación del cadmio es muy ventajosa, ya que vuelve a utilizarse en la fabricación de pilas de níquelcadmio. El níquel se utiliza en la industria del acero. Los datos económicos iniciales reflejan que el reciclaje de pilas de níquelcadmio no era rentable, pero es de esperar que los avances tecnológicos mejoren la situación. Las pilas de óxido mercúrico, comprendidas en la Directiva comunitaria en materia de pilas y baterías, se han utilizado sobre todo en audífonos y están siendo reemplazadas, por regla general, por pilas de litio o zinc-aire. Las pilas de óxido de plata se reciclan, sobre todo en la industria de la joyería, debido al valor del contenido de plata.

$\mathrm{Al}$ reciclar materiales nocivos, es preciso tener el mismo cuidado que durante los procesos de fabricación. Por ejemplo, cabe la posibilidad de que los trabajadores queden expuestos al vapor de mercurio y al óxido de plata durante el reciclaje de las pilas de plata.

La reparación y el reciclaje de los acumuladores de plomo no sólo puede provocar intoxicación por plomo entre los trabajadores, y a veces sus familias, sino también una amplia contaminación del medio ambiente (Matte y cols. 1989). En muchos países, sobre todo en los del Caribe y América Latina, las placas de plomo de las baterías de los automóviles se queman a fin de producir óxido de plomo para esmaltes cerámicos.

\section{Fabricación de cables eléctricos}

La fabricación de cables eléctricos tiene tres focos principales de contaminación: los vapores de los disolventes, la posible liberación de diisocianato de tolueno por la fabricación de hilos metálicos esmaltados y las emisiones al medio ambiente durante la fabricación de los materiales utilizados en los cables. Todo ello requiere controles ambientales apropiados.

\section{Fabricación de lámparas eléctricas}

Los principales problemas ambientales en este campo son la eliminación de los residuos y/o el reciclaje de las lámparas de 
mercurio y la eliminación de los PCB de los estabilizadores de las lámparas fluorescentes. La fabricación de vidrio también puede ser un foco de emisión de óxidos de nitrógeno a la atmósfera.

\section{Electrodomésticos}

Como la industria de los electrodomésticos es en gran medida una industria de montaje, los problemas ambientales son mínimos, siendo la principal excepción las pinturas y los disolventes utilizados como revestimientos superficiales. Es preciso implantar medidas de control de la contaminación de acuerdo con las normas en materia de medio ambiente.

El reciclaje de los aparatos eléctricos comporta la separación de los equipos recuperados en los diferentes materiales, como el cobre y el acero bajo en carbono, que pueden reutilizarse. De ello se ocupan otros capítulos de la presente Enciclopedia.

\section{Referencias}

Agencia Internacional para la Investigación sobre el Cáncer (IARC). 1992. Monographs on the Evaluation of Carcinogenic Risks to Humans, Vol. 54. Lyon: IARC.

Ducatman, AM, BS Ducatman, JA Barnes. 1988. Lithium battery hazard: Old-fashioned planning implications of new technology. 7 Occup Med 30:309-311.

Health and Safety Executive (HSE). 1990. Man-made Mineral Fibres. Executive Guidance Note EH46. Londres: HSE.
Matte TD, JP Fioueroa, G Burr, JP Flesch, RH Keenlyside, EL Baker. 1989. Lead exposure among lead-acid battery workers in Jamaica. Amer $\mathcal{F}$ Ind Med 16:167-177.

McDiarm id, MA, CS Freeman, EA Grossman and J Martonik. 1996. Biological monitoring results for cadmium exposed workers. Amer Ind Hyg Assoc 7 57:1019-1023.

Roels, HA, JP Ghyselen, E Ceulemans, RR Lauwerys. 1992. Assessment of the permissible exposure level to manganese in workers exposed to manganese dioxide dust. Brit 7 Ind Med 49:25-34.

Telesca, DR. 1983. A Survey of Health Hazard Control Systems for Mercury Use and Processing. Report No. CT109-4. Cincinnati, Ohio: NIOSH.

Wallis, G, R Menke, C Chelton. 1993. Workplace field testing of a disposable negative pressure half-mask dust respirator (3M 8710). Amer Ind Hyg Assoc $\mathcal{f}$ 54:576-583. 

Director del capítulo Michael McCann

\section{Sumario}

OPERACIONES DE FUNDICION Y AFINO

Fundición y afino

Pekka Roto. .

Fundición y afino del cobre, plomo y zinc. . . . . . . . . 82.4

Fundición y afino del aluminio

Bertram D. Dinman . . . . . . . . . . . . . . . . . . . . . . . . 82.8

Fundición y afino del oro

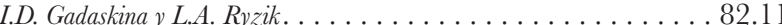

METALURGIA Y METALISTERIA

Fundiciones

Franklin E. Mirer

Forja y estampación

Robert M. Park.

Soldadura y corte térmico

Philip A. Platcow y G.S. Lyndon . . . . . . . . . . . . . . . . . . . 82.25

Tornos

Toni Retsch. . . . .

Rectificado y pulido

K. Welinder

Lubricantes industriales, fluidos de mecanizado y aceites para automóviles Richard S. Kraus . . .

Metales, tratamiento de superficie

7.G. Fones, 7.R. Bevan, 7.A. Catton, A. Zober, N. Fish, K.M. Morse,

G. Thomas, M.A. El Kadeem y Philip A. Platcow. . . . . . . . . . . 82.42

Recuperación de metales

Melvin E. Cassady y Richard D. Ringenwald, Fr. . .

Cuestiones ambientales en el acabado de superficies metálicas y los recubrimientos industriales

Stewart Forbes. 


\section{Perfil general}

La industria de la fundición y afino de metales procesa minerales y chatarra metálicos para obtener metales puros. Las industrias metalúrgicas procesan metales para fabricar componentes de máquinas, maquinaria, instrumentos y herramientas que son necesarios en otras industrias, así como en los restantes sectores de la economía. Como materia prima se utilizan diversos tipos de metales y aleaciones, como productos laminados (barras, flejes, productos de poca sección, chapas o tubos) y estirados (barras, productos de poca sección, tubos o alambre). Entre las técnicas básicas de procesado del metal se encuentran las siguientes:

- fundición y afino de menas y chatarra

- moldeo de metales fundidos para darles una formadeterminada (fundición)
- forja o estampación de metales para darles la forma de una estampa (forja en caliente o en frío)

- soldadura y corte de chapa metálica

- sinterización (compresión y calentamiento de materiales en polvo, incluyendo uno o más metales)

- torneado de metales.

Para el acabado de metales se utiliza una gran variedad de técnicas, como esmerilado y pulido, limpieza con chorro abrasivo y numerosas técnicas de acabado y recubrimiento de superficies (recubrimiento electrolíico, galvanizado, tratamiento térmico, anodizado, pintura en polvo, etc).

\section{OPERACIONES DE FUNDICION Y AFINO}

\section{FUNDICION Y AFINO}

Pekka Roto*

En la producción y afino de metales, una serie de reacciones fisico-químicas distintas separan los componentes valiosos de las materias inservibles. El producto final es un metal que contiene cantidades controladas de impurezas. La fundición y afino primarios producen metales directamente a partir de concentrados de mineral, mientras que la fundición y afino secundarios los producen a partir de chatarra y residuos de procesos. La chatarra está formada por fragmentos y piezas de componentes metálicos, barras, virutas de torno, chapas y alambre que están fuera de especificación o desgastados pero pueden reciclarse (véase el artículo "Recuperación de metales" en este capítulo).

\section{Resumen de procesos}

Para producir metales refinados se utilizan generalmente dos tecnologías de recuperación, los procesos pirometalúrgicos y los hidrometalúrgicos. En los primeros se utiliza calor para separar los metales deseados de otros materiales. En estos procesos se aprovechan las diferencias entre potenciales de oxidación, puntos de fusión, presiones de vapor, densidad y/o miscibilidad de los componentes del mineral cuando se funden. Las tecnologías hidrometalúrgicas se diferencian de los procesos pirometalúrgicos en que los metales deseados se separan de otros materiales utilizando técnicas que aprovechan las diferencias de solubilidad y/o entre las propiedades electroquímicas de los constituyentes mientras se encuentran en solución acuosa.

\section{Pirometalurgia}

Durante el procesado pirometálico, un mineral, después de ser beneficiado (concentrado mediante machaqueo, trituración, flotación y secado), se sinteriza o tuesta (calcina) con otros materiales, tales como polvo de la cámara de sacos filtrantes y fundente. A continuación, el concentrado se funde en un horno de cuba para obtener un lingote fundido impuro que contiene los metales deseados. Este lingote se somete seguidamente a un tercer proceso pirometálico para refinar el metal hasta conseguir el nivel de pureza deseado. Cada vez que se calienta el mineral o el lingote, se crean materiales residuales. El polvo procedente de la ventilación y los gases del proceso puede capturarse en una

\footnotetext{
* Adaptado de la $3^{\text {a }}$ edición, Enciclopedia de salud y seguridad en el trabajo.
}

cámara de sacos y eliminarse o devolverse al proceso, dependiendo del contenido metálico residual. También se captura el azufre del gas, y cuando las concentraciones son superiores al $4 \%$ puede convertirse en ácido sulfúrico. Dependiendo del origen del mineral y de su contenido residual del metales, pueden obtenerse también como subproductos diversos metales, como oro y plata.

La tostación es un importante proceso pirometalúrgico. La tostación por sulfatado se utiliza en la producción de cobalto y zinc. Su fin es separar los metales de forma que puedan transformarse en una forma hidrosoluble para el ulterior procesado hidrometalúrgico.

La fusión de los minerales sulfurosos produce un concentrado de metal parcialmente oxidado (mata). En la fusión, el material inservible, generalmente hierro, forma una escoria con el material fundente y se convierte en su óxido. Los metales útiles adquieren la forma metálica en la etapa de conversión, que tiene lugar en los hornos de conversión. Este método se utiliza en la producción de cobre y níquel. Se produce hierro, ferrocromo, plomo, magnesio y compuestos de hierro por reducción del mineral con carbón vegetal y un fundente (caliza); el proceso de fusión se realiza generalmente en un horno eléctrico (véase también el capítulo Siderurgia). La electrólisis de sales fundidas, empleada en la producción de aluminio, constituye otro ejemplo de proceso pirometalúrgico.

La alta temperatura necesaria para el tratamiento pirometalúrgico de los metales se consigue quemando combustibles fósiles o utilizando la reacción exotérmica del propio mineral (como, por ejemplo, en el proceso de fundición a la llama). El proceso de fundición a la llama constituye un ejemplo de proceso pirometalúrgico ahorrador de energía en el que el hierro y el azufre del concentrado de mineral se oxidan. La reacción exotérmica, acoplada a un sistema de recuperación de calor, ahorra una gran cantidad de energía para la fusión. La elevada recuperación de azufre del proceso es también beneficiosa para la protección del medio ambiente. La mayoría de las fundiciones de cobre y níquel construidas recientemente utilizan dicho proceso.

\section{Hidrometalurgia}

Ejemplos de procesos hidrometalúrgicos son la lixiviación, la precipitación, la reducción electrolítica, el intercambio iónico, la separación por membranas y la extracción con disolventes. La primera etapa de los procesos hidrometalúrgicos es la lixiviación de los metales útiles a partir de materiales menos valiosos, 
por ejemplo, con ácido sulfúrico. La lixiviación a menudo va precedida de un tratamiento previo (p. ej., tostación por sulfatado). El proceso de lixiviación normalmente exige altas presiones, la adición de oxígeno o temperaturas elevadas. También puede realizarse con electricidad. A partir de la solución lixiviada, el metal deseado o su compuesto se recuperan por precipitación o reducción, según distintos métodos. En la producción de cobalto o níquel, por ejemplo, la reducción se realiza con gas.

La electrólisis de metales en soluciones acuosas también se considera un proceso hidrometalúrgico. En el proceso de electrólisis, el ion metálico resulta reducido. El metal se encuentra en una solución ácida débil a partir de la cual precipita en los cátodos por efecto de una corriente eléctrica. La mayoría de los metales no férreos también pueden refinarse por electrólisis.

Comúnmente, los procesos metalúrgicos son una combinación de procesos piro e hidrometalúrgicos, según el concentrado de mineral a tratar y el tipo de metal a refinar. Un ejemplo es la producción de níquel.

\section{Riesgos y su prevención}

La prevención de los riesgos para la salud y los accidentes en la industria metalúrgica es fundamentalmente una cuestión educativa y técnica. Los reconocimientos médicos están en segundo plano y solo desempeñan un papel complementario en la prevención de los riesgos. Con miras a prevenir los riesgos para la salud es sumamente útil mantener un intercambio de información y colaboración armonioso entre los departamentos de planificación, línea, seguridad y medicina del trabajo.

Las medidas preventivas mejores y más baratas son las que se adoptan en la etapa de planificación de una nueva planta o proceso. Al planificar las nuevas instalaciones de producción, hay que tener en cuenta al menos los siguientes aspectos:

- Se han de confinar y aislar las fuentes potenciales de contaminantes aéreos.

- El diseño y ubicación del equipo de proceso debe permitir un fácil acceso para las operaciones de mantenimiento.

- Las áreas en que pueden aparecer riesgos súbitos e inesperados deben supervisarse continuamente. Han de existir señales e indicaciones de advertencia apropiadas. Por ejemplo, las zonas en que pudiera darse exposición a arsenamina o ácido cianhídrico, deben ser objeto de continua vigilancia.

- La adición y manipulación de los productos químicos tóxicos utilizados en el proceso debe planificarse de manera que se evite la manipulación manual.

- El control de higiene industrial debe incluir dispositivos de muestreo personal con el fin de evaluar la exposición real de cada trabajador siempre que ello sea posible. El control fijo y regular de gases, polvos y ruidos ofrece una visión general de la exposición, pero su papel en la valoración de la dosis de exposición es solo complementario.

- En la planificación del espacio, hay que tener en cuenta las necesidades de futuros cambios o ampliaciones del proceso, de manera que no se deterioren los niveles de higiene industrial de la planta.

- Debe existir un sistema continuo de formación y educación del personal de higiene y seguridad, así como de los capataces y trabajadores. En especial, los trabajadores nuevos deben ser rigurosamente informados de los posibles riesgos para la salud y de cómo prevenirlos en sus respectivos ambientes de trabajo. Además, cada vez que se introduzca un nuevo proceso deberá impartirse la correspondiente formación.

- Las prácticas de trabajo son importantes. Por ejemplo, la mala higiene personal en la comida y fumar en el lugar de trabajo pueden aumentar considerablemente la exposición personal.
- La dirección de la empresa debe poseer un sistema de control de la salud y seguridad que facilite los datos adecuados para la toma de decisiones técnicas y económicas.

A continuación se indican algunos de los riesgos y precauciones específicos de los procesos de fundición y afino.

\section{Lesiones}

La industria de fundición y afino presenta un índice de lesiones más elevado que el de la mayoría de los otros sectores. Entre las causas de estas lesiones se encuentran las siguientes: salpicaduras y derrames de metal fundido y escoria que provocan quemaduras; explosiones de gas y por contacto de metal fundido con agua; colisiones con locomotoras y vagonetas en movimiento, grúas móviles y otros equipos móviles; caída de objetos pesados; caídas desde lugares altos (por ejemplo, al acceder a la cabina de una grúa), y lesiones por resbalar y tropezar con obstáculos en el suelo y en las pasarelas.

Las precauciones consisten en una formación adecuada, equipo de protección personal (EPP) apropiado (p. ej., cascos, calzado de seguridad, guantes de trabajo y ropas protectoras); almacenamiento correcto, conservación y mantenimiento del equipo; normas de tráfico para el equipo móvil (incluida la definición de rutas y un sistema eficaz de aviso y señalización), y un programa de protección contra caídas.

\section{Calor}

Las enfermedades por estrés térmico, tales como el golpe de calor, constituyen un riesgo común debido principalmente a la radiación infrarroja procedente de los hornos y el metal en fusión. Esto representa un problema especialmente importante cuando hay que realizar trabajos que exigen gran esfuerzo en ambientes muy calientes.

La prevención de las enfermedades producidas por el calor puede consistir en pantallas de agua o cortinas de aire delante de los hornos, refrigeración puntual, cabinas cerradas y provistas de aire acondicionado, ropas protectoras contra el calor y trajes refrigerados por aire, que proporcionen tiempo suficiente para la aclimatación, pausas de descanso en zonas refrigeradas y un suministro adecuado de bebidas para beber con frecuencia.

\section{Riesgos químicos}

Durante las operaciones de fusión y afino puede producirse exposición a una gran variedad de polvos, humos, gases y otras sustancias química peligrosas. En especial, el machaqueo y la trituración de mineral puede provocar altos niveles de exposición a sílice y a polvos metálicos tóxicos (p. ej. que contengan plomo, arsénico y cadmio). También pueden darse exposiciones al polvo durante las operaciones de mantenimiento de los hornos. Durante las operaciones de fusión, los humos metálicos pueden constituir un problema importante.

Las emisiones de polvo y humos pueden controlarse mediante confinamiento, automatización de los procesos, ventilación local y de dilución, mojado de los materiales, reducción de su manipulación y otros cambios en el proceso. Si esto no resultase adecuado, habría que recurrir a la protección respiratoria.

Muchas operaciones de fundición implican la producción de grandes cantidades de dióxido de azufre procedentes de los minerales sulfurosos y de monóxido de carbono de los procesos de combustión. Son esenciales la ventilación de dilución y la ventilación por extracción local (VEL).

Como subproducto de las operaciones de fundición se forma ácido sulfúrico, el cual se utiliza en el afino electrolítico y en la lixiviación de los metales. Puede producirse exposición a ácido sulfúrico tanto líquido como en forma de neblinas. Se requiere protección cutánea y ocular, y VEL. 
La fusión y afino de algunos metales puede plantear riesgos especiales. Entre otros ejemplos están el níquel carbonilo en el afino de este metal, fluoruros en la fusión de aluminio, arsénico en la fundición y afino de cobre y plomo, y exposiciones a mercurio y cianuro durante el afino de oro. Estos procesos requieren sus propias precauciones especiales.

\section{Otros riesgos}

El deslumbramiento y la radiación infrarroja producidos por los hornos y el metal en fusión, pueden provocar lesiones oculares, incluso cataratas. Deben usarse gafas de montura ajustada y pantallas faciales. Los niveles altos de radiación infrarroja también pueden ocasionar quemaduras en la piel a menos que se utilicen ropas protectoras.

Los altos niveles de ruido producidos por el machaqueo y la trituración del mineral, los ventiladores de descarga de gas y los hornos eléctricos de alta potencia pueden provocar pérdida auditiva. Si no es posible confinar o aislar la fuente de ruido, deberán usarse protectores de oídos. Se deberá implantar un programa de conservación auditiva que incluya pruebas audiométricas y formación al respecto.

Durante los procesos electrolíticos pueden presentarse riesgos eléctricos. Entre las precauciones a adoptar están los procedimientos adecuados de mantenimiento eléctrico, con bloqueo y etiquetado de advertencia; guantes, ropa y herramientas aislados, e interruptores accionados por corrientes de fugas a tierra donde se requieran.

La elevación y manipulación manual de materiales puede ocasionar lesiones de espalda y de las extremidades superiores. Los medios de elevación mecánicos y una formación adecuada acerca de los métodos de elevación pueden reducir este problema.

\section{Contaminación y protección del medio ambiente}

Las emisiones de gases irritantes y corrosivos como el dióxido de azufre, ácido sulfhídrico y cloruro de hidrógeno, pueden contribuir a la contaminación aérea y originar fenómenos de corrosión de los metales y el hormigón, tanto en la planta como en el ambiente circundante. La tolerancia de la vegetación al dióxido de azufre depende del tipo de bosque y suelo. En general, los árboles perennes toleran menores concentraciones de dióxido de azufre que los caducos. Las emisiones de materia particulada pueden contener particulados inespecíficos, fluoruros, plomo, arsénico, cadmio y muchos otros metales tóxicos. El efluente puede contener diversos metales tóxicos, ácido sulfúrico y otras impurezas. Los residuos sólidos pueden estar contaminados con arsénico, plomo, sulfuros de hierro, sílice y otros contaminantes.

La gestión de la fundición debe comprender la evaluación y control de las emisiones procedentes de la planta, tarea especializada que solo debe realizar personal muy familiarizado con las propiedades químicas y toxicidades de los materiales emitidos en los procesos. El estado físico del material, la temperatura a la que abandona el proceso, la presencia de otros materiales en el chorro de gas, etc., son todos factores que han de tenerse en cuenta al planificar las medidas de control de la contaminación aérea. También es deseable contar con una estación meteorológica, que lleve los archivos meteorológicos, y estar preparados para reducir la salida de emisiones cuando las condiciones climáticas no favorezcan la dispersión de los efluentes aéreos. Son necesarias investigaciones de campo para observar los efectos de la contaminación aérea sobre las áreas residenciales y agrícolas.

El dióxido de azufre, uno de los principales contaminantes, se recupera en forma de ácido sulfúrico cuando su cantidad es suficiente. En otro caso, para cumplir las normas sobre emisiones, el dióxido de azufre y otros residuos gaseosos peligrosos se controlan mediante lavado. Comúnmente, las emisiones de partículas se controlan por medio de filtros textiles y cubas de precipitación electrostáticas.

En los procesos de flotación, tales como la concentración de cobre, se utilizan grandes cantidades de agua. La mayor parte de este agua se recicla y se devuelve al proceso. Los residuos, o colas, del proceso de flotación se bombean en forma de lodos a estanques de sedimentación. El agua se recicla al proceso. El agua de proceso que contiene metal y el agua de lluvia se limpian en plantas de tratamiento antes de su vertido o reciclaje.

Los residuos sólidos comprenden escorias de fundición, lodos de descarga producidos en la conversión de dióxido de azufre en ácido sulfúrico y lodos procedentes de balsas (p. ej., estanques de sedimentación). Algunas escorias pueden reconcentrarse y devolverse a las fundiciones para someterlas a un nuevo proceso o para la recuperación de otros metales presentes. Muchos de estos residuos sólidos son peligrosos y deben almacenarse de acuerdo con la normativa ambiental

\section{FUNDICION Y AFINO DEL COBRE, PLOMO Y ZINC*}

\section{Cobre}

El cobre se extrae de explotaciones a cielo abierto y minas subterráneas, dependiendo de la ley del mineral y de la naturaleza del yacimiento de éste. Normalmente, el mineral de cobre contiene menos del $1 \%$ de cobre en forma de minerales sulfurosos. Una vez extraído el mineral a la superficie, se machaca y tritura hasta convertirlo en polvo fino y después se concentra para su ulterior procesado. En el proceso de concentración, se forman lodos mezclando con agua el mineral triturado, se añaden reactivos químicos y se inyecta aire en los lodos. Las burbujas de aire se fijan a los minerales de cobre y se extraen por despumado de la parte superior de las células de flotación. El concentrado contiene entre el 20 y el $30 \%$ de cobre. Los residuos, o ganga caen al fondo de las células y se extraen, se deshidratan mediante espesadores y se transportan en forma de lodos a un estanque para su evacuación. Toda el agua utilizada en esta operación se recupera de los espesadores de deshidratación y el estanque de residuos y se recicla para devolverla al proceso.

La producción de cobre puede realizarse por procedimientos pirometalúrgicos o hidrometalúrgicos según el tipo de mineral que se utilice como carga. Los concentrados de mineral, que contienen minerales de sulfuro de cobre y sulfuro de hierro, se tratan mediante procesos pirometalúrgicos para obtener productos de cobre de alta pureza. Los minerales del óxido, que contienen minerales de cobre oxidados que pueden darse en otras partes de la mina, junto con otros materiales residuales oxidados, se tratan mediante procesos hidrometalúrgicos para obtener productos de cobre de elevada pureza.

La conversión del cobre a partir del mineral hasta obtener el metal, se realiza mediante fusión. En el curso de ésta, los concentrados se secan y se alimentan a hornos, de los que existen distintos tipos. Allí, los minerales sulfurosos se oxidan parcialmente y se funden, obteniéndose una capa de mata, sulfuro de cobre y hierro mezclado con escoria, y una capa superior de residuos.

La mata se somete a un proceso de conversión. La escoria se extrae del horno y se almacena o se desecha apilándola en la propia fundición. Una pequeña cantidad de la misma se vende

* Adaptado de EPA, 1995. 
para utilizarla como balasto de carretera y abrasivo para limpieza por chorro de arena. Un tercer producto del proceso de fundición es el dióxido de azufre, un gas que se recoge, depura y transforma en ácido sulfúrico para su venta o para utilizarlo en operaciones de lixiviación hidrometalúrgica.

Después de la fundición, la mata de cobre se lleva a un convertidor. Durante este proceso, la mata de cobre se vierte en un recipiente cilíndrico horizontal (de $10 \times 4 \mathrm{~m}$ aproximadamente) provisto de una fila de tuberías. Estas, conocidas como tuyères, o toberas, penetran en el cilindro y se utilizan para introducir aire en el convertidor. Se añaden cal y sílice a la mata de cobre para que reaccionen con el óxido de hierro producido en el proceso y formen escoria. También puede añadirse al convertidor chatarra de cobre. El horno gira de manera que las toberas queden sumergidas, y se inyecta aire en la mata fundida con lo cual el resto del sulfuro de hierro reacciona con el oxígeno y forma óxido de hierro y dióxido de azufre. A continuación, se hace girar el convertidor para verter al exterior la escoria de silicato de hierro.

Una vez extraído todo el hierro, se hace girar de nuevo el convertidor y se realiza una segunda inyección de aire, con lo cual el resto del azufre se oxida y se separa del sulfuro de cobre. A continuación, se hace girar el convertidor para verter el cobre fundido, que en esta etapa recibe el nombre de cobre blister, o esponjoso (porque si se permite que se solidifique en este momento presentará una superficie llena de bultos debido a la presencia de oxígeno y azufre gaseosos). El dióxido de azufre extraído del convertidor se recoge y se envía al sistema de depuración de gas junto con el procedente del horno de fundición, y se transforma en ácido sulfúrico. Dado su contenido residual de cobre, la escoria se recicla y se lleva al horno de fundición.

El cobre blister, que contiene un $98,5 \%$ de cobre como mínimo, se afina en dos etapas hasta obtener un cobre de gran pureza. La primera etapa es el afinado a fuego, en el cual el cobre blister fundido se vierte en un horno cilíndrico, parecido a un convertidor, donde primero se inyecta aire y después gas natural o propano a través del metal en fusión para eliminar los últimos vestigios de azufre y cualquier residuo de oxígeno. Seguidamente, el cobre fundido se vierte en una rueda de colada para formar ánodos de suficiente pureza para el electroafinado.

En el electroafinado, los ánodos de cobre se cargan en células electrolíticas y se entremezclan con chapas, o cátodos, iniciales de cobre, en un baño de disolución de sulfato de cobre. Cuando se hace pasar una corriente continua por la célula, el cobre del ánodo se disuelve, es transportado a través del electrolito y se deposita en las chapas iniciales catódicas. Cuando los cátodos han adquirido suficiente espesor se extraen de la célula electrolítica y se coloca en su lugar un nuevo juego de chapas iniciales. Las impurezas sólidas de los ánodos caen al fondo de la célula en forma de lodo, donde finalmente se recogen para procesarlas a fin de recuperar metales preciosos tales como oro y plata. Este material se conoce como fango anódico.

Los cátodos extraídos de la célula electrolítica son el producto primario del productor de cobre y contienen 99,99+\% de este metal. Pueden venderse a fábricas de alambre como cátodos o continuar procesándose para transformarlos en un producto denominado varilla. Al fabricar varilla, los cátodos se funden en un horno de cuba y el cobre fundido se vierte en una rueda de colada con objeto de formar una barra adecuada para laminarla y convertirla en una varilla continua de $3 / 8$ pulgadas de diámetro. Este producto en forma de varilla se envía a las fábricas de alambre, donde se extruye para obtener alambre de cobre de diversos diámetros.

En el proceso hidrometalúrgico, los minerales oxidados y los materiales residuales se lixivian con ácido sulfúrico obtenido en el proceso de fundición. La lixiviación se realiza in situ, o en pilas especialmente preparadas, distribuyendo ácido sobre la parte superior y permitiendo que se infiltre y descienda por percolación a través del material, donde se acumula. El suelo situado debajo de las placas de lixiviación está revestido con un material plástico impermeable y resistente a los ácidos para evitar que el licor de lixiviación contamine las aguas subterráneas. Una vez recogidas, las disoluciones ricas en cobre pueden tratarse eligiendo entre dos procesos - el de cementación o el de extracción por disolvente/extracción electrolítica (SXEW). En el proceso de cementación (apenas utilizado en la actualidad), el cobre de la disolución ácida se deposita sobre la superficie de chatarra de hierro, intercambiándose con éste. Cuando se ha cementado suficiente cobre, el hierro rico en cobre se lleva a la fundición junto con los concentrados de mineral para recuperar el cobre por vía pirometalúrgica.

En el proceso SXEW, la disolución de lixiviación fecunda, o impregnada (PLS), se concentra por extracción del disolvente, con lo cual se extrae el cobre pero no las impurezas metálicas (hierro y otras impurezas). La disolución orgánica cargada de cobre se separa entonces del lixiviado en un tanque de decantación. Se añade ácido sulfúrico a la mezcla orgánica fecunda, con lo cual el cobre se separa en una disolución electrolítica. El lixiviado, que contiene el hierro y otras impurezas, se devuelve a la operación de lixiviación donde el ácido que contiene se utiliza para una ulterior lixiviación. La disolución de separación, rica en cobre, se transfiere a una célula de extracción electrolítica. Este tipo de célula se diferencia de una célula de electroafinado en que utiliza un ánodo permanente insoluble. El cobre de la disolución se deposita electrolíticamente sobre un cátodo de chapa inicial de un modo muy parecido a como se deposita sobre el cátodo de una célula de electroafinado. Una vez agotado el cobre del electrolito, éste se devuelve al proceso de extracción por disolvente, donde se utiliza para separar más cobre de la disolución orgánica. Los cátodos producidos en el proceso de extracción electrolítica se venden o se transforman en varillas igual que los producidos en el proceso de electroafinado.

Las células de extracción electrolítica también se utilizan para la preparación de chapas iniciales para los procesos de electroafinado y extracción electrolítica, depositando el cobre sobre cátodos de acero inoxidable o titanio y separando después el cobre depositado.

\section{Riesgos y su prevención}

Los principales riesgos son la exposición a polvos de mineral durante el procesado y fusión de éste, humos metálicos (de cobre, plomo y arsénico) durante la fundición, dióxido de azufre y monóxido de carbono durante la mayoría de las operaciones de fundición, ruido procedente de las operaciones de machaqueo y trituración y de los hornos, estrés por calor a causa de los hornos y ácido sulfúrico y riesgos eléctricos durante los procesos electrolíticos.

Las precauciones comprenden: ventilación por extracción local de los polvos durante las operaciones de transferencia; ventilación local y de dilución del dióxido de azufre y el monóxido de carbono; un programa de control de ruido y de protección auditiva; ropa y pantallas protectoras, periodos de descanso y líquidos para el estrés por calor; y VEL, equipo de protección personal (EPP) y precauciones eléctricas para los procesos electrolíticos. Comúnmente se utiliza protección respiratoria contra el polvo, humos y dióxido de azufre.

La Tabla 82.5 ofrece una lista de los contaminantes ambientales presentes en las distintas etapas de la fundición y afino del cobre. 
Tabla 82.1 - Materiales de proceso de partida y residuos contaminantes generados en la fundición y afino del cobre.

\begin{tabular}{|c|c|c|c|c|}
\hline Proceso & Materiales de partida & Emisiones a la atmósfera & Residuos del proceso & Otros residuos \\
\hline $\begin{array}{l}\text { Concentración de } \\
\text { cobre }\end{array}$ & $\begin{array}{l}\text { Mineral de cobre, agua, } \\
\text { reactivos químicos, } \\
\text { espesantes }\end{array}$ & & $\begin{array}{l}\text { Aguas residuales de } \\
\text { flotación }\end{array}$ & $\begin{array}{l}\text { Colas conteniendo minerales residuales } \\
\text { como caliza y cuarzo }\end{array}$ \\
\hline Lixiviación de cobre & $\begin{array}{l}\text { Concentrado de cobre, ácido } \\
\text { sulfúrico }\end{array}$ & & Lixiviado incontrolado & Residuo de lixiviación en montones \\
\hline Fundición de cobre & $\begin{array}{l}\text { Concentrate de cobre, fundente } \\
\text { silíceo }\end{array}$ & $\begin{array}{l}\text { Dióxido de azufre, materia particulada } \\
\text { conteniendo arsénico, antimonio, cadmio, } \\
\text { plomo, mercurio y zinc }\end{array}$ & & $\begin{array}{l}\text { Lodos/fangos ácidos de descarga de la } \\
\text { planta, escoria conteniendo sulfuros de } \\
\text { hierro, sílice }\end{array}$ \\
\hline Conversión de cobre & $\begin{array}{l}\text { Mata de cobre, chatarra de } \\
\text { cobre, fundente siliceo }\end{array}$ & $\begin{array}{l}\text { Dióxido de azufre, materia particulada } \\
\text { conteniendo arsénico, antimonio, cadmio, } \\
\text { plomo, mercurio y zinc }\end{array}$ & & $\begin{array}{l}\text { Lodos/fangos ácidos de descarga de la } \\
\text { planta, escoria conteniendo sulfuros de } \\
\text { hierro, sílice }\end{array}$ \\
\hline $\begin{array}{l}\text { Afino electrolíitico del } \\
\text { cobre }\end{array}$ & $\begin{array}{l}\text { Cobre blister, } \\
\text { ácido sulfúrico }\end{array}$ & & & $\begin{array}{l}\text { Lodos conteniendo impurezas tales como } \\
\text { oro, plata, antimonio, arsénico, bismuto, } \\
\text { hierro, plomo, níquel, selenio, azufre y } \\
\text { zinc }\end{array}$ \\
\hline
\end{tabular}

\section{Plomo}

El proceso principal de producción de plomo consta de cuatro etapas: sinterización, fusión, despumación y afinado pirometalúrgico. Para empezar, se introduce en una máquina de sinterización una carga compuesta principalmente de concentrado de plomo en forma de sulfuro de plomo. Pueden añadirse otras materias primas, como hierro, sílice, fundente calizo, coque, sosa, ceniza, pirita, zinc, cáusticos y particulados recogidos de los dispositivos de control de la contaminación. En la máquina de sinterización, la carga de plomo se somete a chorros de aire caliente que queman el azufre, creando así dióxido de azufre. El óxido de plomo que queda después de este proceso contiene alrededor del $9 \%$ de su peso en carbono. A continuación el sinterizado, junto con coque, diversos materiales reciclados y de limpieza, caliza y otros fundentes se cargan, para su reducción, en un horno de cuba, donde el carbono actúa como combustible y funde el material de plomo. El plomo fundido fluye al fondo del horno, donde se forman cuatro capas: "speiss" (el material más ligero, básicamente arsénico y antimonio); "mata" (sulfuro de cobre y otros sulfuros metálicos); escoria del horno de cuba (principalmente silicatos), y lingote de plomo (98\% de plomo en peso).
A continuación se drenan todas las capas. El speiss y la mata se venden a fundiciones de cobre para la recuperación del cobre y de los metales preciosos. La escoria del horno, que contiene zinc, hierro, sílice y cal se almacena en pilas y se recicla en parte. En los hornos de cuba se generan emisiones de óxido de azufre debido a las pequeñas cantidades residuales de sulfuro y sulfatos de plomo contenidas en la carga de sinterizado.

El lingote de plomo en bruto obtenido en el horno de cuba requiere normalmente un tratamiento preliminar en calderas antes de ser sometido a las operaciones de afinado. Durante la despumación, el lingote se agita en una caldera especial y se enfría hasta justo por encima de su punto de congelación (370 a $425^{\circ} \mathrm{C}$ ). Una espuma, compuesta de óxido de plomo, junto con cobre, antimonio y otros elementos, flota hasta situarse en la parte superior y se solidifica por encima del plomo fundido.

La espuma se retira y se lleva a un horno de espuma para recuperar los metales útiles que no son plomo. A fin de mejorar la recuperación de cobre, el lingote de plomo despumado se trata añadiendo materiales portadores de azufre, zinc, y/o aluminio, con lo que el contenido de cobre se reduce al 0,01\% aproximadamente.

Tabla 82.2 • Materiales de proceso de partida y residuos contaminantes generados en la fundición y afino del plomo.

\begin{tabular}{|c|c|c|c|c|}
\hline Proceso & Materiales de partida & Emisiones a la atmósfera & Residuos del proceso & Otros residuos \\
\hline $\begin{array}{l}\text { Sinterización de } \\
\text { plomo }\end{array}$ & $\begin{array}{l}\text { Mineral de plomo, hierro, } \\
\text { sílice, fundente calizo, } \\
\text { coque, sosa, ceniza, pirita, } \\
\text { zinc, cáusticos, polvo de } \\
\text { cámara de sacos filtrantes }\end{array}$ & $\begin{array}{l}\text { Dióxido de azufre, materia particulada } \\
\text { conteniendo cadmio y plomo }\end{array}$ & & \\
\hline Fundición de plomo & Sinterizado de plomo, coque & $\begin{array}{l}\text { Dióxido de azufre, materia particulada } \\
\text { conteniendo cadmio y plomo }\end{array}$ & $\begin{array}{l}\text { Aguas residuales del } \\
\text { lavado de la planta, } \\
\text { agua de granulación } \\
\text { de escoria }\end{array}$ & $\begin{array}{l}\text { Escoria conteniendo impurezas tales como } \\
\text { zinc, hierro, sílice y cal, sólidos de balsas } \\
\text { de superficie }\end{array}$ \\
\hline $\begin{array}{l}\text { Despumación de } \\
\text { plomo }\end{array}$ & $\begin{array}{l}\text { Lingote de plomo, ceniza de } \\
\text { sosa, azufre, polvo de } \\
\text { cámara de sacos filtrantes, } \\
\text { coque }\end{array}$ & & & $\begin{array}{l}\text { Escoria conteniendo impurezas tales como } \\
\text { cobre, sólidos de balsas de superficie }\end{array}$ \\
\hline Afino del plomo & $\begin{array}{l}\text { Lingote de despumación de } \\
\text { plomo }\end{array}$ & & & \\
\hline
\end{tabular}


Durante la cuarta etapa, el lingote de plomo se refina por métodos pirometalúrgicos para eliminar cualquier resto de material comercializable que no sea plomo (p. ej., oro, plata, bismuto, zinc y óxidos metálicos tales como antimonio, arsénico, estaño y óxido de cobre). El plomo se refina en una caldera de hierro colado, en un proceso de cinco etapas. Primero se extraen el antimonio, el estaño y el arsénico. Después se añade zinc y se extraen el oro y la plata en la escoria de zinc. Seguidamente, se refina el plomo por extracción (destilación) del zinc al vacío. El afinado continúa con la adición de calcio y magnesio. Estos dos materiales se combinan con bismuto y forman un compuesto insoluble que se extrae de la caldera por despumación. En la etapa final, pueden añadirse al plomo sosa cáustica y/o nitratos para eliminar cualquier resto de impurezas metálicas. El plomo afinado tendrá una pureza del 99,90 al 99,99\% y puede mezclarse con otros metales para formar aleaciones, o colarse directamente en moldes.

\section{Riesgos y su prevención}

Los principales riesgos son la exposición a polvos de mineral durante el procesado y fusión de éste, humos metálicos (de plomo, arsénico y antimonio) durante la fundición, dióxido de azufre y monóxido de carbono durante la mayoría de las operaciones de fundición, ruido procedente de las operaciones de machaqueo y trituración y de los hornos, y estrés por calor a causa de los hornos.

Las precauciones comprenden: ventilación por extracción local de los polvos durante las operaciones de transferencia; ventilación local y de dilución del dióxido de azufre y el monóxido de carbono; un programa de control de ruido y de protección auditiva; ropa y pantallas protectoras, periodos de descanso y líquidos para el estrés por calor. Normalmente se utiliza protección respiratoria contra el polvo, humos y dióxido de azufre. Es esencial el control biológico del plomo.

La Tabla 82.2 ofrece una lista de los contaminantes ambientales presentes en las distintas etapas de la fundición y afino del plomo.

\section{Zinc}

El concentrado de zinc se produce separando el mineral, que puede contener proporciones tan pequeñas como el $2 \%$ de zinc, de la roca estéril mediante machaqueo y flotación, proceso que normalmente se lleva a cabo en la propia mina. A continuación, se reduce el concentrado de zinc por uno de estos dos métodos: pirometalúrgicamente mediante destilación (calentándolo en una retorta en un horno) o hidrometalúrgicamente por extracción electrolítica. Este último método es el que se utiliza aproximadamente en el $80 \%$ del afinado total de zinc.

El proceso de afinado hidrometalúrgico del zinc consta generalmente de cuatro etapas: calcinación, lixiviación, depuración y extracción electrolítica. La calcinación, o tostación, es un proceso a alta temperatura $\left(700\right.$ a $\left.1000{ }^{\circ} \mathrm{C}\right)$ que convierte el concentrado de sulfuro de zinc en un óxido de zinc impuro llamado calcina. Hay varios tipos de tostación: en horno multiplaza, o de varias soleras; en suspensión, y en lecho fluidizado. Por lo general, la calcinación comienza mezclando los materiales que contienen zinc con carbón. Después, esta mezcla se calienta, o tuesta, para evaporar el óxido de zinc, que a continuación se extrae de la cámara de reacción con la corriente de gas producida. La corriente de gas se dirige a la zona de la cámara de sacos (filtro), donde el óxido de zinc es capturado en el polvo de la cámara.

Todos los procesos de calcinación generan dióxido de azufre, el cual se controla y convierte en ácido sulfúrico como subproducto comercializable del proceso.

El procesado electrolítico de la calcina desulfurada consta de tres etapas básicas: lixiviación, depuración y electrólisis. La lixiviación consiste en disolver la calcina capturada en una disolución de ácido sulfúrico para formar una disolución de sulfato de zinc. La calcina puede lixiviarse una o dos veces. En el método de la doble lixiviación, la calcina se disuelve en una disolución ligeramente ácida para eliminar los sulfatos. Después, se lixivia por segunda vez en una disolución más concentrada que disuelve el zinc. Esta segunda etapa de lixiviación constituye en realidad el comienzo de la tercera etapa de depuración, dado que muchas de las impurezas de hierro se separan de la disolución y del zinc.

Después de la lixiviación, la disolución se depura en dos o más etapas añadiendo polvo de zinc. La depuración de la disolución tiene lugar al forzar el polvo la precipitación de los elementos nocivos, con lo cual éstos pueden eliminarse por filtración. Comúnmente, la depuración se lleva a cabo en grandes tanques de agitación. El proceso se realiza a temperaturas de 40 a $85^{\circ} \mathrm{C}$ y a presiones comprendidas entre la atmosférica y 2,4 atmósferas. Entre los elementos que se recuperan durante la depuración están el cobre, en forma de torta, y el cadmio, que se recupera como metal. Después de la depuración, la disolución esta lista para la etapa final, la extracción electrolítica.

La extracción electrolítica del zinc se lleva a cabo en una célula electrolítica, haciendo circular una corriente eléctrica por la disolución acuosa de zinc desde un ánodo de aleación de plomo y plata. Este proceso produce la carga del zinc en

Tabla 82.3 • Materiales de proceso de partida y residuos contaminantes generados en la fundición y afino del zinc.

\begin{tabular}{|c|c|c|c|c|}
\hline Proceso & Materiales de partida & Emisiones a la atmósfera & Residuos del proceso & Otros residuos \\
\hline Calcinación de zinc & Mineral de zinc, coque & $\begin{array}{l}\text { Dióxido de azufre, materia } \\
\text { particulada conteniendo zinc y } \\
\text { plomo }\end{array}$ & & $\begin{array}{l}\text { Lodos ácidos de descarga de la } \\
\text { planta }\end{array}$ \\
\hline Lixiviación de zinc & $\begin{array}{l}\text { Calcina de zinc, ácido sulfúrico, caliza, } \\
\text { electrolito agotado }\end{array}$ & & $\begin{array}{l}\text { Aguas residuales conteniendo } \\
\text { ácido sulfúrico }\end{array}$ & \\
\hline Depuración de zinc & Solución de zinc-ácido, polvo de zinc & & $\begin{array}{l}\text { Aguas residuales conteniendo } \\
\text { ácido sulfúrico, hierro }\end{array}$ & Torta de cobre, cadmio \\
\hline $\begin{array}{l}\text { Extracción electrolí- } \\
\text { tica del zinc }\end{array}$ & $\begin{array}{l}\text { Zinc en una solución de ácido } \\
\text { sulfúrico/acuosa, ánodos de aleación } \\
\text { de plomo y plata, cátodos de aluminio, } \\
\text { carbonato de bario o estroncio, aditivos } \\
\text { coloidales }\end{array}$ & & Acido sulfúrico diluido & $\begin{array}{l}\text { Lodos/fangos de células } \\
\text { electrolíticas }\end{array}$ \\
\hline
\end{tabular}


suspensión, que se ve obligado a depositarse sobre un cátodo de aluminio sumergido en la solución. A intervalos de 24 a 48 horas se para cada una de las células, se extraen y lavan los cátodos recubiertos de zinc, y se separa éste de las placas de aluminio por medios mecánicos. A continuación, el concentrado de zinc, que normalmente tiene una pureza de hasta el 99,995 \%, se funde y cuela en lingotes.

Las unidades de deposición electrolítica del zinc contienen hasta varios centenares de células. Una parte de la energía eléctrica se convierte en calor, con lo que aumenta la temperatura del electrolito. Las células electrolíticas trabajan a temperaturas comprendidas entre 30 y $35^{\circ} \mathrm{C}$ y a la presión atmosférica. Durante la extracción electrolítica, una parte del electrolito se hace pasar por torres de refrigeración para reducir su temperatura y evaporar el agua que recoge durante el proceso.

\section{Riesgos y su prevención}

Los principales riesgos son la exposición a polvos de mineral durante el procesado y fusión de éste, humos metálicos (de zinc y plomo) durante el afinado y tostación, dióxido de azufre y monóxido de carbono durante la mayoría de las operaciones de fundición, ruido procedente de las operaciones de machaqueo y trituración y de los hornos, estrés por calor a causa de los hornos y ácido sulfúrico y riesgos eléctricos durante los procesos electrolíticos.

Las precauciones comprenden: ventilación por extracción local de los polvos durante las operaciones de transferencia; ventilación local y de dilución del dióxido de azufre y el monóxido de carbono; un programa de control de ruido y de protección auditiva; ropa y pantallas protectoras, periodos de descanso y líquidos para el estrés por calor; y VEL, equipo de protección personal (EPP) y precauciones eléctricas para los procesos electrolíticos. Comúnmente se utiliza protección respiratoria contra el polvo, humos y dióxido de azufre.

Tabla 82.3 ofrece una lista de los contaminantes ambientales presentes en las distintas etapas de la fundición y afino del zinc.

\section{FUNDICION Y AFINO DEL ALUMINIO}

Bertram D. Dinman

\section{Resumen de procesos}

La bauxita se extrae por laboreo a cielo abierto. Los minerales más ricos se utilizan tal como se extraen. Los de baja ley pueden beneficiarse mediante machaqueo y lavado para eliminar la arcilla y la sílice estériles. La producción del metal comprende dos etapas básicas:

1. Afino. Producción de alúmina a partir de la bauxita por el procedimiento Bayer, en el cual la bauxita es digerida a alta temperatura y presión en una solución concentrada de sosa cáustica. El hidrato resultante se cristaliza y calcina para obtener el óxido en un horno de calcinación de lecho fluido.

2. Reducción. Reducción de la alúmina a aluminio virgen mediante el proceso electrolítico de Hall-Heroult, utilizando electrodos de carbón y fundente de criolita.

La explotación experimental sugiere que en el futuro el aluminio podrá obtenerse por reducción directa del mineral.

Actualmente se emplean dos tipos principales de células electrolíticas de Hall-Heroult. En el llamado proceso de "precocción" se utilizan electrodos fabricados como se indica a continuación. En las fundiciones de este tipo normalmente se produce exposición a hidrocarburos policíclicos en las instalaciones de fabricación de electrodos, sobre todo en las unidades de mezcla y en las prensas de conformación. Las fundiciones que utilizan la célula tipo Soderberg no requieren instalaciones para la fabricación de ánodos de carbón cocido. En su lugar, la mezcla de coque y aglutinante de brea se coloca en unas tolvas cuyos extremos inferiores están sumergidos en el caldo de la mezcla de criolita y alúmina. Al ser calentada la mezcla de brea y coque por el caldo de metal y criolita en el interior de la célula, esta mezcla se convierte in situ en una masa grafítica dura. Para que circule una corriente continua se introducen en la masa anódica varillas metálicas eléctricamente conductoras. Estas varillas deben sustituirse periódicamente; al extraerlas, se emiten al ambiente de la nave donde se encuentra la célula considerables cantidades de sustancias volátiles componentes de la brea de alquitrán mineral. A esta exposición se añaden las sustancias volátiles de la brea generadas durante la cocción de la masa de brea y coque.

Durante la pasada década la industria ha tendido o a prescindir de la sustitución o a modificar las instalaciones de reducción del tipo Soderberg existentes, dado el riesgo de carcinogenicidad demostrado que presentan. Asimismo, con la creciente automatización de las operaciones de las células de reducción - en especial el cambio de ánodos, las tareas se realizan con más frecuencia desde grúas mecánicas confinadas. Así pues, en las instalaciones modernas las exposiciones de los trabajadores y el riesgo de padecer trastornos asociados con la fusión del aluminio están disminuyendo gradualmente. Por el contrario, en las economías que no permiten realizar fácilmente las inversiones adecuadas, la persistencia de los antiguos procesos de reducción ejecutados manualmente continuará planteando el riesgo de que se produzcan esos trastornos de origen profesional (véase a continuación) antes asociados con las plantas de reducción de aluminio. De hecho, esta tendencia irá agravándose en las operaciones anticuadas que no han sido objeto de mejoras, en especial a medida que envejezcan.

\section{Fabricación de electrodos de carbón}

Los electrodos necesarios para la obtención del metal puro por reducción electrolítica mediante precocción, se fabrican normalmente en una instalación asociada a este tipo de fundición de aluminio. Los ánodos y cátodos se hacen casi siempre de una mezcla de coque derivado del petróleo, previamente triturado, y brea. Primero se tritura el coque en molinos de bolas, después se transporta y se mezcla mecánicamente con la brea y por último se funde y convierte en bloques en una prensa de moldeo. A continuación, estos bloques anódicos o catódicos se calientan en un horno de gas durante varios días hasta que forman masas grafíticas duras una vez extraídas prácticamente todas las sustancias volátiles. Finalmente, se unen a varillas anódicas o se les practican ranuras con una sierra para alojar en ellas las barras catódicas.

Hay que señalar que la brea empleada para formar estos electrodos es un destilado derivado del carbón o de alquitrán de petróleo. Durante la conversión de este alquitrán en brea por calentamiento, la brea obtenida como producto final ha perdido al hervir casi todos sus componentes inorgánicos de bajo punto de ebullición como, por ejemplo, el $\mathrm{SO}_{2}$, así como los componentes alifáticos y los componentes aromáticos de uno y dos anillos. Por lo tanto, la utilización de esta brea no debiera entrañar los mismos riesgos que los alquitranes de carbón o petróleo, dado que estas clases de compuestos no deberían estar presentes. Existen indicios de que el potencial cancerígeno de estos productos de brea puede no ser tan elevado como la mezcla, más compleja, de alquitranes y otros componentes volátiles asociada con la combustión incompleta del carbón. 


\section{Riesgos y su prevención}

Los riesgos y medidas preventivas para los procesos de fundición y afino de aluminio, son básicamente los mismos que los de la fundición y el afino en general; no obstante, los distintos procesos presentan ciertos riesgos específicos.

\section{Minería}

Aunque se ven en la literatura referencias esporádicas al "pulmón de bauxita", hay pocas pruebas convincentes de la existencia de tal entidad. No obstante, debiera considerarse la posible presencia de sílice cristalina en los minerales de bauxita.

\section{El proceso Bayer}

El empleo extensivo de sosa cáustica en el proceso Bayer presenta frecuentes riesgos de quemaduras químicas de la piel y los ojos. La desincrustación de los tanques con martillos neumáticos provoca grave exposición al ruido. A continuación se comentan los riesgos potenciales que entraña la inhalación de dosis excesivas del óxido de aluminio producido en este proceso.

Todos los trabajadores que intervienen en el proceso Bayer deben ser bien informados acerca de los riesgos que implica la manipulación de sosa cáustica. En todos los lugares de trabajo en los que exista riesgo, deberán preverse fuentes para lavados oculares, lavabos con agua corriente y duchas de lluvia artificial, con instrucciones para su utilización. Se deberán facilitar equipos de protección personal (EPP) (p. ej., gafas de montura ajustada, guantes, mandiles y botas). Asimismo deberán preverse duchas y dobles taquillas (una para la ropa de trabajo y otra para las prendas personales, y se encarecerá a todos los trabajadores la necesidad de lavarse a fondo al final del turno. A todos los operarios que trabajen con metal en fusión deberán proporcionárseles pantallas faciales, respiradores, manoplas, mandiles, brazaletes y polainas como protección contra quemaduras, polvo y humos. Los operarios que trabajen en el proceso de baja temperatura de Gadeau deberán ser provistos de guantes y trajes especiales para protegerles de los vapores de ácido clorhídrico que se desprenden al entrar las células en funcionamiento; la lana ha demostrado poseer buena resistencia a dichos vapores. Los respiradores con cartuchos filtrantes de carbón vegetal y las mascarillas impregnadas de alúmina protegen adecuadamente de los humos y vapores de brea y flúor; como protección frente al polvo de carbón se requieren mascarillas antipolvo eficaces. A los trabajadores sujetos a mayores niveles de exposición al polvo y a los humos y vapores, especialmente en operaciones del proceso Soderberg, debe facilitárseles equipo de protección respiratoria con entrada de aire puro. Cuando se generalice el trabajo mecanizado a distancia desde cabinas cerradas en las naves de crisoles, estas medidas de protección irán siendo menos necesarias.

\section{Reducción electrolítica}

La reducción electrolítica expone a los trabajadores al riesgo de sufrir quemaduras de la piel y accidentes por salpicaduras de metal en fusión, trastornos debidos al estrés por calor, ruido, riesgos eléctricos, y humos y vapores de criolita y ácido fluorhídrico. Las células de reducción electrolítica pueden emitir grandes cantidades de polvo de fluoruros y alúmina.

En los talleres de fabricación de electrodos de carbón deben instalarse equipos de ventilación por extracción con filtros de mangas; el confinamiento de los equipos de trituración de carbón y brea minimiza de un modo más eficaz aún las exposiciones a brea caliente y polvo de carbón. Deberán comprobarse regularmente las concentraciones de polvo atmosférico con un dispositivo de muestreo adecuado. Los trabajadores expuestos al polvo deberán ser sometidos a exploraciones radiológicas periódicas, seguidas de un reconocimiento médico cuando sea necesario.

Con el fin de reducir el riesgo que implica la manipulación de brea, deberá mecanizarse el transporte de este material en la medida de lo posible (por ej., pueden utilizarse camiones cisterna con sistema de calentamiento para transportar la brea líquida a los talleres, donde se bombeará automáticamente a depósitos de brea caldeados). También es prudente realizar exploraciones periódicas de la piel para detectar eritema, epiteliomas y dermatitis, y las cremas barrera a base de alginato puede proporcionar una protección suplementaria.

Antes de que inicien sus tareas, los operarios que realizan trabajos en caliente deben ser instruidos sobre la necesidad de aumentar su ingesta de líquidos y salar abundantemente los alimentos que ingieren. Se les deberá enseñar, tanto a ellos como a sus supervisores, a detectar trastornos incipientes producidos por el calor en ellos mismos y en sus compañeros. Todos los que realicen este tipo de trabajo deberán ser instruidos en la adopción de las medidas necesarias para prevenir la aparición o agravamiento de los trastornos por calor.

Los trabajadores expuestos a altos niveles de ruido deberán recibir equipos de protección auditiva, tales como tapones de oídos que permitan el paso del ruido de baja frecuencia (para que puedan escuchar las órdenes) pero reduzcan la transmisión del ruido intenso de alta frecuencia. Asimismo, deberán ser sometidos periódicamente a exploraciones audiométricas para detectar pérdida auditiva. Por último, se deberá enseñar también al personal a administrar medidas de reanimación cardiopulmonar a las víctimas de accidentes por descargas eléctricas.

Tabla 82.4 - Materiales de proceso de partida y residuos contaminantes generados en la fundición y afino del aluminio.

\begin{tabular}{|c|c|c|c|c|}
\hline Proceso & Materiales de partida & Emisiones a la atmósfera & Residuos del proceso & Otros residuos \\
\hline Afino de bauxita & $\begin{array}{l}\text { Bauxita, hidróxido } \\
\text { sódico }\end{array}$ & Partículas, solución cáustica/vapor de agua & & $\begin{array}{l}\text { Residuo conteniendo silicio, hierro, titanio, } \\
\text { óxidos de calcio y cáusticos }\end{array}$ \\
\hline $\begin{array}{l}\text { Clarificación y precipitación } \\
\text { de alúmina }\end{array}$ & $\begin{array}{l}\text { Lodos de alúmina, } \\
\text { almidón, agua }\end{array}$ & & $\begin{array}{l}\text { Aguas residuales conte- } \\
\text { niendo almidón, } \\
\text { arena y cáusticos }\end{array}$ & \\
\hline Calcinación de alúmina & Hidrato de aluminio & Partículas y vapor de agua & & \\
\hline $\begin{array}{l}\text { Fundición electrolítica } \\
\text { primaria de aluminio }\end{array}$ & $\begin{array}{l}\text { Alúmina, ánodos de } \\
\text { carbón, células elec- } \\
\text { trolíticas, criolita }\end{array}$ & $\begin{array}{l}\text { Fluoruro - gaseoso y en partículas, } \\
\text { dióxido de carbono, dióxido de azufre, } \\
\text { monóxido de carbono, } \mathrm{C}_{2} \mathrm{~F}_{6}, \mathrm{CF}_{4} \text { y } \\
\text { carbonos perfluorados (PFC) }\end{array}$ & & Revestimientos de cuba agotados \\
\hline
\end{tabular}


El riesgo de sufrir salpicaduras de metal en fusión y quemaduras graves está muy extendido en numerosos lugares de trabajo de las plantas de reducción y en operaciones conexas. Además de facilitar prendas de protección (p. ej. manoplas, mandiles, polainas y pantallas faciales) debe prohibirse el uso de prendas de fibras sintéticas, ya que debido al calor del metal líquido tales fibras se funden y adhieren a la piel, agravando con ello las quemaduras.

Se deberá excluir de las operaciones de reducción a quienes lleven marcapasos cardíacos, dado el riesgo de disritmias inducidas por campos magnéticos.

\section{Otros efectos para la salud}

Se han descrito ampliamente los riesgos que entraña para los trabajadores, la población en general y el medio ambiente la emisión de gases, humos y polvo que contienen fluoruros debido al empleo de fundente de criolita (véase la Tabla 82.4). Se han notificado diversos grados de mancha de los dientes permanentes en niños que viven cerca de fundiciones de aluminio mal controladas cuando han estado expuestos durante la fase de desarrollo del crecimiento de los dientes permanentes. Entre los trabajadores de fundiciones antes de 1950, o donde se ha seguido aplicando un control inadecuado o han continuado los vertidos de fluoruro, se han observado grados variables de fluorosis ósea. La primera fase de esta enfermedad consiste en un simple aumento de la densidad ósea, especialmente marcado en los cuerpos vertebrales y la pelvis. Después, a medida que el hueso absorbe más fluoruro, se calcifican los ligamentos de la pelvis. Finalmente, en caso de exposición extrema y prolongada al fluoruro, se produce calcificación de la estructura paravertebral y otras estructuras ligamentosas, así como de las articulaciones. Aunque esta última fase se ha visto en su forma grave en plantas de proceso de criolita, rara vez, o nunca, se han observado fases $\tan$ avanzadas entre trabajadores de fundiciones de aluminio. Aparentemente, los cambios radiológicos, menos graves, en las estructuras óseas y ligamentosas no se asocian con alteraciones de la función arquitectónica o metabólica del hueso. Mediante prácticas correctas de trabajo y una ventilación adecuada, se puede evitar fácilmente que los trabajadores que realizan tales operaciones de reducción desarrollen cualquiera de los cambios radiológicos antes citados, incluso después de pasar de 25 a 40 años realizando ese trabajo. Por último, la mecanización de las operaciones en las naves de crisoles debería reducir al mínimo o eliminar totalmente cualquier riesgo derivado del fluoruro.

Desde principios del decenio de 1980 quedó demostrada definitivamente la aparición de una enfermedad parecida al asma entre los operarios que trabajan en las naves de crisoles de reducción de aluminio. Esta aberración, conocida como asma profesional asociada a la fundición de aluminio (OAAAS), se caracteriza por resistencia variable al flujo de aire, hiperrespuesta bronquial o ambas cosas, y no se ve acelerada por estímulos producidos fuera del lugar de trabajo. Sus síntomas clínicos consisten en sibilancias, rigidez torácica y falta de aliento, y tos improductiva, que no suelen aparecer hasta varias horas después de la exposición en el trabajo. El período de latencia entre el comienzo de la exposición en el trabajo y la aparición del OAAAS es muy variable, ya que puede oscilar entre 1 semana y 10 años, dependiendo de la intensidad y el carácter de la exposición. Generalmente, la enfermedad mejora con la retirada del afectado de su lugar de trabajo después de unas vacaciones, etc., y aumenta en frecuencia y gravedad con las exposiciones repetidas en el trabajo. Aunque se ha relacionado la aparición de esta patología con las concentraciones de fluoruro en la nave de crisoles, no está claro que la etiología del trastorno provenga específicamente de la exposición a este agente químico. Dada la complejidad de la mezcla de polvos y humos (p. ej. fluoruros gaseosos y en partículas, dióxido de azufre y bajas concentraciones de óxidos de vanadio, níquel y cromo) es más probable que tales medidas de fluoruros suplanten a esta compleja mezcla de humos, gases y partículas que encontramos en las naves de crisoles.

Actualmente parece ser que esta enfermedad forma parte de un grupo cada vez más importante de enfermedades de origen profesional: el asma profesional. El proceso causante de este trastorno es difícil de determinar con carácter individual. Los síntomas de OAAAS pueden obedecer a asma preexistente de origen alérgico, hiperrespuesta bronquial inespecífica, síndrome de disfunción reactiva de las vías aéreas (RADS), o a un auténtico asma profesional. Actualmente, el diagnóstico de esta enfermedad resulta problemático; requiere una historia compatible y la presencia de limitación variable del flujo de aire o, en su defecto, producción de hiperresponsividad bronquial inducida farmacológicamente. Si no es demostrable esto último, el diagnóstico es improbable (no obstante, este fenómeno puede llegar a desaparecer tras remitir el trastorno al eliminar las exposiciones en el trabajo).

Dado que el trastorno tiende a agravarse progresivamente con la exposición continuada, casi siempre es necesario apartar a los individuos afectados de las exposiciones reiteradas en el trabajo. Si bien en un principio debiera restringirse a los individuos con asma atópica preexistente la entrada en las naves de células de reducción de aluminio, la ausencia de atopia no permite predecir si esta enfermedad se manifestará después de las exposiciones en el trabajo.

Existen actualmente informes que sugieren una posible relación entre el aluminio y la neurotoxicidad en trabajadores dedicados a la fundición y soldadura de este metal. Ha quedado claramente demostrado que el aluminio se absorbe por los pulmones y se excreta en la orina en niveles superiores a los normales, sobre todo en el caso de operarios que trabajan en las naves de células de reducción. No obstante, gran parte de la literatura relativa a los efectos neurológicos en esos trabajadores se deriva de la presunción de que la absorción de aluminio provoca neurotoxicidad humana. Por lo tanto, de momento y mientras tales asociaciones no sean demostrables con mayor reproducibilidad, la conexión entre el aluminio y la neurotoxicidad profesional debe considerarse especulativa.

Dada la necesidad esporádica de consumir más de $300 \mathrm{kcal} / \mathrm{h}$ durante la sustitución de ánodos o la realización de otras tareas que exigen considerable esfuerzo en presencia de criolita y aluminio en fusión, pueden darse casos de trastornos por calor en épocas calurosas. Tales episodios suelen ocurrir sobre todo cuando el tiempo cambia inicialmente de unas condiciones moderadas a las calurosas y húmedas del verano. También las prácticas de trabajo que determinan la sustitución acelerada de ánodos o el trabajo en dos turnos seguidos en tiempo caluroso, predisponen a los operarios a sufrir tales trastornos derivados del calor. Los trabajadores mal aclimatados al calor o físicamente mal acondicionados, cuya ingesta de sal es inadecuada o padecen enfermedades intercurrentes o han estado enfermos recientemente, son especialmente propensos a sufrir agotamiento y/o calambres por calor mientras realizan esas tareas pesadas. Se han dado casos de golpe de calor en trabajadores de fundiciones de aluminio, si bien con poca frecuencia excepto entre los predispuestos a ello por padecer alteraciones de salud conocidas (p. ej. alcoholismo, envejecimiento).

Se ha demostrado que la exposición a compuestos aromáticos policíclicos por respirar humo y partículas de brea expone, especialmente al personal que trabaja en células de reducción del tipo Soderberg, a un riesgo excesivo de padecer cáncer de vejiga; el exceso de riesgo de cáncer está claramente establecido. Se supone que también están expuestos a ese riesgo los 
trabajadores de las plantas de electrodos de carbón donde se calientan mezclas de coque y brea. No obstante, después de varios días de cocción de los electrodos a unos $1.200{ }^{\circ} \mathrm{C}$, los compuestos aromáticos policíclicos se han quemado o volatilizado casi totalmente y ya no están asociados a esos ánodos o cátodos. Por lo tanto, no está claramente demostrado que las células de reducción que utilizan electrodos precocidos presenten un riesgo excesivo de producir tales trastornos malignos. Se ha sugerido que en las operaciones de reducción del aluminio se dan también otras neoplasias (p. ej., leucemia no granulocítica y cánceres cerebrales); hasta el momento, las pruebas al respecto son fragmentarias e inconsistentes.

En las naves de crisoles, el empleo de martillos neumáticos en las inmediaciones de las células electrolíticas para romper la cascarilla, produce niveles de ruido del orden de $100 \mathrm{dBA}$. Las células de reducción electrolítica funcionan en serie, alimentadas con corriente de baja tensión y alto amperaje, por lo que los casos de sacudida eléctrica no suelen ser graves. No obstante, en la central de fuerza, en el punto donde la acometida de alta tensión se conecta a la red en serie de la nave de crisoles, pueden producirse accidentes graves por descargas, sobre todo teniendo en cuenta que la línea de alimentación eléctrica conduce corriente alterna de alta tensión.

La preocupación que suscitan las exposiciones asociadas con los campos de energía electromagnéticos por sus posibles consecuencias para la salud, ha hecho que se cuestione la exposición de los trabajadores de este sector. Hay que tener en cuenta que la energía que alimenta las células de reducción electrolítica es corriente continua, por lo tanto, los campos electromagnéticos generados en las naves de crisoles son principalmente de tipo estático, o de campo estacionario. En comparación con los campos electromagnéticos de baja frecuencia está menos demostrado aún, tanto clínica como experimentalmente, que estos otros campos produzcan efectos biológicos consistentes o reproducibles. Además, los niveles de flujo de los campos magnéticos medidos en las naves de células actuales suelen estar dentro de los valores límite umbral propuestos a título experimental para los campos magnéticos estáticos, frecuencias subradioeléctricas y campos electrostáticos. También se produce exposición a campos electromagnéticos de ultrabaja frecuencia en las plantas de reducción, especialmente en los extremos lejanos de las mismas, cerca de las naves de rectificación, en cambio los niveles de flujo medidos en las vecinas naves de crisoles son mínimos, muy inferiores a los exigidos por las normas actuales. Por último, no se han aportado de modo convincente pruebas epidemiológicas coherentes o reproducibles de efectos adversos para la salud debidos a los campos electromagnéticos de las plantas de reducción de aluminio.

\section{Fabricación de electrodos}

Los trabajadores que están en contacto con humos de brea pueden sufrir eritema; la exposición a la luz solar induce fotosensibilización con aumento de la irritación. Se han dado casos de tumores de piel localizados entre operarios que trabajan en la fabricación de electrodos y que no practicaban una higiene personal adecuada; después de la separación y el cambio de trabajo, normalmente no se observa difusión ulterior ni recurrencia. Durante la fabricación de electrodos pueden, generarse cantidades considerables de polvo de carbón y brea. En casos de exposición intensa e indebidamente controlada a este tipo de polvo, existen informes esporádicos de que los trabajadores que fabrican electrodos de carbón pueden padecer neumoconiosis simple con enfisema focal, complicada por el desarrollo de lesiones fibróticas masivas. Tanto las neumoconiosis simples como las complicadas son indiferenciables de la patología correspondiente conocida como neumoconiosis de los trabajadores del carbón. La trituración del coque en los molinos de bolas produce niveles de ruido de hasta $100 \mathrm{dBA}$.

Nota del director: La industria de la producción de aluminio está clasificada en el Grupo 1 de causas conocidas de cánceres humanos por la Agencia Internacional para la Investigación sobre el Cáncer (IARC). Diversas exposiciones se han asociado con otras enfermedades (p. ej., el "asma de los talleres de crisoles") que se describen en otros apartados de esta Enciclopedia.

\section{FUNDICION Y AFINO DEL ORO}

\section{I.D. Gadaskina y L.A. Ryzik*}

La minería del oro se practica a pequeña escala por buscadores privados (p. ej., en China y Brasil) y a gran escala en minas subterráneas (p. ej., en Sudáfrica) y explotaciones a cielo abierto (p. ej., en Estados Unidos).

El método de extracción más sencillo es el lavado en batea, que consiste en llenar un plato circular, o batea, con grava o arena que contienen oro, y agitarlo describiendo movimientos circulares bajo una corriente de agua. La arena y la grava, más ligeras, van eliminándose gradualmente por efecto del lavado, quedando las partículas de oro cerca del centro de la batea. La minería hidráulica del oro, más avanzada, consiste en proyectar un potente chorro de agua sobre la grava o la arena que contienen el oro. Con ello el material se disgrega y es eliminado a través de unas canaletas especiales en las que se deposita el oro, mientras que la grava, más ligera, flota y es extraída. Para la minería fluvial se emplean dragas de cangilones, o de rosario, consistentes en embarcaciones de fondo plano que utilizan una cadena de cangilones pequeños para extraer el material del fondo del río y vaciarlo en un recipiente cribador (trómel). El material gira en el trómel al incidir el agua sobre él. La arena portadora de oro se hunde a través de las perforaciones del trómel y cae en unas mesas vibrantes con lo que se consigue una mayor concentración.

Para extraer el oro del mineral se utilizan principalmente dos procesos, la amalgamación y la cianuración. El proceso de amalgamación se basa en la capacidad del oro para alearse con el mercurio metálico y formar amalgamas de diversas consistencias, desde sólida hasta líquida. El oro se separa de la amalgama bastante fácilmente eliminando el mercurio por destilación. En la amalgamación interna, el oro se separa dentro de la machacadora mientras se tritura el mineral. La amalgama extraída de la máquina se lava con agua en unos cuencos especiales para eliminar cualquier ingrediente adicional mezclado con la misma, después de lo cual el mercurio restante se extrae de la amalgama mediante prensado. En la amalgamación externa, el oro se separa fuera de la machacadora, en un amalgamador o canaleta especial (una mesa inclinada cubierta con planchas de cobre). Antes de extraer la amalgama, se añade mercurio fresco y a continuación se prensa la amalgama después de purificada y lavada. En ambos procesos el mercurio se elimina de la amalgama por destilación. El proceso de amalgamación es muy poco utilizado hoy en día, salvo en la minería a pequeña escala, por razones ecológicas.

La extracción de oro mediante cianuración se basa en la capacidad del oro para formar una doble sal estable soluble en agua $\mathrm{KAu}(\mathrm{CN})_{2}$ cuando se combina con cianuro potásico en unión de oxígeno. La pasta obtenida al machacar el mineral de oro está formada por partículas cristalinas grandes, llamadas arenas, y partículas amorfas más pequeñas, que reciben el nombre de limo. La arena, al ser más pesada, se deposita en

* Adaptado de la $3^{\text {a }}$ edición, Enciclopedia de saludy seguridad en el trabajo. 
el fondo de la machacadora y permite que la atraviesen las disoluciones (incluido el limo). El proceso de extracción del oro consiste en introducir el mineral finamente triturado en una tina de lixiviación y filtrar a través de él una disolución de cianuro sódico o potásico. El limo se separa de las disoluciones de cianuro de oro añadiendo espesantes y mediante filtración al vacío. La lixiviación en montones, en la que la disolución de cianuro se vierte sobre un montón enrasado de mineral triturado de gruesa granulometría, está ganando popularidad, especialmente con minerales y ganga de baja ley. En ambos casos, el oro se recupera de una disolución de cianuro de oro añadiendo polvo de aluminio o de zinc. En una operación separada, se añade ácido concentrado en un digestor para disolver el zinc o el aluminio, quedando libre de ese modo el oro sólido.

Bajo la influencia del ácido carbónico, el agua y el aire, así como de los ácidos presentes en el mineral, las disoluciones de cianuro se descomponen y desprenden ácido cianhídrico gaseoso. Para evitarlo, se añade una sustancia alcalina (cal o sosa cáustica). También se produce ácido cianhídrico cuando se añade el ácido para disolver el aluminio o el zinc.

Otro método de cianuración consiste en utilizar carbón activado para separar el oro. Primero se añaden espesantes a la disolución de cianuro de oro y después se forma un lodo con carbón activado para mantener el carbón en suspensión. El carbón portador de oro se elimina por cribado y el oro se extrae utilizando cianuro alcalino concentrado en disolución alcohólica, después de lo cual se recupera el oro mediante electrólisis. El carbón puede reactivarse por tostación y también puede recuperarse y reutilizarse el cianuro.

Tanto la amalgamación como la cianuración producen un metal que contiene una considerable cantidad de impurezas; la ley, o contenido de oro puro, rara vez excede de 900 partes por mil, a menos que se afine electrolíticamente hasta alcanzar una ley de 999.8 o superior.

También se recupera oro como subproducto de la fundición del cobre, el plomo y otros metales (véase el artículo "Fundición y afino del cobre, plomo y zinc" en este capítulo).

\section{Riesgos y su prevención}

El mineral de oro que se encuentra a grandes profundidades se extrae mediante minería subterránea. Esto exige adoptar medidas para evitar la formación y dispersión de polvo durante el laboreo. La separación del oro de los minerales arsenicales provoca exposición de los mineros al arsénico y la contaminación del aire y el suelo con polvo que contiene arsénico.

En la extracción de oro con mercurio, los trabajadores pueden resultar expuestos a altas concentraciones atmosféricas de mercurio al colocar o retirar éste de las canaletas, al purificar o prensar la amalgama, y al separar el mercurio por destilación; se han notificado casos de envenenamiento por mercurio en trabajadores que realizan operaciones de amalgamación y destilación. El riesgo de exposición al mercurio en la amalgamación se ha convertido en un grave problema en varios países del Lejano Oriente y América del Sur.

En los procesos de amalgamación, el mercurio debe colocarse en las canaletas y la amalgama eliminarse de manera que el mercurio no entre en contacto con la piel de las manos (usando palas de mango largo, ropa protectora impermeable al mercurio, etc.). Asimismo, el procesado de la amalgama y la separación o prensado del mercurio deben mecanizarse en lo posible, de manera que las manos no puedan entrar en contacto con el mercurio; el procesado de la amalgama y la eliminación del mercurio por destilación han de llevarse a cabo en locales aislados independientes, con las paredes, techos, suelos, aparatos y superficies de trabajo revestidos de un material que no absorba el mercurio o sus vapores; deben limpiarse con regularidad todas las superficies para eliminar cualquier depósito de mercurio. Todos los locales destinados a operaciones en las que se utilice mercurio deberán contar con ventilación general y ventilación local por extracción. Estos sistemas de ventilación habrán de ser especialmente eficaces en los locales donde se destila la amalgama para separar el mercurio. Las existencias de mercurio han de mantenerse en recipientes de metal herméticamente sellados y colocados debajo de una campana extractora especial; a los trabajadores debe facilitárseles el EPP necesario para trabajar con mercurio, y en los locales utilizados para la amalgamación y la destilación deben efectuarse controles atmosféricos sistemáticamente. También deben realizarse controles médicos.

La contaminación aérea por ácido cianhídrico en las plantas de cianuración depende de la temperatura del aire, ventilación, volumen de material que se procesa, concentración de las soluciones de cianuro utilizadas, calidad de los reactivos y número de instalaciones abiertas. La exploración médica de los trabajadores de las factorías de extracción de oro ha revelado síntomas de envenenamiento crónico por ácido cianhídrico y una elevada frecuencia de dermatitis alérgica, eccema y pioderma (una enfermedad inflamatoria aguda de la piel con formación de pus).

Es especialmente importante organizar correctamente la preparación de las disoluciones de cianuro. Si la apertura de los bidones que contienen las sales de cianuro y la adición de estas sales a las tinas de disolución no están mecanizadas, puede producirse una contaminación sustancial por polvo de cianuro y ácido cianhídrico gaseoso. Las disoluciones de cianuro deben añadirse por medio de bombas dosificadoras automáticas utilizando sistemas cerrados. Debe mantenerse el grado de alcalinidad correcto en todos los aparatos de cianuración de las plantas de cianuración de oro. Además, dichos aparatos deben estar sellados herméticamente y contar con VEL reforzada por una ventilación general adecuada y un sistema de control de fugas. Todos los aparatos de cianuración, así como las paredes, suelos, zonas diáfanas y escaleras de los locales deberán revestirse con materiales no porosos y limpiarse regularmente con disoluciones alcalinas de baja concentración..

El empleo de ácidos para descomponer el zinc en el procesado de fangos de oro puede liberar ácido cianhídrico y arsenamina, por lo tanto, estas operaciones se realizarán en locales independientes especialmente equipados, y utilizando campanas de extracción local.

Estará prohibido fumar y se pondrán a disposición de los trabajadores dependencias separadas para comer y beber. Se deberá disponer de un equipo de primeros auxilios con el material necesario para eliminar inmediatamente cualquier disolución de cianuro que entre en contacto con los cuerpos de los trabajadores y antídotos contra el envenenamiento por cianuro. Se facilitarán a los trabajadores prendas de protección personal impermeables a los compuestos de cianuro.

\section{Efectos ambientales}

Existen pruebas de exposición a vapores metálicos de mercurio y metilación de mercurio en la naturaleza, especialmente donde se procesa el oro. En un estudio del agua, depósitos y peces de zonas mineras de Brasil donde se extrae oro, las concentraciones de mercurio en las partes comestibles del pescado que se consume localmente eran casi seis veces superiores al nivel recomendado oficialmente en ese país para el consumo humano (Palheta y Taylor 1995). En una zona contaminada de Venezuela, buscadores de oro han estado utilizando mercurio durante muchos años para separar el oro de las arenas y el polvo de roca auríferos. El alto nivel de mercurio existente en las capas superficiales del 
suelo y en los sedimentos de goma de la zona contaminada constituye un grave riesgo para la salud pública y en el trabajo.

La contaminación por cianuro de las aguas residuales es también causa de gran preocupación. Las disoluciones de cianuro deben tratarse antes de su evacuación, o bien recuperarse y reutilizarse. Las emisiones de ácido cianhídrico gaseoso del digestor, por ejemplo, se tratan con un producto de lavado antes de su emisión por la chimenea.

\section{METALURGIA Y METALISTERIA}

\section{FUNDICIONES}

\section{Franklin E. Mirer}

La fundición, o colada de metales consiste en verter metal fundido en una cavidad en el interior de un molde resistente al calor, que tiene la forma exterior, o negativa, del modelo del objeto metálico deseado. El molde puede contener un macho para determinar las dimensiones de cualquier cavidad interna en el objeto metálico final. El trabajo de fundición comprende los siguientes pasos:

- confección de un modelo del artículo deseado

- confección del molde y los machos y montaje del molde

- fusión y afino del metal

- colada del metal en el molde

- enfriamiento de la pieza metálica fundida

- separación del molde y el macho de la pieza metálica fundida

- eliminación del metal sobrante de la pieza de fundición acabada

Los principios básicos de la tecnología de la fundición han experimentado pocos cambios a lo largo de miles de años, sin embargo los procesos han alcanzado una mayor mecanización y automatización. Los modelos de madera han sido sustituidos gradualmente por otros de metal y plástico, se han desarrollado nuevas sustancias para la producción de machos y moldes, y se utiliza una amplia gama de aleaciones. El proceso de fundición más importante es el de moldeo de hierro con arena.

Los metales de fundición tradicionales son el hierro, acero, latón y bronce. El sector más grande de la industria de fundición produce fundiciones de hierro gris y fundiciones de hierro dúctil. Las fundiciones de hierro gris utilizan hierro o arrabio (lingotes nuevos) para hacer piezas de fundición de hierro normales. Las fundiciones de hierro dúctil añaden magnesio, cerio u otros aditivos (denominados generalmente aditivos de cuchara) a las cucharas de metal fundido, antes de la colada para hacer piezas de fundición nodular o maleable. Los diferentes aditivos tienen poca influencia en las exposiciones que se producen en los lugares de trabajo. El resto del sector industrial de las fundiciones de metales férreos produce acero y hierro maleable. Los principales clientes de las mayores fundiciones son los sectores del automóvil, construcción y aperos agrícolas. El nivel de empleo en las fundiciones ha descendido al disminuir el tamaño de los bloques de los motores, lo que permite colar éstos en un solo molde, y al haberse sustituido la fundición de hierro por el aluminio. Por el contrario, las fundiciones de metales no férreos, en especial la fundición de aluminio y la fundición inyectada, tienen un alto nivel de empleo. Las fundiciones de latón, tanto las autónomas como las que destinan su producción a la industria de los equipos de fontanería, son un sector en recesión, aunque siguen teniendo importancia en lo que respecta a la higiene industrial. Desde hace algunos años se utilizan en los productos de fundición titanio, cromo, níquel y magnesio, e incluso metales más tóxicos aún, como berilio, cadmio y torio.

Aunque puede considerarse que la industria de la fundición de metales parte de la refusión de material sólido en forma de lingotes metálicos o arrabio, las grandes factorías de la industria del hierro y el acero, o siderurgia, pueden estar tan integradas que la división resulte menos evidente. Por ejemplo, el horno de cuba comercial puede convertir toda su producción en arrabio, pero en las plantas integradas parte del hierro puede utilizarse para producir piezas de fundición, interviniendo así en el proceso de fundición, y el hierro del horno de cuba puede utilizarse en estado de fusión para convertirlo en acero en otras unidades, donde puede ocurrir lo mismo. Existe de hecho una sección aparte del sector del acero denominada por este motivo moldeo en lingotes. En la fundición de hierro normal, la refusión del arrabio es también un proceso de afino. En las fundiciones de metales no férreos el proceso de fusión puede requerir la adición de metales y otras sustancias, constituyendo así un proceso de aleación.

En el sector de la fundición de hierro predominan los moldes hechos de arena de sílice compactada con arcilla. Los machos, que tradicionalmente se hacían cociendo arena de sílice aglutinada con aceites vegetales o azúcares naturales, se han sustituido en gran parte por otros de distinta composición. La moderna tecnología de la fundición ha desarrollado nuevas técnicas de producción de moldes y machos.

En general, los riesgos para la salud y seguridad en las fundiciones pueden clasificarse por tipo de colada, proceso de moldeo, tamaño de colada y grado de mecanización.

\section{Resumen de procesos}

Partiendo de los planos del diseñador, se construye un modelo que se ajusta a la forma externa de la pieza de fundición acabada. De igual manera, se hace una caja de machos que producirá los machos adecuados para determinar la configuración interna del producto final. La colada sobre arena es el método más utilizado, pero existen otras técnicas como la fundición en moldes permanentes utilizando moldes de hierro o acero, la fundición inyectada, en la que el metal fundido, con frecuencia una aleación ligera, se introduce en un molde de metal a presiones de 70 a $7.000 \mathrm{kgf} / \mathrm{cm}^{2}$, y la fundición a la cera perdida, donde se hace un modelo de cera de cada pieza que va a fabricarse y se cubre con un material refractario que formará el molde donde se vierta el metal. En el llamado proceso "a la espuma perdida" se utilizan modelos de espuma de poliestireno en arena para hacer piezas de fundición de aluminio.

Los metales o aleaciones se funden y preparan en uno de los distintos tipos de horno existentes: de cubilote, giratorio, de reverbero, de crisol, de arco eléctrico, de túnel o de inducción sin núcleo (véase la Tabla 82.5). Una vez efectuados los análisis químicos o metalúrgicos pertinentes para comprobar la calidad del metal fundido, éste se vierte en el molde ensamblado, bien sea utilizando una cuchara o bien directamente. Cuando el metal se ha enfriado, el molde, y el material del macho se retiran (desmoldeo por vibración, vaciado o expulsión) y la pieza se limpia y desbasta (eliminación de mazarotas, limpieza por chorro de granalla o chorro de agua y otras técnicas abrasivas). Algunas piezas de fundición requieren soldadura, 


\section{Tabla 82.5 • Tipos de hornos de fundición.}

$\begin{array}{ll}\text { Horno } & \text { Descripción } \\ \text { Cubilote } & \text { Un cubilote es un un horno alto y vertical abierto por } \\ & \text { arriba, provisto de puertas con bisagras en el extremo } \\ & \text { inferior. Se carga por la parte superior con capas } \\ & \text { alternas de coque, caliza y metal, y el metal fundido } \\ & \text { se extrae por el fondo. Entre los riesgos especiales } \\ & \text { están el monóxido de carbono y el calor. }\end{array}$

termotratamiento o pintura para que el artículo acabado cumpla las especificaciones del comprador.

Hay ciertos riesgos comunes a la mayoría de las fundiciones, independientemente del proceso específico de fundición empleado. Un ejemplo es el peligro derivado de la presencia de metal caliente. Además, existen los riesgos propios de un determinado proceso de fundición. Por ejemplo, el empleo de magnesio entraña un cierto peligro de llamaradas que no se da en otras industrias de fundición de metales. Este artículo trata principalmente de las fundiciones de hierro, ya que en ellas están representados la mayor parte de los riesgos típicos de las fundiciones.

En la fundición mecanizada o de producción se emplean los mismos métodos básicos que en la fundición de hierro convencional. Por ejemplo, cuando el moldeo se efectúa a máquina y las piezas se limpian con chorro de granalla o de agua, la máquina suele llevar incorporados dispositivos que controlan la emisión de polvo, con lo cual se reducen los riesgos derivados del polvo. No obstante, con frecuencia la arena se traslada de un lugar a otro sobre una cinta transportadora abierta, y los puntos de transferencia y los derrames de arena pueden ser fuentes de considerables cantidades de polvo en suspensión en el aire.
Debido a las altas tasas de producción, la carga de polvo en suspensión aérea puede ser incluso mayor que en la fundición convencional. Un análisis de los datos correspondientes a muestras de aire tomadas a mediados del decenio de 1970 , reveló que los niveles de polvo en las grandes fundiciones de producción norteamericanas eran mayores que en las pequeñas fundiciones muestreadas durante el mismo período. La instalación de campanas de extracción sobre los puntos de transferencia de las cintas transportadoras, combinada con un escrupulosa limpieza y mantenimiento, debiera ser una práctica común. El empleo de sistemas de transporte neumáticos es a veces económicamente viable y permite un transporte prácticamente libre de polvo.

\section{Fundiciones de hierro}

Resumiendo, se supone que una fundición de hierro comprende las seis secciones siguientes:

1. fusión y colada del metal

2. fabricación de moldes

3. moldeo

4. fabricación de machos

5. desmoldeo (por vibración o expulsión)

6. limpieza de las piezas de fundición.

En muchas fundiciones, casi todos estos procesos pueden llevarse a cabo simultánea o consecutivamente en la misma zona de talleres.

En una típica fundición de producción, después de la fusión el hierro pasa por las operaciones de colada, enfriamiento, desmoldeo, limpieza y expedición de las piezas acabadas. Por su parte, el ciclo de la arena comprende las fases de mezcla, moldeo, desmoldeo y retorno a la unidad de mezcla. La arena se añade al sistema en la fabricación de machos, que comienza con arena nueva.

\section{Fusión y colada}

Para satisfacer los requisitos de fusión y afino del metal la industria de fundición de hierro emplea principalmente el cubilote, un horno alto y vertical abierto por arriba, provisto de puertas con bisagras en el extremo inferior y revestido interiormente con material refractario. Por la parte superior se carga coque, chatarra de hierro y piedra caliza, y por unas aberturas situadas en el fondo (toberas) se inyecta aire a través de la carga. La combustión del coque caliente, funde y purifica el hierro. Los materiales de la carga se introducen por la parte superior del cubilote con ayuda de una grúa mientras el horno está en funcionamiento y deben situarse cerca, normalmente en recintos cercados o recipientes, en el patio adyacente a la maquinaria de carga. A fin de reducir al mínimo el riesgo de lesiones derivado de la caída de objetos pesados, la limpieza y una supervisión eficaz de los montones de materia prima son elementos esenciales. Para reducir la chatarra a un tamaño que resulte manejable para cargar en el horno y llenar las tolvas de carga, suelen utilizarse mazas rompedoras y grúas con grandes electroimanes. La cabina de la grúa debe estar bien protegida y los operadores convenientemente formados.

Los operarios que manipulan la materia prima deben usar guantes de cuero y botas de seguridad. Si no se presta atención al llenar la tolva, el material puede rebosar por exceso de carga, lo cual puede resultar peligroso. Si durante el proceso de carga el ruido que se produce es excesivo, el sonido del impacto metal contra metal puede reducirse colocando revestimientos de caucho amortiguadores de ruidos en los montacargas y recipientes de almacenamiento. Es necesario que la plataforma de carga esté por encima del nivel del suelo, lo cual puede entrañar un riesgo a no ser que sea horizontal y tenga la superficie 
antideslizante y barandillas resistentes a su alrededor y en las aberturas del suelo.

El cubilote genera grandes cantidades de monóxido de carbono, que puede escapar por las compuertas de las bocas de carga y salir impulsado hacia atrás por las corrientes de aire. El monóxido de carbono es incoloro e inodoro, y puede alcanzar niveles tóxicos en el ambiente con gran rapidez. Los operarios que trabajan en la plataforma de carga o las pasarelas circundantes deben contar con una buen formación para reconocer los síntomas de intoxicación por monóxido de carbono. Se requiere una vigilancia continua y puntual de los niveles de exposición. Se deberá tener dispuesto un aparato respirador autónomo y un equipo de reanimación, y los operarios habrán recibido instrucciones para su manejo. Cuando se lleve a cabo una tarea de emergencia, se establecerá y será obligatorio un sistema de control de contaminación para entrada en espacios confinados. Todo el trabajo deberá realizarse bajo observación.

Normalmente hay dos o más cubilotes que funcionan alternativamente, de manera que mientras uno se repara puedan utilizarse los restantes. El período de uso se determinará en función de la experiencia sobre la duración de los revestimientos refractarios y en las recomendaciones de los ingenieros. Deberán establecerse de antemano procedimientos adecuados para la descarga del hierro y para la parada del horno si se forman puntos calientes o no funciona el sistema de refrigeración por agua. En las reparaciones de los cubilotes es necesario que haya operarios dentro del armazón del horno para reparar o renovar los revestimientos refractarios. Estas tareas se considerarán entradas en espacios confinados, por lo que deberán adoptarse precauciones adecuadas. También deberán tomarse precauciones para evitar la descarga de material por las bocas de carga durante esas operaciones. Los operarios llevarán cascos de seguridad que les protejan de la caída de objetos y, si trabajan en altura, también deberán usar arneses de seguridad.

Los trabajadores que descargan los cubilotes (es decir, transfieren el metal fundido desde la piequera del cubilote a un horno de mantenimiento o a la cuchara) deben observar rigurosas medidas de protección personal. Es esencial llevar gafas de montura ajustada y prendas de protección. Los protectores de los ojos deben ser lo bastante resistentes para soportar tanto el impacto de fragmentos a gran velocidad como las pequeñas salpicaduras de metal fundido. Deben extremarse las precauciones para evitar que los restos de escorias (residuos no deseados eliminados del caldo con ayuda de aditivos de piedra caliza) y metal entren en contacto con el agua, ya que ello puede provocar una explosión por vapor. Es labor de los descargadores y capataces asegurarse de que toda persona ajena a los trabajos en el cubilote permanezca fuera de la zona de peligro, delimitada por un radio de unos $4 \mathrm{~m}$ desde el canal de colada. Según las Leyes Británicas para Fundiciones de Hierro y Acero de 1953, es requisito reglamentario fijar una zona prohibida para las personas no autorizadas.

Cuando finaliza la colada, se baja la parte inferior del cubilote a fin de eliminar la escoria y otros materiales no deseados del interior del armazón para que los operarios puedan llevar a cabo el mantenimiento refractario de rutina. La bajada de la parte inferior del cubilote es una operación que requiere formación específica y entraña riesgos, por lo que requiere una supervisión cualificada. Es fundamental que haya un suelo refractario o una capa de arena seca sobre el que derramar los residuos. Si surge algún problema, como el atasco de las bocas inferiores del cubilote, se deberá proceder con gran precaución para evitar que los trabajadores se quemen con la escoria y el metal caliente.

Cuando el metal al rojo blanco es visible, pueden peligrar los ojos de los trabajadores debido a la emisión de radiaciones ultravioleta e infrarroja; una larga exposición puede provocar cataratas.

La cuchara debe secarse antes de llenarla de metal fundido a fin de evitar explosiones por vapor. Debe fijarse un período adecuado de calentamiento con llama.

A los trabajadores de las secciones de fusión y colada de la fundición deben facilitárseles cascos, protección ocular y pantallas faciales con cristales tintados, prendas aluminizadas tales como mandiles, medias altas o polainas (que cubran el pie y la parte inferior de la pierna) y botas. El uso del equipo protector debe ser obligatorio y deben facilitarse instrucciones adecuadas sobre su uso y mantenimiento. En todas las zonas donde se manipule metal fundido se requieren normas estrictas de orden y limpieza, y de exclusión de agua, que deberán observarse con el máximo rigor.

Cuando se cuelgan grandes cucharas de las grúas o transportadores aéreos, deben emplearse dispositivos de control positivo de las cucharas para garantizar que el metal no se derrame si el operario suelta la sujeción. Los ganchos que sostienen las cucharas para metal fundido deben verificarse periódicamente para comprobar la fatiga del metal a fin de prevenir fallos.

En las fundiciones de producción, el molde ensamblado se conduce sobre un transportador mecánico hasta una estación de colada dotada de ventilación. La colada puede efectuarse desde una cuchara controlada manualmente con sistema de asistencia mecánica, una cuchara controlada desde una cabina, o puede ser una operación automática. Normalmente, la estación de colada está dotada de una campana compensadora con alimentación directa de aire. El molde lleno de metal fundido avanza a lo largo del transportador por un túnel de refrigeración con sistema de extracción de aire hasta la unidad de desmoldeo. En algunos talleres de fundición pequeños, la colada en los moldes se realiza sobre el suelo de la fundición y los moldes se dejan enfriar allí. En esta situación, la cuchara debe estar equipada con una campana extractora móvil.

La descarga y transporte del hierro fundido y la carga de los hornos eléctricos crea exposición a humos de óxido de hierro y otros humos de óxidos metálicos. La colada en el molde inflama y piroliza la materia orgánica, produciendo grandes cantidades de monóxido de carbono, humo, hidrocarburos poliaromáticos (HPA) cancerígenos y productos de pirólisis procedentes de los materiales de los machos, que pueden ser cancerígenos y también sensibilizantes respiratorios. Los moldes que contienen grandes cantidades de machos de caja fría aglutinados con poliuretano desprenden un humo denso e irritante que contiene isocianatos y aminas. El medio primario de control de riesgos durante el enfriamiento en el molde es una estación de colada con ventilación por extracción local y túnel de refrigeración.

En las fundiciones con ventiladores de techo para la extracción durante las operaciones de colada, pueden darse grandes concentraciones de humos metálicos en las zonas superiores, donde están situadas las cabinas de las grúas. Si hay operador en ellas, las cabinas deberán estar confinadas y contar con aire filtrado y acondicionado.

\section{Fabricación de modelos}

La fabricación de modelos es una operación muy especializada que implica trasladar los planos de diseño bidimensionales a un objeto tridimensional. Los modelos de madera tradicionales se fabrican en talleres estándar que cuentan con herramientas manuales y maquinaria eléctrica de corte y cepillado. Esta actividad exige adoptar todas las medidas razonablemente posibles para reducir el ruido al mínimo, y facilitar a los operarios protectores de oídos adecuados. Es importante que los trabajadores conozcan las ventajas que supone utilizar tal protección. 
Las máquinas eléctricas de corte y acabado de la madera son fuentes evidentes de peligro, y por lo general no es posible dotarles de defensas adecuadas sin impedir el funcionamiento de la máquina. Los operarios deberán estar versados en los procedimientos de trabajo normales y conocer los riesgos inherentes a este tipo de trabajo.

El aserrado de madera puede crear exposición al polvo, por lo que deben instalarse sistemas de ventilación eficaces que eliminen el polvo de madera del ambiente del taller de modelos. En algunas industrias que utilizan maderas duras, se ha observado cáncer nasal. Este riesgo no se ha estudiado en la industria de la fundición.

La colada en moldes permanentes, al igual que la fundición inyectada, ha constituido un importante avance en la industria de la fundición. En este caso, la fabricación de modelos se sustituye en gran parte por métodos de ingeniería y es, en realidad, una operación de matrizado. Desaparecen la mayoría de los riesgos que entrañan la fabricación de modelos y el uso de arena, pero son sustituidos por el riesgo inherente al empleo de algunos tipos de material refractario para revestir la matriz o el molde. En la moderna fundición de matrices cada vez se emplean más los machos de arena, persistiendo en ese caso los riesgos característicos del polvo de las fundiciones que trabajan con arena.

\section{Moldeo}

El proceso de moldeo más común en la industria siderúrgica es el del molde de "arena húmeda", hecho de arena de sílice, carbón en polvo, arcilla y aglutinantes orgánicos. Otros métodos de fabricación de moldes, basados en los de confección de machos, son el termoendurecimiento, el autofraguado en frío y el endurecimiento por gas. Estos métodos y sus riesgos se tratarán en el apartado relativo a la fabricación de machos. También pueden utilizarse moldes permanentes o el proceso a la espuma perdida, principalmente en la industria de la fundición de aluminio.

En las fundiciones de producción, las operaciones de mezcla de arena, moldeo, montaje de moldes, colada y desmoldeo están integradas y mecanizadas. La arena procedente del desmoldeo es reciclada y se devuelve a la operación de mezcla de arena, donde se le añaden agua y otros aditivos y la arena se mezcla en desterronadoras para mantener las propiedades físicas deseadas.

Para facilitar el ensamblaje, los modelos (y sus moldes) se hacen de dos piezas. En la fabricación manual de moldes, éstos van encerrados en unos bastidores metálicos o de madera llamados semicajas. La mitad inferior del modelo se coloca en la semicaja inferior (o falsa), y a su alrededor se vierte primero arena fina y después arena gruesa. La arena se compacta en el molde por un procedimiento de vibración-apriete, danzadora o presión. La semicaja superior (o cúpula) se prepara de manera análoga. En la cúpula se colocan separadores de madera para formar la mazarota y los bebederos, que son el camino por el que el metal fundido se vierte en la cavidad del molde. Se extraen los modelos, se introduce el macho y se ensamblan y fijan entre sí las dos mitades del molde, quedando de este modo listas para la colada. En las fundiciones de producción, la semicaja superior y la inferior se prepararan sobre un transportador mecánico, se colocan los machos en la semicaja inferior y se ensambla el molde por medios mecánicos.

El polvo de sílice es un problema en potencia dondequiera que se manipula arena. Normalmente, la arena de moldeo se humedece o se mezcla con resina líquida, por lo que la probabilidad de que constituya una fuente significativa de polvo respirable es menor. A veces se añade un separador, como talco por ejemplo, para facilitar la extracción del modelo del molde. El talco respirable provoca talcosis, un tipo de neumoconiosis. El uso de separadores está más difundido donde se utiliza el moldeo manual; en cambio rara vez se ven en los procesos grandes, más automatizados. A veces la superficie del molde se rocía con productos químicos, suspendidos o disueltos en alcohol isopropílico, que después se queman para que el compuesto, por lo general un tipo de grafito, recubra el molde, a fin de conseguir una pieza fundida con un acabado superficial más fino. Esto implica un riesgo inmediato de incendio, por lo que todos los operarios que intervengan en la aplicación de estos recubrimientos deberán contar con ropa protectora pirorretardante y protección para las manos, ya que los disolventes orgánicos también pueden causar dermatitis. Los recubrimientos deben aplicarse en una cabina ventilada para evitar que los vapores orgánicos se difundan en el ambiente de trabajo. Igualmente deberán observarse estrictas precauciones para garantizar que el alcohol isopropílico se guarde y utilice con seguridad. Inmediatamente antes de usarlo deberá trasvasarse a un recipiente pequeño, y los recipientes de almacenamiento grandes se mantendrán suficientemente alejados del proceso de combustión.

La fabricación manual de moldes puede requerir la manipulación de objetos grandes y engorrosos. Los propios moldes son bastante pesados, al igual que las cajas de moldeo. Con frecuencia han de elevarse, acarrearse y apilarse manualmente. Son frecuentes las lesiones de espalda, por lo que se requieren medios auxiliares mecánicos para que los operarios no tengan que elevar a mano objetos demasiado pesados para ser transportados con seguridad.

Para el confinamiento de las mezcladoras, transportadores y estaciones de colada y desmoldeo existen diseños normalizados, con caudales de extracción y velocidades de captura y transporte adecuados. El empleo sistemático de tales diseños y un estricto mantenimiento preventivo de los sistemas de control, permitirá cumplir los límites de exposición al polvo internacionalmente aceptados.

\section{Fabricación de machos}

Los machos introducidos en el molde determinan la configuración interna de una pieza fundida hueca como, por ejemplo, la camisa de agua de un bloque de motor. El macho debe ser lo bastante resistente para soportar el proceso de fundición pero, al mismo tiempo, no ha de ser tan fuerte como para oponer resistencia a su extracción de la pieza fundida durante la fase de vaciado.

Antes del decenio de 1960, las mezclas utilizadas para confeccionar los machos comprendían arena y aglutinantes tales como aceite de linaza, melaza o dextrina (arena petrolífera). La arena se compactaba en una caja de machos con una cavidad de la forma del macho, y después se secaba en un horno. Los hornos de machos generan productos tóxicos de pirólisis por lo que requieren un sistema de chimeneas adecuado y bien mantenido. Normalmente, las corrientes de convección del interior del horno serán suficientes para asegurar la evacuación satisfactoria de los vapores del lugar de trabajo, si bien contribuyen en gran medida a la contaminación atmosférica. Los machos de arena petrolífera acabados pueden producir aún una pequeña cantidad de humo después de haberlos extraído del horno, pero el riesgo es menor, aunque en algunos casos pequeñas cantidades de acroleína en los vapores pueden resultar muy molestas. Los machos pueden tratarse con una "capa antillama" para mejorar el acabado de la superficie de la pieza de fundición, que exige las mismas precauciones que los moldes.

El moldeo y la fabricación de machos en caja caliente o en cáscara son procesos de termoendurecimiento utilizados en las fundiciones de hierro. Se puede mezclar arena nueva con la resina de la fundición, o utilizar arena recubierta de resina, adquirida en sacos, para añadirla a la máquina de machos. 
La arena con resina se inyecta en un modelo metálico (la caja de machos) y a continuación se calienta el modelo - con llama directa de gas natural en el proceso de la caja caliente o por otros medios en el caso de los machos o el moldeo en cáscara. Normalmente, en las cajas calientes se utilizan resinas termoendurecibles de urea - formol o fenol-formol con alcohol furfurílico (furano), mientras que en el moldeo en cáscara se emplea una resina de urea-formol o fenol-formol. Tras un corto período de fraguado, el macho se endurece considerablemente y puede separarse de la placa del modelo con ayuda de punzones. La fabricación de machos en caja caliente y en cáscara produce considerable exposición al formol, probablemente cancerígeno, y a otros contaminantes, dependiendo del sistema. Las medidas de control del formol comprenden el suministro directo de aire en la estación del operador, extracción local en la caja de machos, confinamiento y extracción local en la estación de almacenamiento de machos y resinas con bajo nivel de emisión de formol. Es difícil conseguir un control satisfactorio. Los operarios que trabajan en la fabricación de machos deben recibir vigilancia médica en cuanto a afecciones respiratorias. Se evitará el contacto de la piel y los ojos de fenol-formol y urea-formol, ya que las resinas son irritantes o sensibilizantes y pueden causar dermatitis. Los lavados con agua abundante ayudarán a evitar el problema.

Los sistemas de endurecimiento en frío (sin cocción) actualmente utilizados comprenden: resinas de urea-formol y fenolformol catalizadas con ácidos, con y sin alcohol furfurílico; isocianatos alquídicos y fenólicos; Fascold; silicatos autofraguados; Inoset; arena de cemento y arena fluida o moldeable. Los endurecedores de frío no requieren calentamiento externo para fraguar. Los isocianatos utilizados en los aglutinantes suelen estar basados en isocianato de difenilmetileno (MDI), el cual, si se inhala, puede actuar como un irritante o sensibilizante respiratorio y causar asma. Es aconsejable llevar guantes y gafas protectoras de montura ajustada cuando se manipulan o utilizan estos compuestos. Los isocianatos deben mantenerse cuidadosamente almacenados en recipientes sellados, en un ambiente seco y a una temperatura comprendida entre 10 y $30^{\circ} \mathrm{C}$. Los recipientes vacíos que los hayan contenido deben llenarse y mantenerse sumergidos durante 24 horas en una disolución de carbonato sódico al $5 \%$ para neutralizar cualquier residuo químico que haya quedado en el bidón. En los procesos de moldeo con resina deben observarse estrictamente la mayoría de los principios generales de limpieza y mantenimiento, pero sobre todo deberán extremarse las precauciones al manipular los catalizadores utilizados como fraguantes. Los catalizadores para las resinas de fenol e isocianato aglutinadas con aceite son generalmente aminas aromáticas a base de compuestos de piridina, y se trata de líquidos de olor picante. Pueden provocar graves irritaciones cutáneas y lesiones renales y hepáticas, y también pueden afectar al sistema nervioso central. Estos compuestos se suministran como aditivos separados (aglutinante de tres componentes) o ya mezclados con los materiales oleosos, y durante las fases de mezcla, moldeo, colada y desmoldeo debe proveerse VEL. Para algunos otros procesos sin cocción se utilizan como catalizadores ácido fosfórico y diversos ácidos sulfónicos, que también son tóxicos, por lo que deben adoptarse precauciones adecuadas durante su transporte y empleo para evitar accidentes.

La fabricación de machos con endurecimiento por gas comprende el proceso con dióxido de carbono $\left(\mathrm{CO}_{2}\right)$-silicato y el proceso Isocure (o "Ashland"). Desde el decenio de 1950 se han desarrollado numerosas variantes del proceso con dióxido de carbono $\left(\mathrm{CO}_{2}\right)$-silicato. Este proceso se ha utilizado generalmente para la producción de moldes y machos de tamaño medio a grande. La arena del macho es una mezcla de silicato sódico y arena de sílice, que a menudo se modifica añadiéndole sustancias tales como melaza para que actúen como disgregantes. Una vez rellena la caja de machos, el macho se fragua haciendo pasar dióxido de carbono por la mezcla de que está compuesto. Con ello se forma carbonato sódico y gel de sílice, que actúa como aglutinante.

El silicato sódico es una sustancia alcalina y puede resultar tóxica si entra en contacto con la piel o los ojos, o se ingiere. Es aconsejable contar con una ducha de emergencia cerca de las zonas conde se manipulen grandes cantidades de silicato sódico, y siempre deben llevarse guantes. En todas las zonas de la fundición en que se utilice silicato sódico deberá haber una fuente para lavados oculares fácilmente accesible. $\mathrm{El} \mathrm{CO}_{2}$ puede suministrarse en fase sólida, líquida o gaseosa. Cuando se suministre en botellas o depósitos a presión, deberán adoptarse las máximas precauciones de mantenimiento interno, tales como almacenamiento de botellas, mantenimiento de válvulas, manipulación, etc. También el gas entraña riesgo por sí mismo, ya que puede reducir la concentración de oxígeno en el aire en espacios confinados.

El proceso Isocure se utiliza para machos y moldes. Es un sistema de fraguado por gas en el que una resina, con frecuencia fenol-formol, se mezcla con un diisocianato (MDI) y arena. Esta mezcla se inyecta en la caja de machos y después se gasifica con una amina, normalmente trietilamina o dimetil etilamina, para producir la reacción de reticulado y endurecimiento. Las aminas, que con frecuencia se venden en bidones, son líquidos muy volátiles con un fuerte olor a amoníaco. Existe auténtico peligro de incendio o explosión, por lo que deben extremarse las precauciones, especialmente cuando el material se almacena a granel. El efecto característico de estas aminas es que provocan visión de halos e inflamación de la córnea, aunque también afectan al sistema nervioso central, donde pueden producir convulsiones, parálisis y, a veces, la muerte. Si las aminas entran en contacto con los ojos o la piel, los primeros auxilios incluirán lavado con mucha agua durante quince minutos como mínimo y asistencia médica inmediata. En el proceso Isocure, la amina se aplica en forma de vapor en nitrógeno portador, eliminándose el exceso de amina mediante lavado en una torre de ácido. Las fugas de la caja de machos son la causa más importante de alta exposición, aunque también es considerable la descarga gaseosa de amina de los machos fabricados. Deberán extremarse las precauciones en todo momento al manipular este material, y ha de instalarse un equipo adecuado de ventilación por extracción para eliminar los vapores de las zonas de trabajo.

\section{Vibración, desmoldeo y vaciado}

Una vez enfriado el metal fundido, es preciso extraer del molde la pieza en bruto. Este proceso es muy ruidoso y con frecuencia los operarios quedan expuestos a bastante más de $90 \mathrm{dBA}$ durante una jornada laboral de 8 horas. Si no es posible reducir el ruido, deben suministrarse protectores para los oídos. Normalmente, la masa principal del molde se separa de la pieza de fundición con una sacudida. Con frecuencia. la caja de moldeo, el molde y la pieza de fundición se dejan caer en una rejilla vibratoria para separar la arena (vibración). Esta, atraviesa entonces la rejilla y cae en una tolva o sobre un transportador, donde puede quedar expuesta a separadores magnéticos y reciclarse para ser molida, tratada y reutilizada, o simplemente se desecha. A veces, en lugar de la rejilla se utiliza un chorro de agua a presión, lo que origina menos polvo. En esta fase se extrae también el macho, en ocasiones utilizando también chorros de agua a alta presión.

La pieza de fundición se extrae y transporta a la fase siguiente de la operación de vaciado. Con frecuencia, las piezas pequeñas pueden extraerse de la caja de moldeo expulsándolas mediante un proceso de "punzonado" antes de la vibración, lo que produce menos polvo. La arena origina niveles peligrosos de 
polvo de sílice, ya que al haber estado en contacto con metal fundido se encuentra muy seca. Tanto el metal como la arena están aún muy calientes. Es necesario utilizar protección ocular. Las superficies de tránsito y de trabajo deben mantenerse libres de fragmentos de metal, para evitar tropezar con ellos, y también de polvo, que al agitarse puede quedar de nuevo suspendido en el aire con el consiguiente riesgo de inhalación.

El número de estudios realizados para determinar si los nuevos aglutinantes para machos producen algún efecto adverso para la salud, en especial de los operarios que realizan la extracción de los machos, es relativamente escaso. Los furanos, alcohol furfurílico y ácido fosfórico, resinas de urea-formol y fenolformol, silicato sódico y dióxido de carbono, endurecedores sin cocción, aceite de linaza modificado y MDI, experimentan algún tipo de descomposición térmica al ser expuestos a las temperaturas de los metales en fusión.

Aún no se ha realizado ningún estudio sobre los efectos de las partículas de sílice recubiertas de resina en el desarrollo de neumoconiosis. Se ignora si estos recubrimientos tendrán un efecto inhibidor o acelerador de las lesiones del tejido pulmonar. Se teme que los productos de la reacción del ácido fosfórico puedan liberar fosfina. Experimentos con animales y algunos estudios seleccionados han revelado que el efecto del polvo de sílice sobre el tejido pulmonar se acelera considerablemente cuando la sílice ha sido tratada con un ácido mineral. Las resinas de urea-formol y fenol-formol pueden emitir fenoles libres, aldehídos y monóxido de carbono. Los azúcares añadidos para aumentar la disgregabilidad producen considerables cantidades de monóxido de carbono. Los endurecedores sin cocción liberan isocianatos (MDI) y monóxido de carbono.

\section{Desbarbado (limpieza)}

Después de la vibración y el vaciado se procede a la limpieza de la pieza de fundición, o desbarbado. Los diversos procesos utilizados al efecto reciben diferentes nombres en los distintos lugares, pero en términos generales pueden clasificarse como sigue:

- Limpieza comprende el raspado, desbaste o arranque, eliminación de arena de moldeo adherida y de arena del macho, mazarotas, bebederos, rebabas en forma de película metálica y otras materias fácilmente eliminables con herramientas de mano o herramientas neumáticas portátiles.

- Desbarbado comprende el desarenado y la eliminación de aristas vivas y metal superfluo, como ampollas, resaltes de bebederos, costras y otras imperfecciones, así como la limpieza manual de la pieza de fundición con cortafríos, herramientas neumáticas y cepillos metálicos. Para eliminar los bebederos, efectuar reparaciones de la pieza de fundición y realizar cortes y lavados pueden utilizarse técnicas de soldadura, tales como corte con soplete oxiacetilénico, arco eléctrico, arco y aire comprimido, lavado de polvo y torcha de plasma.

La primera de las operaciones de desbaste es la eliminación de mazarotas. Aproximadamente la mitad del metal fundido en el molde es superflua para la pieza final. El molde debe tener depósitos, cavidades, bebederos y una mazarota, para que pueda llenarse de metal a fin de obtener un objeto fundido completo. Con frecuencia, la mazarota puede eliminarse durante la fase de vaciado, pero a veces esta operación ha de realizarse como una fase aparte del desbarbado o el desbaste. La eliminación de la mazarota se efectúa a mano, normalmente golpeando la pieza de fundición con un martillo. Para reducir el ruido, los martillos de metal pueden sustituirse por otros recubiertos de goma y los transportadores revestirse con la misma goma amortiguadora de ruidos. Los fragmentos de metal caliente que se desprenden pueden constituir un peligro para los ojos, en cuyo caso debe utilizarse protección ocular. Normalmente, las mazarotas desprendidas volverán a la zona de carga de la planta de fundición y no debe permitirse que se acumulen en la sección de eliminación de mazarotas. Después del desmazarotado (a veces antes) la mayoría de las piezas de fundición se limpian con chorro de granalla o en un tambor rotatorio para eliminar los materiales de moldeo no deseados y, en ocasiones, mejorar el acabado de la superficie. Los tambores rotatorios producen altos niveles de ruido. Cabe la posibilidad de que sean necesarios recintos de protección y tal vez la instalación en los mismos de un sistema de extracción localizada.

La mayoría de los métodos de limpieza de piezas empleados en las fundiciones de hierro, acero y metales no férreos son muy parecidos, pero la limpieza y desbarbado de piezas de fundición de acero entraña dificultades especiales debido a la mayor cantidad de arena fundida que tienen adherida en comparación con las de hierro y metales no férreos. La arena fundida e incrustada en la superficie de las piezas de fundición grandes puede contener cristobalita, cuya toxicidad es mayor que la del cuarzo que se encuentra en la arena virgen.

Es necesario limpiar las piezas de fundición con chorro a presión sin aire o en tambores rotatorios antes del desbarbado y esmerilado, a fin de evitar una exposición excesiva al polvo de sílice. La pieza debe quedar libre de polvo visible, aunque puede existir riesgo de exposición a sílice en el esmerilado si ésta se halla incrustada en la superficie, aparentemente limpia, de la pieza metálica. El chorro se proyecta sobre la pieza centrífugamente, sin que sea necesaria la presencia de ningún operario en el interior de la unidad. La cabina de limpieza por chorro de granalla debe contar con un sistema de extracción para evitar cualquier emisión de polvo visible. Solo pueden surgir problemas con el polvo en caso de avería o deterioro de la cabina y/o el ventilador y el colector de polvo.

Para eliminar la arena adherida puede aplicarse a la pieza un chorro de agua, agua con arena o granalla de hierro o acero a alta presión. En varios países (p. ej., el Reino Unido) está prohibida la limpieza por chorro de arena debido al riesgo de silicosis, ya que durante el proceso de abrasión las partículas de arena se vuelven cada vez más finas, con lo que la fracción respirable aumenta continuamente. El agua o la granalla se descargan con un inyector y si éste no se maneja correctamente puede entrañar riesgos para el personal. La limpieza por chorro debe realizarse siempre en un lugar aislado y cerrado. Todos los recintos de limpieza por chorro deben inspeccionarse periódicamente para asegurarse del correcto funcionamiento del sistema de extracción de polvo y la ausencia de fugas por las cuales pudiera escapar la granalla o el agua e introducirse en la fundición. Los cascos de los operarios deben estar homologados y ser objeto de un cuidadoso mantenimiento. Es aconsejable colocar un aviso en la puerta de la cabina indicando al personal que se está realizando la limpieza por chorro y se prohibe el paso a toda persona no autorizada. En determinadas circunstancias pueden montarse en las puertas cierres de retardo conectados al motor de accionamiento del sistema de limpieza por chorro, de manera que sea imposible que se abran las puertas hasta que la operación haya finalizado.

Para alisar la pieza de fundición en bruto se utilizan diversas herramientas de esmerilado. Las muelas pueden montarse en máquinas de bancada o de pedestal, o en esmeriladoras portátiles o de bastidor pendular. Las esmeriladoras de pedestal se utilizan para piezas pequeñas que pueden manipularse fácilmente; las esmeriladoras portátiles y las muelas de disco para superficies, muelas de copa y muelas cónicas se emplean para diversos fines, como alisar las superficies internas de las piezas de fundición; las esmeriladoras de bastidor pendular se usan principalmente para piezas grandes de las que hay que eliminar gran cantidad de metal. 


\section{Otras fundiciones}

\section{Fundición de acero}

El modelo de producción de las molderías de acero (que es distinto del de una acería básica) es similar al de la fundición de hierro; no obstante, las temperaturas del metal son mucho más elevadas. Esto significa que es fundamental protegerse los ojos con lentes coloreados; la sílice del molde se transforma por el calor en tridimita o cristobalita, dos formas de sílice cristalina particularmente peligrosas para los pulmones. A menudo la arena aparece adherida a la pieza de fundición y tiene que extraerse por medios mecánicos, produciéndose con ello un polvo peligroso; por lo tanto, es esencial instalar sistemas de extracción de polvo eficaces y protección respiratoria.

\section{Fundición de aleaciones ligeras}

La fundición de aleaciones ligeras utiliza principalmente aleaciones de aluminio y magnesio. Estas con frecuencia contienen pequeñas cantidades de metales que, en determinadas circunstancias, pueden desprender vapores tóxicos. Cuando la aleación pueda contener dichos componentes, deberán analizarse los vapores para determinar sus elementos constituyentes.

En las fundiciones de aluminio y magnesio, la fundición se realiza habitualmente en hornos de crisol. Es aconsejable instalar sistemas de extracción alrededor de la parte superior de la cuba, para la extracción de los vapores. En los hornos de petróleo, una combustión incompleta a causa de quemadores defectuosos puede hacer que se propaguen por el aire productos tales como monóxido de carbono. Los humos del horno pueden contener hidrocarburos complejos, algunos de los cuales pueden ser cancerígenos. Durante la limpieza del horno y la chimenea existe riesgo de exposición al pentóxido de vanadio concentrado en el hollín del horno procedente de los sedimentos del petróleo.

Normalmente se utiliza espato de flúor como fundente en la fundición del aluminio y pueden desprenderse grandes cantidades de polvo de fluoruros. En algunos casos se ha utilizado cloruro de bario como fundente para aleaciones de magnesio; ésta es una sustancia muy tóxica y, por consiguiente, hay que utilizarla con sumo cuidado. Las aleaciones ligeras a veces pueden desgasearse haciendo pasar dióxido de azufre o cloro (o compuestos específicos que se descomponen y producen cloro) por el metal en fusión; para esta operación es necesario contar con un sistema de ventilación por extracción y equipo protector respiratorio. Para reducir la velocidad de enfriamiento del metal caliente en el molde, se situará en el bebedero una mezcla de sustancias (normalmente aluminio y óxido de hierro) cuya reacción es altamente exotérmica. Esta mezcla "aluminotérmica" desprende vapores densos que en la práctica se ha descubierto que son inocuos. Cuando los vapores son de color marrón puede producirse alarma debido a la sospecha de que contienen óxidos de nitrógeno, sin embargo, tal sospecha es infundada. El aluminio finamente dividido que se produce durante el desbaste de las piezas de fundición de aluminio y magnesio entraña un grave peligro de incendio, y para la captación del polvo deben emplearse métodos en fase húmeda.

La fabricación de piezas de fundición de magnesio entraña un riesgo considerable de incendio y explosión. El magnesio fundido se autoinflamará a no ser que se mantenga una barrera protectora de separación entre éste y la atmósfera; a tal efecto se utiliza mucho el azufre fundido. Los trabajadores de la fundición que aplican manualmente polvo de azufre en el crisol pueden padecer dermatitis y deben llevar guantes de material ignífugo. Puesto que el azufre en contacto con el metal arde constantemente, se desprenden considerables cantidades de dióxido de azufre. Debe instalarse un sistema de ventilación por extracción. Debe informarse a los trabajadores del peligro que entraña el incendio de un crisol o una cuchara de magnesio fundido, ya que puede originar una densa nube de óxido de magnesio finamente dividido. Todos los trabajadores de una fundición de magnesio deben llevar prendas protectoras fabricadas con materiales ignífugos y la ropa recubierta con polvo de magnesio no debe guardarse en taquillas carentes de control de humedad, pues podría producirse una combustión espontánea. Debe eliminarse de la ropa el polvo de magnesio. En las fundiciones de magnesio se utiliza mucho talco para el recubrimiento de los moldes y debe controlarse el polvo para evitar la talcosis. En la inspección de piezas de fundición de aleaciones ligeras se emplean aceites penetrantes y polvos de pulverización para detectar grietas. Se han introducido tintes para mejorar la eficacia de estas técnicas. Se ha descubierto que determinados tintes rojos son absorbidos y se excretan en el sudor, haciendo que se manchen las prendas de vestir del personal; aunque esto resulta molesto, no se han observado efectos en la salud.

\section{Fundiciones de latón y bronce}

Un riesgo especial de las fundiciones de latón y bronce es la emisión de vapores y polvo metálicos tóxicos por las aleaciones normales. Tanto en la fundición como en la colada y el acabado son frecuentes las exposiciones al plomo por encima de los límites de seguridad, sobre todo cuando la composición de las aleaciones tiene un alto contenido en plomo. El peligro por el plomo es particularmente elevado durante la limpieza del horno y la evacuación de las impurezas. La sobreexposición al plomo es frecuente en la fundición y la colada, y también puede producirse durante el esmerilado. Los vapores de zinc y cobre (constituyentes del bronce) son las causas más comunes de la fiebre de los vapores del metal, aunque también se ha observado esta patología en trabajadores de la fundición que utilizan magnesio, aluminio, antimonio, etc. Algunas aleaciones de gran resistencia contienen cadmio, que puede causar neumonía química por exposición aguda y lesiones renales y cáncer de pulmón por exposición crónica.

\section{Proceso de moldeo permanente}

Un adelanto importante ha sido la fundición en moldes de metal permanentes, como en la fundición inyectada. En este caso, la fabricación de modelos es sustituida en gran parte por métodos de ingeniería, siendo en realidad una operación de estampación mediante troqueles. Con ello quedan eliminados la mayoría de los riesgos propios de la fabricación de modelos, al igual que los derivados de la arena, aunque son sustituidos por el riesgo que entraña el uso de cierto tipo de material refractario para revestir el troquel o el molde. En los modernos trabajos de fundición con troquel, se utilizan cada vez más los machos de arena, en cuyo caso siguen existiendo los riesgos derivados del polvo de la fundición con arena.

\section{Fundición inyectada}

El aluminio es un metal de uso común en la fundición inyectada. Alunas piezas de los automóviles, tales como los adornos cromados, son normalmente de fundición inyectada de zinc cobreada, niquelada y cromada. Debe controlarse constantemente el riesgo de fiebre por vapores de zinc, al igual que la neblina de ácido crómico.

Las máquinas de fundición inyectada presentan todos los riesgos comunes a las prensas hidráulicas. Además, el trabajador puede resultar expuesto a neblinas de los aceites empleados como lubricantes de troqueles y deben protegerse de la inhalación de las mismas y el peligro de saturación de la ropa con aceite. Los líquidos hidráulicos resistentes al fuego utilizados en las prensas pueden contener compuestos organofosforosos 
tóxicos, y deben extremarse las precauciones durante el mantenimiento de los sistemas hidráulicos.

\section{Fundición de precisión}

En las fundiciones de precisión es importante el proceso a la cera perdida, en el que los modelos se hacen inyectando cera de moldeo en un troquel; estos modelos se recubren con un polvo refractario fino que hace las veces de material de revestimiento de moldes, y la cera se funde antes que la pieza o por la introducción del metal de la pieza en sí.

La extracción de la cera entraña un gran peligro de incendio, y su descomposición produce acroleína y otros productos peligrosos del proceso de descomposición. Las estufas utilizadas para extraer la cera deben estar convenientemente ventiladas. Se ha utilizado tricloroetileno para eliminar los últimos residuos de cera; existe el riesgo de que este disolvente pueda quedar retenido en los rincones del molde o ser absorbido por el material refractario y vaporizarse o descomponerse durante la colada. Debería abandonarse la inclusión de materiales refractarios a base de amianto en la fundición a la cera perdida, por los riesgos que entraña el amianto.

\section{Problemas de salud y modelos de enfermedad}

Las fundiciones destacan de los demás procesos industriales por su mayor índice de mortalidad debido a derrames de metal fundido y explosiones, mantenimiento de cubilotes, incluido la descarga por el fondo, y riesgos por monóxido de carbono durante la renovación de revestimientos refractarios. Las fundiciones describen una mayor incidencia de lesiones por cuerpos extraños, contusiones y quemaduras, y una menor proporción de lesiones musculosqueléticas que otras instalaciones. También registran los máximos niveles de exposición al ruido.

Un estudio de varias decenas de lesiones mortales en fundiciones reveló las siguientes causas: aplastamiento entre carros del transportador de moldes y estructuras del edificio durante el mantenimiento y la localización de averías, aplastamiento durante la limpieza de desterronadoras teleactivadas, quemaduras por metal en fusión tras el fallo de la grúa, rotura de moldes, rebose de la cuchara de transferencia, erupción de vapor en una cuchara no seca, caídas desde grúas y plataformas de trabajo, electrocución por equipos de soldadura, aplastamiento por vehículos de manutención, quemaduras durante la descarga de cubilotes por el fondo, y atmósfera con alto contenido de oxígeno y sobreexposición a monóxido e carbono durante la reparación de cubilotes.

\section{Muelas}

El estallido o rotura de muelas abrasivas puede ocasionar lesiones mortales o muy graves: la mano o el antebrazo pueden quedar aprisionados y aplastados en los huecos entre la muela y el soporte de apoyo para la pieza en las esmeriladoras de pedestal. Los ojos sin protección corren peligro en todas las fases del trabajo. Los suelos en mal estado de conservación o con obstáculos pueden provocar resbalones y caídas, especialmente cuando se transportan cargas pesadas. La caída de objetos o el desprendimiento de cargas pueden producir lesiones en los pies. Los esfuerzos excesivos durante las operaciones de elevación y transporte pueden producir tirones musculares y tensiones. Los dispositivos de elevación mal mantenidos pueden fallar y provocar la caída de materiales sobre los trabajadores. Igualmente pueden sufrirse sacudidas eléctricas a causa de equipos eléctricos deficientemente mantenidos o carentes de conexión a tierra., en especial herramientas portátiles.

Todos los elementos peligrosos de la maquinaria, en particular las muelas, deben contar con defensas adecuadas, debiendo bloquearse automáticamente la máquina si se retira la defensa durante el proceso. Se eliminarán los huecos peligrosos entre la muela y el apoyo de la pieza en las esmeriladoras de pedestal, y deberán observarse estrictamente todas las precauciones durante la conservación y mantenimiento de las muelas y al regular su velocidad (el trabajo con esmeriladoras portátiles requiere especial precaución). Se deberá exigir el estricto cumplimiento de las normas sobre el mantenimiento de todos los equipos eléctricos y su correcta puesta a tierra. Los trabajadores recibirán instrucciones acerca de las técnicas correctas de elevación y transporte, y deberán saber sujetar cargas a los ganchos de las grúas y demás dispositivos de elevación. Asimismo se facilitará el equipo de protección personal adecuado, como gafas protectoras y pantallas faciales, y protección para los pies y las piernas. Se deberá contar con los medios adecuados para la rápida prestación de primeros auxilios, incluso para lesiones leves, y de asistencia médica competente cuando sea necesario.

\section{Polvo}

Entre las enfermedades de los trabajadores de las fundiciones predominan las causadas por el polvo. Con frecuencia, las exposiciones a sílice están próximas a los límites prescritos o los sobrepasan, incluso en operaciones de limpieza bien controladas en fundiciones de producción modernas y donde las piezas de fundición están libres de polvo visible. Cuando las piezas están cubiertas de polvo o las cabinas tienen fugas, se producen exposiciones que superan varias veces el límite admisible. Es probable que se produzcan sobreexposiciones cuando el polvo visible escapa a la acción de los extractores de ventilación durante el desmoldeo, la preparación de arena o la reparación de revestimientos refractarios.

La silicosis es el riesgo predominante para la salud en los talleres de desbarbado de piezas de fundición de acero; en el desbarbado de piezas de hierro es más frecuente la neumoconiosis mixta (Landrigan y cols. 1986). En la fundición, la incidencia aumenta en razón directa de la duración de la exposición y los niveles de polvo. Existen algunas pruebas de que las condiciones existentes en las fundiciones de acero tienen mayor probabilidad de causar silicosis que las que se dan en las fundiciones de hierro, debido a que los niveles de sílice libre presente son más altos. Los intentos de determinar un nivel de exposición por debajo del cual no se produce silicosis no han dado resultados concluyentes; el umbral es probablemente inferior a 100 microgramos $/ \mathrm{m}^{3}$ y quizá sea tan solo la mitad de ese nivel

En la mayoría de los países está disminuyendo la aparición de nuevos casos de silicosis, en parte debido a los cambios tecnológicos, a la tendencia a prescindir de la arena silícea en las fundiciones y a la preferencia por los revestimientos refractarios básicos en lugar de los de ladrillos de sílice en los hornos de fundición de acero. Una de las razones principales de ello es que la automatización ha hecho que disminuya el número de operarios que trabajan en la producción de acero y en las fundiciones. No obstante, en muchas fundiciones el nivel de exposición al polvo de sílice respirable es aún persistentemente elevado, y en los países donde los procesos son de trabajo intensivo, la silicosis sigue constituyendo un problema importante.

Hace tiempo que se han descrito casos de silicotuberculosis en trabajadores de la fundición. Donde la frecuencia de silicosis ha disminuido, ha habido un descenso paralelo del número de casos de tuberculosis notificados, aunque esta enfermedad aún no ha sido completamente erradicada. En los países donde los niveles de polvo se han mantenido altos, los procesos polvorientos son de trabajo intensivo y la frecuencia de tuberculosis entre la población general es elevada, la tuberculosis sigue siendo una 
causa importante de fallecimientos entre los trabajadores de la fundición.

Muchos de los trabajadores que padecen neumoconiosis sufren también bronquitis crónica, a menudo asociada a enfisema; muchos investigadores han creído durante largo tiempo que, al menos en algunos casos, pueden haber contribuido a ello las exposiciones de origen profesional. También se han notificado casos de neumoconiosis asociada a cáncer de pulmón, neumonía lobular, bronconeumonía y trombosis coronaria en trabajadores de la fundición.

Un reciente análisis de estudios de mortalidad de los trabajadores de la fundición en los que se incluía la industria automovilística norteamericana, mostró que estos trabajadores presentaban índices más altos de muerte por cáncer de pulmón en 14 de 15 estudios. Dado que los índices altos de cáncer de pulmón se han observado en los trabajadores de la nave de limpieza, donde la principal exposición es a la sílice, es probable que se den también exposiciones mixtas.

Los estudios de sustancias cancerígenas en el entorno de la fundición se han centrado en los hidrocarburos policíclicos aromáticos que se forman en la descomposición térmica de los aditivos y aglutinantes de la arena. Se ha sugerido que metales como el cromo y el níquel, y polvos como el de sílice y amianto, también pueden ser responsables de parte del exceso de mortalidad. Las diferencias entre las sustancias químicas empleadas en la fabricación de moldes y de machos, el tipo de arena y la composición de las aleaciones de hierro y acero podrían explicar los diferentes niveles de riesgo que se dan en las distintas fundiciones (IARC 1984).

En 8 de 11 estudios se halló un aumento de mortalidad por enfermedades respiratorias no malignas. También se registraron muertes por silicosis. En los estudios clínicos se encontraron cambios radiológicos característicos de neumoconiosis, déficit de la función pulmonar característicos de obstrucción y aumento de los síntomas respiratorios entre trabajadores de fundiciones de producción modernas y "limpias". Estos hallazgos obedecían a exposiciones producidas con posterioridad al decenio de 1960 y parecen indicar que los riesgos para la salud que entrañaban las antiguas fundiciones aún no han sido eliminados.

La prevención de las enfermedades de pulmón pasa esencialmente por el control del polvo y los humos y vapores; la solución aplicable con carácter general consiste en proveer una buena ventilación general unida a una eficiente ventilación por extracción localizada. Los sistemas de bajo volumen y alta velocidad son los más adecuados para algunas operaciones, en especial las que se realizan con esmeriladoras portátiles y herramientas neumáticas.

Los cortafríos y los cinceles neumáticos utilizados para eliminar la arena adherida a las piezas de fundición producen gran cantidad de polvo finamente dividido. También la eliminación de material sobrante con cepillos metálicos giratorios o manuales produce mucho polvo, por lo que se requiere extracción localizada.

A las esmeriladoras de bancada y de bastidor pendular pueden adaptárseles fácilmente medidas para controlar el polvo. El repaso de piezas pequeñas con esmeriladoras portátiles puede realizarse sobre bancos ventilados por extracción, o puede aplicarse la ventilación en la propia herramienta. También el cepillado puede llevarse a cabo sobre un banco con ventilación. El control del polvo en piezas de fundición grandes supone un problema, pero se han logrado considerables progresos con sistemas de ventilación de bajo volumen y alta velocidad. Se requiere formación y entrenamiento en su utilización para vencer los reparos de los trabajadores, que consideran estos sistemas engorrosos y se quejan de que dificultan la visión de la zona de trabajo.
La limpieza y el desbarbado de piezas de fundición muy grandes donde no es posible utilizar ventilación local, deben realizarse en una zona aislada y en un momento en que estén presentes pocos trabajadores de los que realizan otras operaciones. A cada operario deberá facilitársele un equipo de protección personal adecuado, que se limpie y repare con regularidad, junto con instrucciones sobre su correcta utilización.

Desde el decenio de 1950, se han introducido en las fundiciones diversos sistemas de resinas sintéticas para aglutinar la arena de los machos y moldes. Estos sistemas comprenden generalmente un material base y un catalizador o endurecedor que inicia la polimerización. Muchos de estos reactivos químicos son sensibilizantes (p. ej., isocianatos, alcohol furfurílico, aminas y formol) y actualmente se les relaciona con casos de asma profesional entre trabajadores de la fundición. En un estudio, 12 de 78 trabajadores expuestos a resinas Pepset (método de caja fría) tenían síntomas de asma, y de ellos, seis presentaron una marcada disminución de los caudales de aire en una prueba de provocación con diisocianato de metilo (Johnson y cols. 1985).

\section{Soldadura}

La soldadura en los talleres de desbarbado expone a los trabajadores a humos metálicos, con el consiguiente riesgo de toxicidad y de fiebre por vapores de metal, que depende de la composición de los metales implicados. Para soldar piezas de fundición de hierro hay que utilizar como electrodos varillas de níquel, lo que crea exposición a humos de níquel. La torcha de plasma produce una considerable cantidad de humos metálicos, ozono, óxido de nitrógeno y radiación ultravioleta, y genera elevados niveles de ruido.

Para la soldadura de piezas de fundición pequeñas puede utilizarse un banco ventilado por extracción. Durante las operaciones de soldeo o quemado de piezas de fundición grandes es difícil controlar las exposiciones. Un método eficaz consiste en crear una estación central para estas operaciones y e instalar un sistema de extracción localizada a través de un conducto flexible situado en el punto de soldadura. Esto implica la necesidad de enseñar al trabajador a trasladar el conducto de un punto a otro. Una buena ventilación general y el uso de equipo de protección personal cuando sea necesario, ayudarán a reducir la exposición general al humo y al polvo.

\section{Ruido y vibración}

Los mayores niveles de ruido en la fundición se dan normalmente en las operaciones de vaciado y limpieza, y son más altos en las fundiciones mecanizadas que en las manuales. Incluso el sistema de ventilación puede generar exposiciones próximas a los $90 \mathrm{dBA}$.

Los niveles sonoros en el desbarbado de piezas de fundición de acero pueden ser del orden de 115 a 120 dBA, mientras que en el de las piezas de fundición de hierro están entre 105 y 115 dBA. La British Steel Casting Research Association estableció que las fuentes de ruido durante el desbarbado son las siguientes:

- el escape de la herramienta de desbarbado

- el impacto del martillo o la muela en la pieza de fundición

- la resonancia de la pieza y su vibración contra el soporte

- la transmisión de vibraciones desde el soporte a las estructuras circundantes

- la reflexión directa de ruido por la campana extractora que controla el flujo de aire por el sistema de ventilación.

Las estrategias de control del ruido varían según el tamaño de la pieza, el tipo de metal, la zona de trabajo disponible, el uso de herramientas portátiles y otros factores conexos. Existen ciertas medidas básicas para reducir la exposición al ruido de los 
trabajadores que realizan la operación y sus compañeros, tales como aislamiento en el tiempo y el espacio, confinamiento en recintos completamente cerrados, tabiques parciales insonorizantes, ejecución del trabajo sobre superficies fonoabsorbentes, pantallas deflectoras, paneles y campanas de material fonoabsorbente u otros materiales acústicos. Deberán observarse las directrices sobre límites seguros de exposición diaria y, como último recurso, pueden utilizarse dispositivos de protección personal.

Un banco de desbarbado desarrollado por la British Steel Casting Research Association reduce el ruido de esta operación en 4 a 5 dBA y además lleva incorporado un sistema de extracción para eliminar el polvo. Esta mejora es alentadora y permite confiar en nuevos avances que posibiliten reducciones de ruido aún mayores.

\section{Síndrome de vibración de la mano y el brazo}

Las herramientas vibrantes portátiles pueden causar el fenómeno de Raynaud (síndrome de vibración de la mano y el brazo-HAVS). Este trastorno es más frecuente en desbarbadores de piezas de fundición de acero que de fundición de hierro, y entre los que utilizan herramientas rotativas. La frecuencia de vibración crítica para la aparición de este fenómeno está entre 2.000 y 3.000 revoluciones por minuto y en el intervalo de 40 a $125 \mathrm{~Hz}$.

Actualmente, se cree que el HAVS tiene diversos efectos en varios otros tejidos del antebrazo aparte de los nervios periféricos y vasos sanguíneos. Se asocia con el síndrome del túnel carpiano y cambios degenerativos en las articulaciones. Un reciente estudio de desbarbadores y esmeriladores de acerías reveló que eran dos veces más propensos a padecer contractura de Dupuytren que un grupo de control (Thomas y Clarke 1992).

La vibración transmitida a las manos del trabajador puede reducirse considerablemente mediante la selección de herramientas diseñadas para reducir los rangos nocivos de frecuencia y amplitud; la orientación del orificio de escape en sentido opuesto a la mano; el uso de varios guantes superpuestos o de uno aislante, y la reducción del tiempo de exposición mediante cambios en las operaciones de trabajo, herramientas y períodos de descanso.

\section{Problemas oculares}

Algunos de los tipos de polvo y sustancias químicas que se encuentran en las fundiciones (p. ej., isocianatos, formol y aminas terciarias como dimetiletilamina, trietilamina, etc.) son irritantes y han causado síntomas visuales entre los trabajadores expuestos, tales como picor de ojos y lagrimeo, visión nublada o borrosa, o la llamada "visión gris azulada". Se ha recomendado la reducción ponderada en el tiempo de los niveles de exposición a menos de 3 ppm, en función de la aparición de estos efectos.

\section{Otros problemas}

En operaciones de fabricación de machos en caja caliente bien controladas se dan niveles de exposición al formol iguales o superiores al límite de exposición vigente en Estados Unidos. Cuando el control de riesgos es deficiente pueden encontrarse niveles de exposición varias veces superiores al límite máximo establecido.

$\mathrm{El}$ amianto ha sido muy utilizado en la industria de la fundición y, hasta hace poco, se usaba con frecuencia en la ropa protectora para trabajadores expuestos al calor. Se han detectado sus efectos en estudios radiológicos de trabajadores de la fundición, tanto entre operarios de producción como de mantenimiento que han estado expuestos al amianto; en un estudio transversal se halló la afectación pleural característica en 20 de 900 trabajadores del acero (Kronenberg y cols. 1991).

\section{Exploraciones periódicas}

Todos los trabajadores de la fundición deberían ser sometidos a exploraciones médicas previas a la colocación y periódicas, que incluyan un estudio de síntomas, radiografías de tórax, pruebas de la función pulmonar y audiogramas, con un seguimiento adecuado si se detectan hallazgos cuestionables o anormales. Los efectos añadidos del humo del tabaco al riesgo de problemas respiratorios entre los trabajadores de la fundición imponen la necesidad de incluir consejos acerca del abandono del tabaco en un programa de promoción sanitaria y educación sobre la salud.

\section{Conclusión}

Las fundiciones han constituido una actividad industrial esencial durante siglos. A pesar de los continuos avances tecnológicos, presentan a los trabajadores un abanico de riesgos para la salud y la seguridad. Dado que siguen existiendo riesgos incluso en las plantas más modernas y dotadas de programas ejemplares de prevención y control, proteger la salud y el bienestar de los trabajadores continúa siendo un reto para la dirección y para los trabajadores y sus representantes. Un reto dificil tanto en las paradas de las instalaciones (cuando la preocupación por la salud y seguridad de los trabajadores suele quedar relegada a un segundo plano ante los imperativos económicos) como en los momentos de actividad intensa (cuando la demanda de mayor productividad puede inducir a tomar atajos potencialmente peligrosos en los procesos). La educación y la formación en el control de riesgos siguen siendo, por lo tanto, una necesidad constante.

\section{FORJA Y ESTAMPACION}

Robert M. Park

\section{Resumen de procesos}

Conformar piezas metálicas aplicando grandes fuerzas de tracción y compresión es un proceso común en la fabricación industrial. En las operaciones de estampación, el metal, casi siempre chapas, flejes o rollos de chapa, adquiere formas específicas a temperatura ambiente mediante operaciones de corte, prensado y estirado entre estampas, ejecutadas normalmente en una serie de uno o más pasos de impactos discretos. El acero laminado en frío es la materia prima en muchas operaciones de estampación destinadas a crear piezas de chapa metálica en la industria del automóvil y de los electrodomésticos, y en otros sectores. Aproximadamente el $15 \%$ de los trabajadores de la industria automovilística trabajan en operaciones o plantas de estampación.

En la forja, se aplican fuerzas de compresión a bloques metálicos preformados (piezas en bruto), normalmente después de calentarlos a elevadas temperaturas, y también en uno o más pasos de prensado discretos. La forma de la pieza final la determina la de las cavidades de la estampa o estampas metálicas utilizadas. Con las estampas abiertas, lo mismo que en la forja con martinete, la pieza en bruto se comprime entre una estampa unida al yunque inferior y el pistón vertical. Con las estampas cerradas, al igual que en la forja en prensa la pieza en bruto se comprime entre la estampa inferior y una contraestampa superior unida al pistón.

En las forjas con martinete se utiliza un cilindro de vapor o neumático para elevar el martinete, que después se deja caer por gravedad o es accionado con vapor o aire comprimido. El número y la fuerza de los golpes del martinete son controlados manualmente por el operario. Normalmente, éste sujeta la pieza por el extremo frío mientras acciona el martinete. Hubo un tiempo en que la forja con martinete representaba alrededor de dos terceras partes de la totalidad del trabajo de forja que se 
Figura 82.1 • Forja en prensa.

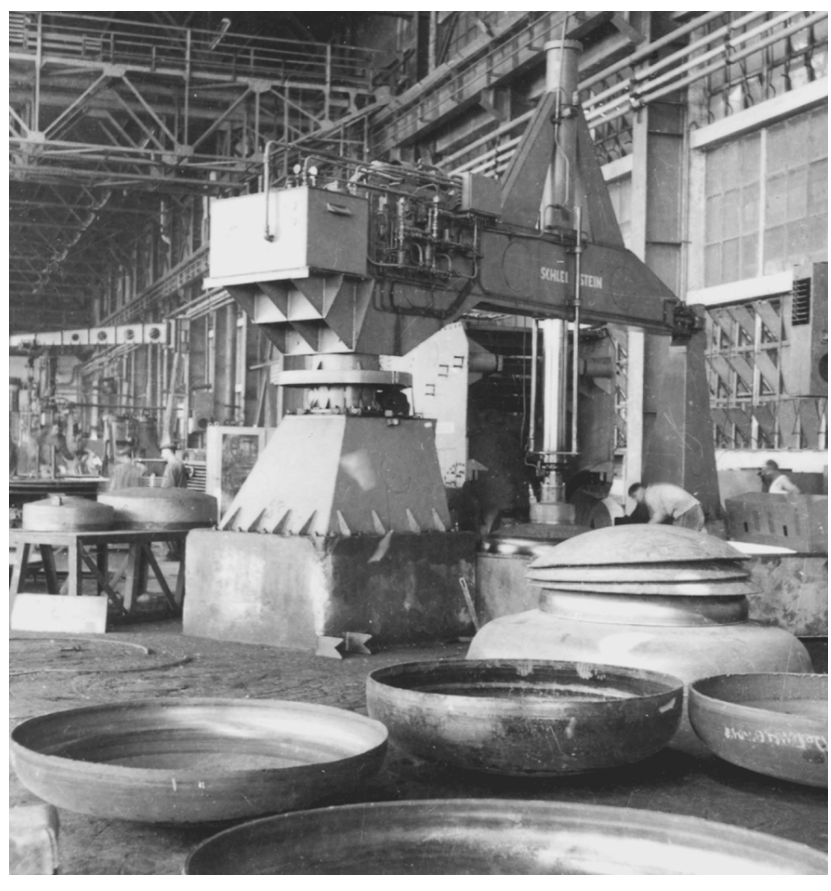

realizaba en Estados Unidos, pero actualmente este método es menos utilizado.

En las forjas con prensa se utiliza un cilindro mecánico o hidráulico para conformar la pieza con un solo golpe lento y controlado (véase la Figura 82.1). Por lo general, la forja con prensa se controla automáticamente. Puede realizarse en caliente o a temperatura normal (forja en frío, extrusión). Una variante de la forja convencional es la laminación, en la que se efectúan continuas aplicaciones de fuerza mientras el operario hace girar la pieza.

Antes de aplicar los golpes con el martinete o la prensa, y entre golpe y golpe, se aplican lubricantes por pulverización u otros métodos a las caras de las estampas y a las superficies de la pieza en bruto.

Las piezas de maquinaria de gran resistencia, tales como ejes, coronas dentadas, bulones y componentes de la suspensión de los vehículos son comúnmente productos de acero forjado. Los componentes de alta resistencia para aviones, como largueros de ala, discos de turbinas y trenes de aterrizaje, se forjan en aleaciones de aluminio, titanio o níquel y acero. Aproximadamente el $3 \%$ de los operarios del sector de automoción trabajan en operaciones o plantas de forja.

\section{Condiciones de trabajo}

En las operaciones de forja y estampación se dan muchos de los riesgos comunes en la industria pesada, como lesiones por esfuerzo repetitivo debidas a la manipulación y proceso repetidos de componentes y al accionamiento de ciertos mandos de las máquinas, tales como botones accionables con la palma de la mano. Las piezas pesadas suponen para los trabajadores riesgos de padecer problemas de espalda y de hombros, así como de trastornos musculosqueléticos de las extremidades superiores. Los operadores de prensas en las plantas de estampación de piezas de automóviles, presentan índices de lesiones por esfuerzo repetitivo comparables a los de los operarios de las plantas de montaje que realizan trabajos de alto riesgo. En la mayoría de las operaciones de estampación y en algunas de forja (p. ej., con martinetes neumáticos o de vapor) se producen ruido y vibraciones de alta intensidad que provocan pérdida de audición y posiblemente enfermedades cardiovasculares; estos ambientes industriales son de los más ruidosos (más de $100 \mathrm{dBA}$ ). Al igual que en otros sistemas de accionamiento automatizado, las cargas de energía que soportan los trabajadores pueden ser considerables, dependiendo de las piezas que se manipulen y de las cadencias de funcionamiento de las máquinas.

En la forja y estampación son frecuentes las lesiones graves como consecuencia de movimientos imprevistos de las máquinas. Tales movimientos pueden deberse a: (1) avería mecánica de sistemas de control de la máquina, tales como mecanismos de embrague en situaciones en que los trabajadores han de estar normalmente dentro del radio de acción de la máquina (un diseño de proceso inaceptable); (2) defectos de diseño o funcionamiento de la máquina que determinan intervenciones no programadas de los trabajadores, como mover piezas atascadas o desalineadas, o (3) procedimientos de mantenimiento inadecuados, de alto riesgo, ejecutados sin el debido bloqueo de la totalidad de la red implicada de la máquina, como la transferencia automatizada de piezas y las funciones de otras máquinas conectadas a la red. La mayoría de las redes de máquinas automatizadas no están configuradas para un bloqueo rápido, eficaz y efectivo o un diagnóstico de averías seguro.

Las neblinas de aceite lubricante de las máquinas producidas durante el funcionamiento normal, son otro riesgo genérico para la salud en las operaciones de forja y estampación con prensas neumáticas, ya que exponen a los trabajadores al riesgo de padecer enfermedades respiratorias, dermatológicas y digestivas.

\section{Problemas para la salud y la seguridad}

\section{Estampación}

Las operaciones de estampación entrañan un alto riesgo de laceraciones graves debido a la necesidad de manipular piezas con cantos vivos. Posiblemente más peligrosa aún es la manipulación de los recortes de contorneado y punzonado de piezas. Los recortes se recogen normalmente mediante canaletas y transportadores de alimentación por gravedad. La eliminación de los atascos que se producen esporádicamente es una actividad de alto riesgo.

Los riesgos químicos específicos de la estampación provienen normalmente de dos fuentes principales: los compuestos de estirado (p. ej., lubricantes de estampas) en las operaciones con prensas y las emisiones de las soldaduras al ensamblar las piezas estampadas. Los compuestos de estirado son necesarios en la mayoría de las estampaciones. El material se pulveriza o se extiende con rodillo sobre la chapa metálica y la propia estampación genera neblinas adicionales. Al igual que otros lubricantes metalúrgicos, los de embutición pueden ser aceites puros o en emulsiones (aceites solubles). Entre los componentes se incluyen fracciones de petróleo, lubricantes especiales (p. ej., derivados de ácidos grasos animales y vegetales, aceites clorados y ceras), alcanolaminas, sulfonatos de petróleo, boratos, espesantes derivados de la celulosa, anticorrosivos y biocidas. Las concentraciones atmosféricas de neblinas en operaciones de estampación pueden alcanzar los niveles de las operaciones comunes de mecanizado, aunque por término medio suelen ser inferiores $\left(0,05 \mathrm{a} 2,0 \mathrm{mg} / \mathrm{m}^{3}\right)$. No obstante, con frecuencia se ve niebla y una película de aceite acumulada sobre las superficies del edificio, y el contacto con la piel puede ser mayor debido a la manipulación extensiva de las piezas. Las exposiciones con mayor probabilidad de riesgo son los aceites clorados (posibilidad de cáncer, enfermedad hepática, trastornos de la piel), derivados de ácidos grasos de colofonia o resina líquida oleosa (sensibilizantes), fracciones de petróleo (cánceres digestivos) y, 
posiblemente, formol (de los biocidas) y nitrosoaminas (de alcanolaminas y nitrito sódico, ya sea como ingredientes de lubricantes de embutición o en recubrimientos superficiales del acero que se recibe). Se ha observado una gran incidencia de cáncer digestivo en dos plantas de estampación de piezas para automóviles. Los crecimientos microbiológicos en sistemas que aplican lubricantes de embutición pasando sobre la chapa metálica un rodillo impregnado en un depósito abierto, pueden exponer a los trabajadores a riesgos de problemas respiratorios y dermatológicos análogos a los de las operaciones de mecanizado.

La soldadura de piezas estampadas se realiza con frecuencia en plantas de estampación, por lo general sin lavado intermedio. Esto produce emisiones tales como humos metálicos y productos de pirólisis y combustión del lubricante de embutición y otros residuos de la superficie. Las operaciones de soldadura habituales (principalmente por resistencia) en las plantas de estampación generan concentraciones atmosféricas totales de partículas del orden de 0,05 a $4,0 \mathrm{mg} / \mathrm{m}^{3}$. El contenido metálico (en forma de humos y óxidos) suele representar menos de la mitad de esas partículas, lo que indica que hasta $2,0 \mathrm{mg} / \mathrm{m}^{3}$ son residuos químicos mal caracterizados. El resultado es una neblina visible en muchas zonas de soldadura de las plantas de estampación. La presencia de derivados clorados y otros ingredientes orgánicos suscita graves preocupaciones en relación la composición del humo de soldadura de estos centros, y exige claramente controles de ventilación. La aplicación de otros materiales antes de la soldadura (tales como imprimación, pintura y adhesivos epóxicos), sobre algunos de los cuales se suelda acto seguido, es causa adicional de preocupación. Las soldaduras de reparación de producción, por lo general realizadas manualmente, suelen crear mayores exposiciones a estos mismos contaminantes atmosféricos. Se han observado índices excesivos de cáncer de pulmón entre soldadores de una planta de estampación de piezas para automóviles.

\section{Forja}

$\mathrm{Al}$ igual que la estampación, las operaciones de forja pueden entrañar un alto riesgo de laceraciones cuando los trabajadores manipulan las piezas forjadas o recortan las rebabas o los bordes inservibles de las mismas. En la forja de alto impacto pueden proyectarse fragmentos, cascarilla de óxido o herramientas, y causar lesiones. En algunas operaciones de forja el trabajador sujeta la pieza con unas tenazas durante el prensado o el impacto, lo que incrementa el riesgo de lesiones musculosqueléticas. En la forja, a diferencia de la estampación, los hornos donde se calientan las piezas (para la forja y el recocido) así como los recipientes de enfriamiento de piezas forjadas calientes suelen estar cerca del lugar de trabajo, lo que crea un elevado riesgo de estrés por calor. Otros factores que contribuyen al estrés por calor son la carga metabólica del trabajador durante el trasiego manual de materiales y, en algunos casos, el calor de los productos de la combustión de los lubricantes de estampas a base de aceite.

La lubricación es necesaria en la mayoría de las operaciones de forja y presenta la particularidad de que el lubricante entra en contacto con piezas que se encuentran a elevada temperatura. Ello provoca su inmediata pirólisis y aerosolización, no solo en las estampas sino también posteriormente, mientras las piezas humeantes se encuentran en los recipientes de enfriamiento. Los lubricantes de estampas de forja pueden contener, entre otros ingredientes, lodos de grafito, espesantes poliméricos, emulsificantes de sulfonatos, fracciones de petróleo, nitrato sódico, nitrito sódico, carbonato sódico, silicato sódico, aceites de silicona y biocidas. Estos lubricantes se aplican por pulverización o, en algunos casos, con una escobilla. Los hornos que se utilizan para calentar el metal a forjar suelen estar alimentados con fuel-oil o gas, o son hornos de inducción. Pueden producirse emisiones en los hornos caldeados con fuel-oil si el tiro es insuficiente y en los hornos de inducción no ventilados cuando la superficie del metal está contaminada, por ejemplo, con aceite o anticorrosivos, o se ha lubricado antes de la forja para su corte con cizalla o con sierra (como cuando se trata de barras). En Estados Unidos, el nivel total de concentración atmosférica de partículas en las operaciones de forja, suele estar comprendido entre 0,1 y $5,0 \mathrm{mg} / \mathrm{m}^{3}$ y varía ampliamente a lo largo de las operaciones debido a las corrientes de termoconvección. Se ha observado un elevado índice de cáncer de pulmón entre los trabajadores que realizan operaciones de forja y termotratamiento en dos plantas de fabricación de rodamientos de bolas.

\section{Medidas de salud y seguridad}

Son pocos los estudios que han evaluado los efectos reales de las exposiciones que se producen en las operaciones de estampación y forja sobre la salud de los trabajadores expuestos. No se ha realizado una caracterización exhaustiva de la toxicidad potencial de la mayoría de las operaciones comunes, con la correspondiente identificación y medición de los principales agentes tóxicos. Hasta hace poco no había sido posible evaluar los efectos de larga duración de la tecnología de lubricación de estampas desarrollada en los decenios de 1960 y 1970 sobre la salud de los trabajadores. En consecuencia, estas exposiciones están reguladas por normas genéricas sobre concentración de polvo o total de partículas en suspensión, como la que establece el límite de $5,0 \mathrm{mg} / \mathrm{m}^{3}$ en Estados Unidos. Aunque es probable que esta norma resulte adecuada en algunas circunstancias, no está demostrado que lo sea en muchas de las operaciones de forja y estampación.

Con un control cuidadoso del procedimiento de aplicación del lubricante en la estampación y forja, es posible reducir en cierta medida las concentraciones de las neblinas de lubricante. La aplicación con rodillo, cuando es viable, es el método más conveniente en la estampación, y si hay que optar por la pulverización resulta beneficioso utilizar la mínima presión de aire posible. Debe investigarse la posibilidad de eliminar los principales ingredientes peligrosos. Los recintos con presión negativa y los colectores de neblina pueden resultar muy eficaces, pero pueden ser incompatibles con la manipulación de las piezas. La filtración del aire descargado de los sistemas neumáticos de alta presión de las prensas reduce la neblina de aceite (y el ruido). El contacto con la piel en las operaciones de estampación puede reducirse mediante la automatización del proceso y el uso de prendas de protección personal adecuadas, que eviten las laceraciones y la saturación de líquido. En cuanto a la soldadura en la planta de estampación, es muy conveniente lavar las piezas antes de soldar, y los cerramientos parciales con ventilación por extracción reducen considerablemente los niveles de humo.

Entre los controles para disminuir el estrés por calor en la estampación y la forja en caliente están reducir al mínimo el trasiego manual de materiales en zonas a elevada temperatura, apantallar los hornos para reducir la radiación de calor, limitar la altura de las bocas y rendijas de descarga de los hornos y utilizar ventiladores de refrigeración. La ubicación de estos ventiladores deberá estar prevista en el diseño de la circulación del aire a fin de controlar las exposiciones a neblinas y el estrés por calor; de otro modo podría ocurrir que la refrigeración se obtuviese a costa de mayores exposiciones.

Mecanizando la manutención de materiales, sustituyendo en la medida de lo posible la forja con martinete por la forja en prensa y ajustando el ritmo de trabajo a niveles ergonómicos, se puede reducir el número de lesiones musculosqueléticas.

Los niveles de ruido pueden reducirse mediante la combinación de una serie de medidas, tales como la conversión de la forja con martinete a forja en prensa en la medida de lo posible, 
el empleo de recintos bien diseñados y la insonorización de los ventiladores de los hornos, embragues neumáticos, conductos de aire y manutención de piezas. Debería implantarse un programa de conservación auditiva.

El equipo de protección personal necesario comprende elementos de protección de la cabeza y los pies, gafas de montura ajustada, protectores de oídos (en las zonas con niveles de ruido excesivos), mandiles y polainas resistentes al calor y al aceite (en caso de empleo abundante de lubricantes de estampas a base de aceite) y protección de ojos y cara contra la radiación infrarroja (alrededor de los hornos).

\section{Riesgos ambientales para la salud}

Los riesgos ambientales derivados de las plantas de estampación son relativamente pequeños en comparación con los de algunos otros tipos de plantas, y comprenden la evacuación de residuos de lubricante de embutición y disoluciones de lavado, y la extracción de humo de soldadura sin la debida limpieza previa. En el pasado, algunas plantas de forja han provocado una grave degradación local de la calidad del aire a causa del humo de forja y del polvo de cascarilla. Sin embargo, esto no tiene por qué ocurrir si se cuenta con un sistema de limpieza del aire de suficiente capacidad. Otro posible riesgo proviene de la eliminación de la chatarra de estampación y de la cascarilla de forja que contienen lubricantes de estampas.

\section{- SOLDADURA Y CORTE TERMICO}

Philip A. Platcow y G.S. Lyndon*

\section{Resumen de procesos}

Soldadura es un término genérico por el que se designa la unión de piezas de metal por sus caras de junta haciendo que éstas se vuelvan plásticas o líquidas mediante la aplicación de calor o presión, o ambas cosas. Las tres fuentes de calor directo comúnmente empleadas son:

1. llama producida por la combustión de un gas con aire u oxígeno

2. arco eléctrico, establecido entre un electrodo y una pieza o entre dos electrodos

3. resistencia eléctrica opuesta al paso de una corriente entre dos o más piezas.

A continuación se describen otras fuentes de calor utilizadas en soldadura (véase la Tabla 82.6).

En la soldadura y corte con gas, se suministra oxígeno o aire y un gas combustible a un soplete (torcha), donde se mezclan antes de la combustión en la tobera. Normalmente, el soplete se sostiene en la mano (véase la Figura 82.2). El calor funde las caras metálicas de las piezas, con lo que éstas se mezclan y quedan unidas. Normalmente se añade un metal o aleación de aportación. La aleación suele tener un punto de fusión más bajo que las piezas a unir; en ese caso, por lo general las piezas no se calientan hasta la temperatura de fusión (soldadura fuerte, soldadura blanda). Pueden utilizarse fundentes químicos para prevenir la oxidación y facilitar la unión de las piezas.

En la soldadura al arco, éste se establece entre un electrodo y las piezas a soldar. El electrodo puede conectarse a una fuente de corriente alterna (CA) o de corriente continua (CG). La temperatura de esta operación es de unos $4.000^{\circ} \mathrm{C}$ cuando las piezas se funden y unen. Normalmente es necesario añadir

* Este artículo es una revisión del artículo "Soldadura y corte térmico", por G.S. Lyndon, de la $3^{\text {a }}$ edición de la Enciclopedia de salud y seguridad en el trabajo.
Figura 82.2 - Soldadura y corte con gas con soplete y varilla de metal de aportación. El soldador está protegido por un mandil de cuero, manoplas y gafas de seguridad.

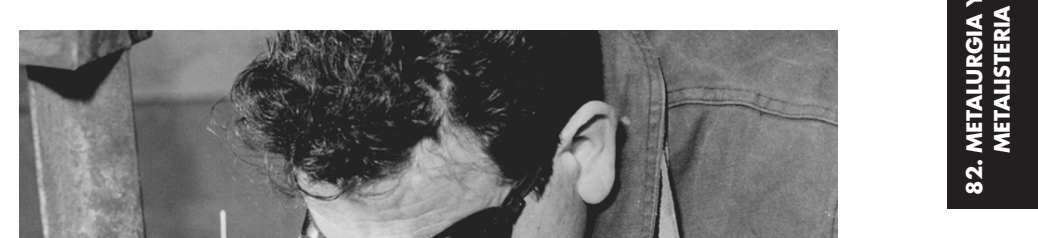

metal fundido a la unión ya sea fundiendo el propio electrodo (procesos con electrodo consumible) o fundiendo por separado una varilla de metal de aportación que no conduce corriente (procesos con electrodo no consumible).

La mayor parte de la soldadura al arco convencional se realiza manualmente por medio de un electrodo consumible revestido, sujeto en un portaelectrodo que el soldador sostiene en la mano. También se utilizan otros muchos procesos de soldadura eléctrica semiautomáticos y automáticos, tales como la soldadura por resistencia o la soldadura con electrodo continuo.

Durante el proceso, la zona de la soldadura debe estar protegida de la atmósfera circundante para prevenir la oxidación y la contaminación. Hay dos tipos de protección: los revestimientos de fundente y la pantalla de gas inerte. En la soldadura al arco con electrodo revestido de fundente, el electrodo consumible consta de un núcleo metálico rodeado de un revestimiento de material fundente, que suele estar constituido por una mezcla compleja de mineral y otros componentes. A medida que avanza la soldadura, el fundente se va fundiendo, recubriendo de este modo el baño de metal en fusión con escoria y envolviendo la zona de la soldadura en una atmósfera de gases protectores (por ej., dióxido de carbono) generados por el fundente caliente. Una vez terminada la soldadura es preciso eliminar la escoria, lo que normalmente se hace mediante picado.

En la soldadura al arco bajo gas protector, una pantalla de gas inerte impide el contacto con la atmósfera y previene la oxidación y la contaminación durante el proceso de soldadura. Los gases inertes normalmente utilizados con este propósito son el argón, helio, nitrógeno o dióxido de carbono. 
Tabla 82.6 • Descripción y riesgos de los procesos de soldadura.

\begin{tabular}{|c|c|}
\hline Proceso de soldadura & Descripción \\
\hline \multicolumn{2}{|l|}{ Soldadura y corte con gas } \\
\hline Soldadura con fusión & $\begin{array}{l}\text { El soplete funde la superficie del metal y la varilla de metal de aportación, con } \\
\text { lo que se produce la unión de las piezas. }\end{array}$ \\
\hline Soldadura fuerte & $\begin{array}{l}\text { Las dos superficies metálicas se unen sin fundir el metal base. La temperatura } \\
\text { de fusión del metal de aportación es superior a } 450^{\circ} \mathrm{C} \text {. El calentamiento se } \\
\text { realiza con llama, por resistencia y por inducción. }\end{array}$ \\
\hline Soldadura blanda & $\begin{array}{l}\text { Similar a la soldadura fuerte, excepto porque la temperatura de fusión del metal } \\
\text { de aportación es inferior a } 450^{\circ} \mathrm{C} \text {. El calentamiento se realiza también con } \\
\text { soldador. }\end{array}$ \\
\hline $\begin{array}{l}\text { Oxicorte de metales y ranuración con } \\
\text { soplete }\end{array}$ & $\begin{array}{l}\text { En una de las variantes, el metal se calienta con una llama y se proyecta sobre } \\
\text { el punto de corte un chorro de oxígeno que se desplaza a lo largo de la línea } \\
\text { a cortar. En la ranuración con soplete se elimina una tira de la superficie metá- } \\
\text { lica sin llegar a traspasar la pieza. }\end{array}$ \\
\hline
\end{tabular}

Soldadura por presión a gas

Las piezas se calientan con chorros de gas mientras están sometidas a presión una contra otra, quedando así unidas por foria.

\section{Soldadura al arco protegida por fundente}

Soldadura por arco metálico protegido Se practica con un electrodo consumible consistente en un alma metálica (SMAC); soldadura al arco con electrodo de varilla; soldadura manual por arco metálico (MMA); soldadura por arco abierto

Soldadura por arco sumergido (SAW)
Riesgos

Humos metálicos, dióxido de nitrógeno, monóxido de carbono, ruido, quemaduras, radiación infrarroja, incendio, explosiones

Humos metálicos (en especial de cadmio), fluoruros, incendio, explosión, quemaduras

Fundentes, humos de plomo, quemaduras

Humos metálicos, dióxido de nitrógeno, monóxido de carbono, ruido, quemaduras, radiación infrarroja, incendio, explosiones

Humos metálicos, dióxido de nitrógeno, monóxido de carbono, ruido, quemaduras, radiación infrarroja, incendio, explosiones

Humos metálicos, fluoruros (en especial con electrodos bajos en hidrógeno), radiación infrarroja y ultravioleta, quemaduras, riesgos eléctricos, incendio; también ruido, 0zono, dióxido de nitrógeno

Fluoruros, incendio, quemaduras, radiación infrarroja, riesgos eléctricos; también humos metálicos, ruido, radiación ultravioleta, ozono y dióxido de nitrógeno electrodo consumible de hilo metálico desnudo. El arco provoca la fusión del fundente y produce un baño protector en la zona de la soldadura.

\section{Soldadura por arco con protección gaseosa}

Soldadura por arco metálico en atmósfera de gas inerte (MIG); soldadura por arco metálico en atmósfera gaseosa (GMAC)

Soldadura con electrodo de tungsteno en atmósfera de gas inerte (TIG); soldadura por arco con electrodo de tungsteno y protección gaseosa (GTAW); soldadura por arco eléctrico en atmósfera de helio ("heliarc")

Soldadura por arco de plasma (PAW) y metalización por arco de plasma; corte por arco de tungsteno

Soldadura al arco con hilo tubular relleno de fundente (FCAW); soldadura por arco metálico bajo gas activo (MAG)

El electrodo es normalmente un hilo metálico desnudo consumible de composición similar a la del metal que se suelda, y avanza continuamente a medida que se funde en el arco.

El electrodo de tungsteno no es consumible, y el metal de aportación consumible se introduce en el arco manualmente.

Es similar a la soldadura TIG, excepto en que el arco y la corriente de gases inertes pasa por un pequeño orificio antes de llegar a la pieza, con lo que se crea un "plasma" de gas fuertemente ionizado que puede alcanzar temperaturas superiores a $33.400^{\circ} \mathrm{C}$. Esta técnica se utiliza también para metalización.

Se practica con un electrodo consumible con alma de fundente, a veces bajo atmósfera protectora de dióxido de carbono (MAG).

\section{Soldadura eléctrica por resistencia}

Soldadura por resistencia (por puntos, Una corriente de alta intensidad y baja tensión circula desde los electrodos por en costura, por protuberancias 0 a tope)
Radiación ultravioleta, humos metálicos, ozono, monóxido de carbono (con gas $\mathrm{CO}_{2}$ ), dióxido de nitrógeno, incendio, quemaduras, radiación infrarroja, riesgos eléctricos, fluoruros, ruido

Radiación ultravioleta, humos metálicos, ozono, dióxido de nitrógeno, incendio, quemaduras, radiación infrarroja, riesgos eléctricos, ruido, fluoruros, monóxido de carbono

Humos metálicos, ozono, dióxido de nitrógeno, radiación ultravioleta e infrarroja, ruido; incendio, quemaduras, riesgos eléctricos, fluoruros, monóxido de carbono, posiblemente rayos $x$

Radiación ultravioleta, humos metálicos, ozono, monóxido de carbono (con gas $\mathrm{C}_{2}$ ), dióxido de nitrógeno, incendio, quemaduras, radiación infrarroja, riesgos eléctricos, fluoruros, ruido

Ozono, ruido (a veces), riesgos por maquinaria, incendio, quemaduras, riesgos elécricos, humos metálicos los dos componentes a soldar. El calor generado en la interfase entre los componentes hace que éstos alcancen las temperaturas de soldadura. Durante el paso de la corriente, la presión ejercida por los electrodos produce un soldadura por forja. No se utiliza fundente ni metal de aportación.

Continúa en la página siguiente. 
Tabla 82. 6 • Descripción y riesgos de los procesos de soldadura.

Continuación.

$\begin{array}{ll}\text { Proceso de soldadura } & \text { Descripción } \\ \text { Soldadura por electroescoria } & \text { Se utiliza para soldadura vertical a tope. Las piezas se disponen verticalmente, } \\ \text { con una pequeña separación entre ellas, y se colocan chapas o zapatas de } \\ \text { cobre en uno o ambos lados de la unión para formar un baño. Se establece un } \\ \text { arco bajo una capa de fundente entre uno o más electrodos de alambre en } \\ \text { avance continuo y una chapa metálica. Se forma un baño de metal fundido, } \\ \text { protegido por fundente o escoria en fusión, que se mantiene fundido por } \\ \text { efecto de la resistencia al paso de la corriente entre el electrodo y las piezas. } \\ \text { El calor generado por resistencia funde los lados de la junta y el electrodo } \\ \text { continuo, llenado así el intersticio de la unión y produciendo la soldadura. } \\ \text { Mientras ésta avanza, el metal y la escoria en fusión se mantienen en la posi- } \\ \text { ción correcta desplazando las chapas de cobre. }\end{array}$

Soldadura por chispa

\section{Otros procesos de soldadura \\ Soldadura por haz de electrones}

Corte por arco de aire

Soldadura por fricción

Soldadura y perforación con laser

Soldadura de espárragos

Soldadura aluminotérmica, o por termita
Las dos piezas metálicas a soldar se conectan a una fuente de corriente de baja tensión y alta intensidad. Al poner en contacto los extremos de los componentes circula una elevada corriente que provoca el salto de una "chispa" y calienta los extremos de los componentes hasta las temperaturas de soldadura. Se obtiene una soldadura por foria aplicando presión.

Una pieza, colocada en una cámara de vacío, es bombardeada por un haz de electrones aplicado mediante una pistola especial a elevada tensión. La energía de los electrones se transforma en calor al chocar el haz contra la pieza, que queda soldada al fundirse el metal.

Se establece un arco entre el extremo de un electrodo de carbón (sujeto en un portaelectrodos manual con su propio suministro de aire comprimido) y la pieza. El metal fundido resultante es expulsado por medio de chorros de aire comprimido.

Técnica de soldadura puramente mecánica en la que uno de los componentes permanece estacionario mientras el otro se hace girar contra él bajo presión. El calor se genera por fricción y la rotación cesa cuando se alcanza la temperatura de forja. Entonces se aplica una presión de forja que efectúa la soldadura.

Los haces laser pueden utilizarse en aplicaciones industriales que requieren una precisión excepcionalmente elevada, por ejemplo montajes miniaturizados y técnicas de microsoldadura en la industria electrónica o hileras para el sector de las fibras artificiales. El haz laser funde y une las piezas.

Entre un espárrago metálico (que actúa como electrodo) sujeto en una pistola de soldar espárragos y la chapa metálica a unir, se establece un arco que eleva la temperatura de los extremos de los componentes hasta el punto de fusión. La pistola aprieta el espárrago contra la chapa y lo suelda. El espárrago está rodeado por una virola cerámica protectora.

Se calienta en un crisol una mezcla de polvo de aluminio y un óxido metálico (de hierro, cobre, etc.) también en polvo, con lo que se produce metal fundido y un intenso calor. Se abre el crisol y el metal fundido fluye a la cavidad a soldar (que está rodeada por un molde de arena). Esta técnica se utiliza con frecuencia para reparar piezas de fundición o de forja.
Riesgos

Quemaduras, incendio, radiación infrarroja, riesgos eléctricos, humos metálicos

Riesgos eléctricos, quemaduras, incendio, humos metálicos

Rayos $X$ a elevados voltajes, riesgos eléctricos, quemaduras, polvos metálicos, espacios confinados

Humos metálicos, monóxido de carbono, dióxido de nitrógeno, ozono, incendio, quemaduras, radiación infrarroja, riesgos eléctricos

Calor, quemaduras, riesgos por maquinaria

Riesgos elécricos, radiación laser, radiación ultravioleta, incendio, quemaduras, humos metálicos, productos de descomposición de los recubrimientos de las piezas

Humos metálicos, radiación infrarroja y ultravioleta, quemaduras, riesgos eléctricos, incendio, ruido, 0zono, dióxido de nitrógeno

Incendio, explosión, radiación infrarroja, quemaduras 
estructuras y maquinarias (p. ej., estructuras de edificios, puentes y torres, barcos, locomotoras y vagones ferroviarios, maquinaria pesada, etc.). El soldador puede tener que llevar todo su equipo al lugar de trabajo, instalarlo y trabajar en espacios confinados o sobre andamiajes. La necesidad de estirarse, arrodillarse o trabajar en otras posturas forzadas e incómodas puede provocar tensión física, fatiga excesiva y lesiones musculosqueléticas. El trabajo en tiempo caluroso y los efectos oclusivos del equipo de protección personal pueden ocasionar estrés por calor, incluso sin el calor generado por el proceso de soldadura.

\section{Botellas de gas a presión}

En las instalaciones de soldadura con gas a alta presión, el oxígeno y el gas combustible (acetileno, hidrógeno, gas ciudad, propano) se suministran a la torcha desde botellas. Los gases almacenados en estas botellas están a elevada presión. Los riesgos especiales de incendio y explosión, y las precauciones necesarias para el empleo y almacenamiento seguros de los gases combustibles se tratan también en otro apartado de esta Enciclopedia. Deberán observarse las siguientes precauciones:

- Solo deberán montarse en las botellas manorreductores diseñados para el gas que se utiliza. Por ejemplo, un manorreductor de acetileno no deberá usarse con gas de hulla o hidrógeno (aunque puede utilizarse con propano).

- Los sopletes deben mantenerse en perfecto estado y limpiarse a intervalos periódicos. Las boquillas se limpiarán con una varilla de madera dura o un alambre de latón blando. La conexión de los sopletes a los manorreductores debe realizarse con tubos de goma especiales reforzados y colocados de manera que no corran riesgo de sufrir daños.

- Las botellas de oxígeno y acetileno deben guardarse separadas y siempre en locales ignífugos donde no haya ningún material inflamable y colocadas de manera que puedan extraerse fácilmente en caso de incendio. Deberán consultarse las normas locales de edificación y protección contra incendios.

- Se observará escrupulosamente el código de colores prescrito o recomendado para la identificación de las botellas y accesorios. Muchos países aplican, en este campo, los códigos de colores aceptados internacionalmente para el transporte de materiales peligrosos. Consideraciones relativas a la seguridad y la creciente migración internacional de trabajadores industriales, subrayan la necesidad de aplicar normas internacionales uniformes a este respecto.

\section{Generadores de acetileno}

En el proceso de soldadura con gas a baja presión, el acetileno se produce normalmente en generadores mediante reacción de carburo cálcico con agua. Después del gas se canaliza por tuberías hasta el soplete de soldadura o de corte, al que también se suministra oxígeno.

Los grupos generadores estacionarios deben instalarse al aire libre o en un edificio bien ventilado, lejos de los talleres principales. La ventilación de la caseta del generador deberá ser capaz de evitar la formación de una atmósfera tóxica o explosiva. Se instalará una iluminación adecuada y los interruptores, otros mecanismos eléctricos y las lámparas estarán situados fuera del edificio o serán antideflagrantes. No se permitirá fumar ni la presencia de llamas, sopletes, equipos de soldadura o materiales inflamables en la caseta del generador o cerca de ésta si está instalado al aire libre. Muchas de estas precauciones rigen también para los generadores portátiles. Estos últimos solo se utilizarán, limpiarán y recargarán al aire libre o en un taller bien ventilado, lejos de cualquier material inflamable.

El carburo cálcico se suministra en tambores sellados, que deben almacenarse y mantenerse secos sobre una plataforma elevada por encima del nivel del suelo. Los almacenes estarán a cubierto y si son colindantes con otro edificio la medianería deberá ser ignífuga. El local utilizado como almacén contará con una ventilación adecuada a través del tejado. Los tambores no se abrirán hasta el momento de cargar el generador, y para ello se deberá proveer y utilizar un abridor especial; los tambores nunca se abrirán con martillo y cortafríos. Es peligroso dejar los tambores de carburo cálcico expuestos a cualquier fuente de agua.

Antes de desmontar un generador, se extraerá todo el carburo cálcico y se llenará de agua el grupo. Se dejará el agua en el grupo al menos media hora para asegurarse de que no quede gas en ninguno de sus componentes. El desmontaje y servicio deberá realizarlos exclusivamente el fabricante del equipo o un técnico especializado. Cuando se recargue o limpie un generador, no deberá reutilizarse ninguna parte de la carga antigua.

Los fragmentos de carburo cálcico acuñados en el mecanismo de alimentación o adheridos a algún componente del grupo se eliminarán cuidadosamente utilizando herramientas de bronce $\mathrm{u}$ otra aleación adecuada, no férrea, que no produzcan chispas.

Todo el personal implicado seguirá estrictamente las instrucciones del fabricante, que deberán estar expuestas de forma claramente visible. Asimismo deberán observarse las siguientes precauciones:

- Entre el generador y cada uno de los sopletes se montará una válvula de contrapresión debidamente diseñada para prevenir cualquier retroceso de llama o reflujo de gas. Después de un retroceso de llama la válvula deberá inspeccionarse con regularidad. El nivel de agua se comprobará a diario.

- Solo se utilizarán sopletes con inyector, diseñados para funcionamiento a baja presión. Para calentamiento y corte, a veces se utiliza gas ciudad o hidrógeno a baja presión. En estos casos, deberá instalarse una válvula antirretorno entre cada soplete y la tubería de suministro.

- Puede producirse una explosión por un "retroceso de llama" producido al sumergir la punta del soplete en el baño de metal fundido o en barro, pintura u otro material que la obstruya. Deben eliminarse las partículas de escoria o metal adheridas a la punta. Esta deberá enfriarse asimismo con frecuencia.

- Se deberán consultar las normas locales de edificación e incendio.

\section{Prevención de incendios y explosiones}

$\mathrm{Al}$ elegir el lugar donde se realizarán las operaciones de soldadura se tendrán en cuenta las paredes circundantes, suelos, objetos cercanos y material de desecho.

Deberán seguirse estos procedimientos:

- Se retirará todo el material combustible o se le protegerá debidamente con chapa metálica u otros materiales adecuados; nunca se utilizarán lonas enceradas.

- Se procurará prescindir de estructuras de madera, o se protegerán de modo análogo. Deberán evitarse los suelos de madera.

- Si hubiese aberturas o grietas en suelos y paredes, se adoptarán medidas de precaución adecuadas; el material inflamable de las dependencias contiguas o el piso situado debajo se trasladará a una posición segura. Se consultarán las normas locales de edificación e incendio.

- Siempre se deberán tener a mano extintores adecuados. Si se trata de una planta de baja presión en la que se utilice un generador de acetileno, se deberán tener preparados también cubos de arena seca; los extintores de polvo seco o dióxido de carbono son satisfactorios. Nunca deberá usarse agua.

- Puede ser necesario contar con equipos de bomberos. Se designará a una persona para que se encargue de vigilar el lugar de 
trabajo durante el menos media hora después de terminado éste, a fin de atajar cualquier conato de incendio.

- Dado que pueden producirse explosiones cuando hay acetileno en el aire en cualquier proporción comprendida entre el 2 y el $80 \%$, se requiere una ventilación y una vigilancia adecuadas que garanticen la ausencia de fugas de gas. Para comprobar si hay fugas se utilizará exclusivamente agua jabonosa.

- El oxígeno deberá ser objeto de un control cuidadoso. Por ejemplo, nunca se liberará en el ambiente de un espacio confinado; muchos metales, prendas de vestir y otros materiales se vuelven activamente combustibles en presencia de oxígeno. En el oxicorte, el oxígeno que no se consume se libera a la atmósfera, por lo tanto, este tipo de trabajo nunca se realizará en un espacio confinado sin contar con una ventilación adecuada.

- Las aleaciones ricas en magnesio u otros metales combustibles deberán mantenerse alejadas de llamas o arcos de soldadura.

- La soldadura de recipientes puede ser extremadamente peligrosa. Si se ignora lo que contenía el recipiente, éste deberá tratarse siempre como si hubiese contenido una sustancia inflamable. Las explosiones pueden evitarse eliminando cualquier material inflamable o haciéndolo no explosivo o ininflamable.

- La mezcla de aluminio y óxido de hierro utilizada en la soldadura aluminotérmica es estable en condiciones normales. No obstante, dada la facilidad con que se inflama el polvo de aluminio y la naturaleza casi explosiva de la reacción, deberán tomarse precauciones adecuadas durante su manipulación y el almacenamiento (evitando la exposición al calor intenso y a posibles fuentes de ignición).

- Para soldar en algunas jurisdicciones se requiere un programa de permisos por escrito para trabajos en caliente. Este programa define las precauciones y procedimientos generales que han de observarse durante los trabajos de soldadura, corte, quemado, etc., y ha de incluir las operaciones específicas a realizar junto a las precauciones de seguridad que deben adoptarse. Será específico para cada planta y puede incluir un sistema de permisos que se completará con cada operación.

\section{Protección contra el calor y los riesgos de quemaduras}

Pueden producirse quemaduras en los ojos y las partes expuestas del cuerpo por contacto con metal caliente y salpicaduras de partículas de metal incandescente o metal fundido. En la soldadura al arco, una chispa de alta frecuencia utilizada para encender el arco puede causar quemaduras pequeñas y profundas si se concentra en un punto de la piel. La radiación infrarroja y visible de alta intensidad emitida por una llama de soldadura con gas u oxicorte y el metal incandescente del baño de soldadura puede causar molestias al operador y a las personas situadas cerca de donde se realiza la operación. Cada una de éstas deberá estudiarse de antemano, a fin de diseñar y poner en práctica las precauciones necesarias. Se usarán gafas de montura ajustada expresamente diseñadas para la soldadura con gas y el oxicorte, a fin de protegerse los ojos del calor y de la luz irradiados por la pieza. Las cubiertas protectoras de los filtros de vidrio deberán limpiarse según se requiera y sustituirse cuando estén rayadas o dañadas. Cuando se proyecte metal fundido o partículas calientes, la ropa protectora que se lleve puesta deberá desviar las salpicaduras. El tipo y espesor de las prendas ignífugas utilizadas se elegirán en función del grado de riesgo. En las operaciones de corte y soldadura al arco, se utilizarán cubrezapatos de cuero o polainas adecuadas para evitar que caigan partículas calientes en el interior de las botas o zapatos. Para proteger las manos y antebrazos del calor, salpicaduras, escoria, etc., son suficientes unas manoplas de cuero con embocaduras de lona o de cuero. Otros tipos de prendas protectoras son los mandiles de cuero, chaquetas, manguitos, guardapiernas y protecciones para la cabeza. En la soldadura sobre la cabeza es necesario utilizar una caperuza y una gorra protectoras. Todas las prendas de protección estarán libres de aceite o grasa y tendrán las costuras por el interior, para que no atrapen glóbulos de metal fundido. La ropa no tendrá bolsillos ni puños o bajos vueltos en los que puedan penetrar chispas, y se llevará de manera que las mangas cubran los guantes, las polainas los zapatos, etc. Se examinarán las prendas protectoras para ver si tienen costuras saltadas o agujeros por los que pueda entrar metal fundido o escoria. Los elementos pesados que queden calientes al terminar la soldadura deberán marcarse siempre con la palabra "caliente" como advertencia para otros trabajadores. En la soldadura por resistencia, el calor producido puede no ser visible y pueden producirse quemaduras por manipular conjuntos calientes. A pesar de que, si las condiciones son correctas, no tienen por qué proyectarse partículas de metal caliente o fundido desde los puntos o el cordón de soldadura, o desde la soldadura por proyección, se utilizarán pantallas ininflamables y se tomarán precauciones. Las pantallas también protegen a los transeúntes de quemaduras en los ojos. No se dejarán piezas sueltas en la garganta de la máquina, ya que podrían ser proyectadas a bastante velocidad.

\section{Seguridad eléctrica}

Aunque en la soldadura al arco manual las tensiones en vacío son relativamente bajas (unos $80 \mathrm{~V}$ o menos), las corrientes de soldadura son elevadas, y los circuitos primarios de los transformadores presentan los riesgos habituales de los equipos que funcionan a la tensión de red. No deberá pasarse por alto, pues, el riesgo de electrocución, especialmente en espacios estrechos o posiciones inseguras.

Antes de empezar a soldar se comprobará siempre la instalación de puesta a tierra del equipo de soldadura. Los cables y conexiones deberán ser resistentes y de la capacidad adecuada. Se utilizará siempre una pinza o un terminal atornillado de puesta a tierra apropiados. Cuando se pongan a tierra dos o más máquinas de soldar conectándolas a la misma estructura, o estén utilizándose también otras herramientas portátiles eléctricas, la conexión a tierra deberá ser supervisada por alguien competente. El sitio en que se trabaje estará seco, será seguro y se hallará libre de obstáculos peligrosos. Es importante que el lugar de trabajo esté bien configurado e iluminado, así como debidamente ventilado, limpio y ordenado. Para trabajar en espacios confinados o en posiciones peligrosas, puede instalarse en el circuito de soldadura protección eléctrica adicional (dispositivos sin carga de baja tensión), asegurándose de que solo hava en el portaelectrodo una corriente de voltaje extremadamente bajo cuando no se esté soldando (véanse comentarios sobre espacios confinados a continuación). Se recomienda utilizar portaelectrodos del tipo en que los electrodos están sujetos por la presión de un muelle o la rosca de un tornillo. Las molestias a causa del calentamiento pueden reducirse mediante un aislamiento térmico eficaz en la parte del portaelectrodo que se sostiene en la mano. Las mordazas y conexiones de los portaelectrodos deberán limpiarse y apretarse periódicamente para evitar el sobrecalentamiento. Se harán las previsiones necesarias para guardar el portaelectrodo de manera segura cuando no se esté utilizando, por medio de un gancho aislado o un soporte totalmente aislado. La conexión del cable estará diseñada de manera que la flexión continuada del cable no provoque el desgaste y fallo del aislamiento. Se evitará arrastrar los cables y los tubos de plástico de alimentación de gas (procesos bajo gas protector) sobre planchas o soldaduras calientes. El conductor del electrodo no deberá entrar en contacto con la pieza o cualquier otro objeto puesto a tierra. No se utilizarán tubos de goma ni cables forrados de goma en ningún lugar próximo a la descarga de alta frecuencia, ya que el ozono corroe la goma. Para todos los suministros desde el transformador al portaelectrodo se utilizarán 
tubos de plástico y cables con cubierta de cloruro de polivinilo (PVC). Tanto los cables con forro de caucho vulcanizado como de caucho natural son satisfactorios en el lado del primario. La suciedad y el polvo metálico u otro tipo de polvo conductor pueden causar una avería en la unidad de descarga de alta frecuencia. Para evitarlo, la unidad deberá limpiarse periódicamente soplando con aire comprimido. Cuando se utilice aire comprimido durante más de unos segundos deberá usarse protección auditiva. Para la soldadura por haz de electrones, antes de cada operación deberá comprobarse la seguridad del equipo utilizado. Se instalará en los distintos armarios un sistema de enclavamientos como protección contra sacudidas eléctricas. Es necesario contar con un sistema fiable de puesta a tierra de todas las unidades y armarios de control. Las tensiones para el equipo de soldadura por plasma utilizado para cortar piezas de gran espesor, pueden ser de hasta $400 \mathrm{~V}$, por lo que hay que prever el peligro consiguiente. La técnica de encendido del arco mediante un impulso de alta frecuencia expone al operario a los riesgos de una desagradable sacudida y una dolorosa y penetrante quemadura por alta frecuencia.

\section{Radiación ultravioleta}

La luz brillante emitida por un arco eléctrico contiene una elevada proporción de radiación ultravioleta. La exposición, incluso momentánea, a destellos de arco, incluidos los destellos dispersos de los arcos de otros trabajadores, puede producir una dolorosa conjuntivitis denominada fotoftalmía. Si alguien resulta expuesto al destello del arco, se deberá procurar atención médica inmediata a la persona afectada. También la exposición excesiva a la radiación ultravioleta puede causar sobrecalentamiento y quemaduras en la piel (efecto de quemadura solar). Las precauciones comprenden:

- Se utilizará una pantalla o un casco provistos de un filtro del grado correcto (véase el artículo "Protección ocular y facial" en otra parte de esta Enciclopedia). Las pantallas planas de mano no proporcionan suficiente protección frente a la radiación reflejada en los procesos de soldadura al arco bajo gas protector y corte por arco con electrodo de carbón, por lo que deberán utilizarse cascos. Debajo del casco se llevarán gafas de montura ajustada con cristales filtrantes o gafas protectoras con pantallas laterales para evitar la exposición cuando se levanta el casco para inspeccionar el trabajo. Los cascos también deberán proteger de las salpicaduras y la escoria caliente. Los cascos y las pantallas de mano van provistos de un cristal filtrante y una cubierta protectora de vidrio en la parte exterior, que deberán inspeccionarse y limpiarse periódicamente, y sustituirse cuando estén arañados o dañados.

- La cara, la nuca y otras partes expuestas del cuerpo deberán protegerse adecuadamente, en especial cuando se trabaje cerca de otros soldadores

- Los ayudantes llevarán, como mínimo, gafas de montura ajustada apropiadas, y otro equipo de protección personal cuando el riesgo lo requiera.

- Todas las operaciones de soldadura al arco se apantallarán para proteger a otras personas que trabajen en las proximidades. Cuando se trabaje en bancos fijos o en talleres de soldadura se instalarán pantallas permanentes y, si esto no fuese posible, se utilizarán pantallas temporales. Todas las pantallas deberán ser opacas, de construcción robusta y de un material ignífugo.

- El uso de pintura negra para el interior de las cabinas de soldadura se ha convertido en una práctica generalmente aceptada, pero la pintura deberá producir un acabado mate. Se utilizará una iluminación ambiente adecuada para prevenir la fatiga visual, que es causa de dolores de cabeza y accidentes.
- Las cabinas de soldadura y pantallas portátiles se comprobarán periódicamente para asegurarse de que no presentan ningún daño a causa del cual el arco pueda afectar a otras personas que trabajen en las proximidades.

\section{Riesgos químicos}

En la soldadura y el oxicorte se producen contaminantes atmosféricos, como humos y gases, procedentes de diversas fuentes:

- el metal que se suelda, el metal de la varilla de aportación o constituyentes de diversos tipos de acero, como acero al níquel o al cromo

- cualquier recubrimiento metálico del elemento que se suelda o de la varilla de metal de aportación (p. ej., zinc y cadmio procedentes del recubrimiento electrolítico, zinc del galvanizado y cobre en forma de una delgada capa de recubrimiento en electrodos continuos de aportación de acero suave)

- pintura, grasa, residuos y otros contaminantes por el estilo presentes en la superficie del elemento que se suelda (p. ej., monóxido de carbono, dióxido de carbono, humo y otros productos de descomposición irritantes)

- capa de fundente sobre la varilla de metal de aportación (p. ej., fluoruro inorgánico)

- la acción del calor o la luz ultravioleta sobre el aire circundante (p. ej., dióxido de nitrógeno, ozono) o sobre hidrocarburos clorados (p. ej., fosgeno)

- gas inerte utilizado como atmósfera protectora (p. ej., dióxido de carbono, helio, argón).

Los humos y gases se eliminarán en la fuente mediante ventilación local por extracción. Esto puede hacerse confinando parcialmente el proceso o instalando campanas que produzcan una corriente de aire de suficiente velocidad a través del lugar de soldadura para asegurar la captura de los humos.

Se prestará especial atención a la ventilación cuando se suelden metales no férreos y ciertos aceros aleados, así como a la protección frente al riesgo de formación de ozono, monóxido de carbono y dióxido de nitrógeno. Existen sistemas de ventilación portátiles y fijos que pueden adquirirse fácilmente. En general, el aire extraído no debe reciclarse. Solo se reciclará si no hay niveles peligrosos de ozono $\mathrm{u}$ otros gases tóxicos y el aire extraído se hace pasar por un filtro de alta eficacia.

En la soldadura por haz de electrones y si los materiales que se sueldan son de naturaleza tóxica (p. ej., berilio, plutonio, etc.), se tomarán precauciones para proteger al operario de cualquier nube de polvo que pueda emitirse al abrir la cámara.

Si existe riesgo para la salud a causa de humos tóxicos (p. ej., plomo) y no es posible la ventilación local por extracción por ejemplo, en la demolición por oxicorte de estructuras recubiertas con pintura de plomo- será necesario utilizar equipo de protección respiratoria. En tales circunstancias, se usará un respirador homologado envolvente de alta eficacia que cubra toda la cara o un respirador motorizado de aire depurado y presión positiva, asimismo de alta eficacia (PAPR). Es necesario un cuidadoso mantenimiento del motor y la batería, sobre todo en el caso del respirador original de presión positiva y alta eficacia. Deberá fomentarse el empleo de respiradores de presión positiva alimentados por tubería de aire comprimido si se dispone de una fuente adecuada de aire comprimido apto para la respiración. Cuando sea necesario utilizar equipo de protección respiratoria se comprobará la seguridad del lugar de trabajo para determinar si es preciso adoptar precauciones suplementarias, teniendo en cuenta las limitaciones de visibilidad, las posibilidades de enredarse, etc., de las personas que usen dicho equipo. 
Figura 82.3 - Soldadura en un espacio cerrado.

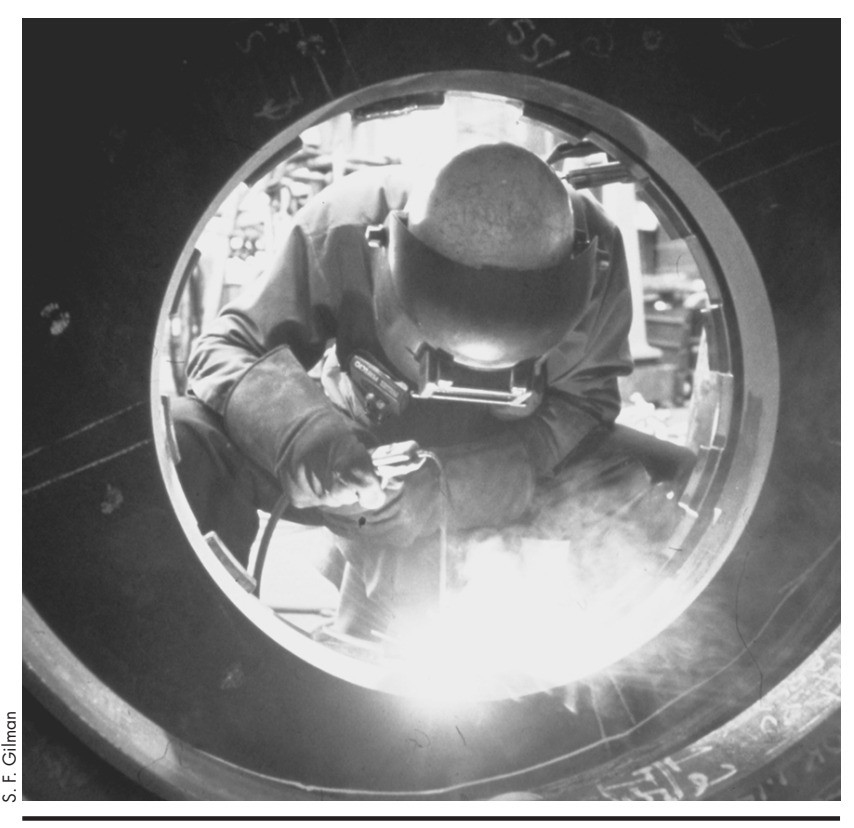

Fiebre por vapores de metal

Este trastorno se observa con frecuencia en trabajadores expuestos a vapores de zinc en el proceso de galvanización o estañado, en la fundición de latón, en la soldadura de metal galvanizado y en la metalización o rociado de metal, así como por exposición a otros metales, como cobre, manganeso y hierro. Se da en trabajadores nuevos y en los que se reincorporan al trabajo después de un fin de semana o unas vacaciones. Es una afección aguda que se manifiesta varias horas después de la inhalación inicial de partículas de un metal o sus óxidos. Comienza con mal sabor de boca seguido de sequedad e irritación de la mucosa respiratoria que provoca tos y en casos aislados disnea y "rigidez" torácica. Estos síntomas pueden ir acompañados de náuseas y dolor de cabeza, y unas 10 a 12 horas después de la exposición, escalofríos y fiebre, que puede ser muy alta. Estos síntomas duran varias horas y van seguidos de transpiración, somnolencia y a menudo poliuria y diarrea. No existe ningún tratamiento específico y la recuperación suele ser completa al cabo de unas 24 horas sin que queden secuelas. Puede evitarse manteniendo la exposición a los vapores metálicos perjudiciales claramente dentro de los niveles recomendados, mediante el empleo de un sistema eficaz de ventilación local por extracción.

\section{Espacios confinados}

La entrada en espacios confinados puede entrañar el riesgo de que la atmósfera sea explosiva, tóxica, deficitaria en oxígeno o presente distintas combinaciones de estas deficiencias. Cualquier espacio confinado de este tipo deberá ser certificado por una persona responsable como seguro para entrar y realizar en él trabajos con arco o llama. Puede ser necesario un programa de entrada en espacios confinados que incluya un sistema de autorizaciones de entrada, y esta clase de programa es muy recomendable para trabajos que deban realizarse en espacios que normalmente no se han construido para estar ocupados continuamente. Como ejemplos cabe mencionar, entre otros, los pozos de registro, cámaras acorazadas, bodegas de buques, etc. La ventilación de los espacios confinados es vital ya que la soldadura con gas, además de producir contaminantes atmosféricos, consume oxígeno. Los procesos de soldadura al arco bajo gas protector pueden reducir el contenido de oxígeno del aire (Véase la Figura 82.3).

\section{Ruido}

El ruido es un riesgo en varios procesos de soldadura, como la soldadura con plasma, algunos tipos de máquinas de soldadura por resistencia y la soldadura con gas. En la soldadura con plasma, el chorro de plasma es expulsado a altísimas velocidades por lo que produce un ruido intenso (hasta $90 \mathrm{dBA}$ ), especialmente en las bandas de alta frecuencia. También el empleo de aire comprimido para eliminar el polvo por soplado produce altos niveles de ruido. Para evitar lesiones de oído deberán usarse tapones o cascos protectores e implantarse un programa de conservación de la audición que incluya pruebas de audiometría (capacidad auditiva) y formación de los trabajadores.

\section{Radiación ionizante}

En los talleres donde se inspeccionan soldaduras radiográficamente con equipos de rayos $\mathrm{X}$ o rayos gamma, deberán observarse estrictamente las advertencias e instrucciones de costumbre. Los trabajadores se mantendrán a una distancia segura de tales equipos. Las fuentes radiactivas deben manipularse exclusivamente con las herramientas especiales necesarias y observando precauciones especiales.

Se cumplirán las reglas locales y gubernamentales al respecto. Véase el capítulo Radiación, ionizante en otra parte de esta Enciclopedia.

En la soldadura por haz de electrones debe proveerse un apantallamiento suficiente para evitar que los rayos X atraviesen las paredes y ventanas de la cámara. Cualquier parte de la máquina que proporcione apantallamiento contra la radiación $\mathrm{X}$ debería estar enclavada de manera que la máquina no pueda activarse a menos que esas partes estén en la posición de protección. Las máquinas deben comprobarse en el momento de su instalación para ver si tienen fugas de radiación X, y después periódicamente.

\section{Otros riesgos}

Las máquinas de soldadura por resistencia tienen al menos un electrodo, que se mueve con una fuerza considerable. Si se pone en marcha una de estas máquinas teniendo un dedo o una mano entre los electrodos, se producirá un grave aplastamiento. A ser posible, deberá diseñarse un sistema de defensas adecuado para la protección del operario. Se pueden reducir al mínimo los cortes y laceraciones desbarbando primero los componentes y usando guantes o manoplas protectores.

Cuando se realicen tareas de mantenimiento o reparación de maquinaria alimentada por fuentes de energía eléctrica, mecánica o de otra clase, deberán observarse los oportunos procedimientos de bloqueo y etiquetado de advertencia.

$\mathrm{Al}$ eliminar la escoria de soldaduras mediante picado u otro procedimiento análogo, se deberán proteger los ojos con gafas de montura ajustada u otros medios.

\section{TORNOS}

\section{Tomi Retsch*}

Los tornos desempeñan un papel muy importante en los talleres de las industrias del metal, como lo demuestra claramente el hecho de que el 90 o $95 \%$ de la viruta producida en el sector de válvulas y racores proviene de estas máquinas herramienta. Alrededor de la décima parte de los accidentes registrados en este

* Adaptado de la $3^{\mathrm{a}}$ edición, Enciclopedia de salud y seguridad en el trabajo. 
sector se deben a los tornos, lo cual representa la tercera parte de todos los accidentes en que intervienen máquinas. Según un estudio sobre la frecuencia relativa de accidentes por máquina llevado a cabo en una planta de fabricación de pequeñas piezas de precisión y de equipos eléctricos, los tornos ocupan el quinto lugar detrás de las máquinas para el trabajo de la madera, las sierras para metales, las prensas mecánicas y las taladradoras. Así pues, no hay duda sobre la necesidad de aplicar medidas de protección para los tornos.

El torneado es un proceso de mecanizado en el que se reduce el diámetro del material por medio de una herramienta provista de un filo especial. El movimiento de corte se produce haciendo girar la pieza a trabajar, y los movimientos de avance y de penetración los efectúa la herramienta. Haciendo variar estos tres movimientos básicos y eligiendo la geometría apropiada del filo de la herramienta y el material, se puede influir sobre la velocidad de arranque de material, la calidad superficial, la forma de la viruta producida y el desgaste de la herramienta.

\section{Estructura de los tornos}

Un torno típico está formado por:

- una bancada con guías mecanizadas para el carro principal y para el cabezal móvil.

- un cabezal fijo montado sobre la bancada, con el husillo principal y el plato

- una caja de cambios para el mecanismo de avance acoplada a la parte delantera de la bancada y que transmite el movimiento de avance, dependiente de la velocidad de corte, a través del husillo de roscar o del husillo de cilindrar y de la caja de maniobra hasta el carro principal.

- un carro principal (o carro de bancada) que va equipado con la guía cruzada que permite el movimiento transversal, y

- un portaherramienta montado sobre la guía cruzada (véase la Figura 82.4).

Este modelo básico de torno admite infinitas variantes, desde la máquina universal hasta el torno automático especial diseñado para un único tipo de trabajo.

Figura 82.4 - Tornos, máquinas de cortar y máquinas de roscar.

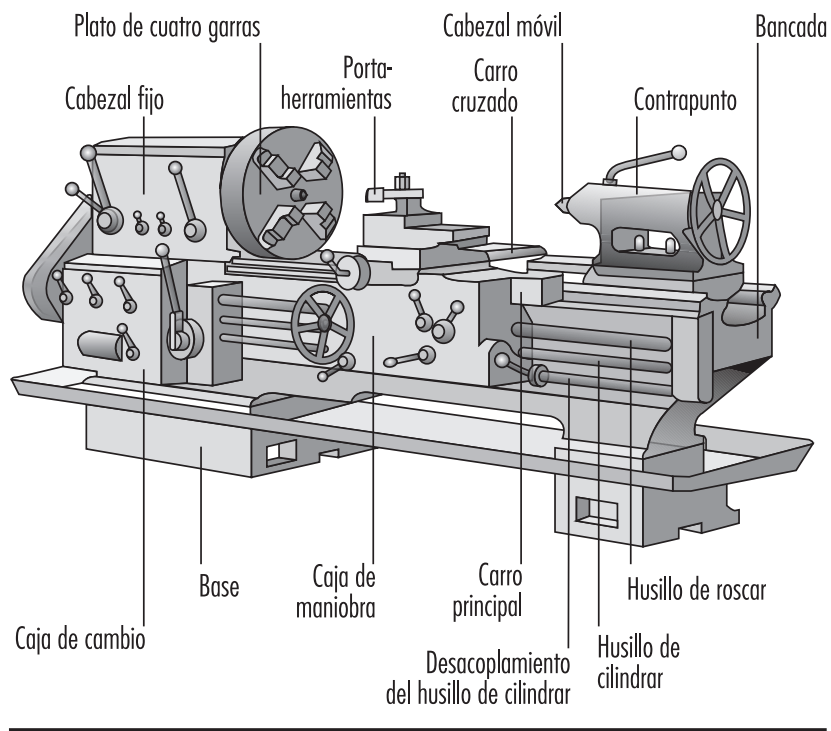

Los tipos de torno más importantes son los siguientes:

- Torno paralelo. Esta es la máquina de tornear de uso más frecuente. Se corresponde con el modelo básico con eje de giro horizontal. La pieza a trabajar se sujeta entre puntos con un plato frontal o con uno de garras.

- Torno multiherramienta. Permite emplear varias herramientas a la vez.

- Torno de torreta, torno revólver. Las máquinas de este tipo permiten mecanizar la pieza por medio de varias herramientas que se van aplicando sucesivamente, una tras otra. Las herramientas van sujetas en una torreta que puede girar para situarlas en posición de corte. Las torretas son generalmente de tipo o disco o de tipo corona, pero también hay tornos con torreta tipo tambor.

- Tornos copiadores. La forma deseada es transmitida desde una plantilla a la pieza mediante un punzón de control.

- Torno automático. En estas máquinas están automatizadas las distintas operaciones, incluido el cambio de pieza. Hay tornos automáticos para barra y tornos automáticos con fijación de la pieza mediante garras.

- Torno vertical (torno taladro). La pieza gira alrededor de un eje vertical, sujeta a una mesa giratoria horizontal.. Este tipo de máquina se emplea normalmente para mecanizar grandes piezas de fundición o de forja.

- Tornos de control numérico (NC) y tornos de control numérico asistido por ordenador (CNC). Todas las máquinas antes mencionadas pueden equiparse con un sistema de control numérico o de control numérico asistido por ordenador. El resultado es una máquina semiautomática o totalmente automática que puede utilizarse de forma prácticamente universal gracias a la gran versatilidad y facilidad de programación del sistema de control.

El desarrollo futuro de los tornos se centrará probablemente en los sistemas de control. Los controles por contacto irán siendo sustituidos cada vez en mayor grado por sistemas de control electrónicos. Por lo que respecta a estos últimos, hay una tendencia a la evolución de los controles programados por interpolación hacia controles programados por memoria. A largo plazo, es previsible que el empleo de ordenadores de proceso cada vez más eficaces tenderá a optimizar el proceso de mecanizado.

\section{Accidentes}

Los accidentes con los tornos obedecen normalmente a las siguientes causas:

- inobservancia de las reglas de seguridad al instalar las máquinas en los talleres (por ejemplo, insuficiente espacio entre máquinas, ausencia de un interruptor de desconexión para cada máquina)

- falta de defensas o ausencia de dispositivos auxiliares (se han dado casos de lesiones graves en operarios que trataron de frenar el husillo del torno ejerciendo presión con una mano contra poleas de transmisión carentes de defensas y en operarios que accionaron inadvertidamente palancas o pedales de embrague sin proteger; también se han producido lesiones por proyección de virutas debido a la ausencia de pantallas abatibles o deslizantes)

- mandos mal situados (por ejemplo, el contrapunto puede atravesar la mano del tornero si éste confunde el pedal que controla las garras portapiezas con el que gobierna el circuito hidráulico para el movimiento del contrapunto)

- condiciones de trabajo desfavorables (es decir, fallos desde el punto de vista de la fisiología laboral)

- falta de equipo de protección personal o uso de ropa de trabajo inadecuada (hay casos de torneros que se han provocado 
lesiones graves e incluso mortales por llevar ropa holgada o el pelo largo y suelto)

- insuficiente formación del personal (un aprendiz se hirió mortalmente cuando torneaba un eje corto montado entre puntos que iba arrastrado por medio de un soporte acodado sujeto a la cabeza del husillo y por otro recto fijado al eje; el soporte atrapó su manga izquierda, la cual se enrolló en la pieza y arrastró violentamente al aprendiz contra el torno)

- mala organización del trabajo, lo cual da lugar al uso de equipos inadecuados (por ejemplo, en una ocasión se mecanizó en un torno convencional una barra que, por ser demasiado larga para este tipo de torno, sobresalía más de un metro del cabezal; además, la abertura de las garras era demasiado grande para la barra por lo que se ajustó introduciendo cuñas de madera. Cuando el husillo del torno comenzó a girar, el extremo libre de la barra se dobló a $45^{\circ}$ y golpeó al operario en la cabeza. El hombre murió a la noche siguiente)

- elementos defectuosos en la máquina (por ejemplo, una chaveta suelta en un embrague puede provocar que empiece a girar el eje del torno mientras el operario está ajustando la pieza en el plato de garras).

\section{Prevención de accidentes}

La prevención de los accidentes con tornos comienza en la fase de diseño. Los proyectistas deben prestar especial atención a los mandos y a los elementos de transmisión.

\section{Mandos}

Todos los tornos deberán estar dotados de un interruptor o seccionador eléctrico que permita efectuar de forma segura los trabajos de mantenimiento y reparación. Este interruptor deberá desconectar la corriente en todos los polos, cortar de forma fiable las conexiones neumáticas e hidráulicas y desahogar la presión de los circuitos. En las máquinas grandes el interruptor de desconexión deberá ser de un diseño tal que pueda bloquearse con un candado en la posición de circuito abierto, como medida de seguridad contra su reconexión accidental.

Los mandos de la máquina estarán dispuestos de manera que el operario pueda distinguirlos y alcanzarlos fácilmente, y que su manipulación no entrañe ningún peligro. Esto significa que los mandos no deberán colocarse nunca en lugares donde solo puedan ser alcanzados pasando la mano sobre la zona de trabajo de la máquina, o donde puedan ser golpeados por virutas proyectadas.

Los interruptores que controlan la presencia de las defensas y las enclavan con la transmisión de la máquina, deberán seleccionarse e instalarse de manera que abran positivamente el circuito tan pronto como la defensa abandone su posición de protección.

Los dispositivos de parada de emergencia deberán provocar la detención inmediata del movimiento peligroso correspondiente. Estarán diseñados y ubicados de manera que puedan ser accionados fácilmente por el trabajador que esté en peligro. Los pulsadores de parada de emergencia deberán ser fácilmente accesibles y de color rojo.

Los elementos de accionamiento de los mecanismos de control que puedan dar lugar a un movimiento peligroso en la máquina, deberán tener una protección que impida todo accionamiento involuntario. Por ejemplo, las palancas de acoplamiento de los embragues en el cabezal y en el carro de bancada deberán contar con dispositivos de enclavamiento o pantallas de seguridad. Un pulsador puede hacerse más seguro alojándolo en un hueco o rodeándolo con un collarín protector.

Los mandos manuales deben estar diseñados y ubicados de manera que el movimiento de la mano se corresponda con el movimiento que se está controlando de la máquina.
Los mandos deberán marcarse por medio de rótulos fácilmente legibles y comprensibles. Para evitar malentendidos o dificultades lingüísticas se recomienda el uso de símbolos.

\section{Elementos de transmisión}

Todos los elementos móviles de transmisión (correas, poleas, engranajes) deberán estar protegidos con una cubierta o defensa adecuada. Las personas encargadas de la instalación de la máquina pueden contribuir de modo considerable a la prevención de los accidentes con el torno. Los tornos deben instalarse de forma que los operarios que los atienden no se estorben ni pongan en peligro mutuamente. Los operarios no deberán estar de espaldas a los pasillos. Cuando los puestos de trabajo vecinos o las zonas de paso estén dentro del alcance de las virutas que salen despedidas, deberán instalarse pantallas protectoras.

Las zonas de paso deberán marcarse con claridad. Deberá dejarse espacio suficiente para los equipos de manutención de materiales, para apilar las piezas y para los armarios de herramientas. Las guías para el material en barras no deberán sobresalir hacia las zonas de paso.

El piso sobre el que permanece el operario deberá estar aislado del frío. Habrá que tener cuidado de que el aislamiento no suponga un obstáculo con el que se pueda tropezar, y de que el revestimiento del piso no pueda volverse resbaladizo ni siquiera cuando quede cubierto por una película de aceite.

Las tuberías y conductos se instalarán de manera que no estorben. Deberán evitarse las instalaciones provisionales.

Las medidas técnicas de seguridad en el taller deberán estar dirigidas en particular hacia los puntos siguientes:

- los dispositivos de sujeción de las piezas (platos fijos, platos de garras, mandriles) deberán equilibrarse dinámicamente antes de utilizarse

- la velocidad máxima admisible de los platos de garras deberá ser marcada por el fabricante sobre el plato y deberá ser respetada por el tornero

- cuando se utilicen platos centradores con rosca plana, deberá garantizarse que no puedan salir despedidas las mordazas al poner en marcha el torno

- los platos de este tipo deberán diseñarse de forma que no pueda sacarse la llave antes de asegurar las mordazas. Normalmente, las llaves de plato deberán diseñarse de manera que sea imposible dejarlas en el plato.

Es fundamental disponer de equipos elevadores auxiliares para facilitar el montaje y desmontaje de platos y mandriles pesados. El plato deberá fijarse firmemente para evitar que se suelte del eje en caso de que se frene repentinamente el torno. Esto puede conseguirse con una tuerca de retención roscada a izquierdas sobre la cabeza del eje, empleando un acoplamiento rápido tipo "Camlock", dotando al plato de una chaveta de enclavamiento o asegurándolo con un anillo de bloqueo dividido en dos mitades.

Cuando se empleen dispositivos hidráulicos para fijación de la pieza, tales como platos de garras, mandriles y contrapuntos accionados hidráulicamente, se habrán de tomar medidas para que sea imposible introducir las manos dentro de la zona peligrosa de cierre de los dispositivos. Esto se puede conseguir limitando a $6 \mathrm{~mm}$ el recorrido del elemento de apriete, colocando los mandos de hombre muerto de manera que no sea posible introducir las manos en la zona peligrosa, o disponiendo una protección móvil que tenga que estar cerrada para que pueda iniciarse el movimiento de apriete.

Cuando sea peligroso poner en marcha el torno con las mordazas del plato abiertas, la máquina deberá ir equipada con un dispositivo que impida iniciar la rotación del eje antes de cerrar las mordazas. La falta de energía no deberá provocar la 
apertura o el cierre de los dispositivos hidráulicos de sujeción de la pieza.

Si disminuye la fuerza de apriete del plato hidráulico, deberá detenerse el giro del eje, y deberá ser imposible ponerlo en marcha. La inversión de la dirección de apriete de dentro a fuera (o viceversa) mientras gira el eje, no deberá provocar el decalado del plato de su posición en el eje. Solo deberá ser posible desmontar los dispositivos de sujeción de su lugar en el eje cuando este último deje de girar.

$\mathrm{Al}$ mecanizar material en barras, la parte que sobresalga del torno deberá estar cubierta por guías adecuadas. Los contrapesos de alimentación de la barra estarán protegidos por cubiertas con bisagras que deberán llegar hasta el suelo.

\section{Platos o perros de arrastre}

Para evitar graves accidentes - en especial durante trabajos de pulido en un torno - no deberán utilizarse arrastres sin proteger. Se deberá emplear un arrastre centrador de seguridad, o en el caso de un arrastre convencional se deberá montar un collarín protector. También se pueden utilizar arrastres autoblocantes o dotar al plato de arrastre de una cubierta protectora.

\section{Zona de trabajo del torno}

Los platos de garras de los tornos universales deberán protegerse con cubiertas abisagradas. Si es posible, las cubiertas protectoras deberán ir enclavadas con los circuitos de accionamiento del eje. Los tornos verticales deberán estar protegidos con barras o placas para evitar lesiones producidas por las piezas giratorias. Deberán disponerse plataformas con barandillas para permitir al operario observar el proceso de mecanizado de forma segura. En ciertos casos pueden instalarse cámaras de televisión para que el operario pueda vigilar el filo y el proceso de corte de la herramienta.

Las zonas de trabajo de los tornos automáticos y de los tornos de control numérico y de control numérico computerizado deberán ser totalmente cerradas. Los cerramientos de las máquinas totalmente automáticas solo deberán tener aberturas para introducir el material a mecanizar, expulsar la pieza torneada y retirar la viruta de la zona de trabajo. Estas aberturas no deberán suponer un peligro al pasar por ellas la pieza terminada, y deberá ser imposible alcanzar la zona de peligro a través de ellas.

Las zonas de trabajo de los tornos semiautomáticos, de control numérico y de control numérico computerizado, deberán estar cerradas durante el proceso de mecanizado. Los cerramientos consisten normalmente en cubiertas deslizantes con interruptores fin de carrera y un circuito de enclavamiento.

Las operaciones que requieren un acceso a la zona de trabajo, tales como el cambio de la pieza o de las herramientas de corte, la medición, etc., no deberán efectuarse mientras el torno no haya parado de una forma segura. El poner a cero una transmisión de velocidad no se considera una parada segura. Las máquinas con este tipo de transmisión deberán tener unas cubiertas protectoras enclavadas que no se puedan desenclavar mientras la máquina no haya parado de una forma segura (por ejemplo, cortando la alimentación eléctrica del motor del eje).

Cuando sea necesario realizar operaciones especiales de ajuste de la herramienta, se dispondrá un mando de movimiento lento que permita ciertos movimientos de la máquina estando abierta la cubierta protectora. En tales casos, el operario podrá estar protegido mediante circuitos de diseño especial que, por ejemplo, permitan efectuar los movimientos solo de uno en uno. Esto se puede conseguir por medio de mandos que requieran utilizar ambas manos.

\section{Viruta}

Las virutas largas son peligrosas porque pueden enredarse en brazos y piernas y causar graves lesiones. Las virutas continuas y en espiral pueden evitarse eligiendo velocidades, profundidades de corte y espesores de viruta adecuados, o empleando herramientas de torneado con rompevirutas de garganta o de escalón. Para retirar la viruta deberán emplearse ganchos para viruta con mango y protector.

\section{Ergonomía}

Las máquinas deberán diseñarse de forma que permitan obtener una máxima producción con un mínimo de esfuerzo por parte del operario. Esto puede lograrse adaptando la máquina al trabajador.

Al diseñar los elementos de un torno sobre los que actúa el hombre deberán tenerse en cuenta los factores ergonómicos. Un diseño racional del puesto de trabajo incluye también la disposición de equipos auxiliares de manutención, tales como accesorios de carga y descarga.

Todos los mandos deberán estar situados dentro de la esfera fisiológica o al alcance de las dos manos. Los mandos estarán dispuestos de forma clara y su forma de accionamiento deberá regirse por la lógica. En las máquinas pensadas para operarios que trabajan de pie, deberán evitarse los mandos accionados por pedal.

La experiencia ha demostrado que es beneficioso diseñar el puesto de trabajo para las dos posiciones, de pie y sentado. Cuando el operario tenga que trabajar de pie se le deberá dar la posibilidad de cambiar de postura. En muchos casos los asientos mullidos proporcionan un gran alivio para pies y piernas cansados.

Deberán tomarse medidas para crear un confort térmico óptimo, teniendo en cuenta la temperatura del aire, la humedad relativa, el movimiento del aire y el calor radiante. El taller deberá estar adecuadamente ventilado. Para eliminar las emanaciones gaseosas deberá haber dispositivos extractores locales. Cuando se mecanicen piezas a partir de material en barras deberán usarse tubos guía revestidos de material fonoabsorbente.

El lugar de trabajo deberá disponer preferiblemente de un alumbrado de distribución uniforme y con un adecuado nivel de iluminación.

\section{Ropa de trabajo y protección personal}

Los monos deberán ser ceñidos y cerrados por botones o cremallera hasta el cuello. No deberán tener bolsillos en el pecho, y las mangas deberán ir ceñidas a las muñecas. No deberán usarse cinturones. Cuando se trabaje en un torno no deberán llevarse anillos ni pulseras. Deberá ser obligatorio usar gafas de seguridad. Cuando se mecanicen piezas pesadas deberán calzarse botas de seguridad con puntera de acero. Siempre que haya que retirar viruta se utilizarán guantes protectores.

\section{Formación}

La seguridad de los torneros depende en gran medida de sus métodos de trabajo. Es, pues, muy importante que reciban una completa formación teórica y práctica para adquirir la destreza necesaria y desarrollar una forma de actuación que les proporcione la máxima seguridad posible. La correcta postura, los movimientos correctos y la correcta selección y manejo de las herramientas deberán convertirse en una rutina hasta el punto de que el operario trabaje correctamente incluso en el caso de que disminuya temporalmente su concentración.

Entre los puntos importantes de un programa de formación están una postura erguida, el adecuado montaje y desmontaje del plato de garras y la colocación precisa y segura de las piezas 
a tornear. Deberá practicarse mucho la forma correcta de sostener las limas y rasquetas y el trabajo seguro con tela esmeril.

Los trabajadores deberán estar bien informados sobre los peligros de lesión que pueden correr al hacer trabajos de medición, de comprobación de ajustes y de limpieza de los tornos.

\section{Mantenimiento}

Los tornos deberán revisarse y lubricarse periódicamente. Las averías se corregirán de inmediato. Cuando una avería comprometa la seguridad, deberá dejarse la máquina fuera de servicio hasta que se lleve a cabo una acción correctora.

Los trabajos de reparación y mantenimiento solo deberán efectuarse después de haber desconectado la máquina de la toma de energía eléctrica.

\section{RECTIFICADO Y PULIDO}

\section{K. Welinder*}

El rectificado, en el más amplio sentido del término, consiste en el empleo de una herramienta provista de granos abrasivos aglutinados que arrancan pequeñas partículas de la pieza que se trabaja. El objetivo es dar a la pieza una forma determinada, corregir sus dimensiones, suavizar su superficie o avivar los filos. El rectificado se utiliza, por ejemplo, para la eliminación de mazarotas y rebabas en una pieza de fundición, la eliminación de la cascarilla del metal antes de la forja o la soldadura y el desbarbado de piezas en chapisterías y talleres de mecanizado. El pulido se emplea para eliminar imperfecciones superficiales, tales como marcas dejadas por herramientas. En el bruñido no se eliminan partículas metálicas, sino que se utiliza un abrasivo fino mezclado con cera o grasa para conseguir un alto brillo superficial.

El rectificado es el más amplio y variado de todos los métodos de mecanización, y se emplea para muy diversos materiales, predominantemente el hierro y el acero, pero también para otros metales, así como madera, plástico, piedra, vidrio, alfarería, etc. El término rectificado abarca también otros métodos de producir superficies muy suaves y brillantes, tales como el pulido, bruñido, afilado y lapeado.

Las herramientas utilizadas son muelas de dimensiones variables, segmentos de rectificado, puntas de rectificado, piedras de afilar, limas, ruedas de pulir, bandas, discos, etc. En las muelas de rectificado y similares el material abrasivo se mantiene unido por medio de aglutinantes formando un cuerpo rígido, generalmente poroso. En el caso de las bandas abrasivas el aglutinante mantiene el abrasivo unido a un material base flexible. Las ruedas de bruñido están hechas con discos de algodón u otro material textil cosidos entre sí.

Los abrasivos naturales, corindón natural o esmeril (óxidos de aluminio), diamante, piedra esmeril (arenisca), pedernal y almandina (granate) han sido reemplazados en su mayor parte por abrasivos artificiales, como óxido de aluminio (alúmina fundida), carburo de silicio (carborundo) y diamantes sintéticos. Se utilizan también diversos materiales de grano fino, tales como yeso, piedra pómez, trípoli, cenizas de estaño y óxido de hierro, especialmente para pulido y bruñido.

El óxido de aluminio es ampliamente utilizado en muelas de rectificado, seguido por el carburo de silicio. Los diamantes naturales y artificiales se utilizan para importantes aplicaciones especiales. El óxido de aluminio, carburo de silicio, esmeril, granate y pedernal, se emplean en bandas de rectificado y pulido.

* Adaptado de la $3^{\text {a }}$ edición, Enciclopedia de salud y seguridad en el trabajo.
En las muelas se utilizan tanto aglutinantes orgánicos como inorgánicos. Los principales tipos de aglutinantes inorgánicos son el silicato vitrificado y la magnesita. Entre los aglutinantes orgánicos destacan la resina fenólica o de urea-formol, la goma y la laca. Los aglutinantes vitrificados y la resina fenólica dominan por completo dentro de sus respectivos grupos. Las muelas de diamante también pueden estar aglutinadas con metales. Los diversos aglutinantes dan a las ruedas diferentes propiedades rectificadoras, así como en relación con la seguridad.

Las bandas y discos abrasivos y de pulido se componen de una base flexible de papel o tela a la cual se une el abrasivo por medio de un adhesivo natural o sintético.

Se utilizan máquinas diferentes para los diversos tipos de operaciones, tales como rectificado de superficies planas, rectificado cilíndrico incluyendo el rectificado sin centros, rectificado de interiores, rectificado de desbaste y corte. Los dos tipos principales son: aquéllos en que la rectificadora o la pieza se mueven a mano y las máquinas con avance mecánico y platos de sujeción. Las máquinas más comunes son las rectificadoras de superficies planas exteriores; rectificadoras, pulidoras y bruñidoras de pedestal; esmeriladoras y pulidoras de disco; rectificadoras de interiores; tronzadoras de discos abrasivos; pulidoras de banda; esmeriladoras, pulidoras y bruñidoras portátiles, y otros diversos tipos de pulidoras y bruñidoras.

\section{Riesgos y su prevención}

\section{Rotura}

El principal riesgo de lesiones en el uso de muelas es que la muela puede romperse durante el rectificado. Normalmente las muelas giran a altas velocidades y hay una continua tendencia hacia velocidades cada vez mayores. La mayoría de las naciones industrializadas tienen reglamentaciones que limitan las velocidades máximas a que pueden girar los diversos tipos de muelas de rectificado.

La medida protectora fundamental es hacer la muela lo más resistente posible. La naturaleza del aglutinante es de la máxima importancia. Las muelas con aglutinantes orgánicos, en especial las resinas fenólicas, son más resistentes que las de aglutinantes inorgánicos y más resistentes a los impactos. Para las muelas de aglutinantes orgánicos se permiten velocidades periféricas muy elevadas.

Las muelas que trabajan a velocidades muy elevadas suelen llevar incorporados varios tipos de refuerzos. Por ejemplo, ciertas muelas están equipadas con cubos de acero para incrementar su resistencia a la rotura. Durante la rotación el esfuerzo principal se desarrolla alrededor del taladro central. Para reforzar la muela, la sección que rodea el taladro central, que no participa en el rectificado, puede hacerse de un material especialmente fuerte que no sea adecuado para el rectificado. Las muelas grandes con la sección central reforzada en esta forma se utilizan especialmente en las acerías para rectificar tochos, lingotes y productos análogos, a velocidades de hasta $80 \mathrm{~m} / \mathrm{s}$.

Sin embargo, el método más corriente de reforzar muelas de rectificado, es introducir fibra de vidrio en su construcción. Las muelas delgadas, tales como las que se utilizan para corte, pueden llevar incorporada fibra de vidrio en el centro o a cada lado, mientras que las muelas de más espesor tienen varias capas de fibra de vidrio cuyo número depende del espesor de la muela.

Con excepción de algunas muelas de rectificado de pequeñas dimensiones, todas las muelas, o un muestreo estadístico de ellas deben someterse a pruebas de velocidad por el fabricante. En dichas pruebas, las muelas se hacen girar durante un cierto 
período de tiempo a una velocidad superior a la permitida en el rectificado. Los códigos sobre pruebas varían de un país a otro, pero generalmente la muela ha de probarse a una velocidad un $50 \%$ superior a la de trabajo. En algunos países los códigos exigen pruebas especiales para las muelas que consisten en girar a mayores velocidades de las normales, en un instituto central de ensayos. El instituto también puede cortar probetas de la muela e investigar sus propiedades físicas. Las muelas de corte se someten a ciertas pruebas de impacto, de curvado, etc. El fabricante también está obligado a asegurarse de que la muela está bien equilibrada antes de su entrega.

La rotura de una muela puede causar lesiones mortales o muy graves a cualquiera que esté en las proximidades y grandes daños a la planta o a los locales. A pesar de todas las precauciones tomadas por los fabricantes, pueden producirse roturas ocasionales de muelas a menos que se utilicen con el debido cuidado. Las medidas de precaución se refieren a los siguientes aspectos:

- Manejo y almacenamiento. Una muela puede resultar dañada o agrietada durante su transporte o manejo. La humedad puede atacar al aglutinante en las muelas de resinas fenólicas y acabar por reducir su resistencia. Las muelas vitrificadas pueden ser sensibles a repetidas variaciones de temperatura. La humedad absorbida irregularmente puede desequilibrar la muela. Por todo ello es muy importante que las muelas se manejen con cuidado en todos los procesos y se mantengan ordenadamente en un lugar seco y protegido.

- Comprobación de posibles grietas. Una muela nueva debe comprobarse para asegurarse de que no está deteriorada y de que permanece seca, lo que puede hacerse con gran facilidad golpeándola ligeramente con un mazo de madera. Una muela vitrificada sin defectos producirá un timbre claro, una muela de aglutinante orgánico un timbre de un tono algo menor; pero ambos pueden diferenciarse del sonido bronco de una muela defectuosa. En caso de duda no deberá utilizarse la muela sin consultar antes al proveedor.

- Pruebas. Antes de poner en servicio la muela nueva deberá probarse a su máxima velocidad, observando las debidas precauciones. Después del rectificado húmedo la muela debe hacerse girar en vacío para que expulse el agua; de otro modo ésta puede acumularse en el fondo de la muela y causar un desequilibrio que puede originar su rotura la próxima vez que se utilice.

- Montaje. Se producen accidentes y roturas cuando las muelas se montan en aparatos inadecuados, por ejemplo en extremos de ejes de máquinas pulidoras. El eje deberá ser del diámetro adecuado, pero no tan grande como para ensanchar el taladro central de la muela; las bridas no deberán ser menores que un tercio del diámetro de la muela y deben ser de acero dulce o un material similar.

- Velocidad. Bajo ninguna circunstancia debe superarse la máxima velocidad de funcionamiento permisible especificada por los fabricantes. Debe colocarse un letrero indicando la velocidad del eje en todas las máquinas de rectificar, y debe marcarse la muela con la máxima velocidad periférica permisible y el correspondiente número de revoluciones para una muela nueva. Deben tomarse precauciones especiales con las máquinas de rectificar de velocidad variable y asegurarse del montaje de muelas de la velocidad admisible adecuada en las rectificadoras portátiles.

- Utillaje. Siempre que sea posible, deben proporcionarse útiles de dimensiones adecuadas y montados rígidamente. Deben ser ajustables y mantenerse lo más cerca posible de la muela para evitar que la pieza pueda forzarse bruscamente contra ella y romperla o, lo que es más probable, que la mano del operario se introduzca en el hueco y se lesione.
Figura 82.5 - Muela abrasiva vitrificada, debidamente protegida, montada en una esmeriladora de superficie y con una velocidad periférica de $33 \mathrm{~m} / \mathrm{s}$.

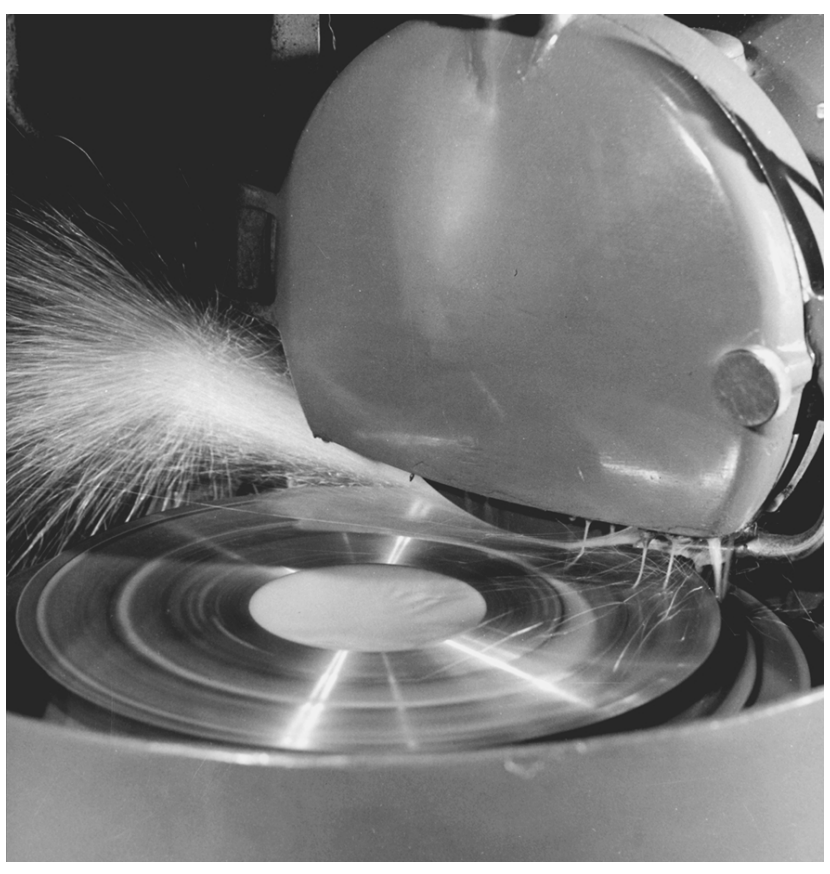

- Defensas. Las muelas abrasivas deben dotarse de defensas suficientemente fuertes para retener los trozos de una muela que se rompa (véase la Figura 82.5). En algunos países existen reglamentaciones detalladas respecto al diseño de las defensas y los materiales a utilizar. En general, debe evitarse el hierro y aluminio fundidos. El distanciamiento de la defensa debe ser lo menor posible y puede ser necesaria una pieza frontal ajustable. Excepcionalmente, cuando la naturaleza del trabajo impide el uso de una defensa, pueden utilizarse bridas protectoras especiales o portaherramientas de seguridad. Los ejes y extremos cónicos de las máquinas pulidoras de doble extremo pueden causar accidentes por enganches a menos que estén provistas de defensas adecuadas.

\section{Lesiones de los ojos}

El polvo, abrasivos, gránulos y fragmentos son un riesgo corriente para los ojos en todas las operaciones de rectificado en seco. Es esencial su protección eficaz con gafas o anteojos y pantallas fijas a la máquina. Estas son especialmente útiles cuando el uso de las muelas es intermitente, por ejemplo para el afilado de herramientas.

\section{Incendios}

El rectificado de aleaciones de magnesio lleva consigo un alto riesgo de incendio a menos que se tomen estrictas precauciones contra la ignición accidental y en la eliminación y riego del polvo. Se requieren esmerada limpieza y mantenimiento en todas las conducciones del sistema de evacuación para evitar el riesgo de incendio y también mantener un funcionamiento eficaz de la ventilación. El polvo textil proyectado en las operaciones de pulido entraña riesgo de incendio, por lo que requiere una esmerada limpieza y ventilación local por extracción. 


\section{Vibración}

Las esmeriladoras portátiles y de pedestal pueden provocar el síndrome de vibración de la mano y el brazo (HAVS), también conocido como "dedo blanco" por ser éste su síntoma más evidente. Entre las recomendaciones se incluye la limitación de la intensidad y duración de la exposición, el rediseño de las herramientas, el uso de equipo de protección y la vigilancia de la exposición y la salud.

\section{Riesgos para la salud}

Aunque las modernas muelas abrasivas no entrañan en sí mismas el grave riesgo de silicosis asociado en el pasado con las muelas de piedra arenisca, puede desprenderse polvo silíceo altamente peligroso de los materiales que se rectifican, por ejemplo, piezas de fundición con arena. Ciertas muelas aglutinadas con resina pueden contener materiales de relleno que crean un polvo peligroso. Además, las resinas a base de formol pueden emitir formol durante el rectificado. En cualquier caso, el volumen de polvo producido al rectificar hace esencial una eficaz ventilación local por extracción. Es más difícil proporcionar este tipo de ventilación en el caso de muelas portátiles, aunque se ha conseguido algún éxito en este sentido mediante el uso de sistemas de captura de bajo volumen y alta velocidad. Debe evitarse el trabajo prolongado y proporcionarse equipo protector respiratorio en caso necesario. Se requiere también ventilación por extracción para la mayoría de las operaciones de lijado con banda, acabado y pulido, y otras similares. En el caso concreto del bruñido, el polvo textil combustible es causa de gran preocupación.

Debe proporcionarse ropa protectora, buenas instalaciones sanitarias y de aseo con duchas y es aconsejable una vigilancia médica, especialmente para los rectificadores de metales.

\section{- LUBRICANTES INDUSTRIALES, FLUIDOS DE MECANIZADO Y ACEITES PARA AUTOMOVILES}

\section{Richard S. Kraus}

La revolución industrial no hubiera sido posible sin el desarrollo de aceites industriales refinados derivados del petróleo, lubricantes, aceites de corte y grasas. Antes de que se descubriese, en el decenio de 1860, que era posible obtener un lubricante superior destilando petróleo crudo al vacío, la industria dependía de aceites naturales y grasas animales tales como el tocino, y del aceite de ballena para la lubricación de piezas móviles. Estos aceites y productos animales eran especialmente susceptibles de fusión, oxidación y descomposición por exposición al calor y a la humedad producidos por las máquinas de vapor que impulsaban la mayoría de los equipos industriales en aquel entonces. La evolución de productos refinados derivados del petróleo prosiguió ininterrumpidamente desde el primer lubricante, que se utilizó para curtir cuero, hasta los modernos aceites y grasas sintéticos que tienen mayor vida útil, cualidades lubricantes superiores y mejor resistencia a los cambios bajo temperaturas y condiciones climáticas variables.

\section{Lubricantes industriales}

Todas las piezas móviles de maquinaria y equipos requieren lubricación. Aunque ésta puede proporcionarse con materiales secos como el Teflón o el grafito, que se utilizan en piezas tales como cojinetes de motores eléctricos pequeños, los aceites y grasas son los lubricantes empleados con más frecuencia. A medida que aumenta la complejidad de la maquinaria se endurecen los requisitos exigidos a los lubricantes y aceites de procesado de metales. Actualmente, los aceites lubricantes van desde los muy fluidos y transparentes utilizados para lubricar instrumentos delicados, hasta los aceites densos, de aspecto parecido al alquitrán, que se emplean para lubricar engranajes grandes como los de las acerías. Se utilizan aceites con requisitos muy específicos en los sistemas hidráulicos y para lubricar grandes máquinas herramienta de control numérico por ordenador tales como las que se emplean en la industria aeroespacial para producir piezas de alta precisión, con tolerancias muy estrictas. Cuando se desea un lubricante de prolongada vida útil, como en los motores eléctricos sellados y lubricados de por vida, donde la prolongación de los intervalos entre cambios de aceite representa un considerable ahorro de costes, así como cuando existen amplias gamas de presión y temperatura, como en las aplicaciones aeroespaciales, o cuando es caro y difícil renovar el lubricante, se utilizan aceites, fluidos y grasas sintéticos, o mezclas de aceites sintéticos y derivados del petróleo.

\section{Aceites industriales}

Los aceites industriales, tales como los aceites lubricantes para ejes y piezas similares, lubricantes para engranajes, aceites hidráulicos y para turbinas, y aceites para transmisiones, están diseñados para cumplir requisitos físicos y químicos específicos y funcionar sin cambios perceptibles durante largos períodos y bajo condiciones variables. Los lubricantes para uso aeroespacial deben cumplir condiciones totalmente nuevas, como limpieza, durabilidad, resistencia a la radiación cósmica y aptitud para funcionar a temperaturas extremadamente altas y bajas, en ausencia de gravedad y en el vacío.

Las transmisiones, turbinas y sistemas hidráulicos contienen fluidos que transfieren fuerza o potencia, depósitos para contener esos fluidos, bombas para impulsarlos de un lugar a otro y equipos auxiliares tales como válvulas, tuberías, radiadores y filtros. Los sistemas hidráulicos, transmisiones y turbinas requieren fluidos de viscosidades específicas y gran estabilidad química para poder funcionar con suavidad y transferir la potencia de forma controlada. Entre las características que deben reunir los buenos aceites hidráulicos y de turbinas están un elevado índice de viscosidad, gran estabilidad térmica, larga vida útil en sistemas circulantes, resistencia a la formación de sedimentos, alta lubricidad, propiedades antiespumantes, protección contra el óxido y buena desemulsionabilidad.

Los lubricantes para engranajes están estudiados para formar películas tenaces y resistentes que proporcionen la necesaria lubricación entre engranajes bajo presiones extremas. Las características de estos aceites comprenden buena estabilidad química, desemulsionabilidad y resistencia al aumento de viscosidad y a la formación de sedimentos. Los aceites para ejes son ligeros, extremadamente limpios y transparentes, con aditivos para mejorar la lubricidad. Las características más importantes de los aceites que se utilizan para lubricar dos superficies planas deslizantes cuando están sometidas a una presión elevada y se mueven a baja velocidad, son la lubricidad y la adherencia para ofrecer resistencia a la expulsión por aplastamiento y a la presión extrema.

Los aceites para cilindros y compresores tienen las características combinadas de los aceites industriales y para automóviles. Deben resistir la acumulación de sedimentos, actuar como agentes de transferencia térmica (cilindros de motores de combustión interna), proporcionar lubricación a los cilindros y pistones, crear estanqueidad para resistir la presión producida por el retorno de gases, ser química y térmicamente estables (en especial el aceite para depresores y bombas de vacío), tener un alto índice de viscosidad y resistir el lavado por agua (cilindros de vapor) y la detergencia. 


\section{Aceites para motores de automóviles}

Los fabricantes de motores de combustión interna y algunas organizaciones, como la Society of Automotive Engineers (SAE) en Estados Unidos y Canadá, han establecido criterios de rendimiento específicos para los aceites destinados a motores de automóviles. Los aceites para motores de automóviles de gasolina y diesel son sometidos a una serie de ensayos de rendimiento para de terminar su estabilidad química y térmica, resistencia a la corrosión, viscosidad, protección contra el desgaste, lubricidad, detergencia y rendimiento a alta y baja temperatura. Después se clasifican conforme a un sistema de códigos que permite a los consumidores determinar su idoneidad para servicio pesado y para diferentes temperaturas y gamas de viscosidad.

Los aceites para motores de automóviles, transmisiones y cajas de cambios se diseñan con altos índices de viscosidad para que soporten los cambios de viscosidad que acompañan a los cambios de temperatura. Los aceites para motores de automóviles están especialmente formulados para resistir la descomposición bajo altas temperaturas al lubricar motores de combustión interna. Los aceites para motores de combustión interna no deben ser demasiado densos, a fin de que puedan lubricar las piezas móviles internas cuando el motor arranca en tiempo frío, pero tampoco deben perder viscosidad a medida que el motor se alienta durante su funcionamiento. Deben poder soportar la acumulación de carbonilla en las válvulas, segmentos y cilindros, y la formación de ácidos o depósitos corrosivos a causa de la humedad. Los aceites para motores de automóviles contienen detergentes diseñados para mantener en suspensión las partículas de carbonilla y las partículas metálicas producidas por el desgaste, para que puedan eliminarse por filtración al circular el aceite y no se acumulen en las piezas internas del motor con lo que éstas resultarían dañadas.

\section{Fluidos de corte}

Los tres tipos de fluidos de corte utilizados en la industria son aceites minerales, aceites solubles y fluidos sintéticos. Los aceites de corte son normalmente una mezcla de aceites minerales de alta calidad y estabilidad, y diversas viscosidades, con aditivos que les confieren características específicas según el tipo de material que se mecaniza y del trabajo que se ha de realizar. Los fluidos de corte solubles en agua son aceites minerales (o sintéticos) que contienen emulsionantes y aditivos especiales, como antiespumantes, anticorrosivos, detergentes, bactericidas y germicidas. Antes de utilizarlos, se diluyen con agua en diversas proporciones. Los fluidos de corte sintéticos, en lugar de emulsiones, son disoluciones de fluidos no derivados del petróleo, aditivos y agua, y algunos de ellos son difícilmente inflamables por ser éste un requisito para mecanizar determinados metales. Los fluidos semisintéticos contienen del 10 al $15 \%$ de aceite mineral. Algunos fluidos especiales tienen a la vez características de aceite lubricante y de fluido de corte debido a la tendencia de estos líquidos a sufrir fugas y entremezclarse en algunas máquinas herramientas tales como las máquinas de roscar automáticas de varios ejes.

Las características deseadas de los fluidos de corte dependen de la composición del metal que se trabaja, de la herramienta que se utiliza y del tipo de operación de corte, cepillado o conformación que se lleva a cabo. Los fluidos de corte mejoran y favorecen el proceso de mecanizado mediante su refrigeración y lubricación (es decir, protegen el filo de la herramienta de corte). Por ejemplo, cuando se trabaja un metal blando que produce un elevado calentamiento, el criterio más importante es la refrigeración. Esta mejora cuando se utiliza un aceite ligero (por ejemplo keroseno) o un fluido de corte de base acuosa. El embotamiento del filo de las herramientas de corte se controla con aditivos antisoldadura o antidesgaste tales como azufre, cloro o compuestos de fósforo. La lubricidad, que es importante cuando se trabaja acero para vencer la abrasividad del sulfuro de hierro, la proporcionan grasas sintéticas y animales o aditivos de aceite de ballena sulfurados.

\section{Otros aceites de mecanizado y de proceso}

Los fluidos de rectificado están estudiados para proporcionar refrigeración y evitar la acumulación de limaduras metálicas en las muelas. Sus características son estabilidad térmica y química, protección contra el óxido (fluidos solubles), prevención de formación de depósitos de goma por evaporación y un punto de inflamabilidad seguro para el trabajo que se realiza.

Los aceites de temple, que requieren una gran estabilidad, se emplean en el tratamiento de metales para controlar los cambios que experimenta la estructura molecular del acero al enfriarse. El temple en aceite ligero se utiliza para cementar piezas de acero pequeñas y baratas. Para producir aceros para máquinas herramienta, que son bastante duros exteriormente y tienen menor resistencia interna, se efectúa un temple más lento. Para el tratamiento de aceros aleados y aceros ricos en carbono se utiliza un aceite de temple discontinuo o polifásico.

Los aceites de laminación son aceites minerales o solubles de fórmula especialmente estudiada para lubricar y dar un acabado suave al metal, en especial al aluminio, cobre y latón, mientras pasa por los trenes de laminación en caliente o en frío. Los aceites de desmoldeo se emplean para recubrir los moldes y troqueles a fin de facilitar la extracción de las piezas metálicas conformadas. Los aceites curtientes todavía se utilizan en la industria de fabricación de fieltro y cuero. Los aceites para transformadores son fluidos dieléctricos de fórmula especial que se utilizan en transformadores y grandes disyuntores e interruptores eléctricos.

Los aceites de transferencia térmica se usan en sistemas abiertos o cerrados y pueden durar hasta 15 años en servicio. Sus características principales son una buena estabilidad térmica, ya que los sistemas funcionan a temperaturas de 150 a $315^{\circ} \mathrm{C}$, estabilidad frente a la oxidación y alta temperatura de inflamabilidad. Estos aceites son normalmente demasiado viscosos para ser bombeados a temperatura ambiente y hay que calentarlos para darles la fluidez necesaria.

Los disolventes derivados del petróleo se utilizan para limpiar piezas mediante rociado, lavado o inmersión. Los disolventes eliminan el aceite y emulsionan la suciedad y las partículas metálicas. Los aceites anticorrosivos pueden ser de base disolvente o acuosa. Se aplican a los rollos de chapa de acero inoxidable, cojinetes y otros componentes mediante inmersión o rociado, y dejan sobre la superficie del metal una película polarizada o de parafina que la protege de las huellas de dedos y la oxidación, al tiempo que repele el agua.

\section{Grasas}

Las grasas son mezclas de líquidos, espesantes y aditivos utilizadas para lubricar piezas y equipos que no pueden hacerse estancos para que retengan el aceite o son difícilmente accesibles, y cuando las fugas o salpicaduras de lubricantes líquidos podrían contaminar productos o crear riesgos. Tienen un amplio campo de aplicaciones y requisitos de rendimiento, desde la lubricación de cojinetes en motores de aviones de reacción a temperaturas bajo hasta la de engranajes de laminadores en caliente, y resisten el lavado con ácidos o agua así como la fricción continua producida en los rodamientos de rodillos de las ruedas de los vagones ferroviarios.

La grasa se hace mezclando jabones metálicos (sales de ácidos grasos de cadena larga) y aceite lubricante a temperaturas de 205 a $315^{\circ} \mathrm{C}$. En las grasas sintéticas se utilizan diésteres, ésteres de silicona o fosfóricos y glicoles de polialquileno como líquidos. Las características de la grasa dependen en gran 
medida del líquido, el elemento metálico (por ej., calcio, sodio, aluminio, litio, etc.) del jabón y los aditivos utilizados para mejorar el rendimiento y la estabilidad, y reducir la fricción. Entre estos últimos están los aditivos para presiones extremas, que recubren el metal con una fina capa de compuestos de azufre metálicos no corrosivos, naftenato de plomo o ditiofosfato de zinc, anticorrosivos, antioxidantes, ácidos grasos para aumentar la lubricidad, aditivos para dar adherencia, colorantes de identificación e inhibidores del agua. Algunas grasas contienen cargas de grafito o molibdeno que recubren las piezas metálicas y les proporcionan lubricación cuando la grasa se ha agotado o descompuesto.

\section{Aditivos para lubricantes industriales, grasas y aceites de motores de automóviles}

Además de materias primas lubricantes de alta calidad, con estabilidad química y térmica y altos índices de viscosidad, es necesario utilizar aditivos para mejorar el fluido y proporcionar las características específicas requeridas a los lubricantes industriales, fluidos de corte, grasas y aceites para motores de automóviles. Entre los aditivos más utilizados están los siguientes:

- Antioxidantes. Los inhibidores de la oxidación, tales como el 2-6 dietil butil terciario, paracresol y fenil naftilamina, reducen la velocidad de deterioro del aceite al romper las moléculas de cadena larga que se forman por exposición al oxígeno. Estos inhibidores se utilizan para recubrir metales como el cobre, zinc y plomo, y evitar su contacto con el aceite a fin de que no actúen como catalizadores, ya que acelerarían la oxidación y formarían ácidos que atacan a otros metales.

- Antiespumantes. Los despumantes, tales como las siliconas y los poliorganosiloxanos, se utilizan en aceites hidráulicos, aceites para engranajes, lubricantes de transmisiones y aceites para turbinas, con el fin de reducir la tensión superficial y eliminar el aire introducido en el aceite por las bombas y compresores, para mantener constante la presión hidráulica y evitar la cavitación.

- Anticorrosivos. Los aditivos anticorrosión, tales como el naftenato de plomo y el sulfonato de sodio, se emplean para evitar que se forme óxido sobre las piezas y sistemas metálicos cuando el aceite circulante se ha contaminado con agua o por la entrada de aire húmedo en los depósitos del sistema al enfriarse éstos cuando el equipo o la maquinaria están parados.

- Aditivos antidesgaste. Los aditivos antidesgaste, como el tricresilfosfato, forman compuestos polares que son atraídos por las superficies metálicas y crean una barrera física protectora adicional en caso de que la película de aceite no sea suficiente.

- Correctores del indice de viscosidad. Ayudan a los aceites a resistir los efectos de los cambios de temperatura. Lamentablemente, su eficacia disminuye con el uso prolongado. Los aceites sintéticos se diseñan con índices de viscosidad muy elevados, lo que les permite conservar su estructura dentro de intervalos de temperatura más amplios y durante períodos de tiempo mucho más largos que los aceites minerales con aditivos correctores del índice de viscosidad.

- Desemulsionantes. Inhibidores del agua y compuestos especiales separan el agua del aceite e impiden la formación de gomas; contienen aceites parafínicos que proporcionan mayor lubricidad. Se utilizan cuando la maquinaria está sujeta a lavado por agua o donde hay mucha humedad, como en cilindros de vapor, compresores de aire y cajas de cambios contaminadas por fluidos de corte solubles.

- Colorantes. Los colorantes se emplean para ayudar a los usuarios a reconocer los distintos aceites utilizados con fines específicos, como lubricantes de transmisiones y aceites para engranajes, a fin de evitar su aplicación errónea.
- Aditivos contra presiones extremas. Los aditivos contra presiones extremas, tales como compuestos grasos sulfurados no corrosivos, ditiofosfato de zinc y naftenato de plomo, se emplean en aceites lubricantes de automóviles, engranajes y transmisiones para formar recubrimientos que protejan las superficies metálicas cuando la película de aceite protectora pierda espesor o sea expulsada por aplastamiento y no pueda evitar el contacto de metal contra metal.

- Detergentes. Los detergentes de metalsulfonatos y metalfenatos se utilizan para mantener en suspensión la suciedad, carbonilla y partículas metálicas producidas por desgaste en aceites hidráulicos y lubricantes de engranajes, motores y transmisiones. Estos contaminantes se eliminan normalmente mediante el paso del aceite por un filtro para evitar que continúen circulando por el sistema, donde podrían causar daños.

- Aditivos para crear adherencia. Los aditivos de adherencia se usan para que los aceites se adhieran a los cojinetes, cárteres de engranajes, grandes engranajes descubiertos en trenes de laminación y máquinas de construcción, y maquinaria aérea, ofreciendo de ese modo resistencia a las fugas. Su adherencia disminuye tras un uso prolongado.

- Emulsionantes. En los aceites solubles se utilizan ácidos y aceites grasos como emulsionantes para favorecer la formación de disoluciones con agua.

- Aditivos para lubricidad. Se emplea grasa animal, tocino, sebo, aceite de ballena y aceites vegetales para dar mayor untuosidad a los aceites de corte y a algunos aceites para engranajes.

- Bactericidas. Se añaden bactericidas y germicidas como fenol y aceite de pino a los aceites de corte solubles para prolongar su vida útil, mantener su estabilidad, reducir olores y prevenir la dermatitis.

\section{Fabricación de lubricantes industriales y aceites para automóviles}

Los lubricantes y aceites industriales, grasas, fluidos de corte y aceites para motores de automóviles se fabrican en instalaciones de mezcla y envasado denominadas "plantas de lubricantes" o "plantas de mezcla". Estas instalaciones pueden estar ubicadas en o junto a refinerías que producen materias primas para lubricantes, o hallarse a cierta distancia de aquéllas y recibir las materias primas en buques cisterna o barcazas, vagones cisterna o camiones cisterna. Las plantas de mezcla y envasado mezclan e incorporan aditivos a las materias primas de los aceites lubricantes para fabricar una amplia gama de productos acabados que después se envían a granel o en distintos envases.

Los procesos de mezcla y composición utilizados para fabricar lubricantes, fluidos y grasas dependen de la antigüedad y refinamiento de las instalaciones, del equipo disponible, de los tipos y fórmulas de los aditivos empleados y de la variedad y volumen de productos fabricados. El proceso puede consistir en la simple mezcla física de las materias primas y aditivos en una cuba utilizando mezcladoras, paletas o agitación por aire, o puede requerir la aportación de calor auxiliar por medio de baterías eléctricas o de vapor para facilitar la disolución e incorporación de los aditivos. Otros fluidos y lubricantes industriales se producen automáticamente mezclando las materias primas y lodos premezclados de aditivos y aceite mediante sistemas de colectores. La grasa puede fabricarse por lotes o mediante un proceso continuo. Las plantas de lubricantes pueden preparar sus propios aditivos a partir de productos químicos o comprar aditivos ya preparados a empresas especializadas; una misma planta puede utilizar ambos métodos. Cuando las plantas de lubricantes fabrican sus propios aditivos y combinados de aditivos, pueden tener que utilizar altas temperaturas y presiones además de reacciones químicas y agitación física para combinar los productos químicos y materiales. 
Una vez producidos, los fluidos y lubricantes pueden permanecer en las cubas de mezcla o almacenarse en depósitos para que los aditivos se mantengan en suspensión o disolución, para tener tiempo de probar el producto a fin de determinar si cumple las especificaciones de calidad y los requisitos de homologación, y para que las temperaturas de proceso vuelvan al nivel del ambiente antes del envasado y expedición de los productos. Una vez concluidas las pruebas, se da salida a los productos acabados para su envío a granel o su envasado en recipientes.

Los productos acabados se envían a granel en vagones o camiones cisterna directamente a los consumidores, distribuidores o plantas externas de envasado. También se envían a los consumidores y distribuidores en vagones o camiones de transporte convencionales envasados en diversos tipos de recipientes, a saber:

- Contenedores intermedios de transporte a granel, metálicos, de plástico o mixtos de metal y plástico o metal y fibra, de 227 l a unos 2.840 l de capacidad, que se expiden como unidades individuales en palets incorporados o no, apilados a 1 ó 2 alturas.

- Bidones metálicos, de fibra o de plástico con una capacidad de 208 l, 114 l ó 180 kg; se envían normalmente en grupos de 4 por palet.

- Tambores de metal o plástico con una capacidad de 601 ó $54 \mathrm{~kg}$, y bidones pequeños de metal o plástico de $19 \mathrm{l}$ ó $16 \mathrm{~kg}$; se apilan sobre palets y se flejan o envuelven en retractilado para mantener la estabilidad.

- Latas o bombonas de plástico de 81 ó 4 l de capacidad; botellas de plástico o de fibra y latas de 11 , y cartuchos de grasa de $2 \mathrm{~kg}$; se embalan en cajas de cartón que se apilan sobre palets y se flejan o envuelven en retractilado para su envío.

Algunas plantas de mezcla y envasado envían palets de productos mixtos y recipientes y envases de tamaños mixtos directamente a pequeños consumidores. Por ejemplo, un envío de un solo palet a una estación de servicio podría estar formado por 1 tambor de lubricante para transmisiones, 2 barriles pequeños de grasa, 8 cajas de envases de aceite para motores de automóviles y 4 bidones pequeños de lubricante para engranajes.

\section{Calidad de los productos}

La calidad de los productos lubricantes es importante para el correcto funcionamiento de las máquinas y equipos y para producir piezas y materiales de calidad. Las plantas de mezcla y envasado fabrican productos acabados derivados del petróleo bajo estrictas especificaciones y requisitos de calidad. Los usuarios deben mantener el nivel de calidad estableciendo prácticas seguras para la manipulación, almacenamiento, dispensación y trasiego de lubricantes desde sus envases o depósitos originales al equipo surtidor y al punto de aplicación de la máquina o el equipo a lubricar o el sistema a rellenar. Algunos complejos industriales han instalado sistemas centralizados de dispensación, lubricación e hidráulicos que reducen al mínimo la contaminación y la exposición. Los aceites industriales, lubricantes, aceites de corte y grasas se deterioran por contaminación con agua o humedad, exposición a temperaturas excesivamente altas o bajas, mezcla inadvertida con otros productos y almacenamiento a largo plazo que permite que los aditivos se separen o sufran alteraciones químicas.

\section{Salud y seguridad}

Puesto que los productos acabados industriales y para automóviles son utilizados y manipulados por consumidores, es necesario que estén relativamente exentos de riesgos. Existe la posibilidad de que se produzcan exposiciones peligrosas al mezclar y componer productos, manipular aditivos, utilizar fluidos de corte y trabajar con sistemas de lubricación por niebla de aceite.

El capítulo Refinerías de petróleo y gas natural de esta Enciclopedia proporciona información relativa a los riesgos inherentes a las instalaciones auxiliares de las plantas de mezcla y envasado, tales como salas de calderas, laboratorios, oficinas, separadores de aceite y agua e instalaciones de tratamiento de residuos, muelles marítimos, almacenamiento en depósitos, operaciones de almacén, sistemas de carga de vagones y camiones cisterna, e instalaciones de carga y descarga de vagones y camiones de transporte de envases.

\section{Seguridad}

La fabricación de aditivos y lodos, composición y mezcla de lotes, y operaciones de mezcla durante el proceso requieren estrictos controles para mantener la calidad deseada del producto y, junto con el uso de equipos de protección personal, reducir al mínimo la exposición a productos químicos y materiales potencialmente peligrosos, así como el contacto con superficies calientes y vapor. Los tambores y otros recipientes de aditivos deben almacenarse de forma segura y mantenerse herméticamente cerrados hasta el momento de utilizarlos. Los aditivos envasados en tambores y sacos han de manejarse correctamente para evitar tirones musculares. Los productos químicos peligrosos deberán almacenarse correctamente, y no deben guardarse productos químicos incompatibles donde puedan mezclarse entre sí. Entre las precauciones que deben adoptarse al trabajar con maquinaria de llenado y envasado están el llevar guantes y evitar pillarse los dedos en los dispositivos de engatillado de tapas de barriles y bidones. No deberán retirarse, desconectarse ni puentearse defensas o sistemas de protección de las máquinas con el fin de acelerar el trabajo. Los contenedores y tambores intermedios de envasado a granel deben inspeccionarse antes de llenarlos para asegurarse de que están limpios y son adecuados.

Se establecerá un sistema de autorizaciones de entrada en espacios confinados para la entrada en depósitos de almacenamiento y cubas de mezcla con fines de limpieza, inspección, mantenimiento o reparación. Igualmente deberá establecerse y ponerse en práctica un procedimiento de bloqueo y etiquetado antes de trabajar en maquinaria de envasado, cubas de mezcla con mezcladores, cintas transportadoras, paletizadoras y demás equipos con piezas móviles.

Se retirarán de la zona de almacenamiento los tambores y contenedores con fugas y se limpiarán los derrames para evitar resbalones y caídas. El reciclaje, quema y evacuación de lubricantes, aceites para motores de automóviles y fluidos de corte residuales, derramados y usados, deberán realizarse de acuerdo con las reglas gubernamentales y los procedimientos establecidos por la empresa. Los trabajadores utilizarán equipos de protección personal adecuados al limpiar derrames y manipular productos usados o residuales. El aceite de motor, fluidos de corte o lubricantes industriales drenados que puedan estar contaminados con gasolina y disolventes inflamables, se guardarán en lugar seguro, lejos de cualquier fuente de ignición, hasta que puedan evacuarse correctamente.

\section{Protección contra incendios}

Aunque la probabilidad de incendio es menor en las operaciones de mezcla y composición de lubricantes industriales y para automóviles que en los procesos de refino, hay que adoptar precauciones al fabricar aceites y grasas de mecanizado debido a las altas temperaturas de mezcla y composición y a los bajos puntos de inflamabilidad de los productos que se utilizan. Se tomarán precauciones especiales para evitar incendios cuando se dispensen productos o se llenen recipientes a temperaturas 
superiores a sus puntos de inflamabilidad. Al trasvasar líquidos inflamables de un recipiente a otro deberán utilizarse técnicas adecuadas de conexión y puesta a tierra para prevenir la acumulación y descarga de energía electrostática. Los motores eléctricos y equipos portátiles deberán tener la homologación adecuada para los riesgos existentes en la zona en que se instalen o utilicen.

Existe riesgo de incendio si la fuga de un producto o la emisión de vapores en las zonas de mezcla de lubricantes y procesado o almacenamiento de grasas entra en contacto con una fuente de ignición. Deberá considerarse el establecimiento y puesta en práctica de un sistema de autorizaciones para trabajos en caliente con el fin de evitar incendios en las instalaciones de mezcla y envasado. Los depósitos de almacenamiento instalados en el interior de edificios se construirán, ventilarán y protegerán de acuerdo con los requisitos gubernamentales y las normas de la empresa. Los productos apilados o almacenados en bastidores no deberán entorpecer el uso de los sistemas de protección contra incendios, las puertas de seguridad en caso de incendio ni las rutas de salida.

El almacenamiento de productos acabados, tanto a granel como en contenedores y otros envases, deberá efectuarse de acuerdo con las prácticas reconocidas y las reglamentaciones sobre prevención de incendios. Por ejemplo, los líquidos y aditivos inflamables en forma de soluciones de líquidos inflamables, pueden almacenarse en edificios externos o en locales de almacenamiento separados interiores o anexos, especialmente diseñados al efecto. Muchos aditivos se almacenan en salas caldeadas (38 a $65^{\circ} \mathrm{C}$ ) o calientes (a más de $65^{\circ} \mathrm{C}$ ) para mantener los ingredientes en suspensión, reducir la viscosidad de los productos densos o facilitar la mezcla y composición. Estos locales de almacenamiento deberán cumplir los requisitos de clasificación eléctrica, drenaje, extracción y ventilación contra explosiones, en especial cuando se almacenen o dispensen líquidos inflamables o combustibles a temperaturas superiores a sus puntos de inflamabilidad.

\section{Salud}

Al realizar operaciones de mezcla, muestreo y composición, deberá considerarse el empleo de equipo de protección personal y respiratoria para evitar exposiciones al calor, vapor, polvo, neblinas, gases, humos, sales metálicas, productos químicos y aditivos. Cuando se realicen actividades de inspección y mantenimiento, al tomar muestras y manipular hidrocarburos y aditivos durante las operaciones de producción y envasado, así como al limpiar derrames y evacuar emisiones gaseosas, puede ser necesario observar prácticas seguras de trabajo y una higiene adecuada, y utilizar protección personal apropiada para evitar la exposición a neblinas de aceite, humos y gases, aditivos, ruido y calor, en concreto:

- Para trabajos de tipo general deberá usarse calzado de trabajo con suela antideslizante o resistente al aceite, y cuando exista riesgo de lesiones en los pies por caída o rodadura de objetos o equipos se utilizará calzado de seguridad homologado con puntera protectora y suela antideslizante o resistente al aceite.

- Para exposiciones peligrosas a productos químicos, polvo o vapor, puede ser necesario usar gafas de montura ajustada y protección respiratoria.

- Al manipular sustancias químicas peligrosas, aditivos y disoluciones cáusticas, y al limpiar derrames de estos productos, deberán usarse guantes, mandiles y calzado impermeables, pantallas faciales y gafas de seguridad resistentes a los productos químicos.

- Al trabajar en pozos u otras zonas con riesgo de lesiones craneoencefálicas, puede ser necesario utilizar protección para la cabeza.
- Deberá proporcionarse un fácil acceso para la adecuada limpieza e instalaciones de secado para controlar derrames y salpicaduras.

El aceite es una causa común de dermatitis, afección que puede controlarse mediante el uso de equipo de protección y prácticas adecuadas de higiene personal. Debe evitarse el contacto directo de la piel con cualquier tipo de grasa o lubricante producido. Los aceites ligeros como el keroseno, los aceites de base disolvente y los lubricantes para ejes desgrasan la piel y causan sarpullidos. Los productos densos, como los aceites para engranajes y las grasas, obstruyen los poros de la piel, lo que provoca foliculitis.

Los riesgos para la salud derivados de la contaminación microbiana del aceite pueden resumirse como sigue:

- Las afecciones de la piel preexistentes pueden agravarse.

- Los aerosoles lubricantes de tamaño respirable pueden causar enfermedades respiratorias.

- Los organismos pueden modificar la composición del producto y hacer que resulte directamente nocivo.

- Pueden introducirse bacterias dañinas procedentes de animales, aves o personas.

Los operarios pueden sufrir dermatitis de contacto cuando están expuestos a fluidos de corte durante la producción, el trabajo o el mantenimiento y al limpiarse las manos cubiertas de aceite con trapos que contienen diminutas partículas metálicas. El metal produce pequeñas laceraciones en la piel que pueden infectarse. Los fluidos de corte de base acuosa que manchan la piel y la ropa pueden contener bacterias y causar infecciones, y los emulsionantes pueden disolver las grasas de la piel. La foliculitis por aceite se produce a causa de la exposición prolongada a fluidos de corte de base oleosa, por ejemplo por llevar ropa empapada en aceite. Los trabajadores deberán quitarse la ropa empapada en aceite y no ponérsela de nuevo hasta que haya sido lavada. También puede ocasionar dermatitis el uso de jabones, detergentes o disolventes para limpiarse la piel. El mejor modo de controlar la dermatitis es observar una higiene adecuada y reducir al mínimo la exposición. Si la dermatitis persiste, se deberá consultar al médico.

En el extenso estudio realizado como base para la elaboración de su documento de criterios, el National Institute for Occupational Safety and Health (NIOSH) de Estados Unidos descubrió una relación entre la exposición a fluidos de mecanizado y el riesgo de padecer cáncer de diversos órganos, como estómago, páncreas, laringe y recto (NIOSH 1996). Aún no se ha determinado cuáles son las fórmulas específicas responsables del elevado riesgo de cáncer.

La exposición profesional a neblinas y aerosoles de aceites se asocia a diversos efectos respiratorios no malignos, como neumonía lipoide, asma, irritación aguda de las vías respiratorias, bronquitis crónica y deterioro de la función pulmonar (NIOSH 1996).

Los fluidos de mecanizado se contaminan fácilmente con bacterias y hongos. Pueden afectar a la piel y, cuando se inhalan en forma de aerosoles contaminados, pueden tener efectos sistémicos.

Para eliminar componentes aromáticos de los lubricantes industriales se utilizan procesos de refinería tales como el hidroacabado y el tratamiento con ácidos, y se ha restringido el uso de materias primas de base nafténica con el fin de reducir al mínimo la carcinogenicidad. También los aditivos introducidos en la mezcla y la composición pueden crear un potencial de riesgo para la salud. Las exposiciones a compuestos clorados y compuestos de plomo, como los que se utilizan en algunos lubricantes y grasas para engranajes, causan irritación de la piel 
y pueden ser potencialmente peligrosos. Se han dado casos de parálisis nerviosas provocadas por triortocresilfosfato al utilizar accidentalmente aceite lubricante para cocinar. Los aceites sintéticos están formados principalmente por nitrito sódico, trietanolamina y aditivos. La trietanolamina comercial contiene dietanolamina, que puede reaccionar con el nitrito sódico y formar un compuesto cancerígeno relativamente débil, la N-nitrosodietanolamina, lo que puede constituir un riesgo. Los lubricantes semisintéticos y los aditivos incluidos en su fórmula presentan los riesgos de ambos productos.

La información relativa a la seguridad de los lubricantes, aceites y grasas es importante tanto para los empleados de los fabricantes de estos productos como para los de sus usuarios. Los fabricantes deberían tener a su disposición fichas técnicas de seguridad (FTS) u otra información sobre todos los aditivos y materias primas utilizados en la mezcla y composición de los productos. Muchas empresas han realizado pruebas epidemiológicas y toxicológicas para determinar los niveles de riesgo de sus productos en relación con cualquier efecto agudo o crónico para la salud. Debería facilitarse esta información a los trabajadores y usuarios mediante etiquetas de advertencia y documentación informativa sobre seguridad de los productos.

\section{Metales, TRATAMIENTO DE SUPERFICIE}

\section{J.G.Jones, J.R. Bevan, J.A. Catton, A. Zober, N. Fish, K.M. Morse, G. Thomas, M.A. El Kadeem y Philip A. Platcow*}

Existe una gran variedad de técnicas de acabado de la superficie de los productos metálicos que se utilizan para que éstos ofrezcan resistencia a la corrosión, ajusten mejor y tengan mejor aspecto (véase la Tabla 82.7). Algunos productos se someten a una secuencia de varias de estas técnicas. En este artículo se describen brevemente algunas de las que se utilizan con más frecuencia.

Para poder aplicar cualquiera de estas técnicas primero es necesario limpiar a fondo los productos. Se utilizan varios métodos de limpieza, individualmente o en secuencia, como por ejemplo esmerilado, cepillado y pulido mecánico (que producen polvo metálico o de óxido - el polvo de aluminio puede ser explosivo), desengrasado al vapor, lavado con disolventes orgánicos de la grasa, limpieza en baños de disoluciones ácidas o alcalinas concentradas y desengrasado electrolítico. Este último consiste en la inmersión en baños que contienen cianuro y un álcali concentrado y en los que el hidrógeno u oxígeno formados electrolíticamente eliminan la grasa, dejando superficies metálicas en bruto libres de óxidos y grasa. La limpieza va seguida de un lavado y secado adecuados del producto.

El diseño apropiado del equipo y un sistema eficaz de ventilación local por extracción reducen el riesgo en parte. A los trabajadores expuestos a salpicaduras deberán proporcionárseles gafas de seguridad o pantallas para los ojos y guantes, mandiles y ropa de protección. Deberá haber cerca duchas de emergencia y fuentes para lavados oculares en perfecto estado de funcionamiento, y los derrames y salpicaduras deberán eliminarse rápidamente mediante lavados. Para utilizar equipos electrolíticos los guantes y el calzado no deberán ser conductores de la electricidad, y deberán adoptarse otras precauciones eléctricas normales, como la instalación de interruptores de fugas a tierra y procedimientos de bloqueo y etiquetado.

* Adaptado de la $3^{\text {a }}$ edición, Enciclopedia de salud y seguridad en el trabajo.

\section{Procesos de tratamiento}

\section{Pulido electrolítico}

El pulido electrolítico se utiliza para producir superficies de aspecto y reflectividad mejorados, eliminar el exceso de metal con objeto de obtener las dimensiones exactas necesarias y preparar la superficie para inspección de imperfecciones. El proceso consiste en la dilución anódica preferente de los puntos altos de la superficie después del desengrasado al vapor y la limpieza alcalina en caliente. Como soluciones electrolíticas se utilizan normalmente ácidos, por lo que se requiere un lavado adecuado a continuación.

\section{Recubrimiento electrolítico}

El recubrimiento electrolítico es un proceso químico o electroquímico consistente en aplicar una capa metálica al producto, por ejemplo níquel para protegerlo contra la corrosión, cromo duro para mejorar las propiedades de la superficie o plata y oro para embellecerla. En ocasiones se utilizan materiales no metálicos. El producto, conectado como cátodo, y un ánodo del metal a depositar se sumergen en una disolución electrolítica (que puede ser ácida, alcalina o alcalina con sales de cianuro y complejos) y se conecta externamente a una fuente de corriente continua. Los cationes con carga positiva del ánodo metálico migran hacia el cátodo, donde son reducidos al metal y depositados en forma de capa delgada (véase la Figura 82.6). El proceso continúa hasta que el nuevo recubrimiento alcanza el espesor deseado; entonces se lava, seca y pule el producto.

$$
\text { Anodo: } \mathrm{Cu} \rightarrow \mathrm{Cu}^{+2}+2 \mathrm{e}^{-} \text {; Cátodo: } \mathrm{Cu}^{2+}+2 \mathrm{e}^{-} \rightarrow \mathrm{Cu}
$$

En la electroconformación, un proceso estrechamente relacionado con el recubrimiento electrolítico, objetos moldeados, por ejemplo, en yeso o plástico, se hacen conductores mediante la aplicación de grafito y después se conectan como cátodo para que el metal se deposite sobre ellos.

En el anodizado, un proceso que ha adquirido creciente importancia en los últimos años, se conectan como ánodo productos de aluminio (también se utilizan titanio y otros metales) y se

Figura 82.6 • Esquema del recubrimiento electrolítico.

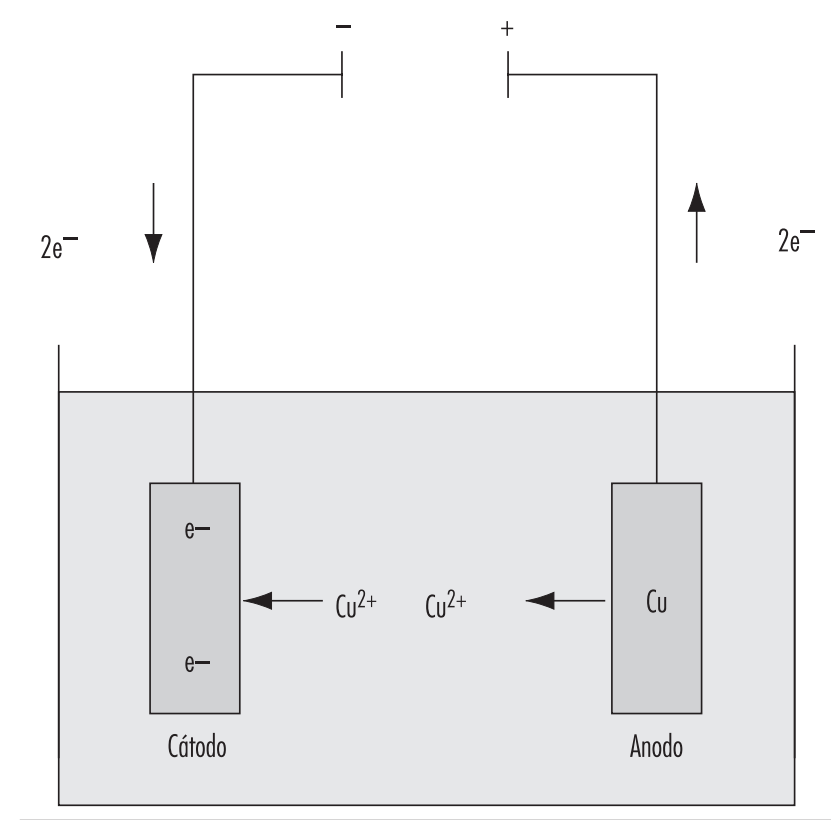


Tabla 82.7 • Resumen de los riesgos inherentes a los distintos métodos de tratamiento de metales.

\begin{tabular}{ll}
$\begin{array}{l}\text { Método de tratamiento } \\
\text { de metales }\end{array}$ & Riesgos \\
\hline Pulido electrolítico & Quemaduras e irritación por productos químicos cáusticos y corrosivos \\
Recubrimiento electrolítico & $\begin{array}{l}\text { Exposición a cromo y níquel potencialmente cancerígenos; } \\
\text { exposición a cianuros; quemaduras e irritación por productos } \\
\text { químicos cáusticos y corrosivos; sacudidas eléctricas; el proceso } \\
\text { puede ser en fase húmeda, con el consiguiente riesgo de resbalones } \\
\text { y caídas; producción de polvo potencialmente explosivo; riesgos } \\
\text { ergonómicos }\end{array}$
\end{tabular}

Esmaltes y vidriados

Riesgos físicos por esmeriladoras, transportadores, molinos; riesgo de quemaduras por líquidos y equipos a altas temperaturas; exposición a polvos que pueden causar cáncer de pulmón

Mordentado

Galvanizado

Termotratamiento

Metalización

Fosfatado

Recubrimiento con plásticos

Imprimación

Exposición a ácido fluorhídrico; quemaduras e irritación por productos químicos cáusticos y corrosivos; riesgo de quemaduras por líquidos y equipos a altas temperaturas

Riesgo de quemaduras por líquidos, metales y equipos a altas temperaturas; quemaduras e irritación por productos químicos cáusticos y corrosivos; fiebre por vapores de metal; posible exposición al plomo

Riesgo de quemaduras por líquidos, metales y equipos a altas temperaturas; quemaduras e irritación por productos químicos cáusticos y corrosivos; posibles atmósferas explosivas de hidrógeno; posible exposición a monóxido de carbono; posible exposición a cianuros; riesgo de incendio por temple en aceite

Riesgo de quemaduras por metales y equipos a altas temperaturas; posibles atmósferas explosivas de polvo, acetileno; fiebre por vapores metálicos de zinc

Quemaduras e irritación por productos químicos cáusticos y corrosivos

Exposición a sensibilizantes químicos

Exposición a diversos disolventes potencialmente tóxicos e inflamables,

\section{Precauciones}

Usar equipo de protección personal adecuado. Instalar un sistema eficaz de ventilación por extracción.

Usar equipo de protección personal adecuado. Instalar un sistema eficaz de ventilación por extracción, normalmente ranurado, de tipo impelente-aspirante. Limpiar los derrames inmediatamente. Instalar pavimento antideslizante. Utilizar procedimientos y puestos de trabajo bien diseñados para evitar el estrés de origen ergonómico.

Instalar defensas adecuadas en las máquinas, incluyendo enclavamientos. Usar equipo de protección personal adecuado. Instalar un sistema eficaz de ventilación por extracción para evitar la exposición al polvo. Puede ser necesario instalar equipos de filtros APAE. exposición a sensibilizantes químicos, exposición a cromo potencialmente cancerígeno

Implantar un programa que evite la exposición al ácido fluorhídrico. Usar equipo de protección personal adecuado. Instalar un sistema eficaz de ventilación por extracción.

Usar equipo de protección personal adecuado. Instalar un sistema eficaz de ventilación por extracción. Implantar un programa de reducción/vigilancia de la exposición al plomo.

Usar equipo de protección personal adecuado. Instalar un sistema eficaz de ventilación por extracción. Colocar letreros advirtiendo de la presencia de equipos y superficies a altas temperaturas. Instalar sistemas para vigilar la concentración de monóxido de carbono. Instalar sistemas adecuados de lucha contra incendios.

Instalar sistemas adecuados de lucha contra incendios. Separar correctamente los productos químicos y los gases. Usar equipo de protección personal adecuado. Instalar un sistema eficaz de ventilación por extracción.

Usar equipo de protección personal adecuado. Instalar un sistema eficaz de ventilación por extracción.

Buscar alternativas a los sensibilizantes. Usar equipo de protección personal adecuado. Instalar un sistema eficaz de ventilación por extracción.

Buscar alternativas a los sensibilizantes. Usar equipo de protección personal adecuado. Instalar un sistema eficaz de ventilación por extracción. Separar correctamente los productos químicos y los gases.

sumergen en ácido sulfúrico diluido. Sin embargo, en lugar de formarse iones de aluminio positivos y de migrar para depositarse en el cátodo, se oxidan con los átomos de oxígeno liberados en el ánodo y se unen a éste formando una capa de óxido. Esta capa es disuelta en parte por la disolución de ácido sulfúrico, con lo que la superficie se hace porosa. A continuación, pueden depositarse en estos poros materiales coloreados o fotosensibles, como por ejemplo en la fabricación de placas de características.

\section{Esmaltes y vidriados}

El esmalte vítreo o de porcelana se utiliza para aplicar un recubrimiento muy resistente al calor, las manchas y la corrosión a determinados metales, normalmente hierro o acero, en una gran variedad de productos, como bañeras, cocinas eléctricas y de gas, menaje de cocina, depósitos y recipientes de almacenamiento, y equipos eléctricos. También se utilizan esmaltes para la decoración de artículos de vidrio y cerámica, joyería y objetos de adorno. El uso especializado de esmaltes en polvo para la producción de prestigiosos objetos ornamentales como los de Cloisonné y Limoges, se conoce desde hace siglos. Los recubrimientos vitrificados se aplican a todo tipo de objetos de alfarería.

Para la fabricación de esmaltes y vidriados se utilizan, entre otros, los siguientes materiales:

- refractarios, como cuarzo, feldespato y arcilla

- fundentes, como borax (borato sódico decahidratado), ceniza de sosa (carbonato sódico anhidro), nitrato sódico, espato flúor, criolita, carbonato de bario, carbonato de magnesio, monóxido de plomo, tetraóxido de plomo y óxido de zinc

- colores, como óxidos de antimonio, cadmio, cobalto, hierro, níquel, manganeso, selenio, vanadio, uranio y titanio

- opacificantes, como óxidos de antimonio, titanio, estaño y circonio, y antimoniato sódico

- electrolitos, como bórax, ceniza de sosa, carbonato y sulfato de magnesio, nitrito sódico y aluminato sódico

- floculantes, como arcilla, gomas, alginato de amonio, bentonita y sílice coloidal. 
El primer paso en todos los tipos de esmaltado vítreo o vidriado consiste en la confección de la frita, o polvo de esmalte. Esto comprende la preparación de las materias primas, su fusión y la aplicación de la frita.

Tras una cuidadosa limpieza de los productos metálicos (por ejemplo, mediante chorro de granalla, baño decapante, desengrasado), puede aplicarse el esmalte por varios procedimientos:

- En el proceso en húmedo, se sumerge el objeto en el baño acuoso de esmalte, se extrae de él y se deja escurrir, o bien, en el "slushing", el baño de esmalte es más grueso y debe sacudirse para desprenderlo del objeto.

- En el proceso en seco el objeto, una vez imprimado, se calienta hasta la temperatura de esmaltado y después se espolvorea con esmalte tamizado. El esmalte se sinteriza sobre el objeto y cuando éste es devuelto al horno, se funde y adquiere una superficie suave.

- Cada vez se utiliza más la aplicación por pulverización, normalmente en una operación mecanizada para la que se requiere una cabina ventilada por extracción.

- Los esmaltes decorativos suelen aplicarse a mano, utilizando pinceles o utensilios similares.

- Los esmaltes vítreos para artículos de loza y porcelana se aplican generalmente por inmersión o pulverización. Aunque algunas operaciones de inmersión están empezando a mecanizarse, en la industria de la porcelana doméstica normalmente las piezas se sumergen a mano. Se sostiene el objeto en la mano, se le sumerge en una cuba de vidriado de grandes dimensiones, se elimina el exceso de esmalte con un giro de muñeca y se coloca el objeto en un secador. Para pulverizar el esmalte debe utilizarse una campana o cabina cerrada provista de un eficaz sistema de ventilación por extracción.

A continuación, los objetos preparados se "cuecen" en un horno o estufa, normalmente caldeados con gas.

\section{Mordentado}

El ataque químico produce un acabado mate o satinado. Casi siempre se utiliza como tratamiento previo al anodizado, lacado, recubrimiento de conversión, pulido o abrillantado químico. Normalmente se aplica al aluminio y al acero inoxidable, aunque también se utiliza para muchos otros metales.

El aluminio se ataca normalmente con disoluciones alcalinas que contienen diversas mezclas de hidróxido de sodio, hidróxido de potasio, fosfato trisódico y carbonato de sodio, junto con otros ingredientes para evitar la formación de escoria. En uno de los procesos más comunes se emplea hidróxido de sodio en una concentración de 10 a $40 \mathrm{~g} / \mathrm{l}$; la disolución se mantiene a una temperatura de 50 a $85^{\circ} \mathrm{C}$ y la inmersión puede durar hasta 10 minutos.

El ataque alcalino va normalmente precedido y seguido de un tratamiento en diversas mezclas de ácido clorhídrico, fluorhídrico, nítrico, fosfórico, crómico o sulfúrico. El tratamiento típico con ácido consiste en inmersiones de 15 a 60 segundos en una mezcla de tres partes en volumen de ácido nítrico y una parte en volumen de ácido fluorhídrico, mantenida a una temperatura de $20^{\circ} \mathrm{C}$.

\section{Galvanizado}

El galvanizado consiste en aplicar un recubrimiento de zinc a diversos productos de acero para protegerlos de la corrosión. Para que el recubrimiento se adhiera correctamente, el producto debe estar limpio y libre de óxido, lo que normalmente requiere varios procesos de limpieza, lavado, secado o recocido antes de que el producto entre en el baño de galvanizado. En el galvanizado por inmersión en baño caliente el producto se hace pasar por un baño de zinc en fusión; el galvanizado "en frío" es, en esencia, un recubrimiento electrolítico como el descrito anteriormente.

Normalmente, los productos fabricados se galvanizan en un proceso por lotes, mientras que para fleje, chapa o alambre de acero, se utiliza el método de banda continua. Puede emplearse fundente para mantener un grado satisfactorio de limpieza tanto del producto como del baño de zinc y facilitar el secado. A veces se utiliza un paso previo de aplicación de fundente seguido de un recubrimiento con fundente de cloruro de amonio en la superficie del baño de zinc, y otras se aplica únicamente este último recubrimiento. Para galvanizar tuberías se sumerge la tubería en una disolución caliente de cloruro amónico de zinc después de limpiarla y antes de introducirla en el baño de zinc fundido. Los fundentes se descomponen y forman gases irritantes de cloruro de hidrógeno y amoníaco, lo que hace necesario utilizar ventilación local por extracción.

Los distintos tipos de galvanizado continuo por inmersión en caliente difieren básicamente en la forma de limpiar el producto y en si la limpieza se realiza durante el proceso.

- limpieza por oxidación a la llama de los aceites de la superficie, con reducción subsiguiente en el horno y recocido dentro del proceso.

- limpieza electrolítica antes del recocido, dentro del proceso.

- limpieza en baño ácido y limpieza alcalina, utilizando un fundente antes de pasar al horno precalentado y recociendo en un horno antes del galvanizado

- limpieza en baño ácido y limpieza alcalina, eliminando el fundente y precalentando en un gas reductor (por ej., hidrógeno) antes del galvanizado.

En la cadena de galvanizado continuo de fleje o banda de acero de poco espesor, se omite el baño ácido y el uso de fundente; se utiliza limpieza alcalina y se mantiene limpia la superficie del fleje calentándola en una cámara o un horno bajo atmósfera reductora de hidrógeno hasta que pasa bajo la superficie del baño de zinc fundido.

El galvanizado continuo de alambre requiere fases de recocido, que normalmente se aplican en una cubeta de plomo fundido situada delante de los tanques de limpieza y galvanizado; enfriamiento al aire o con agua; baño decapante de ácido clorhídrico diluido caliente; lavado; aplicación de un fundente; secado, y después galvanizado en el baño de zinc fundido.

En el fondo del baño de zinc fundido se deposita una espuma constituida por una aleación de hierro y zinc, que hay que retirar periódicamente. Diversos tipos de materiales se hacen flotar en la superficie del baño de zinc para evitar la oxidación del zinc fundido. En los puntos de entrada y salida del alambre o el fleje que se galvanizan se requiere un despumado frecuente.

\section{Termotratamiento}

El termotratamiento, o proceso de calentamiento y enfriamiento de un metal en estado sólido, es generalmente una parte del proceso de los productos metálicos. Casi siempre implica un cambio en la estructura cristalina del metal, que se traduce en una modificación de sus propiedades (por ej., recocido para hacer el metal más maleable, calentamiento y lento enfriamiento para reducir la dureza, calentamiento y temple para aumentarla, calentamiento a baja temperatura para reducir al mínimo las tensiones internas).

\section{Recocido}

El recocido es un tratamiento térmico de "ablandamiento" muy utilizado para facilitar el trabajo en frío del metal, mejorar la mecanizabilidad, eliminar las tensiones del producto antes de que se utilice, etc. Consiste en calentar el metal hasta una temperatura específica, mantenerlo a esa temperatura durante un 
intervalo de tiempo preestablecido y permitir que se enfríe a una determinada velocidad. Se utilizan varias técnicas de recocido:

- Recocido azul, en el que se forma una capa de óxido azul en la superficie de aleaciones a base de hierro

- Recocido brillante, que se lleva a cabo en una atmósfera controlada para reducir al mínimo la oxidación superficial

- Recocido en horno cerrado o en caja cerrada, un método en el que tanto los metales férreos como los no férreos se calientan en un recipiente metálico herméticamente cerrado, con o sin empaquetadura, y después se dejan enfriar lentamente

- Recocido completo o de regeneración, el cual se realiza normalmente en una atmósfera protectora y tiene por objeto la obtención de la máxima ductilidad económicamente posible

- Maleabilización, una clase especial de recocido que se aplica a piezas de fundición de hierro para hacerlas maleables transformando el carbono combinado en el hierro en carbono fino (es decir, grafito)

- Recocido parcial, un proceso a baja temperatura para eliminar tensiones internas inducidas en el metal por trabajo en frío

- Recocido subcrítico o "esferoidización", que mejora la mecanizabilidad al permitir que el carburo de hierro de la estructura cristalina adquiera una forma esferoidal.

\section{Endurecimiento por envejecimiento}

Este es un proceso frecuentemente utilizado en las aleaciones de cobre-aluminio en las cuales el endurecimiento natural que tiene lugar en la aleación se acelera por calentamiento a unos $180^{\circ} \mathrm{C}$ durante una hora aproximadamente.

\section{Homogenización}

Este es un tratamiento que se aplica generalmente a lingotes o productos compactos de polvo de metal y tiene por objeto eliminar o reducir en gran parte la segregación. Se consigue por calentamiento a unos $20^{\circ} \mathrm{C}$ por debajo de la temperatura de fusión del metal durante dos horas o más, y después enfriando bruscamente.

\section{Normalizado}

Proceso similar al recocido completo o de regeneración. Garantiza la uniformidad de las propiedades mecánicas deseadas y produce mayor tenacidad y resistencia a la carga mecánica.

\section{Temple isotérmico}

Tipo especial de proceso de recocido que se aplica generalmente a material de sección transversal pequeña el cual ha de estirarse, por ejemplo, alambre de acero de $0,6 \%$ de carbono. El metal se calienta en un horno ordinario por encima de la temperatura de transformación y después se pasa directamente del horno, por ejemplo a un baño de plomo mantenido a una temperatura de unos $170^{\circ} \mathrm{C}$.

\section{Endurecimiento por temple y revenido}

En una aleación a base de hierro puede conseguirse un aumento de dureza calentando por encima de la temperatura de transformación y enfriando rápidamente a la temperatura ambiente en aceite, agua o aire. Frecuentemente la pieza queda sometida a tensiones internas demasiado elevadas para utilizarla en ese estado por lo que, con objeto de incrementar su tenacidad, se la somete a un revenido calentándola a una temperatura por debajo de la gama de transformación y permitiendo que se enfríe a la velocidad deseada.

El martemple y el austemple son procesos similares, excepto que la pieza se enfría, por ejemplo, en un baño de sal o de plomo mantenido a una temperatura de $400{ }^{\circ} \mathrm{C}$.

\section{Endurecimiento superficial y cementación}

Este es otro proceso de termotratamiento aplicado frecuentemente a las aleaciones a base de hierro, que permite que la superficie del objeto sea dura, mientras que el núcleo permanece relativamente dúctil. El proceso tiene las siguientes variantes:

- Endurecimiento a la llama: consiste en endurecer las superficies del objeto, por ejemplo dientes de engranajes, cojinetes, guías, etc., calentándolas con un soplete de gas a alta temperatura y enfriándolas en aceite, agua u otro medio adecuado.

- Endurecimiento por inducción eléctrica: es similar al endurecimiento a la llama, excepto que el calentamiento es producido por corrientes parásitas inducidas en las capas superficiales.

- Cementación: incrementa el contenido de carbono de la superficie de una aleación a base de hierro calentando la pieza en un medio sólido, líquido o gaseoso, tal como carbón vegetal y carbonato de bario, cianuro de sodio líquido y carbonato de sodio, monóxido de carbono gaseoso, metano, etc., a una temperatura de unos $900{ }^{\circ} \mathrm{C}$.

- Nitruración: incrementa el contenido de nitrógeno de la superficie de una pieza de hierro colado o acero de baja aleación especial por calentamiento en un medio nitrogenado, generalmente gas amoníaco, a unos $500-600{ }^{\circ} \mathrm{C}$.

- Cianuración: es un método de cementación en el cual la composición superficial de una pieza de acero de bajo contenido en carbono se enriquece simultáneamente tanto en carbono como en nitrógeno. Generalmente consiste en el calentamiento de la pieza en un baño de cianuro de sodio fundido al $30 \%$ a una temperatura de $-870{ }^{\circ} \mathrm{C}$ durante una hora, seguido de enfriamiento en aceite o agua.

- Carbonitruración: se trata de un proceso gaseoso para la absorción simultánea de carbono y nitrógeno en la capa superficial del acero calentándolo a una temperatura de 800 a $875^{\circ} \mathrm{C}$ en una atmósfera de gas cementante (véase anteriormente) y un gas nitrificante, por ejemplo 2-5\% de amoníaco anhidro.

\section{Metalización}

La metalización, o rociado de metal, es una técnica para aplicar una capa metálica protectora a una superficie desbastada mecánicamente rociándola con gotas de metal fundido. También se utiliza para recrecer superficies desgastadas o corroídas y recuperar piezas de componentes mal mecanizadas. El proceso se denomina generalmente "Schooping" en honor de su inventor, el Dr. Schoop.

El equipo de metalización consiste en la llamada pistola "Schooping", una pistola de pulverización de mano a través de la cual el metal, en forma de alambre, se alimenta a un soplete de gas combustible y oxígeno que lo funde y, una vez fundido en esta forma, se pulveriza sobre la pieza por medio de una corriente de aire comprimido. La fuente de calor es una mezcla de oxígeno y acetileno, propano o gas natural comprimido. Generalmente el alambre, enrollado en espiral, se endereza antes de ser alimentado a la pistola. Para esta técnica puede utilizarse cualquier metal que pueda estirarse en forma de alambre; la pistola puede aceptar también el metal en forma de polvo en lugar de alambre.

\section{Fosfatado}

Este proceso se aplica principalmente al acero dulce y galvanizado y al aluminio, para aumentar la adhesión y la resistencia a la corrosión de la pintura, cera o aceite. También se utiliza para formar una capa que actúa como una película de separación en la embutición profunda de planchas y mejora su resistencia al desgaste. El tratamiento consiste esencialmente en permitir que la superficie del metal reaccione con una disolución de uno o más fosfatos de hierro, zinc, manganeso, sodio o amonio. Las 
disoluciones de fosfato sódico y amónico se usan para tratamientos mixtos de limpieza y fosfatado. La necesidad de fosfatar piezas multimetálicas y el deseo de aumentar la velocidad de las líneas de producción en las operaciones automatizadas han determinado la necesidad de reducir los tiempos de reacción mediante la adición de aceleradores, tales como fluoruros, cloratos, molibdatos y compuestos de níquel a las disoluciones de fosfatación. Para reducir el tamaño de los cristales y, en consecuencia, aumentar la flexibilidad de los recubrimientos de fosfato de zinc, se añaden afinadores de cristales, tales como el fosfato de zinc terciario o el fosfato de titanio, al baño de lavado previo a la fosfatación. Las etapas de este proceso son las siguientes:

- limpieza con sosa cáustica caliente

- cepillado y lavado

- nueva limpieza con sosa cáustica caliente

- lavado en baño de agua de acondicionamiento

- rociado o inmersión en disoluciones calientes de fosfatos ácidos

- lavado con agua fría

- lavado con ácido crómico templado

- nuevo lavado con agua fría

- secado.

\section{Imprimación}

Las imprimaciones de pinturas orgánicas se aplican a las superficies metálicas para mejorar la adhesión de pinturas a aplicar posteriormente y de retardar la corrosión en la interfase pinturametal. Las imprimaciones normalmente contienen resinas, pigmentos y disolventes, y pueden aplicarse a la superficie del metal, previamente preparada, por medio de brocha, pistola, inmersión, recubrimiento con rodillo o por electroforesis.

Los disolventes pueden ser cualquier combinación de hidrocarburos alifáticos y aromáticos, cetonas, ésteres, alcoholes y éteres. Las resinas corrientemente utilizadas son butinol de polivinilo, resinas fenólicas, alquidos de aceite secantes, aceites epoxídicos, ésteres de epóxido, silicatos de etilo y gomas cloradas. En algunas imprimaciones complejas se utilizan corrientemente agentes de enlace tales como la pentamina de tetraetileno, hexamina de pentaetileno, isocianatos y ureaformol. En la composición de imprimaciones se emplean ciertos pigmentos inorgánicos, como compuestos de plomo, bario, cromo, zinc y calcio, entre otros.

\section{Recubrimiento con plásticos}

El recubrimiento de metales con plásticos puede aplicarse en forma líquida, en forma de polvos que después de vulcanizan o sinterizan por calentamiento, o bien como láminas prefabricadas que se aplican a la superficie del metal con un adhesivo. Los plásticos más corrientemente utilizados son el polietileno, poliamidas (nailon) y PVC (cloruro de polivinilo). En el último se pueden incluir los plastificantes basados en ésteres y estabilizadores monoméricos y poliméricos tales como carbonatos de plomo, sales ácidas grasas de bario y cadmio, dilaurato dibutílico de estaño, mercáptidos alquílicos de estaño y fosfato de zinc. Aunque la mayor parte de los plásticos utilizados son de baja toxicidad y no son irritantes, algunos de los plastificantes son sensibilizadores de la piel.

\section{Riesgos y su prevención}

Como fácilmente puede deducirse de la complejidad de los procesos antes esbozados, el tratamiento de superficie de los metales entraña una gran variedad de riesgos para la seguridad y la salud. Muchos de ellos se presentan normalmente en las operaciones de fabricación, mientras que otros provienen de la exclusividad de las técnicas y materiales utilizados. Algunos representan una amenaza para la vida, no obstante, la mayoría pueden prevenirse o controlarse.

\section{Diseño del lugar de trabajo}

El lugar de trabajo debe diseñarse de manera que permita la entrega de las materias primas y suministros y la retirada de los productos acabados sin entorpecer el proceso en curso. Dado que la mayoría de los productos químicos son inflamables o propensos a reaccionar cuando se mezclan entre sí, es esencial mantenerlos debidamente separados tanto durante el almacenamiento como durante el transporte. Muchas de las operaciones de acabado de metales implican el empleo de líquidos, y cuando se producen fugas, derrames o salpicaduras de ácidos o álcalis deben eliminarse rápidamente mediante lavado. Por la misma razón, deben preverse suelos antideslizantes y con un adecuado sistema de drenaje. Se deberá observar una escrupulosa limpieza para mantener las zonas de trabajo y otras áreas limpias y libres de acumulaciones de material. Los sistemas de eliminación de residuos y efluentes sólidos y líquidos procedentes de los hornos y los extractores de ventilación, deberán diseñarse teniendo en cuenta los aspectos ambientales.

Los puestos de trabajo y las tareas deberían basarse en principios ergonómicos para reducir las tensiones, tirones musculares, fatiga excesiva y lesiones por esfuerzo repetitivo. Las defensas de las máquinas deberán tener un sistema de bloqueo automático que desconecte la alimentación eléctrica de la máquina si se retira la defensa. Las protecciones contra salpicaduras son esenciales. Habida cuenta del peligro de salpicaduras de disoluciones ácidas y alcalinas calientes deberán instalarse cerca fuentes para lavados oculares y duchas de cuerpo fácilmente accesibles. Se colocarán letreros de aviso para alertar a otros miembros del personal de producción y mantenimiento sobre riesgos tales como baños químicos y superficies calientes.

\section{Evaluación de productos químicos}

Deberá evaluarse el potencial de toxicidad y riesgos físicos de todos los productos químicos, y éstos deberán sustituirse por otros menos peligrosos siempre que sea posible. No obstante, dado que el material menos tóxico puede ser más inflamable, también se tendrán en cuenta los riesgos de incendio y explosión. Asimismo se deberá considerar la compatibilidad química de los materiales. Por ejemplo, la mezcla accidental de nitrato y sales de cianuro puede ocasionar una explosión debido a las propiedades fuertemente oxidantes de los nitratos.

\section{Ventilación}

La mayoría de los procesos de recubrimiento de metales requieren una ventilación por extracción local estratégicamente situada para aspirar los vapores u otros contaminantes y alejarlos del trabajador. Algunos sistemas inyectan aire fresco a través del tanque para "empujar" a los contaminantes atmosféricos hacia el lado de evacuación del sistema. Las entradas de aire fresco deben estar situadas lejos de las salidas de ventilación para evitar el reciclaje de gases potencialmente tóxicos.

\section{Equipo de protección personal}

Los procesos deben estar estudiados para prevenir exposiciones potencialmente tóxicas, pero dado que éstas no siempre pueden evitarse totalmente, se deberá proporcionar a los trabajadores equipos de protección personal adecuados, tales como gafas de montura ajustada con o sin pantallas faciales según se requiera, guantes, monos o mandiles y zapatos. Dado que muchas de las exposiciones tienen que ver con disoluciones corrosivas o cáusticas calientes, los elementos protectores deberán estar aislados y ser resistentes a los productos químicos. Si existe riesgo de exposición eléctrica, los equipos de protección personal deberán ser 
eléctricamente no conductores. Estos equipos deberán estar disponibles en cantidad adecuada para permitir que los elementos contaminados húmedos se limpien y sequen antes de que se utilicen de nuevo. Cuando exista riesgo de quemaduras térmicas por metales calientes, hornos, etc., se deberá contar con guantes aislados y otras prendas protectoras.

Un importante complemento es la disponibilidad de instalaciones para lavado y taquillas limpias en los vestuarios, para que la ropa de los trabajadores permanezca libre de contaminación y éstos no se lleven a casa materiales tóxicos.

\section{Formación y supervisión de los trabajadores}

La educación y formación de los trabajadores son esenciales tanto cuando éstos son nuevos en el puesto de trabajo como cuando se han introducido cambios en el equipo o el proceso. Se deberán facilitar fichas técnicas de seguridad (FTS) de cada uno de los productos químicos que expliquen los riesgos químicos $\mathrm{y}$ físicos en idiomas y niveles educativos que garanticen su comprensión por los trabajadores. Las pruebas de cualificación y la formación de reconversión profesional periódica permitirán asegurarse de que los trabajadores han retenido la información necesaria. Es aconsejable una estrecha supervisión para asegurarse de que se están siguiendo los procedimientos correctos.

\section{Riesgos especiales}

Ciertos riesgos son exclusivos del sector de recubrimiento de metales y merecen por ello una consideración especial.

\section{Disoluciones ácidas y alcalinas}

Las disoluciones ácidas y alcalinas calientes utilizadas para la limpieza y tratamiento de metales son particularmente cáusticas y corrosivas. Irritan la piel y las mucosas y son especialmente peligrosas cuando se producen salpicaduras que afectan a los ojos. Es esencial contar con fuentes para lavados oculares y duchas de emergencia. El uso de ropa protectora y gafas de montura ajustada proporcionará protección frente a las inevitables salpicaduras; cuando éstas afecten a la piel se deberá lavar inmediata y abundantemente la zona afectada con agua fría y limpia durante 15 minutos como mínimo; puede ser necesario recibir atención médica, sobre todo si han resultado afectados los ojos.

Se deberán tomar precauciones al utilizar hidrocarburos clorados, ya que puede formarse fosgeno al reaccionar éstos con ácidos y metales. Los ácidos nítrico y fluorhídrico son especialmente peligrosos cuando se inhalan sus gases, porque sus efectos en los pulmones pueden tardar 4 horas o más en manifestarse. Puede aparecer tardíamente bronquitis, neumonía e incluso edema pulmonar potencialmente letal en un trabajador en el que aparentemente la exposición no había producido ningún efecto al principio. Es aconsejable un tratamiento médico profiláctico inmediato y, con frecuencia, la hospitalización de los trabajadores expuestos. El contacto de la piel con ácido fluorhídrico puede ocasionar graves quemaduras sin dolor durante varias horas. Es esencial recibir atención médica con prontitud.

\section{Polvo}

El polvo metálico y de óxido constituye un problema especialmente grave en las operaciones de esmerilado y pulido, y lo más eficaz para su eliminación es la ventilación local por extracción en el punto en que se produce. Los conductos de extracción deben diseñarse de forma que favorezcan un flujo suave y la velocidad del aire debe ser suficiente para impedir que las partículas se separen de la corriente de ventilación. El polvo de aluminio y de magnesio puede ser explosivo, por lo que debe recogerse en una trampa húmeda. El problema del plomo ha disminuido al reducirse su empleo en la cerámica y los esmaltes de porcelana, pero sigue siendo un riesgo profesional generalizado contra el que siempre deben tomarse precauciones. El berilio y sus compuestos han suscitado interés recientemente debido a su posible carcinogenicidad y al riesgo de beriliosis crónica.

Ciertas operaciones, tales como la calcinación, machaqueo y secado de pedernal, cuarzo o piedra; el cribado, mezcla y pesaje de estas sustancias en estado seco y la carga de hornos con tales materiales, entrañan riesgo de silicosis y neumoconiosis. Los citados materiales representan también un peligro cuando se utilizan en procesos en fase húmeda y salpican el lugar de trabajo y la ropa de los trabajadores, convirtiéndose de nuevo en polvo cuando se secan. Las principales medidas preventivas son los sistemas de ventilación local por extracción, una limpieza escrupulosa y una adecuada higiene personal.

\section{Disolventes orgánicos}

Los disolventes y otros productos químicos orgánicos utilizados en ciertos procesos, como el desengrasado, son peligrosos cuando se inhalan. En la fase aguda, sus efectos narcóticos pueden conducir a una parálisis respiratoria y provocar la muerte. En la exposición crónica, sus efectos más frecuentes son la toxicidad para el sistema nervioso central y las lesiones hepáticas y renales. Como protección deben utilizarse sistemas de ventilación local por extracción con una zona de seguridad de 80 a $100 \mathrm{~cm}$ como mínimo entre la fuente y la zona de respiración del trabajador. También deben instalarse sistemas de ventilación en los bancos de trabajo para eliminar los vapores residuales de las piezas terminadas. El desgrasado de la piel por disolventes orgánicos puede ser precursor de dermatitis. Muchos disolventes también son inflamables.

\section{Gianuro}

En el desengrasado electrolítico, el recubrimiento electrolítico y la cianuración se utilizan con frecuencia baños que contienen cianuros los cuales, al reaccionar con el ácido, forman ácido cianhídrico (ácido prúsico), un producto volátil y potencialmente letal. La concentración letal en el aire es de 300 a 500 ppm. También pueden producirse exposiciones mortales por absorción a través de la piel o ingestión de cianuros. Es esencial que los trabajadores que utilizan cianuro observen una escrupulosa limpieza. No se deberá comer sin haberse lavado antes y nunca deberá haber alimentos en la zona de trabajo. Después de una posible exposición accidental a cianuro, deberán lavarse cuidadosamente las manos y la ropa.

Las medidas de primeros auxilios en caso de envenenamiento por cianuro consisten en llevar a la víctima al aire libre, quitarle la ropa contaminada, lavar abundantemente con agua las zonas afectadas, oxigenoterapia e inhalación de nitrito de amilo. Son esenciales la ventilación local por extracción y una adecuada protección de la piel.

\section{Cromo y níquel}

Los compuestos de cromo y níquel utilizados en los baños galvánicos para recubrimiento electrolítico pueden ser peligrosos. Los compuestos de cromo pueden causar quemaduras, ulceración y eccema de la piel y las mucosas, así como una perforación característica del tabique nasal. También puede producirse asma bronquial. Las sales de níquel pueden causar lesiones de la piel alérgicas o tóxico-irritativas rebeldes. Existen pruebas de que tanto los compuestos de cromo como los de níquel pueden ser cancerígenos. Son esenciales la ventilación local por extracción y una adecuada protección de la piel.

\section{Hornos y estufas}

Es necesario adoptar precauciones especiales cuando se trabaja con hornos como los que se utilizan, por ejemplo, en el 
termotratamiento de metales, donde se manipulan componentes a elevadas temperaturas y los materiales utilizados en el proceso pueden ser tóxicos o explosivos, o ambas cosas a la vez. Los medios gaseosos (atmósferas) del horno pueden reaccionar con la carga de metal (atmósferas oxidantes o reductoras) o pueden ser neutros y protectores. La mayoría de estos últimos contienen hasta el $50 \%$ de hidrógeno y el $20 \%$ de monóxido de carbono que, además de ser combustibles, forman mezclas altamente explosivas con el aire a elevadas temperaturas. La temperatura de ignición varía entre 450 y $750{ }^{\circ} \mathrm{C}$, pero una chispa local puede provocar la ignición incluso a temperaturas inferiores. El peligro de explosión es mayor durante el encendido y el apagado del horno. Dado que un horno tiende a aspirar aire mientras se enfría (lo que supone un riesgo especial cuando se interrumpe la alimentación de combustible o energía eléctrica), debería contarse con el suministro de un gas inerte, por ejemplo nitrógeno o dióxido de carbono para utilizarlo con fines de purga cuando se apague el horno o se inyecte una atmósfera protectora en un horno caliente.

El monóxido de carbono es quizá el mayor de los riesgos que presentan los hornos y estufas.. Al ser incoloro e inodoro, con frecuencia alcanza niveles tóxicos antes de que el operario se aperciba de ello. El dolor de cabeza es uno de los primeros síntomas de toxicidad, por lo tanto, si un operario experimenta dolor de cabeza durante el trabajo deberá trasladársele inmediatamente al aire libre. Entre las zonas de peligro están los huecos en los que puede acumularse monóxido de carbono; debe recordarse que la obra de ladrillo es porosa y puede retener el gas durante la purga normal y emitirlo al terminar ésta.

Los hornos de plomo pueden ser peligrosos, ya que el plomo tiende a evaporarse con gran rapidez a temperaturas superiores a $870^{\circ} \mathrm{C}$. Por lo tanto, se requiere un sistema eficaz de extracción de humos. También puede ser peligrosa la rotura o el fallo de una cuba, por o que deberá haber un pozo o un foso de suficiente capacidad para recoger el metal fundido si sucediese ésto.

\section{Incendio y explosión}

Muchos de los compuestos utilizados en el recubrimiento de metales son inflamables y, en ciertas circunstancias, explosivos. La mayoría de los hornos y estufas de secado son de alimentación por gas, por lo que deben adoptarse precauciones especiales, como la instalación de dispositivos de seguridad contra apagado de llama en los quemadores, válvulas de corte por baja presión en las tuberías de suministro y paneles de seguridad contra explosiones en la estructura de las estufas. En las operaciones electrolíticas, el hidrógeno formado en el proceso puede acumularse en la superficie del baño y, si no es evacuado, puede alcanzar concentraciones explosivas. Los hornos deben ventilarse adecuadamente y los quemadores protegerse contra la obstrucción por goteo de material.

También el temple en aceite entraña riesgo de incendio, sobre todo si la carga de metal no se sumerge completamente. Los aceites de temple deberán tener un punto de inflamabilidad elevado, y su temperatura no deberá exceder de $27^{\circ} \mathrm{C}$.

Las botellas de oxígeno y gas combustible comprimidos que se utilizan en el metalizado presentan riesgos de incendio y explosión si no se almacenan y utilizan correctamente. Véase el artículo "Soldadura y corte térmico" en este capítulo, donde se indican con detalle las precauciones necesarias.

Cuando así lo requieran las ordenanzas locales, deberá proveerse y mantenerse en perfecto estado de funcionamiento un equipo adecuado de lucha contra incendios, alarmas incluidas, y se deberá instruir a los trabajadores en su correcta utilización.

\section{Galor}

El uso de hornos, llamas libres, estufas, disoluciones calientes y metales fundidos presenta inevitablemente el riesgo de una exposición excesiva al calor, que se ve agravada en los climas calurosos y húmedos $\mathrm{y}$, en especial, por las prendas y equipos protectores oclusivos. La instalación de un sistema de acondicionamiento de aire para toda una planta puede no ser económicamente viable, pero puede ser útil suministrar aire refrigerado a través de los sistemas de ventilación local. Los descansos en ambientes frescos y una ingesta de líquidos adecuada (los líquidos que se tomen en el puesto de trabajo deberán estar libres de contaminantes tóxicos) ayudará a prevenir la toxicidad del calor. Se deberá enseñar tanto a los trabajadores como a sus supervisores a reconocer los síntomas del estrés por calor.

\section{Conclusión}

El tratamiento de superficie de los metales implica múltiples procesos que entrañan una amplia gama de exposiciones potencialmente tóxicas, la mayoría de las cuales pueden evitarse o controlarse mediante la aplicación diligente de medidas preventivas generalmente reconocidas..

\section{RECUPERACION DE METALES}

\section{Melvin E. Cassady y Richard D. Ringenwald, Jr.}

La recuperación de metales es el proceso consistente en producir metales a partir de chatarra. Estos metales recuperados no se diferencian en nada de los obtenidos mediante el procesado primario de un mineral del metal. Sin embargo, el proceso es ligeramente distinto y la exposición puede ser también diferente. Los controles técnicos son básicamente los mismos. La recuperación de metales es muy importante para la economía mundial dado el progresivo agotamiento de las materias primas y la contaminación del medio ambiente por los materiales de la chatarra.

El aluminio, cobre, plomo y zinc representan el $95 \%$ de la producción de la industria de los metales no férreos recuperados. También se recuperan magnesio, mercurio, níquel, metales preciosos, cadmio, selenio, cobalto, estaño y titanio (el hierro y el acero se tratan en el capítulo Siderurgia. Véase también el artículo "Fundición y afino del cobre, plomo y zinc" en este capítulo).

\section{Estrategias de control}

\section{Principios de control de las emisiones y exposiciones}

La recuperación de metales implica exposiciones a polvo, humos, disolventes, ruido, calor, neblinas ácidas y otros riesgos y materiales potencialmente peligrosos. Puede haber algunas modificaciones viables de los procesos y la manipulación de materiales que eliminen o reduzcan la generación de emisiones, por ejemplo reducir la manutención, rebajar las temperaturas de las cubas, disminuir la formación de impurezas y la generación de polvo en la superficie, y modificar la configuración de la planta para reducir la manipulación de materiales o la agitación del polvo depositado.

En algunos casos es posible reducir la exposición eligiendo máquinas que realicen las tareas de alto riesgo para que no sea necesaria la presencia de operarios en la zona. Esto puede servir también para reducir riesgos ergonómicos debidos a la manipulación de materiales.

Con el fin de evitar la contaminación cruzada de las zonas limpias de la planta, es conveniente aislar los procesos que 
generan emisiones significativas. Una barrera física contendrá las emisiones y reducirá su dispersión. De ese modo, habrá menos personas expuestas y disminuirá el número de fuentes de emisiones que contribuyen a la exposición en las distintas áreas. Esto simplifica las evaluaciones de la exposición y permite determinar y controlar más fácilmente sus fuentes principales. Con frecuencia, las operaciones de recuperación están aisladas del resto de las operaciones de la planta.

A veces es posible confinar o aislar una fuente de emisiones específica. Como los recintos de confinamiento rara vez son herméticos, suele aplicárseles un sistema de extracción por corriente de aire negativa. Una de las formas más corrientes de controlar emisiones es proporcionar ventilación local por extracción en el punto en que se generan las emisiones. Al capturar las emisiones en el lugar donde se originan disminuye el riesgo de que se dispersen en el aire y se evita la exposición secundaria de los operarios por agitación de contaminantes ya depositados.

La velocidad de captura de una campana extractora deberá ser lo bastante grande como para impedir que los humos o el polvo escapen del flujo de aire aspirado por la campana. Dicho flujo deberá tener suficiente velocidad para llevar el humo y las partículas de polvo hasta la campana y vencer los efectos perturbadores de las corrientes transversales y otros movimientos aleatorios del aire. La velocidad necesaria para ello dependerá del tipo de aplicación. Debe restringirse el uso de calentadores de recirculación y ventiladores de refrigeración personal, ya que pueden imponerse a la ventilación local por extracción.

Todos los sistemas de ventilación por extracción o dilución necesitan renovación de aire, por lo que se les conoce también como sistemas de aire de relleno. Si un sistema de este tipo está bien diseñado e integrado en los sistemas de ventilación natural y de confort, cabe esperar un control más eficaz de las exposiciones. Por ejemplo, las salidas de renovación de aire deben colocarse de manera que el aire limpio fluya desde ellas a través de los operarios hacia la fuente de emisiones y desde ésta al sistema de extracción. Esta técnica se utiliza con frecuencia en las islas con admisión de aire puro y con ella el operario queda situado entre el aire limpio entrante y la fuente de emisiones.

Las llamadas zonas limpias se aseguran mediante el control directo de las emisiones y planes de limpieza y mantenimiento. El ambiente de estas zonas registra bajos niveles de contaminantes. A los trabajadores de las zonas contaminadas puede protegérseles mediante cabinas de servicio con admisión de aire puro, islas, casetas elevadas de vigilancia y salas de control, complementadas con protección respiratoria personal.

La exposición media diaria de los trabajadores puede reducirse poniendo a su disposición zonas limpias tales como salas de descanso y comedores con alimentación de aire fresco filtrado. La exposición media a los contaminantes ponderada en el tiempo de los trabajadores puede reducirse si estos pasan algún tiempo en una zona relativamente libre de contaminantes. Otra conocida aplicación de este principio es la isla con admisión de aire puro, en la que se suministra aire fresco filtrado a la zona de respiración del operario en su puesto de trabajo.

Deberá preverse espacio suficiente para campanas extractoras, conductos de aire, salas de control, actividades de mantenimiento, limpieza y almacenamiento de equipos.

Los vehículos con ruedas son fuentes importantes de emisiones secundarias. Donde se utilice el transporte por medio de este tipo de vehículos, pueden reducirse las emisiones pavimentando todas las superficies, manteniendo éstas libres de acumulaciones de materiales polvorientos, reduciendo la longitud de los trayectos y la velocidad de los vehículos y reconduciendo el escape de los vehículos y la descarga de los ventiladores de refrigeración. Se deberá elegir un material de pavimentación apropiado, por ejemplo hormigón, después de considerar factores tales como la carga, utilización y conservación de la superficie. A algunas superficies pueden aplicárseles recubrimientos para facilitar el baldeo de las zonas de tránsito.

Todos los sistemas de ventilación por evacuación, dilución y renovación de aire deberán ser objeto de un adecuado mantenimiento para que permitan un control eficaz de los contaminantes atmosféricos. Además de los sistemas de ventilación general deberá mantenerse el equipo de proceso, a fin de eliminar los derrames de material y las emisiones fugitivas.

\section{Ejecución del programa de métodos de trabajo}

Aunque las normas hacen hincapié en los controles técnicos como medio de asegurar su cumplimiento, los controles de los métodos de trabajo son esenciales para el éxito del programa de control.. Los controles técnicos pueden ser ineficaces a causa de unos malos hábitos de trabajo, de un mantenimiento inadecuado y de una conservación de las instalaciones o una higiene personal deficientes. Los trabajadores que utilizan los mismos equipos en distintos turnos puede sufrir exposiciones atmosféricas muy diferentes a causa de diferencias en estos factores entre unos turnos y otros.

Aunque se descuidan con frecuencia, los programas de métodos de trabajo constituyen una buena práctica de dirección y una buena medida de sentido común; son eficaces en relación con el coste pero requieren una actitud responsable y cooperativa por parte de los trabajadores y de los supervisores de línea. La actitud de la alta dirección en relación con la salud y la seguridad se refleja en la actitud de los supervisores de línea. De igual modo, si los supervisores no velan por el cumplimiento de estos programas, las actitudes de los trabajadores pueden resentirse. Se pueden fomentar las buenas actitudes en relación con la salud y la seguridad por medio de los siguientes métodos:

- un clima de cooperación que propicie la participación de los trabajadores en los programas

- programas oficiales de formación y educación

- promover el programa de salud y seguridad de la planta. Para que el programa sea eficaz es preciso motivar a los trabajadores y ganarse su confianza.

No hay que limitarse a "implantar" los programas de métodos de trabajo. Lo mismo que un sistema de ventilación, requieren mantenimiento y continuas verificaciones para asegurarse de que están funcionando correctamente. Estos programas son responsabilidad tanto de la dirección como de los trabajadores y deben establecerse para enseñar, fomentar y supervisar los "buenos" métodos, es decir, aquellos que aseguran un bajo nivel de exposición.

\section{Equipo de protección personal}

En todos los trabajos deberán usarse sistemáticamente gafas de seguridad con pantallas laterales, monos, calzado de seguridad y guantes de trabajo. Quienes realicen operaciones de fundición y colada de metales o aleaciones, deberán llevar mandiles y guantes o manoplas de cuero u otro material adecuado para protegerse de las salpicaduras de metal fundido.

En aquellas operaciones en las que los controles técnicos no resulten adecuados para controlar las emisiones de polvo o humo, deberá usarse una protección respiratoria adecuada. Si los niveles de ruido son excesivos y no pueden evitarse por medios técnicos o no es posible aislar las fuentes de ruido, se deberá utilizar protección para los oídos. También deberá aplicarse un programa de conservación de la audición que incluya pruebas de audiometría y formación al respecto. 


\section{Procesos}

\section{Aluminio}

La industria del aluminio recuperado utiliza chatarra que contiene aluminio para producir aluminio metálico y aleaciones de aluminio. El proceso utilizado en esta industria comprende tratamiento previo de la chatarra, segunda fusión, aleación y colada. La industria del aluminio de segunda fusión utiliza como materias primas, entre otros materiales, chatarra nueva y vieja, lingotes exudados y algo de aluminio primario. La chatarra nueva está formada por recortes, productos de forja y otros sólidos adquiridos a la industria aeronáutica, fabricantes de estructuras y otras plantas de fabricación. Las virutas de taladrado y de torno son un subproducto del mecanizado de piezas de fundición, varillas y piezas de forja por la industria aeronáutica y la del automóvil. Las impurezas, espumas y escorias se obtienen de las plantas de primera reducción, de las plantas de segunda fusión y de las fundiciones. La chatarra vieja está formada por piezas de automóviles, elementos de uso doméstico y piezas de aviones. El proceso consta de los siguientes pasos:

- Inspección y clasificación. Después de comprar la chatarra de aluminio se la somete a una inspección. La chatarra limpia que no requiere tratamiento previo se transporta al almacén o se carga directamente en el horno de fundición. El aluminio que requiere pretratamiento se clasifica a mano. Se retiran el hierro, acero inoxidable, zinc y latón libres, así como los materiales sobremedida.

- Trituración y cribado. La materia prima para este proceso es la chatarra vieja, en especial las piezas de fundición y la chapa contaminada con hierro. La chatarra, una vez clasificada, se transporta a una trituradora o molino de martillos, donde el material se desmenuza y tritura, y el hierro se separa del aluminio. El material triturado se pasa sobre cribas vibrantes para eliminar la suciedad y las partículas finas.

- Embalado. La chatarra de aluminio voluminosa, como planchas inservibles, piezas de fundición y recortes, se compacta utilizando un equipo de embalado especialmente diseñado al efecto.

- Desmenuzado y clasificación. El cable de aluminio puro con refuerzo o aislamiento de acero, se corta con cizallas tipo cocodrilo, después de lo cual se granula o se reduce a fragmentos aún más pequeños en molinos de martillos para separar del aluminio el alma de hierro y el forro de plástico.

- Calcinación y secado. Las virutas de taladrado y de torno se tratan previamente para eliminar los aceites de corte, grasas, humedad y hierro libre. La chatarra se tritura en un molino de martillos o una trituradora de anillos; la humedad y los materiales orgánicos se volatilizan en un secador rotativo de gas o fuel-oil, los fragmentos secos se criban para eliminar las partículas finas de aluminio, el material restante se trata magnéticamente para separar el hierro, y las virutas limpias y secas se clasifican en cajas de piezas.

- Procesado de impurezas calientes. Se puede separar el aluminio de las impurezas calientes descargadas del horno de afino mediante tratamiento en lotes por fundente con una mezcla de sal y criolita. Este proceso se lleva a cabo en una cuba con revestimiento refractario y rotación mecánica. Periódicamente se drena el metal a través de un orificio existente en la base de la cuba.

- Molturación en seco. En el proceso de molturación en seco, la escoria fría cargada de aluminio y otros residuos se procesa mediante molturación, cribado y concentración hasta obtener un producto que contiene de un 60 a un $70 \%$ de aluminio como mínimo. Para reducir los óxidos y los materiales no metálicos a polvo fino pueden utilizarse molinos de bolas, de varillas o de martillos. La suciedad y otros materiales no recuperables se separan del metal mediante cribado, clasificación por corriente de aire o separación magnética.

- Tostación. Una de las materias primas de este proceso es la hoja de aluminio con dorsal de papel, gutapercha o aislamiento. En el proceso de tostación, los materiales carbonosos asociados con las hojas de aluminio se tuestan y después se separan del producto metálico.

- Exudación de aluminio. La exudación es un proceso pirometalúrgico que se utiliza para recuperar el aluminio de la chatarra con alto contenido de hierro. Son materias primas para este proceso la chatarra, piezas de fundición y escoria de aluminio con alta proporción de hierro. Generalmente se utilizan hornos de reverbero de llama y solera inclinada. La separación se produce al fundirse el aluminio y otros constituyentes de bajo punto de fusión, con lo cual escurren por la solera y pasan por una rejilla a moldes refrigerados por aire, cubos de recogida o pozos de retención. El producto obtenido se denomina "lingotes exudados". Los materiales con punto de fusión más alto, como el hierro, latón y productos de la oxidación formados durante el proceso de exudación, se extraen periódicamente del horno mediante sangrado.

- Fundición y afino en horno de reverbero (con cloro). Se utilizan hornos de reverbero para convertir chatarra limpia clasificada, lingotes exudados o, en algunos casos, chatarra sin tratar, en aleaciones según especificación. La chatarra se carga en el horno por medios mecánicos. Los materiales a procesar se añaden por lotes o mediante alimentación continua. Una vez cargada la chatarra se añade un fundente para evitar el contacto del metal fundido con el aire y su subsiguiente oxidación (fundente protector). Se añaden fundentes disolventes que reaccionan con los materiales no metálicos, tales como residuos de recubrimientos quemados y suciedad, formándose compuestos insolubles que flotan y suben a la superficie en forma de escoria. Después se añaden aleantes, dependiendo de las especificaciones. La desmagnesiación es el proceso consistente en reducir el contenido de magnesio de la carga fundida. Cuando la reducción se efectúa con cloro gaseoso, se inyecta cloro a través de tubos o lanzas de carbono y al burbujear reacciona con el magnesio y el aluminio. En la fase de despumado se extraen de la superficie del caldo los fundentes semisólidos impuros.

- Fundición y afino en horno de reverbero (con flúor). Este proceso es similar al de fundición y afino en horno de reverbero con cloro, pero en lugar de cloro se emplea fluoruro de aluminio.

La Tabla 82.8 ofrece una lista de exposiciones y controles correspondientes a las operaciones de recuperación de aluminio.

\section{Recuperación de cobre}

La industria de segunda fusión del cobre utiliza chatarra que contiene cobre para producir cobre metálico y aleaciones de cobre. Las materias primas empleadas pueden clasificarse como chatarra nueva producida en la fabricación de productos acabados o chatarra vieja procedente de artículos obsoletos, desgastados o recuperados. Entre las fuentes de chatarra vieja están el alambre, accesorios de fontanería, equipos eléctricos, automóviles y electrodomésticos. Otros materiales con un contenido valioso de cobre son las escorias, impurezas y cenizas de fundición, y las barreduras de fundiciones. La recuperación comprende los siguientes pasos:

- Separación y clasificación. La chatarra se clasifica de acuerdo con su contenido de cobre y su estado de limpieza. La chatarra limpia puede separarse a mano para cargarla directamente en un horno de fusión y aleación. Los componentes férreos pueden separarse magnéticamente. El aislamiento y las 
Tabla 82.8 • Controles técnicos y administrativos para el aluminio, por operaciones.

$\begin{array}{ll}\begin{array}{l}\text { Equipo de proceso } \\ \text { Clasificación }\end{array} & \begin{array}{l}\text { Exposición } \\ \text { Desoldadura con soplete - vapores metálicos, por ejemplo de } \\ \text { plomo y cadmio }\end{array} \\ \begin{array}{l}\text { Prituración/cribado y aerosoles inespecíficos, neblinas de aceite, partículas } \\ \text { metálicas y ruido }\end{array} \\ \begin{array}{l}\text { Embalado } \\ \text { Calcinación/secado }\end{array} \\ \begin{array}{l}\text { Partículas inespecíficas que pueden incluir metales, hollín y materias } \\ \text { orgánicas pesadas condensadas. Gases y vapores conteniendo fluo- } \\ \text { ruros, dióxido de azufre, cloruros, monóxido de carbono, hidrocar- } \\ \text { buros y aldehídos }\end{array}\end{array}$

Procesado de impurezas Algunos vapores calientes

$\begin{array}{ll}\text { Molturación en seco } & \text { Polvo } \\ \text { Tostación } & \text { Polvo }\end{array}$

Exudación

Fundición y afino en horno de reverbero (con cloro)

Fundición y afino en horno de reverbero (con flúor)
Vapores y partículas metálicos, gases y vapores inespecíficos, calor y ruido

Productos de la combustión, cloro, cloruros de hidrógeno, cloruros metálicos, cloruros de aluminio, ruido y calor

Productos de la combustión, flúor, fluoruros de hidrógeno, fluoruros metálicos, fluoruros de aluminio, ruido y calor

\section{Controles técnicos y administrativos}

Ventilación por extracción local durante la desoldadura; equipo de protección personal - protección respiratoria al desoldar

Ventilación por extracción local y ventilación general de zonas, aislamiento de la fuente de ruido; equipo de protección personal - protección auditiva

Ningún control

Ventilación por extracción local, ventilación general de zonas, régimen de trabajo/descanso contra el estrés por calor, líquidos, aislamiento de la fuente de ruido; equipo de protección personal - protección auditiva

Ventilación por extracción local, ventilación general de zonas

Ventilación por extracción local, ventilación general de zonas

Ventilación por extracción local, ventilación general de zonas, régimen de trabajo/descanso contra el estrés por calor, líquidos, aislamiento de la fuente de ruido; equipo de protección personal - protección auditiva

Ventilación por extracción local, ventilación general de zonas, régimen de trabajo/descanso contra el estrés por calor, líquidos, aislamiento de la fuente de ruido; equipo de protección personal - protección auditiva y protección respiratoria

Ventilación por extracción local, ventilación general de zonas, régimen de trabajo/descanso contra el estrés por calor, líquidos, aislamiento de la fuente de ruido; equipo de protección personal - protección auditiva y protección respiratoria

Ventilación por extracción local, ventilación general de zonas, régimen de trabajo/descanso contra el estrés por calor, líquidos, aislamiento de la fuente de ruido; equipo de protección personal - protección auditiva y protección respiratoria cubiertas de plomo de los cables se separan a mano o con equipos especialmente diseñados al efecto.

- Briquetado y trituración. Una vez limpios, el alambre, chapa fina, tela metálica, virutas de taladrado y torno, y fragmentos pequeños, se compactan para poder manipularlos con más facilidad. El equipo utilizado para ello consiste en prensas hidráulicas embaladoras, molinos de martillos y molinos de bolas.

- Desmenuzado. La separación del alambre de cobre del aislamiento se lleva a cabo reduciendo el tamaño de la mezcla. Después, el material desmenuzado se clasifica por medios neumáticos o hidráulicos y si hay materiales férreos se separan magnéticamente.

- Trituración y separación por gravedad. Este proceso desempeña la misma función que el desmenuzado, pero utilizando un medio de separación acuoso y materiales diferentes como materia prima, por ejemplo escorias, impurezas, espumas, cenizas de fundición, barreduras y polvo de cámara de sacos filtrantes.

- Secado. Se eliminan las impurezas orgánicas volátiles tales como fluidos de corte, aceites y grasas que contienen las virutas de taladrado y de torno y los fragmentos pequeños.

- Quemado del aislamiento. En este proceso se separan del alambre de cobre el aislamiento y otros revestimientos quemando estos materiales en hornos. La chatarra de alambre se carga por lotes en una cámara de ignición primaria o un postquemador. Después, los productos de combustión volátiles se recogen haciéndolos pasar por una cámara de combustión secundaria o una cámara de sacos. Se genera materia en partículas inespecífica que puede contener humo, arcilla y óxidos metálicos. Los gases y vapores pueden contener óxidos de nitrógeno, dióxido de azufre, cloruros, monóxido de carbono, hidrocarburos y aldehídos.

- Exudación. Los componentes de fusión con baja presión de vapor se eliminan de la chatarra calentando ésta a una temperatura controlada, justo por encima del punto de fusión de los metales que se desea exudar. Por lo general el metal primario, es decir, el cobre, no es el componente que se funde.

- Lixiviación en carbonato de amonio. Se puede recuperar el cobre de una chatarra relativamente limpia por lixiviación y disolución en una disolución básica de carbonato de amonio. Los iones cúpricos de la disolución de amonio reaccionan con el cobre metálico y producen iones cuprosos, que pueden reoxidarse y devolverse al estado cúprico mediante oxidación en aire. Una vez separada la disolución cruda del residuo lixiviado, se recupera el óxido de cobre por destilación al vapor.

- Destilación al vapor. El material lixiviado obtenido en el proceso de lixiviación en carbonato se hierve para precipitar el óxido de cobre, el cual se seca a continuación.

- Reducción hidrotérmica en hidrógeno. La disolución de carbonato de amonio, que contiene iones de cobre, se calienta bajo presión en hidrógeno, con lo que el cobre precipita en forma de polvo. A continuación, el cobre se filtra, lava, seca y sinteriza en una atmósfera de hidrógeno, y el polvo obtenido se tritura y tamiza. 
- Lixiviación en ácido sulfúrico. Se disuelve la chatarra de cobre en ácido sulfúrico para formar una disolución de sulfato de cobre que se utilizará como carga en el proceso de extracción electrolítica. Después de la digestión, el residuo no disuelto se filtra.

- Fundición en convertidor. El cobre negro fundido se carga en un convertidor, recipiente de acero en forma de pera o cilíndrico revestido de ladrillo refractario. Se inyecta aire en las cargas fundidas a través de unas toberas, o tuyères. El aire oxida el sulfuro de cobre y otros metales. Se añade un fundente que contiene sílice para que reaccione con los óxidos de hierro y forme una escoria de silicato férrico. Esta escoria se extrae del horno por despumación, generalmente inclinando el horno, y después se efectúa una inyección de aire y un despumado secundarios. El cobre obtenido en este proceso recibe el nombre de cobre blister y por lo general se le somete a un afinado ulterior en un horno de afinado a fuego.

- Afinado a fuego. El cobre blister procedente del convertidor se afina a fuego en un horno basculante cilíndrico, parecido a un horno de reverbero. La carga de este cobre en el horno de afino se realiza en una atmósfera oxidante. Se extraen las impurezas de la superficie mediante despumado y se crea una atmósfera reductora añadiendo troncos de madera verdes o gas natural. Después se procede a la colada del caldo resultante. Si el cobre va a ser afinado electrolíticamente, se cuela como ánodo.

- Afinado electrolítico. Los ánodos del proceso de afinado a fuego se colocan en un tanque que contiene ácido sulfúrico y por el que circula corriente continua. El cobre del ánodo se ioniza y los iones de cobre se depositan sobre una chapa inicial de cobre puro. $\mathrm{Al}$ disolverse los ánodos en el electrolito, las impurezas se depositan en el fondo de la célula en forma de lodo, el cual puede procesarse de nuevo para recuperar otros metales valiosos. El cátodo de cobre producido se funde y se cuela en moldes de diversas formas.

La Tabla 82.9 ofrece una lista de exposiciones y controles correspondientes a las operaciones de recuperación de cobre.

\section{Recuperación de plomo}

Las materias primas que adquieren las fundiciones de plomo recuperado pueden requerir un procesado previo a su carga en el horno de fundición. En este apartado se tratan los materiales que compran con más frecuencia las fundiciones de plomo recuperado y los controles técnicos y prácticas de trabajo que pueden aplicarse para limitar la exposición de los trabajadores al plomo durante las operaciones de procesado de las materias primas. Hay que señalar que en las instalaciones de recuperación de plomo suele haber polvo de plomo por todas partes y que cualquier corriente de aire producida por vehículos puede agitar este polvo, el cual podrá ser entonces inhalado o adherirse al calzado, la ropa, la piel y el cabello.

\section{Baterías de automóviles}

La materia prima más común en una fundición de plomo recuperado son las baterías procedentes de los desguaces de automóviles. En el proceso de fundición y afino se recupera como plomo metálico aproximadamente el $50 \%$ en peso de cada una de estas baterías. Alrededor del $90 \%$ de las baterías de automóviles que se fabrican hoy en día, tienen la caja o carcasa de polipropileno. Casi todas las fundiciones de plomo de segunda fusión recuperan estas carcasas de polipropileno por el alto valor económico de este material. En la mayor parte de estos procesos pueden generarse humos metálicos, en especial de plomo y antimonio.

Durante la rotura de las baterías de automóviles existe riesgo de formación de arsenamina o estibina debido a la presencia de arsénico o antimonio, utilizados como endurecedores en la aleación de las placas, así como riesgo de presencia de hidrógeno naciente.

Estos son los cuatro procesos más comunes para la rotura de las baterías de automóviles:

1. serrado a alta velocidad

2. serrado a baja velocidad

3. cizallado

4. trituración de la batería completa (triturador o desmenuzador Saturn o molino de martillos).

De estos procesos, los tres primeros implican el corte de la parte superior de la batería para después extraer los grupos o el material que contiene el plomo. El cuarto proceso consiste en triturar la batería completa en un molino de martillos y separar los componentes por gravedad.

La separación de los materiales de las baterías de automóviles se lleva a cabo después de la rotura de las baterías con el fin de separar el material que contiene plomo del material de la carcasa. $\mathrm{Al}$ retirar esta última pueden formarse neblinas ácidas. Las técnicas más utilizadas para esta operación son las siguientes:

- Técnica manual. Es la que emplean la mayoría de las fundiciones de plomo recuperado y sigue siendo la más utilizada por las pequeñas y medianas fundiciones. Tras el paso de la batería por la sierra o la cizalla, un operario vuelca manualmente los grupos o el material que contiene plomo en una pila y coloca la carcasa y la parte superior de la batería en otra pila o en un sistema de transporte

- Tambor giratorio. Después de serrar o cortar la parte superior para separar los grupos de las carcasas, las baterías se colocan en un tambor giratorio. Las nervaduras interiores del tambor provocan la salida de los grupos mientras el tambor gira lentamente. Los grupos caen por las ranuras del tambor mientras que las carcasas son transportadas hasta el extremo de éste y se recogen a la salida. Una vez separadas del material que contiene plomo, las carcasas y las tapas de plástico y goma se someten a un proceso adicional.

- Proceso de inmersión y flotación. El proceso de inmersión y flotación normalmente se combina con el de desmenuzado en molino de martillos o trituradora para fragmentar la batería. Los trozos de ésta, tanto los que contienen plomo como los fragmentos de las carcasas, se introducen en una serie de tanques llenos de agua. El material que contiene plomo se sumerge hasta el fondo de los tanques, de donde se extrae por medio de un transportador de tornillo sin fin o cadena de arrastre, mientras que el material de la carcasa flota y se recoge en la superficie del tanque.

La mayoría de las fundiciones de plomo recuperado compran periódicamente baterías industriales que han sido utilizadas para impulsar maquinaria móvil eléctrica u otros usos industriales. La carcasa de muchas de estas baterías es de acero y para retirarla es preciso abrirla con un soplete o una sierra manual de gas.

\section{Otros tipos de chatarra que se compra por su contenido de} plomo

Las fundiciones de plomo recuperado compran también diversos otros tipos de chatarra para utilizarla como materia prima en el proceso de fundición. Entre estos materiales están chatarra procedente de plantas de fabricación de baterías, espumas de afino de plomo, chatarra de plomo metálico, como lingotes de linotipia y envueltas de cables, y residuos de plomo tetraetilo. Estos tipos de materiales pueden cargarse directamente en hornos de fundición o mezclarse con otros materiales de carga. 
Tabla 82.9 - Controles técnicos y administrativos para el cobre, por operaciones.

\section{Equipo de proceso \\ Separación y clasificación}

Briquetado y trituración

Desmenuzado

Trituración y separación por gravedad

Secado

Quemado del aislamiento

Exudación

$\begin{array}{ll}\begin{array}{l}\text { Lixiviación en carbonato de } \\ \text { amonio } \\ \text { Destilación al vapor }\end{array} & \text { Amoníaco } \\ \begin{array}{l}\text { Reducción hidrotérmica en } \\ \text { hidrógeno }\end{array} & \text { Amoníaco } \\ \text { Lixiviación en ácido sulfúrico } & \text { Neblinas de ácido sulfúrico } \\ \text { Fundición en convertidor } & \text { Metales volátiles, ruido }\end{array}$

Fundición en crisol eléctrico Partículas, óxidos de azufre y de nitrógeno, hollín, monóxido de

Afinado a fuego

Afinado electrolítico carbono, ruido

Oxidos de azufre, hidrocarburos, partículas

\section{Exposiciones}

Contaminantes atmosféricos por manipulación y desoldadura del material o corte de la chatarra

Polvo y aerosoles inespecíficos, neblinas de aceite, partículas metálicas y ruido

Polvo inespecífico, material aislante de cables, partículas metálicas y ruido

Polvo inespecífico, partículas metálicas de fundentes, escorias e impurezas, y ruido

Partículas inespecíficas que pueden incluir metales, hollín y materias orgánicas pesadas condensadas

Gases y vapores conteniendo fluoruros, dióxido de azufre, cloruros, monóxido de carbono, hidrocarburos y aldehídos

Partículas inespecíficas que pueden incluir humo, arcilla y óxidos metálicos

Gases y vapores conteniendo óxidos de nitrógeno, dióxido de azufre, cloruros, monóxido de carbono, hidrocarburos y aldehídos

Vapores metálicos y partículas, gases, vapores y partículas inespecíficos

Metales volátiles, ruido

Acido sulfúrico y metales procedentes de lodos
Controles técnicos y administrativos

Ventilación por extracción local, ventilación general de zonas

Ventilación por extracción local y ventilación general de zonas, aislamiento de la fuente de ruido; equipo de protección personal - protección auditiva y respiratoria

Ventilación por extracción local y ventilación general de zonas, aislamiento de la fuente de ruido; equipo de protección personal - protección auditiva y respiratoria

Ventilación por extracción local y ventilación general de zonas, aislamiento de la fuente de ruido; equipo de protección personal - protección auditiva y respiratoria

Ventilación por extracción local, ventilación general de zonas, régimen de trabajo/descanso, líquidos, aislamiento de la fuente de ruido; equipo de protección personal - protección auditiva y respiratoria

Ventilación por extracción local, ventilación general de zonas, régimen de trabajo/descanso, líquidos, aislamiento de la fuente de ruido; equipo de protección personal - protección respiratoria

Ventilación por extracción local, ventilación general de zonas, régimen de trabajo/descanso, líquidos, aislamiento de la fuente de ruido; equipo de protección personal - protección auditiva y respiratoria

Ventilación por extracción local, ventilación general de zonas; equipo de protección personal - protección respiratoria

Ventilación por extracción local, ventilación general de zonas; equipo de protección personal - gafas con pantallas laterales

Ventilación por extracción local, ventilación general de zonas; equipo de protección personal - protección respiratoria

Ventilación por extracción local, ventilación general de zonas

Ventilación por extracción local, ventilación general de zonas; equipo de protección personal-protección respiratoria y protección auditiva

Ventilación por extracción local, ventilación general de zonas; equipo de protección personal - protección auditiva

Ventilación por extracción local, ventilación general de zonas; equipo de protección personal - protección auditiva

Ventilación por extracción local, ventilación general de zonas

\section{Manutención y transporte de la materia prima}

Una parte esencial del proceso de fundición de plomo recuperado es la manutención, transporte y almacenamiento de la materia prima. Los materiales se transportan con carretillas elevadoras, palas cargadoras o transportadores mecánicos (tornillos sin fin, elevadores de cangilones o cintas transportadoras). El principal medio de transporte de materiales en la industria de segunda fusión es la maquinaria móvil.

Entre los medios de transporte mecánicos que utilizan habitualmente las fundiciones de plomo recuperado están los sistemas de cintas transportadoras, que pueden emplearse para llevar el material de carga del horno desde las zonas de almacenamiento hasta la zona de calcinación del horno; los transportadores de tornillo sin fin, para llevar el polvo del conducto de gases desde la cámara de sacos filtrantes hasta un horno de aglomeración o una zona de almacenamiento, los elevadores de cangilones y los cables o cadenas de arrastre.

\section{Fundición}

La operación de fundición en un taller de fundición de plomo recuperado consiste en reducir la chatarra que contiene plomo a plomo metálico en un horno de cuba o de reverbero.

Los hornos de cuba se cargan con el material que contiene plomo, coque (combustible) caliza y hierro (fundente). Estos materiales se introducen en el horno por la parte superior o por una compuerta de carga situada en el lateral de la cuba, cerca de la parte superior del horno. Entre los riesgos ambientales asociados con las operaciones de los hornos de cuba están los humos y partículas metálicas (en especial plomo y antimonio), calor, ruido y monóxido de carbono. En la industria del plomo de segunda fusión se utilizan diversos mecanismos de transporte del material de carga, de los cuales el más común es probablemente el montacargas de cubetas. Otros son las tolvas vibrantes, cintas transportadoras y elevadores de cubetas. 
Tabla 82.10 • Controles técnicos y administrativos para el plomo, por operaciones.

$\begin{array}{ll}\text { Equipo de proceso } & \text { Exposiciones } \\ \text { Vehículos } & \text { Polvo de plomo de las carreteras y salpicaduras } \\ & \text { de agua que contiene plomo }\end{array}$

Transportadores Polvo de plomo

Rotura de carcasas de Polvo de plomo, neblinas ácidas

baterías

Preparación de cargas Polvo de plomo

Horno de cuba Vapores y partículas metálicos (plomo, antimonio), calor y ruido, monóxido de carbono

Horno de reverbero Vapores y partículas metálicos (plomo, antimonio), calor y ruido

Afino

Colada
Partículas de plomo y posiblemente metales aleantes y agentes fundentes, ruido

Partículas de plomo y posiblemente metales aleantes

\section{Controles técnicos y administrativos}

Baldear las zonas y mantenerlas mojadas. Formación de los operarios, prácticas de trabajo prudentes y una adecuada limpieza son elementos esenciales para reducir al mínimo las emisiones de plomo cuando se trabaja con maquinaria móvil. Confinar el equipo y proveer un sistema de filtración de aire de presión positiva.

También es conveniente equipar los sistemas de cintas transportadoras con poleas de retorno autolimpiantes o limpiadores de cinta si se utilizan para transportar materiales de carga de hornos o polvo de conductos de humos.

Ventilación por extracción local, ventilación general de zonas

Ventilación por extracción local, ventilación general de zonas

Ventilación por extracción local, ventilación general de zonas, régimen de trabajo/descanso, líquidos, aislamiento de la fuente de ruido; equipo de protección personal — protección respiratoria y auditiva

Ventilación por extracción local, ventilación general de zonas, régimen de trabajo/descanso, líquidos, aislamiento de la fuente de ruido; equipo de protección personal - protección respiratoria y auditiva

Ventilación por extracción local, ventilación general de zonas; equipo de protección personal - protección auditiva

Ventilación por extracción local, ventilación general de zonas
Las operaciones de sangrado de los hornos de cuba comprenden la descarga del plomo fundido y la escoria del horno en moldes o cucharas. Algunas fundiciones vierten el metal directamente en una caldera de conservación que lo mantiene en fusión para el afino. El resto de las fundiciones cuelan el metal del horno en bloques y dejan que éstos se solidifiquen.

El aire inyectado para el proceso de combustión entra en el horno de cuba a través de unas toberas en las que de vez en cuando empiezan a acumularse residuos y hay que desatascarlas físicamente, por lo general introduciendo una varilla de acero, para evitar que se obstruyan. El método convencional para ello consiste en quitar la tapa de las toberas e introducir la varilla. Una vez desprendidos los residuos, se coloca de nuevo la tapa.

Los hornos de reverbero se cargan con materia prima que contiene plomo por medio de un mecanismo de carga del horno. En la industria del plomo de segunda fusión, estos hornos suelen tener un arco apoyado o suspendido construido de ladrillo refractario. Muchos de los contaminantes y riesgos físicos asociados con los hornos de reverbero son similares a los de los hornos de cuba. Tales mecanismos pueden ser un cilindro hidráulico, un transportador de tornillo u otros dispositivos similares a los descritos en relación con los hornos de cuba.

Las operaciones de sangrado de los hornos de reverbero son también muy parecidas a las de los hornos de cuba.

\section{Afino}

El afinado del plomo en las fundiciones de plomo recuperado se lleva a cabo en calderas de caldeo indirecto. Por lo general, el metal procedente de los hornos se funde en la caldera y después se ajusta el contenido de oligoelementos para producir la aleación deseada. Los productos usuales son plomo blando (puro) y diversas aleaciones de plomo duro (con antimonio).

En casi todas las operaciones de afino de plomo secundario se emplean métodos manuales para añadir materiales aleantes a las calderas y métodos también manuales de extracción de impurezas. Las impurezas se llevan hasta el borde de la caldera, se extraen con una pala o un cucharón y se vierten en un recipiente.

La Tabla 82.10 ofrece una lista de exposiciones y controles correspondientes a las operaciones de recuperación de plomo.

\section{Recuperación de zinc}

La industria del zinc recuperado utiliza recortes nuevos, espumas y cenizas, espumas de fundición inyectada, impurezas de galvanizado, polvo de conducto de humos y residuos químicos como materias primas para la obtención de zinc. La mayor parte de la chatarra nueva procesada está constituida por aleaciones a base de zinc y cobre procedentes de las cubas de galvanizado y de fundición inyectada. En la chatarra vieja se incluyen planchas viejas de zinc procedentes de grabadores, piezas de fundición inyectada y chatarra formada por varillas y matrices. Los procesos son los siguientes:

- Exudación reverberatoria. Se utilizan hornos de reverbero para separar el zinc de otros metales controlando la temperatura del horno. Como materias primas para este proceso de utilizan chatarra de productos de fundición inyectada tales como parrillas de radiador de automóviles y placas de matrícula, y revestimientos o residuos de zinc. Se carga la chatarra en el horno, se añade fundente y se funde el contenido. A continuación, se extrae el residuo de alto punto de fusión y el zinc fundido pasa directamente desde el horno a los procesos subsiguientes, como fundición, afino o aleación, o a recipientes colectores. Entre los contaminantes del metal están el zinc, aluminio, cobre, hierro, plomo, cadmio, manganeso y cromo. Otros contaminantes son los fundentes, óxidos de azufre, cloruros y fluoruros.

- Exudación rotativa. En este proceso se cargan en un horno de caldeo directo chatarra de zinc, productos de fundición inyectada, residuos y espumas, y se funden. Se despuma el caldo y el zinc metálico se recoge en calderas situadas fuera del horno. A continuación se extrae el material no fusible, es decir, la escoria, antes de recargar el horno. El metal obtenido en este proceso se somete a procesos de destilación o aleación. Los 
contaminantes son similares a los del proceso de exudación en horno de reverbero.

- Exudación en horno de mufla y en caldera. En estos procesos se cargan en el horno de mufla chatarra de zinc, productos de fundición inyectada al vapor, residuos y espumas, se exuda el material y el zinc exudado se somete a procesos de afino o aleación. El residuo se extrae mediante una criba vibrante que separa las impurezas de la escoria. Los contaminantes son similares a los del proceso de exudación en horno de reverbero.

- Trituración y cribado. Los residuos de zinc se pulverizan o trituran para romper los enlaces físicos entre el zinc metálico y los fundentes contaminantes. Después, el material reducido se separa en una fase de cribado o clasificación neumática. La trituración puede producir óxido de zinc y pequeñas cantidades de metales pesados y cloruros.

- Lixiviación con carbonato sódico. Los residuos se tratan químicamente para lixiviar el zinc y convertirlo en óxido de zinc. Primero se tritura y se lava la chatarra, fase en la que se separa el zinc del material por lixiviación. La porción acuosa se trata con carbonato sódico, lo que hace que el zinc se precipite. El precipitado se seca y calcina para obtener óxido de zinc en bruto, y a continuación se reduce el óxido de zinc a zinc metálico. Pueden producirse diversas sales de zinc contaminantes.

- Fundición en caldera, crisol, horno de reverbero y por inducción eléctrica. Se carga la chatarra en el horno y se añaden fundentes. Se agita el baño para formar una espuma que puede recogerse en la superficie. Una vez despumado el horno, se cuela el zinc en cucharas o moldes. Pueden producirse humos de óxido de zinc, amoníaco y cloruro de amonio, cloruro de hidrógeno y cloruro de zinc.

- Aleación. La función de este proceso es producir aleaciones de zinc a partir de chatarra de zinc pretratada, añadiéndole en una caldera de afino fundentes y aleantes solidificados o en fusión. Después se mezcla el contenido, se extraen las impurezas por despumación y se cuela el metal en moldes de diversas formas. Existe riesgo de exposición a partículas que contienen zinc, metales de aleación, cloruros, gases y vapores inespecíficos, y calor.

- Destilación en mufla. El proceso de destilación en mufla se utiliza para recuperar zinc a partir de aleaciones y fabricar lingotes de zinc puro. El proceso es semicontinuo y consiste en cargar el zinc fundido desde un crisol o un horno de exudación a la sección de mufla, vaporizar el zinc, condensar el zinc vaporizado y colarlo en moldes desde el condensador. Periódicamente se extrae el residuo de la mufla.

- Destilación/oxidación en retorta y destilación/oxidación en mufla. El producto del proceso de destilación/oxidación en retorta y destilación/oxidación en mufla es óxido de zinc. El proceso es similar a la destilación en retorta hasta la fase de vaporización pero, en este proceso, se elude el condensador y se añade aire para la combustión. El vapor se descarga en una corriente de aire a través de un orificio. La combustión se produce espontáneamente en el interior de una cámara refractaria revestida de vapor. El producto es transportado por los gases de la combustión y el aire sobrante hasta una cámara de sacos, donde se recoge. El aire sobrante asegura la oxidación completa y la refrigeración del producto. Estos procesos de destilación pueden dar lugar a exposiciones a humos de óxido de zinc, así como a partículas de otros metales y a óxidos de azufre.

La Tabla 82.11 ofrece una lista de exposiciones y controles correspondientes a las operaciones de recuperación de zinc.

\section{Recuperación de magnesio}

La chatarra vieja se obtiene de fuentes tales como piezas procedentes del desguace de automóviles y aviones y planchas litográficas inservibles, así como algunos lodos de fundiciones de magnesio primario. La chatarra nueva se compone de recortes, virutas de torno y de taladrado, espumas, escorias, impurezas y artículos defectuosos de talleres de laminación de chapa y plantas

Tabla 82.11 • Controles técnicos y administrativos para el zinc, por operaciones.

\section{Equipo de proceso}

Exudación reverberatoria

Exudación rotativa

Exudación en horno de mufla y en caldera

Trituración/cribado

Lixiviación con carbonato sódico

Fundición en caldera, crisol, horno de reverbero y por inducción eléctrica

Aleación

Destilación en retorta, destilación/oxidación en retorta y destilación en mufla

Destilación por resistencia de varilla de grafito

\section{Exposiciones}

Partículas que contienen zinc, aluminio, cobre, hierro, plomo, cadmio, manganeso y cromo, contaminantes procedentes de fundentes, óxidos de azufre, cloruros y fluoruros

Partículas que contienen zinc, aluminio, cobre, hierro, plomo, cadmio, manganeso y cromo, contaminantes procedentes de fundentes, óxidos de azufre, cloruros y fluoruros

Partículas que contienen zinc, aluminio, cobre, hierro, plomo, cadmio, manganeso y cromo, contaminantes procedentes de fundentes, óxidos de azufre, cloruros y fluoruros

Oxido de zinc, pequeñas cantidades de metales pesados, cloruros

Oxido de zinc, carbonato sódico, carbonato de zinc, hidróxido de zinc, cloruro de hidrógeno, cloruro de zinc

Vapores de óxido de zinc, amoníaco, cloruro amónico, cloruro de hidrógeno, cloruro de zinc

Partículas conteniendo zinc, metales aleantes, cloruros; gases y vapores inespecíficos; calor

Vapores de óxido de zinc, otras partículas metálicas, óxidos de azufre

Vapores de óxido de zinc, otras partículas metálicas, óxidos de azufre

\section{Controles técnicos y administrativos}

Ventilación por extracción local, ventilación general de zonas, estrés por calor-régimen de trabajo/descanso, líquidos

Ventilación por extracción local, ventilación general de zonas, régimen de trabajo/descanso, líquidos

Ventilación por extracción local, ventilación general de zonas, régimen de trabajo/descanso, líquidos

Ventilación por extracción local, ventilación general de zonas

Ventilación por extracción local, ventilación general de zonas

Ventilación por extracción local, ventilación general de zonas, régimen de trabajo/descanso, líquidos

Ventilación por extracción local, ventilación general de zonas, régimen de trabajo/descanso, líquidos

Ventilación por extracción local, ventilación general de zonas, régimen de trabajo/descanso, líquidos

Ventilación por extracción local, ventilación general de zonas, régimen de trabajo/descanso, líquidos 
Tabla 82.12 - Controles técnicos y administrativos para el magnesio, por operaciones.

\begin{tabular}{clc}
$\begin{array}{c}\text { Equipo de proceso } \\
\text { Clasificación de } \\
\text { chatarra }\end{array}$ & $\begin{array}{c}\text { Exposiciones } \\
\text { Pundición en crisol } \\
\text { abierto }\end{array}$ & $\begin{array}{c}\text { Controles técnicos y } \\
\text { administrativos }\end{array}$ \\
$\begin{array}{c}\text { Vapores y polvo, } \\
\text { alto riesgo de } \\
\text { incendio }\end{array}$ & $\begin{array}{c}\text { Venteo con agualación por extracción local y } \\
\text { ventilación general de zonas y } \\
\text { prácticas de trabajo }\end{array}$ \\
$\begin{array}{c}\text { Polvo y vapores, calor y y } \\
\text { alto riesgo de } \\
\text { incendio }\end{array}$ & $\begin{array}{c}\text { Ventilación por extracción local, } \\
\text { ventilación general de zonas, } \\
\text { régimen de trabajo/descanso, } \\
\text { líquidos }\end{array}$ \\
\hline
\end{tabular}

de fabricación de estructuras. El mayor peligro que entraña la manipulación de magnesio es el de incendio. Los fragmentos pequeños de este metal pueden inflamarse fácilmente a causa de una chispa o una llama.

- Clasificación manual. Este proceso se utiliza para separar las fracciones de magnesio y sus aleaciones de otros metales presentes en la chatarra. Esta última se esparce manualmente y se clasifica de acuerdo con su peso.

- Fundición en crisol abierto. Este proceso se utiliza para separar el magnesio de los contaminantes contenidos en la chatarra clasificada. La chatarra se carga en un crisol, se calienta y se le añade un fundente formado por una mezcla de cloruros de calcio, sodio y potasio. Después, el magnesio fundido se cuela en lingotes.

La Tabla 82.12 ofrece una lista de exposiciones y controles correspondientes a las operaciones de recuperación de magnesio.

\section{Recuperación de mercurio.}

Las principales fuentes de mercurio son amalgamas dentales, baterías de mercurio desechadas, lodos de procesos electrolíticos en los que se utiliza mercurio como catalizador, mercurio procedente del desmantelamiento de plantas de cloroálcali e instrumentos que contienen mercurio. Todos estos procesos pueden contaminarse con vapor de mercurio.
- Trituración. El proceso de trituración se emplea para separar el mercurio residual de los recipientes metálicos, de plástico y de vidrio. Una vez triturados los recipientes, el mercurio líquido contaminado se lleva al proceso de filtración.

- Filtración. Las impurezas insolubles, tales como suciedad, se eliminan pasando la chatarra que contiene vapor de mercurio por un medio filtrante. El mercurio filtrado se lleva al proceso de oxigenación y los sólidos que no pasan por los filtros se envían a la destilación en retorta.

- Destilación al vacio. La destilación al vacío se utiliza para refinar el mercurio contaminado cuando las presiones de vapor de las impurezas son sustancialmente inferiores a la del mercurio. La carga de mercurio se vaporiza en un crisol de calentamiento y los vapores se condensan utilizando un condensador refrigerado por agua. El mercurio purificado se recoge y se envía a la operación de envasado. El residuo que queda en el crisol de calentamiento se lleva al proceso de calentamiento en retorta para recuperar los mínimos restos de mercurio que no se han recuperado en el proceso de destilación al vacío.

- Purificación mediante solución. En este proceso se eliminan los contaminantes metálicos y orgánicos lavando el mercurio líquido sin tratar con un ácido diluido. El proceso consta de los siguientes pasos: lixiviación del mercurio líquido en bruto con ácido nítrico diluido para separar las impurezas metálicas; agitación del ácido y el mercurio con aire comprimido para conseguir una mezcla homogénea; decantación para separar el mercurio del ácido; lavado con agua para eliminar el ácido residual, y filtración del mercurio en un medio como carbón activado o gel de sílice para eliminar los últimos restos de humedad. Además de al vapor de mercurio puede haber exposición a disolventes, compuestos químicos orgánicos y neblinas ácidas.

- Oxigenación. Este proceso consiste en refinar el mercurio filtrado eliminando las impurezas metálicas mediante oxidación por agitación con aire. El proceso de oxidación consta de dos fases, agitación y filtración. En la fase de agitación, el mercurio contaminado se agita con aire en un recipiente cerrado para oxidar los contaminantes metálicos. Después de la agitación, el mercurio se filtra sobre un lecho de carbón vegetal para eliminar los óxidos metálicos sólidos.

- Calentamiento en retorta. Este proceso se utiliza para producir mercurio puro volatilizando el que contiene la chatarra sólida portadora de este metal. El proceso consta de las siguientes fases: calentamiento de la chatarra por medio de una fuente de calor externa en un alambique cerrado o una pila de bateas

Tabla 82.13 • Controles técnicos y administrativos para el mercurio, por operaciones.

\begin{tabular}{|c|c|c|}
\hline Equipo de proceso & Exposiciones & Controles técnicos y administrativos \\
\hline Trituración & Mercurio volátil & $\begin{array}{l}\text { Extracción local; equipo de protección personal - protección } \\
\text { respiratoria }\end{array}$ \\
\hline Filtración & Mercurio volátil & $\begin{array}{l}\text { Ventilación por extracción local; equipo de protección } \\
\text { personal — protección respiratoria }\end{array}$ \\
\hline Destilación al vacío & Mercurio volátil & $\begin{array}{l}\text { Ventilación por extracción local; equipo de protección } \\
\text { personal — protección respiratoria }\end{array}$ \\
\hline Purificación de soluciones & $\begin{array}{l}\text { Mercurio volátil, disolventes, materiales } \\
\text { orgánicos y neblinas ácidas }\end{array}$ & $\begin{array}{l}\text { Ventilación por extracción local, ventilación general de zonas; } \\
\text { equipo de protección personal - protección respiratoria }\end{array}$ \\
\hline Oxidación & Mercurio volátil & $\begin{array}{l}\text { Ventilación por extracción local; equipo de protección } \\
\text { personal — protección respiratoria }\end{array}$ \\
\hline Calentamiento en retorta & Mercurio volátil & $\begin{array}{l}\text { Ventilación por extracción local; equipo de protección } \\
\text { personal — protección respiratoria }\end{array}$ \\
\hline
\end{tabular}


Tabla 82.14 • Controles técnicos y administrativos para el níquel, por operaciones.

\begin{tabular}{|c|c|c|}
\hline Equipo de proceso & Exposiciones & Controles técnicos y administrativos \\
\hline Clasificación & Polvo & Extracción local y sustitución de disolventes \\
\hline Desengrasado & Disolvente & $\begin{array}{l}\text { Ventilación por extracción local y sustitución y/o recuperación de disolventes, } \\
\text { ventilación general de zonas }\end{array}$ \\
\hline Fundición & Vapores, polvo, ruido, calor & $\begin{array}{l}\text { Ventilación por extracción local, régimen de trabajo/descanso, líquidos; } \\
\text { equipo de protección personal - protección respiratoria y auditiva }\end{array}$ \\
\hline Afino & Vapores, polvo, ruido, calor & $\begin{array}{l}\text { Ventilación por extracción local, ventilación general de zonas, régimen de } \\
\text { trabajo/descanso, líquidos; equipo de protección personal - protección } \\
\text { respiratoria y auditiva }\end{array}$ \\
\hline Colada & Calor, vapores metálicos & $\begin{array}{l}\text { Ventilación por extracción local, ventilación general de zonas, régimen de } \\
\text { trabajo/descanso, líquidos }\end{array}$ \\
\hline
\end{tabular}

para vaporizar el mercurio; condensar el vapor de mercurio en condensadores refrigerados por agua, y recoger el mercurio condensado en un recipiente.

La tabla 82.13 ofrece una lista de exposiciones y controles correspondientes a las operaciones de recuperación de mercurio.

\section{Recuperación de níquel}

Las principales materias primas para la recuperación de níquel son aleaciones a base de vapores de níquel, cobre y aluminio, que se encuentran en forma de chatarra vieja o nueva. La chatarra vieja está formada por piezas de diferentes aleaciones procedentes del desguace de aviones y maquinaria, mientras que la nueva consiste en recortes de chapa, virutas y otros fragmentos generados como subproductos de la fabricación de productos aleados. La recuperación de níquel comprende los siguientes pasos:

- Clasificación. La chatarra se inspecciona y se separa a mano de los materiales no metálicos o que no contienen níquel. La clasificación produce exposición al polvo.

- Desengrase. La chatarra de níquel se desengrasa con tricloroetileno. La mezcla se filtra o centrifuga para separar la chatarra de níquel. La disolución agotada de tricloroetileno y grasa se hace pasar por un sistema de recuperación de disolvente. Puede producirse exposición al disolvente durante el desengrase.

- Fundición en horno de arco eléctrico u horno de reverbero rotativo. La chatarra se carga en un horno de arco y se le añade un reductor, normalmente cal. La carga se funde y se cuela en lingotes o se lleva directamente a un reactor para su afino adicional. Pueden producirse exposiciones a humos, polvo, ruido y calor.

- Afino en reactor. $\mathrm{El}$ metal fundido se introduce en un reactor al que se añaden chatarra de base fría y lingotes de níquel, seguidos de cal y sílice. También se añaden materiales aleantes como manganeso, niobio o titanio, para producir una aleación de la composición deseada. Pueden producirse exposiciones a humos, polvo, ruido y calor.

- Colada en lingotes. Este proceso consiste en colar en lingotes el metal fundido del horno o el reactor de afino. El metal se vierte en moldes y se deja enfriar. Después, se extraen los lingotes de los moldes. Pueden producirse exposiciones al calor y a humos metálicos.

Las exposiciones y medidas de control correspondientes a las operaciones de recuperación de níquel se relacionan en la Tabla 82.14.

\section{Recuperación de metales preciosos}

Las materias primas para la industria de los metales preciosos consisten en chatarra vieja y nueva. La chatarra vieja comprende componentes electrónicos procedentes de equipos civiles y militares inservibles y chatarra de la industria dental. La chatarra nueva se genera durante la producción y fabricación de productos de metales preciosos. Los productos obtenidos son los metales elementales, tales como oro, plata, platino y paladio. El procesado de metales preciosos consta de los siguientes pasos:

- Clasificación manual y desmenuzado. La chatarra que contiene metales preciosos se clasifica a mano y se tritura y desmenuza en un molino de martillos. Este tipo de molinos son ruidosos.

Tabla 82.15 - Controles técnicos y administrativos para los metales preciosos, por operaciones.

\begin{tabular}{|c|c|c|}
\hline Equipo de proceso & Exposiciones & Controles técnicos y administrativos \\
\hline Clasificación manual y desmenuzado & El molino de martillos entraña riesgo de ruido & $\begin{array}{l}\text { Material de control de ruido; equipo de protección personal — protección } \\
\text { auditiva }\end{array}$ \\
\hline Incineración & $\begin{array}{l}\text { Materiales orgánicos, gases de combustión y } \\
\text { polvo }\end{array}$ & Ventilación por extracción local y ventilación general de zonas \\
\hline Fundición en horno de cuba & Polvo, ruido & $\begin{array}{l}\text { Ventilación por extracción local; equipo de protección personal - protección } \\
\text { auditiva y respiratoria }\end{array}$ \\
\hline Afinado electrolíitico & Neblinas ácidas & Ventilación por extracción local, ventilación general de zonas \\
\hline Afinado químico & Acido & $\begin{array}{l}\text { Ventilación por extracción local, ventilación general de zonas; equipo de } \\
\text { protección personal - ropa resistente a los ácidos, gafas de seguridad } \\
\text { resistentes a los productos químicos y pantalla facial }\end{array}$ \\
\hline
\end{tabular}


Tabla 82.16 - Controles técnicos y administrativos para el cadmio, por operaciones.

$\begin{array}{ll}\begin{array}{l}\text { Equipo de proceso } \\ \text { Desengrasado de la chatarra }\end{array} & \begin{array}{l}\text { Exposiciones } \\ \text { Disolventes y polvo de cadmio }\end{array} \\ \begin{array}{l}\text { Fundición y afino de aleaciones } \\ \text { Productos de la combustión de aceite y gas, vapores } \\ \text { de zinc, polvo y vapores de cadmio } \\ \text { Vestilación en retorta }\end{array} \\ \begin{array}{l}\text { Fusión /descincado } \\ \text { Vapores y polvo de cadmio, vapores y polvo de zinc, } \\ \text { cloruro de zinc, cloro, cloruro de hidrógeno, estrés } \\ \text { por calor } \\ \text { Polvo y vapores de cadmio, calor }\end{array}\end{array}$

\author{
Controles técnicos y administrativos \\ Extracción local y sustitución de disolventes \\ Ventilación por extracción local y ventilación general de zonas; equipo de \\ protección personal - protección respiratoria \\ Ventilación por extracción local; equipo de protección personal - protección \\ respiratoria \\ Ventilación por extracción local, ventilación general de zonas, régimen de \\ trabajo/descanso, líquidos; equipo de protección personal - protección \\ respiratoria \\ Ventilación por extracción local, ventilación general de zonas, régimen de \\ trabajo/descanso, líquidos; equipo de protección personal — protección \\ respiratoria
}

- Proceso de incineración. La chatarra clasificada se incinera para eliminar el papel, el plástico y los contaminantes orgánicos líquidos. Pueden producirse exposiciones a productos químicos orgánicos, gases de combustión y polvo.

- Fundición en horno de cuba. La chatarra tratada se carga en un horno de cuba junto con coque, fundente y óxidos metálicos de escoria reciclada. La carga se funde y desescoria, obteniéndose cobre negro que contiene los metales preciosos. La escoria dura formada contiene la mayor parte de las impurezas de la escoria. Puede generarse polvo y ruido.

- Fundición en convertidor. Este proceso está destinado a purificar aún más el cobre negro inyectando aire a través del caldo en un convertidor. Los contaminantes metálicos que contienen escoria son eliminados y se reciclan al horno de cuba. El caldo de cobre que contiene los metales preciosos se cuela en moldes.

- Afinado electrolítico. El cobre así obtenido se utiliza como ánodo de una célula electrolítica. De ese modo, el cobre puro se deposita en el cátodo mientras que los metales preciosos caen al fondo de la célula y se recogen en forma de lodos. Como electrolito se utiliza sulfato de cobre. Puede haber exposiciones a neblinas ácidas.

- Afinado químico. El lodo de metales preciosos obtenido en el proceso de afino electrolítico se trata químicamente para recuperar los distintos metales. Se utilizan procesos a base de cianuro para recuperar el oro y la plata, que también pueden recuperarse disolviéndolos en una disolución de agua regia y/o ácido nítrico, seguida de precipitación con sulfato de hierro o cloruro sódico para recuperar el oro y la plata respectivamente. Los metales del grupo del platino pueden recuperarse disolviéndolos en plomo fundido, el cual se trata después con ácido nítrico y deja un residuo del que pueden separarse selectivamente dichos metales por precipitación. A continuación, los precipitados de metales preciosos se funden o incineran para recoger el oro y la plata, que forman granos, y los metales que contienen platino, en forma de esponja. Pueden darse exposiciones al ácido.

Las exposiciones y controles figuran relacionados, por operaciones, en la Tabla 82.15 (véase también "Fundición y afino del oro" en este capítulo).

\section{Recuperación de cadmio}

La chatarra vieja que contiene cadmio se compone de piezas cadmiadas procedentes del desguace de vehículos y embarcaciones, electrodomésticos, herrajes y elementos de fijación, baterías de cadmio, contactos de cadmio de interruptores y relés, y otras piezas usadas de aleaciones de cadmio. La chatarra nueva consiste normalmente en piezas rechazadas que contienen vapores de cadmio y en subproductos contaminados procedentes de industrias del metal. Los procesos de recuperación son los siguientes:

- Tratamiento previo. El tratamiento previo de la chatarra implica el desengrasado al vapor de las piezas de aleación que la componen. Los vapores de disolvente generados calentando

Tabla 82.17 - Controles técnicos y administrativos para el selenio, por operaciones.

$\begin{array}{ll}\text { Equipo de proceso } & \text { Exposiciones } \\ \text { Tratamiento previo de la chatarra } & \text { Polvo } \\ \text { Fundición en retorta } & \text { Gases y polvo de combustión, ruido } \\ \text { Afino } & \mathrm{SO}_{2} \text {, neblina ácida } \\ \text { Destilación } & \text { Polvo y productos de la combustión } \\ \text { Temple } & \text { Polvo metálico } \\ \text { Colada } & \text { Vapores de selenio }\end{array}$

Controles técnicos y administrativos

Extracción local

Ventilación por extracción local y ventilación general de zonas; equipo de protección personal - protección auditiva; control del ruido de los quemadores

Ventilación por extracción local; equipo de protección personal - gafas de seguridad resistentes a los productos químicos

Ventilación por extracción local, ventilación general de zonas

Ventilación por extracción local, ventilación general de zonas

Ventilación por extracción local, ventilación general de zonas 
Tabla 82.18 • Controles técnicos y administrativos para el cobalto, por operaciones.

Equipo de proceso
Clasificación manual
Desengrasado
Limpieza por chorro abrasivo
Baño ácido y proceso de tratamiento
químico
Fundición al vacío
Colada

Exposiciones
Polvo
Disolventes
Polvo - toxicidad dependiente del abrasivo
utilizado
Neblinas ácidas
Metales pesados
Calor

\author{
Controles técnicos y administrativos \\ Baldeo con agua \\ Recuperación de disolventes, extracción local y sustitución de disolventes \\ Ventilación por extracción local; equipo de protección personal contra riesgos \\ físicos y protección respiratoria dependiendo del abrasivo utilizado \\ Ventilación por extracción local, ventilación general de zonas; equipo de \\ protección personal - protección respiratoria \\ Ventilación por extracción local, ventilación general de zonas \\ Ventilación por extracción local, ventilación general de zonas, régimen de \\ trabajo/descanso, líquidos
}

disolventes reciclados se hacen circular por un recipiente que contiene las piezas de distintas aleaciones que componen la chatarra. A continuación, se condensan y separan el disolvente y la grasa desprendida y se recicla el disolvente. Puede producirse exposición a polvo de cadmio y disolventes.

- Fundición y afino. En la operación de fundición y afino, se procesa chatarra de aleación pretratada o chatarra de cadmio elemental para eliminar cualquier impureza y producir cadmio elemental o aleado. Puede haber exposiciones a productos de la combustión de gas y fuel-oil, y a polvo de zinc y cadmio.

- Destilación en retorta. La chatarra de aleación desengrasada se carga en una retorta y se calienta para producir vapores de cadmio que a continuación se recogen en un condensador. El metal fundido queda así preparado para la colada. Hay posibilidad de exposición a polvo de cadmio.

- Fundición/descincado. El cadmio se carga en un crisol y se calienta hasta que alcanza el estado de fusión. Si el metal contiene zinc, se añaden fundentes y clorantes para eliminarlo. Hay potencial de exposición a humos y polvo de cadmio, humos y polvo de zinc, cloruro de zinc, cloro, cloruro de hidrógeno y calor, entre otros.

- Colada. En la operación de colada se forma la línea de productos deseada a partir del cadmio aleado o metálico purificados producidos en el paso anterior. La colada puede producir polvo y humos de cadmio y calor.

Las exposiciones que pueden producirse durante los procesos de recuperación de cadmio y las correspondientes medidas de control, se resumen en la Tabla 82.16 .

\section{Recuperación de selenio}

Las materias primas para este segmento son cilindros de xerocopia usados y chatarra generada durante la fabricación de rectificadores de selenio. Puede formarse polvo de selenio durante todo el proceso. La destilación y la fundición en retorta pueden producir gases de combustión y polvo. La fundición en retorta es ruidosa. En el afino se forma una neblina de dióxido de azufre y una neblina ácida. En las operaciones de colada puede producirse polvo metálico (véase la Tabla 82.17).Los procesos de recuperación son los siguientes:

- Tratamiento previo de la chatarra. En este proceso se separa el selenio por procedimientos mecánicos, tales como el molino de martillos o el tratamiento con chorro de granalla.

- Fundición en retorta. En este proceso, la chatarra pretratada se purifica y concentra mediante una operación de destilación en retorta en la que se funde la chatarra y se separa el selenio de las impurezas por destilación.

- Afino. Este proceso purifica la chatarra de selenio mediante lixiviación con un disolvente adecuado, como una disolución acuosa de sulfito de sodio. Las impurezas insolubles se eliminan por filtración y después se trata el filtrado para precipitar el selenio.

- Destilación. Este proceso produce vapores de selenio de alta pureza. El selenio se funde y destila, y los vapores de selenio se condensan y transfieren como selenio fundido a una operación de formación de productos.

- Temple. Este proceso se utiliza para producir granalla y polvo de selenio purificado. La granalla se obtiene a partir del caldo de selenio y después se seca. Los pasos necesarios para producir el polvo son los mismos, pero en este caso lo que se templan son los vapores de selenio en lugar del selenio fundido.

- Colada. Este proceso se emplea para producir lingotes o productos de otras formas a partir del caldo de selenio. Dichos productos se obtienen colando el selenio fundido en moldes de tamaño y forma adecuados, y enfriando y solidificando el caldo.

\section{Recuperación de cobalto}

Las fuentes de chatarra de cobalto son partículas de esmerilado y virutas de torno de super aleaciones, así como álabes de turbina y piezas de motor anticuados o desgastados. Los procesos de recuperación son los siguientes:

- Clasificación manual. La chatarra sin tratar se clasifica a mano para identificar y separar los componentes de base cobalto, los de base níquel y los no procesables. En esta operación se produce polvo.

- Desengrasado. La chatarra sucia clasificada se carga en una unidad de desengrasado por la que circulan vapores de percloroetileno. Este disolvente elimina la grasa y el aceite de la chatarra. Después se condensa la mezcla de vapores de disolvente, aceite y grasa y se recupera el disolvente. Hay riesgo de exposiciones al disolvente.

- Limpieza por chorro abrasivo. La chatarra desengrasada se limpia con chorro abrasivo para eliminar la suciedad, los óxidos y la corrosión. Puede producirse polvo dependiendo del abrasivo que se utilice.

- Proceso de limpieza en baño ácido y tratamiento químico. La chatarra sometida a limpieza con chorro abrasivo se trata con ácidos para eliminar los residuos contaminantes de óxido y corrosión. Existe riesgo de exposición a neblinas ácidas.

- Fundición al vacío. La chatarra limpia se carga en un horno de vacío y se funde por arco eléctrico o inducción. Puede producirse exposición a metales pesados.

- Colada. La aleación fundida se cuela en lingotes. Hay riesgo de estrés por calor. 
La Tabla 82.18 ofrece un resumen de las exposiciones asociadas con la recuperación de cobalto y de las correspondientes medidas de control.

\section{Recuperación de estaño}

Las principales fuentes de materias primas son recortes de acero estañado, rechazos de empresas fabricantes de envases de hojalata, bobinas de estañado rechazadas procedentes de la industria del acero, impurezas y lodos de estaño, impurezas y lodos de soldadura, piezas de bronce usadas o rechazadas y chatarra de estaño. En muchos de los procesos se forma polvo de estaño y neblinas ácidas.

- Desaluminización. En este proceso se utiliza hidróxido sódico caliente para lixiviar el aluminio contenido en la chatarra de hojalata poniéndola en contacto con el hidróxido sódico, separando la disolución de aluminato sódico de la chatarra residual, bombeando el aluminato de sodio a una operación de afino para recuperar el estaño soluble y recuperando la chatarra de estaño desaluminizada para utilizarla como carga en posteriores procesos.

- Mezcla de cargas. Este proceso es una operación mecánica en la que se prepara un lote adecuado para su carga en el horno de fundición, mezclando lodos e impurezas con un contenido sustancial de estaño.

- Desestañado químico. Este proceso extrae el estaño de la chatarra. Se añade una disolución caliente de hidróxido sódico y nitrito o nitrato de sodio a la chatarra desaluminizada o sin tratar. Una vez completada la reacción de desestañado, la disolución se drena y se bombea a un proceso de afino y colada, después de lo cual la chatarra desestañada se somete a un lavado.
- Fundición de impurezas. Este proceso se emplea para purificar parcialmente las impurezas y producir metal en bruto en el horno fundiendo la carga, colando el metal sin afinar y evacuando las matas y escorias.

- Lixiviación y filtración de polvo. En este proceso se extraen el zinc y el cloro del polvo del conducto de humos por lixiviación con ácido sulfúrico, filtrando la mezcla resultante para separar el ácido y el zinc y el cloro disueltos del polvo lixiviado, secando el polvo en un secador y llevando de nuevo el polvo rico en estaño y plomo al proceso de mezcla de cargas.

- Decantación y filtración en filtro de hojas. Este proceso purifica la disolución de estannato sódico producida en el proceso de desestañado químico. Las impurezas, tales como plata, mercurio, cobre, cadmio, algo de hierro, cobalto y níquel, se precipitan como sulfuros.

- Evapocentrifugado. El estannato sódico se concentra a partir de la solución purificada mediante evaporación y cristalización, y se recupera por centrifugado.

- Afinado electrolítico. En este proceso se produce estaño catódico puro a partir de la disolución purificada de estannato sódico, haciendo pasar dicha solución por células electrolíticas, extrayendo los cátodos una vez depositado el estaño y separando éste de los cátodos.

- Acidificación y filtración. Este proceso produce un óxido de estaño hidratado a partir de la disolución de estannato sódico purificada. El óxido obtenido puede procesarse para producir el óxido anhidro o fundirse para obtener estaño elemental. El óxido hidratado se neutraliza con ácido sulfúrico para formar el óxido de estaño hidratado y se filtra para separar el hidrato como torta de filtro.

Tabla 82.19 • Controles técnicos y administrativos para el estaño, por operaciones.

\begin{tabular}{|c|c|c|}
\hline Equipo de proceso & Exposiciones & Controles técnicos y administrativos \\
\hline Desaluminización & Hidróxido sódico & $\begin{array}{l}\text { Extracción local; equipo de protección personal - gafas de seguridad resistentes a los } \\
\text { productos químicos y/o pantalla facial }\end{array}$ \\
\hline Mezcla de cargas & Polvo & Ventilación por extracción local y ventilación general de zonas \\
\hline Desestañado químico & Sustancias cáusticas & $\begin{array}{l}\text { Ventilación por extracción local; equipo de protección personal - gafas de seguridad } \\
\text { resistentes a los productos químicos y/o pantalla facial }\end{array}$ \\
\hline Fundición de impurezas & Polvo y calor & $\begin{array}{l}\text { Ventilación por extracción local, ventilación general de zonas, régimen de } \\
\text { trabajo/descanso, líquidos }\end{array}$ \\
\hline Lixiviación y filtración de polvo & Polvo & Ventilación por extracción local, ventilación general de zonas \\
\hline Decantación y filtración en filtro de hojas & No se ha determinado ninguna & No se ha determinado ninguno \\
\hline Evapocentrifugado & No se ha determinado ninguna & No se ha determinado ninguno \\
\hline Afinado electrolítico & Neblina ácida & $\begin{array}{l}\text { Ventilación por extracción local y ventilación general de zonas; equipo de protección } \\
\text { personal - gafas de seguridad resistentes a los productos químicos y/o pantalla } \\
\text { facial }\end{array}$ \\
\hline Acidificación y filtración & Neblinas ácidas & $\begin{array}{l}\text { Ventilación por extracción local y ventilación general de zonas; equipo de protección } \\
\text { personal - gafas de seguridad resistentes a los productos químicos y/o pantalla } \\
\text { facial }\end{array}$ \\
\hline Afinado a fuego & Calor & Régimen de trabajo/descanso, equipo de protección personal \\
\hline Fundición & $\begin{array}{l}\text { Gases de combustión, vapores y polvo, } \\
\text { calor }\end{array}$ & $\begin{array}{l}\text { Ventilación por extracción local y ventilación general de zonas, régimen de } \\
\text { trabajo/descanso, equipo de protección personal }\end{array}$ \\
\hline Calcinación & Polvo, vapores, calor & $\begin{array}{l}\text { Ventilación por extracción local y ventilación general de zonas, régimen de } \\
\text { trabajo/descanso, equipo de protección personal }\end{array}$ \\
\hline Afinado en caldera & Polvo, vapores, calor & $\begin{array}{l}\text { Ventilación por extracción local y ventilación general de zonas, régimen de } \\
\text { trabajo/descanso, equipo de protección personal }\end{array}$ \\
\hline
\end{tabular}


Tabla 82.20 - Controles técnicos y administrativos para el titanio, por operaciones.

\begin{tabular}{|c|c|c|}
\hline Equipo de proceso & Exposiciones & $\begin{array}{l}\text { Controles técnicos y } \\
\text { administrativos }\end{array}$ \\
\hline $\begin{array}{l}\text { Desengrasado con } \\
\text { disolvente }\end{array}$ & Disolvente & $\begin{array}{l}\text { Extracción local y recuperación de } \\
\text { disolvente }\end{array}$ \\
\hline Limpieza en baño ácido & Acidos & $\begin{array}{l}\text { Pantallas faciales, mandiles, } \\
\text { mangas largas, gafas o lentes } \\
\text { de seguridad }\end{array}$ \\
\hline Electroafinado & $\begin{array}{l}\text { No se conoce } \\
\text { ninguna }\end{array}$ & No se conoce ninguno \\
\hline Fundición & $\begin{array}{l}\text { Metales volátiles, } \\
\text { ruido }\end{array}$ & $\begin{array}{l}\text { Ventilación por extracción local y } \\
\text { control del ruido de los quema- } \\
\text { dores; equipo de protección } \\
\text { personal - protección auditiva }\end{array}$ \\
\hline Colada & Calor & Equipo de protección personal \\
\hline
\end{tabular}

- Afinado a fuego. Este proceso produce estaño purificado a partir del estaño catódico fundiendo la carga, eliminando las impurezas, como escoria y espuma, vertiendo el metal fundido y colando el estaño metálico.

- Fundición. Este proceso se emplea para producir estaño cuando no es posible el afinado electrolítico. El proceso consiste en reducir el óxido de estaño hidratado con un reductor, fundir el estaño metálico formado, despumar las impurezas, y verter y colar el estaño fundido.

- Calcinación. Este proceso convierte los óxidos de estaño hidratados en óxido estánnico anhidro calcinando el hidrato y extrayendo y empaquetando los óxidos estánnicos.

- Afinado en caldera. Este proceso se emplea para purificar el metal en bruto del horno cargando con él una caldera precalentada, secando la espuma para eliminar las impurezas como escoria y mata, utilizando azufre como fundente para separar el cobre como mata, empleando aluminio como fundente para eliminar el antimonio, y colando el metal fundido en moldes de las formas deseadas.

La Tabla 82.19 ofrece un resumen de las exposiciones asociadas con la recuperación de estaño y de las correspondientes medidas de control.

\section{Recuperación de titanio}

Las dos fuentes principales de chatarra de titanio son los consumidores domésticos y los de titanio. La chatarra doméstica que se genera con el mecanizado y la fabricación de productos de titanio comprende chapas cortadas, planchas, recortes, virutas de torno y virutas de taladrado. La chatarra de consumo se compone de productos de titanio reciclados. Las recuperación se efectúa mediante las siguientes operaciones:

- Desengrasado. En este proceso la chatarra, clasificada por tamaños, se trata con disolvente orgánico vaporizado (por ej., tricloroetileno). La grasa y el aceite contaminantes se separan de la chatarra por la acción del vapor de disolvente. El disolvente se recicla hasta que pierde totalmente su capacidad desengrasante. Una vez agotado, puede regenerarse. La chatarra también puede desengrasarse con vapor y detergente.

- Limpieza en baño. El proceso de limpieza en baño ácido elimina la cascarilla de óxido que queda tras la operación de desengrasado, mediante lixiviación con una disolución de ácido clorhídrico y fluorhídrico. Después del tratamiento con ácido la chatarra se lava con agua y se seca.

- Electroafinado. El electroafinado es un proceso de tratamiento previo de la chatarra de titanio por inmersión en una sal fundida.

- Fundición. La chatarra de titanio pretratada se funde con aleantes en un horno de arco eléctrico al vacío para formar una aleación de titanio. Los materiales utilizados son chatarra de titanio pretratada y aleantes como aluminio, vanadio, molibdeno, estaño, circonio, paladio, niobio y cromo.

- Colada. El titanio fundido se cuela en moldes y al solidificarse se convierte en una barra denominada lingote.

Las medidas de control de las exposiciones que se producen en los procesos de recuperación de titanio se relacionan en la Tabla 82.20.

\section{CUESTIONES AMBIENTALES EN EL ACABADO DE SUPERFICIES METALICAS Y LOS RECUBRIMIENTOS INDUSTRIALES}

Stewart Forbes

\section{Acabado de superficies metálicas}

El tratamiento de la superficie de los metales aumenta su duración y mejora su aspecto. Un mismo producto puede recibir más de un tratamiento de este tipo-por ejemplo, un panel de la carrocería de un automóvil puede fosfatarse, imprimarse y pintarse. Este artículo versa sobre los procesos utilizados para el tratamiento de la superficie de los metales y sobre los métodos empleados para reducir su impacto ambiental.

Las operaciones de una empresa de acabados de superficies metálicas requieren la cooperación entre la dirección de la empresa, los trabajadores, el gobierno y la comunidad para reducir al mínimo eficazmente sus efectos sobre el medio ambiente. A la sociedad le preocupan la magnitud y los efectos a largo plazo de la contaminación del medio ambiente atmosférico, acuático y terrestre. La Gestión ambiental efectiva se basa en un profundo conocimiento de todos los elementos, sustancias químicas, metales y procesos utilizados, y de los productos y elementos generados.

La planificación de la prevención de la contaminación desplaza la filosofia de la gestión ambiental de la reacción ante los problemas a la previsión de soluciones mediante la sustitución de productos químicos, la modificación de procesos y el reciclado interno, de acuerdo con la siguiente secuencia:

1. Aplicar la prevención de la contaminación a todos los aspectos de la empresa.

2. Determinar las corrientes de residuos.

3. Establecer prioridades de actuación.

4. Determinar el origen de los residuos.

5. Definir y ejecutar modificaciones que reduzcan o eliminen los residuos.

6. Medir los resultados.

Estableciendo nuevas prioridades de actuación y repitiendo la secuencia de actuaciones, se consiguen continuas mejoras.

La documentación detallada de los procesos permitirá determinar las corrientes de residuos y establecer prioridades para su reducción. Las decisiones documentadas sobre posibles modificaciones favorecen: 
- la introducción de mejoras fácilmente viables en las operaciones

- las modificaciones de procesos con la participación de clientes y suministradores

- los cambios a actividades menos perjudiciales siempre que sea posible

- la reutilización y el reciclaje cuando no sea posible efectuar cambios

- el uso de vertederos para la evacuación de residuos peligrosos solo como último recurso.

\section{Principales procesos y procedimientos normalizados}

La Limpieza es necesaria porque todos los procesos de acabado de superficies metálicas requieren que las piezas que van a recibir el acabado estén libres de suciedad orgánica e inorgánica, como aceites, óxido y productos pulimentadores. Los tres tipos básicos de limpiadores utilizados son los disolventes, los vapores desengrasantes y los detergentes alcalinos.

Los métodos de limpieza a base de disolventes y de vapores desengrasantes han sido sustituidos casi totalmente por el uso de materiales alcalinos cuando los procesos subsiguientes se realizan en fase húmeda. Siguen utilizándose disolventes y vapores desengrasantes cuando es necesario que las piezas queden limpias y secas sin ningún proceso posterior en fase húmeda. En algunos casos los disolventes volátiles están siendo sustituidos por otros, como los terpenos. En el desengrasado al vapor, algunos materiales peligrosos se han sustituido por otros menos tóxicos, como el 1,1,1-tricloroetano (aunque este disolvente está siendo abandonado gradualmente por su potencial destructor de ozono).

Los ciclos de limpieza alcalinos suelen incluir una operación de inmersión seguida de electrolimpieza anódica y de inmersión en una disolución débilmente ácida. Para limpiar aluminio se emplean por lo general productos exentos de silicatos que no lo atacan químicamente. Los ácidos más utilizados son el sulfúrico, el clorhídrico y el nítrico.

En el anodizado, un proceso electroquímico destinado a aumentar el espesor de la película de óxido depositada sobre la superficie del metal (frecuentemente se aplica al aluminio), las piezas se tratan con disoluciones diluidas de ácido crómico o sulfúrico.

El recubrimiento por conversión se utiliza para proporcionar a la superficie una base para su pintura posterior o con el fin de pasivarla para protegerla de la oxidación. En el cromado, las piezas se sumergen en una disolución de cromo hexavalente con agentes orgánicos activos e inactivos. Para el fosfatado, las piezas se sumergen en ácido fosfórico diluido con otros agentes. La pasivación se efectúa por inmersión en ácido nítrico solo o con dicromato sódico.

El recubrimiento no electrolítico consiste en la deposición de metal sin utilizar electricidad. En la fabricación de placas de circuitos impresos se utiliza el cobreado o niquelado no electrolítico.

El recubrimiento electrolítico consiste en depositar una delgada capa metálica (de zinc, níquel, cobre, cromo, cadmio, estaño, latón, bronce, plomo, estaño y plomo, oro, plata y otros metales, como platino) sobre un sustrato (férreo o no). Los baños de proceso incluyen metales en disolución en fórmulas ácidas, alcalinas neutras y de cianuro alcalino (véase la Figura 82.7).

El fresado químico y el mordentado son procesos de inmersión en disoluciones controladas utilizando reactivos y mordientes químicos. El aluminio se ataca normalmente con sosa cáustica antes del anodizado o el abrillantado químico en una disolución que puede contener ácido nítrico, fosfórico y sulfúrico.

Los recubrimientos por inmersión en caliente consisten en la aplicación de un recubrimiento metálico a la superficie de una pieza por inmersión en metal fundido (zincado o estañado de acero).
Figura 82.7 • Materias de partida y residuos generados en una cadena típica de recubrimiento electrolítico.

MATERIALES DE PARTIDA

RESIDUOS GENERADOS

Embalaje, materias primas, productos químicos

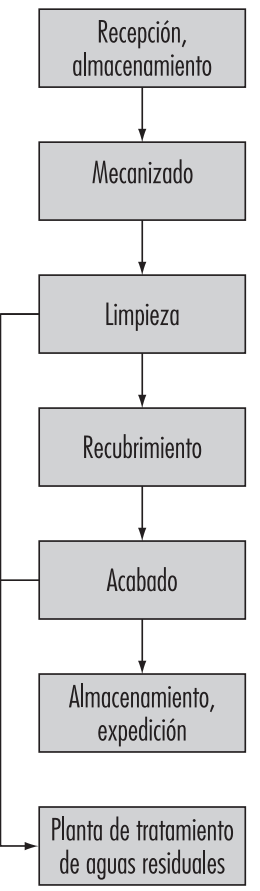

Existencias deterioradas, derrames, tambores, palets, cartón ondulado

Lubricantes metalúrgicos, metal

Limaduras, rebabas, lubricantes metalúrgicos usados

Baños agotados, aceites, hollín,

Productos químicos, agua, energía

Productos químicos, agua, energía

Productos químicos, agua, energía

Materiales acabados, embalaje

Productos químicos de tratamiento, agua, corrientes de residuos de las instalaciones Producto

Papel, material de oficina

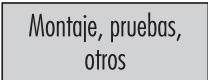

Defectos, aceites, disolventes agua de lavados, recipientes de productos químicos vacíos Baños agotados, aceites, hollín, derrames, agua de lavados, recipientes de productos químicos vacíos Baños agotados, aceites, hollín, derrames, agua de lavados, recipientes de productos químicos vacíos

Producto, embalaje sobrante 0 dañado

Efluente tratado, lodos
Administración

Agua, trapos, disolventes, lubricantes

Agua, muestras, productos químicos y material de laboratorio

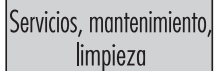

Aseguramiento de la calidad, control de calidad, laboratorio
Papel usado

Aceites residuales, piezas usadas, grasa, trapos sucios

Muestras desechadas, frascos, productos químicos

\section{Buenas prácticas de gestión}

Pueden conseguirse importantes mejoras en lo tocante a seguridad, salud y medio ambiente introduciendo en los procesos mejoras como las siguientes:

- utilizando lavados a contracorriente y controles de conductividad.

- aumentando el tiempo de drenaje

- empleando más o mejores tensoactivos

- utilizando temperaturas de proceso lo más altas posible para reducir la viscosidad y así aumentar la recuperación de escurriduras (recuperación de la solución que ha quedado adherida al metal)

- recurriendo a la agitación con aire en el lavado para aumentar su eficacia

- usando bolas de plástico en los tanques de recubrimiento para reducir la formación de neblinas 
- utilizando mejores sistemas de filtración en los tanques de recubrimiento para reducir la frecuencia del tratamiento de purificación

- colocando un bordillo alrededor de todas las zonas de proceso para contener los derrames

- empleando tratamientos separados para los metales recuperables, tales como el níquel

- instalando sistemas de recuperación, por ejemplo de intercambio iónico, evaporación atmosférica, evaporación al vacío, recuperación electrolítica, ósmosis inversa y electrodiálisis

- complementando los sistemas de recuperación de escurriduras con reducciones de la adherencia de contaminantes y mejores sistemas de limpieza

- utilizando modernos sistemas de control de existencias para reducir los residuos y los riesgos de los lugares de trabajo

- aplicando procedimientos estándar (es decir, procedimientos por escrito, revisiones periódicas de las operaciones y registros cronológicos rigurosos de las mismas) que sirvan de base a una sólida estructura de gestión ambiental.

\section{Planificación ambiental para residuos específicos}

Ciertas corrientes de residuos, normalmente disoluciones de recubrimiento agotadas, pueden reducirse por los siguientes métodos:

- Filtración. Pueden utilizarse filtros de cartuchos o de tierra de diatomeas para eliminar los sólidos acumulados que reducen la eficacia del proceso.

- Mediante tratamiento con carbono pueden eliminarse los contaminantes orgánicos (aplicados sobre todo en el niquelado, en el cobreado electrolítico y en el zincado y cadmiado).

- Agua purificada. Los contaminantes naturales del agua de relleno y de lavado (por ej., calcio, hierro, magnesio, manganeso, cloro y carbonatos) pueden eliminarse mediante desionización, destilación u ósmosis inversa. Mejorando la eficacia del agua de lavado se reduce el volumen de lodos de los baños que requieren tratamiento.

- Congelación de los carbonatos de los baños de cianuro. Reduciendo la temperatura del baño a-3 ${ }^{\circ} \mathrm{C}$ cristalizan los carbonatos formados en el baño de cianuro por descomposición del cianuro, densidades excesivas de corriente anódica y adsorción de dióxido de carbono del aire, y se facilita su eliminación.

- Precipitación. Los contaminantes metálicos que entran en el baño como impurezas de los ánodos, pueden eliminarse por precipitación con cianuro de bario, hidróxido de bario, hidróxido cálcico, sulfato cálcico o cianuro cálcico.

- Alternativas al cromo hexavalente. El cromo hexavalente puede sustituirse por disoluciones de recubrimiento de cromo trivalente para cromados decorativos. En ocasiones, los recubrimientos de conversión de cromo para tratamientos previos a la pintura se pueden sustituir por recubrimientos de conversión sin cromo o químicas de cromo sin lavado.

- Ouímicas de proceso no queladas. En lugar de añadir queladores a los baños de proceso para controlar la concentración de iones libres en la disolución, pueden utilizarse químicas de proceso no queladas para que no sea necesario mantener los metales en disolución. Se puede dejar que estos metales precipiten y extraerlos por filtración continua.

- Productos químicos de proceso sin cianuro. Las corrientes de residuos que contienen cianuro libre se tratan normalmente con hipoclorito o con cloro para producir la oxidación, y en el caso de los cianuros complejos se utiliza por lo general sulfato de hierro para provocar su precipitación. El uso de químicas de proceso sin cianuro elimina un paso de tratamiento y reduce el volumen de lodos.

- Desengrasado con disolventes. En lugar de usar disolventes para desengrasar las piezas antes del proceso, pueden utilizarse baños de limpieza alcalinos calientes. Se puede aumentar la eficacia de los limpiadores alcalinos aplicando corrientes eléctricas o ultrasonidos. Las ventajas que supone evitar los vapores y lodos de disolvente suelen compensar cualquier coste operativo adicional.

- Limpiadores alcalinos. Puede evitarse el tener que desechar los limpiadores alcalinos cuando la acumulación de aceite, grasa y suciedad producida por el uso alcanza un nivel que reduce la eficacia del baño, utilizando dispositivos de despumación para eliminar los aceites que flotan libremente, dispositivos de decantación o filtros de cartucho para eliminar partículas y agentes de coalescencia de aceite y agua, y utilizando microfiltración o ultrafiltración para eliminar los aceites emulsificados.

- Reducción de las escurriduras. Reduciendo el volumen de disolución que queda adherida a las piezas en los baños de proceso disminuye la cantidad de productos químicos valiosos que contaminan el agua de lavado, lo que a su vez reduce la cantidad de lodos generados en un proceso de tratamiento convencional de precipitación de metales.

Hay varios métodos para reducir las escurriduras, entre ellos los siguientes:

- Concentración operativa del baño de proceso. La concentración química deberá ser lo más baja posible con el fin de reducir al mínimo la viscosidad (para un drenaje más rápido) y la cantidad de productos químicos (en la película).

- Temperatura operativa del baño de proceso. La viscosidad de la disolución de proceso puede reducirse elevando la temperatura del baño.

- Tensoactivos. Se puede reducir la tensión superficial de la solución añadiendo tensoactivos al baño de proceso.

- Colocación de la pieza. La pieza deberá colocarse sobre el soporte de manera que la película adherente escurra libremente y no quede retenida en huecos o ranuras.

- Tiempo de extracción o de drenaje. Cuanto antes se extrae una pieza del baño de proceso, más gruesa es la película adherida a la superficie de la pieza.

- Chorros de aire. Se pueden mejorar el drenaje y el secado proyectando un chorro de aire sobre la pieza mientras el soporte de ésta se eleva por encima del tanque de proceso.

- Lavados por aspersión. Pueden utilizarse por encima de los baños calientes para igualar el caudal de lavado con la velocidad de evaporación del tanque.

- Baños de recubrimiento. Se deben eliminar los carbonatos y los contaminantes orgánicos para evitar que se acumule la contaminación, ya que ésta aumenta la viscosidad del baño.

- Tablas de drenaje. Los huecos entre tanques de proceso deben cubrirse con tablas de drenaje para capturar las disoluciones de proceso y devolverlas al baño de proceso.

- Tanques de escurrido. Las piezas deben colocarse en tanques de escurrido (tanques de "lavado estático") antes de la operación de lavado estándar.

Para la recuperación de las escurriduras de productos químicos se utilizan diversas tecnologías, a saber:

- Evaporación. Los evaporadores más comunes son los atmosféricos, pero los evaporadores al vacío permiten ahorrar energía.

- El intercambio iónico se utiliza para la recuperación química del agua de lavado.

- Extracción electrolítica. Se trata de un proceso electrolítico por el que se reducen los metales disueltos en la disolución y se depositan en el cátodo.

- Electrodiálisis. Se realiza utilizando membranas permeables a los iones y aplicando corriente para separar especies iónicas de la disolución. 
- Osmosis inversa. Consiste en el empleo de una membrana semipermeable para producir agua purificada y una disolución iónica concentrada. El agua es obligada a atravesar la membrana aplicando una elevada presión y la mayor parte de las sales disueltas son retenidas por la membrana.

\section{Agua de lavado}

La mayor parte de los residuos peligrosos producidos en las instalaciones de acabado de superficies metálicas proceden de las aguas residuales producidas por las operaciones de lavado que siguen a la limpieza y el recubrimiento metálico. Aumentando la eficacia de lavado de las instalaciones se puede reducir considerablemente el caudal de aguas residuales.

Hay dos estrategias básicas que mejoran la eficacia de lavado. La primera es la turbulencia entre la pieza y el agua de lavado, que puede generarse mediante lavados por aspersión y agitación del agua de lavado moviendo el soporte de la pieza o utilizando corrientes forzadas de agua o aire. La segunda consiste en aumentar el tiempo de contacto entre la pieza y el agua de lavado. Utilizando varios tanques de lavado a contracorriente dispuestos en serie, se reduce la cantidad de agua de lavado utilizada.

\section{Recubrimientos industriales}

El término recubrimientos engloba pinturas, barnices, lacas, esmaltes y gomas lacas, masillas, sellantes y tapaporos, decapantes para pinturas y barnices, limpiadores de brochas de pintura y otros productos de pintura análogos. Los recubrimientos líquidos contienen pigmentos y aditivos dispersos en una mezcla de aglutinante líquido y disolvente. Los pigmentos son compuestos inorgánicos u orgánicos que dan color y opacidad al recubrimiento y afectan a su fluidez y durabilidad. Normalmente contienen metales pesados tales como cadmio, plomo, zinc, cromo y cobalto. El ligante refuerza la adhesividad, cohesividad y consistencia del recubrimiento, y es el principal componente que queda en la superficie cuando la operación de recubrimiento está completa. Como ligantes se utilizan diversos aceites, resinas, gomas y polímeros. Se pueden incorporar a los recubrimientos aditivos tales como cargas de relleno y diluyentes para reducir los costes de fabricación y aumentar la durabilidad del recubrimiento.

Entre los distintos tipos de disolventes orgánicos utilizados en los recubrimientos hay hidrocarburos alifáticos, hidrocarburos aromáticos, ésteres, cetonas, éteres de glicol y alcoholes. Los disolventes dispersan o disuelven los ligantes y reducen la viscosidad y espesor del recubrimiento. Los disolventes utilizados en las fórmulas de los recubrimientos son peligrosos porque muchos de ellos son cancerígenos para el hombre e inflamables o explosivos. La mayoría de los disolventes contenidos en un recubrimiento se evaporan al endurecer éste, con lo que se generan emisiones de compuestos orgánicos volátiles (COV). Las emisiones de COV están siendo objeto de reglamentos cada vez más estrictos, debido a sus efectos negativos para la salud humana y el medio ambiente. La preocupación que suscitan los ingredientes, tecnologías de aplicación y residuos de los recubrimientos convencionales por sus efectos para el medio ambiente, están impulsando el desarrollo de alternativas para prevenir la contaminación.

La mayoría de los recubrimientos se utilizan en productos arquitectónicos, industriales o especiales. Los recubrimientos arquitectónicos se emplean en edificios y en productos para los mismos, así como con fines decorativos y de protección, como en el caso de los barnices destinados a proteger la madera. Las instalaciones industriales incorporan operaciones de recubrimiento en diversos procesos de producción. Las industrias automovilística, de envases metálicos, maquinaria agrícola, recubrimiento de bobinas, muebles y accesorios de madera y metal, y electrodomésticos, son los principales consumidores industriales de recubrimientos.

El diseño de una fórmula de recubrimiento depende de la finalidad de su aplicación. Los recubrimientos proporcionan atractivo estético, previenen la corrosión y protegen las superficies. Su composición viene determinada por factores tales como el coste, función, seguridad del producto, seguridad ambiental, eficiencia del transporte y velocidad de secado y endurecimiento.

\section{Procesos de recubrimiento}

La mayoría de los procesos de recubrimiento comprenden cinco operaciones: manipulación y preparación de las materias primas, preparación de la superficie, recubrimiento, limpieza del equipo y gestión de los residuos.

\section{Manipulación y preparación de las materias primas}

Esta fase comprende el almacenamiento de existencias, las operaciones de mezcla, la dilución y ajuste de los recubrimientos y la distribución de las materias primas por las instalaciones. Se requieren prácticas y procedimientos de control y manutención para producir la menor cantidad posible de residuos por deterioro de material, productos fuera de especificación y preparación inadecuada a causa de una dilución excesiva, con el consiguiente desperdicio. La distribución, tanto si se efectúa manualmente como por medio de un sistema de tuberías, debe planificarse para evitar desperdicios.

\section{Preparación de la superficie}

El tipo de técnica utilizado para preparar la superficie depende de la superficie que se recubre - preparación previa, cantidad de suciedad, presencia de grasa, tipo de recubrimiento a aplicar y acabado requerido de la superficie. Las operaciones de preparación más comunes son el desengrasado, la imprimación o fosfatado y el decapado. En cuanto al acabado de superficies metálicas, el desengrasado comprende el restregado con disolventes, la limpieza en frío o el desengrasado al vapor con disolventes halogenados, la limpieza en disolución acuosa alcalina o en disolución semiacuosa, o la limpieza con hidrocarburos alifáticos para eliminar la suciedad orgánica, tierra, aceite y grasa. La cascarilla de laminación y el óxido se eliminan mediante baños ácidos, limpieza abrasiva o limpieza a la llama.

Aparte de la limpieza, la preparación más común de las superficies metálicas es la fosfatación, que se utiliza para favorecer la adhesión de los recubrimientos orgánicos a las superficies metálicas y retrasar la corrosión. Los recubrimientos con fosfato se aplican por inmersión o rociado de las superficies metálicas con una disolución de fosfato de zinc, hierro o manganeso. La fosfatación es un proceso de acabado de superficies similar al recubrimiento electrolítico; consiste en una serie de baños de productos químicos de proceso y de baños de lavado en los que se sumergen las piezas para dar a la superficie la preparación deseada. Véase el artículo "Metales, tratamiento de superficie" en este capítulo.

Las superficies que requieren reparación, inspección o la renovación del recubrimiento, se someten a un decapado químico o mecánico. El método químico de eliminación de recubrimientos utilizado con más frecuencia es el decapado con disolvente. Estas disoluciones contienen por lo general fenol, cloruro de metileno y un ácido orgánico para disolver el recubrimiento de la superficie. El lavado final con agua para eliminar los productos químicos puede generar grandes cantidades de aguas residuales. El proceso mecánico usual es la limpieza con chorro abrasivo, una operación en seco en la que se utiliza aire 
comprimido para proyectar un medio abrasivo contra la superficie con objeto de eliminar el recubrimiento.

Las operaciones de preparación de la superficie influyen en la cantidad de residuos que genera el proceso de preparación específico. Si la preparación de la superficie es inadecuada y a causa de ello el recubrimiento es deficiente, su eliminación y el nuevo recubrimiento generarán más residuos.

\section{Recubrimiento}

La operación de recubrimiento comprende la transferencia del recubrimiento a la superficie y su endurecimiento sobre ésta. La mayoría de las tecnologías de recubrimiento pertenecen a una de estas cinco clases básicas: recubrimiento por inmersión, recubrimiento con rodillo, recubrimiento por chorro, recubrimiento por aspersión y la técnica más común, el recubrimiento a pistola con productos de base disolvente utilizando aire comprimido.

Los recubrimientos a pistola atomizados con aire comprimido se aplican por lo general en un ambiente controlado para contener las emisiones de disolvente y el exceso de producto aplicado. Los dispositivos utilizados con este último fin son filtros de material textil o cortinas de agua, lo que genera filtros usados o aguas residuales procedentes de los sistemas de depuración de aire.

El endurecimiento se lleva a cabo para convertir el ligante del recubrimiento en una superficie dura, resistente y adherente. Los mecanismos empleados para ello son el secado, natural o en estufa, o la exposición a un haz de electrones o de luz infrarroja o ultravioleta. El endurecimiento genera considerables cantidades de COV cuando los recubrimientos son de base disolvente y entraña riesgo de explosión si las concentraciones de disolvente aumentan por encima del límite inferior de concentración explosiva. Por consiguiente, las instalaciones de endurecimiento están equipadas con dispositivos de control de la contaminación atmosférica para prevenir las emisiones de COV y como control de seguridad contra explosiones.

La preocupación por el medio ambiente y la salud, el endurecimiento de las normativas que afectan a los recubrimientos de composición convencional y el elevado coste de los disolventes y de la evacuación de los residuos peligrosos han creado una demanda de recubrimientos de composiciones alternativas que contengan menos constituyentes peligrosos y cuya aplicación genere menos residuos. Entre los recubrimientos de composición alternativa se encuentran los siguientes:

- Recubrimientos de alto contenido sólido, con doble cantidad de pigmento y resina en el mismo volumen de disolvente que los recubrimientos convencionales. $\mathrm{Su}$ aplicación reduce las emisiones de COV entre un 62 y un 85 \% en comparación con los recubrimientos convencionales de base disolvente y bajo contenido sólido, al ser menor el contenido de disolvente.
- Recubrimientos de base acuosa en los que se utiliza como vehículo una mezcla de agua y un disolvente orgánico, y como base agua. Los recubrimientos de base acuosa generan entre un 80 y un $95 \%$ menos de emisiones de COV y disolventes agotados que los recubrimientos convencionales de base disolvente y bajo contenido sólido.

- Recubrimientos en polvo que no contienen ningún disolvente orgánico, sino que están formados por partículas de pigmento y resina finamente pulverizadas. Estos polvos son o bien termoplásticos (es decir, con resina de alto peso molecular para conseguir recubrimientos gruesos) o termoestables (compuestos de bajo peso molecular que forman una capa delgada antes de la reticulación química).

\section{Limpieza del equipo}

En los procesos de recubrimiento, la limpieza del equipo es una operación necesaria de mantenimiento de rutina que crea considerables cantidades de residuos peligrosos, sobre todo si se utilizan disolventes halogenados para la limpieza. Normalmente, la limpieza del equipo empleado para los recubrimientos de base disolvente se realiza a mano, utilizando disolventes orgánicos para eliminar los recubrimientos del equipo de proceso. Las tuberías requieren una serie de lavados interiores con disolvente hasta que quedan limpias. El equipo de recubrimiento debe limpiarse entre cambios de producto y después de las paradas del proceso. Las prácticas y procedimientos utilizados determinan el nivel de residuos producido por estas actividades.

\section{Gestión de residuos}

Los procesos de recubrimiento generan diversas corrientes de residuos. Los residuos sólidos comprenden recipientes vacíos de productos de recubrimiento, lodos formados por el recubrimiento aplicado en exceso y la limpieza del equipo, filtros y materiales abrasivos agotados, recubrimiento seco y trapos de limpieza.

Los residuos líquidos están formados por agua residual procedente de la preparación de superficies, el control de sobreaplicaciones o la limpieza del equipo, recubrimientos o materiales de preparación de superficies aplicados en exceso o fuera de especificación, sobreaplicaciones por pulverización, derrames y disoluciones de limpieza agotadas. A medida que aumentan los costes de evacuación, van teniendo mayor aceptación los sistemas de reciclaje interno de disolventes en circuito cerrado. Normalmente, los líquidos de base acuosa se tratan en las instalaciones antes de su vertido en sistemas de tratamiento públicos.

Todos los procesos convencionales en los que se utilizan recubrimientos de base disolvente generan emisiones de COV que requieren el empleo de dispositivos de control, tales como unidades de adsorción de carbon, condensadores u oxidantes catalíticos térmicos.

\section{Referencias}

Agencia Internacional para la Investigación sobre el Cáncer (IARC). 1984. Monographs on the Evaluation of Carcinogenic Risks to Humans. Vol. 34. Lyon: IARC.

Buonicore, AJ, T Davis (dirs.). 1992. Air Pollution Engi neering Manual. Nueva York.Van Nostrand Reinhold/Air and Waste Management Association.

Environmental Protection Agency (EPA). 1995. Profile of the Nonferrous Metals Industry. EPA/310-R-95-010. Washington, DC: EPA.

Johnson A, CY Moira, L MacLean, E Atkins, A Dybunico, F Cheng, D Enarson. 1985. Respiratory abnormalities amonost workers in iron and steel industry. Brit f Ind Med 42:94-100.
Kronenberg RS, JC Levin, RF Dodson, JGN Garcia, DE Griffith. 1991. Asbestos-related disease in employees of a steel mill and a glass bottle manufacturing plant. Ann NY Acad Sci 643:397-403.

Landrigan, PJ, MG Cherniack, FA Lewis, LR Catlett, RW Hornung. 1986. Silicosis in a grey iron foundry. The persistence of an ancient disease. Scand $\mathcal{J}$ Work Environ Health 12:32-39.

National Institute for Occupational Safety and Health (NIOSH). 1996. Criteria for a Recommended Standard: Occupational Exposures to Metalworking Fluids. Cincinatti, Ohio: NIOSH.

Palheta, D, A Taylor. 1995. Mercury in environmental and biological samples from a gold mining area in the Amazon Region of Brazil. Science of the Total Environment 168:63-69.
Thomas, PR, D Clarke. 1992 Vibration white finger and Dupuytren's contracture: Are they related? $\mathrm{Oc}$ cup Med 42(3): 155-158.

\section{Otras lecturas recomendadas}

American National Standards Institute (ANSI). 1976. Safety Requirements for the Construction, Care, and Use of Lathes. ANSI B11.6-1976. Nueva York: ANSI.

1988a. The Use, Care, and Protection of Abrasive Wheels. ANSI B7.1-1988. Nueva York: ANSI.

-.1988b. Safety in Welding and Cutting. ANSI Z49.11988. Nueva York: ANSI

American Petroleum Institute (API). 1971. Chemistry and Petroleum for Classroom Use in Chemistry Courses. Washington, DC: API. 
-. 1980. Facts about Oil. Manual 4200. Washington, DC: API.

-. 1984. Safe Operation of Inland Bulk Plants. Publication 2008. Washington, DC: API.

Antoni, H. 1978. Massnahmen zu höherer Sicherheit beim Spannen mit Backenfuttern [Medidas para aumentar la seguridad en la sujección con herramientas de mordaza]. Zeitschrift für industrielle Fertigung 10:611-615.

Burgess, WA. 1995. Recognition of Health Hazards in Industry, $2^{\circ}$ edition. Nueva York: John Wiley \& Sons.

Conferencia Americana de Higienistas Industriales del Gobierno (ACGIH) Committee on Industrial Ventilation. 1992. Industrial Ventilation: A Manual of Recommended Practice, 22 ed. Cincinnati, Ohio: ACGIH.

Exxon Company. 1987. Encyclopedia for the User of Petroleum Products. Houston, Texas: Exxon Company, USA, Marketing Technical Services.

Goldsmith, AH, KW Vorpahl, KA French, PT Jordan, NB Jurinski. 1976. Health hazards from oil, soot and metals at a hot forging operation. Am Ind Hyg Assoc 7 37:217-226.
Gulf Publishing Company. 1964. Petroleum Marketing and Transportation, 1964. Houston, Texas: Gulf Publishing Company.

Harten, GA. 1976. Een nieuwe, ergonomisch verbeterde draaibank [Un torno nuevo y con mejoras ergonómicas]. Tijdschrift voor sociale geneeskunde (Amstelveen) 54(17):575-578.

Kusiak, RA, J Springer, AC Ritchie, J Muller. 1991. Carcinoma of the lung in Ontario gold miners: Possible aetiological factors. Brit f Ind Med 48(12):808817.

Mobil Oil Corporation. 1990. Handling, Storing and Dispensing Industrial Lubricants. Mobil Technical Bulletin. Fairfax, Virginia: Mobil Oil Corporation.

National Institute for Occupational Safety and Health (NIOSH). 1975. Ventilation Requirements for Grinding, Buffing and Polishing Operations. NIOSH Publ. N $\mathrm{N}^{\circ} 75$ 105. Cincinnati, Ohio: NIOSH.

National Safety Council. 1995. Petroleum Section Safety and Health Fact Sheets, 1988-95. Itasca, Illionis: National Safety Council.
Occupational Safety and Health Administration (OSHA). 1979. Prudent Practices for Controlling Lead Exposure in the Secondary Lead Smelting Industry: A Guide for Employers and Employees. Washington, DC: OSHA.

-. 1982. Cooperative Assessment Program Manual for the Secondary Lead Smelting Industry. Washington, DC: OSHA.

- 1984. Cooperative Assessment Program Manual for the Battery Manufacturing Industry. Washington, DC: OSHA.

Ontario Metal Finishing Industry Pollution Prevention Project. 1995. Metal Finishing Pollution Prevention Guide. Ottawa: Environment Canada, Water Technology International, Sheridan Environmental Technology Institute.

Simonato, L, JJ Moulin, B Javeland, G Ferro, P Wild, R Winkelmann, R Saracci. 1994. A retrospective mortality study of workers exposed to arsenic in a gold mine and refinery in France. Am 7 Ind Med 25:652-633. 


\section{MICROELECTRONICA Y SEMICONDUCTORES}

Director del capítulo

M ichad E. W illiams

\section{Sumario}

Perfil general

M ichad E. W illiams ......................... 83.2

Fabricación de semiconductores de silicio

$D$ avid $G$. Baldwin, J ames R. R ubin y Afsaneh $G$ erami . . . . . . . . 83.3

Indicadores de cristal líquido

D avid G. Baldwin, J ames R. R ubin y Afsaneh G erami . . . . . . . . 83.20

Fabricación de semiconductores III-V

$D$ avid G. Baldwin, Afsaneh Gerami y J ames R. Rubin . . . . . . . . 83.22

Instalación de placas de circuito impreso y ordenadores

M ichael E. W illiams . ...................... . 83.27

Efectos sobre la salud y pautas patológicas

D onald V. Lassiter . . . . . . . . . . . . . . . . . . . . . . . 83.33

Cuestiones ambientales y de salud pública

Corky Chew .............................. 83.37 


\section{- Perfil general}

\section{Michael E. Williams}

La diversidad de procesos y productos en el sector de la microelectrónica y los semiconductores es inmensa. El debate sobre salud y seguridad en el trabajo de este capítulo se centra en la producción de circuitos integrados $(\mathrm{CI})$ de semiconductores (tanto en productos basados en silicio como en compuestos de valencia III-V ), la producción de tarjetas de conexionado impreso (PWB), el montaje de tarjetas de circuito impreso (PCB) y el montaje de ordenadores.

EI sector se compone de numerosos segmentos importantes. La Electronics Industry Association utiliza el desglose siguiente en los informes sobre las tendencias, ventas y empleo relativos al sector:

- componentes electrónicos;

- electrónica de consumo;

- telecomunicaciones;

- comunicaciones para la defensa;

- ordenadores y periféricos;

- electrónica industrial;

- electrónica médica.

En los componentes electrónicos se incluyen los tubos electrónicos (p. ej., tubos receptores, de aplicaciones especiales y de televisión), productos de estado sólido [(p. ej., transistores, diodos, $\mathrm{Cl}$, diodos luminiscentes (LED) e indicadores de cristal líquido ( $L C D)$ ] y componentes pasivos y varios (como condensadores, resistencias, bobinas, transformadores y conmutadores).

La electrónica de consumo comprende los aparatos de televisión y otros productos de audio y vídeo domésticos y portátiles, junto con equipos ofimáticos, como ordenadores personales, máquinas de transmisión de facsímiles y contestadores telefónicos. También se incluyen en este apartado el hardware y software de juegos electrónicos, los sistemas de seguridad de viviendas, las cassettes vírgenes de audio y vídeo y los discos flexibles, los accesorios electrónicos y las baterías.

Además de ordenadores para todo uso y especializados, entre los ordenadores y periféricos se incluye el equipo de almacenamiento auxiliar, el equipo de entrada/salida (p. ej., teclados, ratones, dispositivos de exploración óptica e impresoras), terminales, etc. Como las telecomunicaciones, comunicaciones para la defensa y en la electrónica industrial y médica utilizan parte de la misma tecnología, estos segmentos incluyen también equipo especializado.

La aparición del sector de la microelectrónica ha ejercido un efecto profundo en la evolución y estructura de la economía mundial. En el ritmo del cambio en los países industrializados del mundo han influido enormemente los avances en este sector, sobre todo por la evolución del circuito integrado. Este ritmo de cambio puede observarse en el gráfico que representa la evolución temporal del número de transistores por pastilla de circuito integrado (véase la Figura 83.1).

Es significativa la importancia económica de las ventas mundiales de semiconductores. La Figura 83.2 es una proyección de las ventas mundiales y regionales de semiconductores de 1993 a 1998 realizada por la Semiconductor Industry Association.

L os sectores de $\mathrm{Cl}$ de semiconductores y de montaje de ordenadores/ electrónica son únicos, comparados con la mayoría de las demás categorías industriales, en la composición relativa de sus plantillas de producción. Las naves de fabricación de semiconductores tienen un tanto por ciento elevado de
Figura 83.1 • Evolución temporal del número de transistores por pastilla de circuito integrado (1970 a 2000).

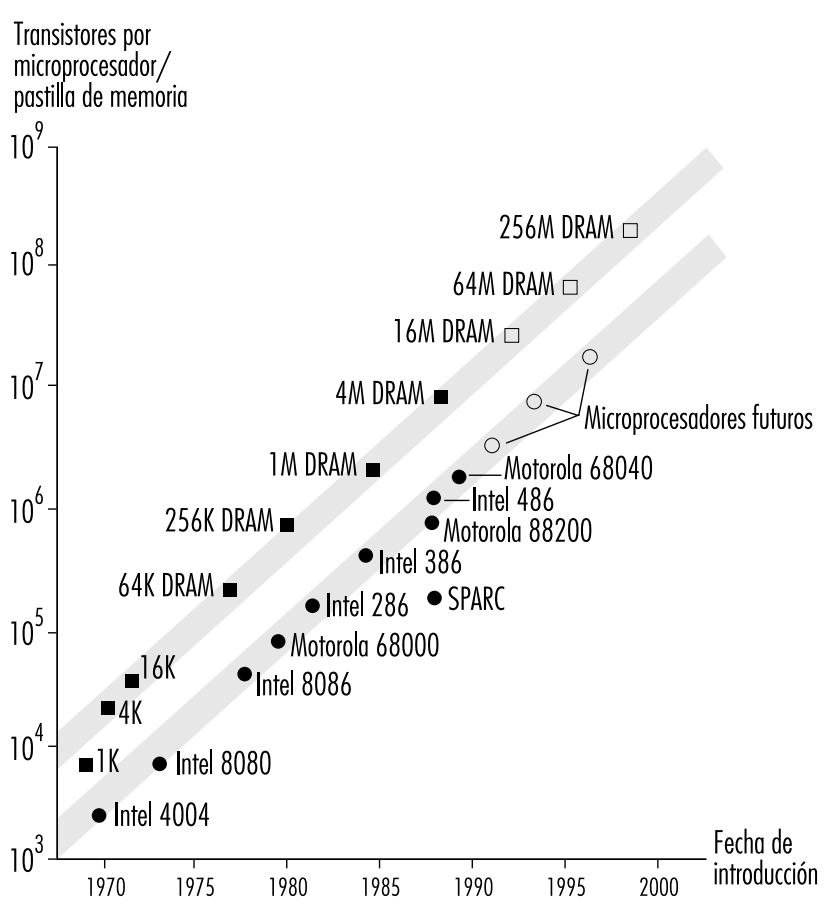

ASKMAR 1990.

trabajadoras que hacen funcionar el equipo de proceso. L as tareas que han de realizar las trabajadoras no exigen por lo general levantar grandes pesos ni poseer una fuerza física excesiva. También es típico que muchas de las tareas a ejecutar necesiten habilidades motoras delicadas y atención a los detalles. Los trabajadores masculinos predominan en las tareas de mantenimiento, en funciones de ingeniería y en la gestión. U na composición similar se encuentra en el segmento de montaje de ordenadores/ electrónica de este sector. 0 tra característica inhabitual de este sector es la concentración de la fabricación en la zona de Asia/ Pacífico del mundo. Esta tendencia se acentúa

Figura 83.2 - Previsión de ventas mundiales de semiconductores, 1993 a 1998.

Miles de millones

de dólares de EE.UU.

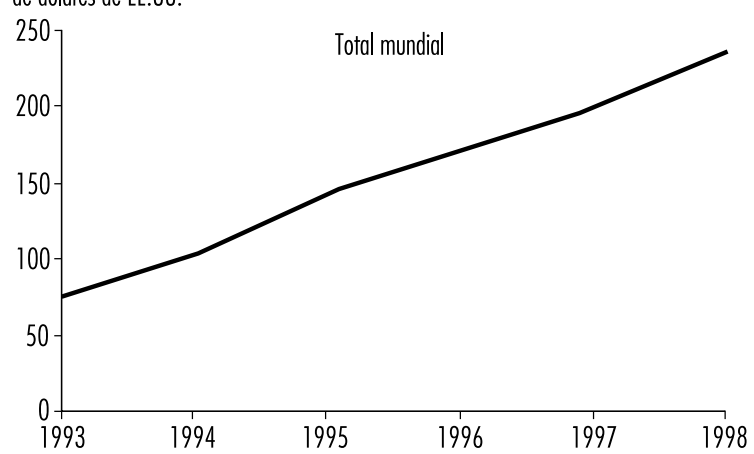

Fuente: SIA 1995 
Figura 83.3 - Sala limpia en una zona de tecnología avanzada donde los operadores trabajan en la fabricación de semiconductores.

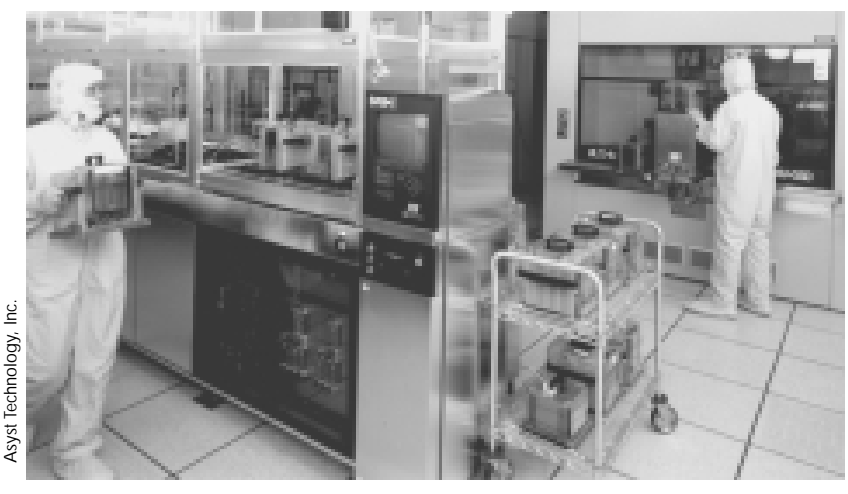

especialmente en los procesos de montaje final o back-end del sector de semiconductores, que consisten en situar en posición y fijar la pastilla del circuito integrado ya fabricado (conocida técnicamente con el nombre de dado) sobre un soporte de pastilla y un marco de conductores. Este proceso exige el posicionamiento preciso de la pastilla, por lo general mediante un microscopio, y habilidades motoras muy finas. También en esta parte del proceso predominan las trabajadoras, y la mayoría de la producción mundial se encuentra concentrada en el arco del Pacífico, con grandes concentraciones en Taiwan, M alasia, Tailandia, Indonesia y Filipinas, y un número creciente en China y Vietnam.

Las naves de fabricación de $\mathrm{Cl}$ de semiconductores poseen diversas propiedades y características poco habituales peculiares a este sector. Ello se debe a que el procesamiento de los $\mathrm{Cl}$ exige unos regímenes y requisitos de control de partículas extremadamente rigurosos. U na zona moderna típica dedicada a la fabricación de $\mathrm{Cl}$ puede recibir la calificación de sala limpia Clase 1 ó menor. Como método de comparación, sabemos que una zona expuesta al medio ambiente exterior tendría una calificación mayor que Clase 500.000; la habitación normal de una vivienda pertenecería a una clase en torno a la Clase 100.000; y una zona de montaje final de semiconductores sería de Clase 10.000 aproximadamente. Para lograr ese nivel de control de partículas es preciso que el trabajador de fabricación se encuentre encerrado por completo en trajes de conejo provistos de sistemas de suministro de aire y de filtros para controlar los niveles de partículas generadas por los trabajadores en la zona de fabricación. Los ocupantes humanos de zonas de fabricación se consideran generadores muy potentes de partículas finas procedentes del aire que exhalan, de la muda de piel y cabello y de su ropa y calzado. Este requisito de vestir ropa cerrada y los procedimientos de trabajo aislado han contribuido a que los trabajadores sientan que trabajan en un ambiente "inhóspito". V éase la Figura 83.3. Asimismo, en la zona fotolitográfica, el proceso comprende la exposición de la oblea a una solución fotoactiva, seguida de la formación de un patrón de imagen sobre la superficie de la oblea mediante luz ultravioleta. Para atenuar la luz ultravioleta (UV) no deseada en esta zona de procesamiento, se utilizan luces amarillas especiales (que no emiten el componente de la longitud de onda U V presente normalmente en la iluminación interior). Estas luces amarillas contribuyen a que los trabajadores tengan la sensación de que están en un ambiente de trabajo diferente y a veces pueden ejercer un efecto desorientador sobre algunos individuos.

\section{FABRICACION DE SEMICONDUCTORES DE SILICIO}

\author{
David G. Baldwin, James R. Rubin y \\ Afsaneh Gerami
}

\section{Resumen del proceso}

La descripción del procesamiento de dispositivos semiconductores de silicio, ya sean dispositivos discretos (un semiconductor que contiene un solo dispositivo activo, como por ejemplo un transistor) o $\mathrm{Cl}$ (conjuntos interconectados de elementos activos y pasivos en un sustrato semiconductor único, capaz de realizar una función de circuito electrónico como mínimo), implica mencionar numerosas operaciones muy técnicas y específicas, y tiene por objeto dar a conocer un marco y una explicación básicos de los pasos principales seguidos en la fabricación de un dispositivo semiconductor de silicio y los problemas de salud y seguridad medioambiental (SSM) asociados.

La fabricación de un $\mathrm{Cl}$ consta de una secuencia de procesos que pueden repetirse muchas veces antes de terminar un circuito. Los $\mathrm{Cl}$ más sencillos utilizan 6 máscaras 0 más para completar procesos de modelado, pero lo corriente es que se empleen de 10 a 24 máscaras. La fabricación de un microcircuito comienza con una oblea de silicio ultrapuro de 10 a 30 centímetros de diámetro. El silicio absolutamente puro es casi un aislante, pero determinadas impurezas, llamadas impurificadores, añadidas en cantidades de 10 a 100 partes por millón, convierten al silicio en conductor de electricidad.

Un circuito integrado puede constar de millones de transistores (también diodos, resistencias y condensadores) hechos de silicio con impurezas, todos ellos conectados mediante el patrón de conductores adecuado para crear lógica del ordenador, su memoria $u$ otro tipo de circuito. Sobre una oblea pueden hacer se centenares de microcircuitos.

$\mathrm{H}$ ay seis pasos principales del proceso de fabricación que se aplican de manera universal a todos los dispositivos semiconductores de silicio: oxidación, litografía, grabado, impurificación, deposición química de vapor y metalización. Estos pasos van seguidos de las operaciones de montaje, prueba, marcado, embalado y expedición.

\section{Oxidación}

En general, el primer paso en el procesamiento de dispositivos semiconductores consiste en la oxidación de la superficie exterior de la oblea para hacer crecer una capa delgada (de alrededor de una micra) de dióxido de silicio $\left(\mathrm{SiO}_{2}\right)$. Esta capa protege en primer lugar la superficie de impurezas y sirve además de máscara en el proceso de difusión posterior. La capacidad de hacer crecer una capa protectora y químicamente estable de dióxido de silicio sobre silicio convierte a las obleas de silicio en el sustrato de semiconductores de uso más extendido.

La oxidación, que se suele llamar oxidación térmica, es un proceso por lotes que tiene lugar en un horno de difusión a alta temperatura. La capa protectora de dióxido de silicio se forma en atmósferas que contienen oxígeno $\left(\mathrm{O}_{2}\right)$ (oxidación seca) u oxígeno combinado con vapor de agua $\left(\mathrm{H}_{2} \mathrm{O}\right)$ (oxidación húmeda). La temperatura del horno varía de 800 a $1.300{ }^{\circ} \mathrm{C}$. También pueden añadirse compuestos de cloro en forma de cloruro de hidrógeno $(\mathrm{HCl})$ que ayuden a controlar las impurezas no deseadas.

En las instalaciones de fabricación más modernas existe una tendencia al uso de hornos de oxidación verticales, que permiten controlar mejor la contaminación dentro de límites estrictos, admiten un mayor tamaño de las obleas y consiguen más 
uniformidad en el procesamiento. Permiten utilizar equipo más pequeño, que ocupa menos del precioso espacio en planta de la sala limpia.

\section{Oxidación seca}

Antes de ser sometidas a oxidación, las obleas de silicio se limpian con un detergente diluido en agua y se enjuagan con xileno, alcohol isopropílico $u$ otros disolventes. Las obleas limpias se secan, se cargan en un soporte de obleas de cuarzo denominado bote y se depositan en el extremo del operador (extremo de carga) del tubo o celda del horno de difusión de cuarzo. El extremo de entrada del tubo (extremo fuente) suministra oxígeno de gran pureza o una mezcla de oxígeno y nitrógeno. El flujo del oxígeno "seco" al interior del tubo de cuarzo se controla para garantizar que exista un exceso de oxígeno que facilite el crecimiento del dióxido de silicio sobre la superficie de la oblea de silicio. La reacción química básica es:

$$
\mathrm{Si}+\mathrm{O}_{2} \rightarrow \mathrm{SiO}_{2}
$$

\section{Oxidación húmeda}

Cuando el agente oxidante es el agua, se suelen utilizar cuatro métodos para introducir vapor de agua-pirofórico, alta presión, borboteador e instantáneo. L as reacciones químicas básicas son:

$$
\begin{gathered}
\text { Pirofórico y alta presión: } \mathrm{Si}+2 \mathrm{O}_{2}+2 \mathrm{H}_{2} \rightarrow \mathrm{SiO}_{2}+2 \mathrm{H}_{2} \mathrm{O} \\
\text { Instantáneo y borboteador: } \mathrm{Si}+2 \mathrm{H}_{2} \mathrm{O} \rightarrow \mathrm{SiO}_{2}+2 \mathrm{H}_{2}
\end{gathered}
$$

La oxidación pirofórica consiste en la introducción y combustión de una mezcla gaseosa hidrógeno/oxígeno. Estos sistemas se denominan en general sistemas de hidrógeno quemado o de antorcha. El vapor de agua se produce cuando por el extremo de entrada del tubo se introducen las cantidades adecuadas de hidrógeno y oxígeno y se deja que reaccionen. Es preciso controlar la mezcla con precisión para garantizar una combustión correcta y evitar la acumulación de gas hidrógeno explosivo.

La oxidación a alta presión (H iPox) recibe el nombre técnico de sistema de pirosíntesis del agua y genera vapor de agua mediante la reacción de hidrógeno y oxígeno ultrapuros. EI vapor de agua se bombea después a una cámara de alta presión y se presuriza a 10 atmósferas, lo que acelera el proceso de oxidación húmeda. También puede utilizarse agua desionizada como fuente de vapor de agua.

En la oxidación en borboteador, se deposita agua desionizada en un recipiente llamado borboteador, donde se mantiene a una temperatura constante por debajo de su punto de ebullición de $100{ }^{\circ} \mathrm{C}$ con ayuda de una envuelta calefactora. Por el lado de entrada del borboteador se introduce gas nitrógeno u oxígeno, que se satura con vapor de agua a medida que sube por el agua y emerge por la salida hacia el horno de difusión. Los sistemas de borboteador parecen ser el método de oxidación más extendido.

En la oxidación instantánea, se procede al goteo continuo de agua desionizada en la superficie caliente del fondo de un recipiente de cuarzo, donde el agua se evapora en seguida al chocar con la superficie caliente. Una corriente de gas portador de nitrógeno u oxígeno pasa por encima del agua en evaporación y arrastra el vapor de agua hasta el horno de difusión.

\section{Litografía}

La litografía, conocida también como fotolitografía o enmascaramiento, es un método de formar patrones exactos sobre la oblea oxidada. El microcircuito electrónico se construye capa por capa, y cada una de éstas recibe un patrón de una máscara especificada en el diseño del circuito.

L os oficios de impresión desarrollaron los antecedentes verdaderos de los procesos actuales de microfabricación de dispo- sitivos semiconductores. Estos avances son los relativos a la fabricación de planchas de impresión, por lo común metálicas, sobre las que la eliminación de material mediante mordientes químicos produce un patrón en relieve superficial. Esta misma técnica básica es la utilizada en la producción de las máscaras maestras empleadas en la fabricación de cada capa del procesamiento de un dispositivo.

Los proyectistas de circuitos digitalizan el sistema de circuitos básico de cada capa. Este esquema computarizado permite la generación rápida de los sistemas de circuitos de la máscara y facilita la realización de los cambios que puedan ser necesarios. Esta técnica se conoce como diseño asistido por ordenador (CAD). Con ayuda de potentes algoritmos de ordenador, estos sistemas de diseño en línea permiten al proyectista disponer y modificar el sistema de circuitos sobre la misma pantalla de visualización con funciones de gráficos interactivas.

El dibujo final, o máscara, de cada capa de circuitos es creada por un ploter, o generador de patrones, controlado por ordenador. Estos dibujos obtenidos con el ploter se reducen después al tamaño real del circuito, una máscara maestra practicada sobre vidrio con relieve en cromo, y luego se reproducen en una placa de trabajo que sirve para la impresión por contacto 0 proyección sobre la oblea.

Estas máscaras delimitan el modelo de las zonas conductoras y aisladoras que se transfieren a la oblea mediante fotolitografía. La mayoría de las empresas no fabrican sus propias máscaras, sino que utilizan las suministradas por un fabricante de máscaras.

\section{Limpieza}

La necesidad de que la superficie exterior de la oblea se encuentre libre de partículas y contaminación exige una limpieza frecuente. Los métodos de limpieza principales son:

- lavado con agua desionizada y detergente;

- disolvente: alcohol isopropílico (IPA), acetona, etanol, terpenos;

- ácido: fluorhídrico $(\mathrm{HF})$, sulfúrico $\left(\mathrm{H}_{2} \mathrm{SO}_{4}\right)$ y peróxido de hidrógeno $\left(\mathrm{H}_{2} \mathrm{O}_{2}\right)$, clorhídrico $(\mathrm{HCl})$, nítrico $\left(\mathrm{HNO}_{3}\right)$ y mezclas;

- cáustico: hidróxido de amonio $\left(\mathrm{N} \mathrm{H}_{4} \mathrm{OH}\right)$.

\section{Aplicación de protector}

Las obleas se recubren con un material protector de polímero basado en disolvente y luego se hacen girar a gran velocidad en una centrifugadora, que distribuye el protector en una capa delgada y uniforme. Luego se evaporan los disolventes, que dejan una película de polímero. Todos los materiales protectores dependen de los cambios inducidos por la radiación (sobre todo ultravioleta) en la solubilidad de un polímero orgánico sintético en el enjuagado con un revelador determinado. Los materiales protectores se clasifican en negativos o positivos, según su solubilidad en el revelador disminuya (negativos) o aumente (positivos) con la exposición a la radiación. En la Tabla 83.1 se identifica la constitución de componentes de diversos sistemas de fotoprotección.

Como la mayoría de los fotoprotectores son sensibles a la luz ultravioleta (UV), la zona de procesamiento se ilumina con luces amarillas especiales que carecen de las longitudes de onda UV, que serían perturbadoras (véase la Figura 83.4).

Los protectores de UV negativos y positivos son los más empleados en el sector, pero los protectores de haces de electrones y de rayos $X$ están ganando cuota de mercado por sus mayores resoluciones. Las preocupaciones en materia de salud en litografía se centran ante todo en los peligros reproductivos potenciales que se asocian a determinados protectores positivos (p. ej., acetato de etilenglicol monoetil éter como portador) que en la actualidad se están eliminando en el sector. Los olores 
Tabla 83.1 • Sistemas de fotoprotección.

\begin{tabular}{|c|c|c|c|}
\hline \multicolumn{4}{|l|}{ Ultravioleta } \\
\hline \multirow[t]{6}{*}{ Cercano $(350-450 \mathrm{~nm})$} & \multirow[t]{3}{*}{ Negativos } & PB & Goma alifática de base azida (isopreno) \\
\hline & & S & acetato de n-butilo, xileno, n-metil-2-pirrolidona, etilbenceno \\
\hline & & D & $\begin{array}{l}\text { Xileno, hidrocarburos alifáticos, acetato de n-butilo, disolvente de Stoddard (producto } \\
\text { de la destilación del petróleo) }\end{array}$ \\
\hline & \multirow[t]{3}{*}{ Positivos } & PB & Orto-diazocetona \\
\hline & & $S$ & $\begin{array}{l}\text { Acetato de éter-monometil-glicol-propileno, lactato de etilo, metoxi-propionato de } \\
\text { metilo, etoxi-propionato de etilo, acetato de n-butilo, xileno, clorotolueno }\end{array}$ \\
\hline & & D & Hidróxido sódico, silicatos, hidróxido potásico \\
\hline Lejano (200- $250 \mathrm{~nm})$ & \multicolumn{3}{|l|}{ Protectores principalmente positivos } \\
\hline \multicolumn{4}{|c|}{ Haz de electrones (en torno a $100 \mathrm{~nm}$ ) } \\
\hline & \multirow[t]{3}{*}{ Negativos } & PB & Copolímero-acrilato de etilo y metacrilato de glicidilo (COP) \\
\hline & & $S$ & $\mathrm{n} / \mathrm{a}$ \\
\hline & & D & $\mathrm{n} / \mathrm{a}$ \\
\hline & \multirow[t]{3}{*}{ Positivos } & PB & Polimetilmetacrilato, polifluoralquilmetacrilato, polialquilaldehído, poli-ciano etilacrilato \\
\hline & & $S$ & Acetato de éter-monometil-glicol-propileno \\
\hline & & D & Alcalinos o IPA, acetato de etilo o metil-isobutil cetona (MIBK) \\
\hline \multicolumn{4}{|l|}{ Rayos $X(0,5-5 \mathrm{~nm})$} \\
\hline & \multirow[t]{3}{*}{ Negativos } & PB & Copolímero-acrilato de etilo y metacrilato de glicidilo (COP) \\
\hline & & $S$ & $n / a$ \\
\hline & & D & $n / a$ \\
\hline & \multirow[t]{3}{*}{ Positivos } & PB & $\begin{array}{l}\text { Polimeilmetatacrilato, orto-diazocetona, (poli) hexafluorobutilmetacrilato, (poli) } \\
\text { buteno-1-sulfona }\end{array}$ \\
\hline & & S & Acetato de éter-monometil-glicol-propileno \\
\hline & & $D$ & $n / a$ \\
\hline
\end{tabular}

$P B=$ base de polímeros; $S=$ disolvente; $D=$ revelador.

ocasionales de los protectores negativos (p. ej., el xileno) también preocupan a los trabajadores. El conjunto de estas preocupaciones hace que los higienistas industriales del sector de semiconductores empleen bastante tiempo en el muestreo de las operaciones de fotoprotección. Aunque el muestreo es útil para caracterizar estas operaciones, se sabe que las exposiciones normales durante las operaciones de centrifugación y revelado suelen ser inferiores al $5 \%$ de la exposición profesional normal debido al contenido en el aire de los disolventes utilizados en el proceso (Scarpace y cols. 1989).

Durante 1 hora de funcionamiento de un sistema de centrifugación, se observó una exposición de 6,3 ppm al acetato de etilenglicol monoetil éter. Esta exposición se debió sobre todo a prácticas de trabajo deficientes durante la operación de mantenimiento (Baldwin, Rubin y H orowitz 1993).

\section{Secado y precocido}

Tras haber aplicado el protector, las obleas se transportan por una guía o se llevan a mano desde la centrifugadora a un horno con temperatura controlada y atmósfera de nitrógeno. U na temperatura moderada (de 70 a $90{ }^{\circ} \mathrm{C}$ ) provoca el endurecimiento (cocido suave) de la fotoprotección y la evaporación de los restos de disolventes.

Para garantizar la adherencia de la capa de protector a la oblea, se aplica a ésta una imprimación de hexametildisilizano (HMDS). El imprimador liga el agua molecular existente en la superficie de la oblea. EI HMDS se aplica directamente en un proceso de inmersión o giro o mediante una imprimación al vapor que ofrece ventajas de proceso y coste sobre los demás métodos.

\section{Alineación de máscara y exposición}

La máscara y la oblea se sitúan en estrecha proximidad con la ayuda de un equipo óptico/ mecánico de precisión, y la imagen de la máscara se alinea con cualquier posible patrón ya existente en la oblea debajo de la capa de fotoprotección. La primera máscara no necesita alineación. En tecnologías más antiguas, la alineación de las capas sucesivas se hace posible con ayuda de un "biscopio" (microscopio de doble lente) y controles de precisión para poner en posición la oblea en relación con la máscara. En tecnologías más modernas, la alineación es automática con ayuda de puntos de referencia sobre las obleas.

Una vez lograda la alineación, una luz ultravioleta de gran intensidad, procedente de una fuente constituida por una lámpara de vapor de mercurio o una lámpara de arco, atraviesa la máscara y expone el protector de los lugares no protegidos por las regiones opacas de la máscara.

Los diversos métodos de alineación y exposición de la oblea son la exposición a un torrente de luz UV (por contacto o proximidad), la exposición UV mediante lente de proyección para reducción (proyección), fase $U \mathrm{~V}$ y repetición de exposición para reducción (proyección), exposición a un torrente de rayos $X$ (proximidad) y exposición a un haz de electrones (escritura directa). El método principal utilizado consiste en la exposición 
Figura 83.4 • Equipo fotolitográfico de "sala amarilla" en una sala limpia de tecnología avanzada.

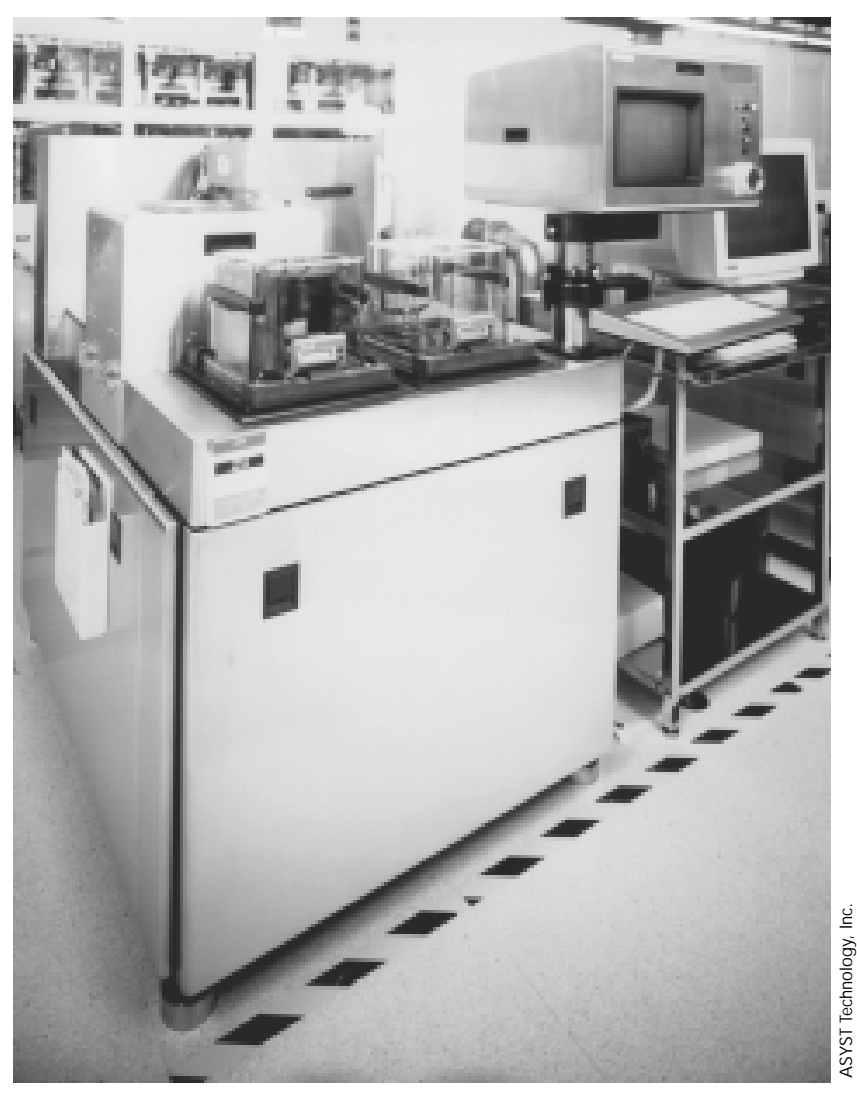

a radiación UV con lámparas de vapor de mercurio y de arco mediante alineadores por proximidad o proyección. Los protectores de UV están diseñados para reaccionar a un espectro amplio de longitudes de onda UV, o formulados para reaccionar con preferencia a una o más de las líneas principales del espectro emitido desde la lámpara (p. ej., línea g a $435 \mathrm{~nm}$, línea $\mathrm{h}$ a $405 \mathrm{~nm}$ y línea i a $365 \mathrm{~nm}$ ).

Las longitudes de onda predominantes de luz UV que ahora se utilizan en fotoenmascaramiento son de $365 \mathrm{~nm}$ o más, pero los espectros de lámparas UV también contienen una energía significativa en la región de longitudes de onda que puede afectar a la salud, que es la región actínica por debajo de $315 \mathrm{~nm}$. L o normal es que la intensidad de la radiación UV que escapa del equipo sea inferior a la procedente de la luz solar en la región actínica y también a las normas establecidas para la exposición profesional al espectro UV.

Durante el mantenimiento, la alineación de la lámpara UV exige en ocasiones encenderla fuera de la cabina del equipo o sin los filtros protectores normales. Los niveles de exposición durante esta operación pueden rebasar los límites de exposición profesionales, pero la ropa normal utilizada en salas limpias (p. ej., delantales, guantes de vinilo, máscaras faciales y gafas de seguridad de policarbonato con inhibidor de UV) suele ser adecuada para atenuar la luz UV hasta niveles inferiores a los límites de exposición (Baldwin y Stewart 1989).

$M$ ientras que las longitudes de onda predominantes de las lámparas ultravioletas utilizadas en fotolitografía son de $365 \mathrm{~nm}$ - mayores, la búsqueda de características más pequeñas en los $\mathrm{Cl}$ avanzados conduce al empleo de fuentes de exposición con longitudes de onda menores, como radiación UV lejana y rayos $X$. U na nueva tecnología a este efecto es el uso de láseres de fluoruro de criptón utilizados en los procesadores paso a paso. Estos procesadores emplean una longitud de onda de $248 \mathrm{~nm}$ con salidas de láser de gran potencia. Pero las cabinas de estos sistemas encierran el haz durante el funcionamiento normal.

Como ocurre con otros equipos que contienen sistemas láser de gran potencia utilizados en la fabricación de semiconductores, la preocupación principal deriva de la necesidad de inactivar los bloqueos internos del sistema durante la alineación del haz. Los láseres de gran potencia son también uno de los peligros eléctricos más importantes en el sector de semiconductores. Incluso después de apagado, en este instrumento persiste una posibilidad de descarga considerable. Escher, Weathers y Labonville (1993) han publicado consideraciones sobre el diseño de controles y seguridad para estos sistemas.

U na fuente de exposición de tecnología avanzada utilizada en litografía son los rayos X. Los niveles de emisión de las fuentes de rayos $X$ para litografía pueden dar lugar a tasas de dosis que se aproximan a 50 milisievert ( 5 rem) anuales en el centro del equipo. Para reducir al mínimo la exposición, se recomienda restringir el acceso a las zonas interiores de las paredes blindadas (Rooney y Leavey 1989).

\section{Revelado}

Durante el paso de revelado, las superficies del protector no polimerizadas son disueltas y eliminadas. A la superficie de la oblea cubierta por el protector se aplica un revelador a base de disolventes mediante la inmersión, el rociado o la atomización. Las soluciones de revelador se identifican en la Tabla 83.1. Después del revelador suele aplicarse un lavado con disolvente (acetato de n-butilo, alcohol isopropílico, acetona, etc.) para eliminar cualquier material residual. El protector que permanece tras el revelado protege las capas individuales durante el proceso posterior.

\section{Cocido}

D espués de la alineación, exposición y revelado del protector, las obleas se llevan a otro horno de temperatura controlada con atmósfera de nitrógeno. La mayor temperatura del horno (de 120 a 135 ㄷ C) origina el curado de la fotoprotección y su polimerización completa sobre la superficie de la oblea (cocido de endurecimiento).

\section{Arranque de la fotoprotección}

La oblea revelada se somete después a un grabado selectivo mediante sustancias químicas húmedas o secas (véase "G rabado" a continuación). L os restos de fotoprotector tienen que eliminarse de la oblea antes de continuar el proceso. Para ello, se emplean soluciones químicas húmedas en baños con temperatura controlada, un incinerador de plasma o un producto químico seco. En la Tabla 83.2 se identifican los agentes químicos húmedos y secos. A continuación se explica el grabado en seco por plasma químico, en que se utilizan el mismo equipo y los mismos principios de operación que para la incineración por plasma.

\section{Grabado}

El grabado elimina las capas de dióxido de silicio $\left(\mathrm{SiO}_{2}\right)$, los metales y el polisilicio, así como los protectores, de conformidad con los patrones deseados, delimitados por la protección. Las dos categorías principales de grabado son el grabado químico húmedo y el seco. El grabado húmedo es el más utilizado y consiste en el empleo de soluciones que contienen los mordientes (por lo común una mezcla de ácidos) en la concentración deseada, que reaccionan con los materiales a eliminar. EI grabado seco consiste en el empleo de gases reactivos en condiciones de vacío en una cámara de alta energía, que también elimina las capas deseadas no cubiertas por el protector. 
Tabla 83.2 • Disolventes de fotoprotección.

Grabado químico húmedo
Acidos
Sulfúrico $\left(\mathrm{H}_{2} \mathrm{SO}_{4}\right)$ y crómico $\left(\mathrm{CrO}_{3}\right)$
Sulfúrico $\left(\mathrm{H}_{2} \mathrm{SO}_{4}\right)$ y persulfato amónico $\left(\left(\mathrm{NH}_{4}\right)_{2} \mathrm{~S}_{2} \mathrm{O}_{8}\right)$
Sulfúrico $\left(\mathrm{H}_{2} \mathrm{SO}_{4}\right)$ y peróxido de hidrógeno $\left(\mathrm{H}_{2} \mathrm{O}_{2}\right)$
Orgánicos
Fenoles, ácidos sulfúricos, triclorobenceno, percloroetileno
Eteres de glicol, etanolamina, trietanolamina
Hidróxido y silicatos de sodio (protector positivo)
Grabado químico seco
Incineración por plasma (denudación)
Fuente de RF (radiofrecuencia) - Frecuencia de $13,56 \mathrm{MHz}$ ó $2.450 \mathrm{MHz}$
Fuente de oxígeno ( $\left.\mathrm{O}_{2}\right)$
Sistemas de bomba de vacío
- Lubricada por aceite con trampa de nitrógeno líquido (tecnología antigua)
- Lubricada con líquidos de perfluoropoliéter inertes (tecnología más moderna)
- Bomba seca (última tecnología)

\section{Grabado químico húmedo}

L as soluciones para grabado químico húmedo se alojan en baños de temperatura controlada polipropileno (poli-pro), polipropileno resistente a la llama (FRPP) o cloruro de polivinilo (PVC). LOS baños suelen estar equipados con extracción localizada del tipo anular o con ranuras de salida de gases en la parte posterior de cada campana de extracción. Campanas verticales de flujo laminar suministran aire sin partículas filtrado de modo uniforme a la superficie superior de los baños de grabado. En la Tabla 83.3 se presentan las soluciones corrientes de reactivos húmedos para ataque químico en relación con la capa superficial que se graba.

Las campanas de suministro de aire montadas en vertical, cuando se emplean junto con escudos antisalpicaduras y extracción localizada, pueden crear turbulencias del aire en determinadas zonas del área de grabado químico húmedo, lo que puede originar una disminución de la eficacia de la extracción localizada para capturar y encaminar los contaminantes desprendidos al aire desde los baños de grabado en funcionamiento.

La causa principal de preocupación en el grabado húmedo es la posibilidad de que la piel entre en contacto con los ácidos concentrados. Si bien todos los ácidos empleados en grabado pueden provocar quemaduras, preocupa sobre todo la exposición al ácido fluorhídrico (HF). El tiempo que transcurre entre el contacto con la piel y la aparición de dolor (hasta 24 horas para soluciones de H F inferiores al $20 \%$ y de 1 a 8 horas para soluciones del 20 al $50 \%$ ) puede retrasar el tratamiento y permitir que las quemaduras sean más graves de lo esperado (H athaway y cols. 1991).

Las quemaduras por ácido han sido desde siempre un problema especial del sector. Pero la incidencia del contacto de la piel con ácidos se ha reducido en los últimos años. Parte de esta reducción se ha debido a las mejoras relativas a los productos utilizados en el proceso de grabado, como el cambio al grabado seco, la utilización de más robótica y la instalación de sistemas de dispensación de sustancias químicas. La reducción de la tasa de quemaduras por ácidos puede atribuirse también a la mejora de las técnicas de manipulación, a la extensión del empleo de equipo de protección personal, al mejor diseño de las etapas húmedas y a la mejora de la formación- todo lo cual exige una atención permanente si se quiere disminuir más aún esta tasa de accidentes (Baldwin y Williams 1996).

\section{Grabado químico seco}

El grabado con productos químicos secos es un campo de interés y aplicación crecientes por su capacidad de controlar mejor el proceso de grabado y reducir los niveles de contaminación. El procesamiento químico en seco consigue el ataque eficaz de las capas deseadas mediante el empleo de gases químicamente reactivos o mediante bombardeo físico.

Se han desarrollado sistemas de grabado con plasma químicamente reactivo que consiguen un grabado eficaz en silicio, dióxido de silicio, nitruro de silicio, aluminio, tántalo, compuestos de tántalo, cromo, wolframio, oro y vidrio. Se utilizan dos sistemas de reactor para el grabado con plasma - el de barril, o cilíndrico, y el de placa en paralelo, o planar.

Tabla 83.3 - Reactivos para grabado químico húmedo.

$\begin{array}{ll}\begin{array}{l}\text { Material a a grabar } \\ \text { Silicio }\end{array} & \text { Mordientes } \\ \text { Silicio policristalino (Si) } & \begin{array}{l}\text { Acidos fluorhídrico, nítrico, acético y yodo } \\ \text { Hidróxido potásico } \\ \text { Diamina de etileno/ pirocatequina } \\ \text { Fluoruro amónico, ácidos acétido glacial y nítrico }\end{array} \\ \text { Dióxido de silicio }\left(\mathrm{SiO}_{2}\right) & \begin{array}{l}\text { Grabado amortiguado con óxido (BOE) - } \\ \text { Fluorhídrico y fluoruro amónico } \\ \text { BOE, etilenglicol, éter de monometilo }\end{array} \\ \text { Nitruro de silicio }\left(\mathrm{Si}_{3} \mathrm{~N}_{4}\right) & \begin{array}{l}\text { Fluorhídrico y nítrico ( grabado P) } \\ \text { Grabadosfórico y fluorhídrico }\end{array} \\ & \text { Fluoruro amónico, ácidos acético y fluorhídrico }\end{array}$
de relleno

Metales

Aluminio (Al)

Cromo-Níquel ( $\mathrm{Cr} / \mathrm{Ni})$

Acidos fosfórico, nitrico, acético y clorhídrico Hidróxido sódico, hidróxido potásico

Acidos clorhídrico y nítrico (agua regia)

Oro ( $\mathrm{Au}$ Acidos clorhídrico y nítrico (agua regia) Yoduro potásico ( KI) Cianuro potásico (KCN) y peróxido de hidrógeno $\left(\mathrm{H}_{2} \mathrm{O}_{2}\right)$ Cloruro férrico $\left(\mathrm{FeCl}_{3}\right)$ y ácido clorhídrico

Plata ( $\mathrm{Ag}) \quad$ Nitrato férrico $\left(\mathrm{FeNO}_{3}\right)$ y etilenglicol Acido nítrico

$\begin{array}{lll}\text { Compuesto } & \text { Fórmula } & \text { Concentración estándar (\%) } \\ \text { Acido acético } & \mathrm{CH}_{3} \mathrm{COOH} & 36 \\ \text { Fluoruro de amonio } & \mathrm{NH}_{4} \mathrm{~F} & 40 \\ \text { Acido acético glacial } & \mathrm{CH}_{3} \mathrm{COOH} & 99,5 \\ \text { Acido clorhídrico } & \mathrm{HCl} & 36 \\ \text { Acido fluorhídrico } & \mathrm{HF} & 49 \\ \text { Acido nítrico } & \mathrm{HNO}_{3} & 67 \\ \text { Acido fosfórico } & \mathrm{H}_{3} \mathrm{PO}_{4} & 85 \\ \text { Hidróxido potásico } & \mathrm{KOH}_{3} & 50 \text { ó 10 } \\ \text { Hidróxido sódico } & \mathrm{NaOH}_{20} & 50 \text { ó } 10 \\ \text { Acido sulfúrico } & \mathrm{H}_{2} \mathrm{SO}_{4} & 96\end{array}$


Ambos se basan en los mismos principios y sólo se diferencian en la configuración.

Un plasma es similar a un gas, salvo en que algunos de los átomos o moléculas del plasma están ionizados y pueden contener un número notable de radicales libres. El reactor típico consta de una cámara de vacío que contiene la oblea y que suele ser de aluminio, vidrio o cuarzo; de una fuente de energía de radiofrecuencia (RF)-por lo común de $450 \mathrm{kHz}, 13,56 \mathrm{M} \mathrm{Hz}$ ó $40,5 \mathrm{M} \mathrm{Hz}$ y de un módulo de control que regula el tiempo del proceso, la composición del gas reactivo, el caudal de gas y el nivel de potencia de la R F. Además, en serie con la cámara del reactor se encuentra una fuente de vacío constituida por una bomba preliminar lubricada con aceite (tecnología antigua) o sin lubricación (última tecnología). Las obleas se cargan en el reactor, sueltas 0 en cassettes, una bomba evacua la cámara y entonces se introduce el gas reactivo (por lo general tetrafluoruro de carbono). El gas ionizado forma el plasma de grabado, que reacciona con las obleas para producir productos volátiles que se bombean hacia el exterior. La introducción de gas reactivo fresco en la cámara mantiene la actividad de grabado. En la Tabla 83.4 se identifican los materiales y gases en plasma que se emplean para el grabado de diversas capas.

O tro método que se desarrolla en la actualidad para el grabado es una corriente de microondas. U tiliza una descarga de microondas de gran densidad de energía para producir átomos metaestables de larga vida que graban el material casi como si éste se sumergiera en ácido.

Los procesos físicos de grabado son similares al chorro de arena en que se utilizan átomos de gas argón para el bombardeo físico de la capa que se desea grabar. Para retirar el material desalojado se emplea una bomba de vacío. El grabado por iones reactivos consiste en una combinación de grabado en seco químico y físico.

El proceso de pulverización consiste en el choque de iones y en transferencia de energía. Este sistema de grabado incorpora un sistema de pulverización por el cual la oblea a grabar se acopla a un electrodo negativo 0 blanco en un circuito de descarga luminiscente. El material de la oblea se pulveriza mediante bombardeo con iones positivos, por lo general de argón, que produce el desalojo de los átomos superficiales. La energía es suministrada por una fuente de RF a $450 \mathrm{kHz}$. Un sistema de vacío en serie permite controlar la presión y eliminar el reactivo.

El grabado y fresado por haz de iones es un proceso de grabado suave que emplea un haz de iones de baja energía. El sistema de haz de iones consta de una fuente para generar el haz de iones, una cámara de trabajo en la que se realiza el grabado 0 fresado, dotada de una placa de blanco para mantener las obleas en el haz de iones, un sistema de bomba de vacío y la electrónica e instrumentos complementarios. El haz de iones se extrae de un gas ionizado (argón o argón/ oxígeno) o plasma, que se genera mediante la descarga eléctrica. Esta se obtiene al aplicar una tensión entre un cátodo de filamento caliente que emite electrones y un ánodo cilíndrico situado en el diámetro exterior de la región de descarga.

El fresado por haz de iones se ejecuta en el intervalo de baja energía del bombardeo iónico, donde sólo tienen lugar interacciones superficiales. Estos iones, por lo común en el intervalo de 500 a $1.000 \mathrm{eV}$, chocan contra un blanco y arrancan átomos superficiales por rotura de las fuerzas que enlazan el átomo con su vecino. El grabado por haz de iones se realiza en una escala energética algo superior, lo que supone un desalojo más brusco de los átomos superficiales.

El grabado con iones reactivos (RIE) es una combinación de sistemas de grabado por pulverización física y reactivos químicos
Tabla 83.4 • G ases mordientes en plasma y materiales grabados.

$\begin{array}{ll}\text { Material } & \text { Gas } \\ \text { Silicio } & \\ \text { Polisilicio ( polisi) y silicio } & \mathrm{CF}+\mathrm{O}_{2}, \mathrm{CCl}_{4}, \mathrm{CF}_{3} \mathrm{Cl}_{1} \mathrm{CF}_{4} \text { y HCl } \\ \text { Dióxido de silicio }\left(\mathrm{SiO}_{2}\right) & \mathrm{C}_{2} \mathrm{~F}_{6}, \mathrm{C}_{3} \mathrm{~F}_{8}, \mathrm{CF}_{4}, \mathrm{SiF}_{4}, \mathrm{C}_{5} \mathrm{~F}_{12}, \mathrm{CHF}_{3}, \\ \mathrm{CCl}_{2} \mathrm{~F}_{2}, \mathrm{SF}_{6}, \mathrm{HF} & \mathrm{CF}_{4}+\mathrm{Ar}_{1} \mathrm{CF}_{4}+\mathrm{O}_{2}, \mathrm{CF}_{4}+\mathrm{H}_{2} \\ \text { Nitruro de silicio }\left(\mathrm{Si}_{3} \mathrm{~N}_{4}\right) & \\ \text { Metales } & \mathrm{CCl}_{4}, \mathrm{BCl}_{3}+\mathrm{He} 0 \mathrm{Ar} \\ \text { Aluminio (Al) } & \mathrm{CCl}_{4} \\ \text { Cromo (Cr) } & \mathrm{Cl}_{2}+\mathrm{Ar}_{0} \mathrm{CCl}_{4}+\mathrm{Ar} \\ \text { Oxido de cromo }\left(\mathrm{CrO}_{3}\right) & \mathrm{CCl}_{2} \mathrm{~F}_{2} \\ \text { Arseniuro de galio }(\mathrm{GaAs}) & \mathrm{CF}_{4} \\ \text { Vanadio (V) } & \mathrm{CF}_{4} \\ \text { Titanio (Ti) } & \mathrm{CF}_{4} \\ \text { Tántalo (Ta) } & \mathrm{CF}_{4} \\ \text { Molibdeno (Mo) } & \mathrm{CF}_{4} \\ \text { Wolframio (W) } & \end{array}$

a bajas presiones. EI RIE utiliza bombardeo iónico para lograr un grabado direccional, y también un gas químicamente reactivo, tetrafluoruro de carbono $\left(\mathrm{CF}_{4}\right) \circ$ tetracloruro de carbono $\left(\mathrm{CCl}_{4}\right)$, para mantener una buena selectividad de la capa de grabado. Se coloca una oblea en una cámara con atmósfera de un compuesto gaseoso químicamente reactivo a baja presión, en torno a 0,1 torr (1,3 × 10-4 atmósferas). U na descarga eléctrica crea un plasma de "radicales libres" (iones) reactivos con energía de algunos centenares de electrovoltios. Los iones inciden verticalmente sobre la superficie de la oblea, donde reaccionan para formar sustancias volátiles que se eliminan mediante un sistema de vacío a baja presión en serie.

L os grabadores secos poseen a veces un ciclo de limpieza cuya misión es eliminar los depósitos que se acumulan en el interior de las cámaras de reacción. Entre los compuestos originales empleados para generar plasmas del ciclo de limpieza se cuentan el trifluoruro de nitrógeno $\left(\mathrm{NF}_{3}\right)$, el hexafluoretano $\left(\mathrm{C}_{2} \mathrm{~F}_{6}\right)$ y el octafluorpropano $\left(\mathrm{C}_{3} \mathrm{~F}_{8}\right)$.

Estos tres gases empleados en el proceso de limpieza, y muchos de los gases utilizados en grabado, forman la piedra angular de un problema medioambiental al que se enfrenta el sector de semiconductores que surgió a mediados de la década de 1990. Se comprobó que varios de los gases muy fluorados tenían una influencia significativa en el calentamiento global (o efecto invernadero). (Estos gases se conocen también como PFC, compuestos perfluorados.) La larga vida atmosférica, la elevada capacidad de influir en el calentamiento global y el aumento significativo del uso de algunos $\mathrm{PFC}$, como $\mathrm{NF}_{3}, \mathrm{C}_{2} \mathrm{~F}_{6}$, $\mathrm{C}_{3} \mathrm{~F}_{8}, \mathrm{CF}_{4}$, trifluormetano $\left(\mathrm{CH} \mathrm{F}_{3}\right)$ y hexafluoruro sulfúrico $\left(\mathrm{SF}_{6}\right)$, obligaron al sector de semiconductores a indagar medios para reducir sus emisiones.

Las emisiones atmosféricas de PFC procedentes del sector de semiconductores se han debido a la escasa eficiencia de los aparatos (muchos consumían sólo del 10 al $40 \%$ del gas utilizado) y a un equipo inadecuado de atenuación de emisiones a la atmósfera. Los depuradores húmedos no son eficaces para eliminar los PFC, y las inspecciones de numerosas unidades de combustión encontraron una eficiencia insuficiente en la 
destrucción de algunos gases, en especial el $\mathrm{CF}_{4}$. Muchas de estas unidades de combustión descomponían el $\mathrm{C}_{2} \mathrm{~F}_{6}$ y el $\mathrm{C}_{3} \mathrm{~F}_{8}$ en $\mathrm{CF}_{4}$. Asimismo, el elevado coste de adquisición de estos dispositivos de reducción, su demanda de energía, su liberación de otros gases de calentamiento global y sus subproductos de combustión, algunos de ellos contaminantes peligrosos del aire, indicaban que la reducción en la combustión no era un método útil para controlar las emisiones de PFC.

En relación con los grabadores en seco, el interés medioambiental se ha puesto en hacer más eficientes las herramientas del proceso, en identificar y desarrollar alternativas menos contaminantes del medio ambiente que estos gases reactivos en seco y en la recuperación/ reciclado de los gases emitidos.

El principal interés en la higiene del trabajo en relación con los equipos grabadores en seco se ha puesto en las exposiciones potenciales del personal de mantenimiento que trabaja en las cámaras de reacción, en las bombas y en otros equipos auxiliares que pueden contener residuos producidos en las reacciones. La complejidad de los grabadores de plasma en metal y la dificultad de caracterizar los olores asociados a su mantenimiento los ha convertido en objeto de muchas investigaciones.

Los productos de reacción formados en aparatos grabadores de plasma en metal son una mezcla compleja de compuestos clorados y fluorados. El mantenimiento de los grabadores en metal implica a menudo realizar operaciones de corta duración que generan olores intensos. Se observó que el hexacloroetano era la causa principal de los olores en un tipo de grabador en aluminio (H elb y cols. 1983). En otro, el cloruro de cianógeno era el problema principal: los niveles de exposición fueron 11 veces superiores al límite de exposición profesional de 0.3 ppm (Baldwin 1985). En otros tipos de grabadores diferentes, es el cloruro de hidrógeno el asociado al olor; la exposición máxima medida fue de 68 ppm (Baldwin, Rubin y Horowitz 1993). Para información adicional sobre este tema, véase M ueller y K unesh (1989).

La complejidad de las sustancias químicas presentes en los escapes de los grabadores en metal ha inducido a los investigadores a desarrollar métodos experimentales para averiguar la toxicidad de estas mezclas (Bauer y cols. 1992a). La aplicación de estos métodos en experimentos con roedores indica que algunas de estas mezclas químicas son supuestos mutágenos (Bauer y cols. 1992b) y toxinas para el aparato reproductor (Schmidt y cols. 1995).

Dado que los grabadores en seco trabajan como sistemas cerrados, lo normal es que la exposición química de los operadores del equipo no tenga lugar mientras el sistema esté cerrado. Una rara excepción ocurre cuando el ciclo de purga de los mordientes de lotes más antiguos no es bastante largo para eliminar de manera adecuada los gases reactivos. Se ha informado de exposiciones breves, pero irritantes, a compuestos de flúor que se encuentran por debajo del límite de detección de los procedimientos normales de vigilancia de higiene industrial cuando las puertas de estos grabadores están abiertas. Este defecto puede corregirse normalmente con sólo aumentar la duración del ciclo de purga antes de abrir la puerta de la cámara de grabado.

La principal preocupación en relación con la exposición de operadores a la energía de R F se refiere al grabado e incineración por plasma (Cohen 1986; Jones 1988). Los casos típicos de fuga de energía de R $F$ pueden ser originados por:

- puertas mal alineadas;

- grietas y orificios en las cabinas;

- tableros metálicos y cables eléctricos que actúan como antenas por puesta a masa incorrecta del grabador;
- inexistencia de una pantalla atenuadora en la ventana de visión del grabador (J ones 1988; H orowitz 1992).

La exposición a R F puede ocurrir también durante el mantenimiento de grabadores, en particular si se ha quitado la cabina del equipo. En la parte superior de un modelo antiguo de grabador de plasma con la tapa quitada para mantenimiento se encontró una exposición de $12,9 \mathrm{~mW} / \mathrm{cm}^{2}$ (H orowitz 1992). $L$ a fuga real de radiación de RF en la zona donde se sitúa el operador era por lo general inferior a $4,9 \mathrm{~mW} / \mathrm{cm}^{2}$.

\section{Impurificación}

La formación de una unión eléctrica entre regiones $p$ y $n$ de una oblea individual de silicio cristalino es el elemento esencial para el funcionamiento de todos los dispositivos semiconductores. Las uniones permiten el paso de corriente en un sentido con mucha más facilidad que en el otro. Constituyen la base de los efectos de diodo y transistor en todos los semiconductores. En un circuito integrado, es preciso introducir un número controlado de impurezas elementales 0 adulterantes en determinadas regiones grabadas del sustrato de silicio, u oblea. Para ello se puede recurrir a técnicas de difusión o implantación iónica. Con independencia de la técnica empleada, las impurezas o adulterantes utilizados para la producción de uniones semiconductoras son siempre los mismos. La Tabla 83.5 identifica los componentes principales que se utilizan para la impurificación, su estado físico, tipo eléctrico $\left(\begin{array}{lll}p & 0 & n\end{array}\right)$ y la técnica básica de unión que se utiliza-difusión o implantación iónica.

Las exposiciones químicas en el trabajo normal de los operadores de hornos de difusión y de unidades de implantación de iones son bajas- por lo general inferiores al límite de detección especificado en los procedimientos de muestreo estándar de higiene industrial. Las preocupaciones relativas a los efectos químicos de este proceso se centran en la posibilidad de liberación de gases tóxicos.

Ya en el decenio de 1970, los fabricantes progresistas de semiconductores comenzaron a instalar los primeros sistemas continuos de vigilancia de gases inflamables y tóxicos. El objetivo esencial de esta vigilancia era detectar vertidos accidentales de los gases impurificadores más tóxicos con umbrales de olor por encima de sus límites de exposición en el trabajo (p. ej., arsina y diborano)

La mayoría de los monitores de aire de higiene industrial en el sector de semiconductores se utilizan para la detección de fugas de gases inflamables y tóxicos. Pero algunas instalaciones emplean también sistemas de vigilancia continua para:

- analizar las emisiones por conductos de salida (chimenea);

- cuantificar concentraciones de sustancias químicas volátiles en el aire ambiente:

- identificar y cuantificar olores en la áreas de fabricación.

L as tecnologías más utilizadas en el sector de semiconductores para este tipo de vigilancia son la detección colorimétrica de gases (p. ej., el detector continuo de gases MDA), los sensores electroquímicos (p. ej., monitores "sensydyne") y la transformada de Fourier en el infrarrojo (p. ej., ACM de Telos) (Baldwin y Williams 1996).

\section{Difusión}

Difusión es un término empleado para describir el movimiento de las impurezas desde las regiones de alta concentración en el extremo de la fuente del horno de difusión hasta regiones de concentración más baja en la oblea de silicio. La difusión es el método más extendido para la formación de uniones. 
Tabla 83.5 • Impurificadores de formación de uniones para difusión e implantación iónica.

\begin{tabular}{|c|c|c|c|c|}
\hline Elemento & Compuesto & Fórmula & Estado & Técnica \\
\hline \multicolumn{5}{|l|}{ Tipo $n$} \\
\hline \multirow[t]{2}{*}{ Antimonio } & Trióxido de antimonio & $\mathrm{Sb}_{2} \mathrm{O}_{3}$ & Sólido & Difusión \\
\hline & Tricloruro de antimonio & $\mathrm{SbCl}_{3}$ & Líquido & Difusión \\
\hline \multirow[t]{4}{*}{ Arsénico } & Trióxido de arsénico & $\mathrm{As}_{2} \mathrm{O}_{3}$ & Sólido & Difusión \\
\hline & Trióxido de arsénico & $\mathrm{As}_{2} \mathrm{O}_{3}$ & Líquido & Difusión- en giro \\
\hline & Arsina & $\mathrm{ASH}_{3}$ & Gas & Difusión e implantación de iones \\
\hline & Pentafluoruro de arsénico & $\mathrm{AsF}_{5}$ & Gas & Implantación de iones \\
\hline \multirow[t]{7}{*}{ Fósforo } & Pentóxido de fósforo & $\mathrm{P}_{2} \mathrm{O}_{5}$ & Sólido & Difusión \\
\hline & Pentóxido de fósforo & $\mathrm{P}_{2} \mathrm{O}_{5}$ & Líquido & Difusión- en giro \\
\hline & Tribromuro de fósforo & $\mathrm{PBr}_{3}$ & Líquido & Difusión \\
\hline & Tricloruro de fósforo & $\mathrm{PCl}_{3}$ & Líquido & Difusión \\
\hline & Oxicloruro de fósforo & $\mathrm{POCl}_{3}$ & Líquido & Difusión \\
\hline & Fosfina & $\mathrm{PH}_{3}$ & Gas & Implantación de iones \\
\hline & Pentafluoruro de fósforo & $\mathrm{PF}_{5}$ & Gas & Implantación de iones \\
\hline \multicolumn{5}{|l|}{ Tipo p } \\
\hline \multirow[t]{9}{*}{ Boro } & Nitruro de boro & BN & Sólido & Difusión \\
\hline & Tribromuro de boro & $\mathrm{BBr}_{3}$ & Líquido & Difusión \\
\hline & Trióxido de boro & $\mathrm{B}_{2} \mathrm{O}_{3}$ & Sólido & Difusión \\
\hline & Trióxido de boro & $\mathrm{B}_{2} \mathrm{O}_{3}$ & Líquido & Difusión- en giro \\
\hline & Trietilborato & $\mathrm{B}\left(\mathrm{COC}_{2} \mathrm{H}_{5}\right)_{3}$ & Líquido & Difusión- en giro \\
\hline & Tetrabromuro de silicio & $\mathrm{SiBr}_{4}$ & Líquido & Difusión \\
\hline & Tricloruro de boro & $\mathrm{BCl}_{3}$ & Líquido & Implantación de iones por difusión \\
\hline & Trifluoruro de boro & $\mathrm{BF}_{3}$ & Gas & Implantación de iones \\
\hline & Diborano & $\mathrm{B}_{2} \mathrm{H}_{6}$ & Gas & Implantación de iones \\
\hline
\end{tabular}

Esta técnica consiste en someter una oblea a una atmósfera caldeada en el horno de difusión. El horno contiene las impurezas deseadas en forma de vapor y da lugar a la creación de regiones con actividad eléctrica dopada, p o n. Las impurezas utilizadas con más frecuencia son el boro para el tipo $p$; y el fósforo $(\mathrm{P})$, arsénico $(\mathrm{As}) \mathrm{o}$ antimonio $(\mathrm{Sb})$ para el tipo $\mathrm{n}$ (véase la Tabla 83.5).

La operación típica consiste en apilar las obleas en un soporte de cuarzo o cápsula y colocarlas en el horno de difusión. Este contiene un tubo largo de cuarzo y un mecanismo que permite el control exacto de la temperatura. El control de la temperatura es de extrema importancia, puesto que las tasas de difusión de las diversas impurezas del silicio dependen primordialmente de la temperatura. Las temperaturas empleadas oscilan entre $900 \mathrm{y}$ 1.300 o $\mathrm{C}$ y dependen de la impureza concreta y del proceso.

El calentamiento de la oblea de silicio hasta una temperatura alta permite que los átomos de impurezas se difundan poco a poco a través de la estructura cristalina. Las impurezas se desplazan más despacio por el dióxido de silicio que a través del propio silicio, fenómeno que facilita a la delgada capa de óxido servir de máscara y por lo tanto permite que la impureza penetre en el silicio sólo en los lugares donde no está protegido. U na vez que se han acumulado impurezas suficientes, las obleas se retiran del horno y la difusión se detiene.

Para disponer del máximo de control, la mayoría de las difusiones se ejecutan en dos pasos-depósito previo y penetración. EI depósito previo, o difusión con fuente constante, es el primer paso y tiene lugar en un horno cuya temperatura se selecciona para conseguir el mejor control de las cantidades de impureza. La temperatura determina la solubilidad de la impureza. Después de un tratamiento comparativamente breve para el depósito previo, la oblea se transporta a un segundo horno, por lo general a mayor temperatura, donde un segundo tratamiento en caliente hace penetrar las impurezas hasta la profundidad de difusión deseada en la retícula de la oblea de silicio.

Las fuentes de impurezas empleadas en el paso de depósito previo están en tres estados físicos distintos: gaseoso, líquido y sólido. La Tabla 83.5 identifica los diversos tipos de impurezas que son fuentes de difusión y sus estados físicos.

Los gases se suministran en general desde botellas de gas con controles o reguladores de presión, válvulas de cierre y diversos accesorios de purga, y se distribuyen por tuberías metálicas de pequeño diámetro.

Los líquidos se suelen suministrar desde borboteadores, que saturan una corriente de gas portador, normalmente nitrógeno, con los vapores del impurificador líquido, como se describe en la sección sobre oxidación húmeda. Otra forma de suministrar líquidos es utilizar el aparato de giro con las impurezas. Esto implica colocar una impureza sólida disuelta en un líquido disolvente portador y después verter la solución sobre la oblea y hacerla girar, de manera similar a la aplicación de fotoprotectores.

Las fuentes sólidas pueden adoptar la forma de oblea de nitruro de boro, que se encierra entre dos obleas de silicio que se 
quieren impurificar y el conjunto se coloca después en un horno de difusión. L as impurezas sólidas también pueden colocarse, en forma de polvo o perla, en una bomba de cuarzo (trióxido de arsénico), verterse a mano en el extremo de entrada de un tubo de difusión o cargarse en un horno fuente separado, en serie con el horno principal de difusión.

Algunos informes han señalado que, en ausencia de controles adecuados, se produjeron exposiciones a arsénico superiores a $0,01 \mathrm{mg} / \mathrm{m}^{3}$ durante la limpieza de un horno de deposición (Wade y cols. 1981) y durante la limpieza de cámaras que alojaban implantadores de iones de fuentes sólidas (M cC arthy 1985; Baldwin, K ing y Scarpace 1988). Estas exposiciones se originaron cuando no se tomaron precauciones para limitar la cantidad de polvo en el aire. Pero cuando los residuos se mantuvieron húmedos durante la limpieza, las exposiciones se redujeron a valores muy por debajo del límite de exposición a las suspensiones en aire.

En las tecnologías de difusión más antiguas, existen peligros para la seguridad durante el desmontaje, la limpieza y la instalación de tubos en el horno. Los peligros son las cortaduras con piezas rotas de cuarzo y las quemaduras con ácido durante la limpieza manual. En tecnologías más modernas, estos peligros han disminuido mediante la limpieza in situ de las tuberías, que elimina gran parte de la manipulación.

Los operadores de hornos de difusión son quienes están más expuestos a los campos electromagnéticos de baja frecuencia (p. ej., 50 a 60 hertz) propios de la sala limpia en fabricación de semiconductores. Se han conocido exposiciones medias superiores a 0,5 microteslas (5 miligauss) durante el funcionamiento real de los hornos (C rawford y cols. 1993). Este estudio también puso de relieve que en el personal de sala limpia que trabajaba en la proximidad de hornos de difusión se determinaron exposiciones medias cuyos valores superaban con claridad a las de otros trabajadores de sala limpia. Este resultado fue coherente con las mediciones puntuales comunicadas por Rosenthal y Abdollahzadeh (1991), quienes observaron que en la proximidad de los hornos de difusión (a $5 \mathrm{~cm}$ de distancia) se obtenían lecturas de hasta 10 a 15 microteslas, mientras que los campos circundantes caían con la distancia menos que los estudiados cerca de otros equipos de sala limpia; incluso a 1,80 metros de distancia de los hornos de difusión, las densidades de flujo medidas fueron de 1,2 a 2 microteslas (Crawford y cols. 1993). Estos niveles de emisión están bastante por debajo de los límites de exposición actuales de seguridad en el trabajo establecidos por la O rganización M undial de la Salud y de los fijados por países individuales.

\section{Implantación iónica}

La implantación iónica es el método más moderno de introducir elementos de impurezas a la temperatura ambiente en obleas de silicio para la formación de uniones. Atomos de impureza ionizados (es decir, átomos a los que se han arrancado uno o más de sus electrones) son acelerados mediante el paso por una diferencia de potencial de decenas de miles de voltios hasta adquirir una energía elevada. Al final de sus recorridos, chocan contra la oblea y se embuten a distintas profundidades, que dependen de su masa y su energía. Como en la difusión tradicional, una capa de óxido modelada 0 un patrón de fotoprotección forman una máscara selectiva en la oblea frente a los iones.

Un sistema típico de implantación iónica consta de una fuente de iones (fuente de impurezas en estado gaseoso, por lo general en botellas miniatura), equipo de análisis, acelerador, lente de enfoque, trampa del haz neutro, cámara de proceso con escáner y sistema de vacío (que suele estar formado por tres conjuntos separados de bombas preliminares en serie y de difusión, de aceite). La corriente de electrones se genera a partir de un filamento calentado por resistencia, de la descarga de un arco 0 de un haz de electrones de cátodo frío.

Por lo general, después de realizado el implante en las obleas, se realiza un paso de cementación a alta temperatura (900 a 1.000 o C) mediante el fortalecimiento con un haz de láser 0 cementación por impulsos con el haz de electrones de una fuente. El proceso de cementación ayuda a reparar el daño causado a la superficie exterior de la oblea implantada por el bombardeo con iones de impurezas.

Con la llegada de un sistema seguro de suministro de las botellas de gas de arsina, fosfina y trifluoruro de boro utilizadas en los implantadores de iones, las posibilidades de liberación catastrófica de estos gases se han reducido en gran medida. Estas pequeñas botellas de gas se llenan con un compuesto al que se adsorben la arsina, la fosfina y el trifluoruro de boro. Los gases se extraen de la botellas mediante la formación de vacío.

Los implantadores de iones son uno de los peligros eléctricos más importantes en el sector de semiconductores. Aunque estén apagados, en el instrumento existe un potencial importante de descarga que ha de ser disipado antes de trabajar dentro del implantador. U na revisión cuidadosa de las operaciones de mantenimiento y de los peligros eléctricos está justificada en todos los equipos recién instalados, pero especialmente en los implantadores de iones.

Durante el mantenimiento de las criobombas de los implantadores de iones se han encontrado exposiciones a hidruros (probablemente a una mezcla de arsina y fosfina) de hasta 60 ppmm (Baldwin, Rubin y Horowitz 1993). También pueden haberse desprendido altas concentraciones de arsina y fosfina de piezas contaminadas de implantadores que se han desmontado durante el mantenimiento preventivo (Flipp, Hunsaker y H erring 1992).

Para limpiar superficies de trabajo contaminadas por arsénico en zonas de implantación iónica se utilizan depuradores portátiles de vacío con filtros de aire particulado de alta eficacia (HEPA). Se han medido exposiciones superiores a $1.000 \mu \mathrm{g} / \mathrm{m}^{3}$ cuando se ha procedido a la depuración incorrecta de las extracciones de los HEPA. Las extracciones de los HEPA, cuando se descargan en el lugar de trabajo, pueden difundir también el olor característico, como de hidruro, asociado a la limpieza de la línea del haz en los implantadores de iones (Baldwin, Rubin y H orowitz 1993).

Si bien constituye una preocupación, no se han publicado informes de exposiciones significativas a las impurezas gaseosas durante los cambios de aceite de las bombas de vacío empleadas con impurezas-quizás porque lo normal es hacerlo en sistema cerrado. La falta de informes de exposición puede ser también consecuencia de los bajos niveles de desprendimiento de hidruros del aceite usado.

El resultado de un estudio de campo en que se calentaron $700 \mathrm{ml}$ de aceite usado en la bomba preliminar de un implantador de iones en el que se utilizaban arsina y fosfina fue que sólo mostró concentraciones detectables de hidruros en el aire del volumen principal de la bomba cuando la temperatura del aceite superó los $70^{\circ} \mathrm{C}$ (Baldwin, K ing y Scarpace 1988). Como las temperaturas normales de funcionamiento de las bombas preliminares mecánicas son de 60 a $80 \stackrel{\circ}{\circ}$, este estudio no reveló que hubiera una exposición potencial significativa.

D urante la implantación iónica, se forman rayos $X$ derivados de la operación. La mayoría de los implantadores están diseñados con suficiente blindaje en su armario (que incluye planchas de plomo colocadas en lugares estratégicos en torno al alojamiento de la fuente de iones y puertas de acceso adyacentes) para mantener la exposición de los trabajadores por debajo de 2,5 microsievert (0,25 milirem) por hora (M aletskos y $\mathrm{H}$ anley 1983). Pero se encontró que un modelo antiguo de 
implantador tenía una fuga de rayos $X$ superior a 20 microsievert por hora ( $\mu \mathrm{Sv} / \mathrm{hr}$ ) en la superficie de la unidad (Baldwin, $K$ ing y Scarpace 1988). Estos niveles se redujeron a menos de 2,5 $\mathrm{\mu Sv} / \mathrm{hr}$ después de instalar el blindaje adicional de plomo. Se observó que otro modelo antiguo de implantador de iones tenía fuga de rayos $X$ alrededor de una puerta de acceso (hasta $15 \mu \mathrm{Sv} / \mathrm{hr}$ ) y en un punto de visión (hasta $3 \mu \mathrm{Sv} / \mathrm{hr}$ ). Se añadió un blindaje de plomo extra para atenuar posibles exposiciones (Baldwin, Rubin y H orowitz 1993).

A demás de exposiciones a rayos $X$ procedentes de los implantadores de iones, se ha postulado la posibilidad de formación de neutrones si el implantador trabaja por encima de 8 millones de electrovoltios ( $\mathrm{M} \mathrm{eV}$ ) o se emplea gas deuterio como fuente de iones (Rogers 1994). Sin embargo, los implantadores suelen estar diseñados para trabajar bastante por debajo de $8 \mathrm{MeV}$, y el empleo del deuterio no es corriente en el sector (Baldwin y Williams 1996).

\section{Depósito de vapores de sustancias químicas}

El depósito de vapores de sustancias químicas (CVD) consiste en la formación de capas adicionales de material sobre la superficie de la oblea de silicio. Las unidades de CVD trabajan en general como un sistema cerrado, y por consiguiente la exposición de los trabajadores a agentes químicos es pequeña o nula. No obstante, puede originarse una breve exposición a cloruro de hidrógeno, superior a 5 ppm, cuando se limpian determinados depuradores previos de CVD (Baldwin y Stewart 1989). En los procesos actuales se suelen emplear dos categorías amplias de deposición-la CVD epitaxial y el tipo más general de CVD no epitaxial.

\section{Depósito epitaxial de vapores de sustancias químicas}

El crecimiento epitaxial es la deposición perfectamente controlada de una sola película delgada de material que posee la misma estructura cristalina que el sustrato existente en la capa de la oblea. Sirve de matriz para fabricar componentes semiconductores en procesos de difusión sucesivos. La mayoría de las películas epitaxiales crecen sobre sustratos del mismo material, como por ejemplo silicio sobre silicio, en un proceso conocido por homoepitaxia. El crecimiento de capas de materiales diferentes sobre un sustrato, como silicio sobre zafiro, se llama procesamiento de dispositivos $\mathrm{CI}$ por heteroepitaxia.

Se utilizan tres técnicas principales para hacer crecer capas epitaxiales: de fase de vapor, de fase líquida y de haz molecular. La epitaxia de fase líquida y la de haz molecular se usan sobre todo en el procesamiento de dispositivos III-V (p. ej., GaAs). Estos se explican en el artículo "Fabricación de semiconductores III-V".

La epitaxia en fase de vapor se utiliza para hacer crecer una película mediante la CV D de moléculas a temperaturas de 900 a $1.300 \stackrel{\circ}{\circ}$. Vapores que contienen el silicio y cantidades controladas de impurezas tipo $\mathrm{p}$ o $\mathrm{n}$ en un gas portador (por lo general hidrógeno) se hacen pasar sobre obleas calentadas para depositar capas de silicio impuro. El proceso se realiza por lo general a la presión atmosférica.

La Tabla 83.6 identifica los cuatro tipos principales de epitaxia en fase de vapor, los parámetros y las reacciones químicas que tienen lugar. La secuencia de depósito que se sigue en un proceso epitaxial normal comprende:

- limpieza del sustrato - lavado físico, desengrase con disolvente, limpieza con ácido (es corriente la secuencia: sulfúrico, nítrico y clorhídrico, y fluorhídrico) y operación de secado;

- carga de las obleas;
Tabla 83.6 • Categorías principales de epitaxia del silicio en fase de vapor.

\begin{tabular}{|c|c|c|}
\hline \multicolumn{3}{|l|}{ Parámetros } \\
\hline Presión & \multicolumn{2}{|l|}{ Atmosférica } \\
\hline Temperatura & \multicolumn{2}{|l|}{$900-1300^{\circ} \mathrm{C}$} \\
\hline Fuentes de silicio & \multicolumn{2}{|c|}{$\begin{array}{l}\text { Silano }\left(\mathrm{SiH}_{4}\right) \text {, tetracloruro de silicio }\left(\mathrm{SiCl}_{4}\right) \text {, triclo- } \\
\text { rosilano }\left(\mathrm{SiHCl}_{3}\right) \text { y diclorosilano }\left(\mathrm{SiH}_{2} \mathrm{Cl}_{2}\right)\end{array}$} \\
\hline Gases impurificadores & \multicolumn{2}{|c|}{ Arsina $\left(\mathrm{AsH}_{3}\right)$, fosfina $\left(\mathrm{PH}_{3}\right)$, diborano $\left(\mathrm{B}_{2} \mathrm{H}_{6}\right)$} \\
\hline $\begin{array}{l}\text { Concentration de gases } \\
\text { impurificadores }\end{array}$ & \multicolumn{2}{|l|}{$\approx 100$ ppm } \\
\hline Gas mordiente & \multicolumn{2}{|c|}{ Cloruro de hidrógeno (HCl) } \\
\hline $\begin{array}{l}\text { Concentración del gas } \\
\text { mordiente }\end{array}$ & \multicolumn{2}{|c|}{$\approx 1-4 \%$} \\
\hline Gases portadores & \multicolumn{2}{|c|}{ Hidrógeno $\left(\mathrm{H}_{2}\right)$, nitrógeno $\left(\mathrm{N}_{2}\right)$} \\
\hline Fuente de calor & \multicolumn{2}{|c|}{ Radiofrequencia (RF) o rayos infrarrojos (IR) } \\
\hline \multicolumn{2}{|c|}{ Tipos de epitaxia en fase de vapor } & Reacciones químicas \\
\hline \multicolumn{2}{|c|}{$\begin{array}{l}\text { Reducción del tetracloruro de silicio con hidrógeno } \\
\left(1.150-1.300^{\circ} \mathrm{C}\right)\end{array}$} & $\mathrm{SiCl}_{4}+2 \mathrm{H}_{2} \rightarrow \mathrm{Si}+4 \mathrm{HCl}$ \\
\hline \multicolumn{2}{|c|}{$\begin{array}{l}\text { Descomposición pirolítica del silano } \\
\left(1.000-1.100^{\circ} \mathrm{C}\right)\end{array}$} & $\mathrm{SiH}_{4} \rightarrow \mathrm{Si}+2 \mathrm{H}_{2}$ \\
\hline \multicolumn{2}{|c|}{ Reducción del triclorosilano con hidrógeno } & $\mathrm{SiHCl}_{3}+\mathrm{H}_{2} \rightarrow \mathrm{Si}+3 \mathrm{HCl}$ \\
\hline \multicolumn{2}{|c|}{ Reducción del diclorosilano } & $\mathrm{SiH}_{2} \mathrm{Cl}_{2} \rightarrow \mathrm{Si}+2 \mathrm{HCl}$ \\
\hline
\end{tabular}

- calentamiento- purificación con nitrógeno y calentamiento hasta alrededor de 500 으, tras lo cual se usa el gas hidrógeno y generadores de R F calientan las obleas por inducción;

- grabado con cloruro de hidrógeno $(\mathrm{HCl})$ - se alimenta la cámara del reactor con $\mathrm{HCl}$ en la concentración usual del 1 al $4 \%$;

- depósito- se dosifican los gases de la fuente de silicio y de impurezas y se depositan sobre la superficie de la oblea;

- enfriamiento- el gas hidrógeno se cambia por nitrógeno, de nuevo a $500 \stackrel{\circ}{\circ}$;

- descarga.

\section{Depósito no epitaxial de vapores de sustancias químicas}

$M$ ientras que el crecimiento epitaxial es una forma muy específica de CVD en la que la capa depositada tiene una estructura cristalina con la misma orientación que la capa de sustrato, la CVD no epitaxial consiste en la formación de un compuesto estable sobre un sustrato calentado mediante la reacción térmica o la descomposición de compuestos gaseosos.

La CVD puede emplearse para depositar numerosos materiales, pero en el proceso de semiconductores de silicio los materiales que suelen encontrarse, además de silicio epitaxial, son:

- silicio policristalino (poli Si);

- dióxido de silicio ( $\mathrm{SiO}_{2}$ - con y sin impurezas; vidrio con impurezas $\mathrm{p}$ );

- nitruro de silicio $\left(\mathrm{Si}_{3} \mathrm{~N}_{4}\right)$.

Cada uno de estos materiales puede depositarse de diversas maneras, y cada uno tiene muchas aplicaciones

En la Tabla 83.7 se recogen las tres categorías principales de CVD, utilizando la temperatura de trabajo como mecanismo de diferenciación.

En casi todos los equipos de CVD se encuentran los componentes siguientes:

- cámara de reacción

- sección de control de gases; 
Tabla 83.7 • Categorías principales de la deposición química del silicio en forma de vapor (CVD).

$\begin{array}{ll}\text { Parámetros } & \text { Atmosférica (APCVD) o baja presión (LPCVD) } \\ \text { Presión } & 500-1.100^{\circ} \mathrm{C} \\ \text { Temperatura } & \left.\text { Silano }\left(\mathrm{SiH}_{4}\right), \text { tetracloruro de silicio }(\mathrm{SiCl})_{4}\right) \text {, amoníaco }\left(\mathrm{NH}_{3}\right) \text {, óxido nitroso }\left(\mathrm{N}_{2} \mathrm{O}\right) \\ \text { Fuentes de silicio y nitruros } & \text { Arsina }\left(\mathrm{AsH}_{3}\right) \text {, fosfina }\left(\mathrm{PH}_{3}\right) \text {, diborano }\left(\mathrm{B}_{2} \mathrm{H}_{6}\right) \\ \text { Fuentes dopadoras } & \text { Nitrógeno }\left(\mathrm{N}_{2}\right) \text {, hidrógeno }\left(\mathrm{H}_{2}\right) \\ \text { Gases portadores } & \text { Sistema de paredes frías- radiofrecuencia (RF) o infrarrojos (IR) } \\ \text { Fuente de calor } & \text { Sistema de paredes calientes- resistencia térmica }\end{array}$

$\begin{array}{llll}\text { Tipo de CVD } & \text { Reacción } & \text { Gas portador } & \text { Temperatura } \\ \text { Temperatura media }\left(\approx 600-1.100{ }^{\circ} \mathrm{C}\right) & & & \\ \text { Nitruro de silicio }\left(\mathrm{Si}_{3} \mathrm{~N}_{4}\right) & 3 \mathrm{SiH}_{4}+4 \mathrm{NH}_{3} \rightarrow \mathrm{Si}_{3} \mathrm{~N}_{4}+12 \mathrm{H}_{2} & \mathrm{H}_{2} & 900-1.1000^{\circ} \mathrm{C} \\ \text { Polisilicio (poliSi) } & \mathrm{SiH}_{4}+\mathrm{CalOr} \rightarrow \mathrm{Si}+2 \mathrm{H}_{2} & \mathrm{H}_{2} & 850-1.0000^{\circ} \mathrm{C} \\ & & \mathrm{N}_{2} & 600-7000^{\circ} \mathrm{C} \\ \text { Dióxido de silicio }\left(\mathrm{SiO}_{2}\right) & \mathrm{SiH}_{4}+4 \mathrm{CO}_{2} \rightarrow \mathrm{SiO}_{2}+4 \mathrm{CO}+2 \mathrm{H}_{2} \mathrm{O} & \mathrm{N}_{2} & 500-9000^{\circ} \mathrm{C} \\ & 2 \mathrm{H}_{2}+\mathrm{SiCl}_{4}+\mathrm{CO}_{2} \rightarrow \mathrm{SiO}_{2}+4 \mathrm{HCl} & \mathrm{H}_{2} & 800-1.0000^{\circ} \mathrm{C} \\ & \mathrm{SiH}_{4}+\mathrm{CO} \rightarrow \mathrm{SiO}_{2}+2 \mathrm{H}_{2}{ }^{*} & \mathrm{H}_{2} & 600-9000^{\circ} \mathrm{C}\end{array}$

Baja temperatura $\left(\approx<600^{\circ} \mathrm{C}\right)$ Silox, Pyrox, Vapox y Nitrox**

Dióxido de silicio $\left(\mathrm{SiO}_{2}\right)$ puro o dopado con $\mathrm{p}$

\begin{tabular}{|c|c|c|c|}
\hline Silox & $\mathrm{SiH}_{4}+2 \mathrm{O}_{2}+$ Dopador $\rightarrow \mathrm{SiO}_{2}+2 \mathrm{H}_{2} \mathrm{O}$ & $\mathrm{N}_{2}$ & $200-500^{\circ} \mathrm{C}$ \\
\hline Pyrox & $\mathrm{SiH}_{4}+2 \mathrm{O}_{2}+$ Dopador $\rightarrow \mathrm{SiO}_{2}+2 \mathrm{H}_{2} \mathrm{O}$ & $\mathrm{N}_{2}$ & $<600^{\circ} \mathrm{C}$ \\
\hline Vapox & $\mathrm{SiH}_{4}+2 \mathrm{O}_{2}+$ Dopador $\rightarrow \mathrm{SiO}_{2}+2 \mathrm{H}_{2} \mathrm{O}$ & $\mathrm{N}_{2}$ & $<600^{\circ} \mathrm{C}$ \\
\hline \multicolumn{4}{|l|}{ Nitruro de silicio $\left(\mathrm{Si}_{3} \mathrm{~N}_{4}\right)$} \\
\hline Nitrox & $3 \mathrm{SiH}_{4}+4 \mathrm{NH}_{3}\left(0 \mathrm{~N}_{2} \mathrm{O}^{*}\right) \rightarrow \mathrm{Si}_{3} \mathrm{~N}_{4}+12 \mathrm{H}_{2}$ & $\mathrm{~N}_{2}$ & $600-700^{\circ} \mathrm{C}$ \\
\hline \multicolumn{4}{|c|}{ Potenciado con plasma a baja temperatura (pasivación) $\left(<600^{\circ} \mathrm{C}\right)$} \\
\hline \multicolumn{4}{|c|}{$\begin{array}{l}\text { Utilización de radiofrecuencia (RF) o deposición electrónica del } \\
\text { reactivo }\end{array}$} \\
\hline Dióxido de silicio $\left(\mathrm{SiO}_{2}\right)$ & $\mathrm{SiH}_{4}+2 \mathrm{O}_{2} \rightarrow \mathrm{SiO}_{2}+2 \mathrm{H}_{2} \mathrm{O}$ & & \\
\hline Nitruro de silicio $\left(\mathrm{Si}_{3} \mathrm{~N}_{4}\right)$ & $3 \mathrm{SiH}_{4}+4 \mathrm{NH}_{3}\left(\right.$ or N $\left.\mathrm{O}^{*}\right) \rightarrow \mathrm{Si}_{3} \mathrm{~N}_{4}+12 \mathrm{H}_{2}$ & & \\
\hline
\end{tabular}

- control de tiempo y secuencia;

- fuente de calor para sustratos;

- manipulación del efluente.

En esencia, el proceso de CV D comprende el suministro de cantidades controladas de los gases fuente de silicio o nitruro, junto con gases portadores, como nitrógeno y/ o hidrógeno, e impurezas gaseosas si se desea, para su reacción química en la cámara del reactor. Se aplica calor para suministrar la energía necesaria para la reacción química, y además se controlan las temperaturas superficiales del reactor y de las obleas. U na vez terminada la reacción, el gas fuente que no reaccionó más el gas portador se extraen por el sistema de manipulación de efluentes y se liberan en la atmósfera.

La pasivación es un tipo funcional de CVD. Consiste en el crecimiento de una capa protectora de óxido sobre la superficie de la oblea de silicio, y por lo general es el último paso de fabricación antes del procesamiento posterior a la fabricación. La capa proporciona estabilidad eléctrica al aislar la superficie del circuito integrado de las condiciones químicas y eléctricas del medio ambiente.

\section{Metalización}

U na vez fabricados los dispositivos en el sustrato de silicio, tienen que conectarse para ejecutar funciones de circuito. Este proceso se denomina metalización, y es un medio de alambrar o interconectar las capas superiores de los circuitos integrados mediante el depósito de patrones complejos de materiales conductores, que encaminan la energía eléctrica en el interior de los circuitos.

El amplio proceso de metalización se diferencia en función del tamaño y el espesor de la capas de metales y otros materiales que se depositan. Estos son:

- película delgada - película de espesor aproximado de una micra o menos;

- película gruesa-película de espesor aproximado de 10 micras o más;

- plaqueado- películas de espesor variable desde delgada hasta gruesa, pero en general películas gruesas.

L os metales más corrientes empleados para la metalización de semiconductores de silicio son: aluminio, níquel, cromo o una 
aleación llamada cromo-níquel, oro, germanio, cobre, plata, titanio, wolframio, platino y tántalo.

También pueden evaporarse 0 depositarse películas delgadas o gruesas sobre diversos sustratos de cerámica o vidrio. Algunos ejemplos de estos sustratos son: alúmina (96 \% $\mathrm{Al}_{2} \mathrm{O}_{3}$ ), berilia $(99 \% \mathrm{BeO})$, vidrio de borosilicato, pirocerámica y cuarzo $\left(\mathrm{SiO}_{2}\right)$.

\section{Película delgada}

La metalización de película delgada se aplica a menudo mediante la técnica de depósito o evaporación en alto vacío o con vacío parcial. Los tipos principales de evaporación en alto vacío son con haz de electrones, instantánea y resistiva, mientras que la deposición con vacío parcial se ejecuta sobre todo por pulverización.

Para realizar cualquier tipo de metalización de película delgada al vacío, el sistema suele constar de los componentes básicos siguientes:

- una cámara que puede evacuarse para conseguir un vacío suficiente para el depósito;

- una bomba (o bombas) de vacío para reducir los gases ambientales en la cámara;

- instrumentación para la vigilancia del nivel de vacío y de otros parámetros;

- un método de depositar o evaporar las capas del material metalizador.

La evaporación por haz de electrones, llamada a veces E-beam, utiliza un haz de electrones enfocado para calentar el material de metalización. Se genera un haz de electrones de alta intensidad de manera similar al creado en el tubo de un televisor. Una corriente de electrones es acelerada mediante un campo eléctrico, generalmente de 5 a $10 \mathrm{kV}$, y enfocada sobre el material a evaporar. El haz de electrones enfocado funde el material contenido en un bloque refrigerado por agua con una depresión grande llamada crisol. El material fundido se vaporiza en la cámara de vacío y se condensa sobre las obleas frías y sobre toda la superficie de la cámara. Después se ejecutan las operaciones estándar de fotoprotección, exposición, revelado y grabado húmedo o seco para delinear la intrincada circuitería metalizada.

La evaporación instantánea es otra técnica aplicada para la deposición de películas delgadas metalizadas. Este método se emplea sobre todo cuando es preciso evaporar al mismo tiempo la mezcla de dos materiales (aleaciones). Algunos ejemplos de películas con dos componentes son: níquel/ cromo (cromo-níquel), monóxido de cromo/ silicio (SiO) y aluminio/ silicio.

En la evaporación instantánea, una barra de cerámica se calienta mediante una resistencia térmica y después se pone en contacto con el filamento o barra caliente una bobina de alambre de alimentación continua, una corriente de gránulos 0 un polvo dosificado por medios vibratorios. Los metales vaporizados recubren entonces la cámara interior y las superficies de la oblea.

La evaporación resistiva (conocida también por evaporación en filamento) es la forma de depósito más sencilla y barata. La evaporación se consigue por el aumento gradual de la corriente que circula por un filamento hasta que empiezan por fundirse los bucles del material a evaporar, y humedecen el filamento. Una vez humedecido el filamento, la corriente que lo atraviesa se aumenta hasta que se produce evaporación. La ventaja principal de la evaporación resistiva es la extensa variedad de materiales que pueden evaporarse

A veces se realiza trabajo de mantenimiento sobre la superficie interior de las cámaras de depósito del evaporador por haz de electrones, llamadas jarras acampanadas. Cuando los técnicos de mantenimiento tienen la cabeza dentro de las jarras acampanadas, pueden originarse exposiciones importantes. La eliminación de los residuos metálicos que se depositan en la superficie interior de las jarras puede originar tales exposiciones. Por ejemplo, se han medido exposiciones de técnicos muy por encima del límite de exposición en el aire para la plata durante la eliminación de residuos de un evaporador utilizado para depositar plata (Baldwin y Stewart 1989).

La limpieza de los residuos de las jarras acampanadas con disolventes orgánicos para limpieza también puede dar lugar a una elevada exposición al disolvente. Se han producido exposiciones de técnicos a metanol por encima de $250 \mathrm{ppm}$ durante este tipo de limpieza. Esta exposición puede eliminarse si se utiliza agua como disolvente de limpieza en lugar de metanol (Baldwin y Stewart 1989).

El proceso de depósito por pulverización tiene lugar en una atmósfera de gas a baja presión o en vacío parcial, con empleo de corriente eléctrica continua ( $\mathrm{DC}, 0$ pulverización catódica) 0 tensiones de RF como fuente de alta energía. En la pulverización, se introducen iones del gas inerte argón en una cámara de vacío después de haberse alcanzado un nivel de vacío satisfactorio mediante el uso de una bomba preliminar. Al aplicar la alta tensión, que suele ser de $5.000 \mathrm{~V}$, se forma un campo eléctrico entre dos placas con cargas opuestas. Esta descarga de alta energía ioniza los átomos de gas argón y hace que se desplacen y aceleren hacia una de la placas de la cámara, llamada blanco. Cuando los iones de argón chocan con el blanco, hecho del material que se desea depositar, desalojan, o pulverizan, estos átomos o moléculas. Los átomos desalojados del material de metalización se depositan entonces, en forma de película delgada, sobre los sustratos de silicio que miran al blanco.

Se ha observado que la fuga de R F desde los costados y partes traseras de muchas unidades de pulverización antiguas superan el límite de exposición de los trabajadores (Baldwin y Stewart 1989). Casi toda la fuga era atribuible a grietas de los armarios causadas por el desmontaje repetido de los paneles de mantenimiento. En modelos más modernos del mismo fabricante, paneles con malla de alambre a lo largo de las juntas impiden fugas importantes. L os pulverizadores antiguos se pueden modificar con malla de alambre 0, como alternativa, puede emplearse cinta de cobre para cubrir las juntas a fin de reducir la fuga.

\section{Película gruesa}

La estructura y la dimensión de la mayoría de las películas gruesas no son compatibles con la metalización de circuitos integrados de silicio, sobre todo por limitaciones de tamaño. Las películas gruesas se usan en su mayoría para la metalización de estructuras electrónicas híbridas, como en la fabricación de LCD.

El proceso de serigrafía es el método predominante en la aplicación de película gruesa. Los materiales que se suelen utilizar en película gruesa son paladio, plata, dióxido de titanio y vidrio, oro-platino y vidrio, oro-vidrio y plata-vidrio.

Las películas gruesas resistivas se depositan y modelan normalmente sobre un sustrato cerámico con ayuda de técnicas serigráficas. El cermet es una forma de película gruesa resistiva compuesta por una suspensión de partículas metálicas conductoras en una matriz cerámica con una resina orgánica como relleno. Las estructuras cermet típicas se componen de cromo, plata u óxido de plomo en una matriz de monóxido o dióxido de silicio.

\section{Plaqueado}

Para formar películas metálicas sobre sustratos semiconductores se utilizan dos tipos básicos de técnicas de plaqueado: galvanotecnia y plaqueado químico. 
En la galvanotecnia, el sustrato a plaquear se coloca en el cátodo, o terminal con cargas negativas, de la cuba de plaqueado y se sumerge en una solución electrolítica. Un electrodo hecho del metal de recubrimiento actúa como ánodo, o terminal con cargas positivas. Cuando se hace pasar una corriente continua por la solución, los iones metálicos que se disuelven en la solución desde el ánodo, emigran con sus cargas positivas hasta depositarse sobre el cátodo (sustrato). Este método de plaqueado se usa para formar películas conductoras de oro o cobre.

En el plaqueado químico, se aplican la reducción y la oxidación simultáneas del metal que formará el plaqueado para depositar un átomo o molécula metálica libre. C omo este método no exige conducción eléctrica durante el proceso de plaqueado, puede emplearse con sustratos de tipo aislante. Níquel, cobre y oro son los metales más corrientes que se depositan de esta manera.

\section{Aleación/cementación}

Después de haber depositado y grabado las interconexiones metalizadas, puede efectuarse un paso final de aleación y cementación. La aleación consiste en colocar los sustratos metalizados, por lo general con aluminio, en un horno de difusión de baja temperatura para garantizar un contacto de baja resistencia entre el aluminio metálico y el sustrato de silicio. Por último, bien durante el paso de aleación o en los sucesivos, las obleas se suelen exponer a una mezcla de gases que contiene hidrógeno en un horno de difusión a la temperatura de 400 a 500 으. El paso de cementación está concebido para optimizar y estabilizar las características del dispositivo al combinar el hidrógeno con átomos no ligados en la interfase silicio-dióxido de silicio o cerca de ella.

\section{Recubrimiento y metalización trasera}

Hay también un paso de metalización opcional denominado recubrimiento trasero. El lado posterior de la oblea puede ser recubierto o nivelado con ayuda de una solución abrasiva húmeda y presión. Puede depositarse un metal, como el oro, en el lado posterior de la oblea por pulverización. Este acabado hace más fácil la conexión del dado separado a la montura en el montaje final.

\section{M ontaje y prueba}

El procesamiento siguiente a la fabricación, que comprende el empaquetado externo, las conexiones, encapsulado, montaje y prueba, se efectúa por lo general en instalaciones de producción independientes que muchas veces radican en países del Sureste de Asia, donde estos trabajos que exigen mano de obra intensiva son más baratos de ejecutar. Además, los requisitos de ventilación para control del proceso y de las partículas suelen ser diferentes (no los de sala limpia) en el procesamiento posterior a la fabricación. Estos pasos finales del proceso de fabricación comprenden operaciones que incluyen la soldadura, desengrase, prueba con sustancias químicas y fuentes de radiación y recorte y marcado con láseres.

En condiciones normales, la soldadura durante la fabricación de semiconductores no origina altas exposiciones al plomo. Para prevenir daños térmicos al circuito integrado, la temperatura de soldadura se mantiene inferior a la temperatura en que pueden formarse humos de plomo fundido (430 ํㅡ). Sin embargo, la limpieza del equipo de soldadura mediante raspado o cepillado de los residuos con contenido de plomo puede originar exposiciones al plomo superiores a $50 \mu \mathrm{g} / \mathrm{m}^{3}$ (Baldwin y Stewart 1989). También se han producido exposiciones al plomo de $200 \mu \mathrm{g} / \mathrm{m}^{3}$ cuando se han empleado técnicas inadecuadas de eliminación de desechos durante operaciones de soldadura por ola (Baldwin y Williams 1996).
Una preocupación creciente en relación con las operaciones de soldadura es la irritación respiratoria y el asma derivadas de la exposición a los productos de pirólisis de los fundentes para soldar, en particular durante la soldadura manual o las operaciones de retoque, puesto que nunca ha estado generalizada la ventilación aspirante en los recintos donde se ejecutan (al contrario que en las operaciones de soldadura por ola, que desde hace algunos decenios se suelen realizar en armarios cerrados que cuentan con extracción de gases) (G oh y N g 1987). V éanse más detalles en el artículo "Montaje de placas de circuito impreso y ordenadores".

Como la colofonia contenida en el fundente para soldar es un sensibilizador, todas las exposiciones al fundente deben reducirse al mínimo posible, con independencia de los resultados que den los muestreos del aire. En particular, las instalaciones de soldadura nuevas deben contar con ventilación aspirante local cuando se vayan a efectuar soldaduras durante períodos de tiempo prolongados (p. ej., superiores a 2 horas).

Los humos generados en la soldadura manual ascienden por convección y entran en las vías respiratorias del trabajador cuando se inclina sobre el punto de soldadura. La manera más eficaz de controlar este peligro, y la más utilizada, es la ventilación aspirante de alta velocidad y bajo volumen en la punta del soldador.

Los dispositivos que devuelven aire filtrado al recinto de trabajo pueden originar, si la eficiencia del filtrado es inadecuada, una contaminación secundaria que puede afectar a las personas presentes en el recinto aunque no se dediquen a la soldadura. El aire filtrado no debe devolverse al recinto de trabajo a menos que la cantidad de soldadura sea pequeña y el recinto tenga una buena ventilación general por dilución.

\section{Clasificación y prueba de obleas}

U na vez terminada la fabricación de obleas, cada una de ellas es sometida a un proceso de clasificación en el que se comprueba el funcionamiento eléctrico de la circuitería integrada de cada pastilla mediante sondas controladas por ordenador. U na oblea individual puede contener desde cien hasta muchos centenares de dados 0 pastillas independientes que han de ser comprobadas. Conocidos ya los resultados de la prueba, las pastillas se marcan físicamente con resina epoxídica monocomponente suministrada por un dispositivo automático. Para identificar y clasificar las pastillas que no cumplen las especificaciones eléctricas deseadas se emplean los colores rojo y azul.

\section{Separación de pastillas}

Una vez probados, marcados y clasificados los dispositivos 0 circuitos integrados en la oblea, es preciso proceder a la separación física individual de las pastillas que se encuentran agrupadas en la oblea. Se han ideado numerosos métodos para separar e individualizar las pastillas - trazado con diamante, trazado con láser y aserrado con rueda de diamante.

El trazado con diamante, el método más antiguo utilizado, consiste en pasar una punta con diamantes incrustados, de forma muy precisa, por la línea del trazado o "calle" de la oblea que separa las pastillas individuales en la superficie de la oblea. La imperfección en la estructura cristalina provocada por el trazado permite doblar y fracturar la oblea a lo largo de esa línea.

El trazado con láser es una técnica de separación de pastillas relativamente reciente. Un láser pulsado muy potente de neodimio-itrio genera un haz que practica en la oblea de silicio una ranura que sigue la línea del trazado. La ranura se convierte en la línea de rotura de la oblea.

Un método de separación de pastillas muy extendido es el aserrado en húmedo-cortar sustratos a lo largo de la calle con 
una sierra circular de diamante de gran velocidad. El aserrado del sustrato de silicio puede ser de corte parcial (trazado) 0 completo (dados). El aserrado genera una lechada húmeda con el material arrancado de la calle.

\section{Sujetar y conectar pastillas}

La pastilla 0 dado individual tiene que quedar sujeta a una montura y a un marco de conductores metálicos. Las monturas suelen estar hechas de material aislante cerámico o plástico. Los materiales de las monturas cerámicas son por lo general de alúmina $\left(\mathrm{Al}_{2} \mathrm{O}_{3}\right)$, pero también pueden ser de berilia $(\mathrm{BeO}) 0$ esteatita ( $\mathrm{M} \mathrm{gO}-\mathrm{SiO}_{2}$ ). Los materiales de las monturas de plástico son de resina termoplástica o termoendurecible.

En general, la sujeción de la pastilla se efectúa por uno de tres tipos distintos de fijación: eutéctica, preforma y epoxídica. $L a$ fijación eutéctica de pastillas consiste en utilizar una aleación de soldadura fuerte eutéctica, como la de oro-silicio. En este método, se efectúa el depósito previo de una capa de oro metálico en la parte posterior de la pastilla. Mediante el calentamiento de la montura por encima de la temperatura eutéctica (370 @ C para oro-silicio) y la colocación de la pastilla sobre la montura, se forma un enlace entre ésta y la pastilla.

La unión con preforma consiste en emplear una pequeña pieza de composición especial (preforma) que se adhiera a pastilla y montura. Se coloca una preforma sobre el área de la montura donde se quiere sujetar la pastilla y se deja que se funda. Entonces se frota la pastilla por esa zona hasta que queda sujeta, y a continuación se enfría la montura.

La unión epoxídica consiste en aplicar un pegamento epoxídico para fijar la pastilla a la montura. Se vierte una gota de epoxia en la montura y encima se coloca la pastilla. Puede ser preciso cocer después la montura a una temperatura elevada para que la epoxia adquiera la dureza adecuada.

Una vez lograda la sujeción física de la pastilla a la montura, es preciso establecer las conexiones eléctricas entre el circuito integrado y los conductores de la montura. Esta operación se ejecuta por técnicas de termocompresión, ultrasónicas o termosónicas, que conectan hilos de oro 0 aluminio entre las áreas de contacto de la pastilla de silicio y de los conductores de la montura.

La unión por termocompresión se emplea a menudo con hilo de oro y consiste en calentar la montura hasta unos 300 o $C$ y formar la unión entre el hilo y las patillas de conexión mediante la aplicación de calor y presión. Se utilizan dos tipos principales de unión por termocompresión- unión con bola y unión con cuña. En la unión con bola, que sólo se utiliza con hilo de oro, éste es suministrado desde un tubo capilar, después es comprimido, y después fundido por una llama de hidrógeno. La llama forma además una nueva bola en el extremo del hilo, bola que será aprovechada en el ciclo de conexión siguiente. La unión con cuña exige utilizar una herramienta de unión en forma de cuña y un microscopio, que ayuda a colocar en su posición exacta la pastilla de silicio y la montura sobre la patilla de conexión. EI proceso se ejecuta en una atmósfera inerte.

La unión ultrasónica emplea un impulso energético de alta frecuencia ultrasónico para inducir un efecto de frotamiento que forma una unión entre el hilo y la patilla de conexión. La unión ultrasónica se realiza sobre todo con hilo de aluminio, y muchos la prefieren a la de termocompresión porque no exige el calentamiento de la pastilla de circuitos durante la operación de conexión.

La unión termosónica es un cambio tecnológico reciente en la conexión con hilo de oro. En ella se utiliza una combinación de energías ultrasónica y térmica, y exige menos calor que la unión por termocompresión.

\section{Encapsulado}

El objetivo esencial del encapsulado es acomodar un circuito integrado en una montura que cumpla los requisitos eléctricos, térmicos, químicos y físicos asociados a la aplicación del circuito integrado.

Las monturas más extendidas son la de conductores radiales, la montura plana y la doble en línea (DIP). Las monturas de conductores radiales se fabrican casi todas de K ovar, que es una aleación de hierro, níquel y cobalto, con sellos de vidrio duro y conductores de Kovar. Las monturas planas tienen un marco de conductores metálicos, por lo general de una aleación de aluminio combinada con componentes cerámicos, de vidrio y metálicos. Las monturas dobles en línea son las más corrientes y a menudo utilizan cerámica o plásticos moldeados.

Las monturas de plástico moldeado para semiconductores se producen sobre todo por dos procesos diferentes-moldeo por transferencia y moldeo por inyección. El moldeo por transferencia es el método de encapsulado en plástico predominante. En él, las pastillas se montan sobre marcos de conductores sin cortar y después se cargan en moldes por lotes. Porciones en polvo 0 bolas de compuestos de plástico termoendurecible para moldeo se funden en una olla caliente y después son impulsados (transferidos) a presión hasta los moldes cargados. Los sistemas de formar porciones en polvo o bolas con compuestos de plástico para moldeo pueden utilizarse con epoxia, silicona 0 silicona/ resinas epoxídicas. El sistema suele consistir en una mezcla de:

- resinas termoendurecibles- epoxia, silicona o silicona/ epoxia;

- endurecedores- novolacas epoxídicas y anhídridos epoxídicos;

- sustancias de relleno- dióxido de silicio $\left(\mathrm{SiO}_{2}\right)$ amalgamado en ślice 0 cristalino y alúmina $\left(\mathrm{Al}_{2} \mathrm{O}_{3}\right)$, por lo general en la proporción de 50-70 \% en peso;

- pirorretardante- trióxido de antimonio $\left(\mathrm{Sb}_{2} \mathrm{O}_{3}\right)$ por lo general en la proporción de 1-5 \% en peso.

El moldeo por inyección emplea un compuesto termoplástico o termoendurecible para moldeo que se calienta hasta su punto de fusión en una botella a temperatura controlada y se hace pasar a presión por una boquilla hasta el molde. La resina se solidifica en seguida, se abre el molde y la montura encapsulada sale expulsada. En el moldeo por inyección se utiliza una extensa variedad de compuestos de plástico. Las resinas epoxídicas y a base de sulfuro de polifenileno (PPS) son las últimas sustancias que se han incorporado al encapsulado de semiconductores.

Los encapsulados finales de dispositivos semiconductores de silicio se clasifican en función de su resistencia a las fugas o capacidad de aislar el circuito integrado de su medio ambiente. Se distingue entre el sellado hermético (estanco al aire) y el no hermético.

\section{Prueba de fugas y envejecimiento}

La prueba de fugas es un procedimiento desarrollado para comprobar la capacidad real de sellado o hermeticidad del dispositivo encapsulado. $\mathrm{H}$ ay dos formas corrientes de realizarla: la detección de fugas con helio y la detección de fugas con trazador radiactivo.

En la detección de fugas con helio, las monturas terminadas se colocan en una atmósfera de helio a presión durante cierto tiempo. El helio puede penetrar a la montura por las imperfecciones del encapsulado. U na vez sacada de la cámara de presurización con helio, la montura es transferida a la cámara de un espectrómetro de masas y se comprueba si hay fugas de helio por las imperfecciones de la montura.

En el segundo método, el helio es sustituido por un gas trazador radiactivo, que suele ser el criptón 85 ( $\mathrm{K}$ r 85), y se 
miden las fugas del gas radiactivo de la montura. En condiciones normales, la exposición del personal debida a este proceso es inferior a 5 milisievert (500 milirem) al año (Baldwin y Stewart 1989). L os controles de estos sistemas suelen ser:

- aislamiento en habitaciones con el acceso restringido al personal necesario únicamente;

- carteles de aviso de radiación en las puertas de entrada a las habitaciones donde haya $\mathrm{K} \mathrm{r}$ 85;

- monitores para la vigilancia permanente de la radiación con alarmas y parada/ aislamiento automáticos;

- sistema de ventilación de salida propio y habitación con presión negativa;

- vigilancia de exposiciones con dosimetría personal (p. ej., película dosimétrica de radiación);

- mantenimiento periódico de alarmas y cierres;

- inspecciones periódicas en busca de fugas de material radiactivo;

- formación en seguridad de los operadores y técnicos;

- garantizar que las exposiciones a la radiación se mantengan tan bajas como sea razonablemente posible (ALAR A).

También se inspeccionan los materiales que entran en contacto con el $\mathrm{K} \mathrm{r} 85$ (p. ej., los $\mathrm{Cl}$ expuestos, aceite usado de bombas, válvulas y juntas tóricas) para cerciorarse de que no emiten radiación a niveles excesivos debido al gas residual que pueda quedar en ellos antes de sacarlos de la zona controlada. Leach-M arshal (1991) suministra información detallada sobre exposiciones y controles de los sistemas detectores de fugas mínimas de $\mathrm{K} r 85$.

El envejecimiento es una operación de effuerzos térmicos y eléctricos para determinar la fiabilidad del dispositivo final encapsulado. Los dispositivos se depositan en un horno con control de temperatura durante un período de tiempo prolongado en la atmósfera ambiente o en una atmósfera inerte de nitrógeno. Las temperaturas oscilan entre $125^{\circ} \mathrm{C}$ y $200{ }^{\circ} \mathrm{C}$ (150 으 es la media), y los períodos de tiempo entre unas pocas horas y 1.000 horas (48 horas en promedio).

\section{Prueba final}

Para la calificación final del rendimiento del dispositivo semiconductor de silicio una vez encapsulado, se realiza una prueba eléctrica final. Como el número y la complejidad de las pruebas necesarias es muy grande, un ordenador se encarga de ejecutar y evaluar la prueba de numerosos parámetros importantes para el funcionamiento del dispositivo.

\section{Marcado y empaquetado}

La identificación física del dispositivo final encapsulado se consigue con uno de los muchos sistemas de marcado. Las dos categorías principales de marcado de componentes son la impresión con contacto y sin contacto. La impresión con contacto recurre por lo común a una técnica de offset giratoria con ayuda de tintas basadas en disolventes. La impresión sin contacto, que transfiere marcas sin establecer contacto físico, comprende la impresión con chorro de tinta o tóner, en la que se utilizan tintas basadas en disolventes o marcado con láser.

Los disolventes empleados como portadores de las tintas de impresión y como predepuradores se componen casi siempre de una mezcla de alcoholes (etanol) y ésteres (acetato de etilo). La mayoría de los sistemas de marcado de componentes diferentes del marcado con láser emplean tintas que exigen un paso adicional de fijado o curado. Estos métodos de curado son: curado al aire, curado por calor (calentamiento directo o rayos infrarrojos) y curado a los rayos ultravioletas. Las tintas para curado con rayos ultravioleta no contienen disolventes.
L os sistemas de marcado con láser utilizan un láser de dióxido de carbono $\left(\mathrm{CO}_{2}\right)$ de gran potencia o un láser de gran potencia de neodimio-itrio. Estos láseres suelen estar incorporados al equipo y tienen armarios de seguridad que rodean el camino del haz y el punto en que el haz entra en contacto con el blanco. Esta disposición elimina los peligros del haz de láser durante las operaciones normales, pero la preocupación aparece cuando se anulan los bloqueos de seguridad. La operación más corriente en que es necesario quitar las protecciones que encierran el haz y anular los bloqueos es la alineación del haz de láser.

Durante estas operaciones de mantenimiento, en teoría deben abandonar la sala donde se encuentre el láser todas las personas, salvo los técnicos de mantenimiento necesarios. Se deberán cerrar con llave las puertas de acceso a la sala y se pondrán en ellas avisos con los signos de seguridad láser. No obstante, los láseres de gran potencia utilizados en la fabricación de semiconductores están situados a menudo en naves de fabricación grandes abiertas, lo que hace inviable el traslado del personal ajeno al mantenimiento mientras éste se realiza. En estos casos se suele establecer una zona de control provisional. Lo normal es que estas zonas de control estén rodeadas de cortinas especiales para láser o pantallas de soldeo capaces de resistir el contacto directo con el haz de láser. La entrada a la zona de control provisional se suele efectuar atravesando un laberinto en el que se pone un signo de aviso siempre que se anulen los cortacircuitos del láser. 0 tras precauciones de seguridad durante la alineación del haz son similares a las exigidas para la operación de un láser de gran potencia y haz abierto (p. ej., formación, protección de los ojos, procedimientos escritos, etc.).

Los láseres de gran potencia son también uno de los peligros eléctricos más importantes en el sector de semiconductores. Incluso después de cortada la alimentación, existe un potencial importante de descarga en el instrumento, que ha de ser disipado antes de trabajar dentro del armario.

Junto con los peligros del haz y eléctricos, también se debe poner gran atención en las operaciones de mantenimiento de los sistemas de marcado con láser a causa del potencial de contaminación química por el pirorretardante trióxido de antimonio y el berilio (las monturas cerámicas que contienen este compuesto estarán rotuladas). Durante el marcado con láseres de gran potencia pueden generarse humos, con lo que se depositarán residuos sobre las superficies del equipo y en los filtros de extracción de humos.

En el pasado se han empleado desengrasantes para limpiar semiconductores antes de marcarlos con códigos de identificación. Es fácil que se originen exposiciones a disolventes por encima del límite de exposición profesional aerotransportada aplicable si un operador coloca la cabeza debajo de las bobinas de refrigeración que provocan la recondensación de vapores, como puede suceder cuando el operador intenta recuperar piezas caídas o cuando un técnico limpia residuos del fondo de la unidad (Baldwin y Stewart 1989). El empleo de desengrasantes ha experimentado una gran reducción en el sector de semiconductores por las restricciones en la utilización de sustancias destructoras del ozono, como los hidrocarburos clorofluorados y los disolventes clorados.

\section{Análisis de fallos y garantía de calidad}

L os laboratorios de análisis de fallos y de la calidad están especializados en realizar diversas operaciones para garantizar la fiabilidad de los dispositivos. Algunas de las operaciones efectuadas en estos laboratorios presentan posibilidades de exposición del trabajador. Entre ellas se cuentan:

- pruebas de marcado que utilizan diversas mezclas disolventes y corrosivas en vasos calentados en chapas calefactoras. Es 
preciso contar con ventilación aspirante local (LEV) en forma de chimenea metálica con las velocidades nominales adecuadas para controlar emisiones transitorias. Las soluciones de monoetanolamina pueden dar lugar a exposiciones que superen su límite de exposición en el aire (Baldwin y Williams 1996).

- prueba de burbujas/ fugas con utilización de hidrocarburos fluorados de alto peso molecular (nombre registrado, F luorinerts).

- unidades de montura por rayos $X$.

El cobalto 60 (hasta 26.000 curios) se utiliza en irradiadores con objeto de comprobar la capacidad de los $\mathrm{Cl}$ para resistir la exposición a la radiación gamma en aplicaciones militares y espaciales. En condiciones normales, las exposiciones personales debidas a esta operación son inferiores a 5 milisievert (500 milirem) por año (Baldwin y Stewart 1989). Los controles de esta operación un tanto especializada son similares a los utilizados en los sistemas de precisión para medir fugas de $\mathrm{K} \mathrm{r} 85$ (p. ej., sala aislada, monitores permanentes de la radiación, vigilancia de la exposición personal, etc.).

En el proceso de análisis de fallos se utilizan pequeñas fuentes alfa "con licencia específica" (p. ej., micro y milicurios de americio 241). Estas fuentes se cubren con un capa protectora delgada, denominada ventana, que permite la emisión de partículas alfa desde la fuente para comprobar la capacidad de funcionamiento del circuito integrado cuando es bombardeado por partículas alfa. Lo normal es que las fuentes se sometan a una inspección periódica ( $p$. ej., semestral) en busca de fugas de material radiactivo, que pueden producirse si la ventana protectora sufre daños. Cualquier fuga detectable suele desencadenar el desmontaje inmediato de la fuente y su devolución al fabricante.

Se utilizan sistemas de rayos $X$ en armario para comprobar el espesor de recubrimientos metálicos y para detectar defectos (p. ej., burbujas de aire en monturas de compuestos de moldeo). Aunque estas unidades no son una fuente de fuga importante, se suelen someter a comprobación periódica (p. ej., anual) con un medidor de mano para reconocimiento de fugas de rayos $X$, y se inspeccionan para garantizar que los cortacircuitos de puerta funcionan correctamente.

\section{Expedición}

La expedición es la última operación en la que intervienen los fabricantes de casi todos dispositivos semiconductores de silicio. Los fabricantes que a su vez son proveedores venden sus productos a otros fabricantes de productos finales, mientras que los fabricantes que producen para sí mismos utilizan los dispositivos en sus propios productos finales.

\section{Estudio de la salud}

En cada paso del proceso se utiliza un conjunto determinado de sustancias químicas y aparatos que originan preocupaciones específicas en materia de salud y seguridad ambiental (SSA). Además de preocupaciones asociadas a pasos concretos del procesamiento de dispositivos semiconductores de silicio, un estudio epidemiológico investigó los efectos sobre la salud en los trabajadores del sector de semiconductores (Schenker y cols. 1992). V éase también la exposición del artículo "Efectos sobre la salud y patrones de enfermedad".

La conclusión principal del estudio fue que el trabajo en instalaciones de fabricación de semiconductores se asocia a un aumento de la tasa de abortos espontáneos (AE). En el componente histórico del estudio, el número de embarazos estudiados en trabajadoras de fabricación y ajenas a la fabricación fue casi igual (447 y 444, respectivamente), pero hubo más abortos espontáneos en fabricación $(n=67)$ que en los procesos ajenos a la fabricación $(n=46)$. U na vez realizado el ajuste por diversos factores que podrían ser causa de sesgo (edad, raza, tabaquismo, estrés, situación socioeconómica e historia de embarazos), el riesgo relativo $(\mathrm{R} R)$ de la fabricación frente a la no fabricación fue de 1,43 (intervalo de confianza al $95 \%=0,95-2,09$ ).

$L$ os investigadores asociaron la mayor tasa de $A E$ con la exposición a determinados éteres de glicol a base de etileno (EGE) empleados en la fabricación de semiconductores. L os éteres de glicol específicos que figuraban en el estudio y que se sospecha que causan efectos adversos en la reproducción son:

- 2-metoxietanol (CAS 109-86-4);

- acetato de 2-metoxietilo (CAS 110-49-6);

- acetato de 2-etoxietilo (CAS 111-15-9).

Aunque no formaban parte del estudio, otros dos éteres de glicol utilizados en el sector, el 2-etoxietanol (CAS 110-80-5) y el éter dimetil glicol dietileno (CAS 111-96-6), ejercen efectos tóxicos similares y han sido prohibidos por algunos fabricantes de semiconductores.

A demás del aumento de la tasa de AE asociada a la exposición a determinados éteres de glicol, el estudio llegó también a las conclusiones siguientes:

- Existía una correlación inconstante entre la exposición a fluoruros (en grabado) y el AE.

- El estrés declarado por las mujeres que trabajaban en procesos de fabricación era un potente factor de riesgo independiente de AE.

- Las mujeres que trabajaban en procesos de fabricación tardaban más tiempo en quedarse embarazadas que las ocupadas en procesos ajenos a la fabricación.

- Los trabajadores de fabricación mostraban un aumento de los síntomas respiratorios (irritación de ojos, nariz y garganta y sibilancia) en comparación con los de procesos ajenos a la fabricación.

- A parecían síntomas musculosqueléticos en la extremidad superior distal, como dolores en mano, muñeca, codo y antebrazo, asociados al trabajo en naves de fabricación.

- Se comunicaron con más frecuencia la dermatitis y caída del cabello (alopecia) en los trabajadores de fabricación que en los demás

\section{Revisión del equipo}

La complejidad del equipo de fabricación de semiconductores, junto con los continuos avances en los procesos de fabricación, convierte a la revisión previa a la instalación de nuevos equipos de proceso en una medida importante para reducir al mínimo los riesgos para la SSA. H ay dos procesos de revisión de equipos que ayudan a garantizar que un equipo nuevo de producción de semiconductores posea los controles de SSA adecuados: la marca $C E$ y las normas internaciones relativas a equipo y materiales de semiconductores (SEM I).

La marca CE es una declaración del fabricante de que el equipo que la lleva cumple los requisitos de todas las directivas aplicables de la Unión Europea (UE). Las directivas que se consideran más aplicables al equipo de fabricación de semiconductores son la Directiva de maquinaria (DM), la Directiva de compatibilidad electromagnética (CEM) y la Directiva de baja tensión (DBT).

En el caso de la Directiva de CEM, es preciso contar con los servicios de una entidad competente (organización con autorización oficial de un Estado miembro de la UE) que defina los requisitos de ensayo y apruebe los resultados de la inspección. La DM y la DBT pueden ser evaluadas por el fabricante o por un organismo encargado (organización con autorización oficial 
de un Estado miembro de la UE). Con independencia del camino elegido (evaluación propia o por terceros), el importador de la partida será el responsable de que el producto importado tenga la marca CE. Puede utilizar la información de la entidad tercera o de la autoevaluación como base de su convencimiento de que el equipo cumple los requisitos de las directivas aplicables, pero en último término preparará la declaración de conformidad y agregará la marca CE por sí mismo.

La asociación internacional de equipo y materiales de semiconductores (SEM I) es una entidad que representa a los proveedores de equipo y materiales de semiconductores e indicadores planos. Entre sus actividades se cuenta el desarrollo de normas técnicas voluntarias por acuerdo mutuo entre proveedores y clientes, encaminadas a mejorar la calidad y la fiabilidad permanente de los productos a precio razonable.

$\mathrm{H}$ ay dos normas SEM I que se aplican en concreto a las preocupaciones relativas a la SSA de equipo nuevo, que son la SEM I S2 y la SEM I S8. La SEMI S2-93, Directrices de seguridad para equipo de fabricación de semiconductores, establece unas consideraciones mínimas de SSA basadas en el rendimiento para el equipo utilizado en la fabricación de semiconductores. La SEM I S8-95, Supplier Ergonomic Success Criteria U ser's Guide (Guía del usuario sobre criterios de éxito ergonómico de proveedores), amplía la sección de la SEM I S2 dedicada a ergonomía.

M uchos fabricantes de semiconductores exigen la certificación por terceros de que un equipo nuevo cumple los requisitos de la SE M I S2. Las directrices para interpretar la SE M I S2-93 y la SEMI S8-95 están contenidas en una publicación del consorcio del sector SEMATECH (SEM ATECH 1996). Puede obtenerse más información sobre SEMI en la red mundial (http:/ / www.semi.org).

\section{Manipulación de sustancias químicas}

\section{Distribución de líquidos}

Desde que los sistemas automáticos de distribución de sustancias químicas han pasado de ser una excepción a convertirse en la norma, el número de quemaduras químicas de los trabajadores ha disminuido. No obstante, en estos sistemas automáticos de distribución es preciso instalar medidas de salvaguarda adecuadas, entre ellas:

- detección de fugas y cierre automático en la fuente de suministro y en las cajas de unión;

- doble confinamiento de conductos si la sustancia química se considera peligrosa;

- sensores de alto nivel en puntos terminales (vasija de baño 0 instrumento);

- parada temporizada de bombas (permite que sólo sea bombeada una cantidad específica a un emplazamiento antes de la parada automática).

\section{Distribución de gases}

La seguridad en la distribución de gases ha experimentado una mejora notable a lo largo del tiempo con la llegada de nuevos tipos de válvulas de botella, la limitación del caudal en los orificios incorporados a la botella, los paneles automáticos de purga de gas, la detección de caudales excesivos con el cierre consiguiente y el perfeccionamiento del equipo de detección de fugas. Por su propiedad pirofórica y su empleo generalizado como sustancia de alimentación, el gas silano representa el peligro más significativo de explosión en el sector. Pero los incidentes con silano se han hecho más predecibles con las nuevas investigaciones efectuadas por Factory M utual y SEM ATECH. Gracias a los orificios de flujo reducido, las presiones de suministro y las tasas de ventilación adecuados, se han eliminado la mayoría de los incidentes de explosión (SEM AT ECH 1995).

En los últimos años se han producido varios incidentes de seguridad por la mezcla no controlada de gases incompatibles. Estos incidentes han obligado a los fabricantes de semiconductores a revisar con frecuencia las instalaciones de tuberías de gas y las cajas de gases auxiliares para impedir la mezcla y/ o el retorno incorrecto de gases.

Los asuntos relativos a las sustancias químicas son los que suelen generar las mayores preocupaciones en la fabricación de semiconductores. No obstante, la mayoría de las lesiones y muertes en el sector se deben a peligros ajenos a las sustancias químicas.

\section{Seguridad eléctrica}

$\mathrm{H}$ ay numerosos peligros eléctricos relacionados con el equipo empleado en este sector. Los cortacircuitos de seguridad desempeñan un papel importante en la seguridad eléctrica, pero son anulados muchas veces por los técnicos de mantenimiento. $\mathrm{N}$ umerosas intervenciones de mantenimiento suelen efectuarse mientras el equipo sigue con alimentación, ya sea total o parcial. Los peligros eléctricos más importantes son los asociados con los implantadores de iones y las fuentes de láser. Aunque la alimentación esté cortada, en el instrumento existe un potencial importante de descarga, que ha de ser disipado antes de trabajar dentro del instrumento. EI proceso de revisión de la SEM I S2 en Estados U nidos y la marca CE en Europa han contribuido a mejorar la seguridad eléctrica de equipo nuevo, pero las operaciones de mantenimiento no siempre se consideran debidamente. Es preciso efectuar una revisión cuidadosa de las operaciones de mantenimiento y de los peligros eléctricos en todo el equipo recién instalado.

El segundo lugar en la lista de peligros eléctricos lo ocupa el conjunto de equipos que genera energía de RF durante los procesos de grabado, pulverización y limpieza de cámaras. Necesitan blindaje y puesta a tierra adecuados para reducir al mínimo el riesgo de quemaduras de R F.

Estos peligros eléctricos y los numerosos aparatos que no se apagan durante las operaciones de mantenimiento exigen que los técnicos de mantenimiento utilicen otros medios para protegerse, como son los procedimientos de bloqueo/ etiquetado. LoS peligros eléctricos no son las únicas fuentes de energía cuyos peligros se pretende eliminar con el bloqueo/ etiquetado. 0 tras fuentes de energía son los conductos presurizados, muchos de ellos con gases o líquidos peligrosos, y los mandos neumáticos. L os mecanismos de desconexión de estas fuentes de energía han de estar en lugares de fácil acceso- dentro del área de fab (fabricación) o montaje en la que operará el trabajador, y no en lugares menos accesibles, como en dependencias auxiliares.

\section{Ergonomía}

La interacción entre el trabajador y los aparatos sigue provocando lesiones. Las distensiones y esguinces musculares son bastante corrientes en el sector de semiconductores, sobre todo en los técnicos de mantenimiento. Es frecuente que el acceso a bombas, tapas de cámaras, etc. no se haya diseñado bien durante la fabricación del instrumento y durante su colocación en la fábrica. Las bombas deben estar colocadas sobre ruedas 0 en cajones o bandejas deslizantes. Para la realización de muchas operaciones es preciso incorporar dispositivos elevadores.

La simple manipulación de obleas origina peligros ergonómicos, sobre todo en instalaciones antiguas. Las más modernas suelen manejar obleas de mayor tamaño, por lo que exigen sistemas de manipulación más automatizados. M uchos de estos sistemas de manipulación de obleas se consideran dispositivos robóticos, y los aspectos relativos a la seguridad con estos 
sistemas han de tenerse en cuenta en el momento de su diseño e instalación (ANSI 1986).

\section{Seguridad contra incendios}

Además del gas silano, que ya ha sido considerado, el gas hidrógeno tiene la capacidad de representar un peligro de incendio importante. Pero es mejor conocido, y en el sector no se han visto muchos casos graves donde haya intervenido el hidrógeno.

Los peligros de incendio más graves están relacionados ahora con los bancos húmedos o baños de grabado. Los materiales plásticos que más se emplean en su construcción (cloruro de polivinilo, polipropileno y polipropileno ignífugo) han intervenido todos en incendios de fábricas. La fuente de ignición puede ser el calefactor de un baño de grabado o plaqueado, los mandos eléctricos montados directamente sobre el plástico o un aparato adyacente. Si se declara un incendio en uno de estos elementos de plástico, la contaminación de partículas y los productos de combustión corrosivos se extienden por toda la zona de fabricación. La pérdida económica es alta por el tiempo de parada de la fabricación mientras se restablecen las condiciones de sala limpia en la zona y el equipo afectados. Es frecuente que algunos equipos caros no se puedan descontaminar como es debido y haya que adquirir equipo nuevo. Por consiguiente, es primordial que la prevención y la protección contra incendios sean adecuadas.

La prevención de incendios puede abordarse con materiales de construcción diferentes, no combustibles. El acero inoxidable es el material de construcción preferido para estos bancos húmedos, pero a veces el proceso no "aceptará" un aparato metálico. $\mathrm{H}$ ay plásticos con menor potencial de generar incendios/ humos, pero todavía no se han ensayado lo suficiente para determinar si serán compatibles con los procesos de fabricación de semiconductores.

En cuanto a la protección contra incendios, estos aparatos han de estar protegidos mediante dispositivos de aspersión no obstruidos. La colocación de filtros HEPA sobre bancos húmedos bloquea muchas veces las cabezas aspersoras. Si ocurre así, se instalan cabezas aspersoras adicionales debajo de los la filtros. Muchas empresas exigen también que se instale un sistema de detección y supresión de incendios dentro de las cavidades de sobrepresión situadas sobre estos aparatos, donde empiezan muchos incendios.

\section{- INDICADORES DE CRISTAL LIQUIDO}

\section{David G. Baldwin, James R. Rubin y Afsaneh Gerami}

Desde el decenio de 1970 están comercializados los indicadores de cristal líquido (LCD), de uso común en relojes, calculadoras, radios y otros productos que necesitan indicadores y tres o cuatro caracteres alfanuméricos. M ejoras recientes de los materiales de cristal líquido permiten fabricar indicadores de gran tamaño. Si bien los LCD son sólo una pequeña parte del sector de semiconductores, su importancia ha aumentado con su empleo en paneles indicadores planos para ordenadores portátiles, ordenadores de viaje muy ligeros y procesadores de texto dedicados. Se espera que la importancia de los LCD siga aumentando a medida que puedan llegar a sustituir al último tubo de vacío que todavía es de uso corriente en electrónica- el tubo de rayos cató$\operatorname{dicos}(T$ RC) (O 'M ara 1993).

La fabricación de los LCD es un proceso muy especializado. Los resultados de la vigilancia de la higiene industrial indican niveles de contaminantes aéreos muy bajos para las diversas
Figura 83.5 - Moléculas básicas de los polímeros de cristal líquido.

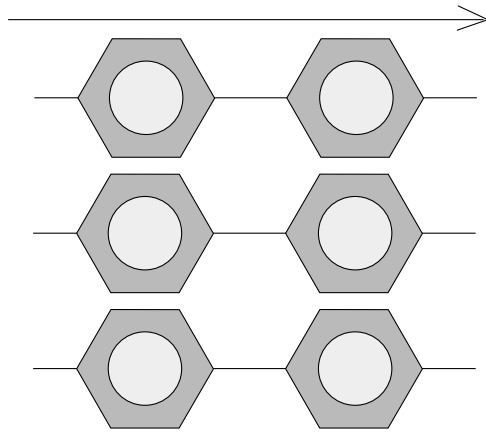

exposiciones a disolventes estudiadas (Wade y cols. 1981). En general, los tipos y cantidades de sustancias químicas tóxicas, corrosivas e inflamables en estado sólido, líquido y gaseoso, y de agentes físicos peligrosos que se utilizan son limitados en comparación con otros tipos de fabricación de semiconductores.

Los materiales de cristal líquido son moléculas en forma de varilla como las del ejemplo de Cianobifenilo mostradas en la Figura 83.5. Estas moléculas poseen la propiedad de hacer girar la dirección de la luz polarizada que las atraviesa. Aunque las moléculas son transparentes a la luz visible, un recipiente con el material líquido aparece lechoso o translúcido, en lugar de transparente. Este fenómeno se debe a que los ejes largos de las moléculas están alineados según ángulos aleatorios, de manera que la luz se dispersa al azar. U na celda indicadora de cristal líquido se dispone de manera que las moléculas siguen una alineación específica, que puede variarse con un campo eléctrico externo, lo que permite cambiar la polarización de la luz entrante.

En la fabricación de paneles indicadores planos, dos sustratos de vidrio se procesan por separado y después se acoplan juntos. El sustrato frontal se modela para crear un conjunto de filtros de colores. El sustrato trasero de vidrio se modela para formar transistores de película delgada y las líneas metálicas de interconexión. Estas dos placas se acoplan en el proceso de montaje y, si es preciso, se trocean y separan en indicadores individuales. En el hueco dejado entre las dos placas de vidrio se inyecta material de cristal líquido. L os indicadores son inspeccionados y comprobados y a cada placa de vidrio se le aplica una película polarizadora.

Son numerosos los procesos individuales que se necesitan para fabricar paneles indicadores planos. Exigen equipo, materiales y procesos especializados. A continuación se esbozan determinados procesos clave.

\section{Preparación del sustrato de vidrio}

El sustrato de vidrio es un componente esencial y costoso del indicador. En cada fase del proceso se precisa un control muy estricto de las propiedades ópticas y mecánicas del material, en especial cuando interviene calentamiento.

\section{Fabricación del vidrio}

Se utilizan dos procesos para fabricar vidrio muy delgado con dimensiones muy precisas y propiedades mecánicas reproducibles. El proceso de fusión, desarrollado por Corning, utiliza una varilla de entrada de vidrio que se funde en una cubeta en forma de cuña y rebosa por encima y sobre los lados de la cubeta. Al caer por ambos lados de la cubeta, el vidrio fundido se junta en una sola lámina en el fondo de la cubeta y puede ser arrastrado hacia abajo como lámina uniforme. El espesor de la lámina 
es controlado por la velocidad de arrastre del vidrio. Pueden obtenerse anchuras de hasta casi $1 \mathrm{~m}$.

0 tros fabricantes de vidrio con las dimensiones adecuadas para hacer sustratos de LCD utilizan el método de flotación, en el que se permite que el vidrio fundido fluya para caer en un lecho de estaño fundido. El vidrio no se disuelve en el estaño metálico ni reacciona con él, sino que flota sobre su superficie. Este fenómeno permite que la gravedad alise la superficie y que las dos caras queden paralelas. (V éase el Capítulo Vidrio, cerámica y materiales afines .)

Se dispone de sustratos de numerosos tamaños, hasta de $450 \times 550 \mathrm{~mm}$ y mayores. El espesor típico del vidrio en los paneles indicadores planos es de 1,1 mm. En algunos indicadores pequeños, como los de buscapersonas, teléfonos, juegos y otros, se emplea vidrio más delgado.

\section{Cortado, biselado y pulido}

D espués del proceso de fusión o flotación, los sustratos de vidrio se cortan a su tamaño, que por un lado suele ser de alrededor de $1 \mathrm{~m}$. El proceso de formado va seguido de distintas operaciones mecánicas, que dependen de la aplicación última del material.

Como el vidrio es frágil y se desportilla o raja fácilmente por los bordes, éstos se biselan, achaflanan o reciben otro tratamiento equivalente que reduzca el astillado durante la manipulación. Las tensiones térmicas en las grietas de los bordes se acumulan durante el procesamiento del sustrato y conducen a la rotura. La rotura del vidrio es un problema importante durante su producción. Además de la posibilidad de ocasionar cortes y desgarros a los trabajadores, representa una pérdida de beneficio, y los fragmentos de vidrio podrían quedar en el equipo y provocar a su vez contaminación por partículas o arañazos a otros sustratos.

Al aumentar el tamaño del sustrato se incrementan las dificultades para pulir el vidrio. Los sustratos grandes se colocan en soportes con ayuda de cera u otro adhesivo y se pulen con una pasta de material abrasivo. A este proceso de pulido le debe seguir una limpieza química completa para eliminar los posibles restos de cera u otros residuos orgánicos, así como los contaminantes metálicos contenidos en la sustancia abrasiva o de pulido.

\section{Limpieza}

Se utilizan procesos de limpieza en sustratos de vidrio desnudo y en sustratos recubiertos de películas orgánicas, como filtros de color, películas de orientación de poliimidas, etc. También los sustratos con películas de semiconductores, aisladores y metales necesitan limpieza en determinados puntos del proceso de fabricación. Se necesita limpieza como mínimo antes de cada paso de enmascaramiento en la fabricación de filtros de color o de transistores de película delgada.

En casi todas las limpiezas de panel plano se emplea una combinación de métodos físicos y químicos, con la utilización selectiva de métodos secos. Después del ataque químico o de la limpieza, los sustratos suelen secarse mediante alcohol isopropílico. (V éase la Tabla 83.8.)

\section{Formación de filtros de color}

La formación de filtros de color sobre el sustrato frontal del vidrio comprende algunos de los pasos de acabado y preparación del vidrio comunes a los paneles frontal y trasero, como son los procesos de biselado y pulimentado. $\mathrm{H}$ ay operaciones que se realizan varias veces sobre el sustrato, como las de modelado, recubrimiento y curado. Existen muchos puntos de semejanza con el procesamiento de las obleas de silicio. Los sustratos de vidrio suelen manipularse en sistemas transportadores para su limpieza y recubrimiento.

\section{M odela do de filtros de color}

En la creación de filtros de color para diversos tipos de paneles indicadores planos se emplean distintos materiales y métodos de aplicación. Puede utilizarse un colorante 0 un pigmento, que pueden depositarse y modelarse de varios modos. En uno de los métodos, se deposita gelatina que después se tiñe en operaciones fotolitográficas sucesivas, con ayuda de equipo de impresión por proximidad y fotoprotectores estándar. En otro, se emplean pigmentos dispersados en el fotoprotector. Otros métodos de formar filtros de color son la electrodeposición, el grabado y la impresión.

\section{Deposición de ITO}

Tras la formación de filtros de color, el paso final es la deposición por pulverización de un material de electrodo transparente. Para ello se emplea el óxido de indio y estaño (ITO), que en realidad es una mezcla de los óxidos $\mathrm{In}_{2} \mathrm{O}_{3}$ y $\mathrm{SnO}_{2}$. Este material es el único idóneo para la aplicación de un conductor transparente a Ios LCD. Se necesita una película delgada de ITO en las dos caras del indicador. La formación de las películas de ITO se realiza por evaporación y pulverización al vacío.

Las películas delgadas de ITO son fáciles de grabar con sustancias químicas húmedas como el ácido clorhídrico, pero a medida que la separación de los electrodos se hace más pequeña y los detalles se hacen más finos, puede ser necesario el grabado en seco para evitar el rebaje de las líneas a causa del exceso de ataque.

\section{Formación de transistores en película delgada}

La formación de transistores en película delgada es muy similar a la fabricación de un circuito integrado.

\section{Deposición de película delgada}

Los sustratos inician el proceso de fabricación con un paso de aplicación de película delgada. Las películas delgadas se depositan mediante CVD o deposición física de vapores (PVD). La CVD reforzada con plasma, conocida también por descarga luminiscente, se utiliza para el silicio amorfo, el nitruro de silicio y el dióxido de silicio.

\section{Modela do del dispositivo}

U na vez depositada la película delgada, se aplica un fotoprotector y se modela la imagen para permitir el grabado de la película delgada en las dimensiones apropiadas. Se depositan y graban un serie de películas delgadas, igual que en la fabricación de circuitos integrados.

\section{Aplicación y frotación de la película de orientación}

Sobre ambos sustratos, el superior y el inferior, se deposita una película delgada de polímero para la orientación de las moléculas de cristal líquido en la superficie del vidrio. Esta película de

Tabla 83.8 • Limpieza de paneles indicadores planos.

$\begin{array}{lll}\text { Limpieza física } & \text { Limpieza en seco } & \text { Limpieza química } \\ \text { Frotar con cepillo } & \text { Ozono ultravioleta } & \text { Disolvente orgánico* } \\ \text { Al chorro } & \text { Plasma (óxido) } & \text { Detergente neutro } \\ \text { Ultrasónica } & \text { Plasma (no óxido) } & \\ \text { Megasónica } & \text { Láser } & \text { Agua pura }\end{array}$

* Los disolventes orgánicos comunes usados en la limpieza química son: acetona, metanol, etanol, n-propanol, isómeros del xileno, tricloroetileno, tetracloroetileno. 
orientación, de un espesor aproximado de 0,1 $\mu \mathrm{m}$, puede ser una poliimida u otro polímero "duro". D espués de la deposición y el cocido, la película se frota con tejido en una dirección específica, lo que deja surcos apenas detectables en la superficie. La frotación puede hacerse con una sola pasada de un paño sobre una correa, alimentada desde un rodillo situado a un lado, que pasa bajo un rodillo en contacto con el sustrato, hasta otro rodillo al otro lado. El sustrato se desplaza debajo del paño en el mismo sentido que éste. En otros métodos, se emplea un cepillo móvil que se desplaza por el sustrato. El pelo del material de frotación es importante. Los surcos sirven para ayudar a las moléculas de cristal líquido a alinearse en la superficie del sustrato y a adoptar el ángulo de inclinación adecuado.

La película de orientación puede depositarse por recubrimiento con giro o por impresión. El método de impresión es más eficiente en aprovechamiento del material; del 70 al $80 \%$ de la poliimida es transferida desde el rodillo de impresión a la superficie del sustrato.

\section{Montaje}

Cuando ha finalizado el paso de frotación del sustrato, se inicia una secuencia automatizada en la cadena de montaje, que comprende:

- aplicación de adhesivo (necesario para sellar los paneles);

- aplicación de separador;

- colocación y alineación óptica de una placa respecto de la otra;

- exposición (calor o UV) para endurecer el adhesivo y unir entre sí las dos placas de vidrio.

El transporte automático de ambas placas, la superior y la inferior, se realiza por la misma cadena. U na placa recibe el adhesivo, y la segunda placa es introducida en la estación del aplicador de separadores.

\section{Inyección de cristal líquido}

En el caso de que en el sustrato se haya construido más de un indicador, los indicadores son separados ahora mediante cortes. En este momento, el material constituyente del cristal líquido puede introducirse en el hueco existente entre los sustratos a través de un orificio que se dejó en el material de sellado. Este orificio de entrada se sella a continuación y queda preparado para la inspección final. Los materiales de cristal líquido se suministran a menudo en forma de dos o tres sistemas componentes que se mezclan en la inyección. Los sistemas de inyección se ocupan de la mezcla y de purgar la celda para impedir que durante el proceso de llenado queden burbujas atrapadas.

\section{Inspección y prueba}

La inspección y la prueba funcional se efectúan después del montaje y de la inyección del cristal líquido. La mayoría de los defectos se deben a partículas (incluidos los defectos de punto y línea) y a problemas del hueco de la celda.

\section{Fijación del polarizador}

El paso final de la fabricación del indicador de cristal líquido propiamente dicho es la aplicación del polarizador en el exterior de cada placa de vidrio. Las películas polarizadoras son películas mixtas que contienen la capa de adhesivo sensible a la presión necesaria para fijar el polarizador al vidrio. Se aplican con ayuda de máquinas automatizadas que distribuyen el material desde rollos u hojas ya cortadas. Las máquinas son variantes de las máquinas de etiquetar desarrolladas para otros sectores. La película polarizadora se fija a ambas caras del indicador.

En algunos casos, antes del polarizador se aplica una película de compensación. Las películas de compensación son películas de polímero ( $p$. ej., policarbonato y metacrilato de polimetilo) que están estiradas en una dirección. Este estirado modifica las propiedades ópticas de la película.

U n indicador terminado tendrá de ordinario circuitos integrados de mando montados en uno de los sustratos de vidrio 0 cerca de él, que por lo general suele ser la cara de transistores de película delgada.

\section{Peligros}

La rotura del vidrio es un peligro importante en la fabricación de LCD. Pueden producirse cortes y laceraciones. 0 tra preocupación es la exposición a las sustancias químicas empleadas en la limpieza.

\section{FABRICACION DE SEMICONDUCTORES III-V}

\author{
David G. Baldwin, Afsaneh Gerami y
} James R. Rubin

EI silicio ha dominado tradicionalmente el desarrollo de la tecnología de los Cl como material semiconductor fundamental. En los últimos años, la atención principal sobre una alternativa al silicio como material de sustrato se ha centrado en los compuestos III-V, como el arseniuro de galio ( $\mathrm{GaAs}$ ). En tanto material semiconductor, el GaAs presenta mejores características que el silicio, como una movilidad de electrones de 5 a 6 veces superior. Esta característica, junto con las propiedades potenciales de semiaislante que posee el GaAs, conduce a un mayor rendimiento en el doble aspecto de la velocidad y el consumo de energía.

EI GaAs tiene una estructura de blenda de zinc formada por dos submallas cúbicas centradas en las caras e interpenetradas que están relacionadas con el crecimiento de material en lingote de alta calidad. La tecnología necesaria en el crecimiento de GaAs es bastante más complicada que la empleada para el silicio, puesto que intervienen un complicado equilibrio bifásico y un componente muy volátil, el arsénico (As). Es necesario el control de la presión de vapor del As en el sistema de crecimiento del lingote para mantener la estequiometría exacta del compuesto $\mathrm{G}$ aAs durante el proceso de crecimiento. Hay dos categorías principales de producción de indicadores y dispositivos de semiconductores III-V cuyos procedimientos de procesamiento tienen viabilidad económica: los indicadores de LED y los dispositivos de $\mathrm{Cl}$ de microondas.

LOS LED se fabrican a partir de G aAs monocristalino en el que se forman uniones $p-n$ por la adición de agentes impurificadores idóneos-que por lo general son teluro, zinc 0 silicio. Sobre el sustrato se hacen crecer capas epitaxiales de materiales III-V ternarios y cuaternarios, como fosfuro de galio y arsénico (GaAsP), que dan por resultado una banda de emisión de longitudes de onda específicas en el espectro visible para indicadores, 0 en el espectro infrarrojo para emisores o detectores. Por ejemplo, la recombinación directa de los electrones y huecos p-n da lugar a luz roja con un pico en torno a $650 \mathrm{~nm}$. Los diodos emisores de luz verde están compuestos por lo general de fosfuro de galio (G aP). En este artículo se explican las etapas del proceso de los LED.

Los dispositivos de $\mathrm{Cl}$ de microondas son una forma especializada de circuito integrado; se utilizan como amplificadores de alta frecuencia (de 2 a $18 \mathrm{G} \mathrm{H}$ z) para radar, telecomunicaciones y telemetría, así como en los amplificadores de octava y multioctava que se emplean en sistemas electrónicos militares. L os fabricantes de dispositivos de $\mathrm{Cl}$ de microondas suelen comprar sustrato de GaAs monocristalino, con o sin capa epitaxial, de proveedores externos (como hacen los fabricantes de dispositivos 
de silicio). Las etapas importantes del proceso son el depósito epitaxial en fase líquida, procesos de fabricación y posteriores a la fabricación similares a la fabricación de los dispositivos de silicio. Las etapas del proceso que exigen una descripción adicional a la del procedimiento para obtener LED se explican también en este artículo.

\section{Fabricación de obleas}

De manera similar al proceso de crecimiento de los lingotes de silicio, piezas elementales de galio y arsénico, junto con pequeñas cantidades de impurezas - silicio, teluro 0 zinc-se hacen reaccionar a temperaturas elevadas para formar lingotes de $\mathrm{G}$ aAs monocristalino impurificado. Se utilizan tres métodos generales de producción de lingotes:

- Bridgeman horizontal o vertical;

- congelación escalonada horizontal o vertical;

- encapsulado líquido Czochralski (LEC) a alta o baja presión.

El compuesto de $\mathrm{G}$ aAs policristalino se forma en condiciones normales por la reacción de vapor de As con $\mathrm{G}$ a metálico a altas temperaturas en ampollas selladas de cuarzo. Por lo general, un depósito de As situado en un extremo de la ampolla se calienta hasta $618^{\circ} \mathrm{C}$. A sí se genera dentro de la ampolla una presión de vapor de As de 1 atmósfera aproximadamente, requisito previo para obtener $\mathrm{GaAs}$ estequiométrico. EI vapor de As reacciona con el $\mathrm{G}$ a metálico mantenido a $1.238{ }^{\circ} \mathrm{C}$ y situado en el otro extremo de la ampolla, en una cápsula de cuarzo o de nitruro de boro pirolítico (PBN). Cuando el arsénico ha reaccionado por completo, se forma una carga policristalina, que se utiliza para el crecimiento monocristalino mediante enfriamiento programado (congelación escalonada) o mediante el desplazamiento físico de la ampolla o del horno hasta conseguir gradientes de temperatura adecuados para el crecimiento (Bridgeman). Este método indirecto (transporte del arsénico) para obtener la composición y el crecimiento del $\mathrm{G}$ aAs se utiliza debido a la alta presión de vapor del arsénico en el punto de fusión del $\mathrm{GaAs}$, de unas 20 atmósferas a $812{ }^{\circ} \mathrm{C}$ y de 60 atmósferas a $1.238{ }^{\circ} \mathrm{C}$, respectivamente.

$O$ tro método para la producción comercial de GaAs monocristalino a granel es la técnica LEC. U n horno Czochralski para el estirado de cristales se carga con trozos de $\mathrm{GaAs}$ en un crisol en cámara de grafito. El G aAs se funde luego a temperaturas próximas a $1.238{ }^{\circ} \mathrm{C}$, y el cristal se estira en una atmósfera presurizada que puede variar según el fabricante desde pocas hasta 100 atmósferas. La masa fundida está encapsulada por completo en un vidrio viscoso, $\mathrm{B}_{2} \mathrm{O}_{3}$, que impide su disociación, puesto que la presión de vapor del As queda igualada o superada por la de un gas inerte (que suele ser argón o nitrógeno) aplicado en la cámara de estirado. U na alternativa es sintetizar GaAs monocristalino in situ mediante la inyección del As en el $\mathrm{G}$ a fundido o la combinación directa de $\mathrm{As}$ y $\mathrm{G}$ a a alta presión.

La fabricación de obleas de $\mathrm{G}$ aAs es el proceso de fabricación de semiconductores en el que existe el mayor potencial de exposiciones químicas importantes en el trabajo diario. Si bien la elaboración de obleas de $\mathrm{G}$ aAs está limitada a un pequeño porcentaje de fabricantes de semiconductores, es precisa una atención especial en este campo. Las grandes cantidades de As utilizadas en el proceso, las numerosas etapas del mismo y el bajo límite de exposición ambiental establecido para el arsénico dificultan el control de estas exposiciones. Artículos de $\mathrm{H}$ arrison (1986); Lenihan, Sheehy y Jones (1989); M clntyre y Sherin (1989) y Sheehy y Jones (1993) suministran información adicional sobre los peligros y controles de este proceso.

\section{Síntesis de lingotes policristalinos}

\section{Carga y sellado de la ampolla}

Trozos de As elemental (99.9999 \%) se pesan y cargan en una cápsula de cuarzo dentro de una vitrina de manipulación con guantes ventilada. Del mismo modo, el Ga $(99.9999 \%)$ puro líquido y las impurezas también se pesan y cargan en una o varias cápsulas de cuarzo o nitruro de boro pirolítico (PBN). Las cápsulas se cargan en una ampolla de cuarzo cilíndrica larga. (En las técnicas de Bridgeman y de congelación escalonada, se introduce también un cristal formador con la orientación cristalográfica deseada, mientras que en la técnica LEC de dos etapas, en la que sólo se necesita en esta fase GaAs policristalino, éste se sintetiza sin el cristal formador.)

Las ampollas de cuarzo se colocan en un horno a baja temperatura y se calientan mientras la ampolla se purga con hidrógeno $\left(\mathrm{H}_{2}\right)$, en un proceso conocido como reacción de reducción con hidrógeno, para eliminar los óxidos. Después de una segunda purga con un gas inerte como el argón, las ampollas de cuarzo se conectan a un montaje de bomba de vacío, son evacuadas y los extremos de las ampollas se calientan y sellan con una antorcha de hidrógeno/ oxígeno. Se crea así una ampolla de cuarzo cargada y sellada, lista para el crecimiento en el horno. El sistema de purga con hidrógeno y de antorcha de hidrógeno/ oxígeno presenta un peligro potencial de incendio/ explosión si no se emplean los dispositivos y equipo de seguridad apropiados (Wade y cols. 1981).

Como el arsénico se somete a calentamiento, este sistema se mantiene con ventilación por aspiración. En el conducto de gases de salida de este sistema pueden formarse depósitos de óxido de arsénico. $\mathrm{H}$ ay que tomar precauciones para evitar la exposición y la contaminación si los conductos se obstruyesen por cualquier causa.

El almacenamiento y la manipulación de trozos de arsénico es un riesgo. Por motivos de seguridad, el arsénico se mantiene a menudo bajo llave y con un estricto control de existencias. También es habitual guardar el arsénico en un armario resistente al fuego dentro del almacén para impedir que sea afectado en caso de incendio.

\section{Crecimiento en horno}

Los métodos de Bridgeman y de congelación escalonada para el crecimiento del lingote monocristalino utilizan ambos las ampollas de cuarzo cargadas y selladas en el interior de un horno a alta temperatura cuyos vapores son evacuados hacia un sistema depurador húmedo. Los principales peligros de exposición durante el crecimiento en el horno se refieren al potencial de implosión o explosión de la ampolla de cuarzo durante el crecimiento del lingote. Esta situación se presenta en ocasiones esporádicas e infrecuentes, y es debida a uno de los motivos siguientes:

- la presión parcial del vapor de As originada por las altas temperaturas aplicadas en el proceso de crecimiento;

- desvitrificación de la ampolla de cuarzo, que crea grietas finas, y la posibilidad consiguiente de despresurización de la ampolla;

- carencia de dispositivos exactos para el control de la alta temperatura en la fuente calefactora - por lo común del tipo de resistencias-, que origina una presurización excesiva de la ampolla de cuarzo;

- mal funcionamiento o fallo del termopar, con el resultado de presurización excesiva de la ampolla de cuarzo;

- exceso de As o escasez de Ga en el tubo de la ampolla, que causan una presión de As extremadamente alta capaz de provocar la despresurización catastrófica de la ampolla. 
El sistema horizontal de Bridgeman consta de un horno multizona en el que la ampolla sellada de cuarzo tiene zonas a distintas temperaturas- el extremo "frío" del arsénico a $618{ }^{\circ} \mathrm{C}$ y la cápsula de cuarzo con galio/ impureza/ cristal formador que contiene la masa fundida a $1.238 \stackrel{\circ}{\circ} \mathrm{C}$. El principio básico del sistema horizontal de Bridgeman implica atravesar dos zonas calentadas (una por encima del punto de fusión del GaAs y otra por debajo de él) en una cápsula de GaAs para conseguir la congelación controlada con precisión del GaAs fundido. EI cristal formador, mantenido en todo momento dentro de la zona de congelación, suministra la estructura de partida del cristal inicial, que define la dirección y la orientación de la estructura cristalina en la cápsula. L a cápsula de cuarzo y la ampolla de $\mathrm{Ga}$ y As se suspenden en la cámara calefactora mediante un juego de envueltas de carburo de silicio llamadas tubos de apoyo, que se sitúan en el sistema del calefactor de resistencias para recorrer mecánicamente toda la distancia de la ampolla. Además, el sistema del horno descansa en una mesa que debe estar inclinada durante el crecimiento para permitir la interfase adecuada entre la masa fundida del GaAs sintetizado y el cristal inicial 0 formador.

En el método de gradiente de congelación, un horno multizona de alta temperatura que utiliza calefacción por resistencias se mantiene de 1.200 a $1.300{ }^{\circ} \mathrm{C}\left(1.237{ }^{\circ} \mathrm{C}\right.$ es el punto de fusión/ solidificación del G aAs). La duración total del proceso de crecimiento del lingote es de unos 3 días y comprende los pasos siguientes:

- calentamiento del horno hasta la temperatura requerida;

- síntesis del GaAs;

- cristal formador o inicial de la masa fundida;

- enfriamiento/ crecimiento del cristal.

La ampolla de cuarzo también se inclina durante el proceso de crecimiento con ayuda de un torno manual del tipo de tijeras.

\section{Rotura de la ampolla}

Después que el lingote de $\mathrm{G}$ aAs monocristalino ha crecido en la ampolla sellada de cuarzo, ésta debe abrirse para sacar la ampolla de cuarzo que contiene el lingote más el cristal formador. La operación puede efectuarse por uno de los métodos siguientes:

- corte del extremo sellado de las ampollas con una sierra circular en húmedo;

- calentamiento y rotura de la ampolla con un soplete de hidrógeno/ oxígeno;

- rotura de la ampolla cargada con un martillo mientras el extractor de aire se mantiene en funcionamiento para controlar el arsénico del aire.

Las ampollas de cuarzo se reciclan mediante la disolución húmeda del arsénico condensado en la superficie interior con agua regia $\left(\mathrm{H} \mathrm{Cl}_{1} \mathrm{HNO}_{3}\right)$ o ácido sulfúrico/ peróxido de hidrógeno $\left(\mathrm{H}_{2} \mathrm{SO}_{4} / \mathrm{H}_{2} \mathrm{O}_{2}\right)$.

\section{Chorreado/limpieza del lingote}

Con objeto de ver los defectos policristalinos y eliminar los óxidos y contaminantes exteriores, el lingote de GaAs monocristalino tiene que limpiarse al chorro de perlas. La operación se efectúa con chorro de carburo de silicio o alúmina calcinada en una cámara de manipulación con guantes bien ventilada. La limpieza húmeda se realiza mediante enjuagues de agua regia o alcohol (alcohol isopropílico y/ o metanol) en baños químicos provistos de ventilación de extracción localizada.

\section{Crecimiento del lingote monocristalino}

EI lingote de GaAs policristalino recuperado de la ampolla se rompe en trozos, se pesa y se coloca en un crisol de cuarzo o de PBN, y sobre su parte superior se coloca un disco de óxido de boro. El crisol se deposita luego dentro de un cultivador (estirador) de cristal presurizado en un gas inerte y se calienta a $1.238 \stackrel{\circ}{ } \mathrm{C}$. A esta temperatura, el GaAs se funde y el óxido de boro, más ligero, se convierte en un encapsulador líquido que impide que el arsénico se disocie de la masa fundida. Se introduce en ésta un cristal formador o inicial por debajo de la cubierta líquida, y bajo contrarrotación se retira poco a poco de la masa fundida, con lo cual se solidifica a medida que abandona la "zona caliente". Este proceso lleva alrededor de 24 horas, en función del tamaño de la carga y del diámetro del cristal.

U na vez terminado el ciclo de crecimiento, se abre el cultivador de cristales para recuperar el lingote monocristalino y para proceder a la limpieza. Cierta cantidad de arsénico escapa de la masa fundida aunque esté cubierta con la capa líquida. Durante este paso del proceso puede haber una exposición significativa al arsénico suspendido en el aire. Para controlarla, el cultivador de cristales se enfría a menos de $100 \stackrel{\circ}{\circ} \mathrm{C}$, lo que provoca el depósito de partículas finas de arsénico sobre la superficie interior del cultivador de cristales. Este enfriamiento ayuda a reducir al mínimo la cantidad de arsénico que queda en suspensión en el aire.

Los depósitos pesados de residuos con contenido de arsénico se dejan en el interior del cultivador de cristales. La eliminación de los residuos en las operaciones normales de mantenimiento preventivo puede originar concentraciones notables de arsénico en el aire (Lenihan, Sheehy y Jones 1989; Baldwin y Stewart 1989; M clntyre y Sherin 1989). Los controles utilizados en esta operación de mantenimiento incluyen a menudo ventilación de extracción localizada, ropa desechable y protección respiratoria.

Cuando se retira el lingote, el cultivador se desmonta. Se utiliza un vacío HEPA para recoger partículas de arsénico de todas las piezas del cultivador. Después de hacer el vacío, las piezas de acero inoxidable se frotan con una mezcla de hidróxido de amonio/ peróxido de hidrógeno para eliminar cualquier resto de arsénico, y se vuelve a montar el cultivador.

\section{Fabricación de obleas}

\section{Difracción de rayos $X$}

La orientación cristalina del lingote de $\mathrm{GaAs}$ se determina con ayuda de una unidad de difracción de rayos $X$, como en el proceso de fabricación de lingotes de silicio. También puede utilizarse un láser de baja potencia en un montaje de producción para determinar la orientación cristalina; pero el método de difracción de rayos $X$ es más exacto y el preferido.

Cuando se emplea difracción de rayos $X$, el haz de rayos $X$ suele estar totalmente encerrado en una cámara protectora que se inspecciona cada cierto tiempo en busca de fugas de radiación. En determinadas circunstancias, no es práctico el encierro total del haz de rayos $X$ en un recinto cerrado. En tal caso, puede exigirse a los operadores que lleven anillos detectores de radiación y se establecen controles semejantes a los adoptados cuando se usan láseres de gran potencia (p. ej., habitación cerrada con el acceso limitado, formación de operadores, encerrar el haz en la medida de lo posible, etc.) (Baldwin y Williams 1996).

\section{Recorte, rectificado y troceado del lingote}

Los extremos o colas del lingote monocristalino se recortan con una sierra de diamantes de una sola hoja lubricada con agua a la que se añaden diversos refrigerantes. El lingote monocristalino se coloca después en un torno que le da forma cilíndrica de 
diámetro uniforme. Este es el proceso de rectificado, que también es un proceso húmedo.

D espués de ser recortados y rectificados, los lingotes de $\mathrm{G}$ aAs se montan con epoxi o cera en un soporte de grafito y se sierran en obleas individuales con sierras automáticas de hojas incrustadas de diamantes en el diámetro interior (ID). Esta operación húmeda se lleva a cabo con ayuda de lubricantes y genera una pasta de GaAs, que es recogida, centrifugada y tratada con fluoruro de calcio para precipitar el arsénico. Se comprueba que la porción flotante no contiene exceso de arsénico, y el lodo se prensa en forma de tarta y se desecha como residuo peligroso. Algunos fabricantes envían la pasta recogida de los procesos de recorte, rectificado y troceado para recuperar el $\mathrm{G}$ a.

Pueden formarse arsina y fosfina en la reacción del GaAs y del fosfuro de indio con la humedad del aire, con otros arseniuros y fosfuros o cuando, durante el procesamiento, el arseniuro de galio y el fosfuro de indio se mezclan con ácidos; se han medido 92 ppmm de arsina y 176 ppmm de fosfina a 5 centímetros de distancia de las hojas de troceado utilizadas para cortar lingotes de GaAs y de fosfuro de indio (M osovsky y cols. 1992, R ainer y cols. 1993).

\section{Lavado de obleas}

U na vez que las obleas de $G$ aAs se han desmontado del soporte de grafito, se limpian por inmersión sucesiva en baños de productos químicos que contienen soluciones de ácido sulfúrico/ peróxido de hidrógeno o ácido acético y alcoholes

\section{Perfilado de bordes}

El perfilado de bordes es también un proceso húmedo realizado en las obleas ya cortadas para formar alrededor de cada oblea un borde que la haga menos propensa a la rotura. Como el corte en la superficie de la oblea es delgado, sólo se genera una pequeña cantidad de pasta.

\section{Pulimentado y bruñido}

Las obleas se montan con cera sobre una placa de pulir o rectificar, con ayuda de una placa calentadora, y se pulen en una máquina que desarrolla una velocidad y presión especificadas. Se vierte una solución de pulimentado en la superficie a pulir (una pasta de óxido de aluminio, glicerina y agua). Tras un breve período de pulimentado, cuando se ha conseguido el espesor deseado, las obleas se enjuagan y se montan en una máquina de bruñido mecánico. Este se realiza con una pasta de bicarbonato sódico, cloro al $5 \%$, agua (o hipoclorito sódico) y sílice coloidal. Las obleas se desmontan después sobre una placa calentadora, la cera se quita con disolventes y las obleas quedan limpias.

\section{Epitaxia}

Las obleas de GaAs monocristalino se utilizan como sustratos para el crecimiento de capas muy delgadas del mismo compuesto III-V o de otros que tengan las propiedades electrónicas u ópticas deseadas. Esta operación ha de ejecutarse de manera que en la capa cultivada continúe la estructura cristalina del sustrato. Este crecimiento cristalino, en que el sustrato determina la cristalinidad y orientación de la capa cultivada, se denomina epitaxia, y son numerosas las técnicas de crecimiento epitaxial utilizadas en la producción de indicadores y dispositivos III-V. Las técnicas más corrientes son:

- epitaxia en fase líquida (LPE);

- epitaxia con haz molecular (M BE);

- epitaxia en fase de vapor (VPE);

- condensación de vapores de sustancias químicas organometálicas (M O C V D) - también llamada epitaxia organometálica en fase de vapor (O M VPE).

\section{E pitaxia en fase líquida}

En la LPE, una capa de material III-V con impurezas se hace crecer directamente sobre la superficie del sustrato de GaAs con ayuda de un soporte de grafito que contiene cámaras separadas para el material que se depositará en las obleas. Se añaden a la cámara superior del soporte cantidades pesadas de los materiales a depositar, mientras que las obleas se colocan en una cámara más baja. EI montaje se coloca en un tubo de reacción de cuarzo en atmósfera de hidrógeno. Se calienta el tubo hasta fundir los materiales a depositar, y cuando la fusión se equilibra, la sección superior del soporte se desliza hasta situarla encima de la oblea. Se reduce entonces la temperatura del horno para formar la capa epitaxial.

La LPE se utiliza sobre todo en epitaxia de los CI por microondas y en la fabricación de LED de longitudes de onda determinadas. EI riesgo principal de este proceso de LPE es el empleo de gas hidrógeno muy inflamable en el sistema, riesgo que puede mitigarse si existen buenos controles técnicos y sistemas de alarma inmediata.

\section{Epitaxia con haz molecular}

La epitaxia al vacío en forma de MBE es una técnica que ha mostrado poseer una gran versatilidad. La M BE de GaAs consta de un sistema de ultravacío que contiene fuentes de haces atómicos o moleculares de Ga y As y de una oblea calentada como sustrato. Las fuentes de haces moleculares suelen ser contenedores de $\mathrm{G}$ a líquido o de As sólido, con un orificio frente a la oblea. Cuando el horno de efusión (o contenedor) se calienta, por el orificio salen átomos de Ga o moléculas de As. El crecimiento del GaAs tiene lugar por lo general a una temperatura del sustrato superior a $450 \stackrel{\circ}{ } \mathrm{C}$.

Durante el mantenimiento de los sistemas M BE con fuente de sólido puede haber exposiciones altas a la arsina. En un estudio se detectaron concentraciones de 0,08 ppm en el aire cuando la cámara de la unidad de MBE se abría para el mantenimiento. La hipótesis de los autores era que la generación transitoria de arsina puede deberse a una reacción entre partículas muy finas de arsénico y vapor de agua, en la que el aluminio actuaría como catalizador (A som y cols. 1991).

\section{E pitaxia en fase de vapor}

Las obleas desengrasadas y bruñidas se someten a un paso de ataque químico y limpieza antes de la epitaxia. Se trata de una operación de decapado secuencial con sustancias químicas húmedas en la que se utilizan ácido sulfúrico, peróxido de hidrógeno y agua en una proporción 5:1:1; un lavado con agua desionizada, y una limpieza/ secado con alcohol isopropílico. También se realiza una inspección visual.

D os son las técnicas principales de V PE aplicadas, basadas en dos sustancias químicas diferentes:

- Ios halógenos-III $\left(\mathrm{G} \mathrm{aCl}_{3}\right)$ y halógenos-V $\left(\mathrm{AsCl}_{3}\right)$ o hidrógeno-V $\left(\mathrm{AsH}_{3}\right.$ y $\left.\mathrm{PH}_{3}\right)$

- los organometálicos III e hidrógeno-V, como $\mathrm{Ga}\left(\mathrm{CH}_{3}\right)_{3}$ y $\mathrm{AsH}_{3}-\mathrm{OMVPE}$.

L a termoquímica de estas técnicas es muy diferente. Las reacciones normales de halógenos van de "calientes" a "frías", y en ellas el halógeno-III se genera en una zona caliente por reacción del elemento III con $\mathrm{HCl}$, y luego se difunde hacia la zona fría, donde reacciona con la variedad $\mathrm{V}$ para formar material III-V. La química metalorgánica es un proceso "de paredes calientes" en el que el compuesto metalorgánico III "agrieta" o piroliza el grupo orgánico y el resto del elemento III y el hidruro $\mathrm{V}$ reaccionan para formar III-V. 
En la VPE, el sustrato de GaAs se coloca en una cámara de calor en una atmósfera de hidrógeno. La cámara se calienta mediante $\mathrm{RF}$ o resistencias. Se hace borbotear el $\mathrm{HCl}$ a través de una cápsula de $\mathrm{Ga}$ para formar cloruro de galio, que luego reacciona con $\mathrm{AsH}_{3}$ y $\mathrm{PH}_{3}$ cerca de la superficie de la obleas para dar GaAsP, que se deposita como capa epitaxial sobre el sustrato. Se pueden añadir varias impurezas (según el producto y la fórmula aplicada). Entre ellas se cuentan pequeñas concentraciones de telururos, selenuros y sulfuros.

Una técnica extendida para la VPE en el procesamiento de LED es el sistema de halógeno-III e hidrógeno-V (hidruro). Consiste en un proceso de dos ciclos-con crecimiento inicial de la capa epitaxial de GaAsP sobre el sustrato de GaAs y, por último, un ciclo de decapado para limpiar de impurezas la cámara del reactor de grafito/ cuarzo. En el ciclo de crecimiento epitaxial, las obleas de GaAs, previamente limpiadas se cargan en un carrusel situado dentro de una cámara de cuarzo del reactor que contiene un depósito de galio líquido elemental a cuyo través se dosifica el paso de gas $\mathrm{H} \mathrm{Cl}$ anhidro para formar $\mathrm{GaCl}_{3}$. Las mezclas gaseosas de hidruro/ hidrógeno (p. ej., $7 \%$ $\mathrm{AsH}_{3} / \mathrm{H}_{2}$ y $10 \% \mathrm{PH}_{3} / \mathrm{H}_{2}$ ) se dosifican también en su paso a la cámara del reactor con la adición de concentraciones en ppm de impurezas organometálicas de teluro y selenio. Las especies químicas en la zona caliente, que es la parte superior de la cámara del reactor, reaccionan entre sí, y en la zona fría, que es la parte inferior de la cámara, forman la capa deseada de GaAsP sobre la oblea así como en el interior de la cámara del reactor.

Los efluentes del reactor son encaminados a un sistema de llama de hidrógeno (cámara de combustión o caja de quemado) para su pirólisis y se expulsan por ventilación a un sistema depurador húmedo. La alternativa es hacer burbujear los efluentes del reactor a través de un medio líquido para atrapar la mayoría de la partículas. EI desafío para la seguridad consiste en la fiabilidad de los propios reactores para "agrietar" los gases. La eficiencia de estos reactores es de alrededor del 98 al 99,5\%; por lo tanto, algunos gases sin reaccionar pueden salir del borboteador cuando son extraídos por los operadores. Estos borboteadores desprenden gases de distintos compuestos de arsénico y fósforo, lo que exige que sean transportados en seguida a un sumidero ventilado antes de su mantenimiento, en el cual son purgados y limpiados para que la exposición del personal sea mínima. El desafío que este proceso impone a la higiene industrial es el de identificar con exactitud los gases efluentes, puesto que la mayoría de los compuestos gaseosos desprendidos de las distintas partes del reactor, y en especial del borboteador, son inestables en el aire y las técnicas tradicionales de recogida y análisis no discriminan lo suficiente entre las diferentes especies químicas.

O tra preocupación es la debida a los depuradores previos de los reactores de VPE, que pueden contener altas concentraciones de arsina y fosfina. Son posibles las exposiciones que rebasen los límites de exposición profesional si estos depuradores previos se abren sin tomar precauciones (Baldwin y Stewart 1989).

El ciclo de decapado se efectúa al final del ciclo de crecimiento y en nuevas partes del reactor para limpiar su superficie interior de impurezas. Se dosifica la entrada de gas $\mathrm{HCl}$ sin diluir en la cámara durante alrededor de 30 minutos, y se calienta el reactor hasta más de $1.200 \stackrel{\circ}{ } \mathrm{C}$. L os efluentes se ventilan hacia el sistema depurador húmedo para su neutralización.

Al final de estos ciclos de crecimiento y decapado, se utiliza una purga general con $\mathrm{N}_{2}$ para arrastrar los gases tóxicos/ inflamables y corrosivos que puedan quedar en la cámara del reactor.

\section{Limpieza del reactor}

Después de cada ciclo de crecimiento, es preciso abrir los reactores de V PE, sacar las obleas y realizar la limpieza física de las partes superior e inferior del reactor. Esta limpieza es ejecutada por el operador.

EI depurador previo de cuarzo del reactor se quita de éste y se coloca en un disipador ventilado, donde se purga con $\mathrm{N}_{2}$, se enjuaga con agua y después se sumerge en agua regia. Esta operación va seguida de otro lavado con agua antes de secar la pieza. Con la purga de $\mathrm{N}_{2}$ sólo se pretende desplazar el oxígeno, dada la presencia de fósforo pirofórico inestable. Aun después de la purga y del lavado con agua, quedan en estas piezas algunos residuos que contienen diversos subproductos arsenicales y fosfóricos. La reacción entre estos residuos y la mezcla fuertemente oxidante/ ácida podría generar cantidades importantes de $\mathrm{AsH}_{3}$ y algo de $\mathrm{PH}_{3}$. También existe posibilidad de exposición en otros procedimientos de mantenimiento de todo este proceso.

El fondo de la cámara de reacción de cuarzo y la placa del fondo (placa base) se limpian por rascado con una herramienta metálica, y las partículas de material (mezcla de GaAs, GaAsP, óxidos de arsénico, óxidos de fósforo y gases de hidruros atrapados) se recogen en un recipiente metálico situado debajo del reactor vertical. Para la limpieza final se emplea un vacío de alta eficiencia.

O tra operación con potencial de exposición química es la limpieza de la trampa del reactor. Para efectuarla se rascan las piezas de grafito de la cámara superior, que tienen una corteza de todos los subproductos ya mencionados más cloruro de arsénico. El procedimiento de rascado genera polvo y se ejecuta en una extracción localizada para reducir la exposición de los operadores. L a tubería de salida del proceso, que contiene todos los subproductos más humedad que forma un residuo líquido, se abre para verter los desechos en un recipiente metálico. Se emplea vacío HEPA para limpiar las partículas de polvo que puedan haberse desprendido durante la transferencia de las piezas de grafito y de la subida y bajada de la campana de vidrio, que expulsa partículas sueltas.

\section{Condensación de vapores de sustancias químicas organometálicas}

La MOCVD está muy extendida en la preparación de dispositivos III-V. A demás de los gases de hidruros empleados como materiales fuente en otros sistemas de CVD (p. ej., arsina y fosfina), en los sistemas MOCVD se usan también alternativas líquidas menos tóxicas (p. ej., butilarsina y butilfosfina terciarias), junto con otros tóxicos como alquilos de cadmio y mercurio (Content 1989; Rhoades, Sands y Mattera 1989; Roychowdhury 1991).

M ientras que la VPE consiste en el proceso de condensación del material de un compuesto, la MOCVD se refiere a las fuentes de sustancia química iniciales utilizadas en el sistema. D os sustancias químicas son las empleadas: haluros y metalorgánicos. El proceso de VPE antes descrito es un proceso con haluro. En la zona caliente se forma un haluro del grupo III (galio), y en la zona fría se deposita un compuesto III-V . En el proceso metalorgánico del $\mathrm{GaAs}$, se dosifica el trimetilgalio introducido en la cámara de reacción junto con arsina, o una alternativa líquida menos tóxica como la butilarsina terciaria, para formar arseniuro de galio. Un ejemplo de reacción típica de MOCVD es:

$$
\left(\mathrm{CH}_{3}\right)_{3} \mathrm{Ga}+\mathrm{AsH}_{3} \rightarrow \mathrm{GaAs}+3 \mathrm{CH}_{4}
$$

$\mathrm{H}$ ay otras sustancias químicas que se utilizan en el proceso por M OCVD de los LED. Los organometálicos utilizados como elementos del grupo III son el trimetilgalio ( $T M G$ a), el trietilgalio (TEGa), el TM indio, TE indio y TM aluminio. En el 
proceso se utilizan también gases hidruros: $100 \% \mathrm{AsH}_{3}$ y $100 \%$ $\mathrm{PH}_{3}$. Las impurezas aplicadas en el proceso son: dimetil zinc (DM Z), bis-ciclopentadienil magnesio y seleniuro de hidrógeno $\left(\mathrm{H}_{2} \mathrm{Se}\right)$. Estos materiales reaccionan a baja presión en la cámara de reacción en atmósfera de $\mathrm{H}_{2}$. La reacción produce capas epitaxiales de AIG aAs, AllnG aP, InA sP y G al nP. Esta técnica se ha venido utilizando en la fabricación de láseres de semiconductores y dispositivos de comunicación ópticos, como transmisores y receptores de fibra óptica. El proceso All nG aP se emplea para producir LED muy brillantes.

De manera semejante a como ocurre en el proceso de VPE, la limpieza del reactor y de las piezas de la M OCV D impone desafíos al proceso y a los higienistas industriales, en especial si en el proceso se utilizan grandes cantidades de $\mathrm{PH}_{3}$ concentrado. La eficiencia de "agrietado" de estos reactores no es tan elevada como la de los reactores de V PE. Se genera una cantidad significativa de fósforo, que origina peligro de incendio. En el procedimiento de limpieza se emplean peróxido de hidrógeno/ hidróxido de amonio diluidos en distintas partes de estos reactores, lo que supone un peligro de explosión si, por error del operador, se emplea una solución concentrada en presencia de un catalizador de metal.

\section{Fabricación de dispositivos}

La oblea de GaAs con una capa de GaAsP que ha crecido por una técnica epitaxial sobre su superficie superior se somete a la secuencia de operaciones para fabricación del dispositivo.

\section{Depósito de nitruro}

Se efectúa una CVD de nitruro de silicio $\left(\mathrm{Si}_{3} \mathrm{~N}_{4}\right)$ a alta temperatura en un horno de difusión estándar. Las fuentes gaseosas son silano $\left(\mathrm{SiH}_{4}\right)$ y amoníaco $\left(\mathrm{N} \mathrm{H}_{3}\right)$, transportados por gas nitrógeno.

\section{Proceso fotolitográfico}

El proceso estándar de fotoprotección, alineación/ exposición, revelado y grabado se utiliza como en el procesamiento de los dispositivos de silicio (véase la sección sobre litografía en el artículo "Fabricación de semiconductores de silicio").

\section{Grabado húmedo}

Se emplean diversas mezclas de soluciones ácidas húmedo-químicas en baños de plástico instalados en estaciones de grabado con ventilación localizada, algunos provistos de sistemas de suministro laminar con filtrado HEPA montados en dirección vertical. Los principales ácidos empleados son sulfúrico $\left(\mathrm{H}_{2} \mathrm{SO}_{4}\right)$, fluorhídrico $(\mathrm{HF})$, clorhídrico $(\mathrm{HCl})$ y fosfórico $\left(\mathrm{H}_{3} \mathrm{PO}_{4}\right)$. Como en el proceso de fabricación del silicio, se usa peróxido de hidrógeno $\left(\mathrm{H}_{2} \mathrm{O}_{2}\right)$ con ácido sulfúrico, y el hidróxido de amonio $\left(\mathrm{NH}_{4} \mathrm{OH}\right)$ permite un grabado cáustico. También se usa una solución de cianuro (sódico o potásico) para grabar aluminio. Pero el grabado con cianuro va quedando anticuado a medida que se desarrollan otros mordientes para este proceso. Como alternativa al grabado húmedo, se utiliza un proceso de grabado con plasma e incineración. Las configuraciones de reactor y los gases reaccionantes son muy similares a los utilizados en el proceso de fabricación de dispositivos de silicio.

\section{Difusión}

Se efectúa una difusión de una fuente sólida de diarseniuro de zinc en una ampolla cerrada dentro de un horno de difusión de vacío a la temperatura de $720 \stackrel{\circ}{\circ}$. con ayuda del gas portador $\mathrm{N}_{2}$. Como impurezas se usan arsénico y arseniuro de zinc. Se pesan en una vitrina de manipulación con guantes, de la misma manera que el sustrato.

\section{Metalización}

Se realiza una evaporación inicial de aluminio con ayuda de un evaporador de haz de electrones. Después del decapado trasero, se lleva a cabo una última etapa de evaporación de oro mediante un evaporador de filamento.

\section{Aleación}

EI paso final de aleación se ejecuta en un horno de difusión a baja temperatura en una atmósfera inerte de nitrógeno.

\section{Decapado trasero}

EI decapado trasero se hace para eliminar materiales depositados $\left(\mathrm{G} \mathrm{aAsP}, \mathrm{Si}_{3} \mathrm{~N}_{4}\right.$, etc.) de la cara posterior de la oblea. Las obleas se montan con cera en una placa de bruñidora y se pulen en húmedo con una pasta de sílice coloidal. Se retira después la cera mediante decapado en húmedo de las obleas con un disolvente orgánico en una estación de grabado químico húmedo con ventilación localizada. 0 tra alternativa al pulimentado húmedo es el pulimentado en seco, que utiliza "arena" de óxido de aluminio.

Se utilizan numerosos protectores y disolventes de protectores, que suelen contener ácido sulfónico (ácido dodecilbenzeno sulfónico), ácido láctico, hidrocarburos aromáticos, naftaleno y catecol. Algunos disolventes de protectores contienen etanoato de butilo, ácido acético y éster de butilo. Se usan protectores y disolventes de protectores tanto negativos como positivos, en función del producto elaborado.

\section{Prueba final}

Como en el procesamiento de dispositivos de silicio, los circuitos LED terminados se comprueban por ordenador y se marcan (véase "Fabricación de semiconductores de silicio"). Se efectúa la inspección final, seguida del ensayo eléctrico de las obleas para marcar las pastillas defectuosas. A continuación se utiliza una sierra húmeda para separar las pastillas individuales, que se envían a montaje.

\section{IN STALACION DE PLACAS DE CIRCUITO IMPRESO Y ORDENADORES}

Michael E. Williams

\section{Tarjetas de cableado impreso}

Las tarjetas de cableado impreso (PWB) son el marco de interconexiones eléctricas y la estructura física que mantiene juntos los distintos componentes electrónicos de una tarjeta de circuito impreso. L as categorías principales de PWB son de una sola cara, de doble cara, multicapa y flexible. La complejidad y los requisitos de espacio de unas tarjetas que cada vez son más densas y pequeñas han exigido que las dos caras de la tarjeta se cubran con circuitos subyacentes. Las tarjetas de una sola cara cumplían los requisitos de las primeras calculadoras y de los dispositivos sencillos de la electrónica de consumo, pero los ordenadores portátiles tipo agenda, los sistemas digitales de ayuda personal y los sistemas personales de música han impuesto las PWB de doble cara y multicapa. EI proceso de modelado de las PWB es en esencia un proceso fotolitográfico que comprende el depósito selectivo y la eliminación de capas de materiales sobre un sustrato aislante que al final constituye el "cableado" eléctrico que se graba o deposita sobre la tarjeta de cableado impreso.

Las tarjetas multicapa contienen dos o más piezas de material aislante con un circuito que se apila y une entre sí. Se establecen conexiones eléctricas de una cara a otra, y con el circuito de la capa interior, por orificios taladrados que después se plaquean 
Tabla 83.9 • Proceso de PW B: aspectos ambientales, de higiene y de seguridad.

Etapas fundamentales del proceso
Preparación del material
Compra de láminas específicas, material de entrada
y cartón de soporte cortado a la medida
Diagrama del proceso asistido por ordenador
Apilar y sujetar
Los paneles recubiertos de cobre se apilan con el
material de entrada y con el cartón de soporte;
se taladran agujeros y las espigas se sujetan.
Taladrar
Máquinas de taladrar de control numérico (N/ C)
Desbarbar
Hacer pasar los paneles taladrados por cepillos
o rueda abrasiva
Electrolisis en cobre
Añadir capa delgada de cobre por los agujeros
(proceso multietapa)

Formar imagen

Protector de película seca- fotopolímero sensible a UV

Protector impreso en pantalla- emulsión sensible a la luz

Protector líquido - protectores líquidos fotosensibles

Recubrimiento del patrón

Limpieza

Recubrimiento de cobre

Recubrimiento de estaño/ plomo

Decapado en bastidor

Arranque, grabado, arranque

Arranque del protector

Grabado alcalino

Arranque del cobre

Máscara de soldadura

Tinta epoxi - impresión de pantalla

Películas secas - laminadas en la PWB

Tinta epoxi líquida fotosensible

Recubrimiento por soldadura

Nivelación de soldadura

Dorado y niquelado

Rotulación de componentes

Serigrafía

Endurecimiento en horno
Aspectos de salud y seguridad

Aspectos ambientales

Diseño aisistido por ordenador- riesgos ergonómicos y de pantallas de PVD

Ruido durante el taladrado; partículas del taladrado que contienen cobre, plomo, oro y resina epoxi/ fibra de vidrio

Ruido durante el taladrado; partículas del taladrado que contienen cobre, plomo, oro y resina epoxi/ fibra de vidrio

Ruido durante el desbarbado; partículas que contienen cobre, plomo, oro y resina epoxi/ fibra de vidrio

Inhalación y exposición dérmica a detergentes, acondicionadores, mordientes, catalizadores- $\mathrm{H}_{2} \mathrm{SO}_{4}, \mathrm{H}_{2} \mathrm{O}_{2}$, éteres de glicol, $\mathrm{KMnO}_{4}, \mathrm{NH}_{4} \mathrm{HF}_{2}$, paladio, $\mathrm{SnCl}_{2}$, CuSO ${ }_{4}$, formaldehído, $\mathrm{NaOH}$

Inhalación y exposición dérmica a protectores, reveladores y decapantes- protectores a base de goma con disolventes: $\mathrm{Na}_{3} \mathrm{PO}_{4}$ y $\mathrm{K}_{2} \mathrm{CO}_{3}$; cloruro cúprico ( $\mathrm{Cl}_{2}$ gas), monoetanol amina (MEA)

Inhalación y peligros dérmicos derivados de la limpieza, cobreado o recubrimiento de estaño/ estaño y plomo y decapado en bastidor- $\mathrm{H}_{3} \mathrm{PO}_{4}, \mathrm{H}_{2} \mathrm{SO}_{4} ; \mathrm{H}_{2} \mathrm{SO}_{4}$ y CuSO${ }_{4} ;$ ácido fluorbórico y $\mathrm{Sn} / \mathrm{Pb}$; concentrado de $\mathrm{HNO}_{3}$

Inhalación y peligros dérmicos del arranque del protector; grabado alcalino 0 arranque del cobre- monoetanol amina (MEA); $\mathrm{NH}_{4} \mathrm{OH} ; \mathrm{NH}_{4} \mathrm{Cl} / \mathrm{NH}_{4} \mathrm{OH} O \mathrm{NH}_{4} \mathrm{HF}_{2}$

Inhalación y peligros dérmicos del prelavado; tintas epoxi y portadores de disolventes; reveladores- $\mathrm{H}_{2} \mathrm{SO}_{4}$; epiclorhidrina + bisfenol A, éteres de glicol (basados en PGMEA); butirolactona gamma.

luz UV del proceso de endurecimiento

Inhalación y peligros dérmicos del fundente, productos de la descomposición y restos de soldadura de

plomo/ estaño- éteres de glicol diluidos+ $<1 \% \mathrm{HCl}$ y $<1 \%$ $\mathrm{HBr}$; aldehídos, $\mathrm{HCl}$, CO; plomo y estaño

Inhalación y peligros dérmicos de ácidos, metales y cianuros- $\mathrm{H}_{2} \mathrm{SO}_{4}, \mathrm{HNO}_{3}, \mathrm{NiSO}_{4}$, cianuro de potasio y oro

Inhalación y peligros dérmicos de tintas epoxi y portadores de disolventes- disolventes basados en éteres de glicol, epiclorhidrina + bisfenol A
Ninguno

Residuos en partículas (cobre, plomo, oro y resina epoxi/ fibra de vidrio) - reciclados o recuperados

Residuos en partículas (cobre, plomo, oro y resina epoxil fibra de vidrio) - reciclados o recuperados

Residuos en partículas (cobre, plomo, oro y resina epoxil fibra de vidrio) - reciclados o recuperados

Vertidos en desagües- ácidos, cobre, productos cáusticos, fluoruros; emisiones a la atmósfera- gases ácidos, formaldehído

Emisiones a la atmósfera- disolventes (COVs), gases ácidos, MEA; líquidos- residuales

Emisiones a la atmósfera- gases ácidos; vertidos en desagües- ácidos, fluoruros, metales (cobre, plomo y estaño)

Emisiones a la atmósfera- MEA, amoníaco, fluoruros; efluentes en agua- amoníaco, fluoruros, metales ( cobre, plomo y estaño), compuestos de protector

Emisiones a la atmósfera- gases ácidos, éteres de glicol (COVs); residuos- disolventes, tintas epoxi

Emisiones a la atmósfera- éteres de glicol (COV), gases ácidos, aldehídos, CO; residuos- soldadura de plomo/ estaño, fundente

Emisiones a la atmósfera- gases ácidos, cianuros; emisiones en agua- ácidos, cianuros, metales; residuos- cianuros, metales

Emisiones a la atmósfera- éteres de glicol (COVs) residuos - tintas y disolventes (pequeñas cantidades)

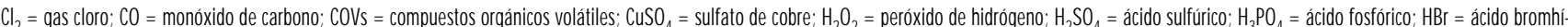
drico: $\mathrm{HCl}=$ ácido clorhídrico: $\mathrm{HNO}=3$ ácido nítrico: $\mathrm{K}_{2} \mathrm{CO}_{3}=$ carbonato potásico: $\mathrm{KMNO}_{4}=$ permanganato potásico; $\mathrm{NA}_{3} \mathrm{PO}_{4}=$ fosfato sódico; $\mathrm{NH}_{4} \mathrm{Cl}=$ cloruro amónico; $\mathrm{NH}_{4} \mathrm{OH}=$ hidróxido amónico; $\mathrm{NiSO}_{4}=$ sulfato de níquel; $\mathrm{Pb}=$ plomo; $\mathrm{Sn}=$ estaño; $\mathrm{SnCl}_{2}=$ cloruro de estaño; $\mathrm{UV}=$ ultravioleta. 
con cobre. El sustrato aislante más extendido es el formado por láminas de fibra de vidrio (laminado de epoxi/ fibra de vidrio). 0 tros materiales empleados son el vidrio (con poliimidas, Teflon o resinas de triacina) y papel recubierto de resina fenólica. En Estados U nidos, las tarjetas laminadas se clasifican por sus propiedades ignífugas; por las de perforado, punzonado y mecanizado; por la absorción de humedad; por las propiedades químicas y de resistencia al calor, y por la rigidez mecánica (Sober 1995). EI FR -4 (sustrato de resina epoxi y tejido de vidrio) está muy difundido para aplicaciones de alta tecnología.

EI proceso real de PWB consta de numerosas etapas y una amplia variedad de agentes químicos. La Tabla 83.9 ilustra un proceso multicapa típico y los aspectos de SSA asociados a este proceso. Las diferencias principales entre una tarjeta de una cara y otra de doble cara es que la de una sola cara empieza por el revestimiento con cobre de una cara de la materia prima y omite el paso de plaqueado químico con cobre. La tarjeta de doble cara estándar tiene una máscara soldada sobre cobre desnudo y se plaquea por los orificios; la tarjeta tiene contactos recubiertos de oro y una inscripción. La mayoría de las PWB son tarjetas multicapa, que son de doble cara con capas internas que han sido fabricadas y embutidas dentro de la montura laminada y después procesadas por un método casi idéntico al de una tarjeta de doble capa.

\section{Montaje de tarjetas de circuito impreso}

El montaje de tarjetas de circuito impreso (PCB) comprende la fijación firme de componentes electrónicos en la PWB mediante soldadura de plomo/ estaño (en una máquina de soldadura por ola 0 aplicada en forma de pasta y después fluidificada en un horno de baja temperatura) o resinas epoxi (endurecidas en un horno de baja temperatura). La PWB subyacente (de una sola cara, de doble cara, multicapa o flexible) determinará las densidades de componentes que pueden fijarse. Numerosos aspectos relativos a proceso y fiabilidad condicionan la selección de los procesos de montaje de PCB que se utilizarán. Los procesos tecnológicos principales son: tecnología de montaje total en superficie (SMT), tecnología mixta (incluye tanto SMT como plaqueado a través de orificio (PTH )) y fijación en cara inferior. Lo normal en las instalaciones modernas de electrónica/ ordenadores es que se utilice la tecnología mixta, en la que algunos componentes se montan en superficie y otros conectores/ componentes se sueldan encima mediante la tecnología de orificio pasante 0 por fluidificado de soldadura. A continuación se describe un proceso "típico" de tecnología mixta, en el cual se aplica el montaje en superficie mediante sujeción con adhesivo, soldadura por ola y soldadura por fluidificación. Con la tecnología mixta, a veces es posible soldar por fluidificación componentes montados en superficie (SM C) por la cara superior de una tarjeta de doble cara y soldar por ola los SM C de la cara inferior. Este proceso es de particular utilidad cuando tienen que mezclarse en una misma tarjeta las tecnologías de montaje en superficie y de orificio pasante, que es la norma en la fabricación electrónica actual. EI primer paso es montar los SM C en la cara superior de la tarjeta mediante la soldadura por fluidificación. A continuación se insertan los componentes a través de orificios. Entonces se invierte la tarjeta y los SM C de la cara inferior se montan con adhesivo en la tarjeta. EI paso final es la soldadura por ola de los componentes sujetos a través de orificios y los SM C de la cara inferior.

Los principales pasos técnicos del proceso de tecnología mixta son:

- limpieza previa y posterior.

- aplicación de pasta de soldar y de adhesivo [(impresión y colocación de plantilla (SM T y PTH)];
- inserción de componentes;

- endurecimiento de adhesivo y fluidificación de soldadura;

- aplicación de fundente (PTH);

- soldadura por ola (PTH):

- inspección y retoque;

- prueba;

- reproceso y reparación;

- operaciones de apoyo- limpieza de plantillas.

A continuación se hace una breve exposición de las implicaciones medioambientales, de salud y seguridad importantes en cada etapa del proceso.

\section{Limpieza previa y posterior}

Las PWB comerciales se compran por lo general a un proveedor de PWB y ya han sido sometidas a una limpieza previa con agua desionizada (DI) para eliminar todos los contaminantes superficiales. Antes de que existiese la preocupación relativa al adelgazamiento de la capa estratosférica de ozono, el fabricante de dispositivos electrónicos hubiera empleado una sustancia empobrecedora de dicha capa, como un clorofluorcarbono (CFC), para la limpieza final o incluso para la limpieza previa. Al final del proceso de montaje de la PCB, era típico realizar una operación de "desengrase en vapor" con un clorofluorcarbono para eliminar residuos de fundente/ soldadura por ola. Pero debido a los problemas de destrucción del ozono y de los estrictos controles reglamentarios sobre la producción de los CFC, en el proceso se introdujeron cambios que permitían omitir la limpieza de los conjuntos PWB terminados o efectuarla únicamente con agua DI.

\section{Aplicación de pasta de soldar y adhesivo (impresión y colocación de plantilla) e inserción de componentes}

La aplicación de pasta de soldar de plomo/ estaño a la superficie de la PWB permite la fijación del componente de montaje superficial en la PWB y es una operación clave para el proceso de SM T. EI material de soldadura actúa como enlace mecánico para la conducción eléctrica y térmica y como recubrimiento para protección superficial y refuerzo de la capacidad de soldadura. La pasta de soldar está compuesta en alrededor del 70 al $90 \%$ (en peso o en volumen) de sustancia no volátil:

- aleación de plomo/ estaño;

- mezcla de resinas modificadas (ácidos de la colofonia o colofonia algo activada);

- activadores (en el caso de productos "sin limpiar", mezclas de sales halogenadas y aminoácidos o sólo ácidos carboxílicos).

Los disolventes (sustancias volátiles) componen el resto del producto (lo habitual es una mezcla de alcohol y éter de glicol que está patentada).

La pasta de soldar se imprime mediante una plantilla, que es un patrón exacto del diseño superficial que se quiere añadir a la superficie de la PWB. La pasta de soldar se empuja por las aberturas de la plantilla hasta los lugares de destino en la PWB mediante un rodillo de goma que recorre con lentitud la plantilla. Esta se retira después y deja depósitos de pasta sobre los puntos adecuados de la tarjeta. Entonces se insertan los componentes en la PWB. Los principales peligros para la SSA están relacionados con la limpieza general y la higiene personal de los operadores que aplican la pasta de soldar a la superficie de la plantilla, limpian el rodillo y limpian las plantillas. La concentración de plomo en la pasta de soldar y la tendencia de la pasta de soldar seca a adherirse a la piel y a las superficies de trabajo del equipo/ instalación exigen la utilización de guantes protectores, una buena limpieza de las superficies de trabajo, la eliminación segura de los materiales de limpieza contaminados (y su 
manipulación en el medio ambiente) y una higiene personal estricta por parte de los operadores (p. ej., lavado de manos con jabón antes de comer, beber o aplicarse cosméticos). Los niveles de exposición por suspensión en el aire suelen ser inferiores al límite de detección del plomo, y si se aplica una buena limpieza general/ higiene personal, las lecturas de plomo en la sangre se sitúan en los niveles de fondo.

La aplicación de adhesivos consiste en la distribución automática de pequeñas cantidades de una resina epoxi (la más corriente es una mezcla de bisfenol A y epicloridrina) en la superficie de la PWB y luego en la "recogida y colocación" del componente y su inserción a través de la resina epoxi en la PWB. Los peligros para la SSA están relacionados sobre todo con los riesgos mecánicos para la seguridad derivados de las unidades de "recogida y colocación", que son conjuntos mecánicos automatizados, a las lanzaderas de componentes en la trasera de las unidades y al riesgo de lesión grave si no se dispone de protecciones adecuadas, células fotoeléctricas y cortacircuitos en piezas mecánicas.

\section{Endurecimiento de adhesivo y fluidificación de soldadura}

Los componentes que se sujetaron mediante impresión por plantilla 0 aplicación de adhesivo se llevan después por una cinta transportadora de altura fija a un horno en serie que "fija" la soldadura por fluidificación de la pasta de soldar a la temperatura aproximada de 200 a $400{ }^{\circ} \mathrm{C}$. Los componentes fijados por el adhesivo epoxi también se hacen pasar por un horno que se encuentra corriente abajo de la fluidificación de soldadura y que suele funcionar de 130 a $160 \stackrel{\circ}{\circ}$. L L os componentes disolventes de la pasta de soldar y la resina epoxi se hacen desaparecer durante el proceso de horneado, pero el componente de plomo/ estaño no se volatiliza. En el conducto de escape del horno de fluidificación se depositarán residuos en forma de telaraña si no se usa un filtro de malla metálica que lo impida. A veces, las PWB pueden quedar atrapadas en el sistema de transporte y se tostarán en el horno, de donde saldrán olores desagradables.

\section{Adición de fundente}

Para formar una junta soldada fiable entre la superficie de la PWB y el conductor del componente, ambos deberán estar limpios de oxidación y así deberán permanecer incluso a las temperaturas elevadas del proceso de soldadura. Asimismo, la aleación fundida para soldar debe empapar las superficies de los metales que se unan. Ello significa que el fundente tiene que reaccionar con los óxidos metálicos y eliminarlos de las superficies que se van a unir, e impedir una nueva oxidación de las superficies limpias. También es preciso que los residuos sean no corrosivos o eliminables con facilidad. Los fundentes empleados en la soldadura de equipo electrónico se clasifican en tres amplias categorías, que se conocen en general como fundentes basados en colofonia, fundentes orgánicos o hidrosolubles y fundentes sintéticos eliminables con disolventes. Los fundentes más modernos, de bajo contenido en sólidos "que no necesitan limpieza" 0 de compuestos orgánicos no volátiles (CONV) pertenecen a la categoría segunda de los citados.

\section{Fundentes basados en colofonia}

Los fundentes basados en colofonia son los más utilizados en el sector de la electrónica como fundentes de rociado o fundentes de espuma. La unidad distribuidora del fundente puede formar parte del equipo de soldadura por ola o ser una unidad autónoma situada en la entrada de alimentación. En principio, los fundentes a base de colofonia tienen resina natural o colofonia, la resina transparente, de color ámbar, que se obtiene después de haber destilado la trementina de la oleorresina y de la resina de pinos. Después de recogida, se calienta y destila la resina para eliminar las partículas sólidas, de donde resulta una forma purificada del producto natural. Es un material homogéneo con un solo punto de fusión. La colofonia es una mezcla aproximada del $90 \%$ de ácido resínico, que casi todo es ácido abiético (ácido orgánico insoluble en agua), y del $10 \%$ de materiales neutros, como derivados del estilbeno y diversos hidrocarburos. En la Figura 83.6 se recoge la estructura química de los ácidos abiético y pimárico.

El agente activo es el ácido abiético, que a la temperatura de soldadura adquiere actividad química y ataca al óxido de cobre superficial de la PWB para formar abietato de cobre. LoS fundentes a base de colofonia tienen tres componentes: el vehículo o disolvente, la colofonia y el activador. El disolvente es un mero vehículo del fundente. Para que sea eficaz, la colofonia debe aplicarse a la tarjeta en estado líquido. Para ello, la colofonia y el activador se disuelven en un sistema de disolventes, que suelen ser alcohol isopropílico (IPA) o mezclas de varios componentes alcohólicos (IPA, metanol o etanol). L uego, el fundente se distribuye por la superficie inferior de la PCB en forma de espuma por la adición de aire o nitrógeno, o se pulveriza en una mezcla "de bajo contenido de sólidos" que tiene un mayor contenido de disolventes. Estos últimos tienen tasas de evaporación diferentes, y es preciso añadir un diluyente a la mezcla fundente para mantener una composición adecuada del fundente. Las principales clases de fundentes a base de colofonia son: colofonia de actividad atenuada (R M A), que es el fundente de uso más generalizado, al que se añade un activador suave; y colofonia activa (RA), al que se ha añadido un activador más agresivo.

El principal peligro para la SSA de todos los fundentes basados en colofonia procede de la base de alcoholes del disolvente. Los peligros para la seguridad guardan relación con la inflamabilidad en almacenamiento y uso, la clasificación y manipulación como residuo peligroso, las emisiones a la atmósfera y los sistemas de tratamiento necesarios para eliminar los COV, además de los aspectos de higiene industrial relacionados con la inhalación y la exposición de la piel (dérmica). Cada uno de estos aspectos exige una estrategia de control diferente, la enseñanza y formación de los trabajadores y la conformidad de permisos/reglamentos (Association of the Electronics, Telecommunications and Business Equipment Industries 1991).

Durante el proceso de soldadura por ola, el fundente se calienta de 183 a 399 oc ; y entre los productos generados que pasan al aire hay aldehídos alifáticos, como el formaldehído.

Figura 83. A Acidos abiético y pimárico.

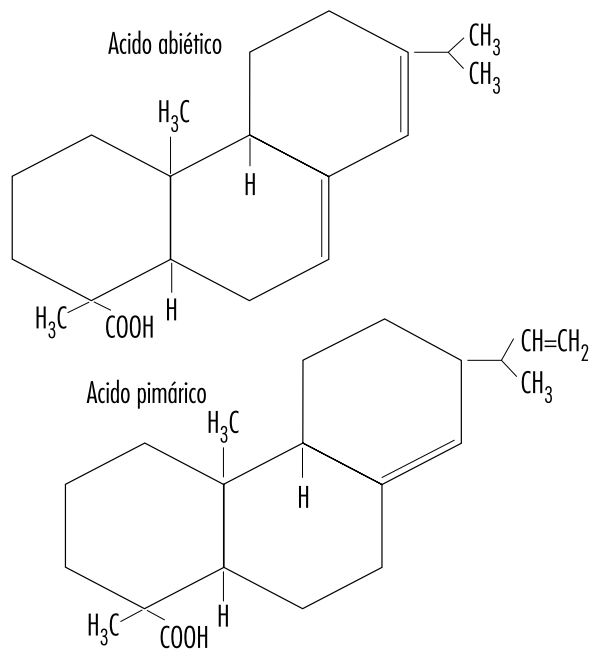


M uchos fundentes contienen también un activador orgánico de clohidrato de amino, que ayuda a limpiar la zona que se suelda y que desprende ácido clorhídrico al calentarse. O tros componentes gaseosos son el benceno, tolueno, estireno, fenol, clorofenol y alcohol isopropílico. Además de los componentes gaseosos del fundente calentado, se genera una cantidad notable de partículas, cuyo tamaño va de 0,01 micras a 1,0 micra, conocidas como humos de colofonia. Se ha observado que estas partículas de material irritan los órganos respiratorios, y también los sensibilizan en individuos propensos (Hausen, Krohn y Budianto 1990). En el Reino U nido, las normas de contaminación atmosférica exigen que los niveles de los humos de colofonia estén controlados hasta los niveles más bajos obtenibles (H ealth and Safety Commission 1992). A demás, la Conferencia americana de higienistas industriales del gobierno (ACGIH) ha establecido un límite umbral independiente para los productos de pirólisis de la soldadura con núcleo de colofonia de $0,1 \mathrm{mg} / \mathrm{m}^{3}$, medidos como formaldehído (ACG IH 1994). La Lead Industries A ssociation, Inc. ha identificado la acetona, el alcohol metílico, los aldehídos alifáticos (medidos como formaldehído), el dióxido de carbono, el monóxido de carbono, metano, etano, ácido abiético y ácidos diterpenos relacionados como productos típicos de la descomposición de la soldadura con núcleo de colofonia (Lead Industries Association 1990).

\section{Fundentes orgánicos}

L os fundentes orgánicos, llamados a veces fundentes intermedios o fundentes solubles en agua, son compuestos más activos que los fundentes a base de colofonia y menos corrosivos que los fundentes ácidos utilizados en los sectores de transformación de metales. Los compuestos generales activos de esta clase de fundentes pertenecen a uno de estos tres grupos:

- ácidos (p. ej., esteárico, glutámico, láctico, cítrico);

- halógenos (p. ej., clorhidratos, bromuros, hidrazina);

- amidas y aminas (p. ej., urea, trietanolamina).

Estos materiales y otras partes de la formulación, como los agentes tensoactivos que ayudan a reducir la tensión superficial de la soldadura, se disuelven en polietilenglicol, disolventes orgánicos, agua o por lo general en una mezcla de varias de estas sustancias. Los fundentes orgánicos deben considerarse corrosivos, pero su eliminación es fácil, basta con utilizar agua caliente.

\section{Fundentes sintéticos activados (AS)}

$M$ ientras que los fundentes basados en colofonia son materiales sólidos disueltos en un disolvente, los fundentes AS suelen ser fórmulas totalmente líquidas (disolvente + fundente). EI disolvente portador se elimina durante la fase de precalentamiento en la soldadura por ola, y deja un residuo húmedo y oleoso sobre la superficie de la PWB, que ha de limpiarse de inmediato tras la soldadura. El principal atributo de los fundentes AS es su capacidad para ser eliminados con disolventes adecuados, como los basados en fluorcarbono. L as restricciones en el uso de sustancias destructoras del ozono, como los fluorcarbonos (Freon T F, Freon TMS, etc.) que se utilizaban en la limpieza de esta clase de fundentes, han limitado en grado notable la utilización de estos últimos.

\section{Fundentes de bajo contenido de sólidos "sin limpieza" o de} compuestos orgánicos no volátiles

La necesidad de eludir, en la limpieza de residuos corrosivos 0 adheridos después de la soldadura, los disolventes de fluorcarbono ha generalizado el empleo de una nueva clase de fundentes que tienen una actividad similar a la de los fundentes R M A y un contenido aproximado de sólidos del $15 \%$. El contenido de sólidos es una medida de su viscosidad y es igual a la relación entre fundente y disolvente. Cuanto menor es el contenido de sólidos, mayor es el porcentaje de disolvente. Cuanto mayor es el contenido de sólidos, más activo es el fundente y mayor es la necesidad de un paso de limpieza tras la soldadura. En el sector de electrónica es corriente utilizar fundentes bajos en sólidos (LSF) que no exigen el paso de limpieza final. D esde la perspectiva de emisiones al medio ambiente, los LSF eliminan la necesidad de desengrasar con vapor de fluorcarbono las tarjetas soldadas por ola, pero su elevado contenido de disolventes hace aumentar la cantidad de disolventes basados en alcoholes que se evaporan, lo que origina mayores niveles de COV. En Estados Unidos y en muchos otros países existe un control estricto de los niveles de emisión de COV al aire. Esta situación fue solucionada por la introducción de fundentes "sin limpieza", cuya base es el agua (en lugar de disolventes), pero que contienen activadores similares y colofonias fundentes. Los ingredientes activos principales se basan en el ácido dicarboxílico (2 a $3 \%$ ), y son típicamente los ácidos glutárico, succínico y adípico. También se incluyen tensioactivos e inhibidores de corrosión (en torno al $1 \%$ ), que dan un pH (acidez) de 3,0 a 3,5. Estos fundentes eliminan prácticamente las emisiones de COV a la atmósfera y otros peligros para la SSA asociados al empleo de fundentes a base de disolventes. LoS productos de descomposición observados en fundentes basados en colofonia siguen siendo aplicables, y el pH débil no exige que el equipo de manipulación del fundente sea resistente a los ácidos. Algunas pruebas anecdóticas señalan problemas, dérmicos o respiratorios potenciales, debidos a los ácidos dicarboxílicos secos, que conservan una débil acidez y a los inhibidores de corrosión que pueden quedar como residuos en monturas de tarjetas, en carritos y en las superficies internas del equipo de soldadura por ola que utilice estos compuestos. También el agua componente de estos fundentes puede no evaporarse por completo antes de llegar a la olla de aleación fundida, lo que puede producir salpicaduras de soldadura caliente.

\section{Soldadura por ola}

La adición de fundente a la superficie inferior de la PWB puede lograrse por medio de un distribuidor de fundente situado en el interior de la unidad de soldadura por ola o por una unidad autónoma colocada a la entrada de la unidad de soldadura por ola. La Figura 83.7 recoge una representación esquemática de una unidad estándar de soldadura por ola con el distribuidor de fundente montado en su interior. Una y otra configuración utilizan el fundente en forma de espuma o de lluvia sobre la PWB.
Figura 83.7 - Esquema de una unidad de soldadura por ola.

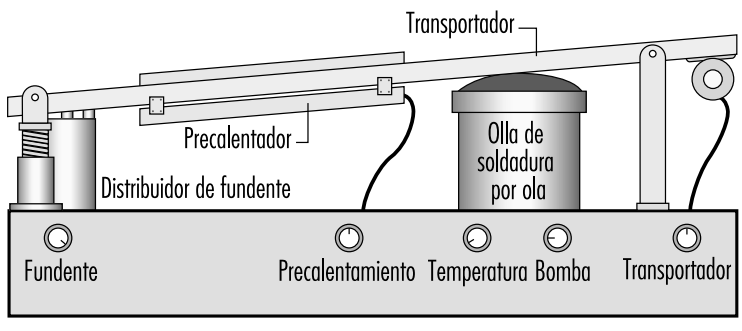

Fuente: Clark 1985. 


\section{Precalentamiento}

Los portadores del fundente tienen que someterse a evaporación antes de efectuar la soldadura. Para lograrlo se emplean precalentadores de alta temperatura que eliminan los componentes líquidos. Los precalentadores utilizados son de dos tipos básicos: radiantes (varilla caliente) y volumétricos (aire caliente). Los calentadores radiantes son corrientes en Estados Unidos y pueden originar la ignición del fundente o disolvente en exceso 0 la descomposición de una PW B si ésta queda inmovilizada debajo del precalentador. Para capturar y evacuar los materiales disolventes/ fundentes evaporados durante estas operaciones, se instala una ventilación de extracción localizada en el lado del distribuidor de fundente/ precalentador de la unidad de soldadura por ola.

\section{Soldadura}

La aleación de soldar (por lo general un $63 \%$ de estaño y un $37 \%$ de plomo) está contenida en un depósito grande llamado olla de soldadura, que cuenta con un calentador eléctrico para mantener la aleación en estado líquido. Los calentadores consisten en un primer calentador potente para obtener la masa fundida inicial y un segundo suministro de calor más pequeño y regulado que controla la temperatura con un termostato.

La soldadura satisfactoria en la tarjeta exige que el diseño de los sistemas de olla de soldadura y bomba de recirculación suministren una "ola" continua de aleación fresca. Al soldar, la aleación pura se va contaminando con compuestos oxidados de plomo/ estaño, con impurezas metálicas y productos de descomposición del fundente. Estos desechos se forman sobre la superficie de la aleación fundida, y cuanto más desechos se forman, mayor es la tendencia a su acumulación. Estos desechos son nocivos para el proceso de soldadura y la ola de soldadura. Si se forma una cantidad suficiente en la olla, pueden ser extraídos por la bomba de recirculación y causar la abrasión del impulsor. Los operadores de soldadura por ola deberán eliminar estos desechos de la ola cada cierto tiempo. Este proceso consiste en que el operador "espume" los desechos solidificados de la masa fundida y recoja los residuos para su recuperación/ reciclado. EI proceso de eliminación de desechos exige que el operador abra la puerta de acceso trasera (que suele tener una configuración de ala hundida) adyacente a la olla de soldadura y espume manualmente los desechos calientes. Durante este proceso, se liberan emisiones visibles de la olla que irritan mucho los ojos, nariz y garganta del operador. Este deberá vestir guantes térmicos, un mandil, gafas de seguridad y un blindaje facial con protección respiratoria [(para partículas de plomo/ estaño, gases corrosivos $(\mathrm{H} \mathrm{Cl})$ y aldehídos alifáticos (formaldehído)]. D esde el interior de la unidad de soldadura por ola se suministra ventilación por extracción localizada, pero es necesario sacar la olla de soldadura del armario principal para que el operador tenga acceso directo a ambos lados de la olla caliente. U na vez sacada la olla, el conducto local de evacuación que está montado en el armario queda inutilizado para eliminar los materiales liberados. Los principales peligros para la salud y la seguridad son: quemaduras térmicas de la soldadura caliente, la exposición respiratoria a materiales antes mencionada, lesiones de espalda por la manipulación de lingotes pesados de aleación y tambores de desechos y exposición a residuos de soldadura/ partículas finas de plomo/ estaño durante las actividades de mantenimiento.

Durante el proceso real de soldadura, las puertas de acceso están cerradas y el interior de la unidad de soldadura por ola está a una presión negativa debido a la ventilación de extracción localizada aplicada al fundente y a los laterales de la olla de soldadura. Esta ventilación y las temperaturas de trabajo de la olla de soldadura (que suele ser de 302 a $316{ }^{\circ} \mathrm{C}$, justo por encima del punto de fusión de la aleación), consiguen hacer
Figura 83.8 - Carro de desechos con cubierta de vacío.

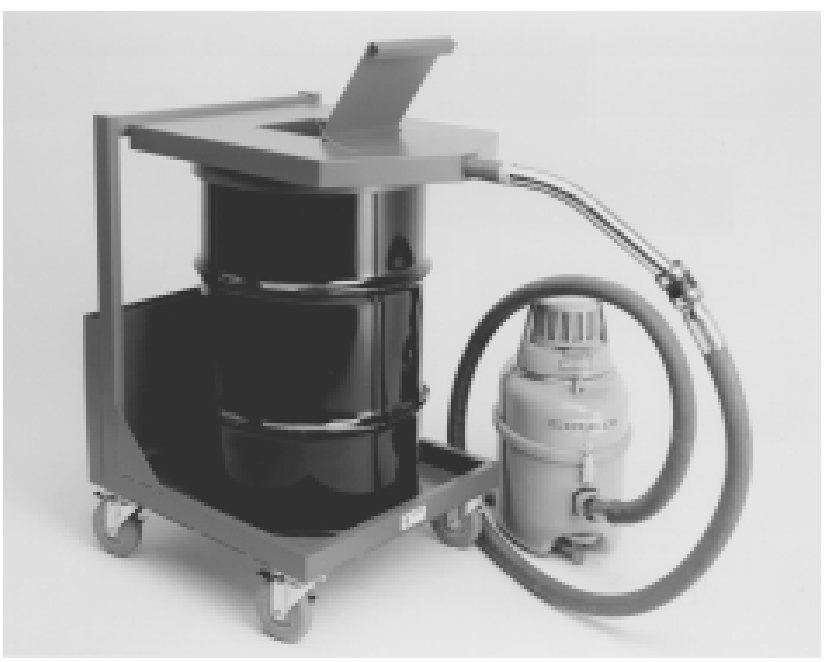

Fuente: Bliss Industries 1996

mínima la formación de humos de plomo. La principal exposición a partículas de plomo/ estaño se origina durante las actividades de eliminación de desechos y mantenimiento del equipo, agitación de los desechos en la olla, transferencia a la vasija de recuperación y limpieza de residuos de soldadura. Durante la operación de eliminación de desechos se forman partículas finas de plomo/ estaño que pueden ser liberadas en el recinto de trabajo y en la zona donde respira el operador de la soldadura por ola. Se han ideado diversas estrategias de control técnico para reducir al mínimo estas exposiciones potenciales a partículas de plomo, incluida la incorporación de ventilación de extracción local en la vasija de recuperación (véase la Figura 83.8), uso de vacíos HEPA para limpieza de residuos y conductos de evacuación flexibles con brazos articulados para situar la ventilación en la olla caliente durante la eliminación de desechos. Debe prohibirse emplear escobas o cepillos para barrer residuos. También será preciso establecer prácticas rígidas de limpieza general y de higiene personal. Durante las operaciones de mantenimiento del equipo de soldadura por ola (que se efectúan con periodicidad semanal, mensual, trimestral y anual), los diversos componentes de la olla caliente se limpian en el propio equipo o se quitan y limpian en una campana de extracción localizada. Estas operaciones de limpieza pueden consistir en el rascado físico o la limpieza mecánica (con una taladradora eléctrica y un suplemento de cepillo de alambre) de la bomba y deflectores de soldadura. En el proceso de limpieza se generan niveles altos de partículas de plomo, por lo que debe llevarse a cabo en un recinto con ventilación de extracción localizada.

\section{Inspección, retoque y prueba}

Las funciones de inspección visual y retoque se realizan después de la soldadura por ola y consiste en utilizar lentes de aumento/luces próximas para la inspección final y el retoque de imperfecciones. La función de retoque puede exigir el uso de un soldador manual de soldadura con barra y aleación con núcleo de colofonia o la aplicación de una pequeña cantidad de fundente líquido y de hilo de aleación de plomo/ estaño. LoS humos que a simple vista salen de la soldadura con barra son productos de descomposición del fundente. Las pequeñas cantidades de perlas de plomo/ estaño que no se adhirieron a la junta soldada pueden representar un problema de limpieza general y 
de higiene personal. Se debe disponer un ventilador adyacente a la estación de trabajo para ventilar por dilución general lejos de la zona donde respira el operador 0 un sistema extractor de humos más sofisticado que recoja los productos de la descomposición en la punta del soldador o adyacente a la operación. Los humos se llevan después a un sistema depurador del aire de salida que incorpore filtración HEPA de partículas y adsorción de gases en carbón activado para los aldehídos alifáticos y los gases de ácido clorhídrico. La eficacia de estos sistemas de ventilación depende mucho de las velocidades de recogida, de la proximidad al punto de generación de humos y de la ausencia de arrastres transversales en la superficie de trabajo. La prueba eléctrica de las PCB terminadas exige equipo y software de prueba especializados.

\section{Reproceso y reparación}

Con los resultados de la prueba de tarjetas, en las tarjetas defectuosas se localizan los fallos de componentes específicos, que son sustituidos. Este reproceso de las tarjetas pueden requerir soldadura a mano. Si es preciso sustituir componentes importantes de la PCB, como el microprocesador, se utiliza una olla de soldadura para reproceso para sumergir la porción de la tarjeta que aloja el componente 0 unión defectuosa en una olla de soldadura pequeña, quitar el componente y después insertar un componente nuevo en la tarjeta. Si el componente es más pequeño o se quita con más facilidad, se utiliza un sistema de aire y vacío que funde la aleación de la junta con aire caliente y aplica vacío para quitar la soldadura. La olla de soldadura para reproceso se aloja en un recinto con ventilación de extracción localizada que posee la velocidad de extracción suficiente para capturar los productos de descomposición del fundente formados cuando se cepilla la aleación líquida en la tarjeta y se hace el contacto de soldadura. Esta olla también forma desechos y exige disponer de equipo y procedimientos para eliminarlos (a escala mucho más pequeña). El sistema de aire y vacío no necesita estar en un recinto cerrado, pero la aleación de plomo/ estaño eliminada tiene que manipularse como residuo peligroso y recuperarse/ reciclarse.

\section{Operaciones de apoyo - limpieza de plantillas}

El primer paso del proceso de montaje de la PCB consistía en el uso de una plantilla que diera el patrón de los puntos de unión y permitiera distribuir por ellos la pasta de soldar de plomo/ estaño. Lo normal es que las aberturas de la plantilla comiencen a obstruirse y haya que quitar los residuos de plomo/ estaño de la pasta de soldar una vez en cada turno. Es habitual efectuar una limpieza previa en la pantalla impresora para retirar la contaminación gruesa de la tarjeta, y para ello la superficie de ésta se frota con una mezcla de alcohol diluido y trapos desechables. Para eliminar todos los residuos restantes, es preciso efectuar un proceso de limpieza húmeda. En un sistema similar a un lavavajillas grande, se emplea agua caliente (a $57^{\circ}$ C) y una solución química de aminas alifáticas diluidas (monoetanol amina) para eliminar de la plantilla por medios químicos la plasta de soldar. Se consigue así extraer de la tarjeta cantidades significativas de aleación de plomo/ estaño que se depositan en la cámara de lavado o en la solución del efuente con agua. Este efluente exige filtración o combinación química del plomo y ajuste del pH relativo a las aminas alifáticas corrosivas (con ácido clorhídrico). Los sistemas limpiadores de plantillas más modernos, de circuito cerrado, utilizan la misma solución de lavado hasta que se agota. La solución es transferida a una unidad de destilación, y las sustancias volátiles se destilan hasta que se forma un residuo semilíquido. Este residuo se manipula después como residuo peligroso contaminado con plomo/ estaño.

\section{Proceso de montaje de ordenadores}

Cuando la PCB final está montada, se transfiere a la operación de montaje de sistemas para su incorporación al producto final, que es el ordenador. Esta operación suele exigir mano de obra intensiva, y en ella las partes componentes que se montarán han de ser transportadas a los puestos de trabajo individuales sobre carritos colgantes a lo largo de la línea de montaje mecanizada. L os principales peligros para la salud y la seguridad se refieren al movimiento de materiales y al colgado (horquillas elevadoras, elevación manual), a las implicaciones ergonómicas del proceso de montaje (recorrido del movimiento, fuerza de inserción necesaria para "poner" componentes, instalación de tornillos y conectores) y el embalaje final, embalaje termoplástico y expedición finales. U n proceso típico de montaje de ordenadores comprende:

- preparación de chasis/ caja;

- inserción de PCB (tarjeta madre e hija);

- inserción de componentes principales (unidad de disco flexible, de disco duro, fuente de alimentación, unidad de CD-ROM ):

- montaje de indicadores (sólo portátiles);

- inserción de ratón y teclado (sólo portátiles);

- cableado, conectores y altavoces;

- montaje de cubierta superior;

- carga del software;

- prueba;

- reproceso;

- carga de batería (sólo portátiles) y embalado;

- embalaje termoplástico.

Las únicas sustancias químicas que pueden utilizarse en el proceso de montaje son las de limpieza final de la caja del ordenador o monitor. Se suele emplear una solución diluida de alcohol isopropílico y agua o una mezcla de limpiadores comerciales (p. ej., Simple G reen- una solución diluida de butil cellosolve y agua).

\section{EFECTOS SOBRE LA SALUD Y PAUTAS PAT OLOGICAS}

\section{Donald V. Lassiter}

Al ser un sector emergente, la fabricación de semiconductores se ha considerado a menudo como el epítome del lugar de trabajo de alta tecnología. D ebido a los estrictos requisitos de fabricación asociados a la producción de múltiples capas de circuitos electrónicos con dimensiones del orden de micras sobre obleas de silicio, el ambiente de sala limpia se ha convertido en sinónimo del lugar de trabajo de este sector. Como algunos de los gases de hidruros empleados en la fabricación de semiconductores (p. ej., arsina, fosfina) se reconocieron pronto como sustancias químicas muy tóxicas, la tecnología de control de la exposición a la inhalación ha sido siempre un componente importante de la fabricación de obleas. Los trabajadores en semiconductores se aíslan más aún del proceso de producción con ropa especial que cubre todo el cuerpo (p. ej., monos), gorros, guardas de zapatos y, muchas veces, mascarillas (o incluso dispositivos suministradores de aire). Desde el punto de vista práctico, las pretensiones de la empresa de obtener productos de gran pureza han derivado también en la protección de los trabajadores contra la exposición.

Además de la ropa de protección personal, en todo el sector de semiconductores se utilizan sistemas muy perfeccionados de ventilación y vigilancia de los posibles productos químicos/ gases del aire para detectar fugas de vapores disolventes tóxicos, ácidos y gases hidruros en partes por millón (ppm) o menos. 
Figura 83.9 - Distribución de las tasas de incidencia de lesiones y enfermedades profesionales por áreas mundiales, 1993 y 1994.

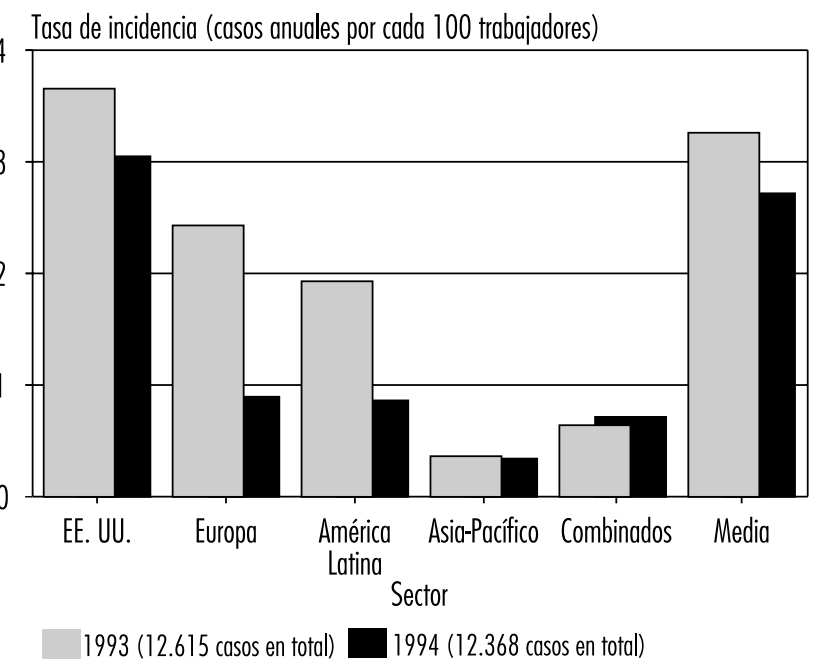

Fuente: Lassiter 1996

Aunque desde el punto de vista histórico el sector has experimentado frecuentes evacuaciones de trabajadores de las salas de fabricación de obleas a consecuencia de fugas reales o supuestas de gases o disolventes, esos episodios de evacuación se han vuelto raros porque las lecciones aprendidas se han aplicado al diseño de sistemas de ventilación, a la manipulación de gases/ sustancias químicas tóxicas y a sistemas cada vez más complejos de vigilancia del aire con muestreo continuo. Pero el valor monetario creciente de las obleas de silicio individuales (junto con unos diámetros en aumento), que pueden contener docenas de microprocesadores o dispositivos de memoria, puede originar un estrés mental a los trabajadores que han de manipular contenedores de estas obleas durante los procesos de fabricación. En un estudio sobre trabajadores de semiconductores se obtuvieron pruebas de tal estrés (H ammond y cols. 1995; $H$ ines y cols. 1995; M cC urdy y cols. 1995).

El sector de semiconductores tuvo su comienzo en Estados U nidos, que tiene mayor número de trabajadores en el sector de semiconductores (alrededor de 225.000 en 1994) que ningún otro país (BLS 1995). No obstante, resulta difícil obtener estimaciones válidas de empleo internacional en este sector porque los trabajadores de semiconductores se agrupan con los de "fabricación de equipo eléctrico/ electrónico" en las estadísticas de la mayoría de las naciones. A consecuencia de los controles técnicos extremadamente estrictos que se necesitan para fabricar dispositivos semiconductores, es más que probable que los puestos de trabajo de semiconductores (es decir, salas limpias) sean comparables, en casi todos los aspectos, en todo el mundo. Este conocimiento, junto con los requisitos oficiales de EE.UU. para recoger todas las lesiones y enfermedades significativas relacionadas con el trabajo, hace que la experiencia con éstas en los trabajadores de semiconductores de EE.UU. sea muy pertinente a escala nacional e internacional. Dicho con sencillez, en este momento hay pocas fuentes internacionales de información y datos interesantes en relación con la experiencia en seguridad e higiene de los trabajadores de semiconductores aparte de la encuesta anual de lesiones y enfermedades profesionales que realiza el Bureau of Labor Statistics (BLS) de Estados Unidos.
En Estados U nidos, que ha recopilado datos sobre lesiones y enfermedades profesionales en todos los sectores desde 1972, la frecuencia de las lesiones y enfermedades relacionadas con el trabajo entre los trabajadores de semiconductores ha sido de las más bajas de todos los sectores de fabricación. Pero se ha manifestado la preocupación de que pueda haber efectos más sutiles sobre la salud en los trabajadores de semiconductores (L aD ou 1986), aunque no se hayan documentado.

Se han celebrado varios simposios relativos a la evaluación de las tecnologías de control en el sector de semiconductores, y varias de las actas de los simposios tratan de asuntos medioambientales y de problemas de seguridad e higiene de los trabajadores (ACGIH 1989, 1993).

A lgunos datos sobre lesiones y enfermedades profesionales en la comunidad internacional de fabricación de semiconductores se han deducido de una encuesta especial realizada en 1995, que comprendía casos comunicados en los años 1993 y 1994. Los datos de esta encuesta se resumen a continuación.

\section{Lesiones y enfermedades profesionales en trabajadores de semiconductores}

En relación con los datos estadísticos internacionales sobre lesiones y enfermedades profesionales entre trabajadores de semiconductores, los únicos datos comparables parecen ser los deducidos de una encuesta de las operaciones de fabricación multinacional de semiconductores realizada en 1995 (Lassiter 1996). L os datos recogidos en esta encuesta se referían a las operaciones internacionales de fabricantes norteamericanos de semiconductores en los años 1993-94. Algunos de los datos de la encuesta incluían operaciones distintas de la fabricación de semiconductores (p. ej., fabricación de ordenadores y unidades de disco), aunque todas las empresas participantes pertenecían al sector de la electrónica. Los resultados de esta encuesta se presentan en las Figuras 83.9 y 83.10, que incluyen datos de la región Asia-Pacífico, Europa, América Latina y Estados U nidos. $C$ ada. caso se refería a una lesión o enfermedad relacionada con el trabajo que exigió tratamiento médico o pérdida o restricción del trabajo. Todas las tasas de incidencia de las figuras se han

Figura 83.10 - Distribución de las tasas de incidencia de lesiones y enfermedades profesionales con días de ausencia del trabajo por áreas mundiales, 1993 y 1994.

Tasa de incidencia (casos anuales por cada 100 trabajadores equivalentes a tiempo completo)

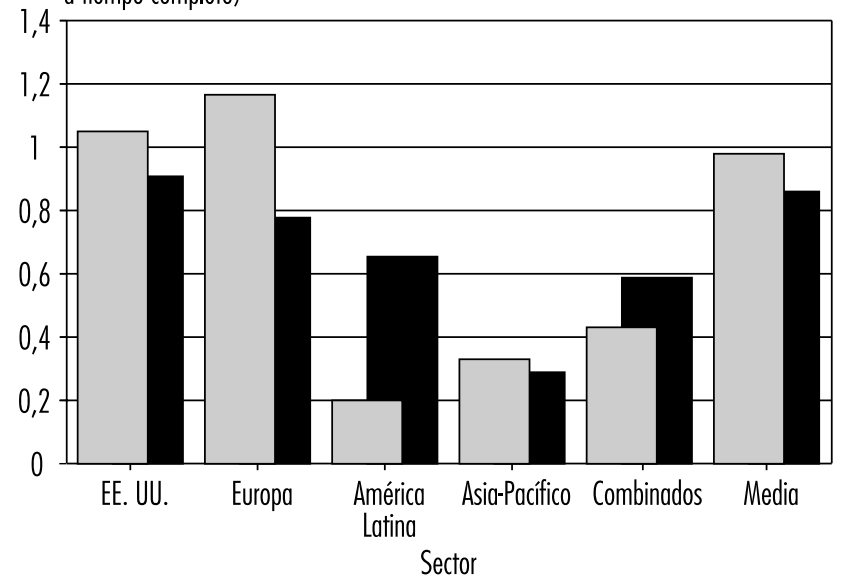

1993 (3.759 casos en total) 1994 (3.910 casos en total)

Fuente: Lassiter 1996 
Figura 83.11 - Incidencia comparada de los casos de días de trabajo perdidos ${ }^{1}$ por tipo de suceso o de exposición, 1993.

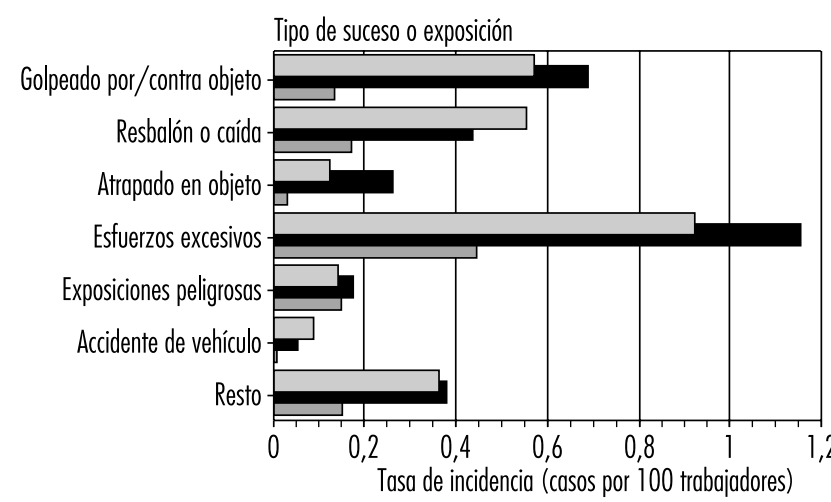

\footnotetext{
Sector privado (tasa)

Toda la fabricación (tasa)

'Casos con días de ausencia del trabajo
}

Fuente: BLS 1993

calculado en número de casos (o días de trabajo perdidos) por 200.000 trabajadores-hora al año. Si no se disponía del total de trabajadores-hora, se utilizaban estimaciones medias anuales de empleo. El denominador de 200.000 trabajadores-hora es igual a 100 trabajadores equivalentes a tiempo completo al año (en el supuesto de 2.000 horas de trabajo por trabajador y año).

La Figura 83.9 refleja las tasas de incidencia de las lesiones y enfermedades profesionales en las distintas regiones del mundo en la encuesta de 1993-94. Las tasas de los países concretos no han sido representadas para garantizar la confidencialidad de las empresas participantes que fueron la única fuentes de datos en determinados países. Así pues, en algunos de los países de la encuesta los datos procedían de una sola instalación. En varios casos, las empresas combinaron todos los datos internacionales en una única estadística. Estos últimos datos aparecen en las Figuras 83.9 y 83.10 como "Combinados".

$\mathrm{La}$ incidencia anual de lesiones y enfermedades profesionales en todos los trabajadores de la encuesta internacional fue de 3,3 casos por cada 100 trabajadores ( 200.000 trabajadores-hora) en 1993 y 2,7 en 1994. Se comunicaron 12.615 casos en 1993 y 12.368 en 1994. La gran mayoría de los casos (12.130 en 1993) se tomaron de empresas de EE.UU. Estos casos se referían a unos 387.000 trabajadores en 1993 y a 458.000 en 1994.

La Figura 83.10 presenta las tasas de incidencia de los casos con días de trabajo perdidos que implicaron días de ausencia del trabajo. Las tasas de incidencia en 1993 y 1994 se basaron en alrededor de 4.000 casos con días de trabajo perdidos en cada uno de los 2 años de la encuesta internacional. EI rango internacional/ regional en tasas de incidencia de esta estadística fue el más estrecho de los medidos. La incidencia de casos con días de trabajo perdidos puede representar la estadística internacional más comparable en relación con la experiencia sobre seguridad e higiene de los trabajadores. La tasa de incidencia de los días de trabajo perdidos (días de ausencia del trabajo) estuvo en torno a 15,4 días de ausencia del trabajo por 100 trabajadores en cada uno de los 2 años.

Los únicos datos detallados conocidos que existen relativos a las características de los casos de lesiones y enfermedades de los trabajadores de semiconductores son los recopilados cada año en EE.UU. por el BLS, que recoge los casos con días de trabajo perdidos. L os casos que aquí se exponen fueron identificados por
Figura 83.12 - Incidencia comparada de los casos de días de trabajo perdidos ${ }^{1}$ por causas de lesión o enfermedad, 1993.

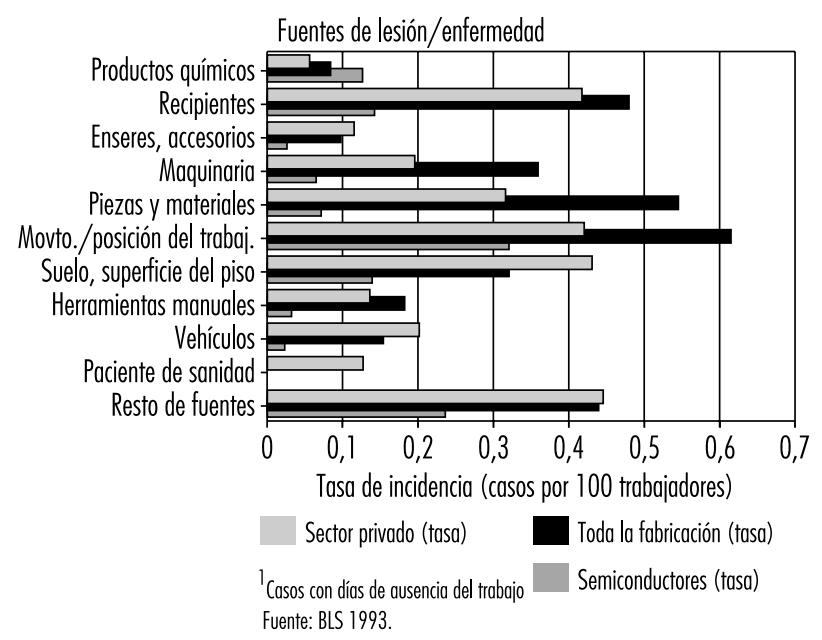

el BLS en su encuesta anual del año 1993. Los datos obtenidos de estos casos aparecen en las Figuras 83.11 a 83.14. Cada Figura compara la experiencia de casos con días de trabajo perdidos en el sector privado, en toda la fabricación y en la fabricación de semiconductores.

En la Figura 83.11 se compara la experiencia de casos con días de trabajo perdidos por los trabajadores de semiconductores norteamericanos durante 1993 en el sector privado y en toda la fabricación en relación con el tipo de caso o exposición. Las tasas de incidencia de casi todas las categorías de esta figura fueron mucho menores en los trabajadores del sector de semiconductores que en los del sector privado o todo el sector de fabricación. Los casos de esfuerzo excesivo en trabajadores de semiconductores fueron inferiores a la mitad de la tasa para

Figura 83.13 - Incidencia comparada de los casos de días de trabajo perdidos ${ }^{1}$ por la naturaleza de la lesión o enfermedad, 1993

Naturaleza de la lesión/enfermedad

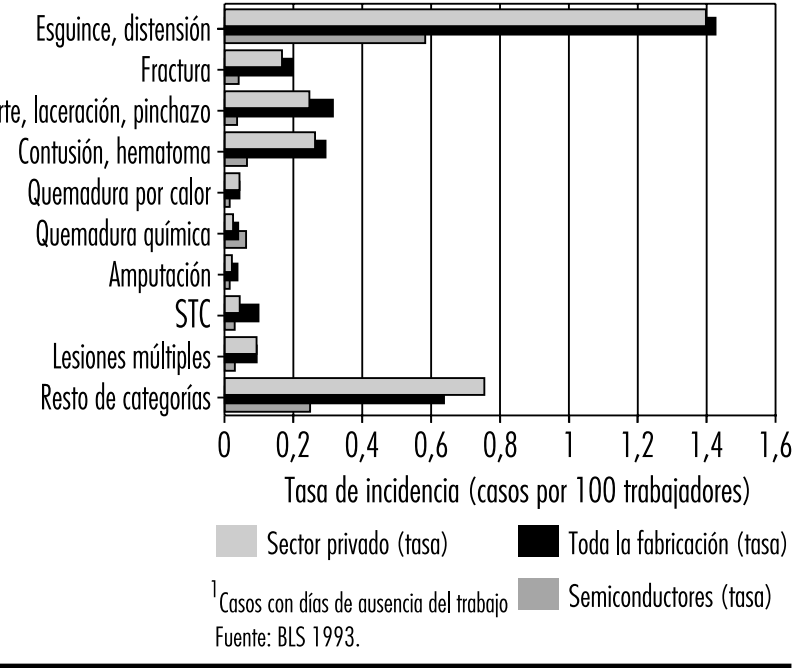


Figura 83.14 - Incidencia comparada de los casos de días de trabajo perdidos ${ }^{1}$ según la parte del cuerpo afectada, 1993.

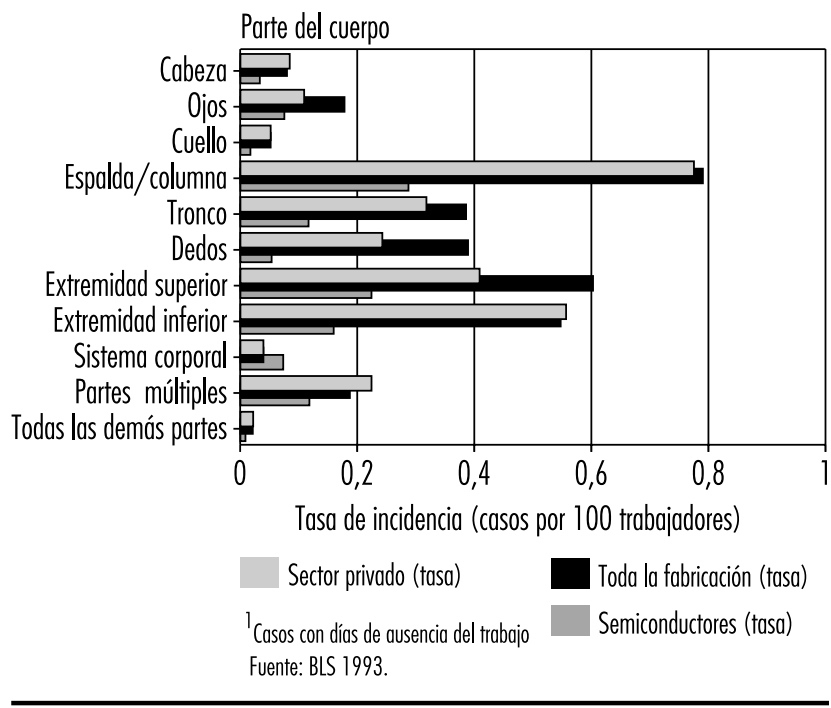

todos los trabajadores del sector de fabricación. La categoría de exposiciones peligrosas (asociada sobre todo a las exposiciones a sustancias químicas) fue equivalente en los tres grupos.

Las distribuciones comparativas de casos con días de trabajo perdidos en función de la fuente de lesión o enfermedad se presentan en la Figura 83.12. L as tasas de incidencia de los casos con días de trabajo perdidos en los trabajadores de semiconductores fueron inferiores a los del sector privado y de todo el sector de fabricación en todas las categorías de fuentes, excepto en los casos asociados a las exposiciones a sustancias químicas.

En la Figura 83.13 se comparan las tasas de incidencia de los casos con días de trabajo perdidos asociados a la naturaleza de la lesión o enfermedad entre los tres grupos. Las tasas en trabajadores de semiconductores fueron inferiores a la mitad de las tasas del sector privado y de todo el sector de fabricación en 1993. La incidencia de quemaduras químicas fue algo superior en los trabajadores de semiconductores, pero fue muy baja en los tres grupos de la comparación. La incidencia del síndrome de túnel carpiano (ST C) en los trabajadores norteamericanos de semiconductores fue inferior a la mitad de la tasa de todo el sector de fabricación.

En la Figura 83.14 se ilustran la distribución y la incidencia de los casos con días de ausencia del trabajo en relación con la parte del cuerpo afectada. Aunque la incidencia de casos que afectaron a sistemas corporales fue baja en todos los grupos de la comparación, la tasa en trabajadores de semiconductores fue algo elevada. En todas las demás partes del cuerpo afectadas, fue mucho más baja la tasa en trabajadores de semiconductores que en los otros dos grupos de la comparación.

\section{Estudios epidemiológicos sobre trabajadores de semiconductores}

La preocupación por las posibles consecuencias para la salud reproductora asociadas al trabajo en empresas de semiconductores surgió en 1983, cuando una trabajadora de la instalación de semiconductores que Digital Equipment Corporation posee en Hudson, M assachusetts, indicó que le parecía haber observado un exceso de abortos entre las trabajadoras de las salas limpias de la instalación. Este alegación, junto con la ausencia de datos internos en la instalación, condujo a un estudio epidemiológico realizado por la School of Public Health de la Universidad de $M$ assachusetts (U mass) en Amherst. El estudio se inició en mayo de 1984 y terminó en 1985 (Pastides y cols. 1988).

Se observó un riesgo elevado de aborto en las zonas fotolitográfica y de difusión en comparación con las trabajadoras no expuestas de otras zonas de la instalación. Se consideró que el riesgo relativo de 1,75 no era estadísticamente significativo ( $p<0,05)$, aunque el riesgo relativo de 2,18 observado en las trabajadoras de las zonas de difusión sí era significativo. La publicación del estudio de la UM ass condujo a que todo el sector de semiconductores solicitara la realización de un estudio más extenso que validase los hallazgos observados y determinase su extensión y las causas posibles.

La Semiconductor Industry Association (SIA) de Estados Unidos patrocinó un estudio más amplio que fue realizado por la Universidad de California en Davis (UC Davis) a partir de 1989. El estudio de la U C D avis fue proyectado para probar la hipótesis de que la fabricación de semiconductores iba asociada al aumento del riesgo de aborto en las trabajadoras de fabricación de obleas. La población del estudio se seleccionó entre 14 empresas que representaban 42 centros de producción de 17 estados. El mayor número de centros (que representaban a casi la mitad de las trabajadoras del estudio) estaba en California.

El estudio de la UC Davis constaba de tres componentes diferentes: un componente transversal (M cCurdy y cols. 1995; Pocekay y cols. 1995); un componente de cohorte histórica (Schenker y cols. 1995), y un componente prospectivo (Eskenazi y cols. 1995). En cada uno de estos estudios era capital la evaluación de la exposición (Hines y cols. 1995; Hammond y cols. 1995). El componente de evaluación de la exposición asignaba trabajadoras a un grupo de exposición relativa (es decir, alta exposición, baja exposición, etc.).

En el componente histórico del estudio, se determinó que el riesgo relativo de las trabajadoras de fabricación, en comparación con las de no fabricación, era de 1,45 (es decir, un $45 \%$ más de riesgo de aborto). El grupo de máximo riesgo identificado en el componente histórico del estudio fue el de las mujeres que trabajaban en operaciones de fotolitografía o grabado. Las mujeres que realizaban operaciones de grabado experimentaban un riesgo relativo de $2,15(\mathrm{R} R=2,15)$. Además, se observó una relación dosis-respuesta en las mujeres que trabajaban con cualquier fotoprotector o revelador en relación con el aumento del riesgo de aborto. Estos datos apoyaban la existencia de una asociación dosis-respuesta para éteres de etilenglicol (EG E), pero no para éteres propilenglicol (PGE).

Aunque en el componente prospectivo del estudio de la UC D avis se observó un aumento del riesgo de aborto en las trabajadoras de fabricación de obleas, los resultados carecían de significación estadística ( $p$ inferior a 0,05 ). Un pequeño número de embarazos redujo de modo significativo la potencia del componente prospectivo del estudio. El análisis por exposición a agentes químicos indicaba el aumento del riesgo para las mujeres que trabajaban con monoetil éter etilenglicol, pero sólo se basaba en 3 embarazos. Un hallazgo importante fue el respaldo general, sin ninguna contradicción, de los resultados del componente histórico.

El componente transversal del estudio indicó un aumento de los síntomas respiratorios superiores sobre todo en los grupos de trabajadoras de hornos de difusión y película delgada. Un hallazgo interesante fue el de los evidentes efectos protectores de diversos controles técnicos relacionados con la ergonomía ( $p$. ej., reposapiés y el uso de un asiento regulable para reducir lesiones de espalda).

En las mediciones del aire efectuadas en las fábricas de obleas se halló que la mayoría de las exposiciones a disolventes fueron 
inferiores al $1 \%$ de los límites de exposición permisibles (PEL) establecidos por la administración de EE. UU.

Un estudio epidemiológico independiente (Correa y cols. 1996) fue efectuado por la U niversidad de John Hopkins (JHU ) sobre un grupo de trabajadoras de semiconductores de IBM Corporation en 1989. La tasa global de abortos espontáneos observada en el estudio de JHU que incluía trabajadoras de sala limpia fue del $16,6 \%$. El riesgo relativo de aborto espontáneo en trabajadoras de sala limpia con la máxima exposición potencial a éteres de etilenglicol fue de 2,8 IC (95\% = 1,4-5,6).

\section{Comentario de los estudios epidemiológicos sobre la reproducción en trabajadoras de semiconductores}

Es notable la coincidencia de los estudios epidemiológicos en el alcance y semejanza de sus resultados. Todos ellos han producido hallazgos similares. Cada estudio documentó un exceso de riesgo de aborto espontáneo en las trabajadoras de fabricación de obleas de semiconductores. D os de los estudios (JHU y U C Davis) pueden indicar una asociación causal con las exposiciones a éteres de glicol basados en etileno. El estudio de la UMass encontró que el grupo de fotolitografía (expuesto a éter de glicol) tenía menos riesgo que el grupo de difusión, que carecía de exposición documentada a éter de glicol. Si bien estos estudios señalan un aumento del riesgo de abortos espontáneos en las trabajadoras de fabricación de obleas, la causa de ese exceso de riesgo no está clara. El estudio de la JHU no documentó un papel significativo de los éteres de glicol, y el estudio de la U C D avis sólo indicó una relación marginal de los éteres de glicol (mediante el modelado de exposiciones y prácticas de trabajo comunicadas) con los efectos en la reproducción. En ambos estudios se realizó un seguimiento escaso o nulo para determinar las exposiciones a éteres de glicol. D espués de concluidos estos estudios, el sector de semiconductores comenzó a cambiar de los éteres de glicol de la serie del etileno a sustitutivos como éteres de glicol de las series de lactato de etilo y propileno.

\section{Conclusión}

Según los mejores datos disponibles en relación con la incidencia anual de lesiones y enfermedades profesionales, los trabajadores de semiconductores están sujetos a menos riesgo que los de otros sectores de fabricación o de todo el sector privado (incluidos muchos sectores de no fabricación). En el ámbito internacional, parece que los datos estadísticos de lesiones y enfermedades profesionales asociados a casos con días de trabajo perdidos pueden ser un indicador bastante fiable de la experiencia mundial en materia de seguridad e higiene de los trabajadores de semiconductores. El sector ha patrocinado varios estudios epidemiológicos independientes en su intento de hallar respuestas a preguntas sobre consecuencias en la salud reproductora relacionadas con el empleo en el sector. Aunque no se ha establecido una asociación definitiva entre los abortos espontáneos observados y las exposiciones a éteres de glicol a base de etileno, el sector ha comenzado a utilizar disolventes de fotoprotectores alternativos.

\section{- CUESTIONES AMBIENTALES Y DE SALUD PUBLICA}

Corky Chew

\section{Visión general del sector}

El sector de la electrónica, comparado con otros, se ha considerado "limpio" en cuanto a sus efectos sobre el medio ambiente. No obstante, las sustancias químicas utilizadas en la fabricación de partes y componentes electrónicos, y los residuos generados, crean problemas medioambientales importantes que han de ser abordados a escala global por el tamaño del sector de la electrónica. Los residuos y subproductos derivados de la fabricación de tarjetas de cableado impreso (PWB), tarjetas de circuito impreso (PCB) y semiconductores son campos de interés en los que el sector de electrónica ha actuado con firmeza en los aspectos de prevención de la contaminación, tecnología de depuración y técnicas de reciclado/ recuperación.

En la actualidad, el incentivo de controlar la huella medioambiental de los procesos electrónicos se ha trasladado en gran medida del acento medioambiental al ámbito económico. A causa de los costes y responsabilidades asociados a residuos y emisiones peligrosas, el sector de la electrónica ha implantado y desarrollado estrictos controles ambientales que han reducido en gran medida los efectos de sus subproductos y residuos. A demás, la sector de la electrónica ha tomado la iniciativa de incorporar objetivos, herramientas y técnicas medioambientales en la conciencia de sus empresas. Ejemplos de este enfoque favorecedor son la prohibición de los CFC y de los compuestos perfluorados y el desarrollo de alternativas "respetuosas del medio ambiente", así como el reciente interés por el "diseño para el medio ambiente" en el desarrollo de productos.

La fabricación de las PWB, PCB y semiconductores exige utilizar gran variedad de sustancias químicas, de técnicas y equipo de fabricación especiales. La peligrosidad asociada a estos procesos de fabricación obliga a la gestión adecuada de los subproductos químicos, residuos y emisiones para garantizar la seguridad de los trabajadores del sector y la protección del medio ambiente en las comunidades donde radiquen las industrias.

Las Tablas $83.10,83.11$ y 83.12 presentan un esbozo de los subproductos y residuos claves que se generan en la fabricación de las PWB, PCB y semiconductores. Además, las tablas presentan los principales tipos de efectos medioambientales y los medios aceptados en general para la mitigación y control de la corriente de residuos. Los residuos que se generan afectan sobre todo a las aguas residuales industriales o al aire, o se convierten en residuos sólidos.

Los siguientes son los medios aceptados en general para mitigar las emisiones en el sector de PWB, PCB y semiconductores. L as opciones de control variarán en función de las posibilidades técnicas, de las disposiciones oficiales y de los componentes/ concentraciones específicas de la corriente de residuos.

\section{Control de las aguas residuales}

\section{Precipitación química}

La precipitación química es el método generalmente utilizado en la eliminación de partículas o metales solubles de los efluentes de aguas residuales. Como los metales no experimentan degradación natural y son tóxicos a concentraciones bajas, es esencial eliminarlos de las aguas residuales industriales. Los metales sólo pueden eliminarse de las aguas residuales por medios químicos, puesto que no son muy solubles en agua; sus solubilidades dependen del $\mathrm{pH}$, de la concentración del metal, del tipo de metal y de la presencia de otros iones. L o normal es que las aguas residuales exijan ajustar el $\mathrm{pH}$ al valor adecuado para lograr la precipitación del metal. Es necesario añadir sustancias químicas a las aguas residuales si se quiere alterar el estado físico de los sólidos disueltos y en suspensión. Los agentes de precipitación más empleados son la cal, la sosa cáustica y los sulfuros. Los agentes de precipitación facilitan la eliminación de metales disueltos y en suspensión por coagulación, sedimentación u oclusión en un precipitado. 
Tabla 83.10 • PW B, generación y controles de residuos.

\begin{tabular}{|c|c|c|c|}
\hline Etapas del proceso & Residuos/materiales peligrosos & Efectos ambientales & Controles $^{1}$ \\
\hline Preparación del material & Ninguna & Ninguna & Ninguno \\
\hline \multirow{2}{*}{ Apilar y sujetar } & Metales pesados/ preciosos & Residuos sólidos ${ }^{2}$ & Reciclar/ recuperar \\
\hline & Resina epoxil/ fibra de vidrio & Residuos sólidos² & Reciclar/ recuperar \\
\hline \multirow[t]{2}{*}{ Taladrar } & Metales pesados/ preciosos & Residuos sólidos² & Reciclar/ recuperar \\
\hline & Resina epoxi/ fibra de vidrio & Residuos sólidos² & Reciclar/ recuperar \\
\hline \multirow[t]{2}{*}{ Desbarbar } & Metales pesados/ preciosos & Residuos sólidos² & Reciclar/ recuperar \\
\hline & Resina epoxi/ fibra de vidrio & Residuos sólidos² & Reciclar/ recuperar \\
\hline \multirow[t]{3}{*}{ Recubrimiento electrolítico con cobre } & Metales & Aguas residuales & Precipitación química \\
\hline & Corrosivos/ cáusticos & Aguas residuales/ aire & Neutralización del pH/ depuración del aire (absorción) \\
\hline & Fluoruros & Aguas residuales & Neutralización química \\
\hline \multirow[t]{3}{*}{ Formar imagen } & Disolventes & Aire & Adsorción, condensación o incineración \\
\hline & Corrosivos & Aire & Depuración del aire (absorción) \\
\hline & Disolventes & Residuos sólidos² & Reciclar/ recuperar/ incinerar \\
\hline \multirow[t]{3}{*}{ Recubrimiento del patrón } & Corrosivos & Aguas residuales/ aire & Neutralización del pH/ depuración del aire (absorción) \\
\hline & Metales & Aguas residuales & Precipitación química \\
\hline & Fluoruros & Aguas residuales & Precipitación química \\
\hline \multirow[t]{3}{*}{ Arranque, grabado, arranque } & Amoníaco & Aire & Depuración del aire (adsorción) \\
\hline & Metales & Aguas residuales & Precipitación química \\
\hline & Disolventes & Residuos sólidos² & Reciclar/ recuperar/ incineración \\
\hline \multirow[t]{3}{*}{ Máscara de soldadura } & Corrosivos & Aire & Depuración del aire (adsorción) \\
\hline & Disolventes & Aire & Adsorción, condensación o incineración \\
\hline & Disolventes/ tintas epoxi & Residuos sólidos² & Reciclar/ recuperar/ incineración \\
\hline \multirow[t]{3}{*}{ Recubrimiento por soldadura } & Disolventes & Aire & Adsorción, condensación o incineración \\
\hline & Corrosivos & Aire & Depuración del aire (adsorción) \\
\hline & Soldadura de plomo/ estaño, fundente & Residuos sólidos² & Reciclar/ recuperar \\
\hline \multirow[t]{4}{*}{ Dorado } & Corrosivos & Aire & Depuración del aire (adsorción) \\
\hline & Corrosivos & Aguas residuales & Neutralización del pH \\
\hline & Metales & Aguas residuales & Precipitación química \\
\hline & Metales & Residuos sólidos² & Reciclar/ recuperar \\
\hline \multirow[t]{2}{*}{ Rotulación de componentes } & Disolventes & Aire & Adsorción condensación o incineración \\
\hline & Disolventes/ tintas & Residuos sólidos² & Reciclar/ recuperar/ incinerar \\
\hline
\end{tabular}

1. El empleo de inspecciones de mitigación depende de los límites de descarga en el emplazamiento específico.

2. Un residuo sólido es cualquier material desechado, con independencia de su estado.

Un resultado de la precipitación química de aguas residuales es la acumulación de lodos. Por lo tanto, se han desarrollado procesos de desecación para disminuir el peso de los lodos mediante centrifugadoras, prensas con filtro, filtros o lechos de secado. Los lodos desecados resultantes pueden destinarse después a la incineración o al vertedero.

\section{Neutralización del pH}

El pH (la concentración de iones hidrógeno o acidez) es un parámetro importante para conocer la calidad de las aguas residuales industriales. Los efectos adversos de $\mathrm{pH}$ extremos en las aguas naturales y en las operaciones de tratamiento de aguas residuales hacen necesario ajustar el $\mathrm{pH}$ de las aguas residuales industriales antes de descargarlas de la instalación de fabricación. El tratamiento tiene lugar en una serie de depósitos vigilados en relación con la concentración de iones hidrógeno en el efluente de aguas residuales. Suele utilizarse ácido clorhídrico o sulfúrico como neutralizante corrosivo, mientras que se emplea hidróxido de sodio como neutralizante cáustico. El agente neutralizante se introduce dosificado en el efluente de aguas residuales para ajustar el pH de la descarga a su valor deseado.

A menudo es preciso ajustar el $\mathrm{pH}$ antes de aplicar otros procesos de tratamiento de aguas residuales. Tales procesos son la precipitación química, la oxidación/ reducción, la adsorción en carbón activado, la disolución y el intercambio de iones.

\section{Control de los residuos sólidos}

Los materiales se consideran residuos sólidos si se abandonan o desechan por eliminación; son quemados o incinerados, o acumulados, almacenados o tratados antes 0 en lugar de ser abandonados (US Code of Federal Regulation 40, Sección 261.2). Los residuos peligrosos presentan en general una o más de las características siguientes: inflamabilidad, poder de corrosión, reactividad, toxicidad. En función de las características del material/ residuo peligroso, son distintos los medios empleados para controlar la sustancia. La incineración es un tratamiento corriente para los residuos de disolventes y metales generados durante la fabricación de PW B, PCB y semiconductores.

\section{Incineración}

La incineración o destrucción térmica se ha convertido en una opción popular de gestionar los residuos inflamables y tóxicos. En muchas circunstancias, los residuos inflamables (disolventes) se emplean como fuente de combustible (mezcla de combustibles) en incineradores térmicos y catalíticos. La incineración adecuada de residuos disolventes y tóxicos proporciona una oxidación 
Tabla 83.11 • PCB, generación y controles de residuos.

\begin{tabular}{|c|c|c|c|}
\hline Pasos del proceso & Residuos/materiales peligrosos & Efectos ambientales & Controles \\
\hline Limpieza & Metales (plomo) & Aguas residuales & $\begin{array}{l}\text { Neutralización del pH, precipitación química, } \\
\text { reciclar plomo }\end{array}$ \\
\hline Pasta de soldar & Pasta de soldar ( plomo/ estaño) & Residuos sólidos & Reciclar/ recuperar \\
\hline Aplicación de adhesivo & Pegamentos epoxi & Residuos sólidos & Incineración \\
\hline Inserción de componentes & & & $\begin{array}{l}\text { Las cintas, carretes y tubos de plástico se } \\
\text { reciclan/ reutilizan }\end{array}$ \\
\hline \multicolumn{4}{|l|}{$\begin{array}{l}\text { Endurecimiento de adhesivo y reflujo de } \\
\text { soldadura }\end{array}$} \\
\hline Fundente & Disolvente (fundente IPA) & Residuos sólidos & Reciclar \\
\hline Soldadura con ola & Metal (escorias de soldadura) & Residuos sólidos & Reciclar/ recuperar \\
\hline Inspección y retoque & Metal (recortes de alambre de plomo) & Residuos sólidos & Reciclar/ recuperar \\
\hline Pruebas & Placas equipadas desechadas & Residuos sólidos & $\begin{array}{l}\text { Reciclar/ recuperar (placas fundidas para } \\
\text { recuperar metales preciosos) }\end{array}$ \\
\hline Reprocesos y reparación & Metal (escorias de soldadura) & Residuos sólidos & Reciclar/ recuperar \\
\hline $\begin{array}{l}\text { Operaciones de apoyo - limpieza de } \\
\text { matrices }\end{array}$ & Metal (plomo/ estaño/ pasta de soldar) & Residuos sólidos & Reciclar/ incinerar \\
\hline
\end{tabular}

completa del combustible y convierte el material combustible en dióxido de carbono, agua y cenizas, por lo que no deja tras sí ninguna responsabilidad relativa a residuos peligrosos residuales. Los medios corrientes de incineración son los incineradores térmicos y catalíticos. La selección del método de incineración depende de la temperatura de combustión, de las características del combustible y del tiempo de permanencia. Los incineradores térmicos trabajan a altas temperaturas y se usan en general con compuestos halogenados. Entre los tipos de incineradores térmicos se encuentran los de horno giratorio, de inyección líquida, los de hogar fijo, los de lecho fluidificado y otros incineradores de diseño moderno.

Los incineradores catalíticos oxidan los materiales combustibles (p. ej., los COV) por inyección de una corriente de gas caliente a través de un lecho de catalizador. La forma del lecho catalizador hace máxima su área superficial de manera que, al inyectar una corriente de gas caliente a través del lecho del catalizador, la combustión puede efectuarse a una temperatura menor que en la incineración térmica.

\section{Emisiones atmosféricas}

La incineración se utiliza también para controlar las emisiones a la atmósfera. Se emplean asimismo los métodos de absorción y adsorción.

\section{Absorción}

L a absorción consiste en el lavado de las emisiones corrosivas a la atmósfera mediante el paso del contaminante a través de un líquido no volátil que lo disuelve (p. ej., agua). El efluente del proceso de absorción suele descargarse en un sistema de tratamiento de aguas residuales, donde se somete al ajuste del pH .

Tabla 83.12 • Generación y controles de residuos en la fabricación de semiconductores.

\begin{tabular}{|c|c|c|c|}
\hline Pasos del proceso & Residuos/ materiales peligrosos & Efectos ambientales & Controles \\
\hline \multirow[t]{6}{*}{ Litografía/ grabado } & Disolventes & Residuos sólidos & Reciclar/ recuperar/ incinerar \\
\hline & Metales & Aguas residuales & Precipitación química \\
\hline & Corrosivos/ cáusticos & Aguas residuales & Neutralización del pH \\
\hline & Corrosivos & Aire & Depuración del aire (absorción) \\
\hline & Ácido sulfúrico & Residuos sólidos & Reciclar/ reprocess \\
\hline & Fluoruros & Aguas residuales & Precipitación química \\
\hline \multirow[t]{2}{*}{ Oxidación } & Disolventes & Residuos sólidos & Reciclar/ recuperar/ incinerar \\
\hline & Corrosivos & Aguas residuales & Neutralización del pH \\
\hline \multirow[t]{2}{*}{ Dopado } & $\begin{array}{l}\text { Gas tóxico (arsina, fosfina, diborano, trifluoruro } \\
\text { de boro, tricloruro de boro, etc.) }\end{array}$ & Aire & $\begin{array}{l}\text { Sustitución por fuentes líquidas/ incineración } \\
\text { (posquemador) }\end{array}$ \\
\hline & Metales (arsénico, fósforo, boro) & Residuos sólidos & Reciclar/ recuperar \\
\hline \multirow[t]{2}{*}{ Deposición química de vapores } & Metales & Residuos sólidos & Incineración \\
\hline & Corrosivos & Aguas residuales & Neutralización del pH \\
\hline \multirow[t]{2}{*}{ Metalización } & Disolventes & Residuos sólidos & Incineración \\
\hline & Metales & Residuos sólidos & Reciclar/ recuperar \\
\hline \multirow[t]{2}{*}{ Montaje y pruebas } & Disolventes & Residuos sólidos & Reciclar/ recuperar/ incineración \\
\hline & Metales & Residuos sólidos & Reciclar/ recuperar \\
\hline \multirow[t]{2}{*}{ Limpieza } & Corrosivos & Aguas residuales & Neutralización del pH \\
\hline & Fluoruros & Aguas residuales & Precipitación química \\
\hline
\end{tabular}


Tabla 83.13 • Matriz de necesidades prioritarias.

Necesidad prioritaria (orden decreciente de
prioridad)
Uso más eficiente, regeneración y reciclado de
sustancias químicas húmedas peligrosas
Reducir residuos sólidos generados por PWB,
conductores y componentes desechados en la
corriente de residuos.
corriente de residuos.

Establecer mejores relaciones con proveedores para reforzar el desarrollo y aceptación de materiales no contaminantes del medio ambiente.

Reducir el efecto de utilizar materiales peligrosos en fabricación de PWB. Usar procesos aditivos que sean competitivos con
los existentes.

Eliminar manchas de agujeros en fabricación de PWB.

Reducir el consumo y vertido de agua.
Enfoque

Extender la vida de baños de plaqueado electrolítico y químico.

Desarrollar sustancias y procesos químicos de reciclado 0 regeneración local.

Eliminar formaldehídos de materiales y sustancias químicas.

Promover reciclado y recuperación/ regeneración en la instalación.

Desarrollar y promover el reciclado de PWB, conductores y componentes desechados.

Desarrollar nuevas herramientas de control y rendimiento de procesos.

Mejorar la soldabilidad de las PWB

Promover asociación entre proveedor, fabricante y cliente para implantar el empleo de materiales no contaminantes.

Reducir el uso de soldadura de plomo cuando sea posible y/ o reducir el contenido de plomo de la soldadura.

Desarrollar alternativas al plaqueado por soldadura, como protección de grabado.

Desarrollar tecnologías de materiales y procesos aditivos simplificadas rentables.

Buscar fuentes y enfoques alternativos para las necesidades aditivas de equipo capital del proceso.

Desarrollar resinas o sistemas de taladrado sin manchas.

Desarrollar un sistema de optimización y reciclado en el uso de agua.

Reducir el número de operaciones de limpieza en la fabricación de PWB.

Eliminar la manipulación y preparación de piezas para reducir la repetición de limpieza.
Tareas seleccionadas

Investigar la extensión de baños.

Investigar purificación/ regeneración en línea.

Investigar sustancias químicas alternativas.

Modificar disposiciones oficiales para promover el reciclado.

Mejorar la línea de producción en problemas de entrada/ salida del baño.

Desarrollar infraestructura de manipulación de material reciclado.

Establecer mejores herramientas de control y evaluación de procesos utilizables por empresas pequeñas y medianas. Entregar placas siempre limpias y soldables.

Desarrollar un sistema de gestión de materiales peligrosos clave para empresas de PWB medianas y pequeñas.

Cambiar especificaciones para aceptar máscara de soldadura sobre cobre desnudo.

Validar la calidad de las alternativas de recubrimiento de plomo.

Colaborar en proyectos para establecer nuevas tecnologías y procesos aditivos de dieléctricos y metalización.

Investigar laminados y materiales preimpregnados alternativos.

Desarrollar el empleo de láser y otros sistemas alternativos de taladrar.

Modificar especificaciones para reducir las exigencias de limpieza.

Investigar métodos alternativos de manipulación de piezas. Cambiar o eliminar sustancias químicas que exijan limpieza.

Fuente: MCC 1994

\section{Adsorción}

Es la adherencia (por fenómenos físicos o químicos) de una molécula de gas a la superficie de otra sustancia, llamada adsorbente. La adsorción se utiliza en general para extraer disolventes de una fuente de emisión a la atmósfera. El carbón activado, la alúmina activada o el gel de sílice son adsorbentes muy utilizados.

\section{Reciclado}

Los materiales reciclables se utilizan, se reutilizan o se recuperan como ingredientes en un proceso industrial para hacer un producto. El reciclado de materiales y residuos es un medio no contaminante y económico de aprovechar con eficacia tipos específicos de corrientes de residuos, como metales y disolventes. Los materiales y residuos pueden reciclarse en la propia empresa, aunque también los mercados secundarios pueden aceptar materiales reciclables. $L$ a elección del reciclado como alternativa para deshacerse de los residuos tiene que evaluarse con criterios financieros, a la vista de la estructura normativa y de la tecnología disponible para reciclar los materiales.

\section{Orientación futura}

A medida que aumenta la exigencia de prevenir la contaminación y que el sector busca medios rentables para abordar el uso y los residuos de los productos químicos, el sector de la electrónica tiene que evaluar nuevas técnicas y tecnologías que le permitan mejorar los métodos de gestionar los materiales peligrosos y la generación de residuos. El enfoque de "final del proceso" tiene que ser sustituido por el diseño de técnicas medioambientales, en que estos temas se consideren en el contexto del ciclo vital completo de un producto, que incluya: conservación del material; operaciones de fabricación eficientes; empleo de los materiales menos perjudiciales para el medio ambiente; reciclado, regeneración y recuperación de productos residuales, y multitud de otras técnicas que garanticen una menor repercusión medioambiental del sector de fabricación electrónica. Un ejemplo es la gran cantidad de agua que se utiliza en los numerosos lavados y otras etapas del proceso en el sector de la microelectrónica. En zonas con escasez de agua, esta situación obliga al sector a buscar alternativas. Pero es esencial cerciorarse de que la alternativa ( $p$. ej., disolventes) no crea problemas medioambientales adicionales.

Como ejemplo de orientaciones futuras en el proceso PWB y PCB, la Tabla 83.13 presenta diversas alternativas para aplicar prácticas más favorables para el medio ambiente y preventivas de la contaminación. En la tabla se identifican las necesidades y enfoques prioritarios. 


\section{Referencias}

American National Standards Institute (ANSI). 1986 Safety Standard for Industrial R obots and Industrial Robot Systems. ANSI/RIA R15.06-1986. Nueva York: ANSI.

ASK M AR. 1990. Computer Industry: Critical T rends for the 1990's. Saratoga, California: Electronic T rend Publications.

Asom, MT, J M osovsky, RE Leibenguth, JL Zilko, $\mathrm{G}$ C adet. 1991. T ransient arsine generation during opening of solid source MBE chambers. J Cryst Growth 112(2-3):597-599.

Association of the Electronics, Telecommunications and Business Equipment Industries (EEA). 1991. Guidelines on the $U$ se of Colophony ( $R$ osin) Solder F luxes in the Electronics Industry. Londres: L eichester $\mathrm{H}$ ouse EEA.

Baldwin, DG, BW K ing, LP Scarpace. 1988. Ion implanters: Chemical and radiation safety. Solid State T echnology 31(1):99-105.

Baldwin, DG, JH Stewart. 1989. Chemical and radiation hazards in semiconductor manufacturing. Solid State T echnology 32(8):131-135.

Baldwin, DG, JR Rubin, M R Horowitz. 1993. Industrial hygiene exposures in semiconductor manufacturing. SSA J ournal 7(1):19-21.

Baldwin, DG, ME Williams. 1996. Industrial hygiene. En Semiconductor Safety $\mathrm{H}$ andbook, dirigido por JD Bolmen. Park Ridge, N ueva Jersey: N oyes.

Baldwin, DG. 1985. Chemical exposure from carbon tetrachloride plasma aluminum etchers. Extended Abstracts, E lectrochem Soc 85(2):449-450.

Bauer, S, I Wolff, N Werner, P H offman. 1992a. $\mathrm{H}$ ealth hazards in the semiconductor industry, a review. Pol J 0 ccup M ed 5(4):299-314.

Bauer, S, N Werner, I Wolff, B Damme, B Oemus, P H offman. 1992b. Toxicological investigations in the semiconductor industry: II. Studies on the subacute inhalation toxicity and genotoxicity of gaseous waste products from the aluminum plasma etching process. T oxicol Ind $\mathrm{H}$ ealth 8(6):431-444.

Bliss Industries. 1996. Solder D ross Particulate Capture System Literature. Fremont, C alifornia: Bliss Industries.

Bureau of Labor Statistics (BLS). 1993. Annual Survey of O ccupational Injuries and IIInesses. Washington, DC BLS, U S D epartment of Labor.

-. 1995. Employment and W ages Annual Averages, 1994 Bulletin. 2467. Washington, DC: BLS, US Department of Labor.

Clark, R H . 1985. H andbook of Printed Circuit M anufacturing. N uevaY ork: $V$ an $N$ ostrand R einhold C ompany.

Cohen, R. 1986. R adiofrequency and microwave radiation in microelectronics industry. En State of the Art R eviews- $O$ ccupational M edicine: The M icroelectronics Industry, dirigido por J LaD ou. Filadelfia, Pensilvania: $\mathrm{H}$ anley $\&$ Belfus, Inc.

Conferencia Americana de H igienistas I ndustriales del Gobierno (ACGIH). 1989. H azard Assessment and Control T echnology in Semiconductor M anufacturing. Chelsea, M ichigan: Lewis Publishers.

-. 1993. H azard Assessment and Control T echnology in Semiconductor M anufacturing II. Cincinnati, O hio: ACGIH

-. 1994. Documentation of Threshold Limit Value, R osin Core Solder Thermal Decomposition Products, as Resin Acids-Colophony. Cincinnati, O hio: AC GIH .

Content, RM . 1989. Control methods for metal and metalloids in III-V materials vapor-phase epitaxy. En $\mathrm{H}$ azard Assessment and Control T echnology in Semiconductor $\mathrm{M}$ anufacturing, dirigido por la Conferencia Americana de Higienistas Industriales del Gobierno. Chelsea, M ichigan: L ewis Publishers.

Coombs, CF. 1988. Printed Circuits H andbook, 3a ed N uevaY ork: M cG raw-H ill Book Company.
Correa A, RH Gray, R Cohen, N R othman, F Shah, H Seacat, M Corn. 1996. Ethylene glycol ethers and risks of spontaneous abortion and subfertility. Am J E pidemiol 143(7):707-717.

Crawford, WW, D Green, WR K nolle, HM Marcos, JA M osovsky, RC Petersen, PA Testagrossa, GH Zeman. 1993. M agnetic field exposure in semiconductor cleanrooms. En $\mathrm{H}$ azard Assessment and Control Technology in Semiconductor M anufacturing II. Cincinnati, O hio: ACGIH.

Escher, G, J Weathers, B Labonville. 1993. Safety de sign considerations in deep-UV excimer laser photolithography. En H azard Assessment and Control T echnology in Semiconductor M anufacturing II. Cincinnati, O hio: Conferencia Americana de Higienistas Industriales del Gobierno.

Eskenazi B, EB Gold, B Lasley, SJ Samuels, SK H ammond, S W right, M O R azor, CJ H ines, M B Schenker. 1995. Prospective monitoring of early fetal loss and clinical spontaneous abortion among female semiconductor workers. Am । Indust $M$ ed 28(6):833-846.

Flipp, N, H H unsaker, P H erring. 1992. Investigation of hydride emissions during the maintenance of ion implantation equipment. Presentado en la American Industrial H ygiene Conference de junio1992, Boston-Paper 379 (no publicado)

Goh, CL, SK N g. 1987. Airborne contact dermatitis to colophony in soldering flux. Contact $D$ ermatitis 17(2):89-93

$\mathrm{H}$ ammond SK, CJ H ines M F Hallock, SR Woskie, SAbdollahzadeh, CR Iden, E Anson, F Ramsey, M B Schenker. 1995. Tiered exposure assessment strategy in the Semiconductor Health Study. Am J Indust M ed 28(6):661-680.

Harrison, RJ. 1986. Gallium arsenide. En State of the Art R eviews- 0 ccupational $M$ edicine: The $M$ icroelectronics Industry, publicado por J LaD ou Filadelfia, Pensilvania: $\mathrm{H}$ anley \& Belfus, Inc.

Hathaway, GL, NH Proctor, JP Hughes, ML Fischman. 1991. Chemical H azards of the W orkplace, 3a ed. Nueva Y ork: V an N ostrand R einhold.

H ausen, BM, K K rohn, E Budianto. 1990. Contact allergy due to colophony (VII). Sensitizing studies with oxidation products of abietic acid and related acids. Contact D ermat 23(5):352-358.

H ealth and Safety Commission. 1992. Approved Code of Practice- Control of Respiratory Sensitizers. Londres: $H$ ealth and Safety Executive

Helb, GK, RE Caffrey, ET Eckroth, QT Jarrett, $C L$ Fraust, JA Fulton. 1983. Plasma processing: Some safety, health and engineering considerations. Solid State T echnology 24(8):185-194.

Hines, CJ, S Selvin, SJ Samuels, SK Hammond, SR W oskie, M F H allock, M B Schenker. 1995. Hierarchical cluster analysis for exposure assessment of workers in the Semiconductor H ealth Study. Am I Indust M ed 28(6):713-722.

H orowitz, M R. 1992. Nonionizing radiation issues in a semiconductor $\mathrm{R}$ and $\mathrm{D}$ facility. Presentado en la American Industrial $\mathrm{H}$ ygiene Conference de junio 1992, Boston-Paper 122 (no publicado).

Jones, JH. 1988. Exposure and control assessment of semiconductor manufacturing. AIP C onf. Proc. (Photovol taic Safety) 166:44-53.

LaD ou, J (dir.). 1986. State of the Art R eviews- O ccupational M edicine: The M icroelectronics Industry. Filadelfia, Pensilvania: $\mathrm{H}$ anley and Belfus, Inc

Lassiter, DV . 1996. W ork injury and illness surveillance on an international basis. Acta de la Third International ESH Conference, M onterrey, California.

Leach-M arshall, JM . 1991. Analysis of radiation detected from exposed process elements from the krypton-85 fine leak testing system. SSA J ournal 5(2):48-60.
Lead Industries Association. 1990. Safety in Soldering, $\mathrm{H}$ ealth Guidelines for Solderers and Soldering. Nueva Y ork: Lead Industries Association, Inc.

Lenihan, K L, JK Sheehy, JH Jones. 1989. Assessment of exposures in gallium arsenide processing: A case study. En $\mathrm{H}$ azard Assessment and Control T echnology in Semiconductor $\mathrm{M}$ anufacturing, dirigido por la Conferencia Americana de Higienistas Industriales del Gobierno. Chelsea, M ichigan: Lewis Publishers.

M aletskoS, C J, PR H anley. 1983. Radiation protection considerations of ion implantation systems. IEEE T rans on N uclear Science N S-30:1592-1596.

M CC arthy, CM . 1985. W orker Exposure during M ainte nance of I on Implanters in the Semiconductor Industry. Tesis de master, U niversidad de U tah, Salt L ake City, $U$ tah, 1984. Compilado en Extended Abstracts, E lectrochem Soc 85(2):448.

M cC urdy SA, C Pocekay, K S H ammond, SR Woskie S) Samuels, M B Schenker. 1995. A crosssectional survey of respiratory and general health outcomes among semiconductor industry workers. Am J Indust M ed 28(6):847-860.

M clntyre, AJ, BJ Sherin. 1989. Gallium arsenide: hazards, assessment, and control. Solid State T echnology 32(9):119-126.

$M$ icroelectronics and Computer T echnology Corporation (M CC). 1994. E lectronics Industry E nvironmental R oadmap. Austin, T exas: M CC.

- . 1996. E lectronics I ndustry E nvironmental Roadmap. Austin, T exas: M CC.

M osovsky, JA, D Rainer, T M oses, WE Q uinn. 1992. Transient hydride generation during IIIsemiconductor processing. Appl Occup Environ $\mathrm{H}$ yg 7(6):375-384

M ueller, M R, RF K unesh. 1989. Safety and health implications of dry chemical etchers. En H azard Assessment and Control T echnology in Semiconductor M anufacturing, dirigido por la Conferencia Americana de Higienistas Industriales del Gobierno. Chelsea, $M$ ichigan: L ewis Publishers.

O 'M ara, WC. 1993. Liquid Crystal Flat Panel Displays. Nueva Y ork: V an N ostrand R einhold.

PACE Inc. 1994. Fume Extraction $\mathrm{H}$ andbook. Laurel, $M$ aryland: PACE Inc.

Pastides, H, EJ Calabrese, DW H osmer, Jr, DR Harris. 1988. Spontaneous abortion and general illness symptoms among semiconductor manufacturers. | 0 ccup M ed 30:543-551.

Pocekay D, SA M cCurdy, SJ Samuels, M B Schenker. 1995. A cross-sectional study of musculoskeletal symptoms and risk factors in semiconductor workers. Am J Indust M ed 28(6):861-871.

Rainer, D, WE Quinn, JA Mosovsky, MT Asom. 1993. III-V transient hydride generation, Solid State T echnology 36(6):35-40.

Rhoades, BJ, DG Sands, VD M attera. 1989. Safety and environmental control systems used in chemical vapor deposition (CVD) reactors at AT \& T - M icroelectronics-R eading. Appl Ind $\mathrm{H} y g$ 4(5):105-109.

R ogers, JW. 1994. R adiation safety in semiconductors. Presentado en la Semiconductor Safety Association Conference de abril 1994, Scottsdale, AZ (no publicado).

R ooney, FP, J Leavey. 1989. Safety and health considerations of an X-ray lithography source. En $\mathrm{H}$ azard Assessment and Control Technology in Semiconductor $M$ anufacturing, publicado por la Conferencia Americana de Higienistas Industriales del Gobierno. Chelsea, M ichigan: L ewis Publishers.

R osenthal, FS, S Abdollahzadeh. 1991. Assessment of extremely low frequency (ELF) electric and magnetic fields in microelectronics fabrication rooms. Appl O ccup E nviron H yg 6(9):777-784. 
Roychowdhury, M. 1991. Safety, industrial hygiene, and environmental considerations for M OCVD re actor systems. Solid State T echnology 34(1):36-38.

Scarpace, L, M Williams, D Baldwin, I Stewart, D Lassiter. 1989. R esults of industrial hygiene sampling in semiconductor manufacturing operations. En $\mathrm{H}$ azard Assessment and Control T echnology in Semiconductor $M$ anufacturing, dirigido por la Conferencia Americana de Higienistas Industriales del Gobierno. Chelsea, M ichigan: Lewis Publishers.

Schenker MB, EB Gold, IJ Beaumont, B Eskenazi, SK H ammond, BL Lasley, SA M CCurdy, SJ Samuels, CL Saiki, SH Swan. 1995. Association of spontaneous abortion and other reproductive effects with work in the semiconductor industry. Am J Indust M ed 28(6):639-659.

Schenker, M, J Beaumont, B Eskenazi, E Gold, K H ammond, B Lasley, S M cCurdy, S Samuels, S Swan. 1992. Final R eport to the Semiconductor I ndustry Association-Epidemiologic Study of Reproductive and $O$ ther $H$ ealth $E$ ffects among W orkers $E$ mployed in the $M$ anufacture of Semiconductors. Davis, California: U niversidad de California.

Schmidt, R, H Scheufler, S Bauer, L Wolff, M Pelzing, R Herzschuh. 1995. Toxicological investigations in the semiconductor industry: III: Studies on prenatal toxicity caused by waste products from aluminum plasma etching processes. Toxicol Ind $H$ ealth 11(1):49-61.

SEM ATECH. 1995. Silane Safety T ransfer Document, 96013067 A-ENG. Austin, T exas: SEM ATECH

-. 1996. Interprative Guide for SEM I S2-93 and SEM I 58-95. Austin, T exas: SEM ATECH

Semiconductor Industry Association (SIA). 1995. W orld Semiconductor Sales F orecast D ata. San José, C alifornia: SIA.

Sheehy, JW, JH Jones. 1993. Assessment of arsenic exposures and controls in gallium arsenide production. Am Ind H yg Assoc f 54(2):61-69.

Sober, DJ. 1995. Selecting Laminates U sing "Fitness for U se" Criteria, Surface M ount T echnology (SM T). Libertyville, Illinois: IH S Publishing G roup.

Wade, R, M Williams, T M itchell, J Wong, B T usé. 1981. Semiconductor industry study. San Francisco, California: California Department of Industrial Relations, Division of Occupational Safety and $\mathrm{H}$ ealth.

\section{O tras lecturas recomendadas}

Carlson, V. 1995. Step-by-Step SM T-Design for T est- Part 2, Surface M ount T echnology (SM T). Libertyville, Illinois: IH S Publishing G roup.
Corbitt, RA. 1990. Standard $\mathrm{H}$ andbook of Environmental Engineering. Nueva York: M CGraw-H ill Publishing Company.

Crawford, TJ. 1995. Step-by-Step SM T - Cleaning- Part 8 , Surface M ount T echnology (SM T). Libertyville, Illinois: IH S Publishing G roup.

Electronic Industries Association (EIA). 1995. E lectronic $M$ arket $D$ ata B ook- Statistical Yearbook of the Electronics Industries. Arlington, V irginia: EIA.

Environmental Protection Agency (EPA). 1995. Profile of the Electronics and Computer Industry. Washington, DC: US EPA, O ffice of Compliance Sector N otebook Project.

Flatt, M . 1992. Printed Circuit B oard B asics: An introduction to the PCB Industry. San Francisco, California: M iller Freeman Inc.

Gilleo, K . 1995. Step-by-Step SM T - Adhesives/ epoxies and Dispensing- Part 5, Surface M ount T echnology (SM T). Libertyville, Illinois: IH S Publishing G roup.

Ginsberg, G. 1989. Surface M ount and R elated T echnologies. N ueva Y ork: M arcel D ekker, Inc.

Gray RH, M Corn, R Cohen, A Correa, R Hakim, W H ou, F Shah, H Zauer. 1993. Final Report: The I ohns $\mathrm{H}$ opkins U niversity Retrospective and Prospective Studies of Reproductive $H$ ealth Among IBM E mployees in Semiconductor $M$ anufacturing. Baltimore, $M$ aryland: U niversidad Johns $\mathrm{H}$ opkins.

H owes, MJ, DV M organ (dirs.). 1985. Gallium Arsenide $M$ aterials, D evices and Circuits. N ueva Y ork: W iley.

H utchins, CL. 1996. Step-by-Step SM T - Rework and re pair- Part 10, Surface M ount T echnology (SM T). Libertyville, Illinois: IH S Publishing G roup.

Hwang, JS. 1995. Step-by-Step SM T-Solder M aterials- Part 3, Surface M ount T echnology (SM T). Libertyville, Illinois: IH S Publishing G roup.

H wang, JS. 1996. Surface M ount T echnology: 1980's vs. 1990 's, Surface M ount Technology (SM T). Libertyville, Illionis: IH S Publishing Group.

IT M, Inc. 1995. Step-by-Step SM T - Printing- Part 4, Surface M ount T echnology (SM T). Libertyville, Illinois: IH S Publishing G roup.

K ear, FW. 1987. Printed Circuit Assembly M anufacturing Nueva Y ork: $M$ arcel D ekker, Inc.

Leow, YH, SK Ng, CL Goh. 1995. Allergic contact dermatitis from epoxy resin in Singapore. Contact D ermat 33(5):355-356.

M anahan, SE. 1994. E nvironmental Chemistry, 6a edición. Boca R atón, Florida: L ewis Publishers.

M anzione, LT. 1990. Plastic Packaging of M icroelectronic D evices. N ueva Y ork: V an N ostrand R einhold.
M eridith S. 1993. R eported incidence of occupational asthma in the U nited K ingdom, 1989-90. J E pide miol Community $H$ ealth 47(6):459-463.

M oreau, WM . 1988. Semiconductor Lithography- Principles, Practices, and M aterials. N ueva Y ork: Plenum.

O 'M ara, WC. 1993. Liquid Crystal Flat Pand Displays. Nueva Y ork: $V$ an N ostrand R einhold.

PACE Inc. 1994. E nvironmental $\mathrm{H}$ ealth and Safety $\mathrm{H}$ azards of Soldering. Laurel, M aryland: PACE Inc

Parker, SP (dir.). 1988. Encyclopedia of Electronics and Computers, $2^{a}$ edición. Nueva Y ork: M CG raw-H ill.

Prasad, R. 1995. Step-by-Step SM T - Component Place ment- Part 6, Surface M ount T echnology (SM T). Libertyville, Illinois: IH S Publishing G roup.

Rooks, S and B Bolliger. 1995. Step-by-Step SM T - T est/ inspection - Part 9 , Surface M ount T echnology (SM T). Libertyville, Illinois: IHS Publishing Group.

Ryssel, H, I Ruge. 1993. I on I mplantation. Nueva Y ork: Wiley.

Salmon, ER. 1987. Encapsulation of E lectronic D evices and Components. N ueva Y ork: M arcel D ekker.

Semiconductor Industry Association (SIA). 1994. The National Technology Roadmap for Semiconductors. San José, C alifornia: SIA.

-. 1995. Semiconductor Industry Comparative Annual I njury and IIIness R ates. San José, California: SIA.

- . 1995. Semiconductor Industry R oadmap. San José, C alifornia: SIA.

Sherman, A. 1987. Chemical Vapor Deposition for M icroe lectronics- Principles, T echnology, and A pplications. Park Ridge, Nueva Jersey: N oyes.

Tolliver, DL. 1988. $\mathrm{H}$ andbook of Contamination Control in M icroelectronics: Principles, Applications, and T echnology. Park R idge: N ueva Jersey: N oyes.

Ungers, LJ, JH Jones, AJ M clntyre, CR M CHenry. 1985. R elease of arsenic from semiconductor wafers. Am Indust $\mathrm{H}$ yg J 46(8):416-420.

Van Zant, P. 1990. M icrochip fabrication-A Practical $G$ uide to Semiconductor Processing, $2^{a}$ ed. Nueva Y ork: $\mathrm{McG}$ raw-Hill.

Warwick, M, P Hedges. 1996. Changes in reduced residue solder pastes, surface mount technology (SM T). En SM T's Guide to Soldering. Libertyville, Illinois: IH S Publishing G roup.

Williams, ME, DG Baldwin. 1995. Semiconductor Industrial $\mathrm{H}$ ygiene $\mathrm{H}$ andbook. Park Ridge, Nueva Jersey: N oyes.

Willis, R. 1995. Step-by-Step SM T-Soldering- Part 7 Surface M ount T echnology (SM T). Libertyville, Illinois: IHS Publishing Group. 


\section{VIDRIO, CERAMICA Y MATERIALES AFINES}

Directores del capítulo

J oel Bender y J onathan P. H ellerstein

\section{Sumario}

Vidrio, cerámica y materiales afines

J onathan P. H ellerstein, J oel B ender, J ohn G. H adley

y Charles M. H ohman . . . . . . . . . . . . . . . . . . . . . . . . . 84.2

Fibras ópticas

Piedras preciosas sintéticas

Basil Dolphin . . . . . . . . . . . . . . . . . . . . . . . 84.27 


\section{- VIDRIO, CERAMICA Y MATERIALES AFINES}

\author{
Jonathan P. H ellerstein, Joel Bender, \\ John G. Hadley y Charles M. H ohman
}

Este capítulo abarca los siguientes sectores productivos:

- Vidrio

- Fibras de vidrio sintéticas

- Alfarería

- Baldosa cerámica

- Productos cerámicos industriales

- Tejas y ladrillos

- Refractarios

- Piedras preciosas sintéticas

- Fibras ópticas.

Es interesante señalar que muchos de estos sectores no sólo tienen raíces en la antigüedad, sino que también comparten varios procesos generales de fabricación. Por ejemplo, todos se basan fundamentalmente en el uso de materias primas que se encuentran en estado natural en polvo o en forma de finas partículas, las cuales se transforman por el calor en los productos deseados. Por lo tanto, a pesar de la variedad de procesos y productos comprendidos en este grupo, estos tratamientos comunes autorizan a adoptar una perspectiva general común de los riesgos potenciales para la salud asociados con tales industrias. Puesto que los distintos sectores de fabricación se componen tanto de segmentos pequeños y fragmentados (por ejemplo, las fábricas de ladrillos) como de grandes plantas de fabricación técnicamente muy avanzadas y con miles de obreros, cada sector se describe por separado.

\section{Riesgos y procesos comunes}

En la fabricación de productos en estos sectores industriales se encuentran riesgos para la salud y medidas de seguridad comunes. L os riesgos y las medidas de control se tratan en otras secciones de la E nciclopedia. Los riesgos de procesos específicos se examinan en apartados individuales de este capítulo.

\section{Tratamiento de las partidas de materias primas:}

En la mayoría de los procesos industriales de fabricación las materias primas sólidas y secas se reciben a granel 0 en sacos. Las materias primas a granel se descargan desde vagones tolva 0 camiones en silos, tolvas o mezcladores por gravedad, conducciones neumáticas, transportadores sinfín, cangilones o cualquier otro método de transporte mecánico. Los pallets de materias primas en sacos (de 20 a $50 \mathrm{Kg}$ ) o en grandes sacos a granel (de 0,5 a 1,0 toneladas) se descargan desde remolques 0 vagones de tren mediante carretillas elevadoras industriales motorizadas, grúas o polipastos. Los materiales, en sacos 0 a granel, se retiran de los pallets manualmente 0 con la ayuda de elevadores motorizados. En general, las materias primas ensacadas se cargan en estaciones de descarga de sacos, o directamente en tolvas de almacenamiento o tolvas pesadoras.

Los riesgos potenciales para la seguridad y la salud asociados a los procesos de descarga, manipulación y transporte de materias primas sólidas incluyen:

- Exposición a ruidos que oscilan de 85 a 100 decibelios dBA. V ibradores neumáticos, compresores, servoválvulas, motores de agitadores, ventiladores y colectores de polvo son algunas de las principales fuentes de ruido.

- Exposición respiratoria a partículas en suspensión en el aire debido al transporte y a la mezcla de materias primas sólidas granulares.
La exposición depende de la composición de las materias primas, pero normalmente incluye sílice $\left(\mathrm{SiO}_{2}\right)$, arcilla, calizas, polvos alcalinos, óxidos metálicos, metales pesados y partículas nocivas

- Riesgos ergonómicos asociados al levantamiento manual o a la manipulación de sacos de materias primas, a vibradores 0 a actividades de líneas de transmisión o mantenimiento del sistema.

- R iesgos físicos debidos al manejo y a la circulación de vagonetas o carretillas motorizadas, al trabajo a alturas elevadas, a la entrada en espacios reducidos y al contacto con fuentes de energía eléctrica, neumática o mecánica, como puntos de corte, piezas giratorias, engranajes, ejes, correas y poleas.

\section{Operaciones de cocción o de fusión}

La fabricación de productos en estos sectores industriales implica operaciones de secado, fusión o cocción en estufas u hornos. En estos procesos el calor se genera por combustión de propano, gas natural (metano) o fuelóleo, fusión por arco eléctrico, microondas, secado dieléctrico, calentamiento con resistencias eléctricas 0 varias de estas técnicas. Los riesgos potenciales que presentan los procesos de cocción o fusión incluyen:

- Exposiciones a productos de la combustión tales como monóxido de carbono, óxidos de nitrógeno( $\left(\mathrm{O}_{x}\right.$ ) y anhídrido sulfuroso.

- H umos y partículas en suspensión en el aire procedentes de materias primas (por ejemplo sílice, metales, polvos alcalinos) o de subproductos (como fluorhídrico, cristobalita y vapores de metales pesados).

- Fuego o explosión asociado a los sistemas de combustión utilizados como fuente de calor o para accionar las carretillas elevadoras; riesgos potenciales de fuego o explosión debidos a los tanques de almacenamiento de combustibles inflamables, circuitos de distribución por tuberías y vaporizadores. LoS circuitos de retroceso o de reserva de combustible que suelen usarse en caso de cortes de gas natural pueden presentar problemas similares de fuego o explosión.

- Exposición a radiación infrarroja procedente del material fundido, que aumenta el riesgo de cataratas o quemaduras en la piel.

- Exposición a energía radiante y temperaturas muy elevadas. El ambiente de trabajo alrededor de los hornos o estufas es extremadamente caluroso. Pueden presentarse importantes problemas relacionados con las temperaturas muy elevadas cuando los trabajos de reparaciones de emergencia o de mantenimiento rutinario se realizan sobre los lugares de cocción o de fusión 0 cerca de ellos. El contacto directo de la piel con superficies calientes o materiales fundidos da lugar a quemaduras graves (véase la Figura 84.1).

- Riesgos de la energía eléctrica. El contacto directo con la energía eléctrica de alta tensión usada para encender resistencias que complementan la cocción con combustibles presenta el riesgo de electrocución y posibles problemas para la salud por exposición a campos electromagnéticos (EM F). L os campos magnéticos y eléctricos intensos pueden interferir con marcapasos u otros dispositivos médicos implantados.

- Exposición a ruidos superiores a 85 a 90 dBA emitidos por los ventiladores de combustión, tolvas de amasado o mezcladores, procesos de alimentación y equipos transportadores.

Manejo del material en la producción, fabricación, embalaje y almacenamiento

EI manejo del material y los procesos de fabricación y embalaje son muy diversos en este sector industrial, como lo son el tamaño, la forma y el peso de los productos. La elevada densidad de los materiales en este sector 0 sus formas voluminosas exponen a riesgos frecuentes. El levantamiento manual y la manipulación 
Figura 84.1 - Técnico de control de calidad tomando muestras de vidrio del horno y usando equipo de protección personal contra el calor y gafas antirrayos I.R.

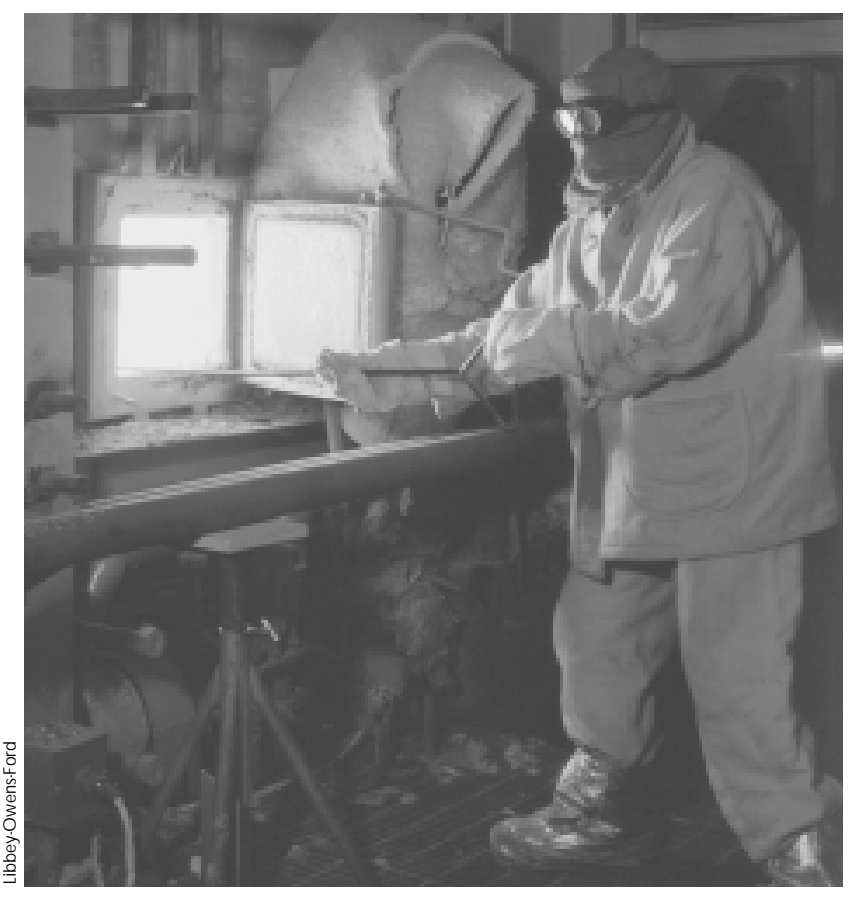

del material en la producción, fabricación, embalaje y almacenamiento en esta industria explica muchas lesiones incapacitantes (véase el apartado "Perfil de lesiones y enfermedades", más adelante). El esfuerzo para disminuir las lesiones se centra en la limitaciones de las operaciones manuales de levantamiento y manipulación de material. Por ejemplo, para eliminar la manipulación del material en determinadas partes de este sector industrial comienzan a utilizarse diseños de embalajes innovadores, automatismos para el apilado y paletizado del producto acabado y vehículos de transporte para el almacenamiento guiados automáticamente. El uso de transportadores, la ayuda de los montacargas de control a distancia (por ejemplo, los montacargas de vacío) y de plataformas de tijeras para la manipulación y paletizado de los productos son prácticas generalizadas en la actualidad (véase la Figura 84.2).

EI uso de automatismos para eliminar el movimiento manual del material desempeña un papel importante en la prevención de las lesiones ergonómicas. Los automatismos han reducido los esfuerzos ergonómicos y las graves lesiones con desgarro que históricamente se han asociado a la manipulación del material (por ejemplo, vidrio plano) por el personal de producción (véase la Figura 84.3). Sin embargo, la mayor utilización de robots y la automatización de procesos introduce los riesgos propios de la maquinaria móvil y la energía eléctrica, lo cual transforma los tipos de peligros o los desplaza a otros operarios (de los trabajadores de producción a los de mantenimiento). El diseño adecuado de controles electrónicos y un ordenamiento lógico, la revisión de las máquinas, la práctica de la interrupción completa de la electricidad y la instauración de procedimientos seguros de uso y mantenimiento son métodos fundamentales para limitar las lesiones de los operarios de mantenimiento y producción.
Figura 84.2 • Utilización del elevador de vacío para la manipulación de paquetes de 20 a 35 kilos de vidrio textil.

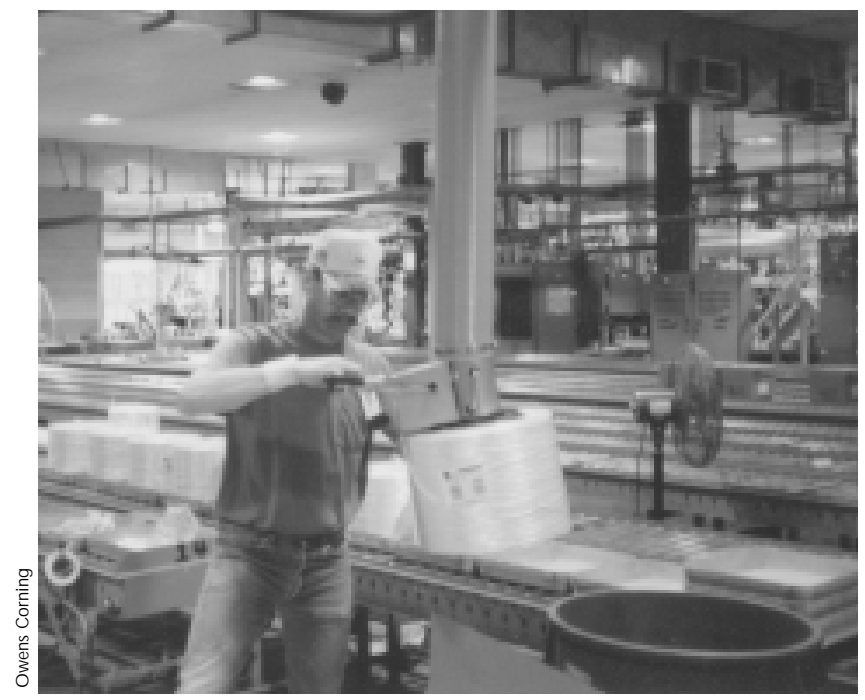

\section{Reacondicionamientos y actividades de reconstrucción}

Durante los reacondicionamientos periódicos o reparaciones en frío de estufas $u$ hornos se presentan numerosos riesgos potenciales para la salud y la seguridad. L as actividades de la construcción llevan asociadas una amplia diversidad de riesgos: riesgos ergonómicos con la manipulación del material (por ejemplo, ladrillos refractarios); riesgo de inhalación de partículas en suspensión de sílice, amianto, fibras cerámicas refractarias 0 materias que contienen metales pesados durante demoliciones; o subproductos del corte y soldadura; golpes de calor; trabajo a alturas elevadas; peligro de resbalar, tropezar o caer; riesgos de

Figura 84.3 - Los robots utilizados en la manipulación de luna pulida reducen los riesgos de heridas y ergonómicos.

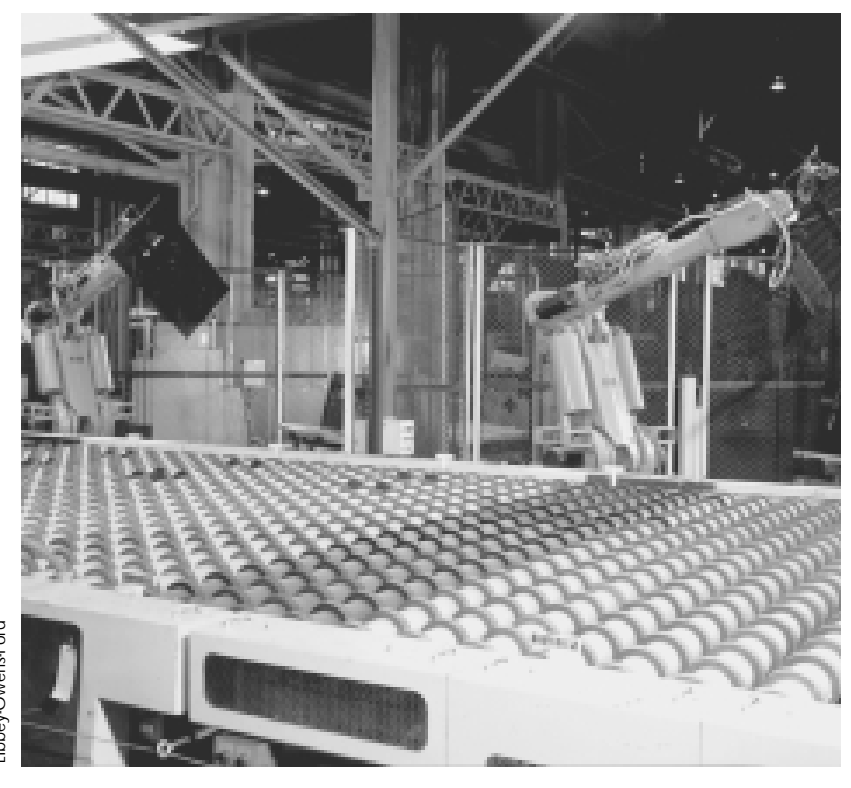


Figura 84.4 • Ingreso a espacios reducidos durante la reconstrucción del horno en una planta de fibra de vidrio. Una llovizna o vaho acuoso reduce las partículas en suspensión en el aire durante la demolición del horno.

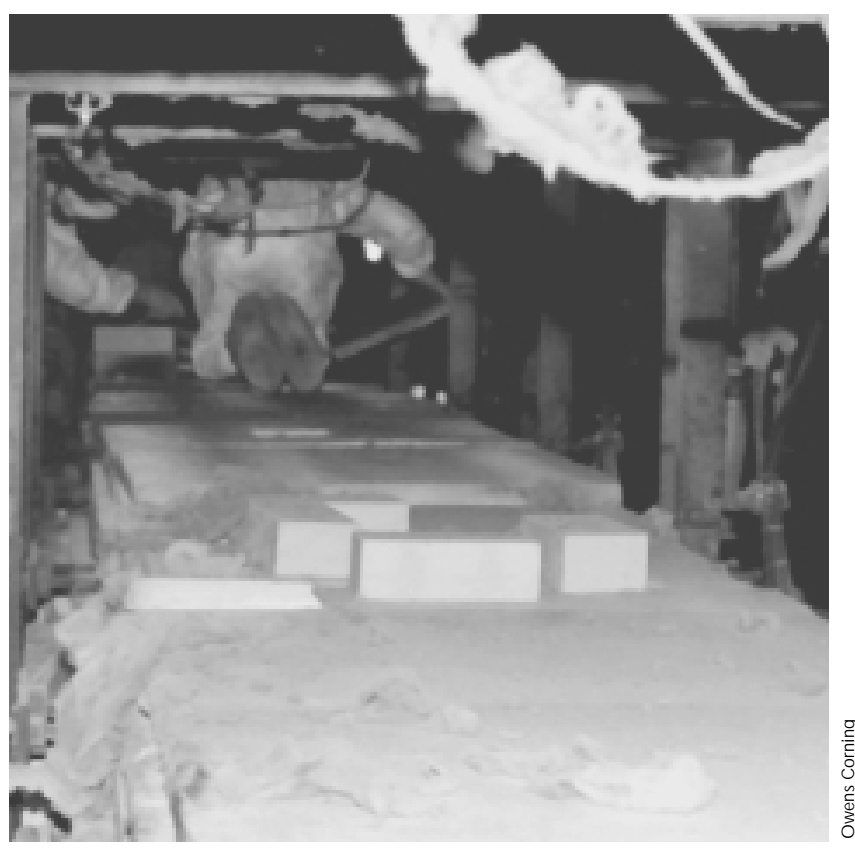

entrada en espacios reducidos (véase la Figura 84.4); y contacto con fuentes de energía peligrosas

\section{Vidrio}

\section{Visión general}

El vidrio se formó naturalmente a partir de elementos comunes presentes en la corteza terrestre mucho antes de que nadie pensara siquiera en experimentar con su composición, darle forma o apelar a las innumerables aplicaciones que tiene en la actualidad. La obsidiana, por ejemplo, es una combinación natural de óxidos fundidos por el intenso calor volcánico y vitrificados (convertidos en vidrio) por enfriamiento rápido en contacto con el aire. Su color negro y opaco se debe al contenido relativamente elevado de óxido de hierro. Su resistencia química y su dureza se comparan favorablemente con las de muchos vidrios comerciales.

La tecnología del vidrio ha evolucionado a lo largo de 6.000 años y algunos principios modernos son de origen muy remoto. La fabricación de los primeros vidrios sintéticos se pierde en la antigüedad y en la leyenda. La loza la inventaron los egipcios, que moldeaban figurillas de arena $\left(\mathrm{SiO}_{2}\right)$, el más conocido de los óxidos vitrificables. Se recubría con natrón, el residuo formado por las inundaciones del Nilo, compuesto principalmente por carbonato cálcico $\left(\mathrm{CaCO}_{3}\right)$, carbonato sódico $\left(\mathrm{Na}_{2} \mathrm{CO}_{3}\right)$, sal común ( $\mathrm{NaCl}$ ) y óxido de cobre (II) (C $\mathrm{COO}$ ) que, calentado por debajo de $1.000^{\circ} \mathrm{C}$, forma una película vitrificada por difusión de los fundentes $\mathrm{CaO}$ y $\mathrm{Na}_{2} \mathrm{O}$ y la subsiguiente reacción en estado sólido con la arena. El óxido de cobre daba a la pieza un atractivo color azul.

De acuerdo con la definición de Morey, "El vidrio es una sustancia inorgánica que se halla en un estado asimilable al líquido, del que es prolongación, pero que, como resultado de un cambio reversible experimentado durante el enfriamiento, alcanza un grado tan alto de viscosidad que puede considerarse sólido a todos los efectos." ASTM define al vidrio como "producto inorgánico de fusión enfriado hasta un estado rígido no cristalino". Tanto los materiales orgánicos como los inorgánicos pueden formar vidrios si su estructura es no cristalina, es decir, si no está ordenada de manera predominante.

Un avance trascendental en la tecnología del vidrio fue el uso de la caña de soplar (véase la Figura 84.5), usado por primera vez en el año 100 a. C aproximadamente. Desde entonces se produjo una rápida evolución en la técnica de fabricación.

El primer vidrio era coloreado debido a la presencia de diversas impurezas, como los óxidos de hierro y cromo. El primer vidrio incoloro se produjo hace unos 1.500 años.

En esa época la fabricación de vidrio se desarrolló en Roma y desde allí se extendió a muchos otros países europeos. Numerosas vidrierías se establecieron en Venecia, donde la técnica conoció un importante desarrollo. En el siglo XIII, muchas de las factorías de vidrio se trasladaron de Venecia a la cercana isla de M urano, que siguen siendo centrando en I talia la producción manual de vidrio.

En el siglo XVI se hacía vidrio en toda Europa. En la actualidad, el cristal de Bohemia de la R epública Checa es bien conocido por su belleza, y de las fábricas de vidrio del Reino U nido e Irlanda salen vajillas de vidrio de plomo de gran calidad. Suecia es otro centro de producción de artículos de vidrio artísticos.

En América del Norte, el primer establecimiento fabril construido fue precisamente una fábrica de vidrio. Los colonos ingleses comenzaron a producir vidrio a comienzos del siglo X V II en Jamestown, Virginia.

$\mathrm{H}$ oy en día el vidrio se fabrica en todo el mundo. Muchos productos de vidrio se producen en líneas totalmente automatizadas. Aunque el vidrio es uno de los materiales más antiguos, sus propiedades son únicas y todavía no han llegado a conocerse en su totalidad.

La actual industria del vidrio abarca varios e importantes segmentos del mercado, tales como vidrio plano, vajilla doméstica y envases, vidrio óptico o de materiales de vidrio para uso científico. Los mercados del vidrio óptico y científico suelen estar muy regulados y en la mayoría de los países se hallan dominados por uno o dos proveedores. Estos mercados mueven un volumen mucho menor que los de consumo. Todos ellos se han desarrollado durante años gracias a innovaciones en la tecnología específica del vidrio 0 a avances en la fabricación. La

Figura 84.5 • La caña de soplar vidrio.

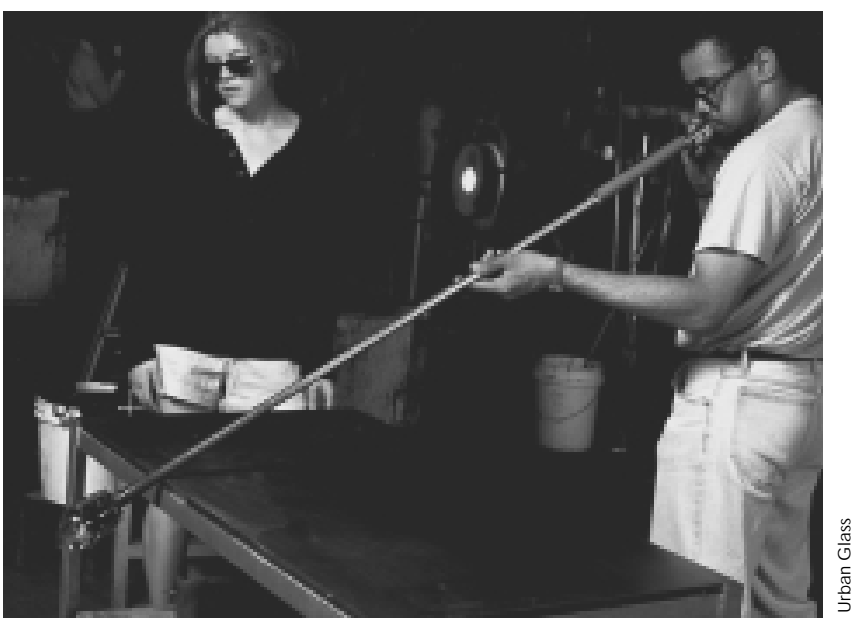


industria del envase, por ejemplo, se vio impulsada por la evolución de las líneas de embotellado rápido implantadas a comienzos del siglo XX. La industria del vidrio plano experimentó un auténtico salto hacia adelante gracias al desarrollo del proceso de vidrio flotado en los primeros años del decenio de 1960. Ambos segmentos mueven en la muchos miles de millones de dólares en todo el mundo.

El vidrio doméstico se divide en cuatro categorías generales:

1. vajilla (servicios de mesa, tazas y jarras);

2. cristalería;

3. recipientes para horno, y

4. recipientes para cocinar.

Aunque es difícil elaborar una estimación mundial, el mercado de la vajilla es del orden de mil millones de dólares solamente en los Estados U nidos. En sus distintas categorías, el vidrio compite con muchos otros materiales, como metales, plásticos y cerámicas.

\section{M étodos de fabricación}

El vidrio es un producto inorgánico de fusión enfriado hasta que alcanza un estado sólido no cristalino. Las características del vidrio son dureza, fragilidad y fractura concoidea. Se fabrica vidrio coloreado, translúcido u opaco variando los materiales disueltos amorfos o cristalinos que lo forman.

Cuando el vidrio se enfría desde el estado de fusión, la viscosidad incrementa gradualmente sin cristalizar en un amplio intervalo de temperaturas hasta que adopta su característica dureza y su forma frágil. El enfriamiento se controla para evitar la cristalización o deformación elástica.

Aunque cualquier compuesto que presente estas propiedades físicas es teóricamente un vidrio, la mayoría de los vidrios comerciales se dividen en tres tipos principales y presentan una amplia diversidad de composiciones químicas.

1. Vidrios de sílicecal-sosa: son los más importantes en términos de cantidad producida y variedad de uso, pues comprenden casi todos los vidrios planos, envases, vajilla económica producida en masa y bombillas eléctricas.

2. Vidrios de sílice potasa-plomo: contienen una proporción variable, pero normalmente alta, de óxido de plomo. En el material óptico se valora su elevado índice de refracción; la cristalería decorativa y doméstica soplada a boca, su facilidad de corte y de pulido; en las aplicaciones eléctricas y electrónicas, su elevada resistividad eléctrica y la protección frente a las radiaciones.

3. Vidrios de borosilicato: su baja dilatación térmica los hace resistentes al choque térmico y por ello son ideales para hornos domésticos, material de vidrio de laboratorio y producción de fibra de vidrio para reforzar plásticos.

Una mezcla vitrificable comercial se compone de diversos ingredientes. Sin embargo, la mayor parte la conforman de 4 a 6 ingredientes, escogidos entre caliza, arena, dolomita, carbonato sódico, bórax, ácido bórico, feldespatos y compuestos de bario y plomo. El resto de la mezcla se compone de aditivos elegidos entre un grupo de 15 a 20 materiales comúnmente denominados ingredientes menores. Estos últimos se añaden durante el proceso de preparación del vidrio para aportar alguna función 0 cualidad específica, como el color, por ejemplo.

La Figura 84.6 ilustra los principios básicos de la fabricación del vidrio. Las materias primas se pesan, se mezclan, se les incorpora vidrio roto (chatarra de vidrio) y se llevan al horno de fusión. Todavía se emplean pequeños crisoles de hasta 2 toneladas de capacidad en la fusión de vidrio para la cristalería de vidrio soplada a boca y de vidrios especiales producidos a pequeña escala. Varios crisoles se calientan juntos en una misma cámara de combustión.

En la fabricación más moderna, la fusión tiene lugar en grandes hornos regenerativos, recuperativos 0 eléctricos de material refractario alimentados con petróleo, gas natural 0 electricidad. A finales del decenio de 1960 y en el de 1970 se comercializó y llegó a utilizarse de manera extensiva la sobrealimentación eléctrica y la fusión eléctrica con enfriamiento en su punto máximo. El objetivo de esta última es el control de la emisión, mientras que la sobrealimentación eléctrica se utilizaba generalmente para mejorar la calidad del vidrio y aumentar el rendimiento.

L os factores económicos que más afectan al uso de la electricidad en hornos de fusión de vidrio están relacionados con el coste del petróleo, la disponibilidad de otros combustibles, los costes de la energía eléctrica, los costes del capital para instalaciones, etc. Sin embargo, en muchos casos la principal razón para el uso de la fusión o sobrealimentación eléctrica es el control del medio ambiente. Muchos lugares en todo el mundo ya tienen 0 esperan tener pronto normas ambientales que restrinjan estrictamente el vertido de diversos óxidos o agregados de partículas. Por ello los fabricantes se enfrentan en muchos lugares a la necesidad de reducir los rendimientos de la fusión del vidrio, de instalar depuradoras o precipitadores de partículas para tratar los gases de escape de la combustión, o de modificar los procesos de fusión e incorporar la fusión o la sobrealimentación eléctricas. En algunos casos, la alternativa a estas modificaciones puede ser el cierre de plantas.

La parte más caliente del horno (superestructura) alcanza una temperatura comprendida entre 1.600 y $2.800^{\circ} \mathrm{C}$. El enfriamiento controlado la reduce hasta $1.00001 .200^{\circ} \mathrm{C}$ en el punto en el cual el vidrio sale del horno. Además, todos los tipos de vidrio se someten a un enfriamiento ulterior controlado (recocido) en un horno especial o túnel de recocido. Las operaciones que siguen dependen del tipo de fabricación.

Además del tradicional vidrio soplado a boca, el soplado automático se usa en máquinas para la producción de botellas y bombillas. Las formas sencillas, tales como aisladores, baldosas, moldes para lentes, etc., se prensan en lugar de soplarse. Algunos procesos de fabricación utilizan una combinación de soplado mecánico y prensado. Los vidrios armado e impreso se laminan. El vidrio plano se extrae del horno en vertical al tiempo que se somete a un proceso de pulido al fuego. Debido a los efectos combinados de la extracción y la gravedad, es inevitable alguna leve deformación.

La luna pulida pasa a través de rodillos enfriados por agua a un horno de recocido. No se deforma, pero después de la fabricación requiere un desbaste y pulido para eliminar daños superficiales. Este proceso ha sido reemplazado de manera generalizada por el del vidrio flotado introducido en años recientes (véase la Figura 84.7). El vidrio obtenido por flotación combina las ventajas del vidrio plano y la luna pulida. EI vidrio flotado tiene una superficie pulida al fuego y está exento de deformaciones.

En el proceso por flotación, una banda continua de vidrio sale del horno de fusión flotando sobre un baño de estaño fundido y se amolda a la superficie perfecta del metal líquido. Sobre el estaño, la temperatura se reduce hasta que el vidrio está suficientemente duro para entrar en los rodillos del túnel de recocido sin que la cara inferior se raye. U na atmósfera inerte evita la oxidación del estaño fundido. El vidrio recocido no requiere ningún tratamiento más y pasa a la fase de corte y embalado automáticos (véase la Figura 84.8).

$\mathrm{L}$ a tendencia en la moderna arquitectura residencial y comercial a la multiplicación de las superficies acristaladas y la necesidad de reducir el consumo de energía, ha puesto mayor énfasis 
Figura 84.6 - Procesos y materiales que intervienen en la fabricación de vidrio.

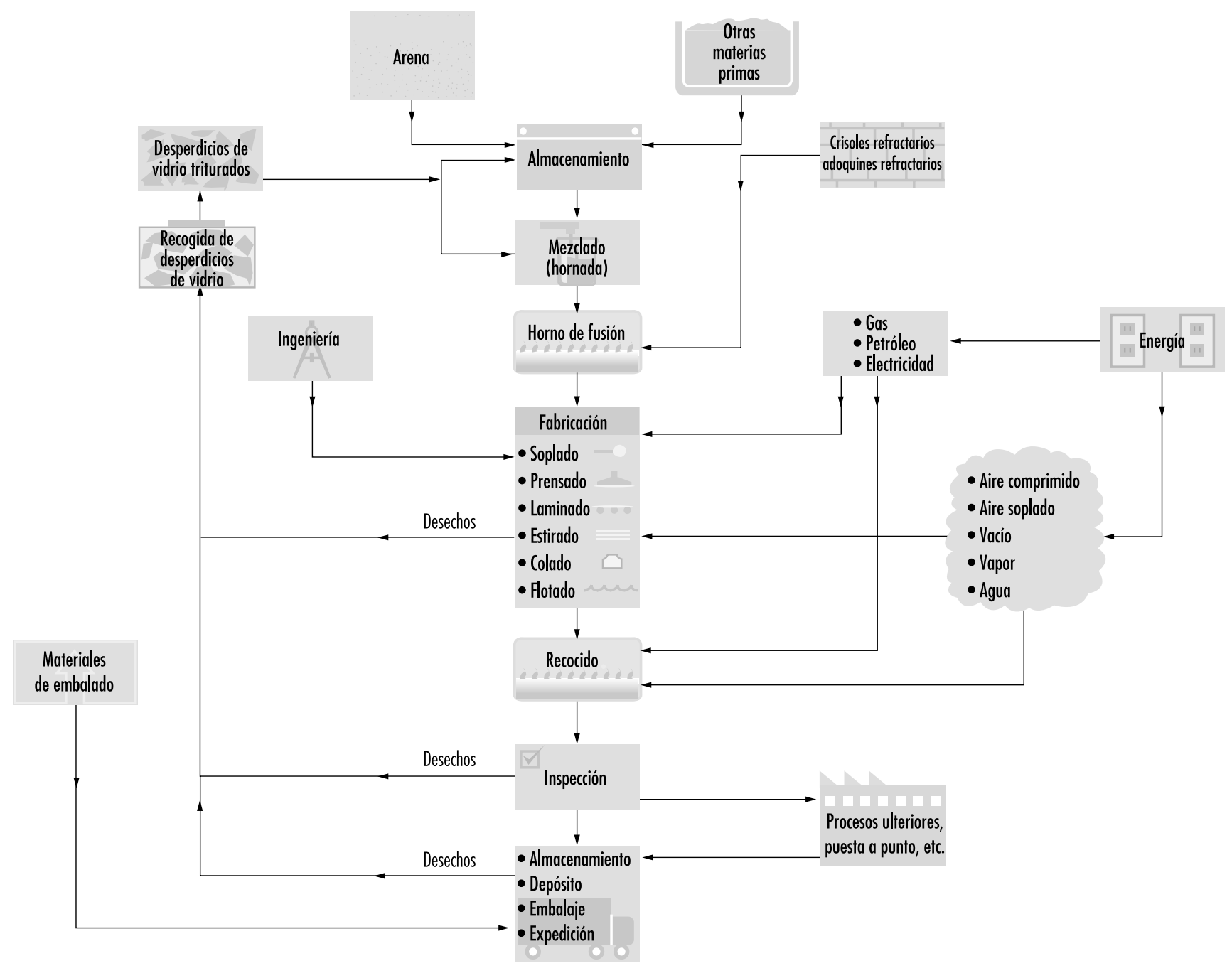

en mejorar el rendimiento energético de las ventanas. Un fino revestimiento depositado en la superficie del vidrio confiere a éste propiedades de baja emisividad o control de la radiación solar. La comercialización de estos productos revestidos exige una tecnología económica de depósito en grandes superficies. Por ello hay cada vez más líneas de fabricación de vidrio flotado equipadas con avanzados métodos de revestimiento.

En los procesos comunes de depósito en fase vapor (CVD), una mezcla compleja de gases se pone en contacto con el sustrato, donde reacciona pirolíticamente para formar un revestimiento en la superficie del vidrio. En general, el equipo de revestimiento consiste en estructuras controladas térmicamente que están suspendidas transversalmente sobre la banda de vidrio. Se monta en el tanque de estaño, en el horno de recocido o en una abertura de éste. Su función es repartir uniformemente los gases precursores a lo ancho de la banda de temperatura controlada y extraer de forma segura los subproductos de los gases de escape procedentes de la zona de depósito. Para formar un revestimiento de capas múltiples se usan varios equipos de montados en serie a lo largo de la banda de vidrio.

Para el tratamiento de los subproductos de los gases de escape generados en un proceso a tan gran escala suele bastar con las técnicas de depuración en húmedo con un filtro-prensa convencional; si no reaccionan fácilmente o no se empapan en las soluciones acuosas, la incineración es la principal alternativa.

Algunos vidrios ópticos se endurecen químicamente por inmersión durante varias horas y a temperaturas elevadas en baños de sales fundidas que normalmente contienen nitratos de litio y potasio.

Vidrios de seguridad: hay dos tipos principales:

1. Vidrio templado obtenido en hornos especiales mediante pretensado por calentamiento seguido de enfriamiento brusco de las piezas de vidrio plano cortadas a la forma y el tamaño deseados.

2. Vidrio laminar, que se forma montando una película de plástico (generalmente polivinil butiral) entre dos hojas delgadas de vidrio plano.

\section{Fibras de vidrio sintéticas}

\section{Visión general}

Las fibras de vidrio sintéticas se producen a partir de una amplia diversidad de materiales. Son silicatos amorfos obtenidos de 
Figura 84.7 - Proceso continuo de flotación.

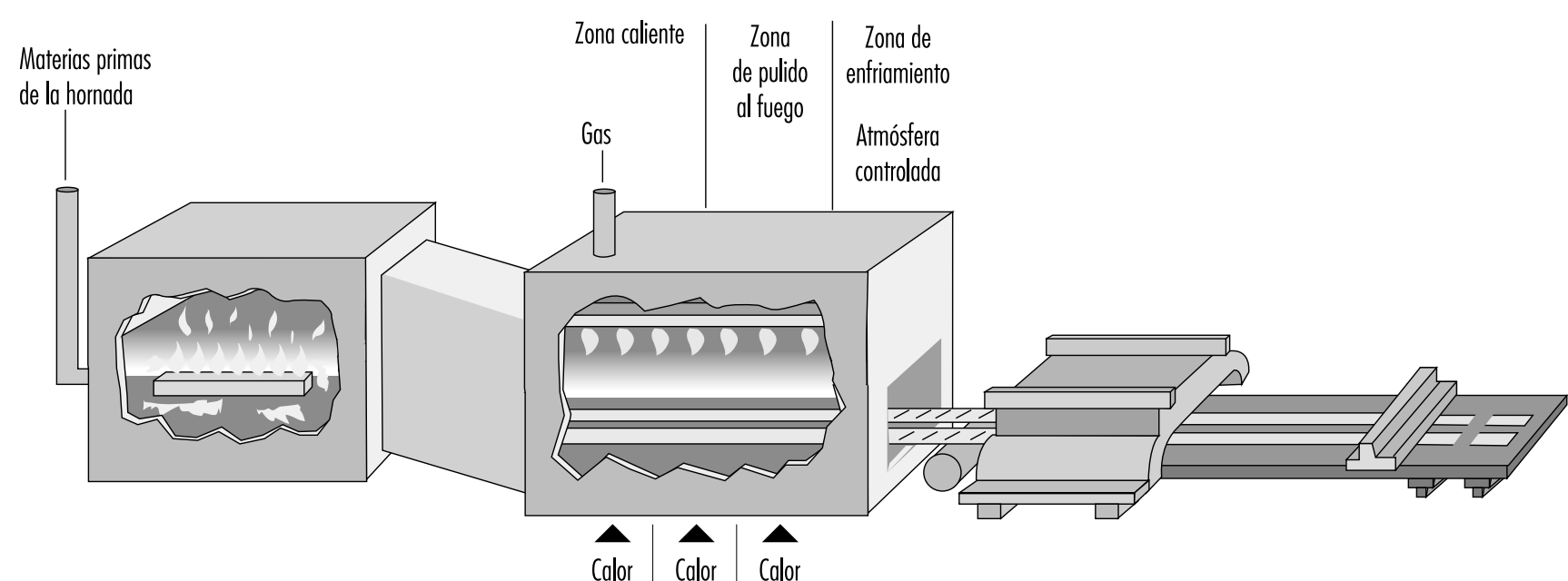

Horno de fusión del vidrio

Baño de flotación

Túnel de recocido

Sección de corte

Fuente: Adaptado de Tooley 1974.

vidrios, rocas naturales, escorias de fundición y otros minerales. $\mathrm{H}$ ay fibras continuas o discontinuas. En general, las continuas son fibras de vidrio estiradas a través de un molde de pequeños orificios y empleadas como refuerzo de otros materiales - plástico, por ejemplo- para formar compuestos de propiedades determinadas. Las fibras discontinuas (generalmente conocidas como lanas) se usan en múltiples aplicaciones, de las cuales la más corriente es el aislamiento acústico y térmico. A los efectos de este análisis, las fibras de vidrio sintéticas se dividen en fibras de vidrio continuas, que incluyen las lanas aislantes hechas de vidrio, roca natural o escoria; y fibras cerámicas refractarias, que generalmente son silicoaluminatos.

La posibilidad de estirar en fibras finas el vidrio pastoso ya era conocida por los vidrieros primitivos y es, en realidad, más

Figura 84.8 - Cinta de vidrio flotado saliendo del túnel de recocido.

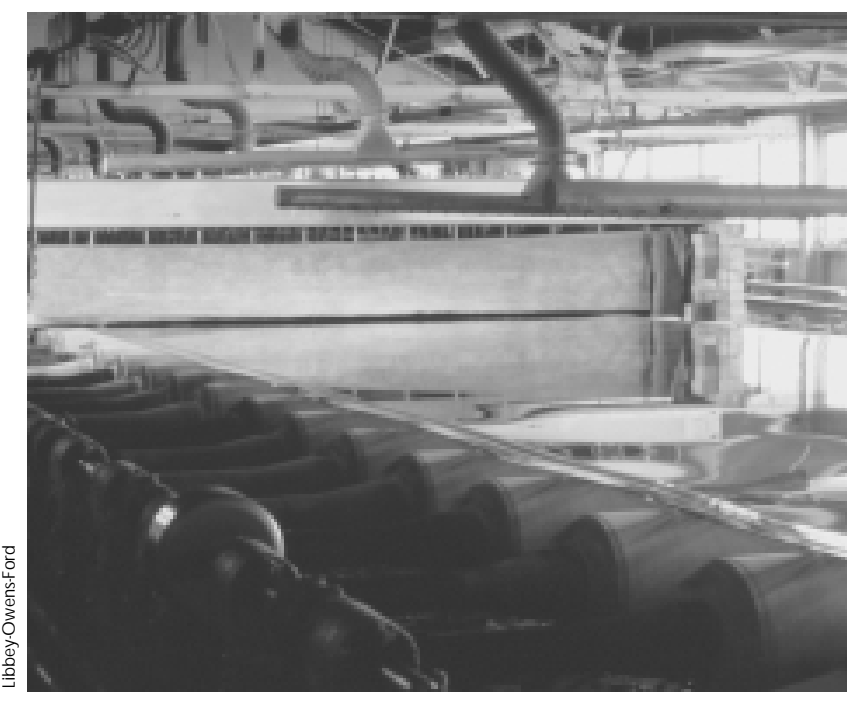

antigua que la técnica del soplado del vidrio. Muchas de las vasijas del primitivo Egipto se hicieron enrollando fibras de vidrio basto en un mandril de arcilla adecuadamente modelado; luego se calentaba el conjunto hasta que las fibras de vidrio afluían unas hacia otras $y$, después de enfriar, se quitaba el núcleo de arcilla. Incluso antes de la llegada del soplado del vidrio en el siglo I, ya se empleaba la técnica de la fibra de vidrio. Los vidrieros venecianos de los siglos XVI y XVII la usaban para decorar la cristalería. En este caso, se enrollaban manojos de fibras blancas opacas sobre la superficie de una vasija lisa y transparente de vidrio soplado (por ejemplo, una copa) y a continuación se fundían en ella por calentamiento.

A pesar de la larga historia de los usos decorativos o artísticos de las fibras de vidrio, su utilización generalizada no resurgió hasta el siglo XX. La producción comercial de fibras de vidrio comenzó en Estados U nidos en el decenio de 1930, y unos años antes en Europa. Las lanas de roca y de escoria habían empezado a elaborarse varios años antes.

La fabricación y el uso de fibras de vidrio sintéticas mueve miles de millones de dólares, ya que estos útiles materiales han llegado a ser un componente importante de la sociedad moderna. Su empleo como aislantes ha reducido drásticamente el consumo de energía para la calefacción y refrigeración de edificios, y este ahorro de energía se ha traducido en importantes disminuciones de la contaminación global asociada con su producción. El número de aplicaciones de los filamentos de vidrio continuos como armazón de una gran cantidad de productos, desde artículos deportivos hasta chips de ordenadores para aplicaciones aerospaciales, se ha estimado en más de 30.000. El desarrollo y la comercialización generalizada de fibras cerámicas refractarias se produjo en el decenio de 1970; estos materiales continúan cumpliendo una función importante en la protección de trabajadores y equipos en diversos procesos de fabricación a temperaturas elevadas.

\section{Procesos de fabricación}

Filamentos de vidrio continuos

Los filamentos de vidrio se forman estirando el vidrio fundido a través de hileras de metales preciosos para obtener hilos de 
Figura 84.9 • Esquema de la boquilla de fusión directa.

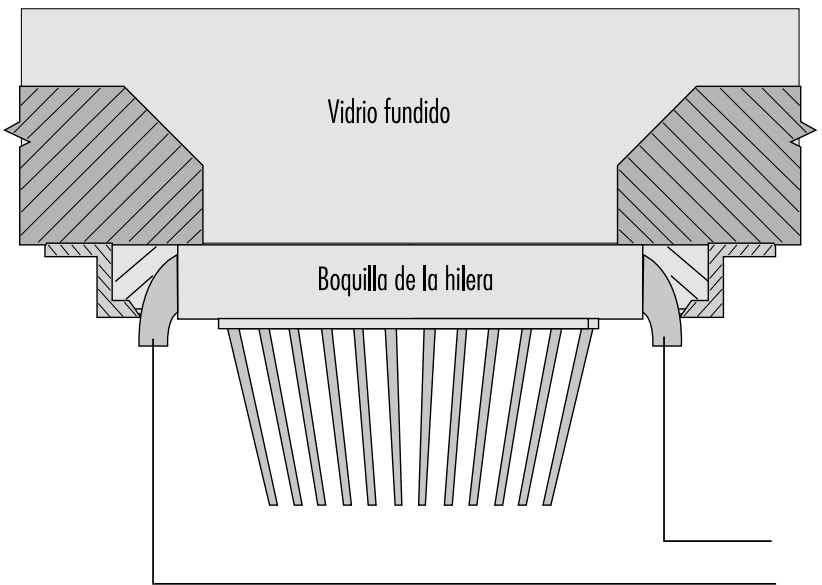

Fuente: Adaptado de Tooley 1974

diámetro prácticamente uniforme. D ebido a los requisitos físicos de las fibras usadas como armazón, sus diámetros son relativamente grandes comparados con los de la lana aislante. Casi todos los filamentos de vidrio continuos tienen diámetros que oscilan entre 5 y $15 \mathrm{~m} 0$ más. Estos diámetros grandes, junto con la estrecha gama de diámetros producidos durante la fabricación, eliminan cualquier riesgo potencial de lesión respiratoria crónica, pues las fibras son excesivamente grandes para ser inhaladas hacia las vías respiratorias bajas.

Las fibras de vidrio continuas se obtienen a partir de las gotas de vidrio fundido que salen de la boquilla de una hilera de finos orificios; estas gotas quedan expuestas al rápido estiramiento causado por la acción de la gravedad. El equilibrio dinámico entre las fuerzas de tensión superficial y el adelgazamiento mecánico hace que la gota adopte la forma de menisco pendiente de la boquilla de la hilera, que se adelgaza hasta el diámetro de la fibra estirada. Para que el estiramiento sea satisfactorio, el vidrio debe mantenerse en un margen estrecho de viscosidades (por ejemplo, entre 500 y 1.000 poises). A viscosidades menores es demasiado fluido y cae desde las boquillas en forma de gotas; en este caso domina la tensión superficial. Por el contrario, a viscosidades mayores la tensión en la fibra durante el adelgazamiento es excesiva. A simismo, el caudal del vidrio a través de la boquilla puede llegar a ser insuficiente para mantener el menisco.

La función de la hilera es alimentar una placa que contiene varios centenares de orificios a temperatura uniforme y acondicionar el vidrio a esta temperatura de modo que las fibras estiradas sean de diámetro uniforme. La Figura 84.9 muestra un diagrama esquemático de las principales características de una hilera de fusión directa conectada a un canal de distribución desde el cual recibe el suministro de vidrio fundido a una temperatura muy próxima a la de paso por las boquillas; por lo tanto, en este caso la función básica de la hilera es también la única.

Las hileras de bolas exigen una segunda operación, que consiste en fundir las bolas o canicas de vidrio antes de acondicionar éste a la temperatura correcta de estirado en fibras. La Figura 84.10 ilustra una hilera de bolas típica. La línea discontinua del interior de la hilera es una placa perforada que retiene las bolas de vidrio no fundidas.

El diseño de las hileras es en gran medida empírico. Por razones de resistencia al ataque del vidrio fundido y de
Figura 84.10 - Esquema de una hilera de bolas.

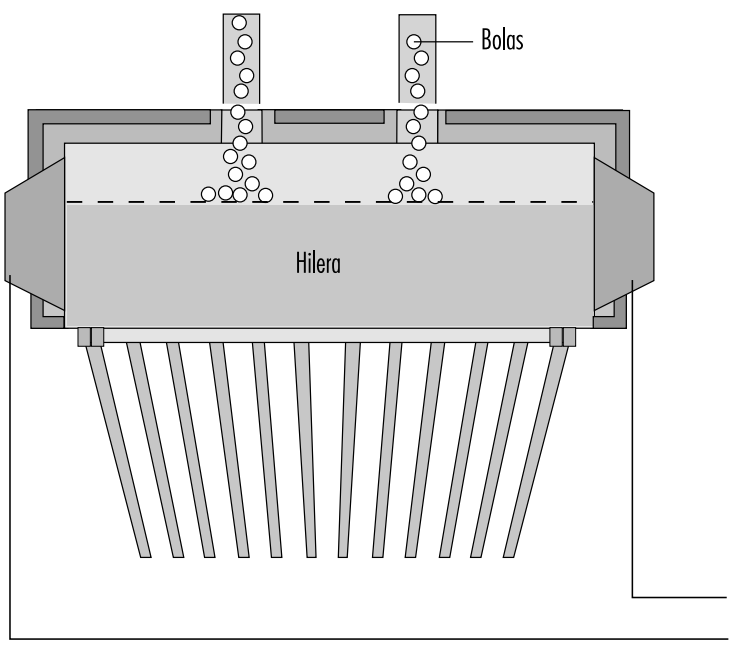

Fuente: Adaptado de Tooley 1974

estabilidad a las temperaturas necesarias para el estirado de fibras se fabrican de aleaciones de platino; se utilizan aleaciones del $10 \%$ y del $20 \%$ de platino-rodio, esta última más resistente a la deformación a temperaturas elevadas.

\section{Figura 84.11 - Filamentos de vidrio textil en el momento de ser extraídos de la hilera. Los filamentos se reúnen en manojos y se enrollan en fardos para el procesado.}

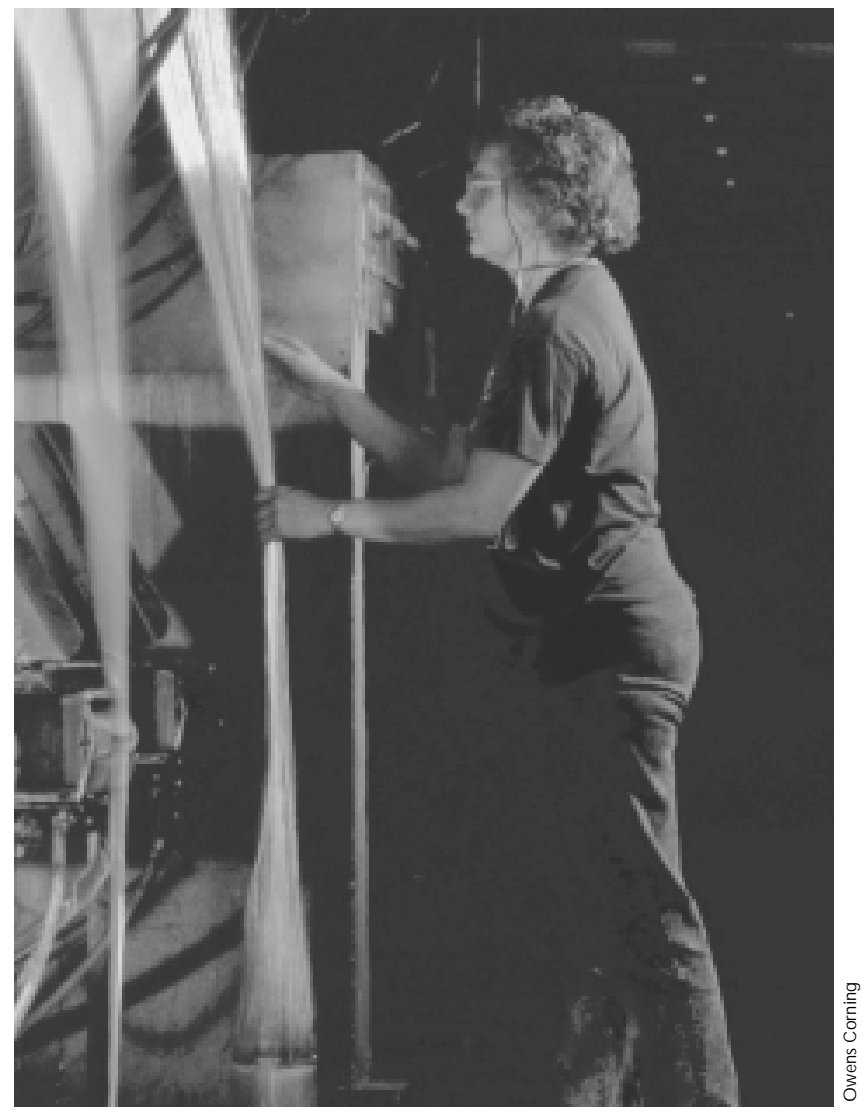


A ntes de reunirlas y consolidarlas en uno o varios cordones, las fibras individuales que se extraen de la boquilla se revisten con un apresto apropiado Estos aprestos para fibras son básicamente de dos tipos:

1. aprestos de almidón oleaginoso, generalmente aplicados a fibras que se emplearán para tejer telas finas u operaciones similares, y

2. agentes de agarre con aprestos fijadores en el caso de fibras destinadas al refuerzo directo de plásticos y caucho.

U na vez formada la fibra, con un aplicador se procede a dar una capa protectora de apresto orgánico y los filamentos continuos se unen en un hilo multifilamento (véase la Figura 84.11) antes de ser arrollados en una bobina. Los aplicadores funcionan dejando que el haz de fibras se abra en forma de abanico y, cuando alcanza una anchura de 25 a $40 \mathrm{~mm}$ en su trayectoria hacia la terminal colectora situada bajo el aplicador, pasan sobre una superficie móvil cubierta con una película de apresto para fibras.
$\mathrm{H}$ ay básicamente dos tipos de aplicadores:

1. aplicadores de rodillo, hechos de caucho, cerámica o grafito, en los que la fibra se desliza sobre la superficie del rodillo recubierta con una película de apresto, y

2. aplicadores de cinta; uno de los extremos de ésta pasa sobre un rodillo motriz que la sumerge en el apresto mientras que el otro pasa sobre una barra fija de acero duro al cromo, posición en la cual las fibras se ponen en contacto con la cinta y toman el apresto.

El revestimiento protector y la técnica de unión de las fibras varían en función del tipo de fibra textil o de refuerzo que se esté fabricando. El objetivo básico es recubrir las fibras con apresto, reunirlas en un hilo y arrollarlas sobre un tubo desmontable en el tambor de bobinado con la mínima tensión necesaria.

La Figura 84.12 ilustra el proceso de fabricación de vidrio continuo.

Figura 84.12 • Fabricación de filamento continuo de vidrio.

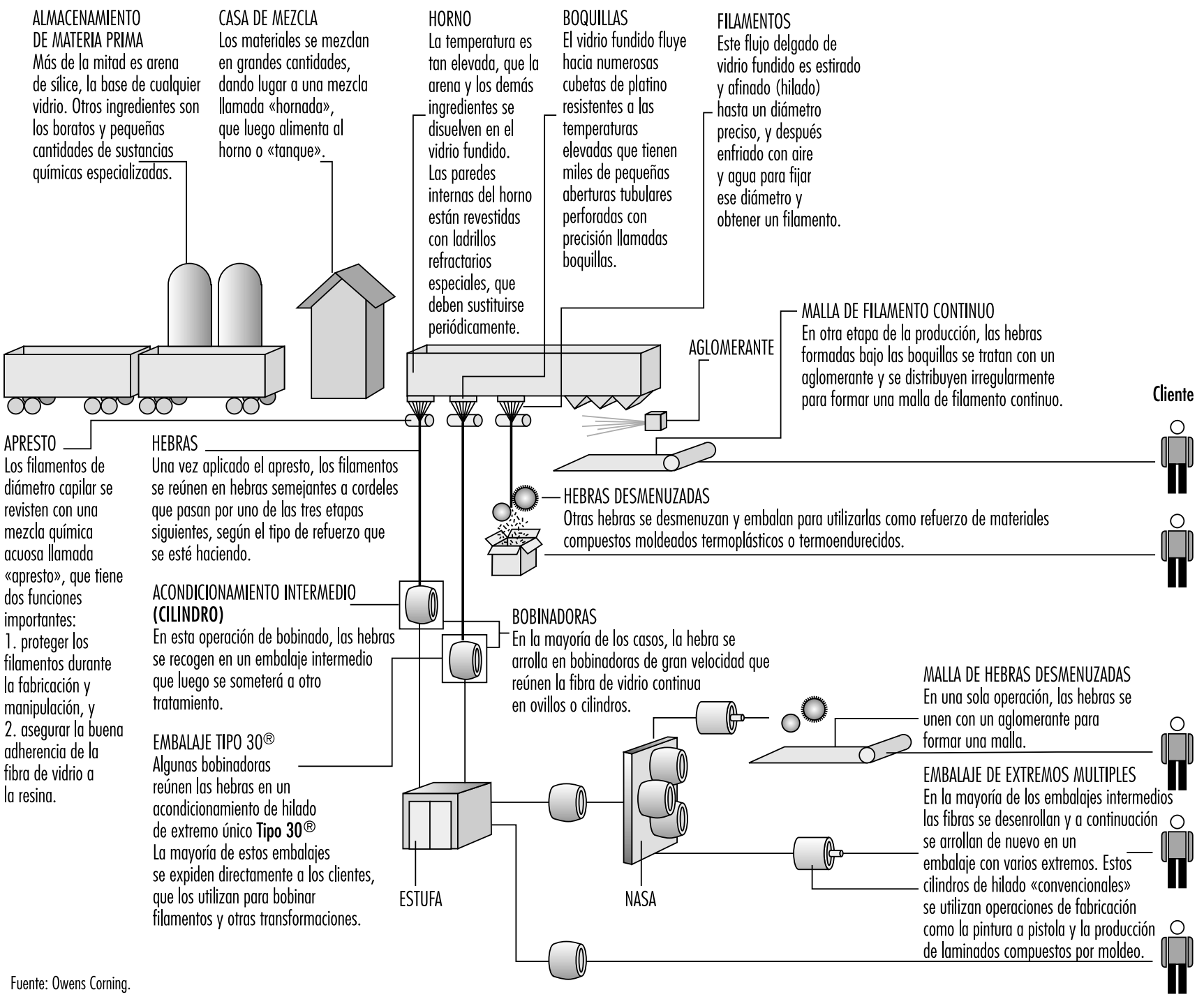


Figura 84.13 • Proceso de rotación para la fabricación de fibras de lana de vidrio.

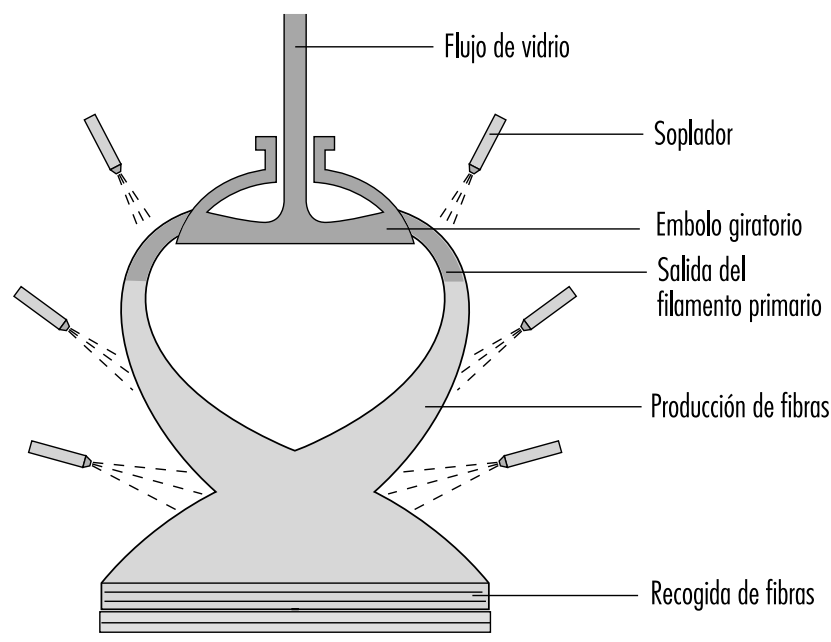

Fabricación de lana aislante

En contraste con los filamentos continuos, las fibras de lana aislante y las de cerámica refractaria se fabrican con técnicas que consumen mucha energía y que consisten en el vertido del material fundido sobre discos giratorios o sobre series de ruedas rotativas. Con estos métodos se obtienen fibras de un intervalo de diámetros mucho más amplio que el de los filamentos continuos. Por tanto, todas las lanas aislantes y fibras cerámicas refractarias contienen una proporción de fibras con diámetros inferiores a 3,0 m que podrían llegar a inhalarse si se fracturan en longitudes relativamente cortas (menos de 200 a $250 \mathrm{~m}$ ). $\mathrm{H}$ ay mucha información sobre la exposición en el lugar de trabajo a fibras artificiales de vidrio aspirables.

En la fabricación de la lana de vidrio se han utilizado varios métodos, tales como el proceso de estirado por soplado y el de soplado por la llama; pero el más difundido es el método giratorio desarrollado a mediados del decenio de 1950. En los últimos años, los procesos giratorios han sustituido ampliamente a los procesos de soplado directo en la producción comercial de aislantes de fibra de vidrio. Todos estos procesos giratorios se valen de un tambor hueco o rotor montado el eje de giro en vertical. En la pared vertical del rotor se practican miles de orificios uniformemente distribuidos alrededor de la circunferencia. Se deja caer vidrio fundido, en régimen controlado, en el centro del rotor, desde donde un distribuidor adecuado lo lleva al interior de la pared vertical perforada. D esde esta posición, la fuerza centrífuga empuja al vidrio radialmente hacia el exterior en forma de filamentos de vidrio individuales que salen por las perforaciones. Para estirar aún más los filamentos, se lanza un fluido de soplado por una o varias boquillas dispuestas en torno al rotor y concéntricas con él. EI resultado final es la producción de fibras con un diámetro medio de 6 a $7 \mathrm{~m}$. El fluido de soplado actúa hacia abajo y por tanto, además de proporcionar el estirado final, también desvía las fibras hacia una superficie de recogida situada debajo del rotor. De camino hacia esta superficie de recogida, las fibras se pulverizan con una sustancia adhesiva apropiada antes de distribuirlas uniformemente sobre ella (véase la Figura 84.13).

En el proceso giratorio, las fibras de lana de vidrio se obtienen dejando fluir el vidrio fundido a través de una serie de pequeños orificios abiertos en un rotor giratorio y estirando después los filamentos primarios por soplado de aire o vapor.

Por el contrario, la lana mineral no se puede producir mediante el proceso giratorio, e históricamente se ha obtenido con ayuda de una serie de mandriles de hilado horizontales. La técnica de fabricación de lana mineral utiliza un juego de rotores (mandriles) montados en cascada que giran muy rápidamente (véase la Figura 84.14). Una corriente de piedra fundida alimenta continuamente uno de los rotores superiores, desde el cual pasa a los demás. El material fundido se distribuye uniformemente sobre la superficie externa de los rotores, desde donde es expulsado en forma de gotitas por la fuerza centrífuga. Las gotitas se adhieren a la superficie del rotor y adoptan la forma de cuellos alargados que, sometidos a un nuevo a estirado acompañado de enfriamiento, se convierten en fibras. Naturalmente, el estirado implica una disminución del diámetro, lo cual a su vez acelera el enfriamiento. Por tanto, hay un límite inferior para el diámetro de las fibras producidas de esta manera y, en consecuencia, no cabe esperar una distribución normal de los diámetros de las fibras en torno al valor medio.

\section{Fibras cerámicas refractarias}

Las fibras cerámicas se producen principalmente por soplado e hilado, con métodos similares a los descritos para las lanas aislantes. En el proceso de estirado por soplado, la alúmina, la ślice y demás materias primas se funden en un horno eléctrico, y el material fundido es arrastrado y soplado con vapor a presión $u$ otro gas caliente. Las fibras obtenidas se recogen en una rejilla-filtro-pantalla. Figura 84.14 - Producción de lana mineral (piedra y
escoria).

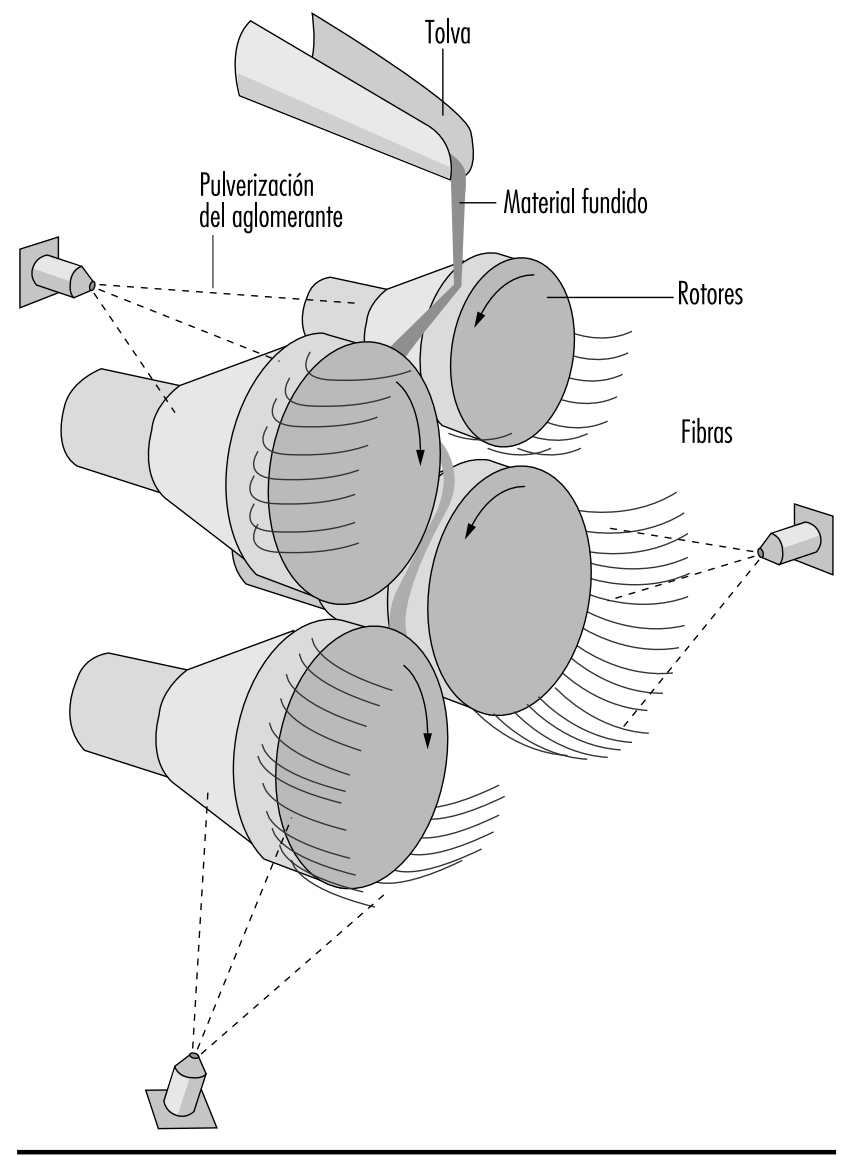




\section{Fibras ópticas}

Las fibras ópticas son hilos de vidrio finos como un cabello diseñados para transmitir los rayos de luz a lo largo de su eje. Diodos de emisión de luz (DEL) o diodos láser convierten las señales eléctricas en las señales ópticas que se transmiten a través de un núcleo cilíndrico interior del cable de la fibra óptica. Las bajas propiedades refringentes del revestimiento externo permiten propagarse a las señales luminosas por reflexión a lo largo del núcleo cilíndrico interior. Las fibras ópticas están diseñadas y fabricadas para propagar a lo largo del núcleo uno o varios haces luminosos transmitidos simultáneamente (véase la Figura 84.15.)

La fibra unimodal se usa principalmente para aplicaciones de telefonía y televisión por cable y en el tendido de redes troncales. La fibra multimodal se usa comúnmente para las comunicaciones de datos y en redes de edificios y otras instalaciones.

\section{Fabricación de fibra óptica}

Para la fabricación de fibras ópticas se requieren materiales y procedimientos que satisfagan ciertos criterios básicos de diseño: a) un núcleo de índice de refracción elevado envuelto en un revestimiento de bajo índice de refracción; b) baja atenuación (pérdida de intensidad) de la señal, y c) baja dispersión o apertura del haz luminoso.

Los materiales básicos que se utilizan comúnmente para fabricar fibras ópticas son vidrio de sílice de gran pureza con otros materiales vítreos (vidrios de fluoruros de metales pesados y vidrios de calcogenuros). También se utilizan materiales policristalinos, monocristalinos, guías de ondas huecas y materiales de plástico. Las materias primas deben ser relativamente puras, con muy bajas concentraciones de metales de transición y grupos hidroxilo (menos de una parte por mil millones). Los métodos de producción deben proteger el vidrio que se está formando del ambiente externo.

Las fibras ópticas se fabrican a partir de una preparación no convencional en fase vapor de un compuesto preformado de vidrio que luego se estira en fibras. Los compuestos de sílice volátil se convierten en $\mathrm{SiO}_{2}$ por hidrólisis a la llama, deposición química de vapor (CVD) u oxidación a gran temperatura. Luego se añaden al vidrio otras impurezas para cambiar sus propiedades. Las variaciones en el proceso de deposición de vapor parten del mismo material, pero difieren en el método utilizado para convertir este material en sílice.

Para la fabricación de fibras ópticas con base de sílice se utiliza uno de los siguientes métodos de deposición en fase vapor: a) deposición de vapor químico modificado (M C VD); b) deposición de vapor químico de plasma (PCVD); $c$ ) deposición de vapor exterior (O VD), y d) deposición de vapor en fase axial (VAD) (véase la Figura 84.16). Debido a sus elevadas presiones de vapor, los tetracloruros de silicio $\left(\mathrm{SiCl}_{4}\right)$ o germanio $\left(\mathrm{G} \mathrm{eCl}_{4}\right)$ y otros haluros líquidos volátiles se transforman en gas cuando se calientan ligeramente. El haluro gaseoso se envía a la zona de reacción y se convierte en partículas de vidrio (véase también el capítulo Microelectrónica y semiconductores.)

Técnicas basadas en MCVD y PCVD. Un tubo de sílice fundida de gran calidad se conecta a un torno de trabajo de vidrio provisto de un soplete de hidrógeno/ oxígeno que lo atraviesa longitudinalmente. A un extremo del tubo de vidrio se conecta una fuente de alimentación de haluro y en el extremo opuesto un depurador para eliminar el exceso del mismo. La superficie del tubo de vidrio se limpia primero mediante pulido al fuego recorriéndola con el soplete. Se añaden diversos reactivos en estado de vapor, que dependen del producto que se esté fabricando. Cuando los haluros pasan a través de la sección del tubo que se está calentado, reaccionan químicamente. Los haluros convierten en sílice las partículas de "hollín" que descienden del soplete y que se depositan sobre la pared interior del tubo de vidrio. Las partículas depositadas se sinterizan en la capa de vidrio. El proceso PCVD es similar al MCVD, con la diferencia de que los haluros se aportan mediante burbujeo y el soplete se sustituye por un haz de microondas para transformar los haluros en vidrio.

Técnicas $O$ VD y VAD. En la primera etapa del proceso de fabricación de la fibra, los vidrios del núcleo y del revestimiento se depositan en forma de vapor en torno a una varilla receptora giratoria para obtener una preforma de "hollín". Los materiales del núcleo se depositan primero, seguidos por los de revestimiento. La totalidad del compuesto preformado debe ser sumamente puro, puesto que tanto el núcleo como el revestimiento son vapores depositados. La geometría de la fibra se determina durante la fase de deposición de la fabricación. Una vez retirada la varilla, el compuesto preformado se coloca en un horno, donde se funde y transforma en vidrio sólido y transparente y se cierra el hueco central. Se pasa gas a través del compuesto preformado para eliminar la humedad residual que afecta negativamente a la atenuación de la fibra (pérdida de señal óptica cuando transmite la luz a lo largo del eje de la fibra). A continuación, los compuestos preformados se lavan con ácido fluorhídrico para asegurar la pureza del vidrio y eliminar los agentes contaminantes.

El compuesto preformado de vidrio se coloca en una hilera delgada para formar un hilo continuo de fibra de vidrio. Primeramente se carga el preformado en la parte superior del horno de estirado. Seguidamente, se calienta la punta del compuesto preformado y comienza a fluir un trozo de vidrio fundido que se extruye (estira) y pasa a través de un monitor de calibre incorporado para asegurar que la fibra mantiene un diámetro exacto especificado (generalmente expresado en micras). El diámetro del revestimiento de la fibra debe responder exactamente a las especificaciones para minimizar la atenuación de las señal en las conexiones. El diámetro del revestimiento externo se utiliza como una guía para alinear los núcleos de la fibra durante su uso. Los núcleos deben estar alineados para que la luz se transmita eficazmente.

Se aplica acrilato u otro revestimiento que se endurece con luz ultravioleta. El objetivo de los revestimientos es proteger la fibra óptica del ambiente durante su uso. La fibra óptica se ensaya para asegurar su conformidad con las normas de fabricación en cuanto a resistencia, atenuación y geometría. Por último, se corta a longitudes predeterminadas y se bobina en carretes de acuerdo con las indicaciones del cliente.

La fabricación de la fibra óptica va acompañada de ciertos riesgos potenciales: a) exposición al ácido fluorhídrico (cuando se limpian los compuestos preformados de vidrio); b) energía radiante y golpes de calor asociados al ambiente de trabajo cerca de tornos y procesos de deposición de vapor; c) contacto directo con superficies calientes o material fundido (compuestos preformados de vidrio); d) exposición al revestimiento de acrilato (sensibilizador de la piel); e) incisiones y laceraciones de la piel durante la manipulación de la fibra, y f) diversos de riesgos físicos ya descritos.

George R. Osborne 
Figura 84.15 • Fibras ópticas uni y multimodales.

Unimodales

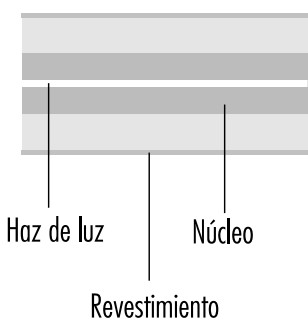

Como el hilado de las fibras de piedra y escoria, el de fibra cerámica produce una elevada proporción de fibras largas y sedosas. En este método, se deja caer una corriente de material fundido sobre discos giratorios rápidos y es expulsada tangencialmente para formar fibras.

\section{Alfarería}

\section{Visión general}

La alfarería es uno de los oficios más antiguos de la humanidad. A lo largo de los siglos se han desarrollado diferentes estilos y técnicas en distintas partes del mundo. Floreciente en Europa durante el siglo XVIII, estuvo fuertemente influenciada por la importación de una excelente porcelana muy decorada procedente del Lejano Oriente, donde Japón había aprendido de China el arte de la cerámica unos 400 años antes. C on la Revolución Industrial y el cambio de las condiciones generales de vida en Europa occidental, la producción creció rápidamente. En la actualidad, casi todos los países fabrican algún tipo de vajilla para uso doméstico, y la cerámica es una exportación importante para algunos de ellos. Estos productos se manufacturan en muchas partes del mundo a escala industrial. Aunque los principios básicos de fabricación no han cambiado, sí ha progresado considerable la forma en que esta fabricación se lleva a cabo. Las innovaciones han afectado de manera especial a la formación o moldeo de la pieza, a la cocción y a la decoración. La generalización del uso de microprocesadores y robots se ha materializado en la fuerte automatización de la producción. Pese a ello, todavía quedan en todos los lugares del mundo muchas alfarerías artesanales que trabajan a pequeña escala.

\section{Métodos de formación}

La técnica de alfarería más primitiva es la fabricación manual. Consiste en arrollar tiras de arcilla que se apilan unas sobre otras y se unen presionando con las manos. La pasta se reblandece trabajándola con agua y a continuación, una vez soldados los cordones de arcilla, se modela el objeto con las manos.

El torno de alfarero se ha convertido en instrumento de creación alfarera. La técnica consiste en depositar una pella de arcilla en el centro de un plato circular giratorio para modelarla con las manos mojadas. El agua impide que el barro se pegue a las manos y, al mismo tiempo, lo mantiene húmedo y maleable. L as asas, pitorros y otras protuberancias de la arcilla torneada se colocan antes de cocer el objeto.

El colado se utiliza ahora con frecuencia para formar objetos de gran calidad y siempre que las paredes de la vasija deban ser muy finas. En un molde de escayola se vierte una mezcla de arcilla y agua llamada barbotina; el molde absorbe el agua de la pasta, que forma una capa delgada en su cara interna. Cuando el depósito de arcilla es lo suficientemente grueso como para formar las paredes del recipiente se vacía el resto de la barbotina, manteniendo la pieza húmeda en el interior del molde hasta que se seque y contraiga lo suficiente para poder extraerla del mismo. El molde se construye de forma que sea desmontable.

U na vez completamente seca, la pieza se pule y prepara para la cocción. Se coloca en una caja de tierra refractaria llamado gaceta, que la protege de las llamaradas y de los gases que se emiten durante el proceso, de la misma forma que un horno casero protege la hogaza de pan. Las gacetas se apilan unas sobre otras en un horno. El horno es una gran estructura de ladrillo refractario y rodeada de conductos por los que penetra el fuego sin que las llamas entren nunca en contacto con la vajilla. El humo podría manchar las piezas si no estuvieran protegidas de esta forma.

La mayoría de las piezas se cuecen al menos dos veces. La primera cochura es la de bizcochar, y la pieza así obtenida es la bizcochada o bizcocho. Después de la cocción, la pieza bizcochada se esmalta. El esmalte es un recubrimiento vítreo y brillante que hace la pieza más resistente y atractiva. Los esmaltes contienen sílice, un fundente para bajar la temperatura de fusión (como plomo, bario, etc.) y óxidos metálicos que actúan como colorantes. Este preparado se aplica al objeto y, cuando está completamente seco, se coloca de nuevo en el horno y se cuece a una temperatura lo suficientemente elevada para que se funda y cubra por entero la superficie de la pieza.

\section{Tipos de cerámica}

- Gres: es una cerámica hecha con arcilla blanca o roja. Se esmalta sobre el soporte crudo antes de entrar en el horno o mediante el procedimiento de "salado" durante la cocción, que produce un material denso y duro.

- Porcelana: es un material cerámico blanco, vitrificado y translúcido. El soporte y el esmalte se llevan a maduración final en una única cocción conjunta para ambos (monococción), que tiene lugar a temperatura muy elevada.

Figura 84.16 • Diagrama de flujo de la fabricación de fibra óptica.

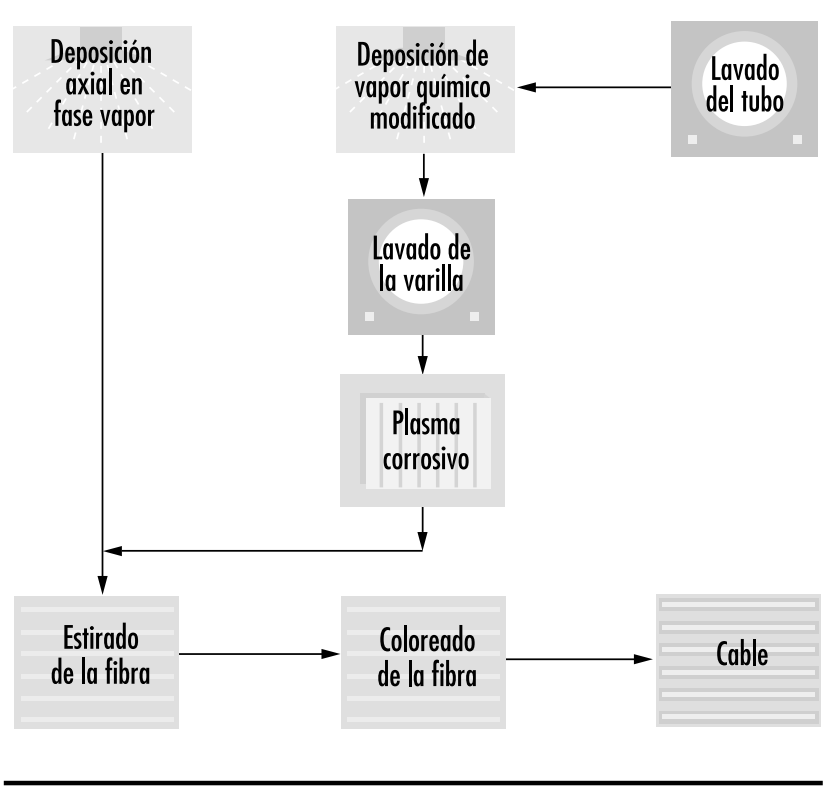


Tabla 84.1 • Componentes típicos del cuerpo (\%).

\begin{tabular}{|c|c|c|c|c|c|c|c|c|}
\hline \multirow[t]{2}{*}{ Pasta } & \multicolumn{3}{|c|}{ Base plástica } & \multicolumn{2}{|c|}{ Fundente } & \multicolumn{3}{|c|}{ Material de relleno (carga) } \\
\hline & Arcilla plástica & Caolín & Arcilla de gres & Piedra & Feldespato & Cuarzo & Huesos calcinados & Otros \\
\hline Barro cocido & 25 & 25 & & 15 & & 35 & & \\
\hline Gres & $30-40$ & & $25-35$ & & $20-25$ & & & 20-30 (chamota) \\
\hline Porcelana & $20-25$ & $20-25$ & & & $15-25$ & $25-30$ & & \\
\hline Loza & & $40-50$ & & & $20-30$ & $15-25$ & & \\
\hline Porcelana de huesos & & $20-25$ & & $25-30$ & & & $45-50$ & \\
\hline
\end{tabular}

- Porcelana de China: es un material cerámico muy similar al anterior. El soporte y el esmalte se cuecen a la vez a temperaturas extremadamente altas.

- Porcelana de huesos: es una variedad de porcelana fabricada con una pasta formada que incorpora huesos calcinados en una proporción de aproximadamente el $40 \%$.

- Loza: tiene una masa blanco o casi blanca. Se produce por bicocción, como la porcelana de China, pero la masa resultante es porosa. El esmalte es similar al de la porcelana, pero obtenido con materiales más baratos.

- M ayólica: es una loza delicadamente esmaltada que se utiliza con fines decorativos u ornamentales. Por lo general, no se intenta obtener una pasta blanca y los esmaltes suelen colorearse.

\section{Procesos de fabricación}

Las propiedades físicas de la cerámica dependen de la composición del soporte o pasta y de las condiciones de cocción. La pasta para cualquier uso particular se selecciona principalmente por sus propiedades físicas, aunque para la vajilla se prefieren casi siempre las pastas blancas.

Los productos industriales (por ejemplo, refractarios, aisladores eléctricos, matrices para catalizadores, etc.) presentan propiedades muy diversas de acuerdo con su destino.

$M$ aterias primas. Los ingredientes básicos de una pasta cerámica se recogen en la Tabla 84.1, que también indica las proporciones de distintas pastas tipo.

La nefelina-sienita se usa a veces como fundente, y la alúmina puede reemplazar parcial o totalmente al cuarzo en algunas pastas de tipo porcelana. La cristobalita (arena calcinada) se usa como carga en algunas pastas cerámicas, en particular en las usadas para revestimientos murales.

La composición de la pasta viene determinada en parte por las propiedades requeridas del producto final y en parte por el método de producción. Una base plástica es esencial para objetos moldeados en húmedo, pero para los procesos de formación no plástica, como el prensado en polvo (seco), la base plástica no es esencial, aunque la arcilla continúa siendo el principal ingrediente en la mayor parte de los productos cerámicos, incluso en aquellos que se preparan por prensado en polvo.

La Tabla 84.1 no recoge cerámicas industriales, pues su composición varía desde todo arcilla plástica (ball clay) o refractaria, sin incorporación de fundentes o cargas; hasta casi todo alúmina con una mínima cantidad de arcilla y sin fundentes.

Durante la cocción, los fundentes se derriten y forman una masa vítrea que aglutina el resto de los ingredientes; la temperatura de vitrificación desciende a medida que aumenta la cantidad de fundentes. Los materiales de relleno (áridos) influyen en la resistencia mecánica de la fracción arcillosa antes y durante la cocción; en la elaboración de vajilla se utiliza tradicionalmente cuarzo (en forma de arena o sílex calcinado), excepto en la preparación de porcelana de huesos, donde se emplean huesos calcinados. EI uso de alúmina o de otras cargas no silíceas, empleadas en la elaboración de cerámicas industriales, está empezando a extenderse a la de otros productos, incluidos los domésticos.

Procesos. Las operaciones básicas de la producción de cerámica son:

- preparación de la pasta;

- conformación;

- bizcochado;

- aplicación de esmalte;

- cocción de vidriado, y

- decoración.

L os procesos preparatorios de calcinación, trituración y pulverización de los áridos (sílex, piedra, etc.) se completan a veces en una planta independiente, pero las operaciones siguientes suelen hacerse todas en una misma factoría. En la sala de pastas los ingredientes se mezclan con agua; se obtiene así la arcilla plástica por filtrado y amasado, y se mezcla con más agua hasta obtener una barbotina de consistencia cremosa. El polvo para el prensado se prepara por secado y molturación.

L as clasificaciones tradicionales de los métodos de conformación se recogen en la Tabla 84.2. En el colado, la suspensión acuosa de pasta (barbotina) se vierte en un molde absorbente, de donde se retira después de un secado parcial. En la actualidad es muy raro el torneado a mano en la fabricación industrial; en la elaboración de vajilla es casi universal el prensado mecánico de un exceso de pasta sobre un molde de yeso o en su interior; el exceso de arcilla se elimina con un nivel que desciende sobre el molde, del que se separa la pasta una vez seca. El moldeado por prensado o extrusión está básicamente restringido a la cerámica industrial. Los materiales prensados en polvo se producen por compactación de polvo de pasta presecado en prensas manuales o mecánicas.

El material conformado se seca y acaba por desbarbado, desbaste, limpieza con esponja húmeda, etc.; se deja así listo para el bizcochado.

Después del bizcochado, se aplica el esmalte por inmersión o por aspersión; la inmersión se hace a mano o mecánicamente. El producto esmaltado se cuece de nuevo. A veces, en particular en

Tabla 84.2 • Procesos de fabricación.

$\begin{array}{ll}\text { Productos } & \text { Procesos habituales } \\ \text { Planchas } & \text { Moldeado de arcilla plástica; colado } \\ \text { Material sanitario } & \text { Colado } \\ \text { Baldosas } & \begin{array}{c}\text { Prensado en polvo (pavimentos o revesti- } \\ \text { mientos gresificados), troquelado (pavi- } \\ \text { mentos) }\end{array} \\ \text { Artículos industriales } & \text { Prensado en polvo, Troquelado }\end{array}$


Figura 84.17 - Diagrama de flujo por tipo de producto cerámico.

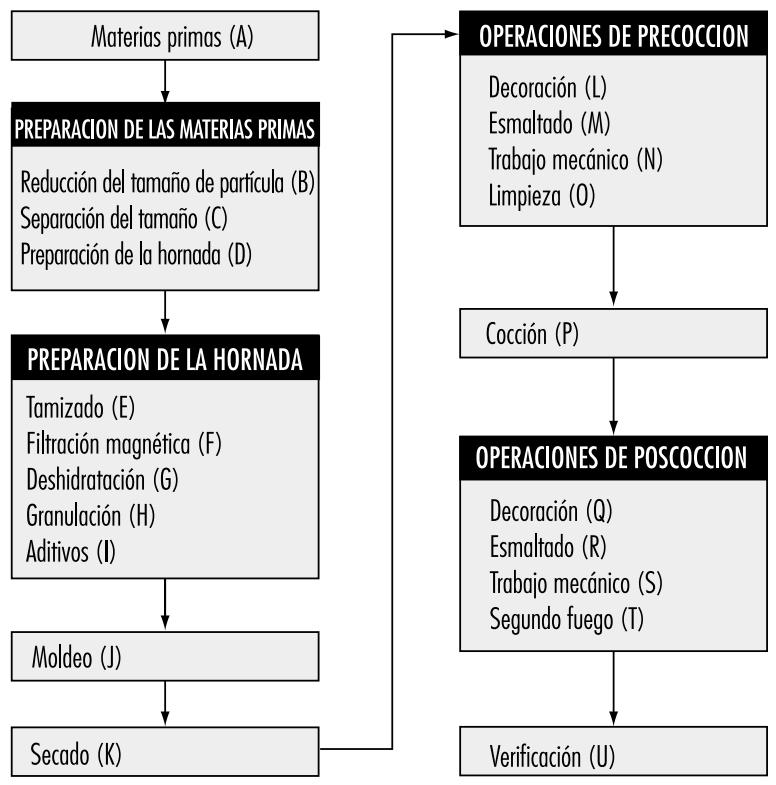

\begin{tabular}{|c|c|}
\hline TIPO DE MATERIAL CERAMICO & $\begin{array}{l}\text { SECUENCIA DE OPERACIONES MULTIPLES } \\
\text { DE PRODUCCION SEGUN EL TIPO DE } \\
\text { MATERIAL CERAMICO }\end{array}$ \\
\hline $\begin{array}{l}\text { Cementos } \\
\text { Ladrillos para la construcción } \\
\text { Cañerías esmaltadas para la constr. } \\
\text { Sanitarios } \\
\text { Porcelana de huesos (colada) } \\
\text { Porcelana de huesos (Haggard) } \\
\text { Porcelana } \\
\text { Refractarios arcillosos (extrusionados) } \\
\text { Refractarios, } \mathrm{M}_{2} \mathrm{O} \\
\text { Azulejos } \\
\text { Esmalte } \\
\text { Materias primas (arcillas lavadas) }\end{array}$ & $\begin{array}{l}A-D / P / L / C / I / U \\
A-D / J / K / P / U \\
A-D / J / K / P / R / T / U \\
A / D / E / F / O / M / P / U \\
A / D-F / J / K / O / P / R / T / Q / T / U \\
A / D-G / J / K / O / P / R / T / Q / T / U \\
A / D-F / J / K / N / M / P / Q / T / U \\
A-D / J / K / P / U \\
A-D / J / K / P / U \\
A / I / D-F / H / E / J / M / K / P / U \\
A / I / D-F / M \\
A / C-F / K / C / U\end{array}$ \\
\hline
\end{tabular}

Fuente: Haber y Smith 1987

la fabricación de loza sanitaria, el esmaltado se aplica sobre la pieza simplemente seca, que a continuación se somete a una única cochura (monococción).

La decoración se aplica sobre o bajo el esmalte, a mano, impresa mecánicamente o con ayuda de calcomanías; la decoración sobre esmalte exige una tercera cocción, y a veces son necesarias cocciones separadas para diferentes colores.

En las etapas finales se clasifican los productos y se embalan para su expedición. La Figura 84.17 recoge las fases por las que pasan los productos cerámicos durante su fabricación.

\section{Baldosas cerámicas}

\section{Visión general}

H ace algún tiempo, el término cerámica denotaba únicamente el arte 0 la técnica de producción de artículos de alfarería. EI origen etimológico está en el griego keramos, que significa "alfarero" o "alfarería". Sin embargo, la palabra griega está relacionada con una raíz sánscrita más antigua que significa "quemar"; en el sentido en que la usaban los propios griegos su significado primordial era simplemente "material quemado" 0 "tierra quemada". El concepto fundamental contenido en el término era el de un producto obtenido gracias a la acción del fuego sobre materiales terrosos.

En el contexto de este artículo, la cerámica tradicional se refiere a los productos normalmente usados como material para la construcción o en el interior de casas e industrias. Aunque la cerámica tradicional tiende a asociarse con técnicas elementales, lo cierto es que en este sector son comunes las tecnologías de fabricación avanzadas. La dura competencia entre fabricantes ha obligado a perfeccionar las técnicas para aumentar el rendimiento y reducir los costes mediante el uso de herramientas y máquinas complejas combinadas con el control del proceso asistido por ordenador.

Los productos cerámicos más antiguos se hacían con materiales arcillosos. Los primitivos alfareros consideraron que la naturaleza plástica de la arcilla era muy apropiada para darle forma. Debido a su tendencia a la contracción, las pastas arcillosas se modificaron con la incorporación de arena gruesa y piedra, que reducen la contracción y el fisurado. En las modernas pastas arcillosas, los aportes comunes no arcillosos son harinas de arena y minerales alcalinos que se añaden como fundentes, mientras que en las formulaciones cerámicas tradicionales es la arcilla la que actúa como plastificante y aglutinante de los demás componentes.

\section{Evolución de la industria}

La producción de baldosas cerámicas secas y cocidas tiene orígenes muy antiguos que se remontan a los pueblos del 0 riente Próximo. La industria de baldosas se desarrolló mucho en Europa, y hacia principios del siglo XX la fabricación de pavimentos y revestimientos alcanzó la escala industrial. D espués de la segunda guerra mundial, este campo experimentó un nuevo avance. Europa (en particular Italia y España), América Latina y Extremo Oriente son en la actualidad las principales zonas de producción industrial de baldosas.

El sector de los pavimentos y revestimientos industriales ha experimentado un fuerte desarrollo desde mediados del decenio de 1980 con la introducción de nuevas tecnologías y automatismos y la integración de la producción en serie en los procesos industriales que aumentaron la productividad y la eficiencia, al tiempo que se redujeron el consumo de energía y los costes. En la actualidad, la fabricación de baldosas es continua en ambos métodos de producción, seco y húmedo, y muchas plantas están casi totalmente automatizadas. Entre las principales innovaciones del sector durante el último decenio se cuentan la molturación en húmedo, el atomizado, el prensado en seco a alta presión, el secadero de rodillos y las tecnologías de cocción rápida.

Se calcula que el valor de la oferta del mercado de baldosas cerámicas de EE.UU. (producción nacional más importaciones) se incrementó anualmente en un 9,2 \% entre 1992 y 1994. Las ventas estimadas de 1994 fueron de 1.300 millones de dólares. Al mismo tiempo, el volumen de ventas aumentó anualmente en un $11,9 \%$ hasta alcanzar los 120,6 millones de metros cuadrados. Esto equivale a una tasa de crecimiento del mercado entre 1982 y 1992 del 7,6 \% en dólares, y del 6,9\% en volumen de ventas.

\section{Clasificación de las baldosas cerámicas.}

\section{Pasta roja y pasta blanca}

En el mercado hay muchos tipos de baldosas cerámicas, que se diferencian por el acabado de la superficie, el color de la pasta 
(roja o blanca), la tecnología de fabricación, las materias primas y el uso al que se destinan. La diferencia entre baldosas "rojas" y "blancas" estriba en la cantidad de minerales de hierro que contiene el soporte; estos minerales reaccionan con los restantes componentes dando una coloración mayor o menor y modificando el comportamiento del soporte durante la cocción.

U na clasificación completa y exhaustiva es muy difícil debido a la extrema heterogeneidad de estos productos, de su procesamiento y de las subsiguientes características. En este capítulo consideraremos las N ormas europeas (EN) y AST M .

Las N ormas EN clasifican las baldosas cerámicas exclusivamente en función de la absorción de agua (que se relaciona directamente con la porosidad) y el método de moldeo (extrusionado o prensado). Los métodos de moldeo se dividen en:

- Grupo A (pavimentos extruidos). Este grupo incluye los extruidos en dos piezas separables (split tiles) y los extruidos individualmente.

- Grupo B (pavimentos y revestimientos prensados en seco).

La N orma europea EN 87, aprobada en N oviembre de 1981, especifica que "Ios pavimentos y revestimientos cerámicos son materiales para la construcción que generalmente se designan para su uso como recubrimiento de suelos y paredes tanto de interiores como de exteriores, sin importar su forma o tamaño".

La especificación para baldosas cerámicas (AN SI A 137.1) del Instituto Nacional Americano de Normalización (ANSI) contiene las siguientes definiciones:

- M osaico: formado por extrusión o prensado de 6,4 a 9,5 mm de grosor, y de menos de $39 \mathrm{~cm}^{2}$ de superficie facial. Su composición de arcillas puede ser porcelánica 0 natural, y sencilla 0 con mezcla abrasiva en su totalidad.

- Azul jo decorativo: baldosa esmaltada, delgada y generalmente no vítrea apta para revestimientos decorativos interiores cuando no se requiere resistencia a la rotura.

- Pavimentos: baldosa esmaltada o no esmaltada de composición porcelánica o natural formada por prensado de áridos y de superficie superior a $39 \mathrm{~cm}^{2}$.

- Baldosa porcelánica: mosaico o pavimento, generalmente fabricado por prensado, de composición densa, impermeable, de grano fino y cara lisa nítidamente formada.

- Baldosa de gres (Quarry tile): baldosa esmaltada o no, moldeada por extrusión a partir de arcilla natural o pizarra, y de superficie facial mayor o igual a $39 \mathrm{~cm}^{2}$.

- Azulejo: baldosa esmaltada con soporte apto para interiores, generalmente no vitrificado y que no debe soportar impactos excesivos, ni grandes cambios térmicos (heladas y deshielos bruscos).

- Tipos particulares de baldosas: comprenden baldosas no esmaltadas (mosaico cerámico, gres, pavimento) y esmaltadas (azulejo, mosaico, gres y pavimento) (ANSI 1988).

L as baldosas se fabrican mediante procesos cerámicos normalizados. Los pavimentos y revestimientos cerámicos se preparan a partir de una mezcla de arcillas plásticas (ball clays), arena, fundentes, colorantes y otras materias primas minerales, que se someten a una serie de operaciones tales como molienda, tamizado, mezclado y humidificado. Se moldean por prensado, extrusión, colado u otros procesos, normalmente a temperatura ambiente; a continuación se secan y por último se cuecen a temperatura elevada. $\mathrm{H}$ ay baldosas esmaltadas, no esmaltadas 0 engobadas. Los esmaltes son recubrimientos vidriados e impermeables, mientras que los engobes son mates, basados en arcillas y probablemente porosos. Se producen tanto por monococción como por bicocción.

LoS soportes cerámicos tradicionales se moldean usando técnicas muy diversas. El proceso específico vendrá determinado por numerosos factores, entre ellos las características del material, el tamaño y el perfil de la pieza, las especificaciones de la misma, el rendimiento de la producción y las prácticas admitidas en la zona.

Los soportes cerámicos son mezclas heterogéneas de una 0 más arcillas y una o más sustancias pulverulentas no arcillosas (áridos). Antes de alcanzar su aspecto final, estos polvos pasan por una secuencia de operaciones en cadena y por fases de cocción y post-cocción (véase la Figura 84.17).

Para los soportes más tradicionales, las técnicas de formación se clasifican en moldeo en plástico blando, moldeo en plástico duro, prensado y colado.

La presión aplicada sirve para reordenar y redistribuir las materias primas en una configuración más compacta. El comportamiento reológico de las pastas arcillosas resulta de la interacción de la arcilla con el agua, que comunica plasticidad al conjunto. En las pastas no arcillosas este mismo comportamiento debe alcanzarse por aportación de plastificantes.

\section{Cerámicas industriales}

\section{Visión general}

La cerámica difiere de otros materiales técnicos (metales, plásticos, productos de la madera, textiles) en una serie de propiedades individuales. La diferencia más característica para un diseñador o usuario potencial de artículos cerámicos quizás sea la forma y el tamaño únicos de cada pieza cerámica. Después de la cocción, la cerámica no permite trabajar o modificar su forma fácilmente si no es con un costoso esmerilado, por lo que debe usarse tal cual es. Excepto alguna baldosa sencilla, varillas y formas tubulares de pequeño tamaño, los materiales cerámicos no se pueden comercializar al centímetro ni ser cortados para encajar en el lugar de colocación.

Todas las propiedades de la cerámica, incluidas la forma y el tamaño, deben determinarse por adelantado desde las primeras etapas del proceso cerámico. La integridad estructural de cada pieza debe preservarse a lo largo de la gran variedad de tensiones térmicas y mecánicas a que se somete durante el proceso, hasta que finalmente es colocada y entra en servicio. Las piezas cerámicas rotas una vez colocadas como consecuencia de diversas causas (fractura frágil al impacto, choque térmico, ruptura dieléctrica, abrasión o corrosión de la escoria fundida) no son fáciles de reparar, y normalmente hay que reemplazarlas.

Se ha avanzado mucho en el conocimiento de los fundamentos y en el control tecnológico de las propiedades de los materiales cerámicos y de su utilización en muchas aplicaciones nuevas, muy técnicas y exigentes. La industria en general, y los sectores de la cerámica técnica y electrónica en particular, han ideado técnicas de producción y control para la fabricación a gran escala de piezas de forma compleja controlando cuidadosamente las propiedades eléctricas, magnéticas y/ o mecánicas, y manteniendo tolerancias dimensionales lo suficientemente buenas como para permitir un ensamblado relativamente fácil con otros componentes.

A hora se fabrican en grandes cantidades numerosos artículos cerámicos normalizados. Muchos productores cerámicos disponen habitualmente de existencias de ladrillos refractarios, crisoles, muflas, tubos de hornos, aislantes, tubos de protección de termopares, dieléctricos de condensadores, juntas estancas y tableros de fibras, con variedad de composiciones y tamaños. Por lo general, lo más rápido y barato es usar artículos en existencia siempre que sea posible; en caso contrario, la mayoría de los fabricantes están preparados para producir artículos por encargo. Cuanto más estrictos sean los requerimientos para una característica determinada de la cerámica, o más restrictivos 
sean los requerimientos para una combinación específica de propiedades, tamaños y formas, tanto más limitados serán los parámetros aceptables de composición, microestructura y configuración. En consecuencia, el coste de fabricación será mayor. Casi todos los fabricantes de cerámica tienen una plantilla de ingenieros y diseñadores con experiencia que están bien cualificados para trabajar con clientes potenciales en los detalles del diseño de la pieza cerámica.

\section{Mercados}

El principal mercado para los productos cerámicos de tecnología avanzada ha sido y seguirá siendo el de la electrónica, pero los pujantes programas de investigación y desarrollo en todo el mundo buscan continuamente nuevas aplicaciones y la identificación de métodos para la mejora de las propiedades cerámicas a fin de poder acceder a esos nuevos mercados.

En Japón, Estados U nidos y Europa O ccidental se fabrican productos cerámicos avanzados cuyas materias primas se comercializan internacionalmente, en especial como polvos, aunque también es importante el volumen de producción interna.

L as principales aplicaciones de las cerámicas industriales son:

- Oxidos: la alúmina es el óxido que más se utiliza hoy en bujías, substratos y aplicaciones abrasivas; la zirconia $\left(\mathrm{ZrO}_{2}\right)$ en sensores de oxígeno, como componente en cerámica piezoeléctrica de titanio-plomo-zirconio (PZT), en aplicaciones abrasivas y recubrimientos de barreras térmicas; los titanatos en condensadores de titanato de bario y piezoeléctricos PZT ; y las ferritas en imanes permanentes, cabezales de grabación magnéticos, dispositivos de memoria, sensores de temperatura y piezas de motores eléctricos.

- Carburos y nitruros: los carburos (principalmente los de sílice y boro) se usan en aplicaciones abrasivas, mientras que los nitruros (principalmente sílice y Sialon) se utilizan en aplicaciones abrasivas y herramientas de corte. El nitruro de aluminio, por su gran conductividad térmica, es el principal rival de la alúmina en el mercado de substratos electrónicos.

- M ezcla de óxidos: el trabajo de investigación y desarrollo en el campo de la cerámica se centra en una serie de nuevas aplicaciones de los materiales cerámicos, todas ellas con un enorme potencial. Tres aplicaciones destacadas son: a) superconductores cerámicos; b) materiales cerámicos para células electroquímicas de óxidos sólidos, y c) compuestos cerámicos para máquinas térmicas.

Los superconductores cerámicos se basan en una serie de sistemas de mezcla de óxidos que incluyen itrio, bario, cobre y estroncio $\left(\mathrm{Y} \mathrm{Ba}_{2} \mathrm{Cu}_{3} \mathrm{O}_{7-8}, \mathrm{Bi}_{2} \mathrm{Sr}_{2} \mathrm{CaCu}_{2} \mathrm{O}_{8}, \mathrm{Bi}_{2} \mathrm{Sr}_{2} \mathrm{Ca}_{2} \mathrm{Cu}_{3} \mathrm{O}_{10}\right)$ estabilizados con óxido de plomo. $L$ as células electroquímicas de óxidos sólidos se basan en conductores iónicos en los cuales el óxido de zirconio estabilizado de gran pureza es normalmente el material elegido. Los componentes cerámicos de las máquinas térmicas que se investigan son compuestos de carburo de silicio, Sialon y zirconio, o como productos cerámicos de fase simple, 0 compuestos cerámica-cerámica o metal-aglomerante (M M C).

\section{Procesos de fabricación}

\section{Desarrollo de la tecnología de fabricación}

Innovaciones del tratamiento: la actividad de investigación y desarrollo está introduciendo nuevas tecnologías de producción de materiales cerámicos. En 1989 se estimó que los materiales cerámicos derivados de estas innovaciones alcanzaron un valor de mercado de dos millones de dólares, la mayor parte del cual era CVD (86\% del total del valor de mercado). 0 tros segmentos de este mercado en crecimiento incluyen infiltración de vapores químicos (CVI), sol-gel y pirólisis de polímeros. Las fibras cerámicas

continuas, los composites, las membranas y los polvos hiperactivos y de gran pureza son algunos de los productos que están fabricándose de manera satisfactoria con estos métodos.

Los métodos usados para convertir estas materias primas en productos acabados comprenden tratamientos especiales del polvo cerámico (por ejemplo, molienda y atomizado) antes de la configuración en crudo y de la cochura final en condiciones controladas. En la formación se usan técnicas de troquelado, prensado isostático, colado, vaciado, extrusión, inyección en molde, prensado en caliente, prensado isostático en caliente (HIP), CV D, etcétera.

Aditivos químicos de ayuda a procesos cerámicos: cada paso de un proceso industrial requiere un control cuidadoso para que las propiedades del producto final se obtengan con la máxima eficiencia de producción y se usan productos químicos que tienen un efecto clave en la optimización del tratamiento de los polvos y el moldeado en crudo. Estos productos químicos se usan como mejoradores de la molturación, floculantes y fijadores, lubricantes para facilitar el desprendimiento de la pieza durante el prensado y minimizar el desgaste del troquel, y plastificantes para contribuir al extrusionado y moldeado por inyección. En la Tabla 84.3 se recogen estos productos químicos. Aunque estos materiales juegan un importante papel económico en la producción, se queman durante la cocción y no tienen efecto alguno sobre el producto acabado. El quemado debe controlarse con precisión para evitar la presencia de carbón residual en los productos acabados, por lo que la investigación y el

Tabla 84.3 • Selección de aditivos químicos empleados para optimizar el tratamiento del polvo y el moldeado en crudo de los productos cerámicos.

\begin{tabular}{|c|c|}
\hline Material & Aplicación o función \\
\hline Alcohol polivinílico & $\begin{array}{l}\text { Ligante para materiales cerámicos } \\
\text { avanzados }\end{array}$ \\
\hline Polietilenglicol & $\begin{array}{l}\text { Ligante para materiales cerámicos } \\
\text { avanzados }\end{array}$ \\
\hline Poliacrilato sódico & Defloculante para colado de barbotinas \\
\hline Poliamida terciaria & Ligante para prensado en seco \\
\hline $\begin{array}{l}\text { Almidón mezclado con aluminosilicato } \\
\text { coloidal seco }\end{array}$ & Ligante para moldeado al vacío \\
\hline $\begin{array}{l}\text { Alúmina catiónica más floculante } \\
\text { orgánico }\end{array}$ & Ligante para moldeado al vacío \\
\hline Almidón de maíz catiónico pre-gelificado & $\begin{array}{l}\text { Floculante para sílice coloidal y ligante } \\
\text { para alúmina }\end{array}$ \\
\hline $\begin{array}{l}\text { Carboximetilcelulosa sódica de gran } \\
\text { pureza }\end{array}$ & Ligante \\
\hline $\begin{array}{l}\text { Silicato alumínico de magnesio inorgá- } \\
\text { nico coloidal }\end{array}$ & Inductor de suspensiones \\
\hline $\begin{array}{l}\text { Carboximetilcelulosa sódica de visco- } \\
\text { sidad media añadida a Veegum }\end{array}$ & $\begin{array}{l}\text { Inductor de suspensiones, estabilizante } \\
\text { de viscosidad }\end{array}$ \\
\hline Polielectrolito amónico & Agente dispersante para atomizados \\
\hline Polielectrolito sódico & $\begin{array}{l}\text { Agente floculante para dar cuerpo a } \\
\text { pulverizadores secantes }\end{array}$ \\
\hline $\begin{array}{l}\text { Celulosa microcristalina y carboximetil- } \\
\text { celulosa sódica }\end{array}$ & Agente espesador \\
\hline Polisilazano & $\begin{array}{l}\text { Auxiliar del proceso, ligante y precursor } \\
\text { para material cerámico avanzado }\end{array}$ \\
\hline
\end{tabular}

Material

Poliacrilato sódico

oliamida terciaria

Amidón mezclado con aluminosilicato

Aúmina catiónica más floculante

orgánico

Carboximetilcelulosa sódica de gran

Silicato alumínico de magnesio inorgásidad media añadida a Veegum

Polielectrolito amónico celulosa sódica

Polisilazano

\section{Aplicación o función}

gante para materiales cerámicos

gante para materiales cerámicos

Defloculante para colado de barbotinas igante para prensado en seco para material cerámico avanzado 
desarrollo de los procesos buscan continuamente métodos que minimicen los efectos de estos materiales.

A demás del desarrollo de las tecnologías para la fabricación de cerámica y productos cerámicos en busca de nuevas aplicaciones, no debería pasarse por alto la influencia de la industria cerámica avanzada sobre la tradicional. Se espera que muchos materiales y procesos de alta tecnología encuentren aplicación en la industria cerámica tradicional cuando esta última se esfuerce por reducir los costos de fabricación, mejorar la calidad y conceder más importancia a la atención al usuario final.

\section{Materias primas}

$\mathrm{H}$ ay ciertos materiales clave directamente usados por la industria cerámica o que representan el punto de partida para la producción de materiales de valor añadido:

- sílice;

- arcilla;

- alúmina;

- magnesia;

- bióxido de titanio;

- óxido de hierro, y

- zircón (silicato de zirconio natural)/zirconia (óxido de zirconio)

La exposición se centrará en las propiedades de la sílice, la alúmina y el zircón/ zirconia.

Sílice: además de su uso en refractarios y cerámica blanca, también es el punto de partida en la fabricación de silicio, carburo de silicio y tetracloruro de silicio. A su vez, el silicio es el punto de partida para la obtención de nitruro de silicio y el tetracloruro de silicio es el precursor para una amplia gama de compuestos organosilíceos, que en condiciones controladas se pirolizan a carburo de silicio de gran calidad y nitruro de silicio.

A pesar de su tendencia a oxidarse, el nitruro de silicio y sus derivados de Sialon, así como también el carburo de silicio, tienen la capacidad potencial de cumplir muchos de los objetivos de propiedades fijados por el mercado de la maquinaria térmica. U na característica del silicio y de los materiales cerámicos derivados del mismo es que se encuentran fácilmente en la corteza terrestre, por lo que ofrecen potencialmente facilidad de suministro en todo el mundo. En la práctica, sin embargo, se requiere un importante consumo energético para la producción de silicio y carburo de silicio. En consecuencia, la fabricación de estos materiales está limitada a los países con energía eléctrica barata y fácilmente asequible.

Alúmina: se encuentra en toda la corteza terrestre como componente de los aluminosilicatos. Por motivos económicos, la alúmina se extrae de la bauxita mediante el proceso Bayer. La bauxita está extendida por todo el cinturón ecuatorial en distintos estados de pureza, y se clasifica en dos tipos: refractaria y metalúrgica.

La bauxita de calidad refractaria la suministran China y $G$ uayana en forma de calcinado a alta temperatura de los yacimientos de los minerales diásporo $\left(\mathrm{Al}_{2} \mathrm{O}_{3} \cdot \mathrm{H}_{2} \mathrm{O}\right)$ en $\mathrm{C}$ hina y gibbsita $\left(\mathrm{Al}_{2} \mathrm{O}_{3} \cdot 3 \mathrm{H}_{2} \mathrm{O}\right)$ en Guyana. Durante la calcinación se forma una compleja unión de fases de corindón $\left(\mathrm{Al}_{2} \mathrm{O}_{3}\right)$, mullita, vidrio de ślice $y$, en menor cantidad, alumino-titanatos. $\mathrm{EI}$ consumo mundial de bauxita de calidad refractaria supera las 700.000 toneladas por año.

La bauxita de calidad metalúrgica se extrae en Australia, Jamaica y Africa 0 ccidental y tiene proporciones variables de alúmina en función de las impurezas principales que presente, tales como sílice y óxido de hierro. La alúmina de los minerales metalúrgicos se extrae de su mena por disolución en hidróxido sódico, que rinde una solución de aluminato sódico, la cual se separa del óxido de hierro y la sílice, que se rechazan como estériles en forma de barro rojo. Del aluminato sódico se precipita esencialmente hidróxido de aluminio puro que se calcina a diversas calidades de alúmina.

Las alúminas de gran pureza utilizadas en la industria cerámica y obtenidas mediante los procesos Bayer se clasifican en alúmina laminada, alúmina fundida o alúmina calcinada.

La alúmina laminada se obtiene por calcinación a elevada temperatura $\left(\sim 2.000{ }^{\circ} \mathrm{C} 03.630^{\circ} \mathrm{F}\right)$ a partir de alúmina calcinada a baja temperatura en grandes hornos rotatorios que utilizan petróleo como combustible. La alúmina fundida se obtiene por fusión eléctrica de la alúmina calcinada. Las alúminas laminada y fundida se venden a la industria refractaria molidas y clasificadas según el tamaño del granos para ser utilizadas en una amplia variedad de productos de gran calidad, como los refractarios de vaciado continuo (por ejemplo, compuertas de corredera ranuradas de un solo canto), o los refractarios monolíticos para aplicación en altos hornos y en la industria petroquímica.

Los alúmina calcinada en polvo constituye la principal materia prima empleada en la industria cerámica avanzada, tanto para aplicaciones electrónicas como de ingeniería. LoS polvos se producen en una amplia variedad de calidades de acuerdo con especificaciones exactas de composición química, tamaño de partícula y tipo de cristal, para adaptarse a una gran diversidad de aplicaciones del producto acabado.

$\mathrm{H}$ ay un comercio internacional de alúminas de gran calidad bien asentado. Muchos de los fabricantes de productos cerámicos tienen en sus plantas instalaciones de molturación y atomizado. Es evidente que el crecimiento del suministro a instalaciones de atomizado está limitado, así como que hay una necesidad constante de alúminas adecuadas a las características de la planta del cliente a fin de que el uso de éstas pueda optimizarse a un precio aceptable. La alúmina es un importante material cerámico que se obtiene con un elevado grado de pureza. La posición dominante de la alúmina como materia prima cerámica se debe a que posee atractivas propiedades a un coste relativamente bajo. Esta eficacia del coste es atribuible a la naturaleza de mercancía indiferenciada que adquiere el movimiento comercial a consecuencia de la gran demanda de alúmina por parte de la industria del aluminio.

Zircón y zirconia. La principal fuente de zirconia es el mineral zircón $\left(\mathrm{ZrO}_{2} \times \mathrm{SiO}_{2}\right)$, que se encuentra en arenas de playa, principalmente en Australia, Sudáfrica y Estados U nidos. El zircón extraído de estas arenas contiene un $\sim 2 \%$ de óxido de hafnio y trazas de $\mathrm{Al}_{2} \mathrm{O}_{3}(0,5 \%), \mathrm{Fe}_{2} \mathrm{O}_{3}(0,1 \%)$ y $\mathrm{TiO}_{2}(0,1 \%)$. A demás, todo los zircones contienen trazas de uranio y torio. El zircón se somete a molturación fina para obtener una gama de productos molidos de tamaño de partícula calibrado. Estos productos se utilizan en piezas de fundición, fundiciones, productos refractarios y fabricación de esmaltes opacos para cerámica blanca.

El zircón es también la fuente principal de zirconia. Se puede clorar en presencia de carbón para obtener tetracloruros de zirconio y silicio, que después se separan por destilación. El tetracloruro de zirconio así obtenido puede usarse para preparar zirconio directamente o como fuente de otros derivados del zirconio. Sinterizado con óxidos alcalinos o alcalinotérreos también se emplea para la descomposición del zircón. La sílice lixivia con agua a partir de los productos descomposición y se obtiene así hidróxido de zirconio que se purifica por disolución ácida y reprecipitación. A continuación se extrae la zirconia por calcinación del hidróxido. El zircón también se convierte en zirconia y ślice en un plasma a $1.800^{\circ} \mathrm{C}\left(3.270^{\circ} \mathrm{F}\right)$ con enfriamiento rápido para impedir la reasociación. La sílice libre se separa por disolución en hidróxido sódico. La zirconia fundida se obtiene en hornos de arco eléctrico a partir de la baddeleyita o de depósitos de zircón/carbono. En este último proceso la 
ślice componente del zircón se reduce por tratamiento térmico con carbono a monóxido de silicio, que se volatiliza antes de la fusión de la zirconia residual.

\section{Resumen}

El sector de la cerámica industrial está muy diversificado y son numerosos los procesos que se llevan a cabo en las propias fábricas. Muchas de las operaciones finales de fabricación se realizan en ambientes semejantes a los de una fundición. Los equipos de manipulación de material en estas plantas transportan materias primas finas potencialmente problemáticas a consecuencia del polvo. Los materiales se someten a temperaturas elevadas y se funden o fusionan en las formas necesarias para las piezas finales. Por consiguiente, en el sector de la cerámica industrial se presentan muchos de los problemas de seguridad propios de toda industria que trabaja a temperaturas elevadas.

\section{Ladrillos y baldosas}

\section{Visión general}

Los ladrillos y las baldosas de arcilla se han utilizado como material de construcción desde los tiempos más remotos en muchas partes del mundo. Cuando se hacen y se cuecen de manera apropiada son más perdurables que algunas piedras, resistentes a las condiciones climatológicas y a los grandes cambios de temperatura y humedad. El ladrillo es un rectángulo de tamaño normalizado que varía ligeramente de una región a otra, pero que básicamente resulta adecuado para ser manipulado con una mano por un albañil; las tejas son placas delgadas, planas o curvas; las baldosas también se emplearse como pavimento.

La industria del ladrillo está muy fragmentada, pues hay muchos proveedores pequeños distribuidos por todo el mundo. En la fabricación de estos productos suelen intervenir proveedores y mercados locales para ahorrar los costes de transporte del producto acabado. Así, en 1994 había 218 plantas de fabricación de ladrillos en Estados U nidos, y en 1992 el número de fabricantes de productos de material arcilloso para la construcción en el Reino U nido era de 182. En general, los fabricantes de ladrillos se sitúan cerca de los depósitos de arcilla para acortar el transporte de la materia prima.
En Estados U nidos, los ladrillos se utilizan básicamente en la construcción de viviendas como material de soporte de carga o de fachada. Puesto que la industria del ladrillo está tan estrechamente vinculada con la de la construcción, la actividad productora depende mucho del sector de construcción de viviendas, y casi totalmente de la actividad industrial que combina la construcción residencial y no residencial.

\section{Procedimientos de fabricación}

\section{Materiales y procesamiento}

El material básico es la arcilla de diversas clases con mezclas de margas, esquistos y arena, de acuerdo con las materias primas y necesidades locales, para obtener las propiedades requeridas de textura, plasticidad, regularidad y contracción, y color.

En la actualidad, la extracción de arcilla suele estar totalmente mecanizada; en general, la fabricación se lleva a cabo junto al lugar de extracción, pero en las empresas grandes la arcilla a veces se transporta con cintas o teleféricos. El tratamiento ulterior de la arcilla varía de acuerdo con su constitución y el producto acabado, pero en general comprende trituración, molturación, tamizado y mezclado. La Figura 84.18 ilustra la cadena de operaciones típica de la fabricación de ladrillos.

La arcilla destinada a la producción de ladrillos cortados con alambre se desmenuza con rodillos y a continuación se le incorpora agua en una mezcladora, se amasa de nuevo y se carga en una amasadora y extrusionadora horizontal. A continuación, la arcilla plástica extruida se corta a la medida con un cortador de alambres. Se obtiene material plástico semiseco y rígido por laminación, tamizado y prensado mecánico. Algunos ladrillos siguen moldeándose a mano.

Cuando se utiliza un material plástico, los ladrillos hay que secarlos al sol y al aire 0 , con mayor frecuencia, en hornos regulados, antes de cocerlos; los de material plástico semiseco o rígido se cuecen de inmediato. La cocción tiene lugar en hornos circulares, a menudo alimentados a mano, o de túnel, alimentados mecánicamente. Los combustibles empleados varían en función de la disponibilidad local. A algunos ladrillos decorativos se les aplica un barniz de acabado.

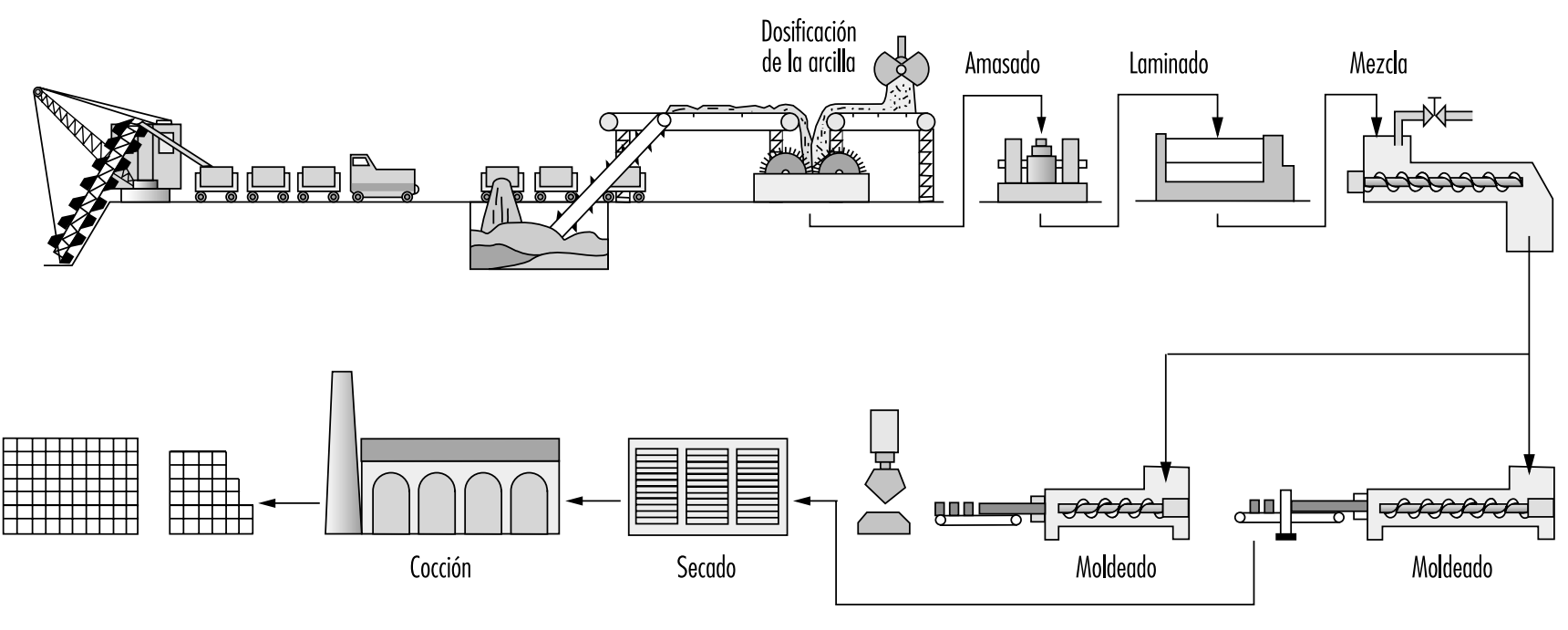




\section{Refractarios}

\section{Visión general}

Tradicionalmente se ha considerado que los refractarios son materiales no metálicos que resisten la degradación ocasionada por gases, líquidos o sólidos corrosivos a temperaturas elevadas. Estos materiales deben soportar el choque térmico causado por calentamiento 0 enfriamiento rápidos, fallos atribuibles a tensiones térmicas, fatiga mecánica por contacto con otros materiales y ataques químicos activados por la elevada temperatura de trabajo. Se utilizan para la fabricación de la mayoría de los productos cerámicos y se necesitan específicamente en estufas, secaderos, hornos y piezas de maquinaria que deben soportar temperaturas elevadas.

Los refractarios han sido casi exclusivamente de base mineral hasta bien avanzado el siglo XX, pero los técnicos expertos en mineralogía empezaron a interesarse por ellos. L os metalúrgicos han experimentando desde la Edad Media con prácticas de escorificación con ácidos y bases y catalogaron las ventajas de ambos tratamientos. De la misma manera, los artesanos de refractarios han experimentado con arena refractaria, con otros minerales de sílice prácticamente pura y con magnesita, un mineral formado predominantemente por $\mathrm{M} \mathrm{gCO}_{3}$ y que rinde M go por calcinación. Cuando en 1856 se inició la producción de acero en convertidores Bessemer, en los que se combinaba el trabajo a temperaturas de más de $1.600^{\circ} \mathrm{C}$ con la formación de escorias ácidas corrosivas, los refractarios «ácidos» de sílice distaban mucho de estar preparados. Cuando en 1857 Siemens inauguró un horno de crisol a temperaturas aún más elevadas y la fabricación de acero adoptó la formación de escorias básicas, pronto se introdujeron revestimientos «básicos» de magnesita. Los refractarios básicos de dolomita $(\mathrm{MgO}-\mathrm{CaO})$ se desarrollaron durante la I Guerra M undial, cuando los aliados dejaron de recibir magnesita desde la Europa continental. M ás tarde, con el desarrollo de otros recursos minerales en todo el mundo, la magnesita volvió a reafirmarse como materia prima.

Por otra parte, en 1863 se inició en el Reino U nido la fabricación de ladrillos aglomerados al carbono que con el tiempo se utilizaron en los hornos de fundición cuando las temperaturas de fabricación se hicieron aún más elevadas. También pasaron rápidamente a las cubas $\mathrm{H}$ all-Héroult de producción de aluminio (1886).

Durante alrededor de 5.000 se había obtenido cal en hornos primero de arcilla y más adelante de ladrillos refractarios. La fabricación de cemento portland exigió por vez primera un refractario innovador cuando en 1877 se introdujeron los hornos

Tabla 84.4 • Utilización de refractarios por industria en Estados Unidos.

\begin{tabular}{lc} 
Industria & $\begin{array}{c}\text { Porcentaje de las ventas } \\
\text { totales en EE.UU. }\end{array}$ \\
Hierro y acero & 51,6 \\
Metales no ferrosos & 7,5 \\
Cemento & 4,9 \\
Vidrio & 5,1 \\
Materiales cerámicos & 9,7 \\
Productos químicos y petróleo & 2,1 \\
Servicios públicos & 0,9 \\
Exportaciones & 7,4 \\
Resto y no especificadas & 10,8 \\
\hline
\end{tabular}

\section{Propiedades de los materiales refractarios}

Las propiedades que caracterizan a los materiales refractarios de calidad dependen de la naturaleza de la aplicación. El aspecto más importante de los materiales se denomina "refractoriedad". Este término se refiere al punto en el cual la muestra empieza a reblandecerse (o fundirse). N ormalmente, los refractarios no tienen un punto de fusión específico; la transición de fase tiene lugar dentro de un intervalo de temperaturas en un fenómeno llamado reblandecimiento. Esta característica suele cuantificarse con el cono pirométrico equivalente ( $P C E)$, que es una medida del contenido de calor expresado por la inclinación del cono durante el ciclo térmico.

Una propiedad relacionada con la anterior, y a menudo más útil, es la temperatura de rotura bajo carga. Los refractarios suelen ceder bajo carga a una temperatura muy inferior a la que les correspondería según su PCE. Para determinar esta variable, se somete el refractario a una carga conocida y se calienta hasta que se pandea o se deforma en general y se anota la temperatura correspondiente. Este valor es de gran importancia, pues sirve para predecir las propiedades mecánicas del refractario durante su uso. La capacidad del refractario para soportar cargas es directamente proporcional a la viscosidad del vidriado presente.

0 tro factor esencial para entender el rendimiento de un refractario es su estabilidad dimensional porque, a lo largo de su uso industrial, los materiales refractarios se someten a ciclos de calentamiento y enfriamiento que originan la dilatación y contracción, respectivamente, de las piezas. Los cambios dimensionales importantes reducen la estabilidad y pueden conducir a la rotura de la estructura refractaria.

Un fenómeno afín muy observado con materiales refractarios es el desconchado, término con el que se designa la fractura, fragmentación o exfoliación del refractario, que provoca la exposición de la masa interna del material. $N$ ormalmente, el desconchado es consecuencia del gradiente de temperatura en el interior del material, la compresión estructural por sobrecarga y la variación del coeficiente de dilatación térmica en el interior del ladrillo. En la fabricación de refractarios se adoptan medidas muy variadas para evitar el desconchado, porque reduce su efectividad.

Los refractarios tienen una amplia diversidad de aplicaciones industriales, que van desde su uso intensivo en la siderurgia del hierro y del acero hasta el más moderado en la industria del cemento y en las empresas de abastecimiento público. Los refractarios se usan básicamente en todos los sectores en los que se emplean temperaturas elevadas para calentar, secar o incinerar materiales. La Tabla 84.4 muestra el desglose actual por sectores del uso de refractarios en Estados Unidos.

Como se ve en dicha tabla, la siderurgia consume más del $50 \%$ de los refractarios producidos en EE.UU. Por ello, son las necesidades de este sector las que han impulsado en buena medida el avance que han experimentado los materiales refractarios.

rotativos. Los primeros revestimientos resistentes se hicieron con ladrillos aglomerados de cemento blanco. Más adelante volvieron a fabricarse en esta industria refractarios comerciales más duraderos.

Los hornos recuperativos y regenerativos introducidos en el decenio de 1950 en el naciente sector del acero se introdujeron también a finales del siglo XX en las industrias de la metalurgia no férrica y el vidrio y obligaron también en estos sectores a reemplazar los ladrillos de arcilla refractaria. A partir de 1909 se 
utilizaron revestimientos de magnesita en los convertidores de cobre y unos 10 años más tarde en los primeros tanques de vidrio modernos. En 1853 se probaron por vez primera los hornos de arco eléctrico para la fabricación de acero que no llegaron a generalizarse hasta 1990. En 1927 una planta de aproximadamente 100 toneladas instalada en Estados U nidos empleaba un revestimiento de magnesita.

Antes de 1950 se instalaron hornos de arco trifásicos y sólo entonces surgió una demanda importante de refractarios más perfeccionados. En el decenio de 1940 se introdujo en los hornos Bessemer y en los de solera abierta el soplado de oxígeno. A finales de 1950 el horno de oxígeno básico (BOF) se impuso en la fabricación de acero. El soplado de oxígeno, por su importancia económica, obligó por vez primera a la industria de refractarios a introducir en sus productos materiales sintéticos a gran escala.

\section{Refractarios moder nos}

La producción de cerámica ha pasado de artesanía a ciencia aplicada. La American Ceramic Society se fundó en 1899 y la British Ceramic Society en 1901. Los diagramas de fase comenzaron a publicarse en el decenio de 1920. Las técnicas de petrografía estaban muy desarrolladas, y comenzaban a entenderse los mecanismos detallados de la degradación y el desgaste refractario. Casi todos los productores de refractarios de Estados U nidos se habían reorganizado y consolidado y estaban en condiciones de investigar por sí mismos. Las herramientas de síntesis refractaria y los instrumentos de investigación se multiplicaban.

L os carbonos sintéticos industriales no eran, por supuesto algo nuevo, pues en el decenio de 1860 se obtuvo coque comercialmente, primero a partir de la hulla y luego del petróleo. El grafito sintético y el carburo de silicio aparecieron casi simultáneamente a comienzos del siglo XX, siguiendo a la invención de Acheson del horno eléctrico de resistencia propia en 1896. Estos productos, de propiedades muy diferentes a las de los óxidos, estimularon rápidamente sus propios usos y mercados.

Se dispone de alúmina sintética, $\mathrm{Al}_{2} \mathrm{O}_{3}$, desde que el método Bayer comenzó a fomentar la producción de aluminio en 1888. La magnesia sintética ( $\mathrm{M} \mathrm{gO}$ ) se obtuvo por primera vez a partir de agua marina en el Reino Unido en 1937, y en Estados Unidos en 1942, estimulada por la necesidad de magnesio en tiempos de guerra. La demanda militar también había espoleado la obtención de zirconia. La cal ha sido un artículo importante a lo largo de los siglos. Muchísimas otras sustancias químicas también fueron consideradas como componentes refractarios, o como aditivos menores y agentes aglomerantes. El único componente químico importante de los óxidos refractarios que ha resistido en general la sustitución por sustancias sintéticas es la sílice $\left(\mathrm{SiO}_{2}\right)$ L as rocas de sílice de gran pureza y las arenas abundan y se emplean en esta industria, así como en la formulación del vidrio.

La incorporación de materiales sintéticos a la fabricación de refractarios ha sido sumamente útil, pero no ha desplazado por completo a las materias primas minerales, ya que son más caros y hay que justificar su mayor costo. Algunos complican mucho el procesamiento de refractarios y obligan a buscar nuevas técnicas para superar estas dificultades. Con frecuencia se han obtenido resultados óptimos mediante la combinación de sustancias sintéticas y materias primas minerales, junto con aportaciones creativas a su procesamiento.

Las mezclas de arcilla con carbón se han empleado para revestir crisoles y cucharas de colada desde los comienzos de la producción de hierro colado; y en el decenio de 1860 en Francia se fabricaron ladrillos de sílice con carbono. A partir de 1960 tanto las técnicas como las composiciones han cambiado espectacularmente. EI uso de refractarios al carbono iniciado con el $\mathrm{MgO}+\mathrm{C}$ se ha multiplicado, impulsado tal vez por el $\mathrm{H}$ orno de $O$ xígeno Básico (BOF); pero en la actualidad no hay casi ningún tipo de refractario de óxido avanzado que no se pueda obtener con o sin la incorporación de carbono o de un precursor de carbono para mejorar el rendimiento en determinadas aplicaciones.

Desde comienzos del decenio de 1900 se vienen obteniendo agregados o granulados refractarios fundidos al arco eléctrico, a los que sucedieron en los de 1920 y 1930 los ladrillos refractarios fundidos en molde de diversas composiciones, en particular de mullita, alúmina, magnesio-alúmina-sílice y alúmina-zirconia-sílice. La mayoría de las veces estos productos se obtenían íntegramente a partir de materias primas minerales.

De hecho, todos los refractarios basados íntegramente en minerales siguen constituyendo una parte importante de la producción. Por lo general, son más baratos, suelen comportarse admirablemente y todavía hay muchas aplicaciones de menor demanda 0 que exigen valores máximos de refractoriedad y resistencia a la corrosión

\section{Sector de los de materiales refractarios}

Los refractarios se utilizan en muchas industrias para recubrir calderas y hornos de todo tipo, pero el mayor porcentaje se emplea en la elaboración de metales. En la industria del acero, un alto horno típico o un horno de solera abierta utilizan muchos tipos diferentes de refractarios, unos de ślice, otros de cromo o magnesita o de las dos cosas y otros de arcilla refractaria.

Cantidades mucho menores se utilizan también en aplicaciones como la obtención de gas, coque y subproductos; centrales eléctricas; plantas químicas; hornos de cocina y estufas; cemento y cal; cerámica; vidrio; esmaltes y barnices; locomotoras y barcos; reactores nucleares; refinerías de petróleo; eliminación de desechos (incineradoras).

\section{Procesos de fabricación}

El tipo de refractario utilizado en toda aplicación específica depende de los requisitos críticos del proceso. Así, los procesos que exigen resistencia a la corrosión por gases o líquidos exigen porosidad baja y elevada resistencia física y a la abrasión. Cuando la condición limitante es la baja conductividad térmica, hay que recurrir a refractarios totalmente distintos. En realidad, suelen emplearse combinaciones de varios. No hay ninguna línea de demarcación clara entre materiales refractarios y no refractarios, aunque se ha mencionado la capacidad para soportar temperaturas superiores a $1.100{ }^{\circ} \mathrm{C}$ sin reblandecerse como requisito práctico de los materiales refractarios industriales.

Los objetivos técnicos de fabricación de un refractario determinado se encarnan en las propiedades y rendimientos que exigen la aplicación a la que se destina. Los instrumentos de fabricación se eligen entre materias primas y entre métodos y parámetros de procesamiento. Los medios para su fabricación comprenden las materias primas y los parámetros y métodos de fabricación. Los requisitos de fabricación están vinculados con las características de la composición de fase y la microestructura - lo que en conjunto se llama carácter del material-, se desarrollan por medio del tratamiento y son responsables de las propiedades y el comportamiento del producto.

\section{Materias primas}

En el pasado, las materias primas refractarias se seleccionaban a partir de diversos depósitos y se utilizaban como minerales extraídos. La extracción selectiva permitía obtener materiales de las propiedades deseadas, y sólo en casos de materias primas costosas, como la magnesita, se requerían procesos de enrique- 
cimiento del mineral. En la actualidad, sin embargo, las materias primas naturales de gran pureza tienen una demanda creciente, al igual que los granulados refractarios sintéticos obtenidos a partir de combinaciones de materias primas beneficiadas de gran pureza. El material producido a partir de la cocción de minerales extraídos en bruto o de mezclas sintéticas se denomina granulado, escoria, escoria común o chamota.

En general, los refractarios se clasifican en cuatro tipos: aluminosilicatos, ślices (o ácidos), básicos y varios.

Los materiales generalmente utilizados en los cuatro tipos de refractarios incluyen:

1. Refractarios de aluminosilicato: arcillas refractarias compuestas principalmente de caolinita [CAS 1318-74-7] $\left(\mathrm{Al}_{2} \mathrm{O}_{3} \times 2 \mathrm{SiO}_{2} \times 2 \mathrm{H}_{2} \mathrm{O}\right)$ con pequeñas cantidades de otros minerales arcillosos, cuarcita, óxido de hierro, dióxido de titanio e impurezas alcalinas. L as arcillas se usan en bruto 0 después de calcinación. Las arcillas en bruto se granulan - molturan finamente para incorporarlas a una mezcla refractaria. Con algunos caolines de gran pureza se forma una suspensión acuosa para lavarlos por flotación, y luego se clasifican y secan para obtener un material consistente y de gran calidad. Las arcillas clasificadas también pueden ser mezcladas y extruidas o nodulizadas y luego calcinadas para obtener chamota caolinítica, o triturar groseramente y cocer directamente la caolinita en bruto. Con la calcinación o cocción la caolinita se descompone en mullita y vidrio silíceo que incorpora las impurezas minerales asociadas con el depósito de arcilla (por ejemplo cuarcita, oxido de hierro, dióxido de titanio y álcalis), consolidándose a elevadas temperaturas en una chamota densa, dura y muy granulada.

2. R efractarios de sílice 0 ácidos: emplean principalmente sílice en forma de cuarcita (arena refractaria) (92\% a $98 \%$ ) triturada y molturada, y cal como aglomerante ( $\mathrm{C}$ aO $)$. Los ladrillos de sílice suelen cocerse dos veces, pues se expanden con el calor (contracción de los ladrillos de arcilla refractaria) y, por tanto, es preferible que hayan completado su expansión antes de colocarlos en las paredes o recubrimientos.

3. R éractarios básicos: usan dolomita, magnesita ( $\mathrm{MgO}$ ), óxido de cobre, hierro o aluminio.

4. R efractarios varios: de la gran variedad de materiales que se emplean en la actualidad, los más comunes son los carburos, como carburo de silicio, grafito, alúmina, berilio, torio, óxido de uranio, amianto y óxido de zirconio.

En la industria se han producido varias revoluciones, de las que forman parte los nuevos métodos mecanizados de manipulación de grandes cantidades de sólidos, la mayor capacidad y la automatización del equipo de procesamiento y las técnicas de adquisición y análisis rápidos de los datos necesarios para controlar los procesos internos. Estos avances han transformado la práctica de fabricación de refractarios.

La Figura 84.19 ilustra la fabricación de las diferentes clases de refractarios. Adopta el estilo de "árbol de decisiones", con las ramas divergentes provistas de números de identificación. $\mathrm{H}$ ay varios caminos, que muestran, cada uno de ellos, un tipo particular de producto refractario.

Estos diagramas de flujo genéricos representan miles de procesos específicos y diferenciados, por ejemplo, por las materias primas, la forma de preparación y la clasificación por tamaño y determinación de las partidas (es decir, cantidad pesada) de cada una, la secuencia y forma de mezclado, etc. Se permiten exclusiones; así, algunos refractarios sin conformar se mezclan en seco y no se mojan hasta la instalación.
Los refractarios y sus productos se presentan a veces preformados (moldeados) o se forman e instalan "in situ", aunque en general se suministran en las siguientes formas:

Ladrillo: las dimensiones estándar de un ladrillo refractario son $23 \mathrm{~cm}$ de longitud por $11,4 \mathrm{~cm}$ de anchura y $6,4 \mathrm{~cm}$ de espesor (ladrillo recto). Se fabrican por extrusión o prensado en seco en prensas mecánicas o hidráulicas. Las piezas formadas se cuecen antes de usarlas o aglomerarse y endurecerse con alquitrán, resina u otros compuestos químicos.

Moldeado por colado: mediante el arco eléctrico se funden mezclas refractarias que se moldean por colado en distintas formas (por ejemplo, bloques para tanques de vidrio que alcanzan dimensiones de hasta 0,33 x 0,66 x 1,33 m). Después del moldeado y el recocido, los bloques se rectifican cuidadosamente con una muela para asegurar un encaje preciso.

R efractarios colados y moldeados a mano: las formas grandes, como quemadores y bloques de cuba, o complicadas, como las piezas de los alimentadores de vidrio, gacetas y similares, se producen por colado de una barbotina de cemento hidráulico o por moldeo a mano. D ebido a que estas técnicas son muy laboriosas, se reservan para aquellos artículos que no pueden elaborarse de otro modo.

Refractarios aislantes: los refractarios aislantes en forma de ladrillo son mucho más ligeros que los ladrillos convencionales de la misma composición debido a su porosidad.

Moldeables y mezclas aplicables a pistola: están compuestos de granulados refractarios a los que se añade un fijador hidráulico que al mezclarlo con agua reacciona y aglutina toda la masa. Estas mezclas están diseñadas para ser aplicadas con una pistola dotada de una boquilla a través de la cual se pulverizan con aire a presión. La mezcla se diluye en agua antes de aplicarla con la pistola o en la propia boquilla.

R efractarios plásticos y mezclas apisonadas: Ios refractarios plásticos son mezclas de granulados refractarios y arcillas plásticas o plastificantes con agua. $\mathrm{H}$ ay mezclas para apisonar con y sin arcilla y suelen utilizarse con un encofrado. La proporción de agua usada con estos productos varía, pero se procura que sea mínima.

\section{Riesgos profesionales y precauciones}

La Tabla 84.5 brinda información sobre muchos de los riesgos potenciales que se presentan en este sector industrial.

\section{Normas de seguridad, problemas de salud y} enfermedades

Este apartado presenta una perspectiva general de los problemas de seguridad y salud de este sector industrial, documentados 0 potenciales. No se ha localizado información internacional sobre lesiones y enfermedades en este sector industrial ni en la bibliografía ni en Internet (en 1997). Se ha utilizado información compilada por el Departamento de Trabajo de Estados U nidos, la O ccupational Safety and Health Administration (OSH A) y la O ficina de Estadísticas Laborales (BLS) para identificar riesgos comunes en el lugar de trabajo y describir las características de las lesiones y enfermedades. Esta información debería ser representativa de la situación en todo el mundo.

\section{Riesgos detectados durante las inspecciones}

Las inspecciones reglamentarias de empresas fabricantes de productos de piedra, arcilla, vidrio y hormigón (Código 32 de la Clasificación industrial (SIC), equivalente al Código 36 ISIC) revelan algunos de los riesgos comunes en este sector. Las citas sobre cumplimiento de los reglamentos emitidas por la O SHA indican que las preocupaciones comunes en materia de salud y seguridad pueden agruparse de la manera siguiente: 
Figura 84.19 - Diagrama de flujo general de la fabricación de refractarios.

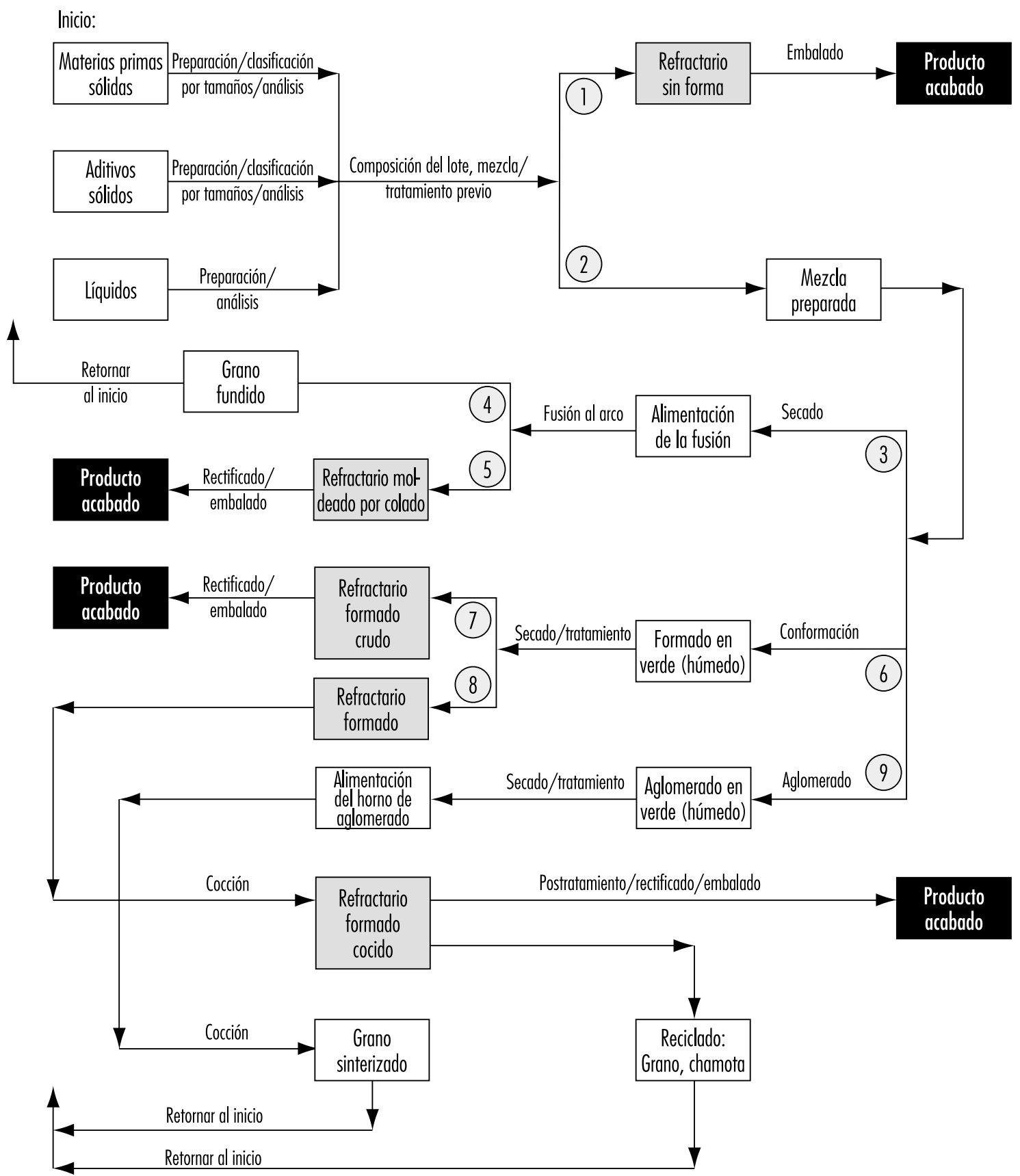

Fuente: Carniglia y Barria 1992.

- comunicación de riesgos físicos y sanitarios debidos a las sustancias químicas utilizadas en el lugar de trabajo;

- control de fuentes de energía peligrosas: procedimientos de bloqueo e identificación mediante carteles situados en torno a la maquinaria o equipo donde una inesperada puesta en marcha o liberación de energía acumulada pudiera causar lesiones. Son peligrosas las energías eléctrica, mecánica, hidráulica, neumática, química, térmica radiante y otras fuentes;

- seguridad eléctrica, que abarca el equipo o el diseño de sistemas eléctricos, métodos de cableado y prácticas y formación en materia de seguridad en el trabajo;
- exigencia de autorizacion para entrar en espacios restringidos: identificación, evaluación y protocolos de acceso seguros;

- equipo protector individual: valoración, selección y uso de protectores para ojos, cara, manos, pies y cabeza;

- máquinas, equipo y herramientas de protección para proteger a los operadores y trabajadores cercanos de los riesgos en el punto de operación, puntos de pinzamiento, piezas giratorias, astillas o chispas; estas medidas afectan a la maquinaria fija y móvil, a las herramientas mecánicas portátiles y al ajuste de protectores y apoyos en máquinas con muelas abrasivas (amoladoras) (véase la Figura 84.20); 
Tabla 84.5 - Riesgos para la salud y la seguridad que pueden presentarse durante la fabricación de materiales de vidrio, cerámica y afines.

\begin{tabular}{|c|c|}
\hline Riesgos & Usos o fuentes de exposición a los riesgos \\
\hline $\begin{array}{l}\text { Generadores de tensión } \\
\text { ergonómicos; riesgos } \\
\text { biomecánicos }\end{array}$ & $\begin{array}{l}\text { Esfuerzo excesivo debido a prácticas de mani- } \\
\text { pulación de material, mala postura, tareas } \\
\text { de frecuencia } 0 \text { duración elevadas que } \\
\text { exigen levantar, empujar o arrastrar }\end{array}$ \\
\hline \multirow[t]{2}{*}{ Riesgos físicos } & $\begin{array}{l}\text { Quedar atrapado por o golpearse contra } \\
\text { instalaciones fijas o móviles }\end{array}$ \\
\hline & $\begin{array}{l}\text { Resbalones, tropiezos y caídas sobre superfi- } \\
\text { cies de circulación y de trabajo, mangueras } \\
\text { y otros accesorios, herramientas o } \\
\text { materiales }\end{array}$ \\
\hline
\end{tabular}

Calor radiante ambientes de trabajo a temperatura elevada materiales

Procesos de calentamiento o fusión durante el mantenimiento 0 las actividades de respuesta de una emergencia

\section{Efectos potenciales (riesgos físicos o Precauciones o estrategias de control efectos sobre la salud)}

Distensiones, esguinces y tirones en la musculatura que afectan a la espalda y a las extremidades superiores e inferiores.

El cansancio físico y mental excesivo puede hacer cometer errores que conducen a incidentes secundarios

Abrasiones, cortes, contusiones, laceraciones, incisiones, fracturas, amputaciones
Tensión fisiológica, golpe de calor o quemaduras por calor pueden requerir demasiado esfuerzo procesos

- Procedimientos de trabajo seguros

- Buenas prácticas de mantenimiento

- Diseño y disposición de equipos

- Equipo de manipulación de material

- Superficies antideslizantes tantes, aislamiento
- Evaluación de las exigencias físicas de tareas que

- Diseño y estructura del puesto de trabajo

- Uso de dispositivos de manipulación de materiales, como montacargas o vehículos motorizados

- Automatización o semiautomatización de los

- Formación sobre técnicas y prácticas adecuadas

- Diseño y estructura del puesto de trabajo

- Protección, pantallas, tabiques, superficies reflec-

- Cubierta de los equipos refrigerada por agua

- Cámaras o salas de control con aire acondicionado

- Ropa y guantes que protejan del calor y prendas interiores refrigeradas por agua

- Aclimatización a los entornos de trabajo muy calurosos, ingestión de agua y electrolitos, regímenes de descanso controlados

Inhalación de partículas Manipulación de las materias primas y de material en producción

suspensión en el aire Exposiciones durante las actividades de procedentes de las mantenimiento de rutina, en trabajos de materias primas, demolición y en actividades de construcción incluidos la sílice cris- o reconstrucciones

talina, arcilla, cal, Las exposiciones pueden producirse como óxido de hierro y consecuencia de equipos no ventilados o de polvos nocivos filtraciones o sellados deficientes en puntos de transmisión, tolvas, cintas transportadoras, montacargas, pantallas, tamices, máquinas mezcladoras, molinos o trituradores, recipientes de almacenamiento, válvulas, tuberías, hornos de secado 0 curado, operaciones de moldeado, etc.

Las materias primas son sumamente abrasivas y deterioran los componentes de los sistemas de transporte y almacenamiento en los procesos de fabricación. El fallo en el mantenimiento de las instalaciones de filtrado, depuradores 0 colectores de polvo y en el uso de aire comprimido para actividades de limpieza aumenta el riesgo de exposición excesiva.

Las operaciones de calentamiento intenso pueden conducir a exposiciones a las formas más peligrosas de silice (cristobalita 0 tridimita)
Van desde la irritación (partículas nocivas) hasta las quemaduras químicas ( cal calcinada u otras materias primas alcalinas) o los efectos crónicos, como insuficiencia 0 enfermedades pulmonares, silicosis o tuberculosis
- Aspiración de los gases de escape de los procesos y locales con instalaciones de filtración, depuradores u otros colectores de polvo

- Buen diseño y mantenimiento de la manipulación de materiales, del proceso de fabricación y de la maquilnaria de traslado y descarga

- Manipulación del material, prácticas de trabajo y reducción y eliminación de residuos adecuados

- Aislamiento de los operarios en salas o cabinas de control presurizadas y automación del traslado del material para reducir al mínimo el tiempo de permanencia en las zonas de polvo

- Protección respiratoria, ropa, guantes y otros equipos de protección individual (EPI)

- Detección y reparación activa de escapes, mantenimiento predictivo y preventivo de la maquinaria, incluidos los colectores de polvo y las válvulas

- Prácticas de limpieza sistemáticas mediante aspiración 0 en húmedo

- Prohibición de la limpieza con aire comprimido

- Exámenes y reconocimientos médicos periódicos, vigilancia e intervención rápida basada en la exposición

Continúa en la página siguiente. 
Tabla 84.5 - Riesgos para la salud y la seguridad que pueden presentarse durante la fabricación de materiales de vidrio, cerámica y afines.

Continuación.

\begin{tabular}{cc}
\hline Riesgos & Usos o fuentes de exposición a los riesgos \\
Laceraciones, abra- & Los trozos de vidrio, cerámica u otros frag- \\
siones o cuerpos & mentos proyectados por el aire pueden \\
extraños; contacto & provocar heridas incisas y lesiones oculares \\
con fragmentos u & grandes. Se presenta un riesgo especial \\
objetos de vidrio o & cuando el vidrio templado "explota" \\
cerámica cortantes & durante la fabricación. \\
& El contacto directo con filamentos de vidrio u \\
& otros, especialmente durante la elaboración \\
& en caliente o el arrollamiento en las opera- \\
& ciones de producción y revestimiento de \\
& filamento continuo \\
& Operaciones de estirado en la fabricación de \\
fibra óptica \\
Laceraciones por & Cuchillas para desbarbar, uñeras, cuchillas \\
herramientas & para escoria de vidrio y otras herramientas \\
manuales & manuales cortantes se usan con frecuencia \\
& en las zonas de producción, embalaje y \\
& almacenamiento o durante las operaciones \\
de mantenimiento
\end{tabular}

Formaldehído por inha- Componentes de aglomerantes y aprestos en lación o contacto directo la industria de la fibra de vidrio

Exposiciones potenciales durante el mezclado de aglomerantes 0 aprestos y durante la producción
Efectos potenciales (riesgos físicos o efectos sobre la salud)

Heridas incisas, laceraciones 0 abrasión de la piel 0 de los tejidos blandos (tendones, ligamentos, nervios, músculos), y cuerpos extraños en los ojos

Riesgo de infección secundaria grave y de exposición dérmica a materiales corrosivos o tóxicos

Cortes en las manos o dedos de las manos y en las extremidades inferiores (piernas)

Toxicidad de metales pesados

Irritación sensorial y de las vías respiratorias

Probable agente cancerígeno humano

sodico) y ácidos

(clorhídrico, sulfú-

rico, fluorhídrico)
Tratamiento de las aguas de proceso de caldera y residuales y control del pH

Procesos de limpieza o de grabado (corrosión) al ácido con ácido fluorhídrico
Corrosivo para la piel o los ojos
Irritante de las vías respiratorias y de las mucosas

El ácido fluorhídrico provoca graves quemaduras en las espinillas, que pueden tardar horas en detectarse
Precauciones 0 estrategias de control

- Uso de guantes protectores resistentes a los cortes

- Guantes de alambre trenzado, malla metálica u otro material adecuado para la manipulación de vidrio plano

- La mecanización y la automatización reducen los riesgos en la producción y manipulación de vidrio plano. El riesgo se transmite a los operarios de mantenimiento

- Establecer prácticas de trabajo para una manipulación segura

- Primeros auxilios para prevenir infecciones

- Cuchillas de hoja rectráctil

- Sustitución de otras herramientas (cizallas o tijeras)

- Vainas o fundas

- Rutina de sustitución y afilado de cuchillas

- Primeros auxilios para prevenir infecciones

- Controles técnicos, entre ellos aspiración en locales y aislamiento de máquinas y procesos

- Herramientas eléctricas móviles con ventilación HEPA

- Uso de cabinas ventiladas para actividades de aplicacion de pinturas o revestimientos con aerosol

- Prácticas de trabajo apropiadas para reducir las partículas en suspension en el aire, incluyendo métodos de humidificación

- Prácticas de limpieza, aspiración HEPA, limpieza con agua, limpieza por chorro de agua

- Higiene personal, lavado por separado de la ropa de trabajo contaminada

- Protección respiratoria y ropa protectora

- Reconocimiento médico y control biológico

- Aspiración de vapores y ventilación general

- Difusión y mezcla automatizadas

- Mantenimiento de hornos de curado, pantallas o filtros, y dinámica de la combustión

- Detección activa de escapes y programa de control de los hornos de curado

- Máscara con protección visual, guantes y ropa protectora frente al contacto directo con sustancias químicas

- Protección respiratoria cuando sea necesaria

- Aislamiento del proceso

- Prácticas de manipulación seguras

- Uso de EPI: protección respiratoria, guantes de goma, máscara con protección visual, delantal de goma, ropa protectora, baño ocularl ducha de seguridad

- Aspiración de los humos para controlar los vapores o aerosoles ácidos

Continúa en la página siguiente. 
Tabla 84.5 - Riesgos para la salud y la seguridad que pueden presentarse durante la fabricación de materiales de vidrio, cerámica y afines.

Continuación.

\begin{tabular}{|c|c|c|c|}
\hline Riesgos & Usos o fuentes de exposición a los riesgos & $\begin{array}{l}\text { Efectos potenciales (riesgos físicos o } \\
\text { efectos sobre la salud) }\end{array}$ & Precauciones o estrategias de control \\
\hline $\begin{array}{l}\text { Epóxidos, acrilatos y } \\
\text { uretanos ( pueden } \\
\text { contener disolventes } \\
\text { como xileno, } \\
\text { tolueno, etc.) }\end{array}$ & $\begin{array}{l}\text { Ingredientes de las resinas, aprestos, aglome- } \\
\text { rantes y revestimientos utilizados en la } \\
\text { producción } \\
\text { Productos de mantenimiento }\end{array}$ & $\begin{array}{l}\text { Sensibilizadores potenciales de la piel o de } \\
\text { las vías respiratorias } \\
\text { Algunos epóxidos contienen epiclorhidrina } \\
\text { sin reaccionar, un posible agente } \\
\text { cancerígeno } \\
\text { Algunos uretanos contienen diisocianato } \\
\text { tolueno sin reaccionar, un posible agente } \\
\text { cancerígeno } \\
\text { Las aminas usadas en algunos métodos de } \\
\text { fraguado son irritantes o corrosivas } \\
\text { Riesgo de deflagración }\end{array}$ & $\begin{array}{l}\text { - Prácticas de manipulación seguras } \\
\text { - Evitar las aplicaciones con aerosol (aplicar con rodillo } \\
\text { o pincel) } \\
\text { - Ventilación } \\
\text { - Exámenes médicos de los usuarios para evitar la } \\
\text { exposición a trabajadores sensibilizados } \\
\text { - Uso de EPp: guantes impermeables, mangas largas } \\
\text { - Cremas protectoras } \\
\text { - Almacenamiento adecuado }\end{array}$ \\
\hline Estireno & $\begin{array}{l}\text { Resinas de poliéster que contienen estireno, } \\
\text { ingrediente de los aprestos }\end{array}$ & $\begin{array}{l}\text { Irritante para ojos, piel, vías respiratorias; } \\
\text { efectos sobre el sistema nervioso central } \\
\text { (SNC) y órganosensibles } \\
\text { Posible agente cancerígeno } \\
\text { Riesgo de deflagración }\end{array}$ & $\begin{array}{l}\text { - Prácticas de manipulación seguras } \\
\text { - Evitar aplicaciones con aerosol (aplicación con rodillo } \\
\text { o pincel) } \\
\text { Ventilación } \\
\text { - Uso de EPP: guantes resistentes a productos } \\
\text { químicos, mangas largas, cremas protectoras } \\
\text { - Respiradores en algunos casos }\end{array}$ \\
\hline Silanos & $\begin{array}{l}\text { Activadores de la adhesión añadidos a los } \\
\text { aprestos, aglomerantes o revestimientos. } \\
\text { Pueden hidrolizarse con liberación de } \\
\text { etanol, metanol, butanol u otros alcoholes }\end{array}$ & $\begin{array}{l}\text { Irritante para los ojos, la piel y las vías } \\
\text { respiratorias; efectos potenciales sobre } \\
\text { el SNC. Las salpicaduras en los ojos } \\
\text { pueden causar lesiones permanentes } \\
\text { Riesgo de deflagración }\end{array}$ & $\begin{array}{l}\text { - Prácticas de manipulación seguras } \\
\text { - EPP: guantes y protección visual } \\
\text { - Ventilación }\end{array}$ \\
\hline Látex & $\begin{array}{l}\text { Zonas de mezcla de aprestos o aglomerantes, } \\
\text { revestimientos y algunos productos de } \\
\text { mantenimiento }\end{array}$ & $\begin{array}{l}\text { Irritante para la piel y los ojos. Algunos } \\
\text { pueden contener formaldehído u otros } \\
\text { biocidas y/ o disolventes }\end{array}$ & $\begin{array}{l}\text { - EPP: guantes, protección visual } \\
\text { - Respiradores en algunos casos }\end{array}$ \\
\hline $\begin{array}{l}\text { Catalizadores y } \\
\text { aceleradores }\end{array}$ & $\begin{array}{l}\text { Sustancias agregadas a resinas o aglome- } \\
\text { rantes para inducir el fraguado durante la } \\
\text { producción o a ciertos productos de } \\
\text { mantenimiento }\end{array}$ & $\begin{array}{l}\text { Irritantes o corrosivos para la piel o los } \\
\text { ojos. Algunos son muy reactivos y sensi- } \\
\text { bles a la temperatura }\end{array}$ & $\begin{array}{l}\text { - Prácticas de manipulación seguras } \\
\text { - EPP, guantes, protección visual } \\
\text { - Almacenamiento adecuado (temperatura y aisla- } \\
\text { miento) }\end{array}$ \\
\hline $\begin{array}{l}\text { Disolventes hidrocarbo- } \\
\text { nados o clorados }\end{array}$ & $\begin{array}{l}\text { Talleres de mantenimiento y operaciones de } \\
\text { limpieza de piezas }\end{array}$ & $\begin{array}{l}\text { Varios: irritación, dermatitis química, } \\
\text { efectos sobre el SNC. Los disolventes no } \\
\text { clorados pueden ser inflamables } \\
\text { Los clorados pueden descomponerse si se } \\
\text { queman o se calientan }\end{array}$ & $\begin{array}{l}\text { - Sustitución por agentes de limpieza menos peli- } \\
\text { grosos (detergentes de base acuosa) } \\
\text { - Cambio de métodos de limpieza: limpieza con agua } \\
\text { a presión, baños de eliminación de recubrimientos, } \\
\text { etc. } \\
\text { - Ventilación de las instalaciones de lavado de piezas } \\
\text { - Uso de EPP: guantes, protección visual/ facial, respi- } \\
\text { radores cuando sea necesario }\end{array}$ \\
\hline $\begin{array}{l}\text { Propano, gas natural, } \\
\text { gasolina, gasóleo }\end{array}$ & $\begin{array}{l}\text { Combustibles para procesos de producción con } \\
\text { calor } \\
\text { Combustibles para carretillas industriales } \\
\text { motorizadas }\end{array}$ & $\begin{array}{l}\text { Riesgo de incendio y explosión } \\
\text { Exposición a monóxido de carbono u otros } \\
\text { productos de la combustión incompleta }\end{array}$ & $\begin{array}{l}\text { - Diseño adecuado e inspecciones de las operaciones } \\
\text { de almacenamiento y distribución y controles de los } \\
\text { procesos de combustión } \\
\text { - Revisiones del análisis de los procesos peligrosos y } \\
\text { ensayos de integridad periódicos } \\
\text { - Prácticas seguras de descarga, llenado y } \\
\text { manipulación } \\
\text { - Métodos de trabajo en zonas calientes } \\
\text { - Ensayos sistemáticos y procesos del control de la } \\
\text { combustión y salida de los gases de combustión }\end{array}$ \\
\hline
\end{tabular}

Continúa en la página siguiente. 
Tabla 84.5 - Riesgos para la salud y la seguridad que pueden presentarse durante la fabricación de materiales de vidrio, cerámica y afines.

Continuación.

\begin{tabular}{|c|c|c|c|}
\hline Riesgos & Usos o fuentes de exposición a los riesgos & $\begin{array}{l}\text { Efectos potenciales (riesgos físicos o } \\
\text { efectos sobre la salud) }\end{array}$ & Precauciones o estrategias de control \\
\hline $\begin{array}{l}\text { Inhalación de } \\
\text { bioaerosoles }\end{array}$ & $\begin{array}{l}\text { Aerosoles que contienen bacterias, mohos u } \\
\text { hongos procedentes del tratamiento con } \\
\text { aerosoles o el agua de refrigeración o humi- } \\
\text { dificación, torres de refrigeración, sistemas } \\
\text { de ventilación, limpieza con agua }\end{array}$ & $\begin{array}{l}\text { Enfermedades transmitidas con el agua, } \\
\text { con síntomas sistémicos inespecíficos } \\
\text { parecidos a los de la gripe, cansancio } \\
\text { Riesgo de dermatitis }\end{array}$ & $\begin{array}{l}\text { - Diseño del proceso y reducción de neblinas } \\
\text { - Tratamiento con funguicidas y bactericidas del agua } \\
\text { de fabricación y refrigeración } \\
\text { - Limpieza y desinfección sistemáticas } \\
\text { - Eliminación o reducción de nutrientes en el sistema } \\
\text { de distribución de agua } \\
\text { - Protección respiratoria } \\
\text { - Ropa de protección personal }\end{array}$ \\
\hline $\begin{array}{l}\text { Fibra de vidrio, fibra de } \\
\text { lana mineral, fibras } \\
\text { cerámicas } \\
\text { refractarias }\end{array}$ & $\begin{array}{l}\text { En los procesos de producción: elaboración de } \\
\text { la fibra, curado por calor, corte o cubica- } \\
\text { ción, arrollamiento, embalaje y construcción } \\
\text { Utilización de materiales de fibra de vidrio en } \\
\text { hornos, conductos y maquinaria de proceso }\end{array}$ & $\begin{array}{l}\text { Las fibras no inhalables pueden provocar } \\
\text { irritación mecánica de la piel o los ojos } \\
\text { Las inhalables pueden provocar irritación } \\
\text { de los ojos, la piel y las vías respirato- } \\
\text { rias. Las fibras duraderas han provocado } \\
\text { fibrosis y tumores en estudios realizados } \\
\text { con animales }\end{array}$ & $\begin{array}{l}\text { - Ventilación general y aspiración local en la maqui- } \\
\text { naria de fabricación } \\
\text { - Métodos de corte } \\
\text { - Prácticas de limpieza adecuadas ( con aire aspirado } \\
\text { en lugar de comprimido) } \\
\text { - Ropa de protección personal (mangas largas) y } \\
\text { lavado frecuente } \\
\text { - Higiene personal } \\
\text { - Respiradores cuando es necesario } \\
\text { - Prácticas de demolición y eliminación con humidifica- } \\
\text { ción para la extracción posterior }\end{array}$ \\
\hline
\end{tabular}

- protección respiratoria: selección, uso, mantenimiento, entrenamiento, autorización médica y ensayo de ajuste de los respiradores;

Figura 84.20 - Los dispositivos de protección de la maquinaria evitan que los operarios sufran accidentes por contacto con ejes giratorios, correas y cadenas de transmisión.

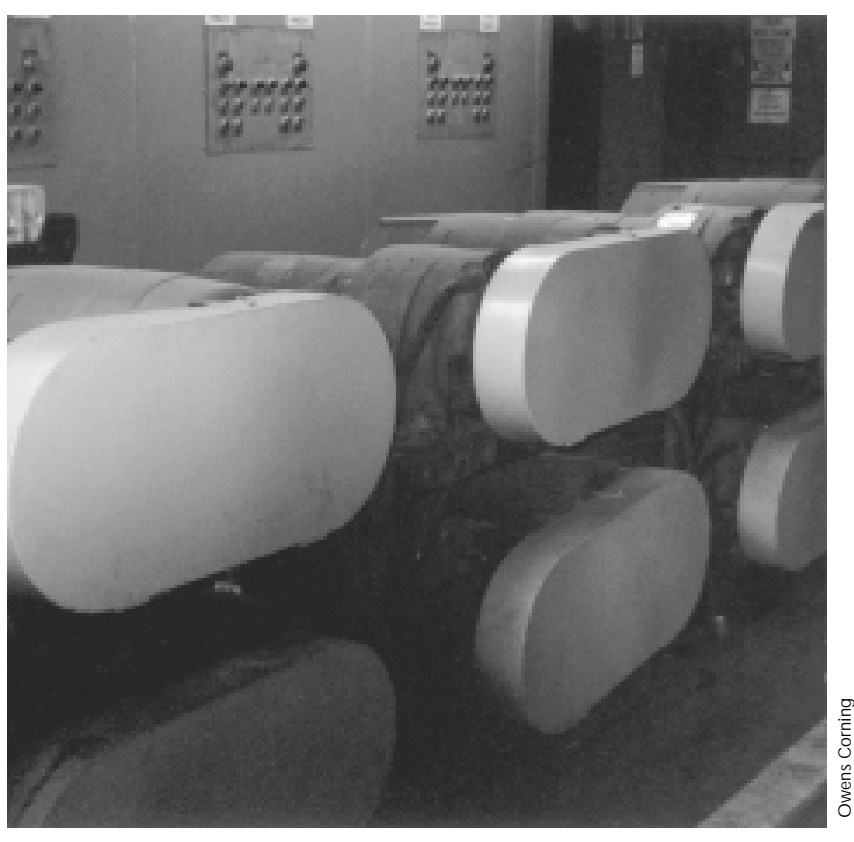

- exposición profesional al ruido: control de exposiciones mediante protección técnica, administrativa o auditiva y puesta en práctica de programas de conservación auditiva;

- prevención de incendios y preparación y respuesta de emergencia: extintores, salidas de emergencia, planos y almacenamiento o uso de materiales inflamables y combustibles;

- superficies de circulación y de trabajo: orificios y aberturas en suelos y tabiques de protección; mantenimiento de instalaciones; y pasillos y zonas de paso para que no presenten riesgo de resbalones, tropiezos o caídas (véase la Figura 84.21);

- vehículos industriales motorizados: diseño, mantenimiento, uso y otras exigencias de seguridad para carretillas elevadoras, carretillas de plataforma, tractores, carretillas manuales motorizadas u otros vehículos industriales especializados propulsados por motores eléctricos o de combustión interna;

- escaleras, escalinatas y andamios fijos y móviles: diseño, inspección o mantenimiento y uso seguro;

- protección de caídas: uso de equipo que impida o detenga las caídas cuando se trabaja a cierta altura;

- corte y soldadura: procedimientos y uso seguro de equipos de corte o soldadura por oxígeno/ acetileno, gas o arco;

- equipo de manipulación de materiales: grúas elevadas y de pórtico, montacargas, cadenas y eslingas, y

- control de exposición a sustancias tóxicas o peligrosas: contaminantes en suspensión en el aire o sustancias químicas específicamente reguladas (por ejemplo, sílice, plomo, asbesto, formaldehído, cadmio 0 arsénico).

\section{Perfil de las lesiones y enfermedades}

\section{Tasas de incidencia de las lesiones y enfer medades}

De acuerdo con los datos del Departamento de Trabajo de Estados U nidos, los fabricantes de productos de piedra, arcilla y vidrio (SIC 32) tienen una tasa total de incidencia "registrable" 


\section{Piedras preciosas sintéticas}

Las piedras preciosas sintéticas son química y estructuralmente idénticas a las naturales. Las piedras de imitación, por el contrario, se han sometido a un tratamiento que las hace semejantes a otras naturales. Unos pocos tratamientos básicos producen diversas piedras preciosas. Se fabrican granates, espinelas, esmeraldas, zafiros y diamantes sintéticos. Casi todas estas piedras se usan en joyería, aunque los diamantes también se emplean como abrasivos, y los rubíes y granates en la construcción de lásers.

La primera piedra preciosa sintética usada en joyería fue la esmeralda. El método de fabricación está registrado y es secreto, pero probablemente se basa en el crecimiento en estado fluido; esta técnica consiste en fundir conjuntamente silicatos de alúmina y berilio con aportes de cromo para dar color. Las esmeraldas cristalizan a partir de la masa fundida, y el proceso puede durar hasta un año.

El proceso Verneuil o de fusión a la llama se usa en la producción de zafiros y rubíes. Consume grandes cantidades de oxígeno e hidrógeno y, por tanto, de energía. Se basa en el calentamiento de un germen de cristalización con llama oxhídrica hasta licuar la superficie seguido de aportación cuidadosa de materia prima en polvo $\left(\mathrm{Al}_{2} \mathrm{O}_{3}\right.$ para producir zafiros, por ejemplo). A medida que se funde la materia prima, se aleja de la llama para que solidifique la zona más alejada del calor y se mantenga en estado líquido y dispuesta para recibir más materia prima la más cercana a la lla ma. El producto final es un cristal en forma de varilla. Los colores se forman añadiendo a la materia prima pequeñas cantidades de distintos iones. El rubí se crea reemplazando el 0,1 \% de los iones de aluminio por átomos de cromo.

La espinela, una piedra preciosa sintética incolora $\left(\mathrm{M} \mathrm{gAl}_{2} \mathrm{O}_{4}\right)$, se obtiene también por el método Verneuil. Junto con el zafiro, en la industria se emplea la espinela para elaborar piedras de una gama de colores muy amplia que se usan como "piedra natal" y en anillos de graduación. Los mismos iones metálicos producen colores distintos en la espinela y el zafiro.

Los diamantes sintéticos se utilizan en aplicaciones industriales que exigen dureza, como corte, pulido, molturación y perforación. Son usos comunes el corte y amolado del granito para elaborar materiales de construcción, la perforación de pozos y el afilado de aleaciones no ferrosas. Además están desarrollándose técnicas de deposición de diamante sobre superficies para hacerlas transparentes, duras y resistentes a los a rañazos.

Los diamantes se forman sometiendo carbono elemental o grafito a presión y temperatura elevadas durante mucho tiempo. La técnica industrial consiste en combinar grafito con catalizadores metálicos y en prensar el conjunto a temperatura elevada (más de $1.500^{\circ} \mathrm{C}$ ). El tamaño y la calidad de los diamantes se controlan ajustando el tiempo, la presión y la temperatura. Para alcanzar en un tiempo razonable las elevadas presiones necesarias para formar los diamantes se emplean grandes moldes de carburo de tungsteno. Estos moldes, de forma parecida a una rosquilla gigante, miden más de $2 \mathrm{~m}$ de ancho y $20 \mathrm{~cm}$ de espesor. La mezcla de grafito y catalizador se coloca en una empaquetadura cerámica, donde es comprimida desde arriba y desde abajo con pistones cónicos. Transcurrido el tiempo especificado, se saca de la prensa la empaquetadura que contiene los diamantes, se rompe y se somete el grafito portador de las gemas a una serie de agentes que destruyen todo el material que no sea diamante. Los reactivos empleados son enérgicos y constituyen una fuente potencial de quemaduras graves y lesiones respiratorias.

Esta misma técnica sirve para fabricar diamantes con calidad de joyería, pero el tiempo de prensado necesario para lograr este efecto la hace prohibitivamente cara.

Los riesgos derivados de la fabricación de diamantes comprenden la exposición potencial a grandes cantidades de agentes ácidos y cáusticos sumamente activos, ruidos, polvo de la formación y rotura de la empaquetadura cerámica y exposición al polvo metálico. 0 tro riesgo potencial es la rotura de los enormes moldes de carburo. Después de un número variable de usos, los moldes se rompen y pueden causar lesiones si no están aislados. La clasificación y el calibrado de los diamantes fabricados plantea problemas ergonómicos, pues su pequeño tamaño convierte el trabajo en tedioso y repetitivo. de lesiones y enfermedades profesionales no mortales de 13,2 casos por 100 trabajadores a jornada completa al año. Este valor es más elevado que los correspondientes al conjunto del sector manufacturero $(12,2)$ y a toda la industria privada $(8,4)$. A proximadamente el $51 \%$ de los casos de "lesiones registrables" en el sector de fabricación de productos de piedra, arcilla y vidrio no se traducen en pérdida de días de trabajo (tiempo fuera del trabajo).

Las tasas de incidencia de los "casos de pérdida total de días de trabajo" basadas en el número de lesiones o enfermedades incapacitantes que se traducen en días de trabajo perdidos por uno de cada 100 trabajadores a jornada completa también se han obtenido a partir de los datos del Departamento de Trabajo de Estados U nidos. La tasa de incidencia total de días de trabajo perdidos incluye los casos en que se pierden días de trabajo y el trabajador no está en condiciones de desempeñar el trabajo en su totalidad (tarea restringida o liviana). Los fabricantes de productos de piedra, arcilla y vidrio tienen una tasa de incidencia total de pérdida de días de trabajo de 6,5 casos por 100 trabajadores por año. Esta tasa es más elevada que las correspondientes al conjunto de la producción manufacturera $(5,5)$ y al conjunto de la industria privada $(3,8)$. Aproximadamente el $93 \%$ de los casos de días de trabajo perdidos en el sector de fabricación de productos de piedra, arcilla y vidrio son consecuencia de lesiones, no de enfermedades profesionales.

La Tabla 84.6 proporciona información más detallada sobre tasas de incidencia de lesiones y enfermedades (combinadas) 0 lesiones (solamente) para diversos procesos de fabricación dentro del sector de fabricación de productos de piedra, arcilla y vidrio (Código SIC 32). Las tasas de incidencia y los datos demográficos pueden no ser representativos de la información global, pero es la información más completa de que se dispone.

\section{Datos demográficos de los casos de lesiones y enfermedades}

Los trabajadores de 25 a 44 años representan aproximadamente el $59 \%$ de los 23.203 casos de tiempo perdido por lesiones 0 enfermedades en el sector de fabricación de productos de piedra, arcilla y vidrio de Estados U nidos. El siguiente grupo más afectado es el de los trabajadores de 45 a 54 años, que suponen el $18 \%$ de los casos de tiempo perdido por lesiones o enfermedades (véase la Figura 84.22).

A proximadamente el $85 \%$ de los casos de tiempo perdido por lesiones y enfermedades en el Código SIC 32 son varones. En el $24 \%$ de los casos de tiempo perdido (ambos sexos), los trabajadores tienen menos de 1 año de servicio en el puesto de trabajo. 
Figura 84.21 - Las superficies de paso y de trabajo deben estar libres de riesgos de tropiezos y resbalones.

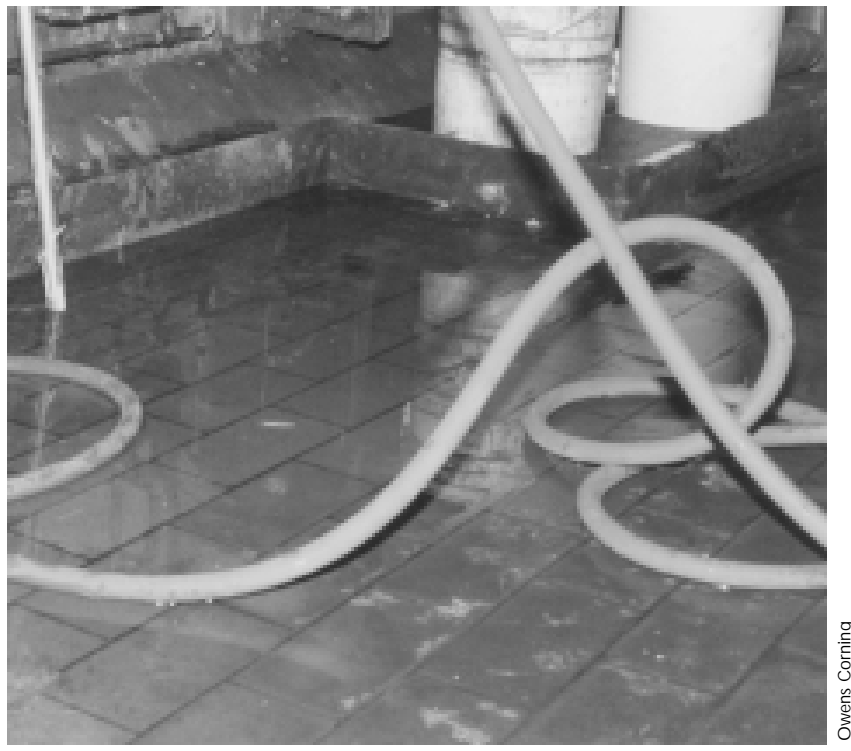

Los trabajadores con 1 a 5 años de servicio en el empleo representan el $32 \%$ de los casos. Los empleados con experiencia que llevan más de 5 años de servicio suponen el $35 \%$ de los casos de tiempo perdido.

Naturaleza. El análisis del perfil de los incidentes de tiempo perdido caracteriza la naturaleza de las lesiones y enfermedades incapacitantes y ayuda a explicar los factores causantes o que contribuyen a ellas. Distensiones y esguinces son las lesiones y patologías dominantes en el sector de fabricación de productos

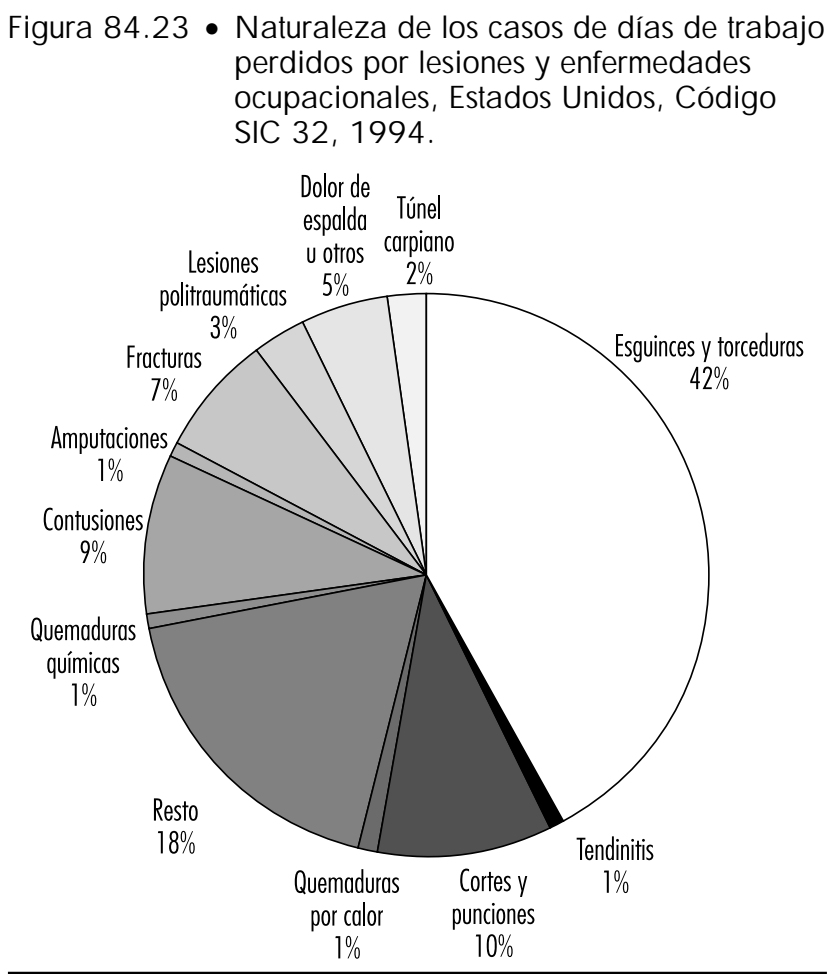

Figura 84.22 • Porcentaje de lesiones y enfermedades con pérdida de tiempo de trabajo, por edades. Estados Unidos, Código SIC 32, 1994

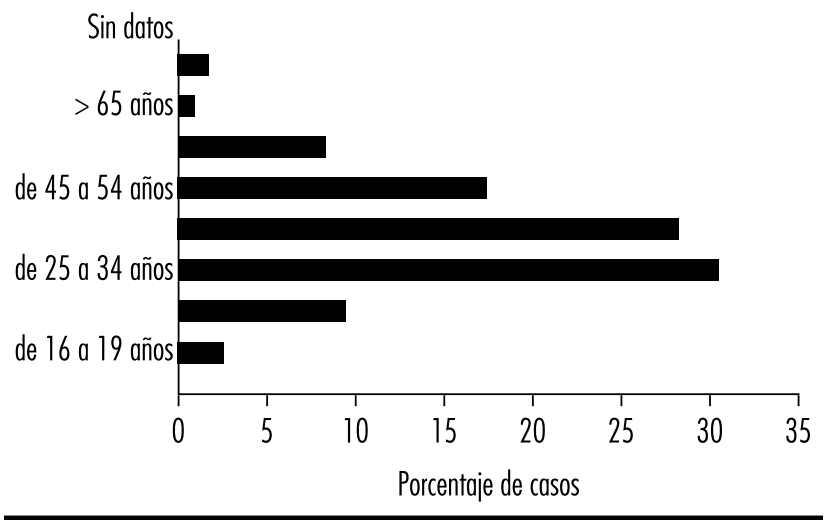

de piedra, arcilla y vidrio. Como ilustra la Figura 84.23 , los esguinces y torceduras constituyen aproximadamente el $42 \%$ de todos los casos de tiempo perdido. Cortes e incisiones (10 \%) son el segundo tipo más común de lesiones o patologías incapacitantes. 0 tras categorías importantes son las contusiones $(9 \%)$, las fracturas (7\%) y el dolor de espalda o de otra parte del cuerpo (5\%). Las quemaduras por calor 0 por sustancias químicas y las amputaciones son más raras ( $1 \%$ o menos).

Sucesos 0 exposiciones. La Figura 84.24 ilustra que el esfuerzo excesivo al levantar objetos ocupa el primer lugar en la lista de sucesos o exposiciones. El esfuerzo excesivo al levantar objetos es un factor causal en aproximadamente el $17 \%$ de los casos incapacitantes; el movimiento repetitivo es la exposición en otro $5 \%$ de casos de incapacitación. El golpe dado por un objeto es la siguiente causa más común, responsable del $16 \%$ de los casos. El impacto contra un objeto causa el $10 \%$ de los casos. 0 tras circunstancias importantes son quedar atrapado en un objeto

Figura 84.24 - Circunstancia o exposición en los casos de días de trabajo perdidos por lesiones 0 enfermedades ocupacionales, Estados Unidos, Código SIC 32, 1995.

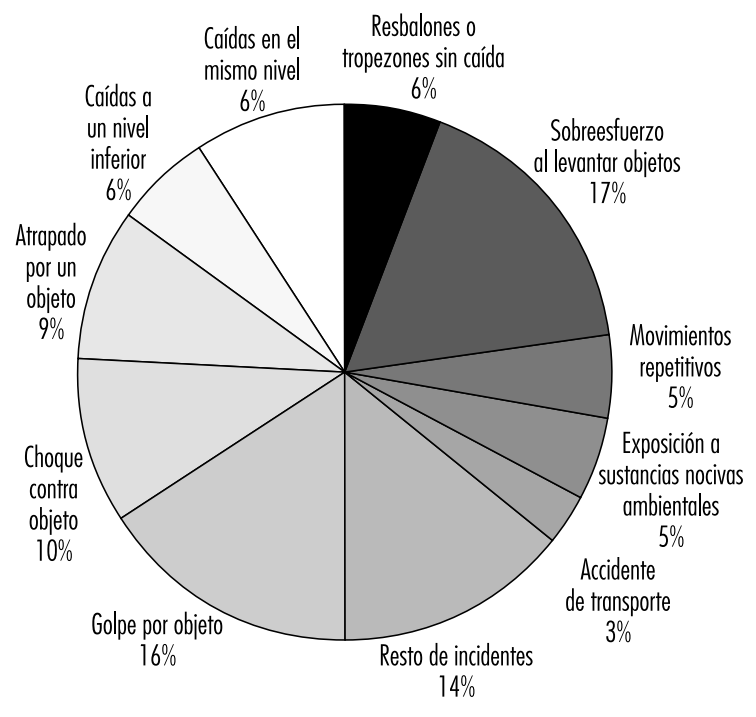


Tabla 84.6 • Tasas de incidencia de las lesiones y enfermedades ocupacionales no mortales por 100 trabajadores a jornada completa para empresas de Estados Unidos en Código SIC 32, industria privada y fabricación, 1994.

\begin{tabular}{|c|c|c|c|c|c|c|c|c|c|c|}
\hline \multirow[t]{2}{*}{ Industria } & \multirow[t]{2}{*}{ Código $\mathrm{SIC}^{2}$} & \multirow{2}{*}{$\begin{array}{l}\text { Empleo } \\
\text { medio } \\
\text { anual }^{3} \\
(000,5)\end{array}$} & \multicolumn{4}{|c|}{$\begin{array}{l}\text { Lesiones y enfermedades } \\
\text { Casos de días de trabajo perdidos }\end{array}$} & \multicolumn{4}{|c|}{$\begin{array}{c}\text { Lesiones } \\
\text { Casos de días de trabajo perdidos }\end{array}$} \\
\hline & & & $\begin{array}{l}\text { Casos } \\
\text { totales }\end{array}$ & Total $^{4}$ & $\begin{array}{l}\text { Con días } \\
\text { de absen- } \\
\text { tismo } \\
\text { laboral }\end{array}$ & $\begin{array}{l}\text { Casos sin } \\
\text { días de } \\
\text { trabajo } \\
\text { perdidos }\end{array}$ & $\begin{array}{l}\text { Casos } \\
\text { Totales }\end{array}$ & Total $^{5}$ & $\begin{array}{l}\text { Con días } \\
\text { de absen- } \\
\text { tismo } \\
\text { laboral }\end{array}$ & $\begin{array}{l}\text { Casos sin } \\
\text { días de } \\
\text { trabajo } \\
\text { perdidos }\end{array}$ \\
\hline Industria privada & & $95.449,3$ & 8,4 & 3,8 & 2,8 & 4,6 & 7,7 & 3,5 & 2,6 & 4,2 \\
\hline Fabricación & & $18.303,0$ & 12,2 & 5,5 & 3,2 & 6,8 & 10,4 & 4,7 & 2,9 & 5,7 \\
\hline Productos de piedra, arcilla y vidrio & 32 & 532,5 & 13,2 & 6,5 & 4,3 & 6,7 & 12,3 & 6,1 & 4,1 & 6,2 \\
\hline Vidrio plano & 321 & 15 & 21,3 & 6,6 & 3,1 & 14,7 & 17,3 & 5,2 & 2,6 & 12,1 \\
\hline $\begin{array}{l}\text { Vidrio y vajilla de vidrio, prensada } 0 \\
\text { soplada }\end{array}$ & 322 & 76,8 & 12,5 & 6,0 & 3,0 & 6,5 & 11,3 & 5,5 & 2,8 & 5,8 \\
\hline Envases de vidrio & 3221 & 33,1 & 14,1 & 6,9 & 3,4 & 7,2 & 13,2 & 6,5 & 3,2 & 6,7 \\
\hline Vidrio prensado y soplado, ncol & 3229 & 43,7 & 11,3 & 5,4 & 2,8 & 5,9 & 9,8 & 4,8 & 2,4 & 5,1 \\
\hline Productos de vidrio comprado & 323 & 60,7 & 14,1 & 6,1 & 3,1 & 8,0 & 12,7 & 5,4 & 2,9 & 7,4 \\
\hline $\begin{array}{l}\text { Productos arcillosos para la } \\
\text { construcción }\end{array}$ & 325 & 32,4 & 14,1 & 7,7 & 4,2 & 6,5 & 13,1 & 7,2 & 4,0 & 5,9 \\
\hline $\begin{array}{l}\text { Ladrillo y baldosas para la } \\
\text { construcción }\end{array}$ & 3251 & $\cdot$ & 15,5 & 8,4 & 5,1 & 7,1 & 14,8 & 7,9 & 5,0 & 6,9 \\
\hline Refractarios arcillosos & 3255 & $\cdot$ & 16 & 9,3 & 4,7 & 6,8 & 15,6 & 9,3 & 4,7 & 6,4 \\
\hline Productos de alfarería y afines & 326 & 40,8 & 13,6 & 6,8 & 3,8 & 6,8 & 12,2 & 6,1 & 3,5 & 6,1 \\
\hline Accesorios sanitarios vitrificados & 3261 & - & 17,8 & 10,0 & 3,8 & 7,8 & 16,1 & 9,0 & 3,5 & 7,1 \\
\hline $\begin{array}{l}\text { Vajilla de mesa y de cocina de } \\
\text { porcelana }\end{array}$ & 3262 & $\cdot$ & 12,8 & 6,3 & 4,4 & 6,5 & 11,0 & 5,6 & 3,8 & 5,5 \\
\hline Materiales eléctricos de porcelana & 3264 & $\cdot$ & 11,3 & 5,8 & 3,7 & 5,6 & 9,8 & 5,0 & 3,4 & 4,8 \\
\hline Productos de alfarería, ncol & 3269 & - & 12,6 & 5,6 & 3,7 & 7,1 & 11,6 & 5,0 & 3,5 & 6,6 \\
\hline Productos de hormigón, yeso y estuco & 327 & 198,3 & 13,4 & 7,0 & 5,6 & 6,4 & 13 & 6,9 & 5,5 & 6,2 \\
\hline Adoquín y ladrillo de hormigón & 3271 & 17,1 & 14,5 & 7,8 & 6,8 & 6,8 & 14 & 7,7 & 6,7 & 6,2 \\
\hline Productos de hormigón, ncol & 3272 & 65,6 & 17,7 & 9,8 & 7,0 & 7,9 & 17,1 & 9,5 & 6,8 & 7,6 \\
\hline Cemento premezclado & 3273 & 98,8 & 11,6 & 6 & 5,3 & 5,6 & 11,5 & 6,0 & 5,3 & 5,5 \\
\hline $\begin{array}{l}\text { Productos minerales varios no } \\
\text { metálicos }\end{array}$ & 329 & 76,7 & 10,7 & 5,4 & 3,3 & 5,3 & 9,8 & 5,0 & 3,2 & 4,9 \\
\hline Productos abrasivos & 3291 & 20 & 10,2 & 3,9 & 2,5 & 6,3 & 9,5 & 3,7 & 2,4 & 5,8 \\
\hline Lana mineral & 3296 & 23,4 & 11,0 & 6,1 & 3,0 & 4,9 & 10,0 & 5,6 & 2,7 & 4,3 \\
\hline Refractarios no arcillosos & 3297 & - & 10,6 & 5,8 & 4,5 & 4,8 & 10,2 & 5,7 & 4,3 & 4,6 \\
\hline Productos minerales no metálicos, nec & 3299 & - & 13,1 & 8,2 & 5,8 & 4,9 & 11,4 & 7,0 & 5,5 & 4,3 \\
\hline
\end{tabular}

ncol = no clasificados en otro lugar. $-=$ no se dispone de datos

1 Las tasas de incidencia representan el número de lesiones y enfermedades por 100 trabajadores a jornada completa y se calcularon como número de lesiones y enfermedades dividido por horas trabajadas por todos los empleados en las 200,000 horas del año civil (el equivalente base de 100 trabajadores a 40 horas por semana y 52 semanas por año). ${ }^{2}$ Manual de Normas de Clasificación Industrial, Edición de 1987.

${ }^{3}$ El empleo se expresa como promedio anual y proviene básicamente del programa de BLS State Current Employment Statistics. ${ }^{4}$ Casos totales, incluidos aquellos que implican sólo actividad laboral restringida, además de los casos de días de absentismo laboral con 0 sin actividad laboral restringida. ${ }^{5}$ Casos de días de ausencia laboral, incluidos aquellos que resultan de días de absentismo laboral, con 0 sin actividad laboral restringida.

Fuente: Basado en el informe nacional de lesiones y enfermedades relacionadas con el trabajo en la industria privada del Departamento de Trabajo, Departamento de Estadística Laboral de EE.UU.

( $9 \%$ ), las caídas en el mismo nivel $(9 \%)$, las caídas a un nivel inferior $(6 \%)$ y los deslizamientos sin caída (6\%). La exposición a sustancias o ambientes nocivos es un factor causal en sólo el $5 \%$ de los casos.

Parte del cuerpo. La parte del cuerpo más frecuentemente afectada es la espalda ( $24 \%$ de los casos) (véase la Figura 84.25 ). L as lesiones interesan las extremidades superiores (dedos, mano, muñeca y brazo combinados) en el $23 \%$ de los casos, con lesión de los dedos de la mano en el $7 \%$ de los casos. Las lesiones de las extremidades inferiores fueron similares (22\% de los casos), siendo la rodilla la parte afectada en el $9 \%$ de los casos.

F uentes. Las fuentes más comunes de los casos de lesiones 0 enfermedades incapacitantes son: piezas y materiales (20\%); posición o movimiento del trabajador (16\%); superficies de 
Figura 84.25 • Parte del cuerpo afectada en los casos de pérdida de días de trabajo por lesión 0 enfermedad, Estados Unidos, Código SIC 32, 1994.

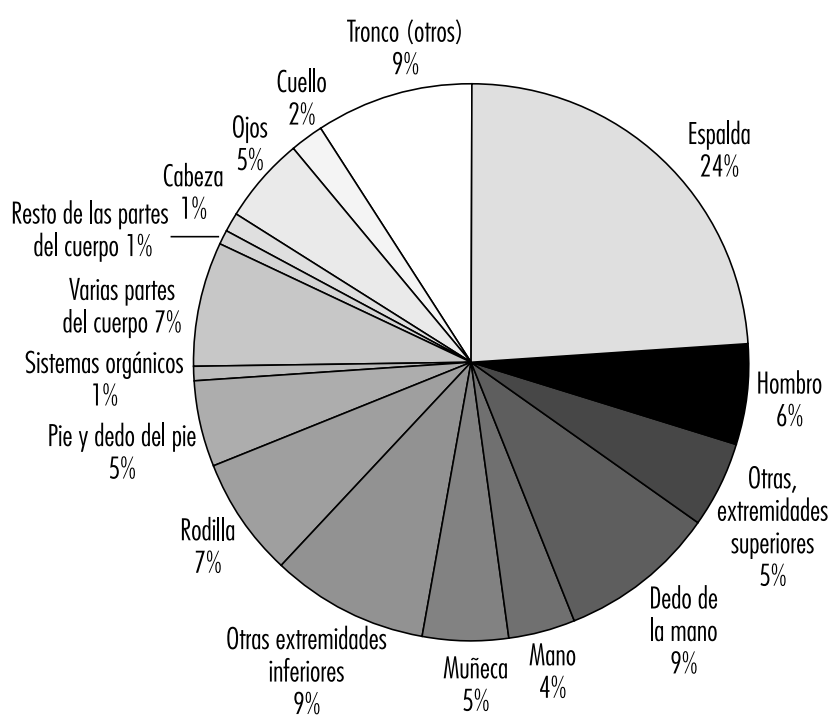

suelos, pasarelas o terreno (15\%); contenedores (10\%); maquinaria (9 \%); vehículos (9\%); herramientas manuales (4\%); mobiliario y accesorios (2\%); y sustancias y productos químicos (2\% ) (véase la Figura 84.26)

\section{Prevención y control de las enfer medades}

Los traumatismos superpuestos asociados con el movimiento repetitivo y el esfuerzo excesivo y prolongado son comunes en este sector industrial. Empiezan a utilizarse equipos robotizados, pero todavía predominan las prácticas manuales. Compresores, ventiladores, extractores, vibradores neumáticos y equipos de embalaje pueden emitir ruidos que superan los 90 a 95 dBA. La protección acústica y un programa de conservación de la capacidad auditiva evitarán alteraciones permanentes de la capacidad auditiva.

E sta industria consume grandes cantidades de sílice cristalina. Deben limitarse las exposiciones durante la manipulación, el mantenimiento y la limpieza. Una buena limpieza con un sistema de aspiración adecuado o con métodos por húmedos reducirá las exposiciones potenciales. Si se han producido exposiciones excesivas a la sílice, deberían realizarse exámenes periódicos con pruebas de funcionalismo pulmonar y radiografías torácicas. También deberían reducirse al mínimo las exposiciones a los metales pesados presentes en las materias primas, esmaltes o pigmentos. EI uso de sustitutos de los metales pesados presentes en los esmaltes también eliminará las preocupaciones sanitarias por la lixiviación de estos compuestos hacia alimentos o bebidas. Las buenas prácticas de mantenimiento y el uso de protecciones respiratorias evitan efectos adversos. Puede ser necesario implantar un sistema de vigilancia médica con control biológico.

Los aglutinantes con formaldehído, epóxidos y silanos son de uso común en la fabricación de fibras de vidrio. D eben tomarse medidas para minimizar la irritación cutánea y respiratoria. En muchos países el formaldehído está clasificado como cancerígeno. Se forman fibras respirables durante la producción,
Figura 84.26 • Fuentes de los casos de días de trabajo perdidos por lesiones y enfermedades ocupacionales, Estados Unidos, Código SIC 32, 1994.

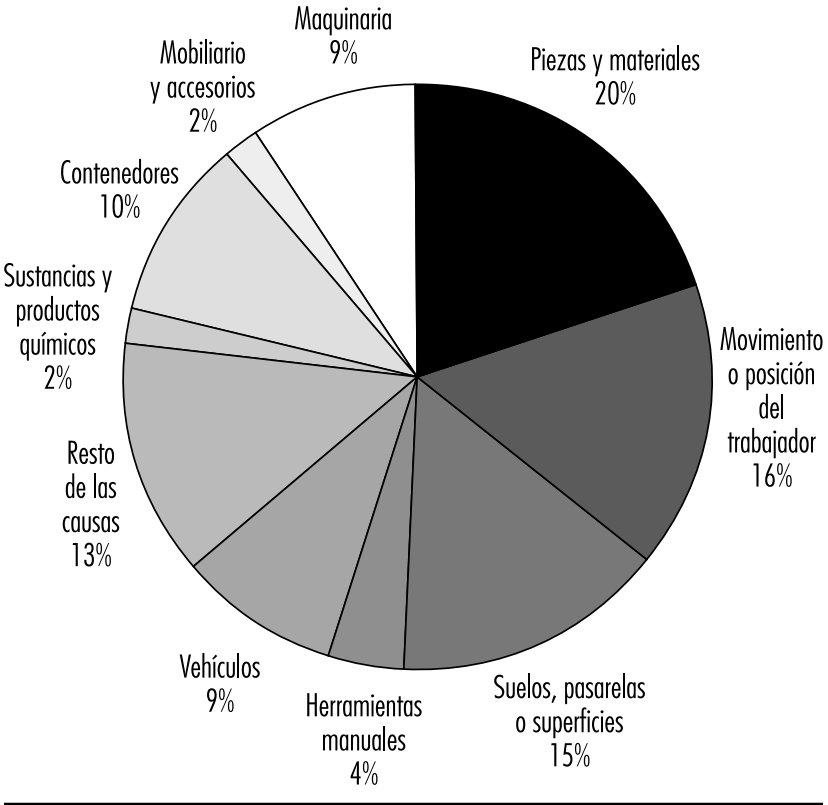

Figura 84.27 • Los aerosoles de agua de condensación reutilizada que no es tratada pueden provocar enfermedades por las materias en suspensión en el agua.

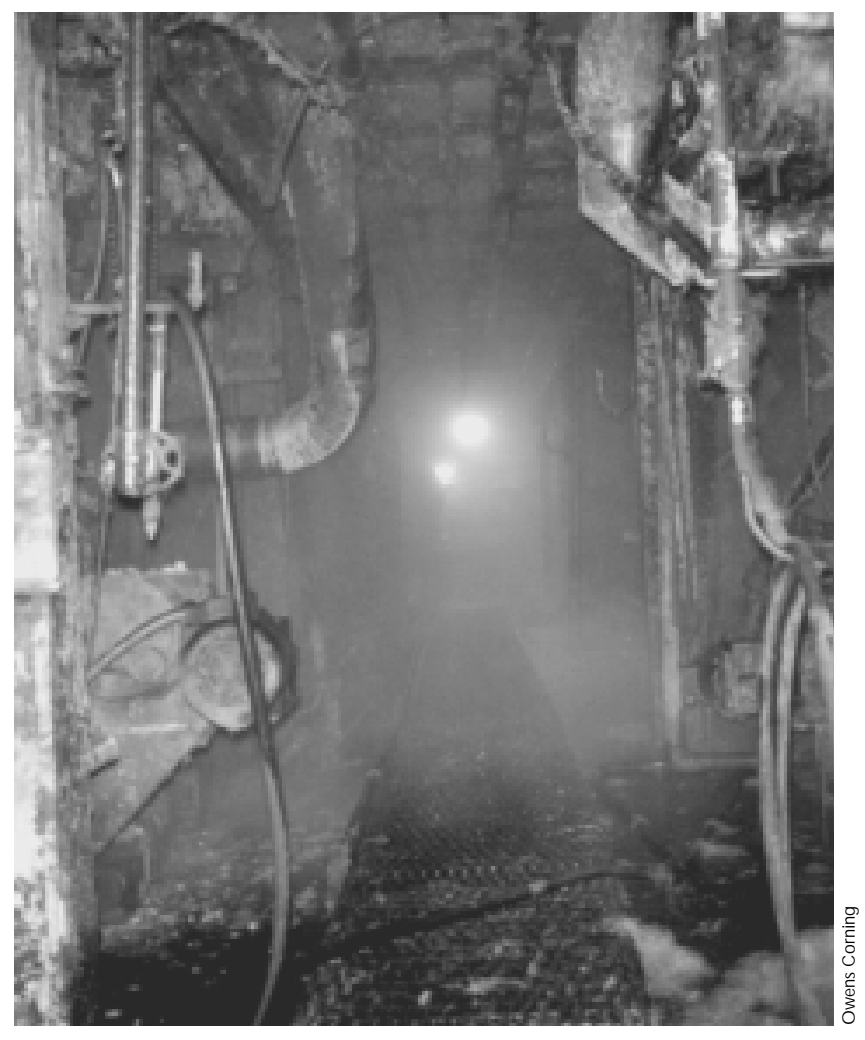


conformación, corte e instalación de productos de vidrio, piedra, escorias y fibra cerámica refractaria. Aunque la exposición a fibras suspendidas en el aire para muchos de estos materiales ha sido generalmente baja (menos de 1 fibra por centímetro cúbico), en las aplicaciones por soplado tienden a ser mucho mayores.

Piedra, escorias y vidrio figuran entre los aislantes comerciales actuales más estudiados. Investigaciones epidemiológicas han revelado que el consumo de cigarrillos influye mucho en la mortalidad por cáncer de pulmón entre los trabajadores fabriles. Estudios de muestras representativas bien realizados no han revelado que las fibras produzcan exceso de mortalidad o morbilidad de pulmón. Investigaciones recientes de inhalación crónica en ratas han revelado que la durabilidad de las fibras vítreas es un determinante crítico de su potencial biológico. La composición, que determina la durabilidad, es muy variable. Para evitar problemas de salud pública, un Comité Técnico de la Comisión Europea ha propuesto recientemente que se someta a prueba la biopersistencia de las fibras vítreas empleando la inhalación a corto plazo. Como fibra de referencia se ha sugerido una composición de lana aislante, que fue ensayada exhaustivamente a la dosis máxima tolerada en ratas sin que se detectasen enfermedades irreversibles.

\section{Medio ambiente y problemas de salud pública}

El principal contaminante en suspensión en el aire emitido durante la fabricación de vidrio, productos cerámicos, alfarería y ladrillo son las partículas. La tecnología de reducción de emisiones más eficaz conocida consistente en instalar depuradores de filtración y precipitadores electrostáticos en húmedo. Están empezando a estudiarse los contaminantes atmosféricos peligrosos emitidos en operaciones de mezcla, aplicación y fraguado de aglomerantes. Pertenecen a esta clase de sustancias el estireno, los silanos y los epóxidos utilizados sobre filamento de vidrio continuo, y el formaldehído, el metanol y el fenol empleados durante la fabricación de piedra, escorias o vidrio. EI formaldehído es un peligroso contaminante atmosférico y se ha convertido en objeto preferencial de las normas de control en las líneas de producción más modernas. Los metales pesados susceptibles de actuar como contaminantes atmosféricos peligrosos, entre ellos el cromo, determinan las normas de control de los hornos de fundición de vidrio, mientras que el $\mathrm{NO}_{x}$ y el $\mathrm{SO}_{x}$ siguen siendo problemas en algunos países. L as emisiones de fluoruros y boro constituyen una preocupación en la producción de filamento de vidrio. El boro puede también convertirse en motivo de inquietud ambiental si en algunos países se exigen fibras de lana de vidrio muy solubles.

D ebido al alto volumen de descarga de aire y a la naturaleza de la formación y fusión del vidrio, en este sector se evaporan cantidades considerables de agua. En Estados Unidos, por ejemplo, hay muchas instalaciones que descargan un volumen nulo de agua de condensación. Cuando contiene materia orgánica, este agua reciclada puede provocar riesgos biológicos en el lugar de trabajo si no se instaura un tratamiento que impida la proliferación de organismos (véase la Figura 84.27). Los residuos generados por este sector industrial comprenden metales pesados, productos corrosivos y cierta cantidad de aglomerantes y disolventes perdidos. El sector de la fibra de vidrio se ha convertido en un destino importante para el reciclaje de envases de vidrio y de vidrio plano. Los productos de lana de vidrio actuales contienen entre un $30 \%$ y un $60 \%$ de vidrio reciclado. También se recuperan los refractarios consumidos y se reutilizan de manera provechosa.

Agradecimientos: quiero manifestar mi gratitud a Dan Dimas, CSP, Libbey$O$ wens-Ford, por las fotografías, y a M ichel Soubeyrand, Libbey-O wens-Ford, por la información sobre deposición de vapores químicos, descrita en el apartado dedicado al vidrio.

\section{Referencias}

American National Standards Institute (ANSI). 1988 Ceramic Tile. ANSI A 137.1-1988. Nueva York: ANSI.

Carniglia y SC Barna. 1992. H andbook of Industrial Re fractories Technology: Principles, Types, Properties and Applications. Park R idge, Nueva J ersey: N oyes Publications.
$\mathrm{H}$ aber, RA, PA Smith. 1987. O verview of Traditional $\mathrm{Ce}$ ramics. New Brunswick, Nueva Jersey: Ceramic Casting Program, Rutgers, U niversidad Estatal de Nueva Jersey.

Persson, HR. 1983. Glass T echnology M anufacturing and Properties. Seúl: Cheong Moon Gak Publishing Company.

Tooley, FV (dir.). 1974. The H andbook of Glass M anufacture. V ols. I ylI. N ueva Y ork: Booksfor Industry, Inc.

\section{0 tras lecturas recomendadas}

K roschwitz, JI, M H owe-Grant (dirs.). 1991. Encyclope dia of Chemical T echnology, $4^{\circ}$ ed. Nueva Y ork: Wiley $\&$ Sons.

Lowenstein, KL. 1983. The M anufacturing T echnology of Continuous G lass Fibres. Amsterdam, N ueva Y ork: Elsevier Science Publishers. 



\section{INDUSTRIA DE LAS ARTES GRAFICAS, FOTOGRAFIA Y REPRODUCCION}

Director del capítulo

David Richardson

\section{Sumario}

Artes gráficas y publicación

Gordon C. Miller . . . . . . . . . . . . . . . . . . 85.2

Características generales

David Richardson.

Servicios de reproducción y duplicación

Robert W. Kilpper. . . . . . . . . . . . . . . . . . . . . . . . 85.6

Efectos sobre la salud y pautas patológicas

Barry R. Friedlander. . . . . . . . . . . . . . . . . . . 85.9

Descripción general de riesgos para el medio ambiente Daniel R. English. . . . . . . . . . . . . . . . . . . . . 85.12

Laboratorios fotográficos comerciales

David Richardson. . 


\section{ARTES GRAFICAS Y PUBLICACION}

\section{Gordon C. Miller}

Descripción general de los métodos de impresión La imprenta se inventó en China en el siglo XI. A finales del XV, Johannes Gutenberg inventó los tipos móviles y la prensa, y desarrolló así la técnica de impresión que ahora se utiliza en el mundo entero. Desde entonces, las artes gráficas han experimentado un crecimiento espectacular y pasado de la sencilla impresión de texto en papel a la de texto y otros originales artísticos en papel y otros materiales (soportes). En el siglo XX, el envasado de toda clase de artículos de consumo ha dado un nuevo y espectacular impulso a la imprenta. Los trabajos de impresión, envasado y publicación, junto con los de revestimiento y plastificado, muy próximos a los anteriores, forman parte de toda clase de productos y procesos cotidianos utilizados en el hogar, el tiempo libre y el trabajo.

El arte de colocar palabras e imágenes sobre papel u otros soportes evoluciona en direcciones que nadie hubiera pensado hace unos años. Se ha creado un amplio abanico de técnicas, que van desde las formas de impresión más antiguas y tradicionales a las más vanguardistas, que se valen de ordenadores y métodos relacionados con éstos. El campo de las artes gráficas lo abarca todo, desde la antigua técnica de los tipos de plomo montados en prensa plana hasta las modernas rotativas basadas en el principio de impresión directa a plancha (véase la Figura 85.1). En algunas empresas, tecnologías tan dispares como éstas conviven literalmente una junto a otra.

Hay cuatro técnicas básicas de impresión con las que se asocian numerosos riesgos para la seguridad, la salud y el medio ambiente.

1. Tipografía o impresión con formas en relieve. Esta técnica, utilizada durante muchos años en las artes gráficas, se basa en la confección de imágenes, por lo común letras o figuras, elevadas en relación con un fondo o área que no se imprime. La tinta se aplica a las partes elevadas, que a continuación se ponen en contacto con el papel o el soporte que vaya a recibir la imagen.

Hay varias formas de crear la imagen en relieve, como la composición letra por letra empleando tipos móviles, con

Figura 85.1 - Operaciones finales del proceso de impresión; el material impreso que sale de la rotativa se corta y se le da la forma del producto definitivo.

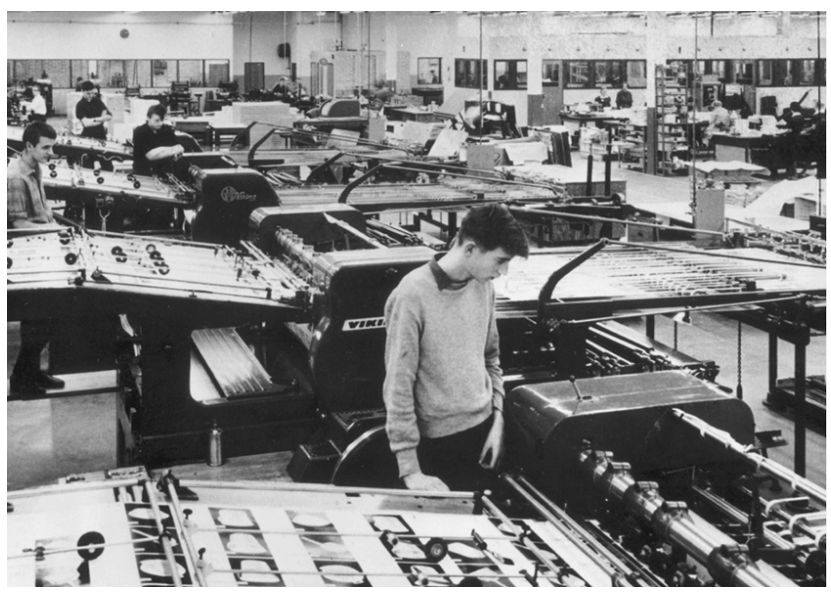

\section{Características generales}

Las industrias gráficas, de la fotografía comercial y de la duplicación son importantes en todo el mundo por motivos económicos. Las industrias gráficas presentan muchas variaciones, tanto por las técnicas que utilizan como en dimensiones. Pero, con inde pendencia de su tamaño (medido en volumen de producción), las técnicas descritas en este capítulo son las más comunes. En cuanto a la producción, existen unas pocas plantas que trabajan a gran escala y muchas pequeñas. Desde el punto de vista económico, las industrias gráficas constituyen uno de los sectores más importantes, y facturan anualmente no menos de 500.000 millones de dólares de EE.UU. en todo el mundo. También es variado el sector de la fotografía comercial, con unas pocas empresas de gran volumen de producción y numerosos laboratorios pequeños. El volumen de trabajos de acabado fotográfico se reparte aproximadamente a partes iguales entre las grandes compañías y las pequeñas. El mercado de la fotografía comercial genera unos ingresos anuales de aproximadamente 60.000 millones de dólares de EE.UU. en todo el mundo, y los trabajos de acabado fotográfico suponen alrededor del $40 \%$ de este total. El sector de la duplicación, formado por empresas de menor volumen con una facturación anual acumulada de unos 27.000 millones de dólares de EE.UU., produce casi 2 billones de copias anuales. Además, existen servicios de reproducción y duplicación a menor escala en casi todas las organizaciones y empresas.

En estos sectores, los riesgos relacionados con la salud, el medio ambiente y la seguridad están evolucionando gracias a la entrada de materiales potencialmente menos peligrosos, las nuevas estrategias industriales de control sanitario y la implantación de nuevas técnicas, como las digitales, la formación electrónica de imágenes y el trabajo con ordenadores. Muchos riesgos sanitarios que han sido importantes históricamente /como el uso de disolventes en las industrias gráficas o de formaldehído como estabilizador en las soluciones de procesamiento de fotografías) dejarán de serlo en el futuro gracias a su sustitución por materiales menos peligrosos o a la implantación de nuevas estrategias de control de riesgos. No obstante, surgirán nuevos riesgos para la salud, el medio ambiente y la seguridad que deberán afrontar los profesionales de la salud y la seguridad. De ello resulta la importancia de la vigilancia de la salud y el medio ambiente como parte de una estrategia eficaz de gestión de riesgos en los sectores de las artes gráficas, la fotografía comercial y la reproducción

\section{David Richardson}

la máquina llamada linotipia, antes de uso común, o con texto formado por procedimientos mecánicos. Estas técnicas son adecuadas para trabajos de impresión sencillos y breves. Para los más voluminosos se prefieren las planchas de impresión de metal, plástico o caucho. La impresión con planchas de caucho o similares suele llamarse flexografía o impresión flexográfica.

Las tintas habitualmente empleadas en estos métodos son al agua o con disolventes; se están investigando y aplicando nuevas tintas que secan por endurecimiento a la luz ultravioleta (UV) o por intervención de otros agentes químico-físicos.

2. Huecograbado. En las técnicas de huecograbado, la imagen se corta en la superficie de una plancha o un cilindro grabados. La plancha se baña en tinta y el exceso se elimina con una cuchilla. A continuación se pone en contacto con el papel o el 
soporte de que se trate para transferir la imagen. Es una técnica adecuada para publicaciones de las que se hacen tiradas largas, como periódicos y materiales de envasado.

Suelen utilizarse tintas a base de disolventes, el más común de los cuales es el tolueno. Se están introduciendo con cierto éxito tintas de aceite de soja y agua, aunque no se adaptan a todas las aplicaciones.

3. Impresión planográfica o litográfica. Se basa en el empleo de materiales con propiedades diferentes. En la forma que se utilizará para imprimir se crean zonas que aceptan el agua con avidez o que la repelen (de modo que aceptan, por ejemplo, las tintas basadas en disolventes). Las zonas receptoras de tinta llevan la imagen, mientras que las afines al agua corresponden al fondo no impreso. En resumen, la tinta se adhiere sólo a determinadas zonas, y de ahí se transfiere al papel o a otro soporte. En muchos casos, esta última operación se realiza con ayuda de una superficie intermedia llamada mantilla, que entra en contacto con el papel. Este proceso de transferencia es la impresión en offset, que se utiliza en muchas aplicaciones de impresión, publicación y envasado.

Hay que señalar que en la impresión en offset no siempre se parte de planchas litográficas. Dependiendo de las necesidades concretas de producción, la tirada en offset se puede combinar con otros métodos de artes gráficas.

En la impresión planográfica o litográfica suelen utilizarse tintas a base de disolventes (es decir, no acuosas), aunque se están difundiendo con rapidez los preparados sin disolventes.

4. Serigrafía y permeografía. La permeografia y la serigrafía se valen de un estarcido montado sobre una pantalla de malla fina. La tinta se aplica a las zonas abiertas de la pantalla y se presiona con una raedera sobre las partes abiertas y el estarcido. De este modo, la tinta atraviesa las partes abiertas y se aplica al soporte situado bajo la malla. La serigrafía se utiliza mucho en trabajos sencillos y tiradas cortas, circunstancias en las que puede resultar más económica que otros métodos. Son aplicaciones típicas la impresión de tejidos, carteles, materiales de exposición y papeles pintados.

En serigrafía se utilizan tintas a base de disolventes o de agua; la elección depende sobre todo del soporte impreso. Como la cobertura serigráfica suele ser más gruesa de lo normal, las tintas son también más viscosas que en otras técnicas de impresión.

\section{Preparación antes de la entrada en prensa}

En este apartado se abordan las operaciones de montaje de los distintos materiales - textos, fotografias, arte, ilustraciones y dibujos - que han de reproducirse en el producto impreso. Todos ellos deben estar completamente acabados, pues una vez confeccionadas las planchas de impresión no es posible cambiar nada. La única forma de corregir errores es repetir la operación. En este trabajo se aplican una serie de principios de artes gráficas que garantizan la estética del producto impreso.

Generalmente, este apartado de la impresión se considera menos peligroso que otros para la salud y la seguridad. La confección de la maqueta o arte final puede exigir un esfuerzo físico considerable; además, existen riesgos para la salud derivados del trabajo con pigmentos, adhesivos de caucho y en aerosol y otros materiales. Buena parte de este trabajo se realiza ahora con ordenadores y se analiza también en el artículo "Artes aplicadas" del capítulo Actividades artísticas, culturales y recreativas. Los riesgos potenciales del trabajo con pantallas y ordenadores se tratan en otros lugares de esta Enciclopedia. El uso de puestos de trabajo bien diseñados desde el punto de vista ergonómico mitiga estos peligros.

\section{Confección de planchas}

Las planchas o cilindros de impresión característicos de las técnicas de imprenta actuales se confeccionan con cámaras fotográficas u ordenadores. Normalmente, el primer paso es la obtención de una imagen fotográfica con la que después se prepara la plancha utilizando métodos fotomecánicos. Durante este proceso, se separan los colores y se definen ciertos aspectos que determinan la calidad de la imagen impresa, como la trama. Las cámaras utilizadas en fotomecánica son aparatos mucho más perfeccionados que los equipos comunes de aficionado. La preparación de las planchas exige una nitidez excepcional, una correcta separación de los colores y un registro perfecto. El ordenador ha eliminado buena parte de las operaciones manuales de montaje y revelado de la imagen.

Los riesgos potenciales propios de este aspecto de las industrias gráficas son similares a los normales en el sector de la fotografía, y se analizan en otros artículos de este mismo capítulo. Durante la confección de las planchas es importante controlar la posible exposición a compuestos químicos.

Una vez creada la imagen, se aplican técnicas fotomecánicas para preparar la plancha de impresión. Dichas técnicas pueden agruparse como sigue:

Métodos manuales. Para formar el relieve de la plancha se pueden utilizar instrumentos manuales, buriles y gubias, y crayones para crear zonas repelentes del agua si se trata de una piedra litográfica (estas técnicas suelen aplicarse a producciones a pequeña escala y trabajos de artes gráficas especiales).

Métodos mecánicos. El relieve se trabaja con tornos, máquinas rayadoras y aparatos similares; también hay máquinas especiales para formar zonas repelentes del agua en planchas litográficas.

Métodos electromecánicos. Sirven para depositar metales en planchas y cilindros.

Métodos electrónicos. Los equipos grabadores electrónicos forman relieves en planchas y cilindros.

Métodos electrostáticos. Se emplean técnicas xerográficas o similares para formar en planchas y cilindros elementos de imagen en relieve o repelentes del agua.

Métodos fotomecánicos. Pueden transferirse a la plancha o el cilindro imágenes fotográficas aplicando revestimientos sensibles a la luz.

La confección fotomecánica de planchas es la técnica más utilizada en la actualidad. En muchos casos, la plancha o el cilindro se tratan con dos o más métodos.

Por la variedad de métodos empleados, la confección de planchas tiene numerosas repercusiones sobre la salud y la seguridad. Los métodos mecánicos, menos utilizados ahora que en el pasado, daban lugar a los problemas de seguridad propios del trabajo mecánico: riesgos asociados con el uso de herramientas manuales y con la maquinaria voluminosa del taller. Los riesgos vinculados con la seguridad y protección de las manos son típicos de la confección de planchas con métodos mecánicos. En esta clase de trabajo se utilizan con frecuencia aceites y limpiadores que pueden ser inflamables o tóxicos.

En muchos talleres siguen utilizándose métodos antiguos junto con equipos más modernos, y los riesgos pueden aumentar. Cuando se trabaja con formas de tipos móviles, se utiliza una linotipia, antes muy común en casi todos los talleres. Esta máquina elabora las letras con plomo, que se mantiene fundido en un crisol, de modo que entran directamente en el taller muchos de los peligros propios de este metal. El plomo, del que se habla en otros lugares de la presente Enciclopedia, puede penetrar en el organismo por inhalación de sus compuestos y al entrar en contacto con la piel puede conducir involuntariamente a la ingestión. La consecuencia posible es una intoxicación 
crónica de baja intensidad por plomo, que ocasiona disfunciones nerviosas y renales y otros signos de toxicidad.

Otros métodos de confección de planchas recurren a los compuestos químicos de chapado y mordido para formar la imagen en la plancha o el cilindro. Para ello se utilizan diversos compuestos, como ácidos y metales pesados (zinc, cromo, cobre y aluminio), así como sistemas orgánicos a base de resinas que forman algunas de las capas superficiales de la plancha. Ahora, hay sistemas que emplean disolventes de petróleo para el tratamiento químico de las planchas. Al planificar la seguridad de las instalaciones, hay que tener en cuenta los riesgos potenciales asociados a estos compuestos. Son muy importantes la ventilación y el equipo de protección personal frente a productos químicos. Además, hay que tener en cuenta los posibles efectos sobre el medio ambiente de los compuestos corrosivos y los metales pesados al organizar la seguridad de los aspectos químicos de la preparación de planchas. El almacenamiento y la mezcla de estos productos químicos también da lugar a riesgos para la salud, que pueden ser considerables en caso de vertido accidental.

Los mordientes que se utilizan en ocasiones para transferir la imagen a la plancha o el cilindro también pueden ser peligrosos. Los sistemas de grabado habituales generan cierta contaminación metálica que puede afectar a quienes los emplean. Los métodos más modernos se basan en un rayo láser que graba la imagen en la plancha. Aunque así se eliminan algunas de las etapas de la confección de planchas, el rayo láser puede ser peligroso para los ojos y la piel. Otros equipos utilizan el láser para ablandar materiales, como los plásticos, en lugar de calentarlos hasta evaporación, lo que provoca en el lugar de trabajo complicaciones derivadas de los vapores y los humos.

En casi todos los casos, la confección de planchas es sólo una parte relativamente pequeña del conjunto de operaciones de producción del taller de artes gráficas; esto limita automáticamente el riesgo, pues en la zona de preparación de planchas trabaja poca gente y se utilizan cantidades pequeñas de materiales. A medida que avanza la técnica se va reduciendo el número de fases necesarias para transportar la imagen a la plancha, lo que a su vez limita las probabilidades de que se produzcan riesgos que afecten a los empleados o al medio ambiente.

\section{Fabricación de tintas}

Las tintas y revestimientos utilizados dependen de la técnica de impresión. Normalmente, las tintas están compuestas por un vehículo y los pigmentos o tintes y resinas que formarán la imagen.

El vehículo mantiene en disolución los pigmentos y demás componentes hasta que la tinta se seca. Son vehículos típicos de las tintas de imprenta los alcoholes, los ésteres (acetatos), las cetonas y el agua. Las empleadas en huecograbado suelen contener proporciones elevadas de tolueno. Ciertas formulaciones más modernas contienen aceite de soja epoxidizado y otros productos no volátiles, que son menos peligrosos. Un componente típico de la tinta es el ligante de resina, que sirve para adherir los pigmentos al soporte una vez seca. Se emplean habitualmente resinas orgánicas sintéticas o naturales, como las acrílicas.

Los pigmentos aportan el color, y se preparan con productos químicos muy variados, entre los que se encuentran metales pesados y compuestos orgánicos.

Las tintas que endurecen a la luz UV se elaboran con acrilatos y no contienen vehículo. No siguen un proceso de endurecimiento y secado. Normalmente, están formadas por una resina y un pigmento. Los acrilatos son sensibilizantes potenciales de la piel y el aparato respiratorio.
Son muchos los riesgos para la salud derivados de la fabricación de tintas. Como en su elaboración intervienen disolventes inflamables, es importante la protección contra incendios en todas las instalaciones de producción. Debe haber rociadores y extintores en perfecto estado de funcionamiento. Los cursos de formación son imprescindibles, pues los empleados tienen que conocer el manejo de estos equipos. Las instalaciones eléctricas deben ser intrínsecamente seguras o bien someterse a pruebas de purga o explosión. El control de la electricidad estática es vital, porque muchos disolventes generan cargas eléctricas cuando circulan por mangueras de plástico o en contacto con el aire. La reducción de la humedad, las tomas de tierra y las conexiones de masa son medidas muy recomendables para controlarla.

Los equipos mezcladores, desde los pequeños hasta los grandes tanques de producción por lotes, presentan muchos riesgos mecánicos. Las cuchillas y mecanismos de mezcla deben protegerse de algún modo durante el funcionamiento y en las fases de preparación y limpieza. Los protectores de máquinas son necesarios y deben estar montados en el lugar correspondiente; cuando se retiren para operaciones de mantenimiento, es imprescindible seguir programas de desbloqueo e identificación.

Debido a las cantidades presentes, la manipulación de materiales también puede plantear riesgos. Aunque es recomendable conducir directamente todos los productos a la zona de manipulación mediante tuberías, muchos componentes deben transportarse manualmente al punto de mezcla en bolsas, tambores y otros recipientes. Esto obliga no sólo a utilizar carretillas elevadoras, grúas y otros equipos mecánicos, sino también a que los empleados encargados de mezclar los productos los manipulen directamente. En estos trabajos son comunes los dolores de espalda y tensiones similares. La enseñanza de unas prácticas de levantamiento correctas constituye un aspecto importante del programa de prevención, así como la elección de métodos mecánicos de elevación que exijan menos intervención humana directa.

Esta clase de manipulaciones favorecen los vertidos accidentales y los incidentes de tipo químico. Hay que adoptar medidas para afrontar estas situaciones de emergencia. Asimismo, hay que cuidar el almacenamiento para evitar los vertidos y la mezcla accidental de compuestos incompatibles.

Por su naturaleza y por las grandes cantidades almacenadas, la exposición de los empleados a los compuestos químicos puede ser motivo de preocupación. Todos los componentes, tanto el vehículo como las resinas y pigmentos, deben evaluarse individualmente y en la mezcla que constituye la tinta. El programa de seguridad ha de contemplar los siguientes aspectos: evaluación de la higiene industrial y toma de muestras para determinar si los niveles de exposición son aceptables; ventilación adecuada para eliminar los compuestos tóxicos; uso de equipo de protección personal adecuado. Como hay riesgo de vertidos y otras causas de exposición excesiva, deben instalarse equipos de emergencia para primeros auxilios. Son recomendables las duchas de seguridad, las bañeras de ojos, los botiquines de primeros auxilios y la vigilancia médica; si estas medidas se descuidan pueden producirse lesiones de la piel, los ojos, el aparato respiratorio y otros órganos. Las consecuencias van desde la simple dermatitis por contacto de la piel con los disolventes hasta lesiones más duraderas por exposición a pigmentos con metales pesados, como el cromato de plomo, que forman parte de ciertas tintas. El espectro tóxico potencial es amplio, dados los muchos compuestos utilizados en la fabricación de tintas y revestimientos. Con la entrada de nuevas técnicas, como las tintas endurecibles por UV, el riesgo puede desplazarse del derivado de los disolventes habituales a la sensibilización por contacto reiterado con la piel. Hay que esforzarse por conocer a fondo los 
riesgos potenciales de los compuestos químicos utilizados en la fabricación de tintas y recubrimientos, y esto es mejor hacerlo antes de la formulación.

Como muchas tintas contienen materiales potencialmente nocivos si llegan al medio ambiente, puede ser necesario implantar controles en el proceso de producción. Asimismo, hay que manipular con cuidado los residuos, los productos de limpieza y los desperdicios, para minimizar el impacto ambiental.

La fuerte presión internacional a favor de la mejora del medio ambiente ha llevado a la introducción de tintas más ecológicas, que utilizan agua como disolvente y resinas y pigmentos menos tóxicos. Estas innovaciones deberían contribuir a reducir los riesgos inherentes a la fabricación de tintas.

\section{Impresión}

Para imprimir hay que entintar la plancha y transferir la tinta al soporte. En los métodos offset, la imagen se transfiere desde una plancha montada en un cilindro a otro cilindro intermedio de caucho (mantilla) y desde éste al soporte elegido, que no siempre es papel, aunque sea uno de los más comunes. Muchas etiquetas decorativas se imprimen con técnicas tradicionales en película de poliéster metalizada al vacío. Los laminados plásticos se pueden imprimir en rotativas de bobina continua y cortarse luego para fabricar el envase.

Como en la impresión se utiliza mucho el color, es normal tirar varias capas, que se aplican al sustrato una por una y se dejan secar antes de imprimir la siguiente. Es un trabajo de gran precisión para conservar el registro entre colores, lo que se consigue con numerosas estaciones de impresión y controles muy perfeccionados de la velocidad y la tensión del papel a su paso por la prensa.

Los riesgos propios del manejo de la prensa son similares a los descritos para la fabricación de tinta. El peligro de incendio es crítico. Como en el caso de la producción de tinta, es imprescindible instalar rociadores y otros medios de protección contra el fuego. También en la prensa se pueden instalar otros sistemas, que actúan como controles complementarios, además de los necesarios extintores. Las instalaciones eléctricas han de cumplir las especificaciones de purga, resistencia a la explosión y seguridad intrínseca. También es importante controlar la electricidad estática, sobre todo si se trabaja con disolventes como alcohol isopropílico y rotativas. Además de los líquidos inflamables, que pueden generar cargas estáticas cuando circulan por mangueras de plástico o en contacto con el aire, casi todas las películas plásticas y las bobinas generan también cargas muy considerables al pasar por encima de los cilindros metálicos. Para eliminar estas cargas hay que controlar la humedad e instalar tomas de tierra y conexiones de masa, así como aplicar técnicas de disipación de electricidad estática centradas en las bobinas de alimentación de las rotativas.

La manipulación directa de los equipos de impresión, soportes y tintas es otra fuente de peligro. En cuanto al almacenamiento, valen los comentarios hechos a propósito de la fabricación de tinta. Es recomendable reducir al mínimo la manipulación directa de equipos, soportes de impresión y tintas. Si es imposible, hay que impartir formación específica para los empleados de la sala de impresión.

A los riesgos propios de la sala de impresión se suman los aspectos de seguridad mecánica derivados del funcionamiento de equipos que ejecutan movimientos y giros rápidos y del desplazamiento del soporte de impresión a una velocidad de más de 500 metros por minuto. Hay que instalar sistemas de vigilancia y alarmas para garantizar la seguridad de los trabajadores. Además, son necesarios sistemas de desconexión e identi- ficación durante las operaciones de reparación y mantenimiento.

Dada la cantidad de máquinas rotativas y la velocidad habitual de muchos trabajos, el ruido suele ser un motivo de preocupación importante, en especial si se trabaja con varias máquinas a la vez, como ocurre en la impresión de periódicos. Si la intensidad sonora no es aceptable, hay que implantar un programa de protección del oído con controles técnicos.

Aunque las tintas suelen secarse al aire en la zona de prensas, es recomendable montar túneles de secado para reducir la exposición a los disolventes volátiles.

Asimismo, ciertas prensas de alta velocidad pueden formar una neblina de tinta. La evaporación de los disolventes y la potencial neblina de tinta presentan un riesgo de inhalación de compuestos que pueden ser tóxicos. Además, la vigilancia sistemática de la impresión, el llenado de depósitos y cubetas, la limpieza de cilindros y volantes y demás tareas afines favorecen el contacto con tintas y disolventes limpiadores.

Como en el caso de la fabricación de tintas, es recomendable poner en marcha un buen programa de muestreo de higiene industrial junto con circuitos de ventilación de capacidad suficiente y equipo de protección personal. En la obligatoria limpieza sistemática de estas prensas, que a veces son enormes, suelen utilizarse disolventes químicos, lo que aumenta el riesgo de contacto con tales productos. Las rutinas de manipulación pueden reducir la exposición, pero no eliminarla por completo, en función del tamaño de la maquinaria de impresión. Como ya se ha señalado, aunque las nuevas tintas y revestimientos constituyen una técnica mejor, siguen planteando riesgos. Así, las tintas endurecibles por UV actúan como sensibilizadores potenciales cuando entran en contacto con la piel y, además, hay riesgo de exposición a radiaciones UV de intensidad peligrosa.

Las emisiones generadas por la impresión y por los disolventes de limpieza, así como los restos de tintas, pueden afectar al medio ambiente. A veces resulta necesario instalar equipos de reducción de la contaminación atmosférica para atrapar y destruir o reciclar los disolventes evaporados de las tintas tras la impresión. Es importante manipular con precaución los residuos generados para minimizar el impacto sobre el medio ambiente. Se recomienda establecer sistemas de manipulación de residuos siempre que haya disolventes y otros componentes reciclables. La investigación está aportando nuevas técnicas que emplean disolventes de limpieza mejores, lo que puede reducir las emisiones y mitigar una posible exposición. Se recomienda estudiar la tecnología de limpieza más moderna para comprobar si hay alternativas a los disolventes, como las soluciones acuosas o basadas en aceites vegetales, que cumplan los requisitos propios de cada trabajo de impresión. No obstante, las soluciones de limpieza al agua que estén contaminadas con tintas a base de disolventes exigen un tratamiento prudente, tanto dentro del taller como para su eliminación.

\section{Acabado}

Una vez impreso, el soporte debe someterse casi siempre a operaciones de acabado antes de que esté listo para el uso a que se destine. Algunos materiales se pueden enviar directamente de la prensa a la maquinaria de envasado, donde se da forma al envase y se llena con el contenido correspondiente o donde se aplican adhesivos y etiquetas. En otros casos, el material se somete a numerosas operaciones de corte y guillotinado antes de montar el libro o el material impreso de que se trate.

Los riesgos para la salud y la seguridad propios del acabado son primordialmente de naturaleza mecánica. Como buena parte del acabado consiste en el corte de los materiales, son lesiones típicas los cortes y laceraciones de dedos, manos, muñecas o brazos. La protección es importante, y debe utilizarse 
en todos los trabajos. También hay que guardar y tirar con precaución las cuchillas para evitar cortes y laceraciones por descuido. Los equipos de mayor tamaño exigen el mismo grado de atención en materia de protección y formación para evitar accidentes.

En el acabado, los trabajos de manipulación de materiales, tanto los que están sin acabar como los productos finales envasados, adquieren proporciones considerables. Si es posible, se utilizarán carretillas elevadoras, grúas y cintas transportadoras. Cuando sea necesario levantar y manipular directamente los productos, se enseñará a los trabajadores los movimientos correctos.

Una evaluación reciente de este aspecto de las industrias gráficas indica que el cuerpo humano se ve sometido a posibles tensiones ergonómicas. Todas las tareas - corte, clasificación, envasado - deben revisarse para determinar sus posibles repercusiones ergonómicas. Si se detectan defectos de esta clase, puede ser necesario modificar el lugar de trabajo para reducir este posible factor de estrés a una intensidad aceptable. Con frecuencia ayuda cierto grado de automatización, pero en casi todos los trabajos de impresión quedan tareas manuales que pueden ocasionar estrés ergonómico. La rotación de puestos de trabajo alivia el problema.

\section{El futuro de la imprenta}

Siempre será necesario el texto impreso sobre un soporte. Pero el futuro de la imprenta se caracterizará por un paso más directo de la información desde el ordenador a la prensa; también cobrará fuerza la impresión electrónica o grabación del texto sobre soportes electromagnéticos o de otro tipo. Aunque los materiales electrónicos sólo se pueden leer con ayuda de otros mecanismos electrónicos, cada vez se trasladarán más textos y obras literarias de los soportes impresos al formato electrónico. Esto reducirá muchos de los riesgos mecánicos y para la salud propios de las industrias gráficas, pero aumentará el número de peligros ergonómicos.

\section{- SERVICIOS DE REPRODUCCION Y DUPLICACION}

\section{Robert W. Kilpper}

En las oficinas modernas hay varios tipos de máquinas de reproducción, desde la ubicua fotocopiadora en seco hasta los equipos especiales, como las reproductoras heliográficas, los fax o las multicopistas, así como otras duplicadoras. En este artículo se agruparán todos estos sistemas en función de la técnica en que se base su funcionamiento. Por su uso generalizado, se prestará mayor atención a las fotocopiadoras en seco.

\section{Fotocopiadoras e impresoras láser}

\section{Procesamiento}

Casi todas las fases de la electrofotografía normal (xerografía) son análogas a las propias de la fotografia. Durante la exposición, el original impreso o fotográfico que se quiere copiar se ilumina con un flash u otra fuente luminosa intensa; la imagen reflejada se enfoca con ayuda de un objetivo en un fotorreceptor sensible a la luz cargado eléctricamente, que pierde la carga en los puntos en que recibe luz. La distribución de ésta en el receptor es igual que en el original. A continuación, el fotorreceptor se revela poniéndolo en contacto con unas esferas portadoras voluminosas que llevan adheridas diminutas partículas cargadas electrostáticamente; estas esferas reveladoras se dejan caer sobre el receptor o se transportan hasta él por medios magnéticos. La imagen latente cargada del fotorreceptor se revela cuando el polvo finamente dividido (que se llama tóner o tinta seca) es atraído electrostáticamente para separarlo del revelador; de este modo, sólo queda el polvillo cargado, que forma la imagen en el receptor. Por último, el tóner se transfiere electrostáticamente a un papel corriente y se fija de modo permanente fundiéndolo con calor o con calor y presión. Un mecanismo limpiador retira del fotorreceptor el tóner residual y lo acumula en un depósito recolector. De este modo, el receptor queda listo para el siguiente ciclo de reproducción. Como lo único que toma el papel receptor del revelador es tóner, el mecanismo de transporte que lo condujo hasta la imagen se hace pasar de nuevo por el alojamiento del revelador y se mezcla con tóner nuevo que se introduce en el sistema desde un frasco o un cartucho intercambiable.

Muchas máquinas aplican presión y calor a la imagen de tóner sobre papel durante el proceso de fusión. El calor es generado por un rodillo fusor que entra en contacto con la superficie que lleva el tóner. Según las características del tóner y de los materiales del fusor, parte de aquél puede adherirse a la superficie de éste en lugar de al papel, lo que determina la pérdida de parte de la imagen. Para evitarlo, se aplica a la superficie del rodillo un lubricante, por lo general un líquido de silicona.

En una impresora láser, la imagen se convierte primero a formato electrónico, es decir se transforma en un conjunto de puntos diminutos (pixeles) utilizando un escáner; otra opción es crear la imagen directamente en ordenador. La imagen digitalizada se graba en el fotorreceptor de la impresora con un haz de láser. El resto del proceso es básicamente similar al descrito para la xerografía común, y tiene por objeto transferir la imagen del fotorreceptor a un papel u otra superficie.

Algunas fotocopiadoras utilizan el llamado revelado líquido, que se diferencia del proceso en seco habitual en que el revelador suele ser un vehículo líquido de hidrocarburos en el que se dispersan partículas de tóner muy finas. El revelado y la transferencia suelen ser análogos al método ya descrito, con la sola diferencia de que el revelador se lava sobre el fotorreceptor y la copia húmeda se seca por evaporación del residuo líquido aplicando calor o calor y presión.

\section{Materiales}

Los consumibles de fotocopiadora son tóners, reveladores, lubricantes de fusor y papel. Aunque no suelen considerarse como tales, los fotorreceptores, el fusor, los rodillos de presión y algunos otros componentes están sometidos a desgaste y deben sustituirse, sobre todo en máquinas con un gran volumen de producción. Estos componentes no suelen considerarse manipulables por el cliente, y su desmontaje y ajuste exigen conocimientos especiales. Muchos modelos recientes incorporan unidades sustituibles por el cliente (CRU) que albergan el fotorreceptor y el revelador en una caja cerrada que sí puede cambiar el cliente. En estas máquinas, los rodillos fusores y demás elementos duran tanto como la propia máquina, o se sustituyen de manera independiente. Siguiendo la tendencia a la reducción de los costes de mantenimiento y una mayor comodidad del cliente, algunas empresas están ampliando los elementos que éste puede reparar sin riesgos mecánicos ni eléctricos; estas operaciones requieren, como máximo, la llamada a un centro de asistencia técnica.

El tóner produce la imagen en la copia. El tóner seco es un polvo fino formado por plásticos, colorantes y pequeñas cantidades de aditivos funcionales. Su principal componente suele ser un polímero plástico; son materias primas comunes los polímeros de estireno y acrílicos, de estireno y butadieno y de poliéster. En los tóners negros se añade negro de humo u otros pigmentos, mientras que en los de color se usan tintes o pigmentos. Durante la fabricación del tóner, el negro de humo 
o los colorantes y el polímero se funden y mezclan, y casi todo el colorante queda envuelto por el polímero. Los tóners secos contienen también aditivos internos o externos que contribuyen a determinar las características de aceptación de cargas estáticas y de fluidez.

Los tóners de revelado en húmedo se parecen a los secos en que están formados por pigmentos y aditivos encapsulados en un polímero. La diferencia estriba en que estos componentes se adquieren en forma de dispersión en un vehículo de hidrocarburo isoparafínico.

Los reveladores suelen ser mezclas de tóner y vehículo. Este transporta literalmente el tóner hasta la superficie del fotorreceptor; suele fabricarse con materiales elaborados a partir de calidades especiales de arena, vidrio, acero o ferrita y pueden revestirse con una pequeña cantidad de polímero para lograr el comportamiento óptimo para cada aplicación. Las mezclas de tóner y vehículo se conocen como reveladores de dos componentes. Los de un solo componente no utilizan vehículo, sino que incorporan óxido de hierro u otro compuesto similar y utilizan un sistema magnético para aplicarlo al fotorreceptor.

Los lubricantes del fusor son casi siempre líquidos a base de siliconas que se aplican a los rodillos fusores para evitar que el tóner se separe de la imagen revelada y se pegue a aquéllos. Algunos son simples polidimetilsiloxanos (PDMS), pero otros contienen aditivos funcionales que mejoran la adherencia al rodillo fusor. Otros se vierten en una cubeta donde una bomba los recoge y los conduce hasta el rodillo. En otras máquinas se aplica a éste con una cinta de tejido impregnado que frota su superficie; en ciertos modelos pequeños y en las impresoras, la aplicación se confía a una mecha impregnada de aceite.

Todas o casi todas las fotocopiadoras modernas admiten papel corriente sin tratar de distintos gramajes. Se fabrican impresos especiales sin carbón para algunas máquinas de alta velocidad; también hay papeles de transferencia que no se funden y que se imprimen en una fotocopiadora o una impresora para a continuación transferir la imagen a una camiseta u otro tejido aplicando presión y calor con una plancha. Las copiadoras especiales para dibujos técnicos y planos de arquitectura suelen utilizar papel cebolla traslúcido.

\section{Riesgos potenciales y prevención}

Los fabricantes responsables han trabajado mucho para minimizar las fuentes de peligro inherentes a la fotocopia. No obstante, hay que solicitar la ficha de seguridad (MSDS) correspondiente a cada consumible o producto químico de mantenimiento utilizado por una máquina determinada.

Quizá el único material al que se puede producir una exposición sustancial durante la fotocopia sea el tóner. Los modernos tóners secos no deberían representar ningún riesgo para la piel o los ojos, salvo quizá en los sujetos más sensibles; además, los equipos más recientes utilizan cartuchos de tóner y CRU que reducen al mínimo el contacto con el polvo. Tampoco los tóners líquidos deberían irritar la piel; sin embargo, su vehículo de hidrocarburos isoparafínicos es un disolvente que puede destruir la grasa dérmica y provocar sequedad y agrietamiento de la piel por exposición repetida. Estos disolventes pueden ser también levemente irritantes para los ojos.

Los equipos bien diseñados no presentan ningún riesgo derivados de la luz intensa, ni siquiera si la platina queda iluminada sin estar cubierta por el original; algunos sistemas de iluminación están conectados con una cubierta opaca que evita la exposición del operador a la fuente. Todas las impresoras láser están clasificadas como equipos láser de Clase I, lo que significa que, en condiciones de funcionamiento normales, la radiación láser (el haz luminoso) es inaccesible, pues está encerrado dentro del mecanismo de impresión y no presenta ningún riesgo biológico. Además, este mecanismo láser no requiere mantenimiento y, en el caso muy improbable de que fuese necesario manipularlo, el fabricante dispone de rutinas de trabajo seguras que han de seguir los especialistas debidamente formados del servicio técnico.

Por último, los equipos bien fabricados no presentan bordes agudos, elementos punzantes ni zonas expuestas a un riesgo de descargas eléctricas que el operador pueda tocar con la mano.

\section{Riesgos para la piel y los ojos}

Los tóners secos no suponen ningún peligro de importancia para la piel ni los ojos, y cabe esperar idénticas cualidades de los lubricantes del fusor elaborados con aceites de silicona. Los polidimetilsiloxanos (PDMS) se han sometido a completas evaluaciones toxicológicas y, en general, se ha observado que no son nocivos. Aunque algunos PDMS de baja viscosidad pueden ser irritantes para los ojos, los empleados como lubricantes del fusor no suelen serlo, y tampoco irritan la piel. Con independencia de la irritación real, cualquiera de estos productos resultará molesto si entra en contacto con la piel o los ojos. La zona afectada se puede lavar con agua y jabón, y los ojos deben enjuagarse con agua durante varios minutos.

Quienes trabajan frecuentemente con tóners líquidos, en especial en condiciones propensas a las salpicaduras, quizá prefieran llevar gafas protectoras o de seguridad con cierres laterales o una pantalla facial. Los guantes recubiertos de caucho o de vinilo evitarán las complicaciones de sequedad de la piel antes mencionadas.

Los papeles también suelen ser benignos. No obstante, se han dado casos de irritación considerable de la piel por no haber adoptado las debidas precauciones durante la fabricación. Unos métodos de producción inadecuados pueden causar la emisión de olores desagradables cuando el papel se calienta al pasar por el fusor en el proceso de copia en seco. En ocasiones, el papel traslúcido defectuosamente manufacturado empleado en copiadoras de dibujos técnicos provoca olores debidos a los disolventes de hidrocarburos.

Además de la base isoparafínica de los tóners líquidos, en el mantenimiento de la máquina se emplean numerosos disolventes, entre ellos los limpiadores de la platina y la tapa y los eliminadores de película, que suelen ser alcoholes o soluciones de alcohol y agua con pequeñas cantidades de surfactantes. Estas soluciones son irritantes para los ojos, pero no irritan directamente la piel. Sin embargo, al igual que los dispersantes del tóner líquido, su acción disolvente puede eliminar la grasa dérmica y provocar grietas. Unos guantes recubiertos de caucho o vinilo y unas gafas o una mascarilla de seguridad con protectores laterales bastarán para evitar esas complicaciones.

\section{Riesgo de inhalación}

El ozono es el mayor motivo de preocupación en la cercanía de las fotocopiadoras. En la relación de riesgos figura a continuación el tóner, junto con el polvillo de papel y los compuestos orgánicos volátiles (COV). En algunas situaciones se producen también olores desagradables.

El ozono se genera sobre todo a consecuencia de las descargas de efecto corona inducidas por los dispositivos (corotrones y descorotrones) que cargan el fotorreceptor antes de la exposición y la limpieza. A partir de cierta concentración, que normalmente sólo provocan las fotocopiadoras, se caracteriza por su olor agradable a trébol cortado. El reducido umbral de olor $(0,0076$ a $0,036 \mathrm{ppm})$ permite detectarlo fácilmente antes de que alcance concentraciones nocivas. Cuando alcanza una concentración suficiente para provocar dolor de cabeza, irritación ocular y dificultad respiratoria, el olor se vuelve intenso y 
picante. No hay que esperar complicaciones debidas al ozono en máquinas bien mantenidas e instaladas en lugares con ventilación suficiente. Pero sí pueden verse afectados los operadores que trabajen en la corriente de aire que sale de la máquina, sobre todo en largas sesiones de copia. Se ha comprobado que ciertos olores identificados como ozono por operadores inexpertos tienen un origen ajeno a la fotocopiadora.

El tóner se ha considerado durante mucho tiempo una sustancia en partículas molesta o una "partícula no clasificada según otro criterio" (PNOC). Estudios realizados por Xerox Corporation en el decenio de 1980 indican que el tóner inhalado desencadena la respuesta pulmonar normalmente asociada con esta clase de partículas insolubles. También se demostró la ausencia de riesgo carcinogénico por exposición a concentraciones muy superiores a las normales en un medio de oficina.

El polvillo de papel está formado por fragmentos de fibras de papel y diversos materiales de carga y relleno, como arcilla, dióxido de titanio y carbonato cálcico. Todos estos materiales se consideran PNOC. No se conoce ningún motivo de inquietud derivado de la exposición al polvillo de papel normal en un medio de oficina.

Los COV emitidos por las fotocopiadoras son subproductos presentes en tóners y piezas de plástico, en componentes de caucho y en lubricantes orgánicos. Aún así, la exposición a compuestos químicos concretos que puede producirse en las proximidades de una fotocopiadora en funcionamiento se encuentra normalmente varios órdenes de magnitud por debajo de todos los límites laborales de exposición.

Los olores emitidos por las fotocopiadoras modernas casi siempre indican una ventilación insuficiente. Los papeles tratados, como los formularios sin carbón o los de transferencia de imagen y, a veces, los traslúcidos utilizados en copiadoras de dibujo técnico, pueden emitir olores derivados de los disolventes hidrocarbonados, aunque las exposiciones estarán muy por debajo de los límites de exposición laborales si la ventilación es suficiente para el trabajo de copia normal. Las fotocopiadoras modernas son aparatos electromecánicos complejos algunos de cuyos componentes (fusores) trabajan a temperaturas elevadas. Además de los olores presentes durante el funcionamiento normal pueden formarse olores cuando alguna pieza falla por efecto del calor, y el plástico o el caucho fundido emiten humos. Obviamente, no hay que permanecer cerca de esta clase de emisiones. Son comunes a casi toda las manifestaciones de olores desagradables las quejas de náuseas y cierta irritación de los ojos o las mucosas. Estas quejas suelen ser una mera indicación de la exposición a un olor desconocido y probablemente desagradable, pero no reflejan necesariamente una toxicidad aguda de importancia. En estos casos, el sujeto afectado casi siempre se recuperará rápidamente si se mueve a un lugar bien aireado. Incluso las exposiciones a humos y vapores generados por piezas sobrecalentadas suelen ser tan breves que no causan ninguna inquietud. Aun así, siempre es prudente acudir al médico si los síntomas persisten o se agravan.

\section{Consideraciones sobre la instalación}

Como ya se ha dicho, las copiadoras emiten calor, ozono y COV. Aunque hay que pedir al fabricante las recomendaciones sobre su ubicación y ventilación y seguirlas, es lógico esperar que para todas las máquinas, salvo quizá las más grandes, una habitación con una circulación de aire razonable (más de dos renovaciones por hora) y espacio alrededor de la máquina suficiente para las operaciones de mantenimiento sean condiciones suficientes para evitar la acumulación de ozono y los olores. Naturalmente, al hacer esta recomendación también se supone que se cumplen todas las propuestas por la Asociación Norteamericana de Técnicos en Calefacción, Refrigeración y Acondicionamiento del
Aire (ASHRAE) para los ocupantes de la sala. Si en un recinto hay varias fotocopiadoras, es preciso asegurarse de que se cumplen las exigencias más estrictas en materia de ventilación y refrigeración. Las máquinas grandes y de gran capacidad de trabajo pueden exigir medidas especiales de control de la temperatura.

El material fungible no requiere precauciones particulares, aparte de las adecuadas para almacenar disolventes especiales y evitar el calor excesivo. El papel debe conservarse en la caja todo el tiempo posible y no abrir el paquete hasta el momento de utilizarlo.

\section{Máquinas de fax}

Procesamiento. En la reproducción facsímil, el documento es explorado por una fuente luminosa que forma una imagen que a continuación se convierte a un formato compatible con la comunicación telefónica. En el extremo receptor, un sistema electroóptico descodifica la imagen transmitida y la imprime mediante un proceso térmico directo, térmico de transferencia, xerográfico o de chorro de tinta.

Las máquinas térmicas tienen una matriz de impresión lineal parecida a una tarjeta de circuito impreso sobre la que pasa el papel. A lo ancho de éste hay alrededor de dos centenares de contactos que se calientan rápidamente cuando los activa una corriente eléctrica. En la impresión directa, el contacto caliente forma un punto negro en el papel tratado; en la impresión por transferencia térmica, el contacto calienta una cinta recubierta similar a la de una máquina de escribir que deposita un punto en el papel.

Las máquinas de fax basadas en el proceso xerográfico utilizan la señal transmitida por el teléfono para activar un haz de láser; a partir de ahí funcionan igual que una impresora láser. También los fax de chorro de tinta funcionan como las impresoras de este tipo.

Materiales. Papel tratado o corriente, carretes de cinta, tóner y tinta son los principales consumibles de un fax. Los papeles térmicos directos se tratan con tintes leucográficos que pasan de blanco a negro por acción del calor. Las cintas están recubiertas en una de sus caras con una mezcla de negro de humo, cera y una base polimérica; esta mezcla es lo bastante firme para no transferirse a la piel si se frota, pero se adhiere al papel cuando se calienta. De los tóners y tintas se ha hablado ya en los apartados dedicados a la fotocopia y la impresión con chorro de tinta.

Riesgos potenciales y prevención. No se han asociado peligros específicos a las máquinas de fax. Algunos de los primeros modelos de impresión térmica directa suscitaron quejas por los olores, pero como tantos otros olores detectados en la oficina, el origen del problema está en el bajo umbral olfativo y, quizá, en una ventilación insuficiente, y no suponen ningún riesgo para la salud. Las máquinas de transferencia térmica suelen funcionar sin olores, y no se ha observado ningún riesgo derivado de los carretes de cinta. Los fax xerográficos plantean los mismos riesgos potenciales que las fotocopiadoras del mismo tipo, aunque su baja velocidad permite descartar prácticamente cualquier motivo de preocupación relacionado con la inhalación.

\section{Heliografía (diazo)}

Procesamiento. Actualmente, cuando se habla de heliografía o cianotipia casi siempre se hace referencia a máquinas de procedimiento diazo. Estas copiadoras se utilizan sobre todo para reproducir planos o dibujos técnicos de gran formato realizados en película, vitela o papel traslúcido. Los papeles con tratamiento 
diazo son ácidos y contienen un copulante que cambia de color al reaccionar con el compuesto diazo; al mismo tiempo, la acidez del papel inhibe la reacción. El original se pone en contacto con el papel tratado y se expone a una luz ultravioleta (UV) intensa procedente de una lámpara fluorescente o de vapor de mercurio. La luz rompe el enlace diazo en las zonas del papel de copia no protegidas de la exposición por la imagen original, y evita que reaccione con el copulante. Después se retira el original y se expone la copia a una atmósfera de amoníaco. La alcalinidad de éste neutraliza la acidez del papel y permite que la reacción de cambio de color entre diazo y copulante produzca una imagen en las zonas protegidas de la radiación UV por el original.

Materiales. Además del papel tratado, los únicos materiales utilizados en el proceso heliográfico son agua y amoníaco.

Riesgos potenciales y prevención. Obviamente, el motivo de preocupación en el trabajo con copiadoras heliográficas es la exposición al amoníaco, que puede provocar irritación de los ojos y las mucosas. Las máquinas modernas disponen de un control de emisiones y, por tanto, la exposición suele ser muy inferior a $10 \mathrm{ppm}$. Ahora bien, los modelos más antiguos pueden exigir intervenciones de mantenimiento cuidadosas y frecuentes, y quizá la extracción de los gases expulsados del local. Hay que tener cuidado al reparar la máquina para evitar las salpicaduras y el contacto con los ojos. Deben observarse las recomendaciones del fabricante sobre el uso de equipo de protección. También hay que ser consciente de que un papel mal fabricado puede causar reacciones dérmicas.

\section{Duplicadores digitales y multicopistas}

Procesamiento. Los duplicadores y las multicopistas comparten el mismo principio básico de funcionamiento, que consiste en "quemar" o "cortar" un cliché que a continuación se monta en un tambor entintado desde el cual la tinta pasa a través de aquél al papel receptor.

Materiales. Estas máquinas consumen clichés, tinta y papel. En el duplicador digital, la imagen explorada se graba digitalmente en un cliché de mylar, mientras que el cliché de papel de multicopista es atacado por una corriente eléctrica. Otra diferencia estriba en que las tintas del duplicador digital son de base acuosa, aunque contienen cierta cantidad de disolvente de petróleo, mientras que la base de las utilizadas en multicopistas es un destilado de naftaleno o una mezcla de glicol-éter y alcohol.

Riesgos potenciales y prevención. Los principales riesgos asociados con duplicadores digitales y multicopistas se derivan de las tintas, pero también existe cierto riesgo potencial de exposición a vapores de cera durante la grabación de la imagen en el duplicador digital, y al ozono durante la confección de los clichés de multicopista. En ambos casos, las tintas pueden irritar los ojos y la piel, aunque la de multicopista tiene, por su mayor contenido en destilados de petróleo, un potencial mayor de inducir dermatitis. El uso de guantes protectores para manipular las tintas y una ventilación adecuada durante el trabajo son suficientes para proteger la piel y evitar los riesgos de inhalación.

\section{Copiadoras al alcohol}

Procesado. Las copiadoras al alcohol utilizan un cliché de imagen inversa recubierto de un pigmento soluble en alcohol. Durante el tratamiento, se aplica al papel de copia una capa delgada de un líquido copiador a base de metanol que extrae una pequeña cantidad de pigmento al entrar en contacto con el cliché y de este modo transfiere la imagen al papel. Las copias pueden desprender metanol durante algún tiempo después de la duplicación.

Materiales. Los principales consumibles de estas máquinas son papel, clichés y líquido de copia.

Riesgos potenciales y prevención. Los líquidos para copiar al alcohol suelen tener como base el metanol y, por tanto, son tóxicos por absorción a través de la piel, por inhalación y por ingestión; también son inflamables. La ventilación debe ser suficiente para que la exposición del operador no rebase los límites laborales vigentes, y ha de existir una zona de secado ventilada. Algunos líquidos de copia modernos utilizan una base de alcohol etílico o de propilenglicol, con lo que se evitan los peligros de intoxicación e inflamación propios del metanol. Hay que seguir las recomendaciones del fabricante en cuanto al uso de equipo protector para manipular todos los líquidos copiadores.

\section{EFECTOS SOBRE LA SALUD Y PAUTAS PATOLOGICAS}

Barry R. Friedlander

Interpretar los datos sobre salud humana en los sectores de la imprenta, el revelado comercial de fotografias y la reproducción no es tarea fácil, pues los procesos son complejos y evolucionan continuamente, a veces de forma espectacular. Aunque la automatización ha reducido sustancialmente las exposiciones ocasionadas por el trabajo manual en las versiones modernas de estas tres disciplinas, el volumen de trabajo por empleado ha aumentado de manera considerable. Además, la exposición dérmica, que constituye una importante vía de exposición en los tres sectores, no está bien caracterizada por los datos sobre higiene industrial conocidos. La documentación sobre casos de efectos menos graves y reversibles (cefaleas e irritación nasal y ocular, por ejemplo) es incompleta y tiene una presencia inferior a la real en la literatura publicada. A pesar de estas dificultades y limitaciones, los estudios epidemiológicos, las encuestas sobre salud y los informes de casos aportan una cantidad considerable de información sobre el estado de salud de los trabajadores.

\section{Industrias gráficas}

\section{Agentes y exposiciones}

Actualmente, hay cinco categorías de procesos de impresión: flexografía, huecograbado, tipografía, litografía y serigrafía. El tipo de exposición propio de cada proceso depende de las tintas de impresión utilizadas y de la probabilidad de inhalación (neblinas, vapores de disolventes, etc.) y de contacto con la piel durante las operaciones de limpieza. Hay que señalar que las tintas están formadas por pigmentos orgánicos o inorgánicos, vehículos grasos o disolventes y aditivos añadidos para atender aplicaciones de impresión especiales. En la Tabla 85.1 se indican algunas características de los distintos procesos de impresión.

\section{Mortalidad y riesgos crónicos}

Hay varios estudios epidemiológicos y documentación de casos sobre las industrias gráficas. Las caracterizaciones de la exposición no están bien cuantificadas en la literatura más antigua. No obstante, se ha documentado la presencia de partículas de negro de humo de tamaño inhalable con hidrocarburos aromáticos policíclicos (benzo(a)pireno) potencialmente cancerígenos enlazados a su superficie en las salas de rotativas tipográficas de los 


\begin{tabular}{|c|c|c|c|}
\hline Tabla 85.1 & $\begin{array}{l}\text { - Exposiciones } \\
\text { gráficas. }\end{array}$ & soten & rias \\
\hline Proceso & Tipo de tinta & Disolvente & Exposiciones potenciales \\
\hline $\begin{array}{l}\text { Flexografía y } \\
\text { huecograbado }\end{array}$ & $\begin{array}{l}\text { Tintas líquidas } \\
\text { (baja } \\
\text { viscosidad) }\end{array}$ & $\begin{array}{c}\text { Volátiles } \\
\text { agua }\end{array}$ & $\begin{array}{l}\text { Disolventes orgánicos: } \\
\text { xileno, benceno }\end{array}$ \\
\hline $\begin{array}{l}\text { Tipografía y } \\
\text { litografía }\end{array}$ & $\begin{array}{l}\text { Tintas compactas } \\
\text { (viscosidad } \\
\text { elevada) }\end{array}$ & $\begin{array}{l}\text { Aceites: } \\
\text { vegetales } \\
\text { minerales }\end{array}$ & $\begin{array}{l}\text { Neblina de tinta: } \\
\text { disolventes hidrocarbo- } \\
\text { nados; isopropanol; } \\
\text { hidrocarburos aromáticos } \\
\text { policíclicos (HAP) }\end{array}$ \\
\hline Serigrafía & $\begin{array}{l}\text { Tintas } \\
\text { semifluidas }\end{array}$ & Volátiles & $\begin{array}{l}\text { Disolventes orgánicos: } \\
\text { xileno, ciclohexanona, } \\
\text { acetato de butilo }\end{array}$ \\
\hline
\end{tabular}

periódicos. En estudios realizados con animales se ha observado que el benzo(a)pireno está fuertemente enlazado a la superficie de las partículas de negro de humo y no se libera fácilmente al pulmón ni a otros tejidos. Esta ausencia de "biodisponibilidad" hace más difícil determinar si el riesgo de cáncer es real. Varios estudios epidemiológicos con cohortes (es decir, grupos seguidos a lo largo del tiempo), pero no todos, han detectado indicios de tasas más altas de cáncer de pulmón entre los impresores (Tabla 85.2). En el curso de una evaluación pormenorizada de más de 100 casos de cáncer de pulmón y 300 controles (estudio de caso-control) realizada sobre un grupo de más de 9.000 trabajadores del sector de las artes gráficas de Manchester, Inglaterra (Leon, Thomas y Hutchings 1994), se observó que la duración del trabajo en una sala de prensas guardaba relación con la aparición de cáncer de pulmón en trabajadores de rotativas tipográficas. Como no se conocen los hábitos de consumo de tabaco de los trabajadores, se ignora la influencia directa del tipo de trabajo en el estudio. No obstante, los resultados sugieren que el trabajo con rotativas tipográficas puede haber presentado cierto riesgo de cáncer de pulmón hace algunos decenios. Dado que la rotativa tipográfica y otras técnicas antiguas todavía subsisten en ciertos lugares del mundo, es posible que aún se puedan hacer evaluaciones preventivas e instaurar los controles necesarios.
Otro grupo de trabajadores muy estudiado ha sido el de los litógrafos. Actualmente, la exposición a disolventes orgánicos (trementina, tolueno, etc.), pigmentos, tintes, hidroquinonas, cromatos y cianatos se ha reducido considerablemente gracias a la introducción del ordenador, la automatización de los procesos y el cambio de materiales. La Agencia Internacional para la Investigación sobre el Cáncer (IARC) ha llegado recientemente a la conclusión de que la exposición profesional a los procesos de impresión posiblemente sea cancerígena para el hombre (IARC 1996). Al mismo tiempo, es importante señalar que la conclusión del IARC se basa en exposiciones históricas que, en la mayor parte de los casos, han cambiado mucho. Estudios sobre melanomas malignos sugieren un riesgo aproximadamente doble al esperado (Dubrow 1986). Aunque algunos autores postulan que el contacto de la piel con hidroquinona podría estar relacionado con el melanoma (Nielson, Henriksen y Olsen 1996), la hipótesis no se ha confirmado en una planta de producción de este compuesto con un grado de exposición considerable (Pifer y cols. 1995). Con todo, hay que favorecer las prácticas que minimizan el contacto de la piel con los disolventes, en particular durante la limpieza de las planchas.

\section{Fotografía}

\section{Exposición y agentes}

El revelado de películas o papeles en blanco y negro o en color puede realizarse manualmente o con máquinas automatizadas de producción a gran escala. El tipo de proceso, los compuestos químicos utilizados, las condiciones de trabajo (ventilación, higiene y equipo de protección personal) y la carga de trabajo afectan a los tipos de exposición y los riesgos sanitarios potenciales del medio ambiente de trabajo. Los puestos de trabajo (es decir, las tareas relacionadas con el procesamiento) que presentan un potencial mayor de exposición a compuestos químicos importantes, como formaldehído, amoníaco, hidroquinona, ácido acético y reveladores para color, se recogen en la Tabla 85.3. La Figura 85.2 ilustra el diagrama de trabajo típico de la manipulación y el revelado de material fotográfico.

En algunos equipos de gran capacidad de producción recientemente diseñados se han combinado y automatizado algunas de las fases del diagrama de trabajo, con lo que se ha reducido la

Tabla 85.2 • Estudios con cohortes sobre el riesgo de mortalidad en el sector de la imprenta.

\begin{tabular}{|c|c|c|c|c|c|c|}
\hline \multirow[t]{2}{*}{ Población estudiada } & \multirow{2}{*}{$\begin{array}{l}\text { Número de } \\
\text { trabajadores }\end{array}$} & \multicolumn{5}{|c|}{ Riesgo de mortalidad* (I.C. 95\%) } \\
\hline & & Período de seguimiento & País & Todas las causas & Todos los cánceres & Cáncer de pulmón \\
\hline Prensistas de periódico & 1.361 & $(1949-65)-1978$ & EE.UU. & $1,0(0,8-1,0)$ & $1,0(0,8-1,2)$ & $1,5(0,9-2.3)$ \\
\hline Prensistas de periódico & 700 & $(1940-55)-1975$ & Italia & $1,1(0,9-1,2)$ & $1,2(0,9-1,6)$ & $1,5(0,8-2.5)$ \\
\hline Tipógrafos & 1.309 & 1961-1984 & EE.UU. & $0,7(0,7-0,8)$ & $0,8(0,7-1,0)$ & $0,9(0,6-1,2)$ \\
\hline Impresores (NGA) & 4.702 & $(1943-63)-1983$ & $\begin{array}{l}\text { Reino } \\
\text { Unido }\end{array}$ & $0,8(0,7-0,8)$ & $0,7(0,6-0,8)$ & $0,6(0,5-0,7)$ \\
\hline Impresores (NATSOPA) & 4.530 & $(1943-63)-1983$ & $\begin{array}{l}\text { Reino } \\
\text { Unido }\end{array}$ & $0,9(0,9-1,0)$ & $1,0(0,9-1,1)$ & $0,9(0,8-1,1)$ \\
\hline Huecograbado & 1.020 & $(1925-85)-1986$ & Suecia & $1,0(0,9-1,2)$ & $1,4(1,0-1,9)$ & $1,4(0,7-2,5)$ \\
\hline Impresores de cartonajes & 2.050 & $(1957-88)-1988$ & EE.UU. & $1,0(0,9-1,2)$ & $0,6(0,3-0,9)$ & $0,5(0,2-1,2)$ \\
\hline
\end{tabular}

* Tasas de mortalidad normalizadas $(T M N)$ = número de muertes observadas dividido por el número de muertes esperadas ajustado al efecto de la edad durante el período de tiempo de que se trate. Una TMN de 1 indica que no hay diferencia entre los valores observados y esperados. Nota: las TMN se dan con intervalos de confianza del $95 \%$.

NGA = National Graphical Association, Reino Unido

NATSOPA = National Society of Operative Printers, Graphical and Media Personnel, Reino Unido.

Fuentes: Paganini-Hill y cols. 1980; Bertazzi y Zoccheti 1980; Michaels, Zoloth y Stern 1991; Leon 1994; Svensson y cols. 1990; Sinks y cols. 1992. 
Tabla 85.3 • Operaciones de los laboratorios fotográficos con potencial de exposición química.

$\begin{array}{ll}\begin{array}{l}\text { Zona de trabajo } \\ \text { Preparación de productos } \\ \text { químicos }\end{array} & \begin{array}{l}\text { Tareas con exposición potencial } \\ \text { Mezcla de productos en solución. } \\ \text { Limpieza del equipo. } \\ \text { Mantenimiento de la zona de trabajo. }\end{array} \\ \begin{array}{l}\text { Laboratorio de análisis } \\ \text { Manipulación de muestras. } \\ \text { Análisis y regeneración de soluciones. } \\ \text { Evaluación del control de calidad. }\end{array} \\ \begin{array}{l}\text { Revelado de películas y } \\ \text { papeles }\end{array} & \begin{array}{l}\text { Procesamiento de películas y papeles con } \\ \text { reveladores, endurecedores y blanqueadores. }\end{array} \\ \begin{array}{l}\text { Retirada de películas y } \\ \text { papeles }\end{array} & \begin{array}{l}\text { Retirada de películas y copias reveladas para } \\ \text { secarlas. }\end{array}\end{array}$

probabilidad de inhalación y contacto con la piel. El formaldehído, un compuesto utilizado durante décadas como estabilizador de la imagen en color, se utiliza en concentraciones cada vez menores en los materiales fotográficos. Según el tipo de proceso y las condiciones del medio ambiente, su concentración en el aire puede oscilar entre valores indetectables en la zona de respiración del operador y aproximadamente $0,2 \mathrm{ppm}$ como máximo en las toberas de salida de los ventiladores de la máquina. También pueden producirse exposiciones durante la limpieza del equipo, al preparar o recargar líquido estabilizador, al vaciar productos de procesamiento y cuando se producen vertidos.

Hay que señalar que, aunque la exposición a productos químicos ha concentrado casi todo el interés de los estudios de higiene en el procesamiento fotográfico, también deben ser objeto de una prevención sanitaria otros aspectos del medio laboral, como la luz débil, la manipulación de materiales o la postura en el puesto de trabajo.

\section{Riesgo de mortalidad}

El único estudio publicado de vigilancia de la mortalidad entre trabajadores del sector fotográfico sugiere que esta profesión no aumenta el riesgo de muerte (Friedlander, Hearne y Newman 1982). El estudio se llevó a cabo en nueve laboratorios de revelado de Estados Unidos y se actualizó para cubrir 15 años de seguimiento (Pifer 1995). Hay que señalar que se trata de un estudio sobre más de 2.000 empleados que trabajaban activamente a principios de 1964 y más del $70 \%$ de los cuales llevaban al menos 15 años ejerciendo su profesión. El grupo se siguió durante 31 años, hasta 1994. Muchas fuentes de exposición importantes al principio de su vida profesional, como tetracloruro de carbono, n-butilamina e isopropilamina, dejaron de utilizarse en los laboratorios hace más de treinta años. No obstante, muchas de las fuentes de exposición clave de los laboratorios modernos (ácido acético, formaldehído y dióxido de azufre) también se utilizaban hace varios decenios, aunque en concentraciones mucho más elevadas. Durante los 31 años de seguimiento, la tasa de mortalidad normalizada (TMN) fue sólo del $78 \%$ de la esperada (TMN 0,78), correspondiente a 677 trabajadores fallecidos en una población de 2.061. No aumentó de forma significativa ninguna causa concreta de muerte. Los 464 empleados que trabajaban en puestos de revelado también presentaron tasas de mortalidad reducidas en comparación tanto con la población general (TMN 0,73) como con los trabajadores por horas (TMN 0,83), y no se observó ningún aumento significativo de ninguna causa de muerte. Sobre la base de los datos epidemiológicos conocidos, no parece que el revelado fotográfico presente mayor riesgo de mortalidad, ni siquiera con las mayores concentraciones de exposición probables en los decenios de 1950 y 1960.

\section{Enfermedades pulmonares}

Se han publicado muy pocos estudios sobre afecciones pulmonares entre los trabajadores de laboratorios fotográficos. Dos artículos (Kipen y Lerman 1986; Hodgson y Parkinson 1986) describen un total de cuatro respuestas pulmonares potenciales a la exposición en laboratorios de revelado; sin embargo, ninguno de los dos aporta datos cuantitativos de exposición medioambiental para evaluar las observaciones pulmonares medidas. En la única investigación epidemiológica realizada sobre este sector (Friedlander, Hearne y Newman 1982) no se observó ningún aumento del absentismo debido a enfermedades pulmonares crónicas; ahora bien, el estudio exigía una baja por enfermedad de ocho días consecutivos. Parece que los síntomas respiratorios pueden agravarse o iniciarse en individuos sensibles a causa de la exposición a concentraciones elevadas de ácido acético, dióxido de azufre y otros agentes utilizados en el revelado fotográfico si la ventilación está mal controlada o si se producen errores durante la mezcla que provoquen la emisión de concentraciones elevadas de tales compuestos. A pesar de todo, en esta profesión, sólo raras veces se han documentado casos de afecciones pulmonares vinculadas al trabajo (Hodgson y Parkinson 1986).

\section{Figura 85.2 - Esquema de las operaciones de procesamiento de materiales fotográficos.}

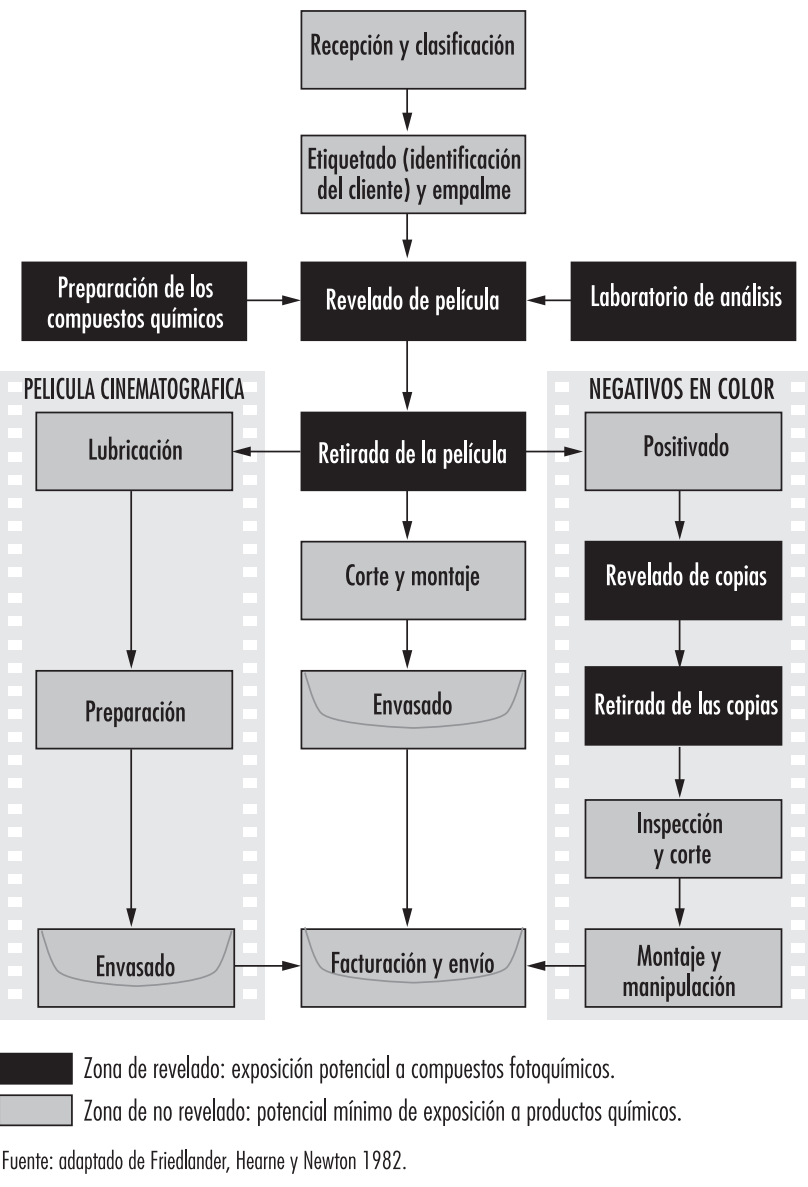




\section{Efectos agudos y subcrónicos}

Se han documentado casos de dermatitis irritativa de contacto y alérgica en trabajadores de laboratorios fotográficos durante varias décadas, desde que empezaron a utilizarse productos de revelado en color a finales del decenio de 1930. Muchos de los casos se producían en los primeros meses de exposición del trabajador. El uso de guantes protectores y la mejora de las técnicas de manipulación han reducido sustancialmente las dermatitis en el laboratorio fotográfico. Las salpicaduras de ciertos compuestos fotoquímicos constituyen un riesgo de lesión corneal. La enseñanza de métodos de lavado de ojos (aclarado durante al menos 15 minutos con agua fría seguido de atención médica) y el empleo de gafas protectoras son especialmente importantes para estos trabajadores, muchos de los cuales operan en medios aislados y muy poco iluminados.

Todavía existe cierta preocupación por los aspectos ergonómicos del trabajo con equipos de revelado fotográfico rápidos de gran volumen de producción. El montaje y desmontaje de grandes bobinas de papel fotográfico puede causar afecciones de espalda, hombros y cuello. Las bobinas pesan entre 13,6 y $22,7 \mathrm{~kg}$ y pueden ser difíciles de manipular, aunque ello depende en parte del acceso a la máquina, instalada a veces en un espacio muy reducido.

Evitan lesiones y tensiones la correcta formación del personal, la previsión de accesos suficientes a las bobinas y la consideración del factor humano en el diseño general del laboratorio.

\section{Prevención y métodos de detección precoz de los efectos}

La protección contra la dermatitis, la irritación respiratoria, las lesiones agudas y los trastornos ergonómicos empieza con la aceptación de que estos desórdenes se pueden producir. La prevención mejora mucho con una adecuada información a los trabajadores (etiquetas, fichas de datos sobre seguridad de los materiales, equipo de protección y programas de formación en materia de protección sanitaria), revisiones periódicas de salud y seguridad en el medio de trabajo y supervisión informada. Facilita asimismo la identificación precoz de afecciones la creación de una unidad médica a la que puedan informar los trabajadores, junto con evaluaciones voluntarias periódicas centradas en la sintomatología respiratoria y de las extremidades superiores mediante cuestionarios y observación directa de las zonas de piel expuestas para detectar posibles signos de dermatitis profesional.

Como el formaldehído es un sensibilizador respiratorio potencial, un poderoso irritante y un posible cancerígeno, es importante evaluar todos los lugares de trabajo para determinar si se utiliza este compuesto (inventario químico y estudio de las fichas técnicas de los materiales), analizar la concentración en el aire (si está indicado por los materiales utilizados), detectar puntos en los que puedan producirse fugas o vertidos y estimar la cantidad que podría escapar y la concentración generada en el peor de los casos. Hay que elaborar un plan de emergencia, anunciarlo de forma bien visible, comunicarlo y practicarlo con regularidad. Para elaborarlo, es preciso consultar con un especialista en salud y seguridad.

\section{Copia}

\section{Agente y exposiciones}

Las fotocopiadoras modernas emiten intensidades muy bajas de radiación ultravioleta a través de la platina, producen algo de ruido y pueden emitir concentraciones bajas de ozono durante el funcionamiento. Utilizan un tóner compuesto primordialmente por negro de humo (para máquinas en blanco y negro) y que forma una imagen oscura sobre papel o película transparente. Por tanto, las exposiciones potenciales crónicas de interés sanitario que afectan a los operadores de fotocopiadoras son: la radiación ultravioleta, el ruido, el ozono y, quizá, el tóner. En las máquinas más antiguas, el tóner podía ser causa de preocupación durante el cambio, pero los modelos más modernos con cartuchos cerrados han reducido drásticamente la exposición potencial respiratoria y dérmica.

El grado de exposición a la radiación ultravioleta que atraviesa la platina de vidrio de la máquina es muy baja. La duración del destello luminoso es de aproximadamente 250 microsegundos, y en funcionamiento continuo la frecuencia puede ser de unos 4.200 destellos por hora, aunque este valor depende del modelo de copiadora. Con la platina de vidrio en su sitio, el espectro emitido oscila entre aproximadamente 380 y $396 \mathrm{~nm}$. Normalmente, la fuente luminosa de las fotocopiadoras no emite UVB. La radiación UVA máxima registrada en la platina es de aproximadamente 1,65 microjulios $/ \mathrm{cm}^{2}$ por destello. Por tanto, la exposición máxima durante 8 horas en la región UV del espectro causada por una fotocopiadora en régimen de trabajo ininterrumpido que produzca alrededor de 33.000 copias al día es de unos 0,05 julios $/ \mathrm{cm}^{2}$ en la superficie de la platina. Este valor es sólo una fracción del valor límite umbral recomendado por la Conferencia Americana de Higienistas Industriales del Gobierno (ACGIH), y no parece presentar ningún riesgo sanitario mensurable, ni siquiera en condiciones de exposición tan exageradas como las que acaban de describirse.

Hay que señalar que algunos trabajadores pueden presentar un riesgo de exposición UV más elevado, como los que padecen hipersensibilidad luminosa, los tratados con medicamentos fotosensibilizadores y los afectados por trastornos pupilares (afaquia). Normalmente se aconseja a quienes se encuentran en alguna de estas situaciones que reduzcan al mínimo la exposición a la radiación UV como medida general de precaución.

Efectos agudos. La literatura no recoge muchos efectos agudos claramente relacionados con la fotocopia. Las máquinas antiguas y mal mantenidas pueden emitir concentraciones detectables de ozono si se utilizan en lugares poco ventilados. Aunque se han documentado síntomas de irritación de las vías respiratorias altas entre empleados que trabajaban en medios con estas características, el cumplimiento de las especificaciones mínimas del fabricante en cuanto a espacio y ventilación, junto con el uso de copiadoras más modernas, ha eliminado en lo esencial la preocupación por las emisiones de ozono.

Riesgos de mortalidad. No se han encontrado estudios en los que se examine el riesgo de mortalidad o de enfermedades crónicas derivado del trabajo prolongado con fotocopiadoras.

\section{Prevención y detección precoz}

Basta seguir las recomendaciones del fabricante para que el uso de las fotocopiadoras quede exento de riesgos en el lugar de trabajo. Quienes experimenten un agravamiento de alguna sintomatología a causa de un uso intenso de máquinas fotocopiadoras deben pedir asesoramiento en materia de salud y seguridad.

\section{DESCRIPCION GENERAL DE RIESGOS PARA EL MEDIO AMBIENTE}

Daniel R. English

\section{Principales riesgos para el medio ambiente}

\section{Disolventes}

Se utilizan disolventes en varias aplicaciones de las industrias gráficas, principalmente para limpiar prensas y otros aparatos, 
disolver los agentes de las tintas y como aditivos en soluciones de alimentación. Además de la preocupación general por las emisiones de compuestos orgánicos volátiles (COV), los disolventes tienen ciertos componentes que pueden persistir en el medio o que presentan una elevada capacidad de destrucción del ozono.

\section{Plata}

Durante el revelado de fotografías en blanco y negro y en color se libera plata de algunas soluciones de tratamiento. Es importante conocer el potencial tóxico de este metal para el medio ambiente con el fin de manipular y eliminar correctamente dichas soluciones. Aunque el ion plata libre es muy tóxico para la vida acuática, su toxicidad es muy inferior cuando adquiere la forma compleja propia de los efluentes del revelado fotográfico. El cloruro, el tiosulfato y el sulfuro de plata, que son las formas en que la plata suele presentarse en las soluciones de revelado, tienen una toxicidad inferior en más de cuatro órdenes de magnitud al nitrato de plata. La plata tiene mucha afinidad por la materia orgánica, el fango, la arcilla y otros componentes propios de los medios naturales, lo que atenúa su impacto potencial sobre los sistemas acuícolas. Dada la concentración extremadamente baja en que el ion plata libre se presenta en los efluentes de revelado fotográfico y en las aguas naturales, la tecnología de complejación de este metal es suficientemente protectora para el medio.

\section{Otros efluentes característicos del revelado fotográfico}

La composición de los efluentes fotográficos varía en función de cada proceso: blanco y negro, diapositivas en color, negativos y positivos en color o alguna combinación de éstos. El agua representa del 90 al $99 \%$ del volumen de los efluentes; el resto está formado en su mayor parte por sales inorgánicas que actúan como tampones y agentes fijadores (solubilizantes de los haluros de plata), quelatos de hierro, como la etilén diamina férrica del ácido tetracético, y moléculas orgánicas que actúan como reveladores y antioxidantes. Los metales más importantes son el hierro y la plata.

\section{Residuos sólidos}

En todas las actividades de las industrias gráficas, fotográficas y de copia se generan residuos sólidos, como envases de cartón y plástico, cartuchos de tóner y otros consumibles o restos varios, como papeles o películas estropeados. La mayor presión que ahora se ejerce sobre la producción industrial de residuos sólidos ha llevado al sector a estudiar con interés la posibilidad de limitarla por medio de la reducción, la reutilización y el reciclaje.

\section{Equipos}

El equipo tiene una influencia obvia en el impacto medioambiental de los procesos de impresión, fotografía y copia. Además, está aumentando el interés por otros aspectos del equipamiento. Un ejemplo es la eficacia energética, que repercute en el impacto ambiental de la producción de energía. Otro es la legislación sobre aceptación de devoluciones, que obliga a los fabricantes a hacerse cargo de los equipos para eliminarlos correctamente cuando lleguen al final de su vida útil comercial.

\section{Técnicas de control}

La eficacia de una determinada metodología de control puede depender en buena medida de los procesos aplicados en un centro, de sus dimensiones y del nivel de control necesario.

\section{Técnicas de control de disolventes}

Hay varias formas de reducir el consumo de disolventes. Los componentes más volátiles, como el alcohol isopropílico, pueden sustituirse por compuestos con menor presión de vapor. En ciertos casos, las tintas y los baños de lavado basados en disolventes pueden sustituirse por otros de base acuosa. Es necesario mejorar muchas de las opciones acuosas para ciertas aplicaciones a fin de que puedan competir eficazmente con los materiales basados en disolventes. También la tecnología de tintas ricas en sólidos puede contribuir a reducir el consumo de disolventes orgánicos.

Es posible disminuir las emisiones de disolventes bajando la temperatura de las soluciones de humectación o alimentación. En ciertas aplicaciones, los disolventes pueden capturarse con carbono activo u otros materiales adsorbentes y reutilizarse. En otros casos, el margen de actuación es demasiado estrecho y los disolventes atrapados no se pueden reutilizar directamente, sino que deben recogerse y reciclarse en otro lugar. Las emisiones de disolventes se pueden capturar en condensadores, que consisten en intercambiadores de calor seguidos de un filtro o un precipitador electrostático. El líquido condensado atraviesa un separador aceite-agua antes de ser eliminado.

En plantas muy grandes pueden utilizarse incineradores (llamados a veces postquemadores) para destruir los disolventes emitidos. Puede utilizarse platino u otro metal precioso para catalizar el proceso térmico. Los sistemas no catalizados operan a temperaturas más altas, pero en contrapartida no son sensibles a los fenómenos de inactivación del catalizador. Para rentabilizar los sistemas no catalizados suele ser necesaria la recuperación térmica.

\section{Técnicas de recuperación de plata}

La eficacia de la recuperación de plata a partir de los efluentes fotográficos depende de la economía de la recuperación y la legislación sobre vertidos. Las principales técnicas de recuperación son electrolisis, precipitación, sustitución de metales e intercambio iónico.

En la recuperación electrolítica se hace pasar una corriente eléctrica por la solución de plata para provocar la deposición del metal en el cátodo, que suele ser una barra de acero inoxidable. Las escamas de plata se recuperan flexionando, triturando o rascando el electrodo; el metal se refina y se reutiliza. Los intentos de reducir la concentración residual de plata muy por debajo de $200 \mathrm{mg} / \mathrm{l}$ son ineficaces y provocan la formación de sulfuro de plata no deseado o de subproductos sulfurados nocivos. Las cubas de fondo compacto pueden reducir más la concentración de plata, pero son más complejas y caras que las de electrodos bidimensionales.

La plata puede recuperarse de una solución mediante precipitación con algún compuesto que forme una sal argéntea insoluble. Los agentes precipitadores más comunes son la trimercaptotriazina trisódica (TMT) y diversos sulfuros. En el último caso, hay que tener cuidado para evitar la producción de sulfuro de hidrógeno, que es muy tóxico. La TMT es una opción intrínsecamente más segura que se ha introducido hace poco tiempo en la industria del revelado fotográfico. La precipitación produce una eficacia de recuperación superior al $99 \%$.

En los cartuchos de sustitución de metales (MRC), la solución cargada de plata circula sobre un depósito de hierro metálico filamentoso. El ion plata se reduce a plata metálica al tiempo que el hierro se oxida a configuraciones iónicas solubles. Los fangos de plata metálica se acumulan en el fondo del cartucho. Los MRG no son adecuados en zonas en que los efluentes de hierro constituyan un riesgo. El método tiene una eficacia de recuperación superior al $95 \%$.

En las técnicas de intercambio de ion, los complejos aniónicos de tiosulfato de plata se intercambian con otros aniones sobre un sustrato de resina. Una vez agotada la capacidad de esta matriz, se regenera extrayendo la planta con una solución concentrada de tiosulfato o convirtiendo la plata a disulfuro de plata en 
medio ácido. En condiciones bien controladas, esta técnica puede reducir la concentración de plata a menos de $1 \mathrm{mg} / \mathrm{l}$, pero sólo puede utilizarse con soluciones de plata y tiosulfato diluidas. En efecto, la columna es extremadamente sensible a la separación de la plata si la concentración de tiosulfato a la entrada es excesiva. Por otra parte, la técnica exige mucho trabajo e instrumental y en la práctica resulta cara.

\section{Otras técnicas de control de efluentes fotográficos}

El método de tratamiento de efluentes fotográficos más rentable es el biológico en una planta secundaria de tratamiento de residuos (estas plantas suelen denominarse instalaciones de tratamiento de propiedad pública, ITPU). Varios componentes o variables de los efluentes fotográficos pueden estar regulados por las licencias de vertidos al alcantarillado. Además de la plata, suelen estar regulado el $\mathrm{pH}$, la demanda biológica de oxígeno y los sólidos totales en disolución. Numerosos estudios han demostrado que los residuos fotográficos (incluidas pequeñas cantidades de plata residuales tras una recuperación razonable del metal sometidos a tratamiento biológico no tienen un efecto perjudicial sobre las aguas receptoras.

Se han aplicado otras técnicas al tratamiento de los residuos fotográficos. En algunas regiones del mundo acaban en incineradoras, hornos de cementera o vertederos definitivos. Hay laboratorios que reducen el volumen de solución mediante evaporación o destilación antes de transportarla. Los efluentes fotográficos se han sometido también a otras técnicas de oxidación, como ozonización, electrolisis, oxidación química y oxidación en aire húmedo.

Otra fuente importante de limitación de la carga para el medio ambiente es la reducción en origen. La cantidad de plata por metro cuadrado que se aplica a los materiales sensibles disminuye cada vez que se lanza al mercado una nueva generación de dichos materiales. Al disminuir la cantidad de plata en los medios, se reduce también la cantidad de compuestos químicos necesarios para procesar una superficie determinada de película o papel. La regeneración y reutilización de soluciones no agotadas ha aliviado asimismo la carga medioambiental por imagen. Así, la cantidad de revelador de color necesaria para tratar un metro cuadrado de papel era en 1996 un $20 \%$ inferior a la necesaria en 1980 .

\section{Minimización de residuos sólidos}

El interés por reducir al mínimo los residuos sólidos estimula el reciclaje y la reutilización de los materiales como alternativa a su eliminación en vertederos. Hay programas de reciclaje de cartuchos de tóner, chasis de película, cámaras de usar y tirar, etc. También crece el reciclaje y la reutilización de los envases. Cada vez son más los componentes de envases y equipos identificados con el fin de mejorar la eficacia de los programas de reciclaje de materiales.

\section{Diseño para el medio ambiente basado en el análisis del ciclo vital}

Todos los aspectos que acaban de tratarse contribuyen a que se preste más atención a la totalidad del ciclo vital de un producto, desde la obtención de las materias primas hasta la solución de los problemas derivados de la conclusión de su vida útil. Se están utilizando dos instrumentos analíticos afines - el análisis del ciclo vital y el diseño para el medio ambiente - con el fin de considerar los posibles perjuicios para el medio ambiente durante las fases de toma de decisiones del diseño, el desarrollo y la venta del producto. El análisis del ciclo vital tiene en cuenta todos los insumos y flujos de materiales que necesita un producto o un proceso, y trata de cuantificar el impacto medioambiental de las distintas opciones. El diseño para el medio ambiente considera diversos aspectos del diseño, como el potencial de reciclaje y reutilización, para minimizar el impacto sobre el medio de la producción o la eliminación del equipo de que se trate.

\section{LABORATORIOS FOTOGRAFICOS COMERCIALES}

\section{David Richardson}

\section{Materiales y procesos}

\section{Revelado en blanco y negro}

En el revelado fotográfico en blanco y negro, la película o el papel expuestos se sacan, en el laboratorio, de un recipiente opaco y se sumergen secuencialmente en soluciones acuosas de revelador, paro y fijador. Por último, la película o el papel se lavan con agua, se secan y quedan en condiciones de uso. El revelador reduce los haluros de plata expuestos a plata metálica. El baño de paro es una solución ácida débil que neutraliza el revelador alcalino y detiene la reducción de los haluros de plata. El baño fijador forma un complejo soluble con los haluros de plata sin exponer, que se extraen de la emulsión durante el lavado junto con diversas sales, tampones e iones de haluros solubles en agua.

\section{Revelado en color}

El revelado en color es más complejo, y casi todas las películas, transparencias y papeles requieren más pasos de tratamiento. A diferencia de los materiales en blanco y negro, que tienen una sola capa de haluros de plata, los materiales en color tienen tres superpuestas, de manera que se forma un negativo de plata por cada una de las tres capas sensibles. Cuando entran en contacto con el revelador, los haluros de plata expuestos se convierten en plata metálica, al tiempo que el revelador oxidado reacciona con un copulante específico de cada una de las capas y forma los pigmentos que componen la imagen.

Otra diferencia estriba en el uso de un baño blanqueador para eliminar la plata metálica innecesaria de la emulsión transformándola en haluros por medio de un agente oxidante. A continuación, los haluros se convierten en un complejo de plata soluble, que se elimina lavando, igual que en blanco y negro. Este procedimiento general de revelado en color presenta algunas diferencias según se trate de diapositivas o de negativos y copias en papel.

\section{Diseño general del revelado}

El revelado consiste esencialmente en el paso de la película o el papel expuesto por una serie de soluciones, sea a mano o utilizando máquinas procesadoras. Aunque los métodos presenten variaciones individuales, todos se asemejan por sus características generales y el equipo utilizado. Así, siempre debe haber una zona de almacenamiento de productos químicos y materias primas, y medios para manipular y clasificar el material fotográfico expuesto recibido. También son necesarios medios e instrumentos para medir, pesar y mezclar productos químicos y para alimentar con estas soluciones los tanques de procesado. Además, para conducir las soluciones a los tanques se emplean diversos mecanismos de bombeo y medida. Los laboratorios profesionales suelen utilizar equipos grandes y muy automatizados para revelar las películas y los papeles. Con el fin de obtener resultados uniformes, en estos equipos se controla la temperatura y, en la mayor parte de los casos, los baños se regeneran con compuestos químicos nuevos a medida que se va tratando el material sensible.

Los grandes centros de revelado suelen disponer de laboratorios de control de calidad que realizan determinaciones 
químicas y miden la calidad fotográfica de la producción. Aunque el empleo de fórmulas químicas ya envasadas evita la necesidad de medir y pesar y de mantener los laboratorios de control, muchas grandes empresas de revelado prefieren elaborar sus propias soluciones a partir de productos químicos adquiridos a granel.

Después de revelar y secar los materiales, algunos reciben lacas y otros recubrimientos protectores o se someten a intervenciones de limpieza. Por último, los materiales se inspeccionan, envasan y preparan para su entrega al cliente.

\section{Riesgos potenciales y prevención}

\section{Peligros propios del cuarto oscuro}

Los riesgos potenciales propios del revelado comercial de fotografías son similares a los de otros trabajos con productos químicos, pero presentan la peculiaridad única de que ciertas partes del proceso se llevan a cabo en la oscuridad. Por tanto, el operador tiene que conocer muy bien el equipo y los riesgos potenciales, así como las medidas que ha de adoptar en caso de accidente. Hay luces de seguridad y gafas infrarrojas que emiten iluminación suficiente para la seguridad del operador. Todos los elementos mecánicos y las partes eléctricas activas deben estar encerrados, y las piezas salientes de la maquinaria han de estar cubiertas. Deben instalarse escotillas de seguridad que impidan la entrada de luz al tiempo que permiten la libre circulación del personal.

\section{Peligros para la piel y los ojos}

Como los proveedores y los métodos de envasado y mezcla de compuestos químicos de revelado son tan diversos, sólo es posible hacer algunas generalizaciones sobre los peligros químicos que presentan. Se manipulan varios ácidos fuertes y productos cáusticos, sobre todo en las zonas de almacenamiento y mezcla. Muchos compuestos de procesado son irritantes para la piel y los ojos y, en algunos casos, provocan quemaduras por contacto directo. El riesgo sanitario más frecuente en los laboratorios de procesamiento fotográfico es la dermatitis de contacto, causada casi siempre por contacto de la piel con soluciones reveladoras alcalinas. La dermatitis puede deberse también a la irritación provocada por soluciones alcalinas o ácidas o, en algunos casos, a alergia dérmica.

Los reveladores de color son soluciones acuosas que normalmente contienen derivados de la $p$-fenilendiamina, mientras que los compuestos para blanco y negro suelen contener $p$-metil-aminofenolsulfato (también llamado metol o agente revelador KODAK ELON) o hidroquinona, o las dos cosas. Los reveladores de color son sensibilizadores de la piel más potentes e irritantes que los de blanco y negro y también pueden inducir reacciones liquenoides. Además, algunas soluciones de procesamiento contienen otros sensibilizadores dérmicos, como formaldehído, sulfato de hidroxilamina y dicloruro de S-[2-(dimetilamino)-etil-isotiouronio. La alergia es más probable tras un contacto reiterado y prolongado con los compuestos de procesado. Quienes padecen afecciones o irritación de la piel suelen ser más sensibles a los efectos de estos productos.

Evitar el contacto con la piel es un objetivo importante en las zonas de revelado fotográfico. Se recomienda utilizar guantes de neopreno para reducirlo, sobre todo en las zonas de mezcla, donde se encuentran las soluciones más concentradas. Si el contacto con los productos fotoquímicos no va a ser prolongado, pueden emplearse guantes de nitrilo de grosor suficiente para evitar rasgaduras y fugas; estos últimos han de inspeccionarse y limpiarse con frecuencia, a ser posible lavando meticulosamente las caras externa e interna con un limpiador de manos no alcalino. Es particularmente importante proporcionar al personal de mantenimiento guantes de protección durante las operaciones de reparación o limpieza de los depósitos y soportes, pues estos elementos pueden estar cubiertos de depósitos químicos. Las cremas protectoras no sirven para este cometido, ya que no son impermeables a todos los productos fotoquímicos y pueden contaminar las soluciones. En el cuarto oscuro hay que llevar un mandil protector o una bata de laboratorio, y la ropa de trabajo ha de lavarse con frecuencia. La ropa de protección reutilizable debe inspeccionarse después de cada uso para ver si presenta signos de pérdida de la impermeabilidad o degradación y sustituirla cuando sea necesario. También hay que usar gafas y pantallas faciales de protección, especialmente en las zonas donde se manipulan compuestos fotoquímicos.

En caso de contacto de estos compuestos con la piel, la zona afectada debe lavarse rápidamente con agua abundante. Como los reveladores y otros compuestos son alcalinos, el lavado con productos no alcalinos ( $\mathrm{pH} 5,0$ a 5,5) reduce el riesgo de dermatitis. Hay que cambiarse en seguida la ropa contaminada con productos químicos y lavar inmediatamente las prendas que hayan recibido vertidos o salpicaduras. Es muy importante que las zonas de mezcla y procesado estén dotadas de instalaciones de lavado de manos y de ojos. También son necesarias duchas de emergencia.

\section{Riesgos por inhalación}

Además de los riesgos potenciales para la piel y los ojos, los gases o vapores emitidos por algunas soluciones fotográficas presentan riesgo por inhalación y emiten olores desagradables, sobre todo en espacios poco ventilados. Ciertas soluciones de revelado en color pueden liberar vapores como ácido acético, trietanolamina y alcohol bencílico, o gases como amoníaco, formaldehído o dióxido de azufre. Estos gases o vapores pueden ser irritantes para las vías respiratorias y los ojos y, en algunos casos, provocar otros efectos secundarios sobre la salud. El potencial patológico de los vapores depende de su concentración y suele observarse sólo a niveles que sobrepasan los límites de exposición profesional. No obstante, debido a la amplia variación individual de sensibilidad, ciertas personas — que padecen afecciones como el asma, por ejemplo- pueden sufrir consecuencias por exposición a concentraciones inferiores a dichos límites.

Algunos compuestos fotoquímicos se detectan por el olor gracias a su bajo umbral olfativo. Aunque el hecho de que un compuesto pueda olerse no significa necesariamente peligro para la salud, los olores fuertes o cuya intensidad va en aumento pueden indicar que la ventilación es insuficiente y debe revisarse.

Una ventilación adecuada para laboratorios fotográficos incluye la dilución general del aire y su extracción del local para renovarlo a un ritmo horario suficiente. Una buena ventilación presenta la ventaja añadida de que crea un ambiente de trabajo más agradable. La magnitud de la ventilación depende de las condiciones de la sala, del producto que se procese, del proceso utilizado y de los compuestos de procesado. Hay que consultar con un especialista en ventilación para garantizar el funcionamiento óptimo de los sistemas de renovación y expulsión de aire de la sala. El procesamiento a alta temperatura y la agitación de las soluciones mediante burbujeo de nitrógeno puede acelerar la liberación de determinados compuestos a la atmósfera. La velocidad del proceso, las temperaturas de las soluciones y la agitación de éstas deben ajustarse al mínimo posible para reducir la liberación potencial de gases y vapores desde los tanques de tratamiento.

Una ventilación general de la sala con valores de, por ejemplo, $4,25 \mathrm{~m}^{3} / \mathrm{min}$ de entrada y $4,8 \mathrm{~m}^{3} / \mathrm{min}$ de salida (equivalentes a 10 renovaciones del aire por hora en una sala de $3 \times 3 \times 3$ metros), con una tasa mínima de renovación de $0,15 \mathrm{~m}^{3} /$ min por $\mathrm{m}^{2}$ de superficie de suelo, suele ser la adecuada 
Figura 85.3 - Ventilación en tanque cerrado.

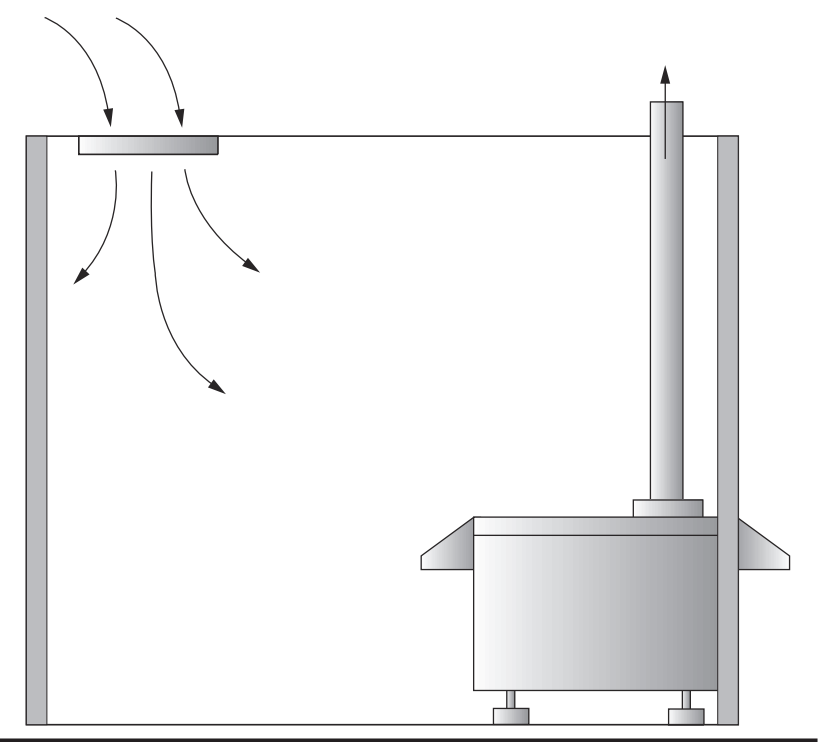

para trabajos de revelado básicos. Un caudal mayor de salida que de entrada provoca una presión negativa y reduce las probabilidades de que los vapores pasen a las zonas contiguas. El aire de escape debe enviarse fuera del edificio, para no redistribuir en su interior los contaminantes potenciales. Si las cubetas de revelado están cerradas y disponen de salida de gases (véase la Figura 85.3), probablemente podrán reducirse los caudales mínimos de entrada y salida de aire.

Ciertas operaciones (como el virado, la limpieza de películas, la mezcla de productos y las técnicas de revelado especiales) pueden exigir mayor caudal de ventilación o el uso de protecciones respiratorias. La extracción del local es importante, porque reduce la concentración de contaminantes atmosféricos que, de otro modo, pondría de nuevo en circulación el sistema general de ventilación por dilución.

En algunos tanques se puede instalar un sistema de ventilación de ranura lateral que extrae los vapores que se forman en la

\section{Figura 85.4 • Extracción en tanque mezclador de} productos químicos con cierre parcial.

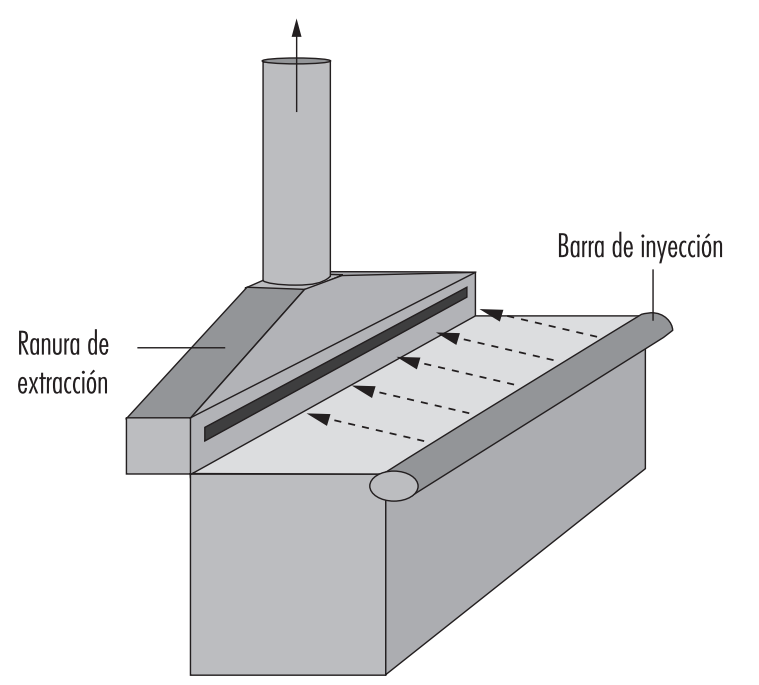

Figura 85.5 • Campana de extracción de tiro ascendente (no recomendable).

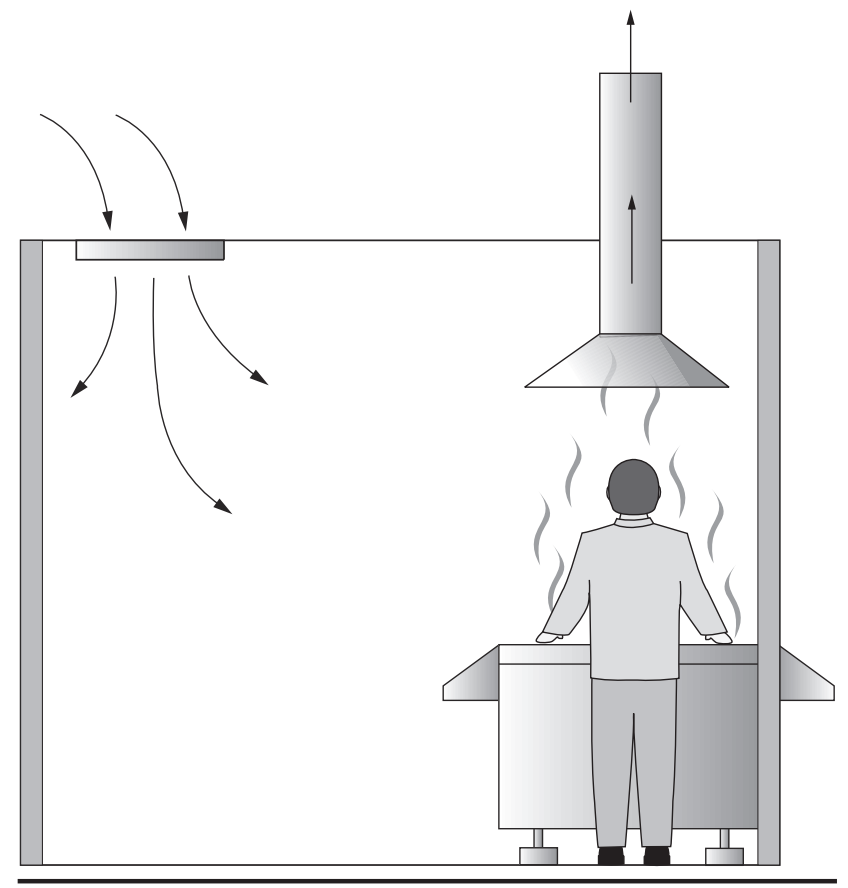

superficie del líquido. Si se diseñan y utilizan correctamente, estos sistemas barren el tanque con una corriente de aire limpio que retira el contaminado de la zona de respiración del operador y de la superficie del tanque. Los sistemas más eficaces son los laterales de inyección y extracción (véase la Figura 85.4). Los sistemas de extracción de campana (véase la Figura 85.5) no son recomendables, porque en muchos casos el operador debe inclinarse sobre el tanque y bajo la campana; en esta posición, el propio extractor atrae los gases contaminantes hacia la zona de inhalación.

Sobre los tanques de mezcla se puede montar una tapa parcial provista de extractor de aire y conectada a la parte estacionaria para completar la ventilación general del laboratorio en las zonas de mezcla. Conviene utilizar tapas completas (herméticas o flotantes) para evitar la liberación de contaminantes atmosféricos potenciales desde la zona de almacenamiento y desde otros tanques. Puede conectarse un tubo de salida flexible a las tapas de los tanques para facilitar la eliminación de los compuestos volátiles (véase la Figura 85.6). Siempre que sea posible hay que usar mezcladores automáticos, que reciben todos los ingredientes de los productos mixtos y los combinan y preparan, y reducen la exposición potencial del operador.

$\mathrm{Al}$ mezclar productos secos, hay que vaciar los recipientes con suavidad para limitar al mínimo la dispersión de polvillo en el aire. Mesas, bancos de trabajo y estanterías deben limpiarse frecuentemente con un paño húmedo para evitar la acumulación y la incorporación al aire de residuos químicos en polvo.

\section{Diseño de las instalaciones}

Las superficies expuestas a contaminación deben construirse de manera que se pueda lavar con agua. Hay que instalar sumideros en los suelos, sobre todo en las zonas de almacenamiento, mezcla y procesamiento. Como siempre que existe riesgo de fugas o vertidos, hay que adoptar medidas preventivas para contener, neutralizar y eliminar correctamente los productos. Los suelos de las zonas que puedan mojarse deben cubrirse con cinta o pintura 
Figura 85.6 - Tanque de mezcla de productos químicos con cierre parcial.

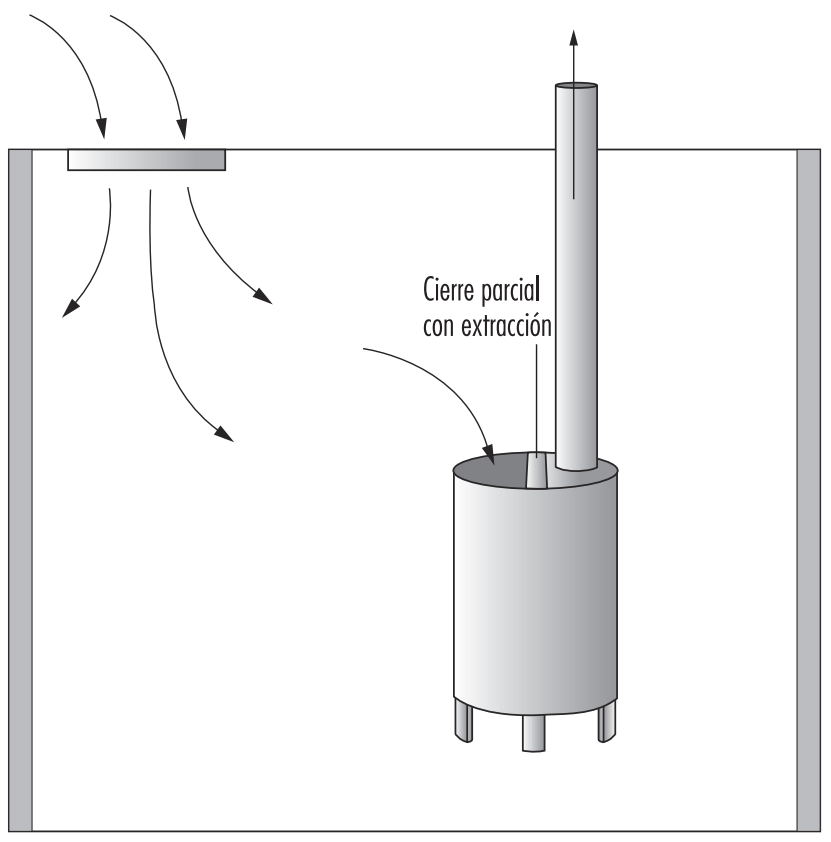

antideslizantes para mejorar la seguridad. También hay que prestar atención al riesgo de descargas eléctricas. Los circuitos eléctricos situados en el agua o cerca de ella deben estar protegidos con interruptores diferenciales y tomas de tierra adecuadas.

Como norma, los compuestos fotoquímicos deben almacenarse en un lugar fresco (a temperaturas no inferiores a $4,4^{\circ} \mathrm{C}$ ), seco (humedad relativa comprendida entre el 35 y el $50 \%$ ) y bien ventilado, donde puedan inventariarse y manipularse con comodidad. Hay que adoptar un sistema de inventario químico activo para que las cantidades de compuestos peligrosos almacenadas sean las mínimas y no se conserve ninguno después de la fecha de caducidad. Todos los recipientes deben estar correctamente etiquetados.

Los productos químicos deben almacenarse de modo que se reduzca al mínimo la probabilidad de que los envases se rompan durante las operaciones de almacenamiento y recuperación. Los envases no deben colocarse en lugares de los que puedan caerse, por encima de la altura de los ojos ni de forma que haya que alargar los brazos para alcanzarlos. Los productos más peligrosos se colocarán a poca altura y sobre una base firme para evitar roturas y salpicaduras en la piel y los ojos. Los que mezclados accidentalmente puedan provocar incendios, explosiones o vapores tóxicos deben guardarse separados. Así, los ácidos fuertes y las bases fuertes, los reductores y los oxidantes y los compuestos orgánicos han de conservarse en almacenes distintos.

Los líquidos inflamables y los combustibles se guardarán en recipientes y cabinas de almacenamiento homologados. Las zonas de almacenamiento se mantendrán frescas y se prohibirá fumar, manipular aparatos de llama abierta, calentadores y cualquier otra cosa que pueda iniciar una combustión accidental. Durante las operaciones de trasvase, los recipientes deben estar correctamente conectados a masa y a tierra. El diseño y la gestión de las zonas de almacenamiento y manipulación de materiales inflamables y combustibles deberán cumplir los reglamentos vigentes de prevención de incendios y sobre instalaciones eléctricas.

Siempre que sea posible, los disolventes y líquidos se dispensarán con ayuda de bombas medidoras en lugar de vertiéndolos. Se prohibirá pipetear soluciones concentradas y cebar sifones con la boca. El uso de preparados previamente pesados o medidos simplifica el trabajo y reduce las oportunidades de accidente. Hay que mantener meticulosamente todas las bombas y conducciones para evitar fugas.

En las zonas de procesado fotográfico se mantendrá siempre la buena higiene personal. Nunca se colocarán compuestos químicos en recipientes de comida o bebida, y viceversa; sólo se utilizarán recipientes especiales para productos químicos. Jamás se llevará comida o bebida a las zonas en que se trabaja con productos químicos, que no se guardarán nunca en refrigeradores destinados a alimentos. Después de manipular productos químicos hay que lavarse las manos escrupulosamente, sobre todo antes de comer o beber.

\section{Formación y enseñanza}

Todo el personal, incluido el de mantenimiento, debe recibir formación en las rutinas de seguridad relevantes para su puesto de trabajo. Es esencial adoptar un programa educativo para todo el personal con el fin de fomentar unas prácticas laborales seguras y evitar accidentes. Dicho programa debería impartirse a los nuevos contratados antes de que empiecen a trabajar, a intervalos regulares a partir de este momento y siempre que en el lugar de trabajo se incorporen elementos que supongan nuevos riesgos potenciales.

\section{Resumen}

La clave para trabajar con seguridad con productos fotoquímicos es conocer el peligro potencial de exposición y reducir el riesgo a un nivel aceptable. Las estrategias de control de riesgos profesionales potenciales en el laboratorio fotográfico deben incluir los elementos siguientes:

- formación del personal en materia de riesgos potenciales y procedimientos de seguridad en el lugar de trabajo;

- estímulo entre el personal de la lectura y comprensión de los medios de información sobre riesgos (fichas técnicas de seguridad y etiquetas, por ejemplo);

- mantenimiento de la limpieza en el lugar de trabajo y buena higiene personal;

- comprobación de que los equipos de procesamiento y de otro tipo están instalados y se utilizan y mantienen de acuerdo con las especificaciones de los fabricantes;

- sustitución de los productos, siempre que sea posible, por otros menos peligrosos o que desprendan menos olores;

- instalación de controles técnicos cuando sea procedente (sistemas generales y locales de extracción de aire, por ejemplo);

- empleo de equipos de protección (guantes, gafas o pantallas faciales) cuando sea necesario;

- adopción de protocolos que garanticen una atención médica rápida a cualquier persona con indicios de lesión, y

- consideración de la instauración de un plan de vigilancia de la exposición medioambiental y la salud de los empleados como medio de comprobar la eficacia de las estrategias de limitación de riesgos.

En el capítulo Actividades artísticas, culturales y recreativas se ofrece más información sobre el revelado en blanco y negro. 


\section{Referencias}

Agencia Internacional para la Investigación sobre el Cáncer (IARC). 1996. Printing Processes and Printing Inks, Carbon Black and Some Nitro Compounds. Vol 65. Lyon: IARC.

Bertazzi, PA, CA Zoccheti. 1980. Mortality study of newspaper printing workers. Am f Ind Med 1:85-97.

Dubrow, R. 1986. Malignant melanoma in the printing industry. Am f Ind Med 10:119-126.

Friedlander, BR, FT Hearne, BJ Newman. 1982. Mortality, cancer incidence, and sickness-absence in photographic processors: An epidemiologic study. 7 Occup Med 24:605-613.

Hodgson, MJ, DK Parkinson. 1986. Respiratory disease in a photographer. Am f Ind Med 9:349-54.

Kipen, H, Y Lerman. 1986. Respiratory abnormalities among photographic developers: A report of three cases. Am f Ind Med 9:341-47.

Leon, DA, P Thomas, S Hutchings. 1994. Lung cancer among newspaper printers exposed to ink mist: A study of trade union members in Manchester, England. Occup and Env Med 51:87-94.

Leon, DA. 1994. Mortality in the British printing industry: A historical cohort study of trade union members in Manchester. Occ and Envir Med 51:7986.

Michaels, D, SR Zoloth, FB Stern. 1991. Does lowlevel lead exposure increase risk of death? A mortal- ity study of newspaper printers. Int $\mathcal{f}$ Epidemiol 20:978-983.

Nielson, H, L Henriksen, JH Olsen. 1996. Malignan melanoma among lithographers. Scand 7 Work Enoiron Health 22:108-11.

Paganini-Hill, A, E Glazer, BE Henderson, RK Ross. 1980. Cause-specific mortality among newspaper web pressmen. 7 Occup Med 22:542-44.

Pifer, JW, FT Hearne, FA Swanson, JL O’Donoghue. 1995. Mortality study of employees engaged in the manufacture and use of hydroquinone. Arch Occup Environ Health 67:267-80.

Pifer, JW. 1995. Mortality Update of the 1964 U.S. Kodak Processing Laboratories Cohort through 1994. Kodak Informe EP 95-11. Rochester, Nueva York: Eastman Kodak Company.

Sinks, T, B Lushniak, BJ Haussler y cols. 1992. Renal cell disease among paperboard printing workers. Epidemiology 3:483-89.

Svensson, BG, G Nise, V Englander y cols. 1990. Deaths and tumours among rotogravure printers exposed to toluene. Br f Ind Med 47:372-79.

\section{Otras lecturas recomendadas}

Bober, TW, TJ Dagon, HE Fowler. 1992. Handbook of Industrial Waste Treatment. Nueva York: Marcel Dekker.

Cunningham, HW. 1992. Air Pollution Engineering Manual. Nueva York: Van Nostrand Reinhold.
Eastman Kodak Company. 1989. The Prevention of Contact Dermatitis in Photographic Work. Kodak publication No. J-4S. Rochester, Nueva York: Eastman Kodak Company.

- 1993. Safe Handling of Photographic Chemicals. Kodak publication No. J-4 Rochester, Nueva York: Eastman Kodak Company.

Gosselin, RE, RP Smith, HD Hodge. 1984. Clinical Toxicology of Commercial Products. Baltimore: Williams and Wilkins.

Health and Safety Executive (HSE). 1986. Chemicals in the Printing Industry: The Provision of Health and Safety Information by Manufacturers, Importers and Suppliers of Chemical Products to the Printing Industry. Londres: HSE.

-. 1995. Chemical Safety in the Printing Industry. Londres: HSE.

Hollins, R. 1994. Practical Printers Handbook. Sutton Coldfield, Reino Unido: Comprint Services.

Kanerva, L, T Estlander, R Jolanki, ML Sysilampi. 1995. Allergy caused by acrylate compounds - history, research and prevention. From research to prevention. Managing Occupational and Environmental Health Hazards, People and Work. Research Reports 4. Acta del International Symposium, 20-23 marzo. Helsinki, Finlandia.

Press Standards Board of Finance. 1994. Newespaper and Magazine Publishing in the UK: Code of Practice. Londres: Press Standards Board of Finance Ltd. 


\section{CARPINTERIA}

Director del capítulo fon Parish

\section{Sumario}

Perfil general

Debra Osinsky. .......................... 86.2

Procesos de carpintería

Fon K. Parish . . . . . . . . . . . . . . . . . . . . . . 86.2

Máquinas copiadoras-fresadoras

Beat Wegmüller.............................. . 86.7

Máquinas de cepillado de madera

Beat Wegmïller........................... 86.10

Efectos sobre la salud y pautas patológicas

Leon f. Warshaw . . . . . . . . . . . . . . . . . . . . . . . . 86.13 
Perfil General

\section{Debra Osinsky}

Tradicionalmente, las fábricas de muebles se han ubicado en Europa y América del Norte. Con el aumento de los costes laborales en los países industrializados, buena parte de la producción de muebles, que requiere mucha mano de obra, se ha desplazado a países del Lejano Oriente. Es probable que esta tendencia continúe a menos que se desarrollen equipos más automatizados.

La mayoría de los fabricantes de muebles son pequeñas empresas. Por ejemplo, en Estados Unidos, alrededor del $86 \%$ de las fábricas incluidas en el sector de los muebles de madera tienen menos de 50 empleados (EPA 1995), lo que es un dato representativo de la situación a nivel internacional

La industria estadounidense de la carpintería se ocupa de la fabricación de mobiliario para el hogar, oficinas, tiendas, edificios públicos y restaurantes, está incluida en el código 25 de la clasificación industrial estándar (SIC, Standard Industrial Classification) del Departamento del Censo (equivalente al código 33 de la SIC internacional) y comprende: mobiliario de madera para el hogar, como camas, mesas, sillas y estanterías; muebles de madera para aparatos de radio y televisión; mobiliario de madera para oficinas, como armarios, sillas y mesas; y accesorios y tabiques de madera para oficinas y establecimientos comerciales, como barras, mostradores, taquillas y estantes.

Dado que las cadenas de montaje de muebles son caras, la mayoría de los fabricantes no suministran un abanico de productos excepcionalmente amplio y es posible que se especialicen en un producto manufacturado, en un grupo de productos o en un proceso productivo (EPA 1995).

\section{PROCESOS DE CARPINTERIA}

\section{Jon K. Parish}

A efectos del presente artículo, se considera que los procesos de la industria carpintera se inician con la recepción de la madera transformada en el aserradero y terminan con la expedición de un artículo o producto de madera terminado. Las primeras fases de la manipulación de la madera se tratan en los capítulos titulados Industria forestal e Industria de la madera.

La industria de la carpintería produce muebles y materiales de construcción diversos, desde suelos de contrachapado hasta tejamaniles. En este artículo se analizan las principales fases de transformación de la madera para fabricar productos de este material, que son: el labrado a máquina de la madera o de paneles manufacturados, el montaje de las piezas mecanizadas y el acabado superficial (p. ej., pintura, tinte, lacado, chapado, etc.). La Figura 86.1 es un diagrama de los flujos de fabricación de los muebles de madera que comprende casi todo el abanico de procesos existentes en este campo.

Secado. Algunas fábricas de muebles compran madera seca, pero otros la secan en obra en un horno o estufa de secado provisto de una caldera. Los desechos de la madera suelen servir de combustible.

Mecanizado. Una vez seca la madera, se procede al aserrado y otras operaciones de mecanización para obtener las piezas del mueble en su forma definitiva, como las patas de una mesa. En una fábrica normal, la madera pasa del cepillo desbastador a la sierra de corte transversal, a la sierra para cortar al hilo, al cepillo de acabado, a la molduradora, al torno, a la sierra circular, a la sierra de cinta, a la copiadora-fresadora, a la fresadora vertical, a la taladradora y escopleadora, a la cinceladora y después a diversas lijadoras. La madera puede tallarse/labrarse a mano con diversas herramientas manuales, entre las que se incluyen cinceles, escofinas, limas, sierras de mano, papel de lija y similares.

En muchos casos, el diseño de los muebles exige el curvado de las piezas de madera. Esta operación se realiza después del proceso de cepillado y suele requerir la aplicación de presión junto con un agente reblandecedor, como el agua, y el aumento de la presión atmosférica. Una vez curvada en la forma deseada, se seca la pieza para eliminar el exceso de humedad.

Montaje. Los muebles de madera pueden acabarse primero y montarse después, o al contrario. Los muebles fabricados con componentes de formas irregulares suelen montarse primero. El proceso de montaje conlleva el uso de adhesivos (sintéticos o naturales) junto con otros métodos de unión, como el claveteado, seguidos de la aplicación de chapas. Las chapas compradas se cortan a la medida y la forma correcta y se encolan a tableros de aglomerado.

Tras el montaje, se inspecciona la pieza para ver si la superficie es suficientemente lisa para el acabado.

Preacabado. Tras el lijado inicial, se logra una superficie más lisa aplicando agua a la pieza con un pulverizador, una esponja o por inmersión, de modo que las fibras de madera se hinchan y "se levantan". Una vez seca la superficie, se aplica una solución de cola o resina y se deja secar. Las fibras levantadas se lijan para alisar la superficie.

Si la madera contiene trementina, que reduce la eficacia de algunos acabados, puede eliminarse con una mezcla de acetona y amoníaco. Después, se blanquea la madera con un agente blanqueador, como el peróxido de hidrógeno, que se aplica con un pulverizador, una esponja o por inmersión.

Acabado superficial. Para el acabado superficial pueden utilizarse gran variedad de revestimientos, que se aplican una vez montado el producto o en una línea de operación plana previa al montaje. Entre los revestimientos normalmente utilizados cabe citar los tapaporos, tintes, glaseados, selladores, lacas, pinturas, barnices y otros acabados, que pueden aplicarse con pulverizador, brocha, tampón, rodillo, por inmersión o con máquina impregnadora.

Los revestimientos pueden llevar una base de disolventes o de agua. Las pinturas contienen muy diversos pigmentos en función del color deseado.

\section{Riesgos y precauciones}

\section{Seguridad en el mecanizado}

La carpintería presenta muchos de los riesgos para la salud y la seguridad que son comunes a la industria en general, pero con una proporción mucho mayor de equipos y operaciones de máximo peligro que la mayoría. En consecuencia, la seguridad exige una atención constante a los hábitos de trabajo por parte de los empleados, una inspección vigilante, y el mantenimiento de un ambiente de trabajo seguro por parte de los empleadores.

Aunque en muchos casos las máquinas y equipos de carpintería pueden comprarse sin las necesarias guardas y otros mecanismos de seguridad, es responsabilidad de la dirección instalar defensas adecuadas antes de utilizar tales máquinas y equipos. Véanse también los artículos titulados "Máquinas copiadorasfresadoras" y "Máquinas de cepillado de la madera".

Máquinas aserradoras. Debe informarse a los empleados sobre las prácticas seguras de operación necesarias para el correcto uso de las distintas sierras de carpintería (véanse las Figuras 86.2 y 86.3). Las directrices específicas son las siguientes:

1. Al introducir material en una sierra de mesa, las manos deberán mantenerse fuera de la línea de corte. Ninguna defensa puede evitar que una persona deje que su mano 
Figura 86.1 • Diagrama de flujos de la fabricación de muebles de madera.

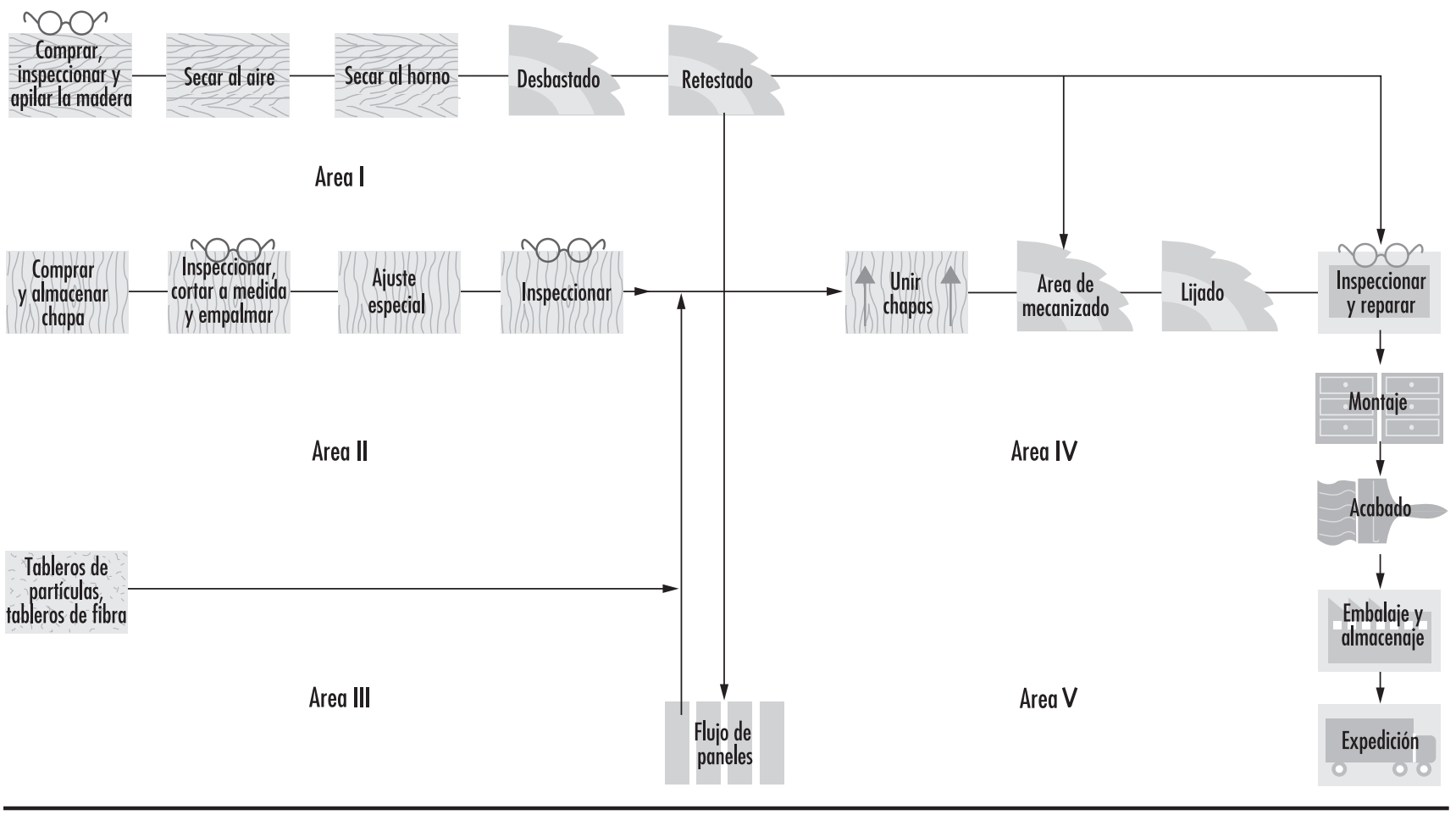

acompañe al material hasta la sierra. Si se corta al hilo con la escuadra de guía cerca de la sierra, deberá utilizarse un útil de empuje o utensilio adecuado para completar el corte. Véase la Figura 86.4.

2. La hoja de la sierra debe situarse de modo que sobresalga lo mínimo posible por encima del material; cuanto más baja esté la hoja, menor será la posibilidad de que se produzca un retroceso. Es una buena práctica mantenerse fuera de la línea del material que se está cortando. Se recomienda llevar un delantal de cuero grueso u otra protección para el abdomen.

3. Siempre es peligroso serrar a pulso. El material ha de apoyarse en una guía o escuadra. Véase la Figura 86.3.

Figura 86.2 - Sierra de cinta.

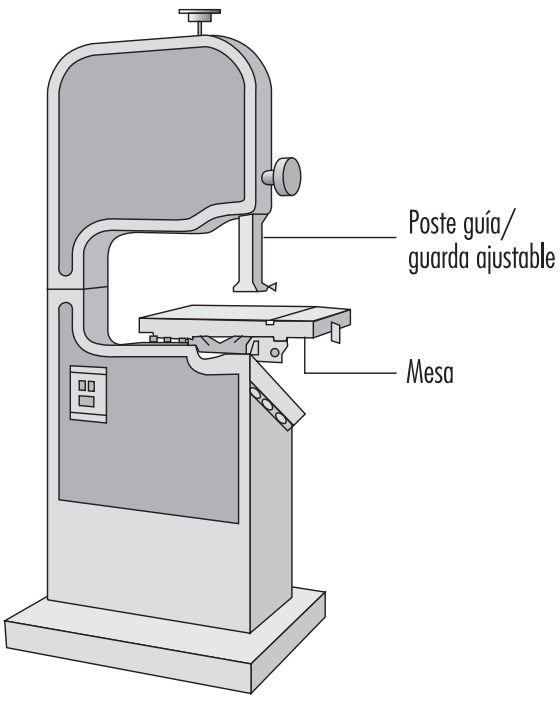

4. La sierra debe ser la adecuada para el trabajo. Por ejemplo, es una práctica poco segura cortar al hilo con una sierra de mesa no provista de un sistema antirretroceso. Es recomendable utilizar delantales antirretroceso.

5. La peligrosa práctica de retirar la defensa de una campana debido a la escasa separación existente por el lado de la guía puede evitarse asegurando un tablero de suplemento a la mesa entre la guía y la sierra y utilizándolo para guiar el material. Nunca debe permitirse que los empleados prescindan de las defensas. Cuando no puedan utilizarse las defensas normales, deberán facilitarse peines, cepos (véase la Figura 86.5) o útiles adecuados.

Figura 86.3 - Sierra circular.

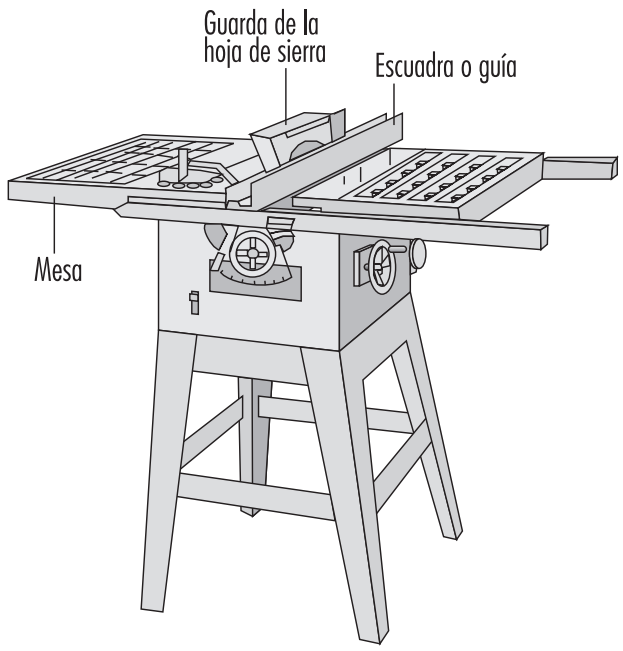


Figura 86.4 • Utiles de empuje.

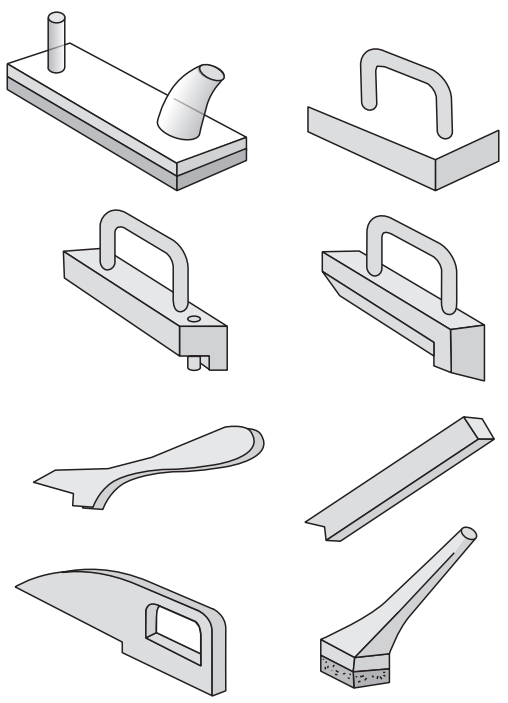

6. Debe evitarse el troceado transversal de tableros largos en una sierra de mesa porque el operario tiene que aplicar una presión considerable con la mano cerca de la hoja de la sierra. Además, los tableros que sobresalen de la mesa pueden ser golpeados por personas o carretillas. El material largo deberá trocearse en una sierra pendular o radial con un banco de apoyo adecuado.

7. El trabajo que deba realizarse en máquinas especiales de alimentación automática, no se efectuará en máquinas genéricas de alimentación manual.

8. Para ajustar la guía de una sierra de mesa sin quitar las defensas, deberá hacerse una marca permanente sobre la mesa para indicar la línea de corte.

9. Se considera una práctica segura parar totalmente las máquinas antes de ajustar las hojas o las escuadras, y desenchufarlas de la red eléctrica antes de cambiar las hojas.

10. Deberá utilizarse una escobilla u otro útil para limpiar el serrín y los desperdicios de una sierra.

Las sierras de mesa también se denominan sierras variadas porque pueden realizar una gran variedad de funciones de aserrado. Por este motivo, el operario deberá disponer de varias defensas, porque no hay ninguna que pueda ofrecer protección para todas las funciones. Véase la Figura 86.3.

Máquinas cortadoras. Las máquinas cortadoras también pueden ser peligrosas si no se equipan con defensas adecuadas y se utilizan siempre con respeto y atención. Los útiles de corte deberán mantenerse bien afilados y correctamente equilibrados en sus husillos.

Figura 86.5 • Protectores-presores vertical y horizontal tipo "peine".

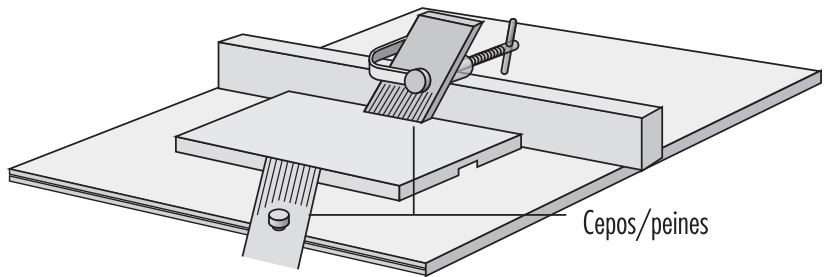

Figura 86.6 - Copiadora-fresadora.

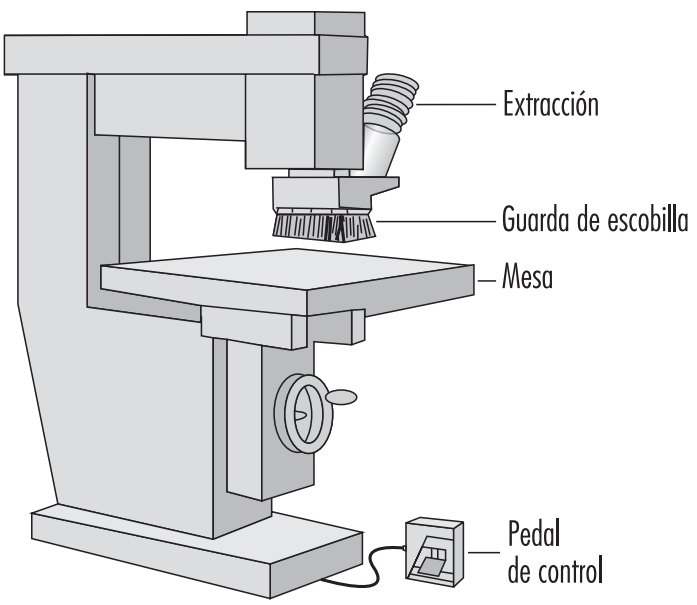

La fresadora ilustrada en la Figura 86.6 tiene una escobilla de defensa. Otras copiadoras-fresadoras pueden tener una defensa anular, una defensa redonda que encierra la fresa de copiado. El propósito de las defensas es mantener las manos separadas de la fresa. Las copiadoras-fresadoras de control numérico por ordenador $(\mathrm{CNC})$ pueden tener varias fresas y son máquinas de gran producción. En las máquinas CNC las manos del operario se mantienen alejadas de la zona de la fresa. Sin embargo, presentan el problema de producir una gran cantidad de serrín. Véase también el artículo titulado "Máquinas copiadorasfresadoras"

Las defensas que se colocan en una cepilladora de juntas o máquina de cepillado superficial tienen por objeto principal mantener las manos del operario separadas de las cuchillas giratorias. La defensa tipo "chuleta de cordero" sólo deja expuesta la parte de las cuchillas que corta el material (véase la Figura 86.7). También deberá colocarse una defensa que cubra la parte expuesta de las cuchillas por detrás de la escuadra o guía.

Figura 86.7 - Cepilladora.

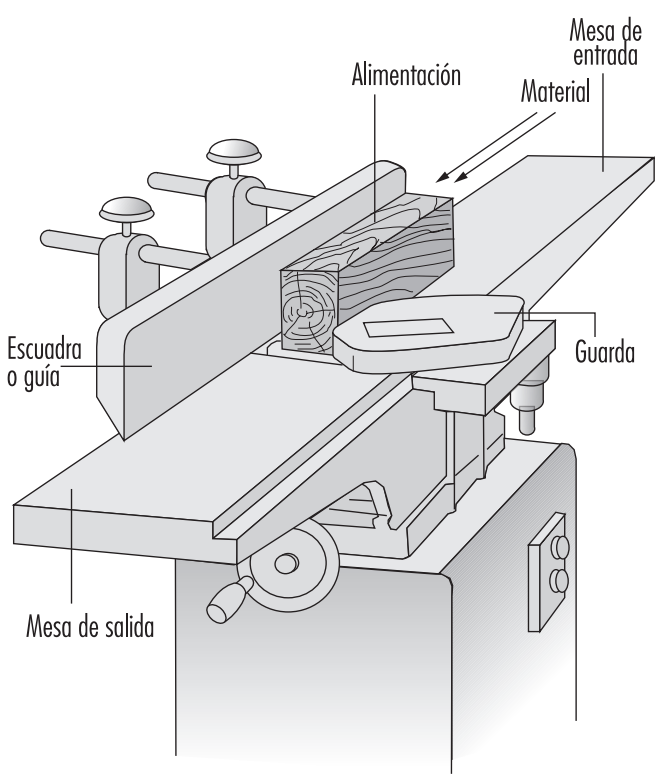


Figura 86.8 • Fresadora vertical (tupí).

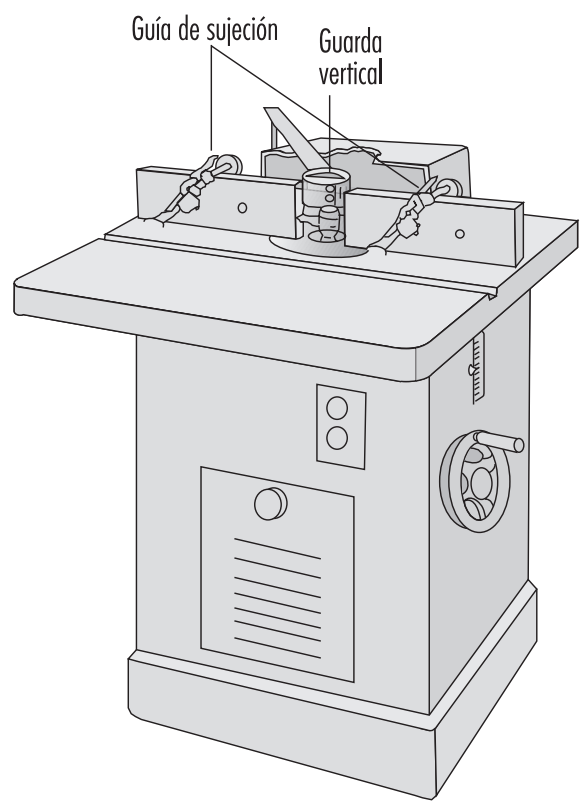

La fresadora vertical es una máquina potencialmente muy peligrosa (véase la Figura 86.8). Si las cuchillas de la fresadora vertical se separan de las abrazaderas superior e inferior del portaherramientas, pueden salir lanzadas con gran fuerza. Además, suele ser preciso sujetar el material cerca de las cuchillas. La sujeción debe realizarse con un portapieza y no con las manos del operario. Pueden utilizarse cepos para sujetar el material a la mesa. Siempre que sea posible se emplearán defensas en forma de anillo o plato. Un plato es un disco de plástico plano y redondo que se monta horizontalmente sobre el portaherramienta por encima de las cuchillas fresadoras.

Es necesario proteger los tornos con una campana porque existe el peligro de que el material salga lanzado de la máquina. Véase la Figura 86.9. Es una buena práctica que la campana esté interconectada con el motor de modo que el torno no funcione si no está colocada la campana.

Las sierras de cortar al hilo deben disponer de lengüetas antirretroceso para evitar que el material cambie de dirección y golpee al operario. Véase la Figura 86.10. Además, el operario deberá llevar un delantal acolchado para mitigar el golpe si llega a producirse el retroceso.

\section{Figura 86.9 - Torno.}

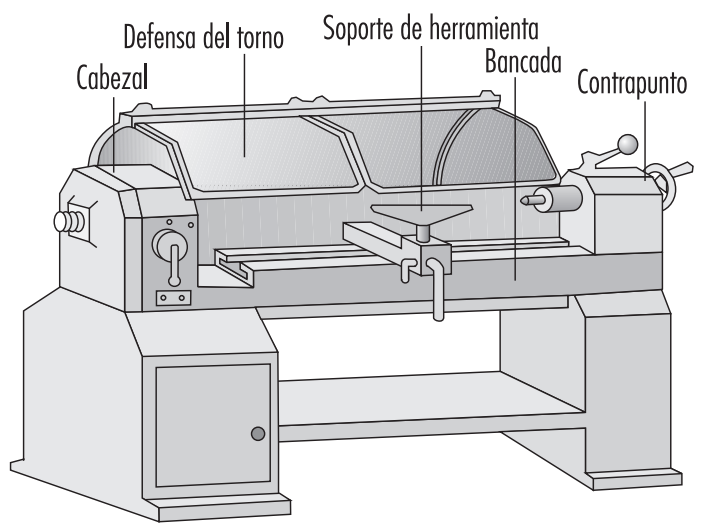

Figura 86.10 - Sierra para cortar al hilo.

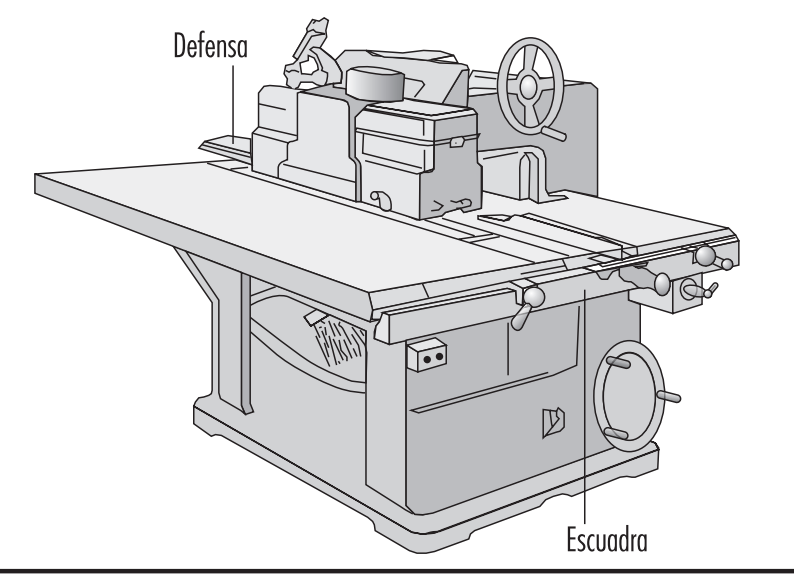

Como la hoja de la sierra radial puede inclinarse lateralmente, deberá utilizarse una defensa que no toque la hoja. Véase la Figura 86.11.

Máquinas lijadoras. Las piezas mecanizadas se lijan con lijadoras de cinta, de impulsos, de disco, de tambor u orbitales. En las correas de lijado se crean puntos en que los operarios pueden quedarse enganchados. Véase la Figura 86.12. Estos puntos de atrapamiento deben protegerse con una campana que forme parte además del sistema de extracción de polvo.

Defensas de las máquinas. En la Figura 86.13 se observa que la abertura entre la defensa y el punto de contacto debe disminuir con la distancia.

Problemas varios de seguridad de las máquinas. Hay que tener cuidado de que el uso de mecanismos de retención/sujeción de material no genere riesgos adicionales.

La mayoría de las máquinas de carpintería hacen necesario que el operario (y su ayudante) lleve protección ocular.

Es una práctica común entre los trabajadores quitarse el serrín de encima utilizando aire comprimido. Deberá avisárseles de que mantengan la presión del aire por debajo de 30 psi (2 bars) y eviten dirigir el chorro directamente a los ojos o a heridas abiertas.

Figura $86.11 \cdot$ Sierra radial.

Dado que la hoja de la sierra radial puede inclinarse lateralmente, deberá utilizarse una defensa que no toque la hoja.

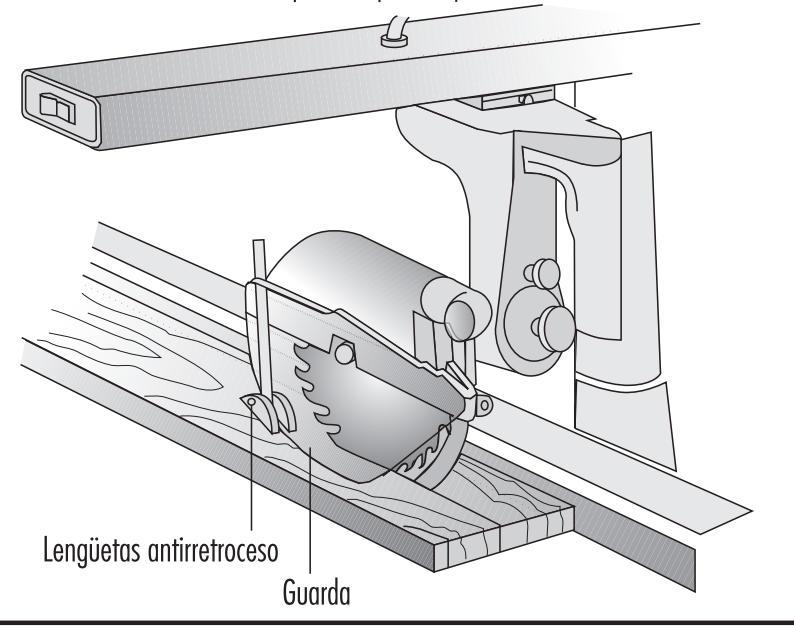


Figura $86.12 \cdot$ Lijadora.

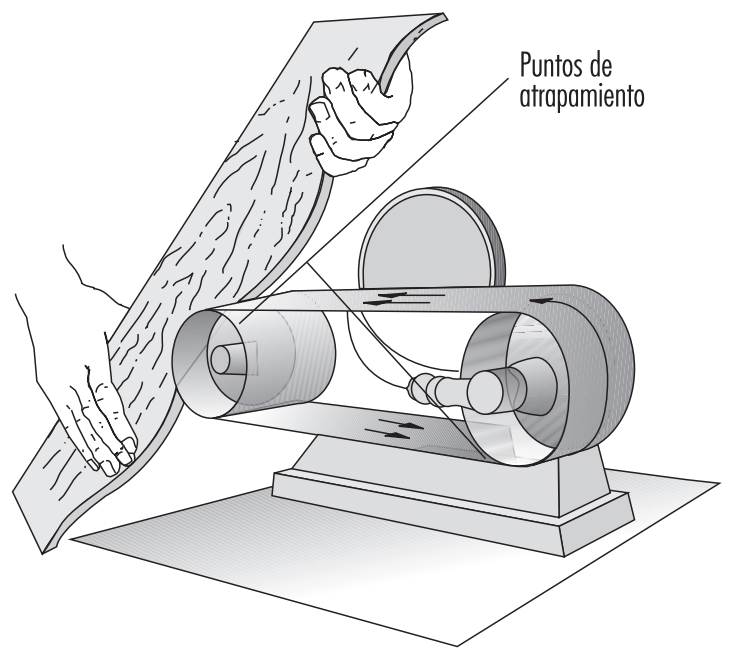

\section{Riesgos del serrín}

Las máquinas que producen serrín deben equiparse con sistemas de extracción de polvo. Si el sistema de extracción es inadecuado para eliminar el serrín, el operario tendrá que llevar una mascarilla. La Agencia Internacional para la Investigación sobre el Cáncer (IARG) ha determinado ya que "existe suficiente evidencia de la carcinogenicidad del serrín para los seres humanos" y que "el serrín es cancerígeno para los seres humanos (Grupo 1)". Otros estudios indican que el serrín puede ser un irritante de las membranas mucosas de los ojos, la nariz y la garganta. Algunas maderas tóxicas son más activamente patógenas y pueden producir reacciones alérgicas y ocasionalmente trastornos pulmonares e intoxicación sistémica. Véase la Tabla 86.1 en la página 86.14.

El mayor uso de maquinaria CNG de gran producción, como copiadoras-fresadoras, espigadoras y tornos, produce más serrín y hace necesaria una nueva tecnología de extracción de polvo.

Control del serrín. La mayoría del serrín producido en un taller de carpintería se elimina por medio de sistemas de extracción local. Ahora bien, suele producirse una acumulación considerable de serrín muy fino asentado en cerchas y otros elementos estructurales, especialmente en las áreas de lijado. Esta situación es peligrosa y presenta un gran potencial de incendio y explosión. Si prende en forma de llamarada el serrín que cubre las superficies, el fuego puede ir seguido de explosiones de fuerza cada vez mayor. Para minimizar esta probabilidad, sería muy aconsejable utilizar una lista de control. Véase el ejemplo del recuadro.

\section{Riesgos de montaje}

Para encolar las chapas a los paneles manufacturados se utilizan gran variedad de adhesivos en función de las características del producto final. Aparte de la cola de caseína, los adhesivos naturales son los menos empleados, y los que más son los adhesivos sintéticos, como el formaldehído ureico. Los adhesivos sintéticos pueden presentar un riesgo de enfermedad cutánea o intoxicación sistémica, especialmente los que liberan formaldehído o disolventes a la atmósfera. Los adhesivos deben manipularse en locales bien ventilados y los focos de emisión de vapores equiparse con ventilación de extracción. A los trabajadores se les deberán facilitar guantes, cremas protectoras, mascarillas y protecciones oculares cuando sea necesario
Las piezas móviles - especialmente las hojas- de las máquinas de corte y unión de chapas deberán protegerse perfectamente. Puede ser necesario instalar controles a dos manos.

\section{Riesgos del acabado}

Acabado superficial. Los disolventes utilizados como vehículo de los pigmentos pulverizados o como diluyentes pueden contener muy diversos compuestos orgánicos volátiles $(\mathrm{COV})$ y llegar a alcanzar concentraciones tóxicas y explosivas en el aire. Además, muchos pigmentos son tóxicos por inhalación de la niebla pulverizada (p. ej., pigmentos de plomo, manganeso y cadmio). Siempre que puedan producirse concentraciones peligrosas de vapor o niebla, deberá utilizarse ventilación de extracción (p. ej., pulverización de pintura en cabina) o pulverizadores de agua. Todas las fuentes de ignición, incluidos fuegos, equipos eléctricos y electricidad estática, deberán eliminarse antes de iniciar las operaciones.

Se pondrá en marcha un activo programa de comunicación de materiales peligrosos para advertir a los empleados de todos los riesgos generados por los productos químicos disolventes, de encolado y de acabado inflamables, corrosivos, reactivos y/o tóxicos y de las medidas protectoras que deban tomarse. Estará prohibido comer en las zonas en que se utilicen dichos productos químicos. Es esencial que los materiales inflamables se almacenen correctamente y que la lana de acero y los trapos sucios que puedan provocar combustión espontánea se desechen por métodos apropiados.

Prevención de incendios. Dada la naturaleza altamente inflamable de la madera (especialmente en forma de serrín y viruta) y de los demás productos existentes en los talleres de carpintería (como disolventes, colas y revestimientos), nunca se insistirá demasiado en la importancia de las medidas de prevención de incendios. Entre dichas medidas cabe destacar:

- la instalación de equipos automáticos de extracción de serrín y viruta en sierras, cepillos, molduradoras y demás, y transporte de los desechos a silos de almacenaje en espera de su eliminación o recuperación;

\section{Figura 86.13 • Distancia entre la defensa y el punto de operación.}

Medidas de

de la guarda

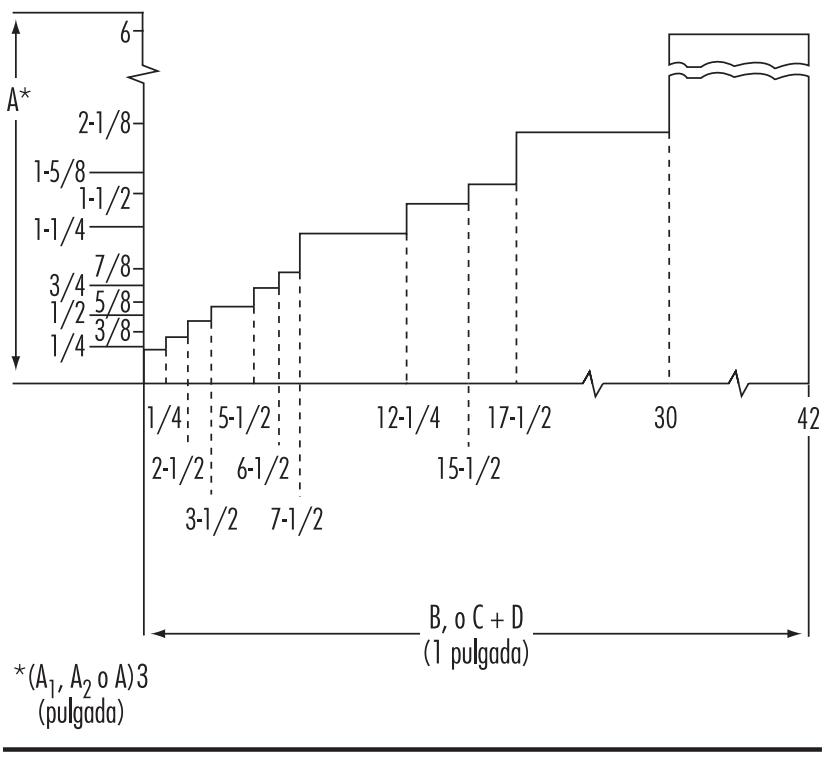


- la prohibición de fumar en el lugar de trabajo y la eliminación de todos los focos de combustión (p. ej., llamas al desnudo);

- la aplicación de procedimientos periódicos de limpieza del serrín y la viruta depositados;

- un adecuado mantenimiento de las máquinas para evitar incidencias tales como el sobrecalentamiento de los rodamientos;

- la instalación de barreras contra incendios, sistemas de aspersión, extintores y mangueras de incendios, y el adiestramiento del personal en el uso de estos equipos;

- el correcto almacenaje de los materiales inflamables;

- la instalación de equipos eléctricos a prueba de explosiones en caso necesario.

\section{Problemas para la salud pública y el medio ambiente}

La fabricación de productos de madera para el consumo puede realizarse sin provocar daños ecológicos de gran alcance. La tala se ha de realizar de modo que los árboles cortados sean reemplazados por otros nuevos. Se puede actuar disuasoriamente para que no se produzca una deforestación importante, como ha ocurrido con los bosques pluviales. Los productos de desecho del mecanizado de la madera (es decir, serrín y viruta) pueden utilizarse en el aglomerado o como combustible.

Aunque la industria carpintera produce residuos sólidos y aguas residuales, lo más preocupante son las emisiones atmosféricas derivadas del uso de madera residual como combustible y de las operaciones de acabado con disolventes. En las operaciones de secado suelen utilizarse calderas alimentadas con madera, mientras que muchos de los materiales de acabado se aplican con pulverizador. En ambos casos, son necesarios controles técnicos que reduzcan las partículas atmosféricas y recuperen o incineren los compuestos volátiles.

El objetivo de estos controles es conseguir que los trabajadores queden expuestos a productos químicos menos tóxicos mientras se encuentran sucedáneos menos peligrosos. El empleo de acabados acuosos en lugar de los basados en disolventes disminuirá los riesgos de incendio.

\section{MAQUINAS COPIADORAS-FRESADORAS}

\section{Beat Wegmüller}

Las máquinas copiadoras-fresadoras estacionarias se utilizan en general para la fabricación de partes de muebles y artículos de madera, pero a veces también para mecanizar plásticos y aleaciones ligeras. Los principales tipos de copiadoras-fresadoras son: fresadoras copiadoras, fresadoras de patrones, máquinas con cabezales móviles de copiado y máquinas copiadoras automáticas. Estas últimas se utilizan para mecanizar varias piezas de trabajo al mismo tiempo.

Una característica común a todas las máquinas copiadorasfresadoras es que la herramienta está situada por encima del soporte de la pieza de trabajo, normalmente una mesa. El eje del husillo de la herramienta es casi siempre vertical, pero en algunas máquinas el cabezal copiador $-\mathrm{y}$ por consiguiente también el eje del husillo - puede estar inclinado. El cabezal de mecanizado baja para mecanizar y vuelve automáticamente a la posición inicial (en reposo). En las máquinas antiguas, el cabezal de mecanizado se baja manualmente accionando un pedal mecánico o palanca de mano. En las modernas, el cabezal suele bajar por medio de un sistema hidráulico o neumático. En la Figura 86.14 se ilustran varios accesorios (zapatas de sujeción, guías, etc.) y la defensa de seguridad de la Organización Nacional Suiza de Aseguradoras de Accidentes (SUVA).

El husillo es impulsado por un accionamiento de correa o directamente por un motor de alta frecuencia, que suele ser de dos velocidades, de 6.000 a $24.000 \mathrm{rpm}$. La velocidad es inferior en las fresadoras de patrones, cuya velocidad más baja puede ser de $250 \mathrm{rpm}$. Las fresadoras de patrones suelen ir provistas de un reductor para seleccionar distintas velocidades.

El diámetro de corte de la herramienta copiadora varía de 3 a $50 \mathrm{~mm}$. Sin embargo, en las fresadoras de patrones especiales, el diámetro de corte de la herramienta puede ser de hasta $300 \mathrm{~mm}$.

\section{Herramientas}

En las máquinas copiadoras-fresadoras se utilizan principalmente fresas de cuchara de un solo filo, fresas de panel de doble filo o fresas de perfil macizo. Al igual que cualquier herramienta, deben diseñarse y fabricarse con materiales que soporten las fuerzas y cargas previstas en servicio. Las máquinas deben utilizarse y mantenerse con arreglo a las instrucciones del fabricante.

Las herramientas de copiado deben:

- llevar marcada de forma clara y permanente la velocidad admisible, p. ej., menos de 20.000 rpm;

- ser de un tipo comprobado por un organismo homologado;

- ser de forma redonda con una mínima proyección radial de los bordes de corte para reducir el peligro de retroceso.

\section{Defensas para la herramientas}

En las máquinas copiadoras-fresadoras en que la herramienta se mueve y la pieza de trabajo permanece fija, deberá evitarse el acceso a la herramienta giratoria por medio de una guarda ajustable (protector de manos), completada con una guarda móvil que pueda bajar hasta la superficie de la pieza de trabajo. El extremo inferior de la guarda móvil puede ser una escobilla.

En las máquinas copiadoras-fresadoras en que la pieza de trabajo se sujeta y/o introduce a mano, es muy recomendable utilizar un mecanismo de seguridad que ejerza una presión vertical sobre la pieza de trabajo. La SUVA ha diseñado una defensa de este tipo, que se ha venido utilizando con éxito desde finales del decenio de 1940 y sigue siendo la defensa más completa de su clase. Sus principales características son:

- prevención de contactos inadvertidos con la herramienta giratoria tanto en la posición de reposo como en la de trabajo;

- facilidad y rapidez de cambio de una talla de zapata por otra. Existen varias tallas de zapatas de sujeción para herramientas con diferentes diámetros de corte;

- ajuste manual de la presión ejercida por la zapata sobre la pieza;

- retorno automático de la zapata a su posición superior cuando el cabezal copiador sube hasta su posición de reposo. La defensa puede ajustarse de modo que la zapata de sujeción sólo pueda levantarse cuando el borde inferior de la herramienta esté por encima del nivel del borde inferior de la zapata; de este modo se evita cualquier contacto inadvertido con la herramienta desde abajo (véase la Figura 86.15) y, en consecuencia, lesiones graves en el dorso de la mano, donde los tendones sólo están protegidos por la piel;

- posibilidad de conectar a la defensa un sistema extractor de viruta.

Esta defensa también permite fresar las piezas de trabajo a lo largo de una guía con ayuda de un tampón de presión horizontal. 


\section{Ejemplo de lista de control}

\section{Orden y limpieza}

1. Es esencial implantar un programa de orden y limpieza diaria

2. La acumulación de 3,2 mm de serrín en cualquier zona es indicativa de la necesidad de limpieza. Hay que resaltar que cualquier acumulación de serrín puede provocar un incendio. Cuanto más fino sea el serrín, mayor será el riesgo.

3. Limpiar el serrín con frecuencia.

a. Limpiar diariamente alrededor de las superficies calientes frotando con un paño.

b. Cuando sea posible, utilizar un aspirador o aventador para limpiar a fondo todas las zonas, incluidas las cerchas, al menos dos veces al año.

c. Cuando las concentraciones sean altas, hacer una zona pequeña cada vez.

d. Cuando hay poca humedad, aumenta el potencial de riesgo, lo que deberá tenerse en cuenta durante las limpiezas por aventado.

4. Programar las limpiezas para cuando los equipos estén parados, como viernes por la tarde y fines de semana.

\section{Mantenimiento eléctrico}

1. Inspeccionar/limpiar todos los motores periódicamente para evitar la acumulación de serrín.

2. Comprobar que todos los cuadros y cajas de conexiones eléctricas cumplen los requisitos de la normativa eléctrica aplicables a la clasificación de su ubicación.

3. Prestar atención a sonidos inusuales, olores inusuales y acumulaciones de serrín visibles en máquinas y motores. Comprobar motores y otros aparatos eléctricos con frecuencia, para detectar sobrecalentamientos.

4. Comprobar que el personal de operación o mantenimiento lubrica los rodamientos de motores, transportadores, cadenas y engranajes convenientemente de forma periódica.

5. Comprobar que los cuadros y cajas de conexiones eléctricas permanecen cerrados y se evita la acumulación de serrín en ellos, incluido el taponamiento de todos los orificios de paso practicables.

\section{Prevención de incendios}

1. Vigilar el cumplimiento de la prohibición de fumar en lugares no autorizados.

2. Adoptar procedimientos para permisos de trabajo en caliente y comprobar que se cumplen dichos procedimientos.

3. No permitir que las máquinas controladas por operarios funcionen sin vigilancia.
4. Montar un dispositivo en la boca del sistema de extracción de polvo para evitar que las chispas de las cintas de lijado y otros elementos chisporroteantes entren en el sistema y provoquen un incendio.

5. Atrapar el metal que pueda entrar en los trituradores de madera instalando imanes en el sistema transportador y detectores de metales en el triturador. Deberán implantarse políticas y procedimientos que eviten la entrada de metales y otros objetos extraños en los trituradores.

6. Realizar inspecciones semanales y mensuales de los sistemas de protección contra incendios, incluidos extintores, mangueras, alarmas y válvulas de control de aspersores.

7. Comprobar que no se acumula serrín en los cuartos de calderas y equipos calentadores, que se cumplen los procedimientos escritos de puesta en marcha de calderas y que se utilizan equipos de la clasificación apropiada.

8. Elegir el procedimiento correcto para apagar fuegos provocados por serrín.

9. Solicitar que la aseguradora o el jefe del cuerpo de bomberos local realice una inspección detallada.

10. Favorecer los simulacros de incendios y las visitas del cuerpo de bomberos local.

11. Instalar sistemas de detección y extinción de chispas en los sistemas de extracción de polvo y comprobar periódicamente que funcionan.

12. Revisar los planes de evacuación y el alumbrado de emergencia, y realizar simulacros de incendios periódicamente en cada turno de trabajo.

\section{Varios}

1. Pedir ayuda a la aseguradora para identificar los riesgos en materia de seguridad, salud e incendios.

2. Ponerse en contacto con las agencias gubernamentales competentes en materia de seguridad para obtener asistencia adicional.

3. Los empleados sólo deberán entrar en los silos de serrín si se cumplen los procedimientos para espacios cerrados.

4. Todos los operarios deberán comprobar que los sistemas de extracción de polvo funcionan correctamente y comunicar inmediatamente cualquier fallo a la dirección.

5. Comprobar si algún objeto obstruye los conductos del sistema de extracción de polvo.

6. Es recomendable que todos los supervisores, miembros del comité de seguridad y otros empleados sean informados del contenido de la presente lista de control voluntaria a fin de lograr una amplia implantación de la misma.

\section{Riesgos}

Las máquinas copiadoras-fresadoras son menos peligrosas que las máquinas molduradoras de husillo vertical. Una razón de ello es el diámetro menor de la mayoría de las herramientas de copiado. Sin embargo, las herramientas de las máquinas copiadoras-fresadoras son fácilmente accesibles y ello representa un riesgo constante para los brazos y manos del operario. Por consiguiente, las fresadoras copiadoras, en que la pieza de trabajo suele introducirse a mano, son las máquinas copiadoras-fresadoras más peligrosas con diferencia.

\section{Causas de accidentes}

Las principales causas de accidentes con copiadoras-fresadoras son:
- contacto inadvertido de la mano o el brazo con la herramienta giratoria en posición de reposo: 1) cuando se retira viruta y serrín de la mesa a mano en lugar de utilizar un útil de madera; 2) cuando no se manipula correctamente la pieza o el portapieza; 3) cuando la manga del operario se enreda en la herramienta giratoria;

- contacto inadvertido de la mano con la herramienta de copiado a consecuencia del retroceso de la pieza de trabajo sujeta con la mano.

El retroceso puede producirse debido a:

- una práctica de trabajo poco segura;

- defectos en la pieza de trabajo (nudos, etc.); 
Figura 86.14 • Mecanismo de seguridad de la SUVA con la herramienta copiadora-fresadora en posición de trabajo.

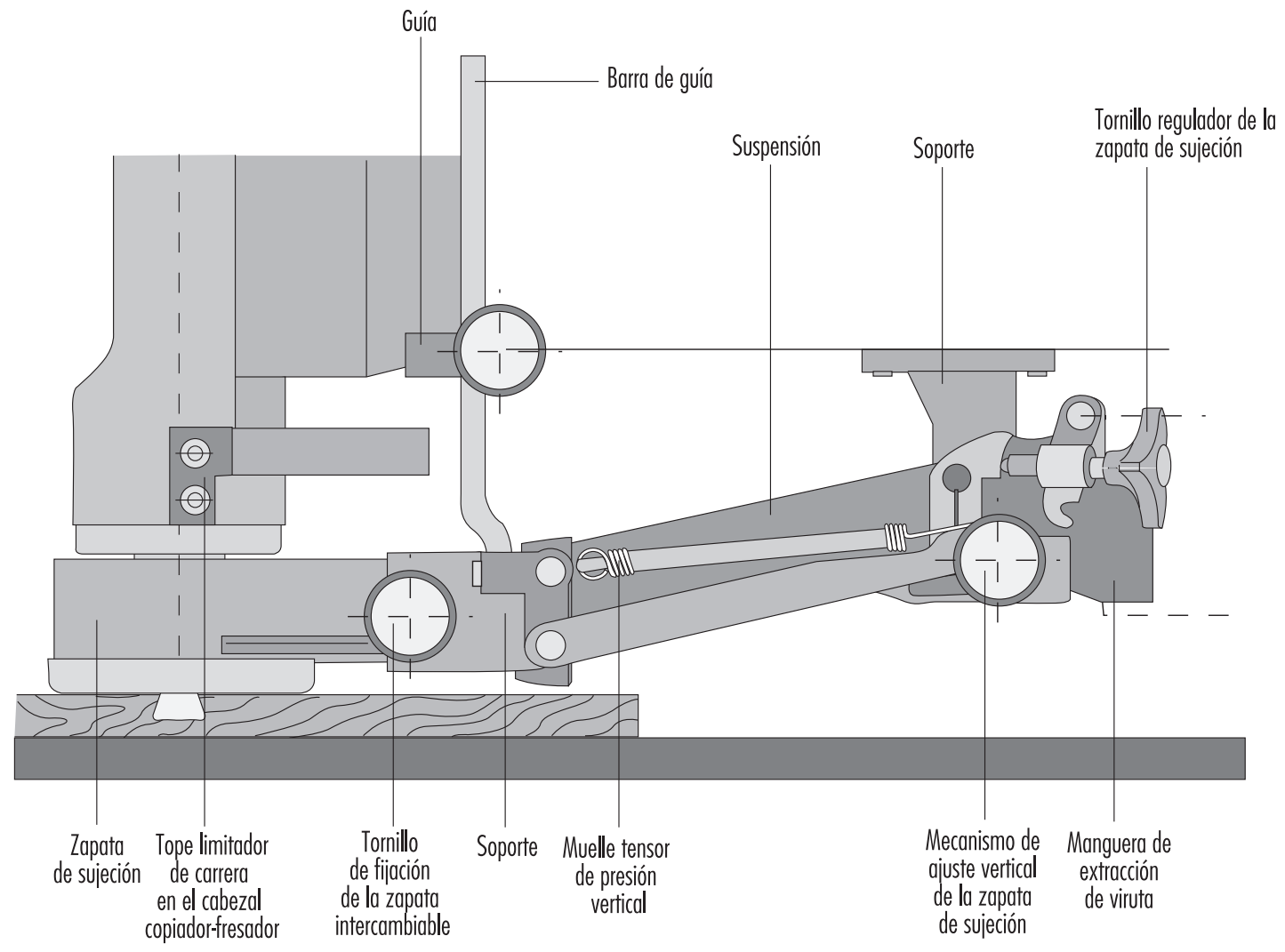

Figura 86.15 - Mecanismo de seguridad de acuerdo con la Figura 86.14, con la herramienta copiadora-fresadora en posición inicial (posición de reposo).
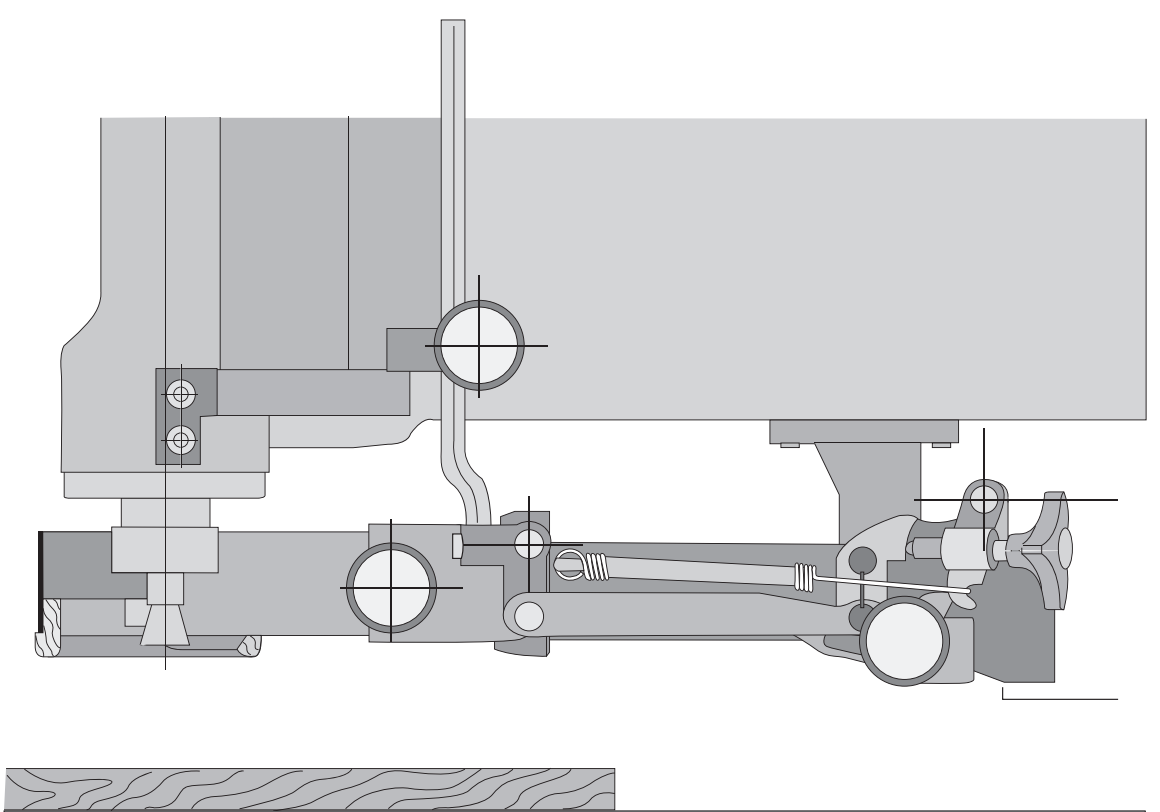
- desplazamiento de piezas de trabajo hasta la herramienta con excesiva brusquedad o desde una dirección incorrecta;

- filos de corte embotados;

- velocidad de corte inadecuada;

- fijación incorrecta de la pieza al portapieza;

- rotura de la pieza de trabajo;

- expulsión de la herramienta o de partes de la misma a causa de un mal diseño, excesiva dureza del material, defectos en el material, exceso de velocidad o deficiente sujeción de la herramienta en el portaherramienta.

En caso de expulsión de una herramienta o pieza de trabajo, no sólo puede sufrir lesiones el operario, sino también otras personas que estén trabajando en la zona.

\section{Medidas de prevención de accidentes}

Dichas medidas deben contemplar:

- el diseño y la construcción de la máquina;

- las herramientas;

- la protección de la herramienta en posición de reposo (véase la Figura 86.15) y en la medida de lo posible en la posición de trabajo (véase la Figura 86.14), en especial si la pieza de trabajo se sujeta e introduce con la mano.

\section{Diseño y construcción de la máquina}

Las máquinas copiadoras-fresadoras deben diseñarse para que su manejo sea seguro. Hay que garantizar que:

- la máquina sea suficientemente rígida;

- el equipo eléctrico cumpla las normas de seguridad;

- los accionadores utilizados para iniciar una función de arranque o movimiento de un elemento de la máquina estén construidos y montados de modo que se minimice la posibilidad de accionamiento inadvertido;

- se impida el acceso a las piezas móviles de las máquinas, como los accionamientos de cinta, los cabezales copiadores hidráulicos o neumáticos o las mesas móviles en máquinas con avances automáticos, por medio de defensas adecuadas;

- el operario pueda ver claramente las revoluciones por minuto reales de la herramienta;

- los dispositivos de seguridad y sistemas de extracción de viruta sean fáciles de instalar;

- se reduzca el nivel de ruido de la máquina en la medida de lo posible.

Además, es aconsejable equipar el accionamiento de la herramienta de la máquina copiadora-fresadora con un freno automático que se active al parar la máquina. El tiempo de frenado no deberá ser superior a 10 segundos.

\section{- MAQUinas DE CEPILLADO DE MADERA}

\section{Beat Wegmüller}

El desarrollo de las máquinas estacionarias de cepillado data de principios del siglo XIX. En las primeras máquinas de este tipo, la pieza de trabajo se fijaba a un carro y se pasaba por debajo de un árbol horizontal provisto de hojas que cubrían todo el ancho de trabajo. En 1850 se construyó en Alemania un cepillo en que la pieza de trabajo se pasaba por encima de un portacuchillas situado entre dos mesas utilizadas para colocar y soportar la pieza de trabajo. Mejoras técnicas aparte, este diseño básico se ha mantenido hasta la fecha. La máquina recibe el nombre de cepilladora superficial (véase la Figura 86.7).
Más recientemente, se diseñaron máquinas para cepillar la superficie superior de una pieza de trabajo hasta un espesor determinado por medio de un portacuchillas horizontalmente giratorio. La distancia entre el diámetro del círculo de corte y la superficie de la mesa que sustenta la pieza de trabajo es ajustable. Estas máquinas se denominan cepilladoras de espesor unilateral

Estos dos tipos básicos de máquina se combinaron finalmente para crear una máquina que pudiera utilizarse tanto para el cepillado superficial como de espesores. Se obtuvieron así cepilladoras mecánicas capaces de trabajar dos, tres y cuatro lados en una pasada.

Desde el punto de vista de la salud y la seguridad en el trabajo, es muy recomendable tomar medidas para la extracción del serrín y la viruta del cepillo (p. ej., conectándolo a un sistema de extracción de polvo). El serrín de la madera dura (roble, haya) y de la madera tropical presenta un riesgo especial para la salud y es obligada su extracción. También deben tomarse medidas para reducir el nivel de ruido de las cepilladoras mecánicas. En muchos países es obligado un freno automático para el portacuchillas.

\section{Máquinas de cepillado superficial}

Una máquina de cepillado superficial tiene un bastidor principal rígido que sustenta la mesa de alimentación de entrada y salida. El portacuchillas está situado entre las dos mesas y va montado sobre rodamientos de bolas. El bastidor principal debe estar diseñado ergonómicamente (es decir, ha de permitir que el operario trabaje con comodidad).

Los mecanismos de control de accionamiento manual deben instalarse de modo que el operario no se encuentre en situaciones peligrosas cuando los accione, y se minimice la posibilidad de accionamiento inadvertido.

El lado del bastidor principal situado frente al operario debe estar exento de piezas que sobresalgan, como volantes, palancas, etc. La mesa de la izquierda del portacuchillas (mesa de salida) se ajusta normalmente a la misma altura que el círculo de corte del portacuchillas, y la mesa de la derecha del portacuchillas (mesa de entrada) a menos altura que la mesa de salida para obtener la profundidad de corte deseada. Los bordes de las mesas no deben entrar en contacto con el portacuchillas en ninguna de las posiciones de ajuste. Sin embargo, la separación entre los bordes de las mesas y el círculo de corte del portacuchillas será lo más pequeña posible para conseguir un buen soporte de la pieza de trabajo.

Las principales operaciones de cepillado mecánico superficial son el allanado y el canteado. La posición de las manos sobre la pieza de trabajo es importante desde el punto de vista operativo y por seguridad. Al allanar, la pieza de trabajo debe alimentarse con una mano mientras se sujeta con la otra sobre la mesa de entrada. En cuanto haya suficiente madera en la mesa de salida, esta última mano podrá pasar con seguridad sobre la defensa de puente para aplicar presión sobre la mesa de salida e irá seguida de la mano alimentadora para completar la operación de alimentación. Al cantear, las manos no deben pasar por encima del portacuchillas mientras esté en contacto con la madera. Su principal función debe ser ejercer una presión horizontal sobre la pieza de trabajo para mantenerla perpendicular a la escuadra.

El ruido producido por el portacuchillas giratorio puede rebasar con frecuencia el nivel considerado perjudicial para el oído. Por consiguiente, son necesarias medidas para reducir el nivel de ruido. Algunas de estas medidas, que han demostrado su utilidad en cepilladoras superficiales, son las siguientes:

- el uso de un portacuchillas "silencioso" (p. ej., una forma redonda de la que las hojas sobresalgan lo mínimo posible, una 
hoja helicoidal en lugar de una hoja recta, herramientas giratorias segmentadas con corte excéntrico);

- mesas de bordes ranurados o taladrados (la configuración y las dimensiones de las aberturas en los bordes de las mesas deben ser tales que no exista riesgo de accidentes; p. ej., las ranuras no tendrán más de $6 \mathrm{~mm}$ de ancho y el diámetro de los taladros no será superior a $6 \mathrm{~mm}$ );

- diseño aerodinámico de los deflectores de viruta por debajo de los bordes de las mesas;

- reducción de la velocidad del portacuchillas a menos de $1.000 \mathrm{rpm}$, siempre que la calidad superficial de la pieza de trabajo siga siendo satisfactoria.

Puede lograrse una reducción del ruido hasta 12 dBA en vacío y $10 \mathrm{dBA}$ con carga. Los portacuchillas deben ser de sección transversal circular, y las gargantas y ranuras de separación de viruta lo más pequeñas posible. Las hojas e inserciones deberán fijarse de forma conveniente, preferiblemente por bloqueo en horma.

El portacuchillas gira a velocidades comprendidas entre 4.500 y $6.000 \mathrm{rpm}$. Los diámetros de los portacuchillas convencionales varían de 56 a $160 \mathrm{~mm}$, y sus largos (anchos de trabajo) de $200 \mathrm{a}$ $900 \mathrm{~mm}$. Por analogía con la cinemática del fresado convencional, la superficie de la pieza de trabajo cepillada con un portacuchillas se compone de arcos cicloides. Por consiguiente, la calidad superficial del trabajo dependerá de la velocidad y del diámetro del portacuchillas, del número de hojas de corte y de la velocidad de alimentación de la pieza de trabajo.

Es recomendable equipar las cepilladoras superficiales con un freno automático para el portacuchillas, que deberá activarse cuando se pare la máquina, no excediendo el tiempo de frenado de 10 segundos.

Se impedirá el acceso al portacuchillas en la parte posterior de la escuadra por medio de una defensa sujeta o bien a la escuadra o bien al soporte de ésta. El portacuchillas situado delante de la escuadra deberá ir protegido por una defensa ajustable de tipo puente fijada a la máquina (p. ej., al bastidor principal en el lado de la mesa de salida) (véase la Figura 86.16). Se evitará el acceso a los elementos de transmisión por medio de una guarda fija.

\section{Riesgos}

Cuando el portacuchillas gira en dirección opuesta a la de alimentación de la pieza de trabajo, hay riesgo de retroceso. Si la pieza de trabajo es expulsada, la mano o los dedos del operario pueden entrar en contacto con el portacuchillas giratorio a menos que se hayan instalado unas defensas adecuadas. También ocurre a menudo que la mano entre en contacto con el portacuchillas

Figura 86.16 • Escuadra o guía y defensa trasera del portacuchillas.

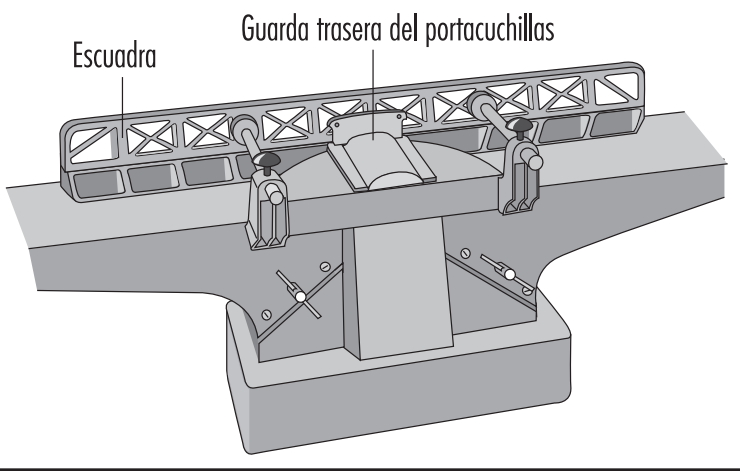

mientras se alimenta la pieza de trabajo con los dedos estirados en lugar de empujarla hacia adelante con el puño cerrado. Si las hojas de corte no están bien aseguradas, pueden salir expulsadas por la fuerza centrífuga y provocar graves heridas y/o daños materiales.

Sistemas de protección para máquinas de cepillado superficial En muchos países, la legislación sobre uso de máquinas de cepillado superficial exige que el portacuchillas esté protegido con un sistema de defensas ajustables a fin de evitar que la mano del operario entre accidentalmente en contacto con el portacuchillas giratorio.

En 1938, la SUVA introdujo una defensa para cepilladoras que cumplía eficientemente todos los requisitos prácticos. Con el paso de los años, esta defensa ha demostrado su utilidad no sólo como sistema de protección, sino también como ayuda en la mayoría de las operaciones. Ha sido muy bien aceptada por el gremio de la carpintería de Suiza, y casi todas las máquinas industriales de cepillado superficial van equipadas con ella. Las características de diseño de esta defensa se han introducido en el borrador de norma europea para máquinas de cepillado superficial, y son las siguientes:

- resistencia y rigidez;

- no se desvía fácilmente, de modo que no deja el portacuchillas expuesto;

- permanece siempre paralela al eje del portacuchillas con independencia de su ajuste horizontal o vertical;

- fácilmente ajustable horizontal y verticalmente sin necesidad de herramientas.

Sin embargo, se siguen produciendo accidentes, debidos principalmente a un ajuste inadecuado de la defensa. En consecuencia, los técnicos de SUVA han desarrollado una guarda de puente que cubre el portacuchillas por delante de la escuadra de forma automática y ejerce una presión constante contra la pieza de trabajo o la escuadra. Esta defensa está disponible desde 1992. Las principales características de diseño de esta nueva guarda, llamada "Suvamatic", son las siguientes:

- completa protección del portacuchillas. Se protege todo el ancho de cepillado con una sola defensa de puente. Puede doblarse utilizando un sistema de bisagras; de este modo se evita que la guarda sobresalga demasiado del frente de la máquina;

- práctico sistema de guía de la pieza de trabajo. El sistema de guía de la pieza de trabajo consiste en un tampón de presión y una guía para la pieza de trabajo. Ambos van montados en la punta de la defensa. Esta última puede inclinarse para guiar la pieza de trabajo, tanto para el allanado como para el canteado;

- aplicación de presión como ayuda de trabajo. Para el canteado, la guarda ejerce presión en la dirección de la escuadra. Después del canteado, cubre automáticamente todo el largo del portacuchillas delante de la escuadra;

- la guarda sube y baja automáticamente. Para el allanado, la guarda es levantada por la guía de la pieza de trabajo. Tras el allanado, baja automáticamente para cubrir el portacuchillas;

- la guarda puede bloquearse en una posición para trabajos de lotes. Para trabajos de lotes, la guarda puede bloquearse en posición vertical justo para adaptarse al espesor de la pieza de trabajo. La defensa volverá automáticamente a esta posición preajustada una vez ejercida la presión descendente;

- sirve para todas las máquinas. Esta defensa puede montarse en todas las máquinas de cepillado superficial y en cepilladoras mecánicas combinadas de superficie y espesor (combinadas cepilladora-fresadora). 


\section{Gepilladoras mecánicas de espesor unilateral}

El bastidor principal de una cepilladora de este tipo aloja el portacuchillas, la mesa de cepillado de espesores y los elementos de alimentación.

Una vez allanada y canteada la pieza de trabajo en una máquina de cepillado superficial, se cepilla al espesor deseado en la cepilladora de espesores. A diferencia de la máquina de cepillado superficial, el portacuchillas de la máquina de cepillado de espesores está situado por encima de la mesa de cepillado y la pieza de trabajo ya no se alimenta a mano sino mecánicamente, por medio de rodillos de avance. Estos rodillos son accionados por un motor independiente (de aproximadamente $1 \mathrm{~kW}$ ) o mediante un reductor de velocidad que recibe la potencia del motor del portacuchillas. Si el accionamiento es independiente, la velocidad de alimentación permanecerá constante, pero si la potencia proviene del motor del portacuchillas, la velocidad de alimentación variará de acuerdo con la velocidad del portacuchillas. Es normal que la velocidad de avance varíe entre 4 y $35 \mathrm{~m} / \mathrm{min}$.

Sobre la superficie superior de la pieza de trabajo descansan dos rodillos de avance montados sobre muelles. El rodillo de avance delante del portacuchillas es ranurado para un mejor agarre de la pieza de trabajo. El rodillo de avance del extremo de salida del portacuchillas es liso. Una barra de presión de entrada y otra de salida situadas junto al portacuchillas ejercen presión sobre la pieza de trabajo encima de la mesa, lo que garantiza un corte limpio y uniforme. El diseño y la disposición de los rodillos de avance y de las barras de presión deben ser tales que sea imposible el contacto con el portacuchillas giratorio.

Los rodillos de avance y las barras de presión por secciones permiten el funcionamiento simultáneo de dos o más piezas de trabajo de espesor ligeramente diferente. Desde el punto de vista de la prevención de accidentes, son esenciales. El ancho de cada sección no deberá ser superior a $50 \mathrm{~mm}$.

En la mesa hay dos rodillos locos, que están diseñados para facilitar el paso de la pieza de trabajo sobre la mesa.

La superficie de la mesa debe ser lisa, sin ranuras ni agujeros. Se han producido accidentes en los que el operario se ha atrapado los dedos entre las aberturas y la pieza de trabajo. El ajuste vertical de la mesa puede ser manual o mecánico. Un tope mecánico debe evitar cualquier contacto de la mesa con el portacuchillas o los rodillos de avance. Hay que asegurarse de que el mecanismo de ajuste vertical mantenga la mesa en una posición estable.

A fin de evitar la alimentación de piezas de trabajo de dimensiones excesivas, se sitúa un mecanismo (p. ej., una barra fija redonda o rectangular) en el lado de entrada de la máquina que limite la altura máxima de las mismas. Rara vez se sobrepasa una altura máxima de $250 \mathrm{~mm}$ entre la superficie de la mesa en su posición más baja y el mecanismo de seguridad antes mencionado. El ancho de trabajo habitual varía entre 315 y $800 \mathrm{~mm}$ (en máquinas especiales, puede alcanzar los $1.300 \mathrm{~mm}$ ).

El diámetro del portacuchillas oscila entre 80 y $160 \mathrm{~mm}$. Normalmente se montan cuatro hojas en el portacuchillas, que gira a velocidades de 4.000 a $6.000 \mathrm{rpm}$ y tiene una potencia de entrada de 4 a $20 \mathrm{~kW}$. La máxima profundidad de corte es de 10 a $12 \mathrm{~mm}$.

Para minimizar el riesgo de retroceso, las cepilladoras de espesores unilaterales deben ir provistos de un mecanismo antirretroceso que abarque todo el ancho de trabajo de la máquina. Dicho mecanismo suele constar de varios elementos acanalados dispuestos sobre una barra. El ancho de cada elemento oscila entre 8 y $15 \mathrm{~mm}$ y cae por su propio peso a la posición de reposo. El punto más bajo del elemento acanalado individual en posición de reposo debe situarse $3 \mathrm{~mm}$ por debajo del círculo de corte del portacuchillas. Los elementos acanalados estarán fabricados en un material (preferiblemente acero) con resistencia a la deformación elástica de $15 \mathrm{~J} / \mathrm{cm}^{2}$ y una dureza superficial de $100 \mathrm{HB}$.

Las siguientes medidas de reducción del ruido han demostrado su utilidad en las cepilladoras mecánicas de espesores unilaterales:

- el uso de un portacuchillas "silencioso" (como el sugerido para las máquinas de cepillado superficial);

- el diseño aerodinámico de las barras de presión y de la campana de extracción de viruta;

- la reducción de la velocidad del portacuchillas;

- el encerramiento parcial o total de la máquina (diseño de las aberturas de entrada y salida con forma de túnel, provisto de material insonorizante en la superficie de cara al foco de ruido);

Con un cerramiento completo bien diseñado puede lograrse una reducción del ruido de hasta $20 \mathrm{dBA}$.

\section{Riesgos}

La principal causa de accidentes de los cepillos mecánicos de espesores unilaterales es el retroceso de la pieza de trabajo. Este suceso puede producirse por:

- un mantenimiento deficiente del mecanismo antirretroceso (los elementos individuales pueden no caer por su propio peso sino pegarse debido a la acumulación de serrín; las ranuras de los elementos pueden cubrirse de resina, embotarse o rectificarse incorrectamente);

- un mantenimiento deficiente de los rodillos de avance y barras de presión por secciones (p. ej., secciones cubiertas de resina u oxidadas);

- carga insuficiente del resorte en los rodillos de avance y barras de presión cuando se alimentan al mismo tiempo varias piezas de espesor no uniforme.

Figura 86.17 - Cepilladora combinada de superficies y espesores /combinada cepilladora-regruesadora.

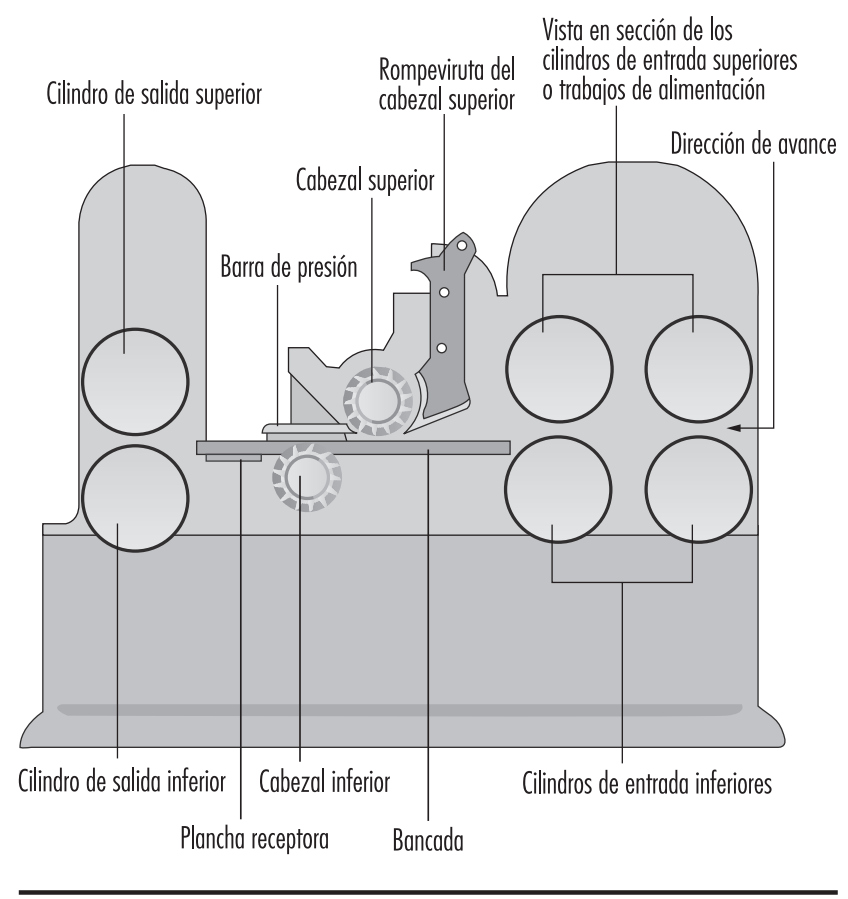


Causas típicas de otros accidentes son:

- el contacto de la mano con el portacuchillas giratorio al retirar viruta y serrín de la mesa con la mano en lugar de utilizar un rastrillo o palo de madera;

- expulsión de las hojas del portacuchillas debido a una fijación incorrecta.

\section{Máquinas combinadas de cepillado de superficies y espesores (combinadas cepilladora-regruesadora)}

El diseño y el funcionamiento de las máquinas combinadas (véase la Figura 86.17) son similares a los de las máquinas antes descritas. Lo mismo puede decirse de la velocidad de avance, la potencia de los motores y el ajuste de mesas y rodillos. Para cepillar espesores, las mesas de cepillado de superficies se retiran, se pliegan o se levantan lateralmente, dejando expuesto el portacuchillas, que se cubre con una campana de extracción de viruta para evitar el acceso. Las máquinas combinadas se utilizan principalmente en pequeños talleres con pocos trabajadores, o cuando el espacio es limitado (es decir, en casos en que no es posible o rentable la instalación de dos máquinas diferentes).

El cambio de una operación a otra suele ser muy laborioso y molesto si sólo hay que mecanizar algunas piezas. Más aún, habitualmente sólo puede usar la máquina una persona cada vez. Sin embargo, desde 1992 se han introducido en el mercado máquinas que permiten el trabajo simultáneo (cepillado de superficies y espesores al mismo tiempo).

Los riesgos de las máquinas combinadas son en gran medida idénticos a los enumerados para las máquinas específicas.

\section{- EFECTOS SOBRE LA SALUd Y PAUTAS PATOLOGICAS}

\section{Leon J. Warshaw}

Los problemas de salud y seguridad registrados en las industrias de aprovechamiento forestal y madereras se analizan en otros capítulos de la presente Enciclopedia. Este artículo trata de la madera que llega de la serrería para ser utilizada en la fabricación de muebles y otros artículos, actividades que realizan principalmente pequeñas empresas. Muchos trabajadores de estas industrias son contratistas autónomos, por lo que no figuran como empleados, y gran número de personas se exponen a riesgos en proyectos de bricolaje y talleres domésticos. Esto significa que muchos trabajadores no están adecuadamente adiestrados, no son supervisados o sólo lo son escasamente, y suelen carecer de defensas y equipos de protección adecuados.

Ahman y cols. (1995a, 1995b, 1996) llaman la atención sobre la exposición de los profesores de artes industriales y carpintería en Suecia. En contraste con los grupos de control no expuestos, sufrían efectos y molestias nasales notables (principalmente reversibles) que aumentaban a medida que se sucedían las clases desde el principio de la semana y remitían en fines de semana, aun cuando las concentraciones de serrín estuvieran por debajo del límite umbral sueco de $2 \mathrm{mg} / \mathrm{m}^{3}$. En varios establecimientos de los Países Bajos, los niveles de serrín sobrepasaban normalmente dicho límite y, durante las operaciones de lijado en una fábrica de muebles, casi todas las exposiciones excedían el límite umbral local de $5 \mathrm{mg} / \mathrm{m}^{3}$ (Scheeper, Kromhout y Boleij 1995).

\section{Lesiones accidentales}

El problema más corriente para la salud en las industrias de la madera y la carpintería es el de las heridas accidentales, que son más frecuentes entre los trabajadores más jóvenes e inexpertos y, en su mayor parte, son relativamente poco importantes. Sin embargo, en ocasiones pueden acarrear deterioros de larga duración o pérdida de extremidades. Cabe citar las lesiones por astillas, que pueden infectarse, y las laceraciones, arañazos y amputaciones resultantes de un uso incorrecto o una protección inadecuada de la maquinaria de carpintería (Ma, Wang y Chou 1991); esguinces y torceduras por levantar pesos imprudentemente o trabajar en posiciones difíciles (Nestor, Bobick y Pizatella 1990); lesiones por movimientos repetitivos que afectan a las manos o los hombros; y lesiones oculares. Muchas de estas lesiones, si no la mayoría, pueden evitarse con una formación adecuada y un uso prudente de las defensas y restricciones de las máquinas, así como con el empleo de equipos de protección personal como guantes y gafas de seguridad. En su caso, han de quitarse inmediatamente las astillas clavadas y prevenir la infección con una rápida limpieza y la aplicación de primeros auxilios a las heridas para minimizar los daños.

\section{Serrín}

La exposición al serrín se produce siempre que se sierra, astilla, cepilla, fresa o lija madera. Los efectos varían dependiendo de la intensidad y duración de la exposición y del tamaño de las partículas. Las partículas en los ojos pueden provocar irritación, y la acumulación de serrín en los pliegues de la piel puede verse agravada por la transpiración y los productos químicos y provocar irritación e infecciones. Estos efectos se reducen aspirando el serrín, utilizando mascarillas y ropa de protección y con buenas prácticas de higiene personal.

\section{Vías nasofaríngeas y respiratorias}

El serrín en las vías nasales puede disminuir la eliminación mucociliar y deteriorar la sensibilidad olfativa (Andersen, Solgaard y Andersen 1976; Ahman y cols. 1996), provocando irritación, estornudos frecuentes, sangrado nasal e infección de los senos nasales (Imbus 1994).

Las exposiciones en una fábrica de muebles (Whitehead, Ashikaga y Vacek 1981) y en serrerías (Hessel y cols. 1995) fueron acompañadas de una disminución en el volumen de espiración forzada en 1 segundo $\left(\mathrm{FEV}_{1}\right)$ y en la capacidad vital forzada (FVG), ajustadas a la edad, la altura y el hábito de fumar. A estos efectos se sumaron incrementos significativos en la falta de aliento y resuello, con sensación de opresión en el pecho, bronquitis y asma. Sin embargo, no hay pruebas convincentes de otras enfermedades pulmonares no cancerosas debidas a la exposición al serrín (Imbus 1994). En un estudio prospectivo de seguimiento realizado durante 6 años con aproximadamente 350.000 varones en los Estados Unidos, los 11.541 individuos que declararon haber estado empleados en ocupaciones relacionadas con la madera tenían un menor riesgo relativo de mortalidad por enfermedades respiratorias no malignas que quienes no declararon haber estado expuestos al serrín (Demers y cols. 1996).

\section{Alergia y asma}

Algunas maderas, especialmente la teca, la mansonia y el pino radiata, contienen productos químicos irritantes (véase en la Tabla 86.1 una larga lista de especies de madera, su origen geográfico y sus efectos sobre la salud). Algunas especies pueden provocar dermatitis alérgica por contacto (p. ej., el abeto Douglas, el cedro rojo occidental, el álamo, el palisandro, la teca, 
la caoba africana y otras maderas "exóticas"). Se ha demostrado que el cedro rojo occidental, el palisandro, la caoba y otras maderas exóticas provocan asma (Imbus 1994).

\section{Cáncer}

Se ha descrito una incidencia inusualmente alta de cáncer nasal entre los trabajadores de carpinterías de Australia, Canadá, Dinamarca, Finlandia, Francia, Italia, Países Bajos, Reino Unido y Estados Unidos (Imbus 1994). Un reciente análisis agrupado de estudios comparativos de 12 grupos humanos en siete países confirmó el alto riesgo de cáncer nasofaríngeo entre los trabajadores de la carpintería (Demers y cols. 1995). La causa de estos excesos de cáncer nasal no se conoce, pero, según informes recientes del Reino Unido y Estados Unidos, el riesgo de cáncer nasal entre los trabajadores de la fabricación de muebles ha disminuido desde la segunda Guerra Mundial, lo que refleja presumiblemente los cambios en el proceso de fabricación (Imbus 1994). No se observó ningún riesgo especial de cáncer sinonasal entre los 45.399 hombres expuestos al serrín incluidos entre los 362.823 inscritos en el estudio de prevención del cáncer de la Sociedad Americana del Cáncer realizado a lo largo de 6 años; según indican los investigadores, el número de casos hallados fue pequeño. Sin embargo, sí se detectó un aumento especialmente alto de la mortalidad por cáncer de pulmón entre los trabajadores de la carpintería que también declararon haber estado expuestos al amianto o al formaldehído, lo que sugiere que la exposición a estos cancerígenos conocidos es la responsable del mayor riesgo observado (Stellman y cols., en prensa).

\section{Exposición a productos químicos}

La madera puede contener contaminantes biológicos. Los hongos y mohos que a menudo se desarrollan en la corteza de los árboles pueden provocar reacciones alérgicas. Se ha demostrado que la inhalación de esporas fúngicas encontradas en el arce, la secoya y los alcornoques causa la enfermedad de la corteza del arce, la secoyosis y la suberosis (Imbus 1994).

La madera suele contener productos químicos exógenos que se aplican durante su transformación. Entre ellos cabe citar: adhesivos, disolventes, aglutinantes resinosos, insecticidas y fungicidas, compuestos impermeabilizantes, pinturas y pigmentos, lacas y barnices. Muchos de ellos son volátiles y pueden ser emitidos durante el tratamiento, calentamiento o incineración de la madera; también se transportan como elementos del serrín. Los más importantes son: tolueno, metanol, xileno, metiletilcetona, alcohol $n$-butílico, 1,1,1-tricloretano y diclorometano (EPA 1995), muchos de los cuales se sabe o se sospecha que son cancerígenos.

\section{Conclusión}

Los riesgos para la salud de las industrias de la madera y la carpintería pueden reducirse con controles técnicos (p. ej., la correcta colocación y protección de la maquinaria, sistemas de ventilación para controlar el serrín y las emisiones químicas) y equipos de protección personal (p. ej., guantes, gafas de seguridad, mascarillas), junto con inspecciones periódicas para garantizar el correcto mantenimiento y uso de los mismos. Tal vez lo más importante sea una formación y un adiestramiento adecuados de los trabajadores y sus supervisores.

\begin{tabular}{|c|c|c|c|}
\hline Nombres científicos & Nombres comerciales & Familia & Perjuicio para la salud \\
\hline Abies alba Mill (A. pectinata D.C.) & Abeto plateado & Pinaceae & Dermatitis; conjuntivitis-rinitis; asma \\
\hline $\begin{array}{l}\text { Acacia spp. } \\
\text { A. harpophylla F. Muell. } \\
\text { A. melanoxylon R. Br. } \\
\text { A. seyal Del. } \\
\text { A. shirley Maiden }\end{array}$ & Acacia australiana & Mimosaceae & $\begin{array}{l}\text { Dermatitis; conjuntivitis-rinitis; asma; efectos } \\
\text { tóxicos }\end{array}$ \\
\hline $\begin{array}{l}\text { Acer spp. } \\
\text { A. platanoides L. }\end{array}$ & Arce & Aceraceae & Dermatitis \\
\hline $\begin{array}{l}\text { Afrormosia elata Harms. } \\
\text { (Pericopsis elata Van Meeuwen) }\end{array}$ & $\begin{array}{l}\text { Afrormosia, kokrodua, asamala, obang, óleo } \\
\text { pardo, bohele, mohole }\end{array}$ & Papilionaceae & Dermatitis; conjuntivitis-rinitis; asma \\
\hline $\begin{array}{l}\text { Afzelia africana Smith } \\
\text { A. bijuga A. Chev. (Intsia bijuga A. Cunn.) } \\
\text { A. palembanica Bak. (Intsia palembanica Bak.) }\end{array}$ & $\begin{array}{l}\text { Doussié, tíndalo, aligua, apa, } \\
\text { chanfuta, lingue merbav, intsia, hintsy }\end{array}$ & Caesalpinaceae & Dermatitis; conjuntivitis-rinitis; asma \\
\hline Agonandra brasiliensis Miers & Pao, marfil, granadillo & Olacaceae & Dermatitis \\
\hline Ailanthus altissima Mill & Sumach chino & Simaroubaceae & Dermatitis \\
\hline $\begin{array}{l}\text { Albizzia falcata Backer } \\
\text { A. ferruginea Benth. } \\
\text { A. lebbek Benth. } \\
\text { A. toona F.M. Bail }\end{array}$ & $\begin{array}{l}\text { latandza } \\
\text { Kokko, siris }\end{array}$ & Mimosaceae & $\begin{array}{l}\text { Dermatitis; conjuntivitis-rinitis; asma; } \\
\text { efectos tóxicos }\end{array}$ \\
\hline $\begin{array}{l}\text { Alnus spp. } \\
\text { A. glutinosa Gaertn. }\end{array}$ & Aliso común, aliso negro & Betulaceae & Dermatitis; conjuntivitis-rinitis; asma \\
\hline $\begin{array}{l}\text { Amyris spp. } \\
\text { A. balsamifera } \mathrm{L} \text {. } \\
\text { A. toxifera Willd. }\end{array}$ & Sándalo venezolano o de las Indias Occident. & Rutaceae & Dermatitis; efectos tóxicos \\
\hline $\begin{array}{l}\text { Anacardium occidentale L. } \\
\text { A. excelsum Skels. }\end{array}$ & Anacardo & Anacardiaceae & Dermatitis \\
\hline
\end{tabular}




\begin{tabular}{|c|c|c|c|}
\hline Nombres científicos & Nombres comerciales & Familia & Periuicio para la salud \\
\hline $\begin{array}{l}\text { Andira araroba Aguiar. (Vataireopsis araroba Ducke) } \\
\text { A. coriacea Pulle } \\
\text { A. inermis H.B.K. }\end{array}$ & Madera de perdiz & Papilionaceae & Dermatitis; conjuntivitis-rinitis; asma \\
\hline $\begin{array}{l}\text { Aningeria spp. } \\
\text { A. robusta Aubr. y Pell. }\end{array}$ & Aningeria & Sapotaceae & Conjuntivitis-rinitis; asma \\
\hline $\begin{array}{l}\text { A. altissima Aubr. y Pell. } \\
\text { Antiaris africana Engl. } \\
\text { A. welwitschi Engl. }\end{array}$ & Alco, ako, chenechén & Moraceae & Efectos tóxicos \\
\hline $\begin{array}{l}\text { Apuleia molaris spruce (A. leiocarpa MacBride) } \\
\text { (A. ferrea Mart.) }\end{array}$ & Secoya & Caesalpinaceae & Dermatitis; efectos tóxicos \\
\hline $\begin{array}{l}\text { Araucaria angustifolia 0. Ktze } \\
\text { A. brasiliana A. Rich. }\end{array}$ & Pino del paraná, araucaria & Araucariaceae & Efectos tóxicos \\
\hline $\begin{array}{l}\text { Aspidosperma spp. } \\
\text { A. peroba Fr. All. }\end{array}$ & Peroba rosa & Apocynaceae & $\begin{array}{l}\text { Dermatitis; conjuntivitis- } \\
\text { rinitis; asma; efectos tóxicos }\end{array}$ \\
\hline A. vargasii A. DC. & $\begin{array}{l}\text { Palo marfil, palo amarillo, pequia marfil, } \\
\text { guatambú, amarilla, pequia }\end{array}$ & & \\
\hline Astrocaryum spp. & Palmera & Palmaceae & Dermatitis; efectos tóxicos \\
\hline Aucoumea klaineana Pierre & Caoba del Gabón & Burseraceae & $\begin{array}{l}\text { Dermatitis; conjuntivitis-rinitis; asma; alveo- } \\
\text { litis extrínseca alérgica }\end{array}$ \\
\hline $\begin{array}{l}\text { Autranella congolensis } \\
\text { A. Chev. (Mimusops congolensis De Wild.) }\end{array}$ & Mukulungu, autracón, elang, bovanga, kulungu & Sapotaceae & Dermatitis \\
\hline Bactris spp. (Astrocaryum spp.) & Palmera & Palmaceae & Dermatitis; efectos tóxicos \\
\hline Balfourodendron riedelianum Engl. & Guatambú, gutambú blanco & Rutaceae & Dermatitis \\
\hline Batesia floribunda Benth. & Acapú rana & Caesalpinaceae & Efectos tóxicos \\
\hline Berberis vulgaris $\mathrm{L}$. & Bérbero & Berberidaceae & Efectos tóxicos \\
\hline $\begin{array}{l}\text { Betula spp. } \\
\text { B. alba L. (B. pendula Roth.) }\end{array}$ & Abedul & Betulaceae & Dermatitis \\
\hline Blepharocarva involucrigera F. Muell. & Nogal ceniciento rosa & Anacardiaceae & Dermatitis; conjuntivitis-rinitis; asma; \\
\hline $\begin{array}{l}\text { Bombax brevicuspe Sprague } \\
\text { B. chevalieri Pell }\end{array}$ & Kondroti, alone & Bombacaceae & Dermatitis \\
\hline $\begin{array}{l}\text { Bowdichia spp. } \\
\text { B. nitida Benth. } \\
\text { B. guianensis Ducke (Diplotropis guianensis Benth.) } \\
\text { (Diplotropis purpurea Amsh.) }\end{array}$ & Sucupira negra & Papilionaceae & Dermatitis \\
\hline Brachylaena hutchinsii Hutch. & Muhuhu & Compositae & Dermatitis \\
\hline Breonia spp. & Molompangady & Rubiaceae & Dermatitis \\
\hline $\begin{array}{l}\text { Brosimum spp. } \\
\text { B. guianense Hub. (Piratinera guianensis Aubl.) }\end{array}$ & Snakewood, letterwood, tigerwood & Moraceae & $\begin{array}{l}\text { Dermatitis; conjuntivitis-rinitis; asma; efectos } \\
\text { tóxicos }\end{array}$ \\
\hline $\begin{array}{l}\text { Brya ebenus DC. (Amerimnum ebenus Sw.) } \\
\text { Brya buxifolia Urb. }\end{array}$ & $\begin{array}{l}\text { Ebano marrón, ébano verde, ébano jamai- } \\
\text { cano, Ebano americano tropical }\end{array}$ & Papilionaceae & Dermatitis \\
\hline $\begin{array}{l}\text { Buxus sempervirens } \mathrm{L} \text {. } \\
\text { B. macowani Oliv. }\end{array}$ & Bojeuropeo, b. del Este de Londres, b. de ElCabo & Buxaceae & $\begin{array}{l}\text { Dermatitis; conjuntivitis-rinitis; asma; efectos } \\
\text { tóxicos }\end{array}$ \\
\hline $\begin{array}{l}\text { Caesalpinia echinata Lam. (Guilandina echinata } \\
\text { Spreng.) }\end{array}$ & Madera de Brasil & Caesalpinaceae & Dermatitis; efectos tóxicos \\
\hline Callitris columellaris F. Muell. & Pino ciprés blanco & Cupressaceae & Dermatitis; conjuntivitis-rinitis; asma \\
\hline $\begin{array}{l}\text { Calophyllum spp. } \\
\text { C. brasiliense Camb. }\end{array}$ & Santamaría, jacareuba, kurahura, galba & Guttiferae & Dermatitis; efectos tóxicos \\
\hline Campsiandra laurifolia Benth. & Acapú rana & Caesalpinaceae & Efectos tóxicos \\
\hline Carpinus betulus & Carpe & Betulaceae & Dermatitis \\
\hline Cassia siamea Lamk. & Tagayasán, muong ten, djohar & Caesalpinaceae & Dermatitis; conjuntivitis-rinitis; asma \\
\hline $\begin{array}{l}\text { Castanea dentata Borkh } \\
\text { C. sativa Mill. }\end{array}$ & Castaño, castaño dulce & Fagaceae & Dermatitis; conjuntivitis-rinitis; asma \\
\hline
\end{tabular}


Tabla 86.1 • Variedades de maderas tóxicas, alérgicas y biológicamente activas. Continuación.

\begin{tabular}{|c|c|c|c|}
\hline Nombres científicos & Nombres comerciales & Familia & Perjuicio para la salud \\
\hline Castanospermum australe A. Cunn. & $\begin{array}{l}\text { Castaño negro, castaño australiano o de } \\
\text { Moreton Bay }\end{array}$ & Papilionaceae & Dermatitis \\
\hline Cedrela spp. (Toona spp.) & Cedro rojo, cedro australiano & Meliaceae & Dermatitis; conjuntivitis-rinitis; asma \\
\hline $\begin{array}{l}\text { Cedrus deodara (Roxb. ex. Lamb.) G. Don } \\
\text { (C. libani Barrel. Ic) }\end{array}$ & Cedro deodara & Pinaceae & Dermatitis; conjuntivitis-rinitis; asma \\
\hline $\begin{array}{l}\text { Celtis brieyi De Wild. } \\
\text { C. cinnamomea Ldl. }\end{array}$ & $\begin{array}{l}\text { Arbol de Diana } \\
\text { Gurenda }\end{array}$ & Ulmaceae & Dermatitis \\
\hline $\begin{array}{l}\text { Chlorophora excelsa Benth. y Hook I. } \\
\text { C. regia A. Chev. } \\
\text { C. tinctoria (L.) Daub. }\end{array}$ & $\begin{array}{l}\text { Iroko, gelbholz, palo de Cuba, kambala, } \\
\text { muule, odum, moule, teca africana, abang, } \\
\text { tatajuba, palo naranjo, mora }\end{array}$ & Moraceae & $\begin{array}{l}\text { Dermatitis; conjuntivitis-rinitis; asma; alveo- } \\
\text { litis alérgica extrínseca }\end{array}$ \\
\hline $\begin{array}{l}\text { Chloroxylon spp. } \\
\text { C. swietenia A.DC. }\end{array}$ & Caoba de Ceilán & Rutaceae & Dermatitis; efectos tóxicos \\
\hline Chrysophyllum spp. & Najara & Sapotaceae & Dermatitis \\
\hline Cinnamomum camphora Nees y Ebeim & Madera de alcanfor asiática, canelo & Lauraceae & Efectos tóxicos \\
\hline Cryptocarya pleurosperma White y Francis & Nogal venenoso & Lauraceae & $\begin{array}{l}\text { Dermatitis; conjuntivitis-rinitis; asma; efectos } \\
\text { tóxicos }\end{array}$ \\
\hline Dacrycarpus dacryoides (A. Rich.) de Laub. & Pino blanco de Nueva Zelanda & Podocarpaceae & Dermatitis; conjuntivitis-rinitis; asma \\
\hline Dacrydium cupressinum Soland & Sempilor, rimu & Podocarpaceae & Conjuntivitis-rinitis; asma \\
\hline Dactylocladus stenostachys Oliv. & Jongkong, marebong, medang tabak & Melastomaceae & Efectos tóxicos \\
\hline $\begin{array}{l}\text { Dalbergia spp. } \\
\text { D. amerimnon Benth. } \\
\text { D. granadillo Pitt. } \\
\text { D. hypoleuca Standl. } \\
\text { D. latifolia Roxb. } \\
\text { D. melanoxylon Guill. y Perr. } \\
\text { D. nigra Fr. All. } \\
\text { D. oliveri Gamble } \\
\text { D. retusa Hemsl. } \\
\text { D. sissoo Roxb. } \\
\text { D. stevensonii Standl. }\end{array}$ & $\begin{array}{l}\text { Ebano } \\
\text { Red foxwood } \\
\text { Palisandro indio, acacia de Bombay, } \\
\text { acacia africana, palisandro, } \\
\text { riopalisandro, palisandro brasileño, } \\
\text { jacarandá } \\
\text { Palisandro birmano } \\
\text { Red foxwood } \\
\text { Nagaed wood, palisandro hondureño }\end{array}$ & Papilionaceae & $\begin{array}{l}\text { Dermatitis; conjuntivitis-rinitis; asma; } \\
\text { efectos tóxicos }\end{array}$ \\
\hline $\begin{array}{l}\text { Dialium spp. } \\
\text { D. dinklangeri Harms. }\end{array}$ & Eyoum, eyum & Caesalpinaceae & Dermatitis; conjuntivitis-rinitis; asma \\
\hline $\begin{array}{l}\text { Diospyros spp. } \\
\text { D. celebica Bakh. } \\
\text { D. crassiflora Hiern } \\
\text { D. ebenum Koenig }\end{array}$ & $\begin{array}{l}\text { Ebano, ébano africano } \\
\text { Ebano de Macassar, ébano africano, } \\
\text { Ebano de Ceilán }\end{array}$ & Ebenaceae & $\begin{array}{l}\text { Dermatitis; conjuntivitis-rinitis; asma; efectos } \\
\text { tóxicos }\end{array}$ \\
\hline $\begin{array}{l}\text { Dipterocarpus spp. } \\
\text { D. alatus Roxb. }\end{array}$ & Keruing, gurium, yang, keruing & Dipterocarpaceae & Dermatitis \\
\hline Distemonanthus benthamianus Baill. & Moringui, ayán, anyarán, caoba nigeriana & Caesalpinaceae & Dermatitis \\
\hline $\begin{array}{l}\text { Dysoxylum spp. } \\
\text { D. fraseranum Benth. } \\
\text { D. muelleri Benth. }\end{array}$ & $\begin{array}{l}\text { Caoba, stavewood, red bean } \\
\text { Caoba rosa }\end{array}$ & Meliaceae & $\begin{array}{l}\text { Dermatitis; conjuntivitis-rinitis; asma; efectos } \\
\text { tóxicos }\end{array}$ \\
\hline $\begin{array}{l}\text { Echirospermum balthazarii Fr. All. (Plathymenia reti- } \\
\text { culata Benth.) }\end{array}$ & Amarillo & Mimosaceae & Dermatitis; conjuntivitis-rinitis; asma \\
\hline $\begin{array}{l}\text { Entandophragma spp. } \\
\text { E. angolense C.D.C. } \\
\text { E. candollei Harms. } \\
\text { E. cylindricum Sprague } \\
\text { E. utile Sprague }\end{array}$ & $\begin{array}{l}\text { Tiama } \\
\text { Kosipo, omo } \\
\text { Sapelli, sapele, aboudikro } \\
\text { Sipo, utile, assié, } \\
\text { Kalungi, mufumbi }\end{array}$ & Meliaceae & Dermatitis; alveolitis alérgica extrínseca \\
\hline $\begin{array}{l}\text { Erythrophloeum guineense G. Don } \\
\text { E. ivorense A. Chev. }\end{array}$ & $\begin{array}{l}\text { Tali, misandra, eloun, masandra, sasswood, } \\
\text { erun, redwater tree }\end{array}$ & Caesalpinaceae & $\begin{array}{l}\text { Dermatitis; conjuntivitis-rinitis; asma; efectos } \\
\text { tóxicos }\end{array}$ \\
\hline Esenbeckia leiocarpa Engl. & Guaranta & Rutaceae & Dermatitis \\
\hline
\end{tabular}


Tabla 86.1 • Variedades de maderas tóxicas, alérgicas y biológicamente activas. Continuación.

\begin{tabular}{|c|c|c|c|}
\hline Nombres científicos & Nombres comerciales & Familia & Perjuicio para la salud \\
\hline $\begin{array}{l}\text { Eucalyptus spp. } \\
\text { E. delegatensis R.T. Back } \\
\text { E. hemiphloia F. Muell. } \\
\text { E. leucoxylon Maiden } \\
\text { E. maculata Hook. } \\
\text { E. marginata Donn ex Sm. } \\
\text { E. microtheca F. Muell. } \\
\text { E. obliqua L. Herit. } \\
\text { E. regnans F. Muell. } \\
\text { E. saligna Sm. }\end{array}$ & $\begin{array}{l}\text { Fresno alpino } \\
\text { Boi gris } \\
\text { Goma amarilla } \\
\text { Goma moteada }\end{array}$ & Myrtaceae & Dermatitis; conjuntivitis-rinitis; asma \\
\hline Euxylophora paraensis Hub. & Boi & Rutaceae & Dermatitis; conjuntivitis-rinitis; asma \\
\hline $\begin{array}{l}\text { Excoecaria africana M. Arg. (Spirostachys africana } \\
\text { Sand) } \\
\text { E. agallocha L. }\end{array}$ & $\begin{array}{l}\text { Sándalo africano, tabootie, geor, madera de } \\
\text { aloe, blind-your-eye }\end{array}$ & Euphorbiaceae & $\begin{array}{l}\text { Dermatitis; conjuntivitis-rinitis; asma; efectos } \\
\text { tóxicos }\end{array}$ \\
\hline $\begin{array}{l}\text { Fagara spp. } \\
\text { F. flava Krug y Urb. (Zanthoxylum flavum Vahl.) } \\
\text { F. heitzii Aubr. y Pell. } \\
\text { F. macrophylla Engl. }\end{array}$ & $\begin{array}{l}\text { Espinillo, caoba de las Indias Occidentales, } \\
\text { atlaswood, olon, bongo, mbanza }\end{array}$ & Rutaceae & $\begin{array}{l}\text { Dermatitis; conjuntivitis-rinitis; asma; efectos } \\
\text { tóxicos }\end{array}$ \\
\hline $\begin{array}{l}\text { Fagus spp. (Nothofagus spp.) } \\
\text { F. sylvatica L. }\end{array}$ & Haya & Fagaceae & Dermatitis; conjuntivitis-rinitis; asma \\
\hline $\begin{array}{l}\text { Fitzroya cupressoides (Molina) Johnston } \\
\text { (F. patagonica Hook. f.) }\end{array}$ & Alerce & Cupressaceae & Dermatitis \\
\hline $\begin{array}{l}\text { Flindersia australis R. Br. } \\
\text { F. brayleyana F. Muell. } \\
\text { F. pimenteliana F. Muell. }\end{array}$ & $\begin{array}{l}\text { Teca australiana, arce de Queensland, arce } \\
\text { silkwood, arce australiano }\end{array}$ & Rutaceae & Dermatitis \\
\hline $\begin{array}{l}\text { Fraxinus spp. } \\
\text { F. excelsior L. }\end{array}$ & Fresno & Oleaceae & Dermatitis \\
\hline $\begin{array}{l}\text { Gluta spp. } \\
\text { G. rhengas L. (Melanorrhoea spp.) } \\
\text { M. curtisii Pierre } \\
\text { M. laccifera wallichii Hook. }\end{array}$ & $\begin{array}{l}\text { Rengas, gluta } \\
\text { Rengawood } \\
\text { Rhengas }\end{array}$ & Anacardiaceae & Dermatitis; efectos tóxicos \\
\hline Gonioma kamassi E. Mey. & Boi de Knysna, kamassi & Apocynaceae & $\begin{array}{l}\text { Dermatitis; conjuntivitis-rinitis; asma; efectos } \\
\text { tóxicos }\end{array}$ \\
\hline Gonystylus bancanus Baill. & Ramin, melawis, akenia & Gonystylaceae & $\begin{array}{l}\text { Dermatitis; conjuntivitis-rinitis; asma; alveo- } \\
\text { litis alérgica extrínseca }\end{array}$ \\
\hline Gossweilerodendron balsamiferum (Verm.) Harms. & Cedro nigeriano & Caesalpinaceae & Dermatitis; conjuntivitis-rinitis; asma \\
\hline Grevillea robusta A. Cunn. & Roble australiano & Proteaceae & Dermatitis \\
\hline Guaiacum officinale L. & Gaiac, guayacán & Zygophyllaceae & Dermatitis; conjuntivitis-rinitis; asma \\
\hline $\begin{array}{l}\text { Guarea spp. } \\
\text { G. cedrata Pell. } \\
\text { G. laurentii De Wild. } \\
\text { G. thompsonii Sprague }\end{array}$ & $\begin{array}{l}\text { Bossé } \\
\text { Peral nigeriano, caoba de cedro } \\
\text { Guarea aromática } \\
\text { Guarea negra }\end{array}$ & Meliaceae & $\begin{array}{l}\text { Dermatitis; conjuntivitis-rinitis; asma; efectos } \\
\text { tóxicos }\end{array}$ \\
\hline $\begin{array}{l}\text { Halfordia scleroxyla F. Muell. } \\
\text { H. papuana Lauterb. }\end{array}$ & Corazón de azafrán & Polygonaceae & Dermatitis; alveolitis alérgica extrínseca \\
\hline $\begin{array}{l}\text { Hernandia spp. } \\
\text { H. sonora L. (H. guianensis Aubl.) }\end{array}$ & Mirobolan, topolite & Hernandiaceae & Dermatitis \\
\hline Hippomane mancinella $\mathrm{L}$. & Manzana de playa & Euphorbiaceae & $\begin{array}{l}\text { Dermatitis; conjuntivitis-rinitis; asma; efectos } \\
\text { tóxicos }\end{array}$ \\
\hline $\begin{array}{l}\text { Illipe latifolia F. Muell. } \\
\text { I. longifolia F. Muell. (Bassia latifolia Roxb.) (B. } \\
\text { longifolia Roxb.) }\end{array}$ & Moak, teca edel & Sapotaceae & Dermatitis \\
\hline $\begin{array}{l}\text { Jacaranda spp. } \\
\text { J. brasiliana Pers. Syn. (Bignonia brasiliana Lam.) } \\
\text { J. coerulea (I.) Gris. }\end{array}$ & $\begin{array}{l}\text { Jacarandá } \\
\text { Caroba, boj }\end{array}$ & Bignoniaceae & Dermatitis \\
\hline
\end{tabular}


Tabla 86.1 • Variedades de maderas tóxicas, alérgicas y biológicamente activas.

Continuación.

Nombres científicos
Juglans spp.
J. nigra L.
J. regia L.
Juniperus sabina L.
J. phoenicea L.
J. virginiana L.
Khaya antotheca C. DC.
K. ivorensis A. Chev.
K. senegalensis A. Juss.

Laburnum anagyroides Medic. (Cytisus laburnum L.) L. vulgare Gris

Larix spp.

L. decidua Mill.

L. europea D.C.

Liquidambar styracifolia L.

Liriodendron tulipifera L.

Lovoa trichilioides Harms. (L. klaineana Pierre)

Lucuma spp. (Pouteria spp.)
L. procera
Maba ebenus Wight.
Machaerium pedicellatum Vog.
M. scleroxylon Tul.
M. violaceum Vog.
Mansonia altissima A. Chev.
Melanoxylon brauna Schott
Microberlinia brazzavillensis A. Chev.
M. bisulcata A. Chev.
Millettia laurentii De Wild.
M. stuhlmannii Taub.
Mimusops spp. (Manilkara spp.)
Mimusops spp. (Dumoria spp.) (Tieghemella spp.)
M. congolensis De Wild. (Autranella congolensis A.
Chev.)
M. djave Engl. (Baillonella toxisperma Pierre)
M. heckelii Hutch. y Dalz. (Tieghemella heckelii
Pierre) (Dumoria heckelii A. Chev.)
Mitragyna ciliata Aubr. y Pell.
M. stipulosa O. Ktze
Nauclea diderrichii Merrill (Sarcocephalus diderrichii
De Wild.)
Nauclea trillessi Merrill
Nesogordonia papaverifera R. Capuron
Ocotea spp.
O. bullata E. Mey
0. porosa L. Barr. (Phoebe porosa Mez.)
O. rodiaei Mez. (Nectandra rodiaei Schomb.)
0. rubra Mez.
O. usambarensis Engl.
Paratecoma spp.
P. alba
P. peroba Kuhlm.

$\begin{array}{ll}\text { Nombres comerciales } & \text { Familia } \\ \text { Nogal } & \text { Juglandaceae }\end{array}$

Cupressaceae

Cedro virginiano, cedro rojo oriental

Ogwango, caoba africana, krala

Caoba de zona seca

Laburno

Alerce

Alerce europeo

Amberbaum, satin-nussbaum

Alamo americano, tulípero

Dibetu, nogal africano, apopo, tigerwood, side

Guapeba, abiurana

massaranduba

Makassar-ebenholz

Jacarandá violeta

Nogal nigeriano

Brauna, grauno

Roble gateado africano

Wengé

Panga-panga

Muirapiranga

Makoré

Mukulungu, autracón

Moabi

Caoba cerezo

Vuku, álamo africano

Abura

Bilinga, opepe, kussia, badi, boj de Africa Occidental

Kotibé, danta, epro, otutu, ovové, aborbora Ocotea

Laurel, nogal brasileño

Greenheart

Louro vermelho

Alcanfor de Africa Oriental

Peroba blanca brasileña

Peroba blanca

Sapotacede

Rubiaceae

Rubiaceae

Tiliaceae

Lauraceae

Bignoniaceae

\section{Perjuicio para la salud}

Dermatitis; conjuntivitis-rinitis; asma

Dermatitis; conjuntivitis-rinitis; asma; efectos tóxicos

Meliaceae Dermatitis; alveolitis alérgica extrínseca

Papilionaceae Dermatitis; conjuntivitis-rinitis; asma; efectos tóxicos

Pinaceae Dermatitis; conjuntivitis-rinitis; asma

$\begin{array}{ll}\text { Hamamelidaceae } & \text { Dermatitis } \\ \text { Magnoliaceae } & \text { Dermatitis } \\ \text { Meliaceae } & \text { Dermatitis; conjuntivitis-rinitis; asma; efectos } \\ & \text { tóxicos } \\ \text { Sapotaceae } & \text { Dermatitis; conjuntivitis-rinitis; asma } \\ & \\ \text { Ebenaceae } & \text { Dermatitis } \\ \text { Papilionaceae } & \text { Dermatitis }\end{array}$

Sterculiaceae Dermatitis; conjuntivitis-rinitis; asma; efectos tóxicos

Caesalpinaceae Dermatitis

Caesalpinaceae Dermatitis; conjuntivitis-rinitis; asma; efectos tóxicos

Papilionaceae Dermatitis; conjuntivitis-rinitis; asma; efectos tóxicos

Dermatitis; conjuntivitis-rinitis; asma; alveolitis alérgica extrínseca; efectos tóxicos
Dermatitis; conjuntivitis-rinitis; asma; efectos tóxicos

Dermatitis; conjuntivitis-rinitis; asma; efectos tóxicos

Efectos tóxicos

Dermatitis; conjuntivitis-rinitis; asma; efectos tóxicos

Dermatitis; conjuntivitis-rinitis; asma; efectos tóxicos 
Tabla 86.1 - Variedades de maderas tóxicas, alérgicas y biológicamente activas. Continuación.

\begin{tabular}{|c|c|c|c|}
\hline Nombres científicos & Nombres comerciales & Familia & Perjuicio para la salud \\
\hline $\begin{array}{l}\text { Parinarium spp. } \\
\text { P. guianense (Parinari spp.) (Brosimum spp.) } \\
\text { P. variegatum }\end{array}$ & $\begin{array}{l}\text { Guyana-satinholz } \\
\text { Antillen-satinholz }\end{array}$ & Rosaceae & Dermatitis \\
\hline $\begin{array}{l}\text { Peltogyne spp. } \\
\text { P. densiflora abeto }\end{array}$ & Abeto azul, amaranto & Caesalpinaceae & Efectos tóxicos \\
\hline Phyllanthus ferdinandi F.v.M. & Palo santo, Guayacán, chow way, tow war & Euphorbiaceae & Dermatitis; conjuntivitis-rinitis; asma \\
\hline $\begin{array}{l}\text { Picea spp. } \\
\text { P. abies Karst. } \\
\text { P. excelsa Link. } \\
\text { P. mariana B.S.P. } \\
\text { P. polita Carr. }\end{array}$ & Abeto europeo, whitewood & Pinaceae & $\begin{array}{l}\text { Dermatitis; coniuntivitis-rinitis; asma; } \\
\text { alveolitis alérgica extrínseca }\end{array}$ \\
\hline $\begin{array}{l}\text { Pinus spp. } \\
\text { P. radiata D. Don }\end{array}$ & Pino & Pinaceae & Dermatitis; conjuntivitis-rinitis; asma \\
\hline $\begin{array}{l}\text { Piptadenia africana Hook } \mathrm{f} . \\
\text { Piptadeniastrum africanum Brenan }\end{array}$ & $\begin{array}{l}\text { Dabema, dahoma, ekhimi } \\
\text { agobin, mpewere, bukundu }\end{array}$ & Mimosaceae & Dermatitis; conjuntivitis-rinitis; asma \\
\hline Platanus spp. & Plátano & Platanaceae & Dermatitis \\
\hline $\begin{array}{l}\text { Pometia spp. } \\
\text { P. pinnata Forst. }\end{array}$ & $\begin{array}{l}\text { Taun } \\
\text { Kasai }\end{array}$ & Sapindaceae & Dermatitis; conjuntivitis-rinitis; asma \\
\hline Populus spp. & Alamo & Salicaceae & Dermatitis; conjuntivitis-rinitis; asma \\
\hline Prosopis juliflora D.C. & Anacardo & Mimosaceae & Dermatitis \\
\hline $\begin{array}{l}\text { Prunus spp. } \\
\text { P. serotina Ehrl. }\end{array}$ & $\begin{array}{l}\text { Cerezo } \\
\text { Cerezo negro }\end{array}$ & Rosaceae & Dermatitis; conjuntivitis-rinitis; asma \\
\hline Pseudomorus brunoniana Bureau & White handlewood & Moraceae & Dermatitis; efectos tóxicos \\
\hline Pseudotsuga douglasii Carr. (P. menziesii Franco) & Abeto Douglas, abeto rojo, abeto Douglas & Pinaceae & Dermatitis; conjuntivitis-rinitis; asma \\
\hline $\begin{array}{l}\text { Pterocarpus spp. } \\
\text { P. angolensis D.C. } \\
\text { P. indicus Willd. } \\
\text { P. santalinus L.f. (Vatairea guianensis Aubl.) }\end{array}$ & $\begin{array}{l}\text { Padauk africano, palisandro de Nueva Guinea, } \\
\text { sándalo rojo, palisandro rojo, madera de } \\
\text { cuasia }\end{array}$ & Papilionaceae & $\begin{array}{l}\text { Dermatitis; conjuntivitis-rinitis; asma; efectos } \\
\text { tóxicos }\end{array}$ \\
\hline Pycnanthus angolensis Warb. (P. kombo Warb.) & Nlomba & Myristicaceae & Efectos tóxicos \\
\hline Quercus spp. & Roble & Fagaceae & Dermatitis; conjuntivitis-rinitis; asma \\
\hline $\begin{array}{l}\text { Raputia alba Engl. } \\
\text { R. magnifica Engl. }\end{array}$ & Arapoca blanca, arapoca & Rutaceae & Dermatitis \\
\hline Rauwolfia pentaphylla Stapf. 0. & Peroba & Apocynaceae & $\begin{array}{l}\text { Dermatitis; conjuntivitis-rinitis; asma; efectos } \\
\text { tóxicos }\end{array}$ \\
\hline $\begin{array}{l}\text { Sandoricum spp. } \\
\text { S. indicum Cav. }\end{array}$ & Sentul, katon, kraton, ketjapi, thitto & Meliaceae & $\begin{array}{l}\text { Dermatitis; conjuntivitis-rinitis; asma; efectos } \\
\text { tóxicos }\end{array}$ \\
\hline $\begin{array}{l}\text { Schinopsis lorentzii Engl. } \\
\text { S. balansae Engl. }\end{array}$ & $\begin{array}{l}\text { Quebracho colorado, q. rojo, San Juan, palo } \\
\text { mulato }\end{array}$ & Anacardiaceae & Dermatitis; efectos tóxicos \\
\hline $\begin{array}{l}\text { Semercarpus australiensis Engl. } \\
\text { S. anacardium L. }\end{array}$ & Marking nut & Anacardiaceae & Dermatitis; efectos tóxicos \\
\hline Sequoia sempervirens Endl. & Secoya, secoya californiana & Taxodiaceae & $\begin{array}{l}\text { Dermatitis; conjuntivitis-rinitis; asma; efectos } \\
\text { tóxicos }\end{array}$ \\
\hline Shorea spp. & $\begin{array}{l}\text { Alan, almon, balau rojo, white heavy, lavan } \\
\text { rojo, I. blanco, I. amarillo, mayapis, } \\
\text { meranti bakau, m. rojo oscuro, m. rojo } \\
\text { claro, m. rojo, m. blanco, m. amarillo, } \\
\text { seraya roja, seraya blanca }\end{array}$ & Dipterocarpaceae & Dermatitis \\
\hline S. assamica Dyer & Lavan amarillo, meranti blanco & & \\
\hline Staudtia stipitata Warb. (S. gabonensis Warb.) & Niové & Myristicaceae & Dermatitis \\
\hline $\begin{array}{l}\text { Swietenia spp. } \\
\text { S. macrophylla King } \\
\text { S. mahogany Jacq. }\end{array}$ & $\begin{array}{l}\text { Caoba, caoba de Honduras, caoba tabasco, } \\
\text { baywood, caoba americana, } \\
\text { caoba cubana }\end{array}$ & Meliaceae & $\begin{array}{l}\text { Dermatitis; conjuntivitis-rinitis; asma; alveo- } \\
\text { litis alérgica extrínseca; efectos tóxicos }\end{array}$ \\
\hline $\begin{array}{l}\text { Swintonia spicifera Hook. } \\
\text { S. floribunda Griff. }\end{array}$ & Merpauh & Anacardiaceae & Dermatitis \\
\hline
\end{tabular}


Tabla 86.1 • Variedades de maderas tóxicas, alérgicas y biológicamente activas. Continuación.

\begin{tabular}{|c|c|c|c|}
\hline Nombres científicos & Nombres comerciales & Familia & Perjuicio para la salud \\
\hline $\begin{array}{l}\text { Tabebuia spp. } \\
\text { T. ipe Standl. (T. avellanedae Lor. ex Gris.) } \\
\text { T. guayacan Hensl. (T. lapacho K. Schum) }\end{array}$ & Araguan, ipé preto, lapacho & Bignoniaceae & $\begin{array}{l}\text { Dermatitis; conjuntivitis-rinitis; asma; efectos } \\
\text { tóxicos }\end{array}$ \\
\hline Taxus baccata $\mathrm{L}$. & Tejo & Taxaceae & $\begin{array}{l}\text { Dermatitis; conjuntivitis-rinitis; asma; alveo- } \\
\text { litis alérgica extrínseca; efectos tóxicos }\end{array}$ \\
\hline $\begin{array}{l}\text { Tecoma spp. } \\
\text { T. araliacea D.C. } \\
\text { T. lapacho }\end{array}$ & $\begin{array}{l}\text { Green heart } \\
\text { Lapacho }\end{array}$ & Bignoniaceae & $\begin{array}{l}\text { Dermatitis; conjuntivitis-rinitis; asma; efectos } \\
\text { tóxicos }\end{array}$ \\
\hline Tectona grandis L. & Teca, djati, kyun, teck & Verbenaceae & $\begin{array}{l}\text { Dermatitis; conjuntivitis-rinitis; asma; alveo- } \\
\text { litis alérgica extrínseca }\end{array}$ \\
\hline $\begin{array}{l}\text { Terminalia alata Roth. } \\
\text { T. superba Engl. y Diels. }\end{array}$ & $\begin{array}{l}\text { Laurel indio } \\
\text { limba, afara, ofram, fraké, korina, akom }\end{array}$ & Combretaceae & Dermatitis; conjuntivitis-rinitis; asma \\
\hline $\begin{array}{l}\text { Thuja occidentalis L. } \\
\text { T. plicata D. Don } \\
\text { T. standishii Carr. }\end{array}$ & $\begin{array}{l}\text { Cedro blanco } \\
\text { Cedro rojo occidental }\end{array}$ & Cupressaceae & $\begin{array}{l}\text { Dermatitis; conjuntivitis-rinitis; asma; efectos } \\
\text { tóxicos }\end{array}$ \\
\hline $\begin{array}{l}\text { Tieghemella africana A. Chev. (Dumoria spp.) } \\
\text { T. heckelii Pierre }\end{array}$ & $\begin{array}{l}\text { Makoré, douka, okola, ukola, makoré, abacu, } \\
\text { baku, cerezo africano }\end{array}$ & Sapotaceae & $\begin{array}{l}\text { Dermatitis; conjuntivitis-rinitis; asma; efectos } \\
\text { tóxicos }\end{array}$ \\
\hline Triplochiton scleroxylon K. Schum & $\begin{array}{l}\text { Obeche, samba, wawa, abachi, African } \\
\text { whitewood, arere }\end{array}$ & Sterculiaceae & Dermatitis; conjuntivitis-rinitis; asma \\
\hline Tsuga heterophylla Sarg. & Tsuga, cicuta occidental & Pinaceae & Dermatitis \\
\hline Turraeanthus africana Pell. & $\begin{array}{l}\text { Avodiré } \\
\text { Lusamba }\end{array}$ & Meliaceae & Dermatitis; alveolitis alérgica extrínseca \\
\hline Ulmus spp. & $0 \mathrm{~lm}$ & Ulmaceae & Dermatitis \\
\hline $\begin{array}{l}\text { Vitex ciliata Pell. } \\
\text { V. congolensis De Wild. y Th. Dur } \\
\text { V. pachyphylla Bak. }\end{array}$ & $\begin{array}{l}\text { Difundu } \\
\text { Evino }\end{array}$ & Verbenaceae & Dermatitis \\
\hline Xylia dolabriformis Benth. & & Mimosaceae & Conjuntivitis-rinitis; asma \\
\hline X. xylocarpa Taub. & Pyinkado & & \\
\hline Zollernia paraensis Huber & Madera de santo, cabralea cangerana & Caesalpinaceae & Dermatitis; efectos tóxicos \\
\hline
\end{tabular}

\section{Referencias}

Ahman, M, E Soderman, I Cynkier, B KolmodinHedman. 1995a. Work-related respiratory problems in industrial arts teachers. Int Arch Occup Environ Health 67:111-118.

Ahman, M, M Holmstrom, H Ingelman-Sundberg. 1995b. Inflammatory markers in nasal lavage fluid from industrial arts teachers. Am $f$ Ind $\mathrm{Med}$ 28:541-550.

Ahman, M, M Holmstrom, I Cynkier, E Soderman. 1996. Work-related impairment of nasal function in Swedish woodwork teachers. Occup Environ Med 53:112-117

Andersen, HC, J Solgaard, I Andersen. 1976. Nasal cancer and nasal mucus-transport rates in woodworkers. Acta Otolaryngol 82:263-265.

Demers, PA, M Kogevinas, P Boffetta, A Leclerc, D Luce, M Guerin, G Battista, S Belli, U BolmAudorf, LA Brinton y cols. 1995. Wood dust and sino-nasal cancer: Pooled reanalysis of twelve casecontrol studies. Am F Ind Med 28:151-166.

Demers, PA, SD Stellman, D Colin, P Boffetta. 1996. Non-malignant respiratory disease mortality among wood workers participating in the American Cancer Society Cancer Prevention Study-2 (CPS-II). Presentado en el 25 encuentro del Congreso Internacional sobre Salud en el Trabajo, Estocolmo, 15-20 septiembre.

Environmental Protection Agency (EPA). 1995. EPA Office of Compliance Sector Notebook Project: Profile of the Wood Furniture and Fixtures Industry. Washington, DC: EPA.

Hessel, PA, FA Herbert, LS Melenka, K Yoshida, D Michaelchuk, M Nakaza. 1995. Lung health in sawmill workers exposed to pine and spruce. Chest 108:642-646.

Imbus, H. 1994. Wooddust. En Physical and Biological Hazards in the Workplace, dirigido por $\mathrm{PH}$ Wald $\mathrm{y}$ GM Stave. Nueva York: Van Nostrand Reinhold.
Ma, W-S A, M-JJ Wang, FS Chou. 1991. Evaluating the mechanical injury problem in the woodbamboo furniture manufacturing industry. Int $\mathcal{f}$ Ind Erg 7:347-355.

Nestor, DE, TG Bobick, TJ Pizatella. 1990. Ergonomic evaluation of a cabinet manufacturing facility. En Proceedings of the Human Factors Society, 34th Annual Meeting. Santa Mónica, California: Human Factors Society.

Scheeper, B, H Kromhout, JS Boleij. 1995. Wood dust exposure during wood-working processes. Ann Occup Hyg 39:141-154.

Stellman, SD, PA Demers, D Colin, P Boffetta. En imprenta. Cancer mortality and wood dust exposure among CPS-II participants. Am f Ind Med.

Whitehead, LW, T Ashikaga, P Vacek. 1981. Pulmonary function status of workers exposed to hardwood or pine dust. Am Ind Hyg Assoc 42:1780-1786. 


\section{CONFECCION Y PRODUCTOS TEXTILES ACABADOS}

Directores del capítulo

Robin Herbert y Rebecca Plattus

\section{Sumario}

Principales sectores y procesos

Rebecca Plattusy Robin Herbert . . . . . . . . . . . . . . . . . . 87.2

Accidentes en el sector de la confección

A.S. Bettenson .

Efectos sobre la salud y aspectos ambientales

Robin Herbert y Rebecca Plattus. . 


\section{- PRINCIPALES SECTORES Y PROCESOS}

\section{Rebecca Plattus y Robin Herbert}

\section{Procesos generales}

En general, los procesos implicados en la producción de prendas de vestir y otros productos textiles acabados han cambiado poco desde los albores de la industria. Aunque la organización del proceso de producción sí ha cambiado, y sigue cambiando, y algunos progresos tecnológicos han perfeccionado la maquinaria, la mayor parte de los riesgos existentes en el ámbito de la seguridad y la salud en este sector siguen siendo los mismos a los que se enfrentaban los primeros trabajadores de la confección.

La principal preocupación en materia de salud y seguridad en el sector textil está relacionada con las condiciones generales del entorno de trabajo. Puestos de trabajo, herramientas y equipos mal diseñados, junto con un sistema de remuneración a destajo y un sistema de producción en cadena, imponen graves riesgos de lesiones musculosqueléticas y estados de estrés. Los talleres de confección suelen estar situados en edificios mal conservados y poco ventilados, con malas condiciones de refrigeración, calefacción y alumbrado. La masificación, junto con un almacenamiento inadecuado de materiales inflamables, suelen crear graves riesgos de incendio. La falta de higiene y limpieza agravan esta situación.

Figura 87.1 • Taller de fabricación de lentejuelas.

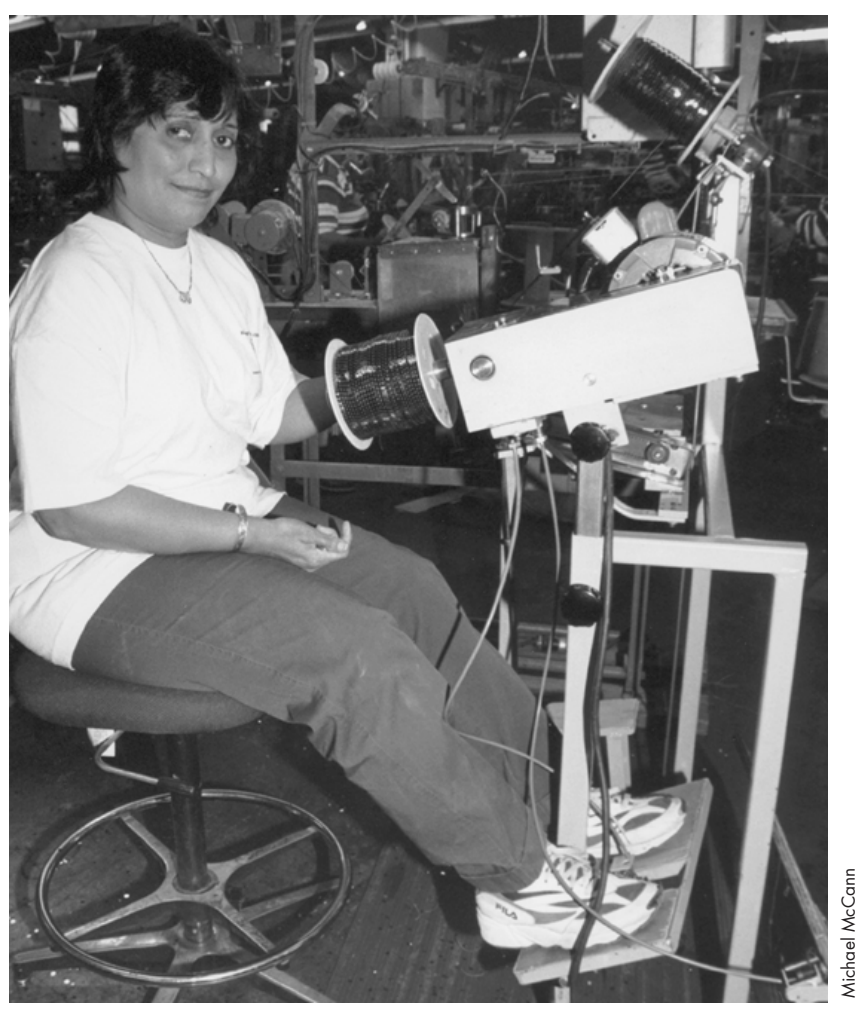

En este taller se lanzó un amplio programa de ergonomía para evitar las lesiones musculosqueléticas. Antes de esta intervención, los operarios tenían que hacer girar repetitivamente de forma manual una manivela situada a la altura de la cintura, con la mano derecha, mientras simultáneamente sostenían las lentejuelas con la mano izquierda. Tras la introducción de un programa ergonómico que incluía medidas de formación, una modificación del control técnico (incluyendo la disponibilidad de una silla ajustable y un pedal automatizado y adaptable) y la ampliación de tareas, se experimentó una gran mejora de las posturas naturales de las articulaciones y un descenso de la sintomatología musculosquelética.
Ha habido importantes avances en el diseño y producción de puestos de trabajo de costura adecuados y ergonómicos, que incluyen mesas y sillas ajustables y tienen en cuenta el posicionamiento correcto del equipo y los instrumentos. Estos puestos de trabajo están disponibles en muchos lugares y se utilizan en algunas instalaciones, sobre todo en las grandes fábricas. Sin embargo, sólo las empresas más grandes y capitalizadas pueden permitirse estas comodidades. El rediseño ergonómico también es posible en otras actividades de fabricación de prendas de vestir (véase la Figura 87.1). Pero la mayor parte de la producción de ropa sigue efectuándose a través de empresas contratistas pequeñas y mal equipadas que, en general, apenas se ocupan del diseño del puesto de trabajo, de las condiciones de trabajo y de los riesgos para la salud y la seguridad.

Diseño del producto y confección de muestras. El diseño de la confección y otros productos textiles lo supervisan los fabricantes, detallistas o distribuidores, y el proceso de diseño lo realizan diseñadores cualificados. A menudo los distribuidores, fabricantes y detallistas de la confección sólo se responsabilizan del diseño, la creación de muestras y la comercialización del producto. Y mientras el distribuidor o el fabricante se encargan de especificar todos los detalles de la producción de las prendas de vestir, la compra del tejido y los accesorios, la labor de producción real a gran escala suelen realizarlo talleres contratados independientes.

La producción de muestras, es decir la creación de un pequeño número de muestras que se utilizan para comercializar el producto y se envían a los talleres contratados como ejemplos del producto acabado, también tiene lugar en las instalaciones del distribuidor. Las muestras las producen operarios altamente cualificados, confeccionistas de muestras, que cosen toda la prenda en máquinas de coser.

Patronaje y corte. El diseño de las prendas de vestir debe separarse en patrones que sirven de modelo para cortar y coser. Tradicionalmente se crea un patrón de cartón para cada pieza y talla; después se preparan patrones escalados según las tallas a fabricar. A partir de estos patrones se crean marcadas de corte de papel, que el cortador utiliza para cortar las piezas del patrón. En las plantas más modernas, las marcadas de corte se crean y se escalan en un ordenador y después se imprimen con un plotter electrónico.

En la fase de corte, primero se extiende el tejido en varias pilas sobre la mesa de corte, cuya longitud y anchura dependen de las exigencias de la producción. A menudo esta tarea la realiza una máquina desplegadora automática o semiautomática, que desenrolla las piezas de tejido a lo largo de la mesa. Los tejidos plisados o estampados pueden extenderse a mano y sujetarse con agujas para asegurar que el plisado y el estampado coincidan. Después se disponen las marcadas sobre el tejido a cortar.

El tejido para la confección de prendas de vestir suele cortarse mediante herramientas de sierra de cinta manuales (véase la Figura 87.2). Las partes más pequeñas se pueden cortar con una troqueladora. La tecnología de corte avanzada incluye el corte por robot, que sigue de forma automática los patrones elaborados en el ordenador.

El corte del tejido encierra diversos peligros. Aunque la hoja de la herramienta de corte esté protegida, la protección debe montarse correctamente para proteger la mano que sujeta el material. Siempre hay que utilizar la protección y colocarla en la posición correcta. Como protección adicional se recomienda que los operarios que corten a máquina lleven un guante protector, preferiblemente de malla metálica. Además del riesgo de corte accidental, cortar tejido también encierra riesgos ergonómicos. Sostener y maniobrar una máquina de corte, mientras avanza por la mesa de corte, puede presentar el riesgo de 
Figura 87.2 • Fábrica de confección en Filipinas.

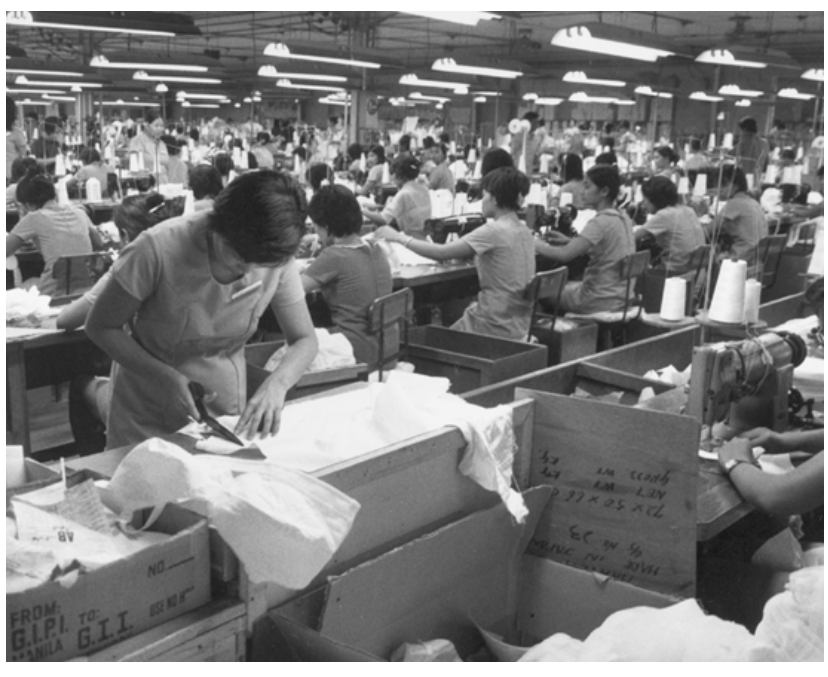

lesiones en el cuello, las extremidades superiores y la espalda. Finalmente, muchos cortadores tienen tendencia a trabajar con la máquina de corte junto a la oreja, exponiéndose a menudo a un ruido excesivo que puede provocar la pérdida de audición.

Manipular las piezas de tejido, que pueden llegar a pesar hasta $32 \mathrm{~kg}$ y deben levantarse por encima de la cabeza hasta el soporte de desplegado, también supone peligros ergonómicos. Un equipo de manipulación adecuado permite eliminar o reducir estos riesgos.

Manejo de la máquina de coser. Normalmente, las piezas de tejido, una vez cortadas, se cosen con una máquina accionada a mano. El tradicional trabajo "en cadena", en el que los paquetes de piezas cortadas avanzan de un operario a otro y cada uno realiza una sola operación, sigue prevaleciendo en el sector a pesar de los importantes cambios de organización del trabajo que han implantado muchos talleres. Este tipo de organización del trabajo divide el proceso de producción en muchas operaciones diferentes, y cada una consiste en un ciclo muy corto que cada operador repite centenares de veces durante una jornada laboral. Este sistema, junto con la remuneración a destajo, que gratifica la velocidad por encima de todo y apenas permite a los trabajadores controlar el proceso de producción, crea un entorno de trabajo que puede llegar a ser muy agotador.

La mayoría de los puestos de trabajo de confección en la actualidad están diseñados sin tener en cuenta la comodidad, la salud o la conveniencia del operario que acciona la máquina de coser (véase la Figura 87.3). Dado que los operarios de máquinas de coser suelen coser sentados en puestos de trabajo mal diseñados realizando la misma operación durante toda la jornada laboral, el riesgo de sufrir trastornos musculosqueléticos es elevado. Las malas posturas resultantes de las condiciones descritas, junto con un trabajo muy repetitivo y el apremio del tiempo, han comportado un índice elevado de trastornos musculosqueléticos ocupacionales (TMEO) entre los operarios de máquinas de coser y otros operarios del sector.

Los avances en el diseño de puestos de trabajo para operarios de la confección, como sillas y mesas ajustables, permiten reducir algunos de los riesgos asociados a las máquinas de coser. Sin embargo, aunque estas mesas y sillas se pueden encontrar fácilmente, a menudo el precio las sitúa fuera del alcance de casi todas las empresas, excepto las más rentables. Además, incluso con puestos de trabajo bien diseñados, permanece el factor de riesgo que supone la repetición.

Los cambios en la organización del trabajo y la introducción del trabajo en equipo, en forma de fabricación modular o flexible, constituyen una alternativa al proceso tradicional de producción tailorista, y puede servir para aliviar algunos de los riesgos para la salud que implica el sistema tradicional. En un sistema de trabajo en equipo, los operarios de máquinas de coser trabajan en grupo para confeccionar toda una prenda, y a menudo se van turnando en las diversas actividades y máquinas.

En uno de los sistemas de trabajo en equipo más populares, los trabajadores trabajan de pie, y no sentados, y se trasladan a menudo de una máquina a otra. La formación cruzada para desempeñar diversos trabajos mejora la cualificación de los trabajadores, quienes pueden controlar más la producción. El cambio de un sistema de remuneración individual a destajo por un sistema de pago por horas o de incentivo para grupos, así como un mayor énfasis en la calidad del proceso de producción, pueden ayudar a eliminar algunos factores que suponen para los trabajadores el de riesgo de desarrollar TMEO.

Sin embargo, algunos sistemas de producción más nuevos, aunque tecnológicamente avanzados, pueden contribuir a un aumento del riesgo de TMEO. Los llamados sistemas de producción por unidades, por ejemplo, están diseñados para transportar mecánicamente los productos cortados de un trabajador a otro mediante una cinta transportadora elevada, acelerando así el avance de los productos y eliminado gran parte de las manipulaciones que antes efectuaban los operarios de máquinas de coser o los auxiliares de planta. Estos sistemas, además de aumentar la producción acelerando la línea, también eliminan el poco tiempo de descanso que tenía el trabajador entre ciclo y ciclo, lo que implica una mayor fatiga y repetición.

$\mathrm{Al}$ instaurar un sistema de producción alternativo, hay que tener en cuenta la evaluación de los factores de riesgo y diseñar

Figura 87.3 - Mujer trabajando con una máquina de coser sin guardaguja.

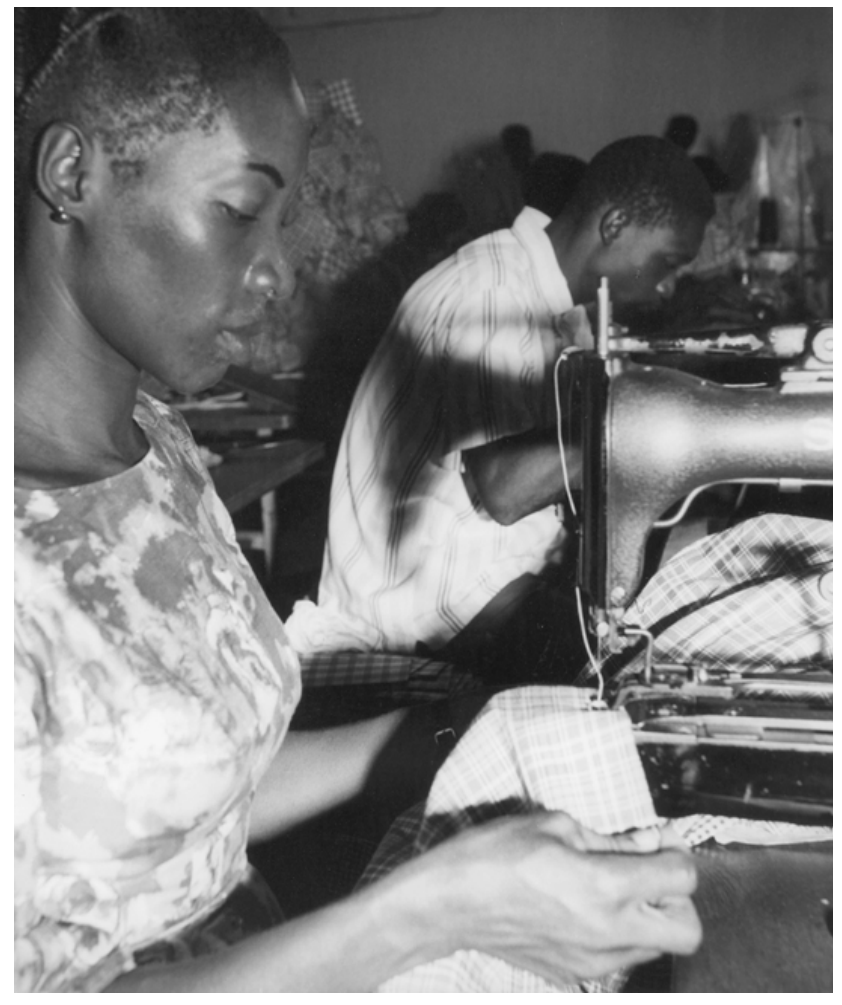


el nuevo sistema pensando en la ergonomía. Por ejemplo, cuando se forma a los trabajadores para desempeñar varios trabajos, hay que combinarlos de forma que se ejerciten las diversas partes del cuerpo y no se imponga una tensión extrema a un músculo o a una articulación. Hay que asegurar que el equipo y la maquinaria pueden adaptarse a todos los trabajadores del grupo.

$\mathrm{Al}$ adquirir un equipo hay que pensar que los propios trabajadores deben poder ajustarlo, y hay que enseñarles cómo hacerlo. Esto es especialmente importante en el sector de la confección, donde a menudo no se dispone del personal necesario para adaptar los equipos a los trabajadores.

Los estudios más recientes han generado cierta alarma sobre la exposición de los operarios de máquinas de coser a fuertes campos electromagnéticos (CEM) generados por los motores de las máquinas de coser. Estos estudios indican que puede existir una relación entre el elevado índice de la enfermedad de Alzheimer (Soebel y cols. 1995) y otras enfermedades crónicas de los operarios de máquinas de coser y la exposición de los operarios a fuertes CEM

Acabado y planchado. Una vez cosida la prenda completa, los planchadores la planchan y los acabadores comprueban que no haya hilos sueltos, manchas $\mathrm{u}$ otros defectos. Los acabadores realizan diversos trabajos manuales como cortar hilos sueltos, coser a mano, volver la ropa y planchar a mano. Los riesgos ergonómicos son un problema para los trabajadores que aprestan, etiquetan, embalan y distribuyen la ropa. Suelen efectuar tareas muy repetitivas, que muchas veces implican trabajar con las manos y los brazos en posiciones incómodas y poco saludables. Los asientos y los puestos de trabajo de estos trabajadores no suelen ser ajustables ni están diseñados pensando en la comodidad o la salud. Los acabadores, incluidos los planchadores, suelen trabajar de pie y en posiciones estáticas, a pesar de que muchos disponen de sillas, banquillos o taburetes. Las superficies de las mesas deberían poder ajustarse a la altura adecuada para el operario y permitirle así trabajar de forma más cómoda. Los bordes de las mesas protegidos con almohadillas y diseñados debidamente podrían eliminar algunas tensiones en las manos, las muñecas y los brazos.

El planchado del producto cosido se realiza, bien con una plancha manual, bien con una plancha de prensa. Los productos cosidos también se pueden planchar a vapor, tanto a mano como mediante un túnel de vapor. Las planchas y las máquinas planchadoras pueden presentar riesgos de quemaduras, así como peligros ergonómicos. Aunque la mayoría están diseñadas para que deban controlarse con las dos manos, eliminando así la posibilidad de que la mano quede bajo la plancha, todavía existen algunas planchas antiguas que no tienen estas características de seguridad. Trabajar con una máquina planchadora también presenta riesgos de lesiones en el hombro, el cuello y la espalda debido a que a menudo hay que llegar muy alto, permanecer siempre de pie y accionar pedales con los pies. Aunque el trabajo podría ser más seguro con una máquina más automatizada y con una posición más correcta del operario, la maquinaria actual no permite eliminar fácilmente la gran tensión que provoca el proceso.

Los etiquetadores, que utilizan pistolas de etiquetado para colocar etiquetas en las prendas acabadas, corren riesgos de lesiones en la mano y en la muñeca debido a esta operación tan repetitiva. Las pistolas automáticas de etiquetado, al contrario que las manuales, pueden ayudar a reducir la fuerza que se necesita para efectuar la operación, aliviando así la tensión que se crea en los dedos y las manos.

Distribución. Los trabajadores de los centros de distribución de ropa están expuestos a todos los peligros de los demás almacenes. La manipulación manual del material es la causa de la mayoría de lesiones de los operarios de almacén. Entre los peligros concretos figuran los de levantar peso y trabajar en alto. Diseñar la distribución del lugar de trabajo teniendo en cuenta que la manipulación de los materiales sea correcta, como la colocación de cintas transportadoras y mesas de trabajo en alturas adecuadas, puede ayudar a evitar muchas lesiones. Los equipos mecánicos de manipulación de material, como carretillas elevadoras y grúas, pueden ayudar a evitar lesiones ocasionadas por tener que levantar materiales pesados o trabajar de forma incómoda.

Exposición a los productos químicos. Los trabajadores de todas las fases de producción de prendas de vestir pueden estar expuestos a productos químicos que se utilizan en el acabado de tejidos. El producto más común es el formaldehído. Se utiliza para que el tejido no se arrugue y los colores sean sólidos, y se desprende del tejido en forma de gas. Los trabajadores también exponen su piel al formaldehído debido al contacto directo durante la manipulación del tejido. La cantidad de formaldehído que libera un tejido depende de diversos factores, como la cantidad utilizada en el acabado, el proceso de acabado y el calor y la humedad del ambiente. La exposición al formaldehído se puede evitar permitiendo que el tejido libere el gas en una zona bien ventilada antes de manipularlo, y con una buena ventilación en las zonas de trabajo, especialmente si el tejido está expuesto a una temperatura y humedad elevadas (por ejemplo, durante el planchado). Los trabajadores que tienen problemas cutáneos debido al contacto con el tejido tratado con formaldehído pueden usar guantes o crema protectora. Finalmente, habría que motivar a los fabricantes a que utilizaran tratamientos alternativos más seguros.

\section{Procesos especiales}

Plisado. El proceso de plisado sirve para formar dobleces o pliegues en un tejido o una prenda. Se aplican temperaturas elevadas y un alto grado de humedad para marcar los pliegues en los diversos tipos de tejido. Los plisadores están expuestos a estas condiciones de temperatura y humedad elevadas que pueden ocasionar la liberación de grandes cantidades de sustancias utilizadas en el acabado del tejido, que no se desprenderían en condiciones de temperatura y humedad normales. A veces se añaden agentes endurecedores a los tejidos que hay que plisar para facilitar la capacidad del tejido para mantener el pliegue. Las cajas y cámaras de vapor exponen el tejido plisado a vapor a presión.

Cauchutado/impermeabilización. Para crear un acabado cauchutado o impermeable, los tejidos se pueden recubrir con una sustancia impermeable. Estos diversos revestimientos, que pueden consistir en un tipo de caucho, suelen diluirse con disolventes, algunos de los cuales plantean graves riesgos para la salud de los trabajadores expuestos. Estos revestimientos pueden ser de benceno o de dimetilformamida, entre otros. Los trabajadores están expuestos a estos productos químicos mientras se mezclan o se vierten, a menudo manualmente, en grandes recipientes en zonas mal ventiladas. También pueden verse expuestos a sus emanaciones cuando vierten las mezclas sobre el tejido para cubrirlo. Las exposiciones peligrosas deberían reducirse al mínimo utilizando sustancias menos tóxicas y proporcionando la ventilación adecuada en el lugar de utilización. Además, las operaciones de vertido y mezcla deberían ser automáticas siempre que fuera posible.

Informatización. Cada vez se utilizan más ordenadores en el sector de la confección, desde los sistemas de fabricación y diseño asistidos por ordenador (CAD/CAM) en los procesos de diseño, marcaje y corte, hasta el seguimiento de los productos durante las operaciones de almacenamiento y envío. Los peligros asociados al uso del ordenador se comentan en otro capítulo de esta Enciclopedia. 
Botones, hebillas y otros ornamentos. Los botones, las hebillas y demás sistemas de cierre de las prendas o productos confeccionados suelen fabricarse en locales independientes de los que confeccionan las prendas de vestir. Los botones se fabrican de diversos materiales, y el material utilizado determinará el proceso de producción. Casi siempre los botones y las hebillas son de plástico o metales moldeados, como el plomo. Durante el proceso de producción, las materias primas calentadas se vierten en moldes y se enfrían. Durante este proceso de moldeo, los trabajadores quedan expuestos a productos químicos o metales tóxicos. Una vez enfriado el material, los trabajadores se ven expuestos a la generación de polvo cuando los productos se pulen y se liman. Estas exposiciones se pueden evitar con una ventilación adecuada durante este proceso de acabado o mediante el aislamiento de estos trabajos. Otros ornamentos, como las lentejuelas, perlas, etc., se producen a partir de plásticos y metales, estampados o moldeados, y pueden exponer a los operarios al riesgo que encierran los productos que los componen.

Accesorios de plástico y productos de plástico cosido. Algunos elementos, como las cortinas de ducha, manteles, impermeables, etc. están formados por diversas piezas de plástico cosidas o unidas. Cuando se cosen productos a partir de hojas de plástico, los peligros son similares a los de otros elementos cosidos. Sin embargo, trabajar con grandes cantidades de material plástico encierra un grave peligro en caso de incendio, dado que el plástico, cuando se calienta o arde, libera materiales tóxicos que pueden ser muy peligrosos. Conviene extremar las precauciones en el ámbito de la prevención de incendios y la protección allí donde se almacenen o se usen grandes cantidades de material plástico.

Además de coserse, los plásticos se pueden pegar por acción del calor o radiaciones electromagnéticas. Cuando los plásticos se calientan liberan sus componentes y pueden exponer a los trabajadores a materias tóxicas. Cuando se utiliza la radiación electromagnética para unir o sellar plásticos, hay que tener cuidado de no exponer a los trabajadores a niveles peligrosos de radiación.

\section{Organización del trabajo}

El sistema de remuneración a destajo, es decir, cuando los trabajadores cobran por la cantidad de unidades que producen, está todavía muy extendido en la confección de prendas de vestir y productos cosidos. El uso continuado del sistema de remuneración a destajo implica riesgos para la salud relacionados con el estrés y con trastornos muculosqueléticos entre los trabajadores del sector de la confección. Como ya se ha dicho antes, un sistema de remuneración alternativo, así como otros sistemas de producción, podrían hacer que la confección fuera más atractiva, menos agotadora y menos peligrosa para los trabajadores que entran a formar parte de dicho sector.

Un sistema de trabajo en equipo, que ofrece a los trabajadores la posibilidad de un mayor control sobre el proceso de producción, así como la oportunidad de trabajar con otras personas, puede ser menos agotador que el tradicional sistema en cadena. Sin embargo, estos sistemas de equipo también pueden provocar tensiones adicionales si se establecen de modo que los trabajadores sean responsables del cumplimiento de las normas por parte de sus colegas. Algunos tipos de sistemas de compensación de grupo, que penalizan a todo un equipo por la lentitud o el absentismo de alguno de sus miembros, pueden crear tensiones dentro del grupo.

Trabajar en casa es también un sistema muy habitual en el sector de la confección. Existen dos posibilidades: el trabajo se envía a casa de un trabajador de la fábrica al final de la jornada para hacerlo por la noche o durante el fin de semana, o bien se envía directamente a la dirección del trabajador, eliminando totalmente su presencia en la fábrica.

El sistema de trabajo a domicilio suele ser sinónimo de explotación de los trabajadores. No es fácil que los organismos que regulan las condiciones laborales, la explotación de menores, las condiciones mínimas de salud y seguridad, los salarios mínimos, etc., puedan controlar el trabajo en el hogar. En muchos casos los operarios que trabajan en casa cobran salarios inferiores a los normales y deben hacerse cargo del coste del material, del equipo y de las herramientas necesarias para la producción. Es posible que los niños también deban realizar tareas en casa, independientemente de su edad o de su capacidad para trabajar con seguridad, o en detrimento de su escolarización o tiempo de ocio. También en estas situaciones abundan los riesgos para la seguridad y la salud, incluyendo la exposición a productos químicos peligrosos, peligros de incendio y cortocircuitos. La maquinaria industrial puede presentar peligros para los niños pequeños en el hogar.

\section{ACCIDENTES EN EL SECTOR DE LA CONFECCION}

\section{A.S. Bettenson*}

Las pequeñas empresas instaladas en locales domésticos poco adecuados que se utilizan para la confección de prendas de vestir suelen presentar un grave peligro de incendio. En cualquier sala de trabajo, grande o pequeña, hay mucho material combustible, y se van acumulando desperdicios combustibles a menos que se ejerza un control muy estricto. Algunos de los materiales utilizados son particularmente inflamables (por ejemplo, resinas de espuma para forros y rellenos, y fibra de coco en partículas muy finas). Es necesario disponer de salidas de emergencia adecuadas y extintores, y conocer el procedimiento a seguir en caso de incendio. El mantenimiento y una buena limpieza no sólo ayudan a prevenir incendios y a limitar su expansión, sino que son esenciales allí donde los productos se transportan mecánicamente.

En general, la frecuencia de accidentes y los índices de gravedad son bajos, pero existe una gran variedad de lesiones menores que se podrían evitar si se tomaran más en serio los primeros auxilios inmediatos. Las hojas de las cuchillas pueden provocar heridas graves si no se protegen adecuadamente; sólo habría que dejar sin protección la parte del filo necesaria para cortar; las cuchillas circulares de las máquinas de corte portátiles también deberían protegerse de forma similar. Si se utilizan máquinas planchadoras es necesario disponer de la protección necesaria, preferiblemente fija, para mantener las manos fuera de la zona de peligro. La máquina de coser presenta dos riesgos principales: los mecanismos motores y la aguja. En muchos lugares todavía existen largas filas de máquinas que funcionan con la transmisión situada debajo del banco. Es esencial que esta transmisión esté debidamente protegida mediante puertas o rejas; la causa de muchos accidentes es que los trabajadores se meten debajo de los bancos para recuperar materiales o cambiar correas. También existen diversos métodos para proteger la aguja y mantener los dedos fuera de la zona de peligro.

El uso de planchas industriales para la confección implica un grave riesgo de aplastamiento y quemaduras. En muchos lugares se utilizan mandos que deben accionarse con las dos manos pero no son del todo satisfactorios; pueden ser objeto de abuso (por ejemplo, accionarlos con la rodilla). Siempre deben ajustarse para que ello no sea posible y evitar la operación con una

\footnotetext{
* Adaptado de la $3^{\text {a }}$ edición de la Enciclopedia de la salud y seguridad en el trabajo.
} 
sola mano. Las protecciones deben evitar que el cabezal ejerza presión sobre la base si hay algo (sobre todo la mano) en la zona donde se trabaja. Todas las planchas, y los sistemas de alimentación de vapor y aire comprimido, requieren una inspección frecuente.

Las herramientas eléctricas portátiles exigen un mantenimiento cuidadoso de los dispositivos de toma de tierra.

Los últimos descubrimientos en materia de soldadura de plásticos (para sustituir costuras, etc.) y de confección de respaldos de espuma suelen implicar el uso de prensas eléctricas, a veces accionadas con pedal, a veces por aire comprimido. Existe el riesgo de quedar físicamente atrapado entre los electrodos y, además, de sufrir quemaduras eléctricas por corriente de alta frecuencia. La única medida de seguridad fiable es aislar las partes peligrosas de modo que el electrodo no pueda funcionar cuando la mano se encuentre en la zona de peligro: el mando a dos manos no ha demostrado ser satisfactorio. Las máquinas de coser deben tener dispositivos de seguridad incorporados.

\section{- EFECTOS SOBRE LA SALUD Y ASPECTOS AMBIENTALES}

\section{Robin Herbert y Rebecca Plattus}

\section{Problemas de salud y tipos de enfermedades}

Los trabajadores de la confección se encuentran en situación de riesgo respecto a los TMEO, el asma industrial, dermatitis de contacto e irritativa, síntomas de irritación en ojos, nariz y garganta, cáncer de pulmón, nasofaríngeo y de vejiga, y pérdida de audición por exceso de ruido. Además, dado que algunos procesos de este sector implican la exposición a gases que emanan de plásticos calientes, polvos metálicos y vapores (sobre todo de plomo), polvo de pieles, polvo de lana y disolventes peligrosos como la dimetilformamida, las enfermedades asociadas a estas exposiciones son también muy comunes entre los trabajadores de la confección. Las exposiciones a campos electromagnéticos generados por los motores de las máquinas de coser son un aspecto que cada vez preocupa más. Se ha establecido una relación entre el empleo de mujeres embarazadas en la confección y los resultados adversos en la reproducción.

La Tabla 87.1 resume el espectro de enfermedades laborales que aparecen en el sector de la confección y textiles acabados.

Trastornos musculosqueléticos. La confección de prendas de vestir implica la realización de tareas monótonas, muy repetitivas y a gran velocidad, que a menudo requieren posturas forzadas e incómodas. Estas exposiciones exponen a los trabajadores de la confección al riesgo de desarrollar TMEO en el cuello, las extremidades superiores, la espalda y las extremidades inferiores (Andersen y Gaardboe 1993; Schibye y cols. 1995). No es raro que los trabajadores de la confección desarrollen TMEO, a menudo con lesiones de los tejidos blandos, como tendinitis y síndromes concomitantes de pinzamientos de nervios, como el síndrome del túnel carpiano (Punnett y cols. 1985; Schibye y cols. 1995).

Los operarios de máquinas de coser y quienes cosen a mano (acabadores y confeccionistas de muestras) efectúan un trabajo que requiere movimientos repetitivos de mano y muñeca, normalmente ejecutados en posturas forzadas de los dedos, las muñecas, los codos, los hombros y el cuello. Por lo tanto, se encuentran en riesgo de desarrollar el síndrome del túnel carpiano, quistes ganglionares, tendinitis del antebrazo, epicondilitis, lesiones en los hombros como la tendinitis bicipital y del manguito de los rotadores, desgarro del manguito de los rotadores y lesiones de cuello. Además, las máquinas de coser exigen normalmente pasar mucho tiempo sentado (a menudo en asientos sin respaldo y realizando tareas que exigen inclinarse hacia adelante a partir de la cintura), alzarse intermitentemente y el uso repetitivo de los pedales. De modo que los operarios de máquinas de coser pueden desarrollar TMEO de la región lumbar y las extremidades inferiores.

Los cortadores, cuyo trabajo requiere levantar y transportar grandes piezas de tejido, así como el manejo de máquinas de corte manuales o informatizadas, también se encuentran en situación de riesgo de desarrollar lesiones musculosqueléticas en el cuello, el hombro, el codo, el antebrazo/muñeca y la región lumbar. Los planchadores se hallan en situación de riesgo de contraer tendinitis y lesiones del hombro, codo y antebrazo, y también pueden desarrollar lesiones relacionadas con el pinzamiento de nervios.

Además de los factores ergonómicos y biomecánicos, los sistemas de producción a destajo y los factores de organización del trabajo descritos con más detalle en el apartado anterior contribuyen a las lesiones musculosqueléticas entre los trabajadores del sector de la confección. En un estudio sobre los trabajadores de dicho sector se descubrió que la duración del empleo en un trabajo a destajo guarda relación con un aumento de la aparición de discapacidades graves (Brisson y cols. 1989). Por lo tanto, la prevención de las lesiones musculosqueléticas ocupacionales puede exigir tanto modificaciones ergonómicas del puesto de trabajo como prestar más atención a la organización del trabajo, incluido el sistema a destajo.

Peligros químicos. Los tejidos tratados con resina que se utilizan para la confección de prendas inarrugables pueden liberar formaldehído. Las exposiciones son mayores durante el corte porque el desprendimiento de gases es mayor cuando las piezas de tejido se desenrollan por primera vez, y durante el planchado, porque el calor fomenta la liberación de formaldehído de los restos de resinas. Lo mismo ocurre en las zonas de producción donde se utilizan grandes cantidades de tejido, y en los almacenes y las zonas de venta al por menor. Muchos talleres de

\section{Tabla 87.1 • Ejemplos de enfermedades laborales que se observan entre los trabajadores de la confección.}

Trastorno
Lesiones musculoesqueléticas
Síndrome del túnel carpiano, tendinitis del
antebrazo, tendinitis de DeQuervains,
epicondilitis, tendinitis bicipital, desgarros
y tendinitis del manguito de los rotadores,
espasmos del trapecio, radiculopatía cervical,
síndrome lumbar, ciática, hernia discal,
artrosis de las rodillas
Asma

Exposición

Fuerza

Repetición

Levantamiento

Posturas forzadas

Trabajar siempre sentado síndrome lumbar, ciática, hernia discal

Formaldehído

Otros tratamientos textiles Calentamiento de plásticos Polvo

Cáncer

Cáncer de vejiga

Tintes

Cáncer de pulmón, nasofaríngeo

Formaldehído

Pérdida de audición

Ruido

Piel

Dermatitis de contacto e irritativa

Formaldehído, tintes textiles

Saturnismo 
confección están mal ventilados y no controlan las temperaturas ambientales. Cuando aumenta la temperatura, se liberan más gases; si hay poca ventilación, se puede acumular una gran concentración de formaldehído en el ambiente. El formaldehído irrita principalmente los ojos, la nariz, la garganta y las vías respiratorias superiores e inferiores. El formaldehído puede ser una causa de asma industrial debido a sus efectos irritativos o a la sensibilización alérgica (Friedman-Jiménez 1994; Ng y cols. 1994). En diversos estudios se ha relacionado la exposición al formaldehído con el desarrollo de cáncer de pulmón y nasofaríngeo (Alderson 1986). Además, la exposición al formaldehído puede comportar dermatitis alérgicas por contacto e irritativas. Los trabajadores de la confección pueden desarrollar una dermatitis crónica, como un eczema, de las manos y los brazos, que probablemente esté relacionada con la sensibilidad al formaldehído. Los efectos irritativos y otros efectos no alérgicos del formaldehído en la salud se pueden reducir al mínimo con la aplicación de sistemas de ventilación adecuados y la substitución de producto siempre que sea posible. Pero la sensibilización alérgica puede ocurrir en niveles más bajos de exposición. Cuando un trabajador de la confección ha desarrollado una sensibilidad alérgica, puede ser necesario evitar la exposición al producto.

Los trabajadores del sector de acabados textiles pueden tener que soportar la exposición a disolventes orgánicos. Los disolventes como el percloretileno, el tricloretileno y el 1,1,1-tricloretano se utilizan con frecuencia en los departamentos de acabado para eliminar manchas. Los efectos sobre la salud de estos productos pueden incluir depresiones del sistema nervioso central, neuropatías periféricas, dermatitis y, con menor frecuencia, intoxicación del hígado. La dimetilformamida (DMF) es un disolvente particularmente peligroso que se emplea en los tejidos impermeables. Su uso en un local de este tipo comportó un brote de hepatitis laboral entre los trabajadores expuestos al producto (Redlich y cols. 1988). El uso de DMF debería evitarse tanto por su hepatotoxicidad como porque se ha descubierto que, en dos casos distintos, estaba relacionada con el cáncer testicular. También a veces se utiliza todavía el benceno en algunos talleres de confección. Su uso debería evitarse escrupulosamente.

Peligros físicos; campos electromagnéticos. Los informes más recientes indican que el manejo de máquinas de coser puede comportar graves exposiciones a campos electromagnéticos (CEM). Los efectos sobre la salud de los CEM todavía no son muy conocidos y en la actualidad son objeto de debate. Sin embargo, en un estudio de casos y controles, en el que se utilizaron tres grupos de datos independientes procedentes de dos países (Estados Unidos y Finlandia), se descubrió que en los tres grupos de datos había una fuerte relación entre la exposición laboral a los CEM y la enfermedad de Alzheimer en los operarios de máquinas de coser y otros con exposiciones medias a altas a los CEM (Sobel y cols. 1995). Un estudio de control de casos sobre la exposición de mujeres embarazadas y la leucemia linfoblástica aguda (LLA) en España indicó que existe un mayor riesgo de LLA en las madres que trabajan en casa durante el embarazo, la mayoría con máquinas de coser. Aunque los autores del estudio pensaron en un principio que la exposición de las mujeres embarazadas al polvo orgánico y a las fibras sintéticas podía ser el origen del aumento observado, se planteó también la posibilidad de la exposición a los CEM como posible agente etiológico (Infante-Rivard y cols. 1991). (Véase el capítulo Radiación no ionizante para más información.)

Otros riesgos y enfermedades laborales. Se ha demostrado en diversos estudios que los trabajadores de la confección se encuentran cada vez más en situación de riesgo en cuanto al desarrollo de asma (Friedman-Jiménez y cols. 1994; Ng y cols. 1994). Además del riesgo potencial de cáncer de pulmón y nasofaríngeo debido a la exposición al formaldehído, los trabajadores de la confección corren un mayor riesgo de contraer cáncer de vejiga (Alderson, 1996). Se ha observado una intoxicación de plomo entre los trabajadores encargados de la producción de botones metálicos. Los trabajadores de almacenes y distribución pueden encontrarse en situación de riesgo de desarrollar las enfermedades asociadas a la exposición a las emanaciones de motores diesel.

El elevado índice de mujeres y niños empleados en el sector de la confección de todo el mundo, junto con el predominio de la subcontratación y el trabajo industrial en el hogar, ha creado un campo ideal para la explotación. El acoso sexual, incluidas relaciones sexuales no consentidas, con los trastornos de salud que comportan, es un grave problema en el sector de la confección, prácticamente en todo el mundo. Los niños que trabajan son especialmente vulnerables a los efectos insalubres de las exposiciones tóxicas y a los efectos de la baja calidad ergonómica de los puestos de trabajo, debido a que su organismo todavía se está desarrollando. También son más vulnerables a los accidentes laborales. Finalmente, dos estudios recientes han revelado una relación entre el trabajo en el sector de la confección durante el embarazo y los resultados adversos en la reproducción, lo que sugiere la necesidad de investigar más en este campo (Eskenazi y cols. 1993; Decouflé y cols. 1993).

\section{Salud pública y aspectos ambientales}

El sector de la confección de prendas de vestir y otros productos textiles acabados es, en general, un sector que provoca relativamente poca contaminación debida a emisiones a la atmósfera, el suelo o el agua. Sin embargo, la emanación de formaldehído puede persistir hasta el detallista, creando un potencial de desarrollo de alergias al formaldehído, sintomatología respiratoria e irritativa, tanto entre el personal de ventas como entre los clientes. Además, algunos de los procesos especiales que se utilizan en el sector de la confección, como el cauchutado y la producción de adornos con plomo, pueden constituir una grave amenaza de contaminación ambiental.

En los últimos años, el incremento de la preocupación por los efectos insalubres relacionados con la exposición al formaldehído y otros tratamientos de tejidos ha dado lugar al desarrollo de una industria "ecológica". Las prendas de vestir y otros productos textiles acabados se cosen a partir de productos naturales y no basados en fibras sintéticas. Además, estos productos naturales no suelen tratarse con agentes antiarrugas y otros aprestos.

Las condiciones de masificación, a menudo insalubres, del sector de la confección constituyen un cultivo ideal para la transmisión de enfermedades infecciosas. En concreto, la tuberculosis ha sido un tema de salud pública recurrente entre los trabajadores del sector de la confección. 


\section{Referencias}

Alderson, M. 1986. Occupational Cancer. Londres: Butterworths.

Anderson, JH, O Gaardboe 1993. Musculoskeletal disorders of the neck and upper limb among sewing machine operators: A clinical investigation. $A m \mathcal{F}$ Ind Med 24:689-700.

Brisson, CB, A Vinet, N Vezina, S Gingras. 1989. Effect of duration of employment in piecework on severe disability among female garment workers. Scand 7 Work Environ Health 15:329-334.

Decouflé, P, CG Murphy, CD Drews, M YearginAllsopp. 1993. Mental retardation in ten-year-old children in relation to their mothers' occupations during pregnancy. Am f Ind Med 24:567-586.

Eskenazi, B, S Guendelman, EP Elkin, M Jasis. 1993. A preliminary study of reproductive outcomes of female maquiladora workers in Tijuana, México. Am 7 Ind Med 24:667-676.
Friedman-Jimenez, G. 1994. Adult onset asthma in women garment workers from the Bellevue Asthma Clinic. PA855. Am 7 Resp Crit Care Med 4:149.

Infante-Rivard, C, D Mur, B Armstrong, C AlvarezDardet, F Bolumar. 1991. Acute lymphoblastic leukemia among Spanish children and mothers' occupation: A case-control study. I Epidemiol Community Health 45:11-15.

Ng, TP, CY Hong, LG Goh, ML Wang, KT Koh, SL Ling. 1994. Risks of asthma associated with occupations in a community-based case control study. Am f Ind Med 25:709-718.

Punnett, L, JM Robins, DH Wegman, WM Keyserling. 1985. Soft tissue disorders in the upper limbs of female garment workers. Scand 7 Work Environ Health 11:417-425.

Redlich, CA, WS Beckett, J Sparer, KW Barwick, CA Reily, H Miller, SL Sigal, SL Shalat, MR Cullen. 1988. Liver disease associated with occupa- tional exposure to the solvent dimethyl fornamide. Ann Intern Med 108:680-686.

Schibye, B, T Skor, D Ekner, JU Christiansen, G Sjogaard. 1995. Musculoskeletal symptoms among sewing machine operators. Scand $\mathcal{f}$ Work Environ Health 21:427-434.

Sobel, E, Z Davanipour, R Sulkava, T Erkinjuntti, J Wikström, VW Henderson, G Buckwalter, JD Bowman, PJ Lee. 1995. Occupations with exposure to electromagnetic fields: A possible risk factor for Alzheimer's disease. Am 7 Epidemiol 142:515-524.

\section{Otras lecturas recomendadas}

Courcel, M. 1979. Prevención de accidentes en el uso de máquinas de coser en la industria textil (La prevention des accidents dus aux machines a coudre). Prevention et securite du travail (Lille) 122:25-29.

Solinger, J. 1961. Apparel Manufacturing Analysis. Nueva York: Textile Book Publishers. 
Director del capítulo

M ichaed M cCann

\section{Sumario}

Perfil general

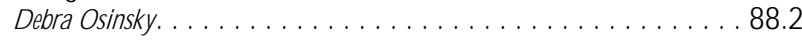

Curtido, acabado de pieles

D ean B. B aker.

Industria peletera

P.E. B raid . .

Calzado, industria

F.L. Conradi y Paulo Portich

Efectos sobre la salud y pautas patológicas

Frank B. Stern

Cuestiones ambientales y de salud pública

J erry Spiegel 


\section{- Perfil general}

Debra Osinsky

Las pieles y el cuero fabricados a partir de pellejos curtidos de animales se utilizan desde hace miles de años para confeccionar prendas de vestir. La industria de la piel y el cuero sigue siendo importante en la actualidad. Con las pieles se fabrican gran variedad de prendas exteriores, como abrigos, chaquetas, sombreros, guantes y botas, así como adornos para otros tipos de prendas. El cuero se utiliza para confeccionar prendas y puede emplearse en la fabricación de otros productos, como la tapicería para automóviles y muebles, y una amplia gama de artículos de piel, como correas de reloj, bolsos y artículos de viaje. El calzado es otro producto tradicional del cuero.

Entre los animales cuya piel se aprovecha industrialmente figuran especies acuáticas como el castor, la nutria, el ratón almizclero y la foca; especies terrestres del hemisferio septentrional, como el zorro, el lobo, el visón, la comadreja, el oso, la marta y el mapache; y especies tropicales como el leopardo, el ocelote y la onza. A demás, se aprovecha la piel de las crías de ciertos animales, como las vacas, caballos, cerdos y cabras. Aunque la mayoría de todos estos animales se cazan con cepos, el visón concretamente se cría en granjas peleteras.

\section{Producción}

Las principales fuentes de cuero son el ganado vacuno, los cerdos, los corderos y las ovejas. En 1990, Estados U nidos era el principal productor de cueros y pieles de origen bovino. 0 tros importantes productores son Alemania (antigua República Federal), Argentina, Australia, China, Francia, e India. Australia, China, la Federación Rusa, India, N ueva Zelanda, el Reino U nido, la República Islámica de Irán y Turquía son importantes fabricantes de pieles de ovinos. Las pieles de cabra se producen en su mayor parte en China, India y Pakistán. Los principales productores de pieles de cerdo son China, Europa O riental y la antigua U R SS.

Un análisis preparado por $\mathrm{L}$ andell M ills $\mathrm{C}$ ommodities Studies (LM C) para la O rganización Internacional del Trabajo (OIT) muestra que el mercado internacional de pieles está dominado cada vez más por unos pocos países productores de A mérica del Norte, Europa O ccidental y O ceanía, que permiten la libre exportación de pieles en cualquier forma. La industria del curtido en los Estados U nidos se ha ido reduciendo constantemente desde 1981, mientras que la mayoría de las fábricas de curtidos supervivientes del norte de Europa se han diversificado con el fin de reducir su dependencia del mercado del cuero para calzado. La producción mundial de calzado ha seguido desplazándose principalmente al sudeste de Asia (O IT 1992).

Varios factores influyen en la demanda global de cuero en todo el mundo: el nivel de ingresos, su tasa de crecimiento y su distribución; el precio del cuero en comparación con los materiales alternativos; y los cambios en la preferencia de los consumidores por el cuero sobre los materiales alternativos en distintos productos.

El sector usuario final que más rápidamente crece en la industria del curtido ha sido el de tapizado en piel, que representó aproximadamente un tercio de la producción mundial de cuero bovino de alta calidad en 1990. M ás de un tercio de toda la piel para tapizado se destina a la industria de los vehículos y, según las previsiones de L M C , las perspectivas de este subsector son bastante brillantes. La proporción de coches con este tipo de tapizado ha aumentado fuertemente durante el decenio de 1990.

La demanda de prendas de piel viene determinada principalmente por los ingresos y la moda, en tanto que esta última influye particularmente en la demanda de tipos concretos de piel. Por ejemplo, una fuerte demanda de la piel ovina más suave y flexible motivó la producción de la napa para prendas de moda a partir de pieles ovinas y cueros vacunos.

Los principales productores de pieles de visón en 1996 fueron Canadá, la Federación Rusa, los países escandinavos y Estados Unidos.

Entre 1980 y 1989, el empleo de mano de obra en el sector del cuero aumentó en C hina, H ungría, India, Indonesia, República de Corea, U ruguay y Venezuela y disminuyó en Australia, Colombia, Filipinas, Kenya, Polonia y Estados Unidos. El empleo en la elaboración del cuero también disminuyó en Dinamarca, Finlandia, N oruega y Suecia. En Botswana, el empleo en la industria de la piel se redujo sensiblemente en 1986, y luego experimentó un acentuado aumento, duplicando en 1988 el nivel de 1980

Existen varias cuestiones que afectarán a la futura producción y empleo en las industrias del cuero, el calzado y la peletería. L as nuevas tecnologías, el traslado de la producción de calzado a países en vías de desarrollo y la legislación medioambiental en la industria del curtido seguirán afectando a las aptitudes y la salud y seguridad de los trabajadores de estas industrias.

\section{CURTIDO, ACABADO DE PIELES}

Dean B. Baker*

EI curtido es el proceso químico mediante el cual se convierten los pellejos de animales en cuero. El término cuero designa la cubierta corporal de los grandes animales (por ejemplo, vacas 0 caballos), mientras que piel se aplica a la cubierta corporal de animales pequeños (por ejemplo, ovejas). Los cueros y pieles son en su mayor parte subproductos de mataderos, aunque también pueden proceder de animales fallecidos de muerte natural, cazados 0 atrapados en cepos. Las curtidurías están situadas generalmente cerca de las zonas de cría de ganado; sin embargo, los cueros y pieles pueden prepararse y transportarse antes del curtido, por lo que la industria está muy esparcida.

El proceso de curtido consiste en reforzar la estructura proteica del cuero creando un enlace entre las cadenas de péptidos. El cuero consta de tres capas: epidermis, dermis y capa subcutánea. La dermis comprende aproximadamente un 30 a un $35 \%$ de proteína, que en su mayor parte es colágeno, siendo el resto agua y grasa. La dermis se utiliza para fabricar la piel después de eliminar las demás capas con medios químicos y mecánicos. En el proceso de curtido se emplean ácidos, álcalis, sales, enzimas y agentes curtientes para disolver las grasas y las proteínas no fibrosas y para enlazar químicamente las fibras de colágeno entre sí.

El curtido se practica desde tiempos prehistóricos. El sistema más antiguo se basa en la acción química de material vegetal que contiene tanino (ácido tánico). Se obtienen extractos de las partes de plantas que son ricas en tanino y se procesan convirtiéndose en líquidos curtientes. L os cueros se remojan en fosos 0 tinas de líquidos cada vez más concentrados hasta que se curten, lo cual puede tardar semanas o meses. Este proceso se utiliza en los países de escasos recursos tecnológicos. Se emplea también en países desarrollados para producir cueros más firmes y gruesos para suelas de zapatos, bolsos, artículos de viaje y correas, aunque se han introducido cambios para reducir el tiempo necesario. El curtido químico, que utiliza sales minerales como el sulfato de cromo, se introdujo en el siglo XIX y se ha convertido en el proceso principal para la producción de piel

* Parte del texto se ha recogido con modificaciones del artículo del que es autor V.P. G upta en la tercera edición de esta E nciclopedia. 
Figura 88.1 - Trabajo manual en una curtiduría de Afganistán.

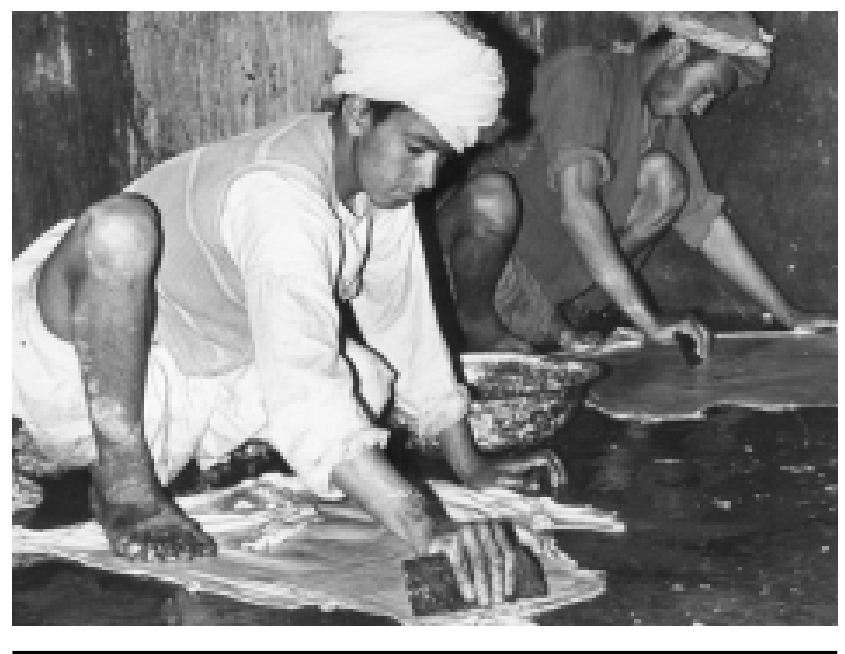

más suave y delgada para artículos como bolsos, guantes, prendas de vestir, tapicería y calzado. El curtido también puede realizarse utilizando aceites de pescado o taninos sintéticos.

La escala y tipología de instalaciones de curtido son muy variadas. Algunas fábricas poseen sistemas altamente mecanizados y utilizan sistemas automáticos cerrados y muchos productos químicos, mientras que otras todavía emplean mucha mano de obra y sustancias curtientes naturales con técnicas que no han variado esencialmente en el curso de los siglos (véase la Figura 88.1). El tipo de producto necesario (por ejemplo, cuero de gran resistencia o pieles finas flexibles) influye en la elección de los agentes curtientes y el acabado necesarios.

\section{Descripción del proceso}

La producción de piel puede dividirse en tres fases: preparación del cuero para el curtido, que incluye procesos como la eliminación del pelo y la carne adherida; proceso de curtido y proceso de acabado. El acabado incluye tareas mecánicas para dar forma y alisar la piel, y métodos químicos para colorear, lubricar, suavizar y aplicar un acabado superficial a la piel (véase la Figura 88.2). Todos estos procesos pueden tener lugar en las mismas instalaciones, aunque es común que el acabado se realice en instalaciones distintas del curtido con el fin de aprovechar los costes de transporte y los mercados locales. De ahí la posibilidad de contaminación cruzada entre los procesos.

Curado y expedición. Como las pieles y los cueros en bruto se deterioran rápidamente, se conservan y desinfectan antes de expedirlos a la curtiduría. Se extraen del armazón o canal y luego se conservan mediante cura. Esta puede realizarse por una amplia variedad de medios. El curado mediante secado es adecuado en regiones en las que se dan las condiciones climáticas de calor y ambiente seco. La operación de secado consiste bien en estirar las pieles sobre bastidores, bien en extenderlas en el suelo bajo la acción del calor del sol. El secado con sal, otro método utilizado, consiste en frotar el lado de la carne con sal. La cura con salmuera o salazón consiste en sumergir los cueros en una solución de cloruro sódico a la que puede haberse añadido naftaleno. Es el método más común de conservación en los países desarrollados.

Antes de expedirlos, los cueros suelen tratarse con DDT, cloruro de zinc, cloruro de mercurio, clorofenoles u otros agentes desinfectantes. Estas sustancias pueden representar riesgos tanto en el lugar de curado como a la recepción en la fábrica.
Preparación. Los cueros y pieles curados se preparan para curtir mediante diversas operaciones, que se denominan colectivamente operaciones de ribera. Primero se seleccionan los cueros, se recortan y seguidamente se lavan en tinas o tambores. Desinfectantes como polvo blanqueador, fluoruro sódico y cloro en el agua impiden la putrefacción de los cueros. Se añaden al agua productos químicos como sosa cáustica, sulfuro sódico y tensoactivos para acelerar el remojo de las pieles saladas 0 secadas.

A continuación, las pieles y cueros remojados se encalan sumergiéndolos en una lechada de cal para desprender la epidermis y las raíces de los pelos y para eliminar otras grasas y proteínas solubles indeseables. En otro método se aplica una pasta depilatoria a base de cal, sulfuro y sal al lado de la piel que está en contacto con la carne, con el fin de economizar pelo y lana. Los cueros encalados se tratan para eliminar los pelos sueltos y se descarnan. L uego se eliminan mecánicamente los residuos epidérmicos y las finas raíces de los pelos mediante la operación denominada labrado.

Estas operaciones van seguidas de la descalcificación y maceración con sales estabilizadoras, como sulfato amónico o cloruro amónico, y la acción de los enzimas proteolíticos neutraliza la elevada alcalinidad de los cueros encalados. En el piquelado, los cueros se ponen en un entorno ácido formado por cloruro sódico y ácido sulfúrico. El ácido es necesario porque los agentes curtientes de cromo no son solubles en condiciones alcalinas. L os cueros curtidos con materia vegetal no necesitan piquelarse.

M uchas de las operaciones de ribera se realizan procesando los cueros en grandes fosos, tinas o tambores. Las soluciones se trasladan a los recipientes a través de tuberías o se vierten en los mismos y posteriormente se vacían a través de tuberías 0 en los desagües abiertos en la zona de trabajo. Los productos químicos pueden añadirse a los recipientes mediante tuberías o manualmente. Se necesita una buena ventilación y equipo de protección personal para evitar la exposición respiratoria y dérmica.

Instalación de curtición. Pueden emplearse varias sustancias para curtir, pero la principal distinción está entre el curtido vegetal y al cromo. El curtido vegetal puede realizarse en foso 0 en bombos giratorios. El curtido rápido, en el que se emplean elevadas concentraciones de taninos, se realiza en tambores giratorios. El proceso de curtido al cromo que se emplea con la mayor frecuencia es el método de un solo baño, en el cual los cueros se tratan en una solución coloidal de sulfato de cromo (III) hasta que se completa el curtido. En el pasado se utilizaba un proceso de curtido al cromo de dos baños, pero implicaba la exposición potencial a sales de cromo hexavalentes y requería más manipulación manual de los cueros. En la actualidad, el proceso de dos baños se considera anticuado y raramente se utiliza.

Una vez curtido, el cuero es procesado para darle forma y acondicionarlo. El cuero se retira de la solución y el exceso de agua se elimina por escurrido. El cuero al cromo debe neutralizarse después de curtirse. El dividido es la división longitudinal del cuero húmedo o seco que es demasiado grueso, para artículos como piel para empeines de calzado y artículos de piel. Se emplean máquinas de cilindrar con cuchillas cortadoras para reducir el cuero al espesor deseado. Puede desprenderse una gran cantidad de polvo cuando el cuero es dividido o rebajado mientras está seco.

Recurtido, coloreado y engrase en baño. D espués del curtido, la mayoría de cueros, salvo los destinados a suelas de zapatos, se someten a coloreado (tintura). En general, el coloreado se realiza en lotes; las operaciones de recurtido, coloreado y engrase en baño se ejecutan todas ellas sucesivamente en el mismo tambor con operaciones intermedias de lavado y secado. Se emplean 
Figura 88.2 - Procesos típicos de curtido y acabado del cuero.

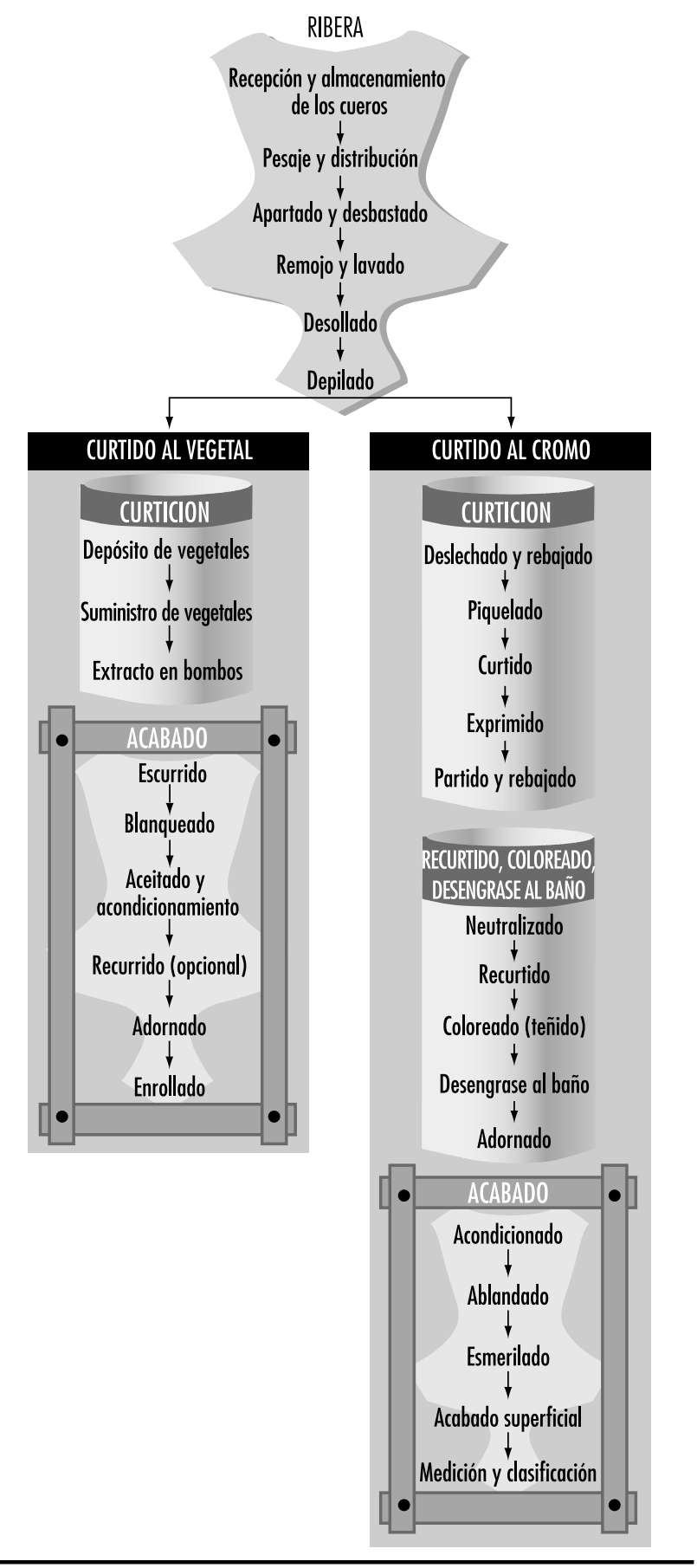

tres tipos principales de tintes: ácidos, básicos y directos. Se utilizan mezclas de tintes para obtener el matiz exacto deseado, por lo que la composición no es siempre conocida, salvo por el proveedor. $L$ a finalidad del engrase en baño es lubricar el cuero para darle resistencia y flexibilidad. Se emplean aceites, grasas naturales, sus productos de transformación, aceites minerales y varias grasas sintéticas.

Acabado. Después del secado, el cuero curtido al vegetal se somete a operaciones mecánicas (fijado y cilindrado) y se le aplica un pulido final. El proceso de acabado del cuero al cromo incluye una serie de operaciones mecánicas y normalmente la aplicación de una capa de cubrición a la superficie del cuero. EI ablandado es una operación mecánica de batido que se utiliza para hacer el cuero más suave. Para mejorar el aspecto final, el lado de flor del cuero se esmerila utilizando un cilindro de esmerilado. Este proceso genera una gran cantidad de polvo.

Se aplica un acabado superficial final que puede contener disolventes, plastificantes, aglutinantes y pigmentos. Estas soluciones se aplican mediante felpas, por revestimiento con flujo 0 por rociadura. Algunas fábricas de curtidos emplean mano de obra para aplicar el acabado utilizando felpas, pero esta operación generalmente la realizan las máquinas. En el revestimiento por flujo, la solución se bombea a un depósito situado por encima de la cinta transportadora que traslada el cuero, y fluye sobre el mismo. En la mayoría de casos, los cueros pintados o rociados no se secan en estufas, sino en bandejas colocadas en estanterías. Esta práctica proporciona una amplia superficie de evaporación y contribuye a la contaminación del aire.

\section{Riesgos y su prevención}

R iesgos de infección. En las primeras fases de las operaciones de ribera puede haber cierto riesgo de infección debido a zoonosis procedente de los cueros en bruto. El ántrax era un riesgo reconocido entre los trabajadores que manipulaban cueros y pieles, especialmente cueros secos y salados. Este riesgo ha sido prácticamente eliminado en las curtidurías debido a la desinfección de los cueros antes de su envío a las instalaciones. Pueden formarse colonias de hongos en los cueros y en la superficie de los líquidos.

Accidentes. Los suelos resbaladizos, mojados y grasientos constituyen un serio riesgo en todos los lugares de una fábrica de curtidos. Todos los suelos deberán ser de material impermeable, tener una superficie uniforme y estar bien drenados. Son imprescindibles un buen mantenimiento y orden y un alto nivel de limpieza. El traslado mecanizado de los cueros y las pieles de una operación a otra y el desagüe de los líquidos de las tinas y tambores ayudarán a reducir los derrames y los problemas ergonómicos de manipulación manual. Los fosos y las tinas deben dotarse de vallas para evitar lesiones por escaldadura, así como el peligro de perecer ahogado.

Existen muchos riesgos relacionados con las piezas de funcionamiento de las diversas máquinas, como los tambores giratorios, rodillos en movimiento y cuchillas. Debe disponerse de protecciones eficaces. Es preciso aplicar también protecciones a toda la maquinaria de transmisión, correas, poleas y engranajes.

Varias operaciones implican el levantamiento manual de los cueros y pieles, lo cual representa un riesgo ergonómico. EI ruido relacionado con la maquinaria es otro riesgo potencial.

Polvo. Se genera polvo en varias operaciones de curtido. Puede producirse polvo químico durante la carga de los tambores de procesado de cueros. EI polvo del cuero se produce durante las operaciones mecánicas. El esmerilado representa la principal fuente de polvo. El polvo en los talleres de curtido puede impregnarse con productos químicos, así como con fragmentos de pelo, moho y excrementos. Para su eliminación se precisa una ventilación eficaz.

R iesgos por productos químicos. La gran variedad de ácidos, álcalis, taninos, disolventes, desinfectantes y otros productos químicos utilizados pueden ser irritantes para las vías respiratorias y la piel. El polvo de materiales curtientes vegetales, la cal y el cuero y las neblinas y vapores de productos químicos que se presentan en los distintos procesos pueden causar bronquitis crónica. Varios productos químicos implican riesgo de dermatosis por contacto. Puede producirse ulceración por cromo en el curtido al cromo, especialmente en las manos. En las operaciones de ribera se producen principalmente exposiciones a compuestos de azufre como sulfuros y sulfatos. Como se trata de 
sustancias alcalinas, existe la posibilidad de que se genere sulfuro de hidrógeno si estas sustancias entran en contacto con ácidos.

L os agentes cancerígenos potenciales utilizados en el curtido y el acabado del cuero son las sales de cromo hexavalentes (en el pasado), tintes de anilina y azoicos, taninos vegetales, disolventes orgánicos, formaldehído y clorofenoles. La Agencia Internacional para la Investigación sobre el Cáncer (IARC) evaluó la industria del curtido a principios del decenio de 1980 y sacó la conclusión de que no había pruebas que indicaran una asociación entre el curtido del cuero y el cáncer nasal (IARC 1981). Informes de casos reales y estudios epidemiológicos desde que la IARC efectuó su evaluación han indicado un creciente riesgo de cáncer entre los trabajadores de curtido y acabado del cuero, incluyendo cáncer de pulmón, cáncer sinonasal y cáncer de páncreas asociados con el polvo y el curtido del cuero (M ikoczy y cols. 1996), así como cáncer de vejiga y de testículos asociado con tintes o disolventes utilizados en el proceso de acabado (Stern y cols. 1987). Ninguna de estas asociaciones está claramente establecida en estos momentos.

\section{INDUSTRIA PELETERA}

\section{P.E. Braid*}

Desde los primeros tiempos se han utilizado medios rudimentarios para conservar las pieles, que todavía se practican en muchas partes del mundo. Normalmente, después de raspada la piel y limpiada por lavado, se impregna con aceite animal, que sirve para conservarla y hacerla más flexible. Después puede batirse 0 masticarse para conseguir una buena impregnación con el aceite.

En la moderna industria peletera, las pieles se obtienen de granjeros, ceperos o cazadores. En esta fase, las pieles se han desenfundado del animal muerto, se han desollado, eliminando los depósitos de grasa por raspado, y se han estirado y secado al aire. L a industria peletera clasifica las pieles según factores como el estado general, la longitud, el rizado y el dibujo del pelo. Todas ellas pasan por una serie de operaciones de tratamiento para conservarlas (véase la Figura 88.3). También pueden teñirse. El tratamiento y la tintura se efectúan en lotes, y generalmente por piezas se trasladan de una operación a otra mediante carretillas manuales.

\section{Tratamiento de las pieles}

En primer lugar, se clasifican las pieles, se les aplica una marca de identificación y se abren utilizando cuchillas y cortadoras mecánicas. Seguidamente se remojan en agua con sal en tinas o barriles durante varias horas para ablandarlas (véase la Figura 88.4). A menudo se utilizan palas rotativas para ayudar en el remojo. A veces se emplea ácido fórmico, ácido láctico y ácido sulfúrico en la operación de remojo. Seguidamente se elimina el exceso de agua en tambores giratorios.

L uego, la cara inferior de la piel se pasa por máquinas descarnadoras de cuchillas redondas muy afiladas por obreros denominados pelambreros (Figura 88.5). También se efectúa el giro manual de dentro afuera y el recorte con cuchillas. Esta operación elimina el tejido conjuntivo suelto de la cara inferior de la piel. Su objeto es eliminar al máximo posible todo tejido que no esté implicado en la fijación del pelo, con lo que se consigue el máximo grado de ligereza y flexibilidad de la piel.

* Adaptado del artículo de este autor incluido en la tercera edición de la E nciclopedia. Se agradece a Gary M eisel y a Tom Cunningham, del Sindicato U nido de Trabajadores del Comercio y la Alimentación, la revisión y adaptación que han hecho del mismo.

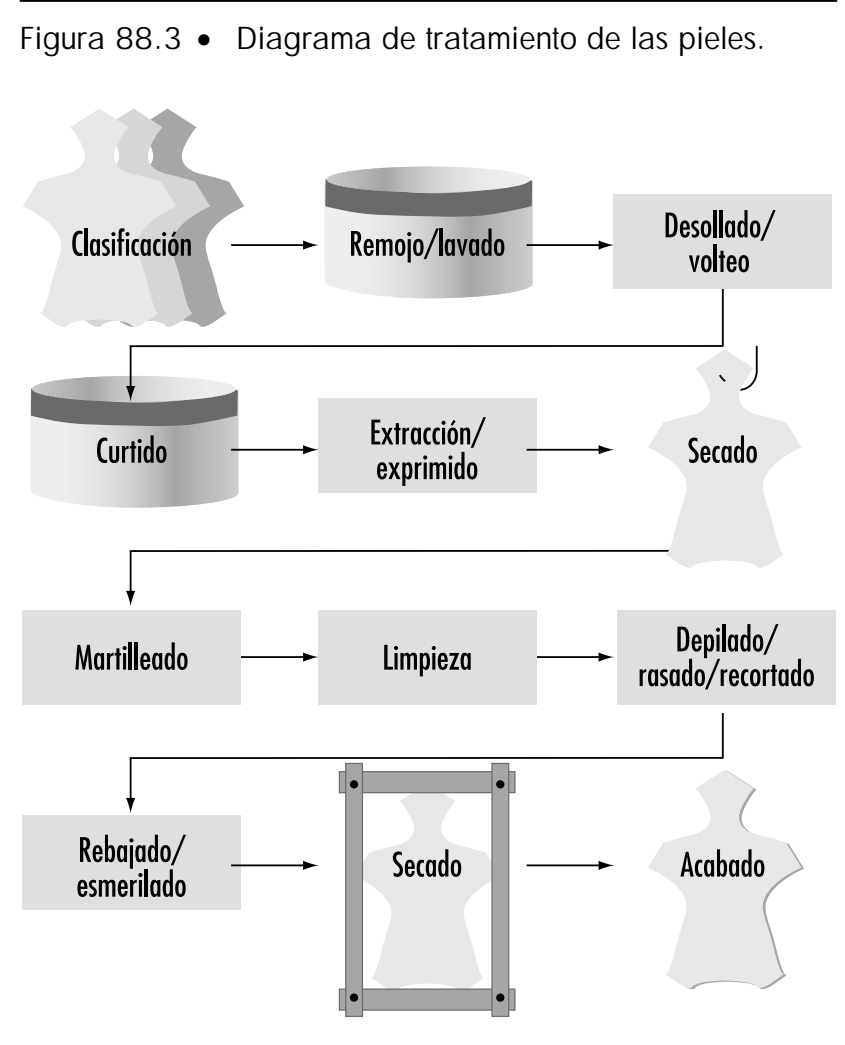

A hora las pieles quedan listas para su curtido y se remojan en solución de alúmina en fosos o tinas. Al igual que para el remojo, se utilizan palas. L a solución de alúmina se acidula algo, generalmente con ácido clorhídrico o sulfúrico. El tratamiento con alúmina puede efectuarse en solución acuosa o de aceite. Se extrae el exceso de líquido y las pieles se secan en cámaras de secado especiales para fijar el colágeno de la piel.

Las pieles curtidas se tratan seguidamente con una solución de aceite en una máquina martilleadora 0 de tipo similar para que el aceite penetre bien en ellas. Seguidamente se limpian en tambores giratorios que contienen serrín, que absorbe la humedad y el exceso de aceite.

Figura 88.4 • Departamento de remojo en un taller de procesado de pieles.

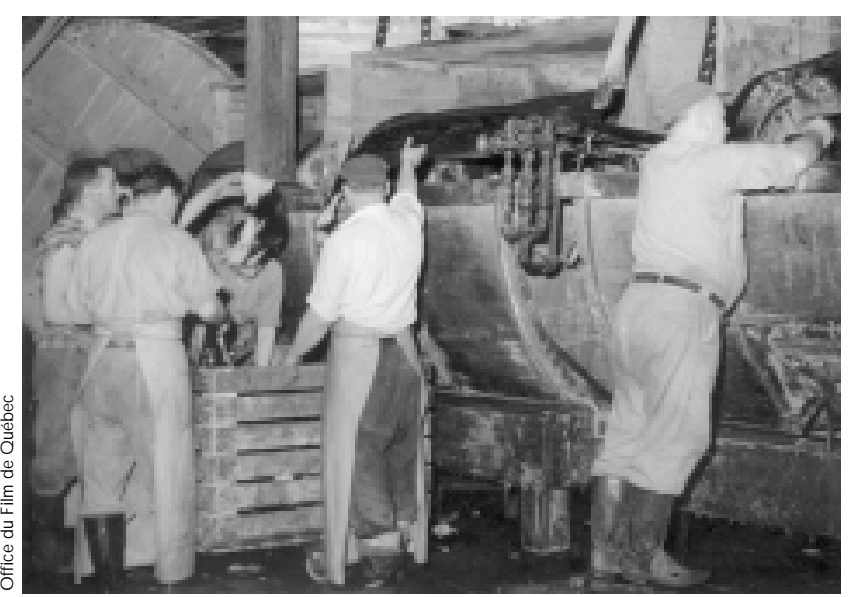


Figura 88.5 • Descarnado a máquina de pieles de cordero.

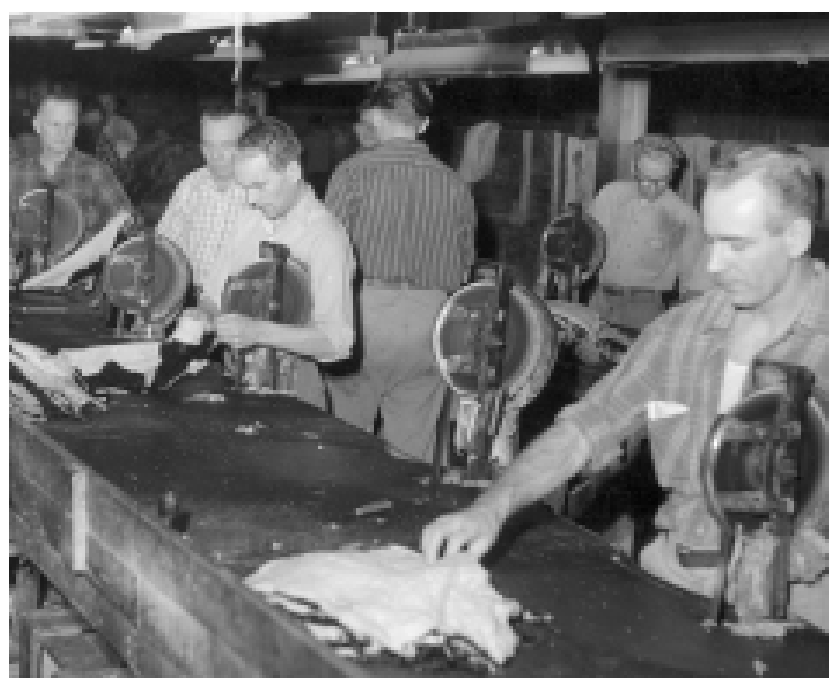

Las pieles contienen pelos protectores, así como fibras más suaves. Los pelos protectores son más rígidos y largos que las fibras y, según el tipo de piel y el producto final deseado, estos pelos pueden eliminarse parcial o totalmente por depilación a máquina 0 manual. Algunas pieles también requieren rasado 0 recorte con cuchillas (véase la Figura 88.6).

0 tras operaciones son el aceitado o "rebajado" con máquinas descarnadoras de cuchilla redondas, el pulido con esmeriles, el secado y el acabado. Esta última operación puede incluir el desengrase, estirado, limpieza, pulido, cepillado y lustrado con lacas y resinas.

\section{Tintura}

Aunque la tintura de las pieles no se consideraba favorablemente en otro tiempo, en la actualidad constituye una tarea aceptada de la preparación de las pieles y se practica ampliamente. Puede realizarse al mismo tiempo que el curtido o en una operación posterior. EI procedimiento habitual implica el tratamiento con una solución alcalina débil (por ejemplo, carbonato sódico) para eliminar la suciedad y los residuos de aceite. Seguidamente las

Figura 88.6 • O peración de rasado en pieles de castor canadiense.

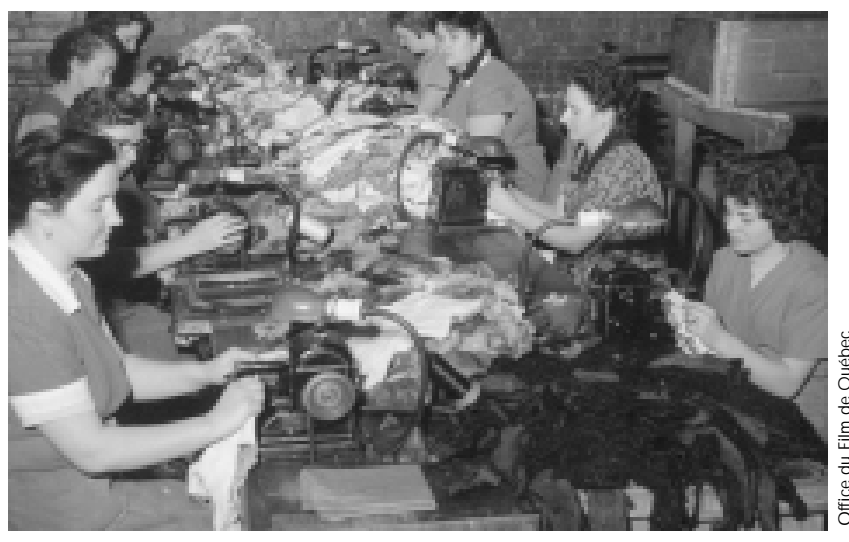

Figura 88.7 • O perarios cosiendo pieles a máquina

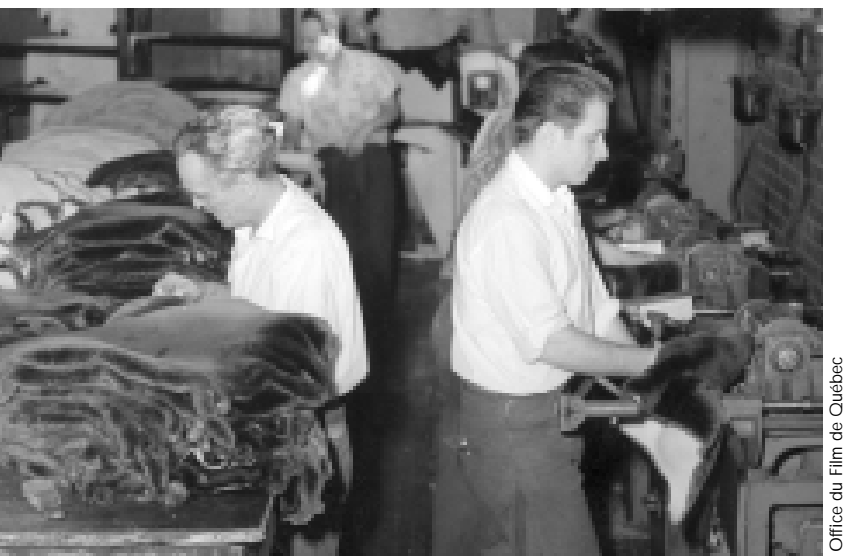

pieles se remojan en una solución de mordiente (por ejemplo, sulfato férrico), tras lo cual se maceran en solución de tinte hasta que se obtiene el color deseado. Luego se aclaran repetidamente y se secan en tambor con ayuda de serrín.

En la tintura pueden utilizarse otros muchos productos químicos, como el amonio, cloruro amónico, formaldehído, peróxido de hidrógeno, acetato o nitrato de plomo, ácido oxálico, perborato sódico, tintes de p-fenilendiamina, tintes de bencidina, etc.

\section{Fabricación de prendas de peletería}

Antes de confeccionarse en prendas de vestir, las pieles pueden cortarse y estirarse por corte y recosido. Esto implica realizar una serie de cortes en diagonal o en forma de $\mathrm{V}$ muy juntos, tras lo cual la piel se estira para alargarla o ensancharla según sea necesario. Seguidamente se recose (véase la Figura 88.7). Este tipo de operación requiere gran destreza y experiencia. Luego se humedece a fondo y se coloca y fija sobre una tabla según un patrón marcado con tiza, se deja secar y se cose. La aplicación del forro y otras operaciones de acabado completan la prenda.

\section{Riesgos y su prevención}

\section{Accidentes}

Algunas de las máquinas utilizadas en la elaboración de las pieles presentan serios riesgos a menos que se instale una protección suficiente: en particular, todos los tambores deben protegerse con una puerta de enclavamiento y las centrífugas utilizadas para la extracción de la humedad han de proveerse de tapas de enclavamiento; las máquinas para corte de las pieles han de estar totalmente cubiertas, salvo en las aberturas de entrada y salida de las pieles.

Las tinas han de cubrirse o equiparse con barandillas suficientes para evitar una inmersión accidental. Las caídas en suelos mojados y resbaladizos pueden evitarse en gran manera manteniendo las superficies impermeables en buen estado, bien drenadas y sujetas a una limpieza frecuente. Las tinas de teñir deben rodearse de canales de desagüe. L os accidentes causados por herramientas manuales pueden reducirse si las empuñaduras están bien diseñadas y las herramientas son objeto de un buen mantenimiento. En el sector de la peletería, las máquinas de coser requieren una protección similar a la utilizada en la industria de la confección (por ejemplo, protección en los mecanismos de impulsión y de las agujas). 


\section{Riesgos para la salud}

El uso por la industria peletera de una elevada proporción de pieles de animales criados en cautividad ha reducido considerablemente la posibilidad de transmisión de enfermedades de los animales al personal que trabaja con las pieles. Sin embargo, puede producirse ántrax en los trabajadores que manipulan animales muertos, pieles, cueros o pelos de animales infectados; es posible vacunar a todas las personas en contacto con los animales. Todos los participantes han de conocer el riesgo y han de poder notificar de inmediato cualquier síntoma sospechoso.

Varios productos químicos utilizados en la industria peletera son irritantes potenciales de la piel. Se trata de los álcalis, ácidos, alúmina, cromatos, agentes blanqueadores, aceites, sal y los compuestos implicados en el proceso de tintura, incluidos varios tipos de tintes y mordientes.

La apertura de balas tratadas con polvos medicinales en sus países de origen, el tamboreado, la depilación y el rasado pueden generar polvo irritante. En las tintorerías, donde se pesan y cuecen sales de plomo, cobre y cromo (y posiblemente tintes carcinógenos), también existe el riesgo de ingestión de polvos tóxicos. Pueden desprenderse vapores perjudiciales de los disolventes y los productos químicos de fumigación. Existe asimismo la posibilidad de que se desarrolle sensibilidad por contacto (alergia) a algunos de estos productos químicos 0 al polvo de uno o más de los tipos de pieles que se manipulan.

La protección principal contra los riesgos del polvo y los vapores es un adecuado sistema de extracción localizada; también se precisa una buena ventilación general en todo el proceso. U nas buenas normas de mantenimiento del orden y la limpieza son importantes para eliminar el polvo. Pueden precisarse mascarillas de respiración para trabajos de corta duración o como complemento del extractor del local en operaciones muy polvorientas. Debe prestarse atención especial a los posibles riesgos en espacios reducidos, como los fosos y tinas que se utilizan para el remojo/ lavado, curtido y tintura.

Es preciso llevar prendas protectoras adecuadas para el proceso en la mayoría de fases de elaboración de las pieles. Se necesita protección de goma para las manos, protección de los pies y las piernas y delantales para los procesos en húmedo (por ejemplo, en las tinas de tintes y mordientes) y como protección contra los ácidos, álcalis y productos químicos corrosivos. D eben preverse unas buenas instalaciones sanitarias y de lavado, incluyendo duchas. Para lavarse las manos no han de emplearse blanqueadores ni jabones alcalinos fuertes.

Pueden producirse problemas ergonómicos a causa del levantamiento y traslado manual de materiales, especialmente al empujar carretillas de mano, y en la carga y descarga manual de pieles (especialmente cuando están húmedas). La automatización de estos procesos ayuda a resolver los problemas. Los movimientos repetitivos en la confección de prendas de piel también son una fuente de problemas ergonómicos.

Pueden producirse enfermedades por esfuerzo debido al calor al trabajar en la sala de secado. Las medidas preventivas incluyen una adecuada extracción del aire caliente y el suministro de aire fresco, la limitación del tiempo de exposición, la fácil disponibilidad de agua potable y la formación para reconocer los síntomas del effuerzo por calor y en primeros auxilios.

EI ruido puede representar un problema en muchas de las máquinas que se utilizan, especialmente en tambores y en máquinas de peinado, rasado y lustrado.

Un examen médico antes de asignar un trabajo determinado a un trabajador puede ayudar a prevenir dermatosis y permitirá que los trabajadores que tengan un historial de sensibilidad puedan ser asignados a trabajos adecuados. La supervisión médica es conveniente; la disponibilidad de material de primeros auxilios a cargo de personas debidamente formadas es esencial.
$\mathrm{H}$ ay que prestar mucha atención a la higiene, la ventilación y la temperatura en los numerosos talleres pequeños en los que se realiza gran parte de la confección de prendas de pieles.

\section{CALZADO, INDUSTRIA}

\section{F.L. Conradi y Paulo Portich*}

El término calzado abarca un vasto campo de productos fabricados a base de materiales muy diversos. Botas, zapatos, sandalias, zapatillas, zuecos, etc., se fabrican entera o parcialmente de cuero, goma, materiales sintéticos y plásticos, lona, cuerda y madera. Este artículo trata de la industria del calzado tal como se entiende generalmente, es decir, la basada en los métodos de fabricación tradicionales. La fabricación de botas de goma (o sus equivalentes sintéticos) es esencialmente una sección de la industria del caucho, que se trata en el capítulo Industria del caucho.

L os zapatos, botas y sandalias hechas de cuero, fieltro y otros materiales se han hecho a mano durante siglos. L os zapatos finos aún se hacen, entera o parcialmente, a mano pero en todos los países industrializados existen actualmente grandes fábricas de producción en serie. Aun así, algunos trabajos se realizan a domicilio. La mano de obra infantil sigue siendo uno de los problemas más serios en la industria del calzado, aunque varios países aplican varios programas internacionales en este campo.

Las fábricas de botas y zapatos se sitúan generalmente cerca de las áreas de producción de cuero (o sea, cerca de las regiones ganaderas). Algunas fábricas de zapatillas y zapatos ligeros se han desarrollado donde había un suministro abundante de fieltros de la industria textil, y en la mayor parte de los países la industria tiende a estar localizada en sus centros de origen. Cueros de diversos tipos y calidades y algunas pieles de reptil constituyeron los materiales originales, con un calidad más dura para las suelas. En los años recientes el cuero ha sido desplazado cada vez más por otros materiales, en especial la goma y los plásticos. L os forros pueden hacerse de lana o tejido de poliamida (nailon) o piel de oveja; los cordones se fabrican con pelo de caballo o fibras sintéticas; el papel, la cartulina y los termoplásticos se usan para refuerzos. En el acabado se utilizan cera natural y coloreada, tintes de anilina y agentes colorantes.

Factores económicos y de otro tipo han transformado la industria del calzado en los últimos años. La fabricación de zapatillas de tenis es uno de los sectores en alza de la industria y ha pasado de la producción en un solo país a la producción a escala mundial, especialmente en países en vías de desarrollo en A sia y América del Sur, con el fin de aumentar la producción y reducir los costes. Esta migración de la producción a los países en desarrollo también se ha producido en otros sectores de la industria del calzado.

\section{Procesos}

Pueden intervenir más de cien operaciones en la fabricación de un zapato, y aquí sólo es posible hacer un breve resumen. La mecanización se ha aplicado a todas las etapas, pero se sigue estrechamente el modelo del proceso manual . La introducción de nuevos materiales ha modificado el proceso sin variar el procedimiento general.

En la fabricación de los empeines, la piel u otros materiales se escogen y preparan y luego se recortan en máquinas de coser (o de conformar) con herramientas de forma con cuchillas sueltas. Las piezas, incluyendo los forros, se "unen"

* Adaptado por P. Portich del artículo de F.L. Conradi incluido en la tercera edición de esta E nciclopedia. 
posteriormente, 0 sea, se cosen o pegan. También pueden realizarse operaciones de perforado, apertura de ojales, etc.

Para fabricar la parte inferior, las suelas, plantillas, tacones y viras se cortan en máquinas giratorias que utilizan cuchillas sueltas, o en prensas de moldeado de suelas; los tacones se fabrican por compresión de tiras de cuero o madera. EI material se recorta, se le da forma y se estampa.

Seguidamente se unen las partes superior e inferior y luego se cosen, pegan, clavan 0 atornillan. D espués de estas operaciones, se les da forma y se nivelan entre rodillos. El acabado final del zapato incluye la aplicación de cera, la tintura, el rociado, pulido y embalaje.

Entre las materias primas utilizadas en el proceso de fabricación, las más importantes desde el punto de vista de los riesgos profesionales son los adhesivos, que comprenden adhesivos naturales, sólidos o líquidos, y soluciones adhesivas a base de disolventes orgánicos.

\section{Riesgos y su prevención}

El uso extendido de líquidos inflamables encierra un considerable riesgo de incendio, y el empleo generalizado de prensas y máquinas de montaje ha introducido un mayor riesgo de accidentes mecánicos en esta industria. L os principales riesgos para la salud son los disolventes tóxicos, las altas concentraciones de polvo en la atmósfera, los riesgos ergonómicos y el ruido que producen las máquinas.

\section{Incendios}

Los disolventes y aerosoles utilizados en los adhesivos y materiales de acabado pueden ser altamente inflamables. Las precauciones recomendadas son las siguientes:

- utilizar los disolventes con el punto de inflamación más bajo posible;

- emplear una buena ventilación general y de extracción localizada en las cámaras de rociado y en los soportes de secado para reducir la concentración de vapores inflamables;

- eliminar los residuos combustibles de las cámaras y bancos de trabajo y proporcionar recipientes cerrados para los desperdicios oleosos y que contienen disolvente;

- mantener despejadas las salidas y los pasillos;

- reducir la cantidad de líquidos inflamables almacenados y mantenerlos en contenedores, cámaras y salas de almacenamiento homologados;

- asegurarse de que la instalación eléctrica y el cableado próximos a disolventes inflamables cumplan la normativa vigente,

- conexión a tierra adecuada de las máquinas pulidoras y otras fuentes de electricidad estática.

\section{Accidentes}

Muchos de los órganos móviles de las máquinas presentan grandes riesgos, en especial las prensas, estampadoras, rodillos y cuchillas. Los cortadores, a base de cuchillas sueltas, de las máquinas giratorias y de coser, pueden causar lesiones graves. Entre las precauciones apropiadas se incluyen como mínimo la disponibilidad de mandos bimanuales (puede ser preferible un dispositivo de célula fotoeléctrica para desconectar automáticamente la corriente), la reducción de la carrera a un nivel seguro en relación con el tamaño del cortador, y el uso de cortadores estables bien diseñados, de altura adecuada, con bridas montadas, quizá con empuñaduras. Deben protegerse con resguardos las prensas de tacones y de moldeo de suelas para impedir que puedan introducirse las manos. Las estampadoras pueden causar quemaduras, así como lesiones por aplastamiento, a menos que se impida la introducción de las manos por medio de protecciones. Los puntos de actuación de los rodillos y cuchillas de las máquinas de laminar y de conformar deben dotarse de las protecciones adecuadas. Las ruedas de matizar y pulir de las máquinas de acabado y los ejes en los que van montadas aquéllas también deben protegerse. Debe haber un programa eficaz de consignación/señalización para los trabajos de reparación y mantenimiento.

\section{Riesgos para la salud}

Los disolventes orgánicos pueden causar efectos agudos y crónicos en el sistema nervioso central. El benceno, que anteriormente se utilizaba en adhesivos y disolventes, ha sido sustituido por tolueno, xileno, hexano, metil-etil-cetona (M EK) y metil-butil-cetona (M BK). Tanto el n-hexano como la MBK pueden causar neuropatías periféricas y han de sustituirse por heptano u otros disolventes.

En diversas fábricas han aparecido brotes de una enfermedad conocida popularmente con el nombre de "parálisis del calzado", y cuyo cuadro clínico corresponde a un forma más 0 menos grave de parálisis. Esta parálisis, de tipo fláccido, se localiza en las extremidades (pélvicas o torácicas) y ocasiona atrofia osteotendinosa con arreflexia y sin alteración de la sensibilidad superficial ni profunda. Clínicamente es un síndrome producido por inhibición funcional o lesión de las motoneuronas inferiores del sistema motor voluntario (tracto piramidal). La evolución natural apunta a la regresión neurológica con recuperación funcional en sentido próximo-distal.

Debe proporcionarse una buena ventilación general y de extracción localizada de los vapores, con el fin de mantener las concentraciones muy por debajo de los niveles máximos admisibles. Si se respetan dichos niveles, también disminuirá el riesgo de incendio. Reducir la cantidad de disolvente utilizado, encapsular los equipos que utilizan disolvente y cerrar los envases que contienen disolvente constituyen también importantes precauciones.

Las máquinas de acabado generan polvo, que debe ser eliminado de la atmósfera mediante sistemas de extracción. Algunos de los abrillantadores, tintes, colorantes y colas de policloropreno pueden entrañar un riesgo de dermatosis. $H$ ay que proporcionar buenas instalaciones de aseo e higiene y fomentar la higiene personal.

El mayor uso intensivo de las máquinas y equipos supone un importante riesgo acústico, que requiere el control del ruido en la fuente u otras medidas preventivas para evitar la pérdida de audición. También debe existir un programa de conservación de la audición.

El trabajo prolongado con máquinas de tachonado, que producen altos niveles de vibración, puede ocasionar el proceso conocido como "dedo blanco" (síndrome de R aynaud). Se aconseja que los turnos de trabajo en dichas máquinas se reduzcan al mínimo posible.

El dolor en la región lumbar y las lesiones por distensiones repetidas son dos enfermedades musculosqueléticas que representan importantes problemas en la industria del calzado. Las soluciones ergonómicas son esenciales para prevenir estos problemas. L os reconocimientos médicos periódicos y previos al empleo, relacionados con los riesgos laborales, constituyen un factor eficaz para la protección de la salud de los trabajadores.

\section{Peligros ambientales y de salud pública}

La C umbre de la Tierra de 1992, celebrada en Río de Janeiro, trató de las preocupaciones medioambientales, y sus propuestas de actuación futura, conocidas como A genda 21, podrían transformar la industria del calzado debido a la importancia concedida al reciclaje. Sin embargo, en general, la mayoría de residuos 
acaban en vertederos públicos. Sin las debidas precauciones, este hábito puede causar la contaminación del suelo y de las aguas freáticas.

Aunque el trabajo a domicilio ofrece ventajas sociales, al reducir el desempleo y fomentar la creación de cooperativas, los problemas para garantizar las precauciones y las condiciones de trabajo adecuadas en el hogar son enormes. Además, otros familiares pueden sufrir riesgos si no participan ya en el trabajo. Tal como se ha comentado anteriormente, la mano de obra infantil sigue siendo un grave problema.

\section{- EFECTOS SOBRE LA SALUd y PAUTAS PATOLOGICAS}

Frank B. Stern

\section{Curtido del cuero}

El principal grupo de la Clasificación Industrial Internacional Uniforme (CIIU) referente al procesado del cuero y las pieles es el 323. En Estados U nidos, el grupo de la Clasificación Industrial Normalizada (SIC) correspondiente a la industria del cuero y de los productos para su fabricación es SIC 311 (O M B 1987). En este grupo se incluyen los establecimientos dedicados a curtir, adobar y acabar cueros y pieles, así como los que fabrican productos de cuero y similcuero acabados y algunos productos similares fabricados con otros materiales. También las manufacturas de cuero, el cuero para correas y la piel para gamuzas se incluyen en SIC 311. Además, algunas partes de SIC 23 (en concreto, SIC 2371 y 2386) comprenden los establecimientos dedicados a la fabricación de chaquetas, prendas de vestir, accesorios y adornos de pieles y establecimientos dedicados a prendas forradas de piel de ovino.

Existen muchas variedades de cuero con distintas características que dependen de la especie animal y de la parte específica del cuerpo del animal del que se obtiene el cuero. Se procesan cueros de pieles de bovino o de caballo; cuero de fantasía de piel de ternero, cerdo, cabra, oveja, etc.; y cuero de reptiles como cocodrilo, lagarto, camaleón, etc.

Los puestos de trabajo en la industria del cuero y de los productos para su fabricación han sido asociados a distintas enfermedades causadas por agentes biológicos, tóxicos y carcinógenos. La enfermedad concreta relacionada con la exposición en la industria del cuero depende de la medida en que el trabajador esté expuesto a los agentes, lo cual depende, a su vez, de la ocupación y la zona de trabajo dentro de la propia industria.

Para el proceso de curtido, primeramente se retira la epidermis del cuero y solamente la dermis se transforma en piel. Durante este proceso, la infección es un riesgo constante, ya que el cuero sirve de medio para numerosos microorganismos. Pueden desarrollarse colonias de hongos, concretamente Aspergillus niger y Penicillus glaucum (M artignone 1964). Para evitar el desarrollo de hongos se han utilizado ampliamente fenoles clorados, específicamente pentaclorofenol; desgraciadamente se ha observado que estos productos químicos son tóxicos para el trabajador. También se han encontrado levaduras de tres géneros ( $\mathrm{R}$ hodotorula, Cladosporium y Torulopsis) ( $\mathrm{K}$ allenberger 1978). El tétanos, el ántrax, la leptospirosis, el afta epizoótica, la fiebre $\mathrm{Q}$ y la brucelosis son ejemplos de enfermedades que podrían contraer los trabajadores durante el proceso de curtido a causa de cueros infectados (Valsecchi y Fiorio 1978).

También se han diagnosticado trastornos de la piel, como eccema y dermatosis por contacto (alérgica), entre los curtidores expuestos a los conservantes aplicados a los cueros (Abrams y Warr 1951). El curtido del cuero y el proceso de acabado han demostrado tener la mayor incidencia de dermatosis de cualquier grupo de trabajo en Estados Unidos (Stevens 1979). Pueden producirse irritaciones de las mucosas de la garganta y la nariz y perforaciones del tabique nasal después de inhalar vapores de ácido crómico liberados durante el proceso de curtido al cromo.

L os curtidores corren el riesgo de estar expuestos a numerosos carcinógenos ocupacionales conocidos o sospechosos, como sales de cromo hexavalentes, colorantes azoicos a base de bencidina, disolventes orgánicos (por ejemplo, benceno y formaldehído), pentaclorofenol, compuestos $\mathrm{N}$-nitrosos, arsénico, dimetilformamida y polvos de cuero en suspensión en el aire. Esta exposición puede dar lugar al desarrollo de distintos cánceres específicos del lugar. Se ha observado un exceso de cáncer de pulmón en estudios realizados en Italia (Seniori, M erler y Saracci 1990; Bonassi y cols. 1990) y en un estudio de control de casos llevado a cabo en Estados U nidos (G arabrant y Wegman 1984), pero este resultado no siempre está respaldado por otros estudios (M ikoczy, Schutz y Hagmar 1994; Stern y cols. 1987; Pippard y Acheson 1985). El cromo y los compuestos arsenicales se han mencionado como posibles coadyuvantes del exceso de cáncer de pulmón. Se ha observado un riesgo muy acentuado de sarcoma de los tejidos

blandos como mínimo en dos estudios sobre curtido realizados por separado, uno en Italia y otro en el Reino U nido; los investigadores de ambos estudios señalan que los clorofenoles utilizados en los talleres de curtido pueden haber producido estos tumores malignos (Seniori y cols. 1989; M ikoczy, Schutz y $\mathrm{H}$ agmar 1994). Se ha observado un triple exceso estadísticamente significativo en la mortalidad por cáncer de páncreas en un estudio de casos y controles realizado en Suecia (Erdling y cols. 1986); también se ha observado un aumento del $50 \%$ del cáncer de páncreas en otro estudio en el que se examinaron tres curtidurías de Suecia (M ikoczy, Schutz y Hagmar 1994) y en un estudio de un taller de curtidos italiano (Seniori y cols. 1989). A pesar del riesgo excesivo de cáncer de páncreas, no se identificó ningún agente medioambiental específico y se consideraron como posibles los factores dietéticos. Se observó un riesgo excesivo de cáncer de testículos entre curtidores del departamento de acabado de una curtiduría; los tres trabajadores con cáncer de testículos habían trabajado durante el mismo periodo de tiempo y estuvieron expuestos a dimetilformamida (Levin y cols. 1987; Calvert y cols. 1990). Se ha observado asimismo un riesgo excesivo de cáncer sinonasal entre trabajadores de la industria del curtido en un estudio de casos-controles realizado en Italia; se indicaron el cromo, el polvo de cuero y los taninos como posibles agentes etiológicos (Comba y cols. 1992; Battista y cols. 1995). Sin embargo, la investigación realizada por la IARC a principios del decenio de 1980 no encontró ninguna prueba de asociación entre el curtido de cuero y el cáncer nasal (IARC 1981). Los resultados de un estudio de la industria de curtidos de China reflejan un exceso de morbosidad estadísticamente significativo en el cáncer de vejiga entre los curtidores que estuvieron expuestos a colorantes a base de bencidina, que aumentó con la duración de la exposición (C hen 1990).

Los accidentes también son una causa principal de incapacidad entre los trabajadores de la industria del curtido. LoS resbalamientos y las caídas en suelos mojados y grasientos son comunes, así como los cortes con cuchillas al recortar los cueros. Además, las máquinas utilizadas para procesar los cueros pueden ser causa de magulladuras, abrasiones y amputaciones. Por ejemplo, los datos del Bureau of Labor Statistics (BLS) de Estados Unidos, correspondientes a 1994, indican para el SIC 311 una tasa de incidencia conjunta de lesiones y enfermedades de 19,1 por cada 100 trabajadores a jornada completa y una tasa de incidencia de lesiones de 16,4. Estos resultados 
superan en más del $50 \%$ a los correspondientes al conjunto de la industria: lesiones y enfermedades, 12,2 por 100 trabajadores a jornada completa, y lesiones 10,4 (BLS 1995)

\section{Calzado}

La manipulación y el procesado del cuero en la fabricación de zapatos y botas puede dar lugar a la exposición a algunos de los mismos productos químicos utilizados en los procesos de curtido y acabado que se han indicado anteriormente, causando enfermedades similares. Además, los productos químicos que se utilizan pueden producir otras enfermedades. La exposición a los disolventes tóxicos empleados en adhesivos y limpiadores y al polvo de cuero en suspensión en el aire es motivo de especial preocupación. Un disolvente preocupante es el benceno, que puede producir trombocitopenia, reducción de hematíes, plaquetas y leucocitos, y pancitopenia. Su uso ha sido eliminado en gran parte en la industria del calzado. También se ha encontrado neuropatía periférica entre los trabajadores de las fábricas de calzado a causa del n-hexano en los adhesivos. Este producto químico se ha sustituido también ampliamente por disolventes menos tóxicos. Se han descrito asimismo cambios electroencefalográficos, lesiones hepáticas y alteraciones del comportamiento en relación con la exposición a los disolventes en las fábricas de calzado.

El benceno se ha considerado un carcinógeno humano (IARC 1982), y varios investigadores han observado un exceso de leucemia entre los trabajadores expuestos al benceno en la industria del calzado. Se realizó un estudio en las mayores instalaciones de fabricación de calzado de Florencia, Italia, con más de 2.000 trabajadores. Sus resultados revelaron un riesgo de leucemia cuatro veces mayor, y se citó el benceno como la fuente de exposición más probable (Paci y cols. 1989). Un seguimiento de este estudio mostró un riesgo más de cinco veces superior entre los trabajadores de la industria del calzado que realizaban tareas en las que la exposición al benceno era elevada ( $F u$ y cols. 1996). En un estudio realizado en el Reino U nido, en el que se examinó la mortalidad entre varones dedicados a la fabricación de calzado, se encontró un elevado riesgo de leucemia entre los trabajadores que manipulaban colas y disolventes que contenían benceno (Pippard y Acheson 1985). Varios estudios de trabajadores de la industria del calzado de Estambul, Turquía, han señalado un excesivo riesgo de leucemia con la exposición al benceno. Cuando el benceno se sustituyó por gasolina, el número absoluto de casos y el riesgo de leucemia disminuyeron considerablemente (A ksoy, Erdem y DinC ol 1974; 1976; Aksoy y Erdem 1978).

Varios tipos de cáncer nasal (adenocarcinoma, carcinoma de células escamosas y carcinoma de células transicionales) se han asociado con el trabajo en la fabricación y reparación de calzado. Se han descrito riesgos relativos a diez veces mayores en estudios realizados en Italia y en el Reino Unido ( $\mathrm{Fu}$ y cols. 1996; Comba y cols. 1992; M erler y cols. 1986; Pippard y Acheson 1985; Acheson 1972, 1976; Cecchi y cols. 1980), pero no en Estados U nidos (D eC oufle y Walrath 1987; Walker y cols. 1993). El elevado riesgo de cáncer nasal correspondió casi enteramente a los trabajadores expuestos "intensamente" al polvo de cuero en las salas de preparación y acabado. Se desconoce el mecanismo por el cual la exposición al polvo de cuero puede aumentar el riesgo de cáncer nasal.

Se han encontrado niveles excesivos de cáncer del sistema digestivo y de las vías urinarias como el cáncer de vejiga ( $M$ alker y cols. 1984; M orrison y cols. 1985), de riñón (Walker y cols. 1993; M alker y cols. 1984), de estómago (Walrath, DeC oufle y Thomas 1987) y del recto (D eC oufle y Walrath 1983; Walrath, DeC oufle y Thomas 1987) en otros estudios entre trabajadores de la industria del calzado, pero no se han descrito de manera uniforme y no se han relacionado con exposiciones concretas en la industria.

L os riesgos ergonómicos que causan trastornos musculosqueléticos ocupacionales (T M EO ) constituyen importantes problemas en la industria de fabricación de calzado. E stos riesgos se deben a los equipos especiales que se emplean y al trabajo manual que requiere movimientos repetitivos, esfuerzos y posturas difíciles del cuerpo. Los datos de BLS muestran que el calzado de caballero es una de las "industrias con las mayores tasas de trastornos no mortales relacionados con traumatismos repetidos" (BLS 1995). Se observó que la incidencia en el total del sector del calzado de enfermedades y lesiones conjuntamente era de 11,9 por 100 trabajadores, siendo 8,6 la incidencia correspondiente a las lesiones solas. Estas incidencias son ligeramente inferiores a las de toda la industria. LoS TMEO en la industria del calzado incluyen trastornos como tendinitis, sinovitis, tenosinovitis, bursitis, quistes ganglionares, distensiones, síndrome del túnel carpiano, dolor lumbar y lesiones en lascervicales.

\section{Trabajadores de la industria peletera}

El procesado de las pieles implica las actividades de tres categorías de trabajadores. L os curtidores descarnan y curten las pieles; los teñidores colorean o tiñen las pieles con tintes naturales 0 sintéticos; y finalmente los trabajadores de expedición clasifican, acoplan y embalan las pieles curtidas. Los curtidores y teñidores están expuestos a posibles carcinógenos que incluyen taninos, tintes oxidativos, cromo y formaldehído, mientras que los trabajadores de expedición están potencialmente expuestos a los residuos de materiales curtientes mientras manipulan las pieles previamente curtidas. El único estudio amplio realizado entre estos trabajadores reveló riesgos estadísticamente elevados de cáncer colorrectal y de hígado entre los teñidores, cáncer de pulmón entre los curtidores y enfermedades cardiovasculares entre los trabajadores de expedición en comparación con las tasas globales de Estados Unidos (Sweeney, Walrath y Waxweiler 1985).

\section{CUESTIONES AMBIENTALES Y DE SALUD PUBLICA}

Jerry Spiegel

EI tratamiento y procesado de pieles y cueros de animales puede originar un notable impacto sobre el medio ambiente. Las aguas residuales evacuadas contienen contaminantes procedentes de los cueros, productos de su descomposición y productos químicos así como varias soluciones agotadas que se utilizan para la preparación del cuero y durante el proceso de curtido. También pueden producirse residuos sólidos y algunas emisiones a la atmósfera.

La principal preocupación pública con respecto a las fábricas de curtidos han sido tradicionalmente los olores y la contaminación del agua a causa de los vertidos no tratados. Recientemente se han planteado otras cuestiones por el creciente uso de productos químicos sintéticos como plaguicidas, disolventes, tintes, agentes de acabado y nuevos productos químicos de procesado, que crean problemas de toxicidad y persistencia.

Por su parte, las simples medidas destinadas a controlar la contaminación producen impactos medioambientales secundarios por cruce de medios como contaminación de las aguas freáticas, contaminación del suelo, vertido de lodos y envenenamiento químico. 
Figura 88.8 - Esquema del impacto a mbiental relacionado con las operaciones de curtido.

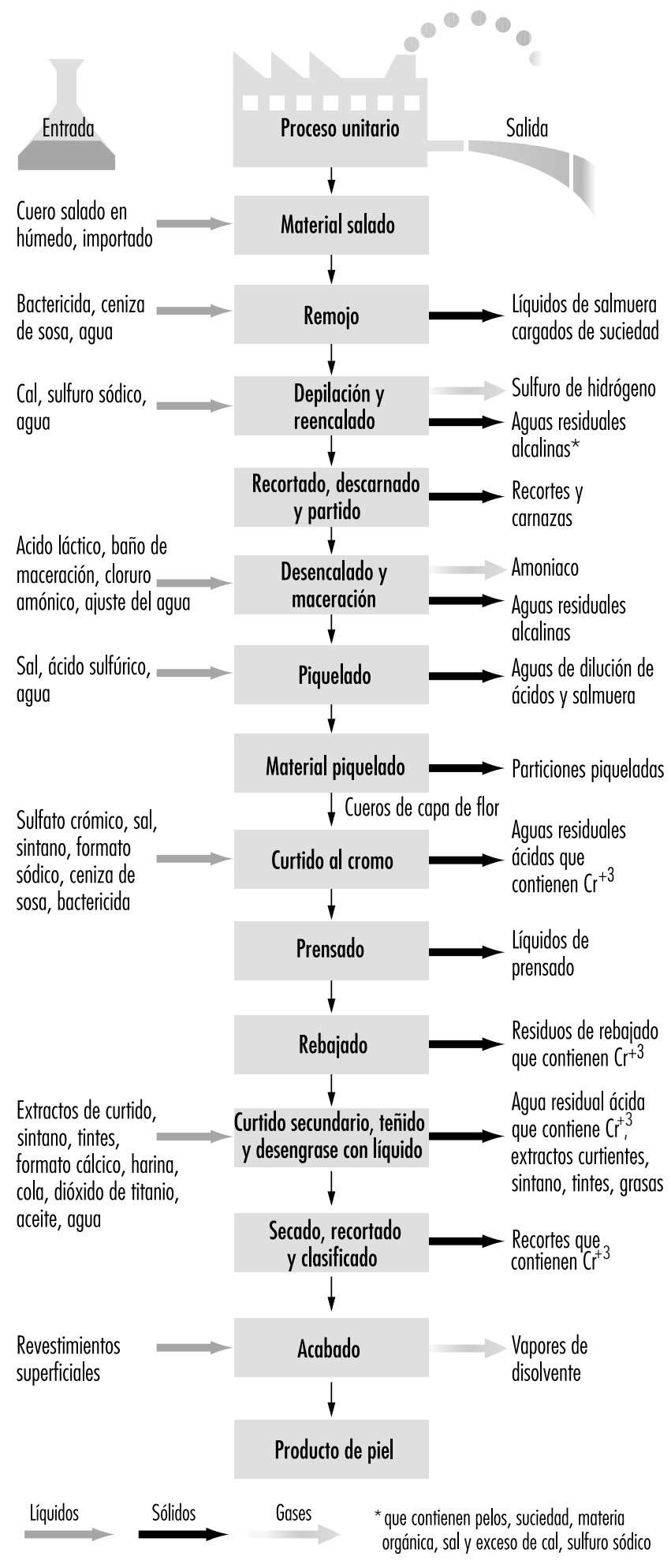

La tecnología de curtido de que se dispone actualmente, basada en un menor consumo de productos químicos y agua, ejerce un impacto menor sobre el ambiente que los procesos tradicionales. Sin embargo, muchos obstáculos se oponen a su aplicación extensiva.
La Figura 88.8 presenta los distintos residuos e impactos ambientales relacionados con los procesos que se utilizan en la industria del curtido.

\section{Control de la contaminación}

\section{Control de la contaminación del agua}

Los residuos de curtido sin tratar en las aguas superficiales pueden producir un rápido deterioro de sus propiedades físicas, químicas y biológicas. Sencillos procesos del tratamiento del efluente a su vertido permiten eliminar más del $50 \%$ de sólidos en suspensión y de la demanda bioquímica de oxígeno. 0 tras medidas más sofisticadas permiten alcanzar niveles más elevados de tratamiento.

Como los efluentes del curtido contienen varios componentes químicos que necesitan tratarse, debe emplearse, a su vez, una serie de procesos de tratamiento. La segregación del caudal es útil para permitir el tratamiento separado de flujos de residuos concentrados.

En la Tabla 88.1 se resumen las opciones tecnológicas disponibles para el tratamiento de los efluentes del curtido.

\section{Control de la contaminación del aire}

Las emisiones a la atmósfera corresponden a tres grandes grupos: olores, vapores de disolventes de las operaciones de acabado y emisiones de gas de la incineración de los residuos.

La descomposición biológica de la materia orgánica así como las emisiones de sulfuros y amoniaco de las aguas residuales son responsables de los característicos olores desagradables que desprenden las curtidurías. La localización de las instalaciones ha sido una cuestión problemática debido a los olores que se han asociado históricamente con estas fábricas. La reducción de estos olores es más bien una cuestión de mantenimiento operativo que de tecnología.

LoS vapores de disolventes y otros productos de las operaciones de acabado, varían según el tipo de productos químicos utilizados y los métodos técnicos empleados para reducir su generación y emisión. Las emisiones de disolvente pueden representar hasta el $30 \%$ del disolvente utilizado, mientras que se dispone de modernos procesos que las reducen a aproximadamente el $3 \%$ en muchos casos.

Tabla 88.1 - O pciones tecnológicas para el tratamiento de los efluentes del curtido.

Tratamiento previo

Tamizado mecánico para eliminar la materia grosera sedimentada

Igualación del flujo (equilibrado)

Tratamiento principal Eliminación del sulfuro de los efluentes de la ribera Eliminación del cromo de los efluentes del curtido Tratamiento físico-químico para la eliminación y neutralización de la demanda bioquímica de oxígeno

Tratamiento secundario Tratamiento biológico Lodo activado (foso de oxidación) Lodo activado (convencional) Estancamiento (aireado)

Tratamiento terciario Nitrificación y denitrificación

Sedimentación y Distintas formas y dimensiones de depósitos y manipulación del lodo recipientes 
Figura 88.9 - Esquema de una planta municipal para la recuperación del cromo.

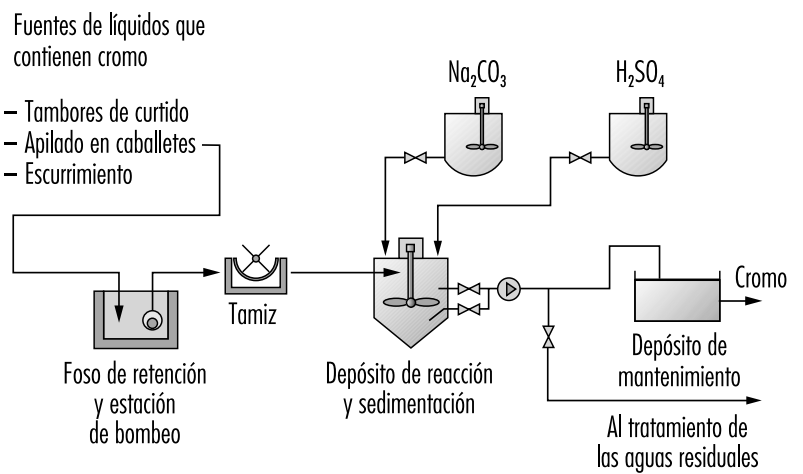

El efluente que entra, después de analizarse, es tratado para producir hidróxido de cromo. Este se redisuelve, se limpia y se somete a un ulterior análisis antes de volver a utilizarse en el proceso de curtido. Fuente: PNUMA 1991

La práctica de muchas curtidurías de incinerar los residuos y recortes sólidos resalta la importancia de contar con un incinerador bien diseñado y de seguir prácticas cuidadosas.

\section{Tratamiento de los residuos}

El tratamiento de los lodos constituye el principal problema de eliminación, aparte del efluente. Los lodos de composición orgánica, si están libres de cromo o sulfuros, sirven para acondicionar suelos y de fertilizante por los compuestos nitrogenados que contienen. Estas ventajas se utilizan del mejor modo arando inmediatamente después de su aplicación. El uso agrícola de las tierras que contienen cromo ha sido objeto de controversia en varias jurisdicciones, donde se han establecido directrices para determinar las aplicaciones aceptables.

Existen varios mercados para la conversión de los recortes y carnazas en subproductos que se utilizan para una gran variedad de finalidades, incluyendo la producción de gelatina, cola, cartón cuero, grasa de sebo y proteínas para piensos animales. Los efluentes del proceso, sujetos a un tratamiento y control de calidad adecuados, a veces se utilizan para el riego cuando hay escasez de agua y/ o la eliminación del efluente está muy restringida.

Para evitar problemas de generación de lixiviados y olores, solamente deben eliminarse en vertederos públicos los sólidos y los lodos deshidratados. D ebe tenerse cuidado para asegurar que los residuos de curtidos no reaccionen con otros residuos industriales, como residuos ácidos, que pueden reaccionar creando gas tóxico de sulfuro de hidrógeno. La incineración en condiciones no controladas puede causar emisiones inaceptables y no se recomienda.

\section{Prevención de la contaminación}

M ejorando las tecnologías de producción para aumentar el control de la contaminación medioambiental se puede alcanzar una serie de objetivos, como:

- aumentar la eficiencia de la utilización de productos químicos

- reducir el consumo de agua o energía

- recuperar o reciclar materiales rechazados.

El consumo de agua puede variar sensiblemente, desde menos de $25 \mathrm{l} / \mathrm{kg}$ de cuero en bruto hasta más de $80 \mathrm{l} / \mathrm{kg}$. El uso eficaz del agua puede mejorarse mediante la aplicación de técnicas como un mayor control del volumen de las aguas de procesado, lavados en "discontinuo" en lugar de "en continuo", modificación de los equipos existentes para obtener menores niveles de flotación; técnicas de bajo nivel de flotación con equipos actualizados, reutilización de aguas residuales en procesos menos críticos y reciclaje de los líquidos de proceso.

El remojado y la depilación tradicionales representan más del $50 \%$ de la demanda bioquímica de oxígeno y la demanda química de oxígeno en efluentes de curtido típicos. Pueden emplearse varios métodos para sustituir el sulfuro, reciclar los líquidos de cal/sulfuro e incorporar técnicas para economizar pelo.

La reducción de la contaminación por cromo puede conseguirse con medidas encaminadas a aumentar los niveles de cromo que se fijan en el baño de curtido y reducir las cantidades que se "purgan" en procesos ulteriores. Otros métodos para reducir la liberación de cromo son el reciclaje directo de los líquidos de cromo usados (lo cual también reduce la salinidad del efluente) y el tratamiento de los líquidos que contienen cromo recogidos, para precipitar el cromo como hidróxido, que seguidamente puede reciclarse. En la Figura 88.9 se ilustra una operación de recuperación de cromo en una planta municipal.

Si se emplea curtido al vegetal, el acondicionamiento previo de los cueros puede mejorar la penetración y fijación de los cueros y contribuir a reducir las concentraciones de taninos en los efluentes. Se han empleado otros agentes curtientes como el titanio en sustitución del cromo para producir sales de toxicidad generalmente menor y generar lodos inertes y más seguros de manipular.

\section{Referencias}

Abrams, H, P Warr. 1951. O ccupational diseases transmitted via contact with animals and animal products. Ind M ed Surgery 20:341-351.

Acheson, E. 1972. A denocarcinoma of the nasal cavity and sinuses in England and $\mathrm{W}$ ales. $\mathrm{Br} J$ Ind $\mathrm{Med}$ 29:21-30.

$-.1976 . \mathrm{N}$ asal cancer in the furniture and boot and shoe manufacturing industries. Prevent $M$ ed 5:295315.

Agencia Internacional para la Investigación sobre el Cáncer (IARC). 1981. Wood, leather and some associated industries. Vol. 28. Lyon: IARC.

-. 1982. Some industrial chemicals and dyestuffs Vol. 29. Lyon: IARC.
Askoy, M, S Erdem, G DinCol. 1974. Leukemia in shoeworkers exposed chronically to benzene. Blood 44:837-841.

-.1976. Types of leukemia in chronic benzene poisoning. A study in thirty-four patients. Acta $\mathrm{H}$ aematol 55:65-72.

Askoy, M, S Erdem. 1978. Followup study on the mortality and the development of leukemia in 44 pancytopenic patients with chronic exposure to benzene. Blood 52:285-292.

Battista, G, P Comba, D O rsi, K Norpoth, A M aier. 1995. Nasal cancer in leather workers: An occupational disease. I C ancer R es Clin O ncol 121:1-6.

Bonassi, S, F M erlo, R Puntoni, F Ferraris, G Bottura. 1990. E pidemics of lung tumors in a Biella tannery. E pidemiol Rev 12:25-30.
Bureau of L abor Statistics (BLS). 1995. Survey of O ccupational I njuries and IIInesses, 1994. Washington, DC: BLS.

Calvert, G, J Fajen, B Hills, W Halperin. 1990. Testicular cancer, dimethylformamide, and leather tanneries. Lancet 336:1253-1254.

Cecchi, F, E Buiatti, D K riebel, L N astasi, M Santucci. 1980. A denocarcinoma of the nose and paranasal sinuses in shoemakers and woodmakers in the province of Florence, Italy. B r J Ind M ed 37:222-226.

Chen, J. 1990. A cohort study of the cancer experience among workers exposed to benzidine-derived dyes in Shanghai ( $\mathrm{C}$ hina) leather-tanning industry. Chin J Prev $M$ ed 24:328-331.

Comba, P, G Battista, S Bell, B de Capus, E M erler, D O rsi, S Rodella, C Vindieni, O Axelson. 1992. A case-control study of cancer of the nose and para- 
nasal sinuses and occupational exposures. Am I Ind $M$ ed 22:511-520.

DeC oufle, $\mathrm{P}, \mathrm{J}$ Walrath. 1983. Proportionate mortality among US shoeworkers, 1966-1972. Am J Ind M ed 4:523-532.

- . 1987. N asal cancer in the US shoe industry: Does it exist? Am J Ind M ed 12:605-613.

Erdling, C, H K ling, U Flodin, O Axelson. 1986. Cancer mortality among leather tanners. $\mathrm{Br}$ J Ind $\mathrm{M} \mathrm{ed}$ 43:484-496.

Fu, H, P Demers, A Costantini, P Winter, D Colin, M K ogevinas, P Boffetta. 1996. Cancer mortality among shoe manufacturing workers: An analysis of two cohorts. 0 ccup E nviron M ed 53:394-398.

Garabrant, D, D Wegman. 1984. Cancer mortality among shoe and leather workers in M assachusetts. Am J Ind M ed 5:303-314.

K allenberger, W. 1978. A study of yeasts in chrome tanning and processing. I Am Leather Chem Assoc 73:6-21.

Levin, S, D Baker, P Landrigan, S M onaghan, E Frumin, M Braithwaite, W T owne. 1987. T esticular cancer in leather tanners exposed to dimethylformamide. Lancet 2:1153.

Malker, H, B M alker, J M CLaughin, W Blot. 1984 $\mathrm{K}$ idney cancer among leather workers. L ancet 1:50.

Martignone, G. 1964. Treatise on Practical T anning T urín: Levrotto and Bella.

Merler, E, A Baldesseroni, R Laria, P Faravelli, R Agostini, R Pisa, F Berrino. 1986. O $n$ the causal association between exposure to leather dust and nasal cancer: Further evidence from a case-control study. Br J Ind M ed 43:91-95.

M ikoczy, Z, A Schutz, L H agmar. 1994. Cancer incidence and mortality among Swedish leather tanners. $O$ ccup E nviron M ed 51:530-535.

M ikoczy, Z, A Schutz, U Stromberg, L H agmar. 1996. Cancer incidence and specific occupational exposures in the Swedish leather tanning industry: A co- hort based case-control study. O ccup Environ M ed 53:463-467.

M orrison, A, A Ahibom, W Verhock, K Aoli, I Leck Y O hno, K O bata. 1985. O ccupational and bladder cancer in Boston, USA, M anchester, Reino U nido, y Nagoya, Japón. J apan J ournal of E pidemiology and Community $\mathrm{H}$ ealth 39:294-300.

O ffice of M anagement and Budget (O M B). 1987. Standard Industrial Classification M anual. Washington, DC: US GPO.

O rganización Internacional del Trabajo (O IT). 1992. Employment and Working Conditions and Competitiveness in the L eather and F ootwear Industry, Informe II, Fourth Tripartite T echnical M eeting for the Leather and Footwear Industry, Sectoral Activities Programme. Ginebra: OIT

Paci, E, E Buiatti, A Costantini, L M iligi, N Puci, A Scarpelli, G Petrioli, L Simonato, R Winkelmann, I $\mathrm{K}$ aldor. 1989. A plastic anemia, leukemia and other cancer mortality in a cohort of shoe workers exposed to benzene. Scand J W ork Environ $H$ ealth 15:313-318.

Pippard, E, E Acheson. 1985. The mortality of boot and shoe makers, with special reference to cancer. Scand I W ork E nviron $\mathrm{H}$ ealth 11:249-255.

Programa de las Naciones U nidas para el M edio Ambiente (PNU M A). 1991. T anneries and the E nvironment. A T echnical G uide to R educing the E nvironmental I mpact of $T$ annery $O$ perations. Industry and Environment $\mathrm{Of}$ fice. Technical Report Series No. 4. París: PNUMA.

Seniori, C, E M erler, R Saracci. 1990. Epidemiological studies on occupational cancer risk in the tanning, leather and shoe industries. M edicina del Lavoro 81:184-211.

Seniori, C, E Paci, I M iligi, E Buiatti, C M artelli, S Lenzi. 1989. Cancer mortality among workers in the Tuscan tannery industry. Br J Ind M ed 46:384388.

Stern, FB, JJ Beaumont, WE Halperin, LI M urphy, BW Hills, JM Fajen. 1987. M ortality of chrome leather tannery workers and chemical exposures in tanneries. Scand J W ork E nviron H ealth 13:108-117.

Stevens, C. 1979. Assessing skin problems of occupational origin. 0 ccup H ealth Safety 48(18):39-43.

Sweeney, M , J Walrath, R Waxweiler. 1985. M ortality among retired fur workers: D yers, dressers (tanners) and service workers. Scand I W ork Environ $\mathrm{H}$ ealth 11:257-264.

Valsecchi, M, A Fiorio. 1978. O perating cycle in the tanning industry and related risks. Securities 63:132144.

Walker, J, T Bloom, F Stern, A O kun, M Fingerhut, W H alperin. 1993. M ortality of workers employed in shoe manufacturing. Scand J W ork E nviron $\mathrm{H}$ ealth 19:89-95.

Walrath, J, P DeC oufle, T Thomas. 1987. M ortality among workers in a shoe manufacturing company. Am J Ind M ed 12:615-623.

\section{O tras lecturas recomendadas}

Bequele, A, WE M yers. 1995. First Things First in Child Labour: E liminating W ork D etrimental to Children. Ginebra: OIT / UNICEF.

Fyfe, A, M Jankanish. 1997. T rade U nions and Child Labour: A Guide to Action. Ginebra: O IT.

Industrial Accident Prevention Association (IAPA). 1983. T anning Industry Safety and $H$ ealth Guide for $H$ ide $T$ anners and $F$ ur D ressers. T oronto: IAPA.

O rganización Internacional del Trabajo. 1996. Globalization of the F ootwear, T extiles and Clothing Industries. Re port for Discussion at the Tripartite $M$ eeting on the Globalization of the F ootwear, T extiles and Clothing I ndustries: $\mathrm{E}$ ffects on $\mathrm{E}$ mployment and W orking Conditions. Ginebra: OIT.

- 1996. Child Labour: T argeting the Intolerable, Informe VI(1), Conferencia Internacional del Trabajo, 86 Sesión, 1998. Ginebra: OIT.

Thorstensen, T C. 1985. Practical leather technology. M alabar, Florida, EE UU R obert E. K rieger Publishing Company. 



\section{INDUSTRIA DE PRODUCTOS TEXTIES}

Directores del capítulo

A. L e I vester y J ohn D. N efus

\section{Sumario}

La industria textil: historia y salud y seguridad

L eon J. W arshaw .............................. 89.2

Tendencias mundiales en la industria textil

J ung-D er W ang. . . .

Producción y desmotado del algodón

W. Stanley Anthony.

Producción de hilo de algodón

Phillip J. Wakelyn ....................... 89.9

Industria de la lana

D.A. $\mathrm{H}$ argrave.

Industria de la seda

J. Kubota . . . . . . . . . . . . . . . . . . . . . . . . 89.14

Viscosa (rayón)

M.M. El Attal .......................... 89.15

Fibras sintéticas

A.E. Q uinn and R. M attiusi . . . . . . . . . . . . . . 89.16

Productos de fieltro natural

J erzy A. Sokal . . . . . . . . . . . . . . . . . . . . . . . 89.17

Tinción, estampado y acabado

J.M . Strother y A.K. Niyogi . . . . . . . . . . . . . . . . . . 89.18

Generos textiles no tejidos

W illiam A. B lackburn y Subhash K. Batra . . . . . . . . . . . 89.21

Tejido y tricotado

Charles Crocker . . . . . . . . . . . . . . . . . . . . 89.23

Alfombras y moquetas

$T$ he $C$ arpet and $R$ ug Institute. . . . . . . . . . . . . . . 89.25

Alfombras tejidas 0 anudadas a mano

M .E. Radjabi . . . . . . . . . . . . . . . . . . . . . . . . 89.28

A fecciones respiratorias y de otro tipo observadas en la industria textil

E. N eil Schachter. . 


\section{- LA INDUSTRIA TEXTIL: HISTORIA Y SALUD Y SEGURIDAD}

\section{Leon J. Warshaw}

\section{La industria textil}

El término industria textil (del latín texere, tejer) se refería en un principio al tejido de telas a partir de fibras, pero en la actualidad abarca una amplia gama de procesos, como el punto, el tufting 0 anudado de alfombras, el enfurtido, etc. Incluye también el hilado a partir de fibras sintéticas o naturales y el acabado y la tinción de tejidos.

\section{Hilado}

En épocas prehistóricas se utilizaban pelo de animales, plantas y semillas para obtener fibras. La seda empezó a utilizarse en China alrededor del año 2600 a.C ., y a mediados del siglo X VIII de la era actual se crearon las primeras fibras sintéticas. Aunque las fibras sintéticas elaboradas a partir de celulosa o productos químicos derivados del petróleo, solas mezcladas entre sí o con fibras naturales se emplean cada vez más, no han conseguido eclipsar por completo a los tejidos de fibras naturales, como la lana, el algodón, el lino o la seda.

La seda es la única fibra natural formada por filamentos que se retuercen para obtener un hilo. Las demás fibras naturales hay que estirarlas, disponerlas en paralelo peinándolas y torsionándolas en una máquina continua de hilar que hace el hilo. El huso fue la primera herramienta para hilar; se mecanizó por primera vez en Europa alrededor del año 1400 d.C. con la invención de la rueda de hilar. A finales del siglo XVII se inventó la máquina de hilar algodón, que acciona varios husos a la vez. M ás adelante, gracias a R ichard Arkwright, que inventó la continua de hilar en 1769, y a Samuel Crompton, que introdujo la selfactina, que permitía a un solo operario manejar un millar de husos a la vez, la hilatura salió de los talleres artesanos rurales y se transformó en producción industrial.

\section{Fabricación de tejidos}

La fabricación de tejidos tiene una historia similar. Ya desde sus orígenes en la antigüedad, el telar manual ha sido la máquina básica para tejer. Las mejoras mecánicas empezaron en tiempos muy antiguos con el desarrollo del lizo, al que se van uniendo hilos de urdimbre alternos; en el siglo XIII d.C. se introdujo la cárcola o pedal, que permite manipular varios grupos de lizos. Con la incorporación del batán sobre bancada, que golpea la trama o los hilos de la trama para colocarlos en su lugar, el telar "mecanizado" se convirtió en el instrumento predominante en Europa y, excepto en las culturas tradicionales donde se mantuvo el manual, en todo el mundo.

La lanzadera volante, inventada por John K ay en 1733, permite al tejedor impulsar la lanzadera automáticamente a todo lo ancho del telar, y fue el primer paso hacia la mecanización de la tejeduría. Edmund Cartwright desarrolló el telar accionado a vapor y en 1788, junto con James Watt, fundó en Inglaterra la primera fábrica textil accionada por vapor. Esto acabó con la dependencia que los talleres textiles tenían del agua, necesaria para accionar las máquinas; ahora podían instalarse en cualquier lugar. 0 tro progreso importante fue la aparición del sistema de tarjeta perforada, inventado en Francia en 1801 por Joseph M arie Jacquard para tejer automáticamente patrones con dibujos. Los primeros telares motorizados eran de madera, y poco a poco se fueron sustituyendo por modelos de acero y otros metales. D esde entonces, el cambio tecnológico los ha ido sustituyendo por aparatos más grandes, más rápidos y mucho más automatizados.

\section{Tintura y estampado}

En un principio se utilizaban tintes naturales para dar color a hilos y tejidos, pero el descubrimiento de los colorantes derivados del alquitrán de hulla en el siglo XIX y de las fibras sintéticas en el XX estimuló el continuo perfeccionamiento de la tintorería. La primera técnica de estampado fue la impresión con bloques coloreados (la serigrafía para tejidos se desarrolló a mediados del siglo X VII), pero pronto fue sustituida por el estampado mecánico. Los cilindros de cobre grabados se utilizaron por primera vez en Inglaterra en 1785, y a esto siguió un perfeccionamiento rápido que culminó en el estampado mecánico con cilindros de seis colores y registro perfecto. Las actuales estampadoras mecánicas producen más de $180 \mathrm{~m}$ por minuto de tejido estampado en 16 colores o más.

\section{Acabado}

Al principio, los tejidos se acababan por cepillado o tundido de la superficie, relleno 0 apresto de la tela, o tratamiento en calandria de rodillos para darle aspecto lustroso. Ahora los géneros se preencogen, se mercerizan (los hilos y tejidos de algodón se tratan con soluciones cáusticas para mejorar la resistencia y el brillo) y se someten a muy variados tratamientos de acabado para hacerlos inarrugables, mantener los pliegues y mejorar la resistencia al agua, el fuego y el enmohecimiento.

Con tratamientos especiales se producen fibras de alto rendimiento, llamadas así por su extraordinaria solidez y resistencia extrema a altas temperaturas. Así, la aramida, una fibra similar al nilon, es más fuerte que el acero, y el kevlar, que se elabora a partir de aramida, se utilizan en la confección de tejidos a prueba de balas y prendas de vestir resistentes tanto al calor como a los productos químicos. 0 tras fibras sintéticas combinadas con carbono, boro, silicio, aluminio y otros elementos se utilizan para confeccionar materiales superligeros y superfuertes, utilizados en aviones, naves espaciales, filtros y membranas resistentes a los productos químicos, y ropa de protección para la práctica deportiva.

\section{De artesanía a industria}

Inicialmente, la producción textil era una actividad artesana propia del medio rural en la que también participaban pequeños grupos de artesanos hábiles. Con el desarrollo tecnológico nacieron las grandes empresas textiles, cuya influencia económica se dejó sentir con especial fuerza en el Reino U nido y los países de E uropa occidental. Los primeros colonos que se establecieron en Estados U nidos llevaron las fábricas textiles a N ueva Inglaterra (Samuel Slater, que había sido supervisor de telar en Inglaterra, construyó de memoria una continua de hilar en Providence, R hode Island, en 1780); la desmotadora de algodón, una máquina inventada por Eli Whitney que limpiaba el algodón en rama a gran velocidad, espoleó la demanda de tejidos de algodón.

Este proceso se vio acelerado por la comercialización de la máquina de coser. A principios del siglo X VIII, varios inventores idearon máquinas para coser telas. En Francia, en 1830, Barthelemy Thimonnier obtuvo una patente por su máquina de coser; pero en 1841, cuando tenía ya 80 máquinas cosiendo uniformes para el ejército francés, la fábrica fue destruida por los sastres, que veían en ella una amenaza para su medio de vida. M ás o menos por aquella época, en Inglaterra, Walter H unt diseñó una máquina perfeccionada, pero abandonó el proyecto porqué pensó que dejaría a las pobres costureras sin trabajo. En 1848, Elias H owe obtuvo una patente en Estados Unidos para una máquina muy parecida a la de $\mathrm{H}$ unt, pero se vio envuelto en numerosos pleitos, que finalmente ganó, pues había acusado a muchos fabricantes de copiar su patente. El invento de la máquina de coser moderna se atribuye a I saac M erritt Singer, 
que diseñó el brazo voladizo, el prensatelas, una rueda que conduce el tejido hacia la aguja y un pedal en vez de una manivela, dejando así las dos manos libres para guiar el tejido. Además de diseñar y fabricar la máquina, fundó la primera empresa de producción a gran escala de máquinas de uso doméstico, con novedades como la publicidad, la venta a plazos y los contratos de mantenimiento.

De este modo, los avances tecnológicos que tuvieron lugar en el siglo XVIII no sólo impulsaron la industria textil moderna, sino que inauguraron el sistema fabril y los profundos cambios de la vida familiar y social que terminarían englobándose bajo la denominación de Revolución Industrial. El cambio continúa, pues los grandes establecimientos textiles se trasladan desde las zonas industrializadas hacia nuevas regiones que prometen mano de obra y energía más baratas, y la competencia fomenta el desarrollo tecnológico continuo, con innovaciones como el control por ordenador, para reducir la necesidad de mano de obra y mejorar la calidad. M ientras, los políticos discuten las cuotas, los cupos y otros obstáculos económicos para ofrecer o mantener las ventajas competitivas de sus países. De este modo, la industria textil no sólo suministra productos esenciales para la creciente población mundial, sino que además ejerce una profunda influencia en el comercio internacional y la economía de las naciones.

\section{Problemas de seguridad y salud}

A medida que iban siendo más grandes, más veloces y más complicadas, las máquinas introducían riesgos nuevos; la creciente complejidad de materiales y procesos multiplicaba los peligros potenciales del lugar de trabajo; y la mecanización y el aumento forzoso de la productividad provocaban un grado de estrés, casi siempre negado o infravalorado, que socavaba el bienestar de los trabajadores. Donde la Revolución Industrial dejó sentir con mayor fuerza su efecto fue probablemente en la vida social, ya que los trabajadores se trasladaban del campo a las ciudades, donde tenían que soportar todos los males de la urbanización. Estos efectos se repiten en la actualidad, cuando el textil y otros sectores se trasladan a países y regiones en vías de desarrollo; la única diferencia es que los cambios son ahora más rápidos.

Los peligros a que se enfrentan los diversos segmentos del sector se resumen en los demás artículos de este capítulo. Subrayan la importancia de la atención y el mantenimiento adecuado de máquinas y equipos, la instalación de protecciones efectivas y rejillas para evitar el contacto con las piezas móviles, la ventilación aspirante local (LEV) como complemento de la buena ventilación general y el control de la temperatura, y el uso de equipos de protección personal (EPP) adecuados siempre que un peligro no se pueda evitar o controlar totalmente con medidas de diseño y modificación o sustitución por materiales menos peligrosos. La necesidad de educación y formación continuas de los trabajadores a todos los niveles y una supervisión efectiva son también temas recurrentes.

\section{Aspectos medioambientales}

L os problemas medioambientales que plantea la industria textil proceden de dos fuentes: los métodos de fabricación de géneros textiles y los riesgos asociados con la forma de utilizar los productos.

\section{M anufacturas textiles}

Los principales problemas ambientales que provocan las fábricas de géneros textiles están relacionados con las sustancias tóxicas que liberan a la atmósfera y las aguas residuales. Además de los agentes potencialmente tóxicos, también los malos olores suelen ser motivo de preocupación, sobre todo cuando las plantas de estampación y tintura están cerca de zonas residenciales. Las salidas de ventilación pueden contener vapores de disolventes, formaldehído, hidrocarburos, ácido sulfhídrico y compuestos metálicos. A veces los disolventes se recuperan y destilan para reutilizarlos. Las partículas se eliminan con un buen filtrado. La depuración es eficaz para los componentes volátiles solubles en agua, como el metanol, pero no funciona en el estampado con pigmentos, cuyas principales emisiones son hidrocarburos. LoS productos inflamables se pueden incinerar, aunque esto es relativamente caro. La solución definitiva, sin embargo, es el uso de materiales con el mínimo de emisiones posible, y no sólo al elegir los tintes, aglutinantes y ligantes que se utilizan en el estampado, sino también con respecto al contenido de formaldehído y monómero residual de los tejidos.

La contaminación de las aguas residuales por tintes no fijados es un problema ambiental grave, no sólo debido al peligro potencial que representa para la salud humana y animal, sino también por el cambio de color, muy notorio. En la tintura ordinaria se logra una fijación de más del $90 \%$ del tinte, pero en la estampación con tintes reactivos es habitual alcanzar sólo un valor del $60 \%$ o menos. Esto significa que más de una tercera parte del tinte reactivo entra en las aguas residuales cuando se lava el tejido una vez teñido. También entran más tintes en las aguas residuales durante el lavado de los tamices, los paños de estampación y los tambores.

En varios países se han establecido límites para el cambio de color de las aguas residuales, pero a menudo son muy difíciles de cumplir sin un sistema de depuración muy costoso. U na solución sería usar colorantes menos contaminantes y desarrollar tintes y agentes espesantes sintéticos que aumenten el grado de fijación y reduzcan así el exceso vertido en las aguas residuales (Grund 1995).

\section{Problemas medioa mbientales en el uso de textiles}

Los residuos de formaldehído y algunos complejos de metales pesados (la mayoría de los cuales son inertes) pueden ser suficientes para irritar la piel y sensibilizar a quienes llevan tejidos teñidos.

El formaldehído y los disolventes residuales de las alfombras y tejidos utilizados en tapicería y cortinas continúan desprendiendo vapores durante algún tiempo. En los edificios cerrados herméticamente con acondicionamiento del aire por recirculación en lugar de por intercambio de aire con el exterior estas sustancias alcanzan en ocasiones una concentración suficiente para inducir síntomas en los ocupantes del edificio, tal como se explica en otros apartados de esta E nciclopedia.

Para garantizar la seguridad de los tejidos, Marks and Spencer, empresa minorista de confección británico-canadiense, estableció límites al contenido en formaldehído en las prendas que compran. D esde entonces, otros fabricantes, de forma destacada Levi Strauss en Estados U nidos, han seguido el ejemplo. En varios países, estos límites se han normalizado en forma de leyes (p. ej. Dinamarca, Finlandia, Alemania y Japón) y, como respuesta a la formación del consumidor, los fabricantes se han adherido voluntariamente a estos límites para tener derecho a utilizar etiquetas ecológicas (véase la Figura 89.1).

\section{Conclusión}

El desarrollo tecnológico sigue perfeccionando la gama de tejidos fabricados por la industria textil y aumenta su productividad. Sin embargo, es sumamente importante que este desarrollo se guíe también por el imperativo de mejorar la salud, la seguridad y el bienestar de los trabajadores. En cualquier caso, es difícil aplicar estas mejoras a las fábricas antiguas que apenas son viables económicamente y que no pueden efectuar las inversiones necesarias, así como en las regiones en vías de desarrollo, ansiosas de 
Figura 89.1 • Etiquetas ecológicas para productos textiles.

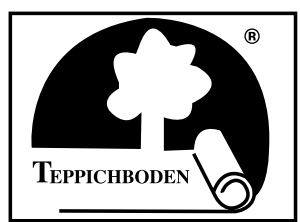

$\mathrm{GuT}^{\circledR}$

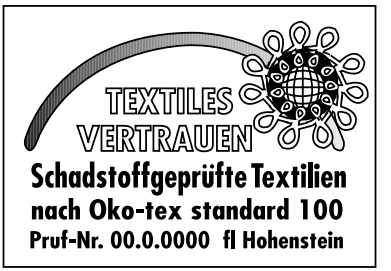

Oko-Tex Standard 100

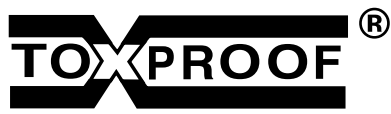

Tox Proof ${ }^{\circledR}$
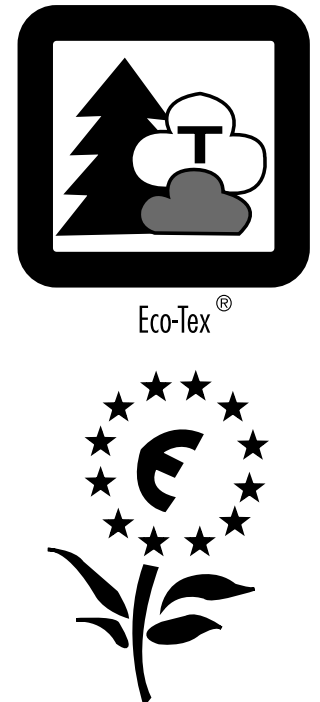

Símbolo ecológico de la UE tener nuevas industrias aunque sea a costa de la salud y la seguridad de los trabajadores. Pero aún en estas circunstancias se avanza mucho mediante la educación y la formación de los trabajadores para reducir al mínimo los riesgos a que pueden verse expuestos.

\section{TENDENCIAS MUNDIALES EN LA IN DUSTRIA TEXTIL}

\section{Jung-Der Wang}

Desde que aparecieron sobre la Tierra, los seres humanos han recurrido a la ropa y el alimento para sobrevivir. La industria de la confección textil empezó muy pronto en la historia de la humanidad. El algodón y la lana empezaron a tejerse y tricotarse a mano para transformarlos en tejidos y prendas de vestir, y la Revolución Industrial no alteró esta forma de confección hasta el final del siglo X VIII y principios del XIX. El hombre empezó a utilizar distintas fuentes de energía para mover las máquinas. N o obstante, el algodón, la lana y las fibras de celulosa siguen siendo las principales materias primas. A partir de la II Guerra M undial, la producción de fibras sintéticas desarrollada por la industria
Figura 89.2 - Variación de la oferta de fibras en la industria textil antes de 1994 y extrapolación hasta 2004.

en miles de toneladas

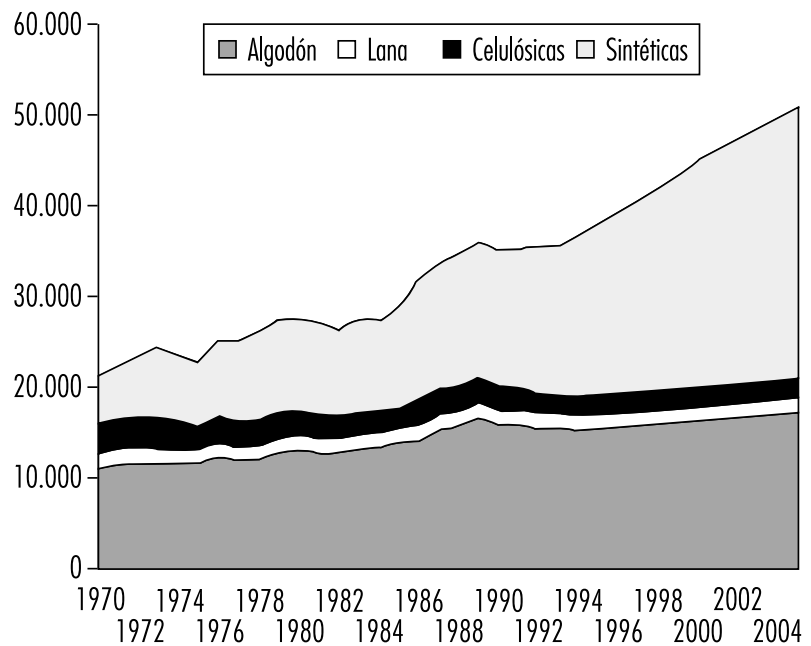

El crecimiento de la oferta de fibras sintéticas es abrumador.

$\begin{array}{llll} & \text { Total } & \text { Sintéticas } & \text { Algodón } \\ 1994 \rightarrow 2000 & 3,5 \% & 5,8 \% & 1,2 \% \\ 2000 \rightarrow 2005 & 2,5 \% & 3,6 \% & 1,2 \%\end{array}$

En el año 2000 la oferta de fibras sintéticas representará más de la mitad de la oferta total de fibras.

$\begin{array}{lll}1994 & 48,2 \% & 41,3 \% \\ 2000 & 55,2 \% & 36,2 \% \\ 2005 & 58,3 \% & 34,0 \%\end{array}$

Fuente: Ministerio de Industria y Comercio Internacional (Japón) 1996.

petroquímica experimentó un gran crecimiento. En 1994, el volumen de consumo de fibras sintéticas en los productos textiles del mundo era de 17,7 millones de toneladas, un $48,2 \%$ del total de fibras, y se espera que sobrepase el $50 \%$ a partir del año 2000 (véase la Figura 89.2).

Según el estudio sobre consumo mundial de fibra para prendas de vestir realizado por la O rganización de las $\mathrm{N}$ aciones Unidas para la Agricultura y la Alimentación (FAO), los índices anuales medios de crecimiento del consumo textil durante 1969-1989, 1979-1989 y 1984-1989 fueron 2,9 \%, 2,3\% y $3,7 \%$, respectivamente. Partiendo de la tendencia de consumo anterior, del crecimiento de la población, del crecimiento

Tabla 89.1 - N úmero de empresas y empleados de la industria textil y de prendas de vestir en determinados países y territorios de la zona de Asia-Pacífico en 1985 y 1995.

\begin{tabular}{|c|c|c|c|c|c|c|c|c|c|c|}
\hline Número de & Año & Australia & China & Hong Kong & India & Indonesia & $\begin{array}{l}\text { Corea, } \\
\text { República de }\end{array}$ & Malaisia & $\begin{array}{l}\text { Nueva } \\
\text { Zelanda }\end{array}$ & Paquistán \\
\hline Empresas & $\begin{array}{l}1985 \\
1995\end{array}$ & $\begin{array}{l}2.535 \\
4.503\end{array}$ & $\begin{array}{l}45.500 \\
47.412\end{array}$ & $\begin{array}{r}13.114 \\
6.808\end{array}$ & $\begin{array}{l}13.435 \\
13.508\end{array}$ & $\begin{array}{l}1.929 \\
2.182\end{array}$ & $\begin{array}{l}12.310 \\
14.262\end{array}$ & $\begin{array}{l}376 \\
238\end{array}$ & $\begin{array}{l}2.803 \\
2.547\end{array}$ & $\begin{array}{l}1.357 \\
1.452\end{array}$ \\
\hline $\begin{array}{l}\text { Empleados } \\
\left(\times 10^{3}\right)\end{array}$ & $\begin{array}{l}1985 \\
1995\end{array}$ & $\begin{array}{l}96 \\
88\end{array}$ & $\begin{array}{l}4.396 \\
9.170\end{array}$ & $\begin{array}{l}375 \\
139\end{array}$ & $\begin{array}{l}1.753 \\
1.675\end{array}$ & $\begin{array}{l}432 \\
912\end{array}$ & $\begin{array}{l}684 \\
510\end{array}$ & $\begin{array}{l}58 \\
76\end{array}$ & $\begin{array}{l}31 \\
21\end{array}$ & $\begin{array}{l}\text { N.D. } \\
\text { N.D. }\end{array}$ \\
\hline
\end{tabular}


Figura 89.3 - Peinado.

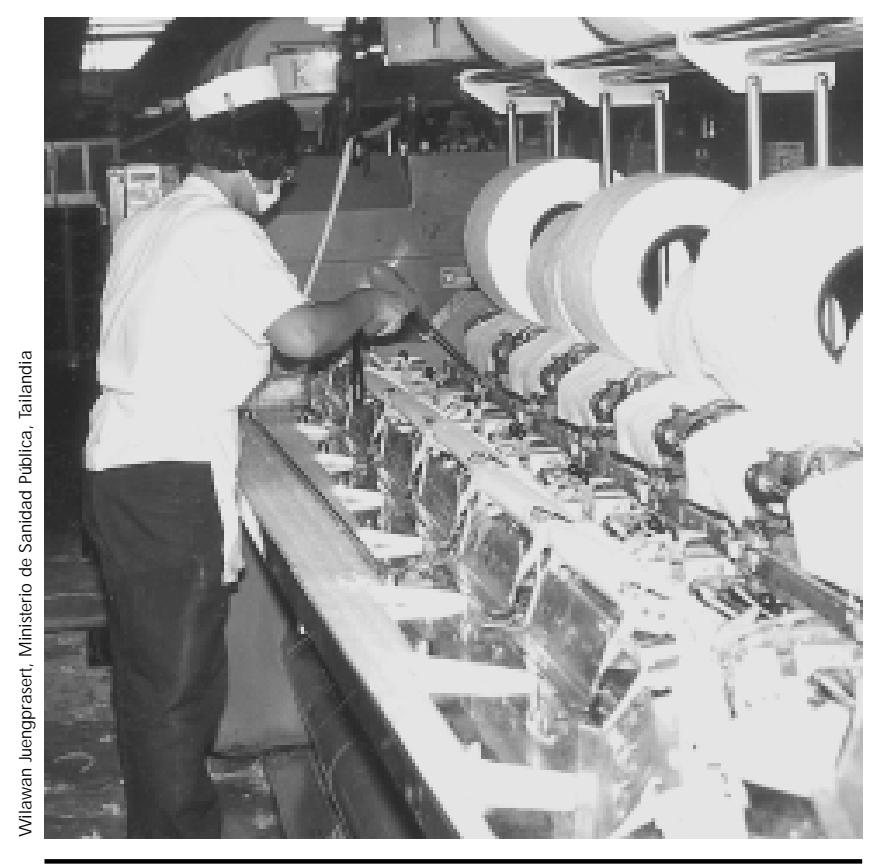

del PIB (Producto Interior Bruto) per cápita y del aumento del consumo de cada producto textil asociado al aumento de los ingresos, la demanda de productos textiles en los años 2000 y 2005 será de 42,2 y de 46,9 millones de toneladas, respectivamente, tal como muestra la Figura 89.2. La tendencia señala que hay un crecimiento coherente de la demanda de productos textiles y que el sector seguirá empleando mucha mano de obra.

0 tro cambio importante es la automatización progresiva de la tejeduría y el tricotado que, junto con el aumento del coste de la mano de obra, ha desplazado la industria desde los países desarrollados hacia los países en vías de desarrollo. Aunque la producción de hilo y tejidos, así como de algunas fibras sintéticas, se han quedado en los países desarrollados, una proporción considerable de los procesos finales del sector de la confección se ha trasladado a los países en vías de desarrollo. En la actualidad, el sector de la confección y textil de la región de Asia y el

Figura 89.4 - Cardado.

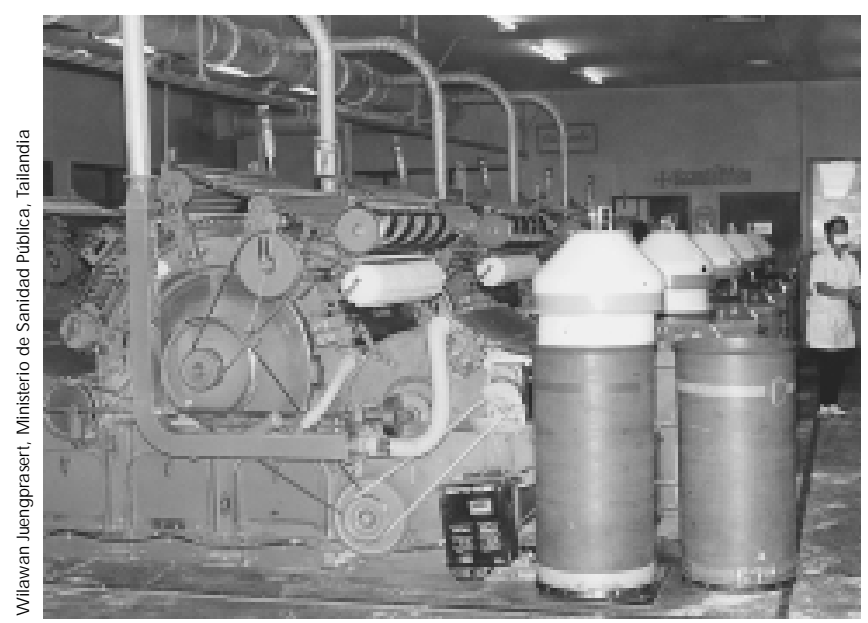

Figura 89.5 - Batán moderno.

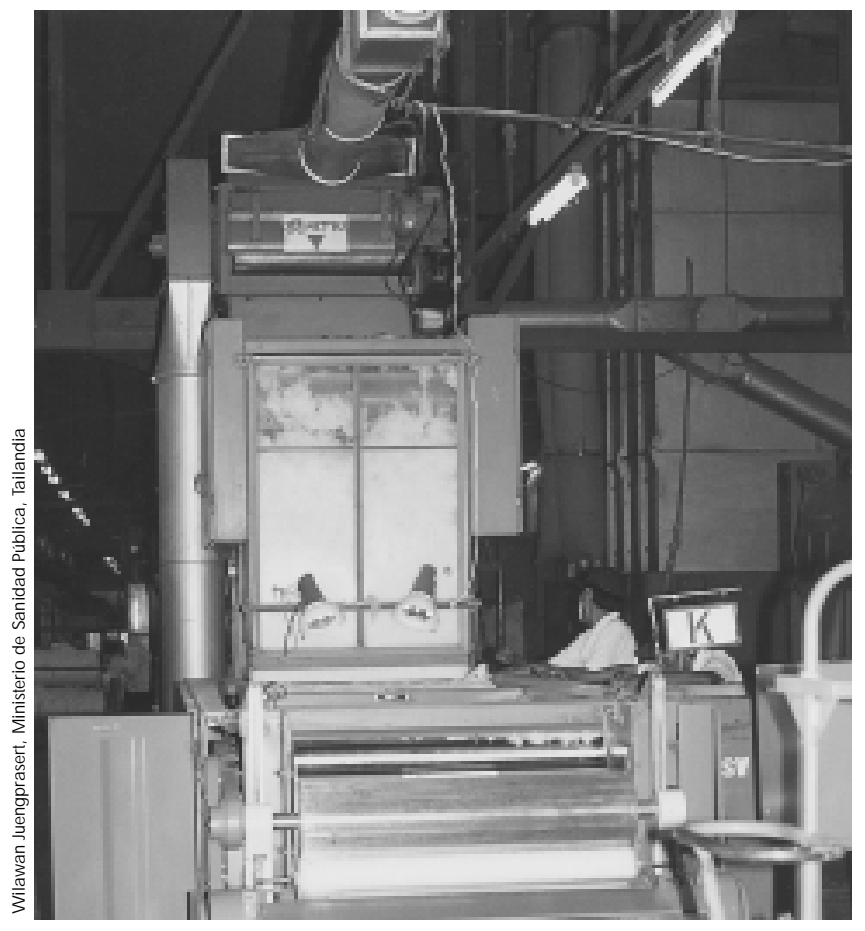

Pacífico supone aproximadamente el $70 \%$ de la producción mundial; la Tabla 89.1 muestra un cambio de tendencia del empleo en esa región. Por este motivo, la seguridad y salud laboral de los trabajadores textiles se ha convertido en un asunto importante en los países en vías de desarrollo; las figuras 89.3 a 89.6 ilustran algunos procesos de la industria textil tal como se llevan a cabo en las regiones menos desarrolladas.

Figura 89.6 - Urdido.

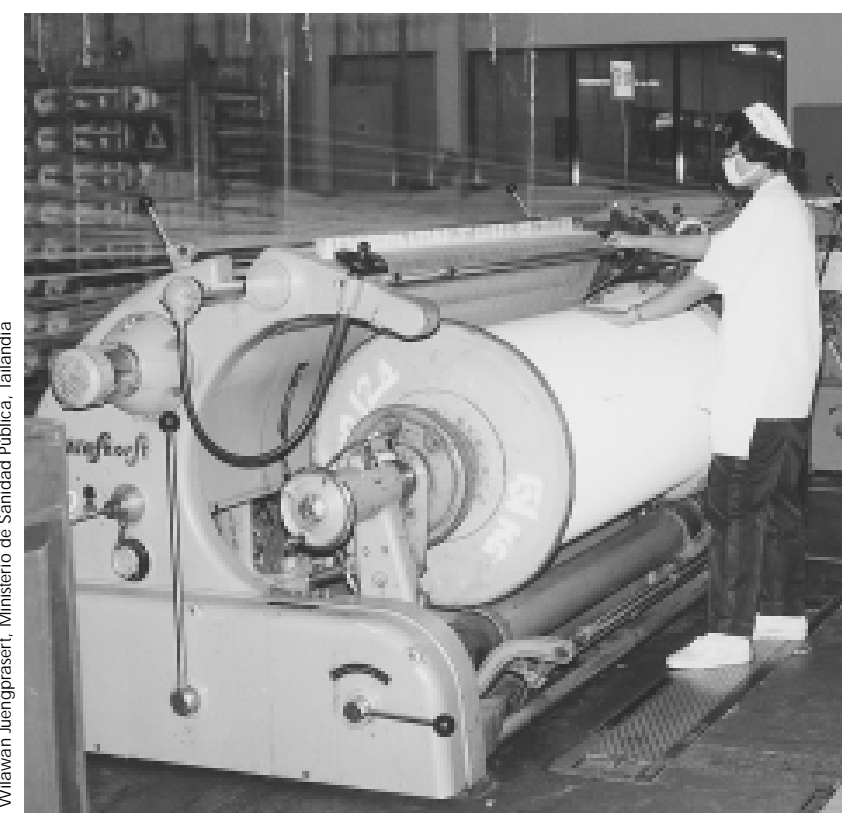




\section{- PRODUCCION Y DESMOTADO DEL ALGODON}

W. Stanley Anthony

\section{Producción de algodón}

La producción de algodón propiamente dicha empieza en cuanto termina la recolección de la última cosecha. Las primeras labores consisten casi siempre en triturar los tallos, arrancar las raíces y labrar el suelo. Casi siempre se aplican fertilizantes y herbicidas antes de preparar la superficie para regar o plantar. D ado que las características del suelo y las prácticas anteriores de fertilización y cultivo determinan un grado de riqueza muy variable, los programas de abonado deberían basarse en análisis de muestras. El control de las malas hierbas es esencial para obtener grandes cantidades de borra de calidad, ya que reducen el rendimiento y la eficacia de la recolección hasta en un $30 \%$. Desde principios de los años sesenta los herbicidas se utilizan masivamente en muchos países para controlar las malas hierbas. Los métodos de aplicación incluyen un tratamiento antes de la plantación para eliminar las malas hierbas ya crecidas, la incorporación al suelo antes de plantar y el tratamiento antes y después de que las plantas despunten.

En la obtención de una buena cosecha de algodón intervienen la preparación del suelo, la humedad del suelo, la temperatura, la calidad de las semillas, las plagas, los fungicidas y la salinidad del suelo. Plantar semillas de gran calidad en un suelo bien preparado es esencial para obtener plántulas de crecimiento rápido, uniforme y vigoroso. Las semillas de buena calidad deben arrojar un índice de germinación del $50 \%$ o más en la prueba de frío. En la prueba de frío y calor, el vigor de la semilla debería ser de 140 o más. Se recomienda una densidad de plantación de 12 a 18 semillas/ metro lineal para obtener una población de 14.000 a 20.000 plantas/ hectárea. Conviene utilizar un sistema adecuado de medición de plantación para asegurar el espaciado uniforme de las semillas, con independencia de su tamaño. Los índices de germinación de las semillas y de crecimiento de las plántulas dependen estrechamente del logro de una gama de temperaturas de 15 a $38^{\circ} \mathrm{C}$.

Las enfermedades precoces de las plántulas deterioran la uniformidad de la plantación y obligan a replantar. L os principales parásitos, como Pythium, R hizoctonia, F usarium y T hielaviopsis, reducen la densidad y abren grandes claros entre las plántulas. Se aconseja plantar únicamente semillas que hayan sido tratadas de forma adecuada con uno o varios fungicidas.

El algodón es similar a otros cultivos en cuanto al uso de agua durante las diversas fases de desarrollo. Normalmente hacen falta menos de $0,25 \mathrm{~cm}$ al día desde el despunte hasta el primer cuarto de temporada. Durante este período la pérdida de humedad del suelo por evaporación puede sobrepasar la cantidad de agua transpirada por la planta. EI consumo de agua aumenta considerablemente a medida que aparecen los primeros capullos, y llega a un nivel máximo de $1 \mathrm{~cm} /$ día en plena floración. Este volumen de agua se refiere a la cantidad total de agua (por precipitación o regadío) necesaria para que un cultivo de algodón prospere sin contratiempos.

Las poblaciones de insectos afectan mucho a la calidad y el rendimiento del algodón. EI control precoz de estas poblaciones es importante para asegurar un desarrollo equilibrado de los frutos y la vegetación. Proteger los primeros frutos es esencial para obtener una buena cosecha. M ás del $80 \%$ del rendimiento se establece durante las primeras 3 ó 4 semanas de fructificación. Durante el período de fructificación es necesario vigilar los cultivos al menos dos veces por semana para controlar la actividad y el daño que estén ocasionando los insectos.
Un programa de defoliación bien gestionado reduce a la mitad de la hojarasca que puede afectar adversamente a la calidad del algodón cosechado. Los reguladores del crecimiento, como el PIX, son defoliantes útiles, porque controlan el crecimiento vegetativo y aceleran la fructificación.

\section{Recolección}

$\mathrm{H}$ ay dos clases de equipos para la recolección mecánica del algodón: el recolector de husillo es una cosechadora selectiva que utiliza husillos cónicos dentados para extraer el algodón de sus cápsulas. Para hacer cosechas estratificadas, basta recorrer el campo varias veces. Por el contrario, la separadora de algodón es una cosechadora no selectiva o de pasada única que recoge tanto las cápsulas abiertas como las agrietadas o cerradas junto con brácteas y otras impurezas.

Las prácticas agronómicas que rinden cosechas uniformes y de calidad suelen contribuir a la eficacia global del cultivo. El terreno ha de estar bien drenado y con las hileras dispuesta de modo que la maquinaria maniobre con eficacia. Los extremos han de estar limpios de hierbas y gramíneas y deben tener un pasillo libre de 7,6 a 9 metros para que las cosechadoras giren y se coloquen en línea con las hileras; también este reborde debe estar limpio de vegetación. La escarificación es perjudicial con tiempo lluvioso; en tal caso, es preferible eliminar las malas hierbas con productos químicos o segándolas. La altura idónea de la planta es no más de 1,2 metros para cosechadoras selectivas y no más de 0,9 metros para máquinas no selectivas; la altura se controla en cierta medida aplicando reguladores del crecimiento en la fase adecuada. Conviene seguir prácticas de cultivo tales que las cápsulas más bajas se formen al menos a $10 \mathrm{~cm}$ de altura sobre el suelo. Todas las labores - fertilización, cultivo, regadío- deben orientarse a la obtención de una cosecha de algodón bien formado.

La defoliación química induce la caída de las hojas. La aplicación de defoliantes minimiza la contaminación por materia vegetal verde y acelera la evaporación del rocío que humedece la borra por las mañanas. No deben aplicarse defoliantes antes de que se hayan abierto al menos el $60 \%$ de las cápsulas; la recolección debe hacerse como mínimo entre 7 y 14 días después de la defoliación (el tiempo exacto depende del producto y de las condiciones meteorológicas). Los desecadores químicos son útiles para preparar las plantas para la recolección. Se entiende por desecación la pérdida rápida de agua seguida de la muerte de los tejidos vegetales. El follaje muerto continúa unido a la planta.

La moderna producción de algodón tiende hacia el acortamiento de la temporada y la recolección en una sola pasada. LoS productos químicos que aceleran la apertura de la cápsula se aplican junto con el defoliador o inmediatamente después de la caída de las hojas. Con estos productos se adelanta la recolección y aumenta el porcentaje de cápsulas que se recogen en la primera cosecha. Dado que provocan la apertura total o parcial de las cápsulas inmaduras, la calidad de la cosecha se puede ver gravemente perjudicada (es decir, el contenido en microaire puede ser bajo) si se aplican demasiado pronto.

\section{Almacenamiento}

EI contenido de humedad del algodón antes y durante el almacenamiento es muy importante; el exceso hace que el algodón almacenado se caliente demasiado, lo que trae como consecuencia la pérdida de poder germinativo de las semillas, la decoloración de la borra e incluso el riesgo de combustión espontánea. No hay que almacenar jamás semillas de algodón con un contenido de humedad de más del $12 \%$. También hay que controlar la temperatura interna de los módulos de almacenamiento recién construidos durante los primeros 507 días de 
almacenamiento del algodón; los módulos que experimentan un aumento de la temperatura de más de $11^{\circ} \mathrm{C}$ o donde se superan los $49^{\circ} \mathrm{C}$ deberían desmotarse inmediatamente para evitar la posibilidad de pérdidas importantes.

Diversas variables influyen en la calidad de la semilla y la fibra. El contenido de humedad es la más importante. O tras variables son la duración del almacenamiento, la cantidad de materia extraña con un elevado contenido de humedad, la variación de la humedad a través de la masa almacenada, la temperatura inicial del algodón en semilla, la temperatura del algodón en semilla durante el almacenamiento, factores climáticos durante el almacenamiento (temperatura, humedad relativa, precipitación) y la protección del algodón contra la lluvia y la humedad del suelo. Si la temperatura es elevada, amarillea antes. Tanto los aumentos de temperatura como la temperatura máxima son muy importantes. El aumento de la temperatura está directamente relacionado con el calor generado por la actividad biológica.

\section{Desmotado}

Anualmente se producen en el mundo unos 80 millones de balas de algodón, de las cuales unos veinte millones proceden de las casi 1.300 desmotadoras que hay en Estados U nidos. La función principal de la desmotadora es separar la borra de la semilla, aunque también debe estar equipada para separar un porcentaje elevado de materia extraña que reduciría considerablemente el valor de la borra desmotada. El desmotado debe tener dos objetivos: a) producir borra de calidad satisfactoria para el mercado del productor; y b) desmotar el algodón con una merma mínima de la calidad de hilatura de la fibra, de modo que satisfaga la demanda de los usuarios finales, el hilandero y el consumidor. Por lo tanto, la conservación de la calidad durante el desmotado exige una selección y un manejo adecuado de cada máquina. La manipulación mecánica y el secado pueden alterar las características de calidad naturales del algodón. Como mucho, el desmotado sólo puede preservar las características de calidad que ya tiene el algodón al iniciar el tratamiento. En los apartados siguientes se comenta brevemente la función de los principales procesos y equipos mecánicos de desmotado.

\section{Maquinaria para algodón en semilla}

El algodón se traslada desde un remolque o módulo hasta una trampa para cápsulas verdes dispuesta en la desmotadora, donde se separan las cápsulas verdes, las piedras y demás materiales extraños pesados. El control automático de la alimentación de la máquina proporciona un flujo de algodón uniforme y bien disperso, de modo que el sistema de limpieza y secado de la desmotadora funciona más eficientemente. EI algodón que no está bien disperso puede atravesar el sistema de secado en forma de grumos, y secarse sólo superficialmente.

En la primera fase del secado, el aire caliente recorre el algodón colocado en estanterías durante 10015 segundos. La temperatura del aire se regula para controlar el grado de desecación. Para evitar daños en la fibra, esta temperatura no debe sobrepasar nunca los $177^{\circ} \mathrm{C}$. L as temperaturas superiores a $150^{\circ} \mathrm{C}$ pueden inducir cambios físicos permanentes en las fibras de algodón. Los sensores de temperatura del secador se montan lo más cerca posible del punto donde confluyen el algodón y el aire caliente. Si se sitúa cerca de la salida de la torre de secado, la temperatura del punto de mezcla podría ser entre 55 y $110^{\circ} \mathrm{C}$ superior a la que marca el sensor. El descenso de temperatura según se avanza hacia la salida de la torre de secado se debe al efecto de la evaporación y la pérdida de calor a través de las paredes de la maquinaria y de las tuberías. El secado continúa a medida que el aire caliente mueve el algodón en semilla hasta el limpiador de cilindros, un grupo de
6 ó 7 cilindros con púas que giran a 400 o 500 rpm. Estos cilindros restriegan el algodón sobre una serie de varillas o rejillas, lo agitan y hacen que las partículas extrañas, como hojas, desechos y suciedad, pasen por las aberturas de la reja. Los limpiadores de cilindros rompen las madejas más gruesas y acondicionan el algodón para una nueva fase de limpieza y secado. Los ritmos de procesado suelen ser de 6 balas por hora por metro de longitud del cilindro.

La máquina de varillas elimina del algodón las partículas extrañas más grandes, como broza y ramas. Estas máquinas utilizan la fuerza centrífuga creada por cilindros de sierra que giran a 300 o 400 rpm para expulsar la materia extraña mientras la sierra sostiene la fibra. El material de desecho expulsado va a parar al sistema de manipulación de desechos. L os índices de procesado más habituales son de 4,9 a 6,6 balas por hora por metro de longitud del cilindro.

\section{Desmotado (separación de la borra de las semillas)}

Después de otra fase de secado y limpieza con cilindros, el algodón se distribuye en la plataforma de cada desmotadora con ayuda de una cinta transportadora y distribuidora. El alimentador-extractor situado sobre la plataforma de la desmotadora dosifica el algodón en semilla para que entre uniformemente a un ritmo controlable y, como función secundaria, lo limpia. El contenido de humedad de la fibra de algodón en la superficie del alimentador-extractor es esencial. La humedad debe ser suficientemente baja como para que sea fácil eliminar la materia extraña en la plataforma de la desmotadora. Pero tampoco debe ser demasiado baja (menos del $5 \%$ ), ya que provocaría la rotura de las fibras individuales al separarlas de la semilla. Esta rotura reduce apreciablemente tanto de la longitud de la fibra como el volumen de la borra. Desde el punto de vista de la calidad, el algodón con un elevado contenido de fibras cortas produce demasiados desechos en la fábrica textil y es menos apreciado. Se evita que se rompan demasiadas fibras manteniendo la humedad entre un 6 y un $7 \%$ en la telera del alimentador-extractor.

Normalmente se utilizan dos tipos de desmotadoras: de sierra y de cilindros. En 1794, Eli Whitney inventó una desmotadora que separaba la fibra de la semilla mediante púas o sierras montadas en un cilindro. En 1796, Henry Ogden $\mathrm{H}$ olmes inventó una desmotadora con sierras y rebordes que sustituyó a la de Whitney y convirtió el desmotado en un proceso continuo en lugar de por lotes. El algodón, normalmente la especie Gossypium hirsutum, entra en la plataforma de la desmotadora de sierra a través de una descortezadora situada en la parte delantera. Las sierras agarran el algodón y lo tiran a través de varillas muy espaciadas denominadas varillas de la descortezadora. Los copos de algodón pasan de las varillas de la descortezadora hasta el fondo de la caja giratoria. El desmotado propiamente dicho - la separación de la borra y la semilla - tiene lugar en la caja giratoria de la plataforma de la desmotadora. La acción del desmotado la realiza un grupo de sierras que giran entre varillas. Las dientes de la sierra pasan entre las varillas en el punto de desmotado. El borde delantero de los dientes es aproximadamente paralelo a la varilla, y el diente tira de las fibras de las semillas, que son demasiado gruesas para pasar entre las varillas. El desmotado a un ritmo superior al que recomienda el fabricante puede reducir la calidad de la fibra, dañar la semilla y provocar atascos. También son importantes las velocidades de la sierra de la plataforma de la desmotadora. Una velocidad elevada suele agravar los daños de las fibras provocados durante el desmotado.

Las desmotadoras de cilindros constituyeron los primeros medios mecánicos para separar la borra de algodón de fibra larga (Gossypium barbadense) de la semilla. La desmotadora Churka, de origen desconocido, estaba formada por dos 
cilindros de superficie dura que giraban juntos a la misma velocidad superficial y separaban la fibra con un rendimiento de alrededor de $1 \mathrm{~kg}$ de borra al día. En 1840, Fones M cCarthy inventó una desmotadora de cilindro más eficaz que consistía en un cilindro desmotador de piel, una cuchilla fija apretada contra el cilindro y otra oscilante que extraía la semilla de la borra a medida que ésta quedaba sujeta entre el cilindro y la cuchilla fija. A finales del decenio de 1950, los fabricantes de máquinas desmotadoras y las empresas desmotadoras privadas de Estados Unidos, con la colaboración del Laboratorio de Investigación del Sudoeste para el Desmotado de Algodón del Servicio de Investigación Agrícola del Departamento de Agricultura de Estados U nidos, desarrollaron una desmotadora de cilindro con cuchilla giratoria. Es la única desmotadora de cilindro que se sigue utilizando en la actualidad en Estados U nidos.

\section{Limpieza de la borra}

El algodón se transporta desde la plataforma de la desmotadora mediante tubos para borra hacia los condensadores donde vuelve a formar un bloque. El bloque se saca del tambor del condensador y entra en un limpiador de borra de sierra. Dentro del limpiador, el algodón pasa a través de los rodillos de alimentación y la bandeja de alimentación que introduce las fibras en la sierra del limpiador. La sierra traslada el algodón bajo una parrilla que elimina las semillas inmaduras y las impurezas con ayuda de la fuerza centrífuga. Es importante que la separación entre los dientes de la sierra y las barras de la parrilla sea la correcta. Las barras de la parrilla deben alinearse con un borde saliente afilado para no mermar la eficacia de la limpieza y evitar la pérdida de borra. Aumentar el ritmo de entrada de borra en el limpiador por encima del ritmo recomendado por el fabricante disminuirá la eficacia de la limpieza y aumentará la pérdida de fibra de calidad. El algodón desmotado en desmotadora de cilindro suele limpiarse con limpiadores no agresivos, sin sierra, para minimizar el daño de la fibra.

Los limpiadores de borra mejoran la calidad del algodón eliminando la materia extraña. En algunos casos mejoran el color de un algodón ligeramente manchado mezclándolo transformándolo en blanco. También mejoran el color de algodones moteados, que salen clasificados como moteados claros 0 blancos.

\section{Embalaje}

EI algodón limpio se comprime en balas que se cubren para protegerlas de la contaminación durante el transporte y el almacenamiento. Se producen tres tipos de balas: planas modificadas, densidad universal de compresión y densidad universal de desmotado. Estas balas se envasan con densidades de 224 y $449 \mathrm{~kg} / \mathrm{m}^{3}$ para las balas planas modificadas y las de densidad universal, respectivamente. En la mayor parte de las desmotadoras, el algodón se embala en una prensa de "doble caja" donde la borra se compacta primero en una caja de prensar mediante un sistema mecánico o hidráulico; después la caja gira y la borra se comprime de nuevo a unos $3200641 \mathrm{~kg} / \mathrm{m}^{3}$ mediante prensas para balas planas modificadas o de densidad universal de desmotado, respectivamente. Las balas planas modificadas se vuelven a comprimir para convertirlas en balas de densidad universal de compresión en una operación posterior para conseguir un volumen mínimo. En 1985, aproximadamente un $98 \%$ de las balas de Estados Unidos eran balas de densidad universal de desmotado.

\section{Calidad de la fibra}

La calidad de la fibra es el resultado de las influencias de todas las fases de producción: selección de la variedad, recolección y desmotado. Algunas características de calidad son básicamente genéticas, mientras que otras dependen de las condiciones ambientales o de los métodos de recolección y desmotado. Los errores cometidos en las operaciones de producción o procesado afectan de manera irreversible a la calidad de la fibra o reducen los beneficios del productor y del fabricante de géneros textiles.

La calidad de la fibra es máxima el día en que se abre la cápsula de algodón. La exposición a la intemperie, la recolección mecánica, la manipulación, el desmotado y el proceso de fabricación pueden disminuir la calidad natural. $\mathrm{H}$ ay muchos factores que indican la calidad general de una fibra de algodón. Los más importantes son la resistencia, la longitud, el contenido de fibra corta (fibras de menos de 1,27 cm), la uniformidad de la longitud, la madurez, la pureza, el contenido de partículas extrañas, el color, el contenido de fragmentos de cáscaras y motas y la pegajosidad. El mercado suele reconocer estos factores, aunque no todos se miden en todas las balas.

El proceso de desmotado influye considerablemente en la longitud de la fibra, la uniformidad y el contenido de fragmentos de cáscaras de semillas, materias extrañas, fibras cortas y motas. Las dos operaciones de desmotado que más influyen en la calidad son la regulación de la humedad de la fibra durante el desmotado y la limpieza y el grado de limpieza de la borra con limpiadores de sierra que se aplique.

El grado de humedad de la borra recomendable durante el desmotado es del 6 al $7 \%$. Los limpiadores de la desmotadora eliminan más partículas extrañas con menos humedad, pero dañan más la fibra. Un grado de humedad mayor conserva la longitud de la fibra, pero complica el desmotado y la borra sale menos limpia, tal como ilustra la Figura 89.7. Si se seca más para eliminar más impurezas, disminuye la calidad del hilo. Aunque la fibra tenga mejor aspecto si se seca hasta un punto determinado, porque se eliminan más partículas extrañas, el mayor contenido de fibras cortas anula las ventajas de la mayor eliminación de partículas.

La limpieza influye poco en el cambio de color real de la fibra, pero peinar las fibras y eliminar las partículas extrañas cambia el color aparente. A veces, al limpiar la borra se mezclan las fibras de modo que se califiquen menos balas como manchadas o poco manchadas. El desmotado no influye en la finura y la madurez. Todos los dispositivos mecánicos o neumáticos utilizados durante la limpieza y el desmotado aumentan el contenido de motas, pero las limpiadoras de borras son las que más influyen. La cantidad de fragmentos de cáscaras en la

\section{Figura 89.7 - Relación entre humedad y limpieza en el desmotado del algodón.}

Daños en

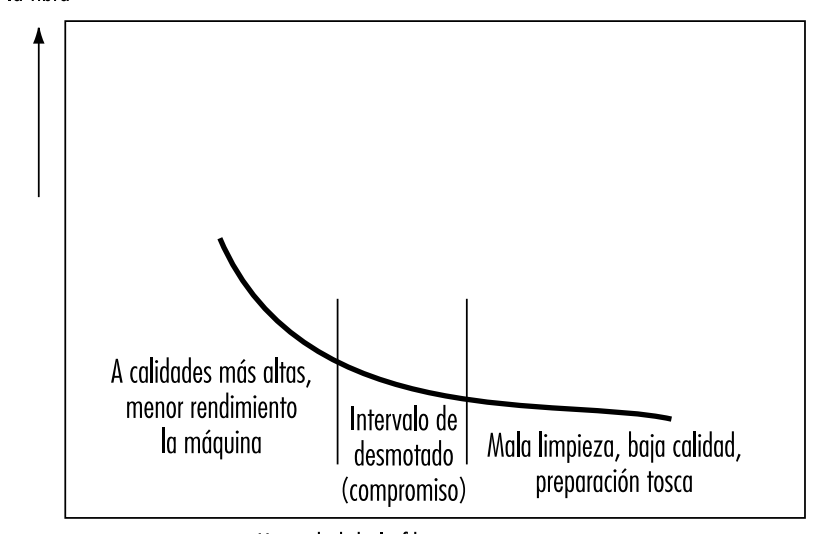

Humedad de la fibra en aumento 
borra desmotada depende del estado de la semilla y la acción de desmotado. Los limpiadores de borra reducen el tamaño de los fragmentos, pero no su cantidad. La resistencia del hilo, el aspecto y la rotura al final del proceso son tres aspectos importantes para la calidad de la hilatura. Todos ellos dependen de la uniformidad de la longitud y, por lo tanto, de la proporción de fibras cortas o rotas. Estos tres aspectos suelen conservarse mejor cuando el algodón se desmota con el mínimo de maquinaria de secado y limpieza.

Se han formulado recomendaciones sobre la secuencia y la cantidad de maquinaria de desmotado para secar y limpiar el algodón recolectado selectivamente con el fin de obtener balas de valor aceptable y proteger la calidad natural del algodón. En general, se han seguido y confirmado en el sector algodonero de Estados U nidos durante varias décadas. Las recomendaciones tienen en cuenta las primas y los descuentos del sistema de comercialización así como la eficacia de la limpieza y los daños de la fibra provocados por las diversas máquinas. En condiciones de recolección especiales, es necesario introducir modificar en estas recomendaciones.

Si la maquinaria de desmotado se utiliza con la secuencia recomendada, se eliminan entre un 75 y un $85 \%$ de las impurezas del algodón. Desgraciadamente durante este proceso la maquinaria también elimina pequeñas cantidades de algodón de buena calidad, de modo que la limpieza merma la cantidad de algodón comercializable. Por lo tanto, esta operación es un compromiso entre el contenido de materias extrañas y la pérdida y deterioro de fibras.

\section{Problemas de seguridad y salud}

La industria de desmotado del algodón, igual que otras industrias transformadoras, encierra muchos peligros. La información procedente de las demandas de indemnización de los trabajadores indica que la mayor parte de las lesiones afectan a las manos o a los dedos, seguidos de la espalda o la columna, los ojos, los pies o los dedos de los pies, los brazos o los hombros, las piernas, el tronco y la cabeza. Aunque la industria ha tomado parte activa en la reducción de riesgos y la formación en materia de seguridad, la seguridad del desmotado siguen siendo un problema grave. La principal fuente de preocupación es la elevada frecuencia de accidentes y las demandas de indemnización de los trabajadores, la gran cantidad de días de trabajo perdidos y la gravedad de los accidentes. El coste económico total de las lesiones y alteraciones de la salud debidas al trabajo en desmotadoras comprende los costes directos (médicos y demás indemnizaciones) y los indirectos (pérdida de días de trabajo, bajas, pérdida de capacidad laboral, mayor coste de los seguros para indemnizar a los trabajadores, pérdida de productividad y muchos otros factores). Los costes directos son más fáciles de determinar y mucho menores que los indirectos.

$M$ uchos reglamentos internacionales en materia de seguridad y salud en relación con el desmotado del algodón proceden de la legislación estadounidense administrada por la Agencia de Seguridad e $\mathrm{H}$ igiene en el Trabajo (O ccupational Safety and $\mathrm{H}$ ealth Administration, OSHA) y la Agencia de Protección Ambiental (Environmental Protection Agency, EPA), que publica reglamentos sobre pesticidas.

También se aplican al desmotado otras normas del ámbito de la agricultura, como los requisitos de señalización de vehículos de circulación lenta aplicables a los tractores y remolques que circulan por las vías públicas, las disposiciones sobre estructuras de protección antivuelco de los tractores y las normas de acondicionamiento adecuado de los locales destinados a trabajadores temporeros. Aunque las desmotadoras se consideran empresas agrícolas y no quedan específicamente amparadas por muchas normativas, es probable que los desmotadores prefieran cumplir algunas como la "Standards for General Industry, Part 1910" (N ormas para la industria en general) de la O SH A. La OSHA tiene tres normas que los desmotadores deberían tener en cuenta: las de los planes para el caso de incendio y otras emergencias (29 CFR 1910.38a), salidas de emergencia (29 CFR 1910.35-40) y exposición al ruido en el trabajo (29 CFR 1910.95). En la 29 CFR 1910.36 y la 29 CFR 1910.37 se incluyen los principales requisitos en cuanto a salidas de emergencia. En otros países, donde los trabajadores agrícolas están cubiertos por el seguro obligatorio, estas normas son ineludibles. El cumplimiento de la normativa sobre ruidos y otros aspectos de la salud y la seguridad se trata en otros apartados de esta E nciclopedia.

Participación de los empleados en los programas de seguridad L os programas más eficaces para el control de pérdidas son aquellos en los que la dirección motiva a los empleados para que sean conscientes de su seguridad. Esta motivación se impone estableciendo una política de seguridad que implique a los empleados en todos los aspectos del programa, participando en la formación en materia de seguridad, dando buen ejemplo y ofreciendo a los empleados los incentivos adecuados.

Las enfermedades profesionales se reducen obligando a usar EPP en las zonas designadas para ello y haciendo que los trabajadores cumplan prácticas de trabajo aceptables. D eberían utilizarse EPP para el oído (tapones u orejeras) y la respiración (mascarillas contra el polvo) siempre que la zona de trabajo tenga un nivel de ruido o una concentración de polvo elevados. A lgunas personas son más sensibles a estos elementos que otras, e incluso con EPP deberían trabajar en otras zonas con niveles más bajos de ruido o de polvo. Los riesgos para la salud relacionados con el levantamiento de pesos o el calor excesivo se limitan mediante formación, el uso de equipos de manipulación de materiales, la indumentaria adecuada, la ventilación y la programación de pausas fuera de la zona de calor.

Todas cuantos intervienen en el desmotado deberían contribuir a la seguridad del trabajo. Para instaurar un ambiente seguro, todo el mundo debe estar motivado para participar plenamente en el programa de control de pérdidas.

\section{ProducCION DE HILO DE ALGOdON}

\section{Phillip J. Wakelyn}

El algodón supone casi la mitad del consumo mundial de fibra textil. China, Estados U nidos, Federación Rusa, India y Japón son los principales países consumidores de algodón. EI consumo se mide por la cantidad de fibra de algodón puro que se compra y se utiliza para confeccionar materias textiles. La producción mundial anual de algodón es de 80 a 90 millones de balas (17.400 a 9.600 millones de kg). China, Estados U nidos, India, Paquistán y Uzbequistán son los principales países productores, y representan más del $70 \%$ de la producción mundial. El resto se reparte entre 75 países. Alrededor de 57 países exportan algodón en rama, y 65 tejidos de este material. M uchos países fomentan la producción nacional para reducir su dependencia de las importaciones.

La hilatura es una secuencia de operaciones que transforman las fibras de algodón en rama en un hilo adecuado para varios productos finales. Se requieren varios procesos para obtener un hilo uniforme, fuerte y limpio, apto para el mercado textil moderno. Un denso paquete de fibras entremezcladas (bala de algodón), que puede contener cantidades variables de materiales 
distintos de la borra y fibras inutilizables (materias extrañas, restos de la planta, motas, etc.) se somete a las diversas operaciones continuas de apertura, mezcla, limpieza, cardado, estirado, mechado e hilatura, para transformar las fibras de algodón en hilo.

Aunque los actuales procesos de producción están muy perfeccionados, la presión de la competencia sigue animando a asociaciones y fabricantes individuales a buscar nuevos métodos y máquinas más eficaces para procesar el algodón que algún día puedan reemplazar a los actuales. Sin embargo, en el futuro inmediato se seguirán utilizando los actuales métodos de mezcla, cardado, estirado, mechado e hilatura. Sólo el espadillado del algodón está abocado a desaparecer en breve.

La hilatura produce hilos para diversos productos finales tejidos o tricotados (prendas de vestir o tejidos industriales), hilos de costura y cordelería. Se fabrican hilos de diversos diámetros y pesos diferentes por unidad de longitud. Aunque el proceso básico de fabricación de hilo no ha variado durante años, las velocidades de producción, la tecnología de control y las dimensiones de los paquetes han ido en aumento. Las propiedades del hilo y la eficacia del procesado están directamente relacionadas con las propiedades de las fibras de algodón procesadas. Las propiedades finales del hilo también dependen de las condiciones de procesado.

\section{Procesos de producción de hilo}

\section{Apertura, mezcla y limpieza}

En general, las fábricas textiles seleccionan las balas según las propiedades que necesitan para producir hilo para un uso determinado. La cantidad de balas mezcladas por las fábricas textiles en cada variedad oscila entre 6 o 12 y más de 50. El tratamiento empieza cuando las balas que hay que mezclar se llevan a la sala de apertura, donde se retiran los sacos y las cuerdas. Las capas de algodón se sacan de las balas a mano y se colocan en alimentadores equipados con cintas transportadoras dentadas, o bien se colocan las balas enteras sobre plataformas que las mueven hacia delante y atrás por debajo o encima de un mecanismo de desplumado. El objetivo es iniciar el proceso de producción secuencial convirtiendo las capas compactadas de algodón embalado en pequeños copos ligeros y esponjosos que facilitarán la eliminación de partículas extrañas. Esta operación se llama "apertura". D ado que las balas llegan a la fábrica con diferentes grados de densidad, lo habitual es cortar las cuerdas de la bala aproximadamente 24 horas antes de procesarlas, para que recuperen su volumen. Así el proceso de apertura es más fácil y se regula el ritmo de alimentación. Las máquinas de limpieza en las fábricas textiles realizan las funciones de apertura y primera fase de limpieza.

\section{Cardado y peinado}

La carda es la máquina más importante del proceso de producción de hilo. En gran parte de las fábricas textiles lleva a cabo la segunda y la última fase de limpieza. La carda es un grupo de tres cilindros cubiertos de alambres y una serie de barras planas también cubiertas de alambres que remueven sucesivamente pequeños copos y grupos de fibras, abriéndolos y separándolos; también eliminan un porcentaje elevado de impurezas y materias extrañas, agrupan las fibras en una cuerda llamada "torzal" y depositan éste en un recipiente en el que se conducirá a nuevos tratamientos (véase la Figura 89.4).

Tradicionalmente, el algodón ha entrado en la carda en forma de "tela de espadillado", formada sobre una "espadadora", una combinación de rodillos alimentadores y batidores con un mecanismo formado por tamices cilíndricos sobre los cuales se recogen y se enrollan en forma de bloque los copos de algodón (véase la Figura 89.5). El bloque sale de los tamices en forma de lámina plana y uniforme y se enrolla. Pero las necesidades de mano de obra y la disponibilidad de sistemas de manipulación automática que mejoran la calidad están contribuyendo a eliminar el espadillado.

La eliminación del espadillado ha sido posible gracias a la instalación de equipos de apertura y limpieza más eficaces y de sistemas de alimentación por gravedad en las cardas. C on este último método, los copos de fibras limpios y abiertos se distribuyen en las cardas con un circuito neumático. Esto mejora la uniformidad y la calidad y reduce el número de trabajadores necesarios.

A lgunas fábricas textiles producen hilo peinado, que es el hilo de algodón más limpio y uniforme. El peinado proporciona una limpieza más profunda que la carda. Elimina las fibras cortas, las motas y las impurezas, y el torzal resultante es muy limpio y lustroso. La peinadora es una máquina complicada formada por rodillos de alimentación ranurados y un cilindro parcialmente cubierto de agujas que extrae las fibras cortas (véase la Figura 89.3).

\section{Estirado y mechado}

El estirado es el primer proceso de producción de hilo que utiliza el estiramiento con cilindros. Según este método, prácticamente todo el estirado se produce por obra de los cilindros. Los contenedores con el torzal procedente del cardado se montan en la fileta de la máquina de estirado. El torzal entra en un sistema de pares de cilindros que se giran a velocidades distintas. El estirado refuerza las fibras del torzal y las estira de modo que la mayoría queden paralelas al eje del torzal. La paralelización es necesaria para conseguir las propiedades deseadas cuando las fibras después se convierten en hilo. El estirado también confiere uniformidad torzal en términos de peso por unidad de longitud y mejora la mezcla. Las fibras que se obtienen en el proceso final de estirado, llamado estirado de acabado, son casi rectas y paralelas al eje del torzal. El peso por unidad de longitud de un torzal que ha pasado por un proceso de estirado de acabado es demasiado elevado para que se pueda convertir en hilo con los sistemas normales de hilatura con anillos.

EI mechado reduce el peso del torzal hasta un valor adecuado para la hilatura y la torsión, que mantiene la integridad de las hebras estiradas. L os recipientes con los torzales procedentes del estirado de acabado o del peinado se colocan en la fileta, y cada uno de los torzales pasa entre dos juegos de cilindros; el segundo gira más rápido, y reduce así el diámetro del torzal desde $2,5 \mathrm{~cm}$ al de un lápiz. La torsión se aplica pasando los haces de fibras por una mechera. El producto se llama mecha y se embala en una bobina de aproximadamente $37,5 \mathrm{~cm}$ de longitud y $14 \mathrm{~cm}$ de diámetro.

\section{Hilatura}

La hilatura es la fase más costosa de la conversión de las fibras en hilo. En la actualidad, más del $85 \%$ del hilo del mundo se produce en máquinas continuas de hilar con anillos, diseñadas para estirar la mecha hasta el tamaño deseado, o número del hilo, y aplicarle la torsión precisa. El grado de torsión es proporcional a la fuerza del hilo. La proporción entre longitud obtenida y longitud suministrada oscila entre 10 y 50 . Las bobinas de mechado se colocan en soportes que permiten que las mechas entren libremente en el rodillo de estirado de la continua de hilar con anillos. Después de la zona de estirado, el hilo pasa a través de un "cursor" hasta una bobina de hilado. El soporte que sostiene la bobina gira a gran velocidad, haciendo que el hilo se hinche a medida que se imparte la torsión. Las longitudes del hilo de la bobina son insuficientes para los procesos posteriores y se 
trasladan a "cajas de hilado" que pasan a la operación siguiente de bobinado o devanado.

En la producción moderna de hilos bastos o más fuertes, la hilatura a cabo suelto está sustituyendo a la hilatura con anillos. Se introduce un torzal de fibras en un rotor de gran velocidad, donde la fuerza centrífuga convierte las fibras en hilos. No hace falta bobina, y el hilo se recoge directamente en el embalaje adecuado para la siguiente operación.

Se dedica mucho trabajo a la investigación y el desarrollo de nuevos métodos de hilatura. En la actualidad se prueban algunos sistemas que podrían revolucionar el sector y alterar la importancia relativa de las propiedades de la fibra tal como se perciben ahora. En general, cuatro de los planteamientos en que se basan los nuevos sistemas son adecuados al algodón. Los sistemas de alma hilada se utilizan para fabricar diversos hilos especiales y de costura. Se han producido comercialmente hilos sin torcer en cantidades limitadas uniendo las fibras con alcohol de polivinilo $u$ otros agentes aglutinantes. La técnica sin torsión es compatible con un ritmo de producción muy rápido y rinde hilos muy uniformes. El punto y otros tejidos de vestir obtenidos con hilo sin torsión tienen un aspecto excelente. En la hilatura por torbellino, que en la actualidad estudian los fabricantes de maquinaria, el torzal se sitúa ante un cilindro abridor, similar al de la hilatura a cabo suelto. L a técnica permite velocidades de producción elevadas, pero de momento los prototipos son muy sensibles a las variaciones en la longitud de la fibra y al contenido de partículas extrañas.

\section{Bobinado y encar retado}

U na vez obtenido el hilo, los fabricantes deben acondicionarlo. EI tipo de acondicionamiento se elige en función del destino del hilo (tejido o tricotado). Bobinado, encarretado, retorcido y encanillado se consideran fases preparatorias para tejer o tricotar. En general, el producto del encarretado se utilizará como hilo de urdimbre (el que recorre el tejido longitudinalmente) y el del bobinado como hilo de relleno o hilo de trama (el dispuesto transversalmente al tejido). Los productos de la hilatura de cabo suelto se saltan estas fases y se envasan para trama o para urdimbre. C on el retorcido se consigue un hilo formado por dos o más hilos entrelazados para un nuevo procesado. En el proceso de encanillado, el hilo se enrolla en bobinas suficientemente pequeñas como para caber dentro de la lanzadera del telar de caja. A veces el encanillado se hace en el telar (véase también el artículo "Tejer y tricotar", en este mismo capítulo).

\section{Tratamiento de los residuos}

En las fábricas textiles modernas, donde el control del polvo es importante, es esencial el tratamiento correcto de los residuos. En las fábricas textiles tradicionales, los residuos se recogían manualmente y se llevaban a un almacén si no se podían reciclar en alguno de los sistemas. Se amontonaban hasta que había cantidad suficiente de un tipo para preparar una bala. Con la tecnología actual, los extractores centrales recuperan automáticamente los desechos de la apertura, el espadillado, el cardado, el estirado y el mechado. La aspiradora central limpia la maquinaria, recoge automáticamente los restos de debajo de las máquinas, como pelusa y motas del cardado, y devuelve los restos no reutilizables procedentes de los condensadores de filtro. La embaladora clásica es la prensa vertical que todavía forma la típica bala de $227 \mathrm{~kg}$. En la tecnología moderna de tratamiento de residuos, los desechos del extractor central se acumulan en un depósito receptor que alimenta una prensa de balas horizontal. Los diversos residuos del sector de la hilatura se reciclan o reutilizan en otras industrias: hilado de estropajos, elaboración de rellenos para colchonería y tapicería con residuos del espadillado, etc.

\section{Problemas de seguridad y salud}

\section{Maquinaria}

Todas las máquinas de manipulación del algodón pueden provocar accidentes, aunque la frecuencia no es elevada. La protección eficaz del gran número de piezas móviles es complicada y requiere atención constante. La formación del personal materia de seguridad en el trabajo es esencial, en particular para impedir que se hagan reparaciones mientras la máquina está en marcha, que es la causa de la mayoría de los accidentes. Todas las máquinas reciben alguna clase de energía (eléctrica, mecánica, neumática, hidráulica, inercial, etc.) que hay que controlar antes de cada reparación u operación de mantenimiento. Es preciso identificar las fuentes de energía, proporcionar el equipo necesario y formar al personal para asegurarse de que se desconectan todas las fuentes de alimentación mientras se manipula la máquina. $\mathrm{H}$ ay que realizar inspecciones regulares para garantizar la observación y aplicación correctas de todas las rutinas de bloqueo y señalización.

\section{Inhalación de polvo de algodón (bisinosis)}

Se ha demostrado que la inhalación del polvo generado en los procesos de conversión de la fibra de algodón en hilos y tejidos es la causa de una enfermedad del pulmón denominada bisinosis que afecta a los trabajadores del textil. $\mathrm{N}$ ormalmente hacen falta entre 15 y 20 años de exposición a niveles elevados de polvo (más de 0,5 a $1,0 \mathrm{mg} / \mathrm{m}^{3}$ ) para que el trabajador presente los síntomas. Las normas de la O SH A y la Conferencia Americana de Higienistas Industriales del Gobierno (American Conference of Governmental Industrial $\mathrm{H}$ ygienists, $A C \mathrm{GIH}$ ) establecen que el límite de exposición al polvo de algodón en la fabricación de hilo debe ser de $0,2 \mathrm{mg} / \mathrm{m}^{3}$ de polvo respirable medido con un decantador vertical. EI polvo, una masa de partículas suspendidas en el aire que se libera a la atmósfera durante la manipulación y transformación del algodón, es una mezcla compleja y heterogénea de restos botánicos, tierra y material microbiológico (bacterias y hongos) de composición y actividad biológica variables. $\mathrm{N}$ o se conoce el agente etiológico ni la patogénesis de la bisinosis. Se cree que los restos de la fábrica de algodón mezclados con fibras y endotoxinas de las bacterias gram negativas presentes en estos materiales podrían ser la causa de la enfermedad o contener su agente etiológico. Lo que sí está claro es que la fibra de algodón en sí, que es principalmente de celulosa, no es la causa, ya que la celulosa es un polvo inerte que no provoca trastornos respiratorios. U n control técnico adecuado de las zonas de procesado textil del algodón (véase la Figura 89.8) junto con unos métodos de trabajo correctos, el control médico y el uso de EPP (Equipos de Protección Personal) pueden eliminar en gran parte la bisinosis. El lavado del algodón con agua templada en autoclave por lotes y los sistemas de bloques continuos reducen la concentración residual de endotoxina, tanto en la borra como en el polvo en suspensión en el aire, a valores inferiores a los asociados con la reducción aguda de la función pulmonar medida por el volumen de espiración forzada durante un segundo.

\section{Ruido}

EI ruido es un problema en las operaciones de hilatura, aunque en algunas fábricas modernas los niveles se encuentran por debajo de los $90 \mathrm{dBA}$, que corresponde a la norma de Estados U nidos, pero sobrepasa la de muchos otros países. Gracias a los esfuerzos de los fabricantes de maquinaria y técnicos industriales, los niveles de ruido siguen disminuyendo a medida que aumenta la velocidad de la maquinaria. La solución para evitar el ruido es 
Figura 89.8 - Sistema de extracción del polvo en una máquina cardadora.

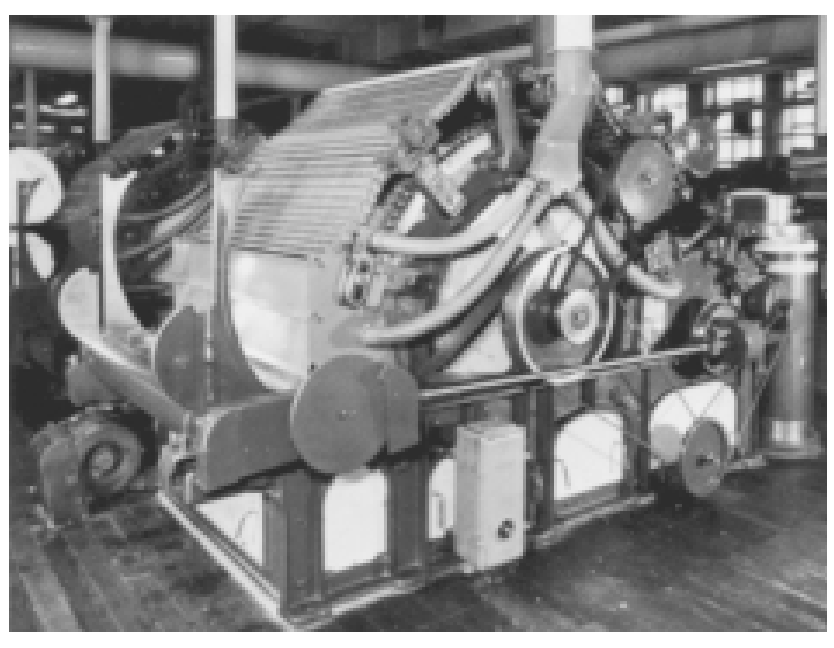

instalar maquinaria más moderna y silenciosa. En Estados Unidos se exige un programa de protección del oído cuando los niveles de ruido sobrepasan los $85 \mathrm{dBA}$; este programa incluye un seguimiento del nivel de ruido, pruebas audiométricas y la disponibilidad de dispositivos de protección de los oídos para todos los empleados cuando la presión acústica no se pueden reducir a menos de $90 \mathrm{dBA}$.

\section{Estrés debido al calor}

Dado que la hilatura a veces exige temperaturas muy altas y humidificación artificial del aire, hay que tener siempre mucho cuidado para no sobrepasar los límites admisibles. Cada vez se utilizan más equipos de aire acondicionado bien diseñados y con buen mantenimiento en vez de los métodos más primitivos de regulación de la temperatura y la humedad.

\section{Sistemas de gestión de la salud y la seguridad en el trabajo}

M uchas de las fábricas textiles más modernas consideran útil tener algún tipo de sistema de gestión de la salud y la seguridad en el trabajo para controlar los riesgos a que los operarios se enfrentan en sus puestos de trabajo. Puede ser un programa voluntario, como el "Q uest for the Best in Health and Safety" (En busca de lo mejor en salud y seguridad) creado por el American Textile $\mathrm{M}$ anufacturers Institute, u obligatorio, como el U S State of California O ccupational Injury and IIIness Prevention Program (T itle 8, California Code of Regulations, Section 3203) (Programa del Estado de California para la prevención de enfermedades y lesiones profesionales). Si se utiliza un sistema de gestión de la salud y la seguridad en el trabajo, debe ser suficientemente flexible y adaptable para que cada fábrica lo ajuste a sus necesidades.

\section{- INDUSTRIA DE LA LANA}

\section{D.A. H argrave*}

Los orígenes de la industria de la lana se pierden en la antigüedad. Nuestros antepasados más remotos aprendieron a domesticar las ovejas, que satisfacían sus necesidades básicas de alimentación y abrigo. Las primeras sociedades humanas

\footnotetext{
* Adaptado de la 3a edición, E nciclopedia de salud y seguridad en el trabajo.
}

frotaban las fibras que sacaban de la oveja para formar un hilo, y a partir de este principio básico se han ido perfeccionando los métodos de manipulación de las fibras. La industria textil lanera ha sido pionera en el desarrollo y la adaptación de métodos mecánicos, y por lo tanto fue una de las primeras en desarrollar el sistema de producción fabril.

\section{Materias primas}

La longitud de la fibra cuando se extrae del animal es el principal factor determinante, pero no el único, del tipo de tratamiento. La lana disponible se clasifica como: a) merino o australia; b) cruzada (mestiza) fina, media o basta; y c) para alfombras. Pero dentro de cada grupo hay varias categorías. La lana merino suele tener menor diámetro y ser más corta, mientras que las lanas para alfombras son de fibra larga y mayor diámetro. A hora se fabrican cada vez más fibras sintéticas similares a la lana que se mezclan con fibra natural y se procesan de la misma forma. También el pelo de otros animales - como el mohair (cabra), la alpaca (llama), el cachemir (cabra, camello), la angora (cabra) y la vicuña (vicuña o llama salvaje)- desempeña un papel importante, aunque secundario, en la industria; estas fibras suelen ser más caras, y normalmente se trabajan sólo en empresas especializadas.

\section{Producción}

$\mathrm{H}$ ay dos sistemas de producción diferentes: el cardado y el peinado. La maquinaria es similar en muchos aspectos, pero los objetivos son distintos. En esencia, el sistema de peinado utiliza las fibras más largas y durante las operaciones de cardado, preparación, paso por el gill y peinado de las fibras se mantienen paralelas y se rechazan las más cortas. EI hilado proporciona un hilo fuerte y delgado que se teje para obtener un género ligero, con la suavidad y firmeza características de los trajes de caballero. En el sistema de cardado, el objetivo es entremezclar y entrelazar las fibras para formar un hilo suave y esponjoso, que cuando se teje proporciona una tela con volumen y una superficie "Ianosa", como la que presentan tweeds, mantas y abrigos gruesos. Dado que la uniformidad de la fibra no es esencial en el sistema de cardado, el fabricante mezcla lana nueva, fibras más cortas rechazadas en el peinado, lanas recuperadas de la destrucción de prendas antiguas, etc.; el "shoddy" (lana regenerada) se obtiene de material regenerado blando y el "mungo" (lana de borra) de material regenerado duro.

$\mathrm{H}$ ay que tener en cuenta, no obstante, que el sector es especialmente complejo y que la condición y el tipo de materia prima utilizada y la especificación de la prenda acabada influirán en el método de producción, en cada una de sus fases y en la secuencia de dichas fases. Así, la lana puede teñirse antes de procesarla, en la fase de hilado o al final del proceso, cuando la pieza ya está tejida. A demás, algunas operaciones se efectúan en establecimientos diferentes.

\section{Riesgos y prevención}

Como en todos los subsectores de industria textil, las grandes máquinas con piezas que se mueven a alta velocidad encierran riesgos tanto por el ruido como por las posibles lesiones mecánicas. También el polvo puede ser un problema. Hay que emplear protecciones y cerramientos en la mayor medida posible para ciertas piezas de tipo general, como engranajes, cadenas y ruedas dentadas, ejes giratorios, correas y poleas, así como otras específicas del sector textil lanero:

- Ios rodillos de alimentación y los tambores de diversos tipos de máquinas abridoras de preparación (por ejemplo, desfibradores, depuradores, garneteadoras, trituradoras de trapos, etc.); 
- los tomadores y rodillos adyacentes de máquinas desborradoras y cardas;

- la entrada entre los cilindros tambor y llevador de las máquinas desborradoras, cardas y garneteadoras;

- los cilindros y peines de las mecheras puercoespín;

- los ejes traseros de las continuas de estirar y mechar;

- las trampas entre el carro y el cabezal de las selfactinas;

- los pernos salientes, pivotes y otros elementos de fijación utilizados en el movimiento de plegado de urdimbre de las máquinas urdidoras;

- los rodillos compresores de las máquinas de desgrasado, enfurtido y escurrido;

- el espacio entre la tela y la enrolladora y el rodillo de las máquinas de vaporización;

- el cilindro de cuchillas giratorias de las máquinas de tundido;

- las palas de los ventiladores de los sistemas de transporte neumático (los paneles de inspección de las tuberías de estos sistemas deben situarse a una distancia segura del ventilador, y el operario ha de tener en cuenta el tiempo que tarda la máquina en desacelerar y detenerse una vez desconectada la corriente; este punto es especialmente importante, porque el operario que desbloquea el sistema normalmente no ve las palas en movimiento), y

- la lanzadera volante, que plantea un problema especial (los telares deberían tener protecciones bien diseñadas para evitar que la lanzadera salga de la calada y para limitar la distancia recorrida en caso de que salga).

EI uso de protecciones para estas piezas peligrosas presenta problemas prácticos. El diseño de la protección debe tener en cuenta las prácticas de los operarios en relación con el proceso de que se trate y, sobre todo, evitar la posible retirada de la protección cuando el operario se encuentre en situación de máximo riesgo (por ejemplo, mecanismos de bloqueo). $\mathrm{H}$ acen falta formación especial y supervisión estricta para impedir que la retirada de desechos y la limpieza se efectúen con la máquina en marcha. La mayor responsabilidad recae en los fabricantes de maquinaria, que deberían garantizar la incorporación de estos dispositivos de seguridad en las máquinas nuevas desde la misma fase de diseño, y en el personal de supervisión, que debería asegurarse de que los trabajadores han recibido formación suficiente para la manipulación segura de la maquinaria.

\section{Distancia entre las máquinas}

El riesgo de accidentes aumenta si no se deja espacio suficiente entre las máquinas. En muchas fábricas antiguas se aprovechaba el espacio al máximo a costa de reducir el espacio libre de pasillos y corredores y para el almacenamiento provisional de materias primas y productos acabados en el taller. En algunas de estas instalaciones, el paso entre las máquinas de cardado es tan estrecho, que es imposible encerrar las correas de los motores con defensas y hay que encajar la protección entre la correa y la polea en el punto de entrada. En estas circunstancias es importante disponer de un fijador de correa bien diseñado y liso. $\mathrm{H}$ ay que respetar las distancias mínimas que recomienda el comité del gobierno británico para determinadas máquinas de la industria textil lanera.

\section{Manipulación de materiales}

Si no se utilizan los métodos mecánicos modernos de carga y manipulación, hay riesgo de lesiones por levantamiento de cargas pesadas. La manipulación de materiales debe mecanizarse al máximo. Y si no es posible, hay que tomar las precauciones que se comentan en otros apartados de esta E nciclopedia. Es particularmente importante que los operarios que introducen y sacan plegadores pesados de los telares y manipulan balas pesadas y voluminosas de lana en los primeros procesos de preparación utilicen técnicas de levantamiento adecuadas. Siempre que sea posible, hay que emplear carretillas o tren de rodillos para mover cargas voluminosas y pesadas.

\section{Incendios}

El riesgo de incendio es a veces grave, especialmente en las fábricas antiguas de varias plantas. La estructura y el diseño de la fábrica han de cumplir la normativa local en materia de salidas de emergencia, sistemas de alarma, extintores y mangueras, alumbrado de emergencia, etc. La limpieza y el buen mantenimiento evitarán la acumulación de polvo y borra, que favorecen la propagación del fuego. No hay que efectuar jamás en horas de trabajo reparaciones que exijan el uso de sopletes u otros equipos con llama. Es necesario enseñar al personal a actuar en caso de incendio; y efectuar simulacros de incendio a intervalos adecuados, a ser posible en coordinación con los bomberos, la policía y el servicio de urgencias médicas.

\section{Seguridad general}

Se ha prestado mucha atención a los accidentes propios del sector textil lanero. Sin embargo, hay que tener en cuenta que la mayoría de los accidentes que tienen lugar en las fábricas textiles ocurren en circunstancias similares a los de otras fábricas - caídas de personas y objetos, manipulación de productos, uso de herramientas manuales, etc.- y que los principios básicos de seguridad son los mismos en la industria lanera que en la mayoría de sectores.

\section{Riesgos para la salud}

\section{Antrax}

L a enfermedad profesional que más se relaciona con la industria de la lana es el ántrax. En otras épocas era un peligro grave, especialmente para los clasificadores de lana, pero en la actualidad está prácticamente erradicada gracias a:

- la mejora de los métodos de producción de los países exportadores, donde el ántrax es endémico;

- la desinfección de los materiales susceptibles de transportar esporas de ántrax;

- la mejora de la manipulación del material posiblemente infectado bajo ventilación de escape durante los procesos de preparación;

- la exposición de la bala de lana a microondas durante tiempo suficiente y a una temperatura que extermine los hongos. E ste tratamiento también ayuda a recuperar la lanolina asociada a la lana;

- los progresos considerables del tratamiento médico, como la inmunización de los trabajadores que se encuentran en situaciones de alto riesgo, y

- la educación y formación de los trabajadores y la instalación de zonas de aseo, y en caso de necesidad, de equipos de protección personal.

Además de las esporas del hongo ántrax, se sabe que también hay en la lana esporas del hongo Coccidiodes immitis, especialmente en el sudoeste de Estados U nidos. Este hongo puede causar la enfermedad conocida por coccidioidomicosis que, como el ántrax, es difícil de pronosticar. El ántrax encierra el peligro añadido de causar úlceras malignas o carbúnculos con un punto negro en el centro cuando entran en el cuerpo a través de una herida en la piel.

\section{Productos químicos}

Se utilizan productos químicos variados para desengrasar (dióxido de dietileno, detergentes sintéticos, tricloretileno y, en el 
pasado, tetracloruro de carbono), desinfectar (formaldehído), blanquear (dióxido de azufre, cloro) y teñir (clorato potásico, anilinas). Los riesgos comprenden inhalación de gases, intoxicación, irritación de los ojos, las membranas mucosas y los pulmones y afecciones dermatológicas. En general la prevención se basa en:

- sustitución por productos químicos menos peligrosos;

- sistemas de ventilación de los locales;

- precaución durante el etiquetado, el almacenamiento y el transporte de líquidos corrosivos o nocivos;

- equipo de protección personal;

- instalaciones de aseo adecuadas (como duchas cuando sea posible), e

- higiene personal estricta.

\section{Otros peligros}

El ruido, la iluminación insuficiente y las temperaturas y humedades elevadas que exige el procesado de la lana afectan a la salud general, salvo que se ejerza un control muy estricto. En muchos países hay normas al respecto. El vapor y la condensación son difíciles de controlar efectivamente en las zonas de tintura, y a menudo se necesita el asesoramiento de personal técnico cualificado. En las zonas de tejido, el control del ruido constituye un problema grave, y en este aspecto todavía queda mucho por hacer. En todas partes debe haber una buena iluminación, sobre todo donde se fabrican tejidos oscuros.

\section{Polvo}

Al riesgo específico de la presencia de esporas de ántrax en el polvo producido en los primeros procesos hay que añadir las grandes cantidades de polvo que producen muchas máquinas, suficientes para provocar irritación de la mucosa de las vías respiratorias, sobre todo durante la operaciones de corte o cardado. Este polvo debe eliminarse con equipos eficaces de ventilación local por extracción (VLE).

\section{Ruido}

Debido a la gran cantidad de piezas móviles de las máquinas, especialmente los telares, las fábricas de lana suelen ser lugares muy ruidosos. Aunque el ruido se atenúa mediante una lubricación adecuada, habría que considerar también la introducción de reflectores de sonidos y otros avances técnicos. En general, la prevención de la pérdida de audición por motivos profesionales exige el uso de tapones u orejeras. Es esencial que los trabajadores reciban formación en torno al empleo adecuado de estos elementos de protección y que se supervisen para comprobar que los utilizan. En muchos países es obligatorio un programa de conservación de la audición, con realización periódica de audiogramas. A medida que se cambia o repara la maquinaria, convendría tomar medidas adecuadas para reducir el ruido.

\section{Estrés en el trabajo}

El estrés en el trabajo y sus repercusiones sobre la salud y el bienestar de los trabajadores es un problema común en la industria. Dado que muchas fábricas textiles funcionan durante las veinticuatro horas del día, el trabajo por turnos es inevitable. Para cumplir las cuotas de producción, las máquinas funcionan ininterrumpidamente, y cada trabajador está "atado" a una o varias, que no puede abandonar ni siquiera para ir al lavabo o hacer una pausa hasta que el relevo ocupa su puesto. Junto con el ruido ambiental y el uso de protectores contra el ruido, esta actividad extremadamente rutinaria y repetitiva supone un auténtico aislamiento de los trabajadores y una falta de interacción social que llega a provocar un estrés alto. La calidad de la supervisión y la disponibilidad de zonas de esparcimiento en el lugar de trabajo influyen mucho en el grado de estrés de los trabajadores.

\section{Conclusión}

Mientras que las grandes empresas están en condiciones de invertir en nuevos desarrollos tecnológicos, muchas otras pequeñas y más antiguas siguen trabajando en plantas viejas con equipos desfasados que todavía funcionan. Los imperativos económicos impiden prestar la atención debida a la seguridad y la salud de los trabajadores. A demás, en muchas zonas desarrolladas se abandonan las fábricas textiles y se abren nuevas plantas en países y zonas en vías de desarrollo donde la mano de obra es más barata y donde no hay normas de seguridad o es fácil incumplirlas. A escala mundial se trata de un importante sector que ocupa mucha mano de obra y en el que una inversión razonable en la salud y el bienestar de los trabajadores aportaría beneficios considerables, tanto para la empresa como para sus trabajadores.

\section{INDUSTRIA DE LA SEDA}

\section{J. Kubota*}

La seda es una fibra lustrosa, resistente y elástica producida por unas larvas llamadas gusanos de seda; el término abarca también el hilo o la tela procedentes de esta fibra. La industria de la seda tiene su origen en $\mathrm{C}$ hina, donde según la tradición era ya conocida el año 2640 a.C. H acia el siglo III d.C., el gusano de seda y su producto llegaron a Japón a través de Corea; probablemente se difundió hacia la India un poco más tarde. Desde allí, la producción de seda fue avanzando lentamente hacia occidente, hasta Europa y el N uevo M undo.

La producción abarca una secuencia de fases que no necesariamente han de llevarse a cabo en una sola empresa o planta. Estas fases son:

- Sericultura. La producción de capullos para aprovechar los filamentos de seda cruda se conoce con el nombre de sericultura, término que abarca la alimentación de los gusanos, la formación de capullos, etc. Lo primero que se requiere es una reserva de moreras suficiente para alimentar a las larvas. Las bandejas en las que se crían los gusanos se mantienen en una sala a una temperatura constante de $25^{\circ} \mathrm{C}$, lo que obliga a utilizar calefacción artificial en los países y estaciones más fríos. L os capullos empiezan a formarse al cabo de unos 42 días.

- H ilado o hilatura. El proceso peculiar del hilado de la seda es el devanado, durante el cual los filamentos del capullo se convierten en una sola hebra continua, uniforme y regular. En primer lugar, la goma natural (sericina) se ablanda en agua hirviendo. Después, en un baño o barreño de agua caliente se unen los extremos de los filamentos de varios capullos, se estiran, se enganchan a una rueda de devanado y se arrollan para formar el hilo de seda cruda.

- Molinaje. En este proceso, las hebras se retuercen y se doblan para formar hilos más consistentes.

- D esengomado. En esta fase, la seda cruda se hierve en una solución de jabón y agua a aproximadamente $95^{\circ} \mathrm{C}$.

- Blanqueo. La seda cruda o hervida se blanquea con peróxido de hidrógeno o de sodio.

- Tejido. El hilo de seda se teje para formar una tela; normalmente esta operación tiene lugar en fábricas distintas del hilado.

- Tinción. La seda se puede teñir cuando todavía es un filamento o hilo o cuando ya está tejida.

\footnotetext{
* Adaptado de la 3ª edición, E ncidopedia de salud y seguridad en el trabajo.
} 


\section{Riesgos para la seguridad y la salud}

\section{M onóxido de carbono}

En Japón, donde la sericultura es una industria muy extendida, se han registrado síntomas menos graves de intoxicación por monóxido de carbono - cefaleas, vértigos y a veces náuseas y vómitos- a causa del uso de fuegos de carbón vegetal en salas de cría mal ventiladas.

\section{Dermatitis}

El M al de los baldes, una dermatitis de las manos de las mujeres que trabajan en el devanado de seda cruda, era bastante habitual en Japón, donde en los años veinte se registró un índice de mortalidad entre las devanadoras del 30 al $50 \%$. El $14 \%$ de las trabajadoras afectadas perdieron un promedio de tres días laborables al año. Las lesiones en la piel, localizadas principalmente en los dedos, las muñecas y los antebrazos, se caracterizaban por eritemas cubiertos con pequeñas vesículas que se convertían en crónicas, pustulares o eczematosas, y eran extremadamente dolorosas. La causa solía atribuirse a los productos en descomposición de las crisálidas muertas y a los parásitos del capullo, pero la experiencia japonesa más reciente indica que es posible que la enfermedad esté relacionada con la temperatura del baño de devanado; hasta 1960, esta temperatura era casi siempre de $65^{\circ} \mathrm{C}$, pero desde la introducción de nuevas instalaciones con temperaturas de 30 a $45^{\circ} \mathrm{C}$, no ha habido más informes de lesiones dérmicas entre las devanadoras.

La manipulación de seda cruda induce reacciones alérgicas de la piel en algunos trabajadores de devanado. Se han observado inflamaciones faciales y oculares aun sin contacto local directo con el baño de devanado. También se han observado casos de dermatitis entre los operarios del molinaje.

\section{Afecciones de las vías respiratorias}

En la antigua Unión Soviética apareció un extraño brote de tonsilitis en las hilaturas de seda debido a las bacterias del agua de los barreños de devanado y de la atmósfera de la zona de capullos. La desinfección y el cambio frecuente del agua del baño de devanado, junto con una buena ventilación en la sala de devanado de capullos, mejoró rápidamente la situación.

Las abundantes observaciones epidemiológicas a largo plazo llevadas a cabo en la antigua Unión Soviética han demostrado además que los trabajadores del sector de la seda natural pueden desarrollar alergias respiratorias que cursan con asma bronquial, bronquitis asmática o rinitis alérgica. Parece que la seda natural puede provocar sensibilización en todas las fases de la producción.

También se ha informado de una situación que ocasiona trastornos respiratorios entre los trabajadores de las continuas de hilar cuando embalan o reembalan la seda en estas máquinas 0 en bobinadoras. Según la velocidad de la máquina, se forma un aerosol con la sustancia proteica que envuelve el filamento de la seda. Este aerosol, cuando se respira en grandes cantidades, provoca una reacción pulmonar muy similar a la de la reacción bisinótica al polvo del algodón.

\section{Ruido}

La exposición al ruido llega a alcanzar niveles dolorosos para los trabajadores de las máquinas de hilado y devanado de las hebras de seda y en los talleres de tejido. La lubricación correcta de la maquinaria y la interposición de reflectores de sonido reducen algo la presión acústica, pero la exposición continua durante toda la jornada laboral tiene efecto acumulativo. Si es imposible reducir el ruido, hay que recurrir a los elementos de protección personal. Como en todos los casos de exposición al ruido, es deseable aplicar un programa de protección auditiva que obligue a realizar audiogramas periódicos.

\section{Medidas de salud y seguridad}

El control de la temperatura, la humedad y la ventilación son importantes en todas las fases de la industria de la seda. H abría que supervisar incluso a quienes trabajan en el hogar, comprobar que la ventilación de las salas de cría es suficiente, y sustituir las estufas de carbón vegetal o queroseno por calefactores eléctricos u otros dispositivos de calentamiento.

Disminuir la temperatura de los baños de devanado ayuda a prevenir la dermatitis. El agua debe cambiarse a menudo y la ventilación ha de ser suficiente. $\mathrm{H}$ ay que evitar en la medida de lo posible el contacto directo de la piel con la seda cruda sumergida en los baños de devanado.

Es esencial disponer buenas instalaciones sanitarias y prestar atención a la higiene personal. En Japón se ha demostrado que lavarse las manos con una solución de ácido acético al $3 \%$ es un buen remedio.

También es deseable someter a revisión médica a los trabajadores nuevos y efectuar exámenes posteriores.

Los riesgos propios de la maquinaria de la industria de la seda son similares a los de la industria textil en general. La prevención de accidentes se consigue con buen mantenimiento, protección adecuada de las piezas móviles, formación continua de los trabajadores y supervisión real. Los telares mecánicos deben estar provistos de guardas para evitar los accidentes provocados por las lanzaderas volantes. La preparación de hilos y tejidos exigen una iluminación excelente.

\section{VISCOSA (RAYON)}

\section{M.M. El Attal*}

El rayón es una fibra sintética procedente de celulosa (pasta de madera) tratada químicamente. Se utiliza solo o mezclado con otras fibras sintéticas o naturales para confeccionar tejidos fuertes, muy absorbentes y suaves, que se pueden teñir con colores intensos y duraderos.

La fabricación del rayón tiene su origen en la búsqueda de una seda artificial. En 1664, el científico británico Robert H ooke, conocido por sus observaciones sobre la célula vegetal, predijo la posibilidad de imitar la seda por medios artificiales; casi dos siglos después, en 1855, se conseguían fibras a partir de una mezcla de ramitas de morera y ácido nítrico. El primer proceso comercial efectivo lo desarrolló en 1884 el inventor francés H ilaire de Chardonnet y, en 1891, los científicos británicos Cross y Bevan perfeccionaron el proceso de la viscosa. En 1895 el rayón ya se producía comercialmente a escala bastante reducida y su uso creció rápidamente.

\section{Métodos de producción}

$\mathrm{H}$ ay varias formas de fabricar rayón, que dependen de su uso previsto.

En el proceso de la viscosa, la celulosa procedente de pasta de madera se moja en una solución de hidróxido sódico, y se extrae el líquido sobrante por compresión para obtener una celulosa alcalina. Se eliminan las impurezas y, una vez triturada en fragmentos similares a grumos blancos que se dejan reposar durante varios días a temperatura controlada, la celulosa alcalina disgregada se transfiere a otro tanque donde se trata con bisulfuro de carbono para formar grumos de xantato de celulosa de color naranja-dorado. Estos grumos se disuelven en hidróxido sódico

\footnotetext{
* A daptado de la 3ª edición, E nciclopedia de salud y seguridad en el trabajo.
} 
diluido para formar un líquido viscoso anaranjado denominado viscosa. Se mezclan varios lotes de viscosa para obtener una calidad uniforme. La mezcla se filtra y se deja madurar durante varios días en condiciones estrictamente controladas de temperatura y humedad. A continuación se pasa por unas boquillas metálicas con orificios muy finos (espineretes o hileras para la extrusión de hilados) y el hilo se sumerge en un baño de ácido sulfúrico al $10 \%$. Se devana en forma de filamento continuo (tortas) o se corta a longitudes determinadas y se teje como la lana 0 el algodón. El rayón de viscosa se utiliza para prendas de vestir y tejidos resistentes.

En el proceso de cupramonio, utilizado para elaborar tejidos con aspecto de seda y medias finas, la pulpa de celulosa disuelta en la solución de hidróxido sódico se trata con óxido de cobre y amoníaco. Los filamentos salen de las hileras, pasan por una tolva de hilado y se estiran hasta alcanzar la finura deseada por obra de un chorro de agua.

En los procesos de viscosa y cupramonio la celulosa se reconstituye, pero el acetato y el triacetato son ésteres de la celulosa y algunos los consideran una clase de fibra diferente. Los tejidos de acetato destacan por su capacidad para aceptar colores vivos y por su buena caída, características que los hacen idóneos para la confección de prendas de vestir. L as fibras cortas de acetato se utilizan para rellenar almohadas, colchones y colchas. Los hilos de triacetato tienen muchas características similares al acetato, pero destacan principalmente por su capacidad para conservar las pinzas y el plisado en la ropa.

\section{Riesgos y prevención}

Los principales riesgos del proceso de la viscosa son las exposiciones al bisulfuro de carbono y al sulfuro de hidrógeno. Ambos ejercen una serie de efectos tóxicos según la intensidad y la duración de la exposición y los órganos afectados; van desde fatiga y mareo, irritación de las vías respiratorias y síntomas gastrointestinales hasta profundos trastornos neuropsiquiátricos, perturbaciones auditivas y visuales, inconsciencia profunda y muerte.

Además, con un punto de inflamación inferior a $-30{ }^{\circ} \mathrm{C}$ y unos límites de deflagración del 1,0 al $50 \%$, el bisulfuro de carbono lleva aparejado un grave riesgo de incendio y explosión.

Los ácidos y álcalis utilizados en el proceso están bastante diluidos, pero siempre hay riesgos en la preparación de las diluciones adecuadas y por salpicaduras a los ojos. Los grumos alcalinos formados durante el troceado irritan las manos y los ojos de los trabajadores, y los vapores que desprenden los ácidos y el sulfuro de hidrógeno en el baño de hilado pueden causar queratoconjuntivitis, caracterizada por lagrimeo excesivo, fotofobia y fuertes dolores oculares.

$\mathrm{M}$ antener concentraciones de bisulfuro de carbono y sulfuro de hidrógeno por debajo de los límites de exposición seguros exige un control riguroso, como el que proporciona un aparato automático de registro continuo. Es aconsejable encapsular completamente la maquinaria y dotarla de mecanismos de ventilación eficientes (con entradas a nivel del suelo, dado que los gases son más pesados que el aire). Los trabajadores deben recibir formación sobre medidas de emergencia por fugas y, además, disponer del equipo protector adecuado. Los trabajadores de mantenimiento y reparación necesitan instrucciones concretas y supervisión para evitar niveles de exposición innecesarios.

Las salas de descanso y las instalaciones sanitarias son requisitos imprescindibles, no lujos. Es deseable someter a examen médico al personal antes de la contratación y practicar revisiones regulares de todos los empleados.

\section{FIBRAS SINTETICAS}

\section{A.E. Quinn and R. M attiusi*}

Las fibras sintéticas están hechas de polímeros sintetizados a partir de elementos químicos o de compuestos desarrollados por la industria petroquímica. Contrariamente a las fibras naturales (lana, algodón y seda), usadas desde muy antiguo, las sintéticas tienen una historia relativamente corta que se remonta sólo al perfeccionamiento del proceso de la viscosa en 1891 por C ross y Bevan, dos científicos británicos. Pocos años más tarde empezó la producción de rayón a pequeña escala, y a principios del siglo XX se producía ya a escala comercial. Desde entonces se ha creado una amplia gama de fibras sintéticas, cada una con unas características especiales que la hacen adecuada para elaborar un tipo determinado de tejido, sola o mezclada con otras fibras. Seguirles la pista es difícil, pues una misma fibra tiene nombres comerciales diferentes en cada país.

Las fibras se crean colando los polímeros líquidos por los orificios de una hilera para obtener un filamento continuo. Este se teje directamente o bien, para conferirle las características de las fibras naturales, por ejemplo, se texturiza para que tenga más volumen, o se prensa para convertirlo en fibra cortada e hilarla.

\section{Clases de fibras sintéticas}

L os principales tipos de fibras sintéticas que se utilizan comercialmente son:

- Poliamidas (nilon). Las amidas poliméricas de cadena larga se identifican con una cifra que indica el número de átomos de carbono de sus componentes químicos, de los cuales se considera que la diamina es el primero. Por tanto, el primer nilon producido a partir de diamina de hexametileno y ácido adípico se denomina en los Estados Unidos y el Reino U nido nilon 66 o 6,6, ya que tanto la diamina como el ácido dibásico tienen seis átomos de carbono. En Alemania se comercializa como Perlon $\mathrm{T}$, en Italia como Nilon, en Suiza como $\mathrm{N}$ ylsuisse, en España como Anid y en Argentina como Ducilo.

- Poliésteres. Introducidos por primera vez en 1941, los poliésteres se obtienen mediante reacción de etilenglicol y ácido tereftálico para formar un material plástico formado por largas cadenas de moléculas que, fundido, se bombea a través de las hileras y se deja que el filamento se endurezca en el aire frío. Sigue una operación de estirado. Los poliésteres tienen nombres comerciales como Terylene en el Reino U nido, Dacron en Estados U nidos, Tergal en Francia, Terital y Wistel en I talia, Lavsan en la Federación Rusa y Tetoran en Japón.

- Polivinilos. El poliacrilonitrilo o fibra acrílica, que se introdujo por primera vez en 1948, es el miembro más importante de este grupo. Se conoce por varios nombres comerciales: Acrilan y O rlon en Estados U nidos, Crylor en Francia, Leacril y Velicren en Italia, Amanian en Polonia, Courtelle en el Reino U nido, etc.

- Poliolefinas. La fibra más conocida de este grupo, llamada Courlene en el Reino U nido, se obtiene de forma similar al nilon. El polímero fundido a $300^{\circ} \mathrm{C}$ pasa por las hileras y se enfría al aireo en agua para formar el filamento, que después se estira.

- Polipropileno. Este polímero, conocido por el nombre de Hostalen en Alemania, M eraklon en Italia y UIstron en el Reino U nido, se hila en estado de fusión, se estira y después se endurece por recocido.

- Poliuretanos. Producidos por primera vez en 1943 con el nombre de Perlon D por reacción de 1,4-butanodiol con diisocianato de hexametileno, los poliuretanos se han convertido en

\footnotetext{
* Adaptado de la 3a edición, E nciclopedia de salud y seguridad en el trabajo.
} 
la base de un nuevo tipo de fibra muy elástica llamada spandex. E stas fibras a veces se denominan elásticas o elastoméricas, por su elasticidad similar a la de la goma. Se fabrican a partir de una goma de poliuretano lineal, que fragua por tratamiento a temperaturas y presiones elevadas y se convierte en un poliuretano "vulcanizado" con gran cantidad de enlaces transversales que se extruye en forma de monofilamento. Este hilo, que se utiliza mucho en prendas de vestir que requieren elasticidad, se cubre con rayón o nilon para mejorar su aspecto sin renunciar a su resistencia. Los hilos de spandex se conocen en Estados U nidos como L ycra, $V$ yrene y $G$ lospan, y en el R eino U nido como Spandrell.

\section{Operaciones especiales}

\section{Corte de fibras}

La seda es la única fibra natural que se presenta en forma de filamento continuo; todas las demás son fibras cortas o discontinuas. Las fibras de algodón suelen tener una longitud de 2,6 cm, las de la lana de 6 a $10 \mathrm{~cm}$, y de 30 a $50 \mathrm{~cm}$ las de lino. Los filamentos sintéticos continuos a veces se hacen pasar a través de una máquina cortadora para asimilarlos a las fibras naturales. Se pueden rehilar en máquinas de hilado de algodón o lana para lograr un acabado exento del aspecto vítreo de algunas fibras sintéticas. Durante el hilado se combinan fibras sintéticas y naturales, o se mezclan diversas fibras sintéticas entre sí.

\section{Rizado}

Para dar a las fibras sintéticas el aspecto y el tacto de la lana, las fibras cortadas retorcidas o enredadas se rizan por diversos métodos. La máquina rizadora tiene unos rodillos estriados calientes que forman un rizo permanente. 0 tra opción es aplicar productos químicos que controlan la coagulación del filamento y dan lugar a fibras de sección asimétrica (con un lado grueso y otro fino, por ejemplo). Si la fibra está húmeda, el lado grueso suele curvarse y formar un rizo. Para obtener hilo texturizado, llamado en Estados U nidos "sin torsión", el hilo sintético se tricota en forma de tejido, se fija térmicamente y después se deshace el tejido con una rebobinadora. El método más nuevo consiste en pasar dos hebras de nilon por un calentador, que eleva su temperatura hasta $180^{\circ} \mathrm{C}$, y después por un huso que gira a alta velocidad para rizarlas. Los husos de la primera máquina giraban a 60.000 revoluciones por minuto (rpm), pero los modelos más nuevos alcanzan velocidades del orden de 1,5 millones de rpm.

\section{Fibras sintéticas para ropa de trabajo}

La resistencia química de la tela de poliéster la hace especialmente adecuada para confeccionar prendas protectoras en las operaciones de manipulación de ácidos. Los tejidos de poliolefina son protectores adecuados en exposiciones largas a ácidos 0 álcalis. EI nilon, que resiste temperaturas muy elevadas, protege bien frente el fuego y el calor; a temperatura ambiente ofrece resistencia elevada a disolventes como el benceno, la acetona, el tricloretileno y el tetracloruro de carbono. La resistencia de determinados tejidos de propileno a una amplia gama de sustancias corrosivas los hace que adecuados para confeccionar prendas de trabajo y de laboratorio.

La ligereza de estas fibras sintéticas las hace preferibles a los tejidos muy vulcanizados o plastificados necesarios para lograr una protección comparable. También son mucho más cómodas en atmósferas calurosas y húmedas. Al seleccionar una prenda protectora confeccionada con fibras sintéticas, hay que comprobar el nombre genérico de la fibra y propiedades tales como el encogimiento, la sensibilidad a la luz, los agentes de limpieza en seco y los detergentes, la resistencia al aceite, los productos químicos corrosivos y los disolventes comunes, la resistencia al calor y la propensión a acumular cargas electrostáticas.

\section{Riesgos y prevención}

\section{Accidentes}

Además de una buena limpieza, que supone mantener los suelos y pasillos limpios y secos para reducir al mínimo los resbalones y las caídas (las cubetas deben ser estancas y, a ser posible, llevar deflectores para contener las salpicaduras), las máquinas, las correas, las poleas y los ejes deben estar debidamente protegidos. Las máquinas para las operaciones de hilado, cardado, bobinado y urdido deben protegerse para evitar que los materiales y las piezas salgan disparados y que las manos de los trabajadores entren en zonas peligrosas. Los dispositivos de bloqueo deben estar en su lugar para evitar que las máquinas se pongan en marcha mientras se realizan operaciones de limpieza y mantenimiento.

\section{Incendio y explosión}

La industria de las fibras sintéticas emplea grandes cantidades de materiales tóxicos e inflamables. Las zonas de almacenamiento de sustancias inflamables deben situarse al aire libre 0 dentro de una estructura especial resistente al fuego, y deben encerrarse con muros de contención o diques para contener los derrames. L a automatización de la entrega de sustancias tóxicas inflamables mediante un sistema bien mantenido de bombas y tubos reducirá el peligro que supone trasladar y vaciar los recipientes. $H$ ay que proporcionar prendas y equipos de extinción de incendios y formar a los trabajadores en su uso mediante simulacros periódicos, preferiblemente realizados bajo la supervisión del servicio local de bomberos.

A medida que los filamentos emergen de las hileras para ser secados o hilados, se liberan grandes cantidades de vapores de disolventes que constituyen un notable peligro de intoxicación y explosión y que hay que eliminar con dispositivos de ventilación por extracción. Es preciso controlar las concentraciones para comprobar que permanecen por debajo de los límites de deflagración del disolvente. Los vapores extraídos se destilan y recuperan o se queman; bajo ningún concepto deben liberarse a la atmósfera exterior.

Si se utilizan disolventes inflamables debe prohibirse fumar y hay que eliminar las luces abiertas, las llamas y las chispas. La instalación eléctrica debe ser resistente al fuego y las máquinas han de estar conectadas a tierra para evitar la acumulación de electricidad estática y la formación de chispas con consecuencias catastróficas.

\section{Riesgo de intoxicación}

La exposición a disolventes y productos químicos tóxicos debe mantenerse por debajo de las concentraciones máximas admisibles con ventilación de extracción adecuada. $\mathrm{H}$ ay que proporcionar equipos protectores de la respiración a los operarios de mantenimiento y reparación y a los encargados de responder a las emergencias ocasionadas por derrames, fugas o incendios.

\section{Productos de fieltro natural}

\section{Jerzy A. Sokal}

El fieltro es un material fibroso que se obtiene entrelazando fibras de piel, pelo o lana mediante aplicación de calor, humedad, fricción y otros tratamientos hasta formar una tela no tejida 
densamente apelmazada. También hay fieltros de telar de agujas, en los que el fieltro se une a una tela de soporte ligera, normalmente lana o yute.

\section{Procesado del fieltro de pelo}

El fieltro de pelo, el más utilizado para sombreros, suele ser de pelo de roedores (conejos, liebres, ratones almizcleros, coipos y castores) aunque, con menos frecuencia, se utilizan también otros animales. Después de clasificarlo, el pelo se trata con peróxido de hidrógeno y ácido sulfúrico y a continuación se corta, se endurece y se tiñe. Para la tinción suelen utilizarse productos sintéticos (colorantes ácidos o tintes con compuestos metálicos complejos). El fieltro teñido se carga con goma laca o poliacetato de vinilo.

\section{Procesado del fieltro de lana}

La lana utilizada para la fabricación de fieltro puede ser nueva 0 recuperada. El yute, que generalmente se obtiene de sacos viejos, se emplea para determinados fieltros de aguja, y se pueden añadir otras fibras como algodón, seda y fibras sintéticas.

La lana se clasifica y selecciona. Para separar las fibras se rompe en una máquina desfibradora de trapos, un cilindro con púas que gira y rompe el tejido, y después se deshilacha en una máquina con rodillos y cilindros cubiertos con alambres con dientes de sierra. Las fibras se carbonizan en una solución con un $18 \%$ de ácido sulfúrico y, después de secarlas a una temperatura de $100^{\circ} \mathrm{C}$, se mezclan y, cuando es necesario, se lubrifican con aceite mineral y un emulsionante. Después del deshilachado y el cardado, que mezcla aún más las fibras y las dispone de forma más o menos paralela unas con otras, el material se deposita en una cinta móvil en forma de capas de tela fina que se enrollan en varillas para formar bloques. Los bloques sueltos se llevan a una sala de endurecido, donde se rocían con agua y se presionan entre dos placas pesadas, de las cuales la superior vibra y hace que las fibras se encrespen y enganchen unas con otras.

Para completar la operación de preparación del fieltro, el material se coloca en recipientes de ácido sulfúrico diluido y se golpea con pesados martillos de madera. Se lava (con incorporación de tetracloroetileno), se escurre el agua y se tiñe, normalmente con colorantes sintéticos. Se pueden añadir productos químicos para que el fieltro sea más resistente a la putrefacción. Las fases finales son secado $\left(a 5^{\circ} \mathrm{C}\right.$ los fieltros suaves y a $112{ }^{\circ} \mathrm{C}$ los duros), esquilado, lijado, cepillado, planchado y rebordeado.

\section{Riesgos para la seguridad y la salud}

\section{Accidentes}

Las máquinas utilizadas para fabricar fieltro tienen cintas móviles, cadenas y motores con ruedas dentadas, tambores y cilindros con púas que se utilizan para el garneteado y deshilachado, prensas pesadas, rodillos y martillos, etc., y todo ello debe estar debidamente protegido y disponer de sistemas de bloqueo para evitar lesiones durante las operaciones de mantenimiento 0 limpieza. La buena limpieza es vital para evitar resbalones y caídas.

\section{Ruido}

M uchas de las operaciones son ruidosas; si no se alcanzan niveles de ruido seguros mediante encapsulamiento, pantallas y una lubricación adecuada, deben facilitarse equipos de protección personal para los oídos. En muchos países es obligatorio aplicar un programa de conservación de la audición con elaboración periódica de audiogramas.

\section{Polvo}

Los lugares de trabajo de la industria del fieltro son polvorientos y no se recomiendan a personas con afecciones respiratorias crónicas. Aunque, afortunadamente, el polvo no está relacionado con ninguna enfermedad particular, es necesario disponer de ventilación por extracción adecuada. El pelo animal provoca reacciones alérgicas en sujetos sensibles, pero parece ser que el asma bronquial es poco frecuente. El polvo también puede ser un peligro en caso de incendio.

\section{Productos químicos}

La solución de ácido sulfúrico que se utiliza en la producción de fieltro suele estar diluida, pero hay que tener cuidado mientras se diluye el ácido concentrado. El peligro de salpicaduras y derrames exige tener muy cerca un lugar para lavarse los ojos y que los trabajadores vayan equipados con prendas protectoras (gafas, delantales, guantes, calzado).

La curtición de determinados fieltros utilizados en la fabricación de papel obliga a usar quinona, que provoca lesiones graves en la piel y las membranas mucosas. El polvo y los vapores de este compuesto provocan manchas en la conjuntiva y la córnea y, en caso de exposición prolongada o repetida, llega a afectar a la visión. Hay que mojar los polvos de quinona para evitar la suspensión de partículas en el aire, manipularlos en recipientes 0 cámaras cerradas con ventilación por extracción, y equipar a los operarios con protección para las manos, los brazos, la cara y los ojos.

\section{Calor e incendios}

La elevada temperatura del material $\left(60^{\circ} \mathrm{C}\right)$ propia del proceso de conformación manual de sombreros obliga a los trabajadores a utilizar protectores para las manos.

El fuego es un riesgo común a las primeras fases, polvorientas, de la producción de fieltro. Pueden iniciarlo una chispa emitida por algún objeto metálico de los que aparecen en la lana reciclada, las elevadas temperaturas de los cojinetes en movimiento 0 defectos de la conexiones eléctricas. El riesgo se repite en las operaciones de acabado si los vapores de los disolventes inflamables penetran en los hornos de secado. Dado que daña el material y oxida la maquinaria, el agua se emplea menos para la extinción de incendios que los extintores de polvo seco. LoS equipos modernos llevan unas aberturas a través de las cuales se pulveriza el material extintor, o están provistos de un dispositivo de liberación automática de dióxido de carbono.

\section{Antrax}

Aunque raramente, se han descrito algunos casos de ántrax por exposición a lana contaminada importada de regiones donde este bacilo es endémico.

\section{TINCION, ESTAMPADO Y ACABADO}

\section{J.M. Strother y A.K. Niyogi*}

\section{Tinción}

La tinción se basa en una combinación de productos químicos o en una fuerte afinidad física entre el tinte y la fibra del tejido. Se utiliza una amplia gama de tintes y procesos, según el tejido y acabado que se persigue.

* El apartado sobre tintura se ha adaptado de la colaboración de A.K. Niyogi' en la 3a edición de la E nciclopedia de salud y seguridad en el trabajo. 


\section{Clases de tintes}

L os tintes ácidos o básicos se utilizan en un baño de ácido débil para lana, seda 0 algodón. Algunos tintes ácidos se aplican después de tratar las fibras con un mordiente de óxido metálico, ácido tánico o dicromato. Los tintes directos, que no son fijos, se utilizan para teñir lana, rayón y algodón; estas fibras se tiñen mediante cocción. Para teñir tejidos de algodón con tintes de azufre se prepara un baño con el tinte, carbonato sódico anhidro, sulfito sódico y agua caliente. Este proceso de tintura también se efectúa mediante ebullición. Para teñir algodón con colorantes azoicos, se disuelve naftol en sosa cáustica acuosa. El algodón se impregna con la solución del naftóxido sódico que se forma y después se trata con una solución de un compuesto diazoico para fijar el tinte en el material. L os colorantes a la tina se transforman en leucocompuestos con hidróxido sódico e hidrosulfito sódico; este proceso se lleva a cabo a una temperatura de 30 a $60^{\circ} \mathrm{C}$. Los tintes dispersos se utilizan para teñir todas las fibras sintéticas hidrófobas. $\mathrm{H}$ ay que utilizar agentes de esponjamiento o portadores de naturaleza fenólica para que estos tintes actúen. L os tintes minerales son pigmentos inorgánicos en forma de sales de hierro y cromo. Después de la impregnación, se precipitan añadiendo una solución alcalina caliente. L os tintes reactivos para el algodón se utilizan en un baño caliente o frío de carbonato sódico anhidro y sal común.

\section{Preparación de tejidos para la tinción}

La preparación previa a la tintura de tejidos de algodón consta de las siguientes etapas: la tela pasa por una tundidora que corta las fibras sueltas adheridas y después, para completar el arreglo se somete brevemente a la acción de una hilera de llamas de gas; las chispas se extinguen pasando el material por una caja de agua. El apresto se elimina pasando la tela por una solución de diastasa. Para eliminar otras impurezas, se lava en un autoclave con hidróxido sódico diluido, carbonato sódico 0 aceite sulfonado durante 8 a 12 horas a temperatura y presión elevadas.

Para el material tejido de color se utiliza un autoclave abierto y se evita el hidróxido sódico. La coloración natural de la tela se elimina con una solución de hipoclorito en pozos de blanqueado, después de lo cual la tela se seca al aire, se lava, se declora con una solución de bisulfito sódico, se aclara de nuevo y se lava a fondo con ácido sulfúrico o clorhídrico diluido. Después de un nuevo lavado final, la tela está lista para la tinción o el estampado.

\section{Proceso de tinción}

La tinción se lleva a cabo en una máquina jigger o fulard, en la cual la tela pasa por una solución de tinte en reposo que se prepara disolviendo el polvo del colorante en un producto químico adecuado y diluyéndolo después en agua. D espués de la tintura, la tela se somete a un tratamiento de acabado.

\section{Tintura del nilon}

La preparación de las fibras de poliamida (nilon) para la tinción comienza con un lavado a fondo, algún tratamiento de fijación y, en ciertos casos, un blanqueado. El tratamiento adoptado para lavar a fondo los tejidos de poliamida depende principalmente de la composición del apresto. Los aprestos solubles en agua a base alcohol polivinílico o ácido poliacrílico se eliminan en un baño con jabón y amoniaco o Lissapol $\mathrm{N}$ u otro detergente similar y carbonato sódico anhidro. Después de lavado, el material se aclara a fondo y ya está listo para la tinción o el estampado, normalmente en una máquina jigger o una barca de torniquete.

\section{Tintura de la lana}

La lana en bruto se lava a fondo mediante un proceso de emulsión, en el que se utiliza una solución de jabón y carbonato sódico anhidro. La operación se efectúa en una máquina de lavar que consiste en una gran tina con rastrillos, un fondo falso y escurridores a la salida. U na vez lavada, la lana se blanquea con peróxido de hidrógeno o bióxido de azufre. Si se utiliza éste último, los productos húmedos se dejan expuestos toda una noche al gas de dióxido de azufre. El gas ácido se neutraliza pasando el tejido por un baño de carbonato sódico y lavando a fondo. Los artículos teñidos se aclaran, se les extrae el agua y se secan.

\section{Riesgos de la tinción y prevención}

\section{Incendio y explosión}

El mayor riesgo de incendio asociado con la tinción lo plantean los disolventes y determinados colorantes inflamables. Ambos tipos de productos deben almacenarse en lugares seguros diseñados de forma adecuada y construidos con materiales resistentes al fuego, con un reborde elevado y en rampa a la entrada, de modo que el líquido de los posibles escapes quede dentro del local y no llegue a ningún sitio en el que pueda explosionar. Es preferible que los almacenes de este tipo se sitúen fuera del edificio principal de la fábrica. Si se guardan grandes cantidades de líquidos inflamables en depósitos externos, la zona debe terraplenarse para contener las fugas.

Iguales medidas deben adoptarse cuando el combustible gaseoso utilizado en las máquinas chamuscadoras proceda de una fracción ligera del petróleo. Es preferible que la planta de gasificación y los almacenes de productos petrolíferos volátiles se ubiquen fuera del edificio principal.

\section{Riesgos asociados con los productos químicos}

Muchas fábricas utilizan soluciones de hipoclorito para blanquear; en otras, el agente blanqueador es cloro gaseoso o polvo decolorante, que libera cloro cuando se vierte en el depósito. En cualquiera de estos casos, los trabajadores pueden quedar expuestos a concentraciones peligrosas de cloro, que irrita la piel y los ojos y es peligroso para el tejido pulmonar porque causa edema pulmonar retardado. Para limitar la liberación de cloro en el aire que respiran los trabajadores, las tinas de blanqueo deben ser recipientes cerrados con lumbreras que reduzcan al mínimo el escape de cloro, de modo que no se sobrepasen los límites de exposición máximos recomendados. Además, hay que comprobar periódicamente las concentraciones de cloro en el ambiente para asegurar que no se supera el límite de exposición.

Las válvulas y demás controles del depósito desde el cual el cloro líquido pasa a las zonas de tintura deben estar bajo la responsabilidad de un operario competente, pues las consecuencias de un escape incontrolado podrían ser catastróficas. Cuando hay que entrar en algún depósito que ha contenido cloro u otros gases o vapores peligrosos, hay que tomar todas las precauciones que se aconsejan para el trabajo en lugares cerrados.

EI uso de álcalis y ácidos corrosivos en el tratamiento de tejidos por ebullición expone a los trabajadores al riesgo de quemaduras. Tanto el ácido clorhídrico como el sulfúrico se utilizan muy a menudo en la tinción. La sosa cáustica se utiliza en las operaciones de blanqueo, mercerizado y tinción. Las pequeñas partículas sólidas suspendidas en el aire constituyen un riesgo para los trabajadores. El dióxido de azufre, que se utiliza en el blanqueo, y el bisulfuro de carbono, usado como disolvente en el tratamiento de la viscosa, también contaminan el ambiente del taller. Los hidrocarburos aromáticos, como el benceno, el tolueno 0 el xileno, las naftas disolventes y las aminas aromáticas, como los colorantes de anilina, son productos químicos peligrosos a los que es probable que los trabajadores queden expuestos. El diclorobenceno forma una emulsión con agua con ayuda de un agente emulsionante y se utiliza para teñir fibras de 
poliéster. Es fundamental el uso de dispositivos de ventilación por extracción.

Muchos colorantes irritan la piel y provocan dermatitis; además, los trabajadores caen a menudo en la tentación de utilizar mezclas peligrosas de abrasivos, álcalis y agentes blanqueadores para eliminar de las manos las manchas de colorante.

Los disolventes orgánicos que se utilizan en los procesos y para limpiar las máquinas también ocasionan dermatitis 0 hacen la piel más vulnerable a la acción irritante de otras sustancias peligrosas. Algunos, como la metil-butil-cetona, causan neuropatías periféricas. Se ha comprobado también que ciertos colorantes, como rodamina $B$, magenta, $\beta$-naftilamina y determinadas bases como la dianisidina, son cancerígenos. El uso de $\beta$-naftilamina prácticamente se ha abandonado ya en la tintura; este asunto se trata con más detalle en otras partes de esta Enciclopedia.

Además de los materiales de fibra y sus contaminantes, la alergia puede ser consecuencia de los aprestos e incluso de los enzimas que se utilizan para eliminarlos.

Hay que proporcionar equipos de protección personal adecuados, también para los ojos, a fin de evitar el contacto con estos productos peligrosos. Es preciso verificar si las cremas protectoras aplicadas en algunos casos son eficaces y si se eliminan con agua. Pocas veces la protección que ofrecen es tan segura como la que proporcionan unos guantes adecuados. Las prendas protectoras deben limpiarse a intervalos regulares, y cuando tengan salpicaduras o estén contaminadas de materiales de tintura deben sustituirse por otras limpias lo antes posible. Los trabajadores deben disponer de instalaciones sanitarias adecuadas para lavarse, bañarse y cambiarse de ropa, y hay que fomentar su uso; la higiene personal es especialmente importante en las operaciones de tintorería. Por desgracia, ha habido casos en que, aún adoptando todas las medidas de protección posibles, ciertos trabajadores siguen siendo vulnerables a los efectos de estas substancias; la única alternativa es trasladarlos a otros puestos de trabajo.

\section{Accidentes}

Se han dado casos de quemaduras graves por entrada accidental de líquido hirviente en un autoclave durante la preparación de la tela antes del tratamiento. Esto puede ocurrir si se abre una válvula accidentalmente 0 si el baño caliente se vierte en un conducto de descarga común de otro autoclave de la serie y entra en el ocupado por una salida abierta. Cuando un trabajador está dentro de un autoclave por cualquier motivo, la entrada y la salida deben estar cerradas, y el autoclave aislado de los demás. Si el dispositivo de bloqueo funciona con llave, ésta debe guardarla siempre el trabajador expuesto a sufrir lesiones en caso de entrada accidental de líquido caliente, y ha de conservarla hasta salir del recipiente.

\section{Estampado}

Las telas se estampan en máquinas de cilindros. El tinte 0 el pigmento se espesa con almidón o se emulsiona, con disolventes orgánicos en el segundo caso. Esta pasta o emulsión es recogida por unos rodillos grabados que estampan el material, y el color se fija después en el vaporizador o la máquina de curado. La tela estampada recibe después el tratamiento de acabado adecuado.

\section{Estampado en húmedo}

El estampado en húmedo se lleva a cabo con sistemas similares a los de tinción, en tina o con colorantes reactivos. Estos métodos se utilizan sólo para los tejidos $100 \%$ de algodón o rayón. Los riesgos para la salud relacionados con este tipo de estampado son los mismos que los mencionados en el apartado anterior.

\section{E stampado con pigmentos basados en disolventes}

E stos sistemas de estampado utilizan grandes cantidades de alcoholes minerales y otros disolventes en el sistema de espesamiento. Los riesgos principales son:

- Incendio. Los sistemas espesantes contienen hasta un $40 \%$ de disolventes y son muy inflamables. Deben almacenarse con mucho cuidado en zonas debidamente ventiladas y con los circuitos eléctricos conectados a tierra. $\mathrm{H}$ ay que tener cuidado durante el traslado de estos productos para evitar las chispas de electricidad estática.

- E misiones a la atmósfera. Los disolventes de este sistema de estampado se evaporan del horno durante el secado y curado. La normativa local dicta los valores admisibles de emisión de compuestos orgánicos volátiles.

- Fangos. Dado que este sistema de impresión se basa en disolventes, la pasta de impresión jamás debe entrar en el sistema de tratamiento de aguas residuales. D eben eliminarse como residuo sólido. L os vertederos de fangos son fuente potencial de contaminación del suelo y las aguas subterráneas. Las zonas de almacenamiento de fangos deben estar impermeabilizadas para evitar este problema.

\section{E stampado con pigmentos al agua}

Ninguno de los riesgos mencionados en relación con el estampado con pigmentos basados en disolventes se asocia a los sistemas de estampado con pigmentos al agua. También se utilizan algunos disolventes, pero en cantidades insignificantes. EI principal riesgo para la salud es la presencia de formaldehído.

El estampado con pigmentos exige un reticulador para aglutinar los pigmentos en el tejido. Los reticuladores se aplican en forma de productos independientes (melamina, por ejemplo) o de componentes de otros productos químicos, como los aglutinantes, los compuestos antimecha o los propios pigmentos. El formaldehído desempeña un papel necesario en la función de los reticuladores.

El formaldehído sensibiliza e irrita y provoca reacciones, a veces violentas, en los trabajadores expuestos a este compuesto por inhalación del aire que rodea la máquina estampadora, mientras funciona 0 al entrar en contacto con el tejido estampado. Estas reacciones van desde una simple irritación de los ojos hasta ampollas en la piel y graves dificultades para respirar. Se ha descubierto que el formaldehído es cancerígeno en los ratones, pero aún no se ha asociado definitivamente con el cáncer en seres humanos. La Agencia Internacional para la Investigación sobre el Cáncer (IARC) lo ha clasificado como producto cancerígeno del Grupo 2A ("Probablemente cancerígeno en humanos").

Para proteger el ambiente local hay que controlar las emisiones de la fábrica para asegurar que los niveles de formaldehído no sobrepasan los estipulados por la normativa vigente.

0 tro riesgo importante es el amoníaco. Dado que la pasta de estampado es sensible al pH (acidez), a menudo se utiliza amoníaco como espesante. $\mathrm{H}$ ay que tener cuidado y manipular el amoníaco en una zona bien ventilada y llevar protección respiratoria si es necesario.

Dado que todos los colorantes y pigmentos utilizados en el estampado suelen ser líquidos, la exposición al polvo no constituye un peligro, como ocurre en el de tintura.

\section{Acabado}

A cabado es un término que se aplica a una gama muy amplia de tratamientos que suelen llevarse a cabo durante la fase final de fabricación, antes de la confección. Algunos acabados se aplican incluso después de la confección. 


\section{Acabado mecánico}

Este tipo de acabado cambia la textura y el aspecto del tejido sin productos químicos. $\mathrm{H}$ ay muchos tipos de acabado mecánico:

- Sanforizado. El tejido pasa entre una cinta de caucho y un cilindro caliente, y después entre un cilindro caliente y una mantilla sinfín para controlar el encogimiento y suavizar el tacto.

- Calandrado. El tejido pasa entre grandes cilindros de acero que aplican una presión de hasta 100 toneladas. A veces se calientan con vapor o con gas a temperaturas de hasta $232{ }^{\circ} \mathrm{C}$. El tratamiento modifica el tacto y el aspecto del tejido.

- Lijado. El tejido pasa sobre unos rodillos cubiertos de arena que modifican la superficie y suavizan el tacto.

- G ofrado. EI tejido pasa entre rodillos de acero calientes grabados con un motivo que se transfiere permanentemente al tejido.

- Termofijado. En este proceso el tejido sintético, normalmente poliéster, pasa por un rame o una máquina termofijadora por semicontacto a temperaturas suficientemente elevadas como para iniciar la fusión molecular del tejido. Estabiliza y evita el encogimiento.

- Cepillado. EI tejido pasa por unos cepillos que giran a altas velocidades para modificar la superficie y el tacto de la tela.

- Esmerilado. El tejido pasa entre un cilindro de acero pequeño y otro grande cubierto de papel esmeril que modifica el aspecto y el tacto del género.

Los principales riesgos son el calor, las elevadas temperaturas que se aplican y las líneas de contacto entre rodillos en las piezas móviles de las máquinas. $\mathrm{H}$ ay que proteger adecuadamente la maquinaria para evitar accidentes y lesiones.

\section{Acabado químico}

El acabado químico se aplica con diversas máquinas (impregnadoras, barcas de tinción, máquinas de tinción al chorro, cubetas, barras atomizadoras, autoclaves, máquinas de paletas, rodillos tangenciales y espumadores).

$\mathrm{H}$ ay una clase de acabado químico que no va acompañado de reacción: la aplicación de un suavizante o un mejorador del tacto para modificar la sensación y la textura del tejido o hacerlo más fácil de coser. No implica riesgos importantes, excepto la posibilidad de irritación por contacto de la piel o los ojos, que se evita usando guantes o gafas adecuados.

El otro tipo de acabado químico sí cursa con reacción: es el acabado con resina de tejidos de algodón para inducir ciertas propiedades físicas, como resistencia al encogimiento y suavidad. Para tejidos de algodón, por ejemplo, se cataliza una resina de dimetildihidroxietilén urea y se aglutina con las moléculas del tejido para modificarlo de forma permanente. El principal riesgo asociado a este tipo de acabado es que la mayoría de las resinas liberan formaldehído durante la reacción.

\section{Conclusión}

Como otras actividades textiles, la tinción, el estampado y el acabado se realizan en plantas antiguas, generalmente pequeñas, donde apenas se presta atención a la seguridad, la salud y el bienestar del trabajador, y en otras más modernas con tecnología de vanguardia donde, en la medida de lo posible, la maquinaria se ha diseñado teniendo en cuenta el control de riesgos. Además de los riesgos específicos analizados en este apartado, subsisten otros de orden general, como la falta de iluminación, el ruido, la maquinaria sin protección, el levantamiento y la manipulación de objetos muy pesados o muy voluminosos, la falta de limpieza, etc. Por lo tanto, es necesario elaborar un programa de salud y seguridad bien formulado y bien aplicado que incluya la formación y la supervisión eficaz de los trabajadores.

\section{GENEROS TEXTILES NO TEJIDOS}

\section{William A. Blackburn y Subhash K. Batra}

L os géneros textiles no tejidos empezaron a investigarse a finales del decenio de 1940, entró en fase de desarrollo durante el siguiente, e inició la difusión comercial en el de 1960. En el curso de los 35 años siguientes, la industria de los géneros no tejidos maduró y abrió mercados, atraídos tanto por sus prestaciones y su buen precio en comparación con los géneros tradicionales como por la oferta de productos desarrollados específicamente para determinados usuarios finales. Este sector ha sobrevivido a las recesiones mucho mejor que el de los textiles convencionales, y ha crecido a un ritmo más rápido. Los problemas de salud y seguridad que plantea son similares a los del resto de la industria textil (ruido, partículas en suspensión, productos químicos para aglutinar las fibras, superficies de trabajo, piezas puntiagudas, quemaduras por exposición a temperaturas elevadas, dolores de espalda, etc.).

En general, el sector goza de buen nivel de seguridad y el número de lesiones por unidad de trabajo estándar es baja y ha respondido a los retos que planteaban las leyes sobre limpieza del agua y del aire. En Estados U nidos, la Administración para la Salud y la Seguridad en el Trabajo (O SH A) ha promulgado varias normas de protección de los trabajadores que exigen formación en materia de seguridad y métodos de trabajo seguros y han mejorado notablemente la protección del trabajador. En todo el mundo, empresas responsables adoptan prácticas parecidas.

L as materias primas utilizadas por el sector son similares a las de los textiles convencionales. Se ha estimado que en este sector consume casi mil millones de kilogramos de diversas materias primas al año. Las fibras naturales utilizadas son principalmente algodón y pasta de madera. Las fibras artificiales son rayón, poliolefinas (polietileno y polipropileno), poliésteres y, en menor medida, nilon, fibras acrílicas, aramidas y otras).

El número de tipos de géneros no tejidos aumentó al principio muy deprisa hasta aproximadamente una decena: ligamento hilado, fusión-soplado, pulpa y mezclas acolchadas al aire, en mojado y en seco (aglutinadas con aguja, térmica químicamente) y procesos de cosido-tricotado. En Estados U nidos, la industria ha saturado muchos de sus mercados finales y en la actualidad busca otros nuevos. En el segmento de los materiales compuestos, los géneros no tejidos experimentan un fuerte crecimiento. El mercado de laminados de géneros no tejidos con películas y otros revestimientos es cada vez más importante. Recientemente se ha puesto bajo sospecha el almacenamiento de géneros no tejidos en rollos, debido a la inflamabilidad de algunos productos que tienen densidades muy bajas y gran superficie. Se considera que los rollos cuya proporción volumen/ peso supera un determinado factor de esponjosidad plantean problemas de almacenaje.

\section{Materias primas}

\section{Fibras celulósicas}

El volumen de algodón blanqueado utilizado en géneros no tejidos ha ido aumentando sin interrupción, y las mezclas de algodón-poliéster y rayón-poliéster aglutinadas por tratamiento en agua son muy atractivas para aplicaciones médicas y de higiene femenina. $\mathrm{H}$ a suscitado interés el uso de algodón sin blanquear en materiales no tejidos, y el tratamiento de aglutinación en agua ha permitido obtener telas experimentales muy atractivas

El rayón ha sido objeto de ciertas presiones por parte de grupos ecologistas, preocupados por el impacto de los 
subproductos del proceso sobre el medio ambiente. Algunas empresas productoras de rayón de Estados U nidos han preferido abandonar el sector antes que enfrentarse al coste de cumplir la normativa impuesta por las leyes de limpieza del aire y el agua. Las empresas que habían optado por cumplir la normativa parecen ahora satisfechas con la modificación de sus procesos.

L as fibras de pasta de madera son un componente importante de los pañales desechables, productos de incontinencia y otros géneros absorbentes. Se utilizan fibras de madera dura y kraft (celulosa al sulfato). Sólo en Estados U nidos, el consumo de fibras de pasta supera los mil millones de kilogramos anuales. Un porcentaje muy pequeño se utiliza en género no tejidos fijados por chorro de aire. Se trata de productos de uso común, como toallas para aplicaciones que van desde la cocina hasta el deporte.

\section{Fibras sintéticas}

Las dos fibras de poliolefina más comunes son el polietileno y el polipropileno. Estos polímeros se convierten en fibras cortadas que después se transforman en géneros no tejidos 0 en telas de ligamento hilado por extrusión de los polímeros para formar filamentos que se convierten en mallas y se aglutinan térmicamente. Algunos de los géneros así producidos se convierten en prendas protectoras; en 1995 se habían fabricado ya más de 400.000 .000 de monos de trabajo con una tela de polietileno muy común obtenida mediante ligamento hilado.

El principal uso de los géneros no tejidos en Estados U nidos (aproximadamente diez mil millones de metros cuadrados) es el revestimiento de pañales desechables. Es el material que entra en contacto con la piel del bebé y los separa de los demás componentes del pañal. Las materiales confeccionadas con estas fibras también se utilizan para productos no desechables y en algunas aplicaciones geotextiles, pues se espera que duren indefinidamente. Los tejidos se degradan por acción de la luz ultravioleta 0 de algunos otros tipos de radiación.

Las fibras termoplásticas de los copolímeros y polímeros de poliéster se utilizan muchísimo en materiales no tejidos, tanto en los procesos de fibra cortada como en los de ligamento hilado. El volumen total estimado de los polímeros de poliolefina y poliéster que consumidos en Estados U nidos para las géneros no tejidos se ha cifrado en más de 250 millones de kilogramos anuales. Las mezclas de fibras de poliéster con pasta de madera fijada en mojado y después aglutinada por tratamiento con agua y protegida con un revestimiento repelente se utilizan mucho en gorros y paños desechables para cirugía. En 1995, el uso de géneros no tejidos como productos desechables para medicina en Estados U nidos sobrepasó los dos mil millones de metros cuadrados anuales.

Las fibras de nilon se utilizan sólo en pequeñas cantidades en forma de fibras cortadas y en un volumen limitado en materiales no tejidos de ligamento hilado. U na de la aplicaciones principales de los géneros no tejidos de nilon de ligamento hilado es el refuerzo de las bases de moquetas y filtros de fibra de vidrio. Estos materiales proporcionan una superficie de baja fricción a las moquetas, lo que facilita su colocación. En los filtros de fibra de vidrio, este tipo de tela ayuda a retener la fibra de vidrio en el filtro y evita que se incorpore a la corriente de aire filtrado. Otros productos no tejidos especiales, como las aramidas, se utilizan en mercados nicho donde se recomienda su uso debido a propiedades como la baja inflamabilidad. Algunos de estos géneros no tejidos se utilizan en la industria del mueble como ignífugos, para reducir la inflamabilidad de sillas y sofás.

\section{Procesos}

\section{Ligamento hilado y fusión-soplado}

L os métodos de ligamento hilado y fusión-soplado parten de polímeros sintéticos que funden, filtran, extruyen, estiran, cargan con electricidad estática, disponen en forma de malla, aglutinan y bobinan. D esde el punto de vista de la seguridad, el proceso exige unas prácticas similares a las del trabajo con extrusionadoras calientes, filtros, hileras y cilindros calentados utilizados para aglutinar.

Los trabajadores deben llevar la protección adecuada para los ojos y evitar las prendas sueltas, corbatas, anillos y demás piezas de joyería que puedan quedar atrapadas en la maquinaria. Además, estos procesos casi siempre implican el uso de grandes volúmenes de aire, y hay que adoptar precauciones especiales para evitar diseños que favorezcan el fuego, como colocar las reactancias de las luces en los conductos de aire. A pagar un fuego en estos conductos es difícil. Es importante que las superficies de trabajo sean seguras, así como mantener el suelo que rodea a la maquinaria libre de obstáculos que impidan la circulación rápida.

En los procesos de ligamento hilado y fusión-soplado es necesario limpiar una parte de la maquinaria quemando los residuos de polímero acumulados. Normalmente ello implica el uso de hornos muy calientes, tanto para limpiar como para almacenar las piezas limpias. 0 bviamente, estas operaciones exigen el uso de guantes adecuados y otras protecciones térmicas, así como ventilación adecuada para reducir el calor y los vapores desprendidos.

Los procesos de ligamento hilado deben sus ventajas económicas en parte al hecho de que son relativamente rápidos y las bobinas tomadoras se pueden cambiar sin interrumpir el proceso. EI diseño del equipo de cambio de rollos y la formación de los operarios deben dejar un margen de seguridad adecuado para estas operaciones.

\section{Colchado en seco}

L os procesos de apertura de balas de fibras, mezcla de fibras para mantener una alimentación uniforme de la carda, cardado para formar mallas de fibras, contrapeado de las mallas para lograr una resistencia óptima en todas las direcciones y aglutinación de la malla, son similares - desde el punto de vista de la seguridad- a las operaciones textiles convencionales. $H$ ay que proteger todos los lugares donde las manos queden expuestas a los rodillos en movimiento. Algunos procesos de colchado en seco generan pequeñas cantidades de fibras en suspensión. EI trabajador debe disponer de equipos de protección personal para evitar la inhalación de la fracción respirable de estas fibras.

Si las mallas de fibras obtenidas deben aglutinarse térmicamente, normalmente habrá una pequeña cantidad (del orden del $10 \%$ en peso) de fibra de menor punto de fusión o en polvo mezclada con el resto. Este material se funde en un horno 0 con rodillos calientes y después se enfría para formar las láminas de tejido. $\mathrm{H}$ ay que asegurar la protección contra la exposición a los entornos calientes. En Estados U nidos se producen anualmente alrededor de 100 millones de kilogramos de géneros no tejidos aglutinados térmicamente.

Si las mallas se aglutinan mediante punzonado, se utiliza un telar de aguja. Se monta una hilera de agujas en los tableros y se pasan por la malla. Las agujas capturan las fibras de la superficie, las transportan a la cara inferior del material y las sueltan en la carrera de vuelta. EI número de perforaciones por unidad de superficie puede ser pequeño (tejidos muy esponjosos) 0 grande (fieltros punzonados). $\mathrm{H}$ ay telares de agujas que actúan por las dos caras del género y admiten varios tableros. L as agujas rotas deben cambiarse. Es imprescindible un mecanismo de 
bloqueo de seguridad de los telares para evitar accidentes durante el mantenimiento. Como en el caso del cardado, se generan fibras cortas, y se recomienda buena ventilación y usar respiradores. Además, se aconseja proteger los ojos contra los fragmentos de agujas rotas, que pueden salir disparados. En Estados U nidos se fabrican anualmente unos 100 millones de kilogramos de géneros no tejidos perforadas con agujas.

La aglutinación con adhesivos suele hacerse pulverizando el aglutinante en una cara del género y vulcanizándolo con aire caliente 0 de algún otro modo. D espués se invierte la malla y se repiten todas las operaciones por la otra cara. A veces se realiza una tercera pasada por el horno para completar el proceso de vulcanización. O bviamente, la zona debe estar bien ventilada para evitar los gases del horno; hay que extraer y eliminar las emanaciones tóxicas (en Estados U nidos así lo exigen algunas leyes sobre limpieza del aire en varios estados). Este tipo de tratamiento ha sido objeto de abundantes presiones a escala internacional para reducir las emisiones de formaldehído a la atmósfera. Recientemente, en Estados Unidos, la EPA ha reducido los límites de liberación de formaldehído a una décima parte de los que se aceptaban antes. Preocupa el hecho de que los nuevos límites desafían el grado de precisión de las actuales técnicas de laboratorio. La industria de adhesivos ha reaccionado ofreciendo nuevos aglutinantes sin formaldehído.

\section{Colchado al aire}

$\mathrm{H}$ ay cierta confusión terminológica en relación con las géneros no tejidos colchados al aire. U na de las variantes del proceso de cardado comprende la distribución aleatoria de las fibras en una corriente de aire. A menudo este proceso se denomina "proceso de material no tejido colchado al aire". O tro proceso muy diferente, también llamado de colchado al aire, consiste en la dispersión de las fibras en una corriente de aire, normalmente con un batán de martillos, y el traslado de la suspensión de fibras a un dispositivo que las deposita en una cinta móvil. La malla que se forma se rocía con aglutinador y se polimeriza. Este proceso se puede repetir de forma continua con diferentes tipos de fibras para obtener géneros no tejidos formados por capas de distinta composición. Este método admite fibras muy cortas, y hay que adoptar precauciones para evitar la exposición a estas fibras en suspensión.

\section{Colchado en mojado}

La tecnología de elaboración de géneros no tejidos fijados en mojado se ha tomado de la fabricación de papel, y consiste en la formación de mallas a partir de dispersiones acuosas de fibras. Este proceso requiere el uso de dispersantes que evitan la formación de grumos irregulares de fibras. La dispersión de fibras se filtra a través de cintas móviles y se escurre presionándolas entre fieltros. En algún punto del proceso suele incorporarse un aglutinante que fija la malla por efecto del calor de secado. 0 bien, en un método más nuevo, la malla se aglutina por tratamiento con chorros de agua a presión muy elevada. La operación final es el secado, que en ocasiones comprende tratamientos de microencrespamiento y otras técnicas similares para suavizar el producto. No se conocen riesgos importantes relacionados con este proceso, y los programas de seguridad suelen basarse en las prácticas comunes de fabricación.

\section{Cosido-tricotado}

Algunas definiciones del concepto de géneros no tejidos excluyen esta técnica, pues se vale de hilos para transformar las mallas en géneros textiles. Ciertas definiciones de productos no tejidos excluyen a todos los que contienen "hilo". En este proceso, la malla se carga en máquinas de cosido-tricotado convencionales para obtener estructuras similares a las del punto, que ofrecen gran número de posibilidades, como el uso de hilos elásticos para elaborar géneros con interesantes propiedades de estiramiento y recuperación. Tampoco este proceso se ha asociado con riesgos excepcionales.

\section{Acabado}

Los acabados de las géneros no tejidos incluyen tratamientos superficiales retardantes de la llama, hidrófobos, antiestáticos, suavizantes, antibacterianos, fusibles, lubricantes, etc. Se aplican en la línea de producción o fuera de ella, según el tratamiento y el tipo de acabado. Los antiestáticos suelen aplicarse en la línea de producción, al igual que tratamientos superficiales como el grabado por efecto corona. Los acabados retardantes del fuego e ignífugos suelen aplicarse fuera de la línea. $\mathrm{H}$ ay tratamientos muy especializados, como la exposición de la malla a plasma de elevada energía para determinar la polaridad de los géneros y mejorar su comportamiento en aplicaciones de filtración. La seguridad de estos procesos químicos y físicos varía con cada aplicación y debe considerarse por separado.

\section{TEJIDO Y TRICOTADO}

\section{Charles Crocker}

Tejer y tricotar son los dos métodos principales de fabricación de tejidos. En la industria textil moderna, estas operaciones se llevan a cabo con máquinas eléctricas automáticas, y los géneros resultantes encuentran una amplia gama de aplicaciones finales, como prendas de vestir, textiles para el hogar y aplicaciones industriales.

\section{Tejeduría}

L a tejeduría es una operación que consiste en entrelazar perpendicularmente dos o más hilos estirados. Es la técnica de fabricación de telas más antigua, pues el telar manual se conoce desde tiempos prebíblicos. La idea básica de entrelazar los hilos continúa vigente en la actualidad.

Los hilos de la urdimbre provienen de una gran bobina llamada plegador, montada en la parte posterior del telar. El extremo de cada hilo de la urdimbre se enhebra a un cuadro de lizos. Este sube o baja los hilos a medida que se teje. El tejido más simple requiere dos cuadros, y los más complicados admiten seis como máximo. El telar jacquard sirve para fabricar telas más decorativas; su principal característica es que los hilos de la urdimbre suben y bajan individualmente. Cada uno de los extremos de los hilos pasa por un peine de piezas de metal montadas en paralelo y muy juntas en el batán de la máquina. El batán describe un movimiento de arco en torno a un pivote de anclaje. Los extremos de los hilos se unen al rodillo tomador. L a tela tejida se bobina en este rodillo.

La técnica más antigua para pasar el hilo de trama por entre los hilos de urdimbre es la lanzadera, que, impulsada en vuelo libre, atraviesa toda la anchura de la urdimbre y va dispensando el hilo de trama de una pequeña bobina. Las tecnologías más modernas y rápidas, como la ilustrada en la Figura 89.9, llamadas sin lanzadera, utilizan chorros de aire o de agua, pequeños proyectiles que corren por una guía, o diminutos espadines para trasladar el hilo de trama.

Los trabajadores de los telares suelen agruparse en una de las cuatro funciones siguientes:

1. O perarios de máquina, comúnmente llamados tejedores, que controlan el área de producción que se les ha asignado para comprobar la producción del tejido, corregir algunos fallos 


\section{Figura 89.9 - Tejedora de chorro de aire.}

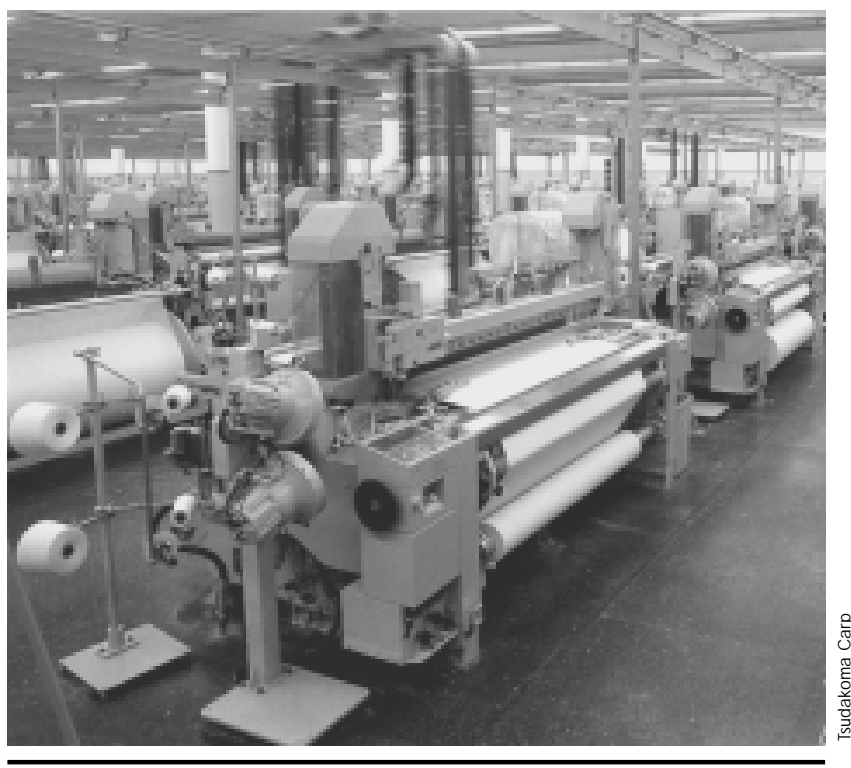

básicos de la máquina como roturas de hilo y arrancar las máquinas paradas.

2. T écnicos de máquina, llamados también mecánicos de telar, que ajustan y reparan los telares.

3. Auxiliares de producción directos, que transportan y cargan la materia prima (hilos de urdimbre y trama) en los telares y descargan y transportan los productos acabados (rollos de tela).

4. Auxiliares de producción indirectos, que realizan tareas de limpieza, lubricación de las máquinas, etc.

\section{Riesgos para la seguridad}

La tejeduría encierra un riesgo moderado para la seguridad del trabajador. Sin embargo, hay varios peligros típicos y una serie de medidas para reducirlos al mínimo.

\section{Caídas}

Las piezas móviles de la maquinaria y las manchas de aceite, grasa 0 agua en el suelo pueden provocar caídas. La buena limpieza es especialmente importante en este sector, dado que en muchos procesos los trabajadores pasan el día circulando por la zona con los ojos fijos en el proceso de producción, no en el suelo.

\section{Maquinaria}

Los mecanismos de transmisión y casi todos los objetos puntiagudos suelen estar protegidos. El batán de la máquina, los cuadros y demás piezas a las que los trabajadores deben acceder con frecuencia son las únicas piezas que sólo están protegidas parcialmente. $\mathrm{H}$ ay que prever espacios amplios de trabajo y circulación alrededor de las máquinas y un buen método de trabajo ayuda a los trabajadores a evitar estas exposiciones. Cuando se teje con lanzadera hay que montar protecciones en el batán para evitar que salga disparada o para desviarla hacia abajo. También hacen falta dispositivos de bloqueo, enclavamientos mecánicos, etc. para evitar la entrada de energía peligrosa cuando los técnicos u otras personas realizan reparaciones u operaciones de mantenimiento en máquinas paradas.

\section{Manipulación de materiales}

Comprende el levantamiento y traslado de rollos de tela pesados, conos de urdimbre, etc. Las carretillas manuales ayudan a descargar o trasladar y transportar pequeñas piezas de tela de los tomadores del telar y reducen el riesgo de lesiones, pues cargan parte del peso del rollo. Se pueden utilizar carretillas industriales motorizadas para trasladar y transportar grandes rollos de tejido desde los tomadores situados delante de la máquina de tejer. Las carretillas con sistemas auxiliares hidráulicos manuales o motorizados son útiles para manipular los conos de urdimbre, que suelen pesar varios cientos de kilos. Los trabajadores que manipulan la urdimbre deben llevar calzado de seguridad.

\section{Extinción de incendios}

La tejeduría genera una cantidad considerable de borra, polvo y partículas de fibra que presentan riesgo de incendio si las fibras son combustibles. L os controles comprenden sistemas de extracción de polvo (situados bajo las máquinas en las fábricas modernas), limpieza regular de la máquina por los trabajadores de mantenimiento y equipos eléctricos diseñados para evitar chispas (por ejemplo, Clase III, División 1, ubicaciones peligrosas).

\section{Riesgos para la salud}

En la tejeduría moderna los riesgos generales para la salud se limitan a la pérdida de audición a causa del ruido y a trastornos pulmonares relacionados con algunas de las fibras que entran en la composición del hilo.

\section{Ruido}

Debido al número de máquinas instaladas en un taller textil normal, la mayoría de los telares emiten niveles de ruido que generalmente sobrepasan los $90 \mathrm{dBA}$. En algunos telares con lanzadera y otros sin lanzadera de gran velocidad, la contaminación acústica puede sobrepasar los 100 dBA. Para evitar lesiones, casi siempre es necesario utilizar protectores adecuados para los oídos y seguir un programa de conservación de la audición.

\section{Polvo de fibra}

$\mathrm{H}$ ace mucho que se asocian ciertos trastornos pulmonares (bisinosis) con el polvo del procesado del algodón en rama y las fibras de lino, asunto que se comenta con más detalle en otros puntos de este capítulo y de la E nciclopedia. En general, una buena ventilación con sistemas de limpieza y filtración del aire del taller y extracción del polvo en la zona de trabajo, mantiene los niveles de polvo por debajo de los máximos permitidos (es decir, $750 \mu \mathrm{g} / \mathrm{m}^{3}$ de aire según la normativa O SH A aplicable al polvo del algodón). Además, se necesitan respiradores de polvo como protección temporal durante las actividades de limpieza. $\mathrm{H}$ ay que imponer un programa de control médico de los trabajadores centrado especialmente en el efecto de estos polvos.

\section{Tricotado a máquina*}

Se llama tricotado mecánico al entrelazamiento de bucles de hilo en máquinas automáticas (véase la Figura 89.10). L as máquinas están equipadas con hileras de pequeñas agujas terminadas en un gancho que tiran de los bucles de hilo recién formado para pasarlos a través de los formados en la pasada anterior. Las agujas tienen un pestillo especial que cierra el gancho para tirar mejor del hilo y después lo abre para soltarlo. Las tricotosas circulares tienen las agujas dispuestas en círculo, y el tejido que forman sale de la máquina en forma de tubo que se enrolla en un cilindro tomador. Por el contrario, las tricotosas rectilíneas y de urdimbre, tienen las agujas dispuestas en línea recta, y el tejido sale de la

* Un porcentaje muy elevado de productos tricotados a mano provienen de talleres familiares. No hay datos fiables sobre el número de trabajadores, generalmente mujeres, empleados en este sector. Recomendamos al lector que consulte el capítulo Actividades culturales, artísticas y de entretenimiento para hacerse una idea general de los riesgos más probables. N ota del editor. 


\section{Figura 89.10 - Tricotosa circular.}

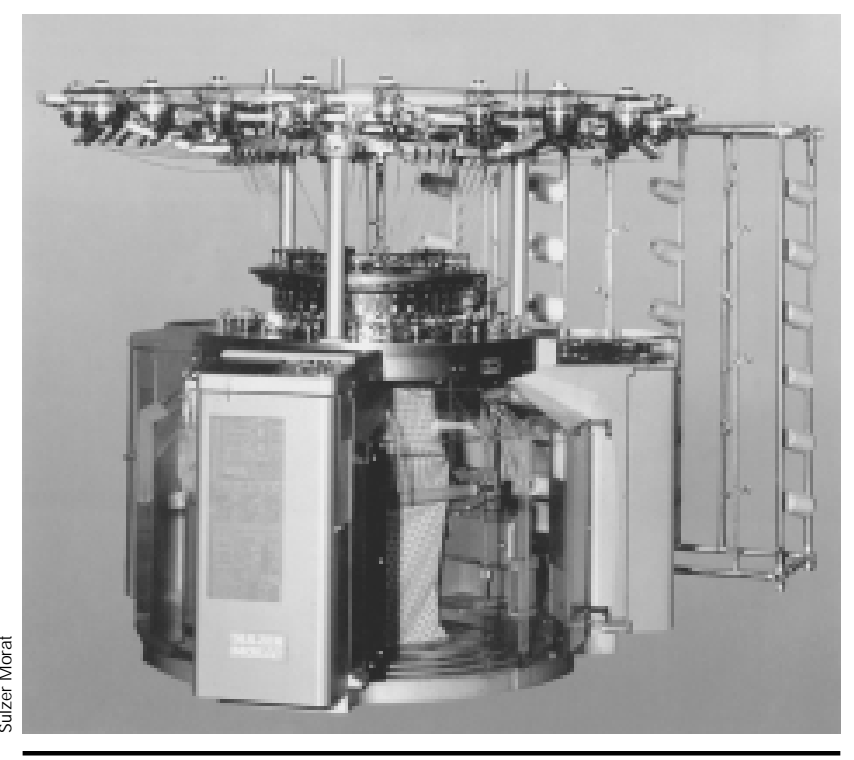

máquina en forma de hoja plana que se enrolla en el cilindro. Las tricotosas circulares y las rectilíneas suelen tomar el hilo de unos conos, y las de urdimbre de unos plegadores similares a los de telar, pero más pequeños.

Los trabajadores de fábricas de tricotado se clasifican por funciones similares a las de los tejedores. Los nombres de los puestos de trabajo reflejan la denominación del proceso.

\section{Riesgos para la seguridad}

Los riesgos para la seguridad en el tricotado son similares a los de la tejeduría, aunque en general inferiores. En el tricotado suelen caer más manchas de aceite en el suelo, pues las agujas requieren más lubricación. El riesgo de quedar atrapado en la máquina es menor, porque hay menos objetos puntiagudos y la mayor parte de la maquinaria se presta a una buena protección. Siguen siendo obligatorios los mecanismos de bloqueo de la alimentación.

La manipulación de rollos de tejido sigue encerrando riesgo de lesiones para el trabajador, pero el peligro propio de la manipulación de plegadores de urdimbre está limitado al tricotado por urdimbre. Las medidas de control de riesgos son similares a las de la tejeduría. Las tricotosas no producen tanta cantidad de borra, partículas y polvo como los telares, pero el aceite que requiere su funcionamiento hace que el riesgo de incendio sea elevado. Los controles son similares a los de la tejeduría.

\section{Riesgos para la salud}

También los riesgos para la salud en el tricotado suelen ser en general inferiores a los de la tejeduría. Los niveles de ruido oscilan entre $80 \mathrm{dBA}$ y poco más de $90 \mathrm{dBA}$. L os trastornos respiratorios de los trabajadores de tricotado que procesan algodón en rama y lino no parecen ser especialmente importantes, y las normativas para estos materiales no suelen aplicarse al tricotado.

\section{- Alfo mbras y MOQUeTAS}

The Carpet and Rug Institute

En Persia se empezaron a confeccionar alfombras tejidas y anudadas a mano varios siglos antes de nuestra era. La primera fábrica de alfombras de Estados U nidos se fundó en 1791 en Filadelfia. En 1839, la industria experimentó un gran cambio cuando Erastus Bigelow inventó el telar mecánico. Ahora casi todas las alfombras y moquetas se confeccionan a máquina en fábricas modernas por uno de los dos procesos siguientes: alfombras de nudos y alfombras teiidas.

La técnica de nudos es la más común. En Estados U nidos, por ejemplo, aproximadamente el $96 \%$ de todas las alfombras de nudos se hacen a máquina, siguiendo un método ideado a partir de la manufactura de cubrecamas del noroeste de G eorgia. La alfombra de nudos se elabora insertando un haz de hilos en un cañamazo de soporte (normalmente polipropileno) y añadiendo a continuación un segundo tejido de soporte con una capa de látex sintético que sujeta los hilos en su lugar y une los dos soportes, a fin de que la alfombra sea más estable.

\section{Confección de alfombras}

Alfombras de mechones hechas a máquina (tufting)

La máquina de anudar utilizada para fabricar alfombras de nudos tiene centenares de agujas (hasta 2.400) montadas en una barra horizontal que cubre toda la anchura del telar (véase la Figura 89.11). La fileta, o hilo en conos dispuesto en raquetas, pasa por unos delgados tubos de guía hacia las agujas de la máquina dispuestas en una barra móvil. En general, cada aguja se alimenta a partir de dos carretes de hilo. El final del primer carrete se empalma con el extremo delantero del segundo, de modo que cuando se agota aquél empieza a utilizarse éste sin necesidad de detener la máquina. Cada extremo de hilo discurre por un tubo guía para evitar que los hilos se enmarañen. A continuación, los hilos pasan por una serie de guías fijas alineadas verticalmente y unidas al cuerpo de la máquina y entran en una última guía situada en el extremo de un brazo que se extiende a partir de la barra de agujas móvil de la máquina. Cuando esta barra se mueve hacia arriba y hacia abajo, la relación entre las dos guías se modifica. La Figura 89.12 ilustra la moqueta de nudos normalmente utilizada en viviendas.

La barra recoge el hilo suelto liberado durante el movimiento ascendente de las agujas. L os hilos se enhebran en las agujas de la barra que les corresponden. L as agujas funcionan simultáneamente a razón 500 carreras por minuto o más en las que describen un movimiento alternativo ascendente y descendente. U na máquina de anudar produce de 1.000 a 2.000 metros cuadrados de alfombra en 8 horas de funcionamiento.

Figura 89.11 - Máquina de anudar alfombras.

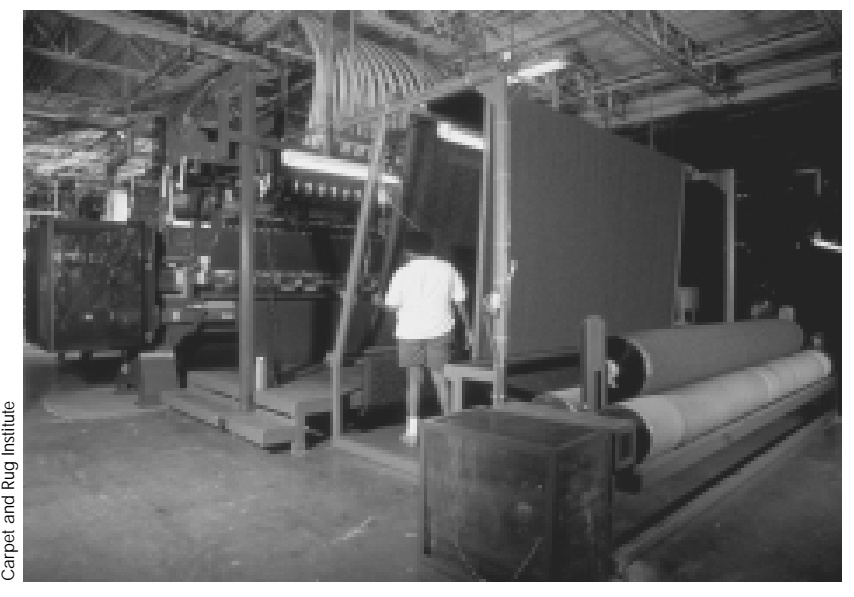


Figura 89.12 - Sección de moqueta doméstica.

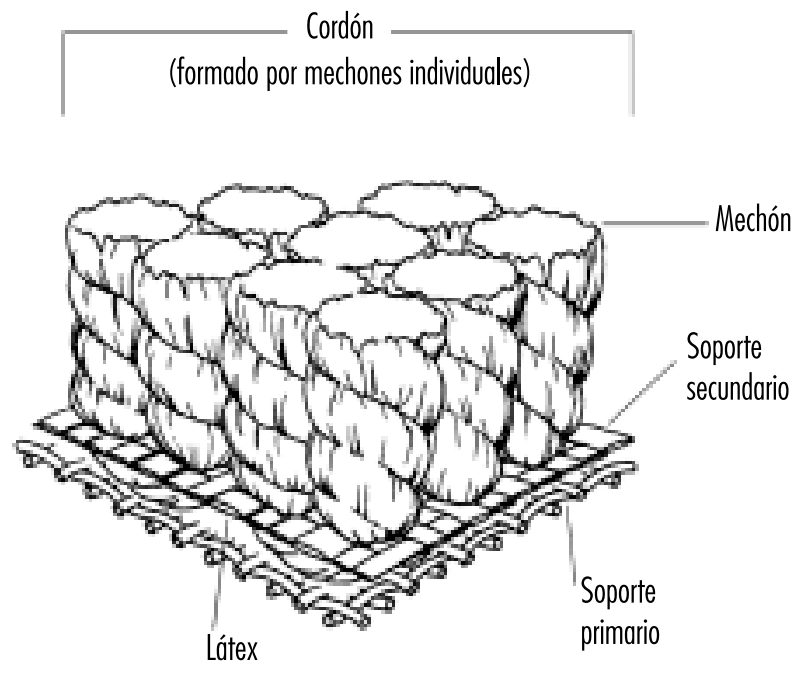

El cañamazo primario en el que se insertan los hilos procede de un rollo situado en la parte delantera de la máquina. La velocidad del rollo de soporte controla la longitud de la puntada y el número de puntadas por unidad de longitud. En sentido transversal, el número de agujas por unidad de longitud determina la densidad del tejido, que suele ser $3 / 1605 / 32$.

Bajo la barra de agujas de la máquina de anudar se encuentran los engarzadores de bucles o una combinación de engarzadores y cuchillos, que recogen y sostienen momentáneamente los hilos que alimentan las agujas. Cuando se forma un bucle, los engarzadores, que tienen forma de palo de hockey invertido, se colocan en la máquina de manera que los bucles formados se alejan de los engarzadores en el momento en que el cañamazo.

Los engarzadores para pelo cortado tienen forma de " $C$ " invertida, con un filo cortante en el lado interior del borde superior; actúan en combinación con unas cuchillas de borde afilado. A medida que el cañamazo recorre la máquina hacia los engarzadores de pelo cortado, los hilos recogidos por las agujas se cortan como con unas tijeras entre el engarzador y el filo cortante de la cuchilla. Las Figuras 89.13 y 89.14 ilustran los bucles ya formados y unidos al cañamazo y varios tipos de bucles comunes.

\section{Alfombras tejidas}

La alfombra tejida tiene un superficie de pelo que se teje simultáneamente con las hebras de urdimbre y trama que forman el soporte integrado. El cañamazo de soporte suele ser de yute, algodón o polipropileno. El pelo es de lana, algodón o cualquier fibra sintética, como nilon, poliéster, polipropileno, fibras acrílicas, etc. El cañamazo se protege con un recubrimiento que mejora la estabilidad. Este tipo de confección no exige cañamazo secundario, que casi nunca se utiliza. La técnica de tejido tiene numerosas variantes, como terciopelo, Wilton o A xminster.

$\mathrm{H}$ ay otras técnicas de confección de alfombras y moquetas - punto, punzonado con agujas, aglutinación por fusión- pero se utilizan mucho menos y sólo para mercados especializados.

\section{Producción de fibra e hilo}

La moqueta se fabrica principalmente a partir de hilos sintéticos - nilon, polipropileno (olefina), poliéster- con cantidades menores de fibra acrílica, lana, algodón y mezclas de cualquiera de estos materiales. En los años sesenta, las fibras sintéticas
Figura 89.13 • Sección de moqueta utilizada en a mbientes no residenciales.

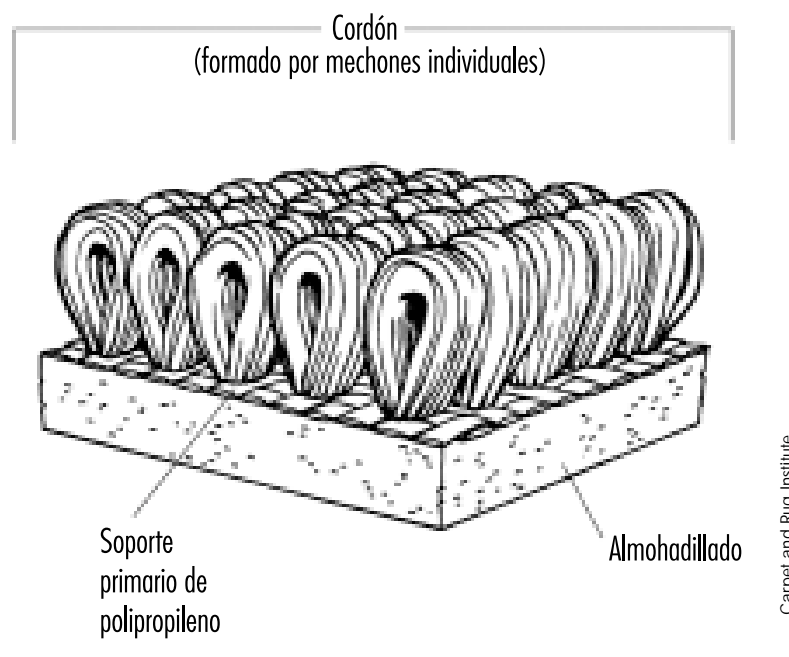

Figura 89.14 - Bucle uniforme; corte y bucle; felpa de terciopelo; sajonia.

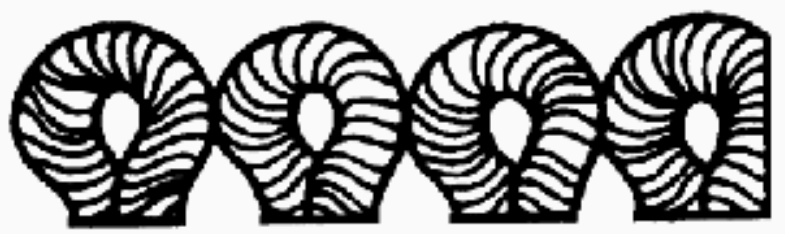

Bucle uniforme

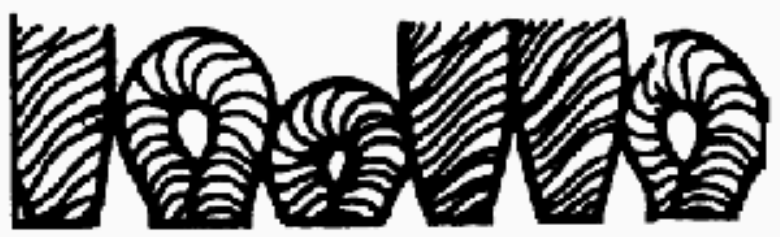

Corte y bucle

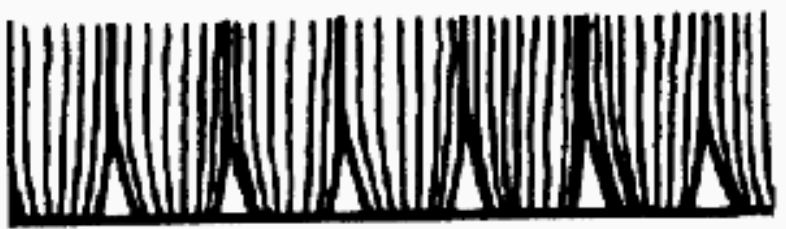

Felpa de terciopeb

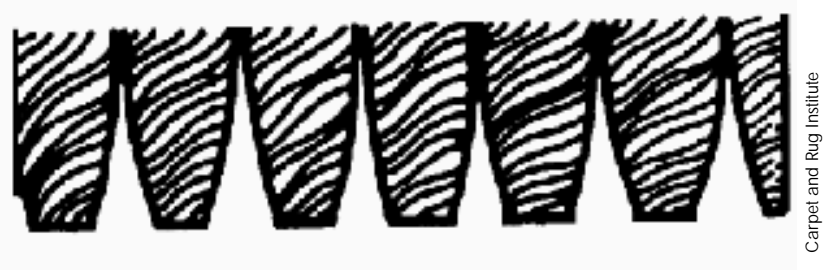


cobraron gran importancia, porque rinden un producto de calidad, duradero y asequible.

Los hilos sintéticos se forman por extrusión de un polímero fundido que pasa a través de los diminutos agujeros de una placa de metal o hilera. Se incorporan ciertos aditivos al polímero fundido para obtener fibras teñidas o no completamente transparentes, más blancas, más duraderas o con otras características. Cuando los filamentos emergen de la hilera, se enfrían, se estiran y se texturizan.

La extrusión confiere a las fibras sintéticas distintas secciones - circular, trilobada, pentalobada, octolobada, cuadrada- en función del diseño y la forma de las perforaciones de la hilera. De estas formas dependen muchas propiedades de la moqueta, como el lustre, el volumen, la retención de la textura y la capacidad de disimular la suciedad.

La fibra extruída se somete a tratamientos como el estirado y el recocido (calentamiento/ enfriado), que aumentan la resistencia a la tracción y en general mejoran las propiedades físicas de la alfombra. EI manojo de filamentos pasa entonces por un proceso de encrespamiento o texturización, que convierte los filamentos rectos en fibras ensortijadas, rizadas o aserradas.

EI hilo se produce a granel, en forma de filamento continuo, o cortado. El hilo continuo es un haz continuo de fibras sintéticas. El hilo extruído se obtiene devanando un número mayor o menor de filamentos, según el calibre denier que quiera obtenerse, en un envase tomador.

La fibra cortada se transforma en hilo mediante operaciones textiles de torcido. La producción de esta clase de fibra empiezan con la extrusión de grandes haces llamados "cables". Este cable se encrespa y se corta en fragmentos de 10 a $20 \mathrm{~cm}$ de longitud. El hilado de las fibras va precedido de tres fases críticas: mezcla, carda y peinado. La mezcla tiene por objeto combinar las fibras de varias balas para que el hilo final teñido no presente estrías de coloración desigual. La carda estira las fibras y las organiza en forma de torzal o mecha. El peinado desempeña tres funciones principales: mezcla las fibras, las coloca en paralelo y reduce el peso por unidad de longitud del haz de fibra, lo que facilita las operaciones de torcido e hilado.

Después del hilado, que adelgaza el torzal hasta el calibre deseado, el hilo se pliega y se retuerce para conseguir diversos efectos. Por último se bobina en conos y queda listo para las operaciones de fijación térmica y trenzado.

\section{Técnicas de coloración}

Dado que las fibras sintéticas tienen varias formas, toman los tintes también de forma distinta y presentan características de coloración diferentes. Las fibras del mismo tipo se pueden tratar o modificar para alterar su afinidad por determinados tintes y obtener así un efecto multicolor o de dos tonos.

Las alfombras y moquetas se colorean tiñendo la fibra o el hilo antes de tejerlos (tintura previa) o tiñendo el género ya anudado (tintura posterior o de productos crudos) antes de aplicar el segundo soporte y los tratamientos de acabado. La tintura previa se aplica en solución, en rama o en el hilo. Las técnicas de tinción posterior son variadas: tintura en pieza; tinción en baño de moqueta sin acabar; tinción en cubeta para lotes de moqueta en crudo de hasta $150 \mathrm{~m}$; y tintura continua, una técnica con la que se colorean cantidades casi ilimitadas, pues se basa en la aplicación de tintas por inyección sobre toda la anchura de la moqueta a medida que avanza en el telar. La maquinaria utilizada en el estampado de alfombras es la misma que en el resto de la industria textil, pero necesariamente reforzada y modificada. Se utilizan estampadoras planas y de pantalla rotativa.

\section{Acabado de alfombras}

El acabado de alfombras y moquetas persigue tres objetivos independientes: anclar cada uno de los nudos al cañamazo de soporte primario, adherir éste a un segundo soporte y tundir y limpiar el pelo de la superficie para darle un aspecto atractivo. EI segundo soporte, de polipropileno tejido, yute o material acolchado, aporta estabilidad a la moqueta.

Primero se recubre el reverso de la moqueta, normalmente por medio de un cilindro que gira en una mezcla de látex sintético y está provisto de una cuchilla dosificadora que extiende el producto. El látex es una solución con una viscosidad de 8.000 a 15.000 centipoise. N ormalmente se aplican 750 a $950 \mathrm{~g}$ de látex por metro cuadrado.

El rollo de soporte secundario se coloca con cuidado sobre el revestimiento de látex y el conjunto se comprimen con un rodillo. Este laminado, que se mantiene plano y sin curvar, pasa por un horno largo, de 24 a 49 metros de longitud, donde se seca a temperaturas de 115 a $150^{\circ} \mathrm{C}$ durante 2 a 5 minutos en tres zonas de calentamiento. Para secar la moqueta es importante que el índice de evaporación sea elevado, y el aire caliente pasa exactamente por las zonas de calentamiento controlado.

Para la superficie, en la que se habrá formado algo de borra durante las operaciones de tintura y acabado, la moqueta se tunde ligeramente. La tundidora es una máquina que cepilla el pelo y lo deja erguido y uniforme; la moqueta pasa por una serie de cuchillas giratorias que tunden o cortan las puntas de la fibra a una altura exacta, ajustable. D os o cuatro cuchillas operan en tándem. La "tundidora doble" tienen un doble juego de cepillos de cerdas duras 0 de nilon y dos cuchillas tundidoras por unidad, que funcionan en tándem.

La moqueta debe superar un exhaustivo proceso de inspección y se embala y se almacena, o se corta, se embala y se expide.

\section{Prácticas de trabajo seguras en fábricas de moqueta}

Las modernas fábricas de moquetas e hilaturas aplican normas de seguridad, supervisan su cumplimiento y, en caso necesario, investigan los accidentes de manera rápida y completa. La maquinaria de producción de alfombras está equipada con protecciones para el personal. Mantener el equipo en buenas condiciones es de gran importancia para mejorar la calidad y la productividad y para la protección de los trabajadores.

Los trabajadores deben recibir formación sobre el uso seguro de la maquinaria eléctrica y los métodos de trabajo ideados para evitar lesiones a consecuencia del arranque inesperado de las máquinas. También deben estar en condiciones de identificar las fuentes de energía peligrosas, el tipo y la magnitud de la energía disponible y los métodos necesarios para aislarla y controlarla. N ecesitan asimismo estar capacitados para diferenciar entre los componentes descubiertos que conducen electricidad y el resto de los elementos eléctricos; para determinar la tensión nominal de los componentes expuestos; y para calcular las distancias que es preciso respetar y las tensiones correspondientes. En las zonas provistas de dispositivos de bloqueo, los trabajadores deben conocer las normas que prohiben poner de nuevo en marcha o alimentar la maquinaria.

Si la maquinaria es antigua, hay que llevar a cabo inspecciones frecuentes e incorporar mejoras cuando sea aconsejable. Los ejes giratorios, las cintas transportadoras, las correas de transmisión de poleas, las transmisiones de cadenas y ruedas dentadas y las grúas y maquinillas deben inspeccionarse periódicamente y protegerse con defensas siempre que sea posible. 
Como en las hilaturas se utilizan carretillas de mano para trasladar el material y como la borra en suspensión y otros residuos de la producción se acumulan en el suelo, hay que limpiar las ruedas para que giren mejor.

Los empleados deben recibir formación sobre la manipulación segura del aire comprimido que suele utilizarse para limpiar.

Las carretillas elevadoras, eléctricas o de propano, se utilizan en todas las fases de la producción de alfombras y en los almacenes. Es esencial mantenerlas correctamente y prestar mucha atención a la carga de combustible segura, al cambio de baterías, etc. Dado que se utilizan en zonas donde hay otros trabajadores, conviene aplicar medidas como las siguientes: vías señalizadas para evitar accidentes (por ejemplo, vías reservadas exclusivamente a los trabajadores, donde las carretillas no puedan circular); colocar señales de stop portátiles en pasillos con movimiento continuo de carretillas; limitar el acceso a los almacenes y muelles a los operadores de las carretillas y al personal encargado de las operaciones de carga y descarga; definir un circuito de circulación en un único sentido.

M odificar el diseño de las máquinas para reducir al mínimo los movimientos repetitivos ayudaría a disminuir la incidencia de lesiones por esta causa. Puede resultar útil animar a los trabajadores a que practiquen regularmente ejercicios sencillos de mano y muñeca y establecer pausas de trabajo adecuadas y cambios de tarea frecuentes.

Las lesiones musculares y óseas debidas al levantamiento y transporte de materiales pesados o voluminosos se reducen con dispositivos elevadores, carretillas manuales y motorizadas, apilando los materiales en plataformas y mesas y procurando en la medida de lo posible mantener el volumen y el peso dentro de valores manejables. También es útil la formación en técnicas de levantamiento adecuadas y la realización de ejercicios de estiramiento muscular, en especial para los trabajadores que se reincorporan al trabajo después de un episodio de dolor de espalda.

Es aconsejable aplicar un programa de conservación de la audición para evitar las lesiones debidas a la presión acústica que generan algunas operaciones fabriles. Un estudio de distribución acústica delimitará las zonas insuficientemente controladas por los dispositivos técnicos y en las que los trabajadores deben llevar equipos de protección y pasar pruebas audiométricas anuales.

Todas las fábricas textiles deben respetar la normativa vigente en materia de ventilación y aspiración de calor, borra y polvo.

\section{- ALFO MBRAS TEJIDAS O ANU DADAS A MANO}

\section{M.E. Radjabi*}

Todas las alfombras "orientales" están tejidas a mano. M uchas se elaboran en lugares de trabajo domésticos, donde todos los miembros de la familia, incluso niños muy pequeños, trabajan en el telar durante largas jornadas y a menudo hasta bien entrada la noche. A veces se trata sólo de una ocupación secundaria de la familia, y en algunas zonas la confección de alfombras se ha trasladado del hogar a una fábrica, casi siempre pequeña.

\section{Operaciones}

Las operaciones de confección de una alfombra son: preparación del hilo, que consiste en clasificar la lana, lavarla, hilarla y teñirla; diseño de la alfombra, y tejeduría propiamente dicha.

\footnotetext{
* Adaptado de la 3a edición, E nciclopedia de salud y seguridad en el trabajo.
}

\section{Preparación del hilo}

En algunos casos, el hilo ya se recibe hilado y teñido. En otros, la fibra bruta, normalmente de lana, se prepara, hila y tiñe en el mismo lugar donde después se va a tejer. U na vez clasificada la fibra de lana por calidades, trabajo que normalmente realizan las mujeres sentadas en el suelo, la lana se lava y se hila a mano. L a tintura se efectúa al aire libre en recipientes abiertos con tintes de anilina o alizarina; los tintes naturales ya no se utilizan.

\section{Diseño y tejeduría}

En los telares artesanos (o tribales, como a veces se les llama), se emplean diseños tradicionales que no es preciso renovar. Pero en los establecimientos industriales que emplean a varios trabajadores hay a veces un diseñador que esboza el diseño en un papel y a continuación lo traslada en color a un cartón cuadriculado a partir del cual el tejedor determina el número y la disposición de los nudos que formarán la alfombra.

El telar casi siempre adopta la forma de dos cilindros de madera horizontales apoyados sobre montantes. U no de ellos está a $10030 \mathrm{~cm}$ del suelo y el otro a unos 3 metros de altura. El hilo de la urdimbre pasa del rodillo superior al inferior siguiendo un plano vertical. Normalmente hay un solo trabajador por telar, pero en las alfombras más anchas puede haber hasta seis colocados uno junto a otro. En la mitad de los casos, los tejedores se sientan en cuclillas en el suelo, frente al rodillo inferior. En otros se instala un estrecho tablón horizontal que se eleva poco a poco hasta unos cuatro metros por encima del suelo a medida que el trabajo avanza. EI tejedor anuda trozos cortos de hilo de lana o seda alrededor de dos hilos de urdimbre y a continuación desplaza a mano el lazo de hilo hasta el extremo ya tejido. Las pasadas de hilo de trama se abatanan en la fibra de la alfombra con un batidor 0 un peine de mano. Los mechones de hilo que sobresalen de la fibra se recortan con unas tijeras.

A medida que se teje, la alfombra se enrolla en el cilindro inferior, cuyo diámetro va en aumento. Cuando los trabajadores están sentados en cuclillas en el suelo, el bulto de este rodillo inferior les impide estirar las piernas, y a medida que aumenta el diámetro de la alfombra ya tejida deben ir retrocediendo e inclinar el cuerpo cada vez más hacia delante para anudar los hilos (véase la Figura 89.15). Este inconveniente se evita cuando los tejedores se sientan en un tablón, que se eleva hasta unos cuatro metros por encima del suelo; pero aún así, no siempre hay espacio suficiente para las piernas, y se ven forzados a

Figura 89.15 - Trabajo en cuclillas ante un telar.

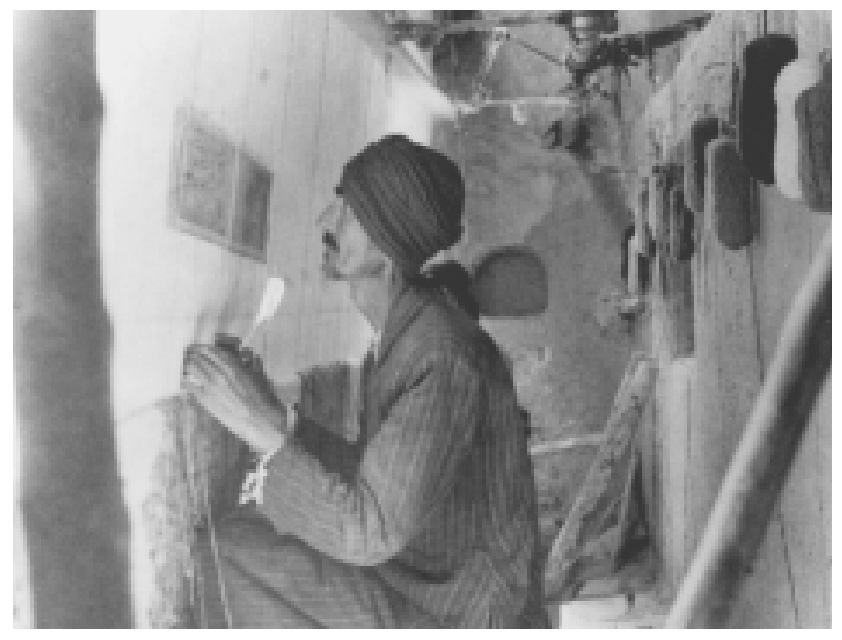


sentarse en posiciones incómodas. En algunos casos, el tejedor cuenta con un respaldo y una almohada (de hecho, una silla sin patas) que se desplaza horizontalmente a lo largo del tablón a medida que el trabajo avanza. Hace poco se han desarrollado nuevos modelos de telares elevados que permiten al tejedor sentarse en una silla con espacio suficiente para sus piernas.

En algunas zonas de la República Islámica de Irán, la urdimbre del telar de la alfombra es horizontal en vez de vertical, y el trabajador se sienta en la misma alfombra mientras trabaja, lo que dificulta todavía más la tarea.

\section{Riesgos propios de la tejeduría de alfombras}

Como industria familiar, la tejeduría de alfombras participa de los riesgos normales en las casas pobres, con habitaciones pequeñas y atestadas, poca luz y mala ventilación. Los útiles y las técnicas se transmiten de generación en generación, y las oportunidades de formación y mejora de los métodos tradicionales son escasas o nulas. L os tejedores de alfombras sufren deformaciones óseas y trastornos visuales y están expuestos a riesgos mecánicos y tóxicos.

\section{Deformaciones óseas}

La posición en cuclillas que han de adoptar los tejedores en telares antiguos y la necesidad de inclinarse hacia delante para anudar los hilos acaban por causar alteraciones óseas graves, a las que frecuentemente se suman las deficiencias nutricionales propias de la pobreza. Los tejedores, sobre todo los que empiezan a trabajar desde niños, desarrollan deformaciones de las piernas (genu valgum) 0 artritis en la articulación de la rodilla. EI estrechamiento de la pelvis que afecta a muchas mujeres les obliga a someterse a cesárea para parir. También son comunes la desviación lateral de la columna vertebral (escoliosis) y la lordosis.

\section{Trastornos de la visión}

La constante concentración de la vista en el punto de tejido o anudado impone un esfuerzo ocular considerable, sobremanera si la iluminación es insuficiente. $\mathrm{H}$ ay que observar que muchos hogares no disponen de luz eléctrica, y el trabajo, que a menudo se realiza también por la noche, se hace a la luz de lámparas de aceite. $\mathrm{H}$ a habido casos de ceguera total al cabo de unos 12 años de dedicación a este trabajo.

\section{Lesiones en manos y dedos}

El constante atar de nudos pequeños y el tirar de la trama a través de la urdimbre provoca inflamación de las articulaciones de los dedos, artritis y neuralgias que culminan en la inutilidad permanente de los dedos.

\section{Estrés}

El alto nivel de cualificación y la atención constante al detalle durante largas horas componen un potente factor de estrés psicosocial, a menudo unido a la explotación y a una disciplina muy estricta. A los niños se les roba la infancia, y cuando se hacen adultos, la falta de contactos sociales esenciales para el equilibrio emocional favorece el desarrollo de enfermedades nerviosas, que se manifiestan en temblor de manos (que merma el rendimiento en el trabajo) y, a veces, trastornos mentales.

\section{Riesgos mecánicos}

Como no se utiliza maquinaria, prácticamente no hay riesgos mecánicos. Si los telares no se mantienen correctamente, la palanca de madera que tensa la urdimbre puede romperse y golpear al tejedor. Este peligro se evita usando tensores especiales de la urdimbre

\section{Riesgos químicos}

L os colorantes, especialmente los que contienen potasio o bicromato sódico, pueden provocar infecciones de la piel o dermatitis. También son peligrosos el amoníaco y los ácidos y álcalis fuertes. Los diseñadores utilizan a veces pigmentos de plomo, y se han dado casos de intoxicación por la costumbre de pasar la punta del pincel entre los labios; los pigmentos de plomo deben sustituirse por colorantes no tóxicos.

\section{Riesgos biológicos}

$\mathrm{H}$ ay riesgo de infección por el ántrax de la lana bruta contaminada procedente de zonas donde el bacilo es endémico. L os organismos públicos competentes deben asegurarse de que se esteriliza la lana antes de entregarla a los talleres 0 a las fábricas.

\section{Medidas preventivas}

La clasificación de la materia prima - lana, pelo de camello o de cabra, etc. - debe hacerse sobre una reja metálica equipada con un extractor de potencia suficiente para arrastrar el polvo hacia un colector situado fuera del lugar de trabajo.

Las salas donde se lava y tiñe la lana deben estar bien ventiladas y los trabajadores han de llevar guantes de goma y delantales impermeables. Conviene neutralizar todos los líquidos residuales antes de arrojarlos a los desagües o alcantarillas.

La sala de diseño y tejeduría ha de estar bien ventilada. Como ya se ha dicho, la falta de luz es un problema grave donde no hay electricidad y cuando el trabajo continúa después de la puesta del sol.

Q uizás la mejora mecánica más importante sea la elevación del cilindro inferior del telar. De esta forma los tejedores no tendrían que sentarse en cuclillas sobre el suelo en una postura poco saludable e incómoda, y podrían trabajar en una silla confortable. Esta mejora ergonómica no sólo beneficiaría la salud de los trabajadores, sino que, una vez adoptada, incrementaría la eficacia y la productividad.

Las salas de trabajo deben mantenerse limpias y bien ventiladas, y los suelos de tierra deben ser sustituidos por pisos debidamente revestidos o pavimentados. Durante la estación fría hace falta una calefacción adecuada. La manipulación manual de la urdimbre impone a los dedos un esfuerzo considerable y puede ocasionar artritis; siempre que sea posible hay que utilizar cuchillos con gancho para las operaciones de sostener y tejer. Sería deseable que los trabajadores pasaran revisiones médicas antes de ser contratados y durante su vida laboral.

\section{Alfombras con mechones hechas a mano}

La confección manual de alfombras de nudos de hilo es muy lenta. El número de nudos oscila entre 2 y 360 por centímetro cuadrado, según la calidad de la alfombra. U na pieza muy grande con un diseño complicado se tarda en hacer un año y tiene centenares de miles de nudos.

La alternativa a esta técnica es usar una herramienta manual especial provista de una aguja a través de la cual se enhebra el hilo. Se suspende verticalmente una tela de algodón en rama en la que se ha dibujado el diseño de la alfombra; el tejedor apoya la herramienta contra la tela y presiona un botón; la aguja atraviesa la tela, se retrae y deja un bucle de hilo de unos $10 \mathrm{~mm}$ de profundidad en el reverso. La herramienta se mueve horizontalmente 2 o $3 \mathrm{~mm}$ y en el anverso de la tela queda un bucle; se oprime de nuevo el botón disparador para formar otro bucle en el reverso. Cuando se adquiere destreza, se pueden hacer casi 30 bucles por minuto. Según el diseño, el tejedor tiene que pararse de vez en cuando para cambiar el color del hilo, según exijan las diversas partes del modelo. U na vez terminada la formación de bucles, la alfombra se descuelga y se coloca en el suelo boca abajo. Se aplica una solución de goma que se cubre 
con una lona de yute. La alfombra se vuelve boca arriba y los bucles de hilo que sobresalen se recortan con una maquinilla eléctrica portátil. En algunos casos, el dibujo se forma cortando los bucles a diversas longitudes.

Los riesgos de esta técnica de confección de alfombras son considerablemente menores que los del anudado manual. EI operario suele sentarse en un tablón delante del tejido y tiene mucho espacio para las piernas. El tablón se eleva a medida que el trabajo avanza. Estaría más cómodo si tuviera un respaldo y un asiento tapizado que se desplazara horizontalmente a lo largo del tablón a medida que el trabajo avanzara. Esta técnica exige menos tensión visual y es poco probable que los movimientos de las manos y los dedos causen problemas.

La solución de goma con que se remata este tipo de alfombras suele contener un disolvente tóxico y muy inflamable. El tratamiento debe aplicarse en salas separadas y con buena ventilación, con al menos dos salidas para casos de incendio y sin llamas ni luces abiertas. Las conexiones eléctricas y la maquinaria de esta sala deben ser a prueba de chispas y de incendio, con el correspondiente certificado. Sólo hay que guardar en las salas la cantidad mínima imprescindible de solución inflamable y tener a mano los extintores correspondientes. El almacén de productos inflamables no debe situarse en el interior de un edificio ocupado, sino en una parcela abierta.

\section{Legislación}

En muchos países, las disposiciones generales de la legislación laboral cubre las normas en materia de seguridad y salud de los trabajadores de este sector. Pero es posible que no sean aplicables a las empresas familiares ni al trabajo doméstico, y son difíciles de controlar en las pequeñas empresas diseminadas por el territorio que, en conjunto, ocupan a muchos trabajadores. La industria tiene fama de explotar a sus trabajadores y utilizar mano de obra infantil, a menudo desafiando la normativa vigente. A mediados del decenio de 1990, los compradores de alfombras de nudos y mechones confeccionadas a mano empezaron a rechazar las piezas elaboradas por trabajadores ilegales o sobreexplotados; esta tendencia se va afianzando en todo el mundo, y cabe esperar que termine con esta forma de esclavitud.

\section{- AFECCIO NES RESPIRAT ORIAS Y DE OTRO TIPO OBSERVADAS EN LA INDUSTRIA TEXTIL}

\section{E. Neil Schachter}

Durante casi 300 años, el trabajo en la industria textil se ha considerado peligroso. R amazzini (1964), a principios del siglo X VIII, describió una forma peculiar de asma entre los cardadores de lino y cáñamo. El "polvo sucio y venenoso" que observó "hace que los trabajadores tosan constantemente y desarrollen progresivamente síntomas asmáticos". Q ue estos síntomas aparecieron realmente en los inicios de la industria textil lo demostraron Bouhuys y colaboradores (1973) en los estudios psicológicos llevados a cabo en Philipsburg $M$ anor (un proyecto de recreación de la vida en las primeras colonias holandesas de North Tarrytown, N ueva York, en Estados U nidos). M ientras en Europa muchos autores del siglo $X I X$ y principios del $X X$ describían cada vez con más frecuencia los síntomas respiratorios de enfermedades relacionadas con el trabajo en las fábricas textiles, éstas siguieron sin ser reconocidas en Estados U nidos hasta que estudios preliminares dirigidos a mediados del siglo XX por Richard Schilling (1981) indicaron que, a pesar de las afirmaciones en contra del sector y del gobierno, la bisinosis era una realidad (American Textile Reporter 1969; Britten, Bloomfield y Goddard 1933; DOL 1945). $M$ uchas investigaciones posteriores han demostrado que trabajadores textiles de todo el mundo se ven afectados por su entorno de trabajo.

\section{Visión general histórica de los síndromes clínicos en la industria textil}

El trabajo en la industria textil se ha asociado con muchos síntomas de afecciones de las vías respiratorias, pero el más prevalente y el más característico es la bisinosis. Muchas fibras vegetales, aunque no todas, cuando se procesan para obtener tejidos, pueden causar bisinosis, como se señala en el capítulo A parato respiratorio. La principal característica de la historia clínica de la bisinosis es su relación con la semana laboral. El trabajador, después de varios años en el sector, describe una presión en el pecho que empieza la tarde del lunes (o el primer día de la semana laboral). La presión remite por la noche, y el trabajador se encuentra bien durante el resto de la semana, hasta el lunes siguiente, cuando vuelve a experimentar el mismo síntoma. Esta disnea del lunes puede mantenerse invariable años o progresar, y entonces los síntomas se presentan en otros días de la semana y finalmente también durante el fin de semana o las vacaciones. Cuando los síntomas ya son permanentes, la disnea es proporcional al esfuerzo. En esta fase puede aparecer tos no productiva. Los síntomas del lunes vienen acompañados de insuficiencia pulmonar durante la jornada, que puede presentarse también otros días, incluso en ausencia de otros síntomas, pero las alteraciones fisiológicas no son acusadas (Bouhuys 1974; Schilling 1956). El funcionalismo pulmonar basal (lunes antes del cambio de turno) se deteriora a medida que la enfermedad progresa. Las alteraciones fisiológicas y respiratorias características que se observan en los trabajadores bisinóticos se han clasificado en una serie de categorías (véase la Tabla 89.2) que en la actualidad son la base de la mayoría de investigaciones clínicas y epidemiológicas. Además de la opresión en el pecho, son frecuentes entre los trabajadores textiles la tos y la bronquitis. E stos síntomas probablemente son variantes de la irritación de las vías respiratorias que causa la inhalación del polvo.

Desgraciadamente no hay ninguna prueba sencilla para establecer el diagnóstico de bisinosis. Este se basa en los síntomas del trabajador y el conocimiento y la familiaridad del médico con las condiciones clínicas e industriales que favorecen la enfermedad. Los datos sobre la función pulmonar, aunque no siempre específicos, pueden ser muy útiles para establecer el diagnóstico y definir el grado de deterioro.

Tabla 89.2 - Grados de bisinosis.

Grado $0 \quad$ Normal; no hay síntomas de opresión en el pecho ni tos.

Grado 1/ 2 Opresión ocasional en el pecho 0 tos 0 ambas cosas el primer día de la semana laboral.

Grado 1 Opresión en el pecho todos los primeros días de la semana laboral.

Grado 2 Opresión en el pecho todos los primeros días de la semana laboral y algún otro día.

Grado 3 Síntomas del nivel 2 con manifestaciones de incapacidad permanente por reducción de la capacidad ventilatoria.

Fuente: Bouhuys 1974 
A demás de la bisinosis clásica, los trabajadores textiles están expuestos a otros complejos de síntomas; en general, cursan con fiebre y son independientes del primer día de la semana laboral.

Las fiebres textiles (fiebre del algodón, fiebre del cáñamo) cursan con hipertermia, tos, escalofríos y rinitis que se declaran al primer contacto con la fábrica o al reincorporarse al trabajo después de una ausencia prolongada. La opresión en el pecho no parece asociada con este síndrome. La frecuencia de estos síntomas entre los trabajadores es muy variable, y oscila entre el 5 \% (Schilling 1956) y la mayoría del personal (U ragoda 1977; Doig 1949; H arris y cols. 1972). N ormalmente, los síntomas remiten al cabo de unos días, aunque continúe la exposición en la fábrica. Se cree que la causa es una endotoxina del polvillo vegetal. La fiebre textil se ha asociado con una entidad que ahora se describe habitualmente en las industrias que utilizan materiales orgánicos: el síndrome del polvo orgánico tóxico(SPO T), que se estudia en el capítulo A parato respiratorio.

La "tos del tejedor" es una afección primordialmente asmática que cursa característicamente con fiebre; afecta tanto a los trabajadores nuevos como a los antiguos. Los síntomas (a diferencia de la fiebre textil) persisten durante meses. El síndrome se ha relacionado con los materiales utilizados para tratar el hilo, como el polvo de semilla de tamarindo (Murray, DingwallFordyce y Lane 1957) y la goma de algarrobo (Vigliani, Parmeggiani y Sassi 1954).

EI tercer síndrome no bisinótico asociado con las operaciones textiles es la "fiebre del colchonero" (Neal, Schneiter y Caminita 1942). El nombre se refiere al contexto en que se describió esta enfermedad, caracterizada por un episodio agudo de fiebre y otros síntomas sistémicos, como trastornos gastrointestinales y malestar retroesternal en los trabajadores que manipulan algodón de baja calidad. El brote se atribuyó a la contaminación del algodón por A erobacter cloacae.

En general, se considera que estos síndromes febriles son clínicamente muy distintos de la bisinosis. Así, en estudios realizados con 528 trabajadores del algodón por Schilling (1956), 38 tenían antecedentes de fiebre textil. La incidencia de esta fiebre entre los trabajadores con bisinosis "clásica" era del $10 \%$ (14/134), frente al $6 \%$ (24/394) de los trabajadores que no tenían bisinosis. L as diferencias no son estadísticamente significativas.

La bronquitis crónica, tal como la define la historia médica, es muy común entre los trabajadores textiles, especialmente entre los no fumadores. Este descubrimiento no es sorprendente, pues la principal característica histológica de la bronquitis crónica es la hiperplasia de las glándulas mucosas (Edwards y cols. 1975; $M$ oran 1983). H ace falta un examen meticuloso para diferenciar los síntomas de la bronquitis crónica y la bisinosis clásica, aunque las molestias de los bronquíticos y los bisinóticos suelen coincidir, y entre los trabajadores textiles concurren probablemente diferentes manifestaciones patofisiológicas de una misma inflamación de las vías respiratorias.

Los estudios patológicos entre los trabajadores textiles son limitados, pero presentan un modelo patológico coherente que interesa a las grandes vías respiratorias (E dwards y cols. 1975; Rooke 1981a; Moran 1983) sin indicios de destrucción del parénquima pulmonar (por ejemplo, enfisema) (M oran 1983).

\section{Curso clínico de la bisinosis}

\section{Enfermedad aguda y enfermedad crónica}

En el sistema de clasificación de la Tabla 89.2 hay implícita una progresión que va de los "síntomas agudos del lunes" a los trastornos respiratorios crónicos y normalmente irreversibles de los trabajadores con bisinosis. Esta progresión se ha demostrado con los datos contrastados de estudios como el de los trabajadores del algodón de Lancashire, Reino U nido, que reveló que la bisinosis era más grave cuando la exposición era más elevada (Schilling 1956). Otros autores describen observaciones similares (M olyneux y Tombleson 1970). Además, esta progresión puede empezar relativamente pronto después de la contratación (es decir, durante los primeros años) (M ustafa, Bos y L akha 1979).

Los datos de muestras representativas también revelan que otros síntomas y complejos sintomáticos respiratorios crónicos, como la bronquitis jadeante o crónica, son mucho más prevalentes entre los trabajadores más antiguos de la industria del algodón que en poblaciones de control similares (Bouhuys y cols. 1977; Bouhuys, Beck y Schoenberg 1979). Los trabajadores del algodón sufren en todos los casos más bronquitis crónica que los controles, incluso ponderando los factores de sexo y tabaquismo. La bisinosis de grado 3 indica que, además de los síntomas, los trabajadores textiles muestran alteraciones de la función respiratoria. La progresión de la primera fase de la bisinosis (grado 1) a la enfermedad avanzada (grado 3) sugiere la asociación de pérdida de funcionalismo pulmonar y grados más graves de bisinosis en los estudios de muestras representativas de trabajadores textiles. Varios de estos estudios de muestras representativas corroboran la hipótesis de que las alteraciones de la función pulmonar durante la jornada (correlacionadas con los episodios agudos de opresión torácica) están relacionadas con alteraciones crónicas irreversibles.

Tras la asociación entre la enfermedad aguda y la enfermedad crónica en los trabajadores textiles se oculta una relación dosisrespuesta de los síntomas agudos que Roach y Schilling documentaron por primera vez en un estudio presentado en 1969. Estos autores descubrieron una fuerte relación lineal entre la respuesta biológica y la concentración total de polvo en el lugar de trabajo. Basándose en estos hallazgos, recomendaron $1 \mathrm{mg} / \mathrm{m}^{3}$ de polvo bruto como nivel de exposición razonablemente seguro. Este resultado fue adoptado más adelante por la ACGIH, y hasta finales de los años setenta fue utilizado como umbral límite para el polvo en la industria del algodón de Estados U nidos. O bservaciones posteriores demostraron que la fracción fina de polvo $(<7 \mu \mathrm{m})$ respondía prácticamente de toda la incidencia de bisinosis (M olyneux y Tombleson 1970; M cK errow y Schilling 1961; M cK errow y cols. 1962; Wood y Roach 1964). En 1973, M erchant y colaboradores elaboraron un estudio sobre los síntomas respiratorios y la función pulmonar en 1.260 trabajadores del algodón, 803 trabajadores de textiles mixtos (algodón-fibras sintéticas) y 904 trabajadores de fibras sintéticas-madera en 22 plantas textiles de Carolina del Norte (Estados U nidos). El estudio confirmó la asociación lineal entre la incidencia de la bisinosis (y la disminución de la función pulmonar) y las concentraciones de polvo sin borra.

La validación de las alteraciones de la función respiratoria indicada por los estudios de muestras de referencia proviene de varias investigaciones longitudinales que complementan y amplían los resultados de estudios anteriores. Estos estudios han subrayado la pérdida acelerada de funcionalismo pulmonar entre los trabajadores textiles del algodón, así como la elevada incidencia de nuevos síntomas.

En una serie de investigaciones con varios miles de trabajadores de fábricas textiles examinados a finales del decenio de 1960 durante un intervalo de cinco años, Fox y colaboradores (1973a; 1973b) descubrieron un aumento de los índices de bisinosis correlacionado con los años de exposición, así como una disminución anual siete veces mayor del volumen espiratorio forzado en 1 segundo $\left(\mathrm{FEV}_{1}\right.$ ) (expresada como porcentaje del volumen esperado) en comparación con los grupos de control.

A principios de los años setenta, Arend Bouhuys inició un estudio singular sobre la enfermedad crónica del pulmón en los trabajadores textiles (Bouhuys y cols. 1977). El estudio era una 
novedad, porque incluía trabajadores activos y jubilados. Estos empleados textiles, de Columbia, Carolina del Sur, en Estados U nidos, trabajaban en una de las cuatro fábricas textiles locales. La selección del grupo se describe en el análisis original. En un principio el grupo estaba formado por 692 individuos, pero el análisis se limitó a 646 blancos que tenían 45 años o más en 1973. Estos individuos habían trabajado una media de 35 años en las fábricas textiles. El grupo de control de los resultados contrastados consistió en blancos de 45 años de edad 0 más procedentes de tres comunidades estudiadas transversalmente: Ansonia y Lebanon, Connecticut, y Winnsboro, Carolina del Sur. A pesar de las diferencias geográficas y socioeconómicas, los residentes de la comunidad no diferían en cuanto a la función pulmonar de los trabajadores textiles que habían ejecutado los trabajos menos polvorientos. Dado que no se observaron diferencias en la función pulmonar o los síntomas respiratorios entre las tres comunidades, sólo se utilizó la muestra de Lebanon, Connecticut, que se estudió en 1972 y 1978, como control para el estudio longitudinal de los trabajadores textiles estudiados en 1973 y en 1979 (Beck, Doyle y Schachter 1981; Beck, D oyle y Schachter 1982).

Tanto los síntomas como la función pulmonar se han examinado exhaustivamente. En el estudio prospectivo se determinó que los índices de incidencia de siete síntomas respiratorios 0 síndromes (incluyendo la bisinosis) eran más elevados entre los trabajadores textiles que entre los controles, incluso ponderando el tabaquismo (Beck, M aunder y Schachter 1984). Al clasificar a los trabajadores textiles entre activos y jubilados, se observó que los que se retiraban durante el curso del estudio eran quienes tenían la mayor incidencia de síntomas. Este descubrimiento sugirió que no eran los trabajadores activos los únicos expuestos al riesgo de padecer síntomas respiratorios, sino que también los trabajadores jubilados seguían en situación de riesgo, seguramente a causa del daño irreversible que habían sufrido sus pulmones.

En esta cohorte se midió la pérdida de funcionalismo pulmonar durante un período de 5 años. El promedio de disminución entre los trabajadores y trabajadoras textiles $(42 \mathrm{ml} /$ año y $30 \mathrm{ml} /$ año, respectivamente) era significativamente mayor que entre los hombres y mujeres de los grupos de control $(27 \mathrm{ml} /$ año y $15 \mathrm{ml}$ / año). Al diferenciar entre fumadores y no fumadores, los trabajadores textiles seguían mostrando pérdidas del FEV superiores a las observadas en los grupos de control.

Muchos autores han planteado la posibilidad de que el problema del tabaquismo pueda dar lugar a confusiones. Dado que muchos trabajadores textiles son fumadores, se ha dicho que la enfermedad crónica del pulmón que se asocia con la exposición al polvo textil podría atribuirse al tabaco. Tomando como base la población de trabajadores textiles de Columbia, la respuesta a esta cuestión se presenta de dos formas. En un estudio de Beck, M aunder y Schachter (1984) se utiliza un doble análisis de varianza para todas las mediciones de la función pulmonar; los resultados demuestra que los efectos del polvo del algodón y el tabaquismo sobre la función pulmonar son aditivos; es decir, el grado de pérdida de función pulmonar debida a un factor (tabaco o exposición al polvo del algodón) no cambia en presencia 0 ausencia del otro factor. Los efectos sobre la FVC (capacidad vital forzada) y el $\mathrm{FEV}_{1}$ son de la misma magnitud (historial de fumador medio de 56 años-cajetilla, exposición textil media de 35 años). En un estudio afín, Schachter y cols. (1989) demostraron que utilizando el ángulo beta, un parámetro que describe la forma de la curva de volumen del caudal espiratorio máximo, se apreciaban diferentes pautas de anomalías de la función pulmonar para los efectos del tabaco y el algodón, de acuerdo con las conclusiones a que antes había llegado M erchant.

\section{Mortalidad}

Los estudios sobre mortalidad por exposición al polvo de algodón no han demostrado una relación causa-efecto coherente. Una revisión de la experiencia de finales del siglo XIX y principios del siglo XX en el Reino Unido sugirió un exceso de mortalidad cardiovascular en los trabajadores textiles de más edad (Schilling y Goodman 1951). En cambio, el estudio de la experiencia de las ciudades textiles de $\mathrm{N}$ ueva Inglaterra desde finales del siglo XIX no reveló una mortalidad excesiva (Arlidge 1892). También $\mathrm{H}$ enderson y Enterline (1973) obtuvieron resultados negativos en un estudio de los trabajadores de las fábricas textiles de $\mathrm{G}$ eorgia empleados entre 1938 y 1951. En cambio, un estudio de Dubrow y Gute (1988) sobre trabajadores textiles varones de R hode I sland fallecidos entre 1968 y 1978 demostró un aumento significativo del índice de mortalidad proporcional (I M P) por afecciones respiratorias no malignas. EI incremento del IM P era coherente con el aumento de la exposición al polvo, pues los operarios de las máquinas de cardar, abrir y peinar arrojaban valores de IM P más altos que los demás trabajadores de la industria textil. U n descubrimiento interesante de éste y otros estudios (Dubrow y Gute 1988; Merchant y O rtmeyer 1981) es la baja mortalidad por cáncer de pulmón entre estos trabajadores, un hallazgo que se ha utilizado para argumentar que el tabaquismo no es una causa de mortalidad importante en estos grupos.

La observación de un grupo de Carolina del Sur sugiere que la enfermedad pulmonar crónica es, en realidad, la causa principal de mortalidad (o un factor de predisposición), dado que entre los trabajadores de 45 a 64 años que murieron durante un seguimiento de 6 años, la función pulmonar medida como FEV residual (observado - previsto) mostró un marcado deterioro en el estudio inicial $\left(F E V R_{1}\right.$ medio $=-0,9$ ) en los varones no fumadores que murieron durante el seguimiento de seis años (Beck y cols. 1981). Es posible que el efecto de la exposición en las fábricas textiles se hubiera visto moderado por un efecto de selección (efecto del trabajador sano). Finalmente, en términos de mortalidad, Rooke (1981b) estimó que de un promedio de 121 muertes que observó anualmente entre trabajadores discapacitados, 39 ocurrieron a consecuencia de la bisinosis.

\section{Más control, menos enfermedad}

Los estudios más recientes procedentes del Reino Unido y Estados U nidos sugieren que la incidencia y las pautas de enfermedad pulmonar entre los trabajadores textiles ha cambiado gracias a la aplicación de normas de calidad del aire más estrictas en la fábricas textiles de estos países. En 1996, Fishwick y colaboradores, por ejemplo, describieron un estudio de una muestra representativa de 1.057 operarios hilanderos en 11 hilaturas de Lancashire. Se hicieron pruebas a un $97 \%$ de los empleados; la mayoría (713) trabajaban con algodón, y el resto con fibras sintéticas. Se diagnóstico bisinosis tan sólo en un 3,5\% de los operarios, y bronquitis crónica en un 5,3\%. Pero el FEV era bajo en los trabajadores expuestos a grandes concentraciones de polvo. Estas incidencias son muy inferiores a las mencionadas en los estudios previos efectuados en estas mismas fábricas. Parece que la baja incidencia de bisinosis y bronquitis se debe a la tendencia decreciente de los niveles de polvo en el Reino Unido. En este grupo, tanto el tabaco como la exposiciones al polvo de algodón influyeron en la pérdida de capacidad pulmonar.

En Estados U nidos, G lindmeyer y colaboradores (1991; 1994) llevaron a cabo entre 1982 y 1987 un estudio prospectivo de 5 años entre los trabajadores de 9 fábricas textiles (6 de algodón y 3 de fibras sintéticas), con un total 1.817 empleados dedicados exclusivamente a la fabricación de hilo, encolado o tejeduría de algodón o de fibras sintéticas. En conjunto, menos del $2 \%$ de estos trabajadores habían tenido episodios bisinóticos. Pero los que se dedicaban a la fabricación de hilo mostraban una mayor 
pérdida anual de función pulmonar que los trabajadores de encolado o tejeduría. Los operarios del proceso de hilado mostraban una pérdida de la función pulmonar proporcional a la dosis y asociada también con la calidad del algodón manipulado. Estas fábricas textiles cumplían las normas de la O SH A, y las concentraciones medias de polvo de algodón respirable sin borra en suspensión en el aire en un promedio de 8 horas eran de $196 \mu \mathrm{g} / \mathrm{m}^{3}$ en la fabricación de hilo y $455 \mu \mathrm{g} / \mathrm{m}^{3}$ en el encolado y la tejeduría. Los autores (1994) describieron alteraciones durante la jornada (el equivalente a la función pulmonar objetiva de los síntomas bisinóticos) con descensos longitudinales del funcionalismo pulmonar. Se descubrió que estas alteraciones a lo largo de la jornada era predictores significativos de los cambios longitudinales.

Aunque en la actualidad el trabajo en las fábricas textiles del mundo desarrollado se asocia con enfermedades menos graves y de menor incidencia, no ocurre lo mismo en los países en vías de desarrollo. Todavía se detecta una gran incidencia de bisinosis en todo el mundo, especialmente donde la normativa oficial es muy tolerante o falta. En una revisión reciente de la literatura, Parikh (1992) comentaba que la incidencia de bisinosis estaba muy por encima del $20 \%$ en países como la India, Camerún, Etiopía, Sudán y Egipto. En un estudio elaborado por Zuskin y cols. (1991), se siguió a 66 trabajadores de fábricas textiles de algodón de Croacia, donde las concentraciones medias de polvo respirable seguían siendo de $1,0 \mathrm{mg} / \mathrm{m}^{3}$. La incidencia de bisinosis se duplicó, y la pérdida anual de función pulmonar era casi el doble de la que se estimaba a partir de las ecuaciones de predicción para no fumadores sanos.

\section{Trastornos no respiratorios asociados con el trabajo en fábricas textiles}

Además de los síndromes respiratorios bien caracterizados que afectan a los trabajadores textiles, se han asociado otros riesgos con las condiciones de trabajo y los productos peligrosos manipulados en el sector.

El trabajo en la industria textil se ha asociado con oncogénesis. Varios estudios preliminares indican una gran incidencia de cáncer colorrectal entre los trabajadores de fábricas textiles de fibras sintéticas (Vobecky y cols. 1979; Vobecky, Devroede y Caro 1984). U n estudio retrospectivo de las fábricas textiles de fibras sintéticas, elaborado por Goldberg y Theriault (1994a), sugiere una asociación con el tiempo pasado en las unidades de extrusión de triacetato de celulosa y polipropileno. Estos autores observaron también otras asociaciones con enfermedades neoplásicas, pero se consideró que eran "no convincentes" (1994b).
La exposición a los colorantes azoicos se ha relacionado con cáncer de vejiga en varias industrias. Siemiatycki y cols. (1994) descubrieron una débil asociación entre el cáncer de vejiga y la manipulación de fibras acrílicas y polietileno. En concreto, se comprobó que los trabajadores que tiñen estos textiles se encontraban en situación de mayor riesgo. Los trabajadores con antigüedad en este sector presentaban un riesgo 10 veces mayor (significación estadística marginal) de cáncer de vejiga. 0 tros autores han informado de hallazgos similares, aunque también hay que tener en cuenta los estudios negativos (Anthony y Thomas 1970; Steenland, Burnett y O sorio 1987; Silverman y cols. 1989).

El trauma por movimientos repetitivos es un riesgo reconocido en la industria textil y vinculado con la maquinaria más rápida (Thomas 1991). Una descripción del síndrome del túnel carpiano (Forst y H ryhorczuk 1988) en el trabajo de una costurera con una máquina de coser eléctrica ilustra la patogénesis de este trastorno. La revisión de las lesiones de la mano atendidas entre 1965 y 1984 en la U nidad Regional de Cirugía Plástica a la que acuden los trabajadores de la lana de Yorkshire reveló que, aunque el empleo en este sector se había dividido por cinco, la incidencia anual de lesiones de la mano se mantenía constante, lo que indicaba que el riesgo en esta población iba en aumento (M yles y Roberts 1985).

La intoxicación hepática entre trabajadores textiles ha sido considerada por Redlich y colaboradores (1988) una consecuencia de la exposición a la dimetilformamida en una fábrica de revestimiento de tejidos. Esta toxicidad se identificó en el contexto de un brote de enfermedades del hígado en $\mathrm{New} \mathrm{H}$ aven, Connecticut, en una fábrica de tejidos revestidos con poliuretano.

El bisulfuro de carbono ( $\mathrm{CS}_{2}$ ) es un compuesto orgánico utilizado en la preparación de textiles sintéticos, y se ha asociado con un aumento de la mortalidad por isquemia cardíaca (H ernberg, Partanen y Nordman 1970; Sweetnam, Taylor y Elwood 1986). Esta observación puede estar relacionada con sus efectos sobre los lípidos de la sangre y la presión diastólica (Eyeland y cols. 1992). Además, este agente se ha asociado también con neurotoxicidad periférica, lesiones de los órganos sensoriales y trastornos de la función hormonal y reproductora. En general, se cree que estos resultados son consecuencia de la exposición prolongada a concentraciones superiores a 10-20 ppm (R iihimaki y cols. 1992).

Se han documentado reacciones alérgicas a los colorantes reactivos, entre ellas eczema, urticaria y asma, en trabajadores de tintura de textiles (Estlander 1988; Sadhro, Duhra y Foulds 1989; Seidenari, M auzini y Danese 1991).

También se ha descrito infertilidad en hombres y mujeres a causa de exposiciones en la industria textil (Rachootin y O Isen 1983; Buiatti y cols. 1984). 


\section{Referencias}

American T extile R eporter. 1969. (10 julio).

Anthony, H M , GM Thomas. 1970. T umors of the urinary bladder. J Natl Cancer Inst 45:879-95.

Arlidge, JT. 1892. The H ygiene, Diseases and M ortality of 0 ccupations. Londres: Percival and $\mathrm{C} 0$.

Beck, GJ, CA Doyle, EN Schachter. 1981. Smoking and lung function. Am R ev Resp D is 123:149-155.

-. 1982. A longitudinal study of respiratory health in a rural community. Am Rev Resp D is 125:375-381.

Beck, GJ, EN Schachter, L M aunder, A Bouhuys. 1981. The relation of lung function to subsequent employment and mortality in cotton textile workers. Chest supl. 79:26S-29S.

Beck, GJ, LR M aunder, EN Schachter. 1984. Cotton dust and smoking effects on lung function in cotton textile workers. Am J E pidemiol 119:33-43.

Bouhuys, A, CA M itchell, RSF Schilling, E Zuskin. 1973. A physiological study of byssinosis in colonial America. T rans N ew York Acad Sciences 35:537-546.

Bouhuys, A, GJ Beck, J Schoenberg. 1979. Epidemiology of environmental lung disease. Yale J Biol M ed 52:191-210.

Bouhuys, A, JB Schoenberg, GJ Beck, R SF Schilling. 1977. Epidemiology of chronic lung disease in a cotton mill community. L ung 154:167-186.

Bouhuys, A. 1974. Breathing. Nueva Y ork: Grune \& Stratton.

Britten, RH, J| Bloomfield, JC Goddard. 1933. H ealth of W orkers in T extile Plants. Boletín no 207. Washington, DC: U S Public H ealth Service.

Buiatti, E, A Barchielli, M Geddes, L Natasi, D K rie bel, M Franchini, G Scarselli. 1984. Risk factors in male infertility. Arch E nviron $\mathrm{H}$ ealth 39:266-270.

Department of Labor (DOL). 1945. Special Bulletin no 18. Washington, DC: DOL, Labor Standards Division.

Doig, AT . 1949. O ther lung diseases due to dust. Postgrad M ed J 25:639-649.

Dubrow, R, DM Gute. 1988. Cause-specific mortality among male textile workers in R hode Island. Am J Ind M ed 13: 439-454.

Edwards, C, J M acartney, G Rooke, F Ward. 1975. The pathology of the lung in byssinotics. Thorax 30:612-623.

Estlander, T. 1988. Allergic dermatoses and respiratory diseases from reactive dyes. Contact Dermat 18:290-297.

Eyeland, GM, GA Burkhart, TM Schnorr, FW Hornung, JM Fajen, ST Lee. 1992. Effects of exposure to carbon disulphide on low density lipoprotein cholesterol concentration and diastolic blood pressure. B rit J Ind M ed 49:287-293.

Fishwick, D, AM Fletcher, AC Pickering, R M CNiven, EB Faragher. 1996. Lung function in Lancashire cotton and man-made fibre spinning mill operatives. 0 ccup E nviron M ed 53:46-50.

Forst, L, D H ryhorczuk. 1988. O ccupational tarsal tunnel syndrome. Brit J Ind M ed 45:277-278.

Fox, AJ, JBL Tombleson, A Watt, AG Wilkie. 1973a. A survey of respiratory disease in cotton operatives: Part I. Symptoms and ventilation test results. B rit ] Ind $M$ ed 30:42-47.

$-.1973 \mathrm{~b}$. A survey of respiratory disease in cotton operatives: Part II. Symptoms, dust estimation, and the effect of smoking habit. B rit J Ind M ed 30:48-53.

Glindmeyer, HW, IJ Lefante, RN Jones, RJ Rando, H M A K ader, H Weill. 1991. Exposure-related de clines in the lung function of cotton textile workers. Am R ev R espir D is 144:675-683.
Glindmeyer, HW, JJ Lefante, R N Jones, RJ Rando, H W eill. 1994. Cotton dust and across-shift change in FEV ${ }_{1}$ Am J Respir Crit Care M ed 149:584-590.

Goldberg, M S, G Theriault. 1994a. R etrospective cohort study of workers of a synthetic textiles plant in Q uebec II. Am J Ind M ed 25:909-922.

- . 1994b. R etrospective cohort study of workers of a synthetic textiles plant in Quebec I. Am J Ind M ed 25:889-907.

Grund, N. 1995. Environmental considerations for textile printing products. J ournal of the Society of $D$ yers and Colourists 111 (1/2):7-10.

H arris, TR, JA M erchant, K H K ilburn, JD H amilton. 1972. Byssinosis and respiratory diseases in cotton mill workers. J O ccup M ed 14: 199-206.

$\mathrm{H}$ enderson, V, PE Enterline. 1973. An unusual mortality experience in cotton textile workers. I 0 ccup M ed 15: 717-719.

H ernberg, S, T Partanen, CH Nordman. 1970. Coronary heart disease among workers exposed to carbon disulphide. Brit J Ind M ed 27:313-325.

M cK errow, CB, RSF Schilling. 1961. A pilot enquiry into byssinosis in two cotton mills in the United States. J AM A 177:850-853.

M CK errow, CB, SA R oach, JC Gilson, R SF Schilling 1962. The size of cotton dust particles causing byssinosis: An environmental and physiological study. B rit J Ind M ed 19:1-8.

Merchant, JA, C O rtmeyer. 1981. M ortality of employees of two cotton mills in N orth Carolina. Chest supl. 79: 6S-11S

M erchant, JA, JC Lumsdun, KH K ilburn, WM O'FalIon, JR Ujda, VH Germino, JD Hamilton. 1973. Dose-response studies in cotton textile workers. I 0 ccup M ed 15:222-230.

M inisterio de Industria y Comercio Internaciona (Japón). 1996. Asia-Pacific T extile and Clothing Industry Form, | une 3-4, 1996. T okio: M inisterio de Industria y Comercio Internacional.

M olyneux, M K B, JBL T ombleson. 1970. An epidemiological study of respiratory symptoms in Lancashire mills, 1963-1966. B rit J Ind M ed 27:225-234.

M oran, TJ . 1983. Emphysema and other chronic lung disease in textile workers: An 18-year autopsy study. Arch E nviron $\mathrm{H}$ ealth 38:267-276.

M urray, R, J Dingwall-Fordyce, RE Lane. 1957. An outbreak of weaver's cough associated with tamarind seed powder. B rit J Ind M ed 14:105-110.

M ustafa, KY, W Bos, AS Lakha. 1979. Byssinosis in T anzanian textile workers. L ung 157:39-44.

Myles, SM, AH Roberts. 1985. Hand injuries in the textile industry. J $H$ and Surg 10:293-296.

Neal, PA, R Schneiter, BH Caminita. 1942. Report on acute illness among rural mattress makers using low grade, stained cotton. J AM A 119:1074-1082.

O ccupational Safety and $\mathrm{H}$ ealth Administration (OSHA). 1985. Final Rule for O ccupational Exposure to Cotton Dust. Federal Register 50, 51120-51179 (13 dic. 1985). 29 CFR 1910.1043. Washington, DC: OSH A.

Parikh, JR. 1992. Byssinosis in developing countries. B rit J Ind M ed 49:217-219.

$R$ achootin, $P$, J O Isen. 1983. The risk of infertility and delayed conception associated with exposures in the Danish workplace. J 0 ccup M ed 25:394-402.

R amazzini, B. 1964. D iseases of W orkers [D e morbis artificum, 1713], traducido al inglés por WC Wright. Nueva Y ork: $\mathrm{H}$ afner Publishing $\mathrm{C} 0$.

Redlich, CA, WS Beckett, J Sparer, K W Barwick, CA Riely, H M iller, SL Sigal, SL Shalat, MR Cullen. 1988. Liver disease associated with occupational ex- posure to the solvent dimethylformamide. Ann Int $M$ ed 108:680-686.

Riihimaki, V, H K ivisto, K Peltonen, E Helpio, A Aitio. 1992. Assessment of exposures to carbon disulfide in viscose production workers from urinary 2-thiothiazolidine-4-carboxylic acid determinations. Am J Ind M ed 22:85-97.

Roach, SA, RSF Schilling. 1960. A clinical and environmental study of byssinosis in the Lancashire cotton industry. B rit J Ind M ed 17:1-9.

R ooke, GB. 1981a. The pathology of byssinosis. Chest supl. 79:67S-71S

- . 1981b. Compensation for byssinosis in G reat Britain. Chest supl. 79:124S-127S

Sadhro, S, P Duhra, IS Foulds. 1989. O ccupational dermatitis from Synocril Red $3 \mathrm{~b}$ liquid (CI Basic Red 22). Contact D ermat 21:316-320.

Schachter, EN, MC Kapp, GJ Beck, LR M aunder, TJ Witek. 1989. Smoking and cotton dust effects in cotton textile workers. Chest 95: 997-1003.

Schilling, RSF, N Goodman. 1951. Cardiovascular disease in cotton workers. B rit J Ind M ed 8:77-87.

Schilling, RSF. 1956. Byssinosis in cotton and other textile workers. Lancet 1:261-267, 319-324.

- . 1981. W orldwide problems of byssinosis. Chest supl. 79:3S-5S.

Seidenari, S, BM M auzini, P Danese. 1991. Contact sensitization to textile dyes: Description of 100 subjects. Contact D ermat 24:253-258.

Siemiatycki, J, R Dewar, L Nadon, M Gerin. 1994. 0 ccupational risk factors for bladder cancer. Am J E pidemiol 140:1061-1080.

Silverman, DJ, LI Levin, RN H oover, P H artge. 1989. $O$ ccupational risks of bladder cancer in the U nited States. I. White men. I Natl Cancer Inst 81:1472-1480.

Steenland, K, C Burnett, AM O sorio. 1987. A case control study of bladder cancer using city directories as a source of occupational data. Am J E pidemiol 126:247-257.

Sweetnam, PM, SWS T aylor, PC Elwood. 1986. Exposure to carbon disulphide and ischemic heart disease in a viscose rayon factory. Brit J Ind $\mathrm{M} \mathrm{ed}$ 44:220-227.

Thomas, RE. 1991. R eport on a multidisciplinary conference on control and prevention of cumulative trauma disorders (CDT) or repetitive motion trauma (RMT) in the textile, apparel and fiber industries. Am Ind H yg Assoc J 52:A562.

U ragoda, CG. 1977. An investigation into the health of kapok workers. B rit J Ind M ed 34:181-185.

Vigliani, EC, L Parmeggiani, C Sassi. 1954. Studio de un epidemio di bronchite asmatica fra gli operi di una tessiture di cotone. M ed L au 45:349-378.

Vobecky, J, G Devroede, J Caro. 1984. R isk of largebowel cancer in synthetic fiber manufacture. Cancer 54:2537-2542.

Vobecky, J, G Devroede, I La C aille, A Waiter. 1979. An occupational group with a high risk of large bowel cancer. Gastroenterology 76:657.

Wood, CH, SA Roach. 1964. Dust in cardrooms: A continuing problem in the cotton spinning industry. B rit J Ind M ed 21:180-186.

Zuskin, E, D Ivankovic, EN Schachter, TJ Witek 1991. A ten year follow-up study of cotton textile workers. Am R ev R espir D is 143:301-305.

\section{O tras lecturas recomendadas}

Bouhuys, A, A Barbero, SE Lindell, SA Roach, RSF Schilling. 1967. Byssinosis in hemp workers. Arch Environ H ealth 14:533-544. 
Bouhuys, A, JV Duyn, HJV Lennep. 1961. Byssinosis in flax workers. Arch $\mathrm{E}$ nviron $\mathrm{H}$ ealth 3:499-509.

Bouhuys, A, LJ Heaply, RSF Schilling, JW Welborn. 1967. Byssinosis in the U nited States. N E ngl J M ed 277:170-175.

Bouhuys, A, SE Lindell, SA Roach, RSF Schilling 1967. Byssinosis in hemp workers. Arch Environ $H$ ealth 14:533-544.

Castellan, RM, SA Olenchock, KB K ingsley, $J \mathrm{~L} H$ ankinson. 1987. Inhaled endotoxin and decreased spirometric values: An exposure-response relationship for cotton dust. N E ngl J M ed 317:605.

Chwat, M, R M ordish. 1963. Byssinosis investigations into cotton plants in Israel. 14th International Conference in $O$ ccupational $\mathrm{H}$ ealth. International Congress Series No 62. Amsterdam: Excerpta M edica.

Collis, EL. 1909. Report of the Inspector of F actory W orkshops. Londres: $\mathrm{H}$ er M ajesty's Stationery O ffice.

Corn, JK . 1981. Byssinosis-An historical perspective. Am J Ind M ed 2:331-351.

Department of Employment. 1974. Safety Recommendations- I oint Standing Committee on Safety in the Cotton and Allied Fibres W eaving Industry. Londres: $\mathrm{Her} \mathrm{M} \mathrm{aj-}$ esty's Stationery 0 ffice.

Gandevia, B, J M ilne. 1965. Ventilatory capacity changes on exposure to cotton dust and their relevance to byssinosis in Australia. Brit J Ind M ed 22:295-304

Gilson, JC, H Stott, BEC Hopwood, SA Roach, CB M CK errow, RSF Schilling. 1962. Byssinosis: The acute effect on ventilatory capacity of dusts in cotton ginneries, cotton, sisal and jute mills. B rit J Ind $M$ ed 18:9-18.

Glindmeyer, HW, JJ Lefante, RN Jones, RJ Rando, HNA K ader, H Weill. 1991. Exposure-related de- clines in lung function of cotton textile workers: R elationship to current workplace standards. Am Rev R espir D is 144:675.

Grandjean, E. 1978. M anagement of the workplace $\mathrm{SO}_{2}$. Prevent $\mathrm{M}$ ed 23:372-378.

Greenhow, EH . 1860. Third Report of the M edical Officer of the Privy Council, Sir J ohn Simon, Appendix 6. Londres: $\mathrm{H}$ er M ajesty's Stationery O ffice.

Grund, N. 1995. Environmental considerations for textile printing products. J ournal of the Society of D yers and Colourists III (1/ 2):7-10.

$\mathrm{H}$ ealth and Safety Executive. 1975. Safety in the Cotton and Allied Fibres Industry: Spinning, W inding, and Sizing. $\mathrm{H}$ ealth and Safety at Work Series N o. 49C. Londres: $\mathrm{H}$ er $\mathrm{M}$ ajesty's Stationery $\mathrm{O}$ ffice.

-. 1980. Opening Processes: Cotton and Allied Fibres. Health and Safety Series Booklet HS(G). Londres: $\mathrm{H}$ er $\mathrm{M}$ ajesty's Stationery $\mathrm{O}$ ffice.

H eyden, S, P Pratt. 1980. Exposure to cotton dust and respiratory disease. Textile workers, brown lung and lung cancer. J AM A 244(16):1797-1798.

$\mathrm{H}$ ill, AB. 1930. Sickness among 0 peratives in L ancashire Cotton Spinning M ills. Industrial H ealth R esearch Board R eport N 0. 59. Londres: Her M ajesty's Stationery $O$ ffice.

H ussman, T. 1996. H ealth effects of indoor-air microorganisms. Scand J W ork E nviron H ealth 22:5-13.

K avaressi, N. 1976. Ergonomics in traditional Iranian industries. J $\mathrm{H}$ um E rgol (T okio) 5:145-147.

K ay, JP. 1831. O bservations and experiments concerning molecular irritation of the lungs as one source of tubercular consumption; and on spinner's phthisis. North Engl M ed Surg] 1:348-363.

Leach, J. 1863. Surat cotton, as it bodily affects operatives in cotton mills. Lancet 2:648-649.
Lu, P, DC Christiani, T Ye, N Shi, Z Gong, H Pai, W Zhang, J Huang, M Liu. 1987. The study of byssinosis in China. Am J Ind M ed 12:743-753.

M anuaba, A. 1976. Problems of ergonomics in Bali, Indonesia. J H um E rgol (T okio) 5:117-131.

M arks, R, AT C Robinson. 1976. Principles of W eaving. $M$ anchester: T extile Institute.

M organ, PGM , SG O ng. 1981. First report of byssinosis in H ong K ong. B rit J Ind M ed 38:290-292.

M ustafa, KY, AS Lakha, M H M illa, U Dalioma. 1978. Byssinosis, respiratory symptoms and spirometric lung function tests in T anzanian sisal workers. B rit $J$ Ind $M$ ed 35:123-128.

Perkins, H H Jr., SA O lenchock. 1995. W ashing cotton by batch processes to control dust and endotoxin. Ann Agric E nviron M ed 2:45.

Proust, AA. 1877. T raité d'hygiène publique et privée. París: $M$ asson.

Rylander, R, HR Imbus, MW Suh. 1979. Bacterial contamination of cotton as an indicator of respiratory effects among card room workers. Brit J Ind $M$ ed 36(4):299-304.

Schrag, PE, AD Gullett. 1970. Byssinosis in cotton textile mills. Am R ev Repir D is 101:497-503.

Spencer, DJ. 1983. Knitting T echnology. O xford: Pergamon Press $L t d$.

Takam, J, B Nemery. 1988. Byssinosis in a textile factory in Cameroon: A preliminary study. Brit J Ind $M$ ed 45: 803-809.

Wakelyn, PJ, GA Greenblatt, DF Brown, VW Tripp. 1976. Chemical properties of cotton dust. Am Ind $H$ yg Assoc j 37(1):22-31.

Wakelyn, PJ, R R Jacobs, IW K irk (eds.). 1986. W ashed Cotton: W ashing T echniques, Processing Characteristics, and $\mathrm{H}$ ealth E ffects. N ueva O rleans, Luisiana: USDA. 



\section{CONSTRUCCION Y \\ MANTENIMIENTO \\ AEROESPACIAL}

Director del capítulo

Buck Cameron

\section{Sumario}

La industria aeroespacial

Buck Cameron . . . . . . . . . . . . . . . . . . . . . . . . 90.2

Seguridad y ergonomía en la construcción aeronáutica Douglas F. Briggs.

Protección contra las caídas en la construcción

y el mantenimiento de los aviones comerciales

Robert W. Hites. . . . . . . . . . . . . . . . . . 90.6

Construcción de motores de aviación

fohn B. Feldman

Controles y efectos sobre la salud

Denis Bourcier. . . . . . . . . . . . . . . . . . . . . . . . 90.11

Guestiones ambientales y de salud pública

Steve Mason . . . . . . . . . . . . . . . . . . . . . . 90.13 


\section{LA INDUSTRIA AEROESPACIAL}

\section{Buck Cameron}

\section{Perfil general}

\section{Historia y tendencias futuras}

Cuando en 1903 Wilbur y Orville Wright efectuaron con éxito su primer vuelo, la construcción de aviones era un oficio que practicaban inventores y aventureros de forma artesanal en pequeños talleres. La aportación, pequeña aunque decisiva, de los aviones militares de la primera Guerra Mundial hizo que la construcción de aviones saliese de los talleres y pasara a la producción en serie. Los aviones de segunda generación permitieron a los operadores de posguerra adentrarse en el ámbito comercial, principalmente en el transporte de correo y carga urgente. Por aquel entonces, los aviones de línea seguían sin presurizar, sus sistemas de calefacción eran deficientes y no podían volar por encima de condiciones climatológicas adversas. A pesar de estos inconvenientes, el tráfico de pasajeros aumentó un $600 \%$ entre 1936 y 1941, aunque continuaba siendo un lujo sólo al alcance de unos pocos. Los significativos avances de la tecnología aeronáutica y la consiguiente utilización de la fuerza aérea durante la segunda Guerra Mundial alentaron el vertiginoso crecimiento de la construcción aeronáutica que tuvo lugar en los Estados Unidos, el Reino Unido y la Unión Soviética tras la finalización del conflicto. A partir de la segunda Guerra Mundial, los misiles tácticos y estratégicos, los satélites de navegación y reconocimiento, y las aeronaves tripuladas fueron ganado protagonismo en el ámbito aeronáutico militar. Las comunicaciones vía satélite y las tecnologías de control geográfico y de previsión meteorológica han ido ganando en importancia comercial. A finales del decenio de 1950, la aparición de los turborreactores comerciales hizo que los viajes en avión fueran más rápidos y cómodos, con lo que se disparó el crecimiento del transporte aéreo comercial. En 1993 la cifra anual de vuelo - en términos de pasajeros/millarondaba los 1,25 billones. Para el año 2013 se espera triplicarla.

\section{Patrones de empleo}

El empleo en las industrias aeroespaciales es muy cíclico. En la Unión Europea, América del Norte y Japón, el empleo directo en este sector pasó de un máximo de 1.770 .000 en 1989, a 1.300 .000 en 1995 , y la mayor parte de dicha reducción de empleo se produjo en los Estados Unidos y el Reino Unido. La gran industria aeroespacial de la Confederación de Estados Independientes se vio significativamente afectada tras el derrumbe de la Unión Soviética. En China y en India existen industrias de construcción aeronáuticas pequeñas, pero en rápido crecimiento. La construcción de cohetes espaciales y de misiles intercontinentales, así como de bombarderos de largo alcance, se ha visto casi exclusivamente restringida a Estados Unidos y la antigua Unión Soviética, a lo que se añaden los lanzamientos espaciales de carácter comercial de Francia. Ahora bien, la construcción de misiles estratégicos de más corto alcance, de misiles tácticos, de bombarderos, de cohetes para aplicaciones comerciales y de aviones de combate está más extendida. La construcción de los grandes reactores comerciales (con capacidad para 100 o más pasajeros) se hace en fábricas europeas y de Estados Unidos (o en cooperación con ellas). La construcción de aparatos regionales (con capacidad inferior a 100 pasajeros) y de reactores de negocios se encuentra mucho más dispersa. La construcción de aparatos destinados a pilotos privados, localizada principalmente en Estados Unidos, descendió de los aproximadamente 18.000 aparatos fabricados en 1978 , a menos de 1.000 en 1992, antes de iniciarse la recuperación del sector.
El empleo se encuentra repartido casi por igual entre los sectores constructores de aparatos militares, reactores comerciales, misiles y vehículos espaciales, y equipos asociados. Por lo que se refiere a las empresas privadas, los puestos de trabajo de la población activa se reparten por igual en las actividades de ingeniería, construcción y servicios administrativos. Cerca del $80 \%$ de los empleados en los sectores aeroespaciales de ingeniería y construcción son hombres, con una abrumadora mayoría de hombres entre profesionales de élite, ingenieros y responsables de producción.

\section{Divisiones del sector}

Las marcadamente distintas necesidades y prácticas de los clientes, públicos y privados, ocasionan la segmentación típica de los constructores aeroespaciales en empresas comerciales o para la defensa, o en divisiones pertenecientes a grandes corporaciones. Las células de avión, los motores (o sistema propulsor sin accesorios) y los equipos de aviónica (equipos electrónicos de navegación, comunicaciones y control de vuelo) son suministrados generalmente por fabricantes independientes. Los motores y los equipos de aviónica pueden suponer (cada uno) hasta una cuarta parte del coste final de un reactor comercial. La construcción aeroespacial integra el diseño, la fabricación, el montaje, la inspección y la prueba de una infinidad de componentes. Los fabricantes han establecido redes internas y externas de proveedores y subcontratistas para poder satisfacer sus necesidades de componentes. Las demandas de carácter económico, tecnológico, comercial y político han supuesto un incremento en la globalización de los sectores de la construcción de componentes y submontajes para la industria de construcción aeronáutica.

\section{Materiales, instalaciones y procesos de construcción}

\section{Materiales}

$\mathrm{Al}$ principio, los fuselajes de los aviones estaban construidos a base de madera y lona, que evolucionaron posteriormente por componentes estructurales metálicos. Las aleaciones de aluminio se han utilizado mucho debido a su ligereza y a su gran resistencia. También se utilizan aleaciones de berilio, titanio y magnesio, especialmente en la construcción de aviones de altas prestaciones. Los materiales compuestos modernos (conjuntos de fibras embutidas en matrices de plástico) son unos sustitutos, resistentes y de larga duración, a los componentes metálicos. Los materiales compuestos ofrecen una resistencia igual o superior a los metales actualmente utilizados, además de un peso menor y una resistencia térmica mayor, con la ventaja adicional - para la aviación militar - de que los fuselajes fabricados con materiales compuestos reducen significativamente el perfil radar. Los sistemas a base de resinas epóxicas son los materiales compuestos más utilizados en el sector aeroespacial: suponen cerca del $65 \%$ de todos los materiales utilizados. Cuando se requieren unos niveles elevados de resistencia a altas temperaturas se utilizan sistemas a base de resinas poliimídicas. Entre otros sistemas a base de resinas cabe destacar los fenólicos, los poliésteres y las siliconas. A menudo se utilizan las aminas alifáticas como agentes de curado. Entre las fibras de soporte utilizadas destacan el grafito, el Kevlar y la fibra de vidrio. Los estabilizadores, los catalizadores, los aceleradores, los antioxidantes y los plastificantes actúan como accesorios para producir la consistencia deseada. Otros sistemas a base de resinas son: los poliésteres saturados e insaturados, los poliuretanos y los polímeros vinílicos, los acrílicos y los que contienen urea y flúor.

Las imprimaciones, las lacas y los esmaltes protegen de la corrosión y de las temperaturas extremas a las superficies más vulnerables. Las capas de imprimación más comunes son las 
hechas de resinas sintéticas pigmentadas con cromato de zinc y con pigmentos extendidos. Secan con gran rapidez, mejoran la adhesión de las capas superiores y evitan la corrosión del aluminio, el acero y sus aleaciones. A las superficies a las que ya se ha aplicado la imprimación se añaden lacas y esmaltes con la intención de que sirvan de capas protectoras exteriores, a efectos de acabado y de coloración. Los esmaltes empleados en aviación se componen de aceites secantes, resinas naturales y sintéticas, pigmentos y disolventes. Dependiendo de sus respectivas aplicaciones, las lacas pueden tener resinas, agentes plastificantes, ésteres de celulosa, cromato de zinc, pigmentos, aprestos y disolventes adecuados. Las mezclas a base de caucho se utilizan habitualmente en pinturas, en materiales para el revestimiento de los depósitos de combustible, en lubricantes y en agentes conservadores, fijaciones del motor, prendas protectoras, mangueras, casquillos y juntas de estanqueidad. Los aceites, naturales y sintéticos, se emplean para refrigerar, lubricar y reducir la fricción en motores, sistemas hidráulicos y herramientas de máquinas. La gasolina de aviación y el combustible empleado por los reactores se obtienen a partir de hidrocarburos derivados del petróleo. Los combustibles sólidos y líquidos de alta energía se utilizan en aplicaciones espaciales y contienen materiales inherentemente peligrosos por sus propiedades químicas y físicas; entre estos materiales cabe citar el oxígeno líquido, la hidracina, los peróxidos y el flúor.

Muchos materiales utilizados en los procesos de fabricación no llegan a formar parte de la propia estructura del avión. Es frecuente que los fabricantes dispongan de decenas de miles de productos homologados para su uso, aunque hay algunos que ni siquiera llegan a utilizarse. Los disolventes empleados son muchos y variados; entre sus variantes hay algunos, como el freón y la metiletilcetona, que causan daños al medio ambiente y que se están sustituyendo por otros disolventes más ecológicos. Las aleaciones de acero que contienen cromo y níquel se utilizan en la fabricación de herramientas, y en las herramientas de corte en particular se emplean cuchillas de metal duro que contienen cobalto y carburo de tungsteno. El plomo, que solía utilizarse en los procesos de fabricación del acero, apenas se emplea en la actualidad, ya que ha sido sustituido por kirkisita.

En total, la industria aeroespacial utiliza más de 5.000 productos químicos y mezclas de compuestos químicos, en su mayoría procedentes de numerosos proveedores, y muchos de los compuestos contienen entre cinco y diez ingredientes. La composición exacta de algunos de estos productos está patentada o es un secreto comercial, lo que añade complejidad a tan heterogéneo grupo.

\section{Instalaciones y procesos de construcción}

La construcción de aviones se hace por lo general en grandes plantas integradas. Las más modernas disponen de sistemas de renovación de aire de gran capacidad, con controles de aire de relleno. Para funciones específicas se añaden sistemas locales de aspiración de aire. En la actualidad, las actividades de fresado químico y de pintura de grandes componentes se efectúan de manera rutinaria en recintos cerrados o cabinas donde el trabajo en las distintas fases está clasificado y automatizado, y donde se producen emanaciones de vapores o vahos. En las instalaciones de construcción aeronáutica más antiguas, el control de riesgos ambientales es más deficiente.

Un numeroso equipo de ingenieros expertos son los que elaboran y perfeccionan las características estructurales de los aviones o de los vehículos espaciales. Otros técnicos se encargan de los niveles de resistencia y durabilidad de los materiales de los componentes y elaboran procesos de fabricación eficaces. Buena parte de la carga de trabajo que suponían los cálculos y los trabajos de delineación -que antes realizaban ingenieros, delineantes y personal técnico- lo hacen ahora los ordenadores: hoy en día los sistemas informáticos integrados se emplean para construir aviones sin necesidad de planos en papel ni de modelos estructurales a escala. El proceso comienza con la fabricación de las piezas a partir de los materiales generales: se hacen plantillas y herramientas, laminación de metal, mecanizado, trabajos con plásticos y materiales compuestos, y otras actividades auxiliares. Las herramientas se fabrican para servir de plantillas y superficies de trabajo sobre las que se fabrican piezas de metal o de materiales compuestos. Las plantillas se emplean como patrones de guía para cortar, taladrar y montar. Por lo general, las subsecciones del fuselaje, los paneles de las puertas y los revestimientos (superficies externas) de las alas y de la cola están fabricados en chapa de aluminio perfilada y cortada con precisión y tratada químicamente. El funcionamiento de las máquinas se controla por ordenador. Grandes fresas montadas sobre raíles efectúan el mecanizado de los largueros de las alas a partir de piezas únicas de aluminio forjado. Las piezas de menor tamaño se cortan con precisión y se moldean con fresas, muelas y tornos. Las conducciones se fabrican con lámina de acero o con materiales compuestos. Los componentes internos, como el suelo, por lo general se fabrican con laminados o con materiales compuestos, a base de múltiples capas de revestimiento muy delgadas pero de gran rigidez, dispuestas sobre estructuras de panal. Los materiales compuestos suelen disponerse (es decir, colocarse cuidadosamente en capas superpuestas) a mano o mecánicamente, para su posterior curado en hornos o en autoclaves.

La fase de montaje comienza con la elaboración de submontajes a partir de las piezas componentes. Entre los submontajes principales destacan las alas, los estabilizadores, las secciones del fuselaje, el tren de aterrizaje, las puertas y los componentes interiores. El montaje de las alas resulta particularmente laborioso, ya que requiere taladrar con precisión numerosos orificios en el revestimiento metálico, en los que se introducen los clavos para remachar. Una vez terminado, el ala se limpia y se sella desde el interior para asegurar la estanqueidad de los depósitos de combustible. El montaje final tiene lugar en inmensas naves de montaje, algunas de las cuales se cuentan entre los edificios de construcción más grandes del mundo. La línea de montaje consta de varias posiciones secuenciales en cada una de las cuales permanece la estructura del avión durante varios días — e incluso hasta más de una semana- mientras se efectúan los trabajos correspondientes. Numerosos trabajos de montaje tienen lugar simultáneamente en cada una de las posiciones, con lo que se originan situaciones en las que puede producirse una exposición cruzada a productos químicos. Las piezas y los submontajes se colocan en la posición apropiada por medio de plataformas rodantes, dispositivos de transporte fabricados a medida y grúas-puente. Estas últimas desplazan la estructura del avión de una posición a otra hasta que queden instalados los trenes de aterrizaje principal y de morro. A partir de ese momento, los desplazamientos se efectúan remolcando la estructura del avión.

Durante la fase final de montaje, las secciones del fuselaje se ensamblan entre sí en torno a un armazón, mediante remaches embutidos. A continuación se colocan las vigas y los largueros de sustentación del suelo del aparato, y se recubre todo el interior con una capa de compuesto anticorrosión. Las secciones delantera y trasera del fuselaje se ensamblan con las alas por medio de la sección de encastre (una estructura en forma de caja que actúa como depósito principal de combustible y como centro estructural del avión). El interior del avión se cubre en su totalidad con mantas de fibra de vidrio que actuarán de aislante, se tienden el cableado eléctrico y las conducciones de aire, al tiempo que las superficies interiores se cubren de paneles 
decorativos. A continuación - y para uso de los pasajeros - se procede a instalar las luces y las máscaras de oxígeno de emergencia, que incorporan habitualmente los portaequipajes. Las cocinas, los aseos y los asientos - ensamblados previamentese instalan manualmente asegurándolos a los raíles de fijación que discurren por todo el suelo del avión, y que permiten cambiar rápidamente la configuración de la cabina de pasajeros, de acuerdo con las necesidades de la compañía. A continuación se instalan los trenes de aterrizaje principal y de morro, así como las plantas motrices y los equipos de aviónica. Una vez comprobado exhaustivamente el funcionamiento de la totalidad de los componentes del avión, éste se remolca hasta un hangar independiente y bien ventilado para proceder a su pintura. El pintado comienza por una capa de imprimación protectora (por lo general a base de cromato de zinc) seguida de una capa decorativa externa a base de pinturas de uretano o epoxídicas. Antes de proceder a su entrega, el avión es sometido a una serie de rigurosas pruebas tanto en tierra como en vuelo.

Además de los trabajadores que participan en los procesos reales de ingeniería y construcción, hay otros muchos dedicados a las tareas de planificación, seguimiento e inspección de trabajos, facilitando así el trasiego de piezas y de herramientas. El personal técnico se encarga del mantenimiento de las herramienta mecánicas y de la puesta a punto de los dispositivos de corte. Se precisan también muchos trabajadores para el mantenimiento de las instalaciones, los servicios de conserjería y manejo del parque de vehículos .

\section{- SEGURIDAD Y ERGONOMIA EN LA CONSTRUCCION AERONAUTICA}

\section{Douglas F. Briggs}

\section{Gestión de la seguridad}

Los sistemas de gestión para la industria de la construcción aeronáutica han reflejado el proceso evolutivo experimentado por la gestión de la seguridad en el ámbito de la construcción tradicional. Los programas de salud y seguridad solían estar muy estructurados, dirigidos por los ejecutivos de las compañías y estructurados jerárquicamente de acuerdo con los sistemas de gestión tradicionales de control y mando. Las grandes compañías del sector aeronáutico y aeroespacial disponen de equipos de profesionales especializados en el campo de la salud y la seguridad (especialistas en higiene industrial, radiofísicos, ingenieros de seguridad, enfermeras, médicos y demás personal técnico) que trabajan con los mandos intermedios para abordar los diversos riesgos para la seguridad que entrañan sus respectivos procesos de construcción. Tal concepción de los programas de seguridad, controlados por los mandos intermedios, supervisados por un encargado de la gestión diaria de riesgos ayudado por un equipo de profesionales especializados en el campo de la salud y la seguridad, fue el modelo original desde el nacimiento del sector. La introducción de normas detalladas en los Estados Unidos a principios del decenio de 1970, hizo que la confianza se depositara cada vez más en los profesionales especializados en materia de salud y de seguridad, no sólo en cuanto al desarrollo de programas, sino también a su aplicación y evaluación. El cambio fue debido a la naturaleza técnica de las normas que no eran del todo comprendidas ni se aplicaban a los procesos de construcción. Como consecuencia, numerosos sistemas de gestión de la seguridad pasaron a convertirse en sistemas basados en el cumplimiento más que en la prevención de lesiones y enfermedades. Los anteriores programas integrados de gestión de la seguridad, controlados por los mandos intermedios, perdieron parte de su eficacia cuando la complejidad de las normas exigió una mayor dependencia con respecto a los equipos de profesionales especializados en salud y seguridad en todos los aspectos de los programas de seguridad, al tiempo que se descargó a los mandos intermedios de ciertas responsabilidades.

Con el aumento a nivel mundial de la importancia concedida a la gestión de la calidad total, la línea de producción ha recobrado su protagonismo. Los constructores del sector aeronáutico están adoptando programas que incluyen la seguridad como un componente integral de todo proceso fiable de construcción. El grado de cumplimiento pasa a ocupar un segundo lugar, en el convencimiento de que, centrándose en procesos fiables la prevención de lesiones y enfermedades constituirá el objetivo prioritario, y las normativas o sus intenciones se cumplirán con el establecimiento de procesos fiables. Actualmente, el conjunto del sector dispone de programas tradicionales, programas basados en procedimientos y técnicas, y programas basados en el comportamiento cuyas aplicaciones son cada vez mayores. Con independencia del modelo específico, los que demuestran los mayores niveles de aciertos en cuanto a la prevención de lesiones y enfermedades son los que cumplen tres requisitos decisivos: a) un compromiso patente tanto por parte de la gerencia como de los trabajadores, b) unas expectativas claras en cuanto al resultado en materia de prevención de lesiones y enfermedades, $\mathrm{y} c$ ) sistemas de responsabilidad y reconocimiento basados tanto en criterios de medidas (datos sobre lesiones y enfermedades) como en indicadores de procesos (porcentaje de comportamiento seguro) o en cualesquiera otras acciones preventivas proactivas que tengan el mismo peso que otros objetivos primordiales de organización. La totalidad de los sistemas antes mencionados conducen a una cultura positiva en materia de seguridad, gestionada por la dirección aunque con amplia participación de los trabajadores tanto en el diseño del proceso como en los esfuerzos para su perfeccionamiento.

\section{Seguridad física}

El sector de la construcción aeronáutica entraña varios riesgos potencialmente graves, debido en buena medida a las descomunales proporciones físicas de algunos de sus productos, a la complejidad de los mismos y al carácter diverso y variable del conjunto de los procesos de construcción y de montaje del sector. La exposición a estos riesgos (ya sea por inadvertencia o control inadecuado) puede originar lesiones graves de inmediato.

En la Tabla 90.1 se ofrece una visión general de los peligros físicos para la seguridad identificados en este sector.

Las fuentes del traumatismo directo e inmediato son variadas: simple caída de una barra de remachar o de cualquier otro objeto; tropezar en superficies irregulares, sucias o escurridizas; caídas desde pasarelas de grúa, escaleras de mano, andamios y grandes estructuras de montaje; contacto con dispositivos eléctricos sin conexión a tierra, con objetos calientes, con soluciones químicas, con cuchillas, brocas y hojas desbastadoras; engancharse los cabellos, las manos o las prendas de vestir en fresadoras, tornos y punzadoras; proyección de partículas, virutas y otros fragmentos al taladrar, desbastar y soldar; y contusiones y cortes ocasionados por golpes contra piezas y componentes de las estructura del avión durante el proceso de construcción.

La frecuencia y gravedad de las lesiones relacionadas con situaciones de riesgo físico que afectan a la seguridad se han ido reduciendo a medida que maduraban los procesos de seguridad en el sector. Las lesiones y enfermedades relacionadas con situaciones de riesgos de carácter ergonómico son fiel reflejo de la mayor preocupación que muestran todas las firmas constructoras y de servicios. 
Tabla 90.1 • Riesgos para la seguridad en las industrias aeronáutica y aeroespacial.

\begin{tabular}{|c|c|c|}
\hline Tipo de riesgo & Ejemplos típicos & Posibles efectos \\
\hline \multicolumn{3}{|l|}{ Físicos } \\
\hline Caída de objetos & $\begin{array}{l}\text { Pistolas de remachado, barras de remachar, pasadores, herra- } \\
\text { mientas de mano }\end{array}$ & Contusiones, lesiones en la cabeza \\
\hline Equipos móviles & Camiones, tractores, bicicletas, carretillas elevadoras, grúas & Contusiones, fracturas, laceraciones \\
\hline Alturas peligrosas & $\begin{array}{l}\text { Escaleras de mano, andamiajes, soportes de aviones, cunas de } \\
\text { montaje }\end{array}$ & Lesiones graves múltiples, muerte \\
\hline Objetos punzantes & Cuchillas, brocas, hojas de sierra o de desbastar & Laceraciones, heridas punzantes \\
\hline Maquinaria en movimiento & Tornos, punzonadoras, fresadoras, cizallas & Amputaciones, avulsiones, lesiones por aplastamiento \\
\hline Fragmentos en suspensión en el aire & Taladrado, lijado, aserrado, escariado, rectificado & Cuerpos extraños en el ojo, abrasiones de la córnea \\
\hline Materiales calientes & $\begin{array}{l}\text { Metales tratados térmicamente, superficies soldadas, aclarados } \\
\text { con agua hirviendo }\end{array}$ & $\begin{array}{l}\text { Quemaduras, formación de ampollas, cambios en la } \\
\text { pigmentación }\end{array}$ \\
\hline Metales calientes, escorias, sedimentos & Soldadura, corte con soplete, trabajos de fundición & Quemaduras graves en la piel \\
\hline Equipos eléctricos & $\begin{array}{l}\text { Herramientas de mano, cables eléctricos, lámparas portátiles, } \\
\text { cajas de empalmes }\end{array}$ & Contusiones, esguinces, quemaduras, muerte \\
\hline Fluidos a presión & Sistemas hidráulicos, engrase sin aire y pistolas pulverizadoras & Lesiones oculares, heridas subcutáneas graves \\
\hline Alteración de la presión del aire & $\begin{array}{l}\text { Ensayos de presurización del avión, autoclaves, cámaras de } \\
\text { pruebas }\end{array}$ & Lesiones en oídos, senos y pulmones, parálisis \\
\hline Temperaturas extremas & $\begin{array}{l}\text { Trabajo con metales en caliente, fundiciones, trabajos de fabrica- } \\
\text { ción con metales en frío }\end{array}$ & Agotamiento por calor, congelaciones \\
\hline Ruidos fuertes & $\begin{array}{l}\text { Remachado, pruebas de motores, taladrado a alta velocidad, } \\
\text { martinetes }\end{array}$ & Pérdida auditiva transitoria o permanente \\
\hline Radiaciones ionizantes & $\begin{array}{l}\text { Radiografía industrial, aceleradores, investigación sobre } \\
\text { radiación }\end{array}$ & Esterilidad, cáncer, síndrome de radiación, muerte \\
\hline Radiaciones no inonizantes & $\begin{array}{l}\text { Soldadura, rayos láser, radares, hornos de microondas, trabajos } \\
\text { de investigación }\end{array}$ & Quemaduras de córnea, cataratas, quemaduras de retina, cáncer \\
\hline Andar o trabajar en superficies & $\begin{array}{l}\text { Lubricantes derramados, herramientas fuera de su sitio, } \\
\text { mangueras y cables eléctricos }\end{array}$ & Contusiones, laceraciones, esguinces, fracturas \\
\hline \multicolumn{3}{|l|}{ Ergonómicos } \\
\hline Trabajos en espacios reducidos & Depósitos de combustible en los aviones, alas & Privación de oxígeno, atrapamiento, narcosis, ansiedad \\
\hline Grandes esfuerzos & $\begin{array}{l}\text { Levantamiento, transporte, patines tubulares, herramientas } \\
\text { manuales, trefiladoras }\end{array}$ & $\begin{array}{l}\text { Fatiga excesiva, lesiones musculosqueléticas, síndrome del túnel } \\
\text { carpiano }\end{array}$ \\
\hline Vibraciones & Remachado, lijado & Lesiones musculosqueléticas, síndrome del túnel carpiano \\
\hline Interfaz hombre-máquina deficiente & Empleo de herramientas, posturas incómodas de montaje & Lesiones musculosqueléticas \\
\hline Movimientos repetitivos & $\begin{array}{l}\text { Tecleado de datos, trabajos de diseño de ingeniería, tendido de } \\
\text { plásticos }\end{array}$ & Síndrome del túnel carpiano, lesiones musculosqueléticas \\
\hline
\end{tabular}

Adaptado de Dunphy y George 1983.

\section{Factores ergonómicos}

Las empresas dedicadas a la construcción aeronáutica gozan de un amplio historial en la utilización de factores humanos en la elaboración de sistemas esenciales para sus productos. La cabina de vuelo ha sido una de las partes más estudiadas de toda la historia del diseño industrial: los técnicos en factores humanos han dedicado sus esfuerzos a optimizar los niveles de seguridad en vuelo. Actualmente, la ergonomía aplicada a la prevención de lesiones y enfermedades, a la que se concede cada vez mayor importancia, no es más que una ampliación del trabajo realizado previamente en el campo de los factores humanos. Es un sector en el que son frecuentes los esfuerzos, las posturas inadecuadas, las acciones repetitivas, el estrés por contacto con máquinas y por vibraciones. La exposición a estos riesgos puede exacerbarse por el hecho de trabajar en espacios reducidos, como el interior de las alas o los depósitos de combustible. Para abordar estos aspectos, el sector acude a ergónomos en diseño de procesos y productos, así como a la "ergonomía participativa", es decir, a equipos interdepartamentales compuestos por personal de producción, supervisores y diseñadores de herramientas e instalaciones que trabajan conjuntamente para reducir los riesgos ergonómicos en sus respectivos procesos.

En el sector de la construcción aeronáutica, una de las preocupaciones clave en materia de ergonomía son los talleres de cableado, que requieren la utilización de numerosas herramientas manuales para desmontar y engarzar, y que precisan el empleo de grandes fuerzas de agarre. En su mayor parte, estas herramientas están siendo sustituidas por otras que, cuando son 
pesadas, se suspenden de dispositivos dotados de contrapesos. Los puestos de trabajo de altura regulable, diseñados tanto para varones como para mujeres, ofrecen la opción de permanecer de pie o sentado. El trabajo se organiza en células, de manera que cada trabajador realiza tareas variadas que reducen la fatiga de cualquier conjunto de músculos concreto. En las líneas alares, otra zona clave, es necesario dotar a los trabajadores, a las piezas y a las herramientas de almohadillas de amortiguación para reducir el estrés provocado por el contacto con máquinas en espacios reducidos. En las líneas alares se emplean también plataformas de trabajo regulables en altura, en vez de escaleras de mano, para reducir al mínimo los riesgos de caídas y permitir que los trabajadores realicen las tareas de taladro y remache en posiciones neutras. Las áreas de remachado siguen constituyendo uno de los principales retos dado que presentan los riesgos derivados tanto de las vibraciones generadas como de los esfuerzos excesivos que es preciso realizar. Para resolver esto están empezando a incorporarse técnicas de remachado electromagnético y remachadoras de bajo retroceso, pero debido tanto a algunos de los criterios de actuación de los propios productos como a las limitaciones prácticas de estas técnicas en alguno de los aspectos del proceso de construcción, ninguna de las dos opciones es una solución de carácter general.

Con la incorporación de materiales compuestos, por cuestiones de rendimiento y de peso, la colocación manual en capas que se hace de los mismos ha supuesto también la aparición de nuevos riesgos potenciales debido a la excesiva utilización de las manos para dar forma, cortar y trabajar estos materiales. Para reducir estos riesgos se están incorporando otras herramientas de tamaño de agarre variable y otros procesos automatizados. Asimismo se utilizan herramientas ajustables para poder trabajar con posturas neutras. En los procesos de montaje constituye todo un reto el número de posturas incorrectas y de operaciones manuales difíciles que se producen, de lo cual suelen ocuparse los procesos ergonómicos participativos. Los riesgos se reducen aumentando la utilización, siempre que sea posible, de dispositivos mecánicos de izada; reorganizando la secuencia de trabajo y estableciendo otras mejoras en el proceso que no sólo se ocupen de los riesgos ergonómicos, sino que beneficien la productividad y la calidad del producto.

\section{- PROTECCION CONTRA LAS CAIDAS EN LA CONSTRUCCION Y EL MANTENIMIENTO DE LOS AVIONES COMERCIALES}

\section{Robert W. Hites}

En el sector de la carga aérea y de las compañías de aviación, los aviones comerciales se utilizan para el transporte de pasajeros y de carga. Los procesos de construcción y de mantenimiento implican actividades de retirada, fabricación, alteración e instalación de componentes en todo el aparato. El tamaño de los aviones varía, aunque algunos (como el Boeing B-747 y el Airbus A340) se encuentran entre los más grandes del mundo; de ahí que ciertas actividades requieran que el personal trabaje a una altura superior a la del suelo o la superficie del terreno.

En el ámbito del sector del transporte aéreo suelen producirse situaciones de caídas potenciales tanto en la fase de construcción como en la de mantenimiento. Aunque cada situación sea única y requiera una solución diferente en términos de protección, el mejor método de protección contra las caídas es la prevención de éstas por medio de un plan estricto de identificación y control de riesgos.

Para que la protección contra las caídas sea eficaz debe haber un compromiso institucional que aborde la totalidad de los aspectos relativos a la identificación y al control de riesgos. Cada operador debe evaluar continuamente las situaciones concretas de exposición a caídas y elaborar un plan de protección lo suficientemente exhaustivo para que contemple todas esas situaciones en el desempeño de su trabajo.

\section{Riesgos de caída}

Siempre que alguien se encuentra en un lugar elevado respecto al suelo está potencialmente expuesto a caer a un nivel inferior. Las caídas que se producen desde lugares elevados suelen originar lesiones graves e incluso mortales. Con ese fin se han elaborado normas, disposiciones y políticas que ayudan a las compañías a abordar la cuestión de los riesgos de caídas que puedan producirse en el transcurso de sus actividades.

Se produce una exposición al riesgo de caída en cualquier situación en la que una persona trabaja en una superficie elevada, cuando la distancia al nivel inmediatamente inferior es de varios metros. La evaluación de las actividades relativas a estas situaciones de exposición conlleva la identificación de todas aquellas áreas o tareas en las cuales existe la posibilidad de que las personas tengan que trabajar sobre superficies elevadas.

Los registros de enfermedades y lesiones (estadísticas laborales, registros de empresas aseguradoras, registros médicos, de seguros, etc.) constituyen una buena fuente de información; sin embargo, es importante no estancarse en los meros hechos históricos.

Cada proceso o área de trabajo debe evaluarse para establecer la posible existencia de situaciones en las que la tarea o el proceso en cuestión requieran que la persona trabaje en una zona o superficie situada a varios metros de altura sobre el nivel inmediatamente inferior.

\section{Clasificación por categorías de las situaciones de caída}

Debido a las dimensiones de los aparatos, no existe prácticamente tarea alguna relacionada con la construcción o con el mantenimiento de este tipo de aeronaves que no entrañe un riesgo potencial de exposición a las caídas para el personal. Las dimensiones de las aeronaves es tal que prácticamente no hay zonas que no se encuentren a varios metros de altura del suelo. Aunque ello da lugar a numerosas situaciones en las que el personal se expone al riesgo de sufrir una caída, aquélla pueden clasificarse en categorías según se trate de trabajos en altura realizados sobre plataformas o de trabajos en altura realizados sobre las superficies del avión. La división tiene su origen en los factores que intervienen al abordar las propias exposiciones al riesgo de sufrir una caída.

La primera categoría se refiere al personal que utiliza plataformas o andamiajes para acceder al avión. Incluye cualquier trabajo efectuado desde una superficie elevada ajena al propio avión y que se utilice, de manera específica, para acceder al mismo. También se incluyen en esta categoría todas aquellas tareas desarrolladas desde sistemas de estacionamiento de aeronaves para su mantenimiento, plataformas alares, soportes de motor, carretillas elevadoras y similares. Los riesgos potenciales de exposición a caídas desde superficies elevadas que se contemplan en esta categoría pueden abordarse por medio de sistemas tradicionales de protección contra las caídas, o mediante los numerosos sistemas de actuación que existen actualmente.

La segunda categoría afecta al personal que utiliza las superficies del avión como plataformas de acceso al mismo. Se incluyen aquí todos los trabajos realizados sobre cualquier superficie del avión, como las alas, los estabilizadores horizontales, el fuselaje, 
Figura 90.1 - Sistema portátil de barandillas para los Boeing 747; el sistema de barandillas protectoras de dos lados se acopla al costado del fuselaje, como protección contra posibles caídas durante los trabajos efectuados en las puertas situadas sobre el ala y en la zona del extradós.

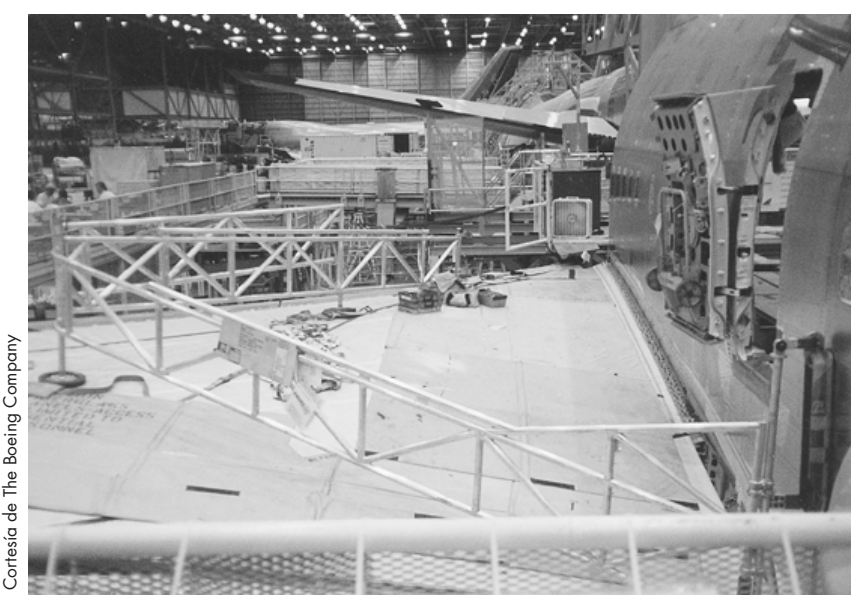

los motores o sus soportes. Los riesgos de exposición potenciales en esta categoría varían mucho en función la tarea de mantenimiento que se esté realizando; en ocasiones requieren planteamientos poco habituales en materia de protección.

La razón para distinguir entre ambas categorías queda clara al tratar de aplicar medidas de protección, es decir, actuaciones destinadas a eliminar o controlar cada riesgo de exposición. Los métodos para controlar las situaciones de riesgo de caídas pueden consistir en controles técnicos, equipos de protección personal (EPP) o controles de procedimiento

\section{Controles técnicos}

Los controles técnicos son medidas por las que se alteran las instalaciones para reducir al mínimo la exposición del personal a situaciones de riesgo. Como ejemplo puede citarse las barandillas, los muros y similares. Los controles técnicos son los métodos preferidos para proteger al personal frente al riesgo de sufrir caídas.

Los controles técnicos son la medida más empleada en las plataformas, tanto en su construcción como en su mantenimiento. Por lo general suele tratarse de barandillas comunes; no obstante, cualquier barrera que cierre los laterales abiertos de una plataforma, supone una protección eficaz para el personal frente al riesgo de sufrir caídas. En caso de que la plataforma esté colocada junto al avión, como suele suceder, el lado que coincide con la nave no necesita barandilla, ya que la protección la ofrece el propio aparato; el riesgo quedaría limitado a los espacios de separación entre el avión y la plataforma.

Por lo común, los controles técnicos no suelen utilizarse para las labores de mantenimiento que se hacen sobre las superficies del avión, ya que cualquier control técnico que se instale en el avión supondría un aumento del peso, con la consiguiente reducción de la eficacia durante el vuelo. Por sí mismos, los controles son ineficaces cuando se diseñan para proteger el perímetro de cualquiera de las superficies del avión, ya que deben ser específicos para cada zona, ubicación y tipo de aparato, y deben colocarse de forma que el aparato no sufra daño alguno. En la Figura 90.1 se muestra un sistema de barandilla portátil para un ala de avión. Los controles técnicos se utilizan mucho en los procesos de fabricación sobre las superficies de los aviones. Son eficaces durante la fabricación, ya que los procesos se llevan a cabo en el mismo lugar y con la superficie del avión en la misma posición en todas las ocasiones, de manera que los controles pueden hacerse a medida para un lugar y una posición concretos.

Una alternativa al empleo de barandillas para los controles técnicos es colocar redes en torno a la plataforma o a la superficie del avión, capaces de recoger a aquellos trabajadores que sufran una caída. Son eficaces para recoger al trabajador que cae, pero su aceptación no es generalizada, ya que son frecuentes las lesiones producidas al chocar con la propia red. Asimismo, son sistemas que requieren su correspondiente procedimiento para la retirada o rescate de las personas que han caído en la red.

\section{Equipos de protección personal (EPP)}

Los EPP contra caídas constan de un arnés de cuerpo entero con un cabo enganchado a un cable salvavidas del barandillado o a cualquier otro tipo de anclaje adecuado. Se trata de sistemas utilizados habitualmente para frenar la caída, aunque pueden emplearse también con sistemas de sujeción contra las caídas.

Figura 90.2 - Andamio de motor, con protección frente a caídas, para trabajadores especialistas en motores de avión.

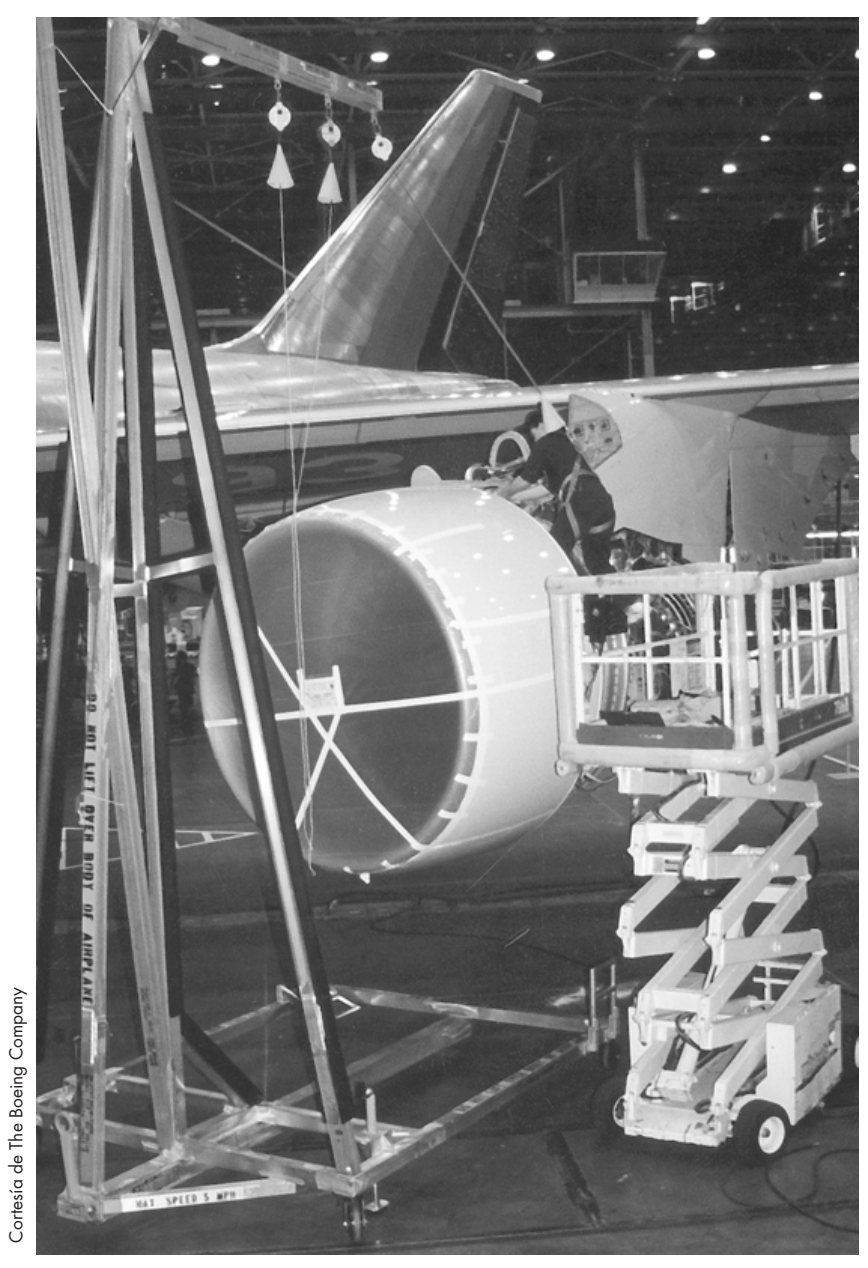


Figura 90.3 • Sistema de desconexión rápida sobre el ala de un Boeing 747.

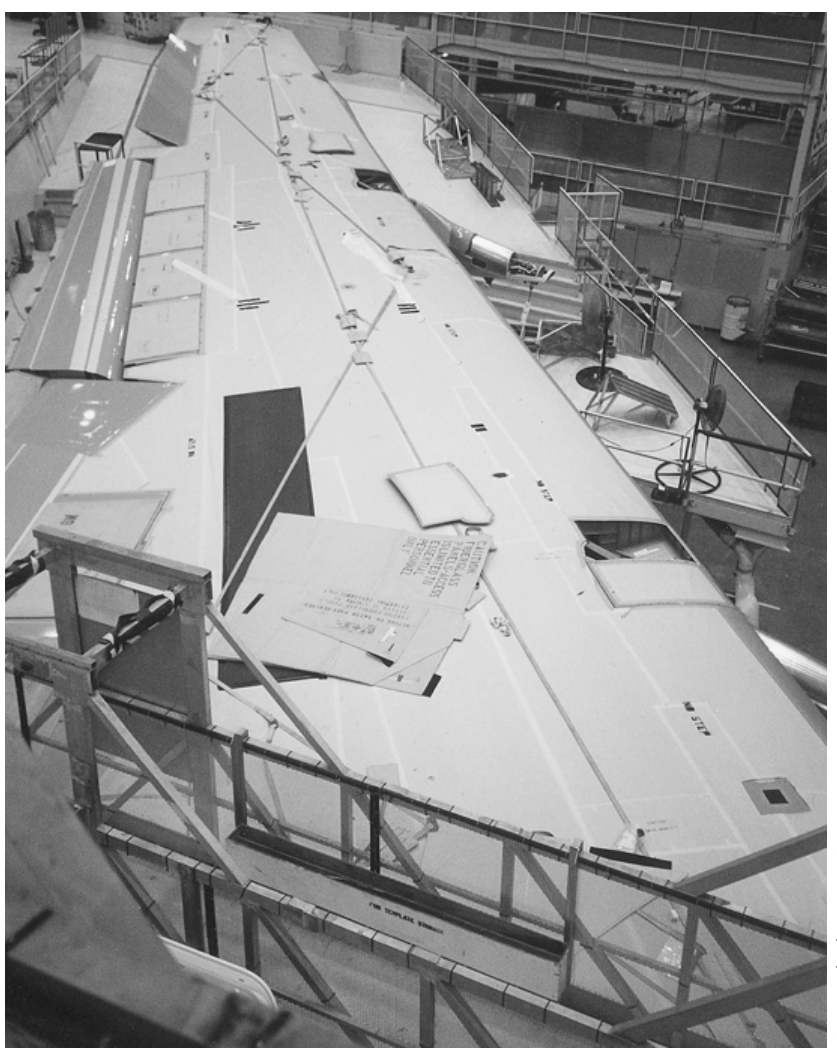

Los equipos de protección personal (EPP), utilizados en sistemas de amortiguación de caídas, son eficaces para evitar que una persona se golpee con el nivel inmediatamente inferior en una caída. Para que resulte eficaz, la distancia prevista de caída no debe superar la distancia hasta el nivel inferior. Aún así, este tipo de sistemas no impiden que la persona pueda lesionarse como consecuencia de la propia amortiguación de la caída. Son sistemas que precisan igualmente de un procedimiento para el rescate/recuperación de las personas una vez que han caído y su caída ha sido amortiguada.

Los sistemas de amortiguación de caídas se utilizan sobre todo al trabajar sobre plataformas en las cuales los controles técnicos resultan ineficaces, generalmente por las propias limitaciones del proceso de trabajo. También se utilizan para trabajar sobre las superficies del avión, debido a las dificultades logísticas asociadas a los controles técnicos. Los aspectos más problemáticos de los sistemas de amortiguación de caídas y del trabajo sobre las superficies del avión son la distancia de caída con respecto a la movilidad del personal y el peso añadido a la estructura del avión para sostener el sistema. La cuestión del peso puede eliminarse si el sistema se diseña de manera que se ancle a algún lugar de la instalación en torno a la superficie del avión, en vez de a la propia estructura del aparato; no obstante, también esto supone una limitación a la capacidad protectora contra las caídas en la ubicación de la propia instalación. En la Figura 90.2 se muestra un andamio portátil utilizado como sistema de amortiguamiento de caídas. Los sistemas de este tipo se emplean en tareas de mantenimiento más que en las de construcción (aunque se usan en ciertos momentos de la fase de construcción).
Figura 90.4 • Zonas de protección contra caídas del sistema de desconexión rápida sobre el ala de un Boeing 747.

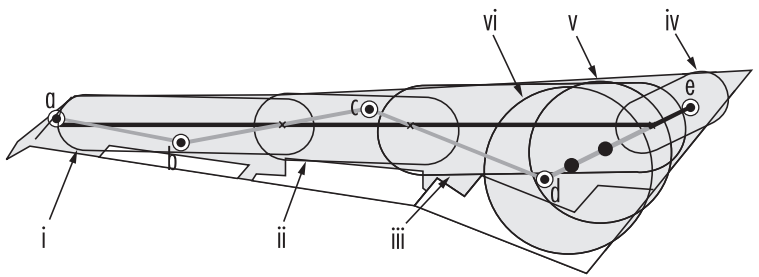

Producción

\begin{tabular}{|c|c|c|}
\hline Descripción: & Línea de vida horizontal: & Longitud de la barandilla: \\
\hline Tipo: & Limitación de caída & Zona i) $152,4 \mathrm{~cm}$ \\
\hline \multicolumn{2}{|c|}{ Anclaje: } & ii) $152,4 \mathrm{~cm}$ con prolongación de $30,48 \mathrm{~cm}$ \\
\hline \multirow{2}{*}{\multicolumn{2}{|c|}{$\begin{array}{l}\text { a) Empalme desmontable } \\
\text { b) Empalme desmontable }\end{array}$}} & iii) $152,4 \mathrm{~cm}$ con prolongación de $91,44 \mathrm{~cm}$ \\
\hline & & iv) $152,4 \mathrm{~cm}$ con prolongación de $30,48 \mathrm{~cm}$ \\
\hline \multicolumn{2}{|c|}{ c) Soporte de enganche de la } & $\begin{array}{l}\text { v) } 152,4 \mathrm{~cm} \text { con prolongación de } 228,6 \mathrm{~cm} \\
\text { vi) } 152,4 \mathrm{~cm} \text { con prolongación de } 304,8 \mathrm{~cm}\end{array}$ \\
\hline
\end{tabular}

cuerda de evacuación

d) Empalme desmontable

Dispositivo de desaceleración: ninguno

e) Soporte empernado

Fuente: Cortesía de The Boeing Company.

Un sistema de sujeción contra caídas está diseñado de manera que el personal no pueda caer por el borde de una superficie. Son sistemas muy parecidos a los de amortiguación, ya que todos los componentes son los mismos; ahora bien, los de sujeción limitan la libertad de movimientos de la persona, que no puede llegar lo suficientemente cerca del borde de la superficie como para caerse. De los sistemas de protección personal, los de sujeción son los preferidos tanto para trabajos de mantenimiento como de construcción, ya que evitan cualquier lesión por las caídas y no precisan de labores de rescate. Su uso no está extendido ni en el trabajo sobre plataformas ni sobre las superficies del avión, debido a las dificultades que entraña el diseño de sistemas que permitan la libertad de movimientos que los trabajadores necesitan para desarrollar su tarea, a la vez que su acceso al borde de la superficie queda restringido. Son sistemas que reducen el problema del peso y de la eficacia al trabajar sobre las superficies del avión, ya que no requieren la resistencia necesaria en los de amortiguamiento. En el momento de imprimir esta publicación, sólo existe un tipo de avión (el Boeing 747) que disponga de un sistema de sujeción contra caídas incorporado a su estructura (véanse las Figuras 90.3 y 90.4).

Hay un cable salvavidas horizontal enganchado a unos ajustes permanentes de la superficie alar, creando así seis zonas de protección. Los trabajadores conectan un cabo de 1,5 $\mathrm{m}$ a unas anillas en forma de "D" o a las extensiones de cincha que corren a todo lo largo del cable salvavidas, desde la zona 1 hasta la zona 4 , y que son fijas en las zonas 5 y 6 . El sistema permite acceder solamente al borde del ala, evitando así la posibilidad de caer desde la superficie de la misma.

\section{Controles de procedimiento}

Los controles de procedimiento se utilizan cuando los controles técnicos y los equipos de protección personal no resultan prácticos ni eficaces. Es el menos utilizado de los métodos de protección, aunque es eficaz si se emplea correctamente. En este tipo de control la superficie de trabajo se considera como un área restringida, a la que tiene acceso únicamente el personal necesario durante unos procesos de mantenimiento concretos. La 
protección contra caídas se consigue mediante procedimientos escritos sumamente estrictos que cubren la identificación de la exposición al riesgo, la comunicación y las acciones individuales. Se trata de procedimientos que mitigan la exposición de la mejor manera posible en circunstancias muy concretas. Deben ser localmente específicos y abordar cada riesgo concreto. Raramente se utilizan para el trabajo sobre plataformas, ni en la fase de construcción ni en la de mantenimiento, aunque sí se utilizan en trabajos de mantenimiento efectuados sobre las superficies del avión.

\section{- CONSTRUCGION DE MOTORES DE AVIACION}

John B. Feldman

La construcción de motores de aviación, tanto de pistón como de turbina, exige la transformación de las materias primas en máquinas de una fiabilidad y precisión extremas. La combinación del transporte aéreo y de unos entornos operativos sometidos a enormes tensiones requiere la utilización de una amplia gama de materiales muy resistentes. Se utilizan métodos de construcción tanto convencionales como exclusivos.

\section{Materiales de construcción}

Los motores de aviación están construidos fundamentalmente de componentes metálicos, aunque en los últimos años se han incorporado materiales plásticos compuestos en la fabricación de determinadas piezas. Para las partes donde es decisivo que confluyan la resistencia y la ligereza (componentes estructurales, secciones de compresor, bastidores de motor), se emplean diversas aleaciones de aluminio y titanio. Las aleaciones de cromo, níquel y cobalto se emplean donde se requiere una resistencia a la corrosión y a las altas temperaturas (cámara de combustión y secciones de turbina). En las partes intermedias se emplean numerosas aleaciones de acero.

Dado que la minimización del peso de una aeronave es un factor decisivo para reducir los costes de los ciclos operativos (maximización de la carga de pago y minimización del consumo de combustible), han empezado a incorporarse nuevos materiales compuestos como sustitutos ligeros de aluminio, titanio y ciertas aleaciones de acero en zonas estructurales y conductos donde no se produce la exposición a elevadas temperaturas. Básicamente, estos materiales compuestos están hechos de poliimida, epoxi y otros sistemas a base de resinas, reforzados mediante fibras de grafito o fibra de vidrio entretejida.

\section{Actividades de construcción}

En la construcción de motores para aviación intervienen prácticamente todas las actividades relacionadas con la metalurgia y la mecanización, entre ellas: forja en caliente (discos de compresor, superficies aerodinámicas); fundición (componentes estructurales, bastidores de motor); esmerilado; mandrinado; torneado; taladrado; fresado; cizallado; serrado; fileteado; soldadura normal; soldadura de latón; etc. Entre los procesos asociados cabe destacar: acabado de metales (anodización, cromado, etc.); galvanizado; tratamiento calórico y pulverización térmica (llama, plasma). La resistencia y gran dureza de las aleaciones empleadas, junto con sus complejas formas y sus holguras de precisión, requieren un mecanizado más difícil y riguroso que el propio de otros sectores industriales.

Algunos de los procesos metalúrgicos más exclusivos de este sector son los fresados químico y electroquímico, la mecanización por descargas eléctricas, el taladrado mediante láser y la soldadura por haz de electrones. Los fresados químico y electroquímico suponen la retirada de metal de grandes superficies de forma que se mantenga o se cree un contorno. Las piezas, dependiendo de su aleación específica, se sumergen en baños controlados de altas concentraciones ácidas, cáusticas o electrolíticas. El metal se retira por la acción química o electroquímica. El fresado químico se emplea a menudo tras el forjado de las superficies aerodinámicas para conseguir el grosor especificado, manteniendo un contorno concreto.

El mecanizado por descargas eléctricas y el taladrado mediante láser se emplean habitualmente para practicar orificios de pequeño diámetro o dar contornos intrincados a los metales duros. En los componentes de las cámaras de combustión y de las turbinas es donde más se utilizan esos orificios, a efectos de refrigeración. La retirada del metal se lleva a cabo mediante la acción termomecánica de alta frecuencia producida por descargas de chispa eléctrica. El proceso se realiza en un baño de aceite mineral dieléctrico. El electrodo actúa a modo de imagen inversa del corte deseado.

La soldadura por haz de electrones se utiliza para la unión de piezas donde se requiere una soldadura de penetración profunda, en geometrías de difícil acceso. La soldadura se genera dirigiendo un haz de electrones acelerado al interior de una cámara de vacío. La energía cinética generada por los electrones al golpear sobre la pieza de trabajo, se transforma en calor para efectuar la soldadura.

En la fabricación de materiales plásticos compuestos o bien se aplican técnicas de acumulación "en mojado", o se utilizan tejidos previamente impregnados. Con la acumulación en mojado, la mezcla viscosa de resinas sin curar se extiende sobre el molde de la herramienta bien mediante pulverización o mediante el empleo de brochas. El material de refuerzo por fibras se aplica manualmente a la resina, añadiendo más resina para dar uniformidad y adaptarse al contorno de la herramienta. Una vez finalizada la aplicación se somete a la presión y temperatura de un autoclave. Los materiales impregnados previamente son láminas semirrígidas, listas para utilizar y parcialmente curadas de materiales compuestos a base de resina y fibra. El material se corta a la medida, se moldea a mano según el contorno y la forma de la herramienta y se cura posteriormente en un autoclave. Las piezas curadas se mecanizan de manera convencional y se instalan en el motor.

\section{Inspección y pruebas}

Para asegurar la fiabilidad de los motores de aviación se llevan a cabo muchos procedimientos de inspección, prueba y control de calidad, durante su construcción y una vez acabado el producto. Entre los métodos habituales de inspección no agresiva cabe destacar el radiográfico, el ultrasónico, el de partículas magnéticas y el de penetración fluorescente. Se utilizan para detectar grietas o fisuras en el interior de las piezas. Una vez ensamblados, los motores se someten a pruebas por lo común en células instrumentales de prueba para su posterior entrega al cliente.

\section{Riesgos para la salud y la seguridad y métodos de control}

Los riesgos para la salud asociados a la construcción de motores para aviación están básicamente relacionados con la toxicidad de los materiales empleados y la potencial exposición a los mismos. El aluminio, el hierro y el titanio no se consideran muy tóxicos; el cromo, el níquel y el cobalto son más problemáticos. Ciertos compuestos y estados de valencia de estos tres últimos metales han demostrado sus cualidades cancerígenas tanto en animales como en seres humanos. Sus formas metálicas son consideradas, 
por lo general, menos tóxicas que sus formas iónicas, que suelen estar presentes en los baños para el acabado metálico y en los pigmentos para pinturas.

Durante el mecanizado convencional, la mayoría de las operaciones se efectúan con refrigerantes o fluidos de corte que reducen al mínimo la generación de vapores y de polvo en suspensión al aire. A excepción del esmerilado en seco, los metales no suelen presentar riesgos por inhalación, aunque sí resulta preocupante la inhalación de las emanaciones de los refrigerantes. En las piezas de los motores de turbina se llevan a cabo labores de esmerilado para suavizar los contornos y conseguir las dimensiones definitivas de las superficies aerodinámicas; para ello suelen utilizarse pequeños esmeriladores manuales. Cuando el esmerilado se realiza en aleaciones de cromo, níquel o cobalto, es preciso disponer de un sistema local de ventilación: mesas de aspiración invertida y dispositivos de esmerilado autoventilados. La dermatitis y los efectos del ruido son otros riesgos asociados al mecanizado convencional. La piel de los trabajadores entra en contacto, en varios niveles, con los refrigerantes y con los fluidos de corte durante los trabajos de reparación, inspección y retirada de piezas. En algunos casos, si el contacto cutáneo se repite origina diversas formas de dermatitis, que por lo general se reducirán al utilizar guantes, cremas protectoras y al mantener unos hábitos higiénicos adecuados. A menudo también hay unos niveles de ruido elevados durante los trabajos de mecanizado aleaciones de paredes delgadas y alta resistencia, debido al rechinado de las herramientas y a las vibraciones de las piezas. Todo ello puede controlarse hasta cierto punto empleando herramientas de mayor rigidez, insonorizando los materiales, modificando los parámetros de las máquinas y manteniendo a punto las herramientas. De lo contrario, será preciso el empleo de equipos de protección personal (p. ej.: auriculares, tapones para los oídos).

Los riesgos para la seguridad asociados a los trabajos de mecanizado convencional comportan posibles lesiones físicas debidas a los movimientos realizados en el punto de actividad, el ajuste y la transmisión motriz. El control se consigue por métodos como las defensas fijas, dispositivos de enclavamiento con mecanismos de cierre en las puertas de acceso, las cortinas de luz, las alfombrillas de contacto y mediante la formación y sensibilización del personal. Cuando se realicen operaciones de mecanización, la protección ocular deberá ser permanente para evitar las posibles lesiones producidas por partículas y esquirlas proyectadas al aire, así como por posibles salpicaduras de fluidos refrigerantes y disolventes.

Los trabajos de acabado metálico, el fresado químico y la galvanización suponen la exposición a concentraciones de ácidos, bases y electrolitos de los depósitos al aire libre. La mayoría de los baños contienen elevadas concentraciones de metales disueltos. Aunque la composición y las condiciones operativas de los baños (concentración, temperatura, agitación, dimensiones) son diferentes, casi todos ellos necesitarán algún tipo de ventilación local para controlar los niveles de emanaciones, gases y vapores en suspensión en la atmósfera. A efectos de control, se utilizan diversos modelos de cubiertas laterales de tipo ranurado. Las organizaciones de carácter técnico, como la Conferencia Americana de Higienistas Industriales del Gobierno (ACGIH) y el American National Standards Institute (ANSI), disponen de diseños de ventilación y pautas de funcionamiento para los diferentes tipos de baño. La naturaleza corrosiva de estos baños obliga a utilizar protecciones tanto para la piel como para los ojos (gafas contra salpicaduras, pantallas faciales, guantes, mandiles, etc.) durante la realización de trabajos en las proximidades de esos depósitos. Tambien deben estar disponibles en todo momento para emergencias las duchas y los dispositivos para lavados oculares.
La soldadura mediante haz de electrones y el taladrado mediante láser también suponen un riesgo por radiación para los trabajadores. La soldadura mediante haz de electrones genera una radiación secundaria por rayos $\mathrm{X}$ (efecto bremsstrahlung). Las cámaras de soldadura son, en cierto modo, un tubo de rayos $\mathrm{X}$ inútil. Es decisivo que la cámara, o el material en el que está construida, contenga algún tipo de protección que reduzca la radiación a los niveles más bajos posibles. Suele hacerse con protecciones de plomo. Han de realizarse periódicamente estudios sobre la radiación. Los rayos láser entrañan riesgos (térmicos) para la piel y los ojos; también existe riesgo potencial por exposición a emanaciones metálicas producidas por la evaporación de los metales base. Los trabajos con láser que entrañan riesgo de radiación deben aislarse y confinarse, en la medida de lo posible, a cámaras con dispositivos de enclavamiento. Debe seguirse con todo rigor un programa completo. La ventilación local es imprescindible siempre que se generen emanaciones metálicas.

Los principales riesgos relacionados con la construcción de piezas plásticas fabricadas a base de materiales compuestos, se deben a la exposición química a componentes de resinas sin reaccionar y a disolventes, durante la extensión de capas en mojado. Un motivo de especial preocupación es la utilización de aminas aromáticas como reactivos en las resinas poliimídicas y como endurecedores en sistemas a base de resinas epoxídicas. Se sabe, o se sospecha, que la gran mayoría de algunos de estos compuestos son cancerígenos para el ser humano y de otros se tiene la sospecha. Tienen también otra serie de efectos tóxicos. La naturaleza sumamente reactiva de estos sistemas de resinas, sobre todo las epoxídicas, aumenta las sensibilidades cutánea y respiratoria. El control de los riesgos durante las operaciones de extendido de capas en mojado deberá contemplar la ventilación local y la utilización generalizada de equipos protección personal para evitar el contacto con la piel. Los trabajos de extendido de capas en los que se empleen láminas previamente impregnadas no suelen entrañar ningún riesgo de exposición a partículas en la atmósfera, pero debe protegerse la piel. Una vez curadas, estas piezas son relativamente inertes, y no entrañan los riesgos de sus reactivos. El mecanizado convencional de piezas, no obstante, puede provocar molestias e irritaciones debidas al polvo y a los materiales compuestos utilizados como refuerzo (grafito, fibra de vidrio, etc.). A menudo resulta necesaria la ventilación local de los trabajos de mecanizado.

Entre los riesgos para la salud que entrañan los trabajos de prueba están las radiaciones (rayos X o rayos gamma) producidas en las inspecciones radiográficas y los ruidos generados en las pruebas finales de productos. Los trabajos radiográficos deberían incluir rigurosos programas de seguridad contra las radiaciones, junto con la correspondiente formación, control de las etiquetas de identificación y análisis periódicos. Las cámaras de inspección radiográfica deben construirse con puertas dotadas de dispositivos de enclavamiento, con luces de aviso de funcionamiento, dispositivos de corte de emergencia y barreras apropiadas. Las celdas o zonas destinadas a la realización de pruebas de productos terminados, sobre todo en el caso de los motores de turbina, deberían acondicionarse acústicamente. Los niveles de ruido detectados en las consolas de control deben controlarse para que no superen los 85 dBA. También deberán adoptarse las medidas oportunas para evitar cualquier acumulación de gases de escape y de vapores de combustibles o disolventes en la zona de pruebas.

Además de los riesgos mencionados para actividades concretas, existen otros, como la exposición a disolventes de limpieza, pinturas, plomo y las actividades relacionadas con la soldadura. Los disolventes para limpieza están presentes en todas las actividades de construcción. Hoy día los disolventes a 
base de cloro y flúor se están sustituyendo por otros a base de aguarrás, alcohol o hidrocarburos de una fracción del petróleo, debido a la toxicidad de aquéllos y a sus efectos reductores de la capa de ozono. Aunque el último goza de mayor aceptación desde el punto de vista ambiental, es también peligroso por su inflamabilidad. Deberá limitarse la cantidad presente en el lugar de trabajo de cualquier disolvente inflamable o combustible y utilizar siempre las contenidas en recipientes homologados que cuenten con medidas adecuadas de protección y extinción de fuegos. A veces se utiliza plomo como lubricante de troqueles para los trabajos de forjado de las superficies aerodinámicas. En tal caso, y debido a su toxicidad, deberá efectuarse un programa de monitorización y control exhaustivo del plomo. Son numerosos los tipos de soldadura convencional que se emplean en los trabajos de construcción, en los que siempre es preciso evaluar las emanaciones metálicas, la radiación ultravioleta y la exposición al ozono. La necesidad de este tipo de controles dependerá de los parámetros concretos de cada actividad y de los metales que se utilicen.

\section{- CONTROLES Y EFECTOS SOBRE LA SALUD}

\section{Denis Bourcier}

Cada vez es mayor la demanda en el mercado para que la industria aeroespacial reduzca el tiempo del flujo de desarrollo de productos, aunque al mismo tiempo se impone la utilización de materiales que cumplan criterios de rendimiento cada vez más limitados y en ocasiones contradictorios. Es posible que la aceleración en la producción y en las pruebas de los productos terminados haga que el desarrollo de procesos y de materiales desplace el desarrollo paralelo de tecnologías de salud ambiental. A lo que puede llegarse es a contar con una serie de productos probados y homologados, pero cuyos efectos sobre la salud y su impacto ambiental son conocidos insuficientemente. Normativas como la Ley de Control de Sustancias Tóxicas (TSCA) de los Estados Unidos requiere: a) la comprobación de los nuevo materiales; b) el desarrollo de análisis de laboratorio prudentes para pruebas de investigación y desarrollo; c) la limitación de importaciones y exportaciones de ciertas sustancias químicas, y d) el control de los estudios sobre la seguridad, la salud y el medio ambiente, así como los archivos de las propias empresas sobre cualquier efecto de importancia sobre la salud debidos a exposición a sustancias químicas.

El aumento de la utilización de fichas técnicas de seguridad (FTS) ha facilitado a los profesionales de la salud la información necesaria para controlar las exposiciones a las sustancias químicas. Con todo, sólo existen fichas con datos toxicológicos completos para unos pocos centenares de los miles de materiales en uso, con el consiguiente reto para los toxicólogos y los higienistas industriales. Debe emplearse en la medida de lo posible una ventilación aspirante localizada y otros controles técnicos para poder controlar la exposición, sobre todo cuando se trate con productos químicos poco conocidos o con índices de contaminación inadecuadamente determinados en su generación. Los aparatos de respiración pueden pasar a un segundo plano si se respaldan con un programa de gestión de la protección respiratoria bien planificado y rigurosamente observado. Deben elegirse aparatos de respiración y otros equipos de protección personal que ofrezcan una adecuada y total protección, sin que su utilización resulte incómoda para los trabajadores.

Ha de informarse de manera eficaz a todos los trabajadores sobre los riesgos y su control antes de introducir cualquier producto nuevo en la zona de trabajo. Puede hacerse mediante presentaciones verbales, boletines, vídeos $\mathrm{u}$ otros medios de comunicación. El método es importante para lograr el éxito al introducir un producto químico nuevo en la zona de trabajo. En las áreas dedicadas a la construcción aeroespacial es frecuente la rotación de los trabajadores, de los materiales y de los procesos de trabajo. La información sobre los riesgos debe entenderse, por tanto, como un proceso continuo. Las comunicaciones por escrito han demostrado su escasa eficacia en este sector si no se cuenta con medios más dinámicos, como pueden ser las reuniones por equipos o las presentaciones en vídeo.

Siempre se ha de estar preparado para responder a las preguntas que puedan plantear los trabajadores. Los ambientes muy complejos desde el punto de vista químico son característicos de las plantas de construcción aeronáutica, especialmente las zonas de montaje. Se requieren esfuerzos intensos, entusiastas y bien planificados en materia de higiene industrial para reconocer y caracterizar los riesgos asociados a la presencia simultánea o correlativa de gran número de productos químicos, muchos de los cuales no han sido sometidos a las pruebas adecuadas para determinar si tienen efectos nocivos para la salud. Los higienistas deben prestar atención a los contaminantes liberados en forma física sobre los cuales no advierte el proveedor y que, por tanto, no figuran en las FTS. Por ejemplo, la aplicación y retirada constante de bandas de materiales compuestos parcialmente curados puede liberar mezclas de resina y disolvente en forma de aerosol que no se medirán eficazmente con métodos de control de vapores.

La concentración y las combinaciones de sustancias químicas son también complejas y muy variables. En los trabajos atrasados que se realizan fuera de la secuencia normal pueden utilizarse materiales peligrosos y no contar con los necesarios controles técnicos o con las medidas personales de protección adecuadas. Las variaciones en las prácticas laborales de cada persona y el tamaño y la configuración de las diferentes estructuras de avión puede repercutir notablemente en la exposición a situaciones de riesgo. Las variaciones en las exposiciones a disolventes entre los trabajadores que efectúan tareas de limpieza en los depósitos alares de combustible de un avión, han sobrepasado dos órdenes de magnitud, debido en parte a los efectos del tamaño corporal en el flujo del aire de dilución en espacios extremadamente reducidos.

Las situaciones de riesgo potencial deben ser identificadas y caracterizadas, y antes de que los materiales o los procesos entren en la zona de trabajo o lleguen a ponerse en práctica deben aplicarse los controles necesarios. Antes de empezar el trabajo hay que elaborar, establecer y documentar unas normas de obligado cumplimiento sobre utilización segura. Cuando la información resulte incompleta, se asumirá el riesgo razonable más alto y se tomarán las medidas de protección oportunas. Deben realizarse con cierta frecuencia y regularidad estudios de higiene industrial para garantizar que los controles son los adecuados y que funcionan correctamente.

La dificultad para caracterizar los riesgos de exposición en los puestos de trabajo de la industria de construcción aeroespacial requiere una estrecha cooperación entre higienistas, expertos clínicos, toxicólogos y epidemiólogos (véase la Tabla 90.2). Es esencial que trabajadores y directivos estén bien informados. Debe alentarse a los trabajadores para que informen de cualquier síntoma, y formarse a los supervisores para que estén atentos a cualquier señal o síntoma de exposición. El control biológico de las exposiciones puede ser de gran ayuda para el control del aire donde las exposiciones son muy variables o donde la exposición cutánea es notable. El seguimiento biológico puede utilizarse también para determinar si los controles son efectivos en la reducción de la absorción de contaminantes a 
Tabla 90.2 • Requisitos de desarrollo tecnológico en materia de sanidad, seguridad y control ambiental para nuevos procesos y materiales.

\section{Parámetro}

Niveles de contaminantes

suspendidos en el aire

salud

Repercusión en el medio ambiente

Caracterización de los residuos
Posible repercusión sobre la

\section{Requisitos tecnológicos}

Métodos analíticos para la cuantificación de

productos químicos

Técnicas de control del aire

Estudios sobre toxicología crónica y aguda

Estudios sobre bioacumulación y biodegradación

Ensayos de compatibilidad química Bioensayos través de la piel por parte de los trabajadores. Deberá efectuarse de manera rutinaria un análisis de los datos médicos por si revelaran algún patrón de síntomas y molestias.

Pintar hangares, fuselajes y depósitos de combustible puede suponer el concurso intensivo de numerosos sistemas generadores de altos volúmenes de gases de escape, durante los trabajos intensivos de pintura, sellado y limpieza. La exposición a sustancias residuales y la incapacidad de estos sistemas para alejar de los trabajadores los flujos de aire requieren por lo común el empleo de aparatos adicionales de respiración. La ventilación aspirante localizada es necesaria en los trabajos de pintura pequeños, el tratamiento de metales y la limpieza con disolventes, en los trabajos químicos en el laboratorio y la aplicación de capas de algunos plásticos. La ventilación por dilución sólo es adecuada en las zonas en las que el empleo de sustancias químicas sea mínimo, o como una ayuda a la ventilación aspirante localizada. Un intercambio de aire significativo durante el invierno puede dar lugar a una excesiva sequedad en el aire interior. Los sistemas de aspiración mal diseñados y que dirigen un flujo excesivo de aire frío hacia las manos o la espalda de los trabajadores (en áreas dedicadas al montaje de pequeñas piezas) pueden empeorar los problemas de brazos, cuello y manos. En las grandes y complejas zonas dedicadas a la construcción aeronáutica debe prestarse atención a la correcta ubicación de las entradas y salidas del sistema de ventilación para evitar que arrastren contaminantes.

La construcción de precisión característica de los productos de la industria aeroespacial requiere entornos de trabajo despejados, organizados y bien controlados. Los contenedores, los bidones y los depósitos que contienen sustancias químicas deben llevar etiquetas que avisen de la peligrosidad potencial de sus contenidos. La información relativa a primeros auxilios estará disponible en todo momento y lugar. En las FTS o en cualquier otro tipo de ficha similar deberá figurar también información sobre respuestas antes emergencias y control de vertidos. Las áreas donde los trabajos sean potencialmente peligrosos deberán estar bien anunciadas mediante carteles y el acceso a las mismas controlado y comprobado.

\section{Efectos de los materiales compuestos sobre la salud}

Los fabricantes aeronáuticos de los sectores civil y militar cada vez dependen más de los materiales compuestos para la construcción de componentes tanto internos como estructurales. Las generaciones de materiales compuestos han ido integrándose progresivamente en los procesos de construcción de todos los sectores, sobre todo en el de la defensa, donde son especialmente valorados por sus cualidades de escasa detectabilidad por parte de los radares. Este medio de fabricación que ha avanzado tan rápidamente es representativo del problema del desplazamiento de los esfuerzos en materia de salud pública por parte de la tecnología de diseño. Los riesgos específicos e inherentes a los componentes de lona o resina de los materiales compuestos antes de su combinación y del curado de las resinas difieren de los riesgos derivados de los materiales ya curados. Además, los materiales parcialmente curados (preimpregnados) pueden conservar las características peligrosas de los componentes de la resina durante los diversos pasos que lleva la fabricación de una pieza de material compuesto (AIA 1995). Las consideraciones toxicológicas de las principales categorías de resinas se recogen en la Tabla 90.3.

El tipo y el grado de riesgo que suponen los materiales compuestos depende básicamente del trabajo específico y del grado de curado de la resina a medida que el material pasa de ser una lona o resina húmeda a ser una pieza seca. La liberación de componentes volátiles de la resina puede ser significativa antes de (y durante) la reacción inicial de la resina y del agente de curado, aunque también puede darse durante el procesado de los materiales que pasen por más de un nivel de curado. La liberación de estos componentes es mayor en condiciones de temperatura elevada o en zonas de trabajo con ventilación deficiente, y sus niveles abarcan desde meros indicios hasta moderados. La exposición de la piel a los componentes de la resina en el estado previo al curado suele ser un factor importante en el riesgo total, por lo que debe tenerse en consideración.

Las emanaciones procedentes de productos de degradación de las resinas puede tener lugar durante diversas operaciones de mecanizado en las que se genera calor en las superficies del material curado. Los productos de degradación aún no están plenamente caracterizados, aunque tienden a variar su estructura química en función de la temperatura y del tipo de resina. Pueden generarse partículas al mecanizar materiales

Tabla 90.3 - Consideraciones toxicológicas de los principales componentes de las resinas utilizadas en los materiales compuestos para aplicaciones aeroespaciales. ${ }^{1}$

\begin{tabular}{|c|c|c|}
\hline Tipo de resina & Componentes $^{2}$ & $\begin{array}{l}\text { Consideraciones } \\
\text { toxicológicas }\end{array}$ \\
\hline Epoxi & $\begin{array}{l}\text { Agentes de curado con } \\
\text { aminas, epicloridrina }\end{array}$ & $\begin{array}{l}\text { Sensibilizador, presunto } \\
\text { cancerígeno }\end{array}$ \\
\hline Poliimida & Monómero aldehído, fenol & $\begin{array}{l}\text { Sensibilizador, presunto cance- } \\
\text { rígeno, sistémico }{ }^{3}\end{array}$ \\
\hline Fenólico & Monómero aldehído, fenol & $\begin{array}{l}\text { Sensibilizador, presunto cance- } \\
\text { rígeno, sistémico }{ }^{3}\end{array}$ \\
\hline Poliéster & Estireno, dimetilanilina & $\begin{array}{l}\text { Narcosis, depresión del } \\
\text { sistema nervioso central, } \\
\text { cianosis }\end{array}$ \\
\hline Silicona & Siloxano orgánico, peróxidos & Sensibilizador, irritante \\
\hline Termoplásticos 4 & $\begin{array}{l}\text { Poliestireno, sulfuro de } \\
\text { polifenileno }\end{array}$ & Sistémico, ${ }^{3}$ irritante \\
\hline
\end{tabular}

I Se ofrecen ejemplos de componentes típicos de resinas no curadas. Pueden estar presentes otros productos químicos de diversa naturaleza toxicológica en forma de agentes para curado, disolventes y aditivos.

2 Se aplica sobre todo a los componentes de resinas húmedas previos a la reacción. En las resinas parcialmente curadas se encuentran diversas cantidades de estas sustancias, y en los materiales curados se han detectados indicios de ellas.

${ }^{3}$ Toxicidad sistémica, indicadora de los efectos producidos sobre varios tejidos.

${ }^{4}$ Se incluyen los termoplásticos como categoría independiente, en dicha separación los productos relacionados se crean durante los trabajos de moldeo al calentarse la sustancia inicial polimerizada. 
Tabla 90.4 • Riesgos derivados de la utilización de productos químicos en la industria aeroespacial.

\begin{tabular}{|c|c|c|}
\hline Agente químico & Fuentes & Enfermedad potencial \\
\hline \multicolumn{3}{|l|}{ Metales } \\
\hline Polvo de berilio & $\begin{array}{l}\text { Mecanizado de aleaciones } \\
\text { de berilio }\end{array}$ & $\begin{array}{l}\text { Lesiones cutáneas, enferme- } \\
\text { dades pulmonares agudas } \\
0 \text { crónicas }\end{array}$ \\
\hline $\begin{array}{l}\text { Polvo y vapor } \\
\text { de cadmio }\end{array}$ & $\begin{array}{l}\text { Soldadura, quemado, } \\
\text { pinturas pulverizadas }\end{array}$ & $\begin{array}{l}\text { Con el tiempo, edema } \\
\text { pulmonar agudo, } \\
\text { Pesiones renales }\end{array}$ \\
\hline Polvo & Vapor y humos de cromo & $\begin{array}{l}\text { Pulverización y lijado de } \\
\text { pinturas de imprimación, } \\
\text { soldadura }\end{array}$ \\
\hline Níquel & Soldadura, lijado & Cáncer de vías respiratorias \\
\hline Mercurio & $\begin{array}{l}\text { Laboratorios, ensayos } \\
\text { mecánicos }\end{array}$ & $\begin{array}{l}\text { Lesiones en el sistema } \\
\text { nervioso central }\end{array}$ \\
\hline \multicolumn{3}{|l|}{ Gases } \\
\hline $\begin{array}{l}\text { Cianuro de } \\
\quad \text { hidrógeno }\end{array}$ & Recubrimiento electrolítico & $\begin{array}{l}\text { Asfixia química, efectos } \\
\text { crónicos }\end{array}$ \\
\hline $\begin{array}{l}\text { Monóxido } \\
\text { de carbono }\end{array}$ & $\begin{array}{l}\text { Tratamientos térmicos, } \\
\text { trabajos en motores }\end{array}$ & $\begin{array}{l}\text { Asfixia química, efectos } \\
\text { crónicos }\end{array}$ \\
\hline $\begin{array}{l}\text { Oxidos de } \\
\text { nitrógeno }\end{array}$ & $\begin{array}{l}\text { Soldadura, recubrimiento } \\
\text { electrolítico, decapado } \\
\text { de metales }\end{array}$ & $\begin{array}{l}\text { Con el tiempo, edema } \\
\text { pulmonar agudo, posibles } \\
\text { lesiones pulmonares } \\
\text { permanentes }\end{array}$ \\
\hline Fosgeno & $\begin{array}{l}\text { Soldadura, descomposición } \\
\text { de vapores de disolventes }\end{array}$ & \\
\hline Ozono & $\begin{array}{l}\text { Soldadura, vuelos a gran } \\
\text { altitud }\end{array}$ & $\begin{array}{l}\text { Lesiones pulmonares crónicas } \\
\text { y agudas, cáncer de vías } \\
\text { respiratorias }\end{array}$ \\
\hline \multicolumn{3}{|c|}{ Compuestos orgánicos } \\
\hline Alifáticos & $\begin{array}{l}\text { Lubricantes para máquinas, } \\
\text { combustibles, fluidos } \\
\text { de corte }\end{array}$ & Dermatitis folicular \\
\hline $\begin{array}{l}\text { Aromáticos, } \\
\text { nitroaromáticos } \\
\text { y aminas } \\
\text { aromáticas }\end{array}$ & $\begin{array}{l}\text { Cauchos, plásticos, } \\
\text { pinturas, tintes }\end{array}$ & $\begin{array}{l}\text { Anemia, cáncer, sensibilización } \\
\text { de la piel }\end{array}$ \\
\hline $\begin{array}{l}\text { Otros compuestos } \\
\text { aromáticos }\end{array}$ & Disolventes & $\begin{array}{l}\text { Narcosis, lesiones hepáticas, } \\
\text { dermatitis }\end{array}$ \\
\hline Halogenados & $\begin{array}{l}\text { Decapantes de pintura, } \\
\text { desengrasantes }\end{array}$ & $\begin{array}{l}\text { Narcosis, anemia, lesiones } \\
\text { hepáticas }\end{array}$ \\
\hline \multicolumn{3}{|l|}{ Plásticos } \\
\hline Fenólicos & $\begin{array}{l}\text { Componentes internos, } \\
\text { conducciones }\end{array}$ & $\begin{array}{l}\text { Sensibilización alérgica, } \\
\text { posible cáncer }\end{array}$ \\
\hline $\begin{array}{l}\text { Epoxi (aminas } \\
\text { endurecedoras) }\end{array}$ & Trabajos de revestimiento & $\begin{array}{l}\text { Dermatitis, sensibilización } \\
\text { alérgica, cáncer }\end{array}$ \\
\hline Poliuretano & $\begin{array}{l}\text { Pinturas, componentes } \\
\text { internos }\end{array}$ & $\begin{array}{l}\text { Sensibilización alérgica, } \\
\text { posible cáncer }\end{array}$ \\
\hline Poliimidas & Componentes estructurales & $\begin{array}{l}\text { Sensibilización alérgica, } \\
\text { posible cáncer }\end{array}$ \\
\hline \multicolumn{3}{|c|}{ Polvos fibrogénicos } \\
\hline Asbesto & $\begin{array}{l}\text { Aviones antiguos y aeronaves } \\
\text { militares }\end{array}$ & Cáncer, asbestosis \\
\hline Silice & $\begin{array}{l}\text { Granallado con abrasivos, } \\
\text { rellenos }\end{array}$ & Silicosis \\
\hline $\begin{array}{l}\text { Carburo de } \\
\text { tungsteno }\end{array}$ & $\begin{array}{l}\text { Rectificado de herramientas } \\
\text { de precisión }\end{array}$ & Neumoconiosis \\
\hline Grafito, Kevlar & $\begin{array}{l}\text { Mecanizado de materiales } \\
\text { compuestos }\end{array}$ & Neumoconiosis \\
\hline \multicolumn{3}{|c|}{ Polvos posiblemente benignos } \\
\hline Fibra de vidrio & $\begin{array}{l}\text { Teiidos aislantes, } \\
\text { componentes internos }\end{array}$ & $\begin{array}{l}\text { Irritación cutánea y de las vías } \\
\text { respiratorias, posibles } \\
\text { lesiones crónicas }\end{array}$ \\
\hline Madera & $\begin{array}{l}\text { Construcción de modelos y de } \\
\text { maquetas de aviones }\end{array}$ & $\begin{array}{l}\text { Sensibilización alérgica, } \\
\text { cáncer de vías respiratorias }\end{array}$ \\
\hline
\end{tabular}

endurecidos o al cortar materiales preimpregnados que contengan restos de materiales de resinas liberados al mover los materiales. Cuando la ventilación aspirante del autoclave no es capaz de eliminar del entorno de trabajo los gases producidos por el secado en hornos, porque el diseño o el funcionamiento son inadecuados, se produce un riesgo por exposición a esos gases.

No debe olvidarse que los polvos procedentes de nuevos materiales textiles que contienen fibra de vidrio, Kevlar, grafito o revestimientos de boro/óxidos metálicos, se consideran unánimemente capaces de producir reacciones fibrogénicas de nivel ligero a moderado; hasta la fecha no ha podido caracterizarse su potencia relativa. Además, la información sobre la contribución relativa de polvos fibrogénicos de varias operaciones de mecanización aún sigue investigándose. Las diversas actividades con materiales compuestos y los riesgos asociados han sido caracterizados (AIA 1995) y se recogen en la Tabla 90.4.

\section{CUESTIONES AMBIENTALES Y DE SALUD PUBLICA}

Steve Mason

Las industrias aeroespaciales se han visto notablemente afectadas por el enorme incremento de las normativas en materia de medio ambiente y de ruidos, que empezaron inicialmente a aplicarse en Estados Unidos y en Europa a partir del decenio de 1970. La Ley de Limpieza de las Aguas, la Ley de Limpieza del Aire y la Ley de Recuperación y Conservación de los Recursos, en Estados Unidos, y las Directivas correspondientes de la Unión Europea han originado voluminosas normativas locales para cumplir con los objetivos marcados en materia de calidad ambiental. Por lo general, estas normativas fomentan la utilización de la mejor tecnología existente, ya se trate de materiales o procesos nuevos, o de equipos de control de los aviones en vuelo más bajo próximos a aeropuertos. Además, hay asuntos de carácter universal, como el calentamiento del planeta y la destrucción de la capa de ozono, que están obligando a que se introduzcan cambios en las actividades tradicionales: por ejemplo, la prohibición del uso de productos químicos como los clorofluorocarburos, salvo en casos excepcionales. La antigua legislación apenas afectó a la industria aeroespacial hasta el decenio de 1980. El crecimiento constante del sector y la concentración de actividades en las proximidades de los aeropuertos y las áreas industrializadas hizo necesaria su regulación. El sector experimentó una revolución en cuanto a programas para el seguimiento y la gestión de emisiones tóxicas lanzadas al medio ambiente en un intento de garantizar la seguridad. El tratamiento de las aguas residuales procedentes de los trabajos de acabado de metales y de mantenimiento de aeronaves se convirtió en algo habitual en las grandes plantas. La segregación de residuos peligrosos, así como su clasificación, declaración y su posterior tratamiento antes de ser desechados se instituyeron como prácticas habituales en sustitución de los rudimentarios programas existentes. Los programas para la limpieza de vertederos se convirtieron en asuntos económicos de primer orden para muchas empresas ya que los costes aumentaron a muchos millones en cada caso. A finales del decenio de 1980 y principios del de 1990, las emisiones contaminantes a la atmósfera, que constituían más del $80 \%$ de las emisiones totales procedentes de las empresas que construyen y operan con aviones, se convirtieron en el centro de la atención legislativa. La Organización de Aviación Civil Internacional (OACI) estableció normas relativas a las emisiones de los motores en 1981 (OACI 1981). 
Tabla 90.5 - Resumen de las Emisiones para Contaminantes Atmosféricos Peligrosos (NESHAP) de Estados Unidos en las instalaciones de construcción y reprocesado.

Proceso
Limpieza manual de componentes
aeroespaciales

Limpieza mediante lavados de
materiales que contengan
compuestos orgánicos volátiles
(COV) ${ }^{2}$ contaminantes
atmosféricos peligrosos (CAP)
Aplicación de imprimaciones y
recubrimientos
(PA para imprimación con menor
contenido de agua
(PA para recubrimientos con un
contenido de agua de
Decapado de superficies exteriores

Recubrimientos con CPA inorgánicos

Máscara de fresado químico CPA con menor contenido de agua

Pulverización superficial en trabajos de recubrimiento con CPA

Equipos de control de la contaminación del aire

Limpieza mediante pistola pulverizadora

Utilización de equipos ${ }^{4}$ de gran eficacia de transferencia

$350 \mathrm{~g} / \mathrm{l}$ de imprimador en aplicaciones promedio ${ }^{5}$

$420 \mathrm{~g} / \mathrm{l}$ de recubrimiento en aplicaciones promedio ${ }^{5}$

Productos químicos carentes de CPA, granallado mecánico, luz de gran intensidad $^{6}$

Maximo permitido de hasta 6 aviones montados a decapar por planta y año con productos químicos con CPA de partículas

$60 \mathrm{~g} / \mathrm{l}$ de producto según la aplicación

Filtro de partículas de etapas múltiples Seguimiento y valores mínimos
aceptables de eficacia

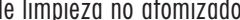

Tabla 90.6 • Riesgos químicos característicos de los procesos de fabricación.

\begin{tabular}{|c|c|c|}
\hline Procesos típicos & Tipo de emisión & Riesgos o productos químicos \\
\hline \multirow{5}{*}{$\begin{array}{l}\text { Recubrimientos, } \\
\text { incluidos } \\
\text { recubrimientos } \\
\text { protectores } \\
\text { temporales, pinturas } \\
\text { y máscaras }\end{array}$} & $\begin{array}{l}\text { Pulverización superficial } \\
\text { de sólidos } \\
\text { y evaporación } \\
\text { de disolventes }\end{array}$ & $\begin{array}{l}\text { Compuestos orgánicos volátiles } \\
\text { (COV) incluidos } \\
\text { metiletilcetona, tolueno, } \\
\text { silenos }\end{array}$ \\
\hline & & $\begin{array}{l}\text { Compuestos destructores del } \\
\text { ozono (CDO) (clorofluo- } \\
\text { rocarburos, } \\
\text { tricloroetano y otros) }\end{array}$ \\
\hline & & Toxinas orgánicas \\
\hline & & Toxinas inorgánicas \\
\hline & $\begin{array}{l}\text { Residuos sólidos, } \\
\text { (p. ej..., reco- } \\
\text { gedores) }\end{array}$ & $\begin{array}{l}\text { COV o las toxinas antes } \\
\text { mencionadas }\end{array}$ \\
\hline \multirow[t]{3}{*}{$\begin{array}{l}\text { Limpieza de } \\
\text { disolventes }\end{array}$} & $\begin{array}{l}\text { Evaporación } \\
\quad \text { de disolventes }\end{array}$ & $\begin{array}{l}\text { COV, destructores de ozono } \\
\text { o toxinas }\end{array}$ \\
\hline & $\begin{array}{l}\text { Residuos sólidos } \\
\text { (recogedores) }\end{array}$ & COV o toxinas \\
\hline & Residuos líquidos & $\begin{array}{l}\text { Restos de disolventes (COV) } \\
\text { y/o agua contaminada }\end{array}$ \\
\hline \multirow[t]{5}{*}{ Decapado } & $\begin{array}{l}\text { Evaporación o trans } \\
\text { porte de disolventes }\end{array}$ & $\begin{array}{l}\text { COV tales como sileno, } \\
\text { tolueno, metiletilcetona }\end{array}$ \\
\hline & & $\begin{array}{l}\text { Toxinas orgánicas (cloruro } \\
\text { de metileno) }\end{array}$ \\
\hline & & Metales pesados (cromados) \\
\hline & $\begin{array}{l}\text { Residuos líquidos } \\
\text { corrosivos }\end{array}$ & $\begin{array}{l}\text { Cáusticos y ácidos incluido } \\
\text { ácido fórmico }\end{array}$ \\
\hline & Polvo, calor, luz & $\begin{array}{l}\text { Polvo tóxico (granallado), } \\
\text { calor (decapado térmico) } \\
\text { y luz }\end{array}$ \\
\hline \multirow{2}{*}{$\begin{array}{l}\text { Anodización de } \\
\text { aluminio }\end{array}$} & Escapes de ventilación & Emanaciones ácidas \\
\hline & Residuos líquidos & Ácidos concentrados \\
\hline \multirow[t]{2}{*}{$\begin{array}{l}\text { Revestimiento con } \\
\text { metales duros }\end{array}$} & Escape de ventilación & $\begin{array}{l}\text { Metales pesados, ácidos, } \\
\text { cianuros complejos }\end{array}$ \\
\hline & Aguas de eniuague & \\
\hline Fresado químico & Residuos líquidos & $\begin{array}{l}\text { Cáusticos y metales pesados, } \\
\text { otros metales }\end{array}$ \\
\hline \multirow[t]{2}{*}{ Sellado } & Disolvente evaporado & $\mathrm{COV}$ \\
\hline & Residuos sólidos & $\begin{array}{l}\text { Metales pesados, indicios de } \\
\text { sustancias orgánicas } \\
\text { tóxicas }\end{array}$ \\
\hline \multirow{2}{*}{$\begin{array}{l}\text { Antióxidos } \\
\text { (recubrimientos } \\
\text { de conversión) }\end{array}$} & Residuos líquidos & $\begin{array}{l}\text { Cromados, cianuro } \\
\text { posiblemente complejo }\end{array}$ \\
\hline & Residuos sólidos & Cromados, oxidantes \\
\hline $\begin{array}{l}\text { Compuestos } \\
\text { anticorrosivos }\end{array}$ & $\begin{array}{l}\text { Partículas, residuos } \\
\text { sólidos }\end{array}$ & $\begin{array}{l}\text { Ceras, metales pesados y } \\
\text { sustancias orgánicas } \\
\text { tóxicas }\end{array}$ \\
\hline $\begin{array}{l}\text { Fabricación de } \\
\text { materiales } \\
\text { compuestos }\end{array}$ & Residuos sólidos & Sustancias volátiles sin curar \\
\hline $\begin{array}{l}\text { Desengrasado de } \\
\text { vapores }\end{array}$ & Vapores liberados & $\begin{array}{l}\text { Tricoloretano, tricoroetileno, } \\
\text { percloroetileno }\end{array}$ \\
\hline Desengrasado acuoso & Residuos líquidos & $\begin{array}{l}\text { COV, silicatos, indicios de } \\
\text { metales }\end{array}$ \\
\hline
\end{tabular}

Las normativas sobre emisiones químicas afectan esencialmente a todos los procesos químicos, a los motores y a las unidades de potencia auxiliares, a las actividades de los vehículos utilizados para el repostaje y el servicio de rampa. Por ejemplo, en Los Angeles, para conseguir la reducción de los medidas para la recolección de residuos

${ }^{1}$ No se recogen aquí la inspección, el mantenimiento de registros ni otros requisitos.

2 Compuestos orgánicos volátiles. Han demostrado ser fotoquímicamente reactivos y precursores de la formación de ozono a nivel del suelo.

${ }^{3}$ Contaminantes Peligrosos del Aire. Son 189 compuestos calificados como tóxicos por la Environmental Protection Agency de Estados Unidos.

4 Entre los equipos recogidos se encuentran las pistolas pulverizadoras electrostáticas de baja presión 0 gran volumen.

${ }^{5}$ Se excluyen los recubrimientos especiales y otros procesos con bajos niveles de emisión.

${ }^{6}$ Se permiten los retoques efectuados utilizando un máximo anual por avión de 26 galones de disolvente comercial con disolvente a base de CPA, 050 galones al año en el caso de aviones militares. 
Tabla 90.7 • Prácticas características relativas al control de emisiones.

$\begin{array}{ll}\text { Procesos } & \text { Emisiones al aire } \\ \text { Recubrimiento: pulverización superficial } & \begin{array}{l}\text { Equipo de control de emisiones } \\ \text { pulverizaciones superficiales (COV y } \\ \text { partículas sólidas) }\end{array}\end{array}$

Limpieza de disolventes con COV

Limpieza de disolventes con compuestos destructores del ozono (CDO)

Limpieza de disolventes con toxinas

Decapado

Anodización de aluminio, recubrimiento metales duros, fresado químico e inmersión en solución de recubrimiento de conversión (producto antioxidante)

Sellado

Compuestos inhibidores de la corrosión

Desengrasado al vapor

Desengrasado acuoso

Controles de emisiones ${ }^{2} \mathrm{y} / 0$ sustitución de materiales

Sustitución debida a la interrupción de la producción de CDO

Sustitución

Controles de emisiones o sustitución por métodos mecánicos 0 que no utilicen CPA

Control de emisiones (depuradores) y/o sustitución en algunos casos

Por lo general innecesario

Filtrados en ventilación

Cristalizadores para volver a condensar los vapores

Sistemas cerrados, o recogida mediante carbón activo

Por lo general innecesario

Emisiones al agua

Tratamiento previo y seguimiento in situ Emisiones al terreno

Tratar y arrojar al vertedero ${ }^{3}$ los residuos de las cabinas de pintura.

Incinerar los productos inflamables y arrojar al vertedero las cenizas.

Reciclar los disolventes siempre que sea posible.

Tratamiento previo y seguimiento in situ Incinerar y arrojar al vertedero los recogedores usados

Por lo general innecesario

Tratamiento previo in situ de aguas de enjuague.

Concentrados ácidos y cáusticos tratados in situ 0 exteriormente

Ninguno

Tratamiento previo y seguimiento in situ Tratar para reducir la toxicidad ${ }^{4}$ y arrojar al vertedero

Fangos de tratamiento estabilizados y arrojados al vertedero

Fangos de tratamiento estabilizados y arrojados al vertedero.

Otros residuos sólidos tratados y arrojados al vertedero

Incinerar y arrojar al vertedero los recogedores usados
Por lo general innecesario

Filtros para recogedores, compuestos residuales y cabinas de pintura ${ }^{5}$ tratados y arrojados al vertedero

Separación de los disolventes utilizados Disolvente tóxico de desengrasado reciclado para el desengrasado de aguas residuales

Tratamiento previo y seguimiento in situ

' La mayoría de las instalaciones aeroespaciales disponen de una planta propia de tratamiento previo de aguas residuales. Algunas incluso realizan el tratamiento total de las mismas.

${ }^{2}$ La eficacia de los controles debe ser generalmente superior al 95 \% en cuanto a retirada/destrucción de concentraciones de entrada. Por lo general suele lograrse un 98 \%, 0 más, mediante la utilización de unidades de carbón activo o de oxidación térmica.

${ }^{3}$ Existen normativas rigurosas en materia de vertidos que especifican el tratamiento y la construcción de vertederos y su seguimiento.

${ }^{4}$ Los niveles de toxicidad se miden por medio de ensayos biológicos y/o de pruebas de lixiviación diseñados para predecir los resultados de los vertederos de residuos sólidos.

5 Las cabinas de pintura suelen disponer habitualmente de filtros. Los trabajos realizados fuera de la secuencia habitual (de retocado, etc.) quedan generalmente exentos por razones prácticas.

niveles de ozono y de monóxido de carbono a nivel del suelo que establecen las normas de la Ley de Limpieza del Aire, sería necesario reducir a la mitad las operaciones de vuelo del aeropuerto internacional de Los Angeles para el año 2005 (Donoghue 1994). Las emisiones allí generadas serán controladas a diario para mantener los límites de las emisiones totales de compuestos orgánicos volátiles y de monóxido de carbono por debajo de los valores totales permitidos. En Suecia se ha gravado con un nuevo impuesto a todos los aviones que emitan dióxido de carbono, debido a su incidencia potencial sobre el calentamiento del planeta. En otros lugares, este tipo de normas han originado la práctica eliminación total del desengrasado a vapor por medio de disolventes clorados, como el tricloroetano, por sus elevadas emisiones procedentes del desengrasado destilado en abierto, por su potencial destructor de la capa de ozono y por la toxicidad del 1,1,1-tricloroetano.
Quizá la normativa de más amplia implantación hasta la fecha es la Norma Aeroespacial Nacional sobre Emisiones para Contaminantes Atmosféricos Peligrosos (NESHAP) de 1995, promulgada por la Agencia Norteamericana de Protección del Medio Ambiente, en el ámbito de las Enmiendas a la Ley de Limpieza del Aire de 1990. Según la norma, toda actividad aeroespacial debe cumplir con la media alcanzada por las 12 mejores de cada 100 prácticas actuales de control vigentes en los Estados Unidos, para así reducir la emisión de contaminantes generada en los procesos con mayores índices de emisión. La fecha límite de esta norma es septiembre de 1998. Los procesos y materiales más afectados son la recogida manual y la limpieza mediante lavado, los imprimadores y las capas superficiales, el decapado de pinturas y los agentes enmascaradores de fresado químico. La normativa permite la modificación o el control de los procesos y obliga a las autoridades locales al 
cumplimiento de sus requisitos en cuanto a material, equipos, prácticas y registros. La importancia de estas normas consiste en la imposición de las mejores prácticas posibles sin apenas tener en cuenta los costes para cada constructor aeroespacial. Como se muestra en la Tabla 90.5, imponen un cambio total: utilización de materiales de limpieza con disolventes con baja presión de vapor, revestimientos que contengan pocos disolventes y tecnología de equipos de aplicación. Se exceptúan los casos en que la seguridad del personal o de los productos (por riesgo de incendios, etc.) podría verse amenazada. En las Tablas 90.6 y 90.7, respectivamente, aparecen resúmenes de las prácticas más habituales en materia de riesgos químicos y de control de emisiones, consecuencia de las normativas ambientales sobre las actividades de construcción y de mantenimiento en los Estados Unidos. En su mayor parte, las normativas europeas no se ocupan del tema de las emisiones atmosféricas tóxicas, aunque sí de la eliminación de toxinas, como el cadmio, contenidas en algunos productos, y de la gradual eliminación de los compuestos destructores de la capa de ozono. En los Países Bajos, por ejemplo, los operadores están obligados a justificar el empleo de cadmio como elemento esencial para la seguridad en vuelo.

Las normativas en materia de ruido han seguido caminos parecidos. La Administración Federal de Aviación de los Estados Unidos y la Organización de Aviación Civil Internacional han fijado una serie de objetivos estrictos para lograr mejoras en la reducción de los niveles de ruido generados por los motores de aviación (p. ej.: la Ley sobre Capacidad y Ruido en los Aeropuertos Norteamericanos de 1990). Las compañías aéreas tienen la alternativa de sustituir los aparatos más antiguos, como los Boeing 727 o los McDonnell Douglas DC-9 (aparatos de la Etapa 2, según las definiciones de la OACI) por aparatos de la nueva generación, o remotorizar y modernizar estos aviones dotándoles de "silenciadores". La retirada del servicio de los ruidosos aviones de la Etapa 2 será obligatoria en los Estados Unidos el 31 de diciembre de 1999, fecha de entrada en vigor de las normativas de la Etapa 3.

Otro riesgo de las actividades aeroespaciales es la amenaza de caída de objetos, como residuos, piezas de aviones y satélites. La frecuencia con que se producen estas caídas es variable, pero la más habitual es el denominado "hielo azul", originado por fugas en los sistemas de drenaje de los lavabos de los aviones, permitiendo el escape de residuos que se congelan en el exterior del avión y terminan por desprenderse y caer. Las autoridades aeronáuticas están considerando la implantación de normativas que exijan inspecciones adicionales para corregir las fugas existentes en los citados sistemas de drenaje. Otros riesgos, como los producidos por los restos de satélites en vuelo, pueden resultar peligrosos en determinados casos (p. ej.: cuando se trate de instrumentos radiactivos o de fuentes de alimentación), aunque el riesgo que suponen para la población en general es extremadamente bajo.

Muchas compañías han constituido organizaciones para abordar la cuestión de la reducción de emisiones. Ya se han establecido los correspondientes objetivos en materia ambiental y se han puesto en vigor las políticas oportunas. La gestión de las autorizaciones, el transporte y manejo seguro de los materiales, su desecho y tratamiento requieren el concurso de ingenieros, técnicos y administradores.

Ingenieros especialistas en medio ambiente, ingenieros químicos y demás técnicos trabajan como administradores e investigadores. Además, el objeto de los programas no es otro que ayudar a la eliminación de las fuentes de emisiones químicas y de ruido en las fases de diseño o de proceso.

\section{Referencias}

Aerospace Industries Association (AIA). 1995. Advanced Composite Material Manufacturing Operations, Safety and Health Practice Observations and Recommendations, dirigido por G. Rountree. Richmond, BC:AIA.

Donoghue, JA. 1994. Smog Alert. Air Transport World 31(9):18.
Dunphy, BE, WS George. 1983. Aviación y aeroespacio, industria. En Enciclpoedia de salud y seguridad en el trabajo, $3^{a}$ edición. Ginebra: OIT.

Organización de Aviación Civil Internacional (OACI). 1981. International Standards and Recommended Practices: Environmental Protection. Anexo 16 de la Convención sobre Aviación Civil Internacional, vol. II. Montreal: OACI.

\section{Otras lecturas recomendadas}

Bourcier, DR, 1989. Exposure evaluation of composite materials with emphasis on cured composite dust. Applied Industrial Hygiene (Diciembre):40-46.

Suppliers of Advanced Composite Materials Association (SACMA). 1991. Safe Handling of Advanced Composite Materials, $2^{\text {a }}$ edición. Arlington, Virginia: SACMA 


\section{VEHICULOS DE MOTOR Y MAQUINARIA PESADA}

Director del capítulo

F ranklin E. M irer

\section{Sumario}

Industria del automóvil y el material de transporte

Franklin E. M irer 


\section{- IN DUSTRIA DEL AUTO MO VIL Y EL MATERIAL DE TRANSPORTE}

Franklin E. M irer

\section{Perfil general}

Dentro de la industria del automóvil y el material de transporte, pueden distinguirse los siguientes sectores:

- automóviles y vehículos de transporte ligeros

- camiones semipesados y pesados

- autobuses

- maquinaria agrícola y de construcción

- carretillas industriales

- motocicletas.

La cadena de montaje característica del vehículo terminado se apoya en diversas instalaciones en las que se fabrican las piezas y componentes. Estos componentes pueden producirse en la empresa matriz o comprarse a otras empresas. La industria del automóvil tiene un siglo de existencia. La producción de los sectores norteamericano, europeo y (desde la segunda Guerra $M$ undial) japonés se ha ido concentrando en un puñado de empresas que mantienen actividades de montaje en A mérica del Sur, A frica y A sia para las ventas a estos mercados. EI comercio internacional de vehículos terminados ha crecido intensamente desde el decenio de 1970, y el tráfico comercial de material

Tabla 91.1 - Procesos de producción para la fabricación de auto móviles.

\begin{tabular}{|c|c|}
\hline Tipo de instalación & Producto y proceso \\
\hline Fundición férrea & $\begin{array}{l}\text { Piezas de fundición para formar bloques y culatas } \\
\text { de motores, y otros componentes, mediante } \\
\text { mecanizado }\end{array}$ \\
\hline $\begin{array}{l}\text { Fundición de aluminio, } \\
\text { convencional e inyectada }\end{array}$ & $\begin{array}{l}\text { Bloques y culatas de motores, cárteres de transmi- } \\
\text { siones, otros componentes de fundición }\end{array}$ \\
\hline Forja y tratamiento térmico & $\begin{array}{l}\text { Piezas premecanizadas para motores, suspensiones } \\
\text { y transmisiones }\end{array}$ \\
\hline Estampación & Paneles y subconjuntos de carrocerías \\
\hline Motor & $\begin{array}{l}\text { Mecanizado de piezas de fundición, ensamblaje } \\
\text { para formar el producto acabado }\end{array}$ \\
\hline Transmisión & $\begin{array}{l}\text { Mecanizado de piezas de fundición y de forja, } \\
\text { ensamblaje para formar el producto }\end{array}$ \\
\hline Vidrio & Parabrisas, ventanillas laterales y luces traseras \\
\hline Piezas de automóviles & $\begin{array}{l}\text { Mecanizado, estampación y montaje, incluyendo } \\
\text { frenos, piezas de la suspensión, calefacción y aire } \\
\text { acondicionado, equipo de control de la contamina- } \\
\text { ción, alumbrado del vehículo }\end{array}$ \\
\hline Eléctrica y electrónica & $\begin{array}{l}\text { Sistemas de encendido, radios, motores, unidades } \\
\text { de control }\end{array}$ \\
\hline $\begin{array}{l}\text { Herrajes y guarniciones } \\
\text { rígidas }\end{array}$ & $\begin{array}{l}\text { Paneles exteriores de la carrocería moldeados en } \\
\text { polímero, componentes embellecedores }\end{array}$ \\
\hline $\begin{array}{l}\text { Guarniciones y equipa- } \\
\text { miento blandos }\end{array}$ & $\begin{array}{l}\text { Cojines de asientos, respaldos, conjuntos de salpica- } \\
\text { dero, paneles interiores de la carrocería }\end{array}$ \\
\hline Montaje del vehículo & $\begin{array}{l}\text { Taller de carrocería, pintura, montaje del chasis, } \\
\text { montaje final }\end{array}$ \\
\hline Depósitos de piezas & $\begin{array}{l}\text { Almacenamiento, pintura y montaje de piezas, } \\
\text { embalaje y expedición }\end{array}$ \\
\hline
\end{tabular}

original y de piezas de recambio procedentes de países en desarrollo es cada vez más importante.

La fabricación de camiones pesados, autobuses y maquinaria agrícola y de construcción

es una actividad distinta de la producción de automóviles, aunque algunos constructores de automóviles fabrican para ambos mercados y hay empresas que producen tanto maquinaria agrícola como de construcción. En estas líneas de productos se utilizan grandes motores diesel en lugar de motores de gasolina. Los ritmos de producción son normalmente más lentos, los volúmenes pequeños y los procesos menos mecanizados.

Los tipos de instalaciones, los procesos de producción y los componentes habituales en relación con los automóviles se indican en la Tabla 91.1. La Figura 91.1 presenta el diagrama de flujo típico de la producción de automóviles. En este sector se distinguen varias actividades industriales: montaje de vehículos de motor y sus carrocerías, montaje de carrocerías de camiones y autobuses, piezas y accesorios de vehículos de motor, fundición de hierro y acero, fundición de metales no férreos, estampación de componentes de automóviles, forja de hierro y acero, equipo eléctrico para motores, adornos, tapicería y guarnecidos, y otras. EI número de personas que trabajan en la fabricación de piezas es superior al de las que trabajan en el montaje. Todos estos procesos se apoyan en actividades de diseño de los vehículos y de construcción y mantenimiento de la planta y el equipo, así como en departamentos de administración y dirección, y en un departamento de distribución y reparaciones. En Estados U nidos, el número de personas que trabajan en concesionarios, estaciones de servicio y centros mayoristas de venta de piezas de recambio para automóviles, duplica al de las que se dedican a actividades de fabricación.

Las plantillas suelen ser predominantemente masculinas. En Estados U nidos, por ejemplo, la proporción de hombres es de un $80 \%$. La tasa de empleo femenina es más alta en trabajos de tapicería y otros de tipo ligero. L as oportunidades de acceso del trabajo manual a puestos de trabajo administrativo, técnico y profesional son limitadas, si bien, los supervisores de cadenas de montaje suelen proceder de las unidades de producción y mantenimiento. Un $20 \%$ de los trabajadores pertenecen a oficios especializados, aunque la proporción varía considerablemente, desde menos del $10 \%$ en las operaciones de montaje hasta casi el $50 \%$ en las de estampación. D ebido a las contracciones de los niveles de empleo en el decenio de 1980, la edad media de los trabajadores a finales del decenio de 1990 excede de los 45 años, generalizándose la contratación de nuevos trabajadores únicamente a partir de 1994.

\section{Principales sectores y procesos}

\section{Fundición de metales fér reos}

La fundición, o colada de metales, consiste en el vertido de metal fundido en una cavidad de un molde resistente al calor, que tiene la forma exterior, o negativa, del modelo del objeto metálico deseado. EI molde puede contener un macho para determinar las dimensiones de una cavidad interna en el objeto metálico final. EI trabajo de fundición consta de los siguientes pasos básicos:

- confección de un modelo del artículo deseado en madera, metal, plástico u otro material;

- confección del molde vertiendo arena y un aglomerante alrededor del modelo, y compactándola o dejando que se endurezca;

- extracción del modelo, introducción de cualquier macho necesario y montaje del molde;

- fusión y afino del metal en un horno; 
Figura 91.1 • Diagrama de flujo de la producción de automóviles.

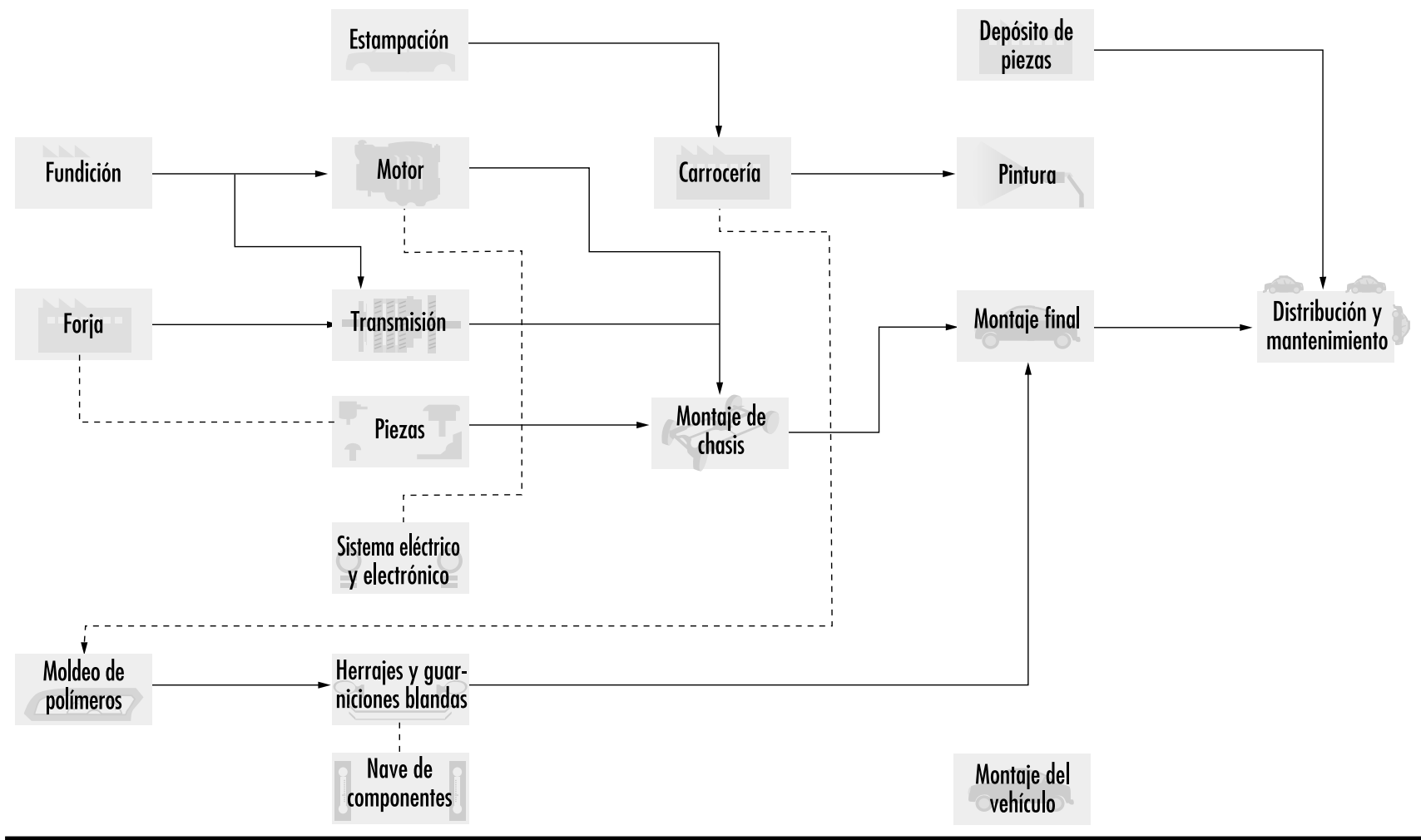

- colada del metal fundido en el molde;

- enfriamiento de la pieza metálica fundida;

- separación del molde y el macho de la pieza metálica fundida por el procedimiento de extracción con punzón (si se trata de piezas pequeñas) y mediante rejillas vibrantes (extracción por vibración) o chorro de agua abrasiva,

- eliminación del metal sobrante (por ej., el metal del bebedero, esto es, el canal por el que el metal fundido entra en el molde) y la arena calcinada de la pieza de fundición terminada (limpieza o eliminación de rebabas) mediante chorreado con granalla de acero, picado manual y esmerilado.

L os talleres de fundición de metales férreos son característicos de la industria del automóvil, para la cual producen bloques, culatas y otros componentes del motor. $\mathrm{H}$ ay dos tipos básicos de talleres de este tipo: las fundiciones de hierro gris y las de hierro dúctil. L as fundiciones de hierro gris utilizan chatarra de hierro o arrabio (lingotes nuevos) para hacer piezas de fundición de hierro normales. Las fundiciones de hierro dúctil añaden magnesio, cerio u otros aditivos (denominados generalmente aditivos de cuchara ) a las cucharas de metal fundido antes de la colada para hacer piezas de fundición nodular o maleable. Los diferentes aditivos tienen poca influencia en las exposiciones que se producen en los lugares de trabajo.

N ormalmente, en los talleres de fundición se utilizan cubilotes o bien hornos de inducción. Un cubilote es un horno alto vertical, abierto por arriba, con puertas de bisagras en la parte inferior. Se carga por la parte superior con capas alternas de coque, caliza y metal; el metal fundido se extrae por el fondo. EI horno de inducción funde el metal haciendo circular una corriente eléctrica de elevada intensidad por unas bobinas de cobre situadas en la parte exterior. Con ello se induce una corriente eléctrica en los bordes exteriores de la carga metálica, calentándose el metal debido a la alta resistencia eléctrica de esta carga. La fusión se desarrolla desde el exterior de la carga hacia el interior.

L os moldes se suelen hacer de arena húmeda (arena silícea, polvo de carbón, arcilla y aglomerantes orgánicos), la cual se vierte alrededor del modelo, compuesto normalmente por dos partes, y después se compacta. Esta tarea puede hacerse de forma manual o mecánica sobre una cinta transportadora. A continuación, se retira el modelo y se ensambla el molde mecánica o manualmente. EI molde debe tener un bebedero.

Si la pieza ha de tener un hueco en el interior, se introduce un macho en el molde. Los machos pueden hacerse de resinas termoestables de fenol-formaldehído (o similares) mezcladas con arena, que después se calienta (método de la caja caliente), o de mezclas de uretano y arena solidificadas con aminas, que se endurecen a temperatura ambiente (método de la caja fría). La mezcla de resina y arena se vierte en una caja de machos que tiene una cavidad con la forma deseada para el macho.

Los productos de fundición gris suelen ser piezas grandes, como bloques de motores. Con el tamaño aumentan los peligros físicos del trabajo y la dificultad de los problemas de control del polvo.

\section{Contaminantes atmosféricos en los procesos de fundición}

Polvo con sílice En las operaciones de acabado, desmoldeo por vibración y extracción, moldeo y confección de machos, y en el mantenimiento del sistema de arena y del departamento de fundición, se encuentra polvo con sílice. En estudios de muestras de aire realizados durante el decenio de 1970, se encontraron habitualmente exposiciones a sílice varias veces superiores al nivel permisible, sobre todo en el acabado. Las exposiciones eran mayores en las fundiciones de producción mecanizada que en los talleres de tipo artesanal. Se ha conseguido reducir los niveles con medidas de mejora de control, como el confinamiento y ventilación por extracción de los sistemas de arena, y el desmoldeo por 
vibración, la mecanización y las mediciones periódicas de higiene industrial. Para la mayoría de las operaciones que se realizan en los talleres existen sistemas de ventilación de diseño estándar. En las operaciones de acabado persisten exposiciones superiores a los límites normales, debido a una retirada inadecuada de la arena después de la vibración y a la calcinación de la sílice en la superficie de las piezas fundidas.

M onóxido de carbono. D urante el mantenimiento de los cubilotes y con ocasión de las perturbaciones de la ventilación de los procesos se registran niveles de monóxido de carbono extremadamente peligrosos. También pueden observarse niveles excesivos en los túneles de enfriamiento. Se han asociado asimismo exposiciones a monóxido de carbono a la fusión en cubilotes y a la combustión del material de carbono contenido en los moldes de arena húmeda. Igualmente puede producirse exposición a dióxido de azufre de origen desconocido, debido quizá a la presencia de contaminantes de azufre en el molde.

H umos metálicos. En las operaciones de fusión y colada se producen humos metálicos. Para extraerlos hay que instalar campanas compensadoras encima de los puestos de colada. De vez en cuando se observan exposiciones excesivas a humos de plomo en talleres de fundición de hierro, y de forma generalizada en los de fundición de latón; los humos de plomo en la fundición gris provienen de la contaminación con plomo de la chatarra de hierro utilizada como materia prima.

0 tros peligros químicos y físicos. En la fabricación de machos y en los productos de la combustión de éstos pueden encontrarse formaldehído, vapores de aminas y productos de pirólisis de isocianatos. En la industria del automóvil es característica la fabricación de machos a gran escala. A mediados del decenio de 1960, la confección de machos de fenol-formaldehído en caja caliente sustituyó a la de machos de aceite y arena, produciéndose importantes exposiciones al formaldehído que, a su vez, determinaron un aumento de los riesgos de irritación respiratoria, anomalías de la función pulmonar y cáncer de pulmón. La protección exige la ventilación por extracción local (VEL) en la máquina de machos, en los puestos de comprobación de machos y en la cinta transportadora, y el empleo de resinas de baja emisión. Cuando se ha sustituido la fabricación de machos de fenol-formaldehído por sistemas de poliuretano endurecido con aminas en caja fría, se requiere un mantenimiento eficaz de las juntas de la caja de machos, y VEL si los machos se almacenan antes de su introducción en el molde, a fin de proteger a los trabajadores de los efectos oculares de los vapores de aminas.

Los operarios que trabajen en estas zonas deben someterse, antes del empleo y después periódicamente, a exploraciones médicas que incluyan una radiografía de tórax, que debe ser examinada por un experto, una prueba de función pulmonar y un cuestionario de síntomas, ya que éstos son esenciales para detectar signos precoces de neumoconiosis, bronquitis crónica y enfisema. $\mathrm{H}$ an de realizarse audiometrías periódicas, dado que la protección auditiva suele ser ineficaz.

En procesos tales como la carga del horno, la extracción mecánica de machos, el desmoldeo y la expulsión de piezas fundidas y la eliminación de rebabas con herramientas neumáticas se dan altos niveles de ruido y vibración.

L os procesos de fundición generan un intenso calor. La carga de calor radiante en la fusión, la colada, el desmoldeo por vibración, la expulsión de machos y la eliminación de bebederos, requiere la adopción de medidas de protección especiales. Entre de estas medidas destaca la concesión de un tiempo de descanso (tiempo fuera del puesto de trabajo) como práctica común. En los meses calurosos de verano suele concederse asimismo un tiempo de descanso adicional. Los trabajadores deben llevar ropa protectora contra el calor y protección ocular y facial para prevenir la formación de cataratas. La existencia de zonas de descanso climatizadas cerca de la zona de trabajo mejora el valor protector del descanso térmico.

\section{Fundición de aluminio}

La fundición de aluminio (fundición convencional e inyectada) se utiliza para la fabricación de culatas, cárteres de transmisión, bloques de motor y otros componentes de automóviles. En la fundición convencional, los productos se funden en moldes permanentes, con y sin machos de arena, aunque se ha introducido el proceso a la espuma perdida, en el cual el modelo de espuma de poliestireno no se extrae del molde sino que es vaporizado por el metal fundido. La fundición inyectada implica la introducción forzada a presión del metal fundido en moldes 0 matrices metálicos. Se utiliza para fabricar grandes cantidades de piezas pequeñas de precisión. Va seguida siempre de la eliminación de rebabas en una prensa de forja y de algunas operaciones de acabado. El aluminio puede fundirse in situ o entregarse ya fundido.

Pueden surgir riesgos por elevada pirólisis del macho. Se producen exposiciones a sílice en talleres de fundición de moldes permanentes cuando hay machos grandes. Para prevenir niveles de exposición peligrosos se requiere ventilación local en el desmoldeo.

\section{0 tras fundiciones no fér reas}

Se utilizan otros procesos de fundición no férrea inyectada y de recubrimiento electrolítico para producir acabados decorativos en distintos productos, herrajes y parachoques. El recubrimiento electrolítico es un proceso por el que se deposita un metal sobre otro mediante un procedimiento electroquímico.

Los adornos de metal brillante se hacían tradicionalmente con fundición inyectada de zinc, recubierta sucesivamente de cobre, níquel y cromo, y acabada después por pulimentación. También las piezas de los carburadores y de los inyectores de combustible son de fundición inyectada. La extracción manual de las piezas de las máquinas de fundición inyectada se sustituye cada vez más por la extracción mecánica, y las piezas metálicas brillantes se sustituyen por piezas metálicas pintadas y por piezas de plástico. Antes, los parachoques se fabricaban por estampación del acero, seguida de recubrimiento metálico, pero en los turismos estos métodos se sustituyen cada vez más por el uso de polímeros.

El recubrimiento electrolítico con cromo, níquel, cadmio, cobre, etc. se realiza normalmente en talleres distintos, e implica la exposición, la inhalación o el contacto con vapores de los baños ácidos de recubrimiento. Se ha relacionado un aumento de la incidencia de cáncer con nieblas de ácido crómico y de ácido sulfúrico. Estas nieblas son también extremadamente corrosivas para la piel y el tracto respiratorio. Los baños de recubrimiento electrolítico deben disponer de etiquetas en las que se indique su contenido y sistemas especiales de ventilación local del tipo impelente-aspirante. Deben añadirse al líquido agentes tensoactivos antiespumantes para minimizar la formación de niebla. Los trabajadores deben llevar protección ocular y facial, protección para manos y brazos, y mandiles. Asimismo han de someterse a revisiones periódicas de salud.

La introducción y extracción de componentes en las cubas son operaciones muy peligrosas que cada vez están más mecanizadas. El pulido y buñido de componentes recubiertos electrolíticamente sobre bandas o discos de fieltro es agotador e implica la exposición a polvo de algodón, cáñamo y lino. El riesgo correspondiente puede minimizarse utilizando un aparato de sujeción o mecanizando el trabajo con máquinas pulidoras tipo "transfer". 


\section{Forja y tratamiento térmico}

La forja en caliente y la forja en frío seguida de tratamiento térmico se utilizan en la industria del automóvil para la fabricación de piezas del motor, la transmisión y la suspensión, así como otros componentes

Tradicionalmente, la forja implicaba el calentamiento de tochos (barras) de hierro en hornos individuales caldeados con fueloil, situados cerca de martinetes de vapor accionados individualmente. Luego se colocaba el hierro caliente en la mitad inferior de una estampa, o matriz, metálica cuya mitad superior estaba unida al martinete. El hierro adquiría el tamaño y la forma deseados mediante múltiples impactos del martinete. En la actualidad, estos procesos se sustituyen por el calentamiento por inducción de los tochos, los cuales se trabajan en prensas de forja que utilizan presión en lugar de impactos para conformar la pieza metálica, y recalcadoras, o por la forja en frío seguida de tratamiento térmico.

EI proceso de forja es extremadamente ruidoso. La exposición al ruido puede reducirse sustituyendo los hornos de fueloil por dispositivos de calentamiento por inducción, y los martinetes por prensas de forja y recalcadoras. EI proceso también produce humos. Los procedentes del fueloil pueden reducirse modernizando el horno.

La forja y el tratamiento térmico son operaciones que producen intenso calor. Para reducir el estrés por calor se requiere la refrigeración puntual mediante la circulación de aire renovado por encima de los trabajadores en las zonas de proceso.

\section{M ecanizado}

Es típico de la industria del automóvil el mecanizado para la producción a gran escala de bloques de motor, cigüeñales, transmisiones y otros componentes. L as operaciones de mecanizado se llevan a cabo en diversas instalaciones y constituyen el proceso predominante en la fabricación de estas piezas. En ellas se producen componentes tales como árboles de levas, engranajes, satélites de diferencial y tambores de freno. Los puestos de mecanizado de un solo operario se sustituyen cada vez más por máquinas de varios puestos, células de mecanizado y cadenas "transfer" de hasta 200 metros de longitud. L os aceites solubles y los refrigerantes sintéticos y semisintéticos se imponen cada vez más a los aceites puros.

En las operaciones de mecanizado son comunes las lesiones por cuerpos extraños; las principales medidas preventivas al respecto son el aumento de la mecanización en la manipulación de materiales y el uso de equipo de protección individual. EI desarrollo de la automatización, en especial las cadenas transfer de gran longitud, implica un mayor riesgo de traumatismos agudos; los programas preventivos se basan en la mejora de los resguardos de las máquinas y el bloqueo de la alimentación de energía.

Entre las medidas de control de máximo nivel contra la niebla de refrigerante deben destacarse el confinamiento total de los puestos de mecanizado y de los sistemas de circulación de líquido; la ventilación local por extractores, con evacuación al exterior o recirculación del aire extraído, siempre a través de un filtro de alto rendimiento; los controles del sistema de refrigeración para reducir la formación de niebla, y el mantenimiento del refrigerante para controlar los microorganismos. Debe prohibirse la adición de nitrito a los líquidos que contienen aminas, por el riesgo de producción de nitrosoamina. No deben usarse aceites con elevado contenido de hidrocarburos polinucleares aromáticos (H PA).

En la cementación, revenido, baños de sales de nitrato y otros procesos de tratamiento térmico del metal en los que se utilizan hornos y atmósferas controladas, el microclima puede ser sofocante y puede haber diversas sustancias tóxicas en el aire (por ej., monóxido de carbono, dióxido de carbono, cianuros).

L os operarios de las máquinas y los trabajadores que manejan residuos de mecanizado y centrifugan aceite de corte antes de su filtrado y regeneración están expuestos a dermatitis. D eben facilitárseles mandiles resistentes al aceite y hay que recomendarles que se laven completamente al finalizar el turno.

El esmerilado y el afilado de herramientas pueden presentar peligro de enfermedad por metal duro (enfermedad pulmonar intersticial) a menos que se mida y controle la exposición al cobalto. Las muelas deben llevar pantallas protectoras, y los esmeriladores han de usar protección ocular y facial y equipo de protección respiratoria.

Normalmente, las piezas mecanizadas se ensamblan para formar un componente terminado, con los consiguientes peligros ergonómicos. En las secciones de montaje de motores, las pruebas y el rodaje de éstos deben realizarse en estaciones provistas de equipos de evacuación de gases de escape (monóxido de carbono, dióxido de carbono, hidrocarburos no quemados, aldehídos, óxidos de nitrógeno) y de instalaciones de control de ruido (cabinas con paredes fonoabsorbentes, placas de asiento aislantes). El ruido puede alcanzar niveles de hasta 100 a $105 \mathrm{~dB}$ con picos de $600 \mathrm{a} 800 \mathrm{~Hz}$.

\section{Estampación}

L a estampación de chapa metálica (de acero) para formar paneles de carrocería y otros componentes, a menudo combinada con el ensamblaje de subconjuntos por soldadura, se lleva a cabo en grandes instalaciones equipadas con prensas mecánicas grandes y pequeñas. Las prensas de carga y descarga individual se han ido sustituyendo por dispositivos mecánicos de extracción y más recientemente por mecanismos de transferencia alternativa que también pueden efectuar operaciones de carga, con lo que se obtienen cadenas de estampación totalmente automatizadas. La fabricación de subconjuntos tales como puertas y capós se realiza en prensas de soldadura por resistencia y, cada vez con más frecuencia, en celdas con transferencia de piezas robotizada.

El proceso principal es la estampación de la chapa de acero, fleje y partes ligeras en prensas mecánicas de 20 a 2.000 toneladas de capacidad.

La seguridad de las prensas modernas requiere la colocación de resguardos eficaces en la maquinaria, la prohibición de introducir las manos al trabajar entre las estampas (troqueles), la aplicación de órganos de mando de seguridad que incluyen los dispositivos de mando a dos manos diseñados para evitar la neutralización, la instalación de embragues de revolución parcial y controladores de freno, el uso de sistemas automáticos de alimentación y expulsión, la recogida de recortes de metal de la prensa y el uso de equipo de protección individual, como mandiles y protección para los pies, piernas, manos y brazos. Deben desecharse las máquinas con embrague de revolución completa y dispositivos apartacuerpos o apartamanos, anticuados y peligrosos. La manipulación de acero laminado con grúas y la carga de los desenrolladores de bobinas de chapa antes del corte de piezas en bruto al principio de una cadena de estampación presenta un grave riesgo para la seguridad.

Los operarios que manejan las prensas están expuestos a elevados niveles de niebla producida por los lubricantes de embutición, cuya composición es similar a la de los líquidos de mecanizado, tales como aceites solubles. En la fabricación de conjuntos soldados se producen humos de soldadura. En la estampación, los niveles de exposición al ruido son muy elevados. Entre las medidas de control del ruido se incluye el uso de silenciadores en las válvulas neumáticas, revestimiento de las canaletas metálicas con material antivibración, insonorización de los carros portapiezas y aislamiento de las prensas; el punto 
de operación de la prensa no es el punto principal de producción de ruido.

Después de la estampación, las piezas se ensamblan para formar subgrupos tales como puertas y capós, utilizando prensas de soldadura por resistencia. Entre los peligros químicos están los relacionados con humos de soldadura, procedentes principalmente de la soldadura por resistencia y de productos de pirólisis de los recubrimientos superficiales, como lubricantes de embutición y sellantes.

\section{Paneles de carrocería y componentes embellecedores de plástico}

Las piezas metálicas de adorno, tales como las molduras cromadas, se sustituyen cada vez más por materiales a base de polímeros. Las piezas rígidas de la carrocería pueden fabricarse con sistemas de poliestireno de poliéster reforzado con fibra de vidrio, sistemas termoestables de acrilonitrilo-butadieno-estireno (ABS) o polietileno. Los sistemas de poliuretano pueden ser de alta densidad para piezas de la carrocería tales como el morro, o de espuma de baja densidad para los asientos y el acolchado del habitáculo.

El moldeo de espuma de poliuretano plantea graves problemas de sensibilización respiratoria por inhalación de monómero de diisocianato y, posiblemente, de catalizadores. Las molestias persisten en operaciones que cumplen los límites de diisocianato de tolueno (DIT). Las exposiciones a cloruro de metileno por lavado a pistola pueden ser considerables. LoS puestos de colada requieren confinamiento y ventilación por extracción local (VEL); los derrames de isocianato deben reducirse al mínimo mediante la instalación de dispositivos de seguridad, y limpiarse cuanto antes por personal cualificado. También los incendios en los hornos de secado son un problema en estas instalaciones. L a fabricación de asientos produce fuertes cargas de estrés ergonómico, que pueden reducirse utilizando aparatos, especialmente para estirar la tapicería sobre los cojines

La exposición al estireno por acumulación de fibra de vidrio debe controlarse mediante confinamiento de los depósitos de alfombrillas y ventilación por extracción local. El polvo producido por el esmerilado de piezas solidificadas contiene fibra de vidrio y también debe controlarse mediante ventilación.

\section{M ontaje del vehículo}

El ensamblaje de los componentes para formar el vehículo terminado se lleva a cabo normalmente sobre una cinta transportadora mecanizada, e intervienen en él más de un millar de trabajadores por turno, con personal de apoyo adicional. El mayor segmento de trabajadores de la industria es precisamente el que interviene en este tipo de proceso.

U na planta de montaje de vehículos está dividida en unidades claramente diferenciadas: taller de carrocerías, en el que se realizan algunas actividades de montaje de subconjuntos que también se llevan a cabo en los talleres de estampación; pintura; montaje de chasis; nave de fabricación de asientos (que puede ser abastecida por proveedores externos) y montaje final. En los últimos años los procesos de pintura han evolucionado hacia fórmulas más reactivas, con menor contenido de disolventes, utilizándose cada vez más los procedimientos de aplicación mecánicos y robotizados. EI taller de carrocerías ha ido automatizándose progresivamente, reduciéndose la soldadura al arco y sustituyéndose por robots las pistolas de soldadura manual por puntos.

El proceso de montaje de vehículos de transporte ligeros (furgonetas, camionetas, vehículos de servicio deportivos) es similar al de montaje de turismos. La fabricación de camiones pesados y maquinaria agrícola y de construcción se caracteriza por un menor nivel de mecanización y automatización, unos ciclos de trabajo más largos, un mayor trabajo físico, un mayor empleo de la soldadura al arco y la utilización de sistemas de pintura diferentes.

En el taller de carrocerías de una planta de montaje se ensambla el armazón del vehículo. Las máquinas de soldadura por resistencia pueden ser de tipo transfer, robotizadas 0 de manejo individual. Aunque las máquinas suspendidas de soldadura por puntos van montadas con un sistema de contrapeso, son pesadas e incómodas de manejar. Las máquinas transfer y los robots han eliminado muchas tareas manuales y liberado a los trabajadores de la proximidad y exposición directa al metal caliente, las chispas y los productos de combustión del aceite mineral que cubre la chapa metálica. No obstante, el aumento del grado de automatización conlleva un mayor riesgo de sufrir lesiones graves para los trabajadores de mantenimiento; en los talleres de carrocerías automatizados se han de disponer programas de desconexión y bloqueo de las fuentes de energía y sistemas automáticos de protección en las máquinas más elaborados, incluyendo detectores de presencia. El grado de utilización de la soldadura al arco es limitado. D urante este trabajo, los operarios se encuentran expuestos a radiaciones intensas de tipo visible y ultravioleta, así como a la inhalación de gases de combustión. Los que realizan trabajos de soldadura al arco necesitan ventilación por extracción local (VEL), pantallas y tabiques protectores, viseras o gafas para soldar, guantes y mandiles.

EI taller de carrocerías presenta los mayores riesgos de heridas y de lesiones por cuerpos extraños.

$\mathrm{H}$ ace algunos años, los métodos de montaje y los procesos de repaso de defectos de los paneles de las carrocerías implicaban operaciones de soldadura blanda con aleaciones de plomo y estaño (que también contenían trazas de antimonio). La soldadura blanda y, en especial, el esmerilado para eliminar el exceso de soldadura entrañaba un grave riesgo de intoxicación por plomo, habiéndose producido algunas muertes cuando se introdujo el proceso en el decenio de 1930. Entre las medidas de protección se incluyeron la instalación de una cabina aislada para esmerilado de soldaduras, el empleo de respiradores que suministraban aire a presión positiva a los esmeriladores de soldaduras, la adopción de medidas de higiene y el control de plomo en sangre. A pesar de ello, se registraron aumentos de las cargas corporales de plomo y casos esporádicos de intoxicación por plomo de trabajadores y sus familias hasta el decenio de 1970. La soldadura con plomo se ha eliminado de las carrocerías de los turismos en Estados Unidos. Además, en esos procesos los niveles de ruido pueden alcanzar de 95 a $98 \mathrm{~dB}$ con picos de 600 a $800 \mathrm{~Hz}$.

Las carrocerías de los automóviles pasan, sobre una cinta transportadora, del taller de carrocerías al de pintura, donde se desengrasan, por lo general mediante aplicación manual de disolventes, se limpian en un túnel cerrado (bonderización) y reciben una capa de imprimación. La imprimación se lija después a mano con una herramienta oscilante y papel abrasivo húmedo, y a continuación se aplican las capas finales de pintura y se secan al horno. En los talleres de pintura, el personal puede inhalar tolueno, xileno, cloruro de metileno, alcoholes minerales, nafta, acetato de butilo y amilo y vapores de alcohol metílico de la carrocería, la cabina de pintura y la limpieza de las pistolas. La pintura a pistola se aplica en cabinas de corriente de aire descendente, con un suministro continuo de aire filtrado. Por lo general, los vapores de disolventes se controlan bien mediante ventilación descendente, la cual es necesaria para garantizar la calidad del producto. Antes, la inhalación de partículas no estaba tan bien controlada, y algunas pinturas contenían sales de cromo y plomo. En una cabina bien controlada, los operarios no debieran necesitar equipo de protección respiratoria para 
cumplir con los límites de exposición. No obstante, muchos llevan voluntariamente respiradores. $L$ as pinturas de poliuretano de dos componentes recientemente introducidas deben aplicarse siempre usando cascos con suministro de aire y espaciando convenientemente las reentradas en la cabina. L as normas sobre protección medioambiental han fomentado el desarrollo de pinturas con gran proporción de sustancias sólidas y menor contenido de disolventes. L os sistemas de resinas más recientes pueden producir un considerable nivel de exposición al formaldehído, y las pinturas en polvo que están introduciéndose en la actualidad son fórmulas epoxídicas que pueden ser sensibilizantes. U na queja frecuente es que las unidades de ventilación recirculan el aire evacuado de las cabinas de pintura y los hornos de secado a las zonas de trabajo situadas fuera de la cabina; este problema puede evitarse instalando chimeneas de extracción de suficiente altura.

En la producción de vehículos comerciales (camiones, tranvías y trolebuses) y de maquinaria agrícola y de construcción, aún se utiliza con frecuencia la pintura manual a pistola debido a las grandes superficies que deben cubrirse y a la necesidad de frecuentes retoques. En estas operaciones puede que todavía se utilicen pinturas con plomo y cromato.

La carrocería pintada se seca en hornos de aire caliente y rayos infrarrojos equipados con extractores y después se lleva al taller de montaje final, en el que se unen los componentes mecánicos. Allí se acoplan la carrocería, el motor y la transmisión, y se montan la tapicería y la guarnición interior. Es en estas tareas donde el trabajo en la cinta transportadora presenta su versión más elaborada. Cada operario ejecuta una serie de tareas en cada vehículo, en ciclos de 1 minuto aproximadamente, mientras el sistema de cintas transporta las carrocerías gradualmente a lo largo de la cadena de montaje. Los procesos requieren una vigilancia constante y pueden ser considerablemente monótonos, por lo que es fácil que generen estrés. Aunque normalmente no requieren un excesivo gasto de energía, casi todos entrañan el riesgo, de moderado a grave, de causar trastornos musculosqueléticos. Las posturas o movimientos que se han de adoptar, por ejemplo cuando se montan componentes en el interior del vehículo o cuando se trabaja debajo de la carrocería (con las manos y antebrazos por encima del nivel de la cabeza), son los peligros más fáciles de combatir, aunque también es necesario reducir la fuerza y la repetición para reducir los factores de riesgo. Después del montaje final, el vehículo se prueba, se acaba y se entrega. La inspección puede limitarse a las pruebas de rodaje sobre un banco de rodillos (donde la ventilación de los humos de escape es importante) o incluir pruebas sobre pistas con distintos tipos de superficie, pruebas de estanqueidad al agua y al polvo, y pruebas en carretera fuera de la factoría.

\section{Depósitos de piezas}

L os depósitos de piezas son un elemento integrante de la distribución del producto acabado y del suministro de piezas de repuesto para reparaciones. Los operarios que trabajan en ellos utilizan dispositivos especiales para retirar las piezas de posiciones elevadas y sistemas automatizados de entrega de piezas en operaciones en tres turnos. Es común la manipulación manual de piezas empaquetadas. En los depósitos de piezas también se realizan a veces operaciones de pintura y otros procesos de producción.

\section{Prueba de prototipos}

La prueba de prototipos es una actividad especializada de la industria del automóvil. Son varias las agresiones fisiológicas que aguardan a los conductores: aceleración y frenado bruscos, sacudidas y vibraciones, monóxido de carbono y humos de escape, ruido, largas temporadas de trabajo en diferentes ambientes y condiciones climáticas. Las pruebas de resistencia implican tensiones especiales. En ocasiones se han producido accidentes mortales con los vehículos.

\section{M ontaje de camiones pesados y de maquinaria agrícola y de construcción}

En estos sectores de la industria del automóvil, los procesos son esencialmente los mismos que en el montaje de turismos y vehículos de transporte ligeros. Entre las diferencias están un ritmo de producción más lento, realizándose algunas operaciones fuera de la cadena de montaje; un mayor volumen de soldadura al arco; el remachado de las cabinas de los camiones; el movimiento de componentes con grúa; el uso de pigmentos que contienen cromato, y el empleo de gasóleo diesel en la salida al final de la cadena de montaje. El número de fabricantes en relación con el volumen de producción es mayor y están menos integrados verticalmente.

\section{Fabricación de locomotoras y vagones}

La fabricación de material ferroviario comprende asimismo segmentos bien diferenciados: locomotoras, vagones de viajeros, vagones de carga y vagones de viajeros de autopropulsión eléctrica. L os procesos de montaje presentan ciclos más largos que en la fabricación de turismos y camiones; se utilizan más las grúas para la manipulación de materiales, y se hace un mayor uso de la soldadura al arco. El gran tamaño de los productos dificulta el control técnico de las operaciones de pintura y crea situaciones en las que los operarios están totalmente encerrados en el producto mientras sueldan o pintan a pistola.

\section{Problemas de salud y patrones de enfermedad}

Aunque los procesos de producción no son exclusivos de la industria automovilística, con frecuencia el efecto combinado de la escala de producción y el alto grado de integración y automatización plantea riesgos especiales para el personal. Los peligros que amenazan a los trabajadores en este complejo sector industrial deben considerarse en función de tres dimensiones: el tipo de proceso, el grupo de clasificación del trabajo y los efectos adversos.

Se distinguen múltiples efectos adversos, con causas y métodos de prevención claramente diferenciados: lesiones graves y mortales; lesiones en general; trastornos por traumatismos repetidos; efectos químicos de corta duración; enfermedad profesional por exposición de larga duración a sustancias químicas; peligros del sector de servicios (incluidas las enfermedades infecciosas y la posible violencia por parte de los clientes), y peligros derivados del medio ambiente de trabajo, tales como estrés de origen psicosocial.

Los grupos de clasificación del trabajo en la industria del automóvil implican, a efectos prácticos, espectros de peligro divergentes: trabajos especializados (personal de mantenimiento, servicio, fabricación e instalación de equipo de producción); manutención mecánica de materiales (operadores de carretillas industriales autopropulsadas y de grúas); servicio de producción (incluido el personal de mantenimiento y limpieza no cualificado); producción fija (el grupo más numeroso, que incluye a los montadores y a los operadores de máquinas); tareas técnicas y administrativas, y funciones ejecutivas y de dirección.

\section{E fectos para la salud y la seguridad comunes a todos los procesos}

Según el US Bureau of Labor Statistics, la industria automovilística presenta uno de los índices generales de siniestralidad laboral más elevados: 1 de cada 3 trabajadores se lesionan al año, siendo las lesiones en 1 de cada 10 casos lo bastante graves para provocar 
pérdida de tiempo de trabajo. El índice de riesgo de mortalidad profesional por lesiones traumáticas agudas en toda la vida laboral es de 1 por cada 2.000. Ciertos peligros son generalmente característicos de los agrupamientos profesionales de la industria del automóvil, en tanto que otros, especialmente los de origen químico, son característicos de determinados procesos de producción.

El trabajo cualificado y las tareas de manutención mecánica entrañan un alto riesgo de lesiones traumáticas graves y mortales. Aunque los profesionales cualificados representan menos del $20 \%$ de la plantilla, sufren el $46 \%$ del total de lesiones mortales de origen profesional. Las tareas de manutención mecánica producen el $18 \%$ de los fallecimientos. La mayor parte de los fallecimientos de trabajadores cualificados ocurren durante las actividades de mantenimiento y servicio, siendo la causa principal la energía incontrolada. Entre las medidas preventivas se incluyen la aplicación de programas de bloqueo de energía, la colocación de resguardos en las máquinas, la prevención de caídas y la seguridad de las carretillas industriales y las grúas, y todas se basan en análisis orientados a la seguridad en el trabajo

En contraste, los trabajos de producción fijos presentan mayores índices de lesiones generales y trastornos por traumatismos repetidos, pero un bajo riesgo de lesiones mortales. Las lesiones musculosqueléticas, como los trastornos por traumatismos repetidos y las tensiones y dislocaciones provocadas por sobreesfuerzo o movimientos repetitivos, que están estrechamente relacionados con los anteriores, representan el $63 \%$ de lesiones con resultado de discapacidad en las instalaciones de montaje y aproximadamente la mitad de las lesiones en procesos de otro tipo. Las principales medidas preventivas son la aplicación de programas ergonómicos basados en análisis de los factores de riesgo y la reducción estructurada de la fuerza, la frecuencia y el estrés postural en trabajos de alto riesgo.

Los trabajos de servicio de producción y los trabajos especializados son los que entrañan la mayor parte de los riesgos químicos agudos y de alto nivel. Normalmente, estas exposiciones se producen durante la limpieza periódica, la respuesta a derrames y alteraciones de procesos, y la entrada en espacios confinados durante las actividades de mantenimiento y servicio. Entre estas situaciones peligrosas destacan las exposiciones a disolventes. Se desconocen las consecuencias de larga duración que estas altas exposiciones intermitentes tienen para la salud. Los operarios que embrean suelos de madera, como los que se utilizan en muchas instalaciones, o queman pernos con soplete en el piso de las naves de estampación, sufren elevadas exposiciones a sustancias volátiles cancerígenas de breas de alquitrán de hulla. En estos grupos se ha observado una mortalidad excesiva por cáncer de pulmón. Las medidas preventivas se centran en la adopción de programas de entrada en espacios confinados y de respuesta a residuos peligrosos y a emergencias, aunque la prevención a largo plazo depende de la modificación del proceso para eliminar la exposición.

Donde más evidentes resultan los efectos de la exposición crónica a sustancias químicas y a algunos agentes físicos es entre los trabajadores de producción fija, debido principalmente a que estos grupos son más fáciles de estudiar. Casi todos los efectos adversos considerados específicos de ciertos procesos se deben a exposiciones comprendidas dentro de los límites de exposición profesional actualmente vigentes, por lo que la protección dependerá de la reducción de los límites admisibles. A corto plazo, las exposiciones y riesgos pueden reducirse adoptando las mejores prácticas posibles, como unos sistemas de extracción bien diseñados y mantenidos.

La pérdida auditiva inducida por ruido es un efecto generalizado en todos los segmentos de la industria.
Todos los sectores de la población activa están sujetos a estrés de origen psicosocial, aunque éste es más evidente en los trabajos administrativos, técnicos, de apoyo administrativo, directivos y profesionales, por el hecho de sufrir generalmente una exposición menos intensa a otros peligros. No obstante, el estrés en el trabajo suele ser más intenso entre los trabajadores de producción y mantenimiento, y los efectos del estrés también suelen ser mayores. No se ha implantado ningún medio eficaz de reducción del estrés causado por el trabajo nocturno y en turnos rotativos, aunque los convenios de turnos preferenciales permiten cierta autoselección, y se compensa con primas de turno a los trabajadores a los que se les asignan los turnos peores. La aceptación de los turnos rotativos por la plantilla es un hecho histórico y cultural. El personal cualificado y de mantenimiento trabaja bastantes más horas extraordinarias y durante las fiestas, vacaciones y paradas, que el personal de producción. Los programas de trabajo incluyen normalmente dos turnos de producción y un turno de mantenimiento más corto; esto ofrece una cierta flexibilidad para horas extraordinarias en periodos de aumento de producción.

En la exposición siguiente se agrupan los peligros químicos y algunos peligros físicos específicos por tipos de producción y se tratan los peligros de lesiones y ergonómicos por clasificaciones laborales.

\section{Fundiciones}

Las fundiciones destacan en la industria del automóvil por su mayor índice de fallecimientos, ocasionados por los derrames de metal fundido y las explosiones, el mantenimiento de cubilotes, incluida la descarga por el fondo, y los riesgos por monóxido de carbono durante la renovación del revestimiento. Se caracterizan asimismo por una mayor proporción de lesiones por cuerpos extraños, contusiones y quemaduras, y una proporción menor de trastornos musculosqueléticos que otras instalaciones. También registran los niveles más altos de exposición al ruido (Andjelkovich y cols. 1990; Andjelkovich y cols. 1995; Koskela 1994; Koskela y cols. 1976; Silverstein y cols. 1986; Virtamo y Tossavainen 1976).

U n reciente análisis de varios estudios de mortalidad en los que se incluía la industria automovilística norteamericana mostró que los trabajadores de las fundiciones presentaban índices más altos de muerte por cáncer de pulmón en 14 de 15 estudios (E gan-Baum, M iller y Waxweiller 1981; M irer y cols. 1985). Dado que los índices elevados de cáncer de pulmón se han observado en los trabajadores de la nave de limpieza, donde la principal exposición es a la sílice, probablemente una de las causas principales sea la exposición a mezclas de polvo que contienen sílice (IARC 1987, 1996), aunque también se dan exposiciones a hidrocarburos polinucleares aromáticos. En 8 de 11 estudios se encontró un aumento de la mortalidad por enfermedad respiratoria no maligna. También se registraron fallecimientos por silicosis. Los estudios clínicos notifican cambios radiológicos característicos de neumoconiosis, anomalías de la función pulmonar características de obstrucción y aumento de los síntomas respiratorios en fundiciones de producción modernas que poseían los más altos niveles de control. Estos efectos se deben a estados de exposición que prevalecen desde el decenio de 1960 e indican claramente que los riesgos para la salud persisten en las condiciones actuales.

Se han observado efectos producidos por amianto en exploraciones radiológicas de trabajadores de fundiciones; entre los sujetos se encuentran operarios tanto de producción como de mantenimiento. 


\section{Operaciones de mecanizado}

En un reciente análisis de varios estudios de mortalidad realizados entre trabajadores que realizaban operaciones de mecanizado se observó un aumento de cáncer de estómago, esófago, recto, páncreas y laringe claramente relacionado con la exposición (Silverstein y cols. 1988; Eisen y cols. 1992). Entre los agentes cancerígenos conocidos históricamente presentes en los refrigerantes se hallan los compuestos polinucleares aromáticos, nitrosoaminas, parafinas cloradas y formaldehído. Aunque las fórmulas actuales contienen cantidades reducidas de estos agentes y las exposiciones a partículas de refrigerante son también reducidas, aún puede existir riesgo de cáncer con los niveles de exposición actuales. Estudios clínicos han documentado asma de origen profesional, aumento de los síntomas respiratorios, disminución de la función pulmonar en cruces de turnos y, en un caso, enfermedad del legionario asociada a la exposición a niebla de refrigerante (DeC oufle 1978; Vena y cols. 1985; M allin, Berkeley y Young 1986; Park y cols. 1988; D elzell y cols. 1993). L os efectos respiratorios son más pronunciados con líquidos sintéticos y aceites solubles, que contienen sustancias químicas irritantes tales como sulfonatos de petróleo, resinas líquidas, etanolaminas, formaldehído y biocidas donadores de formaldehído, así como productos bacterianos tales como endotoxina. Todavía son frecuentes los trastornos de la piel entre los operarios que realizan trabajos de mecanizado, registrándose mayores problemas en los que están expuestos a líquidos sintéticos.

\section{O peraciones de estampación}

L os peligros de lesiones característicos de los trabajos de estampación son los aplastamientos y amputaciones, especialmente de las manos, al quedar aprisionadas en la prensa, y a su vez, las lesiones de manos, pies y piernas originadas por los recortes de metal procedentes de la prensa.

Las instalaciones de estampación presentan una tasa de heridas doble que el promedio de la industria automovilística. En ellas trabajan una proporción de trabajadores cualificados superior a la media, sobre todo si la construcción de estampas se realiza in situ. El cambio de estampas es una actividad especialmente peligrosa.

L os estudios de mortalidad realizados en el sector de la estampación son limitados. En uno de ellos se observó aumento de la mortalidad por cáncer de estómago, y en otro aumento de la mortalidad por cáncer de pulmón entre soldadores de mantenimiento y reparadores de máquinas expuestos a sustancias volátiles de breas de alquitrán de hulla.

\section{H er rajes y recubrimiento electrolítico}

En un estudio de mortalidad entre trabajadores de una planta de herrajes para automóviles se halló mortalidad excesiva por cáncer de pulmón entre operarios de departamentos en los que se realizaban trabajos integrados de fundición inyectada de zinc y recubrimiento electrolítico. Entre las causas probables estaban la niebla de ácido crómico y sulfúrico o los humos de la fundición inyectada.

\section{M ontaje de los vehículos}

Las tasas de lesiones en las operaciones de montaje, incluidos los trastornos por traumatismos acumulados (TTA), son actualmente las más altas del sector del automóvil, debido en gran parte a los trastornos musculosqueléticos por trabajo repetitivo 0 sobreesfuerzo. L os trastornos musculosqueléticos representan más del $60 \%$ de lesiones con resultado de discapacidad en este sector.

En varios estudios de mortalidad realizados en naves de montaje se ha observado un aumento de los fallecimientos por cáncer de pulmón. Ningún proceso específico del sector del montaje ha demostrado ser el responsable, por lo que esta cuestión continúa investigándose.

\section{Prueba de prototipos}

En este trabajo se producen casos de accidentes mortales con los vehículos.

\section{Trabajo de diseño}

El personal de diseño de las empresas automovilísticas han sido causa de preocupación en relación con la salud y la seguridad. Las estampas o matrices para los prototipos se hacen construyendo primero el modelo en madera, para lo cual se utiliza madera muy dura y tableros de estratificado y aglomerado. Los modelos de plástico se fabrican con fibra de vidrio y resinas de poliéster-poliestireno. Los modelos metálicos son básicamente matrices construidas mediante mecanizado de precisión. Se ha comprobado, en repetidos estudios, que los operarios que confeccionan los modelos de madera, plástico y metal sufren excesiva incidencia y mortalidad por cáncer de colon y rectal. No se ha identificado ningún agente causante específico.

\section{Medio ambiente y salud pública}

La legislación medioambiental dirigida a fuentes estacionarias de la industria del automóvil contempla principalmente los compuestos orgánicos volátiles de la pintura a pistola y otros recubrimientos superficiales. Las presiones tendentes a reducir el contenido de disolvente de las pinturas ha cambiado, de hecho, la naturaleza de los recubrimientos utilizados. Estas normas afectan tanto a los proveedores y a las plantas de piezas como al montaje de vehículos. En las fundiciones están sujetas a regulación las emisiones aéreas de partículas y dióxido de azufre, en tanto que la arena usada se trata como residuo peligroso.

Las emisiones de escape y la seguridad de los vehículos son cuestiones críticas de salud pública y seguridad reguladas fuera del ámbito profesional. 


\section{Referencias}

Agencia Internacional para la Investigación sobre el Cáncer (IARC). 1987. Silica and Some Silicates. Vol. 42. Lyon: IARC.

- . 1996. Silica, Some Silicates, Coal D ust and Para-aramid Fibrils. Vol. 68. Lyon: IAR C.

Andjelkovich, DA, DB Janszen, M H Brown, R B Richardson, FJ M iller. 1995. M ortality of iron foundry workers. IV. Analysis of a subcohort exposed to formaldehyde. J O ccup M ed 37:826-837.

Andjelkovich, DA, RM M atthew, RB Richardson, RJ Levine. 1990. M ortality of iron foundry workers. I. O verall findings. J O ccup M ed 32:529-540.

DeC oufle, P. 1978. Further analysis of cancer mortality patterns among workers exposed to cutting oil mists. I N atl Cancer Inst 61:1025-1030.

Delzell, E, M M acaluso, Y Honda, H Austin. 1993. $M$ ortality patterns among men in the motor vehicle manufacturing industry. Am J Ind M ed 24:471-484.

Egan-Baum, E, BA M iller, RJ Waxweiller. 1981. Lung cancer and other mortality patterns among foundrymen. Scand J W ork E nviron H ealth 7 supl. 4:73-89.

Eisen, EA, PE Tolbert, RR M onson, TJ Smith. 1992. $M$ ortality studies of machining fluid exposure in the automobile industry. I. A standardized mortality ratio analysis. Am J Ind M ed 22:809-824.

K oskela, R-S, S H ernberg, R K arava, E Jarvinen, and M M urminen. 1976. A mortality study of foundry workers. Scand J W ork E nviron H ealth 2 supl. 1:73-89.

K oskela, R-S. 1994. Cardiovascular diseases among foundry workers exposed to carbon monoxide. Scand J W ork E nviron H ealth 20:286-293.

M allin, K , L Berkeley, Q Y oung. 1986. A proportiona mortality ratio study of workers in a construction and diesel engine manufacturing plant. Am J Ind M ed 10:127-141.

M irer, F, M Silverstein, N M aizlish, R Park, B Silverstein, L Brodsky. 1985. Dust measurements and cancer mortality at a ferrous foundry. En Silica, Silicosis, and Cancer: Controversy in $O$ ccupational $M$ edicine dirigido por DF Goldsmith. Nueva Y ork: Praeger.

Park, R M , DH W egman, M A Silverstein, N M aizlish, $F$ M irer. 1988. Causes of death among workers in a bearing plant. Am J Ind M ed 13:569-580.

Silverstein, M, N M aizlish, RM Park, B Silverstein $L$ Brodsky, F M irer. 1986. M ortality among ferrous foundry workers. Am I Ind M ed 10:27-43.
Silverstein, M, RM Park, M Marmor, N M aizlish, F M irer. 1988. M ortality among bearing plant workers exposed to metalworking fluids and abrasives. I O ccup M ed 30: 706-714.

Vena, JE, HA Sulty, RC Fielder, RE Barnes. 1985. $M$ ortality of workers in an automotive engine and parts manufacturing complex. $\mathrm{Br} J$ Ind $\mathrm{Med}$ 42:85-93.

Virtamo, M , A T ossaveinen. 1976. Carbon monoxide in foundry air. Scand J W ork E nviron $H$ ealth 2:37-41.

\section{0 tras lecturas recomendadas}

Acquavella, J, T L eet, G Johnson. 1993. O ccupational experience and mortality among a cohort of metal components manufacturing workers. Epidemiology 4:428-434.

Park, RM. 1996. The healthy worker survivor effect and mortality at two automotive engine manufacturing plants. Am J Ind M ed 30:655-663.

Rotimi, C, E Austin, E Delzell, K Day, M M acaluso, Y H onda. 1993. Retrospective follow-up study of foundry and engine plant workers. Am J Ind M ed 24:485-498. 


\section{CONSTRUCCION Y REPARACION DE BUQUES Y EMBARCACIONES DE RECREO}

Director del capítulo

Fames $R$. Thorntoon

\section{Sumario}

Perfil general

Chester Mattheres. . . . . . . . . . . . . . . . . . . . . . 92.2

Construcción y reparación de buques y embarcaciones

James $R$. Thornton. .

Cuestiones ambientales y de salud pública

Frank H. Thorn, Page Ayres y Logan C. Shelman ... 


\section{- Perfil General}

\section{Chester Matthews}

Los complejos buques mercantes, de pasajeros y de guerra del decenio de 1990 están formados por toneladas de acero y aluminio más una gran diversidad de materiales que abarca desde los más comunes a los más exóticos. Un solo buque puede encerrar centenares, e incluso millares, de kilómetros de conductos y cables, y estar dotado de las más avanzadas centrales eléctricas y los equipos electrónicos más refinados disponibles en la actualidad. Deben construirse y mantenerse de forma que soporten las condiciones ambientales más hostiles y estar al mismo tiempo dotados de todo el confort y la seguridad necesarios para la tripulación y el pasaje, así como del grado de fiabilidad preciso para llevar a cabo sus misiones.

La construcción y reparación de buques se cuentan entre las actividades industriales más peligrosas del mundo. A título de ejemplo, y según la Oficina Norteamericana de Estadísticas Laborales (BLS), la construcción y reparación de buques está considerada en todo el mundo una de las tres actividades industriales más peligrosas. Aunque los materiales, los métodos de construcción, las herramientas y los equipos se han perfeccionado extraordinariamente con el paso del tiempo y continúan evolucionando y aunque la formación y el hincapié en materia de salud y seguridad han contribuido a mejorar de manera sustancial las condiciones de trabajo en los astilleros, lo cierto es que en todo el mundo y todos los años se producen lesiones graves e incluso mortales entre los trabajadores del sector de la reparación, la construcción y el mantenimiento de buques.

A pesar de los avances tecnológicos, muchas de las tareas y condiciones asociadas con las operaciones de construcción, botadura, mantenimiento y reparación de buques siguen siendo en la actualidad básicamente iguales que cuando se colocó la primera quilla hace miles de años. El tamaño y la forma de los componentes de un buque, así como la complejidad propia de su montaje y equipamiento, impiden automatizar los trabajos, aunque el avance tecnológico ha aportado cierto grado de automatización. Las tareas de reparación se resisten firmemente a la modernización. El trabajo en el sector exige mucha mano de obra muy cualificada, que con frecuencia se ve obligada a trabajar en circunstancias muy alejadas de las ideales y en condiciones físicas muy difíciles.

Las propias condiciones naturales dificultan mucho el trabajo en los astilleros. Aunque unos pocos están habilitados para realizar bajo techo trabajos de construcción o de reparación de buques, en casi todos se trabaja al aire libre. No hay región climática del planeta en la que no haya astilleros, y mientras que los situados más al norte han de sufrir las inclemencias del tiempo (superficies deslizantes a causa de la nieve y el hielo, pocas horas de luz solar y consecuencias físicos derivadas de las largas horas de actividad laboral sobre superficies de acero heladas, a menudo en posturas incómodas) los expuestos a climas más meridionales han de soportar la tensión del calor, las quemaduras solares, el trabajo en superficies en las que casi se puede cocinar, las picaduras de insectos y hasta las mordeduras de serpientes. Gran parte de estos trabajos se llevan a cabo sobre el agua, bajo ella o en sus proximidades y, a menudo, a las rápidas corrientes de marea se suman los vientos que hacen cabecear y oscilar las mismas superficies de trabajo en que los trabajadores han de efectuar trabajos de gran precisión y en las posturas más variadas, utilizando herramientas y equipos potencialmente muy peligrosos para su integridad física. La fuerza de estos vientos, con frecuencia imprevisibles, hay que tenerla muy en cuenta a la hora de mover, suspender o colocar unidades cuyo peso a menudo excede las 1.000 toneladas con ayuda de una o varias grúas de izada. Son muchas las dificultades que impone el medio natural, y se combinan en una variedad en apariencia infinita de situaciones de riesgo para la salud y la seguridad que deben ser contrarrestadas por medidas preventivas especiales. Es vital que todos los trabajadores esté debidamente informados y formados a este respecto.

A medida que el buque va tomando forma a partir de las primeras planchas de acero que constituyen la quilla, se va convirtiendo en un lugar cada vez más complejo que lleva asociado un subconjunto en constante cambio de peligros potenciales y situaciones de riesgo que requieren, no sólo procedimientos bien fundamentados para la correcta realización del trabajo, sino también mecanismos para identificar y resolver los miles de imprevistos que invariablemente surgen a lo largo del proceso de construcción. Conforme el buque adquiere entidad, van añadiéndose plataformas y andamiajes para facilitar el acceso al casco. La misma construcción real de esta red de plataformas es un trabajo muy especializado y en ocasiones peligroso; y su terminación supone un aumento del riesgo al que están expuestos los trabajadores, proporcional a la elevación de esta estructura sobre el suelo o la superficie del agua. El interior del buque va tomando forma al mismo tiempo que el casco, pues los modernos métodos de construcción permiten apilar unos sobre otros los grandes subconjuntos que forman los recintos interiores de la nave.

Es en este punto del proceso cuando la enorme necesidad de mano de obra de esta actividad resulta más evidente. Las medidas de salud y seguridad deben estar bien coordinadas. La conciencia de los trabajadores (de su propia seguridad y la de quienes les rodean) es fundamental para evitar accidentes laborales.

Cada uno de los recintos interiores del casco está diseñado con un propósito concreto. El casco puede ser un simple hueco destinado a contener lastre o bien albergar depósitos, contenedores de carga, camarotes o un refinado centro de control de combate. En cada caso, la construcción del buque obligará a numerosos especialistas a trabajar muy cerca unos de otros para realizar una variada gama de tareas. En una situación típica, los fontaneros estarán montando válvulas al mismo tiempo que los electricistas tienden cables e instalan circuitos, los pintores aplican retoques, los montadores navales colocan y sueldan planchas en cubierta, las cuadrillas de carpinteros y los especialistas en aislamiento hacen su labor y los controladores comprueban si cierto sistema se activa, todo ello en un mismo sitio. Tales situaciones, y otras aún más complejas, se dan a diario siguiendo una pauta marcada por los cambios del programa, las modificaciones técnicas, la disponibilidad de personal y hasta las condiciones climatológicas.

La aplicación de revestimientos entraña numerosos riesgos. Los trabajos de pintura a pistola deben llevarse a cabo frecuentemente en recintos cerrados, en un ambiente enrarecido por la presencia de partículas volátiles de pinturas, disolventes y diversos revestimientos epóxicos, caracterizados por su capacidad sensibilizadora.

Con el paso de los años, y gracias al desarrollo de mejores equipos, de métodos de construcción más eficaces, de instalaciones más seguras y de un personal mejor formado, se ha progresado mucho en el terreno de la salud y la seguridad de los trabajadores de los astilleros. No obstante, los mayores avances se han logrado, y continúan lográndose, centrando la atención en el trabajador individual y eliminando las conductas que más contribuyen a la accidentalidad. Si bien esto es aplicable a la práctica totalidad de los sectores industriales, la gran cantidad de mano de obra propia del trabajo en los astilleros lo convierte en un factor de especial relevancia. A medida que avanzamos hacia programas de salud y seguridad que suponen una más 
activa participación de los trabajadores y que incorporan sus ideas, no sólo se alcanzan grados más altos de conciencia del riesgo propio de la actividad y de la forma de evitar accidentes, sino que además los propios trabajadores empiezan a considerar los programas como algo suyo. Sólo así se obtienen resultados y se alcanzan los objetivos perseguidos en materia de salud y seguridad.

\section{CONSTRUCCION Y REPARACION DE BUQUES Y EMBARCACIONES}

James R. Thornton

\section{Construcción naval}

La construcción de un buque es un proceso complicado y sumamente técnico, que exige la coordinación de numerosos trabajadores fijos y eventuales bajo el control del contratista principal. La construcción naval puede tener carácter civil o militar. Se trata de un sector de índole internacional en el cual astilleros repartidos por todo el mundo compiten por un mercado bastante limitado.

Desde el decenio de 1980, la construcción naval ha cambiado radicalmente. Antes, la mayor parte de los trabajos de construcción naval tenían lugar en los edificios o las gradas de un astillero, donde se iba levantando el barco construyéndolo casi pieza a pieza. El avance tecnológico y una planificación más detallada permiten ahora construir buques a partir de subunidades o módulos que incorporan instalaciones y sistemas integrados. De esta manera, la conexión de los módulos es relativamente fácil de efectuar. Se trata de un proceso más rápido, menos costoso y que asegura un control de calidad más estricto. Además, este tipo de construcción se presta a la automatización y la robotización, lo cual ahorra dinero y reduce la exposición a riesgos de naturaleza química y física.

\section{Panorámica del proceso de construcción de buques}

La Figura 92.1 esquematiza el método de construcción de buques. El paso inicial es el diseño. Las consideraciones de diseño para los diferentes tipos de buques varían enormemente. Hay embarcaciones de transporte de pasajeros y de carga, de superficie y submarinos, militares y civiles, propulsados por energía nuclear o no nuclear. En la fase de diseño, no solo deben tenerse en cuenta los parámetros de construcción normales, sino también

Figura 92.1 • Diagrama de flujos de construcción naval.

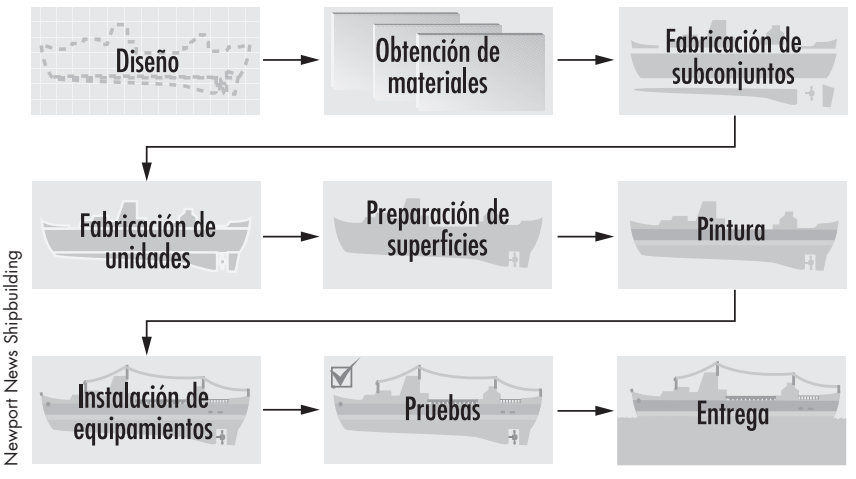

Figura 92.2 - Corte de planchas de acero con soplete automático en un taller de fabricación.

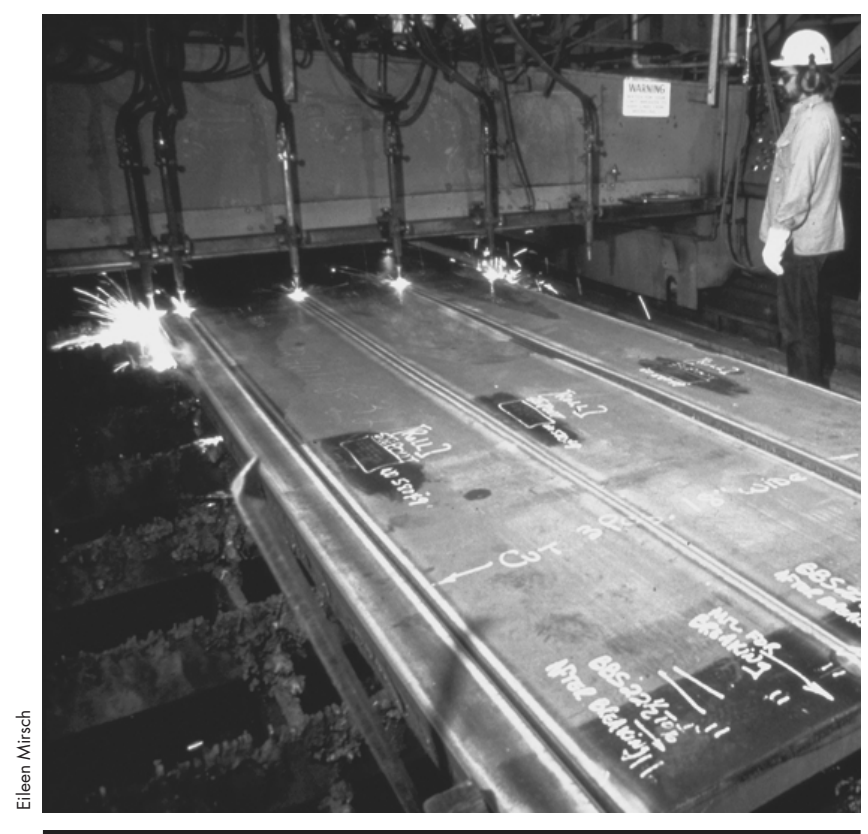

aquellos relativos a la seguridad y los peligros para la salud asociados con las operaciones de construcción o reparación de buques. Además no deben olvidarse los asuntos relativos al medio ambiente.

El componente básico que se emplea en la construcción naval es la plancha de acero.

Las planchas se cortan, conforman, curvan y trabajan de la forma necesaria para darles la configuración definida en el diseño (véanse las Figuras 92.2 y 92.3). Por lo general, las planchas se cortan en equipos automáticos de corte con soplete; las formas así obtenidas se sueldan a continuación para formar vigas en forma de I y de $\mathrm{T}$ u otros largueros estructurales (véase la Figura 92.4)

A continuación, las planchas se envían a los talleres de construcción, donde se ensamblan para formar diversas unidades y subconjuntos (véase la Figura 92.5). En esta fase se empiezan a montar las conducciones, los equipos eléctricos y el resto de las

Figura 92.3 • Curvado de láminas de acero.

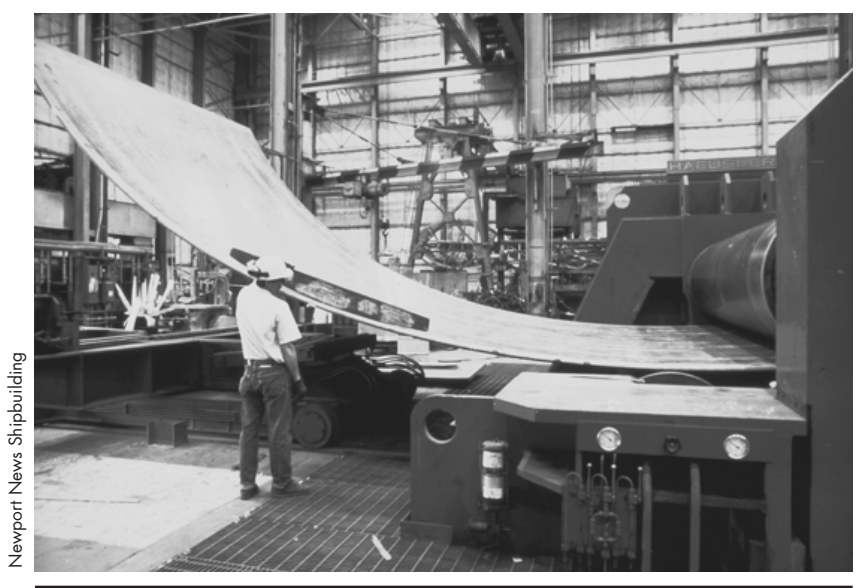


Figura 92.4 - Plancha de acero soldada que forma parte del casco de un buque.

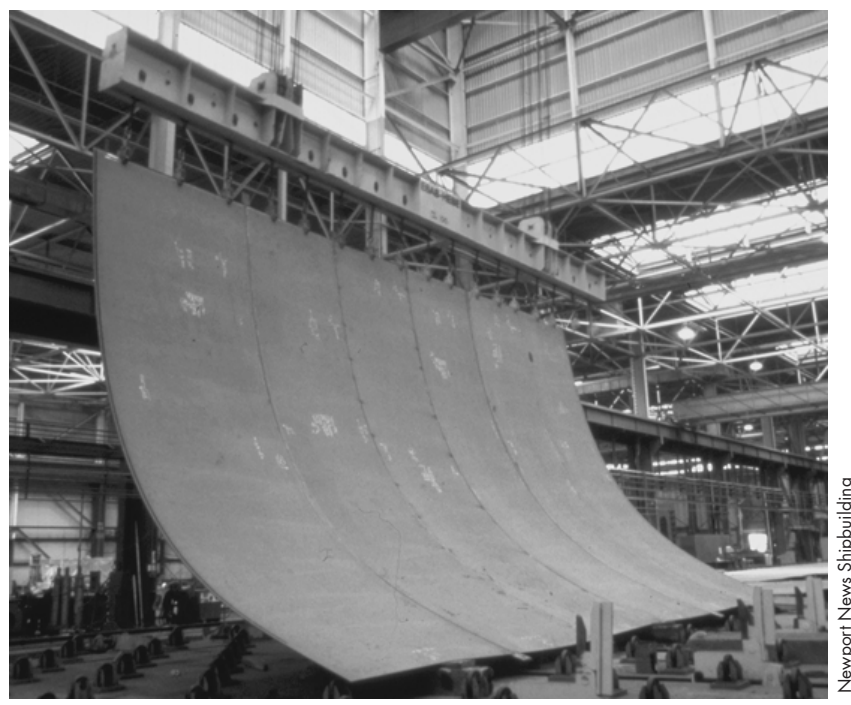

Figura 92.5 • Trabajos en un subconjunto del buque.

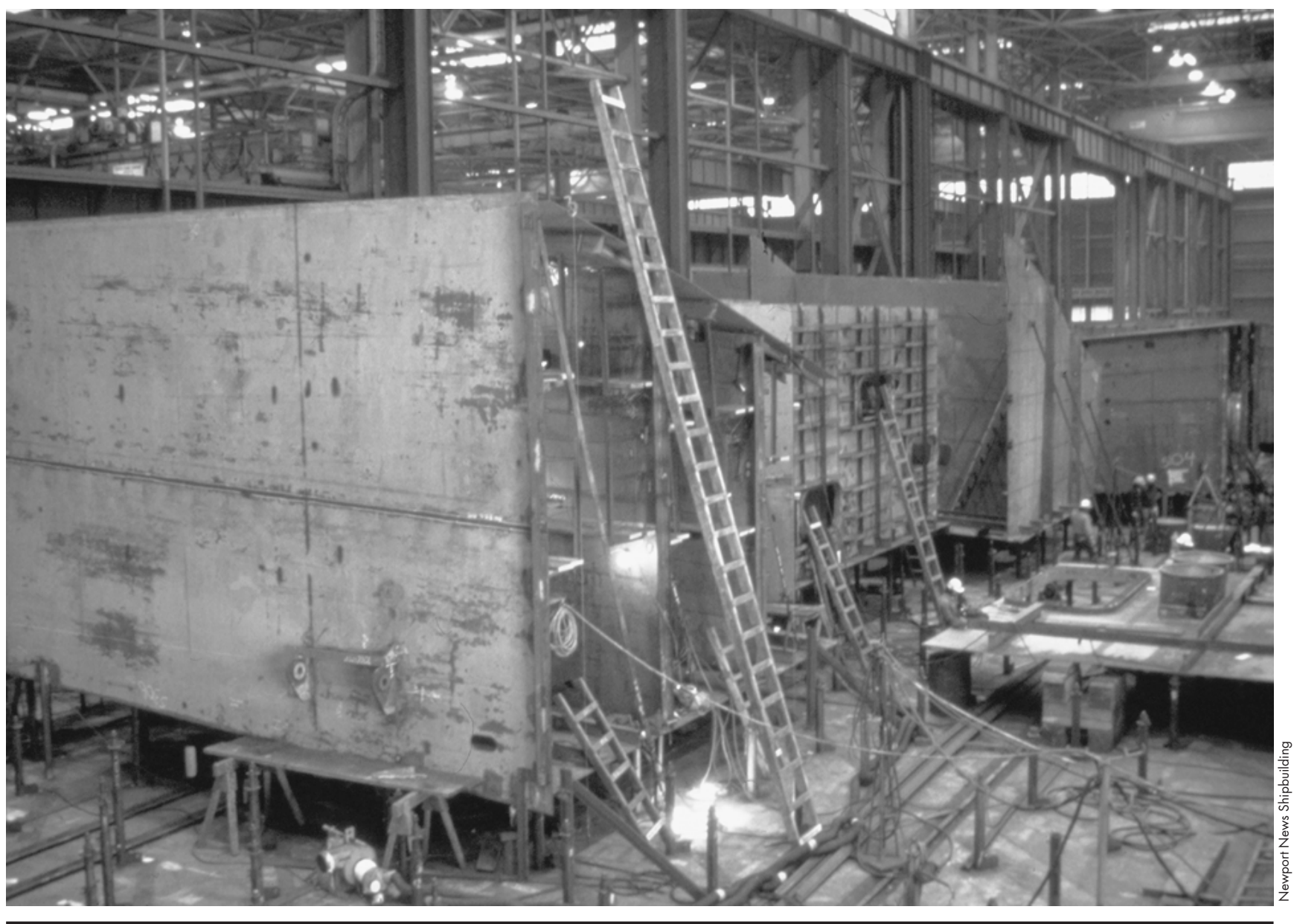

instalaciones, que se integran en las correspondientes unidades. Estas se montan aplicando técnicas de soldadura manual, automática o de los dos tipos. Son varios los métodos de soldadura utilizados. El más común es el de soldadura por electrodo consumible, que une las piezas de acero con el material del electrodo que se consume. También se utilizan las técnicas de gas inerte, arco blindado y electrodos no consumibles.

A continuación, lo normal es trasladar las unidades o subconjuntos a una zona a cielo abierto donde se unen para formar módulos o unidades aún mayores (véase la Figura 92.6). Aquí se realizan nuevas operaciones de montaje y soldadura. A continuación, todas las unidades y soldaduras se someten a inspecciones de control de calidad y pruebas radiográficas, ultrasónicas y de otro tipo, tanto destructivas como no destructivas. Las soldaduras defectuosas se eliminan mediante rectificado, agrupamiento con arco o rotura con cortafríos y se aplican de nuevo. En ese momento se limpian las unidades con chorro de arena y se dejan listas para los trabajos de perfilado y pintura (véase la Figura 92.7). Esta se aplica a brocha, rodillo o pistola, que es el método más común. Muchas pinturas son inflamables, o tóxicas, o peligrosas para el medio ambiente. En este momento se realizan las operaciones de limpieza con chorro de arena y pintura.

Una vez terminadas, las unidades de mayor tamaño se trasladan a la grada, el astillero o la zona de montaje final, donde se ensamblan unas con otras para dar forma al buque (véase la 
Figura 92.6 • Combinación de subconjuntos del buque en bloques mayores.

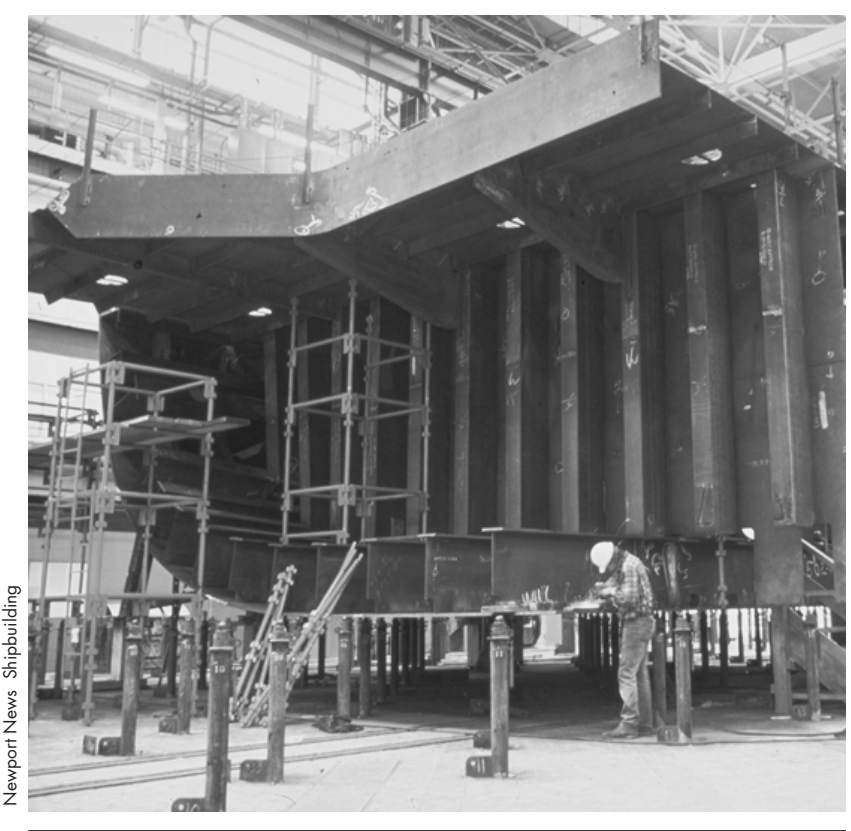

Figura 92.8). De nuevo se llevan a cabo numerosos trabajos de ajuste y soldadura. Una vez que el casco está estructuralmente terminado y definitivamente estanco, se procede a la botadura, que se hace deslizando el buque desde la grada de construcción hasta el agua, inundando el dique seco o bajando el buque hasta el agua. La botadura suele ser un acto solemne y colorista.

Una vez botado el buque hay que aparejarlo, trabajo que exige gran cantidad de tiempo y de equipamientos: instalación de conducciones y cableado, equipamiento de cocinas y camarotes, aislamiento, instalación de equipos electrónicos y ayudas a la navegación y montaje de las máquinas y otros aparatos auxiliares. Estas tareas se encomiendan a distintos oficios especializados.

Una vez finalizada la fase de aparejamiento, el buque se somete a una serie de pruebas en el muelle y en el mar durante las cuales se verifican todos sus sistemas hasta tener la certeza de que es plenamente funcional y operativo. Por último, una vez terminadas todas las labores de verificación y las reparaciones correspondientes, el buque se entrega al cliente.

\section{Construcción en acero}

A continuación se presenta una descripción detallada de la construcción en acero, centrada en los trabajo de corte, soldadura y pintura.

\section{Corte}

La "línea de montaje" del astillero empieza en la zona de almacenamiento del acero. Allí se almacenan listas para su utilización enormes planchas de acero de diferentes tamaños, grosores y resistencias. A continuación el acero se somete a tratamiento con chorro de arena y recibe una capa de imprimación que lo protege durante las distintas fases del proceso de construcción. Las planchas así preparadas se trasladan a los talleres construcción, donde se cortan al tamaño deseado con sopletes automáticos (véase la Figura 92.2). Estas piezas cortadas se sueldan entre sí para dar forma a los componentes estructurales del buque (Figura 92.4).
Figura 92.7 - Limpieza de barcos con chorro abrasivo antes de pintar.

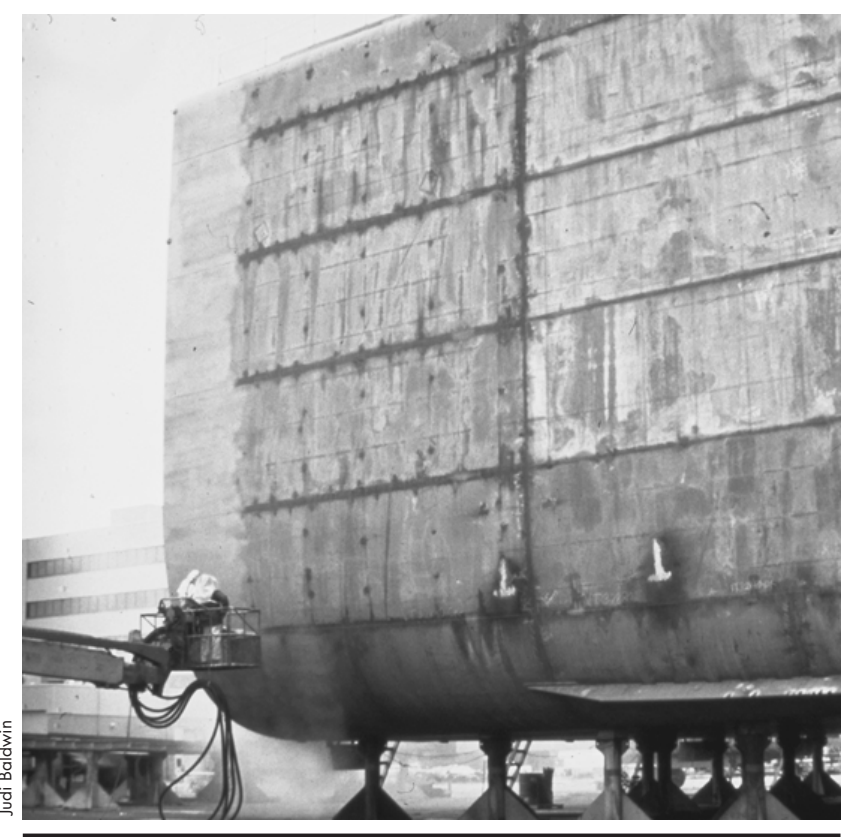

Figura 92.8 - Montaje de la proa en el casco de un buque.

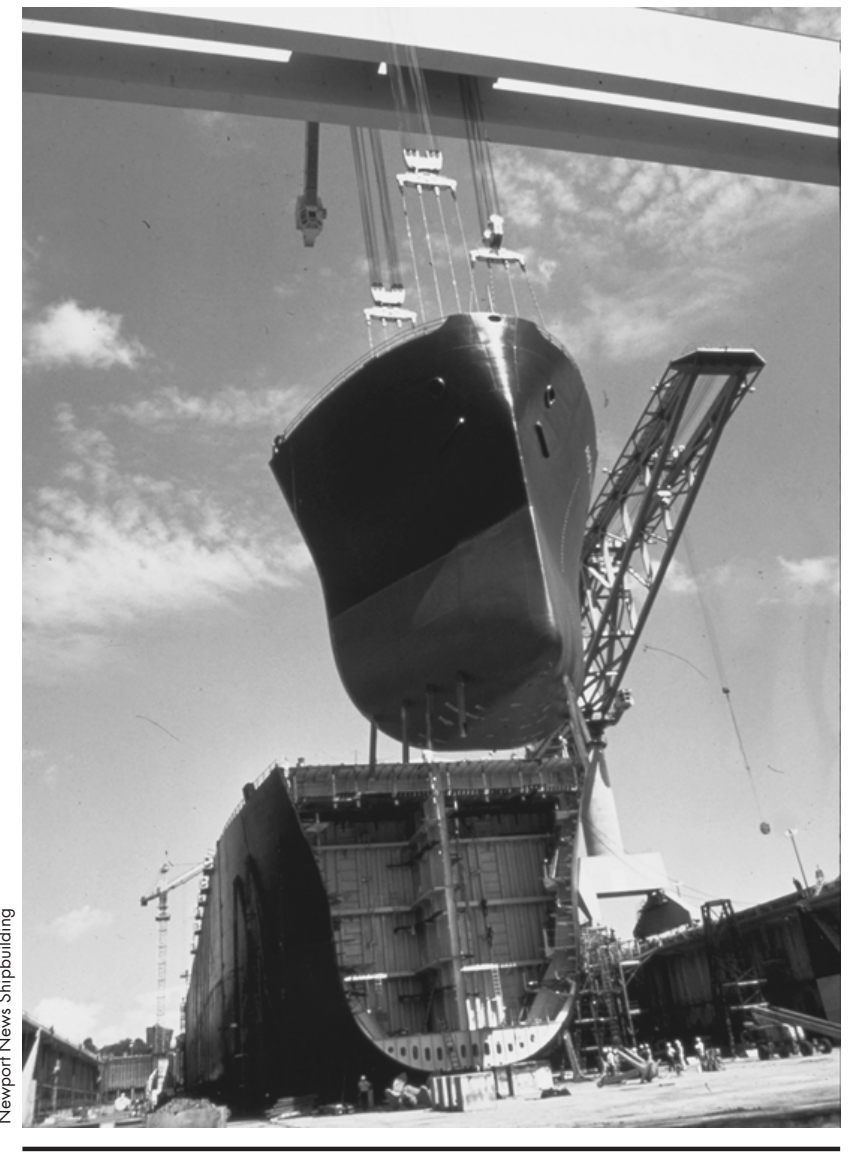




\section{Soldadura}

La estructura de la mayor parte de los buques es un conjunto de elementos de acero dulce y de acero de gran resistencia. Este material tiene excelentes propiedades de ductilidad y adecuación al mecanizado y la soldadura, así como la resistencia que necesitan los buques transoceánicos. El material básico de la construcción naval es el acero de distintas calidades, pero también se emplean aluminio y otros materiales no férricos en el montaje de algunas superestructuras (alojamientos de cubierta, por ejemplo) y en zonas determinadas del buque. Se emplean materiales especiales, como aceros inoxidable y galvanizado o aleaciones de cobre y níquel como protección frente a la corrosión y para mejorar la integridad estructural del buque. En cualquier caso, los materiales no férricos se utilizan en mucha menor cantidad que el acero. Los sistemas de a bordo (ventilación, combate, navegación, conducciones) son casi siempre los que consumen mayor cantidad de estos materiales "exóticos". Son necesarios para desempeñar una variada serie de funciones: propulsión del buque, potencia de reserva, cocinas, unidades de bombeo de combustible, sistemas de combate, etc.

El acero empleado en la construcción puede subdividirse en tres tipos: acero dulce, acero de alta resistencia y aleaciones de acero. Los aceros dulces presentan cualidades muy apreciadas y son fáciles de fabricar, adquirir, conformar y soldar. Los aceros de alta resistencia están aleados con pequeñas cantidades de otros elementos que aportan cualidades mecánicas superiores a las de los aceros dulces. Se han desarrollado aceros especiales de resistencia extremada para la construcción naval. Estos aceros de resistencia y elasticidad elevadas suelen recibir las denominaciones HY-80, HY-100 y HY-130. Sus propiedades en cuanto a resistencia superan a las de los aceros comerciales de alta resistencia. Esta clase de materiales exigen técnicas de soldadura más complejas para no perder sus cualidades; normalmente se sueldan con varillas específicas de cada material previo calentamiento de las uniones. Una tercera clase de aceros, los aceros de aleación incorporan proporciones relativamente grandes de elementos como níquel, cromo o manganeso. Estos materiales, entre los que se encuentra el acero inoxidable, presentan excelentes cualidades de resistencia a la corrosión, y exigen también técnicas de soldadura especiales.

$\mathrm{El}$ acero es un material excelente para la construcción naval, y la elección de los electrodos de soldadura es crítica en todas las aplicaciones de soldadura durante toda la construcción. El objetivo es siempre que la soldadura presente características de resistencia semejantes a las del metal de partida. Como es probable que en los trabajos de soldadura industrial se produzcan algunas imperfecciones de escasa importancia, es práctica frecuente elegir las técnicas y los electrodos de soldadura con el fin de que la unión obtenida sea más resistente que el metal de partida.

Por su magnífica relación resistencia/peso, el aluminio ha ido ganado posiciones como metal adecuado para aplicaciones de construcción naval. Aunque su empleo en la construcción de cascos es limitado, las superestructuras de aluminio son cada vez más comunes, tanto en buques militares como civiles. La construcción integral de aluminio suele reservarse a embarcaciones pequeñas, como pesqueros, yates de recreo, pequeños buques de pasajeros, cañoneras o hidrodeslizadores. El aluminio utilizada en la construcción y reparación naval está casi siempre aleado con manganeso, magnesio, silicio y zinc. Estas aleaciones son fuertes, ofrecen resistencia a la corrosión y toman bien la soldadura.

Las tareas de soldadura o, más exactamente, de soldadura por fusión se ejecutan prácticamente en todas las zonas del astillero. La técnica consiste básicamente en unir metales llevando las superficies en contacto a una temperatura extremadamente alta hasta que se funden junto con un material de relleno. Los bordes de las piezas se calientan hasta que se funden junto con la soldadura de relleno (electrodo, varilla o alambre). La fuente calorífica es casi siempre una llama de gas o un arco eléctrico. El tipo de soldadura se elige en función de las especificaciones del cliente, el ritmo de producción y diversas limitaciones operativas, entre ellas los reglamentos oficiales. A la construcción de buques de guerra se aplican normas más rigurosas que a la de embarcaciones.

Un aspecto importante de la soldadura con fusión es la protección del arco para no degradar la masa de soldadura. La temperatura de esta masa fundida está muy por encima del punto de fusión del metal que se está soldando. A tales temperaturas, la reacción con el oxígeno y el nitrógeno atmosféricos es muy rápida y afecta negativamente a la resistencia de la soldadura. Si se retiene oxígeno y nitrógeno atmosféricos entre el metal soldado y la varilla fundida, se debilitará el material en la zona de soldadura. Para evitar esta degradación de la soldadura y garantizar su calidad, es necesario evitar el contacto con la atmósfera. En casi todos los casos esto se hace aplicando un fundente, un gas o las dos cosas. La evaporación y la reacción del fundente con el electrodo inducidas por el calor determinan la emisión de una combinación protectora de vapores y fundente que impide la entrada de oxígeno y nitrógeno en la soldadura. Esta técnica de protección se describirá en los apartados siguientes, dentro de las técnicas de soldadura relevantes.

En la soldadura por arco eléctrico se establece un circuito entre la pieza soldada y un electrodo o un alambre. Cuando uno de estos dos elementos se mantiene cerca de la pieza trabajada, se genera un arco de temperatura extremadamente elevada. El calor que emite el arco es suficiente para fundir los bordes de la pieza trabajada y la punta del alambre o el electrodo; se trata, por tanto, de una técnica de soldadura por fusión. Hay varios métodos de soldadura por arco eléctrico adecuados para la construcción naval. Todos obligan a proteger de la atmósfera la zona de soldadura, y pueden clasificarse en métodos de protección con gas y métodos de protección con fundente.

De acuerdo con los informes elaborados por los fabricantes de equipos de soldadura y de los correspondientes materiales fungibles y no fungibles, el arco con electrodo consumible es el método de soldadura más común.

Soldadura metálica por arco protegido (SMAW). Los métodos de soldadura con arco eléctrico y protección por fundente se distinguen básicamente por su naturaleza manual o semiautomática y por el tipo de electrodo consumible utilizado. La técnica SMAW utiliza un electrodo consumible (de 30,5 a $46 \mathrm{~cm}$ de longitud) revestido de fundente seco, que se monta en un soporte y que el soldador coloca en contacto con la pieza de trabajo. El electrodo es un núcleo de metal de relleno sólido hecho de material fundido o estirado cubierto por una capa de polvos metálicos. La técnica SMAW se llama también "soldadura por electrodo" y "soldadura por arco". El metal del electrodo está revestido por un fundente que se derrite a medida que se suelda y que recubre de escoria la masa fundida y envuelve toda la zona en una atmósfera de gas protector. La soldadura SMAW manual permite trabajar por debajo del nivel de las manos, en horizontal, en vertical o por encima de la cabeza; también se presta al trabajo semiautomático, con equipos por gravedad que aprovechan el peso del electrodo y el soporte para recorrer la pieza de trabajo.

Soldadura por arco sumergido (SAW). Es una variante de la soldadura por arco eléctrico con protección de material fundente común en muchos astilleros. La técnica consiste en depositar una capa de material fundente granulado sobre la pieza de trabajo para a continuación soldar con un electrodo consumible de alambre metálico sin revestir. Por lo general, el electrodo actúa como material de relleno, aunque en algunos casos se 
añaden gránulos metálicos al fundente. El fundente cubre el arco, se licúa y protege y aísla la zona soldada. La elevada concentración de calor permite depositar grandes cantidades de soldadura con bastante rapidez. Tras la soldadura, el material fundido queda protegido por una capa de fundente, que puede retirarse y recuperarse. La soldadura por arco sumergido sólo puede aplicarse por debajo del nivel de las manos y es idónea para soldar planchas a tope en líneas de construcción de paneles y zonas de curvatura con rodillos y de construcción de estructuras. Esta técnica se aplica casi siempre con equipos totalmente automáticos montados en un carro móvil o en una plataforma autopropulsada que se desplaza sobre la pieza de trabajo. Al ser el funcionamiento automático, buena parte del tiempo se emplea en alinear la junta de soldadura con la máquina. De igual manera, como el arco SAW actúa bajo una capa de material fundente granulado, la tasa de emisión de humos (FGR) o de formación de humos (FFR) es baja y constante bajo diversas condiciones operativas, siempre que la capa de fundente sea suficiente.

Soldadura por arco metálico en atmósfera gaseosa (GMAW). Las técnicas con protección gaseosa constituyen una importante categoría dentro de la soldadura con arco eléctrico. Generalmente se utilizan electrodos de metal sin revestir que actúan en una atmósfera externa de protección formada por gases inertes, activos o una combinación de ambos tipos. Por lo general, los métodos GMAW o de soldadura metálica en gas inerte (MIG) emplean atmósferas gaseosas de protección y electrodos de alambre de pequeño diámetro, consumibles y alimentados automáticamente. Son la respuesta al tan deseado proceso de soldadura continua, sin interrupciones para cambiar electrodos, pues utilizan un alimentador de alambre automático. El mecanismo de bobinado aporta alambre de relleno (que es también el electrodo) a velocidad constante o variable en función de la lectura de un sensor de tensión. En el punto de contacto entre el electrodo y el arco, la pistola de soldadura emite un chorro protector de helio o argón. Para trabajos de soldadura de acero puede utilizarse $\mathrm{CO}_{2}$, un gas inerte o las dos cosas. Suele usarse una combinación de gases para optimizar los costes y la calidad de la soldadura.

Soldadura de arco de tungsteno y protección gaseosa (GTAW). Otro tipo de soldadura con protección gaseosa es la soldadura por arco de tungsteno con protección gaseosa, conocida en ocasiones como soldadura con gas inerte y tungsteno (TIG), o por su nombre comercial Heliarco, dado que el helio fue el primer gas protector utilizado. Se trató del primero de los "nuevos" métodos de soldadura, presentado unos 25 años después de la soldadura por electrodo. El arco se genera entre la pieza de trabajo y un electrodo de tungsteno que no se consume. El gas inerte, por lo general argón o helio, proporciona la atmósfera protectora y garantiza un trabajo limpio y con pocas emanaciones. En el proceso GTAW, el arco no aporta metal de relleno, sino que simplemente funde el material y el alambre, con lo que se consigue una soldadura más limpia. El GTAW es el método más utilizado en los astilleros para soldar aluminio, planchas metálicas y tubos y conductos de pequeño diámetro, o para depositar el primer pase de las soldaduras múltiples en conductos y accesorios de grandes dimensiones.

La soldadura por arco con núcleo de material fundente (FCAW) utiliza un equipo similar al de GMAW, con un alimentador continuo de alambre. La principal diferencia estriba en que el electrodo de FCAW es un alambre tubular con un núcleo interno de material fundente que protege la zona de soldadura. Algunos alambres con núcleo de fundente proporcionan por sí solos una protección suficiente; sin embargo, muchos trabajos de construcción naval ejecutados mediante FCAW exigen una protección suplementaria, que proporciona una atmósfera de gas, para alcanzar las normas de calidad propias del sector.

El método FCAW rinde una soldadura de calidad, con un ritmo de producción y una eficacia superiores a las alcanzadas con las técnicas SMAW tradicionales. Se presta al trabajo en condiciones muy variadas, como en superficies verticales o por encima del nivel de la cabeza. Los electrodos FCAW son un poco más caros que los materiales SMAW, pero en muchas ocasiones el aumento de calidad y productividad compensan el gasto.

Soldadura por arco de plasma (PAW). El más moderno método de soldadura con protección por atmósfera gaseosa es la soldadura metálica por arco de plasma y con gas inerte. El método PAW es muy similar al GTAW, con la diferencia de que el arco debe atravesar un estrechamiento antes de alcanzar la pieza de trabajo. Se obtiene de este modo un chorro de plasma muy rápido a una temperatura elevadísima. El plasma es una corriente ionizante de gas que sirve de soporte al arco y que se genera cuando éste se fuerza a través de un diminuto orificio del soplete. La técnica PAW forma un arco más caliente y concentrado que permite una soldadura más rápida. Salvo por el orificio que acelera el gas, el PAW es idéntico al GTAW, y utiliza un electrodo de tungsteno no consumible en una atmósfera protectora de gas inerte. La técnica PAW se utiliza casi siempre de forma manual y tiene muy pocas aplicaciones en la construcción naval, aunque en ocasiones se emplea en tareas de metalización con soplete. Su principal aplicación en la construcción naval es el corte de acero (véase la Figura 92.9).

Soldadura con gas, soldadura con bronce y estaño. En la soldadura con gas se utiliza el calor generado por la combustión de un gas y normalmente se aporta metal de relleno con una varilla. El combustible más común es una mezcla de acetileno y oxígeno (soldadura oxiacetilénica). El soplete manual dirige la llama a la pieza de trabajo al tiempo que el metal fundido de relleno se deposita en la unión soldada. La superficie de la pieza de trabajo se funde hasta formar una masa de fundición, y el material de relleno penetra en grietas y ranuras. El metal fundido, principalmente metal de relleno, solidifica a medida que el soplete avanza por la pieza de trabajo. La soldadura por gas es relativamente lenta y no se presta al trabajo con equipos automáticos o semiautomáticos, por lo que su uso en astilleros es poco frecuente. El equipo es pequeño y portátil, propio para soldar planchas delgadas (de hasta unos $7 \mathrm{~mm}$ ), tuberías delgadas y conductos HVAC (calefacción, ventilación y aire acondicionado) de chapa metálica, canalizaciones para cables eléctricos y soldadura con bronce o estaño. Para cortar se utiliza un equipo idéntico o similar.

Las soldaduras con estaño o con bronce son técnicas de unión de superficies que trabajan sin fundir el metal de base. Se rellena el espacio entre las superficies con metal líquido y se deja que solidifique. Si la temperatura del metal de relleno es inferior a $450{ }^{\circ} \mathrm{C}$, el proceso se llama soldadura con estaño o estañado; por encima de ese valor se habla de soldadura con bronce. La fuente de calor para la soldadura con estaño es casi siempre un soldador eléctrico, un soplete, una resistencia eléctrica o un dispositivo de inducción. Para soldar con bronce se emplea un soplete, una resistencia o un mecanismo de inducción. La unión con bronce también se hace sumergiendo las piezas en un baño. Las uniones hechas con estaño o bronce carecen de la elevada resistencia que aporta la soldadura por fusión y, por tanto, tienen pocas aplicaciones en trabajos de construcción y reparación naval, salvo la fijación de juntas de conductos delgados, la construcción de elementos de chapa y otras operaciones de ensamblado y mantenimiento, infrecuentes y de poca entidad. 
Figura 92.9 - Corte de planchas de acero con soplete de arco de plasma sumergido.

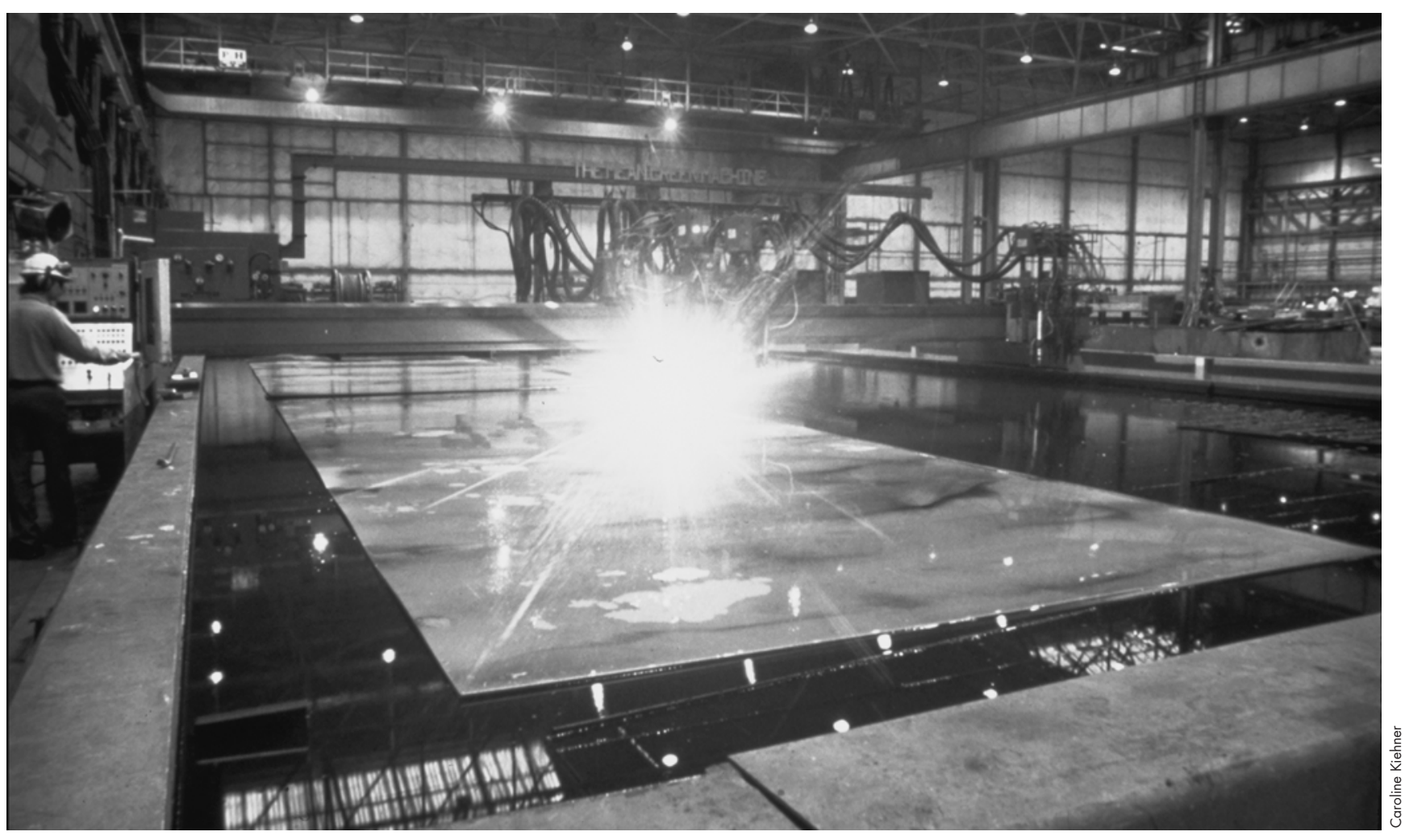

Otros métodos de soldadura. Con escasa frecuencia y por distintas razones, en el astillero se utilizan a veces otras técnicas de soldadura. La soldadura eléctrica con escorias se basa en la transferencia de calor por escorias fundidas, que a su vez funden la pieza de trabajo y el metal de relleno. Aunque el equipo que se utiliza es semejante al de soldadura al arco eléctrico, las escorias se mantienen fundidas por su resistencia a la corriente que circula entre el electrodo y la pieza de trabajo; por tanto, se trata de una forma de soldadura por resistencia eléctrica. Es frecuente colocar una placa de soporte refrigerada bajo la pieza de trabajo para retener la masa fundida. En la soldadura eléctrica por gas se utiliza un equipo similar, pero con un electrodo revestido de fundente y en atmósfera protectora de $\mathrm{CO}_{2}$. Ambas técnicas se prestan muy bien a la soldadura automática vertical de piezas a tope, y es muy eficaz con planchas gruesas. Cabe esperar que estas técnicas se apliquen con mayor frecuencia en el sector de la construcción naval.

Soldadura por aluminotermia. Se basa en el uso de metal líquido extremadamente caliente para fundir la pieza de trabajo y el material de relleno aportado. El metal líquido se obtiene por reacción química entre un óxido fundido y aluminio. El líquido se vierte en la cavidad que forman las piezas que van a soldarse, y el conjunto se envuelve en un molde de arena. Se trata de una técnica muy similar a la fundición por vaciado, y se utiliza sobre todo para reparar piezas vaciadas o forjadas o grandes secciones estructurales, como el armazón de popa.

Soldadura con láser. Es una tecnología nueva que utiliza un haz de láser para fundir y unir las piezas. La viabilidad de la soldadura con láser está demostrada, el coste ha impedido hasta ahora su aplicación comercial. El potencial que presenta como técnica de soldadura eficaz y de alta calidad puede generalizar su uso en la construcción naval del futuro.
Otra técnica relativamente moderna es la soldadura por haz de electrones. Consiste en proyectar un chorro de electrones sobre las piezas a través de un orificio y en atmósfera de gas inerte. Esta técnica no se basa en la conductividad térmica del material, y presenta por ello dos ventajas considerables: menor consumo de energía y poco efecto metalúrgico sobre el acero. Como la soldadura por láser, presenta el inconveniente de su elevado coste.

Soldadura con roblonado. Se trata de una variante de la soldadura al arco en la que se utiliza un roblón como electrodo. La pistola de soldar sujeta el roblón mientras se forma el arco y hasta que se funden el roblón y la plancha; a continuación aplica el primero contra la segunda y los suelda. Como protección se utiliza una férula cerámica que rodea el roblón. La soldadura con roblonado es semiautomática y se emplea habitualmente en construcción naval para la facilitar la instalación de materiales no metálicos, como los aislantes, en superficies de acero.

\section{Pintura y acabado}

Se pinta en casi todos los lugares del astillero. La naturaleza de los trabajos de construcción y reparación de buques obliga a emplear diversos tipos de pintura para aplicaciones distintas, desde productos al agua hasta revestimientos epóxicos de altas prestaciones. El tipo de pintura adecuado para una aplicación determinada depende de las condiciones a las que vaya a estar expuesta. Los instrumentos de aplicación de pintura van desde los simples rodillos y brochas hasta los pulverizadores sin aire y las máquinas automáticas. En general, hay normas de pintura especiales en las siguientes zonas de los buques:

- bajo el agua (fondo del casco)

- línea de flotación

- superestructuras superiores 
- recintos internos y depósitos

- cubiertas a la intemperie

- equipo suelto.

Hay muchos tipos de pinturas para cada una de estas zonas, aunque los buques de guerra suelen regirse por especificaciones distintas (Mil-spec) que imponen tipos determinados de pintura para cada aplicación. Al elegir la pintura hay que considerar muchas variables: condiciones ambientales, intensidad de la exposición al medio ambiente, tiempos de secado o endurecimiento e instrumentos y métodos de aplicación. Muchos astilleros disponen de zonas e instalaciones reservadas para trabajos de pintura. Los talleres cubiertos son caros, pero en ellos se trabaja con mayor eficacia y se obtienen resultados de mejor calidad. Guando se pinta al aire libre, el grado de transferencia es menor y sólo se puede trabajar con buen tiempo.

Sistemas de aplicación de pintura utilizados en los astilleros. Las pinturas se aplican a las distintas partes del buque con fines muy variados. Ninguna pintura cumple con todas las condiciones buscadas (protección anticorrosión, antiincrustaciones y resistencia alcalina, por ejemplo). Las pinturas están compuestas por tres ingredientes principales: pigmento, vehículo y disolvente. Los pigmentos son pequeñas partículas que generalmente determinan el color y muchas de las propiedades asociadas a la aplicación. Son ejemplos de pigmentos: óxido de zinc, talco, carbono, alquitrán de hulla, plomo, mica, aluminio y polvo de zinc. El vehículo es un aglutinante que mantiene unidos los pigmentos de la pintura. Muchas pinturas son conocidas por el tipo de aglutinante: epoxi, alquídicas, uretanos, vinúlicas, fenólicas. El aglutinante también determina en buena medida las prestaciones de la aplicación: flexibilidad, resistencia a los productos químicos, durabilidad, acabado. El disolvente se añade para aclarar la pintura y facilitar su aplicación a las superficies. La porción de disolvente de la pintura se evapora durante el secado. Entre los disolventes más comunes se cuentan la acetona, los diversos tipos de aguarrás mineral, el xileno, la metiletilcetona y el agua. Las pinturas anticorrosión y antiincrustación se utilizan habitualmente para cascos de buque y constituyen los dos tipos más utilizados en el sector de la construcción. Las pinturas anticorrosión se fabrican con bases vinílicas de laca o uretánicas o en los nuevos sistemas de recubrimiento de base epoxídica. En la actualidad los sistemas epoxi son muy aceptados y cumplen todos los requisitos de calidad establecidos para el medio ambiente marino. Las pinturas antïncrustación se utilizan para evitar la proliferación y la adherencia de organismos marinos al casco. Con este fin se utilizan mucho los compuestos a base de cobre. Se trata de pinturas que liberan pequeñas cantidades de sustancias tóxicas en las proximidades del casco del buque. Los colores se obtienen añadiendo negro de humo, óxido de hierro rojo o dióxido de titanio.

Revestimiento de imprimación en astillero. Por lo general, el primer sistema de imprimación que se aplica a las piezas y láminas de acero en bruto es una imprimación de preconstrucción llamada a veces "imprimación de taller". Esta capa es importante para mantener el buen estado de las piezas durante la construcción. La imprimación de preconstrucción se aplica a planchas de acero, troqueles, secciones de tuberías y conductos de ventilación. Este tratamiento cumple dos funciones importantes: $a$ ) preservar el acero para el producto final y $b$ ) mejorar la productividad de la construcción. La mayoría de las imprimaciones de preconstrucción son ricas en zinc, con aglutinantes orgánicos o inorgánicos. Entre las imprimaciones inorgánicas a base de zinc predominan los silicatos de zinc. Los sistemas de recubrimiento a base de zinc protegen los recubrimientos de una manera muy similar a la galvanización. Si el zinc se aplica sobre acero, el oxígeno reaccionará con aquél para dar óxido de zinc, que forma una capa impermeable que impide que el aire o el agua entren en contacto con el acero.

Equipos de aplicación de pintura. En el sector de la construcción naval son muchos los métodos de aplicación de pintura que se utilizan. Dos muy comunes son los pulverizadores sin aire y los pulverizadores por aire comprimido. Los sistemas de pulverización por aire comprimido pulverizan simultáneamente aire y pintura, con lo que parte de la pintura se atomiza (se seca) rápidamente antes de alcanzar la superficie. La eficiencia en la transferencia de los sistemas de pulverización por aire comprimido oscila entre un 65 y un $80 \%$. Este bajo rendimiento se debe sobre todo al exceso de aplicación, a las corrientes y a deficiencias del pulverizador; por su bajo poder de transferencia, este tipo de pulverizadores han quedado obsoletos.

El sistema de aplicación de pintura más usado en el sector de la construcción naval es la pulverización sin aire. Se trata de un sistema que simplemente comprime la pintura por un conducto hidráulico que en uno de sus extremos dispone de una boquilla de pulverización; lo que impulsa la pintura es la presión hidrostática, no la neumática. Para reducir el exceso de aplicación y el desperdicio, en los astilleros se está generalizando la utilización de pulverizadores sin aire. Son mucho más limpios que los de aire comprimido y sufren menos fugas que ellos, pues trabajan a menos presión. El rendimiento de la transferencia es de casi el $90 \%$, según las condiciones. La técnica de HVLP (alto volumen, baja presión) es una novedad en el terreno de la pulverización sin aire que, en determinadas condiciones, mejora aún más el índice de transferencia. Las medidas de eficacia de transferencia son estimativas, y en ellas se tienen en cuenta el goteo y el desperdicio.

La pulverización térmica o pulverización metálica o por llama es la aplicación sobre acero de revestimientos de zinc o aluminio como protección anticorrosión de larga duración. Se trata de un proceso de revestimiento utilizado en numerosas aplicaciones, tanto civiles como militares. Se diferencia de las prácticas de revestimiento tradicionales por lo especializado del equipo y por el ritmo de producción relativamente lento. Hay dos tipos básicos de máquinas para aplicación térmica de revestimientos: alambre de combustión y arco térmico. El alambre de combustión es un sistema de llama a base de gases combustibles con un controlador de alimentación de alambre. Los gases combustibles funden el material, que a continuación se pulveriza sobre las piezas. La máquina eléctrica de pulverización térmica por el contrario, utiliza un arco eléctrico para fundir el material pulverizado por la llama. El equipo incorpora filtración, compresión de aire, arco eléctrico con controlador y pistola pulverizadora para llama de arco. Hay que preparar bien la superficie para que se adhieran los materiales pulverizados por la llama. La forma de preparación más común es el tratamiento con chorro de arena fina (óxido de aluminio, por ejemplo).

El coste inicial de la pulverización térmica es elevado en comparación con el de la pintura, pero resulta económicamente más atractiva cuando se considera todo el ciclo de servicio. Aunque alguno astilleros disponen de sus propias máquinas de pulverización térmica, otros subcontratan este trabajo. La pulverización térmica puede realizarse en el taller o a bordo del buque.

Prácticas y métodos de pintura. Se llevan a cabo tareas de pintura en casi todas las zonas del astillero, desde la imprimación inicial que se aplica al acero hasta los detalles de la pintura definitiva del buque. Los métodos que se emplean al pintar varían enormemente de un proceso a otro. La pintura se mezcla tanto a mano como mecánicamente, por lo general en una zona rodeada de zanjas de contención y pallets para contención auxiliar; algunas de estas zonas son recintos cubiertos. En el astillero se realizan tareas de pintura tanto a cubierto como al aire libre. 
Se utilizan con frecuencia paneles de ladrillo, plástico o acero para contener la pintura pulverizada, neutralizar la acción del viento y capturar las partículas de pintura en suspensión, cuya cantidad se verá reducidas con la implantación de nuevas tecnologías. Al limitar el exceso de pulverización, el astillero ahorra pintura y dinero.

\section{Preparación de superficies y áreas de pintura del astillero}

Podemos dividir las prácticas de pintura y de preparación de superficies en el sector de la construcción y la reparación de buques en cinco grandes áreas. Estas ilustran cómo se realizan las tareas de pintura en el astillero.

Pintura de cascos. Los cascos se pintan tanto en operaciones de reparación como durante la construcción de embarcaciones nuevas. Por lo general, cuando se trata de buques en reparación, la preparación de la superficie y la pintura del casco se lleva a cabo en el dique seco (en el dique de carena de un dique seco flotante). En el caso de los buques de nueva construcción, el casco se prepara y se pinta en la posición de construcción empleando alguna de las técnicas anteriormente descritas. El tratamiento de preparación más común es la limpieza con chorro de arena impulsado por aire o por agua. Este trabajo obliga a utilizar plataformas o equipos elevadores. También la pintura se aplica con pulverizadores y dispositivos elevadores, como ascensores, plataformas de tijera o andamios móviles. Los sistemas para pintar cascos varían de acuerdo al número de capas aplicadas.

Pintura de las superestructuras. La superestructura de un buque comprende las cubiertas abiertas, los alojamientos de cubierta y las demás estructuras dispuestas sobre la cubierta principal. En muchos casos se emplean andamiajes de cubierta para llegar hasta las antenas, los alojamientos y las demás superestructuras. Si hay riesgo de que caiga pintura o restos del material de limpieza a presión al agua que rodea el buque, habrá que adoptar las medidas necesarias para evitarlo. Cuando se trata de buques en reparación, la pintura de las superestructuras suele llevarse a cabo con el buque amarrado. La superficie se prepara con herramientas de mano o con chorro de arena. Una vez preparada la superficie, y tras eliminar los restos de los materiales de limpieza, se empieza a pintar. Por lo general, las pinturas se aplican por pulverización sin aire. Los pintores acceden a las superestructuras por medio de los mismos andamios, escaleras de mano y demás equipos elevadores previamente utilizados en las tareas de preparación. Los protectores colocados para evitar la caída del material chorreado a presión se mantienen para retener la pintura.

Pintura interior de depósitos y de compartimientos. Los depósitos y compartimientos a bordo de los buques han de recubrirse una y otra vez para mantenerlos en servicio. La pintura de depósitos de buques en reparación exige un largo trabajo de preparación de la superficie. La mayoría de los depósitos se encuentran en la parte inferior de los buques (depósitos de lastre, sentinas, depósitos de combustible). Los depósitos se preparan antes de ser pintados lavándolos con disolventes y detergentes que eliminan la grasa y las acumulaciones de combustible. Las aguas residuales generadas durante la limpieza de los depósitos deberán tratarse adecuadamente antes de eliminarlas. Una vez secos los depósitos, se limpian con chorro de arena; este trabajo exige la instalación de algún sistema de circulación del aire en el interior del depósito y otro de aspiración de partículas abrasivas. Se utilizan sistemas de aspiración de anillo líquido y de husillo giratorio. Los aspiradores han de tener potencia suficiente para aspirar del depósito los restos de la limpieza por abrasión. Por lo general, los sistemas de ventilación y aspiración se encuentran en la superficie del muelle y entran en el buque a través de orificios practicados en el casco. Una vez finalizada la limpieza por abrasión de la superficie, y tras haber sido retirados los restos, se empieza a pintar. Todas las labores de preparación y pintura de las superficies de los depósitos del buque (como el trabajo en recintos cerrados) exigen ventilación y respiradores adecuados.

Preparación de la superficie durante la construcción. Una vez que los bloques o unidades múltiples abandonan la zona de montaje, suelen trasladarse a un área de limpieza por chorro de arena donde se preparan para recibir la pintura. Las superficies se chorrean hasta dejar al aire el metal (se elimina toda la imprimación de construcción) (véase la Figura 92.7). El método más frecuente de preparación de la superficie es el tratamiento con chorro de arena impulsado con aire. La siguiente etapa es la aplicación de pintura. Por lo general, los pintores utilizan equipos de pulverización de pintura sin aire desde plataformas de acceso. Una vez que se ha aplicado el recubrimiento al bloque, éste se traslada a la zona de bloques para ser equipado.

Areas de pintura de piezas pequeñas. Muchas de las piezas que componen un buque han de recibir un recubrimiento antes de ser instaladas en sus correspondientes bloques: carretes para mangueras, conductos de ventilación, asientos y puertas se han de pintar antes de instalarlos en el bloque. Las piezas pequeñas suelen prepararse en una zona especial del astillero antes de pintarlas. La pintura en sí puede aplicarse en otro punto distinto de las instalaciones por su mejor adaptación a las necesidades de producción del astillero. Algunas de dichas piezas pequeñas se pintan en los distintos talleres y otras en un local del departamento de pintura.

\section{Preparación de superficies y pintura en bloques y a bordo}

Los trabajos de pintura definitivos tienen lugar a bordo, mientras que los retoques suelen efectuarse en los bloques (véase la Figura 92.10). La pintura de los bloques se retoca por varios motivos. En ocasiones, la pintura ya aplicada ha sufrido daños y hay que restaurarla; otras veces se ha aplicado una pintura incorrecta y es preciso sustituirla. Las pintura de bloques se hace con equipos portátiles de limpieza abrasiva y pintura en las áreas de

Figura 92.10 • Retoques de pintura en el casco de un buque.

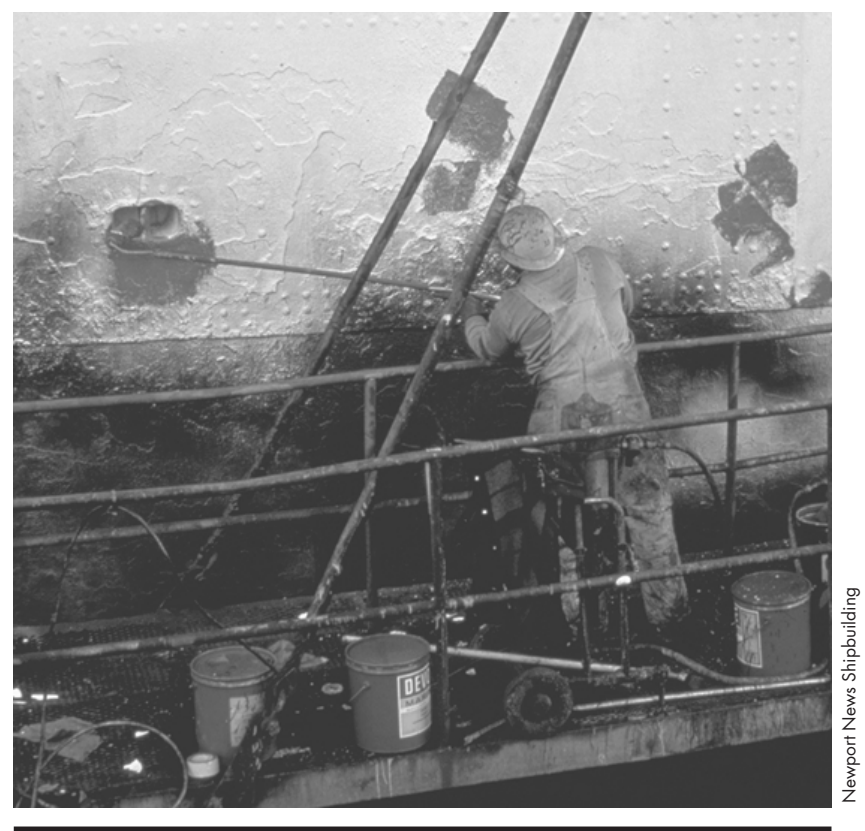


equipamiento de bloques. A bordo del buque hay que pintar las zonas comunes que hay entre los bloques de construcción, y volver a pintar las zonas dañadas por los trabajos de soldadura, reparaciones, equipamiento realizado a bordo, y demás. Las superficies se preparan con herramientas de mano, lijando, cepillando, limpiando con disolventes o utilizando cualesquiera otras técnicas. La pintura se aplica con pulverizadores portátiles sin aire, rodillos y brochas.

\section{Equipamiento}

El equipamiento previo al montaje de los bloques de construcción es el método de construcción naval actualmente empleado en todo el mundo por los astilleros competitivos. Se llama equipamiento a la instalación en los bloques de componentes y subconjuntos diversos (sistemas de conducciones, equipos de ventilación, componentes eléctricos) antes de unirlos entre sí en la fase de montaje. El equipamiento de los bloques en el astillero se presta a la organización en forma de línea de montaje.

El equipamiento a lo largo de la construcción se planifica de manera que el trabajo avance sin interrupciones por todo el astillero. Una vez montada la estructura de acero del bloque, y para simplificar, el equipamiento puede dividirse en tres etapas de construcción principales:

1. equipamiento de unidades

2. equipamiento de bloques

3. equipamiento a bordo.

Equipamiento de unidades: en esta etapa se montan aparejos, piezas, asientos, maquinaria y demás materiales con independencia del bloque del casco (es decir, las unidades se montan aparte de los bloques estructurales de acero). El equipamiento de unidades permite a los trabajadores montar en tierra los sistemas y componentes de a bordo, con la consiguiente facilidad de acceso a talleres y maquinaria. Las unidades se instalan en la etapa de construcción a bordo, o en la fase de bloques. La complejidad, las formas y las dimensiones de las unidades son muy variadas. En algunos casos son tan simples como un motor de ventilador conectado a una cámara de sobrepresión ("plenum") y a una serpentina de refrigeración. Las unidades grandes y complejas más importantes son las máquinas y sus componentes, las calderas, las salas de bombas y demás áreas complejas del buque. El equipamiento por unidades suele implicar el empalme de conducciones y otros componentes seguido de la conexión que da lugar a las unidades. Los recintos de maquinaria son las zonas del buque donde se encuentra la maquinaria (salas de máquinas, estaciones de bombeo y generadores) y en ellas el equipamiento muy numeroso. Equipar las unidades en tierra aumenta la seguridad y la eficacia, pues reduce las horas de trabajo que serían necesarias en bloques o a bordo, en recintos más reducidos y en condiciones de trabajo más difíciles.

Equipamiento de bloques: es la etapa de construcción donde se lleva a cabo la instalación en los bloques de la mayor parte del material de equipamiento. Entre el material de equipamiento que se instala por bloques podemos citar los sistemas de ventilación y de conducciones, las puertas, luces, escaleras de mano, pasamanos, montajes eléctricos, etc. También en esta etapa suelen instalarse muchas unidades. A lo largo de toda la etapa de equipamiento por bloques, éstos pueden izarse, girarse y desplazarse para facilitar la instalación de los materiales de equipamiento en techos, suelos y paredes. Todos los talleres y servicios del astillero han de estar comunicados entre sí en la etapa de equipamiento por bloques, para garantizar que los materiales se instalan correctamente en tiempo y lugar.

Equipamiento a bordo: empieza cuando los bloques han ido izados a bordo del buque en construcción (después de la fase de montaje). El buque puede encontrarse en posición de construcción (en el dique o en las gradas de construcción) o bien amarrado al muelle. Los bloques ya se encuentran equipados en gran parte, aunque todavía resta mucho trabajo por hacer hasta dejar el buque listo para entrar en servicio. El equipamiento a bordo comprende la instalación de bloques y unidades de grandes dimensiones. Forma parte de estos trabajos de instalación el izado a bordo de bloques y unidades de grandes dimensiones seguido de la soldadura o unión mediante pernos en sus respectivas posiciones. También incluye la conexión entre sí de los sistemas de a bordo (conducciones, ventilación, electricidad). El tendido de cables por todo el buque también se hace durante la etapa de equipamiento a bordo.

\section{Pruebas}

Durante la fase de funcionamiento y pruebas se evalúa la funcionalidad de todos los sistemas y componentes instalados. Es en esta etapa cuando se hacen funcionar, se prueban y se revisan todos los sistemas. Cualquier sistema que por alguna razón no supere las pruebas, será retirado, reparado y revisado de nuevo hasta que sea plenamente operativo. Todos los sistemas de conducciones de a bordo se presurizan para localizar con facilidad la posible presencia de fugas. Asimismo, los depósitos han de pasar las correspondientes pruebas estructurales mediante llenado con líquido (agua dulce o de mar) y el posterior examen de su estabilidad estructural. También se comprueban, entre otros muchos, los sistemas eléctrico y de ventilación. La mayoría de las pruebas de funcionamiento y comprobación de los sistemas tienen lugar con el buque amarrado en el muelle del astillero. No obstante, cada vez se tiende más a efectuar estas pruebas en etapas de construcción anteriores (pruebas preliminares en los talleres de producción).

Realizar estas pruebas en etapas de la construcción anteriores facilita la resolución de averías gracias a la mayor accesibilidad a todos los sistemas, aunque las pruebas con sistemas completos siempre han de efectuarse a bordo del buque. Una vez realizadas todas las pruebas con el buque amarrado, éste se hace a la mar y se somete a nuevas pruebas de navegación antes de que se considere plenamente operativo a efectos de navegabilidad y se entregue a su propietario.

\section{Reparación de buques}

\section{Procesos y prácticas de reparación de buques de acero}

Por lo general, el concepto de reparación abarca las intervenciones de transformación, las revisiones generales, los programas de mantenimiento, las reparaciones de grandes daños y las reparaciones de equipos menores. El segmento de la reparación de buques constituye una parte muy importante del sector de la construcción y de las demás actividades navales. En casi todos los astilleros privados, cerca del $25 \%$ de la mano de obra total realiza trabajos de conversión y reparación. En la actualidad son numerosos los buques que necesitan ser actualizados o sometidos a conversiones para cumplir los requisitos de seguridad y medio ambiente. El envejecimiento y la pérdida de rentabilidad de las flotas y los elevados costes de adquisición de buques nuevos están sometiendo a las compañías navieras a grandes tensiones. En términos generales, los trabajos de conversión y reparación efectuados en los astilleros de los Estados Unidos, son sustancialmente más rentables que la propia construcción de buques nuevos. En los astilleros que se dedican a la construcción de buques, los contratos de revisiones generales y conversiones ayudan a estabilizar el empleo durante los períodos en que escasea la construcción nueva, que a su vez aumentan la carga de trabajo de las plantillas dedicadas a reparaciones. El proceso de reparación de un buque es muy semejante al de nueva 
construcción; la principal diferencia es que se trabaja a menor escala y a un ritmo más rápido. La reparación exige más sincronización y mucha capacidad de negociación para obtener contratos. Entre los clientes habituales del segmento de la reparación navales cabe citar la armada, la compañías navieras, y otros propietarios del sector marítimo y naval.

Normalmente, los clientes facilitan las especificaciones contractuales, los planos y los demás elementos estándar. Los contratos pueden ser firmes con precio fijo (FFP), firmes con precio fijo mas tanto de adjudicación (FFPAF), de coste más tanto fijo (CPFF), de coste más tanto de adjudicación (CPAF) o de reparación urgente. El proceso se inicia en el departamento de marketing cuando el astillero recibe una solicitud de oferta (RFP) o una invitación para licitar (IFB). Generalmente, las ofertas de precio más bajo ganan los contratos IFB, en tanto que una adjudicación del tipo RFP no se basa exclusivamente en el factor precio. El grupo de valoración de la reparación prepara una estimación del coste y la correspondiente oferta. La estimación de la licitación incluye por lo general costes de mano de obra, en salarios y horas/hombre, materiales, gastos generales, servicios especiales, subcontratación, horas extraordinarias y primas por trabajos fuera de turno; también se incorporan otras tasas, el coste de utilización de las instalaciones y el coste del dinero; la oferta económica o de licitación se basa en el conjunto de estos costes. Una vez adjudicado el contrato, se elabora un plan de producción.

Planificación, medios técnicos y ejecución de la reparación Aunque en la etapa de presentación de la oferta relativa al contrato se realice cierta planificación previa, aún queda mucho por hacer antes de iniciar el trabajo. Deberán darse lo siguientes pasos: leer y comprender todas las especificaciones contractuales, dividir el trabajo en categorías, integrar el trabajo en un plan lógico de producción y determinar la senda crítica. Los departamentos encargados de la planificación, la disposición de materiales y medios técnicos, las subcontratas y la ejecución de las reparaciones deben colaborar estrechamente para llevar acabo la reparación de la manera más puntual y rentable posible. En muchos casos, las conducciones, conductos de ventilación, equipamientos eléctricos y otros tipos de maquinaria se fabrican antes de que llegue el barco. Los trabajos de preequipamiento y de preembalaje de las unidades reparadas se efectúan en colaboración con los talleres de producción para ejecutar puntualmente los encargos.

\section{Tipos habituales de trabajos de reparación}

Los buques son similares a otros tipos de maquinaria que también requieren frecuentes trabajos de mantenimiento y, en ocasiones, grandes revisiones generales para mantener su capacidad operativa. Muchos astilleros tienen establecidos contratos de mantenimiento para compañías navieras, buques o tipos de buques, que requieren frecuentes trabajos de mantenimiento. Veamos algunos ejemplos de tareas de mantenimiento y reparación:

- limpieza con chorro de arena y repintado del casco, la cubierta de intemperie, la superestructura, los depósitos interiores y las áreas de trabajo;

- reparación e instalación de la maquinaria principal (motores diesel, turbinas, generadores y equipos de bombeo);

- revisiones generales, mantenimiento e instalación (pruebas de caudal, comprobación e instalación de sistemas de conducciones);

- instalación de nuevos sistemas, bien por incorporación de nuevos equipos o por sustitución de otros obsoletos (de navegación, combate, comunicaciones o conducciones);
- reparación modificación y centrado de timón y hélices; y

- habilitación en el buque de nuevos alojamientos para maquinaria (eliminación de estructuras de acero, incorporación de nuevos paramentos, refuerzos y soportes verticales e instalación de nervaduras).

En muchos casos, los contratos de reparación se firman en situaciones de emergencia con escaso plazo de aviso, lo que hace de la reparación naval un trabajo cambiante e imprevisible. Los buques sometidos a reparaciones normales permanecen en el astillero entre 3 días y 2 meses, en tanto que las conversiones y reparaciones de gran magnitud pueden durar más de un año.

\section{Grandes proyectos de reparación y conversión}

Los contratos de grandes proyectos de reparación y conversión son habituales en el sector de la construcción naval. La mayoría de ellos se realizan en astilleros que disponen de capacidad para construir buques, aunque algunos de menor capacidad también pueden hacerse cargo de grandes reparaciones y conversiones.

Veamos a continuación algunos ejemplos de contratos de grandes reparaciones:

- conversión de cargueros en buques hospital;

- corte por la mitad de un buque e instalación de una nueva sección para aumentar la eslora (véase la Figura 92.11);

- sustitución de segmentos estropeados después de haber encallado (véase la Figura 92.12);

- eliminación completa, reconfiguración estructural y equipamiento de sistemas de combate; y

- remodelación general del interior o del exterior del buque (restauración completa de cruceros para el transporte de pasajeros).

Figura 92.11 - Corte por la mitad de un buque para añadir una nueva sección.

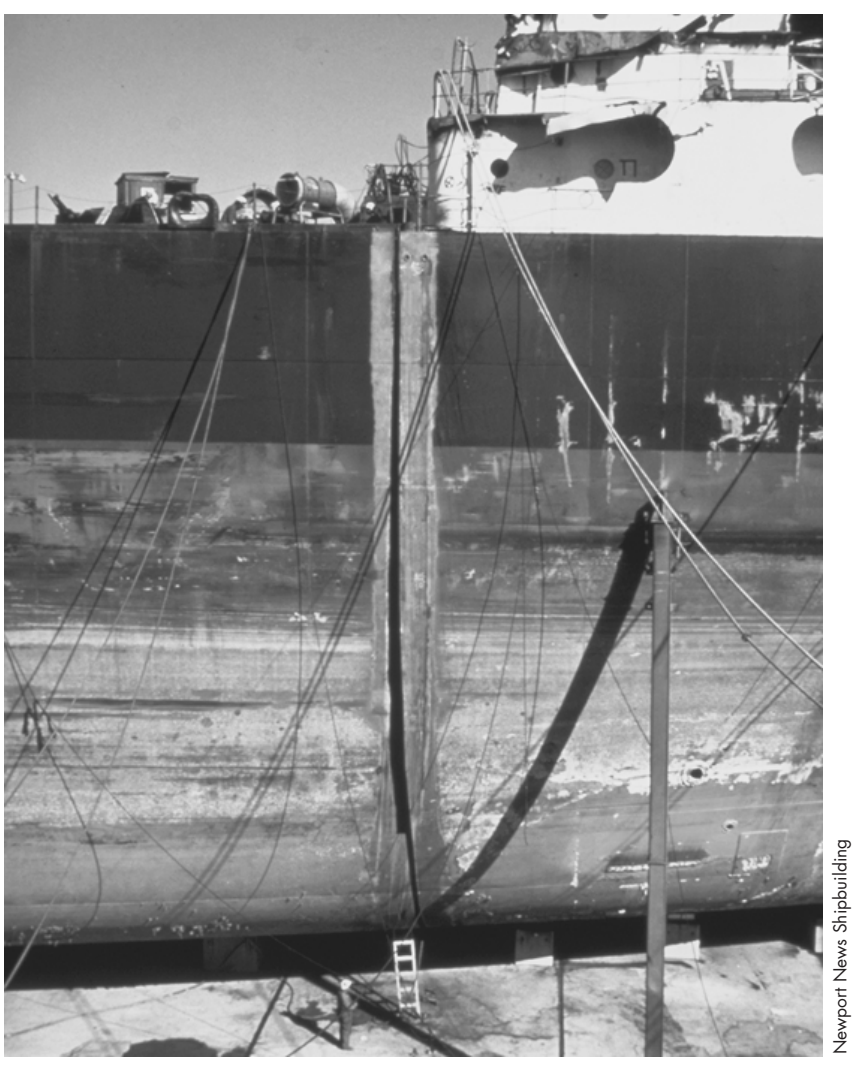


Figura 92.12 • Sustitución de la proa de un barco accidentado.

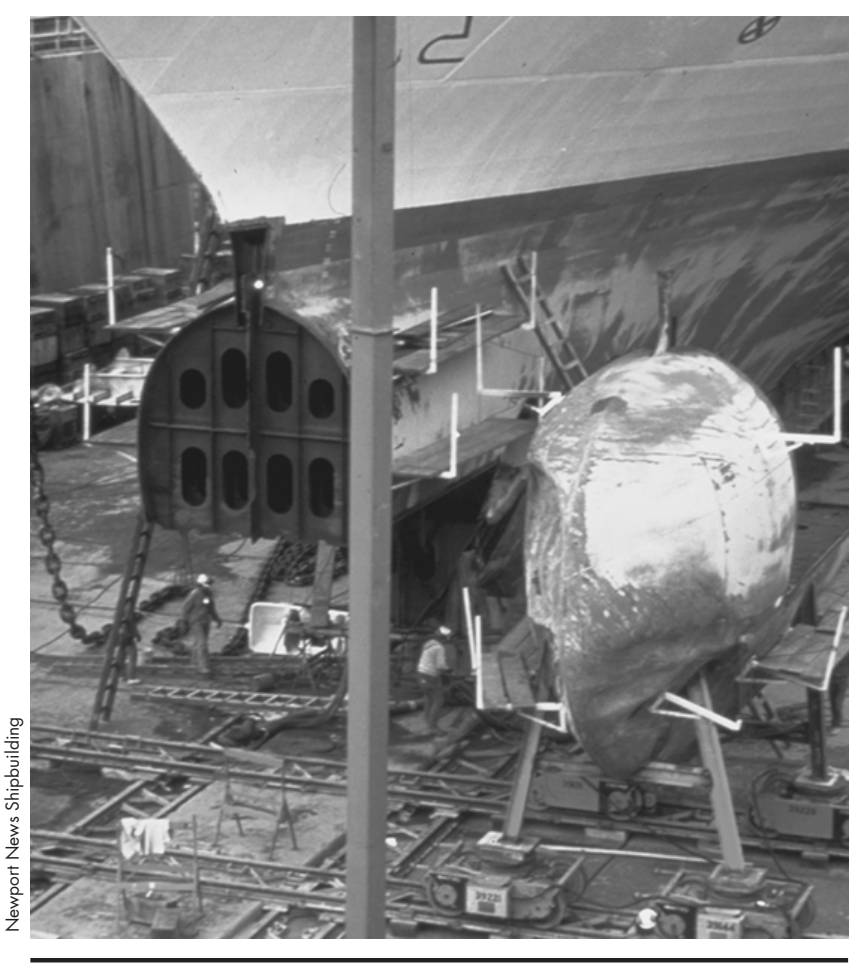

En su mayoría, las grandes reparaciones y conversiones requieren grandes esfuerzos en las áreas de planificación, disposición de medios técnicos y ejecución. En muchas ocasiones se deben efectuar grandes trabajos sobre acero (grandes cortes estructurales en el buque e instalación de nuevas configuraciones). Estos proyectos pueden dividirse en cuatro etapas principales: desmontaje, construcción de la nueva estructura, instalación de los equipos y pruebas. Se emplean subcontratas para la gran mayoría de las reparaciones y las conversiones, con independencia de su magnitud. Los subcontratistas aportan experiencia en ciertas áreas y contribuyen a nivelar la carga de trabajo del astillero. Veamos a continuación algunos de los trabajos que suelen encargarse a los subcontratistas:

- apoyo en la reparación de buques;

- instalación de grandes sistemas de combate (técnicos);

- reconstrucción y reintubación de calderas;

- revisiones generales de compresores neumáticos;

- retirada y eliminación de amianto;

- limpieza de depósitos;

- limpieza con chorro de arena y pintura;

- revisiones generales de sistemas de bombeo;

- construcción de estructuras menores;

- revisión general de maquinillas;

- modificaciones del sistema de vapor principal; y

- construcción de sistemas (conducciones, ventilación, asientos, etc.).

$\mathrm{Al}$ igual que en los casos de nueva construcción, todos los sistemas instalados han de ser sometidos a pruebas de operatividad antes de entregar el buque a su propietario. Los requisitos de las pruebas por lo general se establecen en el propio contrato, aunque también hay otras fuentes de determinación de pruebas. Estas han de programarse, ejecutarse correctamente y controlarse por los departamentos o grupos relevantes (calidad interna del astillero, operaciones de buques, organismos públicos, armadores, etc.). Una vez instalados y debidamente probados los sistemas, la zona, el compartimiento o el sistema forman parte del buque (que queda así terminado).

Hay muchas similitudes entre los trabajos de reparación y de nueva construcción. La principal es que en ambos casos se utilizan esencialmente los mismos métodos, prácticas, instalaciones y talleres de apoyo. Los trabajos de construcción y reparación de buques requieren una mano de obra muy especializada, ya que muchas de las actividades dejan poco margen para la automatización (especialmente en la reparación). Ambas actividades requieren niveles excelentes de planificación, disposición de medios técnicos y comunicación interdepartamental. El flujo de trabajo de una reparación suele ser: valoración, planificación y disponibilidades técnicas; desmontaje; reinstalación de estructuras de acero; construcciones propias de la reparación; pruebas y ensayos; y entrega del buque. En muchos aspectos, el proceso de reparación de un buque es muy similar al de nueva construcción, aunque éste requiera una capacidad organizativa mayor debido a la magnitud de la mano de obra y de la carga de trabajo, del número de piezas que se manejan y de la complejidad de las comunicaciones (programas y planes de producción) que rodean el flujo de trabajo de la construcción de un buque.

\section{Peligros y precauciones}

La construcción y reparación de buques es uno de los sectores industriales más peligrosos. El trabajo se desarrolla en medios peligrosos, tales como recintos cerrados reducidos y alturas considerables. Buena parte del trabajo manual se efectúa con materiales y equipos pesados. Por la gran interrelación que hay entre las tareas, los resultados de un proceso pueden poner en peligro la integridad del personal que trabaja en otro. Además, como gran parte del trabajo se hace al aire libre, la climatología puede crear o agravar situaciones de peligro. Por si esto fuera poco, se emplean numerosos productos químicos, pinturas, disolventes y recubrimientos, los cuales pueden entrañar riesgos importantes para los trabajadores.

\section{Riesgos para la salud}

Riesgos químicos que entrañan peligros para la salud de los trabajadores de los astilleros, y que incluyen:

- polvo originado por la limpieza con chorro de arena;

- exposición a fibras minerales y de amianto en trabajos de aislamiento;

- vapores y emanaciones procedentes de la pulverización de pinturas, recubrimientos, disolventes y diluyentes;

- emisiones de trabajos de soldadura autógena, corte y soldadura con bronce o estaño;

- exposición a los gases empleados en soldaduras diversas, corte y procesos de calentamiento;

- exposición a productos químicos tóxicos de resinas epoxi, pinturas antiincrustación de estaño y cobre orgánicos, pinturas al plomo, aceites, grasas, pigmentos y similares.

Riesgos físicos debidos a la naturaleza manual de los trabajos:

- condiciones ambientales y de temperatura extremas al trabajar a la intemperie;

- riesgos eléctricos;

- problemas ergonómicos asociados debidos al manejo reiterado de materiales pesados y voluminosos;

- radiaciones ionizantes y no ionizantes;

- ruidos y vibraciones; 
- riesgo de falta de oxígeno al trabajar en depósitos, calderas, dobles fondos, etc.;

- caídas y deslizamientos en trabajos realizados al mismo nivel o a gran altura.

\section{Medidas preventivas}

Aunque el sector de la construcción y reparación de buques es muy peligroso, los riesgos para los trabajadores pueden y deben reducirse al mínimo. La base para reducir los riesgos es un programa sólido de salud y seguridad, que parta de la buena relación entre los sindicatos o los trabajadores y la dirección de la empresa.

Hay muchas formas de prevenir o minimizar los peligros identificados en el astillero. Estas formas de enfocar los problemas pueden agruparse de manera general en varias estrategias.

Controles técnicos: se emplean para eliminar o controlar los riesgos en origen. Estos controles constituyen la medida más deseable, pues son muy fiables:

- Sustitución o eliminación. Siempre que sea posible, los procesos que entrañan riesgos o que generan productos tóxicos deben ser eliminados o sustituidos por otros que supongan menos peligro. Se trata de la forma de control más efectiva. Un ejemplo lo constituye la utilización de materiales no cancerígenos en vez de los aislantes de amianto. Otro sería la utilización de plataformas hidráulicas de elevación para manejar materiales pesados en vez de izarlos manualmente. Las pinturas a base de disolventes se pueden sustituir en muchos casos por pinturas con base de agua (productos acrílicos). La automatización o la robótica también contribuyen a eliminar riesgos.

- Aislamiento. En ocasiones, los procesos que no son susceptibles de sustitución o eliminación pueden aislarse de los trabajadores. Frecuentemente, las fuentes de ruido intenso pueden alejarse de los trabajadores para reducir la exposición.

- Cerramiento. Los procesos o los trabajadores pueden protegerse mediante cerramientos para eliminar o reducir los riesgos de exposición. Se puede proteger a los operarios de los equipos mediante cabinas aislantes para eliminar o reducir la exposición a los ruidos, al calor, al frío o incluso a los efectos de los productos químicos nocivos. También los procesos pueden ser objeto de protección mediante cerramientos. Las cabinas para pulverizar, pintar y realizar trabajos de soldadura son ejemplos de cerramiento de procesos para reducir la exposición a materiales potencialmente tóxicos.

- Ventilación. Los procesos que producen materiales tóxicos pueden ventilarse para retener esos materiales en su punto de origen. Se trata de una técnica muy utilizada en astilleros y talleres náuticos, especialmente para controlar las emanaciones y los vapores generados en trabajos de soldadura, los vapores de pintura y otros similares. Numerosos ventiladores y extractores se colocan en las cubiertas de los buques para que extraigan el aire o éste salga al exterior y reducir así los riesgos de exposición. Con frecuencia se emplean ventiladores soplantes para dirigir aire fresco a los compartimientos y mantener así concentraciones de oxígeno aceptables.

Controles administrativos. Se utilizan para reducir al mínimo las exposiciones limitando administrativamente el tiempo que pueden pasar los trabajadores en situaciones potencialmente peligrosas. Por lo general, esto se lleva a cabo mediante la rotación del personal entre áreas escasamente expuestas y otras con mayor índice de exposición. Aunque la cantidad de tiempo acumulado de exposición personal no cambia, sí se reduce la exposición de cada trabajador individual.
Los controles administrativos tienen aspectos negativos. Se trata de una técnica que exige más formación, ya que los trabajadores deben conocer varias técnicas; además, aumenta el número de los expuestos a condiciones potencialmente peligrosas. Asimismo, dado que el número de trabajadores expuestos a situaciones de peligro se duplica desde el punto de vista reglamentario, las responsabilidades potenciales pueden aumentar. No obstante, el control administrativo es eficaz si se aplica adecuadamente.

Controles de protección individuales. Los astilleros han de depender en gran medida de las diversas formas de protección individual. La naturaleza de la construcción y reparación de buques no se presta a concepciones técnicas tradicionales. Los buques son recintos muy reducidos y cuyo acceso está limitado. Un submarino en reparación tiene de 1 a 3 escotillas de $0,76 \mathrm{~m}$ de diámetro, a través de las cuales deben pasar tanto los trabajadores como los equipos. Las conducciones de ventilación que pueden introducirse por ellas están severamente limitadas. De igual forma, en los grandes buques se trabaja en su más profundo interior, y aunque puedan llevarse algunas conducciones de ventilación hasta el nivel deseado, el número de ellas es limitado. Además, los ventiladores que impulsan o extraen el aire por las conducciones de ventilación suelen encontrarse a la intemperie, generalmente en la cubierta principal, por lo que su capacidad también se encuentra en cierta medida limitada.

Además, la construcción y reparación de buques no se efectúa en una línea de montaje, sino en emplazamientos separados, lo que hace prácticamente imposible la instalación de controles técnicos estacionarios. La situación se repite, y con mayor razón, en buques sometidos a trabajos de reparación que sólo duran algunos días. En estas situaciones se emplean mayoritariamente equipos de protección individual.

En los talleres pueden emplearse en mayor medida los métodos de control técnico tradicionales. La mayor parte de los equipos y de la maquinaria que se encuentra en los talleres y en las zonas de montaje se prestan al intervenciones normales de protección, ventilación, etc. No obstante, también en este tipo de situaciones deberán utilizarse equipos de protección individual.

Veamos a continuación las diversas aplicaciones de los equipos de protección individual utilizados en los astilleros:

Soldadura, corte y rectificado. El proceso básico de construcción y reparación de buques exige trabajos de corte, conformación y unión de aceros y otros metales. En el proceso se generan emanaciones metálicas, polvo y partículas. Aunque en ocasiones puede hacerse uso de la ventilación, los soldadores deben utilizar cada vez con más frecuencia dispositivos de respiración para protegerse de las emanaciones y las partículas en suspensión. También deben utilizar protectores oculares para evitar los efectos de las radiaciones ultravioleta e infrarroja y para protegerse de otros riesgos físicos potenciales para ojos y rostro. Para protegerse de las chispas y otras formas de metal fundido, los soldadores deben vestir prendas de manga larga, usar guantes de soldadura y hacer uso de otras protecciones físicas variadas.

Limpieza por chorro de arena y pintura. Durante la construcción y la reparación de un buque, es mucho el trabajo de pintura que se efectúa. En numerosas ocasiones las pinturas y los recubrimientos los especifica el propietario del buque. Antes de pintar, los equipos han de someterse a un cierto grado de limpieza por chorro abrasivo que garantice un buen grado de adherencia y protección.

La limpieza de pequeñas piezas con chorro abrasivo puede efectuarse en un recinto cerrado, tal como una caja de manipulación con guantes. No obstante, las piezas de mayor tamaño se someten a este tratamiento manualmente. Algunas de estas 
operaciones de limpieza se realizan a la intemperie, otras en grandes recintos especialmente destinados a tal fin en el interior de edificios o talleres, y otras en el interior de los propios buques o de secciones de éstos. En muchos casos, los operarios encargados de estas tareas de limpieza por abrasión deben utilizar vestimentas de protección total, protectores contra el ruido y dispositivos respiradores alimentados por aire. Asimismo, deben contar con un suministro adecuado de aire apto para respirar (al menos aire respirable de Grado D).

En alguno países se ha prohibido el empleo de silicio cristalino y, en general no se recomienda su utilización. En caso de que se utilicen materiales con silicio para limpieza por chorro abrasivo, deberán adoptarse medidas de protección personal.

Los materiales tratados con chorro de arena deben pintarse inmediatamente para evitar la "oxidación fulminante" de las superficies. Aunque ni el mercurio, ni el arsénico, ni otros metales de gran toxicidad se emplean ya en pinturas, las comunes en los astilleros contienen generalmente disolventes y pigmentos como el zinc. Otras pinturas son del tipo epoxi. Los pintores que aplican estos recubrimientos deben protegerse adecuadamente. La mayoría de los pintores deben protegerse con respiradores de presión positiva o negativa, así como vestimentas protectoras de cuerpo entero, guantes, cubrecalzado y protectores oculares. En ocasiones los trabajos de pintura deben llevarse a cabo en recintos cerrados o espacios reducidos. En estos casos se utilizan dispositivos respiradores alimentados por aire y vestimentas protectoras de cuerpo entero; también debe haber un programa de autorización para el trabajo en recintos cerrados o en espacios reducidos.

Riesgo de caída de objetos. En los astilleros hay muchas grúas, y gran parte de los trabajos se realizan por encima de las cabezas de los trabajadores. Por lo general, es obligatorio el uso de cascos en todas las áreas de producción del astillero.

Trabajos de aislamiento. Las conducciones y otros componentes han de aislarse para mantener su temperatura y reducir el calor en el interior del buque; en otros casos, el aislamiento es una forma de protección frente al ruido. Durante los trabajos de reparación de un buque, los aislamientos de las conducciones suelen retirarse para acceder a éstas; en estos casos es frecuente encontrarse con materiales de fibra de amianto. Durante los trabajos de construcción naval, se emplean frecuentemente materiales de fibra de vidrio o fibras minerales. En cualquier caso, deberán utilizarse dispositivos respiradores y vestimentas de protección de cuerpo entero adecuadas.

Fuentes de ruido. El trabajo en los astilleros es sumamente ruidoso. Casi todas las operaciones se hacen con metales, que casi siempre suponen un aumento del ruido por encima del límite reglamentario de riesgo para la salud. No todas las fuentes de ruido pueden mantenerse dentro de los límites a base de controles técnicos. Por eso hay que usar protectores individuales.

Peligros para los pies. En los astilleros se realizan muchos movimientos peligrosos para la integridad de los pies de los trabajadores. A menudo es imposible determinar qué zonas del astillero entrañan este peligro y cuáles no. En tales zonas de producción de los astilleros se requiere normalmente el empleo de calzado de seguridad.

Peligros para los ojos. Los trabajadores de los astilleros están expuestos a numerosas fuentes de peligro potencial para los ojos: riesgo propio de la radiación ultravioleta o infrarroja asociada con la soldadura por arco, trabajo con polvo y partículas metálicas procedentes del metal, partículas empleadas en la limpieza por chorro abrasivo, utilización de diversos baños metálicos y de decapado de pintura, y utilización de productos corrosivos y pinturas pulverizadas. Por la ubicua naturaleza de todas estas situaciones de riesgo, es habitualmente obligatorio el empleo de gafas protectoras en todas las áreas de producción de los astilleros, tanto por razones prácticas como administrativas. Para procesos concretos y específicos se requiere el uso de protecciones oculares especiales.

Plomo. Los recubrimientos e imprimaciones con plomo se han utilizado masivamente en los astilleros durante mucho tiempo. Aunque ahora apenas se utilizan estos materiales, en los astilleros que trabajan con buques movidos por energía nuclear se emplean grandes cantidades de plomo metálico como material protector frente a radiaciones. Además, los trabajos de reparación de buques a menudo requieren la eliminación de antiguos recubrimientos que con frecuencia contienen plomo. De hecho, los trabajos de reparación exigen mucha sensibilidad y cuidado con los materiales aplicados o utilizados con anterioridad. Trabajar con plomo obliga a usar vestimentas protectoras de cuerpo entero, guantes, gorro, cubrecalzado y dispositivos respiradores de seguridad.

\section{Construcción de embarcaciones pequeñas}

En algunos aspectos, las embarcaciones de recreo pueden considerarse como buques relativamente pequeños, pues muchos de los procesos empleados para su construcción y reparación son muy parecidos a los empleados en la construcción y reparación de buques, aunque a escala menor. El acero, la madera y los materiales compuestos son los más empleados en la construcción de cascos para embarcaciones pequeñas. Se consideran materiales compuestos los metales reforzados con fibra, las colas reforzadas con fibra, las resinas reforzadas con fibras, adhesivos reforzados con fibras, placas de hormigón armado, los plásticos reforzados con fibra y los plásticos reforzados con fibra de vidrio (GRP). El desarrollo desde principios del decenio de 1950 de métodos de aplicación manual de capas de resina de poliéster de endurecimiento en frío reforzada con fibra de vidrio condujo a una rápida expansión de la construcción náutica que empleaba los GRP, que ha pasado desde el $4 \%$ en el decenio de 1950 a más del $80 \%$ en el de 1980, e incluso a tasas aún mayores en la actualidad.

En los buques de eslora igual o superior a $40 \mathrm{~m}$, la principal alternativa a los GRP no es la madera, sino el acero. A medida que disminuye el tamaño del casco, el coste relativo de la construcción en acero aumenta, hasta dejar de ser competitivo por debajo de $20 \mathrm{~m}$. La necesidad de un margen para la corrosión tiende a aumentar excesivamente el peso en embarcaciones pequeñas con casco de este material. Sin embargo, para buques de más de $40 \mathrm{~m}$, el bajo coste que supone la construcción pesada en acero soldado suele suponer una ventaja decisiva. Salvo que el diseño imaginativo, la mejora de los materiales y la construcción automatizada reduzcan los costes sustancialmente, es poco probable que los plásticos reforzados con fibra de vidrio o de otro tipo lleguen a competir con el acero en embarcaciones de más de $40 \mathrm{~m}$ de eslora, excepto cuando hayan de cumplirse condiciones especiales, como transporte a granel de productos corrosivos o criogénicos, necesidad de un casco no magnético o reducción drástica de peso para mejorar las prestaciones.

En la actualidad, los GRP se utilizan mucho para construir cascos de embarcaciones de recreo, lanchas rápidas, yates de bajura y transoceánicos, embarcaciones de trabajo, lanchas de traslado de prácticos y pasajeros y barcos pesqueros. Su éxito en embarcaciones de pesca, tradicionalmente de madera, se puede atribuir a:

- coste inicial competitivo, especialmente cuando se construyen muchos cascos con el mismo diseño, realzado por el aumento del precio de la madera y la escasez de carpinteros de ribera con la suficiente experiencia;

- ausencia de averías y costes de mantenimiento reducidos gracias al uso de GRP a prueba de fugas y de podredumbre, a 
la resistencia a las incrustaciones de organismos marinos y a los bajos costes de reparación;

- facilidad para obtener formas complejas, necesarias por motivos hidrodinámicos, estructurales o estéticos.

\section{Métodos de fabricación}

La forma más común de construir cascos, cubiertas y mamparas en barcos de GRP grandes y pequeños es utilizar laminados monocapa reforzados con contrafuertes. Hay varios métodos de fabricación de cascos monocapa y tipo sandwich.

Moldeo por contacto. Se trata, con diferencia, del método más común para fabricar cascos de GRP monocapa de todos los tamaños. Consiste en moldear por contacto en moldes abiertos o negativos que se recubren de resina de poliéster de endurecimiento en frío y reforzada con de fibra de vidrio.

El primer paso es la preparación del molde. Para cascos de dimensiones pequeñas o moderadas, los moldes suelen fabricarse en GRP, en cuyo caso lo primero que se monta es una forma de madera revestida con GRP cuya superficie externa reproduce con precisión la del casco La última etapa de la preparación del molde es el pulimento con cera y la aplicación de alcohol polivinílico (PVA) u otro agente desmoldeador similar. El revestimiento empieza por la aplicación de una capa de gel pigmentado a base de resinas de buena calidad. La laminación continúa, antes de que endurezca por completo el recubrimiento de gel, por medio de alguno de los siguiente procesos:

- Pulverización. Los refuerzos o trenzas de fibra de vidrio se rocían con resina de poliéster mezclada en el pulverizador con un agente catalizador y otro acelerador.

- Aplicación manual de capas. La resina mezclada con el catalizador y el acelerador se deposita a discreción sobre el recubrimiento de gel o sobre un contrachapado de refuerzo previamente impregnado a brocha, rodillo o pulverizador.

Estas técnicas permiten la aplicación eficaz de refuerzos muy resistentes (se han utilizado con éxito tejidos de hasta $4.000 \mathrm{~g} / \mathrm{m}^{2}$, aunque para la fabricación a gran escala son preferibles los de 1.500 a $2.000 \mathrm{~g} / \mathrm{m}^{2}$ ), que aceleran la laminación con bajos costes de mano de obra. De forma similar se recubren rápidamente los paneles planos o casi planos de cubiertas y mamparos. Se ha logrado fabricar en serie un tipo de cascos de $49 \mathrm{~m}$, incluidos mamparos y cubiertas, con un plazo de 10 semanas por casco.

Moldeo por compresión. El moldeo por compresión se hace aplicando presión, normalmente acompañada de calor, a la superficie de un laminado aún en fresco para incrementar su contenido en fibra y reducir los vacíos presionando hasta eliminar el exceso de resina y aire.

Moldeo por bolsa de vacío. Este proceso, que podría considerarse como una variante del moldeo por contacto, consiste en colocar sobre el molde una membrana flexible de polietileno o de cualquier otro material equivalente, separada del laminado fresco por una película de PVA, sellar los bordes y someter a vacío el espacio situado bajo aquella para someter el laminado a una presión de hasta 1 bar. El secado se acelera colocando el componente envuelto por la bolsa en un horno o calentando el molde.

Moldeo en autoclave. Se alcanzan presiones mayores (de 5 a 15 bar) y temperaturas más elevadas, condiciones que incrementan el contenido de fibra y mejoran las cualidades mecánicas, realizando el moldeo con bolsa de vacío en el interior de un autoclave (horno presurizado).

Moldeo en matriz adaptada. El material de moldeo sin endurecer, que en el caso de componentes de gran tamaño, como el casco de una embarcación, probablemente sea una mezcla pulverizada a base de resina y fibra de vidrio suelta, o un tejido de fibra de vidrio cortado e impregnado, se comprime entre moldes positivo y negativo igualados, casi siempre de metal, con aplicación de calor en caso necesario. Como los moldes son muy caros, esta técnica sólo es rentable para grandes tiradas, por lo que raras veces se emplea en la construcción de embarcaciones pequeñas.

Devanado de filamentos. Esta técnica consiste en devanar fibras de refuerzo en forma de hilaza continua que se impregna con resina justo antes del devanado (devanado en mojado) o que está previamente impregnada con resina parcialmente endurecida (devanado en seco), en un mandril que define la geometría interna.

Construcción en sandwich. Los cascos, cubiertas y mamparos del tipo sandwich se fabrican mediante moldeo por contacto con resina de poliéster de secado a temperatura ambiente, de manera muy parecida a las estructuras de monocapa. En primer lugar se extiende sobre el molde en negativo la capa externa de GRP. Las tiras de material del núcleo del molde se incrustan en una capa de poliéster o de resina epoxi. La última operación consiste en extender la capa interna de GRP.

Poliéster y resinas epoxi. Las resinas de poliéster no saturadas son, con mucho, los materiales para matrices más utilizados en los laminados estructurales para aplicaciones navales. Estos materiales deben su eficacia al coste moderado, a la facilidad de utilización en técnicas de fabricación por tendido manual o pulverización y a sus buenas prestaciones generales en entornos marinos. Se comercializan tres tipos básicos:

1. Poliéster ortoftálico, producto de la combinación de anhídridos maleicos y ftálicos con un glicol (normalmente propilenglicol); es el material para matrices menos costoso y más utilizado en la construcción de embarcaciones pequeñas.

2. Poliéster isoftálico, que contiene ácido isoftálico en vez de anhídrido ftálico; es más costoso, presenta cualidades mecánicas algo mejores, es resistente al agua y suele utilizarse en la construcción de embarcaciones deportivas de altas prestaciones y en recubrimientos a base de gel marino.

3. Sistemas epoxi bifenólicos, en los cuales el ácido o el anhídrido ftálicos se sustituyen parcial o totalmente por bifenol A; aportan, a un coste sustancialmente más elevado, mayor resistencia al agua y a los productos químicos.

\section{Riesgos para la salud y la seguridad}

Aunque muchos de los riesgos químicos, físicos y biológicos que la construcción naval entraña para la salud y la seguridad son comunes a la construcción de embarcaciones pequeñas, el motivo principal de preocupación reside en la exposición a una diversidad de emanaciones de disolventes y de polvos de epoxi. La exposición incontrolada a estos riesgos puede producir trastornos en el sistema nervioso central, lesiones hepáticas y renales y reacciones de sensibilización. Los controles para estos riesgos potenciales son esencialmente los ya descritos en la sección dedicada a la construcción: controles técnicos, controles administrativos y controles de protección personal.

\section{CuESTIONES AMBIENTALES Y DE SALUD PUBLICA}

Frank H. Thorn, Page Ayres y Logan C. Shelman

Para las normativas sobre emisiones atmosféricas, vertidos y residuos, lo esencial es la protección de la salud pública y el cuidado del bienestar general de la población. Normalmente, la 
"población" está formada por los trabajadores de las instalaciones y quienes habitan en sus proximidades. No obstante, las corrientes de aire transportan los contaminantes de un lugar a otro, e incluso más allá de las fronteras nacionales; los vertidos a las aguas de ríos, lagos y mares viajan de igual forma y van de unos países a otros; y los residuos se transportan dentro del país en que se han producido o a cualquier otro lugar del mundo.

Los astilleros llevan a cabo una gran variedad de actividades durante la construcción o reparación de buques y embarcaciones pequeñas. Muchas de estas actividades generan contaminantes atmosféricos o de las aguas de los que se sabe o se sospecha que causan trastornos y lesiones fisiológicos y metabólicos, como el cáncer o el envenenamiento por plomo. Los contaminantes también actúan de manera indirecta, como agentes mutágenos (que afecten a la bioquímica de la reproducción de las generaciones futuras) o teratógenos (que dañan al feto).

Los contaminantes del aire y el agua pueden inducir efectos secundarios en el hombre. Cuando caen arrastrados por la precipitación, los contaminantes atmosféricos afectan a la calidad del agua que los recibe o de los cultivos y, por tanto, también a la salud pública. Los contaminantes vertidos directamente en el agua degradan su calidad hasta el extremo de que beber ese agua o hasta bañarse en ella supone un peligro para la salud. La contaminación de la tierra, el agua y el aire también afecta a la vida marina y, en última instancia, también a los seres humanos.

\section{Calidad del aire}

Prácticamente todas las actividades relacionadas con la construcción, la reparación y el mantenimiento de buques y embarcaciones pequeñas causan emisiones atmosféricas. Entre los contaminantes atmosféricos regulados en numerosos países se incluyen los óxidos de azufre y nitrógeno, el monóxido de carbono, las partículas (humo, hollín, polvo, etc.), el plomo y los compuestos orgánicos volátiles (COV). Las actividades relacionadas con la construcción y la reparación de buques que generan contaminantes del tipo "óxido" incluyen calderas y otras fuentes de combustión y el calor para el tratamiento de metales, generadores y hornos. Forman partículas los humos de combustión y el polvo formado al trabajar la madera o limpiar con chorro de arena y al lijar, esmerilar y pulir.

En ocasiones hay que fundir parcialmente lingotes de plomo para moldearlos en las formas que exige la protección de los generadores navales de energía nuclear. Se forma polvo de plomo al eliminar la pintura de buques sometidos a revisión general o reparación.

Los contaminantes atmosféricos peligrosos (HAP) son compuestos químicos con propiedades nocivas para la salud confirmadas o sospechadas. Se forman en muchas actividades desarrolladas en los astilleros, como fundición y galvanoplastia, que emiten cromo y otros compuestos metálicos.

Algunos COV, como los alcoholes y las naftas, utilizados como disolventes de pinturas, diluyentes y limpiadores, y numerosas colas y adhesivos, no son HAP. Otros disolventes, utilizados principalmente en pinturas, como xileno y tolueno y diversos compuestos clorados, como tricloroetileno, cloruro de metilo y tricloroetano, sí son HAP.

\section{Calidad del agua}

Dado que los buques y las embarcaciones de recreo se construyen junto al agua, los astilleros han de cumplir con las normativas establecidas por sus respectivos gobiernos en materia de vertidos de aguas residuales. La mayor parte de los astilleros norteamericanos, por ejemplo, aplican un programa denominado "Prácticas
Optimas de Gestión” (BMP) considerado como una importante compilación de tecnologías de control para ayudar a los astilleros a cumplir con los requisitos establecidos en materia de vertidos.

Otra tecnología de control utilizada en astilleros con muelle de carena (dique seco) es el sistema de presa y compuerta. La presa se encarga de retener los sólidos e impide que lleguen a los sumideros y las aguas adyacentes. El sistema de compuertas evita la entrada en los sumideros de los restos de aceite y de partículas flotantes.

En muchos astilleros se ha incorporado recientemente el control de las aguas de tormenta. Las instalaciones han de disponer de un plan de prevención de la contaminación por precipitaciones tormentosas que, mediante la aplicación de diferentes tecnologías de control, impida que la precipitación arrastre los contaminantes hacia las aguas próximas a las instalaciones del astillero.

Muchas instalaciones destinadas a la construcción de buques y embarcaciones pequeñas vierten parte de sus aguas residuales a la red de alcantarillado. Estas instalaciones deben cumplir con los requisitos locales en materia de vertidos a la red pública de alcantarillado. Algunos astilleros están construyendo sus propias plantas de tratamiento previo de aguas residuales, diseñadas para cumplir con la normativa local de calidad de las aguas. Hay dos tipos básicos de plantas de tratamiento previo: en uno, la finalidad primordial es retirar los metales tóxicos, mientras que el objeto del otro es extraer los productos derivados del petróleo.

\section{Gestión de residuos}

Los diferentes segmentos de la construcción naval producen tipos de residuos característicos que se eliminan de acuerdo con las normativas en vigor. Los trabajos de corte y conformación de aceros producen virutas metálicas; las operaciones de limpieza y recubrimiento generan residuos de pinturas y disolventes, polvos de abrasión y restos de recubrimientos viejos. Los residuos metálicos no entrañan por sí mismos peligro alguno para el medio ambiente y pueden reciclarse. Pero los de pinturas y disolventes son inflamables, y los restos de abrasión pueden resultar tóxicos, según de las características de los recubrimientos eliminados.

A medida que toman cuerpo los módulos de acero, se añaden conducciones. La preparación de éstas para su instalación en los módulos produce residuos, entre ellos aguas sucias contaminadas con los productos ácidos y cáusticos utilizados en la limpieza de las conducciones. Estas aguas residuales han de ser tratadas de una manera especial para neutralizar sus propiedades corrosivas y la suciedad y los aceites contaminantes que contienen.

Mientras se fabrican los elementos de acero, se preparan los componentes eléctricos y de ventilación, la maquinaria y las conducciones destinados a la fase de equipamiento del buque. En estas operaciones se producen residuos como los lubricantes y refrigerantes empleados para cortar metales, los desengrasantes y los residuos de galvanoplastia. Los lubricantes, los desengrasantes y los refrigerantes han de ser tratados para eliminar de ellos la suciedad y los aceites antes de verterlos. Las aguas residuales procedentes de los trabajos de galvanoplastia son tóxicas y pueden contener compuestos de cianuro, por lo que requieren tratamientos especiales.

Los buques en reparación deben casi siempre vaciar todas los residuos acumulados durante la travesía. Las aguas residuales de sentina deben ser tratadas para eliminar de ellas los aceites contaminantes. Las aguas fecales se vierten a una red de alcantarillado, donde se someten a tratamiento biológico. Incluso los desperdicios y basuras deben ser objeto de tratamientos especiales para cumplir con las normativas vigentes y evitar así la introducción de plantas y animales foráneos. 


\section{Otras lecturas recomendadas}

National Shipbuilding Research Program (NSRP). 1993. Introduction to Production Processes and Facilities in the Steel Shipbuilding and Repair Industry. NSRP 0382. Arlington,Virginia: NSRP, Office of Naval Research.
-. 1995. Characterizing Shipyard Welding Emissions and Associated Control Options. NSRP 0457. Arlington,Virginia: NSRP, Office of Naval Research.

Smith, CS. 1990. Design of Marine Structures in Composite Materials. Londres y Nueva York: Elsevier Applied Science.
Todd, WF, SA Shulman. 1984. Control of styrene vapor in a large fiberglass boat manufacturing operation. Am Ind Hyg Assoc 7 45:817-825. 


\section{CONSTRUCCION}

Directores del capítulo

Knut Ringen, Jane L. Seegaly

fames L. Weeks

\section{Sumario}

\section{SALUD, PREVENCION Y GESTION}

Riesgos de salud y seguridad en el sector de la construcción

James $L$ Weeks.

Riesgos para la salud en obras subterráneas

Bohuslav Málek. . . . . . . . . . . . . . . . . . . . . . . 93.9

Servicios preventivos sanitarios en la construcción Pekka Roto.

Normas de seguridad y salud: la experiencia de los Países Bajos

Leen Akkers . . .

Factores de organización que afectan a la salud y la seguridad

Doug F. McVittie .

Gestión de calidad y prevención integradas

Rudolf Scholbeck. . .

PRINCIPALES SECTORES YSUS RIESGOS

Principales sectores

Feffrey Hinksman . . . . . . . . . . . . . . . . . . 93.18

Tipos de proyectos y sus riesgos asociados Feffrey Hinksman.

Zanjas

Jack L. Mickle

HERRAMIENTAS, MAQUINAS Y MATERIALES

Herramientas

Scott P. Schneider .

Equipos, máquinas y materiales

Hans Göran Linder.

Grúas

Francis Hardy. ...
Ascensores, escaleras mecánicas y elevadores

7. Staal y Fohn Quackenbush . . . . . . . . . . . . . . . . . . . 93.45

Cemento y hormigón

L. Prodan y G. Bachofen. . . . . . . . . . . . . . . . . . . . 93.50

Estudios de casos: Prevención de las dermatosis profesionales entre los trabajadores expuestos al polvo de cemento Pekka Roto . . . . . . . . . . . . . . . . . . . . . . . . . . . 93.54

Asfalto

Fohn Finklea . . . . . . . . . . . . . . . . . . . . . . . . . . . . . 93.56

Grava

Fames $L$. Weeks. . . . . . . . . . . . . . . . . . . 93.58 


\section{- RIESGOS DE SALUD Y SEGURIDAD EN EL SECTOR DE LA CONSTRUCCION}

James L. Weeks

Los trabajadores de la construcción construyen, reparan, mantienen, restauran, reforman y derriban casas, edificios de oficinas, templos, fábricas, hospitales, carreteras, puentes, túneles, estadios, puertos, aeropuertos, etc. La Organización Internacional del Trabajo (OIT) clasifica dentro del sector de la construcción a aquellas empresas públicas y privadas que erigen edificios para viviendas o para fines comerciales e infraestructuras como carreteras, puentes, túneles, presas y aeropuertos. En Estados Unidos y en algunos otros países, los trabajadores de la construcción también se encargan de la limpieza de vertederos de residuos peligrosos.

La proporción que representa la construcción en el producto interior bruto en los países industrializados varía ampliamente. Representa alrededor del $4 \%$ del PIB en Estados Unidos, el $6,5 \%$ en Alemania y el $17 \%$ en Japón. En la mayoría de los países, las empresas tienen relativamente pocos empleados a jornada completa. Existen muchas empresas especializadas en sus respectivos oficios - electricidad, fontanería o soladores, por ejemplo- que trabajan como subcontratistas.

\section{Los trabajadores de la construcción}

Gran parte de los trabajadores de la construcción son trabajadores no cualificados; otros están clasificados en alguno de los diversos oficios especializados (véase la Tabla 93.1). Los obreros de la construcción engloban del 5 al $10 \%$ de la población activa

Tabla 93.1 • Diversas profesiones de la construcción.

Caldereros

Albañiles, hormigonadores, mamposteros

Carpinteros

Electricistas

Ascensoristas

Cristaleros

Trabajadores de limpieza de materias peligrosas (amianto, plomo, vertidos tóxicos)

Soladores (inclusive de terrazo) y colocadores de moquetas

Colocadores de cartón-yeso (paredes y placas de techo)

Instaladores de aislamientos (mecánicos y de suelos, paredes y techos)

Ferrallistas (refuerzos y estructuras)

Peones

Trabajadores de mantenimiento

Mecánicos

Maquinistas (conductores de grúas y operarios de mantenimiento de maquinaria pesada)

Pintores, yeseros y empapeladores

Fontaneros y plomeros

Techadores

Planchistas

Excavadores de túneles de los países industrializados. En todo el mundo, más del $90 \%$ de los trabajadores de la construcción pertenecen al sexo masculino. En algunos países en vías de desarrollo, la proporción de mujeres es mayor, y suelen concentrarse en trabajos no cualificados. En algunos países, el trabajo se deja a los inmigrantes, y en otros, el sector proporciona empleo relativamente bien pagado y una vía hacia la seguridad económica. Para muchos, el trabajo no cualificado en la construcción constituye la puerta de acceso a la masa laboral asalariada en la construcción o en otros sectores.

\section{Organización del trabajo e inestabilidad laboral} Los proyectos de construcción, en especial los de gran magnitud, son complejos y dinámicos. En una obra pueden trabajar varias empresas a la vez, y el elenco de contratistas varía con las fases del proyecto; por ejemplo, el contratista general estará presente durante toda la obra, los contratistas de la excavación al principio de la misma, luego vendrán los carpinteros, electricistas y fontaneros, seguidos de los soladores, pintores y paisajistas. Y, a medida que se desarrolla el trabajo - cuando se elevan las paredes de un edificio, con los cambios de tiempo o al avanzar un túnel- las condiciones ambientales, como la ventilación o la temperatura, también varían.

Los trabajadores de la construcción suelen contratarse para cada proyecto y pueden pasar solamente unas pocas semanas o meses en un proyecto determinado. De ello se derivan ciertas consecuencias tanto para los trabajadores como para los proyectos. Los trabajadores se ven obligados a establecer una y otra vez relaciones productivas y seguras con otros trabajadores a los que tal vez no conocen, y ello puede afectar a la seguridad en la obra. En el curso de un año, los trabajadores de la construcción pueden haber tenido varios patronos y un empleo tan sólo parcial. Pueden llegar a alcanzar una media de 1.500 horas de trabajo al año, mientras que los trabajadores de las fábricas, por ejemplo, es más probable que trabajen regularmente semanas de 40 horas y 2.000 horas al año. Para recuperar el tiempo inactivo, muchos trabajadores de la construcción tienen otros trabajos - y están expuestos a otros riesgos de salud o seguridad-ajenos a la construcción.

Para un proyecto particular, es frecuente el cambio del número de trabajadores y de la composición de la mano de obra. Este cambio es el resultado tanto de la necesidad de diferentes oficios especializados en las diferentes fases del proyecto como de la alta rotación de los trabajadores, en especial de los no cualificados. En un momento determinado, un proyecto puede incluir una gran proporción de trabajadores sin experiencia, y eventuales que no dominan el idioma común. Aunque el trabajo de la construcción se realiza a menudo por equipos, es difícil desarrollar un trabajo de equipo seguro y eficiente en tales condiciones.

Igual que la mano de obra, el mundo de los contratistas de la construcción también se caracteriza por una alta rotación y consiste principalmente en empresas pequeñas. De los 1,9 millones de contratistas de la construcción de Estados Unidos que figuraban en el censo de 1990, solamente el $28 \%$ tenía algún empleado a jornada completa. Sólo 136.000 (7%) tenían 10 empleados o más. El grado de participación de los contratistas en organizaciones patronales varía según el país. En Estados Unidos solamente participan entre un 10 y un $15 \%$ de los contratistas; en algunos países europeos, la proporción es mayor, pero engloba menos de la mitad de los contratistas. Ello dificulta la labor de identificar a los contratistas e informarles de 
sus derechos y responsabilidades de acuerdo con las leyes y reglamentos relativos a la salud y seguridad u otras cuestiones.

Como en otros sectores, una proporción creciente de contratistas de Estados Unidos y de Europa está formada por trabajadores individuales empleados como autónomos por contratistas generales y subcontratistas que contratan trabajadores. De ordinario, un contratista general no se hace cargo de los gastos sociales como el seguro de enfermedad, el seguro de accidentes, de desempleo, de pensiones, etc. de sus subcontratistas. Tampoco tienen los contratistas generales ninguna obligación con los subcontratistas con respecto a las normas de seguridad y salud; éstas solo cubren los derechos y responsabilidades en relación con sus propios trabajadores. Este sistema proporciona cierta independencia a los individuos que contratan para sus servicios, pero a cambio de suprimir una amplia gama de beneficios. También libera al contratista de la obligación de asegurar a los individuos que son contratistas. Este sistema privado subvierte la política pública y ha sido contestado con éxito en los tribunales, pero continúa existiendo y puede llegar a ser más que un problema para la salud y seguridad de los trabajadores de la obra, independientemente de sus relaciones laborales. La Estadística del US Bureau of Labor (BLS) estima que el $9 \%$ de la población laboral de Estados Unidos es autónoma, pero en la construcción el $25 \%$ de los trabajadores son contratistas independientes autónomos.

\section{Riesgos para la salud en las obras de construcción}

Los trabajadores de la construcción se encuentran expuestos en su trabajo a una gran variedad de riesgos para la salud. La exposición varía de oficio en oficio, de obra a obra, cada día, incluso cada hora. La exposición a cualquier riesgo suele ser intermitente y de corta duración, pero es probable que se repita. Un/a trabajador/a puede no sólo toparse con los riesgos primarios de su propio trabajo, sino que también puede exponerse como observador pasivo a los riesgos generados por quienes trabajan en su proximidad o en su radio de influencia. Este modelo de exposición es una de las consecuencias de tener muchos patronos con trabajos de duración relativamente corta y de trabajar al lado de trabajadores de otros oficios que generan otros riesgos. La gravedad de cada riesgo depende de la concentración y duración de la exposición para un determinado trabajo. Las exposiciones pasivas se pueden prever de un modo aproximado si se conoce el oficio de los trabajadores próximos.

Los riesgos a que están expuestos los trabajadores de determinados oficios se relacionan en la Tabla 93.2

\section{Riesgos de la construcción}

$\mathrm{Al}$ igual que en otros trabajos, los riesgos de los trabajadores de la construcción suelen ser de cuatro clases: químicos, físicos, biológicos y sociales.

\section{Riesgos químicos}

A menudo, los riesgos químicos se transmiten por el aire y pueden presentarse en forma de polvos, humos, nieblas, vapores o gases; siendo así, la exposición suele producirse por inhalación, aunque ciertos riesgos portados por el aire pueden fijarse y ser absorbidos a través de la piel indemne (p. ej., pesticidas y algunos disolventes orgánicos). Los riesgos químicos también se presentan en estado líquido o semilíquido (p. ej., pegamentos o adhesivos, alquitrán) o en forma de polvo (cemento seco). El contacto de la piel con las sustancias químicas en este estado puede producirse adicionalmente a la posible inhalación del vapor, dando lugar a una intoxicación sistémica o una dermatitis por contacto. Las sustancias químicas también pueden ingerirse con los alimentos o con el agua, o pueden ser inhaladas al fumar.
Varias enfermedades se han asociado a los oficios de la construcción, entre ellas:

- silicosis entre los aplicadores del chorros de arena, excavadores en túneles y barreneros

- asbestosis (y otras enfermedades causadas por el amianto) entre los aplicadores de aislamientos con amianto, instaladores de sistemas de vapor, trabajadores de demolición de edificios y otros.

- bronquitis entre los soldadores

- alergias cutáneas entre los albañiles y otros que trabajan con cemento

- trastornos neurológicos entre los pintores y otros oficios expuestos a los disolventes orgánicos y al plomo.

Se han encontrado tasas de mortalidad elevadas por cáncer de pulmón y del aparato respiratorio entre los manipuladores de aislamientos con amianto, los techadores, los soldadores y algunos trabajadores de la madera. La intoxicación por plomo se produce entre los restauradores de puentes y los pintores, y la fatiga por calor (debido al uso de trajes de protección de cuerpo entero) entre los que limpian los vertederos de basuras y los techadores. La enfermedad de los dedos blancos (síndrome de Raynaud) aparece entre algunos operadores de martillos neumáticos y otros trabajadores que manejan perforadoras que producen vibraciones (p. ej., las perforadoras usadas en la excavación de túneles).

El alcoholismo y otras enfermedades relacionadas con el alcohol son más frecuentes de lo que cabría esperar entre los trabajadores de la construcción. No se han identificado causas laborales específicas, pero es posible que ello guarde relación con el estrés originado por la falta de control sobre las posibilidades de empleo, las fuertes exigencias del trabajo, o el aislamiento social debido a unas relaciones laborales inestables.

\section{Riesgos físicos}

Los riesgos físicos se encuentran presentes en todo proyecto de construcción. Entre ellos se incluyen el ruido, el calor y el frío, las radiaciones, las vibraciones y la presión barométrica. A menudo, el trabajo de la construcción se desarrolla en presencia de calores o fríos extremos, con tiempo ventoso, lluvioso, con nieve, niebla o de noche. También se pueden encontrar radiaciones ionizantes y no ionizantes, y presiones barométricas extremas.

La maquinaria que ha transformado la construcción en una actividad cada vez más mecanizada, también la ha hecho mucho más ruidosa. El ruido proviene de motores de todo tipo (vehículos, compresores neumáticos y grúas), cabrestantes, pistolas de remaches, de clavos, para pintar, martillos neumáticos, sierras mecánicas, lijadoras, buriladoras, aplanadoras, explosivos, etc. El ruido está presente en los proyectos de demolición por la misma naturaleza de su actividad. Afecta no sólo al operario que maneja una máquina que hace ruido, sino también a todos los que se encuentran cerca y, no sólo causa pérdida de audición producida por el ruido, sino que enmascara otros sonidos que son importantes para la comunicación y la seguridad.

Los martillos neumáticos, muchas herramientas de mano y la maquinaria de movimiento de tierras y otras grandes máquinas móviles también someten a los trabajadores a vibraciones en todo el cuerpo o en una parte del mismo.

Los riesgos derivados del calor o del frío surgen, en primer lugar, porque gran parte del trabajo de construcción se desarrolla a la intemperie, que es el principal origen de este tipo de riesgos. Los techadores están expuestos al sol, a menudo sin ninguna protección, y muchas veces han de calentar recipientes de alquitrán, recibiendo, por ello, fuertes cargas de calor por radiación y por convección que se añaden al calor metabólico producido por el esfuerzo físico. Los operadores de maquinaria 
Tabla 93.2 • Riesgos primarios en oficios especializados de construcción.

Cada oficio aparece incluido en la lista con la indicación de los riesgos primarios a los que un trabajador de ese oficio se puede ver expuesto. La exposición puede afectar por igual a los supervisores y a los trabajadores. No aparecen en la relación los riesgos comunes a casi todos los subsectores de la construcción —el calor, los factores de riesgo causantes de trastornos musculosqueléticos o la fatiga -.

La clasificación de oficios de la construcción recogida aquí equivale a la adoptada en Estados Unidos. Incluye los oficios de la construcción de acuerdo con la clasificación establecida en el sistema de Clasificación Normalizada de Profesiones desarrollado por el Departamento de Comercio de Estados Unidos. Este sistema clasifica los oficios de acuerdo con las principales cualificaciones que implican.

\begin{tabular}{|c|c|}
\hline Profesiones & Riesgos \\
\hline Albañiles & Dermatitis del cemento, posturas inadecuadas, cargas pesadas \\
\hline Canteros & Dermatitis del cemento, posturas inadecuadas, cargas pesadas \\
\hline Soladores y alicatadores & Vapores de las pastas de adherencia, dermatitis, posturas inadecuadas \\
\hline Carpinteros & Serrín, cargas pesadas, movimientos repetitivos \\
\hline Colocadores de cartón-yeso & Polvo de yeso, caminar sobre zancos, cargas pesadas, posturas inadecuadas \\
\hline Electricistas & $\begin{array}{l}\text { Metales pesados de los humos de la soldadura, posturas inadecuadas, cargas pesadas, } \\
\text { polvo de amianto }\end{array}$ \\
\hline Instaladores y reparadores de líneas elécricas & Metales pesados de los humos de la soldadura, cargas pesadas, polvo de amianto \\
\hline Pintores & Emanaciones de disolventes, metales tóxicos de los pigmentos, aditivos de las pinturas \\
\hline Empapeladores & Vapores de la cola, posturas inadecuadas \\
\hline Revocadores & Dermatitis, posturas inadecuadas \\
\hline Fontaneros & Emanaciones y partículas de plomo, humos de la soldadura \\
\hline Plomeros & Emanaciones y partículas de plomo, humos de la soldadura, polvo de amianto \\
\hline Montadores de calderas de vapor & Humos de soldadura, polvo de amianto \\
\hline Colocadores de moqueta & Lesiones en las rodillas, posturas inadecuadas, pegamentos y sus emanaciones \\
\hline Colocadores de revestimientos flexibles & Agentes adhesivos \\
\hline Pulidores de hormigón y terrazo & Posturas inadecuadas \\
\hline Cristaleros & Posturas inadecuadas \\
\hline Colocadores de aislamientos & Amianto, fibras sintéticas, posturas inadecuadas \\
\hline Maquinistas de pavimentadoras, niveladoras y apisonadoras & Emanaciones del asfalto, humos de los motores de gasolina y gasóleo, calor \\
\hline Operadores de maquinaria de colocación de vías férreas & Polvo de sílice, calor \\
\hline Techadores & Alquitrán, calor, trabajo en altura \\
\hline Colocadores de conductos de acero & Posturas inadecuadas, cargas pesadas, ruido \\
\hline Montadores de estructuras metálicas & Posturas inadecuadas, cargas pesadas, trabajo en altura \\
\hline Soldadores (elécrica) & Emanaciones de la soldadura \\
\hline Soldadores (autógena) & Emanaciones metálicas, plomo, cadmio \\
\hline Barreneros, en tierra, en roca & Polvo de sílice, vibraciones en todo el cuerpo, ruido \\
\hline Operarios de martillos neumáticos & Ruido, vibraciones en todo el cuerpo, polvo de sílice \\
\hline Maquinistas de hincadoras de pilotes & Ruido, vibraciones en todo el cuerpo \\
\hline Maquinistas de tornos y montacargas & Ruido, aceite de engrase \\
\hline Gruístas (grúas torre y automóviles) & Fatiga, aislamiento \\
\hline Operadores de maquinaria de excavación y carga & Polvo de sílice, histoplasmosis, vibraciones en todo el cuerpo, fatiga por calor, ruido \\
\hline Operadores de motoniveladoras, bulldozers y traillas & Polvo de sílice, vibraciones en todo el cuerpo, calor, ruido \\
\hline Trabajadores de construcción de carreteras y calles & Emanaciones asfálticas, calor, humos de motores de gasóleo \\
\hline Conductores de camión y tractoristas & Vibraciones en todo el cuerpo, humos de los motores de gasóleo \\
\hline Trabajadores de demoliciones & Amianto, plomo, polvo, ruido \\
\hline Trabajadores que manipulan residuos tóxicos & Calor, fatiga \\
\hline
\end{tabular}


Figura 93.1 - Trabajador portando una carga sin ropa ni equipo de trabajo adecuados.

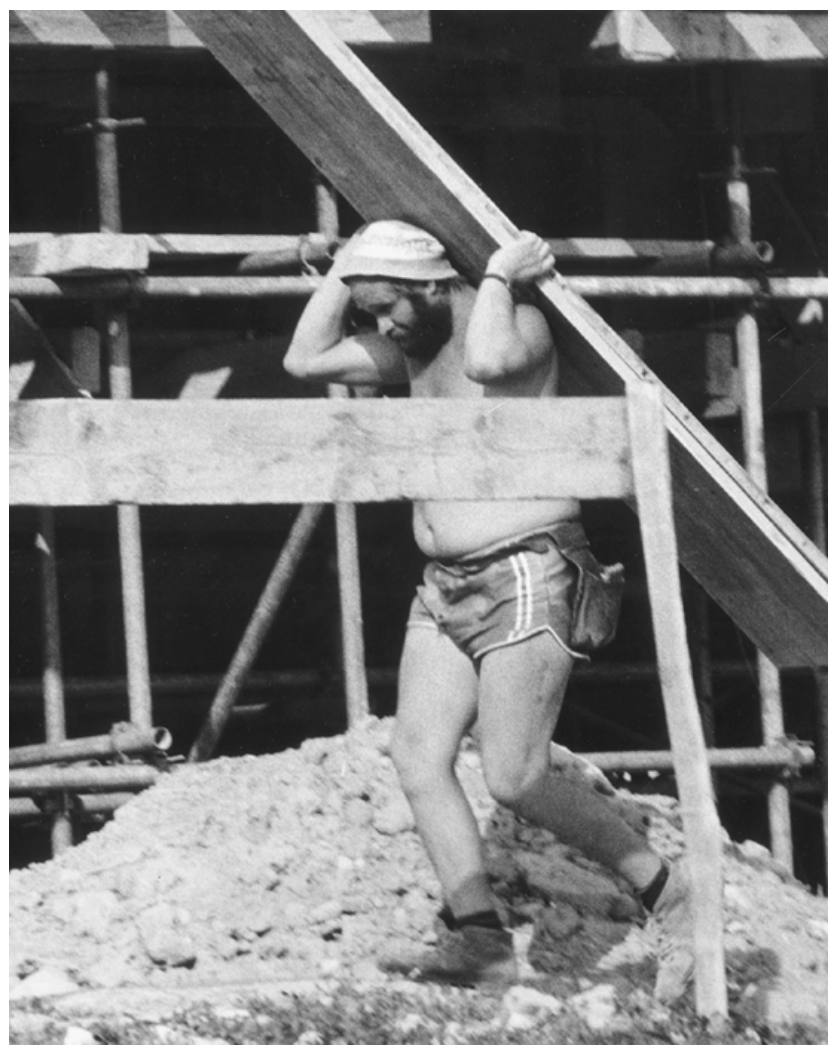

pesada pueden permanecer sentados junto a un motor caliente y trabajar en una cabina cerrada con ventanas y sin ventilación. Los que trabajan en una cabina abierta sin techo carecen de protección contra el sol. Los trabajadores con trajes protectores, como los que se necesitan para la retirada de residuos peligrosos, pueden generar calor metabólico por el esfuerzo físico y obtener escaso alivio por estar embutidos en un traje hermético al aire. También contribuyen a la fatiga térmica la falta de agua o de sombra. Igualmente, los operarios de la construcción pueden trabajar en condiciones de frío extremado durante el invierno, con peligro de congelación e hipotermia y riesgo de resbalar sobre el hielo.

Las fuentes principales de las radiaciones ultravioletas (UV) no ionizantes son el sol y la soldadura por arco eléctrico. La exposición a la radiación ionizante es menos corriente, pero se puede producir durante el examen de soldaduras con rayos $\mathrm{X}$, o también al manejar caudalómetros a base de isótopos radiactivos. Los rayos láser se utilizan cada vez más y pueden causar lesiones, en especial en los ojos, si uno se interpone en la trayectoria del rayo.

Los que trabajan bajo el agua o en túneles presurizados, en cajones de aire comprimido y de buzos están expuestos a una alta presión barométrica. Estos trabajadores corren el riesgo de desarrollar una serie de condiciones asociadas con una presión alta: mal de descompresión, estado de estupefacción por gas inerte, necrosis ósea aséptica y otros trastornos.

Entre las lesiones más comunes de los trabajadores de la construcción figuran las roturas y los esguinces. Estos y muchos trastornos musculosqueléticos (como tendinitis, síndrome del túnel carpal y lumbalgias) pueden ser el resultado de una lesión traumática, de movimientos forzados repetitivos, de posturas inadecuadas o de esfuerzos violentos (véase la Figura 93.1). Las caídas debidas posiciones inestables, huecos sin protección y resbalones en andamios (véase la Figura 93.2) y escaleras son muy corrientes.

\section{Riesgos biológicos}

Los riesgos biológicos se presentan por exposición a microorganismos infecciosos, a sustancias tóxicas de origen biológico o por ataques de animales. Por ejemplo, los trabajadores en excavaciones pueden desarrollar histoplasmosis, que es una infección pulmonar causada por un hongo que se encuentra comúnmente en el terreno.

Dado que el cambio de composición de la mano de obra en cualquier proyecto es constante, los trabajadores individuales puede entrar en contacto con otros y, de resultas de ello, pueden contraer enfermedades contagiosas - gripe o tuberculosis, por ejemplo- - Los trabajadores también pueden estar expuestos al riesgo de contraer la malaria, fiebre amarilla o la enfermedad de Lyme si el trabajo se desarrolla en zonas en la que estos organismos y los insectos portadores son frecuentes.

Las sustancias tóxicas de origen vegetal provienen de la hiedra venenosa, arbustos venenosos, zumaque y ortigas venenosas, que causan sarpullidos en la piel. El serrín de algunas maderas puede producir cáncer, y existen otras (p. ej., la del cedro rojo occidental) que causan alergias.

Los ataques por animales son raros, pero se pueden producir cuando un proyecto de construcción les causa molestias o invade su hábitat. Aquí se pueden incluir las avispas, abejorros, hormigas rojas, serpientes y muchos otros. Los trabajadores bajo

Figura 93.2 - Andamio inseguro en Katmandú, Nepal, 1974.

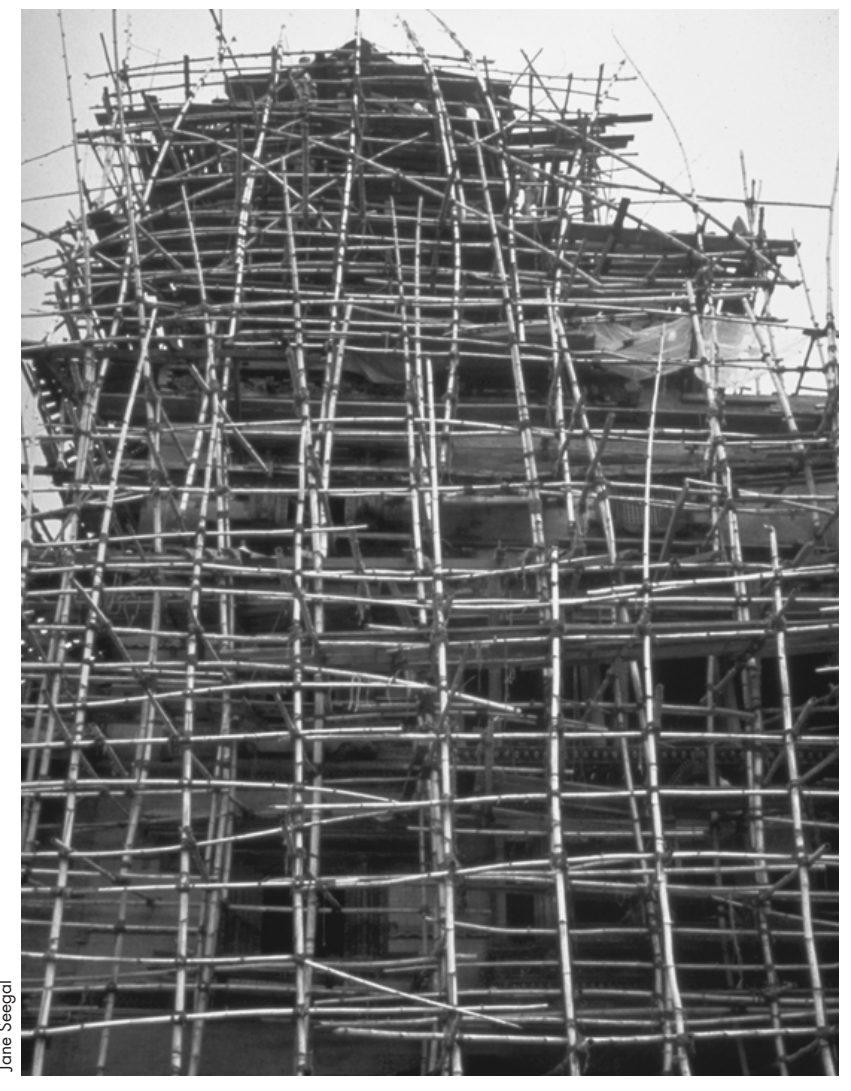


el agua pueden sufrir el riesgo de ataques por tiburones y otras especies de peces.

\section{Riesgos sociales}

Los riesgos sociales provienen de la organización social del sector. La ocupación es intermitente y cambia constantemente, y el control sobre muchos aspectos del empleo es limitado, ya que la actividad de la construcción depende de muchos factores sobre los cuales los trabajadores no tienen control, tales como el estado de la economía o el clima. A causa de los mismos, pueden sufrir una intensa presión para ser más productivos. Debido a que la mano de obra cambia continuamente, y con ella los horarios y la ubicación de los trabajos, y también porque muchos proyectos exigen vivir en campamentos lejos del hogar y de la familia, los trabajadores de la construcción pueden carecer de redes estables y fiables que les proporcionen apoyo social. Ciertas características del trabajo de la construcción, como las pesadas cargas de trabajo, un control y apoyo social limitados son los factores más asociados con el estrés en otras industrias. Estos riesgos no son exclusivos de ningún oficio, pero son comunes a todos los trabajadores de la construcción en una u otra forma.

\section{Evaluación de la exposición}

Para evaluar la exposición, tanto primaria como pasiva, se requiere conocer las tareas que se realizan y la composición de los ingredientes y de los subproductos asociados con cada trabajo o tarea. Generalmente, este conocimiento existe en alguna parte (p. ej., hojas de datos de seguridad de los materiales, las HDSM), pero puede no estar disponible en obra. Gracias al continuo desarrollo de la tecnología de las comunicaciones y la informática, es relativamente fácil obtener tal información y ponerla al alcance de todos.

\section{Control de los riesgos laborales}

La medición y evaluación de la exposición a los riesgos laborales requiere tener en cuenta el modo peculiar en que se produce la exposición de estos trabajadores. Las mediciones y los límites de exposición en la higiene industrial convencional se basan en promedios de jornadas de 8 horas. Pero dado que las exposiciones en la construcción son habitualmente breves, intermitentes, variadas pero de probable repetición, tal tipo de mediciones y límites de exposición no son tan útiles como en otros trabajos. La medición de la exposición puede basarse en tareas mejor que en turnos de trabajo. De acuerdo con este enfoque, se pueden identificar tareas distintas y los riesgos característicos de cada una de ellas. Una tarea es una actividad limitada, como la soldadura, el lijado de cartón-yeso, la pintura, la instalación de fontanería, etc. Si las exposiciones se caracterizan por tareas, deberá ser posible desarrollar un perfil de exposición para un trabajador individual con conocimiento de las tareas que realicen o que se realicen tan próximas a él que puedan provocar una exposición. A medida que aumenta el conocimiento de la exposición basada en las tareas, es posible desarrollar controles basados en las mismas.

La exposición varía con la concentración del riesgo y la frecuencia y duración de la tarea. Como enfoque general del control de riesgos, es posible reducir la exposición reduciendo la concentración o la duración o frecuencia de la tarea. Dado que la exposición en la construcción es intermitente de por sí, los controles administrativos que se basan en reducir la frecuencia o la duración de la exposición son menos prácticos que en otras industrias. Por consiguiente, la manera más eficaz de reducir la exposición consiste en reducir la concentración de riesgos. Otros aspectos importantes del control de la exposición incluyen la disponibilidad de instalaciones sanitarias y de comedor, y la educación y formación.

\section{Reducción de la concentración de la exposición}

Para reducir la concentración de la exposición conviene considerar la fuente, el entorno en que se produce un riesgo y los trabajadores expuestos al mismo. Como regla general, cuanto más próximos a la fuente sean los controles, más eficaces serán y mejor resultado darán. Tres son los tipos de controles que se pueden utilizar para reducir la concentración de los riesgos en el trabajo. Estos son, siguiendo el orden de mayor a menor eficacia:

- controles de ingeniería en la fuente

- controles medioambientales que eliminan el riesgo del entorno - protecciones personales facilitadas al trabajador

\section{Controles de ingeniería}

Los riesgos se originan en una fuente. La manera más eficiente de proteger a los trabajadores de los riesgos es cambiar la fuente primaria con algún cambio tecnológico. Por ejemplo, una sustancia más peligrosa puede ser sustituida por una menos peligrosa. El amianto puede ser sustituido por fibras de vidrio sintéticas no inspirables, y los disolventes orgánicos de las pinturas pueden ser sustituidos por agua. De igual modo, abrasivos sin sílice pueden reemplazar a la arena en el decapado abrasivo (también denominado chorreo de arena). $\mathrm{O}$ se puede cambiar a fondo un proceso, tal como sustituir los martillos neumáticos por martillos de impacto que originan menos ruido y vibraciones. Si al serrar o al taladrar se genera polvo, partículas o ruidos, estos procesos se pueden realizar cortando con cizallas o mediante punzonamiento. Las mejoras tecnológicas reducen los riesgos de algunos problemas musculosqueléticos y otros problemas de salud. Muchos de los cambios son sencillos, por ejemplo, un destornillador a dos manos con un mango más largo aumenta el par de torsión en el objeto y reduce la fatiga en las muñecas.

\section{Controles medioambientales}

Los controles medioambientales se utilizan para eliminar una sustancia peligrosa del entorno, si es portada por el aire, o para protegerse de la fuente, si se trata de un riesgo físico. En un trabajo determinado se puede usar un sistema extractor local (SEL) a base de una campana y un conducto de ventilación para recoger los humos, vapores o el polvo. Sin embargo, puesto que la ubicación de las tareas que emiten materiales tóxicos es variable, y como la estructura también cambia, cualquier SEL tendrá que ser móvil y flexible para adaptarlo a esos cambios. Colectores de polvo con ventiladores y filtros montados sobre ruedas, fuentes de energía autónomas, conductos flexibles y suministros de agua móviles se han utilizado en muchas obras para asegurar la extracción en una serie de procesos generadores de riesgos.

Un método sencillo y eficaz de controlar la exposición a riesgos físicos por radiaciones (ruido, radiación ultravioleta (UV) por soldadura al arco, radiación infrarroja (IR), calor irradiado por objetos calientes) consiste en protegerse de ellos con algún material adecuado. Las planchas de contrachapado protegen de las radiaciones IR y UV, y un material fonoabsorbente o fonorreflectante proporcionará cierta protección de las fuentes de ruido.

Las fuentes principales de fatiga por calor son el clima y el trabajo físico. Los efectos adversos de la fatiga térmica pueden evitarse mediante reducciones de la carga de trabajo, provisión de agua y pausas adecuadas a la sombra y, tal vez, trabajando de noche.

\section{Protección individual}

Cuando los controles de ingeniería o los cambios de prácticas de trabajo no bastan para proteger a los trabajadores adecuadamente, éstos pueden necesitar un equipo de protección individual (EPI) (véase la Figura 93.3). Para que tal equipo sea eficaz, los trabajadores deberán ser instruidos en su uso, y el equipo 
Figura 93.3 • Trabajador de la construcción en Nairobi, Kenya, sin casco ni calzado de protección.

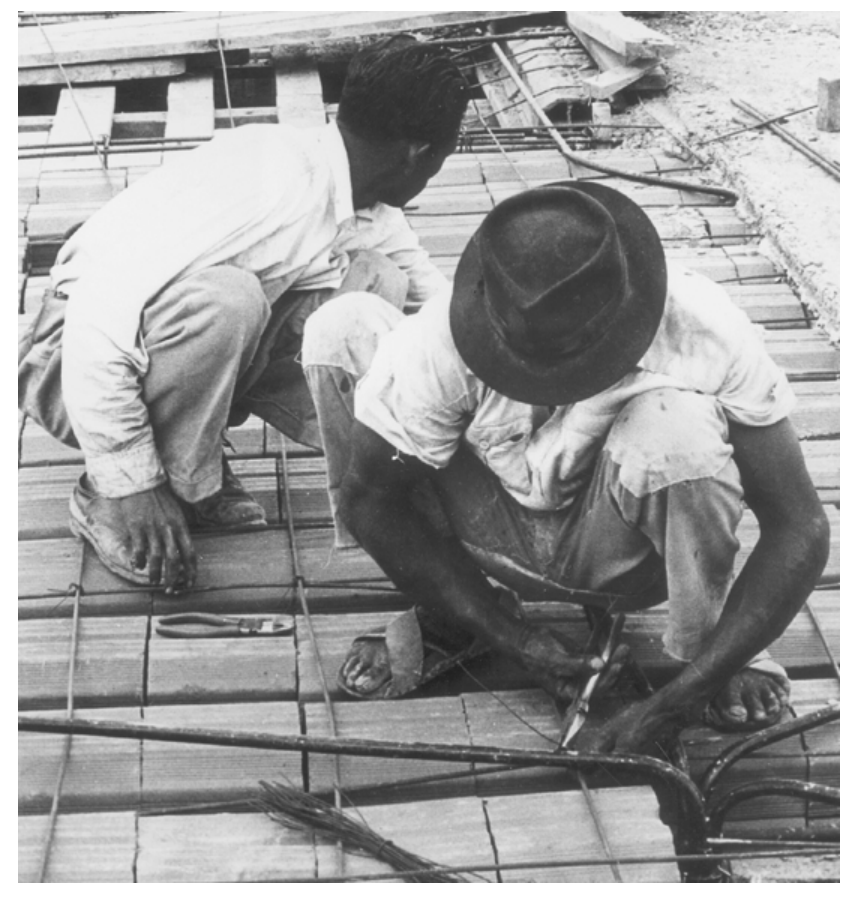

debe acoplarse perfectamente, y asimismo ha de ser revisado y mantenido en buen estado. Además, si otras personas que están en la proximidad pueden estar expuestas al riesgo, deben ser protegidas o se debe impedir su acceso a la zona.

El uso de ciertos equipos personales puede originar problemas. Por ejemplo, los trabajadores de la construcción, a menudo, trabajan en equipo y por ello tienen que comunicarse entre sí, pero el empleo de máscaras respiratorias dificulta la comunicación. El uso de ropa protectora de cuerpo entero puede contribuir a la fatiga por calor, por su pesadez y por no permitir la disipación del calor corporal.

La posesión de equipos de protección sin conocer sus limitaciones también puede crear la ilusión en los trabajadores o en las empresas de que los trabajadores están protegidos cuando la realidad es que, en ciertas condiciones de exposición, no lo están. Por ejemplo, corrientemente no hay guantes que protejan más de 2 horas contra el cloruro de metileno, un ingrediente común para arrancar pinturas. Tampoco hay suficientes datos acerca de la protección que los guantes ofrecen contra mezclas de disolventes como las que contienen a la vez acetona y tolueno o metanol y xileno. El nivel de protección depende de la forma de utilización del guante. Además, los guantes suelen ensayarse con una sola sustancia química a la vez, y raramente durante más de 8 horas.

\section{Instalaciones sanitarias y comedores}

La falta de instalaciones sanitarias y comedores también puede contribuir al aumento de las exposiciones. A menudo, los trabajadores no se pueden lavar antes de las comidas y tienen que comer en el tajo, lo que significa que, inadvertidamente, pueden ingerir sustancias tóxicas que transmiten de sus manos a la comida o a los cigarrillos. La falta de vestuarios en una obra puede ocasionar el traslado de las sustancias contaminantes desde la obra al hogar del trabajador.

\section{Lesiones y enfermedades en la construcción}

\section{Lesiones mortales}

Dado que la construcción comprende una gran proporción de la población activa, las muertes en la construcción también afectan a una población considerable. En Estados Unidos, por ejemplo, la construcción representa del 5 al $6 \%$ de la población activa, pero da cuenta del $15 \%$ de muertes laborales, más que cualquier otro sector. El sector de la construcción en Japón representa el $10 \%$ de la población activa, pero es responsable del $42 \%$ de muertes por causas laborales; en Suecia, las cifras son el $6 \%$ y el $13 \%$, respectivamente.

Las lesiones mortales más comunes en Estados Unidos se deben a caídas (30\%), accidentes de tráfico (26\%), contacto con objetos o maquinaria (p. ej., ser golpeado por un objeto, o resultar atrapado por maquinaria o materiales) (19\%) y exposición a sustancias dañinas (18\%), la mayoría de las cuales (75\%) son electrocuciones por contacto con cables eléctricos, tendidos eléctricos, maquinaria o herramientas con motor eléctrico. Estos cuatro tipos de sucesos son los responsables de la casi totalidad (93\%) de las lesiones mortales registradas entre trabajadores de la construcción en Estados Unidos (Pollack et al. 1996).

Por oficios, en Estados Unidos, la proporción de lesiones mortales más elevada se da entre los trabajadores de carpintería metálica (118 muertes por 100.000 jornadas completas de trabajo para 1992-1993, frente a 17 por 100.000 en el resto de oficios juntos) y de ellas el $70 \%$ de las muertes de trabajadores de carpintería metálica se debió a caídas. Entre los peones se experimentó el mayor número de muertes, con un promedio anual de unas 200. En términos generales, la proporción de muertes fue mayor entre los trabajadores de 55 años o más. La proporción de muertes por tipo de suceso varió según el oficio. Entre los supervisores, las caídas y los accidentes de tráfico causaron el $60 \%$ del total. Entre los carpinteros, pintores, techadores y carpinteros metálicos, las más comunes fueron las caídas, representando el 50, 55, 70 y $69 \%$ de la mortalidad en estos oficios, respectivamente. Entre los ingenieros de mantenimiento y los maquinistas de excavadoras, la causa más común la constituyeron los accidentes de tráfico, que originaron el 48 y $65 \%$ de las muertes en esos oficios, respectivamente. La mayoría de ellos estaban asociados con los camiones volquete. Las muertes por zanjas con pendientes insuficientes o mal apuntaladas siguen siendo una causa de mortalidad importante (McVittie 1995). Los riesgos primarios en los oficios especializados se relacionan en la Tabla 93.2.

Un estudio efectuado entre los trabajadores de la construcción suecos no mostró una tasa de mortalidad general elevada relacionada con el trabajo, pero mostró altas tasas de mortalidad por condiciones específicas (véase la Tabla 93.3).

\section{Lesiones causantes de pérdidas de tiempo o incapacidades}

En Estados Unidos y Canadá, las causas más comunes de lesiones con pérdida de jornadas de trabajo son los esfuerzos violentos; golpes recibidos por objetos; las caídas a un nivel inferior, y los resbalones, traspiés y caídas en el mismo nivel. La categoría de lesión más corriente la constituyen las roturas y esguinces, algunos de los cuales son el origen de dolores y afecciones crónicas. Las actividades más asociadas con lesiones con pérdida de jornadas son el manejo y colocación manuales de materiales (p. ej., colocación de tabiquería seca, tuberías o conductos de ventilación). Los accidentes por desplazamientos (andar, subir, descender) son también comunes. La causa subyacente de muchas de estas lesiones es la falta de limpieza. Muchos resbalones, traspiés y caídas son causados por andar por encima de los escombros de la construcción. 


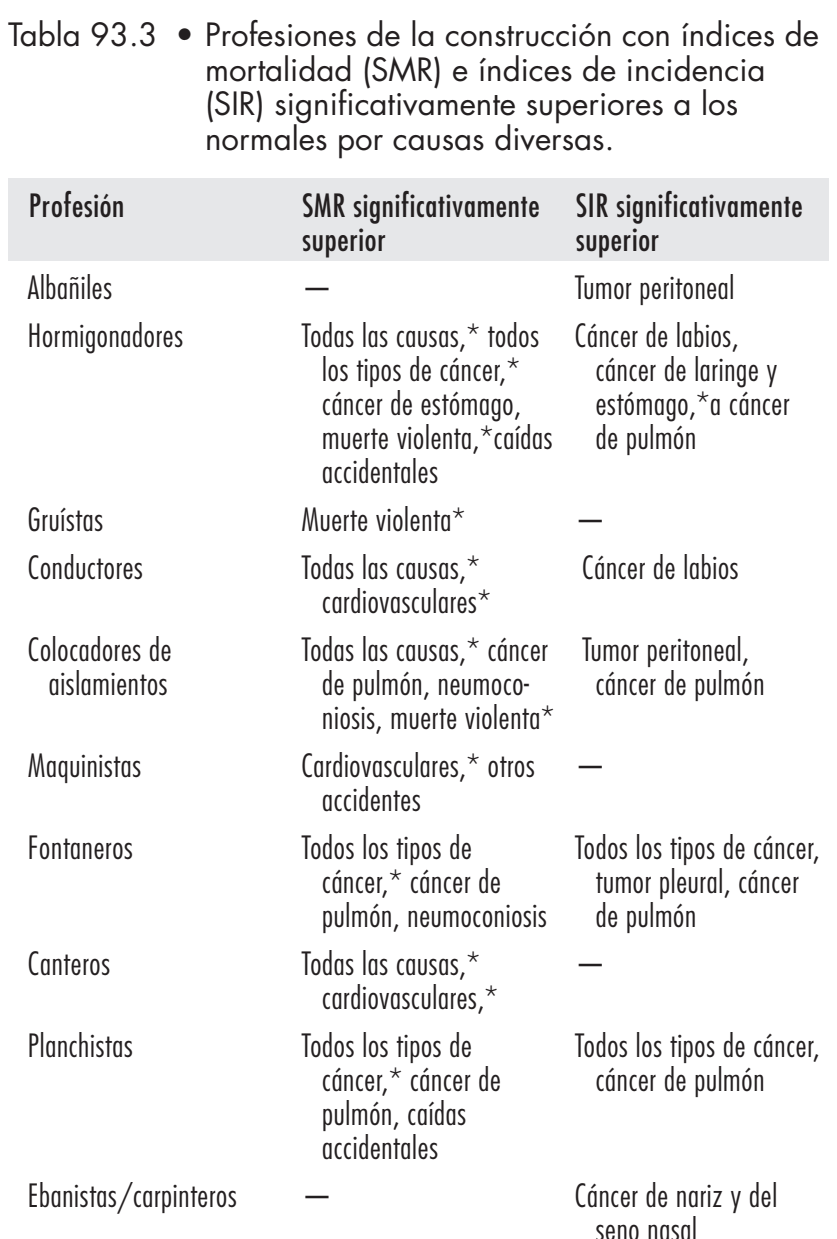
seno nasal

* Los cánceres o causas de muerte son significativamente más numerosos que en las demás profesiones combinadas. "Otros accidentes" incluye las lesiones laborales típicas.

a. El riesgo relativo de contraer cáncer de laringe entre los hormigonadores, comparado con el de los carpinteros, es 3 veces mayor.

b. El riesgo relativo de contraer cáncer de pulmón entre los hormigonadores, comparado con el de los carpinteros, es casi el doble.

Fuente: Engholm y Englund 1995.

\section{Coste de las lesiones y enfermedades}

Las lesiones y enfermedades laborales en la construcción son muy costosas.

Las estimaciones del coste de las lesiones en la construcción en Estados Unidos oscilan entre 10 y 40 millardos de dólares anuales (Meridian Research 1994); tomando un valor medio de 20 millardos, el coste por trabajador de la construcción ascendería a 3.500 dólares al año. A mediados de 1994, las indemnizaciones pagadas a los trabajadores de tres oficios - carpinteros, albañiles y trabajadores de carpintería metálica- representaron una media del 28,6 \% de las nóminas, en todo el país (Powers 1994). Las primas del seguro varían mucho según la especialidad y la jurisdicción. El coste medio de las primas es varias veces más elevado que en la mayoría de los países industrializados, en los que las primas del seguro de accidentes de los trabajadores oscilan del 3 al $6 \%$ de la nómina. Además del seguro de accidentes, existen las primas del seguro de responsabilidad civil y otros costes indirectos, incluyendo la pérdida de rendimiento de los equipos de trabajo, la limpieza (de un desprendimiento de tierras, de un hundimiento, por ejemplo) o las horas extraordinarias ocasionadas por una lesión. Estos costes indirectos pueden representar varias veces el importe de la indemnización por accidente pagada a los trabajadores.

\section{Gestión para un trabajo seguro en la construcción}

Los programas de seguridad efectivos tienen varios rasgos comunes, que se manifiestan en el conjunto de la organización, desde los cargos más altos de un contratista general hasta los directores de proyecto, supervisores, representantes sindicales y trabajadores a pie de obra. Los códigos de práctica se llevan a cabo y se evalúan a conciencia. Se calculan los costes de enfermedad y lesiones y se mide el rendimiento; los que cumplen son recompensados, los que no, son penalizados. La seguridad es parte integrante de los contratos y los subcontratos. Todo el mundo, sin excepción - gerentes, supervisores y trabajadoresrecibe la formación pertinente, general, específica para la obra y el reciclaje que pueda ser necesario. Los trabajadores inexpertos reciben formación en la obra a cargo de los trabajadores veteranos. En los proyectos en que se ponen en práctica estas medidas, los índices de lesiones son notablemente inferiores a los de otros centros similares.

\section{Prevención de accidentes y lesiones}

Las empresas del sector que presentan los índices de lesiones más bajos tienen varias características en común: una declaración de principios claramente definida que es seguida por toda la organización, desde la alta dirección hasta el último escalón en obra. Esta declaración hace referencia a un código específico de actuación que describe detalladamente los riesgos y los controles pertinentes a las ocupaciones y trabajos en la obra. La asignación de responsabilidades es clara y se establecen los niveles de cumplimiento. Se investiga el incumplimiento de estos niveles y se imponen las sanciones pertinentes. Por el contrario, el cumplimiento o mejora de los mismos son premiados. Se emplea un sistema de contabilidad que refleja los costes de cada lesión o accidente y las ventajas económicas de la prevención de lesiones. Los empleados o sus representantes participan en el establecimiento y la administración de un programa de prevención de lesiones. Esta implicación a menudo cristaliza en la formación de un comité conjunto de trabajadores y mandos. Se realizan reconocimientos médicos para determinar la aptitud de los trabajadores para las tareas y obligaciones que tienen asignadas. Estos reconocimientos se realizan cuando el trabajador se incorpora al trabajo por primera vez y cuando se reincorpora después de una ausencia por lesión, enfermedad u otra causa.

Se identifican, analizan y controlan los riesgos con arreglo a las distintas categorías, que se tratarán en otros apartados de este capítulo. Se realizan inspecciones de toda la obra de modo regular y se registran los resultados. Se revisa el equipo para cerciorarse de su manejo seguro (frenos de los vehículos, alarmas, protecciones, etc.). Los riesgos de lesiones incluyen los asociados con los tipos más comunes de lesiones causantes de pérdidas de jornadas de trabajo: caídas de altura o a nivel, el levantamiento u otras formas de manipulación manual de materiales, riesgo de electrocución, riesgos de lesiones con intervención de vehículos de carretera o todo terreno, hundimientos de zanjas y otros. Entre los riesgos para la salud se incluirán las partículas portadas por el aire (sílice, amianto, fibras de vidrio sintéticas, partículas de gasóleo), gases y vapores (monóxido de carbono, vapores de disolventes, escapes de los motores), riesgos físicos (ruido, calor, presión hiperbárica) y otros, como la fatiga. Se establecen preparativos para situaciones de emergencia y se efectúan los ensayos de emergencia precisos.

Estos preparativos incluirán la asignación de responsabilidades, la prestación de primeros auxilios y atención médica inmediata en la obra, las comunicaciones dentro de la obra y 
fuera de ella (ambulancias, familiares, oficinas centrales y sindicatos), transporte, designación de centros de atención sanitaria, acordonamiento y saneamiento de la zona en que se haya producido la emergencia, identificación de testigos y datos documentales de los sucesos. Si fuera necesario, dentro de estos preparativos de emergencia, deben incluirse los medios de evacuación en caso de riesgos incontrolados, como incendios o inundaciones.

Se investigan y registran los accidentes y lesiones. El objeto de los informes es la identificación de las causas que podían haber sido controladas, de modo que en el futuro puedan evitarse sucesos análogos. Los informes se archivarán según un método normalizado para facilitar su análisis y prevención. Para facilitar la comparación de los índices de lesiones entre diversas situaciones, es útil identificar la población laboral dentro de la cual se produce una lesión, y las horas de trabajo de ese grupo, para calcular un índice de lesiones (p. ej., el número de lesiones por hora trabajada o el número de horas trabajadas entre lesiones sucesivas).

Los trabajadores y supervisores reciben formación e instrucción en materia de seguridad. Esta instrucción consiste en la enseñanza de los principios generales de seguridad y salud, está integrada en la formación ocupacional, es específica para cada obra e incluye los procedimientos a seguir en casos de accidente o lesiones. La educación y formación de trabajadores y supervisores es parte esencial de cualquier intento de evitar lesiones y enfermedades. En muchos países, la formación relativa a procedimientos y prácticas de trabajo seguras es impartida por algunas empresas y organizaciones sindicales. Estos procedimientos incluyen el corte y desconexión de las fuentes de suministro eléctrico durante los trabajos de mantenimiento, el uso de cuerdas de amarre cuando se trabaja en altura, la entibación de zanjas, el establecimiento de superficies de paso seguras, etc. Es asimismo importante impartir formación específica para cada obra, que cubra aspectos particulares de la misma, tales como medios de acceso y salida. Deberá también incluirse la formación y la instrucción acerca de sustancias peligrosas. Para inspirar un comportamiento seguro siempre resulta mucho más eficaz la formación práctica, demostrando que se conocen las prácticas de seguridad, que las enseñanzas en clase y los exámenes escritos.

En Estados Unidos, una ley federal exige la formación en torno a ciertas sustancias nocivas. En Alemania, esta misma preocupación condujo al desarrollo del programa Gefahostoff, informationssystem der Berufsgenossenschaften der Bauwirtschaft o GISBAU, que coopera con los fabricantes para determinar el contenido de todas las sustancias utilizadas en las obras de construcción. Asimismo, el programa facilita la información acomodándola a las diferentes necesidades del personal sanitario, directivos y trabajadores. La información puede obtenerse a través de cursos de formación, en publicaciones impresas y en los terminales de ordenador a pie de obra. GISBAU aconseja sobre la manera de sustituir ciertas sustancias nocivas e indica el modo de manejar otras con seguridad. (Véase el Capítulo Empleo, almacenaje y transporte de sustancias químicas.)

La información sobre riesgos químicos, físicos y de otras clases está disponible en la obra en los idiomas propios de los trabajadores. Si se espera que los trabajadores se comporten inteligentemente en la obra, será preciso que tengan la información necesaria para tomar decisiones en situaciones específicas.

Y finalmente, los contratos entre contratistas y subcontratistas deben incluir cláusulas de seguridad. Entre ellas se podría incluir el establecimiento de una organización de seguridad unificada en obras en las que trabajen varias empresas, la especificación de requisitos a cumplir, primas y penalizaciones.

\section{RIESGOS PARA LA SALUD EN OBRAS SUBTERRANEAS}

Bohuslav Málek

\section{Riesgos}

Las obras subterráneas incluyen la construcción de túneles para carreteras, autopistas, vías férreas y el tendido de tuberías de alcantarillado, agua caliente, vapor, conducciones eléctricas, cables telefónicos. Entre los riesgos de este trabajo se incluyen el duro trabajo físico, el polvo de sílice cristalino, el polvo de cemento, el ruido, las vibraciones, los escapes de los motores de gasóleo, las emanaciones químicas radón y la falta de oxígeno. A veces, estos trabajos deben realizarse en ambientes presurizados. Los trabajadores de estas obras corren el riesgo de sufrir lesiones graves y, a menudo, fatales. Algunos riesgos son los mismos que los de la construcción en superficie, pero agravados por la condición de trabajar en un espacio encerrado. Otros riesgos son específicos del trabajo subterráneo. Entre éstos se incluyen: golpes de maquinaria especial, electrocución, sepultamiento por desprendimientos de techo o paredes, asfixia o lesiones por fuegos y explosiones. En los trabajos en túneles se pueden encontrar bolsas de agua no previstas que pueden producir inundaciones y anegamientos.

La construcción de túneles requiere un esfuerzo físico considerable. El consumo de energía durante el trabajo manual suele ser de 200 a $350 \mathrm{~W}$, con una gran parte de carga estática muscular. El ritmo cardíaco durante los trabajos con barrenos de aire comprimido y martillos neumáticos alcanza 150-160 pulsaciones por minuto. El trabajo se suele realizar en condiciones microclimáticas desfavorables de frío y humedad, y a veces en posturas de trabajo fatigosas. Todo ello suele ir acompañado de otros factores de riesgo que dependerán de las condiciones geológicas locales y del tipo de tecnología que se utilice. Esta pesada carga de trabajo puede contribuir notablemente a la fatiga por calor.

La mecanización puede reducir la dureza del trabajo manual. Pero la mecanización conlleva sus propios riesgos. El trabajo de máquinas móviles grandes y potentes en un lugar cerrado introduce riesgos de lesiones graves al personal que trabaja en su proximidad, que puede ser golpeado o aplastado por ellas. La maquinaria para estos trabajos también puede originar polvo, ruido, vibraciones y gases de los tubos de escape de los motores diesel. Por otro lado, la mecanización necesita menos mano de obra, lo que reduce el número de personas expuestas, pero a cambio de un mayor desempleo y todos los problemas que ello lleva consigo.

La sílice cristalina (llamada también sílice libre y cuarzo) aparece de manera natural en muchos tipos de roca. La piedra arenisca es prácticamente sílice pura; el granito puede contener un $75 \%$, los esquistos un $30 \%$, y la pizarra un $10 \%$. La piedra caliza, el mármol y la sal, a efectos prácticos, no contienen sílice alguna. Teniendo en cuenta que la sílice está omnipresente en la corteza terrestre, es preciso tomar muestras de polvo, al menos al comienzo de un trabajo subterráneo y siempre que el tipo de roca cambie a medida que el trabajo avanza.

Siempre que se procede al machacado, perforación, molienda o cualquier otro tipo de pulverización de una roca que contenga sílice, se originará polvo de sílice inhalable. Los principales causantes de la incorporación de polvo de sílice en el aire son las perforadoras de aire comprimido y los martillos neumáticos. El trabajo con estas herramientas se ejecuta más frecuentemente en el frente de avance del túnel y, por tanto, los trabajadores en estas zonas son los que sufren una mayor exposición. En tales 
casos, es de obligada aplicación la tecnología de eliminación del polvo.

Las voladuras no sólo generan escombros que vuelan, sino también polvo y óxidos nitrosos. Para evitar una excesiva exposición, el procedimiento usual consiste en impedir el reingreso en la zona afectada hasta que el polvo y los gases se hayan disipado. Una práctica corriente consiste en hacer las voladuras al final del último turno de trabajo del día y limpiar los escombros durante el turno siguiente.

Al mezclar el cemento se origina polvo de cemento. En altas concentraciones, este polvo irrita la membrana mucosa y respiratoria, pero no se han observado efectos crónicos. Sin embargo, si se deposita sobre la piel y se mezcla con el sudor, el polvo de cemento puede causar dermatosis. Cuando el hormigón húmedo se pulveriza in situ, también puede causar dermatosis.

El ruido producido en los trabajos subterráneos puede ser considerable. Entre las fuentes de ruido principales se incluyen los martillos y perforadoras neumáticos, los motores de gasóleo y los ventiladores. Dado que el trabajo se realiza en un recinto cerrado, existe también un ruido importante a causa de la reverberación. Los niveles de ruido punta pueden sobrepasar los $115 \mathrm{dBA}$, siendo la exposición media ponderada de $105 \mathrm{dBA}$. Existe una tecnología, que debe ser aplicada, para la reducción del ruido de la mayoría de las máquinas.

Los trabajadores en obras subterráneas también pueden encontrarse expuestos a vibraciones en todo el cuerpo producidas por la maquinaria móvil y a vibraciones en brazos y manos a causa del manejo de perforadoras y martillos neumáticos. Los niveles de aceleración transmitidos a las manos por las herramientas neumáticas pueden alcanzar los $150 \mathrm{~dB}$ (equivalentes a $10 \mathrm{~m} / \mathrm{s}^{2}$ ). Los efectos perniciosos de las vibraciones de brazos y manos pueden verse agravados por un ambiente de trabajo frío y húmedo.

Si el terreno tiene una alta saturación de agua o si el trabajo se realiza por debajo del agua, la zona de trabajo puede tener que ser presurizada para mantenerla libre de agua. Para el trabajo por debajo del nivel del agua se utilizan cajones de aire comprimido. Cuando los trabajadores en este ambiente hiperbárico efectúan una rápida transición a la presión atmosférica normal, corren el peligro del mal de descompresión y los trastornos asociados al mismo. Dado que la absorción de la mayoría de gases y vapores tóxicos depende de su presión parcial, a mayor presión, mayor será la absorción. Por ejemplo, 10 ppm de monóxido de carbono $(\mathrm{CO})$ a 2 atmósferas de presión producirán el mismo efecto que 20 ppm CO a 1 atmósfera.

Las sustancias químicas se utilizan en los trabajos subterráneos de diversas formas. Por ejemplo, capas poco coherentes de roca se pueden estabilizar con una inyección de resina de formaldehído de urea, con espuma de poliuretano o con mezclas de cristales de agua sódica con formamida o con acetato de etilo y de butilo. A consecuencia de ello, durante su aplicación se pueden producir en la atmósfera del túnel vapores de formaldehído, amoníaco, alcohol etílico o butílico o diisocianatos. Con posterioridad a su aplicación, estas sustancias contaminantes pueden extenderse por el túnel desde las paredes circundantes, y, por tanto, pueden dificultar el control pleno de su concentración, incluso empleando una ventilación mecánica intensiva.

El radón aparece de forma natural en algunas rocas y puede filtrarse en la atmósfera de trabajo, donde se degradará, convirtiéndose en otros isótopos radiactivos. Algunos de ellos emiten radiaciones alfa y pueden inhalarse, aumentando el riesgo de cáncer de pulmón.

Los túneles que se construyen en zonas habitadas también pueden ser contaminados por sustancias procedentes de las tuberías circundantes. El agua, el gas doméstico y de calefacción, el gasóleo, la gasolina, etc. se pueden filtrar en un túnel, o si algunas de las tuberías portadoras sufren una rotura durante la excavación, pueden penetrar en el lugar en que se está trabajando.

La construcción de pozos verticales empleando tecnología minera plantea problemas de salud similares a los de los trabajos en un túnel. En aquellos en que se encuentran presentes sustancias orgánicas, es de temer la aparición de restos de descomposición microbiana.

Los trabajos de mantenimiento en túneles para el tráfico se diferencian de otros trabajos similares en superficie, principalmente por la dificultad de instalar el equipo de control y seguridad; por ejemplo, ventilación para la soldadura eléctrica; ello puede influir en la calidad de las medidas de seguridad. El trabajo en los túneles en los que discurren tuberías de agua caliente o vapor, acarrea una intensa carga térmica, que exigirá un régimen especial de trabajo y períodos de descanso.

La falta de oxígeno se puede dar en los túneles tanto porque el oxígeno sea desplazado por otros gases, como porque sea consumido por microbios o por oxidación de las piritas. Los microbios también pueden desprender metano o etano que no sólo desplazan al oxígeno sino que, en una concentración suficiente, pueden crear el riesgo de explosiones. El dióxido de carbono (comúnmente denominado en Europa anhídrido carbónico) también es generado por la contaminación microbiana. Las atmósferas de espacios que han permanecido cerrados largo tiempo pueden estar compuestas en su casi totalidad de nitrógeno, del 5 al $15 \%$ de dióxido de carbono y carecer prácticamente de oxígeno.

El anhídrido carbónico se introduce en el pozo desde el terreno circundante debido a los cambios de presión atmosférica. La composición del aire en el interior del pozo puede cambiar muy rápidamente: durante la mañana puede ser normal y por la tarde ser deficiente en oxígeno.

\section{Prevención}

La prevención de la exposición al polvo debe realizarse, en primer lugar, mediante la adopción de medidas técnicas, tales como perforación húmeda (y/o perforación con SEL), regando el material antes de su retirada y carga, SEL en las máquinas del túnel y ventilación mecánica de los túneles. En algunas operaciones, las medidas técnicas de control pueden resultar insuficientes para rebajar la concentración del polvo respirable a un nivel aceptable (p. ej., durante el barrenado y, a veces, en el caso de barrenado con humedad), y, por tanto, puede ser necesario complementar la protección de los trabajadores que realizan tales operaciones con el empleo de máscaras respiratorias. La eficacia de las medidas técnicas de control debe comprobarse mediante el control de la concentración de polvo en el aire. En el caso de polvo fibrógeno, será necesario adaptar el programa de control de modo que permita el registro de la exposición de los trabajadores individualmente. Los datos de exposición individual, junto con los datos de salud de cada trabajador, son necesarios para la valoración del riesgo de neumoconiosis en unas condiciones de trabajo determinadas, así como para la evaluación de la eficacia de las medidas de control a largo plazo. En último lugar, en particular, el registro individual de las exposiciones es necesario para evaluar la aptitud de los trabajadores individuales para continuar en sus puestos de trabajo.

Dada la naturaleza de los trabajos subterráneos, la protección contra el ruido depende mayormente de las protecciones auditivas personales. Una protección eficaz contra las vibraciones, por otra parte, se puede conseguir solamente eliminando o reduciendo las vibraciones mediante la mecanización de las operaciones que entrañan tal riesgo. El EPI no resulta eficaz. Análogamente, el riesgo de dolencias debidas a una sobrecarga 
física de las extremidades superiores sólo puede aminorarse con la mecanización.

Es posible influir en la exposición a sustancias químicas mediante la elección de una tecnología apropiada (eliminando la utilización de resinas de formaldehídos y de la formamida) por medio de un buen mantenimiento (p. ej., de los motores de gasóleo) y con una ventilación adecuada. A veces resultan muy eficaz la organización y la adopción precauciones en el régimen de trabajo, especialmente para la prevención de dermatosis.

El trabajo en lugares subterráneos cuya composición del aire se desconoce exige una estricta observancia de las normas de seguridad. No se permitirá la entrada en tales recintos sin portar equipos respiratorios autónomos. El trabajo debe ejecutarse por grupos de al menos tres personas - un trabajador se introducirá en el espacio subterráneo, con aparato de respiración y cinturón de seguridad, y los otros permanecerán en el exterior sujetando una cuerda amarrada al trabajador que está en el interior-. En caso de accidente es necesario actuar con rapidez. Se han perdido muchas vidas tratando de salvar a la víctima de un accidente, cuando no se tuvo en cuenta la seguridad del que acudía al rescate.

Los reconocimientos médicos periódicos antes y después de la contratación son una parte necesaria de las precauciones de salud y seguridad de los trabajadores en los túneles. La frecuencia de los reconocimientos periódicos y el tipo y rango de los reconocimientos especiales (rayos X, funciones pulmonares, audiometría, etc.) deben fijarse individualmente para cada obra y para cada tarea de acuerdo con las condiciones de trabajo.

Antes de iniciar los trabajos subterráneos es preciso efectuar una inspección del emplazamiento y tomar muestras para planificar los trabajos de excavación. Una vez que el trabajo está en marcha, hay que inspeccionar el tajo diariamente para evitar la caída del techo o la formación de cuevas. El lugar de trabajo de los trabajadores solitarios debe inspeccionarse al menos dos veces en cada turno. Se instalarán equipos contra incendios, estratégicamente situados a todo lo largo del tramo subterráneo.

\section{- SERVICIOS PREVENTIVOS SANITARIOS EN LA CONSTRUCCION}

\section{Pekka Roto}

El sector de la construcción constituye del 5 al $15 \%$ de la economía nacional de la mayoría de los países y generalmente es una de las tres industrias que arroja el mayor índice de riesgos de lesiones laborales. Predominan los riesgos crónicos de salud laboral que se relacionan a continuación (Comisión de las Comunidades Europeas 1993):

- Trastornos musculosqueléticos, sordera laboral, dermatitis y trastornos pulmonares son las dolencias más comunes producidas por el trabajo.

- Un riesgo acrecentado de carcinomas del tracto respiratorio y mesoteliomas causados por exposición al amianto detectados en todos los países en que existen estadísticas de morbilidad y mortalidad laborales.

- Trastornos causados por una nutrición inadecuada, por el tabaco o por el consumo de alcohol y drogas, que se asocian especialmente con los trabajadores inmigrantes, que representan una proporción considerable de los trabajadores de la construcción en muchos países.

Los servicios de salud preventivos para los trabajadores de la construcción deben planificarse dando prioridad a estos riesgos.

\section{Tipos de servicios de salud laboral}

Los servicios de salud laboral para los operarios de la construcción se agrupan en tres modelos principales:

1. servicios especializados para trabajadores de la construcción

2. asistencia sanitaria laboral para trabajadores de la construcción prestada por servicios sanitarios de ámbito más amplio

3. asistencia sanitaria prestada voluntariamente por la empresa.

Los servicios especializados son los más eficaces, pero también son los más caros en términos de costes directos. La experiencia en Suecia indica que los índices de lesiones más bajos en obras de construcción en todo el mundo, y un riesgo muy bajo de enfermedades laborales entre los trabajadores de la construcción, vienen asociados con un trabajo de prevención exhaustivo realizado por servicios especializados. En el modelo sueco, llamado Bygghälsan, se combinan la prevención médica y técnica. Bygghälsan funciona por medio de centros regionales y unidades móviles. Sin embargo, durante la severa recesión económica de finales del decenio de 1980, Bygghälsan recortó seriamente sus actividades sanitarias.

En los países en que existe una legislación de salud laboral, las empresas de construcción generalmente alquilan los servicios de salud requeridos a compañías que sirven a la industria en general. En estos casos, es importante la formación del personal de salud laboral. Sin un conocimiento específico de las circunstancias que rodean a la construcción, el personal médico no puede proporcionar programas preventivos de salud en el trabajo que sean eficaces para las empresas de construcción.

Algunas grandes compañías multinacionales cuentan con programas de seguridad y salud en el trabajo bien desarrollados que forman parte de la cultura de la empresa. Los cálculos comparados de coste-beneficio han demostrado que tales actividades resultan económicamente beneficiosas. Actualmente, los programas de seguridad laboral son parte integrante de la gestión de calidad de la mayoría de las empresas internacionales.

\section{Clínicas móviles}

Dado que las obras de construcción se encuentran a menudo alejadas de cualquier proveedor de servicios de salud, puede ser necesario recurrir a unidades móviles que presten estos servicios. Prácticamente todos los países que tienen servicios de salud laboral especializados en los trabajadores de la construcción utilizan unidades móviles para prestar estos servicios. La mayor ventaja de la unidad móvil es el ahorro de tiempo para acercar los servicios a las obras. Estos centros de salud móviles están instalados en un autobús o caravana especialmente equipados y están adecuados de un modo especial para todo tipo de controles, como reconocimientos médicos periódicos. Los servicios móviles deberán tener la precaución de establecer de antemano acuerdos de colaboración con los proveedores locales de servicios de salud para asegurar el seguimiento, evaluación y tratamiento de los trabajadores, cuyos exámenes hayan dado resultados que puedan sugerir un problema de salud.

El equipo normal de una unidad móvil incluye un laboratorio básico con un espirómetro y un audiómetro, un cuarto para entrevistas y un equipo de rayos $\mathrm{X}$, cuando sea preciso. Es preferible diseñar unidades modulares como espacios multiuso, de modo que puedan utilizarse en diferentes tipos de obras. La experiencia finlandesa indica que las unidades móviles son también adecuadas para estudios epidemiológicos, que se pueden incorporar a los programas de salud en el trabajo si se planifican de antemano adecuadamente.

Contenido de los servicios preventivos de salud en el trabajo La identificación del riesgo en las obras debe orientar la actividad médica, aunque este aspecto sólo sea secundario con respecto a la 
prevención por medio de un diseño, labor de ingeniería y organización del trabajo adecuados. La identificación del riesgo requiere un enfoque pluridisciplinario; ello requiere una estrecha colaboración entre el personal especializado en salud en el trabajo y la empresa. Una opción sería una exploración sistematizada de los riesgos en el lugar de trabajo utilizando listas de comprobación normalizadas.

Los reconocimientos médicos previos al empleo y periódicos se realizan, usualmente, de acuerdo con los requisitos establecidos por la legislación o con las orientaciones facilitadas por las autoridades. El contenido del reconocimiento dependerá del historial de exposiciones de cada trabajador. Los contratos de plazo corto y la frecuente rotación de la mano de obra pueden dar lugar a reconocimientos médicos "frustrados" o "inadecuados", a la pérdida del seguimiento de los resultados o una duplicación injustificada de los reconocimientos médicos. Por tanto, se recomienda la práctica de reconocimientos periódicos regulares para todos los trabajadores. Un reconocimiento de salud tipo debe incluir: un historial de exposiciones, un historial de síntomas y enfermedades con especial énfasis en las dolencias musculosqueléticas y alérgicas, un reconocimiento anatómico básico y pruebas de audiometría, vista, espirometría y presión arterial. Los reconocimientos deben facilitar también consejos sanitarios e información sobre el modo de evitar los riesgos laborales comunes.

\section{Vigilancia y prevención de problemas clave en los trabajos de construcción}

\section{Trastornos musculosqueléticos y su prevención}

Los trastornos musculosqueléticos pueden tener múltiples orígenes. El estilo de vida, la propensión hereditaria y el envejecimiento, junto con esfuerzos físicos inadecuados y lesiones de poca gravedad, son los factores de riesgo comúnmente aceptados como causa de estos trastornos. Los tipos de problemas musculosqueléticos se manifiestan de diferentes maneras en las diversas profesiones de la construcción.

No existe ninguna prueba fiable para predecir el riesgo de un individuo para contraer un trastorno de este tipo. La prevención médica de los trastornos musculosqueléticos se basa en la orientación sobre el estilo de vida y cuestiones ergonómicas. Los reconocimientos previos al empleo y periódicos pueden utilizarse a este fin. Las pruebas generales de resistencia y las radiografías rutinarias del sistema esquelético no tienen un valor específico para la prevención. En su lugar, la detección temprana de síntomas y un historial detallado de los síntomas musculosqueléticos pueden utilizarse como base para la terapia. Un programa que realiza periódicamente sondeos de síntomas para identificar los factores laborales que se pueden cambiar ha demostrado su eficacia. A menudo, los trabajadores que han estado expuestos a fuertes cargas o esfuerzo físico creen que el trabajo les mantiene en forma. Varios estudios han demostrado que tal presunción no es cierta. Por tanto, es importante que en el contexto de los reconocimientos médicos, se informe a los sujetos del examen sobre las maneras adecuadas de mantener su aptitud física. El tabaco se ha asociado con la degeneración del disco lumbar y las lumbalgias. Es por ello que en los reconocimientos médicos periódicos es preciso incluir también información y tratamientos antitabaco (Proyecto de educación sobre la práctica de fumar y los riesgos en el trabajo, 1993).

\section{Pérdida de audición motivada por el ruido en el trabajo}

La prevalencia de la pérdida de audición motivada por el ruido varía entre las profesiones de la construcción, y depende de los niveles y duración de la exposición. En 1974, menos del 20 \% de los trabajadores suecos de la construcción de 41 años de edad tenían una audición normal en ambos oídos. La implantación de un programa exhaustivo de conservación del oído aumentó la proporción de trabajadores con audición normal, dentro del mismo grupo, a casi un $40 \%$ al final del decenio de 1970. Estadísticas efectuadas en la Columbia Británica, Canadá, han mostrado que los trabajadores de la construcción generalmente sufren una pérdida de ó́do importante después de trabajar más de 15 años en su oficio (Schneider et al. 1995). Se cree que algunos factores pueden aumentar la propensión a la pérdida del oído en el trabajo (neuropatía diabética, hipercolesterolemia y exposición a ciertos disolventes ototóxicos). Las vibraciones en todo el cuerpo y el hábito de fumar también pueden tener un efecto aditivo.

Es aconsejable un programa de conservación del oído a gran escala dentro del sector de la construcción. Este tipo de programa requiere no sólo la colaboración a nivel de obra, sino también una legislación que lo apoye. Los programas de conservación del oído deben estar especificados en los contratos de trabajo.

La pérdida de audición en el trabajo es reversible en los primeros 3 ó 4 años siguientes a la exposición inicial. Una detección temprana de la pérdida de audición facilita las posibilidades de prevención. Se recomiendan pruebas regulares para detectar los cambios lo antes posible y para motivar a los trabajadores en su autoprotección. En el transcurso de las pruebas, a los trabajadores expuestos se les debe instruir en los principios de protección individual, así como en el mantenimiento y el empleo adecuado de los medios de protección.

\section{Dermatitis profesional}

La dermatitis profesional se puede evitar principalmente con medidas higiénicas. El manejo adecuado del cemento húmedo y la protección de la piel son medidas de higiene eficaces. Durante los reconocimientos médicos es importante recalcar la importancia de evitar el contacto de la piel con el cemento húmedo.

\section{Enfermedades pulmonares profesionales}

La asbestosis, la silicosis, el asma y la bronquitis profesionales pueden encontrarse entre los trabajadores de la construcción, dependiendo de sus anteriores exposiciones en el trabajo (Instituto finlandés de salud en el trabajo 1987).

No existe ningún método médico para evitar el desarrollo de carcinomas después de la exposición suficiente de una persona al amianto. Las radiografías de pecho regulares, cada tres años, son la recomendación de vigilancia médica más común; hay pruebas de que el reconocimiento por rayos X mejora las perspectivas en el cáncer de pulmón (Strauss, Gleanson y Sugarbaker 1995). La espirometría y la información antitabaco se incluyen normalmente en los reconocimientos médicos periódicos. No existen ensayos para hacer un diagnóstico precoz de tumores malignos relacionados con el amianto.

Los tumores malignos y otras enfermedades pulmonares relacionadas con la exposición al amianto son ampliamente infradiagnosticados. Por tanto, muchos trabajadores de la construcción que tendrían derecho a indemnización se quedan sin ellos. Al final del decenio de 1980 y a principios del decenio de 1990, en Finlandia se realizó un chequeo a escala nacional de los trabajadores expuestos al amianto. El chequeo reveló que tan sólo a un tercio de los trabajadores que padecían enfermedades relacionadas con el amianto y con acceso a los servicios de salud en el trabajo se les habían diagnosticado con anterioridad (Instituto finlandés de salud en el trabajo 1994).

\section{Necesidades especiales de los trabajadores inmigrantes}

En función del emplazamiento de la obra, el contexto social, las condiciones sanitarias y el clima pueden representar riesgos 
importantes para los trabajadores de la construcción. Los trabajadores inmigrantes a menudo sufren problemas psicosociales. Entre ellos se da un mayor riesgo de lesiones en el trabajo que entre los trabajadores nativos. Hay que tener en cuenta su riesgo de ser portadores de enfermedades infecciosas, como el sida, la tuberculosis y otras enfermedades parasitarias. La malaria y otras enfermedades tropicales pueden crear un problema a los trabajadores en aquellos lugares en que son endémicas.

En muchos proyectos de construcción de envergadura se emplea mano de obra extranjera. Es preciso realizar un reconocimiento médico previo en el país de origen. Además, debe evitarse la propagación de enfermedades contagiosas mediante programas de vacunación adecuados. En los países de recepción es necesario impartir formación profesional, educación en materia de seguridad y salud y proporcionar alojamiento. Los trabajadores inmigrantes deben tener el mismo acceso a la asistencia sanitaria y a la seguridad social que los trabajadores nativos (El Batawi 1992).

Además de evitar las dolencias relacionadas con la construcción, el profesional sanitario debe trabajar para promover cambios positivos en el estilo de vida, que puedan contribuir a mejorar la salud general de un trabajador. Los temas más importantes y fructíferos para la promoción de la salud entre los trabajadores de la construcción son la abstención del alcohol y el tabaco. Se ha estimado que un trabajador que fuma le cuesta a su empresa del 20 al $30 \%$ más que uno que no fuma. Las inversiones en campañas antitabaco no sólo son rentables a corto plazo, con menores riesgos de accidentes y ausencias por enfermedad más cortas, sino también a largo plazo, con menores riesgos de contraer enfermedades pulmonares cardiovasculares y cáncer. Adicionalmente, el humo del tabaco tiene efectos nocivos multiplicadores en presencia de la mayoría de polvos, en especial el de amianto.

\section{Beneficios económicos}

Resulta difícil demostrar algún beneficio económico directo de los servicios de salud laboral para una empresa de construcción individual, especialmente si se trata de una pequeña. Sin embargo, los cálculos indirectos de rentabilidad demuestran que la prevención de accidentes y la promoción de la salud son económicamente beneficiosas. Existen cálculos comparativos de coste-beneficio de las inversiones en programas preventivos disponibles para uso interno de las empresas. (Véase Oxenburg 1991, que describe un modelo aplicado ampliamente en Escandinavia).

\section{- NORMAS DE SEGURIDAD Y SALUD: LA EXPERIENCIA DE LOS PAISES BAJOS}

\section{Leen Akkers}

La puesta en práctica de la Directiva CE de Normas Mínimas de Salud y Seguridad en las Obras de Construcción Móviles y Provisionales tipifica las normas legales promulgadas por los Países Bajos y la Comunidad Europea. Su objetivo es mejorar las condiciones de trabajo, combatir las incapacidades y reducir el absentismo por enfermedad. En los Países Bajos estas normas para el sector de la construcción están expresadas en la Arbouw Resolution, Capítulo 2, Sección 5.

Como sucede a menudo, la legislación parece ir por detrás de los cambios sociales que se iniciaron en 1986, año en que las organizaciones patronales y sindicales se reunieron para establecer la Fundación Arbouw con miras a prestar servicios a las empresas de construcción de obras civiles y construcción de infraestructuras, movimiento de tierras, construcción de carreteras y construcciones hidráulicas y los ramos complementarios del sector. De este modo, las nuevas normas apenas constituyen un problema para las empresas responsables que ya se han comprometido a poner en práctica las consideraciones de salud y seguridad. Sin embargo, el hecho de que resulta muy difícil, a menudo, poner en práctica estos principios, ha conducido a su no observancia y a una competencia desleal y, en consecuencia, a la necesidad de una normativa legal.

\section{Normativa legal}

La normativa legal se centra en las medidas preventivas previas al comienzo del proyecto de construcción y durante la ejecución del mismo. A largo plazo, este enfoque proporcionará resultados óptimos.

La Ley de Salud y Seguridad estipula que las evaluaciones de los riesgos deben abarcar no sólo las que se originan a causa de los materiales, preparaciones, herramientas, equipo, etc., sino también las que implican a grupos especiales de trabajadores (p. ej., mujeres embarazadas, trabajadores jóvenes y de edad avanzada, y los que sufren discapacidades).

Las empresas están obligadas a tener por escrito evaluaciones e inventarios de riesgos preparados por expertos habilitados, que pueden ser empleados suyos o contratistas externos. Esta documentación debe incluir recomendaciones para eliminar o limitar los riesgos y debe estipular también las fases del trabajo en que se requerirán especialistas cualificados. Algunas empresas de construcción han desarrollado su propio enfoque de la evaluación, con el nombre de Investigación General Empresarial e Inventario y Evaluación de Riesgos (ABRIE), que ha pasado a ser el prototipo para el sector.

La Ley de Salud y Seguridad obliga a las empresas a ofrecer un reconocimiento de salud periódico a sus empleados. El objeto es identificar los problemas de salud que puedan crear ciertos trabajos especialmente peligrosos para algunos trabajadores a menos que se tomen ciertas precauciones. Este requisito se hace eco de diversos convenios colectivos dentro del sector de la construcción, que durante años vienen exigiendo a las empresas que proporcionen a sus empleados atención médica laboral completa, inclusive reconocimientos médicos periódicos. La Fundación Arbouw ha establecido un contrato con la Federación de centros de atención de seguridad y salud en el trabajo para la prestación de tales servicios. A lo largo de los años se ha acumulado un acervo de valiosas informaciones que ha contribuido a la mejora de las evaluaciones e inventarios de riesgos.

\section{Política en materia de absentismo}

La Ley de Salud y Seguridad también exige a los patronos que tengan una política en materia de absentismo que incluya la estipulación de que cuenten con expertos en este campo para el seguimiento y asesoramiento a los empleados discapacitados.

\section{Responsabilidad conjunta}

Muchos riesgos de salud y seguridad pueden tener su origen en deficiencias del edificio o decisiones inadecuadas de la organización o en una mala organización del trabajo al iniciarse el proyecto. Para soslayar esto, las empresas, los trabajadores y el gobierno llegaron en 1989 a un pacto de condiciones de trabajo. Entre otros aspectos, especificaba la colaboración entre clientes y contratistas y entre estos y los subcontratistas. Esto ha dado lugar a un código de conducta que sirve de modelo para la puesta en práctica de la Directiva Europea sobre obras de construcción móviles y provisionales.

Como parte del pacto, Arbouw ha formulado límites de exposición a materias y sustancias peligrosas, junto con orientaciones 
para su aplicación en diversas operaciones constructivas. Bajo la dirección de Arbouw, el Sindicato de trabajadores de la construcción y de la madera, el Sindicato de la industria FNV y la Asociación de lanas minerales, del Benelux, acordaron un contrato que exigía el desarrollo de productos de lana mineral y lana de vidrio con menor emisión de partículas de polvo, el desarrollo de los métodos de producción con la mayor seguridad posible de estos productos; la formulación y promoción de métodos de trabajo para el uso de los anteriores productos dentro de la mayor seguridad y la ejecución de la investigación necesaria para establecer los límites de seguridad de exposición a los mismos.

Se fijó un límite de exposición a las fibras inspirables de $2 / \mathrm{cm}^{3}$, aunque se consideró que un límite de $1 / \mathrm{cm}^{3}$ era posible. También se acordó la eliminación del uso de materias primas y secundarias que pudieran representar riesgos para la salud, usando como criterio los límites de exposición formulados por Arbouw. Se hará un seguimiento de los resultados siguiendo este acuerdo hasta su fecha de expiración el 1 de enero de 1999.

\section{Galidad del proceso de construcción}

La puesta en práctica de la directiva CE no es una actuación aislada, sino que es parte integral de las políticas de salud y seguridad de las empresas, junto con la política de calidad y medio ambiente. La política de salud y seguridad es un componente crítico de la política de calidad de las empresas. Las leyes y normas sólo se cumplirán si las empresas y los trabajadores de la construcción han tomado parte en su desarrollo. El gobierno ha decidido desarrollar un plan modelo de salud y seguridad que es factible y que se puede hacer cumplir para evitar la competencia desleal de las empresas que pretendan ignorarlo o subvertirlo.

\section{FACTORES DE ORGANIZACION QUE AFECTAN A LA SALUD Y LA SEGURIDAD}

\section{DougJ. McVittie}

\section{Diversidad de proyectos y actividades laborales}

Muchas personas ajenas al sector de la construcción ignoran la diversidad y grado de especialización de los trabajos acometidos por esta industria, aunque a diario contemplan parte de los mismos. Además de las demoras de tráfico causadas por la invasión de las calzadas y las excavaciones en calles, el público puede observar a menudo la construcción de edificios, de parcelaciones y, a veces, el derribo de estructuras. Lo que se esconde a la vista, en la mayoría de los casos, es el ingente volumen de trabajo especializado que se realiza, bien como parte de un proyecto de nueva planta, bien como parte de los trabajos de mantenimiento que se llevan a cabo y que están asociados con casi todas las construcciones del pasado.

La lista de actividades es muy variada, abarcando desde trabajos de electricidad, fontanería, calefacción y ventilación, pintura, trabajos de techado y pavimentación hasta trabajos muy especializados como instalación o reparación de grúas de pórtico, colocación de maquinaria pesada, ignifugación, trabajos de refrigeración e instalación y pruebas de sistemas de comunicaciones.

El valor de la construcción puede medirse en parte según el importe de las licencias de construcción. La Tabla 93.4 muestra el valor de la construcción en Canadá en 1993.

Los aspectos de seguridad y salud en el trabajo dependen en gran medida de la naturaleza del proyecto. Cada tipo de

proyecto y cada actividad laboral presentan diferentes riesgos y soluciones. A menudo, la gravedad, alcance o tamaño del problema están relacionados a su vez con la dimensión del proyecto.

\section{Relaciones cliente-contratista}

Los clientes son aquellos individuos, asociaciones, corporaciones o autoridades públicas por encargo de los cuales se ejecuta una construcción. La gran mayoría de las obras se realizan con arreglo a contratos entre clientes y contratistas. Un cliente puede elegir a un contratista en base a una prestación anterior, o a través de un agente que puede ser un arquitecto o un ingeniero. En otros casos, puede optar por pedir ofertas mediante anuncios y licitaciones. El método que se use y la propia actitud del cliente en relación con la salud y la seguridad pueden ejercer un profundo efecto en la práctica de salud y seguridad del proyecto.

Por ejemplo, si un cliente opta por precalificar a los contratistas para asegurarse de que cumplirán ciertos criterios, el proceso elimina a los contratistas sin experiencia, a los que no han acreditado una ejecutoria satisfactoria y a aquellos que no cuentan con el personal cualificado requerido por el proyecto. Si bien, con anterioridad, la ejecutoria en materia de salud y seguridad no había sido una de las cualificaciones comúnmente solicitadas o tenidas en cuenta por los clientes, en la actualidad está ganando adeptos, primordialmente entre los clientes industriales importantes y entre los organismos públicos que encargan servicios de construcción.

Algunos clientes potencian la seguridad mucho más que otros. En algunos casos, ello es debido al riesgo de daños a sus instalaciones existentes cuando los contratistas tienen que entrar en

Tabla 93.4 • Importe de los proyectos de construcción en Canadá, en 1993 (basado en el importe de las licencias de construcción expedidas en el mismo año).

Tipo de proyecto,
Edificios residenciales (casas, apartamentos)
Edificios industriales (fábricas, instalaciones
mineras)
Edificios comerciales (oficinas, almacenes,
tiendas, etc).
Edificios institucionales (escuelas,
hospitales)
Otros edificios (terminales de aeropuertos,
estaciones de autobuses, granjas, etc.)
Instalaciones maríimas (muelles, dragados)
Carreteras y autopistas
Redes de agua y alcantarillado
Presas y regadíos
Energía eléctrica
(térmica/nuclear/hidráulica)
Ferrocarriles, teléfonos y telégrafos
Gas y petróleo (refinerías, oleoductos,
gasoductos)
Otras obras civiles (puentes, tíneles, etc.)

mporte (S Can)

38.432 .467 .000

2.594.152.000

11.146 .469 .000

6.205 .352 .000

2.936 .757 .000

575.865 .000

6.799 .688 .000

3.025 .810 .000

333.736 .000

7.644 .985 .000

3.069 .782 .000

8.080 .664 .000

3.565 .534 .000

Total $\quad 94.411 .261 .000$
$\%$ del total

Fuente: Statistics Canada 1993. 
ellas para realizar trabajos de mantenimiento o para la ampliación de las mismas. Las compañías petroquímicas, en particular, dejan bien claro que la ejecutoria de seguridad del contratista es una condición clave del contrato.

A la inversa, aquellas firmas que optan por adjudicar el proyecto por medio de una licitación abierta, sin calificación previa, para lograr el precio más bajo, a menudo se topan con contratistas posiblemente no cualificados para ejecutar la obra o que toman atajos para ahorrar tiempo y materiales. Este procedimiento puede tener un efecto adverso en el desarrollo de la salud y la seguridad.

\section{Relaciones contratista-contratista}

Mucha gente que no está familiarizada con la naturaleza de los acuerdos contractuales corrientes en la construcción supone que un contratista ejecuta la totalidad o, al menos, la mayor parte de la construcción de la mayoría de edificios. Por ejemplo, si se trata de la construcción de un nuevo edificio de oficinas, un complejo polideportivo $\mathrm{u}$ otro proyecto de gran impacto, el contratista general suele poner carteles y, a menudo, emblemas de la compañía, para indicar su presencia y crear la impresión de que es "su" proyecto. Años atrás, esta impresión podía haber sido exacta hasta cierto punto, ya que algunos contratistas generales realmente realizaban partes sustanciales del proyecto con personal propio. Sin embargo, desde mediados del decenio de 1970, muchos contratistas generales, por no decir la mayoría, han asumido más el papel de dirección del proyecto en los grandes proyectos y han contratado la casi totalidad del trabajo a una red de subcontratistas, cada uno de los cuales es especialista en una faceta particular del proyecto. (Véase la Tabla 93.5.)

De resultas de ello, el contratista general puede tener realmente en la obra menos personal que algunos de los subcontratistas. Incluso se da el caso de que el contratista principal no tenga ningún personal implicado directamente en las actividades constructivas, sino que se limita a dirigir el trabajo de los subcontratistas. En la mayor parte de los proyectos importantes del sector industrial, comercial e institucional (ICI), existen diferentes niveles de subcontratistas. Típicamente, los subcontratistas del nivel primario tienen contratos con el contratista general. Sin embargo, estos subcontratistas, a su vez, subcontratan parte de sus trabajos a otros subcontratistas de menor dimensión o mayor especialización.

La influencia que este tejido de contratistas puede ejercer en la salud y la seguridad es obvia si se compara con un lugar concreto como una fábrica. En un centro de trabajo típico de una industria concentrada, sólo hay una entidad dirigente, la empresa. Esta tiene la responsabilidad única sobre el centro, las

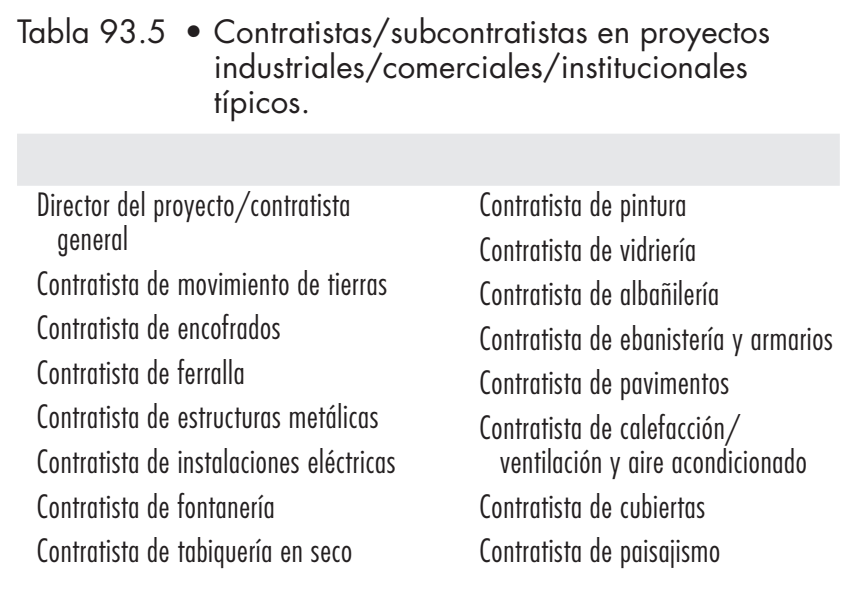

líneas de mando y comunicación son sencillas y directas, y se aplica una misma filosofía corporativa. En un proyecto de construcción puede haber diez o más entidades empresariales (el contratista general y los subcontratistas habituales), y las comunicaciones y la autoridad se transmiten por cauces más complejos, indirectos y a menudo confusos.

La atención prestada a la salud y seguridad por la persona o empresa a cargo del proyecto, puede influir en el comportamiento de los demás respecto a estos temas. Lo contrario también es cierto.

Además, la salud y seguridad de la obra en su conjunto, puede resultar afectada adversamente por la actuación de un subcontratista (p. ej., si un/a subcontratista es descuidado/a, y deja todo en desorden tras de sí al paso de su personal por la obra, su actuación causará problemas al resto de subcontratistas en la misma).

Generalmente, en estos centros de trabajo con multitud de empresas, es más difícil la introducción y gestión de esfuerzos normativos referentes a salud y seguridad. Puede resultar difícil determinar la empresa responsable de ciertos riesgos o de tomar ciertas soluciones, y cualquier control administrativo que puede parecer eminentemente factible en un centro de trabajo con un sólo patrono, necesitará una modificación considerable para funcionar bien en este tipo de proyectos. Por ejemplo, la información relativa a materiales peligrosos utilizados en un proyecto debe impartirse a los que trabajan con ellos o en su proximidad, y los trabajadores deben recibir la instrucción adecuada. En un centro de trabajo fijo, con un sólo patrón, todo el material y la información que le acompaña se obtiene, controla y comunica mucho más fácilmente, mientras que en un proyecto de construcción, cualquiera de los subcontratistas puede introducir materiales peligrosos sin que el contratista general tenga la menor noticia. Adicionalmente, los trabajadores empleados por un subcontratista y que utilizan cierto material pueden haber sido instruidos al respecto, mientras que los equipos que trabajan para otro subcontratista en la misma zona pero haciendo un trabajo totalmente diferente pueden tener una ignorancia total del material y, sin embargo, estar expuestos al mismo riesgo que los que lo emplean directamente.

Otro factor que surge en lo que concierne a las relaciones contratista-contratista atañe al proceso de licitación. Un subcontratista que presenta una oferta demasiado baja puede ejercer recortes que afectarán a la salud y seguridad. En estos casos, el contratista general debe asegurarse de que los subcontratistas prestan su conformidad a las normas, especificaciones y leyes en lo tocante a salud y seguridad. No es raro, en proyectos en los que todos los implicados han presentado ofertas muy bajas, observar la aparición de continuos problemas de salud y seguridad aparejados con un traspaso excesivo de las responsabilidades, hasta que las autoridades legales tienen que intervenir para imponer una solución.

Un problema adicional está relacionado con la programación de la obra y el impacto que la misma puede tener en la salud y seguridad. Al haber varios subcontratistas en la obra a la vez, el conflicto de intereses puede crear problemas. Cada contratista quiere terminar su trabajo lo antes posible. Si dos o más contratistas quieren ocupar el mismo sitio, o si uno tiene que trabajar por encima del otro, pueden surgir problemas. Este problema es más característico de la construcción que de una industria fija, en la que los principales conflictos de intereses suelen darse entre producción y mantenimiento.

\section{Relaciones empresa-trabajador}

Las distintas empresas en un proyecto determinado pueden tener con sus empleados unas relaciones algo distintas de la que es común en los centros de trabajo industriales fijos. Por ejemplo, los 
trabajadores sindicados en una fábrica tienden a pertenecer a un sólo sindicato. Si la empresa necesita más operarios, les entrevista y contrata, los nuevos empleados se hacen miembros de este sindicato. Si hay antiguos trabajadores sindicados en paro, vuelven a ser readmitidos de acuerdo con su antigüedad.

En la parte sindicada del sector de la construcción se aplica un sistema totalmente diferente. Las empresas constituyen asociaciones colectivas que luego negocian convenios con los sindicatos de edificación y obras civiles. La mayoría de los empleados no asalariados del sector contratados directamente trabajan a través del sindicato. $\mathrm{Si}$, por ejemplo, un contratista necesita cinco carpinteros más en un proyecto, el contratista se dirige al sindicato local de carpinteros y solicita que cinco carpinteros se presenten a trabajar en el proyecto en un día determinado. El sindicato notifica a los cinco miembros que encabezan la lista de empleo, que deben presentarse a trabajar en el proyecto con una empresa determinada. Según lo previsto en el convenio colectivo entre la patronal y el sindicato, el contratista puede dar los nombres de los que quiere contratar o puede seleccionar a algunos de la lista. Si no hay miembros afiliados disponibles para cumplimentar la solicitud, el patrono puede contratar trabajadores temporeros que se afiliarán al sindicato, o éste puede buscar trabajadores expertos de otros locales sindicales para poder responder a la petición.

En caso de que no haya sindicatos, las empresas utilizan distintos procedimientos para reforzar su plantilla. Entre ellos, los más comúnmente utilizados consisten en ofertas de empleo previas, oficinas de trabajo locales, transmisión oral y por medio de anuncios en la prensa local.

No es raro que los trabajadores sean contratados por varias empresas diferentes en el curso de un año. La duración del empleo varía con la naturaleza del proyecto y el volumen del trabajo a desarrollar. Esto representa una carga administrativa importante para los contratistas de la construcción, en comparación con sus homólogos en la industria fija (conservación de archivos para liquidaciones del impuesto de la renta, indemnizaciones laborales, seguro de desempleo, cuotas sindicales, pensiones, permisos y otros aspectos legales o contractuales).

Esta situación presenta unos retos singulares frente al típico centro de trabajo de una industria fija. La formación y las cualificaciones no sólo han de ser normalizadas, sino también transferibles de una obra a otra, de un sector a otro. Estas importantes cuestiones afectan a la industria de la construcción de un modo más profundo que a las industrias fijas. Las empresas de la construcción esperan que los trabajadores se incorporen al proyecto con ciertas capacitaciones y habilidades. En la mayoría de los oficios, esto se logra mediante un exhaustivo programa de aprendizaje. Si un contratista solicita cinco carpinteros, espera que el día que los necesita se encontrará en la obra con cinco especialistas cualificados. Si las normas de salud y seguridad requieren una formación especial, la empresa necesita poder acceder a una bolsa de trabajadores con esta preparación, ya que no es fácil impartirla en el momento en que el trabajo ha de comenzar. Un ejemplo de ello es el Programa de Trabajador Certificado que se requiere en los mayores proyectos de construcción en Ontario, Canadá, que implica la existencia de comités conjuntos de salud y seguridad. Puesto que esta formación generalmente no forma parte del programa de aprendizaje, tuvieron que desarrollarse programas de formación alternativos para crear un fondo de trabajadores preparados.

A medida que se dé mayor importancia a la formación especializada o, al menos, a la confirmación del nivel de cualificación, los programas de formación realizados conjuntamente con los sindicatos de la construcción probablemente crecerán en alcance, número y variedad.

\section{Relaciones intersindicales}

La estructura sindical es reflejo de las especializaciones de los contratistas dentro del sector. En un proyecto típico de construcción, en un momento dado, cinco o más oficios pueden coincidir en la obra. Ello implica muchos problemas análogos a los creados por la existencia de varios patronos. No sólo hay que atender a intereses encontrados, sino que los canales de autoridad y comunicación se complican y, a veces, se rarifican en comparación con un centro de trabajo con una sola empresa y un solo sindicato. Ello influye en muchos aspectos de la salud y la seguridad. Por ejemplo, ¿Qué trabajador o sindicato representará a todos los trabajadores del proyecto si la norma exige el nombramiento de un representante de salud y seguridad? ¿Quién ha de recibir formación, quién la impartirá y sobre qué materia?

En el caso de rehabilitación y reincorporación de los trabajadores lesionados, las opciones son mucho más limitadas para los trabajadores cualificados de la construcción que para sus homólogos de las industrias fijas. Por ejemplo, un obrero lesionado en una fábrica puede incorporarse a cualquier otro trabajo, sin necesidad de traspasar importantes barreras jurisdiccionales entre dos sindicatos, porque lo habitual es que en la fábrica haya un solo sindicato. En la construcción, cada sindicato tiene una jurisdicción claramente definida sobre el tipo de trabajo que sus miembros pueden efectuar. Esto limita en gran manera las opciones de los trabajadores lesionados que no están capacitados para los cometidos que realizaban antes de sus lesiones, pero que, a pesar de ello, podrían realizar otros trabajos en el mismo centro de trabajo.

De vez en cuando se suscitan disputas jurisdiccionales acerca de qué sindicato debe realizar ciertos tipos de tareas que tienen connotaciones de salud y seguridad. Entre éstas cabe incluir el montaje de andamios, el manejo de grúas con pluma sobre camión, la retirada de amianto y el estibado. Es preciso que las normas en estos sectores tengan en cuenta las incumbencias jurisdiccionales, en especial en lo relativo a autorizaciones y formación.

\section{Garácter dinámico de la construcción}

Los centros de trabajo de la construcción son, en muchos aspectos, totalmente distintos de los de las industrias fijas. No sólo son diferentes, sino que cambian constantemente. Al contrario que una fábrica que funciona en un sitio determinado día tras día, con la misma maquinaria, los mismos trabajadores, los mismos procesos y, generalmente, las mismas condiciones, los proyectos de construcción se desarrollan y cambian de un día para otro. Se levantan paredes, llegan nuevos trabajadores de distintos oficios, las empresas cambian cuando se terminan los trabajos asignados, y casi todos los proyectos se ven afectados, en algún grado, por los cambios climáticos.

Cuando se termina un proyecto, los trabajadores y las empresas se marchan a otras obras para empezar de nuevo. Esto nos indica el carácter dinámico del sector. Algunos patronos trabajan en varias ciudades, provincias, regiones o incluso países diferentes. Del mismo modo, muchos trabajadores especializados se trasladan con el trabajo. Estos factores influyen en muchos aspectos de la salud y seguridad, incluyendo las indemnizaciones a los trabajadores, las normas de salud y seguridad, la cuantificación del rendimiento y la formación.

\section{Resumen}

El sector de la construcción se enfrenta a unas condiciones muy distintas de las de una industria fija. Estas condiciones deben tenerse en cuenta al considerar las estrategias de control y pueden ayudar a explicar la razón de que las cosas se hagan de un modo diferente en este sector. Las soluciones desarrolladas con los datos suministrados tanto por los trabajadores como por la dirección, 
que conocen las condiciones y la manera de tratarlas con efectividad, ofrecen la mejor oportunidad para mejorar la salud y seguridad.

\section{- GESTION DE CALIDAD Y PREVENCION INTEGRADAS}

\section{Rudolf Scholbeck}

\section{Mejora de la salud y seguridad en el trabajo}

Las empresas de construcción adoptan cada vez más los sistemas de gestión de calidad estipulados por la Organización Internacional de Normalización (ISO), como las series ISO 9000 y las normas subsiguientes basadas en ellas. Aunque en este conjunto de normas no se especifican recomendaciones referentes a la salud y seguridad en el trabajo, existen razones convincentes para la inclusión de medidas preventivas, al poner en práctica un sistema de gestión como el requerido por la ISO 9000.

Las normas de salud y seguridad en el trabajo se redactan, se ponen en práctica y se adaptan continuamente al progreso tecnológico, así como a las nuevas técnicas de seguridad y a los avances de la medicina del trabajo. Sin embargo, con demasiada frecuencia, se soslayan, bien deliberadamente, bien por ignorancia. Cuando esto sucede, los modelos de gestión de seguridad, tales como las series ISO 9000, ayudan a integrar en la gestión la estructura y el contenido de las medidas de prevención. Las ventajas de este enfoque integral son obvias.

La gestión integrada significa que la normativa de salud y seguridad ya no se considerará de un modo aislado, sino que adquieren importancia en los capítulos correspondientes del manual de gestión de la calidad, así como en las instrucciones del proceso y del trabajo, creando de este modo un sistema totalmente integrado. Este enfoque integral puede aumentar las posibilidades de que las medidas de prevención de accidentes reciban una mayor atención en la práctica diaria y, por tanto, reducir el número de accidentes y lesiones en el centro de trabajo. La difusión de un manual que integre los procedimientos de salud y seguridad en el trabajo en los procesos que describe es crucial a estos efectos.

Los nuevos métodos de gestión están encaminados a acercar al personal al centro de los procesos. Los trabajadores que colaboran en ellos se implican de un modo más activo. La información, la comunicación y la cooperación se promueven traspasando las barreras jerárquicas. La reducción de las bajas por enfermedad o por accidentes en el centro de trabajo favorece la puesta en práctica de los principios de gestión de la calidad en la construcción.

Con el desarrollo de nuevos métodos y equipos de construcción, las exigencias de seguridad aumentan de modo continuo. La creciente preocupación por la protección del medio ambiente hace que el problema sea aún más complejo. Es difícil hacer frente a las exigencias de la prevención moderna sin unas normas adecuadas y una articulación centralizada del proceso y de las instrucciones de trabajo. De ahí que en el sistema de gestión de calidad figure por escrito una clara definición de las responsabilidades y una coordinación efectiva del plan de prevención.

\section{Mejora de la competitividad}

Crece la exigencia de que cuando los contratistas presenten sus ofertas para un trabajo, éstas vengan acompañadas de la documentación que acredite la existencia de un sistema de gestión de la seguridad en el trabajo, y su efectividad se ha convertido en uno de los criterios para la adjudicación de un contrato.
La presión de la competencia internacional podría ser mayor en el futuro. Parece prudente, por tanto, integrar de entrada medidas preventivas dentro del sistema de gestión de calidad, mejor que esperar y hacerlo más adelante, obligados por la creciente presión competitiva, cuando la presión del tiempo y los costes de personal y financiación serán mayores. Además, una ventaja no insignificante de un sistema de gestión de calidad y de prevención integrados es que la existencia de tal programa bien documentado probablemente reducirá los costes de cobertura, no sólo para las indemnizaciones a los trabajadores, sino de la responsabilidad civil del constructor.

\section{Dirección de la empresa}

La dirección de la empresa debe comprometerse con la integración de la salud y la seguridad en el trabajo dentro del sistema de dirección. Deberán definirse los objetivos especificando el contenido y el marco temporal de este esfuerzo, e incluirlos en la declaración básica de la política de la empresa. Se dispondrán los recursos necesarios y se asignará el personal adecuado para el cumplimiento de los objetivos establecidos. Generalmente, en las empresas de construcción de medianas y grandes se requiere personal especializado en seguridad. En empresas de menor tamaño, el patrón deberá asumir la responsabilidad de los aspectos preventivos del sistema de gestión de calidad.

El círculo se cierra mediante una revisión periódica de la gestión de la empresa. Deben analizarse y evaluarse las experiencias colectivas de la utilización del sistema integrado de gestión de calidad/prevención, y la dirección de la empresa deberá formular planes para su revisión y crítica posterior.

\section{Evaluación de los resultados}

La evaluación de los resultados del sistema de gestión de seguridad en el trabajo que se ha instituido es el segundo paso en la integración de las medidas preventivas y de la gestión de calidad.

Las fechas, clases, frecuencia y costes de los accidentes deben recopilarse, analizar y compartirse con las personas de la empresa a quienes compitan estas responsabilidades. Tal análisis facilita a la empresa la fijación de prioridades al formular o modificar el proceso y las instrucciones de trabajo. También indica hasta qué punto la experiencia de salud y seguridad en el trabajo afecta a todas las divisiones y a todos los procesos de la empresa de construcción. Por esta razón, la definición de la interfase entre los procesos empresariales y los aspectos preventivos adquiere gran importancia.

En la fase de elaboración de la oferta pueden calcularse con precisión los recursos de tiempo y económicos necesarios para unas medidas de prevención exhaustivas, como por ejemplo las de limpieza de escombros.

Cuando se realiza la compra de los materiales de construcción, debe prestarse atención a la posibilidad de sustitución de materiales potencialmente peligrosos. Desde el comienzo de un proyecto deben asignarse las responsabilidades sobre la salud y seguridad laboral para aspectos específicos y para cada fase del proyecto de construcción. La necesidad y la disponibilidad de formación especial en salud y seguridad en el trabajo, así como los riesgos relativos de lesión y enfermedad deben ser factores determinantes de la adopción de unos procesos de construcción determinados. Estas condiciones deben ponerse de manifiesto con prontitud, de modo que se pueda hacer una selección de trabajadores idóneos y que se puedan organizar los cursos de formación de un modo oportuno.

Las responsabilidades y la autoridad del personal asignado a la seguridad y la manera en que éstas encajen en el trabajo diario deben documentarse por escrito y adjuntarse a la las descripciones de tareas en la obra. El personal encargado de la 
seguridad en el trabajo de una empresa de construcción debe figurar en su organigrama, que junto con una matriz clara de responsabilidades y los esquemas del proceso debe estar incluido en el manual de gestión de calidad.

\section{Un ejemplo de Alemania}

En la práctica, en Alemania, para integrar el sistema de gestión de calidad se han puesto en práctica cuatro procedimientos formales y sus combinaciones:

1. Se preparan, por separado, un manual de gestión de calidad y un manual de gestión de seguridad en el trabajo. Cada uno contiene sus propios procedimientos e instrucciones de trabajo. En casos extremos, este método da lugar a soluciones ineficaces, organizadas aisladamente, que duplican el trabajo y en la práctica no proporcionan los resultados apetecidos.

2. En el manual de gestión de calidad se inserta un capítulo adicional bajo el título "Seguridad y salud en el trabajo". En este capítulo se incluyen todas las declaraciones relativas a salud y seguridad en el trabajo. Algunas empresas constructoras eligen este camino. La inserción de un problema de salud y seguridad en un capítulo separado puede resaltar la importancia de la prevención, pero conlleva el riesgo de ser ignorado como "la rueda de repuesto", y sirve más de prueba de un intento que de orden para adoptar las medidas adecuadas.

3. Todos los aspectos de seguridad y salud en el trabajo se incorporan directamente en el sistema de gestión de calidad. Esta es la realización más sistemática de la idea básica de la integración. La estructura integrada y flexible de los modelos de presentación de las normas alemanas DIN EN ISO 9001-9003 permite tal inclusión.

4. La Asociación Sectorial de la Construcción Subterránea (Berufsgenossenschaft) favorece una integración modular. Este concepto se explica más adelante.

\section{Integración en la gestión de calidad}

A más tardar cuando se completa la evaluación, las personas responsables del proyecto de construcción deben reunirse con los responsables de gestión de calidad y decidir los pasos a dar para integrar, de un modo efectivo, la seguridad en el trabajo dentro del sistema de gestión. Un trabajo de preparación exhaustivo deberá facilitar la fijación de prioridades comunes durante el trabajo que prometan dar resultados preventivos óptimos.
Las exigencias de prevención que se derivan de la evaluación se dividen, en primer lugar, entre las que se pueden catalogar de acuerdo con los procesos específicos de la empresa y las que deben considerarse separadamente por ser más generales, más globales o tienen un carácter tan especial que deben considerarse por separado. Para esta clasificación pueden servir de ayuda las siguientes preguntas: ¿Dónde sería más probable que el lector interesado del manual (el "cliente" o el trabajador) buscara la política preventiva pertinente? ¿En la sección de un capítulo destinado a un proceso específico de la empresa, o en una sección especial de salud y seguridad en el trabajo? Parece más sensato, de acuerdo con ello, que la instrucción de un procedimiento especial para el transporte de materiales peligrosos, en casi todas las empresas de construcción, se incluyera en la sección dedicada a manipulación, almacenaje, embalaje, conservación y transporte.

\section{Coordinación y puesta en práctica}

Después de esta clasificación formal debe venir la coordinación lingüística para garantizar que sea fácilmente legible (esto significa su presentación en el/los idioma/s apropiado/s y en términos fácilmente comprensibles por individuos con niveles educativos característicos de la mano de obra específica). Finalmente, los documentos finales deben ser respaldados de manera formal por la alta dirección de la empresa. En este momento, será útil dar publicidad a la importancia de los procedimientos que han cambiado o de nueva implantación y de las instrucciones de trabajo, por medio de boletines de la empresa, círculos de seguridad, memorándums y otros medios disponibles, y promover su aplicación.

\section{Auditorías generales}

Para evaluar la efectividad de las instrucciones se pueden formular preguntas adecuadas que se incluirán en las auditorías generales. De este modo, el trabajador percibe de una manera inconfundible la coherencia de los procesos de trabajo y las consideraciones de salud y seguridad en el trabajo. La experiencia ha demostrado que, al principio, los trabajadores pueden sorprenderse cuando un equipo auditor, en la obra, en su división específica, les hace preguntas rutinarias sobre prevención de accidentes, sin darle importancia. El aumento posterior de la atención prestada a la salud y seguridad por los trabajadores confirma lo valioso de la integración de la prevención en el programa de gestión de calidad.

\section{PRINCIPALES SECTORES Y SUS RIESGOS}

\section{- PRINCIPALES SECTORES}

\section{Jeffrey Hinksman}

El término industria de la construcción se usa en todo el mundo para englobar un colectivo de empresas con prácticas muy diferentes, que se reúnen por un tiempo limitado en el lugar en que se ha de ejecutar una obra de edificación o de ingeniería civil. La escala de trabajos abarca desde un trabajador único que ejecuta un trabajo que dura sólo unos minutos (p. ej., reparar una teja, con un equipo consistente en martillo y clavos y, tal vez, una escalera) hasta vastos proyectos de edificación o de ingeniería civil que duran varios años y que implican a cientos de contratistas diferentes, cada uno de ellos con su propia cualificación, su maquinaria y su equipo. Sin embargo, a pesar de la enorme variedad de escalas y de la complejidad de los trabajos, los sectores principales de la industria de la construcción tienen mucho en común. Siempre hay un cliente (denominado a veces la propiedad) y un contratista; - excepto en los trabajos de muy poca importancia, siempre habrá un proyectista, un arquitecto o un ingeniero- $y$, si el proyecto requiere una gama de especialidades, se requerirán inevitablemente contratistas adicionales que actuarán como subcontratistas del contratista principal (véase también el Apartado "Factores organizativos que afectan a la salud y seguridad" en este Capítulo). Mientras que edificios agrícolas o residenciales pequeños pueden construirse sobre la base de un acuerdo informal entre el cliente y el constructor, la gran mayoría de trabajos de construcción y obras civiles se ejecutan amparados por las cláusulas de un contrato formal entre el cliente y el contratista. Este contrato expone los detalles de la estructura o de otros trabajos que el contratista ha de ejecutar, el plazo de construcción y el precio. Los contratos pueden contener muchos otros 
detalles aparte de la descripción del trabajo, el plazo y el precio, pero estos tres son los esenciales.

Los proyectos de construcción se dividen en dos grandes categorías: edificación y obras civiles. El término edificación se aplica a los proyectos de casas, oficinas, tiendas, fábricas, escuelas, hospitales, centrales eléctricas y estaciones de ferrocarril, iglesias, etc., es decir, todos los tipos de estructuras que en el lenguaje común se denominan "edificios". El término obras civiles se aplica al resto de estructuras construidas en nuestro entorno, incluyendo carreteras, túneles, puentes, vías férreas, presas, canales y muelles. Hay estructuras que parecen pertenecer a ambas categorías; un aeropuerto implica la construcción de grandes edificios, así como la obra civil necesaria para la creación del aeropuerto propiamente dicho; un muelle conlleva la construcción de edificios de almacén además de la excavación de la dársena y de la elevación de sus muros.

Cualquiera que sea el tipo de estructura, tanto la edificación como las obras civiles implican ciertos procesos, como la construcción o montaje de la estructura, su puesta en funcionamiento, conservación, reparaciones, reformas y, por último, su demolición. Este ciclo de operaciones se repite una y otra vez, independientemente del tipo de estructura.

\section{Pequeños contratistas y autónomos}

Aunque existen variaciones de un país a otro, la construcción es típicamente una industria de pequeñas empresas. Entre un 70 y un $80 \%$ de los contratistas tienen menos de 20 trabajadores propios. Ello es debido a que muchos contratistas empiezan como industriales individuales en trabajos pequeños, probablemente residenciales. A medida que su negocio se amplía, estos industriales empiezan a dar trabajo a un número reducido de trabajadores. La carga de trabajo en construcción es raramente predecible o constante, pues unos trabajos terminan y otros empiezan sin coincidir en el tiempo. Existe la necesidad en la industria de poder desplazar a grupos de trabajadores con ciertas especialidades de obra en obra según lo requiera el trabajo. Los pequeños contratistas cumplen este cometido.

Junto a los pequeños contratistas se mueve una multitud de trabajadores autónomos. $\mathrm{Al}$ igual que la agricultura, la construcción tiene un porcentaje muy alto de trabajadores por cuenta propia. Estos también suelen ser industriales, como carpinteros, pintores, electricistas, fontaneros y albañiles. Pueden encontrar un puesto en pequeñas obras residenciales o formar parte de la mano de obra en proyectos de más envergadura. Durante el período de gran auge de la construcción de finales del decenio de 1980, hubo un aumento de trabajadores que alegaban ser autónomos. Ello fue debido en parte a los incentivos fiscales para los individuos afectados y a la utilización por los contratistas de estos autónomos, que resultaban más baratos que los empleados propios. Además, los contratistas tenían menores costes de seguridad social, no tenían obligación de dar formación a los autónomos y se podían desprender de ellos con más facilidad al acabarse el trabajo.

La presencia en la construcción de tantos pequeños contratistas y trabajadores autónomos suele dificultar una gestión efectiva de la salud y la seguridad en la obra en su conjunto, y con una mano de obra tan móvil, ciertamente resulta más difícil impartir una formación de seguridad adecuada. Un análisis de accidentes mortales en el Reino Unido durante un período de 3 años mostró que aproximadamente la mitad de los accidentes mortales sucedió entre los trabajadores que llevaban en la obra una semana o menos. Los primeros días en cualquier obra son singularmente peligrosos para los trabajadores de la construcción pues, aunque sean industriales experimentados, cada obra es una experiencia única.

\section{Sectores público y privado}

Los contratistas pueden formar parte del sector público (p. ej., el departamento de obras de un ayuntamiento o de un consejo comarcal). Estos departamentos de obras públicas solían llevar a cabo un volumen considerable de trabajos de conservación, especialmente en viviendas, escuelas y carreteras. Recientemente se ha producido un movimiento a favor de alentar una mayor competencia en estos trabajos, en parte a raíz de las presiones ejercidas con miras a mejorar la administración de los fondos. Ello ha conducido, en primer lugar, a la reducción del tamaño de los departamentos de obras públicas, incluso a su total desaparición en algunos lugares, y a la obligación de adjudicar las obras mediante licitaciones competitivas. Los trabajos anteriormente ejecutados por los departamentos de obras públicas se realizan ahora por contratistas del sector privado en estrictas condiciones de "adjudicación a la oferta más barata". Ante la necesidad de reducir costes, los contratistas pueden sufrir la tentación de reducir partidas que ellos consideran gastos generales, como los de seguridad y formación.

La diferencia entre los sectores público y privado también puede hacerse extensiva a los clientes. El gobierno central y local (junto con los servicios públicos y de transporte, si es que están bajo el control de los anteriores) pueden ser clientes de las empresas de construcción. Como tales, generalmente debería considerarse que pertenecen al sector público. El transporte y los servicios públicos regidos por empresas deberían considerarse normalmente como pertenecientes al sector privado. El hecho de que un cliente pertenezca o no al sector público a veces influye en la decisión de incluir ciertas partidas de seguridad o formación en el coste de los trabajos de construcción. Recientemente, clientes tanto del sector público como del privado se han encontrado con parecidas exigencias en esta modalidad de ofertas competitivas.

\section{Trabajos allende las fronteras nacionales}

Un aspecto de los contratos del sector público, cuya importancia va en aumento, es la de recibir invitaciones para licitar obras fuera de las fronteras nacionales. En la Comunidad Europea, por ejemplo, los contratos de gran envergadura que sobrepasen un importe fijado en las Directivas, deben ser anunciados dentro de la Comunidad, de modo que puedan licitar contratistas de todos los países miembros. El efecto buscado es animar a los contratistas a trabajar fuera de las fronteras de sus países. En estos casos, están obligados a trabajar de acuerdo con la legislación nacional de seguridad y salud del país en cuestión. Uno de los objetivos de la Comunidad Europea es la armonización de las normas de seguridad y salud. Los contratistas importantes que trabajan en varias partes del mundo bajo regímenes diferentes deberán, por tanto, familiarizarse con los reglamentos de salud y seguridad de aquellos países en que operan.

\section{Proyectistas}

Tratándose de edificios, el proyectista es habitualmente un arquitecto, aunque en viviendas domésticas de pequeña escala, los propios contratistas pueden poseer la competencia necesaria para el diseño. Si se trata de un edificio grande o complejo, intervienen arquitectos que se encargan del proyecto general, así como ingenieros de estructuras que se ocupan del proyecto de estructura, e ingenieros especialistas que se encargan de proyectar las instalaciones. El arquitecto garantizará las necesidades de espacio para la instalación de la maquinaria y los servicios en los emplazamientos adecuados del edificio. Los ingenieros especialistas se preocuparán de garantizar que la planta y las instalaciones proyectadas funcionen en los niveles de calidad requeridos, cuando se instalen en los lugares previstos por el arquitecto. 
En obras civiles, es más probable que la dirección del proyecto recaiga en un ingeniero de caminos o de estructuras, aunque en ciertos trabajos en los que el impacto visual pueda ser un factor influyente, un arquitecto puede asumir un papel destacado dentro del equipo del proyecto. En la construcción de túneles, ferrocarriles y carreteras, lo probable es que la dirección del proyecto sea asumida por ingenieros de caminos o de estructuras.

El papel del promotor consiste en tratar de mejorar el uso del terreno o de los edificios y sacar un beneficio de tales mejoras. Algunos promotores se limitan a vender el terreno o los edificios mejorados y no tienen un interés posterior; otros conservan la propiedad del terreno o incluso de los edificios y cosechan un interés continuado en forma de alquileres más elevados tras las mejoras.

La habilidad del promotor reside en identificar terrenos vacíos o infrautilizados o edificios obsoletos cuyo valor se incremente aplicando las artes de la construcción. El promotor puede utilizar sus recursos financieros, pero quizás más frecuentemente emplea su habilidad para buscar y atraer otras fuentes de financiación. Los promotores no son un fenómeno moderno; la expansión de las ciudades durante los últimos 200 años se debe en gran parte a ellos. Los promotores pueden ser, a su vez, los clientes de la obra, o simplemente actuar como representantes de otros grupos que facilitan la financiación.

\section{Tipos de contratos}

En contrato tradicional, el cliente acuerda con un proyectista la elaboración de un proyecto y unas especificaciones completas. A partir de aquí, el cliente invita a los contratistas a que presenten ofertas o pujen para ejecutar el trabajo de acuerdo con el proyecto. El papel del contratista se reduce mayormente a la construcción propiamente dicha. La participación del contratista en el diseño o la elaboración de especificaciones consiste principalmente en buscar los cambios que hagan la construcción más fácil o más eficiente: mejorar la "edificabilidad".

Otro acuerdo corriente en la construcción es el contrato de proyecto y obra. El cliente requiere un edificio (tal vez un bloque de oficinas o un centro comercial), pero las únicas ideas definidas que tiene en cuanto a los aspectos de detalle del proyecto son las dimensiones del emplazamiento, el número de personas que habrán de acomodarse o la escala de actividades que en él se desarrollará. En tal caso, el cliente solicita ofertas de proyectistas o contratistas para que cursen propuestas de proyecto y obra. Los contratistas que se dedican a proyectar y construir cuentan con su propia organización de proyectos o mantienen lazos estrechos con un proyectista ajeno a su organización que está dispuesto a trabajar para ellos en el encargo. La modalidad de proyecto y obra puede incorporar dos fases: una fase inicial en la que un proyectista prepara un proyecto preliminar que sirve para la petición de ofertas; y, a continuación, una segunda fase en la que el contratista de proyecto y obra que resulte adjudicatario, realizará el proyecto de ejecución de la obra.

Los contratos de mantenimiento y emergencias cubren una gran variedad de acuerdos entre clientes y contratistas y representan una proporción significativa del trabajo de la industria de la construcción. Generalmente tienen vigencia por un período fijo, requieren que el contratista haga ciertos tipos de trabajos con carácter inmediato (p. ej., trabajos en los que el cliente llama al contratista para que los ejecute al momento). Los contratos de emergencia son utilizados ampliamente por las autoridades públicas que tienen la responsabilidad de suministrar un servicio público que no se puede interrumpir; los organismos públicos, las compañías de servicios públicos y los servicios de transporte hacen amplio uso de los mismos. Las empresas industriales, en especial aquellas con procesos continuos tales como las petroquímicas, también hacen extenso uso de estos contratos para resolver los problemas en sus instalaciones. Habiendo acordado un contrato de tal índole, el contratista se compromete a tener disponibles personal y equipo adecuados para la ejecución de los trabajos, a menudo avisado con muy poca antelación (p. ej., en el caso de contratos de emergencia). La ventaja para el/la cliente es que no necesita tener obreros en su nómina ni conservar maquinaria o equipos para emplear sólo de manera esporádica en trabajos de mantenimiento y casos de emergencia.

La valoración de este tipo de contratos puede basarse en un tanto fijo por año o en el tiempo empleado en la ejecución del trabajo o en una combinación de ambos.

Quizás el ejemplo más comúnmente conocido por el público sea el de mantenimiento de carreteras y reparaciones de urgencia de tendidos eléctricos o tuberías de gas cortadas o dañadas accidentalmente.

Cualquiera que sea la forma de contrato, las posibilidades de que clientes y proyectistas influyan en la seguridad y la salud de los contratistas por efecto de decisiones tomadas en una fase temprana del trabajo son las mismas. La modalidad del proyecto y obra quizás permite una más estrecha cooperación entre proyectista y constructor en materia de salud y seguridad.

\section{Precio}

El precio es siempre un elemento del contrato. Puede ser simplemente una suma estipulada por el coste de realizar el trabajo, tal como la construcción de una casa. Incluso si se trata de un simple tanto alzado, el cliente puede tener que satisfacer parte del precio por adelantado antes de iniciar la obra, para facilitar al contratista la compra de materiales. Sin embargo, el precio puede establecerse en base al coste más un porcentaje, de acuerdo con el cual el/la contratista se resarce de sus costes más una cantidad acordada o un porcentaje en concepto de beneficio. Este acuerdo suele perjudicar al cliente, ya que el contratista no tiene aliciente para reducir los costes. El precio también puede conllevar bonificaciones o penalizaciones, de modo que el contratista reciba un mayor importe, si por ejemplo el trabajo se acaba antes del plazo acordado. Sea cual sea la forma de liquidación de los trabajos, es habitual que los pagos se efectúen en fases a medida que los trabajos avanzan, bien al completarse ciertas partes de la obra en las fechas acordadas, bien sobre la base de algún método convenido para medir la obra realizada. Al final de la construcción propiamente dicha, es habitual que el cliente efectúe una retención acordada del precio total hasta que las deficiencias hayan sido rectificadas o la estructura se haya puesto en servicio.

En el transcurso de la obra, el contratista puede encontrarse con problemas que no habían sido previstos cuando se firmó el contrato con el cliente. Estos pueden motivar cambios del proyecto, del método de construcción o de los materiales. Generalmente tales cambios originan costes adicionales al contratista, que trata de reclamarlos al cliente, basándose en que tales trabajos son "desviaciones" del contrato original. A veces la recuperación del coste de los cambios puede representar la diferencia para el contratista entre ganar o perder dinero en la obra.

El precio de los contratos puede afectar a la salud y seguridad si en la oferta del contratista se incluye una previsión inadecuada para cubrir los costes de accesos seguros, maquinaria de elevación, etc. Esto se hace más difícil en los casos en que, llevados por la intención de asegurarse de que los contratistas no den un precio abusivo, los clientes siguen estrictamente una política de licitación competitiva. Los gobiernos y las autoridades locales aplican políticas de licitación competitiva a sus contratos, y de hecho puede ser obligatoria por ley la adjudicación de los contratos exclusivamente por este método. En esta situación siempre existe el riesgo de que se vea afectada la salud y la seguridad de los operarios de la construcción. $\mathrm{Al}$ reducir costes, los 
clientes pueden resistirse a la tentación de reducir el nivel de calidad de los materiales o los métodos de construcción, pero al mismo tiempo ignorar totalmente que, al aceptar la oferta más baja, han aceptado métodos de trabajo que ofrecen una mayor probabilidad de poner en peligro a los obreros de la construcción. Incluso en una situación de ofertas a la baja, los contratistas en sus ofertas deberán especificar claramente al cliente que ésta cubre adecuadamente el coste de la salud y seguridad que sus propuestas conllevan.

Los promotores pueden influir en la salud y seguridad de la construcción de un modo similar a los clientes; en primer lugar, recurriendo a contratistas que sean competentes en salud y seguridad y arquitectos que consideren la salud y seguridad en sus proyectos y, en segundo lugar, desechando automáticamente las ofertas más bajas. Los promotores generalmente desean que sus promociones tengan éxito, y una medida del éxito de un proyecto debería ser que durante el proceso constructivo no se produzcan problemas importantes de salud y seguridad.

\section{Planificación y normas de edificación}

En el caso de los edificios, ya sean destinados a vivienda, ya sean comerciales o industriales, los proyectos están sujetos a normas de planificación que ordenan las zonas en las que se pueden desarrollar cierto tipo de usos (p. ej., no se puede construir una fábrica en medio de viviendas). Las leyes de planificación pueden ser muy específicas en cuanto al aspecto exterior, los materiales y el volumen de los edificios. Normalmente sólo es posible la construcción de fábricas en las zonas calificadas de industriales.

A menudo también existen ordenanzas de edificación o normas similares que definen con exactitud y detalle muchos aspectos del proyecto y de las especificaciones de los edificios: por ejemplo, el espesor de los muros y maderas, la profundidad de los cimientos, las características del aislamiento, las dimensiones de las ventanas y habitaciones, la distribución del cableado eléctrico y la puesta a tierra, la distribución de la fontanería y las tuberías y muchos más. Los clientes , proyectistas, redactores de especificaciones y contratistas han de seguir estas normas. Las mismas coartan la libertad de elección, pero al mismo tiempo garantizan que los edificios se construyan con una calidad aceptable. En este sentido, las leyes de planificación y las normas de edificación condicionan el proyecto de los edificios y su coste.

\section{Viviendas}

Los proyectos de construcción de viviendas pueden consistir en una sola casa o en grandes grupos de viviendas unifamiliares o apartamentos. El cliente puede ser el dueño/a de cada casa, quien normalmente será el responsable del mantenimiento de la misma. El contratista, habitualmente, seguirá responsabilizándose de la reparación de los defectos de construcción durante un período de algunos meses después de la terminación del edificio. Sin embargo, si el proyecto es de un número elevado de casas, el cliente puede ser un organismo público, local o gubernamental, que tiene la responsabilidad de proporcionar alojamientos. Existen también grandes organismos privados, tales como asociaciones inmobiliarias, por encargo de las cuales es posible la construcción de grupos de casas. Los organismos públicos o privados responsables de facilitar vivienda, generalmente alquilan las casas terminadas a los que las ocuparán, conservando también para sí un mayor o menor grado de responsabilidad en el mantenimiento. Los proyectos de edificación relativos a bloques de apartamentos, generalmente tienen un sólo cliente para la totalidad del bloque, el cual, a continuación, alquila los apartamentos individuales de acuerdo con un contrato de arrendamiento. En este caso, el cliente tiene la responsabilidad de encargarse del mantenimiento, pero traspasa su coste a los inquilinos. En algunos países, la propiedad de cada apartamento individual del bloque puede corresponder a los ocupantes de cada uno de los apartamentos. Existen ciertos acuerdos, a veces por medio de un contratista administrador del conjunto, según los cuales se lleva a cabo el mantenimiento, recaudándose los costes necesarios entre los ocupantes.

A menudo se construyen casas con fines especulativos por parte de un promotor. Los clientes u ocupantes específicos de tales casas pueden ser desconocidos al iniciarse el proceso, pero aparecen en escena después de que la construcción ha comenzado y adquieren o alquilan la propiedad como cualquier otra mercancía. Las casas suelen estar equipadas con instalaciones de electricidad, fontanería y alcantarillado y de calefacción; también pueden contar con una acometida de gas. A veces, con la intención de reducir costes, las casas se entregan sólo parcialmente acabadas, dejando en manos del comprador la instalación de los accesorios y la pintura y decoración del edificio.

\section{Edificios comerciales}

Entre los edificios comerciales se incluyen las oficinas, fábricas, escuelas, hospitales, tiendas: una lista casi interminable de tipos diferentes de edificios. En la mayoría de los casos estos edificios se construyen para un cliente particular. Sin embargo, las oficinas y tiendas se construyen a menudo con fines especulativos, al igual que las viviendas, con la esperanza de atraer compradores o inquilinos. Algunos clientes requieren una oficina o tienda que esté completamente equipada de acuerdo con sus necesidades, pero muy a menudo, el contrato sólo incluye la estructura y los servicios principales, siendo el cliente el que se encarga de la terminación del local mediante acuerdos con contratistas especializados en el equipamiento de oficinas y tiendas.

Los hospitales y las escuelas se construyen para clientes que tienen una idea claramente definida de sus necesidades, y los mismos clientes ofrecen a menudo datos de diseño que se incorporan al proyecto. La instalación y el equipamiento de los hospitales pueden tener un valor superior al de la estructura y llevan aparejado un importante trabajo para que el proyecto satisfaga estrictas normas médicas. El gobierno local o nacional también puede desempeñar un papel en proyectos de escuelas, estableciendo exigencias muy detalladas sobre las necesidades de espacio y equipamiento como parte de su más amplio papel en materia de enseñanza. Los gobiernos nacionales, de costumbre, tienen una normativa muy precisa con respecto a los edificios e instalaciones de hospitales. El equipamiento de los hospitales y edificios de una complejidad análoga es una clase de trabajo de construcción que suele ser ejecutada por subcontratistas especializados. Estos contratistas no sólo han de tener conocimientos de salud y seguridad en la construcción en general, sino también los conocimientos necesarios para garantizar que sus trabajos no puedan afectar negativamente a las actividades propias del hospital.

\section{Construcción industrial}

La edificación o construcción industrial incorpora la utilización de técnicas de producción masiva de la industria manufacturera para producir partes de edificios. El ejemplo por excelencia es el ladrillo, pero normalmente la expresión se aplica a construcciones que utilizan elementos de hormigón que se montan in situ. La construcción industrial se extendió rápidamente después de la segunda guerra mundial para satisfacer la demanda de viviendas baratas, y se encuentra comúnmente en promociones masivas de viviendas. Es posible producir, en las condiciones de trabajo de una fábrica, elementos prefabricados de una precisión uniforme de un modo que sería prácticamente imposible de lograr en las condiciones normales de una obra. 
A veces los elementos de la construcción industrial se fabrican fuera del emplazamiento de la obra, en fábricas que pueden servir a una amplia zona; en algunos casos, cuando la promoción alcanza por sí sola un número elevado de unidades, se instala una factoría a pie de obra para servir a este grupo de modo exclusivo.

Los elementos proyectados para la construcción industrial deben ser estructuralmente bastante resistentes para soportar los esfuerzos al ser transportados, izados colocados en su sitio; deben llevar incorporados puntos de anclaje o ranuras para permitir la fijación de bridas de elevación, y también deberán incluir pestañas o rebajes adecuados para permitir un acoplamiento fácil y sólido de las piezas. La construcción industrial requiere maquinaria de transporte y elevación de las unidades, y espacio y medios para almacenar las piezas con seguridad cuando se entregan en obra, de modo que las piezas no resulten dañadas ni produzcan lesiones a los obreros. Esta técnica de construcción suele producir edificios de escaso atractivo visual, pero, a gran escala, es barata; mediante el montaje de seis piezas se puede construir una habitación con las aberturas de puerta y ventana en su ubicación definitiva.

Se emplean técnicas similares para fabricar elementos de hormigón para estructuras de ingeniería civil, tales como autovías elevadas y revestimientos de túneles.

\section{Proyectos llave en mano}

Algunos clientes de edificios industriales o comerciales, con plantas e instalaciones extensas y complejas, desean simplemente trasladarse a una instalación que se encuentre a punto y funcionando desde el primer día de su ocupación. Los laboratorios se construyen y se equipan, a veces, siguiendo esta modalidad. Tal tipo de acuerdos recibe el nombre de proyectos "llave en mano", y de acuerdo con ellos el contratista debe asegurar que todos los aspectos de la instalación y servicios funcionan perfectamente antes de la entrega del proyecto. El trabajo puede haberse ejecutado amparado por un contrato de proyecto y obra, de modo que, en efecto, el contratista de trabajos llave en mano se ocupa de todo, desde el proyecto hasta la puesta en funcionamiento.

\section{Obras civiles y construcción pesada}

Las obras civiles más conocidas por el público son los trabajos en carreteras. Algunos trabajos de esta índole consisten en la apertura de nuevas carreteras en terreno virgen, pero una gran parte de los mismos abarcan la ampliación y reparación de carreteras existentes. Los contratos de trabajo en carreteras son, generalmente, encargados por organismos municipales o estatales, pero a veces las carreteras permanecen bajo el control de los contratistas durante varios años después de su terminación, tiempo durante el cual están autorizados a cobrar peajes. Si las estructuras de ingeniería civil son financiadas por el gobierno, tanto el proyecto como la construcción real estarán sujetos a una estricta supervisión por funcionarios en nombre del gobierno. Los contratos de construcción de carreteras suelen adjudicarse a los contratistas sobre la base de que un contratista se responsabilice de un tramo de varios kilómetros de la carretera. Existirá un contratista principal para cada tramo, pero la construcción de carreteras involucra una variedad de técnicas, y ciertos aspectos del trabajo tales como los trabajos de ferralla, hormigón, encofrados y pavimentación serán subcontratados por el contratista principal a firmas especializadas. Algunas veces, la construcción de carreteras se ejecuta en la modalidad de contratos de dirección de obra, en cuyo caso una firma consultora de ingeniería se encargará de la dirección de la obra y todos los trabajos serán ejecutados por subcontratistas. Un contratista de dirección de este tipo puede también haber participado en la elaboración proyecto de carretera.
La construcción de carreteras requiere la creación de una superficie cuyas pendientes sean adecuadas para la clase de tráfico que pasará por ella. En un terreno generalmente llano, la formación de la plataforma de la carretera puede incluir el movimiento de tierras: esto es, excavar desmontes y usar los productos de la excavación para hacer terraplenes, construir puentes para cruzar los ríos y perforar túneles en las laderas de las montañas cuando no es posible rodear la obstrucción. En aquellos lugares en que los costes de la mano de obra son más elevados, estos trabajos se realizan empleando maquinaria como excavadoras, traíllas, cargadoras y camiones. Si los costes de mano de obra son bajos, estos trabajos se pueden ejecutar manualmente por gran número de obreros equipados con herramientas de mano. Cualquiera que sea el método adoptado, la construcción de carreteras requiere una minuciosa planificación de los trabajos.

A menudo, el mantenimiento de carreteras requiere la continuidad del servicio mientras se efectúan las reparaciones o mejoras en un sector de la misma. De este modo se origina un cruce peligroso entre el tráfico en movimiento y los trabajos de la construcción que hace aún más importante una buena planificación y organización de la obra. Existen, a menudo, normativas nacionales para la señalización y demarcación con conos de las zonas de trabajo y fijando la distancia de separación que deberá mediar entre construcción y tráfico, lo cual puede ser difícil de conseguir en una zona confinada. El control del tráfico que circula en la proximidad de las carreteras en obras, es habitualmente responsabilidad de la policía local, pero requiere una cuidadosa cooperación entre ésta y los contratistas. La conservación de carreteras origina retenciones de tráfico, y, en consecuencia, los contratistas son presionados para acabar las obras rápidamente; a veces existen premios por adelantar el plazo y penalizaciones por los retrasos. La presión económica no deberá socavar la seguridad de lo que de por sí es un trabajo muy peligroso.

La pavimentación de las carreteras puede implicar el uso de hormigón, piedra u macadam asfáltico. Esto requiere un apoyo logístico importante que garantice que las cantidades necesarias de materiales para la pavimentación lleguen a su destino en condiciones adecuadas para asegurar que la pavimentación proceda sin interrupción. El macadam asfáltico requiere una máquina extendedora especial que mantiene el material en estado plástico durante su extendido. Cuando el trabajo consiste en rehacer una pavimentación, se precisarán equipos adicionales incluyendo picos y martillos rompedores, para demoler y retirar la pavimentación existente. Pesadas apisonadoras se encargan de dar el acabado final al pavimento.

La apertura de túneles y los desmontes pueden requerir el uso de explosivos y, ulteriormente, hay que retirar los escombros producidos por las voladuras. Los costados de los desmontes pueden requerir apuntalamientos permanentes para prevenir los deslizamientos o las caídas de tierras sobre la carretera terminada.

Las carreteras elevadas requieren a menudo estructuras similares a los puentes, especialmente si el tramo elevado cruza una zona urbana en la que el espacio es limitado. Las carreteras elevadas se construyen a menudo con elementos de hormigón armado que puede ser vertido in situ o prefabricados en una fábrica y, a continuación, llevados al lugar de colocación en obra. El trabajo requiere una maquinaria de elevación de gran potencia para izar los elementos prefabricados, los encofrados y las armaduras de hierro.

Es necesario proyectar apoyos provisionales o cimbras para soportar las secciones de las carreteras elevadas o los puentes durante su hormigonado. Estas construcciones provisionales tienen que resistir las cargas producidas por el hormigón 
durante su vertido. El proyecto de estas cimbras es tan importante como el de la misma estructura.

\section{Puentes}

En zonas remotas, los puentes pueden ser simples construcciones hechas de madera. Hoy es más corriente que los puentes se construyan de hormigón armado o acero. También pueden estar revestidos de ladrillo o piedra. Si el puente tiene que salvar una depresión considerable, sobre agua o sobre un cauce seco, su proyecto requiere la labor de proyectistas especializados. Con el empleo de los materiales actuales, la resistencia de un arco o vano de puente no se consigue con una gran masa, que simplemente lo haría demasiado pesado, sino por medio de un proyecto experto. El contratista principal para la construcción de un puente es generalmente un contratista importante de ingeniería civil con una maquinaria adecuada y una dirección capacitada. Sin embargo, subcontratistas especializados pueden encargarse de aspectos importantes del trabajo, como el montaje de la estructura metálica para formar el vano o la prefabricación o colocación de las secciones prefabricadas del vano en su ubicación definitiva. Si el puente cruza sobre el agua, es posible que uno o varios de los estribos que soportan sus extremos tengan que ser construidos dentro del agua, lo que implica pilotajes, ataguías, hormigón en masa o mampostería. Un puente nuevo puede formar parte de un nuevo sistema de carreteras, en cuyo caso es posible que haya que construir carreteras de acceso, posiblemente también elevadas. Un buen proyecto es particularmente importante en la construcción de puentes, de modo que la estructura sea lo bastante resistente para soportar las cargas que circularán por él y para asegurar que no requerirá una conservación o reparación demasiado frecuentes. $\mathrm{El}$ aspecto de un puente es a menudo un factor muy importante, y aquí nuevamente, un buen proyecto puede establecer un equilibrio en el conflicto entre las demandas de la estética y de la buena ingeniería. Es necesario durante la fase de proyecto prever medios de acceso seguros para el mantenimiento de los puentes.

\section{Túneles}

Los túneles son obras civiles de carácter muy especializado. Varían en dimensiones desde el túnel del Canal de la Mancha, con más de $100 \mathrm{~km}$ de galerías por 6 a $8 \mathrm{~m}$ de diámetro, a minitúneles cuya perforación es de dimensiones demasiado reducidas para que puedan entrar los obreros a trabajar y que se abren con máquinas lanzadas desde pozos de acceso y controladas desde la superficie. En zonas urbanas, los túneles pueden constituir la única manera de trazar o mejorar vías de transporte o para dar paso a servicios de agua y alcantarillado. El trazado previsto de un túnel requiere una prospección detallada para confirmar la clase de terreno en el que han de desarrollarse los trabajos y la posible aparición de aguas freáticas. La naturaleza del terreno, la presencia de agua subterránea y el uso final del túnel condicionan la elección del método de construcción del mismo.

Si el terreno es consistente, como la arcilla margosa bajo el Canal de la Mancha, es posible realizar la excavación mecánicamente. Si no se encuentran altas presiones de agua freática durante el reconocimiento preliminar a la construcción, normalmente no es necesario presurizar las zonas de trabajo para mantenerlas libres de agua. Si es obligado trabajar con aire comprimido, ello incrementará los costes notablemente, pues se han de establecer esclusas de aire, los trabajadores necesitarán tiempos de parada para la descompresión, y el acceso a las zonas de trabajo de la maquinaria y los materiales puede ser más dificultoso. Un túnel de grandes dimensiones, para una carretera o ferrocarril, en terreno de roca no dura pero consistente, puede ser excavado empleando un escudo (TBM), máquina que perfora la totalidad del frente. Se trata, en realidad, de un tren de diferentes máquinas unidas que avanzan sobre carriles movidas por sus propios motores. En el extremo frontal lleva una cabeza circular cortante que gira y lanza los productos de la excavación hacia atrás a través del escudo. Detrás de la cabeza cortante van varias secciones del escudo que colocan las dovelas de los anillos de revestimiento del túnel en posición en toda la superficie del mismo, rellenan la lechada entre los anillos y, en un espacio muy reducido, aportan toda la maquinaria para la manipulación y colocación de las dovelas (cada una pesa varias toneladas), retiran los productos excavados, transportan hacia delante la lechada y las dovelas adicionales necesarias y alojan los motores eléctricos y las bombas hidráulicas que accionan la cabeza cortante y los mecanismos de colocación de dovelas.

Un túnel en terreno de roca no dura pero sin la suficiente consistencia para emplear un escudo, puede excavarse usando máquinas como las rozadoras que ejecutan cortes en el frente. Los escombros que produce la rozadora y que caen al suelo del túnel son recogidos por excavadoras y retirados en camión. Esta técnica permite la excavación de túneles que no son de sección circular. El terreno a través del cual se perfora un túnel, en estos casos, no suele ofrecer la suficiente resistencia para mantenerse sin revestir; sin alguna clase de revestimiento pueden producirse desprendimientos de techo y paredes. El túnel puede ser revestido por medio de hormigón de consistencia líquida lanzado sobre un mallazo metálico sujetado en posición mediante pernos de anclaje (el nuevo método "austríaco") o con elementos prefabricados de hormigón.

Si el túnel se practica en roca dura, el frente tendrá que abrirse por medio de voladuras, usando explosivos alojados en barrenos taladrados en el frente rocoso. La habilidad, en este caso, consiste en emplear el mínimo de voladuras para lograr que la roca caiga en el lugar y con el tamaño requeridos, para de este modo facilitar la retirada de escombros. En trabajos de más envergadura se emplearán perforadoras múltiples montadas sobre carriles junto con excavadoras y cargadoras para el desescombro. Los túneles en roca dura no se revisten, simplemente se recortan para que ofrezcan una superficie regular. Si la superficie de la roca se desmenuza con facilidad, con peligro de caída de fragmentos, deberá aplicarse un revestimiento, usualmente algún tipo de hormigón proyectado o prefabricado.

Cualquiera que sea el método de construcción adoptado para el túnel, la eficacia en el suministro de los materiales del túnel y en la retirada del escombro son vitales para el avance del trabajo con éxito. Los trabajos en túneles de gran envergadura pueden requerir la instalación de extensos sistemas de carriles de vía estrecha para prestar apoyo logístico.

\section{Presas}

Las presas pueden estar formadas por ingentes volúmenes de tierra o de roca para crear una masa que resista la presión del agua contenida por ellas; algunas presas están también revestidas de piedra y otras de hormigón armado. En función de la longitud de la presa, su construcción suele requerir un movimiento de tierras de grandes proporciones. Las presas acostumbran a construirse en emplazamientos remotos impuestos por la necesidad de asegurar que el agua afluirá a un lugar en el que sea técnicamente posible restringir el caudal del río. Por ello, antes de comenzar la construcción de la presa habrá que abrir caminos provisionales para llevar la maquinaria, los materiales y el personal al emplazamiento. Los trabajadores en los proyectos de presas pueden hallarse tan lejos de sus hogares que es necesario facilitarles alojamiento a gran escala junto a las instalaciones de construcción usuales. Es necesario desviar el río del emplazamiento de los trabajos, para lo cual se tiene que construir una ataguía y un cauce provisional. 
Una presa construida simplemente de tierra o roca desplazadas requiere una maquinaria importante de excavación, perforación y escariado, además de camiones. Si el muro de la presa se recubre de mampostería o de hormigón, será necesario emplear grúas elevadas y de largo alcance capaces de colocar los mampuestos, los encofrados y el hormigón en el sitio requerido. Será necesario un suministro continuo de hormigón de buena calidad, lo cual exigirá instalar una planta de fabricación de hormigón junto al lugar de los trabajos, cuyo hormigón se colocará por medio de una grúa o se bombeará hasta el lugar de colocación.

\section{Canales y dársenas}

La construcción y reparación de canales y muelles incluye algunos aspectos de otros tipos de trabajos que ya se han descrito, como carreteras, túneles y puentes. Es particularmente importante en la construcción de canales que el reconocimiento del terreno sea muy minucioso antes del comienzo de la obra, en especial en relación con los niveles y para cerciorarse de que el material de la excavación puede usarse en otras partes de la obra. Es grande la deuda de los primeros ingenieros de ferrocarriles con la experiencia de los constructores de canales de un siglo antes. El canal requiere una alimentación de agua que ha de recoger de una fuente natural, como un río o un lago, o se ha de crear una artificial en forma de embalse. La excavación de canales comienza en terreno seco, pero antes o después ha de conectar con un río, un canal, el mar u otra dársena.

La construcción de canales y dársenas requiere el uso de excavadoras y cargadoras que abran el terreno. Los productos de la excavación pueden ser retirados en camiones, o bien se puede transportar por vía acuática. Las dársenas, a veces, se desarrollan en terrenos con un largo historial de uso industrial. Desechos industriales se pueden haber introducido en el terreno a lo largo de muchos años, y los productos retirados durante la excavación o ampliación de las dársenas pueden estar altamente contaminados. El trabajo de reparación de un canal o una dársena es probable que se haya de ejecutar mientras que zonas adyacentes al mismo permanezcan en servicio. Los trabajos pueden tener que necesitar ataguías de protección. El fallo de una ataguía durante la ampliación de los Newport Docks en Gales en los primeros años de este siglo produjo cerca de cien víctimas mortales.

Los clientes en el caso de canales y dársenas suelen ser las autoridades públicas. Sin embargo, a veces se construyen muelles para empresas junto a sus plantas de producción importantes o para clientes que mueven un tipo de mercancías particular (p. ej., automóviles). La reparación y renovación de canales se hace hoy en día frecuentemente para la industria del ocio. $\mathrm{Al}$ igual que las presas, también la construcción de canales y muelles puede tener que ejecutarse en lugares muy remotos, habiendo necesidad de proveer unas instalaciones para los obreros más alejadas que las de una obra normal.

\section{Obras ferroviarias}

La construcción de ferrocarriles sucedió históricamente a los canales y precedió a las carreteras importantes. Los clientes de los contratos de construcción ferroviaria pueden ser compañías ferroviarias u organismos públicos, si los ferrocarriles son financiados por el gobierno. Como en el caso de las carreteras, el proyecto de un ferrocarril que resulte económico y seguro de construir y operar depende de un buen reconocimiento previo del terreno. En general, las locomotoras no funcionan bien en pendientes escarpadas, y, por tanto, los proyectistas del trazado de las vías han de evitar los cambios de nivel, rodeando o atravesando los obstáculos mejor que pasando por encima de los mismos. Los proyectistas de ferrocarriles están sujetos a dos limitaciones particulares en primer lugar, las curvas del trazado de la vía deben tener un radio muy largo (de otro modo los trenes no pueden tomarlas); en segundo lugar, todas las estructuras relacionadas con el ferrocarril - sus puentes, túneles y estacionesdeben estar capacitados para acomodar el gálibo de las mayores locomotoras y material ferroviario que utilice la vía. El gálibo es la silueta del material ferroviario más una separación para facilitar el paso seguro a través de puentes, túneles, etc.

Los contratistas que realizan trabajos de construcción y reparación de ferrocarriles requieren la maquinaria de construcción habitual y un apoyo logístico eficaz para asegurar que las vías, el balasto y el resto de los materiales siempre estén disponibles, incluso en los sitios alejados. Los contratistas pueden usar la vía que acaban de tender para los trenes de suministro de sus obras. Los contratistas que efectúan el mantenimiento de ferrocarriles en funcionamiento tienen que adoptar precauciones para que sus trabajos no interfieran con los movimientos de trenes y para no poner en peligro a los obreros o al público.

\section{Aeropuertos}

La rápida expansión del transporte aéreo desde mediados del siglo XX ha desembocado en una de las formas de construcción más complejas y de mayor importancia: la construcción y ampliación de aeropuertos.

Los clientes de la construcción de aeropuertos suelen ser los gobiernos nacionales o locales u organismos públicos. Algunos aeropuertos se construyen para ciudades importantes. Los aeropuertos raramente se destinan a clientes privados tales como empresas de negocios.

La planificación de la obra a veces se ve dificultada por las limitaciones medioambientales relativas a ruidos y contaminación que se imponen al proyecto. Los aeropuertos requieren un espacio considerable, y si se hallan situados en zonas densamente pobladas, la creación de las pistas y el espacio necesario para los edificios terminales y para los aparcamientos de vehículos pueden requerir la rehabilitación de terrenos abandonados o difíciles por otros motivos. La construcción de un aeropuerto presupone la nivelación de una extensa superficie, lo cual puede requerir el movimiento de tierras e incluso ganar terrenos al mar, y, a continuación, la construcción de numerosos edificios de grandes dimensiones, incluyendo hangares, talleres de mantenimiento, torres de control e instalaciones de abastecimiento de combustibles, además de los edificios terminales y el aparcamiento.

Si el aeropuerto se construye en un terreno poco resistente, los edificios necesitarán cimentarse sobre pilotes. Las pistas requieren buenos cimientos; las capas de grava que apoyan a los pavimentos de hormigón u macadam asfáltico deben ser fuertemente compactadas. La maquinaria que se utiliza para la construcción de aeropuertos es similar en tamaño y tipo a la utilizada en los proyectos importantes de autovías, con la salvedad de que se encuentra concentrada en una zona limitada en vez de extenderse a lo largo de muchos kilómetros en una carretera.

El mantenimiento de aeropuertos es un trabajo singularmente difícil si la renovación del pavimento de las pistas de vuelo ha de efectuarse sin interrumpir las operaciones del aeropuerto. Generalmente al contratista se le asignan un número de horas nocturnas convenido de modo que pueda trabajar en una pista que esté temporalmente sin utilizar. Toda la planta, materiales y trabajadores del contratista han de ser escoltados fuera de las pistas, y estar preparados para regresar al punto de trabajo inmediatamente a la hora de comienzo acordada. El contratista debe acabar su trabajo y abandonar las pistas de nuevo a la hora convenida, en que se reanudan los vuelos. Mientras realiza su trabajo en la pista, el contratista no deberá impedir o poner en peligro el movimiento de aviones en otras pistas adyacentes. 


\section{- TIPOS DE PROYECTOS Y SUS RIESGOS ASOCIADOS}

\section{Jeffrey Hinksman}

Todas las estructuras de edificios y de obras civiles recorren el mismo ciclo de concepción o diseño, trabajos preliminares, edificación (incluyendo la cubierta de un edificio), acabados y prestación de servicios y puesta en marcha final antes de su entrada en servicio. A lo largo de los años, los edificios y estructuras que un día fueron nuevos necesitan mantenimiento, inclusive nueva pintura y limpieza; es probable que sean rehabilitados, reformados o reparados para corregir los daños ocasionados por el tiempo o por un accidente; y, finalmente, tendrán que ser demolidos para dar lugar a una instalación más moderna o porque su uso se ha hecho ya innecesario. Esto sucede con las casas; sucede igualmente con estructuras grandes y complejas como centrales eléctricas y puentes. Cada fase en la vida de la estructura de un edificio o una obra civil presenta riesgos generales (como el riesgo de caídas) o peculiares de ese tipo de proyectos (como el riesgo de derrumbamiento de las excavaciones durante la preparación de los cimientos en un edificio o en una obra civil).

Para cada tipo de proyecto (y, desde luego; para cada fase del proyecto) es posible predecir cuáles van a ser los principales riesgos para la seguridad de los operarios de la construcción. El riesgo de caídas es común a todos los proyectos de construcción, incluso los que se realizan a nivel del terreno. Esto viene avalado por la estadística de accidentes que muestra que la mitad de los accidentes mortales entre los operarios de la construcción implican caídas.

\section{Nuevos locales}

\section{Concepción (proyecto)}

Los riesgos físicos para las personas involucradas en el diseño de nuevos locales surgen normalmente en las visitas del personal profesional para realizar los reconocimientos previos. Las visitas de personal sin compañía alguna a emplazamientos desconocidos o abandonados pueden exponerle a riesgos a causa de accesos peligrosos, huecos sin protección y excavaciones y, en un edificio, a causa de cables eléctricos o maquinaria en estado peligroso. $\mathrm{Si}$ la inspección requiere la entrada en habitaciones o excavaciones que han permanecido cerradas durante cierto tiempo, existe el riesgo de encontrarse con dióxido de carbono o con niveles escasos de oxígeno. Todos los riesgos se ven incrementados si se efectúan las visitas a un sitio sin iluminación después de oscurecer o si el visitante solitario no tiene medios de comunicarse con otras personas para reclamar ayuda. Por regla general, el personal profesional no debería ser requerido a visitar emplazamientos si tiene que hacerlo solo. No deberá hacer visitas después del ocaso a menos que el sitio esté bien iluminado. No deberá entrar en lugares cerrados a menos que antes se haya comprobado fehacientemente que el sitio es seguro. Por último, deberá permanecer en comunicación con su base o tener un medio efectivo de conseguir ayuda.

La concepción o el proyecto propiamente dicho deberán influir de modo importante en la seguridad de los contratistas cuando éstos realicen los trabajos en la obra. De los proyectistas, bien sean arquitectos o ingenieros civiles, cabe esperar más que la simple confección de planos. Al crear su proyecto, deberán, en virtud de su preparación y experiencia, tener una cierta idea del modo en que será probable que se desarrolle el trabajo de los contratistas para hacerlo realidad. Su competencia deberá ser tal que sean capaces de indicar a los contratistas los riesgos que se derivarán de sus métodos de trabajo. Los proyectistas deberán eliminar en su diseño los riesgos que pueden surgir del mismo, haciendo la estructura más "edificable" en lo tocante a salud y seguridad y, siempre que ello sea posible, cambiando los materiales por otros más seguros en sus especificaciones. Deberán mejorar los accesos para el mantenimiento en la fase de proyecto, y reducir la necesidad de que los operarios de mantenimiento corran peligro, incorporando aspectos o materiales que requieran una atención menos frecuente durante la vida del edificio.

En general, los proyectistas sólo pueden eliminar los riesgos en el proyecto hasta cierto punto; normalmente habrá riesgos residuales significativos que los contratistas habrán de tener en cuenta cuando conciban sus propios sistemas de trabajo seguros. Los proyectistas deberán suministrar a los contratistas la información sobre esos riesgos de modo que éstos puedan considerar tanto los riesgos como las medidas de seguridad necesarias, primero cuando oferten la obra y, después, cuando desarrollen sus sistemas para hacer el trabajo con seguridad.

La importancia de incluir en las especificaciones materiales con mejores propiedades para la salud y la seguridad suele ser menospreciada cuando se aborda la seguridad desde el proyecto. Los proyectistas y los redactores de especificaciones deben considerar si se pueden obtener materiales con mejores propiedades tóxicas o estructurales o que se puedan utilizar y mantener con más seguridad. Esto requiere que los proyectistas mediten sobre los materiales que se van a usar y decidan si, de acuerdo con la práctica anterior, protegerán adecuadamente a los obreros de la construcción. A menudo, el factor decisivo en la elección de los materiales es el coste. Sin embargo, los clientes y los proyectistas deberían darse cuenta de que, mientras materiales con mejores propiedades tóxicas o estructurales pueden tener un coste inicial superior, a menudo resultan más rentables durante la vida del edificio, porque los operarios de la construcción y de mantenimiento requieren unos accesos o un equipo de protección menos costosos.

\section{Excavación}

Normalmente, el primer trabajo que se realiza en la obra después del reconocimiento del terreno y del replanteo, una vez que se ha adjudicado el contrato, (suponiendo que no haya necesidad de demoliciones o de despeje del emplazamiento), son los trabajos preliminares para la cimentación. En el caso de pequeñas casas de uso residencial, los cimientos probablemente no necesitarán excavaciones más profundas de medio metro y se excavarán a mano. Para bloques de apartamentos, edificios comerciales e industriales y algunas estructuras de ingeniería civil, los cimientos pueden necesitar bajar varios metros por debajo del nivel del terreno. Esto requerirá la excavación de zanjas en las que se tendrá que trabajar para rellenar los cimientos. Las zanjas de una profundidad superior a 1 metro probablemente se excavarán por medio de máquinas tales como las excavadoras. También se efectúan excavaciones para permitir el tendido de cables y tuberías. Los contratistas utilizan a menudo excavadoras especiales capaces de practicar excavaciones profundas y estrechas. Si los trabajadores tienen que penetrar en estos recintos excavados, los riesgos son esencialmente los mismos que se encuentran en las zanjas de cimentación. Sin embargo, en excavaciones o zanjas para cables y tuberías suele haber mayores posibilidades de adoptar métodos de trabajo que no fuercen a los operarios a introducirse en la excavación.

El trabajo en excavaciones de profundidad superior a $1 \mathrm{~m}$ requiere una cuidadosa planificación y supervisión. El terreno es altamente impredecible; la lluvia, las heladas o la vibración producida por otras actividades constructivas en su proximidad pueden causar el deslizamiento de un terreno aparentemente firme. Lo que parece una arcilla firme y rígida, cuando está 
expuesta al aire se seca y se agrieta; con la lluvia, se ablanda y se desliza. Un metro cúbico de tierra pesa más de 1 tonelada; un trabajador que se vea alcanzado tan sólo por un pequeño desprendimiento de tierras corre el riesgo de resultar con roturas en las extremidades, sufrir aplastamiento de órganos y sofocación. A causa de la importancia vital para la seguridad de elegir un método adecuado de sostenimiento de los costeros de la excavación, antes del comienzo de los trabajos deberá hacerse un reconocimiento del terreno por personal con experiencia en excavaciones seguras, para determinar el tipo y las condiciones del terreno, en particular la presencia de agua.

\section{Apuntalamiento de los costados de la trinchera}

Apuntalamiento de ambos lados. No resulta seguro confiar en el desmonte o "achaflanado" de los lados de la excavación hasta un ángulo seguro. Si se trata de un terreno formado por arena $\mathrm{o}$ limos, el ángulo que ofrece seguridad puede llegar a ser de 5 a $10^{\circ}$ sobre la horizontal, y, generalmente, no hay tanto espacio en la obra para una excavación tan ancha. El método más común de dotar de seguridad al trabajo de excavaciones es sostener ambos lados de la zanja mediante una entibación. Con el sostenimiento de ambos lados, las cargas que transmite el terreno por un lado son contrarrestadas por cargas similares que actúan a través de codales contra los costados opuestos. Es preciso usar madera de buena calidad para fabricar elementos verticales para el sistema de contención, conocidas como tableros de avance. Los tableros de avance se hincan en el terreno en cuanto empieza la excavación; los tableros se colocan borde contra borde, de modo que constituyen una pared de madera. La misma operación se efectúa a ambos lados de la excavación. A medida que ésta se hace más profunda, los tableros de avance se siguen hincando en el terreno antes de seguir bajando. Cuando la excavación llega a 1 metro de profundidad, se introduce una fila de elementos horizontales (denominados carreras o largueros) que se colocan contra los tableros de avance y se mantienen en posición por codales de madera o metálicos, acuñados contra los largueros opuestos con un espaciamiento regular. A medida que la excavación continúa, los tableros son hincados más profundamente en el terreno, juntamente con los largueros y codales; si la excavación es más profunda de 1,2 m será necesario crear una nueva fila de largueros y codales. Lógicamente, una excavación de $6 \mathrm{~m}$ de profundidad requerirá cuatro filas de codales.

Los métodos normales de apuntalamiento con madera no se pueden aplicar si la profundidad es superior a $6 \mathrm{~m}$, o si aparece agua en el terreno. En estas situaciones se requieren otros tipos de apuntalamiento de los laterales de las excavaciones, tales como planchas de acero verticales, separadas firmemente por largueros de madera horizontales y codales metálicos ajustables, o bien una protección total con tablestacas de acero. Ambos métodos ofrecen la ventaja de que las planchas de acero o las tablestacas se pueden hincar mecánicamente antes del comienzo de la excavación propiamente dicha. Además, tanto las planchas como las tablestacas pueden ser retiradas al final del trabajo y usadas de nuevo. Los sistemas de apuntalamiento para excavaciones de una profundidad superior a $6 \mathrm{~m}$ o en terrenos con aguas infiltradas deberán ser proyectados ex profeso; en estos casos las soluciones normales no sirven.

Apuntalamiento de un solo costado. Una excavación que tenga forma rectangular y unas dimensiones demasiado grandes para que se puedan aplicar los métodos descritos anteriormente, puede tener uno o más de sus lados sostenidos por una fila de tableros de avance o planchas de acero. Estos, a su vez, son soportados, en primer lugar, por una o más filas de largueros horizontales que luego se mantienen en su sitio por puntales inclinados firmemente anclados o sujetos a puntos de apoyo.
Otros sistemas. Es posible utilizar cajones prefabricados de acero de ancho regulable que se pueden hacer descender dentro de las excavaciones y dentro de los cuales se puede trabajar con seguridad. También es posible el uso de sistemas de marcos patentados, en los que un marco horizontal se hace descender en la excavación entre los tableros de avance o las planchas de acero; el marco se despliega a la fuerza y aplica la presión para mantener los tableros de avance derechos por la acción de gatos hidráulicos, presión que se puede transmitir mediante una bomba manejada desde un sitio seguro fuera de la excavación.

Formación y supervisión. Cualquiera que sea el método de sostenimiento que se adopte, el trabajo deberá ser ejecutado por obreros cualificados bajo la supervisión de una persona con experiencia. La excavación y sus elementos de sustentación deberán inspeccionarse cada día y después de cada ocasión en que hayan sido dañados o desplazados (p. ej., después de una fuerte lluvia). Lo único que cabe presumir respecto a la seguridad y el trabajo en las excavaciones es que todo tipo de terreno es susceptible de fallar y, por tanto, no se deberá ejecutar ningún trabajo con operarios dentro de una excavación de más de $1 \mathrm{~m}$ de profundidad sin apuntalar. Véase también el apartado "Zanjas" en este Capítulo.

\section{Superestructura}

La erección de la parte principal de una estructura de edificación o de ingeniería civil (la superestructura) tiene lugar después de la culminación de los cimientos. Esta parte del proyecto generalmente exige trabajar en altura por encima del terreno. Las caídas de altura o en el mismo nivel constituyen la causa más importante de accidentes mortales o de lesiones importantes.

\section{Trabajos con escaleras}

Incluso si el trabajo consiste simplemente en la construcción de una casa, el número de obreros que intervienen, la cantidad de materiales que se han de manipular y, en las fases finales, las alturas a las que se tiene que realizar el trabajo, hacen que sea necesario el uso de algo más que simples escaleras para acceder con seguridad a los puestos de trabajo.

Existen limitaciones en el tipo de trabajo que se puede realizar con seguridad desde escaleras. El trabajo a una altura superior a $10 \mathrm{~m}$ sobre el terreno generalmente no puede realizarse con seguridad desde una escalera; las escaleras largas son en sí mismas de peligroso manejo. Los obreros subidos en escaleras tienen un alcance limitado y no pueden llevar con seguridad cualquier tipo de equipos y materiales; el esfuerzo físico para permanecer sobre los peldaños de la escalera limita el tiempo que pueden invertir en tales trabajos. Las escaleras son útiles para ejecutar trabajos de corta duración y con pesos ligeros a una distancia segura, como por ejemplo la inspección, reparación y pintura de pequeñas zonas de la fachada del edificio. Las escaleras también sirven para acceder a los andamios, a las excavaciones y a las estructuras a las que no se ha dotado de un acceso más permanente.

Será necesario el uso de plataformas de trabajo provisionales, la más común de las cuales es el andamio. En bloques de apartamentos de varias plantas, edificios de oficinas o la estructura de un puente resulta necesario el empleo de andamios de diversa complejidad, en función de las características del trabajo.

\section{Andamios}

Los andamios consisten en armazones de acero o madera fácilmente ensamblables sobre los cuales se pueden colocar plataformas de trabajo. Los andamios pueden ser fijos o móviles. Los andamios fijos, es decir, los que se levantan a lo largo de un edificio o estructura, pueden ser independientes o de parales. 
El tipo de andamio independiente lleva pies derechos o zancos a lo largo de ambos lados de las plataformas y es capaz de permanecer en posición vertical sin apoyarse en el edificio. El andamio de parales tiene zancos a lo largo del borde exterior de sus plataformas de trabajo, pero el lado interior se apoya en el propio edificio, y una parte del armazón del andamio, los parales o almojayas, tienen extremos aplanados que se colocan entre las hiladas de la fábrica de ladrillo para lograr su apoyo. Incluso el tipo de andamio independiente necesita ser rígidamente arriostrado o asegurado a la estructura en intervalos regulares si existen plataformas de trabajo por encima de $6 \mathrm{~m}$ o si el andamio está provisto de lonas de protección de las inclemencias del tiempo, lo cual incrementa los esfuerzos debidos al viento.

Las plataformas de trabajo sobre andamios consisten en tableros de madera de buena calidad colocados a nivel y con ambos extremos firmemente apoyados; si la madera es propensa a combarse debido a la carga de personal o materiales, será necesario disponer apoyos intermedios. Las plataformas nunca serán de un ancho menor de $600 \mathrm{~mm}$ si se usan para acceder y para trabajar en ellas, o menor de $800 \mathrm{~mm}$ si también se usan para soportar materiales. Si existe riesgo de caídas de más de $2 \mathrm{~m}$ deberá protegerse el borde exterior con una barandilla rígida, sujeta firmemente a los pies derechos, a una altura comprendida entre 0,91 y 1,15 m sobre la plataforma. Para evitar la caída de materiales desde la plataforma se colocará un zócalo de una altura mínima de $150 \mathrm{~mm}$ sobre la plataforma en todo el borde exterior, también sujeto a los pies derechos. Si se tuvieran que quitar las barandillas y los zócalos para permitir el paso de materiales, deberán reemplazarse lo antes posible.

Los zancos de los andamios deberán mantenerse en posición vertical y firmemente apoyados en su base sobre placas, y si es necesario sobre durmientes de madera. El paso, dentro de los andamios fijos, de un nivel de trabajo a otro se hace generalmente a través de escaleras. Estas deberán estar sujetas debidamente por la parte superior e inferior y prolongarse al menos 1,05 m por encima de la plataforma.

Los principales riesgos del empleo de andamios — caídas de personas o materiales - generalmente se producen por deficiencias tanto en el montaje inicial (omisión de la colocación de una barandilla), por un uso indebido (una carga excesiva) o por una adaptación hecha de modo inadecuado en el curso de los trabajos (p. ej., se añaden lonas para la protección atmosférica sin amarrarlas convenientemente al edificio). Otros ejemplos: tableros de madera de las plataformas de los andamios que se desplazan o se rompen; escaleras que no se amarran en su parte superior e inferior. La lista de acciones que pueden fallar si los andamios no se montan por personal experimentado bajo una supervisión adecuada, es casi interminable. Los mismos montadores de los andamios están, particularmente, expuestos al riesgo de caídas durante el montaje y desmontaje de los mismos, porque a menudo se ven obligados a trabajar en altura, en lugares expuestos sin plataformas de trabajo adecuadas (véase la Figura 93.4).

Andamios torre. Los andamios torre pueden ser fijos o móviles, con una plataforma de trabajo en la parte superior y una escalera de acceso dentro del armazón de la torre. El andamio torre móvil se desplaza sobre ruedas. Tales torres pierden su estabilidad fácilmente y su altura deberá ser limitada; para un andamio torre fijo, la altura no superará más de 3,5 veces la dimensión más corta de la base; para los móviles, la proporción se reduce a 3 veces. La estabilidad de los andamios torre deberá incrementarse mediante el uso de contravientos. No se permitirá que los operarios permanezcan en lo alto de los andamios torre móviles mientras éstos se desplazan o si las ruedas no están bloqueadas.

\section{Figura 93.4 - Montaje de andamios en una obra en Ginebra, Suiza, sin las protecciones adecuadas.}

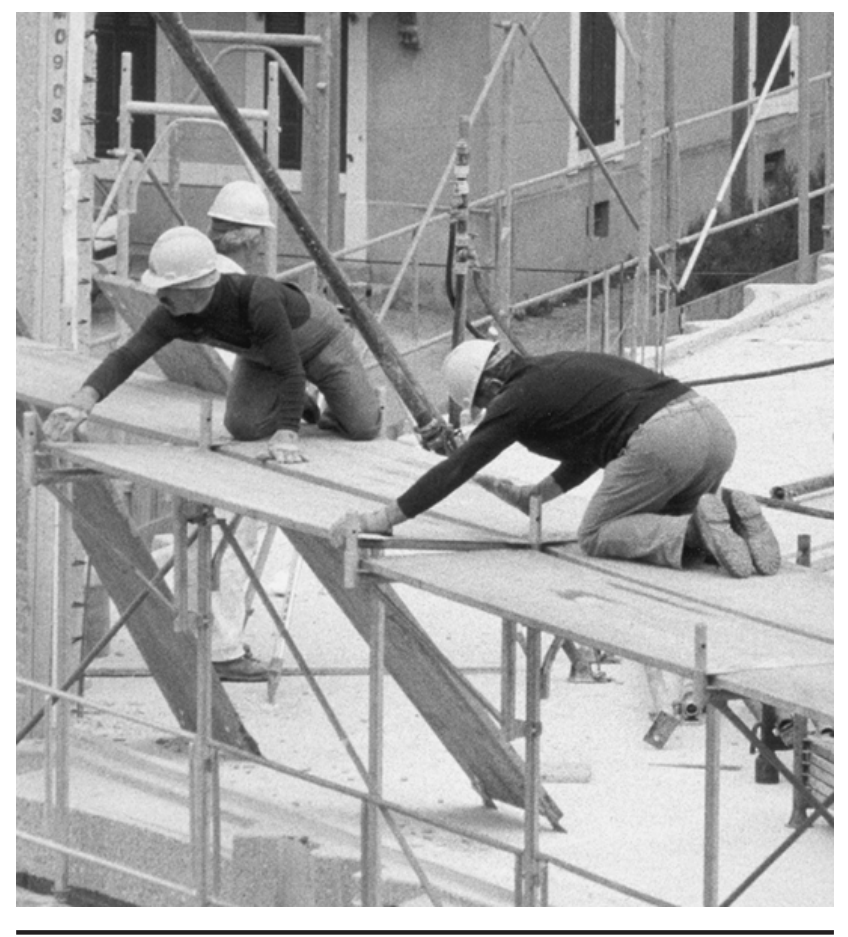

El riesgo principal de estos andamios es el de vuelco, lanzando al personal fuera de su plataforma; ello puede deberse a que la torre es demasiado alta con relación a la base, a la ausencia contravientos o ruedas de bloqueo, o a un uso indebido del andamio, tal vez sobrecargándolo.

Andamios colgantes. La otra categoría principal de andamios está formada por los que andamios colgantes. El andamio colgante es, en esencia, una plataforma de trabajo colgada por medio de cables o tubos de una estructura superior como un puente. El andamio suspendido es también una plataforma o una cesta suspendida por cables, pero en este caso se puede subir y bajar. A menudo se coloca para los trabajos de mantenimiento y pintura, a veces como parte del edificio terminado. En ambos casos, el edificio o la estructura deberá ser capaz de soportar la plataforma suspendida, y los dispositivos de suspensión deben ser lo suficientemente robustos para soportar la carga prevista de personal y materiales, incluyendo las barandillas para evitar caídas. En el caso de plataformas colgantes, al menos, deberá haber tres espiras de cuerda en el tambor del cabrestante cuando la plataforma se halle en su posición más baja. Si no hay dispositivos para evitar la caída de la plataforma suspendida en caso de fallo de un cable, los operarios que están en la plataforma deberán usar un cinturón de seguridad y una cuerda amarrada a un punto de anclaje seguro en el edificio. El personal que utilice estas plataformas deberá ser instruido y tener experiencia en su uso.

El principal riesgo que concierne a los andamios colgantes es el fallo de los dispositivos de soporte, bien de la estructura en sí misma, bien de los cables o tubos de los que cuelga la plataforma. Esto puede deberse a un montaje o instalación incorrecta del andamio colgante o suspendido, a una sobrecarga o a cualquier otro tipo de uso indebido. El fallo de los andamios colgantes ha causado múltiples accidentes mortales y puede poner en peligro a los viandantes. 
Todos los andamios y las escaleras deberán ser inspeccionados por una persona competente, al menos semanalmente, y antes de volver a usarlos después de haber estado expuestos a condiciones meteorológicas que los puedan haber dañado. No deberán emplearse escaleras con largueros agrietados ni peldaños rotos. Los operarios que monten y desmonten los andamios deberán recibir una formación específica y deberán tener experiencia para asegurar su propia seguridad y la de otros que puedan usar los andamios. A menudo los andamios son suministrados por un contratista, quizás el principal, para uso por el resto de contratistas. En este caso, los operarios de algún oficio pueden modificar o desplazar partes de los andamios para facilitar su trabajo, sin restaurar el andamio a continuación, o sin percatarse del riesgo que han creado. Es importante que las disposiciones en materia de coordinación de salud y seguridad en el ámbito de la obra traten eficazmente del efecto de la acción de un oficio en la seguridad de los demás.

\section{Equipo de acceso motorizado}

En algunos trabajos, tanto de construcción como de mantenimiento, puede resultar más práctico utilizar equipos de acceso motorizados que andamios de cualquier tipo. El poder acceder a la parte inferior del tejado de una fábrica en la que se efectúa una renovación del revestimiento o a unas pocas ventanas de un edificio puede ser más barato y seguro que envolver toda la estructura con un andamio. El equipo de acceso motorizado es ofrecido por los fabricantes en diversas formas; por ejemplo: plataformas que se pueden elevar y bajar verticalmente por acción hidráulica o abriendo y cerrando unos gatos de tijera y brazos articulados accionados hidráulicamente, con una plataforma de trabajo o una cesta al final del brazo, denominados comúnmente recogecerezas. Tal equipo suele ser móvil y se puede desplazar al lugar requerido y entrar en servicio en pocos momentos. La utilización segura de este equipo requiere que el trabajo sea compatible con las especificaciones de la máquina descritas por su fabricante (p. ej., el equipo no debe ser sobrecargado ni trabajar a distancias mayores de las señaladas).

El equipo de acceso motorizado precisa un suelo firme y horizontal sobre el cual trabajar; puede ser necesario instalar contravientos para asegurarse de que la máquina no vuelque. Los operarios deben tener acceso a los mandos desde la plataforma de trabajo. También deben estar entrenados en el uso del equipo. Adecuadamente mantenido y manejado, este tipo de equipo puede facilitar un acceso seguro cuando sea prácticamente imposible instalar un andamio; por ejemplo, durante las fases iniciales de montaje de una estructura metálica o para facilitar el acercamiento de los montadores a los puntos de conexión de vigas y pilares.

\section{Montaje de estructuras metálicas}

La superestructura, tanto de edificios como de obras civiles, a menudo implica la erección de importantes estructuras metálicas, a veces de gran altura. Si bien la responsabilidad de garantizar un acceso seguro a los montadores que ensamblan estas estructuras compete principalmente a la dirección de los contratistas de estos montajes, su trabajo puede verse simplificado por los proyectistas de la estructura metálica. Los proyectistas deben asegurarse de que el diseño y la disposición de los taladros para los pernos sean sencillos y de que facilitan una sencilla introducción de los pernos; la disposición de juntas y taladros para pernos debe ser lo más uniforme posible en toda la estructura; conviene prever silletas en los pilares en las conexiones con las vigas, de modo que estas se puedan apoyar mientras los montadores proceden a la inserción de los pernos. En la medida de lo posible, el proyecto debe garantizar que las escaleras formen parte de la estructura inicial para que los montadores tengan que depender menos de las vigas y escaleras para su acceso. Del mismo modo, el diseño debe prever que los taladros se tengan que efectuar en lugares adecuados de los pilares durante la fabricación y antes de la entrega de la estructura en obra, lo que permitirá el amarre de cables tensos a los que los montadores provistos de cinturones de seguridad puedan asegurar maromas corredizas. Se intentará colocar las placas de forjados lo antes posible en estas estructuras, para reducir el tiempo que los montadores han de confiar en los cinturones y maromas de seguridad o en las escaleras. Si la estructura metálica debe permanecer abierta y sin forjados mientras que prosigue el montaje, deberán tenderse redes de seguridad debajo de los niveles de trabajo. En la medida de lo posible, el proyecto de la estructura metálica y las prácticas de trabajo de los montadores de la misma deberán minimizar el ámbito en que los montadores tengan que caminar por la estructura.

\section{Trabajos en cubiertas}

Si la elevación de los muros es una tarea ardua e importante de la construcción de un edificio, la ejecución de la cubierta es igualmente importante y presenta riesgos singulares. Las cubiertas pueden ser planas o inclinadas. En las cubiertas planas el riesgo principal lo constituye la caída de personas y materiales, bien por el borde, bien por aberturas practicadas en la cubierta. Las cubiertas planas suelen construirse de madera, hormigón in situ o losas. Las cubiertas planas deben ser impermeabilizadas para impedir el paso del agua, para lo cual se usan diversos materiales, entre los que se incluyen betunes y fieltros. Todos los materiales precisos para la cubierta han de ser izados hasta el nivel requerido, lo cual puede hacer necesaria la utilización de montacargas o grúas si el edificio es elevado o las cantidades de material de cubrición y de impermeabilizantes son importantes. Puede ser necesario calentar el betún para facilitar su extendido y sellado, lo cual puede implicar la necesidad de subir a la cubierta botellas de gas y recipientes para fundirlo. Los operarios de la cubierta y las personas que se encuentren debajo pueden sufrir quemaduras por el betún caliente y se pueden originar incendios que afecten a la estructura del edificio.

El riesgo proveniente de caídas desde las cubiertas planas se puede evitar rodeando su perímetro con una protección provisional en forma de barandilla de dimensiones análogas a las que se instalan en los andamios. Si el edificio se encuentra aún rodeado por el andamio exterior, éste se puede prolongar hasta el nivel de la cubierta, para ofrecer una protección perimetral a los que trabajan en ella. Las caídas por agujeros en las cubiertas planas se pueden evitar mediante su cubrición o, si han de permanecer abiertos, colocando barandillas en su perímetro.

Los tejados inclinados se encuentran más comúnmente en casas unifamiliares y en edificios de menor volumen. La inclinación del tejado se consigue construyendo un armazón de madera al que se adosará el recubrimiento exterior del mismo, generalmente formado por tejas de hormigón o cerámica. La inclinación del tejado puede ser superior a $45^{\circ}$ sobre la horizontal, pero incluso una pendiente menos pronunciada ofrece riesgos cuando está mojada. Para evitar la caída de los operarios durante la fijación de barrotes, fieltro y tejas, deberán utilizarse escaleras apropiadas. Si estas escaleras no se pueden asegurar o apoyar firmemente por su extremo inferior, deberán llevar un enganche de acero diseñado especialmente para anclarlo sobre las tejas del caballete. Si no existe certeza acerca de la resistencia de estas tejas, la escalera deberá amarrarse firmemente con una cuerda de su peldaño superior, pasándola por encima de las tejas del caballete y llevándola hasta un sólido punto de anclaje.

Tanto en los tejados inclinados como en los curvos o abovedados se usan materiales de cubrición frágiles. Algunas claraboyas se construyen también con materiales frágiles. Los materiales típicos incluyen planchas de fibrocemento, plástico, 
tableros aglomerados tratados y lana de madera. Como los operarios de cubiertas frecuentemente pasan por encima de las planchas que acaban de colocar, se precisa un acceso seguro al lugar de colocación de las planchas y una posición segura desde la cual realizar su trabajo. Esto se logra habitualmente empleando de una serie de escaleras de tejado. Los materiales de cubrición frágiles representan un mayor riesgo para los obreros de mantenimiento, que pueden desconocer su fragilidad. Los proyectistas y los arquitectos pueden mejorar la seguridad de los operarios de cubiertas, en primer lugar, no especificando materiales frágiles.

La colocación de cubiertas, incluso las que son planas, puede resultar peligrosa en condiciones de fuerte viento o bajo una intensa lluvia. Materiales como las planchas, normalmente seguros de manipular, pueden llegar a ser peligrosos en estas condiciones atmosféricas. Los trabajos inseguros en cubiertas no solo ponen en peligro a los operarios que trabajan en ellas, sino que representan un riesgo para las personas situadas debajo. La construcción de cubiertas nuevas es un trabajo peligroso, pero el mantenimiento de las mismas es aún más peligroso, si cabe.

\section{Renovación}

La renovación incluye el mantenimiento de la estructura y los cambios que en ella se realizan a lo largo de su período de vida. El mantenimiento (incluida la limpieza y la reparación del maderamen u otras superficies exteriores, rejuntado del cemento y reparaciones en paredes y cubierta) presenta riesgos de caídas análogos a los de la erección de la estructura, a causa de la necesidad de tener que acceder a partes elevadas de aquella. De hecho, los riesgos pueden ser mayores, ya que durante los trabajos de mantenimiento de menor importancia y de corta duración existe la tentación de ahorrar en la aportación de equipos de acceso seguros: por ejemplo, pretender hacer desde una escalera el trabajo que sólo se puede hacer con seguridad desde un andamio. Esto es particularmente cierto en los trabajos en cubierta, en los que la sustitución de una teja puede llevar unos minutos, pero existe la posibilidad de caída de un trabajador con resultados mortales.

\section{Mantenimiento y limpieza}

Los proyectistas, y de modo especial los arquitectos, pueden mejorar la seguridad de los operarios de mantenimiento y limpieza teniendo en cuenta en sus proyectos y especificaciones la necesidad de un acceso seguro a las cubiertas, a las salas de máquinas, a las ventanas y a otras ubicaciones en el exterior de la estructura. La mejor solución sería evitar completamente el acceso, seguida de la inclusión de un acceso seguro permanente que forme parte de la estructura, quizás una escalera, una pasarela con barandillas o una plataforma de acceso motorizada colgada permanentemente de la cubierta. La solución menos satisfactoria para el personal de mantenimiento es aquella en que el único acceso posible pasa por un andamio similar al usado para la construcción del edificio. Este problema es menos probable que surja en los trabajos de restauración importantes, de mayor duración, pero en las obras de plazo corto, el coste de un andamio total es tal, que existe una mayor tentación de hacer recortes y utilizar equipos de acceso móviles motorizados o andamios torre en trabajos para los que no son propios ni adecuados.

Si la renovación incluye un cambio sustancial del revestimiento del edificio o una limpieza total con chorros de agua a presión o sustancias químicas, la única respuesta que no sólo ofrecerá protección a los obreros sino que también permitirá la colocación de lonas para proteger a los viandantes puede ser el andamiaje de toda la fachada. Las protecciones de los operarios de limpieza con chorro de agua a presión incluyen ropa impermeable, botas y guantes, y una mascarilla facial o gafas para la protección ocular. La limpieza con sustancias químicas tales como ácidos requiere una ropa análoga, pero resistente a los ácidos. Si se usan abrasivos para la limpieza de la estructura, es preciso emplear una sustancia libre de sílice. Dado que el empleo de abrasivos origina un polvo que puede ser nocivo, los operarios tendrán que usar un equipo respiratorio homologado. El repintado de ventanas en un edificio de oficinas alto o en un bloque de apartamentos no se puede hacer con seguridad desde escaleras, aunque habitualmente ello es posible en viviendas unifamiliares. En el primer caso se precisará montar un andamio o colgar andamios suspendidos de la cubierta, tales como cestas, asegurándose de que los puntos de suspensión sean adecuados.

El mantenimiento y la limpieza de las estructuras de obras civiles, como puentes, chimeneas altas o mástiles, puede obligar a trabajar a unas alturas o en unas ubicaciones tales (p. ej., sobre el agua) que imposibiliten el montaje de un andamio normal. Siempre que sea posible deberá realizarse el trabajo desde un andamio fijo suspendido de la estructura. En caso contrario, el trabajo deberá ejecutarse desde una cesta firmemente suspendida. Los puentes modernos incorporan sus propias cestas como parte de la estructura permanente; éstas deben comprobarse perfectamente antes de usarlas para un trabajo de mantenimiento. Las estructuras de ingeniería civil se encuentran frecuentemente expuestas a los agentes atmosféricos; no se permitirá el trabajo en ellas en condiciones de fuerte viento o lluvia intensa.

\section{Limpieza de ventanas}

La limpieza de ventanas presenta sus propios riesgos, especialmente si se realiza desde escaleras colocadas sobre el suelo, o con disposiciones improvisadas para acceder a edificios de mayor altura. La limpieza de ventanas no se suele considerar una parte del proceso constructivo y, sin embargo, es una operación muy generalizada que puede poner en peligro a los limpiadores de ventanas y al público. No obstante, la seguridad de la limpieza de ventanas viene influenciada en parte por el proyecto. Si los arquitectos no tienen en cuenta la necesidad de un acceso seguro o, en lugar de ello, no especifican ventanas que se puedan limpiar desde el interior, entonces la labor del contratista de la limpieza de ventanas será mucho más peligrosa. Si en el proyecto inicial se prevé suprimir la limpieza de ventanas desde el exterior o la instalación de un equipo de acceso adecuado a tal fin, ello puede representar un coste inicial superior, pero a lo largo de la vida del edificio representará un ahorro considerable de gastos de mantenimiento y la reducción del riesgo.

\section{Rehabilitación}

La rehabilitación es una vertiente importante y peligrosa de la renovación. Tiene lugar cuando, por ejemplo, se mantiene la estructura esencial del edificio o del puente, pero una parte ha de ser reparada o sustituida. En las viviendas, la rehabilitación suele implicar el arrancado de ventanas, posiblemente de suelos y las escaleras, junto con la instalación eléctrica y de fontanería, y su sustitución por materiales nuevos y generalmente de mejor calidad. En un edificio comercial de oficinas, la rehabilitación afecta a las ventanas y posiblemente a los suelos, pero también es posible que se haya de arrancar y sustituir el revestimiento de un edificio, instalar un nuevo sistema de ventilación y calefacción y ascensores o renovar la instalación eléctrica.

En las estructuras de obra civil tales como puentes, la rehabilitación puede representar dejar desnuda la estructura básica, reforzándola, renovando partes y reemplazando la vía de rodadura y algún revestimiento.

La rehabilitación presenta los riesgos comunes a todos los obreros de la construcción: caídas de personas y materiales. El 
riesgo se acrecienta cuando los locales permanecen ocupados durante la rehabilitación, como sucede a menudo en locales domésticos tales como bloques de apartamentos, cuando no se dispone de alojamientos alternativos para los moradores. En estas situaciones, éstos últimos y en especial los niños corren los mismos riesgos que los operarios de la construcción. Durante la rehabilitación puede haber riesgos ocasionados por los cables eléctricos de las herramientas portátiles que se necesitan, tales como sierras y taladros. Es importante que el trabajo se planifique minuciosamente para eliminar los riesgos tanto de los operarios como de los inquilinos; éstos necesitan ser informados de lo que se está haciendo y el momento en que se hará. Se impedirá el acceso a las habitaciones, escaleras o balcones donde se ejecuten los trabajos. Las entradas a los bloques de apartamentos pueden necesitar una cubierta para proteger a las personas de la caída de materiales. Al terminar la jornada de trabajo, se retirarán las escaleras y andamios o se condenarán de tal manera que los niños no puedan acceder a ellas y correr peligro. Del mismo modo, deberán retirarse y almacenarse en un lugar seguro las pinturas, las botellas de gas y las herramientas eléctricas.

En los edificios comerciales ocupados donde se rehabiliten los servicios, se imposibilitará la apertura de las puertas de los ascensores. Si la rehabilitación interfiere con el equipo contra incendios y de emergencia, habrá que adoptar disposiciones especiales para avisar a los inquilinos y a los obreros en caso de producirse un incendio. La rehabilitación de locales comerciales y domésticos puede requerir la retirada de materiales que contengan amianto. Esto presenta importantes riesgos de salud para los operarios y los ocupantes cuando regresan al edificio. La retirada de amianto sólo debe ser efectuada por contratistas especialmente preparados y equipados. La zona de la que se retira el amianto necesita ser aislada de otras partes del edificio en el transcurso de los trabajos. Antes del regreso de los ocupantes a las zonas de las que se ha arrancado el amianto, deberá controlarse la atmósfera de las habitaciones y evaluarse los resultados para asegurarse de que los niveles de fibras de amianto contenidos en el aire se hallan por debajo de los permisibles.

La manera más segura de ejecutar una rehabilitación consiste en desalojar totalmente a los ocupantes y personas ajenas; sin embargo, esto a veces es simplemente imposible de llevar a cabo.

\section{Suministros}

La instalación de servicios de suministro en los edificios, como electricidad, gas, agua y telecomunicaciones, suele ser ejecutada por subcontratistas especializados. Los principales riesgos son las caídas debidas a un acceso descuidado, el polvo y los humos producidos por los taladros y las cortadoras y la electrocución o incendio producido por el suministro eléctrico y de gas. Los riesgos son análogos en las viviendas unifamiliares, aunque en menor escala. El trabajo de los contratistas resulta más fácil si al proyectar la estructura, el arquitecto prevé espacio suficiente para colocar las acometidas. Se precisa espacio para los conductos y las rozas en paredes y suelos más el espacio adicional para que los instaladores trabajen con eficacia y seguridad. Las mismas consideraciones se aplican al mantenimiento de las instalaciones después de la entrada en servicio del edificio. Una adecuada atención al detalle en relación con los conductos, rozas y aperturas durante el proyecto inicial de la estructura debería dar como resultado que todos fueran construidos o empotrados dentro de la misma. En tal caso necesario no sería que los obreros hicieran rozas para canales o conductos ni que tuvieran que abrir agujeros usando herramientas eléctricas que originan grandes cantidades de polvo. Si se habilita un espacio adecuado para la maquinaria y los conductos de aire acondicionado y de calefacción, el trabajo de los instaladores resulta más fácil y seguro porque es posible trabajar desde sitios seguros en vez de, por ejemplo, trabajar sobre tableros acuñados en el interior de los conductos verticales. Si el alumbrado y el cableado tienen que instalarse por el techo en habitaciones de mucha altura, los contratistas pueden necesitar andamios torre o de otro tipo, además de escaleras.

La instalación de los servicios deberá hacerse de acuerdo con las normas locales en vigor. Estas, por ejemplo, deberán cubrir todos los aspectos de seguridad de las instalaciones de gas y eléctricas, de modo que los contratistas eléctricos no tengan duda alguna acerca de las normas exigidas para la instalación de cables, aislamiento, puesta a tierra, fusibles, aisladores, y las de instalación de gas, acerca de la protección de tuberías, aislamiento, ventilación adecuada y acoplamiento de dispositivos de seguridad ante fallos de la llama y pérdida de presión. La omisión por parte de los contratistas de ocuparse adecuadamente de estos asuntos de detalle en la instalación o en el mantenimiento de los servicios originará riesgos, tanto para sus propios operarios como para los ocupantes del edificio.

\section{Acabados interiores}

Si la estructura es de ladrillo o de hormigón, el acabado interior puede requerir un revoque de yeso inicial para obtener una superficie que pueda pintarse. El de yesero es un oficio tradicional. Los riesgos principales son la severa fatiga en los brazos y la espalda a causa del acarreo de los sacos de material y de las placas de yeso y, luego, el proceso real de aplicar el revoque, especialmente cuando el operario trabaja en el techo. Después del revoque, los paramentos pueden pintarse. En este caso, el riesgo proviene de los vapores despedidos por los disolventes y a veces por las mismas pinturas. Si es posible deberán usarse pinturas al agua. Si se usan pinturas de base disolvente, las habitaciones deberán estar bien ventiladas, si es necesario por medio de ventiladores. Si se usan materiales tóxicos y no se puede establecer una ventilación, los operarios deberán usar protección individual y respiratoria.

A veces el acabado interior puede precisar la fijación de revestimientos a las paredes. Si ello implica la utilización de pistolas para fijar los paneles al entarimado, el riesgo puede surgir principalmente del modo de manejar la pistola. Los clavos lanzados por un cartucho al ser disparados pueden atravesar paredes y tabiques o pueden rebotar al golpear contra un objeto duro. Los contratistas deben planificar su trabajo con sumo cuidado, incluso, en su caso, impidiendo la presencia de personal en su proximidad.

El acabado puede requerir la fijación de baldosas y losas de diversas clases de material a las paredes y suelos. El corte de grandes cantidades de baldosas cerámicas o losas de piedra por medio de cortadoras con motor eléctrico ocasiona ingentes cantidades de polvo y deberá hacerse en mojado o en un recinto cerrado. El principal riesgo al trabajar con baldosas, incluso las baldosas de moqueta, se deriva de la necesidad de colocarlas mediante colas y pegamentos. Los adhesivos que se usan se basan en disolventes y desprenden vapores que son nocivos y que en un espacio cerrado pueden ser inflamables. Es más, los colocadores de baldosas tienen que estar arrodillados sobre el punto en que se desprenden los vapores. Deberán usarse pegamentos de base acuosa. Si se utilizan pegamentos con base disolvente, las habitaciones deberán estar bien ventiladas (con ayuda de ventiladores), la cantidad de pegamento introducido en la habitación debe ser la mínima y los bidones deberán ser trasvasados a latas más pequeñas usadas por los soladores y almacenados fuera del local de trabajo.

Si el acabado requiere la instalación de materiales de instalación térmica o acústica, como suele ocurrir en los bloques de apartamentos y edificios comerciales, estos pueden venir en 
forma de planchas o baldosas que se cortan, bloques que se unen, entre sí o a una superficie con cemento, o líquidos que se proyectan. Los riesgos incluyen la exposición al polvo, que puede ser irritante y dañino. No se usarán materiales que contengan amianto. Si se usan fibras minerales artificiales, los operarios deberán usar protección respiratoria y ropas protectoras para evitar irritaciones cutáneas.

\section{Riesgos de incendio en acabados interiores}

Muchos de los trabajos de acabado en un edificio conllevan el uso de materiales que incrementan en gran medida el riesgo de incendio. La estructura base puede estar formada por acero relativamente no inflamable, hormigón y ladrillo. Sin embargo las empresas de acabado introducen la madera, tal vez el papel, pinturas y disolventes.

$\mathrm{Al}$ mismo tiempo que se realizan los acabados interiores, se pueden estar ejecutando trabajos con herramientas de motor eléctrico, o tal vez la instalación eléctrica. Casi siempre existe una fuente de ignición por vapor o materiales inflamables usados en los acabados. Muchos incendios muy costosos han estallado durante la ejecución de los acabados, poniendo a los obreros en peligro y generalmente dañando no sólo los acabados del edificio, sino incluso la estructura. Un edificio en fase de acabado es un núcleo cerrado en el cual, posiblemente, centenares de obreros estén usando materiales inflamables. El contratista principal debe asegurar que se establecen las disposiciones adecuadas para facilitar y proteger las vías de escape, para mantener las rutas de acceso libres de obstrucciones, para reducir la cantidad de materiales inflamables almacenados y en uso dentro del edificio, para alertar a los contratistas en caso de incendio y, cuando sea necesario, evacuar el edificio.

\section{Acabados exteriores}

Algunos de los materiales usados para los acabados interiores pueden también ser utilizados en el exterior, pero los acabados exteriores generalmente están relacionados con revestimientos, sellado y pintura. Las llagas de mortero en las fábricas de ladrillo y bloques son generalmente rejuntadas o acabadas a medida que se colocan los bloques o los ladrillos, y no requieren más atención. El exterior de los muros puede estar acabado con un revestido de mortero que luego va pintado, o mediante la aplicación de una capa de árido fino, como el estuco o un guarnecido basto. El acabado exterior, como en general, el trabajo de la construcción, se hace en el exterior y está sometido a los efectos del tiempo. El mayor riesgo, con diferencia, es el riesgo de caídas, a menudo agravado por dificultades para manipular los materiales y los componentes. El uso de pinturas, sellantes y adhesivos que contienen disolventes causa menos problemas que en los acabados interiores, porque la ventilación natural impide la formación de concentraciones de vapor inflamables.

También aquí, los proyectistas pueden influir en la seguridad de los acabados exteriores especificando paneles de revestimiento que se puedan manejar con seguridad (p. ej., ni demasiado pesados, ni demasiado grandes) y estableciendo disposiciones de modo que el trabajo se pueda hacer desde un lugar seguro. La estructura o los forjados del edificio deberán diseñarse de modo que incorporen elementos como pestañas o entrantes que permitan una fácil descarga de los paneles de revestimiento, especialmente cuando su colocación se hace con grúa o montacargas. La especificación de materiales como plásticos para marcos de ventana e impostas elimina la necesidad de pintar y repintar y reduce el mantenimiento ulterior. Esto beneficia a la seguridad de los operarios de la construcción y la de los ocupantes de la casa o apartamento.

\section{Paisajismo}

El paisajismo a gran escala puede incorporar un movimiento de tierras análogo al que se realiza en las obras de carreteras y canales. Puede requerir excavaciones profundas para instalar drenajes; extensas zonas tendrán que pavimentarse con losas u hormigón; es posible que haya que mover rocas. Finalmente, es posible que el cliente desee crear la impresión de una urbanización madura, bien establecida, para lo cual se tendrán que plantar árboles de buena edad. Todo ello requiere excavaciones, zanjas y retirada de tierras. A menudo también requiere una capacidad considerable para izar cargas.

Los contratistas de paisajismo son generalmente especialistas que no dedican gran parte de su tiempo trabajando para contratos de construcción. El contratista principal debe asegurar su incorporación a los trabajos en el momento adecuado (no necesariamente al final del contrato). Las excavaciones importantes y el tendido de tuberías deben ejecutarse, de preferencia, al principio del proyecto, cuando se están realizando los trabajos de cimentación del edificio. Estos trabajos no deben socavar ni poner en peligro el edificio ni sus edificaciones exteriores sobrecargando la estructura de un modo peligroso mediante montones de tierra colocados encima o contra los edificios. Si es preciso arrancar la capa de tierra vegetal y más adelante volver a colocarla, se deberá habilitar suficiente espacio para su acopio en condiciones de seguridad.

El paisajismo también puede ser requerido en instalaciones industriales y en servicios públicos por motivos de seguridad y medioambientales. Alrededor de una planta petroquímica puede ser necesario nivelar el terreno o practicar una pendiente en cierta dirección, posiblemente cubriendo el terreno con gravilla u hormigón para evitar el crecimiento de vegetación. Por otro lado, si la urbanización del contorno de una instalación industrial se hace con la intención de mejorar el aspecto o por razones medioambientales (p. ej., reducir el ruido u ocultar una instalación antiestética), es posible que tengan que ejecutarse terraplenes, montarse pantallas o plantarse árboles. Hoy en día las carreteras y las vías férreas tienen que incluir elementos insonorizadores si pasan cerca de zonas urbanas, u ocultar sus movimientos si atraviesan zonas ecológicamente muy sensibles. El paisajismo no debe ser una idea de último momento, porque además de mejorar el aspecto de una planta o un edificio puede, en función de la naturaleza de la urbanización, conservar el entorno y mejorar la seguridad en general. Por lo tanto, necesita ser proyectado y planificado como parte integrante del proyecto.

\section{Demolición}

La demolición es quizás la operación más peligrosa de la construcción.

Reúne todos los riesgos del trabajo en altura y de la caída de materiales, pero además se lleva a cabo en una estructura que ha sido debilitada bien a causa de la propia demolición, bien a resultas de tormentas, daños producidos por inundaciones, incendios, explosiones o del uso y deterioro natural. Los riesgos que se producen durante la demolición son caídas, golpes o el soterramiento por el material derribado o por el derrumbamiento espontáneo de la estructura, el ruido y el polvo. Uno de los problemas prácticos para asegurar la salud y la seguridad durante la demolición es que se pueda ejecutar muy rápidamente; con los equipos actuales se puede realizar una demolición importante en un par de días.

Existen tres métodos principales para demoler una estructura: derribarla de un modo sistemático; tirarla abajo o volarla mediante el uso de explosivos. El método a elegir viene condicionado por el estado de la estructura, sus alrededores, los motivos de la demolición y su costo. Generalmente el uso de explosivos no será posible si hay edificios próximos. La demolición necesita 
ser planificada con tanto cuidado como cualquier otra fase de la construcción. La estructura a demoler debe ser examinada a fondo estudiando los planos disponibles, de modo que el contratista de la demolición pueda disponer de la mayor información posible sobre su naturaleza, su método de construcción y sus materiales. Comúnmente en los edificios y otras estructuras que se van a demoler se puede encontrar amianto, lo cual exige recurrir a contratistas especializados en su manipulación.

La planificación del proceso de demolición debe garantizar que la estructura no se sobrecargará o se cargará desigualmente con escombros y que se dejen huecos adecuados para la caída de escombros y su retirada segura. Si la estructura resulta debilitada al cortar partes de la misma (especialmente si se trata de hormigón armado u otros tipos de estructura sometidos a esfuerzos importantes) o por el derribo de partes de un edificio tales como forjados o muros interiores, ello no debe debilitar la estructura de modo que se pueda producir un derrumbamiento inesperado. La caída de los materiales de escombro y chatarra deberá planificarse de modo que se puedan retirar o guardar con seguridad y adecuadamente; a veces el coste de un trabajo de demolición depende de la recuperación de la chatarra o de los componentes de valor.

Si la estructura se tiene que demoler sistemáticamente (p. ej., bajando paso a paso), sin usar piquetas mecánicas controladas a distancia, los obreros tendrán que realizar el trabajo necesariamente con herramientas de mano o herramientas mecánicas manuales. Ello supone que deben trabajar en altura en sitios al descubierto o por encima de los huecos practicados para la caída de los escombros. De acuerdo con ello, será preciso usar andamios de trabajo provisionales. La estabilidad de tales andamios no deberá ser puesta en peligro por la retirada de partes de la estructura o por la caída de los escombros. Si las escaleras ya no están disponibles para el uso por los obreros, porque la caja de las mismas se usa para dejar caer los escombros, y se tendrán que habilitar escaleras o andamios exteriores.

La retirada de puntas, agujas u otros elementos elevados situados en lo alto de los edificios resulta a veces más seguro si los operarios trabajan desde cubos debidamente diseñados y colgados del gancho de seguridad de una grúa.

En la demolición sistemática, el método más seguro de proceder es derribar el edificio en un orden opuesto a aquel en que fue construido. La retirada de escombros se debe hacer de manera regular de modo que los accesos y zonas de trabajo no resulten obstruidos.

Si la estructura se ha de derribar por empuje o por tirón o echada abajo, normalmente ha de debilitarse con anterioridad, con los riesgos que ello conlleva. El derribo por tirón se suele hacer eliminando forjados y muros, fijando cables a puntos fuertes en las partes superiores del edificio y usando una excavadora u otra máquina pesada para tirar del cable. Existe un peligro evidente de que los cables salgan volando al romperse a causa de una sobrecarga o por el fallo del punto de anclaje en el edificio. Esta técnica no es viable para edificios muy altos. Para derribar por empuje, igualmente después de debilitar la estructura, se requiere el uso de maquinaria pesada, como empujadoras o palas montadas sobre orugas. Las cabinas de estas máquinas deben ser protegidas con defensas para evitar que los conductores sean lesionados por los escombros al caer. No se permitirá que el emplazamiento resulte obstruido por los escombros caídos, de modo que pueda poner en peligro la estabilidad de la máquina usada para el derribo, por tirón o por empuje.

\section{Demolición con bola}

La forma más común de demolición (y, si se hace adecuadamente, en muchos aspectos la más segura) es derribar a bolazos, usando una bola de acero u hormigón suspendida del gancho de una grúa con un brazo bastante fuerte para resistir los esfuerzos especiales impuestos por el golpe de la bola. El brazo se mueve hacia los lados y la bola se lanza contra el muro a demoler. El riesgo más importante consiste en que la bola se quede atrapada en la estructura o en los escombros, y luego tratar de liberarla tirando con el gancho de la grúa. Ello produce una gran sobrecarga en la grúa y, o bien el brazo de la grúa o el cable se pueden romper. Puede ser necesario que un obrero trepe hasta donde se ha quedado acuñada la bola para liberarla. Sin embargo, esto no se puede hacer si hay peligro de que esa parte del edificio caiga sobre el obrero. Otro riesgo asociado con operadores de grúa menos expertos es dar golpes demasiado fuertes con la bola, los cuales pueden originar la caída accidental de partes del edificio que no estaban programadas.

\section{Explosivos}

La demolición mediante el empleo de explosivos se puede hacer con seguridad, pero se ha de planificar cuidadosamente y ha de ser ejecutada tan sólo por obreros experimentados, bajo una supervisión competente. A diferencia de las demoliciones militares con explosivos, el objetivo de las voladuras no consiste en reducir totalmente el edificio a un montón de escombros. El modo seguro de ejecutarlo, después del debilitamiento de la estructura, consiste en no emplear más explosivo que el necesario para derribar la estructura con certeza, de modo que los escombros puedan ser retirados con seguridad y recuperada la chatarra. Los contratistas que ejecutan la voladura deberán efectuar un reconocimiento de la estructura, y estudiar los planos y toda la información posible sobre el método y los materiales con que fue construida. Sólo con esta información es posible determinar, en primer lugar, si la voladura es idónea; dónde se han de colocar las cargas, cuánto explosivo se tiene que usar, qué pasos pueden ser necesarios para evitar la expulsión de los escombros y qué clase de zonas de separación será necesario establecer alrededor del lugar de la voladura, para proteger a los trabajadores y a los viandantes. Si se tiene que practicar un número de cargas, el disparo eléctrico con detonadores será normalmente más práctico, pero los sistemas eléctricos pueden tener fallos, por lo que en obras más sencillas puede ser más práctico y seguro el uso de un cordón detonador. Los aspectos de las voladuras que requieren una cuidadosa planificación previa son: saber lo que hay que hacer en caso de que falle una detonación o si la estructura no cae como estaba previsto y se queda colgando en un estado de inestabilidad peligroso. Si el trabajo se encuentra próximo a viviendas, carreteras o polígonos industriales, deberá alertarse a los moradores de la zona; la policía local se suele encargar de despejar la zona y cortar el tráfico de peatones y vehículos.

Las estructuras altas, como torres de televisión o de refrigeración, pueden ser demolidas mediante explosivos, con tal de que hayan sido debilitadas de antemano para que caigan con seguridad.

Los trabajadores de las demoliciones están expuestos a altos niveles de ruido a causa de la maquinaria ruidosa y las herramientas, de la caída de escombros y de las explosiones. Normalmente se precisará la utilización de protección acústica. Durante la demolición de edificios se generan grandes cantidades de polvo. Un reconocimiento preliminar deberá determinar dónde y cuándo aparecen plomo o amianto; si ello es posible se deben sacar antes de empezar la demolición. Incluso en ausencia de tan notables riesgos, el polvo de las demoliciones a menudo provoca irritación, aunque no es realmente nocivo, pero se deberá usar una mascarilla antipolvo aprobada si la zona de trabajo no se puede mantener regada para controlar el polvo.

La demolición es a la vez sucia y ardua, y es necesario habilitar un alto nivel de servicios higiénicos, incluyendo aseos, 
duchas, armarios para la ropa normal y para las ropas de trabajo y un local que sirva para descanso y comedor.

\section{Desmontaje}

El desmontaje se diferencia de la demolición en que parte de la estructura o, más comúnmente, una gran pieza de maquinaria, se desmonta y se retira de su emplazamiento. Por ejemplo, la retirada parcial o total de una caldera para su sustitución, o la sustitución de las vigas metálicas del vano de un puente constituyen un desmontaje más bien que una demolición. Los operarios que se encargan del desmontaje suelen realizar muchos trabajos de corte de acero por medio de gas o de oxiacetileno para eliminar partes de la estructura o para debilitarla. Es posible que empleen explosivos para derribar alguna pieza de la maquinaria. Para la retirada de grandes jácenas o piezas de maquinaria emplean maquinaria de elevación pesada. Generalmente, los operarios que realizan estas actividades se enfrentan con los mismos riesgos: caídas, caída de objetos sobre ellos, ruido, polvo y sustancias dañinas que se dan en la demolición propiamente dicha. Los contratistas que llevan a cabo el desmontaje necesitan tener un sólido conocimiento de estructuras para asegurarse de que la remoción se efectúe en un orden que no cause un repentino e inesperado hundimiento de la estructura principal.

\section{Trabajos junto al agua o dentro del agua}

Los trabajos junto al agua o dentro del agua, tal como el mantenimiento y construcción de puentes, el trabajo en dársenas y los trabajos de defensa de orillas marítimas y fluviales presentan riesgos singulares. El riesgo se puede ver incrementado si el agua está en movimiento o es afectada por las mareas, en oposición a las aguas quietas; el rápido movimiento del agua dificulta el rescate de los que se caen en ella. Las caídas en el agua presentan el riesgo de ahogamiento (incluso en aguas poco profundas, si la persona se lesiona al caer, además de hipotermia si el agua está fría, e infección si el agua se encuentra contaminada).

La primera precaución para evitar que los trabajadores caigan es asegurarse de la existencia de pasarelas adecuadas y zonas de trabajo con barandillas. No se permitirá que estas estén húmedas y resbaladizas. Si no es posible el uso de pasarelas, como tal vez en las primeras fases de montaje de la estructura metálica, los obreros deberán llevar cinturón de seguridad y cuerdas amarradas a puntos de anclaje seguros. Estos deberán ser complementados con redes de seguridad tendidas bajo el lugar de trabajo. Se deberán habilitar escaleras y sogas de amarre para ayudar a los obreros que caigan a salir del agua, como por ejemplo en los bordes de las dársenas y de diques de defensa marítima. Mientras los obreros estén en una plataforma desprotegida de barandillas adecuadas o se desplacen para ir o regresar del lugar de trabajo, deben llevar chalecos salvavidas. Las boyas de salvamento y las amarras de rescate deberán colocarse en intervalos regulares a lo largo de la orilla.

La construcción de muelles y el mantenimiento de ríos y diques marítimos implica a menudo el uso de barcazas para transportar los aparejos de pilotar y las excavadoras que retiran los productos del dragado. Tales barcazas equivalen a plataformas de trabajo y deberán llevar unas barandillas adecuadas, salvavidas y sogas de amarre y salvamento. Se deberá habilitar un acceso seguro desde la playa, muelle u orilla del río en forma de pasarelas con barandillas. Estas se dispondrán de modo que se acoplen con seguridad a los niveles cambiantes de las mareas.

También habrá disponibles botes salvavidas, equipados a bordo con amarras y boyas y sogas de rescate. Si el agua está fría o en movimiento, los botes deberán tener una tripulación permanente, y deberán tener motor y estar prestos para efectuar una misión de rescate inmediatamente. Si el agua está contaminada por efluentes o alcantarillado industrial, deberán establecerse mecanismos para transportar a los que caigan a un centro médico o a un hospital para su inmediato tratamiento. $\mathrm{El}$ agua en las zonas urbanas se puede encontrar contaminada por la orina de las ratas que pueden infectar excoriaciones abiertas de la piel, causando el mal de Weil.

Los trabajos sobre el agua se ejecutan a menudo en lugares que suelen estar sujetos a fuertes vientos, lluvia penetrante o heladas. Estas circunstancias aumentan el riesgo de caídas y la pérdida de calor. El tiempo severo puede causar la parada del trabajo, incluso en medio de un turno; para evitar una excesiva pérdida de calor puede ser necesario complementar las ropas de protección al frío o las normales impermeables con ropa interior térmica.

\section{Trabajos submarinos}

\section{Inmersiones}

Las inmersiones constituyen una forma especializada de trabajo submarino. Los riesgos a que se enfrentan los que las realizan son: ahogamiento, mal de descompresión (mal de los buzos), hipotermia a causa del frío y atrapamiento debajo del agua. Las inmersiones pueden ser precisas durante la construcción o mantenimiento de muelles, de diques de defensa del mar y de ríos, de espigones y de estribos de puentes. Frecuentemente han de efectuarse en aguas de escasa visibilidad o en lugares en que existe el riesgo de que el buzo y su equipo queden enredados. La inmersión se puede efectuar desde tierra firme o desde un barco. Si el trabajo precisa de un solo buzo, se necesitará un equipo mínimo de tres personas por razones de seguridad. El equipo constará del buzo que se sumerge, de otro buzo de reserva totalmente equipado, presto a entrar en el agua inmediatamente en caso de emergencia y de un supervisor a cargo de la inmersión. El supervisor de la inmersión deberá encontrarse en un puesto seguro en tierra o en el barco desde el que se va a efectuar la inmersión. Las inmersiones a profundidades menores de $50 \mathrm{~m}$ se llevan a cabo normalmente por hombres rana equipados de trajes húmedos (es decir, trajes que no repelen el agua) y con equipos de respiración submarina independientes con máscara facial abierta (p. ej., equipo de submarinismo). A profundidades superiores a $50 \mathrm{~m} \mathrm{o}$ en aguas muy frías, será necesario que los submarinistas lleven trajes que se calientan con alimentación de agua caliente bombeada y máscaras de respiración cerradas, y un equipo para respirar aire no comprimido, sino mezclado con ciertos gases (p. ej., inmersión con gas mixto). Los submarinistas deben llevar una cuerda de seguridad adecuada y tienen que poder comunicarse con la superficie y, en particular, con el supervisor de la inmersión. Cuando se realiza una inmersión los servicios de emergencia locales deberán ser informados de ello por el contratista de los trabajos.

Tanto el equipo de inmersión como los submarinistas han de pasar exámenes y pruebas. Los submarinistas deberán recibir instrucción hasta un nivel reconocido nacional o internacional, en primer lugar y en todo caso para inmersiones con aire normal y, en segundo lugar, para inmersiones con aire mezclado con gas, si se tiene que emplear este método. Deberán acreditar por escrito que han completado satisfactoriamente un curso de instrucción en inmersión. Los que practican inmersiones deben pasar anualmente un reconocimiento médico a cargo de un doctor con experiencia en medicina hiperbárica. Cada uno tendrá un cuaderno personal en el que se lleve un registro de sus reconocimientos físicos y de las inmersiones realizadas. Si el submarinista ha sido suspendido para hacer inmersiones a causa de un reconocimiento médico, ello también se registrará en el cuaderno de su historial. Un submarinista que se encuentra suspendido no podrá ser autorizado para sumergirse ni para actuar como persona de reserva para la inmersión. Los buzos 
deberán ser consultados por su supervisor si se encuentran en buena condición, en especial si padecen alguna dolencia respiratoria, antes de permitir su inmersión. El equipo de inmersión (trajes, cinturones, cuerdas, máscaras y botellas con sus válvulas) deberá comprobarse cada día antes de su uso.

Los buzos deberán demostrar que saben manejar satisfactoriamente las botellas y válvulas de demanda en presencia de su supervisor.

En caso de accidente u otros motivos para el súbito ascenso de un buzo a la superficie, puede experimentar o sentirse en peligro de experimentar la enfermedad del buzo y requerir una recompresión. Por tal razón es deseable que, antes de comenzar la inmersión, se sepa dónde encontrar una cámara de descompresión médica o en todo caso adecuada para submarinistas. El personal a cargo de la cámara deberá ser alertado de que se está realizando una inmersión. Deberán estar disponibles los medios para el rápido transporte de los submarinistas con necesidad de descompresión.

A causa de su instrucción y del equipo necesario, además del apoyo que precisan por razones de seguridad, el empleo de buzos es muy caro, a pesar de que el tiempo de trabajo real sumergido sea breve. Por estas razones existe la tentación entre los contratistas de trabajos submarinos de utilizar buzos poco instruidos o aficionados o equipos de inmersión faltos de efectivos o equipamiento. Sólo debe recurrirse para este tipo de trabajos a contratistas de confianza y se ha de prestar atención especial para la selección de buzos que afirman haber recibido entrenamiento en otros países con unos niveles menos exigentes.

\section{Cajones}

Los cajones son muy semejantes a cazos invertidos cuyos bordes se asientan en el lecho del puerto o del río. A veces se usan cajones abiertos que, como su nombre indica, están abiertos por su parte superior. Se utilizan en tierra firme para perforar un pozo mediante hinca en terreno blando. El borde inferior del cajón es afilado, los trabajadores excavan en el interior del cajón, y éste se va hincando en el terreno a medida que se retira la excavación, formándose de esta manera el pozo. Cajones abiertos similares se usan en aguas poco profundas, pero su profundidad se puede hacer mayor, añadiendo secciones por arriba, a medida que el cajón se hunde en el fondo del río o del puerto. Los cajones abiertos confían al bombeo el control de la entrada del agua y tierra en la base del cajón. Para trabajos a mayores profundidades tendrá que utilizarse un cajón cerrado. Para desplazar el agua se bombea aire comprimido, y los trabajadores pueden entrar en él a través de una esclusa de aire, generalmente situada en su parte superior, y bajar al lugar de trabajo en la atmósfera de esa cámara. Los obreros pueden trabajar debajo del agua, pero están libres de las limitaciones de llevar un equipo de buceo, y su visibilidad es mucho mejor. Los riesgos en el trabajo en cajones neumáticos son la enfermedad del buzo y - como en todos los tipos de cajón, incluso el cajón abierto más sencillo- el ahogamiento si el agua penetra en el cajón por algún fallo estructural o por pérdida de la presión del aire. Debido al riesgo de entrada de agua, en todo momento deberán estar disponibles medios de escape, tales como escaleras hasta el punto de entrada, tanto en cajones abiertos como neumáticos.

Los cajones deben inspeccionarse diariamente antes de su utilización, por alguien competente y experimentado en este tipo de trabajos. Los cajones serán izados y bajados por unidades individuales con maquinaria pesada de elevación, o pueden montarse a base de sus componentes dentro del agua. El montaje de cajones debe ser supervisado por una persona igualmente competente.

\section{Túneles subacuáticos}

Los túneles, si se perforan en terreno poroso debajo del agua, pueden tener que ejecutarse en atmósfera de aire comprimido. Es una práctica extendida perforar túneles para el transporte público en el centro de las ciudades pasando por debajo de los ríos, debido a la falta de espacio aéreo y a consideraciones medioambientales. Los trabajos con aire comprimido se limitarán al mínimo posible debido a su peligro e ineficacia.

Los túneles subacuáticos en terreno poroso tendrán que revestirse con anillos de hormigón o hierro fundido que se juntan con mortero. Pero en el frente de excavación del túnel y dada la corta longitud del anillado del túnel, no habrá un espacio suficientemente hermético para proseguir el trabajo sin algún medio de agotamiento del agua. Puede ser necesario ejecutar en atmósfera de aire comprimido el trabajo en el frente del túnel y la colocación de anillos y dovelas, que forma parte del proceso de perforación y revestimiento del mismo. Los operarios que conducen el avance (p. ej., en un escudo, manejando el frente cortante rotatorio) o que usan herramientas manuales, y los que manejan la maquinaria de colocación de anillos y dovelas, tendrán que introducirse por una esclusa de aire. El resto del túnel ya revestido no precisará aire comprimido, y, de este modo, será más fácil el tránsito de personal y materiales.

Los trabajadores en túneles que tienen que trabajar en una atmósfera de aire comprimido están expuestos al mismo riesgo de enfermedad de los buzos que los trabajadores en cajones y los submarinistas. La esclusa de aire que da acceso a la cámara de trabajo con aire a presión, deberá ser complementada con una segunda esclusa, por la cual pasarán los trabajadores para efectuar la descompresión al acabar su turno. Si sólo existe una esclusa, ello puede crear embotellamientos y ser peligroso. Los riesgos surgen cuando los obreros no hacen la descompresión con la lentitud suficiente al final del turno, o si la falta de capacidad de la esclusa retrasa la entrada de equipo vital para los trabajos bajo presión. Las esclusas de aire y las cámaras de descompresión deberán estar bajo la supervisión de una persona competente y experimentada en trabajos de túnel bajo aire comprimido y su adecuada descompresión.

\section{ZANJAS}

Jack L. Mickle

Las zanjas son recintos confinados que se excavan, generalmente, para enterrar conducciones de servicios o para ubicar cimientos. Las zanjas, normalmente, tienen mayor profundidad que anchura, considerando el ancho del fondo, y suelen tener una profundidad inferior a 6 metros; se denominan también excavaciones superficiales (poco profundas). Un recinto confinado se define como un espacio que tiene unas dimensiones suficientes para que un obrero se introduzca en él y pueda realizar un trabajo; tiene unos medios limitados para entrar en el mismo y salir de él y no está proyectado para una ocupación continuada. Deberán disponerse varias escaleras para que los obreros puedan evacuar la zanja.

Lo normal es que las zanjas permanezcan abiertas por espacio de unos minutos o unas horas. Las paredes de cualquier zanja acabarán desmoronándose; es simplemente una cuestión de tiempo. La estabilidad aparente a corto plazo constituye una tentación para que el contratista haga entrar a los obreros en una zanja peligrosa, con la esperanza de obtener un rápido avance y una mejora económica. De resultas de ello pueden sobrevenir muertes o lesiones serias y mutilaciones.

Además de estar expuestos a la posibilidad de derrumbamiento de las paredes de las zanjas, los que trabajan dentro de 
las mismas pueden sufrir lesiones o morir a consecuencia de inundaciones por agua o por residuos sanitarios, por la presencia de gases peligrosos o por falta de oxígeno, por caídas, caídas de materiales o herramientas, por entrar en contacto con cables eléctricos cortados o por un salvamento inadecuado.

Como ejemplo, al menos un 2,5\% de las muertes por accidentes laborales que se producen anualmente en EE.UU. son achacables a desprendimientos de tierras. La edad media de los trabajadores muertos en zanjas en EE.UU. es de 53 años. A menudo, una persona joven resulta atrapada por un desprendimiento de tierras y otros trabajadores intentan rescatarle. En los intentos de rescate fallidos, la mayoría de los muertos corresponden a los potenciales salvadores. En caso de derrumbe es preciso llamar inmediatamente a equipos de urgencia adiestrados en este tipo de rescates.

Es esencial la inspección rutinaria de las paredes de la zanja y el uso de los sistemas de protección de los trabajadores. Las inspecciones deben efectuarse diariamente antes de empezar los trabajos y después de cualquier incidencia - tal como tormentas, vibraciones o rotura de tuberías - que pueda incrementar los riesgos. A continuación se incluyen descripciones de las situaciones peligrosas y la manera de evitarlas.

\section{Derrumbamiento de las paredes de la zanja}

La causa más importante de las muertes relacionadas con los trabajos en zanjas es el derrumbamiento de las paredes de las mismas, que puede ocasionar el aplastamiento o la asfixia de los trabajadores.

Las paredes de la zanja pueden resultar debilitadas a consecuencia de actividades realizadas en el exterior, pero en las inmediaciones de la misma. No deben colocarse cargas pesadas en el borde de la zanja. No deben excavarse zanjas en la proximidad de estructuras como edificios o líneas férreas, ya que la excavación puede socavarlas y debilitar sus cimientos, causando de este modo el hundimiento de las estructuras y de las paredes de la zanja. En las fases de planificación conviene solicitar el asesoramiento de un ingeniero o técnico competente. No se debe permitir que los vehículos se aproximen demasiado a los bordes de la zanja; a tal efecto, es aconsejable colocar topes horizontales o banquetas de tierra.

\section{Tipos de terreno y entorno}

La elección adecuada de un sistema de protección de los trabajadores depende del terreno y de las condiciones del entorno. La resistencia del terreno, la presencia de agua y las vibraciones originadas por la maquinaria o por otras causas próximas, son factores que afectan a la estabilidad de las zanjas. Los terrenos en los que se ha practicado una excavación con anterioridad, nunca recuperan su resistencia. La acumulación de agua en una zanja, independientemente de su profundidad, es indicativa de la situación más peligrosa.

Antes de la elección de un sistema adecuado para la protección de los trabajadores, es preciso tener en cuenta la clase del terreno y evaluar el escenario de la construcción. Un plan de seguridad y salud adecuado de un proyecto debe dar respuesta a las condiciones y riesgos singulares del mismo.

Los terrenos se pueden clasificar en dos grandes grupos: cohesivos y granulosos. Los terrenos cohesivos contienen un mínimo del $35 \%$ de arcilla; si se amasan en forma de cilindros de $50 \mathrm{~mm}$ de longitud y $5 \mathrm{~mm}$ de diámetro y se suspenden de un extremo, no se rompen. Las paredes de las zanjas practicadas en terrenos cohesivos se mantienen verticales durante cortos períodos de tiempo. Estos terrenos son responsables de tantas muertes por derrumbamiento como cualquier otro tipo de terreno, ya que el terreno aparentemente es estable y, a menudo, no se toman precauciones.
Los terrenos granulosos consisten en limos, arena, grava o material de mayor tamaño. Estos tipos de terreno, cuando están húmedos, ofrecen una cohesión aparente (a semejanza de los castillos de arena); cuanto más finas son las partículas, mayor es la cohesión aparente. Sin embargo, cuando se encuentran sumergidos o están secos, los terrenos granulosos de tamaño más grueso se desmoronan inmediatamente, hasta alcanzar un ángulo de estabilidad, comprendido entre 30 y $45^{\circ}$, según la forma redondeada o angular de sus partículas.

\section{Protección de los trabajadores}

El ataluzado evita el desplome de las zanjas, al eliminar el peso (del terreno) que puede dar origen a la falta de estabilidad de la zanja. $\mathrm{El}$ ataluzado, incluyendo el banqueo (ataluzado hecho en varios escalones) requiere que la zanja tenga una mayor anchura en su parte superior. El ángulo del talud depende del terreno y de las condiciones en que se encuentra, pero los taludes varían desde 0,75 horizontal: 1 vertical a 1,5 horizontal: 1 vertical. El talud de 1,5 de base por 1 de altura requiere un ensanchamiento de $1,5 \mathrm{~m}$ por cada metro de profundidad, a ambos lados de su parte superior. Incluso la menor inclinación de un talud resulta beneficiosa. Sin embargo, los anchos que requieren los taludes impiden a menudo su aplicación en las obras de construcción.

La entibación se puede usar en todos los casos. Una entibación consiste en un montante a cada lado de la zanja con codales entre ambos (véase la Figura 93.5). Las entibaciones contribuyen a evitar el hundimiento de las paredes de la zanja, al empujar hacia fuera contra las paredes de la misma. Las entibaciones clareadas consisten en , montantes y arriostramientos transversales, con el terreno formando arco entre ellos; se usan en terrenos arcillosos, que son los que presentan una mayor cohesión. Los montantes no deben distar más de $2 \mathrm{~m}$ entre sí. Se pueden alcanzar mayores separaciones entre los arriostramientos mediante el empleo de largueros horizontales que mantengan los montantes en su sitio (véase la Figura 93.6). La entibación tupida se emplea en terrenos granulosos y de escasa cohesión; las paredes de la zanja se protegen totalmente con

Figura 93.5 - Las entibaciones consisten en montantes a ambos lados de la zanja, sujetos por codales.

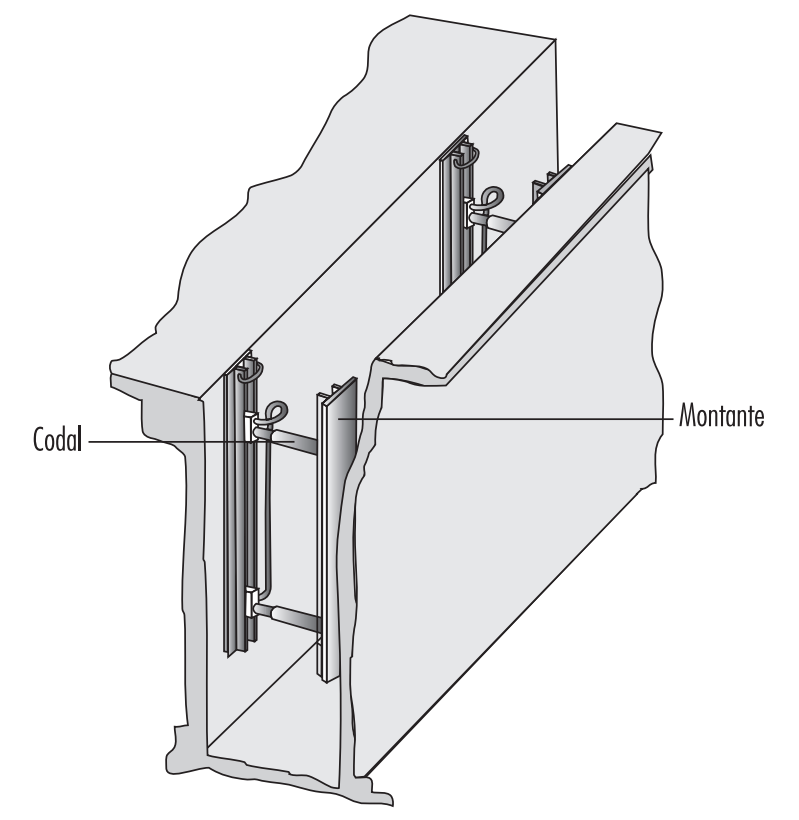


Figura 93.6 - Los largueros mantienen verticales los montantes, permitiendo un mayor espaciamiento de los codales.

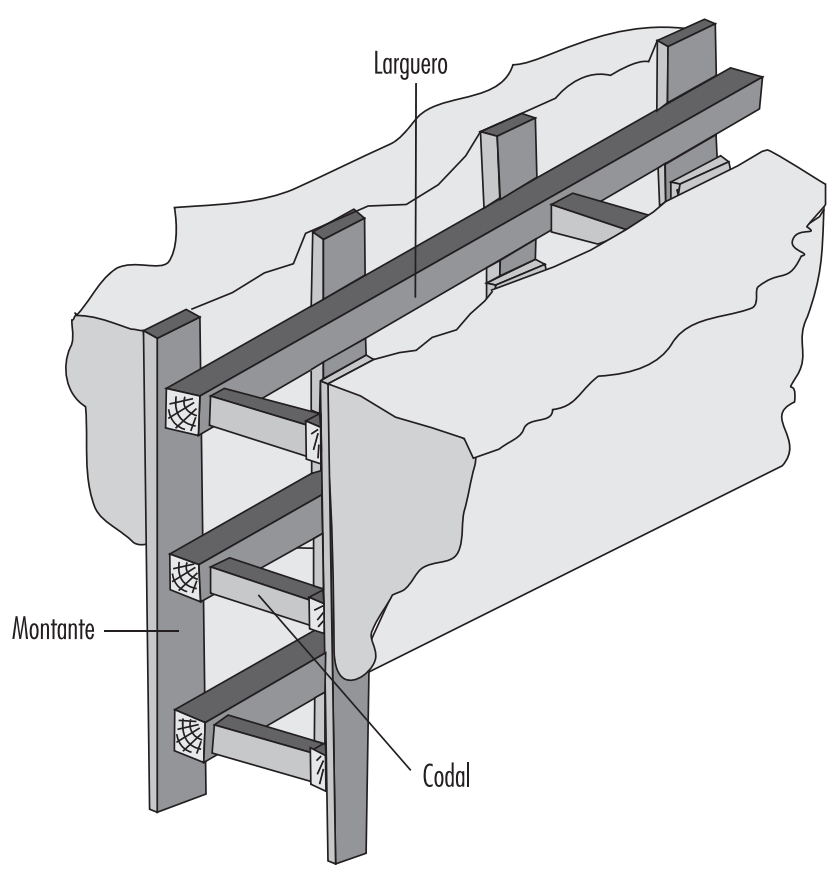

tableros (véase la Figura 93.7). Los tableros pueden ser de madera, metálicos o de fibra de vidrio; son corrientes los paneles de acero. La entibación estanca se emplea cuando se encuentran minas o filtraciones de agua. El empanelado estanco impide que el agua erosione y arrastre las partículas del terreno al interior de la zanja. Un sistema de entibación siempre ha de mantenerse bien apretado contra el terreno para evitar los derrumbamientos. Los codales pueden ser de madera o roscados; pueden ser gatos hidráulicos o neumáticos. Los largueros pueden ser de madera o metálicos.

Los escudos o cajas de excavación de zanjas son elementos de protección individual de gran tamaño; no impiden el derrumbamiento de las paredes de la zanja, pero protegen a los trabajadores que se encuentran en su interior. Los escudos suelen fabricarse de acero o aluminio y su tamaño oscila comúnmente entre 1 a $3 \mathrm{~m}$ de altura y 2 a $7 \mathrm{~m}$ de longitud; existen muchos otros tamaños. Los escudos deben superponerse (véase la Figura 93.8). Deben existir sistemas de protección in situ para contrarrestar los movimientos peligrosos de los escudos en caso de que una pared de la zanja se derrumbe. Uno de estos sistemas consiste en efectuar el relleno a ambos lados del escudo.

Existen en el mercado nuevos productos que combinan las propiedades de una entibación y un escudo; algunos de ellos se utilizan en terrenos de alta peligrosidad. Estas unidades mixtas de entibación-escudo se pueden usar como escudos estáticos o a modo de entibación, transmitiendo empujes contra las paredes de la zanja por vía mecánica o hidráulica. Las unidades de menor tamaño son especialmente útiles cuando se reparan roturas de tuberías de servicios en las calles de una ciudad. Las más voluminosas, formadas por escudos y paneles, se pueden hincar en el terreno por medios mecánicos o hidráulicos. A continuación se excava el terreno en el interior del escudo.
Figura 93.7 - Entibación con tablones y codales en terreno granuloso.

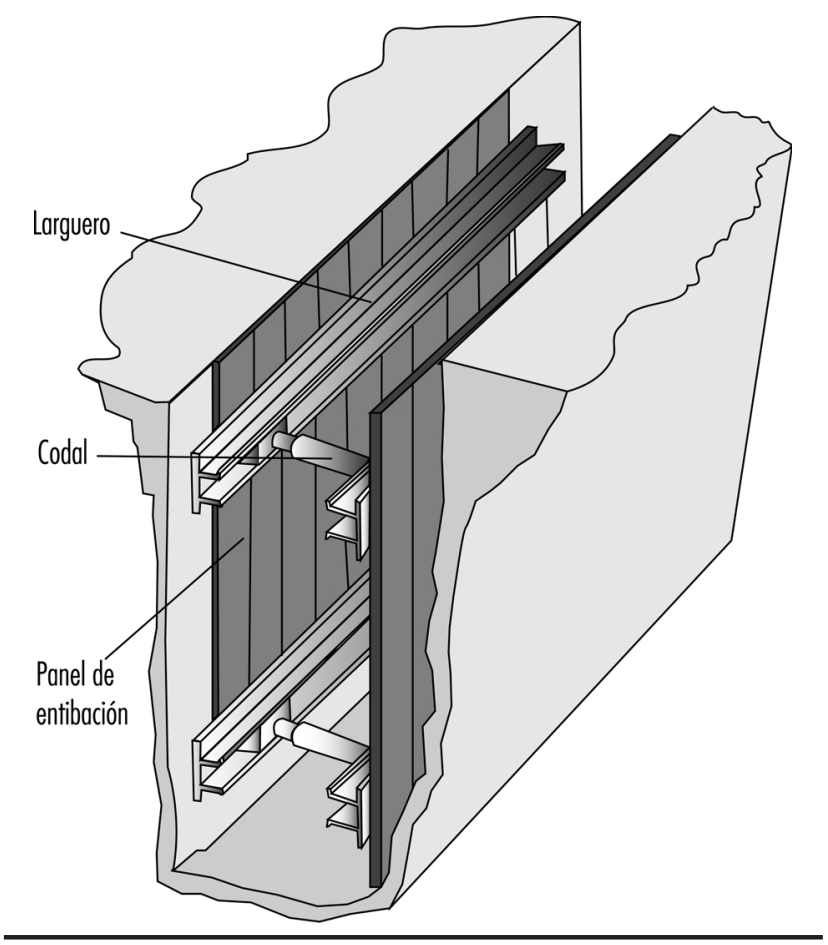

\section{Anegamientos}

Para evitar la inundación de una zanja por aguas corrientes o del alcantarillado se recomiendan varias medidas. En primer lugar, ponerse en contacto con las compañías de servicios para saber dónde se encuentran las tuberías de agua (o de cualquier otro fluido). En segundo lugar, hay que cerrar las válvulas de alimentación de agua a las tuberías que discurren por la zanja. Hay que evitar hundimientos que puedan causar la rotura de tuberías

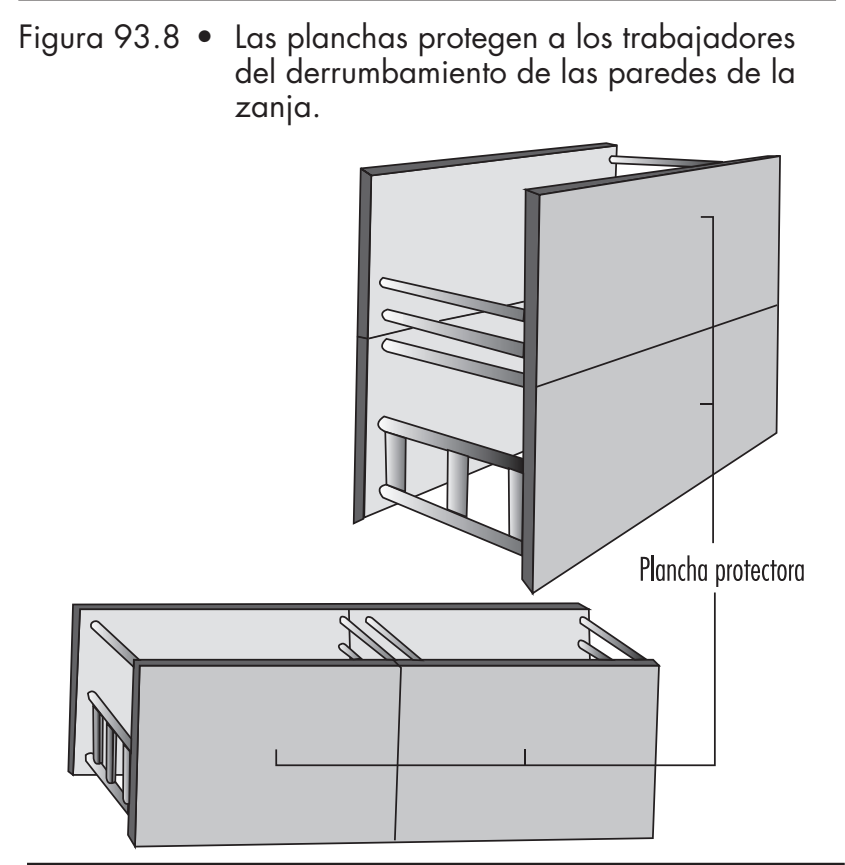


maestras de agua o canalización. Todas las tuberías, así como el resto de equipos deben sustentarse firmemente.

\section{Gases y humos letales y falta de oxígeno}

Las atmósferas dañinas pueden causar la muerte o lesiones de los trabajadores a causa de: falta de oxígeno, incendio, explosión o exposición a gases tóxicos. Siempre que existan o que se sospeche que puedan existir condiciones anormales, es preciso realizar pruebas de la atmósfera de las zanjas. Esto es especialmente válido en las inmediaciones de basuras enterradas, en cámaras subterráneas, en depósitos de combustibles, pozos de registro, ciénagas, plantas de procesos químicos y otras instalaciones que puedan despedir humos o gases tóxicos o que consuman el oxígeno del aire. Deben separarse unos de otros los tubos de escape de la maquinaria de construcción.

La calidad del aire se puede determinar mediante instrumentos desde el exterior de la zanja. Ello se puede lograr haciendo descender un contador o su sonda dentro de la zanja. Los ensayos para determinar la calidad del aire en las zanjas deben efectuarse en el siguiente orden: En primer lugar, el oxígeno debe estar comprendido entre el 19,5 y el $23,5 \%$. En segundo lugar, la inflamabilidad o explosividad no debe superar el $10 \%$ de los límites inferiores inflamables o explosivos (LFL o LEL). En tercer lugar, los niveles de las sustancias potencialmente tóxicas, como el ácido sulfhídrico, deben compararse con la información publicada al respecto. (En Estados Unidos, el Manual de bolsillo de riesgos químicos, del National Institute for Occupational Safety and Health, es una fuente de información que ilustra los límites de exposición permisibles (PEL). Si la atmósfera es normal, los trabajadores pueden entrar en el recinto. Una atmósfera anormal puede ser corregida mediante ventilación, pero no se puede interrumpir su seguimiento y control. Para acceder a colectores de desagüe y recintos similares en los que el aire cambia constantemente se requiere (o debería requerirse) un permiso. Los procedimientos de esta índole exigen un equipamiento completo y un conjunto de 3 personas: un supervisor, un ayudante y una persona que entre.

\section{Caídas y otros riesgos}

Las caídas en las zanjas desde el exterior y en su interior pueden evitarse dotándolas de medios seguros y profusos para entrar y salir de ellas; pasarelas o puentes seguros, por las que los trabajadores y el equipo puedan o deban cruzar por encima de las zanjas; vallas adecuadas para evitar que otros trabajadores, los mirones o la maquinaria se aproximen a la zanja.

Las caídas de materiales o herramientas pueden causar la muerte o lesiones por golpes en la cabeza y en el cuerpo, por aplastamiento o por asfixia. Los productos de la excavación deben apilarse al menos a $0,6 \mathrm{~m}$ del borde de una zanja; se debe colocar una barrera que impida que el terreno y las piedras puedan rodar dentro de la zanja. Hay que evitar que los demás materiales, como tuberías, caigan o rueden dentro de la zanja. No se debe permitir que haya personas trabajando bajo cargas suspendidas o manipuladas por la maquinaria de excavación.

Antes de comenzar la excavación hay que señalizar la situación de todos los conductos, para evitar electrocuciones o graves quemaduras producidas por el contacto con líneas eléctricas. No se puede permitir que las plumas de la maquinaria trabajen cerca de tendidos eléctricos; si es necesario, estas líneas deben ser enterradas o retiradas.

A menudo, una muerte o una lesión grave en una zanja puede ser el corolario de un intento de rescate mal concebido. La víctima y los que tratan de rescatarla pueden encontrarse atrapados o resultar abatidos por gases o humos letales o verse faltos de oxígeno; resultar ahogados; también pueden sufrir mutilaciones por la maquinaria o cuerdas empleadas en el rescate. Estas tragedias añadidas pueden evitarse siguiendo un plan de seguridad e higiene. El equipo, como los contadores de comprobación de la calidad del aire, bombas de agotamiento y ventiladores, debe estar en buen estado de mantenimiento, montado adecuadamente y disponible en el lugar de trabajo. La dirección debe instruir a los trabajadores en torno a las prácticas de seguridad en el trabajo, a la par que exigirles que las respeten y que utilicen todo el equipo de protección individual necesario.

HERRAMIENTAS, MAQUINAS Y MATERIALES

\section{- Herramientas}

\section{Scott P. Schneider}

Las herramientas son particularmente importantes en los trabajos de construcción. Se usan fundamentalmente para unir elementos (p. ej., martillos o pistolas de clavar) o para separarlos (martillos perforadores y sierras). Las herramientas se clasifican frecuentemente en herramientas de mano y herramientas mecánicas. Las herramientas de mano incluyen todas las herramientas sin motor, tales como martillos y alicates. Las herramientas mecánicas se dividen en varias clases, según de la fuente de energía que utilicen: herramientas eléctricas (movidas por electricidad); herramientas neumáticas (movidas por aire comprimido); herramientas de combustible líquido (generalmente movidas por gasolina), herramientas activadas por pólvora (generalmente accionadas por un explosivo y que funcionan como una pistola) y herramientas hidráulicas (movidas por la presión de un líquido). Cada tipo presenta problemas de seguridad particulares.

Las herramientas manuales incluyen una gran variedad de herramientas, desde hachas a llaves de tuerca. El riesgo fundamental con este tipo de herramientas es recibir golpes propinados por la herramienta o por la pieza con que se está trabajando. Las lesiones oculares son muy corrientes al usar las herramientas manuales: por ejemplo, un trozo de madera o de metal puede salir volando e introducirse en un ojo. Algunos de los problemas más importantes se suscitan por el uso de una herramienta inadecuada para un trabajo o de una herramienta carente de un mantenimiento adecuado. El tamaño de la herramienta es importante: hombres y mujeres con manos relativamente pequeñas tienen dificultad para el manejo de herramientas de gran tamaño. Las herramientas embotadas pueden dificultar el trabajo, exigir un esfuerzo mayor y producir más lesiones. Un cincel con la punta roma puede estallar con el impacto y lanzar trozos por el aire. Es también importante que la superficie de trabajo sea adecuada. El corte de material con un ángulo inadecuado puede producir pérdida de equilibrio y lesiones. Además, las herramientas manuales pueden producir chispas que pueden ocasionar explosiones si se está trabajando junto a líquidos o vapores inflamables. En tales casos se necesitan herramientas antichispa, como las fabricadas con latón o aluminio. 
Las herramientas mecánicas, en general, son más peligrosas que las manuales, porque la potencia es mayor. Los principales peligros originados por las herramientas mecánicas se deben a un arranque accidental y a resbalones o pérdida de equilibrio durante su manejo. La fuente de energía también puede causar lesiones o muerte, por ejemplo, por electrocución al trabajar con herramientas eléctricas o por explosión de gasolina causada por herramientas de combustible líquido. La mayoría de las herramientas mecánicas están dotadas de una protección de sus partes móviles cuando la herramienta no está funcionando. Estas protecciones necesitan estar en perfectas condiciones de trabajo y no ser invalidadas. Una sierra circular portátil, por ejemplo, deberá tener una protección superior que cubra la mitad superior de su hoja y una protección inferior retráctil que cubra los dientes cuando la máquina no funciona. La protección retráctil deberá volver automáticamente a cubrir la mitad inferior de la hoja cuando la herramienta deje de funcionar. Las herramientas mecánicas suelen tener interruptores de seguridad que desconectan la herramienta tan pronto como se acciona el interruptor. Otras herramientas están provistas de retenes que deben accionarse antes de que la máquina pueda funcionar. Un ejemplo es una máquina de fijación que tiene que ser presionada contra una superficie antes de poder dispararse.

Uno de los riesgos principales de las herramientas eléctricas es el peligro de electrocución. Un cable pelado o una herramienta sin toma de tierra (que cerrará el circuito eléctrico con tierra en caso de emergencia) puede hacer que la electricidad pase por el cuerpo y produzca la muerte por electrocución. Ello se puede evitar usando herramientas con doble aislamiento (cables aislados en una carcasa aislada), herramientas conectadas a tierra e interruptores para el caso de fallo de la puesta a tierra (que detectan la ausencia de electricidad en un cable y desconectan la herramienta automáticamente); no usando nunca herramientas eléctricas en sitios húmedos o con agua; y usando guantes aislantes y calzado de seguridad. Los cables de conexión tienen que protegerse de posibles daños y abusos.

Otros tipos de herramientas mecánicas incluyen las de disco abrasivo motorizadas, como muelas, cortadoras o pulidoras, que acarrean el riesgo de desprendimiento de trozos despedidos por el disco. Deberá comprobarse el disco para asegurarse de que no tenga grietas y de que no se partirá y volará en pedazos durante su uso. Deberá girar libremente sobre su eje. La persona que lo maneje no se situará nunca delante del disco cuando éste se ponga en marcha, por precaución ante su posible rotura. Es esencial el uso de protecciones oculares cuando se manejen estas herramientas.

Entre las herramientas neumáticas se incluyen cinceladoras, taladros, martillos y lijadoras. Algunas herramientas neumáticas disparan elementos de fijación a alta velocidad y presión contra las superficies y, de resultas de ello, encierran el riesgo de disparar estos elementos contra el usuario u otras personas. Si el objeto a fijar es delgado, la fijación puede atravesarlo y golpear a alguien a una cierta distancia. Estas herramientas pueden ser ruidosas y causar sordera. Las mangueras de aire deberán estar firmemente conectadas antes de su uso para evitar que se desconecten y den latigazos. Asimismo deberán protegerse de posibles daños y abusos. Nunca se apuntará a nadie, ni siquiera a uno mismo, con las pistolas de aire comprimido. Se usarán las protecciones de ojos, cara y auditivas. Quienes manejen los martillos picadores deberán usar calzado de protección por si estas pesadas herramientas les caen encima.

Las herramientas accionadas por gas presentan riesgos de explosión del combustible, en particular durante su llenado. Deberán llenarse sólo después de su parada y enfriamiento. Si se llenan en un espacio cerrado debe habilitarse una buena ventilación. El empleo de estas herramientas dentro de un recinto cerrado también puede causar problemas por exposición al monóxido de carbono.

Las herramientas activadas por pólvora actúan como pistolas cargadas y deberán ser manejadas exclusivamente por personal experimentado en su uso. Nunca se deberán cargar hasta inmediatamente antes de su uso y nunca se dejarán cargadas y abandonadas. El disparo implica dos movimientos: posicionar la herramienta y apretar el gatillo. Las herramientas activadas por pólvora requerirán al menos 5 libras $(2,3 \mathrm{~kg})$ de presión contra la superficie antes de poder dispararse. Estas herramientas no se usarán en atmósferas explosivas. Nunca se apuntará a nadie con ellas deberán inspeccionarse antes de usarlas. Estas herramientas deberán llevar un dispositivo protector de seguridad a la salida del cañón para evitar que despidan fragmentos voladores en el momento del disparo. Las herramientas defectuosas deberán ser retiradas del servicio inmediatamente y etiquetadas o condenadas para asegurarse de que nadie las use hasta que estén reparadas. Las herramientas activadas por pólvora para aplicaciones de fijación no se dispararán contra materiales que el clavo pueda atravesar y dar a alguien, ni deberán aplicarse cerca de un borde, en cuyo caso el material podría astillarse y romperse.

Las herramientas hidráulicas deberán funcionar con un fluido resistente al fuego y su manejo se hará a presiones de seguridad. Un gato deberá tener un mecanismo de seguridad que evite que se le haga actuar a demasiada altura y deberá llevar indicados de un modo visible sus límites de carga. Los gatos tienen que apoyarse sobre una superficie nivelada, centrados, actuar sobre otra superficie nivelada y, para un manejo seguro, la fuerza debe aplicarse uniformemente.

En general, las herramientas se inspeccionarán antes de usarlas, debiendo estar en buen estado de mantenimiento, se manejarán de acuerdo con las instrucciones del fabricante y estarán dotadas de sistemas de seguridad (p. ej., protecciones). Los operarios que las manejen deben utilizar el equipo de protección adecuado (EPI), como gafas de seguridad.

Las herramientas pueden encerrar otros tres riesgos que, a menudo, son ignorados: vibraciones, sobreesfuerzos y torceduras. Las herramientas mecánicas originan un riesgo considerable de vibración en los operarios. El ejemplo más conocido es la vibración producida por las motosierras, que pueden causar la dolencia de "dedos blancos", por la que los nervios y los vasos sanguíneos de las manos resultan dañados. Otras herramientas mecánicas pueden representar una peligrosa exposición a vibraciones de los trabajadores de la construcción. Siempre que sea posible, los trabajadores y los contratistas deberán adquirir herramientas en las que la vibración se ha reducido o eliminado; no se ha demostrado que los guantes antivibraciones hayan resuelto el problema.

Las herramientas de diseño defectuoso pueden contribuir asimismo a la fatiga debido a posturas o empuñaduras inconvenientes que, a su vez, también pueden originar accidentes. Muchas herramientas no están diseñadas para el manejo por operarios zurdos o por individuos con manos pequeñas. El uso de guantes puede dificultar el agarre adecuado de una herramienta, y requiere apretar más para manejar las herramientas mecánicas, lo cual puede causar una fatiga excesiva. El uso de herramientas por los operarios de la construcción para trabajos repetitivos, puede ser también la causa de trastornos traumáticos cumulativos, como síndrome del túnel carpal o tendinitis. El uso de la herramienta idónea para el trabajo, y la elección de herramientas con características óptimas de diseño que se sientan más cómodas en la mano mientras se realiza el trabajo, pueden ayudar a evitar estos problemas. 


\section{EQUIPOS, MAQUINAS Y MATERIALES}

\section{Hans Göran Linder}

Los trabajos de la construcción han experimentado cambios importantes. El sector, que antaño dependía de la destreza artesanal con sencillas ayudas mecánicas, hoy en día se basa en gran medida en máquinas y equipos.

Los nuevos equipos, máquinas, materiales y métodos han contribuido al desarrollo del sector. Hacia mediados del siglo XX aparecieron las grúas de edificación, así como materiales nuevos, como el hormigón ligero. Con el transcurso del tiempo, el sector comenzó a usar elementos de construcción prefabricados junto con nuevas técnicas para la construcción de edificios. Los proyectistas empezaron a usar los ordenadores. Gracias a equipos como los elevadores, algunos de los trabajos se han simplificado en términos de esfuerzo físico, pero también se han hecho más complejos.

En lugar de materiales básicos, de tamaño reducido, como ladrillos, tejas, tablones y hormigón ligero, hoy en día se usan corrientemente elementos de construcción prefabricados. El equipo se ha ampliado desde sencillas herramientas manuales y facilidades de transporte hasta una compleja maquinaria. Del mismo modo, los métodos de trabajo han cambiado: por ejemplo, desde llevar el hormigón en carretillas hasta bombearlo y desde la elevación de materiales a mano al izado de elementos integrados con ayuda de grúas.

Cabe esperar que sigan apareciendo innovaciones en equipos, máquinas y materiales.

\section{Directivas de la Comunidad Europea relativas a la salud y seguridad de los trabajadores} En 1985, la Comunidad Europea (CE) decidió un "Nuevo enfoque de la armonización y normas técnicas" a fin de facilitar el libre movimiento de mercancías. Las directivas de este "nuevo enfoque" son leyes comunitarias que establecen exigencias esenciales para la salud y la seguridad que se deben cumplimentar antes de que los productos puedan suministrarse entre los países miembros o importados a la Comunidad. Un ejemplo de directiva con un nivel fijo de exigencias es la Directiva de maquinaria (Consejo de las Comunidades Europeas 1989). Los productos que cumplen las exigencias de esta directiva llevan un distintivo y pueden ser suministrados en cualquier territorio de la CE. Existen sistemas análogos para los productos cubiertos por la Directiva de productos de construcción (Consejo de las Comunidades Europeas 1988).

Además de las directivas con este nivel de exigencias fijo, existen directivas que establecen los criterios mínimos de las condiciones de los lugares de trabajo. Los Estados miembros de la Comunidad deben cumplir estos criterios o, en su caso, cumplir un nivel de seguridad más estricto estipulado en su normativa nacional. De relevancia específica para el trabajo en la construcción son la Directiva sobre las condiciones mínimas de salud y seguridad en el trabajo para el uso de maquinaria por los trabajadores (89/655/CEE) y la Directiva sobre las condiciones mínimas de salud y seguridad en obras de construcción móviles y provisionales (92/57/CEE).

\section{Andamios}

Uno de los tipos de equipo de construcción que afectan a menudo a la seguridad de los trabajadores son los andamios, medio fundamental para habilitar una superficie de trabajo en altura. Los andamios se usan en conexión con la construcción, reconstrucción, restauración, mantenimiento y trabajos de revisión de los edificios y otras estructuras. Los componentes de los andamios pueden ser usados para otras construcciones, como torres de apuntalamiento (que no se consideran andamios), o para el montaje de estructuras provisionales, como graderíos (es decir, asientos para espectadores) y escenarios para conciertos y otras representaciones públicas. Muchas lesiones laborales están relacionadas con su uso, en particular las causadas por caídas de altura (véase también el apartado "Ascensores, escaleras mecánicas y montacargas" en este capítulo).

\section{Tipos de andamios}

Los andamios de apuntalamiento se pueden montar usando tubos verticales y horizontales conectados por piezas especiales. Los andamios prefabricados se montan con piezas fabricadas de acuerdo con procedimientos normalizados y que van unidas permanentemente a los dispositivos de fijación. Existen varios tipos: el tipo tradicional o modular para la construcción de fachadas, las torres de acceso móviles (TAM), los andamios para artesanos y andamios colgantes.

\section{Ajuste vertical del andamio}

Las plataformas de trabajo de un andamio generalmente permanecen estacionarias. Sin embargo, algunos andamios tienen plataformas de trabajo que se pueden desplazar verticalmente a diferentes posiciones; pueden ir suspendidas de cables que las suben y bajan, o pueden apoyarse sobre el terreno y ser desplazadas por medio de elevadores o cabrestantes hidráulicos.

\section{Montaje de andamios de fachada prefabricados}

El montaje de andamios de fachada prefabricados deberá hacerse de acuerdo con las siguientes recomendaciones:

- El fabricante deberá facilitar instrucciones detalladas para el montaje, las cuales se conservarán en el lugar de trabajo y el montaje deberá ser supervisado por personal competente. Se tomarán precauciones para proteger a las personas que pasen por debajo del andamio, acordonando la zona, erigiendo un andamio adicional que sirva de paso cubierto de peatones, o creando un voladizo de protección.

- La base del andamio se colocará sobre una superficie firme y nivelada. Se colocará una placa de base metálica regulable sobre los tablones o los tableros, a fin de crear una superficie suficiente para la distribución de la carga.

- Un andamio que esté a más de 2 a 3,5 m sobre el suelo deberá estar equipado con protecciones de caídas, comprendiendo una barandilla a una altura mínima de $1 \mathrm{~m}$ sobre la plataforma, una barandilla intermedia y un rodapié. Para trasladar herramientas y materiales dentro y fuera de la plataforma, se puede practicar el hueco menor posible en la barandilla, con un tope inferior y barandillas a ambos lados del mismo.

- Se deberá habilitar un acceso al andamio para que se efectúe normalmente a través de escaleras fijas y no portátiles.

- El andamio deberá estar firmemente sujeto a la fábrica del edificio, de acuerdo con las instrucciones del fabricante.

- La estabilidad del andamio deberá reforzarse mediante elementos diagonales u horizontales (arriostramientos), de acuerdo con las instrucciones del fabricante.

- El andamio deberá estar lo más próximo posible a la fachada del edificio; si la separación es superior a $300 \mathrm{~mm}$, puede ser necesaria una segunda barandilla por la parte interior de la plataforma.

- Si se emplean tablones para formar la plataforma, éstos deben estar sujetos firmemente a la estructura del andamio. Una norma europea de próxima aparición estipula que la flecha (comba) no será superior a $25 \mathrm{~mm}$. 
Figura 93.9 - Excavación mecánica en una obra en Francia.

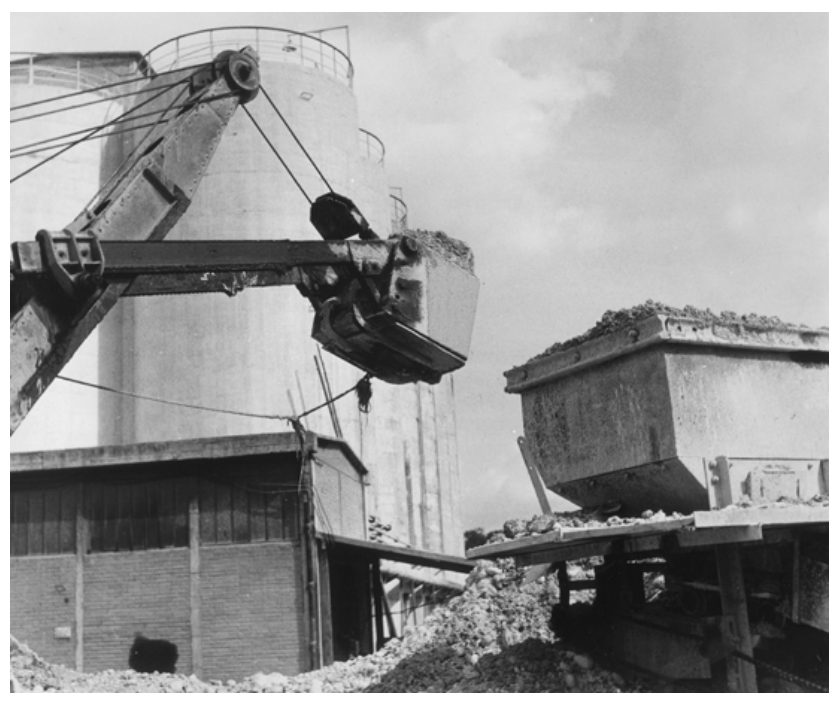

\section{Maquinaria de movimiento de tierras}

La maquinaria para el movimiento de tierras está diseñada fundamentalmente para aflojar, recoger, mover, transportar y distribuir o nivelar la roca o la tierra, y reviste gran importancia en la construcción, las obras públicas y los trabajos agrícolas e industriales (véase la Figura 93.9). Usadas adecuadamente, estas máquinas son versátiles y pueden eliminar gran parte de los riesgos relacionados con la manipulación manual de materiales. Este tipo de maquinaria es altamente eficiente y se usa en el mundo entero.

Las máquinas de movimiento de tierras empleadas en los trabajos de construcción y obras públicas incluyen tractores con topadora (bulldozers), cargadoras, retrocargadoras (véase la Figura 93.10), excavadoras hidráulicas, volquetes, traíllas, niveladoras, tendedoras de tuberías, zanjadoras, compactadoras de terraplenes y excavadoras de cable.

La maquinaria de movimiento de tierras puede poner en peligro al maquinista y al personal que se halle trabajando en su proximidad. El siguiente resumen de los riesgos asociados con estas máquinas está basado en la Norma EN 474-1 de la Comunidad Europea (Comité Europeo de Normalización 1994). Señala los factores relacionados con la seguridad, que se deben considerar cuando se adquieren y emplean estas máquinas.

\section{Acceso}

La máquina debe estar dotada de un acceso seguro al puesto del maquinista y a las zonas de mantenimiento.

\section{Puesto del maquinista}

El mínimo espacio habilitado para el maquinista deberá permitir todas las maniobras necesarias para el manejo seguro de la maquinaria sin fatiga excesiva. No debe existir la posibilidad de que el maquinista tenga un contacto accidental con las ruedas o las orugas o con el equipo de trabajo. El sistema de escape del motor deberá expulsar el gas lejos del puesto del maquinista.

Una máquina con un motor de rendimiento superior a $30 \mathrm{~kW}$ deberá estar equipada con una cabina para el maquinista. Las máquinas cuyo motor sea de una potencia inferior a $30 \mathrm{~kW}$ deberán equiparse con una cabina, en el caso de que se destinen a un trabajo en que la calidad del aire es insalubre. Se efectuará la medición del nivel de ruido transmitido por el aire, producido por excavadoras, tractores, cargadoras y retroexcavadoras, de acuerdo con la norma internacional de ruidos exteriores aerotransportados emitidos por maquinaria de movimiento de tierras (ISO 1985b).

La cabina deberá proteger al maquinista de las condiciones atmosféricas predecibles. El interior de la cabina no deberá presentar bordes cortantes o ángulos agudos que puedan lesionar al maquinista si se cae o resulta lanzado contra los bordes o ángulos. Los tubos y las mangueras situados dentro de la cabina y que contengan fluidos peligrosos, a causa de su presión o temperatura, deberán estar reforzados y protegidos. La cabina deberá tener una salida de emergencia independiente de la entrada habitual. La altura mínima del techo sobre el asiento (es decir, el punto índice del asiento) depende del tamaño del motor de la máquina; para motores entre 30 y $150 \mathrm{~kW}$ deberá ser $1.000 \mathrm{~mm}$. El vidrio deberá ser inastillable. El nivel de ruido en el puesto del maquinista no excederá de 85 dBA (ISO 1985c).

El diseño del puesto del maquinista permitirá que éste divise las zonas de trabajo y desplazamiento de la máquina, preferentemente sin necesidad de inclinarse hacia delante. Si la visibilidad del maquinista resulta clara, espejos o cámaras a distancia con un monitor visible para el maquinista, le permitirán ver la zona de trabajo.

La ventana anterior y, si es necesario, la posterior, deberán estar equipadas con limpia y lavaparabrisas motorizados. Deberán estar provistas de dispositivos para eliminar el vaho y el hielo de, como mínimo, la ventana anterior de la cabina.

\section{Protección de vuelco y de caída de objetos}

Las cargadoras, topadoras, traíllas, niveladoras, volquetes articulados y cargadoras con retroexcavadora de una potencia superior a $15 \mathrm{~kW}$ deberán tener una estructura que las proteja contra el vuelco. Las máquinas que se vayan a usar en lugares en los que existe el riesgo de caída de objetos deberán ser diseñadas para ello y equipadas con una estructura que proteja al maquinista de las caídas de material.

\section{Asiento del maquinista}

La maquinaria prevista para un maquinista sentado deberá estar equipada con un asiento ajustable que le mantenga en una posición estable y que le permita controlar la máquina en todas las condiciones de trabajo previstas. Los ajustes necesarios para

Figura 93.10 - Modelo de retroexcavadora con pala cargadora y dirección articulada.

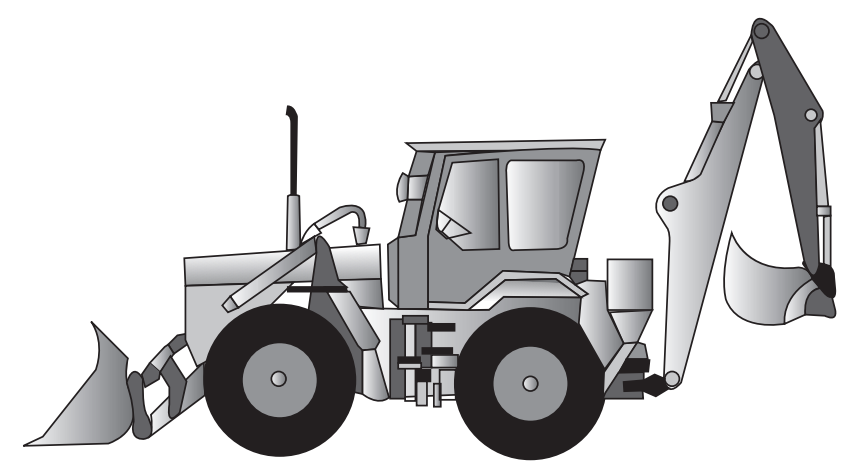

La máquina es versátil. Se puede emplear para excavar, cargar y elevar cargas. La articulación de la máquina permite utilizarla en espacios reducidos. 
acoplarlo a la talla y peso del maquinista deberán poder efectuarse fácilmente sin ayuda de herramientas.

Las vibraciones transmitidas por el asiento del maquinista cumplirán la normativa internacional aplicable en materia de vibraciones (ISO 1982) para tractores-topadora, cargadoras y tractores-traílla.

\section{Mandos e indicadores}

Los mandos principales, indicadores, palancas, pedales, interruptores y demás, deberán estar seleccionados, diseñados y dispuestos de modo que su definición sea clara, con rótulos legibles y dentro del alcance del maquinista. Los mandos de los componentes de la máquina deberán estar diseñados de modo que no se puedan poner en marcha o mover accidentalmente, incluso si están expuestos a interferencias de equipos de radio o telecomunicaciones.

Los pedales deberán ser de un tamaño y forma adecuados; deberán estar forrados con material antideslizante y estar adecuadamente distanciados. Para evitar confusiones, la máquina deberá ser diseñada de modo que pueda manejarse como si fuera un vehículo a motor, con los pedales situados en la misma disposición (esto es, el embrague a la izquierda, el freno en el centro y el acelerador a la derecha).

La maquinaria de movimiento de tierras con mando a distancia deberá diseñarse de modo que se pare automáticamente y quede inmovilizada si se desactivan los mandos o se interrumpe su alimentación de energía.

La maquinaria de movimiento de tierras deberá estar equipada con:

- luces de parada e indicadores de dirección en las máquinas diseñadas para una velocidad de desplazamiento superior a $30 \mathrm{~km} / \mathrm{h}$

- un dispositivo acústico de alarma, controlado desde el puesto del maquinista y cuyo nivel acústico sea, al menos, de $93 \mathrm{dBA}$ a una distancia de $7 \mathrm{~m}$ desde el extremo anterior de la máquina, y

- un dispositivo que permita la instalación de una luz parpadeante.

\section{Movimiento incontrolado}

El reptado (derrape) desde la posición de paro, por cualesquiera razones (p. ej., fugas internas) que no sean las de sus mandos, no podrá constituir un riesgo para los que circulen a su lado.

\section{Sistemas de dirección y frenado}

El sistema de dirección será tal que el control de la dirección se mueva en la misma dirección que se pretende que tome la máquina. El sistema de dirección de las máquinas con neumáticos de goma, con una velocidad de desplazamiento superior a $20 \mathrm{~km} / \mathrm{h}$, deberá cumplir la norma internacional para sistemas de dirección (ISO 1992).

La maquinaria deberá estar equipada con sistemas de frenado de servicio, secundario y de estacionamiento que actúen con eficacia en todas las condiciones previsibles de servicio, carga, velocidad, características y pendiente del terreno. El maquinista podrá reducir la velocidad y parar la máquina por medio del freno de servicio. Para el caso de que éste último falle, se dispondrá de un freno secundario. También se dispondrá un dispositivo mecánico de estacionamiento, a fin de evitar que la máquina se mueva cuando se encuentra parada, y que sea capaz de permanecer en la posición que se adopte. El sistema de frenado también cumplirá la normativa internacional de sistemas de frenado (ISO 1985a).

\section{Alumbrado}

Para posibilitar el trabajo nocturno o en condiciones polvorientas, las máquinas de movimiento de tierras estarán equipadas con luces de tamaño y brillo suficientes para iluminar adecuadamente las zonas de trabajo y maniobra.

\section{Estabilidad}

La maquinaria de movimiento de tierras, incluidos sus componentes y aditamentos, se proyectará y construirá de modo que permanezca estable en las condiciones de funcionamiento previstas.

Los dispositivos cuyo objeto es aumentar la estabilidad de la maquinaria de movimiento de tierras en el modo de trabajo, como estabilizadores y bloqueos de eje oscilantes, deberán estar equipados con dispositivos de enclavamiento que los mantengan en posición, incluso en el caso de fallo de la manguera hidráulica.

\section{Protecciones y cubiertas}

Las protecciones y cubiertas se diseñarán de modo que se mantengan fijas en su ubicación. Cuando el acceso sólo sea necesario en raras ocasiones, las protecciones se fijarán y acoplarán de modo que solamente se puedan desmontar con ayuda de herramientas o llaves. Siempre que sea posible, las protecciones permanecerán sujetas con bisagras a la máquina cuando se abran. Las cubiertas y protecciones deberán estar equipadas con un sistema de apoyo (muelles o cilindros de gas) para asegurarlas en su posición abierta con viento de hasta $8 \mathrm{~m} / \mathrm{s}$ de velocidad.

\section{Componentes eléctricos}

Los componentes y conductores eléctricos se instalarán de modo que se evite la abrasión de los cables y otros posibles deterioros por el uso, así como su exposición al polvo y condiciones ambientales que puedan causar su deterioro.

Las baterías de alimentación estarán provistas de asas y firmemente sujetas en una posición adecuada, de modo que su desconexión y desmontaje se pueda realizar también con facilidad. Como alternativa, un interruptor de fácil acceso situado entre la batería y la tierra permitirá el aislamiento de la primera del resto de la instalación eléctrica.

\section{Depósitos de combustible y fluidos hidráulicos}

Los depósitos para combustibles, fluidos hidráulicos y de otros tipos deberán estar provistos de dispositivos para mitigar cualquier presión interna en caso de apertura y reparación. Deberán tener un fácil acceso para su llenado y estar provistos de tapones de cierre con llave.

\section{Protección contra el fuego}

El suelo y el interior del puesto del maquinista se fabricarán con materiales ignífugos. Las máquinas cuyos motores tengan una potencia superior a $30 \mathrm{~kW}$ estarán dotadas de un sistema de extinción de incendios integrado o dispondrán de un alojamiento para un extintor de incendios de fácil acceso para el maquinista.

\section{Mantenimiento}

Las máquinas se proyectarán y construirán de modo que las operaciones de engrase y mantenimiento se puedan realizar con seguridad; siempre que ello sea posible, con el motor parado. Si el mantenimiento solamente se puede realizar con la máquina en posición levantada, ésta se asegurará mecánicamente. Se tomarán precauciones especiales, como instalar una protección o, al menos, señales de advertencia, si se ha de realizar el mantenimiento con el motor en marcha. 


\section{Rotulado}

Todas las máquinas llevarán, de un modo legible e indeleble, la siguiente información: el nombre y dirección del fabricante, las placas obligatorias, designación de la serie y del tipo, el número de serie (si lo hay), la potencia del motor (en $\mathrm{kW}$ ), la masa de su configuración más habitual (en $\mathrm{kg}$ ) y, si procede, el máximo esfuerzo de tracción al gancho y la carga vertical máxima.

Entre otras indicaciones que pueden ser apropiadas se incluyen: las condiciones de utilización, el distintivo de conformidad (CE) y una referencia a las instrucciones de instalación, uso y mantenimiento. El distintivo $\mathrm{CE}$ indica que la máquina cumple los requisitos de las directivas de la Comunidad Europea pertinentes.

\section{Señalización de alerta}

$\mathrm{Si}$ el movimiento de una máquina origina riesgos que no son patentes para un observador ocasional, se adosarán a la máquina señales de alerta para advertir de la aproximación a la misma, cuando ésta se encuentre funcionando.

\section{Verificación de las condiciones de seguridad}

Es necesario verificar el cumplimiento de los requisitos de seguridad en el diseño y fabricación de una máquina de movimiento de tierras. Esta verificación se asegurará por medio de una combinación de mediciones, inspección visual, pruebas (si existe un método recomendado) y evaluación del contenido de la documentación, que el fabricante deba conservar preceptivamente. La documentación del fabricante acreditará que los componentes adquiridos, como los parabrisas, se han fabricado de acuerdo con las especificaciones.

\section{Manual de funcionamiento}

Con la máquina se entregará un manual de instrucciones para su empleo y mantenimiento, que se guardará junto a la misma. Estará escrito, al menos, en uno de los idiomas oficiales del país en el que se vaya a utilizar la máquina. Describirá en términos sencillos y fácilmente comprensibles los riesgos para salud y seguridad que puede ocasionar, (p. ej., ruido y vibraciones en brazos y manos y en todo el cuerpo) y especificará cuándo es necesario el empleo de equipo de protección individual (EPI). En el puesto del maquinista habrá un espacio destinado a guardar el manual a buen recaudo.

También se suministrará un manual de montaje, que contendrá la información necesaria para que el personal especializado pueda montar, reparar y desmontar la maquinaria con el mínimo riesgo.

\section{Condiciones de funcionamiento}

Además de los requisitos antes especificados con respecto al diseño, el manual de instrucciones deberá especificar los límites de aplicación de la máquina (p. ej., la máquina no deberá desplazarse con un ángulo de inclinación mayor que el recomendado por el fabricante). Si el maquinista advierte defectos, daños o un desgaste excesivo que puedan ocasionar un riesgo para la seguridad, deberá informar inmediatamente a su superior y paralizar la máquina hasta que se realicen la reparaciones necesarias.

No se debe intentar levantar con la máquina una carga de peso superior al especificado en la tabla de capacidades del manual de funcionamiento. El maquinista comprobará la sujeción de las eslingas a la carga y al gancho de elevación y si se da cuenta de que la carga no está sujeta con seguridad, o tiene dudas sobre su seguro manejo, desistirá de su elevación.

Cuando una máquina se desplace con una carga suspendida, ésta se mantendrá lo más próxima posible al terreno para minimizar la inestabilidad potencial, y la velocidad de desplazamiento se acomodará a las condiciones del terreno. Se evitará todo cambio brusco de velocidad y se tomarán precauciones para que la carga no se balancee.

Cuando la máquina se encuentre funcionando, nadie entrará en la zona de trabajo sin advertir al maquinista. Cuando el trabajo requiera que alguna persona permanezca dentro de la zona de trabajo, deberá tener gran cautela y evitará moverse innecesariamente o permanecer debajo de una carga izada o suspendida. Cuando alguien se encuentre dentro de la zona de trabajo de la máquina, el maquinista deberá extremar el cuidado y manejar la máquina solamente cuando tal persona esté a la vista del maquinista o su situación le haya sido notificada. Del mismo modo, en las máquinas que efectúan giros, como las grúas y las retroexcavadoras, se mantendrá despejada la zona detrás de la máquina y dentro de su radio de giro. Si un camión se posiciona para su carga de modo que los escombros puedan caer sobre la cabina del conductor, nadie deberá permanecer en la misma, a menos que tenga una resistencia suficiente para resistir el impacto de los materiales al caer.

$\mathrm{Al}$ inicio del turno de trabajo, el maquinista comprobará los frenos, dispositivos de bloqueo, embragues, dirección y el sistema hidráulico, además de realizar una prueba de funcionamiento sin carga. Cuando compruebe los frenos, el maquinista se asegurará de que la máquina se puede frenar rápidamente, parar a continuación y mantener su posición con seguridad.

Antes de abandonar la máquina al final de la jornada, el maquinista dejará todos los mandos en punto muerto, desconectará la alimentación de fuerza y tomará todas las precauciones necesarias para evitar el uso de la máquina sin autorización. El maquinista tendrá en cuenta las condiciones atmosféricas potenciales que puedan sobrevenir a la superficie de apoyo, y que tal vez puedan ocasionar que la máquina se hiele rápidamente, que vuelque o que se hunda, y adoptar las medidas adecuadas para evitar tales contingencias.

Los componentes y repuestos, como por ejemplo los manguitos hidráulicos, cumplirán las especificaciones del manual de funcionamiento. Antes de intentar cualquier trabajo de sustitución o reparación en los sistemas hidráulico o de aire comprimido, se aliviará la presión. Se seguirán las instrucciones y precauciones facilitadas por el fabricante cuando, por ejemplo se instale algún aditamento para el trabajo. Cuando se realicen trabajos de reparación o mantenimiento se usará el equipo de protección individual (EPI), como un casco y gafas de seguridad.

\section{Posicionamiento de una máquina para el trabajo}

$\mathrm{Al}$ situar una máquina en posición, deberán considerarse los riesgos de vuelco, deslizamiento y hundimiento del terreno. En su caso se efectuará un enclavamiento suficientemente sólido y amplio para asegurar la estabilidad.

\section{Tendido eléctrico}

$\mathrm{Al}$ manejar una máquina en la proximidad de líneas de electricidad aéreas, se tomarán precauciones para evitar el contacto con el tendido. A este respecto es recomendable la cooperación con la compañía eléctrica.

\section{Tuberías, cables y líneas eléctricas enterradas}

Antes de iniciar un proyecto, el contratista o su representante deberá determinar si existen conducciones enterradas de electricidad, gas, agua o tuberías de canalización dentro del emplazamiento y, en tal caso, averiguar y señalizar su situación exacta. $\mathrm{Al}$ maquinista se le darán instrucciones específicas para evitarlas, por ejemplo, por medio de un programa de "consultar antes de excavar". 


\section{Trabajos en carreteras con tráfico}

Cuando una máquina trabaje en una carretera o cualquier otro lugar abierto al tráfico público, se instalarán las señales de tráfico, vallas y demás dispositivos de seguridad adecuados al volumen de tráfico, a la velocidad de los vehículos y a los códigos de circulación locales.

Se recomienda que el transporte de una máquina por una carretera pública se haga con camión o remolque. Se tendrá en cuenta el riesgo de vuelco al cargar y descargar la máquina, habiendo de asegurarla para impedir su deslizamiento durante el transporte.

\section{Materiales}

Entre los materiales usados en construcción se incluyen el amianto, asfalto, ladrillos y piedra, cemento, hormigón, pavimentos, agentes de sellado de láminas, vidrio, pegamento, lana mineral y fibras minerales sintéticas para fines de aislamiento, pinturas e imprimaciones, plástico y goma, acero y otros metales, paneles para muros, yeso y madera. Muchos de ellos se tratan en otros apartados de este Capítulo o en otras partes de esta Enciclopedia.

\section{Amianto}

El uso del amianto en las obras de nueva construcción está prohibido en varios países pero, inevitablemente, se puede encontrar durante la demolición o restauración de edificios viejos. En consecuencia, se requerirán estrictas medidas para proteger a los trabajadores y al público de la exposición al amianto colocado con anterioridad.

\section{Ladrillos, hormigón y piedra}

Los ladrillos se fabrican con arcilla cocida y se clasifican en ladrillo visto y ladrillo para revestir. Pueden ser macizos o aligerados con agujeros. Sus propiedades físicas dependen de la arcilla empleada, de los aditivos, del método de fabricación y de la temperatura de cocción. Cuanto mayor sea ésta, menor será la absorción de agua por el ladrillo.

Los ladrillos, el hormigón y la piedra que contienen cuarzo producen polvo de sílice al cortarlos, taladrarlos o chorreados. Las exposiciones sin protección a la sílice cristalina pueden aumentar la susceptibilidad a la tuberculosis y causar silicosis, una enfermedad pulmonar incapacitadora, crónica y potencialmente mortal.

\section{Pavimentos}

Entre los materiales comúnmente empleados para pavimentos interiores se incluyen la piedra, ladrillos, paneles de suelo, moqueta textil, linóleo y plástico. La colocación de pavimentos de terrazo, baldosas o entarimado de madera pueden exponer a un operario a polvos que pueden causar alergias o dañar la respiración o los pulmones. Además, las colas o adhesivos empleados para la colocación de baldosas o moquetas contienen a menudo disolventes potencialmente tóxicos.

Los colocadores de moquetas pueden dañarse las rodillas al arrodillarse y al golpearse en una rodilla al estirar la moqueta para ajustarla.

\section{Colas y pegamentos}

Los pegamentos se utilizan para unir materiales por adhesión. La cola con base acuosa contiene un agente aglutinante al agua y se endurece cuando el agua se evapora. Los pegamentos con disolventes se endurecen cuando éste se evapora. Puesto que los vapores pueden ser nocivos para la salud, no deberán usarse en locales cerrados o en sitios poco ventilados. Los pegamentos formados por componentes que se endurecen al mezclarse son susceptibles de producir alergias.

\section{Lana mineral y otros tipos de aislamiento}

La función a que se destina un aislamiento en un edificio consiste en asegurar el confort térmico y reducir el consumo de energía. Para lograr un aislamiento aceptable se usan materiales porosos, como lana mineral y fibras sintéticas minerales. Se debe tener gran cuidado en evitar la inhalación de las fibras. Las fibras puntiagudas pueden incluso traspasar la piel y originar una molesta dermatitis.

\section{Pinturas e imprimaciones}

Las pinturas se emplean para decorar el exterior y el interior de los edificios, para proteger materiales como el hierro y la madera contra su corrosión y deterioro, para facilitar la limpieza de los objetos y para señales de tráfico verticales y horizontales.

Hoy en día se evitan las pinturas a base de plomo, pero estas se pueden encontrar durante la restauración o demolición de estructuras más antiguas, en especial las de construcción metálica, como puentes y viaductos. La inhalación o ingestión de los vapores o polvos pueden causar saturnismo con lesión de los riñones o daño permanente del sistema nervioso; estas inhalaciones son particularmente peligrosas para los niños que pueden estar expuestos a polvos de plomo traídos a casa con la ropa o en el calzado de trabajo. Siempre que se usen o encuentren pinturas a base de plomo se adoptarán medidas de precaución.

En la mayoría de países está prohibido el uso de pinturas a base de cadmio o mercurio. El cadmio puede causar problemas renales y ciertos tipos de cáncer. El mercurio puede causar daños en el sistema nervioso.

Las pinturas e imprimaciones al óleo contienen disolventes que pueden ser potencialmente nocivos. Para minimizar las exposiciones a los disolventes se recomienda el uso de pinturas de base acuosa.

\section{Plástico y caucho}

El plástico y el caucho, denominados polímeros, se pueden agrupar en plástico termoplástico o termoestable y goma. Estos materiales se usan en la construcción para ajustes, aislamientos, recubrimientos y para productos como tuberías y accesorios. Las láminas hechas de plástico o goma se usan para forros de ajuste y antihumedad y pueden causar reacciones en los obreros sensibles a estos materiales.

\section{Acero, aluminio y cobre}

$\mathrm{El}$ acero se usa en la construcción como estructura resistente, en forma de redondos para armaduras, para componentes mecánicos y como material de revestimiento. El acero puede ser al carbono o en diversas aleaciones; el acero inoxidable es un tipo de aleación. Las propiedades más importantes del acero son su dureza y su resistencia. La resistencia a la rotura es importante para evitar roturas frágiles.

Las propiedades del acero dependen de su composición y estructura químicas. El acero es tratado térmicamente para aliviar sus tensiones internas y mejorar su soldabilidad, resistencia y dureza a la fractura.

El hormigón puede tener una resistencia a la compresión considerable, pero para que adquiera una resistencia a la tracción aceptable precisa de la unión con barras y mallazos de refuerzo. Estas barras suelen tener un alto contenido de carbono $(0,40 \%)$.

$\mathrm{El}$ acero al carbono o acero "suave" contiene manganeso que, cuando se desprende en los humos de la soldadura, puede causar un síndrome parecido al mal de Parkinson, que puede dar lugar a un trastorno nerviosos paralizante. En ciertas condiciones, el aluminio y el cobre también pueden ser nocivos para la salud. 
Los aceros inoxidables contienen cromo, que aumenta la resistencia a la corrosión, y otros elementos de aleación, como níquel y molibdeno. La soldadura del acero inoxidable puede exponer a los operarios a vapores de cromo o de níquel. Algunas formas de níquel pueden causar asma y cáncer; algunas formas de cromo pueden causar cáncer y problemas de sinusitis y "perforación nasal" (erosión del septo nasal).

Después del acero, el aluminio es el metal más comúnmente usado en la construcción, debido a que tanto el metal como sus aleaciones son ligeros, fuertes y resistentes a la corrosión.

El cobre es uno de los metales más importantes en ingeniería, por su resistencia a la corrosión y su elevada conductividad térmica y eléctrica. Se usa en líneas de transporte de energía, como recubrimientos de paredes y cubiertas y para tuberías. Guando se usa como revestimiento de cubiertas, las sales de cobre arrastradas por la lluvia pueden ser nocivas para el entorno.

\section{Paneles de revestimiento de paredes y yeso}

Los paneles para paredes, frecuentemente recubiertos de asfalto o plástico, se usan como capa de protección contra el agua y el viento y para evitar que el agua se filtre a través de los elementos de la construcción. El yeso es sulfato cálcico cristalizado. El panel de yeso-cartón es un panel sandwich formado por dos capas de cartón que encierran una de yeso; se usa ampliamente como revestimiento de paredes y es resistente al fuego.

El polvo que se produce al cortar el yeso-cartón puede producir alergias cutáneas o lesiones pulmonares; el levantamiento de paneles de tamaño o peso excesivos o en posturas inconvenientes puede causar problemas musculosqueléticos.

\section{Madera}

La madera se utiliza ampliamente en la construcción. Es importante que la madera que se use para la construcción esté seca. Para vigas y cerchas de cubierta, de un vano importante, se usan elementos de madera laminada. Es recomendable tomar medidas para evitar el polvo que, según cada especie, puede causar una serie de enfermedades, incluso el cáncer. En ciertas condiciones, el serrín de la madera puede llegar a ser explosivo.

\section{GRUAS}

\section{Francis Hardy}

Una grúa es una máquina con una pluma, diseñada principalmente para subir y bajar cargas pesadas. Hay dos tipos básicos de grúas: móviles y fijas. Las grúas móviles pueden ir montadas sobre vehículos de motor, barcos o vagones de ferrocarril. Las grúas fijas son del tipo torre. Existen también las grúas pórtico, que discurren por carriles elevados. Hoy en día, la mayoría de las grúas son movidas mecánicamente, aunque algunas todavía funcionan manualmente. Su capacidad, en función del tipo y tamaño, oscila desde unos pocos kilogramos a cientos de toneladas. Las grúas se usan también para hincar pilotes, en dragados, excavaciones, demoliciones y como plataformas de trabajo para personas. Generalmente, la capacidad de una grúa es mayor cuando la carga se encuentra más próxima a su mástil (centro de rotación) y es menor cuando la carga se encuentra más alejada de él.

\section{Riesgos de las grúas}

Los accidentes en que se encuentran implicadas las grúas son generalmente costosos y espectaculares. Las lesiones y las muertes no sólo afectan a los trabajadores, sino frecuentemente a inocentes transeúntes. Existen riesgos en todas las facetas de su funcionamiento, incluyendo el montaje, desmontaje, desplazamiento y mantenimiento. Algunos de los riesgos más comunes relacionados con las grúas son:

- Riesgos eléctricos. Se puede producir el contacto con el tendido eléctrico y el arco formado por la corriente eléctrica a través del aire si la máquina o el cable de elevación se encuentran demasiado próximos a la línea. Cuando se produce el contacto con la línea, el peligro no se limita solamente al operador de la máquina, sino que se extiende a todo el personal situado en su proximidad. El veintitrés por ciento del total de las muertes por accidentes de grúa en Estados Unidos, en 1988-1989, fueron ocasionados por contacto con líneas eléctricas. Aparte de las lesiones a las personas, la corriente eléctrica puede causar daños estructurales en la grúa.

- Fallos de la estructura y sobrecargas. Los fallos de la estructura se producen cuando una grúa o sus componentes de estiba se someten a esfuerzos estructurales que pueden causar daños irreparables. El balanceo o la descarga súbita de la carga, el uso de componentes defectuosos, la elevación de una carga superior a la capacidad admitida, el arrastre de cargas y la recogida de la carga fuera de la vertical pueden causar sobrecargas.

- Falta de estabilidad. La falta de estabilidad es más frecuente en las grúas móviles que en las fijas. Cuando una grúa mueve una carga, balancea su pluma o se mueve fuera de su campo de estabilidad, la grúa tiende a volcar. Las condiciones del terreno también pueden causar fallos de estabilidad. Cuando una grúa no está nivelada, su estabilidad se reduce si la pluma se orienta en ciertas direcciones. Cuando se instala una grúa en un terreno que no puede soportar su peso, el terreno se hundirá, causando el vuelco de la grúa. También se conocen casos en que las grúas han volcado al desplazarse por rampas inadecuadamente compactadas en obras de construcción.

- Caída o deslizamiento de materiales. Los materiales pueden caer o resbalar si no están debidamente sujetados. La caída de materiales puede lesionar a los trabajadores situados en su proximidad o causar daños a las cosas. Los movimientos de material no deseados pueden atrapar o aplastar a los obreros involucrados en la maniobra de carga o descarga.

- Mantenimiento y procedimientos de montaje y desmontaje inadecuados. Un acceso en malas condiciones, la ausencia de protecciones contra caídas y las prácticas inadecuadas han causado lesiones y a veces la muerte de operarios mientras realizaban el mantenimiento, montaje y desmontaje de grúas. Este problema es más común con las grúas móviles, cuyo mantenimiento se realiza sobre el terreno y carecen de dispositivos de acceso. Muchas grúas, en especial los modelos más antiguos, no están provistas de barandillas o peldaños para facilitar el acceso a diversas partes de la grúa. El mantenimiento alrededor de la pluma y encima de la cabina es peligroso si los trabajadores caminan por la pluma sin equipo de protección contracaídas. En las grúas de pluma en celosía, la carga y descarga incorrectas, además del montaje y desmontaje de la pluma, han causado que trozos de ella cayeran sobre los obreros. O bien los tramos de la pluma no estaban adecuadamente apoyados durante las operaciones, o bien la sujeción de los cables que sujetaban la pluma se había realizado defectuosamente.

- Riesgos del ayudante o engrasador. Se produce una situación muy peligrosa cuando la parte superior de la grúa gira más allá de la parte inferior estacionaria durante su funcionamiento normal. Todos los ayudantes que trabajan alrededor de la grúa deberán permanecer fuera de la base de la misma durante su funcionamiento. 
- Riesgos físicos, químicos y de fatiga del gruista. Si la cabina no está aislada, el gruista puede estar expuesto a un ruido excesivo que le cause sordera. Los asientos diseñados inadecuadamente pueden causarle dolores de espalda. La falta de ajuste de la altura del asiento y de su inclinación pueden ocasionar una mala visibilidad desde el puesto del conductor. Un diseño impropio de la cabina contribuye a una mala visibilidad. Los escapes de los motores de gasóleo o gasolina contienen humos que son peligrosos en zonas confinadas. Existe también la preocupación por el efecto de la vibración en todo el cuerpo transmitida por el motor, en especial en las grúas más antiguas. Las limitaciones de tiempo o la fatiga también intervienen en los accidentes de grúas.

\section{Medidas de control}

La operación segura de una grúa es responsabilidad de todas las partes involucradas. Los fabricantes de grúas son responsables del diseño y fabricación de máquinas que sean estables y tengan una sólida estructura. Las capacidades de las grúas tienen que estar computadas adecuadamente, de modo que haya las suficientes salvaguardas para evitar accidentes causados por exceso de carga e inestabilidad. Instrumentos tales como limitadores de carga e indicadores del ángulo y longitud de la pluma ayudan a los maquinistas en el manejo seguro de una grúa. (Los dispositivos sensores de líneas eléctricas han dado resultados no fiables). Todas las grúas deberán tener un indicador de carga-seguro, automático, eficaz y fiable. Además, los fabricantes de grúas deberán introducir adaptaciones del diseño que faciliten un acceso seguro para un manejo y mantenimiento seguros. Los riesgos pueden reducirse con un diseño claro de los paneles de control, insertando una tarjeta al alcance del maquinista que especifique las configuraciones de carga; incluirá barandillas, ventanas antideslumbrantes, ventanas que se extiendan hasta el suelo de la cabina, asientos confortables y aislamiento térmico y acústico. En algunos climas, las cabinas con calefacción y aire acondicionado contribuyen al confort del operario y reducen su fatiga.

Los propietarios de las grúas son los responsables de mantener las máquinas en buenas condiciones asegurándose de que se efectúen inspecciones regulares y un mantenimiento adecuado y empleando a maquinistas competentes. Los propietarios deberán ser capaces de recomendar la máquina más idónea para cada trabajo. Una grúa asignada a un proyecto deberá poder transportar la carga más pesada que le corresponda. La grúa deberá ser inspeccionada por una persona competente antes de ser asignada a un proyecto y, una vez en él, diaria y periódicamente (de acuerdo con las recomendaciones del fabricante), llevando un registro del mantenimiento. Se practicará una ventilación para eliminar o diluir el escape del motor de las grúas que trabajen en zonas cerradas. Igualmente se suministrará protección auditiva, si procede. Los supervisores de la obra deben establecer planes de antemano. Mediante una planificación adecuada se puede evitar tener que trabajar cerca de tendidos eléctricos. Si se tuviera que trabajar cerca de líneas de alta tensión deberán respetarse las distancias de separación obligatoria (véase la Tabla 93.6). Si no se puede evitar el trabajo cerca de las líneas eléctricas, el cable deberá desconectarse o aislarse.

Para ayudar al maquinista cuando trabaje en los límites de proximidad de líneas eléctricas se deberá recurrir a un señalista. El terreno, incluso el acceso y los alrededores de la zona de trabajo, deben poder soportar el peso de la grúa con la carga en suspensión. Si es posible, la zona de trabajo de la grúa se acordonará para evitar lesiones durante la operación de izado. Cuando el maquinista no pueda ver la carga claramente, se utilizará a un señalista. Este último y el maquinista deben estar instruidos y entender bien las señales de mano y otros aspectos del trabajo. Se proveerán aparejos adecuados para la sujeción,
Tabla 93.6 - Distancia preceptiva para voltajes normales en trabajos próximos a tendidos eléctricos de alta tensión.

\begin{tabular}{ll}
$\begin{array}{l}\text { Voltaje normal en kilovoltios } \\
\text { (entre fases) }\end{array}$ & $\begin{array}{l}\text { Distancia mínima preceptiva } \\
\text { en metros (y pies)* }\end{array}$ \\
\hline Hasta 50 & $3,1(10)$ \\
De 50 a 200 & $4,6(15)$ \\
De 200 a 350 & $6,1(20)$ \\
De 350 a500 & $7,6(25)$ \\
De 500 a 750 & $10,7(35)$ \\
De 750 a 1,000 & $13,7(45)$
\end{tabular}

* Los valores en metros se han calculado a partir de los valores recomendados en pies. Fuente: ASME 1994

de modo que los estibadores puedan asegurar que no se produzca la caída o deslizamiento de la carga. El equipo de estiba debe estar entrenado en el embragado y desembragado de las cargas. Una buena comunicación es vital para la seguridad en el manejo de grúas. Todos los aditamentos de seguridad y dispositivos de alarma deberán estar en buen estado de funcionamiento y no se desconectarán en ningún caso. La grúa debe estar nivelada y manejarse con arreglo a la tabla de cargas de la misma. Las patas deberán estar totalmente extendidas o dispuestas de acuerdo con las instrucciones del fabricante. Para evitar una carga excesiva, el maquinista debe conocer de antemano el peso a levantar, y emplear limitadores de carga y otros indicadores. El maquinista siempre trabajará conforme a las prácticas seguras de manejo de grúas. Todas las cargas deberán estar totalmente aseguradas antes de ser izadas. El movimiento con carga debe ser lento; la pluma nunca debe ser prolongada o acortada de tal modo que pueda comprometer la estabilidad de la grúa. No se manejarán las grúas cuando la visibilidad sea escasa o cuando el viento pueda hacer que el maquinista pierda el control de la carga.

\section{Normas y legislación}

Existen numerosas normas escritas o recomendaciones para la fabricación y el manejo de grúas. Algunas están basadas en los principios de diseño, otras en su funcionamiento. Entre los asuntos contemplados por estas normas se incluyen métodos para realizar pruebas de diversos dispositivos de seguridad; el diseño, construcción y características de las grúas; inspecciones, pruebas, procedimientos de mantenimiento y manejo; equipos recomendados y disposición de los mandos. Estas normas forman la base de la legislación oficial y los reglamentos de las empresas en materia de salud y seguridad y formación de los maquinistas.

\section{ASCENSORES, ESCALERAS MECANICAS Y ELEVADORES}

J. Staal y John Quackenbush*

\section{Ascensores}

Un ascensor es una instalación permanente de desplazamiento vertical que accede a dos o más niveles, y que comprende un habitáculo cerrado, o cabina, cuyas dimensiones y medios de

* Adaptado del artículo de la $3^{\text {a }}$ edición de la Enciclopedia de salud y seguridad en el trabajo. Autor: J. Staal. 
construcción permiten claramente el acceso de personas, y que se desplaza entre unas guías verticales rígidas. Un ascensor, por lo tanto, es un vehículo para subir y bajar personas de una planta a otra dentro de un edificio, directamente (control simple por botonera) o con paradas intermedias (control colectivo).

Una segunda categoría la constituye el montacargas que acoge en su interior tanto a personas como a objetos y mercancías, poseyendo características similares a los ascensores.

La tercera categoría la constituye el montacargas de servicio (montaplatos), que es una instalación permanente de elevación que accede a unos niveles definidos, pero cuya cabina es demasiado pequeña para transportar personas. Los montacargas de servicio transportan comida y suministros en hoteles y hospitales, libros en las bibliotecas, correo en los edificios de oficinas, etc. Generalmente, la superficie del piso de este tipo de cabina no excede de $1 \mathrm{~m}^{2}$, su profundidad de $1 \mathrm{~m}$, y su altura de $1,20 \mathrm{~m}$.

Figura 93.11 • Vista esquemática de una instalación de ascensor con los principales componentes.

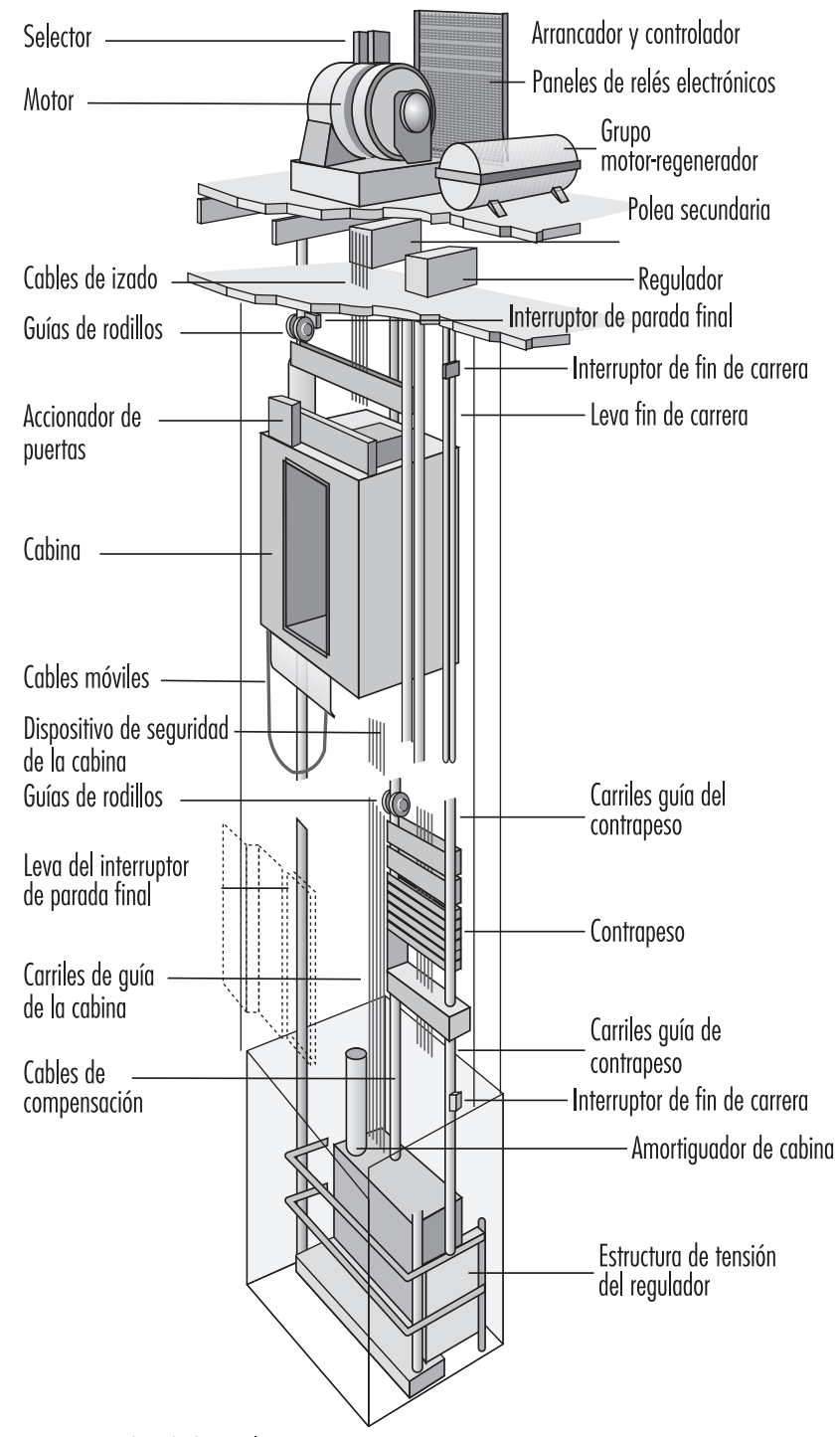

Fuente: Adaptado de Otis Elevator Company.
Los ascensores son movidos directamente por un motor eléctrico (ascensores eléctricos; véase la Figura 93.11) o, indirectamente, por medio del movimiento de un líquido bajo presión generada por una bomba movida, a su vez, por un motor eléctrico (ascensores hidráulicos).

Los ascensores eléctricos casi siempre están movidos por máquinas de tracción, con o sin transmisiones, según la velocidad de la cabina. El término "tracción" quiere decir que la fuerza de un motor eléctrico se transmite a la suspensión múltiple de cables de la cabina y de un contrapeso, por fricción entre las muescas de la polea de tracción o de impulsión de la máquina y los cables.

El uso de los ascensores hidráulicos se ha generalizado desde el decenio de 1970 para el transporte de mercancías y pasajeros, habitualmente hasta una altura no superior a seis plantas. Como líquido presurizante se emplea aceite hidráulico. El sistema más sencillo de acción directa es el que utiliza un émbolo que soporta y desplaza la cabina.

\section{Normalización}

El Comité Técnico 178 de la OIT ha redactado normas para cargas y velocidades hasta $2,50 \mathrm{~m} / \mathrm{s}$; dimensiones de cabinas y huecos de montacargas para dar cabida a pasajeros y mercancías; ascensores para camas y de servicio para edificios residenciales, oficinas, hoteles, hospitales y residencias de ancianos; mecanismos de control, señales y accesorios adicionales; y selección y planificación de ascensores en edificios residenciales. Todos los edificios deberán estar dotados, como mínimo, de un ascensor que permita el acceso en silla de ruedas de las personas disminuidas. La Asociación francesa de normalización (AFNOR) está a cargo de la Secretaría de este Comité Técnico.

\section{Condiciones generales de seguridad}

Todos los países industrializados tienen un código de seguridad redactado y actualizado por un comité nacional de normalización. Dado que este trabajo se inició en el decenio de 1920, los diversos códigos, poco a poco, se han hecho más parecidos y, hoy en día, las diferencias generalmente no son fundamentales. Las casas fabricantes de importancia fabrican unidades que cumplen estos códigos.

En el decenio de 1970, la OIT, en estrecha colaboración con el Comité Internacional para la reglamentación de ascensores (CIRA), publicó un código de prácticas para la construcción e instalación de ascensores y montacargas y, pocos años más tarde, para escaleras mecánicas. El objeto de estas directrices es servir de guía a los países que se han propuesto redactar o modificar normas de seguridad. Un conjunto normalizado de reglas de seguridad para ascensores eléctricos e hidráulicos, montacargas, escaleras mecánicas y bandas transportadoras de personas, con el fin de eliminar barreras técnicas al comercio entre los países miembros de la Comunidad Europea, se encuentra también en el punto de mira del Comité Europeo de Normalización (CEN). El American National Standards Institute (ANSI) ha redactado un código de seguridad para ascensores y escaleras mecánicas.

Los reglamentos de seguridad tienen por objeto diferentes tipos de posibles accidentes relacionados con ascensores: cizallamiento, aplastamiento, caída, impacto, atrapamiento, incendio, electrocución, daños al material, accidentes debidos al uso y accidentes debidos a la corrosión. Las personas que tienen que ser protegidas son: los usuarios, el personal de inspección y mantenimiento y los que se encuentren fuera del hueco del ascensor y de la sala de máquinas. Los objetos a proteger son: las cargas transportadas, los componentes de la instalación del ascensor y el edificio.

Los comités que redactan las normas de seguridad tienen que suponer que todos los componentes están diseñados 
Figura 93.12 • Disposición de la protección inferior de la cabina para evitar atrapamientos.

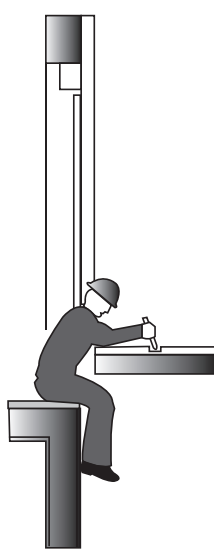

Inseguro

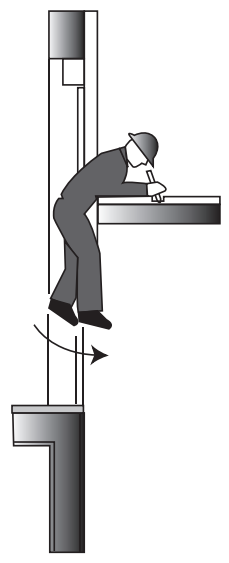

Cabing

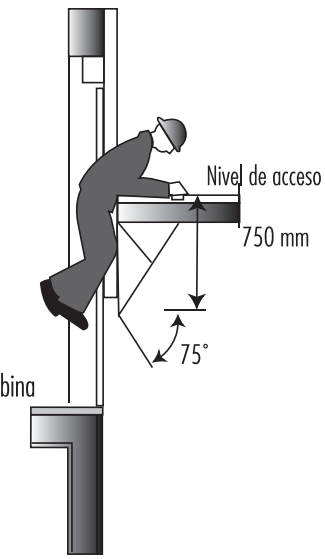

Distancias mínimas de seguridad correctamente, que su construcción eléctrica y mecánica es sólida, que están fabricados con materiales de resistencia y calidad adecuadas y que están libres de defectos. También deben tenerse en cuenta las posibles acciones imprudentes de los usuarios.

El cizallamiento se evita dejando unas separaciones adecuadas entre los componentes móviles y entre las piezas móviles y fijas. El aplastamiento se evita dejando suficiente espacio en la parte superior del hueco del ascensor entre el techo de la cabina en su posición más elevada y la parte alta del hueco, y un espacio libre en el fondo en el que quepa una persona a buen seguro cuando la cabina esté en su posición más baja. Estos espacios están protegidos por topes o amortiguadores.

La protección contra caídas por el hueco del ascensor se obtiene con puertas de acceso sin perforaciones y con una desconexión automática que evita el movimiento de la cabina hasta que las puertas están totalmente cerradas. Las puertas de acceso de tipo corredera y automáticas son las recomendadas para los ascensores de personas.

El impacto se limita restringiendo la fuerza cinética del cierre de las puertas automáticas; el atrapamiento de personas en una cabina enganchada se evita colocando un mecanismo de desenclavamiento de emergencia en las puertas y un medio para que personal especialmente instruido las abra y saque a los pasajeros.

La sobrecarga en una cabina se evita mediante una proporción muy ajustada entre la carga permitida y la superficie libre del piso de la cabina. En todos los ascensores para personas es preciso instalar puertas en la cabina para evitar que aquellas queden atrapadas en el espacio entre el umbral de la cabina y el hueco del ascensor o las puertas de acceso. Los umbrales de las cabinas deberán equiparse con un guardapié de una altura no inferior a $0,75 \mathrm{~m}$ para evitar accidentes, como muestra la Figura 93.12. Las cabinas tienen que estar equipadas con mecanismos de seguridad capaces de detener y aguantar una cabina totalmente cargada en caso de exceso de velocidad o rotura de un cable de suspensión. El mecanismo será activado por un regulador de exceso de velocidad impulsado por la cabina por medio de un cable (véase la Figura 93.11). Cuando los viajeros están de pie y se desplazan en dirección vertical, la deceleración durante el funcionamiento del mecanismo de seguridad debe situarse entre 0,2 y $1,0 \mathrm{~g}\left(\mathrm{~m} / \mathrm{s}^{2}\right)$ para evitar lesiones $(\mathrm{g}=$ aceleración de la gravedad).
En función de la legislación nacional, los ascensores destinados principalmente al transporte de mercancías, vehículos y automóviles acompañados por usuarios autorizados e instruidos pueden utilizar una o dos entradas a la cabina opuestas y sin puertas de cabina, con la condición de que la velocidad autorizada no sobrepase los $0,63 \mathrm{~m} / \mathrm{s}$, que la profundidad de la cabina no sea menor de $1,50 \mathrm{~m}$. y que la pared del hueco enfrente de la entrada, incluso las puertas de desembarque, esté lisa y enrasada. En los ascensores de mercancías de uso industrial (montacargas de mercancías), las puertas de acceso son generalmente puertas automáticas bipartidas en vertical, y habitualmente no cumplen estas condiciones. En tal caso, la puerta de cabina que se requiere es una corredera vertical hecha de mallazo. El ancho de separación entre la cabina del ascensor y las puertas de acceso debe ser el mismo para evitar daños en los paneles del montacargas por carretillas elevadoras u otros vehículos al entrar o salir del montacargas. El diseño de este tipo de montacargas ha de tener en cuenta la carga, el peso del equipo de manutención y los grandes esfuerzos que conlleva la conducción, parada e inversión del movimiento de estos vehículos. Las guías de la cabina requieren un refuerzo especial. Si se permite el transporte de personas, el número admisible se corresponderá con la superficie del piso de la cabina. Por ejemplo, la superficie de un ascensor para una carga de $2.500 \mathrm{~kg}$ deberá ser de $5 \mathrm{~m}^{2}$, suficiente para 33 personas. La carga y el acompañamiento de la misma se hará con sumo cuidado. La Figura 93.13 muestra una situación deficiente.

\section{Controles}

Todos los ascensores modernos están controlados por botonera y ordenador, habiéndose abandonado el sistema de interruptor en la cabina manejado por un ascensorista.

Los ascensores individuales y los integrados en grupos de dos a ocho cabinas suelen estar equipados con mandos colectivos que en el caso de instalaciones múltiples están interconectados. La característica principal de las maniobras colectivas es que las llamadas se pueden hacer en cualquier momento, tanto si la cabina está parada como si está en movimiento, y si las puertas del rellano están abiertas o cerradas. Las llamadas desde el rellano y desde las cabinas se recogen y se almacenan hasta que se les da respuesta. Independientemente de la secuencia en que se reciban, las llamadas se responden por el orden lógico en la dirección del movimiento de la cabina.

\section{Inspecciones y pruebas}

Antes de poner un ascensor en servicio, debe ser inspeccionado y comprobado por una organización aprobada por la administración para establecer la conformidad del ascensor con las normas

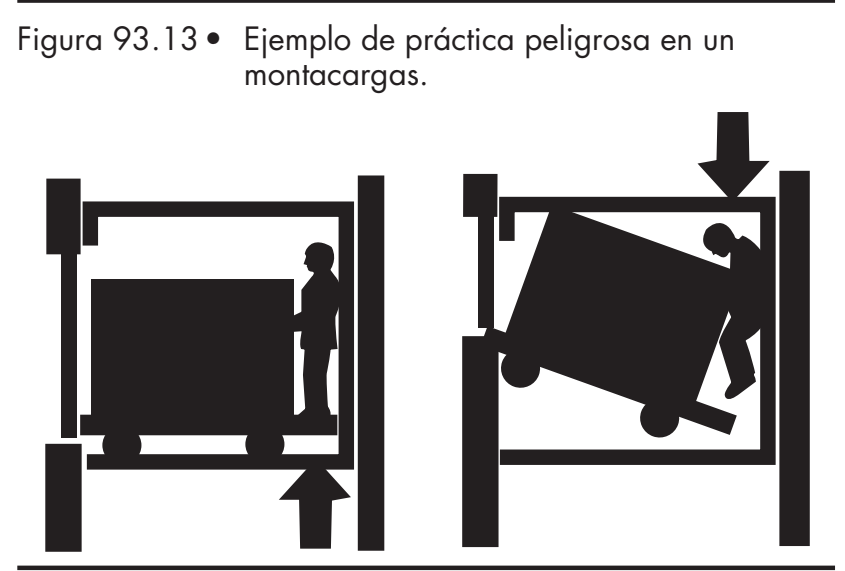


de seguridad del país en que se ha instalado. Los fabricantes facilitarán al inspector un expediente técnico. En los reglamentos de seguridad están relacionados los elementos que se tienen que inspeccionar y comprobar y el modo en que han de realizarse estas pruebas. Se exigen ensayos específicos a cargo de un laboratorio aprobado para: mecanismos de cierre, puertas de acceso (tal vez incluyendo ensayos de incendio), mecanismos de seguridad, reguladores de exceso de velocidad y amortiguadores de aceite. Se incluirán en el registro los certificados de los respectivos componentes usados en la instalación. Después de la puesta en servicio de un ascensor, se efectuarán inspecciones periódicas en intervalos que dependerán del volumen de tráfico. El objeto de estas pruebas es asegurar el cumplimiento del reglamento y el correcto funcionamiento de todos los dispositivos de seguridad. Los componentes que no funcionan en servicio normal, como los mecanismos de seguridad y los topes, deberán comprobarse con una cabina vacía y a velocidad reducida para evitar un excesivo desgaste y esfuerzos que puedan poner en peligro la seguridad del ascensor.

\section{Mantenimiento e inspección}

Un ascensor y sus componentes deben inspeccionarse y mantenerse en buen estado y en un buen nivel de seguridad funcional, en intervalos regulares por parte de técnicos competentes que han adquirido la capacitación y un total conocimiento de los detalles mecánicos y eléctricos del ascensor y de las normas de seguridad bajo la dirección de un instructor cualificado. Preferentemente el técnico será empleado del proveedor o instalador del aparato. Normalmente, un técnico es responsable de un número determinado de ascensores. El mantenimiento incluye trabajos rutinarios como el ajuste y limpieza, el engrase de las piezas móviles, mantenimiento preventivo para anticipar posibles problemas, visitas de emergencia en caso de rotura o de una reparación importante, que se hacen normalmente después de consultar con un supervisor. Sin embargo, el riesgo de seguridad primordial es el de incendio. A causa del riesgo de que un cigarrillo encendido u otro objeto ardiendo pueda caer en el espacio entre el umbral de la cabina y el hueco e incendiar la grasa lubricante en el hueco o residuos acumulados en el fondo, el hueco debe limpiarse con regularidad. Antes de que empiecen los trabajos de mantenimiento, todos los sistemas deberán estar totalmente desconectados. En los edificios con ascensores de una unidad, antes de que comience algún trabajo se colocarán avisos en cada puerta de acceso notificando que el ascensor está fuera de servicio.

Para el mantenimiento preventivo bastan una inspección minuciosa y comprobaciones de la libertad de movimiento, de la condición de los contactos y del correcto funcionamiento del equipo. El equipamiento del hueco se inspecciona desde encima de la cabina. En el techo de la cabina se habilita un mando de inspección con: un conmutador de puesta en marcha y de neutralización del control normal, incluyendo la maniobra de puertas automáticas. Unos pulsadores de presión constante de subida y bajada permiten mover la cabina a velocidad reducida (como máximo 0,63 m/s). La inspección debe basarse en los mecanismos de seguridad (puertas cerradas y enclavadas, etc.) y no será posible sobrepasar los límites de desplazamiento normal.

Un interruptor de parada en el puesto de control de la inspección evita movimientos inesperados de la cabina. La dirección más segura de desplazamiento es hacia abajo. El técnico debe estar en un puesto seguro para observar el entorno de trabajo cuando se mueve la cabina y poseer los mecanismos de inspección adecuados. El técnico debe estar bien sujeto cuando la cabina se desplaza. Antes de marcharse, el técnico debe informar a la persona encargada del ascensor.

\section{Escaleras mecánicas}

Una escalera mecánica es una escalera inclinada, que se mueve de modo continuo y que transporta personas hacia arriba y hacia abajo. Las escaleras mecánicas se utilizan en edificios comerciales, grandes almacenes y en estaciones de metro y ferrocarril, para conducir un torrente de gente por un camino limitado de uno a otro nivel.

\section{Condiciones generales de seguridad}

Las escaleras mecánicas consisten en una cadena continua de escalones arrastrada por un mecanismo con motor eléctrico por medio de dos cadenas de rodillos, una a cada lado. Los escalones van guiados por rodillos que corren por unas guías que mantienen las huellas de los escalones en posición horizontal en la zona útil. A ambos extremos de la escalera, las guías garantizan que en una distancia de 0,80 a $1,10 \mathrm{~m}$, según la velocidad y la contrahuella de la escalera, algunos escalones formen una superficie horizontal. La construcción y dimensiones de los peldaños se muestran en la Figura 93.14. Encima de cada barandilla deberá colocarse un pasamanos a una altura de 0,85 a $1,10 \mathrm{~m}$ del borde del escalón, corriendo paralelamente a los peldaños y prácticamente a la misma velocidad. La barandilla a ambos extremos de la escalera, donde los peldaños se sitúan en posición horizontal, debe prolongarse al menos $0,30 \mathrm{~m}$ más allá del descansillo y el poste con la barandilla al menos 0,60 m (véase la Figura 93.15). El pasamanos debe acometer al poste en un punto bajo por encima del suelo, en el que deberá instalarse una protección con un interruptor de seguridad que detenga la escalera en caso de que queden aprisionados en este punto los dedos o las manos. Otro riesgo de lesiones para los usuarios lo constituyen las holguras necesarias entre el lateral de los escalones y las barandillas, entre los escalones y los peines y entre las huellas y contrahuellas de escalones consecutivos, éstos últimos más particularmente durante la subida y en la zona de la curvatura donde se produce un movimiento relativo entre escalones consecutivos. Para prevenir este riesgo los escalones están dotados de una superficie suave y antideslizante.

Las personas pueden desplazarse y sus pies puedan rozar contra la barandilla, lo que puede causar que queden atrapadas cuando los escalones se nivelan. Señales y avisos claramente legibles, preferentemente pictogramas, deberán avisar y educar a los usuarios.

Una señal deberá instruir a los adultos a llevar de la mano a los niños que no puedan alcanzar el pasamanos y los niños deberán circular siempre de pie. Cuando la escalera se halle

Figura 93.14 • Escalón de una escalera mecánica.

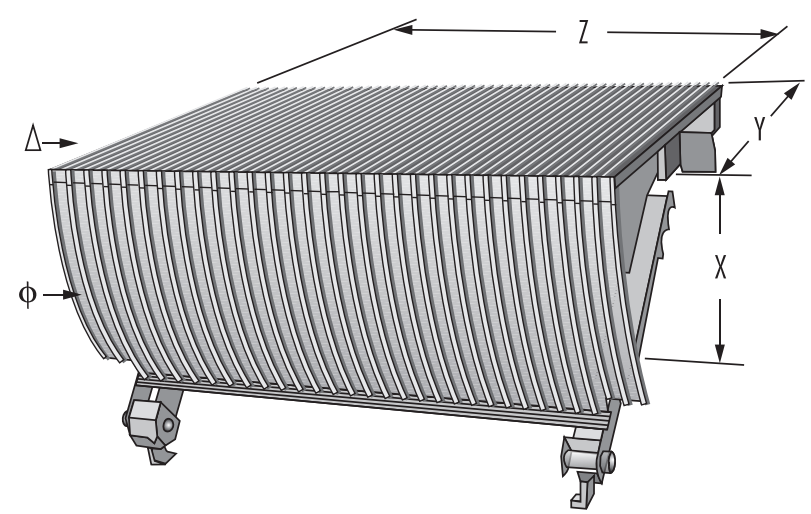

X: Altura entre escalones (no superior a 0,24 m), Y: Profundidad (mínima 0,38 m); $Z$ : Anchura (entre 0,58 y $1,10 \mathrm{~m}$ ). $\Delta$ : Huella del escalón ranurada. $\Phi$ : Contrahuella del escalón ranurada. 
Figura 93.15• Escalera mecánica.

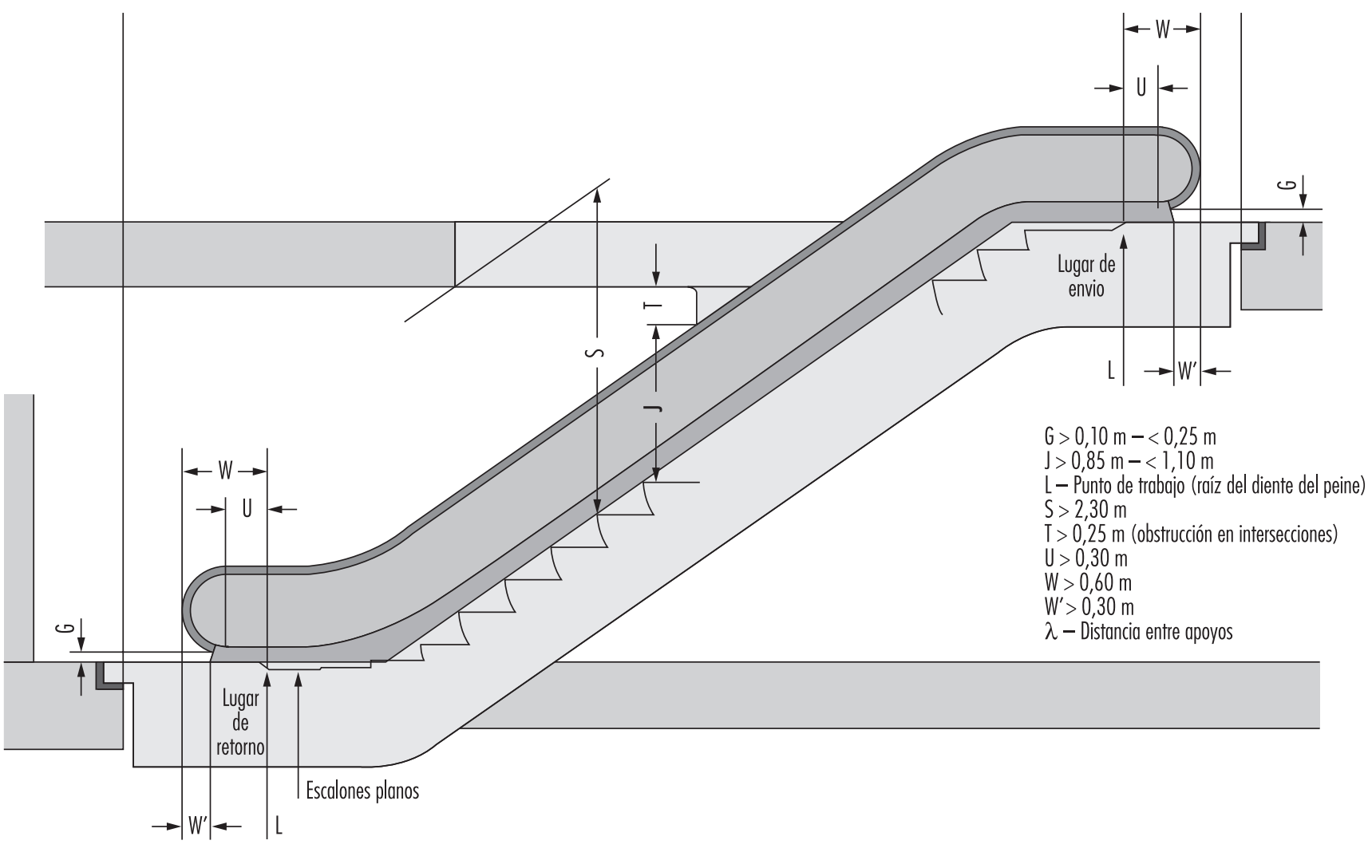

fuera de servicio, ambos extremos deberán estar cerrados con vallas.

La inclinación de una escalera no deberá ser mayor de $30^{\circ}$, aunque se podrá incrementar hasta $35^{\circ}$, si la elevación en vertical es de $6 \mathrm{~m}$ o menos y la velocidad de subida se limita a $0,50 \mathrm{~m} / \mathrm{s}$. Las salas de máquinas y los puestos de impulsión y retorno deberán ser fácilmente accesibles para el personal de mantenimiento y de inspección. Estos espacios pueden hallarse dentro de la caja o estar separados. La altura libre deberá ser de 1,80 m con las tapas, si las hay, abiertas y el espacio deberá ser suficiente para garantizar el trabajo en condiciones de seguridad. La altura libre sobre los escalones en cualquier punto no será inferior a $2,30 \mathrm{~m}$.

La puesta en marcha, parada o inversión del movimiento de una escalera mecánica deberán efectuarse exclusivamente por personal autorizado. Si el código del país permite operar un sistema que arranque automáticamente cuando una persona rebasa un sensor eléctrico, la escalera deberá ponerse en marcha antes de que el usuario llegue al peine. Las escaleras mecánicas deberán estar provistas de un sistema de control que funcione durante el mantenimiento y la inspección.

\section{Mantenimiento e inspección}

El mantenimiento e inspección con arreglo a la pautas anteriormente descritas para los ascensores, suelen venir exigidos por la administración. Se deberá facilitar un expediente técnico con los datos de cálculo principales de la estructura de soporte, peldaños, componentes de movimiento de los peldaños, datos generales, planos de disposición, diagramas de cableado e instrucciones. Antes de poner en servicio una escalera mecánica, deberá ser examinada por una persona u organización aprobada por las autoridades públicas; con posterioridad se realizarán inspecciones periódicas en plazos establecidos.

\section{Transportadores de personas (aceras móviles)}

Un transportador de personas es una pasarela mecánica de movimiento continuo, que se usa para transportar personas entre dos puntos en el mismo nivel o en niveles diferentes. Los transportadores de pasajeros se usan para transportar un gran número de personas en los aeropuertos desde el vestíbulo principal hacia las puertas de embarque, así como en los grandes almacenes y supermercados. Si los transportadores son horizontales, los coches de niños, las carretillas y las sillas de ruedas, así como las carretillas con alimentos y equipajes pueden desplazarse sin riesgo, pero en los transportadores inclinados estos vehículos, algo pesados, solamente se usarán si se pueden enclavar automáticamente. La rampa consta de paletas de metal, similares a las huellas de los escalones de las escaleras mecánicas, pero más largas, o de correas sin fin. Las paletas deberán estar ranuradas en la dirección del desplazamiento, y se colocarán peines en cada extremo. $\mathrm{El}$ ángulo de inclinación no deberá ser mayor de $12^{\circ}$ o de $6^{\circ}$ en los accesos. Las paletas y la correa deberán moverse horizontalmente en una distancia no menor de 0,40 m antes de entrar en el rellano. El transportador se desplaza entre barandillas rematadas en su parte superior con un pasamanos móvil que se mueve aproximadamente a la misma velocidad. La velocidad no será mayor de $0,75 \mathrm{~m} / \mathrm{s}$, a menos que el movimiento sea horizontal, en cuyo caso se admite una velocidad de $0,90 \mathrm{~m} / \mathrm{s}$, siempre que la anchura no exceda de $1,10 \mathrm{~m}$. 
Las condiciones de seguridad para los transportadores de personas en general son análogas a las de las escaleras mecánicas y deberán incluirse en el mismo código.

\section{Elevadores de obra}

Los elevadores de obra son instalaciones provisionales utilizadas en las obras de construcción para el transporte de personas y materiales. Cada elevador consta de una cabina sobre guías y deberá ser manejado por un operario situado dentro de la misma. En años recientes, el diseño de piñón y cremallera ha hecho posible el uso de elevadores de construcción para un transporte eficiente en torres de comunicaciones o para el servicio de chimeneas muy altas. Nadie debe montar en un elevador de materiales, excepto para fines de inspección o mantenimiento.

Las normas de seguridad varían considerablemente. En algunos casos, estos elevadores se instalan respetando la misma normativa de seguridad que para los ascensores de personas y mercancías permanentes de los edificios, excepto que el hueco está rodeado de una fuerte malla metálica en lugar de materiales sólidos, con objeto de reducir su resistencia al empuje del viento. Se necesitan estrictas normas aunque no tanto como para los ascensores de personas; muchos países tienen reglamentos especiales para estos elevadores de obra. Sin embargo, en muchos casos el nivel de seguridad es bajo, la construcción defectuosa, los montacargas son movidos por un cabrestante con motor de gasóleo y la cabina está suspendida de un solo cable de acero. Un elevador de obra deberá ser accionado por un motor eléctrico para asegurar que la velocidad se mantiene dentro de los límites de seguridad. La cabina deberá estar cerrada y provista de protecciones en la entrada a la misma. Las aberturas del hueco en los accesos deberán equiparse con puertas sin perforaciones hasta una altura de $1 \mathrm{~m}$ del suelo, siendo la parte superior de malla metálica con huecos máximos de $10 \times 10 \mathrm{~mm}$. Los umbrales de las puertas de acceso y de la cabina deberán estar provistos de rodapiés adecuados. Las cabinas estarán equipadas con un mecanismo de seguridad. Un tipo común de accidente se produce cuando los trabajadores se desplazan en un elevador diseñado solamente para el transporte de materiales, que carece de paredes laterales o puertas para proteger a los obreros de posibles golpes con una parte del andamiaje, o para evitar su caída durante el viaje. Un elevador de correa consiste en una serie de peldaños sobre una cinta vertical que se desplaza. Una persona que monte en ella corre el peligro de ser arrastrado hasta el extremo superior, no pudiendo hacer un paro de emergencia, y posibles golpes la cabeza o los hombros en el borde de la abertura entre pisos; saltar dentro o fuera después de que el peldaño ha rebasado el nivel del suelo o no poder alcanzar el rellano a causa de un fallo de corriente o por la detención de la correa. De acuerdo con esto, tal tipo de elevador solo debe ser utilizado por personal especializado empleado por el propietario del edificio o alguien designado para ello.

\section{Riesgos de incendio}

Generalmente, el hueco de cualquier ascensor se extiende a lo largo de toda la altura del edificio y está conectado con todas las plantas. El fuego o el humo de un fuego que se declare en la parte inferior del edificio puede propagarse por el hueco a todas las plantas y, en ciertas circunstancias, el hueco del ascensor o grupo de ascensores puede intensificar el fuego a causa del efecto chimenea. Por tanto, un hueco de ascensores no debe formar parte del sistema de ventilación del edificio. El hueco deberá estar totalmente cerrado por paredes sin perforaciones, de material incombustible que no produzca humos nocivos en caso de incendio. Deberá instalarse una ventilación en lo alto del hueco o en la sala de máquinas encima del anterior para permitir la salida del humo a la atmósfera.
Como el hueco, las puertas de entrada deberán ser resistentes al fuego. Los reglamentos de construcción nacionales suelen estipular los requisitos y varían según los países y condiciones. Las puertas de los accesos no se pueden ser estancas al humo si tienen que funcionar de modo fiable.

A pesar de la altura que pueda tener el edificio, las personas no usarán los ascensores en caso de incendio, a causa de los riesgos de parada del ascensor en una zona incendiada o de que los pasajeros queden atrapados en la cabina, en caso de fallo de la energía eléctrica. En general, hay asignado a los bomberos un ascensor que sirve a todas las plantas y que puede ser puesto en servicio por ellos, por medio de un interruptor o una llave especial en la planta principal. La capacidad, velocidad y dimensiones de la cabina de este ascensor debe cumplir ciertas condiciones. Guando los bomberos usan los ascensores, los mandos normales quedan invalidados.

La construcción, mantenimiento y renovación del acabado interior de los ascensores, la instalación de moqueta y la limpieza del ascensor pueden conllevar el uso de disolventes orgánicos volátiles, masillas o pegamentos, que pueden representar un riesgo para el sistema nervioso, además de un riesgo de incendio. Aunque estos materiales se usan sobre otras superficies metálicas, incluyendo escaleras y puertas, el riesgo es severo en los ascensores a causa de su espacio reducido, en el cual las concentraciones de vapores pueden resultar excesivas. El uso de disolventes en la parte exterior de un ascensor también puede ser peligroso, nuevamente a causa de la ventilación limitada, sobre todo en un hueco ciego, donde la ventilación no es posible. (Un hueco ciego es uno que no tiene puerta de salida, habitualmente con un recorrido de varias plantas entre dos destinos; en el caso de un grupo de ascensores que sirve a las plantas $20 \mathrm{y}$ superiores, un hueco ciego se extenderá entre las plantas 1 y 20).

\section{Ascensores y salud}

Si bien los ascensores y montacargas representan riesgos, su empleo también puede ayudar a reducir la fatiga o lesiones musculares serias debidas a la manipulación manual, y puede reducir los costes laborales, especialmente en algunos países en vías de desarrollo. En tales lugares, en los que no se usan ascensores en absoluto, los trabajadores han de acarrear pesadas cargas de ladrillos u otros materiales, ascendiendo por rampas, a una altura de varias plantas, en medio de un tiempo húmedo y tórrido.

\section{CEMENTO Y HORMIGON}

L. Prodan y G. Bachofen*

\section{Cemento}

El cemento es un aglomerante hidráulico empleado en la construcción de edificios y de obras civiles. Es un polvo fino que se obtiene moliendo la escoria de una mezcla de arcilla y piedra caliza calcinada a altas temperaturas. Cuando se añade agua al cemento se forma una pasta que, poco a poco, se va endureciendo hasta alcanzar una consistencia pétrea. Se puede mezclar con arena y grava (árido grueso) para formar mortero y hormigón.

Existen dos tipos de cemento: los naturales y los artificiales. Los cementos naturales se obtienen de materiales naturales que tienen una estructura análoga a la del cemento y sólo requieren su calcinación y molienda para proporcionar cemento

* Adaptado de los apartados "Cemento" por L. Prodan y "Trabajos de hormigón y hormigón armado" por G. Bachofen de la $3^{\text {a }}$ edición de la Enciclopedia de saludy seguridad en el trabajo. 
hidráulico en polvo. El número de cementos artificiales es grande y se encuentra en aumento. Cada tipo tiene una composición y una estructura mecánica diferentes y tiene unos usos y propiedades específicos. Los cementos artificiales se pueden clasificar en cemento portland (que recibe su nombre de la ciudad de Portland, en el Reino Unido) y cemento aluminoso.

\section{Producción}

El proceso portland, que representa, con gran diferencia, la mayor parte de la producción mundial de cemento, se ilustra en la Figura 93.16. Comprende dos etapas: la fabricación de la escoria y el molido de la misma. Las materias primas utilizadas para la fabricación de la escoria son materiales calcáreos, como la piedra caliza, y arcillosos, como la arcilla. Las materias primas se mezclan y se muelen en seco (proceso seco), o con agua (proceso húmedo). La mezcla pulverizada se calcina en hornos inclinados rotatorios o verticales a una temperatura que va de 1.400 a $1.450^{\circ} \mathrm{C}$. Al salir del horno, la escoria se enfría rápidamente para evitar la conversión del silicato tricálcico, principal ingrediente del cemento portland, en silicato bicálcico y óxido de cal.

Las masas de escoria enfriada se mezclan frecuentemente con yeso y otros varios aditivos que controlan el tiempo de fraguado y otras propiedades de la mezcla utilizada. De este modo es posible obtener una amplia gama de cementos diferentes, como por ejemplo: cemento portland normal, cemento de fraguado rápido, cemento hidráulico, cemento siderúrgico, cemento de tras, cemento hidrófobo, cemento marítimo, cementos para pozos de gas y petróleo, cementos para carreteras o presas, cemento expansivo, cemento magnésico, etc. Finalmente, la escoria se pulveriza en un molino, se criba y almacena en silos, dispuesta para su embalaje y transporte. La composición química del cemento portland es la siguiente:

- óxido de calcio $(\mathrm{CaO}): 60$ al $70 \%$

- dióxido de silicio $\left(\mathrm{SiO}_{2}\right)$ (incluyendo un $5 \%$ de $\mathrm{SiO}_{2}$ libre): 19 al $24 \%$

- trióxido de aluminio $\left(\mathrm{Al}_{3} \mathrm{O}_{3}\right): 4$ al $7 \%$

- óxido férrico $\left(\mathrm{Fe}_{2} \mathrm{O}_{3}\right): 2$ al $6 \%$

- óxido de magnesio $(\mathrm{MgO})$ : menos del $5 \%$
El cemento aluminoso produce mortero u hormigón de alta resistencia inicial. Se fabrica a partir de una mezcla de piedra caliza y arcilla con un alto contenido de óxido de aluminio (sin extensores), la cual se calcina a unos $1.400{ }^{\circ} \mathrm{C}$. La composición química del cemento aluminoso es, aproximadamente, la siguiente:

- óxido de aluminio $\left(\mathrm{Al}_{2} \mathrm{O}_{3}\right): 50 \%$

- óxido de calcio $(\mathrm{CaO}): 40 \%$

- óxido férrico $\left(\mathrm{Fe}_{2} \mathrm{O}_{3}\right): 6 \%$

- dióxido de silicio $\left(\mathrm{SiO}_{2}\right): 4 \%$

La escasez de combustibles conduce al aumento de la producción de los cementos naturales, en especial los que utilizan tobas (cenizas volcánicas). Si es necesario, éstas se calcinan a $1.200{ }^{\circ} \mathrm{C}$, en lugar de los 1.400 a $1.450{ }^{\circ} \mathrm{C}$, que se necesitan para la fabricación de portland. La toba debe contener un 70-80 \% de sílice libre amorfa y un 5-10 \% de cuarzo. Con la calcinación, la sílice amorfa se transforma parcialmente en tridimita y cristobalita.

\section{Usos}

El cemento se usa como un aglomerante en morteros y hormigones - una mezcla de cemento, grava y arena-. Variando el método del proceso o incluyendo aditivos, se pueden obtener diferentes tipos de cemento (p. ej., normal, arcilloso, bituminoso, asfáltico, de fraguado rápido, espumoso, impermeabilizante, microporoso, armado, tensado, centrifugado, etc).

\section{Riesgos}

En las canteras de las que se extrae la arcilla, la piedra caliza y el yeso para el cemento, los trabajadores están expuestos a los riesgos propios de las condiciones climatológicas, al polvo producido durante el barrenado y el machaqueo, a las explosiones y a avalanchas de rocas y tierra. Pueden ocurrir accidentes de carretera durante el transporte a las fábricas de cemento.

Durante el proceso de fabricación del cemento, el riesgo principal lo constituye el polvo: En canteras y fábricas de cemento se han medido niveles que oscilan entre 26 y $114 \mathrm{mg} / \mathrm{m}^{3}$. En procesos individuales se han registrado los siguientes niveles de polvo: extracción de arcilla—41,4 mg/ $\mathrm{m}^{3}$; molienda y machacado

Figura 93.16 • Proceso de fabricación de cemento.

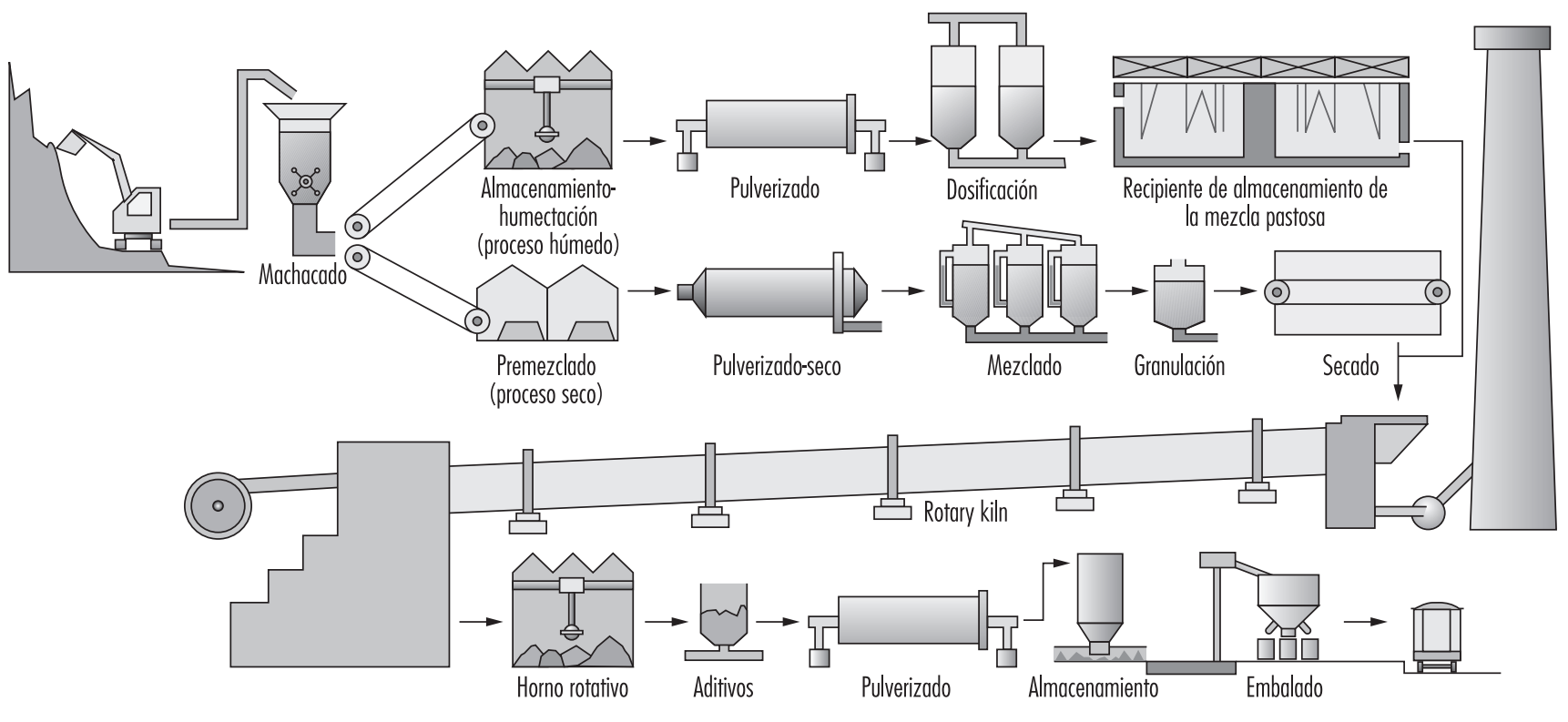


de materia prima - $79,8 \mathrm{mg} / \mathrm{m}^{3}$; cribado- $384 \mathrm{mg} / \mathrm{m}^{3}$; pulverización de la escoria-140 $\mathrm{mg} / \mathrm{m}^{3}$; ensacado del cemento $-256,6 \mathrm{mg} / \mathrm{m}^{3}$; y carga, etc- $179 \mathrm{mg} / \mathrm{m}^{3}$. En las fábricas modernas, que emplean el sistema húmedo, ocasionalmente se alcanzan valores máximos durante breves periodos de 15 a $20 \mathrm{mg}$ polvo $/ \mathrm{m}^{3}$ de aire. La contaminación del aire en las inmediaciones de estas fábricas se ha reducido a un 5-10\% de los antiguos valores, gracias en particular al uso extendido de filtros electrostáticos. El contenido de sílice libre del polvo varía entre el nivel de la materia prima (la arcilla puede contener cuarzo en partículas finas, y puede añadirse arena) y el de la escoria o el cemento, de los cuales la sílice libre normalmente habrá sido eliminada en su totalidad.

Otros riesgos que existen en las fábricas de cemento incluyen las altas temperaturas ambiente, especialmente cerca de las puertas de los hornos y en las plataformas de éstos, el calor radiante y los altos niveles de ruido $(120 \mathrm{~dB})$ en la proximidad de los molinos de bolas. Se han encontrado concentraciones de monóxido de carbono que oscilan entre cantidades traza y 50 ppm cerca de los hornos de piedra caliza.

Entre los cuadros patológicos observados entre los trabajadores de la industria del cemento se incluyen las enfermedades del aparato respiratorio, los trastornos digestivos, las enfermedades de la piel, las enfermedades reumáticas y nerviosas y trastornos de la vista y del oído.

\section{Enfermedades del aparato respiratorio}

Los trastornos del aparato respiratorio constituyen el grupo más importante de enfermedades laborales en la industria del cemento y son el resultado de la inhalación del polvo contenido en el aire y los efectos de las condiciones macro y microclimáticas en el entorno de trabajo. La enfermedad respiratoria más frecuente es la bronquitis crónica, a menudo asociada a enfisema.

El cemento portland normal no causa silicosis, debido a la ausencia de sílice libre. Sin embargo, los trabajadores empleados en la producción de cemento pueden estar expuestos a materias primas que contienen sílice libre en distintos grados. Los cementos resistentes al ácido, que se usan para planchas refractarias, ladrillos y polvo, contienen altos porcentajes de sílice libre, y la exposición a ellos representa un evidente riesgo de silicosis.

La neumoconiosis causada por el cemento aparece en forma de neumoconiosis benigna de cabeza de alfiler o reticular, que puede aparecer después de una exposición prolongada, y cuya progresión es muy lenta. Sin embargo, también se ha observado algún caso de neumoconiosis grave, más probable en trabajadores expuestos a otros materiales distintos de la arcilla y el cemento portland.

Algunos cementos también contienen cantidades variadas de tierra diatomea y toba. Se tiene noticia de que al calentarse, la tierra diatomea se vuelve más tóxica debido a la transformación de la sílice amorfa en cristobalita, una sustancia cristalina aún más patógena que el cuarzo. Una tuberculosis concomitante puede agravar el curso de la neumoconiosis del cemento.

\section{Trastornos digestivos}

Ha llamado la atención la incidencia aparentemente alta de úlceras gastroduodenales en la industria del cemento. Un examen de 269 trabajadores en fábricas de cemento reveló 13 casos de úlcera gastroduodenal $(4,8 \%)$. Subsiguientemente, se provocaron úlceras gástricas en conejillos de indias y en un perro alimentado con polvo de cemento. Sin embargo, un estudio realizado en una factoría de cemento mostró un grado de absentismo por enfermedad del 1,48-2,69 \% debido a úlceras gastroduodenales. Dado que las úlceras pueden atravesar períodos agudos varias veces al año, estas cifras no son excesivas cuando se comparan con las de otras profesiones.

\section{Enfermedades de la piel}

Se informado ampliamente de las enfermedades de la piel y se dice que constituyen un $25 \%$ o más de todas las enfermedades cutáneas laborales. Se han observado varias formas, comprendiendo inclusiones en la piel, erosiones periungulares, lesiones eczematosas difusas e infecciones cutáneas (forúnculos, abscesos y panadizos). Sin embargo, éstas son más frecuentes entre los que usan el cemento (p. ej., albañiles) que entre los trabajadores de las fábricas de cemento.

Ya en 1947 se sugirió que el eczema del cemento podría ser debido a la presencia en el mismo de cromo hexavalente (evidenciado por el ensayo de solución de cromo). Probablemente, las sales de cromo entran en las papilas dérmicas, se combinan con las proteínas y producen una sensibilización de naturaleza alérgica. Puesto que las materias primas empleadas para la fabricación del cemento en general no contienen cromo, se ha indicado como posibles fuentes del cromo en el cemento las siguientes: la roca volcánica, la abrasión del revestimiento refractario del horno, las bolas de acero utilizadas en los molinos de pulverización y las diferentes herramientas empleadas para machacar y moler las materias primas y la escoria. La sensibilización al cromo puede ser la causa que conduce a la sensibilidad al níquel y al cobalto. Se considera que la alta alcalinidad del cemento es un factor importante en las dermatosis del cemento.

\section{Trastornos reumáticos y nerviosos}

Las amplias variaciones macroclimáticas y microclimáticas que se encuentran en la industria del cemento se cree que son la causa de la aparición de diversos trastornos del sistema locomotor (artritis, reumatismo, espondilitis y diversos dolores musculares) y del sistema nervioso periférico (dolores de espalda, neuralgias y radiculitis de los nervios ciáticos).

\section{Trastornos del oído y de la vista}

Se ha registrado hipoacusia coclear moderada entre los trabajadores de molinos de cemento. La principal enfermedad de los ojos es la conjuntivitis, que normalmente sólo requiere cuidados médicos en ambulatorio.

\section{Accidentes}

Los accidentes en las canteras se deben en la mayoría de los casos a desprendimientos de tierra o roca o se producen durante el transporte. En las fábricas de cemento, los principales tipos de lesiones por accidente son contusiones, cortes y rozaduras que se producen durante la manipulación manual.

\section{Medidas de salud y seguridad}

Un requisito básico en la prevención de los riesgos del polvo en la industria del cemento es el conocimiento preciso de la composición y, especialmente, del contenido de sílice libre en todos los materiales utilizados. Es particularmente importante el conocimiento de la composición exacta de los nuevos tipos de cemento aparecidos.

En las canteras, las excavadoras deben estar equipadas con cabinas cerradas y ventilación para asegurar un suministro de aire puro, y deben implantarse medidas de eliminación del polvo durante el barrenado y machaqueo. La posibilidad de intoxicación debida a monóxido de carbono y gases nitrosos desprendidos durante las voladuras puede evitarse asegurándose de que los trabajadores estén a una distancia adecuada durante dichas voladuras y no vuelvan al punto de la explosión hasta que todos los humos hayan desaparecido. Puede ser necesario el uso de 
ropa adecuada para proteger a los trabajadores contra las inclemencias del tiempo.

Todos los procesos que van acompañados de polvo en las fábricas de cemento (pulverizado, cribado, transporte en cintas) deben estar equipados con sistemas de ventilación adecuados, y las cintas transportadoras del cemento o de las demás materias primas deben estar encerradas, tomándose precauciones especiales en los puntos de transferencia. Asimismo, se requiere una buena ventilación en la plataforma de enfriamiento de la escoria, en el lugar de molido de la escoria y en las plantas de ensacado de cemento.

El problema más difícil de control del polvo es el de las chimeneas de los hornos de escoria, que generalmente están dotadas de filtros electrostáticos, precedidos de filtros manga u otro tipo de filtros. Los filtros electrostáticos pueden ser usados también para los procesos de cribado y embalaje, en los que deben combinarse con otros métodos de control de la contaminación del aire. La escoria pulverizada debe transportarse en tornillos sin fin encapsulados.

Los puestos de trabajo con calor excesivo deben equiparse con duchas de aire frío y pantallas térmicas adecuadas. No deben realizarse reparaciones en los hornos de escoria hasta que el horno se haya enfriado adecuadamente y, luego deben hacerlo solamente trabajadores jóvenes y sanos. Estos trabajadores deben mantenerse bajo supervisión médica, para controlar sus funciones cardíaca, respiratoria y sudoral y evitar el shock térmico. Las personas que trabajan en ambientes de calor deben disponer de bebidas saladas, cuando haga falta.

Las medidas de prevención de enfermedades de la piel deben incluir la provisión de duchas y cremas para utilizar después de la ducha. En caso de eczema, puede aplicarse un tratamiento de desensibilización: comenzando por retirar a los trabajadores de la exposición al cemento durante 3-6 meses para permitir su curación, 2 gotas de una solución acuosa de dicromato potásico al 1: 10.000 se aplican a la piel durante 5 minutos, 2 a 3 veces por semana. En ausencia de reacción local o general, el tiempo de contacto se incrementa generalmente a 15 minutos, seguido de un incremento de la concentración de la solución. Este procedimiento de desensibilización puede aplicarse también en el caso de sensibilidad al cobalto, níquel y manganeso. Se ha comprobado que la dermatitis de cromo - e incluso la intoxicación por cromo- se pueden evitar y tratar con ácido ascórbico. El mecanismo de inactivación del cromo hexavalente mediante ácido ascórbico implica la reducción al cromo trivalente, que tiene una menor toxicidad, y la formación compleja subsiguiente de las especies trivalentes.

\section{Trabajos de hormigón y hormigón armado}

Para fabricar el hormigón, se mezclan áridos, como arena y grava, con cemento y agua en hormigoneras horizontales o verticales, movidas a motor, de diversas capacidades, instaladas generalmente a pie de obra, aunque a veces resulta más económico el empleo de hormigón premezclado traído y depositado en un silo en obra. A este fin, las plantas de mezcla de hormigón se instalan en la periferia de las ciudades o cerca de las graveras. Para evitar la disgregación de los componentes de la mezcla, lo cual reduciría la resistencia de las estructuras de hormigón, el transporte se realiza en camiones especiales con tambor giratorio.

Para transportar el hormigón premezclado desde el camión hormigonera o desde el silo hasta la estructura, se emplean grúas torre o elevadores. El tamaño y altura de ciertas estructuras puede requerir también, para el transporte y vertido del hormigón premezclado, la utilización de bombas de hormigón. Hay bombas que elevan el hormigón hasta alturas de 100 metros. Dado que la capacidad de las bombas es mucho mayor que la de las grúas o elevadores, estas bombas se utilizan en especial para la construcción de pilares altos, torres y silos con ayuda de encofrados deslizantes. Las bombas de hormigón suelen ir montadas sobre un camión, y los camiones de tambor giratorio empleados para el transporte del hormigón premezclado van frecuentemente equipados con bombas de hormigón, lo que permite suministrar el hormigón directamente desde la instalación de mezcla sin pasar por un silo.

\section{Encofrados}

Los encofrados han seguido un desarrollo técnico que ha sido posible gracias a la disponibilidad de grúas torre mayores, dotadas de plumas más largas y de mayor capacidad, no siendo ya necesario construir los encofrados "in situ".

Existen encofrados prefabricados de hasta $25 \mathrm{~m}^{2}$, especialmente para la construcción de estructuras verticales, tales como fachadas y paredes divisorias de grandes edificios residenciales e industriales. Estos elementos de encofrado tienen una armadura de acero, están prefabricados en un taller a pie de obra o en una industria especializada, y están forrados de chapa metálica o paneles de madera. Estos elementos se manejan por medio de una grúa y se retiran después de que el hormigón haya fraguado. Según el método de construcción que se siga, los paneles de encofrado prefabricado se bajan al suelo para limpiarlos o se llevan a la siguiente sección de muro preparada para el hormigonado.

Las denominadas mesas de encofrado se emplean para construir estructuras horizontales (p. ej., forjados de suelo para grandes edificios). Estas mesas están formadas por varios elementos estructurales de acero y se pueden ensamblar para formar suelos de distinta superficies. La parte superior de la mesa (es decir, el encofrado del forjado propiamente dicho), se hace descender, una vez fraguado el hormigón, por medio de gatos mecánicos o hidráulicos. Para colocar las mesas, llevarlas al piso siguiente y situarlas en posición se han ideado útiles especiales en forma de pico de ave.

Los encofrados deslizantes o trepantes se emplean para construir torres, silos, pilares de puente y estructuras altas similares. En estos casos se prepara "in situ" un único elemento de encofrado; su sección transversal es igual a la de la estructura a construir y su altura puede variar entre 2 y 4 metros. Las superficies del encofrado en contacto con el hormigón están revestidas de chapas de acero y el conjunto del elemento va unido a unos dispositivos de izado mediante gatos. Como guías de izado se utilizan barras de acero verticales ancladas en el hormigón. El encofrado deslizante es empujado hacia arriba por los gatos, a medida que el hormigón va fraguando, y la colocación de la armadura y el hormigonado prosiguen sin interrupción. Esto significa que el trabajo debe proseguir, día y noche, sin interrupción.

Los encofrados trepantes se diferencian de los deslizantes en que van anclados al hormigón por medio de pasadores roscados. Tan pronto como el hormigón vertido fragua hasta alcanzar la resistencia requerida, se retiran los anclajes roscados, se sube el encofrado a la siguiente altura a hormigonar, se ancla y se prepara para el vertido de hormigón.

Los llamados carros de encofrado se emplean frecuentemente en obra civil, en particular para construir tableros de puentes. El carro de encofrado sustituye a las muy complicadas cimbras, especialmente al construir puentes o viaductos de una longitud considerable. Los encofrados del tablero del puente correspondientes a la longitud de un tramo se montan sobre una armadura de acero, de forma que los distintos elementos del encofrado se pueden colocar en posición por medio de gatos y desmontarse lateralmente o hacia abajo cuando el hormigón haya fraguado. Una vez terminado el tramo se hace avanzar la estructura de soporte una longitud igual a la de un tramo, se 
vuelven a fijar los elementos de encofrado en posición y se hormigona el siguiente tramo.

Cuando se construye un puente utilizando la técnica llamada en voladizo, la estructura de soporte del encofrado es mucho más corta que la que se acaba de mencionar. Esta no se apoya sobre el pilar siguiente del puente, sino que debe anclarse en voladizo. Esta técnica, que se emplea generalmente para puentes muy altos, a menudo utiliza dos estructuras de este tipo, las cuales avanzan por etapas desde los pilares situados a ambos lados del vano.

El hormigón pretensado se emplea principalmente en la construcción de puentes, pero también en la construcción de estructuras de edificios de diseño especial. Los cordones formados por cables de acero en vainas de chapa de acero o de plástico se dejan embebidos en el hormigón al mismo tiempo que las armaduras de refuerzo. Los extremos de los cordones o tendones están provistos de placas de tesado, de modo que los elementos de hormigón pretensado puedan ser tensados con la ayuda de gatos hidráulicos antes de aplicar las cargas sobre ellos.

\section{Elementos prefabricados}

Las técnicas de construcción de los grandes edificios residenciales, puentes y túneles se han racionalizado aún más a base de prefabricar elementos tales como losas para suelos, muros, vigas de puente, etc., en una factoría especial de elementos de hormigón o a pie de obra. Los elementos prefabricados, que después se montan en la obra, eliminan el montaje, traslado y desmontaje de encofrados y andamios muy complicados, y se evita una gran cantidad de trabajo peligroso en altura

\section{Armaduras de refuerzo}

Generalmente las armaduras de refuerzo se entregan en obra cortadas y dobladas de acuerdo con los planos y listas de despiece. Las armaduras de refuerzo se unen unas con otras mediante atado o soldadura, formando jaulas o enrejados, que se colocan en los encofrados antes de verter el hormigón, en caso de prefabricar los elementos de hormigón en obra o en la factoría.

\section{Estudios de casos: Prevención de las dermatosis profesionales entre los trabajadores expuestos al polvo de cemento.}

La forma más corriente de dermatosis profesional que se da entre los trabajadores de la construcción está causada por la exposición al cemento. Según el país, del 5 al $15 \%$ de los trabajadores de la construcción - la mayoría de ellos, albañiles - contraen algún tipo de dermatosis a lo largo de su vida laboral. La exposición al cemento origina dos tipos de dermatosis: (1) dermatitis crónica por contacto, que consiste en una irritación local de la piel expuesta al cemento húmedo; y (2) dermatitis alérgica por contacto, que es una reacción cutánea alérgica generalizada producida por la exposición a la adición de cromo hidrosoluble que se encuentra en la mayoría de los cementos. Un kilogramo de polvo normal de cemento contiene de 5 a $10 \mathrm{mg}$ de cromo hidrosoluble. El cromo tiene su origen en la materia prima y en el proceso de producción (principalmente de las estructuras de acero empleadas en el proceso).

La dermatitis alérgica por contacto es crónica e induce fatiga. Si no se trata adecuadamente, puede llegar a reducir la productividad del trabajador $y$, en muchos casos, puede ser la causa de su jubilación prematura. En los decenios de 1960 y 1970, la dermatitis causada por el cemento fue la causa más comúnmente reseñada de jubilación prematura entre los trabajadores de la construcción en los países escandinavos. Por esta razón, se acometieron procedimientos técnicos e higiénicos para evitar la dermatitis por el cemento. En 1979, científicos daneses sugirieron que la reducción del cromo hexavalente hidrosoluble a cromo trivalente insoluble mediante la adición de sulfato ferroso durante la fabricación podría evitar la dermatosis producida por el cromo (Fregert, Gruvberger y Sandahl 1979)

En 1983, Dinamarca aprobó una legislación que exigía el uso de cemento con menores niveles de cromo hexavalente. A principios de 1987, le siguió Finlandia con una medida legislativa similar y, en 1989 y 1993, respectivamente, Suecia y Alemania adoptaron decisiones administrativas análogas. En estos cuatro países se determinó que el contenido aceptado de cromo hidrosoluble en agua fuera inferior a $2 \mathrm{mg} / \mathrm{kg}$.

Antes de la decisión finlandesa en 1987, el Consejo de Protección de los Trabajadores quiso evaluar la frecuencia de la dermatitis crónica en Finlandia. El Consejo solicitó del Instituto Finlandés de Salud en el Trabajo el control de la incidencia de dermatosis profesional entre los trabajadores de la construcción para evaluar la efectividad de la adición de sulfato ferroso al cemento para evitar la dermatitis producida por el cromo. El Instituto se basó para ello en los datos del Registro finlandés de enfermedades laborales desde 1978 hasta finales de 1992. Los resultados indicaron que la dermatitis en las manos inducida por el cromo había desaparecido prácticamente entre los trabajadores de la construcción, mientras que la incidencia de dermatitis por contacto tóxico había permanecido invariable durante el período estudiado (Roto y otros 1996).

En Dinamarca sólo se detectó un caso de sensibilización a los cromatos a causa del cemento en un total de 4.511 pruebas realizadas entre 1989 y 1994 con los pacientes de un hospital dermatológico; de ellos, 34 eran trabajadores de la construcción. El número de casos positivos de exposición al cromato entre los trabajadores de la construcción esperado era de 10 entre cada 34 sujetos (Zachariae, Agner y Menn J1996).

Cada vez parece más claro que la adición de sulfato ferroso a cemento evita la sensibilización al cromato entre los trabajadores de la construcción. Además, nada indica que la adición de sulfato ferroso al cemento comporte efectos negativos para la salud de los trabajadores expuestos. El proceso es viable desde el punto de vista económico y las propiedades del cemento no se alteran. Se ha calculado que la adición de sulfato ferroso al cemento encarece los costes de producción a razón de 1 dólar estadounidense por tonelada. El efecto reductor del sulfato ferroso dura 6 meses; el producto debe mantenerse seco porque la humedad neutraliza su efecto.

La adición de sulfato ferroso al cemento no cambia su alcalinidad. Por tanto, los trabajadores deben usar una protección adecuada para la piel. En cualquier circunstancia, los trabajadores de la construcción deben evitar el contacto del cemento húmedo con la piel desnuda. Esta precaución es particularmente importante al iniciarse la producción del cemento, cuando los pequeños ajustes de los elementos moldeados se hacen manualmente.

Pekka Roto 


\section{Prevención de accidentes}

La mecanización y racionalización han eliminado muchos de los riesgos tradicionales en las obras de construcción, pero también han creado nuevos peligros. Así, las muertes debidas a caídas de altura han disminuido considerablemente gracias al uso de carros de encofrado, estructuras de soporte de encofrados para la construcción de puentes y otras técnicas. Esto es debido al hecho de que las plataformas de trabajo y las pasarelas con sus barandillas se montan una sola vez y se trasladan junto con el carro de encofrado mientras que en el sistema tradicional de encofrados a menudo se da poca importancia a las barandillas de protección. Por otra parte, los riesgos mecánicos aumentan y los eléctricos son particularmente graves en ambientes húmedos. Los riesgos de salud son debidos al propio cemento, a los aditivos para su fraguado o impermeabilización y a los lubricantes empleados para los encofrados.

A continuación se comentan algunas medidas de prevención importantes que se han de tomar en distintas operaciones.

\section{Mezcla del hormigón}

Dado que el hormigón se mezcla casi siempre a máquina, deberá prestarse atención especial al diseño y disposición de los mandos eléctricos y de las tolvas de carga de las hormigoneras. En particular, al limpiar las hormigoneras puede ocurrir que se accione inadvertidamente un interruptor, poniendo en marcha el tambor o la tolva y causando lesiones al trabajador correspondiente. Por tanto, los interruptores deberán estar protegidos y dispuestos de tal manera que no exista posibilidad de error. Si fuera necesario, deberán estar enclavados o dispondrán de cerradura. Las cucharas de carga deberán estar exentas de zonas peligrosas para el operario de la hormigonera y para los trabajadores que se muevan por zonas de paso próximas. También habrá que asegurarse de que los operarios que limpien los fosos bajo la cuchara de la tolva de carga no se lesionen debido a un descenso accidental de la cuchara.

Los silos para áridos, en especial los de arena, encierran peligros de accidentes mortales. Por ejemplo, los trabajadores que entran en un silo sin una persona que les ayude y sin cinturón de seguridad y cuerda salvavidas pueden caer y quedarse enterrados en el material suelto. Por tanto, los silos deberán estar equipados con vibradores y plataformas desde las cuales se pueda empujar la arena adherida, y deberán colocarse los correspondientes avisos de precaución. No deberá permitirse la entrada de nadie dentro del silo sin estar acompañado de otra persona que le ayude.

\section{Manipulación y colocación del hormigón}

La adecuada distribución de los puntos de trasvase de hormigón y el equipamiento de éstos con espejos y jaulas para recibir los cubos, evitan el peligro de lesionar a un obrero que, en caso contrario, debe extender el brazo para coger el cubo y guiarlo a su posición adecuada.

Los silos de trasvase con elevación hidráulica deberán asegurarse de modo que no se pueda producir su caída súbita por rotura de una tubería.

Cuando se tenga que colocar el hormigón en los encofrados por medio de cubos suspendidos del gancho de la grúa o por bombeo, se instalarán plataformas de trabajo equipadas con barandillas. Las personas que manejen las grúas deberán ser instruidas para este tipo de trabajo y deberán tener una visión normal. Cuando se trate de distancias largas, se tendrá que utilizar una comunicación telefónica bidireccional o a base de walkie-talkies.

Cuando se empleen bombas de hormigón con tuberías y mástiles, deberá prestarse especial atención a la estabilidad de la instalación. Los camiones (mezcladores) con bombas de hormigón incorporadas deberán estar equipados con interruptores enclavados que impidan la puesta en marcha de dos operaciones simultáneamente. Los agitadores deberán estar protegidos de forma que el personal que los maneja no pueda entrar en contacto con las partes móviles. Las cestas para recoger la bola de goma que se lanza a presión por la tubería para su limpieza después del vertido de hormigón, se sustituyen hoy en día por dos codos dispuestos en direcciones opuestas. Estos codos absorben casi toda la presión que se necesita para empujar la bola a través de la tubería, y no sólo eliminan el efecto de latigazo en el extremo de la tubería, sino que además evitan que la bola salga disparada por el extremo de la misma.

$\mathrm{Al}$ utilizar camiones agitadores en combinación con máquinas de hormigonado y equipos de elevación, deberá prestarse especial atención al tendido eléctrico. Las líneas eléctricas deberán aislarse o protegerse con armaduras en toda la zona de trabajo para excluir cualquier contacto accidental, a menos que puedan ser desplazadas. Es importante ponerse en contacto con la compañía eléctrica.

\section{Encofrados}

Son comunes las caídas durante el montaje de los encofrados tradicionales formados por maderas escuadradas y tableros, debido a que, a menudo, se desprecian las necesarias barandillas y rodapiés para las plataformas de trabajo que se han de utilizar sólo durante cortos períodos de tiempo. Actualmente, para acelerar el montaje de los encofrados se utilizan estructuras de soporte de acero, pero en estos casos tampoco se instalan las barandillas y rodapiés de que están provistos, con el pretexto de que sólo se necesitan durante un tiempo muy corto.

Los paneles para encofrados en madera contrachapada, cuyo empleo se extiende cada vez más, ofrecen la ventaja de montarse fácil y rápidamente. Sin embargo, después de varios usos, con frecuencia se utilizan de manera inadecuada como plataformas para andamios improvisados a toda prisa, y generalmente se olvida que las distancias entre los travesaños de apoyo deberían reducirse considerablemente en comparación con los tablones normales. Los accidentes producidos por rotura de paneles de encofrado utilizados de forma inadecuada como plataformas de andamio, siguen siendo bastante frecuentes.

Guando se utilicen elementos de encofrado prefabricados, deberán tenerse en mente dos riesgos fundamentales. Estos elementos se deben almacenar de modo que no puedan volcarse. Además, como no siempre es posible almacenar horizontalmente los elementos de encofrado, éstos deberán asegurarse por medio de puntales. Los elementos de encofrado equipados permanentemente con plataformas, barandillas y rodapiés facilitan su sujeción por eslingas al gancho de la grúa, además de su montaje y desmontaje sobre la estructura que se está construyendo. Estas plataformas constituyen un lugar de trabajo seguro para el personal y eliminan la necesidad de disponer de plataformas de trabajo para el vertido de hormigón. Para que el acceso a las plataformas sea más seguro podrán añadirse escaleras fijas. En particular, en caso de encofrados deslizantes o trepantes, deberán usarse andamios y plataformas de trabajo con barandillas y rodapiés permanentemente fijados a los elementos de encofrado.

La experiencia muestra que prácticamente no se producen accidentes debidos a caídas cuando no se tienen que improvisar o montar rápidamente las plataformas de trabajo.

Desgraciadamente, los elementos de encofrado equipados con barandilla no se pueden emplear en todas partes, y, en particular, en la construcción de edificios pequeños de tipo residencial.

Al trasladar los elementos del encofrado desde el lugar de almacenamiento a la estructura, deberán utilizarse aparejos de 
izado, como eslingas y separadores, de tamaño y resistencia adecuados. Cuando el ángulo de las ramas de la eslinga sea demasiado grande, las piezas de encofrado deberán manejarse con ayuda de separadores.

Los trabajadores que limpian los encofrados están expuestos a un riesgo para la salud que generalmente no se tiene en cuenta: el empleo de muelas portátiles para quitar los residuos de hormigón adheridos a la superficie del encofrado. Los análisis del polvo que se desprende durante este esmerilado han mostrado que contiene un alto porcentaje de partículas respirables y de sílice. Por tanto, deberán tomarse medidas para controlar el polvo (p. ej., muelas portátiles con dispositivos extractores acoplados a una unidad filtrante o un taller cerrado para la limpieza de tableros de encofrado con ventilación a base de extractores)

\section{Montaje de elementos prefabricados}

En la propia factoría deberá utilizarse un equipo especial de elevación, de forma que los elementos puedan moverse y manipularse con seguridad y sin producir ningún tipo de lesión a los trabajadores. Los pernos de anclaje embutidos en el hormigón facilitan el trabajo no sólo en la factoría, sino también en el lugar de montaje. Los elementos grandes deberán levantarse con ayuda de separadores y eslingas de cable cortas, para evitar que se doblen los pernos de anclaje a causa de cargas oblicuas. Si se aplica a los pernos una carga oblicua, el hormigón podrá desconcharse y los pernos se soltarán. La utilización de un aparejo de elevación inadecuado ha sido causa de graves accidentes como consecuencia de la caída de elementos de hormigón.

Para el transporte por carretera de elementos prefabricados tendrán que utilizarse vehículos adecuados. Las piezas prefabricadas tendrán que asegurarse mediante soportes adecuados para que no se pueda producir su vuelco o deslizamiento; por ejemplo, en caso de que el conductor tenga que hacer un frenazo brusco. Las indicaciones del peso expuestas de modo bien visible sobre los elementos facilitarán la tarea al operario de la grúa durante su carga, descarga y montaje en obra.

El equipo de elevación en obra deberá elegirse y manejarse de forma adecuada. Todas las vías de circulación deberán mantenerse en buenas condiciones para evitar el vuelco de los vehículos cargados en sus desplazamientos.

Para el montaje de las piezas deberán erigirse plataformas de trabajo que protejan al personal de caídas desde las alturas. Antes de recurrir a los equipos de protección individual (EPI) deberán considerarse todos los medios posibles de protección colectiva, tales como andamios, redes de seguridad y grúas de pórtico móviles instaladas antes de la terminación del edificio. Por supuesto, es posible equipar a los trabajadores con cinturones de seguridad y cuerdas salvavidas, pero la experiencia ha demostrado que hay trabajadores que sólo utilizan este equipo cuando se les obliga a ello bajo una constante vigilancia. Las cuerdas salvavidas resultan, sin duda, un estorbo al efectuar ciertos trabajos, y algunos trabajadores se precian de ser capaces de trabajar a grandes alturas sin ninguna protección.

Antes de comenzar el proyecto de una construcción prefabricada, el arquitecto, el fabricante de los elementos prefabricados y el contratista deberán reunirse para discutir y estudiar la ejecución y la seguridad de todas las operaciones. Si se conocen de antemano las modalidades de manipulación y elevación que habrá disponibles en la obra, los elementos de hormigón podrán ir provistos, desde la propia fábrica, de elementos de sujeción para barandillas y rodapiés.

Los elementos de forjado, por ejemplo, podrán venir equipados con barandillas y rodapiés prefabricados, fácilmente fijados en fábrica en sus bordes de fachada, antes de ser izados hasta su emplazamiento. Los elementos de pared correspondientes a esa losa de forjado podrán montarse con seguridad, porque los trabajadores estarán protegidos por las barandillas.

Para el montaje de ciertas estructuras industriales altas, las plataformas de trabajo móviles se elevan hasta su sitio por medio de grúas y se cuelgan de pernos de suspensión empotrados en la propia estructura. En tales casos puede ser más seguro trasladar a los trabajadores hasta la plataforma por medio de una grúa (que deberá tener unas características de alta seguridad y que deberá ser manejada por un operario cualificado), que utilizar andamios o escaleras improvisados.

Durante el postensado de los elementos de hormigón deberá prestarse atención al diseño de los cuellos para el postensado, los cuales deberán permitir aplicar, hacer funcionar y quitar los gatos de tesado, sin ningún riesgo para el personal. Para los trabajos de postensado, bajo los tableros de puentes o dentro de los elementos tipo cajón, deberán disponerse ganchos de suspensión para los gatos tensores o aberturas para el paso del cable de la grúa. Este tipo de trabajo requiere también disponer de plataformas de trabajo con barandillas, etc. El suelo de la plataforma deberá ser suficientemente bajo, para poder dejar un amplio espacio de trabajo y permitir un manejo seguro del gato. No deberá permitirse el paso de personas por detrás del gato tensor debido a los graves accidentes que se podrían producir por la gran cantidad de energía liberada en caso de rotura de un elemento de anclaje o de un tendón de acero. Los trabajadores también deberán evitar situarse delante de las placas de anclaje hasta que la lechada inyectada a presión dentro de las vainas de los tendones no haya fraguado. Dado que la bomba de lechada está conectada al gato por medio de tubos hidráulicos, durante el tensado, no se permitirá la permanencia de personas en la zona comprendida entre la bomba y el gato. También es muy importante una perfecta comunicación entre los operarios y de éstos con el supervisor.

\section{Formación}

A la vista de la creciente mecanización y del empleo de gran utilidad de tipos de máquinas, instalaciones y sustancias, adquiere cada vez mayor importancia la formación a fondo de quienes manejan el equipo en particular y de todo el personal de obra en general. Si se quiere disminuir el número de accidentes en las obras de construcción, los trabajadores o ayudantes inexpertos sólo deberán utilizarse en casos excepcionales.

\section{ASFALTO}

\section{John Finklea}

Los asfaltos generalmente pueden definirse como complejas mezclas de componentes químicos de alto peso molecular, predominantemente asfaltenos, hidrocarburos cíclicos (aromáticos o nafténicos) y una cantidad menor de componentes saturados de baja reactividad química. La composición química de los asfaltos depende tanto del petróleo crudo original como del proceso utilizado durante el refino. Los asfaltos derivan predominantemente de los petróleos crudos, especialmente del petróleo crudo de residuo más pesado. El asfalto también se puede encontrar en depósitos naturales, donde es habitualmente el residuo resultante de la evaporación y oxidación del petróleo líquido. Tales depósitos se encuentran en California, China, la Federación Rusa, Suiza, Trinidad y Tobago y Venezuela. A temperatura ambiente, los asfaltos no son volátiles y cuando se calientan se ablandan gradualmente. El asfalto no debe confundirse con el alquitrán, que es fisica y químicamente diferente. 
Los asfaltos tienen una amplia variedad de aplicaciones, incluyendo la pavimentación de calles, carreteras y aeropuertos, materiales para cubiertas, impermeabilización y aislamiento, revestimiento de canales y depósitos de riego; y también el revestimiento de presas y diques. El asfalto constituye también un valioso ingrediente de algunas pinturas y barnices. Se estima que la producción anual de asfalto supera actualmente en todo el mundo los 60 millones de toneladas, de las que más del $80 \%$ se emplean para las necesidades de construcción y mantenimiento y más del $15 \%$ para material de cubiertas.

Las mezclas asfálticas para la construcción de carreteras se preparan calentando y secando mezclas de árido machacado clasificado (calizo o granítico), arena y material de relleno en primer lugar y, a continuación, mezclándolas con un betún de penetración, denominado en Estados Unidos asfalto de destilación directa. Este proceso se ejecuta en caliente. El asfalto también se calienta mediante llama de propano para su aplicación a una calzada.

\section{Exposiciones y riesgos}

Se han efectuado mediciones de la exposición a las partículas de hidrocarburos aromáticos polinucleares $(\mathrm{PAH})$ en diferentes ambientes. La mayoría de los PAH detectados estaban compuestos de derivados de naftaleno, que no se encuentran entre los compuestos de cuatro a seis anillos, que son los que ofrecen una mayor probabilidad de riesgo carcinógeno significativo. En las unidades de procesado de asfalto de las refinerías, los niveles PAH respirables variaron desde cantidades no detectables hasta $40 \mathrm{mg} / \mathrm{m}^{3}$. En el proceso de llenado de bidones, las muestras tomadas en la zona al cabo de 4 horas de inspiración variaron desde $1,0 \mathrm{mg} / \mathrm{m}^{3}$ con viento contrario hasta $5,3 \mathrm{mg} / \mathrm{m}^{3}$ con viento favorable. En las plantas de hormigón asfáltico, las exposiciones a compuestos orgánicos solubles en benceno oscilaron entre 0,2 y $5,4 \mathrm{mg} / \mathrm{m}^{3}$. Durante los trabajos de pavimentación, las exposiciones a PAH inhalable variaron desde menos de $0,1 \mathrm{mg} / \mathrm{m}^{3}$ a $2,7 \mathrm{mg} / \mathrm{m}^{3}$. También se pueden producir exposiciones dignas de consideración entre los trabajadores, durante la fabricación y colocación de los materiales asfálticos para cubiertas. Existe escasa información referente a exposiciones a los humos de asfalto en otras situaciones industriales o durante la aplicación o utilización de los productos asfálticos.

El manejo del asfalto caliente puede causar graves quemaduras, debido a que es pegajoso y no se quita fácilmente de la piel. La principal preocupación, desde el punto de vista toxicológico industrial, es la irritación de la piel y de los ojos por los humos del asfalto caliente. Estos humos pueden causar dermatitis y lesiones parecidas al acné, así como queratosis ligera en caso de exposiciones repetidas y prolongadas. Los humos amarillo-verdosos desprendidos por el asfalto al hervir también pueden causar fotosensibilización y melanosis.

Aunque todos los materiales asfálticos son aptos para la combustión si se calientan suficientemente, los cementos asfálticos y los asfaltos oxidados no arderán normalmente, a menos que su temperatura se eleve unos $260^{\circ} \mathrm{C}$. La inflamabilidad de los asfaltos líquidos depende de la volatilidad y cantidad de petróleo disolvente añadido al material de base. Por ello, los asfaltos líquidos de curado rápido presentan el mayor riesgo de incendio, que disminuye progresivamente con los tipos de curado medio y bajo.

A causa de su insolubilidad en medios acuosos y del alto peso molecular de sus componentes, el asfalto tiene un nivel de toxicidad bajo.

Los efectos sobre el árbol traqueobronquial y los pulmones de los ratones al inhalar un aerosol de asfalto y, en otro grupo que inhaló humo de asfalto calentado, dieron lugar a congestión,

\section{Clases de betunes/asfaltos}

Clase 1: Los betunes de penetración se clasifican por su grado de penetración. Son, generalmente, el producto residual de la destilación atmosférica del petróleo crudo aplicando una posterior destilación al vacío, una oxidación parcial (rectificación al aire), una precipitación por disolventes o una combinación de dichos procesos. En Australia y Estados Unidos, los betunes de unas características aproximadas a las antes descritas reciben el nombre de cementos asfálticos o asfaltos de viscosidad graduada, y se especifican sobre la base de la medición de su viscosidad a $60^{\circ} \mathrm{C}$

Clase 2: Los betunes oxidados se clasifican por su punto de reblandecimiento y grado de penetración. Se producen haciendo pasar aire a través del betún blando y caliente en condiciones de temperatura controladas. Este proceso altera las características del betún, al reducir su susceptibilidad a la temperatura y aumentar su resistencia a diferentes esfuerzos aplicados. En Estados Unidos, los betunes producidos con aire soplado se conocen como asfaltos soplados por aire o asfaltos de trabajo, y son similares a los betunes oxidados.

Clase 3: Los betunes fluidificados (cutback) se producen mezclando betunes de penetración y betunes oxidados con disolventes volátiles adecuados procedentes del petróleo crudo, tales como el éter efílico, queroseno o gasóleo, para reducir su viscosidad y hacerlos más fluidos y fáciles de manejar. Cuando el disolvente se evapora, se recuperan las propiedades iniciales del betún. En los Estados Unidos estos asfaltos se denominan a veces asfaltos de carretera.

Clase 4: Los betunes duros se clasifican normalmente por su punto de reblandecimiento. Se fabrican de manera similar a los betunes de penetración, pero su grado de penetración es inferior y su punto de reblandecimiento es más elevado (es decir, son más frágiles).

Clase 5: Las emulsiones bituminosas son finas dispersiones de gotas de betún (de las clases 1, $3 \circ 6$ ) en agua. Se fabrican usando batidoras de alta velocidad, como los molinos coloidales. El contenido de betún puede oscilar entre el 30 y el $70 \%$ en peso. Las emulsiones pueden ser aniónicas, catiónicas o neutras. En Estados Unidos se denominan asfaltos emulsionados.

Clase 6: Los betunes mezclados o fluxados pueden fabricarse mezclando betunes (principalmente, de penetración) con extractos de disolventes (subproductos aromáticos del refino del petróleo crudo), con residuos termofisurados del petróleo pesado, o con ciertos productos destilados del petróleo pesado con un punto de ebullición final superior a $350{ }^{\circ} \mathrm{C}$.

Clase 7: Los betunes modificados contienen cantidades apreciables (normalmente del 3 al $15 \%$ en peso) de aditivos especiales, como polímeros, elastómeros, sulfuros y otros productos usados para modificar sus propiedades; se emplean para aplicaciones especiales

Clase 8: Los betunes térmicos se fabricaban por destilación prolongada a altas temperaturas de residuos del petróleo. Actualmente ya no se fabrican ni en Europa ni en Estados Unidos.

Fuente: IARC1985.

bronquitis, neumonía, dilatación bronquial, cierta infiltración en las células redondas peribronquiales, formación de abscesos, pérdida ciliar, atrofia epitelial y necrosis. Los cambios patológicos fueron diferentes y algunos animales se mostraron relativamente refractarios al tratamiento. Se llegó a la conclusión de que estos cambios constituían un fenómeno general causado por respirar aire contaminado con hidrocarburos aromáticos, y que el grado de cambio depende de la dosis respirada. Los cobayas y 
las ratas que respiraron humos de asfalto calentado mostraron efectos como neumonías crónicas fibrosas con adenomatosis peribronquial, y las ratas desarrollaron una metaplasia celular escamosa, pero ninguno de los animales presentó lesiones malignas.

Se han realizado pruebas sobre los efectos de la aplicación de asfaltos refinados al vapor a la piel de los ratones. Los asfaltos no disueltos, las disoluciones en benceno y una fracción de asfalto refinado al vapor produjeron tumores de la piel. En la aplicación de los asfaltos refinados al aire (oxidados) a la piel de los ratones, con el material sin diluir no se produjeron tumores cutáneos, pero en un experimento, un asfalto refinado al aire en un disolvente (tolueno) produjo tumores cutáneos tópicos. Dos asfaltos craqueados produjeron tumores cutáneos al aplicarlos a la piel de ratones. Una mezcla de asfaltos destilados al aire y al vapor en benceno produjo tumores en los puntos de aplicación de la piel de ratones. Una muestra de asfaltos refinados al aire calentado, inyectada subcutáneamente en los ratones, produjo algunos sarcomas en los puntos de inyección. Una mezcla de asfaltos destilados al aire y al vapor produjo sarcomas en los puntos de inyección subcutánea en los ratones. Asfaltos destilados al vapor inyectados intramuscularmente produjeron sarcomas locales en un experimento efectuado con ratas. Un extracto de asfalto del pavimento de una carretera y sus emisiones tuvieron efectos mutágenos en la Salmonella typhimurium.

No existen pruebas concluyentes de su carcinogénesis en las personas. Un grupo numeroso de trabajadores de cubiertas expuestos a betunes tanto asfálticos como de alquitrán mostró un riesgo superior de cáncer respiratorio. Asimismo, dos estudios daneses revelan un riesgo superior de cáncer de pulmón, pero algunos de los trabajadores habían estado expuestos también al alquitrán y, probablemente, eran más adictos al tabaco que el resto del grupo. Entre los trabajadores en carreteras en Minnesota (pero no en California) se apreciaron incrementos de cánceres urológicos y leucemia. Aunque los datos epidemiológicos de que se dispone hasta la fecha no bastan para demostrar con un grado razonable de certeza científica que el asfalto represente un riesgo de cáncer para las personas, existe un consenso generalizado de que, a la luz de estudios experimentales, tal riesgo es posible.

\section{Medidas de salud y seguridad}

Ya que el asfalto calentado puede causar serias quemaduras en la piel, los que trabajan con él deben llevar ropas amplias, en buen estado, con el cuello cerrado y las mangas bien bajadas. Han de llevar protecciones en las manos y brazos. Los zapatos deben tener $15 \mathrm{~cm}$ de altura e ir abrochados de manera que no queden resquicios por los que el asfalto caliente pueda entrar en contacto con la piel. También es recomendable el uso de protecciones de cara y ojos cuando se maneja asfalto caliente. Es conveniente disponer de vestuarios para cambiarse la ropa, lavabos y duchas. En las plantas de trituración, donde se produce polvo, y en las calderas de cocción del asfalto de donde se escapan humos, ha de establecerse una ventilación por medio de extractores.

Las calderas de asfalto deben instalarse en un sitio seguro y bien nivelado, para evitar que puedan volcar. Los trabajadores han de situarse al lado de barlovento de las calderas. La temperatura del asfalto calentado debe comprobarse con frecuencia, para evitar un recalentamiento excesivo y un posible incendio. Si se acerca al punto de inflamación, se debe apagar inmediatamente el fuego de las calderas y alejar cualquier llama u otra fuente posible de ignición. Cuando se esté calentando el asfalto debe tenerse a mano un equipo de extinción. Para la extinción de los fuegos producidos por asfaltos, los extintores más adecuados son los de dióxido de carbono y agentes químicos secos. Los extendedores de asfalto y el conductor de una máquina extendedora deben llevar máscaras de respiración de media cara con cartuchos para vapores orgánicos. Además, para evitar la ingestión involuntaria de materiales tóxicos, los trabajadores no deben comer, beber o fumar junto a una caldera.

Si el asfalto fundido toca la piel, debe enfriarse rápidamente con agua fría o con cualquier otro método recomendado por los médicos. Si la quemadura es extensa debe cubrirse con gasas estériles y llevar el paciente al hospital; las quemaduras menores deben ser examinadas por un médico. No deben usarse disolventes para quitar el asfalto de la carne quemada. Tampoco se debe intentar quitar las partículas de asfalto de los ojos; pero la víctima debe acudir inmediatamente al médico.

\section{GRAVA}

James L. Weeks

La grava es un conglomerado suelto de piedra que ha sido extraída de un depósito superficial, del fondo de un río o se ha arrancado de una cantera y se ha machacado al tamaño requerido. La grava tiene multitud de empleos, entre ellos: balasto para vías férreas, carreteras, aceras y cubiertas; como material de relleno en el hormigón (a menudo para cimientos); en urbanización y jardinería; y como material filtrante.

Los principales riesgos de salud y seguridad para quienes trabajan con grava son la sílice portada por el aire, los problemas musculosqueléticos y el ruido. Muchos tipos de roca usados para la producción de grava desprenden, de modo natural, dióxido de sílice en forma de cristales libres. El contenido de sílice de los distintos tipos de roca sin machacar es variable y no es un indicador fiable del porcentaje de polvo de sílice contenido en una muestra de polvo. El granito contiene aproximadamente un $30 \%$ en peso de sílice. El contenido de sílice libre en la caliza y el mármol es menor.

La sílice puede ser llevada por el aire durante las operaciones de cantera, serrado, machaqueo, clasificación y, en menor cuantía, al extender la grava. La generación de sílice en el aire puede evitarse, generalmente, mediante regado y rociado con agua, y, a veces, con sistemas de extracción local (SEL). Además de los trabajadores de la construcción, entre los trabajadores expuestos al polvo de sílice se incluyen los trabajadores de las canteras, los que construyen vías férreas y los que realizan trabajos de urbanización. La silicosis es más frecuente entre los trabajadores de canteras o de plantas de machaqueo que entre aquellos que trabajan con la grava como producto acabado. Se ha observado un elevado riesgo de mortalidad por neumoconiosis y otras enfermedades respiratorias no malignas entre una población de trabajadores en plantas de machaqueo de áridos en Estados Unidos.

Los problemas musculosqueléticos se pueden producir a causa de la carga, descarga o extendido manuales de la grava. Cuanto mayor sea el tamaño del árido y el de la herramienta que se utilice, más arduo se hace el manejo del material con las herramientas de mano. Se puede aminorar el riesgo de roturas y torceduras, haciendo que las tareas pesadas sean compartidas por dos o más trabajadores o mediante el uso de máquinas de tracción animal o mecánica. Las palas o rastrillos de un tamaño menor acarrean o mueven pesos menores que las de mayor tamaño y pueden reducir el riesgo de sufrir problemas musculosqueléticos.

El procesado y manipulación mecánicos de la piedra o la grava producen ruido. El machaqueo de la piedra mediante el 
uso de molinos de bolas, genera ruidos y vibraciones considerables de baja frecuencia. El transporte de grava con tolvas metálicas inclinadas y su mezcla en tambores son dos operaciones ruidosas. Se puede amortiguar el ruido empleando materiales fonoabsorbentes o fonorreflectantes para rodear el molino de bolas, utilizando tolvas forradas con madera u otro material fonoabsorbente (y duradero) o mediante el uso de tambores de mezcla con aislamiento acústico.

\section{Referencias}

Agencia Internacional para la Investigación sobre el Cáncer (IARC). 1985. Polynuclear aromatic compounds, Part 4: Bitumens, coal tars and derived products, shale oils and soots. En IARC Monograph on the Evaluation of the Carcinogenic Risk of Chemicals to Humans. Vol. 35. Lyon: IARC.

American Society of Mechanical Engineers (ASME). 1994. Mobile and Locomotive Cranes: An American National Standard. ASME B30.5-1994. Nueva York: ASME.

Arbetarskyddsstyrelsen (Junta Nacional Sueca de Seguridad y Salud en el Trabajo). 1996. Comunicación personal.

Burkhart, G, PA Schulte, C Robinson, WK Sieber, P Vossenas, K Ringen. 1993. Job tasks, potential exposures, and health risks of laborers employed in the construction industry. Am f Ind Med 24:413-425.

California Department of Health Services. 1987. Califormia Occupational Mortality, 1979-81. Sacramento, California: California Department of Health Services.

Comisión de la Comunidad Europea. 1993. Safety and Health in the Construction Sector. Luxemburgo: Oficina de Publicaciones Oficiales de la Unión Europea.

Comité Europeo de Normalización (CEN). 1994. EN 474-1. Earth-moving Machinery-Safety - Part 1: General Requirements. Bruselas: CEN.

Commission on the Future of Worker-Management Relations. 1994. Fact Finding Report. Washington, DC: US Department of Labor.

Consejo de la Comunidad Europea. 1988. Directiva del Consejo de 21 diciembre 1988 relativa a la aproximación de las disposiciones legales, reglamentarias y administrativas de los Estados Miembros sobre los productos de construcción (89/106/CEE). Luxemburgo: Oficina de Publicaciones Oficiales de la Comunidad Europea.

Consejo de la Comunidad Europea. 1989. Directiva del Consejo de 14 de junio 1989 relativa a la aproximación de las legislaciones de los Estados Miembros sobre máquinas (89/392/CEE). Luxemburgo: Oficina de Publicaciones Oficiales de la Comunidad Europea.

Construction Safety Asociation of Ontario. 1992. Construction Safety and Health Manual. Toronto: Construction Safety Association of Canada.

El Batawi, MA. 1992. Migrant workers. En Occupational Health in Developing Countries, dirigido por J Jeyaratnam. Oxford: Oxford University Press.

Engholm, G, A Englund. 1995. Morbidity and mortality patterns in Sweden. Occup Med: State Art Rev 10:261-268.

Fregert, S, B Gruvberger, E Sandahl. 1979. Reduction of chromate in cement by iron sulphate. Contact Dermat 5:39-42.

Hinze, J. 1991. Indirect Costs of Construction Accidents. Austin, Texas: Construction Industry Institute.

Hoffman, B, M Butz, W Coenen, D Waldeck. 1996. Health and Safety at Work: System and Statistics. Sain Augustin, Alemania: Hauptverband der gewerblichen berufsgenossenschaften.

Instituto Finés de Medicina del Trabajo. 1987. System atic Workplace Survey: Health and Safety in the Construction Industry. Helsinki: Instituto Finés de Medicina del Trabajo.

1994. Asbestos Program, 1987-1992. Helsinki: Instituto Finés de Medicina del Trabajo.
Jack, TA, MJ Zak. 1993. Results from the First National Census of Fatal Occupational Injuries, 1992. Washington, DC: Bureau of Labor Statistics.

Japan Construction Safety and Health Association. 1996. Comunicación personal.

Kisner, SM, DE Fosbroke. 1994. Injury hazards in the construction industry. 7 Occup Med 36:137-143.

Levitt, RE, NM Samelson. 1993. Construction Safety Management. Nueva York: Wiley \& Sons.

Markowitz, S, S Fisher, M Fahs, J Shapiro, PJ Landrigan. 1989. Occupational disease in New York State: A comprehensive reexamination. $A m$ f Ind Med 16:417-436.

Marsh, B. 1994. Chance of getting hurt is generally far higher at smaller companies. Wall Street $\mathcal{F}$.

McVittie, DJ. 1995. Fatalities and serious injuries. $O c$ cup Med: State Art Rev 10:285-293.

Meridian Research. 1994. Worker Protection Programs in Construction. Silver Spring, Maryland: Meridian Research.

Organización Internacional de Normalización (ISO). 1982. ISO 7096. Earth-moving Machinery - Operator Seat-Transmitted Vibration. Ginebra: ISO.

1985a. ISO 3450. Earth-moving Machinery - Wheeled Machines-Performance Requirements and Test Procedures for Braking Systems. Ginebra: ISO.

1985b. ISO 6393. Acoustics - Measurement of Airborne Noise Emitted by Earth-moving Machinery - Operator's Position - Stationary Test Condition. Ginebra: ISO.

-. 1985c. ISO 6394. Acoustics - Measurement of Airborne Noise Emitted by Earth-moving Machinery - Method for Determining Compliance with Limits for Exterior Noise - Stationary Test Condition. Ginebra: ISO. 1992. ISO 5010. Earth-moving Machinery — Rubbertyred Machinery —Steering Capability. Ginebra: ISO.

Organización Internacional del Trabajo (OIT). 1995 Safety, Health and Welfare on Construction Sites: A Training Manual. Ginebra: OIT.

Oxenburg, M. 1991. Increasing Productivity and Profit through Health and Safety. Sydney: CCH International.

Pollack, ES, M Griffin, K Ringen, JL Weeks. 1996. Fatalities in the construction industry in the United States, 1992 and 1993. Am f Ind Med 30:325-330.

Powers, MB. 1994. Cost fever breaks. Engineering NewesRecord 233:40-41.

Ringen, K, A Englund, J Seegal. 1995. Construction workers. En Occupational Health: Recognizing and Preventing Work-related Disease, dirigido por BS Levy y DH Wegman. Boston, Massachusetts: Little, Brown and Co.

Ringen, K, A Englund, L Welch, JL Weeks, JL Seegal. 1995. Construction safety and health. Occup Med: State Art Rev 10:363-384.

Roto, P, H Sainio, T Reunala, P Laippala. 1996. Addition of ferrous sulfate to cement and risk of chomium dermatitis among construction workers. Contact Dermat 34:43-50.

Saari, J, M Nasanen. 1989. The effect of positive feedback on industrial housekeeping and accidents. Int $\mathcal{J}$ Ind Erg 4:201-211.

Schneider, S, E Johanning, J-L Bjlard, G Enghjolm. 1995. Noise, vibration, and heat and cold. Occup Med: State Art Rev 10:363-383.

Schneider, S, P Susi. 1994. Ergonomics and construction: A review of potential in new construction. $A m$ Ind Hyg Assoc 7 55:635-649.
Statistics Canada. 1993. Construction in Canada, 1991-1993. Report No. 64-201. Ottawa: Statistics Canada.

Strauss, M, R Gleanson, J Sugarbaker. 1995. Chest $\mathrm{X}$-ray screening improves outcome in lung cancer: A reappraisal of randomized trials on lung cancer screening. Chest 107:270-279.

Toscano, G, J Windau. 1994. The changing character of fatal work injuries. Monthly Labor Review 117: $17-28$.

Workplace Hazard and Tobacco Education Project. 1993. Construction Workers' Guide to Toxics on the Fob. Berkeley, California: California Health Foundation.

Zachariae, C, T Agner, JT Menn. 1996. Chromium allergy in consecutive patients in a country where ferrous sulfate has been added to cement since 1991. Contact Dermat 35:83-85.

\section{Otras lecturas recomendadas}

American National Standards Institute (ANSI). 1993a. American Standard Safety Code for Elevators and Escalators. Nueva York: ANSI.

1993b. Inspectors Manual for Electric Elevators. Nueva York: ANSI.

. 1994a. Inspectors Manual for Elevators and Moving Walks. Nueva York: ANSI.

1994b. Inspectors Manual for Hydraulic Elevators. Nueva York: ANSI.

Arbouw Foundation. 1994. Atlas of Health and Work Perception in the Construction Industry. Amsterdam: Arbouw Foundation.

Bureau of Labor Statistics (BLS) 1993. Fatal Workplace Injuries in 1991: A Collection of Data and Analysis. Washington, DC: BLS.

Canadian Standards Association (CSA). 1974. CSA Standard 2150-1974: Safety Code for Mobile Cranes. Ontario: CSA.

Chiazze, L, DK Watkins, J Amsel. 1991. Asphalt and risk of cancer in man. Br $\mathcal{F}$ Ind Med 48:538-542.

Construction Safety Association of Canada. 1985. Hearing Protection for the Construction Industry. Toronto: Construction Safety Association of Ontario.

Construction Safety Association of Ontario. 1989. Workplace Hazardous Materials Information System (WHMIS) in Construction. Toronto: Construction Safety Association of Ontario.

- 1992. Construction Safety and Health Manual. Toronto: Construction Safety Association of Ontario.

Dickie, DE and P Eng. 1975a. Crane Handbook. Toronto: Construction Safety Association of Ontario.

1975b. Rigging Manual. Toronto: Construction Safety Association of Ontario.

- 1982. Mobile Crane Manual. Toronto: Construction Safety Association of Ontario.

Klein Tools. 1987. Proper Use and Care of Hand Tools, Pliers, Screwdrivers, Wrenches, Striking and Struck Tools. Chicago, Illinois: Klein Tools.

MacCollum, DV. 1993. Crane Hazards and Their Prevention. Des Plaines, Illinois: American Society of Safety Engineers.

National Institute for Occupational Safety and Health (NIOSH). 1977. Criteria for a Recommended Standard - Occupational Exposure to Asphalt Fumes. Cincinnati, Ohio: NIOSH 
Occupational Safety and Health Administration (OSHA). 1988. Hand and Power Tools. Washington, DC: OSHA.

Ontario Ministry of Labour. Undated. Investigation Reports on Fatal Accidents in Ontario's Construction Industry. Ottawa: Ontario Ministry of Labour. Unpublished.
Organización Internacional del Trabajo (OIT). 1972. Repertorio de Recomendaciones prácticas para Safe Construc tion and Installation of Electric Passenger, Goods and Service Lifts. Ginibra: OIT.

Organización Mundial del la Salud (OMS). 1995. Guidelines on Medical Surveillance of Workers Exposed to Mineral Dusts. Ginebra: OMS.
Society of Automotive Engineers (SAE). 1995. SAE Handbook: On-highway Vehicles and Off-highway Machinery. Vol. 3. Warrendale, Pensilvania: SAE.

Syracuse Research Corporation. 1985. Monograph on Human Exposure to Chemicals in the Workplace: Asphalt. Techinical Report 85-188. Syracuse, Nueva York: Syracuse Research Corporation. 


\section{SERVICIOS DE EDUCACION Y FORMACION}

Director del capítulo Michael McCann

\section{Sumario}

Perfil general

E. Gelpi ................................ 94.2

Centros de enseñanza elemental y secundaria

Michael McCann.....................
Formación profesional y aprendizaje

Gary Gibson . . . . . . . . . . . . . . . . . . . .

Escuelas universitarias y universidades

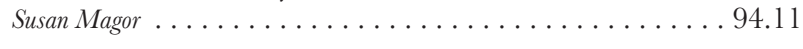

Enseñanza artística Ted Rickard . .

Problemas de salud y pautas patológicas

Steven D. Stellman y Foshua E. Muscat . . . . . . . . . . . . . . . . 94.13

Cuestiones ambientales y de salud pública

Susan Magor 


\section{- Perfil General}

\section{E. Gelpi*}

El ámbito de la docencia se extiende desde los jardines de infancia hasta las instituciones de posgrado, y no sólo abarca la enseñanza académica, sino también la formación científica, artística y técnica en laboratorios, estudios y talleres, así como la formación física en campos de deporte, gimnasios y piscinas. En la mayoría de los países, casi todas las personas reciben en algún momento la influencia de los miembros de esta profesión, y los propios docentes tienen orígenes tan diversos como los alumnos a los que enseñan. Muchos de los miembros veteranos de la profesión desempeñan además tareas administrativas y de gestión.

Por otra parte, el desarrollo de políticas y actividades que promueven la educación a lo largo de toda la vida exige una revisión del concepto convencional de profesorado de las instituciones tradicionales (escuelas, universidades). Los miembros de la profesión docente desempeñan sus tareas utilizando métodos educativos formales e informales, tanto en la formación básica como en la continua, en centros de enseñanza y fuera de ellos.

Aparte de los alumnos en edad escolar y los universitarios, en muchos países surgen nuevos tipos de estudiantes cada vez más numerosos: jóvenes en busca de empleo, mujeres que desean reincorporarse al mercado de trabajo, jubilados, trabajadores emigrantes, personas discapacitadas, grupos comunitarios, etc. En concreto, encontramos categorías de personas que en el pasado estaban excluidas de las instituciones educativas ordinarias: analfabetos y discapacitados.

La diversidad de instalaciones de aprendizaje no es ninguna novedad, y siempre ha existido la autoeducación privada y, de un modo u otro, la formación a lo largo de la vida. Pero hay un factor nuevo: el desarrollo creciente de este último tipo de formación en lugares no concebidos inicialmente como centros de enseñanza (por ejemplo fábricas, oficinas e instalaciones de ocio), y la utilización de nuevos recursos, como asociaciones, medios de comunicación de masas y la autoeducación asistida. Este desarrollo y difusión de las actividades educativas ha dado lugar a un aumento del número de personas dedicadas a la enseñanza con carácter profesional o voluntario.

Muchas de las actividades catalogables en el campo de la educación pueden solaparse: profesores, instructores, conferenciantes, promotores y organizadores de proyectos docentes, consultores en materia de educación y formación profesional, asesores especializados en el desarrollo de la carrera profesional, especialistas en educación de adultos y administradores. En cuanto a los miembros de la profesión docente representados en los mercados de trabajo, se observa que, en la mayoría de países, constituyen una de las categorías más significativas de trabajadores asalariados.

En los últimos años, la importancia de los sindicatos de la enseñanza ha aumentado sin cesar, de acuerdo con el número cada vez mayor de profesores. La flexibilidad de horarios de trabajo les ha permitido desempeñar un papel significativo en la vida política de muchos países.

En numerosos sistemas en los que la escuela se ha convertido en un centro de servicios educativos permanentes o a lo largo de toda la vida, puede encontrarse un nuevo tipo de educador, que no es exactamente un profesor en el sentido antiguo del termino, sino un profesional procedente de variados sectores, incluidos expertos artesanos, artistas, etc., que contribuyen de forma permanente u ocasional al desarrollo de las actividades docentes.

* Adaptado de la $3^{\text {a }}$ edición, Enciclopedia de salud y seguridad en el trabajo.
Las instituciones educativas abren sus puertas a distintos grupos y categorías, prestando cada vez más atención a las actividades externas y dedicadas a no estudiantes. En este sentido, pueden observarse dos tendencias principales: por una parte, se han establecido vínculos con los trabajadores, los centros y los procesos industriales; por otra, se ha instituido una relación cada vez más estable con el desarrollo comunitario, y crece la interacción entre la enseñanza institucional y los proyectos de formación comunitaria.

Las universidades y colegios universitarios procuran renovar la formación inicial del personal docente mediante la oferta de cursos de actualización profesional. Aparte de las disciplinas y los aspectos específicamente pedagógicos, imparten conocimientos de sociología, economía y antropología educativas. Un planteamiento que aún se enfrenta con numerosos obstáculos es lograr que los futuros profesores adquieran experiencia mediante períodos de formación en instalaciones comunitarias, lugares de trabajo o diversas instituciones educativas y culturales. El servicio nacional, generalizado en algunos países, constituye una experiencia sobre el terreno muy útil para estos profesionales.

Las grandes inversiones dedicadas a la comunicación y la información favorecen diversos tipos de autoenseñanza individual y colectiva. La relación entre esta opción y la enseñanza reglada es un problema reciente y cada vez más importante. El paso de la formación autodidacta de las personas que no han asistido a un centro docente a la autoformación permanente de jóvenes y adultos no siempre ha sido correctamente valorado por las instituciones educativas.

Estas nuevas políticas y actividades educativas plantean diversos problemas, como los relativos a los riesgos y su prevención. La educación permanente, que no se limita a la experiencia escolar, convierte distintos emplazamientos, como el entorno comunitario, el lugar de trabajo, el laboratorio y el entorno en general, en instalaciones docentes. Los profesores deben recibir ayuda para llevar a cabo estas actividades y contar con la cobertura de un seguro. En cuanto a la prevención de los riesgos, hay que adoptar iniciativas destinadas a la adaptación de las instalaciones a las actividades educativas. En varios casos, se han acondicionado establecimientos docentes para transformarlos en centros abiertos al conjunto de la población y se han equipado para dejar de ser instituciones educativas en exclusiva y convertirse también en lugares destinados a la realización de actividades creativas y productivas y a la celebración de reuniones.

La relación de los profesores y los instructores con los distintos períodos de la vida de los alumnos y los estudiantes, como el tiempo de ocio, el trabajo, la vida familiar y el aprendizaje, requiere también la dedicación de un esfuerzo considerable a la información, la investigación y la adaptación.

También se han intensificado las relaciones entre los profesores y las familias de los estudiantes; en ocasiones, los parientes del alumno asisten a las clases impartidas en el centro docente. Las diferencias entre los modelos familiares y los educativos exigen de los profesores un gran esfuerzo para lograr un entendimiento mutuo desde el punto de vista psicológico, sociológico y antropológico. Los modelos familiares influyen en las pautas de comportamiento de algunos estudiantes, que pueden vivir una acusada contradicción entre la formación impartida en el hogar y los patrones y normas de comportamiento que rigen en la escuela.

A pesar de su gran variedad, todas las formas de enseñanza se caracterizan por algunos rasgos comunes: el profesor no sólo enseña conocimientos específicos o facilita la adquisición de cualificaciones, sino que también trata de transmitir un modo de pensar; debe preparar al alumno para la siguiente etapa de su desarrollo y fomentar su interés y su participación en el proceso de aprendizaje. 
GENTROS DE ENSEÑANZA ELEMENTAL Y SECUNDARIA

Michael McCann

En los centros de enseñanza elemental y secundaria prestan sus servicios muchos tipos distintos de trabajadores, como profesores, auxiliares docentes, administradores, personal de oficina, personal de mantenimiento, personal de restauración, personal de enfermería y muchos otros necesarios para el funcionamiento de una institución docente. En general, las plantillas de estos centros se exponen a todos los riesgos potenciales que plantean las actividades de interior y administrativas, entre los que se encuentran la contaminación atmosférica de edificios, la iluminación deficiente, una calefacción o refrigeración inadecuadas, la utilización de equipos de oficina, los resbalones y caídas, los problemas ergonómicos debidos a las deficiencias en el diseño del mobiliario de oficina y el peligro de incendio. Las precauciones son las habituales en este tipo de entornos, aunque las normativas

\section{Programas de enseñanza preescolar}

La atención a la infancia, que exige la asistencia física y con frecuencia la educación de niños de corta edad, adopta muchas formas diferentes en diversas partes del mundo. En muchos países en que son habituales las familias extensas, los abuelos y otras mujeres de la familia cuidan de los niños cuando la madre se ausenta para trabajar. En países en que predominan las familias nucleares y/o monoparentales y las madres trabajan, la atención prestada fuera del hogar a los niños sanos que no han alcanzado la edad escolar suele corresponder a escuelas de párvulos o guarderías privadas o públicas. En muchos países (por ejemplo, Suecia), estas instalaciones dedicadas a la prestación de cuidados a la infancia son gestionadas por los ayuntamientos. En Estados Unidos, la mayoría de estos centros son privados, aunque suelen estar regulados por los departamentos locales de sanidad. Una excepción es el Head Start Program destinado a los niños en edad preescolar y financiado por la Administración.

En general, la dotación de personal de los centros de atención a la infancia depende del número de niños y de las características de la instalación. Para grupos reducidos (normalmente menos de 12), el centro puede ubicarse en un domicilio particular en el que el prestador de los cuidados atiende, además, a sus hijos en edad preescolar. La plantilla puede estar compuesta por uno o varios asistentes adultos cualificados de forma que se satisfagan los requisitos relativos al coeficiente de niños por cuidador. Los centros de cuidados de día y las escuelas de párvulos son instalaciones de mayor tamaño y carácter más formal. La formación del personal de estos centros debe ser más completa y las plantillas pueden estar compuestas por un director y profesores cualificados, personal de enfermería bajo la supervisión de un médico, restauradores lespecialistas en nutrición, gestores de servicios de alimentación y cocineros) y otros trabajadores, como los encargados del transporte y el mantenimiento. Los centros de cuidados de día deben disponer de instalaciones como un área de juegos al aire libre, un guardarropa, un área de recepción, aulas y zona de juegos en el interior, cocina, servicios sanitarios, salas de administración, lavandería, etc.

Las obligaciones del personal comprenden la supervisión de los niños en todas sus actividades, el cambio de pañales a los bebés, la atención emocional de los niños, la enseñanza, la preparación y el servicio de comidas, la detección de signos de enfermedad y/o de riesgos para la seguridad y muchas otras funciones.

El personal de las guarderías se enfrenta a muchos de los riesgos existentes en entornos interiores normales, como la presencia de contaminantes en suspensión en el aire, la iluminación deficiente, un control de la temperatura inadecuado, resbalones y caídas, y peligro de incendio. (Véase el artículo titulado "Centros de enseñanza elemental y secundaria".) Sin embargo, el estrés (que a menudo acaba en agotamientol y las infecciones son los riesgos principales a que se exponen estos trabajadores. Otros factores consisten en la necesidad de levantar y transportar a los niños y el contacto con productos para actividades artísticas potencialmente peligrosos

\section{Estrés}

Entre las causas de estrés del personal de las guarderías cabe citar la gran responsabilidad asumida respecto al bienestar de los niños sin recibir a cambio una remuneración y un reconocimiento adecuados; la percepción externa de una falta de cualificación, a pesar de que la formación de muchos de estos trabajadores se sitúa por encima de la media; los problemas de imagen debidos a la amplia difusión concedida a incidentes de malos tratos y abusos a niños protagonizados por miembros del personal de estos centros y que ha dado lugar a la toma de huellas dactilares de trabajadores inocentes tratados como posibles delincuentes; y las deficientes condiciones de trabajo. Entre éstas últimas se cuentan un bajo índice de cuidadores por niño, el ruido continuo, la falta de tiempo y de instalaciones apropiadas para disfrutar de las comidas y los descansos lejos de los niños y la inadecuación de los mecanismos de interacción entre padres y trabajadores, que pueden dar lugar a presiones y críticas innecesarias y posiblemente injustas de los primeros a los segundos.

Como medidas preventivas para reducir el estrés de estos trabajadores figuran la elevación de los salarios y la mejora de las prestaciones; el aumento de los índices de cuidadores por niño con el fin de facilitar la rotación de puestos de trabajo, los descansos, las bajas por enfermedad y la optimización del rendimiento, lo que redunda en una mayor satisfacción en el puesto; el establecimiento de mecanismos formales de comunicación y cooperación entre padres y trabajadores (posiblemente, con la creación de un comité de salud y seguridad conjunto); y el perfeccionamiento de las condiciones de trabajo, concretada en la disposición de sillas para adultos, períodos regulares de "silencio", un área de descanso especial para el personal, etc.

\section{Infecciones}

Las enfermedades infecciosas, como las de carácter diarreico, las provocadas por estreptococos y meningococos, la rubeola y las respiratorias y producidas por citomegalovirus son riesgos profesionales fundamentales del personal de las guarderías (véase la Tabla 94.1). En un estudio de estos trabajadores realizado en Bélgica se observó un aumento del riesgo de padecer hepatitis $A$ (Abdo y Chriske 1990). Hasta el 30 \% de los 25.000 casos de esta enfermedad declarados anualmente en Estados Unidos se ha relacionado con este tipo de centros. Algunos organismos causantes de trastornos diarreicos, como Giardia lamblia, que provoca giardasis, son extremadamente infecciosos. Los brotes pueden presentarse tanto en centros que prestan servicio a poblaciones acomodadas como en los que se dedican a zonas desfavorecidas (Polis y cols. 1986). Ciertas infecciones (como la rubéola y el citomegalovirus) pueden resultar especialmente peligrosas para las mujeres embarazadas y las que planean tener hijos, debido al riesgo de deficiencias de nacimiento causadas por el virus.

Los niños enfermos pueden propagar enfermedades, al igual que los portadores asintomáticos. Las vías de exposición más comunes 

tener hábitos de higiene deficientes. Los contactos de la mano con la boca y de los juguetes con la boca son habituales. La manipulación de juguetes y alimentos contaminados es otra forma de entrada. Algunos organismos pueden sobrevivir en objetos inanimados durante largos períodos de tiempo, que van de horas a semanas. También los alimentos pueden constituir un vector portador si las personas que los manipulan están enfermas o sus manos están contaminadas.

La inhalación de gotículas respiratorias en suspensión en el aire producidas por estornudos o toses realizados sin protección como pañuelos de papel pueden provocar la transmisión de infecciones. Estos aerosoles atmosféricos pueden permanecer suspendidos en el aire durante horas.

El personal de las guarderías que trabaja con niños menores de tres años, sobre todo si todavía no han aprendido a utilizar los sanitarios, está expuesto a un riesgo mayor, en especial al cambiar y manipular pañales usados y contaminados por organismos portadores de enfermedades. son fecales-orales y respiratorias. Los niños de corta edad suelen

Las medidas de precaución consisten en la disposición de las instalaciones convenientes para el lavado de manos; la higiene regular de esta parte del cuerpo entre niños y trabajadores; el cambio de pañales en áreas designadas al efecto y sometidas a desinfecciones periódicas; la evacuación de los pañales usados en recipientes cerrados y cubiertos de plástico que se vacíen a menudo; la separación de las áreas de preparación de los alimentos del resto de zonas; el lavado frecuente de juguetes, áreas de juego, mantas y otros artículos que pueden contaminarse; una ventilación apropiada, la consecución de índices adecuados de número de niños por cuidador, lo que permite una aplicación correcta de los programas de higiene; la formulación de una política de exclusión, aislamiento o restricción de los niños enfermos, dependiendo de la dolencia; y la adopción de las políticas de baja por enfermedad pertinentes para que los trabajadores enfermos puedan permanecer en su domicilio.

\section{Adaptado de Women's Occupational Health Resource Center} 1987

sobre construcción e incendios suelen imponer requisitos específicos para los centros docentes debido al gran número de niños que asisten a los mismos. Otros motivos de preocupación en lo que respecta a este tipo de instalaciones son el amianto (sobre todo para los trabajadores de seguridad y mantenimiento), la pintura al plomo desconchada, los plaguicidas y herbicidas, el radón y los campos electromagnéticos (GEM) (en especial en las escuelas construidas cerca de líneas eléctricas de alta tensión). Los trastornos oculares y respiratorios provocados por el pintado de las aulas y el alquitranado de los techos con presencia de personas en el centro representan otro problema común. Estas actividades deben realizarse cuando el edificio no esté ocupado.

Las tareas académicas básicas que se exigen de todos los profesores consisten en preparar las lecciones, lo que puede incluir el desarrollo de estrategias de aprendizaje, la copia de notas orientativas y la elaboración de recursos visuales auxiliares como ilustraciones, gráficos y similares; impartir la clase, que requiere la presentación de información de un modo organizado que atraiga la atención de los estudiantes y procure su concentración, y puede exigir la utilización de pizarras, proyectores de diapositivas, retroproyectores y ordenadores; redactar, asignar y calificar exámenes; y ofrecer asesoramiento individual a los

Figura 94.1 • Taller metalúrgico industrial en un centro de enseñanza secundaria.

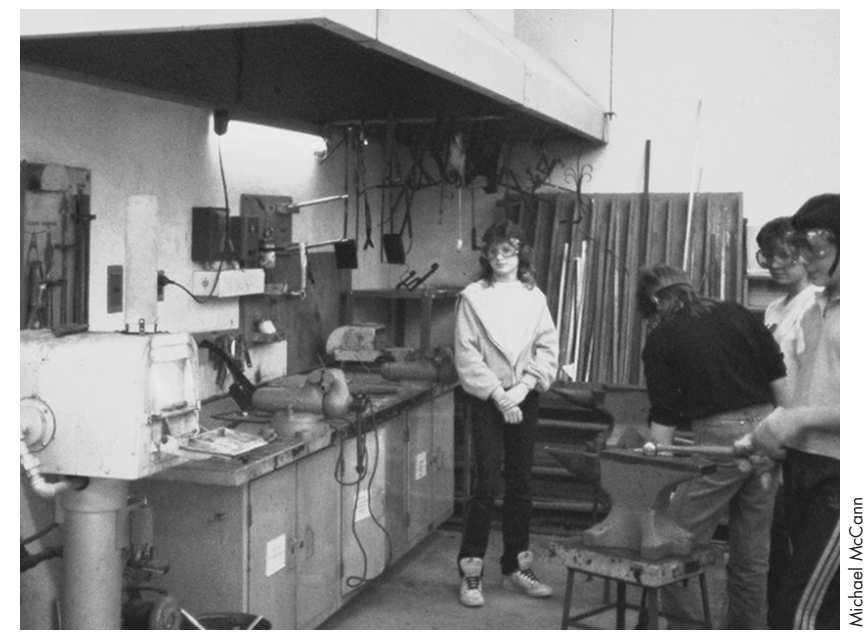

alumnos. La mayor parte de la enseñanza se imparte en las aulas. Además, los profesores especializados en ciencias, arte, formación profesional, educación física y otras áreas, desarrollan buena parte de su actividad docente en instalaciones como laboratorios, talleres de arte, teatros, gimnasios y similares. Asimismo, pueden llevar a los alumnos en visitas de estudios a lugares fuera de la escuela, como museos y zoológicos.

Los profesores desempeñan asimismo tareas especiales, como la supervisión de los estudiantes en los pasillos y la cafetería, la asistencia a reuniones con los administradores, los padres y otras personas, la organización y supervisión de las actividades de ocio y de otro tipo desarrolladas en horario extraescolar y otras obligaciones administrativas. Además, asisten a conferencias y otros actos docentes para mantenerse al día en su campo y progresar en su carrera profesional.

Los profesores se exponen a riesgos específicos. Enfermedades infecciosas como la tuberculosis, el sarampión y la varicela pueden propagarse con facilidad en los centros escolares. Son esenciales, por tanto, las vacunaciones (tanto de alumnos como de profesores), las pruebas de tuberculosis y otras medidas de salud pública normalizadas (véase la Tabla 94.2). La sobreocupación y el ruido en las aulas, la inadecuación de las instalaciones y cuestiones relativas al progreso en la carrera profesional, la seguridad en el puesto de trabajo y la falta general de control sobre las condiciones de trabajo contribuyen a la aparición de graves problemas de estrés, al absentismo y al agotamiento del profesorado. Entre las soluciones se encuentran la adopción de cambios institucionales con el fin de mejorar las condiciones de trabajo y la formulación de programas de reducción del estrés siempre que sea posible. Un problema cada vez mayor, sobre todo en los entornos urbanos, es la violencia contra los profesores por parte de los alumnos y, en ocasiones, de personas ajenas a los centros docentes. En Estados Unidos, muchos estudiantes de enseñanza secundaria, en especial de centros urbanos, llevan armas, incluidas pistolas. En las escuelas que presentan este tipo de problemas, es imprescindible poner en práctica programas organizados de prevención de la violencia. También los auxiliares docentes se enfrentan a muchos de estos riesgos.

Los profesores que imparten clases especializadas pueden verse sometidos a riesgos profesionales adicionales, como la exposición a sustancias químicas, los peligros relacionados con la maquinaria, accidentes, riesgos de carácter eléctrico, niveles de ruido excesivos, radiaciones e incendios, dependiendo del tipo de aula utilizada. 
Tabla 94.1 - Enfermedades infecciosas que afectan al personal docente y a los trabajadores de las guarderías.

\begin{tabular}{|c|c|c|c|}
\hline Enfermedad & Area de incidencia & Modo de transmisión & Observaciones \\
\hline Amebiasis & $\begin{array}{l}\text { Especialmente en trópicos } \\
\text { y subtrópicos }\end{array}$ & $\begin{array}{l}\text { Agua y alimentos contaminados con heces } \\
\text { infectadas }\end{array}$ & Higiene adecuada del agua y las alimentos. \\
\hline Citomegalovirus (CMV) & Todo el mundo & $\begin{array}{l}\text { Gotículas respiratorias en suspensión en el } \\
\text { aire; contacto con orina, saliva o sangre }\end{array}$ & Altamente contagioso; riesgo de defectos de nacimiento. \\
\hline $\begin{array}{l}\text { Eritema infeccioso } \\
\text { (Parvovirus-B-19) }\end{array}$ & Todo el mundo & $\begin{array}{l}\text { Contacto directo de persona a persona } 0 \\
\text { gotículas respiratorias en suspensión en } \\
\text { el aire }\end{array}$ & Levemente contagioso; riesgo para el feto durante el embarazo. \\
\hline $\begin{array}{l}\text { Gastroenteritis, bacteriana } \\
\text { (Salmonella, Shigella, } \\
\text { Campilobacter) }\end{array}$ & Todo el mundo & $\begin{array}{l}\text { Transmisión persona a persona, alimentos } 0 \\
\text { agua a través de la vía fecal-oral }\end{array}$ & $\begin{array}{l}\text { Higiene adecuada de alimentos y agua; exige la aplicación de procedi- } \\
\text { mientos de lavado de manos estrictos; enfermedad declarable en la } \\
\text { mayoría de países. }\end{array}$ \\
\hline $\begin{array}{l}\text { Gastroenteritis, vírica } \\
\text { (Rotavirus) }\end{array}$ & Todo el mundo & $\begin{array}{l}\text { Transmisión de persona a persona, por } \\
\text { alimentos o agua a través de la vía fecal } \\
\text { oral; también por inhalación de polvo que } \\
\text { contiene el virus }\end{array}$ & Higiene adecuada de alimentos y agua. \\
\hline $\begin{array}{l}\text { Giardiasis (parásito } \\
\text { intestinal) }\end{array}$ & $\begin{array}{l}\text { Todo el mundo, pero } \\
\text { especialmente en } \\
\text { trópicos y subtrópicos }\end{array}$ & $\begin{array}{l}\text { Agua y alimentos contaminados; también es } \\
\text { posible por transmisión de persona a } \\
\text { persona }\end{array}$ & $\begin{array}{l}\text { Higiene adecuada de alimentos y agua; enfermedad declarable en la } \\
\text { mayoría de países. }\end{array}$ \\
\hline Gripe & Todo el mundo & $\begin{array}{l}\text { Gotículas respiratorias en suspensión en el } \\
\text { aire }\end{array}$ & $\begin{array}{l}\text { Altamente contagiosa; a las personas de alto riesgo debe administrár- } \\
\text { seles dosis de inmunización. }\end{array}$ \\
\hline Hepatitis A, virus & $\begin{array}{l}\text { Todo el mundo, pero } \\
\text { especialmente en las } \\
\text { regiones mediterráneas } \\
\text { y los países en } \\
\text { desarrollo }\end{array}$ & $\begin{array}{l}\text { Transmisión vía fecal-oral, sobre todo a } \\
\text { través de agua y alimentos contami- } \\
\text { nados; también es posible mediante } \\
\text { contacto directo de persona a persona }\end{array}$ & $\begin{array}{l}\text { Riesgo de abortos y alumbramiento de mortinato; higiene adecuada de } \\
\text { alimentos y agua; enfermedad declarable en la mayoría de países. }\end{array}$ \\
\hline Hepatitis B, virus & $\begin{array}{l}\text { Todo el mundo, } \\
\text { especialmente en } \\
\text { Asia y Africa }\end{array}$ & $\begin{array}{l}\text { Contacto sexual, contacto de heridas en piel } \\
\text { o membranas mucosas con sangre y otros } \\
\text { fluidos corporales }\end{array}$ & $\begin{array}{l}\text { Mayor incidencia en niños ingresados en instituciones (p. ej., con } \\
\text { discapacidades mentales); vacunación recomendada en situaciones } \\
\text { de alto riesgo; utilización de precauciones universales en todas las } \\
\text { exposiciones a sangre y otros fluidos corporales; enfermedad decla- } \\
\text { rable en la mayoría de países. }\end{array}$ \\
\hline $\begin{array}{l}\text { Herpes simple } \\
\text { Tipo I y II }\end{array}$ & Todo el mundo & Contacto con membranas mucosas & $\begin{array}{l}\text { Extremadamente contagioso; común en adultos y en el grupo de } \\
\text { edades comprendidas entre } 10 \text { y } 20 \text { años. }\end{array}$ \\
\hline $\begin{array}{l}\text { Infección por el virus de la } \\
\text { inmunodeficiencia } \\
\text { humana (VIH) }\end{array}$ & Todo el mundo & $\begin{array}{l}\text { Contacto sexual, contacto de heridas en piel } \\
\text { o membranas mucosas con sangre u otros } \\
\text { fluidos corporales }\end{array}$ & $\begin{array}{l}\text { Da lugar al síndrome de inmunodeficiencia adquirida (SIDA); utiliza- } \\
\text { ción de precauciones universales en todas las exposiciones a sangre } \\
\text { y otros fluidos corporales (p. ej., sangrado por la nariz); la declara- } \\
\text { ción anónima de la enfermedad se exige en la mayoría de los } \\
\text { países. }\end{array}$ \\
\hline $\begin{array}{l}\text { Infecciones } \\
\text { estreptocócicas }\end{array}$ & Todo el mundo & Contacto directo de persona a persona & $\begin{array}{l}\text { La infección de garganta, la escarlatina y la neumonía son ejemplos de } \\
\text { este tipo de infecciones. }\end{array}$ \\
\hline $\begin{array}{l}\text { Infecciones por } \\
\text { micoplasma }\end{array}$ & Todo el mundo & $\begin{array}{l}\text { Transmisión a través del aire tras un } \\
\text { contacto cercano }\end{array}$ & $\begin{array}{l}\text { Causa fundamental de la neumonía atíica primaria; afecta principal- } \\
\text { mente a niños entre } 5 \text { y } 15 \text { años de edad. }\end{array}$ \\
\hline $\begin{array}{l}\text { Meningitis por meningo- } \\
\operatorname{cocos} \text { (bacteriana) }\end{array}$ & $\begin{array}{l}\text { Principalmente en Africa } \\
\text { tropical y Brasil }\end{array}$ & $\begin{array}{l}\text { Gotículas respiratorias en suspensión en el } \\
\text { aire, especialmente mediante contacto } \\
\text { cercano }\end{array}$ & Enfermedad declarable en la mayoría de países. \\
\hline $\begin{array}{l}\text { Mononucleosis infecciosa } \\
\text { (Virus de Epstein-Barr) }\end{array}$ & Todo el mundo & $\begin{array}{l}\text { Gotículas respiratorias en suspensión en el } \\
\text { aire; contacto directo con saliva }\end{array}$ & $\begin{array}{l}\text { Especialmente común en el grupo de población de edades compren- } \\
\text { didas entre } 10 \text { y } 20 \text { años. }\end{array}$ \\
\hline Paperas & Todo el mundo & $\begin{array}{l}\text { Gotículas respiratorias en suspensión en el } \\
\text { aire y contacto con saliva }\end{array}$ & $\begin{array}{l}\text { Altamente contagiosa; aislamiento de los niños infectados; puede } \\
\text { causar infertilidad en adultos; los brotes son declarables en algunos } \\
\text { países. }\end{array}$ \\
\hline Pertusis (tos ferina) & Todo el mundo & $\begin{array}{l}\text { Gotículas respiratorias en suspensión en el } \\
\text { aire }\end{array}$ & $\begin{array}{l}\text { No muy grave en adultos; todos los niños menores de } 7 \text { años deben } \\
\text { ser inmunizados. }\end{array}$ \\
\hline
\end{tabular}

Continúa en la página siguiente. 
Tabla 94.1 • Enfermedades infecciosas que afectan al personal docente y a los trabajadores de los centros de cuidados de día.

Continuación

\begin{tabular}{|c|c|c|c|}
\hline Enfermedad & Area de incidencia & Modo de transmisión & Observaciones \\
\hline Rubeola & Todo el mundo & $\begin{array}{l}\text { Gotículas respiratorias en suspensión en el } \\
\text { aire; contacto directo con personas } \\
\text { infectadas }\end{array}$ & $\begin{array}{l}\text { Riesgo de defectos de nacimiento; debe vacunarse a todos los niños y } \\
\text { los miembros del personal; enfermedad declarable en la mayoría de } \\
\text { países. }\end{array}$ \\
\hline Sarampión & Todo el mundo & $\begin{array}{l}\text { Gotículas respiratorias en suspensión en el } \\
\text { aire }\end{array}$ & $\begin{array}{l}\text { Altamente contagioso, constituye un riesgo para los adultos no inmuni } \\
\text { zados que trabajan con niños no vacunados; enfermedad declarable } \\
\text { en la mayoría de países. }\end{array}$ \\
\hline Sarna & Todo el mundo & Contacto directo de piel a piel & Enfermedad infecciosa de la piel causada por acáridos. \\
\hline Tuberculosis (respiratoria) & Todo el mundo & $\begin{array}{l}\text { Gotículas respiratorias en suspensión en el } \\
\text { aire }\end{array}$ & $\begin{array}{l}\text { Altamente infecciosa; la detección de la tuberculosis debe ser efec- } \\
\text { tuada en todos los trabajadores de centros de cuidados de día; } \\
\text { enfermedad declarable en la mayoría de países. }\end{array}$ \\
\hline Varicela & Todo el mundo & $\begin{array}{l}\text { En general, contacto directo de persona a } \\
\text { persona, pero también es posible por gotí- } \\
\text { culas respiratorias en suspensión en el } \\
\text { aire }\end{array}$ & $\begin{array}{l}\text { La varicela es más grave en adultos que en niños; riesgo de defectos } \\
\text { de nacimiento; enfermedad declarable en la mayoría de los países. }\end{array}$ \\
\hline
\end{tabular}

Tabla 94.2 • Riesgos y precauciones de determinadas disciplinas.

\begin{tabular}{|c|c|c|c|}
\hline Disciplina & Actividad/materia & Riesgos & Precauciones \\
\hline \multicolumn{4}{|c|}{ Enseñanza elemental } \\
\hline \multirow[t]{4}{*}{ Ciencia } & Manipulación de animales & $\begin{array}{l}\text { Mordeduras y arañazos, } \\
\text { zoonosis, parásitos }\end{array}$ & $\begin{array}{l}\text { Permitir únicamente la utilización de animales vivos y sanos. Manipular los animales } \\
\text { con guantes gruesos. Evitar los animales que pueden portar parásitos e insectos } \\
\text { transmisores de enfermedades. }\end{array}$ \\
\hline & Plantas & Alergias, plantas venenosas & Evitar las plantas tóxicas y que puedan provocar reacciones alérgicas. \\
\hline & Sustancias químicas & $\begin{array}{l}\text { Problemas dérmicos y } \\
\text { oculares, reacciones } \\
\text { tóxicas, alergias }\end{array}$ & $\begin{array}{l}\text { Evitar la utilización de sustancias químicas tóxicas al tratar con niños. Utilizar } \\
\text { equipos de protección individual adecuados para realizar demostraciones pedagó- } \\
\text { gicas con este tipo de sustancias. }\end{array}$ \\
\hline & Equipos & $\begin{array}{l}\text { Riesgos eléctricos, } \\
\text { riesgos para la seguridad }\end{array}$ & $\begin{array}{l}\text { Seguir los procedimientos normalizados de seguridad en relación con fuentes de } \\
\text { energía eléctrica. Garantizar una protección adecuada en todos los equipos. Alma- } \\
\text { cenar correctamente todos los equipos, herramientas, etc. }\end{array}$ \\
\hline \multirow[t]{9}{*}{ Arte } & & & $\begin{array}{l}\text { Utilizar únicamente materiales no tóxicos. Evitar los disolventes, los ácidos, los } \\
\text { álcalis, los pulverizadores, los tintes químicos, etc. }\end{array}$ \\
\hline & Pintura y dibujo & Pigmentos, disolventes & $\begin{array}{l}\text { Utilizar únicamente pinturas para niños. No emplear pinturas al pastel ni pigmentos } \\
\text { secos. }\end{array}$ \\
\hline & Fotografía & Sustancias fotoquímicas & $\begin{array}{l}\text { No llevar a cabo el revelado de fotos. Enviar los carretes a establecimientos externos } \\
\text { para su revelado, utilizar cámaras Polaroid o copias heliográficas y luz solar. }\end{array}$ \\
\hline & $\begin{array}{l}\text { Artes textiles y elaboración } \\
\text { de teiidos }\end{array}$ & Tintes & $\begin{array}{l}\text { Evitar tintes sintéticos; utilizar tintes naturales como la piel de cebolla, el té, la espi- } \\
\text { naca, etc. }\end{array}$ \\
\hline & Impresión & Acidos, disolventes & Utilizar tintas acuosas para xilografía. \\
\hline & & Herramientas cortantes & Utilizar planchas de linóleo en lugar de bloques de xilografía. \\
\hline & Carpintería & Herramientas & Utilizar únicamente maderas blandas y herramientas de mano. \\
\hline & & Colas & Utilizar colas acuosas. \\
\hline & Cerámica & $\begin{array}{l}\text { Sílice, metales tóxicos, } \\
\text { calor, humos de los } \\
\text { hornos }\end{array}$ & $\begin{array}{l}\text { Utilizar únicamente arcilla húmeda y fregar el suelo. Pintar los productos en vez de } \\
\text { utilizar esmaltes cerámicos. No poner en funcionamiento hornos dentro de las aulas. }\end{array}$ \\
\hline
\end{tabular}

Continúa en la página siguiente. 
Tabla 94.2 Riesgos y precauciones de determinadas disciplinas.

Continuación.

\begin{tabular}{|c|c|c|c|}
\hline Disciplina & Actividad/materia & Riesgos & Precauciones \\
\hline \multicolumn{4}{|c|}{ Enseñanza secundaria } \\
\hline Química & General & & $\begin{array}{l}\text { Todos los laboratorios escolares deben disponer de la siguiente dotación: campanas } \\
\text { de extracción si se trabaja con sustancias químicas tóxicas volátiles; fuentes para } \\
\text { el lavado de ojos; duchas de emergencia (si se aplican ácidos, bases u otras } \\
\text { sustancias químicas concentradas); botiquín; extintores de incendios adecuados; } \\
\text { gafas protectoras, guantes y batas de laboratorio; recipientes y procedimientos de }\end{array}$ \\
\hline
\end{tabular}

Química orgánica Disolventes

Peróxidos y explosivos

Química inorgánica Acidos y bases

Química analíitica

Almacenamiento

Sulfuro de hidrógeno

Incompatibilidades

Inflamabilidad

Biología

Disección

Anestesia de insectos

Extracción de sangre

Microscopio

Cultivo de bacterias

Ciencias físicas

Isótopos radiactivos

Electricidad y magnetismo

Láseres

Ciencias de la tierra

Geología

Contaminación del agua

Atmósfera

Volcanes

Observación solar

Formaldehido riesgos eléctricos aire

Infección, sustancias químicas tóxicas gafas protectoras, guantes y batas de laboratorio; recipientes y procedimientos de evacuación apropiados; equipo de control de fugas. Evitar las sustancias químicas cancerígenas, mutágenas y altamente tóxicas como el mercurio, el plomo, el cadmio, el gas cloro, etc.

Utilizar únicamente en campanas de laboratorio.

Utilizar los disolventes menos tóxicos.

Realizar experimentos a microescala o semimicroescala.

No utilizar explosivos o sustancias químicas como el éter, que puede formar peróxidos explosivos.

Evitar los ácidos y las bases concentrados siempre que sea posible.

No utilizar el sulfuro de hidrógeno. Emplear sustancias sustitutivas.

Evitar el almacenamiento por orden alfabético, que puede dar lugar a la proximidad de sustancias químicas incompatibles. Almacenar por grupos compatibles.

Almacenar los líquidos inflamables y combustibles en armarios diseñados al efecto y aprobados.

No diseccionar especímenes conservados en formaldehido. Utilizar animales de tamaño reducido y congelados en seco, películas y cintas formativas, etc.

Utilizar alcohol ex́lico para la anestesia de insectos. Refrigerar los insectos para su recuento.

Evitar siempre que sea posible. Utilizar lancetas estériles para la determinación del grupo sanguíneo, bajo supervisión estricta.

Evitar el contacto de la piel con el yodo y el violeta de genciana.

Utilizar técnicas estériles con todas las bacterias, por suponer que puede existir contaminación por bacterias patógenas.

Utilizar isótopos radiactivos únicamente en cantidades "exentas" que no requieran la obtención de un permiso. Sólo se autorizará su manejo a profesores cualificados. Adoptar un programa de seguridad en materia de radiación.

Seguir los procedimientos normalizados de seguridad relativos a las fuentes de energía eléctrica.

Daños oculares y dérmicos, Utilizar únicamente láseres de baja potencia (clase I). No mirar nunca directamente a un rayo láser ni pasar éste por la cara o el cuerpo. Los láseres deben disponer de un bloqueo de llave.

Partículas suspendidas en el Triturar las rocas en bolsas de lona para evitar el desprendimiento de partículas. Utilizar gafas protectoras.

No tomar muestras de aguas residuales debido al riesgo de infección. Evitar las sustancias químicas peligrosas en las pruebas de contaminación del agua realizadas sobre el terreno.

Manómetros de mercurio Utilizar únicamente manómetros de aceite 0 agua. Si se utilizan manómetros de mercurio para demostración debe disponerse de un equipo de control para el derramamiento de mercurio.

No utilizar dicromato amónico y magnesio para simular volcanes.

No mirar nunca al sol directamente con los ojos descubiertos o a través de objetivos fotográficos.

Continúa en la página siguiente. 
Tabla 94.2 Riesgos y precauciones de determinadas disciplinas.

Continuación.

$\begin{array}{lll}\text { Disciplina } & \text { Actividad/materia } & \text { Riesgos } \\ \text { Arte y artes industriales } & \text { Todas } & \text { Generales } \\ & \text { Pintura y dibujo } & \text { Pigmentos, disolventes } \\ \text { Fotografía } & \text { Sustancias fotoquímicas, } \\ & \text { ácidos, dióxido de azufre } \\ & \text { Artes textiles } & \text { Tintes, productos auxiliares } \\ & \text { para tinte, humos de cera }\end{array}$

\section{Precauciones}

Evitar las sustancias químicas y los procesos más peligrosos. Disponer de una ventilación adecuada. Véanse asimismo las precauciones del apartado de química.

Evitar los pigmentos de plomo y de cadmio. Evitar las pinturas al óleo, salvo si la limpieza se realiza con aceite vegetal. Utilizar los fijadores por pulverización en el exterior.

Evitar el virado y el revelado en color. Disponer de ventilación por dilución en el cuarto oscuro. Disponer de una fuente para el lavado ocular. Utilizar agua en lugar de ácido acético para el baño de paro.

Utilizar tintes líquidos acuosos o mezclar los tintes en una caja de manipulación con guantes. Evitar los dicromatos corrosivos. No utilizar disolventes para eliminar la cera en los estampados al batik. Disponer de ventilación en el proceso de eliminación de la cera.

Fabricación de papel Alcalis, molinos para pasta

No hervir lejía. Utilizar materiales vegetales en mal estado o estiércol, o reciclar papel y cartón. Utilizar grandes mezcladoras en lugar de molinos industriales, más peligrosos, para elaborar la pasta de papel.

Impresión Disolventes

Acidos, clorato potásico Utilizar cloruro férrico para grabar las planchas de cobre en lugar de mordente

Utilizar tintas de serigrafía acuosas en lugar de las basadas en disolventes. Limpiar las bancadas de las máquinas de huecograbado y las espátulas para entintar con aceite vegetal y líquidos lavavaiillas en lugar de con disolventes. Utilizar láminas de papel en lugar de láminas de laca para serigrafiado. holandés o ácido nítrico en planchas de zinc. Si se utiliza el grabado con ácido nítrico, debe disponerse de una ducha de emergencia, fuentes para lavados oculares y un sistema de aspiración localizada.

Dicromatos Utilizar diazo en lugar de emulsiones fotográficas de dicromato. Utilizar soluciones mojadoras de ácido cítrico en litografías para sustituir a los dicromatos.

Carpintería

Escultura

Joyería
Maderas y polvo de madera

Maquinaria y herramientas

Ruido

Colas

Pinturas y acabados

Plomo, silice, metales tóxicos, humos de horno

Sílice, resinas plásticas, polvo

Humos de soldeo, ácidos
Disponer de sistemas de extracción de polvo en las máquinas de carpintería. Evita las maderas duras, irritantes y alergénicas, las maderas conservadas (p. ej., tratadas con arseniato de cobre cromado). Limpiar el polvo de madera para prevenir el riesgo de incendio.

Instalar protectores en los equipos. Disponer de bloqueos de llave e interruptores de emergencia.

Reducir los niveles de ruido o utilizar protectores auditivos.

Utilizar colas acuosas siempre que sea posible. Evitar las colas basadas en formaldehído/resorcinol y en disolventes.

Utilizar pinturas y acabados acuosos. Utilizar barnices de laca con base de alcohol etílico y no de alcohol metílico.

Adquirir arcilla húmeda. No utilizar barnices de plomo. Comprar barnices preparados en lugar de mezclar barnices secos. Pulverizar los barnices únicamente en las cabinas preparadas al efecto. Encender el horno en el exterior o disponer de un sistema de aspiración localizada. Utilizar gafas de protección infrarroja para mirar hornos en funcionamiento.

Utilizar únicamente herramientas de mano en la escultura en piedra para reducir los niveles de ruido. No utilizar arenisca, granito ni esteatita, que pueden contener sílice 0 amianto. No utilizar resinas de poliuretano, epóxicas o de poliéster. Disponer de ventilación si se van a calentar plásticos a fin de eliminar los productos de descomposición. Limpiar con líquidos o aspirar el polvo generado.

Evitar la soldadura de plata y cadmio y los fundentes de fluoruro. Utilizar hidrogerosufato sódico en lugar de ácido sulfúrico para los baños de desoxidación. Disponer de sistemas de aspiración localizada.

Continúa en la página siguiente. 
Tabla 94.2 Riesgos y precauciones de determinadas disciplinas.

Continuación.

\begin{tabular}{|c|c|c|c|}
\hline \multirow[t]{6}{*}{ Disciplina } & Actividad/materia & Riesgos & Precauciones \\
\hline & Esmaltado & $\begin{array}{l}\text { Plomo, quemaduras, radia- } \\
\text { ción infrarroja }\end{array}$ & $\begin{array}{l}\text { Utilizar únicamente esmaltes sin plomo. Ventilar los hornos de esmaltado. Utilizar } \\
\text { guantes y ropas resistentes al calor y gafas protectoras contra la radiación } \\
\text { infrarroja. }\end{array}$ \\
\hline & Moldeo a la cera perdida & $\begin{array}{l}\text { Humos metálicos, ślice, } \\
\text { radiación infrarroja, calor }\end{array}$ & $\begin{array}{l}\text { Utilizar a partes iguales arena de grano y yeso en lugar de rellenos de cristobalita. } \\
\text { Disponer de sistemas de aspiración localizzda aplicados a los hornos de derretido } \\
\text { de la cera y las operaciones de moldeo. Utilizar ropas y guantes resistentes al } \\
\text { calor. }\end{array}$ \\
\hline & Vidrieras & Plomo, fundentes ácidos & $\begin{array}{l}\text { Utilizar la técnica de la hoja de cobre en lugar de plomo. Utilizar sueldas sin plomo y } \\
\text { sin antimonio. Evitar las pinturas para vidrio al plomo. Utilizar fundentes para } \\
\text { soldadura sin ácidos ni resina de trementina. }\end{array}$ \\
\hline & Soldadura & $\begin{array}{l}\text { Humos metálicos, ozono, } \\
\text { dióxido de nitrógeno, } \\
\text { riesgos eléctricos y de } \\
\text { incendio }\end{array}$ & $\begin{array}{l}\text { No soldar metales recubiertos de zinc, pinturas al plomo o aleaciones con metales } \\
\text { peligrosos (níquel, cromo, etc.). Soldar únicamente metales de composición cono- } \\
\text { cida. }\end{array}$ \\
\hline & Dibujo publicitario & $\begin{array}{l}\text { Disolventes, sustancias foto- } \\
\text { químicas, terminales con } \\
\text { pantallas de vídeo }\end{array}$ & $\begin{array}{l}\text { Utilizar cinta de doble cara en lugar de adhesivo de caucho. Utilizar adhesivos de } \\
\text { caucho con base de heptano y no de hexano. Disponer de cabinas de pulverización } \\
\text { para la aerografía. Utilizar rotuladores de base acuosa o alcohólica en lugar de los } \\
\text { de xileno. } \\
\text { Véase el apartado de fotografía para más información sobre los procesos } \\
\text { fotográficos. } \\
\text { Disponer de asientos ergonómicos, iluminación, etc. apropiados para el uso de } \\
\text { ordenadores. }\end{array}$ \\
\hline \multirow[t]{5}{*}{ Artes escénicas } & Teatro & $\begin{array}{l}\text { Disolventes, pinturas, } \\
\text { humos de soldeo, isocia- } \\
\text { natos, incendios }\end{array}$ & $\begin{array}{l}\text { Utilización de pinturas y tintes acuosos. Evitar las espumas para pulverizador de } \\
\text { poliuretano. Aislar las operaciones de soldeo. Disponer de procedimientos de } \\
\text { montaje seguros. Evitar los productos pirotécnicos, las armas de fuego, la niebla y } \\
\text { el humo y otros efectos especiales peligrosos. Utilizar materiales ignífugos en la } \\
\text { construcción de los decorados. Marcar los escotillones, fosos y partes elevadas. }\end{array}$ \\
\hline & Danza & $\begin{array}{l}\text { Lesiones agudas, } \\
\text { lesiones por esfuerzo } \\
\text { repetitivo }\end{array}$ & $\begin{array}{l}\text { Disponer de suelos de baile apropiados. Evitar programas exhaustivos después de } \\
\text { períodos de inactividad. Realizar un calentamiento adecuado antes de la actividad } \\
\text { y controlar el descenso de temperatura después de la misma. Establecer un } \\
\text { período de recuperación suficiente después de una lesión. }\end{array}$ \\
\hline & Música & $\begin{array}{l}\text { Lesiones musculosqueléticas } \\
\text { (p. ej., síndrome del } \\
\text { túnel carpiano) }\end{array}$ & $\begin{array}{l}\text { Utilizar instrumentos del tamaño adecuado. Disponer de apoyos apropiados para la } \\
\text { ejecución. Establecer un período de recuperación suficiente después de una lesión. }\end{array}$ \\
\hline & & Ruido & $\begin{array}{l}\text { Mantener el ruido a niveles aceptables. Utilizar tapones especiales para los oídos en } \\
\text { caso necesario. Disponer los altavoces para que reduzcan al mínimo los niveles de } \\
\text { ruido. Utilizar materiales insonorizantes en las paredes. }\end{array}$ \\
\hline & & Tensión vocal & $\begin{array}{l}\text { Efectuar un calentamiento adecuado. Procurar una formación y un acondicionamiento } \\
\text { vocales adecuados. }\end{array}$ \\
\hline \multirow[t]{5}{*}{ Mecánica de automoción } & Tambores de freno & Amianto & No limpiar los tambores de freno si no se utilizan equipos aprobados. \\
\hline & Desengrasado & Disolventes & Utilizar detergentes acuosos. Utilizar limpiadores de componentes. \\
\hline & Motores de vehículos & Monóxido de carbono & Utilizar tubos de exhaustación. \\
\hline & Soldadura & & Véase el apartado correspondiente. \\
\hline & Pintura & Disolventes, pigmentos & $\begin{array}{l}\text { Pulverización de pintura únicamente en las cabinas diseñadas al efecto o en el exte- } \\
\text { rior con protección respiratoria. }\end{array}$ \\
\hline \multirow[t]{4}{*}{ Economía doméstica } & Alimentación y nutrición & Riesgos eléctricos & Atenerse a las normas de seguridad establecidas en materia de electricidad. \\
\hline & & $\begin{array}{l}\text { Cuchillos y otros utensilios } \\
\text { afilados }\end{array}$ & Cortar siempre lejos del propio cuerpo. Mantener los cuchillos afilados. \\
\hline & & Incendio y quemaduras & $\begin{array}{l}\text { Disponer de campanas de extracción para hornos con filtros de grasa y salida al exte- } \\
\text { rior. Utilizar guantes de protección al manipular objetos calientes. }\end{array}$ \\
\hline & & Productos de limpieza & $\begin{array}{l}\text { Utilizar gafas, guantes y delantal al manipular productos de limpieza que contengan } \\
\text { ácidos o bases. }\end{array}$ \\
\hline
\end{tabular}


Figura 94.2 - Campanas de extracción de humos y ducha de emergencia en un laboratorio de ciencias de un centro de enseñanza secundaria.

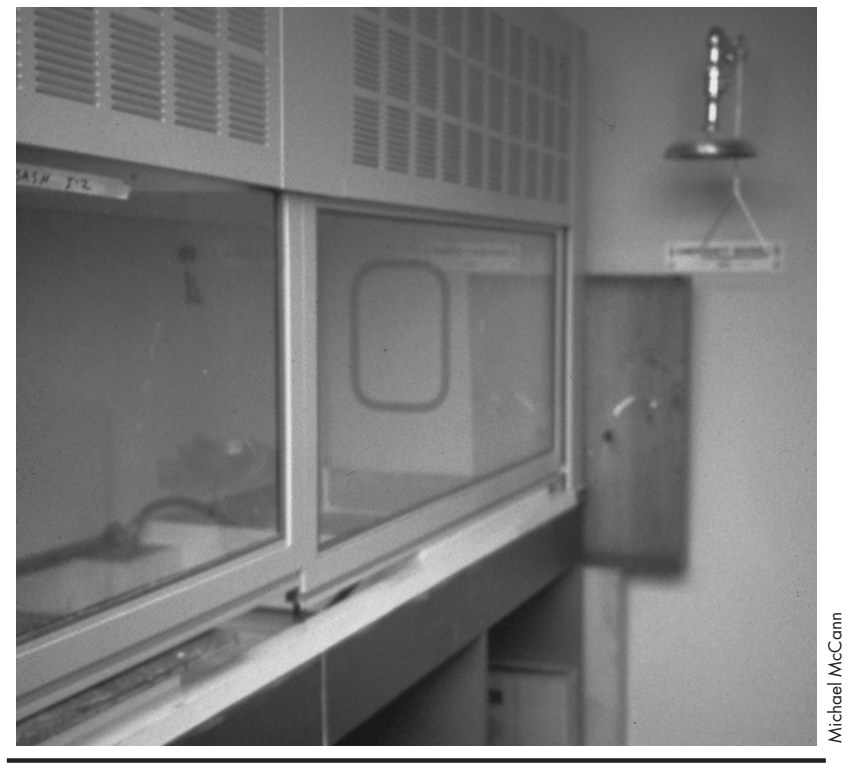

En la Figura 94.1 se muestra un taller metalúrgico industrial en un centro de enseñanza secundaria, y en la Figura 94.2, un laboratorio de ciencias con campanas de ventilación y una ducha de emergencia en un centro de la misma categoría. En la Tabla 94.2 se resumen las precauciones especiales que deben adoptarse, sobre todo en materia de utilización de materiales seguros para las escuelas. Para más información sobre las precauciones normalizadas, véanse los capítulos en que se tratan estos procesos (p. ej., Actividades artísticas, culturales y recreativas y Utilización, almacenamiento y transporte de productos químicos).

En ocasiones, los profesores que participan en programas de educación especial pueden exponerse a riesgos mayores. Son ejemplos de estos peligros la violencia ejercida por estudiantes que sufren perturbaciones emocionales y la transmisión de infecciones como la hepatitis A, B y $\mathrm{C}$ por alumnos ingresados en instituciones y discapacitados en su desarrollo (Clemens y cols. 1992).

\section{- FORMACION PROFESIONAL Y APRENDIZAJE}

Gary Gibson

La enseñanza de los oficios a través de un sistema de aprendizaje se remonta al menos a la época del Imperio Romano, y se mantiene hoy en día en actividades tradicionales como la zapatería, la carpintería, la cantería y otras. Esta forma de capacitación puede tener carácter informal, cuando una persona que desea aprender un oficio encuentra a un empleador cualificado dispuesto a instruirle a cambio de su trabajo. No obstante, la mayoría de los cursos de aprendizaje están reglados y exigen la celebración de un contrato por escrito entre el empleador y el aprendiz, que se compromete a prestar sus servicios al primero durante un tiempo determinado en compensación por la formación recibida. Los programas reglados suelen regirse por normativas relativas a las cualificaciones necesarias para concluir la capacitación establecidas por instituciones como gremios, sindicatos u organizaciones de empresarios. En algunos países, estas dos últimas entidades gestionan directamente los programas, que suelen consistir en una combinación estructurada de formación en el puesto de trabajo e instrucción en las aulas.

Sin embargo, en el mundo tecnológico actual, hay una necesidad cada vez mayor de trabajadores cualificados en numerosas áreas, como técnicos de laboratorio, mecánicos, maquinistas, cosmetólogos, cocineros, personal empleado en el sector de servicios, etc. El aprendizaje de estas actividades que requieren una cualificación suele ofrecerse en el marco de programas de formación profesional desarrollados en escuelas, institutos, centros politécnicos, escuelas universitarias que imparten programas bianuales y otras instituciones similares. En ocasiones, los programas incluyen prácticas en entornos de trabajo reales.

Tanto los profesores como los estudiantes que participan en los programas de formación profesional se exponen a riesgos derivados del contacto con sustancias químicas y agentes físicos, la utilización de maquinaria y riesgos específicos de cada oficio o sector. En muchos programas, los alumnos emplean equipos anticuados donados por las empresas del sector. Son máquinas que no suelen disponer de las medidas de seguridad actuales, como resguardos apropiados, frenos de acción rápida, sistemas de control de ruidos, etc. Con frecuencia, los propios profesores carecen de una formación adecuada sobre los riesgos de la actividad y las precauciones necesarias. Además, es habitual que los centros docentes no cuenten con unos sistemas de ventilación adecuados y otros equipos de prevención.

Los aprendices suelen enfrentarse a situaciones de alto riesgo debido a que se les asignan las tareas más insalubres y peligrosas. A menudo, representan una fuente de mano de obra barata. En este contexto, es aún más probable que los empleadores carezcan de la formación necesaria en materia de riesgos y precauciones propios de la actividad. Los programas informales de aprendizaje no suelen estar regulados y es habitual que los aprendices sometidos a estos riesgos y formas de explotación no tengan posibilidad de recurrir ante ninguna instancia.

Otro problema común a los programas de aprendizaje y la formación profesional es la edad. El acceso a estas vías de capacitación suele producirse entre los 16 y los 18 años. La formación profesional puede iniciarse en los centros de enseñanza primaria. Los estudios realizados indican que un porcentaje desproporcionado de las reclamaciones de indemnización por bajas a causa de accidente son presentadas por trabajadores jóvenes (con edades comprendidas entre los 15 y los 19 años). En Ontario, Canadá, en 1994, el mayor número de trabajadores jóvenes accidentados desarrollaban su actividad en el sector de servicios.

De estas estadísticas se desprende la posibilidad de que los alumnos que acceden a dichos programas no comprendan la importancia de la formación sobre salud y seguridad. También es posible que los períodos de atención y los niveles de comprensión de los alumnos difieran de los característicos en los adultos, lo que debe reflejarse en su formación. Por último, hay que hacer hincapié en sectores como el de los servicios, en el que la salud y la seguridad no han recibido, por lo general, la atención prestada en otros sectores.

En todo programa profesional o de aprendizaje, debe impartirse formación sobre salud y seguridad, incluida la relativa a la comunicación de riesgos. Los profesores o los empleadores deben poseer una capacitación adecuada en materia de riesgos y precauciones, para protegerse a sí mismos e instruir adecuadamente a los alumnos. En el trabajo y en las instalaciones dedicadas a la docencia deben adoptarse las medidas de precaución pertinentes. 


\section{- ESCUELAS UNIVERSITARIAS Y UNIVERSIDADES}

Susan Magor

El gran número y la amplia gama de operaciones y materiales peligrosos que se utilizan en la enseñanza, la investigación y las actividades de servicios auxiliares representan un reto para la gestión de la salud y la seguridad en las escuelas universitarias y las universidades. La propia naturaleza de la investigación conlleva un riesgo: el desafío de los límites del conocimiento y la tecnología actuales. Muchas actividades de investigación en los campos de la ciencia, la ingeniería y la medicina requieren la utilización de instalaciones, tecnologías y equipos complejos y costosos que pueden no estar disponibles con facilidad o encontrarse en una fase inicial de desarrollo. También puede ocurrir que las actividades evolucionen y se transformen sin que las instalaciones en que se llevan a cabo sean modificadas para garantizar su seguridad. Muchas de las actividades de mayor riesgo se efectúan de modo infrecuente, periódico o experimental. Entre los materiales utilizados en la enseñanza y la investigación se encuentran algunas de las sustancias más peligrosas, que presentan riesgos cuya documentación en materia de toxicidad y seguridad es deficiente o nula. Esos materiales suelen ser empleados en cantidades relativamente pequeñas por personal de formación inadecuada y en condiciones que distan de ser las idóneas. Los riesgos en materia de salud y seguridad no siempre son reconocidos de inmediato y con facilidad por el personal académico de alta cualificación, que suele prestar escasa atención a los controles legislativos o administrativos por considerarlos factores que limitan su libertad académica.

Esta libertad es un principio sagrado, defendido enérgicamente por los docentes, que en algunos casos son expertos en sus correspondientes disciplinas. Las restricciones legislativas o institucionales que se consideran lesivas para el mismo se combaten o incluso se desatienden. La imposición de métodos de detección y control de riesgos para la salud y la seguridad en la enseñanza y la investigación no resulta fácil. El personal docente debe convencerse de que las políticas adoptadas a este respecto apoyan y mejoran su misión fundamental y no la limitan. Estas políticas, cuando se aplican, tienden a proteger la función académica y los derechos individuales, más que obedecer a normas y reglamentos externos. Disposiciones en materia de responsabilidad y rendición de cuentas que impliquen directamente a los profesores y los investigadores pueden tener más influencia que las normativas.

En la mayoría de los casos, la legislación, las normas y las directrices sobre salud y seguridad se desarrollan para industrias en las que se utilizan grandes cantidades de un número relativamente pequeño de sustancias químicas, en las que los riesgos están bien documentados y en las que existen procedimientos establecidos y una plantilla estable en el marco de un sistema de gestión definido con precisión. El entorno académico difiere del industrial en casi todos los aspectos. En algunas jurisdicciones, las instituciones académicas pueden estar exentas del cumplimiento de la legislación sobre salud y seguridad.

En general, los sistemas de gestión de estas instituciones son de tipo jerárquico: el personal docente ocupa los puestos de responsabilidad y los profesionales no académicos, los técnicos y el personal auxiliar se sitúa en escalones inferiores. A menudo, se emplea a tiempo parcial a alumnos licenciados para desempeñar diversas funciones de enseñanza e investigación. Miembros del personal docente son designados para ocupar puestos de alta dirección durante mandatos específicos sin tener la experiencia o la formación suficientes para la gestión. Una rotación frecuente puede dar lugar a una falta de continuidad. En este sistema, los investigadores con más experiencia disfrutan de una autonomía relativa para gestionar sus asuntos, incluso en las grandes instituciones. Normalmente, controlan sus propios presupuestos, el diseño de las instalaciones, las adquisiciones, la organización del trabajo y la contratación del personal. Los riesgos pueden pasarse por alto o no detectarse.

Una práctica común a los investigadores de las instituciones académicas es emplear a alumnos licenciados como ayudantes en el contexto de una relación maestro/aprendiz. Estos trabajadores no siempre están protegidos por la legislación sobre salud y seguridad. Incluso cuando existe cobertura, suelen mostrarse reacios a ejercer sus derechos o exponer sus preocupaciones a sus supervisores, que pueden ser también los responsables de evaluar su rendimiento académico. Largas jornadas de trabajo bajo una gran presión, trabajo por la noche y en fin de semana con una supervisión mínima y unos servicios auxiliares exiguos son características habituales de su labor. Las iniciativas de ahorro de costes y conservación de la energía pueden llegar a reducir la prestación de servicios como la seguridad y la ventilación por las noches y los fines de semana. Aunque los estudiantes no suelen estar protegidos por la legislación sobre salud y seguridad, la diligencia debida exige que se les dispense la misma atención que a los trabajadores de plantilla.

\section{Riesgos potenciales}

La gama de riesgos puede ser extremadamente amplia, dependiendo de las dimensiones y el carácter de la institución, del tipo de programas académicos ofrecidos y de la naturaleza de las actividades de investigación (véase la Tabla 94.3). Las pequeñas escuelas universitarias cuya oferta se limita a programas de letras plantean un número relativamente pequeño de riesgos, mientras que en las universidades de ámbito más general, que comprenden facultades de medicina, ingeniería y bellas artes y formulan programas de investigación exhaustivos, los riesgos son más numerosos y, en ocasiones, pueden ser muy graves, como los derivados de sustancias químicas tóxicas y de factores biológicos, riesgos reproductivos, radiaciones ionizantes y no ionizantes y otros agentes físicos.

Las tareas de mantenimiento, de conservación de campos deportivos, de manipulación de materiales peligrosos, de funcionamiento de maquinaria y vehículos de motor y los trabajos de oficina son comunes a la mayoría de las instituciones y plantean riesgos que se analizan en otros capítulos de la presente Enciclopedia.

La violencia en el lugar de trabajo es un problema de creciente importancia y de especial interés para los profesores, el personal en contacto directo con el público, los administradores financieros y el personal de seguridad.

Las grandes instituciones pueden compararse con ciudades a escala en las que la población vive y trabaja. Los problemas de seguridad personal y colectiva están interrelacionados con las cuestiones de salud y seguridad en el trabajo.

\section{Control de los riesgos}

Antes de proceder a la determinación de los riesgos mediante los procesos habituales de inspección e investigación de incidentes y lesiones, y de iniciar las actividades, debe llevarse a cabo una revisión exhaustiva de los programas e instalaciones propuestos. Las características de riesgo profesional y medioambiental de los nuevos proyectos de investigación y programas académicos deben tenerse en cuenta en las primeras etapas del proceso de planificación. Es posible que los investigadores no sean conscientes de los requisitos legislativos o las normas de seguridad aplicables a sus actividades. En muchos proyectos, éstos y los profesionales de la seguridad deben colaborar para desarrollar procedimientos de 
Tabla 94.3 - Resumen de los riesgos existentes en escuelas universitarias y universidades.

\begin{tabular}{|c|c|c|}
\hline Tipo de riesgo & Fuentes & Lugares/actividades \\
\hline $\begin{array}{l}\text { Sustancias químicas tóxicas (carcinó- } \\
\text { genos, teratógenos, sustancias cáus- } \\
\text { ticas, metales pesados, amianto, } \\
\text { sílice) }\end{array}$ & $\begin{array}{l}\text { Sustancias químicas de laboratorio, disolventes, desengra- } \\
\text { santes, colas, suministros para actividades artísticas, manó- } \\
\text { metros, termómetros, sustancias fotoquímicas, tintes, } \\
\text { residuos peligrosos }\end{array}$ & $\begin{array}{l}\text { Laboratorios, estudios de arte, talleres, instalaciones de asistencia } \\
\text { sanitaria, operaciones de mantenimiento, talleres mecánicos, } \\
\text { teatros, cuartos oscuros, ingeniería, campos de hockey }\end{array}$ \\
\hline Inflamables y explosivos & $\begin{array}{l}\text { Sustancias químicas de laboratorio, agentes limpiadores, disol- } \\
\text { ventes, combustibles }\end{array}$ & $\begin{array}{l}\text { Laboratorios, operaciones de mantenimiento, talleres, estudios de } \\
\text { arte, obras }\end{array}$ \\
\hline Pesticidas & Fumigación, control de roedores y plagas, desinfectantes & $\begin{array}{l}\text { Conservación de edificios y campos de deporte, invernaderos, } \\
\text { agricultura }\end{array}$ \\
\hline Agentes biológicos & $\begin{array}{l}\text { Manipulación de animales, cultivos de células y teiidos, sangre } \\
\text { y fluidos corporales, especímenes de diagnóstico, objetos } \\
\text { cortantes contaminados, residuos sólidos }\end{array}$ & $\begin{array}{l}\text { Instalaciones para el cuidado de animales, asistencia sanitaria, } \\
\text { conservación de edificios, laboratorios }\end{array}$ \\
\hline Radiación no ionizante & Láseres, microondas, imanes, electrónica, luz ultravioleta & $\begin{array}{l}\text { Laboratorios, operaciones eléctricas, instalaciones de asistencia } \\
\text { sanitaria, talleres, operaciones técnicas }\end{array}$ \\
\hline Radiación ionizante & $\begin{array}{l}\text { Isótopos radiactivos, cromatografía de gases, rayos x, reactores } \\
\text { de calibración, generadores de neutrones, gestión de residuos }\end{array}$ & Laboratorio, instalaciones médicas, ingeniería \\
\hline Ergonomía & Manipulación de materiales, trabajo de oficina, ordenadores & $\begin{array}{l}\text { Bibliotecas, oficinas, operaciones de mantenimiento, mudanzas, } \\
\text { conductores de camión, servicios de alimentación }\end{array}$ \\
\hline Frío/calor & Trabajo al aire libre, agotamiento & $\begin{array}{l}\text { Conservación de campos de deporte, seguridad pública, manteni- } \\
\text { miento, trabajo sobre el terreno, agricultura y silvicultura }\end{array}$ \\
\hline Ruido & $\begin{array}{l}\text { Maquinaria, calderas y recipientes a presión, ordenadores, } \\
\text { construcción y mantenimiento, sistemas de ventilación }\end{array}$ & $\begin{array}{l}\text { Salas de calderas, imprentas, mantenimiento y conservación de } \\
\text { campos deportivos, operaciones de construcción, salas de ordena- } \\
\text { dores, laboratorios, talleres de construcción de máquinas, estu- } \\
\text { dios de arte }\end{array}$ \\
\hline Violencia & $\begin{array}{l}\text { Comunidad interna, comunidad externa, conflictos domésticos, } \\
\text { desobediencia civil }\end{array}$ & $\begin{array}{l}\text { Aulas, lugares de reunión, departamentos de contabilidad, tiendas, } \\
\text { servicio de comidas, departamento de personal, operaciones de } \\
\text { seguridad }\end{array}$ \\
\hline Electricidad & $\begin{array}{l}\text { Equipos eléctricos, operaciones de construcción y manteni- } \\
\text { miento, trabajos de cableado realizados por aficionados, } \\
\text { acontecimientos especiales }\end{array}$ & $\begin{array}{l}\text { Laboratorios, talleres, centros de mantenimiento, obras, talleres de } \\
\text { electrónica, residencias, teatro, acontecimientos especiales }\end{array}$ \\
\hline Gases comprimidos & $\begin{array}{l}\text { Equipos y operaciones de mantenimiento, operaciones de } \\
\text { soldeo, refrigerantes, equipos para la fabricación de hielo, } \\
\text { construcción }\end{array}$ & $\begin{array}{l}\text { Laboratorios, talleres metálicos, obras, talleres de construcción de } \\
\text { máquinas, canchas de hockey }\end{array}$ \\
\hline Riesgos relativos a la maquinaria & $\begin{array}{l}\text { Manipulación de materiales, robots, tareas de mantenimiento y } \\
\text { construcción }\end{array}$ & $\begin{array}{l}\text { Imprentas, operaciones de mantenimiento y conservación de } \\
\text { terrenos, ingeniería, laboratorios científicos y técnicos, talleres de } \\
\text { construcción de máquinas }\end{array}$ \\
\hline Objetos afilados & $\begin{array}{l}\text { Cristales rotos, instrumentos cortantes, agujas, recipientes de } \\
\text { laboratorio, tubos de ensayo }\end{array}$ & $\begin{array}{l}\text { Conservación de edificios, laboratorios, asistencia sanitaria, estu- } \\
\text { dios de arte, talleres }\end{array}$ \\
\hline
\end{tabular}

seguridad a medida que avanza la investigación y surgen nuevos riesgos.

Teóricamente, la cultura de la seguridad debe incorporarse a la función académica, por ejemplo, mediante la inclusión de información pertinente sobre salud y seguridad en los planes de estudios y en los manuales de prácticas de laboratorio de los alumnos, y la oferta de información específica y de formación a los trabajadores. La comunicación, la formación y la supervisión de riesgos son esenciales.

En los laboratorios, los estudios de arte y los talleres, el control de la ventilación general debe perfeccionarse mediante la instalación de sistemas de aspiración localizada. En algunos casos, puede ser necesario restringir los factores biológicos de riesgo y proporcionar aislamiento o blindaje contra la acción de los isótopos radioactivos. Los equipos de protección personal, aunque no constituyen un método de prevención primaria en la mayoría de las situaciones, pueden ser la opción elegida con carácter temporal o en condiciones experimentales.

Suele requerirse la formulación de programas de gestión de residuos y materiales peligrosos. La adquisición y distribución centralizada de las sustancias químicas peligrosas de uso habitual y los experimentos realizados a microescala en la enseñanza evitan el almacenamiento de grandes cantidades de las mismas en laboratorios, estudios o talleres.

La adopción de un plan de respuesta de emergencia y de recuperación en caso de desastre, para organizar la acción en caso de sucesos graves que superen la capacidad de respuesta ordinaria, atenuará los efectos de este tipo de incidentes sobre la salud y la seguridad.

\section{ENSEÑANZA ARTISTICA}

\section{Ted Rickard}

Los problemas de salud y seguridad planteados por los programas de formación artística se asemejan a los registrados en las instituciones educativas, desde los institutos de enseñanza secundaria a las universidades. Hay, sin embargo, dificultades especiales porque los riesgos no suelen reconocerse y, sobre todo en el ámbito universitario, pueden alcanzar una escala semiindustrial. Entre otros riesgos hay que destacar la inhalación de 
contaminantes en suspensión en el aire, la ingestión o absorción dérmica de toxinas, lesiones derivadas de la utilización de maquinaria y herramientas, resbalones, tropezones y caídas, y lesiones musculoesqueléticas por esfuerzo repetitivo y otras causas. Las medidas de precaución comprenden la instalación de un sistema de ventilación adecuado (tanto por dilución, como por aspiración local), la manipulación y almacenamiento de las sustancias químicas en condiciones de seguridad, la protección de la maquinaria y un mantenimiento correcto de los equipos, una limpieza eficaz, una conservación adecuada y la dotación de puestos de trabajo ajustables. Una precaución fundamental para prevenir todo tipo de problemas de salud y seguridad en el trabajo es impartir una formación adecuada con carácter obligatorio.

\section{Profesores de enseñanza primaria y secundaria}

Los riesgos en los centros de enseñanza primaria y secundaria se plantean en prácticas como la pulverización y el uso inseguro de disolventes y otras sustancias químicas y la ventilación deficiente de los procesos. Con frecuencia, se carece de equipos apropiados y del conocimiento suficiente de los materiales para garantizar la seguridad en el lugar de trabajo. Entre las medidas de precaución se encuentran la realización de controles técnicos eficaces, la mejora del conocimiento de los materiales y la supresión de los productos peligrosos y su sustitución por otros más fiables (véase la Tabla 94.2). De este modo, se facilitará la protección, no sólo de profesores, técnicos, personal de mantenimiento y administradores, sino también de los alumnos.

\section{Profesores de escuelas universitarias y universidades}

Aparte de los mencionados en el apartado anterior, en las escuelas universitarias y las universidades son factores de riesgo la tendencia de estudiantes, profesores y técnicos a realizar actividades más experimentales y utilizar materiales y maquinaria potencialmente más peligrosos. Asimismo, estos profesionales suelen trabajar a una escala mayor y durante períodos de tiempo más largos. Entre las medidas de precaución deben figurar la educación y la formación, la realización de controles técnicos y la dotación de equipos de protección personal, la formulación por escrito de procedimientos y políticas de seguridad y la insistencia en su cumplimiento.

\section{Libertad artística}

Muchos de los profesores y técnicos que participan en la formación artística son además artistas, lo que produce una multiplicación de las exposiciones a los riesgos derivados de materiales y procesos y puede agravar significativamente los peligros para la salud. Cuando se les plantean riesgos en su campo que desconocían o habían pasado por alto, muchos profesores adoptan una actitud defensiva. Los artistas gustan de la experimentación y suelen inscribirse en una cultura contraria a los poderes establecidos y que fomenta el desafío de las normas institucionales. Ahora bien, es importante que la administración del centro sea consciente de que la búsqueda de la libertad artística no es un argumento válido para descuidar las condiciones de seguridad en el trabajo.

\section{Responsabilidad y formación}

En muchas jurisdicciones, los profesores asumen una responsabilidad tanto personal como del centro respecto de la seguridad de los estudiantes en general y de los de menor edad en particular. "Debido a la edad, grado de madurez y experiencia limitada de la mayor parte de los estudiantes, y puesto que los profesores actúan in loco parentis (en lugar de los padres), se espera de los centros docentes que ofrezcan un entorno seguro y establezcan unas pautas de comportamiento razonables para la protección de los estudiantes" (Qualley 1986).

\section{Programas de salud y seguridad}

Es importante que las escuelas asuman su responsabilidad en materia de formación de los profesores de arte y de los gestores en lo que respecta a los riesgos potenciales derivados de los materiales y procesos aplicados, y al modo de proteger a los estudiantes y a sí mismos. Una administración escolar prudente procederá a la formulación por escrito de programas, procedimientos y políticas de salud y seguridad, garantizará su cumplimiento, impartirá una formación regular en materia de seguridad y demostrará un interés real por enseñar el modo de crear arte en condiciones de seguridad.

\section{PROBlemas de SALUd Y PAUTAS PATOLOGICAS}

\section{Steven D. Stellman y Joshua E. Muscat}

Los profesores conforman un segmento amplio y cada vez mayor de la población activa en muchos países. Por ejemplo, en Estados Unidos, más de 4,2 millones de trabajadores fueron incluidos en 1992 en la categoría general de profesores, desde los que imparten formación preescolar hasta los universitarios. Además de los profesores que desarrollan su actividad en las aulas, otros profesionales y técnicos prestan sus servicios en los centros docentes, como el personal de seguridad y de mantenimiento, de enfermería, del servicio de comedor y los mecánicos.

Tradicionalmente, la enseñanza no se ha considerado una profesión que conlleve la exposición a sustancias peligrosas. En consecuencia, son pocos los estudios realizados sobre los problemas de salud derivados de esta actividad. Con todo, los profesores y otros miembros de la plantilla de los centros docentes pueden verse expuestos a una amplia gama de riesgos físicos, químicos, biológicos o de otro tipo.

La contaminación atmosférica en el interior es una causa importante de enfermedades graves entre los profesores. La fuente principal de esta forma de contaminación es un mantenimiento inadecuado de los sistemas de calefacción, ventilación y aire acondicionado. La contaminación de estos sistemas puede provocar enfermedades respiratorias y dermatológicas agudas. Los edificios de reciente construcción o renovados liberan sustancias químicas, polvo y vapores a la atmósfera. Otras fuentes de contaminación atmosférica en el interior son los techos, los aislamientos, las alfombras, las cortinas y los muebles, la pintura, el calafateo y otras sustancias químicas. Los daños provocados por el agua y no reparados, como las goteras, pueden dar lugar al desarrollo de microorganismos en los materiales de construcción y en los sistemas de ventilación y a la emisión de aerosoles biológicos que afectan al sistema respiratorio de profesores y estudiantes por igual. La contaminación de los edificios escolares por microorganismos puede causar enfermedades graves como neumonía, infecciones de las vías respiratorias superiores, asma y rinitis alérgica.

El personal docente especializado en determinados campos técnicos puede verse expuesto a riesgos profesionales específicos. Por ejemplo, los profesores de artes y oficios suelen entrar en contacto con diversas sustancias químicas como disolventes orgánicos, pigmentos y tintes, metales y compuestos metálicos, minerales y plásticos (Rossol 1990). Otros materiales utilizados en este tipo de formación pueden provocar reacciones alérgicas. La exposición a muchas de estas sustancias está estrictamente regulada en los lugares de trabajo de las empresas, pero no en 
las aulas. Los profesores de química y biología manipulan sustancias químicas tóxicas como los formaldehídos y se exponen a otros riesgos biológicos en los laboratorios de los centros docentes. Los profesores de talleres trabajan en entornos cargados de polvo y pueden entrar en contacto con grandes cantidades de polvo de madera y materiales de limpieza, así como soportar niveles de ruido elevados.

La enseñanza es una actividad que suele caracterizarse por un considerable grado de estrés, absentismo y agotamiento. Las fuentes de estrés del profesorado son muchas y pueden variar con el nivel de docencia. Se trata de preocupaciones de carácter administrativo y relacionadas con los planes de estudios, la progresión en la carrera profesional, la motivación de los estudiantes, el tamaño de las aulas, el conflicto entre papeles y la seguridad en el puesto de trabajo. Otras causas de estrés residen en la obligación de soportar el mal comportamiento de los alumnos y, en ocasiones, la violencia y la presencia de armas en las aulas, además de los riesgos físicos o medioambientales como el ruido. Por ejemplo, los niveles de ruido aconsejables en una clase deben oscilar entre los 40 y los 50 decibelios (dB) (Silverstone 1981); sin embargo, en un estudio realizado en varios centros docentes, se registraron niveles medios situados entre los 59 y los 65 dB (Orloske y Leddo 1981). Los profesores pluriempleados tras la jornada de trabajo ordinaria o durante el verano pueden verse expuestos a otros riesgos propios del lugar de trabajo que pueden afectar a su rendimiento y su salud. El hecho de que la mayoría de los profesores sean mujeres (en Estados Unidos, un 75 \%) plantea la cuestión de cómo puede afectar a su salud el doble papel desempeñado como trabajadoras y madres. No obstante, en varios estudios se indica que, a pesar de los altos niveles de estrés detectados, la proporción de muertes producidas por enfermedades cardiovasculares en la población de profesores es inferior a la de otras profesiones (Herloff y Jarvholm 1989), lo que podría deberse a una menor incidencia del tabaquismo y del consumo de alcohol.

Hay una preocupación cada vez mayor por la posibilidad de que algunos entornos escolares contengan materiales cancerígenos como el amianto, campos electromagnéticos (CEM), plomo, plaguicidas o radón y posean una atmósfera contaminada (Regents Advisory Committee on Environmental Quality in Schools 1994). La exposición al amianto es causa de especial preocupación para el personal de seguridad y mantenimiento. Se ha documentado una elevada prevalencia de anormalidades asociadas a enfermedades derivadas del amianto en este tipo de trabajadores (Anderson y cols. 1992). Las concentraciones atmosféricas de dicho material en algunos centros docentes superan a las registradas en otros edificios (Lee y cols. 1992).

Algunos centros escolares se construyeron cerca de líneas eléctricas de alta tensión que son fuentes de CEM. La exposición a estos campos también se produce por contacto con pantallas de vídeo o con instalaciones eléctricas al descubierto. Algunos estudios vinculan una exposición excesiva a CEM con la incidencia de leucemia, cáncer de mama y tumores cerebrales (Savitz 1993). Otro motivo de preocupación es el contacto con plaguicidas aplicados para controlar la propagación de insectos y otras plagas en los centros docentes. Se ha avanzado la hipótesis de que los residuos de plaguicidas medidos en el suero y los tejidos adiposos de las pacientes con cáncer de mama pueden estar relacionados con el desarrollo de esta enfermedad (Wolff y cols. 1993).

La existencia de una proporción mayoritaria de mujeres en el profesorado ha dado lugar a preocupaciones sobre los posibles riesgos de contraer cáncer de mama. En varios estudios se registra un aumento no explicado de las tasas de esta enfermedad. Los certificados de defunción de 23 estados de Estados Unidos entre 1979 y 1987 arrojan unos índices de mortalidad proporcional (IMP) por cáncer de mama de 162 para las profesoras de raza blanca y 214 para las de raza negra (Rubin y cols. 1993). También se observó un aumento de estos índices entre el profesorado del área de Nueva Jersey y Portland-Vancouver (Rosenman 1994; Morton 1995). Aunque este crecimiento de los IMP registrados no se ha vinculado hasta el momento a factores medioambientales específicos u otros factores de riesgo conocidos en relación con el cáncer de mama, ha dado lugar a una mayor sensibilización de las organizaciones de profesores respecto de esta enfermedad y a la generalización de las campañas de exploración y detección precoz.

\section{CUESTIONES AMBIENTALES Y DE SALUD PUBLICA}

Susan Magor

Las instituciones educativas son responsables de garantizar que sus instalaciones y sus prácticas se ajusten a las disposiciones legislativas en materia de salud pública y cumplan con normas reconocidas de precaución para con los trabajadores, los alumnos y la comunidad circundante. En general, la legislación sobre salud y seguridad en el trabajo no contempla a los alumnos, pero los centros docentes deben adoptar hacia ellos como mínimo las mismas medidas de prevención exigidas por la legislación para proteger a los trabajadores. Además, las instituciones educativas tienen la obligación moral de instruir a los alumnos sobre las cuestiones de seguridad personal, pública, profesional y medioambiental que les incumben y que afectan a sus actividades.

\section{Escuelas universitarias y universidades}

Los recintos que albergan grandes instituciones como escuelas universitarias y universidades pueden compararse a pequeñas ciudades por el tamaño de su población, el área geográfica, el tipo de servicios básicos necesarios y la complejidad de las actividades que se llevan a cabo. Además de los riesgos para la salud y la seguridad de carácter profesional generados en dichas instituciones (analizados en el capítulo Servicios públicos y gubernamentales), es necesario abordar una amplia gama de motivos de preocupación relacionados con el hecho de que un gran número de personas vivan, trabajen y desarrollen su actividad académica en un área delimitada.

La gestión de residuos en los campus suele ser un difícil reto. La legislación medioambiental en muchas jurisdicciones exige un control estricto de las emisiones de agua y gas producidas por las actividades de enseñanza, investigación y prestación de servicios. En ciertas situaciones, las inquietudes expresadas por la comunidad externa pueden exigir una actuación en materia de relaciones públicas.

En los programas de evacuación de residuos químicos y sólidos, deben tenerse en cuenta factores profesionales, medioambientales y relacionados con la salud de la colectividad. La mayoría de las grandes instituciones disponen de programas globales para la gestión de los distintos residuos generados: sustancias químicas tóxicas, isótopos radioactivos, plomo, amianto, residuos biomédicos, basura, desechos líquidos y materiales de construcción. Un problema planteado es la coordinación de estos programas en los campus, debido al gran número de departamentos diferentes, que suelen adolecer de una comunicación deficiente entre sí.

Las escuelas universitarias y las universidades difieren de las empresas por las cantidades y los tipos de residuos peligrosos producidos. Por ejemplo, los laboratorios de los campus suelen 
generar cantidades limitadas de sustancias químicas peligrosas muy variadas. Los métodos de control de este tipo de residuos pueden consistir en la neutralización de ácidos y álcalis, la recuperación de disolventes a pequeña escala mediante la destilación y el empaquetado "de laboratorio", caracterizado por la colocación de pequeños contenedores de sustancias químicas peligrosas y compatibles en tambores separados por serrín u otros materiales de embalaje para evitar roturas. Puesto que los campus pueden generar grandes cantidades de residuos de papel, cristal, metal y plástico, es posible aplicar programas de reciclado como demostración de responsabilidad colectiva y como parte de la función educativa.

Algunas instituciones ubicadas en áreas urbanas pueden recurrir en gran medida a la comunidad externa para servicios esenciales como la policía, la protección contra incendios y las actuaciones en caso de emergencia. La gran mayoría de las grandes y medianas instituciones establecen sus propios servicios de seguridad pública en los campus, a menudo en estrecha colaboración con entidades externas. En muchas ciudades universitarias, la institución educativa es la mayor empresa y, en consecuencia, cabe esperar de ella que ofrezca protección a la población que la sostiene.

Los centros universitarios han dejado de estar alejados de las comunidades en que se ubican. Se ha ampliado la proporción de personas que pueden acceder a la formación entre las mujeres, las personas maduras y los discapacitados. La propia naturaleza de las instituciones educativas las coloca en una situación de riesgo específico, pues albergan una población vulnerable en la que se valora el intercambio de ideas y opiniones contrapuestas, pero donde el concepto de libertad de enseñanza no siempre se equilibra con el de responsabilidad profesional. En los últimos años, las instituciones docentes han registrado un aumento de los actos de violencia hacia los miembros de la comunidad educativa cometidos tanto por agentes externos como por componentes de su estructura. Estos actos han dejado de ser sucesos extraordinariamente infrecuentes. A menudo, los campus son escenario de manifestaciones, grandes concentraciones públicas y acontecimientos políticos y deportivos que requieren la adopción de medidas para la seguridad y el control de los asistentes. La adecuación de los servicios encargados de estas funciones, así como de los planes de respuesta de emergencia y de recuperación en caso de catástrofe, debe ser objeto de una evaluación constante y de una actualización periódica con el fin de satisfacer las necesidades de la comunidad. Hay que tener en cuenta las tareas de detección y control de riesgos al establecer los programas de práctica deportiva, planificar las excursiones y desarrollar diversas actividades recreativas. Son necesarios servicios médicos de urgencia incluso para las actividades efectuadas fuera del campus. La gestión de la seguridad personal mejora con la formulación de programas de información y educación sobre riesgos.

Deben abordarse las cuestiones de salud pública relacionadas con la vida en el campus, como el control de las enfermedades contagiosas, la higiene de los servicios de alimentación y los alojamientos, y el suministro de agua potable, aire limpio y terrenos no contaminados. Hay que adoptar programas de inspección, evaluación y control. La formación del alumnado en estas materias suele encargarse al personal de servicio a los estudiantes, aunque los profesionales de la salud y la seguridad en el trabajo también suelen participar. La educación en materia de enfermedades de transmisión sexual, consumo abusivo de drogas y alcohol, patógenos presentes en la sangre, estrés y enfermedades mentales reviste especial importancia en las comunidades universitarias, donde los comportamientos de riesgo pueden aumentar la probabilidad de exposición a los riesgos asociados. Debe disponerse de servicios médicos y psicológicos.

\section{Centros de enseñanza primaria y secundaria}

Los centros de enseñanza primaria y secundaria presentan muchos de los problemas medioambientales y de salud pública de las escuelas universitarias y las universidades, sólo que a una escala inferior. Sin embargo, los colegios y distritos escolares suelen carecer de programas eficaces para la gestión de los residuos. Un problema grave que afecta a numerosos centros docentes es la evacuación de éter explosivo y ácido pícrico acumulado en los laboratorios escolares durante muchos años (National Research Council 1993). Los intentos de evacuar estos materiales por parte de personal no cualificado han dado lugar en varios casos a explosiones. Otra dificultad es la existencia de numerosos centros educativos situados a gran distancia dentro de un mismo distrito escolar. Esta dispersión puede complicar la centralización de los programas de gestión de residuos peligrosos al obligar a transportar estos materiales por carreteras públicas.

\section{Referencia}

Abdo, R, H Chriske. 1990. HAV-Infektionsrisiken in Krankenhaus, Altenheim und Kindertagesstätten. En Arbeitsmedizin im Gesundheitsdienst, Bd. V, dirigido por F Hofmann y U Stößel. Stuttgart: Gentner Verlag.

Anderson, HA, LP Hanrahan, DN Higgins, PG Sarow. 1992. A radiographic survey of public school building maintenance and custodial employees. Environ Res 59:159-66.

Clemens, R, F Hofmann, H Berthold, G Steinert y cols. 1992. Prävalenz von Hepatitis A, B und C be ewohern einer Einrichtung für geistig Behinderte. Sozialpädiatrie 14:357-364

Herloff, B, B Jarvholm. 1989. Teachers, stress, and mortality. Lancet 1:159-160.

Lee, RJ, DR Van Orden, M Corn, KS Crump. 1992. Exposure to airborne asbestos in buildings. Regul Toxicol Pharmacol 16: 93-107.

Morton, WE. 1995. Major differences in breast cancer risks among occupations. 7 Occup Med 37:328-335.

National Research Council. 1993. Prudent Practices in the Laboratory: Handling and Disposal of Chemicals. Washington, DC: National Academy Press.
Orloske, AJ, JS Leddo. 1981. Environmental effects on children's hearing: How can school systems cope. 7 Sch Health 51:12-14

Polis, M y cols. 1986. Transmission of Giardia lamblia from a day care center to a community. Am f Public Hlth $76: 1,142-1,144$

Qualley, CA. 1986. Safety in the Artroom. Worcester, Massachusetts: Davis Publications.

Regents Advisory Committee on Environmental Quality in Schools. 1994. Report to the New York State Board of Regents on the Environmental Quality of Schools. Albany: Universidad del Estado de Nueva York, State Education Department.

Rosenman, KD. 1994. Causes of mortality in primary and secondary school teachers. Am f Indust Med 25:749-58.

Rossol, M. 1990. The Artist's Complete Health and Safety Guide. Nueva York: Allworth Press.

Rubin, CH, CA Burnett, WE Halperin, PJ Seligman. 1993. Occupation as a risk identifier for breast cancer. Am F Public Health 83:1,311-1,315.

Savitz, DA. 1993. Overview of epidemiologic research on electric and magnetic fields and cancer. Am Ind Hyg Assoc f 54:197-204
Silverstone, D. 1981. Considerations for listening and noise distractions. En Designing Learming Environments, dirigido por PJ Sleeman y DM Rockwell. Nueva York: Longman, Inc.

Wolff, MS, PG Toniolo, EW Lee, M Rivera, N Dubin. 1993. Blood levels of organochlorine residues and risk of breast cancer. 7 Natl Cancer Inst 85:648-652.

Women's Occupational Health Resource Center. 1987. Women's Occupational Health Resource Center Newes 8(2): 3-4.

\section{Otras lecturas recomendadas}

Council of State Science Supervisors. 1984. School Science Laboratories: A Guide to Some Hazardous Substances. Washington, DC: US Consumer Product Safety Commission.

McCann, M. 1992. Art Safety Procedures: A Health and Safety Manual for Art Schools and Art Departments. Nueva York: Center for Safety in the Arts.

National Institute for Occupational Safety and Health (NIOSH). 1979. Occupational Safety and Health in Vocational Education. Cincinnati, Ohio: NIOSH.

New York State United Teachers (NYSUT). 1992. Health and Safety Manual for School Employees. Albany: NYSUT 



\section{SERVICIOS DE SEGURIDAD Y DE EMERGENCIA}

Director del capítulo Tee L. Guidotti

\section{Sumario}

Servicios de seguridad y de emergencia

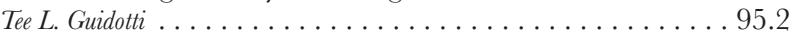

Métodos de extinción de incendios Alan D. Fones.

Riesgos de la lucha contra incendios

Tee L. Guidotti . . . . . . . . . . . . . . . . . . . . . . . . . . 95.5

Funcionarios de policía

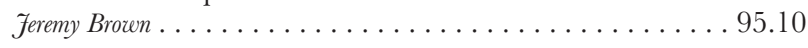

Guardias de seguridad: desarrollo y situación de la seguridad en el trabajo en Alemania

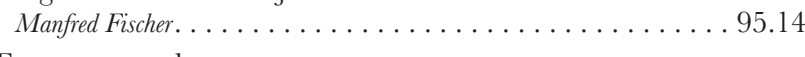

Fuerzas armadas

Foel C. Gaydos, Richard F. Thomas, David M. Sack y Relford Patterson. . 95.16

Riesgos para la seguridad y la salud de los

rescates marítimos

Timothy f. Ungs . . . . . . . . ................. 95.19

Personal auxiliar y de ambulancias

Fohn D. Meyer. . . . . . . . . . . . . . . . . . . 95.21

Personal de control de riesgos por sustancias peligrosas

M. Joseph Fedoruk . . . . . . . . . . . . . . . . . . 95.22 


\section{- SERVICIOS DE SEGURIDAD Y DE EMERGENCIA}

\section{Tee L. Guidotti}

La función de los servicios de seguridad y de emergencia es hacer frente a situaciones excepcionales que suponen riesgos graves. Por lo tanto, las personas que trabajan en tales servicios deben afrontar hechos y situaciones que sobrepasan la experiencia normal de los seres humanos en su vida cotidiana. Aunque cada profesión tiene sus riesgos, peligros y tradiciones, todas comparten algunas características:

- períodos prolongados de relativa tranquilidad o rutina, interrumpidos bruscamente por períodos de gran tensión psicológica

- períodos prolongados de relativa inactividad, interrumpidos bruscamente por períodos de intensa actividad física

- estrictos códigos de conducta y niveles altos de rendimiento, acompañados frecuentemente de instrucciones precisas sobre el modo de hacer el trabajo y de sanciones en caso de incumplimiento

- riesgo personal; el trabajador se expone a unos riesgos que no son frecuentes para el resto de la comunidad

- un objetivo primario de rescatar o proteger a quienes no pueden salvarse por sí mismos

- un objetivo secundario de evitar daños o la destrucción de la propiedad

- trabajo en equipo en condiciones de tensión

- una jerarquía o "cadena de mando" rígida, diseñada para evitar inseguridad y asegurar la observancia de los procedimientos

La forma de organización y los medios aplicados para la realización de las tareas asignadas a estos servicios varían según los casos. Las condiciones en que se realizan estas tareas influyen en la actitud ante el trabajo y en la forma de enfocarlo. Es posible que estas diferencias se comprendan mejor analizando el objeto de control de cada servicio de emergencia.

La lucha contra incendios quizá sea el servicio de seguridad y de emergencia más emblemático. Históricamente, surgió como un medio de prevenir o reducir los daños producidos por el fuego en las propiedades, y se desarrolló como un servicio privado, en el que los trabajadores se esforzaban por salvar los comercios y las viviendas de las personas que pagaban sus primas de seguro y dejaban arder las propiedades de otras personas, aunque fuesen colindantes. La sociedad pronto descubrió que los servicios privados contra incendios eran ineficaces y que sería mucho más útil y práctico hacerlos públicos. De este modo, la lucha contra incendios se convirtió en un servicio municipal o de la administración local en muchos países del mundo. No obstante, subsisten servicios privados de lucha contra incendios en la industria, en muchos aeropuertos y en otros marcos, en los que colaboran con los servicios municipales. Por regla general, los cuerpos de bomberos disfrutan del respeto y la confianza de la comunidad. El objeto de control o "enemigo" en la lucha contra incendios es el fuego, que constituye una amenaza externa. Si un bombero sufre una lesión en el lugar de trabajo, el hecho se percibe como consecuencia de un agente externo, aunque también podría ser una agresión indirecta si el incendio fuera provocado.

Los servicios de policía y las fuerzas armadas tienen encomendado el mantenimiento del orden público, generalmente en respuesta a una amenaza interna (como la delincuencia) o externa (como la guerra). Las fuerzas armadas constituyen el medio fundamental para el cumplimiento de este mandato, utilizando como procedimiento normal las tácticas y los métodos de investigación (inteligencia militar o investigación criminal) más adecuados. La alta probabilidad de abuso y de uso indebido de la fuerza ha inducido a la sociedad en general a imponer unos límites estrictos sobre la forma de utilizar esa fuerza, en particular frente a los ciudadanos. La policía es objeto de una vigilancia más estrecha que otros cuerpos de seguridad y emergencia, con el fin asegurarse que utilizan correctamente la fuerza que monopolizan, lo cual induce a muchos funcionarios de policía a pensar que no se confía en ellos. Para los policías y militares, el objeto de control, o el "enemigo", son otros seres humanos. Esta situación genera una serie de incertidumbres, sentimientos de culpa e interrogantes respecto a los derechos y al comportamiento adecuado que los bomberos no deben sufrir. Cuando un policía o un militar resultan lesionados en el cumplimiento del deber, suele ser como consecuencia directa de las acciones voluntarias llevadas a cabo contra ellos.

La responsabilidad del personal de salvamento y paramédico consiste en rescatar, estabilizar y prestar los primeros auxilios a las personas lesionadas, enfermas o atrapadas en situaciones que no pueden superar por sí solas. A menudo, trabajan hombro con hombro con el personal de lucha contra incendios y con la policía. Para ellos, el objeto de control es el paciente o la víctima que tratan de ayudar y que en modo alguno es un "enemigo". En estas profesiones, los aspectos éticos y morales adquieren especial protagonismo si la víctima es en parte responsable de su situación, como cuando un conductor sufre una intoxicación etílica o un paciente se niega a tomar la medicación. A veces las víctimas no actúan de forma racional, están enfadadas o en una situación de estrés y pueden adoptar un comportamiento amenazador o insultante, lo que resulta embarazoso y frustrante para el personal de salvamento y paramédico, que cree cumplir su obligación en circunstancias poco favorables. Si una de estas personas se lesiona en el lugar de trabajo, esta circunstancia se percibe casi como un abandono, dado que intentaban auxiliar a la víctima.

Los trabajadores que utilizan sustancias y preparados peligrosos suelen formar grupos que se integran en los servicios de lucha contra incendios y adoptan una estructura organizativa similar, aunque en menor escala. Estos equipos realizan evaluaciones y adoptan las medidas iniciales de control de los riesgos químicos o físicos que pueden suponer un peligro para el público en general. El personal de control de residuos peligrosos se integra en unas estructuras menos rígidas que las otras categorías profesionales y se dedica a resolver problemas sobre los que ya se ha experimentado durante algún tiempo. En ambos casos, los trabajadores afrontan un riesgo potencial cuyo principal problema es la incertidumbre. A diferencia de las otras profesiones, en las que el objeto de control era evidente, estos trabajadores se esfuerzan por controlar un riesgo cuya identificación puede resultar difícil. Incluso si se conoce la naturaleza del peligro o de la sustancia química que lo causa, el riesgo de contraer cáncer u otra enfermedad a largo plazo suele ser una incógnita. Con frecuencia los trabajadores ignoran si se trata de una lesión debida al trabajo, dado que los efectos de la exposición a sustancias químicas pueden tardar muchos años en manifestarse.

\section{Riesgos laborales}

El peligro que acecha en mayor medida a todos estos trabajadores es el estrés. Están especialmente sujetos a las denominadas situaciones críticas, que se perciben como un peligro grave o incierto, pero en todo caso probablemente serio, que el sujeto no puede eludir. A diferencia del público en general, el trabajador que ejerce alguna de estas profesiones no puede pasar de largo ni abandonar el lugar, y buena parte de su autoestima proviene del modo en que afrontan estas situaciones. Los trabajadores que 
sobreviven a situaciones críticas suelen atravesar períodos de negación, seguidos de períodos de depresión y de comportamiento confuso. Sus pensamientos se llenan de imágenes de lo que han vivido y de sentimientos de culpa o de incapacidad. Les cuesta concentrarse en lo que hacen y pueden sufrir pesadillas. Las situaciones más críticas se asocian a los casos en que la víctima ha muerto por causa de un error o porque el trabajador no ha podido rescatarla, a pesar de sus esfuerzos.

En muchas de estas profesiones se incluyen también operaciones de salvamento y estabilización de personas que pueden padecer enfermedades infecciosas. Las infecciones más problemáticas son el SIDA y la infección por VIH en general, las hepatitis B y C y la tuberculosis. Tanto el virus del VIH como los de las hepatitis B y $\mathrm{C}$ se transmiten a través de los líquidos corporales, por lo que pueden entrañar un peligro para el personal de control de urgencias si existen heridas sangrantes o el trabajador recibe un mordisco. En la actualidad se suele instruir al personal urgencias para que trate a todas las personas (sean víctimas o delincuentes) como potencialmente infectadas e infecciosas. Las precauciones contra el contagio del VIH se exponen en otro capítulo. La tuberculosis se transmite a través de la tos y los esputos. El riesgo es especialmente grave en la reanimación de pacientes con tuberculosis activa, patología cada vez más frecuente en las barriadas más deprimidas de muchas ciudades.

$\mathrm{El}$ riesgo de sufrir lesiones es común a todas estas profesiones. En efecto, todo incendio entraña una inseguridad, y el peligro inherente al fuego se combina con el riesgo de desplome de las estructuras, hundimiento de los suelos, caídas de objetos y caídas de altura. Evidentemente, la violencia es un riesgo más común para la policía y las unidades de combate de las fuerzas armadas, puesto que su objetivo consiste precisamente en controlar la violencia. No obstante, al margen de la violencia, existen riesgos potenciales de sufrir accidentes traumáticos de circulación, en el manejo incorrecto de armas y, en especial entre los militares, se pueden producir lesiones laborales en la realización de operaciones auxiliares. El personal de control de sustancias peligrosas se ve en la obligación de manipular diversas sustancias químicas desconocidas que entrañan un riesgo de explosión o incendio además de sus propiedades tóxicas.

Los riesgos potenciales para la salud varían sustancialmente de una profesión a otra. Aparte de los efectos del estrés y del peligro de transmisión de enfermedades infecciosas anteriormente indicados, los riesgos sanitarios varían de una profesión a otra.

\section{Medidas de prevención}

Aunque el enfoque preventivo varía en función de cada tipo de trabajo, algunas medidas son comunes a todos o casi todos ellos.

En muchos empleos se exige actualmente a los trabajadores que participen en el proceso denominado de "investigación de incidentes graves" después de ocurrir los mismos. Durante el interrogatorio, el sujeto comenta el incidente en presencia de un especialista en salud mental, con el objeto de conocer su impresión sobre el incidente y su opinión respecto a su propia actuación. El proceso de "investigación de incidentes graves", ha demostrado gran eficacia en la prevención de problemas posteriores derivados de dichos incidentes, como el síndrome de estrés postraumático.

El proceso de selección de los policías y bomberos suele consistir en unas pruebas rigurosas de aptitud física en el momento de la contratación y, en muchos servicios, se exigen programas de ejercicios y de formación permanente para mantener esa aptitud física. Aunque el objetivo central de estos programas es mantener un nivel satisfactorio y constante de rendimiento, uno de sus efectos adicionales es el de reducir la probabilidad de lesiones.
El riesgo de infección es difícil de prever, debido a que las víctimas no siempre muestran síntomas externos de estar infectadas. Actualmente se instruye al personal de urgencias en la adopción de "precauciones generales" para manipular fluidos corporales, y en el uso de equipos de protección, tales como guantes y gafas de seguridad, antes de exponerse al contacto con dichos fluidos. Sin embargo, con frecuencia tales incidentes son imprevisibles o difíciles de controlar si la víctima se muestra violenta o irracional. En caso de riesgo elevado, se aconseja la vacunación contra la hepatitis B. Asimismo, se recomienda el empleo de equipos de reanimación desechables para reducir el riesgo de transmisión de enfermedades infecciosas. Hay que tener especial cuidado con agujas y otros objetos cortantes o punzantes. Cualquier mordisco producido por una persona debe limpiarse cuidadosamente y tratarse con penicilina u otros antibióticos similares. Si se confirma la infección por VIH de la persona a cuyo contacto ha estado expuesto el trabajador o se sospecha la transmisión del virus a partir del pinchazo de una aguja o de otro contacto peligroso con sangre u otros fluidos corporales, debe consultarse con un médico la conveniencia de administrar fármacos antivíricos que reduzcan las posibilidades de infección del trabajador. La transmisión de la tuberculosis a un trabajador expuesto puede confirmarse mediante pruebas dermatológicas y tratarse con medidas profilácticas antes de que se convierta en una enfermedad grave.

Otras medidas preventivas son específicas para cada profesión en particular.

\section{METODOS DE EXTINCION DE INCENDIOS}

Alan D. Jones

La extinción de incendios es una de las funciones más valorada, pero también más peligrosa, del mundo. Quien ingresa en un cuerpo de bomberos lo hace en una institución tradicionalmente rica en dedicación, altruismo y acciones humanitarias. El trabajo de los bomberos no es fácil. Exige elevadas dosis de dedicación personal, verdadera vocación de ayudar al prójimo e identificación con una profesión que exige una cualificación elevada y que expone a quienes la ejercen a un alto nivel de riesgo personal.

Siempre que se produce un siniestro, el cuerpo de bomberos es de los primeros en acudir al lugar del desastre, en el que las condiciones no siempre son favorables. Hay que trabajar duro y rápido, en circunstancias que ponen a prueba la capacidad de resistencia. No todos los siniestros están asociados al fuego. También se producen socavones, derrumbamientos de edificios, accidentes de circulación y de aviación, tornados, incidentes con mercancías peligrosas, desórdenes, operaciones de rescate, explosiones, riadas y urgencias médicas. Las posibles situaciones de emergencia son infinitas.

Todos los bomberos utilizan idénticas tácticas y estrategias para combatir el fuego. Las estrategias son simples: combatir el fuego con sistemas activos o reactivos; en todo caso, el objetivo es siempre el mismo: apagar el incendio. En las zonas urbanas, la lucha contra incendios conlleva una lucha estructural (el tratamiento de los incendios forestales se analiza en el capítulo dedicado a Bosques). La labor de los bomberos comprende la manipulación de mercancías peligrosas y luchar contra el agua y el hielo, así como salvamento en altura y la prestación de primeros auxilios. Los trabajadores del servicio de bomberos deben estar dispuestos a prestar sus servicios las 24 horas del día.

En la Figura 95.1 se indican las prioridades tácticas de los bomberos en su lucha contra el fuego. En estas operaciones se 
Figura 95.1 • Prioridades tácticas de las operaciones de lucha contra incendios estructurales.

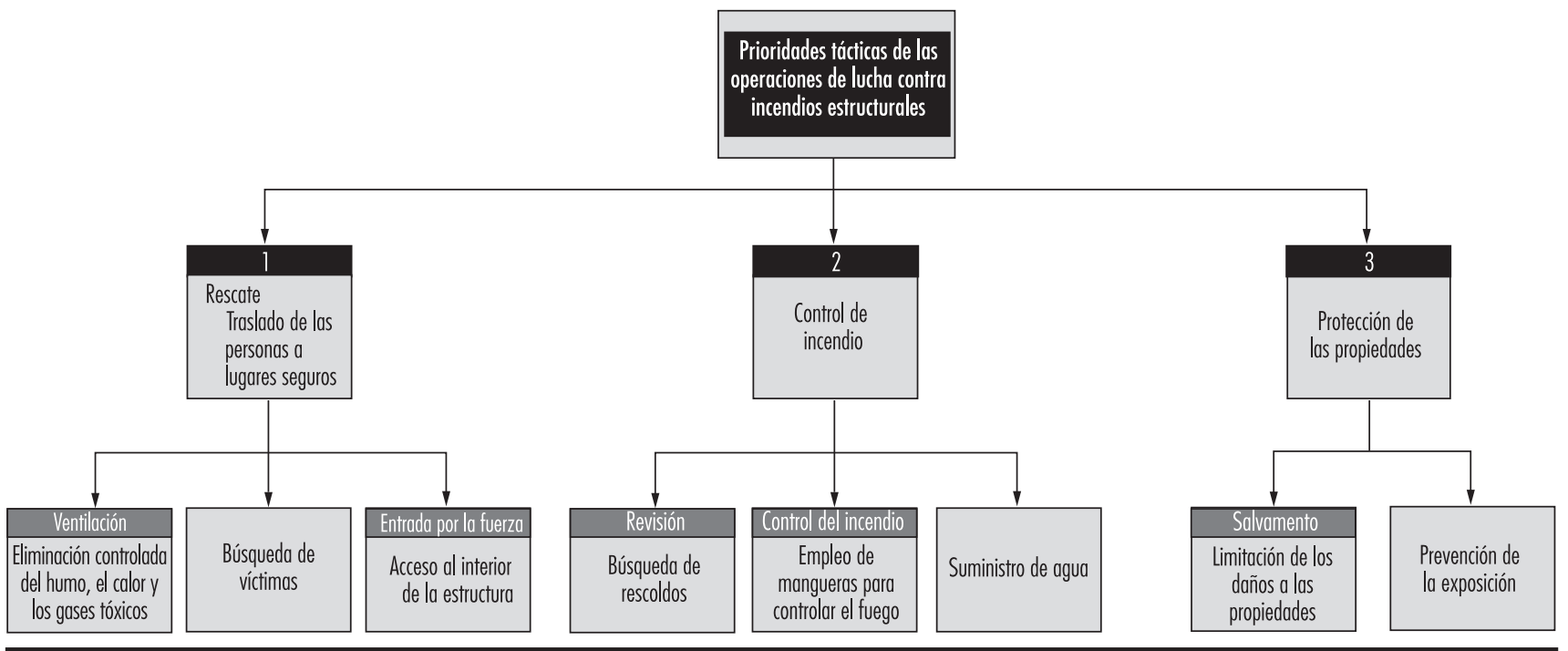

pueden emplear mangueras en líneas de ataque, líneas de refuerzo y líneas de suministro. Otros equipos de trabajo usados normalmente son las escaleras y herramientas cortantes, como hachas y picos. Se emplean igualmente equipos especiales, como lonas de salvamento y medios hidráulicos de rescate, que los bomberos deben conocer y saber usar.

Figura 95.2 • Un bombero dirige el chorro de agua hacia un edificio en llamas.

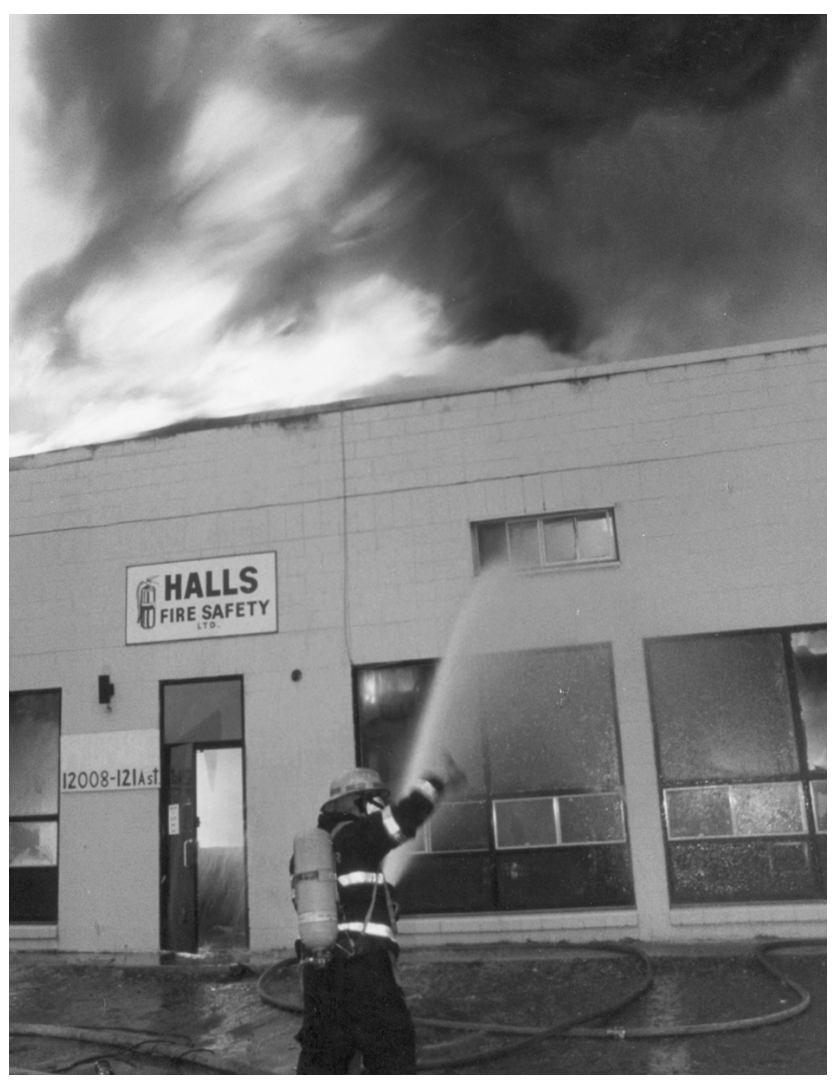

En la Figura 95.2 se muestra un bombero provisto de equipo de protección individual que combate un incendio en un edificio con una manguera de extinción de incendios.

Estas operaciones entrañan los mayores riesgos de sufrir lesiones, con independencia de las herramientas utilizadas y de las operaciones realizadas. Son especialmente frecuentes las lesiones de espalda, las distensiones musculares, las lesiones producidas por caídas y el estrés por calor. La frecuencia de los trastornos cardiopulmonares entre los bomberos se atribuye en parte a la presencia de gases tóxicos y al nivel de actividad física exigido en las áreas de incendios. Esto ha inducido a muchos cuerpos de bomberos a incorporar en sus departamentos programas de aptitud física junto con programas de seguridad total. En muchos lugares se han puesto en práctica medidas para reducir el estrés producido por los incidentes graves, dado que los bomberos afrontan situaciones que pueden generar graves reacciones emocionales. Estas reacciones son normales ante situaciones sumamente anómalas.

La misión del cuerpo de bomberos consiste en preservar la vida y la propiedad; por consiguiente, la seguridad en el escenario de un incendio es de capital importancia. El aumento de la seguridad en el lugar del incendio subyace en muchas de las operaciones que se analizan en este artículo. Muchos de los peligros que acechan en los incendios se deben a la naturaleza misma del fuego. Así, el retroceso de llama y la deflagración pueden ser mortales para los bomberos. El retroceso de llama se debe a la introducción de aire en una zona recalentada en la que se ha consumido el oxígeno. La deflagración es la acumulación de calor en una zona hasta que, de repente, se incendia todo lo que hay en ese área. Ambos fenómenos reducen el nivel de seguridad y contribuyen a incrementar los daños materiales. La ventilación es uno de los métodos de control que utilizan los bomberos; sin embargo, el aumento de la ventilación puede producir graves daños materiales. A menudo se observa como los bomberos rompen ventanas o practican agujeros en el techo, con lo que la intensidad del fuego parece recrudecerse. Esto se debe a que el humo y los gases tóxicos escapan de la zona del incendio. No obstante, se trata de una medida imprescindible en la lucha contra incendios. Se debe prestar especial atención al posible desplome de los techos, al establecimiento de una vía de salida rápida $y$, al uso de mangueras de apoyo para proteger al personal y la propiedad. 
Los bomberos deben situar en primer lugar la seguridad, tener una actitud sensible hacia la seguridad y en el contexto de una estructura organizativa que promueva la seguridad. Además, se les debe suministrar ropa de protección adecuada que les permita libertad de movimientos y les proteja contra el calor. El bombero que combate fuegos estructurales debe llevar trajes resistentes al fuego (ignífugos) y un equipo autónomo de protección respiratoria.

El tipo de ropa a utilizar suele estar en función de los tipos de riesgos a que está expuesto el bombero fuera de la zona del incendio en la línea de lucha contra el fuego; el bombero urbano se suele mover en el interior de una estructura donde se produce un calor intenso y se da la presencia de gases tóxicos. Los cascos, botas y guantes proporcionan a los bomberos la protección adecuada frente a los riesgos a que están expuestos. Las dotaciones de bomberos precisan una formación específica que asegure a sus miembros la adquisición de los conocimientos y habilidades necesarias para realizar su trabajo de forma segura y eficaz. La formación suele consistir en un programa de entrenamiento en el mismo cuerpo, en el que se combina la formación en el puesto de trabajo con estudios teóricos concretos. La mayoría de las administraciones públicas provinciales y estatales cuentan con organismos cuya función es desarrollar diversos programas de formación.

Norteamérica está a la cabeza del mundo en las estadísticas de daños materiales, y muchos de sus organismos públicos tienen establecidos programas de prevención destinados a reducir las pérdidas materiales y de vidas humanas en sus respectivos territorios. La evidencia estadística de que es más barato prevenir que reconstruir, ha impulsado a las administraciones más emprendedoras a realizar una campaña divulgativa de educación pública y aplicación de la normativa. Por otra parte, sólo el $10 \%$ de las empresas que sufren un siniestro total debido al fuego consiguen ser reconstruidas. Esto hace que las pérdidas causadas por el fuego en una comunidad puedan ser inmensas, ya que al coste de la reconstrucción se añade la pérdida irrecuperable de ingresos fiscales, puestos de trabajo y vidas humanas. Esto pone de relieve la importancia de la colaboración del cuerpo de bomberos con la comunidad en un esfuerzo por proteger la vida y la propiedad.

\section{- RIESGOS DE LA LUCHA CONTRA INCENDIOS}

\section{Tee L. Guidotti*}

El personal de la brigada contra incendios puede trabajar a jornada completa, a tiempo parcial, en régimen de pago por servicios prestados, sin cobrar, servicios voluntarios o una combinación de estos sistemas. El tipo de organización elegido dependerá del tamaño de la comunidad, del valor de la propiedad protegida, de los riesgos concretos de incendio y del número de llamadas recibidas habitualmente. Así, las poblaciones importantes precisan de brigadas contra incendios dotadas de todos sus efectivos y plenamente equipadas con los medios adecuados.

En las poblaciones pequeñas, urbanizaciones y zonas rurales con escaso número de llamadas, se cuenta normalmente con

*Agradecemos al cuerpo de bomberos de Edmonton su interés y generosa colaboración en la preparación del presente capítulo. Los diarios Edmonton Sun y Edmonton fournal cedieron desinteresadamente sus imágenes de archivo para ilustrar los artículos dedicados a la extinción de incendios. La señora Beverly Cann, del Centro de Salud Profesional de la Federación Sindical de Manitoba, ha prestado una ayuda inestimable a la preparación del artículo dedicado al personal paramédico y a los auxiliares de ambulancia. voluntarios o bomberos que cobran por cada servicio, bien para completar la totalidad de la dotación del equipo de lucha contra incendios, o para prestar ayuda a brigadas permanentes que normalmente cuentan con unos efectivos mínimos.

Aunque existen cuerpos de bomberos voluntarios eficaces y perfectamente equipados, las poblaciones grandes precisan un cuerpo permanente de bomberos profesionales. Ciertamente, un cuerpo de bomberos voluntarios o a tiempo parcial no es idóneo para realizar un trabajo de vigilancia continua para la prevención de incendios, que constituye una parte esencial de la actividad de un moderno cuerpo de bomberos. Además, los voluntarios y bomberos que cobran por servicios prestados pueden tener otros trabajos, que deberán abandonar durante un tiempo, con el consiguiente perjuicio para las empresas. Si no existe un cuerpo de bomberos permanente, los voluntarios deben presentarse en la central de incendios antes de acudir a una llamada, lo que supone una cierta demora. Si la plantilla de bomberos profesionales es escasa, es imprescindible contar con un refuerzo de bomberos voluntarios o a tiempo parcial. Asimismo, se debe contar con una reserva disponible para prestar auxilio a los cuerpos de bomberos de la vecindad dentro de una política de mutua ayuda.

La profesión de bombero es única, en cuanto que su trabajo se considera peligroso y sucio, pero indispensable e, incluso, prestigioso. Los bomberos son objeto de reconocimiento público por la indispensable labor que realizan. Estos trabajadores son conscientes de los riesgos y de que su trabajo entraña una exposición periódica a sustancias extremas de estrés. Además, los bomberos están también expuestos a graves riesgos físicos y químicos hasta cierto punto poco comunes entre los trabajadores de otros sectores.

\section{Riesgos}

Los riesgos laborales que experimentan los bomberos pueden ser físicos (principalmente estrés térmico, estrés ergonómico y condiciones inseguras), químicos y psicológicos. El nivel de riesgo que un bombero afronta en un determinado siniestro depende de los materiales en combustión, de las características de combustión del incendio, de la estructura incendiada, de la presencia de sustancias químicas distintas de los combustibles, de las medidas adoptadas para controlar el incendio, de la presencia de personas que necesitan ser rescatadas y del puesto ocupado por el bombero durante la lucha contra el fuego. Asimismo, los riesgos y niveles de exposición experimentados por los primeros bomberos que penetran en un edificio en llamas difieren de los de los compañeros que acuden más tarde o que realizan trabajos de desescombro una vez extinguidas las llamas. Tanto entre las brigadas de extinción de incendios como entre los miembros de un mismo equipo de trabajo, se suelen rotar en la realización de las diversas tareas de extinción directa. Además, entre los bomberos existen distintas categorías y grados de responsabilidad. Los capitanes acompañan y dirigen a las brigadas, pero también participan directamente en la lucha contra el fuego en el lugar del siniestro. Los jefes de bomberos dirigen el servicio contra incendios y sólo acuden a los siniestros más graves. No obstante, los bomberos pueden verse expuestos a riesgos extraordinarios en determinadas situaciones.

\section{Riesgos físicos}

Los bomberos afrontan numerosos riesgos físicos que pueden originar graves lesiones corporales. Techos, suelos y paredes pueden derrumbarse de forma imprevista y atrapar a los bomberos. Las deflagraciones son propagaciones rápidas de las llamas en un espacio confinado que ocurre como resultado de la ignición repentina de sustancias gaseosas procedentes de materiales ardientes o candentes en combinación con un 
calentamiento excesivo del aire. Las situaciones que causan deflagraciones pueden atrapar a los bomberos o bloquear las vías de escape. El grado y el número de las lesiones pueden reducirse mediante una formación intensiva, experiencia en el puesto de trabajo, competencia y una buena aptitud física. No obstante, la naturaleza misma del trabajo somete a los bomberos a riesgos derivados de errores de cálculo, de las circunstancias o de las operaciones de salvamento.

Algunos cuerpos de bomberos han creado bases de datos informáticas de los materiales, estructuras y riesgos potenciales que pueden encontrar en su distrito. Un rápido acceso a estas bases de datos ayuda al personal al conocimiento de los riesgos y a prever posibles situaciones de riesgo.

\section{Riesgos térmicos}

Durante la extinción de un incendio puede producirse estrés por calor debido a los efectos del aire caliente, el calor radiante, el contacto con superficies calientes o el calor generado por el propio cuerpo durante el ejercicio físico, que no puede enfriarse durante el incendio. En la extinción de incendios, el estrés por calor se incrementa por las propiedades aislantes de las prendas de protección y por el esfuerzo físico, que contribuyen a generar calor en el organismo humano. El calor puede producir lesiones locales en forma de quemaduras o provocar un estrés térmico general, con el consiguiente riesgo de sufrir deshidratación, golpe de calor y colapso cardiovascular.

El aire caliente no suele constituir, por sí solo, un grave riesgo para los bomberos. El aire seco no puede retener demasiado calor. En cambio, el vapor y el aire caliente cargado de humedad son capaces de producir graves quemaduras, debido a que el vapor de agua puede conservar mucha mayor cantidad de energía calorífica que el aire seco. Por suerte, las quemaduras por vapor no son frecuentes.

Durante un incendio, suele producirse un fuerte calor radiante, capaz de provocar quemaduras por sí solo. La piel de los bomberos también puede sufrir alteraciones características por la exposición prolongada al calor.

\section{Riesgos químicos}

Más del $50 \%$ de las muertes relacionadas con el fuego se deben a la exposición al humo, y no a las quemaduras. Uno de los factores que más contribuyen a la morbilidad y la mortalidad en los incendios es la hipoxia ocasionada por la falta de oxígeno en el ambiente, que provoca pérdida de forma física, confusión e incapacidad para escapar. Los componentes del humo, por separado y en combinación, son igualmente tóxicos. En la Figura 95.3 se muestra a un bombero provisto de un equipo autónomo de protección respiratoria, que rescata a un compañero sin equipo de protección, atrapado en la densa humareda producida por un incendio declarado en un almacén de neumáticos. (Al quedarse sin suministro de oxígeno, el bombero rescatado se quitó como pudo el equipo de respiración y tuvo la enorme fortuna de ser rescatado antes de que fuese demasiado tarde.)

Todo tipo de humo, incluso el que se desprende de un incendio de madera, es peligroso y puede resultar letal si se inhala en una concentración elevada. El humo es una mezcla variable de distintos elementos, cuya toxicidad depende, esencialmente del combustible, del calor desprendido por el fuego y de la cantidad de oxígeno disponible para la combustión. Los bomberos que acuden a extinguir un incendio suelen exponerse a diversas sustancias: monóxido de carbono, dióxido de nitrógeno, cianuro de hidrógeno, dióxido de azufre, cloruro de hidrógeno, aldehídos y compuestos orgánicos, como el benceno. A distintas combinaciones de estos gases corresponden diversos niveles de riesgo. Unicamente el monóxido de carbono y el cianuro de hidrógeno se generan comúnmente en concentraciones letales en el incendio de edificios.

El monóxido de carbono es el factor de riesgo agudo más común, característico y grave para los bomberos. En efecto, la afinidad del monóxido de carbono por la hemoglobina hace que se acumule carboxihemoglobina rápidamente en la sangre al prolongarse la exposición. Los niveles de carboxihemoglobina se incrementan especialmente cuando un esfuerzo físico intenso aumenta la respiración por minuto y, en consecuencia, el aporte de la misma al pulmón de los bomberos que combaten un incendio sin equipo de protección individual. No existe una relación aparente entre la densidad del humo y la cantidad de monóxido de carbono en el aire. En particular, los bomberos deben abstenerse de fumar durante las operaciones de desescombro, en las que aún quedan rescoldos humeantes de los materiales que no han ardido totalmente, puesto que esta acción contribuye a incrementar el nivel ya elevado de monóxido de carbono en sangre. El cianuro de hidrógeno se produce en la combustión a menor temperatura de materiales ricos en nitrógeno, como las fibras naturales del tipo de la seda y la lana, así como de materiales sintéticos comunes, como el poliuretano y el poliacrilonitrilo.

$\mathrm{Si}$ arden hidrocarburos combustibles a bajas temperaturas, pueden formarse hidrocarburos de bajo peso molecular, aldehídos (como el formaldehído) y ácidos orgánicos. También se forman óxidos de nitrógeno en cantidades apreciables cuando la temperatura es elevada a causa de la oxidación del nitrógeno atmosférico, y a temperaturas más bajas, si el contenido de nitrógeno del combustible es suficientemente alto. Los plásticos poliméricos entrañan riesgos específicos. Estos materiales sintéticos, que se introdujeron en la construcción y en el mobiliario

\section{Figura 95.3 • Un bombero rescata a un compañero atrapado por los humos tóxicos producidos en el incendio de un almacén de neumáticos.}

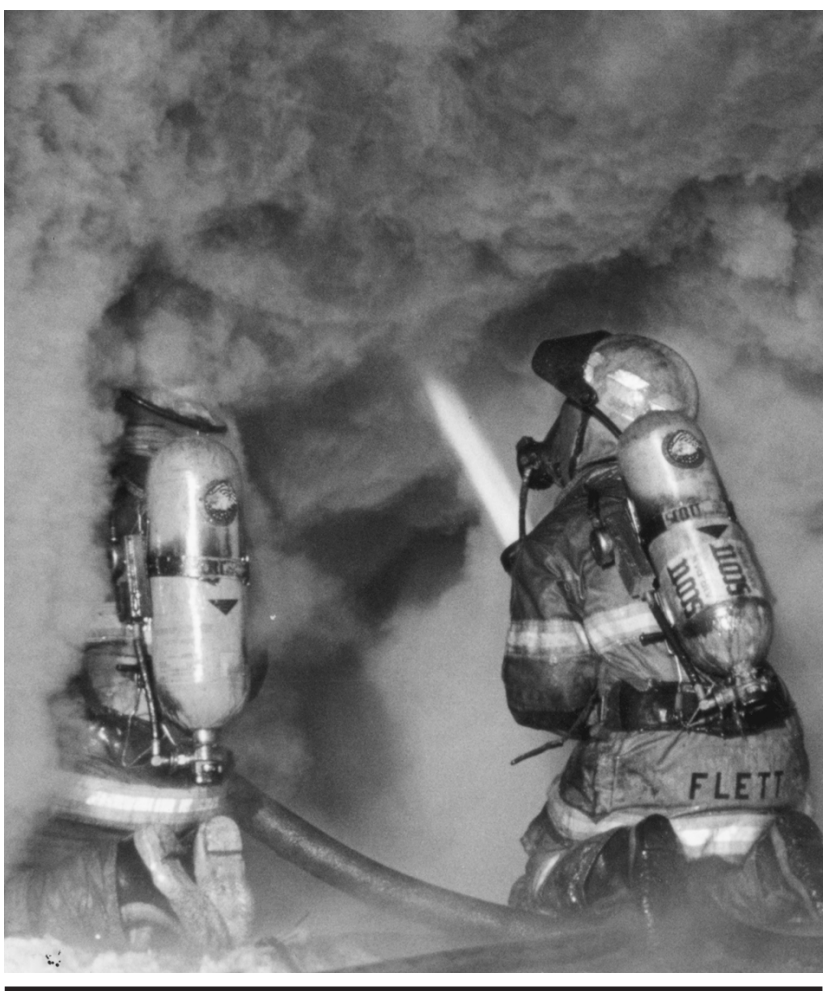


en los años 50, generan al arder sustancias particularmente tóxicas. En efecto, la acroleína, el formaldehído y los ácidos grasos volátiles suelen estar presentes en los rescoldos humeantes de varios polímeros, incluidos el polietileno y la celulosa natural. Los niveles de cianuro aumentan al elevarse la temperatura cuando se queman poliuretano o poliacrilonitrilos; el acrilonitrilo, la piridina de acetonitrilo y el benzonitrilo se producen en cantidades entre los 800 y los 1.000 grados centígrados. Se ha recomendado el uso del cloruro de polivinilo en la fabricación de mobiliario, por considerarse que es un polímero inocuo, debido a que se destruye completamente al arder debido a su elevado contenido de cloro. Por desgracia, este material genera una gran cantidad de ácido clorhídrico y, a veces, de dioxinas si el incendio se prolonga.

El peligro de los materiales sintéticos es mayor en condiciones de fuego lento humeante y sin llamas que en condiciones de elevado calor. El hormigón absorbe gran cantidad de calor y puede actuar como "esponja" de los gases atrapados que posteriormente se liberan del material poroso, lo que libera cloruro de hidrógeno y otros humos tóxicos mucho tiempo después de la extinción del incendio.

\section{Riesgos psicológicos}

Un bombero accede a escenarios de los que huyen otras personas, afrontando un riesgo personal directo mayor que en casi cualquier otra profesión civil. Durante un incendio pueden producirse numerosos percances, dado que la evolución de un gran incendio suele ser a menudo impredecible. Además de velar por su seguridad personal, el bombero tiene que preocuparse por la seguridad de otras personas amenazadas por el fuego. El salvamento de las víctimas es una actividad especialmente estresante.

No obstante, la vida laboral de un bombero es algo más que una secuencia interminable de espera angustiosa jalonada por una serie de incidentes estresantes. En realidad, el bombero disfruta de muchos aspectos positivos en su trabajo. Pocas profesiones gozan de tanto respeto entre sus conciudadanos. Además, la seguridad en el trabajo es considerable entre los bomberos urbanos una vez que han sido contratados, y el salario suele ser bueno comparado con otros trabajos. Por otra parte, el espíritu de equipo y la camaradería son muy fuertes entre los bomberos. Estos aspectos positivos del trabajo contrarrestan los aspectos estresantes y protegen a los bomberos contra las consecuencias emocionales del estrés repetitivo.

$\mathrm{Al}$ sonar la alarma, el bombero experimenta un cierto grado de ansiedad instantánea debido a la imposibilidad de predecir la situación que debe afrontar. El estrés psicológico de este momento es tan grande o, quizás mayor, que el que va a sufrir en el curso de la operación. Los indicadores psicológicos y bioquímicos del estrés han mostrado que los bomberos de guardia experimentan un estrés psicológico permanente que refleja los patrones de estrés psicológico y niveles de actividad observados subjetivamente en los puestos de servicio.

\section{Riesgos para la salud}

Los riesgos más graves a que están expuestos los bomberos son los traumatismos, las lesiones por calor y la inhalación de humos. Los efectos crónicos para la salud de la exposición reiterada no se han conocido bien hasta hace poco, y esta incertidumbre ha originado unas políticas heterogéneas en materia de empleo y de indemnización por accidente de trabajo. Los riesgos profesionales de los bomberos han recibido una considerable atención, debido a la conocida exposición de estos trabajadores a los agentes tóxicos. Existe una abundante bibliografia dedicada a las causas de mortalidad de los bomberos, que se ha enriquecido con la aparición, en años recientes, de varios estudios fundamentales sobre el tema, disponiéndose en la actualidad de una base de datos suficiente para los criterios dominantes en las publicaciones.

La cuestión crítica, en lo que respecta a la indemnización por accidentes es si puede formularse una existencia de riesgo general para todos los bomberos. Esto implica la necesidad de determinar si cabe suponer que todos los bomberos afrontan un riesgo elevado de contraer una determinada enfermedad o un cierto tipo de lesión a causa de su profesión. Para satisfacer el principio probatorio general aplicable en la indemnización por accidente de trabajo, que exige una relación causal razonablemente establecida entre el factor profesional y las consecuencias (concediendo al reclamante el beneficio de la duda), la presunción general del riesgo exige demostrar que el riesgo laboral es, como mínimo, igual que el riesgo presente en el conjunto de la población. Esto se puede demostrar si el grado normal de riesgo en los estudios epidemiológicos es al menos el doble del riesgo previsto, una vez deducidas las incertidumbres en la estimación. Los argumentos contrarios a la presunción en el caso concreto e individual considerado se denominan "criterios de impugnación", ya que pueden utilizarse para cuestionar, o rechazar, la aplicación de la presunción en un caso concreto.

Existen varios factores epidemiológicos inusuales que influyen en la interpretación de los estudios sobre morbilidad y mortalidad laboral en este colectivo. Estos profesionales no muestran un acusado "efecto del trabajador sano" en la mayoría de los estudios de cohorte sobre mortalidad, lo que puede indicar un exceso de mortalidad debida a determinadas causas en comparación con el resto de la población activa sana y físicamente apta. Existen dos clases de efecto en el trabajador sano que pueden encubrir un exceso de mortalidad. Uno de ellos actúa en el momento de la contratación, cuando los nuevos trabajadores son seleccionados para tareas de lucha contra incendios. Debido a las enormes exigencias físicas requeridas para esta tarea, este efecto es muy fuerte, y cabe esperar que contribuya a reducir la mortalidad por enfermedad cardiovascular, especialmente en los años inmediatamente posteriores a la contratación, en los que de todos modos cabe esperar que se produzcan pocos fallecimientos. El segundo efecto del trabajador sano se produce si el trabajador queda discapacitado con posterioridad a su contratación por causa de una enfermedad manifiesta o subclínica y es trasladado a otro puesto o se pierde para el seguimiento. Su contribución relativamente alta al riesgo total se pierde por culpa de un cómputo por defecto. La magnitud de este efecto se desconoce, pero existen indicios racionales de que se produce entre los bomberos. Este efecto no sería evidente en el caso del cáncer, dado que, a diferencia de las enfermedades cardiovasculares, el riesgo de sufrir cáncer guarda poca relación con la capacidad física para el trabajo en el momento de la contratación.

\section{Cáncer de pulmón}

El cáncer de pulmón es el más difícil de evaluar en los estudios epidemiológicos sobre los bomberos. Se ha debatido bastante sobre si la introducción a gran escala, iniciada en los años 50, del empleo de polímeros sintéticos en los materiales de construcción y en la fabricación de mobiliario, ha contribuido a incrementar el riesgo de cáncer entre los bomberos debido a la exposición de éstos a los productos de la combustión. A pesar de la evidente exposición a los agentes cancerígenos que se inhalan con el humo, no se ha podido probar de forma consistente que el exceso de mortalidad por cáncer de pulmón guarde relación con la exposición profesional.

Existen indicios de que el trabajo de los bomberos incrementa el riesgo de sufrir cáncer de pulmón. Esta circunstancia se aprecia especialmente entre quienes han sufrido una mayor 
exposición durante más tiempo. Este riesgo añadido se suma a un mayor riesgo debido al tabaco.

Las pruebas para establecer una relación entre el trabajo de lucha contra incendios y el cáncer de pulmón, indican que existe una ligera relación causal, que no alcanza el nivel de riesgo imputable que se exige para concluir que una determinada asociación se debe "racionalmente" a la actividad laboral. Algunos casos atípicos, como la aparición de un cáncer en un bombero no fumador relativamente joven, parecen avalar esta conclusión.

\section{Otros tipos de cáncer}

Recientemente se ha podido demostrar que otros tipos de cáncer se asocian de forma más consistente con la lucha contra incendios que el cáncer de pulmón.

Existen pruebas concluyentes de una estrecha relación con el cáncer del aparato genitourinario, incluidos los de riñón, uréter y vejiga. Excepto el de vejiga, estos tipos de cáncer son bastante raros, a pesar de lo cual el riesgo a que están expuestos los bomberos es elevado, cercano o superior al doble del riesgo relativo. Esto hace pensar, salvo que existan razones de peso para estimar lo contrario, que este tipo de cáncer está relacionado con el trabajo de los bomberos. Entre las posibles razones para dudar (o rechazar) esta conclusión en un caso concreto se cuentan el gran consumo de tabaco, la exposición laboral previa a agentes cancerígenos, la esquistosomiasis (infección parasitaria que sólo afecta a la vejiga), el abuso de analgésicos, la quimioterapia oncológica y los procesos urológicos que producen estasis y retención prolongada de la orina en el aparato urinario. Todos estos son criterios lógicos de rechazo.

Aunque los hallazgos sobre el cáncer de cerebro y del sistema nervioso central recogidos en la bibliografía existente son sumamente variables, no resulta sorprendente, ya que el número de casos recogidos en todos los informes es relativamente pequeño. Parece improbable que esta relación causal se aclare en un breve período de tiempo. Por lo tanto, es razonable aceptar la existencia de riesgo para los bomberos basándose en las pruebas actuales.

$\mathrm{El}$ aumento del riesgo relativo de cáncer linfático y hematopoyético parece ser extraordinariamente alto. No obstante, el reducido número de estos tipos de cáncer relativamente raros, dificulta la evaluación de la importancia de la asociación hallada en estos estudios. La poca frecuencia de estos tipos de cáncer, ha inducido a los epidemiólogos a incluirlos en una misma categoría, a efectos de efectuar generalizaciones estadísticas. La interpretación se dificulta aún más por la circunstancia de que la inclusión de estas patologías, tan distintas en una misma categoría, tiene poco sentido desde el punto de vista médico.

\section{Enfermedades cardíacas}

No existen pruebas concluyentes de un mayor riesgo global de muerte por enfermedades cardíacas. Si bien en un importante estudio se ha comprobado un exceso del $11 \%$ y un estudio más reducido limitado a la cardiopatía isquémica indicaba un notable exceso del $52 \%$, en la mayoría de los estudios no se ha hallado un riesgo considerablemente mayor para la población. Aunque las estimaciones más altas sean correctas, las estimaciones del riesgo relativo son todavía muy inferiores a las que serían precisas para formular una presunción de riesgo en casos concretos.

Existen algunos indicios, derivados principalmente de estudios clínicos, sobre la existencia de un riesgo de descompensación cardíaca aguda y de ataque cardíaco como resultado de un gran esfuerzo físico repentino y a causa de la exposición al monóxido de carbono. Si bien esta circunstancia no parece entrañar un mayor riesgo de sufrir con posterioridad un ataque cardíaco mortal, si un bombero ha sufrido efectivamente un ataque cardíaco durante un incendio o al día siguiente, parece lógico considerarlo como debido al trabajo. Por consiguiente, aunque es preciso valorar cada caso en función de las circunstancias individuales, la evidencia no demuestra la existencia de un riesgo global elevado para este colectivo.

\section{Aneurisma aórtico}

En pocos estudios se ha contabilizado un número de fallecimientos entre los bomberos por esta causa, suficiente para revestir significación estadística. Si bien en un estudio realizado en Toronto en 1993 se apunta una relación con el trabajo de los bomberos, debe considerarse por el momento una hipótesis no comprobada. Si por último llegase a confirmarse, la magnitud del riesgo justificaría su inclusión en la lista de enfermedades profesionales. Lógicamente, los criterios de rechazo serían la aterosclerosis severa, enfermedades del tejido conjuntivo y vasculitis asociada, así como los antecedentes de traumatismo torácico.

\section{Enfermedades pulmonares}

La exposición a elementos poco comunes, como los humos procedentes de plásticos ardiendo, resulta sumamente tóxica para el pulmón y puede llegar a producir invalidez permanente. La tarea normal del bombero puede provocar trastornos de corta duración similares al asma, que desaparecen al cabo de unos días. No parece que esto aumente, a lo largo de su vida, el riesgo de fallecer de enfermedad pulmonar crónica, a menos que se haya producido una exposición extraordinariamente intensa (riesgo de morir a consecuencia de la inhalación de humos) o que se inhale humo de características poco comunes (especialmente el derivado de la combustión de cloruro de polivinilo (CPV)).

La enfermedad pulmonar obstructiva crónica ha sido ampliamente investigada entre los bomberos, y los hallazgos no avalan la tesis de una asociación con su trabajo, por lo que no procede formular una suposición. Una excepción a esta conclusión pueden ser los raros casos en que aparece una enfermedad pulmonar crónica tras una exposición aguda inusual o intensa y existen antecedentes de complicaciones médicas.

La presunción general de riesgo no es fácil ni racionalmente sostenible cuando la relación es débil o las enfermedades son comunes en el conjunto de la población. Un criterio más eficaz puede ser analizar individualmente cada reclamación basándose en el examen de los factores individuales de riesgo y del perfil global del riesgo. La presunción general de riesgo es más fácil de aplicar a trastornos poco frecuentes con elevados riesgos relativos, en especial si éstos son exclusivos o característicos de determinadas profesiones. En la Tabla 95.1 se resumen las recomendaciones específicas, con los criterios utilizables para rechazar - o cuestionar - su existencia en cada caso concreto.

\section{Lesiones}

Las lesiones asociadas a la lucha contra incendios son fáciles de predecir: quemaduras, caídas y golpes por caídas de objetos. La mortalidad producida por estos factores es notablemente mayor entre los bomberos que en otras categorías de trabajadores. El trabajo de lucha contra incendios se caracteriza por un elevado riesgo de sufrir quemaduras, especialmente para los trabajadores que acuden los primeros al lugar del incendio o que están más cerca de las llamas, como ocurre con el bombero que sostiene la boquilla de la manguera. Asimismo, las quemaduras se asocian más frecuentemente con los incendios en sótanos, cuando existen antecedentes de una lesión anterior al siniestro y cuando la formación se ha impartido fuera del departamento de incendios. Las caídas suelen relacionarse con el uso del equipo de protección respiratoria autónomo y el servicio en las flotillas de camiones. 
Tabla 95.1 • Resumen de recomendaciones, incluidos los criterios de rechazo y consideraciones especiales, para las decisiones sobre indemnización por accidentes de trabajo.

\begin{tabular}{|c|c|c|c|}
\hline & $\begin{array}{l}\text { Estimación del riesgo } \\
\text { (aproximación) }\end{array}$ & Recomendaciones & Criterios de rechazo \\
\hline Cáncer de pulmón & 150 & $\begin{array}{l}\text { A } \\
\text { NP }\end{array}$ & - Consumo de tabaco, antecedentes de exposición a cancerígenos profesionales \\
\hline Enfermedades cardiovasculares & $<150$ & $\begin{array}{l}\text { NA } \\
\text { NP }\end{array}$ & + Episodio agudo en el momento de la exposición o poco después \\
\hline Aneurisma aórtico & 200 & $\begin{array}{l}\text { A } \\
P\end{array}$ & $\begin{array}{l}\text { - Aterosclerosis (avanzada), trastornos del tejido conjuntivo, antecedentes de } \\
\text { traumatismo torácico }\end{array}$ \\
\hline \multirow[t]{3}{*}{ Cáncer del aparato genitourinario } & \multirow[t]{3}{*}{$>200$} & A & + Cancerígenos profesionales \\
\hline & & P & $\begin{array}{l}\text { - Elevado consumo de tabaco, cancerígenos profesionales previos, } \\
\text { esquistosomiasis (sólo en veijga), abuso de analgésicos, quimioterapia } \\
\text { oncológica (clornafazina), circunstancias causantes de estasis urinaria }\end{array}$ \\
\hline & & & / Consumo de café y edulcorantes artificiales \\
\hline \multirow[t]{2}{*}{ Tumores cerebrales } & \multirow[t]{2}{*}{200} & A & $\begin{array}{l}\text { - Neoplasias hereditarias (raras), exposición previa al cloruro de vinilo, } \\
\text { radiación en la cabeza }\end{array}$ \\
\hline & & P & / Traumatismos, antecedentes familiares, tabaquismo \\
\hline $\begin{array}{l}\text { Cáncer de los sistemas linfático } \\
\text { y hematopoyético }\end{array}$ & 200 & $\begin{array}{l}A \\
P\end{array}$ & $\begin{array}{l}\text { - Radiación ionizante, cancerígenos profesionales previos (benceno), estado de } \\
\text { inmunosupresión, quimioterapia oncológica } \\
+ \text { Enfermedad de Hodgkin }\end{array}$ \\
\hline \multirow[t]{3}{*}{ Cáncer de colon y recto } & A & A & + Bajo perfil de riesgo \\
\hline & NP & NP & - Síndromes familiares, colitis ulcerosa \\
\hline & $\begin{array}{l}\text { NA } \\
\text { NP }\end{array}$ & & / Otras exposiciones profesionales \\
\hline \multirow[t]{2}{*}{ Enfermedades pulmonares agudas } & NE & A & Circunstancias del caso \\
\hline & NE & P & \\
\hline \multirow{2}{*}{$\begin{array}{l}\text { Enfermedades pulmonares crónicas } \\
\text { (EPOC) }\end{array}$} & NE & NA & + Secuela de exposición aguda intensa, seguida de recuperación \\
\hline & NE & NP & - Tabaquismo, déficit de proteasa \\
\hline \multicolumn{4}{|c|}{ Claves: } \\
\hline \multicolumn{3}{|c|}{ 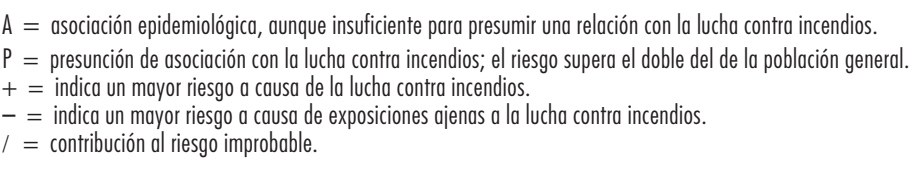 } & $\begin{array}{l}\mathrm{NA}=\text { no hay pruebas epidemiológicas que confirmen la asociación. } \mathrm{NE}=\text { no establecido. } \\
\mathrm{NP}=\text { ausencia de presunción; el riesgo no supera el doble del de la población general. }\end{array}$ \\
\hline
\end{tabular}

\section{Ergonomía}

La lucha contra incendios es una actividad agotadora que suele desarrollarse en condiciones ambientales extremas. Las exigencias de este trabajo son esporádicas e imprevisibles, y se caracteriza por largos períodos de espera, interrumpidos por episodios de actividad intensa.

Una vez iniciada la lucha contra incendios, el esfuerzo físico del bombero se mantiene en un nivel relativamente elevado y constante. Toda exigencia adicional originada por la necesidad de rescatar víctimas o por la incomodidad del equipo de protección individual (por necesario que éste sea) produce una reducción del rendimiento, ya que los bomberos siempre actúan al máximo de su capacidad. El uso del equipo de protección individual ha impuesto nuevas demandas fisiológicas a los bomberos y les ha aliviado de otras, al reducir los niveles de exposición.

Diversos estudios ergonómicos sobre la lucha contra incendios han arrojado considerable luz sobre las tremendas exigencias físicas de este trabajo. Los bomberos ajustan su nivel de esfuerzo físico, medido por la frecuencia cardíaca, a unos patrones previamente establecidos durante los simulacros de incendio.
$\mathrm{Al}$ principio, durante el primer minuto, su frecuencia cardíaca se incrementa rápidamente, hasta el 70 o el $80 \%$ del valor máximo. A medida que se prolonga la intervención de los bomberos, su frecuencia cardíaca se mantiene entre el 85 y el $100 \%$ del máximo.

Las exigencias energéticas requeridas en la lucha contra incendios se complican a causa de las condiciones extremas presentes en muchos incendios en interiores. Las demandas metabólicas que suponen la retención del calor corporal, el calor generado por el fuego y la pérdida de líquido a través del sudor, agravan las exigencias del esfuerzo físico.

La actividad conocida que requiere mayores exigencias es la búsqueda de víctimas en el interior de las construcciones por parte del bombero de "en cabeza" (el primero en penetrar en el edificio), cuya consecuencia es una mayor frecuencia cardíaca media, de 153 pulsaciones por minuto, y una mayor elevación de la temperatura rectal, de $1,3{ }^{\circ} \mathrm{C}$. El trabajo de los bomberos "de refuerzo" (que penetran más tarde en el edificio para combatir las llamas o para realizar nuevos registros en busca de otras víctimas) es el segundo en orden de exigencia, seguido 
del trabajo de la brigada exterior de lucha contra incendios, asistida por el capitán de la brigada (que dirige el trabajo de los bomberos, por regla general, a una cierta distancia del incendio). Otras tareas con niveles de exigencia, en orden decreciente de coste de energía, son las de trepar por las escalas, arrastrar las mangueras y transportar y elevar las escalas móviles.

Durante la lucha contra incendios, la temperatura corporal y la frecuencia cardíaca experimentan un comportamiento recurrente a lo largo de varios minutos: ambos parámetros aumentan ligeramente en respuesta a los trabajos de preparación para la entrada en el edificio, incremento que se acelera como resultado de la exposición al calor ambiental y, a renglón seguido, experimentan un crecimiento más acusado a consecuencia de la elevada carga de trabajo soportada en condiciones de estrés por calor. $\mathrm{Al}$ cabo de 20 a 25 minutos, que es la autonomía habitual de los equipos autónomos de protección respiratoria usados por los bomberos en interiores, el estrés fisiológico se mantiene dentro de unos límites tolerables para una persona sana. En cambio, si la labor de extinción se prolonga y obliga a penetrar varias veces en la estructura en llamas, el tiempo transcurrido entre los cambios de la botella de aire del equipo autónomo de protección respiratorio no permite un refrescamiento, lo que provoca un incremento acumulado de la temperatura basal y un riesgo creciente de sufrir estrés por calor.

\section{Protección personal}

Los bomberos realizan esfuerzos ímprobos durante la lucha contra incendios. En el lugar de un incendio, a los esfuerzos físicos se suman las exigencias metabólicas de la respuesta al calor y a la pérdida de líquidos corporales. El efecto combinado del calor corporal generado por el trabajo y el calor exterior producido por el fuego, puede provocar un aumento acusado de la temperatura corporal, que en situaciones extremas alcanza niveles inusualmente altos. Las pausas de media hora para reemplazar el equipo autónomo de protección respiratoria, no bastan para detener este aumento de la temperatura, que puede llegar a unos niveles peligrosos si la labor de extinción se prolonga. Aunque imprescindibles, los equipos de protección individual, en especial los sistemas de respiración autónomos, imponen a los bomberos un considerable gasto adicional de energía. Asimismo, las ropas protectoras se hacen mucho más pesadas al mojarse.

Los equipos autónomos de protección respiratoria constituyen un elemento eficaz de protección individual que, si se usa correctamente, evita la exposición a los productos de la combustión. Lamentablemente, estos aparatos sólo suelen utilizarse durante la fase "crítica" del incendio, en la que los bomberos luchan denodadamente por extinguir el fuego, y se prescinde normalmente de ellos durante la fase de "revisión", en la que, extinguido el incendio, se inspeccionan los restos para terminar de apagar las ascuas y las llamas que siguen brotando de los rescoldos.

Los bomberos suelen evaluar el riesgo a que están expuestos basándose en la intensidad del humo, y deciden sobre el uso de los equipos autónomos de protección respiratoria únicamente en función de lo que perciben. Esto los induce a cometer graves errores de juicio después de la extinción del incendio, puesto que, aunque la situación parezca estar bajo control, puede ser todavía peligrosa.

Los estudios de salud laboral en la lucha contra incendios se han centrado en buena medida en el mayor gasto energético debido al uso del equipo de protección individual. Ello refleja sin duda el grado en que un asunto de enorme interés general, como es el uso de equipo de protección individual, adquiere una significación especial en la lucha contra incendios.
Si bien los bomberos están obligados a usar diversos equipos de protección individual durante el trabajo, la protección respiratoria es la más preocupante y la que ha merecido mayor atención. Se ha observado una reducción del $20 \%$ del rendimiento en el trabajo por causa del equipo autónomo de protección respiratoria, que constituye un estorbo importante en situaciones extremas y peligrosas. Las investigaciones realizadas han identificado varios factores significativos en la evaluación de las demandas fisiológicas debidas, en concreto, a los equipos respiratorios, entre ellos, las características del respirador, las condiciones fisiológicas del usuario y los efectos de la interacción con otros equipos de protección individual y con las condiciones ambientales.

El típico "atuendo de faena" del bombero puede pesar 23 kilos, lo que obliga a un elevado gasto energético. La ropa de protección contra sustancias químicas (17 kilos), utilizadas para la eliminación de los vertidos, es el siguiente equipo de protección individual más engorroso, seguido del equipo autónomo de protección respiratoria, acompañado con ropa ligera, que es apenas más fatigoso que el uso de ropas ligeras pirorresistentes combinadas con una máscara de bajo índice de resistencia. Se ha establecido una asociación entre el uso de ropa de protección y equipo de extinción de incendios y una retención significativamente mayor del calor generado por el organismo, así como el aumento de la temperatura corporal.

\section{Aptitud física}

Se han realizado numerosos estudios relativos a las características fisiológicas de los bomberos, por regla general basadas en investigaciones sobre las reacciones producidas frente a las exigencias de la lucha contra incendios.

Los estudios de la aptitud física de los bomberos han puesto de manifiesto de forma bastante clara que la capacidad física media de los bomberos es comparable o algo superior a la de la población masculina adulta general. Esto no implica, sin embargo, que su nivel de preparación sea comparable al de los deportistas de competición. Aunque existen programas de preparación física y de protección de la salud para los bomberos, su eficacia no ha sido evaluada de forma convincente.

El acceso de la mujer a la profesión de bombero ha originado un replanteamiento de los estudios y pruebas del rendimiento para ajustarlos a ambos sexos. En los estudios, centrados más en las personas entrenadas para rendir al máximo de sus posibilidades físicas que en las características típicas del solicitante, las mujeres han obtenido una puntuación media menor que los hombres en todos los indicadores del rendimiento, si bien un subgrupo de mujeres ha logrado unos resultados casi idénticos en algunas pruebas. La diferencia global en el nivel de rendimiento se ha atribuido principalmente a un menor peso corporal, que guarda una estrecha y sólida relación con las diferencias del rendimiento. Las pruebas más difíciles para las mujeres eran los ejercicios de subir por las escalas.

\section{FUNGIONARIOS DE POLICIA}

Jeremy Brown

El mantenimiento del orden público constituye un trabajo arduo, difícil y estresante. Aunque es evidente que buena parte del trabajo es sedentario, las contadas actividades que no tienen este carácter, que suelen ser también las más críticas, requieren gran demanda física. En este sentido, el trabajo policial se ha comparado con el trabajo del socorrista de una piscina. Este se pasa la mayor parte del tiempo vigilando desde el borde de la piscina; sin 
embargo, cuando tiene que intervenir, por regla general sin previo aviso, las exigencias físicas y emocionales son extremas. A diferencia del socorrista, el agente de policía puede ser objeto de agresión con un arma blanca o de fuego y, asimismo, se expone a la violencia deliberada de ciertos ciudadanos. Su actividad rutinaria consiste en patrullar calles, estaciones de metro, carreteras rurales, parques y otras áreas. La policía patrulla a pie, en distintos tipos de vehículos (tales como automóviles, helicópteros o automotores sobre nieve), y en ocasiones a caballo. Se necesita una vigilancia constante y, en muchas partes del mundo, la amenaza de violencia es continua. El público demanda la ayuda de la policía en casos de robo, desórdenes, agresión y violencia doméstica. Los servicios de policía participan igualmente en acciones de control de multitudes, búsqueda y rescate, y de asistencia al público en casos de catástrofe natural. A veces, es preciso perseguir a los delincuentes a pie o en un vehículo, apresarlos y controlarlos y, en ciertas ocasiones, el policía debe hacer uso de armas letales. Las actividades rutinarias pueden ceder el paso, sin solución de continuidad o con escaso tiempo de reacción, a una escalada de violencia peligrosa para la vida. Algunos funcionarios de policía trabajan bajo una identidad falsa, a veces durante largos períodos de tiempo. Otros, particularmente los especialistas forenses, están expuestos a productos químicos tóxicos, casi todos están expuestos a riesgos biológicos derivados de la sangre y de fluidos corporales. Los miembros de los cuerpos de policía suelen trabajar en turnos, cuya duración se suele prolongar por la necesidad de realizar funciones administrativas o de comparecer en los juzgados. Las exigencias físicas reales del trabajo policial y las actividades físicas propias de la labor de vigilancia se han estudiado en profundidad y son extraordinariamente similares en distintos cuerpos de policía y en diferentes áreas geográficas. La cuestión de si determinados problemas médicos pueden ser imputables a la profesión policial es aún objeto de controversia.

\section{Violencia}

Lamentablemente, la violencia es un componente del trabajo policial. En Estados Unidos, la tasa de homicidios de policías es más del doble de la de la población general. Las agresiones durante el desempeño de sus tareas es algo común entre los funcionarios de policía. Recientemente se han realizado numerosas investigaciones sobre las actividades susceptibles de degenerar en actos de violencia. En cambio, se han proyectado serias dudas sobre la posibilidad de que las disputas domésticas constituyan situaciones de especial riesgo (Violanti, Vena y Marshall 1986). Más recientemente, se clasificaron las actividades que encierran un mayor riesgo de provocar agresiones a los agentes de policía: en primer lugar se situaban el arresto y control de personas sospechosas; en segundo lugar, los atracos, y en tercer lugar, las disputas domésticas.

El tipo de violencia que amenaza a los funcionarios de policía varía de un país a otro. Por ejemplo, las armas de fuego son más abundantes en Estados Unidos que en el Reino Unido y en el resto de la Europa occidental. En los países en que la intranquilidad política se ha recrudecido recientemente, los agentes de policía pueden ser objeto de atentados con armas de fuego automáticas o de gran calibre. Las heridas por arma blanca pueden producirse en cualquier lugar, si bien las armas largas, como el machete, son más frecuentes en los países tropicales.

Los agentes de policía deben mantener un elevado nivel de aptitud física. La formación del personal de policía debe comprender el control físico de los sospechosos, así como el uso de armas de fuego y de otros medios, como el gas CS, el spray de pimienta y la porra. En algunos lugares es necesario el uso de equipo de protección individual del tipo del chaleco blindado. También es importante contar con un sistema de comunicación que permita la petición de ayuda. Sin embargo, lo más importante de la formación es la prevención de la violencia. La filosofía actualmente dominante en la actuación policial hace hincapié en el concepto de vigilancia de la comunidad y en la integración del funcionario de policía en la vida de la comunidad. Es de esperar que, a medida que esta filosofía sustituya al concepto de incursión armada en la población, se reducirá la necesidad de recurrir a las armas y a los chalecos blindados.

Las secuelas de la violencia no siempre son físicas, pues los actos violentos son extremadamente estresantes, en especial si el incidente se ha saldado con lesiones graves, derramamiento de sangre o muerte. Particular importancia reviste la evaluación de un trastorno por estrés postraumático (TEPT) después de tales incidentes.

\section{Estrés emocional y psicológico}

Resulta evidente que el trabajo de los policías es estresante. Muchos agentes perciben el exceso de trabajo administrativo, que los distrae de la actividad de vigilancia directa, como un factor de estrés importante. El sistema de trabajo por turnos, unido a la incertidumbre sobre lo que puede acaecer durante el turno, contribuye a intensificar el estrés. En los períodos de restricciones presupuestarias, estos factores de estrés se exacerban por la escasez de personal y la insuficiencia del equipo. Las situaciones susceptibles de degenerar en violencia son intrínsecamente estresantes, y el estrés se agudiza significativamente si la escasa dotación de personal complica la prestación de apoyo o si el policía afronta una sobrecarga de trabajo notable.

Además, se ha achacado a los elevados niveles de estrés que el trabajo policial puede causar, problemas como las desavenencias conyugales, el alcoholismo y el índice de suicidios registrados entre los funcionarios de policía. Buena parte de los datos en que se basan estas conclusiones varían de una región a otra. No obstante, es evidente que, en algunos casos, el trabajo de policía es capaz de provocar estos problemas.

Nunca se insistirá bastante en la necesidad de una vigilancia constante que ponga de manifiesto los problemas relacionados con el estrés o de trastornos por estrés postraumático. Las patologías asociadas al estrés pueden adoptar la forma de trastornos del comportamiento, problemas conyugales o familiares y, a veces, alcoholismo o drogadicción.

\section{Cardiopatía aterosclerótica}

Numerosos estudios indican que la enfermedad aterosclerótica es más frecuente entre los funcionarios de policía (Vena y cols. 1986; Sparrow, Thomas y Weiss 1983); sin embargo, otros estudios no corroboran este hallazgo. Se ha afirmado que el incremento de la prevalencia de las enfermedades cardíacas entre los funcionarios de policía obedece casi exclusivamente al mayor riesgo de sufrir infarto de miocardio agudo.

Esta explicación parece lógica, ya que se sabe que los esfuerzos imprevistos de quienes padecen una enfermedad cardíaca constituyen un importante factor de riesgo de muerte súbita. El análisis funcional del puesto de trabajo de los agentes de policía revela que, en el cumplimiento de sus obligaciones, estos funcionarios pueden verse obligados a pasar de una actitud sedentaria a un esfuerzo físico extenuante con ninguna o escasas indicaciones y sin preparación. En efecto, buena parte del trabajo policial es de naturaleza sedentaria, a pesar de lo cual se exige al agente de policía que, si se presenta la ocasión, persiga, capture, derribe y sujete fuertemente a un sospechoso. No resulta, por lo tanto, sorprendente que, aunque la frecuencia de enfermedad coronaria subyacente en los funcionarios de policía no difiera mucho de la existente en el resto de la población, el riesgo de sufrir un infarto de miocardio agudo por causa de la índole del trabajo pueda ser mayor (Franke y Anderson 1994). 
En la evaluación del riesgo de sufrir una enfermedad cardíaca deben tomarse en consideración los factores demográficos del estamento policial. En efecto, la enfermedad cardíaca es más común en los varones maduros, que constituyen un importante porcentaje del cuerpo de policía. Las mujeres, mucho menos propensas durante su edad fértil a sufrir enfermedades cardíacas, representan por regla general un porcentaje sensiblemente menor dentro de las fuerzas policiales.

Para reducir el riesgo de enfermedades cardiacas entre los miembros de la policía es necesario efectuar reconocimientos médicos periódicos a los agentes de policía, realizados por médicos que conozcan este tipo de trabajo y los posibles riesgos cardiacos asociados al mismo (Brown y Trottier 1995). En la evaluación periódica del estado de salud se deben incluir la educación sanitaria y el asesoramiento sobre los factores de riesgo cardíaco. Se dispone de pruebas evidentes que demuestran que programas de promoción de la salud en el trabajo influyen positivamente en la salud de los trabajadores y que la modificación de los factores de riesgo cardíaco reducen el riesgo de muerte por ataque al corazón. Las campañas antitabaco, el asesoramiento en materia de nutrición, el control de la hipertensión y la vigilancia y modificación de los niveles de colesterol, constituyen intervenciones eficaces en el esfuerzo por reducir los factores de riesgo de sufrir enfermedades cardíacas entre los agentes de policía. El ejercicio regular reviste particular importancia en este trabajo de policía. La creación de un entorno de trabajo que eduque al trabajador en la elección de unos hábitos positivos, tanto nutricionales como de forma de vida, y que estimule este tipo de elección, puede surtir unos efectos muy positivos.

\section{Enfermedades pulmonares en el trabajo de policía}

Las pruebas existentes indican que la frecuencia de la enfermedad pulmonar es inferior entre los policías que en el conjunto de la población. Existen, sin embargo, indicios de una mayor frecuencia de cáncer del aparato respiratorio. La mayoría de los agentes de policía no se exponen habitualmente a la inhalación de sustancias tóxicas en mayor medida que el resto de los vecinos de las comunidades en que prestan sus servicios. Sin embargo, existen excepciones a esta regla general, la más importante de las cuales está representada por los funcionarios de policía que realizan funciones de identificación forense. Existen razones para creer que la frecuencia de trastornos respiratorios y, posiblemente, del asma profesional es mayor en estas personas (Souter, van Netten y Brands 1992; Trottier, Brown y Wells 1994). El cianocrilato, utilizado para descubrir huellas dactilares latentes, es un conocido sensibilizador respiratorio. Aparte de la sustancia citada, en este tipo de trabajo, se utilizan habitualmente numerosas sustancias químicas cancerígenas. Esta circunstancia hace que resulte aconsejable que a los policías dedicados a la identificación forense, en especial los que trabajan con huellas dactilares, se les practique anualmente una radiografía de tórax y una espirometría. Por igual razón, en los reconocimientos médicos periódicos de estos funcionarios se debe incluir un estudio detallado del aparato respiratorio.

Aunque el hábito de fumar tiende a decrecer, muchos funcionarios de policía no lo han abandonado, lo que tal vez explique el hecho de que en algunos estudios se haya observado un mayor riesgo de sufrir cáncer de pulmón y de laringe entre los policías. Ciertamente, el tabaco constituye un factor importante de riesgo de sufrir enfermedades cardíacas, aparte de ser la causa principal del cáncer de pulmón. Cuando un agente de policía contrae cáncer de pulmón, se suele plantear la pregunta de si la enfermedad ha sido causada por la exposición profesional, en particular a los agentes cancerígenos cuya presencia en los polvos utilizados para descubrir las huellas dactilares es conocida. Si el policía fuma, resulta imposible atribuir de modo fiable el cáncer a cualquier exposición profesional. Resumiendo, las enfermedades respiratorias no suelen figurar entre los riesgos laborales del trabajo de policía, salvo en quienes realizan trabajos de identificación forense.

\section{Cáncer}

Existen indicios de que el riesgo de cáncer en los funcionarios de policía es algo mayor que en el conjunto de la población. En particular, se ha informado de que el riesgo de cáncer del aparato digestivo (como los de esófago, estómago e intestino grueso) es elevado entre los agentes de policía. Puede hablarse también de un mayor riesgo de cáncer de pulmón y de laringe. En este mismo artículo se ha hablado brevemente sobre el riesgo de cáncer entre los policías que realizan trabajos de identificación forense y que prestan sus servicios en laboratorios forenses. Es igualmente digna de atención la controvertida cuestión del cáncer testicular asociado al uso del radar policial para detectar infracciones de los límites de velocidad.

A pesar de la escasez de datos indicativos sobre un incremento del riesgo de cáncer del aparato digestivo en los funcionarios de policía, la cuestión merece una atenta consideración. En el caso de cáncer de pulmón y de esófago, resulta difícil establecer la conexión causal entre el trabajo de policía y el incremento del riesgo. Por supuesto, es sabido que el hábito de fumar contribuye a incrementar el riesgo de cáncer de pulmón y de esófago, y se sabe que muchos agentes de policía continúan fumando. Otra sustancia que se sabe incrementa el riesgo de sufrir cáncer de esófago es el alcohol, especialmente el whisky. El trabajo de policía es notoriamente estresante, y algunos estudios apuntan a que algunos agentes de policía recurren al alcohol y al consumo de cigarrillos para aliviar la tensión y el estrés de su trabajo.

En el mismo estudio que ha revelado la existencia de un mayor riesgo de cáncer del aparato digestivo se ha puesto de relieve un curioso aumento de la frecuencia de cánceres de los sistemas linfático y hematopoyético en algunos agentes de policía. Este mayor nivel de riesgo, que globalmente no era elevado, se limitaba a un determinado grupo. Esta peculiarísima distribución y el escaso número global de casos, induce a pensar que el hallazgo podría constituir una aberración estadística.

Ya se ha examinado el riesgo de cáncer entre los agentes de policía que realizan trabajo de identificación forense y en laboratorios forenses. La posible toxicidad de una exposición crónica a pequeñas cantidades de diversas sustancias químicas, está en función del tiempo de exposición y de la utilización, en su caso, del adecuado equipo de protección individual. Sobre la base de estas exposiciones, se han llevado a cabo reconocimientos médicos periódicos anuales dirigidos a los riesgos específicos derivados de tales exposiciones.

Las investigaciones recientes apuntan a un posible aumento del riesgo de sufrir cáncer de piel, especialmente melanoma, entre los agentes de policía. Es debatible que esta tendencia se deba a la mayor exposición a los rayos solares que sufren algunos policías que patrullan las calles.

La cuestión relativa al cáncer producido por la exposición a microondas emitidas por las unidades de "radar policial" ha suscitado bastante controversia. Ciertamente, existen indicios de una posible concentración de algunos tipos de cáncer en agentes de policía expuestos (Davies y Mostofi 1993). El aspecto más preocupante es la exposición a las unidades portátiles. Por contra, las últimas investigaciones realizadas en grandes muestras de población no avalan la naturaleza cancerígena de la exposición a estas unidades. En concreto, se ha informado de que el cáncer testicular se asocia a este tipo de exposición. Se afirma que el riesgo máximo se produce cuando se activa la 
unidad portátil y se coloca sobre el regazo del agente. A largo plazo, esta posición del equipo puede generar una exposición acumulada en los testículos. No obstante, no está demostrado, que tal exposición provoque cáncer. Mientras tanto, se recomienda que las unidades de radar policial se coloquen en el exterior del coche patrulla, se dirijan lejos del cuerpo del agente, no se utilicen dentro del coche, se desactiven mientras no se utilicen y se revisen periódicamente en busca de fugas de microondas. Además, en la revisión médica periódica de los policías se debe incluir una palpación detenida de los testículos.

\section{Dolor de espalda}

Los dolores lumbares de espalda, especialmente frecuentes en los hombres de edad madura, constituyen una de las principales causas de absentismo en todo el mundo occidental. Son numerosos los factores que predisponen a sufrir dolores crónicos de espalda y algunos, como el consumo de tabaco, resultan difíciles de comprender empíricamente.

Por lo que respecta a la profesión de conductor, existen pruebas fehacientes de que los conductores profesionales tienen un riesgo considerablemente mayor de sufrir dolores lumbares, y lo mismo puede decirse de los agentes de policía que pasan buena parte de la jornada de trabajo al volante. En efecto, la mayoría de los coches patrulla siguen estando equipados con los asientos que les montan en la fábrica. Aunque existen diversos tipos de respaldos y otros dispositivos que permiten apoyar las vértebras lumbares, el problema persiste.

Existen indicios de que los enfrentamientos físicos pueden contribuir al desarrollo de dolores de espalda. También pueden influir los accidentes de circulación, especialmente de los coches patrulla. También pueden ser factores coadyuvantes algunas prendas utilizadas por los policías, como los cinturones gruesos de cuero provistos de pesados herrajes.

Es importante recordar que el estrés puede precipitar o agudizar el dolor de espalda y que algunos funcionarios de policía pueden considerarlo más aceptable que la necesidad de recuperarse de un traumatismo emocional como causa de baja por enfermedad.

Es evidente que determinados ejercicios concebidos para conservar la flexibilidad y fortalecer los músculos de la espalda pueden contribuir sustancialmente a mejorar el funcionamiento y a reducir los síntomas. Se han publicado numerosos sistemas de clasificación de los dolores de espalda. Las distintas manifestaciones del dolor se abordan mediante diferentes criterios de intervención activa, en el marco de unos programas específicos de fortalecimiento de la musculatura. Es preciso identificar unos esquemas sintomáticos específicos de los agentes de policía e iniciar tratamientos e intervenciones adecuados. Esto exige una evaluación periódica por parte de médicos conocedores de este síndrome clínico y capaces de intervenir eficazmente en el estadio inicial. Es igualmente importante mantener un buen nivel general de aptitud física para evitar que este costoso y generalizado síndrome crónico produzca discapacidad.

\section{Riesgos biológicos}

Se ha informado sobre funcionarios de policía que han contraído el SIDA en el trabajo. En mayo de 1993, el Federal Bureau of Investigations (FBI) de EE.UU. informó de que siete funcionarios de policía habían contraído el SIDA en su trabajo a lo largo de 10 años (Bigbee 1993). Hay que señalar que se trata de un número de casos sorprendentemente pequeño para un período de 10 años en todo el país, y también que se ha discutido si todos estos casos pueden considerarse relacionados con el trabajo. No obstante, es perfectamente posible infectarse con el VIH a consecuencia del trabajo de policía.
Como no existe curación para el SIDA, ni una vacuna que prevenga la enfermedad, la mejor defensa de un policía contra esta infección es la prevención. Siempre que sea posible, los agentes deben utilizar guantes de látex cuando deban exponerse al contacto con sangre u otros elementos de prueba contaminados con ella, sobre todo si se produce algún desgarro de piel en las manos.

Mientras esté de servicio, el agente de policía debe cubrirse cualquier herida o llaga abierta en la piel con un apósito oclusivo. Debe ponerse especial cuidado en la manipulación de agujas, y tanto éstas como las jeringuillas deben guardarse en un recipiente para objetos punzantes que no pueda ser atravesado por las agujas. Hay que evitar el contacto con los bordes afilados y poner especial cuidado en la manipulación de los objetos cortantes recogidos como prueba, en especial si se encuentran contaminados con sangre fresca. A ser posible, deben recogerse con la ayuda de instrumentos mejor que con las manos.

En los intentos de reanimación hay que utilizar guantes de látex y una mascarilla de protección, y siempre se llevarán guantes para prestar primeros auxilios. Si embargo, no hay que olvidar, que el riesgo de infectarse con VIH a causa de las técnicas de reanimación es muy remoto.

Algunas técnicas tradicionalmente utilizadas por la policía deben evitarse. Por ejemplo, el cacheo manual del cuerpo de los sospechosos es peligroso para el agente, pues muchos policías se han pinchado con agujas al emplear este procedimiento. Igualmente peligrosa es la costumbre de registrar recipientes, bolsas e incluso bolsillos revolviendo su contenido con la mano. El contenido de los recipientes tiene que vaciarse en una superficie lisa y examinarse claramente a la vista. Por el mismo motivo, hay que evitar la búsqueda a ciegas debajo de los asientos de los coches y entre el asiento y el respaldo de sillas y sofás. Es mejor desmontar los muebles que obligar a los agentes a introducir a ciegas la mano en sitios en que se pueden ocultar agujas y jeringuillas. Los guantes de látex no evitan los pinchazos con agujas.

El uso de equipos de protección ocular y de mascarillas puede ser aconsejable si existe un riesgo potencial de salpicadura de líquidos corporales, como sangre o saliva. Tiene que haber un sistema establecido de eliminación segura de los equipos de protección individual, y un lugar en el que los policías puedan lavarse las manos. Dado que muy pocos coches patrulla están equipados con lavabos y agua corriente, deben suministrarse a las dotaciones soluciones de lavado previamente envasadas para la higiene de la piel. Por último, debe plantearse la pregunta de qué tiene que hacer el policía que, a pesar de las precauciones adoptadas, sufre una exposición a través de la piel al VIH. Después de limpiar cuidadosamente la herida, el primer paso es determinar si el origen de la exposición es realmente una persona seropositiva, cosa que no siempre resulta posible. El segundo paso consiste en informar al agente de policía del riesgo real de infección, pues muchos legos en medicina magnifican este riesgo. En tercer lugar, hay que informar al funcionario de policía de que debe repetirse las pruebas durante un período mínimo de seis y, posiblemente, nueve meses para descartar el riesgo de infección. Asimismo, hay que adoptar medidas para evitar la infección del compañero sentimental del agente de policía durante un mínimo de seis meses. Finalmente, debe abordarse la cuestión de la profilaxis posterior a la exposición. Existen pruebas crecientes de que la profilaxis con fármacos antivíricos puede ayudar a reducir el riesgo de seroconversión tras una exposición a través de la piel. Estos fármacos se comentan en otro capítulo de la Enciclopedia. Además, la profilaxis es actualmente objeto de amplias investigaciones, por lo que se recomienda la consulta de bibliografía actualizada en busca del método más adecuado. 
Se conocen numerosos casos de hepatitis de origen laboral entre los miembros de las fuerzas de orden público. Si bien, en términos cuantitativos, el riesgo no es excesivamente alto en comparación con el de otras profesiones, se trata de un peligro real de contraer una enfermedad profesional. Los métodos de prevención de la infección con el VIH, que se han descrito anteriormente, son igualmente aplicables a la transmisión del virus de la hepatitis B por la sangre. Dado que la hepatitis B es mucho más contagiosa que el SIDA y mucho más propensa a producir la enfermedad o la muerte a corto plazo, constituye una razón aún más perentoria para adoptar precauciones universales.

Existe una vacuna eficaz contra la hepatitis $\mathrm{B}$, y todos los funcionarios de policía, independientemente de que realicen investigaciones forenses o simples labores de patrulla callejera, deben vacunarse contra la hepatitis B. Los policías también pueden verse expuestos a otros procesos, como la hepatitis $\mathrm{C}$, la tuberculosis y los patógenos aerotransportados.

\section{- Guardias de SEguRIDAD: DESARROLLO Y SITUACION DE LA SEGURIDAD EN EL TRABAJO EN ALEMANIA}

Manfred Fischer

El aumento de los problemas de seguridad a causa del incremento en general de la delincuencia, la apertura de las fronteras del este y en el seno de la propia Unión Europea, así como la incorporación de la antigua República Democrática Alemana, han generado un crecimiento desmesurado del número de compañías de vigilancia y seguridad, así como de la plantilla de esas empresas en Alemania.

A principios de 1995, el número de trabajadores de las más de 1.200 compañías de vigilancia y seguridad existentes era superior a 155.000. Las empresas medianas tienen en su mayoría entre 20 y 200 trabajadores. Existen, no obstante, empresas con menos de 10 trabajadores, y otras que emplean a varios miles. Se observa una tendencia creciente a las fusiones.

Existe en el sector una organización responsable del seguro obligatorio de accidentes de esas empresas y de su personal.

\section{Disposiciones sobre prevención de accidentes}

\section{Antecedentes sobre la normativa de prevención de accidentes y su ámbito de aplicación}

El aumento del número de accidentes hizo que quedara desfasado el Reglamento de Prevención de Accidentes de los Servicios de Vigilancia y Seguridad (VBG 68) que desde mayo de 1964 se venía aplicando a este tipo de trabajo. La norma legal ha sufrido modificaciones y cambios en profundidad, con la participación de representantes de los empresarios trabajadores, compañías de seguros de accidentes, fabricantes y organizaciones sindicales, así como representantes del Ministerio de Trabajo y Asuntos Sociales, de los organismos estatales competentes en materia de inspección industrial, del Ministerio de Defensa, de la Fiscalía, de los cuerpos de policía, de otras instituciones y de un comité especializado. Este comité depende de la oficina central de la Organización Sectorial para la Seguridad e Higiene de las organizaciones sectoriales industriales y funcionalmente de la Administración de la Organización Sectorial.

El nuevo reglamento de prevención de accidentes entró en vigor el 1 de octubre de 1990, al cabo de varios años de consultas, y se aplica a todos los trabajadores y compañías de vigilancia y seguridad. En el nuevo texto legal se establecen las responsabilidades y competencias en las que habrán de basarse los decretos específicos de desarrollo y aplicación del reglamento a cada subsector.

Las tareas realizadas por el personal de seguridad y vigilancia para la protección de personas y bienes son las siguientes:

- vigilancia privada, como la ejercida por los porteros y los vigilantes de los aparcamientos

- seguridad en las obras de construcción y en los pasos con barrera

- vigilancia de propiedades privadas, incluidas las fábricas

- vigilancia de instalaciones militares y de centrales nucleares

- funciones de patrulla y vigilancia de diversas propiedades

- servicios de seguridad en espectáculos artísticos, ferias comerciales y exposiciones

- control de masas

- servicio de correo

- servicios de investigación

- transporte de dinero y valores

- protección individual

- apoyo a las centrales de alarma

- control de emergencias

\section{Responsabilidades generales del empresario}

El empresario, o sus representantes, sólo pueden emplear personas suficientemente capacitadas y adiestradas en la prestación de los servicios de vigilancia y seguridad exigidos. Estas aptitudes deben constar por escrito.

Las actividades del personal, incluida la de notificar las deficiencias y los riesgos específicos, deben constar con detalle en las instrucciones de servicio.

Si el trabajo de vigilancia y seguridad entraña riesgos específicos, debe someterse al personal a una vigilancia adecuada.

Las tareas de seguridad y vigilancia sólo deben emprenderse una vez que los riesgos evitables en el entorno de trabajo se havan eliminado o controlado. A este fin, resulta aconsejable definir por escrito el ámbito y las reglas de seguridad, incluidas las actividades colaterales conocidas.

$\mathrm{Al}$ margen de las obligaciones del cliente, la empresa o sus agentes deben realizar una inspección de la propiedad que va a ser asegurada para detectar posibles riesgos, consignando las incidencias en un registro. Estas inspecciones deben repetirse a intervalos regulares y siempre que las circunstancias lo justifiquen.

La empresa de seguridad o su representante deben exigir al cliente que elimine los riesgos evitables y que extreme las medidas de seguridad en las áreas peligrosas. Hasta tanto no se apliquen estas medidas de seguridad, es preciso establecer unas normas que garanticen de algún modo la integridad de los guardias y demás personal de seguridad. Las zonas peligrosas en que no existan medidas de seguridad eficaces deben excluirse de la vigilancia.

Debe instruirse a los guardias y demás personal de seguridad respecto a las características de la propiedad que deben vigilar y sobre los riesgos concretos a que están expuestos durante el desarrollo de su labor de vigilancia.

Es preciso facilitar al personal de vigilancia y seguridad el equipo y los medios que precisan, específicamente, calzado adecuado, linternas para patrullar en la oscuridad y el equipo de protección individual que necesiten. Hay que formar al personal de seguridad en el uso correcto de esos medios. El equipo y demás medios utilizados por estos trabajadores no deben entorpecer su libertad de movimientos, especialmente de las manos. 


\section{Obligaciones generales del trabajador}

Los trabajadores deben observar las medidas de seguridad en el trabajo y cumplir las instrucciones de servicio, y no deben aceptar del cliente orientaciones contrarias a las normas de seguridad.

Las deficiencias y los riesgos descubiertos, así como las medidas correctoras adoptadas deben notificarse al empresario o a su representante.

Los trabajadores tienen que utilizar correctamente el equipo y los medios que se les facilitan, y no podrán penetrar en recintos e instalaciones cuyo acceso no esté autorizado.

Los trabajadores deben abstenerse de consumir bebidas alcohólicas u otras sustancias tóxicas mientras estén de servicio y durante un período de tiempo razonable antes de iniciar su trabajo, en el que deben presentarse sobrios.

Los trabajadores que precisen gafas o lentes de contacto para la corrección de la visión durante el trabajo de seguridad o vigilancia, deben asegurarlas para evitar su pérdida o llevar unas gafas de repuesto.

\section{Uso de perros}

Por regla general, sólo deben utilizarse en las labores de seguridad perros entrenados y aprobados por adiestradores titulados y competentes. Los perros que no reúnan estos requisitos únicamente deben emplearse en tareas de aviso, siempre que estén bajo el control directo de sus cuidadores, pero no para otras tareas de seguridad. Se deben retirar del servicio los animales que manifiesten tendencias agresivas o havan perdido facultades.

No se debe exigir demasiado a los perros, a los que deben proporcionarse una educación y formación adecuadas, basadas en los hallazgos de las investigaciones de la conducta animal. Es preciso establecer límites adecuados para el tiempo de servicio, unos períodos mínimos de descanso y un tiempo máximo de servicio diario.

La competencia de los cuidadores debe acreditarse regularmente y, si su destreza se reduce respecto de los mínimos exigibles, se les debe retirar la licencia.

Es preciso promulgar normas que garanticen un correcto y seguro manejo de los perros, el contacto con los mismos, la transmisión de su custodia, la colocación y retirada de correas y collares, el empleo de idénticas voces de mando por parte de diferentes entrenadores, la manipulación de la correa y el comportamiento en presencia de terceros.

Para las perreras, se establecen requisitos mínimos relativos tanto a su estado e instalación como a la autorización para el acceso a ellas.

En el transporte de los perros hay que establecer una separación entre las zonas reservadas a los animales y las destinadas a los pasajeros. En ningún caso se deben transportar los animales en el maletero de los coches. Además, cada perro debe ir en un compartimento independiente.

\section{Uso de armas de fuego}

Los trabajadores sólo deben portar armas de fuego por indicación expresa de la empresa o sus representantes, que únicamente deben cursar estas instrucciones en el marco de las disposiciones legales vigentes y sólo a los trabajadores más cualificados, fiables y entrenados.

Los trabajadores autorizados a portar armas de fuego deben participar regularmente en ejercicios de prácticas en los campos de tiro autorizados, en los que el personal debe acreditar su destreza y conocimientos. Se llevará un registro de los resultados de las prácticas. Si el trabajador deja de cumplir los requisitos, se le debe retirar el arma.

Sólo se utilizarán armas de fuego oficialmente probadas y autorizadas, que además deben ser ensayadas, periódicamente y siempre que se detecte alguna anomalía, por personal especializado. La reparación de estas armas se debe encomendar a personal cualificado y oficialmente autorizado.

El personal de seguridad no puede llevar armas blancas ni de lanzamiento de gases, dado que, al repeler una agresión armada, este tipo de armas confiere una falsa sensación de seguridad que conduce a un riesgo extremo sin una adecuada posibilidad de autodefensa.

La observancia de una normativa estricta es garantía de seguridad y eficacia en el uso, tenencia, entrega, carga, descarga y almacenamiento de las armas de fuego y de su munición.

\section{Transporte de dinero y valores}

El elevado riesgo de atracos aconseja utilizar, como mínimo dos personas - una de los cuales se preocupará exclusivamente de la seguridad - en el transporte de dinero en lugares públicos. Idéntica precaución debe adoptarse respecto a los movimientos de los mensajeros entre los vehículos y los puntos de entrega o recogida del dinero.

Sólo se admiten excepciones si 1) el transporte de dinero no es identificable por terceros basándose en la vestimenta o el equipo usados por el personal, el tipo de vehículo utilizado, el itinerario seguido o la realización del transporte; 2) el incentivo para los atracadores se reduce considerablemente ante la presencia de medios técnicos que deben ser claramente reconocibles por terceros, 3) sólo se transportan monedas, y este hecho es claramente discernible por terceros en virtud del itinerario y del modo de realizar el transporte.

Existen diversos medios técnicos que ejercen un considerable efecto disuasorio sobre los potenciales atacantes, como los dispositivos que permanecen constantemente o durante todo el transporte, firmemente acoplados al contenedor del dinero y que, en caso de sustracción violenta o de hurto cometido a la entrega, activan, de forma automática o por el funcionamiento de un temporizador, una alarma óptica consistente en la liberación de humo de color. Se recomienda el uso de dispositivos adicionales del tipo de las alarmas acústicas simultáneas.

El diseño, peso, forma y tamaño de los contenedores utilizados en el transporte de dinero deben facilitar su transporte y manipulación. Estos contenedores no se deben acoplar al cuerpo del mensajero, por el riesgo suplementario que este sistema entraña.

Como norma, el transporte de dinero en vehículos sólo debe realizarse en los debidamente preparados para estos fines. Los vehículos cuya construcción y equipamiento se ajustan a las disposiciones del Reglamento de prevención de accidentes (vehículos) (VBG 12) y, más concretamente, a las Normas de seguridad para vehículos de transporte de dinero $(\mathrm{ZH} 1 / 209)$ son especialmente idóneos para esta función.

El transporte de dinero en vehículos no blindados sólo se permite si se trata exclusivamente de monedas perfectamente identificables como tales y si la operación es absolutamente irreconocible como un transporte de dinero. En este caso, se debe procurar que ni la vestimenta y equipo utilizados por el personal, ni el diseño, equipamiento y marcas del vehículo denoten la naturaleza de la mercancía transportada.

Tanto los horarios e itinerarios de las remesas de dinero, como los puntos de carga y descarga deben modificarse periódicamente. Asimismo, durante las operaciones de carga y descarga en lugares públicos debe permanecer en el vehículo una persona protegida por puertas blindadas.

\section{Dispositivos de alarma y bóvedas de seguridad}

Los dispositivos de alarma y las bóvedas de seguridad se deben proteger adecuadamente de los actos delictivos. En el Reglamento sobre prevención de accidentes "Ventanillas de caja (VBG 120), se establecen los requisitos mínimos que deben cumplir y se regulan los medios de seguridad utilizables en las 
instituciones crediticias y de cambio de moneda en las que se realizan operaciones en metálico.

\section{Comentarios finales}

Existen límites prácticos en todos los intentos por mejorar la seguridad en el trabajo, especialmente en los trabajos de seguridad y vigilancia. En efecto, mientras que en otros sectores el éxito pasa por la adopción de medidas y mejoras estructurales, estas iniciativas sólo tienen una eficacia secundaria en el trabajo de seguridad. En este campo, las mejoras significativas sólo son posibles, en última instancia, modificando la estructura organizativa de la empresa y la conducta humana. En el recién promulgado Reglamento de prevención de accidentes (Guardias y servicios de seguridad) (VBG 68), que en un examen somero puede parecer exagerado y demasiado detallado, se presta especial consideración a este concepto básico.

No resulta sorprendente, por lo tanto que, a partir de la entrada en vigor del reglamento, el índice de accidentes y enfermedades profesionales notificadas entre los trabajadores de las compañías de vigilancia y seguridad, se haya reducido en cerca del $20 \%$, a pesar del incremento global de la tasa de criminalidad. Algunas compañías en las que, además de aplicarse de forma especialmente rigurosa el Reglamento de prevención de accidentes, se han adoptado medidas complementarias de seguridad basadas en un catálogo de criterios publicado, han logrado reducir la frecuencia de los accidentes y enfermedades profesionales hasta en un $50 \%$. La reducción ha sido especialmente notable en la utilización de los perros.

Además, el conjunto de las medidas adoptadas, ha permitido reducir el montante de las primas abonables por el seguro obligatorio de accidentes de las compañías de vigilancia y seguridad, a pesar del incremento de los costes.

Resulta evidente que, en términos globales, el comportamiento seguro sólo es posible a largo plazo mediante la aplicación de reglamentos y normas concretas, además de una formación y supervisión permanentes.

\section{- FUERZAS ARMADAS}

\section{Joel C. Gaydos, Richard J. Thomas, David M. Sack y Relford Patterson}

Las naciones mantienen ejércitos con el propósito de disuadir a los posibles agresores, desactivar posibles conflictos y, en caso necesario, estar preparadas para librar y ganar las guerras. Las fuerzas armadas realizan además otras misiones que se denominan "intervenciones en tiempos de paz" u "operaciones no bélicas": misiones humanitarias, como ayudas urgentes en caso de desastre; operaciones de establecimiento y mantenimiento de la paz; intervenciones contraterroristas y contra el narcotráfico, $\mathrm{y}$ asistencia de seguridad.

Los hombres y mujeres de las fuerzas armadas trabajan en submarinos y buques de superficie, sobre la tierra, en todo tipo de terrenos, con temperaturas extremas y a gran altura. Buena parte del trabajo de los militares se centra en el mantenimiento de las destrezas necesarias para manejar un equipo exclusivamente militar (como submarinos, aviones de combate y tanques) en acciones contra un enemigo armado. Las fuerzas armadas emplean igualmente a un gran número de personas uniformados que realizan labores de mantenimiento y reparación, administrativas, médicas y de otros tipos, en apoyo de los combatientes.

Todos los miembros de las fuerzas armadas se esfuerzan por conservar el dominio de las destrezas militares básicas, como la puntería, además de un elevado nivel de aptitud física que les permita reaccionar adecuadamente si se ven en la necesidad de entrar en combate. Se ejercitan constantemente para desarrollar y mantener su fuerza y su capacidad aerobia. Si se realizan en exceso o de forma inadecuada, estos programas pueden provocar lesiones.

Además de los riesgos profesionales, estos trabajadores uniformados están expuestos al riesgo adicional de contraer enfermedades infecciosas. En efecto, el medio ambiente existente en los campamentos de instrucción básica y el hacinamiento típico de algunas unidades, como los buques de guerra, favorecen la aparición de brotes de enfermedades respiratorias agudas y otras enfermedades infecciosas. El ruido es un problema universal. También, el desplazamiento a diversas partes del mundo conlleva el contacto con agua y alimentos contaminados, y la exposición a los vectores de transmisión de protozoos y de agentes víricos y bacterianos.

Las fuerzas armadas emplean un gran número de trabajadores civiles dedicados a labores de investigación y desarrollo y a la prestación de servicios auxiliares de mantenimiento, administración, etc. Algunos de estos trabajadores civiles cobran de las fuerzas armadas; otros trabajan en empresas contratistas de las instituciones armadas. Existe una tendencia creciente a emplear trabajadores civiles en tareas de apoyo en estrecha proximidad al despliegue de las fuerzas de combate, lo que los expone a idénticos riesgos laborales y ambientales.

\section{Instalaciones fijas}

En muchas instalaciones militares fijas (como talleres de reparación, oficinas administrativas y hospitales), el personal uniformado y los trabajadores civiles realizan tareas similares a las de cualquier centro de trabajo civil. Estas tareas comprenden operaciones de pintura, soldadura, desengrasado, molturación, decapado, manipulación de líquidos hidráulicos, combustibles y agentes limpiadores; empleo de microordenadores y tratamiento de pacientes con enfermedades infecciosas. Sin embargo, la realización de operaciones técnicas en espacios confinados en barcos, submarinos o vehículos blindados, aumenta el riesgo de sobreexposición a sustancias tóxicas. Por otra parte, los buzos deben trabajar a distintas profundidades.

En algunas instalaciones fijas se realizan trabajos de desarrollo, producción, mantenimiento y almacenamiento de ingenios militares especiales, como gas nervioso y mostaza, explosivos militares, propelentes y combustibles especiales, como el nitrato de hidroxilamonio, telémetros de láser, selectores de objetivos, fuentes de radiación de microondas en equipo de radar y comunicaciones, y radiación ionizante procedente de municiones, blindajes y plantas nucleares. Otros materiales, sin ser de uso exclusivamente militar, son frecuentes en el armamento bélico. Si se utiliza equipo militar anticuado, los trabajadores pueden verse expuestos a los bifenilos policlorados de las instalaciones eléctricas, al amianto del revestimiento de las conducciones de vapor y a las pinturas a base de plomo.

\section{Un lugar de trabajo exclusivamente militar}

Aunque los miembros de las fuerzas armadas se encuentran de servicio permanente, los jefes procuran concederles unos períodos de descanso adecuados. Sin embargo, los combates no se ajustan a un horario, y el entrenamiento militar se ajusta a las condiciones previsibles en el combate. Durante el entrenamiento intensivo son comunes la fatiga y la falta de sueño, y esta situación se agudiza cuando se transportan rápidamente fuerzas militares a puntos situados en otros husos horarios y se les obliga a realizar su trabajo tan pronto como llegan. Además, en todas las operaciones militares, en especial en las de gran envergadura que abarcan un territorio extenso y en las que participan fuerzas de tierra, mar y aire de varios países, se produce una presión 
Figura 95.4 - El personal de la cubierta de vuelo de un portaaviones trabaja en la proximidad inmediata de helicópteros y reactores de geometría fija, lo que les expone a riesgos de seguridad, a los productos resultantes de la combustión de los tubos de escape y al ruido.

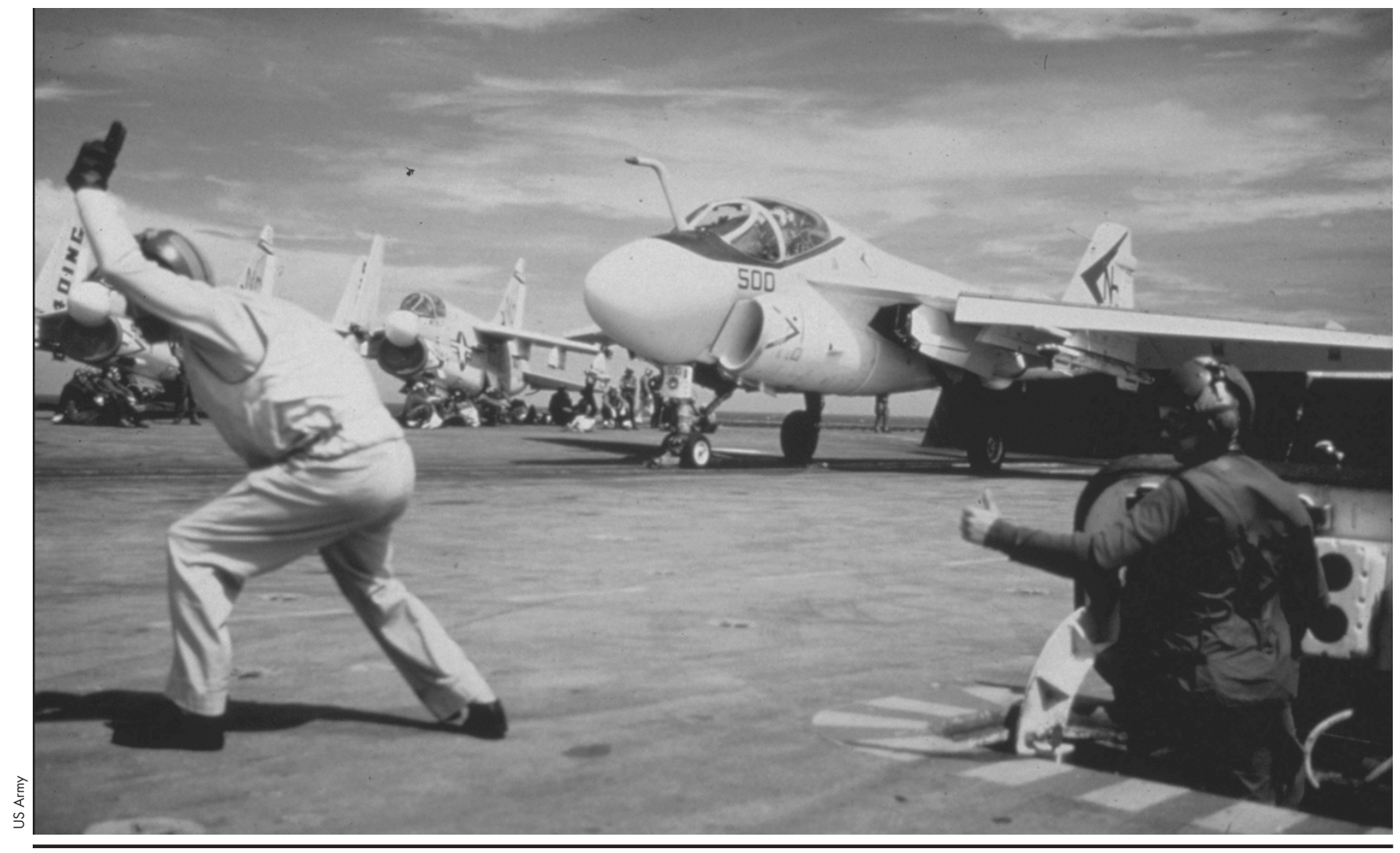

considerable para mantener la coordinación y las vías de comunicación entre los diversos componentes de las fuerzas con el objeto de reducir el riesgo de accidentes, como hacer fuego sobre las fuerzas propias. El estrés se incrementa si la duración de las operaciones impone una prolongada separación familiar o existe la posibilidad de sufrir acciones enemigas.

\section{Buques de la Marina}

En los buques de la marina, los espacios reducidos, las numerosas puertas y escaleras y los pasillos estrechos cercanos al equipo operativo constituyen focos de peligro. La falta de espacio también dificulta los movimientos durante el trabajo y es causa de lesiones ergonómicas (véase la Figura 95.4). En los submarinos, la calidad del aire es fuente de constante preocupación que obliga a una vigilancia constante y a la limitación de los agentes contaminantes innecesarios En todas las instalaciones militares en que existe el riesgo de exposición a plantas nucleares, armas atómicas u otro material radiactivo se evalúan las exposiciones, se implantan controles y se realiza la vigilancia necesaria.

\section{Aeronaves}

En los ejercicios de vuelo en el espacio aéreo participan diversos tipos de aeronaves de geometría fija y de geometría variable, así como helicópteros con rotores de peso fijo y variable. Los tripulantes de las aeronaves militares se exponen a riesgos diferentes de los existentes en el mundo civil. Muchas aeronaves militares son únicas por su diseño, sus características de vuelo y las misiones que realizan. Todos estos tripulantes se exponen frecuentemente a unas fuerzas de aceleración excesivas (fuerzas centrífuga y de gravedad), descompresión, mareo, desincronización de los ritmos circadianos producida por las misiones prolongadas o las operaciones nocturnas y desorientación espacial. Las vibraciones producidas por la aeronave y las turbulencias atmosféricas pueden afectar la visión, generar trastornos motores, producir fatiga y provocar la aparición de problemas en las vértebras lumbares, particularmente en los pilotos de helicópteros. La exposición a los productos de la combustión eliminados por los escapes, el recalentamiento o la ignición de partes de la aeronave pueden suponer un riesgo de intoxicación en el caso de que la nave resulte dañada en combate. La fatiga es un factor de riesgo importante en operaciones prolongadas o vuelos a larga distancia. La desorientación espacial y las percepciones ilusorias sobre la altitud y el movimiento de la aeronave pueden provocar accidentes, especialmente en los combates librados a gran velocidad y baja altura. En condiciones de trabajo difíciles, los equipos de tierra pueden verse presionados por la falta de tiempo para realizar las operaciones de mantenimiento y reaprovisionamiento de combustible, a veces con los motores de la aeronave en marcha.

Los helicópteros se utilizan ampliamente en las operaciones militares como sistemas de armas a baja altitud, plataformas de observación y medios de evacuación sanitaria y de suministro. Estas aeronaves provistas de rotores se asocian con misiones de reconocimiento, riesgos físicos y efectos psicológicos para sus tripulaciones absolutamente únicos. Ciertamente, aunque los helicópteros pueden volar hacia adelante, hacia atrás y lateralmente, son intrínsecamente plataformas de vuelo inestables. Esto hace que sus tripulantes deban mantener una concentración constante y gozar de una excepcional visión y una buena coordinación motora para manipular los sistemas de control de vuelo y evitar estrellarse o colisionar con otros obstáculos durante los vuelos a baja altura. La fatiga es un aspecto especialmente preocupante para los tripulantes que realizan vuelos 
Figura 95.5 - Este generador mecánico de humo produce una cortina de niebla artificial mediante la evaporación del calor. Este sistema convierte el suelo en resbaladizo.

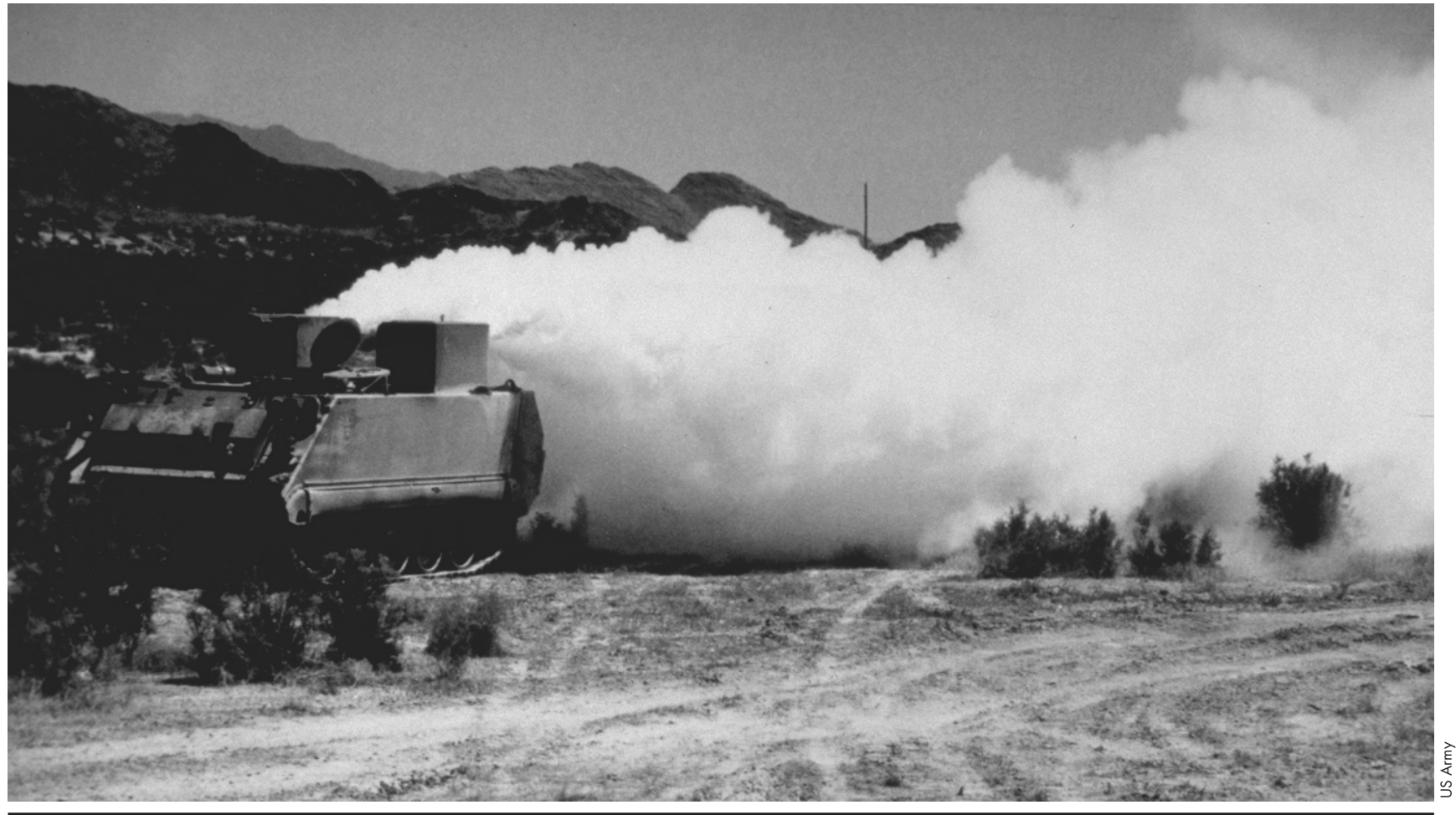

prolongados, un gran número de misiones de corta duración o vuelos a bajo nivel, a ras del terreno, en los que los pilotos se ajustan tanto a los contornos del terreno como lo permiten la velocidad y las prestaciones técnicas de la aeronave. Los vuelos nocturnos a baja altitud son especialmente peligrosos. Aunque los pilotos militares y de las fuerzas de seguridad utilizan normalmente gafas de visión nocturna en estas misiones, éstas pueden limitar la percepción de profundidad, el campo de visión y la discriminación de los colores. Por otra parte, los motores, rotores y transmisiones de los helicópteros generan un amplio espectro de vibraciones que pueden afectar la agudeza visual y producir tensión y fatiga musculares. Estos elementos de la aeronave generan igualmente ruido de elevada intensidad que dificulta la comunicación dentro de la cabina y provoca pérdida de audición. Para reducir este último riesgo, se puede recurrir al encapsulamiento de las piezas más ruidosas, a instalar láminas de materiales aislantes del ruido en las cabinas y, por último, a utilizar diversos equipos auditivos de protección individual para reducir el riesgo de pérdida auditiva. El estrés por calor puede ser un problema especialmente serio para los tripulantes, dada la escasa altitud a que vuelan estas aeronaves. En contraste con el estrellamiento en vuelo horizontal en que consisten normalmente los accidentes de las aeronaves de geometría fija, los accidentes de helicópteros suelen sobrevenir al desplomarse verticalmente las aeronaves. Las lesiones más comunes entre las víctimas de accidentes son la fractura por compresión de la columna vertebral y de la base del cráneo. Entre los dispositivos y elementos de diseño comúnmente utilizados para prevenir y controlar las lesiones figuran los cascos de protección, los sistemas de combustible resistentes al impacto, la construcción de cabinas reforzadas que impidan la penetración de los rotores y sistemas de transmisión y los asientos especiales y otros dispositivos de absorción de impactos.

\section{Fuerzas de tierra}

Las fuerzas de tierra utilizan fusiles, piezas de artillería y misiles, y se desplazan en vehículos sobre terreno irregular. En ocasiones, operan bajo la cobertura de cortinas de humo generadas por combustible diesel, nebulizadores y diversas sustancias químicas (Figura 95.5). Son riesgos comunes la exposición al ruido, la sobrepresión por la detonación de las piezas de artillería a la vibración y a los productos de combustión de los propelentes. Aunque existe el riesgo de sufrir lesiones oculares por arma de fuego, pueden evitarse usando medios de protección ocular adecuados. Las posibilidades de que se produzcan efectos perjudiciales para la salud se incrementan si se producen disparos de misiles o de cañones de grueso calibre en áreas cerradas, como los edificios. La cabina de la tripulación de los vehículos blindados es un recinto cerrado en el que la concentración de partículas de monóxido de carbono puede alcanzar varios miles por millón después de cada disparo, por lo que se precisa un sistema de ventilación eficaz. En algunos vehículos, la prevención del estrés por calor puede exigir el uso de chalecos refrigerantes. La infantería también puede sufrir estrés por calor como resultado del uso de ropas especiales, capuchas y máscaras de protección contra los ataques con armas químicas y biológicas. Estos medios de protección individual pueden ocasionar problemas al obstaculizar la visión y entorpecer los movimientos. En las instalaciones médicas de campaña, las técnicas de control de infecciones y la neutralización de los gases anestésicos residuales pueden plantear problemas específicos.

Las diversas armas de fuego pueden provocar heridas y enfermedades al personal militar. Las armas más tradicionales pueden causar bajas provocadas por los proyectiles y fragmentos de metralla, las detonaciones (que pueden producir contusiones traumáticas en los pulmones) y las llamas procedentes de los artefactos incendiarios, como los que contienen napalm y 
fósforo. El láser utilizado como arma ofensiva puede provocar lesiones oculares. Otros sistemas de armas se basan en el empleo de agentes biológicos, como las esporas de ántrax, o de sustancias químicas del tipo de los agentes anticolinestarásicos.

El uso indiscriminado de minas ha originado preocupación por el número de bajas provocadas entre la población civil. En un sentido estricto, las minas pueden definirse genéricamente como artefactos explosivos diseñados para enterrarse en el suelo. En la práctica, una mina es cualquier explosivo oculto que puede ser detonado por fuerzas enemigas o propias, por animales o por civiles. Las minas se pueden emplear contra el material o contra las personas. Las primeras se dirigen contra los vehículos militares y pueden contener entre 5 y 10 kilos de explosivos, pero precisan una presión mínima de 135 kilos para activarse. Las minas antipersonales se utilizan para lisiar más que para matar. Una cantidad inferior a 0,2 kilos de explosivos oculta bajo el terreno es capaz de arrancar un pie de cuajo, y las partículas infectadas que rodean la mina penetran como proyectiles en las heridas, infectándolas seriamente. El radio de acción de las minas se amplió sustancialmente con la aparición de las minas "saltarinas", en las que una pequeña carga explosiva arroja un bote de metralla a una altura de alrededor de un metro. El bote explota inmediatamente y proyecta fragmentos de metralla a 35 metros de distancia. Algunos modelos avanzados de minas, como el "Claymore", pueden activarse eléctricamente, utilizando un detonador temporizado o un cable, y proyectar centenares de esferas de acero, de $0,75 \mathrm{~g}$ de peso cada una, en un ángulo de 60 grados a una distancia de hasta 250 metros. Esta metralla puede resultar letal o producir graves mutilaciones en un radio de 50 metros.

En la guerra se han utilizado gran variedad de sustancias químicas. En Vietnam se emplearon herbicidas (como el 2,4-D $n$-butil éster mezclado con 2,4,5-T $n$-butil éster, conocido también como el "agente naranja") como defoliantes, con el objeto de despejar el terreno. Algunas sustancias químicas (como el gas lacrimógeno) se han utilizado como agentes discapacitantes con la finalidad de producir efectos físicos, mentales o de ambos tipos. Otras sustancias químicas son sumamente tóxicas y capaces de causar graves lesiones o la muerte. En estas categorías se incluyen los agentes anticolinesterásicos (como el tabún y el sarín), los agentes vesicantes (como el gas mostaza y los arsénicos), los agentes "asfixiantes" que dañan los pulmones (como el fosgeno y el cloro) y los agentes en sangre que bloquean los procesos de oxidación (como el cianuro de hidrógeno y el cloruro de cianógeno).

Además de los conflictos bélicos, los militares pueden estar expuestos a agentes químicos producto de actividades terroristas, en los centros de almacenamiento de sustancias químicas militares en desuso por causa de fugas de contenedores, en los puntos de destrucción -mediante incineración u otros medios- de las sustancias químicas de uso militar y en caso de desenterramiento accidental de antiguos vertederos abandonados de residuos de sustancias químicas.

\section{Sistema de asistencia sanitaria}

La asistencia sanitaria a los militares y trabajadores civiles de las fuerzas armadas se centra en la prevención. El personal médico a menudo observa los vehículos y el equipo militar durante su proceso de desarrollo para detectar y, eventualmente, controlar los posibles riesgos para la salud de los usuarios y el personal de mantenimiento. En los manuales de usuarios y de formación y en los programas educativos, se aborda el tema de la protección frente a riesgos. Además de la asistencia primaria y de los servicios de urgencia, los cuidados médicos comprenden una revisión inicial, revisiones médicas periódicas, la educación y promoción de la salud y la evaluación de las discapacidades. Además, el personal sanitario también participa en la investigación de accidentes. En caso de desplazamiento a zonas que presentan nuevos riesgos sanitarios, es preciso su identificación y evaluación, que nos permita una adecuada intervención, en forma de vacunas, fármacos profilácticos, medidas de protección individual y programas de formación.

El personal sanitario que presta asistencia médica primaria y preventiva a los miembros de las fuerzas armadas, debe conocer las características de las armas utilizadas, tanto en los entrenamientos, como en el campo de batalla, con el objeto de prever las heridas que pueden producirse, adoptar medidas preventivas dirigidas a reducir la morbilidad y mortalidad y prestar el tratamiento adecuado, si se producen incidentes. El equipo de protección individual constituye un medio importante de defensa contra los agentes químicos y biológicos y de prevención de lesiones oculares causadas por proyectiles y láseres. Otras medidas utilizables son la vacunación y la administración de fármacos quimioprofilácticos contra los agentes biológicos, el tratamiento preventivo con fármacos y el uso de antídotos contra los agentes químicos. Es imprescindible formar al personal médico en la detección y el tratamiento precoces de las lesiones y enfermedades producidas por las armas. En efecto, el diagnóstico precoz permite iniciar rápidamente la administración de la terapia adecuada, y tal vez, reducir los índices de morbilidad y mortalidad. Además, los equipos quirúrgicos militares pueden cuidar mejor de sus pacientes y de sí mismos si conocen las características de las heridas que atienden. Por ejemplo, las heridas producidas por fusiles de repetición no suelen exigir un desbridamiento extenso por destrucción de tejidos blandos; las provocadas por balas de fragmentación pueden precisar una exploración en profundidad, y las heridas pueden contener munición sin explosionar.

\section{RIESGOS PARA LA SEGURIDAD Y LA SALUD DE LOS RESCATES MARITIMOS}

Timothy J. Ungs

En los océanos, lagos, ríos y otras grandes masas de agua se producen condiciones ambientales extremas que obligan a un esfuerzo máximo. El factor esencial que define los riesgos para la seguridad y la salud de los rescates marítimos es el mismo medio acuático.

Los rescates marítimos comparten muchos de los riesgos para la seguridad y la salud presentes en las operaciones de salvamento terrestre. El riesgo de transmisión de enfermedades contagiosas, la exposición a sustancias tóxicas, la amenaza de violencia personal y la exposición a diversos agentes físicos (por ejemplo, ruido, vibraciones, radiaciones, etc.) son algunos de los riesgos comunes a las operaciones de rescate terrestres y marítimas. No obstante, en el medio marítimo existen algunos riesgos únicos, y otros que están mucho más acentuados que en el entorno terrestre. En el presente artículo se abordarán los peligros para la seguridad y la salud más típicos de las operaciones de salvamento en el mar.

\section{Medios de actuación}

Antes de analizar los riesgos específicos para la seguridad y la salud, es preciso saber que en un rescate marítimo pueden intervenir barcos, aeronaves o una combinación de ambos. La necesidad de conocer los medios utilizados reside en que las 
características de la exposición a los riesgos están determinados, en parte, por los medios.

Las embarcaciones comúnmente utilizadas en los rescates marítimos se desplazan a velocidades inferiores a los 40 nudos $(74,1 \mathrm{~km} / \mathrm{h})$, poseen una autonomía operativa relativamente limitada (inferior a 200 millas o $320 \mathrm{~km}$ ), son extremadamente sensibles al oleaje y a las condiciones meteorológicas, así como al impacto de los restos flotantes de naufragios y, en general, no suelen plantear problemas con la distribución de la carga. Por su parte, los helicópteros, que son las aeronaves más comúnmente utilizadas en las operaciones de salvamento marítimo, son capaces de volar a más de 150 nudos $(278 \mathrm{~km} / \mathrm{h})$, poseen una autonomía operativa real de 300 millas $(480 \mathrm{~km})$ que aumenta si se reabastecen de combustible en vuelo, son más sensibles a las condiciones meteorológicas que al estado de la mar y su capacidad de carga es bastante limitada.

La elección del medio depende de factores como la distancia, la urgencia, la situación geográfica, la disponibilidad de recursos, las condiciones ambientales y las características de la organización de rescate. Se suele optar por medios de superficie en presencia de factores como la mayor proximidad, la menor urgencia, la proximidad a centros urbanos o áreas desarrolladas, el buen estado de la mar y la ausencia de sistemas e infraestructuras adecuados para el uso de medios aéreos. Se prefieren, en general, los medios aéreos de rescate en caso de mayor distancia, situaciones de urgencia o de lejanía de grandes centros urbanos o áreas desarrolladas, si el mar se presenta agitado y si en la región existen sistemas e infraestructuras aéreos adecuados. Las Figuras 95.6 y 95.7 ilustran ambas modalidades de rescate.

\section{Riesgos marítimos}

Los principales riesgos del rescate marítimo son los inherentes a la naturaleza misma del medio acuático. En efecto, el personal de rescate se expone directamente a los embates del mar y debe estar preparado para salvarse a sí mismo.

El ahogamiento es la causa más frecuente de muerte por accidente de trabajo en el medio marino. Los trabajadores precisan equipo de flotación especial para sobrevivir en el mar durante un cierto tiempo, e incluso los nadadores expertos precisan flotadores para sobrevivir en un mar picado. La supervivencia prolongada (más allá de unas horas) en medio de una tormenta suele ser imposible sin trajes o balsas salvavidas especiales. Circunstancias como las lesiones, la pérdida parcial de la conciencia, el pánico y la confusión o el miedo incontrolable reducen las posibilidades de sobrevivir en el mar.

\section{Figura 95.6 • Salvamento marítimo realizado por un} barco.

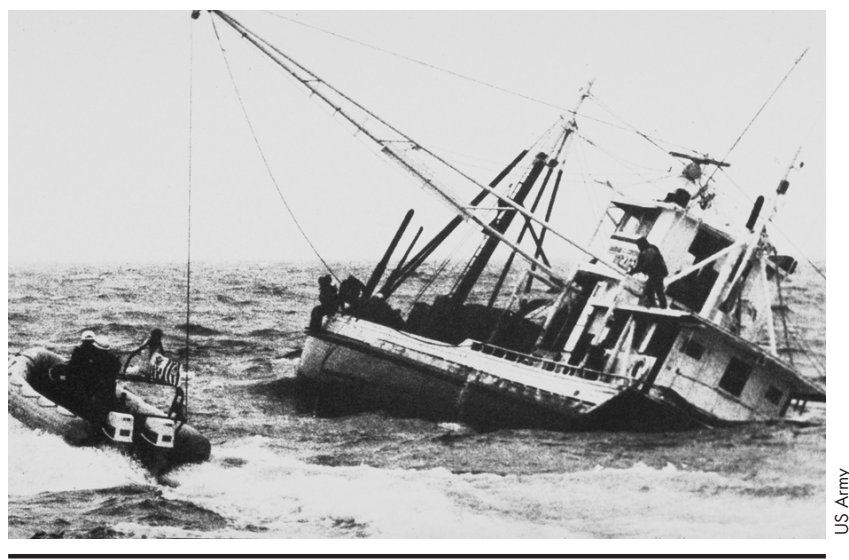

Figura 95.7 - Salvamento marítimo efectuado por un helicóptero.

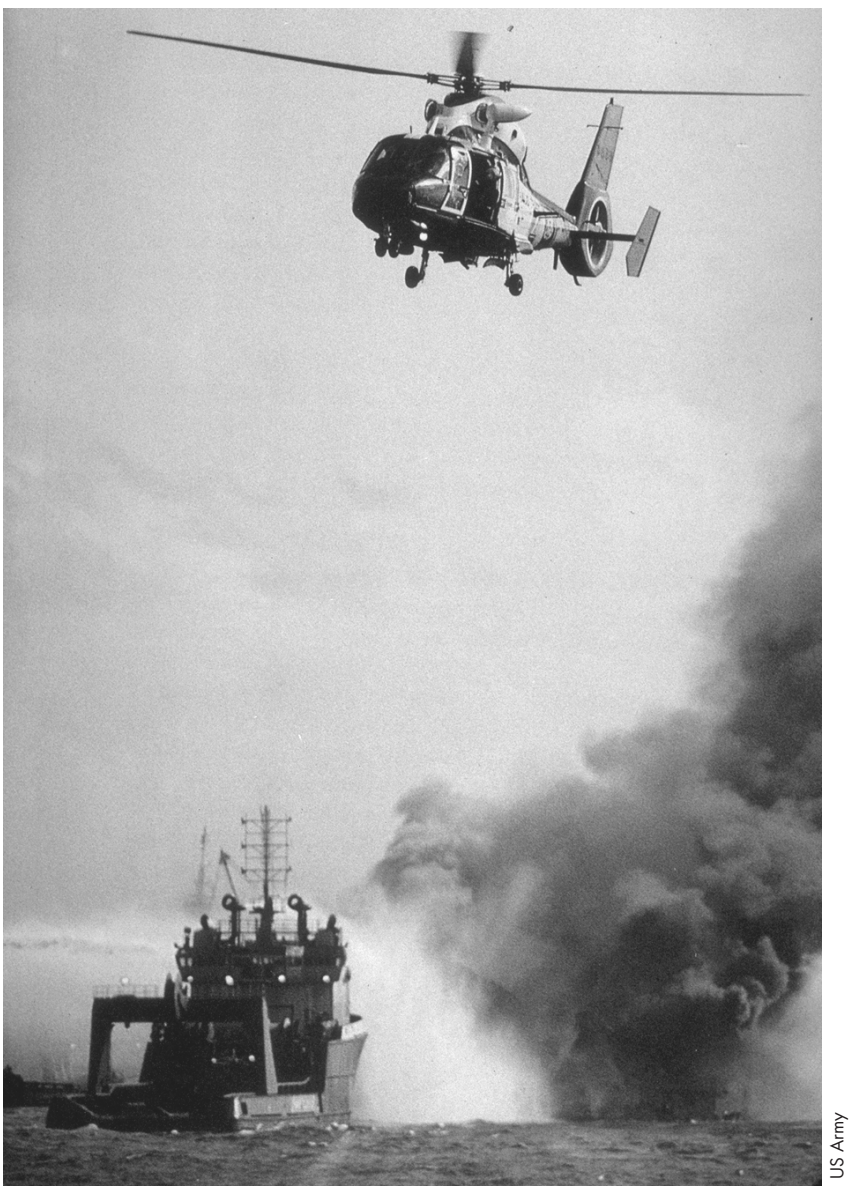

El mar tiene un mayor poder de absorción del calor corporal que el aire. El riesgo de muerte por hipotermia o ahogamiento provocado por la hipotermia aumenta rápidamente al descender la temperatura del agua a menos de 24 grados centígrados. Si la temperatura se aproxima al punto de congelación, el tiempo de supervivencia se cuenta por minutos. Sólo se puede sobrevivir en aguas frías, incluso si el mar está en calma, con ayuda de trajes o balsas salvavidas especiales.

En el medio marino se registran condiciones meteorológicas extremas. El viento, la lluvia, la niebla, las nevadas y las heladas pueden ser intensos y entorpecer la visibilidad y las comunicaciones. Los equipos de rescate corren un peligro constante de mojarse con el oleaje y sus salpicaduras, con la lluvia y las gotas de agua transportadas con el viento y con el agua nebulizada por la turbulencia producida por naves y aeronaves. El agua, en especial salada, puede estropear el equipo mecánico y eléctrico preciso para las operaciones de vuelo y de navegación.

La exposición al agua salada puede causar irritación de la piel, mucosas y ojos. Además, la ingesta de microorganismos infecciosos (especies como Vibrio) agrava el riesgo de sufrir enfermedades gastrointestinales. El agua de los alrededores de la operación de salvamento puede contener agentes contaminantes (por ejemplo, aguas fecales) o sustancias químicas nocivas para la salud humana (por ejemplo, productos del petróleo). En las aguas propicias a las poblaciones de serpientes de agua y de diversos celentéreos (como medusas) existe el riesgo de envenenamiento. Por otra parte, las ropas protectoras térmicas y contra el agua suelen ser engorrosas, entorpecen los movimientos y 
pueden provocar estrés por calor. En días soleados, los rayos ultravioleta pueden producir lesiones oculares y de la piel a los equipos de rescate.

En la superficie de las grandes masas de agua, como los océanos, se suelen producir movimientos ondulantes de las olas que coexisten con la agitación de la superficie. Esto obliga a los equipos de rescate a trabajar en una plataforma inestable, lo que complica los movimientos y operaciones a la vez que entraña un riesgo constante de sufrir mareos. Por otra parte, las embarcaciones de rescate que navegan con mar gruesa suelen dar grandes bandazos que las convierten en plataformas inestables, lo que fomenta la fatiga y el riesgo de sufrir caídas y el impacto de objetos desprendidos, e incrementa la probabilidad de fallos técnicos. Por su parte, las aeronaves que operan en condiciones meteorológicas adversas, experimentan turbulencias que generan fatiga y dificultan las operaciones de izar las víctimas desde la superficie del mar.

\section{Planificación y prevención}

Si bien el medio marítimo puede ser sumamente hostil, los riesgos para la seguridad y la salud asociados a las operaciones de rescate marítimo pueden prevenirse o reducirse mediante una rigurosa política de planificación y prevención. El salvamento puede realizarse con seguridad y eficacia.

La organización responsable del rescate debe ser plenamente consciente de la naturaleza del medio ambiente marino, conocer las características y limitaciones operativas del equipo y del personal, de los sistemas de seguridad y suministrar el equipo, la formación y la dirección necesarios. Los miembros del equipo de rescate deben estar en perfectas condiciones físicas y mentales, conocer el equipo y su funcionamiento, mantenerse alerta y dispuestos a intervenir, mantenerse hábil y conocer las peculiaridades de la situación a que se enfrentan.

El equipo de rescate puede sufrir accidentes marítimos o de aviación que, en cuestión de minutos, puede convertirlos de salvadores en víctimas. La capacidad de supervivencia en caso de siniestro depende, en última instancia, de varios factores:

- supervivencia al impacto

- posibilidad de abandonar la nave

- capacidad de resistencia hasta que se produzca el rescate

En cada fase del esfuerzo por sobrevivir a un accidente, existen unos determinados parámetros de formación, equipamiento, ergonomía y procedimiento que permiten prolongar la supervivencia. Los equipos de rescate marítimo suelen trabajar aislados, sin apoyo cercano y, en ocasiones, a considerable distancia de la costa. Es evidente la necesidad de dotar a los trabajadores de rescate de los medios necesarios para sobrevivir en caso de accidente hasta que se les rescate. Es preciso formar, equipar y preparar a los miembros del equipo de rescate para sobrevivir en las peores condiciones.

\section{- Personal auxiliar y de AMBULANCIAS}

John D. Meyer

El personal auxiliar, incluidos enfermeros de urgencias médicas y personal de transporte de las ambulancias, presta la asistencia sanitaria inicial en el lugar del accidente, siniestro o enfermedad aguda, y transporta a los pacientes a los puntos en que pueden recibir el tratamiento adecuado. Los avances del equipo sanitario y de las comunicaciones, han incrementado las posibilidades de estos trabajadores de reanimar y estabilizar a las víctimas mientras los trasladan a un centro de urgencias. El aumento de la capacidad de los enfermeros de urgencias médicas, va acompañado de la elevación de los riesgos a que se ven expuestos en el cumplimiento de sus funciones. El personal sanitario de urgencias trabaja en pequeños equipos, integrados generalmente por dos o tres personas que con frecuencia realizan su trabajo en instalaciones mal equipadas y de difícil acceso. En el medio ambiente de trabajo se pueden producir riesgos imprevistos o incontrolados de orden biológico, químico y físico. Las situaciones dinámicas rápidamente cambiantes y la hostilidad de los pacientes y del entorno pueden exacerbar los peligros inherentes al trabajo. En el diseño de estrategias para reducir y prevenir las lesiones profesionales, se deben tomar en consideración los riesgos para la salud del personal auxiliar.

Los riesgos a que está expuesto el personal auxiliar se clasifican en cuatro categorías principales: riesgos físicos, riesgos por inhalación, exposición a agentes infecciosos y estrés. Los riesgos físicos comprenden tanto las lesiones musculosqueléticas relacionadas con las tareas profesionales, como los efectos causados por el ambiente de trabajo. El levantamiento de grandes pesos en posiciones difíciles es el mayor riesgo físico que sufren estos trabajadores y es responsable de más de un tercio de las lesiones. Las distensiones de espalda constituyen las lesiones más frecuentes y, según un estudio retrospectivo, el $36 \%$ de las lesiones comunicadas se debían a distensiones lumbares (Hogya y Ellis 1990). El levantamiento de los pacientes y del equipo parecen ser las principales causas de aparición de las lesiones lumbares de espalda, dos tercios de las cuales, aproximadamente, se producen en el lugar de intervención. Las lesiones recurrentes de espalda son frecuentes y pueden provocar una incapacidad de larga duración o permanente que fuerza la jubilación anticipada de trabajadores experimentados. También son frecuentes las contusiones de cabeza, cuello, tronco y extremidades, los esguinces de tobillos, muñecas y manos y las heridas en los dedos. Otras causas de lesiones son los accidentes de circulación y la violencia ejercida tanto por los pacientes como por otras personas. La mayoría de los accidentes de circulación son colisiones provocadas por la premura de tiempo, la sobrecarga de trabajo, las malas condiciones meteorológicas y la formación inadecuada.

Se han notificado lesiones térmicas provocadas por ambientes excesivamente fríos o calientes. El clima y las condiciones meteorológicas locales, unidos al uso de ropas o de equipo inadecuado, producen estrés por calor y lesiones por frío. Por otra parte, en el personal de servicio en las ambulancias se han observado casos de pérdida acelerada de audición provocada por la exposición al ruido ambiental producido por las sirenas, que excede de los umbrales recomendados.

La inhalación de humos y la intoxicación por gases, como el monóxido de carbono, entrañan graves riesgos de lesión respiratoria para el personal auxiliar. Aunque no es muy frecuente, estas exposiciones pueden tener consecuencias nefastas. A veces, el personal que responde inicialmente a una llamada de urgencia se encuentra mal equipado para las labores de rescate y puede ser víctima del humo y los gases tóxicos antes de recibir refuerzos y equipos complementarios.

$\mathrm{Al}$ igual que otros trabajadores de la asistencia sanitaria, el personal auxiliar afronta un riesgo creciente de infección por virus patógenos transmitidos por la sangre, en especial el de la hepatitis B (VHB) y, presumiblemente, el de la hepatitis C. Se hallaron marcadores serológicos de infección por el VHB en el 13 al $22 \%$ de los enfermeros de urgencias médicas, lo que supone del triple al cuádruple de la prevalencia observada en el conjunto de la población (Pepe y cols. 1986). En una encuesta realizada se puso de manifiesto una correlación entre el riesgo de infección y el número de años de servicio en urgencias 
médicas. Las medidas recomendadas para la prevención del contagio del VHB y del VIH entre los trabajadores de la asistencia sanitaria, que se exponen en otro capítulo de la presente Enciclopedia, son igualmente de aplicación al personal auxiliar. En el ámbito de los efectos secundarios, el uso de guantes de látex como medio de protección contra los agentes patógenos en sangre, puede contribuir a un mayor riesgo de urticaria por contacto y otras manifestaciones de alergia a los productos del caucho, similares a las observadas entre los trabajadores sanitarios de los hospitales.

El trabajo paramédico y en las ambulancias, que se desarrolla en ambientes peligrosos e incontrolados y obliga a tomar decisiones críticas con escaso margen de tiempo y sin el apoyo de un equipo adecuado, genera un elevado nivel de estrés laboral. La disminución del rendimiento profesional, la insatisfacción en el trabajo y la pérdida de interés en los pacientes que puede producirse a consecuencia del estrés constituyen un peligro, tanto para los prestadores de la asistencia como para el público en general. Se ha recomendado la intervención de especialistas en salud mental después de producirse algún siniestro importante u otro incidente traumático, junto con otras estrategias para reducir el agotamiento de los trabajadores de urgencias, con el objeto de mitigar los efectos destructivos del estrés en este campo (Neale 1991).

Existen pocas recomendaciones específicamente orientadas a las pruebas selectivas y a la adopción de medidas preventivas entre el personal auxiliar. Todos los trabajadores expuestos a líquidos y materiales infecciosos deben vacunarse contra el virus de la hepatitis B y aprender a protegerse de los agentes patógenos en sangre. Los centros sanitarios de Estados Unidos están obligados a comunicar cualquier exposición no protegida de su personal de urgencias a agentes patógenos en sangre o en el aire, así como a cualquier enfermedad infecciosa poco frecuente o rara, como la tuberculosis (NIOSH 1989). En otros países existen normas legales y directrices similares (Laboratory Center for Disease Control 1995). Especial importancia reviste la observancia de las prácticas habituales en materia de vacunación contra las enfermedades infecciosas (como la vacuna triple contra la rubéola, sarampión y paperas) y el tétanos. Las pruebas selectivas periódicas de la tuberculosis se recomiendan en los casos de posibles exposiciones de alto riesgo. Se ha indicado que el diseño adecuado del equipo, la enseñanza de la mecánica corporal y la información y formación sobre los riesgos puntuales, pueden contribuir a reducir las lesiones en el levantamiento de las víctimas, si bien el ambiente en que se desarrolla buena parte del trabajo del personal de las ambulancias puede hacer ineficaces los controles mejor diseñados. Es preciso analizar cuidadosamente el ambiente en que se realiza el trabajo auxiliar, y suministrar las ropas y el equipo de protección adecuados. El adiestramiento en el uso de equipos autónomos de protección respiratoria, es conveniente para las personas expuestas a gases y humos tóxicos. Por último, es preciso tomar en consideración el desgaste producido por el estrés en el personal paramédico y en los técnicos de urgencias, y elaborar estrategias de formación e intervención destinadas a reducir estos efectos.

\section{- Personal de control de RIESgos POR SUSTANCIAS PELIGROSAS}

\section{Joseph Fedoruk}

Los profesionales dedicados al control de emergencias o accidentes provocados por sustancias peligrosas pueden calificarse, de forma genérica, como personal de control de sustancias peligrosas. Un incidente o situación de emergencia producido por una sustancia peligrosa es un vertido incontrolado o ilegal, real o potencial, de una sustancia peligrosa o de sus subproductos peligrosos. Las urgencias de este tipo pueden producirse durante el transporte o en una instalación fija. Los incidentes durante el transporte pueden ocurrir como resultado de accidentes terrestres, navales o aéreos,. Las instalaciones fijas pueden ser edificios industriales, de oficinas, escuelas, explotaciones agrarias o cualquier otra estructura fija que albergue materiales peligrosos.

Los trabajadores cuya misión principal es controlar las urgencias producidas por sustancias peligrosas, se consideran en general parte de los equipos de control de materiales peligrosos. Entre los profesionales integrantes de estos equipos figuran trabajadores del sector público como los bomberos, policía y personal de transporte, específicamente entrenados para afrontar las situaciones de emergencia debidas a sustancias peligrosas. Las instalaciones fijas, como las fábricas, las refinerías de petróleo y los laboratorios de investigación cuentan, por regla general, con equipos propios de control de materiales peligrosos adiestrados para afrontar los accidentes originados a causa de los materiales peligrosos existentes en el interior de sus recintos. En la normativa sobre medio ambiente se exige, a veces, que dichas instalaciones comuniquen a los organismos públicos cualquier incidente que ocasione un riesgo a la comunidad circundante o en el que se rebase el umbral tolerado de una determinada sustancia peligrosa. Los profesionales de la salud pública, adiestrados en la evaluación de exposiciones y en el control de materiales peligrosos, como los higienistas industriales, suelen integrarse en los equipos de control de materiales peligrosos de los sectores público o privado.

La policía y los bomberos suelen ser los primeros profesionales en responder a las situaciones de emergencia producidas por sustancias peligrosas, dado que pueden encontrarse con fugas de este tipo de sustancias en las estructuras incendiadas o en un accidente de circulación. Estos trabajadores suelen ser los primeros que acuden al lugar del siniestro, y su responsabilidad principal es impedir la exposición del público al vertido, manteniéndolo alejado del lugar del siniestro. Esta misión se lleva normalmente a cabo aplicando métodos de control físico, como las barreras y de control de masas y del tráfico. Los primeros profesionales en acudir al lugar del siniestro no suelen adoptar medidas de contención o control del vertido. Estos trabajadores suelen correr mayores riesgos de exposición a las sustancias peligrosas que el resto del equipo de control de urgencias, ya que normalmente afrontan las fugas sin ayuda del equipo de protección adecuado, además de verse expuestos a emanaciones imprevistas. Los primeros en acudir al lugar del siniestro, suelen recabar la presencia de los equipos de control de materiales peligrosos para que asuman la responsabilidad de la contención del riesgo. En otro artículo del presente capítulo se han expuesto los problemas sanitarios específicos de policías y bomberos.

La tarea fundamental de los equipos de control de materias peligrosas, es contener y controlar los vertidos. Esta labor puede entrañar serios riesgos si en el siniestro intervienen explosivos o sustancias muy tóxicas, como el gas cloro. Corresponde al jefe del equipo decidir sobre las acciones a emprender para solucionar la emergencia. A veces, la elaboración de un plan de control de los accidentes especialmente complicados, como el descarrilamiento de varios vagones de un tren o una explosión seguida de incendio en una planta química, es un proceso lento. En los casos en que la aplicación de medidas de control entrañe, para los equipos de control de materias peligrosas, un riesgo importante de sufrir graves lesiones, puede decidirse no adoptar medidas específicas de contención y dejar que la sustancia se vierta en el medio ambiente. 
La última fase del trabajo de control de emergencias producidas por sustancias peligrosas suele ser la retirada de los residuos peligrosos de dichas sustancias, que suele encargarse a personal de limpieza. En la vigente normativa de seguridad y salud en algunos países, se exige que estos trabajadores reciban una formación especial en las técnicas de control de materiales peligrosos y se sometan a vigilancia médica periódica. A veces, el riesgo de exposición que asumen estos trabajadores es mayor, ya que las operaciones de limpieza los obligan a un estrecho contacto con los materiales peligrosos. Otros profesionales, como los equipos de asistencia sanitaria de urgencia -incluidos los enfermeros de urgencias médicas, el personal auxiliar, el personal médico de las salas de urgencias y otros trabajadores de los hospitales - , se encuentran igualmente expuestos al riesgo de contacto con sustancias peligrosas.

\section{Riesgos potenciales}

Los riesgos potenciales asociados a las situaciones de emergencia debidas a sustancias peligrosas son específicos de cada caso y comprenden riesgos, tanto químicos como radiológicos y biológicos, que pueden estar presentes en forma de gases o vapores, aerosoles -incluidos los nebulizadores - humos, polvos o partículas, sólidos, líquidos o ambos. Los riesgos a que se enfrentan los trabajadores de control de sustancias peligrosas dependen de la potencial exposición al agente, de la reactividad (inflamabilidad, explosividad, etc.) y de la potencial toxicidad.

En Estados Unidos, el sistema de Vigilancia de situaciones de emergencia debidas a sustancias peligrosas (HSEES) de la Agencia de sustancias tóxicas y registro de enfermedades (ATSDR), ofrece información sobre los agentes implicados en las urgencias debidas a sustancias peligrosas. El sistema HSEES es un sistema de vigilancia activa para el seguimiento de los incidentes que afectan a la salud pública (Hall y cols. 1994). El sistema HSEES se desarrolló inicialmente para suplir las deficiencias observadas en otros sistemas norteamericanos de seguimiento de fugas de sustancias peligrosas (Binder 1989). El sistema HSEES no identifica la totalidad de los vertidos, ya que los escapes puntuales ocurridos en instalaciones fijas no se registran. El registro se creó en 1990 e inicialmente abarcaba cinco estados, para extenderse después hasta alcanzar once estados. En 1993, el HSEES registró un total de 3.945 urgencias producidas por sustancias peligrosas. En otros estados del país y en otras naciones funcionan también sistemas de registro de los sucesos producidos por las sustancias peligrosas (Winder y cols. 1992)

Los datos compilados por el HSEES respecto a los distintos tipos de productos químicos liberados durante las emergencias debidas a sustancias peligrosas, incluidas las causantes de lesiones durante el período de 1990-1992, muestran que la mayoría de las sustancias vertidas eran compuestos orgánicos volátiles, herbicidas, ácidos y amoníaco. El mayor riesgo de lesiones se produce durante los accidentes relacionados con cianuros, insecticidas, cloro, ácidos y bases. Durante los años 1990-1992, el 93 \% de los accidentes fueron provocados por la fuga de una única sustancia química, y el $84 \%$ tuvieron lugar en instalaciones fijas.

\section{Consecuencias para la salud}

El personal de control de sustancias peligrosas está expuesto a diversos tipos de riesgos agudos para la salud. La primera amenaza para la salud viene definida por la potencial toxicidad del agente y por el posible contacto con la sangre y otros fluidos corporales de las víctimas del accidente. La segunda amenaza es el riesgo de sufrir lesiones físicas importantes, como quemaduras producidas por la explosión y/o el incendio resultantes de una reacción química inesperada, o como consecuencia del derrumbe de un edificio o de la rotura de un contenedor. El tercer tipo de efecto agudo sobre la salud, es el riesgo de sufrir estrés por calor o agotamiento al realizar un trabajo pesado, a menudo enfundados en ropas protectoras contra sustancias químicas, que reducen la capacidad corporal de enfriamiento mediante la evaporación. Los trabajadores con antecedentes de problemas de salud como una enfermedad cardiovascular o respiratoria, diabetes o pérdidas de la consciencia, o que tomen medicamentos que puedan menoscabar el intercambio de calor o la respuesta cardiorrespiratoria al ejercicio, corren un riesgo añadido si realizan trabajos pesados.

Se dispone de escasa información relativa a las consecuencias para la salud del personal especializado en el control de urgencias producidas por sustancias peligrosas. Según el registro HSEES, 467 de las 4.034 intervenciones de control de situaciones de emergencia producidas entre 1990 y 1992, un $15 \%$ del total, se saldaron con 446 lesiones. Doscientas de las personas lesionadas fueron clasificadas como personal de intervención de urgencias, incluidos bomberos, policías y personal de seguridad, personal médico de urgencias y miembros de los equipos de control de urgencias de materias peligrosas. Casi la cuarta parte del personal de intervención de urgencias (22 \%) no utilizó equipo de protección individual alguno.

Entre los principales efectos conocidos para la salud en las personas lesionadas estaban irritación de las vías respiratorias $(37,3 \%)$, irritación ocular $(22,8 \%)$ y náuseas $(8,9 \%)$. El 6,1\% de los lesionados habían sufrido quemaduras químicas, mientras que el $2 \%$ habían sido víctimas del estrés por calor. Se produjeron once muertes, incluido la de un trabajador de control de urgencias. Las causas del fallecimiento de estas personas fueron traumatismos, quemaduras químicas, asfixia, quemaduras térmicas, estrés por calor y parada cardíaca. Según otros informes, los trabajadores de control de urgencias corren riesgos de sufrir lesiones graves.

Se carece de una descripción sistemática de los riesgos de salud asociados con la exposición crónica a una extensa gama de materiales peligrosos y no se ha realizado ningún estudio epidemiológico de los miembros de los equipos de control de materiales peligrosos. En cambio, algunos estudios epidemiológicos sobre los bomberos que acuden a los lugares de incendio, han puesto de manifiesto la posibilidad de que estos trabajadores tengan un mayor riesgo de desarrollar distintos tipos de cáncer (Véase el artículo titulado "Peligros de la extinción de incendios" en este mismo capítulo).

\section{Medidas preventivas}

Varias medidas, descritas en la Figura 95.8, pueden reducir la frecuencia de los accidentes por situaciones de emergencia debidas a sustancias peligrosas. En primer lugar, la adopción y aplicación de normas de seguridad en la producción y almacenamiento, transporte y utilización de sustancias peligrosas, puede reducir la posibilidad de utilización de métodos de trabajo inseguros. La formación de los trabajadores en prácticas de trabajo adecuadas y en el control de los riesgos es un elemento fundamental de la prevención de accidentes.

En segundo lugar, una adecuada gestión y supervisión de los accidentes puede disminuir sus efectos. En este contexto, resulta vital la dirección del responsable, en caso de accidente, de la actuación del personal y de los trabajadores de limpieza. Es preciso supervisar y evaluar el desarrollo de la intervención de urgencia para garantizar el logro seguro y eficaz de los objetivos.

El tercer grupo de medidas consiste en las actuaciones sanitarias realizadas durante y después de un accidente, que comprenden la prestación de los primeros auxilios necesarios en el lugar del accidente y la adopción de las medidas de descontaminación precisas. La falta de una descontaminación 
Figura 95.8 • Pautas de prevención.

\section{PREVENCION}

- Normativa: adopción de normas relativas al almacenamiento de materiales peligrosos, seguridad de los procesos químicos y manipulación, transporte y descarga de sustancias

- Normativa: "Derecho a conocer"

- Formación de los trabajadores y de los responsables de transporte sobre prácticas de trabajo seguras y en la identificación y prevención de urgencias

- Prácticas de trabajo seguras

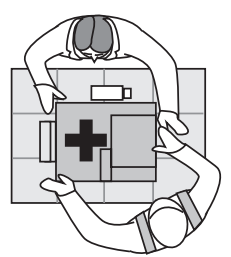

- Métodos de descontaminación de ropa, equipo y personas

- Distancias de seguridad y puntos de refugio

- Equipo de protección individual: selección, utilización y limitaciones del equipo de protección individual específico para el riesgo

\section{GESTION DE INCIDENTES}

- Plan de control de urgencias: Preparación para las urgencias: funciones, línea jerárquica y comunicaciones

- Prácticas de trabajo seguras y equipo de seguridad

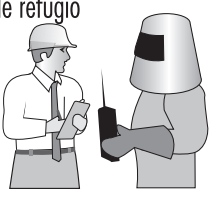

\section{- Primeros auxilios}

- Métodos de descontaminación de personas y ropa

- Tratamiento médico de urgencia

- Vigilancia médica

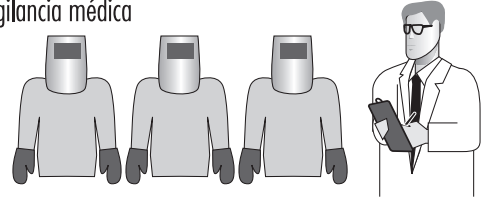

- Identificación y prevención de urgencias

rigurosa de una víctima puede prolongar la absorción del agente tóxico y supone para el personal médico o de control de materias peligrosas un riesgo de exposición a consecuencia del contacto directo con el paciente (Cox 1994). Es igualmente preciso adiestrar a los médicos en el tratamiento específico de los accidentes químicos y en la adopción de equipos de protección individual.

La participación de los trabajadores en el programa de vigilancia médica es una medida que puede ser utilizada para prevenir problemas de salud entre el personal encargado del control de las sustancias peligrosas. La vigilancia de la salud, permite detectar los trastornos en un estadio inicial, antes de que aparezcan efectos adversos importantes. Por otra parte, hace posible la identificación y vigilancia de procesos que, como las enfermedades cardiovasculares, pueden incrementar el riesgo para los trabajadores en la realización de su trabajo. Asimismo, es preciso diagnosticar las deficiencias sensoriales capaces de dificultar las comunicaciones sobre el terreno, como los defectos de visión y audición, con el objeto de determinar si constituyen un grave riesgo durante las labores de control de las sustancias peligrosas.

La mayoría de las medidas preventivas se basan en la conciencia colectiva de los riesgos existentes localmente. Es imprescindible la implantación, con ayuda de personal cualificado, de planes de emergencia sobre control de sustancias peligrosas, y la correcta asignación de los recursos. La conciencia colectiva de los riesgos pasa por informar a la comunidad de los materiales peligrosos existentes en las instalaciones fijas o que son transportados dentro de la comunidad (por carretera, ferrocarril, aguas navegables o aeropuertos). Esta información permite a los cuerpos de bomberos y a otros organismos responsables prepararse para afrontar las situaciones de emergencias. También en las instalaciones fijas y en las empresas de transporte de materiales peligrosos se deben implantar procedimientos para su notificación urgente a las autoridades competentes. Por otra parte, el personal médico debe estar familiarizado con los riesgos potenciales existentes en su comunidad. Es preciso contar con personal médico cualificado para diagnosticar y tratar los síntomas y para prescribir un tratamiento específico para las sustancias peligrosas existentes en su comunidad. Las instalaciones fijas deben establecer enlaces con los servicios locales de urgencia, con el objeto de informarles de los posibles riesgos existentes en el lugar de trabajo y de los suministros e intervenciones precisos para controlar los posibles accidentes en dichas instalaciones. La formación y planificación deben ayudar a mejorar la prestación de la asistencia médica adecuada y reducir el número de muertes y lesiones a causa de los accidentes.

Es igualmente posible que se produzcan situaciones de emergencia debidas a sustancias peligrosas como consecuencia de catástrofes naturales como riadas, terremotos, rayos, huracanes, vendavales y tormentas fuertes. A pesar del aparente incremento de la frecuencia de estos sucesos, se observa un escaso nivel de preparación para estas emergencias (Showalter y Myers 1994). Los esfuerzos de planificación deben hacerse extensivos a las causas naturales de las situaciones de emergencia.

\section{Referencias}

Bigbee, D. 1993. Pathogenic microorganisms - Law enforcement's silent enemies. FBI Law Enforcement Bull May 1993:1-5.

Binder, S. 1989. Deaths, injuries, and evacuation from acute hazardous materials releases. Am $f$ Public Health 79:1042-1044.

Brown, J, A Trottier. 1995. Assessing cardiac risks in police officers. F Clinical Forensic Med 2:199-204.

Cox, RD. 1994. Decontamination and management of hazardous materials exposure victims in the emergency department. Ann Emerg Med 23(4):761-770.

Davis, RL, FK Mostofi. 1993. Cluster of testicular cancer in police officers exposed to hand held radar. Am f Ind Med 24:231-233.

Franke, WD, DF Anderson. 1994. Relationship between physical activity and risk factors for cardio- vascular disease among law enforcement officers. $\mathcal{f}$ Occup Med 36(10):1127-1132.

Hall, HI, VD Dhara, PA Price-Green, WE Kaye. 1994. Surveillance for emergency events involving hazardous substances - United States, 1990-1992. MMWR CDC Surveil Summ 43(2): 1-6.

Hogya, PT, L Ellis. 1990. Evaluation of the injury profile of personnel in a busy urban EMS system. $A m-\mathcal{f}$ Emerg Med 8:308-311.

Laboratory Center for Disease Control. 1995. A national consensus on guidelines for establishment of a post-exposure notification protocol for emergency responders. Canada Communicable Disease Report 21-19:169-175.

National Institute for Occupational Safety and Health (NIOSH). 1989. A Curriculum Guide for Public-safety and Emergency Response Workers. Prevention of Transmis- sion of Human Immunodeficiency Virus and Hepatitus B Virus. Cincinnati: NIOSH.

Neale, AV. 1991. Work stress in emergency medical technicians. F Occup Med 33:991-997.

Pepe, PE, FB Hollinger, CL Troisi, D Heiberg. 1986. Viral hepatitis risk in urban emergency medical services personnel. Ann Emerg Med 15:454- 457.

Showalter, PS, MF Myers. 1994. Natural disasters in the United States as release agents of oil, chemicals, or radiological materials between 1980-1989. Risk Anal 14(2):169-182.

Souter, FCG, G van Netten, R Brands. 1992. Morbidity in policemen occupationally exposed to fingerprint powders. Int $\mathcal{f}$ Envir Health Res 2:114-119.

Sparrow, D, HE Thomas, ST Weiss. 1983. Coronary heart disease in police officers participating in the 
normative aging study. Am 7 Epidemiol 118(No. 4):508-512.

Trottier, A, J Brown, GA Wells. 1994. Respiratory symptoms among forensic ident workers. F Clin Forensic Med 1:129-132.

Vena, JE, JM Violanti, J Marshall, RC Fiedler. 1986. Mortality of a municipal worker cohort: III: Police officers. Am f Ind Med 10:383-397.

Violanti, JM, JE Vena, JR Marshall. 1986. Disease risk and mortality among police officers: New evidence and contributing factors. 7 Police Sci Admin 14(1):17-23.

Winder, C, A Tottszer, J Navratil, R Tandon. 1992. Hazardous materials incidents reporting - Result of a nationwide trial. f Haz Mat 31(2):119-134.

\section{Otras lecturas recomendadas}

Bellamy, RF, R Zajtchuk. 1990. Conventional Warfare, Ballistic, Blast, and Burn Injuries. Textbook of Military Medicine Series. Washington, DC: Walter Reed Army Medical Center.

Blau, TH. 1994. Psychological Services for Law Enforcement. Nueva York: John Wiley \& Sons.
Bonneau, J, J Brown. 1955. Physical ability, fitness and police work. 7 Clin Forensic Med 2:157-164.

Deeter, DP, JC Gaydos. 1993. Occupational Health, the Soldier and the Industrial Base. Textbook of Military Medicine Series. Washington, DC: Borden Institute, Walter Reed Army Medical Center.

DeHart, R. 1985. Fundamentals of Aerospace Medicine. Philadelphia: Lea and Febiger.

Ernsting, J, P King. 1988. Aviation Medicine. Londres: Butterworths.

Gaydos, JC, GA Luz. 1994. Military participation in emergency humanitarian assistance. $\mathcal{F}$ Disaster Studies and Management Marzo 1994:48-57.

Gaydos, JC. 1992. A historical review of the need for military toxicology and the U.S. Army's response. In Chemical Risk Assessment in the Department of Defense $\left(D_{0} D\right)$ : Science, Policy and Practice. Cincinnati: Conferencia Americana de Higienistas Industriales del Gobierno.

Guidotti, TL. 1992. Human factors in firefighting: Ergonomic, cardiovascular, and psychogenic stress-related issues. Int Arch Occup Environ Health 64:1-12.

—. 1992. Occupational health concerns of firefighting. Annu Rev Publ Health 13:151-171.
- 1995. Occupational mortality among firefighters: Assessing the asociation. 7 Occup and Envir Med 37:1348-1356.

Landrock, AH. 1983. Handbook of Plastics Flammability and Combustion Technology. Park Ridge, Nueva Jersey: Noyes Publications.

Legters, LJ, CH Llewellyn. 1992. Military medicine, En Public Health and Preventive Medicine, dirigido por KF Maxey, MJ Rosenau y JM Last. East Norwalk, Connecticut: Appleton and Lange.

Marrs, TC, RL Maynard, FR Sidell. 1996. Chemical Warfare Agents, Toxicology and Treatment. Nueva York: John Wiley \& Sons.

Orris, P, J Melius, RM Duffy. 1995. Firefighters' safety and health. Occup Med: State Art Rev 10(4):691-883.

Rayman, RB. 1990. Clinical Aviation Medicine. Malvern, Pensilvania, US: Lea and Febiger.

Trottier, A, J Brown. 1993. Police Health 1994: A Physicians's Guide for the Assessment of Police Officers. Ottawa: Canada Communication Group.

- 1995. Occupational medicine for policing. 7 Clin Forensic Med 2:105-110.

- 1995. Risks to police officers from biohazards encountered in police work. $f$ Clin Forensic Med 2:11-116.

Tuve, RL. 1976. Principles of Fire Protection Chemistry. Boston: National Fire Protection Association. 



\section{ACTIVIDADES ARTISTICAS, CULTURALES Y RECREATIVAS}

Director del capítulo Michael McCann

\section{Sumario}

\section{ACTIVIDADES ARTISTICAS YARTESANALES}

Actividades artísticas, culturales y recreativas

Michael McCann .

Dibujo, pintura y grabados

Jack W. Snyder

Escultura

Giuseppe Battista . . . . . . . . . . . . . . . . . . . . 96.8

Fotografía

David Richardson. . . . . . . . . . . . . . . . . . 96.11

Metalistería

Angela Babin . . . . . . . . . . . . . . . . . . . . . . . . . . . .96.12

Nuevas tecnologías en el arte

William E. Irwin. . . . . . . . . . . . . . . . . . . . . . . . 96.14

Artesanía textil

Gail Coningsby Barazani . . . . . . . . . . . . . . . . . . 96.15

Cerámica

Monona Rossol . . . . . . . . . . . . . . . . . . . . . . . . 96.17

Artesanía de la madera

Michael McCann .............................96.19

Joyería

Tsun-fen Chengy fung-Der Wang . . . . . . . . . . . . . . 96.21

Artes gráficas

Stephanie Knopp. . . . . . . . . . . . . . . . . . . . . . . . . . . 96.23

ARTES ESCENICAS YAUDIOVISUALES

Danza

Itzhak Siev-Ner. . .

Músicos

fohn P. Chong . . . . . . . . . . . . . . . . . . . . . . . . . 96.26

Cantantes

Anat Keidar

96.28
Actores

Sandra Karen Richman . . . . . . . . . . . . . . . . . . . . . . . . . 96.30

Teatro y ópera

Claes $W$ Englund. ...............................

Producción de cine y televisión

Michael McCann . . . . . . . . . . . . . . . . . . . . . . . 96.34

Emisión de radio y televisión

Nancy Clark . . . . . . . . . . . . . . . . . . . . . . . . . . . 96.38

Periodismo

Aidan White ................. 96.39

ACTIVIDADES CULTURALES Y RECREATIVAS

Museos y galerías de arte

Kathryn A. Makos . . .

Parques zoológicos y acuarios

Ken Sims . . . . ............................... 96.44

Parques y jardines botánicos

Paul V. Lynch ............................... 96

Circos, parques de atracciones y temáticos William Avery. . . . . . . . . . . . . . . . . . . . . . . . . . . . . . 96.48

Corridas de toros y rodeos

Michael McCann . . . . . . . . . . . . . . . . . . . . . . . 96.50

Deportes profesionales

Gordon Huie, Peter F. Bruno y W. Norman Scott . . . . . . . . . . . . . 96.52

Industria del sexo

Priscilla Alexander . . . . . . . . . . . . . . . . . . . . . . . . . 96.55

Vida nocturna

Angela Babin ........... 96.56

La protección del medio ambiente y la salud pública

Michael McCann . . . . .......................... 96.57 


\section{ACTIVIDADES ARTISTICAS, CULTURALES Y RECREATIVAS}

Michael McCann

Las actividades artísticas y recreativas forman parte de la historia de la humanidad desde que el hombre prehistórico comenzó a dibujar los animales que cazaba en las paredes de las cuevas, y a celebrar con bailes y cánticos el éxito de sus cacerías. Desde los tiempos más remotos, todas las culturas han tenido su propio estilo de artes plásticas y escénicas, y han decorado sus objetos cotidianos, como vestidos, muebles o piezas de alfarería. Las modernas tecnologías y el mayor tiempo disponible para el ocio han hecho que gran parte de la economía mundial está dedicada a satisfacer la necesidad de las personas de contemplar y adquirir objetos bellos, así como de divertirse. Este sector de la industria comprende un grupo heterogéneo de instituciones no lucrativas y de empresas comerciales que ofrecen al público este tipo de actividades culturales y recreativas. Por su parte, los artistas y los artesanos son trabajadores que se dedican al arte y a la artesanía por mero placer o con fines comerciales, y que suelen trabajar solos o en grupos cuyo número no excede de diez personas, formados en torno a un núcleo familiar. Todos ellos (artistas y artesanos, actores, músicos, profesionales del circo, personal de parques de atracciones, conservadores de museos, deportistas profesionales, técnicos y otros) suelen estar expuestos a riesgos de accidentes y enfermedades profesionales. El presente capítulo trata de la naturaleza de los riesgos de este tipo. Se excluyen los peligros a los que están expuestos quienes lo hacen como pasatiempo y el público que asiste a las representaciones y los espectáculos, aunque en muchos casos los riesgos son similares.

Las actividades artísticas y recreativas pueden considerarse como una especie de microcosmos dentro del sector industrial. Los riesgos no son muy diferentes de los de otras industrias más convencionales, y pueden tomarse las mismas precauciones. Ahora bien, en el ámbito de las actividades artísticas y artesanales los costes pueden alcanzar niveles prohibitivos en relación con determinados controles técnicos. En estos casos debe considerarse la sustitución de determinados procesos y materiales por otros más seguros. En la Tabla 96.1 se ofrece una relación de precauciones generales que deben adoptarse en el contexto de las actividades artísticas y recreativas.

\section{Actividades artísticas y artesanales}

Los artistas y artesanos suelen trabajar por cuenta propia y por lo común lo hacen en estudios, en sus hogares, o en los patios de sus casas, con medios escasos e inversiones pequeñas. El oficio suele pasar de generación en generación y su aprendizaje es informal, especialmente en países en desarrollo (McCann 1996). En los países industrializados, muchos artistas y artesanos llevan a cabo su aprendizaje en centros de formación profesional.

Aunque hoy en día son millones las personas dedicadas a este sector en todo el mundo y la artesanía es una parte importante de la economía de muchos países, apenas existen estadísticas sobre el número de artistas y artesanos.

Según cálculos de distintas fuentes, en Estados Unidos hay aproximadamente unos 500.000 artistas, artesanos y profesores de arte profesionales. En México se estima que hay unas 5.000 familias dedicadas exclusivamente a la cerámica en sus hogares. La Organización Panamericana de la Salud (OPS) ha revelado que entre 1980 y 1990 el $24 \%$ de la población activa en América Latina trabajaba por cuenta propia (OPS 1994).
En otros estudios de este sector los porcentajes eran similares o superiores (OMS 1976; Henao 1994). Se desconoce el porcentaje correspondiente a artistas y artesanos.

Las actividades artísticas y artesanales han evolucionado gracias a las nuevas tecnologías, y los artistas han ido incorporando a su trabajo procesos y productos químicos modernos, como plásticos, resinas, equipos con dispositivos láser, fotografía, etc. (McCann 1992a; Rossol 1994). En la Tabla 96.2 se recogen los diferentes riesgos físicos y químicos presentes en los procesos artísticos.

$\mathrm{Al}$ igual que otros sectores informales, el de las actividades artísticas y artesanales apenas se encuentra reglamentado, por lo que suele estar excluido de la legislación en materia de indemnizaciones a los trabajadores y de otras disposiciones sobre seguridad y salud en el trabajo. Las instituciones oficiales encargadas de ello desconocen en muchos países los riesgos laborales a los que se exponen los artistas y artesanos, que no están cubiertos por los servicios de salud en el trabajo. Es preciso encontrar el modo de instruir a los artistas y artesanos sobre los riesgos que entrañan los materiales y procesos que emplean, y sobre las precauciones que exigen, así como facilitarles el acceso a los servicios de salud laboral.

\section{Efectos sobre la salud y pautas patológicas}

Apenas se han realizado estudios epidemiológicos entre los trabajadores de las artes plásticas. Una de las principales causas está en la naturaleza descentralizada de estas actividades que, por otra parte, no suelen estar debidamente registradas. La mayoría de los datos disponibles proceden de casos individuales recogidos en distintas publicaciones.

Las artes y los oficios tradicionales originan las mismas enfermedades y accidentes profesionales que la industria a mayor escala. Basta reparar en nombres tan antiguos como los de ciertas enfermedades: el mal del alfarero, la espalda del tejedor o el cólico del pintor. Bernardino Ramazzini definió hace casi tres siglos las enfermedades profesionales del alfarero, del tejedor y del artesano del metal (Ramazzini 1713). Los nuevos procesos y materiales también son causa de muchas enfermedades y lesiones profesionales.

La intoxicación por plomo sigue siendo una de las enfermedades profesionales más comunes entre artistas y artesanos. A continuación se citan algunos ejemplos:

- Un artesano del vidrio de color en Estados Unidos (Feldman y Seldman 1975).

- Alfareros y sus familias en México (Ballesteros, Zúñiga y Cárdenas 1983; Cornell 1988) y en Barbados (Koplan y cols. 1977).

- Familias de Sri Lanka dedicadas a la recuperación de oro y plata a partir de desechos de joyería, empleando una técnica con plomo fundido (Ramakrishna y cols. 1982)

Como ejemplos de enfermedades profesionales en las actividades artísticas y artesanales:

- Sensibilidad al cromo en un artesano textil (MMWR 1982).

- Neuropatía en un serigrafista (Prockup 1978).

- Ataque cardíaco por exposición a cloruro de metileno en un barnizador de muebles (Stewart y Hake 1976).

- Problemas respiratorios en fotógrafos (Kipen y Lerman 1986).

- Mesotelioma en joyeros (Driscoll y cols. 1988).

- Silicosis y otras enfermedades respiratorias en trabajadores de la industria del ágata en la India (Rastogi y cols. 1991). 
Tabla 96.1 • Precauciones relacionadas con los riesgos en las artes y entretenimientos.

Riesgos
Riesgos químicos
General
Contaminantes atmosféricos
(vapores, gases, neblinas
de aerosoles, brumas,
polvos, vapores, humos)
Líquidos

Polvos

Sólidos

Riesgos físicos
Ruidos

Radiación infrarroja

Láser

Calor

Radiación ultravioleta

\section{Precauciones}

Formación sobre los riesgos y precauciones Sustitución de materiales peligrosos por otros más seguros

Controles técnicos

Almacenamiento y manipulación adecuados

No comer, beber ni fumar en las zonas de trabajo

Equipo de protección individual

Sistemas para controlar derrames y salpicaduras

Eliminación segura de los desechos peligrosos

Recinto aislado

Ventilación de dilución 0 aspirante local

Protección de las vías respiratorias

Tapar los envases

Guantes y otras prendas de protección individual Gafas y pantallas de protección facial cuando sea necesario

Duchas de emergencia y fuentes para lavado de ojos cuando sea necesario

Comprar productos en forma líquida o en pasta Cámara de manipulación con guantes incorporados

Ventilación aspirante local

Fregado 0 aspiración del suelo

Protección de las vías respiratorias

Guantes

Maquinaria más silenciosa

Mantenimiento adecuado

Amortiguación de sonidos

Aislamiento e insonorización

Protectores auditivos

Recinto aislado

Protección de la piel y gafas contra radiación UV

Protección de la piel y gafas contra radiación infrarroja

Utilizar rayos láser de la menor potencia posible Recinto aislado

Uso restringido de los rayos y sistemas de

desconexión de emergencia

Gafas contra rayos láser

Aire acondicionado

Ropa ligera y suelta

Pausas de descanso en zonas frescas

Adecuada ingestión de líquidos

\begin{tabular}{|c|c|}
\hline Riesgos & Precauciones \\
\hline Frío & $\begin{array}{l}\text { Ropa de abrigo } \\
\text { Pausas de descanso en zonas con calefacción }\end{array}$ \\
\hline Riesgos eléctricos & $\begin{array}{l}\text { Cableado adecuado } \\
\text { Aparatos con toma de tierra } \\
\text { Interruptores de falla a tierra cuando sean } \\
\text { necesarios } \\
\text { Herramientas, guantes, etc. con aislamiento }\end{array}$ \\
\hline Riesgos ergonómicos & $\begin{array}{l}\text { Herramientas e instrumentos ergonómicos y } \\
\text { de dimensiones adecuadas } \\
\text { Puestos de trabajo bien diseñados } \\
\text { Posturas correctas } \\
\text { Pausas para descansar }\end{array}$ \\
\hline \multicolumn{2}{|l|}{ Riesgos de seguridad } \\
\hline Maquinaria & $\begin{array}{l}\text { Dispositivos de protección en máquinas } \\
\text { Interruptor de parada accesible } \\
\text { Mantenimiento adecuado }\end{array}$ \\
\hline $\begin{array}{l}\text { Partículas proyectadas (por } \\
\text { ejemplo, con bruñidoras) }\end{array}$ & $\begin{array}{l}\text { Recinto aislado. Protección de ojos y cara } \\
\text { según necesidades }\end{array}$ \\
\hline Resbalones y caídas & $\begin{array}{l}\text { Limpieza y barrido del suelo y las superficies } \\
\text { de trabajo } \\
\text { Protección contra caídas para trabajo en alturas } \\
\text { Pasamanos y rodapiés en andamios, pasa- } \\
\text { relas, etc. }\end{array}$ \\
\hline Caída de objetos & $\begin{array}{l}\text { Casco de seguridad } \\
\text { Calzado de seguridad }\end{array}$ \\
\hline Riesgo de incendio & $\begin{array}{l}\text { Vías de evacuación de emergencia adecuadas } \\
\text { Extintores, rociadores, etc. apropiados } \\
\text { Simulacros de incendios } \\
\text { Retirada de desechos combustibles } \\
\text { Pruebas contra incendio de las zonas expuestas } \\
\text { Almacenamiento correcto de líquidos inflamables } \\
\text { y gases comprimidos } \\
\text { Buena sujeción y afianzamiento al trabajar con } \\
\text { líquidos inflamables } \\
\text { Alejar las fuentes de ignición de las sustancias } \\
\text { inflamables } \\
\text { Deshacerse adecuadamente de los trapos } \\
\text { empapados en aceites y disolventes }\end{array}$ \\
\hline
\end{tabular}

Riesgos biológicos
Mohos

Control de la humedad

Secar las superficies que tengan agua

Fregar y limpiar el agua derramada

Bacterias, virus
Vacunación en los casos necesarios

Precauciones globales

Desinfección de materiales y superficies contaminadas
- Asma en talladores de marfil de colmillo de elefante en Africa (Armstrong, Neill y Mossop 1988).

- Problemas respiratorios y ergonómicos en tejedores de alfombras en la India (Das, Shukla y Ory, 1992).

- Noventa y tres casos de neuropatía periférica por el empleo de adhesivos con hexano en el proceso de manufacturación de zapatillas en Japón, a finales del decenio de 1960 (Sofue y cols. 1968).
- Parálisis en 44 aprendices de la industria del calzado en Marruecos, causadas por colas hechas con fosfato tri-ortocresilo (Balafrej y cols. 1984).

- Dolores en piernas, brazos y espalda en personas que trabajaban en sus domicilios confeccionando prendas de vestir en la India (Chaterjee 1990).

Uno de los mayores problemas en el sector de las actividades artísticas y artesanales es el desconocimiento existente sobre los 
Tabla 96.2 • Riesgos de las técnicas artísticas.

\begin{tabular}{|c|c|c|}
\hline Técnicas & Materiales/procesos & Riesgos \\
\hline Aerografía & $\begin{array}{l}\text { Pigmentos } \\
\text { Disolventes }\end{array}$ & $\begin{array}{l}\text { Plomo, cadmio, manganeso, cobalto, mercurio, etc. } \\
\text { Alchoholes minerales, esencia de trementina }\end{array}$ \\
\hline Arte comercial & $\begin{array}{l}\text { Cemento de goma } \\
\text { Rotuladores permanentes } \\
\text { Adhesivos en aerosol } \\
\text { Aerografía } \\
\text { Tipografía } \\
\text { Fotóstatos, pruebas }\end{array}$ & $\begin{array}{l}\text { N-hexano, heptano, fuego } \\
\text { Xileno, alcohol de propilo } \\
\text { N-hexano, heptano, 1,1,1-tricloroetano, fuego } \\
\text { Véase Aerografía } \\
\text { Véase Fotografía } \\
\text { Alcalis, alcohol de propilo }\end{array}$ \\
\hline Arte por ordenador & $\begin{array}{l}\text { Ergonomía } \\
\text { Vídeo }\end{array}$ & $\begin{array}{l}\text { Síndrome del túnel carpiano, tendinitis, puestos de trabajo mal diseñados } \\
\text { Destellos, radiación de frecuencia extremadamente baja }\end{array}$ \\
\hline Artesanía de la fibra & $\begin{array}{l}\text { Véase también Batik, Tejido } \\
\text { Fibras animales } \\
\text { Fibras sintéticas } \\
\text { Fibras vegetales }\end{array}$ & $\begin{array}{l}\text { Antrax y otros agentes infecciosos } \\
\text { Formaldehído } \\
\text { Mohos, alergenos, polvo }\end{array}$ \\
\hline Artesanía de la madera & $\begin{array}{l}\text { Trabajo en máquinas } \\
\text { Encolado } \\
\text { Eliminación de pintura } \\
\text { Pintura y acabado } \\
\text { Conservantes }\end{array}$ & $\begin{array}{l}\text { Heridas, polvo de madera, ruido, incendios } \\
\text { Formaldehídos, resinas epóxicas, disolventes } \\
\text { Cloruro de metileno, tolueno, trementina, alcoholmetílico, etc. } \\
\text { Alcoholes minerales, tolueno, alcohol etílico, etc... } \\
\text { Arseniato de cobre cromado, pentaclorofenol, creosota }\end{array}$ \\
\hline Batik & $\begin{array}{l}\text { Ceras } \\
\text { Tintes }\end{array}$ & $\begin{array}{l}\text { Fuego, ceras, vapores de descomposición } \\
\text { Véase Tintes }\end{array}$ \\
\hline Cerámica & $\begin{array}{l}\text { Polvo de arcillas } \\
\text { Barnices } \\
\text { Colado } \\
\text { Cocción en horno }\end{array}$ & $\begin{array}{l}\text { Silice } \\
\text { Silice, plomo, cadmio y otros metales tóxicos } \\
\text { Talco, materiales asbestiformes } \\
\text { Dióxido de azufre, monóxido de carbono, fluoruros, radiación infrarroja, quemaduras }\end{array}$ \\
\hline Cristal soplado & $\begin{array}{l}\text { Hornadas } \\
\text { Hornos } \\
\text { Coloración } \\
\text { Grabado por corrosión } \\
\text { Chorro de arena }\end{array}$ & $\begin{array}{l}\text { Plomo, ślice, arsénico, etc. } \\
\text { Calor, radiación infrarroja, quemaduras } \\
\text { Vapores metálicos } \\
\text { Acido fluorhídrico, floruro amónico }\left(\mathrm{h}^{+}\right) \\
\text {Sílice }\end{array}$ \\
\hline Dibujo & Fijadores por aerosol & N-hexano, otros disolventes \\
\hline Elaboración de papel & $\begin{array}{l}\text { Separación de las fibras } \\
\text { Molino para pasta } \\
\text { Blanqueamiento } \\
\text { Aditivos }\end{array}$ & $\begin{array}{l}\text { Calentamiento de álcalis } \\
\text { Ruidos, lesiones, descargas eléctricas } \\
\text { Blanqueador de cloro } \\
\text { Pigmentos, tintes, etc. }\end{array}$ \\
\hline $\begin{array}{l}\text { Escultura por vaciado a cera } \\
\text { perdida }\end{array}$ & $\begin{array}{l}\text { Revestimiento } \\
\text { Calentamiento de la cera } \\
\text { Horno de crisol } \\
\text { Vertido del metal } \\
\text { Chorro de arena }\end{array}$ & $\begin{array}{l}\text { Cristobalita } \\
\text { Vapores de la descomposición de la cera, monóxido de carbono } \\
\text { Monóxido de carbono, vapores metálicos } \\
\text { Vapores metálicos, radiación infrarroja, metales fundidos, quemaduras } \\
\text { Sílice }\end{array}$ \\
\hline Escultura, arcilla & Véase Cerámica & \\
\hline Escultura, láser & Láser & Radiación no ionizante, riesgos eléctricos \\
\hline Escultura, neón & Tubos fluorescentes & Mercurio, fósforos de cadmio, riesgos eléctricos, radiación ultravioleta \\
\hline Escultura, piedra & $\begin{array}{l}\text { Mármol } \\
\text { Esteatita } \\
\text { Granito, arenisca } \\
\text { Herramientas neumáticas }\end{array}$ & $\begin{array}{l}\text { Polvos molestos } \\
\text { Sílice, talco, materiales asbestiformes } \\
\text { Silice } \\
\text { Vibraciones, ruidos }\end{array}$ \\
\hline Escultura, plásticos & $\begin{array}{l}\text { Resinas epoxídicas } \\
\text { Resinas de poliéster } \\
\text { Resinas de poliuretano } \\
\text { Resinas acrílicas } \\
\text { Fabricación de plásticos }\end{array}$ & $\begin{array}{l}\text { Aminas, éteres de diglicidilo } \\
\text { Estireno, metacrilato de metilo, peróxido de metiletilcetona } \\
\text { Isocianatos, compuestos de organoestaño, aminas, alcoholes minerales } \\
\text { Matacrilato de metilo, peróxido de benzoilo } \\
\text { Compuestos derivados de la descomposición por calor (p. ej., monóxido de carbono, } \\
\text { ácido clorhídrico, ácido cianhídrico, etc.) }\end{array}$ \\
\hline
\end{tabular}

Continúa en la página siguiente. 
Tabla 96.2 • Riesgos de las técnicas artísticas.

Continuación.

\begin{tabular}{|c|c|c|}
\hline Técnicas & Materiales/procesos & Riesgos \\
\hline Esmaltado & $\begin{array}{l}\text { Esmaltes } \\
\text { Cocción en horno }\end{array}$ & $\begin{array}{l}\text { Plomo, cadmio, arsénico, cobalto, etc. } \\
\text { Radiación infrarroja, quemaduras }\end{array}$ \\
\hline Forja & $\begin{array}{l}\text { Con martillo } \\
\text { Forja caliente }\end{array}$ & $\begin{array}{l}\text { Ruidos } \\
\text { Monóxido de carbono, hidrocarburos aromáticos policíclicos, radiación infrarroja, quemaduras }\end{array}$ \\
\hline Fotografía & $\begin{array}{l}\text { Baño de revelado } \\
\text { Baño de paro } \\
\text { Baño de fiiación } \\
\text { Intensificador } \\
\text { Virado } \\
\text { Revelado en color } \\
\text { Impresión en platino }\end{array}$ & $\begin{array}{l}\text { Hidroquinona, sulfato monometilo-p-aminofenol, álcalis } \\
\text { Acido acético } \\
\text { Dióxido de azufre, amoníaco } \\
\text { Dicromatos, ácido clorhídrico } \\
\text { Compuestos de selenio, sulfuro de hidrógeno, nitrato de uranio, dióxido de azufre, sales de oro } \\
\text { Formaldehído, disolventes, reveladores en color, dióxido de azufre } \\
\text { Sales de platino, plomo, ácidos, oxalatos }\end{array}$ \\
\hline Galvanoplastia & $\begin{array}{l}\text { Oro, plata } \\
\text { Otros metales }\end{array}$ & $\begin{array}{l}\text { Sales de cianuro, ácido cianhídrico, riesgos eléctricos } \\
\text { Sales de cianuro, ácidos }\end{array}$ \\
\hline Grabado en hueco & $\begin{array}{l}\text { Corrosión por ácido } \\
\text { Disolventes } \\
\text { Aguatinta } \\
\text { Fotograbado }\end{array}$ & $\begin{array}{l}\text { Acido clorhídrico y ácido nítrico, dióxido de nitrógeno, cloro, clorato potásico } \\
\text { Alcohol, alcoholes minerales, queroseno } \\
\text { Polvo de resina de trementina, explosión de polvos } \\
\text { Eteres de glicol, xileno }\end{array}$ \\
\hline Grabados en relieve & $\begin{array}{l}\text { Disolventes } \\
\text { Pigmentos }\end{array}$ & $\begin{array}{l}\text { Alcoholes minerales } \\
\text { Véase Pigmentos para pinturas }\end{array}$ \\
\hline $\begin{array}{l}\text { Holografía } \\
\text { (Véase también Fotografía) }\end{array}$ & $\begin{array}{l}\text { Láser } \\
\text { Revelado }\end{array}$ & $\begin{array}{l}\text { Radiación no ionizante, riesgos eléctricos } \\
\text { Bromo, pirogalol }\end{array}$ \\
\hline Joyería & $\begin{array}{l}\text { Soldadura de plata } \\
\text { Baños de decapado } \\
\text { Recuperación del oro }\end{array}$ & $\begin{array}{l}\text { Vapores de cadmio, flujos de fluoruros } \\
\text { Acidos, óxidos de azufre } \\
\text { Mercurio, plomo, cianuro }\end{array}$ \\
\hline Litografía & $\begin{array}{l}\text { Disolventes } \\
\text { Acidos } \\
\text { Talco } \\
\text { Fotolitografía }\end{array}$ & $\begin{array}{l}\text { Alcoholes minerales, isoforona, ciclohexanona, queroseno, gasolina, cloruro de metileno, etc. } \\
\text { Nítrico, fosfórico, fluorhídrico, clorhídrico, etc. } \\
\text { Materiales asbestiformes } \\
\text { Dicromatos, disolventes }\end{array}$ \\
\hline Pasteles & Polvos de pigmentos & Véase Pigmentos para pinturas \\
\hline Pintura & $\begin{array}{l}\text { Pigmentos } \\
\text { Aceites alquídicos } \\
\text { Acrílicos }\end{array}$ & $\begin{array}{l}\text { Plomo, cadmio, mercurio, cobalto, compuestos de manganeso, etc. } \\
\text { Alcoholes minerales, trementina } \\
\text { Restos de amoníaco, formaldehídos }\end{array}$ \\
\hline Serigrafía & $\begin{array}{l}\text { Pigmentos } \\
\text { Disolventes } \\
\text { Emulsiones fotográficas }\end{array}$ & $\begin{array}{l}\text { Plomo, cadmio, manganeso y otros pigmentos } \\
\text { Alcoholes minerales, tolueno, xileno } \\
\text { Dicromato de amonio }\end{array}$ \\
\hline Soldadura & $\begin{array}{l}\text { General } \\
\text { Oxiacetileno } \\
\text { Arco } \\
\text { Vapores metálicos }\end{array}$ & $\begin{array}{l}\text { Vapores metálicos, quemaduras, chispas } \\
\text { Monóxido de carbono, óxidos de nitrógeno, gases comprimidos } \\
\text { Ozono, dióxido de nitrógeno, fluoruros y otros vapores de flujos, radiación ultravioleta e infrarroja, } \\
\text { riesgos eléctricos } \\
\text { Oxidos de cobre, zinc, plomo, níquel, etc. }\end{array}$ \\
\hline Talla de piedras preciosas & $\begin{array}{l}\text { Piedras de cuarzo } \\
\text { Corte, pulido }\end{array}$ & $\begin{array}{l}\text { Silice } \\
\text { Ruidos, sílice }\end{array}$ \\
\hline Tejido & $\begin{array}{l}\text { Telares } \\
\text { Tintes }\end{array}$ & $\begin{array}{l}\text { Problemas de tipo ergonómico } \\
\text { Véase Tintes }\end{array}$ \\
\hline Tintes & $\begin{array}{l}\text { Tintes } \\
\text { Mordientes } \\
\text { Asistentes para el teñido }\end{array}$ & $\begin{array}{l}\text { Tintes fibrorreactivos, tintes de bencidina, tintes de naftol, tintes básicos, tintes de dispersión, } \\
\text { tintes de tina } \\
\text { Dicromato de amonio, sulfato de cobre, sulfato de hierro, ácido oxálico, etc. } \\
\text { Acidos, álcalis, hidrosulfito sódico }\end{array}$ \\
\hline Vidrio en color & $\begin{array}{l}\text { Engarce de plomo } \\
\text { Colorantes } \\
\text { Soldadura } \\
\text { Grabado por corrosión }\end{array}$ & $\begin{array}{l}\text { Plomo } \\
\text { Compuestos de plomo } \\
\text { Plomo, vapores de cloruros de zinc, } \\
\text { Acido fluorhídrico, floruro amónico }\left(\mathrm{h}^{+}\right)\end{array}$ \\
\hline
\end{tabular}

Fuente: Adaptado de McCann 1992a. 
riesgos, los procesos, los materiales y la forma de trabajar con seguridad. Muchos artistas y artesanos que desarrollan enfermedades profesionales no llegan a relacionar su dolencia con la exposición a materiales peligrosos, por lo que tienen menos posibilidades de recibir la atención médica adecuada. Y el riesgo lo corren todos los miembros de una familia, no sólo los adultos y menores que trabajan, sino también los más pequeños, ya que estas actividades suelen realizarse en el hogar (McCann y cols. 1986; Knishkowy y Baker 1986).

Un estudio de las tasas de mortalidad proporcional efectuado por el United States National Cancer Institute con 1.746 artistas de raza blanca reveló una elevada incidencia de muerte entre pintores y, en menor medida, otros artistas, debido a cardiopatía arteriosclerótica y a todos los tipos de cáncer. Las tasas de leucemia y cáncer de vesícula, riñón y colorectal fueron notablemente elevadas en pintores varones. Las tasas de mortalidad proporcional también resultaron altas, aunque en menor grado. Un estudio de casos-control de pacientes con cáncer de riñón confirmó un riesgo relativo de 2,5 entre pintores artísticos, lo que confirmó los resultados del estudio de tasas de mortalidad (Miller, Silverman y Blair 1986). Entre otros artistas varones, las tasas de mortalidad proporcional por cáncer colorectal y de riñón resultaron significativamente elevadas.

\section{Artes escénicas y audiovisuales}

Las artes escénicas comprenden tradicionalmente el teatro, la danza, la ópera, la música, los narradores de historias y otras manifestaciones culturales ante el público. Dentro de la música, existen muchos tipos de actuaciones y lugares donde éstas pueden tener lugar: desde el músico que actúa en la calle, en un bar o en una sala de conciertos, hasta las grandes orquestas que actúan en auditorios. Las compañías de teatro y danza pueden ser de distintos tipos: pequeños grupos informales de escolares y universitarios; compañías de carácter no comercial, que están a menudo subvencionadas por instituciones oficiales o privadas, y compañías de teatro comerciales. Los grupos de artes escénicas suelen realizar giras por diferentes localidades.

Con las modernas tecnologías han nacido las artes audiovisuales: radio, televisión, cine, vídeo, etc., a través de las cuales pueden grabarse y emitirse las representaciones escénicas, los cuentos y otros eventos. Hoy en día, las artes audiovisuales constituyen una industria multimillonaria.

Entre los trabajadores de este sector se encuentran los propios protagonistas: actores, músicos, bailarines, periodistas y otras personas que trabajan ante el público. También se incluye el personal técnico y administrativo: carpinteros, artistas escénicos, electricistas, expertos en efectos especiales, equipos de cámaras de cine o televisión, taquilleros, etc., quienes trabajan fuera de escena, detrás de las cámaras o en tareas no artísticas.

\section{Efectos sobre la salud y pautas patológicas}

Los actores, músicos, bailarines, cantantes y otros artistas escénicos también están expuestos a lesiones y enfermedades profesionales, como accidentes, quemaduras, lesiones por esfuerzos repetitivos, alergias e irritación de la piel y vías respiratorias, ansiedad teatral (miedo escénico) y estrés. Muchas de estas lesiones son propias de un determinado grupo de artistas y se verán en artículos aparte. Cualquier problema físico, por leve que sea, afecta al artista de manera que éste no puede desarrollar sus capacidades al cien por cien, lo que origina pérdidas de tiempo e incluso de empleo. En los últimos años, la prevención, el diagnóstico y el tratamiento de las lesiones sufridas por los actores han dado paso a un nuevo campo de la medicina, el dedicado a las artes, que en un principio fue una especialidad de la medicina deportiva (véase "Historia de la medicina de las artes escénicas" en este capítulo).

Un estudio de tasas de mortalidad proporcional entre actores de cine y de teatro reveló un aumento notable de los cánceres de esófago y vejiga entre mujeres, con una tasa 3,8 veces superior en actrices de teatro frente a las de cine (Depue y Kagey 1985). Los actores varones presentaron incrementos significativos de tasas de mortalidad proporcional (aunque no en la tasa global de mortalidad por cáncer) en cáncer de páncreas y colon; la incidencia de cáncer de testículos resultó ser en ambos métodos el doble de lo esperado. Las tasas de mortalidad por suicidios y accidentes (excepto de tráfico) fueron bastante elevadas tanto entre hombres como en mujeres, mientras que los datos sobre cirrosis hepática dieron valores elevados entre los varones.

Un estudio reciente sobre lesiones en 313 actores de 23 espectáculos de Broadway, en Nueva York, reveló que el 55,5 \% había sufrido al menos una lesión, con una media de 1,08 lesiones por individuo (Evans y cols. 1996). Entre los bailarines de Broadway, las lesiones más frecuentes se localizaron en: extremidades inferiores, (52\%), espalda (22\%) y cuello (12\%), propiciadas en gran medida por la inclinación de los escenarios. Las lesiones más frecuentes entre los actores se localizaron en: extremidades inferiores (38\%), zona lumbar (15\%) y cuerdas vocales (17\%). Los humos y nieblas artificiales en el escenario fueron algunas de las causas principales de estas últimas.

En 1991, el United States National Institute for Occupational Safety and Health investigó los efectos sobre la salud de la niebla artificial empleada en los escenarios de cuatro espectáculos de Broadway (Burr y cols. 1994). En todos ellos la niebla artificial estaba hecha principalmente con glicol, aunque en un caso también se utilizó aceite mineral. En un estudio mediante cuestionarios entre 134 actores de estos espectáculos, con un grupo de control de 90 actores de cinco espectáculos que no empleaban niebla artificial, se encontraron más síntomas entre los actores expuestos a los efectos de la niebla artificial. Entre ellos, afecciones de las vías respiratorias inferiores (irritación de mucosas y fosas nasales) y de las altas (tos, sibilancias, broncoespasmos y disnea). El estudio de seguimiento no pudo demostrar una correlación expresa entre la exposición a la niebla artificial y el asma, quizá debido al corto número de respuestas.

En la industria del cine hay un índice elevado de accidentes, hasta el punto de que en California se clasifica la actividad como "de alto riesgo", en gran parte debido a los ejercicios acrobáticos de los actores especialistas. En el decenio de 1980 ocurrieron más de 40 accidentes mortales en el rodaje de películas producidas en Estados Unidos (McCann 1991). Entre 1980 y 1988 las estadísticas en California arrojan un índice de 1,5 muertes por cada 1.000 heridos, en comparación con la media global de 0,5 en ese Estado durante en el mismo período.

Numerosos estudios demuestran que entre los bailarines se dan índices elevados de síndrome de sobrecarga física y lesiones agudas. Entre los bailarines de ballet se aprecia una acentuada incidencia del síndrome de sobrecarga física $(63 \%)$, de fracturas por estrés (26\%) y de afecciones graves $(51 \%)$ y leves $(48 \%)$ a lo largo de sus carreras profesionales (Hamilton y Hamilton 1991). Un estudio con cuestionarios entre 141 bailarines (80 mujeres), de 18 a 37 años de edad, de siete compañías de ballet y baile moderno profesional del Reino Unido, reveló que $118(84 \%)$ de los bailarines sufrieron al menos una lesión relacionada con el baile y que afectó a su profesión, y en 59 casos $(42 \%)$ tuvieron lugar en los últimos seis meses (Bowling 1989). Setenta y cuatro de ellos (53 \%) manifestaron sufrir al menos una lesión crónica. Entre éstas, las más comunes se localizaron en la espalda, el cuello y los tobillos. 
Al igual que ocurre con los bailarines, entre los músicos también se dan numerosos casos de síndrome de sobrecarga física. En un estudio mediante cuestionarios llevado a cabo en 1986 por la Conferencia Internacional de Músicos Sinfónicos y de Opera, entre 4.025 miembros de 48 orquestas de EE.UU., se pudo comprobar que en un $76 \%$ de las 2.212 respuestas recibidas aparecían problemas médicos que afectaban al ejercicio de la profesión, y en un $36 \%$ se trataba de patologías graves (Fishbein 1988). La más frecuente fue el síndrome de sobrecarga física, presente en un $78 \%$ de los músicos de instrumentos de cuerda. Otro estudio efectuado en 1986 en ocho orquestas de Australia, Estados Unidos e Inglaterra, constató un porcentaje del $64 \%$ de casos de síndrome de sobrecarga física, de los cuales el $42 \%$ presentaba un nivel de síntomas significativo (Frye 1986).

La pérdida auditiva entre los músicos de rock es un tema del que se ha ocupado ampliamente la prensa. Ahora bien, también se produce entre los intérpretes de musica clásica. En un estudio se midieron los niveles de sonido en el Lyric Theatre y en el Concert Hall de Gotenburgo, Suecia, y se registraron cifras de 83 a 89 dBA. Las pruebas de audición que se hicieron a 139 músicos de ambos sexos, pertenecientes a los citados teatros, demostraron que $59(43 \%)$ presentaban umbrales de tono puro por debajo de lo correspondiente a su edad, siendo el grupo de los músicos de instrumentos de viento los que acusaban mayor pérdida de audición (Axelsson y Lindgren 1981).

En un estudio efectuado entre1994 y 1996 sobre el nivel de ruido en los fosos de las orquestas de nueve espectáculos de Broadway, en la ciudad de Nueva York, se constataron medias de niveles de ruido entre 84 y $101 \mathrm{dBA}$, con funciones de una duración media de dos horas y treinta minutos (Babin 1996).

El colectivo de carpinteros, artistas escénicos, electricistas, cámaras y el resto del personal técnico de apoyo están expuestos, entre otros, a los peligros de los productos químicos de los materiales empleados en establecimiento de decorados, atrezo y vestuarios. Muchos de estos productos también se utilizan en las artes plásticas. Por desgracia, no se dispone de estadísticas sobre este colectivo de trabajadores.

\section{Actividades culturales y recreativas}

Esta sección abarca varias industrias recreativas y de divertimento que no contemplan los epígrafes "Actividades artísticas y artesanales" y "Artes escénicas y audiovisuales": museos y galerías de arte; acuarios y parques zoológicos; parques y jardines botánicos; circos, parques de atracciones y temáticos; corridas de toros y rodeos; deportes profesionales; industria del sexo y establecimientos de diversión nocturnos.

\section{Efectos sobre la salud y pautas patológicas}

La industria de las actividades culturales y recreativas comprende numerosas y variadas profesiones: actores y músicos, técnicos, conservadores de museos, encargados de animales, vigilantes de parques de atracciones, empleados de restaurantes, personal de limpieza y mantenimiento, etcétera. Gran parte de los riesgos inherentes a las artes y los oficios, y a las artes escénicas y audiovisuales están presentes también entre determinados grupos de trabajadores de la industria de las actividades culturales y recreativas. Son colectivos que se exponen además a otros riesgos profesionales: productos de limpieza, plantas tóxicas, animales peligrosos, SIDA, zoonosis, drogas peligrosas, situaciones de violencia, etc. Dada la variedad y dispersión de esta industria, no existen estadísticas generales sobre lesiones y enfermedades profesionales; las estadísticas disponibles se incluyen en los artículos correspondientes.

\section{DIBUJO, PINTURA Y GRABADOS}

Jack W. Snyder

El dibujo consiste en hacer marcas en una superficie con el fin de expresar sentimientos, experiencias o visiones. El soporte más común es el papel, y entre los instrumentos se hallan los secos, como el carboncillo, los lápices de colores, de tiza, de grafito, punta metálica y pasteles; y líquidos, como tintas, rotuladores y pinturas. La pintura se basa en la aplicación de un medio líquido, acuoso o no acuoso (pintura), sobre una superficie aprestada, con una capa de imprimación y obturada, como un lienzo, un papel o una tabla. Entre los medios acuosos están la acuarela, el temple, los polímeros acrílicos, el látex y el fresco. Los no acuosos son el aceite de linaza, los barnices y desecantes, las resinas alquídicas, la cera derretida o encáustica, los acrílicos de disolventes orgánicos, las resinas epóxicas, los esmaltes, los colorantes y las lacas. Las pinturas y tintas suelen estar hechas con agentes colorantes (tintes y pigmentos), un medio líquido (disolventes orgánicos, aceite o agua), aglutinantes, espesantes, antioxidantes, conservantes y estabilizantes.

Los grabados son obras de arte realizadas mediante el traslado de una imagen entintada de una superficie (taco, pantalla o plancha de metal o piedra) a un papel, plástico o tejido. El proceso del grabado consta de los pasos siguientes: a) preparación de la imagen; $b$ ) grabado, y c) limpieza final. Al repetir el paso del grabado pueden realizarse múltiples copias de la imagen; por el contrario, las monoimpresiones sólo permiten una única reproducción.

En el grabado en hueco se practican incisiones lineales por medios mecánicos (grabado, punta seca) o por corrosión de una plancha metálica con ácido para crear zonas hendidas en la plancha que forman la imagen. Para proteger las zonas de la plancha que no deben ser atacadas por el ácido se utilizan diferentes sustancias protectoras con disolventes y otros materiales, como resina de trementina y pinturas en aerosol (aguatinta). En el grabado, la tinta (fabricada con aceite de linaza) se pasa por la plancha con un rodillo y se retira la tinta sobrante, con lo que la tinta se queda únicamente en las zonas y líneas hendidas. La impresión del grabado se realiza colocando el papel sobre la plancha entintada y presionándolo con una prensa para trasladar la imagen al papel.

El grabado en relieve se realiza rebajando las partes de la plancha de madera o linóleo que no van a grabarse, dejando la imagen resaltada; ésta se recubre con tintas acuosas o grasas y se traspasa al papel.

La litografía con piedra se basa en el dibujo de una imagen con lápices grasos u otros materiales que la hagan receptiva a la tinta hecha con aceite de linaza, tratando luego la plancha con ácidos para que las zonas que no corresponden a la imagen reaccionen receptivamente al agua y repelan la tinta. La imagen se lava con alcoholes minerales u otros disolventes, se entinta con un rodillo y se procede a su impresión. La litografía con planchas metálicas suele necesitar un contragrabado previo con sales de dicromato. Cuando las tiradas son grandes, las planchas metálicas se tratan con lacas de vinilo que contienen disolventes de cetonas.

La serigrafía es un proceso de estarcido en el que se realiza una imagen en negativo sobre una pantalla de tela, bloqueando algunas zonas de la misma. Cuando se utilizan tintas a base de agua, el material de bloqueo no debe ser soluble en agua, y viceversa. A menudo se utilizan plantillas de plástico recortadas que se adhieren a la pantalla por medio de disolventes. La impresión se lleva a cabo aplicando la tinta a la pantalla de manera que atraviese las partes sin bloquear, lo que crea una imagen en 
Figura 96.1 - Serigrafía con campana extractora.

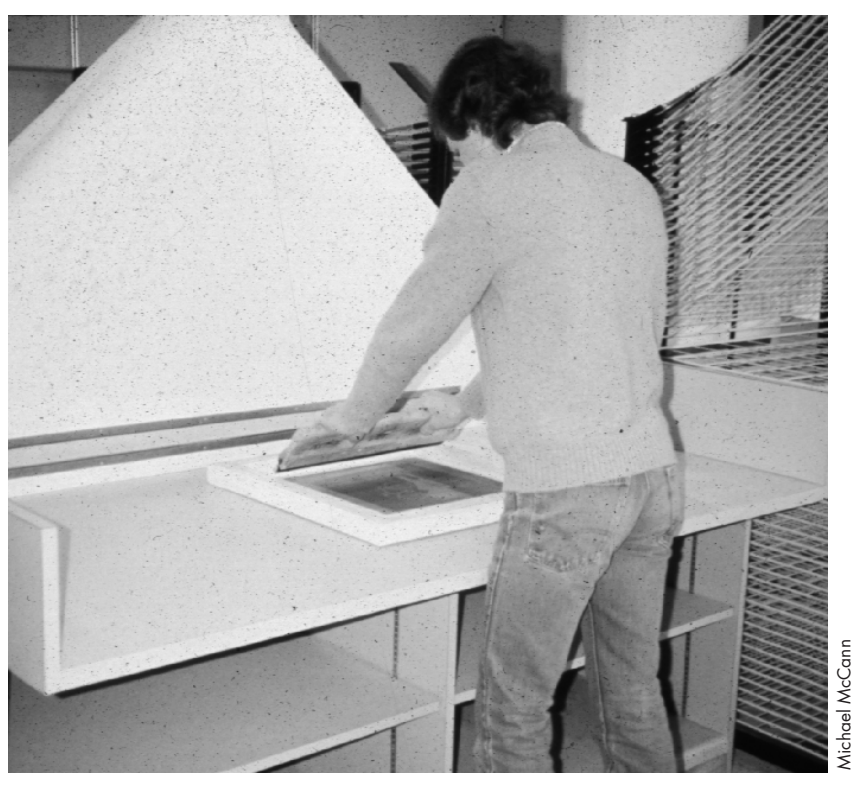

positivo que se recoge en el papel colocado bajo la pantalla. Cuando se realizan impresiones de series numerosas se liberan al aire grandes cantidades de vapores de disolventes.

Las impresiones a partir de un "collage" (collagraph, en inglés) se hacen mediante técnicas de grabado en hueco o en relieve sobre una superficie o "collage" a los que se ha dado textura previamente, que pueden estar hechos de distintos materiales pegados con colas a la plancha.

El fotograbado puede hacerse con planchas fotosensibles (diazos) para litografía o grabado en hueco, o aplicando la emulsión fotográfica directamente sobre la plancha o la piedra. A menudo se emplea una mezcla de goma arábiga y dicromatos sobre la piedra litográfica (grabado a la goma). La imagen fotográfica se traslada a la plancha y ésta se expone a la luz ultravioleta (por ejemplo, bombillas de arco de carbono, lámparas de xenón o luz del sol). Con el revelado, las partes no expuestas de la emulsión fotográfica se borran y se imprime la plancha. Los materiales de las películas y reveladores suelen contener álcalis y disolventes peligrosos. En los procesos de fotoserigrafía puede aplicarse directamente sobre la pantalla una emulsión de dicromatos o diazos, o, indirectamente, adherir una película fotosensible a la pantalla después de la exposición.

En las técnicas de grabado con tintas grasas, la tinta se limpia con disolventes, aceites vegetales o detergente lavavajillas. Los disolventes se utilizan igualmente para limpiar los rodillos de aplicar la tinta. Las tintas acuosas se limpian con agua, y las que llevan disolventes se limpian con grandes cantidades de disolventes, lo que convierte este paso en uno de los pasos más peligrosos del proceso de grabado. Las emulsiones fotosensibles se eliminan de las pantallas con blanqueadores de cloro o detergentes con enzimas.

Los dibujantes, pintores y grabadores están expuestos a graves riesgos para la salud y la seguridad. Los más importantes se deben a los ácidos (en litografía y grabado en hueco), los alcoholes (en pinturas, goma lacas, resinas, diluyentes de barnices y decapantes), álcalis (en pinturas, baños de tinte, reveladores y líquidos para limpiar películas), polvos (en tizas, carboncillos y pasteles), gases (en aerosoles y en los procesos de grabado, litografiado y fotografiado), metales (en pigmentos, productos químicos para fotografía y emulsiones), vahos (en aerosoles, aerógrafos y aguatintas), pigmentos (en tintas y pinturas), polvo (en pigmentos secos, sustancias químicas para fotografía, resinas, talco, yeso), conservantes (en pinturas, colas, endurecedores y estabilizantes) y disolventes (como hidrocarburos alifáticos, aromáticos y clorados, éteres de glicol y cetonas). Las vías de exposición más frecuentes son la inhalación, la ingestión y el contacto con la piel.

Algunos de los problemas de salud mejor documentados entre pintores, dibujantes y grabadores son: lesiones en los nervios periféricos por n-hexano en estudiantes de arte que utilizan pegamentos de caucho y adhesivos en aerosoles; lesiones en el sistema nervioso central y periférico causados por disolventes en serigrafistas; supresión de médula ósea relacionada con el uso de disolventes y éteres de glicol en litógrafos; crisis o agudizaciones asmáticas tras la exposición a aerosoles, vapores, polvos, mohos o gases; ritmo cardíaco anormal tras la exposición a disolventes de hidrocarburos, como el cloruro de metileno, el freón, el tolueno y el 1,1,1-tricloroetano, presentes en colas y líquidos correctores; quemaduras en la piel, las fosas nasales y las mucosas por ácidos, álcalis y fenoles; lesiones hepáticas causadas por disolventes orgánicos; e irritación, inmunorreacción, erupción y ulceración en la piel por exposición al níquel, a los cromatos y dicromatos, a las resinas epóxicas, a la esencia de trementina y al formaldehído.

Aunque no están bien documentados, el dibujo, la pintura y el grabado están asociados a un aumento en el riesgo de leucemia, tumores renales y de vejiga. Entre los carcinógenos a los que están expuestos pintores, dibujantes y grabadores se incluyen: cromatos y dicromatos, difenilos policlorados, tricloroetileno, ácido tánico, cloruro de metileno, glicidol, formaldehído y compuestos de cadmio y arsénico.

Algunas de las medidas preventivas más importantes en pintura, dibujo y grabado son: la sustitución de materiales que contienen agua por otros que contienen disolventes orgánicos; la instalación de una correcta ventilación de dilución y ventilación aspirante local (véase la Figura 96.1); una adecuada manipulación, etiquetado, almacenamiento y desecho de pinturas, líquidos inflamables y disolventes usados; la utilización de equipos de protección individual, como guantes, delantales, gafas protectoras y respiradores; el rechazo a los productos que contengan metales tóxicos, sobre todo plomo, cadmio, mercurio, arsénico, cromatos y manganeso. Entre los disolventes cuyo uso hay que evitar se encuentran los que contienen benceno, tetracloruro de carbono, metil n-butilcetona, n-hexano y tricloroetileno.

Otras medidas destinadas a reducir los riesgos para la salud asociados a la pintura, el dibujo y el grabado son: educar a los jóvenes artistas, de manera constante y desde sus comienzos, sobre los peligros que entrañan los productos y materiales, y adoptar leyes que hagan obligatorio el etiquetado de los productos artísticos donde se advierta de los peligros para la salud y la seguridad a corto y largo plazo.

\section{ESCULTURA}

Giuseppe Battista

En el pasado, el grabado y la talla de la piedra, la madera, el hueso y otros materiales eran artes escultóricas. Más tarde, la escultura desarrolló y adoptó técnicas más refinadas para modelar arcilla y escayola, así como métodos de moldeado y soldadura de metales y vidrio. A lo largo del último siglo se han incorporado a la escultura nuevas técnicas y materiales: espuma 
Tabla 96.3 • Riesgos de las piedras comunes.

$\begin{array}{ll}\begin{array}{l}\text { Componentes peligrosos } \\ \text { Silice cristalina libre }\end{array} & \text { Piedras } \\ & \begin{array}{c}\text { Piedras duras: granito, basalto, jaspe, } \\ \text { pórfiro, ónix, pietra serena } \\ \text { Piedras blandas: esteatita (jaboncillo de } \\ \text { sastre), arenisca, pizarra, arcillas, } \\ \text { algunas calizas }\end{array} \\ \text { Posible contaminación por asbesto } & \text { Piedras blandas: esteatita, serpentina } \\ \text { Silice libre y asbesto } & \text { Piedras duras: mármol, travertino } \\ & \text { Piedras blandas: alabastro, toba, } \\ & \text { mármol, yeso }\end{array}$

plástica, papel, materiales encontrados y diferentes fuentes de energía, como la luz, la energía cinética, etc. Por otra parte, muchos escultores modernos persiguen la participación activa del espectador.

En la escultura es frecuente aprovechar el color natural de los materiales y tratar las superficies para obtener un determinado color, resaltar sus características naturales o modificar los reflejos de la luz. Son técnicas que se aplican en la fase final de la obra de arte. Los riesgos para la salud y la seguridad de los artistas y de sus ayudantes tienen su origen en las características de los materiales; en la utilización de herramientas y equipos; en las diversas fuentes de energía (sobre todo la eléctrica) que requiere el funcionamiento de las herramientas, y en el calor desprendido en la soldadura y otras técnicas de fundido.

La falta de información entre los artistas y la concentración en su trabajo son factores que explican la escasa atención que suelen prestar a las medidas de seguridad, lo que puede originar graves accidentes y la aparición de enfermedades profesionales.

Algunos riesgos están ligados al diseño del lugar de trabajo o a la organización de éste (p. ej., por realizar demasiadas tareas al mismo tiempo). Aunque los riesgos de este tipo existen en todos los lugares de trabajo, en el ámbito de las actividades artísticas y artesanales las consecuencias pueden ser mucho más graves.

\section{Precauciones generales}

Pueden citarse las siguientes: un diseño apropiado del estudio, que tenga en cuenta el tipo de fuentes de energía utilizadas y la ubicación y movilidad de los materiales; separación de las actividades peligrosas, señaladas por carteles de advertencia; instalación de sistemas de extracción para controlar y eliminar polvos, gases, humos, vapores y aerosoles; utilización de equipos de protección individual adecuados y de la talla correcta; instalaciones de limpieza eficaces, como duchas, lavabos, fuentes para el lavado de ojos, etc.; conocimiento suficiente de los riesgos que comporta la utilización de sustancias químicas y de las normativas que rigen su uso, con el fin evitar, o al menos reducir, daños potenciales; información actualizada acerca de los posibles riesgos de accidente y de las normas en materia de higiene, y formación sobre primeros auxilios. Es necesario que haya una ventilación aspirante local que elimine el polvo en suspensión en el aire junto al lugar en que éste se produce, que es donde suele ser más abundante. Asimismo, es recomendable aspirar, en seco o con agua, o fregar el suelo y las superficies de trabajo todos los días.

\section{Principales técnicas de escultura}

La escultura en piedra comprende el tallado de piedras duras y blandas, piedras preciosas, escayola, cemento, etc. El modelado de esculturas se realiza con materiales más dúctiles: modelado y vaciado en escayola y arcilla, talla de madera, trabajo de metales, soplado de vidrio, la escultura en plástico y en otros materiales, así como otras técnicas mixtas. Véanse también los artículos "Metalistería" y "Artesanía de la madera". El soplado del vidrio se trata en el capítulo Vidrio, cerámica y materiales similares.

\section{Escultura en piedra}

La piedras empleadas en escultura se dividen en duras y blandas. Las blandas se trabajan manualmente con sierras, cinceles, martillos o limas, y también con herramientas eléctricas.

Las piedras duras, como el granito, y otros materiales, como los bloques de cemento, se emplean también para crear obras de arte y objetos decorativos, para lo cual se necesitan herramientas eléctricas o neumáticas, aunque los acabados pueden hacerse manualmente.

\section{Riesgos}

La inhalación prolongada de grandes cantidades del polvo de ciertas piedras que contienen sílice cristalina libre, producido en superficies recién cortadas, puede causar silicosis. Con las herramientas eléctricas y neumáticas se produce una mayor concentración de polvo en el aire, que, por otra parte, es más fino que el generado con herramientas manuales. El mármol, el travertino y la piedra caliza son materiales inertes y no entrañan riesgos para los pulmones; el yeso (sulfato de calcio) irrita la piel y las mucosas.

La inhalación de fibras de asbesto, incluso en pequeñas cantidades, puede causar cáncer de pulmón (laringe, tráquea, bronquios, pulmón y pleura) y posiblemente cáncer del tubo digestivo y otros órganos. Tales fibras se hallan presentes en la serpentina y en el talco. La asbestosis (fibrosis pulmonar) sólo se contrae por inhalación de dosis elevadas de fibras de asbesto, algo no frecuente en este oficio (véase la Tabla 96.3, que resume los peligros que entrañan las piedras más comunes).

Los martillos neumáticos, las sierras y lijadoras eléctricas y las herramientas manuales producen niveles elevados de ruido que pueden causar pérdidas de audición y otros problemas en el sistema nervioso autónomo (incremento del índice cardíaco, alteraciones gástricas, etc.), trastornos psicológicos (irritabilidad, pérdida de concentración, etc.), y otros problemas de salud de carácter general, como dolor de cabeza.

El uso de herramientas neumáticas y eléctricas puede provocar lesiones en la microcirculación de los dedos y facilitar la aparición del fenómeno de Raynaud, así como patologías degenerativas en el antebrazo.

Cuando se trabaja en posiciones difíciles o se levantan objetos pesados pueden aparecer molestias lumbares, contracturas musculares, artritis y bursitis en las articulaciones (rodilla, codo).

El riesgo de accidente suele estar relacionado con la utilización de herramientas afiladas activadas por una fuerza (manual, eléctrica o neumática) de gran potencia. Al romper la piedra, las esquirlas suelen salir proyectadas con violencia al entorno de trabajo; también se producen desplazamientos y caídas de bloques y superficies incorrectamente fijados. El agua empleada en los distintos procesos puede hacer resbaladizos los suelos y originar cortocircuitos.

Los pigmentos y colorantes (especialmente en aerosoles) utilizados para aplicar las capas finales (pinturas y lacas) exponen al trabajador a la inhalación de compuestos tóxicos (plomo, cromo, níquel), irritantes o alérgicos (acrílicos y resinas); estos últimos pueden afectar a las mucosas y al tracto respiratorio.

La inhalación de emanaciones de disolventes de pinturas en cantidades importantes durante una jornada de trabajo, o de pequeñas cantidades durante más tiempo, puede causar trastornos agudos o crónicos del sistema nervioso central. 


\section{Precauciones}

El alabastro es una alternativa más segura que la esteatita y otras piedras blandas peligrosas.

Deben utilizarse herramientas neumáticas o eléctricas que dispongan de un colector de polvo. El local de trabajo ha de limpiarse con frecuencia, con una aspirador o una fregona, y debe contar con una ventilación adecuada.

Hay aparatos respiradores que protegen al sistema respiratorio de la inhalación de polvos, disolventes y vapores de aerosoles. Los oídos pueden protegerse con tapones, y los ojos con gafas protectoras. Los guantes de cuero previenen posibles accidentes en las manos, y los de goma, más finos y forrados de algodón, sirven para evitar el contacto de la piel con sustancias químicas. Debe usarse calzado de seguridad y antideslizante para evitar lesiones en los pies causadas por la caída de objetos pesados. Durante las operaciones largas y complicadas debe vestirse ropa apropiada, y no llevar corbatas, bisutería ni cualquier otra prenda que pueda engancharse en las máquinas. El cabello largo ha de recogerse o cubrirse con un gorro. También es conveniente tomar una ducha después de cada jornada de trabajo y no llevar a casa la ropa y el calzado de trabajo.

Los compresores de las herramientas neumáticas deben colocarse alejados de la zona de trabajo; las zonas donde el ruido sea habitual deben aislarse, y durante la jornada de trabajo han de hacerse pausas frecuentes en sitios confortables. Se utilizarán herramientas neumáticas y eléctricas con mangos cómodos (equipados con amortiguadores de descargas, siempre que sea posible) que eviten el flujo de aire directo sobre las manos del operador, y se recomiendan los estiramientos y masajes durante la jornada de trabajo.

Las herramientas cortantes deben utilizarse a la mayor distancia posible del cuerpo y de las manos, y nunca deben usarse herramientas deterioradas.

Las sustancias inflamables (pinturas, disolventes) deben mantenerse alejadas de las llamas, los cigarrillos encendidos o cualesquiera otras fuentes de calor.

\section{Modelado de esculturas}

El material más común en esta modalidad de escultura es la arcilla (arcilla blanda natural o mezclada con agua); también se utilizan cera, escayola, hormigón y plástico (a menudo reforzado con fibra de vidrio).

La facilidad para modelar figuras depende directamente de la maleabilidad del material empleado, y suele hacerse con herramientas de madera, metal o plástico.

Algunos materiales, como las arcillas, pueden endurecerse tras el calentamiento en un horno. El talco se emplea también como arcilla semilíquida (barbotina), y puede vertirse en moldes y cocerse en el horno una vez seca.

Son arcillas similares a las utilizadas en la industria de la cerámica y pueden contener cantidades considerables de sílice cristalina libre (véase el artículo "Cerámica").

Las arcillas no endurecidas, como la plastilina, contienen partículas finas de arcillas mezcladas con aceites vegetales, conservantes y, en ocasiones, disolventes. Las arcillas endurecidas, también llamadas arcillas de polímeros, están compuestas de cloruro de polivinilo y sustancias plastificantes, como diversos ftalatos.

Para modelar la cera, primero se calienta y luego se vierte en moldes. Puede hacerse también con herramientas calientes. Las ceras contienen compuestos naturales o sintéticos (ceras de colores). Muchos tipos de ceras se disuelven con sustancias como el alcohol, la acetona, los alcoholes minerales, el aguarrás, la ligroína y el tetracloruro de carbono.
Tabla 96.4 • Principales riesgos derivados de la utilización de materiales empleados en el modelado de esculturas.

$\begin{array}{ll}\text { Materiales } & \text { Riesgos y precauciones } \\ \text { Arcillas } & \begin{array}{l}\text { Riesgos: silice cristalina libre; el talco puede estar contami- } \\ \text { nado por asbesto; durante las operaciones de calenta- } \\ \text { miento pueden liberarse gases tóxicos. }\end{array}\end{array}$

Precauciones: Véase "Cerámica".

Plastilina Riesgos: los disolventes y conservantes pueden provocar irritación de piel y mucosas, además de reacciones alérgicas en determinadas personas.

Precauciones: los individuos sensibles deben buscar otros materiales.

Arcillas duras Riesgos: algunos agentes endurecedores y plastificantes (ftalatos) de arcillas pueden ser tóxicos para el aparato reproductor o cancerígenos. Durante los procesos de calentamiento puede liberarse ácido clorhídrico, especialmente si se produce un exceso de calentamiento.

Precauciones: evitar el calentamiento en exceso y la utilización de hornos destinados a cocinar alimentos.

Ceras Riesgos: los vapores sobrecalentados son inflamables y potencialmente explosivos. Los vapores de acroleína, producidos por la descomposición de las ceras sobrecalentadas, son potentes irritantes y sensibilizantes de las vías respiratorias. Los disolventes de ceras pueden resultar tóxicos por contacto o inhalación; el tetracloruro de carbono es cancerígeno y muy tóxico para el hígado y los riñones.

Precauciones: evitar llamas abiertas. No utilizar placas eléctricas calientes con elementos que generen calor. Calentar a la mínima temperatura posible. No utilizar tetracloruro de carbono.

Plásticos tratados Riesgos: el calentamiento, el procesamiento con máquinas y el corte de plásticos puede provocar la descomposición de materiales peligrosos, tales como cloruro de hidrógeno (del cloruro de polivinilo), cianuro de hidrógeno (de los poliuretanos y plásticos), estireno (del poliestireno) y monóxido de carbono, de la combustión de plásticos. Los disolventes empleados para encolar plásticos también entrañan riesgos de incendio y riesgos para la salud.

Precauciones: ventilación adecuada al trabajar con plásticos y disolventes.

Resinas plásticas Riesgos: la mayoría de los monómeros de resinas (por ejemplo, estireno, metacrilato de metilo, formaldehído) son peligrosos en caso de contacto con la piel o inhalación. El endurecedor de peróxido de metiletilcetona para las resinas de poliéster puede causar ceguera si salpica a los ojos. Los endurecedores epoxídicos son irritantes y sensibilizadores de la piel y vías respiratorias. Los isocianatos empleados en las resinas de poliuretano pueden causar crisis graves de asma.

Precauciones: ventilación adecuada cuando se trabaje con resinas, equipo de protección individual (guantes, aparatos respiradores, gafas especiales), medidas de prevención de incendios, etc. No utilizar resinas de poliuretano en aerosol.

Cristal soplado Véase Vidrio, cerámica y materiales similares. 
La escayola, el hormigón y el papel mâché tienen características distintas: no es necesario calentarlos ni fundirlos, y se trabajan en marcos de metal o de fibra de vidrio, o se introducen en moldes.

En las técnicas de escultura en plástico se distinguen dos categorías principales:

- el modelado con materiales previamente polimerizados (fundido, plancha o lámina) que pueden calentarse, ablandarse, encolarse, cortarse, refinarse, pulirse, etc.,

- el modelado con plásticos no polimerizados. El material se trabaja con monómeros, produciéndose una reacción química que origina la polimerización.

Los plásticos pueden estar hechos de poliéster, poliuretano, aminorresinas, resinas fenólicas, resinas acrílicas, resinas epóxicas y resinas de silicona. Durante la polimerización pueden verterse en moldes, aplicarse manualmente, imprimirse, laminarse y rayarse con catalizadores, aceleradores, endurecedores, pesos y pigmentos.

En la Tabla 96.4 figuran los riesgos y precauciones relacionados con los materiales más comunes en las distintas actividades de modelado.

\section{- FotOGRAFIA}

\section{David Richardson}

\section{Fotografía en blanco y negro}

En el trabajo de la fotografía en blanco y negro, el papel o la película expuestos se extraen de un envase estanco a la luz en un cuarto oscuro para sumergirlos en sucesivas cubetas con disoluciones de líquido revelador, baño de paro y fijador. Después del lavado en agua y una vez secos, la película o el papel están listos para su uso. El líquido revelador convierte el haluro de plata expuesto a la luz en plata metálica. El baño de paro es una solución ligeramente ácida que neutraliza la disolución alcalina del revelador, deteniendo el proceso de reducción del haluro de plata. El fijador forma un complejo soluble con el haluro de plata sin exponer, el cual, en combinación con diversas sales solubles en agua, con amortiguadores e iones de haluro, es eliminado de la emulsión en los procesos de lavado. Los rollos de película pueden revelarse también dentro de una cubeta a la que se añaden las distintas disoluciones.

\section{Riesgos potenciales para la salud}

Debido a la extensa variedad de fórmulas empleadas por cada fabricante, y a los diferentes métodos de empaquetado y mezclado de los productos fotográficos, sólo pueden hacerse recomendaciones generales acerca de los riesgos que presenta la fotografía en blanco y negro. La afección más común es la dermatitis de contacto, originada principalmente por el contacto de la piel con los líquidos reveladores. Se trata de soluciones alcalinas que suelen contener hidroquinona y, en algunos casos, p-metilaminofenolsulfato (conocido también como metol o KODAK ELON). Los reveladores irritan la piel y los ojos y pueden causar reacciones alérgicas de la piel en individuos sensibles. El ácido acético es el componente más peligroso en los baños de paro. Aunque los baños de paro concentrados son muy ácidos y pueden causar quemaduras por contacto en piel y ojos, las soluciones de trabajo sólo presentan una capacidad irritante baja o moderada. Los fijadores contienen tiosulfato de sodio (hypo) y diferentes sulfitos (por ejemplo, metabisulfito sódico) y no entrañan grandes riesgos para la salud.

Además de los riesgos para la piel y los ojos, existe el peligro de inhalación de gases y vapores de determinadas soluciones fotográficas, sin olvidar las molestias que producen los malos olores, especialmente en locales insuficientemente ventilados. Algunos productos químicos empleados en fotografía (por ejemplo, los fijadores) emiten gases, como el amoníaco o el dióxido de azufre, generados por degradación de las sales de amonio y sulfito, respectivamente. Son gases que, al igual que el ácido acético que desprenden los baños de paro, pueden irritar las vías respiratorias superiores y los ojos. El efecto irritante de estos gases y vapores depende de la concentración, aunque la exposición normal de los trabajadores que manejan estos productos no suele llegar a niveles de riesgo. Las personas más sensibles (con problemas de salud previos, como el asma) pueden presentar síntomas tras exposiciones por debajo de los límites habituales en la profesión. Debido al bajo umbral de olor de los productos químicos, son fáciles de detectar. Aunque el fuerte olor no implica necesariamente peligro para la salud, la existencia de olores fuertes, o de el aumento en la intensidad de éstos pueden indicar que el sistema de ventilación no es el adecuado y que precisa ser revisado.

\section{Gestión de riesgos}

La clave para trabajar de forma segura con los productos químicos de fotografia es conocer los posibles riesgos para la salud que entraña la exposición a ellos y mantener los niveles de riesgo en valores aceptables. El reconocimiento y control de dichos riesgos empieza por leer y comprender las etiquetas de los productos y las fichas técnicas de seguridad.

En el cuarto oscuro es importante evitar el contacto de la piel con los productos del revelado. Los guantes de neopreno resultan muy útiles como medida de prevención, sobre todo en las zonas donde se mezclan los distintos productos y donde se encuentran las soluciones más concentradas. Los guantes deben tener un espesor suficiente para reducir la posibilidad de rasgaduras o agujeros y deben revisarse y lavarse con frecuencia, por fuera y por dentro, a ser posible con jabón de manos no alcalino. Además de los guantes deben utilizarse pinzas para evitar el contacto con la piel. Las cremas protectoras no son recomendables para trabajar con productos químicos, ya que algunos de ellos pueden traspasarlas y se corre el riesgo de contaminar las diferentes soluciones fotográficas. Sí conviene utilizar delantales y batas de laboratorio dentro del cuarto oscuro, así como lavar frecuentemente la ropa de trabajo. Se recomienda asimismo llevar gafas protectoras, especialmente en las zonas donde se manipulan líquidos fotográficos concentrados.

En caso de contacto de la piel con estos productos, debe lavarse la zona afectada lo antes posible con agua abundante. Ya que algunos de los materiales empleados, como los reveladores, son alcalinos, puede reducirse el riesgo de que se produzca una dermatitis utilizando un jabón no alcalino (con un pH de 5,0 a 5,5) para lavarse las manos. La ropa ensuciada por un producto químico debe cambiarse de inmediato, y cualquier salpicadura o derrame ha de limpiarse nada más producirse. En las zonas destinadas al revelado y las mezclas es importante disponer de medios para lavarse las manos y enjuagarse los ojos, y cuando se utiliza ácido acético glacial o concentrado también debe contarse con duchas para emergencias.

Otro aspecto fundamental en lo que respecta a la seguridad en el cuarto oscuro es la existencia de una ventilación adecuada. La cantidad necesaria depende de las condiciones del local y de los productos químicos utilizados. Para trabajos básicos de 
fotografía en blanco y negro lo adecuado es disponer de una ventilación general (por ejemplo, de 4,25 $\mathrm{m}^{3} /$ min de ventilación de entrada, y de $4,8 \mathrm{~m}^{3} / \mathrm{min}$ de ventilación aspirante, lo que equivale a diez renovaciones del aire por hora en una habitación de $3 \times 3 \times 3 \mathrm{~m}$ ), y contar con una tasa mínima de renovación de aire exterior de $0,15 \mathrm{~m}^{3} / \mathrm{min} / \mathrm{m}^{2}$ de superficie. El aire de salida debe dirigirse al exterior del edificio para evitar la redistribución de agentes contaminantes. Los procesos más delicados, como el virado (que en lugar de plata emplea sulfuro de plata, selenio y otros metales), el intensificado (oscurecimiento de partes de la imagen con productos como el dicromato potásico o clorocromato potásico) y las mezclas (con polvos y soluciones concentradas) requieren ventilación aspirante local suplementaria o protección respiratoria.

\section{Revelado en color}

Existen diferentes procesos para la fotografía en color, de mayor complejidad, que utilizan también productos químicos potencialmente peligrosos. De los distintos aspectos de la fotografia en color se ocupa el capítulo Industrias gráficas, de la fotografía comercial y de la duplicación. Al igual que ocurre con la fotografía en blanco y negro, en la fotografía en color son factores fundamentales para la seguridad evitar el contacto de la piel con los productos químicos y disponer de una ventilación adecuada.

\section{MeTAlisteria}

Angela Babin

La metalistería implica la fundición, la soldadura (autógena, fuerte y blanda), la forja, la fabricación y el tratamiento de superficie de los metales. En los países en desarrollo su popularidad va en aumento, ya que los artistas han comenzado a emplear los metales como material básico para sus esculturas. Además de existir fundiciones artísticas de carácter comercial, suelen formar parte de los programas de estudios de arte de las facultades.

\section{Riesgos y precauciones}

\section{Fundición}

Los artistas pueden enviar sus obras a fundiciones comerciales o fundirlas en sus propios estudios. Para fundir piezas pequeñas suele utilizarse el método de vaciado a la cera perdida. Algunos de los metales y aleaciones más comunes son el bronce, el aluminio, el latón, el peltre, el hierro y el acero inoxidable. El oro, la plata y a veces el platino, se emplean para obras de pequeño tamaño, especialmente en joyería.

El proceso de vaciado a la cera perdida consta de los pasos siguientes:

1. elaboración de la forma en positivo;

2. elaboración del molde;

3. calentamiento de la cera;

4. fundido del metal;

5. retirado de escorias;

6. vertido del metal fundido dentro del molde,

7. retirada del molde.

La forma en positivo puede realizarse directamente en cera. También puede hacerse en escayola y otros materiales, o un primer molde de caucho en negativo y la forma final en positivo en cera. El proceso de calentamiento de la cera supone un riesgo de incendio y puede originar la descomposición de la cera por exceso de calor.
El molde suele hacerse aplicando un revestimiento que contiene sílice en forma de cristobalita, lo que entraña un riesgo de silicosis. Resulta más seguro emplear escayola mezclada al $50 \%$ con arena de grano 30. También pueden hacerse moldes con arena y aceites, resinas de formaldheído y otras resinas como aglutinantes. Muchas de estas sustancias son tóxicas por inhalación y al contacto con la piel, por lo que requieren protección para la piel y una ventilación adecuada.

La forma en cera se funde en un horno, lo que hace necesaria una ventilación por extracción localizada que elimine la acroleína y otros productos irritantes originados por la descomposición de la cera.

El fundido del metal suele hacerse en un crisol dentro del horno de gas, con una campana de extracción al exterior para eliminar el monóxido de carbono y los humos de los metales (zinc, cobre, plomo, aluminio, etc.).

El crisol con el metal fundido se saca del horno, se eliminan las escorias de la superficie y se vierte el metal líquido dentro de los moldes (Figura 96.2). Las piezas de metal de menos de $30 \mathrm{~kg}$ de peso pueden levantarse manualmente; a partir de ese peso se requieren medios mecánicos. En los procesos de eliminación de escorias y en el vertido de los metales fundidos es necesario disponer de la ventilación adecuada para eliminar los humos metálicos. Los moldes de arena y resina también entrañan peligros derivados de los productos generados por la descomposición por efecto del calor. Es esencial utilizar máscaras de protección facial contra el calor y la radiación infrarroja, así como ropa especial para protegerse del calor y las salpicaduras de metales fundidos. Los suelos de cemento deben protegerse de los derrames de metal fundido con una capa de arena.

$\mathrm{Al}$ romper los moldes se producen exposiciones a sílice, lo que hace necesaria la ventilación por extracción localizada o el uso de respiradores. Una variante del proceso de vaciado con cera es el método de vaporización de espuma, en el que se emplea espuma de poliestireno o poliuretano en lugar de cera. El método con espuma durante el vertido del metal derretido puede liberar productos peligrosos, como el ácido cianhídrico de la espuma de poliuretano. Los artistas emplean a menudo fragmentos de metales de origen diverso. Esta técnica puede resultar

Figura 96.2 • Vertido de metal fundido en la fundición artística.

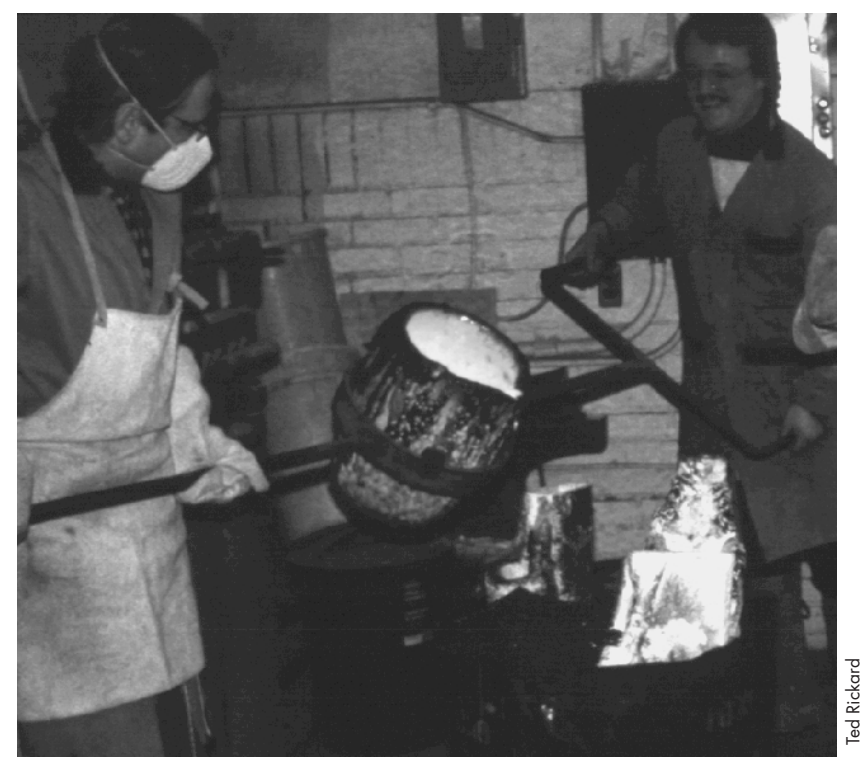


peligrosa por la presencia de pinturas con plomo o mercurio, y metales como cadmio, cromo, níquel, etc.

\section{Fabricación}

El metal puede cortarse, taladrarse y pulirse con sierras, taladros y limas. El proceso del pulido puede irritar los ojos y la piel, y las herramientas eléctricas pueden provocar descargas al trabajador. El uso indebido de estas herramientas origina accidentes. Para evitar que las esquirlas de metal alcancen los ojos al salir proyectadas, deben usarse gafas protectoras, y todos los equipos eléctricos han de estar conectados a tierra. Las herramientas deben manejarse y guardarse diligentemente, y los metales han de estar sujetos para evitar accidentes.

\section{Forja}

En el trabajo de forja en frío se emplean martillos, mazos, yunques y otras herramientas similares para modificar la forma de las piezas de metal. En la forja en caliente, el metal se somete a temperaturas elevadas. Todo ello genera gran cantidad de ruido, con la consiguiente pérdida de audición. Las pequeñas esquirlas de los metales pueden dañar los ojos y la piel si no se toman las precauciones necesarias. La forja en caliente entraña también el riesgo de quemaduras. Las principales medidas de prevención son la utilización de buenas herramientas, la protección de los ojos, la limpieza regular, el uso de ropa de trabajo adecuada, el aislamiento de la zona de forja y el uso de orejeras o tapones para los oídos.

En las fraguas se queman gases, carbón de coque y otros combustibles. Es necesario tener instalada una campana extractora para eliminar el monóxido de carbono y las posibles emisiones de hidrocarburos policíclicos aromáticos, así como para evitar el recalentamiento. Los ojos deben protegerse de la radiación infrarroja mediante gafas especiales.

\section{Tratamiento de superficie}

El tratamiento mecánico de las superficies (cincelado y repujado) se realiza con martillos; el grabado, con herramientas punzantes; el grabado por corrosión, con ácidos; el fotograbado, con ácidos y emulsiones fotográficas; la galvanoplastia (recubrimiento de un metal con una película metálica) y la electroplastia (recubrimiento de una superficie no metálica con una película de metal), con soluciones de ácido y cianuro; y la coloración de los metales, con numerosos productos químicos.

En la galvanoplastia y la electroplastia suelen emplearse sales de cianuro cuya ingestión puede resultar mortal. La mezcla accidental de ácido y cianuro produce gas cianhídrico, cuya inhalación o absorción a través de la piel puede causar la muerte en pocos minutos. En muchos países, la gestión para la eliminación de deshechos y residuos de disoluciones de cianuro está sujeta a estrictas normativas. La galvanización con disoluciones de cianuro debe hacerse en una planta comercial; si no fuera posible, deben emplearse otros productos que no contengan sales de cianuro ni sustancias con dicho compuesto.

Los ácidos son corrosivos y para manejarlos hay que protegerse la piel y los ojos; se recomienda, pues, un sistema de ventilación por extracción localizada fabricado con materiales resistentes a la corrosión por ácidos.

La anodización de metales, como el titanio y el tántalo, implica su oxidación en el ánodo de un baño electrolítico con el fin de darles color. El ácido fluorhídrico puede utilizarse para la limpieza previa, pero debe evitarse su empleo a menos que se haga con guantes, gafas y un delantal de protección.

Las pátinas de óxido para colorear metales se pueden aplicar en frío o en caliente. Los compuestos de plomo y arsénico son muy tóxicos en cualquiera de sus formas. Otros productos
Figura 96.3 • Aplicación de una pátina sobre metal con campana extractora.

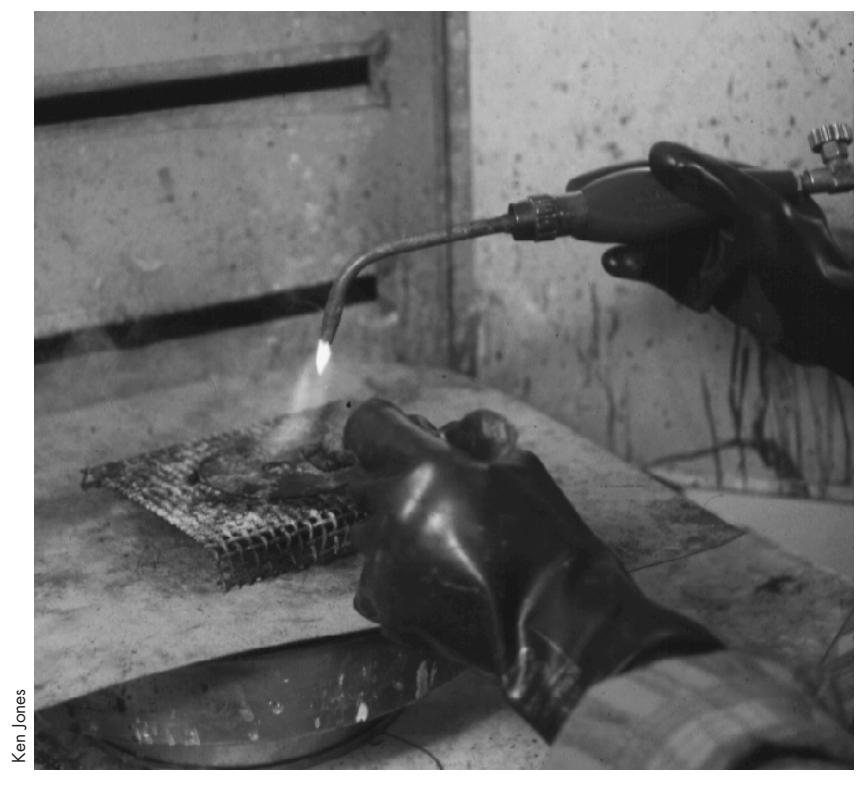

pueden emitir gases tóxicos al calentarse, así: las disoluciones de ferricianuro potásico liberan gas de ácido cianhídrico; las disoluciones de ácido arsénico, gas arsina, y las de sulfuro, gas de ácido sulfhídrico.

Los procesos de coloreado de metales precisan una óptima ventilación (Figura 96.3). Deben evitarse los compuestos de arsénico y el calentamiento de disoluciones de ferrocianuro potásico.

\section{Procesos de acabado}

Algunos tratamientos para acabados metálicos son la limpieza, el bruñido, el limado, el chorro abrasivo con arena y el pulido. En los procesos de limpieza se utilizan ácidos (baño de decapado), y presentan los riesgos inherentes a la manipulación de estas sustancias y de los gases producidos durante el baño de decapado (como el dióxido de nitrógeno y el ácido nítrico). Durante el bruñido se generan polvos finos de metales (susceptibles de inhalación) y se proyectan partículas pesadas (peligrosas para los ojos).

El chorro de arena es un proceso muy peligroso, sobre todo cuando se emplea arena real, que suele contener partículas de sílice cuya inhalación puede provocar silicosis en poco tiempo. Es recomendable sustituir la arena por partículas de vidrio, óxido de aluminio o carburo de silicio. La escoria que produce la fundición sólo debe emplearse si se comprueba mediante análisis químico la ausencia de sílice o de metales peligrosos, como el arsénico o el níquel. En estos procesos es necesaria una ventilación adecuada o una protección para las vías respiratorias.

El pulido con abrasivos como la esponja de hierro (óxido de hierro) o el trípoli resulta potencialmente peligroso, puesto que aquélla puede estar contaminada con grandes cantidades de sílice libre, mientras que éste contiene sílice. Todo ello hace necesaria una ventilación adecuada durante el pulido de metales.

\section{Soldadura}

Los riesgos físicos que entraña la soldadura son los incendios, las descargas eléctricas procedentes de los equipos de soldadura, 
las quemaduras por chispas de metales fundidos y las lesiones causadas por una exposición excesiva a radiación infrarroja y ultravioleta. Las chispas de la soldadura pueden saltar a distancias de 12 metros. Los rayos infrarrojos pueden causar quemaduras y lesiones en los ojos. Los rayos ultravioleta producen quemaduras, y si la exposición es continuada pueden causar cáncer de piel. La soldadura de arco eléctrico entraña el riesgo de contraer conjuntivitis y padecer lesiones de córnea por exposición a radiación ultravioleta. Es necesario proteger la piel y los ojos contra la radiación ultravioleta e infrarroja. Los sopletes oxiacetilénicos producen monóxido de carbono, óxidos de nitrógeno y acetileno sin quemar (de baja toxicidad). El acetileno que se encuentra en el mercado contiene otros gases tóxicos e impurezas en pequeñas cantidades.

Las bombonas de gases comprimidos pueden causar incendios y explosiones, y, junto con las mangueras y conexiones, deben inspeccionarse y mantenerse en buen estado, guardándose en lugares secos, bien ventilados y fuera del alcance de personas no autorizadas. Los envases de combustible deben almacenarse en lugares separados de las bombonas de oxígeno.

La energía producida por la soldadura de arco puede convertir el nitrógeno y el oxígeno del aire en óxidos de nitrógeno y ozono, irritantes pulmonares. Cuando se trabaja con soldadura de arco a una distancia menor de seis metros de disolventes desengrasantes clorados puede producirse gas de fosgeno por efecto de la radiación ultravioleta.

La vaporización de metales, las aleaciones y los electrodos empleados en la soldadura de arco producen emanaciones metálicas. También los flujos de fluoruros producen vapores tóxicos.

En todo trabajo de soldadura es necesaria una ventilación adecuada; en la soldadura de acero es suficiente una ventilación de dilución, pero la mayor parte de las labores de soldadura requieren un sistema de ventilación por extracción localizada.

Deben emplearse campanas con pestaña móviles o con rendijas laterales, y respiradores cuando no se disponga de ventilación.

Muchos humos y polvos generados por los metales pueden provocar sensibilidad e irritación de la piel, como el polvo de bronce (cobre, zinc, plomo y estaño), cadmio, níquel, titanio y cromo.

A ello se añaden otros problemas cuando se sueldan materiales revestidos de varias sustancias (por ejemplo, pinturas con plomo o mercurio).

\section{NUEVAS TECNOLOGIAS EN EL ARTE}

William E. Irwin

En este artículo se recogen los aspectos básicos en materia de salud y seguridad en actividades artísticas que emplean rayos láser, ordenadores y en la escultura fluorescente. Los artistas creativos recurren a menudo a la tecnología para su trabajo y como campo de experimentación, lo que aumenta los riesgos de posibles lesiones. Las medidas principales de prevención son la protección de la piel y los ojos, y la reducción de riesgos de descargas eléctricas y la exposición a productos químicos tóxicos.

\section{Rayos láser}

Los rayos láser pueden dañar la piel y los ojos del artista y del público, ya sea por contemplación directa o por sus reflejos. La gravedad de las lesiones por rayos láser depende de su potencia. Los rayos láser de alta potencia pueden causar lesiones graves y producir reflejos más peligrosos. Los fabricantes han establecido una clasificación del I al IV: la clase I no presenta peligro de radiación, mientras que la clase IV emite radiaciones muy peligrosas.

Los artistas han empleado todo tipo de rayos láser para sus creaciones artísticas, sobre todo el de longitud de onda visible. Aparte de los controles de seguridad necesarios en cualquier equipo de láser, su aplicación artística requiere detenerse en algunas consideraciones.

En las exhibiciones de rayos láser, es importante proteger al público del contacto directo con el rayo y de la radiación diseminada, mediante aislamientos de plástico o cristal y pantallas opacas. En los planetarios y otros lugares cerrados donde se ofrecen espectáculos no es recomendable dirigir a la zona del público rayos de nivel I, ni exponerle a sus reflejos. La radiación de las clases III y IV debe mantenerse a distancias seguras de los artistas y del público. Las distancias normales de seguridad son $3 \mathrm{~m}$ cuando hay un operador que controla el rayo, y $6 \mathrm{~m}$ cuando no se necesita un control continuo. Los procesos de instalación, alineamiento y comprobación de equipos de láser de las clases III y IV deben hacerse siguiendo instrucciones escritas. Algunas medidas de seguridad son: el aviso previo a su activación, los controles clave, los enclavamientos de seguridad a prueba de fallos y los botones de reajuste manual para los de la clase IV. El manejo de equipos de ésta última clase debe realizarse con gafas de protección especial.

Los equipos de láser destinados a espectáculos y fines artísticos utilizan rayos con movimientos rápidos que resultan más seguros debido a que el contacto con la piel o los ojos apenas dura unos instantes. Aún así, los operadores deben utilizar dispositivos de seguridad para no sobrepasar los límites de exposición en caso de fallo del equipo de monitorización. Cuando se proyectan al aire libre ha de impedirse el vuelo de aviones en niveles peligrosos del haz, así como la iluminación de edificios altos u operadores de equipos en alturas con niveles de radiación superiores a la Clase I.

La holografía es la proyección de una fotografía tridimensional de un objeto por medio de rayos láser. La mayoría de las imágenes se proyectan fuera del eje del haz de láser, mientras que la contemplación entre haces no suele ser peligrosa. Para reducir los riesgos de posibles lesiones puede emplearse una caja transparente alrededor del holograma. Algunos artistas producen imágenes fijas a partir de sus hologramas, y muchos de los productos químicos empleados en el revelado son tóxicos y deben manejarse con las debidas precauciones para evitar accidentes. Algunos de esos productos son: ácido pirogálico, álcalis, ácidos sulfúrico y bromhídrico, bromo y sales de dicromatos y parabenzoquinona. Existen sustitutos más seguros para la mayoría de estos compuestos.

Los rayos láser presentan otros peligros además de los radiológicos. En la mayoría de los espectáculos se utilizan unidades de alto voltaje y amperaje, con el correspondiente riesgo de electrocución, sobre todo en la fase de diseño y durante el mantenimiento. Los láser de color tienen sustancias tóxicas, y los rayos de alta potencia pueden generar aerosoles tóxicos, sobre todo cuando el haz llega al objetivo.

\section{Arte de neón}

El arte de neón utiliza tubos de este material para crear esculturas iluminadas. Una de las aplicaciones más típicas es la de los anuncios luminosos. Para hacer esculturas de neón hay que doblar el vidrio plomado en la forma deseada, bombardeando con alto voltaje el tubo de cristal al que se le ha hecho el vacio para eliminar las impurezas, y añadir pequeñas cantidades de gas neón o mercurio. La iluminación se consigue por excitación de los gases que hay en el interior del tubo, al aplicar una corriente de alto voltaje a través de los electrodos sellados a cada extremo 
Figura 96.4 • Elaboración de una escultura fluorescente con el artista detrás de una pantalla protectora.

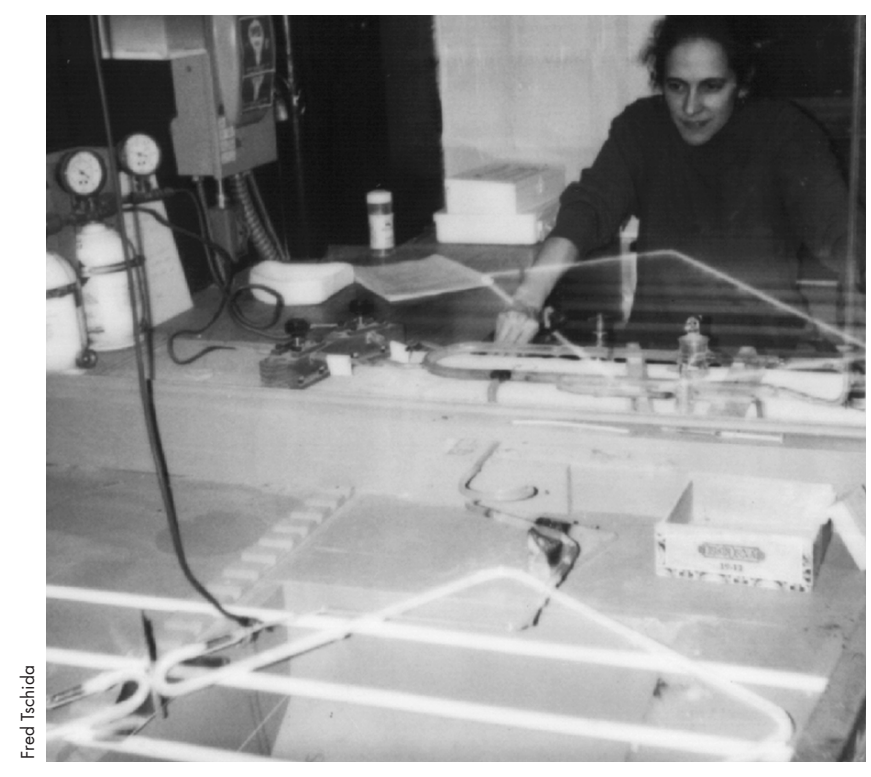

del mismo. Para obtener diferentes colores, se recubre el tubo con fósforos fluorescentes que convierten la radiación ultravioleta procedente del mercurio o del gas neón en luz visible. Los altos voltajes se obtienen a partir de transformadores elevadores.

El riesgo de electrocución es mayor cuando la escultura está conectada al transformador de bombardeo para la eliminación de las impurezas del tubo, o cuando está enchufada a su fuente de alimentación durante las pruebas o la exposición (Figura 96.4). La corriente eléctrica que pasa por el tubo también provoca la emisión de luz ultravioleta que a su vez reacciona con el cristal impregnado de fósforo, formando distintos colores. Una parte de la radiación ultravioleta puede llegar a atravesar el cristal y causar lesiones a las personas cercanas, por lo que deben usarse gafas especiales de protección.

Algunos fósforos que impregnan el tubo son potencialmente tóxicos, como determinados compuestos de cadmio. En ocasiones se añade mercurio al gas neón para crear un color azul llamativo. El mercurio es volátil a temperatura ambiente y su inhalación es muy peligrosa por su elevada toxicidad.

El mercurio debe manejarse con extremo cuidado cuando se introduce en el tubo y debe guardarse en envases sellados e irrompibles. Los artistas deben emplear bandejas para que no se derrame el mercurio y disponer de equipos para recogerlo. Nunca debe aspirarse, pues se dispersaría en forma de vaho por la salida de aire de la aspiradora.

\section{Arte por ordenador}

Los ordenadores pueden utilizarse con fines artísticos: para la pintura, la visualización de imágenes fotográficas escaneadas, la producción de gráficos para impresión y televisión (por ejemplo, los créditos en pantalla), y para varios efectos de animación y especiales destinados al cine o la televisión. El uso del ordenador con fines artísticos es un fenómeno cada vez más extendido. Suele implicar problemas de ergonomía por lo común relacionados con tareas repetitivas y con una incorrecta distribución de sus componentes. Los más comunes son: molestias en las muñecas, los brazos, los hombros, el cuello y problemas de la vista. La mayoría son de carácter leve, aunque pueden aparecer también lesiones incapacitantes, como la tendinitis crónica o el síndrome del túnel carpiano.

La actividad creativa por ordenador suele requerir largos períodos de manejo del ratón o del teclado para diseñar y ajustar los trabajos. Es importante que los usuarios de ordenador efectúen pausas periódicas, que resultan más eficaces cuando se hacen en intervalos frecuentes y cortos, en lugar de largos descansos cada dos horas.

La distribución de los distintos componentes con respecto al usuario, un diseño que le permita una postura correcta y que asegure la comodidad visual son factores fundamentales. Los componentes de un puesto de trabajo con ordenador deben poder ajustarse con facilidad a las diferentes tareas y a las personas que lo utilizan.

La vista cansada puede prevenirse efectuando pausas para que los ojos descansen, impidiendo los reflejos y destellos, y colocando la pantalla a la altura de los ojos. Otra forma de reducir las molestias oculares es utilizar monitores con una frecuencia de imagen de $70 \mathrm{~Hz}$, para disminuir el parpadeo.

Los efectos de la radiación que emiten los ordenadores son diversos. Los niveles de emisión de radiación ultravioleta, visible, infrarroja, de radiofrecuencia y microondas suelen ser bajos o normales. No están muy claros los posibles efectos sobre la salud de las ondas de baja frecuencia originadas por los circuitos eléctricos y los componentes electrónicos de los ordenadores. Hasta la fecha no se han encontrado pruebas científicas de los riesgos que entraña la exposición a los campos magnéticos relacionados con los monitores de ordenador, que, por otra parte, no emiten niveles peligrosos de rayos $\mathrm{X}$.

\section{ARTESANIA TEXTIL}

\section{Gail Coningsby Barazani}

Los artesanos textiles contemporáneos ejercen muchas y diversas actividades: costura, tejido, fabricación de papel, artesanía del cuero, etc., ya sea manualmente o valiéndose de máquinas (véase la Tabla 96.5). En la preparación de las fibras o en el acabado de los tejidos se llevan a cabo diferentes procesos de cardado, bobinado, teñido, acabado y blanqueado (véase la Tabla 96.6). Por último, los tejidos pueden pintarse, serigrafiarse, tratarse con emulsiones fotográficas, tostarse y modificarse por otros métodos. En otros artículos de este capítulo se describen estas técnicas.

Prácticamente no hay límites en cuanto a los materiales que pueden utilizarse, ya sean sintéticos, de origen animal o vegetal. Los artistas recogen semillas, vides o pelos de animales que encuentran, o compran productos tratados con aceites, fragancias, tintes, pinturas o plaguicidas (por ejemplo, veneno para ratas en cordeles o cuerdas utilizado para fines agrícolas). También se emplean materiales importados de origen animal y vegetal tratados para eliminar insectos portadores de enfermedades, esporas y hongos. Otros materiales son: trapos viejos, huesos y plumas, maderas, plásticos y cristales.

\section{Fuentes de posibles riesgos para la salud en la artesanía textil}

\section{Productos químicos}

$\mathrm{Al}$ igual que en la mayoría de los lugares de trabajo, los principales riesgos para la salud en la artesanía textil son los contaminantes atmosféricos, como gases, humos, polvos y vapores originados por los materiales o durante los distintos procesos, y que pueden inhalarse o entrar en contacto con la piel. Además 
Tabla 96.5 • Descripción de las distintas modalidades de artesanía textil.

$\begin{array}{ll}\text { Procesos } & \text { Descripción } \\ \text { Cestería } & \text { Elaboración manual mediante técnicas de tejido, doblado o } \\ & \text { trenzado de cestas, bolsos, esteras, etc., con materiales } \\ & \text { como cañas, bejucos o pitas. Es frecuente la utilización de } \\ & \text { cuchillos y tijeras, y a menudo las cestas trenzadas se cosen } \\ & \text { juntas. } \\ \text { Batik } & \text { El Batik es un método de teñido de tejidos por el que se aplica } \\ & \text { sobre éstos (con un djanting) cera derretida que forma una } \\ & \text { capa protectora, se tiñe el tejido y se elimina la cera con } \\ & \text { disolventes o mediante el planchando entre papel de } \\ & \text { periódico. } \\ \text { Ganchillo } & \text { El ganchillo y el punto son similares, excepto que en el } \\ & \text { primero se utiliza una aguja con gancho para entrelazar el } \\ \text { hilo en el tejido. } & \text { Adorno de tejidos, cuero, papel u otros materiales mediante } \\ \text { Bordado } & \text { bordaduras cosidas con hilo y aguja. El acolchado entra } \\ & \text { dentro de esta categoría. } \\ \text { Punto } & \text { El punto es la técnica de crear un tejido entrelazando hilos en } \\ & \text { series de nudos utilizando agujas largas manuales o } \\ & \text { máquinas tejedoras. }\end{array}$

Trabajo del cuero La artesanía del cuero comprende dos fases básicas: corte, grabado, cosido y otros procesos físicos; y encolado, teñido y acabado del cuero. En la primera fase se emplean diversas herramientas. En la segunda se utilizan disolventes, tintes, lacas y otros productos similares. Para el curtido véase el capítulo Cuero, pieles y calzado.

Macramé El macramé es una modalidad de punto ornamental para fabricar bolsos, tapices y otros objetos similares.

Elaboración de La elaboración de papel implica la preparación de la pulpa y papel su posterior fabricación. Para ello se utilizan distintas plantas, maderas, vegetales, trozos de papel usado, etc. Se separan las fibras normalmente mediante cocción en álcalis, se lavan y se colocan en un batidor para comprobar la preparación de la pulpa. Después se fabrica el papel presionando la pulpa en una plancha de alambre o de tejido, dejando que se seque al aire, o presionándola entre capas de fieltro. El papel puede tratarse con colas, tintes, pigmentos y otros materiales.

Serigrafía Véase "Grabado".

Teijdo La modalidad de teiido supone el empleo de una máquina llamada telar que combina dos juegos de hilaturas, la urdimbre y la trama, para formar los teiidos. La urdimbre se hila en grandes carretes que ocupan todo el largo del telar. Los hilos de la urdimbre se entrelazan a través del telar, formando hilos paralelos. La trama es alimentada desde los lados del telar mediante bobinas. La lanzadera del telar conduce los hilos de la trama a través del telar horizontalmente por encima y por debajo de los hilos alternos de la urdimbre. Para endurecer los hilos y evitar que se rompan durante el teiido se emplean aprestos de almidón. Existen muchas clases de telares, tanto mecánicas como manuales.
Tabla 96.6 • Descripción de los procesos de manufacturas textiles.

\begin{tabular}{ll} 
Procesos & Descripción \\
\hline Cardado & Proceso de limpieza y reforzamiento de las fibras en líneas \\
& paralelas, cardándolas (a mano o con máquinas especiales) \\
& y retorciéndolas hasta darles forma de cuerda. Durante este \\
& proceso suelen formarse grandes cantidades de polvo.
\end{tabular}

Bobinado En el bobinado se emplea una rueca accionada con un pedal, que combina varios hilos para obtener un ovillo.

Acabado Las puntas y pelos que sobresalgan pueden eliminarse quemándolas, y el tejido puede desaprestarse con enzimas o limpiarse hirviéndolo en álcalis para eliminar la grasa y la cera.

Teñido L L L ovillos y los tejidos pueden teñirse con numerosos tintes (naturales, directos, ácidos, básicos, dispersantes, fibrorreactivos y otros) dependiendo del tipo de hilo. Muchos procesos de teñido requieren el calentamiento en el baño de tinte hasta acercarse a punto de ebullición. Pueden utilizarse muchos elementos de ayuda al teñido, como ácidos, álcalis, sales, hidrosulfito de sodio y en los tintes naturales, mordientes como urea, dicromato de amonio, amoníacos, sulfato de cobre y sulfato de hierro. Los tintes se adquieren normalmente en forma de polvo. Algunos pueden contener disolventes.

Blanqueamiento Las fibras pueden blanquearse con blanqueadores de cloro para eliminar los colores.

de los riesgos químicos que entrañan los tintes, la pinturas, los ácidos, los álcalis, los productos antipolillas, etc., las fibras y los tejidos pueden estar contaminados por materiales biológicos causantes de enfermedades.

\section{Polvos de origen vegetal}

Muchos trabajadores de la industria expuestos al polvo de algodón en rama, pita, yute y otras fibras vegetales en sus puestos de trabajo han desarrollado problemas crónicos de pulmón, como bisinosis, enfermedad cuyos primeros síntomas son opresión torácica y falta de aliento, y que puede acabar en situación de incapacidad al cabo de los años. La exposición al polvo de fibras vegetales puede provocar irritación pulmonar y enfermedades como asma, fiebre del heno, bronquitis y enfisema. Otras sustancias relacionadas con las fibras vegetales, como mohos, tintes y aprestos, pueden causar alergias y otras reacciones.

\section{Polvos de origen animal}

Las fibras de origen animal, como lana, pelo, piel y plumas, a menudo se encuentran contaminadas con bacterias, mohos, piojos y garrapatas, y pueden causar fiebre Q, sarna, problemas respiratorios, erupciones en la piel, ántrax, alergias, etc., si no han sido tratadas o fumigadas antes de su uso. Se han dado casos de muerte por inhalación de ántrax en artesanos tejedores, uno de ellos ocurrido en California en 1976.

\section{Materiales sintéticos}

No se conocen bien los efectos del polvo de las fibras de poliéster, nailon, acrílicas, rayón y acetatos. Algunas fibras plásticas liberan gases, componentes o residuos que permanecen en la fábrica después de su manufactura, como sucede con el formaldehído liberado por las fibras de poliéster y las de planchado 
Figura 96.5 - Tejido con un telar manual.

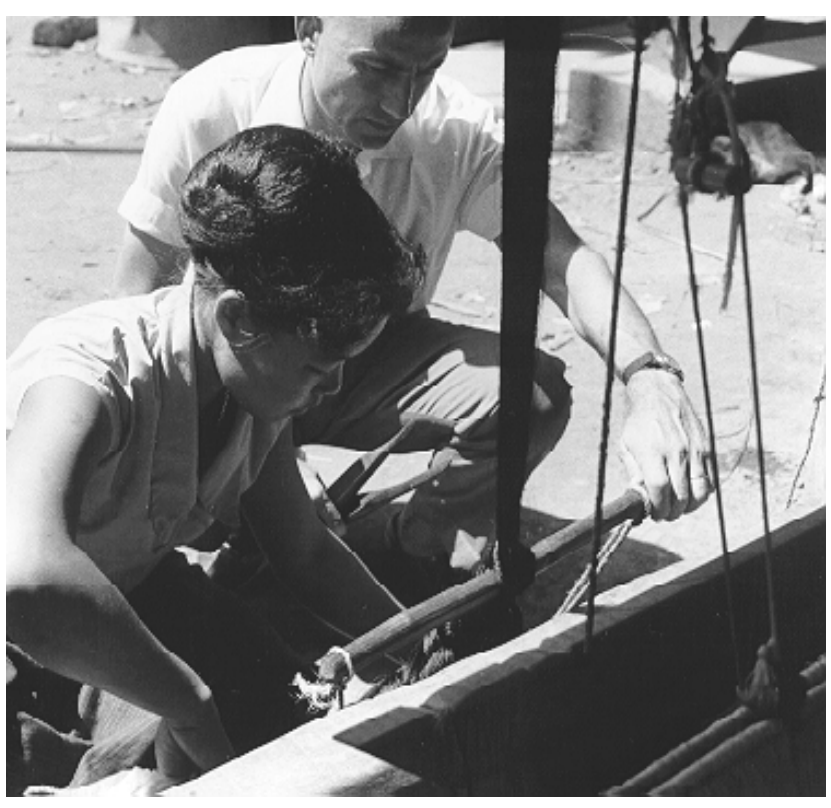

permanente. En individuos sensibles se han dado casos de respuestas alérgicas en locales y almacenes que tenían estos materiales, y algunas personas han sufrido erupciones cutáneas al llevar ropa hecha de estas fibras, incluso después de varios lavados.

Los procesos de calentamiento, abrasado y otras formas de modificación química de los materiales sintéticos pueden liberar gases y vapores potencialmente peligrosos.

\section{Efectos físicos en el trabajo con fibras y tejidos}

Las características físicas de los materiales pueden afectar al trabajador. Los materiales ásperos, espinosos o abrasivos pueden provocar cortes y raspaduras en la piel. Las fibras de vidrio, las hierbas rígidas y la rota pueden penetrar en la piel y causar infecciones y erupciones. Los trabajadores de tejidos pasan sentados largos períodos de tiempo durante su trabajo, con movimientos repetitivos de los brazos, muñecas, manos y dedos, e incluso de todo el cuerpo, exponiéndose a dolores y posibles lesiones musculares. Así, los tejedores pueden contraer el síndrome del túnel carpiano, dolores de espalda o deformaciones esqueléticas al tejer en cuclillas con telares antiguos (sobre todo los niños), trastornos en las manos y los dedos (hinchazón en articulaciones, artritis, neuralgias) al coser y atar nudos, y vista cansada a consecuencia de una iluminación insuficiente (Figura 96.5). Muchos de estos problemas también se dan en otros oficios textiles en los que el trabajo requiere coser, atar nudos, tejer con aguja, etc. En los procesos de costura existe además el riesgo de pincharse con las agujas.

Los trabajadores de la industria de fabricación de papel pueden sufrir lesiones de espalda al levantar grandes y pesadas pantallas con la pasta de papel empapada en agua.

\section{Precauciones}

Como en todo trabajo, los riesgos están en función de la duración de la jornada, el número de días de trabajo y de semanas al año, el volumen de trabajo, las características del lugar de trabajo y la naturaleza de la actividad en sí. También pueden afectar a la salud del trabajador las condiciones de ventilación e iluminación.
Una o dos horas semanales en un telar con el ambiente cargado de polvo no provoca problemas serios de salud, excepto para individuos alérgicos al polvo. Por el contrario, períodos prolongados de tiempo en esas condiciones durante meses o años pueden acarrear serios trastornos de salud. Por otra parte, basta con levantar un objeto pesado de forma incorrecta para sufrir una lesión de la columna.

En el trabajo con fibras y tejidos deben seguirse las siguientes precauciones generales:

- Emplear únicamente materiales de origen animal o vegetal que hayan sido convenientemente tratados y fumigados. Otros materiales deberán limpiarse o lavarse, y almacenarse en recipientes cerrados para reducir los niveles de polvo.

- Barrer y fregar con frecuencia los suelos y superficies de la zona de trabajo.

- En muchos países se exige a los fabricantes que faciliten información sobre los aspectos de seguridad y riesgos de determinados productos químicos (tintes, adhesivos, pinturas o disolventes) incluidos en los artículos que comercializan, recogida a menudo en forma de fichas técnicas de seguridad (FTS). Debe solicitarse dicha información.

- Evitar comer, beber y fumar en el lugar de trabajo.

- Efectuar descansos periódicos y realizar ejercicios en trabajos que supongan movimientos repetitivos.

- Modificar los procesos de trabajo a fin de reducir la necesidad de realizar demasiados esfuerzos y de levantar pesos excesivos. Por ejemplo, en la fabricación de papel pueden utilizarse pantallas más pequeñas para la pasta o levantarla entre dos personas.

- Utilizar ventilación aspirante cuando se trabaje con pinturas a pistola y materiales que desprendan polvo, o al calentar cera y utilizar materiales que contengan disolventes, como pinturas grasas y rotuladores de tinta.

- Evitar el calentamiento de ácidos y álcalis, siempre que sea posible, y llevar delantales, guantes, gafas y pantallas protectoras faciales.

- Tener en cuenta que el polvo, los gases y los vapores se extienden por los edificios y pueden afectar a otras personas, especialmente a niños, bebés, personas mayores y enfermos crónicos.

- Consultar con higienistas industriales o con profesionales de la salud y la seguridad antes de montar un taller de producción.

\section{Ceramica}

\section{Monona Rossol}

Numerosos objetos de cerámica y arcilla, como vajillas, esculturas, baldosas decorativas, muñecas, etc., se fabrican tanto en grandes industrias como en pequeños talleres y estudios, en las aulas de escuelas, universidades y escuelas profesionales, y en las casas particulares, bien como pasatiempo o como industria casera. Las diferentes modalidades pueden agruparse en cerámica y alfarería, aunque la terminología varía en función de cada país. En la cerámica, los objetos se fabrican por colado: vertiendo en moldes una pasta de agua, arcilla y otros ingredientes. Los objetos de arcilla se retiran del molde, se desbastan y decoran, y se cuecen en el interior de un horno. Algunos artículos se destinan a la venta en esta fase del proceso (porcelana sin vidriar); otros se decoran con barnices hechos de sílice y otras sustancias que proporcionan superficies de aspecto vidriado. En la alfarería, los objetos se forman con arcilla plástica y suelen modelarse a mano o utilizando un torno de alfarero, y después se cuecen. A continuación las piezas pueden barnizarse. La cerámica hecha 
por colado suele barnizarse y pintarse con pintura china, que se comercializa envasada en forma líquida o en seco (Figura 96.6). Los artículos de alfarería pueden barnizarse con productos comerciales o con barnices elaborados por los propios alfareros. La fabricación de estos objetos abarca desde artículos de terracota y loza, cocidos a bajas temperaturas, hasta otros de gres y porcelana, sometidos a procesos de cocción a altas temperaturas.

\section{Arcillas y barnices}

Las arcillas y barnices son mezclas de sílice, aluminio y minerales metálicos. Tales ingredientes suelen contener bastantes partículas que pueden inhalarse, como las que se hallan en la sílice molida y las bolas de arcilla. Aunque las arcillas y barnices se componen básicamente de los mismos tipos de minerales (véase la Tabla 96.7), los barnices están diseñados para fundirse a temperaturas inferiores (tienen más fundente) que los materiales a los que se aplican. El plomo es un fundente común. Los minerales naturales de plomo, como la galena y los óxidos de plomo derivados de la quema de las placas de baterías de automóviles y otros desechos, se emplean como fundentes y han causado muertes entre alfareros y sus familias en algunos países en desarrollo. Los barnices comerciales para uso industrial y doméstico suelen contener plomo y otras sustancias mezcladas y previamente calcinadas en forma de frita en polvo. Los barnices están diseñados para su maduración durante la oxidación o la reducción por cocción (véase más adelante) y pueden contener compuestos metálicos en los colorantes. Hay metales como el plomo, el cadmio y el bario que pueden pasar a los alimentos cuando se utilizan vajillas de cerámica.

Entre otros procesos especiales de tratamiento de superficies se encuentran los barnices de brillo metálico, que tienen aceites viscosos y disolventes como el cloroformo; los efectos iridiscentes conseguidos al arrojar sales metálicas (cloruros de estaño, hierro, titanio o vanadio, por lo común) en forma de humo sobre las superficies durante el horneado, y pinturas nuevas que contienen resinas plásticas y disolventes, que al secarse presentan un aspecto semejante al de la cerámica cocida. Algunas superficies de arcilla de texturas especiales tienen tapaporos, como la vermiculita, la perlita y la chamota (ladrillos refractarios)

La exposición a los distintos ingredientes de las arcillas y los barnices se produce sobre todo durante los procesos de mezcla, lijado y aplicación de barnices con aerosoles, y también al limar
Figura 96.6 • Decoración de jarrones con pinturas para cerámica.

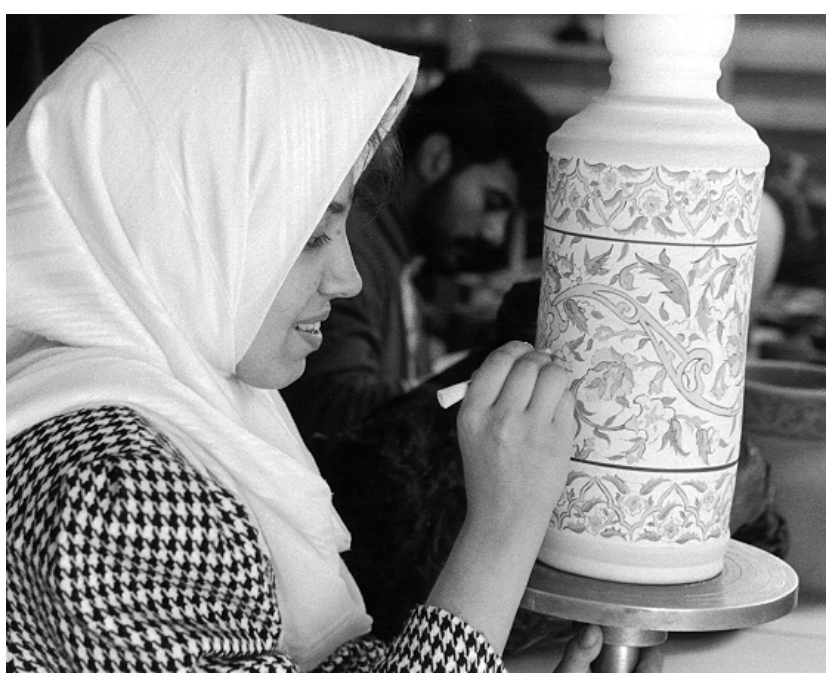

y eliminar las imperfecciones del barniz cocido en la base de los objetos y los restos de las bandejas del horno (Figura 96.7). La limpieza de las bandejas de los hornos expone al trabajador a residuos de pedernal, caolín y otros productos del revestimiento del horno. El polvo silíceo de los materiales del horno y de la porcelana sin vidriar resulta más peligroso, ya que se encuentra en forma de cristobalita. Los riesgos principales son: silicosis y otras neumoconiosis causadas por la inhalación de determinados minerales, como sílice, caolín, talco y asbesto anfíboles fibrosos en algunos talcos; la exposición a metales como el plomo, el bario y el litio; afecciones como el síndrome del túnel carpiano ("el pulgar del alfarero") por el trabajo con el torno; lesiones de espalda por excavar arcillas, levantar sacos pesados de minerales y por la eliminación manual de las burbujas de aire; resbalones y caídas en suelos mojados; electrocución con tornos eléctricos y otros equipos situados sobre superficies húmedas; alergia a los mohos de las arcillas; infecciones bacterianas o por hongos en la piel y la matriz de las uñas, y accidentes con mezcladoras de arcillas, amasadoras, rodillos de corte y otros equipos similares.

Tabla 96.7 • Compuestos de los cuerpos de cerámica y barnices.

\author{
Componentes básicos \\ Arcillas (silicatos de hidroaluminio) \\ Caolín y otras arcillas blancas \\ Arcillas rojas ricas en hierro \\ Arcillas cocidas \\ Bolas de arcilla \\ Bentonita
}

\section{Otros compuestos y algunas fuentes minerales}

Flujos

Sodio, potasio, plomo, magnesio, litio, bario, boro, calcio, estroncio, bismuto

Las fuentes incluyen óxidos y carbonatos de los metales anteriores, feldespatos, talco, sienita nefelina, bórax, colemanita, yeso blanco, fritas de plomo, silicatos de plomo

\section{Alúmina}

Oxido de aluminio, corindón, la fuente usual en barnices procede de arcillas y feldespatos
Silice

Cuarzo de pedernal, arena, tierra de diatomeas; cristobalita de sílice calcinada o minerales de sílice cocidos

\section{Opacificantes}

Estaño, zinc, antimonio, zirconio, titanio, flúor, cerio, arsénico

Las fuentes incluyen óxidos y carbonatos de los metales anteriores, fluorita criolita, rutilo, silicato de zirconio

\section{Colorantes}

Cobalto, cobre, cromo, hierro, manganeso, cadmio, vanadio, níquel, uranio

Las fuentes incluyen óxidos, carbonatos y sulfatos de los metales anteriores, cromatos, espinel y otros complejos metálicos 
Figura 96.7 - Exposición a polvo de arcilla y barniz en el lijado manual de una pieza de alfarería.

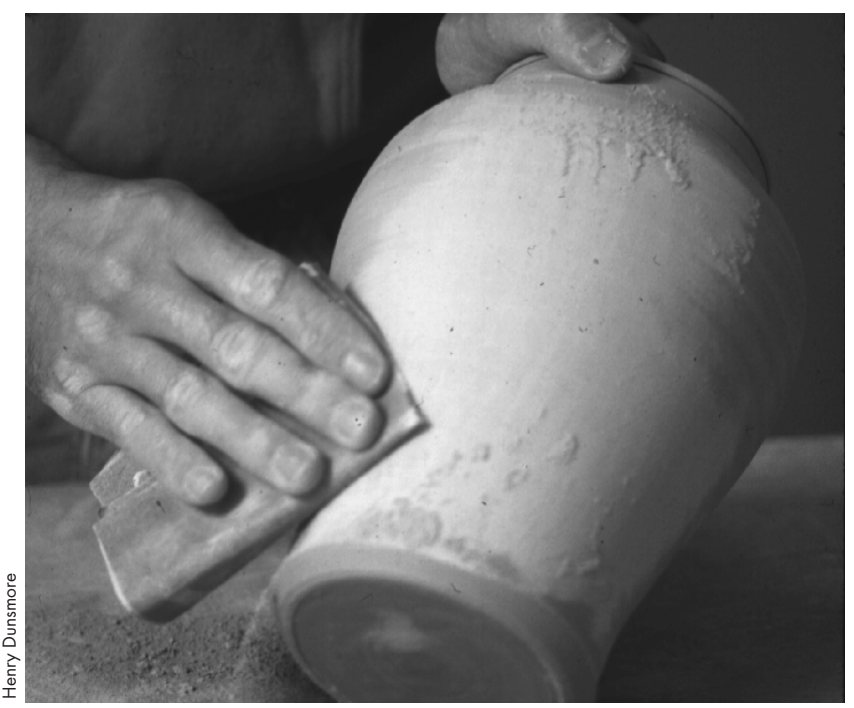

Precauciones generales: evitar el calentamiento del plomo en abierto; emplear sustitutos del plomo, frita de plomo, cadmio y materiales que contengan asbesto; aislar las zonas de trabajo del resto de la casa y lugares destinados a la familia y los niños; conservar y mantener limpio el lugar de trabajo; controlar los polvos; utilizar ventilación por extracción localizada en los procesos con aerosoles y generadores de polvo (Figura 96.8); utilizar equipos respiradores; efectuar los descansos necesarios; levantar pesos de una forma segura; equipar las máquinas con dispositivos de seguridad; y utilizar interruptores de falla a tierra en los tornos y en el resto de los equipos eléctricos.

\section{El cocido en el horno}

Los hornos pueden tener el tamaño de un vagón de ferrocarril, o ser pequeños, como los usados para pruebas de baldosas y la cocción de pequeñas miniaturas. El calentamiento se realiza con electricidad o con combustibles, como gas, madera o petróleo. En los hornos eléctricos los objetos se cuecen básicamente en ambientes oxidantes. La cocción por reducción se lleva a cabo ajustando las proporciones de combustible/aire para provocar una reducción química. Algunos métodos de cocido son: cocción por sales, el método raku (piezas al rojo vivo dentro de materiales orgánicos, como paja húmeda para obtener objetos de arcilla ahumada por reducción), hornos ascendentes (hornos con múltiples cámaras de madera o carbón en los lados), cocción por serrín (hornos llenos con piezas y serrín), y cocción con hendidura abierta con numerosos combustibles, como hierba, madera o estiércol.

Los antiguos hornos de combustible suelen estar mal aislados debido a los materiales empleados en su construcción, por lo común arcilla cocida, ladrillo y barro. Las grandes cantidades de leña que se queman en estos hornos, puede aumentar la escasez de madera en los países en desarrollo. Los hornos comerciales están aislados con ladrillos refractarios, cemento refractario o fibra de cerámica. Los hornos más antiguos aún utilizan aislamientos de asbesto. El uso de la fibra de cerámica refractaria está muy extendido en los hornos industriales y entre los empleados por aficionados a la artesanía. También existen pequeños hornos de fibra que se calientan dentro de un aparato de microondas doméstico.
Figura 96.8 • Ventilación por extracción en la mezcla de arcillas.

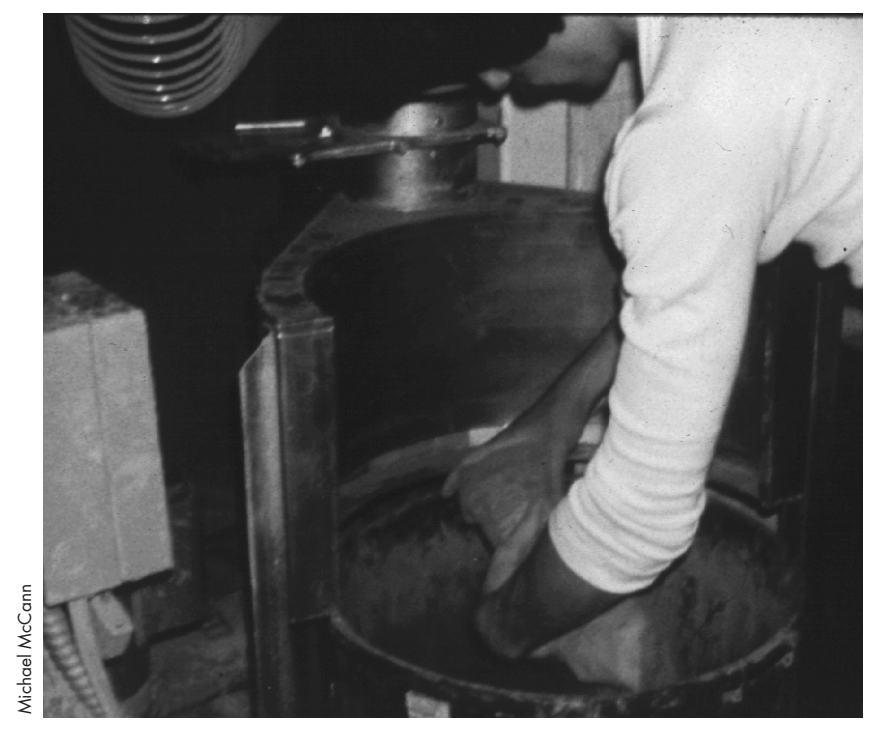

Los hornos producen emisiones de los combustibles y materias orgánicas, que pueden contaminar los minerales de las arcillas y barnices, además de óxidos de azufre, flúor y cloro de minerales, como la criolita, la sodalita, así como humos de metales. La cocción por sales produce ácido clorhídrico. Las emisiones resultan especialmente peligrosas cuando se emplean combustibles como maderas pintadas o tratadas y petróleos de desecho. Los principales peligros son: sensibilización e irritación de las vías respiratorias por inhalación de aldehídos, óxidos de azufre, halógenos y otras emisiones; asfixia por monóxido de carbono; cáncer por inhalación de fibras de asbesto y cerámica; lesiones oculares por rayos infrarrojos procedentes de los hornos encendidos, y lesiones por quemaduras.

Entre las medidas más importantes se encuentran las siguientes: utilización de combustibles limpios; aislamiento de los hornos que evite el desperdicio de combustible; sustitución de fibras de asbesto y cerámica por ladrillo refractario; eliminación o aislamiento de las fibras aisladoras existentes; ventilación de hornos en interiores; ubicación de los hornos en zonas donde no haya materiales combustibles; instalación en los hornos de dos interruptores de desconexión automática, y empleo de gafas especiales contra radiación infrarroja y guantes para manipular objetos calientes.

\section{ARTESANIA DE LA MADERA}

\section{Michael McCann}

La artesanía de la madera es una actividad muy extendida en todo el mundo para fabricar diversos enseres o como forma de expresión artística. El trabajo de la madera abarca la talla de objetos, la fabricación de muebles y armarios, (Figura 96.9), la elaboración de instrumentos musicales, etc. Algunas de las técnicas empleadas son la talla, (Figura 96.10), el laminado, el encolado, el serrado, el lijado, la eliminación de pinturas, el pintado y el acabado. Las maderas empleadas pueden ser duras o blandas, y también existen maderas tropicales, maderas contrachapadas, tableros de aglomerado, y, en ocasiones, maderas tratadas con plaguicidas y conservantes. 
Figura 96.9 - Fabricación de muebles.

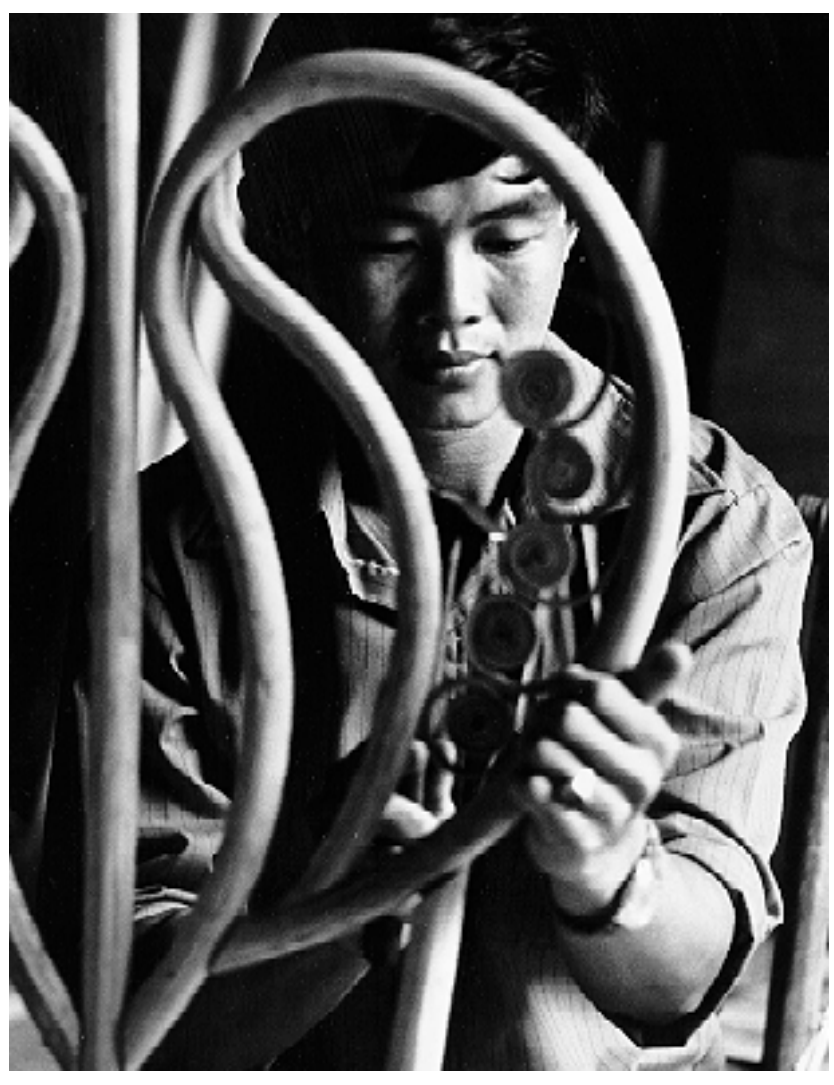

\section{Riesgos y precauciones}

\section{Maderas}

Hay muchas maderas peligrosas; sobre todo las tropicales. Las reacciones más frecuentes son las alergias y la irritación a causa de la savia, del polvo de madera o de la misma madera, además de conjuntivitis, alergias respiratorias, neumonía por hipersensibilidad y otras reacciones tóxicas. La inhalación de polvo de maderas duras está relacionada con un tipo de cáncer nasal y de los senos nasales (adenocarcinoma). Véase el capítulo Industria de la madera.

Algunas de las medidas preventivas: evitar el uso de maderas que produzcan sensibilización por parte de individuos con antecedentes de alergia y en objetos cuyo uso implique el contacto frecuente con personas; y controlar los niveles de polvo mediante ventilación por extracción localizada o aparatos respiradores. Cuando se trabaja con maderas susceptibles de causar alergias o irritaciones de la piel deben usarse guantes o cremas de protectoras. Al finalizar el trabajo deben lavarse bien las manos.

\section{Maderas contrachapadas y tableros de conglomerado}

La madera contrachapada y tableros de aglomerado (p. ej.: los tableros de partículas) están hechos con láminas finas de madera engomada o con astillas y polvo de madera, mezcladas con colas de ureaformaldehído o de fenolformaldehído. Tales materiales pueden emitir formaldehído sin reaccionar durante varios años después de su fabricación, sobre todo los tableros de aglomerado. El calentamiento y tratamiento con máquinas de este tipo de materiales puede provocar la descomposición de las colas, liberando formaldehídos que producen irritación de la piel, ojos y vías respiratorias, además de ser fuerte agente sensibilizador y posible carcinógeno para los humanos.

Como medidas preventivas se recomienda emplear materiales que contengan bajos niveles de formaldehído, evitar el almacenamiento de grandes cantidades de contrachapados y aglomerados en el taller, y utilizar recolectores de polvo en las máquinas con extracción al exterior.

\section{Conservantes de la madera y otros tratamientos}

Las maderas suelen tratarse con productos plaguicidas y conservantes en alguna de las fases de su tala, transformación o transporte. El pentaclorofenol y sus sales, la creosota y el arseniato cromado de cobre, son sustancias cuya venta está prohibida en Estados Unidos como conservantes de la madera, debido a sus posibles daños al aparato reproductor y efectos cancerígenos. Aún así, estos productos pueden encontrarse en maderas viejas, y, por otra parte, el arseniato de cobre cromado está autorizado como tratamiento comercial (por ejemplo, en la madera "verde", en las instalaciones de patios de recreo, etc.). En el tratamiento de maderas también se utilizan otros productos químicos, como los ignífugos y los blanqueadores.

Como medidas de prevención hay que evitar la manipulación de maderas tratadas con pentaclorofenol o creosota, y utilizar ventilación por extracción localizada o aparatos respiradores con filtros eficaces para trabajar con maderas tratadas con arsenato de cobre cromado. Por último, no deben quemarse maderas tratadas con creosota, pentaclorofenol o arsenato de cobre cromado.

\section{Talla y trabajo de la madera con máquinas}

La madera puede tallarse con cinceles, escofinas, sierras manuales, papel de lija, etc. Se trabaja también con sierras eléctricas, lijadoras y otras máquinas y herramientas eléctricas. Los riesgos más frecuentes son la exposición al polvo de madera, los niveles excesivos de ruido, los accidentes con las herramientas y

Figura 96.10 - Tallado de la madera con herramientas manuales.

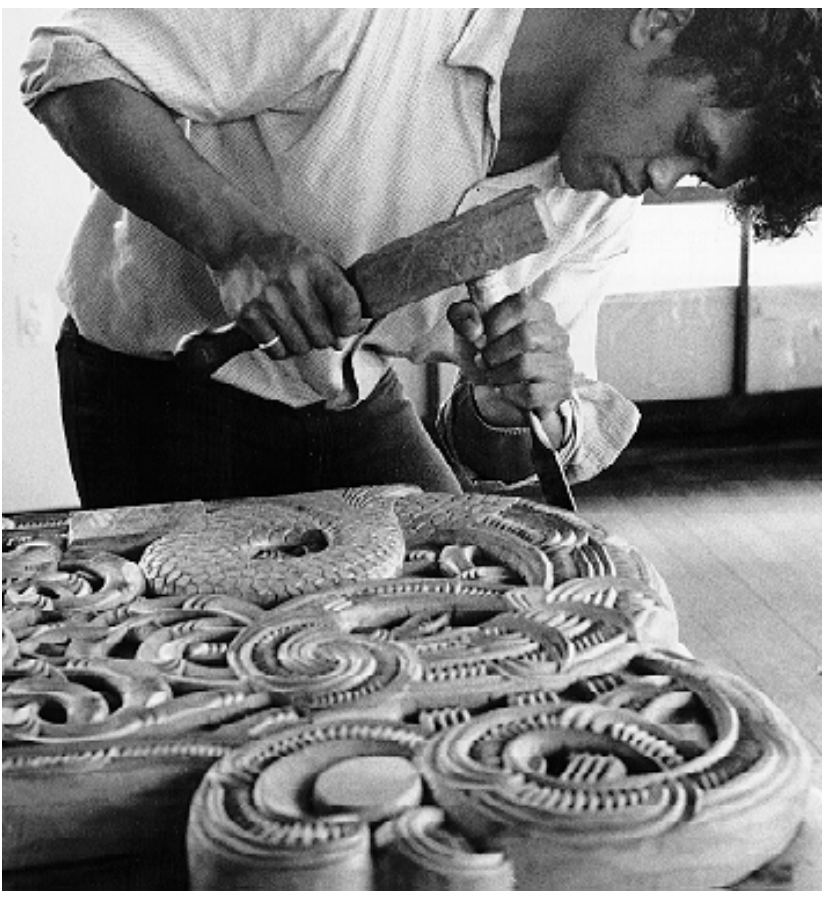


Figura 96.11 - Maquinaria para trabajar la madera con recolector de polvo.

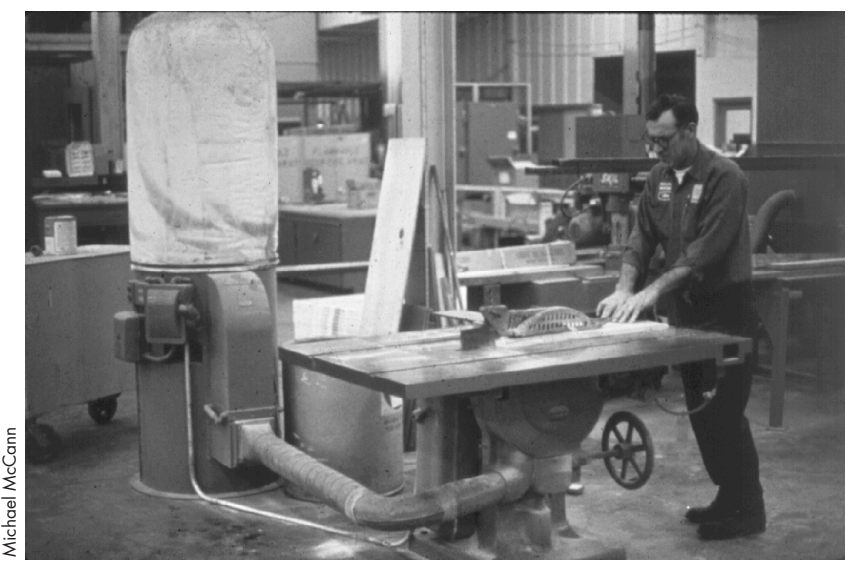

máquinas, las descargas eléctricas y los incendios provocados por cables en mal estado, y los incendios de las maderas. Las herramientas vibrantes (por ejemplo, las sierras de cadena) pueden causar el denominado "dedo blanco" (fenómeno de Raynaud), con entumecimiento de manos y dedos.

Entre las precauciones que deben tomarse están la instalación en las máquinas de recolectores de polvo y defensas (Figura 96.11), la recogida y limpieza del serrín para reducir el riesgo de incendio, la utilización de gafas protectoras (y en ocasiones, pantallas de protección) y la reducción de ruidos. Otras medidas recomendables son el uso de herramientas y máquinas apropiadas para cada actividad, reparando de inmediato los equipos defectuosos; la conservación de las herramientas manuales bien afiladas y su utilización con métodos seguros; el mantenimiento en buen estado de los cables y aparatos eléctricos, evitando alargadores que puedan causar tropiezos; y, por último, evitar corbatas, cabellos largos sueltos, mangas sueltas y cualquier objeto que pueda quedar atrapado en las máquinas.

\section{Encolado de maderas}

Para pegar maderas y fabricar laminados se emplean diversas colas, como adhesivos de contacto, colas de caseína, colas de resinas epóxicas, colas de resinas de formaldehídos, colas para piel, colas blancas (emulsión de acetato de polivinilo) y colas instantáneas de cianocrilato. La mayoría de estos productos contienen sustancias tóxicas que pueden causar lesiones en la piel, los ojos y el aparato respiratorio.

Como medidas de prevención se recomienda la no utilización de colas de resinas de formaldehídos; el empleo de colas a base de agua en lugar de productos con disolventes; el uso de guantes o cremas protectoras cuando se trabaje con colas de resinas epóxicas, adhesivos con disolventes o colas de resinas de formaldehído; y la ventilación del lugar de trabajo cuando se usen colas de resinas epóxicas, de cianocrilatos y disolventes. Los disolventes inflamables deben mantenerse alejados de cualquier fuente de fuego.

\section{Pintura y acabado}

Las maderas pueden pintarse con muchos tipos de pintura; colorearse, lacarse y barnizarse; y tratarse con aceite de linaza y de otros tipos. Entre los materiales empleados en los procesos de acabado están el barniz de laca, los revestimientos de poliuretano y las ceras. Muchos de estos productos se aplican con aerosoles, y algunos artesanos elaboran sus propias pinturas con pigmentos secos. Los principales riesgos para la salud son la inhalación de polvo de pigmentos tóxicos (sobre todo los pigmentos de cromato de plomo), la inhalación y el contacto con la piel de disolventes, el peligro de incendio por disolventes inflamables, y la combustión espontánea de trapos impregnados con disolventes y esencia de trementina.

Como medidas preventivas se recomienda utilizar pinturas comerciales en lugar de pinturas de fabricación propia; abstenerse de comer, beber o fumar en la zona de trabajo; sustituir las pinturas con disolventes por otras a base de agua, y colocar los trapos impregnados de aceites y disolventes en botes con cierre automático, o incluso dentro de cubos de agua.

Con los disolventes deben adoptarse ciertas precauciones, como el empleo de gafas protectoras y guantes y de una ventilación adecuada del local; el trabajo en exteriores, y la utilización de aparatos respiradores con cartuchos para vapores orgánicos. Es recomendable aplicar los productos con brocha, cuando sea posible, para evitar los riesgos de los aerosoles. Los procesos de acabado con aerosoles deben realizarse dentro de cabinas a prueba de explosiones de aerosoles y empleando aparatos respiradores con filtros para aerosoles y cartuchos para vapores orgánicos; deben evitarse las llamas abiertas, los cigarrillos encendidos y otras fuentes de ignición (por ejemplo, pilotos encendidos) al aplicar acabados inflamables o al utilizar aerosoles.

\section{Eliminación de pinturas}

La eliminación de las pinturas y barnices viejos se realiza con productos decapantes que contienen disolventes tóxicos y por lo común inflamables. Los productos "no inflamables" para eliminar pinturas suelen contener cloruro de metileno. Se emplea también sosa cáustica (hidróxido de sodio), ácidos y sopletes. Los tintes de maderas viejas suelen eliminarse con productos blanqueadores que contienen álcalis corrosivos y ácido oxálico, peróxido de hidrógeno e hipoclorito. Los sopletes a veces vaporizan la pintura, con el consiguiente riesgo de intoxicación por el plomo que tienen algunas pinturas; asimismo pueden provocar incendios.

Respecto a las precauciones necesarias al manejar disolventes para eliminar la pintura, véase la sección anterior. Hay que emplear guantes y gafas protectoras para trabajar con sosa cáustica, y blanqueadores de ácido oxálico o de cloro. Es recomendable disponer de una ducha de emergencia y una fuente para el lavado de los ojos. Por último, deben evitarse los sopletes para eliminar pinturas con plomo.

\section{JOYERIA}

Tsun-Jen Cheng y Jung-Der Wang

La industria de la joyería utiliza piedras preciosas y semipreciosas, piedras sintéticas, conchas, corales, perlas, metales preciosos, esmaltes metálicos y otros materiales más modernos, como resinas epóxicas y polímeros de vinilo, con el fin de fabricar anillos, pendientes, collares, colgantes y otros objetos de adorno personal. El tamaño y los procesos de trabajo de los talleres de joyería son variables, como lo son los riesgos a ellos asociados.

\section{Procesos, riesgos y precauciones}

\section{Piedras preciosas e incrustaciones}

Gran parte de la manufactura de joyas consiste en la incrustación de piedras preciosas en metales preciosos o aleaciones de 
éstos. Las piedras se cortan con la forma deseada y luego se pulen. Los metales que sirven de base se modelan y pulen. Las incrustaciones se han hecho tradicionalmente con moldes de "inyección". Las aleaciones con un punto de fusión bajo, como las de cadmio y mercurio, se han empleado también en la fundición de metales. Los métodos de vaciado recientes han supuesto un avance, al permitir mayor calidad en los objetos fundidos. Las piedras se pegan a sus bases de metal mediante adhesivos, por soldadura o por grapas aplicadas mecánicamente sobre partes del marco de metal. Las bases suelen revestirse con capas de metales preciosos.

Los riesgos para la salud suelen originarlos las exposiciones a humos de metales, vapores de ceras o polvo de las piedras y metales, y la escasa iluminación, que puede dañar la vista. El trabajo con piezas finas de joyería requiere en general una ventilación adecuada, iluminación suficiente y el empleo de lentes de aumento. Se recomiendan también puestos de trabajo con un diseño ergonómico apropiado.

\section{Corte y pulido de piedras}

Las piedras preciosas, semipreciosas y sintéticas (diamante, jade, rubí, granate, jaspe, travertino, ágata, ópalo, turquesa y amatista) suelen cortarse en la forma deseada con pequeñas sierras antes de su incrustación. Los riesgos más frecuentes son las heridas en la piel y en los ojos, y los peligros para la salud derivados de la inhalación de polvos (por ejemplo, silicosis causada por piedras de cuarzo).

Entre otras medidas preventivas se encuentran la instalación de recolectores de polvo, de sistemas de ventilación, el empleo de lentes de aumento, la adecuada iluminación del lugar de trabajo, el diseño ergonómico de los puestos de trabajo e instrumentos y el empleo de gafas protectoras.

\section{Fundición de metal por vaciado}

A partir de diseños originales creados por artistas se fabrican moldes de caucho o silicona en los que se introduce la cera. Tales moldes de cera se encierran en otros de yeso mate o de sílice. El conjunto resultante se calienta en un horno a fin de extraer la cera del bloque, y después se rellena con metal fundido mediante centrifugación. Acto seguido se rompe el molde para recobrar la pieza de metal y se procede a su pulido y, en ocasiones, a electrochapado con una capa fina de metal precioso.

Para fabricar piezas de metal suelen emplearse metales preciosos y aleaciones de éstos, como oro, plata, platino y cobre, o zinc y estaño. Son actividades que entrañan determinados riesgos: incendios o explosiones de gases inflamables utilizados en la fundición de los metales, y quemaduras ocasionadas por la escayola caliente de los vaciados o de los bloques, por derramaniento de metales fundidos, por hornos y soldaduras oxiacetilénicas. Otros riesgos proceden de la posible inhalación de humos de metales y polvo de plata, oro, zinc, plomo, estaño, etc.

Entre las medidas preventivas deben citarse la utilización de métodos alternativos de fundición para rebajar los niveles de exposición y toxicidad; la instalación de sistemas adecuados de ventilación y extracción de polvos y humos de metales; la colocación de recolectores de polvo; el empleo de equipos de protección individual, como gafas protectoras, guantes aislantes y ropa de trabajo apropiada, y el almacenamiento de los gases inflamables en lugares adecuados.

\section{Esmaltado}

El esmaltado consiste en la fusión de polvo de plomo o de partículas de cristales de borosilicato en combinación con distintos óxidos coloreados, sobre una base metálica para crear una superficie esmaltada. La base de metal puede ser de plata, oro o cobre.
Los colorantes más frecuentes son el antimonio, el cadmio, el cobalto, el cromo, el manganeso, el níquel y el uranio.

\section{Limpieza}

La superficies de los metales deben limpiarse previamente con un soplete o dentro de un horno para eliminar restos de aceites y grasas. Después se someten a un baño diluido de ácido nítrico o sulfúrico, o de bisulfato sódico, elemento más seguro, para eliminar el hollín. Los principales riesgos son las quemaduras por calor y por ácidos, por lo que deben emplearse guantes, delantales y gafas protectoras.

\section{Aplicación}

Algunos esmaltadores pulen y esparcen los esmaltes para obtener partículas con el tamaño deseado. Las técnicas de aplicación comprenden el pulido, el rociado, el estarcido y el esparcido o recubrimiento de la superficie metálica con el esmalte. El mayor riesgo es la inhalación del polvo del esmalte o de la neblina del aerosol, especialmente con esmaltes que contengan plomo, por lo que se recomienda utilizar esmaltes sin esa sustancia y emplear elementos de protección de las vías respiratorias. En el esmalte tabicado se separan esmaltes de distintos colores mediante alambres metálicos soldados al metal. (Véase más adelante la soldadura con plata). En el esmaltado por levantamiento de la superficie, se graban los diseños mediante corrosión con cloruro de hierro o ácido nítrico, y las zonas deprimidas se rellenan con esmalte. Otra técnica consiste en aplicar esmalte mezclado con resinas en esencia de trementina. Todos los procesos requieren ventilación adecuada y precauciones para evitar el contacto con la piel.

\section{Galentamiento en horno}

El metal esmaltado se calienta después en un horno de tamaño reducido. La ventilación del lugar es necesaria para extraer los vapores tóxicos de los metales, los fluoruros y los productos de la descomposición de gomas y otros materiales orgánicos de los esmaltes. Las quemaduras por calor y la radiación infrarroja entrañan también riesgos, por lo que se recomienda el empleo de gafas protectoras y guantes antitérmicos.

El acabado de las piezas esmaltadas se lleva a cabo limando los bordes y puliendo la superficie esmaltada, para lo que se requieren las precauciones acostumbradas a fin de prevenir la inhalación de polvos y el contacto con la piel.

\section{Joyería con metales}

El trabajo de joyería con metales implica el corte, el doblado y otras formas de manufactura de metales, además de la galvanoplastia, la anodización, la soldadura, el encolado y el acabado, entre otros procesos. Muchos de ellos se tratan en el artículo "Metalistería" y algunas aplicaciones específicas se contemplan a continuación.

\section{Galvanoplastia}

En los procesos de galvanoplastia se utilizan materiales como el oro, la plata y el cobre, además de ácidos fuertes y cianuros. Los riesgos más frecuentes son las descargas eléctricas y las quemaduras por derramamiento de ácidos y álcalis, a los que se añaden la inhalación de humos de metales, ácidos y cianuros, disolventes orgánicos y de ácido cianhídrico.

Como medidas de prevención citaremos las siguientes: evitar las disoluciones de cianuros y su mezcla con ácidos, disponer de un sistema de ventilación aspirante local así como de una cubierta para reducir el nivel de neblinas tóxicas, almacenar debidamente los productos químicos, adoptar las precauciones necesarias contra posibles descargas eléctricas y utilizar equipos de protección individual. 


\section{Soldado y engomado}

Los procesos de soldado se realizan con diferentes metales, como estaño, antimonio, plata, cadmio, zinc y bismuto. Los principales peligros son las quemaduras y la inhalación de vapores de metales como el plomo y el cadmio (Baker y cols. 1979), y de sustancias como fluoruros y ácidos.

En estos procesos es frecuente el empleo de resinas epóxicas y agentes de secado rápido con disolventes para pegar piedras y piezas de metal, y los riesgos presentes son incendio y explosión, inhalación de vapores de disolventes y contacto de la piel con resinas epóxicas y otros adhesivos y disolventes.

Algunas precauciones importantes son la utilización de pegamentos que no contengan plomo ni cadmio, una buena ventilación por extracción localizada (VEL), el almacenamiento de los productos químicos en lugares adecuados, una iluminación suficiente y el empleo de equipos de protección individual.

\section{Pulido del metal}

Para el pulido y corte se emplean tornos e instrumentos lineales de distintos tamaños. Los riesgos para la salud más frecuentes son las heridas en la piel por rozamiento, la inhalación de polvo de metales, los movimientos repetitivos, las vibraciones, las posturas forzadas y los esfuerzos.

Como medidas de prevención debe disponerse de: sistemas de ventilación aspirante local, recolectores de polvo, gafas protectoras y herramientas y puestos de trabajo con diseños ergonómicos.

\section{Conchas}

En joyería también se emplean materiales como el nácar (de la concha de las ostras), el coral, el abulón u oreja marina y otros tipos de conchas. Los procesos de corte, taladrado, serrado, desbastado, pulido, acabado, etc., presentan riesgos, como las heridas en manos y ojos causadas por bordes afilados y por alcance de partículas proyectadas, la irritación de las vías respiratorias y las reacciones alérgicas por inhalación de polvo fino de concha. Además, en el caso del nácar, pueden originarse neumonías por hipersensibilidad y osificación con inflamación del periostio, especialmente en gente joven.

Algunas medidas preventivas que deben adoptarse son: el lavado a fondo de las conchas para eliminar todo resto de materia orgánica, el empleo de técnicas de pulido y lijado en mojado, y el trabajo con ventilación por extracción localizada o la protección de las vías respiratorias y gafas protectoras para evitar lesiones en los ojos.

\section{Cuentas}

Las cuentas se pueden fabricar con una extensa variedad de materiales, como vidrio, plástico, semillas, huesos, conchas, perlas, gemas, etc. Uno de los materiales más modernos utilizados en la fabricación de cuentas y en otros campos de la joyería es el cloruro de polivinilo curado por calor (arcillas de polímeros). Los riesgos principales son las lesiones en los ojos y la inhalación de polvo al taladrar agujeros para engarzar los alambres o cadenas. Es recomendable emplear técnicas de pulido y lijado en mojado, y trabajar con VEL o con protección de las vías respiratorias y gafas protectoras. Las arcillas de polímeros pueden liberar cloruro de hidrógeno, una sustancia irritante si se calienta por encima de las temperaturas recomendables. Para el curado por calor no deben usarse hornos de cocina domésticos. Otras sustancias peligrosas en estas arcillas de polímeros son los plastificantes, como el dietilexilftalato, que puede ser cancerígeeno y causar lesiones en el sistema reproductor.

\section{ARTES GRAFICAS}

\section{Stephanie Knopp}

Se definen como artes gráficas (también denominadas diseño gráfico, arte comercial, diseño visual y comunicación visual) la organización de ideas y conceptos en forma visual para comunicar un mensaje a un público determinado. Los artistas gráficos hacen sus trabajos en muchos soportes: revistas, libros, pósteres, embalajes, películas, vídeos, diseño de exposición y, más recientemente, en formas digitales, como el diseño por ordenador, las presentaciones multimedia y las páginas en Internet. Pueden distinguirse dos clases de profesionales de la comunicación visual: los diseñadores gráficos, que trabajan con la tipografía, la maquetación de páginas, la fotografía y la ilustración; y los ilustradores, que trabajan exclusivamente con imágenes visuales. Ambas facetas suelen solaparse, aunque, por lo común, los diseñadores gráficos contratan ilustradores para que elaboren visualmente las ideas que aquéllos usarán después en un contexto tipográfico.

\section{Diseño gráfico}

Los riesgos del diseño gráfico de finales del decenio de 1990 son muy diferentes a los de hace unos pocos años, cuando algunos diseñadores aún utilizaban medios de impresión mecánicos (Figura 96.12). Hoy en día, prácticamente toda la maquetación de páginas y el diseño gráfico se hacen en formato digital antes de su impresión en papel; incluso muchos de los diseños están destinados a formatos digitales, como disquetes, CD-ROM o páginas de Internet. Los diseñadores gráficos emplean ordenadores para crear y guardar textos e imágenes. Los trabajos creados digitalmente se guardan en disquetes, soportes extraíbles o CDs, y se entregan al cliente para su presentación final (diseños de envoltorios, revistas, títulos de películas, pósteres, efectos de escritorio de empresa y otras aplicaciones).

Es importante que los diseñadores gráficos sean conscientes de los riesgos que entraña el trabajo prolongado con ordenadores. Por desgracia, se trata de una tecnología demasiado reciente y no se conocen bien los riesgos. Los problemas de salud relacionados con el trabajo con pantallas de visualización de datos (PVD) (también denominadas pantallas de representación visual) son: vista cansada, cefaleas, dolor de espalda, rigidez del cuello, manos y muñecas doloridas, mareos, náuseas, irritabilidad y estrés. También se han dado episodios de lesiones de piel y dermatitis relacionadas con el trabajo con PVD. A pesar de que los efectos de las PVD han sido estudiados durante dos décadas, no existen pruebas que relacionen el trabajo continuo con terminales de ordenador y los problemas de salud a largo plazo. Las PVD emiten niveles de radiación relativamente bajos, y no se ha demostrado que su utilización pueda causar efectos adversos permanentes.

El diseño ergonómico de los puestos de trabajo, la eliminación de brillos y los descansos frecuentes pueden hacer de este trabajo una actividad más segura que la mayoría de las otras profesiones artísticas. De hecho, la revolución digital ha reducido en gran medida los riesgos para la salud tradicionalmente relacionados con el diseño gráfico.

\section{Ilustración}

Los ilustradores crean imágenes con diversos medios y técnicas para distintos fines comerciales: revistas, cubiertas de libros, embalajes, carteles de películas, anuncios y otras formas de publicidad y promoción. Por lo común, los ilustradores trabajan por cuanta propia y son contratados por los directores artísticos para un determinado proyecto; otros trabajan en editoriales o empresas de tarjetas de felicitación. Así pues, puesto que estos 
Figura 96.12 • Rotulación manual en artes gráficas.

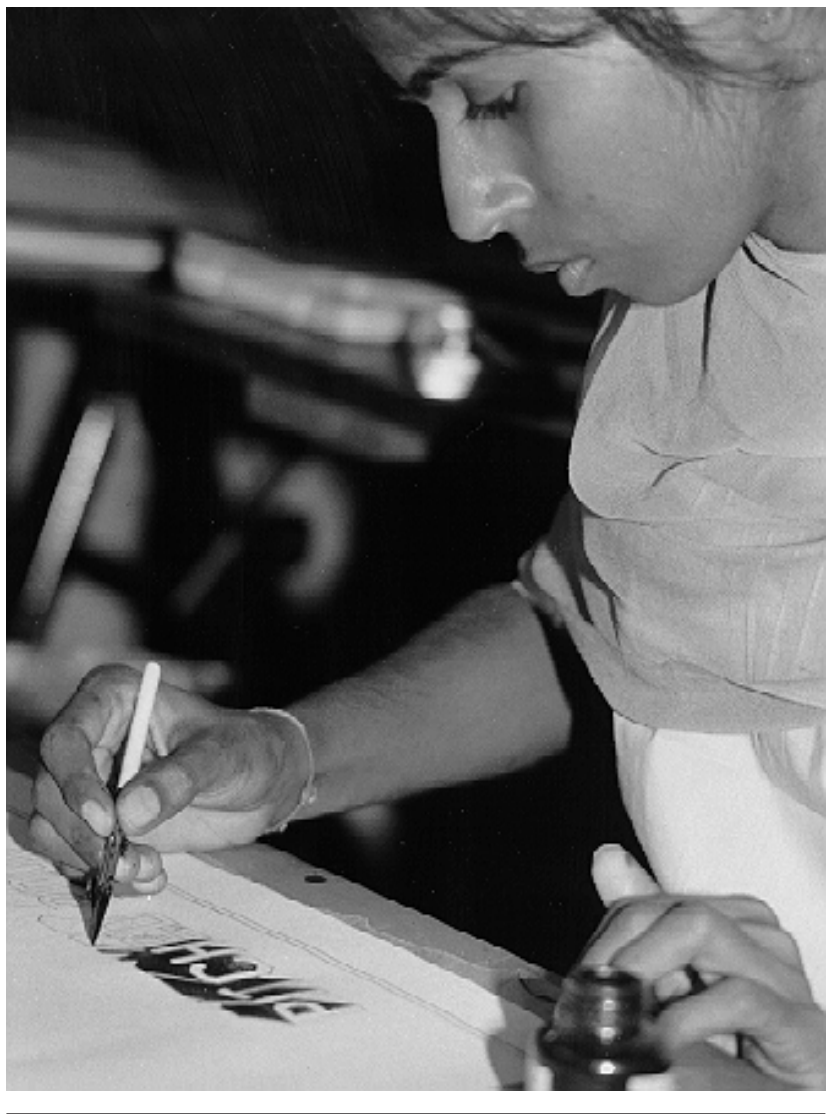

profesionales suelen crear su propio espacio de trabajo, de ellos dependen las condiciones de seguridad.

La variedad de los materiales empleados por los ilustradores es tan extensa como el número de técnicas y estilos de la ilustración contemporánea. Los artistas deben ser conscientes de los riesgos que entraña cada técnica y medio concretos. Los materiales más comunes en dibujo y pintura son los rotuladores, las acuarelas, los óleos, las tintas de color, los lápices de colores, los pasteles secos, los pasteles aceitosos, los tintes, las pinturas acrílicas y los guaches.

Muchos colores contienen compuestos peligrosos, como el xileno y los destilados del petróleo; en los pigmentos hay a veces ingredientes tóxicos, como el mercurio, el cadmio, el cobalto y el plomo. Como medidas de prevención: el estudio debe contar con una ventilación adecuada, deben utilizarse guantes y aparatos respiradores para trabajar con materiales grasos (y especialmente, aerosoles) y emplearse otros productos más seguros cuando sea posible (por ejemplo, pinturas a base de alcohol o agua). Los pasteles pueden resultar peligrosos cuando se convierten en polvo en suspensión en el aire. Es decisivo contar con una ventilación adecuada cuando se emplean materiales que puedan ser inhalados y alcanzar los pulmones. Por último, no es recomendable comer, beber o fumar mientras se trabaja con materiales tóxicos.

Debido a la variedad de materiales empleados por los ilustradores, es necesario abordar por separado las condiciones de seguridad en el trabajo, sobre todo si se considera que cada artista tiene su propia técnica y selección de materiales. Las leyes de algunos países obligan a los fabricantes a facilitar información sobre los ingredientes y riesgos de sus productos. Los artistas deben examinar detenidamente los materiales que vayan a emplear, y trabajar de la forma más segura posible con los medios disponibles.

\section{Adhesivos}

Los adhesivos más comunes son los pegamentos de goma, los adhesivos en aerosol, los pegamento de contacto, las termoencoladoras eléctricas, las hojas de adhesivo en seco, las barras o los lápices adhesivos, las pistolas de cola caliente, los materiales adhesivos de transferencia, las cintas adhesivas de doble capa y las colas solubles en agua. Los riesgos que entrañan estos productos son: la presencia de sustancias como el n-hexano (neurotóxico) en algunos pegamentos de goma y de contacto; las colas de acción instantánea con cianocrilato; la presencia de sustancias tóxicas en el aire y el riesgo de incendio por el uso de adhesivos en aerosol; y las quemaduras al manejar pistolas de cola caliente fundida. Muchos de los adhesivos más corrientes (sobre todo, los pegamentos de goma) también irritan la piel.

Gran parte de los riesgos pueden reducirse con una ventilación apropiada y con el uso de guantes. Es recomendable asimismo la utilización, siempre que sea posible, de adhesivos no tóxicos, como las termoencoladoras eléctricas, los materiales adhesivos de transferencia, las hojas de adhesivo en seco, las cintas adhesivas de doble capa y las colas solubles en agua. Los pegamentos de caucho y los adhesivos en aerosol con heptano son menos tóxicos que los que contienen hexano, aunque todos ellos son inflamables.

\section{Disolventes}

Los disolventes más comunes son los diluyentes de pegamento de goma, la esencia de trementina, la acetona, el líquido corrector y los destilados minerales. Los riesgos relacionados con estos productos son: irritación de la piel, cefaleas, lesiones en los sistemas respiratorio y nervioso, lesiones renales y hepáticas, y peligro de incendio. Como medidas de prevención deben usarse productos alternativos más seguros (los destilados minerales son menos tóxicos que la esencia de trementina) y pigmentos acuosos que no necesiten limpiarse con disolventes. Otras medidas importantes son: una ventilación adecuada o el empleo de elementos de protección de las vías respiratorias, el almacenamiento apropiado de los productos y la utilización de guantes y gafas como protección contra salpicaduras.

\section{Aerosoles}

Los productos de aplicación con aerosoles, como los fijadores, los marcadores, los barnices, los texturadores y los aerógrafos pueden ser peligrosos para el aparato respiratorio y causar irritación en la piel, cefaleas, mareos y náuseas, debido a sustancias tóxicas como el tolueno y el xileno. A veces se producen efectos adversos a largo plazo, como lesiones renales, hepáticas y lesiones en el sistema nervioso. Los aerosoles suelen ser inflamables y no deben utilizarse cerca de llamas o fuentes de calor. Entre otras precauciones cabe citar una ventilación adecuada en el estudio, el empleo de aparatos respiradores y la utilización de pigmentos no tóxicos en los aerógrafos.

\section{Herramientas de corte}

Los instrumentos para cortar, como las cuchillas y los cortapapeles pueden ocasionar lesiones por cortes y, en el caso de las grandes guillotinas para papel, seccionar los dedos. Como medidas preventivas, las cuchillas y los cortapapeles deben manejarse con cuidado, procurando mantener las manos alejadas de las hojas de corte, y todos los instrumentos deben mantenerse bien afilados. 


\section{ARTES ESCENICAS Y AUDIOVISUALES}

\section{DANZA}

\section{Itzhak Siev-Ner}

La danza es una forma de comunicación o expresión artística a través de movimientos corporales rítmicos y estructurados, generalmente acompañados de música. Existen muchas clases de danza: bailes ceremoniales, folclóricos, bailes de salón, ballet clásico, bailes modernos, jazz, flamenco, claqué, etc. Cada una de estas modalidades requiere efectuar movimientos especiales y poseer unas cualidades físicas determinadas. Aunque el público suele relacionar la danza con una actividad sutil y placentera, es cierto que muy pocas personas son conscientes de que se trata en realidad de una de las manifestaciones atléticas más duras y exigentes. Entre el 75 y $80 \%$ de las lesiones relacionadas con la danza corresponde a los miembros inferiores, de las cuales el $50 \%$ fueron lesiones en tobillos y pies (Arheim 1986). La mayoría de las lesiones son debidas a sobrecarga física (cerca del $70 \%$ ) y el resto suele ser de tipo agudo (esguince, fractura de tobillo, etc.).
La medicina que se ocupa de los profesionales de la danza es una profesión multidisciplinaria debido a que las causas de las lesiones obedecen a numerosos factores y los tratamientos han de tener en cuenta las necesidades específicas de los bailarines y artistas. El objetivo de los tratamientos es la prevención de los factores de estrés más peligrosos de modo que el bailarín pueda seguir trabajando, así como adquirir y perfeccionar su creatividad artística y su bienestar psíquico.

Es recomendable iniciar la educación en edades tempranas, para desarrollar fuerza y flexibilidad. Con todo, los procesos de formación incorrectos pueden acarrear lesiones en los bailarines más jóvenes. Es fundamental emplear técnicas adecuadas, ya que una postura incorrecta y otros malos hábitos en el baile pueden causar deformaciones y lesiones por sobrecarga física (Hardaker 1987). Uno de los movimientos más básicos es la rotación de los miembros inferiores hacia afuera (en dehors). Este ejercicio debe realizarse en las articulaciones de las caderas; si se fuerza la rotación anatómica externa de estas articulaciones se pueden producir compensaciones. Las más frecuentes son la

\section{Historia de la medicina de las artes escénicas}

Aunque el interés en los aspectos fisiológicos de la música data de épocas antiguas, la primera recopilación sobre enfermedades profesionales en las artes escénicas es el tratado de Bernardino Ramazzini Enfermedades de los trabajadores, escrito en 1713 Durante los siglos XVIII y XIX continuó el interés esporádico por la medicina en las artes. En 1932 veía la luz la traducción inglesa de la obra de Kurt Singer Diseases of the Music Profession: A Systematic Presentation of Their Causes, Symptoms and Methods of Treatment, el primer libro de texto que recopilaba todos los conocimientos existentes en la época sobre la medicina de las artes escénicas. Después de la II Guerra Mundial, la literatura médica comenzó a recoger casos de artistas lesionados. Así mismo, la literatura musical también empezó a incluir ciertos temas y artículos. Entre los profesionales de la danza fue creciendo en paralelo el interés por estos asuntos.

Uno de los hitos en el desarrollo de la medicina de las artes escénicas como modalidad interdisciplinaria fue el Simposio del Danubio sobre Neurología, celebrado en la ciudad de Viena en el año 1972. La conferencia se centró en la música, y como fruto de sus trabajos se publicó el estudio Music and the Brain: Studies in the Neurology of Music, por MacDonald Critchley y R.A. Henson. En el mismo año tuvo lugar la celebración de la primera Conferencia sobre la Salud de los Profesionales de la Voz, organizada por la Fundación para la Voz. Estas conferencias tienen carácter anual y sus trabajos se publican en el Journal of Voice.

El público ha permanecido ajeno a los adelantos producidos, mientras los artistas lesionados y los profesionales de la medicina han ido aumentando su cooperación. En 1981, un artículo en el New York Times describía los problemas en las manos de los pianistas Gary Graffman y Leon Fleisher, así como su tratamiento en el Hospital General de Massachusetts. Se trataba de los primeros músicos de gran popularidad que admitían sus problemas físicos, y la publicidad dada trajo a la luz la existencia de un grupo de artistas con lesiones hasta entonces desconocidas.

Desde entonces, el campo de la medicina de las artes escénicas se ha desarrollado a gran velocidad, con numerosas conferencias, publicaciones, nuevas clínicas y asociaciones. En 1983 se celebró la primera conferencia sobre Problemas Médicos de Músicos y Bailarines, en colaboración con el Festival Musical de Aspen, en la ciudad de Aspen, estado de Colorado. Actualmente esta conferencia se celebra anualmente y es posiblemente la más importante en este campo. En el curso de este tipo de reuniones suelen incluirse ponencias a cargo de profesionales de la salud, además de demostraciones y clases magistrales impartidas por artistas.

En el año 1986 comenzó a publicarse la revista Medical Problems of Performing Artists, la única publicación enteramente dedicada a la medicina de las artes, y que recoge muchas de las ponencias presentadas en las conferencias de Aspen. Otras revistas que tratan asuntos similares son Journal of Voice, Kinesiology and Medicine for Dance, y International Journal of Arts-Medicine. En 1991, se publicó el Textbook of Performing Arts Medicine, editado por Robert Sataloff, Alice Brandfonbrener y Richard Lederman, convirtiéndose en el primer texto moderno en la materia.

A medida que aumentaba el número de conferencias y publicaciones fueron abriéndose clínicas dedicadas a los profesionales de las artes. Por lo general, estas clínicas se localizan en las grandes ciudades, como Nueva York, San Francisco o Chicago, donde pueden atender a orquestas y compañías de baile. En la actualidad existen más de una veintena de ellas en Estados Unidos y algunas más en otros países.

Los profesionales de la salud que trabajan en el campo de la medicina de las artes escénicas han fundado distintas asociaciones para continuar la investigación y educación. La asociación de la Medicina de las Artes Escénicas, fundada en 1989, es hoy en día patrocinadora de las conferencias de la ciudad de Aspen. Hay otras organizaciones dedicadas a este tema, como la Asociación Internacional para la Medicina y Ciencia de la Danza, la Asociación Internacional para la Medicina en las Artes y la Asociación de Consultores Médicos para Orquestas Británicas.

La investigación en el campo de la medicina de las artes escénicas se ha desarrollado, pasando de la publicación de casos individuales y los estudios de prevalencia a sofisticados proyectos con tecnologías avanzadas. Los nuevos tratamientos se acercan más a las necesidades específicas de los artistas y los esfuerzos empiezan a centrarse en la prevención y la educación. 
rotación interna de los pies hacia el interior, el genuvalgo y la hiperlordosis de la región lumbar. Son posturas que contribuyen a desarrollar deformaciones como el hallux valgus (desplazamiento del primer dedo hacia los demás) y posibles inflamaciones tendinosas, como la del flexor largo del primer dedo (Hamilton 1988; Sammarco 1982).

Es importante conocer bien las características anatómicas de cada persona y las cargas biomecánicas extrañas, como las existentes en posiciones concretas (por ejemplo, al apoyarse sobre los dedos de los pies) para saber qué medidas preventivas deben adoptarse a fin de evitar lesiones y problemas de salud (Teitz, Harrington y Wiley 1985).

El entorno juega un papel importante para el bienestar de los bailarines. Los suelos deben ser flexibles y tener la capacidad de absorber los golpes para evitar la acumulación de traumas en pies, piernas y espina dorsal (Seals 1987). La temperatura y la humedad son asimismo importantes durante las actuaciones. Otro aspecto decisivo es la dieta, debido a la presión a la que están sometidos los bailarines a fin de conservar la línea y mantener un aspecto agradable (Calabrese, Kirkendal y Floyd 1983). Determinados trastornos psicológicos pueden derivar en anorexia o bulimia.

El estrés psicológico contribuye a causar ciertos desarreglos hormonales que pueden presentarse en forma de amenorrea. La incidencia del estrés por fracturas y osteoporosis puede aumentar el desequilibrio hormonal en los bailarines (Warren, Brooks-Gunn y Hamilton 1986). Los problemas psicológicos pueden verse potenciados por el estrés emocional que supone la competencia con otros compañeros y la presión directa de los coreógrafos, profesores y directores (Schnitt y Schnitt 1987).

Es importante aplicar métodos de seguimiento para detectar los factores de riesgo físico y psíquico de los estudiantes y profesionales, para así prevenir posibles problemas de salud.

Otros factores que aumentan la vulnerabilidad de los bailarines son los cambios en los ritmos de actividad (a la vuelta de unas vacaciones, después de enfermedades o embarazos), en la intensidad del trabajo (ensayos antes de una gira), en la coreografía, los estilos y técnicas, así como las condiciones del entorno (suelos, escenarios o tipo de calzado).

\section{MUSICOS}

John P. Chong

La actividad del músico se basa en una combinación de destreza de los músculos, nervios y huesos (sistema musculosquelético). Tocar un instrumento requiere una serie de movimientos repetitivos y precisos efectuados con frecuencia en posturas forzadas durante largos períodos de tiempo (Figura 96.13). A veces son factores que originan problemas de salud. Por ora parte, las condiciones de trabajo adversas tales como la exposición a niveles excesivos de ruido, las largas actuaciones sin descansos y una preparación insuficiente para repertorios e instrumentos nuevos y difíciles, pueden afectar también a la salud de los músicos de cualquier edad o nivel profesional. El conocimiento de los riesgos, los diagnósticos precisos y el tratamiento temprano son aspectos que ayudan a prevenir discapacidades profesionales que amenacen una carrera artística.

\section{Problemas neuromusculosqueléticos}

Diferentes estudios realizados en Estados Unidos, Canadá y Australia fijan en un $60 \%$ la cifra de músicos con lesiones que pueden acabar con sus carreras durante su edad activa. En estudios clínicos transversales realizados por sectores se han analizado la prevalencia de trastornos en músculos y tendones, los síndromes de compresión de vías nerviosas periféricas y problemas de control motriz. Los resultados revelan diferentes diagnósticos por exceso de ejercicio, como distensiones en músculos y tejidos conjuntivos, que controlan los movimientos flexores y extensores de las muñecas y dedos, causados por el esfuerzo repetitivo de los músculos y tendones. Otros diagnósticos frecuentes son los dolores en diversas partes del cuerpo a consecuencia del mantenimiento de posturas extrañas y desequilibradas durante largos períodos de tiempo tocando un instrumento musical. Los músicos pertenecientes a los grupos que se describen a continuación ejercen presiones sobre las ramificaciones nerviosas de las muñecas y antebrazos, hombros, brazos y cuello. Los calambres y espasmos musculares (distonía focal) son otros problemas comunes que suelen afectar a los músicos a lo largo de sus carreras profesionales.

Instrumentos de cuerda: violín, viola, cello, contrabajo, arpa, guitarra clásica y guitarra eléctrica

Muchos problemas de salud en los instrumentistas de cuerda están relacionados con la manera de sujetar el instrumento y la postura adoptada, tanto de pie como sentados, durante los conciertos. Por ejemplo, la mayoría de los violinistas y violistas sujetan el instrumento entre la barbilla y el hombro izquierdo. Este suele elevarse y la parte izquierda de la barbilla desciende para permitir que la mano izquierda pueda pisar las cuerdas del instrumento. La postura provoca una contracción estática que causa dolor de hombros y cuello, trastornos en la articulación temporomandibular, que afectan a los nervios y músculos de la mandíbula, y síndrome de compresión del plexo branquial con dolor y entumecimiento en el cuello, hombros y parte superior del tórax. Permanecer sentado durante períodos prolongados, en una postura estática y, sobre todo, inclinada, provoca dolor en los músculos largos que sostienen el cuerpo. Los músicos que tocan el contrabajo, el arpa y la guitarra clásica suelen efectuar doblamientos estáticos de la espina dorsal. Las guitarras eléctricas suelen ser

Figura 96.13 • Orquesta.

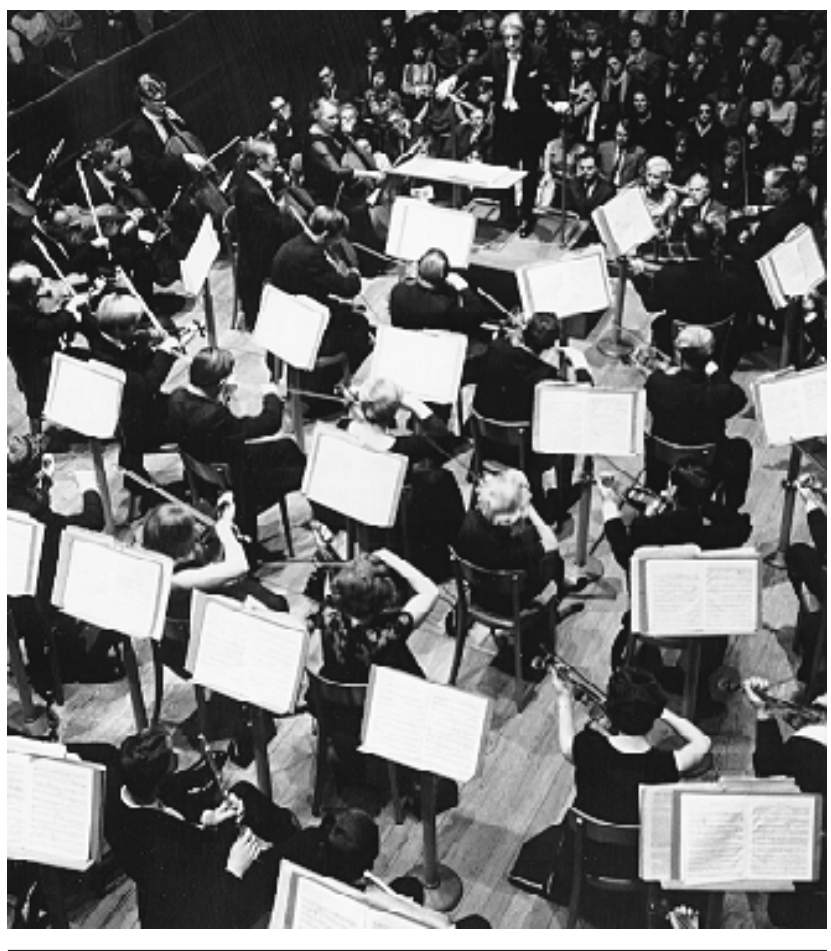


bastante pesadas y se sujetan con una banda sobre el hombro izquierdo y el cuello, lo que contribuye a la presión de los nervios de los hombros y parte superior del brazo (plexo braquial), con la correspondiente aparición de dolores. Estos problemas relacionados con la postura y la sujeción del instrumento favorecen la contractura y compresión de músculos y nervios de la muñeca y de los dedos por una alineación incorrecta. Así, la muñeca izquierda puede realizar demasiados movimientos repetitivos de flexoextensión que ocasionan distensión de los músculos extensores de los dedos y la muñeca, y la aparición del síndrome del túnel carpiano. La presión sobre los nervios de los hombros y el brazo (tronco inferior del plexo braquial) puede causar lesiones en el codo, como el síndrome del codo dolorido y la neuropatía cubital.

\section{Instrumentos de teclado: piano, clavicordio, órgano, sintetizador y piano eléctrico}

Para tocar instrumentos de teclado se adoptan posturas similares a las de la escritura con un teclado. La orientación de la cabeza hacia el frente y hacia abajo para mirar las teclas y las manos, y los movimientos repetitivos para leer la partitura, pueden provocar dolores en los nervios y músculos del cuello y la espalda. Los hombros suelen redondearse, y a ello se añaden posturas que proyectan la cabeza al frente y ritmos de respiración profunda. La compresión crónica del paquete vasculonervioso que atraviesa los músculos del cuello, hombros y parrilla costal provoca a veces la aparición del síndrome torácico. Además, la tendencia de algunos músicos a doblar las muñecas y curvar los dedos mientras mantienen estiradas las articulaciones de las manos y dedos provoca una tensión excesiva en los músculos de las muñecas y de los dedos en el antebrazo. Por otra parte, la colocación repetitiva del pulgar debajo de la mano produce una tensión de los músculos de este dedo que extienden y flexionan los músculos extensores del dedo en el dorso de la mano. Los esfuerzos especiales y repetitivos para tocar octavas y acordes con teclas distantes generan tensión en la cápsula articular de las muñecas y favorecen la aparición de ganglios. La contracción prolongada de los músculos que giran y mueven los brazos hacia arriba y hacia abajo puede provocar síndrome de atrapamiento de nervios. Los calambres y espasmos musculares (distonía focal) son frecuentes en este grupo de instrumentistas, algunos de los cuales necesitan educación neuromuscular para corregir hábitos de movimientos que pueden derivar en tales patologías.

\section{Instrumentos de viento y de metal: flauta, clarinete, oboe, saxofón, fagot, trompeta, trompa, trombón, tuba y gaita}

Los músicos que tocan estos instrumentos adoptan posturas diferentes dependiendo de la necesidad de controlar la respiración, ya que la postura condiciona la zona de la respiración diafragmática e intercostal de donde proviene el aliento. En estos instrumentos es importante la forma de sujetar la embocadura, ejercicio en el que intervienen los músculos faciales y laríngeos. La embocadura controla la producción del sonido haciendo vibrar la lengüeta o la pieza de la boca. La postura afecta al modo en que el músico sujeta el instrumento mientras está de pie o sentado, y condiciona también la forma de pisar las teclas y agujeros del instrumento que seleccionan las notas. Así, la flauta de agujeros tradicional requiere movimientos sostenidos de aducción y flexión (inclinación hacia adelante) del hombro izquierdo, abducción (movimiento hacia atrás) del hombro derecho y ligeros movimientos rotatorios hacia la izquierda de la cabeza y el cuello. La muñeca izquierda suele flexionarse en exceso, manteniendo la mano extendida para sujetar el instrumento con ambos pulgares y el dedo índice de la mano izquierda flexionados, y con el dedo meñique de la mano derecha como contrapeso. Con ellos se provoca tensión en los músculos del antebrazo y en los extensores de los dedos. La tendencia a proyectar la cabeza y el cuello hacia adelante y la respiración profunda aumentan el riesgo de aparición del síndrome de compresión del plexo branquial.

\section{Instrumentos de percusión: tambores, platillos, timbales,} xilófono, marimba, tabla y taiko

La utilización de baquetas, mazos o las propias manos para golpear los distintos instrumentos de percusión provoca el rebote rápido de las muñecas y dedos. La vibración producida se transmite a la mano y al brazo con riesgo de lesiones por esfuerzo repetitivo en las zonas musculotendinosas y en los nervios periféricos. A estas lesiones pueden contribuir ciertos factores biomecánicos, como la cantidad de esfuerzo, la naturaleza repetitiva de la interpretación y la carga estática de los músculos. En este grupo de músicos son frecuentes el síndrome del túnel carpiano y la formación de nódulos en las vainas tendinosas.

\section{Pérdida de audición}

El riesgo de pérdida de audición depende de la intensidad y duración de la exposición a los sonidos musicales. En un pasaje tranquilo de una composición orquestal, los niveles de exposición pueden alcanzar $100 \mathrm{~dB}$, con picos de valores de $126 \mathrm{~dB}$ medidos a la altura del hombro de un músico situado en el centro de la orquesta. En la posición del director de una orquesta o banda, los niveles suelen ser de $110 \mathrm{~dB}$. Los niveles de exposición de los músicos de rock y de jazz pueden ser mucho más altos, según las características acústicas del escenario o del foso, el sistema de amplificación y la situación de los altavoces y de los otros instrumentos. La duración media de exposición suele ser de unas 40 horas por semana, aunque en ocasiones los músicos pueden llegar a tocar hasta 60 y 80 horas semanales. La pérdida de audición entre los músicos es un fenómeno más frecuente de lo que se cree. Aproximadamente el $89 \%$ de los músicos profesionales que han sufrido lesiones musculosqueléticas también presentan niveles auditivos anormales, con pérdidas de audición de entre 3 y $6 \mathrm{KHz}$.

Pueden utilizarse protectores de oídos, aunque adaptados a cada instrumento (Chasin y Chong 1992). Con un filtro o un atenuador acústico adaptado a unos tapones ajustables es posible reducir la intensidad de los sonidos de alta frecuencia, medida a la altura del tímpano, disminuyendo el riesgo de posibles lesiones. La utilización de orificios sincronizados o ajustables en los tapones corrientes permite el paso sin atenuación de los sonidos correspondientes a bajas frecuencias y de cierta energía armónica. Algunos tapones de oídos están diseñados para facilitar una ligera amplificación a fin de alterar la percepción de la voz del cantante, lo que le permite reducir el riesgo de esfuerzo vocal. Los riesgos de pérdida auditiva pueden reducirse notablemente en función de la naturaleza acústica y el impacto psíquico del instrumento, y del grado de exposición a la música de alrededor. Al mejorar la percepción por parte del artista de la intensidad relativa del instrumento pueden reducirse los riesgos de lesiones por esfuerzo repetitivo, ya que disminuye relativamente la fuerza de los movimientos repetitivos.

Existen técnicas prácticas para rebajar la exposición acústica de los músicos sin que ello afecte su interpretación (Chasin y Chong 1995). Los altavoces pueden elevarse por encima del nivel del suelo, lo que origina una pérdida mínima de sonidos de baja frecuencia, aunque mantiene el volumen suficiente para que el músico pueda tocar a un nivel más bajo. Los músicos que tocan instrumentos de alta intensidad y con un elevado nivel direccional, como las trompetas y los trombones, deben situarse en plataformas para que el sonido pase por encima del resto de los músicos y se reduzca su impacto. Enfrente de una orquesta debe haber un espacio de $2 \mathrm{~m}$ sin obstáculos, y los pequeños 
instrumentos de cuerda deben contar con al menos $2 \mathrm{~m}$ de espacio libre por encima de ellos.

\section{Cantantes}

Anat Keidar

Se denomina cantante a cualquier persona cuya carrera o profesión se basa en la utilización de la voz en un contexto musical que no es el del discurso ordinario. A diferencia de los percusionistas, violinistas y pianistas, el instrumento del cantante es su propia voz, y su bienestar no solamente depende de la salud de la laringe (donde se origina el sonido) y las cuerdas vocales (donde se modifica el sonido), sino también del funcionamiento adecuado y de la coordinación de la mayoría de los sistemas corporales y mentales.

Muchos de los estilos de canto que hay en el mundo presentan aspectos litúrgicos, culturales, lingüísticos, étnicos y geopolíticos, únicos y heredados; otros estilos, por el contrario, son más universales. Algunos de los estilos frecuentes en Estados Unidos y países occidentales son: el canto clásico tradicional (oratorio, ópera, canciones, etc.), el canto vocal armónico, el jazz, el teatro musical (Broadway), el canto coral, el gospel, el folk, el country, el canto popular, el rhythm and blues, el rock 'n' roll (incluidos el heavy metal, el rock alternativo, etc.) y otros estilos. Cada uno de ellos tiene sus propias formas, hábitos y factores de riesgo.

\section{Problemas vocales}

A diferencia de los músicos no vocalistas, los problemas vocales son vitales en el caso de los cantantes. Incluso entre los cantantes más experimentados, las deficiencias vocales tienen mayor efecto en las voces altas (sopranos y tenores) que en las bajas (mezzo-sopranos, altos, barítonos y bajos). Por otra parte, algunos cantantes (por ejemplo, de pop, gospel o rock) se esfuerzan en exceso buscando y potenciando un estilo personal que les provoca patologías vocales que pueden derivar en una voz ronca, sorda, y diplofónica (diferentes notas simultáneas). Tales cantantes, en parte debido a sus insuficiencias vocales, tienden a cantar con grandes esfuerzos, sobre todo en las notas más altas, y ese esfuerzo confiere un efecto dramático añadido para parte del público que lo contempla como un sacrificio del cantante en el proceso artístico.

La incidencia de las lesiones profesionales de carácter general entre los cantantes y, en particular, de los trastornos de la voz, no está demasiado documentada en la bibliografía médica. Según estimaciones de este autor, entre un 10 y un $20 \%$ de los cantantes de Estados Unidos sufren algún tipo de trastorno crónico en la voz. Los factores que influyen en la incidencia de lesiones vocales son numerosos. Muchos cantantes fuerzan la capacidad y la resistencia de su voz más allá de sus límites por criterios artísticos o estéticos y por la forma de actuar, la demanda del público, las imposiciones económicas y la presión social. Por otra parte, los cantantes suelen negar, trivializar o ignorar los síntomas de alarma y los propios diagnósticos de lesiones vocales (Bastian, Keidar y Verdolini-Marston 1990).

\section{Ansiedad teatral}

La ansiedad teatral o miedo escénico es, al igual que el miedo, la pena o la alegría, una emoción con componentes físicos y psicológicos. Las respuestas motoras, las reacciones automáticas, los recuerdos y las ideas se entremezclan activamente. La ansiedad teatral ya no se considera un síntoma aislado sino un síndrome que abarca actitudes, rasgos y conflictos inconscientes que se activan bajo determinadas circunstancias.

Todas las personas sufren algún tipo de ansiedad teatral a lo largo de sus vidas. Determinados trabajos cara al público, como el de los artistas en el escenario, generan aún más ansiedad teatral que otras profesiones. Incluso profesionales con años de experiencia puede sufrir problemas de esta naturaleza.

La ansiedad teatral suele caracterizarse por ansiedad irracional acompañada de síntomas físicos no deseados que tienen efectos limitantes y pueden provocar conductas descontroladas. Esta situación suele darse cuando se realiza una actividad que puede ser objeto de las críticas de los demás, como hablar en público, dar un concierto, realizar exámenes, relaciones sexuales, etc. Algunos de los síntomas derivados de la ansiedad teatral son temblor en manos y labios, diarrea, sudoración en las manos y palpitaciones. Estos síntomas, además de limitar la calidad del trabajo de la persona, también pueden perjudicar el futuro de su carrera.

Algunos expertos relacionan la ansiedad teatral con una práctica y hábitos de preparación inadecuados, experiencia insuficiente, repertorios inapropiados, etc. Otras teorías se inclinan por los pensamientos negativos y la baja autoestima como origen de la ansiedad teatral. Por último, también se ha buscado el motivo del estrés y la ansiedad ante el público en el llamado estrés profesional, en el que intervienen sentimientos de falta de adecuación, anticipación del castigo y la crítica y la pérdida de reconocimiento. Aún reconociendo que no existe acuerdo sobre las causas de la ansiedad teatral, y asumiendo que los motivos deben ser complejos, la realidad demuestra que se trata de un fenómeno muy extendido, y que incluso alcanza a músicos de la fama de Yehudi
Menuhin o Pablo Casals, de quienes se sabe que han sufrido ansiedad teatral a lo largo de sus respectivas carreras.

Los rasgos personales están estrechamente ligados a la ansiedad teatral. Lo que para una persona supone un simple reto puede resultar catastrófico para otra; la ansiedad teatral depende en gran medida de la percepción personal de una situación amenazante. Los individuos introvertidos son más propensos a sufrir ansiedad teatral que las demás personas. En determinados casos, el éxito puede agravar el miedo y la ansiedad teatral de un artista, periudicando su capacidad creativa y comunicativa.

A menudo resulta inevitable un poco de miedo y estrés, y cierta dosis de nerviosismo, para lograr una buena actuación. La línea que separa los niveles de ansiedad aceptables para actuar satisfactoriamente, y aquellos que requieren intervención terapéutica, sólo puede definirse por el propio artista.

La ansiedad teatral es un fenómeno complejo; sus diferentes componentes conducen a reacciones cambiantes según las situaciones. Los factores sociales, los aspectos individuales, las situaciones en el trabajo y el desarrollo personal, contribuyen por igual a dificultar el análisis generalizado del problema.

Algunos métodos para reducir la ansiedad teatral son el desarrollo de estrategias personales para salir airoso en situaciones comprometidas y las técnicas de relajación, como la biorretroalimentación, que implican esfuerzos dirigidos a transformar los pensamientos negativos sobre situaciones irrelevantes y las preocupaciones anticipadas en situaciones y tareas con una orientación más positiva. También es muy frecuente la utilización de medicamentos como betabloqueantes y tranquilizantes (Nubé 1995), a pesar de que el nivel de medicación sigue siendo un tema controvertido, recomendándose únicamente bajo supervisión médica debido a los posibles efectos secundarios y contraindicaciones.

\section{Jacqueline Nubé}


Los problemas más frecuentes son los trastornos benignos en las mucosas, es decir, la capa externa o cubierta de los pliegues vocales (normalmente llamados cuerdas vocales) (Zeitels 1995). Entre los problemas agudos están la laringitis y la inflamación transitoria (edema) de los pliegues vocales. Las lesiones crónicas en las mucosas comprenden inflamación de los pliegues vocales, nódulos ("callosidades"), pólipos, quistes, hemorragia submucosal (sangrado), ectasia capilar (dilatación), laringitis crónica, leucoplaquia (placas blancas) y desgarros en las mucosas y pliegues de la glotis (surcos profundos en los tejidos). Aunque el tabaco y el consumo de alcohol pueden agravar estos trastornos, no debe olvidarse que las lesiones benignas en las mucosas suelen estar directamente relacionadas con la forma e intensidad del uso de la voz y son ocasionados por traumas vibratorios (Bastian 1993)

\section{Causas de los problemas vocales}

$\mathrm{Al}$ determinar las causas de los problemas vocales en los cantantes hay que distinguir entre los factores intrínsecos y los extrínsecos. Los primeros están relacionados con la personalidad, el comportamiento vocal (incluido el lenguaje) dentro y fuera del escenario, las técnicas vocales y los hábitos de consumo (especialmente si existe abuso de ciertos productos, medicación inadecuada, malnutrición y deshidratación). Los factores extrínsecos están relacionados con los agentes contaminantes en el ambiente, las alergias, etc. Los datos clínicos ponen de manifiesto que los factores intrínsecos son los más determinantes.

Las lesiones vocales suelen ser causa de procesos acumulativos de mal uso o esfuerzo excesivo de la voz en la actividad profesional de un cantante o en su vida social y privada. No es fácil saber la proporción de lesiones atribuibles a cada una de estas dos facetas. Factores de riesgo frecuentes son las excesivamente largas sesiones de ensayo cantando a plena voz, la necesidad de cantar con infecciones de las vías respiratorias superiores por falta de sustituto y el exceso de tiempo dedicado al canto. La mayoría de los cantantes saben que no deben actuar más de una hora y media al día (en términos netos), aunque por desgracia muchos de ellos no respetan los límites de su voz. Algunos cantantes se entusiasman con nuevas técnicas y formas de expresión innovadoras, nuevos repertorios, etc., y ensayan hasta 4, 5 ó 6 horas diarias. Aún más grave resulta forzar la voz cuando aparecen síntomas de lesiones (como pérdida de notas altas, incapacidad para cantar suavemente, retraso respiratorio al iniciar los sonidos, "vibrato inestable" o aumento del esfuerzo foniátrico). Hay otras personas responsables también de las lesiones vocales de los cantantes: los promotores de conciertos, quienes apuran en exceso las fechas de las actuaciones, y los ejecutivos, que alquilan los estudios de grabación durante 12 horas seguidas para grabar todas las canciones de un CD, desde el principio hasta el final.

Aunque la práctica totalidad de los cantantes están expuestos a sufrir lesiones agudas a lo largo de sus carreras profesionales, se considera que aquellos que tienen una educación musical y pueden ajustar el cante a sus limitaciones vocales, y los que han recibido una formación adecuada de la voz, tienen menos posibilidades de padecer problemas crónicos que los cantantes sin la debida educación musical, quienes suelen aprender de memoria los repertorios, cantando repetidamente y acompañándose de cintas de demostración o de grabaciones de otros cantantes. Esta última actividad puede forzarles a cantar en un tono, escala o estilo poco adecuados para su voz. Los cantantes que periódicamente se ponen en manos de profesionales expertos en la voz no necesitan recurrir tan a menudo a esfuerzos vocales para compensar pérdidas de voz y suelen lograr un mayor equilibrio entre las demandas artísticas y la longevidad de sus voces. Los buenos profesores son conscientes de la capacidad normal (esperada) de cada instrumento, y suelen distinguir las limitaciones técnicas y físicas, siendo los primeros en detectar las señales de aviso del deterioro de la voz.

Otra circunstancia que puede causar problemas a los cantantes es la amplificación del sonido. Muchos grupos de rock amplifican no sólo la voz del cantante sino todos los instrumentos, y cuando los niveles de ruido impiden que los comentarios del público lleguen hasta el cantante, éste no puede saber que está cantando demasiado alto y que la técnica que utiliza es errónea, lo cual puede contribuir al desarrollo de patologías vocales.

Hay otros factores importantes ajenos a la actividad de cantar. Los cantantes deben ser conscientes de que los mecanismos para cantar y hablar son inseparables. De hecho, los cantantes pasan más tiempo hablando que cantando, aunque las técnicas para hablar correctamente suelen descuidarse, lo que afecta negativamente a la capacidad de cantar.

Hoy en día los cantantes viajan frecuentemente en tren, autobús y avión para ofrecer sus actuaciones. Las giras exigen una adaptación psicológica y la necesidad de ajustes en distintos niveles. Los cantantes necesitan dormir suficientemente para poder actuar en las mejores condiciones. Los cambios bruscos de zona horaria obligan a los cantantes a permanecer despiertos cuando sus relojes internos están enviando a los diferentes sistemas corporales señales de preparación para el sueño, y, a la inversa, deben dormir cuando el cerebro está preparado para desarrollar las actividades normales de la jornada. Tales interrupciones del ciclo diario acarrean numerosos síntomas debilitantes, como insomnio crónico, cefaleas, abstemia, mareos, irritabilidad y pérdida de memoria (Monk 1994). Los cantantes que actúan en sesiones nocturnas sufren también alteraciones del sueño, frecuentemente potenciadas con la ingestión de alcohol, estimulantes y drogas con o sin prescripción médica (EFP, especialidades farmaceúticas publicitarias), muchas de ellas con efectos adversos sobre la voz. Los viajes implican a menudo estancias prolongadas en un automóvil, tren o avión, lo que añade nuevas molestias. Según muchos cantantes, la respiración del aire mal filtrado (frecuentemente reciclado), contaminado, deshumificado (seco) (Feder 1984) puede provocar molestias respiratorias, traqueitis, bronquitis y faringitis, que pueden durar varios días después del viaje.

La inestabilidad ambiental y el ritmo frenético de los calendarios conducen a hábitos de comida inestables y poco sanos. Además de depender de la comida ofrecida en restaurantes y de los cambios impredecibles de las horas de comida, muchos artistas hacen la comida principal del día después de su actuación, generalmente bien entrada la noche. Dormir poco tiempo después de acabar de comer, sobre todo en el caso de personas con sobrepeso y de comidas picantes, grasas o ácidas, o si se han tomado café y bebidas alcohólicas, puede favorecer el reflujo gastroesofágico, que tiene lugar cuando los ácidos del estómago suben por el esófago hasta la laringe y la garganta. Los síntomas resultantes pueden ser muy perjudiciales para los cantantes. Los trastornos de las comidas son bastante frecuentes entre los cantantes. En el ámbito de la ópera y la música clásica se dan muchos casos de excesos en las comidas y de obesidad, mientras que en los musicales y entre los artistas de música pop, sobre todo en artistas femeninas jóvenes, se ha detectado que una quinta parte de los cantantes presentaban problemas relacionados con la alimentación, como anorexia y bulimia. En esta última patología son frecuentes los vómitos, peligrosos igualmente para la voz.

Otro factor es la exposición a sustancias contaminantes, como formaldehído, disolventes, pinturas y polvo, así como a alergenos como el polen de árboles, hierbas y semillas, polvo, esporas de mohos, partículas procedentes de pelo, las plumas o la piel de animales y perfumes (Sataloff 1996). Algunas de estas sustancias 
pueden estar presentes tanto en el escenario como fuera de él. Además, en su ambiente de trabajo los cantantes sufren la exposición a otros agentes nocivos para la voz, como el humo de los cigarrillos y el humo artificial de efectos especiales en el escenario. Los cantantes consumen un mayor porcentaje de capacidad vital que cualquier hablante. Por otra parte, cuando su actividad viene acompañada de ejercicio intenso (como bailar) el número de ciclos respiratorios por minuto se ve incrementado y la respiración se efectúa por la boca, lo que lleva a inhalar durante las actuaciones grandes cantidades de humo de tabaco y del procedente de las nieblas artificiales.

\section{Tratamiento de las afecciones vocales}

Dos de los aspectos más importantes en el tratamiento de los problemas vocales de los cantantes son la automedicación y los tratamientos inadecuados por parte de médicos sin una preparación específica sobre la voz y sus problemas. Sataloff $(1991,1995)$ estudió los posibles efectos secundarios de los medicamentos consumidos habitualmente por los cantantes. La mayoría de ellos (ya sean estimulantes, prescritos médicamente, publicitarios o como suplementos vitamínicos), tienen algún tipo de efecto secundario sobre la voz. La automedicación para combatir "alergias", "flemas" o "congestiones nasales", supone la ingestión de sustancias que acaban dañando el sistema vocal. Asimismo es posible que la voz del cantante quede seriamente dañada por la prescripción de esteroides para reducir la inflamación crónica debida a hábitos y abusos de la voz, sin ocuparse de la verdadera causa del problema. También existen casos bien documentados de lesiones vocales causadas por intervenciones quirúrgicas poco recomendables o mal practicadas (Bastian 1996). A fin de evitar lesiones como consecuencia de los tratamientos, los cantantes deben conocer bien su voz y consultar únicamente a profesionales de la salud con la debida experiencia en el tratamiento de las afecciones vocales, y que sepan educar y potenciar la voz de los cantantes.

\section{ACTORES}

\section{Sandra Karen Richman}

Actuar implica desplazarse mentalmente al mundo de la fantasía y dar a vida a un personaje para una representación. Los actores toman parte en diferentes ámbitos de las artes y el espectáculo, como el teatro, el cine, la televisión, los espectáculos de entretenimiento, los parques temáticos, etc. Los actores están expuestos al estrés, a los riesgos físicos y a los químicos. La ansiedad teatral (miedo escénico) se trata en un apartado especial.

\section{Estrés}

Entre las causas del estrés se incluyen la enorme competencia por la escasez de empleo, la presión por tener que realizar actuaciones a diario, incluso más de una por día (como sucede en los parques temáticos o cuando hay sesión de tarde), el trabajo nocturno, las giras, los plazos de rodaje, la repetición de tomas (sobre todo cuando se filman anuncios de televisión), etc. También existen presiones psicológicas al tener que adoptar y mantener el papel de un personaje, en las que se incluye el estrés por tener que expresar ciertas emociones en un momento determinado y las tácticas utilizadas a menudo por los directores para que el actor reaccione de una manera concreta. Como resultado, entre los actores se dan índices mayores de alcoholismo y suicidio. La solución a muchas de estas causas de estrés pasa por una mejora en las condiciones de trabajo y de vida, sobre todo en giras y rodajes en exteriores. También pueden ser útiles ciertas medidas personales, como la terapia y las técnicas de relajación.

\section{Vestuario}

Cuando se encuentran cerca de las llamas y otras fuentes de ignición, muchas prendas entrañan un riesgo de incendio. El vestuario y las máscaras de los efectos especiales pueden crear problemas de estrés por calor y exceso de peso.

El vestuario de cualquier actor que trabaje cerca de llamas abiertas debe ser tratado con un agente ignífugo. Los actores que utilicen ropas pesadas o no apropiadas para el clima, han de tener sus períodos de descanso. Si el vestuario está hecho de metal pesado o contiene una estructura de madera, puede ser necesario suministrar aire frío dentro de la ropa. Así mismo han de tomarse medidas para desprenderse fácilmente de dichas ropas en caso de emergencia.

\section{Maquillaje teatral}

En algunas personas, el maquillaje utilizado en el teatro puede producir alergias cutáneas e irritación en los ojos. La práctica extendida de compartir el maquillaje o aplicarlo de un mismo recipiente a diferentes personas, puede crear riesgos de transmisión de infecciones bacterianas. Según los expertos médicos, no hay probabilidad de transmisión del VIH y otros virus a través del maquillaje. Otro problema es el uso de aerosoles para el pelo y otros productos en vestuarios sin ventilación. El maquillaje de efectos especiales puede contener materiales más peligrosos, como poliuretano, resinas de goma de silicona y una amplia variedad de disolventes.

Deben tomarse ciertas precauciones básicas al aplicar el maquillaje, como lavarse las manos antes y después de aplicarlo, no utilizar maquillaje pasado, no fumar, comer ni beber durante su aplicación; usar agua potable en lugar de saliva para humedecer los pinceles; evitar crear polvo en el aire, y utilizar vaporizadores en lugar de aerosoles. Cada actor debe tener su propio estuche de maquillaje, siempre que resulte práctico. Al aplicar maquillaje a varias personas han de utilizarse esponjas desechables, pinceles y aplicadores individuales, lápices de labios individuales (o divididos y con etiquetas), etc. En el maquillaje de efectos especiales debe usarse la menor cantidad posible de productos tóxicos. El vestuario debe tener un espejo, buena iluminación y sillas confortables.

\section{Escenas peligrosas}

Una escena peligrosa es toda secuencia de acción que entraña un riesgo de lesión superior al habitual para los actores o para cualquier otra persona del plató. En muchas de esas situaciones los actores son doblados por especialistas con experiencia y entrenamiento para llevar a cabo dichas secuencias de acción. Ejemplos de escenas potencialmente peligrosas son las caídas, las peleas, las escenas con helicópteros, las persecuciones de coches, los incendios y las explosiones. Se precisa una planificación previa y procedimientos de seguridad por escrito. Véase el artículo "Producción de cine y televisión" para más detalles sobre las escenas peligrosas.

\section{Otros riesgos}

Otros riesgos para los actores, sobre todo en rodajes en exteriores, son las condiciones ambientales (calor, frío, agua contaminada, etc.), las escenas acuáticas con posible riesgo de hipotermia, y los efectos especiales (nieblas y humo artificiales, pirotecnia, etc.) Debe prestarse una atención especial a estos factores antes de comenzar el rodaje. En el teatro, las escenas donde hay polvo, grava, nieve artificial, etc., pueden causar problemas de irritación en ojos y vías respiratorias si se utilizan materiales peligrosos o materiales usados, lo que es posible que origine contaminación biológica. Otro peligro es el creciente acoso al que se ven sometidos actores y actrices, así como otras celebridades, con posibles amenazas o violencia real. 


\section{Actores infantiles}

La utilización de niños en las producciones teatrales y cinematográficas puede llevar a la explotación de los mismos a menos que se establezcan procedimientos para garantizar que no trabajen muchas horas seguidas, que no se les exponga a situaciones peligrosas y que reciban la educación adecuada. También son motivo de preocupación los efectos psicológicos en niños que intervienen en escenas teatrales o cinematográficas con violencia simulada. En muchos países las leyes laborales infantiles no protegen adecuadamente a los actores infantiles.

\section{TEATRO Y OPERA}

\section{Claes W Englund}

Existen diversos aspectos en materia de salud y seguridad en el teatro y la ópera, que abarcan desde los problemas de la industria en general hasta los aspectos específicos artísticos y culturales. El proceso de llevar a cabo una representación, tanto en el teatro como en la ópera, incluye más de 125 profesiones distintas; estas representaciones pueden tener lugar en aulas y pequeños teatros, o en grandes teatros de la ópera y salas de conferencias. Con mucha frecuencia, las compañías de teatro y ópera efectúan giras por todo el país y en el extranjero, actuando en diversos edificios.

Las distintas profesiones comprenden las artísticas: artistas, actores, cantantes (solistas y coros), músicos, bailarines, entrenadores, coreógrafos y directores; las profesiones técnicas y de producción: directores técnicos, jefes de iluminación y electricidad, ingenieros de sonido, tramoyistas, montadores, peluqueros, personal de tintes y vestuario, utileros, costureros, etc.; y personal administrativo: jefes de contabilidad, directores de personal, directores de auditorio, jefes de abastecimiento, directores de contratación, personal comercial, personal de taquillas, publicistas, etc.

En el teatro y la ópera existen riesgos de seguridad industrial en general, como levantar objetos pesados, y riesgos de accidentes debido a los horarios irregulares, a lo que se añaden factores específicos del teatro, como la disposición de las instalaciones, las complejas adaptaciones técnicas, la mala iluminación, las temperaturas extremas y la necesidad de trabajar con horarios ajustados y cumplir con los plazos acordados. Los riesgos son los mismos para los artistas que para el personal técnico.

Un comportamiento adecuado con respecto a la salud y la seguridad en el trabajo exige tanto cuidar la mano del violinista o la muñeca de un bailarín de ballet, como tener una visión más amplia de la situación de los empleados en su totalidad, incluidos los riesgos físicos y los psicológicos. Las salas de teatro están abiertas al público, cuya salud y seguridad exige asimismo cuidados.

\section{Seguridad contra incendios}

En las salas de teatro y ópera existen varios tipos de peligros de incendio, entre los que se cuentan: peligros generales, como salidas bloqueadas o cerradas, o en número y tamaño insuficiente; falta de entrenamiento para seguir los planes de emergencia en caso de incendio; peligros entre bastidores (por ejemplo, almacenamiento inadecuado de pinturas y disolventes, decorados y otros materiales combustibles, trabajos de soldadura cerca de materiales combustibles y carencia de salidas adecuadas para los vestuarios); peligros en el escenario, como la pirotecnia y las llamas, la existencia de cortinas, adornos, atrezo y decorados combustibles, la falta de salidas del escenario y de sistemas de rociado; y peligros causados por el público, como fumar, bloquear los pasillos y sobrepasar el aforo permitido. En caso de incendio en un teatro, todos los pasillos, corredores y escaleras deben estar totalmente despejados de sillas y otros obstáculos para facilitar la evacuación. Las salidas de emergencia deben estar bien señalizadas. Los timbres de alarma, las alarmas contra incendios, los extintores, los sistemas de rociado, los detectores de calor y humo y las luces de emergencia deben funcionar correctamente. Es necesario subir y bajar la cortina de protección contra incendios en presencia del público, a menos que se haya instalado un sistema de rociado automático. Cuando el público abandona la sala, ya sea por una emergencia o al final de la representación, todas las puertas de salida deben estar abiertas.

Deben existir procedimientos de control de incendios y practicarse simulacros de emergencias. En cada representación debe haber una o más personas encargadas de controlar los incendios, a menos que el departamento de bomberos destaque parte de su personal. Todo el decorado, el atrezo, las cortinas y demás materiales presentes en el escenario han de ser incombustibles. Si se utilizan efectos pirotécnicos o llamas, debe obtenerse la correspondiente autorización cuando sea necesaria, y establecer procedimientos de seguridad para su uso. El equipo de iluminación del escenario y bastidores y los sistemas eléctricos deben cumplir las normas y contar con el mantenimiento adecuado. Ha de eliminarse el material combustible y otros peligros de incendio. Fumar debe estar prohibido en cualquier teatro, excepto en las áreas destinadas para ello.

\section{Aparejos y estructuras metálicas}

Los escenarios de teatro y de ópera tienen estructuras próximas al techo de las que cuelgan los aparatos de iluminación, y aparejos para subir y bajar decorados, y, en ocasiones, también a los actores sobre el escenario. Existen escaleras y pasarelas elevadas para que los técnicos de iluminación y otros operarios trabajen en las alturas. En el escenario, tanto los artistas como el personal técnico deben prestar mucha atención al equipo que hay sobre sus cabezas. El decorado del teatro puede moverse vertical y horizontalmente. El movimiento horizontal de éste desde el lateral puede hacerse manual o mecánicamente, por medio de cables desde las estructuras del techo, operados desde el cuarto de decorados. Al utilizar los cables y contrapesos es muy importante observar los procedimientos de seguridad establecidos. Existen diferentes tipos de sistemas de cordajes que utilizan energía hidráulica y eléctrica. Estos sólo deben ser manejados por personal entrenado y cualificado. Los procedimientos de seguridad para el levantamiento de cordajes incluyen: inspección de todo el equipo antes de utilizarlo y después de modificarlo; no exceder la carga para la que está preparado; seguir los procedimientos de seguridad en la carga, descarga y puesta en funcionamiento; vigilar continuamente cualquier pieza en movimiento; prevenir a todo el personal antes de mover cualquier objeto por la estructura del techo, y asegurarse de que no haya nadie debajo cuando se mueve el decorado. El personal de iluminación debe tomar las medidas de seguridad apropiadas en el momento de montar, conectar y orientar los focos (Figura 96.14). Las luces y focos han de estar sujetos a sus rieles con cadenas de seguridad. Guando se esté trabajando en las alturas, el personal que se encuentre en el escenario debe usar calzado y casco de seguridad.

\section{Vestuario y maquillaje}

\section{Vestuario}

El vestuario puede ser confeccionado por los ayudantes de este departamento en los mismos talleres del teatro. Se trata de un trabajo duro, especialmente el manejo y transporte de los trajes antiguos. El trabajo con máquinas de coser, secadoras, planchas, 
Figura 96.14 • Montaje de luces y focos sobre el suelo para preparar la iluminación.

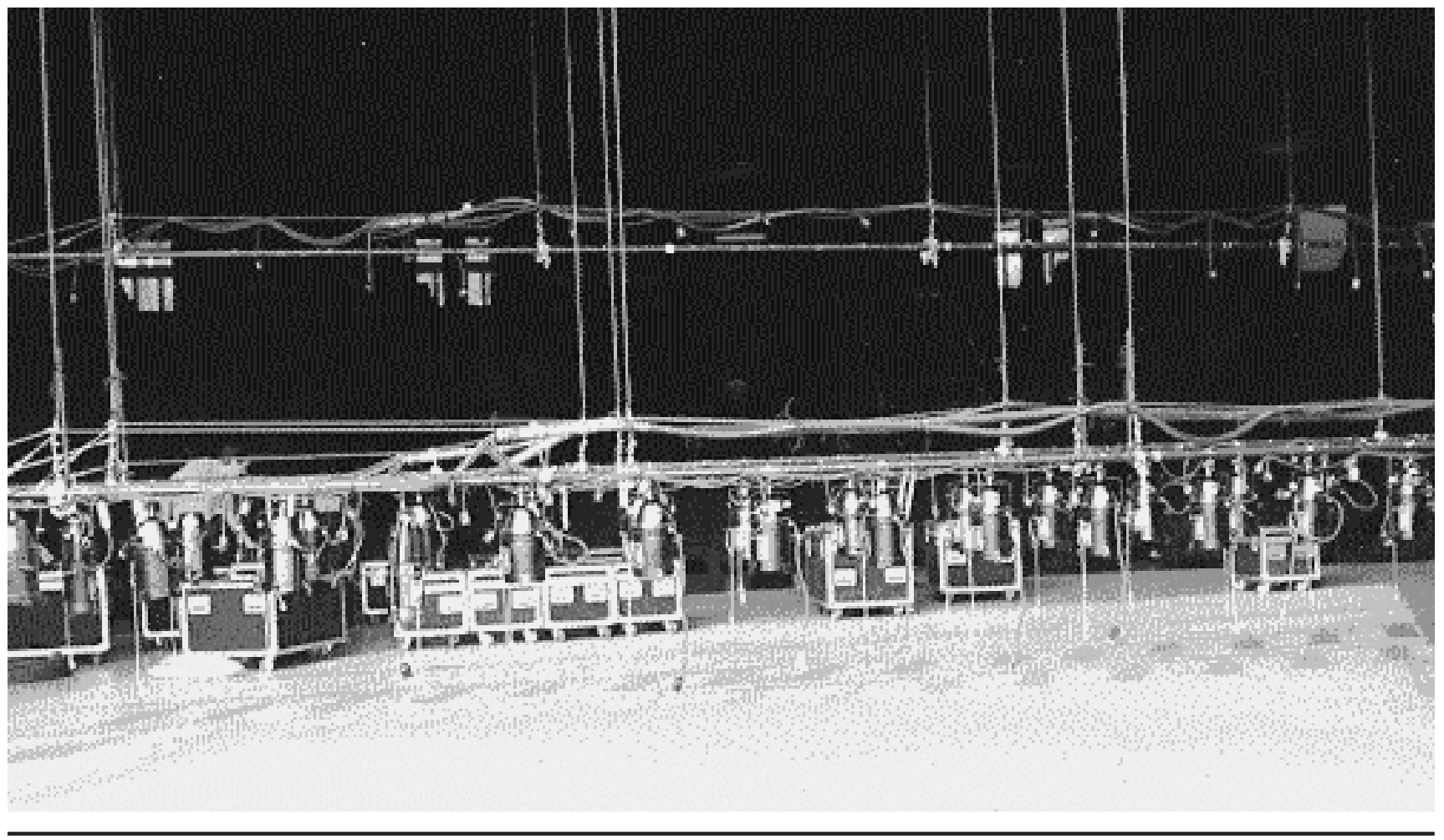

tablas de planchar y equipos eléctricos puede producir dolores corporales, cefaleas, tensiones musculosqueléticas, esguinces y otras lesiones, y el polvo de los tejidos puede constituir un riesgo para la salud. En la limpieza y secado de trajes, pelucas y calzado se utilizan numerosos disolventes líquidos y aerosoles peligrosos.

Los trajes pesados pueden dar mucho calor bajo las luces de los focos. El cambio frecuente de ropa entre escenas puede ser una fuente de estrés. Si hay llamas en el escenario, es esencial que el vestuario sea incombustible.

Entre las medidas preventivas para los ayudantes de vestuario cabe destacar las siguientes: seguridad eléctrica apropiada, iluminación adecuada y ventilación para disolventes y aerosoles; sillas, mesas de trabajo y tablas de planchar ajustables, así como conocimiento de los peligros que pueden suponer los tejidos para la salud.

\section{Maquillaje}

Por lo común, los actores han de usar en cada representación gruesas capas de maquillaje durante varias horas. En el teatro y la ópera son normalmente maquilladores y peluqueros profesionales quienes aplican el maquillaje y se encargan de la peluquería. Es frecuente que el maquillador trabaje en varias representaciones en un corto período de tiempo. El maquillaje puede contener una gran variedad de disolventes, tintes, pigmentos, aceites, ceras y otros ingredientes, muchos de los cuales pueden producir irritación o alergias. El maquillaje de efectos especiales puede implicar la utilización de adhesivos y disolventes peligrosos. El maquillaje aplicado en los ojos puede ocasionar lesiones por abrasión. El maquillaje compartido entraña un riesgo de transmisión de contaminación bacteriana (aunque no hepatitis ni VIH). El uso de aerosoles en camerinos cerrados presenta el riesgo de su inhalación. Para desmaquillar se utilizan grandes cantidades de cremas; también se emplean disolventes para eliminar el maquillaje de efectos especiales.

Después de cada representación deben tomarse precauciones, como retirar el maquillaje lavándose con jabón, limpiar pinceles y esponjas (si no son de un solo uso), emplear aplicadores individuales para el maquillaje y mantener los cosméticos en lugares frescos. La sala de maquillaje debe tener espejos, iluminación flexible y sillas adecuadas.

\section{Montaje y desmontaje de escenarios}

El decorado del teatro requiere un plató fijo construido con materiales pesados; sin embargo es muy frecuente que durante una representación se realicen varios cambios de decorado, lo que requiere cierta movilidad. Igualmente, para un teatro de repertorio puede construirse un decorado modificable que pueda transportarse fácilmente; para mayor facilidad, puede estar construido sobre ruedas.

Los empleados del teatro pueden sufrir lesiones al montar, desmontar y trasladar los decorados, y también al mover los contrapesos. Entre las zonas de riesgos se encuentran la espalda, los brazos y las piernas. Cuando acaba la temporada, debido al cansancio, suelen producirse accidentes al desmontar el plató. Las precauciones que deben tomarse son: usar casco y calzado de protección, contar con los medios, procedimientos y equipos adecuados para levantar cargas, prohibir la entrada a personal no autorizado y no trabajar cuando se está fatigado.

La pintura y demás productos químicos entrañan también un peligro para los decoradores o pintores mientras pintan, clavan y colocan los telones. Los carpinteros se exponen a riesgos derivados de lugares de trabajo inseguros, ruidos y vibraciones y aire contaminado. Los riesgos a los que están expuestos los encargados de hacer máscaras y pelucas están por lo general relacionados con la postura de trabajo, así como con 


\section{Talleres de decorados}

En teatros, películas de cine, televisión, parques de atracciones y temáticos, y otros espectáculos similares, se construyen y pintan escenarios para sus presentaciones. A menudo, los escenarios se hacen con medios propios. También existen talleres especializados en la construcción de grandes escenarios que luego transportan y levantan en su destino final. La diferencia principal entre las dos modalidades citadas (pequeños escenarios de un teatro o grandes tendidos y edificios para películas de cine) estriba en el volumen de trabajo y el personal que interviene en él. En los pequeños teatros se da una mínima especialización del trabajo, mientras que en los grandes montajes las tareas son llevadas a cabo por carpinteros, pintores de escenarios, soldadores, etc

Aunque los escenarios de los teatros y estudios de cine o televisión pueden parecer muy reales, normalmente son sólo una ilusión. Las paredes de una habitación no son más que tendidos ligeros (paneles de lienzo pintado soportados por marcos de madera). Las partes traseras del escenario suelen ser telones de fondo (cortinas de gran tamaño pintadas, representando un ambiente determinado) que pueden levantarse y desplegarse para cada escena. Algunos montajes de apariencia sólida, como árboles, rocas, jarrones, figuras o esculturas, puede que estén fabricados con papel mâché, escayola, espuma de poliuretano y otros materiales. Hoy en día se emplea una extensa variedad de materiales para fabricar escenarios, incluidos maderas, plásticos, metales, fibras sintéticas, papeles y otros productos industriales modernos. Los escenarios a los que deban subir o escalar los artistas deben contar con estructuras sólidas y las medidas de seguridad correspondientes.

Los procesos y productos químicos más comunes en estos montajes apenas difieren de los del resto de las instalaciones de ocio y recreo. Los escenarios al aire libre permiten la utilización de determinados materiales como el cemento, que, por la capacidad limitada para soportar pesos, no son aptos para los escenarios de interiores. Los niveles de riesgo están en función de los tipos y cantidades de productos químicos empleados, así como de las precauciones adoptadas. Para el escenario de un teatro pueden utilizarse litros de espuma de poliuretano, mientras que el interior de un túnel en un parque temático puede llegar a necesitar grandes cantidades de resinas. En los pequeños montajes sobre el mismo escenario los empleados suelen tener menos conciencia de los riesgos, y el habitual hacinamiento combinado con la presencia de actividades incompatibles, como soldaduras y utilización de disolventes, aumentan dichos riesgos.

\section{Trabajo con maderas}

En esta clase de montajes suelen emplearse maderas, tableros de conglomerado, planchas de contrachapado y Plexiglas. Los riesgos incluyen: accidentes con las máquinas y herramientas para las maderas, instrumentos manuales y eléctricos; descargas eléctricas; incendios de polvo de madera combustible; y problemas por inhalación de polvo de madera, formaldehídos, y la descomposición de productos de metacrilatos de metilo producida por el trabajo mecánico con tableros de contrachapado, conglomerados de maderas y Plexiglas, o la exposición a los disolventes empleados en los adhesivos.

Las precauciones incluyen dispositivos de seguridad en las máquinas, seguridad adecuada en los elementos eléctricos, almacenamiento y conservación apropiados para evitar riesgo de incendios, recolectores de polvo, buena ventilación y protección para los ojos.

\section{Soldaduras, corte y bronceado}

En la construcción de los escenarios y decorados suelen emplearse marcos de acero y aluminio, y para su montaje se utilizan distintas modalidades de soldadura de arco y oxiacetilénica. Estas actividades exponen a los trabajadores a lesiones por incendios provocados por chispas, fuego y explosiones de gases comprimidos, y descargas eléctricas de las soldaduras de arco; otros peligros para la salud proceden de vapores metálicos, flujos, gases de las soldaduras (ozono, óxidos de nitrógeno, monóxido de carbono) y radiación ultravioleta.

Las precauciones incluyen la retirada o protección de los materiales combustibles, el almacenamiento y manejo adecuado de los envases de gases comprimidos, equipos eléctricos seguros, ventilación adecuada y el uso de equipos de protección personal.

\section{Pintura de escenarios y decorados}

En la pintura de escenarios, telones y decorados se utilizan pinturas, lacas, barnices, tintes y otros revestimientos. Las pinturas y tintes pueden estar hechos con agua o con aceites. A menudo se mezclan en el mismo taller los pigmentos y tintes en polvo, y los compuestos de cromato de plomo siguen siendo muy frecuentes, igual que los aerosoles, para los grandes montajes. Los disolventes se emplean para disolver tintes, resinas y diluyentes, así como para eliminar pinturas y otros revestimientos, o en la limpieza de herramientas, brochas e incluso las manos. Los riesgos principales proceden del contacto de la piel con disolventes y la inhalación de los vapores de éstos, neblinas de aerosoles y el polvo de tintes y pigmentos secos. Por otra parte, los disolventes pueden causar incendios, especialmente cuando se aplican mediante aerosoles.

Como medidas preventivas se recomienda prescindir de pigmentos de plomo, utilizar tintes y pinturas a base de agua, ventilación adecuada para trabajar con disolventes, protección de las vías respiratorias al emplear aerosoles, manejo y almacenamiento adecuado de los líquidos inflamables, y métodos adecuados para deshacerse de pinturas y disolventes usados.

\section{Resinas plásticas}

Las resinas de espuma de poliuretano, las epoxídicas, las de poliéster y otras resinas se emplean con frecuencia en la fabricación de grandes decorados y escenarios. La aplicación con aerosoles de resinas de espuma de poliuretano conteniendo disocianato difenilmetano es especialmente peligrosa y puede causar asma y neumonía química. Las resinas epoxídicas, las resinas de poliéster y los disolventes son productos irritantes para la piel, los ojos y las vías respiratorias, y pueden ocasionar incendios.

Las medidas preventivas incluyen la sustitución de los materiales peligrosos por alternativas más seguras (como pegamento o celastic en lugar de espuma de poliuretano en aerosoles, o productos a base de agua como alternativa a los disolventes grasos), ventilación con extracción, manejo y almacenamiento adecuado, métodos apropiados de eliminación de desechos y equipos de protección personal.

\section{Decorados y figuras}

Las resinas plásticas también se utilizan para fabricar armaduras, máscaras, cristales rompibles y otros elementos de los decorados. Otros materiales frecuentes son maderas, escayolas, metales, plásticos, además de una amplia variedad de adhesivos grasos y acuosos. Las precauciones necesarias son similares a las descritas anteriormente.

Michael McCann 
los peligros para la salud derivados del uso de resinas (por ejemplo, cuando realizan cabezas calvas y narices falsas). Los productos tóxicos son un peligro para la salud y pueden producir alergias, irritación de la piel y problemas asmáticos.

\section{Normativas}

En muchos países existen leyes nacionales (por ejemplo, ordenanzas en cuanto a edificios) y normas locales sobre seguridad en caso de incendio. En el caso de las estructuras en el techo que sujetan los aparejos de iluminación y de los sistemas de rieles y poleas, las directivas de la Comisión Europea - por ejemplo, la de maquinaria (89/392/CEE) y la de aparatos para levantar personas - forman parte de la legislación nacional. Otros países cuentan también con una legislación en materia de salud y seguridad que afecta a las salas de teatro y de ópera.

\section{- PRODUCCION DE CINE Y TELEVISION}

\section{Michael McCann}

La industria del cine y la televisión está extendida por todo el mundo. La producción cinematográfica puede tener lugar en estudios fijos, en grandes platós comerciales o en cualquier lugar de rodaje en exterior. Las compañías productoras cinematográficas varían en tamaño desde grandes empresas que poseen sus propios estudios, hasta las pequeñas compañías que alquilan estudios comerciales. La producción de programas televisivos, telenovelas, vídeos y anuncios publicitarios tiene mucho en común con la producción cinematográfica.

La producción cinematográfica suele emplear varios escenarios y un gran número de especialistas. La fase de planificación incluye: guión acabado, presupuesto y plazo estimado de finalización de la película, elección de los tipos de exteriores y estudios, diseño del ambiente de la película escena por escena, selección del vestuario, planificación de la secuencia de acción, ángulos de cámara y esquemas de iluminación.

Una vez completada la planificación, comienza el minucioso proceso de elección de exteriores, de construcción de escenarios, de adquisición de atrezo, de disposición de la iluminación y de contratación de actores, especialistas, operadores de efectos especiales y demás personal de apoyo. Después de etapa de planificación de la preproducción se pasa al rodaje. El paso final es la elaboración y la edición de la película, que no son objeto de tratamiento en este artículo.

La producción de cine y televisión entraña numerosos riesgos químicos, eléctricos y de otros tipos, muchos de los cuales son específicos de la industria cinematográfica.

\section{Riesgos y precauciones}

\section{Emplazamiento del rodaje}

El rodaje en un estudio o en un plató tiene la ventaja de contar con instalaciones y equipos permanentes, incluidos sistemas de ventilación, electricidad, iluminación, almacenes de decorados y vestuario, etc., así como un control mayor sobre las condiciones ambientales. Los estudios pueden ser muy amplios a fin de incluir numerosas situaciones de rodaje.

El rodaje en exteriores, especialmente en localizaciones remotas al aire libre, es más difícil y peligroso que en un estudio, ya que deben ofrecerse medios de transporte, comunicaciones, energía, alimentos, agua, servicios médicos, acomodamiento, etc. Filmar en exteriores puede exponer al equipo y a los actores a muchas situaciones de riesgo, entre las que se encuentran: animales salvajes; reptiles y plantas venenosas; disturbios civiles; climas extremos y condiciones climatológicas locales adversas; enfermedades contagiosas; agua y comida contaminadas; edificios con estructuras poco seguras; edificios contaminados con asbesto o plomo; riesgos biológicos, etc. El rodaje en el agua, las montañas, los desiertos y otros lugares peligrosos plantea peligros obvios.

El estudio previo para localizar exteriores de rodaje debe incluir una valoración de estos y otros peligros potenciales para determinar la necesidad de adoptar precauciones especiales o decidir lugares alternativos.

Al fabricar un escenario para el cine puede ser necesario construir o modificar uno o varios edificios, levantar decorados en interiores o al aire libre, etc. Estos pueden ser a tamaño natural o a escala reducida. Los escenarios y los decorados deben ser suficientemente sólidos para soportar las cargas necesarias (véase el apartado "Talleres de decorados" en este capitulo).

\section{Seguridad para la vida de las personas}

Entre las medidas esenciales para la seguridad de las personas están: garantizar que haya salidas adecuadas, señalizar las rutas de acceso y salida y mantenerlas despejadas de equipos y cables eléctricos, así como retirar, almacenar y manejar correctamente los materiales combustibles, los líquidos inflamables y los gases comprimidos. En los rodajes en exteriores, la vegetación seca que haya por los alrededores y los materiales combustibles, como el serrín o las tiendas de campaña, deben retirarse o acondicionarse para que sean ignífugos.

Los automóviles, las embarcaciones, los helicópteros y otros medios de transporte son comunes en los rodajes, y causan muchos accidentes y fallecimientos, tanto si se usan como transporte como para filmar. Es esencial que todos los conductores de los vehículos terrestres y aéreos estén perfectamente cualificados y que cumplan las leyes y normas correspondientes a su actividad.

\section{Andamiajes y rieles aéreos}

Tanto en exteriores como en el estudio, los aparatos de iluminación se instalan en los decorados, en andamiajes fijos o sobre estructuras próximas al techo permanentes. Las mismas instalaciones sirven para levantar decorados y para efectos especiales como suspender actores en el aire. Los riesgos que entraña son el derrumbamiento de los andamios, la caída de focos y otros objetos y el fallo de los sistemas de levantamiento de decorados y personas.

Entre las medidas preventivas están las construcciones sólidas y seguras, la colocación de barandillas y bordillos, los soportes adecuados para los andamios móviles y la fijación de todos los equipos. La construcción, el funcionamiento, el mantenimiento, la inspección y la reparación de los sistemas de poleas deben ser realizados únicamente por profesionales debidamente entrenados y especializados. Nadie, a excepción del personal autorizado, debe tener acceso a los andamios y pasarelas de estos montajes.

\section{Equipo eléctrico e iluminación}

Por lo común, las luces de las cámaras y las necesidades eléctricas diarias de un plató requieren grandes cantidades de energía. Antiguamente se utilizaba corriente continua, pero hoy en día es común utilizar corriente alterna. A veces se utilizan fuentes de energía independientes, sobre todo en exteriores. Ejemplos de riesgos en el área de la electricidad son el cortocircuitado de cables o equipos eléctricos, la inadecuación del cableado, el deterioro de los equipos o los cables, la falta de una toma a tierra correcta y el trabajo en lugares húmedos. La conexión a las fuentes de energía y la desconexión al acabar los rodajes son dos de las actividades más peligrosas. 
Todo el trabajo eléctrico debe ser realizado por electricistas autorizados y debe cumplir las normas y reglamentos obligatorios en materia de seguridad eléctrica. A ser posible, para más seguridad debería utilizarse corriente continua alrededor del agua o, en su defecto, instalar interruptores de fallo a tierra.

La iluminación puede entrañar riesgos para la salud y de tipo eléctrico. Las lámparas fluorescentes de alta tensión, como son los tubos de neón, las lámparas de haluro de metal y las lámparas de arco con electrodo de carbón, son especialmente peligrosas por los riesgos de tipo eléctrico, la radiación ultravioleta y las emisiones de humos tóxicos.

El equipo de iluminación debe conservarse en buenas condiciones, inspeccionarse de forma periódica, y sus componentes han de asegurarse de forma que no se inclinen ni se caigan. Reviste especial importancia el control de las lámparas de arco de alto voltaje, ya que la ruptura de las lentes podría producir fugas de radiación ultravioleta.

\section{Cámaras}

Los operadores de cámara están expuestos a situaciones muy peligrosas, como filmar desde un helicóptero, un vehículo móvil, una grúa donde va situada la cámara o la ladera de una montaña. Los equipos de cámara más frecuentes suelen contar con trípodes fijos, cámaras móviles sobre plataformas con ruedas (dollies), grúas para filmar desde arriba y coches con cámaras para tomas de vehículos en movimiento. Se han producido fallecimientos entre los operadores de cámara al filmar en condiciones arriesgadas o próximos a escenas peligrosas y de efectos especiales.

Existen ciertas precauciones básicas con respecto a las grúas para las cámaras, como comprobar los controles de elevación, asegurar una superficie estable para la base y el pie de la grúa; comprobar que la superficie del recorrido esté bien preparada, establecer una distancia de seguridad entre la grúa y los cables eléctricos de alta tensión y disponer de arneses de sujeción para las personas donde sea necesario.

En lugar de montar las cámaras fuera del vehículo que ha de filmarse, se recomiendan los coches con cámaras incorporadas, diseñados para instalar cámaras y remolcar el vehículo que se está filmando. Existen ciertas precauciones que deben adoptarse, como elaborar una lista de comprobación de seguridad, limitar el número de personas en el vehículo, adjudicar el sistema de poleas a personal experto, contar con procedimientos para interrumpir operaciones y contar con un sistema de comunicación por radio.

\section{Actores, extras y dobles}

Véase el artículo "Actores" en este capítulo.

\section{Vestuario}

Del vestuario se ocupan los ayudantes de vestuario, que pueden estar expuestos a diferentes tintes, colorantes, disolventes peligrosos, aerosoles, etc., y a menudo sin ningún tipo de ventilación.

Los disolventes con cloro empleados en la limpieza son muy peligrosos y han de ser sustituidos por otros productos, como los alcoholes minerales. Cuando se utilizan tintes en aerosol o materiales que contienen disolventes, es preciso contar con ventilación aspirante local. Los polvos han de mezclarse en una cámara de manipulación con guantes incorporados.

\section{Efectos especiales}

En la industria cinematográfica se utiliza una amplia variedad de efectos especiales para simular sucesos reales que de otra forma serían demasiado peligrosos, irrealizables o costosos de llevar a cabo. Entre ellos están las nieblas, el humo, los efectos pirotécnicos, las armas de fuego, la nieve, la lluvia, el viento, los efectos producidos por ordenador y los platós en miniatura o a escala reducida. Muchos de ellos entrañan riesgos significativos, entre otros: la utilización de rayos láser y productos químicos tóxicos, como el mercurio para proporcionar un efecto plateado; elevar objetos o personas mediante poleas, y los peligros eléctricos asociados con la lluvia y otros efectos acuáticos. Se deben tomar las precauciones necesarias con dichos efectos especiales.

Las precauciones generales que deben tomarse ante efectos especiales peligrosos son: elaborar una planificación adecuada, contar con los procedimientos de seguridad por escrito, emplear a operadores especializados y con experiencia, utilizar los mínimos efectos peligrosos posibles, establecer una coordinación con el departamento de bomberos y otros servicios de emergencia, informar con claridad sobre el uso que pretende darse a los efectos especiales (permitiendo que cualquiera pueda negarse a participar), prohibir la presencia de niños en las proximidades, realizar ensayos detallados para probar los efectos, despejar el plató de todo el personal que no sea esencial, contar con un sistema de comunicaciones de emergencia, minimizar el número de repetición de tomas y tener preparados procedimientos para interrumpir la producción.

La pirotecnia se utiliza para crear efectos como las explosiones, los incendios, la luz, el humo y los golpes sonoros. Los materiales pirotécnicos son por lo general explosivos de escasa potencia (normalmente de clase B), como la pólvora de destello, papel de destello, algodón de pólvora, pólvora negra y pólvora sin humo. Se utilizan en tiros de balas (detonadores), cartuchos de fogueo, tiroteos, mechas, morteros, balas de humo y en muchas otras circunstancias. No deben utilizarse explosivos de clase A, como la dinamita, aunque a veces se utiliza la mecha detonante. Algunos de los principales problemas asociados con la pirotecnia son: el disparo prematuro del efecto pirotécnico, la provocación de un incendio por utilizar cantidades mayores de las necesarias, falta de medios apropiados para extinción de fuego y falta de técnicos con la experiencia necesaria.

Además de las precauciones de carácter general, existen otras especiales para los explosivos, tales como almacenarlos en el lugar adecuado, utilizar el tipo de explosivo correcto y en las cantidades mínimas necesarias para conseguir el efecto y realizar pruebas cuando no haya personas alrededor. $\mathrm{Al}$ utilizar efectos pirotécnicos debe prohibirse fumar y hay que contar con

Figura 96.15 • Efectos especiales con fuego.

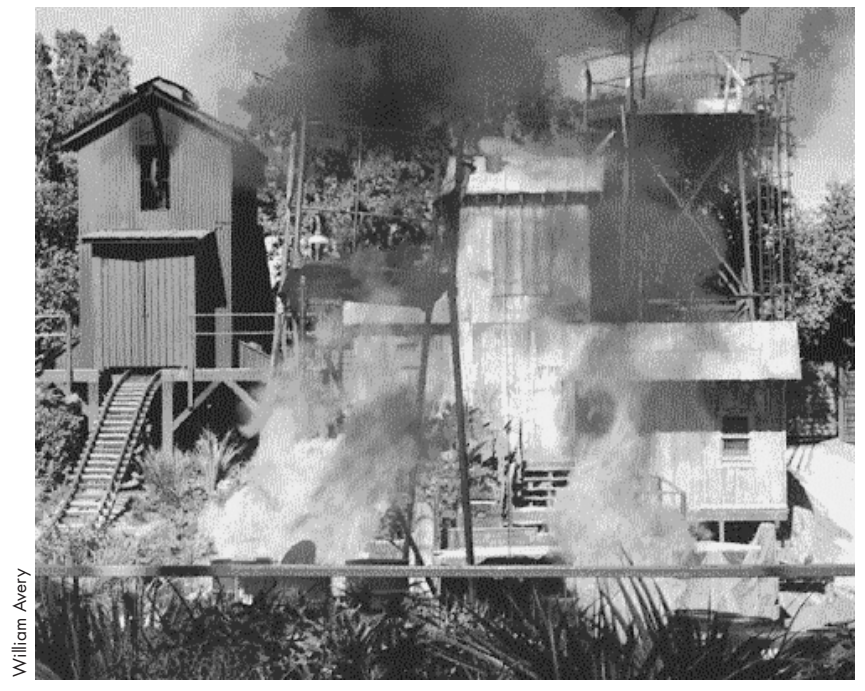


un equipo de bomberos y personal adiestrado. El material debe ser explosionado por controles de disparo electrónicos, y es imprescindible una ventilación adecuada.

Los efectos de fuego se utilizan tanto para estufas ordinarias de gas y chimeneas como para los fuegos destructivos que aparecen al arder coches, casas, bosques e incluso personas. (Figura 96.15). En algunos casos, el fuego puede ser simulado por medio de luces parpadeantes y otros efectos electrónicos. Entre los materiales utilizados para crear efectos de fuego están los quemadores de gas propano, el pegamento de goma, la gasolina y el queroseno, que suelen utilizarse conjuntamente con efectos pirotécnicos especiales. El riesgo reside en que pueda perderse el control sobre el fuego y en el calor que éste genera. Otros riesgos están causados por un mantenimiento deficiente del equipo generador de fuego, por el uso excesivo de materiales inflamables o la presencia involuntaria de otros materiales combustibles y por el almacenamiento inadecuado de líquidos y gases combustibles e inflamables. Los operadores de efectos especiales sin experiencia pueden ser también causa de accidentes.

Las medidas preventivas especiales son similares a las que deben tomarse en pirotecnia: sustitución de la gasolina, el pegamento de goma y demás sustancias inflamables por los combustibles líquidos y en forma de gel que se fabrican en la actualidad. Todo material que se encuentre en el área de fuego debe ser incombustible o resistente a las llamas, incluido el vestuario de los actores que trabajen en las proximidades.

Los efectos de niebla y humo son habituales en los rodajes. Las sustancias generadoras de niebla suelen ser hielo seco (dióxido de carbono), nitrógeno líquido, destilados del petróleo, generadores de humo de cloruro de zinc (que también pueden contener hidrocarburos clorados), cloruro de amonio, aceite mineral, nieblas de glicol y neblinas. Algunos de los materiales utilizados, como los destilados del petróleo y el cloruro de zinc, son poderosos irritantes respiratorios y pueden producir neumonía química. El hielo seco, el nitrógeno líquido y las neblinas de agua entrañan riesgos químicos leves, aunque pueden desplazar oxígeno en recintos cerrados, restringiendo así las condiciones necesarias para el desarrollo de la vida. Los sistemas generadores de neblinas pueden causar problemas de contaminación microbiológica. Hay ciertas pruebas recientes de que es posible que los componentes de determinados humos y neblinas artificiales considerados inofensivos hasta la fecha, como el aceite mineral y los glicoles, causen irritación respiratoria.

Las medidas preventivas son: evitar los humos y nieblas más peligrosos; utilizar la niebla con el equipo diseñado para ello; limitar el período de utilización y el número de repetición de tomas, y evitar utilizarlos en recintos cerrados. Las nieblas deben despejarse mediante extracción tan pronto como sea posible. Los operadores de cámara han de usar protección respiratoria.

Las armas de fuego son muy comunes en las películas, y se utilizan tipos muy variados, desde armas antiguas hasta escopetas y ametralladoras. En muchos países (entre los que no se incluye Estados Unidos), está prohibida la munición real. Sin embargo, la munición de fogueo, utilizada frecuentemente junto con disparos de balas reales con el fin de simular impactos de bala verdaderos, ha producido muchas lesiones y muertes. La munición de fogueo consiste en una funda de metal con detonador de percusión y pólvora sin humo, rematada con un fajo de papel que puede ser expulsado a gran velocidad cuando se dispara. Algunas armas de fogueo modernas utilizan insertos especiales de plástico con detonador y pólvora de destello, produciendo únicamente un fogonazo y ruido. Los cartuchos de fogueo se usan frecuentemente junto con disparos de bala; el mecanismo se basa en insertar en el objeto que debe golpear la bala un detonador rodeado de plástico, simulando así impactos reales de bala. Aparte de la munición real, existen varios peligros, como utilizar armas de fogueo a corta distancia, mezclar munición real y de fogueo, o cargar un arma con la munición inadecuada. También pueden ser peligrosas las armas de fuego modificadas de forma incorrecta y la falta de entrenamiento en el uso de armas de fogueo.

La munición real y las armas de fuego sin modificar han de estar prohibidas en el escenario, por lo que se utilizarán, siempre que sea posible, reproducciones sin capacidad de fuego. Es esencial utilizar armas que no disparen balas reales, armas de fogueo inofensivas. Las armas de fuego han de ser controladas periódicamente por el utilero u otro personal especializado. Todas las armas de fuego y la munición han de estar guardadas bajo llave. En escena nunca se debe apuntar a un actor con un arma, y tanto los cámaras como cualquier persona que se encuentre en las proximidades deben utilizar protección para armas de fogueo.

\section{Escenas peligrosas}

Una escena peligrosa puede definirse como cualquier secuencia de acción que entrañe un riesgo de lesión superior al habitual para los actores y demás personas en el plató. Con la creciente demanda de realismo en el cine, las escenas peligrosas han pasado a ser muy comunes. Ejemplo de escenas potencialmente peligrosas son las caídas desde grandes alturas, las peleas, las escenas en helicópteros, las persecuciones de coches, los incendios y las explosiones. Aproximadamente la mitad de los accidentes ocurridos en los rodajes están relacionados con estas escenas peligrosas y, a menudo, también con los efectos especiales.

Este tipo de acciones pueden poner en peligro no sólo a los especialistas, sino también a los operarios de cámara y a otros actores. La mayor parte de las precauciones a las que se ha hecho alusión en el caso de los efectos especiales pueden aplicarse también a las escenas peligrosas. Además, el especialista ha de tener experiencia en el tipo de escena que se esté filmando. Debe haber un coordinador encargado de todas las escenas de este tipo, pues el especialista no siempre puede rodar la escena y controlar al mismo tiempo los aspectos de seguridad, especialmente cuando varios especialistas trabajan en la misma escena.

Las aeronaves, especialmente los helicópteros, son las que más accidentes fatales múltiples han causado en la producción cinematográfica. Los pilotos no están a menudo suficientemente cualificados para las escenas peligrosas. Las maniobras acrobáticas, los vuelos rasantes o peligrosamente cercanos al decorado cuando se utilizan efectos pirotécnicos, así como el rodaje desde helicópteros con las puertas abiertas o desde la plataforma de aterrizaje de los hidroaviones sin una protección adecuada contra las caídas, son algunas de las situaciones más peligrosas (véase el artículo "Helicópteros" en esta Enciclopedia).

Una de las medidas preventivas es contratar a un asesor de vuelo independiente, aparte del piloto, para que supervise los aspectos de seguridad. Otras medidas de seguridad son restringir el personal en un radio de 15 metros alrededor de la aeronave cuando esté estacionada, y contar con procedimientos escritos para filmar en tierra cerca del vehículo cuando éste tenga el motor en marcha o durante los aterrizajes y despegues. Es esencial la coordinación con los responsables de los efectos de pirotecnia y cualquier otro especialista de efectos especiales peligrosos, y deben establecerse procedimientos de seguridad para los operadores de cámara que filman desde la aeronave. También es preciso disponer de procedimientos para interrumpir una operación cuando sea necesario.

Las secuencias de acción con vehículos también son fuente de muchos accidentes y defunciones. Los efectos especiales como las explosiones, las colisiones, las caídas al agua y las persecuciones con múltiples coches suelen ser causa de accidente. Las 
Figura 96.16 - Utilización de maniquíes para rodar una escena en una montaña rusa.

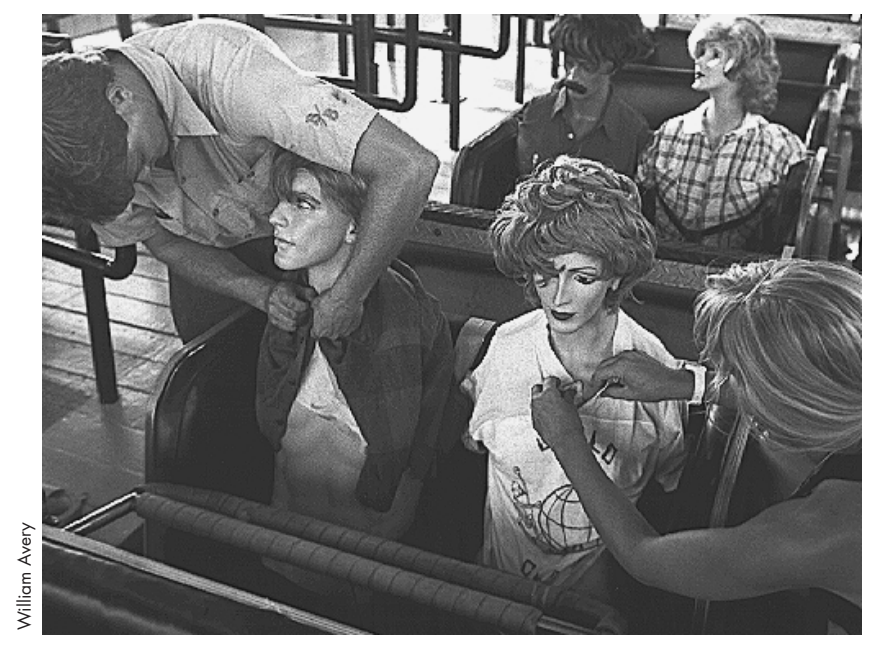

escenas con motocicletas son incluso más peligrosas que con automóviles, ya que la protección individual del conductor en aquéllas es menor.

Como precaución especial deben utilizarse coches con cámara. El empleo de especialistas para todas las colisiones que aparezcan en la escena y la prestación de formación especial a los pasajeros del vehículo que no sean especialistas puede contribuir a disminuir la tasa de accidentes. Otras medidas de seguridad son: contar con un equipo de seguridad adecuado, inspeccionar todas las rampas y demás accesorios utilizados en la escena, emplear maniquíes en las colisiones, explosiones y otras secuencias de alto riesgo y no dirigir los coches directamente hacia la cámara, si hay un operador detrás. Véase la Figura 96.16 como ejemplo de utilización de maniquíes para el rodaje de una secuencia en una montaña rusa. Para la filmación de automóviles en interiores con el motor en marcha es necesaria una ventilación adecuada. Las motocicletas utilizadas en escenas peligrosas deben estar equipadas con un interruptor de anclaje que apague el motor en el momento en que el conductor se separa de la motocicleta.

Las escenas peligrosas con fuegos y explosiones suponen un gran riesgo para los especialistas y requieren más medidas preventivas que las utilizadas para efectos especiales. Los especialistas que están directamente expuestos a las llamas han de usar gel protector (por ejemplo, Zel Jel) en el pelo, la piel, la ropa, etc. Deben llevar un traje protector adecuado, incluyendo prendas ignífugas bajo la ropa, y guantes y botas resistentes al fuego; y en ciertas ocasiones, botellas de oxígeno ocultas. En caso de emergencia, debe disponerse de personal especialmente adiestrado con extintores de dióxido de carbono.

En las escenas de peleas los especialistas están expuestos a puñetazos y otros tipos de golpes sin armas, o deben usar cuchillos, espadas, armas de fuego, etc. En muchas peleas en el cine o el teatro no se utilizan especialistas, con lo que el riesgo es mayor debido a la falta de adiestramiento.

Las armas simuladas, como los cuchillos y espadas con filo retráctil, son un dispositivo de seguridad. Las armas deben estar cuidadosamente almacenadas, y el adiestramiento para su uso resulta fundamental. El actor debe aprender a caer y a utilizar las diferentes armas. Hay que contar con una coreografía adecuada, realizar varios ensayos de las peleas y utilizar ropa y accesorios protectores. Nunca debe dirigirse un golpe directamente a un actor. Si la pelea implica un alto grado de riesgo, tal como caer por unas escaleras o salir despedido por una ventana, el actor debe ser sustituido por un especialista.

Existen varios tipos de caídas en el cine: caída por un tramo de escaleras o de un caballo, salto por el aire desde un trampolín o con un sistema de catapulta, o caídas desde más altura desde un acantilado o un edificio (Figura 96.17). Las caídas que no han sido adecuadamente preparadas han producido muchas lesiones y muertes.

Las escenas con caídas peligrosas sólo deben ser ejecutadas por dobles especialistas. Cuando sea posible, la caída ha de ser simulada. Por ejemplo, una caída por un tramo de escaleras puede ser filmada en varias tomas, con varios escalones cada vez, para que el especialista no pierda el control; una caída desde un edificio puede simularse mediante una caída de unos pocos metros sobre una red y el resto de la escena utilizando un maniquí. En las caídas desde gran altura debe estar presente un coordinador de caídas y utilizarse un sistema especializado de caída y detención para disminuir adecuadamente la velocidad. Las caídas desde más de 4 metros requieren dos observadores de seguridad. Otras medidas preventivas para las caídas comprenden airbags, almohadillas para atenuar los golpes mediante lonas rellenas de caucho esponjoso, sacos de arena, etc., dependiendo del tipo de escena. La comprobación de todos los equipos es una medida fundamental.

Las escenas con animales son muy arriesgadas debido a la imprevisibilidad de sus reacciones. Ciertos animales, como los grandes felinos, pueden atacar cuando se asustan y los de gran tamaño, como los caballos, resultan a veces peligrosos debido a su envergadura. En los rodajes no deben utilizarse animales peligrosos, enfermos o sin domar. Los reptiles venenosos, como las

Figura 96.17 - Caída de un especialista desde gran altura.

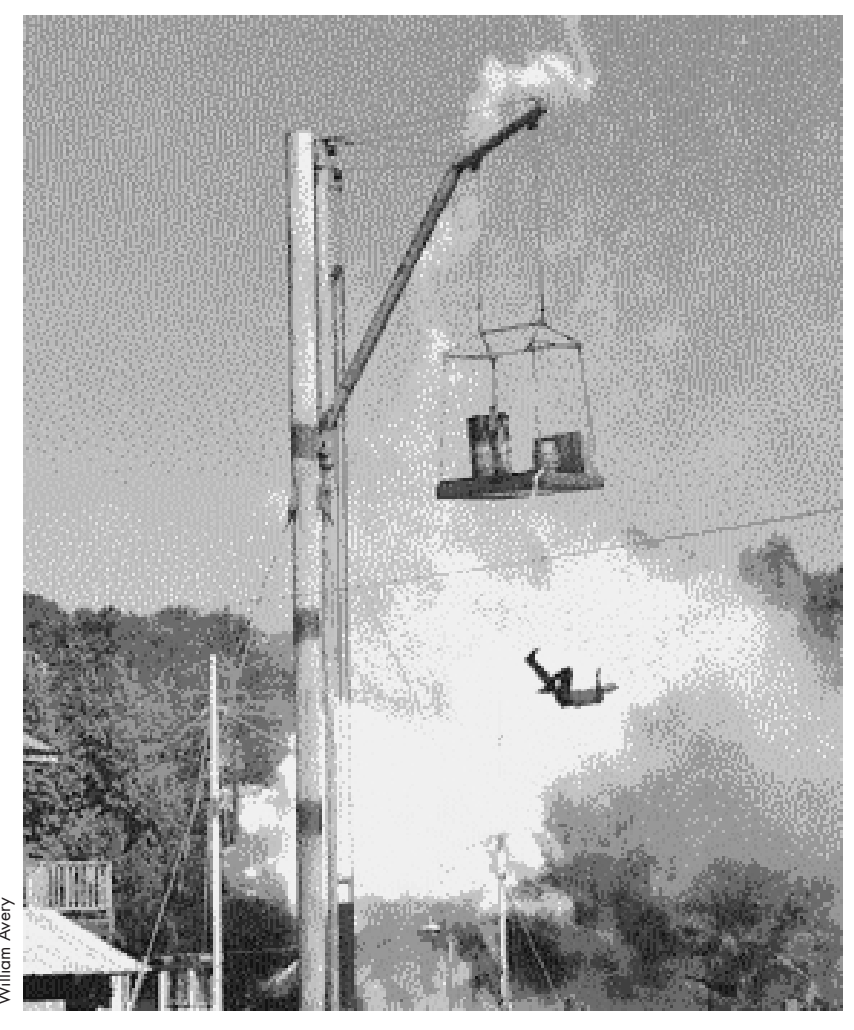


serpientes de cascabel, son particularmente peligrosos. Aparte de los riesgos para las personas, también ha de tenerse en cuenta la salud y seguridad de los propios animales.

Unicamente deben trabajar con animales las personas especializadas en su manejo. El rodaje con animales requiere una serie de medidas de seguridad, como disponer de extintores de fuego, mangueras contra incendios, redes y tranquilizantes. Los animales deben disponer del tiempo necesario para familiarizarse con el entorno, y sólo debe permitirse la entrada al escenario al personal necesario. Deben evitarse las situaciones que puedan molestar a los animales y procurar no exponerlos a ruidos intensos o destellos de luz siempre que sea posible, a fin de evitarles daños y mantenerlos tranquilos. Determinadas escenas (por ejemplo, cuando aparecen reptiles venenosos o una manada de caballos) requieren precauciones especiales.

Entre las escenas peligrosas en el agua están el buceo, la filmación en rápidos de ríos, escenas con lanchas veloces y batallas navales. Algunos de los riesgos son: ahogamiento, hipotermia en agua fría, obstrucciones bajo el agua y contaminación. En todas las escenas acuáticas peligrosas hay que contar con equipos de emergencia y la presencia de buzos profesionales. Otras medidas preventivas son asegurarse de que todos los actores u operadores de cámara que utilicen aparatos respiradores autónomos bajo el agua disponen de la correspondiente licencia de buceo, y contar con un equipo de respiración de reserva (SCUBA). También hay que disponer de sistemas de descompresión de emergencia en el lugar del rodaje para las inmersiones de más de $10 \mathrm{~m}$. Por último, es necesario contar con embarcaciones de rescate y equipos de seguridad adecuados, como redes y cuerdas para el rodaje en aguas rápidas.

\section{Programas en materia de salud y seguridad}

La mayoría de los estudios cinematográficos más importantes disponen de un responsable de salud y seguridad a tiempo completo, cuya misión consiste en la supervisión y el cumplimiento del programa en este campo. El alquiler de los estudios a otras productoras, práctica cada vez más habitual, suele dificultar la asunción de responsabilidades y la autoridad de estos profesionales. La mayoría de las productoras no cuentan con planes de salud y seguridad en el trabajo. Es fundamental la presencia de un encargado de esta materia con plena autoridad para establecer procedimientos de seguridad y exigir su cumplimiento, así como la coordinación de las actividades con otros responsables de los planes de producción, como los coordinadores de secuencias peligrosas, los encargados de efectos especiales, los expertos en armas de fuego y el regidor (quien suele ser responsable de la seguridad de los montajes, cámaras, andamios, etc.), todo ellos profesionales expertos y especializados en aspectos de seguridad. La comunicación entre la dirección y los empleados puede llevarse a cabo mediante reuniones periódicas de un comité de salud y seguridad que abarque a los representantes de los distintos departamentos, trabajadores y sindicatos. Los sindicatos de trabajadores suelen tener comités sobre salud y seguridad en el trabajo que pueden aportar su experiencia y asesoramiento.

\section{Servicios médicos}

En las producciones cinematográficas es fundamental disponer de servicios médicos generales y de emergencia. Los estudios de cine suelen contar con un departamento médico permanente, algo menos frecuente en el caso de las compañías de producción. Para decidir si es preciso contar con servicios médicos en exteriores hay que efectuar un estudio de evaluación de los posibles riesgos para la salud, entre otros: la necesidad de vacunación en ciertos países, las enfermedades locales endémicas, las circunstancias climáticas y ambientales, además de evaluar la calidad de los sistemas de salud locales. En una fase posterior deben analizarse a fondo los principales riesgos y la necesidad de disponer de equipos médicos y de emergencia para determinar los planes de seguridad más adecuados. En los rodajes en lugares apartados y en situaciones de alto riesgo es necesaria la presencia de médicos especialistas en emergencias. Siempre que exista acceso rápido a servicios de emergencia adecuados, será suficiente con personal especializado en emergencias, aunque no sean de tipo médico. También es importante planificar de antemano la seguridad en los transportes. La falta de medios adecuados de transporte de emergencia ha sido la causa de más de un accidente con consecuencias mortales (Carlson 1989; McCann 1989).

\section{Normativa}

Aunque existen pocas normas en materia de salud y seguridad en el trabajo dirigidas a la industria cinematográfica en particular, puede aplicarse la reglamentación general sobre seguridad de prevención de incendios, riesgos de descargas eléctricas, andamiajes y ascensores, procesos de soldadura, etc. Los departamentos de bomberos suelen exigir permisos especiales para determinados rodajes y en algunas ocasiones es necesaria la presencia de unidades de bomberos durante la filmación de determinadas escenas.

Muchos de los operadores de efectos especiales, dispositivos de rayos láser, montajes pirotécnicos o de armas de fuego necesitan estar en posesión de la correspondiente licencia. Algunas actividades pueden estar sometidas a reglamentaciones obligatorias, como en la adquisición, almacenamiento y utilización de fuegos artificiales o el empleo de armas de fuego.

\section{EMISION DE RADIO Y TELEVISION}

\section{Nancy Clark}

Las actividades propias de la producción de radio y televisión incluyen la emisión y grabación de imágenes tomadas tanto en exteriores como en interiores, la edición de grabaciones sonoras y cintas de vídeo, la transmisión y recepción de emisiones, la gestión de gráficos e información electrónica y el mantenimiento de cintas y equipos. Los ingenieros y técnicos de transmisiones elaboran emisiones grabadas o en directo destinadas a grandes cadenas convencionales y de transmisión por cable, emisoras locales y compañías productoras. Entre las principales profesiones de este sector cabe destacar las siguientes: operadores de cámaras, técnicos de sonido, editores de cintas, operadores de ordenadores, técnicos de mantenimiento, locutores y otros artistas de la radio y la televisión.

Las emisiones y demás actividades de apoyo pueden desarrollarse en lugares lejanos, en estudios o talleres especiales y de mantenimiento. Los empleados están expuestos a muchos de los riesgos inherentes a los trabajos con medios tecnológicos, como una calidad deficiente del aire interior, el mal diseño de los puestos de trabajo y la radiación electromagnética de baja frecuencia (ya que para transmitir y recibir emisiones se emplea tecnología de microondas, y la densidad de los equipos electrónicos produce niveles relativamente altos de campos energéticos de baja frecuencia). A fin de proteger a los trabajadores es recomendable instalar distintos tipos de apantallamiento para estos equipos y situarlos en lugares adecuados. 


\section{Riesgos y precauciones}

\section{Localizaciones lejanas}

El personal encargado de las cámaras y del sonido ha de desplazarse para cubrir informaciones y acontecimientos especiales para las grandes cadenas y emisoras locales. Estos empleados transportan hasta el lugar de la noticia todo el material necesario para la emisión, como cámaras, equipos de sonido e iluminación, trípodes y cables eléctricos. Con la aparición de las cámaras ligeras con grabación de sonido incorporada, basta una sola persona para manejar el equipo. Algunos riesgos frecuentes son los tropiezos, los resbalones, las caídas y el estrés de origen musculosquelético. La violencia presente en los disturbios y las guerras expone a estos profesionales a riesgos de lesiones o incluso la muerte. Otras fuentes de riesgos de lesiones graves y enfermedades para los miembros de los equipos son la climatología adversa, las multitudes, los desastres ambientales y los terrenos difíciles.

Los riesgos pueden reducirse valorando anticipadamente la posibilidad de estallidos violentos y trabajando en lugares seguros. En determinados casos es recomendable emplear equipos de protección individual, como cascos y chalecos a prueba de balas. Las lesiones musculosqueléticas pueden prevenirse utilizando equipos apropiados con profesionales bien preparados y siguiendo métodos seguros para levantar objetos pesados.

Algunas noticias y la información sobre el tráfico se graban y emiten a bordo de helicópteros; el aterrizaje imprevisto y los accidentes de estos aparatos han causado heridas y muertes entre los profesionales de la radio y la televisión. Es esencial cumplir con los requisitos establecidos para la adecuada formación y la certificación de los pilotos, para el mantenimiento preventivo de los equipos y para la prohibición de llevar a cabo operaciones arriesgadas, como volar demasiado cerca de otros helicópteros u otras estructuras. Sobre este tema, véase el capítulo "Helicópteros" en este volumen.

Las tomas en determinados acontecimientos deportivos, como los torneos de golf y las carreras de coches, suelen realizarse desde andamios y plataformas elevadas, empleándose grúas y montacargas donde se colocan los equipos y sus operadores. Estas estructuras y maquinarias son similares a las utilizadas en la construcción y en la producción cinematográfica, con los riesgos de sufrir caídas, golpearse con objetos desprendidos y electrocutarse al entrar en contacto con cables aéreos y equipos eléctricos.

Al igual que en la construcción, deben tomarse medidas preventivas, como la realización de inspecciones periódicas y la construcción de plataformas, barandillas y rodapiés para evitar la caída de objetos, facilitar accesos mediante escaleras de mano, mantener los equipos eléctricos debidamente protegidos y con tomas a tierra, así como respetar las recomendaciones en situaciones de alertas meteorológicas.

\section{Producciones en estudio}

El trabajo en estudio tiene la ventaja de que los trabajadores están familiarizados con el entorno donde manejan las cámaras, los equipos de sonido y los de efectos especiales. Los riesgos en el trabajo son similares a los de los estudios de cine: estrés de origen musculosquelético, peligros de carácter eléctrico, ruidos (especialmente en los estudios de emisoras de música rock) y la exposición a los humos y nieblas artificiales. Algunas medidas preventivas posibles son el diseño ergonómico de equipos y zonas de trabajo, la colocación de defensas en los aparatos e instalaciones eléctricas, el control de los niveles de sonido, la selección cuidadosa de las nieblas y humos artificiales y una ventilación adecuada.

\section{Edición, manejo y almacenamiento de cintas}

Las grabaciones sonoras y las cintas de vídeo deben editarse antes de su difusión. Las condiciones de este trabajo dependen del tamaño de las instalaciones y no es rara la realización simultánea de diferentes operaciones de edición. Las actividades de edición requieren prestar especial atención al material; las salas de edición suelen estar llenas de gente, contar con escasa iluminación, ventilación inadecuada y exceso de ruido, además de entrañar peligros de carácter eléctrico. El diseño de los espacios y equipos resulta a veces poco ergonómico, las tareas son repetitivas, el ambiente es ruidoso y existe riesgo de incendios. Es necesario que el diseño del lugar de trabajo sea el apropiado y debe abarcar el espacio, la iluminación y ventilación, la insonorización y la instalación de dispositivos de seguridad en las instalaciones eléctricas. En los almacenes de cintas antiguas deben realizarse inspecciones regulares y el material ha de manejarse adecuadamente. Algunas productoras cuentan con filmotecas donde se guardan antiguas películas de celuloide (nitrocelulosa), material que no se emplea en la actualidad y que es altamente inflamable y potencialmente explosivo, lo que entraña riesgos de incendio y mortales.

En las cintas suelen incluirse gráficos e imágenes realizadas con ordenadores, una actividad que requiere largas horas delante de la pantalla. Las condiciones de este trabajo dependen del tamaño y la disposición de los elementos de la instalación. Los requisitos de diseño de las zonas de trabajo son semejantes a los de cualquier otro puesto de trabajo con ordenadores.

\section{Talleres de mantenimiento}

Los técnicos y mecánicos se encargan del mantenimiento de las cámaras, las grabadoras, los equipos de edición y demás aparatos, y sus condiciones de trabajo difieren poco de las de sus homólogos en otros sectores industriales. Las piezas electrónicas y los contactos eléctricos suelen limpiarse con disolventes orgánicos que producen residuos como freón, acetona, metanol, metiletilcetona y cloruro de metileno. Los componentes metálicos se reparan con soldaduras (blanda y autógena) y herramientas eléctricas. Entre los riesgos están la inhalación de vapores de disolventes y metales, el contacto de la piel con sustancias disolventes, los incendios y accidentes con las máquinas. Entre las posibles medidas de prevención se encuentran las siguientes: sustitución de los materiales peligrosos por otros más seguros, la ventilación y extracción de los vapores de los disolventes y de las emisiones liberadas en los procesos de soldadura blanda y autógena, así como la instalación de defensas en las máquinas.

\section{Periodismo}

\section{Aidan White}

Aunque el periodismo es una profesión rodeada de un halo romántico, también es una de las más peligrosas. Entre 1990 y 1997, más de 500 periodistas y trabajadores de los medios de comunicación perdieron la vida, muchos de ellos asesinados por mafias, grupos paramilitares y terroristas. Centenares de redactores y reporteros resultan lesionados todos los años, física y psicológicamente, a causa de los horrores de la guerra y de los conflictos sociales. Véase la Figura 96.18.

La tendencia a la manipulación y el control de la información se hace cada vez más patente a medida que van en aumento la cantidad de información y la rapidez de su difusión; hoy en día la información llega a todo el mundo en cuestión de segundos, 
Figura 96.18 - Argel, Argelia, 11 de febrero de 1996: Las oficinas destruidas de Le Soir, uno de los tres periódicos alcanzados por un coche bomba terrorista.

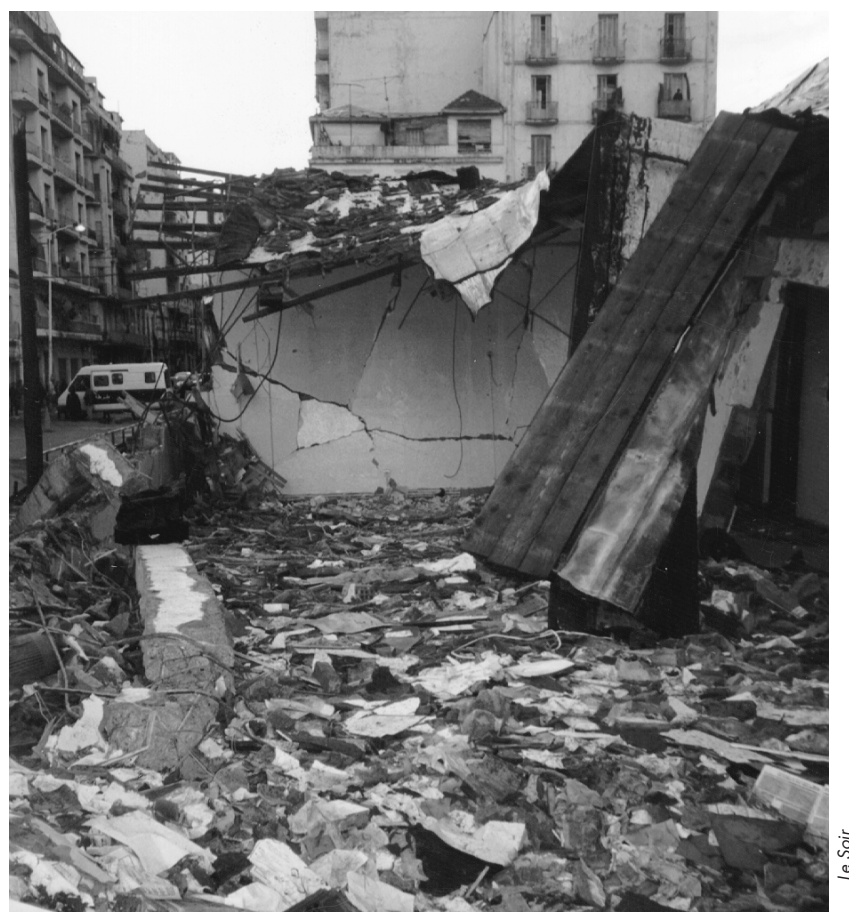

gracias a la tecnología de los satélites de comunicaciones, y las noticias alcanzan los hogares de la gente nada más producirse.

Por ello, los periodistas y el personal auxiliar que les acompaña, como los encargados de las cámaras y del equipo técnico, entrañan una amenaza para cualquier grupo, institucional o de otra índole, que no desee hacer públicas sus actuaciones. Como resultado se producen los ataques específicamente dirigidos a periodistas y medios de comunicación.

El problema de la "censura violenta" se agrava a causa de la competencia comercial de la industria de los medios de comunicación y por la desregulación existente en muchos de estos trabajos. Los profesionales de los medios de comunicación compiten duramente por el mercado y sufren una considerable presión para conseguir imágenes y reportajes cada vez más dramáticos y sensacionalistas. Hoy en día, muchos trabajadores de los medios de comunicación corren mayores riesgos que en otras épocas.

Es una situación que puede agravar el hecho de que pocas empresas de comunicación se preocupan de adiestrar a sus trabajadores para que sepan enfrentarse a situaciones violentas y conflictos, un aspecto fundamental para su seguridad. Los profesionales de los medios de comunicación deben ser capaces de tomar decisiones coherentes sobre los riesgos presentes en situaciones de gran movilidad informativa, poseer conocimientos sobre primeros auxilios y recibir los consejos de los periodistas más veteranos a la hora de cubrir informaciones en escenarios particularmente peligrosos.

El grupo más vulnerable de esta profesión (los periodistas freelance y los contratados temporalmente) rara vez recibe algún tipo de formación, incluso cuando existen medios para ello. Hoy en día se contratan muchos más trabajadores freelance que antes, por lo general para cubrir información en los países donde se están produciendo las noticias, lugares a los que no siempre viajan con un seguro de vida o de atención médica, careciendo del derecho a recibir indemnizaciones si resultan heridos.

Al trabajar en circunstancias imprevisibles, los periodistas están expuestos a diferentes riesgos y, en ocasiones, resulta imposible evitar heridas e incluso la muerte. No obstante, todavía queda mucho camino por recorrer respecto a los esfuerzos necesarios para disminuir los niveles de riesgo. En Argelia, donde fueron asesinados 60 periodistas entre junio de 1994 y marzo de 1996, los sindicatos, las empresas y las autoridades han aunado sus esfuerzos para reducir los riesgos.

Todavía se necesitan grandes esfuerzos por parte de las empresas de comunicación y los representantes de los trabajadores a fin de aumentar la protección de estos profesionales. Entre otras medidas, es necesario adoptar las siguientes:

- Preparación adecuada de los periodistas antes de ser enviados a una misión informativa. Las empresas de comunicación deben facilitar asistencia técnica y establecer programas de formación destinados a mejorar la seguridad personal, realizando análisis de riesgos respecto a cada destino o misión informativa.

- Seguros de vida y asistencia médica para todo el personal que cubra información sobre el terreno, estableciendo procedimientos que aseguren que cualquier persona que pueda estar expuesta a alguna clase de riesgo esté debidamente asegurada.

Por otra parte, las empresas de comunicación deben invertir las tendencias actuales que aumentan la precariedad de las condiciones sociales y profesionales en las que trabajan los periodistas. Es necesario aumentar las inversiones en materia de formación profesional y ética periodística, con el fin de destacar la importancia del periodismo de investigación y preservar la salud democrática de la sociedad.

Los propios periodistas desempeñan un papel primordial y deben asumir la responsabilidad de adoptar las máximas medidas de seguridad personal y reducir el riesgo para ellos y para sus compañeros. Por otra parte, los periodistas deben observar una irreprochable conducta profesional y no traicionar la ética periodística al recopilar, elaborar y difundir la información.

No son sólo los profesionales de los medios de comunicación quienes han de dar pasos importantes para lograr estos objetivos; los gobiernos, responsables de la seguridad de todos los ciudadanos, deben establecer las condiciones para que los periodistas y las empresas de comunicación cuenten con la máxima protección y seguridad frente a la violencia.

Los gobiernos y los poderes públicos deben dejar de considerar a los periodistas como parte del aparato de seguridad del Estado, absteniéndose de solicitarles datos e información para ser utilizados en el curso de investigaciones llevadas a cabo por organismos oficiales.

Uno de los aspectos más preocupantes del periodismo es el intento por parte de los gobiernos de emplear la actividad periodística para fines de vigilancia y espionaje, una práctica que puede convertir a los periodistas que viajan en sospechosos, exponiéndoles a presiones intimidatorias.

La reducción de los riesgos es la clave fundamental. Aunque resulta imposible garantizar una seguridad absoluta, los gobiernos, las empresas de comunicación y los propios profesionales deben evitar que se den las condiciones que faciliten situaciones de violencia contra los medios de comunicación. Un buen comienzo sería reconocer que ninguna historia, por dramática que pueda ser, merece la pérdida de una vida. 


\section{ACTIVIDADES CULTURALES Y RECREATIVAS}

\section{MUSEOS Y GALERIAS DE ARTE}

Kathryn A. Makos

Los museos y galerías de arte son centros educativos y recreativos para el público en general. Existen varias clases de museos según sus diferentes temas: arte, historia, ciencia, historia natural, infantiles, etc. Las exposiciones, conferencias y publicaciones que los museos ofrecen al público son sólo parte de sus actividades. La función esencial de los museos y las galerías de arte es reunir, conservar, estudiar y exponer obras de valor artístico, histórico, cultural o científico. La investigación (literaria, "in situ" y en laboratorio) y el cuidado de las colecciones no expuestas al publico suelen representar la mayor proporción de trabajo. Las colecciones expuestas al público sólo suponen una parte del total de las adquisiciones de los museos o galerías de arte, muchas de cuyas obras están guardadas en almacenes o se encuentran cedidas a otras exposiciones y proyectos de investigación. Los museos pueden funcionar como instituciones independientes o estar adscritos a universidades, organismos públicos, dependencias de cuerpos armados, parques y lugares históricos e incluso a determinadas industrias.

Las actividades de un museo pueden dividirse según las funciones más destacadas: actividades generales en el edificio, exposición de colecciones, actividades educativas, gestión de la colección (incluidos los estudios "in situ") y la conservación. Los principales trabajos de un museo, que en ocasiones pueden solaparse en función del tamaño de su plantilla, son los siguientes: personal de mantenimiento del edifico, vigilantes, carpinteros, conservadores, ilustradores y artistas, bibliotecarios y educadores, investigadores, especialistas en embalajes y recepción de material, y personal de seguridad.

\section{Actividades generales en el edificio}

El funcionamiento de los museos y galerías de arte entraña muchos riesgos para la salud y problemas de seguridad comunes a otras actividades, además de otros específicos de estas instituciones. Igual que otros edificios, el aire interior de los museos puede tener una calidad deficiente, y las actividades de mantenimiento, las reparaciones y las actividades de custodia y seguridad entrañan los correspondientes riesgos. Los sistemas de prevención de incendios son esenciales para la seguridad de los trabajadores y del público, así como para preservar la integridad de colecciones de valor incalculable.

Los servicios generales incluyen: vigilantes; técnicos de los sistemas de calefacción, ventilación, aire acondicionado (HVAC) y calderas; pintores; electricistas; fontaneros; soldadores y mecánicos. Los riesgos más comunes son los resbalones, tropiezos y caídas; lesiones en los miembros inferiores y en la espalda; descargas eléctricas, y explosiones o incendios provocados por las bombonas de gases comprimidos y los trabajos con procesos a elevadas temperaturas. Los riesgos para la salud comprenden la exposición a materiales peligrosos, a ruidos, a vapores de metales, gases y emanaciones, a radiación ultravioleta, así como dermatitis provocadas por sustancias grasas, disolventes, resinas epóxicas y productos plastificantes. Los vigilantes están expuestos a salpicaduras de los productos químicos de limpieza, reacciones químicas por la mezcla inadecuada de estos productos, dermatitis, aspiración del polvo al barrer e inhalación del plomo de las pinturas o de sustancias conservantes residuales en los lugares destinados al almacenamiento de las colecciones, lesiones con objetos de cristal de laboratorio o al trabajar cerca de sustancias sensibles y equipo de laboratorio, así como a peligros de tipo biológico durante la limpieza de los excrementos de los pájaros en el exterior del edificio.

Los edificios más antiguos son propensos a originar mohos y la calidad del aire interior no suele ser buena, carecen de barreras de vapor de los muros exteriores y los sistemas de ventilación normalmente son viejos y de mantenimiento difícil. Las obras de renovación pueden dejar al descubierto materiales peligrosos, tanto en edificios centenarios como en los más modernos. Algunos ejemplos de estos materiales son las pinturas con plomo, revestimientos de mercurio en antiguas superficies pulimentadas y asbesto en aislamientos y acabados decorativos. En los edificios antiguos es preciso conjugar la preservación de los aspectos históricos con el cumplimiento de las normas de seguridad en el diseño y la disponibilidad de facilidades para personas con discapacidades. Los sistemas de ventilación por extracción no deben dañar la fachada del edificio. Las limitaciones urbanísticas para los tejados de los cascos históricos de las ciudades pueden impedir la construcción de torres de extracción con la altura necesaria. Las barreras empleadas para separar las zonas en obras deben ser independientes sin posibilidad de fijarse a los muros con elementos históricos. Los trabajos de renovación no deben dañar las estructuras subyacentes hechas con maderas y acabados de valor. Todas estas restricciones pueden aumentar los riesgos. Es fundamental la instalación de sistemas de detección y extinción de incendios así como la construcción con materiales retardadores.

Entre las precauciones que deben adoptar están la utilización de equipos de protección individual para ojos, cara, cabeza, oídos y aparato respiratorio; los sistemas de seguridad eléctrica; la colocación de defensas en las máquinas; los programas de bloqueo y carteles de advertencia; el almacenamiento adecuado para sustancias peligrosas y el empleo de bombonas seguras para gases comprimidos; los sistemas de detección y extinción de incendios; los recolectores de polvo, los sistemas de ventilación por extracción y el empleo de filtros de aire particulado de alta eficacia (HEPA); la formación adecuada para levantar y manipular objetos pesados de forma segura; los sistemas seguros de montacargas; el empleo de poleas, eslingas y elevadores hidráulicos; el control de derrames de sustancias químicas; las duchas de seguridad y de lavado de ojos; los equipos de primeros auxilios; y la información sobre los peligros y programas de formación de los empleados sobre los riesgos de los materiales y de las distintas tareas (especialmente los vigilantes en los laboratorios) y medios de protección.

\section{Exposiciones y exhibiciones}

La organización y el montaje de las exposiciones en un museo engloban una serie de actividades: por ejemplo, una exposición de animales en un museo de ciencias naturales requiere la fabricación de urnas y expositores; la reconstrucción del hábitat natural de los animales; la reproducción de modelos de los animales; la producción de materiales escritos, orales y representaciones gráficas de apoyo a los elementos expuestos; la iluminación adecuada, y muchas otras cosas. Entre las tareas necesarias para montar las exposiciones se encuentran: carpintería; metalistería; trabajo con plásticos, resinas plásticas y otros materiales; artes gráficas y fotografía.

El montaje de las exposiciones y los talleres gráficos entraña riesgos comunes con la artesanía de la madera, la escultura, las artes gráficas, la metalistería y la fotografía. Algunos riesgos 
Tabla 96.8 • Riesgos y precauciones de las actividades de coleccionismo.

\section{Procesos}

Trabajo de campo y manipulación de especímenes

Taxidermia y preparación osteológica

Ilustradores y análisis microscópicos realizados por los conservadores y sus técnicos

Fumigantes y plaguicidas

Investigación en el laboratorio

Transporte, recepción y preparación de colecciones cedidas para exposiciones

\section{Riesgos y precauciones}

Lesiones de tipo ergonómico causadas por esfuerzos repetitivos en la excavación de rocas fósiles y el levantamiento de grandes pesos; riesgos biológicos a causa de la limpieza de superficies ensuciadas con excrementos de aves, reacciones alérgicas (dérmicas y pulmonares) causadas por excrementos de insectos, manipulación de especímenes vivos y muertos, sobre todo de aves y mamíferos y otros teiidos enfermos (placas, virus Hanta); y riesgos químicos procedentes de sustancias conservantes.

Entre las precauciones están los controles sobre aspectos ergonómicos; aspiradores con filtros de alta eficacia (HEPA) para controlar detritus alergenos, huevos de insectos, larvas; medidas generales a fin de evitar la exposición de los empleados a agentes infecciosos en animales; y una ventilación adecuada o protección de las vías respiratorias al trabajar con sustancias conservantes peligrosas.

Los riesgos para la salud en la preparación de muestras de pieles, esqueletos y especímenes completos, y en la limpieza y restauración de antiguos ejemplares disecados, proceden de la exposición a los disolventes y desengrasantes empleados para limpiar pieles y restos de esqueletos (después de la maceración); restos de conservantes, sobre todo arsénico (de aplicación interna y externa); preparaciones osteológicas (hidróxido de amomio, disolventes, desengrasantes); formaldehído para conservación de órganos después de las autopsias (o necropsias); alergenos de los excrementos de insectos; contactos con especímenes enfermos; asbesto-escayola en antiguos ejemplares disecados. Los riesgos relativos a la seguridad y a los incendios comprenden los esfuerzos por levantamiento de grandes pesos; lesiones por manejar herramientas eléctricas, cuchillos 0 instrumentos afilados.

Las precauciones comprenden ventilación aspirante local; aparatos respiradores, guantes, delantales; utilizar cepillos y aspiradores con filtro de alta eficacia (HEPA) para limpiar las pieles y ordenar los pelos en lugar de emplear aire comprimido de baja presión o únicamente un cepillado enérgico; y usar desinfectantes en las zonas donde se realizan necropsias y otras manipulaciones. Solicitar información de las autoridades medioambientales sobre los productos permitidos para taxidermia y conservación.

La exposición a medios peligrosos en la observación e corta distancia procede de sustancias como: xileno, alcoholes, formaldehído/glutaraldehído y tetróxido de osmio empleado en histología (disecciones, coloraciones, observación de muestras) para escaneo y observación microscópica de transmisión de electrones.

Para tomar las precauciones adecuadas véase Investigación en laboratorio.

Aunque es necesario evitar el daño causado a las colecciones por parte de los insectos, la utilización indiscriminada de productos químicos puede tener efectos secundarios adversos en la salud de los empleados y en las propias colecciones. En la actualidad se han establecido programas de gestión integrada de plaguicidas como una forma práctica de controlar plagas, reduciendo los riesgos para las colecciones y la salud de los empleados. Entre los fumigantes y plaguicidas químicos más comunes (muchos de ellos prohibidos o de uso restringido en la actualidad) se encuentran los siguientes: DDT, naftalina, PDB, diclorvos, óxido de etileno, tetracloruro de carbono, dicloruro de etileno, bromuro de metilo y fluoruro de sulfurilo. Muchos de estos productos pueden pasar inadvertidos, son muy tóxicos o letales para los seres humanos en bajas concentraciones.

La precauciones comprenden los equipos de protección individual, los aparatos respiradores, la ventilación, la protección frente a salpicaduras, la vigilancia médica, los aspiradores con filtros de alto rendimiento (HEPA), personal autorizado para su aplicación y muestreo del aire antes de volver a utilizar las zonas fumigadas.

Las tareas peligrosas comprenden las moleculares de carácter sistemático; la investigación del ADN y el almacenamiento de células vivas y cultivo de tejidos (medios de crecimiento); DMSO, isótopos radioactivos, numerosos disolventes, ácidos, éter de etilo; líquidos criogénicos para congelación en seco (nitrógeno, etc.); y el empleo de tintes de bencidina.

La precauciones comprenden la protección criogénica (guantes, pantallas de protección facial, delantales, zonas bien ventiladas, válvulas de seguridad, sistemas para almacenamiento y transporte de elementos de alta presión), compartimientos de bioseguridad, aparatos respiradores y campanas para radiación en laboratorio, compartimientos con ventilación local para equipos de pesado y de visión por microscopio; asientos limpios con filtros de alta eficacia (HEPA), guantes y ropa de laboratorio, protección ocular, aspiradoras con filtros de alta eficacia para el control de detritus de alergenos, huevos de insectos, larvas; y precauciones generales para evitar la exposición de los empleados del laboratorio y los de seguridad a agentes infecciosos de los animales.

Exposición a sustancias desconocidas y materiales de embalaje potencialmente peligrosos (por ejemplo, embalajes forrados con fibras de asbesto) procedentes de países con normativas poco exigentes respecto a los requisitos de información sobre los riesgos medioambientales.

Las precauciones comprenden información apropiada sobre los riesgos en colecciones cedidas a otras instituciones y comprobación de que la documentación de las colecciones recibidas ofrece información sobre su contenido. 
Tabla 96.9 • Riesgos del coleccionismo de objetos.

Fuente del riesgo
Plantas, vertebrados e invertebrados

Artes decorativas, cerámica, piedras y metales

Entomología

Muebles

Minerales

Riesgos varios

Pinturas, impresiones y papel

Especímenes paleobiológicos

Fotografía

Cajas de almacenamiento

Productos textiles, prendas de vestir

\section{Riesgo}

Medios de almacenaje que contengan formaldehído, ácido acético, alcohol, el formaldehído para fijadores en el trabajo sobre el terreno, clasificación para conservación en alcohol, cloruro de mercurio en especímenes vegetales disecados, conservantes de arsénico y mercurio para aves y mamíferos, adhesivos para disecaciones; alergenos de excrementos de insectos.

Los pigmentos y conservantes pueden contener mercurio. Los objetos bañados en oro o plata pueden contener cianuro en su acabado (que puede liberarse mediante lavados con agua). Los objetos de celuloide (marfil de Francia) pueden provocar incendios. Las joyas esmaltadas pueden contener pigmentos de uranio radiactivo.

Exposición a naftalina y paradiclorobenceno (PDB) al rellenar los cajones de almacenamiento de muestras y al observar especímenes; sales de cianuro empleadas en los preparados para la recolección en frascos en el trabajo sobre el terreno.

Los muebles pueden estar tratados con capas de pentaclorofenol para conservar las maderas, pigmentos de plomo y otros metales tóxicos. En la limpieza y restauración se utilizan tratamientos con alcoholes minerales, decapantes de cloruro de metileno, barnices y lacas.

Especímenes radiactivos, minerales y metales naturales de alta toxicidad (plomo, asbestiformes), ruidos y resinas epoxídicas en los procesos de corte.

Antiguos medicamentos en colecciones médicas, odontológicas y veterinarias (que se hayan degradado, que sean sustancias ilegales 0 se hayan vuelto reactivas o potencialmente explosivas); pólvora, armas de fuego; tetracloruro de carbono en dispositivos de extinción de incendios pertenecientes a los siglos XIX y XX; ácidos de baterías de vehículos; $P C B$ en transformadores, condensadores y otros objetos de colecciones de electricidad; mercurio en generadores estáticos, faros y colecciones científicas; asbesto en trofeos disecados, figuras fundidas y numerosos aparatos domésticos, barnices cerámicos, cableado y productos textiles.

Pueden contener pigmentos altamente tóxicos de plomo (blanco de plomo, amarillo de plomo), cadmio, cromo (carcinogénico en forma de cromato), cobalto (sobre todo violeta de cobalto 0 arsenato de cobalto), manganeso y mercurio. El cianuro puede estar presente en algunas tintas de imprimir y en antiguos papeles decorativos (siglo XIX); el mercurio se ha empleado en pinturas y teiidos para impedir la proliferación de hongos; los tintes de negro de humo y de alquitrán mineral son cancerígenos. Para la limpieza y restauración de estos materiales se emplean disolventes, barnices, lacas, blanqueadores de dióxido de cloro y otros productos.

Riesgos de tipo ergonómico y otros derivados de la excavación de rocas y yacimientos que pueden contener cristales de silice, asbesto o minerales radiactivos; resinas epoxídicas y plásticos líquidos para moldes de fósiles; ruidos; disolventes y ácidos para la digestión de rocas (el fluorhídrico es el ácido más peligroso).

Las películas de nitrocelulosa entrañan riesgo de combustión espontánea, y el ácido nítrico de las películas en descomposición produce quemaduras. Deben hacerse copias en películas modernas. La restauración de los colores con selenio presenta los riesgos de exposición al selenio y dióxido de azufre, y requiere una ventilación adecuada.

Las superficies con pinturas de plomo y cadmio, los embalajes tratados con arsénico y los aislantes de asbesto presentan problemas al deshacerse de estos materiales. Los residuos con estas sustancias son peligrosos al limpiar el interior y exterior de las cajas; las sustancias aspiradas deben considerarse desechos peligrosos.

Los riesgos proceden de: tintes (sobre todo de bencidinas), niveles de fibra, arsénico para encajes y otros conservantes, mercurio para tratamientos de fieltrado; materiales vegetales tóxicos para decoración de prendas de vestir; mohos, alergenos de restos y excrementos de insectos. específicos para la salud y la seguridad pueden derivarse de la instalación de exposiciones en salas sin la ventilación adecuada, la limpieza de los expositores con residuos de materiales y tratamientos peligrosos, la exposición a formaldehído durante montajes fotográficos de especímenes conservados en líquidos y el corte de alta velocidad de maderas tratadas con sustancias retardadoras del fuego, susceptibles de liberar gases ácidos irritantes (óxidos de azufre y fósforo).

Las principales precauciones que deben adoptarse son el empleo de equipos de protección individual, la insonorización y sistemas de extracción local en la maquinaria de trabajo con madera; la ventilación adecuada en las mesas de gráficos, cabinas para serigrafías, zonas destinadas a mezcla de pinturas, zonas para las resinas plásticas y para el revelado de fotos, y la utilización de tintas acuosas.

\section{Actividades educativas}

Las actividades educativas de un museo comprenden conferencias, distribución de publicaciones y actividades artísticas y científicas que requieren el contacto de las manos con las obras expuestas, entre otras. Pueden estar dirigidas al publico adulto o infantil. Las actividades artísticas y científicas requieren a menudo la utilización de sustancias tóxicas en habitaciones y salas sin la debida ventilación ni otros requisitos, la manipulación de aves y otros animales disecados con conservantes a base de arsénico, equipos eléctricos, etc. Tanto el personal docente como los participantes en estas actividades están expuestos a los riesgos, sobre todo los niños. Los programas educativos deben estudiarse con atención para determinar las precauciones necesarias y las actividades que no pueden desarrollarse de forma segura dentro del museo. 


\section{Gestión de las colecciones de arte y objetos artísticos}

La gestión de las colecciones de arte comprende: adquisición y recogida en el lugar de origen, control de inventario, técnicas de almacenamiento adecuadas, conservación y eliminación de plagas. El trabajo de campo puede suponer la excavación en yacimientos arqueológicos, la conservación de insectos, plantas y otras muestras, la elaboración de figuras y moldes de distintos especímenes, la excavación de rocas fósiles, etc. Entre las funciones del personal de conservación de un museo se encuentran la manipulación de especímenes, su análisis mediante diversas técnicas (rayos $\mathrm{X}$, microscopio), el control y la eliminación de plagas, la preparación de los objetos para su exposición y la organización de exposiciones itinerantes.

En todas las facetas de conservación, incluidos los trabajos sobre el terreno, existen riesgos inherentes a la manipulación de los objetos y especímenes, los residuos de sustancias procedentes de métodos antiguos de conservación y fumigación (no documentados por el titular original del hallazgo), y otros peligros relacionados con plaguicidas y fumigaciones. En la Tabla 96.8 se recogen los riesgos más frecuentes y las precauciones que deben adoptarse en algunas de estas actividades.

Otros peligros provienen de los mismos objetos de la colección. Los elementos conservados en líquidos presentan riesgos relacionados con la exposición a formaldehído, utilizado como fijadores y conservantes; con la clasificación de especímenes preservados en formaldehído o alcohol (generalmente etanol o isopropanol), y otros riesgos como los derivados de los "líquidos misteriosos" de colecciones prestadas de otras instituciones. Las colecciones de objetos en seco presentan los riesgos siguientes: residuos de sustancias conservantes, como trióxido de arsénico, cloruro de mercurio, estricnina y DDT, y compuestos vaporizantes que dejan residuos o recristalización, como las tiras plaguicidas de diclorvos/vapona, paradiclorobenceno (PDB) o naftalina. Véase la Tabla 96.9 que recoge una lista con numerosos riesgos relacionados con la gestión de colecciones. Esta tabla también incluye los riesgos asociados a la conservación de especímenes.

Los aspectos en materia de salud y seguridad en el trabajo son similares a los de la industria en general. Las medidas de prevención comprenden: inventario de los métodos y tratamientos de conservación, equipos de protección individual con guantes de vinilo (no de látex) para manipular especímenes secos y guantes impermeables, y protección contra salpicaduras de sustancias líquidas. Otras precauciones son la vigilancia médica de los riesgos para la salud en general y para el aparato reproductor en particular; buenos hábitos de higiene, como lavar por separado la ropa de trabajo (mejor si se hace en una lavadora del lugar de trabajo); evitar el barrido en seco (se recomiendan las aspiradoras con filtros de aire particulado de alta eficacia); evitar aspiradores que recojan aguas en colecciones sospechosas; empleo de métodos adecuados para deshacerse de los desechos; e información y formación del personal sobre los riesgos de los productos químicos.

\section{Laboratorios de conservación}

Las tareas de conservación, a menudo en laboratorios industriales, consisten en la limpieza y restauración (por medios físicos o químicos) de pinturas, papeles, fotografías, libros, manuscritos, sellos, muebles, tejidos, cerámica y vidrio, metales, piedras, instrumentos musicales, uniformes y trajes, cueros, cestas, máscaras y otros objetos etnográficos. Los riesgos específicos de las actividades de conservación abarcan desde la exposición intermitente a partículas de sustancias químicas conservantes hasta las exposiciones más graves por el manejo de grandes cantidades de sustancias químicas para la conservación de estatuas y especímenes de grandes vertebrados. También pueden originarse lesiones de tipo ergonómico por posiciones forzadas de la mano en el manejo de pinceles para pintar y restaurar figuras escultóricas y por el levantamiento de objetos de gran peso. En la limpieza y restauración de los objetos de una colección se emplean diversos disolventes y otras sustancias químicas. Muchas de las técnicas empleadas para la restauración de obras de arte en mal estado son las mismas (con el consiguiente parecido en los riesgos y aspectos de seguridad) que las utilizadas en la creación original de dichas obras. Otros riesgos proceden de la composición y acabado de los propios objetos, como se describe en la Tabla 96.9. Respecto a las medidas preventivas, véase la sección precedente.

\section{PARQUeS ZOOLOGICOS Y ACUARIOS}

\section{Ken Sims}

Los parques zoológicos, los parques de animales en libertad y de safaris, los centros de aves y los acuarios comparten métodos de mantenimiento y cuidado de especies exóticas. Los animales son mantenidos para su exhibición, para fines didácticos, de investigación científica y para su conservación. Aunque siguen siendo frecuentes los métodos tradicionales de mantener a los animales en jaulas, pajareras y estanques, las colecciones más modernas han ido adoptando hábitat más acordes con las necesidades de cada especie. La calidad del espacio destinado a un animal es aún más importante que la cantidad y puede mejorar las condiciones de seguridad de sus cuidadores. Los peligros a los que éstos últimos están expuestos provienen en primer lugar del tamaño y la ferocidad natural de algunas especies, aunque existen otros factores de riesgo.

Los principales grupos de animales son: aves, mamíferos, reptiles, anfibios, peces e invertebrados. Entre los problemas comunes a todos los grupos están las toxinas, las enfermedades que transmiten (zoonosis) y los cambios en el estado de ánimo en los animales.

\section{Mamíferos}

Las distintas clases y hábitos de los mamíferos requieren una extensa variedad de técnicas de cría. Los más grandes en tamaño son herbívoros, como los elefantes, y los cuidados necesarios son similares a los de otros animales domésticos, puesto que carecen de facultades para saltar, trepar, esconderse o roer. Los depredadores de mayor tamaño, como los osos y los grandes felinos, requieren cercados con amplios márgenes de seguridad, puertas dobles de acceso y la instalación de dispositivos para su inmovilización y aprisionamiento. Las especies con especial agilidad para saltar y trepar representan un peligro adicional para sus guardianes, que no poseen dichas habilidades. El uso de cercas electrificadas es una práctica bastante extendida. Para la captura y manejo de estos animales se emplean métodos de acorralamiento, redes, inmovilización, cuerdas, y dardos cargados con sedantes.

Aves

Por su tamaño, la mayoría de las aves pueden atraparse con guantes y una red. Las más grandes, como los avestruces y los casuarios, incapaces de levantar el vuelo, requieren cajas de madera para su inmovilización.

\section{Reptiles}

Los grandes reptiles carnívoros pueden atacar de forma violenta, al igual que algunas serpientes. Los ejemplares en cautividad 
suelen mostrar una apariencia apacible que puede provocar un exceso de confianza en sus cuidadores. El ataque de una boa constrictora de gran tamaño puede arrollar y ahogar a su aterrorizado cuidador, de mayor peso que el animal. Determinadas serpientes venenosas son capaces de "escupir", lo que obliga a emplear gafas especiales. Los métodos para sujetar y manejar a estos reptiles incluyen redes, sacos, ganchos, garfios, nudos corredizos y drogas sedantes.

\section{Anfibios}

Unicamente las salamandras gigantes y los sapos de gran tamaño son capaces de provocar mordeduras desagradables. Los riesgos que presentan el resto de los anfibios proceden de las excreciones tóxicas.

\section{Peces}

Por lo general, los peces no resultan peligrosos, a excepción de las especies venenosas, las anguilas eléctricas y los grandes depredadores. Los riesgos se pueden reducir empleando redes y, en ocasiones, es recomendable el aturdimiento por medios eléctricos o químicos.

\section{Invertebrados}

En este grupo existen especies letales que requieren un manejo indirecto. Los principales riesgos se deben a la identificación errónea y la habilidad para el camuflaje o a su pequeño tamaño, consiguiendo sorprender a las personas menos atentas.

\section{Toxinas}

Bien sea para defenderse o para procurarse alimento, muchas especies han desarrollado a lo largo de su evolución complejas toxinas que liberan al morder, picar, escupir o por secreción, y cuya cantidad puede ser desde inocua o leve hasta mortal. Las medidas para prevenir estos accidentes deben considerar la posibilidad de los casos más graves y no debe permitirse la exposición a las especies letales de un cuidador en solitario. En los procedimientos de cría deben evaluarse los riesgos, señalizar claramente los peligros, restringir el acceso a estas especies a personal convenientemente adiestrado, mantener al día la lista de antídotos en estrecha colaboración con servicios médicos locales especializados, predeterminar las reacciones de los cuidadores a los antídotos y establecer sistemas de alarma eficaces.

\section{Zoonosis}

Los riesgos de zoonosis pueden mantenerse a niveles muy bajos mediante programas de salud de los animales y de higiene de los guardianes. Algunas enfermedades son mortales, como en el caso de la rabia, que no tiene tratamiento en las fases finales. Casi todas ellas son evitables y pueden tratarse eficazmente si se diagnostican a tiempo y correctamente. Igual que sucede en otros oficios, la incidencia de alergias es un fenómeno creciente y la mejor forma de tratarlas es evitar la exposición a los agentes irritantes que puedan identificarse.

Debe prestarse especial atención a los rasguños y mordeduras de ejemplares "no venenosos", pues incluso las mordeduras que aparentemente no llegan a rasgar la piel pueden producir un rápido envenenamiento de la sangre (septicemia). Las mordeduras de los carnívoros y de los monos son especialmente peligrosas; un ejemplo extremo son las mordeduras de los dragones de Comodo cuya microflora en la saliva es de tal virulencia que una presa que consiga escapar a su ataque puede morir de inmediato por septicemia y shock.

Es muy recomendable la profilaxis frente al tétanos y la hepatitis para la mayoría de los empleados.
Figura 96.19 • Utilización de la voz y el lenguaje corporal con los animales.

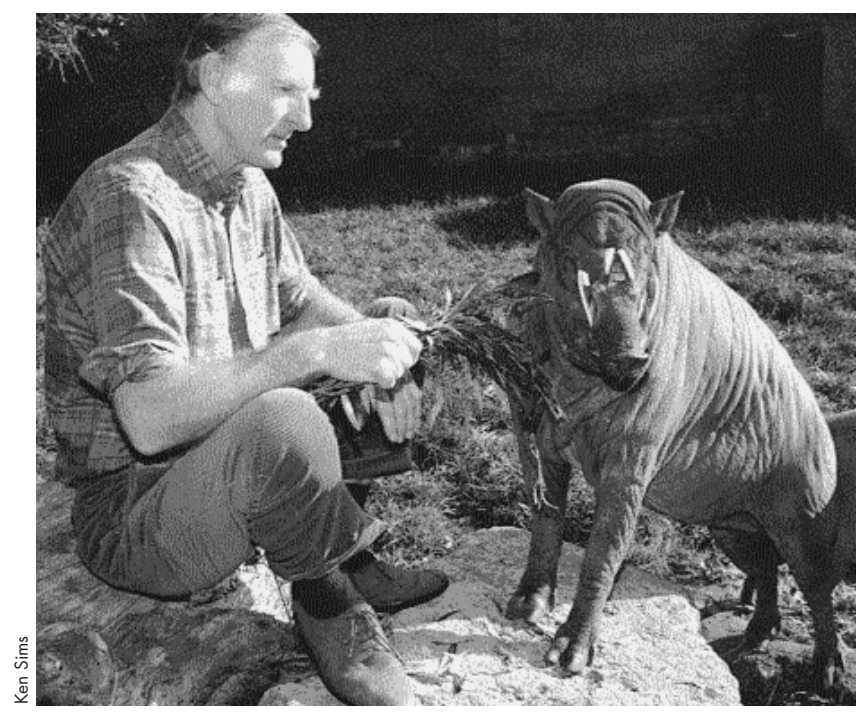

\section{Estados de ánimo}

La respuesta de los animales puede ser infinitamente variada, y en algunos casos muy peligrosa, ante la aproximación de las personas. Aunque la observación de los cambios en el estado de ánimo de los animales puede alertar a los cuidadores, muy pocas especies muestran signos fácilmente interpretables por el ser humano. El estado de ánimo de los animales puede verse alterado por una combinación de estímulos visibles e invisibles, como la estación del año, la duración del día, la hora del día, los ciclos sexuales, los períodos de cría, las jerarquías, la presión barométrica y los ruidos de alta frecuencia procedentes de equipos eléctricos. Los animales no son máquinas programadas y, aunque su conducta resulta a menudo predecible, tienen la capacidad de reaccionar de forma inesperada, posibilidad ante la cual incluso los más expertos cuidadores deben estar alerta.

\section{Seguridad de las personas}

Los empleados con mayor experiencia deben enseñar a los trabajadores menos experimentados a valorar los riesgos. Para mantener niveles de seguridad aceptables es importante extremar constantemente las precauciones, sobre todo al alimentar a los grandes carnívoros. Las reacciones de los animales difieren según el cuidador, sobre todo en función del sexo de éste. Así, un animal que se muestra sumiso con un determinado cuidador puede llegar a atacar a otro. La seguridad también puede reforzarse por la comprensión y el empleo del lenguaje corporal, una forma de comunicación que los animales dominan mejor que los seres humanos. El tono de la voz y el volumen pueden calmar a un animal o provocar su agresividad (Figura 96.19).

La ropa de trabajo debe escogerse con especial cuidado, evitando los colores llamativos y las prendas ruidosas. Los guantes proporcionan protección para manejar a algunos animales, pero no resultan apropiados con las serpientes, al reducir la sensibilidad táctil.

A los guardianes y otros empleados encargados de impedir que el público penetre en los recintos de los animales, o de enfrentarse a personas violentas o problemáticas, se les ha de facilitar formación adecuada sobre la manera de actuar en esas 
situaciones, y deben contar con medios para solicitar ayuda, reduciendo los riesgos para ellos.

\section{Normativa}

A pesar de la variedad de situaciones peligrosas que pueden presentarse con las especies exóticas, la mayoría de los riesgos en el lugar de trabajo son los generales que existen en fábricas con maquinaria, productos químicos, superficies, electricidad, etc., por lo que deben aplicarse las leyes de seguridad y salud en el trabajo generales, utilizando el sentido común para adaptarlas a la naturaleza específica de estos trabajos.

\section{- PARQUeS Y JARDINES BOTANICOS}

Paul V. Lynch

La naturaleza de los riesgos para la salud y los aspectos de seguridad en el trabajo de los empleados de parques y jardines botánicos pueden agruparse en las siguientes categorías: ambientales, mecánicos, biológicos o químicos, debidos a la vegetación, a los animales salvajes y a los seres humanos. Los riesgos varían en función de la ubicación del parque o jardín (urbanos, en suburbios, zonas silvestres, etc.).

\section{Riesgos ambientales}

Los empleados de los parques y jardines trabajan en todo tipo de regiones geográficas y suelen pasar al aire libre la mayor parte, si no toda, la jornada, exponiéndose a todo tipo de temperaturas y condiciones climáticas extremas que pueden causar desde desvanecimientos y golpes de calor hasta hipotermias y congelación.

En los emplazamientos urbanos puede existir tráfico rodado, y los trabajadores están expuestos a emisiones tóxicas como monóxido de carbono, partículas de carbono sin quemar, óxido nitroso, ácido sulfúrico, dióxido de carbono y paladio (procedente de la descomposición de los convertidores catalíticos).

Algunas de estas instalaciones están localizadas en las zonas más altas de regiones montañosas, circunstancia que puede provocar mal de altura en empleados procedentes de otras regiones, y en aquellos con propensión a padecer tensión alta o baja.

Los empleados de los parques suelen participar en las tareas de búsqueda y rescate, así como en las actividades de control durante y después de desastres naturales como terremotos, huracanes, inundaciones, erupciones volcánicas, entre otros, corriendo los peligros inherentes a dichas situaciones.

Todos los trabajadores deben estar debidamente formados respecto a los riesgos ambientales propios de sus zonas geográficas y se les debe facilitar ropa y equipos adecuados, tanto para temperaturas altas como bajas, además de agua y racionamiento suficientes.

\section{Riesgos mecánicos}

Los trabajadores de los parques y jardines deben trabajar y estar familiarizados con una amplia gama de equipos mecánicos, desde pequeñas herramientas manuales y equipos eléctricos de jardinería (segadoras, máquinas rotatorias de labranza, sierras de cadena, etc.) hasta pequeños tractores, máquinas quitanieves, camionetas y maquinaria pesada de construcción. Además, en muchos casos disponen de talleres propios equipados con máquinas y herramientas eléctricas, como sierras de mesa, tornos, taladradoras, bombas de aire comprimido, etc.

Todos los empleados que necesiten utilizar estos equipos y herramientas deben estar adecuadamente formados para su manejo y conocer los riesgos y dispositivos de seguridad; ha de facilitárseles equipos apropiados de seguridad individual e instrucciones para su empleo. Algunas tareas requieren utilizar toda clase de vehículos de motor, helicópteros o cabinas aéreas por cable; los empleados que operan estos vehículos deben estar en posesión de los correspondientes permisos y pasar revisiones periódicas. Las personas que viajen como pasajeros deben conocer los riesgos de estos aparatos y las medidas de seguridad correspondientes.

\section{Riesgos biológicos y químicos}

El contacto continuo con el público es algo frecuente en todos los trabajos que tienen lugar en parques y jardines, lo que expone a los trabajadores a posibles contagios de enfermedades víricas y bacterianas. Por otra parte, también existe el riesgo de contagio de infecciones por animales salvajes, como la rabia, la psitacosis o la enfermedad de Lyme, entre otras.

Los trabajadores de parques y jardines suelen estar expuestos a distintas cantidades de plaguicidas, herbicidas, fungicidas, fertilizantes y otros productos químicos de uso agrario, además de pinturas tóxicas, diluyentes, barnices y lubricantes utilizados en las tareas de mantenimiento y transporte y en los equipos.

Con la proliferación de las drogas ilegales no es extraño que los empleados y trabajadores de parques naturales y bosques puedan dar con laboratorios clandestinos de estas sustancias. Los productos químicos utilizados en estos locales pueden causar la muerte y lesiones neurológicas permanentes. El personal que trabaja en zonas urbanas o rurales también puede encontrarse con restos de materiales utilizados por personas drogodependiente, como jeringuillas, agujas hipodérmicas, cucharas y pipas. Los pinchazos en la piel con alguno de estos elementos pueden provocar enfermedades como la hepatitis o el SIDA.

Es fundamental instruir a los trabajadores respecto a los riesgos y las medidas de seguridad necesarias; hay que facilitarles la realización de exámenes médicos así como atención inmediata a aquéllos expuestos a estos percances. También es importante que se informe al médico del tipo y duración de la exposición a dichos peligros. En caso de encontrar restos de útiles de administración de drogas como los anteriormente descritos, los empleados deben abstenerse de tocarlos, señalizando la zona y avisando a profesionales competentes en asuntos legales.

\section{Riesgos de la vegetación}

Aunque la gran mayoría de las especies vegetales no presentan riesgos destacables para la salud de las personas, en las regiones agrestes (y en ciertas zonas urbanas y suburbanas) existen plantas venenosas como la ortiga, y árboles como el zumaque venenoso o el árbol de las pulgas. Los riesgos para la salud de estas especies abarcan desde urticarias leves hasta reacciones alérgicas graves, según la sensibilidad del individuo y la naturaleza de la exposición.

Conviene no olvidar que un $22 \%$ del total de la población mundial sufre reacciones alérgicas de algún tipo, que pueden ser tanto leves como graves, y responder a unas pocas sustancias o a varios cientos de ellas, tanto de origen vegetal como animal. En casos extremos, estas reacciones pueden causar la muerte si no se tratan en el momento.

Antes de comenzar a trabajar en zonas con vegetación, los empleados deben ser examinados para descubrir posibles alergias a determinados alergenos y, en caso positivo, prescribir la medicación adecuada.

El personal que trabaja en medio de la vegetación debe poseer conocimientos sobre las especies cuya ingestión puede resultar peligrosa, saber reconocer los síntomas de envenenamiento por ingestión y conocer los antídotos. 


\section{Riesgos de los animales salvajes}

Los empleados de los parques naturales pueden encontrarse con toda la gama de especies animales existentes y deben estar familiarizados con las distintas clases de animales, sus hábitos, los posibles riesgos y, cuando resulte necesario, la forma de tratarlos con seguridad. Estos animales pueden ser desde ejemplares urbanos domésticos, como perros o gatos, hasta roedores, insectos y serpientes, especies salvajes de aves, osos, pumas, serpientes y arañas venenosas, etc.

Es necesario facilitar la formación necesaria para poder reconocer los distintos animales y saber cómo tratarlos, además de las enfermedades que pueden transmitir. Los trabajadores también deben disponer de los equipos para tratamiento de mordeduras de serpientes e insectos venenosos y de las instrucciones para utilizarlos. Por último, en determinadas regiones apartadas es necesario contar con personal adiestrado en el uso de armas de fuego y que porte dichas armas para protección individual.

\section{Riesgos atribuibles a las personas}

Además de los riesgos antes mencionados sobre posibles contagios de enfermedades de los visitantes, una parte importante de los riesgos a los que está expuesto el personal de los parques y, en menor medida, de los jardines botánicos, procede de la acción deliberada o accidental de las personas que acuden a visitar el lugar. Estos riesgos abarcan desde la necesidad de efectuar búsquedas y rescates de personas extraviadas o accidentadas (a veces en lugares remotos y de difícil acceso) hasta las intervenciones frente a actos de vandalismo, personas embriagadas, peleas o incluso asaltos a los propios trabajadores. También se exponen los empleados de los parques y jardines a los accidentes de tráfico causados por vehículos conducidos por los visitantes y otras personas que circulan por las cercanías.

Cerca del $50 \%$ de los incendios declarados en zonas salvajes están originados por la acción del hombre, ya sea por accidente o intencionadamente, y los empleados del parque se ven obligados a intervenir.

Así mismo, el personal de los parques y jardines también debe intervenir ante los riesgos de daños y destrucción de los bienes públicos, haciendo frente al peligro que presentan dichas situaciones en función de la clase de bienes amenazados y de la magnitud de los daños (pistas rurales, pasarelas peatonales, puertas interiores, cañerías, etc.).

Por lo general, las personas que se dedican a estos trabajos suele estar sensibilizadas respecto a la conservación ambiental, y muchas de ellas llegan a sufrir distintas formas de estrés y de problemas de salud relacionados con el comportamiento negligente de determinados visitantes de los parques y jardines. Por ello, es importante estar alerta ante las posibles manifestaciones de estrés por dichos motivos y tomar las medidas correspondientes. Entre éstas pueden resultar de gran utilidad los cursillos para superar el estrés entre los trabajadores.

\section{Violencia}

La violencia en el lugar de trabajo es desgraciadamente un fenómeno cada vez más frecuente, con evidentes riesgos de lesiones y que puede ser de carácter físico o psíquico. Las diferentes clases de violencia abarcan desde las simples amenazas verbales hasta los asesinatos en masa, como el ocurrido en 1995 por atentado con bomba al edificio de oficinas federales de los EE.UU. en Oklahoma City, estado de Oklahoma. En 1997, un agente de policía de origen indio fue asesinado al intentar entregar una orden judicial en una reserva india en el sudoeste del país. Existe otra modalidad de violencia psicológica bastante común pero de la que apenas se habla, para la que suele emplearse el eufemismo de "política de oficina" y que puede llegar a tener efectos similares de desgaste en los trabajadores.

Violencia de tipo físico. En Estados Unidos son frecuentes los ataques a empleados federales, estatales o locales que trabajan en zonas remotas o menos remotas en parques naturales y recreativos. Aunque muchos de estos episodios violentos sólo tienen como resultado algunas heridas, en ocasiones los asaltantes portan armas de fuego peligrosas. Se han dado casos de personas del público irritadas que han irrumpido en las oficinas de organismos federales que gestionan espacios naturales, esgrimiendo armas, y que han tenido que ser reducidas.

Estos incidentes violentos causan lesiones leves o mortales. Los asaltos pueden proceder de personas sin armas o de individuos con porras, palos, pistolas, rifles, cuchillos, explosivos o sustancias químicas peligrosas. A menudo los atentados se dirigen contra vehículos y otros bienes empleados por la institución federal que gestiona el parque natural o recreativo.

Otros casos se deben a acciones de empleados despedidos o irritados que buscan vengarse de sus antiguos jefes o de los actuales. Tampoco resulta extraño que los empleados de los parques naturales se encuentren con personas que cultivan o fabrican drogas ilegales en zonas remotas, y que no dudan en recurrir a la violencia para defender lo que consideran su territorio. El personal de los parques naturales y recreativos, y en especial los encargados de mantener el orden, deben enfrentarse a ciertas personas que, bajo los efectos de las drogas o el alcohol, infringen la ley y alteran el orden, presentando comportamientos violentos al ser detenidos.

Violencia psíquica. Aunque no es tan conocida, esta clase de violencia también produce daños considerables. Denominada comúnmente "política de oficina", se trata de una estrategia psicológica, posiblemente tan antigua como la misma civilización, empleada para ganar una posición de ventaja entre los compañeros, en el lugar de trabajo o sobre otros adversarios que se perciben como más débiles, y se manifiesta a través de la destrucción de la credibilidad de otras personas o grupos de personas, a menudo sin que éstas sean conscientes de ello.

En ocasiones se ejerce abiertamente a través de los medios de comunicación o determinadas leyes, con el fin de conseguir ciertas ventajas políticas (por ejemplo, acabar con la credibilidad de un organismo oficial para recortar su financiación).

Esta clase de violencia suele afectar negativamente en la moral de la persona o grupo de personas que la sufren y, en situaciones extremas y poco frecuentes, puede llevar a los individuos a actuar violentamente contra las vidas de sus detractores.

Muchas víctimas de esta violencia llegan a sufrir estrés postraumático que perdura años después de la agresión. Los efectos son similares a los de la neurosis de guerra que sufren los militares después de largos períodos en combate y que les llega a afectar durante años. Las personas afectadas pueden necesitar tratamiento psicológico.

Medidas de protección. El constante aumento de los riesgos de episodios violentos en el lugar de trabajo hace necesario que los trabajadores reciban un adiestramiento completo para reconocer y evitar las situaciones potencialmente peligrosas y aprendan a hacer frente a las personas violentas y fuera de control.

- Siempre que sea posible, establecimiento de medidas adicionales de seguridad en zonas de gran concurrencia.

- Disponibilidad para los empleados que trabajan lejos de las oficinas o talleres de un sistema de comunicación bilateral por radio para solicitar ayuda cuando sea necesario.

- En determinados casos, adiestrar a los empleados en el uso de armas de fuego para protección individual. 
- Las instituciones responsables de los parques naturales e instalaciones al aire libre deben llevar a cabo anualmente un estudio sobre la seguridad de sus recintos, con el fin de determinar los riesgos y las medidas necesarias para proteger a sus empleados.

- La gestión a todos los niveles debe ejercer una vigilancia especial para contrarrestar los riesgos de tipo psicológico en cuanto aparezcan, perseguir y corregir los rumores infundados y asegurarse de que todos los trabajadores conozcan con precisión los planes de funcionamiento de la institución y de sus puestos de trabajo.

Asistencia posterior al incidente. También resulta esencial (no sólo para el trabajador o trabajadores afectados por la violencia, sino para el resto de los empleados) que la víctima reciba, además de cuidados médicos inmediatos, atención y consejo psicológicos para superar el estrés. Los efectos de este tipo de violencia pueden perdurar bastante tiempo después de sanar las heridas físicas, incidiendo negativamente en la capacidad del trabajador para desempeñar satisfactoriamente su función.

A medida que aumenta la población, también lo hace la incidencia de la violencia, y, hoy por hoy, los únicos remedios son una buena preparación y saber reaccionar a tiempo y eficazmente.

\section{Conclusión}

Los trabajadores que se ven obligados a trabajar en todo tipo de ambientes deben gozar de buena salud y estar en buena forma física, objetivos que pueden alcanzarse adoptando un régimen constante de ejercicio físico moderado y sometiéndolos a exámenes médicos periódicos específicos del tipo de trabajo de cada persona. Todos los trabajadores deben recibir la formación necesaria para el desempeño de sus actividades, así como sobre los riesgos y cómo evitarlos.

Los equipos deben conservarse en buen estado de funcionamiento.

Todos los trabajadores destinados en lugares lejanos deberán estar equipados con una radio de comunicación bilateral y permanecer en contacto periódico con la base central.

Es conveniente que todo el personal posea conocimientos básicos —y más avanzados, si es posible - en materia de primeros auxilios, incluida la resucitación cardiopulmonar, para poder auxiliar a personas del público o a sus propios compañeros cuando no se disponga de asistencia médica inmediata.

\section{- CirCos, PARQUES DE ATRACCIONES Y TEMATICOS}

\section{William Avery}

Los circos y los parques de atracciones y temáticos tienen la finalidad común de entretener al público. Los espectáculos de circo pueden tener lugar en grandes carpas provisionales con gradas para los espectadores o en edificios estables, y el público acude para contemplar desde sus asientos las actuaciones de animales, payasos y acróbatas. Los parques de atracciones y temáticos son instalaciones de recreo por donde el público pasea y participa activamente en una extensa variedad de atracciones. Los parques de atracciones suelen ofrecer varios tipos de atracciones en las que se monta en un medio de transporte, exhibiciones, juegos de destreza, barracas, tiendas y auditorios para actuaciones, entre otros. En los parques temáticos hay expositores, edificios e incluso pequeños pueblos que ilustran un tema determinado. Personajes con disfraces alusivos a un tema en particular - por ejemplo, disfrazados con trajes antiguos en un pueblo de la época, o con disfraces de personajes de dibujos animados - participan en los espectáculos y pasean entre el público. Otra clase de entretenimiento son las ferias con atracciones en las que el público se monta en algún medio de transporte, espectáculos con animales y otras actividades como artistas tragafuegos, además de exhibiciones y competiciones de animales y productos de granja. El tamaño de las instalaciones varía desde las pequeñas atracciones de paseos en carritos tirados por ponis con un solo encargado, hasta los grandes parques temáticos con miles de empleados. Estos últimos suelen contar con aparcamientos, servicios públicos, servicios de seguridad y de emergencia, e incluso hoteles.

El tipo de trabajo es muy variado, como lo es también la preparación necesaria para las diferentes tareas. Los empleados de estas instalaciones comprenden: taquilleros, acróbatas, domadores y cuidadores de animales, encargados de los servicios de comidas y bebidas, mecánicos, actores disfrazados y operadores de atracciones, entre muchos otros. Los aspectos relativos a la seguridad en el trabajo y los riesgos para la salud son los usuales de la industria en general, además de los específicos de las actividades circenses y de parques de atracciones y temáticos. Los principales riesgos y precauciones relacionadas con estas actividades se describen a continuación.

\section{Acróbatas y equilibristas}

Los circos en especial ofrecen muchas actividades acrobáticas y de equilibrio, entre las que cabe mencionar las realizadas por los funámbulos y otros artistas que trabajan en el aire, los gimnastas, los malabaristas que utilizan fuego y los que hacen números con caballos. Los parques de atracciones y temáticos también pueden ofrecer espectáculos como los citados. Los riesgos principales son las caídas, los errores de apreciación, los equipos mal revisados y la fatiga física debido al exceso de actuaciones diarias. Los accidentes más frecuentes son las lesiones musculosqueléticas y tendinosas.

Entre las precauciones necesarias pueden incluirse las siguientes: preparación física óptima de los artistas, descansos apropiados y una buena dieta, estableciendo turnos en las actuaciones. Antes de las funciones deben revisarse pormenorizadamente todos los equipos, atrezo, andamiajes y dispositivos de seguridad y de bloqueo de emergencia. Los artistas nunca deben actuar cuando estén enfermos, lesionados o tomando alguna medicación que pueda impedirles realizar su trabajo en condiciones seguras.

\section{Manejo de animales}

Aunque los animales son más frecuentes en las ferias y circos, también algunos parques de atracciones ofrecen actividades con animales, como los paseos en poni. Encontramos animales en los circos en las actuaciones de doma de tigres y leones, en exhibiciones de equitación y en otras donde participan animales entrenados. Los elefantes ejecutan ejercicios y son montados por sus domadores, además de exhibirse y realizar tareas como animales de trabajo. En las competiciones de las ferias participan caballos, cerdos y vacas. En ocasiones se exhiben animales exóticos en jaulas y en demostraciones como las realizadas con serpientes. La reacción imprevisible de los animales junto al exceso de confianza de sus cuidadores, quienes pueden llegar a bajar la guardia, implican el consiguiente riesgo de que se produzcan lesiones o incluso la muerte. Una de las profesiones consideradas más peligrosas es la doma de elefantes. Se ha calculado que existen unos 600 cuidadores de elefantes en Estados Unidos y Canadá, y que entre estos profesionales se produce una muerte anual como media. Las actuaciones con serpientes venenosas también son muy peligrosas y el artista puede perder la vida en caso de resultar mordido. 
Figura 96.20 • Un trabajador llevando un pesado disfraz.

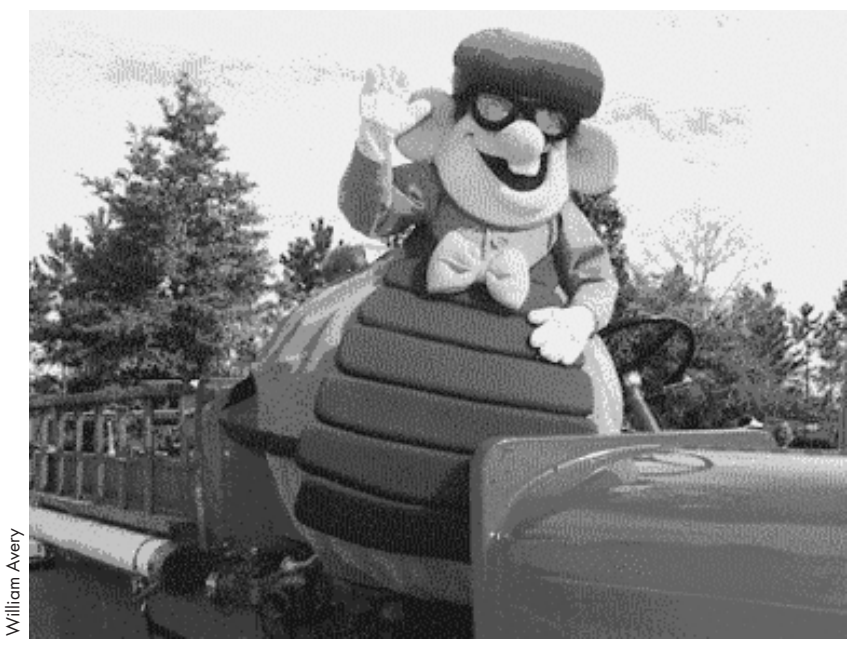

Una de las principales precauciones básicas es el entrenamiento constante e intensivo en el manejo de estos animales y la necesidad de insistir en la necesidad de que los empleados han de estar siempre alerta. Es recomendable utilizar sistemas de protección para evitar el contacto cuando los empleados trabajen en las zonas reservadas para animales capaces de causar heridas graves o la muerte. Estos sistemas consisten en la instalación de barrotes y el acotamiento de zonas vedadas al paso de personas. La formación en materia de seguridad debe incluir el ruido y otros estímulos en las actuaciones con animales en la pista a la vista del público. Cuando se trabaja con reptiles venenosos es necesario contar con los correspondientes antídotos, equipos de protección como guantes, protecciones para las piernas, pinzas para las serpientes y botes de dióxido de carbono. El cuidado y la alimentación de los animales también requieren una gran atención por parte de los cuidadores con el fin de evitar accidentes.

Figura 96.21 - Carga de artefactos pirotécnicos para una exhibición de fuegos artificiales.

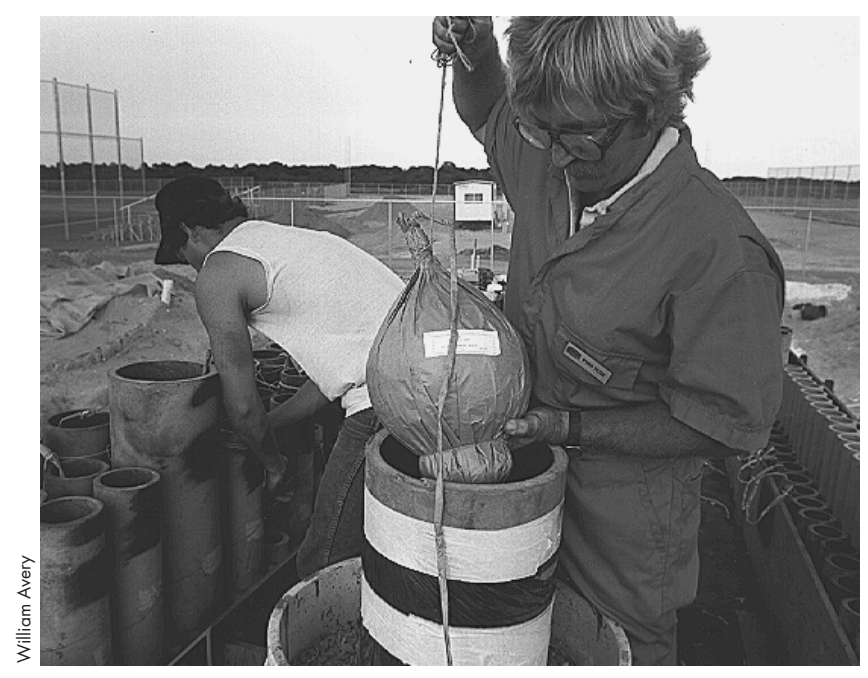

Figura 96.22 • Pañol para almacenar fuegos artificiales.

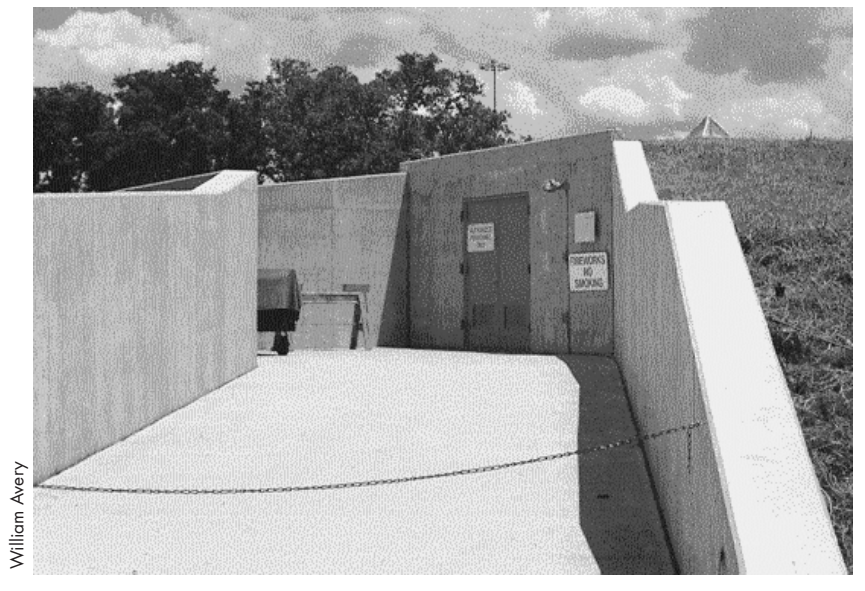

\section{Personajes disfrazados}

Los actores disfrazados de personajes históricos o de dibujos animados suelen llevar trajes pesados y aparatosos y actúan en un escenario o bien pasean mezclados con el público. El peso de los disfraces y la distribución inadecuada del peso puede provocarles lesiones de cuello y espalda (Figura 96.20). Otros riesgos son la fatiga, el exceso de calor y los golpes y empujones de la gente. Véase también "Actores".

Algunas precauciones incluyen: utilizar disfraces con las medidas apropiadas para el individuo; reducir en lo posible el peso, especialmente sobre los hombros; beber agua con frecuencia, sobre todo en las épocas de calor; reducir el tiempo de actividad con la gente, ya que resulta muy estresante; establecer turnos e ir siempre acompañados de personas sin disfraz que vigilen y contengan al público.

\section{Fuegos artificiales}

Los fuegos artificiales y los efectos especiales de pirotecnia son exhibiciones muy frecuentes (Figura 96.21). Los principales riesgos son el encendido accidental, las explosiones no controladas y los incendios.

Las precauciones deben incluir las siguientes medidas: la detonación de los artificios pirotécnicos sólo debe realizarse por personal profesional y debidamente habilitado. Deben observarse los procedimientos establecidos para su transporte, almacenamiento y detonación (Figura 96.22), así como las normas, reglamentos y ordenanzas aplicables en la localidad donde tengan lugar. En las instalaciones donde se desarrolle la exhibición debe haber equipos de seguridad y de extinción de incendios aprobados y de acceso inmediato.

\section{Servicios de comidas}

En los circos y en los parques de atracciones y temáticos se puede adquirir comida en bandejas y carros que llevan los empleados, en barracas e incluso en restaurantes. Los riesgos de estas actividades están originados por la necesidad de atender a un público numeroso durante períodos muy cortos de tiempo y con una elevada demanda. Entre estos trabajadores son frecuentes las caídas, las quemaduras, los cortes y las lesiones por movimientos repetitivos. El transporte de bandejas entre la gente puede ocasionar lesiones de espalda. Los riesgos aumentan durante los períodos de mayor demanda, en los que, entre otras lesiones, es más fácil la aparición de tendinitis y síndrome del túnel carpiano 
Figura 96.23 • Grúa levantando una atracción.

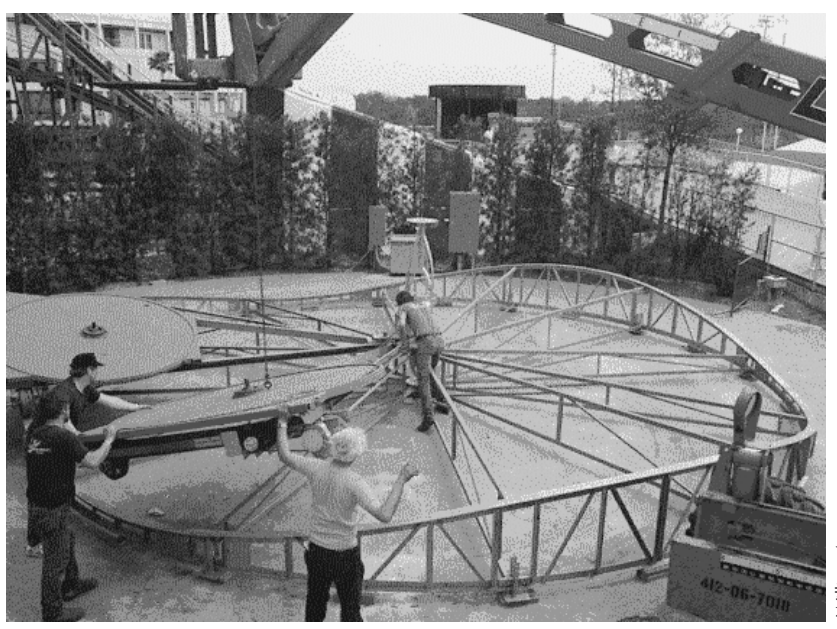

por movimientos repetitivos, por ejemplo, al manejar el cucharón de servir bolas de helado.

Algunas medidas de precaución que deben adoptarse para la seguridad de los trabajadores son el aumento del personal durante las horas de mayor trabajo y limpiar, barrer y fregar el suelo. Para reducir las lesiones por movimientos repetitivos, en relación con el ejemplo de los repartidores de helados se recomienda la utilización de cremas de helado más blandas, que reduzcan el esfuerzo del trabajador; el establecimiento de turnos cortos en estas funciones; el calentamiento de los cucharones de servir para facilitar su penetración en la crema de helado y el empleo de mangos con diseños ergonómicos.

\section{Decorados, atrezo y expositores}

En el montaje de escenarios, expositores, casetas, paisajes artificiales y edificios, los riesgos son muy parecidos a los existentes en la construcción: descargas eléctricas, heridas graves, lesiones en los ojos y otros accidentes derivados del manejo de herramientas y equipos eléctricos. La construcción al aire libre y el empleo de atrezo, decorados y expositores aumentan los riesgos de accidentes producidos por derrumbamiento de estructuras mal edificadas, de caídas y de lesiones del cuello y espalda (véase también el apartado "Talleres de decorados" en este mismo capítulo).

Como precauciones generales han de observarse las instrucciones de los fabricantes, las recomendaciones sobre equipos de protección y las instrucciones para la utilización segura de máquinas y herramientas eléctricas. El peso del atrezo debe reducirse al mínimo para evitar lesiones debidas al levantamiento de cargas pesadas. El atrezo, los decorados y los expositores destinados para uso al aire libre deben tener en cuenta los efectos del viento y otras condiciones propias de los exteriores. Los soportes que vayan a emplearse con pesos de seres vivos deben calcularse correctamente y deben verificarse los factores de seguridad relativos a la construcción. Deben considerarse las cualidades ignífugas de los materiales en función de la función que van a cumplir y observar las ordenanzas aplicables para la prevención de incendios.

\section{Operadores de atracciones y personal de mantenimiento}

Hay muchos tipos de atracciones: norias, montañas rusas, cabinas acuáticas, góndolas giratorias, teleféricos, etc. Los operadores de estas atracciones y el personal de mantenimiento trabajan en los lugares con mayor riesgo de sufrir lesiones graves. En concreto, estos empleados están expuestos a descargas eléctricas y pueden ser arrollados por las cabinas en movimiento o quedar atrapados entre la maquinaria. Además, también deben operar y mantener los transformadores y equipos de suministro de electricidad.

Es importante aplicar programas que reduzcan los riesgos en caso de paradas accidentales e interrupción repentina del servicio, como la asignación personal de candados con una llave única; instrucciones escritas para manipular circuitos eléctricos, maquinaria, sistemas hidráulicos y de aire comprimido y otras fuentes de posible liberación de energía; y la comprobación de que el suministro de energía queda convenientemente apagado. Siempre que dos personas trabajen con una misma pieza de la maquinaria, cada una de ellas deberá disponer de su propia llave.

\section{Espectáculos ambulantes}

Los circos y muchas atracciones suelen viajar por distintas localidades, utilizando un camión en el caso de las más pequeñas, y en tren los grandes circos. Durante la instalación, el desmantelamiento o transporte del equipo, los trabajadores se exponen a riesgos como caídas, amputaciones de miembros o incluso la muerte (Figura 96.23). La necesidad de cumplir con las fechas y los apretados calendarios de actuaciones pueden llevar a realizar estas tareas con precipitación, sin tener en cuenta los procedimientos de seguridad para ahorrar tiempo.

Como medidas preventivas, los empleados deben recibir la formación necesaria, proceder con cuidado y observar las instrucciones de seguridad de los fabricantes en el montaje, el desmantelamiento y la carga, descarga y transporte de los equipos. También debe extremarse el cuidado cuando se emplean elefantes u otros animales para mover equipos pesados. Los cables, cuerdas, poleas, grúas y montacargas deben ser inspeccionados antes de utilizarse. Los conductores de los vehículos deben observar las medidas obligatorias y recomendadas para el transporte por carretera. En el transporte por tren de personas, animales y equipos, los empleados deben recibir formación especial sobre procedimientos de emergencia y seguridad.

\section{CORRIDAS DE TOROS Y RODEOS}

\section{Michael McCann}

Las corridas de toros son un espectáculo muy popular en España, en los países de habla hispana de América Latina (especialmente en México), en el sur de Francia y en Portugal. El desarrollo de las corridas está jalonado de ritos, con desfiles, ceremonias muy concretas y trajes tradicionales con abundante colorido. Los toreros gozan de gran respeto y suelen prepararse desde edades tempranas con métodos de aprendizaje informales.

Los rodeos son un espectáculo deportivo más reciente, en el que los vaqueros compiten mostrando su destreza al realizar distintas actividades de su trabajo cotidiano. Hoy en día los rodeos son manifestaciones deportivas formalizadas de gran popularidad en Estados Unidos, oeste de Canadá y México. Los vaqueros (y algunas vaqueras) profesionales de los rodeos suelen recorrer los diferentes certámenes que se celebran dentro del circuito. Las principales especialidades en el rodeo son la monta de potros salvajes, la monta de toros, el derribo de novillos y la captura de terneros con lazo.

Corridas de toros. En una corrida de toros participan los toreros, sus subalternos (banderilleros y picadores) y los propios toros. 
Figura 96.25 - Corrida de toros.

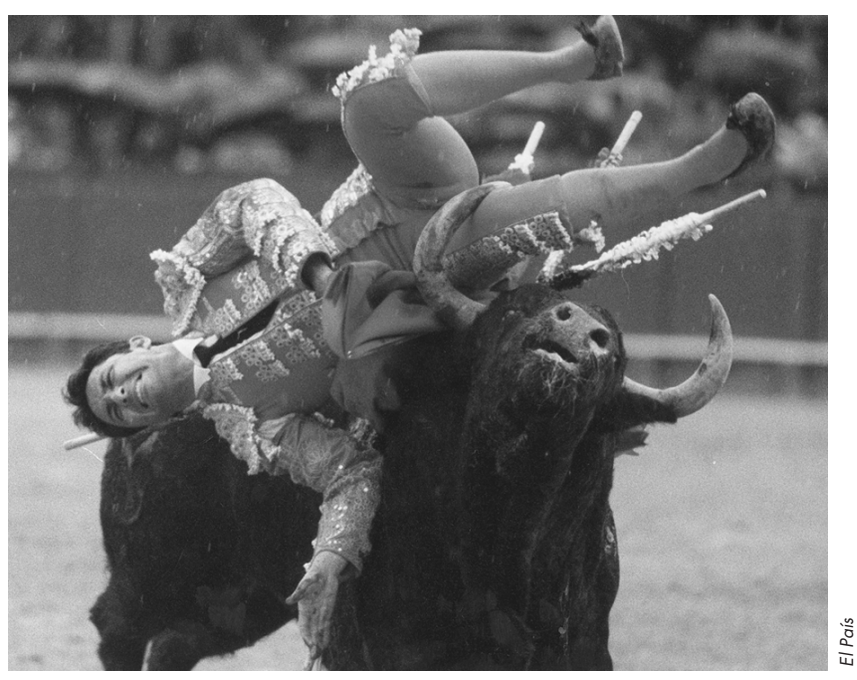

Cuando el toro hace su entrada en el ruedo desde el chiquero, el torero atrae su atención mediante una serie de pases con el capote. El toro se siente atraído por el movimiento del trapo, no por su color, ya que los toros no distinguen los colores. El mérito del torero reside en acercarse lo más posible a los cuernos del toro. Desde hace siglos, los toros de lidia son criados y entrenados para embestir con agresividad. La segunda parte de la corrida consiste en debilitar al toro mediante los puyazos de los picadores montados en caballos, tras lo cual los banderilleros, que van a pie, clavan las banderillas en los hombros del animal a fin de que baje la cabeza para poder matarlo.

En el último tercio de la corrida, el torero intenta matar al toro clavándole la espada entre las paletillas, con lo que busca atravesar la vena aorta. Antes de darle muerte, el torero debe realizar una serie de pases específicos con la muleta. Cuanto más arriesgue el torero, mayor será su triunfo y, lógicamente,

Figura 96.24 - Payaso de rodeo distrayendo al toro después de la caída de un jinete.

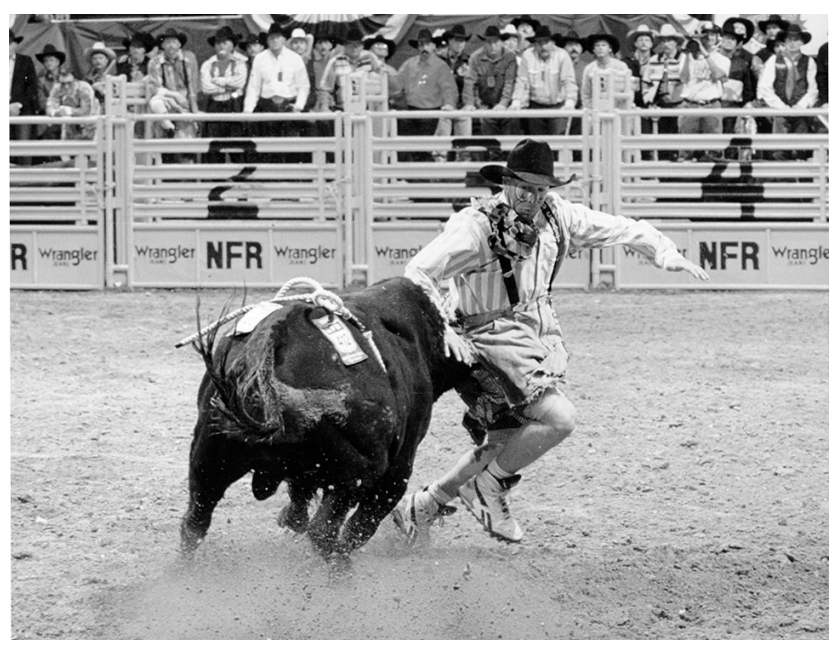

mayores serán las posibilidades de recibir una cornada del toro (véase la Figura 96.25). Los toreros suelen sufrir al menos una cogida por temporada y realizan una media de 100 corridas en cada una.

El principal riesgo al que están expuestos los toreros y sus subalternos son las lesiones por cogidas del animal que, con sus cuernos, puede provocarles la muerte. También hay posibilidad de que contraigan tétanos por heridas con las astas del toro. Un estudio epidemiológico realizado en Madrid reveló que solamente el $14,9 \%$ de los toreros profesionales estaban vacunados contra esa enfermedad, mientras que un 52,5\% habían sufrido alguna lesión profesional (Domínguez y cols. 1987). Son pocas las precauciones que se toman en las corridas de toros; los picadores llevan una protección de acero en las piernas, mientras que los demás participantes dependen únicamente de su preparación y destreza o de la de sus caballos. Una precaución fundamental es disponer de la adecuada asistencia médica de emergencia en la misma plaza (véase el artículo "Cine y televisión” en este capítulo).

Rodeos. Las especialidades más peligrosas de un rodeo son la monta de potros salvajes y el derribo de novillos. En la monta de potros y toros salvajes el objetivo es permanecer el mayor tiempo posible sobre la grupa del animal; se realiza tanto con silla de montar como sin ella. En el derribo de novillos, el vaquero a caballo intenta tumbar al animal y sujetarlo por los cuernos contra el suelo. La modalidad de atrapar becerros con un lazo consiste en alcanzar el animal con una cuerda desde el caballo, saltar a tierra y atarle las patas traseras y delanteras en el menor tiempo posible.

Además de los concursantes del rodeo hay otros participantes que también asumen riesgos, como los encargados de atender a los concursantes derribados y de recoger a los animales; o los payasos que participan en el rodeo, cuya misión es entretener a los animales, especialmente los toros, para que los jinetes derribados puedan ponerse a salvo (Figura 96.24). Los payasos realizan su trabajo a pie y con disfraces de gran colorido para atraer la atención de los animales. Estos profesionales corren el riesgo de ser pisoteados o corneados por los toros, y pueden sufrir lesiones de rodilla al ser despedidos de los caballos, en los codos al sujetarse a los potros y toros durante su monta, y en la cara cuando los toros echan la cabeza hacia atrás. Los jinetes también pueden lesionarse al ser aplastados en la rampa mientras esperan montados la apertura de la puerta para soltar los animales. Las lesiones graves y los accidentes mortales no son raros. El $37 \%$ de las lesiones de estos profesionales corresponde a los jinetes de toros (Griffin y cols. 1989). Las lesiones cerebrales y de médula son particularmente importantes (MMWR 1996). En un estudio con 39 profesionales del rodeo se contabilizaron 76 deformaciones en el codo en 29 jinetes de potros y toros (Griffin y cols. 1989). Sus autores atribuyeron dichas lesiones a la hiperextensión constante del brazo para sujetarse al animal, así como a las frecuentes caídas.

La habilidad de los jinetes, ayudantes y payasos, es el arma principal para reducir los riesgos de lesiones. También es fundamental el buen adiestramiento de los caballos. Por otra parte, se recomienda utilizar protectores en los codos de los jinetes de potros y toros. Aunque todavía es extraño ver chalecos de seguridad, protectores bucales y cascos, su empleo comienza a ser aceptado. En ocasiones se han utilizado también máscaras faciales en la monta de toros. Igual que en las corridas de toros, una precaución básica es la necesaria atención médica de urgencia disponible en el mismo recinto.

También corren riesgos los encargados de cuidar y alimentar a los animales en los rodeos y corridas de toros. Véase también "Parques zoológicos y acuarios" en este mismo capítulo. 


\section{DEPORTES PROFESIONALES}

Gordon Huie, Peter J. Bruno y W. Norman Scot

Las lesiones son muy frecuentes en el ámbito de los deportes. Los riesgos de sufrir accidentes pueden reducirse mediante una buena preparación y el empleo de equipos de protección.

Todos los deportistas se ven en la necesidad de preparase físicamente durante todo el año. Con el entrenamiento, los huesos, ligamentos y músculos reaccionan fisiológicamente ganando tamaño y fuerza (Clare 1990). Esto aumenta la agilidad del atleta y ayuda a reducir los riesgos de lesiones por golpes y choques. Todos los atletas que practican deportes que requieren levantamiento de peso y manifestaciones de fuerza deben estar bajo la supervisión de un preparador físico especializado.

\section{Deportes de contacto}

Los deportes de contacto, como el fútbol americano o el hockey sobre hielo, son especialmente peligrosos. La naturaleza agresiva del fútbol americano implica acciones como el choque o derribo del jugador contrario. El juego se basa en la posesión del balón desplazando físicamente a cualquier contrario que se cruce en el camino del jugador. Los elementos de la indumentaria de los jugadores deben estar bien ajustados para una adecuada protección (Figura 96.26). El casco con la correspondiente protección facial es una de las prendas esenciales en este deporte (Figura 96.27). Debe estar bien sujeto para evitar que resbale o gire, y las correas deben atarse sin que supongan una molestia para el jugador (American Academy of Orthopedic Surgeons 1991).

Por desgracia, en ocasiones es utilizado por algunos jugadores para lastimar a sus contrarios, práctica que puede causar lesiones en la médula y parálisis. En el hockey sobre hielo, la presencia del casco puede motivar la confianza de los jugadores para emplear el stick contra los jugadores del equipo contrario, provocándoles heridas en la cara y en el cuerpo.

Las lesiones de rodilla son muy frecuentes en el fútbol y en el baloncesto. Las protecciones elásticas (Figura 96.28) proporcionan sujeción por compresión y son muy útiles para las

Figura 96.26 - Hombreras ajustadas de fútbol americano.

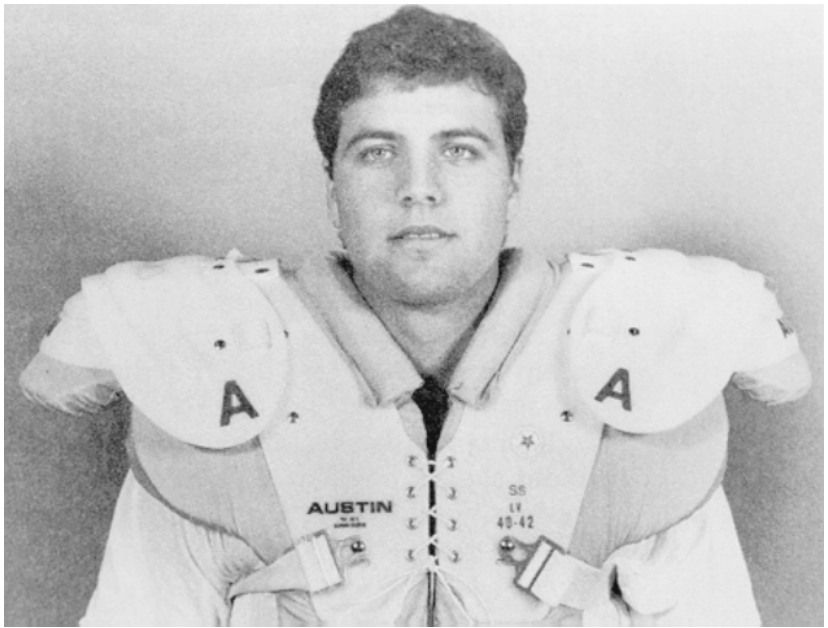

Fuente: American Academy Orthopedic Surgeons 1991
Figura 96.27 - Casco de fútbol americano.

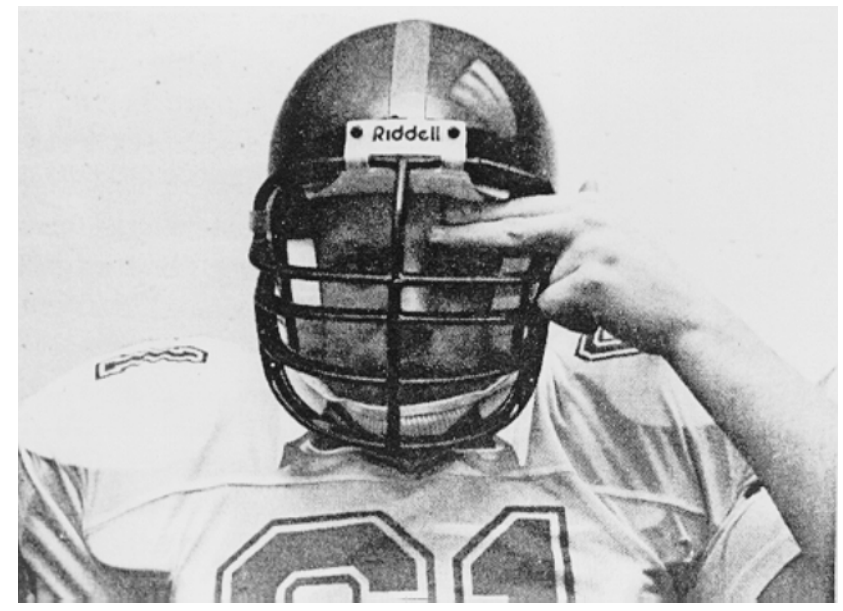

Fuente: Clare 1990

lesiones más leves. Los ligamentos y cartílagos de la rodilla son partes especialmente propensas a sufrir distensiones y choques traumáticos. El frecuente traumatismo combinado de cartílago y ligamento fue descrito por primera vez por O’Donoghue (1950).

Figura 96.28 • Rodillera.

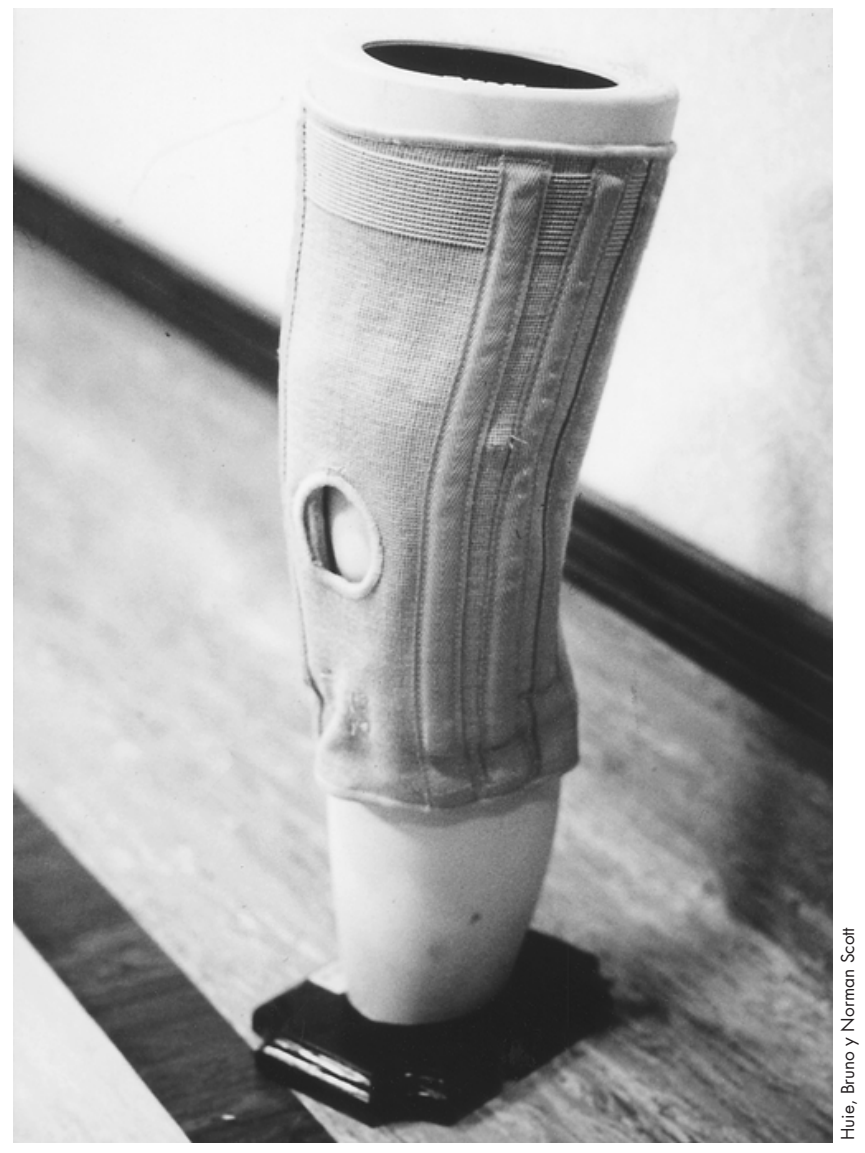

ENCICLOPEDIA DE SALUD Y SEGURIDAD EN EL TRABAJO 
Figura 96.31 - Guantes acolchados para hockey sobre hielo.

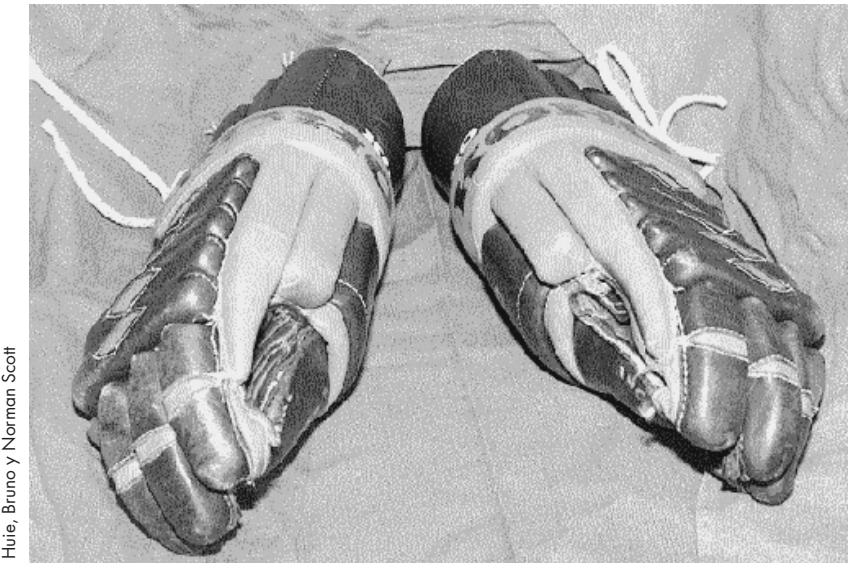

Esta lesión suele ir acompañada de un "chasquido" audible, seguido de inflamación cuando existe lesión de ligamentos. En ocasiones es preciso recurrir a la cirugía antes de reanudar la práctica del deporte. En la fase posoperatoria puede usarse un vendaje para impedir el giro de los ligamentos. También resulta muy útil dicho vendaje en aquellos deportistas con desgarro parcial de los ligamentos cruzados anteriores, conservando suficientes fibras sanas para continuar practicando su actividad deportiva. Los vendajes deben estar adecuadamente acolchados para proteger la zona lesionada y a los demás jugadores (Sachare 1994a).

La velocidad que alcanzan los jugadores de hockey y la dureza del puck hacen obligatorio el uso de casco y de prendas acolchadas (Figura 96.31). Los cascos deben llevar una protección facial para evitar lesiones en la cara y roturas de dientes. A pesar de la protección del casco y las prendas acolchadas en las partes más vitales, tanto en el hockey sobre hielo como en fútbol americano se producen frecuentes fracturas de miembros y de médula.

En la práctica de ambos deportes es esencial contar con personal médico y un equipo de emergencia completo (incluidos instrumentos de diagnóstico, equipos de resucitación, dispositivos de inmovilización, medicamentos, material para heridas, camillas rígidas y férulas) (Huie y Hershman 1994). Todos los deportes de contacto deben contar con las citadas medidas de prevención. Es necesario realizar radiografías de todas las lesiones que se produzcan. Las resonancias magnéticas son un medio especialmente útil para determinar la existencia de lesiones en tejidos blandos.

\section{Baloncesto}

Aunque el baloncesto es también un deporte de contacto, los jugadores no emplean protecciones. El juego consiste en conseguir la posesión del balón si tocar al contrario. La buena forma y la velocidad de los jugadores para evitar el contacto físico son fundamentales para reducir los riesgos de lesiones.

Las más frecuentes entre los jugadores de baloncesto son los esguinces de tobillo, que afectan a cerca del $45 \%$ de estos deportistas (Garrick 1977; Huie y Scott 1995). Los ligamentos afectados por estas lesiones suelen ser el haz medial del ligamento deltoideo, los ligamentos peroneoastragalinos anterior y posterior, y el ligamento calcáneoperoneo lateral. Es necesario realizar radiografías de la pierna para descartar una fractura de Maisonneuve o de otro tipo (VanderGriend, Savoie y Hughes 1991). En los esguinces crónicos de tobillo puede
Figura 96.29 • Tobillera rígida.

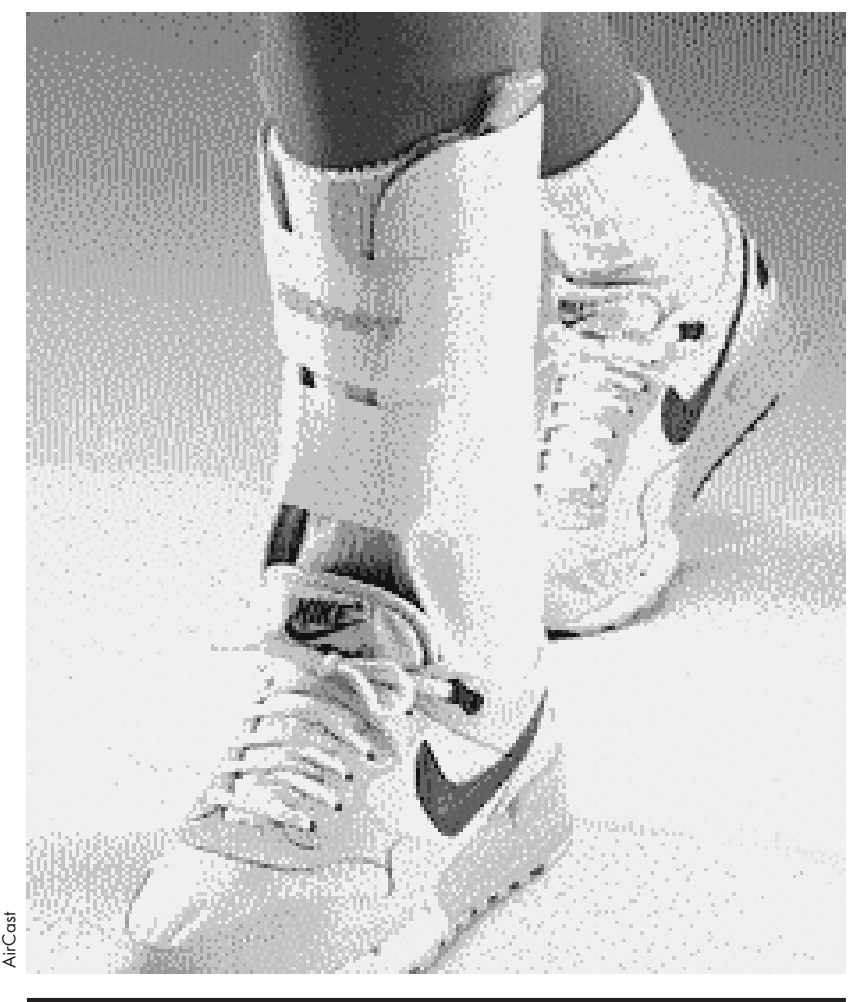

utilizarse una tobillera semirrígida para reducir el riesgo de nuevas lesiones de ligamentos (Figura 96.29).

También son habituales las lesiones en los dedos por rotura de ligamentos, que pueden derivar en dedos en martillo, cuello de cisne o la deformación de Boutonierre (Bruno, Scott y Huie 1995). Esta clase de lesiones es muy frecuente y suele producirse por golpes con el balón, otros jugadores y el tablero o los bordes de la canasta. El vendaje de los tobillos y dedos puede contribuir a evitar torceduras accidentales y la hiperextensión de las articulaciones. También se dan frecuentes heridas en la cara y rotura de tabique nasal por golpes contra los brazos y huesos prominentes de los contrarios, o contra el suelo y otros elementos fijos de la cancha. La incidencia de este tipo de lesiones puede reducirse empleando una máscara ligera para proteger la cara.

Figura 96.30 - Máscara de catcher.

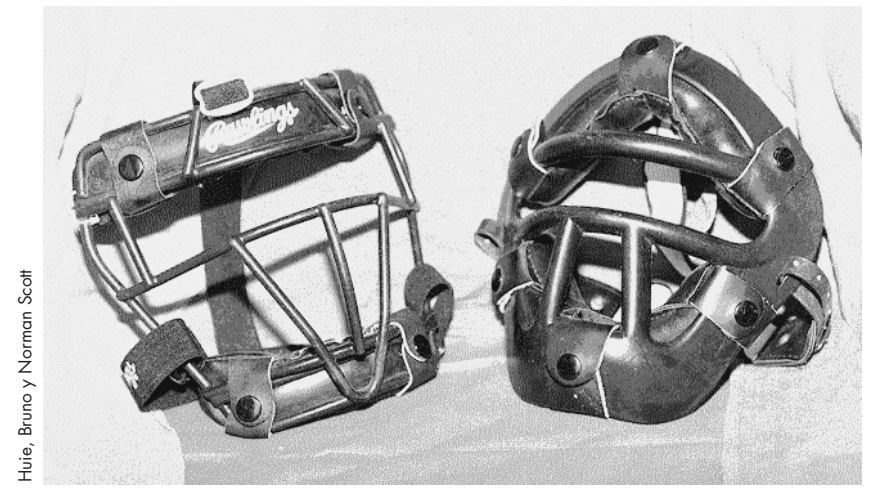




\section{Béisbol}

Las pelotas de béisbol son proyectiles de extraordinaria dureza. El jugador tiene que estar constantemente pendiente de la pelota, y no sólo por seguridad, sino por que así lo requiere la estrategia del juego. El equipo de protección incluye un casco de bateador para el jugador atacante, un protector pectoral y un casco y máscara de catcher (Figura 96.30) para el defensor. En los lanzamientos, la pelota puede alcanzar una velocidad superior a los $150 \mathrm{~km}$./hora y provocar fractura de huesos. En caso de heridas en la cabeza, debe someterse al jugador a un completo análisis neurológico, siendo necesarias radiografías en caso de pérdida de conocimiento.

\section{Fútbol}

El fútbol es un deporte de contacto cuya práctica puede causar lesiones traumáticas en los miembros inferiores, siendo el esguince de tobillo una de las más frecuentes. Las tobilleras semirrígidas y los vendajes contribuyen a evitar estas lesiones. Se ha comprobado que la eficacia de los vendajes en los tobillos comienza a disminuir después de 30 minutos de ejercicios enérgicos. También son frecuentes los desgarros de los ligamentos anteriores cruzados de la rodilla, precisando intervención quirúrgica en caso de que el futbolista quiera continuar su carrera deportiva. Otra lesión muy común es el síndrome de astillamiento mediotibial (espinilla astillada) con posible inflamación del periostio tibial. En casos extremos pueden darse fracturas de huesos. A pesar de que el tratamiento requiere de 3 a 6 semanas de reposo y la administración de medicación antiinflamatoria no esteroide (AINES), muchas grandes estrellas y jugadores profesionales suelen reducir el tratamiento a una sola semana para volver cuanto antes a practicar el fútbol. Los tirones en la ingle y los tendones pueden aparecer cuando no se efectúa el oportuno calentamiento y estiramiento muscular previo de las piernas. Las espinilleras frontales ayudan a reducir los efectos traumáticos de los golpes recibidos en la tibia.

\section{Esquí}

Aunque la práctica del esquí no requiere el empleo de equipo de protección, conviene utilizar gafas para evitar lesiones en los ojos y filtrar el brillo del sol sobre la nieve. La rigidez de las botas de esquiar proporciona cierta protección a los tobillos. Cuentan con unos mecanismos para poder quitárselas con rapidez en caso de caída del esquiador y, aunque resultan muy útiles, también pueden provocar accidentes. Durante la temporada de invierno son frecuentes las lesiones de rodillas, con ligamentos y cartílagos dañados, tanto en esquiadores inexpertos como entre los más veteranos. La modalidad profesional de descenso requiere el uso de casco, por la velocidad que llegan a alcanzar los esquiadores y la dificultad para frenar en caso de desviarse de su trayectoria.

\section{Boxeo y artes marciales}

El boxeo y las artes marciales son modalidades deportivas violentas donde apenas se utilizan protecciones. Los guantes de los boxeadores profesionales suelen ser más pesados para aumentar su efectividad. En los niveles amateur, los púgiles suelen llevar protectores en la cabeza para aminorar el impacto de los golpes recibidos. La agilidad del boxeador y su fuerza y velocidad pueden reducir el riesgo de lesiones. Las fuerzas en el bloqueo resultan más bien desviadas que absorbidas. En este deporte son muy frecuentes las fracturas y las lesiones en tejidos blandos. Igual que en el voleibol, los golpes repetidos en los dedos y huesos carpianos causan fracturas, subluxaciones, dislocaciones y desgarros de ligamentos. Los vendajes en las manos y muñecas proporcionan algún tipo de protección, aunque mínima. Según algunos estudios, las lesiones cerebrales a lago plazo son un problema grave entre los boxeadores (Consejo de Asuntos Científicos de la American Medical Association 1983). La mitad de un grupo de boxeadores profesionales con más de 200 combates presentaban señales neurológicas derivadas de neuropatías traumáticas.

\section{Carreras de caballos}

Las carreras de caballos requieren el uso de casco, tanto a nivel profesional como amateur. Aunque estos cascos proporcionan cierta protección a la cabeza, en las caídas no ofrecen sujeción al cuello o espina dorsal. La experiencia y el sentido común son factores que ayudan a evitar caídas, pero hasta los más experimentados jinetes pueden sufrir lesiones graves y parálisis si caen sobre la cabeza. Muchos jinetes utilizan chalecos protectores como precaución contra caídas en las que pueden resultar pisoteados por los caballos, un tipo de accidente que puede causar la muerte. En las carreras de trotones, los sulkies o carros de dos ruedas tiradas por un caballo pueden colisionar en choques múltiples y causar lesiones graves a los participantes. De otros riesgos inherentes al manejo de los caballos se trata en el capítulo sobre "Cría de ganado".

\section{Primeros auxilios}

Como norma general, al producirse una lesión es suficiente con aplicar hielo, (Figura 96.32), compresión, elevación y administración de AINES. Las heridas abiertas deben cerrarse con vendajes apretados y luego someterse a evaluación y sutura. El jugador con heridas debe ser retirado del campo inmediatamente para evitar contagios a otros jugadores a través de la sangre (Sachare 1994b). Los lesionados que sufran pérdida

Figura 96.32 - Crioterapia compresiva.

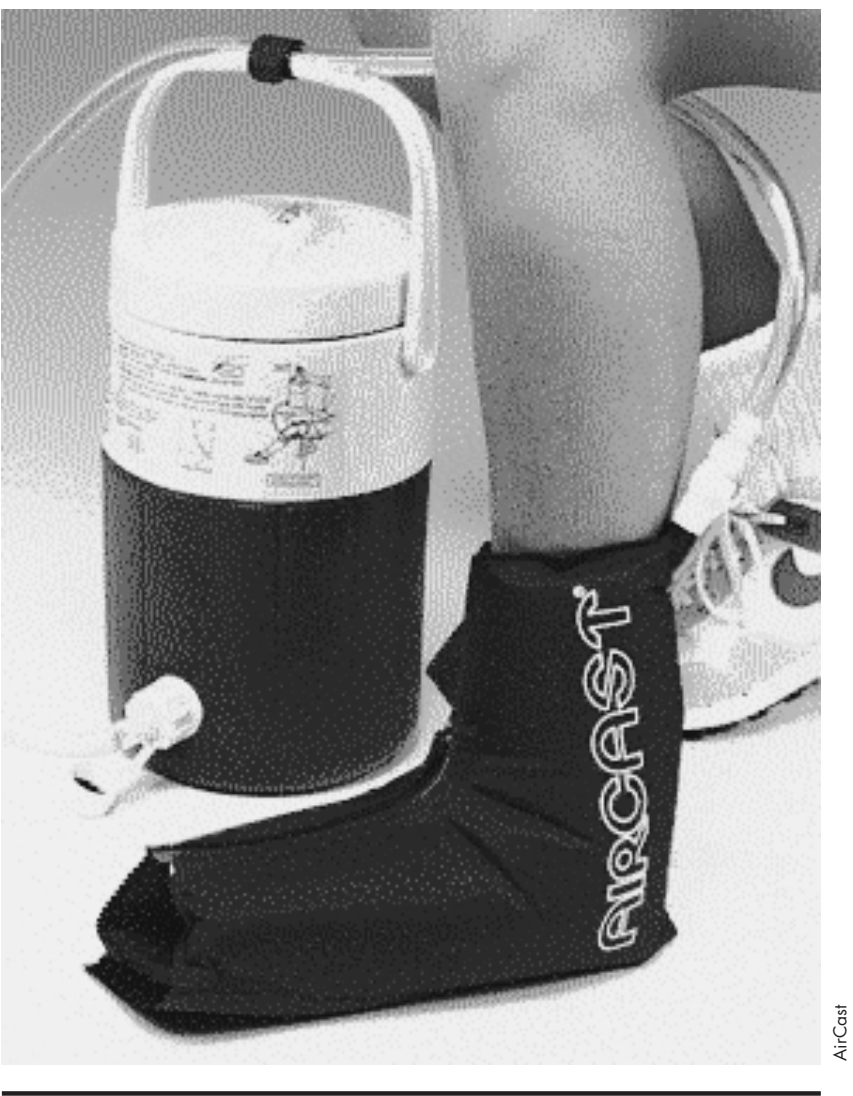


de conocimiento deberán ser sometidos a reconocimiento neurológico.

\section{Forma física}

Los atletas profesionales con patologías cardíacas sintomáticas o asintomáticas en ocasiones se muestran remisos a divulgar su problema. En los últimos años se han dado casos de atletas con patologías cardíacas que les han causado la muerte. Los incentivos económicos de las competiciones deportivas en los niveles profesionales más altos inducen a muchos de estos deportistas a ocultar tales problemas por miedo a quedar descalificados. La obtención de historias médicas previas y familiares, junto con electrocardiogramas y análisis rutinarios, son algunos métodos bastante eficaces para identificar a las personas de riesgo. Los atletas con un diagnóstico de riesgo que, pese a ello y a consideraciones de índole médico-legal, insistan en continuar compitiendo deben ir acompañados de personal especializado con equipos de resucitación de emergencia en todas sus actuaciones.

La presencia de los árbitros en los partidos no sólo pretende mantener la fluidez del juego, sino también evitar que los jugadores puedan lesionar a sus contrarios. La mayoría de los árbitros se comporta con objetividad y tiene la facultad de suspender un juego si surge alguna emergencia. En todos los deportes de competición, los partidos se viven con emoción y altas dosis de adrenalina, siendo misión de los árbitros ayudar a los jugadores a encauzar esa energía de una forma positiva.

Gran parte de los esguinces y torceduras pueden evitarse con una buena preparación física y realizando calentamientos y estiramientos de músculos antes de comenzar una actividad deportiva. Estos ejercicios previos preparan a los músculos para trabajar a pleno rendimiento, reduciendo las posibilidades de esguinces y torceduras (microtraumatismos). Los calentamientos consisten en pequeños ejercicios de gimnasia realizados durante 3 o 5 minutos, seguidos de suaves estiramientos de los músculos durante otros 5 o 10 minutos. Con los músculos a pleno rendimiento, el atleta puede maniobrar con mayor agilidad y rapidez para evitar posibles percances.

\section{- INDUSTRIA DEL SEXO}

\section{Priscilla Alexander}

La industria del sexo es una actividad importante, tanto en los países en desarrollo, donde además supone una notable fuente de divisas, como en los industrializados. Pueden establecerse dos categorías claramente definidas: a) la prostitución, que consiste en un intercambio sexual directo o en un servicio de tipo sexual a cambio de dinero u otra forma de compensación económica, y b) la pornografia, que implica la realización de determinados trabajos de índole sexual, en ocasiones entre dos o más personas, con destino a aparecer en fotografías, películas de cine y vídeo, o bien en teatros y clubes nocturnos, siempre que no suponga contacto sexual con un cliente que paga por el servicio. La división entre pornografía y prostitución no siempre está clara; algunas prostitutas también realizan bailes y actuaciones eróticas para clientes privados, y algunos trabajadores de la pornografía llegan a tener relaciones sexuales con personas de su público, como puede suceder en los clubes de baile con "striptease".

La situación legal de la pornografía y la prostitución es distinta según los países, siendo muy extensa su variedad: desde la prohibición total del intercambio de sexo por dinero y de los lugares donde se realiza, como es el caso de Estados Unidos; o la despenalización del intercambio en sí, manteniendo la prohibición de los negocios del sexo, como ocurre en muchos países europeos; hasta la tolerancia de la prostitución independiente u organizada en países como Holanda, y la regulación de la prostitución bajo las leyes sobre higiene y salud pública, prohibiendo su ejercicio marginal, en ciertos países de Asia y América Latina. Incluso en los países donde se encuentra legalizada, los gobiernos han permanecido pasivos y muy pocos, si es que hay alguno, se han esforzado para aplicar las normas de higiene y sanidad a fin de proteger la salud de los trabajadores de la industria del sexo. A pesar de ello, desde comienzos del decenio de 1970, las prostitutas y actores eróticos han comenzado a organizarse en muchos países (Alexander 1987; Pheterson 1989), y han empezado a abordar los aspectos de seguridad en el trabajo para intentar reformar la situación jurídica de su profesión.

Un aspecto particularmente delicado es la participación de adolescentes en la industria del sexo. Aunque el espacio disponible en este artículo no permite abordar este problema con mayor detenimiento, es importante que las soluciones a la prostitución de los adolescentes sean tratadas en el contexto más general de la pobreza y el trabajo infantil en el mundo, en lugar de hacerlo como un fenómeno aislado. Otro aspecto igualmente problemático es el ejercicio de la prostitución bajo coacción, y no por iniciativa personal. Una gran mayoría de los trabajadores de la industria del sexo ejercen la profesión de forma ocasional, dedicándose a este trabajo entre 4 y 6 años como media en la mayoría de los países. Muchos de ellos trabajan únicamente unos pocos días o de modo intermitente (por ejemplo, al tiempo que realizan otros trabajos), mientras que otros lo realizan hasta 35 años o más. El factor más importante que lleva a ejercer la prostitución es el dinero, y en todos los países, el trabajo en la industria del sexo está mucho mejor remunerado que cualquier otra ocupación que no requiera una educación y especialización. En algunos países, las prostitutas llegan a ganar mucho más dinero que los médicos y abogados. Los movimientos a favor de los derechos de estos trabajadores han puesto de manifiesto la evidente dificultad para abordar los aspectos del libre consentimiento y las coacciones mientras su trabajo siga siendo ilegal y en gran medida estigmatizado. Es importante prestar apoyo a los trabajadores de este sector para promover su organización en sindicatos, asociaciones profesionales, programas de ayuda y organizaciones con vocación política.

\section{Riesgos y precauciones}

Enfermedades de transmisión sexual (ETS). Los riesgos más evidentes para los trabajadores de la industria del sexo, y que más preocupación han suscitado en el curso de la historia, son las ETS: sífilis, gonorrea, clamidia, úlcera genital, tricomoniasis, herpes y, más recientemente, el virus de inmunodeficiencia humana $(\mathrm{VIH})$ y el SIDA.

En todos los países, el riesgo de contraer SIDA y otras ETS es mayor entre los trabajadores más modestos de esta industria; por ejemplo, los que trabajan en las calles de las ciudades de países industrializados, en burdeles de Asia y América Latina o en comunidades pobres de países africanos. Estudios realizados en países occidentales han revelado que el contagio de HIV entre las prostitutas suele estar relacionado con el uso de drogas por vía intravenosa, ya sea por parte de la misma prostituta o de su compañero, y la ingestión de "crack", un derivado de la cocaína que se fuma, y no tanto con el número de clientes o el ejercicio de la prostitución en sí. Apenas existen estudios sobre trabajadores de la industria pornográfica, aunque todo hace pensar que la situación es muy similar. Los principales factores de contagio no están tan claros en los países en desarrollo, donde, de acuerdo con algunos investigadores, una mayor prevalencia de las ETS convencionales no tratadas puede propiciar la transmisión del VIH. Otros factores están relacionados con el empleo de agujas hipodérmicas no estériles, adquiridas a 
vendedores callejeros o en clínicas con recursos escasos, para el tratamiento de la ETS. El uso de drogas por vía intravenosa se ha relacionado también con el contagio del SIDA en los países occidentales (Estébanez, Fitch y Nájera 1993). Entre los varones dedicados a la prostitución, la transmisión del VIH también se asocia a las relaciones homosexuales, aunque las drogas por vía intravenosa y el sexo en el contexto del mundo de la droga siguen siendo factores decisivos.

Como medida de precaución deben utilizarse preservativos de látex o poliuretano en las felaciones y en el coito anal y vaginal, y siempre que sea posible con lubricantes (a base de agua para preservativos de látex y a base de aceites para los de poliuretano), métodos de barrera de látex o poliuretano para cunilingus y contacto oral-anal, y guantes para estimulación manual de los genitales. Aunque el empleo de preservativos ha aumentado entre las prostitutas de la mayoría de los países, su utilización en la industria de la pornografía es poco frecuente. Algunas trabajadoras usan espermicidas como medida de protección. Sin embargo, aunque el espermicida nonoxinol-9 ha demostrado cierta capacidad para matar el VIH en laboratorio y reduce la incidencia de las ETS convencionales entre determinadas poblaciones, su eficacia para prevenir el VIH no esta suficientemente demostrada. Por otra parte, el empleo del nonoxinol-9 más de una vez al día se ha relacionado con una elevada incidencia de desgarro epitelial en la vagina (que puede aumentar los riesgos de infección por el virus del SIDA en las trabajadoras de la industria del sexo) y, en ocasiones, con un aumento de las infecciones de fermentación vaginal. Su utilización para el sexo anal no ha sido estudiada.

Otro aspecto importante es el acceso a una atención sanitaria más sensibilizada con los problemas de los trabajadores de la industria del sexo, y que incluya otros problemas de salud, además de las ETS. Los intentos tradicionales de la sanidad pública de establecer registros y licencias obligatorias, así como exámenes médicos periódicos, no han resultado eficaces para reducir los riesgos de contagio entre estos trabajadores y, por otra parte, contravienen las directrices de la Organización Mundial de la Salud, opuestas a los exámenes obligatorios.

Lesiones. A pesar de la falta de estudios serios sobre otros riesgos profesionales, los datos anecdóticos apuntan a posibles lesiones de muñeca por esfuerzo repetitivo entre las prostitutas que realizan estimulación manual, o dolores de mandíbula relacionados con la práctica de la felación. Por otra parte, las prostitutas que trabajan en la calle y las bailarinas eróticas pueden desarrollar problemas de espalda, rodilla y pies, causados por el uso de zapatos de tacón. Algunas prostitutas han contraído infecciones crónicas de riñones y vejiga por trabajar con la vejiga llena, o no saber qué posición adoptar para prevenir las penetraciones profundas durante el coito vaginal. Por último, algunos grupos de prostitutas son muy vulnerables a la violencia, especialmente en países que aplican con excesiva dureza las leyes contra la prostitución. Las modalidades de violencia abarcan violaciones y otras agresiones de tipo sexual, lesiones y asesinatos, cometidos por policías, clientes, propietarios de negocios de prostitución o los propios compañeros sentimentales de las prostitutas. Los riesgos de sufrir lesiones son mayores entre las prostitutas más jóvenes y menos experimentadas, sobre todo aquéllas que comienzan a trabajar en su adolescencia.

Dentro de las medidas de prevención deben contemplarse la formación de los trabajadores para saber realizar los diferentes actos sexuales de forma segura, evitando lesiones por esfuerzos repetitivos e infecciones de vejiga, y el aprendizaje de técnicas de autodefensa que reduzcan la vulnerabilidad ante los ataques violentos, sobre todo entre los trabajadores más jóvenes. En el caso de los ataques violentos, es importante que los policías y fiscales muestren una clara determinación a la hora de aplicar las leyes contra violaciones y otros delitos cuando las víctimas son trabajadores de la industria del sexo.

Drogas y alcohol. Las prostitutas que trabajan en clubes nocturnos suelen ser presionadas por los dueños para animar a beber a los clientes y acompañarles en la consumición de bebidas alcohólicas, lo que supone un grave riesgo para aquellas personas propensas al alcoholismo. Otro peligro son las drogas que empiezan a tomar algunos trabajadores para aguantar el estrés de su trabajo (como heroína, cocaína o anfetaminas). También es frecuente el caso de drogadictos que recurren a la prostitución para poder financiar su hábito. El riesgo de contraer el VIH, hepatitis y otras infecciones bacterianas se agrava con el uso de drogas por vía intravenosa cuando se comparten agujas usadas.

Estos problemas pueden reducirse permitiendo a las prostitutas tomar bebidas no alcohólicas con los clientes, facilitando jeringuillas y agujas estériles y, cuando sea posible, sustitutos legales a los trabajadores usuarios de drogas por vía intravenosa, y promocionando el acceso a programas de desintoxicación de drogas y alcohol.

\section{VIDA NOCTURNA}

Angela Babin

En este grupo se incluye una extensa variedad de locales, como bares, clubes nocturnos, discotecas, salas de baile, topless, barras americanas, casinos, salas de juego, billares, cines y locales de apuestas. Los distintos trabajos incluyen encargados de barra, camareros, animadores, crupieres, personal de seguridad, músicos, bailarines, bailarinas de "striptease" y operadores de proyectores de cine. Algunos hoteles y restaurantes también suelen ofrecer entretenimiento nocturno. La mayoría de estos trabajadores comparten categorías de riesgos similares.

Trabajos por turnos. Los trabajadores de las actividades nocturnas, como los encargados de barra, trabajan a menudo por turnos fijos, mientras que otros como los músicos que trabajan en clubes, suelen hacerlo en turnos más irregulares. Esta condición laboral puede tener consecuencias en la salud física y psicológica de los trabajadores y afectarles desde el punto de vista social. No son raros los turnos de hasta 10 y 14 horas entre los camareros.

Violencia. La violencia en el lugar de trabajo es un problema importante en los establecimientos que sirven bebidas alcohólicas y en los locales de juego. Estudios llevados a cabo por el National Institute of Occupational Safety and Health (NIOSH) sobre los índices de homicidios entre la población trabajadora de ese país en el período 1980-1989, asignaron a los camareros de barra la octava posición entre los grupos de trabajadores de mayor riesgo, con un índice de homicidios de 2,1 por cada 100.000 , siendo la media global de todos los trabajadores de 0,7 homicidios por cada 100.000. Entre los factores de riesgo de estos empleados se destacaban el intercambio de dinero con el público, la práctica del trabajo en solitario o en pequeños grupos, las jornadas hasta altas horas de la noche o que comienzan de madrugada, y el trabajo en zonas con índices elevados de criminalidad. Las medidas de precaución para reducir estos riesgos comprenden: aumentar la visibilidad e iluminación en el lugar de trabajo, evitar el manejo de cantidades importantes de dinero en efectivo y colocar carteles visibles que adviertan que no se dispone de sumas considerables de dinero en caja, así como instalar alarmas silenciosas y cámaras ocultas y adiestrar a los empleados para saber cómo reaccionar ante robos y situaciones similares. Otras medidas pueden ser: 
solicitar vigilancia policial periódica y facilitar a los trabajadores pantallas blindadas y chalecos antibalas en situaciones que así lo requieran.

Previsión de incendios. Muchos pequeños clubes nocturnos, salas de baile y de cine no cumplen con las normas establecidas de seguridad y emergencia para este tipo de locales. Existen varios casos de incendios que han acabado en tragedia en establecimientos con una afluencia de público muy superior al aforo permitido. Los riesgos pueden reducirse cumpliendo las ordenanzas en materia de seguridad la prevención de incendios, estableciendo sistemas de emergencia, disponiendo de extintores y adiestrando a los trabajadores en su utilización, además de otros procedimientos de emergencia (Malhotra 1984).

Fumadores pasivos. En muchos locales de entretenimiento nocturno, los trabajadores se exponen al humo de los clientes fumadores, lo que aumenta el riesgo de sufrir cáncer de pulmón y ataques cardíacos (NIOSH 1991). Otro riesgo para los camareros y encargados de barra es el cáncer de laringe asociado al humo del tabaco. Estos problemas se ven agravados en muchos pequeños locales que no cuentan con la ventilación adecuada. Aunque en varios países se están haciendo esfuerzos para regular la exposición al humo del tabaco de los fumadores pasivos, la implantación de restricciones por parte de las autoridades está lejos de ser universal. Los riesgos para el fumador pasivo pueden reducirse sustancialmente con ventilación y aparatos para limpiar el aire, como los precipitadores electrostáticos, y restringiendo la posibilidad de fumar.

Abuso de alcohol y drogas. Algunos trabajos favorecen el consumo de bebidas alcohólicas. Un estudio realizado sobre este problema ha revelado una incidencia elevada de muerte por cirrosis hepática, enfermedad estrechamente relacionada con el consumo de alcohol, entre camareros, músicos y encargados de barra (Olkinuora 1984). En los locales de entretenimiento nocturno, las bebidas alcohólicas son de fácil acceso y existe una presión social que incita a la bebida. Por otra parte, el trabajo en turnos de noche y los viajes por motivos de trabajo conducen a un alejamiento del hogar, lo que favorece el consumo de alcohol. Otros factores que contribuyen al consumo de drogas de los empleados son la mala gestión y la ausencia de vigilancia, el miedo escénico teatral (en el caso de los músicos) o la necesidad de permanecer despierto durante los turnos de noche, así como la propensión de algunos patrocinadores al abuso de las drogas. Los programas de educación bien diseñados y la asistencia a los trabajadores víctimas de estos problemas pueden ayudar a reducir el riesgo de alcoholismo y drogadicción entre los trabajadores del sector de entretenimiento nocturno.

Ruidos. El exceso de ruidos puede ser un problema importante en bares y restaurantes. Mientras que en las discotecas y clubes musicales se da por hecho que la música ha de sonar a gran volumen, la exposición excesiva a los ruidos también puede ser problemática en algunos bares y locales donde suena únicamente música grabada, a menudo a un volumen excesivo. En las discotecas son normales los niveles de ruido superiores a los 100 decibelios (dB) (Tan, Tsang y Wong 1990). Un estudio realizado en 55 clubes nocturnos de Nueva Jersey (Estados Unidos) detectó niveles de ruido entre los 90 y 107 dB. La exposición de los trabajadores al exceso de ruido puede reducirse colocando los altavoces y las máquinas de discos lejos de sus puestos de trabajo e instalando pantallas acústicas. Siempre que sea posible, debe reducirse el volumen de la música o facilitar a los empleados tapones para los oídos.

Dermatitis. Muchos problemas de piel de los trabajadores del sector de entretenimiento nocturno son similares a los que sufren las personas que manipulan alimentos. Las infecciones de la piel, como la candidiasis de las manos, pueden aparecer como consecuencia de trabajar con vasos sucios, productos de limpieza y el lavado de vajillas con agua y jabones. Una forma de evitar estos problemas es utilizar máquinas lavavajillas automáticas. También se han dado casos de sensibilidad a ciertos alimentos entre encargados de barra, como las pieles de limones y naranjas (Cardullo, Ruszkowski y Deleo 1989), así como otros síntomas, como los eczemas causados por la menta. Se han dado casos de sensibilidad que han acabado en dermatitis: un crupier en el juego del blackjack, que desarrolló sensibilidad a las sales de cromatos empleadas en los tintes verdes de los tapetes de las mesas de juego (Fisher 1976).

Problemas musculosqueléticos. Entre los trabajadores de locales de entretenimiento nocturno también se dan lesiones por movimientos repetitivos y otros problemas relacionados con el diseño del puesto de trabajo. Los músicos y bailarines son especialmente propensos a sufrir lesiones musculosqueléticas y sus problemas específicos se tratan en otros artículos de este capítulo. Se han dado casos de síndrome del túnel carpiano en camareros de barra que pasan horas lavando vasos y platos y en crupieres que barajan y distribuyen naipes en casinos. Estos riesgos pueden reducirse diseñando mejor las tareas y puestos de trabajo y efectuando descansos más frecuentes durante los turnos. Los encargados de barra, camareros y crupieres deben permanecer a menudo de pie durante turnos de trabajo que pueden durar hasta 10 y 12 horas, lo que aumenta el riesgo de sufrir dolores de espalda y problemas circulatorios y musculosqueléticos. Las alfombrillas de caucho ondulado y un calzado con suela confortable pueden ayudar a combatir estos problemas.

Cabinas de proyección de películas. Las cabinas de proyección de películas de los cines son lugares de tamaño muy reducido donde frecuentemente el calor es excesivo. Los equipos antiguos de proyección utilizan lámparas de arco de carbono para proyectar las imágenes, mientras que los más modernos emplean lámparas de gas xenón. En ambos casos puede darse algún tipo de exposición a ozono y radiación ultravioleta. Se han llegado a detectar niveles de ozono entre 0,01 y 0,7 partes por millón en estas cabinas, donde el ozono se origina por la radiación ultravioleta que ioniza el oxígeno en el aire (Maloy 1978). Por otra parte, la utilización de lámparas de arco de carbono como fuente de luz se ha relacionado con la liberación de vapores de tierras raras, dióxido de carbono, monóxido de carbono, ozono, radiación electromagnética y calor ambiental. En este tipo de recintos es necesaria la instalación de ventilación por extracción.

Efectos especiales. En muchas discotecas y clubes nocturnos se emplean diversos tipos de efectos especiales, como nieblas artificiales, rayos láser y artefactos pirotécnicos. Los operadores de estos efectos deben ser profesionales especialistas con el adiestramiento adecuado sobre los aspectos de seguridad. La radiación ultravioleta emitida por la luz "negra" puede presentar determinados riesgos, especialmente para las bailarinas de "striptease" y animadoras de discotecas (Schall y cols. 1969). Para proteger a estos profesionales se ha llegado a recomendar la instalación de pantallas de cristal. Los diferentes aspectos sobre los efectos especiales se tratan con mayor detenimiento en otros artículos de este capítulo.

\section{LA PROTECCION DEL MEDIO AMBIENTE Y LA SALUD PUBLICA}

Michael McCann

\section{Artes plásticas}

Las actividades de las artes plásticas pueden provocar diferentes problemas ambientales y dar lugar a numerosas cuestiones 
relacionadas con la salud pública. Si bien a una escala mucho menor, en las artes plásticas se utilizan muchos de los productos químicos y técnicas contaminantes del aire y el agua empleados habitualmente en los procesos industriales.

Algunos desechos peligrosos producidos por los artistas son: a) sustancias tóxicas, como disolventes, compuestos de plomo, cromatos y soluciones de cianuro; b) sustancias inflamables y líquidos combustibles (trapos empapados en aceites y esencia de trementina), sustancias oxidantes, como clorato potásico y dicromatos, y gases comprimidos inflamables; c) desechos corrosivos, como ácidos con $\mathrm{pH}$ inferior a 2 y álcalis con $\mathrm{pH}$ superior a 12; y d) desechos reactivos, como peróxidos orgánicos o soluciones de cianuros y sulfuros. Los artistas y artesanos no suelen conocer los métodos adecuados para deshacerse de estas sustancias, aún siendo conscientes de su peligrosidad. El método más usual es echar los líquidos por el desagüe o sobre la tierra, tirar los objetos con el resto de la basura, o dejar que las sustancias se evaporen. Si bien las cantidades de cada uno de los desechos no son generalmente demasiado importantes, también es cierto que la suma de todos ellos puede alcanzar niveles contaminantes peligrosos.

En Estados Unidos, Canadá y otros países, los artistas que trabajan en sus hogares suelen estar excluidos de las ordenanzas sobre deshechos industriales. Muchas localidades establecen días determinados en los que los particulares pueden acudir a los lugares señalados para depositar sus desechos peligrosos. No obstante, incluso en aquellos países que disponen de normativas y ordenanzas para regular las actividades de los pequeños negocios de artistas, los esfuerzos para aplicar las normas sobre desechos peligrosos son más bien escasos.

Los distintos métodos de deshecho de sustancias y materiales son en gran parte los mismos que los empleados en la industria: reducción, separación selectiva y concentración, reciclado, recuperación energética y de materiales, incineración y tratamiento, y eliminación en tierras seguras. Estos métodos son más accesibles para algunos artistas que para otros.

La mejor forma de tratar los deshechos peligrosos es la eliminación o reducción de los productos que contienen materiales tóxicos, empleando otras sustancia más seguras: por ejemplo, utilizando barnices sin plomo en esmaltes y en alfarería; y en serigrafía, usando tintas a base de agua y otros materiales, en lugar de productos grasos.

Un método sencillo para reducir la cantidad de sustancias peligrosas y evitar que contaminen la basura corriente consiste en separar selectivamente los materiales peligrosos del resto, por ejemplo, las pinturas acuosas de las de naturaleza grasa.

Algunos métodos de concentración tradicionales en la industria, como la evaporación de grandes cantidades de emulsiones fotográficas de deshecho, no suelen estar al alcance de la mayoría de los artistas.

La reutilización de los materiales (como disolventes empleados para eliminar y limpiar pinturas) y la cesión de estos materiales o sustancias a otras personas que puedan aprovecharlas, son dos ejemplos posibles de reciclado. Los talleres de estampación, que producen grandes cantidades de trapos impregnados con disolventes y sustancias grasas, pueden contratar servicios de lavandería para su reutilización.

Existen diferentes procesos de tratamiento de residuos, siendo uno de los más comunes la neutralización por el artista de las soluciones ácidas y alcalinas. La incineración suele estar reservada para la quema de serrín de maderas. También es frecuente la evaporación de las sustancias disolventes, un sistema que reduce la contaminación de las aguas, pero que contribuye a la polución atmosférica.

Una de las posibilidades menos perjudiciales para el medioambiente es depositar los deshechos en lugares seguros y adecuados, algo no siempre posible para los artistas de los países en desarrollo.

Un aspecto relativo a la salud pública en el ámbito de las artes plásticas es la exposición de los niños a los productos químicos presentes en una gran cantidad de materiales, incluidos los objetos destinados específicamente al público infantil, como los disolventes en la punta de fieltro de los rotuladores y el plomo del barniz de los objetos de cerámica. Los niños y demás miembros de una familia pueden sufrir la exposición a sustancias y a condiciones peligrosas presentes en el hogar.

Otro problema muy extendido en numerosos países es la intoxicación por plomo, que se da en casos como la ingestión de alimentos guardados o cocinados en cacharros de loza con barnices de plomo. Los riesgos derivados de la lixiviación del plomo en los barnices empleados en la alfarería han desaparecido prácticamente en la industria comercial gracias a la legislación estatal y a controles de calidad adecuados. La Organización Mundial de la Salud ha aprobado directrices sobre la lixiviación del plomo y cadmio en artículos destinados a alimentos y bebidas, aunque el coste de los métodos de análisis requeridos son prohibitivos para los artesanos alfareros, quienes simplemente deben abstenerse de utilizar barnices con plomo para los objetos destinados a alimentos y bebidas.

\section{Artes escénicas y audiovisuales}

Los teatros, los establecimientos de decorados y la producción cinematográfica y de televisión son actividades que también generan desechos peligrosos, pues emplean muchos de los productos químicos utilizados en las artes plásticas. Las soluciones son las mismas: la sustitución de pinturas a base de disolventes por otras de naturaleza acuosa ha contribuido en gran medida a reducir la contaminación causada por productos disolventes.

Uno de los aspectos de salud pública más importante en los teatros (y otros lugares con afluencia de público) es la seguridad en caso de incendio. Muchos teatros y pequeños locales de actuaciones, especialmente los no comerciales, incumplen a menudo las ordenanzas de seguridad y rebasan peligrosamente el aforo, siendo numerosas las tragedias en el ámbito de las artes escénicas a causa de incendios, con pérdidas de vidas humanas. El empleo de nieblas artificiales en los escenarios puede provocar ataques de asma a los espectadores asmáticos de las primeras filas en locales sin ventilación y extracción adecuadas para evacuar dichos humos y efectos especiales.

\section{Actividades recreativas}

Las instalaciones dedicadas al ocio y el entretenimiento, como los parques de atracciones y los parques temáticos, pueden entrañar los mismos riesgos por residuos sólidos y por contaminación en general que los generados por una pequeña ciudad. Los parques zoológicos, circos y otros espectáculos con animales tienen problemas de contaminación similares a los de la cría de ganado, si bien a una escala mucho menor.

Uno de los problemas de salud pública común a todos lugares de recreo donde se sirven comidas es la posibilidad de intoxicación por salmonelosis y la transmisión de hepatitis y otras enfermedades por falta de controles de higiene adecuados.

Otro caso preocupante en términos de salud y seguridad públicas son los espectáculos de masas, como algunos conciertos de música pop y acontecimientos deportivos. El abuso de drogas y bebidas alcohólicas, la masificación, el exceso de público en pie y la ausencia de la planificación necesaria ha provocado numerosos incidentes con disturbios y escenas de pánico, causando heridos y muertos entre el público asistente. Por otra parte, la falta de cumplimiento de los requisitos mínimos de calidad en los materiales es la causa directa de incendios y derrumbamiento de gradas y localidades para el público 
ocurridos en algunos países. Par evitar estas situaciones es necesaria una normativa más eficaz, además de otras medidas como los controles del número de personas que acuden a estos eventos.

Los visitantes de los parques naturales y zoos también están expuestos a determinados riesgos, siendo numerosos los casos de ataques de animales salvajes a personas que se han introducido en los recintos de las fieras de los parques zoológicos, perdiendo la vida o recibiendo heridas de extrema gravedad. En los parques naturales también se han producido muertes de visitantes que se han acercado demasiado a los animales. Otro problema frecuente son los individuos inexpertos que se adentran en los grandes parques naturales, extraviándose en mitad de una tormenta o despeñándose por montañas, lo que obliga a la movilización de gran cantidad de personal y equipos de rescate.

La industria del sexo, y en especial la prostitución, presenta grandes riesgos, como las enfermedades de transmisión sexual y los peligros por robo a los clientes. Estas circunstancias son aún más frecuentes en los países donde el ejercicio de la prostitución no se encuentra convenientemente regulado. Por otra parte, la prostitución suele estar asociada a otras actividades ilegales.

\section{Referencias}

American Academy of Orthopedic Surgeons. 1991 Protective equipment. En Athletic Training and Sports Medicine. Park Ridge, Illinois: APOS

Arheim, DD. 1986. Dance Injuries: Their Prevention and Care. St. Louis, Misuri: CV Mosby Co.

Armstrong, RA, P Neill, R Mossop. 1988. Asthma induced by ivory dust: A new occupational cause. Thorax 43(9): 737-738.

Axelsson, A, F Lindgren. 1981. Hearing in classical musicians. Acta Oto-Larynogologica 92 Suppl. 377:3-74.

Babin, A 1996. Orchestra pit sound level measurements in Broadway shows. Presentado en el 26 Encuentro anual de la American Public Health Association. Nueva York, 20 noviembre.

Baker, EL, WA Peterson, JL Holtz, C Coleman, PJ Landrigan. 1979. Subacute cadmium intoxication in jewellery workers: an evaluation of diagnostic procedures. Arch Environ Health 34:173-177.

Balafrej, A, J Bellakhdar, M El Haitem, H Khadri. 1984. Paralysis due to glue in young apprentice shoemakers in the medina of Fez. Rev Pediatrie 20(1):43-47.

Ballesteros, M, CMA Zuniga, OA Cardenas. 1983. Lead concentrations in the blood of children from pottery-making families exposed to lead salts in a Mexican village. B Pan Am Health Organ 17(1): $35-41$.

Bastian, R, A Keidar, K Verdolini-Marston. 1990. Simple vocal tasks for detecting vocal fold swelling. Fournal of Voice 4(2):172-183.

Bastian, RW. 1993. Benign mucosal and saccular disorders; benign laryngeal tumors. En OtolaryngologyHead and Neck Surgery, dirigido por CW Cumming. St. Louis, Misuri: CV Mosby Co.

1996. Vocal fold microsurgery in singers. Fournal of Voice 10(4):389-404

Bowling, A. 1989. Injuries to dancers: Prevalence, treatment and perception of causes. British Medical Journal 6675:731-734.

Bruno, PJ, WN Scott, G Huie. 1995. Basketball. En The Team Physicians's Handbook, dirigido por MB Mellion, WM Walsh and GL Shelton. Filadelfia, Pensilvania: Mosby Yearbook.

Burr, GA, TJ Van Gilder, DB Trout, TG Wilcox, R Friscoll. 1994. Health Hazard Evaluation Report: Actors' Equity Association/The League of American Theaters and Producers, Inc. Doc. HETA 90-355-2449. Cincinnati, Ohio: US National Institute for Occupational Safety and Health.

Calabrese, LH, DT Kirkendal, M Floyd. 1983. Menstrual abnormalities, nutritional patterns and body composition in female classical ballet dancers. Phys Sports Med 11:86-98.

Cardullo, AC, AM Ruszkowski, VA DeLeo. 1989. Allergic contact dermatitis resulting from sensitivity to citrus peel, geriniol, and citral. 7 Am Acad Dermatol 21(2):395-397.
Carlson, T. 1989. Lights! Camera! Tragedy. TV Guide (26 August):8-11.

Chasin, M, JP Chong. 1992. A clinically efficient hearing protection program for musicians. Med Prob Perform Artists 7(2):40-43.

1995. Four environmental techniques to reduce the effect of music exposure on hearing. Med Prob Perform Artists 10(2):66-69.

Chaterjee, M. 1990. Ready-made garment workers in Ahmedabad. B Occup Health Safety 19:2-5.

Clare, PR. 1990. Football. En The Team Physicians's Handbook, dirigido por MB Mellion, WM Walsh y GL Shelton. St. Louis, Misuri: CV Mosby Co.

Cornell, C. 1988. Potters, lead and health-Occupational safety in a Mexican village (resumen de la reunión). Abstr Pap Am Chem S 196:14.

Council on Scientific Affairs of the American Medical Association. 1983. Brain injury in boxing. FAMA 249:254-257.

Das, PK, KP Shukla, FG Ory. 1992. An occupational health programme for adults and children in the carpet weaving industry, Mirzapur, India: A case study in the informal sector. Soc Sci Med 35(10):1293-1302

Delacoste, F, P Alexander. 1987. Sex Work: Writings by Women in the Sex Industry. San Francisco, California: Cleis Press.

Depue, RH, BT Kagey. 1985. A proportionate mortality study of the acting profession. Am J Ind Med 8:57-66.

Domínguez, R, JR de Juanes Pardo, M García Padros, F Rodríguez Artalejo. 1987. Antitetanic vaccination in a high-risk population. Med Segur Trab 34:50-56.

Driscoll, RJ, WJ Mulligan, D Schultz, A Candelaria 1988. Malignant mesothelioma: a cluster in a Native American population. New Engl $7 \mathrm{Med}$ 318:1437-1438.

Estébanez, P, K Fitch, Nájera 1993. HIV and female sex workers. Bull WHO 71(3/4):397-412.

Evans, RW, RI Evans, S Carjaval, S Perry. 1996. A survey of injuries among Broadway performers. Am f Public Health 86:77-80.

Feder, RJ. 1984. The professional voice and airline flight. Otolaryngology-Head and Neck Surgery, 92(3):251-254

Feldman, R, T Sedman. 1975. Hobbyists working with lead. New Engl f Med 292:929.

Fishbein, M. 1988. Medical problems among ICSOM musicians. Med Prob Perform Artists 3:1-14.

Fisher, AA. 1976. "Blackjack disease" and other chromate puzzles. Cutis 18(1):21-22.

Frye, HJH. 1986. Incidence of overuse syndrome in the symphony orchestra. Med Prob Perform Artists 1:51-55.

Garrick, JM. 1977. The frequency of injury, mechanism of injury and epidemiology of ankle sprains. Am J Sports Med 5:241-242.
Griffin, R, KD Peterson, J Halseth, B Reynolds. 1989. Radiographic study of elbow injuries in professional rodeo cowboys. Phys Sports Med 17:85-96.

Hamilton, LH, WG Hamilton. 1991. Classical ballet: Balancing the costs of artistry and athleticism. Med Prob Perform Artists 6:39-44.

Hamilton, WG. 1988. Foot and ankle injuries in dancers. En Sports Clinics of North America, dirigido por L Yokum. Filadelfia, Pensilvania: Williams and Wilkins.

Hardaker, WTJ. 1987. Medical considerations in dance training for children. Am Fam Phys 35(5): 93-99.

Henao, S. 1994. Health Conditions of Latin American Workers. Washington, DC: American Public Health Association.

Huie, G, EB Hershman. 1994. The team clinician's bag. Am Acad Phys Asst 7:403-405.

Huie, G, WN Scott. 1995. Assessment of ankle sprains in athletes. Phys Assist f 19(10):23-24.

Kipen, HM, Y Lerman. 1986. Respiratory abnormalities among photographic developers: A report of 3 cases. Am f Ind Med 9:341-347.

Knishkowy, B, EL Baker. 1986. Transmission of occupational disease to family contacts. Am f Ind Med 9:543550.

Koplan, JP, AV Wells, HJP Diggory, EL Baker, J Liddle. 1977. Lead absorption in a community of potters in Barbados. Int J Epidemiol 6:225-229.

Malhotra, HL. 1984. Fire safety in assembly buildings. Fire Safety f 7(3):285-291.

Maloy, E. 1978. Projection booth safety: New findings and new dangers. Int Assoc Electr Inspect Newes 50(4): 20-21.

McCann, M, N Hall, R Klarnet, PA Peltz. 1986. Reproductive hazards in the arts and crafts. Presentado en la conferencia anual de la Society for Occupational and Environmental Health Conference on Reproductive Hazards in the Environment and Workplace, Bethesda, Maryland, 26 abril.

McCann, M. 1989. 5 dead in movie heliocopter crash. Art Hazards Newes 12:1.

- 1991. Lights! Camera! Safety! A Health and Safety Manual for Motion Picture and Television Production. Nueva York: Center for Safety in the Arts.

- 1992a. Artist Beware. Nueva York: Lyons and Burford. 1992b. Art Safety Procedures: A Health and Safety Manual for Art Schools and Art Departments. Nueva York: Center for Safety in the Arts.

- 1996. Hazards in cottage industries in developing countries. Am f Ind Med 30:125-129.

Miller, AB, DT Silverman, A Blair. 1986. Cancer risk among artistic painters. Am f Ind Med 9:281-287.

MMWR. 1982. Chromium sensitization in an artist's workshop. Morb Mort Weekly Rep 31:111.

- 1996. Bull riding-related brain and spinal cord injuries - Louisiana, 1994-1995. Morb and Mort Weekly Rep 45:3-5.

Monk, TH. 1994. Circadian rhythms in subjective activation, mood, and performance efficiency. En Principles and Practice of Sleep Medicine, 2 edición, dirigido por 
M. Kryger y WC. Roth. Filadelfia, Pensilvania: WB Saunders

National Institute for Occupational Safety and Health (NIOSH). 1991. Environmental Tobacco Smoke in the Workplace: NIOSH Current Intelligence Bulletin 54. Cincinnati, Ohio: NIOSH

Norris, RN. 1990. Physical disorders of visual artists. Art Hazards Neres 13(2):1.

Nubé, J. 1995. Beta Blockers and Performing Musicians. Tesis doctoral. Amsterdam: Universidad de Amsterdam.

O’Donoghue, DH. 1950. Surgical treatment of fresh injuries to major ligaments of the knee. $f$ Bone Foint Surg 32:721-738.

Olkinuora, M. 1984. Alcoholism and occupation. Scand 7 Work Environ Health 10(6):511-515.

- 1976. Injuries to the knee. En Treatment of Injuries to Athletes, dirigido por DH O'Donoghue. Filadelfia, Pensilvania: WB Saunders.

Organización Mundial de la Salud (OMS). 1976. Meeting on Organization of Health Care in Small Indus tries. Ginebra: OMS.

Pan American Health Organization, (PAHO). 1994 Health Conditions in the Americas. Vol. 1. Washington, DC: PAHO.

Pheterson, G. 1989. The Vindication of the Rights of Whores. Seattle, Washington: Seal Press.

Prockup, L. 1978. Neuropathy in an artist. Hosp Pract (noviembre):89.

Qualley, CA. 1986. Safety in the Artroom. Worcester, Maryland: Davis Publications.

Ramakrishna, RS, P Muthuthamby, RR Brooks, DE Ryan. 1982. Blood lead levels in Sri Lankan families recovering gold and silver from jewellers' waste. Arch Environ Health 37(2):118-120.

Ramazzini, B. 1713. De morbis artificum (Diseases of Workers). Chicago, Illinois: University of Chicago Press.

Rastogi, SK, BN Gupta, H Chandra, N Mathur, PN Mahendra, T Husain. 1991. A study of the prevalence of respiratory morbidity among agate workers. Int Arch Occup Environ Health 63(1):21-26.

Rossol, M. 1994. The Artist's Complete Health and Safety Guide. Nueva York: Allworth Press.

Sachare, A.(dir.). 1994a. Rule \#2. Section IIC. En The Official NBA Basketball Encyclopedia. Nueva York: Villard Books.

- 1994b. Basic Principle P: Guidelines for infection control. En The Official NBA Basketball Encyclopedia. NuevaYork: Villard Books.

Sammarco, GJ. 1982. The foot and ankle in classical ballet and modern dance. En Disorders of the Foot, dirigido por $\mathrm{MH}$ Jahss. Filadelfia, Pensilvania: WB Saunders.

Sataloff, RT. 1991. Professional Voice: The Science and Art of Clinical Care. Nueva York: Raven Press.

- 1995. Medications and their effect on the voice. Journal of Singing 52(1):47-52.

- 1996. Pollution: Consequences for singers. Journal of Singing 52(3):59-64.

Schall, EL, CH Powell, GA Gellin, MM Key. 1969. Hazards to go-go dancers to exposures to "black" light from fluorescent bulbs. Am Ind Hyg Assoc $\mathcal{f}$ 30:413-416.

Schnitt, JM, D Schnitt. 1987. Psychological aspects of dance. En The Science of Dance Training, dirigido por P Clarkson y M Skrinar. Champaign, Illinois: $\mathrm{Hu}$ man Kinetics Press.

Seals, J. 1987. Dance surfaces. En Dance Medicine: A Comprehensive Guide, dirigido por A Ryan y RE Stephens. Chicago, Illinois: Pluribus Press.

Sofue, I, Y Yamamura, K Ando, M Iida, T Takayanagi. 1968. N-hexane polyneuropathy. Clin Neurol 8:393-403.
Stewart, R, C Hake. 1976. Paint remover hazard. JAMA 235:398

Tan, TC, HC Tsang, LL Wong. 1990. Noise surveys in discotheques in Hong Kong. Ind Health 28(1):37-40.

Teitz, C, RM Harrington, H Wiley. 1985. Pressure on the foot in point shoes. Foot Ankle 5:216-221.

VanderGriend, RA, FH Savoie, JL Hughes. 1991. Fracture of the ankle. En Rockwood and Green's Frac tures in Adults, dirigido por CA Rockwood, DP Green y RW Bucholz. Filadelfia, Pensilvania: JB Lippincott Co.

Warren, M, J Brooks-Gunn, L Hamilton. 1986. Scoliosis and fracture in young ballet dancers: Relationship to delayed menarcheal age and amenorrhea. New Engl f Med 314:1338-1353.

Zeitels, S. 1995. Premalignant epithelium and microinvasive cancer of the vocal fold: the evolution of phonomicrosurgical management. Laryngoscope 105(3):1-51.

\section{Otras lecturas recomendadas}

Alexander, P. 1995. Sex workers fight against AIDS An international perspective. En Women Resisting AIDS: Strategies of Empowerment, dirigido por BE Schneider y N Stoller. Filadelfia, Pensilvania: Temple University Press.

- 1997. Making a living: Women who go out. En Women's Experiences with AIDS, dirigido por M Ankrah y L Long. Nueva York: Columbia University Press.

American National Standards Institute (ANSI). 1993 American National Standard for Safe Use of Lasers. Nueva York: ANSI.

Association of Systematics Collections. 1994. Guidelines for Institutional Policies and Planning in Natural Histon Collections. Washington, DC: Association of Systematics Collections.

Avery, B. 1992. Special Event \& Show Safety Guide (Fireworks, Animal Handling, Power Tools). Orlando, Florida.

Babin, A, M McCann. 1992. Waste Management and Disposal for Artists and Schools. Nueva York: Center for Safety in the Arts.

Barnard, MA. 1993. Violence and vulnerability: Conditions of work for streetwalking prostitutes. Sociol ogy of Health and Illness 15(5):683-705.

Bastian, R, K. Verdolini, A. Keidar. 1989. The team approach to management of patients with voice disorders. NATS foumal 45(5):16-19.

Bastian, RW. 1987. Vocal fold surgery in singers. Med Prob of Perform Artists 66: 49-52.

- 1988. Factors leading to successful evaluation and management of patients with voice disorders. Ear, Nose and Throat Fournal 67:411-420.

1990. Prevention of voice disorders. En The Principles of Singing, 2 edición, dirigida por KE Miller. Englewood Cliffs, Nueva Jersey: Prentice-Hall.

Bouchayer, M, G Cornut. 1988. Microsurgery for benign mucosal disorders. Ear, Nose and Throat foumal 67:446-466.

California State Fire Marshall Film Advisory Committee. 1988. Film Industry Fire/life Safety Handbook. Sacramento, California: California State Fire Marshall.

Canadian Centre for Occupational Health and Safety (CCOHS). 1988. Infograms on Hand Tools. Hamilton, Ontario: CCOHS.

1988. Infograms on Powered Hand Tools. Hamilton, Ontario: CCOHS.

- 1988. Infograms on Woodworking Machines. Hamilton, Ontario: CCOHS.

Chong, JP, M Lynden, D Harvey, M Peebles. 1989. Occupational health problems of musicians. Can Fam Phys 35:2341-2348.
Chong, JP. 1996. The human performance approach to prevention. En Musicians and the Prevention of Hearing Loss, dirigido por M Chasin. San Diego, California: Singular Publishing, Inc

1997. Physical therapy for physical problems. En Chronic Musculoskeletal Injuries in the Workplace, dirigido por D Ranney. Filadelfia, Pensilvania: WB Saunders.

Clark, N. 1990. Health and Safety Manual for Broadcast Employees. Nueva York: National Association of Broadcast Employees and Technicians Local 16.

Colton, R, J Casper. 1990. Understanding Voice Problems: A Physiological Perspective for Diagnosis and Treatment. Baltimore, Maryland: Williams and Wilkins.

Critchley, M, RA Henson. 1980. Music and the Brain: Studies in the Neurology of Music. Londres: Heinemann.

Federación Sueca de Teatro y Universidad de Lund. 1989. A Study of the Theatre's Working Environment and It. Future Development. Informe de un círculo de investigación en colaboración con la Federación Sueca de Teatro y la Universidad Sueca de Lund. Suecia: Federación Sueca de Teatro y Universidad Sueca de Lund.

Ford, C, D Bless. 1990. Phonosurgery: Assessment and Surgical Management of Voice Disorders. Filadelfia, Pensilvania: Raven Press.

Health and Safety Commission. 1985. Zoos-Safety, Health and Welfare Standards for Employers and Persons at Work. Londres: Her Majesty's Stationery Office.

Industry Wide Labor-Management Safety Committee for the Motion Picture and Television Industry. 1986. Safety Bulletins. Hollywood, California: Industry Wide Labor-Management Safety Committee for the Motion Picture and Television Industry.

Kleinsasser, O. 1979. Microlaryngoscopy and Endolaryngeal Microsurgery: Technique and Typical Findings, $2^{\mathrm{a}}$ edición. Baltimore, Maryland: University Park Press.

Lockwood, AH. 1989. Medical problems of musicians. New Engl f Med 320:221-227.

Massachusetts Institute of Technology (MIT). 1994 Health and Safety Guidelines for Computer Use at MIT. Cambridge, Massachusetts: MIT

Miller, PL. 1991. Arsenic, Old Lace, and Stuffed Owls May Be Dangerous to Your Health: Hazards in Museum Collections. Champaign, Illinois: Illinois Heritage Association.

Morrison, M, L Rammage. 1994. The Management of Voice Disorders. San Diego, California: Singular Publishing Group, Inc.

National Fire Protection Association (NFPA). 1991. Protection of Museums and Museum collections. Quincy, Massachusetts: NFPA.

National Institute for the Conservation of Cultural Property (biblioteca de consulta): Washington, DC.

Ontario Film and Television Industry Section 11 Advisory Committee. 1990. Safety Guidelines for the Film and Television Industry in Ontario. Toronto: Ontario Ministry of Labor.

Pheterson G. The Prostitution Prisim. Amsterdam: University of Amsterdam Press.

Phongpaichit, P. 1982. From Peasant Girls to Bangkok Masseuses. Ginebra: OIT.

Phoon, WO. 1988. Chemical hazards: Metals. En Practical Occupational Health, dirigido por WO Phoon. Singapur, Hong Kong y New Delhi: PG Publishing.

Reid, F. 1978. The Staging Handbook. Londres: AC Black.

Rose, CL. 1995. Storage of Natural History Collections. Pittsburgh, Pensilvania: Society for the Preservation of Natural History Collections.

Rossol, M. 1991. Stage Fright: Health and Safety in the Theater. Nueva York: Allworth Press.

- 1996. Keeping Clay Work Safe and Legal, $2^{\mathrm{a}}$ edición. Brandon, Oregón: National Council on Education in the Ceramic Arts.

Sataloff, RT, AG Brandfonbrener, RJ Lederman. 1990. Textbook of Performing Arts Medicine. Filadelfia, Pensilvania: Raven Press. 
Shaver, FM. 1995. Prostitution: On the dark side of the service industry. En Post-Critical Criminology. Scarborough, Ontario: Prentice Hall.

Singer, K. 1932. Diseases of the Musical Profession: A Systematic Presentation of Their Causes, Symptoms and Methods of Treatment. Nueva York: Greenberg.

Sliney, D, M Wolbarsht. 1985. Safety with Lasers and Other Optical Sources. Nueva York: Plenum Press.
Smith, S, HFT Holt 1993. The Artist's Manual. Nueva York: Mayflower Books.

Spandorfer, M, D Curtiss, JW Snyder. 1993. Making Art Safely. Nueva York: Van Nostrand Reinhold.

Sundberg, J. 1987. The Science of the Singing Voice.

Dekalb, Illinois: Northern Illinois University Press.

Titze, I. 1993. Principles of Voice Production. Englewood Cliffs, Nueva Jersey: Prentice Hall.
Truong, T-D. 1990. Sex, Money and Morality: Prostitution and Tourism in South-East Asia. Londres: Zed Books.

Vanwesenbeeck, I. 1994 Prostitutes' Well-being and Risk. Amsterdam: VU University Press.

White, L. 1990. The Comforts of Home: Prostitution in Colonial Nairobi. Chicago, Illinois: University of Chicago Press.

Zycherman, LA, JR Schrock. 1988. A Guide to Museum Pest Control. Washington, DC: Association of Systematics Collections. 

Directora del capítulo Annalee Yassi

\section{y}

\section{Sumario}

Asistencia sanitaria: naturaleza y problemas de salud en el trabajo

Annalee Yassiy Leon F. Warshaw . . . . . . . . . . . . . . . . . . . . 97.2

¿Son también trabajadores sanitarios?

Leon F. Warshaw . . . . . . . . . . . . . . . . . . . . . . . 97.2

Servicios sociales

Susan Nobel . . .

Trabajadores de la atención domiciliaria:

la experiencia de Nueva York

Lenora Colbert. . . . . . . . . . . . . . . . . . . 97.11

Estudio de un caso: Violencia en el trabajo sanitario

Daniel Murphy . . . . . . . . . . . . . . . . . . . . . . 97.12

La práctica de la salud y seguridad en el trabajo:

la experiencia rusa

Valery P. Kaptsov y Lyudmila P. Korotich.

ERGONOMIA Y ASISTENCIA SANITARIA

Perspectiva de la ergonomia hospitalaria

Madeleine R. Estryn-Béhar.

La tensión en el trabajo de asistencia sanitaria

Madeleine R. Estryn-Béhar. . . . . . . . . . . . . . . . 97.20

Horarios de trabajo y trabajo nocturno en la asistencia sanitaria

Madeleine R. Estryn-Béhar.

MEDIO AMBIENTE FISICO Y ASISTENCIA SANITARIA

Exposición a agentes físicos

Robert M. Lerey . . . . . . . . . . . . . . . . . . . 97.30

Ergonomía del medio ambiente físico de trabajo

Madeleine Estryn-Béhar. . . . . . . . . . . . . . . . . . . 97.33

Prevención y manejo de los dolores de espalda en el personal de enfermeria

Ulrich Stössel . . . . . . . . . . . . . . . . . . . . . . . . . . . 97.38

Tratamiento del dolor de espalda

Leon F. Warshaw .......................... 97.41

\section{LOS TRABAJADORES SANITARIOS Y LAS ENFERMEDADES
INFECCIOSAS}

Perspectiva de las enfermedades infecciosas

Friedrich Hofmann . . . . . . . . . . . . . . . . . . . . . 97.42

Prevención de la transmisión profesional de los agentes patógenos en sangre

Linda S. Martin, Robert F. Mullan y David M. Bell . .

Prevención, control y vigilancia de la tuberculosis

Robert 7. Mullan .......................... 97.50

SUSTANCIAS QUIMICAS PRESENTES EN EL MEDIO

AMBIENTE SANITARIO

Perspectiva de los riesgos de origen químico en la asistencia sanitaria

Jeanne Mager Stellman

Abordaje de los riesgos de origen químico en los hospitales

Annalee Yassi ............................... 97.57

Gases anestésicos residuales

Xavier Guardino Solá . . . . . . . . . . . . . . . . . . . . . . . . 97.60

Los trabajadores sanitarios y la alergia al látex

Leon f. Warshaw . . . . . . . . . . . . . . . . . . . . . . 97.63

EL MEDIO AMBIENTE HOSPITALARIO

Edificios destinados a la asistencia sanitaria Cesare Catananti, Gianfranco Damiani y Giovanni Capelli . . . . . . . . . 97.65

Hospitales: problemas de salud pública y medioambientales

M.P. Arias . . ......................... 97.70

Tratamiento de los residuos hospitalarios M.P. Arias . . . . . . . . . . . . . . . . . . . . . 97.72

Manejo de la eliminación de los residuos sanitarios peligrosos según ISO 14000 Ferry Spiegel y Fohn Reimer. 
- ASISTENCIA SANITARIA: NATURALEZA Y PROBLEMAS DE SALUD EN EL TRABAJO

\section{Annalee Yassi y Leon J. Warshaw}

El sector de la asistencia sanitaria es intensivo en mano de obra y, en la mayoría de los países, sus trabajadores constituyen un segmento importante de la población activa y realizan una gran variedad de labores técnicas, profesionales y auxiliares en muy diversos entornos. Además de personal sanitario, técnicos de laboratorio, farmacéuticos, trabajadores sociales y otros especialistas clínicos, el sector emplea personal administrativo, de limpieza, restauración y lavandería, así como ingenieros, electricistas, pintores y personal de mantenimiento dedicado a conservar y reparar los edificios y el equipo que albergan. A diferencia de los trabajadores que prestan asistencia directa, este personal auxiliar sólo tiene contactos esporádicos y casuales con los pacientes.

Los trabajadores sanitarios, mujeres en su mayoría, pertenecen a distintos grupos étnicos y sociales y poseen distintos

\section{¿Son también trabajadores sanitarios?}

En el estudio del bienestar y la seguridad de los trabajadores sanitarios se suele pasar por alto a los alumnos de las facultades de medicina y de odontología, de las escuelas de enfermería, y de otros centros de formación de profesionales y voluntarios que prestan servicios altruistas en los centros sanitarios. Al no ser trabajadores en el sentido técnico y jurídico del término, en muchos países no tienen derecho a indemnización por accidentes de trabajo ni al seguro médico obligatorio de los trabajadores, y los administradores de los centros sanitarios tienen tan sólo una obligación moral de velar por su salud y seguridad.

La dimensión clínica de su formación puede poner a los estudiantes de medicina, enfermería y odontología en contacto con pacientes de enfermedades infecciosas. De hecho, estos alumnos ejecutan o bien colaboran en diversos procedimientos invasivos, como la extracción de muestras de sangre, y con frecuencia realizan también tareas de laboratorio con líquidos corporales y con muestras de orina o heces. Disfrutan de libertad para deambular por las dependencias del centro y para acceder a las áreas potencialmente peligrosas, por lo general sin apercibirse de los riesgos, que no suelen indicarse. Además, trabajan con escasa o nula supervisión, debido a que sus instructores tienen escasos conocimientos sobre la protección de la salud y seguridad, por la que no suelen interesarse.

Aunque los voluntarios no suelen participar en la asistencia clínica, suelen establecer contactos humanos con los pacientes y están sujetos a escasas restricciones respecto a las dependencias del centro a las que pueden acceder.

Normalmente, los estudiantes y voluntarios comparten con los trabajadores sanitarios los riesgos derivados de la exposición a factores potenciales de riesgo. Estos riesgos se multiplican en los momentos de crisis y en las situaciones de urgencia, cuando se asume voluntariamente el riesgo o se tiene la obligación de hacerlo. Está claro que, aunque no se diga nada en los reglamentos y leyes vigentes, ni en los manuales de procedimiento interno, estas personas tienen derecho a recibir el mismo interés y protección que los trabajadores de plantilla de la asistencia sanitaria.

Leon J. Warshaw niveles educativos. Muchos de ellos, particularmente los dedicados a la atención domiciliaria, trabajan en puestos de bajo nivel y precisan una formación básica considerable. En la Tabla 97.1 se relacionan diversas funciones sanitarias y los profesionales que las desempeñan.

Tabla 97.1 - Ejemplos de funciones de la asistencia sanitaria y profesionales que las desempeñan $\left({ }^{*}\right)$.

\begin{tabular}{|c|c|c|}
\hline Función & $\begin{array}{l}\text { Categoría } \\
\text { profesional }\end{array}$ & Profesiones específicas \\
\hline \multirow[t]{3}{*}{$\begin{array}{c}\text { Cuidado directo } \\
\text { del paciente }\end{array}$} & $\begin{array}{l}\text { Profesiones de } \\
\text { diagnóstico }\end{array}$ & $\begin{array}{l}\text { Médicos } \\
\text { Odontólogos }\end{array}$ \\
\hline & $\begin{array}{l}\text { Profesiones de } \\
\text { evaluación y } \\
\text { tratamiento }\end{array}$ & $\begin{array}{l}\text { Enfermeras tituladas } \\
\text { Farmacéuticos } \\
\text { Ayudantes de médicos } \\
\text { Terapeutas (por ejemplo, } \\
\text { fisioterapeutas) } \\
\text { Optometristas } \\
\text { Dietistas y técnicos en nutrición }\end{array}$ \\
\hline & Asesoramiento & $\begin{array}{l}\text { Trabajadores sociales } \\
\text { Clérigos }\end{array}$ \\
\hline Apoyo técnico & Técnicos sanitarios & $\begin{array}{l}\text { Técnicos clínicos de laboratorio } \\
\text { Higienistas dentales } \\
\text { Técnicos de documentación sanitaria } \\
\text { Técnicos de radiología } \\
\text { Auxiliares de enfermería tituladas } \\
\text { Técnicos de servicios de urgencia }\end{array}$ \\
\hline \multirow[t]{7}{*}{ Servicios } & Servicios de salud & $\begin{array}{l}\text { Auxiliares de odontología } \\
\text { Auxiliares sanitarios distintos de los } \\
\text { auxiliares de enfermería } \\
\text { Auxiliares de enfermería, celadores y } \\
\text { cuidadores }\end{array}$ \\
\hline & $\begin{array}{l}\text { Servicios de } \\
\text { alimentación }\end{array}$ & $\begin{array}{l}\text { Cocineros } \\
\text { Trabajadores de cocina }\end{array}$ \\
\hline & Servicios personales & Peluqueros y peluqueras \\
\hline & $\begin{array}{l}\text { Servicios de } \\
\text { lavandería }\end{array}$ & Trabajadores de lavandería \\
\hline & $\begin{array}{l}\text { Servicios de } \\
\text { mantenimiento }\end{array}$ & $\begin{array}{l}\text { Fontaneros, electricistas y otros oficios } \\
\text { Conserjes y personal de limpieza } \\
\text { Operarios del cuarto de calderas } \\
\text { Jardineros }\end{array}$ \\
\hline & $\begin{array}{r}\text { Servicios de } \\
\text { seguridad }\end{array}$ & Guardias \\
\hline & $\begin{array}{l}\text { Servicios de } \\
\text { transporte }\end{array}$ & Conductores de ambulancias \\
\hline $\begin{array}{l}\text { Apoyo } \\
\text { administrativo }\end{array}$ & $\begin{array}{l}\text { Servicios } \\
\quad \text { administrativos }\end{array}$ & $\begin{array}{l}\text { Personal de facturación } \\
\text { Profesionales de tratamiento de la } \\
\text { documentación } \\
\text { Operadores del equipo informático } \\
\text { Trabajadores administrativos de los } \\
\text { consultorios médicos } \\
\text { Telefonistas }\end{array}$ \\
\hline \multirow[t]{2}{*}{ Investigación } & $\begin{array}{l}\text { Profesiones } \\
\text { científicas }\end{array}$ & Científicos y médicos investigadores \\
\hline & $\begin{array}{l}\text { Personal de } \\
\text { laboratorio }\end{array}$ & $\begin{array}{l}\text { Técnicos de laboratorio } \\
\text { Cuidadores de animales }\end{array}$ \\
\hline
\end{tabular}

* Las categorías profesionales se corresponden, en parte, con las utilizadas por la Oficina de Estadísticas Laborales del Departamento de Trabajo de Estados Unidos. 
Figura 97.1 • Manipulación de material biológico contaminado.

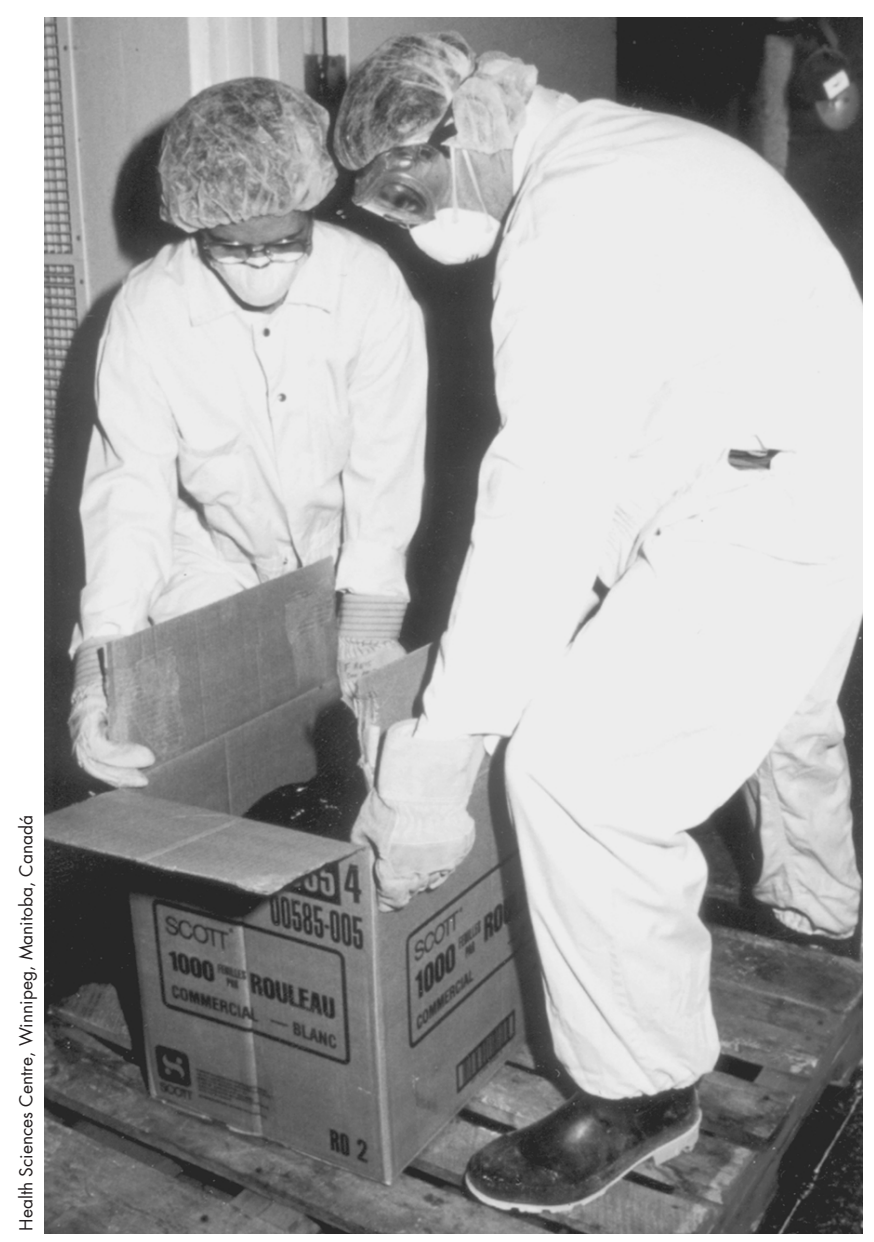

Un segmento del sector sanitario (que, por desgracia, suele ser demasiado pequeño y estar escasamente dotado en la mayoría de los casos) presta servicios de prevención directa e indirecta. Sin embargo, la actividad del sector se centra sobre todo en el diagnóstico, tratamiento y cuidado de los enfermos. Esto produce una situación especial, dado que los pacientes muestran diversos niveles de dependencia física y emocional que los diferencian de los clientes de otros sectores que prestan una atención directa, como el comercio minorista, la restauración y la hostelería. En efecto, los enfermos precisan - y suelen recibir - una atención y una consideración especiales, a menudo con carácter urgente, que se prestan muchas veces a expensas de la comodidad y la seguridad del propio trabajador.

Por su dimensión y por el número de trabajadores que emplean, los centros asistenciales dedicados a los pacientes agudos y crónicos constituyen, quizás, los elementos más notables del sector de la asistencia sanitaria. Estos centros se complementan con una red de ambulatorios, clínicas de cirugía ambulatoria, laboratorios clínicos y de anatomía patológica, farmacias, clínicas de radiología, servicios de ambulancias y cuidados de urgencia, consultas individuales y colectivas y servicios de cuidados a domicilio. En algunos casos, estos servicios radican en el mismo hospital o en otro centro gestionado por él; en otros, funcionan de modo independiente. Es de subrayar las profundas diferencias existentes en el nivel de prestación de la asistencia sanitaria, que varía desde los servicios perfectamente organizados, de "tecnología punta" que se prestan en los centros urbanos de los países desarrollados, hasta la escasez de recursos asistenciales predominante en las comunidades rurales de las naciones en desarrollo y en muchas áreas marginales de las grandes ciudades.

El sector de la asistencia sanitaria sustenta un impresionante entramado educativo y de investigación en el que alumnos, profesores, investigadores y personal auxiliar suelen participar en el cuidado de los pacientes y establecer contacto directo con los mismos. En este entramado se incluyen facultades y escuelas de medicina, odontología, salud pública, trabajo social y otras especialidades técnicas asociadas a la asistencia sanitaria.

El sector de la asistencia sanitaria ha experimentado profundas transformaciones en los últimos decenios. El envejecimiento de la población, especialmente en las naciones industrializadas, ha propiciado el uso de las residencias asistidas y de los medios y servicios de atención domiciliaria. Además de promover la creación de nuevos tipos de centros atendidos por categorías emergentes de un personal especialmente cualificado, el desarrollo científico y tecnológico ha restado algo de protagonismo a los hospitales para enfermos agudos. Actualmente, muchos servicios se prestan de forma ambulatoria. Por último, las tensiones presupuestarias provocadas por la espiral de los costes de la asistencia sanitaria han obligado a reestructurar el sector sanitario, al menos en las naciones de desarrollo con la consiguiente presión en favor de una reducción de los costes que se pretende lograr reorganizando los servicios de asistencia sanitaria.

Los trabajadores sanitarios que están en contacto directo con los pacientes en cualquier entorno asistencial se exponen a una serie de riesgos específicos. Afrontan, entre otros, el riesgo de contagiarse de los pacientes que atienden y de sufrir lesiones musculosqueléticas al sostenerles, levantarles o trasladarles. El personal auxiliar que no interviene directamente en la atención del paciente (como el de lavandería, limpieza y manipulación de materiales), además de exponerse continuamente a la acción de productos químicos como los de limpieza y desinfectantes industriales, corre el riesgo de infectarse con los desechos y ropa de cama contaminados (véase la Figura 97.1). Está también la ética profesional de estos trabajadores, que les obliga, especialmente en situaciones de urgencia, a anteponer el bienestar y la seguridad de los pacientes a los propios. El esfuerzo por superar el estrés causado por los fracasos terapéuticos, la muerte y la agonía suele llevar al trabajador a desarrollar un síndrome de burnout. Este cuadro se complica con los efectos del trabajo por turnos, la escasez, voluntaria o no, de recursos humanos y la necesidad de atender a las exigencias, a veces injustificadas, de pacientes y familiares. Por último, está el riesgo - especialmente grave para los empleados que trabajan solos o se ven obligados a desenvolverse en espacios poco seguros- de sufrir agresiones y actos de violencia de los pacientes. Estos riesgos se examinan en mayor profundidad en otros artículos del presente capítulo y en otras partes de esta Enciclopedia.

Según un informe del National Institute for Occupational Safety and Health (NIOSH), de Estados Unidos, los pinchazos con agujas, las luxaciones musculosqueléticas y las lesiones de la columna vertebral son, probablemente, los riesgos más comunes en el sector de la asistencia sanitaria (Wugofski 1995). En la Conferencia sobre Riesgos Profesionales organizada por la Organización Mundial de la Salud (OMS) en 1981 se definieron cinco áreas de riesgo especialmente graves:

- cortes, laceraciones y fracturas

- lesiones de la columna vertebral

- escasez de equipo de protección individual 
Figura 97.2 • Recipiente para evacuación de instrumentos y dispositivos cortantes o punzantes.

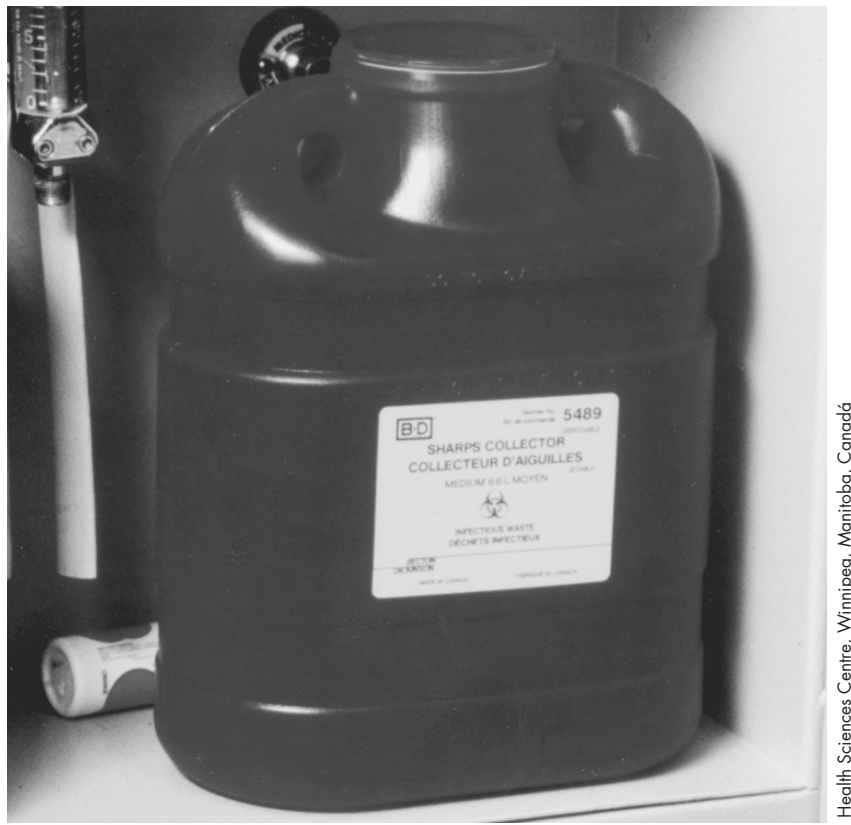

- deficiente mantenimiento de los equipos mecánicos y eléctricos

- agresiones de los pacientes.

\section{Riesgos biológicos}

Aunque los factores biológicos que suponen un riesgo de contagio de enfermedades infecciosas abundan en todo el mundo, constituyen un problema especialmente grave en las naciones en desarrollo. Si bien el virus de la hepatitis B (VHB) constituye una amenaza prácticamente universal para los trabajadores sanitarios, su importancia es especialmente grande en los países africanos y asiáticos en los que es endémico. Como se examina posteriormente en este mismo capítulo, el riesgo de infección por el VHB como consecuencia de un contacto percutáneo con sangre infectada con el antígeno de superficie de la hepatitis B (HBsAG) es unas cien veces mayor que el de infección por el virus de la inmunodeficiencia humana (VIH) en virtud del contacto con sangre infectada por el VIH (30\% frente al 0,3\%). Sin embargo, se ha producido, ciertamente, un aumento de la preocupación por la exposición parenteral a la sangre y los líquidos corporales, desde la época anterior al VIH a la época del SIDA. McCormick y cols. (1991) hallaron que las notificaciones de heridas producidas por instrumentos afilados se triplicó en un período de 14 años, y que las heridas sufridas por el personal de los centros asistenciales se habían multiplicado por nueve. Globalmente, las enfermeras sufren dos tercios de las heridas producidas por pinchazos con agujas. Yassi y McGill (1991) observan igualmente que las enfermeras y, más concretamente, las estudiantes de enfermería, constituyen el grupo de mayor riesgo en este sentido, aunque comentan igualmente que alrededor del 7,5 \% del personal médico manifiesta haberse expuesto al contacto con la sangre y los líquidos corporales, si bien el porcentaje real puede ser superior, debido a que no todos los casos se informan. Estos datos son congruentes con otros informes en el sentido de que, si bien existe una mayor tendencia a informar de los pinchazos con agujas, como consecuencia de una mayor conciencia del riesgo del VIH y el SIDA, en algunos grupos no se comunican todos los casos.
Según Sterling (1994), se oculta entre el 40 y el $60 \%$ de las lesiones producidas por las agujas.

Algunos factores de riesgo contribuyen claramente al contagio de enfermedades transmisibles por la sangre. En el artículo "Prevención de la transmisión profesional de los agentes patógenos en sangre" se analizan esos factores. Ciertamente, la exposición frecuente se ha asociado a unas elevadas tasas de seroprevalencia de la hepatitis B entre los trabajadores de los laboratorios, cirujanos y anatomopatólogos. El riesgo de sufrir hepatitis $\mathrm{C}$ también se incrementa. No obstante, se observa una clara tendencia a prestar mayor atención a la prevención de las heridas por agujas. La adopción de determinadas precauciones generales constituye un importante avance. En el sistema de precauciones generales se da por supuesto que todo líquido con un contenido de sangre es potencialmente infeccioso y que es preciso adoptar las cautelas debidas en todos los casos. En los puntos de más fácil acceso de las áreas de tratamiento se observa un número creciente de depósitos de seguridad como el que ilustra la Figura 97.2. Las nuevas técnicas, como los dispositivos sin aguja para las inyecciones intravenosas y la toma de muestras de sangre, han resultado ser un método eficaz para reducir las lesiones producidas por agujas (Yassi y McGill 1995).

La sangre y los líquidos corporales no constituyen la única fuente de infección de los trabajadores sanitarios. En efecto, la frecuencia de la tuberculosis ha vuelto a incrementarse en algunas partes del mundo en que su expansión se había contenido y, como se verá posteriormente en este mismo capítulo, constituye un riesgo creciente para la higiene industrial. En ésta y otras infecciones nosocomiales, el problema se complica por la circunstancia de que muchos de los microorganismos activos se han hecho resistente a los fármacos. Está, asimismo, el problema planteado por los nuevos brotes de agentes infecciosos fatales, como el virus Ebola. En el artículo "Perspectiva de las enfermedades infecciosas" se resumen los principales riesgos de infección que amenazan a los trabajadores sanitarios.

\section{Riesgos químicos}

Los trabajadores sanitarios se exponen a muy diversos agentes químicos, como desinfectantes, esterilizantes, reactivos químicos, fármacos y anestésicos, para citar sólo algunos grupos. En la Figura 97.3, en la que se observa un armario de la zona de un gran hospital en la que se producen prótesis, ilustra la extensa gama de sustancias químicas que se utilizan en los centros

Figura 97.3 • Armario de sustancias químicas peligrosas.

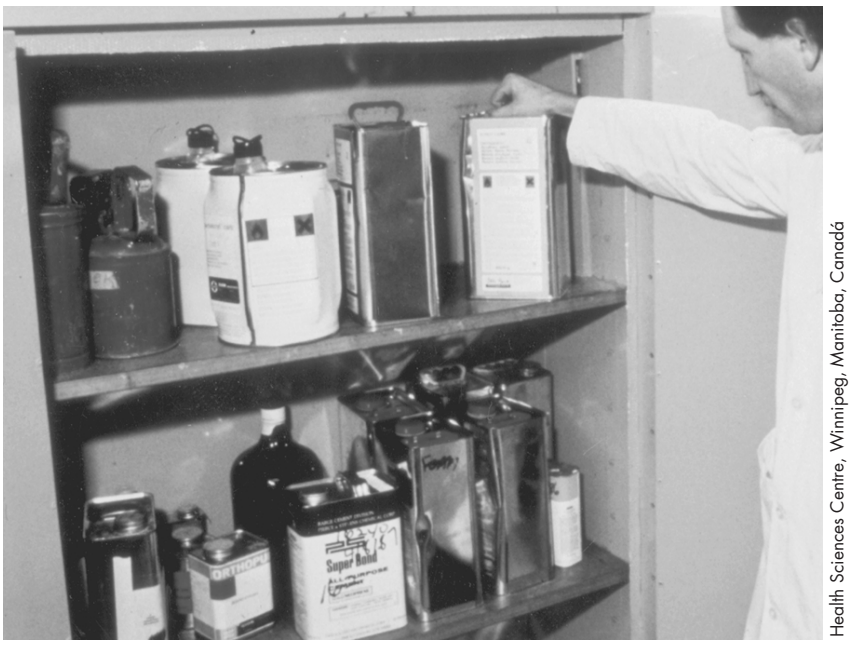


sanitarios. Algunos, como el formaldehído y el óxido de etileno, se consideran mutágenos, teratógenos y cancerígenos humanos. La prevención está en función de la naturaleza de la sustancia química implicada, del mantenimiento del aparato en que se utiliza o se aplica, de los controles ambientales, de la formación de los trabajadores y, en algunos casos, de la disponibilidad de equipo de protección individual adecuado. Muchas veces, los controles son simples y no excesivamente costosos; por ejemplo, Elias y cols. (1993) describen el sistema utilizado en un centro sanitario para reducir la exposición al óxido de etileno. En otros artículos del presente capítulo se examina la gestión de los riesgos químicos.

\section{Los riesgos físicos y el medio ambiente de la industria de la construcción}

Además de los agentes contaminantes específicamente ambientales que acechan a los trabajadores sanitarios, en numerosos centros sanitarios se han detectado problemas con la calidad del aire en el interior de las instalaciones. En su estudio de los síntomas experimentados por los profesionales de los quirófanos, Tran y cols. (1994) observan la presencia del "síndrome del edificio enfermo" en un hospital. Esto subraya la enorme importancia de las decisiones relativas al proyecto y mantenimiento de los edificios destinados a la asistencia sanitaria. Particular atención merece la correcta ventilación de áreas como los laboratorios, quirófanos y farmacias, la disponibilidad de campanas y la prevención del acceso de vapores saturados de sustancias químicas al sistema general de acondicionamiento de aire. El control de la recirculación del aire y el uso de equipo especial (como unos filtros adecuados y lámparas ultravioletas) constituye un elemento esencial de la transmisión de la difusión atmosférica de los agentes infecciosos. En el artículo "Edificios destinados a la asistencia sanitaria" se analizan diversos aspectos del proyecto y construcción de estos centros.

Los riesgos físicos también son ubicuos en los medios hospitalarios (véase, en este mismo capítulo, "Exposición a agentes físicos"). Si no se garantiza un mantenimiento correcto y una toma de tierra adecuada, el equipo eléctrico utilizado en los

Figura 97.4 - Equipo eléctrico en un hospital.

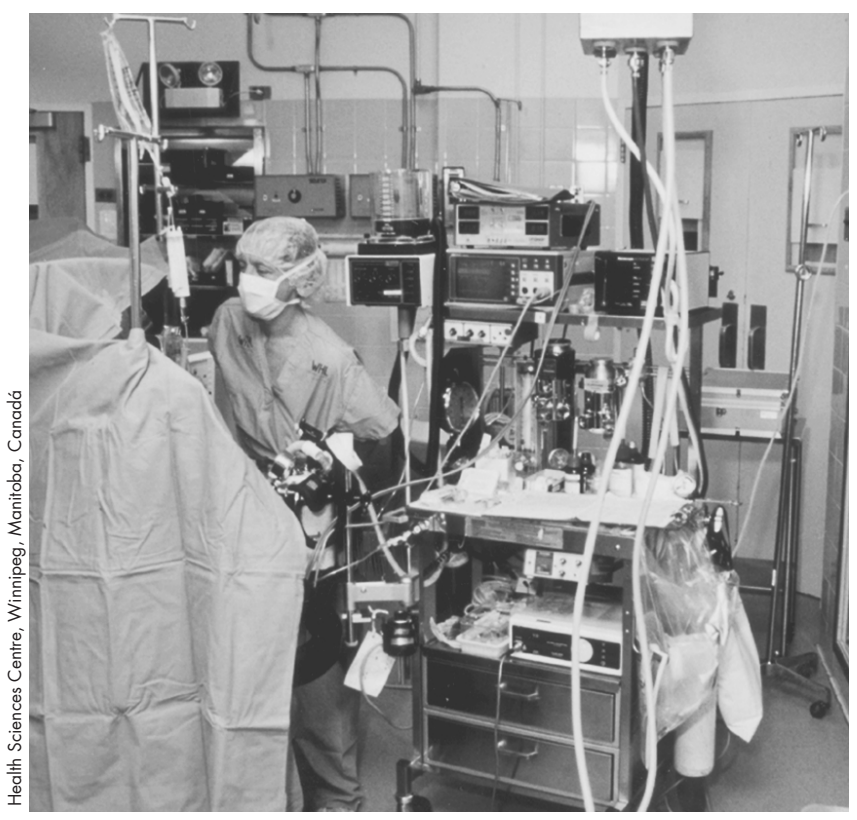

Tabla 97.2 - Niveles de ruido integrados: 1995.

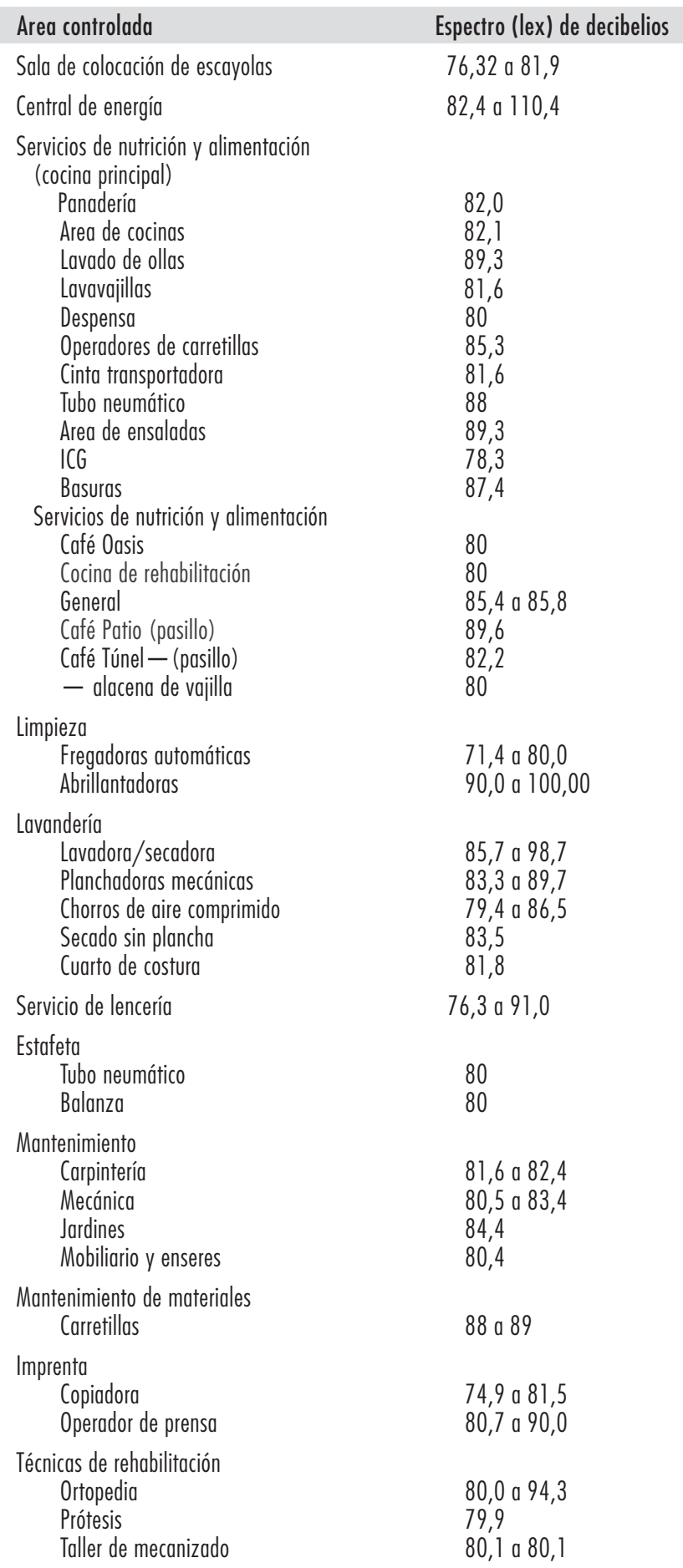

Observación: "Lex" es el nivel de ruido equivalente, o nivel de ruido constante, en decibelios que, si se mantuviese en un lugar de trabajo durante 8 horas, contendría la misma energía acústica.

hospitales puede suponer un riesgo de electrocución para pacientes y trabajadores por igual (véase la Figura 97.4). En los entornos cálidos y húmedos, la exposición al calor puede constituir un problema para las personas que trabajan en áreas como lavanderías, cocinas y cuartos de calderas. La radiación ionizante entraña un riesgo especial para el personal de radiología, 
tanto de diagnóstico (como rayos $\mathrm{X}$, angiografía, radiología dental y exploraciones mediante tomografía axial computadorizada), como terapéutica. El control de la exposición a estas radiaciones se efectúa rutinariamente en los servicios especializados, en los que se practica una supervisión rigurosa, trabajan técnicos altamente cualificados y se cuenta con equipo debidamente protegido y mantenido, pero puede constituir un problema cuando se utiliza equipo portátil en las salas de urgencias, unidades de cuidados intensivos y quirófanos. También puede constituir un riesgo para el personal auxiliar y de limpieza que trabaja en áreas potencialmente expuestas. En muchos lugares no se forma adecuadamente a los trabajadores para afrontar estos riesgos. La exposición a la radiación ionizante puede constituir asimismo un riesgo en las unidades de medicina nuclear diagnóstica y terapéutica, y en la preparación y administración de dosis de radiofármacos. En ciertos casos, no obstante, la exposición a la radiación sigue constituyendo un grave problema (véase, en este mismo capítulo, el artículo "La práctica de la salud y seguridad en el trabajo: la experiencia rusa").

En contraste con la idea generalizada de que los hospitales son lugares silenciosos, Yassi y cols. (1991) han comprobado la inusitada generalización de la pérdida de audición inducida por

Tabla 97.3 • Opciones ergonómicas para la reducción del ruido.

\begin{tabular}{|c|c|c|}
\hline Area de trabajo & Proceso & Opciones de control \\
\hline Central de energía & Area general & $\begin{array}{l}\text { Aislamiento de la fuente } \\
\text { Cabina acústica para el personal }\end{array}$ \\
\hline Dietética & Lavavaiillas & $\begin{array}{l}\text { Proceso automático } \\
\text { Uso de barreras y deflectores } \\
\text { del ruido } \\
\text { Reubicación }\end{array}$ \\
\hline Limpieza & Abrillantadora & Criterios de compras \\
\hline Lavandería & Secadora/lavadora & $\begin{array}{l}\text { Aislamiento y reducción de } \\
\text { las vibraciones } \\
\text { Uso de barreras y deflectores } \\
\text { del ruido } \\
\text { Reubicación } \\
\text { Materiales amortiguadores } \\
\text { Modificación de los chorros } \\
\text { de aire } \\
\text { Reubicación de las máquinas }\end{array}$ \\
\hline Estafeta & $\begin{array}{l}\text { Tubo neumático } \\
\text { Máquina de sellar }\end{array}$ & $\begin{array}{l}\text { Criterios de compras } \\
\text { Cerramiento }\end{array}$ \\
\hline Mantenimiento & Equipo diverso & $\begin{array}{l}\text { Criterios de compras } \\
\text { Mantenimiento adecuado } \\
\text { Reubicación } \\
\text { Materiales amortiguadores }\end{array}$ \\
\hline $\begin{array}{l}\text { Mantenimiento y trans- } \\
\text { porte de materiales/ } \\
\text { servicio de lencería }\end{array}$ & Carretillas & $\begin{array}{l}\text { Mantenimiento } \\
\text { Suelos lisos } \\
\text { Reducción de las vibraciones } \\
\text { Materiales amortiguadores }\end{array}$ \\
\hline Imprenta & $\begin{array}{l}\text { Operador de } \\
\text { prensa }\end{array}$ & $\begin{array}{l}\text { Mantenimiento } \\
\text { Criterios de compras } \\
\text { Cerramiento de la fuente } \\
\text { Reubicación de las máquinas } \\
\text { Barreras y deflectores del ruido }\end{array}$ \\
\hline $\begin{array}{l}\text { Técnicas de } \\
\text { rehabilitación }\end{array}$ & Ortopedia & $\begin{array}{l}\text { Criterios de compras } \\
\text { Materiales de absorción } \\
\text { del ruido } \\
\text { Barreras y deflectores del ruido }\end{array}$ \\
\hline
\end{tabular}

Figura 97.5 • La incorporación de los pacientes constituye un riesgo ergonómico en la mayoría de los hospitales.

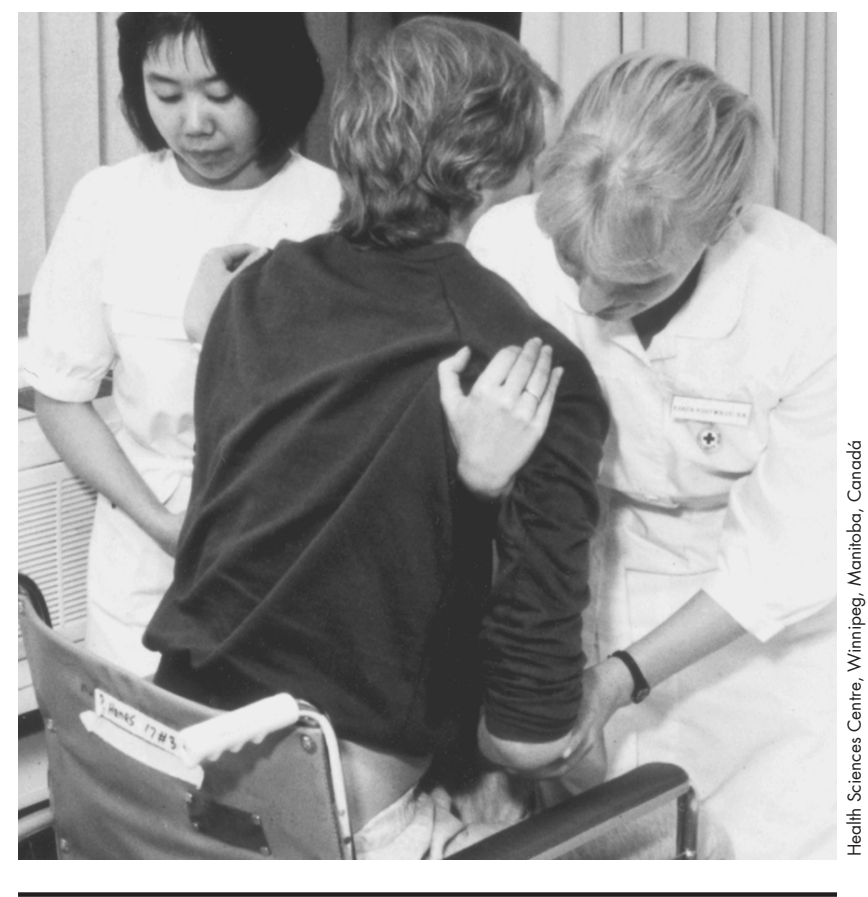

el ruido entre el personal de los hospitales (véase la Tabla 97.2). Tanto en los artículos "Control de los riesgos físicos en los centros sanitarios" y "Ergonomía del medio ambiente físico de trabajo" como en la Tabla 97.3 de este mismo capítulo se ofrecen algunos consejos útiles para el control de este riesgo.

Las lesiones más comunes y costosas que sufren los trabajadores sanitarios son, con mucho, las de columna vertebral. Enfermeras y auxiliares corren el mayor riesgo de sufrir lesiones musculosqueléticas, debido a los frecuentes esfuerzos que realizan para incorporar y trasladar a los pacientes. Yassi y

\section{Figura 97.6 - La pintura de zonas elevadas constituye uno de los riesgos ergonómicos característicos de los hospitales.}

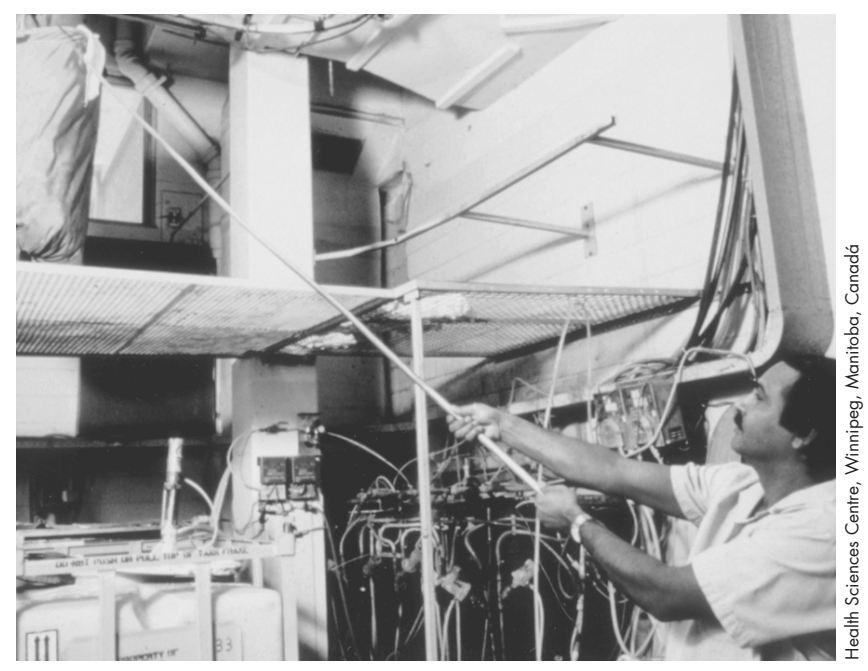




\section{Figura 97.7 • La colocación de escayolas implica la exposición a numerosos factores de presión ergonómica.}

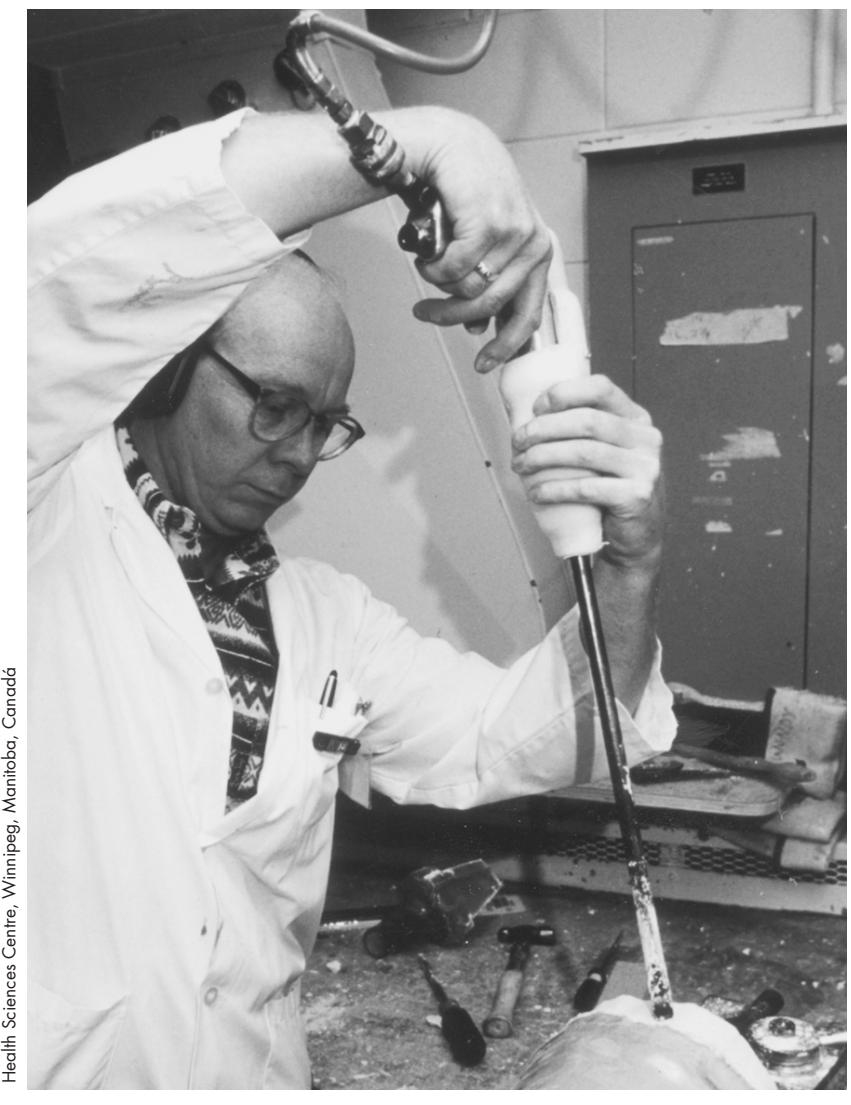

cols. (1995a) sintetizan la epidemiología de las lesiones de columna entre las enfermeras de un hospital. Sus hallazgos se corresponden con los datos conocidos en el ámbito internacional. Los hospitales se decantan en medida creciente por las medidas preventivas, que comprenden la formación del personal y el uso de dispositivos mecánicos para incorporar a los pacientes. En muchos de ellos se prestan, además, servicios avanzados de diagnóstico, terapéuticos y de rehabilitación que contribuyen a reducir la pérdida de horas de trabajo y los casos de discapacidad, constituyendo un eficaz ahorro (Yassi y cols. 1995b). La creciente importancia de la ergonomía hospitalaria justifica su inclusión en el presente capítulo. La cuestión específica de la prevención y atención de los dolores de espalda en el personal de enfermería, uno de los problemas más graves que afronta esta categoría de trabajadores sanitarios, también se aborda en este mismo capítulo, en el artículo "Prevención y gestión de los dolores de espalda en el personal de enfermería". En la Tabla 97.4, se indica el total de lesiones producidas durante un año.

En el examen de los problemas ergonómicos y de los trastornos musculosqueléticos, es preciso tener en cuenta que, si bien las personas que atienden personalmente a los pacientes suelen exponerse a los mayores riesgos (véase la Figura 97.5), muchos de los trabajadores auxiliares de los hospitales afrontan presiones ergonómicas similares (véanse las Figuras 97.6 y 97.7). Los problemas ergonómicos que afectan a los trabajadores de la lavandería de los hospitales son bien conocidos (Wands y Yassi 1993) (véanse las Figuras 97.8, 97.9, y 97.10) y son igualmente comunes entre los odontólogos, otorrinolaringólogos y cirujanos,
Figura 97.8 - El trabajo de lavandería del tipo que se ilustra en la foto puede producir lesiones por estrés repetitivo en las extremidades superiores.

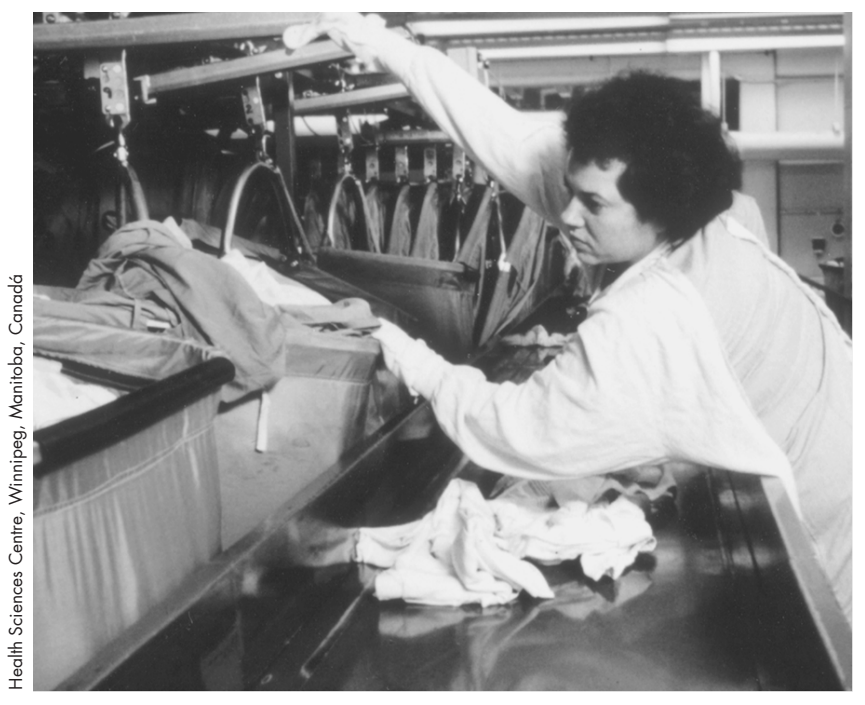

y muy especialmente entre los microcirujanos, tocólogos, ginecólogos y otros profesionales de la salud que deben trabajar en posturas forzadas.

\section{Problemas organizativos}

En el artículo "La tensión en el trabajo de asistencia sanitaria" se abordan algunos de los problemas organizativos que se suscitan en los hospitales y se sintetizan los principales hallazgos de Leppanen y Olkinuora (1987), que examinan diversos estudios suecos y finlandeses del estrés entre los trabajadores sanitarios. Los cambios que se suceden rápidamente en este sector han producido un sensible incremento de los síntomas de frustración,

Figura 97.9 - Esta parte del trabajo de lavandería obliga a permanecer en una postura forzada.

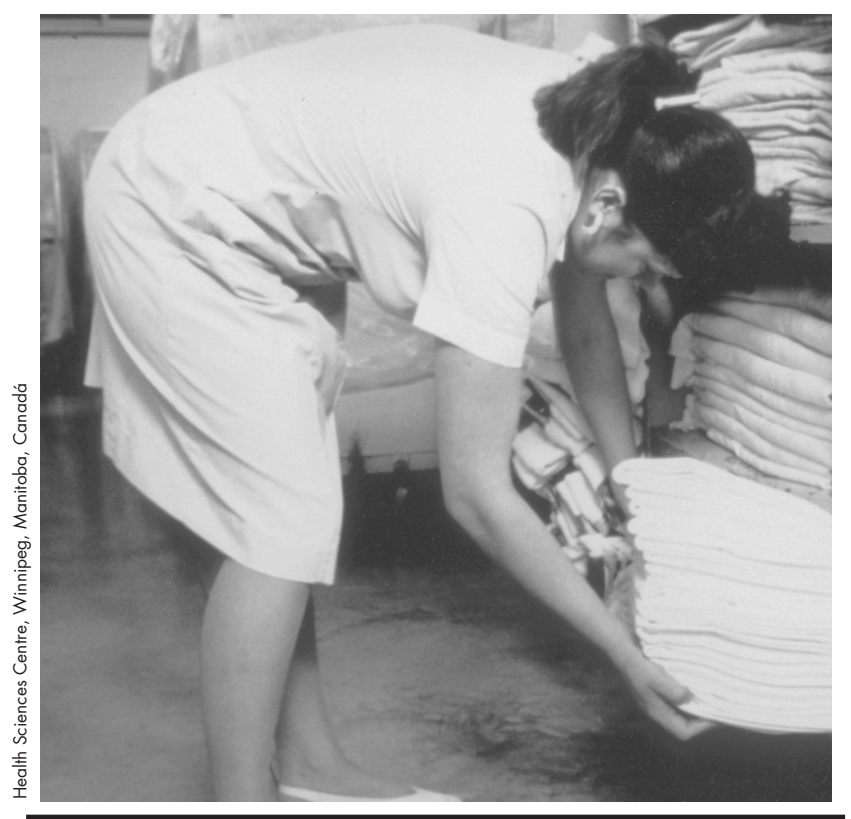


Figura 97.10 • Una instalación de lavandería mal diseñada puede producir tensión en la espalda.

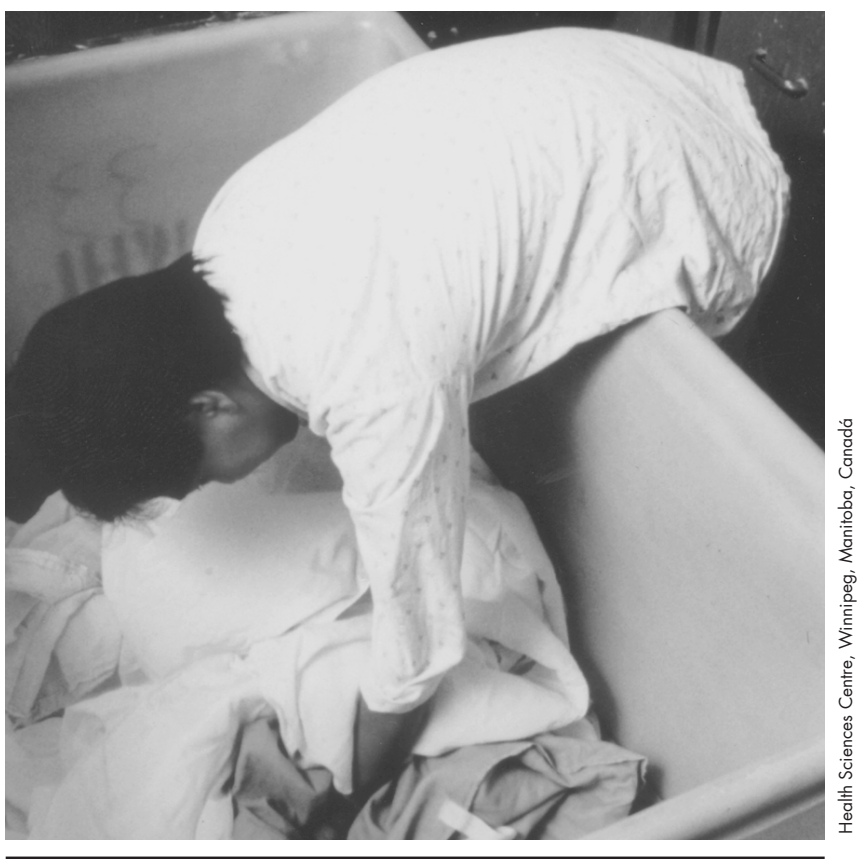

alienación y burnout entre los trabajadores sanitarios. A este problema se añade la creciente frecuencia del maltrato a los pacientes que se observa en muchos hospitales (Yassi 1994). En contra de la idea generalizada de que el problema psicosocial más agudo que agobia a los trabajadores sanitarios es su contacto con la agonía y la muerte, se hace cada vez más patente que la naturaleza misma del sector, con su estructura jerárquica, su falta de estabilidad en el puesto de trabajo y unas elevadas exigencias que no se corresponden con la dotación de recursos, es la causa de la serie de enfermedades relacionadas con el estrés que afecta a los trabajadores sanitarios.

\section{Naturaleza del sector de la asistencia sanitaria}

Stellman escribió en 1976: "Si alguna vez se ha preguntado cómo se puede trabajar con pacientes y conservar la salud, la respuesta es que no se puede" (Stellman 1976). Aunque esta respuesta no ha variado, los riesgos potenciales han evolucionado ostensiblemente, desde las enfermedades infecciosas, las lesiones de columna vertebral y de otro tipo, y los síntomas de burnout, hasta una extensa serie de exposiciones a factores ambientales, físicos y psicosociales potencialmente tóxicos. La actividad de los trabajadores sanitarios sigue estando escasamente vigilada y escasamente regulada. Sin embargo, se han logrado progresos en la prevención de los riesgos para la salud y la seguridad en los hospitales. Una subcomisión de la Comisión Internacional de Medicina del Trabajo (CIMT) se ocupa de este problema, y se han publicado las actas de varias conferencias internacionales que aportan información de utilidad (Hagberg y cols. 1995). En Estados Unidos, tanto los Centros de Control y Prevención de Enfermedades como el National Institute for Occupational Safety and Health (NIOSH) han formulado recomendaciones para la solución de muchos de los problemas del sector de la asistencia sanitaria que se examinan en el presente artículo (véase, por ejemplo, NIOSH 1988). El volumen de la literatura dedicada a las cuestiones de la salud y la seguridad ha crecido rápidamente y se han publicado algunas interesantes reseñas de la situación de la salud y la seguridad en el sector de la asistencia sanitaria en Estados Unidos (por ejemplo, Charney 1994; Lewy 1990; Sterling 1994). Se hacen cada vez más evidentes tanto la necesidad de sistematizar la recogida, el análisis y el estudio de datos relativos a los riesgos presentes en el sector de la asistencia sanitaria como la conveniencia de encargar esa labor a unos equipos multidisciplinarios de higiene industrial.

Al estudiar la salud y seguridad en el trabajo en el sector de la asistencia sanitaria, es imprescindible valorar los profundos cambios que se están produciendo en su seno. La "reforma" de la asistencia sanitaria que se desarrolla en la mayor parte de las naciones industrializadas está provocando unos niveles considerables de inestabilidad e incertidumbre entre los trabajadores del sector, a quienes se pide que asimilen los veloces cambios que experimentan sus tareas y que, a menudos, van acompañados de una mayor exposición al riesgo. La transformación del sistema de asistencia sanitaria se ha visto impulsada, en parte, por los avances de la ciencia y la medicina, el desarrollo de procesos tecnológicos revolucionarios y la adquisición de nuevas cualificaciones. Sin embargo, la transformación responde también - quizás, en mayor medida - a unos conceptos de eficacia en función del coste y eficiencia organizativa, en los que nociones como los "recortes" y el "control de costes" parecen convertirse con frecuencia en objetivos prioritarios. En varios países se implantan nuevos incentivos en distintos niveles de la organización. La subcontratación de trabajos y servicios que tradicionalmente producía una numerosa plantilla de trabajadores fijos se está convirtiendo rápidamente en la norma. Se asegura que esta subcontratación de trabajos ha contribuido a que los políticos y gestores del sistema sanitario alcancen su objetivo a largo plazo de hacer que la prestación de la asistencia sanitaria sea, a la vez, más flexible y controlable. A su vez, estos cambios han contribuido a modificar unas funciones en otro tiempo bien perfiladas y a erosionar las tradicionales relaciones jerárquicas entre planificadores, administradores, médicos y otros profesionales de la salud. La aparición de empresas privadas de asistencia sanitaria en muchos países ha generado una nueva dinámica en la financiación y gestión de los servicios de salud. En muchos casos, los trabajadores sanitarios se han visto forzados a aceptar un nuevo marco de relaciones laborales caracterizado por la degradación de unos servicios que ahora realizan trabajadores menos cualificados y peor pagados, la reducción de plantillas y una reorganización del trabajo que se ha traducido en la implantación de la jornada partida y del trabajo a tiempo parcial. Al mismo tiempo, se ha venido produciendo un crecimiento lento, pero constante, del número de especialistas paramédicos, como auxiliares sanitarios, enfermeras no tituladas, comadronas y trabajadores sociales psiquiátricos, que cobran menos que el personal al que reemplazan. (El coste final, tanto social como sanitario, para los trabajadores sanitarios y para el público - pacientes y contribuyentes - no se ha determinado aún.)

Una tendencia creciente en Estados Unidos que también empieza a manifestarse en el Reino Unido y los países del norte de Europa es la "asistencia gestionada", basada en la creación de entidades financiadas mediante las cotizaciones por afiliado que abonan las compañías de seguros o los organismos públicos para costear la prestación de un extenso repertorio de servicios de salud a una masa de afiliados voluntarios. El objetivo es reducir los costes de la asistencia sanitaria "gestionando" el proceso, utilizando los trámites administrativos y la asistencia sanitaria primaria como "filtros" que permiten reducir los elevados costes de hospitalización, la remisión a especialistas que cobran honorarios elevados y la aplicación de técnicas de diagnóstico costosas; y rehusando dar cobertura a nuevas modalidades de costoso tratamiento "experimental". La creciente aceptación de estos regímenes de asistencia gestionada, impulsada por una 
Tabla 97.4 • Número total de lesiones, mecanismo y naturaleza de las mismas (un hospital, todos los departamentos), 1 de abril de 1994 a 31 de marzo de 1995.

\begin{tabular}{|c|c|c|c|c|c|c|c|c|c|c|c|c|c|}
\hline \multicolumn{13}{|c|}{ Naturaleza de la lesión sufrida } & \multirow[t]{2}{*}{ Total } \\
\hline $\begin{array}{l}\text { Mecanismo } \\
\text { de la lesión }\end{array}$ & $\begin{array}{l}\text { Sangre/ } \\
\text { líquido } \\
\text { corporal }\end{array}$ & $\begin{array}{l}\text { Corte/ } \\
\text { lacera- } \\
\text { ción } 1\end{array}$ & $\begin{array}{l}\text { Magu- } \\
\text { lladura/ } \\
\text { abrasión/ } \\
\text { aplasta- } \\
\text { miento }\end{array}$ & $\begin{array}{l}\text { Luxa- } \\
\text { ción/ } \\
\text { dis- } \\
\text { tensión }\end{array}$ & $\begin{array}{l}\text { Frac- } \\
\text { tura/ } \\
\text { disloca- } \\
\text { ción }\end{array}$ & $\begin{array}{l}\text { Quema- } \\
\text { dura/ } \\
\text { escalda- } \\
\text { dura/ } \\
\text { descarga }\end{array}$ & $\begin{array}{l}\text { Mor- } \\
\text { disco } \\
\text { humano }\end{array}$ & $\begin{array}{l}\text { Vidrios } \\
\text { rotos }\end{array}$ & $\begin{array}{l}\text { Cefalea/ } \\
\text { dificul- } \\
\text { tades } \\
\text { respira- } \\
\text { torias }\end{array}$ & $\begin{array}{l}\text { Condi- } \\
\text { ciones } \\
\text { de tra- } \\
\text { bajo }{ }^{2}\end{array}$ & Otras $^{3}$ & $\begin{array}{l}\text { Desco- } \\
\text { nocida }\end{array}$ & \\
\hline \multicolumn{14}{|l|}{ Esfuerzo } \\
\hline $\begin{array}{l}\text { Traslado de } \\
\text { un paciente }\end{array}$ & & & & 105 & & & & & & & & & 105 \\
\hline $\begin{array}{l}\text { Incorporación de } \\
\text { un paciente }\end{array}$ & & & & 83 & & & & & & & & & 83 \\
\hline $\begin{array}{l}\text { Asistencia a un } \\
\text { paciente }\end{array}$ & & & & 4 & & & & & & & & & 4 \\
\hline $\begin{array}{l}\text { Volteo de un } \\
\text { paciente }\end{array}$ & & & & 27 & & & & & & & & & 27 \\
\hline Caída por rotura & & & & 28 & & & & & & & & & 28 \\
\hline $\begin{array}{l}\text { Empujar } \\
\text { equipo }\end{array}$ & & & 1 & 25 & & & & & & & & & 26 \\
\hline $\begin{array}{l}\text { Izar } \\
\text { equipo }\end{array}$ & & 1 & & 52 & 1 & & & & & & & & 54 \\
\hline $\begin{array}{l}\text { Arrastrar } \\
\text { equipo }\end{array}$ & & & & 14 & & & & & & & & & 14 \\
\hline $\begin{array}{l}\text { Combinación } \\
\text { de equipo/ } \\
\text { paciente }\end{array}$ & & & & 38 & & & & & & & & & 38 \\
\hline Otros & & & & 74 & & & & & & & & & 74 \\
\hline Caída & & 3 & 45 & 67 & 3 & & & 1 & & & & & 119 \\
\hline $\begin{array}{l}\text { Golpe/tropiezo/ } \\
\text { empujón }\end{array}$ & & 66 & 76 & 5 & & & & 2 & & 2 & 1 & & 152 \\
\hline $\begin{array}{l}\text { Atrapamiento en/ } \\
\text { debajo de/ } \\
\text { entre }\end{array}$ & & 13 & 68 & 8 & 1 & & & 1 & & & & & 91 \\
\hline $\begin{array}{l}\text { Exposición a sustan- } \\
\text { cias peligrosas }\end{array}$ & & 3 & 1 & & & 4 & & & 19 & 16 & 12 & & 55 \\
\hline \multicolumn{14}{|l|}{ Agresiones al personal } \\
\hline $\begin{array}{l}\text { Pacientes } \\
\text { Visitantes } \\
\text { Otros }\end{array}$ & 16 & 11 & 51 & 28 & & & 8 & 3 & & 1 & 2 & & $\begin{array}{r}120 \\
0 \\
0\end{array}$ \\
\hline $\begin{array}{l}\text { Salpicaduras/vertidos } \\
\text { (sangre/liquidos } \\
\text { corporales) }\end{array}$ & 80 & & & & & & & & & & 1 & & 81 \\
\hline $\begin{array}{l}\text { Reacción medicamen- } \\
\text { tosa/inumnológica }\end{array}$ & & & & & & & & & & & 2 & & 2 \\
\hline $\begin{array}{l}\text { Exposición a enferme- } \\
\text { dades infecciosas }\end{array}$ & & & & & & & & & & 5 & 5 & & 10 \\
\hline Agujas & 159 & 22 & & & & & & & & & & & 181 \\
\hline Cortes con bisturíes & 34 & 14 & & & & & & & & & & & 48 \\
\hline 0 tros 5 & & 3 & 1 & & & 29 & & & & 1 & 6 & & 40 \\
\hline $\begin{array}{l}\text { Desconocido } \\
\text { (no se ha infor- } \\
\text { mado de accidente) }\end{array}$ & & & & & & & & & & & & 8 & 8 \\
\hline Total & 289 & 136 & 243 & 558 & 5 & 33 & 8 & 7 & 19 & 25 & 29 & 8 & 1.360 \\
\hline
\end{tabular}


agresiva campaña de promoción entre los particulares y las organizaciones patrocinadas por gobiernos y empresarios, hacen difícil que los médicos y proveedores de asistencia sanitaria en general se resistan a participar. Para los que se incorporan al sistema existe una serie de incentivos y desincentivos financieros que influyen en sus valoraciones y condicionan su comportamiento. La pérdida de su tradicional autonomía ha sido especialmente dolorosa para muchos médicos y ha contribuido a modificar profundamente sus relaciones con otros profesionales de la asistencia sanitaria.

Los cambios que se suceden rápidamente en la organización del sector de la asistencia sanitaria influyen profundamente, de forma directa e indirecta, en la salud y la seguridad de sus trabajadores. Estos cambios afectan tanto a la formación, asignación y supervisión de los trabajadores como a la medida en que se abordan los problemas que afectan a su salud y seguridad. Esta circunstancia se debe tener presente en el examen que sigue de los riesgos para la salud de los trabajadores sanitarios. Por último, aunque aparentemente no exista una relación directa con el contenido del presente capítulo, es preciso examinar las repercusiones del bienestar y del rendimiento de estos trabajadores en la calidad y eficacia de los servicios que prestan a sus pacientes.

\section{- SERVICIOS SOCIALES}

Susan Nobel

\section{Panorámica de la función de los trabajadores sociales}

Los trabajadores sociales trabajan en entornos muy variados y con personas de condición muy diversa. Prestan sus servicios en centros sanitarios comunitarios, hospitales, residencias sanitarias, programas de desintoxicación de drogadictos, escuelas, organismos de atención a la familia, organizaciones de adopción y acogida, centros de cuidados de día e instituciones públicas y privadas de atención a la infancia. Los trabajadores sociales suelen acudir a las viviendas para inspeccionar sus condiciones y entrevistarse con los vecinos. Estos profesionales trabajan para sindicatos, empresas privadas, organizaciones humanitarias internacionales, asociaciones pro derechos humanos, servicios penitenciarios y de libertad condicional, organismos de atención a los ancianos, organizaciones ciudadanas, universidades y centros de enseñanza superior. Aumenta su presencia en la escena política. Muchos trabajadores sociales ejercen como psicoterapeutas a jornada parcial o completa. Su objetivo consiste en "mejorar el funcionamiento de la sociedad prestando asistencia psicológica y material a los necesitados" (Payne y Firth-Cozens 1987).

Normalmente, los trabajadores sociales en posesión de un doctorado desarrollan su labor en los campos de la organización comunitaria, la planificación, la investigación, la docencia y otras áreas interdisciplinarias. Los licenciados en trabajo social, por su parte, suelen decantarse más por la asistencia pública y la atención de los ancianos, de los deficientes mentales y, en general, de los individuos con problemas de desarrollo. Los trabajadores sociales que han realizado cursos de posgraduados enfocan su actividad en mayor medida hacia la sanidad mental, el trabajo en el medio laboral y la medicina clínica (Hopps y Collins 1995).

\section{Peligros y cautelas}

\section{Estrés}

La investigación demuestra que en la aparición del estrés en el trabajo contribuyen en distinta medida la inseguridad en el puesto de trabajo, la retribución insuficiente, la sobrecarga de trabajo y la falta de autonomía. Todos estos elementos están presentes en la vida profesional de los trabajadores sociales de finales del decenio de 1990. Está generalmente aceptado que el estrés suele contribuir a la aparición de enfermedades. Según un estudio, entre el $50 \%$ y el $70 \%$ de todos los síntomas comunicados por los trabajadores sociales se asocian al estrés (Graham, Hawkins y Blau 1983).

A medida que los trabajadores sociales han accedido a la condición de empresarios y a los puestos de dirección, y el ejercicio privado de esta profesión se ha incrementado, se han hecho más vulnerables a las demandas judiciales por negligencia profesional en países como Estados Unidos, en los que se admite este tipo de responsabilidad, lo cual contribuye a incrementar el estrés. Además, los trabajadores sociales se vienen ocupando de forma creciente de cuestiones bioéticas, que afectan a la vida y la muerte, los protocolos de investigación, el trasplante de órganos y la asignación de recursos. A menudo se echa en falta un apoyo suficiente al esfuerzo psicológico que la solución de estos problemas exige de ellos. La presión de una carga de trabajo en aumento y la mayor dependencia de la tecnología contribuyen a reducir el contacto humano, fenómeno que, aunque común a la mayoría de las profesiones, resulta especialmente doloroso para unos trabajadores que, al elegir profesión, han optado por la relación directa con las personas.

En muchos países se ha producido un alejamiento de los programas financiados con fondos públicos, tendencia que afecta directamente a los trabajadores sociales. La tendencia actual no es favorable a los valores y objetivos generalmente compartidos por los trabajadores sociales: pleno empleo, prestaciones sociales a los menos favorecidos e igualdad de oportunidades para la promoción personal. La reducción del gasto en los programas de asistencia a los pobres ha producido lo que ha dado en llamarse un "estado del bienestar invertido" (Walz, Askerooth y Lynch 1983). Esta situación ha producido, entre otros resultados, un incremento del estrés entre los trabajadores sociales. A medida que los recursos disminuyen, la demanda de servicios aumenta; y al tiempo que el estado de bienestar se debilita, los sentimientos de frustración e ira se recrudecen, tanto entre los usuarios como entre los propios trabajadores sociales. Para ellos, se puede producir un conflicto entre la adhesión a sus valores profesionales y el respeto de las normas legales. Por ejemplo, en el código ético de la U.S. National Association of Social Workers se exige guardar con los usuarios una reserva que únicamente puede quebrantarse por "motivos profesionales apremiantes". Además, los trabajadores sociales deben promover el acceso a los recursos con objeto de "alcanzar o defender la justicia social". Esta situación ambigua puede resultar problemática para los profesionales y ser causa de estrés.

\section{Violencia}

La violencia en el trabajo preocupa enormemente a los profesionales. Los trabajadores sociales, por su vocación de solucionar problemas en el ámbito más personal, son particularmente vulnerables a este riesgo. En efecto, trabajan con unas emociones poderosas en las que se concentra la relación con los usuarios. Un corolario de esta situación suele ser que el usuario se ve imposibilitado de solucionar sus problemas y acude a la ayuda de los trabajadores sociales. A veces, el contacto con estos profesionales es involuntario, como ocurre, por ejemplo, en los programas de atención a la infancia en que se evalúan las posibilidades de los padres. Los patrones culturales también pueden obstaculizar la aceptación de ayuda de personas pertenecientes a otro entorno cultural, del otro sexo (la mayoría de los trabajadores sociales son mujeres) o ajenos al entorno familiar. A veces existen barreras lingüísticas que obligan al uso de intérpretes, circunstancia que 
puede dificultar o, incluso, imposibilitar totalmente la relación y arrojar una imagen sesgada de la situación. Ciertamente, las barreras lingüísticas reducen la fluidez de las comunicaciones que resulta imprescindibles en este campo. Por otra parte, los trabajadores sociales desarrollan a veces su labor en barrios con un elevado índice de delincuencia, y también en ocasiones se ven obligado a realizar trabajo "de campo" con usuarios que viven en esas zonas.

El nivel de aplicación de medidas de seguridad en los servicios de asistencia social es desigual y, en términos generales, insuficiente. La prevención de la violencia en el lugar de trabajo se basa en la formación, los métodos de gestión y la modificación del entorno físico, de los sistemas de comunicación, o de ambos a la vez (Breakwell 1989).

Griffin (1995) sugiere el siguiente programa de seguridad:

- formación en el ejercicio constructivo de la autoridad

- intervención en las situaciones de crisis

- seguridad en la oficina y en el exterior

- diseño de las instalaciones

- técnicas generales de prevención

- medios de prevención de la violencia.

\section{Otros riesgos}

Dado que los trabajadores sociales prestan sus servicios en unos entornos tan variados, se encuentran expuestos en su lugar de trabajo a muchos de los peligros que se examinan en otros capítulos de esta Enciclopedia. Conviene recordar, no obstante, que entre esos peligros figuran los edificios mal ventilados o con una atmósfera contaminada ("edificios enfermos") y el riesgo de infección. Cuando la financiación es escasa, el mantenimiento de las instalaciones se resiente y el riesgo aumenta. El elevado porcentaje de trabajadores sociales que presta sus servicios en hospitales y centros de asistencia ambulatoria incrementa el riesgo de exposición a infecciones. En efecto, los trabajadores sociales tienen contacto con pacientes de hepatitis, tuberculosis y otras enfermedades altamente contagiosas, además de con personas portadoras del virus de la inmunodeficiencia humana (VIH). Para responder a los riesgos que afectan a todos los trabajadores de la salud, es preciso mejorar la formación y las medidas de control de las infecciones, como ya se ha hecho por imperativo legal en muchos países. Sin embargo, el riesgo persiste.

Es evidente que algunos de los problemas que afrontan los trabajadores sociales son inseparables de una profesión orientada a mitigar el sufrimiento humano y a la que afecta en tan gran medida el clima sociopolítico. En las postrimerías del siglo $\mathrm{XX}$, el estado del trabajo social se puede describir como fluido. Los valores, ideales y recompensas de esta profesión forman igualmente el núcleo de los peligros que entraña para quienes la ejercen.

\section{- TRABAJADORES DE LA ATENCION DOMICILIARIA: LA EXPERIENCIA DE NUEVA YORK}

\section{Lenora Colbert}

El empleo en gran escala de trabajadores de atención domiciliaria se inició en la ciudad de Nueva York en 1975 en respuesta al crecimiento de la población de enfermos crónicos y de edad avanzada, como alternativa a los costosos servicios de las residencias, en muchas de las cuales había largas listas de ese tipo de enfermos en espera de ingresar. Por otra parte, el nuevo sistema permitía una atención más personalizada en una época en que las residencias asistidas se valoraban como instituciones despersonalizadas que prestaban una asistencia deficiente. La atención domiciliaria ofrecía igualmente la oportunidad de un primer empleo a trabajadores no cualificados, principalmente mujeres, muchas de las cuales estaban acogidas a la asistencia social.

Inicialmente, estos trabajadores eran empleados del Departamento de Recursos Humanos del municipio; sin embargo, este servicio se "privatizó" en 1980 y, en lo sucesivo, los trabajadores fueron seleccionados, formados y contratados por instituciones sociales sin ánimo de lucro de ámbito comunitario y por las organizaciones tradicionalmente dedicadas a la prestación de asistencia sanitaria, como los hospitales homologados por el Estado de Nueva York para la prestación de servicios de atención domiciliaria. Existen varias categorías de personal: amas de casa, prestadores de cuidados personales, asistentes sanitarios, prestadores de cuidados domiciliarios y personal de limpieza, en función de su nivel de cualificación y del tipo de servicio que prestan. El servicio que se ofrece a cada usuario depende de la evaluación de sus necesidades y de su estado de salud, realizada por profesionales titulados de la sanidad (médicos, enfermeras y trabajadores sociales).

\section{Trabajadores de la atención domiciliaria}

Las características de los trabajadores de la atención domiciliaria de Nueva York les otorgan un perfil único. Una reciente encuesta realizada por Donovan, Kurzman y Rotman (1993) puso de relieve que el $94 \%$ eran mujeres, con una edad media de 45 años. Alrededor del $56 \%$ de esta fuerza de trabajo había nacido fuera del territorio continental de Estados Unidos, y cerca del $51 \%$ había abandonado el sistema escolar sin terminar el bachillerato. Unicamente el $33 \%$ de estos trabajadores se identificaron como casados, el $33 \%$ se encontraban separados o divorciados, y el $26 \%$ estaban solteros, si bien el $86 \%$ del total tenían hijos, de cuyo porcentaje había un $44 \%$ con hijos menores de 18 años de edad. Según la encuesta citada, el $63 \%$ de los trabajadores convivía con sus hijos, al tiempo de que el $26 \%$ vivía con su cónyuge.

En 1991, los ingresos medios familiares de este grupo se situaban en 12.000 dólares anuales. En el 81 \% de las familias, el prestador de atención domiciliaria era el principal soporte económico de la familia. En 1996, el salario anual de los trabajadores de la atención domiciliaria empleados a jornada completa oscilaba entre 16.000 y 28.000 dólares; los trabajadores contratados a tiempo parcial ganaban menos.

Este bajo nivel de ingresos produce serios problemas económicos a las personas encuestadas: el $56 \%$ confesaba no poder costearse una vivienda adecuada; el $61 \%$ se manifestaba incapaz de renovar los muebles y enseres domésticos; el $35 \%$ se quejaba de no tener dinero suficiente para comprar todos los alimentos que precisaba la familia; el $36 \%$ no disfrutaba de la cobertura de Medicare ni podía costearse los servicios médicos que precisaba. Colectivamente, su situación financiera empeorará irremediablemente a medida que los recortes del gasto público fuerce a reducir la cantidad y calidad de los servicios de atención domiciliaria que se prestan.

\section{Servicios de atención domiciliaria}

Los servicios prestados por los trabajadores de la atención domiciliaria son una función de las necesidades de los usuarios que atienden. Los aquejados de discapacidades más graves precisan ayuda en las "actividades básicas de la vida cotidiana" (esto es, para lavarse, vestirse, ir al cuarto de baño, acostarse o sentarse y levantarse de la cama o de los asientos) y para tomar el alimento. Los que disfrutan de un mayor nivel de capacidad funcional 


\section{Estudio de un caso: Violencia en el trabajo sanitario}

Un paciente psicótico, al que no se conocían tendencias agresivas, había sido ingresado por la fuerza en un gran hospital psiquiátrico situado en los alrededores de cierta ciudad. Al cabo de unos días, el paciente escapó de la sala de seguridad en que estaba internado y sus familiares comunicaron a la administración del hospital que había regresado a su hogar. Siguiendo el procedimiento establecido, acudieron tres enfermeros en una ambulancia para volverle a conducir al centro sanitario. Según la costumbre, en el trayecto de ida se detuvieron para recoger a un policía de escolta. Al llegar al domicilio, el policía permaneció en el exterior, listo para intervenir si se producía un incidente violento. Al penetrar los enfermeros en la casa, los familiares del paciente les informaron de que éste permanecía sentado en una habitación de la primera planta. Cuando se aproximaron a él y le pidieron amistosamente que los acompañase al hospital para continuar el tratamiento, el hombre sacó un cuchillo de cocina que tenía escondido. Uno de los enfermeros sufrió una puñalada en el pecho; otro recibió varios cortes en la espalda y, el tercero quedó con diversas heridas en un brazo y en la mano. Aunque salvaron la vida, los enfermeros tuvieron que ser hospitalizados. Al ver al policía entrar en la habitación, el paciente entregó el cuchillo sin ofrecer resistencia.

Daniel Murphy

precisan ayuda en las "actividades mecánicas de la vida cotidiana", que comprenden las labores domésticas (limpiar, hacer las camas, lavar la vajilla, etcétera), hacer la compra, preparar y servir las comidas, lavar y planchar, uso del transporte público o privado y administración financiera. Los trabajadores de la atención domiciliaria pueden poner inyecciones, administrar medicamentos y aplicar tratamientos como la gimnasia pasiva y los masajes recetados por el médico del usuario. Uno de los servicios más valorados es la compañía y la ayuda para participar en actividades recreativas.

La dificultad de la labor de los trabajadores de la atención domiciliaria es una función directa del entorno doméstico y, aparte del estado físico, del comportamiento de los usuarios y de los familiares que convivan con ellos. Muchos usuarios (y los propios trabajadores que les prestan atención domiciliaria) viven en barrios marginales con elevados índices de delincuencia, mal servicio de transporte público y unos servicios públicos deficientes. Muchos viven en edificios deteriorados, con escasa o nula dotación de ascensores, pasillos y escaleras oscuros y sucios, carentes de calefacción y agua caliente, instalaciones sanitarias degradadas y unos electrodomésticos en pésimas condiciones. El traslado hacia y desde las viviendas de los usuarios es lento e incómodo.

Muchos usuarios sufren discapacidades funcionales muy acentuadas y precisan ayuda en todo. La debilidad del sistema muscular y de coordinación motriz de los usuarios, unida a la pérdida de audición y de visión y a la incontinencia urinaria e intestinal que suelen sufrir, convierten el trabajo en una tarea pesada. Los trastornos mentales, como la demencia senil, la ansiedad y la depresión, así como los problemas de comunicación, la pérdida de memoria y las barreras lingüísticas contribuyen también a exacerbar las dificultades. Por último, las exigencias excesivas y el trato desconsiderado por parte de los usuarios y de sus familiares puede llegar a la violencia.

\section{Peligros en el trabajo de atención domiciliaria}

Entre los peligros que el personal de atención sanitaria afronta con mayor frecuencia en su trabajo destacan los siguientes:

- trabajo en solitario, sin ayuda

- falta de preparación y formación, y supervisión nula o escasa

- trabajo en viviendas deterioradas, situadas en vecindarios de alto riesgo

- dolores de espalda y lesiones musculosqueléticas producidas al incorporar a los usuarios

- actos de violencia en los domicilios y barrios

- enfermedades infecciosas (a veces, en efecto, no se informa al trabajador sanitario del estado de salud del usuario ni se les suministran los guantes, batas y mascarillas que precisan)

- productos de limpieza y las sustancias químicas de uso doméstico, que con frecuencia están incorrectamente etiquetados y almacenados

- acoso sexual

- estrés en el trabajo.

El estrés es, probablemente, el riesgo más generalizado y se suele exacerbar debido a que el trabajador suele estar solo en la vivienda del usuario, con escasos medios para pedir ayuda si se presentan problemas. El estrés aumenta a medida que las medidas de contención del gasto se traducen en la reducción de las horas de servicio prestado a cada cliente.

\section{Estrategias preventivas}

Se han propuesto diversas estrategias destinadas a promover la salud y seguridad en el trabajo del personal de la atención domiciliaria y mejorar su situación:

- elaboración y promulgación de unas normas de prestación de la atención domiciliaria, acompañadas por una elevación de los niveles de educación y formación que haga posible que los trabajadores cumplan esas normas

- educación y formación en la identificación y evitación de los peligros derivados de la presencia de sustancias químicas y otros factores de riesgo en el domicilio

- formación en las técnicas de incorporación, traslado y ayuda física a los usuarios discapacitados en el contexto de la atención domiciliaria

- evaluación preliminar de las necesidades de los usuarios, complementadas por la inspección del domicilio, con objeto de descubrir y eliminar o controlar los peligros potenciales y de aportar el equipo necesario

- reuniones periódicas con los supervisores y otros trabajadores de la atención domiciliaria, con objeto de contrastar experiencias y recibir instrucciones. El vídeo puede constituir un medio auxiliar útil en la demostración de técnicas. Estas reuniones se pueden complementar con enlaces telefónicos que permitan a los trabajadores comunicarse entre sí con objeto de intercambiar información y aligerar su sensación de aislamiento

- creación, dentro de cada organismo, de una comisión de salud y seguridad encargada de examinar los accidentes y problemas relacionados con el trabajo y de adoptar las medidas preventivas adecuadas

- aplicación de un programa de asistencia a los trabajadores que canalice la prestación de ayuda para que los trabajadores superen sus propios problemas psicosociales, dentro y fuera del trabajo

La educación y formación se debe impartir durante la jornada de trabajo en un lugar y dentro de un horario convenientes para los trabajadores. Este esfuerzo se debe complementar mediante la distribución de material informativo - que, en su caso, debe ser plurilingüe - adaptado al bajo nivel educativo de la mayoría de los trabajadores. 


\section{LA PRACTICA DE LA SALUD Y SEGURIDAD EN EL TRABAJO: LA EXPERIENCIA RUSA}

\section{Valery P. Kaptsov y Lyudmila P. Korotich}

El trabajo de los profesionales de la medicina es de un gran valor social y, en estos últimos años, el apremiante problema de las condiciones de trabajo y del estado de salud de los trabajadores sanitarios ha sido objeto de amplios estudios. Sin embargo, este trabajo es de tal naturaleza que la adopción de medidas preventivas y de mejora no basta para eliminar ni reducir la fuente principal de peligros en el trabajo resultantes del contacto de médicos y otros trabajadores sanitarios con los pacientes. En este contexto, el problema de la prevención de las enfermedades profesionales es bastante complicado.

En no pocos casos, tanto el equipo médico y de diagnóstico como los métodos de tratamiento aplicados en las instituciones sanitarias puede perjudicar la salud de sus trabajadores, por lo que es preciso aplicar normas de higiene y medidas preventivas capaces de controlar los niveles de exposición a los factores de riesgo. Los estudios realizados en diversas instituciones sanitarias de Rusia han puesto de relieve que las condiciones de trabajo existentes en muchos centros no son óptimas y pueden contribuir al deterioro de la salud del personal médico y auxiliar e, incluso, facilitar el desarrollo de enfermedades profesionales.

Entre los factores físicos susceptibles de afectar gravemente la salud del personal sanitario de la Federación Rusa, la radiación ionizante es uno de los más importantes. En efecto, decenas de miles de trabajadores de la salud se exponen a la radiación ionizante en el trabajo. En el pasado se promulgaron leyes especiales tendentes a limitar los niveles de radiación al que podían exponerse los especialistas durante períodos de tiempo prolongados sin riesgo para la salud. En tiempos recientes se ha ampliado el campo de aplicación de los métodos de control de los rayos $\mathrm{X}$, que actualmente abarca no sólo a los radiólogos, sino también a los cirujanos, anestesistas, traumatólogos, especialistas en rehabilitación y personal de nivel medio. Los niveles de radiación en el lugar de trabajo y las dosis de rayos $\mathrm{X}$ recibidas por estas personas pueden ser, incluso, mayores que las dosis que reciben los radiólogos y los auxiliares de laboratorio de radiología.

El equipo y los instrumentos que emiten radiación no ionizante y ultrasonidos se han generalizado igualmente en la medicina moderna. Puesto que muchos métodos fisioterápicos se aplican, precisamente, en virtud de los beneficios terapéuticos del tratamiento, esos mismos efectos biológicos pueden resultar peligrosos para quienes los administran. Los usuarios de instrumentos y máquinas generadores de radiación no ionizante se quejan con frecuencia de trastornos funcionales de los sistemas nervioso y cardiovascular.

El estudio de las condiciones de trabajo reinantes en los centros en que se utilizan ecografías para el diagnóstico y tratamiento ha puesto de manifiesto que el personal se exponía durante el 85 al $95 \%$ de la jornada de trabajo a niveles de ultrasonidos de elevada frecuencia y baja intensidad comparables a las exposiciones experimentadas por los operarios de la defectoscopia ultrasónica industrial. Estas personas acusaban deficiencias del sistema neurovascular periférico del tipo del síndrome angiodistónico, la polineuritis vegetativa, la disfunción vascular, etcétera.

El ruido no suele citarse como un factor grave de riesgo profesional entre los trabajadores rusos de la asistencia sanitaria, excepto en los centros odontológicos. Si se emplea un torno de alta velocidad (entre 200.000 y 400.000 revoluciones por minuto), la energía máxima del sonido desciende hasta una frecuencia de 800 herzios. A $30 \mathrm{~cm}$ de distancia del torno colocado en la boca del paciente, los niveles de ruido oscilan entre 80 y 90 dBA. Un tercio del espectro total de sonido se sitúa dentro de la franja más nociva para el oído (esto es, entre 1.000 y 2.000 herzios).

Muchos focos de ruido concentrados en un mismo punto generan niveles que rebasan los límites tolerables. Con objeto de crear unas condiciones óptimas, se recomienda colocar fuera de los quirófanos las máquinas de suministro de anestesia, el equipo de respiración y las bombas de circulación artificial de la sangre.

En los servicios de cirugía, especialmente en los quirófanos, y en las unidades de rehabilitación y cuidados intensivos, así como en otras áreas críticas, se hace preciso mantener unos determinados niveles de temperatura, humedad y circulación del aire. El diseño óptimo de los centros sanitarios modernos y la instalación en los mismos de sistemas de ventilación y aire acondicionado crean un microclima favorable. Sin embargo, en las unidades quirúrgicas deficientemente diseñadas, el uso de ropas escasamente holgadas (como guantes, batas, gorros y mascarillas) y la exposición al calor irradiado por las lámparas y el resto del equipo hacen que muchos cirujanos y otros miembros de los equipos quirúrgicos experimenten sensaciones de "recalentamiento". Se seca el sudor de la frente del cirujano que se estanca en las cejas, para evitar que enturbie su visión o contamine las heridas quirúrgicas.

Como consecuencia de la generalización del tratamiento en cámaras hiperbáricas en la práctica médica, facultativos y enfermeras se ven ahora frecuentemente expuestos a presiones atmosféricas excesivas. En la mayoría de los casos, esta situación perjudica a los equipos médicos que realizan intervenciones quirúrgicas en este tipo de cámaras. Se cree que la exposición a presiones atmosféricas elevadas puede afectar desfavorablemente distintas funciones corporales, en dependencia del nivel de presión y del tiempo de exposición.

La postura en que se realiza el trabajo es igualmente importante para los médicos. Aunque realizan la mayor parte de las tareas de pie o sentados, algunas actividades les obligan a permanecer largo tiempo en posturas forzadas e incómodas. Esto es especialmente cierto en el caso de los odontólogos, otorrinolaringólogos, cirujanos (sobre todo, los especialistas en microcirugía), tocólogos, ginecólogos y fisioterapeutas. Se ha asociado el trabajo que obliga a permanecer largos períodos de pie en situación estática a las hemorroides y a la aparición de venas varicosas en las piernas.

La exposición continua, intermitente o casual a las sustancias químicas potencialmente peligrosas que se utilizan en los centros sanitarios también puede entrañar riesgos para el personal. Entre estas sustancias, se estima que los anestésicos inhalables son los más nocivos para la salud humana. En efecto, se pueden formar grandes concentraciones de esos gases, no sólo en los quirófanos y salas de parto, sino también en las áreas preoperatorias en que se administra la anestesia y en las salas de recuperación de los pacientes, que exhalan los gases al recuperarse de la anestesia. Los niveles de concentración son una función de la mezcla de gases que se suministre, del tipo de equipo utilizado y de la duración de la operación. Se ha podido establecer que las concentraciones de gases anestésicos en el campo respiratorio de los cirujanos y anestesistas presentes en los quirófanos alcanzan unos valores entre dos y catorce veces mayores que la concentración máxima admisible (CMA). La exposición a los efectos de los gases anestésicos se ha asociado al deterioro de la fertilidad de los anestesistas de ambos sexos y a la aparición de anomalías en los fetos tanto de las mujeres anestesistas como de las esposas de los anestesistas varones (véanse el capítulo El sistema 
reproductivo y el artículo "Gases anestésicos residuales" en este mismo capítulo).

En las áreas de tratamiento en que se administran numerosas inyecciones, la concentración de fármacos en el campo respiratorio de las enfermeras puede rebasar los límites admisibles. La exposición a los medicamentos suspendidos en el aire se puede producir al esterilizar jeringuillas, eliminar las burbujas de aire presentes en las mismas y al aplicar aerosoles.

Entre las sustancias químicas susceptibles de afectar la salud del personal sanitario se encuentran el hexaclorofeno (posible causa de efectos teratogénicos), el formaldehído (sustancia irritante, sensibilizadora y cancerígena), el óxido de etileno (con efectos tóxicos, mutágenos y cancerígenos), los antibióticos capaces de producir alergias e inhibir las respuestas inmunológicas, las vitaminas y las hormonas. Existe asimismo un riesgo de exposición a los insecticidas y a las sustancias químicas industriales que se utilizan en el trabajo de mantenimiento y limpieza.

Muchos fármacos utilizados en el tratamiento del cáncer son, en sí mismo, agentes mutágenos y cancerígenos. Se han puesto en práctica diversos programas especiales de formación destinados a evitar que los trabajadores que participan en la preparación y administración de dichos fármacos se expongan a estos agentes citotóxicos.

Una de las dimensiones del trabajo de muchos especialistas sanitarios está constituida por el contacto con los pacientes infectados. Toda enfermedad infecciosa contraida como consecuencia de tal contacto se considera de origen profesional. La hepatitis viral se ha revelado como la más peligrosa para el personal. Se ha informado de casos de contagio de hepatitis vírica de los ayudantes de laboratorio (al examinar muestras de sangre), los trabajadores de los servicios de hemodiálisis, anatomopatólogos, cirujanos, anestesistas y otros especialistas que tienen contacto directo con la sangre de los pacientes infectados (véase, en este mismo capítulo, el artículo "Prevención de la transmisión profesional de agentes patógenos en sangre").

No parece haberse producido últimamente ninguna mejora en la situación de salud de los trabajadores sanitarios de la Federación Rusa. El porcentaje de casos de incapacidad temporal de origen profesional ha seguido oscilando entre el 80 y el $96 \%$ entre los médicos empleados, y entre el 65 y el $75 \%$ entre los trabajadores sanitarios de nivel medio. Aunque este porcentaje de absentismo es muy elevado, es preciso tener en cuenta que el autotratamiento y el tratamiento informal no comunicado están muy generalizados entre los trabajadores sanitarios, lo que supone que muchos casos no se reflejen en las estadísticas oficiales. Así lo ha confirmado una encuesta realizada entre una muestra de médicos, en la que el $40 \%$ de los entrevistados reconocieron que enfermaban una o más veces al año, aunque no acudían a un médico en ejercicio en busca de asistencia ni presentaban parte de enfermedad. Estos datos se vieron corroborados por una serie de exploraciones médicas en las que se detectaron 127,35 casos de discapacidad por cada 100 trabajadores explorados.

La morbilidad también se incrementa con la edad. En estas exploraciones se observó que el nivel de morbilidad era seis veces más elevado entre los trabajadores con más de 25 años de servicios que entre los que no llevaban 5 años en el puesto de trabajo. Las patologías más comunes eran los problemas circulatorios $(27,9 \%)$, las enfermedades del aparato digestivo (20\%) y los trastornos musculosqueléticos $(20,72 \%)$. La mayoría de los casos registrados de las dos primeras patologías eran de etiología extraprofesional.

Se pudo determinar que el $60 \%$ de los médicos y el $46 \%$ del personal de nivel medio sufría enfermedades crónicas, muchas de las cuales se asociaban directamente con las tareas profesionales.
Muchas de las enfermedades observadas tenían una relación directa con la labor profesional. Por ejemplo, se observó que los especialistas en microcirugía que trabajan en posturas forzadas sufrían frecuentemente osteocondriosis; los quimioterapeutas sufrían frecuentes anomalías cromosómicas y anemia; las enfermeras que estaban en contacto con una gran diversidad de medicamentos presentaban diversas reacciones alérgicas que oscilaban entre las dermatosis y la bronquitis asmática y la inmunodeficiencia.

Los problemas sanitarios de los trabajadores de la sanidad rusa se abordaron por vez primera en el decenio de 1920. En 1923 se creó en Moscú una oficina especial de consulta científica, cuyos estudios se publicaron en cinco colecciones tituladas El trabajo y la vida del personal médico de Moscú y la provincia de Moscú. Desde entonces se han editado otros estudios dedicados a esta cuestión. Sin embargo, tales trabajos sólo tuvieron resultados óptimos a partir de 1975, con la creación del Laboratorio de Higiene Industrial en el Instituto RAMS de Higiene Industrial, en el que se coordinaban todos los estudios del problema. Analizada la situación existente, la investigación se orientó a los objetivos siguientes:

- estudio de las características del flujo de trabajo en las principales especialidades médicas

- evaluación de los elementos integrantes del medio ambiente de trabajo

- análisis de la morbilidad de los trabajadores sanitarios

- adopción de medidas de mejora de las condiciones de trabajo, reducción de la fatiga y prevención de enfermedades.

Sobre la base de los estudios realizados por el Laboratorio de Higiene Industrial y otras instituciones, se elaboraron diversas propuestas y recomendaciones orientadas a la prevención y reducción de la frecuencia de las enfermedades profesionales entre los trabajadores de la sanidad.

Se cursaron instrucciones de que los trabajadores sanitarios fuesen sometidos a exploraciones médicas previas a su contratación y con carácter periódico a partir de la misma. El objeto de las exploraciones era prevenir las enfermedades comunes y profesionales, además de los accidentes de trabajo. Se elaboró una lista de factores de riesgo y de peligro en su trabajo, que comprendía una serie de recomendaciones sobre la frecuencia de las exploraciones médicas, el equipo de especialistas que debían participar en las exploraciones y el número de ensayos de laboratorio y de estudios funcionales, así como una relación de las contraindicaciones médicas asociadas a determinados factores de riesgo profesional. Para cada grupo estudiado se incluía una lista de enfermedades profesionales, en la que se indicaban las formas nosológicas y se ofrecía una relación aproximada de las tareas del puesto de trabajo y de los factores de riesgo capaces de producir cada enfermedad profesional.

Con objeto de controlar las condiciones de trabajo imperantes en los centros de tratamiento y prevención, se creó un Certificado de Condiciones Técnicas y Sanitarias de Trabajo en los centros sanitarios. Este certificado se puede utilizar como guía para la realización de campañas sanitarias y la mejora de la seguridad en el trabajo. Para que un centro consiga el certificado, es preciso llevar a cabo un estudio - con la participación de especialistas en los servicios médicos y las demás organizaciones interesadas - de la situación general existente en los servicios y salas, con objeto de medir los niveles de riesgo para la salud y seguridad.

Los departamentos de higiene de las instituciones de medicina preventiva se han establecido en los modernos centros de inspección sanitario-epidemiológica. Los objetivos de esos departamentos incluyen el perfeccionamiento de las medidas 
para la prevención de las infecciones nosocomiales y sus complicaciones en los hospitales y la creación de unas condiciones óptimas para el tratamiento y la protección de la salud y seguridad de los trabajadores sanitarios. Los médicos de la sanidad pública y sus auxiliares realizan la supervisión preventiva del proyecto y construcción de los edificios destinados a la prestación de asistencia sanitaria. Además, verifican la climatización de las instalaciones, el diseño de los lugares de trabajo, la idoneidad de las condiciones de trabajo y de las instalaciones dedicadas al descanso y la alimentación del personal que trabaja por el sistema de turnos (véase, en este mismo capítulo, el artículo "Edificios dedicados a la asistencia sanitaria"). Supervisan igualmente la documentación técnica del equipo, los procesos tecnológicos y las sustancias químicas de nueva incorporación. La inspección sanitaria de rutina comprende la monitorización de los factores de riesgo profesional en el lugar de trabajo y la consignación de los datos recogidos en el Certificado de Condiciones Técnicas y Sanitarias de Trabajo ya mencionado. Se establece la evaluación cuantitativa de las condiciones de trabajo y la priorización de las medidas de mejora de la sanidad, sobre la base de determinados indicadores del peligro y el riesgo inherentes en los elementos que conforman en medio ambiente de trabajo y de la intensidad y dureza de las tareas. La frecuencia de los estudios de laboratorio está en función de las necesidades especificas de cada caso. Cada estudio suele comprender el análisis y medición de los parámetros del microclima, la medición de los indicadores del aire ambiental (por ejemplo, el contenido de bacterias y sustancias peligrosas), la evaluación de la efectividad de los sistemas de ventilación, la evaluación de los niveles de iluminación natural y artificial, y la medición de los niveles de ruido, de ultrasonidos, de radiación ionizante, etcétera. Se recomienda igualmente la medición, basada en la documentación de referencia, del tiempo de exposición a los factores de riesgo.

En cumplimiento de las instrucciones del gobierno ruso y de acuerdo con la práctica vigente, las normas sanitarias y de higiene se deben revisar sobre la base de los nuevos datos conocidos.

ERGONOMIA Y ASISTENCIA SANITARIA

\section{- Perspectiva de la eRgonomia HOSPITALARIA}

\section{Madeleine R. Estryn-Béhar}

La ergonomía es una ciencia aplicada que se ocupa de la adaptación del trabajo y del lugar de trabajo a las características y capacidades del trabajador, con objeto de que éste pueda realizar de forma segura y eficaz las tareas encomendas. La ergonomía se orienta a compatibilizar las capacidades físicas del trabajador con las exigencias objetivas del puesto de trabajo (como fuerza, resistencia, destreza, flexibilidad, capacidad para soportar posturas forzadas, agudeza visual y auditiva), así como su estado mental y emocional en relación con la forma de organización del trabajo (por ejemplo, horarios y cargas de trabajo y estrés relacionado con el trabajo). A ser posible, se adaptan tanto el mobiliario, el equipo y las herramientas utilizadas por el trabajador como el propio medio ambiente de trabajo, con objeto de facilitar la actividad productiva sin riesgos para el trabajador ni para sus compañeros o el público en general. A veces se impone mejorar la adaptación del trabajador al puesto de trabajo, por ejemplo, mediante una formación especial y el uso de equipo de protección individual.

La aplicación de la ergonomía al trabajo en los hospitales se ha generalizado desde mediados del decenio de 1970. El esfuerzo se orienta actualmente hacia las personas responsables de la atención directa del paciente (como médicos y enfermeras) y las que prestan servicios auxiliares (como técnicos de laboratorio, farmacéuticos y personal de servicio, trabajadores de mantenimiento y limpieza y personal de seguridad).

Se han realizado extensas investigaciones de la ergonomía del trabajo hospitalario, la mayoría de las cuales se han orientado a determinar la medida en que los administradores de los centros sanitarios deben conceder autonomía al personal a su cargo para elaborar estrategias tendentes a conciliar una carga de trabajo aceptable con una asistencia de calidad. La ergonomía participativa se ha generalizado de forma creciente en los hospitales en estos últimos años. Específicamente, los pabellones se han reestructurado sobre la base de análisis ergonómicos de la actividad, realizados en colaboración con el personal paramédico, y la ergonomía participativa ha inspirado la adaptación del equipo destinado a la prestación de asistencia sanitaria.

En el estudio de la ergonomía hospitalaria, el análisis de los puestos de trabajo debe llegar, como mínimo, hasta el nivel de servicio; en este sentido, merecen especial atención la distancia entre las salas y la ubicación del equipo.

La tensión física es uno de los principales factores determinantes de la salud de los trabajadores sanitarios y de la calidad del servicio que prestan. Aparte de esto, es preciso tomar igualmente en consideración las frecuentes interrupciones que deterioran la prestación de la asistencia y el efecto de los factores psicológicos asociados a la vivencia de las enfermedades graves, la vejez y la muerte. De forma análoga, la percepción del paciente de la calidad de la atención hospitalaria es una función de la eficacia del tratamiento recibido, de su relación con los médicos y demás personal, de la alimentación y del entorno arquitectónico.

La ergonomía hospitalaria descansa en gran medida en la acumulación e interacción de factores, tanto personales (como fatiga, aptitud, edad y formación), como externos (como organización del trabajo, horario, diseño de la planta, mobiliario y equipo, comunicación y apoyo psicológico en el seno del equipo), que se combinan para influir en la ejecución del trabajo. La identificación exacta del trabajo realmente realizado por el personal de asistencia sanitaria se basa en la observación ergonómica de jornadas de trabajo completa y en la recogida de información válida y objetiva sobre los movimientos, posturas, actuación cognitiva y control emocional precisos para satisfacer las exigencias del trabajo. Esto contribuye a la identificación de los factores que pueden dificultar la realización de un trabajo eficaz, seguro, confortable y saludable. Este enfoque contribuye igualmente a conocer la capacidad de sufrimiento y de satisfacción en el trabajo de los trabajadores. En las recomendaciones finales se debe tomar en consideración la interdependencia de las distintas categorías de profesionales y auxiliares que atienden a los mismos pacientes.

Estas consideraciones sirven de punto de partida para ulteriores investigaciones más específicas. El análisis de la tensión producida por la utilización del equipo básico (camas, carrillos para el servicio de comidas, equipo móvil de rayos $\mathrm{X}$ ) puede 
contribuir a aclarar las condiciones del uso correcto. La medición de los niveles de iluminación se puede complementar, por ejemplo, con información relativa al tamaño y relieve de las etiquetas de los fármacos. En el caso de que las señales de alarma emitidas por diferentes aparatos utilizados en las unidades de cuidados intensivos puedan confundirse, podría resultar útil el análisis de su espectro acústico. La informatización de los gráficos clínicos sólo debe llevarse a cabo una vez analizadas las estructuras formales e informales de soporte de la información. Por consiguiente, la interdependencia de los diversos elementos que integran el medio ambiente de trabajo de un determinado profesional de la asistencia sanitaria debe tomarse siempre en consideración en el análisis de los factores aislados.

Es imprescindible analizar los diversos factores que influyen en la prestación de la asistencia: tensión física, cognitiva y afectiva, horario, ambiente, arquitectura y protocolos de higiene. Conviene adaptar los horarios y las áreas comunes de actividad a las necesidades del equipo de trabajo si se pretende mejorar la calidad global de la atención al paciente. La ergonomía participativa constituye un medio de aplicar información específica a la producción de importantes mejoras generalizadas a la vida laboral. La participación de todas las categorías de personal en las etapas clave de la búsqueda de soluciones contribuye a recabar su apoyo irrestricto a los cambios que finalmente se lleven a cabo.

\section{Posturas en el trabajo}

Estudios epidemiológicos de los trastornos musculosqueléticos y de las articulaciones. Diversos estudios apuntan a que las posturas forzadas y el empleo de técnicas de manipulación inadecuadas son la causa de que se haya duplicado el número de problemas lumbares, musculares y de las articulaciones que producen absentismo y requieren tratamiento. Este fenómeno, que se analiza en mayor profundidad en otros artículos del presente capítulo y en otros capítulos de la Enciclopedia, se asocia a la tensión física y cognitiva.

Las condiciones de trabajo varían de uno a otro país. Al comparar las condiciones existentes en Alemania y Noruega, Siegel y cols. (1993) hallaron que el $51 \%$ de las enfermeras alemanas sufrían ocasionalmente dolores lumbares, frente a sólo un $24 \%$ de sus colegas noruegas. Las condiciones de trabajo diferían, ciertamente, de uno a otro país; así, en los hospitales alemanes, la proporción entre enfermeras y pacientes era el doble que en Noruega, al tiempo que el número de camas de altura ajustable era de la mitad, y menos enfermeras alemanas disponían de equipo para mover a los pacientes que sus colegas noruegas (el $78 \%$ frente al $87 \%$ en los hospitales noruegos).

Estudios epidemiológicos del embarazo y sus consecuencias. Dado que el personal de los hospitales suele ser mayoritariamente femenino, la influencia del trabajo en el embarazo suele ser importante (véanse los artículos dedicados al embarazo y el trabajo en otros artículos de esta Enciclopedia). Por ejemplo, Saurel-Cubizolles y cols. (1985) estudiaron en Francia una muestra de 621 mujeres que se reincorporaron al trabajo en el hospital después del parto y hallaron que el aumento de la tasa de partos prematuros se asociaba a la realización de pesadas tareas domésticas (como la limpieza de suelos y ventanas), el transporte de cargas pesadas y la permanencia durante largos períodos de pie. La tasa de partos prematuros se incrementaba al combinar varias de estas tareas: del $6 \%$ en los casos en que sólo actuaba uno de los factores citados, al $21 \%$ en los casos en que intervenían dos o más factores. Las diferencias seguían siendo considerables una vez ajustadas las cifras en función de la antigüedad, las características sociales y demográficas y la categoría profesional. Estos factores se asociaban igualmente a una mayor frecuencia de contracciones y de internamientos clínicos durante el embarazo y, en promedio, a unas bajas laborales más prolongadas.

En Sri Lanka, Senevirane y Fernando (1994) compararon 130 embarazos de enfermeras tituladas con 126 gestaciones de empleadas administrativas que, en principio, realizaban un trabajo más sedentario; los antecedentes socioeconómicos y el recurso a los cuidados prenatales eran similares en las dos categorías. Los cocientes de probabilidades de que se produjesen complicaciones del embarazo $(2,18)$ y partos prematuros $(5,64)$ eran elevados entre las enfermeras tituladas.

\section{Observación ergonómica de las jornadas de trabajo}

El efecto de la tensión física en los trabajadores sanitarios se ha podido determinar gracias a la observación sistemática de la jornada de trabajo. Las investigaciones realizadas en Bélgica (Malchaire 1992), Francia (Estryn-Béhar y Fouillot 1990a) y Checoslovaquia (Hubacova, Borsky y Strelka 1992) han puesto de relieve que estos trabajadores permanecen de pie entre el 60 y el $80 \%$ de la jornada (véase la Tabla 97.5). Además, se observó que las enfermeras belgas pasaban alrededor del $10 \%$ de su tiempo agachadas, sus colegas checoslovacas dedicaban el $11 \%$ de la jornada laboral a cambiar de posición a los pacientes, y las francesas pasaban entre el 16 y el $24 \%$ de la jornada laboral en posturas incómodas - por ejemplo, en cuclillas o agachadascon los brazos alzados o transportando pesos.

En Francia, las enfermeras del turno de noche pasaban algo más de tiempo sentadas, si bien al finalizar el turno tenían que hacer las camas y atender a los pacientes, para lo cual debían adoptar posturas incómodas. Aunque las auxiliares de enfermería les ayudan en estas tareas, es preciso contrastar su situación con las enfermeras del turno de mañana, en el que estas tareas se asignan normalmente a dos auxiliares de enfermería. Por regla general, las enfermeras que trabajan en el turno de día pasan menos tiempo en posturas forzadas. Las auxiliares de enfermería permanecían continuamente de pie y trabajaban en posturas forzadas entre el $31 \%$ (turno de tarde) y el $46 \%$ (turno de mañana) del tiempo, debido, en gran medida, al uso de un equipo inadecuado. Las salas de hospitalización de estos hospitales docentes de Bélgica y Francia ocupaban un área muy extensa y se dividían en habitaciones que albergaban de una a tres camas cada una. Las enfermeras que trabajaban en estas salas andaban una media de 4 a 7 kilómetros diarios.

La observación ergonómica pormenorizada de la totalidad de la jornada de trabajo (Estryn-Béhar y Hakim-Serfaty 1990) resulta útil para conocer las interacciones de los factores determinantes de la calidad de la asistencia y el modo de realizar el trabajo. Consideremos las situaciones muy diversas que se producen en una unidad de cuidados intensivos de pediatría y en una sala de reumatología. En las unidades de reanimación de pediatría, la enfermera pasa el $71 \%$ del tiempo en las habitaciones de los pacientes y el equipo utilizado con cada uno de ellos se mantiene en unos carrillos individuales surtidos por las auxiliares de enfermería. Las enfermeras que trabajan en esta unidad sólo se desplazan de lugar unas 32 veces por turno y andan un total de 2,5 kilómetros. Pueden comunicarse con los médicos y las demás enfermeras que se encuentran en el vestíbulo contiguo o en la sala de enfermeras a través de intercomunicadores instalados en las habitaciones de los pacientes.

En cambio, la sala de enfermeras del pabellón de reumatología está muy alejado de las habitaciones de los pacientes y la preparación de las intervenciones es sumamente laboriosa (38\% de la duración del turno). Esto hace que las enfermeras sólo puedan pasar el $21 \%$ de su tiempo en las habitaciones de los pacientes y deban desplazarse unas 128 veces por turno, recorriendo en total unos 17 kilómetros. Así se ilustra claramente la 
Tabla 97.5 • Distribución del tiempo de las enfermeras según tres estudios.

\begin{tabular}{|c|c|c|c|}
\hline & Checoslovaquia & Bélgica & Francia \\
\hline Autores & Hubacova, Borsky y Strelka 1992 & Malchaire $1992^{2}$ & Estryn-Béhar y Fo \\
\hline Servicios & 5 servicios médicos y quirúrgicos & Cirugía cardiovascular & 10 servicios méd \\
\hline \multicolumn{4}{|l|}{$\begin{array}{l}\text { Tiempo medio en las principales posturas, } \\
\text { y distancia total recorrida: }\end{array}$} \\
\hline $\begin{array}{l}\text { Porcentaje de las horas de trabajo pasadas de pie } \\
0 \text { andando }\end{array}$ & $76 \%$ & $\begin{array}{l}\text { Mañana 61\% } \\
\text { Tarde 77\% } \\
\text { Noche 58\% }\end{array}$ & $\begin{array}{l}\text { Mañana } 74 \% \\
\text { Tarde } 82 \% \\
\text { Noche } 66 \%\end{array}$ \\
\hline $\begin{array}{l}\text { Agachada, en cuclillas, con los brazos extendidos, } \\
\text { llevando cargas }\end{array}$ & $11 \%$ & & $\begin{array}{l}\text { Mañana 16\% } \\
\text { Tarde 30\% } \\
\text { Noche 24\% }\end{array}$ \\
\hline Inmóvil, con el cuerpo flexionado & & $\begin{array}{l}\text { Mañana } 11 \% \\
\text { Tarde } 9 \% \\
\text { Noche 8\% }\end{array}$ & \\
\hline Distancia recorrida & & $\begin{array}{l}\text { Mañana } 4 \text { km } \\
\text { Tarde } 4 \text { km } \\
\text { Noche } 7 \text { km }\end{array}$ & $\begin{array}{l}\text { Mañana } 7 \text { km } \\
\text { Tarde } 6 \mathrm{~km} \\
\text { Noche } 5 \mathrm{~km}\end{array}$ \\
\hline $\begin{array}{l}\text { Porcentaje de las horas de trabajo pasadas con } \\
\text { los pacientes }\end{array}$ & Tres turnos: $47 \%$ & $\begin{array}{l}\text { Mañana 38\% } \\
\text { Tarde 31\% } \\
\text { Noche 26\% }\end{array}$ & $\begin{array}{l}\text { Mañana 24\% } \\
\text { Tarde 30\% } \\
\text { Noche 27\% }\end{array}$ \\
\hline
\end{tabular}

Número de observaciones por turno: 174 observaciones en 3 turnos. ${ }^{2}$ Mañana: 10 observaciones ( 8 h); tarde: 10 observaciones ( 8 h); noche: 10 observaciones (11 h). ${ }^{3}$ Mañana: 8 observaciones ( 8 h); tarde: 10 observaciones $(8 \mathrm{~h})$; noche: 9 observaciones $(10-12 \mathrm{~h})$.

interrelación existente entre la tensión física, los problemas lumbares y los factores organizativos y psicológicos. La necesidad de desplazarse rápidamente para buscar el equipo y recabar información obliga a las enfermeras a evacuar consultas en los pasillos y no les permite sentarse mientras prestan asistencia, atender a sus pacientes ni ofrecer respuestas integradas y personalizadas.

La observación sistemática de dieciocho enfermeras holandesas que trabajaban en salas de hospitalización de larga duración reveló que pasaban el 60 \% del tiempo realizando esfuerzos físicos ingentes, sin contacto directo con los pacientes (Engels, Senden y Hertog 1993). Las labores de limpieza y la preparación de las intervenciones absorbían más del $20 \%$ del tiempo teóricamente dedicado a realizar actividades "ligeramente peligrosas". En total, el 0,2 \% del tiempo del turno lo pasaban en posturas que exigían una modificación inmediata; y otro $1,5 \%$, en posiciones que exigían una rectificación rápida. El contacto con los pacientes constituía la actividad más frecuentemente asociada a esas posturas de riesgo. Los autores recomendaron la modificación de las técnicas de manipulación de los pacientes y de otras tareas menos peligrosas, aunque más frecuentes.

Dada la tensión física que produce el trabajo de las auxiliares de enfermería, la medición permanente de la frecuencia cardíaca constituye un complemento eficaz de la observación directa. Raffray (1994) aplicó esta técnica a la identificación del trabajo de mantenimiento más arduo y recomendó que no se asignase el personal a este tipo de trabajos durante toda la jornada.

El análisis de fatiga electromiográfico es igualmente eficaz cuando la postura corporal debe permanecer aproximadamente estática, por ejemplo, durante las operaciones con endoscopio (Luttman y cols. 1996).

\section{Influjo de la arquitectura, el equipo y la organización}

Shindo (1992) demostró la inadecuación del equipo utilizado por las enfermeras, especialmente las camas, en 40 hospitales japoneses. Además, las habitaciones, tanto las de seis a ocho pacientes como las habitaciones individuales reservadas a los más graves, estaban mal diseñadas y eran extremadamente pequeñas. Matsuda (1992) informa de que estas recomendaciones deben redundar en un aumento de la comodidad, la seguridad y la eficacia del trabajo de las enfermeras.

Según un estudio francés (Saurel 1993), la dimensión de las habitaciones de los pacientes era inadecuado en 45 de 75 salas de hospitalización de media y larga duración. Los problemas más comunes eran los siguientes:

- falta de espacio (30 salas)

- dificultad para manipular el equipo de traslado de los pacientes (17 salas)

- espacio insuficiente para el mobiliario (13 salas)

- necesidad de retirar las camas de las habitaciones para trasladar a los pacientes (12 salas)

- dificultad de acceso y mal diseño del mobiliario (10 salas)

- puertas excesivamente pequeñas (8 salas)

- dificultad para circular entre las camas (8 salas).

El espacio medio disponible por cama para los pacientes y enfermeras es la raíz de todos estos problemas y se reduce a medida que aumenta el número de camas por habitación: $12,98 \mathrm{~m}^{2}, 9,84 \mathrm{~m}^{2}, 9,60 \mathrm{~m}^{2}, 8,49 \mathrm{~m}^{2}$ y $7,25 \mathrm{~m}^{2}$, respectivamente, para las habitaciones de una, dos, tres, cuatro y más de cuatro camas. Se logra un índice más ajustado del área útil disponible para el personal restando la superficie ocupada por las camas $\left(1,8\right.$ a $\left.2 \mathrm{~m}^{2}\right)$ y el resto del equipo. El Ministerio de Sanidad francés prescribe una superficie útil de $16 \mathrm{~m}^{2}$ para las habitaciones individuales, y de $22 \mathrm{~m}^{2}$ para las dobles. Por su parte, el Ministerio de Sanidad de Québec recomienda unos valores respectivos de $17,8 \mathrm{~m}^{2}$ y $36 \mathrm{~m}^{2}$.

Retornando a la cuestión de los factores que favorecen el desarrollo de los trastornos lumbares, se halló que el 55,1 \% de las 7.237 camas comprobadas estaban provistas de mecanismos 
de modificación de la altura; de ese número, sólo el 10,3\% disponían de mandos eléctricos. Los sistemas de traslado de pacientes, que permiten reducir el trabajo físico de incorporación de los enfermos, son escasos. Estos sistemas se utilizaban sistemáticamente en el 18,2 \% de las 55 salas examinadas, mientras que en más de la mitad de las salas se utilizaban "raras veces" o "nunca." En el 58,5 \% de las 65 salas inspeccionadas se observó que la maniobrabilidad de los carrillos de servicio de las comidas era "escasa" o "relativamente escasa". En el 73,3 \% de las 72 salas inspeccionadas se informó que el equipo móvil no era objeto de un mantenimiento periódico.

En casi la mitad de las salas estudiadas no había sillas en las habitaciones para uso de las enfermeras, debido, en la mayoría de los casos, a lo reducido del espacio disponible. Sólo podían sentarse en los vestíbulos; en diez unidades tampoco había asientos en la sala de enfermeras. Incluso, trece de las unidades estudiadas carecían de vestíbulo y en cuatro de ellas se utilizaba la despensa con este fin. En treinta de las salas analizadas, estos recintos carecían de asiento.

Según las estadísticas correspondientes a 1992, publicadas por la Confederation of Employees of the Health Services Employees (COHSE) del Reino Unido, el 68,2 \% de las enfermeras se quejaban de no disponer de suficientes medios mecánicos para incorporar y manipular a los pacientes, y el 74,5 \% tenían la impresión de que se les obligaba a asumir los problemas lumbares como un aspecto normal de su trabajo.

En Québec, el Sector de Asuntos Sociales de la Asociación para la Salud y Seguridad en el Trabajo (Association pour la santé et la sécurité du travail, secteur affaires sociales - ASSTAS) puso en práctica en 1993 el proyecto "Prevención-Planificación-Renovación-Construcción" (Villeneuve 1994). A lo largo de 18 meses, se recabó la financiación de casi un centenar de proyectos bilaterales. El objetivo del programa es promover la inversión en prevención abordando los problemas de salud y seguridad en el estadio inicial de concepción de los proyectos de planificación, renovación y diseño.

La asociación culminó en 1995 la modificación de las especificaciones de diseño de las habitaciones de los pacientes en las unidades de cuidados de larga duración. Habiendo determinado que las tres cuartas partes de los accidentes de trabajo que afectan a las enfermeras se producen en las habitaciones de los pacientes, recomendó la modificación de las dimensiones de estas habitaciones, de modo que en las nuevas habitaciones se debe dejar suficiente espacio en torno a las camas, además de contar con medios mecánicos para incorporar al paciente. Estas habitaciones miden 4,05 por 4,95 metros y tienen una configuración más cuadrada que las viejas estancias rectangulares. Para facilitar el trabajo, se diseñaron e instalaron, en colaboración con el fabricante, medios de incorporación del paciente, montados en el techo.

La asociación trabaja actualmente en la modificación de las normas de construcción de los cuartos de baño, escenario habitual de accidentes de trabajo, que, sin embargo, son menos frecuentes que en las habitaciones. Por último, se estudia la posibilidad de solar los cuartos de baño con revestimiento antideslizante (con un coeficiente de fricción superior a la norma mínima de 0,50$)$, teniendo en cuenta que los pacientes ganan en autonomía con una superficie antideslizante que impida que ellos y las enfermeras resbalen.

\section{Evaluación del equipo destinado a reducir la tensión física}

Aunque se han formulado algunas propuestas para mejorar la maniobrabilidad de las camas (Teyssier-Cotte, Rocher y Mereau 1987) y de los carrillos de servicio de comidas (Bouhnik y cols.), la acogida ha sido muy limitada. Tintori y cols. (1994) estudiaron el uso de camas de altura variable provistas de dispositivos eléctricos de elevación del paciente, así como de sistemas mecánicos de elevación del colchón. Tanto el personal sanitario como los pacientes se mostraron satisfechos con los sistemas de elevación de los pacientes; en cambio, los elevadores mecánicos resultaron ser poco satisfactorios, ya que la adaptación de las camas precisaba más de ocho pedaladas, cada una de las cuales requería desarrollar con el pie una fuerza superior a la normal. En efecto, es mucho más cómodo pulsar un botón situado junto a la cabecera del paciente mientras se conversa con él que accionar un pedal situado al pie de la cama (véase la Figura 97.11). Las prisas hacían que el elevador del colchón no se utilizase en la mayoría de los casos.

Van der Star y Voogd (1992) hicieron un seguimiento de un grupo de trabajadores sanitarios que atendían a un total de 30 pacientes usuarios de un nuevo modelo de cama a lo largo de un período de seis semanas. Las observaciones obtenidas sobre las posturas de los trabajadores, la elevación de la superficie de trabajo, el contacto físico entre enfermeras y pacientes y la superficie de trabajo disponible se contrastaron con los datos obtenidos en la misma sala a lo largo de las siete semanas precedentes a la introducción del nuevo modelo. El uso de éste permitía reducir el tiempo total que los trabajadores permanecían en posturas forzadas mientras lavaban a los pacientes del $40 \%$ al $20 \%$; en el cambio de sábanas, la cifra se redujo del $35 \%$ al $5 \%$. Además, los pacientes disfrutaban de mayor autonomía y, en ocasiones, podían cambiar de postura por sí mismos, utilizando unos mandos eléctricos de control que permitían elevar el tronco y las piernas.

En los hospitales suecos, todas las habitaciones dobles están dotadas de mecanismos de elevación de los pacientes montados en el techo (Ljunsberg, Kilbom y Goran 1989). Se han diseñado unos programas rigurosos, como el denominado Proyecto April, para evaluar la interrelación entre condiciones laborales, organización del trabajo, la creación de un centro dedicado a la

\section{Figura 97.11 - Los dispositivos electrónicos para la elevación del tronco en las camas de los hospitales permiten reducir sensiblemente el número de accidentes en la incorporación de los pacientes.}

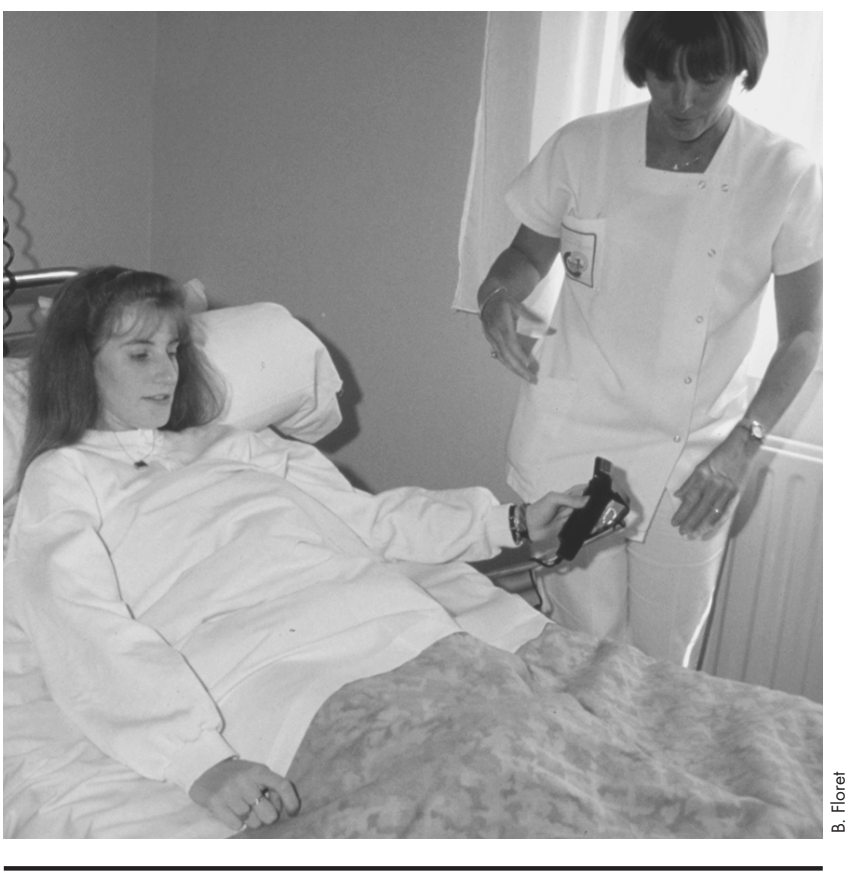


enseñanza de la prevención de los problemas de espalda y la mejora de la aptitud física para el trabajo (Öhling y Estlund 1995).

En Québec, la ASSTAS elaboró un método global de análisis de las condiciones de trabajo que producen problemas lumbares en los hospitales (Villeneuve 1992). Entre 1988 y 1991, este método facilitó la modificación del medio ambiente de trabajo y del equipo utilizado en 120 salas hospitalarias, así como una reducción del $30 \%$ de la frecuencia y gravedad de las lesiones profesionales. Un análisis de coste-beneficio realizado en 1994 por dicha asociación demostró que la aplicación sistemática de dispositivos de elevación de los pacientes montados en el techo de las habitaciones reduciría la frecuencia de los accidentes de trabajo e incrementaría la productividad respecto de los valores alcanzados con el uso continuo de los elevadores desplazables por el suelo (véase la Figura 97.12).

\section{Factores individuales y facilitación de la actividad}

Las mujeres francesas no realizan, por regla general, una gran actividad física. En efecto, el $68 \%$ de las 1.505 enfermeras estudiadas por Estryn-Béhar y cols. (1992) no practicaban deporte alguno, siendo la inactividad más acentuada entre las madres y las trabajadoras no cualificadas. En Suecia, si bien se ha valorado la utilidad de los programas de mejora de la aptitud física para el trabajo del personal sanitario (Wigaeus Hjelm, Hagberg y Hellstrom 1993), dicha utilidad está en función de que los posibles participantes no terminen la jornada de trabajo demasiado cansados para participar.

La adopción de unas posturas más inocuas en el trabajo es igualmente una función del uso de ropa adecuada (Lempereur 1992). La calidad del calzado es particularmente importante. Se debe evitar el uso de zapatos de suela dura. El empleo de suelas de material antideslizante contribuye a prevenir los accidentes de trabajo producidos por caídas y resbalones, que en algunos países constituyen la segunda causa en importancia de accidentes causantes de bajas laborales. Si ajustan mal, los zapatones y botas utilizados por el personal quirúrgico para prevenir la acumulación de electricidad estática puede provocar caídas.

Las caídas en suelos lisos se pueden prevenir solando las estancias con material antideslizante que no precisen cera. También es posible reducir el riesgo de caídas, especialmente en los escalones y vanos, aplicando técnicas que faciliten la evaporación de la humedad del suelo. Una de las técnicas recomendadas por los departamentos de sanidad consiste en utilizar una sola fregona por estancia, lo que supone, además, la ventaja de reducir el trasiego de cubos de agua.

En el condado sueco de Vasteras, la aplicación de diversas medidas prácticas contribuyó a reducir la frecuencia de los síndromes dolorosos y el índice de absentismo en un $25 \%$ como mínimo (Mosling 1992). En los archivos (esto es, en la estancia destinada a guardar registros e historiales) se eliminaron las estanterías bajas y altas, y se colocó una pizarra deslizante ajustable en la que el personal puede tomar notas. También se habilitó una recepción dotada de archivadores móviles, un ordenador y un teléfono. La altura de los archivadores móviles es regulable y hace posible que los empleados la adapten a sus necesidades, además de facilitar la transición de la postura sentado a la postura de pie durante el trabajo.

\section{Importancia de las técnicas "antideslizantes"}

En muchos países se ha propuesto la aplicación de técnicas de manipulación de los pacientes diseñadas para prevenir las lesiones de espalda. Los escasos resultados que se han obtenido hasta el presente (Dehlin y cols. 1981; Stubbs, Buckle y Hudson 1983) apuntan a la necesidad de profundizar el trabajo en este campo.
Figura 97.12 • El uso de dispositivos montados en el techo para la incorporación de los pacientes contribuye a reducir los accidentes.

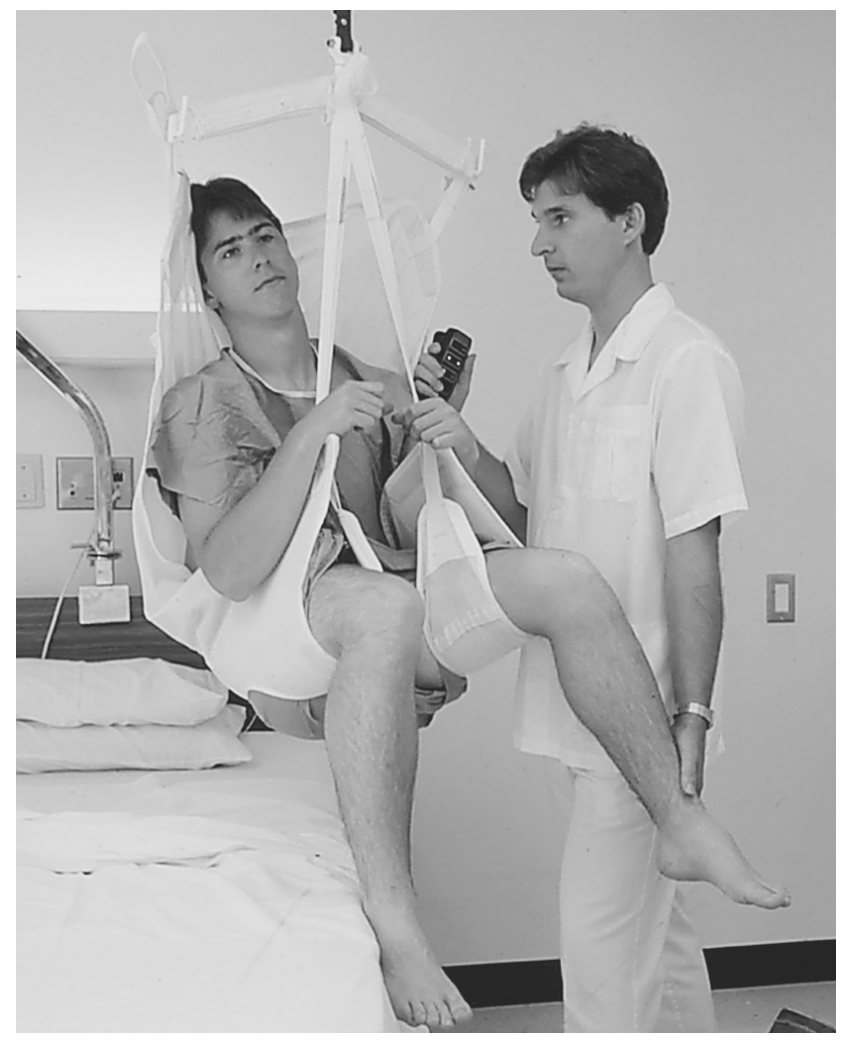

El departamento de kinesiología de la Universidad holandesa de Groninga ha elaborado un programa integral de manipulación de los pacientes (Landewe y Schröer 1993), cuyos elementos principales son los siguientes:

- identificación de la relación entre la manipulación de los pacientes y la tensión de espalda

- demostración de la utilidad de las técnicas "antideslizantes"

- sensibilización de las estudiantes de enfermería, a lo largo del programa de estudios, sobre la importancia de prevenir la tensión de espalda

- aplicación de las técnicas de solución de problemas

- atención a la aplicación y evaluación.

Con las técnicas "antideslizantes", la solución de los problemas asociados al traslado de los pacientes se basa en el análisis sistemático de todos los aspectos de la actividad, especialmente los relacionados con los pacientes, las enfermeras, los medios materiales, el trabajo en equipo, las condiciones generales de trabajo y las barreras ambientales y psicológicas a la utilización de los medios de incorporación de los pacientes (Friele y Knibbe 1993).

La aplicación de la norma europea EN 90/269, de 29 de mayo de 1990, sobre los problemas de espalda, es un punto de partida excelente para la aplicación de esta técnica. Además de exigir a las empresas que implanten unas estructuras de organización del trabajo adecuadas y de instalar el equipo - especialmente, medios mecánicos - indicado para evitar que los trabajadores manipulen manualmente pesos importantes, en la norma se subraya la importancia de aplicar políticas de eliminación del riesgo basadas en la formación. En la práctica, la adopción de posturas adecuadas y el uso de técnicas correctas 
depende de la cantidad de espacio útil, de la disponibilidad del mobiliario y el equipo adecuados, de una colaboración efectiva en la organización del trabajo y de la calidad de la asistencia, de una buena aptitud física para el trabajo y del uso de ropa de trabajo cómoda. El resultado neto de la concurrencia de estos factores es un mayor nivel de prevención de los problemas de espalda.

\section{- LA TENSION EN EL TRABAJO DE ASISTENCIA SANITARIA}

Madeleine R. Estryn-Béhar

\section{Tensión cognitiva}

La observación sistemática ha permitido conocer que la jornada laboral de las enfermeras se caracteriza por una reorganización continua de los horarios de trabajo y por las interrupciones continuas.

Diversos estudios realizados tanto en Bélgica (Malchaire 1992) como en Francia (Gadbois y cols. 1992; Estryn-Béhar y Fouillot 1990b) han puesto de manifiesto que las enfermeras realizan entre 120 y 323 tareas distintas durante la jornada de trabajo (véase la Tabla 97.6). El trabajo se interrumpe frecuentemente a lo largo de la jornada (entre 28 y 78 interrupciones diarias). Muchos de los centros estudiados eran grandes unidades para hospitalizados de corta duración en las que el trabajo de las enfermeras consistía en una larga secuencia de tareas breves y distantes en el espacio. La planificación de los horarios de trabajo se complica por la existencia de un proceso incesante de innovación tecnológica, la estrecha interdependencia del trabajo de los diversos equipos profesionales y la prevalencia de unos esquemas irracionales de organización del trabajo.

Gadbois y cols. (1992) constataron una media de 40 interrupciones por jornada de trabajo, de las cuales el $5 \%$ eran provocadas por los pacientes, el $40 \%$ por la pobreza de la información, el $15 \%$ por llamadas telefónicas, y el $25 \%$ por el equipo. Ollagnier y Lamarche (1993) realizaron una observación sistemática de las enfermeras en un hospital suizo y constataron entre 8 y 32 interrupciones diarias, en función de las salas. En promedio, las interrupciones duraban el 7,8 \% de la jornada de trabajo.

Este tipo de interrupciones del trabajo, provocadas por las inadecuadas estructuras de transmisión de la información, impide que los trabajadores realicen la totalidad de las tareas asignadas y generan insatisfacción en el trabajo. La consecuencia más grave de esta deficiencia organizativa es la reducción del tiempo disponible para los pacientes (véase la
Tabla 97.5). En los tres estudios primeramente citados, las enfermeras no dedicaban a sus pacientes, en promedio, más del $30 \%$ de su tiempo. En Checoslovaquia, país en que las habitaciones con varias camas eran comunes, las enfermeras hacían menos desplazamientos entre las habitaciones y dedicaban el $47 \%$ del turno de trabajo a los pacientes (Hubacova, Borsky y Strelka 1992). Esto pone claramente de relieve la interacción entre arquitectura, niveles de dotación de personal y estrés mental.

Estryn-Béhar y cols. (1994) realizaron un seguimiento de siete profesiones y horarios de trabajo distintos en dos salas de medicina especializadas con similares características espaciales y situadas en un mismo edificio elevado. Mientras que el trabajo en una de las salas se encontraba sumamente segmentado y había dos equipos, compuestos, cada uno, por una enfermera y una auxiliar de enfermería que atendía a la mitad de los pacientes, en la otra sala no existía esta segmentación y los pacientes recibían asistencia básica de dos auxiliares de enfermería. Mientras que no se observaron diferencias entre las dos salas en cuanto a la frecuencia de las interrupciones provocadas por los pacientes, las interrupciones asociadas al funcionamiento de los equipos de profesionales eran claramente más frecuentes en la sala en que la labor no estaba segmentada (entre 35 y 55 interrupciones, en contraste con una franja de entre 23 y 36 interrupciones. respectivamente). En la sala últimamente citada, las auxiliares de enfermerías, las enfermeras del turno de mañana y las del turno vespertino sufrían, respectivamente, un 50 , un 70 y un $30 \%$ más de interrupciones que sus compañeras de la sala en que el trabajo se fragmentaba.

De lo anterior se deduce que la fragmentación contribuye a reducir el número de interrupciones y la discontinuidad de los turnos de trabajo. Estas observaciones se utilizaron en la planificación de la reestructuración de la sala, en colaboración con el personal médico y paramédico, con objeto de facilitar la fragmentación del trabajo en la oficina y en el área de preparación. El nuevo espacio es de estructura modular y fácilmente divisible en tres espacios (uno para los médicos y uno para cada uno de los equipos de enfermeras), separados entre sí por tabiques de vidrio deslizantes y provistos de un mínimo de seis asientos. La instalación de dos mostradores confrontados entre sí en el área común destinada a la preparación hace posible que las enfermeras que deben interrumpir su trabajo de preparación puedan, al regresar al mismo, encontrar su material en el mismo lugar y estado, inalterado por la actividad de sus compañeras.

\section{Reorganización de los horarios de trabajo y los servicios} técnicos

La actividad profesional en los departamentos técnicos es mucho más que la mera suma de las tareas asociadas a cada prueba. Según un estudio realizado en varios departamentos de energía

Tabla 97.6 - Número de tareas independientes realizadas por las enfermeras, e interrupciones durante cada turno.

$\begin{array}{llll} & \text { Bélgica } & \text { Francia } & \text { Francia } \\ \text { Autores } & \text { Malchaire 1992 } & \text { Gadbois y cols. } 1992^{2} & \text { Estryn-Béhar y Fouillot 1990b3 } \\ \text { Servicios } & \text { Cirugía cardiovascular } & \text { Cirugía (C) y medicina (M) } & \text { Diez servicios médicos y quirúrgicos } \\ \text { Número de tareas independientes } & \text { Mañana } 120 / 8 \mathrm{~h} & \mathrm{C} \text { (día) } 276 / 12 \mathrm{~h} & \text { Mañana } 323 / 8 \mathrm{~h} \\ & \text { Tarde } 213 / 8 \mathrm{~h} & \mathrm{M} \text { (día) } 300 / 12 \mathrm{~h} & \text { Tarde } 282 / 8 \mathrm{~h} \\ & \text { Noche } 306 / 8 \mathrm{~h} & \text { Noche } 250 / 10-12 \mathrm{~h} \\ \text { Número de interrupciones } & & \text { C (día) } 36 / 12 \mathrm{~h} & \text { Mañana } 78 / 8 \mathrm{~h} \\ & & \text { M (día) } 60 / 12 \mathrm{~h} & \text { Tarde } 47 / 8 \mathrm{~h} \\ & & \text { Noche } 28 / 10-12 \mathrm{~h}\end{array}$

Número de horas de observación: ${ }^{1}$ Mañana: 80 h; tarde: 80 h; noche: 110 h. $\quad 2$ Cirugía: 238 h; medicina: 220 h. ${ }^{3}$ Mañana: 64 h; tarde: 80 h; noche: 90 h. 
nuclear (Favrot-Laurens 1992), los técnicos en medicina nuclear dedicaban una parte muy pequeña de su tiempo a tareas técnicas. Una parte muy importante de su tiempo se dedicaba a coordinar la actividad y la carga de trabajo en diversos lugares de trabajo, a transmitir información y a realizar los ajustes inevitables. Estas responsabilidades derivaban de la obligación de los técnicos de estar familiarizados con la práctica totalidad de las pruebas, y de dominar la información técnica y administrativa fundamental, además de la información específicamente asociada a las pruebas, como el momento y el punto de inyección.

\section{Tratamiento de la información necesario para la prestación de la asistencia}

Cierto fabricante de equipo de electroencefalografía pidió a Roquelaure, Pottier y Pottier (1992) que simplificasen el uso del equipo. La respuesta de los autores consistió en facilitar la lectura de la información visual transmitida por los indicadores, que era excesivamente complicada o, sencillamente, poco clara. Como indican los autores, las máquinas de la "tercera generación" provocan problemas considerables, debido, en parte, al uso de unidades de representación visual repletas de información escasamente legible. La interpretación de estas pantallas exige la aplicación de técnicas de trabajo complejas.

Sin embargo, en términos generales, se ha prestado muy escasa atención a la necesidad de presentar la información de forma que facilite la rápida toma de decisiones en las unidades de asistencia sanitaria. Por ejemplo, según un estudio realizado sobre 240 medicamentos sólidos de uso oral y 364 inyectables (Ott y cols. 1991), la legibilidad de la información contenida en las etiquetas deja todavía mucho que desear. Se recomienda que las etiquetas de los frascos de medicamentos sólidos de uso oral administrados por enfermeras, que sufren frecuentes interrupciones en su trabajo y atienden a varios pacientes, tengan un fondo mate y un texto en caracteres de una altura no inferior a 2,5 mm, y que brinden amplia información sobre el medicamento en cuestión. Sólo el $36 \%$ de los 240 medicamentos estudiados satisfacían los dos primeros criterios; y únicamente el $6 \%$ cumplían los tres. Asimismo, en el $63 \%$ de las etiquetas de los 364 inyectables el texto estaba impreso en caracteres menores de 2,5 mm.

En numerosos países no anglófonos, los indicadores de los paneles de control de la maquinaria siguen etiquetados en inglés. En muchos países se encuentran en vías de desarrollo sistemas de software para las historias clínicas. En Francia, el desarrollo de estas aplicaciones de software suele estar motivado por el deseo de mejorar la gestión de los hospitales y se emprende sin un estudio adecuado de la compatibilidad del software con los sistema de trabajo reales (Estryn-Béhar 1991). Esto hace que el software pueda contribuir de hecho a aumentar complejidad del trabajo de enfermería, en lugar de reducir la tensión cognitiva. Forzar a las enfermeras a recorrer en pantalla múltiples páginas de información para conseguir los datos que precisan para aplicar una prescripción puede contribuir a incrementar la frecuencia de los errores y de los lapsos de memoria.

Si bien en los países escandinavos y en Norteamérica los historiales de los pacientes se han informatizado en buena medida, no se puede perder de vista que los hospitales de esos países disfrutan de un elevado coeficiente personal-pacientes y que, por ese motivo, las interrupciones del trabajo y la continua reformulación de las prioridades son menos acuciantes en esas naciones. Por el contrario, el empleo de software de los historiales clínicos en los países con menores ratios personal-pacientes puede facilitar la elaboración de resúmenes y el replanteamiento de las prioridades.

\section{Errores humanos en la anestesia}

En su estudio de los factores inductores de los errores en la aplicación de anestésicos realizado en Estados Unidos, Cooper, Newbower y Kitz (1984) hallaron que el diseño del equipo era de importancia capital. Los 538 errores analizados, asociados en gran medida al equipo y a la administración de fármacos, estaban relacionados con la división de funciones y con los sistemas aplicados. En opinión de Cooper, la mejora del diseño del equipo y de los aparatos de monitorización permitiría reducir el número de errores en un $22 \%$, al tiempo que una formación complementaria de los anestesistas que utilizan nuevas tecnologías, como los simuladores de anestesia, produciría una reducción del $25 \%$. Otras de las recomendaciones formuladas se orientan a la organización del trabajo, la supervisión y las comunicaciones.

\section{Alarmas acústicas en los quirófanos y las unidades de cuidados intensivos}

Diversos estudios han puesto de relieve que en los quirófanos y unidades de cuidados intensivos se utilizan demasiadas clases de alarmas. Los anestesistas participantes en cierto experimento sólo pudieron identificar correctamente el $33 \%$ de las alarmas, y tan sólo dos de ellos superaron el $50 \%$ de aciertos (Finley y Cohen 1991). En otro experimentos similar, los anestesistas y auxiliares de anestesista sólo lograron identificar correctamente el $34 \%$ de las alarmas (Loeb y cols. 1990). El análisis retrospectivo del experimento permitió establecer que el $26 \%$ de los errores de las enfermeras obedecía a la semejanza de las alarmas acústicas, al tiempo que el $20 \%$ se debía a la analogía funcional de las mismas. Momtahan y Tansley (1989) informan de que las enfermeras de las salas de recuperación de la anestesia y los anestesistas sólo pudieron identificar correctamente las alarmas en el 35 y el $22 \%$ de los casos, respectivamente. En otro estudio realizado por Momtahan, Hétu y Tansley (1993), 18 médicos y técnicos lograron identificar únicamente entre 10 y 15 de 26 alarmas utilizadas en los quirófanos, mientras que 15 enfermeras de cuidados intensivos sólo pudieron identificar entre 8 y 14 de 23 alarmas utilizadas en esas unidades.

De Chambost (1994) estudió las alarmas acústicas emitidas por 22 máquinas diferentes utilizadas en una unidad de cuidados intensivos de la región de París. Sólo se identificaron las alarmas emitidas por el electrocardiógrafo y por uno de los dos tipos utilizados de bombas de perfusión continua. Las otras alarmas no fueron inmediatamente reconocidas y el personal responsable tuvo que acudir a la habitación del paciente para identificar el origen de la señal y regresar más tarde con el equipo adecuado. El análisis espectral de los sonidos emitidos por ocho máquinas puso de manifiesto la existencia de notables similitudes e indica la posible existencia de un efecto de enmascaramiento entre las señales.

La excesiva frecuencia del uso injustificado de las alarmas ha sido especialmente criticada. O’Carroll (1986) observó durante tres semanas el origen y la frecuencia de las señales de alarma en una unidad de cuidados intensivos y halló que sólo 8 de las 1.455 alarmas se asociaban a situaciones potencialmente letales. Muchas falsas alarmas provenían de los monitores y bombas de perfusión. Se observaron escasas variaciones en la frecuencia de las alarmas del día a la noche.

Los resultados obtenidos del estudio de las alarmas en anestesiología han sido similares. En su estudio de 50 pacientes y cinco monitores de anestesia de uso frecuente, Kestin, Miller y Lockhart (1988) informan de que sólo el $3 \%$ de los casos correspondían a un riesgo efectivo para el paciente, al tiempo que el $75 \%$ de las alarmas resultaron infundadas (provocadas por movimientos del paciente, interferencias y problemas mecánicos). En promedio, diez alarmas fueron activadas por los 


\section{Errores humanos y tareas críticas en la braquioterapia de poscarga a distancia: Sugerencias para mejorar el rendimiento del sistema}

La braquioterapia de poscarga a distancia es una técnica médica de tratamiento del cáncer, en la que se utiliza un dispositivo controlado por ordenador para la introducción y extracción a distancia de fuentes radiactivas en las inmediaciones de un determinado objetivo (o tumor) situado en el cuerpo. Se ha informado de algunos problemas asociados a las dosis administradas, que se han atribuido a errores humanos (Swann-D'Emilia, Chu y Daywalt 1990). Callan y cols. (1995) evaluaron el error humano y las tareas críticas de esta técnica en 23 centros de Estados Unidos. Su evaluación incluyó seis fases:

Fase 1: Funciones y tareas: Se estimó que la preparación del tratamiento constituía la tarea más difícil, debido a que producía la mayor tensión cognitiva. Además, las distracciones producían efectos considerables en la preparación.

Fase 2: Interferencias hombre-sistema. Con frecuencia, los trabajadores no estaban familiarizados con las técnicas que manejaban. No podían percibir desde sus puestos de trabajo las señales de control ni otros datos fundamentales. En muchos casos, no se les facilitaba información alguna sobre el estado del sistema.

Fase 3: Procedimientos y prácticas. La indefinición de los procedimientos aplicados para pasar de una operación a la siguiente y para trasladar información y material entre distintas tareas podía originar la pérdida de datos fundamentales. Los sistemas de verificación eran inexistentes o poco fiables.

Fase 4: Políticas de formación: El estudio puso de manifiesto la inexistencia de programas de formación formales en la mayor parte de los centros.
Fase 5: Estructuras de apoyo organizativo. La comunicación durante la aplicación de la braquiterapia estaba sujeta a errores. Los métodos de control de calidad eran también inadecuados.

Fase 6: Identificación y clasificación de las circunstancias favorecedoras del error humano. En total, se identificaron y clasificaron 76 circunstancias favorecedoras del error humano. Asimismo, se definieron y evaluaron diversos métodos alternativos.

Diez tareas críticas estaban especialmente sujetas a error:

- programación, identificación y seguimiento de los pacientes

- fijación de la posición del aplicador

- localización del volumen del objetivo

- localización de la posición del tumor

- dosimetría

- equipo de tratamiento

- inicio del plan de tratamiento

- cambio de fuentes

- calibración de las fuentes

- registro y garantía de calidad de rutina

El mayor número de errores se producía durante el tratamiento. Se analizaron treinta errores asociados al tratamiento y se halló que los fallos se producían durante la ejecución de cuatro o cinco subtareas. La mayor parte de los errores ocurrían durante la administración del tratamiento. El segundo tipo de errores en orden de frecuencia se producía en la planificación del tratamiento y se asociaba al cálculo de la dosis. Se ha iniciado un proceso de mejora del equipo y de la documentación, en colaboración con los fabricantes. propios pacientes, para una frecuencia media de una alarma cada 4,5 minutos.

Una respuesta habitual a las falsas alarmas consiste en neutralizarlas. Según McIntyre (1985), el 57 \% de los anestesistas canadienses reconocieron haber desactivado deliberadamente alguna alarma. Obviamente, esto puede provocar graves accidentes.

En los estudios citados se subraya el diseño defectuoso de las alarmas de los hospitales y se insiste en la necesidad de normalizarlas sobre la base de la ergonomía cognitiva. Tanto Kestin, Miller y Lockhart (1988) como Kerr (1985) han recomendado que en la modificación de los dispositivos de alarma se tomen en consideración el riesgo y la reacción correctiva del personal sanitario. Como indican Keyser y Nyssen (1993), en la prevención de los errores humanos en la aplicación de la anestesia se integran distintas medidas de orden tecnológico, ergonómico, social, organizativo y de formación.

\section{Tecnología, error humano, seguridad de los pacientes y tensión} psicológica percibida

El análisis riguroso del proceso del error es de gran utilidad. Sundström-Frisk y Hellström (1995) informan de que la deficiencia del equipo, el error humano, o ambos factores a la vez, fueron la causa de 57 fallecimientos y 284 lesiones ocurridos en Suecia entre 1977 y 1986. Los autores entrevistaron a 63 equipos de trabajo de unidades de cuidados intensivos que se habían visto implicados en 155 incidentes ("cuasiaccidentes") relacionados con el uso de equipo médico avanzado y que, en su mayor parte, no se habían notificado a las autoridades. Se elaboraron setenta escenarios típicos de "cuasiaccidentes". Entre las posibles causas identificadas figuraban el uso de equipo y documentación técnica inadecuados, los procedimientos, el medio ambiente físico, el volumen de la plantilla y el estrés. La adopción de nuevo equipo puede ser causa de accidentes si el mismo ha sido defectuosamente adaptado a las necesidades de los usuarios y si su adopción no va acompañada de una modificación en profundidad de los sistemas de formación y de los métodos de trabajo.

Para prevenir los lapsus de memoria, las enfermeras han desarrollado diversos procedimientos mnemotécnicos y técnicas de previsión y prevención de percances. Sin embargo, se siguen produciendo percances y, aun en el caso de que los pacientes no lleguen a enterarse de los errores, los "cuasiaccidentes" provocan sentimientos de culpa al personal sanitario. En el recuadro de este artículo se describen algunas dimensiones del problema.

\section{Tensión emocional o afectiva}

El trabajo de las enfermeras, especialmente si entraña el riesgo de muerte o enfermedad grave, puede ser una importante fuente de tensión emocional y producir sentimientos de burnout, fenómenos que se analizan en mayor profundidad en otros capítulos de esta Enciclopedia. La capacidad de las enfermeras para luchar contra este tipo de estrés es una función de la amplitud de su red de apoyo y de sus posibilidades de promover y mejorar la calidad de vida de los pacientes. En el texto que sigue se sintetizan los principales hallazgos del análisis realizado por Leppanen y Olkinuora (1987) de diversos estudios sobre el estrés realizados por suecos y finlandeses.

En Suecia, las principales razones dadas por los profesionales de la sanidad para abrazar esa profesión han sido el "imperativo ético" del trabajo, su utilidad y la posibilidad de ejercer la competencia. Sin embargo, casi la mitad de las auxiliares de enfermería consideraba que sus conocimientos eran inadecuados para su trabajo; y una cuarta parte de las enfermeras, la quinta parte de las enfermeras tituladas, la séptima parte de los médicos y la décima parte de las jefas de enfermería se consideraban incompetentes para tratar algunos tipos de pacientes. La incompetencia para tratar los problemas psicológicos era el problema 
más frecuentemente citado y se encontraba especialmente generalizado entre las auxiliares de enfermería, aunque también lo acusaban las enfermeras y enfermeras jefe. Los médicos, en cambio, se estiman capacitados en este campo. Los autores centran su análisis en la difícil situación de las auxiliares de enfermería, que, paradójicamente. a pesar de pasar más tiempo con los pacientes que los otros especialistas, no pueden informar a aquéllos de su enfermedad ni del tratamiento que reciben.

En diversos estudios se ha puesto de manifiesto una ausencia de claridad en la delimitación de las responsabilidades. Pöyhönen y Jokinen (1980) informan de que sólo el 20 \% de las enfermeras de Helsinki tenían una información sistemática de sus tareas y de los objetivos de las mismas. En un estudio realizado en una sala de pediatría y en una institución para discapacitados, Leppanen demostró que la estructuración de las tareas no dejaba a las enfermeras suficiente tiempo para planificar y preparar su trabajo, realizar labores administrativas y colaborar con los miembros de su equipo profesional.

La asunción de responsabilidades sin una correlativa capacidad de toma de decisiones constituye un factor de estrés. Así, el $57 \%$ de las enfermeras destinadas a los quirófanos estimaban que la ambigüedad de la delimitación de sus responsabilidades exacerbaba su tensión cognitiva; el $47 \%$ de las enfermeras de los servicios de cirugía manifestaban no dominar algunas de sus tareas y consideraban que las expectativas divergentes de los pacientes y de ellas mismas eran una causa de estrés. Por otra parte, el $47 \%$ de las entrevistadas experimentaban un recrudecimiento del estrés cuando se producían problemas en ausencia de los médicos.

Los resultados de tres estudios epidemiológicos europeos indican que aproximadamente el $25 \%$ de las enfermeras experimentan sensaciones de burnout (Landau 1992; Saint-Arnaud y cols. 1992; Estryn-Béhar y cols. 1990) (véase la Tabla 97.7). Estryn-Béhar y cols. realizaron un estudio de 1.505 trabajadoras sanitarias utilizando un baremo de tensión afectiva que englobaba información sobre el ambiente de trabajo y la labor en equipo, la congruencia de la cualificación con el trabajo, el tiempo dedicado a hablar con los pacientes y la frecuencia de las respuestas vacilantes o vagas a éstos. Se observaron sensaciones de burnout en el $12 \%$ de las enfermeras con un nivel bajo, el $25 \%$ de las trabajadoras sanitarias con un nivel moderado, y el $39 \%$ de las enfermeras con un nivel elevado, de tensión cognitiva. La relación entre burnout e incremento de la tensión afectiva era aún más estrecha. En efecto, se observaron sensaciones de burnout en el $16 \%$ de las enfermeras con un nivel bajo, el $25 \%$ de las trabajadoras sanitarias con un nivel moderado, y el $64 \%$ de las enfermeras con un nivel elevado, de tensión afectiva. Después del ajuste realizado mediante un análisis logístico de regresión con variables múltiples para tomar en consideración los factores sociales y demográficos, las mujeres que manifestaban un nivel elevado de tensión afectiva acusaban un cociente de probabilidades de burnout de 6,88 en comparación con las mujeres que manifestaban un índice más bajo.

Saint-Arnaud y cols. informan de la existencia de una correlación entre la frecuencia de la sensación de burnout y la puntuación obtenida con el baremo compuesto de tensión cognitiva y afectiva. Los hallazgos de Landau corroboran estos resultados.

Por último, el $25 \%$ de las 520 enfermeras del servicio de oncología de un hospital general francés presentaban un elevado nivel de burnout (Rodary y Gauvain-Piquard 1993). Estos elevados niveles se asociaban estrechamente, en la mayoría de los casos, a la falta de apoyo. Las quejas más frecuentemente aducidas por las enfermeras con mayores sensaciones de burnout se centraban en la escasa consideración de que eran objeto en su servicio, en que no se tenía en cuenta su conocimiento de los pacientes y en la poca importancia concedida a la calidad de vida de éstos. Otras quejas frecuentemente formuladas eran el miedo físico a los pacientes y la incapacidad para organizar su horario de trabajo. Es de subrayar, en el contexto de esos resultados, la elevada tasa de suicidios observada por Katz (1983) entre las enfermeras.

\section{Efectos de la carga de trabajo, la autonomía y las redes de} apoyo

En un estudio de 900 enfermeras canadienses se puso de manifiesto la relación existente entre la carga de trabajo y cinco índices de la tensión cognitiva, medida según el cuestionario de Ilfeld: puntuación global, agresividad, ansiedad, dificultades cognitivas y depresión (Boulard 1993). Se identificaron cuatro categorías. Las enfermeras con una importante carga de trabajo, elevada autonomía y suficiente apoyo social (11,76\%) acusaban diversos síntomas asociados al estrés. El menor nivel de estrés correspondía a las enfermeras con una reducida carga de trabajo, elevada autonomía y suficiente apoyo social (33,75 \%). La frecuencia de los síntomas asociados al estrés era elevada entre las enfermeras con una carga de trabajo considerable, escasa autonomía y escaso apoyo social $(42,09 \%)$, al tiempo que el nivel de estrés era bajo entre las enfermeras con una escasa carga de trabajo, poca autonomía e insuficiente apoyo social (10,40\%), si bien los autores comentan que esas trabajadoras pueden experimentar sentimientos de frustración.

Estos resultados demuestran igualmente que la autonomía y el apoyo, en lugar de mediatizar la relación entre carga de trabajo y salud mental, afectan directamente a la carga de trabajo.

Tabla 97.7 • Tensión cognitiva y afectiva, y sensación de burn-out entre los trabajadores sanitarios.

\begin{tabular}{|c|c|c|c|}
\hline & Alemania $^{1}$ & Canadá $^{2}$ & Francia $^{3}$ \\
\hline Número de personas & 24 & 868 & 1.505 \\
\hline Método & Inventario de Burn-out de Maslach & $\begin{array}{l}\text { Indice llfeld de Síntomas } \\
\text { Psiquiátricos }\end{array}$ & Cuestionario de Salud General Goldberg \\
\hline Gran agotamiento emocional & $33 \%$ & $20 \%$ & $26 \%$ \\
\hline Nivel de burn-out, por turnos & $\begin{array}{l}\text { Mañana 2,0; tarde 2,3; turno } \\
\text { partido } 3,4 \text {; noche } 3,3\end{array}$ & & Mañana 25\%; tarde 25\%; noche 29\% \\
\hline $\begin{array}{l}\text { Porcentaje de trabajadores que sufren de gran } \\
\text { agotamiento emocional, por niveles de tensión }\end{array}$ & & $\begin{array}{l}\text { Tensión cognitiva y afectiva: baja } \\
\text { 16,5\%; alta } 36,6 \%\end{array}$ & $\begin{array}{l}\text { Tensión cognitiva: baja 12\%, media 25\%, } \\
\quad \text { alta } 39 \% \\
\text { Tensión afectiva: baja 16\%, media 35\%, } \\
\text { alta } 64 \%\end{array}$ \\
\hline
\end{tabular}

'Landau 1992. 2 Saint Arnand y cols. 1992. ${ }^{3}$ Estryn-Béhar y cols. 1990. 
Función de las enfermeras jefe

Tradicionalmente, se ha considerado que la satisfacción de los trabajadores con sus supervisores dependen de una correcta definición de las responsabilidades y de un buen nivel de comunicación y retroinformación. Kivimäki y Lindström (1995) aplicaron un cuestionario a las enfermeras empleadas en 12 salas de cuatro servicios médicos y entrevistaron a las enfermeras jefes de cada sala. Las salas se clasificaron en dos grupos en función de su nivel de satisfacción con la supervisión (seis salas satisfechas y seis salas insatisfechas). Los niveles de comunicación, retroinformación, participación en la toma de decisiones y existencia de un clima de trabajo propicio a la innovación eran superiores en las salas "satisfechas". Con una sola excepción, las enfermeras jefe de las salas "satisfechas" aseguraron que, con una frecuencia mínima anual, mantenían una larga conversación - de una o dos horas de duración - con cada trabajadora. Por el contrario, sólo una de las enfermeras jefe de las salas "insatisfechas" utilizaba este sistema.

Las enfermeras jefe de las salas "satisfechas" alentaban a las integrantes del equipo a expresar sus ideas y opiniones, y no admitían que sus subordinadas criticasen o se mofasen de las enfermeras propensas a formular sugerencias, además de esforzarse sistemáticamente por suministrar retroinformación útil a las enfermeras que formulaban puntos de vista discrepantes o novedosos. Por último, las enfermeras jefe de todas las salas "satisfechas" - pero de ninguna de las otras salas - tenían una elevada conciencia de su función en la generación de un clima favorable a la crítica constructiva.

\section{Funciones psicológicas, relaciones y organización}

La estructura de las relaciones afectivas entre las enfermeras varía de uno a otro equipo. Según el estudio de una muestra de 1.387 enfermeras empleadas regularmente en el turno de noche y de 1.252 enfermeras adscritas regularmente al turno de mañana o de tarde, la prolongación del tiempo de trabajo era más frecuente durante el turno primeramente citado (Estryn-Béhar y cols. 1989a). El inicio temprano y la finalización tardía del trabajo eran más frecuentes entre las enfermeras del turno de noche. Si bien el reconocimiento de disfrutar de un ambiente de trabajo "bueno" o "muy bueno" era más frecuente en el turno de noche, era menos frecuente la impresión de disfrutar de "buenas relaciones con los médicos". Por último, las enfermeras que trabajaban de noche aseguraban disponer de más tiempo para hablar con los pacientes, si bien esto exacerbaba la preocupación y la incertidumbre sobre la respuesta adecuada a las inquietudes de los enfermos, que también son más numerosas de noche.

Büssing (1993) halló que la despersonalización afectaba con mayor frecuencia a las enfermeras que trabajaban en horarios atípicos.

\section{El estrés de los médicos}

La negación y represión del estrés constituyen mecanismos de defensa habituales. A veces, los médicos intentan reprimir sus problemas trabajando mucho, desmarcándose de las emociones y adoptando actitudes victimistas (Rhoads 1977; Gardner y Hall 1981; Vaillant, Sorbowale y McArthur 1972). A medida que se debilitan estas barreras y que quiebran las técnicas de adaptación, las crisis de angustia y frustración se hacen más y más frecuentes.

Valko y Clayton (1975) hallaron que la tercera parte de los internos experimentaban episodios graves y frecuentes de estrés emocional y depresión, y que una cuarta parte de ellos pensaban en el suicidio. McGue (1982) consideraba que un mejor conocimiento del estrés y de las reacciones al estrés facilitaría la formación y el desarrollo personal de los médicos y contribuiría a modificar las expectativas sociales. Estos cambios contribuirían globalmente a la mejora de la asistencia.

Se pueden desarrollar unos comportamientos evasivos, acompañados a menudo del deterioro de las relaciones profesionales y personales. En un punto dado del proceso, el médico cruza finalmente la línea del franco deterioro de la salud mental y se producen episodios de drogadicción, enfermedad mental o, incluso, suicidio. En algunos casos la atención de los pacientes llega a resentirse, con el resultado del deterioro de la exploración y el tratamiento de los enfermos, el abuso sexual y los comportamientos patológicos (Shapiro, Pinsker y Shale 1975).

En un estudio de 530 suicidios de médicos registrados por la American Medical Association a lo largo de un período de cinco años se pudo establecer que el $40 \%$ de los suicidios de mujeres y el $20 \%$ de los suicidios de varones se produjeron entre personas de menos de 40 años (Steppacher y Mausner 1974). En un estudio sueco de las tasas de suicidio registradas entre 1976 y 1979 se halló que entre los miembros de algunas profesiones sanitarias se producían tasas más elevadas que en el conjunto de la población (Toomingas 1993). La tasa de mortalidad normalizada entre las médicos era de 3,41, la más elevada de las registradas, mientras que la tasa correspondiente a las enfermeras era de 2,13 .

Lamentablemente, los casos de deterioro de la salud mental entre los profesionales de la sanidad suelen ser obviados o, incluso, rechazados por sus colegas, que procuran ocultar que ellos mismos padecen estos problemas (Bissel y Jones 1975). Ciertamente, las manifestaciones leves o moderadas de estrés son mucho más frecuentes entre los profesionales de la sanidad que los trastornos psiquiátricos declarados (McCue 1982). El correcto pronóstico de estos casos es una función de un diagnóstico precoz y del apoyo de los compañeros (Bitker 1976).

\section{Grupos de debate}

Se han realizado en Estados Unidos diversos estudios de los efectos de los grupos de debate sobre los síntomas de burnout. Aunque se ha documentado la obtención de resultados positivos (Jacobson y McGrath 1983), es de subrayar que se han producido en instituciones en que se disponía de tiempo suficiente para el debate sistemático en un entorno sosegado y adecuado (por ejemplo, hospitales con un elevado coeficiente personal-pacientes).

En una recensión de la literatura dedicada a ponderar el éxito de los grupos de debate se ha puesto de relieve la importancia de estos grupos en las salas cuyos pacientes sufren en una proporción elevada de secuelas permanentes y deben aprender a aceptar cambios en su forma de vida Estryn-Béhar 1990).

Kempe, Sauter y Lindner (1992) valoraron los méritos de dos técnicas de apoyo a las enfermeras al borde del burnout que trabajaban en salas de geriatría. Una consistía en un curso de seis meses, compuesto de trece sesiones de asesoramiento profesional; la otra, en un curso de 12 meses de duración, compuesto de 35 sesiones de "grupo Balint". La clarificación y tranquilidad aportadas por las sesiones de "grupo Balint" eran eficaces únicamente si iban acompañadas de un profundo cambio institucional. A falta de esos cambios, la conflictividad puede incluso exacerbarse, y la insatisfacción, incrementarse. A pesar del peligro de burnout, las enfermeras conservaron su enorme profesionalidad y se las ingeniaban para proseguir su trabajo. Estas tácticas compensatorias debían aplicarse en el contexto de una carga de trabajo enormemente elevada. En efecto, el $30 \%$ de las enfermeras hacían más de 20 horas extraordinarias al mes, el $42 \%$ debían afrontar las consecuencias de la escasa dotación de personal durante más de dos tercios de su jornada de trabajo, y, a menudo, el $83 \%$ de las enfermeras tenían que trabajar solas con personal no cualificado. 
Se contrastó la experiencia de estas enfermeras geriátricas con las de sus compañeras que trabajaban en salas de oncología. El índice de burnout era elevado entre las jóvenes enfermeras de oncología, pero se reducía con la antigüedad. Por el contrario, la frecuencia de los síntomas de consunción entre las enfermeras de geriatría se incrementaba con los años y alcanzaba unos valores más elevados que entre sus compañeras de oncología. La ausencia de efectos de la antigüedad en la reducción de los síntomas obedece a las características del trabajo de geriatría.

\section{Necesidad de actuar sobre múltiples factores determinantes}

Algunos autores han extendido el estudio de la gestión eficaz del estrés a los factores organizativos asociados al estrés afectivo.

Así, el análisis de los factores psicológicos y sociológicos formaba parte de los esfuerzos de Theorell por aplicar mejoras casuísticas en las salas de urgencia, de pediatría y de psiquiatría juvenil (Theorell 1993). La tensión afectiva existente antes y después de los cambios se cuantificó utilizando cuestionarios y midiendo los niveles de prolactina en plasma, que reflejan las sensaciones de impotencia en situaciones críticas.

El personal de los servicios de urgencia tenía elevados niveles de tensión afectiva y solía disfrutar de un estrecho margen de decisión. Esto se atribuyó a su confrontación frecuente con situaciones de "vida o muerte", a la intensa concentración que les exigía el trabajo, al gran número de pacientes que tenía que atender y a la imposibilidad de controlar el tipo y número de éstos. En cambio, al tener con los pacientes un contacto habitualmente corto y superficial, estaban menos expuestos al sufrimiento.

Esta situación demostró ser más controlable en las salas de pediatría y de psiquiatría juvenil, en las que se habían implantado procedimientos terapéuticos y de diagnóstico. Los niveles de sobrecarga de trabajo fueron más bajos que en los servicios de urgencia. No obstante, los trabajadores de estas salas trabajaban con niños afectados de graves padecimientos físicos y mentales.

Los grupos de debate de las distintas salas concretaron los cambios organizativos recomendables. El personal de las salas de urgencia se mostró especialmente interesado en los cambios organizativos y formuló una serie de recomendaciones relativas a cuestiones como el tratamiento de las víctimas de violaciones y a los pacientes de edad avanzada sin familia, la evaluación del trabajo y las medidas aconsejables cuando un médico se retrasa. Los debates fueron seguidos de una serie de cambios concretos, como la creación de una plaza de médico jefe y de un servicio de guardia de internistas.

El personal de las salas de psiquiatría juvenil se interesaba especialmente por el desarrollo personal. La reestructuración de los recursos a cargo del médico jefe hizo posible que la tercera parte del personal se sometiese a sesiones de psicoterapia.

En las salas de pediatría se organizaron reuniones quincenales para todo el personal. Al cabo de seis meses se observaba una mejora de las redes de apoyo social, la flexibilidad en la toma de decisiones y el contenido del trabajo.

Los factores identificados en el curso de estos estudios ergonómicos, psicológicos y epidemiológicos pormenorizados constituyen exponentes valiosos de la organización del trabajo. Las investigaciones dedicados a estos factores difieren sensiblemente de los estudios en profundidad de las interacciones multifactoriales y se centran en la descripción práctica de determinados factores específicos.

En 1993, Tintori y Estryn-Béhar (1994) detectaron algunos de estos factores en 57 salas de un gran hospital de la región de París. En 46 salas se observaba un solapamiento superior a 10 minutos entre los turnos, si bien oficialmente no había en
41 de las salas solapamiento alguno entre los turnos nocturno y matutino. En la mitad de los casos estudiados, las auxiliares de enfermería de los tres turnos asistían a estas sesiones informativas. Los médicos de 12 de las salas participaron en las sesiones de mañana y tarde. Durante los tres meses precedentes al estudio sólo 35 salas habían organizado reuniones dedicadas al análisis del pronóstico y las altas de los pacientes, así como el grado de comprensión y la reacción de los mismos a sus patologías. Durante el año previo al estudio, los trabajadores del turno de día de 18 de las salas no habían recibido formación alguna, y únicamente en 16 salas se había impartido alguna formación a los trabajadores del turno de noche.

Algunas de las nuevas salas de estar no se utilizaban, ya que distaban entre 50 y 85 metros de las habitaciones de algunos pacientes. Por lo tanto, el personal prefería celebrar sus reuniones informales en torno a la máquina de café de un saloncito pequeño, pero cercano. Los médicos también disfrutaban de la pausa para tomar café durante el turno de día de 45 salas. Sin duda, las quejas de las enfermeras sobre las frecuentes interrupciones de la labor y sobre su sensación de agobio por el trabajo son imputables, en parte, a la escasez de asientos (menos de cuatro en 42 de las 57 salas) y a la falta de espacio en las salas de enfermeras, en las que nueve trabajadoras deben permanecer la mayor parte de la jornada.

La interacción entre el estrés, la organización del trabajo y las redes de apoyo se evidencia en los estudios de la unidad de atención domiciliaria del hospital de Mostala, Suecia (Beck-Friis, Strang y Sjöden 1991; Hasselhorn y Seidler 1993). El riesgo de experimentar consunción, que se suele considerar elevado en las unidades de cuidados paliativos, no se revela significativo en estos estudios, en los que, ciertamente, se pone de manifiesto un mayor nivel de satisfacción en el trabajo que de estrés profesional. La rotación del personal y las interrupciones del trabajo eran escasas en esas unidades, cuyo personal manifestaba una elevada autoestima. Este resultado se atribuía a los criterios de selección del personal, al buen trabajo de equipo, a una retroinformación positiva y a la educación continua. Los costes de personal y de capital fijo de las unidades oncológicas para enfermos terminales suelen oscilar entre el 167 y el $350 \%$ de los correspondientes a los servicios hospitalarios de atención domiciliaria. En 1993 había en Suecia más de 20 unidades de este tipo.

\section{HORARIOS DE TRABAJO Y TRABAJO NOCTURNO EN LA ASISTENCIA SANITARIA}

\section{Madeleine R. Estryn-Béhar}

Durante mucho tiempo, las enfermeras y auxiliares de enfermería eran las únicas mujeres que trabajaban de noche en muchos países (Gadbois 1981; Estryn-Béhar y Poinsignon 1989). Aparte de los problemas ya estudiados entre los hombres, las mujeres que desempeñan estos trabajos tienen otras dificultades asociadas a sus responsabilidades familiares. La falta de sueño se ha establecido fehacientemente y subsiste la preocupación sobre la calidad de la asistencia que pueden prestar a falta de un descanso adecuado.

\section{Organización de los horarios y obligaciones familiares}

Aparentemente, las percepciones personales de la vida social y personal determinan, al menos, en parte, la decisión de aceptar o 


\begin{tabular}{|c|c|c|}
\hline & Turnos rotatorios (\%) & Turnos de día (\%) \\
\hline Trabajo físico intenso & 55,5 & 31,3 \\
\hline Trabajo mental intenso & 80,2 & 61,9 \\
\hline Trabajo frecuentemente agotador & 46,8 & 24,8 \\
\hline Plantilla insuficiente & 74,8 & 43,8 \\
\hline Pausas insuficientes & 78,4 & 56,6 \\
\hline $\begin{array}{l}\text { Injerencia del trabajo en } \\
\text { la vida privada }\end{array}$ & 52,8 & 31,0 \\
\hline Insatisfacción con los horarios & 36,9 & 2,7 \\
\hline Falta de sueño frecuente & 34,9 & 19,5 \\
\hline Fatiga frecuente al levantarse & 31,3 & 17,3 \\
\hline
\end{tabular}

Fuente: Van Deursen y cols. 1993.

rehusar el trabajo nocturno. A su vez, estas percepciones inducen a los trabajadores a quitar importancia o magnificar sus problemas de salud (Lert, Marne y Gueguen 1993; Ramaciotti y cols. 1990). Entre el personal no cualificado, la remuneración constituye el factor determinante de la aceptación o desestimación del trabajo nocturno.

Otros horarios de trabajo también pueden plantear problemas. Los trabajadores del turno de mañana deben despertarse a veces antes de las 05:00 y sacrificar así una parte del sueño tan esencial para su recuperación. Por su parte, los turnos vespertinos suelen finalizar entre las 21:00 y las 23:00 horas, con la consiguiente limitación de la vida social y familiar. Esto hace que únicamente el $20 \%$ de las mujeres empleadas en los grandes hospitales universitarios tengan unos horarios de trabajo sincronizados con el resto de la sociedad (Cristofari y cols. 1989).

Las quejas sobre los horarios de trabajo son más frecuentes entre los trabajadores sanitarios que entre el resto de los trabajadores $(62 \%$ contra $39 \%)$ y figuran, ciertamente, entre las más frecuentemente formuladas por las enfermeras (Lahaye y cols. 1993).

Un estudio ha permitido conocer la correlación entre la satisfacción en el trabajo y los factores sociales, incluso no existiendo falta de sueño (Verhaegen y cols. 1987). Las enfermeras de la muestra estudiada que sólo trabajaban en el turno de noche mostraban mayor satisfacción en el trabajo que las que rotaban en los diversos turnos. Las diferencias se atribuían a la circunstancia de que todas las del turno de noche habían optado por ese horario y habían estructurado su vida familiar en torno al mismo, al tiempo que, para las enfermeras que rotaban en los turnos, incluso el servicio ocasional en el turno de noche suponía una perturbación de su vida personal y familiar. Sin embargo, Estryn-Béhar y cols. (1989b) informan de que las madres que trabajan exclusivamente en el turno de noche se mostraban más fatigadas y causaban baja con mayor frecuencia que sus compañeros varones.

En los Países Bajos, las quejas sobre el trabajo eran más frecuentes entre las enfermeras que rotaban en los turnos que entre sus compañeras que sólo trabajaban de día (Van Deursen y cols. 1993) (véase la Tabla 97.8).

\section{Perturbaciones del sueño}

En los días laborables, las enfermeras del turno de noche duermen, como media, dos horas menos que el resto de las enfermeras (Escribá Agüir y cols. 1992; Estryn-Béhar y cols. 1978; Estryn-Béhar y cols. 1990; Nyman y Knutsson 1995). Según diversos estudios, también duermen mal (Schroër y cols. 1993; Lee 1992; Gold y cols. 1992; Estryn-Béhar y Fonchain 1986).

En una serie de entrevistas con 635 enfermeras de Massachusetts, Gold y cols. (1992) hallaron que el 92,2 \% de las que alternaban el turno de mañana con el de tarde conservaban un período "puente" de sueño nocturno de cuatro horas con el mismo horario a lo largo del mes, en contraste con sólo el 6,3\% de las limitadas al turno de noche y ninguna de las que alternaban en los turnos diurnos y nocturnos. El cociente de probabilidades de "sueño inadecuado", ajustado en función de la edad y la antigüedad, era de 1,8 en las enfermeras del turno de noche y de 2,8 en las que rotaban en varios turnos, incluido el de noche, respecto a sus compañeras de los turnos de mañana y de tarde. Además, el cociente de probabilidades de tomar somníferos era de 2,0 en las enfermeras de noche y de turnos rotativos, en contraste con las de los turnos de mañana y de tarde.

\section{Problemas afectivos y fatiga}

La frecuencia de los síntomas asociados al estrés y de las quejas de haber dejado de disfrutar con su trabajo era mayor entre las enfermeras finlandesas que rotaban en los turnos que entre las demás enfermeras (Kandolin 1993). Estryn-Béhar y cols. (1990) informan de que la puntuación obtenida por las enfermeras del turno de noche en el Cuestionario de Salud General utilizado en la evaluación de la salud mental, en comparación con las enfermeras del turno de día (índice de probabilidades de 1,6), apunta a un peor estado de salud.

En otro estudio realizado por Estryn-Béhar y cols. (1989), se entrevistó a una muestra representativa de la cuarta parte del total de trabajadores del turno de noche (1.496 personas) en 39 hospitales de la región de París. Se observan diferencias en los hallazgos, en función del sexo y la cualificación (cualificados = enfermeros jefe y enfermeros; no cualificados = auxiliares de enfermería y asistentes). El $40 \%$ de las mujeres cualificadas y el $37 \%$ de las no cualificadas; y el $29 \%$ de los varones cualificados y el $20 \%$ de los no cualificados, se quejaban de fatiga excesiva. El aumento de la fatiga era una queja común al $42 \%$ de las mujeres cualificadas y el $35 \%$ de las no cualificadas, y el $28 \%$ de los varones cualificados y el $24 \%$ de los no cualificados. Un tercio de los trabajadores del turno de noche, y un porcentaje sustancialmente mayor de mujeres, manifestaban sufrir de frecuentes accesos de irritabilidad. Las mujeres sin hijos manifestaban síntomas de fatiga excesiva, aumento de la fatiga y accesos de irritabilidad en una proporción dos veces mayor que sus compañeros en idéntica situación familiar. El incremento respecto de las cifras correspondientes a los varones solteros sin hijos era aún más acentuado entre las mujeres con uno o dos hijos, y más notable aún (del cuádruplo) para las mujeres con un mínimo de tres hijos.

Según un estudio sueco de una muestra estratificada de 310 trabajadores de la sanidad (Nyman y Knutsson 1995), el $58 \%$ de los trabajadores del turno de noche y el $42 \%$ de sus compañeros del turno de día se quejaban de un aumento de la fatiga. Por su parte, el $15 \%$ de los trabajadores del turno de día y el $30 \%$ de sus colegas del turno de noche acusaban una fatiga intensa en el trabajo. Casi una cuarta parte de los trabajadores del turno de noche confesaban que se dormían durante el trabajo. Por otra parte, el $20 \%$ de los trabajadores del turno de noche y el $9 \%$ de sus compañeros del turno diurno acusaban falta de memoria.

En Japón, la asociación de salud y seguridad en el trabajo publica los resultados de la exploración médica de todos los trabajadores por cuenta ajena del país. En su informe figuran los 
resultados de la exploración de 600.000 trabajadores del sector de la seguridad e higiene. Las enfermeras suelen rotar en los turnos de trabajo, y las que trabajan de noche suelen quejarse más de sufrir fatiga, seguidas de las trabajadoras de los turnos vespertino y de mañana, por ese orden (Makino 1995). Los síntomas más frecuentemente acusados por las enfermeras del turno de noche son el insomnio, la tristeza y la dificultad para concentrarse, registrándose también numerosas quejas sobre la fatiga acumulada y la dislocación de la vida social (Akinori e Hiroshi 1985).

\section{Trastornos afectivos y del sueño entre los médicos}

Los investigadores se han interesado por los efectos del contenido y la duración del trabajo en la vida privada de los médicos jóvenes y en el riesgo de padecer depresión. Valko y Clayton (1975) hallaron que el $30 \%$ de los jóvenes médicos residentes sufrían una crisis depresiva de una duración media de cinco meses durante su primer año de residencia. Cuatro de los 53 médicos residentes estudiados habían mostrado inclinaciones suicidas, y tres de ellos habían concretado planes para privarse de la vida. Tanto Reuben (1985) como Clark y cols. (1984) informan de índices de depresión similares.

En una investigación mediante cuestionario, Friedman, Kornfeld y Bigger (1971) hallaron que los internos afectados de falta de sueño acusaban mayor propensión a la tristeza, el egoísmo y la modificación de su vida social que los internos más descansados. En las entrevistas que siguieron a los cuestionarios, los internos afectados de falta de sueño manifestaron sufrir de dificultades para el razonamiento lógico, depresión, irritabilidad, despersonalización, reacciones impropias y pérdida momentánea de memoria.

En un estudio longitudinal de un año de duración, Ford y Wentz (1984) realizaron cuatro evaluaciones de 27 internos durante su internado. A lo largo de este período, cuatro internos sufrieron, al menos, un grave episodio de depresión diagnosticado según los criterios normalizados, y otros once sufrieron una depresión clínica. Los episodios de ira, fatiga y cambios de humor se incrementaron a lo largo del año, en proporción inversa al número de horas de sueño de la semana anterior.

En una revisión de las investigaciones publicadas se han reseñado seis estudios en los que los internos que habían pasado una noche en vela mostraban mal humor, falta de motivación, deterioro de la capacidad de razonamiento, aumento de la fatiga y ansiedad (Samkoff y Jacques 1991).

Devienne y cols. (1995) realizaron entrevistas de una muestra estratificada de 220 médicos generales de la región de París, 70 de los cuales hacían guardias nocturnas. La mayoría de los médicos adscritos a las guardias $(65 \%$ de los hombres y $88 \%$ de las mujeres) manifestaron sufrir perturbaciones del sueño mientras se encontraban de guardia y reconocían experimentar grandes dificultades para recuperar el sueño después de haber sido despertados. El $22 \%$ de los hombres y el $44 \%$ de las mujeres manifestaban que solían despertarse durante la noche por causas ajenas al servicio. Asimismo, el $15 \%$ de los hombres y el $19 \%$ de las mujeres confesaban haber sufrido o haber estado a punto de sufrir un accidente de circulación motivado por la somnolencia. Este riesgo era mayor entre los médicos que hacían más de cuatro guardias mensuales $(30 \%)$ que entre los que hacían tres o cuatro guardias al mes $(22 \%)$ y entre los que se encontraban de guardia de una a tres veces por mes $(10 \%)$. El $69 \%$ de las mujeres y el $46 \%$ de los hombres manifestaban que, el día siguiente a una guardia, tenían problemas de concentración y la sensación de que su eficacia se reducía, al tiempo que el $37 \%$ de los hombres y el $31 \%$ de las mujeres confesaban sufrir cambios de estado de ánimo. El déficit de sueño acumulado no se recuperaba el día siguiente a la guardia.

\section{Vida social y familiar}

Una encuesta realizada con una muestra de 848 enfermeras que trabajaban en turno de noche puso de manifiesto que, el mes anterior, la cuarta parte de las entrevistadas no habían salido ni habían recibido visitas, al tiempo que la mitad sólo habían realizado esas actividades sociales en una ocasión (Gadbois 1981). Un tercio de las encuestadas habían rehusado alguna invitación por causa del cansancio, y las dos terceras partes sólo había salido una vez, porcentaje éste que se elevaba al $80 \%$ entre las madres.

Kurumatani y cols. (1994) revisaron las hojas de control de horas de 239 enfermeras japonesas que habían rotado en los turnos de trabajo durante un total de 1.016 días, hallando que las enfermeras con hijos pequeños dormían menos y dedicaban menos tiempo al ocio que las compañeras que no compartían esa situación familiar.

Estryn-Béhar y cols. (1989b) observan que las mujeres son mucho menos propensas que los hombres a dedicar, al menos, una hora semanal a la práctica de deportes individuales o de equipo (el $48 \%$ de las mujeres cualificadas y el $29 \%$ de las no cualificadas, contra el $65 \%$ de los varones cualificados y el $61 \%$ de los no cualificados). Asimismo, las mujeres manifiestan mucha menos tendencia que los hombres a frecuentar (no menos de cuatro veces por mes) locales de espectáculos (el $13 \%$ de las mujeres cualificadas y el $6 \%$ de las no cualificadas, en comparación con el $20 \%$ de los varones cualificados y el $13 \%$ de los no cualificados). En cambio, hombres y mujeres compartían en proporciones similares otras actividades domésticas, como la lectura y la televisión. El análisis multivariable puso de manifiesto que los hombres sin hijos eran más propensos a dedicar, al menos, una hora semanal a la práctica deportiva que las mujeres de características similares, y el desfase se acentúa a medida que aumenta el número de hijos. En efecto, los hábitos de lectura son una función, más del tiempo dedicado a cuidar de los hijos que del sexo. Un porcentaje considerable de los individuos incluidos en la muestra estudiada eran progenitores solteros. Esta circunstancia era muy infrecuente entre los varones cualificados $(1 \%)$, menos infrecuente entre los no cualificados $(4,5 \%)$, relativamente común entre las mujeres cualificadas $(9 \%)$ y sumamente frecuente entre las no cualificadas $(24,5 \%)$.

Según el estudio realizado por Escribá Agüir (1992) sobre los trabajadores de la sanidad española, la incompatibilidad de la rotación de turnos con la vida familiar y social constituía la principal fuente de insatisfacción. Además, el trabajo nocturno (permanente o alternante) perturbaba la sincronización de sus horarios con los del cónyuge.

La falta de tiempo libre perjudica seriamente la vida privada de internos y residentes. Landau y cols. (1986) hallaron que el $40 \%$ de los residentes reconocían tener graves problemas conyugales, de los que un $72 \%$ de ellos culpaba a su trabajo. McCall (1988) observa que los residentes no tienen apenas tiempo para cultivar sus relaciones sociales. Este problema es especialmente acusado entre las mujeres cercanas al final de su ciclo de vida fértil de bajo riesgo.

\section{Trabajo por turnos irregulares y embarazo}

Axelsson, Rylander y Molin (1989) distribuyeron un cuestionario entre 807 trabajadoras del hospital de Mölna, Suecia. El peso al nacer de los hijos de las trabajadoras no fumadoras que alternaban en varios turnos era sensiblemente inferior al de los niños de las mujeres que trabajaban exclusivamente de día. Las diferencias eran más acusadas respecto a los niños no primogénitos $(3,489 \mathrm{~kg}$ frente a $3,793 \mathrm{~kg})$. Se hallaron diferencias análogas en 
los recién nacidos no primogénitos de mujeres que trabajaban en los turnos de tarde $(3,073 \mathrm{~kg})$ o que alternaban turnos cada 24 horas $(3,481 \mathrm{~kg})$.

\section{Concentración y calidad del trabajo entre las enfermeras del turno de noche}

Englade, Badet y Becque (1994) realizaron un EEG Holter a dos grupos de nueve enfermeras. El experimento puso de manifiesto que el grupo al que no se permitió dormir sufría falta de concentración caracterizada por un estado de somnolencia y, en algunos casos, incluso por episodios de sueño de los que no era consciente. Un grupo experimental recurrió al sueño polifásico en un intento por recuperar algo de sueño durante las horas de trabajo, al tiempo que no se permitió al grupo de control recuperar el sueño atrasado.

Estos resultados son similares a los hallazgos de una encuesta realizada entre 750 enfermeras de California (Lee 1992), según la cual el $4 \%$ de las enfermeras del turno de noche y el 4,3\% de las que rotaban en los turnos manifestaban sufrir frecuentes déficits de concentración; en cambio, ninguna de las pertenecientes al resto de los turnos manifestó tener problemas de falta de atención. El 48,9 \% de las enfermeras del turno de noche, el 39,2 de las que rotaban en los turnos, el 18,5\% de las que trabajaban en el turno de día y el 17,5 \% de las del turno vespertino manifestaban experimentar ocasionales déficits de atención. Por su parte, el 19,3\% del total de las enfermeras de noche y de las que rotaban en los turnos confesaban haber tenido dificultad para mantenerse despiertas mientras asistían a los pacientes durante el mes precedente a la encuesta, en contraste con el 3,8 \% de sus compañeras de los turnos diurno y vespertino. Asimismo, el $44 \%$ de las enfermeras pertenecientes a los dos grupos primeramente citados manifestaron que les resultaba difícil mantener el estado de vigilia mientras conducían durante el mes precedente a la encuesta, en comparación con el $19 \%$ de las enfermeras del turno de día y el $25 \%$ de sus compañeras del turno de tarde.

Smith y cols. (1979) estudiaron 1.228 enfermeras de 12 hospitales norteamericanos. La tasa de accidentes de trabajo entre los sujetos de la muestra era de 23,3 en las enfermeras que rotaban en los turnos, 18 en las del turno de noche, 16,8 en sus compañeras de día y 15,7 en las del turno de tarde.

En un esfuerzo por mejorar la definición de los problemas asociados al déficit de concentración de las enfermeras del turno de noche, Blanchard y cols. (1992) realizaron un seguimiento de la actividad y las incidencias registradas a lo largo de una serie de noches. El estudio se llevó a cabo en seis salas cuya actividad comprendía desde cuidados intensivos hasta la atención de enfermos crónicos. En cada sala se llevó a cabo un seguimiento continuo de una enfermera durante la segunda noche (del turno de noche) y dos seguimientos durante la tercera y cuarta noches (en función del horario de trabajo). No se registraron incidencias con resultados graves. En la segunda noche, el número de incidencias pasó a ser, de ocho registradas durante la primera mitad de la noche, a dieciocho durante la segunda mitad. En la tercera y cuarta noches, el incremento fue, respectivamente, de 13 a 33 y de 11 a 35 incidencias. Los autores subrayan la importancia de las pausas para dormir en la limitación del riesgo.

Utilizando una muestra de 635 enfermeras de Massachusetts, Gold y cols. (1992) recopilaron datos de la frecuencia y las consecuencias de los déficit de concentración. El 35,5 \% de las enfermeras que rotaban en los turnos, incluido el de noche, el $32,4 \%$ de las enfermeras de noche, y el 20,7 de sus compañeras de los turnos de mañana y de tarde que, excepcionalmente, trabajaban de noche manifestaron haber experimentado, como mínimo, un episodio de somnolencia durante el trabajo. Menos del $3 \%$ de las enfermeras de los turnos de mañana y de tarde se quejaron de estos problemas.
El cociente de probabilidades de sufrir somnolencia durante la conducción hacia y desde el lugar de trabajo era de 3,9 en las enfermeras que rotaban en los turnos -incluido el nocturnoy de 3,6 en las que trabajaban en este turno, respecto a las enfermeras de los turnos de mañana y de tarde. El cociente de probabilidades de producción de accidentes y errores durante el año precedente (accidentes de circulación en los trayectos hacia y desde el lugar de trabajo), errores en la medicación o en el método de trabajo, y accidentes de trabajo asociados a la somnolencia) era de casi 2 en las enfermeras que rotaban en los turnos, incluido el de noche, respecto a sus compañeras de los turnos de mañana y de tarde.

\section{Efectos de la fatiga y la somnolencia en el rendimiento de los médicos}

Varios estudios han demostrado que la fatiga y el insomnio inducidos por el trabajo nocturno y las guardias contribuyen a deteriorar el rendimiento de los médicos.

Wilkinson, Tyler y Varey (1975) remitieron por correo un modelo de cuestionario a 6.500 médicos de los hospitales británicos. El $37 \%$ de los 2.452 facultativos que respondieron manifestaron que su rendimiento se resentía de los horarios de trabajo excesivamente prolongados. En su respuesta a las preguntas de un cuestionario convencional, 141 médicos residentes confesaron haber sufrido errores por causa del exceso de trabajo y la falta de sueño. En otro estudio realizado en los hospitales de la provincia canadiense de Ontario, el $70 \%$ de los 1.806 médicos investigados se manifestaron preocupados por los efectos que la carga de trabajo tendría sobre la calidad (Lewittes y Marshall 1989). Específicamente, el $6 \%$ de los sujetos de la muestra $-\mathrm{y}$ el $10 \%$ de los internos - reconocieron que solían sentir preocupación por el riesgo de que la fatiga deteriorase la calidad de la asistencia que dispensaban.

Dada la dificultad de realizar evaluaciones en tiempo real del rendimiento del trabajo clínico, diversos estudios de los efectos del insomnio en los médicos se han basado en pruebas neuropsicológicas.

En la mayoría de los estudios revisados por Samkoff y Jacques (1991), los residentes privados de sueño durante una noche mostraron escaso deterioro del rendimiento en la realización de pruebas rápidas de destreza manual, tiempo de reacción y memoria. En catorce de las investigaciones citadas se utilizaron baterías de pruebas. En cinco de las pruebas, los efectos sobre el rendimiento fueron ambiguos; en seis de ellas, se observó un déficit de rendimiento; sin embargo, en otras ocho, no se apreció déficit alguno.

Rubin y cols. (1991) estudiaron una muestra de 63 residentes de una sala asistencial, antes y después de una guardia de 36 horas, seguida de una jornada completa de trabajo, utilizando una batería de pruebas de comportamiento informatizadas, autoevaluadas por los sujetos. Los médicos sometidos a la prueba con posterioridad a la guardia mostraron déficit significativos del rendimiento en las pruebas de concentración visual, velocidad y precisión de codificación y memoria a corto plazo. La duración del sueño de que disfrutaron los residentes durante la guardia fue como sigue: un máximo de dos horas en 27 sujetos, un máximo de cuatro horas en 29 sujetos, un máximo de seis horas en 4 sujetos y un máximo de siete horas en 3 sujetos. Lurie y cols. (1989) informan igualmente en su estudio de una duración escasa del sueño.

No se ha observado virtualmente ninguna diferencia en la ejecución de actos clínicos de corta duración, reales o simulados como rellenar un volante para el laboratorio (Poulton y cols. 1978; Reznick y Folse 1987), simular una sutura (Reznick y Folse 1987), una intubación endotraqueal (Storer y cols. 1989) y un cateterismo venoso y arterial (Storer y cols. 1989) - entre 
los sujetos privados de sueño y el grupo de control. La única diferencia consistió en una ligera prolongación del tiempo consumido por los residentes insomnes para realizar el cateterismo endotraqueal.

Por otra parte, diversos estudios han puesto de relieve la existencia de diferencias significativas respecto a las tareas que precisan atención continua o concentración intensa. Por ejemplo, los internos privados de sueño cometieron el doble de errores en la lectura de electrocardiogramas de 20 minutos que sus compañeros más descansados (Friedman y cols. 1971). En dos estudios, uno consistente en simulaciones basadas en pantallas de visualización de 50 minutos de duración (Beatty, Ahern y Katz 1977), y otro basado en simulaciones en vídeo de 30 minutos (Denisco, Drummond y Gravenstein 1987), se ha observado un rendimiento inferior de los anestesiólogos que habían permanecido insomnes una noche. Según otro estudio, una muestra de residentes que no habían podido dormir experimentó una sensible reducción del rendimiento en un examen de tipo test de cuatro horas de duración (Jacques, Lynch y Samkoff 1990). Goldman, McDonough y Rosemond (1972) utilizaron un circuito cerrado cinematográfico en el estudio de 33 procedimientos quirúrgicos. Se halló que los cirujanos que habían dormido menos de dos horas "rendían menos" que sus colegas más descansados. El tiempo consumido por la ineficacia o la indecisión de los cirujanos (esto es, por los actos mal preparados) superaba el $30 \%$ de la duración total de la operación.

Bertram (1988) examinó durante un mes las hojas clínicas de ingreso en urgencias rellenadas por los residentes de segundo año. Respecto a un determinado diagnóstico, se consignaba menos información sobre el historial clínico y los resultados de las exploraciones médicas a medida que aumentaba el número de pacientes y de horas de trabajo.

Smith-Coggins y cols. (1994) analizaron el EEG, el estado de ánimo, el rendimiento cognitivo y el rendimiento motor de seis médicos de salas de urgencia a lo largo de dos períodos de 24 horas: uno de trabajo diurno y descanso nocturno, el otro, de trabajo nocturno y sueño durante el día.

Los médicos que trabajaban de noche dormían mucho menos (328,5 frente a 496,6 minutos) y rendían bastante menos. La reducción del rendimiento motor se reflejaba en el mayor tiempo necesario para realizar una intubación simulada (42,2 frente a 31,56 segundos) y en el mayor número de errores en los protocolos.

El rendimiento cognitivo de los sujetos se evaluó en cinco períodos de prueba distribuidos a lo largo del turno. En cada prueba, se pidió a los médicos que examinasen 4 historiales extraídos de un lote de 40, los clasificasen y relacionasen los procedimientos iniciales, el tratamiento y los ensayos de laboratorio indicados. El rendimiento de los médicos de ambos turnos se reducía con el paso de las horas. El número de respuestas correctas de los médicos del turno de noche fue inferior al de sus compañeros del turno de día.

Los médicos que trabajaban durante el día mostraban menos somnolencia, mayor satisfacción y más lucidez que los del turno nocturno.

En las directrices adoptadas en los países de habla inglesa sobre el horario de trabajo de los médicos en prácticas se suelen tomar en consideración estos hallazgos y actualmente se tiende a una jornada semanal máxima de 70 horas y al establecimiento de períodos de descanso después de las guardias. En Estados Unidos, como consecuencia de la muerte - ampliamente comentada en la prensa - de un paciente atribuida a los errores de un médico residente mal supervisado y agobiado por el trabajo, se promulgó en el Estado de Nueva York una ley por la que se limitaban las horas de trabajo de los médicos residentes y se definía la función de los médicos de cabecera en la supervisión de su actividad.

\section{Contenido del trabajo nocturno en los hospitales}

El trabajo nocturno se ha infravalorado durante mucho tiempo. En Francia, por ejemplo, la enfermera recibía el nombre de "garde", término que denota la idea de que la misión de estos profesionales se circunscribía a vigilar el sueño de los pacientes, sin prestarles asistencia. La falsedad de esta idea se fue evidenciando a medida que la duración de la hospitalización se reducía y aumentaba la incertidumbre de los pacientes sobre su hospitalización. Los enfermos hospitalizados precisan frecuentes intervenciones técnicas durante la noche, precisamente cuando el coeficiente enfermeras-pacientes es menor.

La importancia del tiempo que las enfermeras pasan con los pacientes se ha puesto de relieve en un estudio basado en el seguimiento continuado de la ergonomía de la labor de las enfermeras de cada uno de los tres turnos de trabajo existentes en diez salas (Estryn-Béhar y Bonnet 1992). El tiempo que las enfermeras pasaban en las habitaciones de los pacientes suponía, en promedio, el $27 \%$ de la duración de los turnos de mañana y de noche, y el $30 \%$ del turno de tarde. En cuatro de las diez salas estudiadas, las enfermeras pasaban más tiempo con los pacientes durante la noche que por el día. Aunque, obviamente, la extracción de muestras de sangre era menos frecuente durante la noche, otras intervenciones médicas, como la vigilancia de las constantes vitales, la medicación y la administración, el ajuste y la supervisión de goteos y transfusiones intravenosas, eran más frecuentes durante la noche en seis de las siete salas en las que se realizaban análisis detallados. El número total de intervenciones de asistencia directa, técnicas y no técnicas, era mayor durante la noche en seis de las siete salas.

Las posturas adoptadas por las enfermeras durante el trabajo variaban de uno a otro turno. El porcentaje de tiempo que estas trabajadoras pasaban en posición sentada (preparación, redacción, consulta, contacto con los pacientes, pausas, etc.) era mayor durante la noche en siete de las diez salas, y rebasaba el $40 \%$ de la duración del turno en seis de las salas encuestadas. De noche, sin embargo, el tiempo que pasaban en posturas incómodas (agachadas, inclinadas, con los brazos extendidos, llevando pesos, etc.) rebasaba el $10 \%$ de la duración del turno en la totalidad de las salas, y superaba el $20 \%$ de ese tiempo en seis salas. En cinco salas, el porcentaje de tiempo pasado en posturas incómodas era mayor durante la noche. Ciertamente, las enfermeras del turno de noche también cambian sábanas y realizan diversas tareas relacionada con la higiene y de alivio y evacuación, que en los turnos de día corresponden normalmente a las auxiliares de enfermería.

Las enfermeras del turno de noche se ven a veces obligadas a desplazarse con frecuencia. En efecto, en todas las salas de la muestra, esas trabajadoras realizaban más de cien desplazamientos durante el turno, y en seis de las salas, la frecuencia de los desplazamientos era mayor durante la noche. Sin embargo, como las rondas estaban programadas a las 00:00, las 2:00, las 4:00 y las 6:00 horas, las enfermeras sólo tenían que desplazarse largas distancias en las salas de cuidados intensivos infantiles. En todo caso, las enfermeras de tres de las siete salas en las que existían servicios de podometría debían andar más de seis kilómetros.

Las conversaciones con los pacientes eran más comunes durante la noche, superando la cota de 30 por cada turno en la totalidad de las salas; en cinco de las salas, estos contactos eran más frecuentes de noche. En cambio, las conversaciones con los médicos eran más raras y, por regla general, breves. 
Leslie y cols. (1990) realizaron un seguimiento continuo, durante 15 días invernales consecutivos, de la labor de 12 de los 16 internos del servicio clínico de un hospital de 340 camas de la ciudad escocesa de Edimburgo. En cada sala se atendía a unos 60 pacientes. El seguimiento abarcó un total de 22 turnos de día (08:00 a 18:00 horas) y 18 guardias (18:00 a 08:00 horas), equivalentes a 472 horas de trabajo. La duración teórica de la jornada semanal de los internos oscilaba entre 83 y 101 horas, en función de que se encontrasen de guardia el fin de semana. Sin embargo, además del horario de trabajo oficial, cada interno pasaba, en promedio, 7,3 horas semanales realizando diversas actividades en el hospital. Un equipo de observadores cualificados adscritos a cada interno se dedicó a recoger datos del tiempo invertido, minuto a minuto, en la realización de cada una de una serie de 17 actividades.

El mayor período de trabajo continuo observado fue de 58 horas (de las 08:00 horas del sábado a las 06:00 horas del lunes), y el mayor período de trabajo fue de 60,5 horas. Se calculó que la baja por enfermedad de una semana de un interno obligaría a otros dos internos de la sala a incrementar su carga de trabajo en 20 horas.

En la práctica, en las salas que admitían pacientes durante los turnos de guardia, los internos que hacían consecutivamente el turno de día, la guardia y el turno de noche sólo dejaron de trabajar 4,6 de las 34 horas transcurridas. Durante esas 4,6 horas, consumidas en comidas y en descansar, seguían de guardia y disponibles para el servicio. En las salas en que no se admitía nuevos pacientes durante las guardias, la carga de trabajo sólo se reducía pasada la medianoche.
Los horarios de las guardias vigentes en otras salas obligaban a los internos a pasar unos 25 minutos de cada turno fuera de la suya. En promedio, durante el turno de noche debían andar 3 kilómetros y pasar 85 minutos (entre 32 y 171 minutos) en otras salas.

Por otra parte, algunas tareas, como la de rellenar peticiones de exploraciones y gráficas clínicas, se suelen realizar fuera de las horas habituales de trabajo. Una observación no sistemática de este trabajo adicional puso de manifiesto que supone unos 40 minutos complementarios al final de cada turno (18:00 horas).

Durante el día, los internos dedicaban entre el 51 y el $71 \%$ de su tiempo a prestar asistencia a los pacientes, en contraste con un 20 y un $50 \%$ durante la noche. Según otro estudio realizado en Estados Unidos, entre el 15 y el $26 \%$ del tiempo de trabajo se invertía en la atención a los pacientes (Lurie y cols. 1989)

En el estudio se llegaba a la conclusión de que eran precisos más internos y de que no debía exigírseles que se desplazasen a otras salas durante las guardias. La contratación de otros tres internos permitió reducir la jornada semanal a una media de 72 horas y finalizar el trabajo a las 18:00 horas, exceptuadas las guardia. Los internos también consiguieron librar media jornada al finalizar las guardias y antes de iniciar las guardias de fines de semana. Dos de las salas contrataron sendas secretarias en prácticas que, en una jornada semanal de 10 horas, rellenaban entre 700 y 750 impresos en cada sala. En opinión de los médicos titulares y de las enfermeras, la medida contribuyó a mejorar la eficacia de las rondas, ya que la información precisa se había consignado correctamente.

\section{MEDIO AMBIENTE FISICO Y ASISTENCIA SANITARIA}

\section{EXPOSICION A AGENTES FISICOS}

\section{Robert M. Lewy}

Los trabajadores sanitarios afrontan numerosos peligros físicos.

\section{Peligros eléctricos}

El incumplimiento de las normas de seguridad en el diseño y uso del equipo eléctrico es la infracción más frecuente en todos los sectores. En los hospitales, los fallos del sistema eléctrico constituyen la segunda causa en orden de importancia de los incendios. Además, en estos centros se utiliza una gran variedad de equipo eléctrico en entornos peligrosos (por ejemplo, en lugares húmedos o mojados, o en la vecindad de sustancias combustibles o inflamables).

La conciencia de estas circunstancias y del peligro que pueden entrañar para la integridad de los pacientes ha inducido a la mayoría de los hospitales a prestar una atención especial a la mejora de la seguridad de los sistemas eléctricos de las áreas de asistencia a los pacientes. No obstante, en ocasiones se descuidan las áreas no asistenciales y no es raro encontrar en ellas aparatos eléctricos pertenecientes a los trabajadores o al mismo hospital:

- clavijas de tres hilos (puestas a tierra) empalmadas a cables de dos hilos (sin conexión a tierra)

- terminales de conexión a tierra doblados o cortados

- aparatos eléctricos empalmados a "crucetas" de clavijas múltiples

- alargadores de cables con una inadecuada conexión a tierra
- cables empalmados a clavijas con una conexión a tierra inadecuada (el $25 \%$ de los aparatos de rayos X examinados en un hospital carecían de un cableado adecuado).

\section{Prevención y control}

Es preciso que todas las instalaciones eléctricas se ajusten a los reglamentos y normas de seguridad aplicables. Se recomiendan diversas medidas de prevención de incendios y descargas a los trabajadores:

- realización de inspecciones periódicas de todas las áreas de trabajo a cargo de un ingeniero eléctrico, con objeto de detectar y eliminar posibles factores de riesgo, como la presencia de aparatos y equipo eléctrico carente de conexión a tierra o de un mantenimiento adecuado

- inclusión de la seguridad de los sistemas eléctricos, tanto en las directrices, como en los programas de formación en el centro de trabajo.

Se debe enseñar a los trabajadores a:

- no utilizar el equipo eléctrico con las manos mojadas, sobre superficies húmedas o mientras están en suelos mojados

- no utilizar dispositivos capaces de hacer saltar los fusibles o activar interruptores de circuitos hasta que se hayan revisado

- no utilizar ningún equipo, aparato eléctrico o roza que parezca estar dañado o en pobres condiciones de mantenimiento

- utilizar alargadores exclusivamente de forma temporal y en situaciones de urgencia

- elegir alargadores capaces de soportar el voltaje generado

- desconectar el equipo antes de desenchufarlo 
- comunicar inmediatamente cualquier descarga (incluidos los simples chispazos) y no reutilizar el equipo afectado hasta tanto no haya sido inspeccionado.

\section{Calor}

Si bien los efectos del calor sobre la salud de los trabajadores de los hospitales pueden consistir en golpes de calor, agotamiento, desmayos y calambres, estos episodios no son frecuentes. Mucho más comunes son los efectos, más moderados, de la fatiga, la incomodidad y la incapacidad de concentración. La importancia de esos fenómenos reside en que incrementan el riesgo de accidentes.

La exposición al calor se mide mediante termómetros especiales que analizan los efectos de la radiación de calor y la humedad con la temperatura y que deben ser manejados por personal cualificado.

Los ambientes más recalentados de los hospitales suelen ser los del cuarto de calderas, la lavandería y la cocina. Sin embargo, en muchos lugares, en los edificios antiguos y mal ventilados, carentes de un sistema de climatización adecuado, el calor puede ser agobiante en verano. El calor también puede plantear problemas en entornos con temperaturas elevadas en los que el personal sanitario deba usar guantes, batas, gorras y mascarillas.

\section{Prevención y control}

Aunque a veces resulta imposible mantener algunos entornos hospitalarios a unas temperaturas agradables, existen medios de mantener la temperatura dentro de unos niveles aceptables y mitigar los efectos del calor sobre los trabajadores:

- asegurar una ventilación adecuada. A veces, resulta imprescindible complementar el sistema central de acondicionamiento de aire con el uso de ventiladores de pie, por ejemplo

- garantizar el suministro de agua potable fría

- rotar el personal de forma que pueda disfrutar de descansos periódicos

- permitir que los trabajadores disfruten de pausas frecuentes en lugares frescos.

\section{Ruido}

La exposición a ruidos de gran intensidad en el lugar de trabajo es uno de los principales peligros que afrontan los trabajadores. A pesar de la imagen tradicional de los hospitales como lugares silenciosos, estos centros pueden ser sitios muy ruidosos.

La exposición a ruidos de gran intensidad puede producir pérdida de la agudeza auditiva. En efecto, las exposiciones breves a ruidos intensos son capaces de provocar una pérdida de audición denominada "variación temporal del umbral". Esta variación puede subsanarse mediante un alejamiento prolongado de los ruidos de alta intensidad; por el contrario, el deterioro nervioso producido por la exposición prolongada a ruidos potentes no es reversible.

En Estados Unidos, la Occupational Safety and Health Administration (OSHA) ha fijado en 90 decibelios el límite tolerable para ocho horas de trabajo. En los casos de exposición a intensidades medias superiores a 85 decibelios por período de ocho horas, se impone la aplicación de un programa de protección de la audición. (Los sonómetros, que son los instrumentos básicos de medición del ruido, se suministran con tres escalas de ponderación. En las normas de la OSHA se utiliza la escala A, expresada en decibelios)

Según el National Institute of Environmental Health Services, los ruidos de 70 decibelios de potencia surten los efectos siguientes:
- constricción de los vasos sanguíneos, capaz de provocar un aumento de la presión arterial y de reducir la circulación en manos y pies y producir una sensación de frialdad

- dolor de cabeza

- mayor irritabilidad

- dificultad para comunicarse con los compañeros

- reducción de la capacidad de trabajo

- mayor dificultad para realizar las tareas que exigen vigilancia, concentración y atención al detalle.

La intensidad del ruido puede ser tan grande que la productividad se reduzca en áreas como las de servicio de comidas y de trabajos mecánicos (en los que se suelen incluir los cuartos de calderas), las oficinas administrativas, los archivos de registros clínicos y las salas de enfermeras. El nivel del ruido puede ser igualmente excesivo en lavanderías, imprentas y áreas en construcción.

\section{Prevención y control}

Si del análisis del nivel de ruido existente en un centro se infiere que la exposición de los trabajadores al ruido excede de los límites fijados por la OSHA, se impone la ejecución de un programa de reducción de los decibelios. El programa consiste en las medidas siguientes:

- mediciones periódicas

- controles técnicos, del tipo del aislamiento sonoro de los aparatos más ruidosos, la instalación de amortiguadores y de moquetas y falsos techos aislantes

- controles administrativos que permitan limitar la exposición de los trabajadores a ruidos excesivos.

Aparte de las medidas de reducción del ruido, se debe poner en práctica un programa de protección de la audición, consistente en las medidas siguientes:

- pruebas de audición aplicables a los nuevos trabajadores, que sirvan de pauta para las evaluaciones posteriores

- exploración audiométrica anual

- uso de medios de protección de la audición en tanto no se implanten los controles del ruido y en los casos en que los niveles del ruido no se puedan mantener dentro de los límites tolerables.

\section{Ventilación inadecuada}

La regulación específica de la ventilación de las diversas clases de equipo es una materia técnica que no cabe analizar en este contexto. Sin embargo, tanto en las instalaciones antiguas como en las de nueva planta se plantean problemas globales de ventilación que son dignos de mención.

En las instalaciones antiguas, construidas con anterioridad a la generalización del uso de los sistemas de calefacción y acondicionamiento de aire, la solución de los problemas de ventilación debe ser, por regla general, puntual. El problema suele residir en la dificultad para mantener una temperatura uniforme y una circulación adecuada del aire.

En las edificaciones nuevas, herméticamente cerradas, se suele experimentar el denominado "síndrome del edificio cerrado" o "síndrome del edificio enfermo". Si el sistema de circulación no permite una rápida renovación del aire, la concentración de agentes irritantes puede aumentar hasta límites capaces de producir irritación en ojos y garganta y secreción abundante de la nariz. Estos factores, que pueden provocar reacciones serias en las personas sensibles, se pueden exacerbar por el efecto de diversas sustancias químicas procedentes de fuentes como aislamientos de goma espuma, moquetas, adhesivos y productos de limpieza. 


\section{Prevención y control}

Si bien la ventilación de las áreas más críticas ha sido tradicionalmente objeto de especial atención, las áreas de uso general han recibido normalmente mucha menos atención. Es preciso inducir a los trabajadores a que comuniquen cualquier irritación que se produzca en el lugar de trabajo. Si no es posible mejorar localmente la calidad del aire, puede resultar necesario trasladar a los trabajadores que hayan adquirido una sensibilidad especial a los agentes irritantes presentes en su puesto de trabajo.

\section{Humos de láser}

Durante las intervenciones quirúrgicas que se realizan en las unidades de electrocirugía y de cirugía por láser, se liberan humos como consecuencia de la destrucción térmica de los tejidos. Según estudios realizados en Estados Unidos por el National Institute for Occupational Safety and Health (NIOSH), estas emanaciones pueden contener gases y vapores tóxicos del tipo del benceno, el cianuro de hidrógeno y el formaldehído; bioaerosoles, material celular vivo y muerto (incluidas partículas de sangre) y diversos virus. En concentraciones elevadas, estos humos pueden provocar a los trabajadores sanitarios irritaciones oculares y de las vías respiratorias superiores, además de afectar la vista de los cirujanos. Estos humos, de olor desagradable, pueden contener materiales mutágenos.

\section{Prevención y control}

La exposición a las sustancias contaminantes en suspensión en esos humos se puede controlar eficazmente con una correcta ventilación de la sala, complementada por un sistema puntual de salida de aire dotado de una potente unidad de extracción (por ejemplo, una bomba de vacío provista de una embocadura de admisión colocada a unos cinco centímetros del campo operatorio) que funcione automáticamente mientras dure la intervención. Tanto el sistema de ventilación de la sala como el dispositivo puntual de salida del aire se deben dotar de filtros y absorbentes que retengan las partículas sólidas y absorban o neutralice los gases y vapores. Estos filtros y absorbentes se deben monitorizar y reemplazar regularmente, y ser objeto de una cuidadosa eliminación, al entrañar un riesgo biológico.

\section{Radiación}

\section{Radiación ionizante}

Si la radiación ionizante penetra en las células vivas, puede, bien destruirlas directamente (esto es, producir quemaduras o caída del cabello), bien alterar el material genético celular (esto es, provocar cáncer o perturbación de la función reproductora). Las normas aplicables a la radiación ionizante se pueden referir a la exposición (la cantidad de radiación que recibe el cuerpo) o a la dosis (la cantidad de radiación absorbida por el cuerpo) y se pueden expresar en milirems (mrem) - la unidad de radiación normalmente utilizada - o en rems (1.000 milirems).

En varios países se han promulgado normas por las que se regulan la adquisición y el uso, transporte y evacuación de sustancias radiactivas, además de fijarse límites a la exposición (y, en algunos casos, a las dosis que pueden absorber diversas partes del cuerpo), por lo que aportan un alto grado de protección a los trabajadores. Asimismo, las instituciones que utilizan materiales radiactivos con fines de tratamiento o investigación suelen aplicar medidas específicas de control interno además de las previstas en las leyes.

Los mayores peligros para los trabajadores sanitarios pueden provenir, tanto de la dispersión de pequeñas partículas que se desvían o rebotan de la fuente hacia el entorno inmediato, como de la exposición accidental, bien porque acceden inopinadamente a un área no identificada como radiactiva, bien por causa del deficiente mantenimiento del equipo.

El personal sanitario de los servicios de radiodiagnóstico (incluidos los rayos $\mathrm{X}$, la fluoroscopía y la angiografía con fines de diagnóstico, la radiografía dental y los escáneres mediante tomografía axial computadorizada), de radioterapia, de los procedimientos terapéuticos y de diagnóstico de la medicina nuclear, y de los laboratorios que utilizan radiofármacos, son objeto de un minucioso seguimiento y comprobación de su exposición, y sus puestos de trabajo se suelen encontrar suficientemente protegidos contra la radiación, aunque esta protección resulta insuficiente en muchos lugares.

En algunas áreas que no suelen estar señalizadas como de radiación se precisa una rigurosa monitorización del personal que garantice la adopción de las debidas cautelas y la protección de los pacientes que puedan quedar expuestos. Estas medidas deben abarcar las unidades de angiografía, las salas de urgencia y de cuidados intensivos, los quirófanos y los lugares en que se utiliza equipo portátil de rayos $\mathrm{X}$.

\section{Prevención y control}

Se recomienda encarecidamente la adopción de las siguientes medidas preventivas de la radiación ionizante (rayos X y radioisótopos):

- Los recintos que albergan equipo emisor de radiación se deben identificar claramente y sólo se debe permitir la entrada al personal autorizado.

- Los pacientes o sus familiares deben guardar las placas. Si es preciso retener al paciente, las placas se deben entregar a un familiar. Si el personal se ve en la necesidad de conservar las placas o de retener a los pacientes, debe rotarse en esta tarea con objeto de reducir la dosis que cada persona recibe.

- En los recintos en que se utilizan unidades portátiles de radios $\mathrm{X}$ y de radioisótopos sólo se debe permitir la permanencia de los pacientes y del personal cualificado.

- Antes de trasladar una unidad portátil de rayos X, se debe advertir a los trabajadores que se encuentren en las inmediaciones.

- Las unidades de rayos X se deben dotar de mandos que impidan su activación accidental.

- Las puertas de acceso a las salas de rayos X deben permanecer cerradas mientras se utiliza el equipo.

- Antes de cada utilización, es preciso verificar que todos los conos y filtros de los aparatos de rayos $\mathrm{X}$ se han colocado debidamente.

- Es preciso identificar claramente a los pacientes que han sido objeto de implantes radiactivos o han sido sometidos a otros tratamientos de radiología. Asimismo, es preciso etiquetar indistintamente la ropa de cama, los vendajes y demás desechos generados por estos pacientes.

Los trabajadores expuestos a la acción directa de la radiación o que trabajan en áreas en que la dispersión es elevada deben usar delantales, guantes y gafas especiales de plomo. Todos los años se debe verificar si el revestimiento de plomo de estos medios de protección presenta fisuras.

Los trabajadores expuestos a la radiación ionizante debe usar dosímetros, cuyo funcionamiento se debe revisar periódicamente en un laboratorio con un buen nivel de control de la calidad, registrándose los resultados. Es preciso documentar, no sólo el nivel de exposición de cada trabajador, sino también la recepción y evacuación de la totalidad de los radioisótopos.

En las unidades de radioterapia se deben verificar periódicamente las dosis utilizando dosímetros sólidos de fluoruro de litio para verificar la calibración del sistema. Los quirófanos se deben 
dotar de un sistema de entrecierre de las puertas con el equipo de radiología y de dispositivos de alarma visual.

Durante el tratamiento interno o intravenoso con sustancias radiactivas, se debe colocar al paciente en un recinto cuya situación contribuya a reducir el riesgo de exposición del personal y del resto de los pacientes; además es preciso colocar letreros de advertencia a la entrada. Aparte de limitar el tiempo de contacto del personal con los focos de riesgo, se deben extremar las cautelas en la manipulación de la ropa de cama y los vendajes y demás desechos generados por estos pacientes.

Las medidas siguientes contribuyen a reducir el riesgo en las operaciones de radioscopia y angiografía:

- uso de equipo protector completo

- reducción del número de personas presentes en la sala

- interruptores de "hombre muerto" (que exigen el control activo del operador)

- tamaño y energía mínimos del haz de rayos

- protección máxima para reducir la dispersión.

El personal de quirófano debe usar un equipo de protección integral durante la aplicación de radiación y, siempre que sea posible, los trabajadores deben mantenerse alejados de los pacientes un mínimo de dos metros

\section{Radiación no ionizante}

Los rayos ultravioleta, el láser y las microondas son focos de radiación no ionizante. Aunque, por regla general, esta forma de radiación es menos peligrosa que la ionizante, precisa un cuidado especial para prevenir lesiones.

La radiación ultravioleta se utiliza en las lámparas germicidas, en algunos tratamientos dermatológicos y en los filtros de aire de algunos hospitales, además de generarse en las operaciones de soldadura. La exposición de la piel a la luz ultravioleta produce eritema, envejece la piel e incrementa el riesgo de sufrir cáncer de piel. La exposición de los ojos puede producir una conjuntivitis temporal, aunque sumamente dolorosa y, si la exposición es prolongada, se puede producir una pérdida parcial de la visión.

Las normas reguladoras de la exposición a la radiación ultravioleta no son de aplicación general. El mejor método de protección pasa por la educación y el uso de gafas protectoras ahumadas.

En Estados Unidos, el Bureau of Radiological Health de la Food and Drug Administration regula el uso de los rayos láser, que clasifica en cuatro categorías, I a IV. El láser utilizado para colocar a los pacientes en radiología se incluye en la clase I y entraña un riesgo mínimo. En cambio, el láser quirúrgico constituye un grave riesgo para la retina y la intensidad del haz luminoso puede provocar una pérdida total de la visión. La elevada tensión que exigen hace que todos los rayos láser entrañen el riesgo de descarga eléctrica. La desviación fortuita del haz del láser durante una intervención quirúrgica puede causar lesiones a los trabajadores. Tanto el Ejército de Estados Unidos como el American National Standards Institute han promulgado directrices sobre el uso del láser. Por ejemplo, los operadores de láser deben usar gafas ajustadas de protección específicamente diseñadas para cada clase de láser y cuidar de no enfocar el rayo hacia superficies reflectantes.

El principal riesgo que entraña la exposición a las microondas, que en los hospitales se utilizan principalmente para preparar y calentar las comidas de los pacientes, además de la aplicación de diatermia, es su efecto calórico sobre el cuerpo humano. El cristalino y las gónadas, al tener menos irrigación sanguínea que elimine el calor, son sumamente vulnerables. Aunque los efectos de la exposición a largo plazo de baja intensidad no se conocen, existen indicios de que puede repercutir en el sistema nervioso, además de reducir el número de espermatozoides y causar malformaciones en éstos (que, en el peor de los casos, son parcialmente reversibles al cesar la exposición) y cataratas.

\section{Prevención y control}

La norma fijada por la OSHA para la exposición a las microondas es de 10 milivatios por centímetro cuadrado $((10 \mathrm{mV} / \mathrm{cm})$ como protección contra los efectos términos de los microondas. En otros países en que se han fijado límites de protección contra los daños al aparato reproductor y al sistema nervioso, los niveles tolerables pueden ser exponencialmente inferiores (esto es, $0,01 \mathrm{mV} / \mathrm{cm}$ a $1,2 \mathrm{~m})$.

Para garantizar la seguridad de los trabajadores, es preciso mantener perfectamente limpios los hornos microondas, con el fin de conservar la estanqueidad de los cierres de las puertas, además de verificar las posibles filtraciones con una periodicidad mínima trimestral. Antes de cada aplicación de diatermia, se deben verificar las posibles filtraciones del equipo en el entorno del terapeuta.

Los trabajadores sanitarios deben ser conscientes del peligro que entraña la exposición a los rayos ultravioletas y al calor infrarrojo utilizado en el tratamiento, y de la necesidad de protegerse adecuadamente la vista mientras usan o reparan equipos de ultravioleta, como lámparas germicidas y purificadores de aire, o equipo o instrumentos de infrarrojos.

\section{Conclusiones}

Los agentes físicos entrañan una importante fuente de riesgos para los trabajadores de hospitales, clínicas y consultorios en los que se realizan actos de diagnóstico y de tratamiento. Estos agentes se analizan en profundidad en otros capítulos de la presente Enciclopedia. El control de los mismos se basa en la educación y formación de todos los profesionales sanitarios y trabajadores auxiliares implicados, así como en la vigilancia continua y la monitorización sistemática, tanto del equipo, como de la forma de utilizarlo.

\section{ERGONOMIA DEL MEDIO AMBIENTE FISICO DE TRABAJO}

\section{Madeleine Estryn-Béhar}

En diversos países se han promulgado directrices sobre los niveles de ruido, temperatura e iluminación en los hospitales. Sin embargo, estas directrices raras veces se toman en consideración en las especificaciones facilitadas a los diseñadores de hospitales.

\section{Ruido}

En los hospitales es importante distinguir entre el ruido de origen mecánico capaz de deteriorar la audición (más de $85 \mathrm{dBA}$ ) y el ruido producido por la degradación del entorno, el trabajo administrativo y la prestación de asistencia (65 a 85 dBA).

\section{Ruido de origen mecánico capaz de deteriorar la audición}

Antes del decenio de 1980, algunas publicaciones ya se habían hecho eco de este problema. Van Wagoner y Maguire (1977) estimaron la frecuencia de la pérdida de audición entre 100 trabajadores de un hospital situado en una zona urbana de Canadá. Identificaron cinco áreas en las que los niveles de ruido oscilaban entre 85 y $115 \mathrm{dBA}$ ): el cuarto de contadores, la lavandería, el fregadero y la imprenta, además de las zonas en que los trabajadores de mantenimiento empleaban herramientas manuales o 
eléctricas. Se detectó una pérdida de audición en el $48 \%$ de los 50 trabajadores empleados en estas áreas ruidosas, en contraste con un $6 \%$ de los trabajadores asignados a otras dependencias más silenciosas.

Yassi y cols. (1992) realizaron una encuesta preliminar con objeto de identificar las áreas de un hospital canadiense en que los niveles de ruido eran peligrosamente altos. Después se recurrió a la planimetría y la dosimetría integrada para realizar un estudio en profundidad de estas zonas. Se descubrió que los niveles de ruido superiores a los $80 \mathrm{dBA}$ no eran infrecuentes. Se llevó a cabo un estudio pormenorizado de la lavandería, la unidad central de proceso, el departamento de nutrición, la unidad de rehabilitación y el cuarto de contadores. La dosimetría integrada reveló la existencia de niveles de hasta $110 \mathrm{dBA}$ en algunos de estos lugares.

En la lavandería de un hospital español, los niveles de ruido rebasaban los $85 \mathrm{dBA}$ en todos los puestos de trabajo y llegaban a $97 \mathrm{dBA}$ en algunos puntos (Montoliu y cols. 1992). En algunos puestos de trabajo de la lavandería de un hospital francés se observaron niveles de ruido de entre 85 y $94 \mathrm{dBA}$ (Cabal y cols. 1986). Si bien la modificación de la maquinaria permitió reducir el nivel de ruido generado por las máquinas de planchado a presión hasta $78 \mathrm{dBA}$, esta solución no se pudo aplicar a otras máquinas por problemas de diseño.

Según un estudio realizado en Estados Unidos, los instrumentos quirúrgicos eléctricos generan niveles de ruido entre 90 y 100 dBA (Willet 1991). En este mismo estudio se halló que 11 de 24 cirujanos traumatólogos padecían de una seria pérdida de audición. En las conclusiones del trabajo se hacía hincapié en la necesidad de mejorar el diseño del instrumental. Se ha informado de que las alarmas de vacío y de monitorización generan unos niveles de ruido de hasta 108 dBA (Hodge y Thompson 1990).

\section{Ruido asociado a la degradación del medio ambiente, el trabajo administrativo y la prestación de asistencia}

Un seguimiento sistemático de los niveles de ruido presentes en seis hospitales egipcios reveló la presencia de ruidos excesivos en las oficinas, salas de espera y pasillos (Noweir y al-Jiffry 1991). Esta circunstancia se atribuyó a las características arquitectónicas del hospital y de parte de su maquinaria. Los autores recomendaron el uso de equipo y materiales de construcción más apropiados y la aplicación de métodos de mantenimiento correctos.

El trabajo en las primeras instalaciones computadorizadas se resentía de la mala calidad de las impresoras y de la insuficiente acústica de las oficinas. Un estudio sobre cajeros de la región de París reveló que tenían que hablar con los clientes y tramitar facturas y pagos en una sala atestada cuyo bajo techo de escayola carecía de capacidad de absorción acústica. Con una sola impresora funcionando (en la práctica funcionaban las cuatro) los niveles de ruido superaban los $78 \mathrm{dBA}$ en el caso de los pagos y los $82 \mathrm{dBA}$ para el de las facturas.

En un estudio realizado en 1992 en un centro de gimnasia de rehabilitación dotado de 8 bicicletas de rehabilitación para pacientes cardíacos, rodeadas de cuatro áreas reservadas al uso privado de los pacientes, se detectaron unos niveles de ruido entre 75 y $80 \mathrm{dBA}$ en el entorno de las bicicletas de rehabilitación, y entre 65 y $75 \mathrm{dBA}$ en la vecina área de musculación. Estos niveles de ruido pueden dificultar la prestación de cuidados personalizados.

Para Shapiro y Berland (1972), el ruido producido en los quirófanos constituye el "tercer contaminante", puesto que incrementa la fatiga del cirujano, surte efectos psicológicos y fisiológicos y reduce la precisión de los movimientos. Se midieron los niveles de ruido durante una colecistectomía y en el curso de una ligadura de trompas. Se produjeron ruidos molestos al abrirse un paquete de guantes ( $86 \mathrm{dBA})$, al instalarse una plataforma en el suelo (85 dBA), al ajustarla (75 a $80 \mathrm{dBA})$, al entrechocar los instrumentos quirúrgicos (80 dBA), al aspirar la tráquea del paciente $(78 \mathrm{dBA})$, con la botella de succión continua (75 a $85 \mathrm{dBA}$ ) y por efecto de los tacones de los zapatos que llevaban las enfermeras (68 dBA). Los autores aconsejaron el uso de instrumentos de plástico termorresistente, más silenciosos, y para reducir el eco, el empleo de materiales fáciles de limpiar, distintos del vidrio o la cerámica, en paredes, suelos y techos.

Se han observado niveles de ruido entre 51 y 82 dBA y entre 54 y $73 \mathrm{dBA}$ en el cuarto de la centrífuga y en el cuarto del analizador automático de un laboratorio de análisis clínicos. El lex (que expresa la exposición durante la totalidad del turno) en el puesto de control era de 70,44 dBA, permaneciendo el nivel de ruido por encima de $70 \mathrm{dBA}$ durante 3 horas. En el puesto técnico, el Leq se situó en $72,63 \mathrm{dBA}$, con 7 horas por encima de $70 \mathrm{dBA}$. Se recomendó la adopción de las medidas siguientes: instalación de teléfonos con ajuste de la intensidad del timbre, agrupamiento de las centrifugadoras en un recinto cerrado, reubicación de las fotocopiadoras e impresoras y protección de las impresoras con mamparos.

\section{Asistencia y bienestar de los pacientes}

En algunos países se recomiendan unos niveles máximos de ruido para las unidades asistenciales de $34 \mathrm{dBA}$ durante la noche y de 40 dBA por el día (Turner, King y Craddock 1975). Falk y Woods (1973) fueron los primeros en llamar la atención sobre esta cuestión en su estudio de los niveles y focos de ruido en las incubadoras de neonatología, las salas de recuperación y dos salas de una unidad de cuidados intensivos. Se registraron los siguientes niveles medios a lo largo de un período de 24 horas: 57,7 dBA $(74,5 \mathrm{~dB})$ en las incubadoras, 65,5 dBA (80 dB lineales) en la cabecera de los pacientes en la sala de recuperación, 60,1 dBA $(73,3 \mathrm{~dB})$ en la unidad de cuidados intensivos, y 55,8 dBA $(68,1 \mathrm{~dB})$ en la habitación de un paciente. Los niveles de ruido registrados en la sala de recuperación y en la unidad de cuidados intensivos era una función del número de enfermeras. Los autores subrayan la probable estimulación del sistema hipófiso-suprarrenal como consecuencia de la intensidad del ruido y el consiguiente incremento de la vasoconstricción periférica. Se manifiesta igualmente una cierta preocupación por la posible perdida de audición de los pacientes tratados con antibióticos aminoglucósidos. Estos niveles de ruido se consideraban incompatibles con el sueño.

Diversos estudios, realizados en su mayoría por enfermeras, demuestran que el control del ruido contribuye a recuperar y mejorar la calidad de vida de los pacientes. En las conclusiones de diversos estudios realizados en distintas salas de neonatología especializadas en el cuidado de recién nacidos con escaso peso se ha puesto de relieve la necesidad de reducir el ruido producido por el personal, el equipo y la actividad radiológica (Green 1992; Wahlen 1992; Williams y Murphy 1991; Oëler 1993; Lotas 1992; Halm y Alpen 1993). Halm y Alpen (1993) han estudiado la relación entre los niveles de ruido en las unidades de cuidados intensivos y el bienestar psicológico de los pacientes y sus familiares (y, en casos extremos, incluso de psicosis post-reanimación). Los efectos del ruido ambiental en la calidad del sueño han sido objeto de una evaluación rigurosa en condiciones experimentales (Topf 1992). En las unidades de cuidados intensivos, la difusión de determinados sonidos grabados se asociaba al deterioro de diversos parámetros del sueño.

En las conclusiones de un estudio de diversas salas se informa de la producción de niveles máximos de ruido superiores a $80 \mathrm{dBA}$ en la cabecera de los pacientes, especialmente en las 
unidades de cuidados intensivos y de respiración asistida (Meyer y cols. 1994). Los niveles de iluminación y de ruido fueron objeto de un seguimiento continuo durante siete días consecutivos en una unidad de cuidados intensivos, en varias habitaciones con una sola y con varias camas de una unidad de respiración asistida, y en una habitación privada. Los niveles de ruido eran muy elevados en todos los casos. Especialmente elevado era el número de picos superiores a $80 \mathrm{dBA}$ en las unidades de cuidados intensivos y de respiración asistida, registrándose el valor máximo entre las 12:00 y las 18:00 horas, y el mínimo entre las 00:00 y las 06:00 horas. Se estimaba que el insomnio y la interrupción del sueño influían negativamente en el funcionamiento del aparato respiratorio de los pacientes y dificultaban su desconexión de la ventilación mecánica.

En su estudio de diez salas hospitalarias de la región de París, Blanpain y Estryn-Béhar (1990) detectaron pocas máquinas ruidosas, como enceradoras, heladeras y hornillos. No obstante, el tamaño y la calidad de las superficies de las salas contribuían a reducir o amplificar tanto el ruido generado por las máquinas como el procedente (aunque con menor intensidad) de los carrillos, las alarmas y los sistemas de ventilación. Los niveles de ruido superiores a $45 \mathrm{dBA}$ (observados en 7 de 10 salas) perjudicaban el descanso de los pacientes. Por otra parte, el ruido perturbaba al personal sanitario que realizaba tareas de gran precisión que exigían una elevada concentración. En 5 de las 10 salas observadas, los niveles de ruido en el cuarto de enfermeras alcanzaban los $65 \mathrm{dBA}$, y en otras dos salas se midieron niveles de $73 \mathrm{dBA}$. En tres de las despensas se midieron valores superiores a $65 \mathrm{dBA}$.

En algunos casos, se han utilizado en las construcciones elementos arquitectónicos con fines decorativos sin tomar en consideración sus efectos en la acústica. Por ejemplo, a partir del decenio de 1970 se generalizó el uso de techos y paredes de vidrio en las áreas diáfanas de ingreso de los pacientes. Los niveles de ruido producidos no contribuyen a crear un entorno sosegado en el que los pacientes que tramitan su ingreso en el hospital puedan rellenar tranquilamente los impresos. La presencia de fuentes en un vestíbulo de estas características producía en la recepción un ruido de fondo de $73 \mathrm{dBA}$ de intensidad, que obligaba a las recepcionistas a pedir a la tercera parte de las personas que solicitaban información que repitiesen las frases.

\section{Estrés por calor}

Costa, Trinco y Schallenberg (1992) estudiaron los efectos de la instalación de un sistema de flujo laminar, que mantenía la esterilidad del aire, en el estrés por calor en un quirófano. La temperatura del campo operatorio se elevó, como media, en unos $3{ }^{\circ} \mathrm{C}$ y llegó a rebasar los $30,2^{\circ} \mathrm{C}$. Esta subida se asociaba a un deterioro del bienestar térmico del personal, obligado a usar una ropa que favorece la retención del calor.

Cabal y cols. (1986) estudiaron el estrés por calor en la lavandería de un hospital del centro de Francia con anterioridad a la renovación de aquélla. Observaron que la humedad relativa en el puesto de trabajo más caluroso, el tendedero de batas, era del $30 \%$, y que la temperatura radiante alcanzaba los $41^{\circ} \mathrm{C}$. Tras la colocación de dobles cristaleras y de unas paredes exteriores reflectantes, así como tras el aumento de la frecuencia de la renovación del aire a unas 10 a 15 veces por hora, los parámetros de bienestar térmico alcanzaron unos niveles normales en la totalidad de los puestos de trabajo, independientemente de las condiciones meteorológicas reinantes en el exterior. El estudio de la lavandería de un hospital español puso de relieve que las temperaturas elevadas asociadas a un alto grado de humedad generan un medio ambiente de trabajo asfixiante, especialmente en las áreas de planchado, en las que las temperaturas pueden rebasar los 30 grados (Montoliu y cols. 1992).

Blanpain y Estryn-Béhar (1990) describieron el medio ambiente de trabajo físico existente en diez salas en las que previamente habían estudiado el desarrollo del trabajo. Se efectuaron mediciones de la temperatura en cada una de las diez salas. La temperatura nocturna en las habitaciones de los pacientes puede descender por debajo de los $22^{\circ} \mathrm{C}$, dado que los pacientes utilizan mantas. Durante el día, mientras los pacientes permanezcan relativamente inactivos, una temperatura de $24^{\circ} \mathrm{C}$ resulta aceptable, pero no se debe rebasar, dado que algunas de las labores realizadas por las enfermeras exigen un esfuerzo considerable.

Las temperaturas siguientes se registraron entre las 07:00 y las 7:30: $21,5{ }^{\circ} \mathrm{C}$ en las salas de geriatría, $26^{\circ} \mathrm{C}$ en una habitación no esterilizada de la sala de hematología. A las 14:30 de un día soleado se observaron las temperaturas siguientes: $23,5{ }^{\circ} \mathrm{C}$ en la sala de urgencias y $29^{\circ} \mathrm{C}$ en la sala de hematología. Las temperaturas vespertinas rebasaban los $24{ }^{\circ} \mathrm{C}$ en 9 de 19 casos. La humedad relativa en cuatro de las cinco salas equipadas con sistemas de acondicionamiento de aire central era inferior al $45 \%$, y menor del $35 \%$ en dos salas.

La temperatura vespertina también rebasaba los $22{ }^{\circ} \mathrm{C}$ en los nueve cuartos de preparación de la medicación, y de 26 grados en tres cuartos de curas. La humedad relativa era inferior al $45 \%$ en todos los cuartos de las salas equipadas con aire acondicionado. En las despensas, la temperatura oscilaba entre los $18 \mathrm{y}$ $\operatorname{los} 28,5^{\circ} \mathrm{C}$.

Se observaron temperaturas entre 22 y $25{ }^{\circ} \mathrm{C}$ en los evacuatorios de los orinales, donde también se producían malos olores y donde, a veces, se almacenaba ropa sucia. En los dos armarios empotrados destinados a la ropa sucia se registraban temperaturas de entre 23 y 25 grados, superiores a los 18 grados que se estimaban más adecuados.

Se analizaron numerosas quejas sobre la falta de bienestar térmico en una encuesta realizada entre 2.892 trabajadoras de diversas salas hospitalarias de la región de París (Estryn-Béhar y cols. 1989a). El $47 \%$ de las enfermeras de los turnos de mañana y tarde, y el $37 \%$ de sus compañeras del turno de noche se quejaban de pasar calor continuamente o a menudo. Además de que las enfermeras debían realizar algunos esfuerzos físicos notables, como cambiar varias camas consecutivamente, la temperatura reinante en las habitaciones era demasiado elevada para trabajar cómodamente llevando ropa de poliéster y algodón, que dificultan la evaporación, o las batas y máscaras precisas para prevenir las infecciones nosocomiales.

Por otra parte, el $46 \%$ de las enfermeras del turno de noche y el $26 \%$ de sus compañeras de los turnos de mañana y de tarde manifestaban que, frecuente o continuamente, pasaban frío. Unicamente el $11 \%$ y el $26 \%$ señalaron que nunca pasaban frío.

Para ahorrar energía, la calefacción de los hospitales se reducía frecuentemente durante la noche, cuando los pacientes se tapaban con mantas. Sin embargo, las enfermeras, que debían permanecer vigilantes a pesar de la reducción cronobiológicamente determinada de la temperatura corporal, se veían obligadas a ponerse una chaqueta (no siempre muy higiénica) hacia las 04:00 horas. Como consecuencia del estudio, en algunos hospitales se colocaron radiadores ajustables en el cuarto de enfermeras.

Diversos estudios realizados entre 1.505 mujeres de 26 unidades sanitarias por un equipo de médicos del trabajo puso de relieve que la rinitis y la irritación ocular eran más frecuentes entre las enfermeras que trabajaban en salas provistas de aire acondicionado (Estryn-Béhar y Poinsignon 1989) y que el trabajo en una atmósfera climatizada se asociaba a un incremento de casi el $100 \%$ en la frecuencia de dermatosis de 
probable origen profesional (cociente de probabilidades ajustado: 2) (Delaporte y cols. 1990).

\section{Iluminación}

Algunos estudios han puesto de relieve que la importancia de una buena iluminación se sigue infravalorando en los departamentos administrativos y generales de los hospitales.

Cabal y cols. (1986) observaron que los niveles de iluminación en la mitad de los puestos de trabajo de la lavandería de cierto hospital no superaban los 100 lux. Después de la renovación del sistema, eran de 300 lux en la totalidad de los puestos de trabajo, de 800 lux en el cuarto de costura, y de 150 lux entre los túneles de lavado.

Blanpain y Estryn-Béhar (1990) observaron unos niveles máximos de iluminación inferiores a 500 lux en 9 de 10 salas. Asimismo, el nivel de iluminación no llegaba a 250 lux en cinco farmacias que carecían de iluminación natural, y era inferior a 90 lux en otras tres farmacias. Es de subrayar que la dificultad que experimentan las personas mayores para leer la letra pequeña de las etiquetas se mitiga incrementando la iluminación.

La orientación de los edificios puede elevar la intensidad de la iluminación diurna hasta unos niveles capaces de perturbar el descanso de los pacientes. Por ejemplo, en las salas de geriatría, las camas más alejadas de las ventanas recibían 1.200 lux, al tiempo que las más cercanas recibían hasta 5.000 lux. El único medio de amortiguar la luz en estas habitaciones consistía en entrecerrar las persianas opacas de las ventanas, si bien las enfermeras no podían trabajar en las habitaciones en tales condiciones. En ciertos casos, se forraban de papel las persianas para reducir un tanto la intensidad de la luz.

En algunas unidades de cuidados intensivos, la iluminación es demasiado intensa para que los pacientes puedan descansar (Meyer y cols. 1994). Un grupo de enfermeras norteamericanas y alemanas ha estudiado los efectos de la luz sobre el sueño de los pacientes en varias salas de neonatología (Oëler 1993; Boehm y Bollinger 1990).

Los cirujanos de un hospital, molestos por el reflejo de la luz sobre los azulejos blancos, pidieron que se cambiase el alicatado del quirófano. Con ello se pudo reducir los niveles de iluminación presentes fuera del área libre de sombras (15.000 a 80.000 lux); sin embargo, esta medida se tradujo en unos niveles de sólo 100 lux en el área de trabajo de las enfermeras, de 50 a 150 lux en la zona utilizada para almacenar el equipo, 70 lux en la cabecera del paciente y 150 lux en el campo operatorio del anestesista. Para evitar deslumbramientos susceptibles de reducir la precisión de los movimientos del cirujano, se colocaron bombillas fuera del campo visual de los cirujanos. Asimismo, se colocaron reostatos para limitar la intensidad de la iluminación en el campo de trabajo de las enfermeras a un nivel entre 300 y 1.000 lux, y situar el nivel general entre los 100 y los 300 lux.

\section{Construcción de un hospital con amplia iluminación natural}

En 1981 se inició la planificación de la construcción del hospital Saint Mary, en la isla de Wight, con el objetivo de reducir a la mitad el coste de la energía. En el proyecto definitivo se preveía una amplia iluminación natural y el uso de contraventanas de doble cristalera que pudiesen abrirse en verano. Incluso el quirófano tiene vistas al exterior y las salas de pediatría están situadas en la planta baja para facilitar el acceso al área de juegos infantiles. En las otras salas, situadas en la segunda y tercera (y última) plantas, existen puntos de iluminación en techos y ventanas. El proyecto, muy adecuado para climas templados, puede ser causa de problemas si el hielo o la nieve impiden la iluminación indirecta o si las elevadas temperaturas generan un importante efecto invernadero.

\section{Arquitectura y condiciones de trabajo}

\section{Diseño flexible y multifuncionalidad}

Los criterios dominantes entre 1945 y 1985, en especial el temor a la rápida obsolescencia, se reflejaron en la construcción de hospitales policlínicos constituidos por módulos idénticos (Games y Taton-Braen 1987). En Estados Unidos, esta tendencia se tradujo en el desarrollo del sistema Harnes, cuyo primer exponente fue el hospital Dudley, construido en 1974. Posteriormente se construyeron otros setenta hospitales inspirados en idénticos principios. En Francia se construyeron varios hospitales inspirados en el modelo Fontenoy.

El diseño arquitectónico no debería entorpecer la adopción de los cambios impuestos por la evolución de la tecnología y de los métodos terapéuticos. Por ejemplo, se debe procurar que elementos como los tabiques, los subsistemas de circulación de fluidos y los conductos técnicos se puedan retirar fácilmente. Sin embargo, esta flexibilidad no se debe interpretar como una adhesión al concepto de multifuncionalidad integral, que se traduce en la construcción de instalaciones inadecuadas para cualquier especialidad. Por ejemplo, la superficie necesaria para almacenar maquinaria, botellas, instrumentos desechables y medicamentos varía entre las salas geriátricas, de cirugía y de cardiología. El desconocimiento de esta circunstancia se traduce en el empleo de las estancias para fines para los que no están concebidas (por ejemplo, la dedicación de los cuartos de baño al almacenamiento de botellas).

El hospital californiano de Loma Linda es un exponente del mejor diseño hospitalario que ha servido de modelo. En él, los servicios de enfermería y de medicina técnica están situados por encima y por debajo de las plantas de servicios técnicos, y esta estructura "en emparedado" facilita el mantenimiento y el ajuste de la circulación de los fluidos.

Lamentablemente, la arquitectura hospitalaria no siempre refleja las necesidades de los trabajadores y se ha culpado al diseño multifuncional de diversos problemas asociados a la tensión física y psicológica. Piénsese en una sala de 30 camas, dividida en habitaciones individuales y dobles, y en la que sólo existe un área para cada clase de servicios (cuarto de enfermeras, despensa, almacenes de materiales desechables, de ropa de cama y de medicamentos), ajustada en todos los casos al diseño multifuncional. En esta sala, la gestión y la prestación de asistencia obligan a las enfermeras a desplazarse continuamente, con las consiguientes interrupciones del trabajo. Un estudio comparativo de diez salas puso de relieve que la distancia entre el cuarto de enfermeras y la habitación más alejada determina en buena medida tanto el grado de fatiga de las trabajadoras (en función de la distancia recorrida) como la calidad de la asistencia (en función del tiempo de permanencia en las habitaciones) (Estryn-Béhar y Hakim-Serfaty 1990).

En su estudio de los hospitales australianos, Patkin (1992) calificó de desastre ergonómico esta disfunción entre el diseño arquitectónico de espacios, pasillos y materiales, de una parte, y los imperativos del trabajo sanitario, de otra.

\section{Análisis preliminar de la ordenación espacial de las áreas de enfermería}

El primer modelo matemático de la naturaleza, los objetivos y la frecuencia de los desplazamientos del personal, basado en el Indice de Tráfico de Yale, apareció en 1960 y fue perfeccionado por Lippert en 1971. Sin embargo, centrar la atención en un problema aislado puede, incluso, contribuir a empeorar otros. Por ejemplo, la ubicación de las dependencias de las enfermeras en el 
centro del edificio, con objeto de reducir las distancias a recorrer, puede contribuir a empeorar las condiciones de trabajo si obliga a las enfermeras a pasar más del $30 \%$ del tiempo en unas estancias desprovistas de ventanas, con los consiguientes efectos negativos asociados a los problemas psicológicos y de iluminación y ventilación

La distancia entre las salas de pacientes y las áreas de preparación es menos importante en los entornos en que existe una elevada relación trabajadores/pacientes y en que la existencia de una unidad central de preparación facilita la entrega de los suministros varias veces al día, incluidos los festivos. Por otra parte, el tiempo de espera para acceder a los ascensores es menor en los hospitales de gran altura con más de 600 camas, en los que el número de elevadores no se encuentra limitado por imperativos presupuestarios.

\section{Investigación del diseño de unidades hospitalarias especializadas, aunque flexibles}

A finales del decenio de 1970, el Ministro de Sanidad británico encomendó a un equipo de ergonomistas la creación de una base de datos sobre la formación ergonómica y sobre el diseño ergonómico de las áreas de trabajo de los hospitales (Haigh 1992). Hitos relevantes del éxito del programa han sido la modificación de las dimensiones del mobiliario del laboratorio en función de las exigencias del trabajo de microscopía, así como la remodelación de las salas de maternidad en función de las necesidades del trabajo de las enfermeras y de las preferencias de las parturientas.

Cammock (1981) puso de relieve la necesidad de separar las áreas de las enfermeras de las zonas comunes y reservadas al público, con entradas independientes a las áreas de enfermería y del público, y comunicaciones independientes entre estas áreas y las comunes. Asimismo, se debe evitar el acceso directo del público a las áreas de enfermería.

El Krankenanstalt Rudolfsstiftung es el primer hospital piloto del proyecto Hospitales Europeos Saludables. Este proyecto piloto vienés abarca ocho subproyectos, uno de los cuales, el proyecto de reorganización de los servicios constituye un intento, concebido en colaboración con los ergonomistas, de fomentar la reordenación funcional del espacio disponible (Pelikan 1993). Así, se remozaron todas las habitaciones de una unidad de cuidados intensivos y se instalaron carriles para los mecanismos de elevación de los pacientes en el techo de todas las habitaciones.

En un estudio comparativo de 90 hospitales holandeses se ha puesto de manifiesto que las unidades pequeñas (plantas de menos de 1.500 metros cuadrados) son más eficaces, dado que permiten a las enfermeras adaptar su trabajo a las necesidades específicas del tratamiento ocupacional y de los familiares (Van Hogdalem 1990). El diseño también contribuye a incrementar el tiempo que las enfermeras pueden dedicar a los pacientes, al tardar menos en desplazarse y tener menos desorganización. Por último, la utilización de unidades pequeñas reduce el número de áreas de trabajo desprovistas de iluminación natural.

En un estudio desarrollado en el sector sueco de la administración sanitaria se puso de relieve que el rendimiento de los trabajadores en los edificios dotados de salas de conferencias y despachos independientes era mayor que en los de diseño diáfano (Ahlin 1992). La existencia en Suecia de un instituto dedicado al estudio de las condiciones de trabajo en los hospitales, así como de una legislación que exige consultar con los representantes de los trabajadores antes y durante la ejecución de los proyectos de construcción o remodelación, ha supuesto como consecuencia la aplicación sistemática del diseño participativo, inspirado en la formación y actuación ergonómicas (Tornquist y Ullmark 1992).

\section{Diseño arquitectónico basado en la ergonomía participativa} Los trabajadores deben participar en el diseño de los cambios organizativos y del comportamiento asociados a la puesta en funcionamiento de un nuevo espacio de trabajo. El equipamiento y la organización adecuados de un lugar de trabajo pasa por el análisis de los aspectos organizativos que se deben acentuar o modificar. Dos estudios pormenorizados de dos hospitales ilustran este punto.

Estryn-Béhar y cols. (1994) comentan los resultados de la renovación de las áreas comunes de una sala de medicina interna y una sala de cardiología del mismo hospital. A lo largo de siete días laborables completos se realizó una observación ergonómica del trabajo realizado por cada grupo profesional, y los resultados se analizaron durante dos días de reuniones con los miembros de cada grupo. Los grupos de estudio estaban integrados por representantes de todos los estamentos profesionales (jefes de servicio, supervisores, internos, enfermeras, auxiliares de enfermería, subalternos) de la totalidad de los turnos. Se dedicó una jornada completa al desarrollo de soluciones arquitectónicas y organizativas para cada uno de los problemas observados. Se dedicaron otros dos días a la simulación de las actividades típicas por parte de la totalidad del grupo, en colaboración con un arquitecto y un ergonomista, utilizando maquetas modulares de cartón y modelos a escala de objetos y personas. Esta simulación permitió a los representantes de los diversos estamentos profesionales llegar a un consenso sobre las distancias y la ordenación del espacio dentro de cada sala. Las especificaciones de diseño sólo se redactaron al finalizar este proceso.

Idéntico método participativo se aplicó en una unidad de cuidados intensivos de cardiología de otro hospital (EstrynBéhar y cols. 1995a, 1995b). Se halló que en la sala de enfermería se realizaban cuatro clases de actividades virtualmente incompatibles entre sí:

- preparación del material, que requería el uso de un escurridor y un desagüe

- descontaminación, en la que también se utilizaba el desagüe

- reuniones, monitorización y escritura. El área dedicada a estas actividades se utilizaba igualmente a veces para preparar el material

- almacenamiento de productos limpios (tres unidades) y de desecho (una unidad).

Como las cuatro áreas se solapaban, las enfermeras debían cruzar el espacio destinado a reuniones, escritura y monitorización para acceder a las otras áreas. La disposición del mobiliario les obligaba a cambiar de dirección tres veces para llegar al escurridor. Por otra parte, las habitaciones de los pacientes menos graves y de cuidados intensivos se alineaban a lo largo de un mismo pasillo. Asimismo, las unidades de almacenamiento se encontraban en el extremo de la sala más alejado de la sala de enfermeras.

Después de la remodelación, la antigua disposición longitudinal de las tareas y de la circulación ha sido reemplazada por una disposición transversal, que facilita el acceso directo desde un espacio central diáfano. Actualmente, el área dedicada a reuniones, escritura y monitorización se encuentra al fondo de la sala, en un espacio tranquilo y contiguo a las ventanas, aunque accesible. Las áreas dedicadas a las preparaciones limpias y sucias se encuentran junto a la entrada de la estancia y se hallan separadas por un amplio espacio diáfano. Las habitaciones de los pacientes de cuidados intensivos son lo bastante espaciosas para acoger el equipo de urgencia, una mesa para las preparaciones y un lavabo profundo. Los pacientes de las habitaciones de cuidados intensivos pueden ser observados continuamente 
desde las áreas de preparación a través de una cristalera de separación. El área de almacenamiento central se reestructuró y se racionalizó. Existe un plano de cada espacio de trabajo y de almacenamiento.

\section{Arquitectura, ergonomía y países en desarrollo}

Estos problemas también se plantean en los países en desarrollo, en los cuales las reformas suelen implicar la eliminación de las salas colectivas. Los estudios ergonómicos permitirían detectar los problemas existentes y evitar la aparición de otros. Por ejemplo, la construcción de salas divididas exclusivamente en habitaciones individuales y dobles incrementa la distancia que el personal debe recorrer. Una atención insuficiente a la dotación de personal y al diseño de las salas de enfermeras, de las cocinas y farmacias auxiliares y a los espacios de almacenamiento puede suponer una reducción drástica del tiempo que las enfermeras dedican a los pacientes y complicar la organización del trabajo.

Además, en la aplicación a los países subdesarrollados del modelo de hospital multifuncional propio de las naciones industrializadas no se tienen en cuenta las diferentes actitudes culturales hacia la utilización del espacio. Manuaba (1992) observa que tanto el diseño de las salas hospitalarias de las naciones industrializadas como el equipo médico que se utiliza en las mismas se adaptan mal a la realidad de las naciones en desarrollo, y añade que las habitaciones son excesivamente pequeñas para acoger a los visitantes, que constituyen un elemento fundamental del proceso curativo.

\section{Higiene y ergonomía}

Muchas infracciones de las normas de asepsia que se producen en los entornos hospitalarios sólo resultan comprensibles y subsanables en el contexto de la organización del trabajo y del espacio disponible. La aplicación efectiva de las modificaciones necesarias pasa por un análisis ergonómico que permita definir mejor las interdependencias de las tareas de los distintos equipos que sus características individuales, así como el descubrimiento de las eventuales discrepancias entre el trabajo real y el teórico, especialmente respecto al que se describe en los protocolos oficiales.

La contaminación por contacto manual fue uno de los objetivos iniciales de la lucha contra las infecciones nosocomiales. En teoría, el personal se debe lavar cuidadosamente las manos al entrar y salir de las habitaciones de los pacientes. Aunque en la educación y la formación continua de las enfermeras se hace hincapié en los resultados de los estudios epidemiológicos descriptivos, la investigación apunta a la persistencia de los problemas asociados a la higiene de las manos. En un estudio de 1987, basado en la observación continua de turnos completos de ocho horas en 10 salas, Delaporte y cols. (1990) observaron que, en promedio, las enfermeras del turno de mañana se lavaban las manos un total de 17 veces; las del turno de tarde, 13 veces; y 21 veces las del turno de noche.

Las enfermeras se lavaban las manos entre la mitad y la tercera parte de la frecuencia recomendada en función del número de contactos con los pacientes (esto es, sin tomar en consideración la actividad de preparación del material); entre las auxiliares de enfermería, el porcentaje oscilaba entre la quinta y la tercera parte. Sin embargo, resulta evidentemente imposible lavarse las manos antes y después de cada intervención, por imperativo tanto del tiempo como del deterioro de la piel, dada la fragmentación de la actividad, la cantidad de intervenciones, las frecuentes interrupciones y la concomitante repetición de las intervenciones que agobian al personal. Esto resalta la importancia de la reducción de las interrupciones del trabajo, que se debe anteponer a la simple exigencia de lavarse las manos, que, en todo caso, no puede realizarse más de 25 a 30 veces diarias.
Similares hábitos de higiene de las manos se observaron en una serie de observaciones efectuadas en 1994, a lo largo de 14 días laborables completos, coincidentes en el período de reorganización de dos salas de un hospital universitario (EstrynBéhar y cols. 1994). En todos los casos observados, las enfermeras no habrían podido prestar la asistencia necesaria si hubiesen regresado a la sala de enfermeras para lavarse las manos. Por ejemplo, en las unidades de pacientes hospitalizados de corta duración se extraían muestras de sangre a todos los pacientes y, casi inmediatamente, se les administraba medicación oral e intravenosa. A determinadas horas del día, la intensidad de la actividad imposibilita la higiene de las manos con la frecuencia adecuada. En un caso, un enfermero del turno de tarde, encargado de 13 pacientes de una sala de medicina interna, penetró en las habitaciones de los pacientes 21 veces en una sola hora. La pobreza de las estructuras de difusión y transmisión de la información contribuía a incrementar el número de visitas que se veía obligado a realizar. Dada la imposibilidad de lavarse las manos 21 veces en una hora, el enfermero sólo se lavaba cuando atendía a los pacientes más vulnerables (esto es, los afectados de insuficiencia pulmonar).

En el diseño arquitectónico inspirado en principios ergonómicos se toman en consideración diversos factores asociados a la limpieza de las manos, especialmente los relativos a la accesibilidad y ubicación de los lavabos, aunque también los concernientes al establecimiento de unos circuitos sucios y limpios realmente funcionales. La reducción del número de interrupciones a través del análisis participativo de la organización contribuye a generalizar la higiene de las manos.

\section{PREVENCION Y MANEJO DE LOS DOLORES DE ESPALDA EN EL PERSONAL DE ENFERMERIA}

Ulrich Stössel

\section{Epidemiología}

El peso específico de los dolores de espalda entre las patologías frecuentes en las sociedades industriales desarrolladas va en aumento. De acuerdo con las estadísticas facilitadas por el National Genter for Health Statistics de Estados Unidos, las enfermedades crónicas de la espalda y la columna vertebral constituyen el grupo dominante entre los trastornos que afectan a los norteamericanos económicamente activos menores de 45 años. Las estadísticas tradicionalmente fiables de accidentes de trabajo existentes en países como Suecia indican que las lesiones musculosqueléticas son dos veces más frecuentes entre los trabajadores de los servicios de salud que en otros sectores (Lagerlöf y Broberg 1989).

En su análisis de la frecuencia de los accidentes realizado en un hospital norteamericano de 450 camas, Kaplan y Deyo (1988) constataron entre las enfermeras una frecuencia anual de lesiones de las vértebras lumbares de entre el 8 y el $9 \%$, traducida en una media de 4,7 días de baja por enfermedad. Por lo tanto, de todas las categorías de trabajadores de la sanidad, el personal de enfermería era el más afectado por esta patología.

Como se evidencia de una recensión de los estudios realizados a lo largo de los últimos veinte años (Hofmann y Stössel 1995), este trastorno ha sido objeto de extensas investigaciones epidemiológicas. Por otra parte, tales investigaciones - sobre todo las orientadas a suministrar datos internacionalmente homologables - tropiezan con diversas dificultades metodológicas. A veces se investigan todas las categorías de trabajadores de los 
hospitales; otras, tan sólo las enfermeras son objeto de estudio. En algunos estudios se subraya la conveniencia de distinguir, dentro de las enfermeras, entre las tituladas y las auxiliares de enfermería. Puesto que el personal de enfermería es predominantemente femenino (alrededor del $80 \%$ en Alemania) y en las estadísticas de frecuencia y prevalencia de este trastorno no se aprecian divergencias significativas respecto a los enfermeros, las diferencias por sexos parecen ser menos relevantes para el análisis epidemiológico.

Más importante es la cuestión de las herramientas de investigación utilizables en el estudio de los dolores de espalda y sus grados. Además de la interpretación de las estadísticas sobre accidentes, indemnización y tratamiento, es frecuente encontrar en la literatura internacional un cuestionario normalizado, aplicado retrospectivamente, destinado a ser rellenado por las personas encuestadas. En otros métodos de investigación se utilizan técnicas de investigación clínica del tipo de los estudios de función ortopédica y de los procedimientos de exploración radiológica. Por último, en los métodos más recientes se utilizan también los modelos biomecánicos y las observaciones directas o en vídeo para el estudio de la fisiopatología del rendimiento laboral, particularmente en la medida en que afecta a la región sacrolumbar (véase Hagberg y cols. 1993 y 1995).

La determinación epidemiológica, basada en las tasas comunicadas de incidencia y prevalencia, también plantea dificultades. Los estudios epidemiológico-culturales y la comparación de distintos sistemas sanitarios demuestran que la percepción del dolor difiere no sólo entre los miembros de distintas sociedades, sino también dentro de cada sociedad (Payer 1988). Por otra parte, está la dificultad de graduar objetivamente la intensidad de una experiencia subjetiva como el dolor. Por último, la impresión prevalente entre las enfermeras de que el dolor de espalda forma parte del trabajo es causa de que muchas veces no se denuncie.

Los estudios comparativos internacionales basados en el análisis de las estadísticas oficiales de enfermedades profesionales son escasamente fiables para una evaluación específica de este tipo de trastorno, debido a las divergencias entre las diversas normativas legales y reglamentarias aplicables a las enfermedades profesionales en distintos países. Además, constituye un axioma aplicable a cada país que estos datos poseen la misma fiabilidad que las comunicaciones en que se basan.

Resumiendo, gran número de estudios realizados revelan que entre el 60 y el $80 \%$ del personal de enfermería (con una edad media de 30 a 40 años) ha sufrido dolores de espalda, al menos, una vez durante su vida laboral. En cambio, los índices de casos comunicados no superan el $10 \%$. En la clasificación de los dolores de espalda se ha tenido en cuenta la útil distinción de Nachemson y Anderson (1982) entre dolor de espalda y dolor de espalda con ciática. En un estudio todavía no publicado, se ha determinado que la sensación subjetiva de ciática es útil para la catalogación de los resultados de las posteriores exploraciones por tomografía computarizada y de las imágenes obtenidas por resonancia magnética.

\section{Costes económicos}

Las estimaciones de los costes económicos difieren sustancialmente en dependencia parcial de las posibilidades y condiciones de diagnóstico, tratamiento e indemnización existentes en un lugar y un momento determinados. Así, en Estados Unidos, Snook (1988b) estimó respecto a 1976 que los costes del dolor de espalda ascendían a 14.000 millones de dólares, al tiempo que para 1983 se calcularon unos costes de 25.000 millones de dólares. Los cálculos de Holbrook y cols. (1984), que estimaron los costes totales para 1984 en algo menos de 16.000 millones de dólares, resultan más fiables. Según Ernst y Fialka (1994) los costes en el Reino Unido pudieron haberse incrementado entre 1987 y 1989 en 2.000 millones de dólares de Estados Unidos. Según las estimaciones de costes directos e indirectos efectuada por Cats-Baril y Frymoyer (1991), los costes generados por el dolor de espalda han seguido creciendo. En 1980, el US Bureau of National Affairs informó de que el dolor de espalda crónico generaba costes de 80.000 dólares anuales por cada caso crónico.

Según las estadísticas elaboradas en Alemania por las dos principales cajas de seguro de accidentes de trabajo (Berufsgenossenschafen), en 1987 se perdieron alrededor de 15 millones de jornadas de trabajo por causa del dolor de espalda. Esta cifra equivale, aproximadamente, a la tercera parte del total de jornadas laborales perdidas al año. Estos costes parecen incrementarse actualmente a una media de 800 marcos por jornada de trabajo perdida.

Se puede afirmar, por lo tanto, que, al margen de las diferencias nacionales y de las categorías profesionales, los problemas de espalda y su tratamiento constituyen no sólo un problema humano y médico, sino también una tremenda carga financiera. Por consiguiente, parece aconsejable prestar especial atención a la prevención de estos trastornos en las categorías profesionales especialmente afectadas, como las enfermeras.

En principio, en la investigación de las causas de los trastornos lumbares asociados al trabajo sufridos por las enfermeras, es preciso diferenciar entre los imputables a un accidente o suceso determinado y los que carecen de una génesis tan específica. Ambas situaciones, si no se tratan debidamente, pueden provocar dolores crónicos de espalda. Como reflejo de sus presuntos conocimientos de medicina, las enfermeras se muestran mucho más propensas a la automedicación y la autoprescripción - y a prescindir de las consultas médicas - que otros estamentos de la población laboral. Esto no es siempre desventajoso, ya que muchos médicos, o bien no saben tratar los dolores de espalda, o bien les conceden escasa importancia y se limitan a recetar calmantes y aplicaciones locales de calor. Esta actitud refleja, en parte, el viejo tópico de que "el dolor de espalda está incluido en el sueldo"y, en parte también, la tendencia a creer que los trabajadores que se quejan de dolores crónicos de espalda son simuladores.

El estudio pormenorizado de los trastornos de la columna dorsal como secuelas de los accidentes de trabajo son un fenómeno reciente (véase Hagberg y cols. 1995). Esto vale igualmente para el análisis de los denominados "cuasiaccidentes", que puede facilitar información específica respecto a las causas de los accidentes de trabajo.

En la mayoría de los estudios realizados, la causa de los trastornos lumbares se ha atribuido a las exigencias físicas del trabajo de enfermería, esto es, a la necesidad de incorporar, sostener y desplazar a los pacientes y de manipular equipo y materiales pesados o voluminosos sin ayuda de medios auxiliares ergonómicos y sin la asistencia de otras personas. Estas actividades se realizan a menudo en posturas corporales forzadas, de difícil equilibrio y en situaciones de resistencia - consciente o no- de los pacientes a la acción de las enfermeras. Los esfuerzos por evitar la caída de un paciente pueden provocar lesiones a la enfermera o a los auxiliares. Sin embargo, se observa en las investigaciones actuales una clara tendencia a usar el lenguaje de la concausalidad y al análisis tanto de la base biomecánica de las exigencias a que se somete el cuerpo como de la predisposición anatómica.

Además de las deficiencias biomecánicas, puede existir una predisposición a este tipo de lesiones en virtud de la fatiga, la debilidad muscular (especialmente de los abdominales, los radiales externos y los cuádriceps), la pérdida de flexibilidad de los tendones y ligamentos, y las diversas modalidades de artritis. 
El estrés psicosocial excesivo puede contribuir de dos formas: a) tensión muscular inconsciente prolongada y espasmos coadyuvantes a la fatiga muscular y la propensión a las lesiones, y b) irritación e impaciencia generadoras de intentos repentinos de actuar sin esperar a los auxiliares. El enriquecimiento de la capacidad para afrontar el estrés y la disponibilidad de apoyo social en el lugar de trabajo (Theorell 1989; Bongers y cols. 1992) resultan de especial utilidad si no es posible controlar los factores de estrés.

\section{Diagnóstico}

Diversas situaciones y disposiciones - atribuibles al medio ambiente de trabajo - se añaden a los factores de riesgo derivados de la biomecánica de las fuerzas que actúan sobre la columna vertebral y de la configuración de los aparatos de apoyo y de auxilio a los desplazamientos. Si bien los resultados de las investigaciones actuales no son concluyentes en este punto, subsisten algunos indicios de que la frecuencia mayor y recurrente de los factores psicosociales de estrés presentes en el trabajo de enfermería puede reducir el umbral de sensibilidad a las actividades físicamente agotadoras, lo que contribuye a incrementar el grado de vulnerabilidad. En todo caso, la existencia de tales factores de estrés parece ser menos decisiva a este respecto que el modo en que el personal de enfermería los aborda en situaciones críticas y que la posibilidad de que dicho personal cuente con apoyo social en el lugar de trabajo (Theorell 1989; Bongers y cols. 1992).

El diagnóstico correcto de los dolores lumbares precisa una historia médica completa y un detallado historial profesional que comprenda los accidentes con resultado de lesiones y los cuasiaccidentes y los antecedentes de dolores de espalda. En la exploración física se deben incluir la evaluación de la postura y la deambulación, la palpación de las superficies debilitadas y la medición de la fuerza muscular, el grado de movimiento y la flexibilidad de las articulaciones. Los síntomas de debilidad en las piernas, zonas de entumecimiento y dolores que irradian debajo de la rodilla justifican una exploración neurológica en busca de posibles afectaciones de la médula espinal o los nervios periféricos. La exploración minuciosa del estado emocional, las actitudes y la tolerancia al dolor puede revelar la presencia de problemas psicosociales.

Los estudios y exploraciones radiológicos raras veces resultan útiles, dado que en la inmensa mayoría de los casos el problema reside más en los músculos y ligamentos que en las estructuras óseas. De hecho, muchas personas que jamás han padecido dolor de espalda presentan deformaciones óseas. La atribución del dolor de espalda a causas determinadas radiológicamente, como el estrechamiento de los espacios interdiscales y la espondilosis, puede inducir a la prescripción de tratamientos innecesariamente agresivos. Se desaconseja la mielografía a menos que se prevea la posibilidad de una intervención quirúrgica de la columna.

Los ensayos clínicos de laboratorio son de utilidad en la evaluación del estado general de salud y pueden contribuir al descubrimiento de enfermedades sistémicas del tipo de la artritis.

\section{Tratamiento}

Se recomiendan distintos sistemas de tratamiento, en función de la naturaleza del trastorno. Además de las medidas ergonómicas orientadas a permitir el regreso de los lesionados a su puesto de trabajo, a veces se hacen imprescindibles intervenciones quirúrgicas y radiológicas agresivas, farmacológicas, físicas, fisioterapéuticas y, también, psicoterapéuticas, en ocasiones en combinación (Hofmann y cols. 1994). Sin embargo, la inmensa mayoría de los casos se resuelven independientemente del tratamiento recomendado. En el recuadro adjunto se analiza el tratamiento con mayor profundidad.

\section{La prevención en el medio ambiente de trabajo}

La prevención primaria del dolor de espalda en el lugar de trabajo se basa en la aplicación de principios ergonómicos y el uso de medios auxiliares, combinados con la preparación física y la formación de los trabajadores.

A pesar de las reservas frecuentemente formuladas por el personal de enfermería respecto al uso de medios auxiliares para incorporar, colocar y desplazar a los pacientes, crece la importancia de los métodos ergonómicos de prevención (véase Estryn-Béhar, Kaminski y Peigné 1990; Hofmann y cols. 1994).

Además de los grandes sistemas (como los alzadores adosados al techo y los alzadores móviles de pie), se han incorporado al trabajo de enfermería una serie de pequeños y útiles dispositivos (plataformas giratorias, deslizadores, cojines elevadores, andaderas, escalerillas de acceso a las camas, moquetas antideslizantes, etc.). En la elección de estos medios se debe procurar que su utilización efectiva se ajuste al principio asistencial del área de enfermería en que se utilicen. Allí donde el uso de los medios auxiliares de incorporación de los pacientes colisiona con la filosofía asistencial prevalente, el nivel de aceptación de dichos medios por el personal de enfermería tiende a ser escaso.

Aun cuando se utilicen medios auxiliares, es imprescindible aprender las técnicas de incorporación, traslado y apoyo. Lidström y Zachrisson (1973) describen una "escuela informal" que funciona en Suecia, en la que un grupo de fisioterapeutas con formación pedagógica dictan cursos explicativos de la estructura de la columna vertebral y sus músculos, el funcionamiento de los mismos en diversos movimientos y posturas, y sus posibles trastornos, y enseñan la utilización de las técnicas de elevación y manipulación más eficaces en la prevención de lesiones. Klaber Moffet y cols. (1986) describen el éxito de un programa similar desarrollado en el Reino Unido. Esta enseñanza de las técnicas de elevación y traslado reviste especial importancia allí donde, por una u otra razón, el empleo de medios auxiliares no resulta posible. Diversos estudios han puesto de manifiesto que el aprendizaje de estas técnicas se debe revisar continuamente, dado que los conocimientos adquiridos durante la instrucción se suelen "olvidar" en la práctica.

Lamentablemente, el esfuerzo físico requerido por la talla, el peso, el tipo de enfermedad y la posición de los pacientes no siempre es soportable por las enfermeras, que tampoco pueden controlar siempre el entorno físico ni la organización del trabajo. Por consiguiente, es importante que tanto los directivos de la institución como los supervisores del personal de enfermería participen en los programas de instrucción, con el fin de que, al tomar decisiones sobre el medio ambiente de trabajo, el equipo y la asignación de tareas, se puedan tomar en consideración los factores que configuran unas condiciones "domésticas" de trabajo favorables. Por otra parte, en la distribución del personal, en especial por lo que respecta al número de pacientes por enfermera y a la disponibilidad de personal auxiliar, se deben tomar en consideración tanto el bienestar de las enfermeras como la filosofía asistencial prevalente en el hospital, algo que los hospitales de los países escandinavos parecen haber conseguido de forma paradigmática. Este aspecto adquiere particular importancia en los casos en que los imperativos fiscales imponen una reducción del personal y recortes en el gasto de adquisición y mantenimiento del equipo.

Los conceptos globales más recientes - en los que esta formación se valora más como una serie de programas de desplazamiento de pacientes y enfermeras que como el aprendizaje de técnicas de incorporación de la cama y traslado de los 


\section{Tratamiento del dolor de espalda}

La mayoría de los episodios de dolor de espalda ceden claramente al cabo de varios días de reposo seguidos de la reanudación gradual de la actividad dentro de los límites permitidos por el dolor. Aunque los analgésicos no opiáceos y los fármacos antinflamatorios no esteroideos pueden contribuir al alivio del dolor, no acortan el proceso. [Dado que algunos de estos fármacos reducen el nivel de atención y el tiempo de reacción, su consumo debe hacerse con cautela en el caso de los conductores de vehículos y de las personas que realizan tareas en las que cualquier distracción momentánea pueda perjudicarles]. Diversas modalidades de fisioterapia (como aplicaciones locales de frío o calor, diatermia, masajes, manipulación) suelen aportar un alivio temporal del dolor y resultan particularmente útiles previamente a unos ejercicios graduales destinados a inducir la recuperación de la tonicidad y relajación de los músculos, así como la flexibilidad. El reposo en cama prolongado, la tracción y el uso de fajas lumbares tienden a retrasar la recuperación y a prolongar el período de incapacidad (Blow y Jayson 1988).

El mejor tratamiento del dolor crónico de espalda es un régimen de prevención secundaria, basado en hábitos como descansar el tiempo necesario, dormir sobre un colchón rígido, sentarse en sillas de respaldo plano, usar calzado cómodo y ajustado al pie, mantener una postura natural y no permanecer demasiado tiempo de pie en la misma posición. El riesgo de efectos secundarios desaconseja el consumo excesivo o prolongado de medicamentos. En algunos casos, resultan aconsejables las inyecciones en los "puntos desencadenantes", unos nódulos blandos localizados en músculos y ligamentos, de acuerdo con el informe de Lange (1931).

El ejercicio de los músculos posturales clave labdominales, dorsales, glúteos y de los muslos) es la base del tratamiento de los dolores crónicos y la prevención de las molestias de espalda. Kraus (1970) ha recomendado un tratamiento basado en ejercicios de fortalecimiento destinados a corregir la debilidad muscular; ejercicios de relajación para aliviar la tensión, la espasticidad y la rigidez; ejercicios de estiramiento para minimizar las contracturas, y ejercicios para mejorar el equilibrio y la coordinación. Advierte el autor que estos ejercicios se deben personalizar en función de la exploración del paciente y de pruebas funcionales de la fuerza muscular, la capacidad para sostener pesos y la elasticidad, como las de Kraus-Weber (Kraus 1970). Con objeto de evitar los efectos adversos de los ejercicios, en cada sesión se deben incluir ejercicios de calentamiento y de enfriamiento, así como otros de puesta a punto y relajación; asimismo, el número, duración e intensidad de los ejercicios se debe incrementar gradualmente, a medida que mejora el estado del paciente. No basta con entregar a éste un folleto o una hoja de instrucciones con los ejercicios; en un principio, el paciente precisa una instrucción individualizada y una monitorización de la correcta ejecución de los ejercicios.

En 1974, la Young Men's Christian Association (YMCA) de Nueva York puso en práctica el programa "La vía $Y$ para una espalda sana", basado en la asistencia a un curso barato de formación para el ejercicio basado en los ejercicios de Kraus. El programa adquirió una dimensión nacional en 1976 y, posteriormente, se implantó en Australia y en varios países europeos (Melleby 1988). Constituido por dos sesiones semanales impartidas durante seis semanas, el programa está a cargo de instructores especialmente cualificados de la YMCA y de diversos voluntarios, y se imparte principalmente en los centros urbanos de la asociación, si bien algunas empresas han contratado su realización en sus centros de trabajo. Un 80 \% de los millares de personas afectadas de dolores crónicos o recurrentes de espalda que han participado en el programa manifiestan que los dolores han desaparecido o remitido.

Leon J. Warshaw pacientes - podrían marcar el rumbo de los acontecimientos futuros en este campo. Los métodos de ergonomía participativa y los programas de mejora sanitaria en los hospitales (enfocados como desarrollo organizativo) deben ser igualmente objeto de un análisis e investigación más intensivos como posibles estrategias futuras (véase el artículo titulado "Perspectiva de la ergonomía hospitalaria").

Dado que los factores psicosociales del estrés también contribuyen a moderar la percepción y el control de las exigencias físicas del trabajo, los programas de prevención se deben diseñar de modo que los compañeros y superiores colaboren en el logro de la satisfacción en el trabajo, se evite a los trabajadores un esfuerzo físico y mental excesivo y se les aporte un nivel adecuado de apoyo social.

Las medidas de prevención deben ir más allá de la vida profesional y abarcar tanto el trabajo doméstico (las labores domésticas y el cuidado de los niños pequeños que es preciso tomar en brazos constituyen actividades especialmente peligrosas) como el deporte y otras manifestaciones del ocio. Toda persona que padezca dolores de espalda persistentes o recurrentes, con independencia de su etiología, debe adoptar con la máxima diligencia las medidas preventivas adecuadas.

\section{Rehabilitación}

La clave de la rápida recuperación consiste en la pronta movilización y la rápida reanudación de la actividad, dentro de los límites de la tolerancia y el bienestar. La mayoría de los pacientes con lesiones agudas de espalda se recuperan plenamente y regresan a sus ocupaciones habituales sin problemas. Se debe evitar la reanudación sin limitaciones de las actividades hasta que el ejercicio haya permitido la recuperación total de la fuerza y flexibilidad musculares y haya eliminado el miedo y el recelo que pueden causar la recidiva de la lesión. Para muchas personas que manifiestan tendencia a la recidiva y a convertirse en pacientes crónicos, la fisioterapia, combinada con el ejercicio y el control de los factores psicosociales, suele ser de utilidad. Es conveniente que estas personas se reincorporen en alguna medida al trabajo cuanto antes. La eliminación temporal de las actividades más fatigosas y la limitación de la jornada de trabajo, unida a la reincorporación gradual a la actividad normal, contribuye en estos casos a que la recuperación sea más completa.

\section{Capacidad física para el trabajo}

En la literatura especializada se atribuye un mero valor de pronóstico limitado a la exploración selectiva previa al acceso al puesto de trabajo (US Preventive Services Task Force 1989). Las consideraciones éticas y algunas normas jurídicas, como la Ley de norteamericanos con discapacidades, complican la exploración selectiva previa al trabajo. Está generalmente aceptado que las radiografías de la espalda carecen de valor, especialmente si se toman en consideración su coste y la innecesaria exposición a la radiación. Es preciso examinar tanto a los nuevos enfermeros y trabajadores sanitarios en general como a los que se reincorporan al cabo de un período de incapacidad provocado por dolores de espalda, con objeto de descubrir la posible predisposición a este tipo de problema y de facilitar a los afectados el acceso a los programas de formación y aptitud física que contribuyan a prevenir las recaídas.

\section{Conclusiones}

Es posible reducir sensiblemente los efectos socioeconómicos del dolor de espalda, que aqueja frecuentemente a las enfermeras, mediante la aplicación de métodos y tecnologías ergonómicos en la organización del trabajo y de su entorno, a 
través de una preparación física que incremente la capacidad de la musculatura posicional, mediante la educación y formación en la realización de actividades problemáticas y, si se producen dolores de espalda, mediante un tratamiento basado en una mínima intervención médica y una pronta reincorporación a la vida activa.

\section{LOS TRABAJADORES SANITARIOS Y LAS ENFERMEDADES INFECCIOSAS}

\section{PERSPECTIVA DE LAS ENFERMEDADES INFECGIOSAS}

\section{Friedrich Hofmann}

Las enfermedades infecciosas tienen un peso considerable en el total mundial de enfermedades profesionales entre los trabajadores sanitarios. Dado que los procedimientos de comunicación de los casos varían de uno a otro país, y que las enfermedades consideradas profesionales en un país se pueden catalogar como comunes en otro, resulta difícil obtener información precisa sobre su frecuencia y su peso específico en el número total de enfermedades profesionales que aquejan a los trabajadores sanitarios. Los índices oscilan entre el $10 \%$ registrado en Suecia (Lagerlöf y Broberg 1989) y el $33 \%$, aproximadamente, observado en Alemania (BGW 1993) o casi el $40 \%$ de Francia (EstrynBéhar 1991).

La prevalencia de las enfermedades infecciosas está en función directa de la eficacia de las medidas preventivas, como la vacunación y la profilaxis posterior a la exposición. Por ejemplo, durante el decenio de 1980, la frecuencia de la hepatitis vírica se redujo al 12,7 \% gracias a la implantación de la vacunación contra la hepatitis B (Estryn-Béhar 1991). Esta tendencia se manifestó antes, incluso, de que apareciese la vacuna contra la hepatitis $\mathrm{A}$.

Recíprocamente, es de esperar que, al reducirse las tasas de vacunación en muchos países (como en la antigua Federación Rusa y Ucrania, de la desaparecida Unión Soviética, durante 1994-1995), se incrementen los casos de difteria y de poliomielitis entre los trabajadores sanitarios.

Por último, se han comunicado casos de infecciones ocasionales por estreptococos, estafilococos y Salmonella typhi entre los trabajadores sanitarios.

\section{Estudios epidemiológicos}

Las siguientes enfermedades infecciosas, relacionadas por orden de frecuencia, constituyen las patologías infecciosas relacionadas con el trabajo más frecuentes en todo el mundo entre el personal sanitario:

- hepatitis B

- tuberculosis

- hepatitis $\mathrm{C}$

- hepatitis A

- hepatitis, no A-E.

Las siguientes (que no se relacionan por orden de frecuencia) son igualmente importantes:

- varicela

- sarampión

- parotiditis

- rubéola

- Ringëlröteln (infecciones víricas por el parvovirus B 19)

- VIH/SIDA

- hepatitis D

- hepatitis por virus de Epstein-Barr

- hepatitis por citomegalovirus.
Es más que dudoso que los numerosísimos casos de infección intestinal (Salmonella, Shigella, etc.) que suelen figurar en las estadísticas sean realmente de origen profesional, ya que el contagio de estas infecciones suele ser por vía fecal/oral.

Existe abundante información estadística acerca de la importancia epidemiológica de estas infecciones asociadas al trabajo, principalmente en relación con la hepatitis B y su prevención, aunque también con la tuberculosis y las hepatitis A y C. Se han realizado asimismo estudios epidemiológicos del sarampión, la parotiditis, la rubéola, la varicela y la Ringenröteln. No obstante, al utilizar estos estudios es preciso distinguir entre los que se refieren a la incidencia (por ejemplo, la determinación de las tasas anuales de infección por hepatitis B), los estudios de prevalencia seroepidemiológicos y los restantes estudios de prevalencia (como las pruebas de tuberculina).

\section{Hepatitis B}

$\mathrm{El}$ riesgo de infección de la hepatitis $\mathrm{B}$-que se transmite principalmente mediante el contacto con la sangre producido por los pinchazos con jeringuillas - entre los trabajadores sanitarios depende de la frecuencia de esta enfermedad en la población atendida. En Norteamérica y en los países de la Europa septentrional, central y occidental, esta patología afecta al $2 \%$, aproximadamente, de la población. La cifra se eleva al $7 \%$ en la Europa meridional y sudoriental, y en la mayoría de las regiones asiáticas. En Africa, zonas del norte del continente sudamericano y el Asia oriental y sudoriental se han observado tasas de hasta el $20 \%$ (Hollinger 1990).

Según un estudio belga, unos 500 trabajadores sanitarios contraían la hepatitis B en la Europa septentrional todos los años, mientras que la cifra en la Europa meridional era de 5.000 (Van Damme y Tormanns 1993). Los autores estiman que, en la Europa occidental, el número de contagios anuales entre los trabajadores sanitarios es de unos 18.200. De esta cifra, llegan a desarrollar hepatitis crónica unos 2.275 trabajadores, de los que 220 contraen cirrosis hepática y 44 terminan sufriendo carcinoma del hígado.

Según un importante estudio realizado con una muestra de 4.218 trabajadores sanitarios de Alemania, donde el $1 \%$ de la población da positivo en la prueba del antígeno de superficie de la hepatitis B $(\mathrm{HBs} \mathrm{Ag})$, el riesgo de contraer hepatitis B es cerca de 2,5 veces mayor entre los trabajadores sanitarios que en el conjunto de la población (Hofmann y Berthold 1989). El mayor estudio realizado hasta la fecha, sobre una muestra de 85.985 trabajadores de la sanidad de todo el mundo, puso de relieve que los trabajadores de los servicios de diálisis, anestesiología y dermatología eran los más propensos a contraer hepatitis B (Maruna 1990).

El riesgo que suponen los trabajadores sanitarios con síntomas de hepatitis B crónica suele pasar desapercibido. Se conocen más de 100 casos en todo el mundo en los que el foco de contagio no ha sido el paciente, sino el médico. El caso más llamativo conocido es el de un médico suizo que infectó a 41 pacientes (Grob y cols. 1987).

Aunque el principal vector del contagio del virus de la hepatitis B son las heridas producidas por agujas contaminadas por sangre infectada (Hofmann y Berthold 1989), el virus se ha 
detectado en otros líquidos corporales, como el semen, las secreciones vaginales, el líquido cefalorraquídeo y el exudado pleural (CDC 1989).

\section{Tuberculosis}

En la mayoría de los países, la tuberculosis sigue siendo la primera o segunda enfermedad profesional en orden de importancia entre los trabajadores sanitarios (véase el artículo "Prevención, control y vigilancia de la tuberculosis"). Numerosos estudios han puesto de relieve que, si bien el riesgo se mantiene a lo largo de la vida profesional, es mayor durante la fase de formación. Por ejemplo, en un estudio realizado en Canadá en el decenio de 1970 se halló que la tasa de tuberculosis entre las enfermeras duplicaba la existente entre las mujeres de otras profesiones (Burhill y cols. 1985). Asimismo, en Alemania, país en que la tasa de tuberculosis en el conjunto de la población es de 18 casos por 100.000, la cifra se eleva a unos 26 por 100.000 entre los trabajadores sanitarios (BGW 1993).

Los estudios basados en la prueba de tuberculina permiten realizar una estimación más ajustada del riesgo de contraer tuberculosis. La reacción positiva a esta prueba denota, bien una infección por Mycobacterium tuberculosis o por otras bacterias, bien la inoculación previa de la vacuna BCG. Si la antigüedad de la inoculación es de veinte años o mayor, se presume que el resultado positivo denota, como mínimo, un contacto con los bacilos de la tuberculosis. En la actualidad, la prueba de tuberculina se realiza mediante el sistema del parche, cuyos resultados se interpretan entre cinco y siete días después. Un extenso estudio realizado en Alemania sobre la base de este tipo de pruebas epidérmicas dio como resultado una tasa de positividad entre los profesionales de la salud sólo moderadamente más alta que en el conjunto de la población (Hofmann y cols. 1993); sin embargo, otros estudios de amplio espectro han demostrado la existencia de un nivel de riesgo mucho más elevado de tuberculosis en algunos servicios de salud que en otros.

Más recientemente, se ha suscitado una cierta ansiedad ante el incremento del número de casos de contagio por microorganismos resistentes a los fármacos. Esta cuestión reviste especial importancia para el diseño de un sistema de prevención destinado a los trabajadores sanitarios aparentemente sanos cuyas pruebas de tuberculina se hayan vuelto positivos como consecuencia de la exposición a los pacientes de tuberculosis.

\section{Hepatitis A}

Dado que el virus de la hepatitis A se transmite casi exclusivamente a través de las heces, el número de trabajadores sanitarios expuestos al contagio es sustancialmente menor que en el caso de la hepatitis B. Un anterior estudio realizado en Berlín reveló que el personal de pediatría era el más expuesto a esta infección (Lange y Masihi 1986). Estos resultados se vieron confirmado posteriormente por una encuesta realizada en Bélgica (Van Damme y cols. 1989). Asimismo, los estudios realizados en Alemania sudoccidental revelaron la existencia de un mayor nivel de riesgo para las enfermeras, el personal de enfermería de pediatría y las mujeres de la limpieza (Hofmann y cols. 1992; Hofmann, Berthold y Wehrle 1992). En un estudio realizado en la ciudad alemana de Colonia se puso de manifiesto la inexistencia de riesgos entre las enfermeras de geriatría, en contraste con las tasas de prevalencia más elevadas entre el personal de los centros pediátricos. Otro estudio puso de relieve el mayor riesgo de contraer hepatitis A entre las enfermeras de pediatría de Irlanda, Alemania y Francia; en este último país, el mayor nivel de riesgo se detectó en las unidades de psiquiatría en que se atienden niños y pacientes adolescentes. Por último, en un estudio de las tasas de infección entre las personas minusválidas se puso de relieve un nivel de riesgo más elevado entre los pacientes y los trabajadores que los asisten (Clemens y cols. 1992).

\section{Hepatitis $C$}

La hepatitis C, descubierta en 1989, se transmite, como la hepatitis $\mathrm{B}$, a través de la sangre introducida en el sistema circulatorio por las inyecciones administradas con jeringuillas infectadas. No obstante, hasta hace poco tiempo, la información disponible sobre este riesgo para los trabajadores sanitarios ha sido escasa. En un estudio realizado en Nueva York en 1991 entre 456 dentistas y 723 controles se puso de manifiesto una tasa de infección del 1,75\% entre los primeros y de sólo un $0,14 \%$ entre los segundos (Klein y cols 1991). Un grupo de investigadores alemanes demostró la prevalencia de la hepatitis $\mathrm{C}$ en la prisiones y la atribuyó al elevado consumo de drogas intravenosas entre los reclusos (Gaube y cols. 1993). En un estudio austríaco se halló que el $2 \%$ de una muestra de 294 trabajadores sanitarios eran seropositivos a los anticuerpos de la hepatitis $\mathrm{C}$, cifra muy superior a la registrada en el conjunto de la población (Hofmann y Kunz 1990). Este resultado se vio corroborado por otro estudio realizado entre los trabajadores sanitarios de la ciudad alemana de Colonia (Chriske y Rossa 1991).

Un estudio realizado en Friburgo, Alemania, reveló que el contacto con minusválidos de residencias asistidas, particularmente los afectados de parálisis cerebral infantil y trisomía 21 , los pacientes hemofilicos y los dependientes de drogas administradas por vía intravenosa presentaba un alto riesgo de contagio de hepatitis $\mathrm{C}$ para los trabajadores responsables de su cuidado. Particularmente elevada es la tasa de prevalencia entre el personal de los servicios de diálisis, y el riesgo relativo para el conjunto de los trabajadores de la sanidad se estableció en el 2,5\%, sobre la base de una muestra relativamente pequeña.

En 1993 se descubrió otra posible fuente de contagio, al hallarse que un caso de hepatitis se había producido como consecuencia de una salpicadura en un ojo (Sartori y cols. 1993).

\section{Varicela}

Las investigaciones sobre la prevalencia de la varicela, enfermedad particularmente grave en los adultos, han revestido la forma de pruebas de anticuerpos de la varicela (anti VZV), practicadas en países anglosajones. Así, aunque se halló una tasa de seronegativos del $2,9 \%$ en una muestra de 241 trabajadores sanitarios entre 24 y 62 años de edad, la cifra se elevaba al 7,5\% entre los menores de 35 años (McKinney, Horiwitz y Baxtiola 1989). Otro estudio realizado en una clínica pediátrica dio una tasa de negatividad del $5 \%$ en una muestra de 2.730 personas analizadas; sin embargo, estos datos resultan menos significativos si se tiene en cuenta que las pruebas serológicas se realizaron exclusivamente en personas sin antecedentes de haber tenido varicela. En cambio, en un estudio realizado en Friburgo se detectó un riesgo de infección por varicela sustancialmente mayor entre el personal de los hospitales pediátricos. En este estudio, realizado sobre una muestra de 533 trabajadores sanitarios y administrativos de los hospitales generales y pediátricos, se puso de relieve la existencia de inmunidad a la varicela en el $85 \%$ de las personas menores de 20 años.

\section{Parotiditis (paperas)}

$\mathrm{Al}$ estimar los niveles de riesgo de parotiditis, es preciso distinguir entre los países en que la vacunación es obligatoria y aquéllos otros en que es voluntaria. En el primer grupo de naciones, la práctica totalidad de los niños y jóvenes han sido vacunados, por lo que la parotiditis apenas supone riesgo para el personal de la asistencia sanitaria. En el segundo grupo de países, en el que se incluye Alemania, los casos de parotiditis aumentan. La falta de inmunidad hace que aumenten las complicaciones, especialmente 
entre los adultos. En un informe sobre un brote epidémico producido entre una población de esquimales no inmunizados de la isla de San Lorenzo (situada entre Siberia y Alaska) se evidenció la frecuencia de complicaciones del tipo de la orquitis en los varones, la mastitis en las mujeres y la pancreatitis en ambos sexos (Philip, Reinhard y Lackman 1959).

Lamentablemente, los datos epidemiológicos sobre la parotiditis entre el personal de la asistencia sanitaria son muy escasos. Un estudio realizado en Alemania en 1986 mostró que, aun cuando la tasa de inmunidad entre los niños de 10 a 15 años era del $84 \%$, al ser la vacunación voluntaria, es de presumir que el porcentaje tienda a reducirse. Un estudio realizado en Friburgo en 1994 sobre una muestra de 774 personas demostró un aumento significativo del riesgo entre los trabajadores de los hospitales pediátricos (Hofmann, Sydow y Michaelis 1994).

\section{Sarampión}

La situación del sarampión es similar a la de la parotiditis. Por causa de su carácter altamente contagioso, el riesgo de infección de los adultos se concreta a medida que se reducen los índices de inmunidad. En un estudio realizado en Estados Unidos se halló un porcentaje de inmunidad superior al $99 \%$ (Chou, Weil y Arnmow 1986), habiéndose determinado que el $98 \%$ de los integrantes de una muestra de 163 alumnas de enfermería eran inmunes (Wigand y Grenner 1988). Un estudio realizado en Friburgo dio unos índices del 96 al $98 \%$ entre las enfermeras pediátricas y el personal de enfermería general, al tiempo que las cifras entre el personal no médico se situaban únicamente entre el 87 y el 90 \% (Sydow y Hofmann 1994). Estos datos avalarían la recomendación de que la vacunación fuese obligatoria para el conjunto de la población.

\section{Rubéola}

La contagiosidad de la rubéola se sitúa entre el sarampión y la parotiditis. Las investigaciones demuestran que un $10 \%$ de los trabajadores de la sanidad no están inmunizados (Ehrengut y Klett 1981; Sydow y Hofmann 1994) y, por consiguiente, corren un gran riesgo de infección en cada exposición. Aunque, por regla general, no es una enfermedad grave para los adultos, durante las primeras dieciocho semanas del embarazo la rubéola puede surtir efectos terribles en el feto: aborto, muerte fetal y malformaciones congénitas (véase la Tabla 97.9) (South, Sever y Teratogen 1985; Miller, Vurdien y Farrington 1993). Puesto que estos efectos se pueden producir antes, incluso, de que la mujer conozca su embarazo, y dado que las trabajadoras de la asistencia sanitaria, en especial, las que tienen contacto cercano con los pacientes, son más propensas a la exposición, resulta especialmente aconsejable fomentar (y quizás, incluso, exigir) la vacunación de todas las trabajadoras de la asistencia sanitaria en edad fértil que no sean inmunes.

\section{$V I H / S I D A$}

Durante los decenios de 1980 y 1990, la seroconversión del VIH (esto es, la producción de una reacción positiva en una persona que anteriormente había dado una reacción negativa) se convirtió, para los trabajadores sanitarios, en un riesgo menor, aunque en modo alguno desdeñable. A principios de 1994 se conocían en Europa 24 casos perfectamente acreditados, más otros 35 casos posibles (Pérez y cols. 1994), al tiempo que en Estados Unidos se habían documentado 43 casos y se había informado de otros 43 casos posibles (CDC 1994a). Lamentablemente, al margen de la evitación del contacto con la sangre y los líquidos corporales infectados, no existen medidas preventivas eficaces. En el artículo "Prevención de la transmisión profesional de los agentes patógenos en sangre" se describen y sugieren algunas medidas profilácticas para las personas que han estado expuestas.

\section{Otras enfermedades infecciosas}

Las demás enfermedades infecciosas relacionadas al principio del presente artículo no se han configurado todavía como peligros significativos para la salud del personal de la asistencia sanitaria, bien por no haberse identificado e informado, bien porque su epidemiología no se ha estudiado aún. Los informes esporádicos de casos aislados o de un pequeño número de casos apuntan a la conveniencia de investigar la identificación y prueba de indicadores serológicos. Por ejemplo, según un estudio del tifus desarrollado durante 33 meses por los Centros de Control de Enfermedades (CDC), el $11,2 \%$ de los casos aislados no asociados a brote alguno se produjeron en trabajadores de laboratorio que habían examinado muestras de heces (Blazer y cols. 1980).

El futuro se presenta oscurecido por dos problemas simultáneos: la aparición de nuevos agentes patógenos (por ejemplo, nuevas amenazas, como la hepatitis $G$ y nuevos microorganismos, como el virus Ebola y el morbilivirus equino, recientemente descubierto en Australia como una amenaza letal para la población caballar y humana) y el continuo desarrollo de la resistencia a los fármacos de microorganismos bien conocidos, como el bacilo de la tuberculosis. Los trabajadores sanitarios serán, probablemente, los primeros en exponerse sistemáticamente a estos riesgos, lo cual confiere la máxima importancia a una pronta y precisa identificación de los mismos y al estudio epidemiológico de sus patrones de susceptibilidad y transmisión.

\section{Prevención de las enfermedades infecciosas entre los trabajadores sanitarios}

El principio básico de la prevención de las enfermedades infecciosas consiste en persuadir a los trabajadores sanitarios, al personal auxiliar y a los profesionales de la salud de que los centros sanitarios constituyen "caldos de cultivo" de infecciones, en los que cada paciente representa un riesgo potencial. Esto es importante no sólo para las personas que participan directamente en las actividades terapéuticas y diagnósticas, sino también para los trabajadores que recogen y manipulan muestras de sangre, heces y otros materiales biológicos, o que tienen contacto con vendajes, ropa de cama, platos y otros enseres. En ciertos casos, incluso la aspiración del aire ambiental puede ser peligrosa. Por consiguiente, en cada centro sanitario se debe elaborar un protocolo escrito pormenorizado en el que se describan los riesgos potenciales y las medidas precisas para su evitación, control o eliminación. A continuación, se debe formar a la totalidad del personal en la aplicación de esas medidas y controlar su actividad con objeto de garantizar la correcta ejecución del programa. Por último, todo fallo de las medidas adoptadas se debe registrar y comunicar para facilitar su modificación o la readaptación profesional.

Tabla 97.9 - Anomalías congénitas tras la infección por la rubéola.

\begin{tabular}{|c|c|c|c|c|c|}
\hline \multicolumn{6}{|c|}{ Estudios realizados por South, Sever y Teratogen (1985) } \\
\hline Semana de embarazo & 4 & $5-8$ & $9-12$ & $13-16$ & 17 \\
\hline Tasa de deformidad (\%) & 70 & 40 & 25 & 40 & 8 \\
\hline \multicolumn{6}{|c|}{ Estudios realizados por Miller, Vurdien y Farrington (1993) } \\
\hline Semana de embarazo & 10 & $11-12$ & $13-14$ & $15-16$ & 17 \\
\hline Tasa de deformidad (\%) & 90 & 33 & 11 & 24 & 0 \\
\hline
\end{tabular}


Otras medidas accesorias importantes son la identificación de las áreas y el etiquetado de los materiales que entrañen un mayor riesgo de infección, así como el suministro de guantes, batas, máscaras, fórceps y otros dispositivos de protección. Lavarse las manos con jabón germicida y agua corriente (siempre que sea posible) no sólo contribuye a proteger la salud del trabajador, sino también a reducir el riesgo de transmisión de enfermedades a los compañeros y pacientes.

Tanto las muestras de sangre y líquidos corporales como las salpicaduras y los materiales manchados de los mismos se deben tratar como si estuviesen infectados. El uso de contenedores de plástico rígido para la eliminación de agujas y otros instrumentos afilados, así como la observancia de la diligencia debida en la evacuación de los residuos potencialmente infecciosos, constituyen importantes medidas preventivas.

Antes o inmediatamente después de que los trabajadores sanitarios accedan al empleo, es preciso elaborar una historia médica pormenorizada y realizar pruebas serológicas y de parches. Siempre que sea aconsejable y no existan contraindicaciones, se

Tabla 97.10 • Indicaciones para la vacunación de los trabajadores sanitarios.

Enfermedad Complicaciones ¿Quiénes deben vacunarse?
Difteria
\[ \begin{array}{l}\text { En caso de epidemia, todos los trabajadores que } \\ \text { no estén demostradamente inmunizados, } \\ \text { aparte de esta vacunación recomendada, se } \\ \text { aplica la vacuna combinada TD siempre que } \\ \text { exista un riesgo de epidemia para la totalidad } \\ \text { del personal }\end{array} \]

Hepatitis A

Los trabajadores del área de pediatría y de las unidades de enfermedades infecciosas, de los laboratorios de microbiología y de las cocinas, además del personal femenino de limpiezo

Hepatitis B

Todos los trabajadores seronegativos expuestos a un posible contacto con sangre o líquidos corporales

Gripe

Se ofrece regularmente a todos los trabajadores

Sarampión Encefalitis Trabajadores seronegativos del área de pediatría

Parotiditis Meningitis Trabajadores seronegativos del área de pediatría

Otitis

Pancreatitis

Rubéola Embriopatía Trabajadores seronegativos de las áreas de pediatría/tocología/ambulancias, y personal femenino seronegativo en edad fértil

Poliomielitis Todos los trabajadores, como los que participan en las campañas de vacunación

Tétanos Obligatoria para todos los trabajadores de jardinería y de las áreas técnicas, se ofrece a la totalidad de los trabajadores, se utiliza la vacuna combinada TD

Tuberculosis En todos los casos, con carácter voluntario a la totalidad de los trabajadores de las áreas de neumología y cirugía del pulmón (BCG)

Varicela Riesgos fetales Trabajadores seronegativos de las salas de pediatría 0, como mínimo, de las salas de encefalomielitis, oncología pediátrica (protección del paciente) y oncología deben administrar las vacunas indicadas, especialmente contra la hepatitis B, la hepatitis A y la rubéola (véase la Tabla 97.10). En todo caso, la presencia de una seroconversión puede denotar la existencia de una infección adquirida y la conveniencia de aplicar un tratamiento profiláctico.

\section{Tratamiento profiláctico}

En algunos casos en que se sabe que el trabajador no está inmunizado y ha estado expuesto a un foco, real o muy probable, de infección, procede la aplicación de un programa profiláctico. En especial, si el trabajador presenta síntomas de inmunodeficiencia, se le debe administrar inmunoglobulina humana. Si se dispone de suero "hiperinmune" específico, como en la parotiditis y la hepatitis $\mathrm{B}$, resulta preferible. Si se trata de infecciones que, como la hepatitis $\mathrm{B}$, pueden tener una incubación lenta, o si se dispone de dosis suplementarias "de refuerzo", como en el tétanos, se puede administrar una vacuna. Si no se dispone de vacunas, como ocurre en las infecciones por meningococos, se pueden aplicar antibióticos profilácticos, solos o como complemento de la inmunoglobulina. Se han desarrollado tratamientos profilácticos de otros fármacos para la tuberculosis y, más recientemente, para las posibles infecciones por el VIH que se analizan en otros artículos del presente capítulo.

\section{PREVENCION DE LA TRANSMISION PROFESIONAL DE LOS AGENTES PATOGENOS EN SANGRE}

Linda S. Martin, Robert J. Mullan

y David M. Bell

La prevención de la transmisión profesional de los agentes patógenos en sangre, incluidos el virus de la inmunodeficiencia humana, el de la hepatitis $\mathrm{B}$ y, más recientemente, el virus de la hepatitis $\mathrm{C}$, ha despertado considerable interés. Si bien los trabajadores sanitarios constituyen el estamento profesional más expuesto al riesgo de infección, todo trabajador que entre en contacto con muestras de sangre $\mathrm{u}$ otros líquidos corporales potencialmente infecciosos presenta un peligro. Entre los grupos profesionales de riesgo por causa de su exposición profesional a los agentes patógenos en sangre figuran, además de los empleados en la asistencia sanitaria, los trabajadores de la seguridad pública, de los servicios de urgencia y otros grupos, como los investigadores de laboratorio y el personal de servicios funerarios. El riesgo de transmisión profesional de los agentes patógenos en sangre, incluido el VIH, continuará incrementándose a medida que crezca el número de personas portadoras de VIH y otras infecciones en sangre.

En Estados Unidos, los Centros para el Control y Prevención de Enfermedades (CDG) recomendaron en 1992 y 1993 que los pacientes con el síndrome de inmunodeficiencia adquirida fuesen tratados teniendo en cuenta las (ya obsoletas) "precauciones con la sangre y los líquidos corporales" (CDC 1982; CDC 1983). La evidencia documental de que el VIH - el agente causante del SIDA - se había transmitido a los trabajadores sanitarios a través de exposiciones cutáneas y percutáneas y mucocutáneas a sangre infectada por el VIH, así como el descubrimiento de que la condición de infectados de VIH de la mayoría de los pacientes o de las muestras de sangre con los que habían tenido contacto los trabajadores sanitarios era desconocida en el momento del contacto, indujo a los CDC a recomendar que las precauciones con la sangre y los líquidos corporales se aplicasen a todos los pacientes, según el método 
denominado de "precauciones universales" (CDC 1987a, 1987b). Si bien estas precauciones universales obvian la necesidad de identificar a los pacientes con infecciones en la sangre, no tienen porqué reemplazar a las prácticas generales de control de infecciones. Entra las precauciones universales se incluyen la higiene de las manos, el uso de barreras protectoras (como guantes, gafas ajustadas, batas y medios de protección facial) cuando se prevé un posible contacto con la sangre, y el cuidado en el uso y eliminación de agujas y otros instrumentos afilados en todos los contextos de la asistencia sanitaria. Asimismo, es preciso desinfectar o esterilizar convenientemente los instrumentos y demás equipo reutilizable empleado en los procedimientos invasivos (CDC 1988a, 1988b). Las posteriores recomendaciones de los CDC se han orientado a la prevención de la transmisión del VIH y el VHB al personal de seguridad pública y servicios de urgencia (CDC 1988b), a la gestión de la exposición profesional al VIH - incluidas las recomendaciones sobre el uso de zidovudina (CDG 1990), la inmunización contra el VHB y la gestión de la exposición al VHB (CDG 1991a), el control de las infecciones en la odontología (CDC 1993) y la prevención de la transmisión del VIH de los trabajadores sanitarios a sus pacientes durante la aplicación de procedimientos invasivos (CDC 1991b).

Si bien las recomendaciones de los CDC carecen de fuerza legal en Estados Unidos, a menudo han servido de pauta para la promulgación de normas legales y la adopción voluntaria de medidas por la industria. Un organismo regulador federal, la Occupational Health and Safety Administration (OSHA), promulgó en 1991 una norma sobre la Exposición profesional a los agentes patógenos en sangre (OSHA 1991). La OSHA postula que una conjunción de controles técnicos y de prácticas de trabajo, ropas y equipo protectores, formación, vigilancia médica, letreros y señales, junto con otras medidas, puede contribuir a reducir o eliminar la exposición a los agentes patógenos en sangre. En la norma se establece igualmente la obligación de las empresas de facilitar la vacunación del personal contra la hepatitis B.

La Organización Mundial de la Salud también ha publicado algunas recomendaciones y directrices relativas al SIDA en el lugar de trabajo (OMS 1990, 1991). En 1990, la Unión Europea adoptó una directiva (90/679/CEE) sobre la protección de los trabajadores contra los riesgos derivados de la exposición a los agentes biológicos en el trabajo. En ella se estipula que las empresas deben evaluar los riesgos para la salud y seguridad de los trabajadores, y se establece una distinción entre las actividades consistentes en el trabajo con agentes biológicos o en el uso deliberado de los mismos (como los laboratorios) y las actividades en que la exposición es accidental (como la atención a los pacientes). El control se basa en un sistema jerarquizado de procedimientos. Se postulan medidas especiales de almacenamiento, especificadas en función de las características de los agentes, para algunas clases de laboratorios y centros sanitarios (McCloy 1994). En Estados Unidos, los CDG y los National Institutes of Health también han formulado recomendaciones específicamente dirigidas a los laboratorios (CDC 1993b).

Desde que se identificó el VIH como agente patógeno en sangre, los hallazgos sobre la transmisión del VHB han servido de modelo útil de investigación de los modos de transmisión de aquél. En efecto, ambos virus se transmiten por vía sexual, perinatal y sanguínea. El VIH se encuentra presente en la sangre de los individuos positivos del antígeno e de la hepatitis $\mathrm{B}(\mathrm{HBeAg}$, indicador de una infecciosidad elevada) en concentraciones de alrededor de $10^{8}$ a $10^{9}$ partículas víricas por mililitro $(\mathrm{ml})$ de sangre (CDC 1988b). El VIH está presente en la sangre en concentraciones muy inferiores, de entre $10^{3}$ a $10^{4}$ partículas víricas $/ \mathrm{ml}$ en los afectados de SIDA, y entre 10 y 100 partículas/ml en los afectados asintomáticos de VIH (Ho, Moudgil y Alam 1989). El riesgo de transmisión del VHB a los trabajadores sanitarios como consecuencia de una exposición percutánea a una muestra de sangre positiva en la prueba del $\mathrm{HBeAg}$ es unas 100 veces mayor que el riesgo de transmisión de VIH como consecuencia de la exposición percutánea a sangre infectada de VIH (esto es, un $30 \%$ frente a un $0,3 \%)($ CDC 1989).

\section{Hepatitis}

La hepatitis, puede ser provocada por diversos agentes, como toxinas, drogas, enfermedades autoinmunes y agentes infecciosos. Los virus constituyen la causa más frecuente de la hepatitis (Benenson 1990). Se han identificado tres tipos de hepatitis víricas: hepatitis B (antiguamente denominada hepatitis sérica), que constituye el principal riesgo para los trabajadores sanitarios; hepatitis C, que es la causa principal de la hepatitis no A no B de transmisión parenteral; y la hepatitis $\mathrm{D}$, o hepatitis delta.

Hepatitis $B$. El principal factor de riesgo profesional de transmisión de agentes patógenos en sangre a los trabajadores sanitarios es el virus de la hepatitis $\mathrm{B}$ (VHB). Entre los trabajadores norteamericanos frecuentemente expuestos al contacto con sangre, la prevalencia de pruebas serológicas de infección por el VHB oscila entre el 15 y el $30 \%$, en contraste con el $5 \%$ para el conjunto de la población. La eficacia en función del coste de la exploración serológica orientada a detectar las personas susceptibles entre los trabajadores sanitarios está en función de la prevalencia de la infección, del coste de los ensayos y de los costes de la vacuna. No se han establecido efectos adversos de la vacunación en personas que presentan ya los anticuerpos del VHB. La vacuna contra la hepatitis B inmuniza contra la enfermedad durante un mínimo de 12 años, pero actualmente no se recomiendan las dosis de recuerdo. Los CDC estiman que, en 1991, se produjeron en Estados Unidos unos 5.100 casos de infección profesional por el VHB entre los trabajadores sanitarios, con unos 1.275 a 2.550 casos de hepatitis aguda clínica, 250 hospitalizaciones y unos 100 fallecimientos (datos no publicados de los CDC). En 1991, unos 500 trabajadores sanitarios se convirtieron en portadores del VHB. Estas personas pueden sufrir secuelas de aparición tardía, como enfermedades hepáticas crónicas, cirrosis y cáncer de hígado.

Se recomienda vacunar contra el VHB a los trabajadores de la seguridad pública y la asistencia sanitaria que se expongan al contacto con la sangre en el lugar de trabajo (CDC 1991b). Después de una exposición percutánea a una muestra de sangre, la decisión de aplicar un tratamiento profiláctico se basa en la ponderación de diversos factores: el conocimiento del origen de la sangre, la situación del HBsAg del donante de la muestra, y la respuesta a la vacuna de la persona expuesta. Se recomienda la vacunación contra la hepatitis $\mathrm{B}$ de toda persona no vacunada previamente. En su caso, la inmunoglobulina de la hepatitis (HBIG) se debe administrar tan pronto como sea posible después de la exposición, dado que su eficacia al cabo de 7 días de exposición no está clara. En la Tabla 97.11 figuran las recomendaciones específicas de los CDC (CDC 1991b).

En el apartado 3 del artículo 14 de la Directiva n ${ }^{\circ}$ 89/391/CEE sobre vacunación sólo se exige la administración de vacunas eficaces, si existen, a los trabajadores que no están inmunizados. Esta directiva fue posteriormente modificada por la Directiva 93/88/CEE, en la que figura un código de recomendaciones prácticas en el sentido de vacunar gratuitamente a los trabajadores expuestos, informarles de las ventajas y desventajas de la vacunación y la no vacunación, y suministrarles un certificado de vacunación (OMS 1990).

La administración de la vacuna contra la hepatitis B y la aplicación de controles medioambientales adecuados previenen la práctica totalidad de las infecciones profesionales por el VIH. 
Tabla 97.11 - Recomendación de profilaxis postexposición en los casos de exposición percutánea o permucosa al virus de la hepatitis B en Estados Unidos.

\begin{tabular}{|c|c|c|c|}
\hline \multirow[t]{2}{*}{ Persona expuesta } & \multicolumn{3}{|l|}{ Si la fuente es: } \\
\hline & HBsAg' positiva & $\begin{array}{l}\text { HBsAg } \\
\text { negativa }\end{array}$ & $\begin{array}{l}\text { Fuente no contro- } \\
\text { lada o desconocida }\end{array}$ \\
\hline No vacunada & $\begin{array}{l}\text { HBIG } 1 \text { e iniciar } \\
\text { vacuna } \mathrm{HB}^{3}\end{array}$ & $\begin{array}{l}\text { Iniciar } \\
\text { vacuna HB }\end{array}$ & Iniciar vacuna HB \\
\hline \multicolumn{4}{|l|}{$\begin{array}{l}\text { Vacunada } \\
\text { anteriormente }\end{array}$} \\
\hline $\begin{array}{l}\text { Respuesta } \\
\text { documentada }\end{array}$ & Ningún tratamiento & $\begin{array}{l}\text { Ningún } \\
\text { tratamiento }\end{array}$ & Ningún tratamiento \\
\hline $\begin{array}{l}\text { Falta de } \\
\text { respuesta } \\
\text { documentada }\end{array}$ & $\begin{array}{l}\text { HBIG } 2 \text { o bien } \\
\text { HBIG } 1 \text { e iniciar } \\
\text { revacunación }\end{array}$ & $\begin{array}{l}\text { Ningún } \\
\text { tratamiento }\end{array}$ & $\begin{array}{l}\text { Si la fuente es cono- } \\
\text { cidamente de alto } \\
\text { riesgo, tratarla } \\
\text { como si fuese } \\
\text { HBsAg positiva }\end{array}$ \\
\hline $\begin{array}{l}\text { Respuesta } \\
\text { desconocida }\end{array}$ & $\begin{array}{l}\text { Exposición a } \\
\text { anti-HBs } \\
\text { 1. Si son } \\
\text { adecuados } \\
\text { ningún trata- } \\
\text { miento } \\
\text { 2. Si son inade- } \\
\text { cuados, HBIGxI y } \\
\text { vacuna de } \\
\text { recuerdo }\end{array}$ & $\begin{array}{l}\text { Ningún } \\
\text { tratamiento }\end{array}$ & $\begin{array}{l}\text { Exposición a } \\
\text { anti-HBs } \\
\text { 1. Si son } \\
\text { adecuados, ningún } \\
\text { tratamiento } \\
\text { 2. Si son inade- } \\
\text { cuados, vacuna de } \\
\text { recuerdo }\end{array}$ \\
\hline
\end{tabular}

${ }^{1} \mathrm{HBsAg}=$ Antígeno de superficie de la hepatitis. ${ }^{2} \mathrm{HBIG}=$ antígeno de superficie de la hepatitis; dosis de $0,06 \mathrm{ml} / \mathrm{kg} \mathrm{IM}$.

${ }^{3}$ Vacuna $H B=$ vacuna contra la hepatitis B. $\quad{ }^{4}$ Anti-HBs = anticuerpos del antígeno de superficie de la hepatitis $B . \quad 5$ anti HBs adecuados $10 \mathrm{mUl} / \mathrm{mL}$.

Asimismo, la reducción de la exposición a la sangre y de la frecuencia de los pinchazos con agujas en el entorno de la asistencia sanitaria contribuye a reducir el riesgo de transmisión de otros virus en sangre.

Hepatitis C. El virus de la hepatitis $\mathrm{C}$ (VHC) se transmite de forma similar al VHB, si bien la infección persiste indefinidamente en la mayoría de los casos y suele producir secuelas a largo plazo (Alter y cols. 1992). La prevalencia de anticuerpos del VHC entre los trabajadores de la sanidad norteamericana oscila entre el 1 y el $2 \%$ (Alter 1993). Los trabajadores sanitarios que se pinchan accidentalmente con agujas contaminadas con sangre seropositiva al VHC corren un riesgo del 5 al $10 \%$ de infectarse por el VHC (Lampher y cols. 1994; Mitsui y cols. 1992). Se ha conocido un caso de transmisión del VHC por una salpicadura de sangre a la conjuntiva (Sartori y cols. 1993). También en este caso la prevención consiste en la observancia de las precauciones universales y en la evitación de las heridas percutáneas, dado que no existe vacuna y la inmunoglobulina no parece ser eficaz.

Hepatitis D. La hepatitis D precisa la presencia del virus de la hepatitis B para su replicación, esto significa que el VHD sólo puede afectar a una persona en el contexto de una coinfección con el VHB agudo o de una sobreinfección de una infección crónica. La infección por el VHD puede agravar las enfermedades hepáticas. Lettau y cols. (1986) informan de un caso de hepatitis $\mathrm{D}$ de origen profesional. La administración de la vacuna contra la hepatitis B a las personas susceptibles al VHB sirve, asimismo, para prevenir la sobreinfección por el VHD; en cambio, no existe vacuna para prevenir la sobreinfección por el VHD de un portador del VHB. Otras medidas preventivas son la observancia de las precauciones universales y la evitación de las heridas percutáneas.

\section{VIH}

Los primeros casos de SIDA se identificaron en junio de 1981. En un principio, más del $92 \%$ de los casos comunicados en Estados afectaban a varones homo o bisexuales. Sin embargo, a finales de 1992 empezaron a detectarse casos de SIDA entre consumidores de drogas inyectables, hemofílicos tratados con concentrados del factor coagulante, receptores de transfusiones de sangre, niños y haitianos. El SIDA es el resultado de la infección por el VIH, que se aisló en 1985. La enfermedad ha conocido una rápida difusión. Por ejemplo, en Estados Unidos, los primeros 100.000 casos de SIDA se produjeron entre 1981 y 1989; los segundos 100.000 casos, entre 1989 y 1991 y, en junio de 1994, se habían comunicado en ese país 401.749 casos (CDC 1994b).

El SIDA ha asolado a muchos países de todo el mundo, pertenecientes a Africa, Asia y Europa. El 31 de diciembre de 1994, se había comunicado a la OMS un total de 1.025.073 casos en niños y adultos, cifra que supone un incremento del $20 \%$ respecto a los 851.628 casos comunicados hasta el mes de diciembre de 1993. Se estima que, desde el inicio de la pandemia (entre finales del decenio de 1979 y principios del siguiente), 18 millones de adultos y alrededor de 1,5 millones de niños se han infectado por el VIH (OMS 1995).

Si bien se ha detectado la presencia del VIH en sangre humana, leche materna, secreciones vaginales, semen, saliva, lágrimas, orina, líquido cefalorraquídeo y líquido amniótico, sólo se han identificado el semen, la sangre, la secreción vaginal y la leche materna como vectores de la transmisión del virus. Los CDC han informado también de la transmisión del VIH por el contacto en el entorno doméstico con la sangre u otras secreciones o excreciones corporales de personas infectadas de SIDA (CDC 1994c). Las vías acreditadas de transmisión profesional del VIH son el contacto percutáneo o mucocutáneo con sangre infectada por el VIH. La vía percutánea supone un riesgo mayor de infección que el contacto mucocutáneo.

Varios factores influyen en la probabilidad de transmisión profesional de agentes patógenos en sangre, tales como el volumen de fluido presente en la exposición, el título del virus, la duración de la exposición y el estado inmunológico del trabajador. Se precisan datos complementarios para determinar con exactitud la importancia de estos factores. Los datos preliminares de un estudio de casos y controles de los CDC indican que, en la exposición percutánea a la sangre infectada por el VIH, el riesgo de transmisión del VIH es mayor si el proceso del VIH está avanzado en el paciente y si la exposición implica un mayor inóculo de sangre (esto es, si la causa de la herida es un pinchazo con una aguja hueca de gran calibre) (Cardo y cols. 1995). El título del virus puede variar de uno a otro individuo y, con el tiempo, en un mismo individuo. Asimismo, la sangre procedente de los pacientes de SIDA, especialmente en la fase terminal, puede ser más infecciosa que la procedente de pacientes en los estadios iniciales de la infección por el VIH, salvo, posiblemente, durante el período de enfermedad asociado a infecciones agudas (Cardo y cols. 1993).

\section{Exposición profesional a la infección por el VIH}

En diciembre de 1996, los CDC habían informado de 52 casos de trabajadores sanitarios norteamericana - 19 laborantes, 21 enfermeras, 6 médicos y 6 trabajadores de otras categoríasreconocidamente seropositivos al VIH como consecuencia de una exposición documentada al mismo. Cuarenta y cinco de los 52 trabajadores sanitarios habían tenido contactos 
percutáneos; 5 se habían expuesto a contactos mucocutáneos; uno había tenido tanto un contacto percutáneo como una exposición mucocutánea; y la vía de exposición era desconocida en otro de los casos. Adicionalmente, se ha informado de otros 111 casos de infección posiblemente relacionada con el trabajo. Estos casos sospechosos se han investigado y no se han podido relacionar con riesgos no profesionales o asociados a la transfusión; todos los afectados manifestaron haber experimentado exposiciones profesionales percutáneas o mucocutáneas, bien a la sangre o los líquidos corporales, bien a soluciones de laboratorio que contenían VIH; sin embargo, no se pudo confirmar la seroconversión al VIH en virtud de una exposición profesional (CDC 1996a).

Según un resumen realizado en 1993 por el Centro del SIDA del Communicable Disease Surveillance Centre del Reino Unido, se había informado de 37 casos de transmisión profesional del VIH en Estados Unidos, 4 en el Reino Unido, y 23 en otros países (Francia, Italia, España, Australia, Sudáfrica, Alemania y Bélgica), con un total de 64 seroconversiones documentadas como resultantes de una exposición profesional concreta. Entre los 118 casos posibles o presuntos se habían contabilizado 78 en Estados Unidos, 6 en el Reino Unido y 35 en otros países (Francia, Italia, España, Australia, Sudáfrica, Alemania, México, Dinamarca, Países Bajos, Canadá y Bélgica) (Heptonstall, Porter y Gill 1993). Es probable que el número de casos comunicados de infección profesional por el VIH constituya únicamente una parte del número real, debido, entre otras causas, a que muchos casos no se comunican.

\section{Actuación tras la exposición al VIH}

Las empresas deben poner a disposición de sus trabajadores un sistema que permita iniciar sin pérdida de tiempo la evaluación, asesoramiento y seguimiento de toda exposición profesional comunicada que entrañe para el trabajador un riesgo de infección por el VIH. Se debe educar y alentar a los trabajadores a que comuniquen toda exposición tan pronto como se produzca, con objeto de poder adoptar las medidas adecuadas (CDC 1990).

Si se produce una exposición, esta circunstancia se debe indicar en la historia médica confidencial del trabajador, con indicación de la hora y fecha de la misma; la tarea o labor realizada al producirse la exposición; los pormenores de ésta; la descripción de la fuente de la exposición, con indicación, en su caso, de si se trataba de materiales que contuviesen VHI o VHB, y los detalles de las medidas de asesoramiento, gestión posterior a la exposición y seguimiento. El incidente se debe poner en conocimiento de la fuente concreta de la infección y se debe recabar su acuerdo para someterla a la prueba serológica de infección por el VIH. Si no se obtiene ese acuerdo, es preciso diseñar políticas de realización de pruebas de las posibles fuentes de infección, de conformidad con las normas vigentes, obteniendo en todos los casos el consentimiento de los donantes de las muestras.

Si la fuente de la infección tuviese SIDA, fuese conocidamente seropositiva al VIH, se negase a someterse a una prueba o su situación respecto al VIH fuese desconocida, procede realizar una evaluación clínica y serológica del trabajador, con objeto de detectar la posible infección por el VIH tan pronto como sea posible después de la infección (medidas iniciales) y, si el resultado es negativo, someterle a pruebas periódicas durante un mínimo de 6 meses a partir de la exposición (por ejemplo, 6 semanas, 12 semanas y 6 meses después de la exposición), con objeto de detectar la posible infección por el VIH. Se debe aconsejar al trabajador que comunique y busque asistencia médica para toda enfermedad aguda que se produzca durante el período de seguimiento. Asimismo, hay que aconsejarle que, durante el seguimiento, se abstenga de donar sangre, semen u órganos, así como de mantener relaciones sexuales, excepto utilizando medidas que prevengan la transmisión del VIH.

En 1990, los CDC publicaron una declaración relativa a la gestión de la exposición al VIH en la que formulaban algunas recomendaciones sobre el uso de la zidovudina (ZDV) tras la exposición. Después de una cuidadosa revisión de los datos conocidos, se indicaba que la insuficiencia de aquéllos, incluidos los referidos a animales y al ser humano, imposibilitaba la evaluación de la eficacia de la zidovudina (CDC1990).

En 1996, la disponibilidad de información en el sentido de que la profilaxis post-exposición (PPE) con zidovudina podía reducir el riesgo de transmisión del VIH después de una exposición profesional a muestras de sangre infectada por dicho virus (CDC 1996a) indujo al Servicio de Salud Pública de Estados Unidos (Public Health Service, PHS) a actualizar una declaración suya anterior sobre la gestión de la exposición profesional al VIH incorporando los nuevos hallazgos y recomendaciones sobre la PPE (CDC 1996b). Aunque se han registrado fracasos en la profilaxis post-exposición con ZDV (Tokars y cols. 1993), se ha asociado ésta a una disminución de un $79 \%$ del riesgo de seroconversión por el VIH después de una exposición percutánea a sangre infectada con VIH según un estudio de casoscontroles realizado entre una muestra de trabajadores sanitarios (CDC 1995).

Si bien los estudios realizados con pacientes infectados por el VIH han aportado información sobre la potencia y toxicidad de los fármacos antirretrovíricos, no está claro hasta qué punto esta información es aplicable a personas no infectadas sometidas a PPE. En los pacientes infectados por el VIH, el tratamiento de combinación con los nucleósidos ZDV y lamivudina (3TC) presenta una mayor actividad antirretrovírica que la ZDV sola y es activo contra muchas cepas del VIH resistentes a la ZDV sin un incremento significativo de la toxicidad (Anón. 1996). La adición de un inhibidor de la proteasa contribuye a incrementar todavía más la actividad retrovírica. Entre los inhibidores de la proteasa, el indinavir (IDV) es aún más potente que el saquinavir a las dosis actualmente prescritas y aparentemente produce menos interacciones con otros fármacos y menores efectos adversos a corto plazo que el ritonavir (Niu, Stein y Schnittmann 1993). Se dispone de escasos datos que permitan evaluar la posible toxicidad a largo plazo (esto es, retardada) derivada de la administración de estos fármacos a personas no infectadas por el VIH.

Las recomendaciones del Servicio de Salud Pública de Estados Unidos que se reseñan seguidamente son provisionales, ya que descansan sobre datos escasos relativos a la eficacia y la toxicidad de la PPE y el riesgo de infección por el VIH resultante de diversos tipos de exposición. Dado que la mayoría de las exposiciones profesionales al VIH no dan lugar a la transmisión de la infección, es preciso evaluar cuidadosamente la toxicidad potencial al prescribir la PPE. Podría ser aconsejable un cambio del régimen posológico, sobre la base de factores como el probable perfil de resistencia a los fármacos antirretrovíricos del VIH del paciente causante de la exposición, la disponibilidad local de fármacos e instalaciones médicas, el tratamiento farmacológico, concomitante, y la toxicidad famacológica presentes en el trabajador expuesto. Si se recurre a la PPE, se deben incluir en la monitorización de la toxicidad farmacológica un hemograma completo y pruebas de la función química, hepática y renal en el momento basal y dos semanas después de iniciar la PPE. Si se observa toxicidad subjetiva u objetiva, se debe considerar la posible reducción o sustitución de la dosis y puede estar indicada la realización de nuevos estudios diagnósticos.

Se debe recomendar la quimioprofilaxis a los trabajadores expuestos tras exposiciones profesionales asociadas al mayor riesgo de transmisión del VIH. Respecto a las exposiciones que 
suponen un riesgo inferior, pero no despreciable, puede ofrecerse la PPE, ponderando el menor riesgo con el empleo de fármacos de eficacia y toxicidad inciertas. La PPE no está justificada si el riesgo derivado de la exposición es despreciable (véase la Tabla 97.12,). Se debe comunicar a los trabajadores expuestos que se sabe poco sobre la eficacia y la toxicidad de la PPE, que se dispone de datos limitados sobre la toxicidad de agentes distintos de la ZVD en las personas no infectadas por el VIH y en las embarazadas, y que el trabajador expuesto tiene derecho a negarse a recibir cualquier fármaco de los prescritos para la PPE.

La PPE se debe iniciar a la mayor brevedad, a ser posible una o dos horas después de la exposición. Si bien las investigaciones realizadas en animales indican que es probable que la PPE resulte ineficaz si no se inicia entre las 24 y las 36 horas siguientes a la exposición (Niu, Stein y Schnittmann 1993; Gerberding 1995), no se ha establecido el intervalo a partir del cual no implica beneficios para los seres humanos. Se puede considerar la posibilidad de iniciar el tratamiento al cabo de un intervalo más largo (por ejemplo, entre una y dos semanas) en las exposiciones de mayor nivel de riesgo; en efecto, aunque no se prevenga la infección, el tratamiento precoz de la infección aguda por el VIH puede resultar útil (Kinloch-de-los y cols. 1995)

Si se desconoce si el individuo causante de la exposición y el propio trabajador expuesto se encuentran infectados por el VIH, la decisión de aplicar la PPE debe tener un carácter casuístico, basado en el riesgo de exposición y en la probabilidad de que el paciente efectiva o presuntamente causante de la exposición se encuentre infectado.

\section{Otros agentes patógenos en sangre}

Se ha comprobado que la sífilis, la malaria, la babesiosis, la brucelosis, la leptospirosis, las infecciones arbovíricas, la fiebre recurrente, la enfermedad de Creutzfeld-Jakob, el virus T-linfotrópico humano del tipo 1 y la fiebre hemorrágica vírica también pueden transmitirse por la sangre (CDC 1988a; Benenson 1990). Sin embargo, se conocen pocos o ningún caso de transmisión profesional de estos agentes patógenos.

\section{Prevención de la transmisión de los agentes patógenos en sangre}

Existen diversos métodos de prevención de la transmisión profesional de los agentes patógenos en sangre. La prevención de la exposición - piedra angular de la salud en el trabajo - se puede lograr aplicando medidas de sustitución (por ejemplo, de un instrumento peligroso por otro más seguro), medidas de control técnico (como la implantación de controles que eliminen o reduzcan los peligros) o controles administrativos (como la prohibición de encapsular las agujas aplicando técnicas ambidextras), y utilizando equipo de protección individual. La mejor opción consiste en dar soluciones técnicas al problema.

Con objeto de reducir la exposición a los agentes patógenos en sangre, se recomienda el cumplimiento de los métodos generales de control de las infecciones, así como de las pautas generales de precaución. De éstas últimas, las más importantes consisten en el uso de equipos de protección individual, como guantes, batas y gafas protectoras, siempre que se prevea la exposición a líquidos corporales. Los guantes constituyen una de las barreras más eficaces entre el trabajador y los focos infecciosos, ya que, aunque no evitan los pinchazos con agujas, protegen la piel. Deben usarse guantes - que no se deben lavar- siempre que se vaya a estar en contacto con sangre u otros líquidos corporales. Las precauciones comprenden, asimismo, la evitación de las heridas producidas por agujas, bisturíes y otros instrumentos cortantes, tanto durante las intervenciones como al limpiar los propios instrumentos usados, así

Tabla 97.12 • Recomendaciones provisionales del Servicio de Salud Pública de Estados Unidos para la quimioprofilaxis tras exposición profesional al VIH, por tipos de exposición y fuentes de materiales, 1996.

\begin{tabular}{|c|c|c|c|}
\hline Tipo de exposición & Fuentes de materiales ${ }^{?}$ & Profilaxis antirretrovírica ${ }^{2}$ & Régimen antirretrovírico ${ }^{3}$ \\
\hline Percutánea & $\begin{array}{l}\text { Sangre } \\
\text { Riesgo máximo } 0^{4} \\
\text { Riesgo aumentado }{ }^{4} \\
\text { Riesgo no aumentado } 4 \\
\text { Líquidos con contenido visible de sangre, otros líquidos potencialmente } \\
\text { infecciosos } 6 \text {, } 0 \text { tejidos } \\
\text { Otros líquidos corporales (p. ej., orina) }\end{array}$ & $\begin{array}{l}\text { Recomendada } \\
\text { Recomendada } \\
\text { Ofrecida } \\
\text { Ofrecida } \\
\text { No ofrecida }\end{array}$ & $\begin{array}{l}\text { ZVD más 3TC más IDV } \\
\text { ZDV más 3TC, } \pm \text { IDV5 } \\
\text { ZDV más 3TC } \\
\text { ZDV más 3TC }\end{array}$ \\
\hline Mucosas & $\begin{array}{l}\text { Sangre } \\
\text { Líquidos con contenido visible de sangre, otros líquidos potencialmente } \\
\text { infecciosos }, 0 \text { tejidos } \\
\text { Otros líquidos corporales (p. ej., orina) }\end{array}$ & $\begin{array}{l}\text { Ofrecida } \\
\text { Ofrecida } \\
\text { No ofrecida }\end{array}$ & $\begin{array}{l}\text { ZDV más } 3 T C, \pm I^{2} V^{5} \\
Z D V, \pm 3 T^{5}\end{array}$ \\
\hline Piel, riesgo aumentado ${ }^{7}$ & $\begin{array}{l}\text { Sangre } \\
\text { Líquidos con contenido visible de sangre, otros líquidos potencialmente } \\
\text { infecciosos }, 0 \text { teijidos } \\
\text { Otros líquidos corporales (p. ej., orina) }\end{array}$ & $\begin{array}{l}\text { Ofrecida } \\
\text { Ofrecida } \\
\text { No ofrecida }\end{array}$ & $\begin{array}{l}\text { ZDV más } 3 T C, \pm I^{2 D V} 5 \\
Z D V, \pm 3 T C^{5}\end{array}$ \\
\hline \multicolumn{4}{|c|}{ 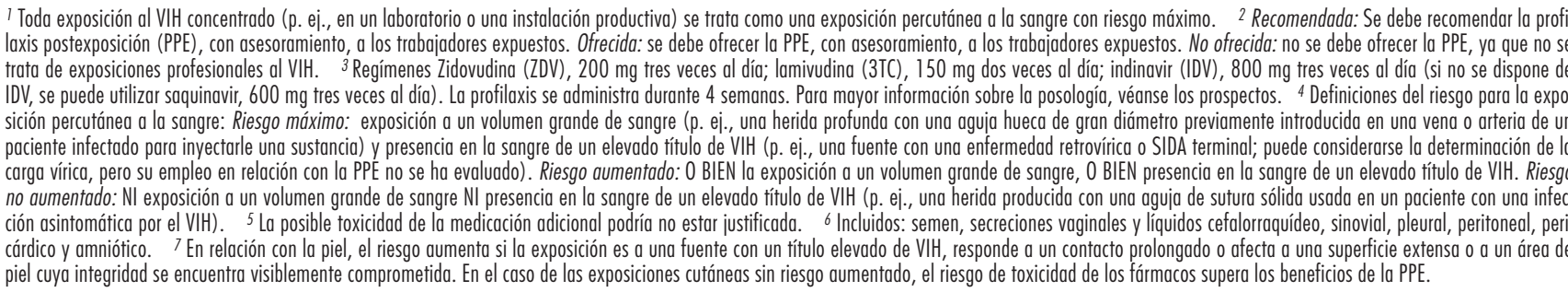 } \\
\hline
\end{tabular}


como al desechar las agujas utilizadas y en la manipulación de los instrumentos afilados después de cada intervención.

\section{Exposición percutánea a la sangre}

Dado que el mayor riesgo de infección proviene de la exposición parenteral derivada del uso de instrumentos afilados, como las agujas, las medidas técnicas, como la modificación de las agujas, los sistemas de administración sin aguja, el empleo de agujas de sutura y la adecuada selección de los contenedores de evacuación de los instrumentos afilados desechados, con objeto de reducir el riesgo de lesiones percutáneas, constituyen elementos fundamentales de las precauciones generales.

La mayoría de los casos de inoculación percutánea se deben a los pinchazos accidentales con agujas, que en la mayor parte de los casos se producen al tapar éstas. Se han apuntado varias causas al respecto: la imposibilidad de eliminar inmediatamente las agujas, la escasez de contenedores para la eliminación de los instrumentos afilados, la falta de tiempo, la escasa destreza y la interacción de los pacientes.

La modificación del diseño de las agujas y demás instrumentos afilados contribuye a prevenir una buena parte de las lesiones percutáneas. Es preciso colocar una barrera fija entre la aguja utilizada y las manos del trabajador, que deben permanecer en todo momento detrás de la aguja. Los eventuales elementos de seguridad se deben incorporar al instrumento. El diseño debe ser sencillo y debería requerirse poca o ninguna formación (Jaggen y cols. 1988).

El diseño de unos dispositivos de inyección más seguros debe complementarse con la evaluación de los mismos. En 1992, la American Hospital Association (AHA) publicó unas pautas para la selección, adquisición y adopción de agujas más seguras en los hospitales (AHA 1992). En el documento se indica que, "dado que, a diferencia de los fármacos y otros medios terapéuticos, las agujas para inyección no se someten a ensayos clínicos para verificar su seguridad y eficacia, los hospitales dependen fundamentalmente de sus propios medios para seleccionar los productos más adecuados a sus necesidades institucionales concretas". En este documento de la AHA se ofrecen pautas para la selección y adopción de agujas más seguras, así como unos cuestionarios de evaluación y una relación, sólo parcial, de los productos que se comercializan en Estados Unidos.

Antes de iniciar el empleo de un nuevo tipo de aguja, los centros sanitarios deben cerciorarse de la eficacia de su sistema de control. Para evaluar exactamente la eficacia de los nuevos elementos, la cifra de exposiciones comunicadas se debe expresar en una tasa de incidencia. Se pueden utilizar diversos denominadores para informar sobre la frecuencia de las heridas por agujas: pacientes-días, número de horas trabajadas, cantidad de instrumentos adquiridos, número de instrumentos utilizados y número de intervenciones realizadas. La recogida de información específica sobre las lesiones producidas por los instrumentos constituye un factor importante de la evaluación de la eficacia del nuevo instrumental. En la recogida de datos específicos sobre las lesiones producidas por agujas se deben tomar en consideración aspectos como la distribución, el almacenamiento y el seguimiento de los nuevos productos; la identificación de los usuarios; la eliminación de otros instrumentos; la compatibilidad de los nuevos instrumentos con otros equipos (especialmente con el equipo de inyección intravenosa); la facilidad de uso, y los fallos mecánicos. Diversos factores pueden sesgar los resultados: el cumplimiento, la selección de los sujetos, los procedimientos aplicados, las repeticiones de las actuaciones, la contaminación, el índice de comunicación de casos y el seguimiento. Los resultados se pueden cuantificar de varias formas: tasa de lesiones por agujas, cumplimiento de los trabajadores sanitarios, complicaciones en la asistencia a los pacientes y costes.
Finalmente, la formación y la retroinformación suministrada por los trabajadores constituyen elementos importantes de cualquier programa de prevención de las lesiones provocadas por las agujas. El nivel de aceptación de los usuarios constituye un elemento crítico que, sin embargo, no ha recibido la atención que merece.

La aplicación de medidas adecuadas de control técnico pueden contribuir a la eliminación o la reducción de las lesiones percutáneas. Si las comisiones de evaluación de productos integradas por los trabajadores sanitarios colaboran con los administradores y los departamentos de compras para determinar qué instrumentos seguros se precisan y dónde, resulta posible compatibilizar la seguridad con la eficacia en función del coste. Ciertamente, la transmisión profesional de los agentes patógenos en sangre es costosa, tanto en recursos como por sus efectos sobre los trabajadores, y todo pinchazo con agujas causa un estrés innecesario al trabajador y puede mermar su rendimiento, hasta el punto de precisar, en ciertos casos, la remisión a los servicios de salud mental para que éstos procedan a aplicar medidas de apoyo.

En resumen, la aplicación de una política global de prevención es imprescindible para el mantenimiento de un entorno sano y seguro en la prestación de la atención sanitaria. En las estrategias preventivas se incluyen la vacunación, la profilaxis postexposición y la prevención o evitación de los pinchazos por agujas. La prevención de las lesiones percutáneas pasa por mejorar la seguridad de los dispositivos provistos de aguja, la aplicación de técnicas de seguridad en el uso y eliminación de aquéllos y el cumplimiento de las recomendaciones para el control de las infecciones.

Agradecimiento: Los autores agradecen la colaboración prestada por Mariam Alter, Lawrence Reed y Barbara Gooch en la revisión del manuscrito.

\section{PREVENCION, CONTROL Y VIGILANCIA DE LA TUBERCULOSIS}

Robert J. Mullan

El peligro de infección por Mycobacterium tuberculosis es bien conocido en los centros sanitarios. El nivel de riesgo para los trabajadores varía sensiblemente en función del tipo de centro, de la frecuencia de la tuberculosis en la comunidad, de la población de pacientes atendidos, de la categoría laboral de los trabajadores, del área del centro en que preste sus servicios el trabajador y de la eficacia de las actuaciones de control de la infección de tuberculosis. El riesgo suele ser mayor en las áreas en que se atiende a los pacientes antes del diagnóstico e inicio del tratamiento antituberculoso y de la adopción de medidas de aislamiento (esto es, en las salas de espera de los servicios clínicos y en los servicios de urgencia), así como en las áreas en que se aplican procedimientos de diagnóstico o tratamiento que estimulan la tos. La transmisión nosocomial de Mycobacterium tuberculosis se ha asociado al contacto estrecho con personas infectadas por la tuberculosis y a la realización de determinados actos médicos, como la broncoscopia, la intubación endotraqueal y la aspiración, la irrigación de abscesos abiertos y las autopsias). El estímulo de la expectoración y los tratamientos con aerosoles que estimulan la tos también pueden contribuir a aumentar la capacidad de transmisión de Mycobacterium tuberculosis. Los trabajadores de los centros sanitarios deben ser especialmente conscientes de la necesidad de prevenir la transmisión del Mycobacterium tuberculosis en los centros en que trabajan o reciben asistencia personas inmunodeprimidas (por ejemplo, los infectados por el VIH), en especial si se aplican 
tratamientos inductores de la tos, como la estimulación de la expectoración o la administración de aerosoles de pentamidina.

\section{Transmisión y patogénesis}

El Mycobacterium tuberculosis flota en partículas en suspensión atmosférica, o núcleos de gotitas, que se generan cuando las personas con tuberculosis pulmonar o laríngea estornudan, tosen, hablan o cantan. El tamaño estimado de las partículas oscila entre 1 y $5 \mu \mathrm{m}$, por lo que las corrientes de aire normales pueden mantenerlas en suspensión durante bastante tiempo y esparcirlas por una habitación o un edificio. La infección se produce cuando una persona susceptible inhala los núcleos de gotitas en que flota el Mycobacterium tuberculosis y estos núcleos atraviesan la boca o las vías nasales, las vías respiratorias superiores y los bronquios, hasta llegar a los alvéolos pulmonares. Una vez aquí, los macrófagos alveolares absorben los microorganismos y los diseminan por todo el cuerpo. Entre dos y diez semanas después de la infección inicial por Mycobacterium tuberculosis, la respuesta inmune limita la multiplicación y difusión de los bacilos de la tuberculosis; no obstante, algunos bacilos permanecen latentes y viables durante muchos años, y este estado se denomina de infección por tuberculosis latente. Los individuos que padecen esta infección suelen dar resultados positivos en la prueba dérmica de la tuberculina-derivado proteico purificado (PPD), pero no manifiestan síntomas de tuberculosis activa y no resultan contagiosos.

Por regla general, las personas que se infectan por Mycobacterium tuberculosis tienen un $10 \%$ de posibilidades de desarrollar una tuberculosis declarada durante su vida. El riesgo es mayor durante los dos primeros años siguientes a la infección. Las personas inmunodeprimidas experimentan un mayor riesgo de evolución de la infección latente a la tuberculosis declarada, y el VIH constituye el mayor factor de riesgo conocido de esta evolución. Los sujetos que, padeciendo una infección tuberculosa latente, se coinfectan por el $\mathrm{VIH}$, presentan un riesgo anual entre el 8 y el $10 \%$ de desarrollar una tuberculosis declarada. Los infectados por el VIH que ya se encuentran seriamente inmunodeprimidos y que posteriormente se infectan por $M y c o-$ bacterium tuberculosis tienen un riesgo aún mayor de desarrollar una tuberculosis activa.

La probabilidad de que una persona expuesta a Mycobacterium tuberculosis se infecte efectivamente depende esencialmente de la concentración de núcleos de gotitas infecciosos en el aire y de la duración de la exposición. Algunas características de los pacientes de tuberculosis facilitan la transmisión:

- localización de la enfermedad en pulmones, vías respiratorias o laringe

- presencia de tos u otros fenómenos espiratorios forzados

- presencia de bacilos acidorresistentes en el esputo

- tendencia del paciente a no cubrirse la boca o la nariz al toser o estornudar

- presencia de cavernas en las radiografías de tórax

- duración insuficiente o incorrecta de la quimioterapia

- administración de tratamientos que provoquen la tos o produzcan la aspersión de Mycobacterium tuberculosis (como la estimulación del esputo).

Algunos factores medioambientales también propician la transmisión:

- exposición en espacios relativamente pequeños y cerrados

- inadecuada ventilación local o general, que reduzca la dilución o la eliminación, o ambos procesos, de los núcleos de gotitas infecciosos

- recirculación de aire impregnado de núcleos de gotitas infecciosos en suspensión.
Las características de las personas expuestas al Mycobacterium tuberculosis que pueden influir en el riesgo de infección no se conocen bien. En general, quienes han estado previamente afectados por el Mycobacterium tuberculosis suelen ser menos susceptibles a posteriores infecciones. Sin embargo, pueden producirse reinfecciones de personas previamente infectadas, especialmente si se encuentran gravemente inmunodeprimidas. La vacunación con el bacilo de Calmette y Guérin (BCG) probablemente no influye en el riesgo de infección; por el contrario, reduce el riesgo de que la tuberculosis latente evolucione a una tuberculosis declarada. Por último, aunque está perfectamente demostrado que la infección por el VIH incrementa el riesgo de que la tuberculosis latente evolucione a una tuberculosis declarada, se desconoce si la infección por el VIH incrementa el riesgo de infección en caso de exposición al Micobacterium tuberculosis.

\section{Epidemiología}

Recientemente se han comunicado en Estados Unidos varios brotes de tuberculosis en diversos centros sanitarios. Muchos de estos brotes han consistido en la transmisión de cepas resistentes a múltiples fármacos de Mycobacterium tuberculosis, tanto a pacientes como a los trabajadores sanitarios. En la mayoría de estos pacientes y en algunos de los trabajadores sanitarios, la nueva infección se desarrolló rápidamente hasta declararse la tuberculosis. Estos brotes produjeron una elevada tasa de mortalidad (entre el 43 y el $93 \%$ ). Asimismo, el intervalo entre el diagnóstico y el fallecimiento fue breve (un promedio de 4 a 16 semanas). Diversos factores propiciaron estos brotes: demora en el diagnóstico de tuberculosis, retraso en la identificación de la resistencia a los fármacos y en el inicio de un tratamiento eficaz, todo lo cual dio lugar a una infecciosidad prolongada, una demora en el inicio del aislamiento de los pacientes y una duración insuficiente del mismo, una ventilación inadecuada de las habitaciones de aislamiento, precauciones insuficientes en la aplicación de tratamientos inductores de tos y ausencia de una protección respiratoria adecuada.

\section{Fundamentos del control de la infección por la tuberculosis} La eficacia de un programa de control de la infección por la tuberculosis se basa en la rápida detección, aislamiento y tratamiento eficaz de los pacientes con tuberculosis declarada. Todo plan de este tipo debe hacer hincapié en estos tres objetivos. En todos los centros sanitarios, especialmente en los que trabajan o reciben asistencia personas con un alto riesgo de infectarse de tuberculosis, es preciso elaborar, actualizar periódicamente y evaluar unos métodos y políticas de control de la enfermedad que faciliten la adopción de las medidas precisas para prevenir la transmisión del Mycobacterium tuberculosis.

El programa de control de la infección por la tuberculosis debe descansar en una escala ordenada de las medidas de control. El primer nivel de esta escala - el que afecta al mayor número de personas - se basa en la aplicación de medidas administrativas orientadas principalmente a reducir el riesgo de exponer a personas no infectadas al contacto con otras personas con tuberculosis. Se recomiendan las medidas siguientes:

- elaboración y aplicación de protocolos y políticas que permitan una rápida detección, aislamiento, diagnóstico, evaluación y tratamiento de las personas que tengan probablemente tuberculosis

- aplicación de métodos de trabajo eficaces por parte de los trabajadores (por ejemplo, usar correctamente medios de protección respiratoria y mantener cerradas las puertas de acceso a las habitaciones de aislamiento)

- educación, formación y asesoramiento a los trabajadores en todo lo relativo a la tuberculosis 
- exploración selectiva de los trabajadores con objeto de detectar posibles infecciones y síntomas de tuberculosis.

El segundo nivel de la escala jerárquica consiste en la aplicación de medidas de control técnico destinadas a prevenir la difusión y reducir la concentración de núcleos de gotitas infecciosas. Se recomiendan los controles siguientes:

- control directo de los focos aplicando extractores de aire puntuales

- control de la dirección de la corriente de aire con objeto de prevenir la contaminación del aire en las áreas contiguas al foco infeccioso

- dilución y eliminación del aire contaminado a través del sistema general de ventilación

- purificación del aire mediante filtración o mediante irradiación ultravioleta germicida.

Los dos primeros niveles de la escala jerárquica contribuyen a reducir sustancialmente el número de áreas del centro en que se puede producir la exposición a la tuberculosis infecciosa, y también reducen, aunque no eliminan totalmente, el riesgo en las escasas áreas en que aún es posible la exposición a Mycobacterium tuberculosis (por ejemplo, las habitaciones de aislamiento de los pacientes conocida o presuntamente infectados de tuberculosis, así como las salas de tratamiento en las que se aplican a esos pacientes aerosoles o técnicas de inducción de la tos). Como las personas que acceden a esas áreas pueden quedar expuestas al Mycobacterium tuberculosis, el tercer nivel de la escala jerárquica consiste en el empleo de equipo individual de protección respiratoria, tanto en ellas, como en algunas otras situaciones concretas en que el riesgo de infección por Mycobacterium tuberculosis puede ser relativamente mayor.

Se han sugerido algunas medidas específicas de reducción del riesgo de transmisión del Myobacterium tuberculosis:

1. Asignar a determinados empleados del centro sanitario la responsabilidad de supervisar la creación, aplicación, evaluación y mantenimiento del programa de control de la infección por la tuberculosis

2. Evaluar el riesgo de transmisión de Mycobacterium tuberculosis en todas las áreas del centro sanitario; elaborar un programa escrito de control de infección por la tuberculosis, basado en la evaluación realizada; y repetir periódicamente la evaluación del riesgo, con objeto de evaluar la eficacia del programa de control de la infección. Las medidas de control de la infección por la tuberculosis en cada centro sanitario se deben basar en una evaluación rigurosa del riesgo de transmisión del Mycobacterium tuberculosis en ese entorno específico. El primer paso de la elaboración del programa de control de la infección por la tuberculosis debe consistir en una evaluación inicial del riesgo que permita conocer el riesgo de transmisión del Mycobacterium tuberculosi en cada área y en cada categoría laboral presente en el centro. Esto permitirá adoptar medidas adecuadas de control de la infección basadas en el riesgo efectivo. Debe efectuarse una evaluación del riesgo en todas las áreas de asistencia tanto hospitalaria como ambulatoria (por ejemplo, las consultas médicas y de odontología).

La clasificación del riesgo relativo a un centro dado, a un área específica y a una determinada categoría profesional se debe basar en el perfil de la tuberculosis en la comunidad en cuestión, en la cantidad de pacientes infectados de tuberculosis admitidos en el área o sala en cuestión, o en el número estimado de pacientes infectados de tuberculosis a los que los trabajadores pertenecientes a una determinada categoría profesional se encuentren expuestos, y en el resultado del análisis de las conversiones de pruebas PPD de los trabajadores sanitarios (si procede) y la posible transmisión interpersonal del Mycobacterium tuberculosis. Independientemente del nivel de riesgo, el tratamiento de los pacientes conocida o presuntamente infectados por la tuberculosis no se debe modificar. Sin embargo, el índice de posibles casos de tuberculosis entre los pacientes, la frecuencia de las pruebas dérmicas de PPD de los trabajadores sanitarios, el número de habitaciones de aislamiento de pacientes tuberculosos y otros factores dependerán del nivel de riesgo de transmisión del Mycobacterium tuberculosis existente en el centro, área o categoría profesional en cuestión.

3. Elaborar, implantar y aplicar protocolos y políticas que permitan una rápida detección, diagnóstico, evaluación y tratamiento eficaz de los pacientes con tuberculosis infecciosa. Son diagnosticables de tuberculosis los pacientes con tos persistente (esto es, que se prolongue durante más de 3 semanas) u otros síntomas indicadores de una posible tuberculosis activa (por ejemplo, esputo sanguinolento, sudoración nocturna, pérdida de peso, anorexia o fiebre). No obstante, el índice de casos sospechosos varía en función de la frecuencia de esta patología y de otras características de la población atendida por el centro sanitario. Así, el índice de casos presuntamente tuberculosos puede ser muy elevado en las áreas geográficas y entre los grupos de pacientes en que la frecuencia de la tuberculosis es alta. Es preciso aplicar una política correcta de diagnóstico y adoptar precauciones eficaces respecto a los pacientes sospechosos de padecer tuberculosis.

4. Impulsar la realización de pruebas y el tratamiento precoz de los pacientes ambulatorios susceptibles de padecer tuberculosis. La exploración de los pacientes de los centros ambulatorios y de los servicios de urgencia debe ir acompañada de un vigoroso esfuerzo por identificar prontamente a los afectados de tuberculosis declarada. Es preciso formar a los trabajadores responsables del contacto inicial con los pacientes en los centros que atienden a grupos de riesgo de infección tuberculosa para que formulen preguntas que faciliten la identificación de los pacientes con síntomas de posible infección tuberculosa. Estos pacientes deben evaluarse rápidamente con objeto de que pasen el menor tiempo posible en los centros ambulatorios. Durante su evaluación se deben adoptar las debidas medidas de protección contra la tuberculosis.

Entre otras precauciones que se han de adoptar en los entornos de asistencia ambulatoria figuran la de colocar a estos pacientes en áreas separadas del resto de los pacientes y no en las salas de espera comunes (a ser posible, en una sala u otra dependencia que satisfaga los requisitos de aislamiento aplicables a los pacientes tuberculosos), entregarles mascarillas quirúrgicas, pedirles que las conserven puestas y facilitarles pañuelos de papel para cubrirse nariz y boca al estornudar y toser. Las mascarillas quirúrgicas están diseñadas para impedir que las secreciones respiratorias se incorporen a la atmósfera ambiental. Mientras no se encuentren en una sala de aislamiento antituberculoso, los pacientes sospechosos de padecer la enfermedad deben llevarlas para reducir la expulsión de núcleos de gotitas a la atmósfera. No tienen que emplear filtros de micropartículas, diseñados para filtrar el aire que se inhala. Los pacientes conocida o presuntamente infectados de tuberculosis no deben usar en ningún caso respiradores provistos de válvula de exhalación, ya que este dispositivo no constituye una barrera contra la expulsión de núcleos de gotitas a la atmósfera.

5. Iniciar prontamente y mantener el aislamiento preventivo de los pacientes con tuberculosis infecciosa que queden hospitalizados. En los hospitales y demás centros se debe ingresar a los pacientes conocida o presuntamente infectados de 
tuberculosis en habitaciones de aislamiento provistas de los sistemas de ventilación actualmente recomendados (véase más adelante). En las instrucciones escritas sobre adopción del aislamiento se deben especificar las condiciones del mismo, la persona o personas facultadas para disponer o poner fin al aislamiento, los métodos aplicables, el tratamiento de los pacientes que no observen las medidas de aislamiento y los criterios aplicables a la interrupción del aislamiento.

6. Política eficaz de altas. Antes de dar de alta a un paciente de tuberculosis hospitalizado en un centro sanitario, el personal debe coordinar con las autoridades sanitarias la continuidad de la asistencia. En el procedimiento sobre altas se deben incluir, como mínimo, una cita previa con el prestador de asistencia ambulatoria que deba tratar al paciente hasta su curación, medicación suficiente para consumir hasta la fecha de la cita en el servicio ambulatorio y la colocación del paciente bajo tratamiento (esto es, tratamiento bajo observación directa o inserción en los programas de extensión sanitaria del departamento de salud pública). La aplicación del procedimiento se debe iniciar antes de dar de alta al paciente.

7. Desarrollo, instalación, mantenimiento y evaluación de los sistemas de ventilación y otras medidas de control técnico, con objeto de reducir el riesgo de exposición al Mycobacterium tuberculosis en suspensión atmosférica. Los extractores de aire constituyen el sistema de control técnico más extendido y, con frecuencia, el modo más eficaz de neutralizar los contaminantes atmosféricos, que se eliminan cerca de la fuente, antes de que se dispersen. Esto hace aconsejable el uso del sistema, siempre que sea posible, en los lugares en que se imparten tratamientos con aerosoles. Existen dos tipos básicos de dispositivos de extracción puntual basados en el uso de campanas: el sistema interior - en el que la campana cubre total o parcialmente el foco infeccioso- y el tipo exterior, en el que el foco infeccioso se encuentra fuera de la campana, aunque cerca de ésta. Las campanas o tiendas totalmente cerradas son siempre preferibles a los modelos exteriores, debido a su mayor capacidad para evitar que los agentes contaminantes fluyan hacia el campo respiratorio de los trabajadores. El sistema de ventilación general se puede utilizar con diversos fines, incluidas la dilución y eliminación del aire contaminado, el control de la circulación del aire en las estancias y la regulación de la dirección de circulación del aire. En el sistema general de ventilación se utilizan dos procesos para conservar la calidad del aire. En efecto, el flujo de aire no contaminado se mezcla con la atmósfera contaminada de la estancia (proceso de dilución), que posteriormente se expulsa de la estancia a través del sistema de extracción. Este proceso reduce la concentración de los núcleos de gotitas en la atmósfera de la estancia. Los índices recomendados de ventilación general de los centros sanitarios se suelen expresar en número de renovaciones del aire por hora (RAH). La cifra es el coeficiente entre el volumen de aire que entra en la habitación cada hora y el volumen de la habitación, y es igual al flujo de aire de salida ( $Q$ en pies cúbicos por minuto), dividido entre el volumen de la estancia $(\mathrm{V}$, en pies cúbicos), multiplicado por 60 (esto es, RAH $=\mathrm{Q} / \mathrm{V} \times 60$ ). Con objeto de reducir la concentración de los núcleos de gotitas, el flujo de aire en las habitaciones de aislamiento y de tratamiento debe ser superior a 6 RAH. Siempre que sea posible, este índice se debe incrementar, como mínimo, hasta 12 RAH, bien ajustando o modificando el sistema de ventilación, bien utilizando medios auxiliares (por ejemplo, recirculación del aire mediante sistemas de filtración fijos HEPA o purificadores de aire portátiles). El diseño de los centros sanitarios reconstruidos o de nueva planta debe hacer posible que en las habitaciones de aislamiento de los pacientes tuberculosos se alcance un flujo mínimo de aire de $12 \mathrm{RAH}$. El sistema de ventilación general se debe diseñar y equilibrar de modo que el aire fluya desde las áreas menos contaminadas (esto es, más limpias) hacia las más contaminadas (menos limpias). Por ejemplo, debe fluir desde los pasillos hacia las habitaciones de aislamiento, con objeto de prevenir la difusión de los agentes contaminantes al resto de las estancias. En algunas salas de tratamientos especiales en las que se utilizan procedimientos quirúrgicos e invasivos, el aire fluye desde la sala hacia el pasillo, con objeto de mantener una atmósfera más pura mientras se realizan tales operaciones. Las técnicas que inducen la tos o se basan en el empleo de aerosoles (por ejemplo, la broncoscopia y la irrigación de abscesos tuberculosos) no se deben aplicar en las estancias en que el aire circule en este sentido con pacientes susceptibles de estar infectados de tuberculosis. Se pueden utilizar de diversos modos filtros HEPA para reducir o eliminar los núcleos de gotitas infecciosos del aire de las estancias o de los extractores. Estos métodos comprenden la colocación de filtros HEPA en las conducciones de extracción que liberan el aire de las tiendas en la estancia inmediata, en conducciones o en unidades adosadas al techo o a la pared, para la recirculación del aire en una habitación concreta (sistemas de recirculación fijos), en purificadores portátiles del aire, en conducciones de extracción utilizadas para eliminar los núcleos de gotitas del aire expulsado al exterior, bien directamente, bien a través del equipo de ventilación, y en las conducciones que descargan el aire de las habitaciones de aislamiento de los pacientes tuberculosos en el sistema general de ventilación. En todos los casos, los filtros HEPA deben ser objeto de una instalación cuidadosa y de un mantenimiento minucioso, con objeto de garantizar su correcto funcionamiento.

Para las áreas de uso común, en las que el riesgo de transmisión del Mycobacterium tuberculosis es relativamente elevado, se pueden utilizar lámparas de ultravioleta (UVGI) como complemento de la ventilación, con objeto de reducir la concentración de núcleos de gotitas infecciosas, si bien la eficacia de estos aparatos no ha sido evaluada suficientemente. Las unidades ultravioleta se pueden instalar en un pasillo o una sala, con objeto de irradiar el aire de la parte superior de la estancia, y asimismo en las conducciones para irradiar el aire que pasa por las mismas.

8. Desarrollo, ejecución y evaluación de un programa de protección de las vías respiratorias. Los dispositivos personales de protección de las vías respiratorias (esto es, las mascarillas) están recomendados para las personas que acceden a las habitaciones de aislamiento de los pacientes tuberculosos, a los trabajadores que asisten en la aplicación a esos pacientes de aerosoles y tratamientos inductores de la tos y a las personas que trabajan en otros entornos en que no existen controles técnicos ni administrativos que las protejan contra los núcleos de gotitas infecciosas suspendidas en el aire. Entre las situaciones de riesgo se incluyen el traslado en ambulancias de pacientes susceptibles de estar infectados de tuberculosis y la realización de intervenciones quirúrgicas u odontológicas de urgencia en esos pacientes, antes de determinar si son infecciosos.

9. Educación y formación del personal de asistencia sanitaria en el tratamiento de la tuberculosis, los métodos eficaces de prevenir la transmisión del Mycobacterium tuberculosis y los beneficios del programa de exploración selectiva. Es preciso formar a todos los trabajadores sanitarios, incluidos los médicos, en los aspectos de la tuberculosis que afectan a su categoría profesional. A ser posible, la formación se debe impartir antes de asignar el primer destino, y evaluarse 
periódicamente (por ejemplo, una vez al año) la conveniencia de impartir una formación complementaria. El nivel y contenido de esta formación varía en función de las tareas asignadas al trabajador y del nivel de riesgo presente en el centro (o en el área concreta) en que preste sus servicios. En todo caso, el programa debe constar de los elementos siguientes:

- conceptos básicos de la transmisión, patogénesis y diagnóstico de Mycobacterim tuberculosis, incluida información sobre la diferencia entre la infección latente por tuberculosis y la tuberculosis declarada, los síntomas de la enfermedad y la posibilidad de reinfección

- riesgo de exposición profesional a los pacientes infectados de tuberculosis en el centro sanitario, incluida información sobre la frecuencia de la tuberculosis en el propio centro y en la comunidad, capacidad del centro para aislar adecuadamente a los pacientes con tuberculosis declarada, y situaciones que suponen un mayor riesgo de exposición al Mycobacterium tuberculosis

- políticas y métodos de control de las infecciones que reducen el riesgo de transmisión del Mycobacterium tuberculosis, incluida información sobre la estructura jerárquica de las medidas de control de la tuberculosis, así como sobre los documentos y procedimientos aplicados en el centro. Se deben facilitar medios de control puntuales al personal sanitario que trabaje en las áreas que precisen medidas de control complementarias de las previstas en el programa de control de la tuberculosis.

- importancia de un mantenimiento adecuado de los medios de control técnico (por ejemplo, limpieza de las lámparas ultravioleta y mantenimiento de una presión negativa en las habitaciones de aislamiento de los pacientes tuberculosos)

- objetivo de las pruebas dérmicas PPD, significado de un resultado positivo de estas pruebas, y necesidad de participar en el programa de pruebas dérmicas

- principios que informan el tratamiento preventivo en los casos de infección tuberculosa latente, incluidas las indicaciones, el empleo, la eficacia y los eventuales efectos secundarios de los fármacos

- obligación del trabajador sanitario de procurar una pronta evaluación médica si se produce la conversión de una prueba PPD, o si se presentan síntomas que puedan corresponderse con los de la tuberculosis. La evaluación médica hará posible que el trabajador sanitario infectado de tuberculosis reciba el tratamiento adecuado y contribuirá a prevenir la transmisión de Mycobacterium tuberculosis a sus compañeros

- principios que inspiran el tratamiento farmacológico de la tuberculosis declarada

- necesidad de comunicar al centro todo diagnóstico positivo de tuberculosis activa de un trabajador sanitario, con objeto de iniciar la investigación de las posibles exposiciones

- obligación del centro sanitario de guardar reserva sobre el estado de salud del trabajador, sin perjuicio de ofrecerle el tratamiento adecuado y de cerciorarse de que no es infeccioso antes de reincorporarse a su trabajo.

- mayores riesgos asociados a la infección por tuberculosis en personas infectadas por el VIH u otras formas graves de inmunodeficiencia celular, incluidos: a) la mayor frecuencia y rapidez de desarrollo de la tuberculosis clínica en virtud de la infección por Mycobacterium tuberculosis, b) las diferencias en la manifestación clínica de la enfermedad, y c) la elevada tasa de mortalidad asociada a la tuberculosis resistente a múltiples fármacos en esas personas
- posible desarrollo de alergia cutánea, a medida que se deteriora la función inmunológica (medida por recuentos de linfocitos T CD4+)

- información relativa a la eficacia y seguridad de la vacunación con el bacilo de Calmette y Guérin (BCG) y a los principios de la exploración PPD entre los sujetos vacunados con el BCG

- política del centro sanitario en relación con la reasignación voluntaria de tareas a los trabajadores sanitarios inmunodeprimidos.

10. Elaboración y ejecución de un programa periódico de asesoría y exploración selectivos de los trabajadores sanitarios, con objeto de detectar casos latentes y activos de tuberculosis. Es preciso poner en práctica un programa de asesoría, exploración selectiva y prevención de la tuberculosis para dar protección tanto a los trabajadores sanitarios como a los pacientes. Es preciso detectar y evaluar a todos los trabajadores sanitarios con resultados positivos de la prueba de PPD, conversiones positivas de la misma prueba o síntomas de una posible tuberculosis, con objeto de descartar un diagnóstico de tuberculosis activa y, en su caso, iniciar un tratamiento clínico o preventivo. Asimismo, los resultados del programa de exploración selectiva mediante PPD de los trabajadores sanitarios facilita la evaluación de la eficacia de las medidas actuales de control de infecciones. Debido al mayor riesgo de rápida evolución del estado de infección latente al de tuberculosis activa en presencia del virus de la inmunodeficiencia humana, los infectados por el VIH y las personas gravemente inmunodeprimidas, es preciso que todos los trabajadores sanitarios sepan si su estado de salud o el tratamiento médico que reciben es capaz de producir una grave inmunodeficiencia celular. Los trabajadores expuestos a la posible infección por el VIH deben conocer su situación inmunológica al respecto (esto es, se les debe alentar a que busquen voluntariamente asesoría y se sometan a pruebas para conocer la existencia de anticuerpos del VIH). Se deben aplicar de forma rutinaria las directrices vigentes en materia de asesoría y pruebas. El conocimiento de su situación sanitaria permite al trabajador adoptar las medidas preventivas adecuadas y considerar su posible traslado voluntario a otro puesto de trabajo.

11. Información a todos los trabajadores sanitarios de la necesidad de observar las recomendaciones vigentes en materia de control de las infecciones, con objeto de reducir sensiblemente el riesgo de exposición a los agentes infecciosos; la observancia de esas recomendaciones contribuye en gran medida a reducir el riesgo de contraer enfermedades profesionales. Asimismo, se les debe informar de los posibles riesgos que implica para las personas seriamente inmunodeprimidas la prestación de asistencia sanitaria a los pacientes con determinadas enfermedades infecciosas, como la tuberculosis. Es preciso insistir en que la limitación del contacto con los pacientes con tuberculosis es la medida de protección más eficaz que los trabajadores sanitarios gravemente inmunodeprimidos pueden adoptar para evitar infectarse por Mycobacterium tuberculosis. Podría resultar aconsejable que quienes padeciendo una inmunodeficiencia celular grave, se arriesguen a exponerse al Mycobacterium tuberculosis, consideren la posibilidad de cambiar de entorno de trabajo para evitar el riesgo. También es preciso informar a los trabajadores sanitarios de la posibilidad legal que se les ofrece en muchos países de solicitar un traslado voluntario a otras áreas y tareas que impliquen un mínimo riesgo de exposición al Mycobacterium tuberculosis. Esta es una opción personal que les corresponde adoptar una vez informados de los eventuales riesgos para su salud. 
12. Realización, por parte de las empresas, de los ajustes que sean razonablemente necesarios (como el traslado a otros puestos de trabajo) para los trabajadores cuyo estado de salud comprometa su inmunidad celular y trabajen en entornos en que puedan quedar expuestos al Mycobacterium tuberculosis. Es preciso remitir a los trabajadores conocidamente inmunodeficientes a los servicios de medicina del trabajo para que se les ofrezca atención individualizada sobre el riesgo de contraer tuberculosis. Si el trabajador lo solicita, la empresa debe permitirle, sin obligarlo, trasladarse a un entorno de trabajo en el que el riesgo de exposición al Mycobacterium tuberculosis sea el menor posible.

13. Información a todos los trabajadores sanitarios de que los trabajadores inmunodeficientes deben ser objeto, por parte de su médico de cabecera, de un seguimiento y unas exploraciones que permitan identificar la presencia de enfermedades infecciosas, incluida la tuberculosis. Con ocasión de las pruebas PPD, se debe someter a los trabajadores conocidamente portadores del VIH o gravemente inmunodeficientes a pruebas de anergia cutáneas. Se debe considerar la posibilidad de repetir las pruebas, con una periodicidad mínima semestral, en los trabajadores inmunodeprimidos que hayan podido quedar expuestos al Mycobacterium tuberculosis, debido al elevado riesgo de que, si se infectan, su estado evolucione rápidamente a una tuberculosis activa.

14. Mantenimiento de la reserva sobre la información suministrada por los trabajadores sanitarios respecto a su eventual inmunodeficiencia. Esta reserva se debe mantener aunque soliciten su traslado a otro puesto de trabajo. Cada centro sanitario debe implantar un procedimiento formal de protección de la información confidencial.

15. Evaluación urgente de los posibles episodios de transmisión de Mycobacterium tuberculosis en los centros sanitarios, incluyendo las conversiones de las pruebas epidérmicas de PPD entre los trabajadores sanitarios, los casos epidemiológicamente asociados entre éstos o los pacientes, y los eventuales contactos con pacientes o trabajadores sanitarios con tuberculosis que no han sido rápidamente diagnosticados y aislados. En ciertos casos, se aconseja la realización de investigaciones epidemiológicas: por ejemplo, si se registran conversiones de la prueba de PPD o casos de tuberculosis activa entre los trabajadores sanitarios, si se registra una posible transmisión interpersonal del Mycobacterium tuberculosis, $\mathrm{o}$ en las situaciones en que los pacientes o los trabajadores afectados de tuberculosis activa no hayan sido rápidamente identificados y aislados, exponiéndose así a las demás personas presentes en la instalación al riesgo de transmisión del Mycobacterium tuberculosis. Los objetivos globales de la investigación epidemiológica en esos supuestos son los siguientes:

- determinar la probabilidad de que se haya producido efectivamente la transmisión e infección por Mycobacterium tuberculosis

- determinar la extensión de la transmisión del Mycobacterium tuberculosis

- identificar a las personas expuestas que se hayan infectado, para que puedan recibir el tratamiento clínico adecuado

- detectar los factores que hayan podido contribuir a la transmisión e infección, y decidir las actuaciones adecuadas

- evaluar la eficacia de las actuaciones realizadas, con objeto de determinar si la exposición y la transmisión del Mycobacterium tuberculosis ha finalizado.

16. Coordinación de las actividades con las autoridades sanitarias locales, comunicación de los casos y adopción de medidas para la realización de un seguimiento adecuado de los pacientes dados de alta, así como para la continuación y finalización del tratamiento. Tan pronto como se descubra o se sospeche que un paciente o un trabajador sanitario tiene una tuberculosis activa, se debe remitir al afectado al departamento de salud pública, con objeto de establecer un seguimiento adecuado y realizar una investigación sobre sus posibles contactos dentro de la comunidad. La comunicación al departamento de salud pública debe hacerse con antelación suficiente al alta del paciente, con objeto de facilitar el seguimiento y la continuación del tratamiento. Se debe aplicar un programa de seguimiento del alta, en coordinación con el paciente o, en su caso, con el trabajador sanitario afectado, con el departamento de salud pública y con los servicios ambulatorios.

\section{- PeRsPeCTIVA DE LOS RIESGOS DE ORIGEN QUIMICO EN LA ASISTENCIA SANITARIA}

\section{Jeanne Mager Stellman}

La exposición a sustancias químicas potencialmente peligrosas es un fenómeno cotidiano en la vida de los trabajadores sanitarios. Estos se exponen a dichas sustancias durante la aplicación de los procedimientos terapéuticos y de diagnóstico, en los trabajos de laboratorio, en las actividades de preparación y eliminación del material e, incluso, en las secreciones de los pacientes, por no mencionar las actividades "logísticas" que se realizan en todos los lugares de trabajo, como la limpieza y el trabajo doméstico, el lavado y planchado, los trabajos de fontanería y las labores de mantenimiento. A pesar de la amenaza constante de exposición a tales sustancias y al gran número de trabajadores afectados - en muchos países, el sector de la asistencia sanitaria es, invariablemente, uno de los más ricos en mano de obra- el problema ha merecido escasa atención por parte de los responsables de la investigación y regulación de la salud y seguridad en el trabajo. La gran mayoría de las sustancias químicas de uso general en los hospitales y otros entornos sanitarios no se encuentran amparadas en las normas nacionales e internacionales sobre exposición a riesgos profesionales. De hecho, es muy poco lo que se ha hecho hasta el presente para identificar las sustancias químicas más utilizadas, y mucho menos para estudiar tanto los mecanismos y la intensidad de la exposición a su actividad como la epidemiología de sus efectos en los trabajadores sanitarios afectados.

Esta situación puede estar cambiando en muchos países en que se han promulgado y se aplican disposiciones basadas en el principio del derecho a la información, tales como los Sistemas de información sobre materiales peligrosos en el lugar de trabajo como el Workplace Hazardous Materials Information Systems (WHMIS). Las disposiciones de este tipo parten del principio de que se debe informar a los trabajadores del nombre y naturaleza de las sustancias químicas a las que pueden quedar expuestos en el trabajo. Su promulgación ha supuesto un gran reto para los administradores del sector sanitario, que se han visto obligados a 
requerir los servicios de los profesionales de la salud y seguridad en el trabajo con objeto de realizar un inventario actualizado de la naturaleza y la situación de dichas sustancias químicas.

La amplia gama de puestos de trabajo y categorías profesionales, así como la complejidad de su interacción en el lugar de trabajo sanitario, exigen una diligencia y una perspicacia considerables por parte de los responsables de la salud y seguridad. El problema se complica a causa de la tradicional actitud altruista de anteponer el cuidado y el bienestar de los pacientes a la salud y el bienestar de quienes les prestan servicios. Otra complicación proviene de la circunstancia de que, con frecuencia, estos servicios deben prestarse en situaciones de extremada urgencia, en las que, a veces, se olvida o se prescinde deliberadamente de las principales medidas preventivas y de protección.

\section{Tipos de exposiciones a sustancias químicas en el entorno de la asistencia sanitaria}

En la Tabla 97.13 se relacionan los tipos de sustancias químicas presentes en el lugar de trabajo sanitario. Los trabajadores de laboratorio se exponen a la vasta gama de reactivos químicos que utilizan; los histólogos, a los colorantes y tinciones; los anatomopatólogos, a las soluciones de fijado y preservación (el formaldehído es un potente sensibilizador); el amianto, por su parte, constituye un peligro para los trabajadores que reparan o restauran los centros sanitarios más antiguos.

Aunque se utilizan profusamente para combatir o prevenir la difusión de los agentes infecciosos, los desinfectantes, detergentes y esterilizantes suponen un peligro relativamente pequeño para los pacientes que se exponen a sus efectos durante períodos relativamente breves. Con todo, aun cuando las dosis puntuales empleadas en cada ocasión sean relativamente pequeñas, sus efectos acumulados a lo largo de la vida laboral pueden acarrear un serio riesgo a los trabajadores sanitarios.

La exposición profesional a los fármacos puede provocar tanto reacciones alérgicas del tipo de las que se han venido describiendo durante muchos años entre los trabajadores que administran penicilina y otros antibióticos como problemas mucho más serios con agentes altamente cancerígenos, como los antineoplásicos. El contacto puede producirse, bien durante la preparación o la administración de las dosis inyectables, bien al proceder a la eliminación de los dispositivos utilizados en la inyección. Si bien el peligro implícito en este mecanismo de exposición se conoce desde hace muchos años, sólo se ha

Tabla 97.13 • Categorías de sustancias químicas utilizadas en la asistencia sanitaria.

\begin{tabular}{ll} 
Tipo de sustancias químicas & Localizaciones más probables \\
Desinfectantes & Areas dedicadas a los pacientes \\
Esterilizantes & $\begin{array}{l}\text { Suministro central } \\
\text { Quirófano } \\
\text { Consultas externas } \\
\text { Centros de rehabilitación }\end{array}$ \\
Medicamentos & $\begin{array}{l}\text { Areas dedicadas a los pacientes } \\
\text { Fearmacia }\end{array}$ \\
Productivos de laboratorio & Laboratorios \\
limpieza de & Conjunto del hospital \\
Ingredientes y productos alimentarios & Cocina \\
Plaguicidas & Cafetería \\
& Conjunto del hospital \\
\hline
\end{tabular}

valorado plenamente cuando se detectó una actividad mutágena en la orina de un grupo de enfermeras que habían administrado fármacos antineoplásicos.

Otro mecanismo de exposición es la administración de aerosoles medicamentosos inhalables. Aunque se ha estudiado con alguna profundidad la administración de agentes antineoplásicos, como la pentamidina y la ribavarina, por esta vía, en el momento de redactar el presente artículo no se había publicado ningún estudio sistemático de los efectos tóxicos de los aerosoles sobre los trabajadores sanitarios.

Los gases anestésicos constituyen otro foco de peligro para los trabajadores sanitarios. Estas sustancias químicas producen una serie de efectos biológicos, concretamente en el sistema nervioso. Algunos estudios recientes indican que, con el tiempo, la exposición reiterada a los mismos puede repercutir negativamente sobre el sistema reproductivo de los trabajadores de ambos sexos. No se puede olvidar que los gases anestésicos residuales se pueden concentrar en la atmósfera de las salas de recuperación, dado que los gases acumulados en la sangre y los tejidos de los pacientes se eliminan con la respiración.

Los agentes químicos esterilizantes y desinfectantes constituyen otra importante fuente de peligro de origen químico para los trabajadores sanitarios. Utilizadas principalmente en la esterilización del equipo no desechable, como el instrumental quirúrgico y los aparatos de tratamiento respiratorio, las sustancias químicas esterilizantes del tipo del óxido de etileno resultan eficaces debido a que actúan sobre los agentes infecciosos y los destruyen. La alquilación, proceso en virtud del cual los grupos metilo o alquilo se combinan químicamente con entidades ricas en proteínas, como los grupos amino de la hemoglobina y el $\mathrm{ADN}$, tiene un potente efecto biológico. Si bien en los organismos sanos puede no surtir efectos tóxicos directos, este proceso se debe clasificar como potencialmente cancerígeno mientras no se demuestre lo contrario. Por su parte, el óxido de etileno en sí, es un conocido agente cancerígeno que produce diversos efectos adversos sobre la salud que se comentan en otro artículo de la presente Enciclopedia. Su potente acción alquilante, dado que además se trata probablemente del esterilizante más utilizado en los materiales termosensibles, ha promovido su utilización generalizada como sonda clásica en el estudio de la estructura molecular.

Durante muchos años, los métodos utilizados en la esterilización química del instrumental y otros materiales quirúrgicos han causado un riesgo innecesario y temerario a no pocos trabajadores sanitarios. No se tomaban ni las medidas más simples para impedir o limitar la exposición. Así, era práctica común dejar entreabierta la puerta de la unidad de esterilización para que escapase el exceso de óxido de etileno, o bien dejar el instrumental recién esterilizado destapado y expuesto a la atmósfera ambiental hasta haber reunido una cantidad suficiente de instrumentos para utilizar eficazmente la unidad de aireación.

La fijación de prótesis metálicas o cerámicas, tan común en cirugía ortopédica y odontológica, puede producir exposición a sustancias químicas tan peligrosas como la sílice. Si bien tanto las prótesis como las resinas acrílicas que se emplean para fijarlas suelen ser biológicamente inertes, los trabajadores sanitarios pueden verse expuestos a los monómeros y otros reactivos químicos utilizados en el proceso de preparación y aplicación. Muchas de estas sustancias químicas son agentes sensibilizadores que producen secuelas crónicas en los animales. Por ejemplo, la preparación de empastes de amalgama de mercurio puede provocar la exposición al mercurio. El derrame y dispersión de gotitas de mercurio constituye un grave riesgo, ya que éstas pueden permanecer inadvertidas en el medio ambiente de trabajo durante muchos años. La exposición aguda de los pacientes a sus efectos no parece causar riesgos; en cambio, las 
Tabla 97.14 - Productos químicos mencionados en la Base de datos de sustancias peligrosas (HSDB).

En la Base de datos de sustancias peligrosas (HSDB) se indica que los productos químicos siguientes se utilizan en una u otra área de la asistencia sanitaria. La HSDB, elaborada por la US National Library of Medicine, es una compilación de datos de más de 4.200 productos químicos distribuidos que son conocidamente tóxicos. La exclusión de la lista de un determinado producto no implica su falta de toxicidad, sino su ausencia de la HSDB.

\begin{tabular}{|c|c|c|}
\hline $\begin{array}{l}\text { Lista de aplicaciones } \\
\text { de la HSDB }\end{array}$ & Nombre químico & Número CAS* \\
\hline Desinfectantes; antisépticos & $\begin{array}{l}\text { cloruro de benzalconio } \\
\text { bórax } \\
\text { ácido bórico } \\
\text { cloruro de cetil piridinio } \\
\text { m-cresol } \\
\text { 2-clorofenol } \\
\text { 4-clorofenol } \\
\text { hexaclorofeno } \\
\text { metil etil cetona } \\
\text { fenol } \\
\text { tri-m-cresil fosfato (lisol) }\end{array}$ & $\begin{array}{l}0001-54-5 \\
1303-96-4 \\
10043-35-3 \\
123-03-5 \\
95-57-8 \\
106-48-9 \\
70-30-4 \\
108-39-4 \\
78-93-3 \\
108-95-2 \\
563-04-2\end{array}$ \\
\hline Esterilizantes & $\begin{array}{l}\text { beta-propiolactona } \\
\text { crotonaldehído } \\
\text { óxido de etileno } \\
\text { formaldehído } \\
\text { glutaraldehído }\end{array}$ & $\begin{array}{l}57-57-8 \\
4170-30-3 \\
75-21-8 \\
50-00-0 \\
111-30-8\end{array}$ \\
\hline $\begin{array}{l}\text { Reactivos de laboratorio: } \\
\text { tinciones biológicas }\end{array}$ & $\begin{array}{l}\text { 2,4-xilidina (base magenta) } \\
\text { acridina roja } \\
\text { parafucsina básica } \\
\text { magenta básico } \\
\text { Cl-ácido azul } 9 \\
\text { Cl-ácido verde } 3 \\
\text { Cl-ácido rojo } 14 \\
\text { Cl-directo azul } 1 \\
\text { Cl-directo rojo } 28 \\
\text { Cl-directo amarillo } 11 \\
\text { Cl-ácido verde } 3 \\
\text { curcumina } \\
\text { heamtoxilina } \\
\text { cloruro de hexametil-p- } \\
\text { rosanilina (violeta) } \\
\text { verde malaquita } \\
\text { tetróxido de osmio } \\
\text { ponceau } 3 R\end{array}$ & $\begin{array}{l}3248-93-9 \\
2465-29-4 \\
569-61-9 \\
3248-93-9 \\
129-17-9 \\
4680-78-8 \\
3567-69-9 \\
2429-74-5 \\
573-58-0 \\
1325-37-7 \\
4680-78-8 \\
458-37-7 \\
517-28-2 \\
\\
548-62-9 \\
569-64-2 \\
20816-12-0 \\
3564-09-8\end{array}$ \\
\hline
\end{tabular}

implicaciones a largo plazo de la exposición reiterada sobre la salud de los trabajadores sanitarios no son bien conocidas.

Por último, algunas técnicas médicas, como la cirugía por láser, la electrocauterización y el uso de otros dispositivos de radiofrecuencia y alta energía puede provocar una degradación térmica de los tejidos y otras sustancias, que de lugar a la emanación de humos y vapores. Por ejemplo, se ha demostrado que el corte de escayolas hechas con vendajes impregnados de resinas de poliéster libera vapores potencialmente tóxicos.

\section{El hospital como "minimunicipio"}

La relación de los trabajos y tareas realizados por el personal de los hospitales y otros grandes centros sanitarios podría perfectamente servir de índice de materias de las páginas amarillas de la guía telefónica de un municipio relativamente grande. Todas estas actividades generan exposiciones a sustancias químicas inherentes a la actividad laboral concreta, además de las exposiciones típicas del medio ambiente sanitario. Así, los pintores y los trabajadores de mantenimiento se exponen a la acción de los disolventes y lubrificantes. Los trabajadores de limpieza se exponen a los jabones, detergentes y otros agentes limpiadores, plaguicidas y demás sustancias químicas empleadas en la limpieza. Los cocineros se exponen a los vapores potencialmente cancerígenos que se generan al cocer o freir alimentos, así como al óxido de nitrógeno derivado del empleo del gas natural como combustible. Incluso los trabajadores administrativos se exponen a los efectos de los "toners" utilizados en impresoras y fotocopiadoras. En otro artículo de la presente Enciclopedia se examinan la frecuencia y los efectos de la exposición a estas sustancias químicas.

Un riesgo de origen químico, que disminuye en importancia a medida que más y más trabajadores sanitarios dejan de fumar y que un mayor número de centros sanitarios se convierten en áreas libres de tabaco, es el de los fumadores pasivos.

\section{Exposiciones químicas inhabituales en la asistencia sanitaria}

En la Tabla 97.14 se ofrece una relación parcial de los productos químicos más frecuentes en los centros sanitarios. Su toxicidad o inocuidad está en función de su propia naturaleza y propiedades biológicas, de la intensidad y duración de la exposición, de la vulnerabilidad del trabajador expuesto y de la rapidez y eficacia de las contramedidas aplicadas. Lamentablemente, no ha aparecido aún un compendio de la naturaleza, mecanismos de acción, efectos y tratamiento de la exposición de los trabajadores sanitarios a los productos químicos.

Se producen algunas exposiciones específicas del entorno de trabajo en la asistencia sanitaria que avalan el criterio de que se precisa un elevado nivel de monitorización para proteger plenamente a los trabajadores contra esos riesgos. Por ejemplo, se ha informado recientemente del caso de un grupo de trabajadores sanitarios que experimentaron mareos al inhalar los vapores tóxicos desprendidos por un paciente sometido a tratamiento por una exposición masiva a sustancias químicas. También se ha informado de casos de intoxicación por cianuro emitido por los pacientes. Aparte de los efectos tóxicos directos de los gases anestésicos residuales en los anestesistas y otras personas presentes en los quirófanos, está el problema - que muchas veces se ignora - creado por el empleo frecuente en esas áreas de equipo de gran potencia energética, capaz de transformar los gases anestésicos en radicales libres, estado en el que pueden resultar cancerígenos.

\section{ABORDAJE DE LOS RIESGOS DE ORIGEN QUIMICO EN LOS HOSPITALES}

Annalee Yassi

La amplia gama de sustancias químicas utilizadas en una multitud de entornos hospitalarios exige un enfoque sistemático de su control. Un enfoque casuístico de la prevención de la exposición y de sus efectos nocivos resultaría, simplemente, insuficiente para resolver un problema de tanta magnitud. Además, como se indica en el artículo "Perspectiva de los riesgos de origen químico en la asistencia sanitaria", se echa en falta un estudio riguroso de muchas de las sustancias químicas presentes en el entorno hospitalario. Por una parte, constantemente entran en explotación nuevas sustancias químicas y, respecto a otras sustancias cuyo uso se ha generalizado considerablemente (como los guantes de látex), sus efectos nocivos apenas comienzan a 
conocerse. Por consiguiente, si bien resulta útil aplicar las medidas de control técnico recomendadas para sustancias específicas, se precisa un enfoque más sistemático, en el que los procedimientos y medidas de control de sustancias químicas específicas se inserten en un marco sólido de control global de las sustancias químicas.

El control de los riesgos de origen químico en los hospitales se debe basar en los principios clásicos de las buenas prácticas de higiene industrial. Dado que en los centros sanitarios existe el hábito de contemplar la salud a través del prisma médico, centrado en el tratamiento individualizado de los pacientes, se precisa un esfuerzo suplementario para dar a la manipulación de las sustancias químicas una orientación realmente preventiva y lograr que las medidas se centren más en el lugar de trabajo que en el trabajador.

Las medidas de control medioambiental (o técnicas) constituyen la clave de la prevención de las exposiciones nocivas. No obstante, todos los trabajadores deben recibir una formación suficiente en la aplicación correcta de las técnicas de prevención de las exposiciones. Ciertamente, en la legislación inspirada en el principio del "derecho a saber", que se analiza más adelante, se exige informar a los trabajadores de los peligros que les amenazan en el lugar de trabajo y de las correspondientes medidas de seguridad. La prevención secundaria, aplicada en el ámbito individual, es competencia de los servicios médicos y comprende también la supervisión facultativa para determinar si los efectos sanitarios de la exposición son susceptibles de detección médica. Comprende asimismo una intervención médica rápida y adecuada en caso de producirse una exposición accidental. Es preciso reemplazar las sustancias más tóxicas por otras de menor toxicidad, aislar los procesos siempre que sea posible, y procurar que la ventilación sea suficiente.

Aunque se pongan en práctica todos los medios indicados para prevenir o reducir la exposición, si ésta se produce finalmente (por ejemplo, si se derrama una sustancia química), es preciso contar con procedimientos que permitan una reacción rápida y eficaz para proceder a su eliminación.

\section{Aplicación de los principios generales de control de los riesgos de origen químico en el medio ambiente hospitalario}

El primer paso en el control de un peligro consiste en la identificación del mismo, lo cual, a su vez, exige conocer las propiedades físicas, los componentes químicos y las propiedades toxicológicas de la sustancia en cuestión. Estas características se relacionan en las fichas técnicas de seguridad de los materiales que tienden a generalizarse por imperativo legal en muchos países. No obstante, todo buen especialista en la salud en el trabajo es consciente de que estas fichas técnicas pueden ser incompletas, especialmente por lo que respecta a los efectos a largo plazo o a los efectos de la exposición crónica a dosis bajas. Esto obliga a buscar en la literatura para complementar el contenido de las mismas.

El segundo paso en el control de un peligro consiste en caracterizar el riesgo. ¿Posee la sustancia química en cuestión potencial cancerígeno? ¿Se trata de un alergeno? ¿Un teratógeno? ¿Son sus efectos irritantes a corto plazo los más preocupantes? La evaluación de la exposición dependerá de la respuesta a estas interrogantes.

El tercer paso en el control de los peligros de origen químico consiste en evaluar la exposición efectiva. El componente más importante de este proceso consiste en el diálogo con los trabajadores sanitarios. En algunos casos se impone el uso de métodos de monitorización, con objeto de determinar si los controles de exposición funcionan correctamente. Estos métodos pueden consistir en un muestreo por áreas, utilizando, bien una muestra aleatoria, bien una muestra integrada, en función de la naturaleza de la exposición; también pueden consistir en un muestro personal; en ciertos casos, que se analizan posteriormente, cabe considerar la conveniencia de una monitorización médica, si bien esto sólo suele hacerse en última instancia y siempre en apoyo de otros medios de evaluación de la exposición.

Una vez conocidas las propiedades de la sustancia química en cuestión y evaluadas la naturaleza y la magnitud de la exposición, el paso siguiente consiste en determinar el nivel de riesgo. Para ello suele ser necesario contar, por lo menos, con alguna información sobre las respuestas a las dosis.

Una vez evaluado el riesgo, el siguiente paso del proceso consiste, evidentemente, en controlar la exposición, con objeto de eliminar o, al menos reducir aquél a la mínima expresión. Para ello es preciso, ante todo, aplicar los principios generales de control de la exposición.

\section{Organización de un programa de control de las sustancias químicas en los hospitales}

\section{Los obstáculos clásicos}

La ejecución de unos programas adecuados de salud en el trabajo en los centros sanitarios ha ido a la zaga de la identificación de los peligros. La normativa laboral fuerza cada vez más a los administradores de los hospitales a tomar en consideración todos los aspectos de los servicios y prestaciones que ofrecen a sus trabajadores, ya que aquéllos han dejado de disfrutar de las exenciones que antes les confería la costumbre o los privilegios legales. La nueva normativa legal obliga a los hospitales de muchos países a poner en práctica programas de control.

Sin embargo, los obstáculos no han desaparecido. En efecto, la mentalización de los hospitales hacia la atención del paciente, que induce a dar prioridad al tratamiento en detrimento de la prevención, y la predisposición del personal a las "consultas de pasillo" informales, han entorpecido la implantación de los programas de control. La circunstancia de que los químicos de laboratorio, los farmacéuticos y otras varias categorías de profesionales con una sólida formación toxicológica se encuentren ampliamente representados en los órganos directivos no ha servido precisamente, en la mayor parte de los casos, para fomentar el desarrollo de los programas. Se escucha a veces la pregunta: ¿Para qué queremos un higienista industrial si tenemos tantos expertos en toxicología? Si la implantación de nuevos procedimientos amenaza con influir en las tareas que realizan y en los servicios que prestan estos profesionales altamente cualificados, la situación puede ser aún peor: "No podemos eliminar la sustancia $\mathrm{X}$, porque es el mejor bactericida conocido". O bien: "Si aplicamos el procedimiento que usted indica, el cuidado de los pacientes se resentirá". Por otra parte, la pretensión de no necesitar más formación está generalizada entre los profesionales de la asistencia sanitaria y entorpece la aplicación de los elementos esenciales del control de los peligros de origen químico. En el ámbito internacional, la tendencia a la reducción del gasto en asistencia sanitaria constituye otro obstáculo notorio.

Otra fuente de especial preocupación para los hospitales es la protección de la información confidencial que atañe a los trabajadores sanitarios. Mientras que los profesionales de la higiene industrial deberían limitarse a indicar que la Sra. X no puede trabajar con la sustancia $Z$ y debe ser trasladada a otro puesto, la curiosidad del personal clínico hace a éste más proclive a solicitar explicaciones médicas que sus colegas de otras especialidades. Es posible que la Sra. X presente una enfermedad hepática y que la sustancia $\mathrm{Z}$ sea tóxica para el hígado; también puede ser alérgica a la sustancia, o acaso esté embarazada y la sustancia resulte potencialmente teratógena. A pesar de que la 
necesidad de trasladar de puesto a una determinada persona no sea una cuestión rutinaria, se debe proteger el carácter confidencial de la información médica siempre que resulte necesario.

\section{Legislación basada en el derecho a la información}

En muchos países de todo el mundo se han promulgado leyes inspiradas en el principio del derecho a la información. Así, en Canadá, los Sistemas de información sobre materiales peligrosos en el lugar de trabajo (Workplace Hazardous Materials Information Systems, WHMIS) han revolucionado la manipulación de las sustancias químicas en la industria. Este programa de ámbito nacional consta de tres elementos: 1) fijación de todos los materiales peligrosos de etiquetas normalizadas indicativas de la naturaleza del riesgo; 2) suministro de WHMIS con indicación de los componentes, peligros y medidas de control relativos a cada sustancia; y 3) capacitación de los trabajadores en la interpretación del contenido de las etiquetas y los WHMIS y en la utilización segura de los productos.

De conformidad con los WHMIS canadienses y con el sistema de comunicación de peligros de la OSHA, se exige que los hospitales hagan un inventario de todas las sustancias químicas que almacenan, con objeto de identificar y manipular las sustancias controladas de conformidad con las disposiciones legales. En cumplimiento de las disposiciones legales relativas a la formación del personal, los hospitales se han visto obligados a contratar higienistas industriales suficientemente cualificados, y entre los beneficios indirectos de esta política, especialmente cuando se ejecutan programas bipartitos de formación de formadores, se incluye la creación de un nuevo espíritu de trabajo en equipo en la solución de otros problemas de salud y seguridad.

\section{Compromiso de la empresa y función del comité paritario de salud y seguridad}

El factor más importante del éxito de todo programa de salud y seguridad en el trabajo es el compromiso de la empresa con la ejecución eficaz del mismo. Los procedimientos y sistemas de seguridad en la manipulación de las sustancias químicas deben ser documentos escritos debatidos en todos los niveles de la organización y aprobados y ejecutados como parte de la política de la empresa. El control de los peligros de orden químico en los hospitales debe ser objeto de políticas tanto generales como específicas. Por ejemplo, ha de existir una política relativa a la responsabilidad por la aplicación de la legislación tutelar del derecho a saber, en la que se definan claramente las obligaciones de cada cual y los procedimientos aplicables por las personas situadas en cada uno de los niveles de la organización (por ejemplo, quién elige a los formadores, cuántas horas laborables se dedican a la preparación y realización de la formación, a quién se deben comunicar las faltas de asistencia, etcétera). Debe existir igualmente un política general relativa a los vertidos accidentales durante las operaciones de limpieza, en la que se especifiquen las responsabilidades respectivas del trabajador y del departamento en que se haya producido el vertido; se indiquen el protocolo y las instrucciones relativos a la comunicación al equipo de urgencias, incluidos los expertos y las autoridades competentes, tanto hospitalarias, como externas; se establezcan procedimientos para el seguimiento de los trabajadores expuestos, etcétera. Asimismo, se deben promulgar políticas específicas sobre la manipulación, el almacenamiento y la eliminación de categorías específicas de sustancias químicas.

No basta con que la dirección se comprometa decididamente con estos programas; también los trabajadores, a través de sus representantes, deben participar activamente en la elaboración y aplicación de los procedimientos y políticas. En algunos países funcionan, por imperativo legal, comités paritarios de salud y seguridad, que se reúnen con una periodicidad mínima legalmente establecida (bimensual en los hospitales de Manitoba), se rigen por normas de procedimiento escritas y levantan acta de lo acordado. De hecho, como reconocimiento de la importancia de estos comités, la Junta de Indemnización por Accidentes de Trabajo de Manitoba concede a las empresas una reducción de las cotizaciones que han de abonar sobre la base del buen funcionamiento de los comités paritarios. La eficacia de los comités está en función de la correcta selección de sus miembros, que, específicamente, deben ser elegidos por sus compañeros, conocer la legislación, poseer un nivel adecuado de educación y formación, y disponer de tiempo suficiente para investigar las incidencias puntuales y realizar inspecciones. En relación con el control de las sustancias química, las funciones del comité paritario son tanto proactivas como reactivas, puesto que colabora en la fijación de prioridades y el desarrollo de las políticas preventivas, además de canalizar las inquietudes de los trabajadores que no están satisfechos con la eficacia de los controles aplicados.

\section{El equipo multidisciplinario}

Como se ha indicado anteriormente, el control de los peligros de origen químico en los hospitales precisa un esfuerzo multidisciplinario. Como mínimo, requiere el concurso de especialistas en higiene industrial. En la mayoría de los hospitales existe un departamento de mantenimiento que cuenta con personas conocedoras del equipo físico y del diseño técnico, capaces de asesorar al higienista en la determinación de las eventuales modificaciones necesarias del lugar de trabajo. Las enfermeras también tienen una función destacada que desempeñar en la evaluación de las quejas e inquietudes, y en la prestación de asistencia a los médicos del trabajo en la determinación de si se precisa una actuación clínica. Es preciso que en los hospitales se reconozca que muchos profesionales de la salud poseen conocimientos especialmente importantes para el control de los riesgos de origen químico. Por ejemplo, sería inconcebible elaborar unos procedimientos y políticas de control de las sustancias químicas empleadas en el laboratorio sin el concurso de los químicos de laboratorio, o elaborar métodos de manipulación de los fármacos antineoplásicos sin la colaboración del personal de farmacología y de oncología. Si bien resulta, simplemente, prudente que los profesionales de la higiene industrial que trabajen en cualquier sector consulten con el personal de línea antes de aplicar medidas de control, sería un error imperdonable no hacerlo así en los entornos de la asistencia sanitaria.

\section{Recogida de datos}

$\mathrm{Al}$ igual que en los demás sectores y como ocurre con todos los problemas, la recogida de datos es necesaria en la fijación de prioridades y en la evaluación del éxito de los programas. Por lo que respecta a la recogida de datos relativos a los riesgos químicos en los hospitales, es preciso, como mínimo, recoger datos sobre exposiciones accidentales y vertidos (con objeto de dedicar a estas áreas una atención especial que prevenga la recurrencia); registrar la índole de los problemas y quejas (por ejemplo, olores anormales) y confeccionar estadísticas de los casos clínicos, para poder detectar, por ejemplo, cualquier incremento de la frecuencia de la dermatitis en un área o una categoría profesional determinadas.

\section{Seguimiento integral}

Los hospitales han adquirido creciente conciencia de su obligación de proteger el medio ambiente. Se toman en consideración no sólo las propiedades de las sustancias químicas que entrañan un peligro para el lugar de trabajo, sino también las propiedades que afectan el medio ambiente. Además, ya no es admisible verter sustancias químicas peligrosas en el sumidero ni liberar vapores 
tóxicos en la atmósfera. Por consiguiente, los programas de control de las sustancias químicas en los hospitales deben hacer posible el seguimiento de las mismas desde su adquisición (o bien, en algunos casos, su síntesis local), hasta su evacuación final, pasando por el almacenamiento y la manipulación en el servicio.

\section{Conclusiones}

Actualmente se acepta que hay millares de sustancias químicas potencialmente muy tóxicas en el medio ambiente de trabajo de los centros sanitarios; todas las categorías laborales pueden quedar expuestas a un amplio y complejo espectro de riesgos. Sin embargo, si se aplica un criterio global y sistemático, apoyado por una plantilla plenamente informada y participativa, es posible afrontar el riesgo que entrañan las sustancias químicas y controlar los efectos de la exposición a las mismas.

\section{GASES ANESTESICOS RESIDUALES}

\section{Xavier Guardino Solá}

Los primeros anestésicos inhalables, que comenzaron a utilizarse en el decenio de 1840, fueron el éter dietílico, el óxido nitroso y el cloroformo. Mucho más tarde (hacia 1930 - 1940) empezaron a utilizarse el ciclopropano y el tricloroetileno, mientras que el empleo del fluoroxeno, el halotano y el metoxiflurano se inició en el decenio de 1950. A finales del decenio de 1960 se usaba el enflurano y, finalmente, en el decenio de 1980 se introdujo el isoflurano. Este es actualmente el anestésico inhalable más utilizado, a pesar de ser más costoso que los otros. En la Tabla 97.15 figura una sinopsis de las propiedades físicas y químicas del metoxiflurano, el enflurano, el halotano, el isoflurano y el óxido nitroso, los anestésicos más comúnmente utilizados (Wade y Stevens 1981).

Todos ellos, con la sola excepción del óxido nitroso $\left(\mathrm{N}_{2} \mathrm{O}\right)$, son hidrocarburos o éteres líquidos clorofluorados que se aplican mediante vaporización. El isoflurano es el más volátil de estos compuestos, el que más lentamente se metaboliza y el menos soluble en la sangre, en los lípidos y en el hígado.

Normalmente, el gas $\mathrm{N}_{2} \mathrm{O}$ se mezcla con un anestésico halogenado, aunque a veces ambos agentes se emplean por separado, en función del tipo de anestesia que se precise, de las características del paciente y del sistema de trabajo del anestesista. Las concentraciones más utilizadas oscilan entre el 50 y el $66 \%$ de $\mathrm{N}_{2} \mathrm{O}$, y entre el 2 y el $3 \%$ del anestésico halogenado, correspondiendo el resto normalmente a oxígeno.

La anestesia del paciente se suele iniciar mediante la inyección de un sedante, seguida de un anestésico inhalado. El paciente recibe un volumen del orden de 4 o 5 litros por minuto. Retiene una parte del oxígeno y de los gases anestésicos de la mezcla, y el resto se exhala directamente a la atmósfera o se recicla en el sistema de respiración artificial, en función, entre otros factores, del tipo de mascarilla utilizado, de que el paciente se encuentre intubado y de que se disponga de un sistema de reciclaje. En caso afirmativo, el aire exhalado se puede reciclar después de depurarse, o bien se puede esparcir en la atmósfera, expulsarse del quirófano o eliminarse utilizando un aspirador. El reciclaje (en circuito cerrado) no se utiliza habitualmente y muchos aparatos de respiración artificial no disponen de sistema de extracción, lo que hace que todo el aire exhalado por el paciente, incluidos los gases anestésicos residuales, vaya a parar a la atmósfera del quirófano.

El número de trabajadores que se exponen profesionalmente a los gases anestésicos residuales es elevado, ya que la lista no se limita al anestesista y sus ayudantes, sino que se extiende al resto del personal que permanece algún tiempo en el quirófano (cirujanos, enfermeras y personal auxiliar), a los cirujanos maxilofaciales, al personal de las salas de maternidad y de las unidades de cuidados intensivos en que se administra a los pacientes anestésicos inhalables, y a los cirujanos veterinarios. También en las salas de recuperación se detecta la presencia de gases anestésicos residuales exhalados por los pacientes. Se encuentran estos gases asimismo en las áreas contiguas a los quirófanos, dado que, por razones de asepsia, éstos se mantienen a una presión positiva y tal circunstancia favorece la contaminación de las áreas adyacentes.

Tabla 97.15 • Propiedades de los anestésicos inhalados.

\begin{tabular}{|c|c|c|c|c|c|}
\hline & Isoflurano, forano & Enflurano, etrano & Halotano, fluotano & Metoxiflurano, pentrano & $\begin{array}{l}\text { Oxido dinitroso, } \\
\text { Oxido nitroso }\end{array}$ \\
\hline Peso molecular & 184,0 & 184,5 & 197,4 & 165,0 & 44,0 \\
\hline Punto de ebullición & $48,5 \quad C$ & $56,5 C$ & $50,2 \quad C$ & $104,7 \quad C$ & - \\
\hline Densidad & 1,50 & $1,52(25 \mathrm{C})$ & $1,86(22 \quad c)$ & $1,41(25 \quad C)$ & - \\
\hline Presión de vapor a 20 C & 250,0 & $175,0(20 \mathrm{C})$ & $243,0(20 \quad c)$ & $25,0(20 \mathrm{C})$ & - \\
\hline Olor & Agradable, penetrante & Agradable, como el éter & Agradable, dulce & Agradable, afrutado & Agradable, dulce \\
\hline \multicolumn{6}{|l|}{ Coeficientes de separación: } \\
\hline Sangre/gas & 1,40 & 1,9 & 2,3 & 13,0 & 0,47 \\
\hline Cerebro/gas & 3,65 & 2,6 & 4,1 & 22,1 & 0,50 \\
\hline Grasa/gas & 94,50 & 105,0 & 185,0 & 890,0 & 1,22 \\
\hline Hígado/gas & 3,50 & 3,8 & 7,2 & 24,8 & 0,38 \\
\hline Músculo/gas & 5,60 & 3,0 & 6,0 & 20,0 & 0,54 \\
\hline Aceite/gas & 97,80 & 98,5 & 224,0 & 930,0 & 1,4 \\
\hline Agua/gas & 0,61 & 0,8 & 0,7 & 4,5 & 0,47 \\
\hline Goma/gas & 0,62 & 74,0 & 120,0 & 630,0 & 1,2 \\
\hline Tasa de metabolismo & 0,20 & 2,4 & $15-20$ & 50,0 & - \\
\hline
\end{tabular}




\section{Efectos en la salud}

Los problemas provocados por la toxicidad de los gases anestésicos no se estudiaron en profundidad antes del decenio de 1960, a pesar de que, pocos años después de generalizarse el empleo de los anestésicos inhalados, empezó a sospecharse la existencia de una relación causal entre las patologías (asma, nefritis) que sufrían algunos de los primeros anestesistas profesionales y el trabajo que realizaban (Ginesta 1989). En este sentido, la aparición de un estudio epidemiológico de más de 300 anestesistas soviéticos - la encuesta Vaisman (1967)_ constituyó el punto de partida de varios otros estudios epidemiológicos y toxicológicos. Estos estudios - realizados principalmente durante el decenio de 1970 y principios del siguiente - se centraban en los efectos de los gases anestésicos, generalmente el óxido nitroso y el halotano, en las personas expuestas profesionalmente a sus efectos.

Los efectos observados en la mayoría de estos estudios consistían en un incremento de los abortos espontáneos entre la mujeres expuestas antes y durante el embarazo, así como entre las compañeras de los varones expuestos; un incremento de las malformaciones congénitas en los hijos de madres expuestas; y manifestaciones de trastornos hepáticos, renales y neurológicos, así como de algunos tipos de cáncer, en hombres y mujeres por igual (Bruce y cols. 1968, 1974; Bruce y Bach 1976). Si bien los efectos tóxicos del óxido nitroso y del halotano (y, probablemente, de sus sustitutivos) sobre el organismo no son exactamente idénticos, se suelen estudiar conjuntamente, dado que la exposición se suele producir de forma simultánea.

Es probable que exista una correlación entre estas exposiciones y un incremento de ciertos riesgos, especialmente de aborto espontáneo y malformaciones congénitas de los hijos de mujeres expuestas durante el embarazo (Stoklov y cols. 1983; Spence 1987; Johnson, Buchan y Reif 1987). Esta posibilidad genera una considerable preocupación en muchas de las personas expuestas. Sin embargo, un análisis estadístico riguroso arroja dudas sobre la existencia de tal relación, y los estudios más recientes refuerzan tales dudas, al tiempo que los análisis cromosómicos arrojan resultados ambiguos.

Los estudios realizados por Cohen y colaboradores (1971, 1974, 1975, 1980) para la American Society of Anesthetists (ASA) se basaron en una extensa serie de observaciones. En trabajos aparecidos posteriormente se critican algunos aspectos técnicos de los estudios iniciales, particularmente por lo que respecta a los métodos de muestreo y, en especial, a la correcta selección de un grupo de control. Otras deficiencias señaladas han sido la falta de información fiable respecto a las concentraciones a que se expusieron los individuos, los métodos de tratamiento de los falsos positivos y la ausencia de control de factores como el consumo de tabaco y alcohol, el historial de la función reproductiva de las personas y la esterilización voluntaria. Esto hace que, en la actualidad, algunos de los estudios se consideren, incluso, irrelevantes (Edling 1980; Buring y cols. 1985; Tannenbaum y Goldberg 1985).

Los ensayos de laboratorio realizados indican que la exposición de animales a unas concentraciones ambientales de gases anestésicos equivalentes a las que se producen en los quirófanos produce, ciertamente, un deterioro del crecimiento, el desarrollo y el comportamiento de adaptación (Ferstanding 1978; ACGIH 1991). Los resultados, sin embargo, no son concluyentes, puesto que en algunos de estos experimentos se han provocado exposiciones de niveles anestésicos o subanestésicos, a concentraciones significativamente superiores a las de gases anestésicos residuales normalmente presentes en la atmósfera de los quirófanos (Saurel-Cubizolles y cols. 1994; Tran y cols. 1994).

No obstante, incluso reconociendo que no se ha podido establecer concluyentemente la existencia de una relación entre los efectos nocivos y la exposición a los gases anestésicos residuales, no es menos cierto que la presencia de esos gases y de sus derivados metabólicos se detecta fácilmente en la atmósfera de los quirófanos, en el aire exhalado y en los líquidos corporales. Por lo tanto, dada la preocupación existente respecto a su posible toxicidad, y puesto que resulta técnicamente posible hacerlo sin un gasto y un esfuerzo desproporcionados, convendría adoptar medidas tendentes a eliminar o reducir a niveles mínimos las concentraciones de gases anestésicos en los quirófanos y áreas contiguas (Rosell, Luna y Guardino 1989; NIOSH 1994).

\section{Niveles máximos de exposición admisibles}

La American Conference of Governmental Industrial Hygienists (ACGIH) ha establecido un valor límite ambral-media ponderada en el tiempo (TLV-TWA) de 50 ppm por metro respecto para el óxido nitroso y el halotano (ACGIH 1994). La TLV-TWA constituye la pauta aplicable a la producción del compuesto, y se recomienda que las concentraciones en los quirófanos se mantengan en niveles inferiores, por debajo de 1 ppm por metro (ACGIH 1991). La NIOSH ha fijado un límite de 25 ppm por metro para el óxido nitroso y de 1 ppm por metro para los anestésicos halogenados, recomendando, además que, si se utilizan juntos, la concentración de compuestos halogenados se reduzca a 0,5 ppm por metro (NIOSH 1977b).

Por lo que respecta a los valores alcanzables en los líquidos biológicos, el límite recomendado para el óxido nitroso en orina al cabo de 4 horas de exposición a unas concentraciones ambientales medias de 25 ppm por metro oscila entre $13 \mathrm{y}$ $19 \mathrm{mg} / \mathrm{L}$, y al cabo de 4 horas de exposición en unas concentraciones ambientales medias de $50 \mathrm{ppm}$ por metro oscila entre 21 y 39 mg/L (Guardino y Rosell 1995). Si la exposición es a una mezcla de un anestésico halogenado y óxido nitroso, los valores cuantificados del óxido nitroso sirven de punto de partida para controlar la exposición, ya que, a medida que las concentraciones utilizadas son mayores, se facilita la cuantificación.

\section{Medición analítica}

La mayoría de los procedimientos descritos para medir los gases anestésicos residuales en el aire se basan en la captación de esos compuestos mediante su absorción en bolsas o contenedores inertes, para su posterior análisis por cromatografía de gases o por espectroscopia de infrarrojos (Guardino y Rosell 1985). Se utiliza igualmente la cromatografía de gases para medir el contenido de óxido nitroso en orina (Rosell, Luna y Guardino 1989), mientras que el isoflurano no se metaboliza fácilmente, por lo que no se suele cuantificar.

\section{Niveles habituales de concentraciones de gases residuales en la atmósfera de los quirófanos}

En situaciones en que no se han adoptado medidas preventivas, como la extracción de los gases residuales o la introducción de un suministro suficiente de aire fresco en los quirófanos, se han medido concentraciones de más de 6.000 ppm por metro de óxido nitroso y de 85 ppm por metro de halotano (NIOSH 1977). Se han medido concentraciones de hasta 3.500 ppm por metro y $20 \mathrm{ppm}$ por metro, respectivamente, en la atmósfera ambiental de algunos quirófanos. La aplicación de medidas correctivas permite reducir estas concentraciones a valores inferiores a los límites medioambientales anteriormente citados (Rosell, Luna y Guardino 1989). 


\section{Factores que influyen en la concentración de gases anestésicos}

Los factores que más directamente influyen en la presencia de gases anestésicos residuales en el entorno del quirófano son los siguientes:

Método de anestesia. La primera cuestión que es preciso considerar es el método de anestesia, con independencia de que se intube o no al paciente y del tipo de mascarilla que se utilice. En las intervenciones odontológicas, laríngeas y de otros tipos en que se excluye la intubación, el aire exhalado por el paciente constituye una importante fuente de emisión de gases residuales, a menos que se coloquen dispositivos de captación del aliento cerca del campo respiratorio del paciente. Esto hace que los cirujanos maxilofaciales constituyan un grupo de especial riesgo (Cohen, Belville y Brown 1975; NIOSH 1977a), al igual que los veterinarios (Cohen, Belville y Brown 1974; Moore, Davis y Kaczmarek 1993).

Proximidad del foco emisor. Como suele ser la regla en la higiene industrial, cuando se conoce la fuente de emisión de un agente contaminante, la proximidad a esa fuente es el principal factor que se debe considerar en relación con la exposición personal. En este caso, los anestesistas y sus asistentes son las personas más directamente afectadas por la emisión de gases anestésicos residuales, y se ha podido determinar que las concentraciones personales se sitúan en torno al doble de los niveles medios observados en el aire de los quirófanos (Guardino y Rosell 1985).

Tipo de circuito. Ni que decir tiene que, en los pocos casos en que se emplean circuitos cerrados, con reinspiración posterior a la purificación y nuevo suministro de oxígeno y del anestésico necesario, sólo se producen emisiones si el funcionamiento del equipo es defectuoso o si existe alguna filtración. En los demás casos, el riesgo depende de las características del sistema utilizado y de que resulte o no posible acoplar un sistema de extracción al circuito.

Concentración de gases anestésicos. Otro factor que se debe tomar en consideración es la concentración de los anestésicos utilizados, dado que, obviamente, existe una relación directa entre dicha concentración y las cantidades presentes en la atmósfera del quirófano (Guardino y Rosell 1985). Este factor reviste especial importancia en las intervenciones quirúrgicas de larga duración.

Tipos de operaciones quirúrgicas. Otros aspectos que se deben tomar en consideración son la duración de la operación, el tiempo transcurrido entre los actos médicos realizados en el mismo quirófano y las características concretas de cada intervención, que a menudo son determinantes de la clase de anestésico utilizada. La duración de la operación influye directamente en la concentración residual de gases anestésicos en el aire. En los quirófanos en que las intervenciones se programan consecutivamente, el tiempo transcurrido entre las mismas también influye en la presencia de gases residuales. Según algunos estudios realizados en grandes hospitales en que los quirófanos se utilizan ininterrumpidamente, en que los quirófanos de urgencias son objeto de una utilización más intensiva que la usual, o en que los quirófanos se emplean para realizar operaciones prolongadas (trasplantes, laringotomías, etc.), se detecta una concentración importante de gases residuales antes, incluso, de la primera intervención del día, lo cual contribuye a incrementar los volúmenes de gases residuales en las intervenciones posteriores. Por otra parte, algunas intervenciones obligan a interrumpir temporalmente la inhalación de anestésicos (por ejemplo, si se practica la circulación extracorpórea), lo cual supone igualmente interrumpir la emisión de gases anestésicos residuales a la atmósfera del entorno (Guardino y Rosell 1985).

Características específicas del quirófano. Según estudios realizados en quirófanos de distinto tamaño, diseño y ventilación (Rosell, Luna y Guardino 1989), estas características influyen en gran medida en la concentración de gases anestésicos residuales en la sala. En efecto, las menores concentraciones de gases anestésicos residuales se han medido en los quirófanos grandes y diáfanos, al tiempo que en los quirófanos más reducidos (por ejemplo, en los de pediatría) se suelen medir concentraciones de gases residuales más elevadas. El sistema general de ventilación del quirófano $-\mathrm{y}$ su buen funcionamiento - constituyen un factor determinante de la reducción de la concentración de gases anestésicos. Por su parte, el diseño del sistema de ventilación también influye en la circulación de los gases residuales dentro del quirófano y en su concentración en diferentes puntos y a diversas alturas, como se puede verificar fácilmente mediante un muestreo cuidadoso.

Características específicas del equipo de anestesia. La emisión de gases en el quirófano está en función directa de las características del equipo de anestesia utilizado. El diseño del sistema - esto es, si comprende un dispositivo de retorno de los gases sobrantes, si se puede acoplar a un aspirador o expulsarse del quirófano, si presenta filtraciones, cables desconectados, etcétera- se debe tomar en consideración al investigar la presencia de gases anestésicos residuales en el quirófano.

Factores especificos del equipo de trabajo del anestesista. El anestesista y su equipo constituyen el último elemento del estudio, pero no necesariamente el menos importante. El conocimiento del equipo de anestesia, de sus posibles problemas y del nivel de mantenimiento que recibe - por parte tanto del equipo de trabajo como del personal de mantenimiento del hospital- influyen en gran medida en la liberación de gases anestésicos residuales en la atmósfera del quirófano (Guardino y Rosell 1995). Se ha demostrado fehacientemente que, incluso aplicando la tecnología adecuada, la reducción de la concentración ambiental de gases anestésicos constituye un objetivo imposible si los métodos de trabajo de los anestesistas y sus ayudantes no se inspira en una filosofía preventiva (Guardino y Rosell 1992).

\section{Medidas preventivas}

Las medidas preventivas básicas que se precisan para reducir efectivamente la exposición profesional a los gases anestésicos residuales se pueden resumir en los seis puntos siguientes:

1. Los gases anestésicos se deben considerar un riesgo profesional. A pesar de que, desde una perspectiva científica, no se haya demostrado de forma concluyente que surtan efectos nocivos en la salud de las personas profesionalmente expuestas a ellos, es muy probable que algunos de los efectos mencionados en este artículo se asocien directamente a la exposición a los mismos. Por este motivo, resulta aconsejable clasificarlos como riesgos de intoxicación profesional.

2. Se deben utilizar sistemas de expulsión de los gases residuales. Los sistemas de expulsión constituyen el medio técnico más eficaz en la reducción del volumen de gases residuales en la atmósfera del quirófano (NIOSH 1975). Estos sistemas deben reunir dos requisitos básicos: han de ser capaces de almacenar o de eliminar completamente la totalidad del aire exhalado por el paciente, y se deben diseñar de modo que ni la respiración del paciente ni el funcionamiento normal del equipo de anestesia se ven afectados, dotándoseles de dispositivos de seguridad independientes para cada función. Las técnicas más generalizadas son: conexión directa con un aspirador provisto de una cámara de regulación flexible que facilite la emisión discontinua de los gases del ciclo respiratorio; impulsión del flujo de gases exhalados por el paciente hacia el aspirador sin necesidad de una conexión directa; e impulsión del flujo de gases procedentes del paciente hacia el retorno del sistema de ventilación instalado en el quirófano y expulsión de esos gases del quirófano y del edificio. Todos estos sistemas son técnicamente fáciles de instalar y muy eficaces 
en función del coste; concretamente, se recomienda utilizar inhaladores incorporados al diseño.

En los casos en que no sea posible utilizar sistemas que eliminen directamente los gases residuales en virtud e las características específicas de una intervención, se puede recurrir a la extracción puntual cercana a la fuente de emisión, siempre que esta técnica no afecte al sistema general de ventilación ni a la presión positiva presente en el quirófano.

3. El sistema de ventilación general debe permitir un mínimo de 15 renovaciones del aire por hora en el quirófano. Es preciso regular perfectamente el sistema de ventilación general del quirófano, que, no sólo debe mantener una presión positiva y responder a las características termohigrométricas de la atmósfera ambiental, sino también efectuar un mínimo de 15 a 18 renovaciones por hora. Es igualmente necesario aplicar un procedimiento de monitorización que asegure el correcto funcionamiento del sistema.

4. Se debe efectuar un mantenimiento preventivo sistemático y regular del circuito de anestesia. Es preciso establecer una rutina de mantenimiento preventivo que comprenda la inspección sistemática de los inhaladores. Al poner en funcionamiento el equipo, se debe verificar si se emiten gases al medio ambiente, además de comprobar que el equipo funciona de forma segura para el paciente. Es igualmente preciso verificar el adecuado funcionamiento del circuito de anestesia, comprobando si existen fugas, reemplazando periódicamente los filtros y revisando las válvulas de seguridad.

5. Se deben aplicar controles medioambientales y biológicos. La aplicación de controles de este tipo proporciona información no sólo sobre el correcto funcionamiento de los diversos elementos técnicos (extracción de gases, ventilación general), sino también respecto a si los métodos de trabajo son eficaces para mantener para reducir la emisión de gases a la atmósfera. Actualmente, estos controles no plantean problemas técnicos y resultan económicos de aplicar, razón por la que se recomienda su utilización.

6. Es imprescindible educar y formar al personal expuesto. La reducción efectiva de la exposición profesional a los gases anestésicos residuales pasa por informar a todo el personal quirúrgico de los riesgos potenciales y formarlos en la aplicación de las técnicas indicadas. Esto es especialmente cierto respecto a los anestesistas y sus auxiliares, ya que son los más directamente involucrados en el proceso y los responsables del mantenimiento del equipo de anestesia y del acondicionamiento del aire.

\section{Conclusiones}

Aunque no se ha demostrado de forma definitiva, existen importantes elementos de juicio de que los gases anestésicos residuales pueden resultar perjudiciales para los trabajadores sanitarios. Las muertes fetales y las malformaciones congénitas de los hijos de las trabajadoras y de las compañeras de los trabajadores sanitarios constituyen las más importantes manifestaciones de toxicidad. Por ser técnicamente factible a un coste reducido, resulta aconsejable reducir hasta niveles mínimos la concentración de estos gases en la atmósfera de los quirófanos y áreas adyacentes. Este objetivo se basa, por una parte, en el uso y mantenimiento correctos del equipo de anestesia y de los sistemas de ventilación y acondicionamiento de aire, y por otra, en la educación y formación de todo el personal afectado, especialmente de los anestesistas y sus auxiliares, que suelen exponerse a concentraciones más elevadas. Dadas las peculiares condiciones de trabajo existentes en los quirófanos, la enseñanza de los hábitos y métodos de trabajo correctos reviste particular importancia en el esfuerzo por reducir a la mínima expresión el volumen de gases anestésicos residuales.

\section{LOS TRABAJADORES SANITARIOS Y LA ALERGIA AL LATEX}

\section{Leon J. Warshaw}

Con la adopción de las precauciones generales contra las infecciones transmitidas por la sangre, que exigen el uso de guantes siempre que los trabajadores sanitarios se expongan al contacto con pacientes o materiales posiblemente infectados por la hepatitis B o el VIH, la frecuencia y gravedad de las reacciones alérgicas al látex de caucho natural se han incrementado sensiblemente. Así, el Departamento de Dermatología de la Universidad de Erlangen-Nuremberg, en Alemania ha informado de que, entre 1989 y 1995, el número de pacientes con alergia al látex se ha multiplicado por doce. Las manifestaciones sistémicas más graves aumentaron del $10,7 \%$ en 1989 al $44 \%$ en 1994-1995 (Hesse y cols. 1996).

Parece paradójico que se atribuyan tantos problemas a los guantes de goma, que empezaron a utilizarse hacia finales del siglo XIX con el objeto, precisamente, de proteger las manos de las enfermeras y demás trabajadores sanitarios. Era la época de la cirugía antiséptica, en la que tanto el instrumental como las instalaciones quirúrgicas se bañaban en soluciones cáusticas de ácido carbólico y bicloruro de mercurio. Estas sustancias, además de matar los gérmenes, maceraban las manos de los miembros del equipo quirúrgico. Según una versión que se ha trocado en leyenda romántica, William Stewart Halsted, uno de los "gigantes" de la cirugía de la época, inventó los guantes de goma hacia 1890 para que le resultase más grato tomar de las manos a Caroline Hampton, su auxiliar de enfermería, con la que terminó casándose (Townsend 1994). Aunque se puede atribuir a Halsted la introducción y popularización de los guantes quirúrgicos de goma en Estados Unidos, muchos otros contribuyeron al proceso en opinión de Miller (1982), que cita un informe del uso de estos guantes en el Reino Unido, publicado medio siglo antes (Acton 1848).

\section{Alergia al látex}

Taylor y Leow describen sucintamente la alergia al látex de caucho natural (véase el artículo "Dermatitis por contacto con la goma y alergia al látex" en el capítulo Industria del caucho) como "una reacción alérgica del tipo I, inmediata y mediada por la inmunoglobulina E, casi siempre debida a las proteínas del látex de caucho natural presentes en los artículos médicos y de otro tipo hechos de látex. El espectro de síntomas clínicos oscila desde la urticaria por contacto, la urticaria generalizada, la laringitis alérgica, la conjuntivitis alérgica, el angioedema (inflamación grave) y el asma hasta la anafilaxia (grave reacción alérgica que amenaza la vida). Los síntomas pueden producirse, bien por el contacto directo de la piel, normal o inflamada, con guantes u otros materiales con contenido de látex, bien de forma indirecta, mediante el contacto de las mucosas con las proteínas del látex de caucho natural aerosolizado o con partículas de polvo de talco que lleven adheridas proteínas de látex de caucho natural, o mediante la inhalación de tales sustancias. Estos contactos indirectos pueden provocar una reacción del tipo IV a los aceleradores del caucho (aproximadamente el $80 \%$ de la "alergia a los guantes de látex" constituye una reacción del tipo IV a los aceleradores). El diagnóstico se confirma, bien mediante pruebas del parche, pinchazo, raspado u otras pruebas cutáneas, bien mediante estudios serológicos de la inmunoglobulina. En algunos 
individuos, la alergia al látex se asocia a la alergia a determinados alimentos (como plátano, castañas, aguacate, kiwi y papaya).

Aunque más extendida entre los trabajadores sanitarios, la alergia al látex se observa también entre los trabajadores de las plantas de producción de caucho, en otros grupos de trabajadores que utilizan normalmente guantes de látex, como el personal de los invernaderos (Carillo y cols. 1995) y en los pacientes con una historia de múltiples intervenciones quirúrgicas (como espina bífida, malformaciones urogenitales congénitas, etc.) (Blaycock 1995). También se conocen casos de reacciones alérgicas posteriores al empleo de preservativos de látex (Jonasson, Holm y Leegard 1993) y se sabe que, en un caso, se evitó una posible reacción indagando los antecedentes de una reacción alérgica a un gorro de natación de goma (Burke, Wilson y McCord 1995). Se han observado reacciones en pacientes sensibles debido a que las agujas hipodérmicas utilizadas en la preparación de dosis de medicaciones parenterales absorbieron proteína de látex de caucho natural al atravesar los tapones de caucho de los frascos.

Según un estudio recientemente realizado con una muestra de 63 pacientes afectados de alergia al látex de caucho natural, se precisó una media de 5 años de trabajar con productos de látex para que apareciesen los primeros síntomas, generalmente una urticaria de contacto. Algunos pacientes también padecían rinitis o disnea. Pasaron otros dos años antes de que se manifestasen los primeros síntomas en las vías respiratorias inferiores (Allmeers y cols. 1996).

\section{Frecuencia de la alergia al látex}

Para determinar la frecuencia de la alergia al látex de caucho natural, se realizaron pruebas de alergia a una muestra de 224 trabajadores de la Facultad de Medicina de la Universidad de Cincinnati, que comprendía enfermeras, técnicos de laboratorio, médicos, terapeutas de la respiración, administrativos y personal de limpieza (Yassin y cols. 1994). Un total de 38 miembros de la muestra $(17 \%)$ dieron positivo a las partículas de látex, oscilando la frecuencia del $0 \%$ para el personal de limpieza al $38 \%$ para el personal de odontología. La exposición de los individuos sensibles al látex produjo picores al $84 \%$ de la muestra, erupción cutánea al $68 \%$, urticaria al $55 \%$, lagrimeo y picor en los ojos al $45 \%$, congestión nasal al $39 \%$ y estornudos al $34 \%$. Se produjo anafilaxia en el 10,5\% de los casos.

En un estudio similar realizado en la Universidad de Oulo, en Finlandia, el $56 \%$ de una muestra de 534 trabajadores sanitarios que utilizaban cotidianamente guantes de protección de látex o de vinilo presentaba problemas cutáneos producidos por los guantes (Kujala y Reilula 1995). Había rinorea o congestión nasal en el $13 \%$ de los trabajadores que empleaban guantes espolvoreados. La prevalencia de problemas cutáneos y respiratorios era sensiblemente mayor entre los trabajadores que usaban guantes durante más de dos horas al día.

Valentino y cols. (1994) informan de cuatro casos de asma provocada por el látex entre los trabajadores de un hospital regional italiano, al tiempo que en el Mayo Medical Center, de Rochester, Minnesota, en el que se realizaron pruebas a 342 trabajadores que manifestaban síntomas de una posible alergia al látex, se registraron 16 episodios de anafilaxia asociada al látex en 12 sujetos, habiéndose producido 6 de los episodios citados con posterioridad a la pruebas dermatológicas (Hunt y cols. 1995). Los investigadores de la clínica Mayo también informaron de problemas respiratorios entre un grupo de trabajadores que, aunque no usaban guantes, trabajaban en las inmediaciones de un área en que se utilizaba un gran número de guantes, debido, probablemente, a las partículas de proteína de látex/polvo de talco suspendidas en el aire.

\section{Control y prevención}

La principal medida preventiva consiste en reemplazar los guantes y demás elementos de látex de caucho natural por elementos similares producidos con otros materiales. Esta medida se basa en la participación de los departamentos de compras y suministros, que deben disponer igualmente el etiquetado de todos los artículos de látex, con objeto de evitar la exposición de las personas sensibles a esa sustancia. Esta medida beneficiaría no sólo al personal sanitario, sino también a los pacientes con antecedentes de alergia al látex. También son peligrosos los aerosoles de látex generados por el polvo de látex. Incluso los trabajadores sanitarios que no emplean guantes de látex y que son alérgicos a este material se pueden ver afectados por los guantes espolvoreados de látex utilizados por sus compañeros. Un serio problema es el de las sensibles variaciones en el contenido de alergenos de látex en los guantes suministrados por distintos fabricantes e, incluso, entre diversas partidas producidas por un mismo fabricante.

Los fabricantes de guantes experimentan con guantes producidos con materiales con un menor contenido de látex de caucho natural y con revestimientos que obvian la necesidad de usar polvos de talco para facilitar su colocación y retirada. El objetivo consiste en producir guantes fáciles de usar, sin alergenos y que, no obstante, constituyan una barrera eficaz contra la transmisión del virus de la hepatitis $\mathrm{B}$, el VIH y otros agentes patógenos.

Se debe elaborar una historia médica pormenorizada, con especial atención a los episodios previos de exposición al látex, de todos los trabajadores sanitarios que manifiesten síntomas de alergia a esta sustancia. Los casos sospechosos se pueden verificar realizando pruebas cutáneas o serológicas. Dado el evidente riesgo de provocar una reacción anafiláctica, las pruebas cutáneas siempre deben ser realizadas por personal médico experimentado.

En la actualidad no existen alergenos para la desensibilización, por lo que el único remedio consiste en evitar la exposición a productos que contengan látex. En algunos casos, esto puede implicar un traslado a otro puesto de trabajo. Weido y Sim (1995), de la Facultad de Medicina de la Universidad de Texas, en Galveston, recomiendan que se aconseje a las personas pertenecientes a grupos de alto riesgo que lleven consigo adrenalina autoinyectable para su empleo en caso de reacción sistémica.

Como consecuencia de una serie de brotes de alergia al látex ocurridos en 1990, el Mayo Medical Center encargó a un grupo de trabajo multidisciplinario la solución del problema (Hunt y cols. 1996). Posteriormente, este grupo de trabajo se estructuró formalmente en un Grupo Especial contra la Alergia al Látex, integrado por miembros de los servicios de alergología, medicina preventiva, dermatología y cirugía, además del Director de Compras, el Director Clínico de Enfermería Quirúrgica y el Director de Salud de los Empleados. Se incluyeron artículos sobre la alergia al látex en las circulares dirigidas al personal y en los boletines informativos de la empresa, con objeto de familiarizar con el problema a los 20.000 miembros de la plantilla e inducir a los sospechosos de padecer alergia a consultar con el médico. En el marco del programa, se desarrolló un procedimiento normalizado de verificación de la sensibilidad al látex, además de una serie de técnicas de cuantificación de los alergenos del látex presentes en los productos manufacturados y de la cantidad y el tamaño de las partículas de los alergenos del látex en suspensión en el aire. Estas últimas técnicas resultaron ser lo suficientemente sensibles para medir la exposición experimentada por cada trabajador durante la realización de tareas de alto riesgo. Se adoptaron medidas de monitorización de la transición gradual al empleo de guantes con bajo nivel de alergenos, y un efecto secundario de las medidas consistió en la reducción de los costes al concentrar las compras de guantes en el grupo 
reducido de proveedores capaces de satisfacer la exigencia de un bajo nivel de alergenos, así como en la disminución de la exposición tanto del personal como de los pacientes conocidamente sensibles al látex de caucho natural.

Con la finalidad de sensibilizar al público respecto a los riesgos de la alergia al látex de caucho natural, se creó una organización de consumidores, denominada Delaware Valley Latex Allergy Support Network. La organización cuenta con una página en Internet (http://www.latex.org) y con una línea telefónica gratuita (1-800 LATEXCO), destinadas a ofrecer información actualizada sobre la alergia al látex a los pacientes alérgicos y a quienes les cuidan. La organización, que cuenta además con un Grupo de Asesoramiento Médico, gestiona una librería especializada y un centro de productos, y promueve el intercambio de experiencias entre los aquejados de reacciones alérgicas.

\section{Conclusiones}

Las alergias al látex constituyen un problema cada vez más serio para los trabajadores sanitarios. La solución consiste en reducir en la máxima medida posible el contacto con los alergenos del látex en el medio ambiente de trabajo, principalmente mediante la adopción de guantes y medios quirúrgicos sin contenido de látex.

\section{EL MEDIO AMBIENTE HOSPITALARIO}

\section{EDIFICIOS DESTINADOS A LA ASISTENCIA SANITARIA}

\author{
Cesare Catananti, Gianfranco Damiani \\ y Giovanni Capelli
}

La conservación y mejora de la salud, y la seguridad y el bienestar de las personas que acuden a los centros sanitarios, se ven seriamente comprometidos si no se cumplen una serie de recomendaciones constructivas concretas. En efecto, los centros sanitarios son lugares muy especiales, en los que coexisten entornos heterogéneos. En la etiología de un amplio espectro de patologías influyen distintas personas, actividades varias desarrolladas en cada entorno, y numerosos factores de riesgo. Los entornos de los centros sanitarios se clasifican, aplicando criterios de organización funcional, en varias categorías: unidades de enfermería, quirófanos, servicios de diagnóstico (unidad de radiología, laboratorios, etc.), servicios ambulatorios, áreas administrativas (oficinas), áreas de alimentación, servicios de lencería, servicios técnicos y áreas de equipamiento, corredores y pasillos. El grupo de personas que acuden a los hospitales está constituido por personal sanitario, pacientes hospitalizados con problemas agudos o de larga duración, pacientes ambulatorios y visitantes. Las actividades comprenden las específicamente sanitarias - de diagnóstico, terapéuticas y de cuidados - y las comunes a otros edificios públicos: trabajo administrativo, mantenimiento técnico, preparación de comidas, etcétera. Los factores de riesgo pueden consistir en agentes físicos (radiación ionizante y no ionizante, iluminación y factores microclimáticos), sustancias químicas (disolventes orgánicos y desinfectantes), agentes biológicos (virus, bacterias, hongos, etcétera), factores ergonómicos (posturas, levantamiento de pesos, etc.) y factores psicológicos y organizativos (por ejemplo, percepciones medioambientales y horas de trabajo). Las enfermedades asociadas a los factores anteriormente mencionados oscilan entre las molestias y el malestar de origen medioambiental (por ejemplo, molestias térmicas y síntomas irritativos) y las patologías graves (como las infecciones nosocomiales y las lesiones traumáticas). Desde esta perspectiva, la evaluación y el control de los riesgos se deben enfocar con criterios interdisciplinarios y con la participación de médicos, higienistas, ingenieros, arquitectos, economistas, etcétera, y se basan en la observancia de ciertas medidas preventivas en el diseño, planificación, construcción y administración del edificio. Los requerimientos específicamente arquitectónicos destacan especialmente entre las medidas preventivas ya mencionadas y, de acuerdo con las directrices sobre higiene en la construcción establecidas por Levin (1992), son las siguientes:

- requisitos de planificación del emplazamiento

- requisitos relativos al diseño arquitectónico

- requisitos relativos a los materiales de construcción y el mobiliario

- requisitos relativos a los sistemas de calefacción, ventilación y aire acondicionado y a las condiciones microclimáticas.

El presente artículo se centra en los edificios destinados a hospitales generales. Evidentemente, se precisarían ciertas adaptaciones en los centros especializados (clínicas traumatológicas, hospitales oftalmológicos y otológicos, maternidades, instituciones psiquiátricas, centros de asistencia a enfermos de larga duración y centros de rehabilitación), en las unidades ambulatorias, en las unidades de urgencia y en los consultorios individuales y colectivos. Estas adaptaciones estarían en función del número y las características de los pacientes (incluido su estado físico y mental) y del número y las tareas realizadas por los trabajadores sanitarios. Algunos detalles contribuyen a mejorar la seguridad y el bienestar del personal y los pacientes por igual en todos los centros sanitarios:

- ambientación, que comprende, no sólo la decoración, la iluminación y el control del ruido, sino también la compartimentación y el equipamiento del local de modo que los trabajadores no queden aislados con visitantes y pacientes potencialmente violentos

- sistemas de ventilación que reduzcan a la mínima expresión la exposición a los agentes infecciosos y a los gases y sustancias químicas potencialmente tóxicos

- instalaciones para guardar la ropa y los efectos personales de los pacientes y sus visitantes, de forma que se reduzca el riesgo de contaminación

- taquillas, vestuarios, cuartos de aseo y servicios sanitarios para el personal

- lavabos, convenientemente situados, en todas las habitaciones y áreas de tratamiento

- entradas, ascensores y cuartos de aseo a los que puedan acceder sillas de rueda y camillas

- diseño de los archivos y áreas de almacenamiento de forma que se reduzca en lo posible la necesidad de agacharse, inclinarse, estirarse y levantar grandes pesos

- sistemas de alarma y comunicaciones automáticos y controlados por los trabajadores

- medios de recogida, almacenamiento y eliminación de residuos tóxicos, vestimenta y ropa de cama contaminada, etcétera. 
Exigencias de la planificación del emplazamiento La elección del emplazamiento del centro sanitario se debe basar en cuatro criterios básicos (Catananti y Cambieri 1990; Klein y Platt 1989; Decreto del Presidente del Consejo de Ministros 1986; Comisión de las Comunidades Europeas 1990; NHS 1991a, 1991b).

1. Factores medioambientales. El terreno debe ser lo más llano posible. En efecto, aunque los ascensores, escaleras mecánicas y rampas pueden servir para superar las ondulaciones, dificultan el acceso de los minusválidos y personas de edad avanzada, además de contribuir a incrementar el coste del proyecto y la carga de trabajo de los cuerpos de bomberos y equipos de evacuación. Se deben evitar los emplazamientos azotados por fuertes vientos y, además, el lugar ha de estar alejado de los focos de contaminación y ruidos (especialmente de los basureros y fábricas). Es preciso evaluar los niveles de radón y sus derivados, y adoptar medidas para reducir la exposición. En los climas muy fríos, se debe estudiar la posibilidad de empotrar serpentines térmicos para derretir la nieve así evitar caídas y accidentes en los aparcamientos, aceras y entradas.

2. Estructura geológica. Es preciso huir de las zonas sísmicas o, en su defecto, aplicar conceptos constructivos antisísmicos. La elección del emplazamiento debe ir precedida de un estudio hidrogeológico, con objeto de evitar infiltraciones en la cimentación.

3. Factores urbanísticos. El emplazamiento debe ser de fácil acceso para los posibles usuarios, ambulancias y vehículos de transporte de suministros y de evacuación de residuos. Además, el área debe estar atendida por los servicios de transporte público y otros medios de infraestructura (agua, gas, electricidad y alcantarillado). También es conveniente que el emplazamiento se encuentre cerca de un cuartel de bomberos y que éstos y el equipo de extinción de incendios puedan acceder fácilmente a todas las áreas de la instalación.

4. Disponibilidad de espacio. Es preciso contar con espacio disponible para la expansión del centro y para la construcción de aparcamientos suficientes.

\section{Diseño arquitectónico}

En el diseño arquitectónico de los centros sanitarios se deben seguir algunos criterios:

- tipo de centro: hospital (para pacientes agudos, hospital rural, hospital comunitario), centro sanitario, residencia asistida (centro de asistencia de larga duración, residencia especializada, lugar residencial), centro de medicina general (NHS 1991a; NHS 1991b; Kleczkowski, Montoya-Aguilar y Nilsson 1985; ASHRAE 1987)

- dimensiones del área de ingresos

- problemas de gestión: costes, flexibilidad (adaptabilidad)

- tipo de ventilación: en efecto, los edificios climatizados son de diseño compacto y vertical, con la menor superficie posible de paramentos externos, con objeto de reducir el intercambio de calor entre el interior y el medio exterior; en cambio, las edificaciones con ventilación natural suelen tener una configuración alargada y poco profunda, con objeto de aumentar la exposición del conjunto a la brisa y de reducir la distancia de los puntos interiores a las ventanas (Llewelyn-Davies y Wecks 1979)

- coeficiente edificación/superficie

- calidad del medio ambiente: la seguridad y la comodidad son consideraciones esenciales.

Estos criterios inducen a los diseñadores de los centros sanitarios a optar por la configuración arquitectónica más adecuada a cada situación. Básicamente, las opciones oscilan entre una construcción horizontal, compuesta por varias edificaciones diseminadas, y un bloque monolítico, vertical u horizontal (Llewelyn-Davies y Wecks 1979). El diseño primeramente citado (preferible para los hospitales con baja densidad de utilización) se suele utilizar en los centros de hasta 300 camas, debido a los menores costes de construcción y gestión. Se trata de una opción especialmente recomendable para los pequeños hospitales rurales y los hospitales comunitarios (Llewelyn-Davies y Wecks 1979). La segunda opción (que se suele preferir para los centros de alta ocupación) resulta eficaz en función del coste en los centros de más de 300 camas y se recomienda especialmente para los hospitales para enfermos agudos (Llewelyn-Davies y Wecks 1979). Las dimensiones y la distribución de los espacios interiores son una función de diversas variables, entre las que destacan las tareas, los procedimientos, la circulación y la comunicación con otras áreas, el equipamiento, la carga de trabajo prevista, los costes y la flexibilidad, convertibilidad y posibilidad de uso compartido. La compartimentación, las salidas, las alarmas de incendio, los sistemas de extinción automáticos y las demás medidas de prevención y protección contra incendios deben ajustarse a las normas locales. Además, se han formulado varias otras formulaciones específicas para cada área de los centros sanitarios:

1. Unidades de hospitalización. El plano de las unidades asistenciales se suele inspirar en uno de los tres modelos básicos siguientes (Llewelyn-Davies y Wecks 1979): una sala diáfana (la sala "Nightingale"), esto es, una estancia amplia con 20 a 30 camas, alineadas a lo largo de ambas paredes y con la cabecera cerca de las ventanas; el modelo "Rigs", en el que las camas se colocaban paralelamente a las paredes y, en un principio, se colocan en estancias diáfanas situadas a ambos lados de un pasillo central (según el modelo del hospital Rigs, de Copenhague), aunque en los hospitales construidos posteriormente, estas estancias laterales suelen estar cerradas y se transforman en habitaciones con 6 a 10 camas; y el modelo de habitaciones pequeñas, con una a cuatro camas. La elección del diseño óptimo depende de cuatro variables: la necesidad de camas (si es elevada, resulta preferible una sala diáfana), el presupuesto (si es reducido, la opción de la sala diáfana es también la más económica), las necesidades de aislamiento (si se estiman elevadas, hay que optar por las habitaciones reducidas) y la intensidad de los cuidados requeridos (si resulta elevada, se aconseja optar por el modelo de la sala diáfana o por el modelo de Rigs, con unidades de 6 a 10 camas). Las necesidades mínimas de espacio se sitúan entre 6 y 8 metros cuadrados por cama en las salas diáfanas, incluida la superficie reservada a la circulación y a las estancias auxiliares (Llewelyn-Davies y Wecks 1979); entre 5 y 7 metros cuadrados por cama para las habitaciones colectivas; y en 9 metros cuadrados para las habitaciones individuales (Decreto del Presidente del Consejo de Ministros 1986; American Institute of Architects Committee on Architecture for Health 1987). En las salas diáfanas, los servicios sanitarios se deben situar cerca de las camas de los pacientes (Llewelyn-Davies y Wecks 1979). En las habitaciones individuales y colectivas, se debe instalar un lavabo, se puede prescindir del retrete si las habitaciones individuales o dobles están dotadas de cuarto de baño (American Institute of Architects Committee on Architecture for Health 1987). La sala de enfermeras debe ser lo suficientemente espaciosa para albergar mesitas y sillas para tomar notas; mesas y armarios para el almacenamiento y la preparación de medicamentos, instrumentos y suministros; sillas para reuniones con los médicos y otros miembros del personal, un fregadero y acceso a un cuarto de baño para el personal. 
2. Areas quirúrgicas. Aquí hay que considerar dos áreas diferenciadas: los quirófanos y las áreas de servicio (American Institute of Architects Committee on Architecture for Health 1987). Existen varias clases de quirófanos:

- quirófanos generales, que precisan una superficie diáfana mínima de 33,5 metros cuadrados

- sala de cirugía ortopédica (optativa), que precisa una superficie cerrada de almacenamiento para las tablillas y el equipo de tracción

- sala de cirugía cardiovascular (optativa), que precisa un espacio diáfano mínimo de 44 metros cuadrados. En el área diáfana del complejo quirúrgico, cerca del quirófano, se debe construir un cuarto de bombas suplementario, destinado al almacenamiento y mantenimiento de los suministros y accesorios de la bomba de circulación extracorpórea

- sala de endoscopia, con un área diáfana mínima de 23 metros cuadrados

- sala de espera de los pacientes, administración de anestesia y recuperación de la anestesia.

Las áreas de servicio deben comprender: una instalación de esterilización, equipada con un autoclave de gran velocidad; instalaciones de fregado; instalaciones de almacenamiento de gases anestésicos, y vestuario para el personal.

3. Unidades de diagnóstico. En cada unidad de radiología se debe incluir (Llewelyn-Davies y Wecks 1979; American Institute of Architects Committee on Architecture for Health 1987):

- un mostrador de recepción y citas, y áreas de espera

- salas de radiografía de diagnóstico, que precisan 23 metros cuadrados para las pruebas de radioscopia, y unos 16 metros cuadrados para las pruebas radiográficas, además de un área de control protegida y, en su caso, unas estructuras rígidas de apoyo del equipo montado en el techo

- en su caso, cuarto oscuro, que precisa casi 5 metros cuadrados y una ventilación adecuada para el revelador

- área de preparación de medios de contraste, instalaciones de limpieza, área de control de calidad de placas, área destinada al equipo informático y área de almacenamiento de placas

- área destinada a visionar las placas y dictar informes.

Las paredes de las áreas de radiología deben tener un grosor de 8 a $12 \mathrm{~cm}$ si son de hormigón, y de 12 a $15 \mathrm{~cm}$ si son de ladrillos.

Los diagnósticos realizados en los centros sanitarios suelen basarse en pruebas de hematología, química clínica, microbiología, anatomopatología y citología. En todo laboratorio debe haber áreas de trabajo, medios de almacenamiento de materiales y muestras (refrigerados o no), medios de recogida de muestras, medios y equipo de esterilización final y eliminación de residuos, y, en su caso, una instalación especialmente destinada al almacenamiento de material radiactivo (American Institute of Architects Committee on Architecture for Health 1987).

4. Consultas externas. Según el American Institute of Arhitects Committee on Architecture for Health (1987), las consultas externas deben comprender: salas de exploración general (7,4 metros cuadrados), salas de exploraciones especializadas (de superficie variable en función del equipo necesario) y salas de tratamiento (11 metros cuadrados). Además, se precisa un área administrativa destinada al ingreso de los pacientes ambulatorios.

5. Area administrativa (oficinas). Se precisan áreas idénticas a las de cualquier edificio de oficinas. También se necesita una dársena de carga y áreas de almacenamiento para la recepción de suministros y equipo, y para la expedición de los materiales que no se eliminen a través del sistema específico de evacuación de residuos.

6. Instalaciones dedicadas a la alimentación. Según el American Institute of Architects Committee on Architecture for Health, si se dispone de este tipo de instalaciones, se les debe dotar de los elementos siguientes: un centro de control destinado a la recepción y supervisión de los suministros de alimentos, espacios de almacenamiento (incluidas cámaras frigoríficas), instalaciones para la preparación de los alimentos, instalaciones de lavado, área de concentración y distribución de las raciones, comedor, fregaderos (situados en un cuarto u otra dependencia separada del área de preparación y servicio de las comidas) almacenes y cuartos de aseo para el personal de la cocina.

7. Areas dedicadas a la lencería (optativas). Si se dispone de estas áreas, deben constar de los elementos siguientes: una habitación dedicada a la recepción y almacenamiento de la ropa sucia, un área de almacenamiento de la lencería limpia, un área destinada a revisar y remendar la lencería limpia, y lavabos (American Institute of Architects Committee on Architecture for Health 1987).

8. Areas destinadas al equipo y los servicios técnicos. En todo centro sanitario se deben destinar unos espacios adecuados, de dimensión y características variables, a los fines siguientes: calderas (y, en su caso, almacenamiento de combustible), suministro de electricidad, generador de emergencia, talleres $\mathrm{y}$ almacenes de mantenimiento, almacenamiento de agua fría, cuartos de máquinas (para la ventilación centralizada o local) y gases anestésicos (NHS 1991a).

9. Pasillos y corredores. El diseño de estos espacios debe facilitar la orientación de los visitantes y evitar interrupciones del trabajo del personal; asimismo, los materiales limpios deben circular por vías totalmente separadas de las materias sucias. Los pasillos deben tener una anchura mínima de 2 metros (Decreto del Presidente del Consejo de Ministros 1986). Los ascensores y accesos deben ser lo bastante espaciosos para permitir la libre circulación de camillas y sillas de ruedas.

\section{Especificaciones para el mobiliario y los} materiales de construcción

En la elección de los materiales utilizados en los modernos centros sanitarios se procura normalmente disminuir el riesgo de accidentes e incendios; se eligen materiales no inflamables que no desprendan gases ni humos nocivos al arder (American Institute of Architects Committee on Architecture for Health 1987). La tendencia en la elección de materiales para el solado de los hospitales ha evolucionado del linóleo y la piedra al cloruro de polivinilo (PVG). En los quirófanos, el PVG es el material más adecuado para evitar los efectos electrostáticos que pueden hacer explosionar los gases anestésicos inflamables.

Hasta hace algunos años, las paredes se pintaban; hoy, los revestimientos de PVC y de fibra de vidrio son los acabados más utilizados en los paramentos. Los falsos techos se construyen generalmente de fibras minerales, que han reemplazado a la rasilla de yeso, y parece manifestarse una tendencia al uso del acero inoxidable en los techos (Catananti y cols. 1993). No obstante, en un enfoque integral se debe tener presente que todos los materiales y enseres pueden influir en los sistemas medioambientales externos e internos. Una elección rigurosa de los materiales de construcción no sólo permite reducir la contaminación del medio ambiente y los elevados costes sociales, sino también mejorar la seguridad y la comodidad de los ocupantes del edificio. Al mismo tiempo, los materiales y acabados interiores pueden influir en el funcionamiento y la administración del inmueble. Por otra parte, en la elección de los materiales utilizados en los hospitales se deben tomar igualmente en 
Tabla 97.16 - Criterios y variables que se deben considerar en la elección de los materiales.

\begin{tabular}{|c|c|}
\hline Criterios & Variables \\
\hline Rendimiento funcional & $\begin{array}{l}\text { Carga estática, carga en tránsito, carga de impacto, } \\
\text { durabilidad, requisitos arquitectónicos }\end{array}$ \\
\hline Seguridad & $\begin{array}{l}\text { Riesgo de rotura, riesgo de incendio (reacción al } \\
\text { fuego, pirorresistencia, inflamabilidad), carga elec- } \\
\text { trostática (riesgo de explosión), energía eléctrica } \\
\text { dispersa (riesgo de descarga eléctrica), superficie } \\
\text { áspera (riesgo de herida), riesgo de intoxicación } \\
\text { (emisiones químicas peligrosas), riesgo de desliza- } \\
\text { miento, radiactividad }\end{array}$ \\
\hline Confort y amenidad & $\begin{array}{l}\text { Confort acústico (características asociadas al ruido), } \\
\text { confort óptico y visual (características asociadas a la } \\
\text { luz), confort táctil (consistencia, superficie), confort } \\
\text { higrotérmico (características asociadas al calor), } \\
\text { aspecto estético, emisiones de olores, percepción de } \\
\text { la calidad del aire interior }\end{array}$ \\
\hline Higiene & $\begin{array}{l}\text { Hábitat de seres vivos (insectos, mohos, bacterias), } \\
\text { vulnerabilidad a las manchas y al polvo, facilidad de } \\
\text { limpieza, lavado y desinfección, procedimientos de } \\
\text { mantenimiento }\end{array}$ \\
\hline Flexibilidad & $\begin{array}{l}\text { Posibilidad de modificación, factores de conformación } \\
\text { (dimensiones y morfología de los tableros o } \\
\text { losetas) }\end{array}$ \\
\hline Impacto medioambiental & $\begin{array}{l}\text { Materias primas, fabricación industrial, gestión de } \\
\text { residuos }\end{array}$ \\
\hline Coste & $\begin{array}{l}\text { Coste de materiales, de instalación y de } \\
\text { mantenimiento }\end{array}$ \\
\hline
\end{tabular}

Fuente: Catananti y cols. 1994

consideración criterios específicos, como la facilidad de las operaciones de limpieza, fregado y desinfección y la idoneidad para servir de hábitat de seres humanos. En la Tabla 97.16 figura una clasificación más pormenorizada de los criterios que se deben valorar en esta tarea, derivados de la Directiva del Consejo $n^{\circ}$ 89/106/CE (Consejo de las Comunidades Europeas 1988).

Por lo que respecta a la emisión de olores, es de subrayar que una adecuada ventilación tras la realización de trabajos de solado o de revestimiento de paredes permite reducir la exposición de los trabajadores y pacientes a los agentes contaminantes del entorno interior (en especial a los compuestos orgánicos volátiles $(\mathrm{COV}))$ que desprenden los materiales y enseres utilizados en la construcción.

\section{Especificaciones para los sistemas de calefacción, ventilación y aire acondicionado, y para las condiciones microclimáticas}

El control de las condiciones microclimáticas vigentes en los centros sanitarios se puede ejercer a través de los sistemas de calefacción, ventilación y acondicionamiento de aire (Catananti y Cambieri 1990). Los sistemas de calefacción (por ejemplo, los radiadores) sólo permiten regular la temperatura y pueden bastar para las unidades de hospitalización comunes. La ventilación, que modifica la velocidad de circulación del aire, puede ser natural (por ejemplo, utilizando materiales de construcción porosos), complementaria (a través de las ventanas) o artificial (empleando medios mecánicos). La ventilación artificial se recomienda especialmente para las cocinas, lavanderías y áreas de servicios técnicos. Los sistemas de acondicionamiento del aire, particularmente recomendados para determinadas áreas de los centros sanitarios, como los quirófanos y las unidades de cuidados intensivos, deben asegurar:

- el control de los factores microclimáticos (temperatura, humedad relativa y velocidad de circulación del aire)

- el control de la pureza del aire y de las concentraciones de microorganismos y sustancias químicas (por ejemplo, gases anestésicos, disolventes volátiles, olores, etcétera). Esto puede conseguirse mediante una filtración y renovación adecuadas del aire, y el mantenimiento de unas relaciones de presión correctas entre las áreas adyacentes y el flujo laminar de aire.

Las especificaciones generales para los sistemas de acondicionamiento de aire se refieren al emplazamiento exterior de las tomas de aire, a los medios de filtración del aire y a los puntos de salida de éste (ASHRAE 1987). Las tomas de aire exteriores deben situarse a suficiente distancia, como mínimo 9 metros, de los focos de contaminación, como las salidas de los tubos de escape del equipo de combustión, los sistemas de vacío médicoquirúrgicos, las salidas de aire de los sistemas de ventilación del propio hospital o de los edificios adyacentes, las áreas susceptibles de captar los gases nocivos procedentes del escape de los vehículos y las salidas de los desagües. Además, deben emplazarse a una altura mínima de 1,8 metros sobre el nivel del suelo. Si estos elementos se instalan en el techo, su separación de éste debe ser, como mínimo, de 0,9 metros.

El número y la eficiencia de los filtros deben ser los adecuados para las áreas concretas servidas por los sistemas de acondicionamiento de aire. Por ejemplo, en los quirófanos, unidades de cuidados intensivos y salas de trasplante de órganos se deben instalar dos planchas filtrantes con una eficiencia del 25 y $90 \%$. La instalación y el mantenimiento de los filtros deben ajustarse a determinados criterios: ausencia de fugas entre los segmentos de los filtros y entre cada lecho filtrante y el marco de soporte, instalación en el sistema de filtros de un manómetro que permita la lectura de la presión y la detección de los filtros agotados, y dotación de instalaciones adecuadas que faciliten el mantenimiento sin contaminar el flujo de aire. Las salidas del aire fresco deben emplazarse en el techo, con un sistema perimétrico o multipunto de extracción del aire cerca del suelo (ASHRAE 1987).

En la Tabla 97.17 se indican las tasas de ventilación de las distintas áreas de los centros sanitarios que son compatibles con la pureza del aire y la comodidad de los ocupantes.

ASHRAE (1987) ha formulado las siguientes especificaciones concretas para los sistemas de acondicionamiento de aire y las condiciones microclimáticas de diversas áreas hospitalarias:

Unidades de hospitalización. En las salas comunes de hospitalización se recomienda mantener una temperatura de $24{ }^{\circ} \mathrm{C}$ y una humedad relativa del $30 \%$ en invierno, y la misma temperatura, aunque con una humedad relativa del $50 \%$, en verano. En las unidades de cuidados intensivos se recomienda mantener una escala de temperaturas entre 24 y $27^{\circ} \mathrm{C}$, con una humedad relativa mínima del $30 \%$ y máxima del $60 \%$, unida a una presión atmosférica positiva. En las unidades de hospitalización de pacientes inmunodeprimidos se debe mantener una presión positiva respecto a las áreas adyacentes, aconsejándose el empleo de filtros HEPA.

En las salas de hospitalización de pacientes de larga duración se recomienda mantener una temperatura de $24{ }^{\circ} \mathrm{C}$ y una humedad relativa oscilante entre el 30 y el $60 \%$. En las unidades de cuidados especiales se deben mantener las mismas condiciones microclimáticas que en las de cuidados intensivos. 
Tabla 97.17 - Necesidades de ventilación en distintas áreas de los centros sanitarios.

\begin{tabular}{|c|c|c|c|c|c|}
\hline Areas & $\begin{array}{l}\text { Relación de } \\
\text { presión con } \\
\text { las áreas } \\
\text { contiguas }\end{array}$ & $\begin{array}{l}\text { Renovaciones } \\
\text { mínimas de aire } \\
\text { por hora de } \\
\text { suministro a la sala } \\
\text { en aire exterior }\end{array}$ & $\begin{array}{l}\text { Renovaciones } \\
\text { mínimas totales } \\
\text { del aire por hora } \\
\text { de suministro } \\
\text { a la sala }\end{array}$ & $\begin{array}{l}\text { Todo el aire se } \\
\text { expulsa } \\
\text { directamente } \\
\text { al exterior }\end{array}$ & $\begin{array}{l}\text { Recirculado } \\
\text { dentro de } \\
\text { las salas }\end{array}$ \\
\hline \multicolumn{6}{|l|}{ Unidades de hospitalización } \\
\hline Sala de pacientes & $+/-$ & 2 & 2 & Optativo & Optativo \\
\hline Cuidados intensivos & P & 2 & 6 & Optativo & No \\
\hline Pasillo de pacientes & $+/-$ & 2 & 4 & Optativo & Optativo \\
\hline \multicolumn{6}{|l|}{ Quirófanos } \\
\hline Quirófanos (todo el sistema exterior) & $P$ & 15 & 15 & $\mathrm{Si}^{1}$ & No \\
\hline Quirófanos (sistema de recirculación) & $p$ & 5 & 25 & Optativo & $\mathrm{No}^{2}$ \\
\hline \multicolumn{6}{|l|}{ Dependencias de diagnóstico } \\
\hline Radiología & $+/-$ & 2 & 6 & Optativo & Optativo \\
\hline \multicolumn{6}{|l|}{ Laboratorios } \\
\hline Bacteriología & N & 2 & 6 & Sí & No \\
\hline Química clínica & $P$ & 2 & 6 & Optativo & No \\
\hline Anatomía patológica & N & 2 & 6 & Sí & No \\
\hline Serología & $P$ & 2 & 6 & Optativo & No \\
\hline Esterilización & N & Optativo & 10 & Sí & No \\
\hline Lavado de cristalería & N & 2 & 10 & Sí & Optativo \\
\hline \multicolumn{6}{|l|}{ Salas de alimentación } \\
\hline Centros de preparación de alimentos ${ }^{3}$ & $+/-$ & 2 & 10 & Sí & No \\
\hline Lavado de vajillas & $\mathrm{N}$ & Optativo & 10 & Sí & No \\
\hline \multicolumn{6}{|l|}{ Servicio de lencería } \\
\hline Lavandería (general) & $+/-$ & 2 & 10 & Sí & No \\
\hline $\begin{array}{l}\text { Clasificación y almacenamiento de la lencería } \\
\text { sucia }\end{array}$ & N & Optativo & 10 & Sí & No \\
\hline Almacenamiento de lencería limpia & $p$ & 2 (Optativo) & 2 & Optativo & Optativo \\
\hline
\end{tabular}

$P=$ Positiva. $N=$ Negativa. + / - = No se precisa el control continuo de la dirección.

1 En los quirófanos, el consumo de un $100 \%$ de aire procedente del exterior se debe limitar a los supuestos en que la normativa local lo exija, pero sólo si se emplea equipo de recuperación del calor. ${ }^{2}$ Se pueden utilizar sistemas de recirculación del aire en las salas que posean la capacidad de filtrado exigible en el área. ${ }^{3}$ Las áreas de preparación de alimentos deben estar dotadas de sistemas de ventilación que cuenten un exceso de suministro de aire para mantener una presión positiva cuando las campanas no funcionen. El número de renovaciones del aire se puede modificar en la medida necesaria para controlar los olores cuando el área no se utilice.

Fuente: ASHRAE 1987.

Quirófanos. En los quirófanos se recomienda mantener una escala de temperaturas entre 20 y $24^{\circ} \mathrm{C}$, así como una humedad relativa entre el 50 y el $60 \%$, y una presión positiva del aire. Se debe instalar, bien un sistema independiente de salida del aire, bien un sistema especial de aspiración, con objeto de eliminar los restos de gases anestésicos (véase, en este mismo capítulo, el artículo "Gases anestésicos residuales").

Unidades de diagnóstico. En el área de radiología, las salas de radioscopia y de radiografía precisan temperaturas de 24 a $27^{\circ} \mathrm{C}$ y una humedad relativa del 40 al $50 \%$. Los laboratorios se deben dotar de unos sistemas adecuados de extracción provistos de campanas, con objeto de reducir el volumen de humos, vapores y bioaerosoles peligrosos. El aire expulsado de las campanas de las unidades de laboratorio clínico, bacteriología y anatomopatología se debe descargar en el exterior, sin recircular. Asimismo, el aire expulsado de los laboratorios de enfermedades infecciosas y virología se debe esterilizar antes de expulsarse al exterior.
Area de preparación de alimentos. Se deben instalar campanas sobre las cocinas con objeto de eliminar el calor y los olores y humos.

Servicios de lencería. En el cuarto de distribución se debe mantener una presión negativa respecto de las áreas adyacentes. En la zona de planchado y preparación se deben colocar sistemas de extracción directa sobre las lavadoras y planchadoras mecánicas, con objeto de reducir la humedad.

Areas de servicios técnicos y equipo. En todos los lugares de trabajo se deben instalar sistemas de ventilación que limiten la temperatura a $32{ }^{\circ} \mathrm{C}$.

\section{Conclusiones}

La base de las especificaciones arquitectónicas especiales para los centros sanitarios es la adaptación de las especificaciones normalizadas de uso general a unas directrices basadas en índices de carácter subjetivo. Ciertamente, los índices subjetivos, del tipo del Predicted Mean Vote (PMV) (Fanger 1973) y el olf, una medida 
del olor (Fanger 1992), permiten formular predicciones de los niveles de comodidad de los pacientes y trabajadores sin pasar por alto las diferencias relativas a la vestimenta, el metabolismo y el estado de salud. Por último, los planificadores y arquitectos diseñadores de hospitales deben aplicar las enseñanzas de la "ecología de la construcción" (Levin 1992), para la que la vivienda implica una serie completa de interacciones entre los edificios, sus ocupantes y el medio ambiente. Por consiguiente, en la planificación y construcción de los centros sanitarios se debe tomar en consideración más el conjunto del "sistema" que determinados marcos de referencia parciales.

\section{HOSPITALES: PROBLEMAS DE SALUD PUBLICA Y MEDIOAMBIENTALES}

M.P. Arias

Un hospital no es un entorno social aislado; su misión le impone unas responsabilidades sociales muy serias. El hospital debe integrarse en su entorno y tratar de reducir sus efectos sobre éste, contribuyendo así al bienestar de quienes viven en las proximidades.

Desde una perspectiva normativa, el sector sanitario nunca se ha situado al mismo nivel que los demás en cuanto a los riesgos sanitarios implícitos. Como consecuencia, hasta hace poco no ha existido una legislación específica al respecto, si bien en estos últimos años se ha procurado subsanar tal deficiencia. A diferencia de lo que ocurre en muchas otras actividades, en las que la salud y la seguridad se integran en la organización, en la mayoría de los centros sanitarios se presta aún muy escasa atención al problema.

Esto podría obedecer, en parte, a la actitud de los propios trabajadores sanitarios, que a veces se muestran más interesados en la investigación y la adquisición de nuevas tecnologías y en las más modernas técnicas de tratamiento y diagnóstico que en investigar los efectos que estos avances pueden tener en su propia salud y en el medio ambiente.

El progreso de la ciencia y la asistencia sanitaria se debe combinar con la protección del medio ambiente, ya que las políticas medioambientales aplicadas en un hospital pueden afectar a la calidad de vida tanto de sus propios trabajadores como de las personas que viven en el entorno.

\section{Programas integrados de salud, seguridad y medio ambiente}

Los trabajadores sanitarios constituyen un grupo importante, de dimensión comparable a las grandes empresas del sector privado. Todos los días acude a los hospitales un número considerable de personas, visitantes, pacientes hospitalarios y ambulatorios, representantes comerciales y de productos médicos, subcontratistas, etcétera, todos los cuales se exponen en mayor o menor medida a los riesgos potenciales generados por las actividades realizadas y, al mismo tiempo, contribuyen en alguna medida a mejorar o empeorar la seguridad y el cuidado del entorno de los propios centros.

Se impone la adopción de medidas estrictas para proteger a los trabajadores sanitarios, al gran público y al entorno circundante de los efectos nocivos de la actividad hospitalaria. Esta actividad implica el uso de tecnologías crecientemente complejas, la administración de fármacos sumamente potentes (cuya manipulación puede surtir efectos importantes e irreparables en quienes los preparan y administran), el empleo frecuentemente incontrolado de sustancias químicas y la exposición a enfermedades infecciosas que, en algunos casos, son incurables.

Los riesgos del trabajo sanitario son múltiples. Algunos se detectan fácilmente; otros, en cambio, resultan muy difíciles de identificar, lo cual obliga a que las medidas que se adopten deban ser, en todos los casos, rigurosas.

Algunas categorías de profesionales sanitarios experimentan una exposición especialmente intensa a los riesgos comunes al conjunto de este sector, además de los riesgos específicos de su profesión o de la actividad laboral que realizan.

Esto implica la necesidad de incorporar el concepto de prevención a la cultura de la asistencia sanitaria, desde tres perspectivas distintas:

- la seguridad, en el sentido más amplio del término, con inclusión de la psicología social y la ergonomía en los programas de mejora de la calidad de vida en el lugar de trabajo

- la higiene, en el sentido de reducción en la máxima medida posible de la presencia de factores físicos, químicos y biológicos capaces de afectar la salud de las personas presentes en el medio ambiente de trabajo

- el medio ambiente, mediante la adopción de medidas de protección de la naturaleza y de las personas que viven en la comunidad circundante, y de reducción de los efectos en el medio ambiente.

Debemos ser conscientes de que el medio ambiente se asocia directa y estrechamente a la seguridad e higiene en el lugar de trabajo, dado que en éste se consumen recursos naturales y éstos recursos se reincorporan más tarde al entorno exterior. Nuestra calidad de vida será mejor o peor según que utilicemos adecuadamente o no esos recursos y las tecnologías adecuadas.

Se precisa la participación de todos en el esfuerzo por establecer:

- unas políticas de conservación de la naturaleza que aseguren la supervivencia del patrimonio natural que nos rodea

- unas políticas de mejora del medio ambiente y de control de la contaminación interior y medioambiental encaminadas a integrar la actividad humana en el medio ambiente

- una investigación medioambiental y unas políticas de formación que permitan mejorar las condiciones de trabajo y reducir los efectos sobre el medio ambiente

- un diseño de las políticas organizativas que permita fijar objetivos y elaborar normas y metodologías de protección de la salud de los trabajadores y del medio ambiente.

\section{Objetivos}

El objetivo de este programa debe ser:

- modificar la cultura y los hábitos de los profesionales sanitarios en el sentido de promover los comportamientos más adecuados a la protección de su salud

- fijar unos objetivos y establecer unas pautas de seguridad interior, higiene y protección medioambiental, a través de una planificación y una organización adecuadas

- a través de la investigación y la educación medioambiental, mejorar los métodos de trabajo con objeto de evitar repercusiones negativas en la salud y el medio ambiente

- promover la participación de todos los trabajadores y responsabilizarles de la protección de la salud en el lugar de trabajo

- desarrollar un programa eficaz, tanto de promulgación y divulgación de directrices, como de supervisión de su observancia continua

- clasificar y gestionar correctamente los residuos generados 
- controlar los costes, evitando los gastos añadidos que no tengan una contrapartida en el incremento de los niveles de salud y seguridad o de calidad medioambiental.

\section{Plan}

Un hospital se puede concebir como un sistema en el que, mediante diversos procesos, se prestan una serie de servicios que constituyen su objetivo principal.

Antes de iniciar el proceso, se necesita un determinado volumen de energía, inversión y tecnología, que, a su vez, genera determinadas emisiones y residuos. El único objetivo consiste en prestar servicios.

Además de estos requisitos previos, se deben tomar en consideración las condiciones existentes en las áreas del edificio en que hayan de desarrollarse las actividades, dado que aquéllas tienen un diseño determinado y se han construido con ciertos materiales básicos.

El éxito de un proyecto integrado de salud, seguridad y medio ambiente descansa en el control, la planificación y la coordinación.

\section{Metodología}

La complejidad y diversidad de los riesgos presentes en el campo de la asistencia sanitaria exige la creación de grupos multidisciplinarios si se quiere solucionar cada problema específico.

Es preciso que los trabajadores sanitarios puedan colaborar en los estudios de seguridad y participar en la toma de decisiones destinadas a mejorar sus condiciones de trabajo. Esto genera una actitud más positiva ante los cambios y un mayor grado de aceptación de las directrices.

Los servicios de seguridad, higiene y protección medioambiental deben asesorar, estimular y coordinar los programas que se desarrollan en el centro. La responsabilidad de su ejecución debe recaer en los directores del servicio en que se ejecute el programa. Este es el único modo de que participe el conjunto de la organización.

En cada caso concreto, se deben determinar las variables siguientes:

- sistema utilizado

- parámetros del estudio

- tiempo de ejecución.

El estudio ha de constar de los elementos siguientes:

- diagnóstico inicial

- análisis del riesgo

- decisión sobre la línea de actuación.

Para que la ejecución del plan sea eficaz, será preciso, en todos los casos:

- educar e informar al público sobre los riesgos

- mejorara la gestión de los recursos humanos

- perfeccionar los canales de comunicación.

El estudio puede ser de naturaleza global y abarcar el centro sanitario en su conjunto (ejemplo, sistema interno de evacuación de los residuos hospitalarios), o puede ser parcial y limitarse a un área concreta (por ejemplo, la de preparación de los fármacos utilizados en la quimioterapia del cáncer).

El estudio de estos factores permite hacer una estimación del grado en que no se cumplen las medidas de seguridad, tanto desde el punto de vista jurídico como desde la perspectiva científica. En este contexto, el concepto jurídico comprende los avances científicos y tecnológicos que se van produciendo y que requieren una revisión y modificación continuas de la normativa vigente.
Sería, ciertamente, muy deseable que las leyes y los reglamentos aplicables a la seguridad, higiene y protección medioambiental fuesen idénticos en todos los países, ya que esto facilitaría extraordinariamente el uso y gestión de los productos y tecnologías externos.

\section{Resultados}

Los ejemplos siguientes ilustran algunas de las medidas que se pueden adoptar en la aplicación de la metodología expuesta.

\section{Laboratorios}

Se puede crear un servicio de asesoramiento, integrado por profesionales de los diversos laboratorios y coordinado por el servicio de seguridad e higiene del centro sanitario. El objetivo central consistiría en mejorar la seguridad e higiene del personal de todos los laboratorios, implicando y responsabilizando a la totalidad de los profesionales de cada laboratorio y procurando, al mismo tiempo, que su actividad no repercuta negativamente en la salud pública ni en el medio ambiente.

Se deben adoptar las medidas siguientes:

- establecer el uso compartido de materiales, productos y equipo entre los diferentes laboratorios, con objeto de mejorar el aprovechamiento de los recursos

- reducir las existencias de productos químicos en los laboratorios

- preparar un manual básico de seguridad e higiene

- impartir cursos de formación de todo el personal de laboratorio en estas cuestiones

- entrenamiento para afrontar las urgencias.

\section{Mercurio}

Al romperse un termómetro, el mercurio se derrama en el entorno. Se ha puesto en práctica un proyecto piloto de desarrollo de termómetros irrompibles, para lograr que finalmente reemplacen a los de vidrio. En algunos países, como Estados Unidos, los termómetros electrónicos han reemplazado en gran medida a los de mercurio.

\section{Formación de los trabajadores}

La formación y participación de los trabajadores es el elemento central de todo programa integral de salud, seguridad y protección del medio ambiente. Aunque disponiendo de tiempo y de recursos suficientes se pueden superar casi todos los escollos técnicos presentes en un problema, no es posible alcanzar una solución definitiva sin informar a los trabajadores de los riesgos y enseñarles a controlarlos y evitarlos. La educación y formación deben ser un proceso continuo e integrador de las medidas de salud y seguridad en el resto de los programas de formación del hospital.

\section{Conclusiones}

Los resultados logrados hasta ahora en la aplicación de este método de trabajo avalan nuestro optimismo. De hecho, indican que, si se informa a las personas de los motivos de las cosas, su actitud ante el cambio se hace muy positiva.

La reacción del personal de asistencia sanitaria ha sido muy positiva, y se siente más motivado en su trabajo y mejor valorado si participa directamente en el proceso de estudio y de toma de decisiones. A su vez, esta participación contribuye a educar al trabajador sanitario y a extender el grado de responsabilidad que está dispuesto a aceptar.

Aunque los objetivos del proyecto son a largo plazo, sus efectos positivos compensan con creces el esfuerzo y la energía invertidos en el mismo. 


\section{TRATAMIENTO DE LOS RESIDUOS HOSPITALARIOS}

M.P. Arias

La adaptación de las directrices vigentes en materia de evacuación de los residuos hospitalarios y la mejora del nivel interno de seguridad e higiene se deben integrar en un plan global de gestión de los residuos hospitalarios en el que se fijen los objetivos deseados. Esto se debe perseguir coordinando correctamente los servicios interiores y exteriores, así como concretando las responsabilidades en cada una de las fases de la gestión. El objetivo central del plan consiste en proteger la salud de los trabajadores sanitarios y de los pacientes, visitantes y público en general, en el hospital y fuera de él.

Tampoco se puede pasar por alto la salud de las personas que entran en contacto con los residuos, una vez que éstos han abandonado el hospital: por el contrario, es preciso reducir el riesgo para las mismas.

El plan se debe promover y aplicar en el marco de una estrategia global en la que se tomen permanentemente en consideración tanto las realidades del lugar de trabajo como el conocimiento y la formación del personal implicado.

En la ejecución de un plan de tratamiento de los residuos se siguen las etapas siguientes:

- informar a la dirección del centro sanitario

- designar a las personas responsables en el nivel ejecutivo

- crear un comité de tratamiento de residuos, integrado por personal de los servicios generales y de los servicios médicos y de enfermería, presidido por el director de evacuación de residuos.

El comité debe estar integrado por personal de servicios generales y de los servicios médicos y de enfermería. Su coordinación corresponde al director de gestión de residuos del centro sanitarios, que ha de actuar:

- elaborando un informe sobre el funcionamiento actual del servicio de tratamiento de residuos del centro

- elaborando un plan de mejora del tratamiento

- elaborando, en colaboración con el departamento de recursos humanos, un programa de formación de la totalidad del personal del centro

- ejecutando el plan bajo el control y seguimiento del comité de tratamiento de residuos.

\section{Clasificación de los residuos hospitalarios}

Hasta 1992, el sistema seguido en el marco del concepto clásico de gestión de los residuos consistía en clasificar la mayoría de los residuos hospitalarios como peligrosos. A partir de entonces se ha venido aplicando una filosofía más avanzada de la gestión, en virtud de la cual sólo se considera peligroso un pequeño porcentaje del enorme volumen de residuos generados.

Se tiende a la adopción de un criterio de gestión avanzado. Según este criterio, la clasificación de los residuos descansa en la presunción de que sólo un pequeño porcentaje de los mismos es peligroso.

Los residuos se deben clasificar siempre en el punto de emisión y se distinguen, en función de su naturaleza y de su fuente, en los grupos siguientes:

- Grupo I: residuos que se pueden asimilar a los desechos urbanos.

- Grupo II: residuos hospitalarios no específicos.
- Grupo III: residuos hospitalarios específicos o residuos peligrosos.

- Grupo IV: residuos citostáticos (sobrantes de fármacos antineoplásicos no adecuados para fines terapéuticos, así como los materiales no reutilizables que hayan estado en contacto con ellos, como agujas, jeringuillas, catéteres, guantes y medios de inyección intravenosa).

En función de su estado fisico, los residuos se pueden clasificar como sigue:

- sólidos: residuos con un contenido líquido inferior al $10 \%$

- líquidos: residuos con un contenido líquido superior al $10 \%$.

Los residuos gaseosos, como los clorofluorocarbonos (CFG) procedentes de congeladores y frigoríficos, no se suelen recoger (véase el artículo "Gases anestésicos residuales").

Por antonomasia, no se consideran de carácter sanitario los residuos siguientes:

- los residuos radiactivos que, por su naturaleza misma, se manipulen de forma específica en los servicios de protección radiológica

- los cadáveres y grandes piezas anatómicas que se quemen o se incineren de conformidad con las normas aplicables

- las aguas residuales.

\section{Residuos del grupo I}

Todos los residuos generados en los centros sanitarios que no se asocian directamente a la asistencia sanitaria se consideran residuos sólidos urbanos. Según las disposiciones vigentes de la Generalidad de Cataluña - y en la mayoría de las otras comunidades autónomas españolas -, los municipios deben realizar una recogida selectiva de los residuos, por lo que es conveniente facilitarles la labor. Los residuos siguientes son asimilables a los desechos urbanos en función de su lugar de origen:

\section{Residuos alimentarios}

- restos de alimentos

- alimentos sobrantes y productos de ración

- contenedores.

Residuos generados por los usuarios del hospital y por el personal no sanitario

- residuos de los productos de limpieza

- residuos abandonados en las habitaciones (por ejemplo, periódicos, revistas y flores)

- residuos generados por los trabajos de jardinería y las reformas.

Residuos generados por las actividades administrativas

- papel y cartón

- plásticos.

Otros residuos

- contenedores de vidrio

- contenedores de plástico

- envases de cartón y otros materiales de embalaje

- productos de ración caducados.

Los residuos sólidos urbanos no incluidos en otras categorías de evacuación selectiva se echan en bolsas de polietileno blancas que evacúan los subalternos.

\section{Residuos del grupo II}

En el grupo II se incluyen todos los residuos generados como subproductos de las actividades sanitarias que no constituyen un riesgo para la salud ni el medio ambiente. Por motivos de seguridad e higiene industrial, el tipo de gestión interna recomendado 
para este grupo difiere del que se propone para los residuos del grupo I.

\section{Residuos generados por las actividades hospitalarias:}

- materiales manchados de sangre

- gasas y otros materiales utilizados en el tratamiento de los pacientes no infecciosos

- equipo sanitario usado

- colchones

- cadáveres de animales o piezas anatómicas de los mismos, procedentes de los centros de cría o de los laboratorios, siempre que no se les hayan inoculado agentes infecciosos.

Los residuos del grupo II se depositan en bolsas de polietileno amarillas, que evacúa el personal subalterno.

\section{Residuos del grupo III}

En el grupo III se incluyen los residuos hospitalarios que, por su naturaleza o su origen, pueden producir riesgos a la salud o el medio ambiente si no se adoptan determinadas precauciones durante su manipulación y evacuación.

Los residuos del grupo III se clasifican como sigue:

Instrumentos afilados y puntiagudos:

- agujas

- bisturíes.

Residuos infecciosos. En la Tabla 97.18 se relacionan los residuos del grupo III (incluidos los materiales de un solo uso) generados por el diagnóstico y tratamiento de los pacientes con enfermedades infecciosas.

\section{Residuos de laboratorio:}

- materiales contaminados con residuos biológicos

- residuos generados por el trabajo con animales inoculados con sustancias biológicamente peligrosas.

Los residuos del grupo III se depositan en contenedores rígidos de polietileno, no reutilizables, identificables mediante un código de colores y herméticamente sellados (en Cataluña se exige el color negro). Los contenedores - en cuyas etiquetas se debe indicar claramente que contienen "residuos hospitalarios peligrosos" - deben mantenerse en la sala hasta su recogida por el personal subalterno. Los residuos del grupo III no se deben comprimir en ningún caso.

Con objeto de facilitar su evacuación y reducir el riesgo en la mayor medida posible, los contenedores no se deben rellenar totalmente, de modo que puedan cerrarse con facilidad. No hay que manipular los residuos una vez colocados en estos contenedores rígidos. Está prohibido evacuar los residuos biológicamente peligrosos vertiéndolos en el sistema de desagüe.

\section{Residuos del grupo IV}

Los residuos del grupo IV son los sobrantes de fármacos antineoplásicos no aptos para fines terapéuticos, así como el material no reutilizable que haya estado en contacto con aquéllos (agujas, jeringuillas, catéteres, guantes, instrumentos para inyección intravenosa, etcétera).

Por el peligro que suponen para las personas y el medio ambiente, los residuos hospitalarios del grupo IV se deben recoger en contenedores rígidos, impermeables, no reutilizables y sellados, identificables mediante un código de color (que en Cataluña es azul). Además, en las etiquetas se debe indicar nítidamente: "Material contaminado químicamente: agentes citostáticos".
Tabla 97.18 - Enfermedades infecciosas y residuos de grupo III.

$\begin{array}{ll}\text { Infecciones } & \text { Residuos contaminados } \\ \text { Fiebres hemorrágicas víricas } & \text { Todo tipo de residuos } \\ \text { Fiebre congo-crimeana } & \\ \text { Fiebre de Lassa } & \\ \text { Virus Marburg } & \\ \text { Ebola } & \\ \text { Fiebre de Junín } & \\ \text { Fiebre de Machupo } & \\ \text { Arbovirus } & \\ \text { Absettarow } & \\ \text { Hanzalova } & \\ \text { Hypr } & \\ \text { Kumlinge } & \\ \text { Enfermedad del bosque de } & \\ \text { Kiasanur } & \\ \text { Fiebre de Omsk } & \\ \text { Encefalitis rusa de } & \\ \text { primavera-verano } & \\ \text { Brucelosis } & \\ \text { Difteria } & \text { Pus } \\ & \text { Difteria faríngea: secreciones respiratorias } \\ & \text { Difteria cutánea: secreciones de lesiones } \\ \text { Cólera } & \text { cutáneas } \\ \text { Encefalitis de Creutzfelt-Jakob } & \text { Heces } \\ \text { Borm } & \text { Heces } \\ \text { Tularemia } & \text { Secreciones de lesiones cutáneas } \\ & \text { Tularemia pulmonar: secreciones respiratorias } \\ \text { Antrax } & \text { Tularemia cutánea: pus } \\ \text { Peste } & \text { Antrax cutáneo: pus } \\ \text { Rabia } & \text { Antrax respiratorio: secreciones respiratorias } \\ \text { Fiebre Q } & \text { Peste bubónica: pus } \\ \text { Tuberculosis activa } & \text { Peste neumónica: secreciones respiratorias } \\ & \text { Secreciones respiratorias } \\ & \text { Secreciones respiratorias } \\ & \text { Secreciones respiratorias } \\ & \\ & \\ & \end{array}$

\section{Otros residuos}

Inspirados en la conciencia medioambiental y en la necesidad de mejorar la gestión de los residuos en beneficio de la comunidad, los centros sanitarios, con la colaboración de todo el personal, los visitantes y los profesionales sanitarios, deben promover y facilitar la evacuación selectiva (esto es, en contenedores especiales) de materiales reciclables como los siguientes:

- papel y cartón

- vidrio

- aceites usados

- pilas

- cartuchos de tóner para impresoras de láser

- contenedores de plástico.

Se deben aplicar las ordenanzas dictadas por las autoridades sanitarias locales sobre la recogida, el transporte y la eliminación de estos tipos de materiales.

La evacuación de equipo, mobiliario y otros materiales voluminosos no descritos en estas directrices se debe ajustar a las normas dictadas por las autoridades competentes en materia medioambiental. 


\section{Transporte interno y almacenamiento de los residuos}

El personal subalterno se debe encargar del trasiego interno de todos los residuos generados dentro del hospital, según unos horarios fijos. Es preciso observar las recomendaciones siguientes en el transporte de residuos dentro del hospital:

- Los contenedores y bolsas deben permanecer cerrados durante el transporte

- Los carrillos dedicados a esta labor deben tener una superficie lisa y ser fáciles de limpiar

- Los carrillos se deben dedicar exclusivamente al transporte de residuos

- Los carrillos se deben fregar diariamente con agua, jabón y lejía

- Los contenedores y bolsas con residuos no se deben arrastrar por el suelo

- Los residuos no se deben transferir de un receptáculo a otro.

Es preciso dedicar un área del hospital a la función específica de almacenar residuos. Este espacio se debe ajustar a las normas vigentes y satisfacer, en particular, los requisitos siguientes:

- estar cubierto

- identificarse claramente mediante letreros

- presentar superficies lisas, de fácil limpieza

- estar dotado de agua potable

- disponer de desagües que faciliten la eliminación de los residuos líquidos y del agua utilizada para fregar el área de almacenamiento

- dotarse de un sistema de protección contra las plagas animales

- emplazarse lejos de las ventanas y de las entradas de aire de los sistemas de ventilación

- dotarse de sistemas de extinción de incendios

- ser de acceso restringido

- dedicarse exclusivamente al almacenamiento de residuos.

Todas las operaciones de trasiego y almacenamiento de residuos hospitalarios se deben realizar en las máximas condiciones de seguridad e higiene. Es preciso recordar, en especial, lo siguiente:

- se debe evitar el contacto directo con los residuos

- las bolsas no se deben llenar en exceso, con objeto de facilitar su cierre

- no hay que vaciar el contenido de las bolsas en otras bolsas.

\section{Residuos líquidos: biológicos y químicos}

Los residuos líquidos se dividen en biológicos y químicos

\section{Residuos líquidos biológicos}

Por regla general, los residuos líquidos biológicos se pueden verter directamente en el sistema de desagüe del hospital, dado que no precisan tratamiento alguno previo a su evacuación. Las excepciones a la regla son los residuos líquidos generados por los pacientes con enfermedades infecciosas y los cultivos líquidos de los laboratorios de microbiología, que se recogen en unos contenedores especiales antes de evacuarse.

Es preciso verter los residuos directamente en el sistema de desagüe y evitar salpicaduras y derrames. Si esto no es posible y los residuos se recogen en contenedores no reutilizables difíciles de abrir, no se debe forzar la apertura, sino evacuar el contenedor sin abrir, al igual que con los residuos sólidos del grupo III. Si los residuos líquidos se eliminan del mismo modo que los sólidos del grupo citado, se debe tener presente que las condicione de trabajo difieren en la desinfección de los residuos sólidos y líquidos. Esto se debe tener en cuenta para garantizar la eficacia del tratamiento.

\section{Residuos líquidos químicos}

Los residuos líquidos químicos generados en los hospitales (por regla general, en los laboratorios) se clasifican en los grupos siguientes:

- residuos líquidos que no deben verterse en los desagües

- residuos líquidos que se pueden verter en los desagües después de tratarse

- residuos líquidos que se pueden verter en los desagües sin necesidad de tratamiento previo.

Esta clasificación se basa en ciertos principios de protección de la salud y la calidad de vida de la comunidad en su conjunto. En concreto, se protegen:

- el suministro de agua

- el sistema de alcantarillado

- las plantas de depuración de las aguas residuales.

Los residuos líquidos que entrañen un grave riesgo para las personas o el medio ambiente por su carácter tóxico, nocivo, inflamable, corrosivo o cancerígeno se deben recoger separadamente para facilitar su posterior recuperación o destrucción. La recogida se hace como sigue:

- cada clase de residuo líquido se debe recoger en un contenedor independiente

- el contenedor se debe etiquetar, con indicación del nombre del producto o del principal componente, por su volumen,

- cada laboratorio, excepto el de anatomía patológica, debe suministrar sus propios contenedores para los residuos líquidos, cuyos contenedores deben etiquetarse correctamente, con indicación del material o del grupo de materiales que contiene. Periódicamente (a ser posible, al finalizar cada día laborable), estos contenedores se deben vaciar en otros contenedores perfectamente etiquetados, que se mantengan en la sala para ser regularmente retirados por el subcontratista encargado de evacuar el material en cuestión

- una vez etiquetados todos los receptáculos con el nombre del producto o grupo de productos que contenga, se deben introducir en contenedores especiales en los respectivos laboratorios

- el responsable del laboratorio o la persona en quien éste delegue debe firmar o sellar un justificante de control.

A continuación, el subcontratista debe entregar este justificante en el departamento responsable de la seguridad, higiene y protección del medio ambiente.

\section{Mezclas de residuos líquidos químicos y biológicos}

El tratamiento de los residuos químicos es más agresivo que el de los residuos biológicos, y las mezclas de ambas clases de residuos se deben tratar como si se tratase de residuos meramente químicos. En el etiquetado de los contenedores se debe indicar la presencia de residuos biológicos.

Los materiales, líquidos o sólidos, que posean propiedades cancerígenas, mutágenas o teratógenas se deben evacuar en contenedores rígidos, identificados mediante un código de colores y específicamente diseñados y etiquetados para este tipo de residuos.

Los cadáveres de animales que hayan sido inoculados con sustancias biológicamente peligrosas se deben colocar, para su evacuación, en contenedores rígidos cerrados, que se esterilicen antes de reutilizarse.

\section{Eliminación de instrumentos afilados y puntiagudos}

Una vez utilizados, los instrumentos afilados y puntiagudos (como agujas y lancetas) se deben introducir en contenedores rígidos, especialmente diseñado para instrumentos cortantes distribuidos 
estratégicamente por el hospital Estos instrumentos se eliminan como residuos peligrosos, aunque se hayan utilizado en pacientes no infecciosos. Se deben colocar siempre en los recipientes rígidos mencionados.

Se debe advertir reiteradamente a todos los trabajadores sanitarios del peligro de sufrir cortes y pinchazos accidentales, e insistir en que comuniquen cualquier accidente que se produzca, con objeto de facilitar la adopción de medidas preventivas. Se les debe advertir, especialmente, de que no traten de reponer el casquete de las agujas hipodérmicas usada antes de ponerlas en el contenedor correspondiente.

Siempre que sea posible, las agujas que hayan de colocarse sin recubrir en el contenedor de instrumentos afilados se deben separar de las jeringuillas, que, una vez despojadas de la aguja, se pueden eliminar como residuos del grupo II. Muchos contenedores llevan incorporado un dispositivo que permite separar la jeringuilla de la aguja sin riesgo de sufrir pinchazos, con lo que, además, se consigue más espacio libre en el contenedor para las agujas. La evacuación de estos contenedores especiales para instrumentos afilados, que el personal sanitario no debe abrir en ningún caso, se encomienda al personal subalterno, que se encarga de depositarlo en los puntos designados para la posterior eliminación de su contenido.

$\mathrm{Si}$ no resultase posible separar la aguja en condiciones mínimas de seguridad, la estructura formada por la aguja y la jeringuilla se debe clasificar como biológicamente peligrosa y guardarse en los recipientes especiales para instrumentos afilados.

El personal subalterno se responsabiliza de retirar estos materiales.

\section{Formación del personal}

Se debe poner en práctica un programa de formación continua diseñado para educar a los trabajadores de todos los niveles en la necesidad de observar siempre las instrucciones sobre recogida, almacenamiento y eliminación de todo tipo de residuos. Es especialmente importante educar al personal subalterno y de limpieza en los detalles de los protocolos de identificación y manipulación de las diversas categorías de residuos peligrosos. Igualmente, es preciso formar al personal subalterno, de seguridad y de lucha contra incendios en la adopción de medidas adecuadas en caso de urgencia.

También es importante informar y educar al personal subalterno en la adopción de medidas adecuadas en caso de accidente.

Especialmente al inicio del programa, se debe instar al personal subalterno a que informe de cualquier problema capaz de obstaculizar la realización de estas tareas. A este fin, se le puede facilitar fichas o impresos en los que anotar las incidencias.

\section{Comité de tratamiento de residuos}

Se debe crear un comité permanente de tratamiento de residuos que se reúna regularmente, con periodicidad mínima trimestral, para controlar la ejecución del programa y resolver los problemas que dificulten su ejecución. Este comité, que debe tener acceso, en caso necesario, a la alta dirección, ha de estar abierto a todos los trabajadores del hospital que tengan algún problema o preocupación en relación con la eliminación de los residuos.

\section{Ejecución del plan}

La forma en que se gestione el programa de tratamiento de residuos puede resultar determinante de su éxito o fracaso.

Dado que el apoyo y la cooperación de los diferentes comités y servicios del hospital son fundamentales, es preciso que estamentos como el personal administrativo, el comité de seguridad e higiene y el comité de prevención de infecciones conozcan los detalles del programa. Resulta igualmente necesario conseguir la homologación del mismo por parte de organismos locales como el departamento de salud, sanidad y protección del medio ambiente. Todos estos organismos pueden aportar sugerencias útiles, en particular por lo que respecta a los efectos del programa en sus respectivas áreas de competencia.

Concluido el diseño del programa, la ejecución de un ensayo piloto en un área o departamento seleccionado permitirá limar algunas asperezas y superar eventuales problemas imprevistos. Finalizado el ensayo piloto y analizados los resultados, se puede implantar gradualmente el programa en el conjunto del centro sanitario. Se puede organizar una sesión de presentación del programa en cada unidad o departamento, apoyada por medios audiovisuales, acompañada de la distribución de textos explicativos y seguida de la entrega de los contenedores y bolsas necesarios. Una vez iniciado el programa, una visita de inspección del departamento o la unidad en cuestión permitiría realizar las rectificaciones precisas. Esto serviría de cauce al apoyo y la participación de todo el personal, sin los cuales ningún programa puede lograr sus objetivos.

\section{MANEJO DE LA ELIMINACION DE LOS RESIDUOS SANITARIOS PELIGROSOS SEGUN ISO 14000}

\section{Jerry Spiegel y John Reimer}

En uno de los más importantes complejos hospitalarios docentes de Canadá se ha desarrollado e iniciado la aplicación de un Sistema de Gestión del Medio Ambiente, en el que se utiliza la norma 14001 de la Organización Internacional de Normalización (ISO) como especificación de la actuación. El centro, denominado Health Sciences Centre (HSC), está integrado por cinco hospitales y los correspondientes laboratorios clínicos y de investigación, y ocupa una superficie de unas 15 hectáreas en la región central de Winnipeg. Siete de los 32 flujos de residuos sólidos producidos en el complejo se consideran peligrosos. El texto que sigue es un resumen de las operaciones hospitalarias dirigidas a la eliminación de los residuos peligrosos.

\section{ISO 14000}

El sistema de normas ISO 14000 es un típico modelo de perfeccionamiento continuo basado en un sistema de gestión controlada. La norma ISO 14001 se ciñe exclusivamente a la estructura del sistema de gestión del medio ambiente. Las organizaciones que observan esta norma implantan procedimientos orientados a lo siguiente:

- adoptar una política medioambiental que conceda una elevada prioridad a la protección del medio ambiente

- detectar consecuencias medioambientales y fijar objetivos de actuación

- identificar y cumplir los requisitos legales

- establecer esquemas de competencias y responsabilidades en materia de medio ambiente en el conjunto de la empresa

- implantar controles del cumplimiento de la normativa legal y del logro de los objetivos de actuación

- supervisar e informar de la actuación en materia de medio ambiente, y auditar el Sistema de Gestión del Medio Ambiente

- evaluar la gestión e investigar las posibilidades de mejora.

En la Tabla 97.19 se describe la estructura jerárquica implantada en el HSC para la ejecución de todos estos procesos. 
El objetivo de las normas ISO consiste en inducir a las empresas a incorporar todos los valores medioambientales a la toma de las grandes decisiones y a no limitarse al cumplimiento de la legalidad establecida. Puesto que las normas ISO no son documentos técnicos, la responsabilidad de cuantificar los objetivos continúa correspondiendo a los organismos públicos o a las organizaciones especializadas independientes.

\section{Concepto del sistema de gestión}

La aplicación del marco normativo global de la ISO en un determinado centro sanitario se basa en la aplicación de unos sistemas de gestión del tipo que se describe en la Tabla 97.19 en la que se expone la forma en que el HSC ha abordado esta cuestión. Cada nivel del sistema se apoya en una documentación diseñada para confirmar la diligente ejecución del proceso. Si bien esto supone un volumen considerable de trabajo, el esfuerzo se compensa con la coherencia de los resultados obtenidos y con la información especializada que la empresa conserva aunque algún personal cualificado abandone la empresa.

El objetivo principal del Sistema de Gestión del Medio Ambiente consiste en la implantación de unos procedimientos congruentes, controlados y repetitivos de tratamiento de los aspectos medioambientales. Se ha diseñado un baremo de puntuación, basado en la norma ISO 14001, para facilitar a la dirección la evaluación del rendimiento del hospital. Este baremo se ajusta estrechamente a los parámetros de la norma ISO 14001 y, con la experiencia, se convertirá en el protocolo de auditoría del hospital.

\section{Aplicación del Sistema de Gestión del Medio Ambiente al tratamiento de los residuos peligrosos}

Tratamiento in situ de los residuos peligrosos

$\mathrm{El}$ actual sistema de tratamiento de los residuos peligrosos en el HSC consta de los aspectos siguientes:

- protocolo de asignación de responsabilidades
- descripción del proceso en forma textual y mediante un diagrama de flujo

- Guía de evacuación de los residuos peligrosos, destinada al personal

- programa de educación del personal

- sistema de monitorización del rendimiento

- mejora continua mediante el trabajo en equipos multidisciplinarios

- procedimiento de búsqueda de colaboradores externos.

En la Tabla 97.20 se describen las funciones y responsabilidades de las cuatro principales unidades de la organización que participan en el tratamiento de los residuos peligrosos.

\section{Descripción del proceso}

El primer paso en la descripción de un proceso consiste en concretar los factores (véase la Tabla 97.21).

$\mathrm{El}$ siguiente paso es relacionar las actividades que intervienen en la correcta evacuación de los residuos (véase la Tabla 97.22).

\section{Comunicación}

En apoyo de la descripción del proceso, el hospital preparó una Guía para la evacuación de los residuos peligrosos, destinada a la formación del personal en la correcta evacuación de los materiales residuales peligrosos. En ella se ofrece información sobre las medidas concretas aplicables en la identificación y eliminación de los residuos peligrosos. También se ofrece información suplementaria acerca de la legislación vigente y del Sistema de información sobre materiales peligrosos en el lugar de trabajo (WHMIS), además de la que se puede obtener a través de los contactos con los principales asesores.

Se creó una base de datos destinada a compilar toda la información significativa en relación con cada uno de los riesgos presentes en el proceso, desde el origen de los residuos peligrosos hasta la evacuación final (por ejemplo, origen y frecuencia de las peticiones telefónicas de ayuda para establecer las áreas que eventualmente exijan una mayor formación; origen, clase, cantidad y frecuencia de las peticiones de eliminación de residuos formuladas por cada uno de los departamentos usuarios;

Tabla 97.19 • Estructura jerárquica del Sistema de Gestión del Medio Ambiente (SGM) del HSC.

\begin{tabular}{|c|c|}
\hline Nivel del SGM & Objetivo \\
\hline $\begin{array}{l}\text { Documento rector } \\
\text { Plan de misión/estratégico }\end{array}$ & $\begin{array}{l}\text { Comprende las expectativas del Consejo de Administración respecto a cada clase de actuación sanitaria, así como sus exigencias respecto a la } \\
\text { competencia corporativa en cada clase. }\end{array}$ \\
\hline $\begin{array}{l}\text { Nivel } 1 \\
\text { Requisitos de servicios }\end{array}$ & $\begin{array}{l}\text { Especifica los servicios que se deben prestar en respuesta a las necesidades de los clientes y propietarios (incluidas las disposiciones legales } \\
\text { vigentes). }\end{array}$ \\
\hline $\begin{array}{l}\text { Nivel } 2 \\
\text { Política corporativa }\end{array}$ & $\begin{array}{l}\text { Especifica los métodos, sistemas, procesos y recursos que deben aplicarse a la satisfacción de las necesidades de los clientes y propietarios, } \\
\text { así como los objetivos, fines y niveles de actuación que se deben alcanzar para asegurar la satisfacción de esas necesidades (p. ej., un } \\
\text { listado de los sistemas y procesos que se precisan, incluido el nivel de responsabilidad por cada uno). }\end{array}$ \\
\hline $\begin{array}{l}\text { Nivel } 3 \\
\text { Descripciones de los } \\
\text { sistemas }\end{array}$ & $\begin{array}{l}\text { Describen el diseño de todos los sistemas o procesos operativos que deben funcionar para satisfacer las exigencias de los clientes y propieta- } \\
\text { rios (p. ej., criterios y límites de la ejecución de los sistemas; todos los puntos de recogida de datos y comunicación de información; puesto } \\
\text { responsable del sistema y de cada elemento del proceso, etc.). }\end{array}$ \\
\hline $\begin{array}{l}\text { Nivel } 4 \\
\text { Instrucciones de trabajo }\end{array}$ & $\begin{array}{l}\text { Contiene una descripción detallada de las tareas (métodos y técnicas específicos) incluidas en cada actividad laboral (p. ej., se describe la } \\
\text { tarea; se identifica el puesto responsable de su ejecución; se especifican las cualificaciones precisas para ejecutar la tarea; se estipula el } \\
\text { método de educación o formación exigible para adquirir esas cualificaciones; se concretan los parámetros de ejecución e idoneidad de la } \\
\text { tarea, etc.). }\end{array}$ \\
\hline $\begin{array}{l}\text { Nivel } 5 \\
\text { Registros de ejecución del } \\
\text { trabajo y del proceso }\end{array}$ & $\begin{array}{l}\text { Sistematiza y registra los datos cuantificables de los resultados de la operación de los sistemas, procesos y tareas diseñados para verificar si } \\
\text { la ejecución se ajusta a las especificaciones (p. ej., medidas del buen funcionamiento del proceso o sistema; asignación de recursos y } \\
\text { cumplimiento del presupuesto; eficacia, eficiencia, calidad, riesgos, aspectos éticos, etc.). }\end{array}$ \\
\hline $\begin{array}{l}\text { Nivel } 6 \\
\text { Informes de actuación }\end{array}$ & $\begin{array}{l}\text { Analiza registros y procesos con objeto de determinar el nivel de cumplimiento de los objetivos fijados para cada especificación de servicios } \\
\text { (nivel l) en función de las necesidades de clientes y propietarios (por ejemplo, cumplimiento, calidad, eficacia, riesgo, utilización) y de los } \\
\text { recursos financieros y de personal. }\end{array}$ \\
\hline
\end{tabular}




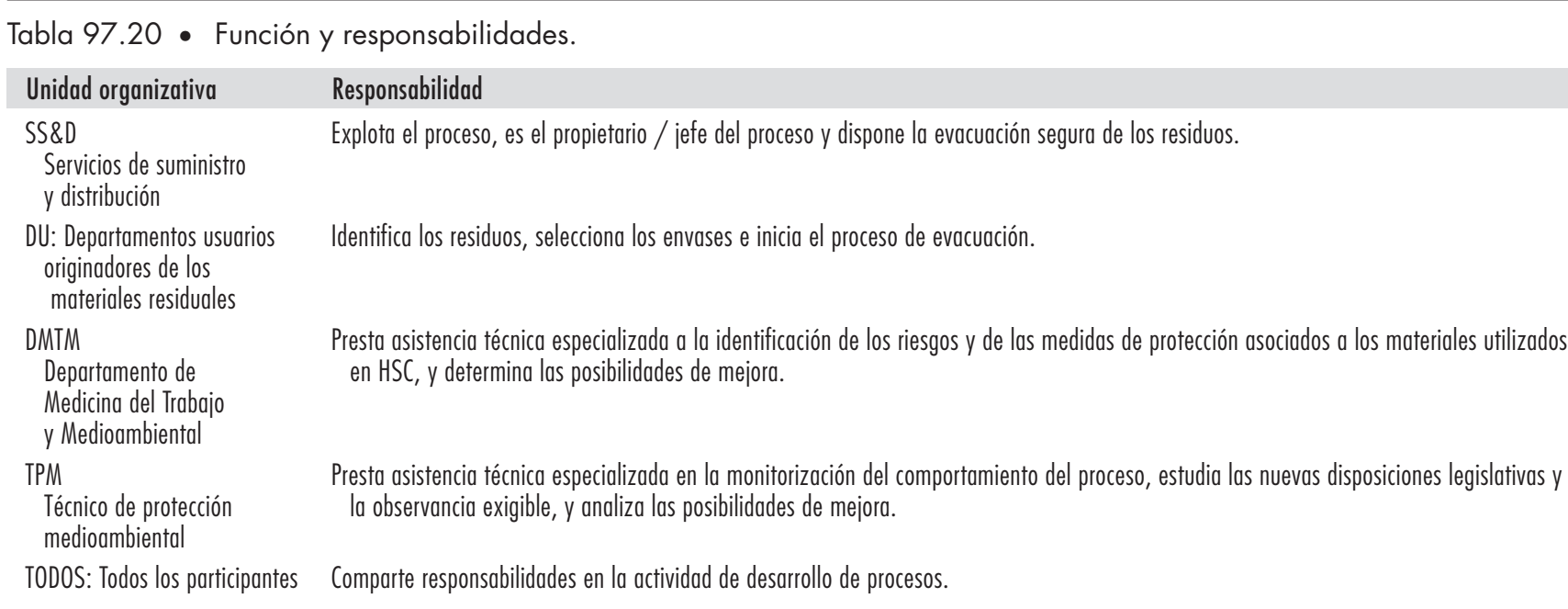

consumo de contenedores y otros envases). Toda desviación respecto del procedimiento establecido se registra en el impreso de comunicación de incidencias utilizado en la empresa. Los resultados de la actividad de control de la actuación se ponen en conocimiento de la dirección y del consejo de administración. Para promover la aplicación eficaz del proceso, se elaboró un programa de formación del personal sobre la base de la información contenida en la guía. Todos los actores principales del proceso asumen responsabilidades concretas en la educación del personal.

\section{Mejora continua}

Con objeto de estudiar las posibilidades de mejora continua, el HSC creó un equipo multidisciplinario para la mejora del tratamiento de los residuos. Su función estriba en analizar todos los aspectos de la gestión de los residuos. Además de promover la mejora continua, en el procedimiento de tratamiento de los residuos peligrosos se han incorporado mecanismos específicamente destinados a instar la revisión del proceso. Hasta el presente, se han formulado algunas propuestas de mejora características:

\section{Tabla 97.21 - Aportaciones al proceso.}

\begin{tabular}{|c|c|}
\hline $\begin{array}{l}\text { Unidad } \\
\text { organizativa }\end{array}$ & $\begin{array}{l}\text { Ejemplos de aportaciones al proceso y de aportaciones } \\
\text { de apoyo }\end{array}$ \\
\hline $\begin{array}{l}\text { SS\&D } \\
(\text { (SS\&D) }\end{array}$ & $\begin{array}{l}\text { Gestionar las existencias de impresos y etiquetas de Solicitud de } \\
\text { Evacuación de Residuos Peligrosos } \\
\text { - impresos y etiquetas de petición de órdenes. }\end{array}$ \\
\hline $\begin{array}{l}\text { SS\&D } \\
\text { (DU, DMTM, } \\
\text { TPM (SS\&D) }\end{array}$ & $\begin{array}{l}\text { Mantener en almacén existencias de contenedores de vertido de } \\
\text { residuos a disposición de los DU } \\
\text { - mantener unas existencias adecuadas de contenedores } \\
\text { a disposición de los DU } \\
\text { - contar con existencias de contenedores suficientes para } \\
\text { cumplir lo solicitado por DU. }\end{array}$ \\
\hline DMTM & Elaborar el Esquema de Determinación de Clasificación SYMBAS. \\
\hline TPM & $\begin{array}{l}\text { Elaborar la lista de materiales respecto a los cuales HSC se haya } \\
\text { registrado en el organismo oficial competente como entidad } \\
\text { generadora de residuos }\end{array}$ \\
\hline SS\&D & $\begin{array}{l}\text { Elaborar una base de datos de las clasificaciones SYMBAS, de las } \\
\text { especificaciones de embalaje, de las clasificaciones TDG, y de } \\
\text { los datos de la monitorización de todos los materiales } \\
\text { evacuados por HSC. }\end{array}$ \\
\hline
\end{tabular}

- elaborar una lista de los materiales peligrosos que se deben seguir desde su adquisición

- preparar información sobre la vida útil de los materiales, cuando sea apropiado, para su inclusión en la base de datos de clasificación de los mismos

- verificar la integridad física de las existencias

- adquirir bandejas que impidan el derrame de las sustancias vertidas

- investigar la posibilidad de que los vertidos penetren en el sistema de desagüe

- estudiar si las actuales áreas de almacenamiento son suficientes para el volumen de residuos previsto

- implantar un método de evacuación de los materiales antiguos indebidamente etiquetados.

En las normas ISO se exige la observancia de la normativa legal y se establece la necesidad de que las empresas adopten políticas a este fin. Según las normas ISO, la existencia de un compromiso de la empresa, de un sistema de medición y de una documentación aporta a las autoridades reguladoras una pista más visible y útil para verificar la observancia. Es posible que la oportunidad de coherencia que ofrecen las normas ISO permita automatizar el proceso de comunicación de los principales elementos de la actuación medioambiental a las autoridades competentes.

Tabla 97.22 - Lista de actividades.

$\begin{array}{ll}\text { Unidad } & \text { Ejemplos de actividades precisas } \\ \text { DU } & \begin{array}{c}\text { Solicitud de orden, etiquetado y envase para la evacuación de } \\ \text { residuos peligrosos, cursada por el SS\&D de conformidad con } \\ \text { el procedimiento normalizado de petición de materiales. }\end{array} \\ \text { SS\&D } & \text { Entrega de solicitud, etiqueta y envase a DU } \\ \text { DU } & \text { Determinación del carácter peligroso de un material de desecho } \\ & \text { (consultar con MSDS, DMIN y estudiar aspectos tales como la } \\ & \text { dilución, la mezcla con otros productos químicos, etc.) } \\ \text { DU } & \text { Clasificar los materiales de desecho utilizando el Esquema de } \\ & \text { Determinación de Categoría Química de SYMBAS y la informa- } \\ & \text { ción de WHMIS. La clasificación se puede consultar en la Base } \\ \text { de datos de SS\&D respecto a los materiales previamente elimi- } \\ \text { nados por el HSC. En caso necesario, solicitar inicialmente la } \\ \text { colaboración de SS\&D y, posteriormente, de DMIN. }\end{array}$




\section{Referencias}

Abdo, R, H Chriske. 1990. HAV-Infektionsrisiken in Krankenhaus, Altenheim und Kindertagesstätten. En Arbeitsmedizin im Gesundheitsdienst, Band 5, dirigido por F Hofmann y U Stössel. Stuttgart: Gentner Verlag.

Acton, W. 1848. On the advantages of caouchoue and gutta-percha in protecting the skin against the contagion of animal poisons. Lancet 12:588.

Ahlin, J. 1992. Interdisciplinary case studies in offices in Sweden. En Corporate Space and Architecture. Vol. 2. París: Ministére de l'équipment et du logement.

Akinori, H, O Hiroshi. 1985. Analysis of fatigue and health conditions among hospital nurses. F Science of Labour 61:517-578.

Allmeers, H, B Kirchner, H Huber, Z Chen, JW Walter, X Baur. 1996. The latency period between exposure and the symptoms in allergy to natural latex: Suggestions for prevention. Dtsh Med Wochenschr 121 (25/26):823-828.

Alter, MJ, HS Margolis, K Krawczynski, FN Judson, A Mares, WJ Alexander, PY Hu, JK Miller, MA Gerber, RE Sampliner. 1992. The natural history of community-acquired hepatitis $\mathrm{C}$ in the United States. New Engl f Med 327:1899-1905.

Alter, MJ. 1986. Susceptibility to varicella zoster virus among adults at high risk for exposure. Infec Contr Hosp Epid 7:448-451.

- 1993. The detection, transmission, and outcome of hepatitis C infection. Infect Agents Dis 2:155-166.

American Hospital Association (AHA). 1992. Implementing Safer Needle Practice. Chicago, Illinois: AHA.

American Institute of Architects Committee on Architecture for Health. 1987. Guidelines for Construction and Equipment of Hospital and Medical Facilities. Washington, DC: American Institute of Acrchitects Press.

American Institute of Architects. 1984. Determining Hospital Space Requirements. Washington, DC: American Institute of Architects Press.

American Society of Heating, Refrigerating and Airconditioning Engineers (ASHRAE). 1987. Health facilities. En ASHRAE Handbook: Heating, Ventilating and Air-conditioning Systems and Applications. Atlanta, Georgia: ASHRAE.

Anon. 1996. New drugs for HIV infection. Medical Let ter of Drugs and Therapeutics 38:37.

Axelsson, G, R Rylander, I Molin. 1989. Outcome of pregnancy in relation to irregular and inconvenient work schedules. Brit f Ind Med 46:393-398.

Beatty, J SK Ahern, R Katz. 1977. Sleep deprivation and the vigilance of anesthesiologists during simulated surgery. En Vigilance, dirigido por RR Mackie. Nueva York: Plenum Press.

Beck-Friis, B, P Strang, PO Sjöden. 1991. Work stress and job satisfaction in hospital-based home care. fournal of Palliative Care 7(3):15-21.

Benenson, AS (dir.). 1990. Control of Communicable Disease in Man, 15 edición. Washington, DC: American Public Health Association.

Bertold, H, F Hofmann, M Michaelis, D NeumannHaefelin, G Steinert, J Wölfle. 1994. Hepatitis C-Risiko für Beschäftigte im Gesundheitsdienst? En Arbeitsmedizin im Gesundheitsdienst, Band 7, dirigido por F Hofmann, G Reschauer, y U Stössel. Stuttgart: Gentner Verlag.

Bertram, DA. 1988. Characteristics of shifts and second-year resident performance in an emergency department. NY State J Med 88:10-14.

Berufsgenossenschaft für Gesundheitsdienst und Wohlfahrtspflege (BGW). 1994. Geschäftsbericht.

Bissel, L, R Jones. 1975. Disabled doctors ignored by peers. Presented at the American Medical Asso- ciation Conference on the Imparied Physician, 11 abril, San Francisco, California.

Bitker, TE. 1976. Reaching out to the depressed physician. FAMA 236(15):1713-1716

Blanchard, M, MM Cantel, M Faivre, J Girot, JP Ramette, D Thely, M Estryn-Béhar. 1992. Incidence des rythmes biologiques sur le travail de nuit. En Ergonomie à l'hôpital, dirigido por M Estryn-Béhar, G Gadbois y M Pottier. Toulouse: Edition Octares.

Blanpain, C and M Estryn-Béhar. 1990. Measures d'ambiance physique dans dix services hospitaliers. Performances 45:18-33.

Blaycock, B. 1995. Latex allergies: Overview, prevention and implications for nursing care. Ostomy Wound Manage 41(5):10-12,14-15.

Blazer, MJ, FJ Hickman, JJ Farmer, DJ Brenner. 1980. Salmonella typhi: The laboratory as a reservoir of infection. Fournal of Infectious Diseases 142:934-938.

Blow, RJ, MIV Jayson. 1988. Back pain. En Fitness for Work: The Medical Approach, dirigido por FG Edwards, RL McCallum, PJ Taylor. Oxford: Oxford University Press.

Boehm, G, E Bollinger. 1990. Significance of environmental factors on the tolerated enteral feeding volumes for patients in neonatal intensive care units. Kinderarzliche Praxis 58(6):275-279.

Bongers, P, RD Winter, MAJ Kompier, VV Hildebrandt. 1992. Psychosocial Factors at Work and Musculoskeletal Diseases. Review of the literature. Leiden, Paises Bajos: TNO

Bouhnik, C, M Estryn-Béhar, B Kapitaniak, M Rocher, P Pereau. 1989. Le roulage dans les établissements de soins. Document pour le médecin du travail. INRS 39:243-252.

Boulard, R. 1993. Les indices de santé mentale du personnel infirmier: l'impact de la charge de travail, de l'autonomie et du soutien social. En La psychologie du travail à l'aube du XXI siècle. Actes du $7^{\circ}$ Congrès de psychologie du travail de langue française. Issy-lesMoulineaux: Editions EAP.

Breakwell, GM. 1989. Facing Physical Violence. Londres: British Psychological Society.

Bruce, DL, KA Eide, HW Linde, JE Eckenhoff. 1968. Causes of death among anesthesiologists: A 20 years survey. Anesthesiology 29:565-569.

Bruce, DL, KA Eide, NJ Smith, F Seltzer, MH Dykes. 1974. A prospective survey of anesthesiologists mortality, 1967-1974. Anesthesiology 41:71-74.

Bruce, DL, MJ Bach. 1976. Effects of Trace Concentration. of Anesthetic Gases on Behavioral Performance of Operating Room Personnel. DHEW (NIOSH) Publication No. 76-169. Cincinnati, Ohio: NIOSH.

Burhill, D, DA Enarson, EA Allen, S Grzybowski. 1985. Tuberculosis in female nurses in British Columbia. Can Med Assoc f 132:137.

Buring, JE, CH Hennekens, SL Mayrent, B Rosner, ER Greenberg, T Colton. 1985. Health experiences of operating room personnel. Anesthesiology 62 : 325-330.

Burke, FJ, MA Wilson, JF McCord. 1995. Allergy to latex gloves in clinical practice: Case reports. Ouintessence Int 26(12):859-863.

Burton, R. 1990. St. Mary's Hospital, Isle of Wight: A suitable background for caring. Brit Med 7 301:1423-1425.

Büssing, A. 1993. Stress and burnout in nursing: Studies in different work structures and work schedules. En Occupational Health for Health Care Workers, dirigido por M Hagberg, F Hofmann, U Stössel y G Westlander. Landsberg/Lech: Ecomed Verlag.

Cabal, C, D Faucon, H Delbart, F Cabal, G Malot. 1986. Construction d'une blanchisserie industrielle aux CHU de Saint-Etienne. Arch Mal Prof 48(5):393-394
Callan, JR, RT Kelly, ML Quinn, JW Gwynne, RA Moore, FA Muckler, J Kasumovic, WM Saunders, RP Lepage, E Chin, I Schoenfeld, DI Serig. 1995. Human Factors Evaluation of Remote Afterloading Brachytherapy. NUREG/CR-6125. Vol. 1. Washington, DC: Nuclear Regulatory Commission

Cammock, R. 1981. Primary Health Care Buildings: Briefing and Design Guide for Architects and Their Clients. Londres: Architectural Press.

Cardo, D, P Srivastava, C Ciesielski, R Marcus, P McKibben, D Culver, D Bell. 1995. Case-control study of HIV seroconversion in health care workers after percutaneous exposure to HIV-infected blood (extracto). Infect Control Hosp Epidemiol 16 supl:20.

Carillo, T, C Blanco, J Ouiralte, R Castillo, M Cuevas, F Rodríguez de Castro. 1995. Prevalence of latex allergy among greenhouse workers. $f$ Allergy Clin Immunol 96(5/1):699-701.

Catananti, C, A Cambieri. 1990. Igiene e Tecnica Ospedaliera (Organización e higiene hospitalarias). Roma: II Pensiero Scientifico Editore.

Catananti, C, G Capelli, G Damiani, M Volpe, GC Vanini. 1994. Multiple criteria evaluation in planning selection of materials for health care facilities. Preliminary identification of criteria and variables. En Healthy Buildings '94, Proceedings of the 3rd International Conference 1:103-108.

Catananti, C, G Damiani, G Capelli, G Manara. 1993. Building design and selection of materials and furnishings in the hospital: A review of international guidelines. En Indoor Air '93, Proceedings of the 6th International Conference on Indoor Air Quality and Climate 2:641-646.

Cats-Baril, WL, JW Frymoyer. 1991. The economics of spinal disorders. En The Adult Spine, dirigido por JW Frymoyer. Nueva York: Raven Press.

Centers for Disease Control (CDC). 1982. Acquired immunodeficiency syndrome (AIDS): Precautions for clinical laboratory staffs. Morb Mortal Weekly Rep 31:577-580.

1983. Acquired immunodeficiency syndrome (AIDS): Precautions for health-care workers and allied professionals. Morb Mortal Weekly Rep 32:450451.

- 1987a. Human immunodeficiency virus infection in health-care workers exposed to blood of infected patients. Morb Mortal Weekly Rep 36:285-289.

- 1987b. Recommendations for prevention of HIV transmission in health-care settings. Morb Mortal Weekly Rep 36 supl. 2:3S-18S.

1988a. Universal precautions for prevention of transmission of human immunodeficiency virus, hepatitis $\mathrm{B}$ virus, and other bloodborne pathogens in health-care settings. Morb Mortal Weekly Rep 37:377-382,387-388.

1988b. Guidelines for prevention of transmission of human immunodeficiency virus and hepatitis B virus to health-care and public-safety workers. Morb Mortal Weekly Rep 37 supl. 6:1-37.

- 1989. Guidelines for prevention of transmission of human immunodeficiency virus and hepatitis B virus to health-care and public-safety workers. Morb Mortal Weekly Rep 38 supl. 6.

1990. Public Health Service statement on management of occupational exposure to human immunodeficiency virus, including considerations regarding post-exposure use. Morb Mortal Weekly Rep 39 (No. RR-1).

-. 1991a. Hepatitis B virus: A comprehensive strategy for eliminating transmission in the United States through universal childhood vaccination: Recommendations of the Immunization Practices Advisory Committee (ACIP). Morb Mortal Weekly Rep 40 (No. RR-13). 
1991b. Recommendations for preventing transmission of human immunodeficiency virus and hepatitis B virus to patients during exposure-prone invasive procedures. Morb Mortal Weekly Rep 40 (No. RR-8).

1993a. Recommended infection-control practices in dentistry. Morb Mortal Weekly Rep 42 (No. RR-8):1-12.

. 1993b. Biosafety in Microbial and Biomedical Laboratories, 3rd edition. DHHS (CDC) Publication No. 93-8395. Atlanta, Georgia: CDC.

1994a. HIV/AIDS Surveillance Report. Vol. 5(4). Atlanta, Georgia: CDC

1994b. HIV/AIDS Prevention Newsletter. Vol. 5(4). Atlanta, Georgia: CDC.

-. 1994c. Human immunodeficiency virus in household settings-United States. Morb Mortal Weekly Rep 43:347-356.

1994d. HIV/AIDS Surveillance Report. Vol. 6(1). Atlanta, Georgia: CDC.

1994e. Guidelines for preventing the transmission of Mycobacterium tuberculosis in health-care facilities. Morb Mortal Weekly Rep 43 (No. RR-13):5-50.

-. 1995. Case-control study of HIV seroconversion in health-care workers after percutaneous exposure to HIV-infected blood-France, United Kingdom, and United States. Morb Mortal Weekly Rep 44:929933.

1996a. HIV/AIDS Surveillance Report. Vol 8(2). Atlanta, Georgia: CDC.

- 1996b. Update: Provisional Public Health Service recommendations for chemoprophylaxis after occupational exposure to HIV. Morb Mortal Weekly Rep 45:468-472.

Charney, W (dir.). 1994. Essentials of Modern Hospital Safety. Boca Ratón, Florida: Lewis Publishers.

Chou, T, D Weil, P Arnmow. 1986. Prevalence of measles antibodies in hospital personnel. Infec Contr Hosp Epid 7:309-311.

Chriske, H, A Rossa. 1991. Hepatitis-CInfektionsgefährdung des medizinischen Personals. En Arbeitsmedizin im Gesundheitsdienst, Band 5, dirigido por F Hofmann y U Stössel. Stuttgart: Gentner Verlag.

Clark, DC, E Salazar-Gruesco, P Grabler, J Fawcett. 1984. Predictors of depression during the first 6 months of internship. Am f Psychiatry 141:10951098.

Clemens, R, F Hofmann, H Berthold, G Steinert. 1992. Prävalenz von Hepatitis, A, B und C bei Bewohern einer Einrichtung für geistig Behinderte. Sozialpädiatrie 14:357-364.

Cohen, EN, JW Bellville, BW Brown, Jr. 1971. Anesthesia, pregnancy and miscarriage: A study of operating room nurses and anesthetists. Anesthesiology $35: 343-347$

- 1974. Occupational disease among operating room personnel: A national study. Anesthesiology 41:321340

1975. A survey of anethestic health hazards among dentists. 7 Am Dent Assoc 90:1291-1296.

Cohen, EN. 1980. Anasthetic Exposure in the Workplace. Littleton, Massachusetts: PSG Publishing Co.

Comisión de las Comunidades Europeas. 1990. Recomendación de la Comisión de 21 de febrero, 1990, sobre Protección de las personas contra exposiciones a radón en ambientes de interior. 90/143/Euratom (traducción italiana).

Conferencia Americana de Higienistas Idustriales del Gobierno (ACGIH). 1991. Documentation of the Threshold Limit Values and Biological Exposure Indices, 6 edición. Cincinnati, Ohio: ACGIH

1994. TLVs: Threshold Limit Values and Biological Exposure Indices for 1994-1995. Cincinnati, Ohio: ACGIH
Consejo de las Comunidades Europeas. 1988. Directiva de 21 diciembre, 1988, relativa a la aproximación de las disposiciones legales, reglamentarias y administrativas de los Estados Miembros sobre los productos de construcción. 89/106/CEE).

Cooper, JB, RS Newbower, RJ Kitz. 1984. An analysis of major errors and equipment failures in anesthesia management: Considerations for prevention and detection. Anesthesiology 60(1):34-42.

Cooper, JB. 1984. Toward prevention of anesthesic mishaps. International Anesthesiology Clinics 22:167183.

Costa, G, R Trinco, G Schallenberg. 1992. Problems of thermal comfort in an operating room equipped with laminar air flow system. En Ergonomie à l'hôpital (Ergonomía hospitalaria), dirigido por M Estryn-Béhar M, C Gadbois y M Pottier. International Symposium París 1991. Toulouse: Editions Octares.

Cristofari, M-F, M Estryn-Béhar, M Kaminski, E Peigné. 1989. Le travail des femmes à l'hôpital. Informations Hospitalières 22/23:48-62.

De Chambost, M. 1994. Alarmes sonnantes, soignantes trébuchantes. Objectif soins 26:63-68.

De Keyser, V, AS Nyssen. 1993. Les erreurs humaines en anesthésies. Le Travail humain 56(2/3):243-266.

Decreto del Presidente del Consejo de Ministros. 1986. Directiva a las Regiones sobre Requisitos de las instalaciones privadas de asistencia sanitaria. 27 junio.

Dehlin, O, S Berg, GBS Andersson, G Grimby. 1981. Effect of physical training and ergonomic counselling on the psychosocial perception of work and on the subjective assesment of low-back insuffuciency. Scand F Rehab 13:1-9.

Delaporte, MF, M Estryn-Béhar, G Brucker, E Peigne, A Pelletier. 1990. Pathologie dermatologique et exercice professionnel en milieu hospitalier. Arch Mal Prof 51(2):83-88.

Denisco, RA, JN Drummond, JS Gravenstein. 1987. The effect of fatigue on the performance of a simulated anesthetic monitoring task. F Clin Monit 3:22-

Devienne, A, D Léger, M Paillard, A Dômont. 1995. Troubles du sommeil et de la vigilance chez des généralistes de garde en région parisienne. Arch Ma Prof 56(5):407-409.

Donovan, R, PA Kurzman, C Rotman. 1993. Improving the lives of home care workers: A partnership of social work and labor. Soc Work 38(5):579-585.

Edling, C. 1980. Anesthetic gases as an occupational hazard. A review. Scand 7 Work Environ Health 6:85-

Ehrengut, W, T Klett. 1981. Rötelnimmunstatus von Schwesternschülerinnen in Hamberger Krankenhäusern im Jahre 1979. Monatsschrift Kinderheilkdunde 129:464-466.

Elias, J, D Wylie, A Yassi, N Tran. 1993. Eliminating worker exposure to ethylene oxide from hospital sterilizers: An evaluation of cost and effectiveness of an isolation system. Appl Occup Environ Hyg 8(8):687-692.

Engels, J, TH Senden, K Hertog. 1993. Working posures of nurses in nursing homes. En Occupational Health for Health Care Workers, dirigido por M Hagberg, F Hofmann, U Stössel y G Westlander. Landsberg/Lech: Ecomed Verlag.

Englade J, E Badet, G Becque. 1994. Vigilance et qualité de sommeil des soignants de nuit. Revue de l'infirmière 17:37-48.

Ernst, E, V Fialka. 1994. Idiopathic low back pain: Present impact, future directions. European fournal of Physical Medicine and Rehabilitation 4:69-72.

Escribà Agüir V, S Pérez, F Bolumar, F Lert. 1992. Retentissement des horaires de travail sur le sommeil des infirmiers. En Ergonomie à l'hôpital (Ergonomía hospitalaria), dirigido por M Estryn-Béhar, C
Gadbois y M Pottier. International Symposium París 1991. Toulouse: Editions Octares.

Escribà Agüir, V. 1992. Nurses' attitudes towards shiftwork and quality of life, Scand J Soc Med 20(2):115118

Estryn Béhar, M, G Milanini, T Bitot, M Baudet, MC Rostaing. 1994. La sectorisation des soins: Une organisation, un espace. Gestion hospitalière 338:552569

Estryn-Béhar, M and C Hakim-Serfaty, 1990. Organisation de l'espace hospitalier. Techn hosp 542:55-63.

Estryn-Béhar, M, B Kapitaniak, MC Paoli, E Peigné, A Masson. 1992. Aptitude for physical exercise in a population of female hospital workers. Int Arch $\mathrm{Oc}_{c}$ cup Environ Health 64:131-139.

Estryn-Béhar, M, C Gadbois, E Peigné, A Masson, V Le Gall. 1989b. Impact of nightshifts on male and female hospital staff. En Shiftwork: Health and Performance, dirigido por G Costa, G Cesana, K Kogi y A Wedderburn. Acta del Simposio internacional sobre trabajo nocturno y por turnos. Frankfurt: Peter Lang.

Estryn-Béhar, M, C Gadbois, E Vaichere. 1978. Effets du travail de nuit en équipes fixes sur une population féminine. Résultats d'une enquête dans le secteur hospitalier. Arch Mal Prof 39(9):531-535.

Estryn-Béhar, M, E Peigné, A Masson, C GirierDesportes, JJ Guay, D Saurel, JC Pichenot, J Cavaré. 1989a. Les femmes travaillant à l'hôpital aux différents horaires, qui sont-elles? Que décriventelles comme conditions de travail? Que souhaitentelles? Arch Mal Prof 50(6):622-628.

Estryn-Béhar, M, F Fonchain. 1986. Les troubles du sommeil du personnel hospitalier effectuant un travail de nuit en continu. Arch Mal Prof 47(3):167172;47(4):241.

Estryn-Béhar, M, G Milanini, MM Cantel, P Poirier, P Abriou, y el grupo de estudio de ICU. 1995a. Interest of participative ergonomic methodology to improve an intensive care unit. En Occupational Health for Health Care Workers, $2^{\mathrm{a}}$ edición, dirigida por M Hagberg, F Hofmann, U Stössel y G Westlander. Landsberg/Lech: Ecomed Verlag.

- 1995b. Participative ergonomic methodology for the new fitting out of a cardiologic intensive care unit. En Occupational Health for Health Care Workers, $2^{a}$ edición, dirigida por M Hagberg, F Hofmann, U Stössel y G Westlander. Landsberg/Lech: Ecomed Verlag.

Estryn-Béhar, M, G Milanini. 1992. Concevoir les espaces de travail en services de soins. Technique Hospitalière 557:23-27.

Estryn-Béhar, M, H Poinsignon. 1989. Travailler à l'hopital. París: Berger Levrault.

Estryn-Béhar, M, JP Fouillot. 1990a. Etude de la charge physique du personnel soignant, Documents pour le médecin du travail. INRS: 27-33.

- 1990b. Etude de la charge mentale et approche de la charge psychique du personnel soignant. Analyse du travail des infirmières et aides-soignantes dans 10 services de soins. Documents pour le médecin du travail INRS 42:131-144.

Estryn-Béhar, M, M Kaminski, E Peigné, N Bonnet, E Vaichère, C Gozlan, S Azoulay, M Giorgi. 1990. Stress at work and mental health status. $\mathrm{Br} F$ Ind Med 47:20-28.

Estryn-Béhar, M, M Kaminski, E Peigné. 1990. Strenuous working conditions and musculoskeletal disorders among female hospital workers. Int Arch Occup Environ Health 62:47-57.

Estryn-Béhar, M, M Kaminski, M Franc, S Fermand, F Gerstle F. 1978. Grossesse er conditions de travail en milieu hospitalier. Revue frang gynec 73(10) 625631 .

Estryn-Béhar, M, N Bonnet. 1992. Le travail de nuit à l'hôpital. Quelques constats à mieux prendre en compte. Arch Mal Prof 54(8):709-719. 
Estryn-Béhar, M. 1990. Les groupes de parole: Une stratégie d'amélioration des relations avec les malades. Le concours médical 112(8):713-717.

1991. Guide des risques professionnels du personnel des services de soins. París: Editions Lamarre.

Falk, SA, F Woods. 1973. Hospital noise-levels and potential health hazards, New England $7 \mathrm{Med}$ 289:774-781.

Fanger, PO. 1973. Assessment of man's thermal comfort in practice. Br f Ind Med 30:313-324.

- 1992. Sensory characterization of air quality and pollution sources. En Chemical, Microbiological, Health and Comfort Aspects of Indoor Air Quality - State of the Art in SBS, dirigido por $\mathrm{H}$ Knoppel y P Wolkoff. Dordrecht, NL: Kluwer Academic Publishers.

Favrot-Laurens. 1992. Advanced technologies and work organization of hospital teams. En Ergonomie à l'hôpital (Ergonomía hospitalaria), dirigido por $\mathrm{M}$ Estryn-Béhar, C Gadbois y M Pottier. International Symposium París 1991. Toulouse: Editions Octares.

1992. Sensory characterization of air quality and pollution sources. En Chemical, Microbiological, Health and Comfort Aspects of Indoor Air Quality — State of the Art in Sick Building Syndrome, dirigido por H Koppel y P Wolkoff. Bruselas y Luxemburgo: CEE.

Ferstandig, LL. 1978. Trace concentrations of anesthetic gases: A critical review of their disease potential. Anesth Analg 57:328-345.

Finley, GA, AJ Cohen. 1991. Percieved urgency and the anaesthetist: Responses to common operating room monitor alarms. Can F Anaesth 38(8):958-964

Ford, GV, DK Wentz. 1984. The internship year: A study of sleep, mood states, and psychophysiologic parameters. South Med f 77:1435-1442.

Friedman, RC, DS Kornfeld, TJ Bigger. 1971. Psychological problems associated with sleep deprivation in interns. Fournal of Medical Education 48:436-441.

Friele, RD, JJ Knibbe. 1993. Monitoring the barriers with the use of patient lifts in home care as perceived by nursing personnel. En Occupational Health for Health Care Workers, dirigido por M Hagberg, F Hofmann, U Stössel, G Westlander. LandsbergLech: Ecomed Verlag.

Gadbois, C, P Bourgeois, MM Goeh-Akue-Gad, J Guillaume, MA Urbain. 1992. Contraintes temporelles et structure de l'espace dans le processus de travail des équipes de soins. En Ergonomie à l'hôpital (Ergonomía hospitalaria), dirigida por M EstrynBéhar, C Gadbois y M Pottier. International Symposium París 1991. Toulouse: Editions Octares.

Gadbois, CH. 1981. Aides-soignantes et infirmières de nuit. En Conditions de travail et vie quotidienne. Montrougs: Agence Nationale pour l'Amélioration des Conditions de Travail.

Games, WP, W Tatton-Braen. 1987. Hospitals Design and Development. Londres: Architectural Press.

Gardner, ER, RC Hall. 1981. The professional stress syndrome. Psychosomatics 22:672-680.

Gaube, J, H Feucht, R Laufs, D Polywka, E Fingscheidt, HE Müller. 1993. Hepatitis A, B und C als desmoterische Infecktionen. Gessundheitwesen und Desinfextion 55:246-249.

Gerberding, JL. Sin fecha. Open trial of Zidovudine Postexposure-chemoprophylaxis in Health Care Workers with Occupational Exposures to Human Immunodeficiency Virus. Skript SFGH

1995. Management of occupational exposures to blood-borne viruses. New Engl F Med 332:444-451.

Ginesta, J. 1989. Gases anestésicos. En Riesgos del trabajo del personal sanitario, dirigido por IJ Gestal. Madrid: Editorial Interamericana McGraw-Hill.

Gold, DR, S Rogacz, N Bock, TD Tosteson, TM Baum, FE Speizer, CA Czeiler. 1992. Rotating shift work, sleep and accidents related to sleepiness in hospital nurses. Am f Public Health 82(7):10111014

Goldman, LI, MT McDonough, GP Rosemond. 1972 Stresses affecting surgical performance and learning: Correlation of heart rate, electrocardiogram, and operation simultaneously recorded on videotapes. F Surg Res 12:83-86.

Graham, C, G Hawkins, W Blau. 1983. Innovative social work practice in health care: Stress management. En Social Work in a Turbulent World, dirigido por M Dinerman. Washington, DC: National Association of Social Workers.

Green, A. 1992. How nurses can ensure the sounds patients hear have a positive rather than negative effect upon recovery and quality of life. Intensive है Critical Care Nursing fournal 8(4):245-248.

Griffin, WV. 1995. Social worker and agency safety. En Encyclopaedia of Social Work, 19 edición. Washington, DC: National Association of Social Workers.

Grob, PJ. 1987. Cluster of hepatitis B transmission by a physician. Lancet 339:1218-1220.

Guardino, X, MG Rosell. 1985. Exposición laboral a gases anestésicos. En Notas técnicas de prevención. $\mathrm{N}^{\circ}$ 141. Barcelona: INSHT.

1992. Exposure at work to anesthetic gases. A controlled risk? Janus 12:8-10.

- 1995. Exposure monitoring to anesthetic gases. En Occupational Health for Health Care Workers, dirigido por M Hagburg, F Hoffmann, U Stössel y G Westlander. Solna: National Institute of Occupational Health.

Hagberg, M, F Hofmann, U Stössel, G Westlander (dirs.). 1993. Occupational Health for Health Care Work ers. Landsberg/Lech: Ecomed Verlag.

Hagberg, M, F Hofmann, U Stössel, G Westlander (dirs.). 1995. Occupational Health for Health Care Workers. Singapur: Comisión Internacional para la Salud en el Trabajo.

Haigh, R. 1992. The application of ergonomics to the design of workplace in health care buildings in the U.K. En Ergonomie à l'hôpital (Ergonomía hospitalaria), dirigido por M Estryn-Béhar, C Gadbois y M Pottier. International Symposium París 1991. Toulouse: Editions Octares.

Halm, MA, MA Alpen, 1993. The impact of technology on patient and families. Nursing Clinics of North America 28(2):443-457.

Harber, P, L Pena, P Hsu. 1994. Personal history, training, and worksite as predictors of back pain of nurses. Am f Ind Med 25:519-526.

Hasselhorn, HM, E Seidler.1993. Terminal care in Sweden-New aspects of the professional care of dying. En Occupational Health for Health Care Workers, dirigido por M Hagberg, F Hofmann, U Stösse U y G Westlander. Landsberg/Lech: Ecomed Verlag.

Hasselhorn, HM. 1994. Antiretrovirale prophylaxe nach kontakt mit HIV-jontaminierten. En Flüssigkeiten in Infektiologie, dirigido por F Hofmann. Landsberg/Lech: Ecomed Verlag.

Heptonstall, J, K Porter, N Gill. 1993. Occupational Transmission of HIV: Summary of Published Reports. Londres: Communicable Disease Surveillance Centre AIDS Centre.

Hesse, A, Lacher A, HU Koch, J Kublosch, V Ghane, KF Peters. 1996. Update on the latex allergy topic. Hauzarzt 47(11):817-824.

Ho, DD, T Moudgil, M Alam. 1989. Quantitation of human immunodeficiency virus type 1 in the blood of infected persons. New Engl f Med 321:1621-1625.

Hodge, B, JF Thompson. 1990. Noise pollution in the operating theatre. Lancet 335:891-894.

Hofmann, F,H Berthold. 1989. Zur Hepatitis-BGefährdung des Krankenhauspersonals-Möglichkeiten der prae-und postexpositionellen Prophylaxe. Medizinische Welt 40:1294-1301.
Hofmann, F, B Sydow, M Michaelis. 1994a. Mumps - berufliche Gefährdung und Aspekte der epidemiologischen Entwicklung. Gessundheitwesen und Desinfextion 56:453-455.

- 1994b. Zur epidemiologischen Bedeutung der Varizellen. Gessundheitwesen und Desinfextion 56:599-601.

Hofmann, F, G Wehrle, K Berthold, D Köster. 1992. Hepatitis A as an occupational hazard. Vaccine 10 supl. 1:82-84.

Hofmann, F, H Berthold, G Wehrle. 1992. Immunity to hepatitis A in hospital personnel. Eur $\mathcal{J}$ Clin Microbiol Infect Dis 11(12):1195.

Hofmann, F, M Michaelis, A Siegel, U Stössel. 1994 Wirbelsäulenerkrankungen im Pflegeberuf. Medizinische Grundlagen und Prävention. Landsberg/Lech: Ecomed Verlag.

Hofmann, F, M Michaelis, M Nübling, FW Tiller. 1995. European Hepatitis - A Study. Publikation in Vorereitung.

Hofmann, F, U Stössel, J Klima. 1994. Low back pain in nurses (I). European Fournal of Physical and Medical Rehabilitation 4:94-99.

Hofmann, F, U Stössel, M Michaelis, A Siegel. 1993. Tuberculosis - Occupational risk for health care workers? En Occupational Health for Health Care Workers, dirigido por M Hagberg. Landsberg/Lech: Ecomed Verlag.

Hofmann, F, U Stössel. 1995. Environmental health in the health care professions: Biological, physical, psychic, and social health hazards. Reviewes on Environmental Health 11:41-55.

Hofmann, H, C Kunz. 1990. Low risk of health care workers for infection with hepatitis-C virus. Infection 18:286-288.

Holbrook, TL, K Grazier, JL Kelsey, RN Stauffer. 1984. The Frequency of Occurrence, Impact, and Cost of Selected Musculoskeletal Conditions in the United States. Park Ridge, Il: American Academy of Orthopedic Surgeons.

Hollinger, FB. 1990. Hepatitis B virus. En Virology, dirigido por BN Fiedles y DM Knipe. Nueva York: Raven Press.

Hopps, J, P Collins. 1995. Social work profession overview. En Encyclopedia of Social Work, 19 edición. Washington, DC: National Association of Social Workers.

Hubacova, L, I Borsky, F Strelka. 1992. Work physiology problems of nurses working in inpatients departments. En Ergonomie à l'hôpital (Ergonomía hospitalaria), dirigido por M Estryn-Béhar, C Gadbois y M Pottier. International Symposium París 1991. Toulouse: Editions Octares.

Hunt, LW, AF Fransway, CE Reed, LK Miller, RT Jones, MC Swanson, JW Yunginger. 1995. An epidemic of occupational allergy to latex involving health care workers. $f$ Occup Environ Med 37(10):1204-1209.

Jacobson, SF, HK MacGrath. 1983. Nurses under Stress. Nueva York: John Wiley \& Sons.

Jacques, CHM, MS Lynch, JS Samkoff. 1990. The effects of sleep loss on cognitive performance of resident physicians. 7 Fam Pract 30:223-229.

Jagger, J, EH Hunt, J Brand-Elnagger, RD Pearson. 1988. Rates of needle-stick injury caused by various devices in a university hospital. New Engl $7 \mathrm{Med}$ 319:284-288.

Johnson, JA, RM Buchan, J S Reif. 1987. Effect of waste anesthetic gas and vapor exposure on reproductive outcome in veterinary personnel. $\mathrm{Am}$ Ind Hyg Assoc 7 48(1):62-66.

Jonasson, G, JO Holm, J Leegard. Rubber allergy: An increasing health problem? Tuidsskr Nor Laegeforen 113(11):1366-1367.

Kandolin, I. 1993. Burnout of female and male nurses in shiftwork. Ergonomics 36(1/3):141-147. 
Kaplan, RM, RA Deyo. 1988. Back pain in health care workers. En Back Pain in Workers, dirigido por RA Deyo. Filadelfia, Pensilvania: Hanley \& Belfus.

Katz, R. 1983. Causes of death among nurses. Occup Med 45:760-762.

Kelin, R, K Freemann, P Tavlor, C Stevens. 1991. Occupational risk for hepatits $\mathrm{C}$ virus infection among New York City dentists. Lancet 338:15391542.

Kempe, P, M Sauter, I Lindner. 1992. Special characteristics of nurses for the aged who made use of a training program aimed to reduce burn-out symptoms and first results on treatment outcome. En Ergonomie à l'hôpital (Ergonomía hospitalaria), dirigido por M Estryn-Béhar, C Gadbois, M Pottier. International Symposium París 1991. Toulouse: Edition Octares.

Kerr, JH. 1985. Warning devices. Br f Anaesth 57:696708.

Kestin, IG, RB Miller, CJ Lockhart. 1988. Auditory alarms during anesthesia monitoring. Anesthesiolog) 69(1):106-109.

Kinloch-de-los, S, BJ Hirschel, B Hoen, DA Cooper, B Tindall, A Carr, H Sauret, N Clumeck, A Lazzarin, E Mathiesen. 1995. A controlled trial of Zidovudine in primary human immunodeficiency virus infection. New Engl f Med 333:408-413.

Kivimäki, M, K Lindström. 1995. The crucial role of the head nurse in a hospital ward. En Occupationa Health for Health Care Workers, dirigido por M Hagberg, F Hofmann, U Stössel y G Westlander. Landsberg/Lech: Ecomed Verlag.

Klaber Moffet, JA, SM Chase, I Portek, JR Ennis. 1986. A controlled study to evaluate the efectiveness of the back pain school in the relief of chronic low back pain. Spine 11:120-122

Kleczkowski, BM, G Montoya-Aguilar, NO Nilsson. 1985. Approaches to Planning and Design of Health Car Facilities in Developing Areas. Vol. 5. Ginebra: OMS.

Klein, BR, AJ Platt. 1989. Health Care Facility Planning and Construction. Nueva York: Van Nostrand Reinhold.

Kraus, H. 1970. Clinical Treatment of Back and Neck Pain. Nueva York: McGraw-Hill.

Kujala, VM, KE Reilula. 1995. Glove-induced derma and respiratory symptoms among health care workers in one Finnish hospital. Am 7 Ind Med 28(1): 89-98.

Kurumatani, N, S Koda, S Nakagiri, K Sakai, Y Saito, H Aoyama, M Dejima, T Moriyama. 1994. The effects of frequently rotating shiftwork on sleep and the family life of hospital nurses. Ergonomics 37:995-1007.

Lagerlöf, E, E Broberg. 1989. Occupational injuries and diseases. En Occupational Hazards in the Health Professions, dirigido por DK Brune y C Edling. Boca Ratón, Florida: CRC Press.

Lahaye, D, P Jacques, G Moens, B Viaene. 1993. The registration of medical data obtained by preventive medical examinations on health care workers. En Occupational Health for Health Care Workers, dirigido por M Hagberg, F Hofmann, F, U Stössel y G Westlander. Landsberg/Lech: Ecomed Verlag.

Lampher, BP, CG Linneman, CG Cannon, MM DeRonde, L Pendy, LM Kerley 1994. Hepatitis C virus infection in health care workers: Risk of exposure and infection. Infect Control Hosp Epidemio 15:745-750

Landau, C, S Hall, SA Wartman, MB Macko. 1986. Stress in social and family relationships during medical residency. Fournal of Medical Education 61:654-660.

Landau, K. 1992. Psycho-physical strain and the burn-out phenomen amongst health care professionals. En Ergonomie à l'hôpital (Ergonomía hospitalaria), dirigido por M Estryn-Béhar, C Gadbois y M
Pottier. International Symposium París 1991. Toulouse: Editions Octares.

Landewe, MBM, HT Schröer. 1993. Development of a new, integrated patient transfer training program-Primary prevention of low back pain. En Occupational Health for Health Care Workers, dirigido por M Hagberg, F Hofmann, U Stössel y G Westlander. Landsberg/Lech: Ecomed Verlag.

Lange, M. 1931. Die Muskelhärten (Myogelosen). Munich: JF Lehman Verlag.

Lange, W, KN Masihi. 1986. Durchseuchung mit Hepatitis-A- und B-Virus bei medizinischem Personal. Bundesgesundheitsol 29;183-87.

Lee, KA. 1992. Self-reported sleep disturbances in employed women. Sleep 15(6):493-498.

Lempereur, JJ. 1992. Prévention des dorso-lombalgies. Influence du vêtement de travail sur le comportement gestuel. Spécifications ergonomiques. Cah Kinésither 156,4 .

Leppanen, RA, MA Olkinuora. 1987. Psychological stress experienced by health care personnel. Scand $\mathcal{J}$ Work Environ Health 13:1-8.

Lert, F, MJ Marne, A Gueguen. 1993. Evolution des conditions de travail des infirmières des hôpitaux publics de 1980 à 1990. Revue de l'Epidémiologie et de santé publique 41:16-29.

Leslie, PJ, JA Williams, G McKenna, G Smith, RC Heading. 1990. Hours, volume, and type of work of preregistration house officers. Brit Med 7 300:10381041

Lettau, LA, HJ Alfred, RH Glew, HA Fields, MJ Alter, R Meyer, SC Hadler, JE Maynard. 1986. Nosocomial transmission of delta hepatitis. Ann Intern Med 104:631-635.

Levin, H. 1992. Healthy buildings - Where do we stand, where do we go? En Chemical, Microbiological, Health and Comfort Aspects of Indoor Air Quality: State of the Art in Sick Building Syndrome, dirigido por H Knoppel y P Wolkoff. Bruselas y Luxemburgo: CEE.

Lewittes, LR, VW Marshall. 1989. Fatigue and concerns about quality of care among Ontario intern and residents. Can Med Assoc f 140:21-24.

Lewy, R. 1990. Employees at Risk: Protection and Health of Health Care Workers. Nueva York: Van Nostrand Reinhold.

Lindström, A, M Zachrisson. 1973. Ryggbesvär och arbetssoförmaga Ryyggskolan. Ett Försok till mer rationeli fysikalist terapi. Socialmet T 7:419-422.

Lippert. 1971. Travel in nursing units. Human Factors 13(3):269-282.

Ljungberg, AS, A Kilbom, MH Goran. 1989. Occupational lifting by nursing aides and warehouse workers. Ergonomics 32:59-78.

Llewelyn-Davies, R, J Wecks. 1979. In-patient areas. En Approaches to Planning and Design of Health Care Facilities in Developing Areas, dirigido por BM Kleczkowski y R Piboleau. Ginebra: WHO.

Loeb, RG, BR Jones, KH Behrman, RJ Leonard. 1990. Anesthetists cannot identify audible alarms. Anesthesiology 73(3A):538.

Lotas, MJ. 1992. Effects of light and sound in the neonatal intensive care unit environment on the lowbirth-weight infant. NAACOGS Clinical Issues in Perinatal \& Womens Health Nursing 3(1):34-44.

Lurie, HE, B Rank, C Parenti, T Wooley, W Snoke. 1989. How do house officers spend their nights? A time study of internal medicine house staff on call. New Engl f Med 320:1673-1677.

Luttman, A, M Jäger, J Sökeland, W Laurig. 1996. Electromyographical study on surgeons in urology II. Determination of muscular fatigue. Ergonomics 39(2):298-313.

Makino, S. 1995. Health problems in health care workers in Japan. En Occupational Health for Health Care Workers, dirigido por M Hagberg, F Hofmann,
U Stössel y G Westlander. Landsbeg/Lech: Ecomed Verlag.

Malchaire, JB. 1992. Analysis of the work load of nurses. En Ergonomie à l'hôpital (Ergonomía hospitalaria), dirigido por M Estryn-Béhar, C Gadbois y M Pottier. International Symposium París 1991. Toulouse: Editions Octares.

Manuaba, A. 1992. Social-cultural approach is a must in designing hospital in developing countries, Indonesia as a case study. En Ergonomie à l'hôpital (Ergonomía hospitalaria), dirigido por M Estryn-Béhar, C Gadbois y M Pottier. International Symposium París 1991. Toulouse: Editions Octares.

Maruna, H. 1990. Zur Hepatitis-B-Durchseuchung in den Berufen des Gesundheits und Fürsorgewesens der Republik Österreichs, Arbeitsmed. Präventivmed. Sozialmed 25:71-75.

Matsuda, A. 1992. Ergonomics approach to nursing care in Japan. En Ergonomie à l'hôpital (Ergonomía hospitalaria), dirigido por M Estryn-Béhar, C Gadbois, and $\mathrm{M}$ Pottier. International Symposium París 1991. Toulouse: Editions Octares.

McCall, T. 1988. The impact of long working hours on resident physicians. New Engl $\mathfrak{f}$ Med 318(12):775-778.

McCloy, E. 1994. Hepatitis and the EEC Directive. Presentado en la $2^{\text {a }}$ Conferencia Internacional sobre Salud en el Trabajo en los Trabajadores de Asistencia Sanitaria, Estocolmo.

McCormick, RD, MG Meuch, IG Irunk, DG Maki. 1991. Epidemiology for hospital sharp injuries: A 14-year prospective study in the pre-AIDS and AIDS era. Am f Med 3B:3015-3075.

McCue, JD. 1982. The effects of stresses on physicians and their medical practice. New Engl $f$ Med 306:458-463

McIntyre, JWR. 1985. Ergonomics: Anaesthetists' use of auditory alarms in the operating room. Int $\mathcal{F}$ Clin Monit Comput 2:47-55

McKinney, PW, MM Horowitz, RJ Baxtiola. 1989. Susceptibility of hospital-based health care personnel to varicella zoster virus infection. Am f Infect Control 18:26-30.

Melleby, A. 1988. Exercise program for a healthy back. En Diagnosis and Treatment of Muscle Pain. Chicago, Illinois: Quintessence Books.

Meyer,TJ, SE Eveloff, MS Bauer, WA Schwartz, NS Hill, PR Millman. 1994. Adverse environmental conditions in the respiratory and medical intensive care unit settings. Chest 105:1211-1216.

Miller, E, J Vurdien, P Farrington. 1993. Shift age in chickenpox. Lancet 1:341.

Miller, JM. 1982. William Stewart Halsted and the use of the surgical rubber glove. Surgery 92:541-543.

Mitsui, T, K Iwano, K Maskuko, C Yanazaki, H Okamoto, F Tsuda, T Tanaka, S Mishiros. 1992. Hepatitis $\mathrm{C}$ virus infection in medical personnel after needlestick accidents. Hepatology 16:1109-1114.

Modig, B. 1992. Hospital ergonomics in a biopsychosocial perspective. En Ergonomie à l'hôpital (Ergonomía hospitalaria), dirigido por M Estryn-Béhar, C Gadbois y M Pottier. International Symposium París 1991. Toulouse: Editions Octares.

Momtahan, K, R Hétu, B Tansley. 1993. Audibility and identification of auditory alarms in the operating room and intensive care unit. Ergonomics 36(10):1159-1176

Momtahan, KL, BW Tansley. 1989. An ergonomic analysis of the auditory alarm signals in the operating room and recovery room. Presentado en el Encuentro Anual de la Canadian Acoustical Association, 18 octubre, Halifax, Nueva Escocia.

Montoliú, MA, V González, B Rodríguez, JF Quintana, L Palenciano.1992. Conditions de travail dans la blanchisserie centrale des grands hôpitaux de Madrid. En Ergonomie à l'hôpital (Ergonomía hospitalaria), dirigido por M Estryn-Béhar, C Gadbois y 
M Pottier. International Symposium París 1991. Toulouse: Editions Octares.

Moore, RM, YM Davis, RG Kaczmarek. 1993. An overview of occupational hazards among veterinarians, with particular reference to pregnant women. Am f Ind Hyg Assoc 54(3):113-120.

Morel, O. 1994. Les agents des services hospitaliers. Vécu et santé au travail. Arch mal prof 54(7):499-508.

Nachemson, AL and GBJ Anderson. 1982. Classification of low back pain. Scand 7 Work Environ Health 8:134-136.

National Health Service (NHS). 1991a. Design Guide. The Design of Community Hospitals. Londres: Her Majesty's Stationery Office.

. 1991b. Health Building Note 46: General Medical Practice Premises for the Provision of Primary Health Care Service. Londres: Her Majesty's Stationery Office.

National Institute for Occupational Safety and Health (NIOSH) 1975. Development and Evaluation of Methods for the Elimination of Waste Anesthetic Gases and Vapors in Hospitals. DHEW (NIOSH) Publication No. 75 137. Cincinnati, Ohio: NIOSH

1997a. Control of Occupational Exposure to $\mathcal{N} 2 O$ in the Dentral Operatory. DHEW (NIOSH) Publication No. 77-171. Cincinnati, Ohio: NIOSH.

1977b. Criteria for a Recommended Standard: Occupational Exposure to Waste Anesthetic Gases and Vapor. DHEW (NIOSH) Publication No. 77-1409. Cincinnati, Ohio: NIOSH.

1988. Guidelines for Protecting the Safety and Health of Health Care Workers. DHHS (NIOSH) Publication No. 88-119. Cincinnati, Ohio: NIOSH.

- 1994. NIOSH Alert: Request for Assistance in Controlling Exposures to Nitrous Oxide during Anesthetic Administration. DHHS (NIOSH) Publication No. 94-100. Cincinnati, Ohio: NIOSH.

Niu, MT, DS Stein, SM Schnittmann. 1993. Primary human immunodeficiency virus type 1 infection: Review of pathogenesis and early treatment interventions in human and animal retrovirus infections. f Infect Dis 168:1490-1501.

Noweir, MH, MS al-Jiffry. 1991. Study of noise pollution in Jeddah hospitals. Fournal of the Egyptian Publi Health Association 66 (3/4):291-303.

Nyman, I, A Knutsson. 1995. Psychosocial wellbeing and sleep quality in hospital night and day workers. En Occuaptional Health for Health Care Workers, dirigido por M Hagberg, F Hofmann, U Stössel y G Westlander. Landsberg/Lech: Ecomed Verlag.

O'Carroll, TM. 1986. Survey of alarms in an intensive therapy unit. Anaesthesia 41:742-744.

Objectif Prévention No spécial. 1994. Le lève personne sur rail au plafond: Outil de travail indispensable. Objectif Prévention 17(2):13-39.

Occupational Safety and Health Administration (OSHA). 1991. Occupational Exposure to Bloodborne Pathogens: Final Rule. 29 CFR Part 1910.1030. Washington, DC: OSHA.

Oëler, JM. 1993. Developmental care of low birth weight infants. Nursing Clinics of North America 28(2):289-301

Öhling, P, B Estlund. 1995. Working technique for health care workers. En Occupational Health for Health Care Workers, dirigido por M Hagberg, F Hofmann, U Stössel y G Westlander G. Landsberg/Lech: Ecomed Verlag.

Ollagnier, E, Lamarche MJ. 1993. Une intervention ergonomique dans un hôpital suisse: Impact sur la santé de l'organisation du personnel et des patients. En Ergonomie et santé, dirigido por D Ramaciotti and A Bousquet. Actes du XXVIII e congrès de la SELF Ginebra: SELF.

Organización Mundial de la Salug (OMS). 1990. Guidelines on AIDS and First Aid in the Workplace. OMS AIDS Series No. 7. Ginebra: OMS.
1991. Biosafety Guidelines for Diagnostic and Research Laboratories Working with HIV. OMS AIDS Series No. 9. Ginebra: OMS.

- 1995. Weekly Epidemiological Report (13 enero).

Ott, C, M Estryn-Béhar, C Blanpain, A Astier, G Hazebroucq. 1991. Conditionnement du médicament et erreurs de médication. 7 Pharm Clin 10:61-66.

Patkin, M. 1992. Hospital architecture: An ergonomic debacle. En Ergonomie à l'hôpital (Ergonomía hospitalaria), dirigido por M Estryn-Béhar, C Gadbois M Pottier. International Symposium París 1991. Toulouse: Editions Octares.

Payer, L. 1988. Medicine and Culture: The Variety of Treatment in the United States, England, West Germany and France. Nueva York: H. Holt.

Payne, R, J Firth-Cozens (dirs.) 1987. Stress in Health Professions. Nueva York: John Wiley \& Sons. 1995. Determination of dinitrogen oxide $\left(\mathrm{N}_{2} \mathrm{O}\right)$ in urine as control to anesthetic exposure. En Occupational Health for Health Care Workers, dirigido por M Hagberg, F Hoffmann, U Stössel y G Westlander. Solna: National Institute of Occupational Health.

Pelikan, JM. 1993. Improving occupational health for health care workers within the health promoting hospital: Experiences from the Vienna WHO model project "health and hospital". En Occupational Health for Health Care Workers, dirigido por M Hagberg, F Hofmann, U Stössel y G Westlander. Landsberg/Lech: Ecomed Verlag.

Pérez, L, R de Andrés, K. Fitch, R Nájera. 1994. Seroconversiones a VIH tras sanitarios en Europa. Presentado en la $2^{\mathrm{a}}$ Reunión Nacional sobre el SIDA Cáceres.

Philip, RN, KRT Reinhard, DB Lackman. 1959. Observations on a mumps epidemic in a "virgin" population. Am f Hyg 69:91-111.

Pottier, M. 1992. Ergonomie à l'hôpital-hospital ergonomics. En Ergonomie à l'hôpital (Ergonomía hospitalaria), dirigido por M Estryn-Béhar, C Gadbois M Pottier. International Symposium París 1991. Toulouse: Editions Octares.

Poulton, EC, GM Hunt, A Carpenter, RS Edwards. 1978. The performance of junior hospital doctors following reduced sleep and long hours of work. Ergonomics 21:279-295.

Pöyhönen, T, M Jokinen. 1980. Stress and Other Occupational Health Problems Affecting Hospital Nurses. Vantaa, Finlandia: Tutkimuksia.

Raffray, M. 1994. Etude de la charge physique des AS par mesure de la fréquence cardiaque. Objectif soins 26:55-58.

Ramaciotti, D, S Blaire, A Bousquet, E Conne, V Gonik, E Ollagnier, C Zummermann, L Zoganas. 1990. Processus de régulation des contraintes économiques physiologiques et sociales pour différents groupes de travail en horaires irréguliers et de nuit. Le travail humain 53(3):193-212

Reuben, DB. 1985. Depressive symptoms in medical house officers: Effects of level of training and work rotation. Arch Intern Med 145:286-288.

Reznick, RK, JR Folse. 1987. Effect of sleep deprivation on the performance of surgical residents. $A m$ f Surg 154:520-52.

Rhoads, JM.1977. Overwork. FAMA 237:2615-2618.

Rodary, C, A Gauvain-Piquard 1993. Stress et épuisement professionnel. Objectif soins 16:26-34.

Roquelaure, Y, A Pottier, M Pottier. 1992. Approche ergonomique comparative de deux enregistreurs electroencéphalographiques. En Ergonomie à l'hôpital (Ergonomía hospitalaria), dirigido por M EstrynBéhar, C Gadbois y M Pottier. International Symposium París 1991. Toulouse: Editions Octares.

Rosell, MG, P Luna, X Guardino. 1989. Evaluación y control de contaminantes químicos en hospitales. Documento técnico $\mathrm{N}^{\circ}$ 57. Barcelona: INSHT.
Rubin, R, P Orris, SL Lau, DO Hryhorczuk, S Furner, R Letz. 1991. Neurobehavioral effects of the on-call experience in housestaff physicians. f Occup Med 33:13-18.

Saint-Arnaud, L, S Gingras, R Boulard, M Vezina, H Lee-Gosselin. 1992. Les symptômes psychologiques en milieu hospitalier. En Ergonomie à l'hôpital (Ergonomía hospitalaria), dirigido por M EstrynBéhar, C Gadbois y M Pottier. International Symposium París 1991. Toulouse: Editions Octares.

Samkoff, JS, CHM Jacques. 1991. A review of studies concerning effects of sleep deprivation and fatigue on residents' performance. Acad Med 66:687-693.

Sartori, M, G La Terra, M Aglietta, A Manzin, C Navino, G Verzetti. 1993. Transmission of hepatitis $\mathrm{G}$ via blood splash into conjunctiva. Scand 7 Infect Dis 25:270-271.

Saurel, D. 1993. CHSCT Central, Enquete "Rachialgies" Résultats. París: Assistance Publique-Höpitaux de Paris, Direction du personnel et des relations sociales.

Saurel-Cubizolles, MJ, M Hay, M Estryn-Béhar. 1994. Work in operating rooms and pregnancy outcome among nurses. Int Arch Occup Environ Health 66:235241

Saurel-Cubizolles, MJ, MKaminski, J LlhadoArkhipoff, C Du Mazaubrum, M Estryn-Behar, C Berthier, M Mouchet, C Kelfa. 1985. Pregnancy and its outcome among hospital personnel according to occupation and working condition. Fournal of Epidemiology and Community Health 39:129-134.

Schröer, CAP, L De Witte, H Philipsen. 1993. Effects of shift work on quality of sleep, health complaints and medical consumption of female nurses. En $O c$ cupational Health for Health Care Workers, dirigido por M Hagberg, F Hofmann, U Stössel y G Westlander. Landsberg/Lech: Ecomed Verlag.

Senevirane, SR, De A, DN Fernando. 1994. Influence of work on pregnancy outcome. Int $\mathcal{F}$ Gynecol Obstet VOL: 35-40.

Shapiro, ET, H Pinsker, JH Shale. 1975. The mentally ill physician as practitioner. FAMA 232(7):725-727.

Shapiro, RA, T Berland. 1972. Noise in the operating room. New Engl f Med 287(24):1236-1238.

Shindo, E. 1992. The present condition of nursing ergonomics in Japan. En Ergonomie à l'hôpital (Ergonomía hospitalaria), dirigido por M Estryn-Béhar, C Gadbois y M Pottier. International Symposium París 1991. Toulouse: Editions Octares.

Siegel, A, M Michaelis, F Hofmann, U Stössel, W Peinecke. 1993. Use and acceptance of lifting aids in hospitals and geriatric homes. En Occupational Health for Health Care Workers, dirigido por M Hagberg, F Hofmann, U Stössel y G Westlander. Landsberg/Lech: Ecomed Verlag.

Smith, MJ, MJ Colligan, IJ Frocki, DL Tasto, 1979. Occupational injury rates among nurses as a function of shift schedule. Fournal of Safety Research 11(4):181-187.

Smith-Coggins, R, MR Rosekind, S Hurd, KR Buccino. 1994. Relationship of day versus night sleep to physician performance and mood. Ann Emerg Med 24:928-934.

Snook, SH. 1988a. Approaches to the control of back pain in industry. En Back Pain in Workers, dirigido por RA Deyo. Filadelfia: Hanley \& Belfus.

1988b. The costs of back pain in industry. En Back Pain in Workers, dirigido por RA Deyo. Filadelfia: Hanley \& Belfus.

South, MA, JL Sever, L Teratogen. 1985. Update: The congenital rubella syndrome. Teratology 31:297-392.

Spence, AA. 1987. Environmental pollution by inhalation anaesthetics. Br F Anaesth 59:96-103.

Stellman, JM. 1976. Women's Work, Women's Health: Myths and Realities. Nueva York: Pantheon. 
Steppacher, RC, JS Mausner. 1974. Suicide in male and female physicians. FAMA 228(3):323-328.

Sterling, DA. 1994. Overview of health and safety in the health care environment. En Essentials of Modern Hospital Safety, dirigido por W Charney. Boca Ratón, Florida: Lewis Publishers.

Stoklov, M, P Trouiller, P Stieglitz, Y Lamalle, F Vincent, A Perdrix, C Marka, R de Gaudemaris, JM Mallion, J Faure. 1983. L'exposition aux gaz anethésiques: Risques et prévention. Sem Hôs 58(29/39):2081-2087.

Storer, JS, HH Floyd, WL Gill, CW Giusti, H Ginsberg. 1989. Effects of sleep deprivation on cognitive ability and skills of pediatrics residents. Acad Med 64:29-32.

Stubbs, DA, PW Buckle, PM Hudson. 1983. Back pain in the nursing profession; I Epidemiology and pilot methodology. Ergonomics 26:755-765.

Sundström-Frisk C, M Hellström.1995. The risk of making treatment errors, an occupational stressor. En Occupational Health for Health Care Workers, dirigido por M Hagberg, F Hofmann, U Stössel y G Westlander. Landsberg/Lech: Ecomed Verlag.

Swann-D’Emilia, B, JCH Chu, J Daywalt. 1990. Misadministration of prescribed radiation dose. Medical Dosimetry 15:185-191.

Sydow, B, F Hofmann. 1994. Resultados inéditos.

Tannenbaum, TN, RJ Goldberg. 1985. Exposure to anaesthetic gases and reproductive outcome: A review of epidemiologic literature. $f$ Occup Med 27:659-671

Teyssier-Cotte, C, M Rocher, P Mereau. 1987. Les lit dans les établissements de soins. Documents pour le médecin du travail. INRS 29:27-34.

Theorell T. 1993. On the psychosocial environment in care. En Occupational Health for Health Care Workers, dirigido por M Hagberg, F Hofmann, U Stössel y G Westlander. Landsberg/Lech : Ecomed Verlag.

Theorell, T. 1989. The psychosocial working environment. En Occupational Hazards in the Health Professions, dirigido por DK Brune y G Edling. Boca Ratón, Florida: CRC Press.

Tintori, R, M Estryn-Behar, J De Fremont, T Besse, P Jacquenot, A Le Vot, B Kapitaniak. 1994. Evaluation des lits à hauteur variable. Une démarche de recherche en soins infirmiers. Gestion. Hospitalières 332:31-37.

Tintori, R, M Estryn-Béhar. 1994. Communication: Où, quand, comment? Critères ergonomiques pour améliorer la communication dans les services de soins. Gestions Hospitalières 338:553-561.

Tokars, JI, R Marcus, DH Culver, CA Schable, PS McKibben, CL Bandea, DM Bell. 1993. Surveillance of HIV infection and zidovudine use among health care workers after occupational exposure to HIV-infected blood. Ann Intern Med 118:913-919.

Toomingas, A. 1993. The health situation among Swedish health care workers. En Occupational Health for Health Care Workers, dirigido por M Hagberg, F Hofmann, U Stössel y G Westlander. Landsberg/Lech: Ecomed Verlag.

Topf, M. 1992. Effects of personal control over hospital noise on sleep. Research in Nursing \& Health 15(1):19-28.

Tornquist, A, P Ullmark. 1992. Corporate Space and Architecture, Actors and Procedures. París: Ministère de l'équipement du logement et des transports.

Townsend, M. 1994. Just a glove? Br f Theatre Nurs $4(5): 7,9-10$.

Tran, N, J Elias, T Rosenber, D Wylie, D Gaborieau, A Yassi. 1994. Evaluation of waste anesthetic gases, monitoring strategies and corelations between nitrous oxide levels and health symptoms. Am Ind Hyg Assoc 755(1):36-42.

Turner, AG, CH King, G Craddock. 1975. Measuring and reducing noise. Noise profile of hospital shows that even "quiet" areas are too noisy. Hospital JAHA 49:85-89

US Preventive Services Task Force. 1989. Guide to Clinical Preventive Services: An Assessment of the Effectiveness of 169 interventions. Baltimore: Williams \& Wilkins.

Vaillant, GE, NC Sorbowale, G McArthur. 1972 Some psychologic vulnerabilities of physicians. Nere Engl f Med 287:372-375.

Vaisman, AI. 1967. Working conditions in surgery and their effects on the health of anesthesiologists. Esk Khir Anesteziol 12:44-49.

Valentino, M, MA Pizzichini, F Monaco, M Governa. 1994. Latex-induced asthma in four healthcare workers in a regional hospital. Occup Med (Oxf) 44(3):161-164.

Valko, RJ, PJ Clayton. 1975. Depression in the internships. Dis Nerv Syst 36:26-29.

Van Damme, P, GA Tormanns. 1993. European risk model. En Proceedings of the European Conference on Hepatitis $B$ as an Occupatioonal Hazard. 10-12.

Van Damme, P, R Vranckx, A Safary, FE Andre, A Mehevs. 1989. Protective efficacy of a recombinant deoxyribonucleic acid hepatitis $\mathrm{B}$ vaccine in institutionalized mentally handicapped clients. $A m \mathcal{F}$ Med 87(3A):265-295.

Van der Star, A, M Voogd. 1992. User participation in the design and evaluation of a new model hospital bed. En Ergonomie à l'hôpital (Ergonomía hospita laria), dirigido por M Estryn-Béhar, C Gadbois, M Pottier. International Symposium París 1991. Toulouse: Editions Octares.

Van Deursen, CGL, CAM Mul, PGW Smulders, CR de Winter. 1993. Health and working situation of day nurses compared with a matched group of nurses on rotating shift work. En Occupational Health for Health Care Workers, dirigido por M Hagberg, F Hofmann, U Stössel y G Westlander. Landsberg/Lech: Ecomed Verlag.

Van Hogdalem, H. 1990. Design guidelines for architects and users. En Building for People in Hospitals, Workers and Consumers. Luxemburgo: Fundación Europea para la Mejora de las Condiciones de Vida y de Trabajo.

Van Wagoner, R, N Maguire. 1977. A study of hearing loss among employees in a large urban hospital. Canadian Fournal of Public Health 68:511-512.

Verhaegen, P, R Cober, DE Smedt, J Dirkx, J Kerstens, D Ryvers, P van Daele. 1987. The adaptation of night nurses to different work schedules. Ergonomics 30(9):1301-1309.

Villeneuve, J. 1992. Une demarche d'ergonomie participative dans le secteur hôspitalier. En Ergonomie a l'hôpital (Hospital ergonomics), dirigido por M EstrynBéhar, C Gadbois y M Pottier. International Symposium París 1991. Toulouse: Editions Octares.

1994. PARC: Des fondations solides pour un projet de rénovation ou de construction Objectif prévention (Montreal) 17(5):14-16.

Wade, JG, WC Stevens. 1981. Isoflurane: An ansaesthetic for the eighties? Anesth Analg 60(9):666-682.

Wahlen, L. 1992. Noise in the intensive care setting. Canadian Critical Care Nursing Foumal, 8/9(4/1):9-10.

Walz, T, G Askerooth, M Lynch. 1983. The new upside-down welfare state. En Social Work in a Tur bulent World, dirigido por M Dinerman. Washington, DC: National Association of Social Workers.

Wands, SE, A Yassi. 1993. Modernization of a laundry processing plant: Is it really an improvement? Appl Ergon 24(6):387-396.

Weido, AJ, TC Sim. 1995. The burgeoning problem of latex sensitivity. Surgical gloves are only the beginning. Postgrad Med 98(3):173-174,179-182,184.

Wiesel, SW, HL Feffer, RH Rothmann. 1985. Industrial Low Back Pain. Charlottesville, Virginia: Michie.
Wigaeus Hjelm, E, M Hagberg, S Hellstrom. 1993. Prevention of musculoskeletal disorders in nursing aides by physical training. En Occupational Health for Health Care Workers, dirigido por M Hagberg, F Hofmann, U Stössel y G Westlander. Landsberg/Lech: Ecomed Verlag.

Wigand, R, Y Grenner. 1988. Personaluntersuchungen auf Immunität gegen Masern, Varizellen und Röteln, Saarländ. Ärztebl 41:479-480.

Wilkinson, RT, PD Tyler, CA Varey. 1975. Duty hours of young hospital doctors: Effects on the quality of work. 7 Occup Psychol 48:219-229.

Willet, KM. 1991. Noise-induced hearing loss in orthopaedic staff. 7 Bone Foint Surg 73:113-115.

Williams, M, JD Murphy. 1991. Noise in critical care units: A quality assurance approach. Fournal of Nursing Care Quality 6(1):53-59.

Wugofski, L. 1995. Occupational accident in health care workers-Epidemiology and prevention. En Occupational Health for Health Care Workers, dirigido por M Hagberg, F Hofmann, U Stössel y G Westlander. Singapore: Comisión Internacional para la Salud en el Trabajo.

Yassi, A, D Gaborieau, I Gillespie, J Elias, G Seyoum. 1991. The noise hazard in a large health care facility. F Occup Med 33(10):1067-1070.

Yassi, A, J Gaborieau, J Elias, D Willie. 1992. Identification and control of hazardous noise levels in a hospital complex. En Ergonomie à l'hôpital Ergonomía hospitalaria), dirigido por M Estryn-Béhar, C Gadbois y M Pottier. International Symposium París 1991. Toulouse: Editions Octares.

Yassi, A, J Khokhar, R Tate, J Cooper, C Snow, S Vallentyne. 1995a. The epidemiology of back injuries in nurses at a large Canadian tertiary care hospital: Implications for prevention. Occup Med 45(4):215-220.

Yassi, A, M McGill. 1991. Determinants of blood and body fluid exposure in a large teaching hospital: Hazards of the intermittent intravenous procedure. American Fournal of Infection Control 19(3):129-135.

- 1995. Efficacy and cost-effectiveness of a needleless intravenous access system. American Fournal of Infection Control 22(2):57-64

Yassi, A, R Tate, JE Cooper, C Snow, S Vallentyne, J Khokhar. 1995b. Early intervention for backinjured nurses at a large Canadian tertiary care hospital: An evaluation of the effectiveness and cost benefits of a two-year pilot project. Occup Med 45(4):209-214.

Yassi, A. 1994. Assault and abuse of health care workers in a large teaching hospital. Can Med Assoc $\mathcal{J}$ 151(9):1273-1279

Yassin, MS, MB Lierl, TJ Fisher, K O'Brien, J Cross, C Steinmetz. 1994. Latex allergy in hospital employees. Ann Allergy 72(3):245-249.

\section{Otras lecturas recomendadas}

Adegboye, AA, GB Moss, F Sovinka, JK Krieiss. 1994. The epidemiology of needlestick and sharp instrument accidents in a Nigerian hospital. Infec Contr Hosp Epid 15:27-31.

Alter, MJ. 1994. Occupational exposure to heapatitis C virus: A dilemma. Infec Contr Hosp Epid 15:742744 .

American Hospital Association (AHA). 1983. Chemical Hazardous Waste Assessment. Chicago, Illinois: AHA.

Bell, DM, JW Curran. 1992. Human immunodefiency virus infection. En Hospital Infections, dirigido por JV Bennett y PS Brachman. Boston: Little, Brown \& Co.

Browden, FJ, B Pollet, F Birrell, EM Dax. 1993. Occupational exposure to the human immunodefiency virus and other blood-borne pathogens. A six-year prospective study. Med F Austral 158:810-812.

Centre Nationale de l'équipment hospitalier. 1982. Guide technique pour la gestion el lélimination des dèchets 
hospitaliers. París: Centre Nationale de l'équipement hospitalier.

Cockcroft, A, K Oakley, C Gooch, S Mastin. 1994 Anxiety and perception of risk of HIV and hepatitis $\mathrm{B}$ infection among health-care workers reporting accidental exposures to blood and other body fluids. AIDS Care 6:205-214

Environmental Protection Agency. 1986. Guide for In fectious Waste Management. Washington, DC: EPA

Estryn-Béhar, M. 1996. Ergonomie hospitalière: Théorie et pratique. París: Estem éditions.

- 1997. Stress et souffrance des soignants à l'hôpital-Re connaissance, analyse et prévention. París: Estem éditions.

Francioli, P, J Jost. 1994. Mise a jour sur les exposition au VIH en milieu medical: mesures generales, chimioprophylaxie, declaration. Bulletin de l'Office Federale de la Sante Publique (Suisse) 37:617-630.

Gaffney, K, M Murphy, F Mulcahy. 1992. Phlebotomy practices, needlestick injuries, hepatitis B status, among interns in a Dublin hospital. Irish Medical fournal 85:102-104.

Garner, JS, BP Simmons. 1983. Guideline for isolation precautions in hospitals. Infec Contr Hosp Epid $4: 245-325$.

Garner, JS, MS Favero. 1985. Guideline for Handwashing and Hospital Environmental Control. Atlanta, Georgia: CDC.

Gerberding, JL. 1994. Incidence and prevalence of human immunodeficiency virus, hepatitis B virus, hepatitis $\mathrm{C}$ virus, and cytomegalovirus amon health care personnel at risk for blood exposure: $\mathrm{Fi}$ nal report from a longitudinal study. Fournal of Infectious Diseases 170:1410-1417.

Gestall, JJ. 1993. Risegos del trabajo del personal sanitario. Madrid: Interamericana-McGraw Hill.
Guardino, X. 1992. Seguridad y condiciones de trabajo en el aboratorio. Madrid: INSHT.

Hersey, JC, LS Martin. 1994. Use of infection control guidelines by workers in health care facilities to prevent occupational transmission of $\mathrm{HBV}$ and $\mathrm{HIV}$ Results from a national survey. Infec Contr Hosp Epid 15:243-252.

Ippolito, G, G DeCarli, V Puro, N Petrosillo, R Bertucci. 1994. Device-specific risk of needlestick injury in Italian health care workers. $\mathcal{F} A M A$ 272:607-610.

Klein, RS, K Freeman, PE Taylor, CE Stevens. 1992. Occupational risk for hepatitis $\mathrm{C}$ virus infection among New York City dentists. Lancet 338:15391542

Lot, F, D Abiteboul. 1994. Infections professionelles par le VIH en France; le point as 31 decembre 1993 Bulletin Epidemiologique Hebdormadaire 25:111-113.

Mallon, DF, W Shearwood, SA Mallal, MA French, RL Dawkins. 1992. Exposure to blood borne infections in health care workers. Med f Austral 157:592-595.

Marcus, R, DH Culver, DM Bell. 1993. Risk of human immunodeficiency virus infection among emergency department workers. Am F Med 94:363-370.

Marcus, R, P Srivastava, DM Bell. 1995. Occupational blood contact among pre-hospital emergency medical service workers: a prospective study. Annals of Emergency Medicine en imprenta.

Nelsing, S, TL Nielsen, JO Nielsn. 1993. Exposure to blood and risk of infection among health personnel. Ugeskrift for Laeger 155:3359-3363.

Organización Mundial de la Salug (OMS). 1985. Management of Waste from Hospital and Other Health Care Establishments. Copenhage: Oficina Regional de la OMS para Europa.
Panlilio, AL, BA Welch, DM Bell, 1992. Blood and amniotic fluid contact sustained by obstetrical personnel during deliveries. Am $\mathcal{f}$ Obstet Gynecol 67:703-708.

Panlilio, AL, CN Shapiro, GN Schable. 1995. Serosurvey of human immunodeficiency virus, hepatitis B virus, and hepatitis $\mathrm{C}$ virus infection among hospital-based surgeons. Fournal of the American $\mathrm{Col}$ lege of Surgeons 180:16-24.

Puro, V, E Lo Presti, I D'Ascanio, S Aaniratti, A Benedetto, G Ippolito. 1993. The seroprevalance of HIV, HBV, and HCV infections in patients coming to the departments of general surgery of a public hospital (S. Camillo, Roma). Mnerva Chirurgica 48:349-354.

Puro, V, G Ippolito, E Guzzanti. 1992. Zidovudine prophylaxis after accidental exposure to HIV: The Italian experience. AIDS Care 6:963-969.

Rhodes, RS, DN Bell. 1995. Prevention of bloodborne pathogen transmission in surgery and obstetrics. Surgical Clinics of North America en imprenta.

Stellman, JM, SD Stellman, J Berek, A Ezraty. 1978. The role of the Union Health and Safety Committee in evaluating the health hazards of hospital workers: A case study. Preventive Medicine 7(3):332-337.

Thomé-Kozmiensky, KJ. 1982. Recycling International. Berlín: E. Freitag.

Tokars, JI, DM Bell, DH Culver. 1992. Percutaneous injuries during surgical procedures. FAMA 267:2899-2904.

Tokars, JI, ME Chamberland, CA Schable. 1992. A survey of occupational blood contact and human immunodeficiency virus infection among orthopedic surgeons. FAMA 268:489-494.

Williams, WW. 1983. Guideline for infection control in hospital personnel. Infec Contr Hosp Epid 4 supl:326-349. 
Director del capítulo Pam Tau Lee

\section{Sumario}

Perfil general

Pam Tau Lee. ......................... 98.2

Restaurantes

Neil Dalhouse . . . . . . . . . . . . . . . . . . . . . . 98.2

Hoteles

Pam Tau Lee. . . . . . . . . . . . . . . . . . . . . . . . . . . . . 98.6

Efectos sobre la salud y pautas patológicas

Leon f. Warshaw . . . . . . . . . . . . . . . . . . . 98.9 


\section{Perfil General}

\section{Pam Tau Lee}

En todos los países hay hoteles y restaurantes, cuyas economías están estrechamente ligadas a la industria del turismo, los viajes de negocios y los congresos. El turismo es el principal sector económico en muchos países.

La función principal de un restaurante es servir comidas y bebidas a la gente fuera de sus casas. Existen diferentes tipos: establecimientos con varios comedores y plantillas numerosas (caros, por lo general); locales y cafés de "ambiente familiar", cuyos clientes suelen pertenecer a la misma localidad; bares cuya actividad principal es servir con rapidez la comida en la barra; restaurantes de comida rápida en los que el público hace su pedido en la barra y en pocos minutos está lista, generalmente para llevar fuera del establecimiento, y cafeterías con autoservicio, donde los clientes eligen platos cocinados colocados en expositores. Muchos restaurantes tienen salones o un bar aparte donde se sirven bebidas alcohólicas, mientras que otros, de mayor tamaño, disponen de salones para banquetes y celebraciones. En muchos países hay también vendedores callejeros con puestos de comida, que pertenecen por lo común al sector informal de la economía.

La función principal de un hotel es dar alojamiento a los huéspedes. Existen muchas clases de hoteles, desde los hostales y los moteles donde pernoctan turistas y personas en viajes de negocios, hasta los grandes complejos de lujo, como centros de ocio, balnearios y hoteles para congresos. Muchos hoteles suelen ofrecer servicios auxiliares de restaurante, bar, lavandería, gimnasio y gabinete médico, salón de belleza, peluquería, centro de negocios y tiendas de artículos de regalo.

Los restaurantes y hoteles pueden estar regentados por una persona, una familia, un grupo de socios o incluso por grandes empresas que, con frecuencia, en lugar de ser propietarias de un establecimiento perteneciente a una cadena, ceden en régimen de franquicia su nombre y su estilo a los propietarios de la localidad.

La plantilla de un restaurante comprende jefes y personal de cocina, camareros y jefes de rango, ayudantes de camarero, encargados de barra, cajeros y personal de guardarropa. En los restaurantes más grandes el personal está sumamente especializado en sus funciones.

Un gran hotel cuenta por lo común entre sus empleados con recepcionistas, porteros y botones, personal de seguridad, encargados de garaje y aparcamiento, personal de habitaciones, encargados de lavandería, personal de mantenimiento, personal de cocina y restaurante y personal de oficina.

Los trabajos que se hacen en un hotel son en su mayoría manuales y el nivel de educación que exigen es mínimo. Hoy día, el grueso de la plantilla de los hoteles en los países desarrollados suelen formarlo mujeres e inmigrantes, mientras que en los países en desarrollo se acude a la población local. Los niveles de ocupación hotelera siguen unos ciclos estacionales, lo que deriva en la coexistencia de un pequeño grupo de empleados fijos junto con un número considerable de trabajadores temporales y a tiempo parcial. Por lo general, el nivel de los sueldos suele ser medio o bajo. La elevada rotación laboral se debe a estos factores.

El panorama laboral es muy parecido en el caso de los restaurantes, aunque en éstos el número de varones en plantilla suele ser superior. Los sueldos son bajos en muchos países, por lo que los ingresos de camareros y ayudantes dependen en su mayor parte de las propinas que reciben de los clientes. En muchos lugares las propinas se incluyen automáticamente en la cuenta.
En los locales de comida rápida, los empleados suelen ser jóvenes que cobran el salario mínimo.

\section{RESTAURANTES}

\section{Neil Dalhouse}

Un restaurante puede variar en tamaño: desde un pequeño local de comidas hasta el restaurante de un gran hotel, y comprende por lo común tres zonas principales: la cocina, donde se prepara y guisa la comida; el servicio de comidas a los clientes en el restaurante, y el bar, una sala que ofrece comidas y bebidas alcohólicas, amenizadas con música y espectáculos en vivo o grabados.

\section{Cocinas}

El personal de cocina comprende: los jefes de cocina y los cocineros, que preparan y cocinan la comida; los encargados de la despensa, cuya misión es preparar los alimentos que van a cocinarse y mantener al día el inventario de provisiones, y las asistentas encargadas de la limpieza y el mantenimiento de las dependencias de la cocina.

En las cocinas ocurren varios tipos de accidentes, como quemaduras con freidoras, resbalones a causa de la grasa en el suelo o cortes con cuchillos. La falta o escasez de mantenimiento en la zona de la cocina pueden originar accidentes. Los suelos recién fregados deben estar indicados con un cartel de "Suelo mojado" para evitar lesiones por caídas entre el personal de cocina. Las fuentes y platos han de guardarse de forma segura para impedir que se caigan. En las entradas y salidas deben colocarse alfombrillas, y la cera que se aplique al suelo en estas zonas ha de ser antideslizante. No deben dejarse nunca cajas, cubos de basura ni otros obstáculos en los pasillos. Si hay baldosas sueltas, cables al descubierto, sustancias derramadas por el suelo o existe cualquier otra circunstancia susceptible de causar un accidente, deberá notificarse y atenderse lo antes posible, para lo cual el centro de trabajo ha de disponer de un procedimiento para tales notificaciones.

También existe peligro de accidentes si no se usan los medios adecuados para alcanzar los enseres guardados en las estanterías más altas, a las que se llegará mediante escaleras o taburetes con peldaños, nunca cajas o sillas. Las escaleras y taburetes han de guardarse en un lugar apropiado y mantenerse en buen estado de conservación.

\section{Máquinas, cuchillos y aparatos para cortar}

Los accidentes y las lesiones se producen con frecuencia si no se toman las medidas de seguridad adecuadas. El tipo de aparatos para cortar, la incesante actividad y la presión de trabajo presentes en los restaurantes durante las horas de las comidas aumentan el riesgo de accidentes.

Las picadoras de carne, las batidoras, las máquinas de cubitos de hielo y los lavavajillas son algunas de las máquinas más frecuentes en una cocina y su uso indebido puede provocar cortes, aprisionamiento de miembros en piezas móviles o descargas eléctricas. Para prevenir estos riesgos, el personal de cocina debe recibir formación completa antes de manejar los aparatos y seguir las indicaciones del fabricante para su uso seguro. Otras medidas para evitar posibles lesiones son: asegurarse de que las máquinas estén apagadas y desenchufadas antes de proceder a su limpieza; llevar ropa cómoda y prescindir de colgantes y adornos sueltos que puedan caerse o quedar atrapados en las máquinas (por el mismo motivo los empleados con pelo largo deben llevar una red para recogerse el cabello), y 
realizar revisiones con regularidad por parte de personal autorizado. Además, nunca deben introducirse los alimentos en las máquinas con las manos.

Las cortadoras de carne, utilizadas también para cortar frutas y verduras, son muy comunes en las cocinas y son los aparatos potencialmente más peligrosos entre los equipos de cocina. $\mathrm{Al}$ manejar una máquina de cortar, las defensas deberán colocarse siempre en su lugar. La limpieza de estos equipos requiere especial cuidado, sobre todo cuando las hojas de corte están a la vista. Después de utilizar la cortadora, el empleado debe ponerla en la posición de parada y desenchufarla.

Los cuchillos pueden producir heridas graves si se utilizan indebidamente o si no están guardados en un lugar apropiado. El personal de cocina suele emplear cuchillos para cortar y trocear carne y verduras antes de cocinarlas. Para evitar lesiones deben observarse algunas medidas: no utilizar los cuchillos para actividades ajenas a su uso específico (por ejemplo, como abrelatas); mantenerlos bien afilados, de lo contrario la presión ejercida es mayor y aumenta el riesgo de que resbale la hoja; transportarlos asidos por el mango y con la hoja hacia el suelo, y guardarlos en su sitio nada más acabar su limpieza.

\section{Hornos y fogones}

Las quemaduras de la piel son el mayor peligro al que está expuesto el personal de cocina que maneja hornos y fogones. Las lesiones por este motivo varían desde ligeras escaldaduras superficiales hasta quemaduras de tercer grado. Como medida preventiva se recomienda utilizar manoplas protectoras para transportar las cazuelas, levantar las tapas de las mismas o retirarlas del horno. No debe dejarse que la grasa se acumule en las zonas cercanas al horno para evitar resbalones e incendios. Si los hornos que se utilizan son de gas, debe conectarse el piloto antes de encenderlo.

Las freidoras son otro aparato común en las cocinas, empleadas para las frituras de carnes y verduras. El mayor peligro que entrañan son las quemaduras en la piel por salpicaduras de grasa caliente. Para manejar con seguridad una freidora se recomiendan las medidas siguientes: evitar que el aceite se caliente en exceso y se incendie; limpiar de grasa el suelo alrededor de la freidora; no llenarla demasiado de aceite para impedir que llegue a rebosar, y prestar un cuidado especial a la hora de filtrar o cambiar el aceite de la freidora. Se llevará puesto siempre un equipo de protección personal, como guantes, delantales y camisetas de manga larga.

Los hornos de microondas se utilizan mucho en las cocinas para calentar la comida rápidamente o cocinarla. Los peligros más frecuentes que entrañan cuando su mantenimiento no es el correcto son las descargas eléctricas y la exposición a fugas de radiación de microondas. Se trata de una radiación que, en función de la intensidad y la duración de la exposición, puede causar lesiones a los órganos más sensibles del cuerpo humano. Es posible que los marcapasos y otros implantes médicos se vean afectados igualmente por la radiación. La puerta y las juntas de cierre del microondas deben estar limpias de residuos de grasa y comida, que pueden impedir que el aparato cierre correctamente y se produzca un escape de radiación al exterior. Deben colocarse en las proximidades del horno instrucciones sobre su funcionamiento en las debidas condiciones de seguridad. Todos los hornos deben someterse a revisiones periódicas para mantenerlos en buen estado y detectar posibles fugas de radiación. Las reparaciones y ajustes necesarios han de llevarse a cabo por técnicos especializados.

\section{Platos cocinados a la vista del cliente}

Los platos flameados o cocinados junto a la mesa de los comensales pueden provocar quemaduras al camarero y a los clientes si no se emplean los métodos adecuados. Sólo debe servir este tipo de platos el personal debidamente instruido y que sepa manejar combustible líquido o semisólido. Para apagar posibles incendios es necesario contar con un extintor de dióxido de carbono.

\section{Cámaras de refrigeración y congeladores}

Las grandes cámaras de refrigeración y congelación se utilizan en las cocinas para guardar alimentos preparados y sus ingredientes. Además de las bajas temperaturas, el principal peligro radica en que el personal de cocina quede atrapado en caso de cierre accidental de la puerta. Todas las cámaras frigoríficas deben contar con tiradores de apertura en el interior y con interruptores de alarma, cuya ubicación conocerá todo el personal que las utilice normalmente.

En la cámaras frigoríficas se debe entrar con cuidado, ya que la condensación existente en su interior hace que el suelo esté muy resbaladizo. El suelo deberá mantenerse siempre limpio de grasa y de restos de alimentos. Antes de cerrar el establecimiento hay que asegurarse de que nadie haya quedado encerrado dentro de las cámaras frigoríficas.

\section{Temperaturas extremas}

Todo el personal de cocina de los restaurantes está expuesto a estrés por calor, aunque es el jefe de cocina o cocinero quien está sometido a una mayor exposición, ya que su trabajo se desarrolla muy cerca de los hornos y fogones. Las extremadamente altas temperaturas que alcanza el aire en las inmediaciones de las fuentes de calor, combinadas con los pesados uniformes que muchos jefes de cocina están obligados a llevar, pueden causar ciertos problemas de salud. Por lo común, el personal de cocina padece, entre otros: tensión arterial elevada, trastornos de la piel, dolores de cabeza y fatiga. También son frecuentes el agotamiento por calor y los golpes de calor, y se han dado casos extremos en que se han producido desmayos y pérdida de conocimiento.

Para combatir el estrés por calor es preciso mejorar la ventilación con campanas extractoras de aire caliente, organizar los períodos de trabajo/descanso y beber grandes cantidades de agua a lo largo de la jornada de trabajo. Así mismo, el personal de cocina debe estar educado para reconocer los síntomas de los trastornos por calor.

Son trabajadores expuestos por lo común a temperaturas extremas al pasar de las cámaras frigoríficas a las cocinas, cambios bruscos que pueden acarrear problemas respiratorios. Algunos empleados permanecen largos períodos de tiempo dentro de las cámaras, desempaquetando, ordenando cajas y limpiando el interior, para lo cual debe proporcionárseles ropa de protección adecuada.

\section{Ventilación}

Para eliminar olores, grasas y humos de las cocinas se necesitan sistemas de ventilación apropiados. La grasa en suspensión en el aire puede depositarse sobre los distintos equipos de la cocina, volviéndolos resbaladizos. Los sistemas de ventilación comprenden extractores, conducciones de aire y campanas. Los filtros de estos dispositivos deben retirarse y limpiarse con regularidad.

\section{Limpieza general}

\section{Lavado de la vajilla}

Las máquinas lavavajillas pueden producir quemaduras en la piel al retirar platos calientes o al acceder a su interior antes de que haya finalizado el ciclo de lavado. Nunca deben sobrecargarse, pues podrían obstruirse y dejar de funcionar, y deben utilizarse guantes a la hora de retirar los platos de su interior. 


\section{Productos de limpieza}

Para mantener las cocinas de los restaurantes en las mejores condiciones de limpieza e higiene se emplean diversas clases de productos. Para limpiar la grasa de los hornos y las cocinas suelen emplearse los que contienen amoníaco, sustancia irritante para la piel y los ojos. Al utilizar productos con amoníaco hay que ventilar el lugar mediante campanas y extractores.

Los productos empleados para desatascar desagües son cáusticos y causan quemaduras en la piel y lesiones en los ojos. Para protegerse de sus salpicaduras deben llevarse guantes de goma y mascarillas faciales. Los jabones y detergentes presentes en los productos para limpiar los suelos pueden provocar dermatitis e irritación de la garganta en caso de inhalación del polvo del jabón. Los empleados sensibles a este tipo de polvo necesitan llevar mascarillas desechables.

Es preciso observar determinados procedimientos al manejar productos de limpieza a fin de eliminar los riesgos que entrañan para los trabajadores. Así, deben guardarse debidamente etiquetados y lejos de los lugares reservados a los alimentos; nunca deben mezclarse, sobre todo con lejía, cuya combinación con otros productos de limpieza puede resultar peligrosa. En muchos países existen fichas técnicas de seguridad (FTS), con información sobre el contenido de los productos de limpieza, sus efectos y las instrucciones para su correcto manejo.

\section{Compresores de basura}

Los compresores de basura se utilizan para reducir en volumen las grandes cantidades de desperdicios procedentes de las cocinas. Deben estar diseñadas para funcionar únicamente con la tapa cerrada, a fin de evitar que las manos o el pelo queden atrapados, y el suministro de agua ha de ser suficiente para que su funcionamiento resulte eficaz y seguro. Es importante extremar el cuidado para que no se introduzcan cristales, metales o plásticos en el compresor de basura, ya que la máquina se atascaría y dejaría de funcionar.

\section{Pesticidas}

Suelen utilizarse en los restaurantes para combatir los insectos que atrae la presencia de alimentos. Aunque la mayoría de los pesticidas usados en cocinas y restaurantes apenas presentan peligro para los seres humanos, algunas personas especialmente sensibles a ellos pueden sufrir iritaciones en la piel y otras reacciones alérgicas.

Para evitar la incorrecta utilización de los pesticidas, es necesario que los encargados y el personal de limpieza reciban formación previa y, en el caso de que la infestación de insectos sea grave, acudir a técnicos autorizados. Todos los envases de productos pesticidas deben llevar impresas las instrucciones, que el usuario ha de leer antes de proceder a su aplicación, sobre todo las referentes a la seguridad de su uso en zonas donde haya alimentos.

\section{Servicio de comidas}

El personal adscrito al servicio de comidas comprende: camareros encargados del comedor, camareros encargados de los aperitivos, los encargados de los cócteles, los encargados de la barra, los que acompañan al cliente hasta la mesa, los encargados de los banquetes y los ayudantes de camarero. Las funciones de estos empleados consisten en servir comidas y bebidas, acompañar a los clientes hasta sus mesas, y la limpieza y el mantenimiento de los comedores.

\section{Resbalones y caídas}

Pueden producirse lesiones al resbalar sobre un suelo húmedo o al caerse por tropezar con cajas, carritos o cubos de basura situados en cocinas y comedores. Entre estas lesiones están los esguinces, los traumatismos en las extremidades, lesiones cervicales y dorsales, y cortes ocasionados por la caída sobre objetos cortantes. Para evitar estos riesgos, los empleados deben llevar siempre un calzado resistente, con tacón bajo y suela de goma. La comida, la grasa y el agua derramadas en el suelo deben limpiarse de inmediato, y los cables sueltos han de fijarse bien al suelo.

Todas las alfombrillas del comedor deben ser antideslizantes o contar con un reverso de goma o similar. Deben revisarse las moquetas por si hay zonas desgastadas o levantadas que puedan provocar tropiezos del personal del servicio de comidas. Las zonas del suelo donde se produzca la transición de moqueta a baldosas debe estar debidamente señalizada para advertir al personal del cambio de superficie.

La disposición del comedor es otro factor importante en la prevención de accidentes. Los recodos difíciles, la escasez de luz y las puertas angostas en la cocina pueden provocar choques accidentales entre los camareros. Los ángulos abiertos y bien señalizados, y una iluminación suficiente en las puertas facilitan el paso y la seguridad del personal del servicio de comidas.

\section{Quemaduras}

El personal del servicio de comidas puede sufrir quemaduras en la piel por salpicaduras de líquidos calientes, como café o sopa, o por la cera derretida de las velas que iluminan y decoran las mesas. Para evitarlo, los camareros nunca deben llenar en exceso los vasos y platos al servir bebidas calientes en la mesa. $\mathrm{Al}$ servir sopa, deben tener cuidado de no salpicar y procurar no llenar los platos en exceso.

Los encargados de llevar cafeteras y teteras al comedor deben protegerse las manos con una servilleta.

\section{Lesiones musculosqueléticas}

Las lesiones por esfuerzos repetitivos (LER) y otros problemas musculosqueléticos son frecuentes en los empleados que rutinariamente llevan bandejas pesadas, y que tienen que inclinarse y estirarse para quitar, limpiar y poner las mesas o trasladar cajas con los suministros para el restaurante. Estos riesgos pueden reducirse mediante una buena planificación de los puestos de trabajo y de sus horarios, de manera que las labores del personal destinado al servicio de comidas tengan carácter rotatorio, a fin de disminuir las tareas repetitivas.

La formación en materia de ergonomía (y de factores de riesgo de lesiones por esfuerzo repetitivo) es también de gran utilidad para evitar este tipo de lesiones entre el personal del servicio de comidas.

Muchas lesiones cervicales y dorsales se deben al uso de una técnica inadecuada al levantar pesos. Con frecuencia, el transporte de bandejas sobrecargadas con platos y vasos de forma incorrecta puede originar lesiones cervicales y aumentar el riesgo de caída de la bandeja y lesionar a otra persona. Los riesgos de lesiones pueden reducirse con una formación adecuada sobre cómo levantar y llevar las bandejas correctamente. Así, la distribución equilibrada de platos y vasos por toda la bandeja y la colocación de la palma de una mano en el centro de la base, mientras se sujeta el borde frontal con la otra, contribuye a crear un entorno más seguro en el comedor.

\section{Estrés}

Los comedores de los hoteles pueden ser lugares muy estresantes por la presión que supone dar un servicio eficaz dentro de un horario apretado. También influyen en el estrés del personal del servicio de comidas los turnos de trabajo, la incertidumbre sobre sus ingresos, ya que dependen en gran parte de las propinas, y el trato con algunos clientes difíciles e irritables. A ello se añaden otros factores estresantes de tipo físico, como el ruido o la mala 
calidad del aire ambiental. Algunos de los síntomas de estrés más frecuentes son: dolor de cabeza, taquicardia, úlcera, irritabilidad, insomnio y depresión.

$\mathrm{Al}$ objeto de prevenir y reducir el estrés es recomendable mantener reuniones de trabajo en las que los empleados tengan la oportunidad de compartir puntos de vista sobre la forma de mejorar el método de trabajo, así como asistir a cursillos sobre técnicas de gestión del estrés, mejora de la calidad del aire y reducción del nivel de ruido. Son aspectos de los que se ocupa esta Enciclopedia más detenidamente en otros apartados.

\section{Bares y salas}

El concepto de bares y salas abarca desde pequeños locales y bares de copas hasta grandes discotecas y locales con actuaciones. La mayor parte de los riesgos que entrañan estos establecimientos se abordan con más detalle en otros apartados de esta Enciclopedia.

Los cristales rotos son un peligro frecuente en los bares debido a la gran cantidad de vasos y botellas utilizados en estos establecimientos. Empleados y clientes corren el riesgo de ingerir accidentalmente fragmentos de cristales de vasos rotos. También existe el peligro de sufrir cortes en los dedos. Para reducir estos riesgos deben observarse varias medidas, como la inspección periódica para detectar vasos agrietados o con fragmentos rotos. Todos los vasos que no estén en perfecto estado se retirarán de inmediato. Tampoco deben cogerse varios vasos con una sola mano, introduciendo un dedo dentro de cada vaso, ya que pueden romperse al chocar unos con otros.

Nunca debe usarse un vaso para recoger cubitos de hielo. Para poner hielo en los vasos debe emplearse un recogedor metálico. En caso de rotura de un vaso de cristal encima del hielo, hay que dejar que éste se derrita completamente y retirar con cuidado todos los trozos de cristal. Los cristales rotos jamás deben recogerse con las manos sin protección.

Fumadores pasivos. Los empleados de los bares y salas están expuestos al humo de los fumadores, especialmente en locales muy concurridos, lo cual entraña un riesgo, ya que se ha asociado el cáncer de pulmón y otros problemas respiratorios con la condición de fumador pasivo. Así pues, es imprescindible realizar los mayores esfuerzos para mejorar la ventilación de los bares y acotar zonas de no fumadores.

Resbalones y caídas. El ajetreo propio de los bares con gran afluencia de público contribuye a que se produzcan resbalones y caídas. Las bebidas derramadas sobre el suelo y el goteo de algunas botellas hacen que la zona del interior de la barra resulte especialmente peligrosa para los camareros, por lo que es necesario fregar el suelo cada cierto tiempo. Fuera de la barra, hay que fregar el suelo inmediatamente después de que alguien derrame su bebida. Cuando el suelo está recubierto con moqueta, ésta debe inspeccionarse regularmente para detectar cualquier irregularidad o desperfecto donde la gente pueda tropezar. Todos los empleados deben llevar calzado no deslizante con suela de goma.

Si en el local existe una pista de baile, el suelo de ésta deberá ser de madera o de otro material que permita deslizarse sobre él, pero su color tendrá que diferenciarse de las otras zonas del local.

Levantamiento de pesos. Entre las labores de un empleado de bares está la de levantar cajas pesadas y barriles de cerveza, para lo cual ha de utilizar, siempre que sea posible, una carretilla. Si se levantan pesos de forma incorrecta pueden producirse lesiones cervicales, dorsales y de rodilla. Cualquier maniobra de levantamiento de peso ha de realizarse con una técnica que garantice la seguridad.

Los camareros de los bares suelen llevar bandejas pesadas llenas de bebidas, lo que origina estrés cervical y dorsal. Es conveniente, pues, que aprendan técnicas apropiadas para llevar bandejas. Mantenerse en buena forma física es también importante para prevenir lesiones en la espalda.

Ruidos. El exceso de ruido en locales con actuaciones en directo puede causar lesiones auditivas en los empleados. La exposición a niveles de 90 decibelios (dB), el límite legal establecido en los Estados Unidos y otros países, origina en determinadas personas una pérdida auditiva. Todos los empleados expuestos a niveles entre 85 y $90 \mathrm{~dB}$ durante 8 horas al día han de someterse a una audiometría.

Para evitar este tipo de lesiones debe limitarse el tiempo de exposición a niveles elevados de ruido, además de intentar reducir el volumen del sonido. Si lo anterior no resulta posible, existen medidas de protección personal, como los tapones para los oídos.

Gases comprimidos. Se hallan presentes en los bares que sirven bebidas con gas. Los envases de estas bebidas deben guardarse boca arriba para evitar posibles explosiones.

\section{Seguridad contra incendios}

Todos los empleados de restaurantes deben saber utilizar los extintores y conocer la localización de las alarmas contra incendios. Un programa de prevención de incendios eficaz debe contemplar la formación del personal para que sepa detectar cualquier riesgo de incendio y cómo proceder en caso de que llegue a producirse. Los números de teléfono de emergencia y las instrucciones para llamar deben hallarse en un lugar destacado, y todos los empleados deben conocer los planes y vías de evacuación del local. Deben estar especialmente formados para apagar cualquier fuego pequeño que se produzca en la cocina.

La clave para la prevención de incendios en un restaurante está en un buen mantenimiento y conservación. Debe inspeccionarse todo el local para que no se acumulen restos de aceite, grasa o basura. Una vez usados, los materiales combustibles, como los aerosoles o los trapos con grasa, deben guardarse en contenedores o cubos de basura convenientemente tapados. Los conductos de ventilación, los filtros y los extractores de la cocina no deben tener grasa, lo que, por otra parte, ayudará a mantener los equipos e instalaciones en buen estado de funcionamiento.

Las salidas de emergencia de los restaurantes deben estar señalizadas con claridad y los accesos a las salidas estarán en todo momento despejados, sin cajas, cubos de basura u otro tipo de desechos. En un programa de prevención no deben faltar sistemas de detección de incendios y pulverizadores de agua.

\section{Cajeros}

Los cajeros de un restaurante son los encargados de la caja registradora: manejan el efectivo que entra en el establecimiento, elaboran las facturas de los clientes y atienden al teléfono. Los restaurantes suelen ser objeto de asaltos y robos en los que los cajeros pueden resultar lesionados e incluso muertos. La dirección debe prestar formación al personal de caja en cuanto al manejo del dinero y la forma de comportarse en caso de robo. Otras medidas de prevención consisten en situar la caja en un lugar abierto e iluminado, e instalar alarmas en esa zona que refuercen la seguridad en caso de robo. Una vez cerrado, el local deberá estar bien seguro y las salidas protegidas por alarmas y señalizadas para ser utilizadas exclusivamente en caso de emergencia.

\section{Ergonomía}

El personal de caja, sobre todo de los establecimientos de comida rápida y de las cafeterías, pueden llegar a sufrir lesiones por esfuerzo repetitivo a causa del diseño de sus puestos y de la elevada carga de trabajo. Entre las medidas de prevención están que el puesto de trabajo tenga un buen diseño, con la caja 
registradora a la altura apropiada, y que los asientos sean flexibles, de manera que permitan aliviar la presión ejercida sobre las piernas y la región lumbar.

\section{- Hoteles}

\section{Pam Tau Lee}

Los distintos departamentos de un hotel suelen ser los siguientes: recepción, cuya misión es gestionar las reservas y los servicios de recepción de los clientes; servicio de limpieza, responsable de la limpieza y suministro de enseres de las habitaciones de los clientes y espacios de uso común; mantenimiento, departamento encargado de la conservación y limpieza a gran escala, de las instalaciones, la pintura, las reparaciones y restauraciones; servicio de comidas y bebidas; administración y contabilidad, y otros servicios, como gabinetes médicos, salones de belleza, peluquerías y tiendas de artículos de regalo.

\section{Riesgos por departamentos}

\section{Recepción}

La recepción engloba las siguientes categorías laborales: directores, empleados de mostrador, telefonistas, botones, personal de seguridad, conserjes, chóferes y aparcacoches. Entre los peligros para la salud y la seguridad, los principales son los siguientes:

Pantallas de visualización de datos (PVD). Los empleados de mostrador, los telefonistas y otros empleados que atienden al público suelen trabajar con terminales de ordenador. Se ha demostrado que el trabajo con ordenadores en ciertas condiciones puede provocar determinadas lesiones por esfuerzo repetitivo (LER), como el síndrome del túnel carpiano (en las muñecas) y lesiones en hombros, cuello y espalda. Los empleados se exponen a riesgos especiales si el puesto de trabajo requiere la adopción de posturas extrañas, o si el trabajo con la PVD es ininterrumpido y sin pausas para descansar. Las PVD también pueden producir fatiga visual y otros problemas en los ojos. Entre las medidas de prevención se incluyen: puestos de trabajo informáticos ajustables, formación al personal para colocar adecuadamente su equipo y mantenimiento de posturas correctas, sin olvidar las pausas para descansar y estirarse.

Trabajo por turnos. Muchos empleados encargados de la atención al cliente trabajan en turnos que pueden variar en función del nivel de ocupación diario. Es posible que haya trabajadores en plantilla que deban trabajar en turno de día y noche, o en turnos partidos con días libres distribuidos aleatoriamente. Algunos efectos del trabajo por turnos sobre la salud física y mental son: perturbaciones del sueño, problemas de estómago y estrés. A ello se añade la posibilidad de que los trabajadores recurran a las drogas o a los medicamentos para conciliar el sueño y ajustarse a horas de trabajo inusuales. Los trabajadores deben recibir información sobre los riesgos para la salud que entraña el trabajo por turnos. Siempre que sea posible, los trabajadores deberán disfrutar del tiempo libre necesario entre turnos rotativos para permitir la normalización del sueño.

Hay otros aspectos referentes a los turnos de tarde y noche que merecen especial atención, como los factores de seguridad, la disponibilidad de comidas sanas durante la jornada de trabajo y una buena ventilación (el aire acondicionado suele apagarse durante la noche).

Mala calidad del aire en interiores. Los empleados pueden convertirse en fumadores pasivos en lugares como el vestíbulo, el bar, el comedor o las habitaciones de los huéspedes. Sin la ventilación apropiada, los fumadores pasivos corren el riesgo de contraer cáncer de pulmón y sufrir enfermedades cardíacas.
Levantamiento de peso. Los riesgos originados por el levantamiento de peso son frecuentes en el personal cuya labor es cargar, descargar y transportar equipajes y suministros para congresos. Si no se presta formación a los empleados sobre las técnicas correctas para levantar pesos, pueden darse casos de lesiones en cuello, espalda, rodillas y tobillos. Es recomendable usar carretillas portaequipajes que se encuentren en buen estado y tengan un dispositivo de bloqueo de seguridad y ruedas que permitan un deslizamiento suave.

Riesgos en garajes y aparcamientos. El personal encargado de los garajes de los hoteles incluye: aparcacoches, cajeros y encargados de mantenimiento. Se trata de empleados que suelen trabajar a tiempo parcial con un elevado índice de rotación laboral.

Entre otros peligros se halla el de ser atropellados por un vehículo, el de inhalar gases de los tubos de escape (que contienen monóxido de carbono además de otras toxinas) o el de verse expuestos a sustancias químicas presentes en productos para automóviles, para limpieza o en pinturas. También están expuestos al asbesto procedente del polvo de los frenos de los vehículos; pueden sufrir caídas de escaleras y otros equipos de mantenimiento, o tropiezos y resbalones por la existencia de líquidos derramados, nieve o desperfectos en el pavimento, sin olvidar los riesgos por posibles atracos.

Algunas medidas para prevenir accidentes con automóviles son la señalización clara de los carriles de circulación y pasos de peatones, indicadores del sentido de la circulación del tráfico, señales de "stop" en cruces y el acotado de zonas en obras.

Los trabajadores expuestos a los gases de los tubos de escape, las emanaciones tóxicas de pinturas y otros productos químicos, deben tener la posibilidad de respirar aire puro y recibir formación sobre los riesgos que entrañan y sus efectos sobre la salud.

Las estufas de queroseno que en ocasiones utilizan los trabajadores de los aparcamientos pueden despedir emanaciones tóxicas y no debe permitirse su uso. Cuando sea necesario recurrir a estufas, éstas deberán ser eléctricas, estar vigiladas y debidamente conectadas a tierra.

Los derrames de aceite y agua, y cualquier desperdicio en el suelo deben limpiarse de inmediato. La nieve ha de retirarse e impedir que se acumule.

\section{Servicio de limpieza}

En este grupo se incluyen el personal de limpieza de habitaciones, el personal de lavandería y los supervisores. Sus funciones suelen concretarse en la limpieza y mantenimiento de las habitaciones, los espacios de uso común y las salas recreativas y de reuniones. También suelen encargarse del servicio de lavandería de los huéspedes. Los principales riesgos para su salud y seguridad son los siguientes:

Lesiones por esfuerzo repetitivo (LER). El trabajo del personal de limpieza conlleva esfuerzos, como levantar pesos repetidamente, inclinarse y agacharse para limpiar y fregar los cuartos de baño, cambiar la ropa de cama, aspirar las alfombras, limpiar el polvo de muebles y paredes y empujar los carritos de la limpieza de una habitación a otra. El personal de lavandería también corre el riesgo de sufrir lesiones por esfuerzos repetitivos a causa de los estiramientos y rápidos movimientos necesarios para doblar, clasificar y apilar la ropa.

Para el transporte de los equipos y enseres, los empleados utilizan carritos, que deben estar en perfecto estado de mantenimiento y tener las ruedas engrasadas para permitir un deslizamiento suave y transportar cargas pesadas sin riesgo de tropiezos. Además, los carritos deben ser relativamente ligeros, fáciles de manejar y permitir al que lo lleva ver con claridad por dónde va.

Tanto el personal de limpieza como el de lavandería tienen que recibir formación sobre aspectos de ergonomía y de cómo 
levantar correctamente pesos. También deberán conocer los factores de riesgo de las LER y los métodos para reducir su incidencia.

Productos químicos. Las doncellas y encargadas de la limpieza de las habitaciones emplean productos químicos para lavabos, bañeras, retretes, suelos y espejos, algunos de los cuales pueden ocasionar dermatitis, problemas respiratorios y otras afecciones. Algunos de los productos que contienen amoníaco, detergentes y disolventes, son irritantes para la piel, los ojos, las fosas nasales y la garganta. Determinados productos a base de disolventes pueden producir lesiones en los riñones y en los órganos reproductores. Los desinfectantes suelen contener compuestos del fenol, que pueden causar irritación y posiblemente cáncer.

Como medidas de prevención se recomienda la utilización de guantes protectores y el empleo de productos menos peligrosos. También es necesaria una ventilación adecuada, abriendo las ventanas o mediante ventiladores y extractores de aire. Los productos químicos deben almacenarse en zonas con el correcto mantenimiento, lejos de los lugares destinados a comidas y descanso.

Debe prestarse formación a los trabajadores sobre los riesgos que entrañan los productos químicos y sus efectos sobre la salud, de una forma que todos ellos puedan comprender, lo que en ocasiones requerirá la traducción a su lengua materna.

Tropiezos y caídas. El personal de limpieza necesita trasladarse con rapidez durante su trabajo, circunstancia que favorece los resbalones en suelos mojados, las caídas desde las bañeras u otras superficies durante la limpieza y los tropiezos con cordones, sábanas y colchas u otros obstáculos. Por otra parte, el personal de lavandería corre el riesgo de resbalar sobre los suelos mojados.

Debe ofrecerse formación al personal, prestando especial atención a las medidas de seguridad que deben adoptarse para prevenir caídas y a los métodos de trabajo que reduzcan la necesidad de trabajar con prisa.

Cortes. El riesgo de cortarse con cristales, hojas de afeitar usadas y otros desechos puede reducirse utilizando bolsas en las papeleras y colocando en los cuartos de baño dispositivos especiales para deshacerse de estos instrumentos. Los empleados deben recibir instrucciones sobre los procedimientos apropiados para manipularlos.

Agujas de jeringuillas. Las agujas hipodérmicas usadas y dejadas por los clientes en las papeleras, entre la ropa o por la habitación, comportan un riesgo para los empleados del hotel que pueden contraer enfermedades infecciosas por pinchazos accidentales. El personal de limpieza y de lavandería son los que mayores posibilidades tienen de encontrarse con agujas usadas. Por ello, es preciso que reciban instrucciones para que comuniquen estos hechos y sepan cómo deshacerse de las agujas. Deben ponerse a disposición del personal cajas de recipientes homologados para agujas, y el hotel deberá contar con procedimientos médicos y de asesoramiento eficaces para atender a los empleados que se hayan pinchado con agujas hipodérmicas usadas.

Estrés por calor. Las actividades de los encargados de la lavandería de un hotel consisten en lavar, planchar, doblar y entregar la ropa. El calor procedente de las máquinas unido a una ventilación inadecuada puede originar estrés por calor. Los síntomas más frecuentes son: dolor de cabeza, náuseas, irritabilidad, fatiga, desvanecimientos y pulso acelerado. Si estos síntomas no se tratan a tiempo pueden derivar en convulsiones y problemas más graves.

El estrés por calor puede prevenirse instalando sistemas de aire acondicionado, aislando las fuentes de calor, ventilando las zonas de calor con extractores de aire caliente, haciendo pausas frecuentes en zonas frescas, bebiendo agua abundante y llevando ropa suelta y cómoda. Si la temperatura es moderadamente calurosa (menos de $35^{\circ} \mathrm{C}$ ), con un ventilador puede ser suficiente.

\section{Mantenimiento}

El personal de mantenimiento se encarga de la limpieza a gran escala y de las tareas de montaje, pintura, reparación y restauración de las instalaciones generales. Los riesgos a los que están expuestos son los siguientes:

Productos químicos. Los trabajadores del servicio de mantenimiento emplean a menudo productos de limpieza tóxicos para abrillantar suelos y limpiar moquetas, paredes, mobiliario, objetos de bronce y mármoles. Determinados productos pueden causar irritación en la piel, los ojos, las fosas nasales y la garganta, además de afectar al sistema nervioso y provocar lesiones renales, pulmonares, hepáticas y del aparato reproductor.

Las pinturas y los productos de restauración suelen contener disolventes. Las pinturas de secado rápido se utilizan para poder disponer de habitaciones y espacios comunes con la mayor rapidez, aunque contienen disolventes en concentraciones elevadas. Las colas empleadas para fijar moquetas y suelos y para otras tareas de restauración suelen contener también disolventes tóxicos. Los disolventes pueden irritan la piel, los ojos, las fosas nasales y la garganta; asimismo pueden dañar el sistema nervioso y provocar lesiones en riñones, pulmones, hígado y órganos reproductores, y ciertos disolventes son conocidos por ser causa de cáncer.

Los pesticidas y herbicidas se emplean en cocinas, comedores, zonas de uso común, vestuarios, además de en el exterior, en jardines y accesos. Algunos de estos productos causan problemas respiratorios y producen irritaciones en la piel, los ojos, las fosas nasales y la garganta, además de causar lesiones en el sistema nervioso, los riñones, el hígado y otros órganos.

Las medidas preventivas incluyen formación en materia de productos químicos, una ventilación adecuada y la utilización de equipos de protección personal. Todos los trabajadores que precisen utilizar un aparato respirador, deberán recibir instrucciones previas para seleccionar el aparato y el cartucho correctos y para, probar, usar y mantener el equipo en buen estado. Por otra parte, los empleados deben pasar un examen médico para comprobar que están en condiciones físicas de trabajar con un aparato respirador. Lo más idóneo es utilizar, en la medida de lo posible, productos químicos menos tóxicos.

Asbestos. El asbesto está presente en muchos hoteles, ya que se ha utilizado durante años como aislante y retardador del fuego, por lo que se encuentra en tuberías, techos y recubrimientos de suelos. Se trata de un material sumamente tóxico que puede provocar asbestosis, cáncer de pulmón o mesotelioma (un tipo de cáncer).

$\mathrm{Su}$ peligrosidad aumenta a medida que pasa el tiempo o se deteriora, convirtiéndose en un polvo peligroso. Los hoteles que tienen asbesto en sus instalaciones han de ser revisados periódicamente para comprobar su estado.

Deben extremarse las precauciones para proteger a los empleados y huéspedes cuando hay polvo de asbestos (por envejecimiento o deterioro del material, o durante los trabajos para su eliminación). Los empleados y huéspedes del hotel deben mantenerse alejados y la zona deberá estar debidamente señalizada, contratándose personal especializado para disminuir los riesgos. Una vez finalizados los trabajos, la zona tiene que ser inspeccionada por técnicos profesionales. En las nuevas construcciones y en las remodelaciones se deben utilizar otros materiales alternativos.

Tropiezos y caídas. El personal de mantenimiento puede sufrir caídas al subirse a escaleras y montacargas para alcanzar lugares elevados, como techos, arañas de cristal, apliques, paredes y 
balcones. Estos trabajadores han de recibir la formación adecuada.

\section{Servicio de comidas y bebidas}

Este grupo de trabajadores está compuesto por el personal de cocina, los encargados de fregar platos, los encargados del servicio de restaurante, el personal del servicio de habitaciones, los que acompañan al cliente a sus mesas y los encargados de barra.

Lesiones por esfuerzo repetitivo (LER). El personal del servicio de habitaciones y del servicio de restaurante puede sufrir LER al servir comidas, ya que con frecuencia recorren largas distancias con bandejas demasiado pesadas. Los carros del servicio de habitaciones ayudan a reducir estos riesgos, aunque deben ser fáciles de manejar y encontrarse en buen estado. Si los carros disponen de recipientes para calentar platos, los empleados deben recibir la formación adecuada para su manejo.

Tropiezos y caídas. Los suelos en cocinas y zonas por donde pasa el personal de servicio han de mantenerse limpios y secos para prevenir posibles caídas. Los líquidos derramados deben limpiarse de inmediato. Véase también el apartado "Restaurantes" en este mismo capítulo.

\section{Otros servicios}

Piscinas y gimnasios. Muchos hoteles tienen piscinas y gimnasios para los clientes, además de duchas, saunas, baños con burbujas, salas de pesas y vestuarios.

Los productos empleados para limpiar y desinfectar las duchas y vestuarios pueden irritar la piel y las vías respiratorias. Por otra parte, los encargados del mantenimiento de las piscinas suelen utilizar cloro en forma sólida o gaseosa, sustancia que puede causar quemaduras y serios problemas respiratorios, e incluso puede llegar a explotar si no es manejada de forma correcta. Todos los empleado que trabajen con este tipo de productos químicos deben recibir la formación correspondiente.

Los trabajadores encargados del mantenimiento de las piscinas y los gimnasios están expuestos a sufrir lesiones por caídas y resbalones. Es importante que los suelos sean antideslizantes y se encuentren en buen estado de mantenimiento y con drenajes apropiados. Los charcos de agua deben secarse al instante.

Tiendas de artículos de regalo. Muchos hoteles cuentan con tiendas de artículos de regalo y de otros productos para sus clientes. Los empleados pueden sufrir caídas, esguinces y cortes al desempaquetar y colocar la mercancía. Para prevenir estos riesgos, los encargados deben recibir formación sobre las técnicas adecuadas para levantar pesos y disponer de carros para el transporte de las mercancías. Los pasillos deben mantenerse despejados para evitar posibles accidentes.

Salones de belleza y peluquerías. El personal de peluquería y cosmética está expuesto a lesiones, como irritaciones de la piel provocadas por productos para el cabello, quemaduras con toallas calientes y tenacillas de rizar, y cortes o pinchazos con tijeras y hojas de afeitar.

La exposición repetida a determinadas sustancias químicas, como las utilizadas en la fabricación de tintes para el cabello, puede ser peligrosa para las vías respiratorias y llegar a provocar cáncer. También existe el peligro de sufrir LER debido al continuo sometimiento de las manos a posturas extrañas. Los empleados deben conocer los peligros de los productos químicos y los aspectos ergonómicos, y aprender métodos de trabajo que reduzcan estos riesgos, utilizando guantes y delantales cuando trabajen con tintes, blanqueadores, líquidos para permanentes y otros productos químicos. Los locales deben tener una ventilación adecuada que proporcione aire puro y elimine humos, sobre todo en las zonas donde los empleados mezclan las sustancias. Las tijeras y hojas de afeitar deben mantenerse en buen estado para facilitar el corte, como se explica en otros capítulos de esta Enciclopedia.

\section{Para todas las profesiones}

Acoso sexual. El personal de limpieza y otros empleados de los hoteles están expuestos a acoso sexual por parte de los clientes y de otras personas, y deben recibir instrucciones precisas para afrontar esas situaciones.

La dirección del hotel ha de establecer una política clara sobre la manera de notificar y responder ante este tipo de incidentes.

Incendios y otras emergencias. Las situaciones de emergencia y los desastres pueden provocar muertos y heridos, tanto entre los clientes como entre los empleados. Los hoteles deben tener planes de emergencia con vías de evacuación, procedimientos de emergencia y sistemas de comunicación para emergencias, además de métodos de evacuación rápida de los clientes. Ciertos directores, además de los operadores de la centralita deben tener instrucciones precisas sobre cómo coordinar el sistema de comunicaciones de emergencia con el personal y los clientes.

Son fundamentales la formación del personal y la celebración de reuniones entre los empleados y la dirección para que los programas de prevención y respuesta ante situaciones de emergencia sean eficaces. En las sesiones de formación y en las reuniones deberá incluirse la traducción para los trabajadores que lo necesiten. Es necesario que la formación se haga periódicamente, debido a la gran rotación laboral existente entre los trabajadores de la hostelería. También deben programarse periódicamente ejercicios de simulación de situaciones de emergencia, que incluirán recorridos por las vías de evacuación y prácticas del papel asignado a cada empleado y otros procedimientos para casos de emergencia.

También es necesario un programa de prevención de incendios con inspecciones periódicas. Las dirección y los empleados deben asegurarse de que las salidas no estén bloqueadas, de que los materiales inflamables estén guardados correctamente, de que las campanas extractoras de la cocina se limpien con regularidad y de que los aparatos eléctricos se encuentren en buen estado (sin cables pelados). En la decoración de interiores deben emplearse materiales ignífugos, y colocarse pantallas protectoras delante de las chimeneas. Asimismo los ceniceros han de vaciarse correctamente y las velas se utilizarán únicamente dentro de envases semicerrados.

Todas las dependencias de los hoteles y los locales auxiliares, como salones de belleza, restaurantes y tiendas de artículos de regalo, deben cumplir los códigos en materia de incendios. Las habitaciones y los espacios comunes deben estar equipados con detectores de humos y pulverizadores de agua. Los extintores deben estar repartidos por todo el hotel. Las salidas han de estar bien señalizadas e iluminadas. El hotel dispondrá de generadores auxiliares que proporcionen alumbrado de emergencia y otros servicios.

En todas las dependencias deben figurar las instrucciones de evacuación. Muchos hoteles facilitan a los clientes un vídeo en sus respectivas habitaciones con las distintas medidas de seguridad. Las personas con deficiencias auditivas deberán ser alojadas en habitaciones con alarmas visuales de colores brillantes para alertarles de las emergencias, y a los que tengan deficiencias visuales se les ofrecerá información en braille con las medidas de emergencia.

Los hoteles deben contar con un sistema central de alarma capaz de localizar exactamente cualquier sospecha de incendio y de informar automáticamente a los servicios de emergencia, además de emitir por el sistema disponible para dirigirse al público los correspondientes avisos a clientes y empleados. 


\section{- EFECTOS SOBRE LA SALUd Y PAUTAS PATOLOGICAS}

\section{Leon J. Warshaw}

Los hoteles y restaurantes constituyen un sector de servicios de gran tamaño, muy diverso y donde se trabaja intensamente, y está integrado en su mayor parte por pequeñas empresas. Aunque existe un número determinado de grandes corporaciones, algunas de las cuales persiguen la uniformidad de sus métodos y normas de funcionamiento, sus hoteles y restaurantes suelen ser propiedad de particulares, a menudo en régimen de franquicia en lugar de en propiedad. Los establecimientos de comidas y bebidas de los hoteles se dejan frecuentemente en manos de operadores de franquicia.

Entre los empresarios de este sector existe un elevado nivel de fracaso, que les lleva en muchas ocasiones a situaciones de insolvencia antes de quebrar y cerrar su negocio. A ello se deben las políticas de ahorro con respecto a las plantillas, a las compras y el mantenimiento de equipos o a la adquisición de los suministros necesarios. También deriva en un abandono de los programas de formación de los empleados y en un rechazo a destinar los escasos recursos a medidas de promoción y protección de la salud y la seguridad de los trabajadores.

La mayoría de estos puestos de trabajo no precisa especialización alguna, y sus ingresos son mínimos o muy bajos (en algunos casos, se completan con las propinas, que dependen de la generosidad de los clientes). Por consiguiente, son puestos que atraen únicamente a trabajadores con educación y experiencia mínimas; además, al no ser necesario un especial dominio del lenguaje, muchos de estos trabajos son cubiertos por inmigrantes y trabajadores pertenecientes a minorías étnicas. Las oportunidades de promoción y ascenso son inexistentes en muchos casos. Los turnos son necesarios para mantener la actividad del hotel las veinticuatro horas del día; en los restaurantes, las horas punta de las comidas suelen estar cubiertas por trabajadores a tiempo parcial. La clientela suele ser estacional y muchos establecimientos reducen su actividad o incluso llegan a cerrar durante la temporada baja, lo cual deriva en una mínima o nula estabilidad del puesto de trabajo. El resultado de todos estos factores es una elevada rotación laboral de los trabajadores en este sector.

\section{Estrés en el trabajo}

Muchos de los trabajadores de la hostelería están expuestos a estrés en sus trabajos a causa de los períodos de actividad intensa y la necesidad de agradar a los clientes, de cuyas propinas a menudo dependen sus ingresos. Con frecuencia tienen que atender órdenes poco razonables o imposibles de cumplir y están a merced de la actitud abusiva de sus jefes y de los propios clientes. Numerosos trabajos, sobre todo los correspondientes a cocinas y lavanderías, se desempeñan en ambientes estresantes con temperaturas y humedad elevadas, ventilación insuficiente, escasa iluminación y alto nivel de ruido (Ulfvarson, Janbell y Rosen 1976).

\section{Violencia}

Los hoteles y restaurantes ocupan uno de los primeros puestos en la lista de centros de trabajo con mayor incidencia de delitos con violencia entre los trabajadores. Según los datos recogidos en un estudio, en más del $50 \%$ de este tipo de incidentes violentos en los que se vieron envueltos trabajadores de hoteles y restaurantes se produjeron muertes (Hales y cols. 1988). Entre los factores de riesgo de homicidio en el lugar de trabajo a los que están expuestos los trabajadores de este sector están: intercambio de dinero con el público, trabajo en solitario o en grupos reducidos, trabajo en horas tardías de la noche o tempranas de la mañana, y custodia de objetos y propiedades de valor (Warshaw y Messite 1996).

\section{Tipos de lesiones y enfermedades}

Según un estudio de la Bureau of Labor Statistics de Estados Unidos, el $76 \%$ del total de lesiones y accidentes laborales entre los empleados de hoteles correspondieron al personal de limpieza y de servicio de comidas y bebidas (US Bureau of Labor Statistics 1967). Por otra parte, un estudio realizado en Dinamarca reveló que en su mayoría se trataba de problemas musculosqueléticos y de la piel (Direktoratet for Arbejdstilsynet 1993). Muchos de los problemas cutáneos tienen su origen en la exposición a jabones, agua caliente, sustancias químicas de detergentes y otros materiales de limpieza y encerado, y en algunos casos, en los pesticidas. Las lesiones musculosqueléticas, a excepción de las que se detallan a continuación, suelen originarse por resbalones, caídas, levantamiento y manejo de objetos pesados o voluminosos.

\section{Esguinces, torceduras y lesiones por esfuerzo repetitivo}

Es habitual encontrar lesiones dorsales, torceduras y esguinces en conserjes, porteros y botones, ya que tienen que levantar y transportar equipajes (un problema agravado a la llegada o salida de grupos turísticos numerosos); en el personal de cocina y otros empleados, que reciben y almacenan suministros, y en el personal de limpieza, que han de levantar los colchones, hacer las camas y manejar la ropa para lavar. Una lesión típica en los camareros que sirven helados y otros postres helados es la del túnel carpiano, producida por el esfuerzo repetitivo al manejar los cucharones o paletas de helado.

\section{Cortes y heridas}

Los empleados de los restaurantes y los encargados de fregar los platos sufren frecuentes cortes y heridas al manejar cacharros de barro y vasos rotos, y al utilizar y limpiar cuchillos y máquinas de cortar. También corren un riesgo semejante las camareras de habitaciones al vaciar las papeleras donde puede haber cristales rotos y hojas de afeitar usadas. Se trata de riesgos evitables si se utilizan bolsas para las papeleras, que pueden retirarse sin necesidad de entrar en contacto con el contenido.

\section{Quemaduras y escaldaduras}

Las quemaduras y escaldaduras son habituales entre los jefes de cocina, los encargados de fregar platos y el personal de cocina y lavandería en general. Las quemaduras de aceite caliente ocurren por salpicaduras accidentales mientras se está cocinando la comida, o al introducir alimentos en freidoras con aceite hirviendo; al añadir, filtrar o retirar el aceite, o cuando se limpian las parrillas y freidoras aún calientes. También ocurren accidentes por resbalones de los trabajadores sobre suelos mojados o grasientos, que acaban en una caída encima de una parrilla o una llama. Una lesión típica en los restaurantes es la quemadura en la piel al servir platos o bebidas flameadas (Achauer, Bartlett y Allyn 1982).

\section{Productos químicos industriales}

Igual que sucede en muchas pequeñas industrias, en los hoteles y restaurantes también se manipulan, almacenan y desechan los productos químicos industriales de forma incorrecta. Así, es habitual que los productos de limpieza, desinfectantes, pesticidas y otros "venenos" domésticos se guarden sin etiquetar, encima de envases de alimentos abiertos o de zonas destinadas a la preparación de comidas. Además, cuando se emplean en pulverizadores, la inhalación por parte de las personas suele ser demasiado elevada. 


\section{El sector de la comida rápida}

Se trata de una de las industrias de mayor crecimiento en Estados Unidos y cada vez más frecuente en otros países, a lo que se añade que es una de las mayores fuentes de puestos de trabajo para los jóvenes. Las quemaduras y heridas son los peligros más frecuentes en estos establecimientos. Conviene subrayar que el reparto de pizzas y comidas a domicilio es muy peligroso debido a las políticas comerciales que fomentan la conducción imprudente con bicicletas y automóviles (Landrigan y cols. 1992).

\section{Medidas de prevención}

Los procesos estandarizados de trabajo y la formación y supervisión apropiadas son factores clave para la prevención de enfermedades y lesiones relacionadas con el trabajo en el sector de la hostelería. Debido al bajo nivel de educación y a las dificultades con el idioma, es fundamental que el material y los ejercicios de formación resulten de fácil comprensión (puede ser necesario emplear varios idiomas). Por otra parte, la elevada rotación de estos trabajadores obliga a repetir las sesiones de formación con cierta regularidad. Por último, los ejercicios deben complementarse con inspecciones frecuentes para comprobar el cumplimiento de las medidas esenciales para una adecuada conservación y eliminación de riesgos de accidentes.

\section{Ejercicios de emergencias}

Además de las inspecciones periódicas para comprobar el estado de los equipos contra incendios (detectores de humos, sistemas de pulverización, extintores, mangueras y alumbrado de emergencia) y de comprobar que las salidas de emergencia estén bien señalizadas y despejadas, deben realizarse ejercicios periódicos de adiestramiento con los trabajadores para evitar que ellos o los clientes puedan quedar atrapados en caso de incendio o explosión. Al menos en alguna ocasión, estos ejercicios deben llevarse a cabo con la colaboración de los cuerpos de bomberos, policía y equipos de rescate.

\section{Conclusiones}

Un diseño adecuado y una pronta puesta en marcha de las medidas de prevención resultan fundamentales para reducir la frecuencia de las lesiones y enfermedades profesionales entre los trabajadores de la hostelería. La eficacia de los programas de formación y adoctrinamiento puede quedar sustancialmente reducida por las barreras idiomáticas y el bajo nivel de educación de muchos de estos trabajadores, a lo que se añade la necesidad de repetirlos con regularidad a causa de la elevada rotación laboral en este colectivo. No hay que olvidar que la seguridad y la salud de los trabajadores de este sector son factores esenciales para la satisfacción y disfrute de los clientes, de quienes, en definitiva, depende el éxito (e incluso la supervivencia) del negocio.

\section{Referencias}

Achauer, BM, RH Bartlett, PA Allyn. 1982. Face flambe. FAMA. 247:2271.

Direktoratet for Arbejdstilsynet. 1993 Hotel og restauration Copenhage: Direktoratet for Arbejdstilsynet.

Hales, T, PJ Seligman, SC Newman, CL Timbrook. 1988 Occupational injuries due to violence. $\mathcal{F}$ Occup Med. 30:483-487.

Landrigan, PJ, SH Pollack, R Belleville, JG Godbold. 1992. Child labor in the United States: Historical background and current crisis. Mount Sinai fournal of Medicine 59:498-503.

Ulfvarson, U, H Janbell, G Rosen . 1976. Fyskaliska och kemiska faktorer i hotell - och restauranganställdas arbetsmiljö. Arbete och hälsa-Vetenskaplig skriftserie. Estocolmo: Arbetarskyddsverket.

US Bureau of Labor Statistics. 1967. Work Injuries and Accident Causes in Hotels, BLS Report No. 329 Washington, DC: US Department of Labor.
Warshaw, LJ, J Messite. 1996. Workplace violence: Preventive and interventive strategies. Fournal of $\mathrm{OC}$ cupational and Environmental Medicine 38:993-1006.

\section{Otras lecturas recomendadas}

Kohr, RL. 1991. Accident Prevention for Hotels, Motels and Restaurants. Nueva York: Van Nostrand Reinhold. 


\section{OFICINAS Y COMERCIO MINORISTA}

Director del capítulo

Fonathan Rosen

\section{Sumario}

Naturaleza del trabajo en oficinas y comercios

Charles Levenstein, Beth Rosenbergy Ninica Howard . . . . . . . . . 99.2

Profesionales y directivos

Nona McQuay

Oficinas: resumen de riesgos

Wendy Hord . . . . . . . . . . . . . . . . . . . . . . 99.6

La seguridad del cajero: situación en Alemania

Manfred Fischer. . . . . . . . . . . . . . . . . . . . . . 99.9

Teletrabajo

Famie Tessler. . . . . . . . . . . . . . . . . . 99.11

El comercio minorista

Adrienne Markowitz . . . . . . . . . . . . . . . . . . . . . . . . . . . 99.13 


\section{- NATURALEZA DEL TRABAJO EN OFICINAS Y COMERCIOS}

\section{Charles Levenstein, Beth Rosenberg y Ninica Howard}

\section{Organización del trabajo y estrés}

Tradicionalmente se ha pensado que el trabajo de oficina y venta es limpio, fácil y seguro. Aunque en estos campos son poco frecuentes los accidentes graves que pongan en peligro la vida, hay riesgos laborales que reducen la calidad de vida y en algunos casos producen enfermedades graves e incluso la muerte.

El estrés puede definirse como un estímulo físico o psicológico que produce tensión o alteración del equilibrio psicológico normal del individuo. La reacción de estrés característica se presenta con dolor de cabeza, alteraciones gastrointestinales y del sueño, hipertensión y otros desórdenes cardiovasculares, ansiedad, depresión y aumento del consumo de alcohol y drogas. El trabajo en oficinas y comercios minoristas es estresante a causa de la estructura de esos sectores y de la organización del trabajo.

\section{Estructura del trabajo}

Las empresas utilizan cada vez más trabajadores con contratos temporales o a tiempo parcial (trabajadores eventuales o temporales). Con frecuencia, estas medidas aportan la ansiada flexibilidad de las jornadas de trabajo, pero tienen sus costes. Las estadísticas laborales de la Administración demuestran, por ejemplo, que en Estados Unidos un trabajador medio a tiempo parcial gana sólo el $60 \%$ de lo que gana un trabajador a jornada completa por hora trabajada. No sólo se les paga menos, sino que las prestaciones a las que tienen derecho, como seguros de enfermedad, pensiones, bajas por enfermedad y vacaciones, son sustancialmente inferiores a las de los trabajadores a jornada completa. Menos del $25 \%$ de los trabajadores a tiempo parcial tienen un seguro de enfermedad pagado por la empresa, en comparación con casi el $80 \%$ de los trabajadores a jornada completa. El 60 \% de éstos tienen pensiones, mientras que sólo el $25 \%$ de los trabajadores a tiempo parcial cuentan con esta cobertura. En 1990 había en los Estados Unidos cerca de 5 millones de trabajadores a tiempo parcial que habrían preferido trabajar a jornada completa. Otros países están experimentando transformaciones similares del trabajo . Así, en la Unión Europea el $15 \%$ de la población activa y en torno al $20 \%$ de los empleados en oficinas y comercios tenían trabajos a tiempo parcial en 1991, y el 8,4 \% de los empleados de oficinas y comercios eran eventuales (De Grip, Hovenberg y Willems 1997).

Además del salario inferior y los menores derechos, esta organización del trabajo tiene otros aspectos negativos. Los eventuales viven a menudo con el estrés de no saber cuándo trabajarán. Suelen hacer también más horas extras, porque con frecuencia se les contrata para períodos punta. Las legislaciones de muchos países no ofrecen la misma protección ni para trabajadores a tiempo parcial ni para eventuales, incluso en lo que se refiere a la normativa sobre seguridad y salud en el trabajo y a las normas sobre seguro de desempleo y pensiones. Son pocos los que cuentan con representación sindical. Un estudio encargado por la US Occupational Safety and Health Administration sobre el trabajo no estable en el sector petroquímico demuestra que los trabajadores que no gozan de contrato estable reciben menos formación en salud y seguridad, y entre ellos el porcentaje de accidentes es mayor que entre los trabajadores fijos (Murphy y Hurrell 1995). No deberían minusvalorarse las consecuencias médicas de una mano de obra cada vez más temporal y con menor representación sindical.

\section{Organización del trabajo}

Cuando en el conocido estudio a largo plazo sobre enfermedades cardiovasculares, llamado US Framingham Heart Study, se examinó la relación entre situación laboral e incidencia de enfermedades coronarias, se descubrió que el $21 \%$ de las mujeres empleadas en oficinas o comercios desarrollaban enfermedades coronarias, porcentaje que es casi el doble que en el caso de las mujeres que no trabajaban en oficinas o eran amas de casa. Según el modelo de estrés laboral de control de exigencias de Karasek, el trabajo que se caracteriza por grandes exigencias y poco control o margen amplio de toma de decisiones es el más estresante, por el desequilibrio entre responsabilidad y capacidad para responder (Karasek 1979, 1990). Ocupaciones como el trabajo en oficinas y comercios, la fabricación de aparatos electrónicos, la confección textil y la transformación de aves de corral se caracterizan por el aburrimiento, los riesgos ergonómicos y el poco control del puesto de trabajo. El trabajo en oficinas y comercio se situaba entre los más estresantes en este aspecto.

Reconocer los determinantes sociales, económicos y físicos de los efectos sobre la salud relacionados con las fuentes de estrés en el trabajo en lugar de concentrarse exclusivamente en la patología personal es el primer paso para afrontar de forma completa y a largo plazo los problemas relacionados con el estrés. Aunque son muchos los que pueden beneficiarse de los programas de ejercicios de relajación dirigidos al individuo, los programas de gestión del estrés en el lugar de trabajo deberían tener también en cuenta las limitaciones sociales y económicas de carácter más amplio que determinan el contexto de la vida cotidiana de los trabajadores.

\section{Galidad del aire}

Muchos edificios sufren una contaminación grave de su atmósfera interior. En las oficinas, la combinación de un diseño deficiente de la ventilación, el cerramiento hermético de los edificios y la acumulación de productos químicos procedentes de los materiales de construcción, las máquinas de oficina y el humo del tabaco dan como resultado una contaminación ambiental considerable. Los microorganismos (hongos y bacterias) proliferan en los circuitos de aire acondicionado y humidificación, los condensadores de evaporación y las torres de refrigeración de muchos edificios de oficinas. El resultado es el "síndrome del edificio hermético", acompañado de un amplio abanico de síntomas que dependen de la situación y que comprende alergias e infecciones respiratorias, como la enfermedad del legionario, que, en ocasiones, alcanzan proporciones epidémicas. Tal vez el contaminante ambiental más común en las oficinas sea el humo del tabaco, que multiplica hasta por un factor de cinco la concentración de partículas respirables suspendidas en el aire en relación con una oficina en la que no se fume. Como quiera que se ha relacionado el consumo de tabaco por parte de uno de los miembros de una pareja con el aumento de riesgo de cáncer de pulmón del otro miembro no fumador, los trabajadores de oficina que no fuman podrían correr también ese riesgo.

\section{Riesgos ergonómicos}

Los riesgos ergonómicos en el comercio minorista han aumentado en los últimos años a medida que se han introducido nuevas tecnologías y estructuras organizativas. La tendencia dominante en el comercio minorista es la construcción de autoservicios y establecimientos más grandes. La introducción del escáner electrónico ha creado ciclos más cortos y ha hecho que el trabajo sea más reiterativo. Además, el lugar de trabajo con frecuencia no está adaptado a las nuevas tecnologías y muchas prácticas laborales pueden provocar estrés musculosquelético.

En muchos estudios e investigaciones se ha detectado una tasa más alta de alteraciones traumáticas acumuladas entre cajeros 
que entre otros puestos y una relación proporcional a la dosis entre el trabajo y esas alteraciones. Estos trabajos requieren habitualmente altos niveles de actividad de las extremidades superiores y, como resultado, muchos cajeros sufren el síndrome del túnel carpiano, tendinitis y tenosinovitis. Los dependientes muestran niveles moderados de actividad con las muñecas y altos niveles de actividad con los talones. El diseño del mostrador donde está la caja influye mucho en la postura y las pautas de movimientos del cajero y hace que adopte malas posturas, extienda mucho el brazo y levante cosas con frecuencia. Por todo ello, son comunes las molestias de cuello, hombros, codo y espalda. Por permanecer mucho tiempo de pie, cajeros y dependientes sufren también dolores de espalda a consecuencia de las fuerzas de compresión asociadas con la actividad. Además, estar mucho tiempo de pie provoca malestar en las piernas, rodillas y pies y favorece la formación de varices. Mover pilas de productos demasiado pesadas o demasiado grandes constituye otro riesgo para la espalda.

Hay otros muchos sectores del comercio minorista que experimentan éstas y otras alteraciones. Por ejemplo, la floristería y la peluquería se relacionan frecuentemente con problemas de la piel, como erupciones cutáneas y dermatitis crónica. Las lesiones más comunes en establecimientos donde se sirve comidas y bebidas son las laceraciones y quemaduras. El resultado de estos factores y de la elevada tasa de rotación de los empleados y la insuficiente formación derivada de ello es un entorno que favorece el dolor crónico, las incomodidades y el riesgo de lesiones por acumulación de traumatismos.

\section{Empleos de oficina}

La imagen del trabajo de cuello blanco como una actividad segura y limpia es a menudo engañosa. El espectacular cambio experimentado por la mano de obra, con aumento de la especialización laboral, las tareas repetitivas y las exigencias físicas y la reducción del espacio de trabajo ha provocado muchas lesiones y enfermedades ergonómicas. Las lesiones más obvias están relacionadas con la seguridad, como caídas en suelos resbaladizos, tropezones con cables eléctricos, golpes con cajones abiertos de archivadores y traslado de objetos pesados, como cajas de papel y muebles. La generalización de los ordenadores en las oficinas ha dado lugar a un nuevo patrón de problemas de salud. Las zonas del cuerpo afectadas con más frecuencia por alteraciones traumáticas acumuladas son los miembros superiores y el cuello. El uso prolongado de pantallas de visualización de datos (PVD) puede producir también inflamación de músculos, articulaciones y tendones de la espalda y las piernas. Graves alteraciones de las muñecas, como el síndrome del túnel carpiano, tendinitis y tenosinovitis se relacionan a menudo con la utilización de PVD. Estas alteraciones son consecuencia de la extensión continua de la muñeca durante el uso del teclado o de la presión mecánica directa causada por el borde del escritorio. Los numerosos, rápidos y precisos movimientos de los dedos propios de la mecanografia también son causa de lesiones. El mantenimiento de los hombros inmóviles en una posición elevada como consecuencia de la altura excesiva de la superficie de trabajo puede provocar tendinitis. Como a menudo ocurre, permanecer mucho tiempo sentado, conducta característica de la utilización de PVD, reduce la circulación sanguínea y aumenta los trastornos circulatorios en piernas y pies debido a la compresión de los tejidos de aquéllas. El dolor lumbar es una molestia frecuentemente relacionada con el hecho de permanecer mucho tiempo sentado, puesto que las fuerzas de compresión que actúan sobre la espina dorsal son elevadas, en especial si la silla no está bien diseñada. Otros efectos habituales sobre la salud del uso de PVD son la fatiga visual y los dolores de cabeza por iluminación inadecuada o parpadeo de las PVD. El ordenador, normalmente, no es el único equipo presente en oficinas grandes. El ruido generado por la combinación de fotocopiadoras, máquinas de escribir, impresoras, teléfonos y sistema de ventilación es con frecuencia superior a los 45 a 55 decibelios recomendados para una conversación personal o telefónica fácil, y puede interferir con la concentración y elevar los niveles de irritación y estrés que se han relacionado con enfermedades coronarias.

\section{Riesgos ambientales}

Los principales riesgos ambientales de oficinas y comercios minoristas están relacionados con la sociedad de consumo: el desarrollo de centros comerciales y los problemas con aguas subterráneas relacionados con el desarrollo de "zonas verdes". En muchas áreas residenciales de países industrializados avanzados, el desarrollo del comercio minorista y de las oficinas en centros comerciales amenaza tanto la viabilidad de las áreas urbanas céntricas como de los espacios abiertos periféricos. En Asia y África los problemas son diferentes: el crecimiento enorme y no planificado de las áreas urbanas ha traído consigo una división geográfica más acusada de las clases sociales. Pero tanto en el norte como en el sur algunas ciudades se han convertido en zonas donde se amontonan los pobres y los excluidos, a medida que los centros comerciales y complejos de oficinas y las clases más privilegiadas abandonan las áreas urbanas. No hay trabajo para el futuro ni las posibilidades de consumo asociadas con él, y por consiguiente las zonas urbanas se han deteriorado. Los nuevos esfuerzos de las organizaciones de justicia ambiental han radicalizado el debate sobre el desarrollo de hábitos de vida, compra y trabajo urbanos.

El desarrollo de las oficinas plantea también el problema del derroche de papel. El papel plantea un problema de agotamiento de recursos (la tala de bosques para obtener pasta de papel) y de acumulación de residuos sólidos. Una campaña internacional contra el cloro también ha puesto de manifiesto los riesgos químicos relacionados con la producción papelera. Pero el reciclado del papel ha atraído la atención de quienes tienen conciencia ambiental, lo que ha inducidos a los sectores del papel y la pasta a aumentar la fabricación de productos de papel reciclado y a buscar alternativas a los compuestos de cloro. La distribución y almacenamiento de datos en formato electrónico podría ser una solución a largo plazo.

El enorme problema del exceso de materiales de embalaje es una preocupación ambiental básica. Por ejemplo, el vertedero de Fresh Kills, que recoge la basura de Nueva York, es el mayor de Estados Unidos; tiene una extensión de 1.200 hectáreas y recibe aproximadamente 14.000 toneladas diarias de basura. Actualmente, y en algunas partes, el vertedero tiene una profundidad de 50 metros, pero se espera que alcance los 140 metros en diez años y eso que no se incluyen los residuos comerciales o industriales no tóxicos. La mayor parte de estos residuos son papeles y plásticos que podrían reciclarse. En Alemania se exige a los fabricantes de mercancías que recojan los materiales de embalaje. De este modo se estimula decididamente a las empresas a que reduzcan las prácticas derrochadoras de comercialización al por menor.

\section{PROFESIONALES Y DIRECTIVOS}

\section{Nona McQuay}

El lugar de trabajo, especialmente en los países industrializados, es cada vez más un mundo de administrativos o trabajadores de cuello blanco. Así, en 1994, el 57,9 \% de los trabajadores de Estados Unidos eran de cuello blanco, y las profesiones de servicios representaban un $13,7 \%$ del total. Las ocupaciones 
profesionales han pasado del cuarto lugar por número de personas empleadas al tercero (AFL-CIO 1995). La Tabla 99.1 enumera los puestos de trabajo profesionales normalizados según la Clasificación normalizada internacional de ocupaciones (ISCO-88). El porcentaje de trabajadores de cuello blanco entre los afiliados a sindicatos y organizaciones nacionales ha pasado del $24 \%$ en 1973 al $45 \%$ en 1993 (AFL-CIO 1995). Se espera que el empleo en ocupaciones profesionales directivas y técnicas aumente más rápidamente que la media.

Una característica de los profesionales que trabajan en oficinas y de los directivos es que su puesto obliga en ocasiones a tomar decisiones y asumir responsabilidades sobre el trabajo de otros. Algunos directivos o profesionales (por ejemplo, ingenieros, personal de enfermería o trabajadores sociales) trabajan en industrias y están sujetos a riesgos industriales iguales a los del resto del personal. También hay directivos y ejecutivos que trabajan en edificios y oficinas alejados de la propia industria. Ambos grupos de trabajadores administrativos están sujetos a los riesgos del trabajo de oficina: estrés en el trabajo, deficiente calidad del aire en interiores, agentes químicos y biológicos, lesiones por esfuerzos repetitivos (LER), preocupación por la seguridad contra incendios, acoso sexual y violencia o agresiones en el trabajo. Véase también el artículo "Oficinas: un resumen de riesgos" en este capítulo.

\section{Cambios demográficos}

En un estudio realizado en los años 70 sobre la "dureza" de las ocupaciones ejecutivas, no había un número suficiente de mujeres en puestos de dirección como para incluirlas en el estudio (Maddi y Kobasa 1984). En la década de los 90 ha aumentado la representación de la mujer y de las minorías en puestos de autoridad, trabajos profesionales y trabajos no tradicionales. Sin embargo, un "techo de cristal" hace que la mayoría de las mujeres se concentren en los niveles inferiores de la jerarquía organizativa: en Estados Unidos, por ejemplo, sólo el $2 \%$ de los altos cargos directivos son desempeñados por mujeres.

A medida que la mujer ocupa puestos tradicionalmente masculinos, surge la cuestión de si su experiencia en el lugar de trabajo provocará un aumento de enfermedades coronarias semejante al de los hombres. En el pasado, cuando se han debido enfrentar a la presión de tener que lograr algún objetivo, las mujeres han sido menos reactivas que los hombres a las secreciones de hormonas relacionadas con el estrés. Sin embargo, en estudios sobre mujeres en tareas no tradicionales (estudiantes de ingeniería, conductoras de autobús y abogadas) un experimento de laboratorio demostró que las mujeres tienen un aumento de secreción de epinefrina casi tan agudo como el de los hombres expuestos a una tarea difícil, considerablemente mayor que el de las empleadas de oficina que desempeñan

Tabla 99.1 • Profesionales.

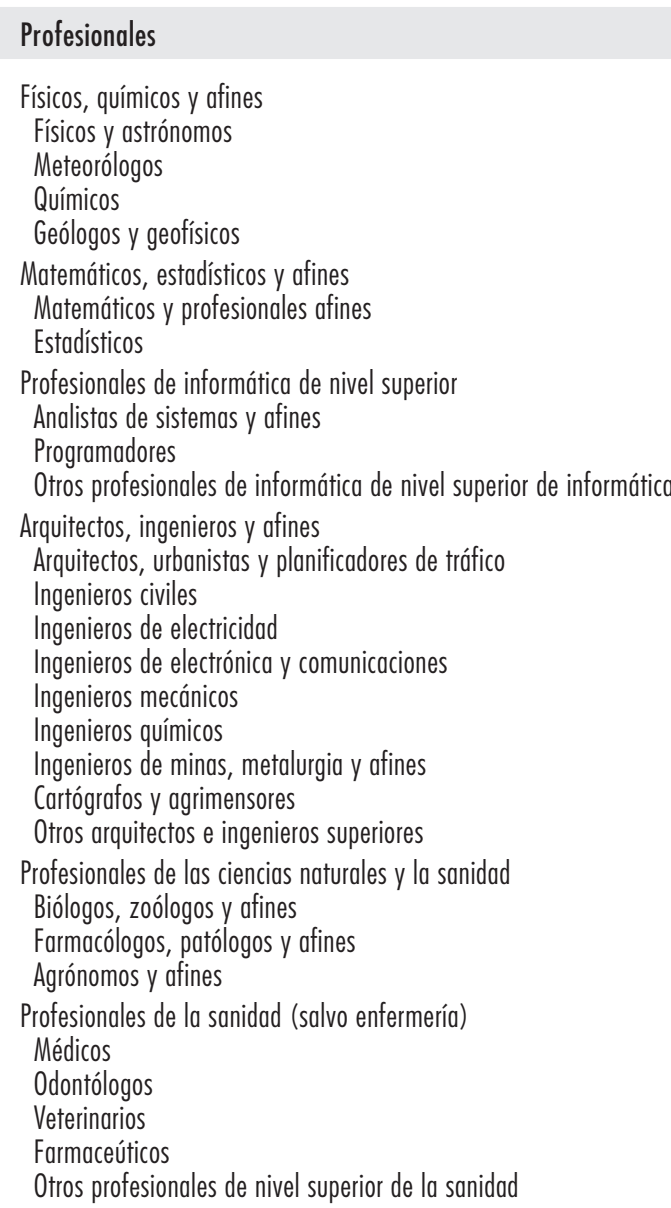

Fuente: OIT 19900

Enfermeros y matronas

Profesores de universidad y otros centros de enseñanza superior

Profesores de enseñanza secundaria

Profesores de enseñanza primaria

Profesores de educación especial

Otros profesionales de la enseñanza

Especialistas en métodos didácticos y pedagógicos

Inspectores de enseñanza

Profesionales de organización y administración de empresas

Profesionales de contabilidad

Profesionales de recursos humanos

Otros profesionales de organización y administración de empresas

Profesionales del derecho

Abogados

Jueces

Otros profesionales del derecho

Archiveros, bibliotecarios y afines

Archiveros y conservadores de museos

Bibliotecarios y afines

Profesionales en las ciencias sociales y humanas

Economistas

Sociólogos, antropólogos y afines

Filósofos, historiadores y profesionales de ciencias políiticas

Filólogos, intérpretes y traductores

Psicólogos

Profesionales del trabajo social

Escritores y artistas de la creación o la interpretación

Escritores, periodistas y afines

Escultores, pintores y afines

Compositores, músicos y cantantes

Coreógrafos y bailarines

Actores, directores de cine, teatro y afines

Profesionales de la religión 
tareas tradicionales. Un estudio sobre hombres y mujeres con funciones directivas realizado en 1989 demostró que ambos sexos tienen una pesada carga de trabajo, presiones de tiempo, plazos y responsabilidad sobre otros. Las mujeres directivas hablaban de falta de comunicación en el trabajo y del conflicto entre el trabajo y la familia como fuentes de estrés, lo que no ocurría con los directivos varones. Éstos mostraban una mayor satisfacción laboral. Se descubrió que las mujeres directivas no contaban con el apoyo de una fuerte red laboral. Estudios sobre mujeres profesionales y sus cónyuges demostraron que la responsabilidades relacionadas con el cuidado de los hijos eran soportadas en mayor medida por las mujeres, mientras que los hombres se encargaban de tareas que no exigían una dedicación en momentos tan concretos, como puede ser el cuidado del césped (Frankenhaeuser, Lundberg y Chesney 1991).

Aunque los estudios no indican que el trabajo conduzca al tabaquismo, el estrés en el lugar del trabajo está relacionado con el incremento de las tasas de tabaquismo y con dificultades a la hora de dejar de fumar. En 1988 se observó una mayor tasa de tabaquismo entre mujeres profesionales que entre profesionales varones (Biener 1988). El tabaquismo es un modo de conducta para hacer frente al estrés. Por ejemplo, las enfermeras que fumaban cigarrillos presentaban un mayor nivel de estrés en el trabajo que las enfermeras no fumadoras. En el estudio sobre mujeres y salud era más probable que las trabajadoras asalariadas presentasen tensión en el trabajo (45 \%) que las trabajadoras por horas $(31 \%)$, y les resultaba más difícil relajarse después del trabajo $(57 \%)$ que a las trabajadoras por horas (35\%) (Tagliacozzo y Vaughn 1982).

Cambios internacionales han provocado una reestructuración política y social que lleva a gran número de personas a emigrar de sus países de origen. La adaptación del lugar de trabajo a grupos minoritarios tiene como consecuencia una representación más diversa de trabajadores en los puestos directivos. Entre las consecuencias de estos cambios figuran el análisis del factor humano, las políticas de personal y la educación para la diversidad. Pueden ser necesarios cambios ergonómicos para acomodar diversas tallas y tipos corporales. Los choques entre culturas no son raros; por ejemplo, los valores relativos a la alta productividad o a la gestión del tiempo pueden variar de unas naciones a otras. Hoy en día se intenta inculcar una mayor sensibilidad hacia esas diferencias culturales a medida que se camina hacia una economía global (Marsella 1994).

\section{Nuevas estructuras de la organización del trabajo}

La generalización de las técnicas participativas como medio de obtener información y dirigir organizaciones, tales como los comités paritarios y los programas de mejora de la calidad, han cambiado las estructuras típicamente jerárquicas de algunas de ellas. Como resultado, los que tienen puestos de dirección citan con frecuencia la ambigüedad de papeles y la exigencia de nuevas aptitudes como causas de estrés.

Si el carácter del trabajo directivo y de supervisión sigue constituyendo un desafio, el individuo con alto estrés y baja incidencia de enfermedades puede describirse como un "ejecutivo duro". Tales ejecutivos se han caracterizado por su compromiso en las diversas parcelas de sus vidas (por ejemplo, la familia, el trabajo, las relaciones interpersonales), por alimentar un mayor sentido de control sobre lo que ocurre y por contemplar el desafío de modo positivo. Mientras que acontecimientos estresantes (por ejemplo, reducciones de personal) debilitan a ciertos trabajadores, el modelo de dureza proporciona un efecto amortiguador. Por ejemplo, durante períodos de cambio organizativo, el empeño en mantener sensación de control por parte de los trabajadores pueden incluir una mayor claridad en las descripciones de actividades laborales y puestos de trabajo y la percepción del cambio como fuente de posibilidades y no como una pérdida (Maddi y Kobasa 1984).

\section{Cambios tecnológicos en el lugar de trabajo}

El trabajo se ha modificado de tal forma que, además de las capacidades mentales que se exigen al profesional, ahora también se esperan de éste conocimientos técnicos. La utilización del ordenador, el fax, el teléfono y la videoconferencia, el correo electrónico, las presentaciones audiovisuales y otras nuevas tecnologías han cambiado la función de muchos directivos y han creado riesgos ergonómicos y de otro tipo relacionados con las máquinas que ayudan en estas funciones. Se ha acuñado el término estrés técnico para describir el impacto de las nuevas tecnologías de la información. En 1991, por primera vez en la historia, las empresas norteamericanas gastaron más en equipo informático y de comunicaciones que en máquinas industriales, mineras, agrícolas y de construcción.

Los ordenadores influyen en la manera en que ahora se organizan el trabajo de los profesionales y los procesos de trabajo. Entre los posibles efectos de este cambio hay que citar la fatiga visual, los dolores de cabeza y otros efectos del trabajo con PVD. La Organización Mundial de la Salud (OMS) informó en 1989 de que los factores psicológicos y sociológicos afectan al trabajo con ordenadores al menos tanto como los ergonómicos. Entre las consecuencias involuntarias de la utilización de ordenadores se incluyen el aislamiento del operador informático y el aumento del trabajo con ordenadores fuera de la empresa, con módems de alta velocidad (véase también el artículo "Teletrabajo", en este mismo capítulo)

\section{Estrés profesional}

Un riesgo bien conocido es el del estrés profesional, al que ahora se atribuyen trastornos fisiológicos, en particular enfermedades cardiovasculares. El estrés se trata por extenso en varios capítulos de esta Enciclopedia.

Un estudio sueco sobre ingenieros de telecomunicaciones sugiere que la mayor parte de los estudios sobre el estrés, que normalmente se han basado en trabajos que requieren una cualificación baja o media, no son aplicables a los profesionales cualificados. En este estudio se aplicaron tres intervenciones de reducción del estrés al grupo de profesionales con los siguientes resultados beneficiosos: sensación de control sobre el propio trabajo (pensar para trabajar frente a trabajo que provoca fatiga mental); disminución de la fatiga mental; efecto duradero sobre las interacciones y los apoyos sociales; mejora de las concentraciones elevadas de prolactina; disminución de los trombocitos en circulación (factor de riesgo de accidentes cerebrovasculares); y mejora de los indicadores de riesgo cardiovascular (Arnetz 1996).

A medida que se ha ido conociendo el coste humano y financiero del estrés profesional, muchas organizaciones han introducido iniciativas dirigidas a reducirlo y a mejorar la salud del empleado en el lugar de trabajo. Dichas intervenciones se centran en el individuo (técnicas de relajación y programas de ayuda al empleado); en la relación individuo-organización (adecuación persona-entorno, participación y autonomía); y en la organización (estructuras organizativas, formación, selección y colocación).

\section{Violencia}

Los directivos y profesionales corren el riesgo de padecer violencia y agresiones debido a su visibilidad y a la posibilidad de que se produzcan reacciones adversas a sus decisiones. Lo más frecuente es que la violencia y las agresiones se produzcan cuando el dinero cambia de manos, en entornos minoristas o 
donde hay clientes problemáticos. Los lugares de trabajo con un mayor riesgo de homicidio (por orden decreciente) son: empresas de taxis, tiendas de bebidas alcohólicas, gasolineras, agencias de detectives, centros de justicia y orden público, ultramarinos, joyerías, hoteles y establecimientos donde se sirven comidas y bebidas. El homicidio en el lugar de trabajo fue la principal causa de muertes relacionadas con el trabajo para las mujeres y la tercera para el conjunto de los trabajadores en Estados Unidos desde mediados del decenio de 1980 hasta mediados del de 1990 (NIOSH 1993; Stout, Jenkins y Pizatella 1989).

\section{Riesgos de viaje}

Aproximadamente 30 millones de personas viajaron desde países industrializados a países en desarrollo en 1991, la mayoría en viaje de negocios. La mitad de los viajeros eran residentes de Estados Unidos o Canadá que viajaban sobre todo a México. Los viajeros europeos representaban el $40 \%$ del total y visitaban en su mayoría África y Asia. Los riesgos para la salud de los viajeros internacionales se producen cuando viajan a países en desarrollo con tasas endémicas elevadas de enfermedades para las que el viajero tiene concentraciones bajas de anticuerpos. Un ejemplo es el del virus de la hepatits A (VHA), que se trasmite a 3 de cada 1.000 viajeros a países en desarrollo y que alcanza una tasa de 20 por 1.000 entre aquéllos que viajan a zonas rurales y no tienen cuidado con la alimentación y la higiene. La hepatitis A es una enfermedad trasmitida por los alimentos (y por el agua). Hay una vacuna introducida en Suiza en 1992 y recomendada por el Advisory Committee on Immunization Practices para individuos que viajan a zonas con incidencia elevada de VHA (Perry 1996). En otros capítulos de esta Enciclopedia se proporciona más información y referencia sobre dichos riesgos.

Otros riesgos relacionados con los viajes incluyen los accidentes de vehículos a motor (la principal causa de fallecimientos en el lugar de trabajo en los Estados Unidos), el desfase horario debido a largos viajes en avión, las ausencias familiares prolongadas, las alteraciones gastrointestinales, los accidentes en transporte público, el crimen, el terrorismo y la violencia. Los organismos de control de enfermedades y las embajadas orientan al viajero en relación con estos riesgos.

\section{Intervenciones sobre salud y seguridad}

Entre las medidas para mejorar las condiciones laborales de los profesionales y directivos cabe citar las siguientes:

- Se debería incluir a todos los profesionales directivos y supervisores en programas de formación sobre salud y seguridad en el lugar de trabajo.

- Los programas para dejar de fumar en el lugar de trabajo resultan adecuados, pues son oportunos, permiten practicar los comportamientos para dejar de fumar durante las horas de trabajo (cuando resulta más necesario para enfrentarse a episodios estresantes) e incentivan el abandono del tabaco.

- Los programas de gestión del estrés y del tiempo mejoran la productividad y la satisfacción del trabajador.

- La diversidad en el lugar de trabajo será habitual en el próximo siglo. La formación sobre diversidad mejora la comprensión intercultural.

- Las mujeres que desempeñan puestos profesionales y directivos necesitan un programa de apoyo en el lugar del trabajo que les ayude a desempeñar sus exigentes funciones en el hogar y en el trabajo: permisos familiares, grupos de apoyo y mayores oportunidades de ascenso y control sobre el trabajo.

- Todos los trabajadores deberían contar con programas de asistencia confidenciales y exentos de elementos de juicio.

- Los riesgos del trabajo con ordenadores obligan a hacer hincapié en la organización, el entorno, el equipo y la formación, así como a incorporar mejoras técnicas en los ordenadores, el monitor y el diseño de los lugares de trabajo de los teletrabajadores.

- Los viajeros necesitan tiempo para aclimatarse a otras zonas horarias y países, información sanitaria actualizada que los proteja y tiempo libre para atender las necesidades de la familia y su seguridad.

- Todos los trabajadores necesitan controles técnicos, de las prácticas laborales y de los equipos de protección que les defiendan de actos violentos y agresiones de terceros. La formación del personal y la protección de las oficinas debería incluir la prevención, la protección personal y ayuda y asesoramiento después de una agresión.

\section{OFICINAS: RESUMEN DE RIESGOS}

\section{Wendy Hord}

Los trabajadores de oficina desempeñan gran diversidad de tareas, entre ellas contestar al teléfono; relacionarse con el público; manejar dinero; recibir y enviar correo; abrir correo; mecanografiar y transcribir; manejar maquinaria de oficina (ordenadores, calculadoras, fotocopiadoras, etc.); archivar; levantar paquetes y otros objetos; y tareas profesionales como escribir, editar, llevar la contabilidad, investigar, realizar entrevistas y similares. La Tabla 99.2 enumera los trabajos de oficina normalizados.

Tabla 99.2 - Empleados de oficinas y comercio.

\section{Empleados de oficina}

Secretarios y operadores de máquinas de oficina

Taquígrafos y mecanógrafos

Operadores de máquinas de tratamiento de textos y afines

Operadores de entrada de datos

Operadores de calculadoras

Secretarios

Auxiliares contables y financieros

Empleados de contabilidad y cálculo de costes

Empleados de servicios estadísticos y financieros

Empleados encargados del registro de materiales y de transporte

Empleados de control de abastecimiento e inventario

Empleados de servicios de apoyo a la producción

Empleados de servicios de transporte

Empleados de bibliotecas y servicios de correos y afines

Empleados de bibliotecas y archivos

Empleados de servicios de correos

Codificadores de datos, correctores de pruebas de imprenta y afines

Escribientes y públicos y afines

Otros oficinistas

Cajeros, taquilleros y afines $s$

Cajeros y expendedores de billetes

Pagadores y cobradores de ventanilla y taquilleros

Receptores de apuestas y afines

Prestamistas

Cobradores y afines

Empleados de servicios de información a la clientela

Empleados de agencias de viajes

Recepcionistas y empleados de informaciones

Telefonistas

Fuente: OIT 1990a. 
A menudo se piensa que los trabajadores de oficina disfrutan de un ambiente de trabajo agradable y seguro. Aunque el trabajo de oficina no sea tan peligroso como el que se realiza en otros muchos lugares, son varios los problemas de salud y seguridad propios de este medio. Algunos de ellos suponen riesgos considerables para los trabajadores.

\section{Riesgos y trastornos médicos}

Los resbalones, tropiezos, y caídas son causa frecuente de lesiones en las oficinas. Las inclemencias meteorológicas, como la lluvia, la nieve o el hielo, provocan riesgo de resbalones fuera de los edificios y dentro de ellos cuando los suelos mojados no se limpian con prontidud. Los cables eléctricos y de teléfono situados en pasillos y vías de paso son causa frecuente de tropezones. Las moquetas viejas, raídas y abombadas aumentan el riesgo de que se enganchen los tacones de los zapatos y, por tanto, de caídas. Parecido riesgo presentan los enchufes eléctricos situados en el suelo de pasillos y vías de paso.

Los cortes y contusiones se producen en entornos de oficina por diversas causas. Los cortes con papel son frecuentes cuando se manipulan carpetas, sobres y folios. Los trabajadores están expuestos a lesiones al golpearse contra mesas, puertas o cajones que se han dejado abiertos y que no se ven. Los materiales y suministros de oficina mal apilados suponen riesgo de lesión si se desmoronan o si se colocan de manera que alguien pueda tropezar con ellos sin darse cuenta. También provocan cortes las guillotinas y los cantos de cajones, escritorios y mesas.

Los riesgos eléctricos se presentan cuando hay cables eléctricos expuestos al deterioro en pasillos y vías de paso. En las oficinas es frecuente el uso incorrecto de alargadores en sustitución de enchufes fijos, para alimentar un número excesivo de aparatos (con el consiguiente riesgo de sobrecarga) o de calibre insuficiente (alargadores conectados a cables preparados para soportar corrientes superiores). En muchas oficinas se utilizan adaptadores o clavijas manipulados, sobre todo para conectar equipos que necesitan toma de tierra (clavijas con tres patillas) en enchufes de dos tomas, de manera que la toma de tierra queda sin conectar. Se establece así una conexión eléctrica insegura. A veces se rompen las patillas de toma de tierra de las clavijas para conectarlas en bases con sólo dos orificios.

El estrés es un problema de salud psicosocial importante para muchas oficinas. Son muchos los factores que provocan el estrés, entre ellos el ruido de las máquinas y el exceso de gente, las malas relaciones con los supervisores o compañeros de trabajo, el aumento de la carga de trabajo y la falta de control sobre éste.

Las dolencias musculares y óseas y las lesiones de tejidos blandos, como la tendinitis, son consecuencia del uso de muebles y equipos no ajustados a las necesidades físicas individuales del trabajador. La tendinitis se produce por el movimiento repetitivo de ciertas partes del cuerpo; son ejemplos comunes las lesiones de los dedos debidas a la escritura constante o al archivo y la extracción de expedientes en archivadores demasiado llenos. Muchos trabajadores de oficina sufren lesiones por movimientos repetitivos, como el síndrome del túnel carpiano, el síndrome de la salida torácica o la lesión del nervio ulnar, a consecuencia del uso de equipos mal ajustados y de la ausencia de pausas cuando se teclea de manera continua (en un ordenador) o cuando se ejecutan otras actividades repetitivas. Los muebles y aparatos mal diseñados favorecen las malas posturas y a la compresión de los nervios de las extremidades inferiores, ya que muchos trabajadores de oficina pasan mucho tiempo sentados; todos estos factores contribuyen a la aparición de lesiones en la región lumbar y las extremidades inferiores, y lo mismo sucede cuando se trabaja siempre de pie.

La utilización continuada de ordenadores y la iluminación general deficiente provocan fatiga visual entre los trabajadores de oficina. Como consecuencia de ello, muchos experimentan pérdida de visión, dolor de cabeza, escozor de ojos y cansancio ocular. El ajuste de la iluminación y del contraste de la pantalla del ordenador y la alteración frecuente del punto de enfoque son precauciones necesarias para aliviar los trastornos visuales. La iluminación debe ser adecuada para la tarea.

Los procedimientos en caso de incendio y de emergencias son fundamentales en la oficina. Muchas carecen de procedimientos establecidos adecuados para que los trabajadores abandonen el edificio en caso de incendio o de cualquier otra emergencia. Estos procedimientos o planes de emergencia deberían publicarse por escrito y practicarse (mediante simulacros de incendio) para que los ocupantes de la oficina se familiaricen con el lugar hacia el que deben dirigirse y con lo que tienen que hacer. Esto garantiza que todos los trabajadores abandonarán el edificio con rapidez y de manera segura en caso de incendio real o de otra emergencia. La seguridad en caso de incendio se ve a menudo comprometida por el bloqueo o la falta de señalización de las salidas, el almacenamiento de productos químicos incompatibles o materiales combustibles, la avería de las alarmas y otros sistemas de lucha contra el fuego o la falta total de medios adecuados de notificación a los trabajadores en caso de urgencia.

\section{Violencia}

Actualmente se considera que la violencia en el lugar de trabajo es un riesgo importante. Como se afirmó en el capítulo Violencia, en Estados Unidos el homicidio es la principal causa de muerte entre las mujeres trabajadoras y la tercera causa en el conjunto de los trabajadores. Las agresiones no mortales son mucho más frecuentes de lo que la mayoría de la gente imagina. Los trabajadores de oficina que tratan con el público - los cajeros, por ejemplo- están expuestos a un riesgo de violencia mayor. También hay violencia interna (trabajador contra trabajador). Pero la inmensa mayoría de los actos violentos que ocurren en una oficina los provocan personas ajenas a ella. Los trabajadores de oficinas públicas corren un riesgo mucho mayor de incidentes violentos en el lugar de trabajo porque administran leyes y reglamentos que muchos ciudadanos contemplan con hostilidad, sea verbales o física. En Estados Unidos, el sector público emplea sólo al $18 \%$ de los trabajadores, pero éstos sufren el $30 \%$ de todas las agresiones en el lugar de trabajo.

Las oficinas se hacen más seguras limitando el acceso a las zonas de trabajo, cambiando o creando políticas y procedimientos que ayuden a eliminar fuentes de hostilidad y proporcionen procedimientos de emergencia e instalando equipos de seguridad adecuados para cada oficina. En el artículo que describe las exigencias alemanas sobre seguridad de los empleados de banca se recogen algunas medidas para mejorar la seguridad.

\section{Calidad del aire en interiores}

La deficiente calidad del aire en interiores (CAI) es probablemente la queja más frecuente sobre seguridad y salud de los trabajadores de oficina. La influencia sobre la productividad, el absentismo y la moral de una CAI deficiente es considerable. La Environmental Protection Agency (EPA) de Estados Unidos ha situado la CAI entre los 5 principales problemas de salud pública del decenio de 1990. Son muchas las causas de deficiente calidad del aire. Entre ellas están los edificios cerrados o herméticos que reciben un volumen insuficiente de aire exterior, el hacinamiento, el mantenimiento inadecuado de los sistemas de ventilación, la presencia de plaguicidas, productos de limpieza y otros productos químicos, los daños provocados por el agua y la proliferación de hongos, la instalación de habitáculos y tabiques que bloquean el paso del aire hacia las zonas de trabajo, la humedad excesiva o insuficiente y la suciedad (o la limpieza deficiente). 
Tabla 99.3 • Contaminantes del aire de interiores que pueden encontrarse en oficinas.

\begin{tabular}{|c|c|}
\hline Contaminante & Fuentes \\
\hline Amoníaco & Máquinas de cianotipia, soluciones de limpieza \\
\hline Amianto & $\begin{array}{l}\text { Aislantes, materiales de acabado, retardadores del fuego } \\
\text { suelos y techos falsos }\end{array}$ \\
\hline Dióxido de carbono & Aire exhalado por personas, combustión \\
\hline Monóxido de carbono & Emisiones de automóviles, humo de tabaco, combustión \\
\hline Formaldehído & $\begin{array}{l}\text { Asilante de espuma de urea-formaldeido y resina de } \\
\text { urea-formaldeido utilizados en derivados de la madera, } \\
\text { como aglomerados y contrachapados; humo de tabaco }\end{array}$ \\
\hline Freones & Filtraciones de sistemas de aire acondicionado \\
\hline Alcohol metílico & Máquinas copiadoras al alcohol \\
\hline Microorganismos (virus, bacterias, hongos) & $\begin{array}{l}\text { Sistemas de aire acondicionado y humidificación, } \\
\text { condensadores de evaporación, torres de refrigeración, } \\
\text { papeles mohosos, libros viejos, papel de prensa de } \\
\text { desecho }\end{array}$ \\
\hline
\end{tabular}
carbono, óxido de nitrógeno, partículas de plomo, óxidos de azufre)

Oxidos de nitrógeno

Ozono

Polvos y vapores de pinturas (orgánicos, plomo, Superficies recién pintadas, pintura vieja, agrietada mercurio)

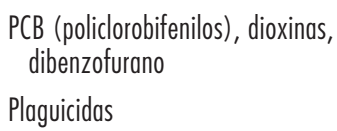

Radón y productos de desintegración

Disolventes (cloruro de metileno, 1,1,1-tricloroetano, percloroetileno, hexano, heptano, alcohol etílico, éteres de glicol, xileno, etc.)

Gases esterilizantes (óxido de etileno)

Humo de tabaco (exposición pasiva a partículas, monóxido de carbono, formaldehído, alquitrán y nicotina)

Compuestos orgánicos volátiles (COV)

Estufas y calentadores de gas, combustión, emisiones de vehículos de motor, humo de tabaco

Fotocopiadoras y otras máquinas eléctricas

Transformadores eléctricos, reactancias de fluorescentes viejos

Pulverización de plantas y locales

Materiales de construcción de edificios, como cemento y piedra; sótanos

Correctores líquidos y limpiadores para máquinas de escribir, adhesivos aplicados con pulverizador, gomas adhesivas, almohadillas entintadoras, rotuladores, productos de limpieza y tintas de impresión

Sistemas para esterilizar circuitos de aire acondicionado y humidificación

Cigarrillos, pipas, cigarros

Fotocopiadoras y otras máquinas de oficina, moquetas,

\section{Efectos sobre la salud}

Aparato respiratorio, irritación de ojos y piel

fibrosis pulmonar, cáncer

Dolores de cabeza, náuseas, mareos

Dolores de cabeza, debilidad, mareos, náuseas; exposición prolongada relacionada con enfermedades cardiacas

Irritación del aparato respiratorio, ojos y piel, náuseas, dolores de cabeza, fatiga, posibilidad de cáncer

Irritación del aparato respiratorio; arritmia cardiaca a concentraciones altas

Irritación del aparato respiratorio y la piel

Infecciones respiratorias, respuestas alérgicas

Irritación del aparato respiratorio y de los ojos, dolores de cabeza (véase monóxido de carbono), daños genético

Irritación del aparato respiratorio y de los ojos

Irritación del aparato respiratorio y de los ojos, dolores de cabeza, daño genético

Irritación del aparato respiratorio y de los ojos; daños neurológicos, renales y de la médula espinal a niveles de exposición altos plásticos nuevos
Deficiencias espermáticas y fetales, erupciones cutáneas, lesiones hepáticas y renales, cáncer

Según el tipo de compuesto: lesiones hepáticas, cáncer, lesiones neurológicas, irritación de la piel, del aparato respiratorio y de los ojos

Lesiones genéticas, cáncer,, lesiones fetales y espermáticas, etc. debidas a la radiación ionizante

Depende del disolvente: irritación de la piel, los ojos y el aparato respiratorio; dolores de cabeza, mareos, náuseas; lesiones hepáticas y renales

Depende de los productos químicos: irritación del aparato respiratorio y de los ojos, lesiones genéticas, cáncer

Irritación del aparato respiratorio y de los ojos; puede provocar enfermedades propias de los fumadores

Irritación del aparato respiratorio y de los ojos, reacciones alérgicas

Fuente: Stellman y Henifin 1983.

La Tabla 99.3 enumera los contaminantes comunes del aire en interiores presentes en muchas oficinas. Las máquinas de oficina son también fuente de contaminantes del aire. Por desgracia, casi nunca se tienen en cuenta las emisiones de las máquinas de oficina al diseñar los circuitos de ventilación.

La prevalencia de una CAI deficiente ha contribuido al aumento del asma profesional y otras alteraciones respiratorias, la sensibilidad y las alergias a productos químicos. También son frecuentes los casos de irritación de los ojos y la piel, imputables asimismo a una CAI deficiente. Deben tomarse medidas para investigar y corregir los problemas que degradan la CAI, de conformidad con las normas y recomendaciones sobre calidad del aire.

Provocan dermatitis (tanto alérgica como irritativa) muchos de los contaminantes del aire recogidos en la Tabla 99.3 como disolventes, residuos de plaguicidas, tintas, papeles especiales, 
cintas de las máquinas de escribir, limpiadores, etc. La mejor solución es la identificación de la causa y su sustitución.

\section{LA SEGURIDAD DEL CAJERO: SITUACION EN ALEMANIA}

\section{Manfred Fischer}

\section{El trabajo en el banco: ahora más seguro para el personal}

¿Qué medidas a largo plazo pueden adoptarse para que robar bancos sea menos atractivo? Las nuevas disposiciones de la normativa de prevención de accidentes (NPA) alemana sobre la "ventanilla del cajero" (VBG 120) reducen de manera sustancial el riesgo de que los empleados resulten heridos o muertos en atracos.

El conocimiento preciso de la conducta de los ladrones de bancos es fundamental. Con este fin, la Organización de comercio de la Administración estudia los robos de bancos desde 1966. Estos estudios han demostrado, por ejemplo, que los ladrones de bancos prefieren sucursales pequeñas con pocos empleados. Aproximadamente un tercio de los robos a bancos se producen poco después de abrir o justo antes de cerrar. El objetivo es salir del banco robado en muy poco tiempo (en 2 ó 3 minutos) y con el mayor botín posible. Muchos ladrones de bancos trabajan a partir de la suposición errónea, pero muy extendida, de que en una ventanilla de caja puede haber 100.000 marcos o más. Los resultados de estos y otros estudios aparecen en las secciones de la NPA "Construir y equipar" y "Operaciones en la ventanilla del cajero". A continuación se proponen medidas para proteger al empleado que reducen drásticamente las expectativas de los ladrones de bancos. El éxito de estas medidas depende de que los empleados las cumplan estrictamente en la práctica diaria.

¿Qué exigencias básicas se establecen en la NPA sobre la "ventanilla del cajero". En el apartado 7 de la NPA relativo la "Ventanilla del cajero" se establece la exigencia principal: "la protección de los asegurados se basa en proteger los billetes de forma que se reduzca considerablemente el incentivo para el robo".

¿Cómo se materializa esto en la práctica diaria? En zonas abiertas al público, el dinero fácilmente accesible sólo debería guardarse y manejarse en habitaciones protegidas por paneles a prueba de balas o de rotura.

La cantidad máxima de dinero accesible permitida aparece en el apartado 32: se admite un máximo acumulado de 50.000 marcos si hay ventanillas a prueba de balas, otras protecciones irrompibles y al menos 6 empleados presentes. No se podrán sobrepasar los 10.000 marcos cuando se utilicen protecciones irrompibles (pero no ventanillas a prueba de balas) junto con cajas equipadas con sistemas de apertura retardada. En todo momento debe de haber al menos 2 empleados presentes que deben mantener el contacto visual.

Para que el robo del banco sea lo menos atractivo posible, las cantidades de dinero accesible deben mantenerse muy por debajo de los máximos establecidos en la NPA relativa a "la ventanilla". Además, el apartado 25 exige que la empresa elabore instrucciones para establecer la máxima cantidad accesible permitida en cada sucursal. Las cantidades superiores que puedan ser necesarias deberían guardarse en cajas de apertura retardada que dificulten el acceso a los ladrones de bancos.

Las ventanillas que no están equipadas con protecciones a prueba de bala o irrompibles y que no dispongan de un mecanismo central para dispensar dinero o de un cajero automático operado por el empleado no deberían tener a mano billetes de banco accesibles.

\section{Protección de ventanillas y puertas}

Las puertas de entrada y salida del personal a las áreas de caja que contienen dinero en efectivo deben protegerse de manera que sean invisibles e inaccesibles desde el exterior, para que los ladrones de bancos no puedan interceptar fácilmente a los empleados que entran y salen del recinto del banco. Asimismo, deben instalarse mirillas para que aquéllos se aseguren de que no corren ningún peligro.

Para impedir que los ladrones entren en las dependencias del banco sin ser vistos, las puertas deben contar con mecanismos que las mantengan siempre cerradas.

Como la visión de los billetes supone un incentivo considerable para el robo, las ventanillas detrás de los cuales se manipulan deben estar protegidas de la vista y el acceso. Las estadísticas demuestran que la observancia estricta de esta exigencia tiene como resultado la reducción drástica de robos en ventanillas y entradas de personal.

A diferencia de las puertas de entrada y salida del personal, las abiertas al público deben tener una vista despejada para detectar cuanto antes la presencia de ladrones y hacer sonar una alarma para pedir ayuda. Por tanto, es importante que la vista no esté obstaculizada por carteles o similares.

\section{Vigilancia óptima del local}

Para identificar al ladrón lo antes posible y obtener pruebas válidas ante el tribunal, en la NPA relativa a "ventanillas" se establece la obligatoriedad de un equipo de vigilancia adecuado. También es importante para determinar si el ladrón obtuvo el dinero por la fuerza o amenazó a los empleados, puesto que los actos particularmente brutales agravan la pena. Las imágenes de calidad reducen el incentivo para el robo de un banco.

Las instrucciones sobre "Equipamiento de vigilancia óptima de locales (EVOL) SP 9.7/5" de julio de 1993 sólo permitían cámaras individuales como EVOL estándar. Las fotografías son superiores a las tomas de vídeo a efectos de identificación, porque proporcionan más detalle y constituyen una prueba más sólida. El inconveniente es que las fotografias sólo están disponibles después de que la cámara haya sido activada. El progreso técnico ha llevado al Comité técnico de la Administración a autorizar el uso de cámaras de vídeo como posibles EVOL. Actualmente se está preparando la normativa correspondiente. Establece que la limitada resolución de las imágenes de vídeo deberá compensarse con el registro desde dos puntos de vista. Por tanto, hay que instalar al menos dos cámaras para identificar al ladrón y para grabar en vídeo acontecimientos esenciales.

Una instalación de vídeo adecuada graba de manera continua $\mathrm{y}$, de ese modo, proporciona la imagen de identificación sin necesidad de activar ninguna cámara. Otras ventajas del sistema son el registro en color, la rápida disponibilidad de las fotografías, la transmisión de imágenes a la policía, incluso durante el robo, y la posibilidad de verificar en todo momento el funcionamiento de la cámara.

\section{Seguridad de las ventanillas de caja}

La NPA sobre ventanillas de caja autoriza:

- las cabinas y los recintos de cristal irrompible y a prueba de balas;

- las separaciones motorizadas;

- las separaciones irrompibles junto con pantallas a prueba de balas;

- el equipo centralizado de dispensación de dinero; y

- los cajeros automáticos operados por los empleados. 
Además, los cajeros automáticos operados por los empleados responden a las exigencias del apartado 7 , puesto que su utilización puede reducir la cantidad de dinero en las cabinas o en salas separadas.

Para cumplir con la NPA sobre ventanillas de caja hay que conocer el número de empleados necesarios en el mostrador y las cantidades que se ingresan y abonan (cantidades y número de operaciones) antes de construir o remodelar las ventanillas. La seguridad óptima sólo se alcanza cuando la seguridad de caja responde a la actividad real.

\section{Presencia constante con contacto visual}

Ciertas medidas de seguridad bancaria exigen la presencia de un mínimo de 2 a 6 empleados que mantengan contacto visual entre sí. Esta exigencia se deriva del hecho de que los ladrones de bancos prefieren las sucursales pequeñas y con mucho dinero, en las que los empleados, cuando se ven amenazados por un arma, no pueden retirarse detrás de un escudo a prueba de balas.

Las protecciones a prueba de balas sólo pueden utilizarse cuando en la zona de ventanillas haya siempre 6 empleados que mantengan contacto visual. Esto no equivale a una sucursal con una plantilla de 6 personas, donde no siempre todo el mundo está en su puesto de trabajo debido a vacaciones, enfermedad, visitas a clientes, etc. La experiencia demuestra que esta condición sólo se cumple cuando en la sucursal trabajan entre 8 y 10 empleados. Otra opción es recurrir a un servicio rotativo de sustituciones que garantice la presencia del número mínimo de empleados.

Para garantizar la presencia constante de 2 empleados que mantengan contacto visual, la sucursal debe tener 3 ó 4 trabajadores.

Es importante que la sucursal no se abra antes de que estén presentes el mínimo necesario de trabajadores. El mínimo de empleados en las ventanillas debe mantenerse incluso cuando se celebren consultas en salas contiguas.

\section{Seguridad mediante separación}

\section{Sucursales pequeñas}

Son "sucursales pequeñas" aquéllas en las que no está garantizada la presencia de al menos 2 empleados que mantengan contacto visual. Para estas sucursales, los paneles a prueba de balas y las separaciones irrompibles ofrece buena protección, ya que los empleados no tienen que abandonar el área protegida en caso de robo. Las consultas se llevan a cabo en un área protegida por paneles irrompibles que garantiza la buena comunicación. La protección a prueba de balas, detrás de la cual debe guardarse el efectivo accesible, ha de estar situada de forma que los empleados no puedan ser amenazados con un arma desde la zona de los clientes. Las transacciones de dinero tienen lugar a través de una escotilla reglamentaria o un cajón corredizo. Como en caso de ataque el empleado debe ir a la zona con protección antibalas, la seguridad personal está garantizada. Esta zona no debe abandonarse bajo ninguna circunstancia, ni siquiera cuando se entrega el dinero al ladrón.

Las separaciones a prueba de bala representan una alternativa para sucursales con 1 a 3 empleados. Ofrecen protección mecánica frente al atraco bancario típico, puesto que todos los empleados están separados del ladrón por ellas. El inconveniente es que la seguridad se obtiene a costa de la comunicación con los clientes. Por tanto, la separación total a prueba de balas sólo es adecuada para sucursales pequeñas.

\section{Sucursales grandes}

La cabina de caja es una forma de seguridad en la que sólo el puesto de trabajo del cajero está separado del área de los clientes.
Esta opción sólo tiene sentido cuando el cajero realiza todo su trabajo en la cabina y no tiene que salir de ella.

Antes de instalar una cabina, hay que determinar si la única actividad del cajero es el manejo del dinero. Normalmente, éste no es el caso en sucursales pequeñas con sólo 2 o 4 empleados. $\mathrm{Si}$ el cajero tiene otras tareas que realizar fuera de la cabina, no se cumplen las exigencias de seguridad de la NPA, pues debe estar siempre separado de los clientes para quedar protegido de un ataque corporal. En la práctica, lo que sucede una y otra vez es que mientras el cajero realiza actividades fuera de la cabina la puerta se mantiene abierta con una cuña o se deja la llave en la cerradura. De esta manera se pone en peligro la seguridad de la cabina, lo que resulta muy interesante para posibles ladrones. La cabina a prueba de balas dificulta la comunicación entre el cajero y los clientes. Pero como quiera que las conversaciones más largas se producen en lugares de trabajo no protegidos, esta circunstancia no representa un gran problema. Más difícil es garantizar la ventilación y el aire acondicionado en cabinas de caja pequeñas.

La separación motorizada es una pared de acero móvil integrada en el mostrador que se eleva en una fracción de segundo en caso de emergencia por activación de varios disparadores. De esta forma se crea una separación a prueba de balas que deja a los empleados en el interior de un recinto protegido. Para impedir que un ladrón entre de manera inadvertida, debe estar activada siempre que no haya empleados en el área acorazada, o cuando el trabajo que se esté realizando exija que el personal esté fuera del mostrador. Con el fin de evitar la activación constante, este tipo de paneles de acero sólo deberían utilizarse en zonas en las que haya entre 2 y 4 empleados.

Además, los puestos de trabajo de los cajeros pueden aislarse con paneles antibalas. A tal fin pueden instalarse separaciones totales para todos los empleados y cabinas de caja. Sin embargo, esta forma de seguridad exige la presencia constante en el vestíbulo principal de al menos 6 empleados que mantengan contacto visual.

La separación total a prueba de balas y las cabinas de caja pueden utilizarse también en presencia de un mínimo de 2 empleados que mantengan contacto visual cuando el dinero en efectivo accesible no supere los 10.000 marcos. En este caso es necesario un receptáculo para el dinero con sistema de apertura retardada, de manera que el empleado no tenga que abandonar constantemente la zona protegida para ir a buscar efectivo. Los ladrones de banco evitan las cabinas de caja si tienen poco dinero o si tardan mucho en entregarlo. En este caso, es importante para la protección de los empleados que la existencia del receptáculo con sistema de apertura retardada se anuncie a la entrada y en la zona de caja. Esto hace que el ladrón potencial sepa inmediatamente que el empleado no tiene control sobre el receptáculo y que sólo puede esperar un botín pequeño.

\section{Seguridad sin billetes de banco accesibles en el vestíbulo principal}

La seguridad es posible incluso sin construir ninguna separación entre empleados y clientes. Pero para reducir así el incentivo es necesario que no haya cantidades accesibles de dinero en la zona de los empleados. El dinero ingresado debe guardarse inmediatamente en una caja fuerte instalada en un lugar no abierto al público, de manera que el ladrón no pueda amenazarlo. Los empleados reciben el dinero mediante un sistema de tubos de distribución instalado en el vestíbulo principal. El dinero ingresado se envía a la caja de caudales por esta vía. Cuando se sigue este método, no se prescribe ningún número mínimo de empleados en la sala principal. Sin embargo, este tipo de seguridad alarga los tiempos de espera para los clientes. La ventaja es 
que los ladrones potenciales no tienen prácticamente ninguna posibilidad de conseguir nada.

Los cajeros automáticos (CA) para empleados son otra solución para hacer pagos en efectivo de manera que el dinero no sea accesible desde el vestíbulo principal. Estas máquinas tienen entre 4 y 6 depósitos para billetes en un receptáculo protegido de apertura retardada. Para realizar pagos, se solicita la cantidad mediante un teclado, que sirve también para activar la alarma en caso de emergencia. El empleado recibe el dinero después de un tiempo de espera que depende de la cantidad de dinero y se fija en el apartado 32 de la NPA sobre "ventanillas de caja". Los tiempos de espera elegidos mantienen un buen servicio pero, como se prolongan cuando se solicitan cantidades grandes, disuaden a los ladrones. Los ingresos en efectivo se protegen en cajas de apertura retardada o con doble cierre.

Si se utiliza un CA manejado por un empleado debe haber siempre 2 trabajadores que mantengan contacto visual. Por ello, esta forma de seguridad es adecuada sólo para sucursales con 3 o 4 empleados. Las consultas se celebran en una sala de conferencias sólo cuando queden dos o más empleados en la zona de clientes durante la conversación.

Hay que preparar instrucciones y medidas de actuación apropiadas en caso de avería de un CA accionado por los empleados. Entre las medidas debe haber una caja fuerte de emergencia y procedimientos organizativos que garanticen la continuación del trabajo de conformidad con lo establecido por la NPA sobre ventanillas bancarias.

\section{Ordenes e instrucciones de la empresa}

La empresa debe preparar instrucciones para cada ventanilla y comprobar regularmente su cumplimiento. En las instrucciones se describe brevemente todo lo que suele suceder durante los atracos y lo que debe hacerse mientras duran y después. Además, hay que dar instrucciones diarias y obligar a utilizar el equipo de seguridad instalado. Esto es especialmente importante cuando hay grandes cantidades de billetes accesibles. Las instrucciones deben indicar también la manera de guardar otros objetos de valor. Los empleados de ventanilla deben recibir formación sobre estas políticas de empresa al menos dos veces al año.

El propósito de estas instrucciones es claro: garantizar que los empleados siguen las exigencias de la NPA sobre "ventanillas bancarias" para su propia seguridad y para que el atraco al banco sea lo menos atractivo posible.

\section{- Teletrabajo}

\section{Jamie Tessler}

El teletrabajo o trabajo en la propia casa es cada vez más común en el mundo de la empresa en todo el mundo. Este artículo se ocupa de los riesgos para la salud y la seguridad laboral propios del teletrabajo (del griego tele, que significa "lejano"). El grado de responsabilidad de la empresa en relación con las condiciones de trabajo seguras y saludables de los empleados depende del contrato o el acuerdo que haya entre cada trabajador y la empresa y de la legislación laboral aplicable.

Aunque el teletrabajo está extendido sobre todo en los Estados Unidos, donde integra a 8 millones de trabajadores y un $6,5 \%$ de la población activa, otros países también tienen cifras importantes de teletrabajadores: más de 560.000 en el Reino Unido, 150.000 en Alemania y 100.000 en España. En Irlanda hay más de 32.000, lo que representa el 3,8 \% de la población activa (OIT 1997).
La generalización de los contratos de teletrabajo se explica por los siguientes factores:

- el empeño de la empresa en reducir el tiempo, coste e impacto ambiental de los desplazamientos diarios al lugar de trabajo;

- las medidas legislativas orientadas a reducir la contaminación atmosférica debida al tráfico;

- los cambios técnicos, la informatización y las comunicaciones electrónicas, que permiten a las empresas contratar trabajadores para que desarrollen su actividad en lugares alejados;

- el coste de mantener los grandes espacios de oficina necesarios para albergar a numerosos trabajadores;

- la posibilidad de facilitar el acceso al empleo a personas discapacitadas o con responsabilidades familiares o que no pueden desplazarse por cualquier otro motivo;

- es una estrategia para reducir el absentismo, y

- la aceptación de que los trabajadores tienen diversos ciclos internos de productividad y creatividad.

El aumento de la productividad constituye otro factor, pues numerosos estudios han demostrado que el teletrabajo va acompañado de importantes aumentos de productividad (OIT 1990b).

Hay varias formas de contratación de teletrabajo:

- El empleado trabaja para la empresa en su propia casa, a jornada completa (o a tiempo parcial), y tiene los mismos derechos que los empleados que trabajan en las instalaciones de la empresa.

- El empleado trabaja a jornada completa para la empresa, pero sólo trabaja fuera de casa durante un número específico de días por semana o por mes.

- El trabajador es considerado un contratista independiente y no tiene los mismos derechos que los empleados que trabajan en la empresa, que tampoco le proporciona equipo.

\section{Riesgos de salud y seguridad del teletrabajo}

Los riesgos de salud y seguridad del teletrabajo son los propios del entorno de oficina normal, a los que se añaden algunos motivos de inquietud peculiares.

\section{Calidad del aire en interiores}

La mayor parte de los hogares carecen de sistemas mecánicos de ventilación. Por el contrario, los intercambios de aire en el hogar dependen de la ventilación natural. Su eficacia depende de factores como el tipo de aislamiento del edificio, etc. No hay forma de garantizar el suministro de aire fresco del exterior. Si la ventilación natural es insuficiente para extraer los contaminantes interiores, será necesario reforzarla.

He aquí algunos contaminantes comunes en interiores domésticos:

- exposición a gas natural o a monóxido de carbono procedentes de sistemas de calefacción ineficaces o estufas con fugas;

- vapores y gases de fotocopiadoras, impresoras y otras máquinas de oficina;

- exposición pasiva continua a sustancias químicas, gases o polvo como resultado de reformas en el hogar del trabajador;

- exposiciones a emanaciones procedentes de otras actividades si el hogar del trabajador se encuentra en un edificio multiusos (un edificio de viviendas con un instituto de belleza, una tintorería o un restaurante de comida rápida en la planta baja);

- riesgos de exposición a gas radón si la oficina se encuentra en el sótano, en zonas en las que los materiales de construcción o del propio suelo desprenden ese gas. 


\section{Riesgo de incendio}

Es poco frecuente que la instalación eléctrica doméstica sea adecuada para el equipamiento eléctrico utilizado habitualmente en el teletrabajo, como impresoras, fotocopiadoras y otras máquinas de oficina. La instalación de estos aparatos sin tener en cuenta la capacidad de la instalación eléctrica del hogar aumenta el riesgo de incendio. La normativa local sobre edificación prohibe en algunos lugares la adaptación de la instalación eléctrica a las nuevas necesidades. Muchos pisos de alquiler y hogares con varias unidades carecen de medidas de evacuación adecuadas, tienen bloqueadas las salidas de emergencia o cerradas las puertas de salida.

\section{Riesgos ergonómicos}

Los empleados que trabajan en casa suelen utilizar sus sillas, mesas, estanterías y demás muebles para desempeñar sus tareas. Los puestos de trabajo con ordenadores normales en el entorno doméstico no permiten los ajustes que exige el trabajo intensivo. La falta de espacio horizontal, en estanterías y zonas de almacenamiento obliga a inclinarse en exceso, adoptar malas posturas, alargar los brazos más de la cuenta y adoptar otras posturas que favorecen las lesiones traumáticas acumuladas (LTA). El trabajo en entornos fríos o con climatización desigual también favorece las lesiones musculares y óseas.

\section{Iluminación}

La iluminación inadecuada es causa de malas posturas, fatiga visual y alteraciones visuales. A veces es necesario instalar una iluminación especial para superficies de trabajo o soportes de documentos. Las paredes y las superficies del mobiliario deben ser neutras y tener un acabado no deslumbrante. Aunque esta estrategia se utiliza cada vez más en entornos de oficina, todavía no es habitual en la decoración y el diseño domésticos.

\section{Estrés profesional}

El trabajo a jornada completa en entornos domésticos priva al trabajador de los beneficios personales y profesionales del trato constante con otros trabajadores, compañeros y mentores. El aislamiento impide en ocasiones la incorporación del trabajador a actividades de desarrollo profesional, el aprovechamiento de las oportunidades de promoción y la aportación de ideas a la organización. Los trabajadores muy sociables tienen una dependencia especial del contacto humano y se resienten en lo personal y lo profesional cuando les falta. La ausencia de servicios de apoyo administrativo carga sobre los empleados la obligación de realizar ciertas tareas de oficina. La empresa debe fomentar la participación de los teletrabajadores en reuniones del personal y otras actividades de grupo, personalmente o por medios electrónicos (teleconferencia) si así lo imponen las limitaciones físicas y geográficas.

Los empleados con hijos, familiares discapacitados o padres de edad avanzada encontrarán ventajoso el trabajo en casa. Pero atender a las necesidades de familiares a cargo puede afectar a la concentración que exigen las responsabilidades laborales. El estrés derivado de esta situación afecta negativamente al trabajador, incapaz de cumplir con sus obligaciones laborales a pleno rendimiento y de estar a la altura de las expectativas de la empresa. El teletrabajo no debería considerarse como un sustituto del cuidado de niños o ancianos. Como la capacidad de equilibrar el trabajo y otras responsabilidades en el entorno doméstico varía mucho de unos trabajadores a otros, hay que evaluar caso por caso la necesidad de servicios de apoyo para evitar el estrés profesional excesivo y la consiguiente pérdida de productividad. No debería obligarse a ningún trabajador a aceptar un contrato de teletrabajo contra su voluntad.

\section{Indemnización por lesiones y enfermedad}

Con frecuencia las enfermedades profesionales se instauran como consecuencia de exposiciones acumuladas a lo largo de mucho tiempo. La prevención de estas lesiones se basa en la identificación rápida de los factores de riesgo, la solución del problema aplicando el método adecuado y el tratamiento médico del trabajador afectado en cuanto aparecen los primeros signos o síntomas.

Hasta el momento, la responsabilidad de la empresa por accidentes y lesiones en el entorno doméstico ha sido tratada caso por caso. La mayoría de las normativas nacionales sobre salud y seguridad en el trabajo no incluyen políticas formales sobre la seguridad de los teletrabajadores. El serio impacto de esta tendencia deberá evaluarse cuidadosamente y afrontarse mediante el establecimiento de normas internacionales.

Cuando los acuerdos de teletrabajo transforman al empleado en contratista independiente, la carga de muchas responsabilidades pasa también a éste. Cuando el trabajo se realiza en el hogar por un contratista independiente, la empresa no se siente obligada a proporcionar un lugar de trabajo sano y seguro, acceso a atención médica preventiva y curativa para el trabajador y su familia, seguridad social, seguro de discapacidad y compensación para trabajadores que se han lesionado y necesitan recuperación. Esta tendencia destruye derechos de los trabajadores y protecciones sociales obtenidos después de décadas de lucha y negociación.

\section{Protección del teletrabajador}

El contrato entre trabajador y empresa debe contemplar aspectos tales como el entorno global del trabajo, las normas de salud y seguridad, la formación y el equipo. Las empresas deberían inspeccionar el lugar de trabajo doméstico (en visitas previamente acordadas) para garantizar la seguridad del trabajador y para identificar y corregir factores de riesgo que puedan contribuir a enfermedades o lesiones. La inspección debería evaluar el aire en interiores, la ergonomía, los riesgos en desplazamientos, la iluminación, la exposición a sustancias químicas y otras cuestiones. Deben establecerse normas claras sobre el suministro del material de oficina necesario para llevar a cabo el trabajo. Hay que delimitar con claridad las responsabilidades en relación con los bienes de la empresa (y del trabajador) que se pierden o sufren daños debido a incendios, catástrofes naturales o robo. Salvo en casos de negligencia, los empleados deben estar exentos de responsabilidad financiera.

Además, los contratos de teletrabajo deberían evaluarse de manera regular para identificar a aquellos trabajadores que descubren que el trabajo en casa no va con ellos.

\section{Resumen}

Son muchas las ventajas del teletrabajo, y deberían fomentarse los contratos de teletrabajo beneficiosos para tareas y trabajadores maduros que pueden tener mucho que ganar trabajando en casa. El teletrabajo ha permitido a personas discapacitadas alcanzar un grado mayor de independencia y disfrutar de oportunidades profesionales a las que previamente no podían acceder. Por su parte, las empresas pueden retener a trabajadores valiosos. Sin embargo, el contrato de teletrabajo debe garantizar la continuidad de los derechos del empleado y la protección de la salud y la seguridad profesional. 
EL COMERCIO MINORISTA

\section{Adrienne Markowitz}

Se llama comercio minorista a la venta de productos a los consumidores. Las empresas venden cualquier cosa, desde automóviles hasta prendas de vestir, desde alimentos hasta televisores. En muchos países, lo que antes era un sector formado principalmente por tiendas y almacenes pequeños, está ahora dominado por poderosos grupos multinacionales que cuentan con grandes supermercados y compiten por el mercado mundial. Los cambios tecnológicos y la competencia han cambiado las descripciones de los puestos de trabajo, los riesgos relacionados con estos trabajos y la naturaleza de la mano de obra.

En los países desarrollados, los pequeños comerciantes luchan por competir con las grandes empresas de comercio minorista. En Estados Unidos, Canadá, la Comunidad Europea y el
Pacífico, el comercio minorista se ha trasladado desde el centro de las ciudades a centros comerciales en las afueras. Estas grandes cadenas multinacionales venden los mismos productos y marcas que las tiendas de barrio tradicionales, pero limitan sustancialmente la capacidad de elección del consumidor y expulsan a la competencia del mercado mediante el poder de compra, la capacidad de invertir en publicidad y los bajos precios. Con frecuencia, un gran almacén asumirá pérdidas en ciertos productos para atraer a los consumidores; esta técnica con frecuencia genera otras ventas.

En países en vías de desarrollo con economías predominantemente agrarias, los sistemas de trueque y los mercados al aire libre siguen siendo habituales. Pero también en ellos empiezan a introducirse las grandes empresas multinacionales del comercio minorista.

Cada tipo de establecimiento tiene sus propios riesgos. El trabajo en el comercio minorista en países en vías de desarrollo y

\section{Mercados al aire libre}

El sector informal representa entre el 20 y el 70 \% de la población activa urbana en los países en vías de desarrollo (con una media del $40 \%$ ), y los comerciantes y vendedores ambulantes de estos mercados al aire libre comprenden una porción significativa del sector. Este trabajo es por su propia naturaleza precario, con jornadas largas y remuneración baja. Los ingresos medios no llegan en ocasiones al $40 \%$ de los normales en el sector estructurado. Muchos trabajadores de mercados al aire libre no sólo carecen de un lugar estable en el que ejercer su actividad, sino que a veces se ven además obligados a prescindir de infraestructuras de apoyo. No disfrutan de la misma protección o seguridad social que los trabajadores del sector estructurado y están expuestos a situaciones de violencia. Apenas hay estadísticas morbilidad y mortalidad relacionadas con este oficio (Bequele 1985).

Los trabajadores de los mercados al aire libre, sean de países desarrollados 0 en desarrollo, como los ilustrados en las Figuras 99.1 y 99.2, están expuestos a numerosos riesgos de salud y seguridad y a las emisiones de los vehículos de motor, que

Figura 99.1 - Mercado de alimentos al aire libre de Malatia, Islas Salomón, 1995.

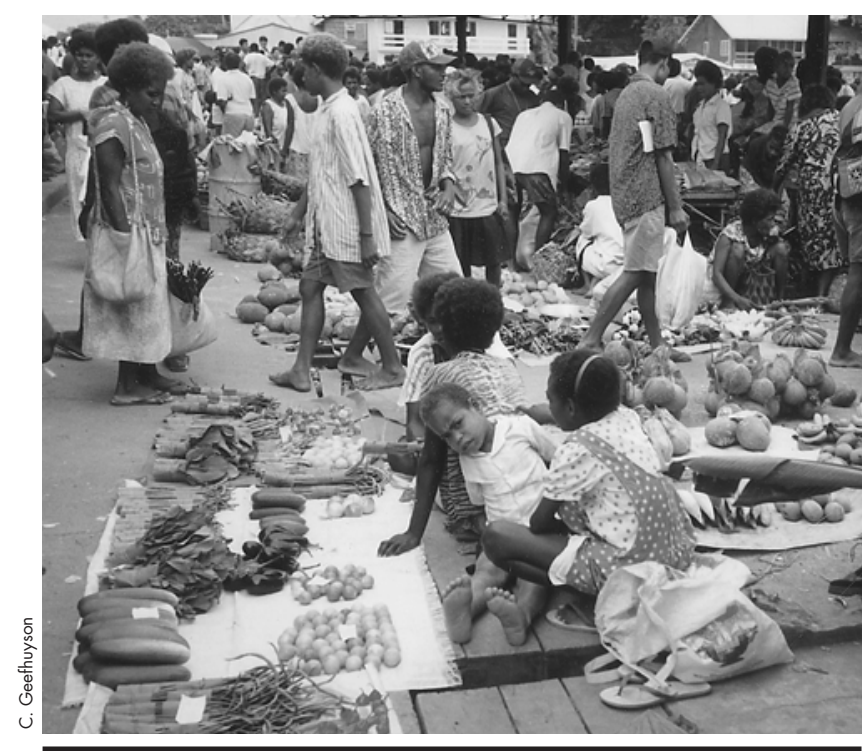

contienen compuestos como monóxido de carbono e hidrocarburos aromáticos policíclicos. También deben sufrir toda clase de condiciones climatológicas. En zonas tropicales y desérticas están sujetos a estrés por calor y deshidratación. En climas fríos, a temperaturas bajo cero que provocan entumecimiento, escalofríos o congelación. Los trabajadores de mercados al aire libre carecen de acceso a instalaciones sanitarias adecuadas.

El sector no estructurado en general, y los mercados al aire libre en particular, están relacionados con el trabajo infantil. En torno a 250 millones de niños trabajan a jornada completa o a tiempo parcial en todo el mundo (OIT 1996); los vendedores callejeros son los trabajadores infantiles más visibles. Estos niños, incluidos los vendedores callejeros, normalmente no reciben educación y con frecuencia se ven obligados a levantar cargas pesadas y realizar otras tareas que pueden provocar discapacidades permanentes.

John G. Rodwan, Jr.

Figura 99.2 - Cestos pesados de erizos de mar distribuidos por un pequeño comerciante, Japón, 1989.

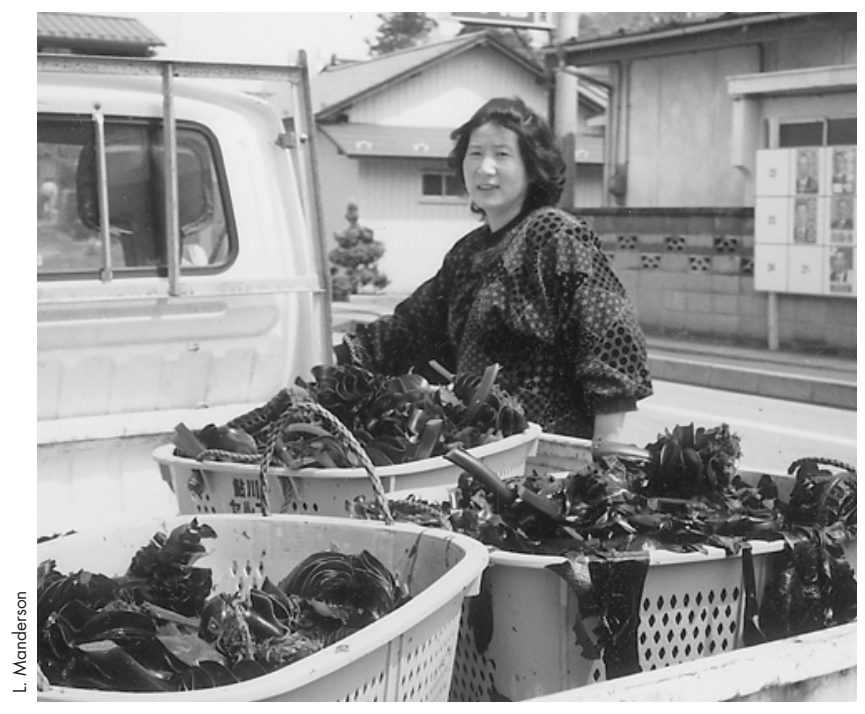


Tabla 99.4 • Estadísticas laborales en el comercio minorista (selección de países).

\begin{tabular}{|c|c|c|c|c|c|c|c|}
\hline País & $\begin{array}{l}\text { Porcentaje } \\
\text { de hombres } \\
\text { en la } \\
\text { población } \\
\text { activa (\%) }\end{array}$ & $\begin{array}{l}\text { Porcentaje de } \\
\text { hombres en el } \\
\text { comercio mino- } \\
\text { rista y mayorista, } \\
\text { hoteles y restau- } \\
\text { rantes (\%) }\end{array}$ & $\begin{array}{l}\text { Porcentaje } \\
\text { de mujeres } \\
\text { en la } \\
\text { población } \\
\text { activa (\%) }\end{array}$ & $\begin{array}{l}\text { Porcentaje de } \\
\text { mujeres en el } \\
\text { comercio mino- } \\
\text { rista y mayorista, } \\
\text { hoteles y restau- } \\
\text { rantes (\%) }\end{array}$ & $\begin{array}{l}\text { Porcentaje total } \\
\text { de población en } \\
\text { el comercio mayo- } \\
\text { rista y minorista, } \\
\text { hoteles y restau- } \\
\text { rantes (\%) }\end{array}$ & $\begin{array}{l}\text { Número total } \\
\text { de personas } \\
\text { que han } \\
\text { sufrido } \\
\text { lesiones }\end{array}$ & $\begin{array}{l}\text { Porcentaje de } \\
\text { personas que } \\
\text { han sufrido } \\
\text { lesiones en el } \\
\text { comercio } \\
\text { minorista (\%) }\end{array}$ \\
\hline Burkina Faso & 51,3 & 1,0 & 48,7 & 1,5 & 2,6 & 1.858 & $8,7^{1}$ \\
\hline Costa Rica & 69,9 & 11,0 & 30,1 & 7,4 & 18,4 & 156.782 & $7,0^{2}$ \\
\hline Egipto & 75,9 & 7,3 & 24,1 & 1,2 & 8,4 & 60.859 & $2,5^{2}$ \\
\hline Alemania & 52,3 & 4,5 & 47,7 & 7,0 & 11,5 & 29.847 & $20,1^{3}$ \\
\hline Grecia & 63,0 & 10,9 & 37,0 & 7,0 & 17,0 & 23.959 & $10,5^{4}$ \\
\hline Italia & 63,1 & 11,7 & 36,9 & 6,9 & 8,6 & 767.070 & $8,1^{5}$ \\
\hline Japón & 59,5 & 11,0 & 40,5 & 10,9 & 21,9 & 2.245 & 9,7 \\
\hline México & 69,1 & 10,8 & 30,9 & 9,6 & 20,5 & 456.843 & 16,96 \\
\hline Países Bajos & 58,9 & 9,1 & 41,1 & 8,0 & 17,1 & 64.657 & 16,5 \\
\hline Noruega & 54,5 & 7,9 & 45,5 & 8,9 & 16,7 & 26.473 & 5,0 \\
\hline Singapur & 59,8 & 13,2 & 40,2 & 9,0 & 22,0 & 4.019 & $0,2^{7}$ \\
\hline Suecia & 52,0 & 6,8 & 48,0 & 6,5 & 13,3 & 43.459 & 6,6 \\
\hline Tailandia & 55,5 & 5,8 & 49,5 & 6,8 & 12,6 & 103.296 & $3,1^{8}$ \\
\hline Reino Unido & 56,2 & 8,3 & 43,8 & 9,5 & 17,8 & 157.947 & $11,0^{9}$ \\
\hline Estados Unidos & 54 & 11,1 & 46,0 & 10,0 & 21 & 295.340 & $23,6^{10}$ \\
\hline
\end{tabular}

1 Incluidos los accidentes en el desplazamiento al lugar de trabajo; incluidas las enfermedades profesionales.

2 Incluidos los accidentes en el desplazamiento al lugar de trabajo; establecimientos con 1000 más trabajadores.

${ }^{3}$ Series correspondientes al territorio de la República Federal Alemana antes de 1990; incluidos los accidentes en el desplazamiento al lugar de trabajo.

${ }^{4}$ Incluidas enfermedades profesionales; incluidos casos no mortales sin pérdida de días de trabajo.

\footnotetext{
5 Incluidos los accidentes en el desplazamiento al lugar de trabajo; personas que han perdido más de tres días de trabajo por período de discapacidad.

${ }^{6}$ Incluidos los casos no mortales sin pérdida de días de trabajo.

7 Incluidos los accidentes en el desplazamiento al lugar de trabajo; incluidas enfermedades profesionales; incluidos los casos no mortales sin pérdida de días de trabajo.

8 Incluidos los accidentes en el desplazamiento al lugar de trabajo.

9 Sólo empleados; excluidos accidentes de tráfico; inicio del año en abril de 1993.

10 Incluidas enfermedades profesionales.
}

en transición es con frecuencia muy diferente al trabajo en el comercio minorista en los países desarrollados; los grupos con grandes cadenas de centros comerciales todavía no son dominantes y el trabajo en el comercio minorista se lleva a cabo principalmente en mercados al aire libre bajo todo tipo de condiciones atmosféricas.

Los grupos multinacionales tienden a modificar las condiciones de trabajo: desalientan al sindicalismo, reducen el personal al mínimo imprescindible, bajan los salarios, los centros comerciales contratan principalmente trabajadores a tiempo parcial, desciende la edad media de los trabajadores y se reducen las compensaciones extrasalariales.

En todo el mundo las horas de apertura de los centros comerciales han cambiado de tal modo que algunos permanecen abiertos las 24 horas del día, los 7 días de la semana. Antes, un trabajador que hacía el turno de noche o en días festivos recibía una remuneración extra; ahora el pago de horas extras ha desaparecido, pues las largas jornadas laborales se han convertido en norma. En Estados Unidos, por ejemplo, las vacaciones tradicionales son ahora negociables cuando el centro comercial permanece abierto las 24 horas del día, 7 días a la semana.

Los cambios en la forma en la que se lleva a cabo la actividad han impuesto cambios fundamentales en la mano de obra.
Como muchos trabajos se han visto reducidos a la marginalidad del empleo a tiempo parcial y requieren poca cualificación, los trabajadores no reciben formación ninguna. Los que antiguamente veían en el comercio minorista una carrera profesional, ven ahora cómo cambian de empleo con frecuencia o lo abandonan por completo, pues el trabajo en el comercio minorista se ha convertido en temporal y a tiempo parcial.

Es difícil calcular la población activa que trabaja en el sector del comercio minorista. El sector informal juega un papel significativo en los países en desarrollo (véase recuadro). Muchas veces los problemas de salud y seguridad pasan inadvertidos, los gobiernos no los registran y se consideran parte del trabajo.

En muchos de los países que sí llevan a cabo estadísticas, los trabajadores del comercio minorista, del comercio al por mayor y de hoteles y restaurantes se agrupan en una única categoría. Las estadísticas de todo el mundo demuestran que el porcentaje de personas que trabajan en los sectores del comercio minorista, mayorista, hoteles y restaurantes va desde más del $20 \%$ en algunos países de Asia a menos del $3 \%$ en Burkina Faso (véase Tabla 99.4). Aunque los hombres superen en número a las mujeres en la población activa, el porcentaje de mujeres en el sector del comercio minorista es mayor, al menos en la mitad de los países sobre los que se dispone de estadísticas. 


\section{Procesos, riesgos y prevención}

\section{Cajeros}

Muchos cajeros trabajan con cajas registradoras que les obligan a utilizar un teclado numérico miles de veces al día para marcar el precio del artículo. Normalmente se teclea con la mano derecha mientras que con la mano izquierda se mueven los productos desde delante del cajero a la parte posterior de la caja, donde se empaquetan. Esto se hace con frecuencia en puestos de trabajo mal diseñados, lo que obliga a los cajeros a levantar productos pesados, estirarse en exceso para alcanzarlos o girar con frecuencia el cuerpo para moverlos de un sitio a otro. Tales movimientos hacen que recaigan cargas diferentes sobre cada lado del cuerpo, lo que provoca dolor en la parte baja de la espalda, enfermedades de las extremidades inferiores y lesiones por movimientos repetitivos, como tendinitis, síndrome del túnel carpiano, tenosinovitis, síndrome de la salida torácica y problemas en la cadera, piernas y pies.

Los puestos de trabajo bien diseñados, con escáner automáticos, cintas transportadoras flexibles elevadas, consolas bajas para las bolsas, personal extra para meter los productos en bolsas y asientos flexibles (para que los cajeros se puedan sentar de forma que alivien las tensiones de la parte inferior de la espalda y de las piernas) ayudan a eliminar presiones sobre las extremidades superiores, tensiones y movimientos giratorios.

\section{Láseres}

Los lectores de códigos de barras y los escáner de mano de los supermercados son normalmente equipos láser de clase 2 que emiten radiación infrarroja en la longitud de onda 760 a $1.400 \mathrm{~nm}$; no se consideran peligrosos si el haz de láser no se mira durante mucho tiempo seguido. Todo láser emite una luz intensa que puede dañar la retina. Los ojos son vulnerables al calor, no tienen sensores térmicos y no disipan el calor de manera eficaz. Las prácticas de seguridad recomendadas deberían incluir como mínimo la formación de los trabajadores sobre los riesgos de mirar el haz luminoso y el daño las lesiones que esta práctica puede causar. El programa de protección de los trabajadores debe incluir reconocimientos oculares para descartar el riesgo de lesiones.

\section{Dependientes de comercio}

Los dependientes de comercio minorista mueven grandes cantidades de productos desde los camiones a los muelles de embarque y desde allí a las estanterías de la zona de venta del centro comercial. Los productos vienen empaquetados en cajas de cartón de diversos pesos. La descarga manual de los camiones y el traslado de las cajas de productos a la puerta del almacén es en ocasiones causa de trastornos musculares o esqueléticos. La tarea de poner precio a los productos y colocarlos en las estanterías somete a un gran esfuerzo la espalda, las piernas y el cuello. Las etiquetadoras provocan fácilmente el síndrome del túnel carpiano y otras lesiones por esfuerzo repetitivo, ya que someten a un esfuerzo excesivo y repetitivo la muñeca, los dedos y la palma de la mano. La apertura de cajas con un cuchillo o una cuchilla lleva consigo el riesgo de sufrir cortes en las manos, los brazos y otras partes del cuerpo. Cortar cartón con un cuchillo poco afilado exige un esfuerzo extra que repercute en las palmas de las manos.

Las carretillas elevadoras motorizadas y manuales y otros dispositivos de este tipo ayudan a mover artículos de una parte a otra del centro comercial. Las mesas de ruedas, los gatos de tijera y los carros de mano ayudan a situar los productos a cierta altura y a colocar los productos en las estanterías sin que la espalda sufra al levantar objetos y girar. Las etiquetadoras automáticas y los productos etiquetados en fábrica impiden que las muñecas y extremidades superiores sufran por movimientos
Figura 99.3 - Corte manual de cecina para su venta local, Japón, 1989.

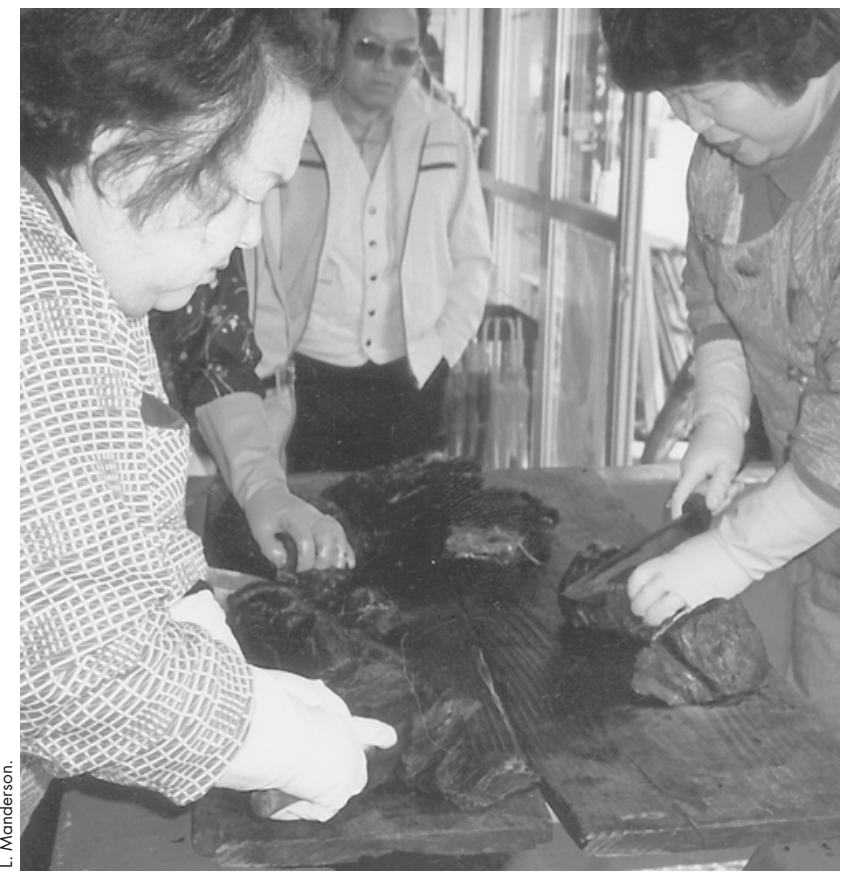

repetitivos. Las cuchillas bien afiladas ahorran esfuerzos al abrir cajas.

\section{Carniceros y charcuteros}

Los carniceros y charcuteros trabajan con sierras, afiladores, máquinas de cortar y cuchillos (véase la Figura 99.3). Las cuchillas sin proteger o las que se atascan o sueltan amputan dedos y producen cortes, aplastamientos y contusiones. Las máquinas deben estar debidamente ancladas al suelo para que no vuelquen ni se muevan. Las cuchillas han de mantenerse limpias de restos. Las máquinas atascadas se desatascan con instrumentos de madera después de haberlas desconectado. No debe desatascarse ninguna máquina mientras está encendida. Los cuchillos deben mantenerse afilados para evitar lesiones en las muñecas, manos y brazos. Los mangos de los cuchillos, cuchillas y mazos deben mantenerse limpios para que no resbalen.

Cuando la carne se pesa de forma mecánica y se empaqueta en bandejas de poliestireno con una película de plástico termosoldada, los vapores y gases que emanan del plástico caliente pueden causar el "asma del empaquetador de carne" e irritación de ojos, nariz y garganta, dificultades respiratorias, dolores en el pecho, escalofríos y fiebre. El equipo de ventilación local por extracción (VAL) debe montarse cerca del elemento calentador, de forma que los vapores no lleguen a los trabajadores, sino que se expulsen fuera del lugar de trabajo.

Los carniceros entran y salen de las cámaras frigoríficas muchas veces a lo largo del día. La ropa de trabajo debe incluir prendas preparadas para el trabajo en esas cámaras.

Los suelos y vías de paso se vuelven resbaladizos por la presencia de carne, grasa y agua. Los resbalones, tropezones y caídas son causas frecuentes de lesiones. Todo el material de desecho debe separarse con cuidado y mantenerse fuera de las superficies de paso. Las esteras por las que se camina o sobre las que se permanece de pie deben limpiarse diariamente o siempre que se ensucien. 


\section{Exposición a sustancias químicas}

Los trabajadores del comercio minorista están cada vez más expuestos a sustancias químicas peligrosas procedentes de productos de limpieza, plaguicidas, raticidas, fungicidas y conservantes. Los trabajadores de ferreterías, de tiendas de repuestos de automóviles y otros están potencialmente expuestos a sustancias químicas peligrosas debido al almacenamiento de pinturas, disolventes, ácidos, productos cáusticos y gases comprimidos. La peligrosidad o toxicidad de las sustancias químicas varía en función de la naturaleza de los productos que se almacenan en cada establecimiento. Estos productos no necesariamente se consideran peligrosos. Los trabajadores de grandes almacenes, por ejemplo, desarrollan a veces sensibilidad y alergia a los perfumes pulverizados como demostración.

Los productos de limpieza utilizados en supermercados y otros establecimientos de comercio minorista contienen cloro, amoníaco, alcoholes, productos cáusticos y disolventes orgánicos. Los equipos de limpieza que hacen el turno de noche aplican estos productos en centros comerciales sin ventilación natural y mientras los sistemas de ventilación mecánica no están funcionando a plena capacidad. Estos productos químicos afectan al organismo cuando se utilizan en el lugar de trabajo a concentraciones y en cantidades industriales. La información sobre seguridad de las sustancias químicas debe encontrarse en el lugar de trabajo a disposición de los trabajadores. Los envases de productos químicos deben llevar etiquetas con el nombre del producto e información sobre el efecto que causan en el organismo, así como el equipo protector que debe utilizarse para evitar enfermedades. Es necesario formar a los trabajadores sobre los riesgos sanitarios vinculados con la utilización de productos químicos, la vía por la que penetran en el organismo y la forma de evitar la exposición.

Los trabajadores del comercio minorista que trabajan en puestos callejeros están expuestos a las emisiones procedentes del tráfico rodado, y lo mismo sucede con los destinados a la trastienda, que inhalan las emisiones de los camiones que entran a los muelles de carga. Los productos de la combustión incompleta que se encuentran en las emisiones de los vehículos a motor incluyen, entre otros, monóxido de carbono e hidrocarburos aromáticos policíclicos. Las emisiones de gases y partículas afectan al cuerpo de diversas formas. El monóxido de carbono provoca mareos y náuseas, es asfixiante y limita la capacidad de transporte de oxígeno de la sangre. Los camiones de reparto deben mantener el motor apagado durante la descarga. Puede ser necesario instalar un circuito de ventilación por extracción para alejar el aire contaminado de los trabajadores; el mantenimiento y la limpieza de este circuito deben ajustarse a un programa sistemático.

Muchas prendas de vestir y géneros textiles se tratan con formaldehído para evitar la formación de moho. Este compuesto afecta a quienes lo respiran. En los grandes almacenes con abundantes existencias de prendas de vestir y géneros textiles que carecen de sistemas adecuados de ventilación natural o mecánica, el formaldehído se acumula e irrita los ojos, la nariz y la garganta. También irrita la piel y las vías respiratorias, provoca alergias y se considera probablemente cancerígeno.

Para eliminar parásitos de los establecimientos comerciales se aplican con frecuencia plaguicidas, raticidas $y$ fungicidas. Muchos afectan a los sistemas nervioso, respiratorio y circulatorio humanos, no sólo a los de insectos y roedores o a las plantas. Es importante no pulverizar estas sustancias de forma indiscriminada en presencia de personas y mantener a todo el mundo alejado de las zonas tratadas hasta que resulte seguro volver a ellas. Los encargados de aplicar estos productos deben recibir formación sobre métodos de trabajo seguros.
Los edificios "herméticos" (sin ventanas practicables ni ventilación natural) necesitan sistemas mecánicos de ventilación. Estos deben garantizar una renovación suficiente del aire por reciclaje e incorporación de aire fresco exterior en una proporción suficiente. El aire debe calentarse o refrigerarse en función de la temperatura ambiente exterior.

\section{Higiene}

La higiene personal es importante en el comercio minorista, especialmente cuando los empleados manejan alimentos, dinero y productos químicos peligrosos. Los sanitarios, lavabos y lugares para beber deben mantenerse en condiciones higiénicas y estar disponibles en áreas en las que los empleados puedan utilizarlos en horas de trabajo. Estas instalaciones deben contar con agua corriente limpia, jabón y toallas. Hay que inculcar en los empleados el hábito de lavarse bien las manos después de utilizar los servicios y antes de volver al trabajo. En toda la zona de trabajo ha de haber agua potable fresca y limpia. La buena limpieza es imprescindible para impedir la presencia de parásitos y la acumulación de basura, que debe recogerse con regularidad.

En mercados al aire libre es difícil mantener instalaciones sanitarias, pero en cualquier caso hay que esforzarse por instalar servicios y lavabos.

\section{Climatología}

En los mercados al aire libre, los trabajadores están expuestos a los elementos y al calor y el frío. En los supermercados, los cajeros trabajan a menudo en la parte delantera de los locales, cerca de las puertas de entrada y salida, por lo que se ven expuestos a corrientes de aire frío y caliente. La instalación de cortinas de aire delante de las puertas que dan al exterior ayuda a bloquear las corrientes y a mantener la temperatura de la zona de cajas al mismo valor que en el resto del local.

\section{Prevención de incendios}

Los establecimientos minoristas están expuestos a numerosos peligros en caso de incendio: salidas cerradas o bloqueadas, escasez de entradas y salidas, presencia de materiales combustibles e inflamables, sistemas de calefacción e instalaciones eléctricas deficientes o provisionales, etc. Los trabajadores sólo sabrán combatir el fuego si han recibido formación sobre el modo de pedir ayuda, manejar los extintores y evacuar el local. Los extintores deben ser adecuados para el tipo de fuego y han de inspeccionarse regularmente y mantenerse en buen estado. Los simulacros de incendios son necesarios para que los trabajadores sepan cómo salir de los locales en caso de emergencia.

\section{Estrés}

Los grandes grupos económicos que operan en el sector del comercio minorista tienden a cambiar los contratos a jornada completa por otros a tiempo parcial. Muchos grandes centros comerciales de distribución permanecen ahora abiertos las 24 horas del día y todos los días del año, lo que impone turnos de trabajo incompatibles con la vida social normal. La alteración del reloj biológico interno que controla los fenómenos físicos naturales, como el sueño, provoca insomnio, alteraciones gastrointestinales, dolores de cabeza y depresiones. Cambiar de turno, trabajar durante las vacaciones y a tiempo parcial provoca estrés emocional y físico tanto en el trabajo como en casa. La vida familiar normal se ve gravemente comprometida y la vida social reducida.

Cada vez es más frecuente trabajar hasta altas horas de la noche, con la consiguiente sensación de inseguridad personal y el temor a robos y otras formas de violencia durante el trabajo. En Estados Unidos, por ejemplo, el homicidio es una causa importante de muerte en el trabajo para las mujeres, y muchas de estas muertes se producen durante un robo. Manejar dinero, 
trabajar solo o hasta muy avanzada la noche son situaciones que deberían evitarse. La revisión periódica de las medidas de seguridad debe formar parte de todo programa de seguridad y prevención de la violencia.
Los salarios a tiempo parcial, con poca o ninguna compensación extrasalarial, aumentan el estrés en el trabajo y obliga a muchos trabajadores a buscar otros empleos para mantener a sus familias y conservar las prestaciones por enfermedad.

\section{Referencias}

American Federation of Labour and Congress of Industrial Organizations (AFL-CIO). 1995. Current Statistics on White Collar Employees. Publication \#95-3. Washington, DC: AFL-CIO, Department for Professional Employees.

Arnetz, BB. 1996. Techno-stress: A prospective psychophysiological study of the impact of a controlled stress reduction program in advanced telecommunications system design work. Fournal of Occupational and Environmental Medicine 38(1):53-65.

Bequele, A. 1985. Workers in the rural and urban informal sectors in developing countries. En Introduc tion to Working Conditions and Environment, dirigido por J-M Clerc. Ginebra: OIT.

Biener, L. 1988. Gender and Stress. Nueva York: Free Press.

De Grip, A, J Hoevenberg, E Willems. 1997. Atypical employment in the European Union. Int Labour Rev 136(1):49-71.

Euro-FIET Commerce Trade Section. 1996. Conference on Economic Transformation and Internationalisation in the Services and Finance Sectors of Central and Eastern Europe, abril, Praga, República Checa.

Frankenhaeuser, M, U Lundberg, M. Chesney. 1991 Women, Work, and Health: Stress and Opportunities. Nueva York y Londres: Plenum Press.

Hetes, R, M Moore, G Northheim. 1995. Office Equip ment: Design, Indoor Air Emissions, and Pollution Preven tion Opportunities. Washington, DC: US Environmental Protection Agency.

Karasek, RA. 1979. Job demands, job decision latitude, and mental strain: Implications for job design. Adm Sci Q 24:285-308.

- 1990. Lower health risk with increased job contro among white collar workers. If Organ Behar 11:171-185.

Maddi, SR, Kobasa, SC. 1984. The Hardy Executive: Health Under Stress. Homewood, Illinois: Dow JonesIrwin.

Marsella, AJ. 1994. Work and well-being in an ethnoculturally pluralistic society: Conceptual and methodological issues. En Fob Stress in a Changing Workforce. Washington, DC: American Psychological Association.

Murphy, L, J Hurrell, Jr. 1995. Job stress interventions. En Managing Workplace Safety and Health: The Case of Contract Labor in the U.S. Petrochemical Industry. Washington, DC: American Psychological Association.

National Institute for Occupational Safety and Health (NIOSH). 1993. NIOSH Update: NIOSH Urges Immediate Action to Prevent Workplace Homicide. DHHS (NIOSH) Publication No. 94-101. Cincinatti, Ohio: NIOSH.

Organización Internacional del Trabajo (OIT). 1990a. International Standard Classification of Occupations: ISCO-88. Ginebra: OIT

- 1990b. Telework. Conditions of Work Digest. Vol. 9(1). Ginebra: OIT.

- 1994. Yearbook of Labour Statistics. Ginebra: OIT

—. 1995. Mearbook of Labour Statistics. Ginebra: OIT.

- 1996. Child Labour: Targeting the Intolerable. Report VI(1), Conferencia Internacional del Trabajo, 86 Sesión. Ginebra: OIT.

—. 1997. Working trends: Labour trends. World Work Mag ILO 19:26-27.

Perry, GF. 1996. Occupational medicine forum. Fournal of Occupational and Environmental Medicine 38(4):339-341.

Price Waterhouse. 1991. Doing Business in Siveden. Nueva York: Price Waterhouse.

Silvestri, G. 1993. The American workforce, 19922005: Occupational employment: Wide variations in growth. Monthly Labor Review (Noviembre).

Stellman, JM, MS Henifin. 1983. Office Work Can Be Dangerous to Your Health. Nueva York: Pantheon Books.

Stout, N, EL Jenkins, TJ Pizatella. 1996. Occupational injury mortality rates in the United States: Changes from 1980 to 1989. Am F Public Health 86(1):73-77.

Tagliacozzo, R, S Vaughn. 1982. Stress and smoking in hospital nurses. Am f Public Health. 72:441-448.

\section{Otras lecturas recomendadas}

Amott, T. 1993. Caught in the Crisis: Women and the U.S. Economy Today. New York: Monthly Review Press.

Bachman, R. 1994. Violence and theft in the workplace. En US Department of Fustice Crime Data Brief. NCJ-148199. Washington, DC: US Department of Justice.

Bair, FE. 1988. International Marketing Handbook, $3^{\text {a }}$ edición. Detroit, Michigan: Gale Research.

Blascovich, J, E Katkin. 1995. Cardiovascular Reactivity to Psychological Stress and Disease. Washington, DC: American Psychological Association.

Confederación Internacional de Organizaciones Sindicales Libres (CIOSL). 1993. World Action Programme. Ginebra: International Federation of Commercial, Clerical, Professional and Technical Employees.

Greenbaum, J. 1995. Windows on the Workplace: Computers, Fobs and the Organization of Office Work in the Late Twentieth Century. Nueva York: Monthly Review Press.

Huws, U (dir.). 1995. Action Programmes for the Protection of Homeworkers: Ten Case-studies from around the World. Ginebra: OIT.

Huws, U, S Pordo. 1995. Employment of Homeworkers: Examples of Good Practice. Working Paper CONDI/T/WP.5/1995. Ginebra: OIT.

International Confederation of Free Trade Unions (ICFTU). 1996. The Global Market - Trade Unionism's Greatest Challenge. Brussels: ICFTU.

Makower, J. 1981. Office Hazards. Washington, DC: Tilden Press.

National Institute for Occupational Safety and Health (NIOSH). 1996. NIOSH Current Intelligence Bulletin 57: Violence in the Workplace, Risk Factors and Prevention Strategies. DHSS (NIOSH) Publication No. 96-100. Cincinatti, Ohio: NIOSH.

Organización Internacional del Trabajo (OIT). 1992. Preventing Stress at Work. Conditions of Work Digest. Vol 11. Ginebra: OIT.

Rosenstock, L. 1986. Clinical Occupational Medicine. Filadelfia, Pensilvania: WB Saunders. 



\section{SERVICIOS PERSONALES Y}

COMUNITARIOS

Directora del capítulo Angela Babin

\section{Sumario}

Servicios de limpieza en interiores

Karen Messing. . . . . . . . . . . . . . . . . . . . . . . 100.2

Peluquería y cosmética

Laura Stocky fames Cone. . . . . . . . . . . . . . . . . . . . . 100.6

Lavanderías y limpieza en seco

Gary S. Earnest, Lynda Ewers y Avima M. Ruder. . . . . . . . . . . . 100.10

Servicios funerarios

Mary O. Brophy y fonathan T. Haney . . . . . . . . . . . . . 100.14

Empleados del hogar

Angela Babin ............................. . 100.16 


\section{SERVICIOS DE LIMPIEZA EN INTERIORES}

Karen Messing

\section{Perfil general}

Las labores de limpieza consisten en quitar el polvo, lavar y pulir superficies, lavar paredes, barrer, fregar y pulir los suelos y retirar la basura y el agua sucia. Son labores que se llevan a cabo en oficinas, edificios comerciales y administrativos, hogares y fábricas. A veces se realizan en espacios cerrados, con poca ventilación, o en espacios cuyo diseño no está pensado para la limpieza. Las personas encargadas de estas tareas pueden trabajar por cuenta propia, estar contratadas por la empresa propietaria de las instalaciones que deben limpiar o trabajar para contratistas privados. Dependiendo del lugar que limpian y de los detalles de las tareas asignadas, estas personas se designan con los términos: personal de limpieza, empleados de mantenimiento, asistentas, vigilantes o conserjes. Por ejemplo, los vigilantes y los conserjes pueden combinar tareas de limpieza con labores de mantenimiento y reparación.

Tradicionalmente, el personal de limpieza ha trabajado de forma relativamente autónoma, en comparación con otras categorías de empleo similares. La inspección del trabajo está a cargo de supervisores, aunque los usuarios de las instalaciones también hacen comentarios sobre la limpieza. Los trabajadores suelen organizar sus tareas y elaboran sus propios procedimientos (Messing, Haëntjens y Doniol-Shaw 1993). Sin embargo, en las superficies comerciales de Norteamérica, las rutas que debe seguir el personal de limpieza están determinadas, cada vez más, por medios informáticos para tener en cuenta el mobiliario, las superficies de suelo y las aglomeraciones. El tiempo total necesario se calcula en función de la frecuencia idónea de las operaciones, de la zona que se desea limpiar y del tiempo estimado según el tipo de zona. La inspección puede realizarse mediante un procedimiento de comprobación al azar programado por ordenador. Algunos de estos procedimientos pueden subestimar notablemente la tarea realizada en espacios compartidos, sobre todo si el inventario no se actualiza regularmente (Messing, Chatigny y Courville 1996).

En Canadá, la limpieza ocupa el octavo lugar entre las profesiones más frecuentes de los varones y el décimo lugar entre las mujeres; estas últimas constituyen el $46 \%$ de los empleados de esta profesión (Armstrong y Armstrong 1994). En Francia, en 1991, había 229.000 empleados de limpieza que trabajaban para 9.000 empresas de limpieza; aproximadamente una tercera parte de ellos eran inmigrantes y el $64 \%$, mujeres (Bretin 1994). En Dinamarca, el $85 \%$ de los 130.000 empleados de limpieza son mujeres (Nielsen 1995). En algunos países, las tareas en las fábricas y servicios se dividen con frecuencia en "ligeras" y "pesadas", y se asignan, de manera formal o informal, a las mujeres y a los varones, respectivamente, con diferencia salarial en algunos casos (Gobierno de Quebec 1994). Las mujeres se encargan de quitar el polvo y abrillantar las superficies, limpiar los baños y vaciar las papeleras, mientras que los varones barren, friegan y abrillantan los suelos y llevan la basura a los incineradores (Messing, Haëntjens y Doniol-Shaw 1993; Messing, Doniol-Shaw y Haëntjens 1993; Messing, Chatigny y Courville 1996). En otros países, los varones y las mujeres realizan, indistintamente, todas las tareas de limpieza (Nielsen 1995; Hagner y Hagberg 1989). La edad de los empleados de limpieza es relativamente superior a las de otros trabajadores (Bretin y cols. 1992; Messing 1991; Nielsen 1995).

\section{Factores de riesgo y estrategias de prevención}

Las tareas de limpieza pueden realizarse con herramientas manuales, como cepillos, escobas, trapos y fregonas, o con la ayuda de máquinas. Se utilizan diversos productos químicos para disolver la suciedad y hacer que las superficies estén limpias y brillantes. La dificultad de la tarea varía dependiendo del tipo de superficie (lisa, rugosa, porosa), la altura y la geometría de los objetos que hay que limpiar, la cantidad de objetos en un espacio determinado y las tareas realizadas en estos espacios. En algunos lugares la necesidad de limpieza puede reducirse o eliminarse mediante cambios de diseño en los objetos (como los inodoros autolimpiables).

\section{Carga musculosquelética}

La limpieza, sobre todo la del mobiliario y los servicios así como el vaciado de las papeleras, conlleva cambios rápidos de postura y la adopción de posturas incómodas y forzadas (véase la Tabla 100.1). Es necesario limpiar muchos objetos a distintas alturas; una secuencia típica para quitar el polvo en una habitación de hospital es: mesa $(81 \mathrm{~cm})$, televisor $(196 \mathrm{~cm})$, mesa $(81 \mathrm{~cm})$, teléfono $(81 \mathrm{~cm})$, lámpara (hasta $188 \mathrm{~cm})$, patas de la mesa $(11 \mathrm{~cm})$, silla $(46 \mathrm{~cm})$, pantalla $(81 \mathrm{~cm})$, sillón $(46 \mathrm{~cm})$, alféizar de la ventana $(89 \mathrm{~cm})$, esfingomanómetro de pared $(154 \mathrm{~cm})$, patas de la silla (desde el suelo hasta $46 \mathrm{~cm}$ ), instalación de oxígeno (137 cm) (Messing, Chatigny y Courville 1995).

Tabla 100.1 - Posturas observadas durante la limpieza del polvo de un hospital.

\begin{tabular}{lccllll} 
Actividad & Duración & Extensión (\%) & Neutral (\%) & Flexión $<45^{\circ}(\%)$ & Flexín $\geq 45^{\circ}$ (\%) & $\begin{array}{l}\text { No observable } \\
\text { en vídeo (\%) }\end{array}$ \\
$\begin{array}{l}\text { Limpieza del puesto de } \\
\text { enfermeras }\end{array}$ & $3 \mathrm{~m}, 26 \mathrm{~s}$ & - & 13,6 & 86,4 & - & - \\
Papeleras (3) & $1 \mathrm{~m}, 26 \mathrm{~s}$ & - & 19,8 & 71,1 & 9,2 & - \\
Servicios (2) & $5 \mathrm{~m}, 17 \mathrm{~s}$ & 2,8 & 26,6 & 63,1 & 7,5 & - \\
Pasillo de los servicios (2) & $3 \mathrm{~m}, 53 \mathrm{~s}$ & 6,6 & 18,6 & 71,0 & 3,8 & 0,3 \\
Salas blancas & $8 \mathrm{~m}, 45 \mathrm{~s}$ & 3,7 & 29,8 & 60,1 & 2,9 & 3,5 \\
Área de recepción & $3 \mathrm{~m}, 13 \mathrm{~s}$ & - & 24,7 & 74,4 & - & 0,9 \\
Oficina de las secretarias & $10 \mathrm{~m}, 20 \mathrm{~s}$ & 3,6 & 32,0 & 59,7 & 0,3 & 4,4 \\
Total & $36 \mathrm{~m}, 20 \mathrm{~s}$ & 3,0 & 26,4 & 65,8 & 2,7 & 2,2 \\
Fuente: Messing, Chatigny y Courville 1995. & & & & & \\
\hline
\end{tabular}


La limpieza del suelo requiere movimientos repetitivos [ciclo temporal básico de 1 a 2 segundos, según el estudio de Sogaard, Fallentin y Nielsen (1996)] y una flexión moderada y sostenida de la espalda. Las manos ejercen una presión constante para pasar los aspiradores y las mopas, tareas que requieren una fuerza de unos $10 \mathrm{~kg}$ (Messing, Chatigny y Courville 1996). Sogaard, Fallentin y Nielsen (1996) determinaron que la flexión media de la espalda al fregar los suelos era de $28^{\circ}$ y la del cuello, de $51^{\circ}$. Hagner y Hagberg (1989) observaron cargas musculares estáticas, especialmente en la articulación del hombro. Nordin y cols. (1986) observaron una flexión importante del tronco en una tarea de mantenimiento simulada que incluía fregar los suelos. La limpieza del suelo y los objetos generalmente se realiza con movimientos repetitivos. Sogaard (1994) indica que los movimientos repetitivos y continuos con pausas poco frecuentes en la actividad pueden agotar al número relativamente reducido de fibras musculares involucradas y producir trastornos musculares.

Para limpiar, es necesario mover numerosos objetos. Durante 66 minutos de limpieza y abrillantado de suelos fue necesario mover 0,7 objetos por minuto, con pesos de hasta $10 \mathrm{~kg}$; durante 23 minutos dedicados a quitar el polvo se movieron 3,7 objetos por minuto, con pesos de hasta $2 \mathrm{~kg}$ (Messing, Chatigny y Courville 1995).

Winkel y cols. (1983) y Hagner y Hagberg (1989) observaron que al haber aumentado la especialización y uniformidad se han reducido las oportunidades de variar los movimientos corporales y la postura durante el trabajo de limpieza. Así, es importante proporcionar un tiempo de descanso adecuado. La división formal o informal de las tareas por sexos puede aumentar la posibilidad de problemas musculosqueléticos debido a la disminución en la diversidad de movimientos (Messing, Haëntjens y Doniol-Shaw 1993).

\section{Carga cardiovascular}

La carga cardiovascular puede ser considerable. Durante la limpieza de una oficina o unos servicios realizada por mujeres, Johansson y Ljunggren (1989) registraron una frecuencia cardíaca de 123 latidos/minuto, equivalente al $65 \%$ de la frecuencia máxima para la media de edad de 29,8 años y que corresponde a cerca del $35 \%$ de la captación máxima de oxígeno estimada o $\mathrm{VO}_{2 \max }$, un valor cercano al de los trabajadores de la construcción. Las tareas de limpiar o fregar produjeron frecuencias cardíacas similares, de 122 a 127 latidos/minuto. Hagner y Hagberg (1989) observaron un elevado consumo de oxígeno (hasta un $40 \%$ del $\mathrm{VO}_{2 \max }$ ) durante el fregado del suelo en condiciones experimentales. Sogaard (1994) determinó que la tensión cardiovascular relativa en las mujeres de la limpieza de un colegio, medida en el lugar de trabajo, equivalía al $53 \%$ del $\mathrm{VO}_{2 \max }$

Para evitar problemas musculosqueléticos y reducir la carga cardiovascular, la carga de trabajo debe ser adecuada y el tiempo de descanso, suficiente. Al diseñar los espacios y los procedimientos y al adquirir el mobiliario, debe tenerse en cuenta la facilidad para la limpieza. Pasar el aspirador requiere menos fuerza si las moquetas están bien colocadas y no forman arrugas. El uso de las herramientas adecuadas es importante; por ejemplo, los cepillos extensibles para limpiar reducen la necesidad de estirarse o trepar para llegar a los sitios más altos. Las flexiones prolongadas pueden evitarse si se utilizan herramientas y productos químicos eficaces que permitan limpiar rápidamente y si la limpieza se realiza con suficiente frecuencia para que la suciedad no se endurezca. La práctica habitual de reducir la ventilación en los edificios después de la jornada o durante la noche, cuando se realiza la limpieza, debe evitarse, ya que reduce la calidad del aire para los empleados de la limpieza, que trabajan durante este tiempo. Para evitar la sobrecarga de trabajo cuando las tareas de limpieza se planifican por medios informáticos, es necesaria una observación y verificación cuidadosa para asegurarse de que los tiempos asignados son realistas y tienen en consideración el uso múltiple de los espacios que se limpian. El inventario de las salas y los objetos limpiados debe actualizarse con frecuencia.

Se han desarrollado procedimientos y aparatos para vaciar las papeleras en los contenedores y éstos en los incineradores, con el fin de evitar el levantamiento manual.

\section{Productos químicos}

Los productos químicos se clasifican en jabones, detergentes, desinfectantes, productos para porcelana, polvos limpiadores, disolventes de cera y quitaesmaltes, disolventes, plaguicidas y productos para limpiar desagües. A veces contienen, además, colorantes y aromatizantes. Es posible que con estos productos haya contacto o absorción a través de la piel o inhalación, lo que puede causar lesiones en la piel, los ojos, la garganta o los pulmones. El riesgo de exposición depende de la concentración del producto químico y de la forma en que se utilice. Los atomizadores volatilizan los productos químicos y aumentan la exposición. Algunos productos son irritantes a concentraciones bajas y corrosivos a concentraciones elevadas (ácidos, agentes oxidantes o bases). Otros son buenos disolventes o detergentes que pueden dañar la barrera protectora de la piel y hacer ésta más vulnerable a otros agentes químicos. Otros productos contienen metales (níquel, cobalto, cromo) u otras sustancias que pueden actuar como alergenos.

Los productos de limpieza se venden habitualmente a concentraciones elevadas y se diluyen "in situ" antes de utilizarse. La práctica habitual de utilizar los productos a concentraciones superiores a las recomendadas, con el fin de limpiar más rápido o mejor, es una fuente de sobreexposición y debe evitarse con una formación adecuada y ajustando la carga de trabajo. La mezcla de productos químicos distintos puede producir intoxicación accidental o quemaduras. El trabajo con productos químicos fuertes en zonas mal ventiladas puede ser un peligro para los trabajadores y debe evitarse.

La base de datos danesa de registro de productos PROBAS contiene información sobre 2.567 productos de lavado y limpieza. De ellos, setenta se consideran potencialmente peligrosos y susceptibles de causar daños crónicos o agudos en la salud por sus propiedades corrosivas, cancerígenas, tóxicas para la reproducción, alergénicas o neurotóxicas (Borglum y Hansen 1994). Se muestran en la Tabla 100.2. En un estudio del registro PROBAS se encontraron 33 alergenos de contacto en los productos de limpieza (Flyvholm 1993).

Los empleados de limpieza de las fábricas y hospitales pueden estar expuestos a los productos químicos o riesgos biológicos asociados con las actividades que se realizan en los espacios que limpian. Si no se integra a los empleados de la limpieza en los programas de formación y en la red social de la plantilla habitual, es posible que sean menos conscientes de estos riesgos que los demás trabajadores. Por ejemplo, un estudio reflejó que los empleados de limpieza forman el grupo que está expuesto con más frecuencia a los productos químicos peligrosos de todas las categorías de trabajadores de hospital (Weaver y cols. 1993).

Hay cierta controversia sobre el uso de guantes durante las tareas de limpieza. Los guantes desempeñan un papel importante en la protección de la piel contra los agentes nocivos siempre que se ajusten correctamente y estén hechos de un material impermeable y resistente. Ahora bien, el uso constante de guantes puede impedir que la transpiración se evapore, y la humedad que se crea es un medio favorable al crecimiento de agentes infecciosos. El uso de guantes se asoció con problemas de la piel en una amplia muestra de empleados de limpieza 
Tabla 100.2 • Productos químicos peligrosos utilizados para la limpieza.

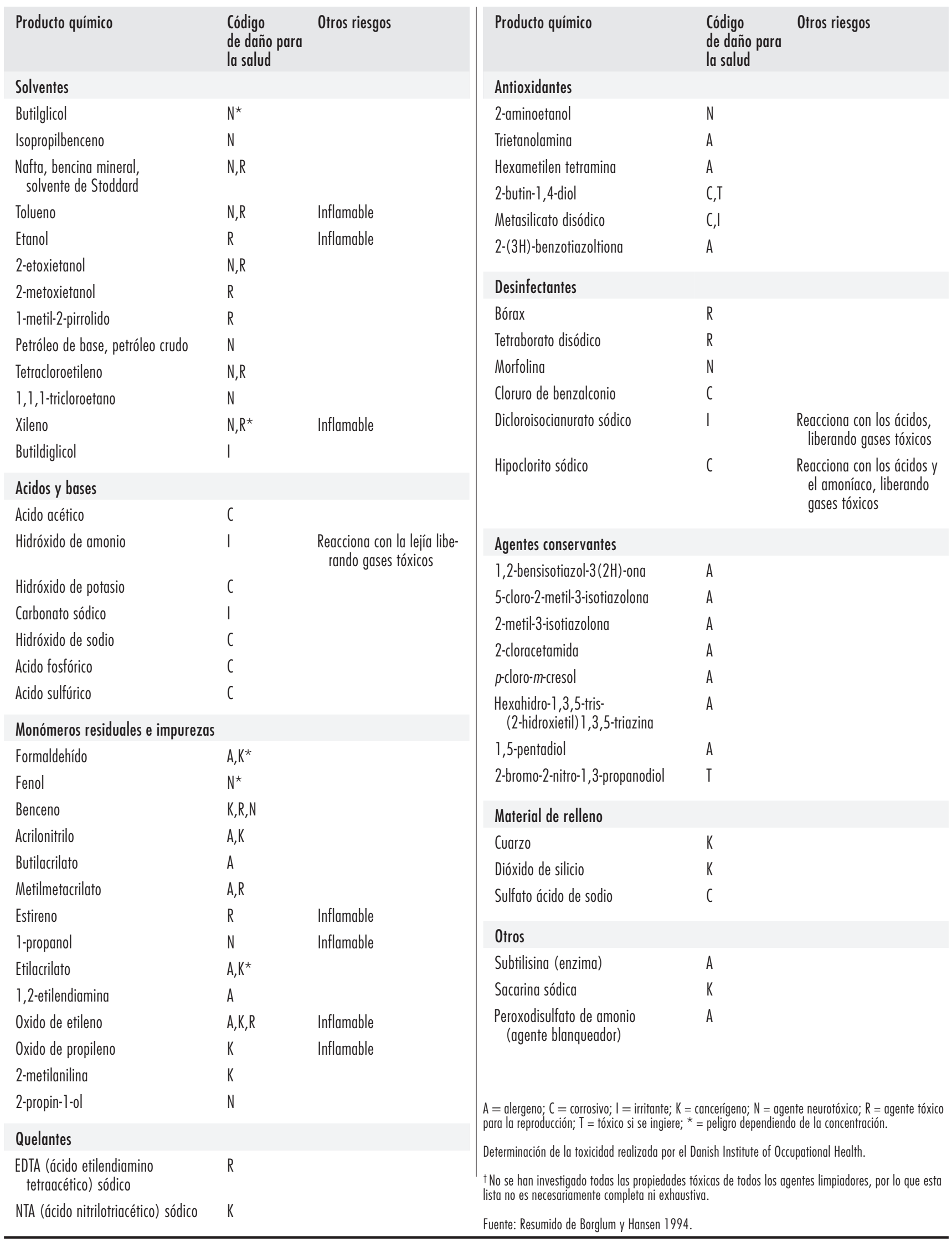


daneses (Nielsen 1996). Así, lo mejor es utilizar los guantes el tiempo mínimo posible para la protección. La necesidad de utilizar guantes puede evitarse mediante el uso de instrumentos con mangos largos o modificaciones en los métodos. El uso de guantes de algodón debajo de los guantes de goma o plástico puede reducir la humedad y proteger contra las alergias a algunos de los materiales de los guantes (Foussereau y cols. 1982). Algunas cremas de manos contienen irritantes y deben evitarse (Hansen 1983).

Existen otras prácticas que reducen la exposición a los productos químicos. Cuando se guardan o se preparan las soluciones de limpieza, debe existir una buena ventilación y los procedimientos deben permitir la preparación sin necesidad de tocar o respirar los productos químicos. La tentación de trabajar con productos químicos sin diluir disminuirá si los trabajadores cuentan con el tiempo y los instrumentos adecuados. Otra posibilidad es que los empleados de limpieza utilicen productos químicos sin diluir o con fragancias alergénicas con el fin de indicar a los demás que han llevado a cabo su trabajo. Esto puede lograrse por otros medios, como la utilización de procedimientos de inspección transparentes y la comunicación con los demás trabajadores y usuarios de los servicios de limpieza.

En un manual publicado por la ciudad de Nueva York (Michaels, sin fecha) se ofrece información útil sobre la prevención de la exposición a los productos químicos.

\section{Otros riesgos para la salud}

Los empleados de limpieza trabajan con frecuencia en turnos de tarde o de noche para no alterar el curso normal de las actividades que se llevan a cabo en los mismos espacios. Por este motivo, pueden sufrir los efectos habituales sobre los biorritmos del trabajo por turnos. Además, existe un cierto riesgo de exposición a la violencia si trabajan en áreas aisladas.

Los empleados de limpieza, en especial los que trabajan fuera de los horarios normales de trabajo del inmueble o los que no forman parte del personal de plantilla, pueden quedar excluidos de la red social de su lugar de trabajo (Messing, en prensa). Es posible que no tengan acceso a las instalaciones adecuadas para los descansos y las comidas. Aparte de los efectos psicológicos de la exclusión, estos empleados pueden verse privados de la información sobre riesgos que se proporciona rutinariamente a los demás trabajadores, a pesar de los requisitos legales que existen en muchas jurisdicciones sobre este tipo de información. Así, además de la importancia de la textura de las superficies y del diseño para su trabajo, es posible que ni a ellos ni a sus supervisores se les consulte al tomar decisiones importantes relacionadas con las adquisiciones o la planificación. Es algo que ocurre sobre todo si el personal de limpieza es contratado por otra empresa. Es fundamental, por lo tanto, que se haga un esfuerzo especial para incluir a estos empleados en las actividades de promoción de la salud y la seguridad en el trabajo que se lleven a cabo. La información sobre las características de los productos químicos, sobre los procedimientos de trabajo y sobre la seguridad debe exponerse a los empleados de limpieza y estar claramente indicada en el lugar de trabajo.

\section{Efectos sobre la salud y pautas patológicas}

La salud de los profesionales de la limpieza es peor que la de otros trabajadores (Nielsen 1995; ASSTSAS 1993; Sogaard 1994). Según un análisis del Quebec Health Survey, si se compara a los empleados de limpieza con otros trabajadores, una vez corregidos los datos por la edad, la prevalencia de problemas crónicos de espalda y cardiopatías de todo tipo es mayor en las mujeres dedicadas a la limpieza que en cualquier otra categoría de trabajadoras, y los varones de este gremio tienen la mayor prevalencia de problemas musculosqueléticos y cardiopatías
(Gervais 1993). Las mujeres embarazadas dedicadas a la limpieza tienen un mayor riesgo de abortos (McDonald y cols. 1986), de partos prematuros (McDonald y cols. 1988) y de dar a luz niños con bajo peso (McDonald y cols. 1987).

En algunos estudios epidemiológicos poblacionales a gran escala se ha observado un alto índice de cáncer entre estos trabajadores. La tasa de ciertos tumores cerebrales en varones de raza blanca de Estados Unidos es especialmente elevada entre los empleados de limpieza (Demers, Vaughan y Schommer 1991). En las mujeres, el cáncer cervical invasivo es aproximadamente cinco veces más frecuente en las empleadas de limpieza que en otras mujeres (Savitz, Andrews y Brinton 1995). Tales resultados se atribuyen a la exposición a productos químicos, sobre todo a los disolventes.

Los problemas musculosqueléticos son frecuentes. En Dinamarca, Nielsen (1995) observó que los trabajadores que dejaban la actividad de la limpieza presentaban una frecuencia de síntomas musculosqueléticos menor que los que continuaban con la profesión. La limpieza fue una de las cinco actividades con mayor índice de dolor en los hombros o en el cuello, tendovaginitis y dolores lumbares (Sogaard, Fallentin y Nielsen 1996). En un estudio epidemiológico poblacional se observó que las mujeres de la limpieza eran particularmente propensas a presentar osteoartritis en las rodillas, en comparación con otras trabajadoras suecas (Vingard y cols. 1991). En Quebec, el personal de limpieza de los hospitales de Quebec padece el doble de accidentes laborales y enfermedades que el trabajador sanitario medio: 23,8 frente a 13,9 por cada 100 trabajadores a tiempo completo equivalentes por año (ASSTSAS 1993). La mayoría de las lesiones estuvieron relacionadas con el tronco o las extremidades superiores (ASSTSAS 1993). Un estudio comparativo entre varones y mujeres dedicados a la limpieza en la región de París, en Francia, indicó que los varones tenían más dolor de espalda y las mujeres más dolor en las articulaciones (Opatowski y cols. 1995). La diferencia se debe, probablemente, a aspectos específicos de las tareas asignadas a uno y otro sexo (Messing, Haëntjens y Doniol-Shaw 1993; Messing, Doniol-Shaw y Haëntjens 1993; Messing, Chatigny y Courville 1996).

Los empleados de limpieza tienen un alto índice de problemas cutáneos, como dermatitis y eczema (Gawkrodger, Lloyd y Hunter 1986; Singgih y cols. 1986). En muestras amplias de empleados de limpieza en hospitales se observaron prevalencias puntuales de enfermedades de la piel del 15 al $18 \%$, y una duración de la prevalencia en función del empleo del $39 \%$ (Hansen 1983; Delaporte y cols. 1990). Los trabajadores que pasaban más tiempo con las manos húmedas presentaban más problemas de piel (Nielsen 1996). Además, corrían el riesgo de lesión o infección por cristales rotos, agujas u objetos punzantes al manipular la basura (ASSTSAS 1993).

Los especialistas de la salud en el trabajo han observado recientemente síntomas de estrés relacionado con el trabajo en estos trabajadores, por lo que sugieren examinar de nuevo el sistema de trabajo (Toivanen, Helin y Hänninen 1993). El bajo prestigio de esta profesión puede ser una causa de angustia para los empleados de limpieza (Messing, en prensa).

Los accidentes, las infecciones y la contaminación ambiental pueden evitarse mediante directrices claras y adecuadamente difundidas sobre los desechos peligrosos en fábricas, hospitales, oficinas y edificios públicos. Debido a que las restricciones impuestas a otros trabajadores pueden impedir que se preste la suficiente atención a la prevención de riesgos para el personal de limpieza, debe posibilitarse la consulta entre ambos grupos de trabajadores para decidir el tamaño y la colocación adecuados de las papeleras, la separación de residuos y el etiquetado apropiado. El personal de limpieza debe estar siempre 
incluido en la planificación o revisión de las prácticas de eliminación de residuos, de forma que puedan proponerse métodos realistas.

\section{Peluqueria y COSMetica}

\section{Laura Stock y James Cone}

\section{Visión general}

Se calcula que más de un millón de personas trabajan en aproximadamente 150.000 peluquerías y barberías en Estados Unidos. Estos peluqueros y cosmetólogos realizan una amplia variedad de servicios, como afeitar, cortar y peinar el cabello, manicura y pedicura, aplicación de uñas postizas y diversos procesos químicos para el cabello, como decoloración, tinte, alisado y permanente. Además, algunos profesionales ofrecen también tratamientos faciales y depilación.

Estos trabajadores pueden estar expuestos a diversos riesgos potenciales para la salud y la seguridad en el trabajo, como por ejemplo:

Productos químicos. De acuerdo con un análisis realizado por el National Institute of Occupational Safety and Health (NIOSH) de EE.UU., el $30 \%$ de los casi 3.000 productos químicos que se utilizan en cosmética están clasificados por el Gobierno de EE.UU. como sustancias tóxicas. La ventilación en muchas de las peluquerías es con frecuencia inadecuada para eliminar la exposición química.

Enfermedades. Debido al contacto cercano con los clientes, estos trabajadores pueden estar expuestos a varias enfermedades contagiosas, desde resfriados comunes hasta impétigo, varicela y hepatitis.

Riesgos ergonómicos. Los peluqueros y cosmetólogos padecen también varios trastornos musculosqueléticos asociados con los movimientos repetitivos, la permanencia de pie durante mucho tiempo, el espacio de trabajo reducido y el mal diseño de las herramientas y los equipos.

Horarios. El horario de trabajo puede ser amplio e irregular. Muchos profesionales de este sector trabajan en "turnos partidos", dividiendo la jornada laboral para prestar entre $12 \mathrm{y}$ 14 horas de servicio a los clientes.

Otros problemas. Existen otros riesgos relacionados con la falta de limpieza y conservación, con la electricidad y con los incendios.

Como resultado de la exposición a éstos y otros riesgos, cada vez más personas se ven obligadas a abandonar la profesión elegida. Un estudio reciente realizado por Nellie Brown, director del Chemical Hazards Information Program de la Universidad de Cornell, determinó que el $20 \%$ de los estilistas del cabello en Estados Unidos dejan su trabajo debido a enfermedades relacionadas con él (New York Times Magazine, 7 de marzo de 1993).

A pesar de que cada vez hay más pruebas del riesgo, existen pocas normativas que protejan a los peluqueros y cosmetólogos. En Estados Unidos, los productos cosméticos están regulados por la Food and Drug Administration (FDA), que se ocupa de la protección del consumidor y cuya capacidad de abordar el problema de la salud y la seguridad de los trabajadores es limitada. Al igual que los organismos reguladores de muchos otros países, la FDA no exige a los fabricantes de los productos que realicen pruebas de seguridad antes de la comercialización, que indiquen los componentes de las fórmulas en las etiquetas de los productos que se venden sólo para uso profesional o que proporcionen información a la FDA sobre las quejas de los clientes. La FDA tampoco comprueba los productos de forma rutinaria por iniciativa propia; todas las pruebas que realiza se dedican a los riesgos para los consumidores, no para los trabajadores, aunque el riesgo que corren estos últimos puede ser mayor debido al uso diario y prolongado de los productos químicos cosméticos.

Los intentos por regular este sector se complican aún más por las distintas definiciones a escala local, nacional e internacional de las tareas que realizan los peluqueros y cosmetólogos. En Estados Unidos, los requisitos para la concesión de licencias varían de un Estado a otro y en muchos países ni siquiera existen requisitos para las licencias.

\section{Principales procesos y riesgos}

\section{Riesgos químicos}

Los peluqueros y cosmetólogos están expuestos a una amplia variedad de productos químicos durante su actividad diaria: corren el riesgo de absorber los productos químicos a través de la piel o los ojos, de inhalar vapores o partículas peligrosas y de ingerir toxinas que hayan contaminado los alimentos, las bebidas o el tabaco. La Figura 100.1 ofrece algunas directrices para reducir el riesgo de la exposición.

Los productos químicos pueden afectar al organismo de distintas formas dependiendo de la concentración de la sustancia en el producto, su toxicidad, la vía de entrada al organismo (inhalación, contacto con la piel, ingestión) y el tiempo de exposición. Las características individuales, como el estado general de salud, el embarazo y el tabaquismo también pueden influir sobre el riesgo de una persona.

Existen millares de productos químicos distintos asociados con los trabajos cosmetológicos. Con el fin de determinar las sustancias químicas específicas que contiene un producto y sus efectos, es importante que los profesionales tengan acceso a las etiquetas de los productos y a las fichas técnicas de seguridad (FTS) y las comprendan.

\section{Procesos químicos comunes}

Teñido del cabello. Las soluciones de tintes para el cabello se aplican manualmente mediante una botella con aplicador o una bocha. Es también frecuente que los clientes soliciten teñirse las cejas o las pestañas.

Los productos químicos utilizados en los tintes para el cabello son los colorantes orgánicos sintéticos, los colorantes metálicos complejos y los tintes vegetales. Los colorantes sintéticos son con frecuencia tintes oxidantes permanentes que utilizan agua oxigenada para oxidar diaminas aromáticas; son irritantes para los ojos, la nariz y la garganta. Los tintes orgánicos sintéticos contienen un grupo amino que está entre las causas más frecuentes de sensibilización alérgica. Los tintes metálicos pueden contener compuestos de plomo.

Los tintes con colorantes derivados del alquitrán contienen a veces mutágenos. El riesgo para la salud humana de los tintes que han resultado mutagénicos en ensayos in vitro no está claramente determinado. Sin embargo, la producción de tintes no mutagénicos es posible y debe fomentarse. Por ejemplo, la alheña, un tinte vegetal, es uno de los tintes más antiguos conocidos y no se sabe que tenga efectos mutagénicos o cancerígenos.

Decoloración del cabello. Las soluciones decolorantes se aplican manualmente mediante una botella con aplicador o una bocha. Son soluciones que pueden contener agua oxigenada, peróxido de sodio, hidróxido de amonio, persulfato de amonio o persulfato potásico. Se trata de productos químicos que pueden irritar la piel, los ojos, la nariz, la garganta o los pulmones. El uso de polvos decolorantes de persulfato se ha asociado también con el desarrollo de asma entre los cosmetólogos (Blainey y cols. 1986).

Moldeado permanente. El moldeado permanente generalmente se hace en varias fases: lavar el cabello, enrollarlo en rizadores, aplicar una solución de tioglicolato o similar, aclarar y 
Figura 100.1 • Reducción de la exposición a los riesgos químicos.

EVITAR LOS PRODUCTOS QUIMICOS PELIGROSOS.

- Disponer de etiquetas y fichas técnicas de seguridad (FTS) para todos los productos de peluquería.

- Utilizar productos químicos menos tóxicos. Evitar los productos con componentes muy tóxicos, como los colorantes derivados del alquitrán, el formaldehído, los éteres de glicol y el metilmetacilato.

- Utilizar métodos en los que se empleen pocos o ningún producto químico; por ejemplo:

- alisado por calor en lugar de por medios químicos

- puntas plásticas o tiras de tejido en lugar de uñas postizas

- Utilizar elementos para humedecer o rociadores por bombeo en lugar de aerosoles.

UTILIZAR PRACTICAS DE TRABAJO QUE REDUZCAN LA EXPOSICION

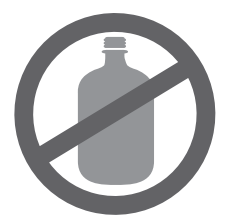

- Mantener las botellas y otros envases cerrados cuando no se ưtilicen.

- Aislar los procesos de trabajo peligrosos (por ejemplo, mezclar los productos químicos en una zona separada y bien ventilada).

- No comer, beber ni funar mientras uitiza los productos químicos para evitar la contaminación.

- Lavarse las manos perfectamente después de utilizar los productos químicos, antes de tocarse los ojos, la cara o la boca y antes de comer, beber o fumar.

- Desechar los productos químicos de forma correcta: no tirar los que son peligrosos por el desagüe ni echarlos a la basura.

- Mantener una buena limpieza (limpiar inmediatamente cualquier derrame).

- Evitar la realización del mismo procedimiento químico todo el día.

- Guardar los productos químicos en un lugar fresco y seco, donde no reciban directamente la luz solar. Sujetar los recipientes para evitar que se rompan.

- No guardar productos químicos incompatibles en un mismo lugar(por ejemplo, ácidos y bases).

gaRANTIZAR UNA VENTILACION ADECUADA.

- Proporcionar una buena ventilación general a toda la peluquería. Suministrar aire mecánicamente a través de respiraderos y retornos de aire. Si la ventilación mecánica no es posible, suministrar aire fresco abriendo las ventanas y las puertas y utilizando ventiladores.

- No colocar nunca los ventiladores de forma que dirijan los productos químicos hacia la cara (hacia la zona de respiración).

- Dirigir el aire de forma que aleje los productos químicos de la cara.

- Proporcionar ventilación aspirante local (una campana de extracción) en todas las zonas de mezclado, mesas de manicura y mesas de uñas postizas:

- Asegurarse de que el ventilador de la unidad es suficientemente potente para que resulte eficaz.

- Colocar la campana lo más cerca posible de la operación que genere el producto químico (por ejemplo, la mano de las clientas)

- Dirigir la salida de la campana hacia el exterior

- Si es imposible dirigirla hacia una ventana, un conducto de extracción o un drenaje, asegurarse de que el sistema cuenta con los filtros adecuados y cambiarlos regularmente.

UTILIZAR EL EQUIPO DE PROTECCION PERSONAL ADECUADO

- Utilizar siempre guantes para realizar los moldeados o alisados permanentes, paro aplicar los tintes y los champús.

- Seleccionar el tipo adecuado de guantes para el producto químico que se va a manipular.

- Desechar los guantes si están dañados o si los productos químicos los han atravesado y han llegado hasta la piel.

- Utilizar camisas de manga larga, batas o ropa holgada para evitar el contacto de los productos químicos con la piel.

- Utilizar una mascarilla especial para polvo a fin de protegerse al limar las uñas. Este tipo de mascarillas protegen únicamente contra el polvo, por lo que debe utilizarse un respirador de cartucho cuando se produzcan vapores 0 aerosoles químicos.

- Utilizar gafas protectoras o de seguridad al mezclar, verter o utilizar productos químicos que puedan dañar los ojos.

neutralizar con un agente oxidante. También se utilizan atomizadores de agua.

Las soluciones para el moldeado permanente pueden contener alcohol, bromatos, hidróxido de sodio, ácido bórico (perborato o borato), tioglicolato de amonio o monotioglicolato de glicerol. Algunos de estos productos químicos pueden tener efectos sobre el sistema nervioso central (cefaleas, mareos, náuseas, somnolencias), irritar los ojos, la nariz y la garganta, causar problemas pulmonares (dificultad para respirar o tos); irritar la piel o producir quemaduras o reacciones alérgicas (congestión nasal, estornudos, asma o dermatitis alérgica).

Manicura, pedicura y uñas postizas. El cuidado de las uñas comprende: remojar la cutícula en agentes suavizantes, utilizar cortauñas, emplear limas o esmeriles, aplicar cremas de manos y aplicar y quitar el esmalte. Las uñas postizas (de acrílico, gel, fibra vidrio, porcelana, tejido) pueden aplicarse con un pincel sobre las uñas o pegarse. Una vez que han endurecido, se liman para darles la forma deseada.

Entre las numerosas sustancias químicas presentes en los productos para las uñas están: acetona, etilmetacrilato y otros acrilatos, metiletilcetona, etilacetato, lanolina y dimetil-p-toluidina. Estas sustancias pueden producir irritación de la piel, los ojos, la nariz, la garganta y los pulmones, así como efectos sobre el sistema nervioso central. Algunos productos para las uñas también contienen formaldehído, asociado con alergias y con cáncer de pulmón si el uso es prolongado. Algunos productos contienen éteres de glicol, xileno y tolueno, asociados con problemas reproductores en animales de laboratorio.

El uso del metilmetacrilato (MMA) en los productos de uñas postizas se prohibió en Estados Unidos en 1974, a pesar de lo cual sigue utilizándose. Un estudio realizado en 1982 reveló que 8 de 29 productos para uñas postizas contenían metilmetacrilato, y otro estudio realizado en 1986 detectó niveles cuantificables de MMA en el ambiente de algunas peluquerías. Es un producto químico que, en contacto con la piel, puede causar hormigueo, adormecimiento y palidez de los dedos. También produce alergia cutánea en muchas personas. Una alergia al MMA puede producir sensibilidad cruzada a otros metacrilatos de uso común. En algunos productos, el MMA se ha sustituido por otros acrilatos que causan también sensibilización. En la Figura 100.2 se muestra una mesa de tiro invertido diseñada para minimizar la exposición del manicuro a los productos químicos.

Lavado y peinado del cabello. El lavado del cabello consiste en aplicar un champú y aclarar con agua. Durante este servicio se aplican a veces acondicionadores y otros productos para el tratamiento capilar. El secado del cabello puede realizarse de varias formas: manualmente con una toalla, con un secador de mano o con un secador fijo debajo del cual se sienta el cliente. El peinado conlleva generalmente el uso de geles, cremas o aerosoles. El lavado del cabello suele ser el primer paso para otros servicios que se realizan en la peluquería, como el peinado y la fijación, el tinte o la permanente. En las peluquerías más grandes puede haber una persona encargada exclusivamente de lavar el cabello a los clientes.

Los champús y los acondicionadores pueden contener alcohol, destilados del petróleo y formaldehído. Todas estas sustancias se han asociado con dermatitis y alergias, incluida el asma. El uso prolongado del formaldehído también se ha asociado al cáncer.

Los aerosoles pueden contener polivinilpirrolidona, que se ha asociado con enfermedades pulmonares y otras enfermedades respiratorias, como la tesaurosis. También contienen varios disolventes.

Alisado del cabello. Las soluciones para el alisado del cabello se aplican con una brocha y, a continuación, se estira el cabello para deshacer el rizo natural. Los productos para alisar el cabello pueden contener hidróxido de sodio, agua oxigenada, bromatos, amoníaco, tioglicolato y monotioglicolato de glicerol. Estos productos pueden ser irritantes para los ojos, la nariz y la garganta, y a veces producen efectos sobre el sistema nervioso central y dermatitis. 


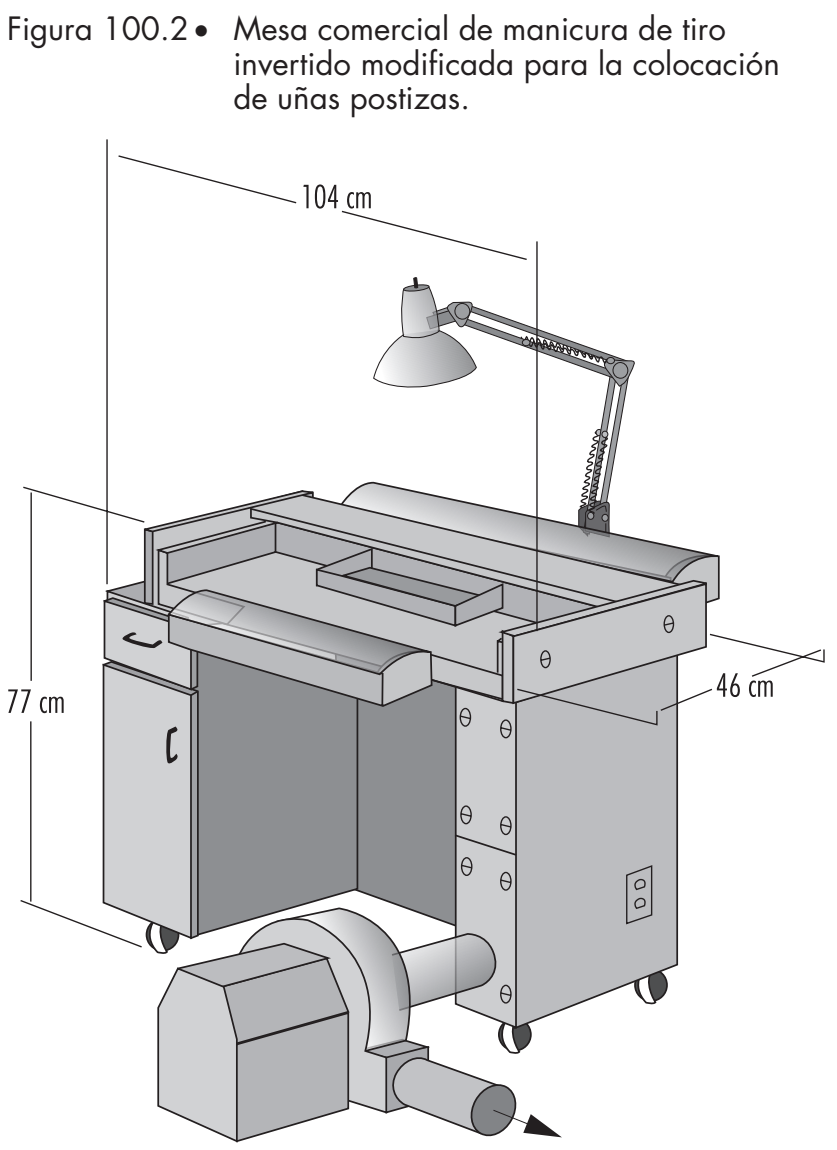

Fuente: Spencer y cols. 1996.

Otros procesos químicos. Entre los distintos productos que aplican los cosmetólogos están las cremas y los polvos faciales, el rímel, los delineadores de ojos, las barras de labios, etcétera. Son productos que contienen una amplia variedad de disolventes, colorantes, pigmentos, conservantes, aceites, ceras y otros productos químicos que pueden causar alergia o irritación de la piel.

Los cosmetólogos también depilan. Los tratamientos depilatorios consisten en la aplicación de cera caliente y el uso de productos depilatorios químicos, que generalmente contienen compuestos alcalinos que pueden causar dermatitis.

\section{Riesgos ergonómicos}

Los peluqueros y cosmetólogos corren el riesgo de sufrir trastornos musculosqueléticos debido a los requisitos físicos de su trabajo y al mal diseño de los equipos, los instrumentos y los espacios de trabajo. He aquí algunos de ellos:

- Problemas en manos y muñecas, como tendinitis y el síndrome del túnel carpiano. Los factores de riesgo son: la flexión y el giro de la muñeca durante el corte y el peinado, la sujeción de secadores manuales y el uso de cepillos redondos o pinzas para rizar. Estos trastornos también se han relacionado con pinzamientos producidos por cortar con tijeras poco afiladas o inadecuadas.

- Problemas de hombros, como tendinitis y bursitis. Se asocian con la necesidad de alargar constantemente el brazo para coger los productos o de sostener los brazos por encima de la altura de los hombros para cortar o peinar (véase la Figura 100.3).
- Problemas de cuello y espalda, que van desde dolores comunes hasta problemas graves, como pinzamiento de nervios o rotura de discos. Están asociados con la flexión y giro continuos durante las actividades de lavado del cabello, el corte por debajo del nivel de las orejas y las actividades de manicura y pedicura.

- Problemas de piernas y pies, por ejemplo, tumefacción, callosidades y venas varicosas. Estos problemas pueden ser el resultado de permanecer de pie durante períodos prolongados en suelos duros, con zapatos con un mal soporte del arco.

\section{Prevención de los trastornos musculosqueléticos}

Para evitar los trastornos musculosqueléticos es importante aplicar los principios ergonómicos al diseño de las tareas, los instrumentos y los puestos de trabajo. La ergonomía es la ciencia de adaptar el lugar de trabajo a las necesidades del cuerpo humano, para lo cual ofrece formas de minimizar las posturas forzadas y los movimientos repetitivos, así como el uso excesivo de la fuerza, aumentando así la salud, la seguridad y la comodidad.

Las soluciones ergonómicas son:

- Mobiliario ajustable. Por ejemplo, existen sillas para los clientes que se pueden subir, bajar o girar. También hay sillas para manicuros que cuentan con soporte para la espalda, reposabrazos y asientos que se pueden inclinar para ajustarse a la flexión hacia adelante.

- Tijeras. Deben estar bien afiladas, lubricadas y diseñadas para ajustarse a la mano de cada persona.

- Rizadores y secadores. Deben tener mangos flexibles y poderse utilizar sin necesidad de flexionar o girar excesivamente la muñeca.

- Lavabos independientes, que permitan lavar el cabello sin necesidad de girar o flexionar la espalda.

- Sillas o bancos con ruedas, que permitan a los profesionales realizar muchos trabajos sentados (o alternar entre la posición sentada y de pie).

Figura 100.3 - Trabajo con los brazos por encima del nivel del hombro en una peluquería en Zimbabue.

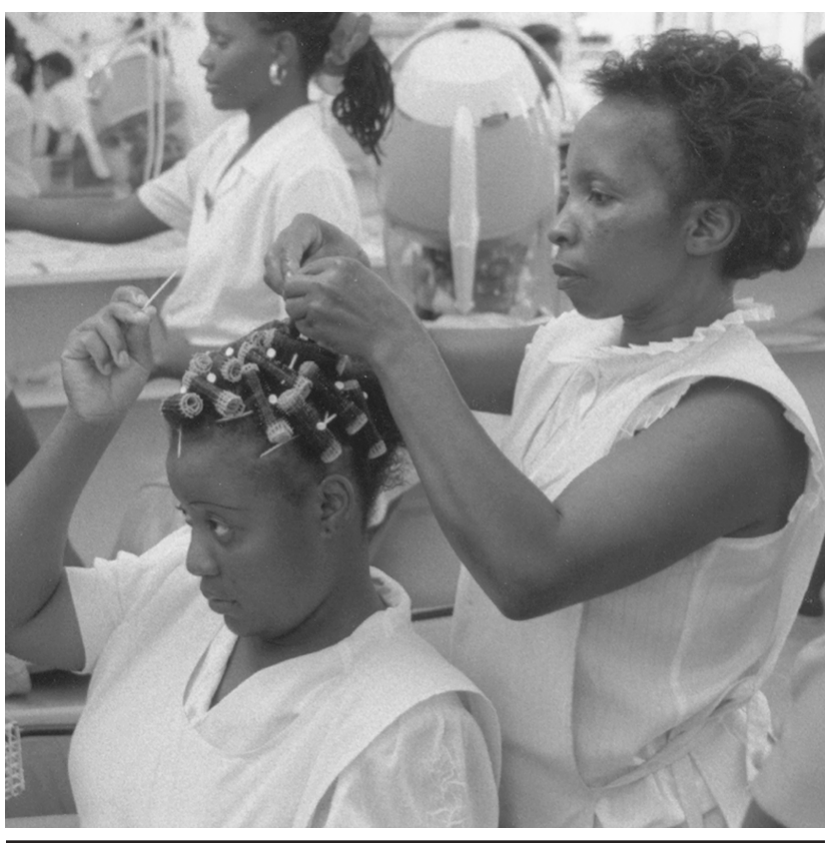


- Puesto de trabajo adecuado, con un diseño que considere aspectos como guardar los materiales de uso en un lugar de fácil acceso, alfombrar los suelos para amortiguar la dureza y situar los armarios a la altura correcta para minimizar los estiramientos o flexiones.

- Programación de los clientes, con el fin de variar las tareas y procesos que realizan los profesionales durante la jornada.

- Formación para los técnicos sobre la mecánica corporal y las prácticas laborales correctas, como la forma adecuada de levantar objetos, la conveniencia de doblar el cuerpo a la altura de la cadera en lugar de la cintura y utilizar técnicas de corte que minimicen la extensión y giro de la muñeca.

\section{Enfermedades infecciosas}

El trabajo realizado por peluqueros y cosmetólogos conlleva la proximidad con los clientes. Comprender cómo se transmiten las enfermedades infecciosas puede ayudar a estos profesionales a prevenir las infecciones. Las enfermedades infecciosas se pueden propagar de las siguientes maneras:

- a través del aire (por ejemplo, infecciones de las vías respiratorias superiores, como los resfriados o la gripe);

- a través del agua o los alimentos contaminados (por ejemplo, la hepatitis, las salmonellas o la giardia);

- a través de picaduras de insectos u otros animales (por ejemplo, piojos);

- a través del contacto directo de la piel con personas infectadas (por ejemplo, la sarna, los piojos, la tiña, el impétigo, el herpes simplex, los resfriados y la varicela),

- raramente, a través de la exposición a la sangre de una persona infectada (por ejemplo, la hepatitis B o el VIH/SIDA).

A pesar de que no se han registrado casos de peluqueros o cosmetólogos infectados con VIH/SIDA en el trabajo y la infección por hepatitis $\mathrm{B}$ relacionada con el trabajo es sumamente rara en estas profesiones, la exposición a los patógenos transportados por la sangre podría ocurrir en situaciones raras de contacto con la sangre. Las posibles fuentes de exposición serían la punción de la piel con instrumentos manchados con sangre infectada (cuchillas de afeitar, pinzas, agujas de tatuaje o maquinillas para cortar el pelo) o por la entrada de sangre infectada al organismo a través de una herida abierta, una llaga o un rasguño.

Por este motivo, en muchos países se ha dejado de afeitar a los clientes. Además del riesgo para los técnicos, existe la posibilidad de transmisión de infecciones de la piel y de otro tipo de un cliente a otro a través de los instrumentos no esterilizados.

La exposición a microorganismos dañinos puede evitarse mediante precauciones sencillas:

- Las manos deben lavarse frecuentemente con agua y jabón.

- Se deben utilizar guantes de goma para proteger al técnico y al cliente si alguno de ellos tiene lesiones, úlceras o rasguños en la piel.

- Los instrumentos cortantes deben manipularse cuidadosamente, y cuando se desechen, se hará en recipientes homologados para evitar heridas.

- Todos los instrumentos, equipo y superficies estarán debidamente desinfectadas.

- Las toallas deben desinfectarse.

- Los trabajadores deben vacunarse contra la hepatitis B.

\section{Otros riesgos}

Riesgo de incendio

Algunos de los productos utilizados en las peluquerías contienen productos químicos inflamables o combustibles. Entre las fuentes de ignición están los cigarrillos, las cerillas o los mecheros encendidos; una chispa de un interruptor de la luz, un contacto eléctrico o un cable desgastado; un objeto caliente como un rizador, una estufa, una bombilla o una placa caliente. Para evitar accidentes, hay que asegurarse de que los productos químicos se utilicen y se guarden adecuadamente. Los compuestos inflamables y combustibles deben mantenerse alejados de las fuentes de llamas, chispas y de los objetos calientes; el equipo eléctrico debe comprobarse para detectar la existencia de cables rotos o desgastados que puedan producir chispas o calentarse. Todas las peluquerías deben contar con un plan de prevención de incendios y de evacuación, y con extintores adecuados y en perfecto estado de funcionamiento.

\section{Limpieza y conservación generales}

Las peluquerías suelen estar llenas de objetos y de gente. Las estanterías sobrecargadas pueden ser inestables. Los técnicos corren el riesgo de resbalarse o caerse debido a los líquidos derramados, al equipo o a los cables mal colocados. Los pasillos estrechos y abarrotados limitan la capacidad del trabajador para moverse libremente sin obstrucciones. La limpieza y la conservación deben hacerse en todas las zonas de la peluquería, lo cual comprende: mantener los pasillos despejados, limpiar inmediatamente los productos derramados, guardar los objetos pesados en los estantes más bajos y asegurarse de que la gente pueda moverse libremente por todo el espacio.

\section{Riesgos eléctricos}

Los aparatos eléctricos que se emplean en las peluquerías son: maquinillas para cortar el pelo, secadores, aparatos faciales y equipo de electrólisis. Todos ellos deben comprobarse para detectar posibles desgastes en los cables y para cerciorarse de que la conexión a tierra es adecuada. Puesto que el equipo eléctrico y los contactos están en una zona de posibles salpicaduras, deben utilizarse interruptores rojos de circuito de pérdida a tierra para evitar descargas.

\section{Problemas de salud y pautas patológicas}

\section{Enfermedades de la piel}

Las dermatitis por irritación o alergia únicamente en las manos, o en manos y cara, son un problema común que presentan entre el 10 y el $20 \%$ de los cosmetólogos (Van der Walle y Brunsveld 1994). Suele ocasionar una erupción característica entre los dedos. Los signos de la dermatitis son: enrojecimiento, sequedad y piel cuarteada de las manos. También puede aparecer eczema en las puntas de los dedos, con crestas en los bordes de las uñas. Los trabajadores jóvenes parecen tener un mayor riesgo, probablemente porque se les asignan las tareas de lavado y permanenteado del cabello. Las causas más frecuentes de la erupción cutánea de tipo alérgico en los cosmetólogos son el tioglicolato de glicerol, el tioglicolato de amonio, el sulfato de níquel, los conservantes con persulfato de amonio y los tintes para el cabello ( $p$-fenilendiamina o resorcinol) (Villaplana, Romaguera y Grimalt 1991).

En la mayoría de los casos, una vez que se desarrolla una dermatitis alérgica, no suele mejorar, aunque se utilicen guantes. El uso de guantes de látex puede ser un factor de riesgo importante para las respuestas alérgicas; en caso de que se desarrolle una alergia al látex hay que sustituirlos por guantes de vinilo. Si un trabajador desarrolla alergia al látex, puede ser necesario cambiar el tipo de guantes en toda la peluquería para evitar que se repita la respuesta alérgica en el trabajador.

Otras enfermedades de la piel típicas de los peluqueros son el granuloma por la implantación de cabello y las quemaduras con agua caliente. También pueden presentar venas varicosas como 
resultado del tiempo que permanecen de pie. Los instrumentos cortantes, como las tijeras, el equipo de afeitado y las maquinillas eléctricas para cortar el pelo pueden causar heridas en la piel. Estas heridas pueden favorecer el desarrollo de dermatitis debido a la exposición a los productos químicos.

\section{Problemas pulmonares}

La rinitis alérgica ("fiebre del heno") y el asma se han asociado con la exposición a las soluciones para el moldeado permanente (Schwartz, Arnold y Strohl 1990) y, sobre todo, al persulfato de amonio (Gamboa y cols. 1989). Los decolorantes del cabello y la alheña (Starr, Yunginger y Brahser 1982) se han asociado con asma de origen profesional en los cosmetólogos.

\section{Riesgos relacionados con la reproducción}

Un estudio reciente muestra un aumento moderado en el riesgo de abortos espontáneos entre las cosmetólogas que trabajaban a tiempo completo y realizaban un gran número de servicios químicos. El uso de formaldehído y la exposición a los productos químicos utilizados en manicura y en la remodelación de las uñas se han asociado específicamente con un mayor riesgo de abortos espontáneos (John, Savitz y Shy 1994).

\section{Cáncer}

Se ha determinado que los cosmetólogos tienen un mayor riesgo de desarrollar ciertos tipos de cáncer, como el linfoma no hodgkiniano (Zahm y cols. 1992; Pearce 1992), el cáncer urotelial o de vejiga (Steineck y cols. 1990) y el cáncer de mama (Koenig 1994).

\section{LAVANDERIAS Y LIMPIEZA EN SECO}

Gary S. Earnest, Lynda Ewers y Avima M. Ruder

\section{Visión general}

Las lavanderías comerciales comenzaron como empresas domésticas, pero se han convertido en negocios con ciertos riesgos únicos en cuanto a la salud y la seguridad. Los trabajadores de lavanderías especializadas en servicios para los hospitales se enfrentan a posibles riesgos biológicos, y las dedicadas a la limpieza de ropa de trabajo para las industrias de fabricación o servicio entrañan riesgos químicos específicos.

Se considera que la limpieza en seco nació en Francia en 1825, cuando un trabajador de una fábrica de teñido y lavado derramó el aceite de una lámpara en un mantel sucio (IARC 1995a). Cuando se secó el mantel, las manchas habían desaparecido. El aceite para lámparas es un hidrocarburo. Otros disolventes de hidrocarburos similares, como la trementina, el queroseno, el benceno y la gasolina, se utilizaron también en la incipiente industria de limpieza en seco. Todos estos disolventes tenían un importante inconveniente: eran inflamables y originaban con frecuencia incendios y explosiones (Wentz 1995). En 1928, W.J. Stoddard introdujo un disolvente de petróleo prácticamente inodoro con una temperatura de inflamabilidad mayor, lo que redujo el riesgo de incendios. El disolvente de Stoddard obtuvo una amplia aceptación en el sector y aún se utiliza en la actualidad.

A principios de este siglo, los avances en la síntesis de hidrocarburos clorados permitieron elaborar disolventes no inflamables para la limpieza en seco. En un principio se utilizó el tetracloruro de carbono, pero debido a su toxicidad y agresividad con los metales, textiles y colorantes, se reemplazó gradualmente, en los decenios de 1940 y 1950, por el tricloroetileno y el tetracloroetileno (también conocido como percloroetileno o PERC) (Wentz 1995). El PERC $\left(\mathrm{C}_{2} \mathrm{Cl}_{4}\right)$ es un líquido incoloro, transparente y pesado, con olor etéreo. En la actualidad, aproximadamente el $90 \%$ de los establecimientos de limpieza en seco de EE.UU. utilizan PERC (EPA 1991a).

A pesar de que las prácticas de limpieza varían de un país a otro y de un establecimiento a otro, las lavanderías y las tintorerías son habitualmente negocios pequeños; aproximadamente el $70 \%$ de las tintorerías en EE.UU. tienen menos de cuatro empleados, que habitualmente realizan la limpieza en el mismo local. Los empleados de estos establecimientos, muchos de los cuales trabajan más de ocho horas al día, son a veces los miembros de una familia, incluidos, en algunos casos, los niños. En muchos países la familia vive en el mismo inmueble en el que se encuentra el negocio. En las empresas más grandes, la tendencia es contar con varios puntos de "recogida" de ropa, donde los clientes dejan las prendas sucias. Estas prendas se transportan a una instalación central y posteriormente se devuelven a los puntos de recogida donde se entregan a los clientes. Tal organización permite reunir los desechos peligrosos en un solo sitio y reduce la exposición a los disolventes de los trabajadores en los puntos de recogida.

\section{El proceso de lavado y limpieza en seco}

El proceso comienza generalmente cuando un cliente lleva las prendas sucias al establecimiento. La ropa actual está hecha de numerosas fibras y tejidos distintos. Las prendas se inspeccionan y se clasifican de acuerdo con su peso, color, acabado y tipo de tejido antes de cargar las máquinas. Las manchas visibles se tratan antes o después del lavado con varios productos químicos, dependiendo del tipo de mancha.

La limpieza consta de tres pasos: lavado, extracción y secado (Figura 100.4). En el proceso de limpieza en húmedo (lavandería) se utilizan detergentes, agua y, en algunos casos, vapor. En la limpieza en seco se añade detergente y agua al disolvente para ayudar a eliminar la suciedad. Las prendas se introducen

\section{Figura 100.4 • Representación gráfica del proceso de limpieza en seco.}

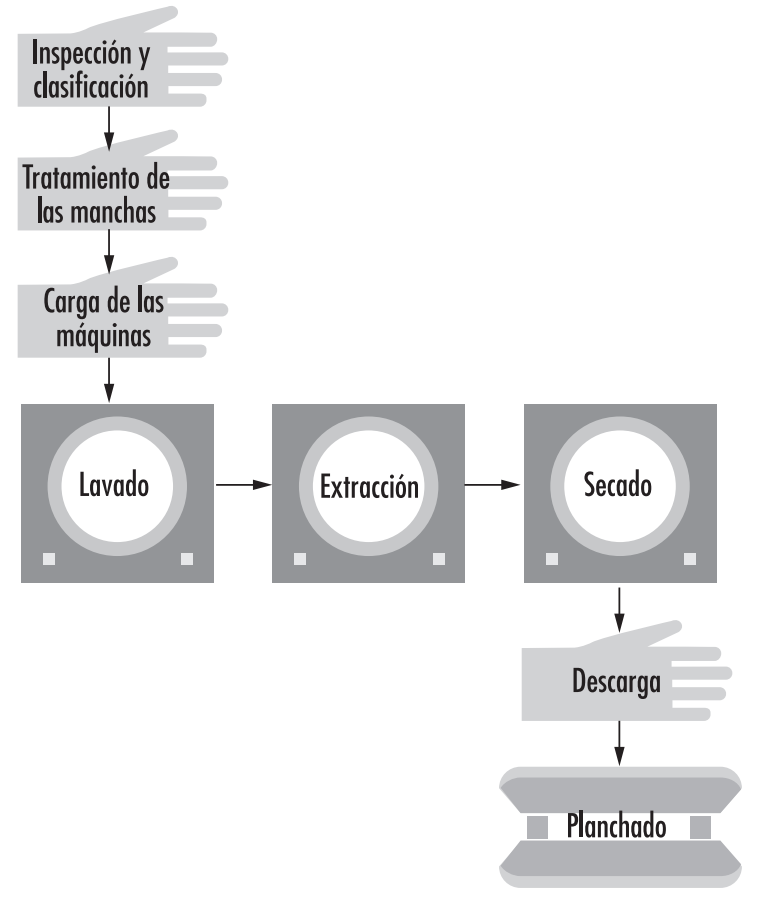


manualmente en la máquina y la solución limpiadora se inyecta automáticamente. El contenido de la máquina se agita durante un tiempo y después se centrifuga a gran velocidad para extraer el agua o el disolvente y se seca en máquinas de tambor. Al salir de la secadora, las prendas se planchan para eliminar las arrugas y devolverles la forma original.

En muchos países existen actualmente normativas estrictas para controlar la exposición y las emisiones de PERC debido a los riesgos para la salud y para el ambiente asociados a él. En respuesta a estas normativas, los procesos de limpieza en seco están cambiando. Ahora se han mejorado los sistemas de purificación de los disolventes y de recuperación del vapor; se están elaborando otros disolventes y diseñando nuevos métodos de limpieza con inmersión en agua para limpiar prendas tradicionalmente tratadas con disolventes. Estos procesos se detallan a continuación.

\section{Equipo de transferencia frente a equipo de seco a seco}

Existen dos tipos básicos de máquinas que se utilizan para la limpieza en seco: las de transferencia y las de seco a seco. Las primeras, más antiguas y más baratas, requieren la transferencia manual de las prendas cargadas de disolventes de las máquinas de lavado a las secadoras. Este proceso produce una exposición excesiva de los trabajadores al PERC. Debido al uso elevado de disolventes y a la producción de emisiones y exposición, las máquinas de transferencia de PERC ya no se fabrican en Estados Unidos; sin embargo, aún es posible adquirir algunas de estas máquinas usadas o reacondicionadas.

En 1994, al menos el 70 \% de las máquinas de PERC en Estados Unidos, por ejemplo, eran máquinas de seco a seco, que utilizan un proceso de un solo paso que evita la transferencia de las prendas. Muchos establecimientos están cambiando o han cambiado ya las máquinas de transferencia por las máquinas de seco a seco debido a que las normas ambientales son cada vez más estrictas en este sentido; sin embargo, en algunos sitios se sigue utilizando el equipo de transferencia para aumentar la productividad y para evitar la inversión necesaria para la adquisición de la maquinaria nueva. En Estados Unidos, las máquinas de petróleo son en su mayoría unidades de transferencia.

Las máquinas de seco a seco pueden tener salida de vapores o no. Las máquinas con salida emiten los vapores de disolvente directamente a la atmósfera o a través de algún sistema de recuperación de vapor durante el proceso de aireación. Las máquinas sin salida de vapores son básicamente sistemas cerrados que sólo se comunican con el ambiente exterior cuando se abre la puerta. Estas máquinas pasan el aire caliente de secado a través de un sistema de recuperación de vapor y después lo devuelven al tambor de secado y omiten el paso de aireación.

\section{Purificación de los disolventes: filtración y destilación}

Las tintorerías utilizan la filtración y la destilación para recuperar y purificar los disolventes. La filtración elimina la suciedad insoluble, los residuos no volátiles y los tintes sueltos en el disolvente. En ocasiones se utiliza también, sobre todo en Estados Unidos, para eliminar la suciedad soluble. La filtración es un proceso continuo: el disolvente pasa a través de un polvo adsorbente y de un filtro de cartucho o de disco; estos sistemas requieren un mantenimiento periódico. Cada sistema de filtración produce cartuchos o polvos contaminados.

La destilación, que se utiliza en el $90 \%$ de las tintorerías en EE.UU., elimina los aceites solubles, los ácidos grasos y las grasas que no elimina la filtración (International Fabricare Institute 1990). La destilación tiene lugar cuando el PERC se calienta hasta su punto de ebullición de forma que se evapora y posteriormente se condensa de nuevo a su forma líquida.
Durante este proceso, las impurezas no volátiles, que no se evaporan, permanecen en el destilador y se desechan como residuos peligrosos. Tanto la filtración como la destilación producen residuos sólidos que contienen PERC; sin embargo, los fabricantes de máquinas para limpieza en seco intentan desarrollar nuevas técnicas de filtración y destilación que reduzcan la cantidad de residuos peligrosos producidos. Esto redundará, en último término, en un ahorro importante para los propietarios al reducir el gasto que conlleva la eliminación de los residuos peligrosos.

\section{Recuperación de los vapores de PERC}

Para recuperar los vapores de PERG se utilizan principalmente dos tecnologías: los adsorbentes de carbón y los condensadores refrigerados. Estas dos tecnologías, tradicionalmente independientes, se combinan en las máquinas más modernas. Por ejemplo, la adsorción por carbón se utiliza en cerca del $35 \%$ de las máquinas controladas en Estados Unidos. Los adsorbentes de carbón logran una reducción del vapor de un 95 a un $99 \%$ al eliminar el PERC del aire. Los vapores cargados de disolvente pasan sobre el carbón activado, que tiene una gran capacidad de absorción. Posteriormente, este carbón se regenera y se recupera el PERC, o bien se desecha como residuo peligroso, cuando está saturado con PERC. La regeneración del carbón se realiza por lo común con vapor o aire caliente y puede realizarse automáticamente después de cada carga o al final de la jornada. Si no se realiza con regularidad, la capa de carbón se saturará y resultará ineficaz para recuperar el PERC. El sistema de adsorción admite grandes volúmenes de aire con concentraciones relativamente bajas de disolvente sin perder su alta eficacia de eliminación de PERC, pero es necesaria una regeneración frecuente y el vapor de la regeneración produce agua contaminada.

Los condensadores refrigerados enfrían el aire cargado de disolvente por debajo del punto de rocío del vapor para recuperar el PERG y funcionan según el principio de que la capacidad del aire para retener el disolvente varía con la temperatura. Los condensadores refrigerados se utilizan en aproximadamente el $65 \%$ de las máquinas controladas. El proceso puede alcanzar un control del vapor del $95 \%$ en las máquinas de seco a seco y del $85 \%$ en las máquinas de transferencia. Los condensadores requieren poco mantenimiento y minimizan la producción de agua contaminada, ya que la regeneración por vapor es innecesaria. Se requieren, sin embargo, concentraciones de disolvente más elevadas que en el caso de los adsorbentes de carbono. Es posible que el vapor de agua cause problemas, ya que puede condensarse y congelarse, interfiriendo con el flujo de gas y la transferencia de calor (EPA 1991b).

\section{Disolventes alternativos al PERC}

El PERC ha sido sustituido por otros disolventes para la limpieza en seco. Los disolventes inflamables derivados del petróleo tienen límites de exposición superiores al PERG y son menos agresivos que éste al eliminar la suciedad. Debido a que su presión de vapor es inferior a la del PERG, la exposición por inhalación es generalmente menor. Ahora bien, pueden producir efectos adversos para la salud, como asfixia, depresión del sistema nervioso central e irritación de la piel y las mucosas. La contaminación de los hidrocarburos alifáticos con benceno aumenta significativamente el riesgo.

En Alemania se han adoptado dos estrategias distintas para reducir el riesgo de incendio que conllevan los disolventes derivados del petróleo: la elaboración de disolventes más seguros y los cambios en el diseño de las máquinas.

Los disolventes derivados del petróleo elaborados recientemente y muy utilizados en Alemania son parafinas de cadena recta, ramificada o cíclica, con una longitud de 10 a 
12 carbonos. Los disolventes de este tipo tienen una duración en la atmósfera de algunos días, no contienen halógenos, no destruyen la capa de ozono y su papel en el efecto invernadero es mínimo. A continuación se exponen algunos de los requisitos en Alemania para los disolventes derivados del petróleo para la limpieza en seco (Hohenstein Institute 1995):

- rango de ebullición entre $180^{\circ}$ y $210^{\circ} \mathrm{C}$;

- contenido de compuestos aromáticos, benceno, halogenados y compuestos aromáticos policíclicos inferior a $0,01 \%$ de peso;

- temperatura de inflamabilidad superior a $55^{\circ} \mathrm{C}$,

- estables térmicamente en condiciones de funcionamiento.

Las máquinas de limpieza en seco fabricadas actualmente en Alemania para los disolventes derivados del petróleo son mucho más seguras que las antiguas. Debido a que los derivados del petróleo son combustibles, es necesario que las máquinas en las que se utilizan cuenten con medidas de seguridad adicionales. Los avances técnicos mejoran la seguridad de las máquinas y reducen notablemente el riesgo de incendio y explosión. Se pueden adoptar las siguientes medidas por separado o combinadas:

- Utilización de un gas inerte, como nitrógeno o argón, para desplazar el oxígeno del tambor y asegurarse de que la concentración de oxígeno sea suficientemente baja (aproximadamente un $4 \%$ ) para evitar la combustión.

- Accionamiento en condiciones de vacío para extraer el oxígeno y reducir su concentración a menos del $4 \%$.

- Comprobación de que no se supera el límite inferior de explosividad (LIE) o bien, si éste no se conoce, asegurarse de que la temperatura se mantiene $15^{\circ} \mathrm{C}$ por debajo del punto de inflamabilidad.

- Cerciorarse de que la concentración de vapor se mantiene un $50 \%$ por debajo del LIE, controlando la temperatura de funcionamiento o proporcionando un flujo de aire suficientemente elevado.

\section{Limpieza en húmedo}

Es una tecnología en evolución, que difiere del lavado tradicional en que se trata de un sistema menos agresivo y sirve para muchos tejidos que antes se limpiaban en seco. Cuatro factores fundamentales intervienen en la eliminación de la suciedad: temperatura, tiempo, acción mecánica y agentes químicos. Sólo mediante la combinación adecuada de estos factores se logran los mejores resultados de limpieza (Vasquez 1995). Existen pequeñas variaciones en la limpieza en húmedo mediante maquinaria, pero todas las técnicas utilizan lo siguiente:

- detergentes y agentes quitamanchas especialmente formulados para la limpieza en húmedo;

- una mayor extracción de agua previa al secado (velocidades de extracción de hasta aproximadamente 1.000 revoluciones por minuto);

- control riguroso de la temperatura y el contenido de humedad durante el proceso de secado,

- durante el lavado, la acción mecánica de las máquinas es menor y se logra mediante la reducción de la velocidad y el establecimiento de límites de tiempo.

Las prendas se lavan con varios niveles de acción mecánica limitada, basados en el tipo de prenda y el grado de suciedad. El secado es lo que más riesgo entraña. Muchas fibras pueden secarse completamente sin ninguna dificultad; ahora bien, las prendas delicadas o las que encogen deben secarse durante sólo algunos minutos y acto seguido, dejarlas secar al aire. Debido a estos problemas, la mayoría de las prendas lavadas en húmedo requieren un trabajo final mayor que las prendas limpiadas con disolventes. Los largos períodos de secado y el trabajo final adicional aumentan notablemente el tiempo de proceso (Earnest y Spencer 1996).

En la actualidad, el uso de la limpieza en húmedo es limitado debido a que la tecnología no ha logrado eliminar completamente la necesidad de disolventes. Se calcula que la limpieza en húmedo permite limpiar con seguridad aproximadamente entre un 30 y un $70 \%$ de las prendas tradicionalmente limpiadas en seco (Rice y Weinberg 1994). Aún existen problemas relacionados con los daños a las fibras, la decoloración y, aún más importante, la eficacia de la limpieza. El uso inadecuado de la limpieza en húmedo puede exponer a los propietarios de los negocios a asumir responsabilidades por las prendas dañadas. Por este motivo, quienes apoyan la limpieza en seco intentan persuadir a los fabricantes de ropa para que utilicen tejidos que se limpien mejor en húmedo.

\section{Riesgos en las lavanderías y las tintorerías}

\section{Riesgos asociados con el PERC}

En el lugar de trabajo, el PERC puede entrar al organismo humano a través de la exposición respiratoria y dérmica (ATSDR 1995). Los síntomas asociados con la exposición respiratoria son: depresión del sistema nervioso, daño hepático y renal (RSG 1986); problemas de memoria, confusión, mareos, cefaleas, somnolencia e irritación de ojos, nariz y garganta. La exposición dérmica repetida puede producir dermatitis con sequedad, fisuras y descamación (NIOSH 1977).

Los estudios realizados en EE.UU. por el National Cancer Institute y el National Toxicology Program han establecido una asociación entre la exposición al PERC y el cáncer en animales. De los estudios en humanos se infiere un mayor riesgo de cáncer de las vías urinarias (Duh y Asal 1984; Blair y cols. 1990b; Katz y Jowett 1981), de esófago (Duh y Asal 1984; Ruder, Ward y Brown 1994) y de páncreas (Lin y Kessler 1981) entre los trabajadores de tintorerías. La Agencia Internacional para la Investigación sobre el Cáncer (IARC) clasificó recientemente el PERG en el grupo 2A (probablemente cancerígeno para el hombre) y la limpieza en seco en el grupo 2B (posiblemente cancerígena para el hombre) (IARC 1995b). La Agencia de Protección para el Medio Ambiente (EPA) clasifica el PERC como un contaminante atmosférico peligroso.

Los datos de la Administración para la Salud y la Seguridad en el Trabajo de Estados Unidos (OSHA) incluyen numerosas muestras de tintorerías que superan el límite de exposición permisible (PEL) de 100 ppm, de concentración media ponderada (TWA) en 8 horas (OSHA 1993). El operador de la máquina es el más expuesto, por lo común, a las mayores concentraciones de PERC. Los estudios del Instituto Nacional para la Salud y la Seguridad en el Trabajo (NIOSH) de EE. UU. revelan que muchas tintorerías tienen máquinas tradicionales y una exposición de los operadores sumamente elevada durante la carga y la descarga. Debido a que estas operaciones se realizan frecuentemente durante todo el día, en muchos casos la exposición sólo por esta actividad puede representar entre el 50 y el $75 \%$ de la TWA para el operador (Earnest 1996). La exposición profesional se puede reducir mediante el uso de máquinas de limpieza en seco modernas, la sustitución de los disolventes, el aislamiento de los procesos y una ventilación local y general eficaz cerca de las máquinas de limpieza en seco.

\section{Exposición a otros productos químicos además del PERC}

En las lavanderías y establecimientos de limpieza en seco existe una amplia variedad de productos químicos. Existe un riesgo potencial de exposición por contacto con la piel o los ojos o por la inhalación de vapores. También pueden producirse lesiones en la 
piel por la exposición aguda o crónica. Los productos químicos que se evaporan rápidamente y tienen un alto índice de toxicidad suponen un riesgo potencial de inhalación, aunque este riesgo se considera generalmente menos grave que las lesiones oculares o cutáneas. Los productos químicos utilizados habitualmente en Estados Unidos como quitamanchas son: tricloroetileno, cetonas sobre todo, la metilisobutil cetona (MIBK), la nafta de petróleo y el ácido fluorhídrico. Los oxidantes, como los blanqueadores a base de cloro, pueden representar un riesgo si se utilizan en presencia de muchos compuestos comunes, como la trementina, el amoníaco o los gases de combustibles. Los detergentes que contienen enzimas pueden causar reacciones inmunes en muchos trabajadores. La exposición conjunta del disolvente de limpieza en seco, PERG, y otros productos químicos también entraña riesgos.

\section{Factores de riesgo ergonómicos}

Los riesgos ergonómicos en el sector de las lavanderías se relacionan principalmente con el planchado. Es una tarea dinámica y repetitiva que requiere estiramientos, sujeciones precisas y posturas poco naturales. Los factores de riesgo ergonómicos también están presentes durante la manipulación del material, cuando puede ser necesario levantar pesos considerables, sobre todo en las lavanderías comerciales.

\section{Riesgo de incendio}

Tradicionalmente, el sector de la limpieza en seco ha tenido problemas con los incendios, debidos en parte al uso de líquidos inflamables y combustibles como agentes limpiadores. La inflamabilidad de los disolventes derivados del petróleo sigue siendo un riesgo agudo de salud y seguridad. Aproximadamente un $10 \%$ de las tintorerías de Estados Unidos utilizan disolventes tradicionales derivados del petróleo, como el disolvente de Stoddard o disolventes minerales. Incluso las tintorerías que utilizan PERG no inflamable tienen un riesgo importante de incendio. Si se calienta lo suficiente, el PERC puede descomponerse en ácido clorhídrico y gases de fosgeno. La producción de cianuro de hidrógeno o monóxido de carbono es otro motivo de preocupación durante un incendio. El cianuro de hidrógeno se produce cuando se queman materiales que contienen nitrógeno, como es el caso de muchas fibras naturales y sintéticas. El monóxido de carbono se forma durante la combustión incompleta. Todas las tintorerías tienen numerosos combustibles y fuentes de ignición potenciales.

Los diseñadores de la maquinaria para la limpieza en seco deben evitar las situaciones que puedan provocar incendios y cerciorarse de que las máquinas funcionen de forma segura. Asimismo, los propietarios de las tintorerías deben adoptar las medidas necesarias para evitar las situaciones de riesgo. Algunas de las causas de incendio más frecuentes en todos los sectores son los fallos eléctricos, la fricción, las llamas, las chispas, la electricidad estática, las superficies calientes y el fumar (NIOSH 1975).

\section{Quemaduras}

Las instalaciones de limpieza tienen varias fuentes posibles de quemaduras graves. Durante el planchado pueden producirse quemaduras por contacto con la cabecera de la plancha, con las líneas por donde discurre el vapor o con el propio vapor. El aislamiento de las conducciones y las superficies y el uso de diversas técnicas de protección ayuda a evitar las quemaduras.

A pesar de que las calderas modernas tienen un diseño más seguro que los modelos anteriores, aún se utilizan para producir grandes cantidades de vapor y deben funcionar de forma segura. Muchas de las precauciones necesarias se encuentran en el código 32, Normativa para las plantas de limpieza en seco, de la
National Fire Protection Association de EE.UU. y en su publicación Fire Protection Handbook (NFPA 1991). Entre las recomendaciones que contienen estos documentos están los requisitos de códigos de construcción, el almacenamiento adecuado y el aislamiento de los productos inflamables, la disponibilidad de extintores y mangueras para incendios. Las recomendaciones relacionadas con la acumulación de gases alrededor de la caldera proponen formas para eliminar las fugas de gas y garantizar una ventilación adecuada.

\section{Riesgos mecánicos}

Los riesgos mecánicos son siempre un motivo de preocupación cuando se utilizan equipos accionados por motor. Las planchas representan un riesgo mecánico importante. Las planchas diseñadas para activarse con una sola mano dejan al operador una mano libre que puede quedar atrapada por la plancha. Las correas, las cadenas de transmisión, los ejes y las conexiones deben estar protegidas para evitar el contacto accidental. Todos los componentes móviles de las máquinas deben estar protegidos para evitar que alguna parte del cuerpo se enganche con un pincho, saliente o punto cortante. El método más común de evitar riesgos es realizando las operaciones en espacios cerrados, fijando los dispositivos, utilizando barreras móviles, dispositivos de eliminación, controles remotos, dispositivos en los que se utilicen las dos manos y dispositivos electrónicos de seguridad.

\section{Riesgos eléctricos}

Son muchas las medidas que pueden adoptarse para limitar los riesgos eléctricos. El aislamiento y las conexiones a tierra adecuados son especialmente importantes. La identificación y protección de las zonas con corriente viva también ayudan a prevenir daños por descargas eléctricas. Los riesgos eléctricos pueden incrementarse si hay humedad. Los interruptores de circuito de pérdida a tierra están diseñados para cortar la corriente si se detecta el paso de alta corriente a través de una vía no prevista. Al seleccionar el equipo eléctrico, deben seguirse las recomendaciones de los códigos y normas establecidos, como el código 70 de la National Fire Protection Association de EE.UU., el Código eléctrico nacional y el código C2 del American National Standards Institute. De las directrices para el uso apropiado de los equipos eléctricos se ocupa otro capítulo de esta Enciclopedia.

\section{Estrés por calor}

El estrés por calor puede afectar a los trabajadores que deben permanecer durante períodos prolongados en los ambientes cálidos que existen en muchos establecimientos de limpieza. El estrés por calor puede aumentar en los meses de verano, sobre todo si el establecimiento no cuenta con aire acondicionado (algo habitual en este sector). Tanto los factores físicos como ambientales pueden modificar los efectos del calor. La falta de climatización, la relación entre la superficie corporal y el peso, la edad y las enfermedades, el equilibrio entre agua y sales y la capacidad física para el trabajo tienen su peso en la probabilidad de que un individuo resulte afectado por el estrés por calor.

\section{Resbalones, tropezones y caídas}

El riesgo de resbalones, tropezones y caídas es muy acentuado en el caso de los establecimientos de limpieza, con frecuencia llenos de gente y equipos. Al no existir pasillos claramente definidos y debido al gran número de recipientes que contienen agua o disolventes, es frecuente que ocurran derrames y que el suelo esté resbaladizo. Para controlar este riesgo, debe insistirse en la regularidad de las limpiezas, planificarse adecuadamente el diseño del local y disponerse de un suelo antideslizante. El lugar de trabajo ha de mantenerse limpio, ordenado y con buenas condiciones de 
higiene, y si se derrama algún producto se limpiará lo antes posible.

\section{Riesgos biológicos}

Las personas que clasifican la ropa blanca de los hospitales en las lavanderías corren el riesgo de herirse con algún objeto cortante olvidado entre las sábanas o en los bolsillos de los uniformes. Algunas veces, el personal de las lavanderías y las tintorerías se encuentra con prendas manchadas recientemente con líquidos corporales humanos contaminados. Las prendas que proceden de consultorios o laboratorios médicos o dentales, bancos de sangre, centros de tratamiento de drogodependencias, clínicas, tanatorios, ambulancias y otras dependencias de asistencia sanitaria pueden considerarse, por sentido común, como materiales potencialmente infecciosos. En muchos países, los establecimientos que manipulan las prendas de estas procedencias deben cumplir ciertas normas industriales relacionadas con la exposición, como las normativas de la OSHA sobre los patógenos transportados por la sangre.

\section{Riesgos ambientales y de salud pública}

Los riesgos ambientales y de salud pública han producido en los últimos años cambios notables en las normativas ambientales que afectan al sector de la limpieza en seco. Los apartamentos y locales comerciales contiguos pueden estar expuestos a los vapores de PERC por difusión a través de las paredes o los techos; a través de las aberturas de entrada de aire en los techos, los huecos para el paso de las tuberías o las salidas de humos, y a través de las emisiones de PERG al exterior que entran de nuevo al inmueble a través de las ventanas abiertas o de los sistemas de ventilación. Los derrames frecuentes o masivos que se producen durante el traslado de los disolventes del camión de reparto a la máquina de limpieza en seco pueden contaminar la tierra o el agua subterránea. La contaminación del suelo también es posible por la eliminación inadecuada del agua del separador al drenaje. Por último, los consumidores también están expuestos a residuos de PERG en las prendas que no se hayan secado adecuadamente. Hay que tener esto en cuenta, sobre todo si la máquina de lavado no funciona correctamente o si se acorta el ciclo de secado para aumentar la productividad.

Agradecimiento: la mayor parte de este artículo se basa en los materiales recopilados y publicados por el Instituto Nacional para la Salud y la Seguridad en el Trabajo (NIOSH) de EE.UU.

\section{- SERVICIOS FUNERARIOS}

Mary O. Brophy y Jonathan T. Haney

\section{Visión general}

Si se considera que la población mundial es de 5.000 millones de personas, todos los días mueren entre un cuarto y medio millón de ellas. Aunque muchas son niños, antes o después, todo el que nace ha de morir. A pesar de la diversidad de creencias culturales y religiosas que rodean a la muerte, es necesario eliminar los restos corporales de las personas. En general, los dos métodos principales para ello son el entierro y la cremación. Ambos se han aplicado a los restos humanos sin tratamiento previo. Muchas culturas, sin embargo, practican ritos funerarios que indican un cierto tratamiento del cadáver. Los ritos más sencillos consisten en lavar la superficie externa con hierbas y especias para retrasar o enmascarar el inicio de la descomposición y el olor asociado con el tejido muerto. Otros ritos más sofisticados incluyen procedimientos invasivos, como el embalsamamiento y la extracción de los órganos internos. Durante el embalsamamiento suele sustituirse la sangre por un líquido especial o conservante. La egipcia fue una de las primeras culturas que desarrolló y practicó el embalsamamiento de los muertos, práctica muy empleada en el siglo XX en Europa occidental y América del Norte. Tras el embalsamamiento se puede realizar el entierro o la cremación. Fuera de Europa occidental y América del Norte, el entierro o la cremación no suelen ir precedidos por el embalsamamiento.

\section{Procesos funerarios}

La preparación y entierro de un difunto comprende numerosas tareas, como:

- el lavado de la superficie del cuerpo con varios preparados;

- vestido del cuerpo con una mortaja;

- la autopsia, en algunas circunstancias, que conlleva procedimientos intrusivos, como la disección y el análisis de la sangre y los tejidos corporales;

- el embalsamamiento y la extracción de los órganos internos;

- la aplicación de cosméticos para disimular el daño visible si el cuerpo se va a exponer;

- el transporte del cuerpo al lugar del entierro o cremación;

- el transporte del cuerpo y del ataúd y su colocación en la sepultura;

- cavado y rellenado de la sepultura,

- la posible exhumación del cuerpo y su autopsia posterior.

Siempre existen tres tipos de riesgo asociados con la manipulación de cadáveres: infecciosos, psicológicos y ergonómicos. Si se realiza el embalsamamiento, existe, además, un cuarto riesgo: la exposición química. En muchos Estados de Estados Unidos las leyes establecen que el cuerpo debe ser embalsamado si se va a exponer en un ataúd abierto.

\section{Riesgos de infección}

La muerte sobreviene con frecuencia debido a alguna enfermedad. Después de la muerte, los gérmenes que causaron la enfermedad pueden seguir viviendo en el cuerpo del difunto e infectar a las personas que lo manipulen. Algunas enfermedades contagiosas, como la peste y la viruela, se extendieron debido al manejo inadecuado de las víctimas de las mismas. Se debe considerar la vía de exposición al evaluar los riesgos de contagio asociados con la manipulación de cadáveres. Muchas enfermedades se transmiten al tocar una fuente de contaminación e introducir posteriormente el microorganismo o patógeno que causa la enfermedad a través de las mucosas al frotarse los ojos o la nariz, o si se ingiere el patógeno. Algunas enfermedades pueden contraerse por la simple inhalación del patógeno, riesgo especial durante la exhumación, cuando los restos están secos o durante las operaciones en las que pasan al aire en forma de partículas diminutas ciertas partes del cuerpo humano, como por ejemplo, al serrar el hueso de un difunto. El contagio de enfermedades se favorece cuando se utilizan instrumentos punzantes o cortantes durante los ritos funerarios, ya que estas prácticas introducen la posibilidad de exposición parenteral.

Los riesgos microbianos pueden clasificarse de muy distintas formas: por el tipo de microorganismo que causa la enfermedad, el tipo de enfermedad, su gravedad y la vía de contagio. Quizá la forma más útil de tratar los riesgos de contagio de los trabajadores de las funerarias es por la vía de infección: por inhalación, por contacto o parenteral, por punción de la superficie corporal.

La ingestión, como vía de exposición, puede controlarse mediante una higiene personal adecuada, es decir, lavándose las manos siempre antes de beber o fumar y manteniendo los alimentos, bebidas o cualquier objeto que se lleve a la boca (como los cigarrillos) fuera de las áreas de posible contaminación. Es asimismo importante para controlar la exposición química. Si a la apropiada higiene personal se añade la 
utilización de guantes impermeables para manipular los cuerpos, la probabilidad de infección se reduce.

La exposición por inhalación sólo tiene lugar cuando los microorganismos que causan la enfermedad pasan al ambiente. En el caso de los trabajadores de las funerarias, las dos formas principales por las que esto ocurre es en las operaciones de exhumación y de autopsia, cuando se utiliza una sierra para cortar el hueso. La tercera posibilidad de que los patógenos, por ejemplo, la tuberculosis, se dispersen en el ambiente es al expulsar el aire de los pulmones de un cuerpo durante la manipulación. A pesar de que entre las epidemias del pasado se cuentan la peste, el cólera, el tifus, la tuberculosis, el ántrax y la viruela, sólo los microorganismos que causan estas dos últimas enfermedades parecen ser capaces de sobrevivir durante algún tiempo después del entierro (Healing, Hoffman y Young 1995). Estos patógenos podrían encontrarse en cualquiera de los tejidos blandos, no en los huesos, y sobre todo en los tejidos blandos momificados o secos y, por lo tanto, que pueden deshacerse. La bacteria del ántrax puede formar esporas que siguen siendo activas durante largos períodos, especialmente si no existe humedad. Por microscopía electrónica, se han identificado los pequeños virus de la viruela intactos en tejidos de cuerpos enterrados en 1850. Ninguno de estos virus fue capaz de desarrollarse en un cultivo de tejidos y se consideraron no infecciosos (Baxter, Brazier y Young 1988). Sin embargo, los virus de la viruela conservan su capacidad infecciosa después de 13 años de conservación en seco en condiciones de laboratorio (Wolff y Croon 1968). En un artículo publicado en la revista Fournal of Public Health (RU) en el decenio de 1850 se explicaba la capacidad infecciosa de la viruela en restos enterrados doscientos años antes en Montreal, cuando se extendió esta enfermedad en el Nuevo Mundo (Sly 1994).

Tal vez la fuente más probable de exposición por inhalación durante la exhumación sean las esporas de hongos. Siempre que se manipula un material antiguo de cualquier tipo, debe utilizarse protección contra la inhalación de esporas. Los respiradores con filtros de aire particulado de alta eficacia (HEPA), elaborados principalmente como protección contra la tuberculosis y el polvo de plomo, son bastante eficaces también contra las esporas de hongos. Además de los problemas de microorganismos, es necesario evaluar la exposición al polvo de madera o plomo antes de realizar la exhumación.

La vía principal de infección de la tuberculosis es la inhalación. La incidencia de esta enfermedad ha aumentado durante el último cuarto del siglo XX, sobre todo debido a la menor vigilancia de la salud pública y a la aparición de cepas bacterianas resistentes a varios grupos de antibióticos. Un estudio reciente realizado en la Escuela de Salud Pública de la Universidad Johns Hopkins (Baltimore, Maryland, EE.UU.) indica que el 18,8\% de los embalsamadores dan resultados positivos en las pruebas dérmicas de tuberculina. Sólo con el 6,8 \% de las personas que trabajaban en los servicios funerarios, pero que no eran embalsamadores, se obtuvieron resultados positivos con la misma prueba. Este bajo nivel de reactividad es similar al de la población general (Gershon y Karkashion 1996).

Los virus de la hepatitis B (VHB) y de la inmunodeficiencia humana (VIH) son infecciosos si entran en contacto con las membranas mucosas o si entran al torrente sanguíneo a través de un corte o una herida. Un estudio realizado con empleados de servicios funerarios en Maryland indicó que el $10 \%$ habían tenido una exposición a través de las membranas mucosas en los 6 meses previos y el $15 \%$ habían tenido alguna herida con aguja en el mismo período (Gershon y cols. 1995). En otros estudios realizados en EE.UU. se describen heridas con agujas en un 39 a un $53 \%$ de los empleados de servicios funerarios en un período de 12 meses (Nwanyanwu, Tubasuri y Harris 1989). En Estados
Unidos, la prevalencia del VHB es de entre 7,5 y 12,0\% en los directores de funerarias no vacunados, y de 2,6\% o menos en los empleados de funerarias vacunados. La tasa de vacunación descrita varía entre el 19 y el $60 \%$ de los empleados de funerarias en Estados Unidos. En el caso, del VIH, a diferencia del VHB, no existe actualmente una vacuna.

El VIH y el VHB sólo son infecciosos cuando el virus entra en contacto con las membranas mucosas o se introduce en el torrente sanguíneo de otra persona. El virus no se absorbe a través de la piel intacta. Las membranas mucosas pueden ser la boca, la nariz y los ojos. Estos virus pueden entrar a la sangre a través de un corte o abrasión de la piel, o cuando se perfora o se corta la piel con un instrumento contaminado con el virus. Las manos cuarteadas por sequedad o los padrastros pueden permitir la entrada de estos virus. Así, para evitar la transmisión de estas enfermedades es importante contar con una barrera impermeable a los líquidos corporales, evitar la salpicadura de líquidos contaminados en los ojos, la nariz y la boca y evitar pinchazos o cortes con instrumentos contaminados con VIH o VHB. El uso de guantes de látex y protectores faciales puede constituir una protección suficiente. Con todo, los guantes de látex tienen una duración limitada en función de la cantidad de luz y calor a la que hayan estado expuestos. En general, el látex debe someterse a pruebas de resistencia si se ha almacenado durante más de un año. Estas pruebas consisten en llenar el guante de agua y observar si existe alguna fuga durante un tiempo mínimo de dos minutos. En algunos países occidentales, como Estados Unidos y Gran Bretaña, se ha adoptado el principio de las precauciones universales, lo que significa que todos los cuerpos se tratan como si estuvieran infectados con VIH y VHB.

\section{Riesgos psicológicos}

En muchas culturas es la familia del difunto la que prepara el cuerpo para el entierro o la cremación; en otras, hay personas dedicadas a estas funciones. Existe un efecto psicológico en los humanos cuando están en contacto con personas muertas. El efecto psicológico es real, con independencia de los procedimientos utilizados en los ritos funerarios. La identificación y evaluación de los efectos que tienen los ritos funerarios sobre las personas que los realizan ha despertado interés recientemente.

A pesar de que los riesgos psicológicos de trabajar en una empresa de servicios funerarios no se han estudiado con detalle, los efectos psicológicos de manipular los restos humanos procedentes de una muerte traumática se han analizado recientemente. Los efectos psicológicos más importantes parecen ser la ansiedad, la depresión y la somatización (la tendencia a manifestar síntomas físicos), además de irritabilidad, trastornos del apetito y del sueño y aumento en el consumo de alcohol (Ursano y cols. 1995). En bastantes personas que han manipulado a víctimas de muertes traumáticas se ha observado trastorno por estrés postraumático (TEPT). Inmediatamente después de un accidente en el que los trabajadores de rescate manipularon restos humanos, entre el 20 y el $40 \%$ de ellos pasaron a formar parte de una categoría de alto riesgo, de acuerdo con las pruebas psicológicas realizadas, aunque sólo se diagnosticó TEPT a un $10 \%$ de los trabajadores. Los efectos psicológicos aún se detectaban un año después del accidente, aunque con una incidencia mucho menor. No obstante, se han observado efectos psicológicos adversos en algunas personas varios años después del suceso traumático.

Muchos de estos estudios se realizaron con militares, y de ellos se deduce que las tasas de estrés generalizado son mayores en los individuos no experimentados que no son voluntarios y que los indicadores de estrés continúan altos hasta que no transcurre un año del incidente traumático. La empatía o la identificación del 
trabajador de la funeraria con la persona fallecida parece estar asociada con un mayor nivel de estrés psicológico (McCarroll y cols. 1993; McCarroll y cols. 1995).

En un estudio se evaluaron las causas de la muerte de 4.046 embalsamadores y directores de servicios funerarios en Estados Unidos entre 1975 y 1985 y se observó una tasa de mortalidad proporcional (TMP) por suicidio de 130. La TMP es una relación entre el número real de suicidios entre los embalsamadores y directores de funerarias y el número de suicidios que se esperaría en un grupo de individuos de otras profesiones con edad, raza y sexo equivalentes. La relación se multiplica después por 100. El objetivo de este estudio fue evaluar el riesgo de cáncer en los empleados de servicios funerarios y, por lo tanto, no se profundizó en los resultados estadísticos sobre el suicidio.

\section{Ergonomía}

El cadáver de un adulto es pesado y generalmente debe ser trasladado al lugar del entierro o la cremación. Aún utilizando medios de transporte mecánicos, un cuerpo muerto debe transportarse del lugar de la muerte al vehículo y de éste al lugar del entierro o la cremación. Por respeto al difunto, esta labor suelen realizarla personas.

Durante la preparación del cuerpo y el entierro, los empleados de los servicios funerarios deben trasladar el cadáver un gran número de veces. Aunque no se han encontrado estudios sobre este tema, el dolor y las lesiones lumbares se asocian con el levantamiento repetitivo y prolongado de objetos pesados. Existen dispositivos que pueden ser de utilidad en este tipo de tareas.

\section{Riesgos químicos}

Los procedimientos de embalsamamiento emplean varios productos químicos potentes en el espacio de trabajo de los empleados de servicios funerarios. De ellos, tal vez sea el formaldehído el más utilizado y el más tóxico: es irritante para las membranas mucosas, los ojos, las membranas nasales y el aparato respiratorio y se ha asociado con cambios celulares mutagénicos y con el desarrollo de cáncer, así como con asma de origen profesional. Durante las últimas décadas, se ha reducido continuamente el nivel de exposición profesional asociado con una ausencia de efectos adversos. La media ponderada en 8 horas del límite de exposición varía entre 0,5 ppm en Alemania, Japón, Noruega, Suecia y Suiza y $5 \mathrm{ppm}$ en Egipto y Taiwan (IARC 1995c). Se han notificado niveles de formaldehído de entre 0,15 y 4,3 ppm, con niveles instantáneos de hasta 6,6 ppm, en embalsamamientos individuales. Un embalsamamiento dura por lo común entre 1 y 2 horas. La exposición adicional al formaldehído está asociada con la aplicación de cremas de embalsamamiento y la aplicación de polvos secadores y endurecedores, y con los derrames.

Las ratas expuestas de manera crónica a 6-15 ppm de formaldehído (Albert y cols. 1982; Kerns y cols. 1982; Tobe y cols. 1985) o reiterada a 20 ppm por períodos de 15 minutos (Feron y cols. 1988), han desarrollado carcinomas nasales (Hayes y cols. 1990). Los informes de la IARC aportan pruebas epidemiológicas limitadas de una asociación entre la exposición industrial al formaldehído y el desarrollo de cáncer nasal y de faringe en humanos (Olsen y Asnaes 1986; Hayes y cols. 1986; Roush y cols. 1987; Vaughan y cols. 1986; Blair y cols. 1986; Stayner y cols. 1988). Ahora bien, en varios estudios con trabajadores de servicios funerarios se observa una mayor incidencia de leucemia y tumores cerebrales (Levine, Andjelkovich y Shaw 1984; Walrath y Fraumeni 1983). Aparte de los efectos cancerígenos, el formaldehído es irritante para las membranas mucosas y se considera un sensibilizante fuerte para el desarrollo del asma de nueva aparición en adultos. Los mecanismos por los que el formaldehído causa asma se conocen pero menos que los que producen cáncer.

Otros productos químicos potencialmente tóxicos utilizados en las soluciones de embalsamamiento son el fenol, el metanol, el alcohol isopropílico y el glutaraldehído (Hayes y cols. 1990). Este último parece ser incluso más irritante que el formaldehído para las membranas mucosas y afecta al sistema nervioso central a concentraciones superiores a $500 \mathrm{ppm}$. El metanol afecta asimismo al sistema nervioso y, sobre todo, al sistema visual. El fenol parece afectar al sistema nervioso, a los pulmones, al corazón, al hígado y a los riñones y se absorbe rápidamente a través de la piel. Nuestros conocimientos de toxicología y nuestra capacidad de evaluar el riesgo derivado de la exposición simultánea a varios productos químicos no son suficientes para analizar los efectos fisiológicos de las mezclas a las que están expuestos los embalsamadores y los directores de los servicios funerarios. Blair y cols. (1990a) consideraron que la elevada incidencia de la leucemia y los tumores cerebrales observada en los trabajadores profesionales (aunque no en los de la industria), era resultado de la exposición a productos que no eran el formaldehído.

Los avances recientes en el diseño de mesas de disección indica que la aspiración invertida local de los vapores reduce sustancialmente la exposición de las personas que trabajan en las proximidades (Coleman 1995). El uso de guantes para realizar las operaciones que requieren el contacto de la piel con los líquidos y cremas de embalsamamiento reduce también el riesgo. Existe una cierta preocupación, sin embargo, porque algunos de los guantes de látex comerciales puedan ser permeables al formaldehído. Por este motivo, los guantes de protección deben seleccionarse cuidadosamente. Además de la preocupación inmediata por el riesgo de la exposición al formaldehído, existen cada vez más pruebas de que las filtraciones en los cementerios pueden arrastrar el formaldehído y contaminar las aguas subterráneas.

La exhumación de cadáveres supone asimismo un riesgo de exposición a sustancias químicas. A pesar de que su uso durante siglos ha sido esporádico, durante los siglos XVIII y XIX se acostumbraba revestir los ataúdes con plomo. La inhalación de polvo de madera se ha asociado con problemas respiratorios y el polvo de madera contaminada con hongos entraña un doble riesgo. Antiguamente se utilizaban también compuestos de arsénico y mercurio como conservantes, lo que representaba un riesgo durante la exhumación.

\section{EMPLEADOS DEL HOGAR}

Angela Babin

\section{Visión general}

El trabajo doméstico consiste en realizar labores para otra familia en el domicilio de esta última. El término empleado del hogar no debe confundirse con el de ama de casa, que se refiere a quien realiza las tareas de su propia casa, o con el de encargado de limpieza y mantenimiento, que trabaja en instituciones como hospitales o colegios. El empleo doméstico representa un ambiente de trabajo único y, con frecuencia, aislado. La posición del empleado doméstico siempre se considera inferior a la de la familia para la que trabaja. Antiguamente, el trabajo doméstico lo realizaban esclavos o siervos. Algunos de los términos utilizados actualmente para los trabajadores domésticos son: sirvienta, asistenta, mayordomo, au pair o niñera. A pesar de que los trabajadores 
domésticos pueden ser varones o mujeres, es más frecuente que sean mujeres quienes realizan estas labores y con frecuencia reciben salarios inferiores a los primeros. Los trabajadores domésticos suelen ser inmigrantes o miembros de minorías étnicas, nacionales o religiosas del país en el que están empleados.

Hay que distinguir entre los empleados domésticos "internos" de los que viven en su propia casa y acuden al lugar de trabajo. Los trabajadores internos se encuentran aislados de su propia familia y con frecuencia, también de su propio país de origen. En este último caso, los contratos laborales y los beneficios de seguridad social y de otro tipo suelen ser nulos. En ocasiones, el alojamiento se considera una parte del salario o incluso el pago completo por los servicios realizados. Se trata de una situación especialmente grave para los trabajadores extranjeros. A veces, los incumplimientos en cuanto al salario convenido, las bajas por enfermedad, los horarios de trabajo, la paga por vacaciones y la regulación de los horarios y las funciones del trabajo ni siquiera pueden comentarse debido a que el trabajador no conoce adecuadamente el idioma y carece de un abogado o de un sindicato que lo apoyen, así como de un contrato de trabajo y de dinero que le permita salir de una situación peligrosa (Anderson 1993; OIT 1989). Los empleados del hogar no tienen derecho a prestaciones, no tienen a quién acudir para denunciar los incumplimientos y con frecuencia carecen de posibilidades de abandonar el empleo.

Los lugares en los que más se emplea a los trabajadores domésticos son: Gran Bretaña, el Golfo Pérsico y los Países Árabes, Grecia, Hong Kong, Italia, Nigeria, Singapur y Estados Unidos. Los trabajadores domésticos en estos países proceden, en su mayoría, de países como Bangladesh, Brasil, Colombia, Etiopía, Eritrea, India, Indonesia, Marruecos, Nepal, Nigeria, Filipinas, Sierra Leona y Sri Lanka (Anderson 1993). En Estados Unidos, muchos trabajadores domésticos son inmigrantes de América Central, América Latina y las islas del Caribe. Los trabajadores domésticos son en ocasiones inmigrantes ilegales o con visados limitados, por lo que no tienen acceso a los servicios sociales básicos con los que cuentan otros trabajadores.

\section{Tareas generales}

Las tareas que realizan los trabajadores domésticos pueden ser:

- Trabajo en la cocina: comprar, cocinar y preparar los alimentos, servir y recoger la mesa y fregar y guardar la vajilla y los utensilios de cocina.

- Limpieza y mantenimiento de la casa: cuidar del mobiliario y la decoración, fregar los platos, limpiar la plata y la casa, incluidos baños, suelos, paredes, ventanas y, en ocasiones, limpiar también las dependencias anexas, como los cuartos de los invitados, el garaje y los cobertizos.

- Cuidado de la ropa: lavar, tender y planchar la ropa, y en ocasiones, coserla y llevarla a la tintorería y recogerla.

- Guidado de los niños y los ancianos: cuidar a los niños, cambiarles los pañales o vestirlos, bañarlos, supervisar sus comidas y actividades, llevarlos al colegio y recogerlos a la salida. Los trabajadores domésticos realizan también actividades relacionadas con el cuidado de los ancianos, como supervisarlos, bañarlos, hacerles compañía, acompañarlos al médico y tareas médicas sencillas.

\section{Riesgos y precauciones}

En general, la intensidad de los riesgos asociados con el trabajo de los empleados internos es mucho mayor que el de los trabajadores que se desplazan diariamente al lugar de trabajo.

\section{Riesgos físicos}

Algunos de los riesgos físicos son: largas jornadas de trabajo, tiempo de descanso insuficiente y, en ocasiones, comida insuficiente, exposición al agua caliente y fría, exposición al ambiente caluroso de la cocina, problemas musculosqueléticos, sobre todo de la espalda y la columna, originados por cargar a los niños, mover los muebles y arrodillarse para limpiar el suelo. Las lesiones asociadas con la llamada "rodilla de sirvienta" se han equiparado con las de la "rodilla del colocador de moquetas". A pesar de que la mecanización de ciertos procesos de abrillantado y encerado de suelos han reducido el trabajo que requería arrodillarse, muchos trabajadores lo siguen realizando aún, casi siempre sin ningún tipo de protección (Tanaka y cols. 1982; Turnbull y cols. 1992).

Las precauciones comprenden: limitar el horario de trabajo, proporcionar el tiempo necesario para el descanso y las comidas, utilizar guantes para las actividades de limpieza en las que se emplee agua, formación sobre las técnicas adecuadas para levantar objetos, usar aparatos mecanizados para la limpieza y abrillantado de los suelos, con el fin de minimizar el tiempo que el trabajador debe estar de rodillas y emplear protectores de rodillas para las tareas ocasionales.

\section{Riesgos químicos}

Durante las tareas de limpieza, los trabajadores domésticos pueden estar expuestos a diversos ácidos, álcalis, disolventes y otros productos químicos que pueden causar dermatitis (véase también "Servicios de limpieza en interiores", en este mismo capítulo). Las dermatitis pueden exacerbarse por la inmersión de las manos en agua caliente o fría (Scolari y Gardenghi 1966). Los trabajadores domésticos en ocasiones no conocen adecuadamente los materiales que emplean ni la forma de utilizarlos con seguridad. No existe una formación apropiada sobre el manejo o los riesgos que entrañan esos productos. Por ejemplo, se notificó un caso de intoxicación grave en un trabajador que utilizaba polvo de carbonato de cadmio para limpiar la plata. El trabajador utilizó el producto durante un día y medio y presentó dolores abdominales, opresión de la garganta, vómitos y bajo pulso. La recuperación duró 24 días (Sovet 1958).

Muchos de los productos utilizados o manipulados por los trabajadores domésticos son alergenos conocidos. Entre ellos están los guantes de goma natural, las plantas de interior, las ceras y productos de abrillantado, los detergentes, las cremas de manos, los antisépticos y las impurezas en los detergentes y blanqueadores. Las dermatitis irritantes pueden ser precursoras de dermatitis alérgicas por contacto en estos trabajadores y con frecuencia comienzan con el desarrollo de parches eritematosos en el dorso de las manos (Foussereau y cols. 1982). La inhalación de disolventes, plaguicidas, polvo, mohos, etc. también puede ocasionar problemas respiratorios.

Las precauciones son: uso de productos de limpieza lo menos tóxicos posibles, formación en cuanto al manejo de los materiales y la seguridad de los distintos detergentes y productos de limpieza, así como sobre el uso de cremas y guantes protectores. La utilización de productos sin fragancias puede ser más recomendable para las personas susceptibles a las alergias (Foussereau y cols. 1982).

\section{Riesgos biológicos}

Los trabajadores domésticos encargados de cuidar a niños pequeños son los que tienen el mayor riesgo de contagiarse con distintas enfermedades, sobre todo al cambiar los pañales y al entrar en contacto con alimentos y agua contaminada. Las precauciones son lavarse cuidadosamente las manos después de cambiar y manipular los pañales sucios, desecharlos de forma correcta y manipular los alimentos con la higiene adecuada. 


\section{Riesgos psicológicos y de estrés}

Algunos riesgos psicológicos y de estrés están relacionados con el aislamiento de la familia y la comunidad en la que viven los empleados domésticos, la falta de vacaciones pagadas o de compensación por bajas debidas a enfermedad o maternidad, la protección inadecuada de los salarios, las violaciones y los malos tratos físicos y mentales, los horarios demasiado extensos y, en general, la falta de beneficios o contratos. Los trabajadores internos están expuestos a un mayor número de riesgos, incluidos la violencia, el acoso, los malos tratos físicos y mentales y las violaciones (Anderson 1993).

En 1990, la embajada filipina en Singapur presentó un informe de ocho muertes: seis suicidios y dos asesinatos, de trabajadores domésticos filipinos en un plazo de seis meses. El suicidio está poco investigado y los informes publicados al respecto son escasos; sin embargo, la embajada de Filipinas informó de hasta 40 suicidios en un período de tiempo determinado (Gulati 1993).

En menor grado, los mismos riesgos son aplicables a los trabajadores domésticos "externos". En un estudio llevado a cabo en Ohio (Estados Unidos) sobre las demandas de indemnización presentadas por abusos sexuales entre 1983 y 1985, se observó que el $14 \%$ de las violaciones correspondían a camareras de moteles y empleadas domésticas (Seligman y cols. 1987).

La prevención de los abusos contra los trabajadores domésticos puede lograrse mediante una legislación que proteja a este gremio, indefenso en comparación con otros. En Estados Unidos, la contratación de inmigrantes ilegales como trabajadores domésticos era una práctica habitual hasta que se aprobó la ley de reforma y control de la inmigración de 1986. Esta ley aumentó las sanciones que podían imponerse a quienes contrataran a estos trabajadores. Ahora bien, en los países desarrollados la demanda de ayuda doméstica crece continuamente. En Estados Unidos, los trabajadores domésticos deben ganar al menos el salario mínimo y, si perciben más de 1.000 dólares anuales de una sola fuente, tienen derecho a prestaciones por desempleo y a seguridad social (Anderson 1993).

En otros países también se han adoptado medidas para proteger a estos trabajadores domésticos vulnerables. Canadá comenzó en 1981 el Programa de asistentes internos, que se modificó en 1992. Este programa incluye el reconocimiento de los inmigrantes empleados como trabajadores domésticos.

El reconocimiento de los trabajadores domésticos inmigrantes es el primer paso para poder abordar los problemas de salud y seguridad y su prevención. Una vez que se reconoce a estos trabajadores y sus dificultades, pueden abordarse y mejorarse las condiciones peligrosas de trabajo mediante normativas del gobierno, la creación de sindicatos y grupos de apoyo privados, y mediante iniciativas sanitarias dirigidas a las mujeres.

Efectos sobre la salud y pautas de enfermedad

Un estudio sobre los datos de mortalidad de 1.382 empleadas domésticas en la Columbia Británica (Canadá) reveló una mortalidad superior a la esperada por cirrosis hepática, muerte accidental por exposición, homicidio y accidentes de todo tipo combinados. El número de muertes por neumonía y cáncer del recto y ocular también fue superior al esperado. Los autores indican que uno de los principales factores responsables del elevado número de muertes por cirrosis hepática podría deberse a que muchas trabajadoras domésticas en la Columbia Británica proceden de Filipinas, donde la hepatitis B es una enfermedad endémica (McDougal y cols. 1992). Otros estudios señalan el alcoholismo como un posible factor. En la revisión de un estudio sobre mortalidad realizado en California (Estados Unidos), se observó una relación entre el aumento de la mortalidad por cirrosis en mujeres y las ocupaciones siguientes: empleada doméstica y sirvienta privada, camarera, asistentes de enfermería, celadoras y cuidadoras. Los autores concluyen que sus datos respaldan la relación entre estas profesiones y la mortalidad por cirrosis y, además, que la mayor mortalidad por cirrosis está asociada con los empleos de menor estatus y con aquellos en los que el alcohol es fácilmente accesible (Harford y Brooks 1992).

En su estudio de 1989 sobre las enfermedades de la piel de origen profesional, la British Association of Dermatologists observó que de 2.861 casos notificados $96 \%$ de los cuales correspondían a dermatitis por contacto), las actividades de "limpieza y tareas domésticas" ocupaban el segundo lugar como categoría profesional en el caso de las mujeres (8,4 \%) (Cherry, Beck y Owen-Smith 1994). Asimismo, en las respuestas positivas a las pruebas con parches dermatológicos realizadas a 6.818 pacientes, las profesiones más comunes en las mujeres fueron: empleada doméstica, empleada de oficina, empleada de limpieza, costurera y cosmetóloga. El trabajo doméstico estaba relacionado con 943 de las respuestas positivas a las pruebas con parches (Dooms-Goossens 1986).

Otros estudios señalan una asociación con alergias y enfermedades respiratorias. Se llevó a cabo una revisión sobre las enfermedades pulmonares alérgicas de origen profesional inducidas por sustancias químicas orgánicas y se observó que la categoría de trabajadores domésticos era una de las más afectadas por los alergenos respiratorios (Pepys 1986). En un estudio realizado en Suecia sobre la mortalidad debida al asma, se investigó a las mujeres incluidas en el censo nacional de empleo de 1960. Se calcularon los índices de mortalidad normalizados, corregidos por el tabaquismo, para cada profesión. Se observó una mayor mortalidad por asma entre los cuidadores, las criadas, las camareras y las empleadas de limpieza (Horte y Toren 1993).

Hay una falta de información estadística y sanitaria relacionada con los trabajadores domésticos, sobre todo en el caso de los inmigrantes extranjeros, quizá debido a que su situación es provisional e incluso ilegal en los países en los que trabajan. El reconocimiento por parte de las autoridades gubernamentales es lo único que permitirá una mayor investigación y protección de la salud de estos trabajadores. 


\section{Aspectos medioambientales}

Muchos de los procesos descritos en los artículos de este capítulo pueden generar residuos peligrosos como, por ejemplo, solventes, ácidos, álcalis, formaldehído, etc.

En la limpieza en seco, existe la preocupación de la contaminación del aire de los apartamentos que se encuentran sobre las tintorerías con los vapores de percloroetileno. Las instalación de maquinaria para la purificación y recuperación de los vapores de solvente, la centralización de la limpieza en seca (utilizando los establecimientos locales como puntos de recogida y entrega de prendas) y el desarrollo de métodos de limpieza en húmedo que minimicen el uso de solventes puede reducir estos problemas.

Las empresas de servicios funerarios que realizan embalsamamientos generan residuos peligrosos tanto químicos (como el formaldehído) como biológicos (sangre y materiales que la contienen). En la mayoría de los países en los que se realizan embalsamamientos se obliga a desechar estos residuos como materiales peligrosos. En los crematorios, puede ocurrir contaminación del ambiente por mercurio derivado de los empastes dentarios con amalgamas que contienen mercurio.

La mayoría de los establecimientos de cosmetología que generan residuos químicos los vierten al drenaje o los desechan junto con la basura. Esto sucede también en el caso del personal de limpieza, tanto en los hogares como en las instituciones, que generan residuos en forma de solventes, ácidos y otros productos de limpieza que contienen sustancias químicas peligrosas. La existencia de un gran número de generadores que producen individualmente pequeñas cantidades de residuos crea un problema local; las tecnologías de control estándar focales no se pueden implementar en estos casos. Por ejemplo, incluso en instituciones grandes como los hospitales, las sustancias químicas para la limpieza se utilizan en pequeñas cantidades en todo el edificio y frecuentemente se guardan en varios sitios distintos.

Existen varias soluciones para este problema. Una podría ser el proceso actual de desarrollo de sustitutos menos peligrosos, especialmente la sustitución de los solventes con productos basados en agua. Otra solución es la adopción de procedimientos que garanticen que únicamente se adquiera la cantidad de productos necesarios para el futuro inmediato, para evitar la acumulación de productos antiguos que sea necesario desechar. El utilizar todo el producto contenido en el envase antes de tirarlo a la basura puede reducir la contaminación por este origen. En los últimos años, algunos países, como Estados Unidos y Canadá, han establecido programas locales de residuos peligrosos a nivel doméstico en los que los residuos como solventes y productos de limpieza pueden llevarse a puntos centrales de recogida que aceptan estos residuos sin ningún cargo y los desechan de acuerdo con los procedimientos adecuados.

Michael McCann

\section{Referencias}

Agencia Internacional para la Investigación sobre el Cáncer (IARC). 1995a. Dry cleaning, some chlorinated solvents and other industrial chemicals (Dry cleaning). En IARC Monographs on the Evaluation of Carcinogenic Risk to Humans. Vol. 63. Lyon: IARC.

1995b. Dry cleaning, some chlorinated solvents and other industrial chemicals (Tetrachloroethylene). En IARC Monographs on the Evaluation of Carcinogenic Risks to Humans. Lyon: IARC.

1995c. Wood dust and formaldehyde. En IARC Monographs on the Evaluation of Carcinogenic Risks to Humans. Lyon: IARC.

Agency for Toxic Substances and Disease Registry (ATSDR). 1995. Toxicological Profile for Tetrachloroethylene (Update-draft for Public Comment). Atlanta, Georgia: US ATSDR.

Albert, RE, AR Sellakumar, S Laskin, K Kuschner, N Nelson, CA Snyder. 1982. Gaseous formaldehyde and hydrogen chloride induction of nasal cancer in the rat. FNCI 68: 597-603

Anderson, B. 1993. Britain's Secret Slaves: An Investigation into the Plight of Overseas Domestic Workers. Human Right Series No. 5, Anti-slavery International and Kalayaan: Justice for Overseas Domestic Workers.

Armstrong, P, H Armstrong. 1994. The Double Ghetto, $3^{\mathrm{a}}$ edición. Toronto: McClelland and Stewart.

Association pour la santé et la sécurité au travail, secteur affaires sociales (ASSTSAS). 1993. Entretien sanitaire. Montreal: ASSTSAS

Baxter, PJ, AM Brazier, SEJ Young. 1988. Is smallpox a hazard in church crypts? $\mathrm{Br} \mathcal{F}$ Ind Med 45: 359 360 .

Blainey, AD, S Ollier, D Cundell, RE Smith, RJ Davies. 1986. Occupational asthma in hairdressing salons. Thorax 41:42-50.

Blair, A, P Stewart, PE Tolbert, D Grauman, FX Moran, J Faught, J Rayner. 1990b. Cancer and other causes of death among laundry and dry cleaning workers. Br 7 Ind Med 47:162-168.

Blair, A, PA Stewart, M O'Berg, W Gaffey, J Walrath, J Ward, R Bales, S Kaplan, D Cubit. 1986. Mortality among industrial workers exposed to formaldehyde. FNCI 76: 1071-1084

Blair, A, R Saracci, PA Stewart, RB Hayes, C Shy. 1990a. Epidemiologic evidence on the relationship between formaldehyde exposure and cancer. Scand 7 Work, Environ and Health 16:381-391.

Borglum, B, AM Hansen. 1994. A Survey of Washing and Cleaning Agents (en danés, resumen en inglés). AMI Report 44. Copenhage, Dinamarca: Instituto Danés de Salud en el Trabajo.

Bretin, H, N Frigul, I Metenier, L Aussel, A Thébaud-Mony. 1992. Des femmes chomeuses en mauvaise santé. Kremlin-Bicêtre, Francia: INSERM Unité 292

Bretin, H. 1994. Santé des ouvriers du nettoyage à Montréal et à Paris: La face cachée du travail dans la ville. KremlinBicêtre, Francia: INSERM Unité 292.

Cherry, NM, MH Beck, V Owen-Smith. 1994. Surveillance of Occupational Skin Disease in the United Kingdom: The OCC-Derm Project. US NIOSH Publication No. 94-112. Acta del 9 Simposio Internacional sobre epidemiología y la salud en el trabajo, 23-25 septiembre 1992, Cincinnati, Ohio: US NIOSH.

Coleman, R. 1995. Reducing the levels of formaldehyde exposure in gross anatomy laboratories. Anat $\operatorname{Rec} 243: 531-533$

Delaporte, M-F, M Estryn-Behar, G Brucker, E Peigne, A Pelletier. 1990. Pathologie dermatologique et exercice professionnel en milieu hospitalier. Arch mal prof 51(2):83-88.

Demers, PA, TL Vaughan, RR Schommer. 1991. Occupation, socioeconomic status and brain tumor mortality: A death certificate-based case-control study. FOM 33(9):1001-1006.
Dooms-Goossens, A. 1986. A computerized retrieval system of contact allergenic substances. Seminars in Dermatology 5(3):249-254.

Duh, RW, NR Asal. 1984. Mortality among laundry and dry cleaning workers in Oklahoma. Am f Public Health 74:1278-1280.

Earnest, GS, AB Spencer. 1996. Lessons from Europe: Reducing Occupational Exposure and Environmental Emissions to Perchloroethylene in Commercial Dry Cleaning (ECTB No. 201-07). Cincinnati, Ohio: US NIOSH.

Earnest, GS. 1996. Evaluation and control of perchloroethylene exposures during dry cleaning. Appl Occup Environ Hyg 11(2): 125-132.

Environmental Protection Agency (EPA). 1991a. Drycleaning Facilities - Background Information for Proposed Standards (EPA Publication No 50/3-91-020a). Research Triangle Park, Carolina del Norte: Office of Air Quality Planning and Standards, Environmental Protection Agency.

1991b. National emission standards for hazardous air pollutants for source categories: Perchloroethylene emissions from dry cleaning facilities, proposed rule and notice of public hearing. Federal Reg 56(236):64382-64402.

Feron, VJ, JP Bruyntjes, RA Woutersen, HR Immel, LM Appelman. 1988. Nasal tumors in rats after short-term exposure to a cytotoxic concentration of formaldehyde. Canc Lett 39: 101-111.

Flyvholm, M-A. 1993. Contact allergens in registered cleaning agents for industrial and household use. $\mathrm{Br}$ 7 Ind Med 50:1043-1050.

Foussereau, J, C Benezra, HI Maibach, N Hjorth. 1982. House personnel. En Occupational Contact Dermatitis, Clinical and Chemical Aspects. filadelfia: W. B. Saunders Company.

Gamboa, PM, CG de la Cuesta, BE García, JG Castillo, A Oehling. 1989. Late asthmatic reaction in a 
hairdresser, due to inhalation of ammonium persulfate salts. Allergologia et immunopathologia 17:109-111.

Gawkrodger, DJ, MH Lloyd, JAA Hunter. 1986 Occupational skin disease in hospital cleaning and kitchen workers. Contact Dermatitis 15:132-135.

Gershon, RRM, C Karkashion. 1996. The risk of TB in funeral service workers: Preliminary results. Presentado en los encuentros de la American Public Health Association, noviembre, Nueva York.

Gershon, RRM, D Vlahox, H Farzadegan, A Miriam. 1995. Occupational risk of human immunodeficiency virus, hepatitis $B$ virus, and hepatitis $C$ virus infections among funeral service practitioners in Maryland. 1995. Infec Contr Hosp Epid 16: 194-197.

Gervais, M. 1993. Bilan de santé des travailleurs québécois. Montréal: Institut de recherche en santé et en sécurité du travail du Quebec.

Government of Quebec. 1994. Décret sur le personnel d'entretien d'édifices publics de la région de Montréal. Québec: Éditeur officiel

Gulati, L. 1993. Women Migrant Workers in Asia: A Review. New Delhi. ITO Equipo Regional Asiático para la Protección del Empleo.

Hagner, I-M, M Hagberg. 1989. Evaluation of two floor-mopping work methods by measurement of load. Ergonomics 32 (4): 401-408.

Hansen, KS. 1983. Occupational dermatoses in hospital cleaning women. Contact Dermatitis 9:343-351.

Harford, TC, SD Brooks. 1992. Cirrhosis mortality and occupation. F Stud Alcohol 53(5):463-468.

Hayes, RB, A Blair, PA Stewart, RF Herrick, H Mahar. 1990. Mortality of U.S. embalmers and funeral directors. Am f Ind Med 18: 641-652.

Hayes, RB, JW Raatgever, A de Bruyn, M Gerin. 1986. Cancer of the nasal cavity and paranasal sinuses and formaldehyde exposure. Int $\mathcal{f}$ Canc 37: 487-492.

Healing, TD, PN Hoffman, SEJ Young. 1995. The infection hazards of human cadavers. Communicable Dis Rev 5: R61-R68.

Hohenstein Institute. 1995. Requirements for the Use of Hydrocarbon Solvents in the Dry Cleaning Industry. Boennigheim, Alemania: Hohenstein Institute.

Horte, LG, K Toren. 1993. Smoking adjusted mortality due to asthma in a population of Swedish working women. Br f Ind Med 50(6):575-576.

International Fabricare Institute. 1990. Focus on Dry Cleaning: Distillation. Silver Spring, Maryland: International Fabricare Institute.

Johannsson, S-E, G Ljunggren. 1989. Perceived exertion during a self-imposed pace of work for a group of cleaners. Applied Ergonomics 20 (4):307-312.

John, EM, DA Savitz, CM Shy. 1994. Spontaneous abortion among cosmetologists. Epidemiology 5:147155.

Katz, RM, D Jowett. 1981. Female laundry and dry cleaning workers in Wisconsin: A mortality analysis. Am f Public Health 71:305-307.

Kerns, WD, KL Pavkov, DJ Donofrio, EJ Gralla, JA Swenberg. 1982. Carcinogenicity of formaldehyde in rats and mice after long-term inhalation exposure. Canc Res 43: 4382-4392.

Koenig, KL. 1994. Hair dye use and breast cancer: A case-control study among screening participants. Am J Epi 133:985-995.

Levine, RJ, DA Andjelkovich, LK Shaw. 1984. The mortality of Ontario undertakers and a review of formaldehyde-related mortality studies. $f \mathrm{O} c c \mathrm{Med}$ 26: 740-746.

Lin, RS, II Kessler. 1981. A multifactorial model for pancreatic cancer in man: Epidemiologic evidence. 7AMA 245:147-152.

McCarroll, JE, RJ Ursano, CS Fullerton, A Lundy. 1993. Traumatic stress of a wartime mortuary, anticipation of exposure to mass death. 7 Nerv Ment Dis 181: 545-551.
1995. Anticipatory stress of handling human remains from the Persian Gulf War. $\mathcal{F}$ Nero Ment Di 183: 698-703.

McDonald, AD, B Armstong, N Cherry, C Delorme, AD Nolin, JC McDonald, D Robert. 1986. Spontaneous abortion and occupation. $f$ Occ Med 28:1232-1238.

McDonald, AD, JC McDonald, B Armstong, N Cherry, AD Nolin, D Robert. 1988. Prematurity and work in pregnancy. $\mathrm{Br}$ F Ind Med 45:56-62.

McDonald, AD, JC McDonald, B Armstong, N Cherry, G Delorme, AD Nolin, D Robert. 1987. Occupation and pregnancy outcome. $\mathrm{Br} \mathcal{F}$ Ind $\mathrm{Med}$ 44:521-526.

McDougal, L, PR Band, JJ Spinelli, WJ Threlfall, RP Gallagher. 1992. Mortality patterns in female domestic workers. Am J Ind Med 21(4):595-599.

Messing, K, C Chatigny, J Courville. 1995. Travail prescrit, travail réel, travail perçu: l'entretien sanitaire «lourd» et «léger» en milieu hospitalier. Annal of the Société d'ergonomie de langue française: 578-585.

1996. L'invisibilité du travail et la division léger/lourd dans l'entretien sanitaire: Impact sur la santé et la sécurité du travail. Objectif Prévention. 19(2):13-16.

Messing, K, C Haëntjens, G Doniol-Shaw. 1993. L'invisible nécessaire: l'activité de nettoyage des toilettes sur les trains de voyageurs en gare. Le travail humain 55:353-370.

Messing, K, G Doniol-Shaw, C Haëntjens. 1993. Sugar and spice: Health effects of the sexual division of labour among train cleaners. Int $\mathcal{f}$ Healt Services 23 (1):133-146.

Messing, K. 1991. Occupational Health Concerns of Canadian Women/La santé et la sécurité des travailleuses canadi ennes. Ottawa: Human Resources Canada.

En imprenta. Hospital trash: Cleaners speak of their role in disease prevention. Med Anthropol Quar.

Michaels, David. Undated. Right-to-know Handbook for Custodial Assistants. Nueva York: City of New York Mayor's Office of Operations, Citywide Office of Occupational Safety and Health and District Council 37 Education Fund.

National Fire Protection Association (NFPA). 1991. Fire Protection Handbook. Quincy, Massachusetts: NFPA

National Institute for Occupational Safety and Health (NIOSH). 1975. Health and Safety Guide for Laundries and Dry Cleaners. NIOSH Publication No. 273-831. Cincinnati, Ohio: US NIOSH.

1977. Occupational Diseases: A Guide to Their Recogni tion. NIOSH Publication No. 77-181. Cincinnati, Ohio: US NIOSH

Nielsen, J. 1995. Occupational Health of Cleaners (en danés, resumen en inglés). Tesis doctoral. thesis. Copenhage, Dinamarca: Arbejdsmiljjoinstituttet. 1996. The occurrence and course of skin symptoms on the hands among female cleaners. Contact Derma titis 34: 284-291.

Nordin, M, G Hultman, R Philipsson, S Ortelius, GBJ Andersson. 1986. Dynamic measurements of trunk movements during work tasks. En The Ergonomics of Working Postures, dirigido por N Corlett, J Wilson y Manenica. Filadelfia: Taylor \& Francis.

Nwanyanwu, OC, TH Tubasuri, G Harris. 1989. Exposure to and precautions for blood and body fluids among workers in the funeral home franchises of Fort Worth, Texas. Am J Infect Control 17: 208-212.

Occupational Safety and Health Administration OSHA). 1993. Occupational Safety and Health Administration, base de datos, reglamentos, documentos e información técnica. OSHA-CD-ROM OSHA A93-2). Base de datos inédita.

Olsen, JH, S Asnaes. 1986. Formaldehyde and the risk of squamous cell carcinoma of the sinonasal cavities. Br 7 Ind Med 43: 769-774.

Opatowski, S, P Varaillac, C Richoux, N Sandret, I Peres, D Riffiod, Y Iwatsubo. 1995. Enquête sur les ouvriers nettoyeurs d'Ile-de-France, Archives des maladies professionnelles 56 (3):219-220.

Organización Internacional del Trabajo (OIT). 1989. Conditions of Work Digest: Home Work. Vol. 8, No. 2 Ginebra: OIT.

Pearce, N. 1992. Increasing incidence of NonHodgkin's lymphoma: Occupational and environmental factors. Canc Res 52 (Supl): 5496s-5500s.

Pepys, J. 1986. Occupational allergic lung disease caused by organic agents. 7 Allergy Clin Immunol 78(5) Part 2: 1,058-1,062.

Rice, B, J Weinberg. 1994. Dressed to Kill: The Dangers of Dry Cleaning and the Case for Chlorine-free Alternatives. A Greenpeace/Pollution Probe Report. Toronto. Pollution Probe, Sunset Chemicals Project for the Great Lakes.

Roush, GC, J Walrath, LT Stayner, SA Kaplan, JT Flannery, A Blair. 1987. Nasopharyngeal cancer, sinonasal cancer and occupations related to formaldehyde: A case-control study. FNCI 79: 1221-1225.

Royal Society of Chemistry (RSC). 1986. Organochlorine Solvents: Health Risks to Workers (EUR10531EN). Luxemburgo: Royal Society of Chemistry, Comisión de las Comunidades Europeas.

Ruder, AM, EM Ward, DP Brown. 1994. Cancer mortality in female and male dry cleaning workers. f Occup Med 36:867-874.

Savitz, DA, KW Andrews, LA Brinton. 1995. Occupation and cervical cancer. 7 Occup and Envir Med 37(3):357-361.

Schwartz, HJ, JL Arnold, KP Strohl. 1990. Occupational allergic rhinitis in the hair care industry. Reactions to permanent wave solutions. $7 \mathrm{Occ} \mathrm{Med}$ $32: 473-475$

Scolari, FG, B Gardenghi. 1966. Problems of preselection, prevention, and recovery in occupational dermatology. Giornale Italiano di Dermatologia 107 (5): 1259-1270

Seligman, PJ, SC Newman, CL Timbrook, WE Halperin. 1987. Sexual assault of women at work. $A m \mathcal{F}$ Ind Med 12 (4):445-450.

Singgih, SIR, H Latinga, JP Nater, TE Woest, JA Kruyt-Gaspersz. 1986. Occupational hand dermatoses in hospital cleaning personnel. Contact Dermatitis 14: 14-19.

Sly. 1994. Epidemic of small-pox in Quebec, supposed to depend upon the opening of an intramural cemetery 214 years old. Can 7 Publ Hlth (mayojunio): 149.

Sogaard, K, N Fallentin, J Nielsen. 1996. Workload during floor cleaning. The effect of cleaning methods and work technique. Eur 7 App Physiol.

Sogaard, K. 1994. Biomechanics and Motor Control during Repetitive Work: A Biomechanical and Electromyographical Study of Floor Cleaning. Ph.D. thesis. Copenhage, Dinamarca: Department of Physiology, National Institute of Occupational Health.

Sovet, U. 1958. Poisoning caused by powder used in the cleaning of silver. Presse Medicale 10 (9):69-70.

Spencer, AB, CF Estil, JB McCammon, RL Mickelsen, OE Johnston. 1996. Control of ethyl methacrylate exposures during the application of artificial fingernails. Amer Ind Hyg Assoc 7 58: 214-218.

Starr, JC, J Yunginger, GW Brahser. 1982. Immediate type I asthmatic response to henna following occupational exposure in hairdressers. Annals of Allergy 48:98-99.

Stayner, LT, L Elliott, L Blade, R Keenlyside, W Halperin. 1988. A retrospective cohort mortality study of workers exposed to formaldehyde in the garment industry. Am f Ind Med 13: 667-681.

Steineck, G, N Plato, SE Norell, C Hogstedt. 1990. Urothelial cancer and some industry-related chemicals: An evaluation of the epidemiologic literature. Am f Ind Med 17:371-391.

Tanaka, S, AB Smith, W Halperin, R Jensen. 1982. Carpet-layer's knee. New England $7 \mathrm{Med}$ 307(20): 1276-1277. 
Tobe, M, T Kaneko, Y Uchida, E Kamata, Y Ogawa, Y Ikeda, M Saito. 1985. Studies on Inhalation Toxicity of Formaldehyde. Informe del Servicio Nacional de Laboratorio Médico y Sanitario. Tokio: Department of the Organism Safety Research Centre.

Toivanen, H, P Helin, O Hänninen. 1993. Impact of regular relaxation training and psychosocial working factors on neck-shoulder tension and absenteeism in hospital cleaners. f Occup Med 35(11): 1123-1130.

Turnbull, N, J Dornan, B Fletcher, S Wilson. 1992. Prevalence of spinal pain among the staff of a district health authority. Occup Med 42(3):143-148.

Ursano, RJ, CS Fullerton, TC Kao, VR Bhartiya. 1995. Longitudinal assessment of posttraumatic stress disorder and depression after exposure to traumatic death. F Nerv and Ment Dis 183: 36-42.

Van der Walle, HB,VM Brunsveld. 1994. Dermatitis in hairdressers. Contact Dermatitis 30:217-221.
Vasquez, C. 1995. Wet Cleaning Equipment. Chicago: Center for Neighborhood Technology.

Vaughan, TL, C Strader, S Davis, JR Daling. 1986. Formaldehyde and cancers of the pharynx, sinus and nasal cavity. Occupational exposures. Int $f$ Canc 38: 677-683.

Villaplana J, G Romaguera, F Grimalt. 1991. Contact dermatitis from resorcinol in a hair dye. Contact Dermatitis 24:151-152.

Vingard, E, L Alfredsson, I Goldie, C Hogstedt. 1991. Occupation and osteoarthrosis of the hip and knee: A register-based cohort study. Int $\mathcal{f}$ Epidemiol 20 (4):1025-1031

Walrath, J, JF Fraumeni. 1983. Mortality patterns among embalmers. Int $\mathcal{f}$ Canc 31:407-411.

Weaver, V, MA McDiarmid, JA Guidera, FE Humphrey, JA Schaefer. 1993. Occupational chemical exposures in an academic medical center. 7 Occup Med 35(7):701-706.
Wentz, M. 1995. The evolution of environmentally responsible fabricare technologies. American Drycleaner 62(7):52-62.

Winkel, J, B Ekblom, M Hagberg, B Jonsson. 1983. The working environment of cleaners. Evaluation of physical strain in mopping and swabbing as a basis for job redesign. En Ergonomics of Workstation Design, dirigido por TO Kialseth. Toronto: Butterworth.

Wolff, HL, JJAB Croon. 1968. The survival of small pox virus (Variola Mivor) in natural circumstances. Bull World Health Organ 38: 492-493.

Zahm, SH, DD Weisenburger, PA Babbitt, RC Saal, JB Vaught, A Blair. 1992. Use of hair coloring products and the risk of lymphoma, multiple myeloma, and chronic lymphocytic leukemia. Am J Public Health 82:990-997. 



\section{SERVICIOS PUBUCOS Y ESTATALES}

Director del capítulo

$D$ avid $L E$ $G$ rande

\section{Sumario}

$R$ iesgos para la seguridad y la salud en el trabajo en los servicios públicos y gubernamentales

David $L$ eg rande. . . . . . . . . . . . . . . . . . . . . . . . 101.2
Servicios de inspección

Servicios postales

R oxanne Cabral.

Telecomunicaciones

$D$ avid L E Grande.

$R$ iesgos en las plantas de tratamiento de aguas residuales (residuos)

$M$ ary 0 . B rophy

Recogida de basuras domésticas

M adelene B ourdouxhe. . . . . . . . . . . . . . . . . . . . . . . . . 101.13

Limpieza viaria

J.C. Gunther, J r. . . . . . . . . . . . . . . . . . . . . 101.16

Tratamiento de las aguas residuales

M. Agamennone. . . . . . . . . . . . . . . . . . . . . . . 101.18

Industria de reciclado municipal

David E. M alter . . . . . . . . . . . . . . . . . . . . . . . . . . . 101.21

O peraciones de eliminación de residuos

J ames W. Platner . . . . . . . . . . . . . . . . . . . 101.23

Generación y transporte de residuos peligrosos:

problemas sociales y éticos

Colin L. Soskolne. .

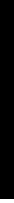




\section{- RIESG OS PARA LA SEGURIDAD Y LA SALUD EN EL TRABAJO EN LOS SERVICIOS PUBLICOS Y GUBERNAMENTALES}

\section{David LeG rande}

Los servicios públicos y gubernamentales abarcan una gran diversidad de categorías industriales y profesionales, incluidos, por ejemplo, los trabajadores de los servicios de telecomunicaciones y postales, los servicios de inspección y de campo, así como las actividades de tratamiento de aguas residuales, reciclado, vertido controlado y residuos peligrosos. Según la situación en cada país, sectores como los servicios de telecomunicaciones y postales pueden ser de competencia pública o privada.

Los riesgos para la seguridad y la salud en el trabajo y ambientales en los servicios públicos y gubernamentales son: la exposición a productos químicos, los relacionados con la ergonomía, los patógenos transmitidos por la sangre, la tuberculosis, los riesgos por maquinaria, la violencia, los vehículos de motor y los materiales inflamables. Cabe esperar que en el futuro, a medida que los servicios públicos y gubernamentales se amplíen y se hagan más complejos, aumenten y se difundan aún más los riesgos para la salud y la seguridad en el trabajo. Paralelamente, impulsadas por iniciativas tripartitas (trabajadores, directivos y administración), las mejoras en el reconocimiento y control de los riesgos para la salud y seguridad en el trabajo permitirán una resolución más eficaz de los riesgos identificados.

\section{Problemas de salud y tipos de daños a la salud}

$\mathrm{H}$ ay determinadas pautas 0 tendencias identificables de problemas de salud en el trabajo que se han asociado al tipo de tarea - p. ej., el uso de pantallas de visualización de datos (PVD) o productos químicos- y al lugar en el que se trabaja (es decir, en el interior 0 al aire libre).

\section{Trabajo en interiores}

Los principales riesgos asociados con el trabajo en interiores son una ergonomía deficiente o inadecuada del diseño y de la organización del trabajo; calidad insuficiente del aire interior 0 de los sistemas de calefacción, ventilación y aire acondicionado; productos químicos; amianto; violencia en el centro de trabajo y campos electromagnéticos (radiación de baja intensidad).

Se han asociado síntomas y trastornos de la salud con la exposición a estos riesgos. Desde mediados de los años 80 se han notificado un gran número de dolencias físicas de las extremidades inferiores relacionadas con la ergonomía, entre las que destacan el síndrome del túnel carpiano, la desviación del cúbito, el síndrome de la abertura torácica superior y la tendinitis. M uchos de ellos están relacionados con la introducción de nuevas tecnologías y, en particular, de las pantallas de visualización de datos (PVD), así como con el uso de herramientas manuales y equipos de trabajo. Entre las causas de las enfermedades identificadas se incluyen factores físicos y de organización del trabajo.

A partir de la concepción técnica y la construcción de "edificios herméticos" en los años 70 , se ha observado una tendencia al aumento de la incidencia de síntomas y enfermedades de las vías respiratorias superiores y dermatológicas. Tales problemas de salud se relacionan con el mantenimiento inadecuado de los sistemas de calefacción, ventilación y aire acondicionado; con contaminantes químicos y agentes microbiológicos, y con el suministro insuficiente de aire fresco y circulación del aire.
La exposición a productos químicos en ambientes de trabajo interiores se ha relacionado con síntomas y enfermedades de las vías respiratorias superiores y dermatológicos. Fotocopiadoras, mobiliario, alfombras y moquetas, materiales de limpieza (disolventes) y los sistemas de calefacción, ventilación y aire acondicionado emiten una gran variedad de contaminantes químicos diferentes. Un síndrome concreto, la múltiple sensibilidad química, se ha asociado con exposiciones a agentes químicos en ambientes de trabajo interiores.

Puede producirse exposición al asbesto cuando se realizan trabajos de reforma y mantenimiento de los edificios y los productos o materiales a base de amianto se deterioran o dañan, lo que hace que sus fibras queden flotando en el aire.

Desde los años 80, la violencia en el centro de trabajo y los problemas resultantes para la seguridad y la salud se han hecho cada vez más frecuentes. Los ambientes laborales en los que se ha comprobado un aumento de los índices de violencia reúnen las características siguientes: manejo de dinero, trato directo con el público, trabajos aislados, contacto con pacientes o clientes que pueden ser violentos y atender reclamaciones de consumidores o clientes. En materia de salud, lo que preocupa son los daños físicos y la muerte. Por ejemplo, en 1992 los homicidios fueron, en EE.UU., la segunda causa de muerte en el centro de trabajo (supusieron el $17 \%$ de las muertes en el lugar de trabajo). Además, desde 1980 a 1989 los homicidios fueron la primera causa de muerte de mujeres en el trabajo, como se comenta con más detalle en el Capítulo 51, Violencia, de esta Enciclopedia.

El trabajo con equipos electrónicos y la consiguiente exposición a los campos electromagnéticos o a las radiaciones no ionizantes, se ha convertido en algo muy común, al igual que la exposición a productos que emiten radiaciones no ionizantes de alta frecuencia, como equipos de láser y microondas, termoselladores por radiofrecuencia y herramientas y generadores eléctricos. Todavía no está clara la relación entre tales exposiciones y los efectos posteriores en la salud, como cáncer, trastornos de la visión y de la piel, para lo cual es necesario seguir investigando. En la presente Enciclopedia se dedican varios capítulos a estos temas.

\section{Trabajo al aire libre}

Los riesgos ambientales relacionados con el trabajo al aire libre son la exposición a productos químicos, plomo, residuos sólidos y peligrosos, condiciones ambientales, ergonomía inadecuada, vehículos de motor, equipos eléctricos y mecánicos y emisiones de campos electromagnéticos.

Se produce exposición a productos químicos en varias categorías profesionales identificadas, como operaciones de eliminación de residuos, servicios de suministro de agua y saneamiento, tratamiento de aguas residuales, recogida de basuras domésticas, recogida de correo y trabajos técnicos en telecomunicaciones. Tal exposición se ha relacionado con enfermedades de vías respiratorias superiores, dermatológicas, cardiovasculares y del sistema nervioso central. Los trabajadores de telecomunicaciones sufren exposición al plomo al realizar operaciones de empalme y de eliminación de cables de telecomunicaciones de plomo. Se han vinculado a estos contactos una gran diversidad de síntomas y enfermedades, entre las que cabe citar anemia, trastornos del sistema nervioso periférico y central, esterilidad, lesiones renales y defectos de nacimiento.

Los ambientes de trabajo peligrosos son comunes a las operaciones de eliminación de residuos, servicios de suministro y saneamiento de agua, tratamiento de aguas residuales y recogida de basuras domésticas. Los riesgos para la seguridad y la salud en el trabajo son los derivados de residuos microbiológicos y médicos, productos químicos, ergonomía inadecuada, vehículos 


\section{Informe de caso: violencia y guardas de parques urbanos en Irlanda}

La misión de los guardas de los parques de las grandes ciudades irlandesas es "mantener la paz", "atender al público" (es decir, prevenir el vandalismo y responder a cualquier queja que se les pueda exponer) y realizar "funciones de limpieza ligera" (es decir, retirar basuras y desperdicios, como botellas rotas, agujas y jeringas tiradas por drogadictos y preservativos usados). No tienen un horario fijo: empiezan hacia el mediodía y permanecen en su puesto hasta que anochece, momento en que se supone que han de cerrar las puertas del parque. Esto significa un horario prolongado en verano, compensado en cierta medida por los días más cortos del invierno.

En la mayoría de los parques hay un guarda que trabaja solo, aunque pueda haber otros trabajadores municipales ocupados en plantaciones, jardinería y otras tareas del parque. El único edificio del parque suele ser el almacén en el que se guarda el material de jardinería, y que puede servir de refugio al personal ante las inclemencias del tiempo. Para evitar que rompan la armonía del paisaje, estos almacenes o casetas suelen situarse en lugares apartados de la vista del público, donde están expuestos a los malos tratos de gamberros y pandillas de jóvenes merodeadores.

Los guardas de parques se exponen a menudo a la violencia. Una política de empleo que favorecía la contratación de personas con discapacidades leves se modificó recientemente al comprobar que el conocimiento general de tales problemas convertía a estos guardas en objetivos fáciles de agresiones violentas. Los funcionarios públicos no estaban cubiertos por la legislación irlandesa sobre seguridad y salud, que hasta hace poco sólo era aplicable a fábricas, obras en construcción, muelles y otras industrias de procesamiento. Debido a ello, no existían medidas formales en respuesta a la violencia contra los trabajadores de parques que, a diferencia de sus equivalentes en algunos otros países, carecían de armas de fuego o de otro tipo. Tampoco tenían acceso a asesoramiento postviolencia.

La tendencia a asignar a un parque determinado guardas que vivían en sus proximidades, suponía una mayor probabilidad de que pudieran identificar a los alborotadores como posibles responsables de actos de violencia. No obstante, esto también aumentaba el riesgo de represalias para el guarda por haber "señalado" a los culpables, lo que le hacía sentirse menos dispuesto a presentar denuncias formales contra sus asaltantes.

de motor, espacios confinados y equipos eléctricos y mecánicos. Los síntomas y enfermedades identificados son: problemas de las vías respiratorias superiores, dermatológicos, musculosqueléticos de las extremidades superiores e inferiores, cardiovasculares, del sistema nervioso central y visuales. 0 tras causas de preocupación son las heridas cortantes, el agotamiento y el golpe de calor.

El diseño inadecuado de las herramientas y los equipos de trabajo es común a todas las ocupaciones en servicios públicos y gubernamentales realizados al aire libre. Entre los riesgos figura el uso de herramientas manuales y eléctricas, maquinaria y vehículos de motor mal diseñados. Los problemas para la salud asociados son los síntomas y enfermedades musculosqueléticas de las extremidades superiores e inferiores. Lo que más preocupa en materia de seguridad son los problemas visuales, las torceduras, los esguinces y las fracturas y roturas de huesos.

Los riesgos asociados con los vehículos de motor derivan del diseño deficiente del equipo (p. ej., tolvas, compactadoras y equipo aéreo), así como del funcionamiento inadecuado de la maquinaria y del equipo. Los problemas para la salud resultantes comprenden lesiones musculosqueléticas y muerte. LoS
La falta de una presencia policial adecuada en los parques y la salida muy rápida de prisión de las personas condenadas por hechos de tal índole eran con frecuencia golpes muy duros contra la moral de las víctimas de la violencia.

Los sindicatos representantes de los guardas y otras autoridades públicas, han promovido activamente iniciativas para hacer frente a la violencia. Actualmente incluyen formación para el reconocimiento y la prevención de la violencia en los cursos que patrocinan para los representantes de la seguridad pública.

Aunque la legislación irlandesa sobre seguridad y salud ampara ahora a los trabajadores con autoridad pública, sería beneficiosa la creación de un comité nacional para afrontar tanto el control de la violencia como la prestación de asistencia posterior a sus víctimas. Si bien existen actualmente directrices de prevención de la violencia para facilitar la tarea a quienes se ocupan de valorar los riesgos de violencia en los lugares de trabajo, su uso debe hacerse obligatorio para todas las profesiones en las que exista riesgo de violencia. Además, son deseables el aumento de los recursos de la fuerza de policía de la ciudad y la intensificación de la coordinación con ella para hacer frente al problema de la violencia y las agresiones en los parques públicos.

Es preciso poner a la disposición de todos los trabajadores que se enfrenten al riesgo de violencia en sus puestos de trabajo, formación sobre el modo de tratar a las personas y posibles grupos violentos. Tal formación podría incluir cómo abordar y tratar a las personas que muestren indicios de llevar a cabo una agresión violenta, así como métodos de autodefensa.

También serían de utilidad unas mejores comunicaciones para dar cuenta de situaciones problemáticas y solicitar ayuda. La instalación de teléfonos en todos los almacenes de parques sería un primer paso útil, mientras que los intercomunicadores y los teléfonos portátiles serían de utilidad en caso de alejamiento del almacén. Los sistemas de cámaras de vídeo para vigilancia de los lugares más estratégicos, como los almacenes de los parques y las instalaciones deportivas, podrían disuadir de la práctica de la violencia.

\section{Daniel Murphy}

accidentes debidos a vehículos de motor son responsables del mayor número de lesiones y de fallecimientos en trabajos en exteriores.

Los riesgos relacionados con equipos eléctricos y mecánicos son el diseño deficiente del equipo, las descargas eléctricas y la electrocución, así como la exposición a productos químicos. LoS problemas para la salud comprenden torceduras, esguinces, roturas de huesos, trastornos de los sistemas nervioso central y cardiovascular y trastornos dermatológicos y de las vías respiratorias superiores, además de la muerte.

El trabajo con equipos de transmisión eléctrica o en su proximidad más inmediata y los campos electromagnéticos asociados a emisiones de radiaciones no ionizantes, se ha relacionado con la aparición de determinados síntomas y trastornos del sistema nervioso central, así como con el cáncer. No obstante, las investigaciones científicas y epidemiológicas no han definido todavía claramente el grado de daño causado por los campos electromagnéticos.

Las actividades de los servicios públicos y gubernamentales realizadas al aire libre presentan varios problemas ambientales y 
de salud pública. Por ejemplo, es posible que se utilicen y se evacuen inadecuadamente productos químicos, agentes microbiológicos, aguas residuales y basuras domésticas, lo que puede originar su filtración tanto a las aguas subterráneas como a ríos, lagos y mares, con la consiguiente contaminación del medio ambiente. A su vez, esos residuos pueden originar la contaminación de la red de suministro de agua, así como la creación de vertederos tóxicos. Esa contaminación se ha relacionado con el deterioro y la destrucción tanto del medio ambiente como de la salud pública. Los efectos asociados para la salud pública son: síntomas y trastornos dermatológicos, del sistema nervioso central y cardiovasculares, así como determinados tipos de cáncer.

\section{- SeRVICIOS DE IN SPECCION}

Jonathan Rosen

Las administraciones nacionales, estatales o provinciales, municipales y locales, cuentan con inspectores adscritos a una gran diversidad de organismos cuya función es comprobar el cumplimiento de leyes, ordenanzas y reglamentos destinados a promover y proteger la seguridad y la salud tanto de los trabajadores como del público en general. Este es el papel tradicional de un gobierno, promulgar leyes para evitar riesgos socialmente inaceptables, y asignar después a organismos el establecimiento de programas para lograr el cumplimiento de las normas establecidas. El inspector 0 investigador es una persona clave, ya que ocupa un lugar de primera línea en la verificación del cumplimiento de la normativa legal.

Un ejemplo de mandato legislativo de este tipo es la función de la inspección de los lugares de trabajo para determinar la observancia de las medidas de seguridad y salud. L os inspectores visitan los centros de trabajo para comprobar el cumplimiento de los reglamentos aplicables al lugar de trabajo, los posibles riesgos laborales y ambientales, las herramientas, las máquinas y los equipos utilizados y los métodos de trabajo, incluido el uso de equipos de protección individual (EPI). Los inspectores tienen autoridad para iniciar sanciones (citaciones, multas económicas $y$, en casos extremos, proceso penal) cuando encuentren deficiencias. Al amparo de la legislación promulgada en algunos países, las autoridades regionales comparten con las estatales las responsabilidades en materia de inspección.

O tros campos en los que los organismos gubernamentales tienen responsabilidades inspectoras son la protección del medio ambiente, la regulación de los alimentos y los medicamentos, la energía nuclear, el comercio y la aviación civil interestatales, la salud pública y la protección del consumidor. Las inspecciones en los campos de la ingeniería y la construcción se organizan generalmente a escala local

En todo el mundo, las funciones y protecciones básicas en las que se centran los servicios de inspección son semejantes, aunque varíen la legislación y las estructuras administrativas en cada caso. Estos aspectos se comentan en otro capítulo de esta Enciclopedia.

A fin de proteger a los trabajadores y las instalaciones, de evitar sanciones legales y la publicidad negativa que entrañan y de reducir al mínimo la responsabilidad jurídica y los costes de las prestaciones compensatorias a los trabajadores, las empresas del sector privado realizan a menudo inspecciones y auditorías internas para comprobar que cumplen la normativa. Las auditorías internas pueden realizarlas trabajadores cualificados de la propia empresa o consultores externos contratados. U na reciente tendencia, destacable en $E$ stados $U$ nidos y algunos otros países desarrollados, ha sido la proliferación de consultoras privadas y departamentos universitarios que ofrecen a las empresas servicios relacionados con la seguridad y la salud en el trabajo.

\section{Riesgos}

En general, los inspectores se enfrentan exactamente a los mismos riesgos que deben identificar y corregir. Por ejemplo, los inspectores de seguridad y salud en el trabajo pueden visitar lugares de trabajo en los que existan un medio ambiente tóxico, niveles sonoros perjudiciales, agentes infecciosos, riesgos de radiación, incendio o explosión y edificios y equipos en condiciones de seguridad deficientes. Para los diferentes trabajadores en un medio ambiente concreto, los inspectores deben prever los tipos de riesgos que pueden encontrar cualquier día, y cerciorarse de que disponen de las herramientas y los EPI que pudieran necesitar. En todos los casos, deben estar preparados para la peor situación imaginable; así, al entrar en una mina han de estar preparados para enfrentarse a una atmósfera deficiente en oxígeno, incendios, explosiones y derrumbamientos. Por otro lado, los inspectores que verifiquen unidades de aislamiento en centros de asistencia sanitaria deben protegerse de los microorganismos contagiosos.

El estrés laboral es uno de los principales riesgos para los inspectores. Entre los numerosos factores causantes, tenemos:

- El estrés en el trabajo va en aumento a medida que los recortes fiscales causan reducciones de los presupuestos de los organismos, lo que a menudo origina escasez de personal. Las presiones consiguientes para atender una carga de trabajo creciente influyen de modo inevitable en la capacidad para mantener la calidad y la integridad de las inspecciones.

- También es causa de estrés para el inspector hacer cumplir escrupulosamente las normas y reglamentos que él mismo puede reconocer como inadecuadas en situaciones concretas. $Y$ cuando las circunstancias no permitan pasarlas por alto, el inspector puede que tenga que soportar las quejas por la imposición de normas y reglamentos impopulares.

- Las empresas, y a veces también los trabajadores, pueden sentirse ofendidos por la "intrusión" del inspector en el lugar de trabajo y por su necesidad de mantener una actitud suspicaz ante posibles subterfugios u ocultaciones. Ello hace que a menudo el trabajo del inspector sea desagradable y estresante. Este antagonismo puede agravarse hasta el punto de llegar a las amenazas y la violencia.

- El inspector puede sentirse responsable cuando debido al descuido 0 a riesgos desconocidos en el lugar de trabajo se originen graves daños a un trabajador 0 , peor aún, se produzca un siniestro que afecte a numerosas personas.

- Al igual que muchos trabajadores autónomos, los inspectores pueden sufrir contratiempos burocráticos, como la lejanía, una vigilancia inadecuada, la falta de apoyo, el papeleo interminable y la separación del hogar, la familia y los amigos.

- La necesidad de entrar en barrios poco seguros puede exponerles a ser víctimas de delitos y actos de violencia.

- Por último, y sobre todo cuando se les exije el uso de uniforme, pueden ser vistos como enemigos por quienes abrigan resentimientos contra el organismo concreto o contra la Administración en su conjunto. La explosión de una bomba ocurrida en 1996 en el edificio de oficinas federales de Estados U nidos en la ciudad de O klahoma, en EE.UU., es un ejemplo de tal hostilidad al Gobierno.

L os organismos que emplean a inspectores, deben tener políticas de seguridad y salud claramente definidas en las que se describan las medidas apropiadas para proteger la salud y el bienestar de los inspectores, sobre todo los que trabajan en este campo. En 
Estados U nidos, por ejemplo, la O SH A incluye esa información en sus directivas obligatorias. En algunos casos, este organismo exige que los inspectores dejen constancia del uso del equipo de protección adecuado durante una inspección, ya que la infracción por el propio inspector de las normas y medidas de seguridad y salud puede comprometer la integridad de la inspección.

La educación y la formación son la clave para preparar a los inspectores a protegerse debidamente. Cuando se promulguen nuevas normas y se emprendan nuevas iniciativas o programas, debe formarse a los inspectores en la prevención de enfermedades y lesiones en lo que respecta a ellos mismos, además de instruirles sobre los nuevos requisitos y sus procedimientos de aplicación. Por desgracia, rara vez se ofrece una formación de este tipo.

Como parte de los programas de formación para luchar contra el estrés en el trabajo, que raramente se ofrecen, debería formarse a los inspectores en técnicas de comunicación y de trato con personas enfadadas y con una actitud insultante.

En la Tabla 101.1 se enumeran algunos de los tipos de inspectores gubernamentales y los riesgos a los cuales pueden ser expuestos. En otro capítulo de esta E nciclopedia se ofrece información más detallada sobre el reconocimiento y el control de esos riesgos.

Un fenómeno de reciente aparición en numerosos países, que a muchos les parece preocupante, es la disminución del énfasis en la inspección como mecanismo para exigir el cumplimiento

Tabla 101.1 • Riesgos de los servicios de inspección.

\begin{tabular}{|c|c|c|}
\hline Profesiones & Tareas & Riesgos asociados \\
\hline $\begin{array}{l}\text { Controladores de las } \\
\text { normas de segu- } \\
\text { ridad y salud en el } \\
\text { trabajo }\end{array}$ & $\begin{array}{l}\text { Investigar y citar riesgos } \\
\text { para la seguridad y salud }\end{array}$ & $\begin{array}{l}\text { Gran variedad de riesgos } \\
\text { para la seguridad y la } \\
\text { salud }\end{array}$ \\
\hline Inspectores agrícolas & $\begin{array}{l}\text { Investigar la seguridad y la } \\
\text { salud de los trabajadores } \\
\text { agrícolas }\end{array}$ & $\begin{array}{l}\text { Equipo agrícola, productos } \\
\text { químicos, plaguicidas, } \\
\text { agentes biológicos y } \\
\text { ambiente exterior }\end{array}$ \\
\hline $\begin{array}{l}\text { Inspectores } \\
\text { ambientales }\end{array}$ & $\begin{array}{l}\text { Investigar en centros agrí- } \\
\text { colas e industriales la } \\
\text { contaminación del aire, el } \\
\text { agua y el suelo }\end{array}$ & $\begin{array}{l}\text { Riesgos químicos, físicos, } \\
\text { biológicos }\end{array}$ \\
\hline Inspectores sanitarios & $\begin{array}{l}\text { Investigar en residencias } \\
\text { para ancianos y hospitales } \\
\text { el cumplimiento de las } \\
\text { normas hospitalarias } \\
\text { sobre seguridad y salud }\end{array}$ & $\begin{array}{l}\text { Riesgos infecciosos, } \\
\text { químicos, radiactivos }\end{array}$ \\
\hline $\begin{array}{l}\text { Inspectores de } \\
\text { alimentos }\end{array}$ & $\begin{array}{l}\text { Investigar la seguridad y } \\
\text { salubridad de productos } \\
\text { alimenticios y de } \\
\text { establecimientos }\end{array}$ & $\begin{array}{l}\text { Insectos y agentes microbio- } \\
\text { lógicos asociados; } \\
\text { agentes químicos, } \\
\text { violencia y perros }\end{array}$ \\
\hline $\begin{array}{l}\text { Inspectores de } \\
\text { ingeniería y } \\
\text { construcción }\end{array}$ & $\begin{array}{l}\text { Investigar el cumplimiento } \\
\text { de las normas de cons- } \\
\text { trucción de edificios y de } \\
\text { protección contra incen- } \\
\text { dios y reglas de } \\
\text { mantenimiento }\end{array}$ & $\begin{array}{l}\text { Estructuras, equipos y mate- } \\
\text { riales de construcción no } \\
\text { seguros }\end{array}$ \\
\hline $\begin{array}{l}\text { Inspectores de } \\
\text { aduanas }\end{array}$ & $\begin{array}{l}\text { Investigar si entran en los } \\
\text { límites territoriales contra- } \\
\text { bando y materiales } \\
\text { peligrosos }\end{array}$ & $\begin{array}{l}\text { Explosivos, drogas, riesgos } \\
\text { químicos y biológicos }\end{array}$ \\
\hline
\end{tabular}

de la normativa. Ello ha conducido a la pérdida de categoría y reducción de la dotación económica y humana de los organismos responsables y a la erosión de sus servicios de inspección. Existe una preocupación creciente, no sólo por la seguridad y la salud de las plantillas de inspectores, sino también por la salud y el bienestar de los trabajadores y el público en general cuya protección les está encomendada.

\section{SeRVICIOS POSTALES}

\section{Roxanne Cabral}

Aunque la obligación social de la mayoría de las administraciones de correos (recogida, clasificación y reparto y procesamiento del correo nacional e internacional preservando la seguridad de los envíos postales) no ha experimentado cambios en el último siglo, los métodos mediante los que se lleva a cabo esta obligación sí se han transformado debido a los rápidos avances tecnológicos y al aumento del volumen del correo. Países industrializados como Australia, Francia, Alemania, Suecia, el Reino Unido y otros, procesan cada uno miles de millones de envíos postales al año. En 1994, el servicio de correos de Estados U nidos repartió casi 200 millones de objetos postales, lo que supone un aumento del volumen postal del $67 \%$ desde 1980. La competencia de empresas privadas que han entrado en este mercado, sobre todo en los sectores de paquetería y mensajería rápida, así como otros avances tecnológicos, como máquinas de fax, módems informáticos, correo electrónico, transferencia electrónica de fondos y sistemas por satélite, también han modificado las comunicaciones personales y comerciales. Dado que muchas de las operaciones que realizan las empresas privadas coinciden con las de los servicios postales, los riesgos a los que se enfrentan sus trabajadores son también los mismos.

La mayoría de las administraciones postales son propiedad de los gobiernos y funcionan bajo su control, aunque tal situación está cambiando. Por ejemplo, Argentina, Australia, Canadá, A lemania, Países Bajos, Suecia, Reino U nido y Estados U nidos han privatizado, en distinta medida, sus operaciones postales. La adjudicación en régimen de franquicia o bajo contrato de trabajo y servicios se hace cada vez más frecuente en las administraciones postales de los países industrializados.

Las administraciones postales son a menudo, especialmente en los países industrializados, las que ocupan un mayor número de trabajadores, en algunos países alrededor de cientos de miles de personas. Aunque los avances tecnológicos no han modificado drásticamente la estructuración de las administraciones postales, sí han alterado los métodos de clasificación y reparto del correo. Dado que los servicios de correos han exigido durante mucho tiempo gran cantidad de mano de obra (por lo que los salarios y las prestaciones suponen hasta el $80 \%$ de los costes de explotación totales en algunos países), los esfuerzos por reducir estos costes, así como mejorar la productividad y aumentar la eficiencia de funcionamiento, han favorecido la implantación de avances tecnológicos mediante inversiones de capital. En numerosos países industrializados, el objetivo es automatizar totalmente el proceso del correo hasta el punto de entrega.

\section{Operaciones}

$L$ as operaciones postales se dividen en tres fases principales: recogida, clasificación y reparto. Los servicios administrativos y de mantenimiento también son aspectos integrales de las operaciones postales. L os cambios tecnológicos en los métodos operativos, sobre todo en la fase de clasificación, han reducido la necesidad de trabajadores, por lo que éstos están más aislados, 
al requerirse una plantilla más reducida para hacer funcionar los nuevos equipos postales. Las mejoras tecnológicas también han originado una reducción de las cualificaciones exigidas a los trabajadores, al haber sustituido los ordenadores tareas como la memorización de los códigos postales y la realización de pruebas diagnósticas en equipos mecánicos.

El trabajo por turnos sigue siendo una práctica común en las operaciones postales, dado que la mayor parte del correo se recoge al final del día, y es transportado y clasificado por la noche. M uchas administraciones postales ofrecen reparto de correo a particulares y empresas seis días a la semana. La frecuencia del servicio exige que la mayoría de las operaciones postales funcionen las 24 horas del día, siete días a la semana. En consecuencia, el estrés psicológico y fisiológico originado por el trabajo a turnos y nocturno sigue suponiendo un problema para multitud de trabajadores de correos, sobre todo durante el ajetreado turno de noche en los grandes centros de procesamiento postal.

La mayoría de las administraciones postales del mundo industrializado se organizan con centros de proceso de gran tamaño que surten a pequeñas oficinas de distribución y reparto. Los centros de proceso, a menudo de varias plantas y varios miles de metros cuadrados de superficie, están equipados con grandes máquinas, equipo de manipulación de materiales, vehículos de motor y talleres de reparación y pintura similares a ambientes de trabajo industriales. No obstante, las oficinas de destino más pequeñas son por lo general más limpias y menos ruidosas, guardando mayor similitud con el ambiente existente generalmente en oficinas.

\section{Riesgos y su prevención}

Aunque la tecnología ha eliminado numerosas tareas peligrosas y monótonas realizadas por los trabajadores de correos, han surgido riesgos diferentes que, si no se atienden debidamente, pueden ser perjudiciales para la seguridad y la salud de los trabajadores postales.

\section{Servicios de mostrador}

Las tareas desempeñadas por los trabajadores destinados a servicios postales en mostrador dependen del tamaño de la oficina de correos y del tipo de servicios ofrecidos por la administración postal. Las funciones generales de los trabajadores en mostradores y ventanillas son la venta de sellos e impresos para giros postales, el pesado y franqueado de cartas y paquetes y la información postal a los clientes. Dado que este personal maneja directamente dinero en su relación con el público, corre un mayor riesgo de sufrir robos con violencia. Para el personal de ventanilla que trabaja solo en un lugar próximo a zonas con un alto índice de delincuencia o por la noche o de madrugada, la violencia en el lugar de trabajo puede ser un riesgo laboral importante si no se adoptan medidas de protección apropiadas. La posibilidad de que exista tal violencia también contribuye $a$ un estrés mental desmedido. De igual modo, son factores que contribuyen al estrés, la presión diaria derivada del trato con el público y la responsabilidad de manejar cantidades de dinero relativamente grandes.

Las condiciones ambientales y la organización física del puesto de trabajo también pueden contribuir a los riesgos para la seguridad y la salud. Los problemas de calidad del aire en interiores, como el polvo, la falta de aire fresco y los cambios de temperatura, pueden causar incomodidades al trabajador de oficina postal. Los puestos de trabajo deficientemente diseñados que exigen al sujeto trabajar en posturas forzadas a causa de la situación del equipo (p. ej., caja registradora, balanza, recipientes para correo y paquetes), la permanencia prolongada de pie o sentado en sillas incómodas y no adaptables, así como el levantamiento de paquetes pesados pueden originar trastornos musculosqueléticos.

Son medidas preventivas de estos riesgos la mejora de la seguridad mediante la instalación de una adecuada protección exterior e interior, las puertas, ventanas y mamparas de vidrio a prueba de balas y alarmas silenciosas, asegurarse de que los trabajadores no trabajen solos, proporcionarles la formación necesaria para responder ante situaciones de emergencia y asegurarse de que el público tenga un acceso limitado y controlado al local. Las evaluaciones ergonómicas y de la calidad del aire en interiores también pueden contribuir a la mejora de las condiciones de trabajo del personal dedicado a la atención al público.

\section{Clasificación}

El paso de las operaciones manuales a los sistemas mecanizados y automáticos ha influido en gran medida en la fase de manipulación y clasificación de las operaciones postales. Por ejemplo, mientras que antes los trabajadores de correos tenían que memorizar diversos códigos que correspondían a rutas de reparto, esa tarea se realiza actualmente por medio de ordenadores. Desde principios de los años 80 , la tecnología ha mejorado hasta tal punto que actualmente muchas máquinas pueden "leer" una dirección y aplicar un código. En los países industrializados, la tarea de clasificar el correo ha pasado del ser humano a las máquinas.

\section{Manipulación de materiales}

Aunque la tecnología ha reducido la cantidad de clasificación manual de cartas y paquetes pequeños, sus repercusiones han sido menores en los movimientos de contenedores, paquetes y sacas de correo en el interior de las instalaciones postales. El correo transportado en camiones, aviones, ferrocarril o barco a grandes centros de proceso y clasificación puede trasladarse internamente a zonas de clasificación diferentes mediante sistemas de

Figura 101.1 • El manejo manual de paquetes pesados es un riesgo ergonómico grave. Son necesarios límites de peso y de tamaño de los paquetes.

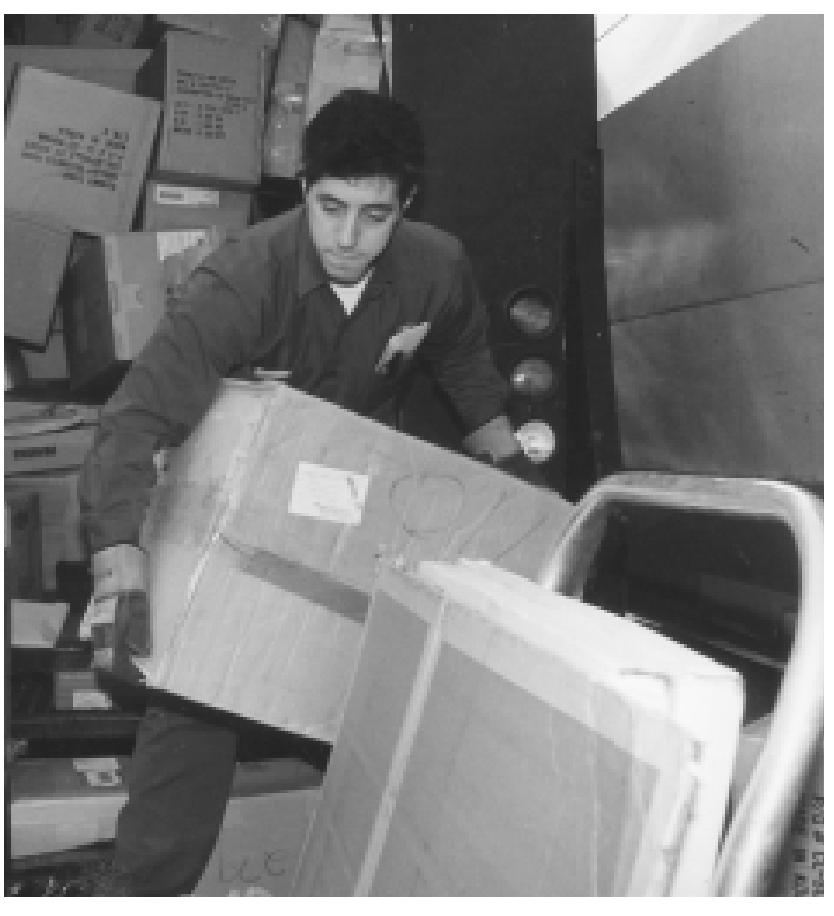


cintas transportadoras complejos. Carretillas elevadoras, volquetes mecánicos y cintas transportadoras más pequeñas pueden ayudar a los trabajadores postales a descargar y cargar camiones y a colocar el correo en los complejos sistemas de transporte por cinta. No obstante, todavía es preciso realizar a mano algunas tareas de manipulación de materiales, sobre todo en los centros postales de menor tamaño. Las operaciones para separar el correo destinado al proceso mecánico del que debe clasificarse a mano, es una tarea que no se ha automatizado por completo. En función de los reglamentos de la administración postal o de la reglamentación nacional en materia de seguridad y salud, pueden implantarse límites sobre cargas pesadas para evitar que los trabajadores tengan que manipular y manejar contenedores de correo y paquetes demasiado pesados (véase la Figura 101.1).

L as tareas de manipulación de materiales, también exponen a los trabajadores de correos a riesgos eléctricos y a partes móviles de la maquinaria que pueden causar lesiones. Aunque el polvo de papel es una molestia para casi todos los trabajadores postales, los que se ocupan primordialmente de tareas de manipulación de materiales inhalan por lo general polvo cuando abren por primera vez sacas de correo y contenedores. También son estos trabajadores los primeros que entran en contacto con cualquier material biológico o químico que pueda haberse vertido durante el transporte.

Los esfuerzos para reducir el cansancio y las lesiones de espalda comprenden la automatización de algunas de las tareas que requieren una manipulación manual. El traslado de palés de correo mediante carretillas elevadoras, el uso de recipientes rodantes para transportar el correo en el interior de una dependencia y la instalación de descargadores automáticos de contenedores son métodos para automatizar tareas de manipulación de materiales. En algunos países industrializados se utiliza la robótica para ayudar a tareas de manipulación de materiales, como la descarga de contenedores en cintas transportadoras. La reglamentación sobre la cantidad de peso levantada y transportada por los trabajadores y la formación de éstos en las técnicas adecuadas de manejo de cargas también pueden ayudar a reducir la incidencia de lesiones y dolores de espalda.

A fin de controlar la exposición a productos químicos y biológicos, algunas administraciones de correos establecen prohibiciones en relación al tipo y la cantidad de materiales peligrosos que pueden enviarse por correo, y exigen asimismo que tales materiales sean identificables por los trabajadores postales. D ado que cierta cantidad de correo se enviará indudablemente sin añadir las debidas advertencias, es preciso que los trabajadores reciban formación que les permita actuar frente a vertidos de materiales potencialmente peligrosos.

\section{Manual/mecánico}

A medida que mejora la tecnología de clasificación, la clasificación manual de cartas está quedando rápidamente desfasada. Sin embargo, todavía es necesaria en cierta medida en numerosas administraciones postales, sobre todo en los países en desarrollo. La clasificación manual de cartas exige a los trabajadores colocarlas una por una en distintas casillas, tras lo cual se empaqueta el correo de cada una de ellas y se colocan los paquetes en contenedores o sacas para su envío. La clasificación manual es una actividad repetitiva realizada por el trabajador de pie o sentado en una banqueta.

Los trabajadores manuales también realizan la clasificación manual de los paquetes. Puesto que éstos son generalmente de mayor tamaño y mucho más pesados que las cartas, con frecuencia los trabajadores deben ponerlos en recipientes distintos situados a su alrededor. Los trabajadores que realizan esta tarea de clasificación, a menudo corren riesgo de lesiones o trastornos que afectan a hombros, brazos y espalda.
La automatización ha eliminado muchos de los riesgos ergonómicos asociados con la clasificación manual de cartas y paquetes. Cuando no se disponga de tecnología de automatización, debe darse a los trabajadores la oportunidad de rotar a tareas diferentes para aliviar el cansancio de una zona determinada del cuerpo. También deben permitirse descansos adecuados a los trabajadores que realicen tareas repetitivas.

En los sistemas de clasificación mecánica modernos, los trabajadores se sientan ante un teclado mientras las cartas pasan mecánicamente delante de ellos (Figura 101.2). Los pupitres de codificación se disponen en paralelo o uno detrás de otro. Con frecuencia los operadores tienen que memorizar centenares de códigos que corresponden a zonas diferentes e introducir un código para cada carta en un teclado. A menos que estén debidamente ajustados, estos teclados pueden exigir al operador más fuerza para pulsar las teclas que los teclados informáticos modernos. El operador procesa alrededor de cincuenta a sesenta cartas por minuto. Basándose en el código introducido por el trabajador, las cartas se separan en cajas diferentes, de las que se recogen para empaquetarlas y enviarlas a su lugar de destino

Los riesgos ergonómicos que originan trastornos musculosqueléticos, sobre todo tendinitis y síndrome del túnel carpiano, son el problema más importante para los operadores de la clasificación mecanizada. M uchas de las máquinas utilizadas se diseñaron hace varias décadas, cuando no se aplicaban los

Figura 101.2 - O peradores de pupitre codificador clasificando cartas con ayuda de maquinaria informatizada.

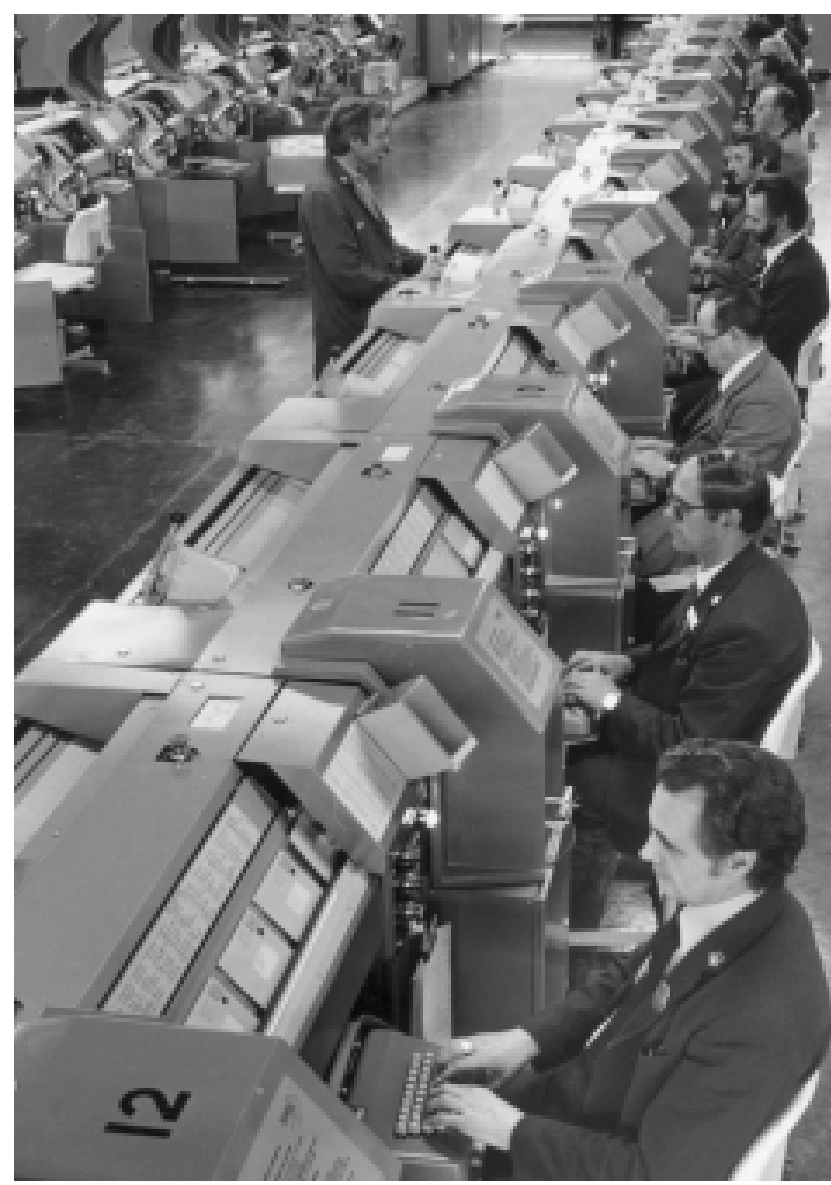


principios ergonómicos con la misma diligencia que en la actualidad. Los equipos de clasificación automática y las pantallas de visualización de datos (PVD), están reemplazando rápidamente a estos sistemas de clasificación mecánicos. En muchas administraciones postales, en las que la clasificación mecánica sigue siendo el sistema principal, los trabajadores pueden rotar a otros puestos, tomarse descansos a intervalos regulares o hacer ambas cosas. La dotación de sillas cómodas y el ajuste de la fuerza de los teclados son otras modificaciones que pueden mejorar el trabajo. Aunque supongan molestias e incomodidades para el operador, el ruido y el polvo del correo no son por lo general riesgos importantes.

\section{Pantallas de visualización de datos (PVD)}

Las terminales de clasificación basadas en PVD están empezando a sustituir a las clasificadoras mecánicas. En lugar de encontrarse ante los objetos postales reales, el operador ve aparecer en la pantalla imágenes ampliadas de las direcciones. Gran parte del correo que se procesa clasificándolo mediante PVD, ha sido rechazado 0 apartado previamente por las clasificadoras automáticas como no procesable.

L a ventaja de la clasificación mediante PVD es que hace innecesaria la proximidad física al correo. A través de módems informáticos pueden enviarse las imágenes a las PV D situadas en otra dependencia, o incluso en una ciudad distinta. Para el operador de PVD, esto significa que el entorno de trabajo es por lo general más cómodo, sin el ruido de fondo de las máquinas clasificadoras o el polvo del correo. No obstante, la clasificación mediante PVD es un trabajo muy agotador para la vista y con frecuencia sólo consiste en una tarea: teclear a partir de imágenes de cartas. Al igual que la mayoría de las tareas de clasificación, se trata de una función monótona pero que exige al mismo tiempo una fuerte concentración del operador para mantener los niveles de productividad exigidos.

Las molestias musculosqueléticas y la fatiga ocular son las molestias más comunes de los operadores de PVD. Son medidas adecuadas para reducir el cansancio físico, ocular y mental, el equipo adaptable, como teclados y sillas, la iluminación apropiada para reducir reflejos y los descansos periódicos. A demás, dado que estos operadores trabajan a menudo en entornos parecidos a oficinas, deben atenderse las quejas relativas a la calidad del aire interior.

\section{Automatización}

El tipo más avanzado de clasificación reduce la necesidad de que los trabajadores intervengan directamente en la codificación y separación de los distintos objetos postales. Por lo general bastan 203 trabajadores para manejar una clasificadora automática. En uno de los extremos de la máquina, un trabajador carga el correo en una cinta mecánica que pasa cada carta por delante de una lectora de caracteres ópticos (LCO). La LCO lee o escanea la carta, y se imprime en ésta un código de barras. A continuación se separan las cartas automáticamente en docenas de cajas situadas en el otro extremo de la máquina. Los trabajadores retiran de las cajas los paquetes de correo separado y los transportan a la fase siguiente del proceso de clasificación. L as clasificadoras automáticas más grandes son capaces de procesar entre 30.000 y 40.000 objetos postales por hora.

Aunque esta automatización ya no precisa un teclado para codificar el correo, los trabajadores siguen estando expuestos a tareas repetitivas y monótonas que entrañan riesgos de sufrir trastornos musculosqueléticos. La retirada de los paquetes de correo separado en las diferentes cajas y su colocación en contenedores $u$ otros equipos de manipulación de materiales, supone una tensión física sobre los hombros, la espalda y los brazos. Los operadores se quejan también de problemas de muñecas y manos por tener que coger constantemente pilas de correo. La exposición al polvo causa a veces más problemas a quienes trabajan con clasificadoras automáticas que a los demás trabajadores postales debido al mayor volumen de correo procesado.

Son muchas las administraciones de correos que han adquirido hace poco el equipo para clasificación automática. A medida que aumenten las quejas de molestias musculosqueléticas, los diseñadores y fabricantes de equipos se verán obligados a tener más en cuenta los principios ergonómicos, en sus intentos de lograr un equilibrio entre las necesidades de productividad y el bienestar de los trabajadores. Por ejemplo, en Estados U nidos, las autoridades en materia de seguridad y salud han llegado a la conclusión de que parte de los equipos de clasificación automática de correo presentan importantes deficiencias ergonómicas. Aunque puede intentarse modificar el equipo o los métodos de trabajo para reducir los riesgos de molestias musculosqueléticas, tales modificaciones no son tan eficaces como el diseño adecuado del equipo (y de los métodos de trabajo) desde el principio.

O tro problema es el riesgo de lesiones, al eliminar atascos en las máquinas o durante las operaciones de mantenimiento y reparación, para las que se precisa una formación adecuada y la aplicación de dispositivos de bloqueo.

\section{Reparto}

Las operaciones postales se sirven de numerosos métodos de transporte para distribuir el correo: aéreo, ferroviario, marítimo y por carretera. Para distancias cortas y reparto local, el correo se transporta en vehículos a motor. El correo, que debe recorrer generalmente menos de varios cientos de kilómetros desde los grandes centros de proceso a las oficinas postales más pequeñas, suele transportarse en trenes o grandes camiones, mientras que los desplazamientos por aire y mar se reservan para las distancias mayores entre los grandes centros de proceso.

Al aumentar espectacularmente el uso de vehículos para servicios de reparto en las dos últimas décadas, los accidentes y lesiones derivados del uso de camiones, furgonetas y automóviles de correos se han convertido en el problema de seguridad y salud en el trabajo más importante y grave para algunas administraciones postales. Los accidentes con vehículos son la causa principal de mortalidad en el trabajo. Además, aunque el aumento del uso de vehículos de reparto y la instalación de más buzones de almacenamiento de correo en las calles, han ayudado a reducir la cantidad de tiempo que deben caminar los carteros, sigue habiendo problemas de molestias musculosqueléticas y lesiones de espalda por causa de las pesadas carteras de correo que deben llevar en su ruta. A simismo, están aumentando los robos y otras agresiones violentas contra los repartidores de correo. Las lesiones causadas por resbalones, tropezones y caídas, sobre todo en condiciones climatológicas adversas, y los ataques de perros son los riesgos más graves a los que se enfrentan los carteros. Por desgracia, no puede hacerse gran cosa para eliminar estos riesgos concretos, salvo aumentar las precauciones.

Las medidas encaminadas a reducir la probabilidad de accidentes con vehículos incluyen la instalación de frenos antibloqueo y de espejos retrovisores extra para mejorar la visibilidad, el aumento del uso de cinturones de seguridad, la mejor formación de los conductores, la realización de inspecciones de mantenimiento de los vehículos más frecuentes y la mejora de las carreteras y del diseño de los vehículos. Para eliminar los riesgos ergonómicos asociados con la carga y el transporte del correo, algunas administraciones postales facilitan carritos con ruedas 0 carteras especiales para correo en las que el peso se distribuye por igual en los hombros del trabajador, en lugar de concentrarse en un solo lado. Para reducir el peligro de violencia en el 
lugar de trabajo, los repartidores pueden llevar dispositivos de comunicaciones bidireccionales, y sus vehículos pueden estar dotados de un sistema de seguimiento. Además, por razones ambientales y de prevención de la exposición a los gases de escape de los motores diesel, algunos vehículos postales están impulsados por gas natural o electricidad.

\section{Reparación y mantenimiento}

L os trabajadores responsables del mantenimiento, la limpieza y la reparación diarios de las dependencias y los equipos postales, incluidos los vehículos de motor, se enfrentan a riesgos semejantes a los de los que se ocupan del mantenimiento en otras actividades industriales. La exposición a operaciones de soldadura, riesgos eléctricos, caídas desde andamios, productos químicos contenidos en productos de limpieza y lubricantes de máquinas, amianto en revestimientos de frenos y polvo, son ejemplos de riesgos asociados con tareas de mantenimiento.

\section{- TELECOMUNiCACIONES}

David LeG rande

Se entiende por telecomunicaciones el acto de comunicarse con otros por medio de equipos electrónicos como teléfonos, módems informáticos, satélites y cables de fibra óptica. L os sistemas de telecomunicación comprenden los cables de telecomunicación que van desde el usuario a la central de conmutación local (bucles locales), las instalaciones de conmutación que suministran la conexión de comunicaciones al usuario, las líneas que transmiten las llamadas entre las oficinas de conmutación y, por supuesto, el usuario.

Desde principios a mediados del siglo $X X$ se introdujeron las centrales telefónicas, los sistemas de conmutación electromecánicos, los cables, los repetidores, los sistemas portadores y los equipos de microondas. Como consecuencia, los sistemas de telecomunicación se extendieron por las zonas industrializadas del mundo.

Desde 1950 hasta 1984, se produjeron continuos avances tecnológicos. Por ejemplo, se introdujeron por todo el sector de las telecomunicaciones los sistemas por satélite, los sistemas de cable mejorados, el uso de tecnología digital, la fibra óptica, la informática y la telefonía de vídeo. Estos cambios permitieron la expansión de los sistemas de telecomunicaciones por más lugares del mundo.

En 1984, una sentencia judicial acabó con el monopolio de las telecomunicaciones de que disfrutaba en Estados Unidos la empresa A merican Telegraph and Telephone (AT \&T). Tal acontecimiento coincidió con numerosos cambios rápidos e importantes en la tecnología del propio sector de las telecomunicaciones.

Hasta los años 80, los servicios de telecomunicaciones se consideraban servicios públicos que operaban en un marco legislativo que preveía un régimen de monopolio en prácticamente todos los países. Junto con el desarrollo de la actividad económica, la aparición de nuevas tecnologías ha conducido a la privatización del sector de las telecomunicaciones. Esta tendencia culminó en la desmembración de la AT\&T y en la desregulación del sistema de telecomunicaciones de Estados U nidos. En otros países se están realizando actividades de privatización semejantes.

Desde 1984, los avances tecnológicos han producido y ampliado sistemas de telecomunicación capaces de ofrecer un servicio universal a todos los habitantes del mundo, algo que está ocurriendo a medida que la tecnología de las telecomu- nicaciones converge con otras tecnologías de la información. En este proceso intervienen campos relacionados, como los de la electrónica y el proceso de datos.

L as repercusiones de la introducción de nuevas tecnologías en el trabajo han sido ambivalentes. No cabe duda alguna de que se ha reducido los niveles de empleo y los de cualificación de los puestos de trabajo, produciéndose una radical sustitución, tanto de las tareas de los trabajadores de telecomunicaciones, como de las cualificaciones y la experiencia que se les exigen. No obstante, algunos prevén en el futuro un crecimiento del empleo, como resultado del aumento de las actividades comerciales estimulado por la desregulación del sector de las telecomunicaciones, que originará muchos puestos de trabajo altamente cualificados

Los puestos de trabajo del sector de las telecomunicaciones pueden dividirse en los de técnicos especialistas y los de personal administrativo. Entre los primeros están los empalmadores e instaladores de cables, los técnicos de instalaciones exteriores, los de oficinas centrales y los de estructuras. Se trata de puestos de trabajo muy especializados, sobre todo a consecuencia de los nuevos equipos tecnológicos. Por ejemplo, los trabajadores deben tener conocimientos muy amplios en los campos eléctrico, electrónico y/ o mecánico por su relación con la instalación, el servicio y el mantenimiento del equipo de telecomunicación. La formación se adquiere mediante clases teóricas y formación en el puesto de trabajo.

Las tareas administrativas comprenden operadores de información, personal de servicio a clientes, representantes de cuentas y administrativos de ventas. Por lo general, exigen el manejo de equipos de comunicaciones, tales como PV D, centralitas y máquinas de fax, que se utilizan para establecer conexiones locales o de larga distancia, realizar el trabajo de oficina comercial en el lugar de trabajo o fuera de él y mantener contactos de venta con los clientes.

\section{Riesgos y controles}

Los riesgos para la seguridad y la salud existentes en el sector de las telecomunicaciones pueden clasificarse según el tipo de tareas o servicios que se realizan.

\section{Operaciones de construcción y montaje}

En general, se dan los mismos riesgos que en el campo de la construcción, aunque existen varias actividades destacables que son específicas de las telecomunicaciones, como el trabajo en altura en postes o torres, la instalación de sistemas de cableado para telecomunicaciones y la excavación para tendido de cables. En las telecomunicaciones son aplicables las medidas de protección habituales, como trepadores de postes, arneses de seguridad, plataformas de elevación y entibación adecuada de las excavaciones. C on frecuencia estos trabajos se realizan durante reparaciones de urgencia exigidas por causa de tormentas, corrimientos de tierras o inundaciones.

\section{Electricidad}

Al realizar trabajos de telecomunicaciones es de suma importancia el uso seguro de la electricidad y los equipos eléctricos. Las medidas preventivas normales contra la eletrocución, las descargas eléctricas, los cortocircuitos y los incendios o explosiones son plenamente aplicables a las telecomunicaciones. U na fuente importante de peligro puede surgir cuando los cables de telecomunicaciones y eléctricos se encuentran en estrecha proximidad.

\section{Tendido y mantenimiento de cables}

EI tendido y el mantenimiento de cables supone una preocupación importante en cuanto a la seguridad y la salud. EI trabajo en 
cables subterráneos, conductos de tubería y cámaras de empalme exige el manejo de pesados tambores de cable y la introducción de los cables en los conductos subterráneos mediante tornos mecánicos y equipo especial para manipularlos, así como el empalmado o unión de los cables y su aislamiento o impermeabilización. Durante los trabajos de empalme y aislamiento, los trabajadores se ven expuestos a riesgos para la salud, como plomo, disolventes e isocianatos. Las medidas preventivas comprenden el uso de los productos químicos menos tóxicos, una ventilación adecuada y EPI. Es frecuente que el trabajo de mantenimiento y reparación se realice en espacios confinados, como registros y recintos subterráneos. Un trabajo de este tipo exige equipo de protección respiratoria adecuado, arnés y equipo de elevación, así como la presencia de un trabajador en la superficie que sea capaz de realizar reanimación cardiopulmonar de urgencia

0 tro trabajo causante de problemas para la seguridad y salud en el trabajo, es el realizado con cables de telecomunicaciones de fibra óptica, que se instalan como alternativa a los que llevan fundas de plomo y poliuretano porque permiten transmitir muchas más comunicaciones y tienen un tamaño mucho menor. En lo que concierne a la seguridad y la salud, implica posibles quemaduras en los ojos o en la piel a causa de la exposición al rayo láser cuando se desconectan o rompen los cables. Si esto ocurre, deberán implantarse medidas técnicas de control y suministrar a los trabajadores EPI adecuados.

Asimismo, el trabajo de instalación y mantenimiento de cables realizado en edificios, lleva aparejada una posible exposición a productos que contienen amianto. Esta exposición se produce a consecuencia del deterioro o la descomposición de productos que contienen amianto, como conducciones, compuestos para parcheado y encintado, losetas para suelos y techos y rellenos de refuerzo de pinturas y selladores. A finales de los años 70 , se prohibieron en muchos países o se desaconsejó el uso de los productos que contienen amianto. El cumplimiento de su prohibición en todo el mundo eliminará la exposición y los consiguientes trastornos de salud para las generaciones de trabajadores futuras, pero en los edificios antiguos todavía quedan grandes cantidades de amianto a las que hay que enfrentarse.

\section{Servicios de telégrafos}

Los trabajadores de telégrafos utilizan PVD y, en algunos casos, equipo telegráfico para realizar su trabajo. Un riesgo frecuente asociado con este tipo de trabajo son los traumatismos musculosqueléticos acumulativos de las extremidades superiores. Estos problemas de salud pueden reducirse al mínimo y prevenirse si se presta mayor atención al diseño ergonómico de los puestos de trabajo, al entorno laboral y a los factores de organización del trabajo.

\section{Servicio detelecomunicaciones}

Los circuitos automáticos de conmutación y conexión son los componentes responsables del funcionamiento de los sistemas de telecomunicaciones modernos. Las comunicaciones se establecen generalmente mediante microondas y ondas de radiofrecuencia, además de cables y alambres. La exposición a microondas y radiofrecuencias entraña riesgos potenciales. Según los datos científicos disponibles, no existen indicios de que la exposición a la mayoría de los tipos de equipos de telecomunicaciones emisores de radiación se relacione directamente con trastornos de la salud. No obstante, los trabajadores pueden estar expuestos a niveles altos de radiación de radiofrecuencia cuando trabajan en las proximidades de líneas eléctricas de alta tensión. Se han recogido datos que indican una relación entre estas emisiones y el cáncer. Se están realizando más investigaciones científicas para determinar con mayor claridad la gravedad de este riesgo, así como el equipo y los métodos de prevención adecuados. Además, se han asociado problemas de salud a las emisiones de los equipos telefónicos celulares. Se están realizando investigaciones posteriores para extraer conclusiones respecto a posibles riesgos para la salud.

La inmensa mayoría de los servicios de telecomunicaciones se realizan utilizando PVD. EI trabajo con PVD se asocia con la aparición de trastornos musculosqueléticos acumulativos de las extremidades superiores (sobre todo de la mano y la muñeca). M uchos sindicatos de telecomunicaciones, como Communications Workers of America (EE.UU.), Seko (Suecia) y Communication Workers U nion (Reino U nido), han identificado índices catastróficos de trastornos musculosqueléticos acumulativos en los puestos de trabajo con PVD entre los trabajadores a quienes representan. El diseño adecuado de los puestos de trabajo con PV D teniendo en cuenta las variables del puesto, el entorno y la organización del trabajo, reducirán al mínimo y prevendrán estos problemas de salud.

O tros problemas de salud son el estrés, el ruido y las descargas eléctricas.

\section{RIESG OS EN LAS PLANTAS DE TRATAMIENTO DE AGUAS RESIDU ALES (RESIDUOS)}

Mary O. Brophy

Si no se trataran los residuos, la concentración actual de personas e industrias en numerosas regiones del mundo haría muy rápidamente incompatible la vida con el medio ambiente. Aunque es importante la reducción de la cantidad de residuos, es esencial un tratamiento adecuado. En una planta de tratamiento entran dos tipos básicos de residuos: los humanos/ animales y los industriales. Los seres humanos excretan unos 250 gramos de residuos sólidos por persona y día, que incluyen 2.000 millones de bacterias coliformes y 450 millones de estreptococos por persona y día ( $M$ ara 1974). Las tasas de producción de residuos sólidos industriales oscilan entre 0,12 toneladas por trabajador al año en instituciones profesionales y científicas, y 162 toneladas en serrerías y talleres de cepillado de madera (Salvato 1992). Aunque algunas plantas de tratamiento de residuos se dedican exclusivamente a uno u otro tipo de material, la mayoría se ocupan tanto de residuos de origen animal como industrial.

\section{Riesgos y su prevención}

El objetivo de las plantas de tratamiento de aguas residuales es eliminar la mayor cantidad posible de contaminantes sólidos, líquidos y gaseosos, siempre que sea técnica y económicamente posible. Existe una gran variedad de procesos diferentes para eliminar los contaminantes de las aguas residuales: sedimentación, coagulación, condensación, aireación, desinfección, filtración y tratamiento de lodos. (Véase también el artículo "Tratamiento de aguas residuales" en este mismo capítulo.) EI riesgo específico asociado con cada proceso varía en función del diseño de la planta de tratamiento y de los productos químicos utilizados en los distintos procesos, pero cabe distinguir riesgos físicos, microbiológicos y químicos. La clave para prevenir o reducir al mínimo los efectos adversos asociados con el trabajo en plantas de tratamiento de aguas residuales es prevenir, identificar, evaluar y controlar los riesgos. 
Figura 101.3 • Boca de registro con la tapa retirada.

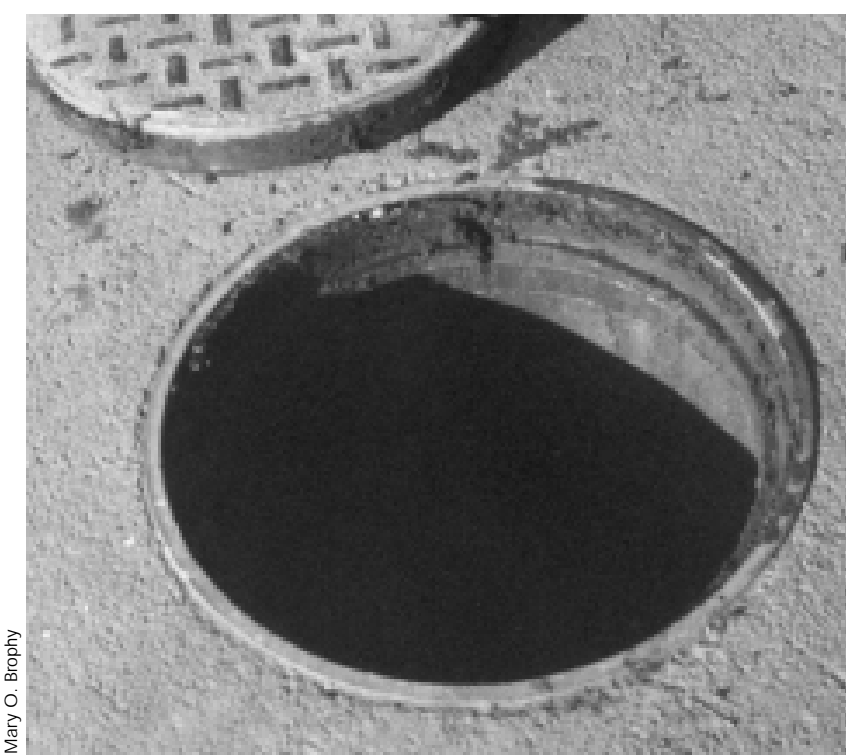

\section{Riesgos físicos}

Los espacios cerrados, la puesta en marcha inadvertida de máquinas o partes de ellas y los resbalones y caídas entrañan riesgos físicos. Las consecuencias de un riesgo físico pueden a menudo ser inmediatas, irreversibles y graves, o incluso mortales. Los riesgos físicos varían en función del diseño de la planta. No obstante, la mayoría de las plantas de tratamiento de aguas residuales tienen espacios confinados, entre ellos bóvedas o cuevas subterráneas de acceso difícil, registros (Figura 101.3) y tanques de sedimentación vaciados de su contenido líquido, por ejemplo, con motivo de reparaciones (Figura 101.4). Los equipos de mezclado, rastrillos para lodos, bombas y dispositivos mecánicos utilizados para diversas operaciones en las plantas de tratamiento de aguas residuales pueden causar mutilaciones, e incluso la muerte, si se ponen en funcionamiento involuntariamente mientras un trabajador realiza tareas de reparación o mantenimiento.

Figura 101.4 - Tanque vacío en una planta de tratamiento de aguas residuales.

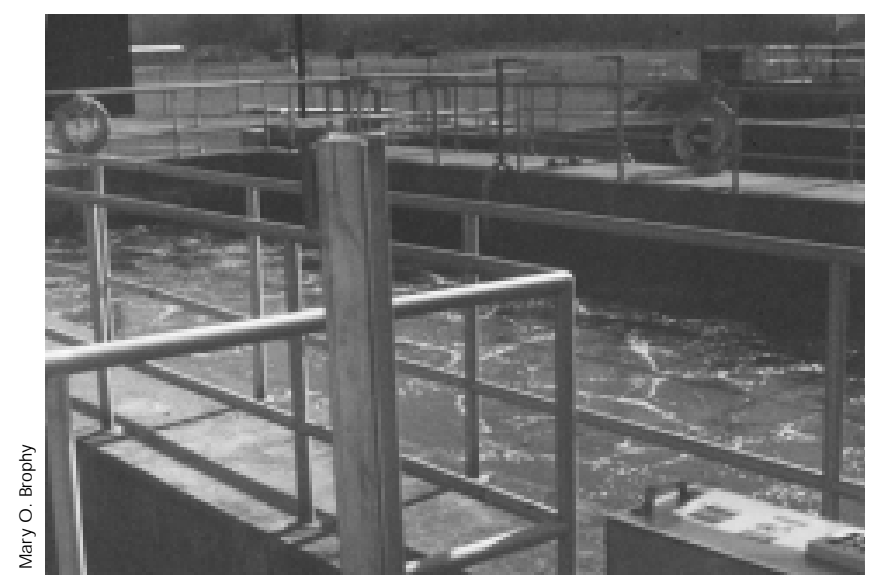

Figura 101.5 • Unidad de renovación de aire para entrar en un espacio cerrado.

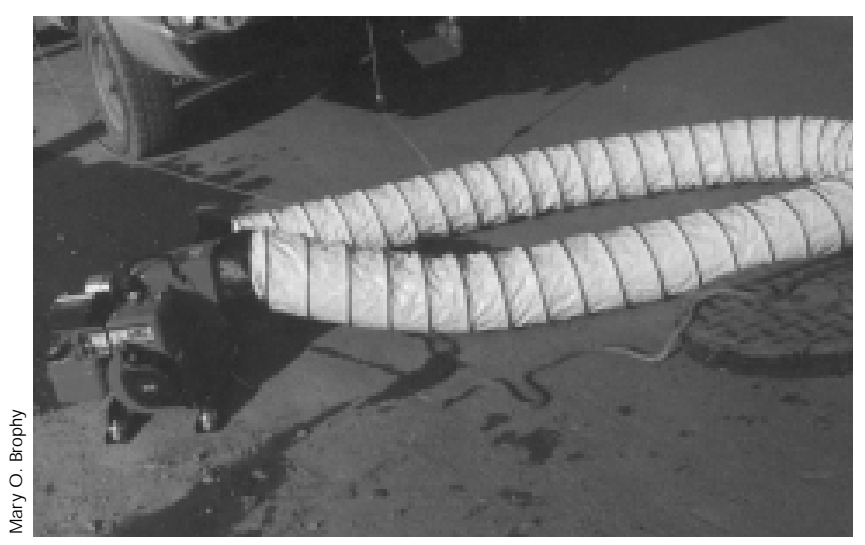

L as superficies húmedas, frecuentes en tales plantas, contribuyen al riesgo de resbalones y caídas.

La entrada a espacios confinados es uno de los riesgos más comunes para los trabajadores que se ocupan del tratamiento de aguas residuales, y uno de los más graves. No es fácil dar una definición universalmente válida de un espacio confinado, pero en general se considera que es una zona con medios limitados de entrada y salida que no se diseñó para la permanencia continuada de personas y que carece de la ventilación adecuada. Existen riesgos cuando el espacio confinado se asocia con escasez de oxígeno, o la presencia de un producto químico tóxico o de un material inundante, como el agua. El descenso de los niveles de oxígeno puede deberse a diversas circunstancias, como su sustitución por otro gas (p. ej., metano o sulfuro de hidrógeno), el consumo de oxígeno por la degeneración del material orgánico contenido en el agua residual o por el consumo de las moléculas de oxígeno en el proceso de oxidación de alguna estructura dentro del espacio confinado. Dado que la observación humana directa no permite descubrir la existencia de niveles bajos de oxígeno en espacios confinados, es de suma importancia utilizar un instrumento capaz de determinar el nivel de oxígeno antes de entrar en un recinto de esas características.

Nuestra atmósfera contiene un $21 \%$ de oxígeno al nivel del mar. Cuando el porcentaje de oxígeno del aire que se respira desciende a alrededor del 16,5\%, la respiración de la persona se hace más rápida y superficial, aumenta la frecuencia cardíaca y se empieza a perder coordinación. Con valores inferiores al $11 \%$, se sufren náuseas, vómitos, incapacidad para moverse e inconsciencia. Con niveles de oxígeno situados entre estos dos puntos puede producirse inestabilidad emocional y alteración del juicio. Cuando las personas entran en un recinto con niveles de oxígeno inferiores al 16,5\%, pueden sentir inmediatamente una desorientación tal que les impida salir de ellos, y caer después en la inconsciencia. Si la falta de oxígeno es lo bastante acusada, el sujeto puede quedar inconsciente después de una sola inspiración. Si no acuden en su rescate, puede morir en cuestión de minutos. Aun en caso de que se produzcan el rescate y la reanimación se pueden producirse lesiones permanentes (Wilkenfeld y cols. 1992).

La falta de oxígeno no es el único riesgo existente en un espacio confinado. Puede darse la presencia de gases tóxicos en concentración lo bastante alta para causar lesiones graves, e incluso la muerte, a pesar de existir niveles de oxígeno adecuados. Más adelante se comentan los efectos de los productos químicos tóxicos encontrados en espacios confinados. Uno de los medios más eficaces de controlar los riesgos 
asociados con los niveles bajos de oxígenos (inferiores al 19,5\%) y con las atmósferas contaminadas con productos químicos tóxicos es una ventilación mecánica concienzuda y adecuada del recinto confinado antes de permitir la entrada a él de persona alguna. Para ello suele utilizarse un conducto flexible por el que se insufla aire exterior al interior del espacio confinado (véase la Figura 101.5). Hay que asegurarse de que no se introducen también en el recinto las emanaciones de un generador 0 del motor del ventilador (Brophy 1991).

Las plantas de tratamiento de aguas residuales tienen a menudo maquinaria de gran tamaño para trasladar de un lugar a otro de la planta los lodos o las aguas residuales sin tratar. Cuando se reparen equipos de este tipo, hay que cortar totalmente el suministro de corriente a la máquina. Además, el conmutador para reconectar el equipo a la red eléctrica debe estar bajo el control de la persona que realice las reparaciones, lo que evita que otro trabajador de la planta conecte inadvertidamente el equipo. La elaboración e implantación de procedimientos para lograr estos objetivos se denomina programa de bloqueo/advertencia, y la ineficacia o insuficiencia de un programa de este tipo puede originar mutilaciones de partes del cuerpo como dedos, brazos y piernas, desmembración o incluso el fallecimiento.

En las plantas de tratamiento de aguas residuales existen con frecuencia grandes depósitos y recipientes de almacenamiento. En ocasiones las personas tienen que trabajar encima de los recipientes o caminar al lado de pozos que se han vaciado de agua y pueden tener una caída de 2,5 a 3 metros (véase la Figura 101.4). Debe facilitarse a los trabajadores la protección necesaria contra las caídas, así como formación adecuada en materia de seguridad.

\section{Riesgos microbiológicos}

Los riesgos microbiológicos se asocian primordialmente con el tratamiento de residuos humanos y animales. Aunque a menudo se añaden bacterias para alterar los sólidos que contienen las aguas residuales, el riesgo para los trabajadores en el tratamiento de aguas residuales procede sobre todo de la exposición a los microorganismos presentes en los residuos humanos y de otras especies animales. Cuando se utiliza la aireación durante el proceso de tratamiento de aguas residuales, estos microorganismos pueden quedar suspendidos en el aire. No se ha evaluado de modo concluyente el efecto, a largo plazo, en el sistema inmunitario de los individuos expuestos a estos microorganismos durante períodos de tiempo prolongados. Además, los trabajadores que retiran los residuos sólidos de la corriente entrante, antes de que se inicie tratamiento alguno, están expuestos a menudo a los microorganismos contenidos en el material, que salpica su piel y afecta a sus membranas mucosas. L os resultados del contacto con microorganismos presentes en las plantas de tratamiento de aguas residuales durante períodos prolongados, son con frecuencia más insidiosos que los originados por exposiciones intensas agudas. No obstante, estos efectos también pueden ser irreversibles y graves.

Los tres tipos principales de microbios presentes en esta clase de exposición son los hongos, las bacterias y los virus. Todos ellos pueden causar enfermedades, tanto agudas como crónicas. Se han presentado síntomas agudos, como problemas respiratorios, dolores abdominales y diarrea, en trabajadores de tratamiento de residuos (Crook, Bardos y Lacey 1988; Lundholm y Rylander 1980). Las enfermedades crónicas, tales como el asma y la alveolitis alérgica, se han asociado tradicionalmente con la exposición a niveles elevados de microbios en suspensión en el aire y, recientemente, con exposición microbiológica durante el tratamiento de los residuos domésticos (Rosas y cols. 1996;
Johanning, O Imstead y Yang 1995). Están empezando a publicarse informes de concentraciones significativamente elevadas de hongos y bacterias en instalaciones para tratamiento de residuos, deshidratación de lodos y fabricación de "compost" (Rosas y cols 1996; Bisesi y K udlinski 1996; Johanning, O Istead y Yang 1995). O tra fuente de microbios en el aire son los depósitos de aireación que se utilizan en numerosas plantas de tratamiento de aguas residuales.

A demás de por inhalación, los microbios pueden transmitirse por ingestión y por contacto con piel que no esté intacta. Es importante la higiene personal, incluido el lavado de manos antes de comer, fumar e ir al servicio. Los alimentos, bebidas, cubiertos, cigarrillos y todo lo que puede llevarse a la boca debe mantenerse alejado de las zonas de posible contaminación bacteriana.

\section{Riesgos químicos}

Los efectos de la exposición a productos químicos en plantas de tratamiento de aguas residuales pueden ser tanto inmediatas y mortales, como a largo plazo. En el proceso de coagulación, condensación, desinfección y tratamiento de lodos se utilizan diversos productos químicos. El producto elegido está determinado por el contaminante o contaminantes del agua residual sin tratar; algunos residuos industriales exigen tratamientos químicos un tanto singulares. No obstante, los principales riesgos de los productos químicos utilizados en los procesos de coagulación y floculación son, por lo general, la irritación cutánea y lesiones oculares debidas a un contacto directo, especialmente cuando se trata de soluciones que tienen un $\mathrm{pH}$ (acidez) inferior a 3 o superior a 9. La desinfección del efluente se consigue a menudo mediante cloro líquido o gaseoso. El uso de cloro líquido puede causar lesiones oculares en caso de salpicaduras a los ojos. También se utilizan ozono y luz ultravioleta para conseguir la desinfección del efluente.

U n medio de controlar la eficacia del tratamiento de las aguas residuales es determinar la cantidad de material orgánico que permanece en el efluente después de completar el tratamiento, lo que puede hacerse averiguando la cantidad de oxígeno que sería necesaria para biodegradar el material orgánico contenido en 1 litro de líquido durante un período de 5 días. Es lo que se denomina demanda biológica de oxígeno en 5 días ( $\mathrm{DBO}_{5}$ ).

En las plantas de tratamiento de aguas surgen riesgos químicos de la descomposición de material orgánico que origina la producción de sulfuro de hidrógeno y metano, de los residuos tóxicos vertidos en el alcantarillado y de los contaminantes producidos por operaciones realizadas por los propios trabajadores.

El sulfuro de hidrógeno está presente casi siempre en las plantas de tratamiento de aguas residuales; también se le conoce como el gas de las alcantarillas, y tiene un olor peculiar desagradable, con frecuencia identificado con el de huevos podridos. Sin embargo, el olfato humano se acostumbra rápidamente al olor. Las personas expuestas al sulfuro de hidrógeno a menudo pierden la capacidad para detectar su olor (es decir, sufren fatiga olfatoria). A demás, aun en caso de que el sistema olfativo sea capaz de detectar el sulfuro de hidrógeno, no es capaz de calibrar exactamente su concentración en la atmósfera. El sulfuro de hidrógeno interfiere bioquímicamente en el mecanismo de transporte de electrones y bloquea la utilización de oxígeno en el plano molecular. El resultado es la asfixia y, en última instancia, la muerte por falta de oxígeno en las células del tronco encefálico que controlan la frecuencia respiratoria. En los espacios confinados existentes en las plantas de tratamiento de aguas residuales pueden existir, y con frecuencia existen, niveles altos de sulfuro de hidrógeno (superiores a 
100 ppm). La exposición a concentraciones muy altas de este gas puede ocasionar la supresión casi instantánea del centro respiratorio del tronco encefálico. EI National Institute for $\mathrm{O}$ ccupational Safety and Health (NIOSH) de Estados Unidos ha considerado inmediatamente peligrosa para la vida y la salud (IPVS) la concentración de 100 ppm de sulfuro de hidrógeno. Casi siempre existen concentraciones más bajas de sulfuro de hidrógeno (inferiores a 10 ppm) en algunas zonas de las plantas de tratamiento de aguas residuales. A estos niveles más bajos, el sulfuro de hidrógeno puede ser irritante para el aparato respiratorio, ir acompañado de dolores de cabeza y causar conjuntivitis (Smith 1986). El gas se produce por la descomposición de materia orgánica, y en la industria, durante la producción de papel (proceso K raft), el curtido del cuero (eliminación del pelo con sulfuro sódico) y la producción de agua pesada para reactores nucleares.

El metano es otro gas producido por la descomposición de materia orgánica. Además de desplazar al oxígeno, el metano es explosivo. Pueden alcanzarse concentraciones que originen una explosión en presencia de una chispa o fuente de ignición.

Las plantas que manipulen residuos industriales deben tener un conocimiento exhaustivo de los productos químicos utilizados en cada una de las industrias que recurren a sus servicios, y una relación práctica con los directivos de esas industrias para que puedan recibir información inmediata de cualquier cambio de los procesos y el contenido de los residuos. El vertido de disolventes, combustibles y cualquier otra sustancia en sistemas de alcantarillado supone un riesgo para los trabajadores de tratamiento de aguas, no sólo a causa de la toxicidad del material vertido, sino también porque el vertido es imprevisto.

Siempre que se realice una operación industrial, como el soldado o la pintura pulverizada, en un espacio cerrado hay que tener especial cuidado de facilitar una ventilación suficiente para prevenir el riesgo de explosión y para eliminar el material tóxico producido. Cuando la operación realizada en un espacio confinado origina una atmósfera tóxica, con frecuencia es necesario proteger al trabajador con un equipo de protección respiratoria, ya que la ventilación del espacio confinado puede no garantizar que la concentración del producto químico tóxico se mantenga por debajo del límite de exposición permisible. La selección y la adaptación de un equipo de protección respiratoria adecuado pertenecen a la esfera de la higiene del trabajo.

0 tro riesgo químico grave en las plantas de tratamiento de aguas residuales es el uso de gas de cloro gaseoso para descontaminar el efluente de la planta. EI cloro gaseoso está contenido en recipientes diversos con pesos desde $70 \mathrm{~kg}$ hasta 1 tonelada. Algunas plantas de tratamiento de aguas muy grandes utilizan cloro transportado en vagones ferroviarios. El cloro gaseoso es sumamente irritante para los alveolos pulmonares, incluso en concentraciones de sólo unas pocas ppm. La inhalación de concentraciones más altas de cloro puede causar inflamación de los alveolos pulmonares y producir el "síndrome de sufrimiento respiratorio del adulto", que causa una mortalidad del $50 \%$. Cuando una planta de tratamiento de aguas residuales utiliza grandes cantidades de cloro (1 tonelada o más), no sólo existe riesgo para sus trabajadores, sino también para la comunidad circundante. Por desgracia, las plantas que utilizan las mayores cantidades de cloro suelen estar situadas en grandes centros metropolitanos con densidad de población elevada. Se dispone de otros métodos de descontaminación del efluente de las plantas de tratamiento de aguas, como el tratamiento con ozono, el uso de solución de hipoclorito líquido y la irradiación ultravioleta.

\section{RECOGIDA DE BASURAS DOMESTICAS*}

Madeleine Bourdouxhe

\section{Visión general}

A parte de los pocos trabajadores de los municipios de la provincia de Q uebec, Canadá, que tienen servicios de recogida de basuras propios, hay miles de trabajadores de recogida de basuras y conductores empleados en centenares de empresas del sector privado.

Numerosas empresas privadas recurren de modo total 0 parcial a personas que tienen camiones alquilados o propios y son responsables del personal de recogida que trabaja para ellos. En el sector existe una fuerte competencia, dado que los contratos municipales se conceden a quien ofrece el precio más bajo, y es habitual la rotación anual de las empresas. La competencia elevada también conduce a tasas de recogida de basuras domésticas bajas y estables, y la recogida de basuras cuenta con el porcentaje más bajo de los impuestos municipales. No obstante, a medida que se llenan los vertederos existentes, los costes por este concepto aumentan, lo que obliga a los municipios a considerar el uso de sistemas de gestión de residuos integrados. Todos los trabajadores municipales están sindicados. $L a$ sindicación de los del sector privado se inició en los años 80 , y supone actualmente del 20 al $30 \%$ de los trabajadores.

\section{Procesos de trabajo}

La recogida de basuras es un oficio peligroso. Dado que los camiones de recogida son similares a prensas hidráulicas, se deduce que la recogida de basuras es como trabajar en una prensa industrial móvil en condiciones mucho más exigentes que las de la mayoría de las fábricas. En la recogida de basuras, la máquina se desplaza por el tráfico viario haciendo paradas, y los trabajadores tienen que alimentarla corriendo detrás de ella y arrojando en su interior objetos irregulares de volumen y peso variables que contienen objetos invisibles y peligrosos. Por término medio, los recogedores manipulan 2,4 toneladas de basura por hora. La eficacia de las operaciones de recogida de residuos sólidos depende totalmente de los factores determinantes de la velocidad y el ritmo de trabajo. La necesidad de evitar el tráfico en horas punta y los cierres de pasos o puentes impone presiones de tiempo en los puntos de recogida y durante el transporte. La velocidad también tiene importancia durante la descarga en vertederos e incineradoras.

$\mathrm{H}$ ay varios aspectos de la recogida de basuras que influyen en la carga de trabajo y en los riesgos. En primer lugar, la remuneración es fija, es decir, en el día de recogida tienen que recogerse totalmente las basuras domésticas de la zona especificada en el contrato. Dado que el volumen de residuos depende de las actividades de los residentes y varía de un día a otro y según la estación, la carga de trabajo también varía enormemente. En segundo lugar, los trabajadores están en contacto directo con los objetos y los residuos que se recogen, lo que supone una gran diferencia respecto a la situación existente en los sectores de recogida de residuos comerciales e industriales, en los que camiones de carga frontal equipados con horquillas elevadoras automáticas o camiones de tapa abatible recogen los contenedores llenos de residuos. Ello significa que los trabajadores de esos sectores no manipulan los contenedores de residuos ni están

*En numerosas poblaciones, son trabajadores municipales los que realizan la recogida de basuras domésticas, mientras que en otras la realizan empresas privadas. En este artículo se ofrece una panorámica de los procesos y los riesgos basada en observaciones y experiencias en la provincia de Q uebec, Canadá. N ota del director del capítulo. 
Figura 101.6 - Camión de recogida automática de basuras de carga lateral.

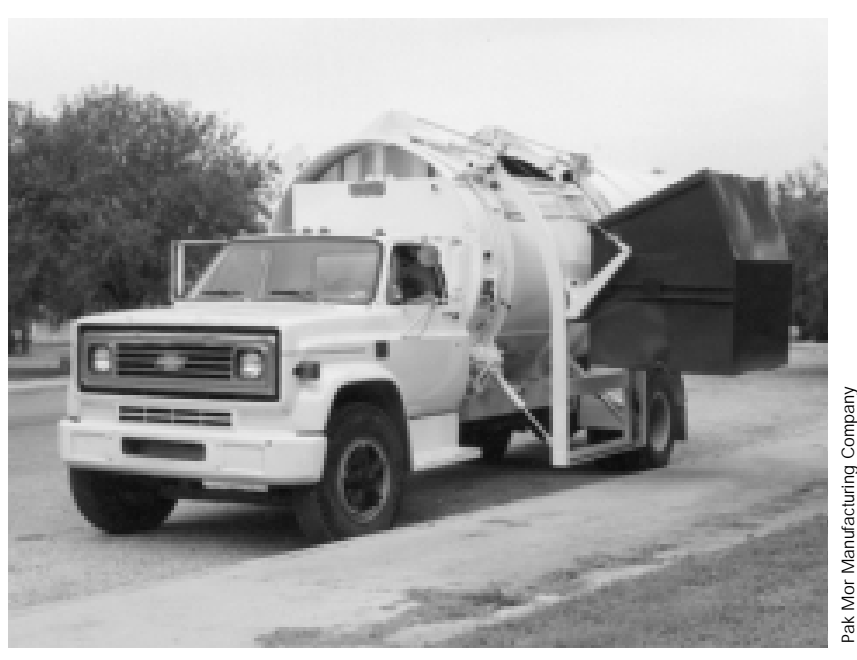

en contacto directo con éstos. Así pues, las condiciones de trabajo de estos recogedores se parecen más a las de los conductores de camiones de basuras domésticas que a las de los recogedores de éstas.

Por otro lado, la recogida en zonas residenciales (también llamada recogida doméstica) es fundamentalmente manual, y los trabajadores siguen manipulando una amplia variedad de objetos y recipientes de tamaño, naturaleza y peso variables. En algunos municipios residenciales y rurales se ha implantado la recogida semiautomática, consistente en el uso de cubos de basura domésticos móviles y recogedores de carga lateral (Figura 101.6). Sin embargo, la mayoría de las basuras domésticas siguen recogiéndose de forma manual, sobre todo en las ciudades. Así pues, la característica principal de esta tarea es un ejercicio físico importante.

\section{Riesgos}

Un estudio en el que se realizaron observaciones y estimaciones de campo, entrevistas con directivos y trabajadores, un análisis estadístico de 755 accidentes de trabajo y un análisis de secuencias de vídeo, revelaron varios riesgos potenciales (Bourdouxhe, Cloutier y G uertin 1992).

\section{Carga de trabajo}

Por término medio, los recogedores de basuras manipulan a diario $16.000 \mathrm{~kg}$, repartidos en más de 500 puntos de recogida, lo que equivale a una densidad de recogida de $550 \mathrm{~kg} / \mathrm{km}$. La recogida dura casi 6 horas, lo que indica que se recogen 2,4 toneladas/hora, y exige caminar $11 \mathrm{~km}$ durante una jornada completa de trabajo de 9 horas. La velocidad media de recogida es de 4,6 km/ hora, a lo largo de un territorio de casi $30 \mathrm{~km}$ de aceras, calles y callejones. Los períodos de descanso se limitan a unos pocos minutos en equilibrio precario sobre la plataforma trasera 0 , en el caso de los conductores-recogedores de camiones de carga lateral, al volante. Esta exigente carga de trabajo tiene por agravantes factores como la frecuencia de subidas y bajadas del camión, la distancia cubierta, las formas de desplazamiento, el esfuerzo estático necesario para mantener el equilibrio en la plataforma trasera (como mínimo, $13 \mathrm{~kg}$ de fuerza), la frecuencia de las operaciones de manipulación por unidad de tiempo, la variedad de las posturas exigidas (movimientos de flexión), la frecuencia de sacudidas y movimientos de torsión del tronco y el elevado ritmo de recogida por unidad de tiempo en algunos sectores. El hecho de que en el $23 \%$ de los recorridos observados se superara el límite de peso recomendado en la norma sobre manipulación de cargas de la A sociación Francesa de N ormalización (AFNOR), es testimonio elocuente de las consecuencias de estos factores. $C$ uando se consideran las capacidades de los trabajadores (establecidas en 3 toneladas/ hora para camiones de carga trasera y 1,9 toneladas/ hora para los de carga lateral), la frecuencia con la que se supera la norma de la AFNOR se eleva al $37 \%$.

\section{Diversidad y naturaleza de los objetos manipulados}

La manipulación de objetos y recipientes de peso y volumen variables interrumpe la continuidad de las operaciones y rompe los ritmos de trabajo. Los objetos de este tipo, a menudo escondidos por los residentes, comprenden artículos pesados, grandes 0 voluminosos, cortantes o puntiagudos, e incluso materiales peligrosos. L os riesgos encontrados con más frecuencia se enumeran en la Tabla 101.2.

Para los trabajadores supone una gran ayuda que los residentes clasifiquen las basuras en bolsas de colores determinados y cubos domésticos con ruedas, que facilitan la recogida y permiten un mejor control del ritmo de trabajo y el esfuerzo.

\section{Condiciones climáticas y naturaleza de los objetos transportados}

Las bolsas de papel mojadas y las bolsas de plástico de mala calidad que se desgarran y esparcen su contenido por la acera, los cubos de basura congelados y los cubos domésticos encajados en montones de nieve pueden originar incidentes y maniobras de recuperación peligrosas.

Tabla 101.2 O O bjetos peligrosos encontrados en la recogida de basuras domésticas.

Vidrio, cristales de ventanas, tubos fluorescentes

Ácido de baterías, latas de disolvente o pintura, botes de aerosoles, cilindros de gas, aceite de motores

Restos de construcción, polvo, yeso, serrín, cenizas de chimenea

Trozos de madera con clavos

Jeringas, residuos médicos

Restos de jardines, hierba, piedras, tierra

Muebles, aparatos eléctricos, otras basuras domésticas de gran tamaño

Basuras precompactadas (en edificios de apartamentos)

Número excesivo de pequeños contenedores procedentes de negocios pequeños y restaurantes

Grandes cantidades de residuos vegetales y animales en sectores rurales

Bolsas extragrandes

Contenedores prohibidos ( $p$. ej., sin asas, de peso excesivo, bidones de aceite de

200 litros, bidones de cuello estrecho, cubos de basura sin tapas)

Bolsas pequeñas aparentemente ligeras que en realidad son pesadas

Número excesivo de bolsas pequeñas

Bolsas y cajas de papel que se desgarran

Toda la basura que está oculta a causa de su peso excesivo o toxicidad, o que sorprende a los trabajadores desprevenidos

Contenedores comerciales que deben vaciarse con un sistema improvisado, a menudo inadecuado y peligroso 
Figura 101.7 - Camión compactador cerrado de carga trasera.

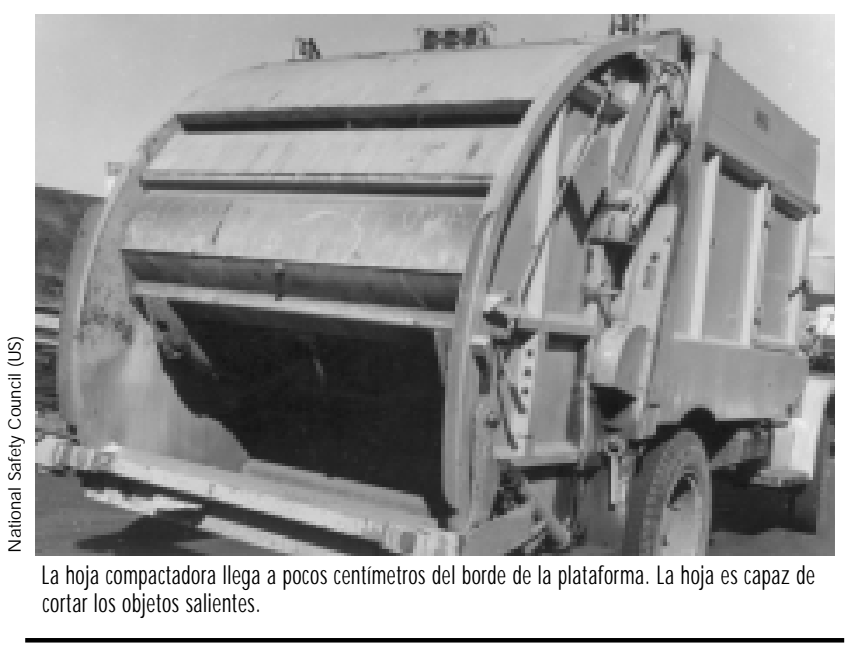

\section{Plan de trabajo}

La necesidad de apresurarse, los problemas de tráfico, los vehículos aparcados y las calles atestadas son factores todos que contribuyen a crear situaciones peligrosas.

En un intento de reducir su carga de trabajo y mantener un ritmo de trabajo alto pero constante, a pesar de estas limitaciones, los trabajadores tratan con frecuencia de ahorrar tiempo y esfuerzo adoptando estrategias de trabajo que pueden ser peligrosas. Las observadas más a menudo son desplazar a patadas las bolsas o cajas de cartón hacia el camión, cruzar en zigzag la calle para recoger sus dos lados, asir las bolsas mientras el camión está en movimiento, llevar bolsas debajo del brazo 0 pegadas al cuerpo, utilizar el muslo para ayudar a cargar las bolsas o cubos de basura, recoger a mano la basura esparcida por el suelo y la compactación manual (empujar la basura que rebosa de la tolva con las manos cuando el sistema de compactación es incapaz de procesar la carga con rapidez suficiente). Por ejemplo, en la recogida en zonas residenciales con un camión de carga trasera, se observaron casi 1.500 situaciones por hora que podrían originar accidentes o aumentar la carga de trabajo, clasificadas como sigue:

- 53 subidas y bajadas de la plataforma trasera del camión;

- 38 carreras cortas;

- 482 movimientos de flexión;

- 203 sacudidas;

- 159 movimientos de torsión;

- 277 acciones potencialmente peligrosas (incluidas 255 estrategias encaminadas a reducir la carga de trabajo ahorrando tiempo o esfuerzo);

- 285 ejemplos de aumento de la carga de trabajo,

- 274 objetos o recipientes peligrosos o pesados.

La recogida con camiones de carga lateral (ver Figura 101.6) o cubos domésticos pequeños disminuye el manejo de objetos pesados y peligrosos y la frecuencia de las situaciones que pudieran derivar en accidentes 0 en un incremento de la carga de trabajo.

\section{Uso de las vías públicas}

La calle es el lugar de trabajo de los recogedores de basura, lo que les expone a riesgos como el tráfico de vehículos, el acceso bloqueado a los recipientes de basura de los residentes, la acumulación de agua, nieve y hielo, y los perros de la vecindad.

\section{Vehículos}

Los camiones de carga trasera (Figura 101.7) tienen a menudo escalones demasiados altos o poco profundos y plataformas traseras a las que es difícil subir y cuyo descenso se asemeja peligrosamente a un salto. Las barandillas demasiado altas o demasiado próximas a la carrocería del camión sólo sirven para agravar la situación. Estas condiciones aumentan la frecuencia de caídas y de choques con estructuras adyacentes a la plataforma trasera. Además, el borde superior de la tolva es muy alto, por lo que los trabajadores más bajos tienen que gastar energía adicional elevando los objetos desde el suelo hasta ella. En algunos casos, los trabajadores utilizan las piernas o los muslos como apoyo o fuente de potencia añadida cuando cargan la tolva.

Las características de los camiones de carga lateral y de las operaciones relacionadas con su carga, originan movimientos repetitivos específicos que probablemente causen problemas musculares y articulares en el hombro y la parte superior de la espalda. L os conductores-recogedores de camiones de carga lateral tienen otra limitación más, ya que se enfrentan tanto a la tensión física de la recogida como a la mental de la conducción.

\section{Equipo de protección individual}

Aunque el valor teórico de los EPI es incuestionable, es posible que resulte insuficiente en la práctica. En concreto, el equipo puede ser inadecuado para las condiciones en las que se realiza la recogida. Las botas, en especial, son incompatibles con la estrecha altura útil de las plataformas traseras y los elevados ritmos de trabajo exigidos por la forma en que se organiza la recogida. Los guantes fuertes resistentes a los pinchazos pero flexibles son valiosos como protección frente a las lesiones de las manos.

\section{Organización}

Algunos aspectos de la organización del trabajo aumentan la carga de trabajo y, en consecuencia, los riesgos. Al igual que ocurre en la mayoría de las situaciones en que se cobra por una tarea concreta, las principales ventajas para los trabajadores de este sistema es la capacidad de gestionar su tiempo de trabajo y ahorrar tiempo adoptando un ritmo rápido cuando lo consideren adecuado. Ello explica por qué han fracasado los intentos, basados en consideraciones de seguridad, de frenar el ritmo de trabajo. Algunos planes de trabajo superan las capacidades de los trabajadores.

La influencia de un sinnúmero de variaciones del comportamiento de los residentes en la creación de riesgos añadidos merece un estudio aparte. Residuos prohibidos o peligrosos ocultos hábilmente en la basura normal, recipientes no normalizados, objetos excesivamente grandes o pesados, desacuerdos sobre las horas de recogida e incumplimiento de las normas son aspectos que aumentan el número de riesgos, así como la posibilidad de que surjan conflictos entre residentes y recogedores de basuras, por lo que el papel de estos últimos suele quedar reducido al de "policías de la basura", educadores y mediadores en los conflictos entre municipios, empresas y residentes.

La recogida de materiales para reciclado no está exenta de problemas a pesar de la baja densidad y el ritmo de recogida de los residuos, bastante inferiores a los de la recogida tradicional (salvo por la recogida de hojas para fabricación de "compost"). La frecuencia por horas de situaciones que podrían originar accidentes es a menudo alta. $\mathrm{H}$ ay que tener presente el hecho de que se trata de un tipo de trabajo nuevo para el que existen pocos trabajadores preparados. 
Tabla 101.3 • Accidentes de trabajo más comunes en la recogida de basuras domésticas, Q uebec, Canadá.

\begin{tabular}{|c|c|c|}
\hline Lesión & Causa & $\begin{array}{l}\text { Porcentaje } \\
\text { de accidentes } \\
\text { estudiados }\end{array}$ \\
\hline $\begin{array}{l}\text { Dolor de espalda u } \\
\text { hombro }\end{array}$ & $\begin{array}{l}\text { Movimientos de sacudida o torsión } \\
\text { durante la recogida de bolsas }\end{array}$ & 19 \\
\hline Lesiones de espalda & $\begin{array}{l}\text { Esfuerzos excesivos al levantar } \\
\text { objetos }\end{array}$ & 18 \\
\hline Esguinces de tobillo & $\begin{array}{l}\text { Caídas o resbalones al bajar del } \\
\text { camión o rodearlo }\end{array}$ & 18 \\
\hline $\begin{array}{l}\text { Aplastamiento de manos, } \\
\text { dedos, brazos o rodillas }\end{array}$ & $\begin{array}{l}\text { Golpes de contenedores u objetos } \\
\text { pesados, quedar atrapado entre el } \\
\text { vehículo y los contenedores o coli- } \\
\text { siones con parte del vehículo } 0 \\
\text { automóviles aparcados }\end{array}$ & 18 \\
\hline $\begin{array}{l}\text { Cortes de manos y muslos } \\
\text { de profundidad variable }\end{array}$ & $\begin{array}{l}\text { Vidrio, clavos o jeringas, aparecen } \\
\text { durante la carga de la tolva }\end{array}$ & 15 \\
\hline Rozaduras y hematomas & Contacto o colisiones & 5 \\
\hline $\begin{array}{l}\text { Irritación de ojos o } \\
\text { aparato respiratorio }\end{array}$ & $\begin{array}{l}\text { Polvo o salpicaduras de líquidos } \\
\text { sufridas durante el trabajo cerca de } \\
\text { la tolva durante el compactado }\end{array}$ & 5 \\
\hline Otros & & 2 \\
\hline
\end{tabular}

En varios casos, los trabajadores se ven obligados a realizar actividades tan peligrosas como subir a la caja de compactación para entrar en los compartimientos y mover pilas de papel y cartón con los pies. También se han observado varias estrategias de trabajo encaminadas a acelerar el ritmo de trabajo, como la reclasificación del material que va a reciclarse y la retirada de objetos de la caja de reciclaje para llevarlos al camión, en lugar de llevar la caja al camión. La frecuencia de los incidentes y las alteraciones de la actividad normal en este tipo de recogida es especialmente alta. Estos incidentes se deben a que los trabajadores realizan actividades específicas que son peligrosas en sí mismas.

\section{Accidentes de trabajo y prevención}

La recogida de basuras domésticas es un oficio peligroso, y las estadísticas respaldan esta impresión. La tasa media anual de accidentes de trabajo en este sector, para todos los tipos de empresa, es de casi 80 accidentes por cada 2.000 horas de recogida. Ello equivale a que 8 de cada 10 trabajadores sufran al menos una lesión al año. Se producen cuatro accidentes por cada 1.000 camiones de 10 toneladas cargados. Por término medio, cada accidente origina 10 días de trabajo perdidos y una compensación de 820 dólares (canadienses). Los índices de frecuencia y gravedad de las lesiones varían según las empresas, observándose índices más altos en las empresas municipales (74 accidentes/ 100 trabajadores, frente a 57/ 100 trabajadores en las privadas) (Bourdouxhe, Cloutier y Guertin 1992). Los accidentes más comunes se enumeran en la Tabla 101.3.

L os recogedores sufren de modo característico laceraciones de manos y muslos, mientras que los conductores padecen esguinces de tobillo a consecuencia de caídas al bajar de la cabina y los conductores-recogedores de camiones de carga lateral sufren dolor de hombros y de la parte superior de la espalda a causa de los movimientos de sacudida. La naturaleza de los accidentes depende también del tipo de camión, aunque puede considerarse asimismo reflejo de los oficios específicos asociados con los camiones de carga trasera y lateral. Estas diferencias están relacionadas con el diseño del equipo, el tipo de movimientos necesarios y la naturaleza y la densidad de la basura recogida en los sectores en los que se utilizan estos dos tipos de camiones.

\section{Prevención}

A continuación aparece una lista de diez aspectos en los que la introducción de mejoras podría aumentar la seguridad de la recogida de basuras domésticas:

1. gestión de la seguridad y la salud (p. ej., desarrollo de programas de prevención de accidentes basados en un conocimiento de los riesgos profesionales mejor adaptado a las tareas reales por parte de los trabajadores);

2. formación y contratación;

3. organización del trabajo, de la recogida y de la carga de trabajo;

4. vehículos:

5. formación y condiciones de trabajo de los trabajadores auxiliares, ocasionales y temporales;

6. contratos de recogida;

7. gestión pública;

8. colaboración entre las asociaciones de empresas (municipales y privadas), los trabajadores y los organismos decisorios municipales o regionales;

9. estabilidad de la mano de obra,

10. investigación sobre el equipo de protección personal, el diseño ergonómico de los camiones, la subcontratación de trabajadores y la seguridad.

\section{Conclusión}

La recogida de basuras domésticas es una actividad importante, pero peligrosa. La protección de los trabajadores se hace más difícil cuando se contrata este servicio con empresas del sector privado que, como ocurre en la provincia canadiense de Q uebec, pueden subcontratar a su vez el trabajo a numerosos subcontratistas de menor tamaño. Para conseguir mantener la salud y la seguridad de los trabajadores, es preciso afrontar y controlar una gran cantidad de riesgos ergonómicos y de accidentes, agravados por las cuotas de trabajo, la climatología adversa y los problemas viarios y de tráfico locales.

\section{LIMPIEZA VIARIA}

\section{J.C. G unther, Jr.*}

La prevención de las enfermedades transmitidas por la suciedad, la evitación de daños a los vehículos por objetos peligrosos y la satisfacción de contemplar una ciudad limpia y atractiva son ventajas derivadas de la limpieza de las calles. Los rebaños de animales o los vehículos de tracción animal, que causaban antaño condiciones poco higiénicas, han dejado de ser un problema, por lo general; sin embargo, el aumento de la población mundial, con la elevación consiguiente de los residuos generados, el aumento del número y el tamaño de las fábricas, el crecimiento del número de vehículos y periódicos y la introducción de recipientes y productos desechables han aumentado la cantidad de residuos en las calles y el problema de la limpieza viaria.

\footnotetext{
*A daptado de la 3a edición, E ncidopedia de salud y seguridad en el trabajo.
} 


\section{Organización y procesos}

Las autoridades municipales, conscientes de la amenaza que supone para la salud la suciedad de las calles, han intentado reducir el peligro al mínimo mediante la organización de servicios de limpieza viaria en los departamentos de obras públicas. En estos servicios, un inspector responsable de organizar la frecuencia de limpieza de diversos distritos tendrá a su cargo capataces responsables de operaciones de limpieza específicas.

Normalmente, los distritos comerciales se barrerán a diario, mientras que las vías de mayor tráfico y las zonas residenciales se barrerán una vez por semana. La frecuencia dependerá también de si llueve o nieva, de la topografía y de la educación cívica para la prevención de la basura esparcida.

El inspector también decidirá acerca de los medios más efectivos para mantener las calles limpias, que pueden ser el barrido a mano por una persona o grupo, el lavado con manguera o el barrido o lavado mecánicos. N ormalmente se utiliza una combinación de métodos basados en la disponibilidad de equipo, el tipo de suciedad que suele encontrarse en la zona y otros factores. En regiones en las que nieva en abundancia, puede utilizarse en ocasiones un equipo quitanieves especial.

El barrido a mano suele efectuarse en horario diurno y limitarse a los bordillos de las aceras o a la limpieza de zonas adyacentes. El equipo utilizado consta de escobas, rascadores y palas. Los barrenderos que trabajan individualmente suelen recorrer rutas especiales y limpiar unos $9 \mathrm{~km}$ de bordillo por jornada de trabajo en condiciones favorables, pero esta cifra puede ser inferior en zonas comerciales congestionadas.

La basura recogida por el barrendero se echa en un carrito que él mismo empuja, y que vacía en recipientes colocados a intervalos a lo largo de su ruta; estos recipientes se vacían periódicamente en camiones de basura. C uando se barre en grupo, la basura se acumula en pilas a lo largo de los bordillos y se carga directamente en camiones. Por lo común, en un grupo de 8 barrenderos hay 2 cargadores. El barrido en grupo es particularmente eficaz cuando se trata de grandes labores de limpieza, como las requeridas después de tormentas, desfiles u otros acontecimientos especiales.

El barrido a mano tiene las ventajas de que se adapta fácilmente a las distintas clases de basura, puede utilizarse en zonas inaccesibles para las máquinas, es posible realizarlo incluso cuando existe mucho tráfico sin obstaculizar apenas el movimiento de los vehículos y puede llevarse a cabo en tiempo de heladas y en pavimentos cuyas condiciones de superficie no permiten la limpieza mecánica. Sus inconvenientes son: el trabajo en medio del tráfico es peligroso; se levanta polvo; la basura acumulada junto a los bordillos puede ser dispersada por el viento o el tráfico si no se recoge pronto, y puede ser muy costoso en zonas de mano de obra cara.

El lavado con manguera no se considera hoy en día una operación económica. Sin embargo, es eficaz cuando hay gran cantidad de basura o barro adherido a la superficie de calzadas en las que hay gran cantidad de coches aparcados o en zonas de mercados. Suelen realizarlo por la noche equipos de dos hombres, uno de los cuales maneja la manguera y dirige el chorro, en tanto que el otro conecta la manguera a la boca de riego. El equipo material comprende la manguera, la boquilla y una llave para la boca de riego.

Las máquinas barredoras constan de un chasis motorizado equipado con cepillos, transportadores, rociadores y depósito. Suelen utilizarse a últimas horas de la noche o primeras de la mañana en los distritos comerciales, y durante el día en las zonas residenciales. La acción limpiadora se limita a los bordillos y zonas adyacentes, que es donde más desperdicios se acumulan.

La máquina la maneja un hombre, y suele limpiar unos $36 \mathrm{~km}$ de bordillo durante una jornada de trabajo de 8 horas. Son factores que influyen en el rendimiento: el número de veces y la distancia que hay que recorrer para vaciar la basura o cargar agua, la densidad del tráfico y la cantidad de basura recogida.

Las ventajas de las barredoras mecánicas son que limpian bien, con rapidez y sin levantar polvo durante el trabajo; que recogen la basura al tiempo que barren; que pueden utilizarse durante la noche, y que son relativamente económicas. Sus desventajas son que no pueden limpiar debajo de los coches aparcados ni en zonas sin pavimentar; que no son eficaces en calles sin empedrar, mojadas o fangosas; que el rociador de agua no puede utilizarse en tiempo de heladas y el barrido en seco levanta polvo, y que requieren operarios especializados y personal para la conservación.

Las máquinas de lavado son en realidad depósitos de agua montados sobre un chasis motorizado provisto de una bomba y una boquilla para dar presión y dirigir el chorro de agua contra la superficie de la calzada. La máquina limpia unos $36 \mathrm{~km}$ de calzada de $7 \mathrm{~m}$ de anchura en una jornada de 8 horas.

$L$ as ventajas de la máquina lavadora son que puede utilizarse a pleno rendimiento sobre pavimentos mojados o fangosos, limpia con rapidez, bien y bajo los vehículos aparcados sin levantar polvo y puede emplearse de noche o en horas de poco tráfico. Los inconvenientes son que precisa una limpieza adicional para obtener un resultado eficaz en los lugares en que las condiciones de la calle, de la basura o del alcantarillado no son favorables; que molesta a los peatones o a los conductores de otros vehículos, a los que salpica; que no puede utilizarse en tiempo de heladas y que exige operarios especializados y personal de conservación.

\section{Riesgos y su prevención}

La limpieza viaria es una ocupación peligrosa, debido a que se realiza en medio del tráfico y está relacionada con basura y desperdicios, con la consiguiente posibilidad de infección, cortes por cristales, latas, etc. En las zonas muy pobladas, los barrenderos manuales están expuestos a grandes cantidades de monóxido de carbono y a un alto nivel de ruido.

La protección contra los riesgos del tráfico consiste en entrenar a los barrenderos en diversos modos de evitar el peligro, como realizar el trabajo de frente al sentido del tráfico, dotarlos de uniformes claramente visibles y colocar banderines rojos u otras señales en sus carritos. Las máquinas barredoras y lavadoras se hacen más visibles mediante la colocación de luces intermitentes y banderines, y pintándolas de manera distintiva.

L os barrenderos municipales, y sobre todo los manuales, están expuestos a las inclemencias del tiempo, y en ocasiones pueden tener que trabajar en condiciones muy adversas. Enfermedades, infecciones y accidentes pueden prevenirse en parte mediante el uso de equipo de protección personal, monos, guantes, botas y, en parte, con la formación adecuada. Un equipo mecanizado como el que exige la retirada de la nieve sólo debe ser manejado por personal especializado.

Es conveniente la instalación de un lugar central fácilmente accesible en el que se disponga de instalaciones para el lavado (incluidas duchas cuando sea posible), un vestuario debidamente preparado para cambiarse de ropa y secarla, un comedor y un botiquín de primeros auxilios. Es deseable un reconocimiento médico periódico.

Problemas ambientales de la retirada de la nieve La retirada y eliminación de la nieve plantea varios problemas ambientales preocupantes relacionados con el posible vertido de residuos, sales, aceites, metales y partículas en las aguas superficiales locales. La concentración de partículas, como el plomo, originadas por emisiones a la atmósfera de zonas industriales y automóviles supone un peligro especial. El peligro de que el agua 
resultante del fundido de la nieve llegue a los organismos acuáticos y de que se produzca contaminación del suelo y de las aguas subterráneas, se ha contrarrestado mediante la adopción de prácticas de manipulación seguras que protegen las zonas sensibles de la exposición. En varias provincias canadienses (p. ej., Q uebec, O ntario, $M$ anitoba) se han adoptado directrices especiales para la eliminación de la nieve.

\section{- TRATAMIENTO DE LAS AGUAS RESIDUALES}

\section{Agamennone*}

Las aguas residuales se tratan para eliminar los elementos contaminantes y para respetar los límites impuestos por la legislación. Para ello, se intenta conseguir que los contaminantes del agua se conviertan en sólidos insolubles (lodos), en líquidos (aceites 0 gasolinas) 0 en gases (nitrógeno) mediante la aplicación de tratamientos apropiados. A continuación, se utilizan técnicas bien conocidas para separar el agua residual, depurada de los contaminantes que se han convertido en insolubles y devolverla a los cauces naturales. Los gases se dispersan en la atmósfera, mientras que los residuos líquidos y sólidos (lodos, aceites, grasas) suelen ser separados antes de someterlos a un nuevo tratamiento. Según las características del agua residual y el grado de depuración necesario, puede haber uno o varios tratamientos. En la depuración de las aguas residuales pueden distinguirse los procesos físicos (primarios), biológicos (secundarios) y terciarios.

\section{Procesos físicos}

Los distintos procesos de tratamiento físico van encaminados a eliminar los contaminantes insolubles.

\section{Cribado}

Se hacen pasar las aguas residuales por tamices que retienen los sólidos más gruesos que pueden bloquear o dañar los equipos de depuración (como válvulas y bombas). El producto del tamizado se trata según las condiciones locales.

\section{Eliminación de arenas}

La arena contenida en los vertidos tiene que eliminarse, ya que debido a su mayor densidad tiende a sedimentarse en el interior de las tuberías, por lo que puede dañar los equipos por abrasión (centrifugadoras, turbinas, etc.). Por lo general, la arena se elimina haciendo pasar las aguas residuales por un conducto de sección transversal constante a una velocidad de 15 a $30 \mathrm{~cm} /$ segundo. La arena se sedimenta en el fondo del canal, y puede utilizarse, después de un lavado para eliminar las sustancias putrescibles que contenga, como material inerte para la construcción, por ejemplo.

\section{Eliminación de aceites y gasolinas}

Es obligado eliminar los aceites y las grasas no emulsionables porque se adherirían a los equipos de depuración (como sedimentadores y clarificadores) y dificultarían los procesos biológicos posteriores. Las partículas de grasas y aceites ascienden a la superficie cuando se hacen pasar las aguas residuales a una velocidad adecuada por depósitos de sección rectangular. Son retiradas mecánicamente, pasando un rasero, y pueden utilizarse como combustible. Para la eliminación de gasolinas y lubricantes se utilizan con frecuencia separadores multiplaca compactos de alta eficacia. Se vierten desde arriba las aguas residuales para

\footnotetext{
*A daptado de la 3ae edición, E nciclopedia de salud y seguridad en el trabajo.
}

hacerlas pasar por pilas de placas inclinadas planas; las sustancias oleaginosas se adhieren a las superficies inferiores de estas placas y se desplazan a la parte superior, donde se recogen. U na vez realizadas ambas tareas, las aguas desgrasadas son evacuadas por la parte de abajo.

\section{Sedimentación, flotación y coagulación}

Son procesos por los que se eliminan las partículas sólidas de las aguas residuales, las de más peso (de más de $0,4 \mu \mathrm{m}$ de diámetro) por sedimentación, y las ligeras (de menos de 0,4 $\mu \mathrm{m}$ ) por flotación. Este tratamiento se basa también en las diferentes densidades de los sólidos y en el flujo de las aguas que se hacen pasar a través de los tanques de sedimentación y de flotación, construidos a base de hormigón o de acero. Las partículas que se quieren separar se recogen en el fondo o en la superficie, sedimentándose 0 ascendiendo a velocidades que son proporcionales al cuadrado del radio de las partículas y a la diferencia de densidad entre dichas partículas y la densidad aparente del agua residual que las contiene. Las partículas coloidales (como proteínas, látex y emulsiones oleaginosas) de tamaños comprendidos entre 0,4 y $0,001 \mu \mathrm{m}$ no se separan, ya que estos coloides se hidratan y normalmente adquieren una carga eléctrica negativa mediante la adsorción de iones. En consecuencia, las partículas se repelen entre sí y no pueden coagularse ni separarse. Sin embargo, si se "desestabilizan", estas partículas pueden coagularse formando copos de más de $4 \mu \mathrm{m}$, que ya pueden separarse como lodos en los tanques convencionales de sedimentación o flotación. La "desestabilización" se consigue por coagulación añadiendo, por ejemplo, entre 30 y $60 \mathrm{mg} / \mathrm{I}$ de algún coagulante inorgánico [sulfato de aluminio, sulfato de hierro (II) o cloruro férrico (III)]. L os coagulantes producen la hidrólisis bajo ciertas condiciones de $\mathrm{pH}$ (acidez), formándose iones metálicos de carga positiva polivalente que neutralizan la carga negativa de los coloides. La floculación (la aglomeración de las partículas coaguladas en copos) se facilita añadiendo entre 1 y $3 \mathrm{mg} / \mathrm{I}$ de polielectrolitos orgánicos (agentes floculantes), con lo que se obtienen copos de 0,3 a $1 \mu \mathrm{m}$ de diámetro que son mucho más fáciles de separar. Suelen utilizarse tanques de sedimentación de flujo horizontal, de sección rectangular y de fondo plano 0 inclinado. Las aguas residuales entran en el tanque por una de las cabeceras, y el agua depurada sale por el borde del lado opuesto. También se utilizan tanques de sedimentación de flujo vertical, que son cilíndricos y cuyo fondo tiene forma de cono invertido. Las aguas residuales entran en el depósito por el centro, y el agua depurada sale por una hendidura del borde superior, donde es recogida y transportada por un canal circular. En los dos tipos de tanque, los lodos se depositan en el fondo y se llevan a un colector, si es necesario mediante un mecanismo de rastrillo. La concentración de sólidos en los lodos es del 2 al $10 \%$, mientras que la del agua depurada es de 20 a $80 \mathrm{mg} / \mathrm{l}$.

L os tanques de flotación son normalmente cilíndricos y tienen instalados difusores de pequeñas burbujas de aire en el fondo, entrando los vertidos en el tanque por el centro. Las partículas se adhieren a las burbujas, ascienden a la superficie y allí son desespumadas, mientras que el agua depurada se evacua por la parte de abajo. En los "tanques de flotación de aire disuelto", más eficientes, las aguas residuales son saturadas con aire inyectado a una presión de 2 a 5 bar, tras lo que se le permite expandirse hacia el centro del tanque, donde las diminutas burbujas resultantes de la descompresión arrastran a las partículas hacia la superficie.

En comparación con la sedimentación, los procesos de flotación consiguen lodos más espesos con una velocidad de separación de partículas más rápida, por lo que el equipo necesario es más pequeño. Como contrapartida, los costes operativos son 
mayores y la concentración de sólidos en el agua depurada es más alta.

Para conseguir la coagulación y la floculación de un sistema coloidal se necesitan varios tanques conectados en serie. En el primero, que está equipado con un agitador, se añade un coagulante inorgánico y, si es necesario, un ácido o un álcali para corregir el $\mathrm{pH}$ de las aguas que se quieren tratar. La suspensión se pasa a continuación a un segundo tanque, equipado con un agitador de alta velocidad. Se añade aquí el polielectrolito, que se disuelve en pocos minutos. Los copos se forman en el tercer tanque, que cuenta con un agitador lento, y son evacuados al cabo de 10 a 15 minutos.

\section{Procesos biológicos}

Los procesos de tratamiento biológicos eliminan los contaminantes biodegradables orgánicos por medio de microorganismos. Estos organismos digieren los contaminantes en un proceso aeróbico 0 anaeróbico (con o sin la presencia de oxígeno atmosférico) y los convierten en agua, gases (dióxido de carbono y metano) y una masa microbiana sólida e insoluble que puede separarse con cierta facilidad. En el caso de los vertidos industriales resulta especialmente importante conseguir las condiciones adecuadas para que se desarrollen los microorganismos: presencia de compuestos de nitrógeno y fósforo, trazas de microelementos, ausencia de sustancias tóxicas (metales pesados, etc.), temperatura y valor de $\mathrm{pH}$ óptimos. Los tratamientos biológicos incluyen tanto los procesos aeróbicos como los anaeróbicos.

\section{Procesos aeróbicos}

Son más o menos complejos según el espacio disponible, el grado de purificación exigido y la composición de los vertidos que deban tratarse.

\section{Estanques de estabilización}

Son generalmente rectangulares y de 3 a $4 \mathrm{~m}$ de profundidad. Los vertidos entran por una parte, permanecen allí entre 10 y 60 días y abandonan el estanque, una parte por el lado opuesto, otra por evaporación y otra parte infiltrándose en el suelo. EI grado de purificación conseguido se sitúa entre el 10 y el $90 \%$ según el tipo de vertidos y el contenido de demanda biológica de oxígeno residual a los 5 días $\left(D_{0} B_{5}\right)$ es de $<40 \mathrm{mg} / \mathrm{l}$. El oxígeno lo suministra la atmósfera por difusión a través de la superficie del agua y por medio de la actividad de las algas fotosintéticas. LoS sólidos en suspensión de las aguas residuales y los que proceden de la actividad microbiana se sedimentan en el fondo, donde son estabilizados por los procesos aeróbicos y anaeróbicos, dependiendo de la profundidad de los estanques, que afecta tanto a la difusión del oxígeno como a la de la luz solar. La difusión del oxígeno se suele acelerar con aireadores superficiales, que permiten reducir el volumen de los estanques.

Este tipo de tratamiento resulta muy económico si se dispone de espacio suficiente, pero exige suelos arcillosos para evitar la contaminación de las aguas subterráneas por los efluentes tóxicos.

\section{Activación de los lodos}

Se utiliza en tratamientos acelerados realizados en tanques de hormigón o de acero de entre 3 y 5 metros de profundidad, en los que las aguas residuales entran en contacto con una suspensión de microorganismos (2-10 g/l) que se oxigenan por la acción de aireadores de superficie o por la inyección de burbujas de aire. Al cabo de 3 a 24 horas, la mezcla de agua tratada y microorganismos se traslada a un tanque de sedimentación, donde los lodos originados por la acción de los microorganismos se separan del agua. Parte de los microorganismos se devuelve al tanque aireado, y otra parte se evacua.
Hay diversos tipos de procesos de activación de lodos (sistemas de contacto-estabilización, utilización de oxígeno puro, etc.) que ofrecen una eficiencia de purificación superior al $95 \%$ incluso para vertidos industriales, aunque exigen controles precisos y un alto consumo de energía para el suministro de oxígeno.

\section{Filtros de percolación}

Con esta técnica, los microorganismos no se administran en suspensión a las aguas residuales, sino que están adheridos a un material de relleno sobre el cual se rocían los vertidos. El aire circula a través de este material y suministra el oxígeno necesario sin consumo alguno de energía. Según el tipo de aguas residuales, y para aumentar la eficiencia, se hace circular de nuevo parte del agua tratada a la parte superior del lecho filtrante.

Cuando existe terreno disponible, se utilizan materiales de relleno de bajo coste y del tamaño apropiado (gravilla, escorias, piedrecillas, etc.), y debido al peso del lecho, el filtro de percolación suele construirse en forma de un tanque de hormigón de 1 metro de altura, por lo general hundido en el suelo. Si no hay suficiente terreno, pueden utilizarse materiales de relleno más ligeros, aunque más costosos, como paneles de plástico de alto rendimiento, con una gran superficie específica (hasta $250 \mathrm{~m}^{2} / \mathrm{m}^{3}$ de material) que se apilan en torres de percolación de hasta 10 metros de altura.

Las aguas residuales se distribuyen por la parte superior del lecho filtrante por medio de un mecanismo de dispersión fijo o móvil, y se recogen en el fondo para su recirculación eventual a la parte superior y su paso a un tanque de sedimentación donde se depositan los lodos. U nas aperturas en el fondo de los filtros de percolación permiten la circulación del aire por todo el lecho filtrante. Con este proceso se ha alcanzado un rendimiento en la eliminación de contaminantes de entre el 30 y el $90 \%$, habiéndose instalado en muchos casos varios filtros conectados en serie. Esta técnica, que exige poco consumo de energía y es fácil de operar, se ha extendido ampliamente, y es especialmente recomendable para los casos en que existe abundancia de terreno, como ocurre en los países en desarrollo.

\section{Biodiscos}

Una serie de discos planos de plástico, montados paralelamente en un eje horizontal rotatorio, se sumergen parcialmente en las aguas residuales contenidas en un tanque. Debido a la rotación, la capa biológica que cubre los discos entra en contacto con los vertidos y con el oxígeno atmosférico. Los lodos biológicos desprendidos de los discos permanecen en suspensión en las aguas tratadas, actuando el sistema como activador de lodos y como tanque de sedimentación al mismo tiempo. Los biodiscos son aconsejables para el tratamiento de vertidos de comunidades e industrias de tamaño pequeño y medio, ocupan poco espacio, son fáciles de manejar, consumen poca energía y alcanzan rendimientos de depuración de hasta el $90 \%$.

\section{Procesos anaeróbicos}

Se realizan mediante dos tipos de microorganismos: las bacterias hidrolíticas, que descomponen las sustancias complejas (polisacáridos, proteínas, lípidos, etc.) en ácido acético, hidrógeno, dióxido de carbono y agua, y las bacterias metanógenas, que convierten estas sustancias en biomasa (que puede eliminarse por sedimentación) y en biogás, que contiene de un 65 a un $70 \%$ de metano, siendo el resto dióxido de carbono. El biogás tiene un alto valor calorífico.

Estos dos grupos de microorganismos, que son muy sensibles a las sustancias tóxicas, actúan simultáneamente en ausencia de aire y con un valor de $\mathrm{pH}$ casi neutro, exigiendo algunos de ellos una temperatura de entre 20 y $38^{\circ} \mathrm{C}$ (bacterias mesófilas) y otros, 
más delicados, de 60 a $65^{\circ} \mathrm{C}$ (bacterias termófilas). El proceso se lleva a cabo en digestores cerrados de acero o fabricados con hormigones especiales en cuyo interior se mantiene la temperatura adecuada por medio de termostatos. Es característico el proceso de contacto, en el que tras el digestor viene un tanque de sedimentación para separar los lodos, que son recirculados en parte al digestor, del agua tratada.

Los procesos anaeróbicos no necesitan oxígeno ni tampoco consumen energía para suministrar este oxígeno, y de ellos se obtiene biogás, que puede utilizarse como combustible y permite reducir los costes de funcionamiento. En contrapartida, son menos eficientes que los procesos aeróbicos $\left(D_{0} O B_{5}\right.$ residual: 100 a $1.500 \mathrm{mg} / \mathrm{l})$, son más lentos y más difíciles de controlar, aunque sirven para destruir los microorganismos fecales y patógenos. Se utilizan para tratar residuos muy contaminados, como lodos de sedimentación de alcantarillas, exceso de lodos como resultado de tratamientos de activación de lodos o con filtros de percolación y vertidos industriales con una $\mathrm{DOB}_{5}$ de hasta $30.000 \mathrm{mg} / \mathrm{l}$ (p. ej., de destilerías, fábricas de cerveza, refinerías de azúcar, mataderos y papeleras).

\section{Procesos terciarios}

Los procesos terciarios, más complejos y costosos, se basan en reacciones químicas o en técnicas físicas o fisicoquímicas específicas para eliminar los contaminantes no biodegradables hidrosolubles tanto orgánicos (tintes, fenoles, etc.) como inorgánicos (cobre, mercurio, níquel, fosfatos, fluoruros, nitratos y cianuros), sobre todo los procedentes de los vertidos industriales, ya que muchas veces no pueden ser eliminados por otros medios. Los tratamientos terciarios también se utilizan cuando se desea que el agua tratada tenga un alto grado de pureza, de forma que pueda utilizarse como agua potable 0 en procesos industriales (máquinas de vapor, sistemas de refrigeración o procesos que precisen agua para aplicaciones especiales). Los procesos terciarios más importantes se detallan a continuación.

\section{Precipitación}

Se realiza en reactores fabricados con materiales apropiados equipados con agitadores en los que se añaden reactivos químicos a temperatura y $\mathrm{pH}$ controlados para conseguir convertir en insolubles los elementos contaminantes. El precipitado obtenido en forma de lodo se separa por medio de técnicas convencionales para el tratamiento de aguas. En los vertidos de las industrias de fertilizantes, por ejemplo, los fosfatos y los fluoruros se convierten en insolubles haciéndoles reaccionar con cal a temperatura ambiente y en un medio con $\mathrm{pH}$ alcalino. El cromo (industria de curtidos), el níquel y el cobre (talleres de galvanizado) se precipitan como hidróxidos a $\mathrm{pH}$ alcalino, después de haber sido reducidos con $\mathrm{m}$-disulfito a un $\mathrm{pH}$ igual o inferior a 3.

\section{Oxidación química}

El contaminante orgánico se oxida en reactores similares a los utilizados para la precipitación. La reacción continúa, por lo general, hasta que se obtienen agua y dióxido de carbono como productos finales. Los cianuros, por ejemplo, son destruidos a la temperatura ambiente añadiendo hipoclorito sódico e hipoclorito cálcico al pH alcalino, mientras que los colorantes azoicos y la antraquinona se descomponen mediante peróxido de hidrógeno y sulfato ferroso a pH 4,5. Los vertidos colorantes procedentes de la industria química contienen entre un 5 y un $10 \%$ de sustancias orgánicas no biodegradables, que pueden ser oxidadas a temperaturas de 200 a $300{ }^{\circ} \mathrm{C}$ a alta presión en reactores fabricados con materiales especiales mediante el insuflado de aire y oxígeno en el líquido (oxidación húmeda); en ocasiones se utilizan catalizadores. L os gérmenes patógenos que puedan permanecer en las aguas residuales después de su tratamiento son oxidados por cloración u ozonización para convertir las aguas en aptas para el consumo humano.

\section{Absorción}

Algunos contaminantes (p. ej., fenoles procedentes de los vertidos de las plantas de coque, colorantes en el agua con fines industriales o para el consumo potable y tensoactivos) son eliminados eficazmente por absorción mediante polvo o gránulos de carbón activo, que son muy porosos y tienen una gran superficie específica (hasta $1.000 \mathrm{~m}^{2} / \mathrm{g}$ o más). El polvo del carbón activo se añade en cantidades debidamente medidas al agua residual contenida en tanques con agitadores, y entre 30 y 60 minutos más tarde el polvo añadido se retira una vez sedimentado. El carbón activo en gránulos se utiliza en torres instaladas en serie, por las que se hacen pasar las aguas residuales. EI carbón consumido es regenerado en estas torres, es decir, los contaminantes absorbidos son eliminados mediante tratamiento químico (los fenoles son arrastrados con sosa) o por oxidación térmica (caso de los colorantes).

\section{Intercambio iónico}

C iertas sustancias naturales (como las zeolitas) o compuestos artificiales (resinas, permutita) cambian, de forma reversible y estequiométrica, los iones vinculados a ellos por los contenidos en las aguas residuales, aunque se encuentren sumamente diluidos. EI cobre, el cromo, el níquel, los nitratos y el amoníaco, por ejemplo, son eliminados haciendo circular las aguas residuales a través de columnas recubiertas de resina. Cuando las resinas se han agotado, se recuperan lavándolas con soluciones regeneradoras. Los metales se recuperan en forma de solución concentrada. Este tratamiento, aunque costoso, resulta eficaz y aconsejable para los casos en que se requiere un alto grado de pureza (p. ej., para aguas residuales contaminadas por metales tóxicos).

\section{Osmosis inversa}

En casos especiales es posible conseguir aguas de gran pureza, apropiadas para bebida, haciendo pasar vertidos diluidos a través de membranas semipermeables. En el lado de la membrana en que se encuentran los vertidos, los contaminantes (cloruros, sulfatos, fosfatos, tintes, ciertos metales) quedan depositados en forma de soluciones concentradas que tienen que ser eliminados o tratados para su recuperación. Los vertidos diluidos son sometidos a presiones de hasta 50 bar en plantas especiales que contienen membranas sintéticas, hechas de acetato de celulosa u otros polímeros. El coste de funcionamiento de este proceso es bajo, y pueden conseguirse rendimientos de separación superiores al $95 \%$.

\section{Tratamiento de los lodos}

EI tratamiento de las aguas residuales para hacer insolubles los contaminantes da lugar a la producción de cantidades considerables de lodos (del 20 al $30 \%$ de la demanda química de oxígeno (DQ 0$)$ eliminada, que está intensamente diluida $(90-99 \%$ de agua). La evacuación de estos lodos de forma que no se deteriore el medio ambiente presupone el uso de tratamientos con un coste de hasta el $50 \%$ de los requeridos para la purificación de las aguas residuales. Los tipos de tratamiento dependen del destino de los lodos, determinado a su vez por sus características y por la situación local. Los lodos pueden destinarse a:

- La fertilización o el vertido en el mar, si están fundamentalmente exentos de sustancias tóxicas y contienen compuestos nitrogenados y fosforados (lodos procedentes de tratamientos biológicos). Para su traslado pueden utilizarse cintas transportadoras fijas, camiones o barcazas. 
- Enterramiento sanitario en fosas, alternando capas de basura y de tierra. Si las basuras contienen sustancias tóxicas, las fosas tienen que impermeabilizarse, pues de lo contrario aquéllas pueden ser arrastradas por las precipitaciones atmosféricas al interior del suelo. Las fosas deben situarse lejos de manantiales y de la capa freática. Las basuras orgánicas no estabilizadas se mezclan normalmente con un 10 a un $15 \%$ de cal para retrasar la putrefacción.

- Incineración en hornos rotatorios de lecho fluido si las basuras son ricas en sustancias orgánicas y no contienen metales volátiles. Si es necesario, se les añade algún combustible, debiendo purificarse los humos emitidos.

Los lodos son deshidratados antes de su evacuación tanto para reducir su volumen como para abaratar el coste de su tratamiento, y a menudo se estabilizan para evitar su putrefacción y hacer inofensiva cualquier sustancia tóxica que pudieran contener.

\section{Deshidratación}

Incluye un espesamiento previo, realizado en tanques concentradores parecidos a los de sedimentación, donde se dejan reposar los lodos entre 12 y 24 horas y se les quita una parte del agua sobrenadante, mientras que los lodos espesados se retiran por la parte inferior. Después, el lodo espesado se deshidrata por centrifugación o por filtración (en condiciones de vacío o de presión) con equipos convencionales, o mediante exposición al aire libre en capas de $30 \mathrm{~cm}$ de espesor en tanques de hormigón para la desecación de fangos de unos $50 \mathrm{~cm}$ aproximadamente de altura y con un fondo inclinado cubierto con una capa de arena para facilitar el drenaje del agua. Los lodos que contienen sustancias coloidales suelen desestabilizarse previamente por coagulación y floculación, de acuerdo con las técnicas que ya hemos descrito.

\section{Estabilización}

La estabilización comprende la digestión y la destoxificación. La absorción es un tratamiento a largo plazo de los lodos durante el cual pierden entre el 30 y el $50 \%$ de su materia orgánica, lo que va acompañado de un aumento de su contenido de sales minerales. Los lodos ya no son putrescibles, todos los patógenos son destruidos y se mejora la filtrabilidad. La absorción puede ser de tipo aeróbico, cuando los lodos son aireados durante 8-15 días a la temperatura ambiente en tanques de hormigón. Este proceso es parecido al tratamiento comentado de la activación de los lodos. Las absorciones de tipo anaeróbico se realizan en plantas similares a las utilizadas para los tratamientos anaeróbicos de las aguas residuales, completándose el proceso en 30-40 días a $35-40^{\circ} \mathrm{C}$, y dando lugar a la producción de biogás. La alternativa térmica consiste en tratar los lodos con aire calentado entre 200 y $250^{\circ} \mathrm{C}$, a una presión de más de 100 bar, durante 15 a 30 minutos (combustión húmeda), o tratándolos en ausencia de aire durante $30-45$ minutos $180^{\circ} \mathrm{C}$ y a la presión autógena.

La destoxificación hace inofensivos los lodos que contienen metales (cromo, níquel, plomo, etc.), que son solidificados tratándolos con silicato de sodio y se convierten autotérmicamente en los silicatos insolubles correspondientes.

\section{- INDUSTRIA DE RECICLADO MUNICIPAL}

\section{David E. Malter}

\section{Visión general}

El término reciclado tiene significados diferentes para las distintas personas. Para los consumidores, puede consistir en apartar las botellas y las latas para su recogida en la acera. Para los fabricantes de materias primas o de productos, significa la inclusión de materiales reciclados en el proceso. Para quienes prestan servicios de reciclado, puede ser sinónimo de prestación de servicios de recogida, clasificación y envío rentables. En cuanto a los chatarreros, supone la búsqueda de materiales reciclables en cubos de basura y residuos para vendérselos a establecimientos de reciclado. Por otro lado, para los responsables políticos de todos los niveles de gobierno significa el establecimiento de normas que regulen la recogida, el aprovechamiento y la reducción del volumen de los residuos que deben eliminarse, y la obtención de ingresos por la venta de los materiales reciclados. Para que el reciclado se realice de modo eficaz y seguro, es preciso educar a los diversos grupos para que colaboren y compartan la responsabilidad por su éxito.

La industria del reciclado ha crecido de modo constante desde sus inicios hace un siglo. $\mathrm{H}$ asta los años 70 , se mantuvo prácticamente inalterada como actividad voluntaria del sector privado, realizada primordialmente por chatarreros. Al surgir la incineración en los años 70, se hizo conveniente separar determinados materiales antes de echar al horno las basuras. Este concepto se introdujo en consideración a los problemas de emisiones creados por los metales, baterías, plásticos y otros materiales desechados en las basuras urbanas que estaban causando el cierre de numerosas incineradoras antiguas como contaminantes del medio ambiente. La creciente preocupación por los temas ambientales supuso un primer impulso para la separación organizada de las basuras urbanas, de plásticos, aluminio, hojalata, papel y cartón del grueso. En principio, la industria del reciclado no era económicamente viable como negocio autosostenible, pero a mediados de los años 80 , la necesidad de materiales y el aumento de sus precios condujeron al desarrollo de numerosas instalaciones de reciclado de materiales (IR M ) destinadas a la manipulación de materiales reciclables de todo tipo en Estados U nidos y Europa.

\section{Mano de obra}

La amplia variedad de capacidades técnicas y conocimientos prácticos necesarios hace que en las IRM se precisen trabajadores muy diversos. Según se trate de una IR M que ofrezca servicios completos o una sola operación de la línea de clasificación, se emplean, por lo general, los grupos de trabajadores siguientes:

- Los operadores de equipo pesado (retroexcavadoras, cucharas prensiles (bivalvas), bulldozers, etc.) trabajan en el suelo basculante, coordinando el movimiento de las basuras desde la zona de estacionamiento del suelo basculante hasta la de clasificación de los materiales.

- Los clasificadores de materiales, que suponen el grueso de la plantilla, separan y clasifican los materiales reciclables por producto, por color o siguiendo ambos criterios, lo que puede hacerse totalmente a mano o con ayuda de equipo. A continuación, los materiales clasificados se embalan en fardos o con tablas.

- Los operadores de horquillas el evadoras son responsables de trasladar los fardos terminados desde su salida de la embaladora hasta la zona de almacenamiento, y desde allí a los camiones u otros medios de transporte.

- Los trabajadores de mantenimiento están adquiriendo una importancia creciente a medida que evoluciona la tecnología y que se hacen cada vez más complicados las máquinas y los equipos.

\section{Procesos e instalaciones}

La industria del reciclado ha crecido muy rápidamente, y ha desarrollado numerosos procesos y técnicas diferentes a medida 
que avanzaba la tecnología de clasificación de los materiales reciclables. Los tipos más comunes de instalación son las IRM de servicios completos, que sólo admiten materiales reciclables y sistemas sencillos de clasificación y procesado.

\section{IRM deservicios completos}

Estas instalaciones reciben los materiales reciclables mezclados con el resto de los residuos sólidos urbanos. De modo característico, el ciudadano deposita los materiales reciclables en bolsas de plástico de colores que se colocan en el recipiente para la basura. Esto permite a la comunidad combinar los materiales reciclables con otros residuos urbanos, lo que elimina la necesidad de disponer de vehículos y contenedores de recogida independientes. Una secuencia de operaciones característica comprende los siguientes pasos:

- Las bolsas que contienen la basura y los materiales reciclables se descargan desde el vehículo de recogida al suelo basculante/ de recepción.

- La mezcla de basura y materiales reciclables se desplaza por medio de una cuchara de almeja o retroexcavadora a una cinta transportadora.

- La cinta transportadora lleva el material a la zona de clasificación, en la que una criba cilíndrica (o trómel rotatorio) abre las bolsas y permite el paso de las partículas muy pequeñas de suciedad, arena y gravilla por los orificios a un recipiente de recogida para su eliminación.

- Los materiales restantes se clasifican de modo semiautomático mediante cribas o discos según el peso y el volumen. El vidrio se separa por su mayor peso, los plásticos por su mayor ligereza y los materiales de fibra de papel por su volumen.

- Los trabajadores clasifican a mano los materiales, por lo común desde una posición elevada encima de búnkers en los que pueden almacenarse los materiales. Estos se separan en función del grado de papel, del color del vidrio, de las propiedades físicas del plástico, etc.

- Los materiales de desecho se recogen y retiran mediante cargas en camiones con remolque.

- Los materiales separados se desplazan desde los búnkers por medio de horquillas elevadoras o de un "suelo móvil" (es decir, una cinta transportadora) hasta una máquina empacadora 0 a un proceso de desmenuzado y empacado.

- El fardo así formado se descarga de la máquina y se traslada a la zona de almacén con una horquilla elevadora.

- Los fardos recogidos se envían por ferrocarril o en camiones con remolque. En lugar de realizar el empacado, algunas IR M cargan los materiales sueltos en vagones de ferrocarril 0 camiones con remolque.

\section{IRM sólo para materiales reciclables}

En este sistema, sólo llegan a la IR M los materiales reciclables; el grueso de las basuras urbanas va a parar a otros lugares. Se trata de un sistema semiautomático avanzado de clasificación y procesado en el que todos los pasos son idénticos a los antes descritos. Debido al menor volumen manejado, el número de trabajadores es más reducido.

\section{Sistema declasificación/ procesado sencillo}

Se trata de un sistema de trabajo exhaustivo, en el que la clasificación se realiza de forma manual. Es característico el uso de una cinta transportadora para desplazar el material de un puesto de trabajo al siguiente, a fin de que cada clasificador recoja un tipo de material a medida que la cinta pasa por su puesto. Una secuencia típica de un sistema de procesado sencillo y barato comprendería los pasos siguientes:

- Los productos reciclables mezclados se reciben en un suelo basculante y se llevan a la cinta transportadora de clasificación principal por medio de una retroexcavadora.

- Las botellas de vidrio se separan manualmente por colores (esmerilado, topacio, verde, etc.).

- Los recipientes de plástico se clasifican por grado y se amontonan para su empacado.

- Las latas de aluminio se retiran a mano y se introducen en una compactadora o empacadora.

- Los materiales restantes se descargan en una pila o contenedor de residuos para su eliminación.

\section{Equipo y maquinaria}

La maquinaria y equipos utilizados en una IR M están determinados por el tipo de proceso y los volúmenes de materiales manejados. En una IR M semiautomática típica, se incluirían:

- abridores de bolsas;

- separadores magnéticos:

- cribas (discos, agitadores o trómel);

- equipo de clasificación de material (mecánico o neumático);

- trituradoras de vidrio;

- empacadoras y compactadoras;

- separadores de corriente parásita de Foucault (para separación de metales no ferrosos);

- cintas transportadoras,

- material rodante.

\section{Riesgos para la salud y la seguridad}

Los trabajadores de IRM se enfrentan a una gran variedad de riesgos ambientales y laborales, muchos de ellos impredecibles debido a que el contenido de los residuos cambia continuamente. Entre esos riesgos cabe destacar

- Las enfermedades infecciosas causadas por residuos biológicos y médicos.

- La toxicidad aguda y crónica a causa de los productos químicos domésticos, los disolventes y otros productos químicos desechados. Este riesgo no es muy grande (salvo cuando los residuos industriales van a parar a las basuras urbanas), ya que los productos químicos domésticos no suelen ser muy tóxicos, y sólo están presentes en cantidades relativamente pequeñas.

- Disolventes y combustibles y humos de escapes (especialmente operarios de vehículos y trabajadores de mantenimiento).

Tabla 101.4 • Lesiones más comunes en la industria del reciclado.

\begin{tabular}{|c|c|c|}
\hline Tipo de lesión & Causa de la lesión & $\begin{array}{l}\text { Parte del cuerpo } \\
\text { afectada }\end{array}$ \\
\hline $\begin{array}{l}\text { Cortes, abrasiones y } \\
\text { desgarros }\end{array}$ & $\begin{array}{l}\text { Contacto con materiales } \\
\text { cortantes }\end{array}$ & Manos y antebrazos \\
\hline Distensión & Levantamiento & Zona lumbar de la espalda \\
\hline Partículas en los ojos & $\begin{array}{l}\text { Polvo en el aire y objetos } \\
\text { volantes }\end{array}$ & 0jo \\
\hline Movimientos repetitivos & Clasificación manual & Extremidades superiores \\
\hline
\end{tabular}


- Exposiciones a calor, frío e inclemencias climatológicas, debido a que muchas IRM están expuestas a los elementos atmosféricos.

- Niveles perjudiciales de ruido cuando las máquinas pesadas funcionan en espacios confinados.

- R iesgos físicos, como resbalones y caídas, heridas punzantes, cortes y abrasiones, distensiones musculares, esguinces y lesiones por movimientos repetitivos. Los clasificadores suelen estar continuamente de pie, mientras que los operarios de vehículos deben soportar a veces asientos y controles de manejo mal diseñados.

- Polvo y partículas en suspensión en el aire.

En la Tabla 101.4 se enumeran los tipos más frecuentes de lesiones en el sector del reciclado.

\section{Prevención}

L os trabajadores de IR M pueden verse expuestos a cualquier tipo de residuos que llegue a ellas, así como al entorno en constante cambio en el que trabajan. La dirección de una instalación de este tipo debe conocer en todo momento el contenido del material que llega a ella, y estar pendiente de la formación y la supervisión de los trabajadores y del cumplimiento de las normas y reglamentos de seguridad, del uso apropiado de los EPI y del mantenimiento de la maquinaria y los equipos. Merecen una total atención las consideraciones de seguridad siguientes:

- precauciones de bloqueo/ advertencia de seguridad;

- limpieza y orden generales;

- mantenimiento de las salidas;

- preparación para emergencias y, cuando sea necesario, acceso a primeros auxilios y asistencia médica;

- programas de prevención de la audición;

- protección frente a agentes patógenos transmitidos por la sangre;

- mantenimiento preventivo de máquinas y equipos;

- señales de tráfico y de peligro para peatones por material rodante;

- espacios confinados

- prevención de incendios y formación y equipos de lucha contra el fuego;

- gestión de residuos domésticos peligrosos,

- disponibilidad y uso de EPI de buena calidad y del tamaño adecuado.

\section{Conclusión}

El reciclado municipal es una industria relativamente nueva que cambia rápidamente a medida que crece y que su tecnología evoluciona. La seguridad y la salud de su mano de obra dependen de un diseño adecuado de los procesos y los equipos, así como de la formación y supervisión apropiadas de sus trabajadores.

\section{O PERACIONES DE ELIMINACION DE RESIDUOS}

James W. Platner

Los trabajadores que se ocupan de la eliminación y manipulación municipales de basuras se enfrentan a riesgos de seguridad y salud en el trabajo tan variados como los materiales que manejan. Sus principales quejas se refieren a los olores y a la irritación de las vías respiratorias superiores, relacionada por lo general con el polvo. Sin embargo, los verdaderos problemas en materia de seguridad y salud en el trabajo varían en función del proceso de trabajo y de las características de los residuos manejados [residuos sólidos urbanos (RSU) mixtos, residuos sanitarios y biológicos, residuos reciclados, residuos agrícolas y alimentarios, cenizas, restos de construcción y residuos industriales]. Los agentes biológicos, como bacterias, endotoxinas y hongos, pueden entrañar riesgos, sobre todo para los trabajadores con alteraciones del sistema inmunitario e hipersensibles. Además de las preocupaciones relacionadas con la seguridad, las repercusiones sanitarias han sido predominantemente problemas de salud respiratorios en trabajadores, incluidos los síntomas del síndrome tóxico por polvos orgánicos (ST PO), la irritación de la piel, los ojos y las vías aéreas superiores y casos de enfermedades pulmonares graves, como asma, alveolitis y bronquitis.

El Banco M undial (Beede y Bloom 1995) calcula que en 1990 se generaron 1.300 millones de toneladas de R SU, lo que supone un promedio de dos tercios de kilogramo por persona y día. Sólo en Estados U nidos, se cifra en 343.000 el número de trabajadores ocupados en la recogida, transporte y eliminación de RSU, según las estadísticas de la O ficina del Censo de 1991. En los países industrializados, los flujos de residuos son cada vez más diferenciados, y los procesos de trabajo tienen una complejidad creciente. Los esfuerzos para segregar y definir mejor las composiciones de los flujos de residuos son a menudo críticos para identificar los riesgos profesionales y los controles apropiados, así como para controlar las repercusiones en el medio ambiente. La mayoría de los trabajadores en la eliminación de residuos siguen enfrentándose a exposiciones y riesgos imprevisibles derivados de multitud de vertederos abiertos, a menudo con un sistema de combustión abierto.

Los aspectos económicos de la eliminación, reutilización y reciclado de residuos, así como los relativos a la salud pública, están generando cambios rápidos en la manipulación de residuos en todo el mundo, para conseguir la máxima recuperación de recursos y reducir la dispersión de residuos en el medio ambiente. En función de los factores económicos locales, el resultado es la adopción de procesos de trabajo que exigen cada vez más mano de obra o más capital. Las prácticas con una mano de obra abundante atraen a un número creciente de trabajadores a entornos de trabajo peligrosos y afectan generalmente a rebuscadores de basuras del sector informal que clasifican a mano las basuras urbanas y venden los materiales reciclables y reutilizables. El aumento de la capitalización no ha generado automáticamente mejoras de las condiciones de trabajo, ya que el aumento del trabajo dentro de espacios confinados (p. ej., en operaciones de preparación de compost en bidones 0 en incineradoras) y el del procesado mecánico de residuos pueden originar una mayor exposición tanto a los contaminantes en el aire como a los riesgos mecánicos, a menos que se implanten los controles adecuados.

\section{Procesos de eliminación de residuos}

Los procesos utilizados son muy diversos, y a medida que aumentan los costes de recogida, transporte y eliminación de los residuos para satisfacer normas ambientales y comunitarias cada vez más exigentes, puede estar justificada en razón del coste una diversidad creciente de procesos. Estos procesos se subdividen en función de los cuatro enfoques básicos que pueden utilizarse, en combinación o en paralelo, para diversos tipos de residuos. E sos cuatro procesos básicos son la dispersión (vertido en tierra o agua, evaporación), la oxidación (incineración, preparación de compost), almacenamiento/ aislamiento (vertederos controlados 
de residuos sanitarios y peligrosos) y reducción (hidrogenación, absorción anaeróbica). Estos procesos tienen en común algunos riesgos profesionales generales asociados con la manipulación de residuos, pero también llevan aparejados riesgos específicos del proceso de trabajo.

\section{Riesgos profesionales comunes en la manipulación de residuos}

Sea cual sea el proceso concreto de eliminación de residuos que se utilice, el simple hecho de procesar RSU y otros residuos entraña determinados riesgos comunes (Colombi 1991; Desbaumes 1968; M almros y Jonsson 1994; M almros, Sigsgaard y Bach 1992; Maxey 1978; Mozzon, Brown y Smith 1987; Rahkonen, Ettala y Loikkanen 1987; Robazzi y cols. 1994).

Es frecuente que estén mezclados con las basuras normales materiales muy peligrosos no identificados; son ejemplos los plaguicidas, los disolventes inflamables, los productos químicos industriales y los residuos biopeligrosos, que pueden aparecer en la basura doméstica. Este riesgo puede evitarse sobre todo, mediante la separación de los distintos residuos y, en particular, de los residuos industriales y la basura doméstica.

Los olores y la exposición a compuestos orgánicos volátiles (COV) mixtos pueden originar náuseas, pero están por lo común bastante por debajo de los valores límite umbral (TLV) de la Conferencia Americana Gubernamental de Higienistas Industriales $(A C G I H)$, incluso dentro de espacios cerrados (ACGIH 1989; Wilkins 1994). EI control típico comprende el aislamiento del proceso, como en los digestores anaeróbicos sellados o en los bidones para preparación de "compost", con lo que se reduce al mínimo el contacto de los trabajadores mediante el recubrimiento diario con humus o limpieza de la estación de transferencia y el control de los procesos de degradación biológica, en particular reduciendo al mínimo la degradación anaeróbica mediante el control del contenido de humedad y la aireación.

Es posible controlar los gérmenes patógenos transmitidos por insectos y roedores cubriendo a diario los residuos con humus. Botros y cols. (1989) comunicaron que el $19 \%$ de los trabajadores de la basura de EI Cairo tenían anticuerpos frente a Rickettsia typhi (procedente de pulgas), un germen patógeno causante de enfermedad en los seres humanos.

La inyección o el contacto con la sangre de residuos infecciosos, tales como agujas y residuos manchados de sangre, se controlan de modo óptimo en el lugar de origen mediante la separación y esterilización de residuos de ese tipo antes de desecharlos, y por el uso de recipientes resistentes a los pinchazos para su eliminación. El tétanos es también una auténtica preocupación en casos de lesiones en la piel. Se precisa inmunización actualizada.

La ingestión de Giardia y otras especies patógenas para el aparato digestivo puede controlarse reduciendo al mínimo la manipulación y el contacto mano-boca (incluido el consumo de tabaco), suministrando agua potable garantizada, facilitando a los trabajadores servicios higiénicos y de aseo y manteniendo una temperatura adecuada en las operaciones de fabricación de "compost" para destruir los agentes patógenos antes de la manipulación en seco y envasado en bolsas. Son especialmente indicadas las precauciones para los microorganismos Giardia presentes en los lodos de aguas residuales y pañales infantiles desechables en RSU, así como para tenias y lombrices procedentes de residuos de aves de corral y mataderos.

La inhalación de bacterias y hongos presentes en el aire es especialmente temible cuando aumenta el procesamiento mecánico (Lundholm y Rylander 1980) con compactadoras (Emery y cols. 1992), maceradoras o desmenuzadoras, aireación, operaciones de embolsado y cuando se permite que descienda el contenido de humedad. Como resultado, aumentan los trastornos respiratorios (Nersting y cols. 1990), la obstrucción bronquial (Spinaci y cols. 1981) y la bronquitis crónica (Ducel y cols. 1976). Aunque no existen directrices formales, la Asociación de Salud Laboral Holandesa (1989) recomendó mantener el número total de bacterias y hongos por debajo de 10.000 unidades formadoras de colonias por metro cúbico (ufc/ $\mathrm{m}^{3}$ ), y por debajo de $500 \mathrm{ufc} / \mathrm{m}^{3}$ el de cualquier microorganismo patógeno individual (los niveles al aire libre son de alrededor de $500 \mathrm{ufc} / \mathrm{m}^{3}$ para bacterias totales, y los valores en interiores son representativamente menores). Estos niveles pueden superarse de modo regular en las operaciones de fabricación de "compost".

Los hongos y las bacterias forman biotoxinas, incluidas las endotoxinas generadas por las bacterias gramnegativas. La inhalación o ingestión de una endotoxina, incluso después de destruir a las bacterias que la produjeron, puede causar fiebre y síntomas parecidos a los de la gripe sin infección. El grupo de trabajo holandés sobre métodos de investigación de la contaminación biológica en interiores, recomienda que se mantengan niveles de bacterias gramnegativas en el aire inferiores a $1000 \mathrm{ufc} / \mathrm{m}^{3}$ para evitar los efectos de las endotoxinas. Las bacterias y los hongos pueden producir una gran variedad de otras toxinas potentes que también plantean riesgos profesionales

El agotamiento por calor y el golpe de calor pueden ser graves, sobre todo cuando el agua potable garantizada está disponible en cantidades limitadas y cuando se utilizan EPI en lugares que se sabe que contienen residuos peligrosos. En los monos de PVC-Tyvek ${ }^{\circledR}$ sencillos se observa un estrés por calor equivalente a añadir de 6 a $11^{\circ} \mathrm{C}$ al índice de temperatura de globo de bulbo húmedo (WBGT) (Paull y Rosenthal 1987). Cuando la W BG T supera $27,7^{\circ} \mathrm{C}$, las condiciones se consideran peligrosas.

Las heridas o enfermedades de la piel son dolencias frecuentes en las operaciones de manipulación de residuos (Gellin y Zavon 1970). Las lesiones directas de la piel debidas a cenizas cáusticas y otros contaminantes irritantes de los residuos, combinadas con exposiciones intensas a microorganismos patógenos, desgarros y pinchazos frecuentes de la piel y, de modo característico, disponibilidad limitada de instalaciones para lavado, originan una incidencia elevada de problemas de la piel.

Los residuos contienen una gran variedad de materiales capaces de causar desgarros y pinchazos, guardando especial relación con las operaciones en las que se usa de forma intensiva la mano de obra, como la clasificación de las basuras para reciclado o el removido manual de "compost" de RSU, y en los procesos mecánicos como la compactación, el triturado o el desmenuzado, de donde pueden salir elementos proyectados. Las medidas de control exigidas son las gafas de seguridad y el calzado y los guantes resistentes a pinchazos y cortes.

Los riesgos derivados del uso de vehículos atañen tanto a quienes los manejan (vuelco, atrapamiento), como a los trabajadores de a pie, por posible atropello. Todo vehículo que funcione en superficies inestables o irregulares debe estar dotado de protecciones antivuelco que resistan el peso del vehículo y permitan al operador sobrevivir. D ebe separarse en lo posible el tráfico de peatones y vehículos en distintas zonas señalizadas, sobre todo cuando la visibilidad sea limitada, como ocurre en los casos de incineración al aire libre, por la noche y en talleres de fabricación de "compost", en los que en tiempo frío pueden formarse densas neblinas.

En los trabajadores con residuos puede producirse aumento de reacciones broncopulmonares atópicas como asma (Sigsgaard, Bach y M almros 1990) y reacciones cutáneas, sobre todo cuando los niveles de exposición a polvos orgánicos son elevados. 


\section{Riesgos de procesos específicos}

\section{Dispersión}

La dispersión incluye el vertido de los residuos en medios acuáticos, la evaporación en el aire o el vertido sin esfuerzo alguno de contención. EI vertido en los océanos de RSU y residuos peligrosos se está reduciendo rápidamente. Sin embargo, se calcula que el 30-50\% de los R SU no se recogen en las ciudades de los países en desarrollo (Cointreau-Levine 1994), sino que por lo general se queman 0 se vierten en conductos y calles, donde representan una importante amenaza para la salud pública.

La evaporación, en ocasiones con calentamiento activo a bajas temperaturas, se utiliza como alternativa más barata a las incineradoras u hornos, sobre todo para contaminantes orgánicos de líquidos volátiles, como disolventes o combustibles que están mezclados con residuos no combustibles, como el suelo. Pueden existir riesgos para los trabajadores en la entrada a espacios confinados y atmósferas explosivas, sobre todo en operaciones de mantenimiento, en las que deben utilizarse controles apropiados de las emisiones al aire.

\section{Almacenamiento/ aislamiento}

El aislamiento consiste en una combinación de ubicaciones distantes y contención física en vertederos cada vez más seguros. L os vertederos sanitarios característicos exigen la excavación con equipo de movimiento de tierras, el vertido de los residuos, la compactación y el recubrimiento diario con suelo o "compost" para reducir la infestación por animales nocivos, los olores y la dispersión. Pueden instalarse cubiertas y/o revestimientos de arcilla o plástico impermeable para limitar la infiltración de agua y la lixiviación en las aguas subterráneas. Es posible usar pozos de prueba para evaluar la migración del lixiviado del lugar del vertido y permitir su control dentro del vertedero. Los trabajadores son: operadores de equipos pesados; conductores de camiones; vigilantes que pueden ser responsables de rechazar residuos peligrosos y dirigir el tráfico de los vehículos y rebuscadores de basuras del sector informal, que pueden clasificar los residuos y apartar los materiales reciclables

En las regiones que dependen del carbón o la madera para combustible, las cenizas pueden suponer una parte considerable de los residuos. Es necesario apagar los rescoldos antes del vertido, o tener vertederos sólo para las cenizas, para evitar los incendios. Las cenizas pueden causar irritación cutánea y quemaduras cáusticas. Las cenizas en el aire causan diversos riesgos para la salud, incluida la irritación respiratoria y de las mucosas, así como problemas respiratorios agudos (Shrivastava et al. 1994). Las cenizas en el aire de baja densidad también pueden originar riesgos de ingestión, y pueden ser inestables cuando se utiliza equipo pesado y en excavaciones.

En multitud de naciones, la eliminación de residuos sigue consistiendo en el simple vertido con incineración abierta, que puede combinarse con búsqueda de componentes reutilizables - reciclables con valor por parte de trabajadores del sector informal. Estos trabajadores corren riesgos de salud y seguridad graves. Se calcula que en M anila, Filipinas, trabajan 7.000 rebuscadores de basuras en el vertedero de R SU, mientras que en Yakarta lo hacen 8.000 y en Ciudad de M éxico, 10.000 (Cointreau-Levine 1994). Debido a las dificultades para controlar las prácticas de trabajo en sectores informales, un paso importante para controlar estos riesgos es lograr que la separación de materiales reciclables y reutilizables se haga en el proceso de recogida de basuras formal. Pueden realizar esta tarea quienes generan la basura, incluidos los consumidores 0 los trabajadores domésticos o los trabajadores de recogida/ clasificación [p. ej., en Ciudad de M éxico dedican oficialmente el
$10 \%$ de su tiempo a clasificar residuos para la venta de reciclables, mientras que en Bangkok dedican el $40 \%$ (Beede y Bloom 1995)], o es posible disponer operaciones de separación de residuos antes de su eliminación (como separación magnética de los residuos metálicos).

Las hogueras abiertas exponen a los trabajadores a una mezcla potencialmente tóxica de productos de degradación, como ya se ha comentado. Dado que los rebuscadores de basuras pueden recurrir a la incineración al aire libre para facilitar la separación de metales y vidrio de las basuras combustibles, quizá sea necesario recuperar los materiales que merezcan la pena antes del vertido para eliminar esas prácticas de incineración.

Al lograr separar los residuos peligrosos del flujo general de basuras, se reducen los riesgos de los trabajadores con RSU, al tiempo que aumentan las cantidades que manejan los trabajadores de los vertederos de residuos peligrosos. Para conseguir una seguridad elevada en el tratamiento de los residuos peligrosos y en los puntos de eliminación, se necesita una declaración detallada de la composición de los residuos, niveles altos de utilización de EPI para los trabajadores y una formación exhaustiva de éstos en el control de los riesgos. Los vertederos seguros entrañan riesgos peculiares, como los de resbalar y caer cuando las excavaciones están revestidas de plástico o geles de polímero para reducir la migración del lixiviado, problemas dermatológicos potencialmente graves, estrés por calor relacionado con el trabajo durante períodos prolongados con trajes impermeables y control de la calidad del aire suministrado. LoS operadores de equipo pesado, los trabajadores manuales y los técnicos dependen en gran medida de los EPI para reducir al mínimo su grado de exposición.

\section{Oxidación (incineración y preparación de "compost")}

Las hogueras al aire libre, la incineración y el combustible derivado de residuos son los ejemplos más evidentes de oxidación. Cuando el contenido de humedad es suficientemente bajo y el contenido de combustible lo bastante alto, se hacen esfuerzos crecientes para aprovechar el valor como combustible de los R SU mediante la generación de combustible derivado de las basuras en forma de briquetas comprimidas, o mediante la incorporación de plantas de cogeneración de electricidad o de vapor a las incineradoras de basuras municipales. Tales operaciones pueden generar grandes cantidades de polvos secos a causa de los effuerzos para producir un combustible con un valor calorífico constante. Sigue siendo necesario evacuar las cenizas residuales, por lo general a vertederos.

Los riesgos existentes en las incineradoras de RSU son muy diversos (K nop 1975). Así, los trabajadores suecos de estas incineradoras presentaban un aumento de las cardiopatías isquémicas (G ustavsson 1989), mientras que en un estudio de estos trabajadores en Filadelfia, Pensilvania, no se encontró una correlación entre las consecuencias para la salud y los grupos de exposición (Bresnitz y cols. 1992). Se han hallado concentraciones de plomo en sangre algo elevadas en trabajadores de incineradoras, relacionadas primordialmente con exposiciones a cenizas de precipitadores electrostáticos (M alkin y cols. 1992).

L as exposiciones a cenizas (p. ej., de sílice cristalina, radioisótopos, metales pesados) pueden ser importantes no sólo en las operaciones de las incineradoras, sino también en vertederos y plantas de hormigón ligero en las que se utilizan cenizas como aditivo. Aunque el contenido de ślice cristalina y de metales pesados varía con el combustible, éste puede presentar un riesgo importante de silicosis. Schilling (1988) observó efectos sobre la función pulmonar y síntomas respiratorios en los trabajadores 
expuestos a cenizas, pero en la radiología no se apreciaban cambios.

La degradación térmica de los productos de pirólisis originados por la oxidación incompleta de numerosos productos residuales puede generar riesgos importantes para la salud. Estos productos pueden ser cloruro de hidrógeno, fosgeno, dioxinas y dibenzofuranos procedentes de residuos clorados, como plásticos de cloruro de polivinilo (PVC) y disolventes. $L$ os residuos no halogenados también pueden originar productos de degradación peligrosos, incluidos hidrocarburos poliaromáticos, acroleína, cianuro de lanas y seda, isocianatos del poliuretano y compuestos organoestannicos de gran variedad de plásticos. Estas mezclas complejas de productos de degradación pueden variar enormemente en función de la composición de los residuos, las velocidades de alimentación, la temperatura y el oxígeno disponible durante la combustión. Si bien los productos de degradación causan una preocupación notable en caso de quemado en hogueras al aire libre, las exposiciones de los trabajadoras de incineradoras de RSU parecen ser relativamente bajas (Angerer y cols. 1992).

En las incineradoras y hornos rotatorios de RSU y residuos peligrosos, el control de los parámetros de combustión y del tiempo de permanencia de los residuos sólidos y gaseosos a temperaturas elevadas es decisivo para la destrucción de los residuos, al tiempo que reduce al mínimo la generación de productos de degradación más peligrosos. Los trabajadores se ocupan del funcionamiento de la incineradora, la carga y transferencia de residuos al interior de la incineradora, la entrega de los residuos y la descarga de los camiones, el mantenimiento del equipo, la limpieza general y la retirada de cenizas y escorias. Aunque el diseño de la incineradora puede limitar las tareas manuales necesarias y las exposiciones de los trabajadores, con diseños que exijan un menor aporte de capital, pueden existir exposiciones significativas de los trabajadores y una necesidad de regular la entrada a espacios confinados (p. ej., para retirar la escoria que dejan los residuos de vidrio en la parrilla de la incineradora).

\section{Preparación de "compost"}

En los procesos biológicos aeróbicos, la temperatura y la velocidad de oxidación son menores que en la incineración, pero sigue siendo oxidación. La fabricación de "compost" a partir de residuos agrícolas y de talleres, lodos de aguas residuales, RSU y restos de alimentos es cada vez más común en operaciones urbanas. L as tecnologías en rápido desarrollo para el tratamiento biológico de los residuos peligrosos e industriales comprenden a menudo una secuencia de procesos de digestión aeróbicos y anaeróbicos. El "compost" suele prepararse en forma de montones 0 en recipientes grandes que faciliten la aireación y el mezclado. El objetivo de las operaciones para obtener el "compost" es crear una mezcla de residuos con proporciones óptimas de carbono y nitrógeno (30:1), y mantener después la humedad entre 40 a $60 \%$ por peso, una proporción de oxígeno superior al $5 \%$ y niveles de temperatura de 32 a $60^{\circ} \mathrm{C}$ para que puedan crecer las bacterias aeróbicas y otros microorganismos (Cobb y Rosenfield 1991). Tras la separación de los reciclables y de los residuos peligrosos (que exige por lo común la separación a mano), se trituran RSU a fin de crear una mayor superficie para la acción biológica. El triturado puede originar niveles de ruido y de polvo altos, lo que está relacionado con una protección mecánica significativa. En algunas operaciones se utilizan molinos con martillos móviles calibrados para poder reducir la clasificación en el extremo frontal.

Las operaciones de preparación de "compost" en recipientes o bidones exigen mucho capital, pero permiten un control más eficaz de los olores y del proceso. La entrada a espacios confinados es un riesgo importante para los trabajadores de mantenimiento, ya que pueden liberarse concentraciones elevadas de $\mathrm{CO}_{2}$, con el consiguiente déficit de oxígeno. El bloqueo del equipo antes del mantenimiento también es fundamental, puesto que entre los mecanismos figuran accionadores de tornillo y cintas transportadoras internos.

En las operaciones de preparación de "compost" en pilas que no requieren tanto capital, los residuos se desmenuzan o trituran y se colocan en largos montones que se airean mecánicamente por medio de conductos perforados o simplemente dándolos la vuelta, ya sea con palas cargadoras o a mano. Pueden cubrirse 0 techarse los montones para facilitar el mantenimiento de un contenido de humedad constante. Cuando se utiliza equipo especial para dar la vuelta a los montones, los látigos mezcladores de cadena giran a velocidad alta a través del "compost", y debe evitarse que entren en contacto con las personas. Al girar estos látigos a través del montón, proyectan objetos, lo que puede ser peligroso. Los operadores deben garantizar que queda una distancia de seguridad suficiente en los alrededores del equipo.

La toma periódica de la temperatura con sondas permite vigilar el progreso de la elaboración del "compost" y garantizar que existen temperaturas lo bastante altas para destruir los gérmenes patógenos y permitir la supervivencia de los microorganismos beneficiosos. Con contenidos de humedad del 20-45\%, cuando la temperatura supere $93^{\circ} \mathrm{C}$ también puede existir riesgo de incendio por combustión espontánea (de modo muy similar a los incendios de silos). La máxima probabilidad de que ocurra es cuando los montones tienen más de $4 \mathrm{~m}$ de altura. Es posible evitar los incendios si se mantiene la altura de los montones por debajo de $3 \mathrm{~m}$ y se les da la vuelta cuando la temperatura supera los $60^{\circ} \mathrm{C}$. En las instalaciones deben existir bocas de riego y un acceso adecuado entre los montones para controlar los posibles incendios.

Los riesgos en las operaciones de fabricación de "compost" incluyen los mecánicos y los de tráfico originados por los tractores y camiones utilizados para dar la vuelta a los montones de residuos, con el objeto de mantener la aireación y el grado de humedad. En los climas más fríos, las temperaturas elevadas del "compost" pueden producir una densa neblina a ras del suelo, en una zona de trabajo ocupada por operadores de equipos pesados y trabajadores de a pie. Son más frecuentes las náuseas, los dolores de cabeza y las diarreas en los trabajadores con "compost", que en sus compañeros de una planta de agua potable (Lundholm y Rylander 1980). Pueden surgir problemas de olor a consecuencia del control deficiente de la humedad y el aire necesarios para el proceso de elaboración del "compost". Si se permite que existan condiciones anaeróbicas, se genera sulfuro de hidrógeno, aminas y otros materiales olorosos. Además de las preocupaciones características en trabajadores de eliminación de residuos, la fabricación de compost con intervención de microorganismos en crecimiento activo puede elevar las temperaturas de los RSU en grado suficiente para destruir los gérmenes patógenos, pero también puede producir exposiciones a mohos y hongos y a sus esporas y toxinas, sobre todo en operaciones de embolsado de "compost" y cuando se deja que éste se seque. Se han evaluado en varios estudios los hongos, bacterias, endotoxinas y otros contaminantes en el aire en las operaciones de fabricación de "compost" (Belin 1985; Clark, Rylander y Larsson 1983; Heida, Bartman y Van der Zee 1975; Lacey y cols. 1990; M illner y cols. 1994; Van der Werf 1996; Weber y cols. 1993). Existen ciertos indicios de aumento de los trastornos respiratorios y de reacciones de hipersensibilidad en los trabajadores con "compost" (Brown y cols. 1995; Sigsgaard y cols. 1994). Es indudable que las infecciones respiratorias por 
bacterias y hongos (K ramer, K urup y Fink 1989) suponen una preocupación para los trabajadores inmunodeprimidos, como los que tienen SIDA y los que reciben quimioterapia contra el cáncer.

\section{Reducción (hidrogenación y digestión anaeróbica)}

En la digestión anaeróbica de aguas residuales y residuos agrícolas se utilizan tanques cerrados, a menudo con contactos de cepillos rotatorios si los nutrientes están diluidos, lo que puede plantear problemas graves para los trabajadores de mantenimiento en caso de entrada a espacios confinados. En numerosos países se utilizan también con frecuencia digestores anaeróbicos, como generadores de metano, que pueden emplear como combustible residuos agrícolas, sanitarios o alimentarios. En muchos países se exige actualmente la recogida de metano de vertederos de RSU y el quemado o la compresión para su uso cuando la generación de metano supera umbrales especificados, pero en la mayoría de los vertederos no existe humedad suficiente para que la digestión anaeróbica se realice de modo eficiente. La generación de sulfuro de hidrógeno también es un resultado común de la digestión anaeróbica, y puede causar irritación ocular y fatiga olfatoria a niveles bajos.

En los últimos tiempos, la reducción/ hidrogenación a temperaturas altas se ha convertido en una opción de tratamiento de los residuos químicos orgánicos. Pueden emplearse para ello instalaciones más pequeñas, y en consecuencia potencialmente más móviles, con menos aporte de energía que una incineradora de alta temperatura, dado que los catalizadores metálicos permiten que se realice la hidrogenación a temperaturas más bajas. Los residuos orgánicos pueden convertirse en metano y utilizarse como combustible para continuar el proceso. Lo que más preocupa en cuanto a la salud de los trabajadores son las atmósferas explosivas y la entrada en espacios confinados para limpieza, eliminación de lodos y mantenimiento, los riesgos del transporte y la carga de los residuos de alimentación líquidos, así como la posibilidad de derrame.

\section{Resumen}

A medida que los residuos se consideran recursos para el reciclado y reutilización, su procesado aumenta, lo que está originando un cambio rápido de la industria de eliminación de residuos en todo el mundo. Los riesgos para la seguridad y la salud de los trabajadores de las operaciones de evacuación de residuos, a menudo no se limitan a los peligros normales, sino que comprenden numerosos problemas para la salud de carácter crónico y agudo. Con frecuencia se hace frente a estos riesgos con EPI mínimos e instalaciones higiénicas y sanitarias insuficientes. Los esfuerzos para reducir los residuos industriales y prevenir la contaminación, están desplazando cada vez más los procesos de reciclado y reutilización de las operaciones de eliminación de residuos por contrato o externas al campo del trabajo de producción.

Las prioridades en el control de los riesgos para la seguridad y la salud en el trabajo en este sector industrial, en rápida evolución, deben ser:

- la integración del sector de trabajo informal en el proceso de trabajo formal;

- la dotación de servicios y lavabos adecuados y de agua potable;

- la eliminación de hogueras al aire libre y de la dispersión de residuos en el medio ambiente;

- la separación de los distintos flujos de residuos para facilitar su caracterización y la identificación de medidas de control y de prácticas de trabajo apropiadas;

- la reducción al mínimo del tráfico mixto de vehículos y peatones en las zonas de trabajo;
- la adopción de prácticas de excavación adecuadas a las características del suelo y de los residuos;

- la previsión y el control de los riesgos antes de entrar en espacios confinados:

- en operaciones que originen gran cantidad de polvo, reducir la exposición al mínimo:

- el uso de gafas de seguridad y de calzado y guantes resistentes a cortes y pinchazos

- la integración de los aspectos relativos a la seguridad y la salud cuando se apliquen planes de cambio de procesos, sobre todo durante la transición del vertido abierto y los vertederos controlados a operaciones cerradas más complejas y potencialmente más peligrosas, como la fabricación de "compost", la separación mecánica o manual para reciclado, las operaciones de conversión de residuos en energía o las incineradoras.

En este período de cambio rápido en la industria, es posible introducir mejoras importantes en la seguridad y la salud de los trabajadores con un coste bajo.

\section{GENERACION Y TRANSPORTE DE RESIDUOS PELIGROSOS: PROBLEMAS SO CIALES Y ETICOS}

\section{Colin L. Soskolne*}

Entre los residuos peligrosos figuran, por ejemplo, los materiales radiactivos y los productos químicos. EI desplazamiento de estas sustancias desde su lugar de origen a otras localidades se ha denominado "comercio tóxico", actividad que suscitó preocupación a finales de los años 80, sobre todo en A frica (Vir 1989). La identificación de estas prácticas hizo que se despertara el interés sobre la cuestión de la justicia ambiental, reconocida recientemente, también conocida en algunos casos como racismo ambiental (Coughlin 1996).

Vir (1989) señaló que a medida que la legislación en materia de protección ambiental se hacía cada vez más estricta en Europa y Estados Unidos, y que aumentaba el coste de la eliminación, los "basureros" o "comerciantes de residuos" empezaron a dirigir su atención a las naciones más pobres como destinatarios posibles y voluntarios de sus productos de desecho, lo que supondría para estos países más pobres una fuente de ingresos muy necesaria. Algunos de estos países se habían mostrado dispuestos a aceptar estos residuos por una parte del coste que las naciones desarrolladas habrían tenido que pagar, de otro modo, por su eliminación. Para las "naciones que naufragan económicamente, es una oferta atractiva" (V ir 1989).

Asante-Duah, Saccomanno y Shortreed (1992) muestran el crecimiento exponencial en Estados U nidos de la producción de residuos peligrosos desde 1970, con una elevación similar de los costes asociados con el tratamiento y su eliminación. Se muestran partidarios de un comercio controlado de residuos peligrosos, que debe ser "regulado e informado". Señalan que "Ios países que generan cantidades pequeñas de residuos peligrosos deben contemplar el comercio de residuos como una opción económica importante, siempre que los destinatarios de los residuos no comprometan su sostenibilidad ambiental". Seguirán generándose residuos peligrosos, y existen países para los que un aumento de algunas de estas sustancias no elevaría el riesgo para la salud de las generaciones presentes o futuras, por

*A daptado de Soskolne 1997, con autorización. 
lo que podría ser económicamente rentable para ellos aceptar residuos.

$\mathrm{H}$ ay otros autores que sostienen que los residuos sólo deben eliminarse en su lugar de origen, y no transportarse en modo alguno (Puckett y Fogel 1994; C ray 1991; Southam News 1994), y lo hacen partiendo del argumento de que la ciencia es incapaz de ofrecer garantía alguna de la ausencia de riesgo.

Un principio ético que dimana del argumento anterior es el del respeto de la autonomía (es decir, el respeto de las personas), que también incluye cuestiones de autonomía nacional. L a cuestión decisiva que se plantea es la de si un país destinatario tiene capacidad para valorar adecuadamente el nivel de riesgo asociado con un envío de residuos peligrosos. Para la valoración son imprescindibles la declaración completa por parte del país de origen, del contenido de un envío y un grado de capacidad técnica local que permita valorar las repercusiones posibles en el país receptor.

Dado que en las comunidades de los países en desarrollo es menos probable que exista información sobre los posibles riesgos asociados con los residuos enviados, el fenómeno "en mi casa, no", tan evidente en las regiones del mundo más acomodadas, es menos probable en las menos favorecidas. A demás, los trabajadores de estas zonas no suelen disponer de una infraestructura relacionada con la protección de los trabajadores, incluida información referente al etiquetado de los productos con los que entran en contacto. En consecuencia, los trabajadores de los países más pobres que participen en el manejo, el almacenamiento y la eliminación de residuos peligrosos carecerían de la formación necesaria para saber cómo protegerse. C on independencia de estas consideraciones éticas, en el análisis definitivo habría que sopesar las ventajas económicas derivadas de la aceptación de esos envíos de residuos frente a los posibles efectos nocivos que podrían surgir a corto, medio y largo plazo.

Un segundo principio ético que se desprende del argumento anterior es el de la justicia distributiva, centrada en la pregunta de quién asume los riesgos y quién obtiene ventajas. Cuando existe un desequilibrio entre los que asumen los riesgos y los que obtienen ventajas, no se respeta el principio de la justicia distributiva. Con frecuencia han sido trabajadores necesitados quienes se han expuesto a los riesgos sin posibilidad alguna de beneficiarse del fruto de sus esfuerzos. Así ha ocurrido en el contexto de la producción, en países en desarrollo, de mercancías relativamente costosas en beneficio de mercados del primer mundo. O tro ejemplo, es el de los ensayos de vacunas 0 fármacos nuevos en personas de países en desarrollo, que nunca podrían permitirse el acceso a ellos en sus países.

\section{Hacia el control del transporte de los residuos peligrosos}

A causa de la necesidad reconocida de controlar mejor los vertidos de residuos peligrosos, ministros de 33 países firmaron en marzo de 1989 el Convenio de Basilea (Asante-Duah, Saccomanno y Shortreed 1992), en el que se contemplaban los movimientos transfronterizos de residuos peligrosos y se exigía la notificación a los países destinatarios y su consentimiento antes de que pudiera realizarse ningún envío de residuos.

Posteriormente, el Programa de las $\mathrm{N}$ aciones U nidas para el Medio Ambiente (PNUMA) lanzó su Programa para una Producción más Limpia en colaboración estrecha con los gobiernos y el sector industrial en defensa de tecnologías no generadores de residuos (Rummel-Bulska 1993). En marzo de 1994, se prohibieron completamente todos los movimientos transfronterizos de residuos peligrosos desde los 24 países ricos industrializados, miembros de la O rganización para la C ooperación y el Desarrollo Económico (OCDE) a otros estados no miembros de la OCDE. La prohibición fue de carácter inmediato para la eliminación definitiva, y entra en vigor al comienzo de 1998 para todos los residuos peligrosos que se afirma están destinados a operaciones de reciclado o recuperación (Puckett y Fogel 1994). Los países que más se opusieron al establecimiento de una prohibición total fueron Australia, Canadá, Japón y Estados Unidos. A pesar de esta oposición, hasta la penúltima votación de un grupo de gobiernos de gran peso industrial, la prohibición se aprobó finalmente por consenso (Puckett y Fogel 1994).

G reenpeace ha insistido en la necesidad de una prevención primaria para resolver la crisis creciente originada por los residuos atacando de raíz el problema, es decir, reduciendo al mínimo la generación de residuos por medio de tecnologías de producción limpias (Greenpeace 1994a). Al formular esta propuesta, G reenpeace identificó a los países más importantes que exportan residuos peligrosos (Australia, Canadá, Alemania, Reino Unido y Estados Unidos) y a algunos de los que los importan '[Bangladesh, China (incluido Taiwan), India, Indonesia, Malasia, Pakistán, Filipinas, República de Corea, Sri Lanka y Tailandia]. En 1993, Canadá, por ejemplo, había exportado unos 3,2 millones de kilogramos de cenizas que contenían plomo y zinc a la India, la República de Corea y Taiwan, China, y 5,8 millones de kilogramos de residuos de plásticos a Hong Kong (Southam News 1994). Greenpeace $(1993,1994)$ también aborda el alcance del problema en lo que respecta a sustancias concretas y métodos de eliminación.

\section{Valoración de los riesgos}

La epidemiología está en el centro de la valoración del riesgo para la salud, que se invoca cuando en una comunidad surge la preocupación por las consecuencias, si existen, de la exposición a sustancias peligrosas y potencialmente tóxicas. EI método científico aplicado por la epidemiología al estudio de los factores ambientales causantes de una mala salud puede ser fundamental para proteger a comunidades sin defensa, tanto frente a los riesgos como frente a la degradación ambientales. $L$ a valoración del riesgo realizada antes de un envío correspondería probablemente al ámbito del comercio legal, mientras que si se realizara después de la llegada de un envío, se emprendería para determinar si estaban o no justificadas cualesquiera medidas sanitarias, por lo que probablemente habría sido un envío ilegal.

Entre las preocupaciones para la persona que valore los riesgos estaría la evaluación de los riesgos, es decir, qué riesgos existen, si es que hay alguno, en qué grado y en qué forma podrían manifestarse. A demás, dependiendo del tipo de riesgo, quien valore el riesgo debe hacer una evaluación de la exposición para establecer qué posibilidades existen de que las personas estén expuestas a la sustancia o sustancias peligrosas por inhalación, absorción a través de la piel o ingestión (por contaminación de la cadena alimentaria o directamente con los alimentos).

En lo que respecta a los intercambios comerciales, la autonomía exigiría el consentimiento voluntario y sin coacción de las partes. No obstante, difícilmente cabe pensar siquiera en unas circunstancias no coactivas ante la situación de necesidad económica de un país importador del mundo no desarrollado. El equivalente a este caso, es la norma ética actualmente aceptada que no permite la coacción a los participantes en investigación por medio del pago de algo más que los costes directos (p. ej., los salarios no percibidos) por el tiempo invertido en la participación en un estudio (CIOS 1993). O tras cuestiones éticas serían en este caso, por un lado, la verdad en presencia de incógnitas o de incertidumbre científica, y por otro, el principio de caveat emptor (¡cuidado, comprador!). El principio ético de no 
maleficencia exige hacer más bien que mal. En este caso, las ventajas económicas a corto plazo de cualquier acuerdo comercial para aceptar residuos tóxicos debe sopesarse frente al efecto perjudicial a más largo plazo para el medio ambiente, la salud pública y, posiblemente, también para las generaciones futuras.

Por último, la justicia distributiva exige el reconocimiento por las partes que firman un acuerdo comercial de quién obtendrá las ventajas y quién cargará con los riesgos de cualquier trato. L as prácticas generalizadas en épocas pasadas de verter residuos y situar cementerios de residuos peligrosos en las comunidades de Estados Unidos sin medios para defenderse, han llevado al reconocimiento de lo que se denomina actualmente justicia o racismo ambiental (Coughlin 1996). A demás, hoy en día, son temas esenciales objeto de debate público en general, las cuestiones relacionadas con la sostenibilidad y la integridad ambientales.

Agradecimientos: La Dra. Margaret-Ann Armour, del Departamento de Q uímica de la U niversidad de Alberta, facilitó bibliografía de gran utilidad sobre el tema del comercio de sustancias tóxicas, así como material procedente de la "Conferencia sobre residuos peligrosos" de la cuenca del Pacífico celebrada en noviembre de 1993 en la U niversidad de $\mathrm{H}$ awai.

La oficina de $\mathrm{G}$ reenpeace en Toronto, $\mathrm{O}$ ntario (C anadá), brindó una ayuda inestimable al facilitar ejemplares de las referencias bibliográficas de G reenpeace citadas en este artículo.

\section{Referencias}

Angerer, J, B Heinzow, DO Reimann, W Knorz, $\mathrm{G}$ Lehnert. 1992. Internal exposure to organic substances in a municipal waste incinerator. Int Arch $O$ ccup E nviron H ealth; 64(4):265-273.

Asante-Duah, DK, FK Saccomanno, JH Shortreed 1992. The hazardous waste trade: $C$ an it be controlled? E nviron Sci T echnol 26:1684-1693.

Asociación Holandesa de Salud en el Trabajo. 1989 Protocol Onderzoeksmethoden Micro-biologische Binnenlucht- verontreinigingen [M étodos de investigación en polución biológica de aire de interior]. Informe de grupo de trabajo. La Haya, Países Bajos: Asociación $\mathrm{H}$ olandesa de Salud en el T rabajo.

Beede, DE, DE Bloom. 1995. The economics of municipal solid waste. W orld Bank Research Observer. 10(2):113-115

Belin, L. 1985. Health problems caused by actinomycetes and moulds in the industrial environment. Allergy Suppl. 40:24-29.

Bisesi, M, D Kudlinski. 1996. M easurement of airborne gram-negative bacteria in selected areas of a sludge dewatering building. Presentado en la Conferencia y Exposición de $\mathrm{H}$ igiene Industrial A mericana, 20-24 mayo, Washington, DC.

Botros, BA, AK Soliman, M Darwish, $S$ el Said, IC M orrill, TG K siazek. 1989. Seroprevalence of murine typhus and fievre boutonneuse in certain human populations in Egypt. I Trop $\mathrm{M} \mathrm{ed} \mathrm{H}$ yg. 92(6):373-378

Bourdouxhe, M, E Cloutier, S Guertin. 1992. É tude des risques d'accidents dans la collecte des ordures ménagères. M ontreal: Institut de recherche en santé de la sécurité du travail.

Bresnitz, EA, J Roseman, D Becker, E Gracely. 1992. Morbidity among municipal waste incinerator workers. Am J Ind M ed 22 (3):363-378.

Brophy, M. 1991. Confined space entry programs W ater Pollution Control $\mathrm{F}$ ederation Safety and $\mathrm{H}$ ealth B $\mathrm{BL}$ letin (Spring):4.

Brown, JE, D M asood, JI Couser, R Patterson. 1995. $\mathrm{H}$ ypersensitivity pneumonitis from residential composting: residential composter's lung. Ann Allergy, Asthma \& Immunol 74:45-47.

Clark, CS, R Rylander, L Larsson. 1983. Levels of gram-negative bacteria, aspergillus fumigatus, dust and endotoxin at compost plants. Appl Environ M icrobio 45:1501-1505.

Cobb, K, J R osenfield. 1991. M unicipal Compost M anage ment $\mathrm{H}$ ome Study Program. Ithaca, N ueva Y ork: Cor nell Waste $M$ anagement Institute.

Cointreau-L evine, SJ. 1994. Private Sector Participation in M SW Services in D eveloping Countries: The Formal Sector, V ol. 1. W ashington, DC: W orld Bank.

Colombi, A. 1991. R iesgos para la salud en los trabajadores industriales de residuosdesechos industriales (en italiano). M ed Lav 82(4):299-313.
Conferencia Americana de $\mathrm{H}$ igienistas Industriales de Gobierno (ACGIH ). 1989. Guidelines for the Assessment of Bioaerosols in the Indoor Environment. Cincinnati, O hio: ACGIH

Consejo de O rganizaciones Internacionales de Ciencias M édicas (COICM). 1993. International E thica Guidelines for B iomedical Research Involving $\mathrm{H}$ uman Subjects. Ginebra: CIOM S.

Coughlin, SS. 1996. Environmental justice: The role of epidemiology in protecting unempowered communities from environmental hazards. Sci T otal E nviron 184:67-76.

Cray, C. 1991. W aste M anagement Inc.: An Encyclopedia of Environmental $C$ rimes and $O$ ther $M$ isdeeds, 3 a edición (revisada). Chicago, Illinois: G reenpeace U SA.

Crook, B, P Bardos, I Lacey. 1988. Domestic waste composting plants as source of airborne microorganisms. En Aerosols: Their Generation, B ehavior and Application, dirigido por WD Griffiths. Londres: Aerosol Society.

D esbaumes, P. 1968. Estudio de los riesgos inherentes a las industrias de tratamiento de desechos y basuras (en francés). R ev M ed SuisseR omande 88(2):131-136.

Ducel, G, JJ Pitteloud, C Rufener-Press, M Bahy, P R ey. 1976. La importancia de la exposición bacteriana en los trabajadores sanitarios al recoger basuras (en francés). Soz Praventivmed 21(4):136-138.

Emery, R, D Sprau, YJ Lao, W Pryor. 1992. Release of bacterial aerosols during infectious waste compaction: An initial hazard evaluation for healthcare workers. Am Ind H yg A ssoc f 53(5):339-345.

Gellin, GA, M R Zavon. 1970. O ccupational dermatoses of solid waste workers. Arch Environ $\mathrm{H}$ ealth 20(4):510-515.

Greenpeace. 1993. W e've B een $H$ ad! M ontreal's Plastics Dumped $O$ verseas. Greenpeace International Toxic Trade R eport. Washington, DC: G reenpeace Public Information.

- . 1994a. The W aste Invasion of A sia: A G reenpeace Inven tory. G reenpeace T oxic T rade R eport. Washington, DC: G reenpeace Public Information.

-. 1994b. Incineration. G reenpeace Inventory of T oxic T echnologies. W ashington, D C: G reenpeace Public Information.

Gustavsson, P. 1989. M ortality among workers at a municipal waste incinerator. Am J Ind $M$ ed 15(3):245-253.

H eida, H , F Bartman, SC van der Zee. 1975. O ccupational exposure and indoor air quality monitoring in a composting facility. Am Ind $\mathrm{H}$ yg Assoc | 56(1): 39-43.

Johanning, E, E O Imsted, C Y ang. 1995. M edical issues related to municipal waste composting. Presentado en la Conferencia y Exposición de $\mathrm{H}$ igiene Industrial Americana, 22-26 mayo, $\mathrm{K}$ ansas City, K S.
K nop W. 1975. Seguridad en el trabajo en plantas incineradoras (en alemán) Z entralbl Arbeitsmed 25(1):15-19.

K ramer, MN, VP K urup, JN Fink. 1989. Allergic bronchopulmonary aspergillosis from a contaminated dump site. Am R ev R espir D is 140:1086-1088.

Lacey, J, PAM Williamson, P K ing, R P Barbos. 1990. Airborne M icroorganisms Associated with D omestic W aste Composting. Stevenage, Reino Unido: Warren Spring Laboratory.

Lundholm, M, R R ylander. 1980. O ccupational symptoms among compost workers. J O ccup $M$ ed 22(4):256-257.

M alkin, R, P Brandt-R auf, J Graziano, M Parides. 1992. Blood lead levels in incinerator workers. E nviron Res 59(1):265-270.

M almros, P, P Jonsson. 1994. Wastes management: Planning for recycling workers' safety. W aste $M$ anagement \& R esource R ecovery 1:107-112.

M almros, P, T Sigsgaard, B Bach. 1992. O ccupational health problems due to garbage sorting. W aste $M$ anagement \& R esearch 10:227-234.

M ara, DD. 1974. Bacteriology for Sanitary Engineers. Londres: Churchill Livingstone.

M axey, M N. 1978. Hazards of solid waste management: bioethical problems, principles, and priorities. E nviron $\mathrm{H}$ ealth Perspect 27:223-230.

Millner, PD, SA O lenchock, E Epstein, R Rylander, J H aines, J Walker. 1994. Bioaerosols associated with composting facilities. Compost Science and U tilization 2:3-55.

M ozzon, D, DA Brown, JW Smith. 1987. O ccupational exposure to airborne dust, respirable quartz and metals arising from refuse handling, burning and landfilling. Am Ind H yg Assoc I 48(2):111-116.

Nersting, L, P M almros, T Sigsgaard, C Petersen. 1990. Biological health risk associated with resource recovery, sorting of recycle waste and composting. Grana 30:454-457.

Paull, JM , FS R osenthal. 1987. Heat strain and heat stress for workers wearing protective suits at a hazardous waste site. Am Ind H yg Assoc | 48(5):458-463.

Puckett, J , C Fogel 1994. A Victory for Environment and J ustice: The $B$ ase $B$ an and $H$ ow It $H$ appened. Washington, DC: G reenpeace Public Information.

Rahkonen, P, M Ettala, I Loikkanen. 1987. Working conditions and hygiene at sanitary landfills in Finland. Ann 0 ccup H yg 31(4A):505-513.

Robazzi, M L, E Gir, T M M oriya, J Pessuto. 1994. El servicio de recogida de basuras: riesgos profesionales contra efectos dañinos para la salud (en portugués). R ev E sc Enferm U SP 28(2):177-190.

Rosas, I, C Calderon, E Salinas, J Lacey. 1996. Airborne microorganisms in a domestic waste transfer station. En A erobiology, dirigido por M M uilenberg y H Burge. Nueva Y ork: Lewis Publishers.

Rummel-Bulska, I. 1993. The Basel Convention: A global approach for the management of hazard- 
ous wastes. Trabajo presentado en la Conferencia de la Cuenca del Pacífico sobre R esiduos Peligrosos, U niversidad de $\mathrm{H}$ awaii, N oviembre.

Salvato, JA. 1992. Environmental Engineering and Sanitation. Nueva Y ork: John Wiley and Sons.

Schilling, CI, IP Tams, RS Schilling, A Nevitt, CE Rossiter, B Wilkinson. 1988. A survey into the respiratory effects of prolonged exposure to pulverised fuel ash. Br J Ind M ed 45(12):810-817.

Shrivastava, DK, SS K apre, K Cho, YJ Cho. 1994. Acute lung disease after exposure to fly ash. Chest 106(1):309-311.

Sigsgaard, T, A Abel, L Donbk, P Malmros 1994. Lung function changes among recycling workers exposed to organic dust. Am J Ind $\mathrm{Med}$ 25:69-72.
Sigsgaard, T, B Bach, P M almros. 1990. Respiratory impairment among workers in a garbage-handling plant. Am J Ind M ed 17(1):92-93.

Smith, RP. 1986. Toxic responses of the blood. En Casarett and Doull's Toxicology, dirigido por CD K laassen, MO Amdur y J Doull. Nueva York: $M$ acmillan Publishing Company.

Soskolne, C. 1997. International transport of hazardous waste: Legal and illegal trade in the context of professional ethics. Global Bioethics (septiembre/ octubre).

Southam N ews. 1994. Export ban on toxic waste proposed. E dmonton 」 ournal (9 marzo):A12.

Spinaci, S, W Arossa, G Forconi, A Arizio, E Concina. 1981. Prevalencia de las obstrucciones bronquiales funcionales e identificación de grupos de riesgo en una población de trabajadores industriales (en italiano). M ed L av 72(3):214-221.

Van der Werf, P. 1996. Bioaerosols at a Canadian composting facility. B iocycle (septiembre): 78-83.

Vir, AK. 1989. Toxic trade with Africa. Environ Sci T echnol 23:23-25.

Weber, S, G K ullman, E Petsonk, WG Jones, S O lenchock, W Sorensen. 1993. O rganic dust exposures from compost handling: $C$ ase presentation and respiratory exposure assessment. Am । Ind $\mathrm{Med}$ 24:365-374.

Wilkenfeld, C, M Cohen, SL Lansman, M Courtney, MR Dische, D Pertsemlidis, LR K rakoff. 1992. $\mathrm{H}$ eart transplantation for end-stage cardiomyopathy caused by an occult pheochromocytoma. I H eart L ung T ransplant 11:363-366. 


\section{INDUSTRIA DEL TRANSPORTE $Y$ EL ALMACENAMIENTO}

Director del capítulo LaMont Byrd

\section{Sumario}

Perfil general

LaMont Byrd . . .

Retos para la salud y la seguridad de los trabajadores en la industria del transporte y del almacenamiento

Leon 7. Warshaw. .

\section{TRANSPORTE AEREO}

Operaciones aeroportuarias y de control del tráfico aéreo Christine Proctor, Edward A. Olmsted y E. Evrard. . . .

Estudios de caso de controladores del tráfico aéreo en Estados Unidos e Italia

Paul A. Landsbergis ...

Operaciones de mantenimiento de aeronaves Buck Cameron. . . .

Operaciones de vuelo de aeronaves

Nancy Garcia y H. Gartmann . .

Medicina aeroespacial: efectos de la gravedad, la aceleración y la microgravedad en el entorno aeroespacial Relford Patterson y Russell B. Rayman . . .

Helicópteros

David L. Huntzinger .

\section{TRANSPORTE POR CARRETERA}

Conducción de camiones y autobuses

$$
\text { Bruce A. Millies }
$$

Ergonomía de la conducción de autobuses Alfons Grösbrink y Andreas Mahr.

Operaciones de suministro de combustible y mantenimiento de vehículos de motor Richard S. Kraus

Violencia en las gasolineras

Leon 7. Warshaw. .

\section{TRANSPORTE FERROVIARIO}

Explotaciones ferroviarias

Neil McManus

Metros

George 7. McDonald . .

TRANSPORTE FLUVIAL Y MARITIMO

Transporte fluvial y marítimo e industrias marítimas Timothy 7. Ungs y Michael Adess . . . . . . . . . . . . . . . . . 102.45

ALMACENAMIENTO

Almacenamiento y transporte de petróleo crudo, gas natural, productos de petróleo licuados y otras sustancias químicas

Richard S. Kraus.

Almacenamiento

fohn Lund . 


\section{Perfil General}

\section{LaMont Byrd}

Forman parte de este sector las industrias que intervienen en el transporte de mercancías y pasajeros en todo el mundo. Su estructura es compleja y tiene una importancia vital para las economías a escala local, nacional y mundial.

\section{Importancia económica}

El sector del transporte es esencial para la viabilidad económica de los estados. Afecta de forma decisiva a factores de importancia económica como el empleo, la utilización de materias primas y bienes manufacturados, la inversión de capital público y privado y la generación de ingresos fiscales.

En la mayoría de los países industrializados, el transporte representa entre el 2 y el $12 \%$ del empleo remunerado (OIT 1992). Sólo en Estados Unidos, el Departamento de Transporte significó que en 1993 unos 7,8 millones de trabajadores prestaban sus servicios en empresas de transporte por carretera (DOT 1995). La participación de este sector en el producto interior bruto (PIB) y en el empleo total tiende a reducirse a medida que aumenta la renta de cada país.

Asimismo, el transporte es un consumidor fundamental de materias primas y productos acabados en la mayor parte de los países industrializados. Por ejemplo, en Estados Unidos, el sector del transporte utiliza el $71 \%$ del total del caucho producido, un
$66 \%$ de todo el petróleo refinado, un $24 \%$ de todo el zinc, un $23 \%$ de todo el cemento, y un $23 \%$ del total del acero, un $11 \%$ del total de cobre y el $16 \%$ del total de aluminio (Sampson, Farris y Shrock 1990).

La inversión de capital con fondos públicos y privados en camiones, buques, aeronaves, aeropuertos y otros equipos e instalaciones sobrepasa ampliamente los centenares de miles de millones de dólares en los países industrializados.

Asimismo, el sector del transporte desempeña un papel esencial en la generación de ingresos en forma de los impuestos. En países industrializados, el transporte de pasajeros y de mercancías es objeto de fiscalización exhaustiva (Sampson, Farris y Shroch 1990; Gentry, Semeijn y Vellenga 1995). Habitualmente, estos impuestos gravan los carburantes, como la gasolina y el gasóleo, así como los fletes y los billetes para el transporte de pasajeros, y su cuantía anual es superior a centenares de miles de millones de dólares.

\section{Evolución del sector}

En las etapas primitivas del sector de transporte, la geografia condicionaba en gran medida la forma de transporte. A medida que se perfeccionó la tecnología de la construcción, pudieron superarse muchas de las barreras geográficas que limitaban el desarrollo de este sector. En consecuencia, las formas de transporte predominantes han evolucionado de acuerdo con la tecnología disponible.

Figura 102.1 • Distribución de la red viaria mundial 1988-1989, en kilómetros.

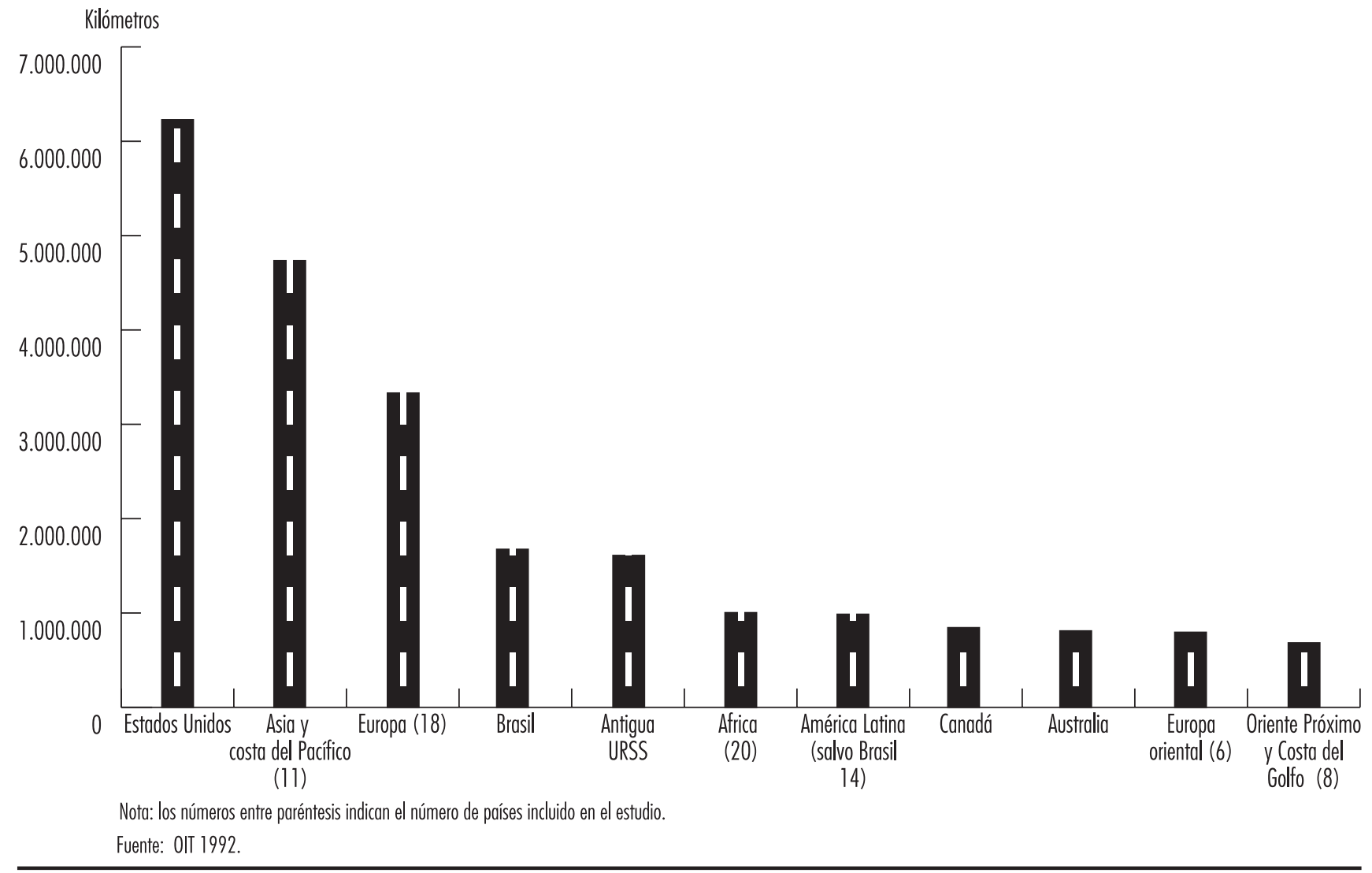


Figura 102.2 • Distribución de la red ferroviaria mundial, 1988-1989, en kilómetros.

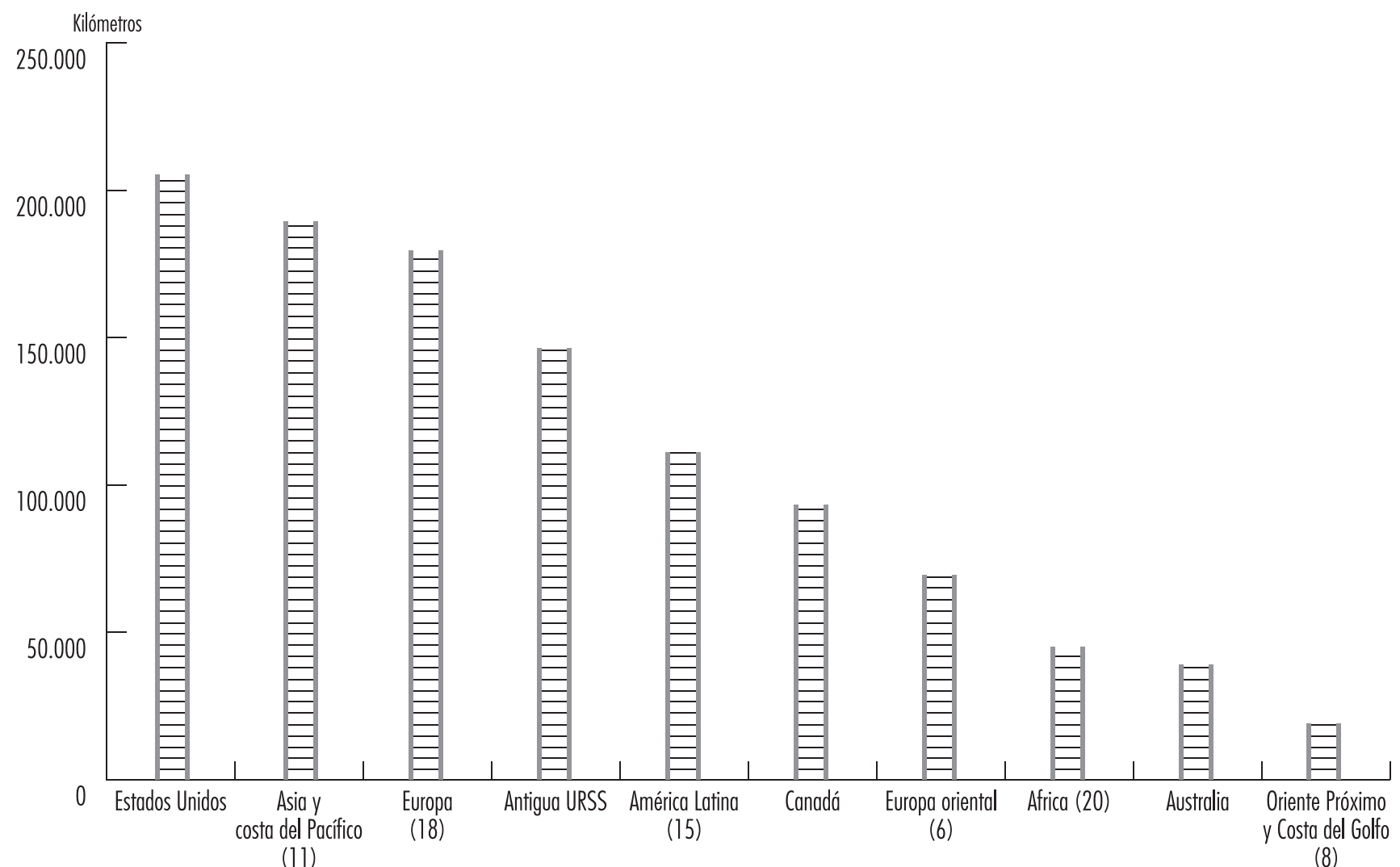

Nota: los números entre paréntesis indican el número de países incluido en el estudio. Fuente: OIT 1992.

Antiguamente, el transporte marítimo constituía el medio fundamental para el transporte de mercancías y pasajeros. La navegación por los grandes ríos y la construcción de canales elevó sustancialmente el volumen de transporte interno a lo largo de estas vías. A finales del siglo XIX, el ferrocarril comenzó a imponerse como medio de transporte más utilizado. Debido a su capacidad intrínseca para superar barreras naturales como montañas y valles mediante el empleo de túneles y puentes, ofrecía la flexibilidad de la que carecían las vías fluviales. Además, a diferencia del transporte por estas vías, el ferrocarril apenas se ve afectado por las condiciones invernales.

Numerosos gobiernos nacionales se concienciaron de las ventajas estratégicas y económicas del transporte por ferrocarril. Así, se concedieron a las empresas de este subsector subvenciones públicas para facilitar la expansión de las redes ferroviarias.

A principios del siglo XX, el desarrollo del motor de combustión interna, combinado con la generalización del uso de vehículos motorizados popularizó el transporte por carretera como sistema de desplazamiento. Con el perfeccionamiento de las carreteras y autopistas, el transporte basado en la utilización de estas vías hizo posible la entrega de mercancías a domicilio. Esta flexibilidad es muy superior a la que pueden ofrecer el ferrocarril y las vías fluviales. Con el tiempo, debido a las mejoras en la construcción de carreteras y en el motor de combustión original, el transporte por carretera evolucionó como un medio más rápido que el ferrocarril en muchas regiones del mundo. En consecuencia, esta forma de desplazamiento se ha convertido en la más utilizada para el transporte de mercancías y pasajeros.

El sector del transporte siguió evolucionando con la aparición de las aeronaves. La utilización de estos vehículos como medio de transporte de mercancías y pasajeros comenzó en la Segunda Guerra Mundial. Inicialmente, los aviones se empleaban fundamentalmente para transportar correo y soldados. No obstante, a medida que se perfeccionaron los métodos de construcción y aumentó el número de pilotos formados, el transporte aéreo se generalizó. En la actualidad, éste modo constituye un sistema rápido y seguro. No obstante, en términos de tonelaje total, el porcentaje de bienes transportados por vía aérea es muy reducido.

\section{Estructura del sector}

En general, la información sobre la estructura de los sistemas ferroviarios en los países industrializados es fiable y comparable (OIT 1992). Los datos correspondientes sobre redes de carreteras ofrecen menos garantías. En cuanto a la información relativa a la estructura de las vías fluviales, puede confiarse en su veracidad, ya que no se ha modificado sustancialmente en los últimos 


\section{Retos para la salud y la seguridad de los trabajadores en la industria del transporte y del almacenamiento}

La industria del transporte y el almacenamiento se enfrenta a diversos retos en lo que respecta a la salud y la seguridad de los trabajadores. El personal dedicado a la carga y la descarga de mercancías, así como al almacenamiento, la colocación y la recuperación de materiales corren el riesgo de padecer de lesiones musculoesqueléticas, resbalones y caídas debidos a la existencia de superficies de trabajo inconsistentes, irregulares o resbaladizas, así como de ser golpeados por caída de objetos. Véase la Figura 102.3. Las personas encargadas del funcionamiento y el mantenimiento de vehículos y otro tipo de maquinaria no sólo son vulnerables a dichas lesiones, sino también a los efectos tóxicos de combustibles, lubricantes y humos de escape. Si no se tienen en cuenta los principios ergonómicos en el diseño de asientos, pedales y tableros de instrumentos, los conductores de trenes, aviones y vehículos de motor (los utilizados en almacenes y carreteras) no sólo podrán ser objeto de trastornos musculoesqueléticos y fatiga indebida, sino que también serán propensos a sufrir contratiempos que pueden dar lugar a accidentes.

Todos los trabajadores (así como la población en general) puede entrar en contacto con sustancias tóxicas en el caso de fugas, vertidos e incendios. Puesto que gran parte de las actividades se llevan a cabo en el exterior, el personal que presta sus servicios en los sectores del transporte y el almacenamiento se ve expuesto a condiciones meteorológicas extremas de calor, frío, lluvia, nieve y hielo, que hacen el trabajo más arduo y también más peligroso. Las tripulaciones aéreas deben adaptarse a los cambios de la presión barométrica. El ruido es un problema constante para los que conducen ciertos vehículos y los que trabajan cerca de éstos y otros equipos.

\section{Estrés}

Posiblemente, el riesgo más extendido en este sector es el estrés profesional. Sus causas son numerosas:

Adaptación a los horarios de trabajo. Muchos trabajadores del sector soportan la carga de tener que adaptarse al cambio de turnos, y las tripulaciones aéreas, que recorren grandes distancias de este a oeste y en dirección contraria, deben ajustarse a la modificación de los ritmos circadianos de su organismo. Estos dos factores pueden causar somnolencia y fatiga. El peligro de deficiencia funcional debido al cansancio ha llevado a estipular en leyes y reglamentos el número de horas y los turnos que pueden realizarse sin un período de descanso. En general, estas disposiciones son aplicables a las tripulaciones de aviación, las dotaciones de trenes $y$, en la mayoría de los países, a los conductores de camiones y autobuses. Muchos de los miembros de este último grupo son contratistas autónomos o empleados de pequeñas empresas y, con frecuencia, los motivos económicos les obligan a desobedecer estas normativas. Siempre se producen situaciones de emergencia a causa de problemas de tráfico, condiciones meteorológicas o accidentes que exigen la superación de los límites relativos a los horarios de trabajo. Actualmente, siguiendo una tendencia iniciada por las líneas aéreas, las grandes empresas de transporte utilizan ordenadores para controlar las jornadas de trabajo de su personal, con el fin de comprobar el cumplimiento de las disposiciones y reducir al mínimo los períodos de inactividad forzada de los trabajadores y de los equipos.

Horarios. El transporte de viajeros en su mayor parte, y el de mercancías en una gran proporción, se rigen por programas en los que se establecen las horas de salida y llegada. La necesidad de cumplir horarios que suelen caracterizarse por su escasa flexibilidad constituye a menudo un importante factor de estrés para conductores y tripulaciones.

Trato con el público. Hacer frente a las exigencias del público, en ocasiones poco razonables y con frecuencia expresadas de forma apremiante, representa una fuente considerable de estrés para las personas que deben tratar con los pasajeros en las estaciones, los despachos de billetes y en ruta. Los conductores de vehículos para el transporte por carretera deben convivir con otros vehículos, las normativas de tráfico y los agentes encargados de velar por su cumplimiento

Accidentes. Los accidentes, ya se deban a averías de los equipos, errores humanos o condiciones ambientales, colocan a sector del transporte en los primeros puestos de las listas de fallecimientos acaecidos en el trabajo en la mayoría de los países. Incluso cuando una lesión en concreto no reviste gravedad, el trastorno por estrés postraumático (TEPT) puede provocar una discapacidad considerable y prolongada y, en ciertos casos, obliga a cambiar de trabajo.

Aislamiento. Muchos de los trabajadores del sector del transporte prestan su servicio en solitario y su contacto con otras personas es escaso o nulo (p. ej., conductores de camión, operarios de salas de control, centros de vigilancia de cambio de vías y torres de señales). Si surge un problema, la consecución de ayuda puede plantear dificultades y demorarse. Además, si el personal no se mantiene ocupado, el aburrimiento puede provocar pérdidas de atención que favorecen los accidentes. El trabajo en solitario, sobre todo para los que conducen taxis, limusinas y camiones de reparto, constituye un factor de riesgo importante en cuanto a la posibilidad de sufrir asaltos con intenciones criminales y otras formas de violencia.

Estancias fuera de casa. Los transportistas suelen verse obligados a permanecer fuera de su domicilio durante períodos de días o semanas (en la industria marítima, de meses). Al estrés derivado de vivir con el equipaje preparado y de tener que adaptarse a comidas y alojamientos desconocidos, hay que añadir el causado por la separación de familiares y amigos.

\section{Problemas de salud}

En la mayoría de los países industrializados, se obliga al personal dedicado al transporte en general, y a los conductores y miembros de tripulaciones operativas en particular, a someterse a exploraciones médicas periódicas con el fin de comprobar su capacidad física y psicológica para cumplir con los requisitos establecidos en la legislación. La agudeza visual y auditiva, la visión del color, la fuerza y flexibilidad musculares y la ausencia de factores de propensión al síncope son algunos de los aspectos analizados. No obstante, las adaptaciones permiten a muchas personas con enfer medades o discapacidades crónicas trabajar sin que ello suponga un peligro para sí mismos o para los demás. (En Estados Unidos, por ejemplo, la Ley federal de ciudadanos estadounidenses con discapacidades obliga a las empresas a incorporar dichas adaptaciones.)

\section{Drogas y alcohol}

Los medicamentos con y sin receta consumidos en el tratamiento de diversos trastornos (p. ej., hipertensión, ansiedad y otros trastornos hipercinéticos, alergias, diabetes, epilepsia, migrañas y resfriado común) pueden provocar somnolencia y periudicar la capacidad de atención, el tiempo de reacción y la coordinación, sobre todo cuando se combinan con la ingestión de bebidas alcohólicas. La frecuencia de los casos de abuso de alcohol y drogas ilegales entre los transportistas ha dado lugar a la formulación voluntaria o impuesta por la legislación de programas para comprobar la ingestión de estas sustancias.

\section{Resumen}

La salud y la seguridad de los trabajadores en la industria del transporte y el almacenamiento son aspectos fundamentales, no sólo para los propios interesados, sino también para las personas que pueden verse afectadas como pasajeros o peatones. Por tanto, su protección es una responsabilidad conjunta de las empresas, los trabajadores y sus sindicatos a todas las escalas.

Leon J. Warshaw 
Figura 102.3 • El levantamiento de paquetes por encima de la altura del hombro constituye un riesgo ergonómico.

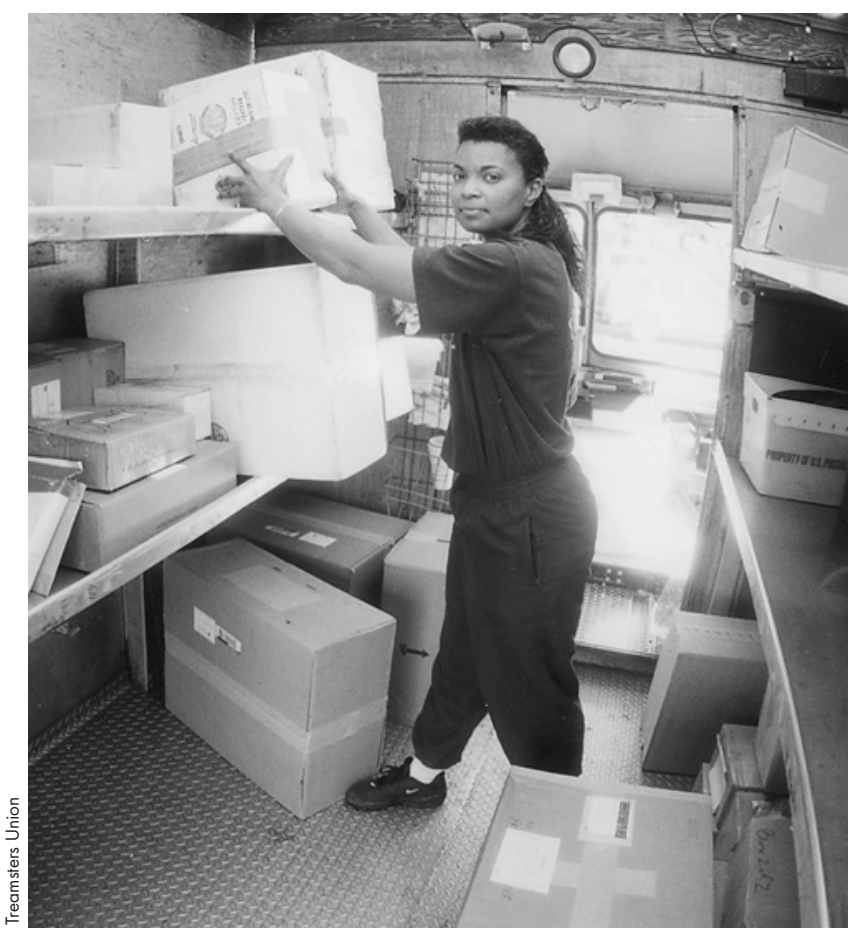

decenios. En cualquier caso, los datos sobre el transporte en los países en desarrollo son escasos y poco fiables.

Los países europeos formaron bloques económicos y políticos que han tenido una influencia sustancial en este sector. En Europa, el transporte por carretera domina el movimiento de mercancías y pasajeros. El desplazamiento en camiones, y en especial la utilización de cargas parciales en los remolques, es gestionado por pequeñas empresas nacionales y regionales. Este subsector es objeto de una regulación exhaustiva y se caracteriza por su elevada fragmentación. Desde principios del decenio de 1970, el volumen total de mercancías transportadas por carretera ha aumentado en un $240 \%$. En cambio, el transporte ferroviario ha caído en torno al $8 \%$ (Violland 1996). En cualquier caso, varios países europeos han emprendido iniciativas encaminadas a mejorar la eficacia de esta forma de desplazamiento y promueven el transporte intermodal.

En Estados Unidos, el medio de transporte fundamental es la red de carreteras. En 1993, según datos de la Oficina de Transporte Motorizado del Departamento de Transporte, había más de 335.000 empresas en las que prestaban servicio camiones de mediano y gran tonelaje (DOT 1995). En esta lista se incluyen las empresas que transportan sus propios productos, pequeñas empresas privadas y las empresas comunes o que trabajan por contrato dedicadas al alquiler de camiones de carga plena o parcial. En la mayoría de los casos (58 \%), estas empresas disponen de seis o menos camiones. Sus flotas están compuestas por un total de 1,7 millones de vehículos tractores con remolque,
4,4 millones de camiones de mediano y gran tamaño y 3,8 millones de remolques. La red viaria de Estados Unidos creció en un $2 \%$ entre 1980 y 1989 (OIT 1992).

El sistema ferroviario de este país se ha reducido, sobre todo porque algunas líneas han perdido su catalogación en primera clase y porque se han abandonado las menos rentables. Canadá ha ampliado su red de ferrocarriles en un $40 \%$, debido fundamentalmente a un cambio en su sistema de clasificación. La red de carreteras de ese país se ha reducido en un 9 \% (OIT 1992).

En los países industrializados de la costa del Pacífico, las redes viarias y ferroviarias varían mucho, debido principalmente a la disparidad de niveles de industrialización. Así, la densidad de estos sistemas en la República de Corea es similar al alcanzado en Europa, mientras que en Malaysia es sustancialmente inferior, aunque registra unas elevadas tasas de crecimiento (más del $53 \%$ en el caso de las carreteras desde 1980) (OIT 1992).

En Japón, el sector está dominado por la red viaria, a través de la cuál se traslada un 90,5\% del volumen total de mercancías. Un $8,2 \%$ se transporta por vías fluviales y un 1,2\% por ferrocarril (Magnier 1996).

Los países en desarrollo de Asia, Africa y América Latina suelen adolecer de sistemas de transporte adecuados. Se han emprendido un número importante de iniciativas para optimizarlos, pero la inestabilidad de las divisas y la escasez de trabajadores cualificados y equipos dificultan el crecimiento. Los sistemas de transporte han crecido considerablemente en Venezuela, México y Brasil.

En general, el sector del transporte en Oriente Medio ha crecido, y países como Kuwait e Irán ocupan una posición destacada en esta forma de desarrollo. Debe señalarse que, debido a la extensión de los estados, la baja densidad de población y la aridez del clima, es necesario superar problemas específicos que limitan el desarrollo de los sistemas de transporte en esa región.

En las Figuras 102.1 y 102.2 se ofrece una visión general de las redes viarias y ferroviarias en ciertos países y regiones del mundo.

\section{Garacterísticas de los trabajadores del sector}

El transporte contribuye significativamente al empleo en la mayoría de los países, tanto en el sector privado, como en el público. No obstante, a medida que aumenta la renta por habitante, la repercusión de esta industria en el empleo total disminuye. El número global de trabajadores que prestan sus servicios en empresas de transporte ha experimentado un descenso regular desde el decenio de 1980. Esta reducción obedece a diversos factores, en especial a los avances tecnológicos que han permitido automatizar muchas de las tareas de construcción, mantenimiento y explotación de los sistemas de transporte. Además, numerosos países han promulgado leyes en las que se desregulan muchas industrias vinculadas a esta actividad, lo que en última instancia ha determinado la pérdida de puestos de trabajo.

Los trabajadores empleados actualmente en empresas relacionadas con el transporte deben caracterizarse por una cualificación y una competencia elevadas. Debido a los rápidos avances de la tecnología aplicada en el sector, estos trabajadores y los que inicien su actividad en el futuro deben recibir una formación continua y someterse a programas de reconversión profesional. 


\section{OPERACIONES AEROPORTUARIAS Y DE CONTROL DEL TRAFICO AEREO}

\author{
Christine Proctor, Edward A. Olmsted \\ $y$ E. Evrard*
}

El transporte aéreo comercial exige la interacción de varios grupos, entre los que se cuentan las administraciones, los operadores aeroportuarios, los operadores de aeronaves y los fabricantes de aeronaves. En general, las primeras intervienen en la regulación global de este tipo de transporte, la supervisión de los operadores de aeronaves (incluidos el mantenimiento y el funcionamiento), la certificación y la inspección de la fabricación, el control del tráfico aéreo, la gestión de las instalaciones aeroportuarias y la seguridad. Los operadores aeroportuarios pueden ser instituciones de la administración local o entidades comerciales. Suelen responsabilizarse del funcionamiento general del aeropuerto. En cuanto a los operadores de aeronaves, puede tratarse de líneas aéreas generales y empresas de transporte comercial (de titularidad pública o privada), empresas dedicadas al transporte de mercancías, corporaciones y propietarios privados de estos vehículos. Habitualmente, se encargan del funcionamiento y el mantenimiento de las aeronaves, de la formación del personal y de la gestión del billetaje y las operaciones de embarque. La responsabilidad respecto a la seguridad varía según los casos; en algunos países, recae en los operadores de aeronaves, en otros, en la administración o los operadores aeroportuarios. Los fabricantes son responsables del diseño, la fabricación y la comprobación, así como de la prestación de servicios auxiliares y la mejora de las aeronaves. Asimismo, existen acuerdos internacionales relativos a los vuelos realizados entre distintos países.

En el presente artículo se examina la situación de los trabajadores que participan en todos los aspectos del control de vuelos (es decir, aquéllos que controlan las aeronaves comerciales desde el despegue al aterrizaje y mantienen las torres de radar y otras instalaciones de control de vuelos) y al personal aeroportuario que lleva a cabo el mantenimiento, carga los aviones, se ocupa del equipaje y las mercancías transportadas y presta servicios a los pasajeros. El personal se clasifica en las categorías siguientes:

- controladores del tráfico aéreo;

- personal de mantenimiento de las instalaciones de servicios aéreos y de las torres de radar;

- personal de tierra;

- manipuladores de equipaje, y

- agentes del servicio a pasajeros.

\section{Operaciones de control de vuelos}

Las autoridades de la Administración competentes en materia de aviación, como la Administración Federal de Aviación (FAA) de los Estados Unidos, controlan el vuelo de las aeronaves comerciales desde el despegue al aterrizaje. Su misión fundamental consiste en la orientación de las aeronaves mediante el radar y otros equipos de seguimiento que evitan colisiones y mantienen las rutas establecidas. El personal dedicado a estas tareas trabaja en aeropuertos, instalaciones de control de aproximación a aeropuertos dotadas de radar (Tracons) y centros regionales de larga distancia, y está compuesto por controladores del tráfico aéreo y trabajadores de mantenimiento de los servicios de pista. Estos centran su actividad en las torres de control, los Tracons y centros

* Parte del texto se ha adaptado del artículo "Aviación, personal de tierra" de E. Evrard, incluido en la $3^{\mathrm{a}}$ edición de la presente Enciclopedia. regionales de control del tráfico aéreo, radiofaros y torres y equipos de radar y constan de técnicos en electrónica, ingenieros, electricistas y operarios de mantenimiento. La orientación de los aviones mediante instrumentos se realiza con arreglo a las normas de vuelo asistido (IFR). Los controladores del tráfico aéreo, que trabajan en torres de control, Tracons y centros regionales, llevan a cabo el seguimiento de las aeronaves con la ayuda del Sistema Nacional General de Control del Espacio Aéreo (GNAS). Su función básica es evitar colisiones y velar por el cumplimiento de las rutas previstas. Cuando un avión pasa de una jurisdicción a otra, la responsabilidad sobre el mismo se traslada de un tipo de controlador a otro.

Centros regionales, torres de control de aproximación dotadas de radar y torres de control aeroportuarias

Los centros regionales dirigen los aviones a partir del momento en que han alcanzado una altitud considerable. Se trata de las mayores instalaciones de los organismos de aviación. Los controladores de estos centros traspasan aeronaves a los Tracons u otros centros similares y reciben las que éstos les traspasan, y utilizan la radio y el radar para mantener la comunicación con los aviones. Un avión que sobrevuela un país es objeto en todo momento de un seguimiento efectuado por un centro regional y pasa de uno a otro a medida que se va desplazando. Las áreas de vigilancia de los distintos centros se solapan, y éstos reciben información suministrada por las instalaciones de radar de largo alcance. Esta información se envía por duplicado a través de enlaces radiofónicos y líneas telefónicas, con el fin de disponer en todo momento de al menos una de las formas de comunicación. El tráfico aéreo transoceánico, que no puede ser observado mediante el radar, es gestionado por los centros regionales a través de la radio. Los técnicos e ingenieros mantienen los equipos de seguimiento electrónico y los sistemas de producción ininterrumpida de energía, que incluyen generadores de emergencia y gran número de baterías de reserva.

Figura 102.4 • Un controlador de tráfico aéreo frente a una pantalla de radar de un centro de control local manual.

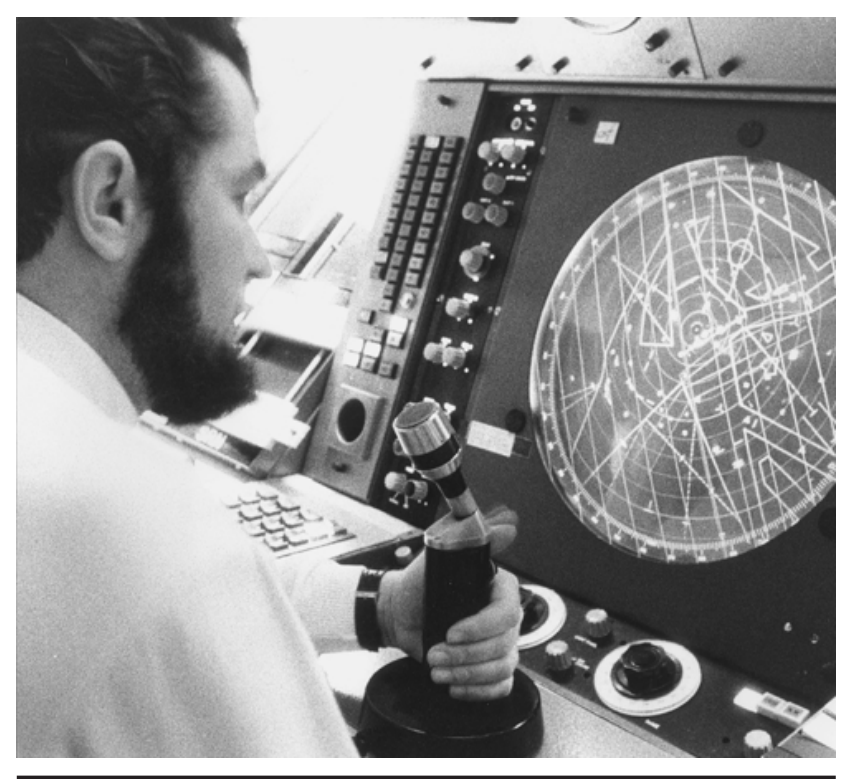


Los controladores de tráfico aéreo que operan en los Tracons se ocupan de los aviones que vuelan a baja altitud y en un radio de $80 \mathrm{~km}$ alrededor del aeropuerto, y utilizan la radio y el radar para mantener la comunicación con las aeronaves. Los Tracons reciben información de seguimiento de los radares de vigilancia aeroportuaria (ASR). Estos sistemas de seguimiento se encargan de la detección en el aire, consultan con el radiofaro e identifican el avión y su información de vuelo. El personal de los Tracons y las tareas efectuadas por éstos son similares a los habituales en los centros regionales.

Hay dos tipos de sistemas de control regionales y de aproximación: no automatizados o manuales y automatizados.

En los sistemas manuales de control del tráfico aéreo las comunicaciones por radio entre controlador y piloto se complementan con información procedente de los equipos de radar primarios o secundarios. El rastro del avión puede seguirse como un eco móvil en las pantallas de tubos de rayos catódicos (véase la Figura 102.4). Los sistemas manuales han sido sustituidos por los automáticos en la mayoría de países.

En los sistemas automatizados de control del tráfico aéreo la información relativa al avión sigue basándose en el plan de vuelo y en los radares primario y secundario, pero los ordenadores hacen posible la presentación alfanumérica en pantalla de todos los datos referentes a cada aeronave y el seguimiento de su ruta. Asimismo, los equipos informáticos se utilizan para anticipar la posibilidad de conflicto entre dos o más aviones en rutas idénticas o convergentes sobre la base de los planes de vuelo y las separaciones normalizadas. La automatización exime al controlador de muchas de las actividades que debe efectuar en un sistema manual, y amplía el tiempo disponible para tomar decisiones.

Las condiciones de trabajo son diferentes en los sistemas manuales y automatizados de los centros de control. En los primeros, la pantalla es horizontal u oblicua y el operario debe inclinarse en una posición incómoda, con la cara a una distancia que oscila entre los 30 y los $50 \mathrm{~cm}$ de aquélla. La percepción de ecos móviles en forma de puntos depende de su brillo y su contraste con la pantalla. Puesto que la intensidad lumínica de algunos de estos ecos es muy escasa, la iluminación del entorno de trabajo debe ser muy débil para asegurar la mayor sensibilidad visual posible.

En los sistemas automatizados, las pantallas electrónicas de presentación de datos son verticales o casi verticales, y el operario puede trabajar sentado normalmente a una distancia de lectura mayor. Tiene a su alcance teclados dispuestos en posición horizontal para regular la presentación de los caracteres y símbolos que transmiten los diversos tipos de información y puede alterar su forma y brillo. La iluminación de las salas de trabajo puede aproximarse a la intensidad de la luz diurna, ya que el contraste sigue siendo muy satisfactorio con 160 lux. Estas características del sistema automatizado colocan al operario en una posición mucho mejor para aumentar su eficacia y reducir la fatiga visual y mental.

El trabajo se realiza en una inmensa sala con iluminación artificial, sin ventanas y repleta de pantallas. Este entorno cerrado, a menudo alejado de los aeropuertos, permite un escaso contacto social durante el desarrollo de la actividad, que exige mucha concentración y capacidad de decisión. El aislamiento relativo es mental y físico, y apenas hay oportunidad de distraerse. Se considera que todos estos factores contribuyen al estrés.

Todos los aeropuertos disponen de una torre de control. Los controladores que trabajan en estos emplazamientos dirigen los aviones durante la entrada y la salida y utilizan el radar, la radio y los prismáticos para mantener la comunicación con las tripulaciones, tanto en las operaciones realizadas en las pistas de rodadura como en las de despegue y aterrizaje. Estos profesionales reciben los aviones de los Tracons o los trasladan a éstos. La mayoría de los sistemas de radar y otros dispositivos de seguimiento se sitúan en los aeropuertos. Su mantenimiento corre a cargo de técnicos e ingenieros.

Las paredes de la sala de control de la torre son transparentes, ya que la visibilidad ha de ser perfecta. Por tanto, el entorno de trabajo es completamente distinto al del control regional de aproximación. Los controladores de tráfico aéreo ven directamente los movimientos de las aeronaves y otras actividades. Tienen contacto con algunos de los pilotos y participan en la vida del aeropuerto. El entorno no es cerrado y ofrece muchos puntos de interés.

\section{Personal de mantenimiento de las instalaciones de navegación aérea}

El personal de mantenimiento de las instalaciones de navegación aérea está formado por técnicos especialistas en sistemas de radar, navegación y comunicación y en medio ambiente.

Los técnicos en sistemas de radar mantienen y manejan los sistemas de radar aeroportuarios y de largo alcance. Su actividad comprende tareas de mantenimiento, calibración y localización de averías de equipos electrónicos.

Los técnicos en sistemas de navegación y comunicación mantienen y operan los equipos de comunicación por radio y otros sistemas de navegación afines empleados en el control del tráfico aéreo. Su trabajo les exige, como en el caso anterior, el mantenimiento, la calibración y la localización de averías de equipos electrónicos.

Los técnicos de medio ambiente mantienen y ponen en funcionamiento los equipos y los edificios (centros regionales, Tracons e instalaciones aeroportuarias, incluidas las torres de control) del organismo de aviación. Entre las tareas que deben realizar figuran la puesta a punto de los equipos de calefacción, ventilación y aire acondicionado y el mantenimiento de los generadores de emergencia, los sistemas de iluminación del aeropuerto, los bancos de baterías de los equipos de suministro de energía ininterrumpido (SEI) y otros equipos eléctricos afines.

Los riesgos profesionales de estos tres grupos de trabajadores comprenden la exposición al ruido; el trabajo encima o cerca de componentes eléctricos activos, incluido el contacto con fuentes de alta tensión; la exposición a los rayos $\mathrm{X}$ generados por klistrones y magnetrones; la posibilidad de caída desde torres de radar elevadas o durante el uso de trepadores de subida y escaleras para acceder a torres y antenas de radio; y, posiblemente, la exposición a PCB al manipular condensadores antiguos y trabajar en transformadores eléctricos. Asimismo, estos profesionales pueden entrar en contacto con microondas y fuentes de radiofrecuencia. Según un estudio de un grupo de trabajadores que manejaban equipos de radar en Australia (Joyner y Bangay 1986), el personal no suelen estar expuestos a niveles de radiación de microondas superiores a los $10 \mathrm{~W} / \mathrm{m}^{2}$, salvo que trabajen con guías de onda abiertas (cables de microondas) y componentes con ranuras de guía de ondas o en el interior de cabinas de transmisión con formación de arcos eléctricos de alta tensión. Los técnicos de medio ambiente también trabajan con sustancias químicas utilizadas en el mantenimiento de edificios, como las que se utilizan en el tratamiento del agua de calderas y otras aplicaciones, el amianto, las pinturas, el combustible diesel y los ácidos de batería. Muchos de los cables eléctricos y otro tipo de conducciones utilizados en los aeropuertos son subterráneos. Las labores de inspección y reparación de estos sistemas suelen exigir el acceso a espacios confinados y la exposición a los riesgos que éstos comportan, como presencia de atmósferas tóxicas o asfixiantes, caídas, electrocución o la posibilidad de quedar atrapado. 
Los trabajadores de mantenimiento de las instalaciones de navegación y el personal de tierra que trabaja en la zona operativa de los aeropuertos está expuesto a los gases de escape de los reactores. En varios estudios realizados en aeropuertos en los que se tomaron muestras de estas emisiones se obtuvieron resultados similares (Eisenhardt y Olmsted 1996; Miyamoto 1986; Decker 1994) que señalan la presencia de aldehídos, como butilaldehído, acetaldehído, acroleína, metacroleína, isobutilaldehído, propionaldehído, crotonaldehído y formaldehído. Esta última sustancia se registró en concentraciones significativamente superiores a las del resto, seguida del acetaldehído. Los autores de estos estudios indicaron que, probablemente, el formaldehído presente en las emisiones de escape constituye la causa principal de las irritaciones oculares y respiratorias detectadas en las personas expuestas. Dependiendo de cada estudio, no se detectaron óxidos de nitrógeno o se detectaron en concentraciones inferiores a 1 parte por millón (ppm) en los gases de escape. La conclusión es que ni los óxidos de nitrógeno ni de otro tipo influyen en gran medida en la irritación. Asimismo, se observó que los gases de escape de los reactores contiene 70 tipos distintos de hidrocarburos, y que hasta 13 de ellos consisten esencialmente en olefinas (alquenos). Se ha comprobado que la exposición a los metales pesados presentes en los gases de escape de los reactores no representa un peligro para la salud en las áreas que rodean a los aeropuertos.

Las torres de radar deben equiparse con vallas normalizadas alrededor de las escaleras y las plataformas para evitar caídas, y con dispositivos de bloqueo para evitar el acceso al reflector parabólico cuando éste se encuentra en funcionamiento. Los trabajadores que acceden a las torres y a las antenas de radio deben utilizar los accesorios normalizados para subir escaleras y equipos de protección individual contra caídas.

El personal maneja equipos y sistemas eléctricos activados y desactivados. La protección frente a los riesgos de origen eléctrico debe incluir la formación sobre prácticas de trabajo seguras, procedimientos de bloqueo e identificación y uso de equipos de protección individual (EPI).

La emisión de microondas del radar se genera con equipos de alta tensión que utilizan un tubo de klistrón. Este emite rayos $\mathrm{X}$ y puede constituir una fuente de exposición cuando los trabajadores desmontan la carcasa para trabajar cerca del tubo. Esta carcasa debe permanecer montada en todo momento, salvo cuando se efectúen tareas de conservación del tubo de klistrón, que deben realizarse en un tiempo mínimo.

El personal debe utilizar la protección auditiva apropiada (tapones y auriculares, por ejemplo) al trabajar cerca de fuentes de ruido, como aviones a reacción y generadores de emergencia.

Otros controles exigen la oferta de formación sobre manipulación de materiales, seguridad de vehículos, equipos de intervención en caso de emergencia y procedimientos de evacuación, así como equipos empleados para acceder a espacios confinados (incluidos los detectores de radiactividad en el aire de lectura directa, ventiladores y sistemas de recuperación mecánica).

\section{Controladores del tráfico aéreo y personal de los servicios de vuelo}

Los controladores del tráfico aéreo desarrollan su labor en centros de control regionales, Tracons y torres de control de aeropuertos. La mayor parte de su actividad se centra en el trabajo en consolas de control desde las que realizan el seguimiento de los aviones en pantallas de radar y en la comunicación por radio con los pilotos. El personal de los servicios de vuelo ofrece a éstos información sobre las condiciones meteorológicas.

Los riesgos con que se enfrentan los controladores del tráfico aéreo incluyen posibles trastornos visuales, ruido, estrés y dificultades ergonómicas. En su momento se consideraron con preocupación las emisiones de rayos $\mathrm{X}$ de las pantallas de radar. No obstante, se ha observado que éstas no constituyen un peligro con las tensiones de trabajo utilizadas.

La Organización Internacional de Aviación Civil (OACI) ha recomendado normas generales de ergonomía para los controladores de tráfico aéreo y los reglamentos nacionales civiles y militares proponen otras más detalladas, siendo especialmente precisas las que afectan a la vista y el oído.

\section{Trastornos visuales}

En ocasiones, las superficies amplias y transparentes de las torres de control de los aeropuertos provocan deslumbramiento por la acción del sol, y el reflejo de la arena o el hormigón de las construcciones próximas incrementa la luminosidad. Esta tensión para los ojos es causa de migrañas, por lo general pasajeras. Se evitan rodeando la torre de control de hierba, prescindiendo de materiales como hormigón, asfalto o grava y construyendo los paneles transparentes de la sala con un material teñido de verde. Si el color no es demasiado fuerte, la agudeza visual y la percepción de los colores siguen siendo suficientes, pero se absorbe el exceso de radiación que provoca el deslumbramiento.

Hasta aproximadamente el año 1960, los estudios de frecuencia de fatiga ocular de los controladores imputable a la observación de las pantallas de radar arrojaron resultados desiguales, pero parece haber sido elevada. Desde entonces, la atención prestada a los errores de refracción visual en la selección de los controladores de radar, su corrección en los controladores en ejercicio y la mejora constante de las condiciones de trabajo ante la pantalla han contribuido a reducir considerablemente este tipo de dolencia. No obstante, en ocasiones, la fatiga ocular afecta a controladores con una vista excelente. Este hecho puede atribuirse a la iluminación excesivamente tenue de las salas, a la iluminación irregular de la pantalla, al brillo de los propios ecos y, en especial, a la oscilación de la imagen. La mejora de las condiciones de visión y la insistencia en optimizar las especificaciones técnicas de los nuevos equipos han reducido mucho esta fuente de fatiga ocular y en ocasiones han logrado eliminarla. Asimismo, la tensión postural se ha considerado hasta fecha reciente causa posible de fatiga ocular para los operadores que trabajan muy cerca de la pantalla durante una hora sin interrupciones. Los trastornos visuales son cada vez menos frecuentes, y es probable que desaparezcan o que se produzcan sólo en contadas ocasiones en el sistema de radar automatizado (por ejemplo, cuando hay algún defecto de proyección o cuando el ritmo de las imágenes está mal ajustado).

Básicamente, se entiende por disposición racional de las instalaciones la que facilita la adaptación de los lectores de las pantallas a la intensidad de la iluminación ambiental. En una estación de radar no automatizada, la adaptación a una situación de semioscuridad en la sala de operación se logra pasando de 15 a 20 minutos en otra sala con luz tenue. La iluminación de la primera, la intensidad lumínica de las pantallas y el brillo de los puntos de luz deben estudiarse con detalle. En el sistema automatizado, los signos y los símbolos se leen con una iluminación ambiental que oscila entre 160 y 200 lux, y se evitan las desventajas del entorno oscuro del método no automatizado. En cuanto al ruido, a pesar de las modernas técnicas de aislamiento, el problema sigue siendo grave en las torres de control instaladas junto a las pistas.

Los lectores de pantallas de radar y de monitores electrónicos de datos son sensibles a los cambios en la iluminación ambiente. En el sistema no automatizado, los controladores deben utilizar gafas que absorban el $80 \%$ de la luz entre 20 y 30 minutos antes de entrar en el lugar de trabajo. En el automatizado, estas gafas 


\section{Estudios de caso de controladores del tráfico aéreo en Estados Unidos e Italia}

\section{Estados Unidos}

El elevado nivel de estrés de los controladores del tráfico aéreo (CTA) se apuntó por primera vez en Estados Unidos en el Informe Corson de 1970 (US Senate, 1970), en el que se analizaban condiciones de trabajo como las horas extraordinarias, la escasez de descansos periódicos, el aumento del tráfico aéreo, la insuficiencia de los períodos de vacaciones, las deficiencias del entorno físico de trabajo y el "resentimiento y antagonismo mutuos" entre la patronal y los trabajadores. Esta situación contribuyó a las movilizaciones laborales de los ATC de 1968 y 1969. Además, las primeras investigaciones médicas en la materia, incluido un estudio de gran alcance de la Universidad de Boston correspondiente al período 1975-1978 (Rose, Jenkins y Hurst 1978), plantearon la posibilidad de que estos profesionales puedan correr un riesgo superior al normal de sufrir enfermedades vinculadas al estrés, como la hipertensión.

Tras la huelga de CTA de 1981 en Estados Unidos, en la que el estrés en el trabajo fue una de las cuestiones principales, el Departamento de Transporte volvió a designar un grupo de trabajo para analizar los factores de estrés y el estado de ánimo de estos trabajadores. En el Informe Jones de 1982, resultado de esta iniciativa, se recoge que el personal de FAA, asignado en una amplia gama de puestos, expresó su opinión desfavorable respecto al diseño de los puestos de trabajo, la organización laboral, los sistemas de comunicación, la supervisión, el apoyo social y la satisfacción con el trabajo. La forma habitual de estrés de los CTA consistía en un incidente episódico agudo (como un cuasiaccidente aéreo), combinado con las tensiones interpersonales derivadas del estilo de gestión. El grupo de trabajo señaló que un 6 \% de los CTA encuestados se encontraba "agotado" (había experimentado una pérdida amplia y debilitante de la confianza en su capacidad para desempeñar su trabajo). La proporción de individuos en esta situación alcanzaba el $21 \%$ en el colectivo de trabajadores de 41 o más años de edad, y el $69 \%$ entre los que habían prestado servicio durante 19 o más años.

El grupo de trabajo Jones, en una revisión de sus recomendaciones efectuada en 1984, concluía que "las condiciones son tan desfavorables como en 1981, o quizá algo peores". Los principales motivos de preocupación consistían en el aumento del volumen de tráfico, la inadecuada dotación de personal, el bajo estado de ánimo y el aumento del índice de agotamiento. Esta situación dio lugar a la resindicalización de los CTA de Estados Unidos en 1987, con la elección de la National Air Traffic Controllers Organization (NATCA) como representante en las negociaciones colectivas.

En un estudio de 1994, los CTA del área de la ciudad de Nueva York señalaron la continuación de las deficiencias de personal y su inquietud respecto al estrés profesional, el trabajo por turnos y la calidad del aire en el interior. Las recomendaciones para la mejora del estado de ánimo y de la salud se referían a las oportunidades de traslado, la jubilación anticipada, la flexibilización de los horarios, la disposición de instalaciones para practicar ejercico en el trabajo y el aumento de la dotación de personal. En 1994, el porcentaje de CTA del nivel 3 y 5 que declaraban sentirse "muy agotados" era superior a la proporción correspondiente registrada en los estudios nacionales de 1981 y 1984 lexcepto en el caso de los CTA que prestaban servicio en centros en 1984). Las instalaciones de nivel 5 deben hacer frente a los mayores niveles de tráfico áereo, y las de nivel 1 a los menores (Landsbergis y cols. 1994). La sensación de agotamiento se vinculaba con la experiencia de un "cuasiaccidente" en los 3 años anteriores, la edad, los años de servicio como CTA, el trabajo en instalaciones de nivel 5, las deficiencias en la organización del trabajo y la escasez del apoyo prestado por jefes y compañeros.

Sigue estudiándose la programación de turnos adecuada para los CTA, incluida la posibilidad de establecer jornadas de 10 horas en semanas laborales de 4 días. Se ignoran los efectos para la salud a largo plazo de la combinación de turnos rotatorios y semanas de trabajo comprimidas.

\section{Un programa de reducción del estrés profesional de los CTA en Italia sometido a negociación colectiva}

En el organismo responsable del tráfico áereo civil en Italia (AAAV) trabajan 1.536 CTA. Los representantes del AAAV y los sindicatos establecieron varios acuerdos entre 1982 y 1991 encaminados a mejorar las condiciones de trabajo. Son los siguientes:

1. Modernización de los sistemas de radio y automatización de la información aeronáutica, los procesos de datos de vuelo y la gestión del tráfico aéreo. De esta forma, se dispone de información más fiable y de más tiempo para adoptar decisiones, eliminando numerosas congestiones de tráfico peligrosas y estableciendo una carga de trabajo más equilibrada.

2. Reducción de las horas de trabajo. Actualmente, la semana de trabajo oscila entre 28 y 30 horas.

3. Cambio de la programación de turnos:

- rotación de turnos rápida: un día en cada turno;

- un turno de noche seguido de dos días de descanso:

- ajuste de la duración del turno a la carga de trabajo: de 5 a 6 horas por la mañana, 7 horas por la tarde, de 11 a 12 horas por la noche;

- períodos de sueño breves en el turno de noche;

- mantenimiento de la rotación de turnos tan regular como sea posible para permitir una mejor organización de la vida personal, familiar y social; e

- instauración de una pausa amplia (de 45 a 60 minutos) para la comida en cada turno de trabajo.

4. Reducción de los factores de estrés ambiental. Se han emprendido iniciativas para lograr la reducción del nivel de ruido y la mejora de la iluminación.

5. Mejora en la ergonomía de los nuevos cuadros de control, pantallas y sillas.

6. Mejora de la forma física. En las grandes instalaciones se dispone de gimnasios.

Los estudios efectuados durante este período indican que el programa ha resultado beneficioso. El turno de noche no ha resultado excesivamente estresante; el rendimiento de los CTA no ha empeorado de manera significativa al final de los tres turnos, sólo 28 CTA han sido despedidos por razones de salud en 7 años, y se ha registrado un gran descenso de los "cuasifallos" a pesar del gran aumento del tráfico aéreo.

Paul A. Landsbergis 
especiales no son imprescindibles, aunque las personas con sensibilidad acusada al contraste entre la iluminación de los símbolos en la pantalla y la del entorno de trabajo consideran que unas gafas de capacidad de absorción intermedia contribuyen a la comodidad de sus ojos. También reducen la fatiga ocular. Se recomienda a los controladores de pista que empleen gafas que absorban el $80 \%$ de la luz cuando se expongan a una iluminación solar intensa.

\section{Estrés}

El riesgo profesional más grave para los controladores del tráfico aéreo es el estrés. Su tarea principal es adoptar decisiones sobre los movimientos de las aeronaves en el sector del que son responsables: niveles de vuelo, rutas, cambios de dirección cuando hay conflicto con la que sigue otro aparato o si la congestión en un sector da lugar a retrasos, tráfico aéreo, etc. Asimismo, en los sistemas no automatizados, el controlador debe preparar, clasificar y organizar la información en la que fundamenta su decisión. Los datos que recibe se encuentran en estado bruto y es preciso elaborarlos. En sistemas muy automatizados, los instrumentos ayudan al controlador a tomar decisiones, de modo que su tarea se limita a analizar los datos generados por el trabajo en equipo y presentados de forma racional por dichos instrumentos. Aunque la actividad se simplifica mucho, el responsable de autorizar la decisión propuesta al controlador sigue siendo el propio controlador, y esta actividad continúa provocando estrés. Las responsabilidades del puesto, la presión del trabajo en ciertos momentos de tráfico denso o complejo, la congestión cada vez mayor del espacio aéreo, la concentración constante, los turnos de trabajo rotativos y la conciencia de la catástrofe que puede derivarse de un error crean una situación de tensión continua que da lugar a reacciones de estrés. La fatiga del controlador se presenta en tres formas clásicas: aguda, crónica o sobretensión y agotamiento nervioso. (Véase asimismo el recuadro sobre los estudios - caso de los controladores de tráfico aéreo de Estados Unidos e Italia.)

El control del tráfico aéreo exige la prestación de un servicio ininterrumpido de 24 horas diarias todos los días del año. Las condiciones de trabajo de los controladores incluyen turnos, un ritmo de actividad y descanso irregular y la prestación de servicio cuando la mayoría de las personas disfrutan de vacaciones. Los períodos de concentración y relajación durante la jornada laboral y los días de descanso durante la semana son indispensables para evitar la fatiga profesional. Por desgracia, este principio no puede estar recogido en las normas generales, puesto que la organización del trabajo en turnos depende de distintas variables que pueden ser legales (número máximo autorizado de horas de trabajo consecutivas) o puramente profesionales (carga de trabajo en función de la hora del día o de la noche) o por muchos otros factores basados en consideraciones sociales o familiares. Respecto a la duración idónea de los períodos de concentración sostenida en el trabajo, los experimentos realizados ponen de manifiesto que deben establecerse descansos breves de al menos unos pocos minutos después de períodos de servicio ininterrumpido que oscilan entre media hora y una hora y media, pero que no es necesario imponerse pautas estrictas para alcanzar el objetivo deseado: el mantenimiento del nivel de concentración y la prevención de la fatiga operativa. Es esencial interrumpir los períodos de actividad ante la pantalla con fases de descanso, sin entorpecer la continuidad del trabajo por turnos. Hacen falta nuevas investigaciones para determinar la duración idónea de los períodos de concentración sostenida y de relajación durante la jornada laboral, así como el mejor ritmo de descanso semanal, anual y vacacional, para elaborar normas más homogéneas.

\section{Otros riesgos}

Se plantean asimismo cuestiones ergonómicas que deben considerarse al trabajar en puestos de control y que son similares a las relacionadas con los operadores de ordenadores; también hay que examinar la calidad del aire en el interior. Los controladores del tráfico aéreo están asimismo expuestos a los llamados episodios acústicos, que son sonidos intensos transmitidos por los cascos; duran sólo unos pocos segundos, pero alcanzan valores de presión acústica de hasta $115 \mathrm{~dB}$.

En los servicios de vuelo hay que considerar el riesgo asociado con los láseres utilizados en los instrumentos de medida de la altura de las nubes, así como todo lo relativo a la ergonomía y la calidad del aire en interiores.

\section{Otro personal de los servicios de control de vuelo}

Se incluye aquí al personal encargado de la inspección de vuelo, la seguridad, la renovación y la construcción de instalaciones aeroportuarias, el apoyo administrativo y los servicios médicos.

Los inspectores de aviación giran inspecciones de vuelo y mantenimiento de las líneas aéreas. Comprueban si las empresas comerciales de transporte aéreo cumplen las normas mínimas de navegación aérea. Inspeccionan los hangares y otras instalaciones aeroportuarias y viajan en las cabinas de los aparatos que realizan vuelos comerciales. Investigan asimismo accidentes, incidentes y otros contratiempos relacionados con la aviación.

Entre los riesgos de esta actividad se cuentan la exposición al ruido producido por las aeronaves, al combustible y los gases de escape de los motores de reacción durante el trabajo en hangares y otras zonas aeroportuarias y el contacto con materiales peligrosos y organismos patógenos de la sangre durante la investigación de accidentes de aviación. Los inspectores de vuelo se enfrentan a muchos de los riesgos que afectan al personal de tierra, por lo que son aplicables precauciones similares.

El personal de seguridad incluye a los oficiales de aviación. Estos profesionales se encargan de la seguridad interna en las aeronaves y de la externa en los accesos. En esencia, se trata de actividades policiales y de investigación criminal relacionadas con aviones y aeropuertos.

El personal dedicado a la renovación y la construcción de instalaciones aeroportuarias aprueba los planes de modificación y las nuevas edificaciones. Suele estar formado por ingenieros y su actividad es en buena medida de oficina.

El personal administrativo se ocupa de la contabilidad, los sistemas de gestión y la logística. El personal médico de aviación presta servicios de medicina del trabajo a los empleados de las entidades competentes en materia de aviación.

Los controladores del tráfico aéreo, el personal de servicios de vuelo y otros trabajadores que desarrollan su actividad en oficinas deben recibir formación ergonómica acerca de las posturas adecuadas para sentarse, los equipos de respuesta en caso de emergencia y los procedimientos de evacuación.

\section{Operaciones aeroportuarias}

El personal de tierra de los aeropuertos se ocupa del mantenimiento y la carga de las aeronaves. Se incluyen aquí los trabajadores dedicados a la manipulación del equipaje de los pasajeros y de las mercancías transportadas por vía aérea, así como los agentes del servicio de pasajeros, que se encargan de registrar a éstos y de comprobar su equipaje.

Todas las operaciones de carga (pasajeros, equipaje, mercancías, combustible, suministros, etc.) son controladas y coordinadas por un supervisor que elabora el plan de carga. Este documento se entrega al piloto antes del despegue. Cuando se han llevado a cabo todas las operaciones y se han realizado 
todos los controles e inspecciones que el piloto considera necesarios, el controlador del aeropuerto autoriza el despegue del aparato.

\section{Personal de tierra}

\section{Mantenimiento y revisión de aeronaves}

Todas las aeronaves se revisan cada vez que aterrizan. El personal de tierra se encarga del mantenimiento rutinario general, la inspección visual, incluido el control del nivel de combustible y del equipo, las reparaciones menores, la limpieza interior y exterior y el abastecimiento de combustible y existencias. En cuanto el aparato aterriza y se detiene en la zona de descarga, un equipo de mecánicos inicia una serie de comprobaciones y operaciones de mantenimiento que dependen del tipo de avión. Estos trabajadores reponen combustible, verifican diversos sistemas de seguridad que deben inspeccionarse después de cada aterrizaje, examinan el diario de vuelo para constatar las incidencias o deficiencias que la tripulación haya observado durante el vuelo y, en caso necesario, efectúan reparaciones. (Véase asimismo el artículo "Operaciones de mantenimiento de aeronaves" incluido en el presente capítulo.) En condiciones meteorológicas adversas, es posible que los mecánicos deban llevar a cabo otras tareas, como la desincrustación de hielo de las alas, el tren de aterrizaje, los alerones, etc. En climas cálidos, se presta especial atención al estado de los neumáticos de la aeronave. Una vez concluidas estas labores, los mecánicos pueden declarar que la aeronave se encuentra en condiciones de volar.

Cada cierto número de horas de vuelo se practican inspecciones de mantenimiento y revisiones más completas.

El abastecimiento de combustible es una de las operaciones de mantenimiento más peligrosas. La cantidad que debe repostarse se determina en función de factores como la duración del vuelo, el peso en el despegue, la trayectoria de vuelo, las condiciones meteorológicas y las posibles desviaciones.

Los equipos de limpieza se ocupan de acondicionar las cabinas de las aeronaves, sustituir el material sucio o deteriorado (cojines, mantas, etc.) vaciar los aseos y rellenar los depósitos de agua. Asimismo, estos trabajadores desinfectan la aeronave bajo la supervisión de las autoridades sanitarias públicas.

Otro equipo se encarga del abastecimiento de alimentos y bebidas, equipos de emergencia y otros productos necesarios para el bienestar de los pasajeros. Las comidas se preparan de acuerdo con estrictas normas de higiene para eliminar el riesgo de intoxicación alimentaria, sobre todo en el caso de la tripulación. Ciertos platos se congelan a $-40{ }^{\circ} \mathrm{C}$, se almacenan a $-29^{\circ} \mathrm{C}$ y se recalientan en vuelo.

El trabajo de mantenimiento en tierra incluye la utilización de equipos motorizados y no motorizados.

\section{Garga de equipajes y mercancías}

Los manipuladores de equipajes y mercancías se encargan del traslado de estos artículos. Las mercancías transportadas por avión son muy variadas, desde frutas y verduras frescas o animales vivos hasta isótopos radiactivos o maquinaria. Puesto que estas tareas de manipulación exigen esfuerzo físico y la utilización de equipos mecanizados, los trabajadores están expuestos a un riesgo mayor de lesiones y disfunciones ergonómicas.

El personal de tierra y los manipuladores de carga se enfrentan a numerosos riesgos comunes, como el trabajo a la intemperie en todo tipo de condiciones meteorológicas y la exposición a posibles contaminantes en suspensión en el aire procedentes del combustible y los gases escape de los reactores y a los chorros de agua y aire lanzados por las hélices. Estos pueden cerrar puertas con violencia, golpear a las personas o derribar equipos mal sujetos, provocar el giro de los propulsores de turbohélice y lanzar residuos sobre motores o personas. El personal de tierra también está expuesto a accidentes acústicos. Un estudio realizado en China ha demostrado que el personal de pista que se encuentra cerca de las salidas de los motores recibe una presión acústica superior a $115 \mathrm{~dB}$ (Wu y cols. 1989). El tráfico de vehículos en las pistas y las zonas de estacionamiento de aeronaves es muy intenso, y el riesgo de accidente y colisión elevado. Las operaciones de repostaje son muy peligrosas, y los trabajadores están expuestos a derrames de combustible, fugas, incendios y explosiones. El personal situado en dispositivos elevadores, brazos de grúa, plataformas o soportes de acceso corre el riesgo de caerse. Otro riesgo profesional es el trabajo por turnos en condiciones de presión por falta de tiempo.

Deben desarrollarse y aplicarse reglamentos estrictos de movimiento de vehículos y formación de conductores. En este último aspecto, hay que insistir en el cumplimiento de los límites de velocidad, el respeto de los límites y la garantía de que los aviones disponen del espacio suficiente para maniobrar. Hay que asegurar el mantenimiento adecuado de la superficie de las pistas y el control eficaz del tráfico terrestre. Todos los vehículos autorizados para operar en el aeropuerto deben estar claramente señalizados para facilitar su identificación por los controladores del tráfico aéreo. Los equipos utilizados por el personal de tierra han de someterse a inspecciones y operaciones de mantenimiento periódicas. Los trabajadores que desarrollan su actividad en dispositivos elevadores, brazos de grúa, plataformas o soportes de acceso deben protegerse de posibles caídas mediante la instalación de barandillas y el empleo de equipos de protección individual. Hay que utilizar dispositivos de protección auditiva (como tapones y auriculares) para evitar la exposición a los ruidos. Otros elementos del EPI son la ropa de trabajo adecuada elegida en función de las condiciones meteorológicas, los protectores de pies antideslizantes reforzados en la puntera y los dispositivos de protección adecuados para ojos, cara, manos y resto del cuerpo empleados al aplicar los líquidos para desincrustar el hielo. En las operaciones de abastecimiento de combustible, deben adoptarse medidas rigurosas en materia de protección y prevención de incendios, entre ellas las conexiones a masa y a tierra las medidas necesarias para evitar chispas eléctricas y la prohibición de fumar, manipular llamas abiertas o estacionar vehículos en un radio de $15 \mathrm{~m}$ alrededor de la aeronave. Los equipos de extinción de incendios deben mantenerse y ubicarse en el área donde se desarrolle la actividad. Hay que impartir formación regular sobre las medidas que deben adoptarse en caso de vertido de combustible o incendio.

Los manipuladores de equipajes y cargas deben almacenar y apilar las mercancías con seguridad y recibir formación sobre las técnicas de izado adecuadas y las posturas de espalda que deben evitarse. La entrada en las zonas de carga de aeronaves y la salida de ellas a bordo de carretillas y cabezas tractoras exige precauciones extremas. Hay que emplear la ropa de protección adecuada al tipo de mercancía o equipaje (guantes para manipular animales vivos, por ejemplo). En las cintas transportadoras, carruseles y distribuidores de carga deben instalarse interruptores de emergencia y protectores.

\section{Agentes del servicio de pasajeros}

Los agentes del servicio de pasajeros expiden billetes, registran a los pasajeros y facturan su equipaje. Asimismo, pueden orientar al pasaje al embarcar. Algunos de estos trabajadores pasan todo el día de pie ante un monitor de ordenador. Entre las precauciones adoptadas para afrontar estos riesgos ergonómicos figuran 
el empleo de asientos y moquetas amortiguadoras para aliviar el cansancio, las pausas en el trabajo y la adopción de medidas ergonómicas y antirreflejos en los monitores. Además, el trato con los pasajeros puede constituir una fuente de estrés, sobre todo cuando se producen retrasos en los vuelos o se plantean problemas con los transbordos, etc. Las averías de los sistemas informatizados de reserva de vuelos también son causa de estrés.

Las instalaciones de peso y facturación de equipajes deben minimizar la necesidad de que trabajadores y pasajeros levanten y manipulen maletas, y las cintas transportadoras, carruseles y distribuidores de equipajes deben disponer de interruptores de emergencia y dispositivos de protección. Asimismo, los agentes deben recibir formación sobre las técnicas de izado adecuadas y las posturas de la espalda que deben evitarse.

En los equipos de inspección se utilizan instrumentos fluoroscópicos para examinar el equipaje y otros artículos transportados por los viajeros. El blindaje protege a los trabajadores y al público en general de las emisiones de rayos $\mathrm{X}$ y, si su ubicación no es adecuada, los seguros de bloqueo impiden que el equipo funcione. De acuerdo con un estudio realizado hace algunos años por el National Institute for Occupational Safety and Health (NIOSH) y la Air Transport Association en cinco aeropuertos de Estados Unidos, las exposiciones totales máximas a rayos $\mathrm{X}$ documentadas eran muy inferiores a los topes establecidos por la Food and Drug Administration (FDA) y la Occupational Safety and Health Administration (OSHA) (NIOSH 1976). Los trabajadores deben emplear dispositivos de control corporal para medir las exposiciones a la radiación. El NIOSH recomendó la adopción de programas de mantenimiento periódicos para supervisar la eficacia de los blindajes.

Los agentes del servicio de pasajeros y demás personal del aeropuerto deben conocer con detalle los planes y procedimientos de evacuación de las instalaciones en caso de emergencia.

\section{- OPERACIONES DE MANTENIMIENTO DE AERONAVES}

\section{Buck Cameron}

Las operaciones de mantenimiento de aeronaves están muy repartidas dentro de cada país y entre distintos países y corren a cargo de mecánicos militares y civiles. Estos trabajadores desarrollan su actividad en aeropuertos, centros de mantenimiento, aeródromos privados, instalaciones militares y a bordo de aeronaves de transporte. Son empleados de empresas dedicadas al transporte de pasajeros y de mercancías, contratistas de servicios de mantenimiento, operadores de aeródromos privados, empresas agrarias y propietarios de flotas públicas y privadas. Mientras que en los aeropuertos pequeños trabajan sólo algunos mecánicos, en los grandes aeródromos y centros de mantenimiento las plantillas tienen miles de trabajadores. Hay dos clases de trabajos de mantenimiento: los necesarios para mantener el funcionamiento diario (mantenimiento de línea) y los de control, mantenimiento y restauración periódica de aeronaves (mantenimiento de base). En la primera categoría se incluye el mantenimiento en ruta (entre el aterrizaje y el despegue) y el mantenimiento nocturno. El mantenimiento en ruta agrupa los controles operativos y las reparaciones esenciales para el vuelo realizados con el fin de resolver las anomalías detectadas durante el vuelo. Suelen tratarse de intervenciones menores, como la sustitución de luces de emergencia, neumáticos o componentes de aviónica, pero su alcance llega hasta el cambio de un motor. El segundo es más amplio y engloba las reparaciones pospuestas durante los vuelos del día.

Las empresas aéreas controlan los intervalos, la distribución y la naturaleza del mantenimiento de sus aparatos y los documentan en un manual que, en la mayoría de las jurisdicciones, debe remitirse para su aprobación al organismo competente en materia de aviación. Estas tareas se realizan en el curso de verificaciones regulares, clasificadas con las letras A a D y especificadas en el manual mencionado. La regulación de estas actividades asegura la inspección, el mantenimiento y la restauración de las aeronaves en los intervalos oportunos. Pueden incorporarse controles menos exhaustivos en la actividad de mantenimiento de la línea, pero el trabajo más intenso se realiza en los centros especializados. Los daños de las aeronaves y las averías de sus componentes se reparan según las necesidades.

\section{Operaciones de mantenimiento de línea y sus riesgos}

El mantenimiento en ruta suele efectuarse bajo una gran presión de tiempo en líneas de vuelo activas y concurridas. Los mecánicos están expuestos a las condiciones ambientales de ruido, intemperie y tráfico de vehículos y aeronaves, que agravan los peligros propios de esta actividad. Las condiciones climáticas alcanzan en ocasiones extremos de frío, calor, viento, lluvia, hielo y nieve. Las tormentas eléctricas constituyen un riesgo considerable en ciertas regiones.

Aunque los actuales motores para la aviación comercial son claramente más silenciosos que los de generaciones anteriores, aún emiten niveles de ruido muy superiores a los establecidos por los organismos reguladores, sobre todo si los aparatos deben salir de las puertas de embarque valiéndose de sus propios motores. Los motores a reacción y de turbohélice de mayor antigüedad provocan exposiciones a niveles de ruido superiores a $115 \mathrm{~dB}$. Las unidades de potencia auxiliar (UPA) de las aeronaves, los equipos terrestres de acondicionamiento del aire y producción de electricidad, los remolques, los camiones cisterna y los equipos de manipulación de mercancías contribuyen a la elevación del ruido de fondo. Los niveles de éste en las pistas o en las áreas de estacionamiento de aeronaves rara vez bajan de $80 \mathrm{~dB}$, por lo que exigen la selección cuidadosa y la utilización sistemática de protectores auditivos. Hay que buscar dispositivos que ofrezcan una capacidad de atenuación excelente y, a la vez, sean razonablemente confortables y permitan una comunicación básica. Los sistemas dobles (tapones más auriculares) mejoran la protección y facilitan la acomodación a niveles de ruido de mayor o menor intensidad.

Entre los equipos móviles, además de las aeronaves, se cuentan los furgones de equipajes, los autobuses de personal, los vehículos de abastecimiento de comidas, los equipos de apoyo en tierra y las escaleras telescópicas. Para mantener los horarios de salida y la satisfacción de los clientes, estos equipos deben desplazarse con rapidez en áreas de las pistas a menudo congestionadas, incluso en condiciones ambientales adversas. Los motores de las aeronaves plantean el riesgo de que el personal de pista sea absorbido por éstos o golpeado por la ráfaga de aire creada por las hélices o el chorro de escape. La reducción de la visibilidad durante la noche y las inclemencias meteorológicas aumentan el riesgo de que mecánicos y otro personal de pista se vean afectados por los equipos móviles. Los materiales reflectantes en la ropa de trabajo ayudan a mejorar la visibilidad, pero es esencial que todos estos trabajadores reciban una formación adecuada sobre las normas de tráfico en las pistas, que deben aplicarse con rigor. Las caídas, la causa más frecuente de lesión 
grave entre los mecánicos, se analizan en otros capítulos de la presente Enciclopedia.

Las sustancias químicas con las que hay riesgo de contacto en las pistas son líquidos descongelantes (normalmente, contienen etilenglicol o propilenglicol), aceites y lubricantes. El queroseno es el combustible habitual de los motores a reacción comerciales (Jet A). Los fluidos hidráulicos que contienen tributil fosfato causan irritaciones oculares intensas, aunque pasajeras. La entrada en depósitos de combustible, aunque es relativamente infrecuente en las pistas, debe incluirse en programas globales de acceso a espacios confinados. También hay riesgo de contacto con los sistemas de resinas utilizados para reparar materiales compuestos, como los paneles de los depósitos de mercancías.

El mantenimiento nocturno suele hacerse en circunstancias de mayor control, en hangares para el servicio en línea o en líneas de vuelo inactivas. La iluminación, los puestos físicos de trabajo y la tracción son mucho mejores que en el mantenimiento en ruta, pero es probable que sean inferiores a las habituales en las bases de mantenimiento. Cuando varios mecánicos trabajan simultáneamente en un mismo aparato, es vital imponer una planificación y una coordinación rigurosas para controlar el movimiento de personas, la activación de los componentes del avión (motores, superficies de control de vuelo, etc.) y el uso de productos químicos. Es esencial una conservación adecuada para evitar la acumulación de conductos de aire, repuestos y herramientas, así como limpiar derrames y fugas. Estos requisitos revisten aún mayor importancia en el mantenimiento de base.

\section{Operaciones de mantenimiento de base y sus riesgos}

Los hangares de mantenimiento son grandes estructuras en las que caben numerosas aeronaves. En los mayores hay sitio para varios aparatos de grandes dimensiones, como el Boeing 747. Cada una de las naves sometida a mantenimiento dispone de un área de trabajo independiente. Los hangares cuentan con talleres especializados en la reparación y reinstalación de componentes. Las áreas de actividad suelen clasificarse en chapa metálica, interiores, hidráulica, plásticos, ruedas y frenos, sistemas eléctricos y equipos de aviónica y emergencia. Pueden establecerse zonas de soldadura, talleres de pintura y áreas para pruebas no destructivas. Es probable que las operaciones de limpieza de piezas se realicen en toda la instalación.

Si se realizan trabajos de pintura y decapado, el hangar debe disponer de ventilación para garantizar los controles de contaminantes atmosféricos en el lugar de trabajo y la protección del medio ambiente. Las sustancias decapantes suelen contener cloruro de metileno y otros productos corrosivos, entre ellos ácido fluorhídrico. Las pinturas de imprimación para aeronaves contienen a menudo un componente de cromato para prevenir la corrosión. Las capas exteriores son epoxídicas o de poliuretano. El diisocianato de tolueno (TDI) ya no suele utilizarse en estas pinturas, sustituido por isocianatos de mayor peso molecular, como el 4,4-difenilmetano diisocianato (MDI) o por prepolímeros. Estas sustancias también presentan riesgo de asma por inhalación.

Los motores se revisan en el centro de mantenimiento, en un taller de reparación especializado o en las instalaciones de un subcontratista. En la reparación de motores se aplican técnicas de trabajo con metales, como rectificado, limpieza con chorro de arena o con productos químicos, galvanoplastia o chapado con chorro de plasma. La sílice se ha sustituido en casi todos los casos por materiales menos peligrosos en la limpieza de piezas, pero los materiales de base y revestimientos pueden provocar polvos tóxicos cuando se eliminan por chorreado o lijado. En la limpieza y el chapado de metales se utilizan muchos compuestos potencialmente peligrosos para la salud de los trabajadores y el medio ambiente, como productos corrosivos, disolventes orgánicos y metales pesados. En general, el cianuro es motivo de preocupación inmediata y obliga a elaborar planes especiales de actuación en caso de emergencia. Las operaciones de pulverización de plasma también merecen atención especial. Esta técnica consiste en incorporar metales finamente pulverizados en la corriente de plasma generada con una fuente eléctrica de alta tensión para recubrir piezas metálicas con las partículas; el equipo utilizado emite niveles muy altos de ruido y luz. Entre los riesgos físicos se cuentan el trabajo en altura, el levantamiento de pesos y la actividad en posiciones incómodas. Son medidas de precaución útiles los sistemas de ventilación local por extracción, EPI y dispositivos de protección contra caídas, la formación sobre las técnicas de levantamiento adecuadas, el uso de maquinaria elevadora siempre que sea posible y la revisión de los diseños desde el punto de vista ergonómico. Así, los movimientos repetitivos que exigen actividades como la conexión de cables se reducen con herramientas especializadas.

\section{Aplicaciones militares y agrarias}

Las operaciones relacionadas con aeronaves militares presentan riesgos singulares. El JP4, un combustible para motores de reacción más volátil que el Jet $\mathrm{A}$, está a veces contaminado con $n$-hexano. La gasolina de aviación, utilizada en algunos aparatos de hélice, es muy inflamable. Los motores de los aviones militares, incluidos los de transporte, suelen estar menos insonorizados que los comerciales, y el ruido que emiten aumenta cuando entran en funcionamiento los postquemadores. A bordo de los portaaviones, los riesgos, de por sí numerosos, se multiplican. Al ruido de los motores se suma el de las catapultas de vapor y los postquemadores; además, el espacio de la cubierta de vuelo es extremadamente reducido, y la propia pista está en movimiento. Debido a las exigencias que plantea el combate, la cabina del piloto y las zonas calientes próximas se aíslan con amianto.

La necesidad de reducir la visibilidad para el radar ha favorecido la multiplicación de los materiales compuestos en el fuselaje, las alas y las estructuras de control de vuelo. Estas áreas pueden quedar dañadas en combate o por exposición a condiciones climáticas extremas, lo que obliga a realizar reparaciones extensas. Estas tareas de reparación sobre el terreno llevan aparejado un riesgo considerable de exposición a resinas y componentes en polvo. El berilio también es habitual en las aplicaciones militares. En los generadores auxiliares se utilizan hidrazidas, y el armamento anticarro lleva en ocasiones munición de uranio de bajo poder radioactivo. Entre las precauciones que deben adoptarse figura la utilización del EPI adecuado, incluidos los dispositivos de protección respiratoria. Siempre que sea posible, deben emplearse equipos portátiles de ventilación por extracción.

Las tareas de mantenimiento de aeronaves para usos agrícolas (pulverizadores de cultivos) favorecen la exposición a plaguicidas, en forma de producto único o, con mayor frecuencia, de mezcla de varios que contaminan uno o varios aparatos. Los productos de degradación de ciertos plaguicidas son más peligrosos que el producto inicial. La exposición por vía dérmica es a veces considerable, y su importancia aumenta con la transpiración. Este tipo de aparatos y sus componentes externos deben someterse a una limpieza exhaustiva antes de su reparación o bien trabajar con EPI para protección respiratoria y dérmica o las dos cosas. 


\section{- Operaciones de VUELO DE AERONAVES}

\section{Nancy Garcia y H. Gartmann*}

En el presente artículo se abordan las cuestiones relacionadas con la salud y la seguridad en el trabajo de las tripulaciones de aviación civil; para más información, véanse los artículos "Operaciones aeroportuarias y de control del tráfico aéreo", "Operaciones de mantenimiento de aeronaves" y "Helicópteros".

\section{Personal técnico de la tripulación}

El personal técnico es el responsable del manejo del avión. Dependiendo del tipo de aeronave, forman esta categoría el comandante, el copiloto (o primer oficial), y el ingeniero de vuelo o un segundo oficial (un piloto).

El comandante (o piloto jefe) es el responsable de la seguridad de la aeronave, los pasajeros y otros miembros de la tripulación. Es el representante legal de la empresa de transporte aéreo y ésta y los organismos nacionales de aviación le otorgan la autoridad necesaria para cumplir con estas obligaciones. El comandante dirige todas las operaciones de la cabina de vuelo y está al mando del conjunto del aparato.

El copiloto recibe órdenes directas del comandante y actúa como su representante por delegación o en su ausencia. Es el ayudante principal del comandante en los aviones de última generación con dos tripulantes en la cabina de vuelo, y el único en los antiguos bimotores.

En muchos aviones algo más antiguos presta servicio un tercer tripulante técnico, sea un ingeniero de vuelo o un tercer piloto (normalmente denominado segundo oficial), responsable de la situación mecánica de la aeronave y de sus equipos. En los aviones más modernos se han automatizado muchas de las funciones del ingeniero de vuelo; en este caso, los pilotos realizan las tareas no automatizadas que en otras situaciones correrían de cuenta del ingeniero.

En ciertos vuelos de larga distancia, la tripulación puede complementarse con un piloto que cuente con grado de comandante, un primer oficial supernumerario y, si es preciso, un ingeniero de vuelo auxiliar.

En la legislación nacional e internacional se estipula que el personal técnico de aviación sólo puede prestar servicio cuando posea una licencia válida expedida por el organismo nacional competente. Para conservar este permiso, los miembros de la tripulación técnica deben recibir formación en centros docentes una vez al año y someterse a pruebas en el simulador de vuelo (un dispositivo en el que se imitan las condiciones de vuelo y de emergencia reales) dos veces al año y en vuelo real una vez al año.

Otra condición para la obtención y renovación de la licencia es superar un reconocimiento médico, semestral en el caso de pilotos de líneas aéreas de transporte y comerciales de 40 años o más, y anual en el caso de ingenieros de vuelo y pilotos comerciales de menos de 40 años. Los criterios mínimos los establecen la OACI y los reglamentos nacionales. Los organismos nacionales competentes están facultados para autorizar a ciertos médicos con experiencia en medicina aeronáutica para realizar tales pruebas. Se trata de médicos del Ministerio del Aire, médicos aeronáuticos de las Fuerzas Armadas, oficiales médicos de las líneas aéreas o médicos privados designados por un organismo nacional.

* Adaptado del artículo "Aviación, personal de vuelo" de H. Gartmann, incluido en la $3^{\mathrm{a}}$ edición de la presente Enciclopedia.

\section{Personal de cabina}

La tripulación de la cabina de pasaje (auxiliares de vuelo) son ante todo responsables de la seguridad de los pasajeros. Efectúan tareas rutinarias con este fin, y se encargan de controlar la seguridad y los riesgos de la cabina de pasaje. En casos de emergencia, se ocupan de organizar las medidas aplicables en cada momento y la evacuación de los viajeros en condiciones de seguridad. Durante el vuelo, estos tripulantes han de estar preparados para responder a situaciones como la presencia de humo o fuego en la cabina, turbulencias, urgencias médicas, pérdidas de presión y secuestros aéreos u otras amenazas terroristas. Además de sus responsabilidades en casos de emergencia, la tripulación de cabina se encarga de prestar servicio a los pasajeros.

La tripulación mínima oscila entre 1 y 14 personas, en función del tipo de aeronave, el número de pasajeros que admite y la normativa nacional. Los convenios laborales contienen a veces otras cláusulas sobre dotación de personal. A estos auxiliares puede añadirse un sobrecargo o jefe de servicio. La supervisión de la tripulación suele corresponder a un auxiliar jefe que, a su vez depende directamente del comandante.

Los reglamentos nacionales no suelen obligar al personal de cabina a tener licencias como las obligatorias para el personal técnico, pero sí a haber recibido la instrucción y la formación adecuadas en materia de medidas de emergencia. Los reconocimientos médicos periódicos no suelen imponerse por ley, pero algunas empresas aéreas los exigen para controlar el estado de salud de los tripulantes.

\section{Riesgos y su prevención}

Todos los miembros del personal de vuelo se exponen a una amplia gama de factores de estrés, tanto físico como psicológico, a sufrir accidentes aéreos u otra clase de incidentes de vuelo y a contraer diversas enfermedades.

\section{Estrés físico}

La falta de oxígeno, uno de los principales problemas de la medicina aeronáutica en los primeros tiempos de la aviación, era hasta fecha reciente una cuestión de importancia menor en el transporte aéreo moderno. En reactores que vuelan a 12.000 metros de altitud, la cabina se mantiene a una presión equivalente a sólo 2.300 metros y, en consecuencia, las personas sanas no suelen presentar síntomas de deficiencia de oxígeno o hipoxia. La tolerancia a esta deficiencia es variable, pero se supone que, para un sujeto sano y sin entrenamiento, el límite a partir del cual aparecen los primeros síntomas es de 3.000 metros.

Pero la llegada de aparatos de nueva generación ha vuelto a plantear la preocupación por la calidad del aire en la cabina. La atmósfera en estos espacios está formada por aire extraído de los compresores del motor y, a menudo, también por aire reciclado procedente de la propia cabina. El caudal del aire exterior que entra en la cabina oscila entre sólo $0,2 \mathrm{~m}^{3}$ por minuto y persona y $1,42 \mathrm{~m}^{3}$, según el tipo de aeronave y su antigüedad, así como el lugar de la cabina. En los aparatos nuevos, la proporción de aire reciclado es muy superior a la habitual en los antiguos. Esta duda sobre la calidad del aire es específica de la cabina de pasajeros. En la cabina de pilotaje, el caudal de aire suelen alcanzar los 4,25 $\mathrm{m}^{3}$ por minuto y miembro de la tripulación. Este mayor caudal tiene por objeto cumplir los requisitos de refrigeración de los equipos de aviónica y electrónica.

Las quejas por la deficiente calidad de la atmósfera de la cabina expresadas por tripulaciones y pasajeros han aumentado en los últimos años, lo que ha llevado a algunos organismos nacionales a investigar este tipo de situaciones. Los reglamentos nacionales no estipulan caudales de ventilación mínimos para la cabina. El caudal real en estos recintos no suele medirse una vez 
que la aeronave comienza a prestar servicio, ya que no hay disposiciones que así lo exijan. El mínimo caudal y la utilización de aire reciclado, unidos a otros aspectos de la calidad del aire como contaminantes químicos, microorganismos, alérgicos, humo de tabaco y ozono, obligan a realizar más evaluaciones y estudios.

Mantener una temperatura agradable en la cabina no es ningún problema en aparatos modernos; sin embargo y debido a la enorme diferencia de temperatura entre el interior y el exterior del avión, la humedad no puede elevarse lo suficiente. Por ello, tanto la tripulación como los pasajeros deben respirar una atmósfera extremadamente seca, sobre todo en vuelos de larga distancia. La humedad de la cabina depende del índice de ventilación en ésta, del número de viajeros, de la temperatura y de la presión. Los valores registrados en los aviones actuales oscilan entre el $25 \%$ y menos del $2 \%$. Algunos pasajeros y tripulantes sufren sequedad de ojos, nariz y garganta y otras molestias en vuelos de más de 3 o 4 horas. No hay pruebas concluyentes de que la baja humedad relativa afecte de forma generalizada o grave a la salud del personal de vuelo. Con todo, deben adoptarse las precauciones necesarias para evitar la deshidratación; la ingestión adecuada de agua, zumos y otros líquidos debería bastar para evitar molestias.

Los trastornos debidos al movimiento (mareos, malestar y vómitos a causa de los movimientos anormales y las altitudes alcanzadas por las aeronaves) representaron un problema para los pasajeros y las tripulaciones de la aviación civil durante décadas; el problema persiste en la actualidad en el caso de los pequeños aviones deportivos, los aparatos militares y la acrobacia aérea. En los aviones a reacción modernos, este inconveniente tiene una entidad mucho menor y ocurre con menos frecuencia gracias a las mayores velocidades y pesos de despegue de los aparatos, las altitudes de crucero superiores (que alejan a los aviones de las zonas de turbulencias) y a la utilización de radares meteorológicos (que permiten localizar y evitar borrascas y tormentas). También influye en la disminución de la frecuencia de estos trastornos el diseño más espacioso y abierto de las cabinas en las aeronaves actuales, que ofrece mayor sensación de seguridad, estabilidad y comodidad.

\section{Otros riesgos físicos y químicos}

El ruido de las aeronaves, tan importante para el personal de tierra, es menos grave para las tripulaciones de los modernos aviones a reacción que para el personal de los antiguos aparatos con motores de pistones. La eficacia del aislamiento y otras medidas de atenuación ha contribuido a eliminar este riesgo en la mayoría de los entornos de vuelo. Asimismo, la optimización de los equipos de comunicación han minimizado los niveles de ruido de fondo generados por estas fuentes.

La exposición al ozono es un riesgo conocido y poco controlado que afecta a tripulaciones y pasajeros. Este elemento se forma en la atmósfera a las altitudes utilizadas por los aviones comerciales a reacción como resultado de la conversión fotoquímica del oxígeno inducida por la radiación solar ultravioleta. La concentración media de ozono en el ambiente aumenta con la latitud y en primavera. También varía con los sistemas meteorológicos, que en ocasiones provocan el descenso de masas de ozono hasta altitudes inferiores.

Denuncian la exposición a esta sustancia síntomas como tos, irritación de las vías respiratorias altas, picor de garganta, molestias o dolores en el pecho, dificultades o dolor al respirar profundamente, disnea, resuello, migraña, fatiga, congestión nasal e irritación ocular. La mayoría de las personas detectan el ozono a una concentración de 0,02 ppm, y ciertos estudios han demostrado que la exposición a valores de 0,5 ppm o más merma sustancialmente el mecanismo pulmonar. Quienes realizan trabajos moderados o intensos detectan la contaminación por ozono antes que quienes descansan o desarrollan un esfuerzo leve. Así, los auxiliares de vuelo (físicamente activos durante los vuelos), experimentan los efectos de la contaminación por ozono antes y con mayor frecuencia que la tripulación técnica o los pasajeros del mismo vuelo.

En un estudio realizado a finales del decenio de 1970 por el organismo responsable de la aeronáutica de Estados Unidos (Rogers 1980) se analizó la contaminación por ozono en varios vuelos (en su mayoría realizados entre 9.150 y 12.200 metros). En un $11 \%$ de los casos observados se registraron concentraciones superiores a los límites autorizados. Entre los métodos empleados para reducir al mínimo este tipo de exposición se cuentan la elección de rutas y altitudes con el fin de evitar las áreas de concentración elevada y la utilización de equipos de tratamiento del aire; suelen utilizarse con este fin convertidores catalíticos, aunque están expuestos a contaminación y pérdida de eficacia. Las normativas (cuando las hay) no exigen la realización periódica de pruebas de rendimiento ni el control de la concentración de ozono en vuelos reales. Las tripulaciones, en especial las de la cabina de pasaje, han solicitado mejoras en el seguimiento y control de esta forma de contaminación.

Otro motivo de preocupación importante para el personal técnico y de cabina es la radiación cósmica, que engloba formas de radiación transmitidas a través del espacio y procedentes del sol y otras fuentes. La mayor parte de la radiación que se desplaza por el espacio es absorbida por la atmósfera terrestre, pero la protección disminuye con la altitud. El campo magnético de la tierra también ofrece cierta protección, que es máxima cerca del ecuador y menor a latitudes superiores. Las tripulaciones aéreas están expuestas durante el vuelo a niveles de radiación cósmica superiores a los recibidos en tierra.

La magnitud de la exposición a la radiación depende del tipo y la duración del vuelo; así, un tripulante que vuele muchas horas a altitudes y latitudes elevadas (en rutas polares, por ejemplo) se expondrá a valores de radiación máximos. El organismo responsable de aviación civil de Estados Unidos (FAA) ha estimado que la dosis media de radiación cósmica a largo plazo de los miembros de tripulaciones aéreas oscila entre 0,025 y 0,93 milisieverts ( $\mathrm{mSv}$ ) por cada bloque de 100 horas (Friedberg y cols. 1992). Basándose en los cálculos de la FAA, un tripulante que vuele 960 horas anuales (o una media de 80 horas al mes) recibirá una dosis anual de 0,24 a $8,928 \mathrm{mSv}$. Estos niveles de exposición son inferiores al límite profesional recomendado de $20 \mathrm{mSv}$ al año (media quinquenal) establecidos por la Comisión Internacional de Protección Radiológica (GIPR).

No obstante, la CIPR recomienda que la exposición profesional a radiaciones ionizantes no exceda de $2 \mathrm{mSv}$ durante la gestación. Además, el National Council on Radiation Protection and Measurements (NCRP) de Estados Unidos, aconseja que la exposición no supere los $0,5 \mathrm{mSv}$ al mes una vez confirmado el embarazo. Si una tripulante presta servicio un mes entero en vuelos con los niveles de exposición máximos, la dosis mensual sobrepasaría los límites recomendados. El mantenimiento de esta situación durante más de 5 o 6 meses determina una exposición superior al límite de $2 \mathrm{mSv}$ aconsejado durante el embarazo.

La exposición durante varios años a radiaciones de baja intensidad provoca cáncer y defectos genéticos y congénitos del feto expuesto al factor de riesgo mientras se encuentra en el útero. La FAA estima que el riesgo añadido de padecer una forma mortal de cáncer por exposición a la radiación en vuelo oscila entre 1/1.500 y 1/94, según la ruta y el número de horas de trabajo; el riesgo añadido de padecer un defecto genético grave por exposición de uno de los padres a la radiación cósmica varía 
entre 1 por cada 220.000 y 1 por cada 4.600 nacidos vivos; y el riesgo de retraso mental y cáncer infantil en niños expuestos en el útero a esta forma de contaminación oscila entre 1 por cada 20.000 y 1 por cada 680 , según la ruta y el número de horas de vuelo de la madre durante el embarazo.

En el informe de la FAA se llega a la conclusión de que "no es probable que la exposición a la radiación sea un factor que limite las horas de vuelo de una tripulante no embarazada", puesto que, incluso la cantidad de radiación recibida anualmente por un miembro de la tripulación que trabaje un bloque de 1.000 horas es inferior a la mitad del límite medio anual recomendado por la CIPR. Pero el caso de una tripulante embarazada es diferente. La FAA estima que una mujer en estas condiciones que trabajase un bloque de 70 horas al mes superaría el límite de cinco meses en un tercio de los vuelos analizados (Friedberg y cols. 1992).

Hay que señalar que estos cálculos de riesgo y exposición no son aceptados universalmente. Las estimaciones de las hipótesis sobre tipos y mezclas de partículas radiactivas presentes en altitud que se manejen y del factor ponderal o de calidad aplicado para determinar las dosis correspondientes a algunas de estas formas de radiación. Algunos científicos consideran que el riesgo real al que se enfrentan las tripulaciones aéreas puede ser superior al descrito. Es necesario avanzar en el control de los entornos de vuelo con instrumentación fiable para determinar con mayor claridad la magnitud de la exposición a la radiación.

Mientras no se conozcan datos más seguros, los miembros de las tripulaciones aéreas deben reducir al mínimo la exposición a todo tipo de radiaciones. En cuanto a la exposición en vuelo, la disminución de las horas pasadas en el aire y la maximización de la distancia a la fuente de contaminación puede afectar directamente a la dosis recibida. La disminución mensual y anual de las horas de vuelo y la selección de vuelos a altitudes y latitudes inferiores atenúan la exposición. Un tripulante con posibilidades de influir en sus asignaciones de trabajo puede optar por volar menos horas al mes, combinar vuelos nacionales e internacionales o pedir permisos cada cierto tiempo. Una tripulante embarazada puede optar por darse de baja durante el embarazo. Puesto que el primer trimestre es el período crucial para protegerse de la radiación, las tripulantes que prevean un embarazo pueden considerar la solicitud de un permiso, sobre todo si realizan rutas polares de larga distancia periódicamente o carecen de control sobre sus asignaciones de vuelo.

\section{Deficiencias ergomómicas}

El principal problema ergonómico para los miembros de la tripulación técnica consiste en la necesidad de prestar servicio durante mucho tiempo sentados, pero variando de posición y en un área de trabajo muy limitada. En esta postura (limitados por el cinturón de seguridad que sujeta la cintura y los hombros), deben llevar a cabo diversas tareas, como mover las manos, piernas y cabeza en distintas direcciones, consultar instrumentos a una distancia aproximada de 1 metro y situados por encima y por debajo de ellos, enfrente y a los lados, escudriñar el horizonte, consultar mapas o manuales a poca distancia $(30 \mathrm{~cm})$, escuchar a través de auriculares y hablar por un micrófono. Los asientos, la instrumentación, la iluminación, el microclima de la cabina del piloto y la comodidad del equipo de comunicaciones por radio han sido y siguen siendo objeto de mejoras continuas. Los puestos de pilotaje actuales, denominados a menudo "cabinas de cristal", introducen nuevas dificultades derivadas del uso en estos recintos de tecnología de vanguardia y sistemas de automatización; mantener la vigilancia y la conciencia de la situación en estas condiciones plantea nuevos motivos de preocupación para los diseñadores de aeronaves y el personal técnico que presta sus servicios en ellas.
La tripulación de la cabina del pasaje debe afrontar un conjunto de problemas ergonómicos totalmente diferentes. Uno de los principales consiste en la necesidad de permanecer de pie y moverse durante el vuelo. En las fases de elevación y descenso y en zonas de turbulencias, los miembros de esta tripulación deben caminar sobre suelos inclinados; en algunas aeronaves, la inclinación de la cabina se mantiene en torno al $3 \%$ también durante la travesía. Asimismo, muchos de estos suelos se diseñan de forma que crean un efecto de rebote al andar, lo que supone otro factor de estrés para los auxiliares que deben moverse constantemente durante los vuelos. Otra dificultad ergonómica importante para estos profesionales es la utilización de carritos móviles, que pesan de 100 a $140 \mathrm{~kg}$ y deben ser empujados y arrastrados a lo largo de la cabina. Además, las deficiencias en el diseño y en los mecanismos de frenado de muchas unidades han elevado el número de lesiones por esfuerzo repetitivo (LER) entre los auxiliares de vuelo. Actualmente, las empresas aéreas y los fabricantes de carritos consideran con mayor atención las características de estos equipos y los nuevos diseños propuestos han producido mejoras ergonómicas. Otros problemas están relacionados con la necesidad de levantar y transportar artículos pesados o voluminosos en espacios restringidos o manteniendo posturas incómodas.

\section{Carga de trabajo}

La carga de trabajo de los miembros de las tripulaciones aéreas depende de la tarea desempeñada, la disposición ergonómica, el horario de trabajo y otras muchas circunstancias. Otros factores que afectan a la tripulación técnica son:

- la duración del período de descanso entre vuelos y el número de horas dedicadas al sueño durante el mismo;

- la reunión operativa previa y los problemas detectados en la misma;

- los retrasos previos a la salida;

- la duración de los vuelos;

- las condiciones meteorológicas en el lugar de partida, en ruta y en el destino;

- el número de segmentos del vuelo;

- el tipo de equipo utilizado;

- la calidad y la cantidad de las comunicaciones por radio;

- la visibilidad durante el descenso, el deslumbramiento y la protección contra el sol;

- las turbulencias;

- los problemas técnicos de la aeronave;

- la experiencia de los otros miembros de la tripulación;

- el tráfico aéreo (sobre todo en los lugares de origen y de destino), y

- la presencia de personal de la compañía aérea o de los organismos nacionales para comprobar la competencia de la tripulación.

Algunos de estos factores revisten la misma importancia para la tripulación de la cabina del pasaje. Además, éstos están sometidos a la influencia de los factores específicos siguientes:

- la presión del tiempo en vuelos cortos, con muchos pasajeros y requerimientos de servicio amplios;

- los servicios extraordinarios demandados por los pasajeros, el carácter de algunos de ellos y, en ocasiones, los abusos verbales o físicos de los mismos;

- los cuidados y la atención especiales requeridos por ciertos pasajeros (niños, discapacitados, personas de edad avanzada, personas en situación de urgencia médica);

- duración de las actividades preparatorias, y

- falta de elementos o equipos necesarios para la prestación del servicio (comida o bebida insuficientes, etc.). 
Las medidas adoptadas por la dirección de las empresas aéreas y las administraciones públicas con el fin de mantener la carga de trabajo de las tripulaciones dentro de unos límites razonables consisten en la mejora y la ampliación del control del tráfico aéreo, la imposición de topes adecuados a los horarios de actividad y de requisitos relativos a los períodos de descanso mínimos, la ejecución de las actividades preparatorias por parte de distribuidores y personal de mantenimiento, abastecimiento de comidas y limpieza, la automatización de los equipos y las tareas en la cabina del piloto, la normalización de los procedimientos de servicio, la adecuación de la dotación de personal y la disposición de equipos eficaces y fáciles de utilizar.

\section{Horarios de trabajo}

Uno de los factores más importantes que afectan a la salud y la seguridad en el trabajo de los miembros de las tripulaciones técnicas y de cabina de pasaje (y, sin duda, el más analizado y polémico) es la fatiga producida por los vuelos y la forma de recuperarse. Se consideran aquí una amplia gama de actividades relacionadas con la programación de los vuelos: duración de los períodos de prestación de servicio, número de horas de vuelo (diarias, mensuales y anuales), períodos de reserva o de guardia y disponibilidad de tiempo para el descanso, tanto en el trabajo como en el domicilio. Los ritmos circadianos, sobre todo en lo que se refiere a los intervalos y la duración del sueño, con todas sus implicaciones fisiológicas y psicológicas, son especialmente significativos para las tripulaciones de aviación. Las alteraciones de la percepción del tiempo debidas a los vuelos nocturnos y las travesías de este a oeste o en dirección contraria a través de diversa $^{\mathrm{s}}$ franjas horarias plantean los problemas más graves. Los aviones de última generación, capaces de mantenerse en vuelo hasta 15 o 16 horas seguidas, han exacerbado el conflicto entre los programas de las empresas aéreas y las limitaciones humanas.

Las normativas encaminadas a limitar los períodos de actividad y vuelo y establecer mínimos de descanso difieren de un país a otro. En algunos casos, estos instrumentos legales no se han adaptado al ritmo del cambio científico y tecnológico ni garantizan necesariamente la seguridad de los vuelos. Hasta hace poco apenas se habían adoptado medidas de normalización de estos reglamentos. Los intentos actuales de armonización han sido motivo de preocupación para los miembros de las tripulaciones aéreas, que temen que los países con normativas más protectoras se vean obligados a aceptar otras menos estrictas y adecuadas. Además de las normativas nacionales, muchos de estos profesionales han tenido la oportunidad de negociar en sus convenios colectivos condiciones más favorables sobre las horas de servicio. Aunque estos acuerdos son importantes, casi todos los tripulantes consideran que la reglamentación de la jornada de trabajo es esencial para su salud y su seguridad (y la de los pasajeros) y que, por tanto, es necesario que los organismos nacionales desarrollen adecuadamente unas normas mínimas.

\section{Estrés psicológico}

En los últimos años, las tripulaciones de aviación se han enfrentado con un factor de estrés mental grave: el riesgo de secuestros, bombas y ataques armados en los aviones. Aunque las medidas de seguridad de la aviación civil en todo el mundo se han intensificado y han mejorado mucho, también los terroristas se han perfeccionado. La piratería aérea, el terrorismo y otros delitos siguen constituyendo una amenaza real para todos los tripulantes. La prevención de este tipo de actuaciones exige el compromiso y la cooperación de las autoridades nacionales y la presión de la opinión pública mundial. Por otra parte, estos trabajadores deben seguir recibiendo formación especial e información sobre medidas de seguridad y ser advertidos puntualmente de las posibles amenazas de piratería aérea y terrorismo.

Los miembros de las tripulaciones comprenden la importancia de iniciar sus tareas en un estado mental y físico adecuado para garantizar que la fatiga y el estrés ocasionado por el propio vuelo no afecten a la seguridad. En ocasiones, la disposición para prestar servicio puede verse perjudicada por los factores de estrés psicológico y físico, y es responsabilidad del tripulante reconocer si se encuentra en condiciones o no de desempeñar su labor. No obstante, en ciertos casos, puede que estos efectos no resulten evidentes de inmediato para las personas sometidas a presión. Por esta razón, la mayoría de las empresas aéreas, asociaciones de tripulantes y sindicatos han creado comités de normas profesionales para asistir a los trabajadores en este área.

\section{Accidentes}

Por fortuna, los accidentes de aviación que acaban en catástrofe son infrecuentes; en cualquier caso, constituyen un riesgo para los miembros de las tripulaciones aéreas. Estos accidentes casi nunca obedecen a una causa única y bien definida; en la inmensa mayoría de los casos, hay que buscar la causa en la conjunción de varios factores técnicos y humanos.

Las deficiencias en el diseño de los equipos o las averías de éstos, sobre todo como consecuencia de un mantenimiento inadecuado, son dos causas mecánicas de los accidentes. Un tipo de fallo humano importante, aunque relativamente raro, es la muerte súbita debida, por ejemplo, a un infarto de miocardio; en otros casos se producen pérdidas repentinas del conocimiento (ataques epilépticos, síncopes cardíacos y desmayos motivados por intoxicación alimentaria o de otro tipo). El fallo humano puede deberse asimismo al deterioro paulatino de determinadas funciones, como el oído o la vista, aunque no se ha atribuido ningún accidente grave a este tipo de anomalías. La prevención de accidentes debidos a causas médicas es una de las tareas más importantes de la medicina aeronáutica. Una selección meticulosa del personal, los reconocimientos médicos periódicos, la investigación de las bajas por enfermedad o accidente, el contacto médico continuo con las condiciones de trabajo y los estudios de la higiene industrial limitan de manera considerable el riesgo de incapacitación repentina o deterioro progresivo de la tripulación técnica. Asimismo, el personal técnico debe efectuar controles sistemáticos de las prácticas de programación de los vuelos con el fin de evitar los incidentes y accidentes debidos a la fatiga. Todas las empresas aéreas modernas, bien gestionadas y de cierto tamaño disponen de su propio servicio médico para cubrir estas necesidades.

Los avances en la prevención de accidentes de aviación son con frecuencia resultado de la investigación detallada de cada suceso. Un análisis sistemático de todos los incidentes, aunque sean menores, efectuado por un consejo de investigación formado por expertos técnicos, operativos, estructurales, médicos y de otras especialidades, es esencial para determinar todas las causas de lo sucedido y formular recomendaciones que faciliten la prevención en el futuro.

En el ámbito de la aviación, se han promulgado normas estrictas con el fin de evitar los accidentes debidos al consumo de alcohol y otras drogas. Los tripulantes no deben consumir alcohol en cantidades incompatibles con sus requisitos profesionales, y su ingestión en el curso de las 8 horas previas al inicio del vuelo está totalmente prohibida. El consumo de drogas está estrictamente prohibido. Su ingestión por razones médicas se somete a un control exhaustivo y, en general, no se permiten durante el vuelo o en el período inmediatamente anterior al mismo, salvo excepciones prescritas por el médico responsable del vuelo. 
El transporte aéreo de materiales peligrosos es otra causa de accidentes e incidentes de aviación. En un reciente estudio referido a un período bianual (de 1992 a 1993), se contabilizaron más de 1.000 incidentes en un solo país en los que intervinieron este tipo de materiales en aviones de transporte de pasajeros o de mercancías. En fecha más reciente, un accidente acaecido en Estados Unidos con el resultado del fallecimiento de 110 pasajeros y tripulantes tuvo entre sus causas el transporte de una carga peligrosa. Este tipo de sucesos se debe a la influencia de varios factores. Es posible que los expedidores y los pasajeros desconozcan el riesgo vinculado a los materiales que presentan para su transporte o incluyen en su equipaje. En ocasiones, personas sin escrúpulos optan por cargar ilegalmente materiales peligrosos prohibidos. La ampliación de las restricciones impuestas a este tipo de mercancías y la mejora de la formación de los tripulantes, pasajeros, expedidores y cargadores contribuiría a la prevención de incidentes en el futuro. En otras normativas sobre prevención de accidentes se regulan el suministro de oxígeno, las comidas de la tripulación y los procedimientos en caso de enfermedad.

\section{Enfermedades}

No se conocen ni se han documentado enfermedades profesionales específicas de los tripulantes. No obstante, ciertas dolencias afectan con mayor frecuencia a estos trabajadores que a otros. Los resfriados comunes y las infecciones de las vías respiratorias altas son habituales, debido en parte a la insuficiente humedad durante los vuelos, la irregularidad de los horarios, el contacto con gran número de personas en un espacio restringido, etc. Un resfriado común, sobre todo si produce congestión de las vías respiratorias altas, que carece de importancia para un oficinista, puede incapacitar a un tripulante si impide la compensación de la presión en el oído medio en el ascenso y, sobre todo, en el descenso. Además, las enfermedades que exigen tratamiento farmacológico impiden en ocasiones la prestación de servicio durante cierto tiempo. Asimismo, los viajes frecuentes a zonas tropicales aumentan la exposición a enfermedades infecciosas, en particular malaria e infecciones del aparato digestivo.

La estancia prolongada en espacios limitados, como la cabina de un avión, también aumenta el riesgo de contraer enfermedades infecciosas transmitidas por el aire, como la tuberculosis, si un pasajero o un tripulante las padece en su fase contagiosa.

\section{MEDICINA AEROESPACIAL: EFECTOS DE LA GRAVEDAD, LA ACELERACION Y LA MICROGRAVEDAD EN EL ENTORNO AEROESPACIAL}

\section{Relford Patterson y Russell B. Rayman}

Desde que un avión con motor volase por vez primera durante cierto tiempo sin interrupciones en Kitty Hawk, Carolina del Norte (Estados Unidos) en 1903, la aviación se ha convertido en una actividad internacional básica. Se estima que, desde 1960 a 1989, el número anual de pasajeros en vuelos regulares pasó de 20 millones a más de 900 millones (Poitrast y deTreville 1994). Los aviones militares se han transformado en sistemas de defensa indispensables para las fuerzas armadas de muchos países. Los avances en la tecnología aeronáutica y, en particular, en el diseño de equipos de mantenimiento de su duración, han contribuido al rápido desarrollo de los programas espaciales tripulados. Los vuelos orbitales son relativamente frecuentes, y astronautas y cosmonautas trabajan en vehículos y estaciones espaciales durante períodos prolongados.

En el entorno aeroespacial, los factores de estrés físico que afectan a la salud de tripulaciones, pasajeros y astronautas son la reducción de las concentraciones de oxígeno en el aire, la disminución de la presión barométrica, el estrés térmico, la aceleración, la ingravidez y otros riesgos potenciales (DeHart 1992). En el presente artículo se describen las consecuencias médicas de la exposición a la gravedad y la aceleración durante el vuelo en la atmósfera y de la microgravedad en el espacio.

\section{Gravedad y aceleración}

La combinación de gravedad y aceleración propia de los vuelos en la atmósfera tiene consecuencias fisiológicas que afectan a tripulantes y pasajeros. En la superficie terrestre, la gravedad afecta a casi todas las formas de actividad física humana. El peso de un individuo es igual a la fuerza ejercida sobre la masa de su cuerpo por el campo gravitatorio de la Tierra. El símbolo utilizado para expresar la magnitud de la aceleración de un objeto en caída libre cerca de la superficie terrestre es $g$, que equivale a una aceleración de aproximadamente 9,8 m/s2 (Glaister 1988a; Leverett y Whinnery 1985).

Hay aceleración cuando un objeto en movimiento aumenta su velocidad. Por velocidad se entiende la rapidez y dirección del movimiento de un objeto. Se llama deceleración a la aceleración negativa, que causa la reducción de la velocidad. La aceleración (y la deceleración) es una cantidad vectorial (tiene magnitud y dirección). Hay tres tipos de aceleración: lineal, o cambio de velocidad sin modificación de la dirección; radial, o cambio de dirección sin modificación de la velocidad; y angular, o cambio de velocidad y dirección. Las aeronaves en vuelo están capacitadas para maniobrar en todas las direcciones, y la tripulación y el pasaje pueden experimentar aceleraciones lineales, radiales o angulares. En la aviación, las aceleraciones aplicadas suelen expresarse como múltiplos de la aceleración debida a la gravedad. Por convención, $G$ es la unidad que expresa la proporción entre la aceleración aplicada y la constante gravitacional (Glaister 1988a; Leverett y Whinnery 1985).

\section{Biodinámica}

La biodinámica es la ciencia que estudia la fuerza o la energía de la materia viva y constituye un área de interés fundamental en el campo de la medicina aeroespacial. Las aeronaves modernas son fácilmente maniobrables y capaces de volar a velocidades muy elevadas, y transmiten la aceleración a sus ocupantes. La influencia de la aceleración en el cuerpo humano depende de la intensidad, la velocidad inicial y la dirección. Esta suele describirse mediante un sistema de coordenadas de tres ejes $(x, y, z)$ con el eje vertical $(z)$ paralelo al eje longitudinal del cuerpo, el eje $x$ orientado de delante hacia atrás y el eje $y$ dispuesto transversalmente (Glaister 1988a). Estas aceleraciones se clasifican en dos tipos generales: sostenida y transitoria.

\section{Aceleración sostenida}

Los ocupantes de un avión (o de una nave espacial mientras se mueve en la atmósfera bajo la influencia de la gravedad durante el despegue y la reentrada) experimentan aceleraciones como respuesta a las fuerzas aerodinámicas del vuelo. Los cambios prolongados de velocidad que dan lugar a aceleraciones de duración superior a 2 segundos pueden derivarse de modificaciones en la velocidad o la dirección de vuelo de la aeronave. Los efectos fisiológicos de la aceleración sostenida obedecen a la deformación continua de los tejidos y órganos del cuerpo y a los cambios del flujo sanguíneo y la distribución de los fluidos corporales (Glaister 1988a). 
La aceleración positiva o en dirección hacia la cabeza a lo largo del eje $z\left(+G_{z}\right)$ es el principal motivo de preocupación desde el punto de vista fisiológico. En el transporte aéreo civil, las aceleraciones $G_{\mathrm{z}}$ son infrecuentes, pero se producen ocasionalmente y con una intensidad moderada en ciertos despegues y aterrizajes y en condiciones de turbulencia. Los pasajeros experimentan breves sensaciones de ingravidez durante descensos repentinos (aceleración $G_{\mathrm{z}}$ negativa) si no están sujetos al asiento. Una aceleración brusca e imprevista puede hacer que los tripulantes o los pasajeros que no están sujetos se golpeen contra las superficies internas de la cabina y sufran lesiones.

A diferencia del transporte civil, el pilotaje de aparatos militares de alto rendimiento o de aviones acrobáticos o de fumigación genera fácilmente aceleraciones lineales, radiales y angulares muy superiores. Se producen aceleraciones positivas considerables cuando un avión rápido de este tipo modifica el curso de vuelo o se eleva a gran velocidad después de un picado. Un avión de combate moderno tiene un rendimiento $+G_{\mathrm{z}}$ suficiente para exponer a sus ocupantes a aceleraciones positivas de 5 a $7 G$ durante 10 a 40 segundos (Glaister 1988a). Los tripulantes experimentan un aumento de peso de los tejidos y las extremidades con valores de aceleración relativamente modestos como $+2 G_{z}$. Así, en el curso de una maniobra aeronáutica que genere $+2 G_{\mathrm{z}}$ el peso de un piloto de $70 \mathrm{~kg}$ aumentará hasta $140 \mathrm{~kg}$.

El aparato cardiovascular es el sistema orgánico más importante para determinar la tolerancia y la respuesta generales al estrés debido a $+G_{\mathrm{z}}$ (Glaister 1988a). Los efectos de la aceleración positiva sobre la visión y el rendimiento mental se deben a la reducción del caudal sanguíneo y de la aportación de oxígeno a los ojos y el cerebro. Para bombear sangre hacia esos órganos, el corazón debe superar la presión hidrostática de la sangre en cualquier punto del sistema circulatorio más las fuerzas inerciales generadas por la aceleración $G_{\mathrm{z}}$ positiva. La situación es similar a la que se produce al tirar hacia arriba de un globo lleno en parte de agua y observar la distensión del mismo hacia abajo debida a la fuerza inercial resultante que actúa sobre la masa de agua. La exposición a aceleraciones positivas llega a provocar pérdida temporal de la visión periférica o total de la consciencia. Los pilotos militares de aeronaves de alto rendimiento corren el riesgo de sufrir pérdida momentánea de la visión y el conocimiento inducida por $G$ al exponerse a una aceleración positiva a lo largo del eje $+G_{\mathrm{z}}$ de inicio rápido o sostenida. Suelen producirse arritmias cardiacas benignas como consecuencia de la exposición a valores altos y sostenidos de aceleración $+G_{z}$, pero su trascendencia clínica suele ser mínima en ausencia de enfermedades previas; la aceleración $-G_{\mathrm{z}}$ no suele darse, por las limitaciones de diseño y rendimiento de las aeronaves, salvo en vuelo invertido, bucles exteriores, giros sobre el eje y otras maniobras similares. El efecto fisiológico básico de la exposición a la aceleración $-G_{\mathrm{z}}$ es el aumento de la presión vascular en la parte superior del cuerpo, la cabeza y el cuello (Glaister 1988a).

Las aceleraciones sostenidas perpendiculares al eje longitudinal del cuerpo se denominan transversales y son relativamente infrecuentes en la mayoría de las situaciones aeronáuticas, con excepción de los despegues desde portaaviones auxiliados por catapultas, reactores o cohetes y del lanzamiento de cohetes, como el transbordador espacial. Las aceleraciones habituales en estos dispositivos militares son moderadas y apenas afectan al organismo, ya que las fuerzas de inercia actúan en ángulo recto respecto al eje longitudinal del cuerpo. En general, los efectos son menos pronunciados que en la aceleración $G_{\mathrm{z}}$. La aceleración lateral en el eje $\pm G_{\mathrm{y}}$ no es frecuente, salvo en aparatos experimentales.

\section{Aceleración transitoria}

La respuesta fisiológica individual a las aceleraciones transitorias breves revisten especial importancia en el contexto de la prevención de accidentes en aeronaves y la protección de tripulantes y pasajeros. La duración de este tipo de aceleración es tan escasa (muy inferior a un segundo) que el organismo no llega a alcanzar un estado estacionario. La causa más común de lesión en los accidentes de aviación consiste en la brusca deceleración que se produce cuando una aeronave choca contra la tierra o el agua (Anton 1988). Guando un avión choca contra el suelo se genera una enorme cantidad de energía cinética que genera fuerzas perjudiciales para la aeronave y sus ocupantes. El organismo humano responde a estas fuerzas aplicadas mediante una combinación de aceleración y tensión. Las lesiones se deben a la deformación de los tejidos y los órganos y al trauma de las partes anatómicas causado por la colisión con los componentes estructurales de la cabina del piloto o del pasaje del avión.

La tolerancia humana a la deceleración brusca es variable. La naturaleza de las lesiones depende del carácter de la fuerza aplicada (si el impacto es con superficies afiladas o romas). En el momento del choque, las fuerzas generadas dependen de las deceleraciones longitudinales y horizontales aplicadas a los ocupantes. Las fuerzas deceleradoras bruscas suelen clasificarse en tolerables, nocivas y mortales. Las primeras producen lesiones traumáticas como abrasiones y contusiones; las segundas, traumas de moderados a graves no necesariamente discapacitantes. Se estima que una aceleración de aproximadamente $25 G$ mantenida durante 0,1 segundos es el límite tolerable a lo largo del eje $+G_{z}$; el límite a lo largo del eje $-G_{z}$ es de unos $15 G$ durante 0,1 segundos (Anton 1988).

Son varios los factores que afectan a la tolerancia humana a la aceleración de corta duración. Entre ellos figuran la magnitud y la duración de la fuerza aplicada, la velocidad inicial de la misma, su dirección y el lugar de la aplicación. Debe tenerse en cuenta que las personas son capaces de soportar fuerzas mucho mayores dirigidas perpendicularmente al eje longitudinal del cuerpo.

\section{Contramedidas de protección}

La selección física de los miembros de la tripulación efectuada para determinar enfermedades previas graves que agraven el riesgo en el entorno aerospacial es una función esencial de los programas médicos especializados. Además, los tripulantes de aeronaves de alto rendimiento pueden adoptar contramedidas para protegerse de los efectos adversos de las aceleraciones extremas experimentadas durante el vuelo. Deben recibir formación para conocer los numerosos factores que reducen su tolerancia al estrés provocado por $G$. Estos factores de riesgo son la fatiga, la deshidratación, el estrés por calor, la hipoglucemia y la hipoxia (Glaister 1988b).

Tres de las medidas que los tripulantes de aeronaves de alto rendimiento emplean con el fin de contrarrestar los efectos adversos de la aceleración sostenida durante el vuelo son la tensión de los músculos, la expiración forzada contra la glotis (parte posterior de la lengua) total o parcialmente cerrada y la respiración bajo presión positiva (Glaister 1988b; DeHart 1992). Las contracciones musculares forzadas aumentan la presión sobre los vasos sanguíneos y así reducen la estasis venosa y elevan el retorno venoso y el gasto cardiaco, con el consiguiente aumento del caudal sanguíneo al corazón y la parte superior del cuerpo. Aunque eficaz, esta maniobra exige la aplicación de un esfuerzo activo extremo y provoca fatiga en poco tiempo. La expiración contra la glotis cerrada, denominada maniobra de Valsalva (o procedimiento $M-1$ ) incrementa la presión intratorácica (en el pecho) y en la parte superior del cuerpo; no obstante, 
el resultado es breve y puede ser perjudicial si se prolonga, ya que reduce el retorno venoso y el gasto cardiaco. Forzar la expiración contra la glotis parcialmente cerrada es una maniobra de acción voluntaria anti- $G$ más eficaz. La respiración bajo presión positiva es otro método de elevar la presión intratorácica. Las presiones positivas se transmiten la red arterial e induce el incremento del caudal sanguíneo a los ojos y el cerebro. Este procedimiento debe combinarse con la utilización de trajes anti- $G$ para evitar la estasis excesiva en la parte inferior del cuerpo y las extremidades.

Las tripulaciones militares se entrenan para mejorar la tolerancia a $G$. En estos entrenamientos suele emplearse una máquina centrífuga consistente en una cabina unida a un brazo rotatorio que gira y genera aceleración $+G_{\mathrm{z}}$. Así se familiarizan con los síntomas fisiológicos y aprenden los métodos adecuados para neutralizarlos. La educación física, en particular la encaminada a fortalecer todo el cuerpo, también es eficaz. Uno de los dispositivos mecánicos más comunes utilizados como equipo de protección para reducir la exposición a $+G$ es el traje anti- $G$ inflado neumáticamente (Glaister 1988b). El modelo típico, parecido a un pantalón, es un conjunto de cámaras de aire que envuelven el abdomen, los muslos y las pantorrillas y que se inflan automáticamente con una válvula anti- $G$ montada en el avión que responde a las aceleraciones. Una vez hinchado, el traje eleva la presión en los tejidos de las extremidades inferiores. Así se mantiene la resistencia vascular periférica y se reducen la estasis de sangre en el abdomen y las piernas y el desplazamiento hacia abajo del diafragma, lo que contrarresta el aumento de la distancia vertical entre el corazón y el cerebro causado por la aceleración positiva (Glaister 1988b).

La supervivencia a las aceleraciones transitorias propias de los accidentes de aviación depende de la eficacia de los sistemas de contención y del mantenimiento de la integridad de la cabina del piloto y del pasaje, que minimiza la penetración de componentes dañados del avión en el espacio vital (Anton 1988). La función de los cinturones de seguridad, las bandas de sujeción y otros sistemas de contención es limitar el movimiento de la tripulación y los pasajeros y atenuar las consecuencias de la deceleración brusca que se produce en el momento del impacto. La eficacia de este tipo de mecanismos depende de su capacidad para transmitir cargas entre el cuerpo y el asiento o la estructura del vehículo. Los asientos atenuadores de energía y los orientados en sentido contrario a la marcha son otros componentes del diseño de una aeronave que limitan las lesiones. Otros recursos técnicos aplicados a la protección de accidentes son el diseño del fuselaje con mecanismos de absorción de energía y el perfeccionamiento de la estructura de los asientos para reducir la rotura mecánica (DeHart 1992; DeHart y Beers 1985).

\section{Microgravedad}

Desde el decenio de 1960, astronautas y cosmonautas han tripulado numerosas misiones en el espacio, incluidos seis alunizajes realizados por los estadounidenses. La duración de las misiones ha oscilado entre algunos días y varios meses, y hasta un año en algunas misiones rusas. Estos vuelos han estimulado los estudios médicos y científicos sobre anomalías fisiológicas de los tripulantes durante los vuelos y después de éstos. Para la mayoría de los autores, estos problemas pueden atribuirse a la exposición a la ingravidez o la microgravedad. Aunque son transitorios, con una recuperación total del orden de días o meses después del regreso a la Tierra, nadie puede afirmar con plena certeza que sean tan benignos en misiones de 2 o 3 años, como las que se prevén para un viaje de ida y vuelta a Marte. Las anomalías fisiológicas principales (y sus contramedidas) pueden clasificarse como cardiovasculares, musculosqueléticas, neurovestibulares, hematológicas y endocrinológicas (Nicogossian, Huntoon y Pool 1994).

\section{Riesgos cardiovasculares}

Hasta la fecha, no se han registrado en el espacio problemas cardiacos graves, como insuficiencias o ataques, aunque varios astronautas han desarrollado anomalías del ritmo cardiaco de carácter transitorio, sobre todo al efectuar actividades extravehiculares (AEV). En un caso, un cosmonauta ruso tuvo que regresar a la Tierra antes de lo previsto como medida de precaución.

Por otra parte, la microgravedad parece inducir inestabilidad de la presión arterial y el pulso. Aunque este efecto no perjudica la salud ni el rendimiento de la tripulación durante el vuelo, en torno a la mitad de los astronautas experimentan sensaciones intensas de mareo y vértigo inmediatamente después de las misiones y, en algunos casos, desmayos (síncopes) o cuasidesmayos (presíncopes). Se cree que la causa de esta intolerancia al mantenimiento de la posición vertical se debe a la caída de la presión arterial al volver a entrar en el campo gravitatorio terrestre, combinada con la disfunción de los mecanismos compensatorios del organismo. Por tanto, la presión arterial baja y la reducción del pulso no contrarrestados por una respuesta orgánica normal a estas anomalías fisiológicas da lugar a la aparición de los síntomas mencionados.

Aunque estos episodios de síncope o presíncope son pasajeros y carecen de secuelas, sigue habiendo motivos de preocupación por varias razones. En primer lugar, en el caso de que una nave espacial sufra durante la vuelta a la Tierra una situación de emergencia, como un incendio al aterrizar, por ejemplo, resultará extremadamente difícil para los astronautas escapar con rapidez. En segundo lugar, los astronautas que alunicen tras pasar cierto tiempo en el espacio serán más propensos a los desmayos y a padecer los síntomas previos a éstos, aunque el campo gravitatorio de la luna sea seis veces menor que el terrestre. Por último, estos síntomas cardiovasculares pueden ser mucho más graves e incluso mortales en misiones de larga duración.

Por estas razones, se ha trabajado mucho en la búsqueda de contramedidas para prevenir o, al menos, atenuar los efectos de la microgravedad en el sistema cardiovascular. Aunque hay varias actualmente en estudio y algunas son prometedoras, en ningún caso se ha podido comprobar la verdadera eficacia de ninguna. Los estudios realizados se han centrado en los ejercicios en vuelo basados en la utilización de tapices rodantes, ergómetros de bicicleta y bancos de remos. Además, se han efectuado otros análisis con presión negativa en la parte inferior del cuerpo (LBNP). Algunos datos indican que la reducción de la presión en esa zona del organismo (mediante la utilización de equipos compactos especiales) mejora la capacidad de éste para compensar las anomalías (es decir, para elevar la presión arterial y el pulso cuando disminuyen excesivamente). La contramedida basada en la LBNP resulta aún más eficaz si el astronauta ingiere a la vez cantidades moderadas de agua salada de composición especial.

Para resolver las anomalías cardiovasculares, no sólo hay que perfeccionar estas contramedidas, sino además desarrollar otras nuevas.

\section{Riesgos musculosqueléticos}

Todos los astronautas que regresan del espacio experimentan cierto grado de debilitamiento o atrofia muscular, sea cual sea la duración de la misión. Los músculos más afectados son los de las extremidades, cuyo tamaño, fuerza, resistencia y capacidad de trabajo quedan reducidos. Aunque el mecanismo de estas alteraciones sigue sin definirse con claridad, se explica parcialmente por la falta de uso prolongado; el trabajo, la actividad y el 
movimiento en condiciones de microgravedad apenas exigen esfuerzo, ya que todo carece prácticamente de peso. Esta circunstancia favorece inicialmente la realización de las labores de la misión, pero, constituye sin duda una dificultad al volver al campo gravitatorio, sea lunar o terrestre. La debilidad no sólo puede impedir las actividades posteriores al vuelo (incluidas las tareas en la superficie lunar), sino que también compromete la salida rápida en caso de emergencia tras el aterrizaje. Otro factor que debe considerarse es la posibilidad de que, en el curso de una $\mathrm{AEV}$, deban efectuarse en la nave reparaciones que exijan mucho esfuerzo físico. Entre las medidas en estudio aplicables en estos casos figuran los ejercicios en vuelo, la estimulación eléctrica y la medicación anabolizante (testosterona o esteroides afines). Por desgracia, en el mejor de los casos, estas medidas sólo retrasan la disfunción muscular.

Además del desgaste muscular, todos los astronautas experimentan una lenta pero inexorable pérdida de tejido óseo en el espacio (unos $300 \mathrm{mg}$ por día, o el 0,5 \% del calcio óseo total por mes). Este efecto ha sido documentado mediante radiografías de los huesos obtenidas después de los vuelos, sobre todo de aquéllos que soportan peso (es decir, el esqueleto axial). Su causa es la pérdida paulatina y constante de calcio con la orina y las heces. Este deterioro es motivo de gran preocupación, con independencia de la duración del vuelo. En consecuencia, la pérdida de calcio y la erosión ósea constituyen un factor limitante del vuelo, salvo que se adopten contramedidas eficaces. Aunque el mecanismo preciso de esta significativa anomalía fisiológica no se conoce por completo, no cabe duda de que se debe en parte a la ausencia de fuerzas gravitatorias que influyan sobre los huesos, así como a la falta de uso, como en el caso del desgaste muscular. Si la pérdida ósea se mantuviera indefinidamente, en especial en misiones de larga duración, los huesos se volverían tan frágiles que acabarían produciéndose fracturas, incluso con grados de esfuerzo moderados. Por otra parte, el flujo constante de calcio expulsado con la orina a través de los riñones favorece la formación de cálculos renales, con el resultado de dolores agudos, hemorragias e infección. Es obvio que, en el espacio, cualquiera de estas complicaciones serían muy graves.

Desgraciadamente, no se conocen contramedidas capaces de prevenir con eficacia la pérdida de calcio en los vuelos espaciales. Se han probado diversos métodos, como el ejercicio físico (tapices rodantes, ergómetros de bicicleta y bancos de remos), basándose en la hipótesis de que estos ejercicios físicos voluntarios normalizarán el metabolismo óseo y evitarán, o al menos atenuarán, la pérdida de masa ósea. Otras medidas en estudio son la administración de complementos de calcio, vitaminas y diversos medicamentos (como los difosfonatos, cuya capacidad para prevenir la pérdida ósea en pacientes con osteoporosis ha sido comprobada). Si ninguna de estas medidas simples resultan eficaces, es posible que la solución consista en generar gravedad artificial mediante la rotación continua o intermitente de los vehículos espaciales. Aunque este movimiento puede producir fuerzas gravitatorias similares a las de la Tierra, representaría una pesadilla técnica y multiplicaría los costes.

\section{Riesgos neurovestibulares}

Más de la mitad de los astronautas sufren de la enfermedad del movimiento en el espacio (EME). Aunque los síntomas varían, casi todos los sujetos experimentan sensibilización estomacal, náuseas, vómitos, cefaleas y somnolencia. El movimiento rápido de la cabeza agrava los síntomas. La EME suele declararse entre unos minutos y unas horas después de la ingestión de alimento, y remite por completo transcurrido un período de 72 horas. Es interesante señalar que, en ocasiones, los síntomas reaparecen después del regreso a la Tierra.
La EME, en particular los vómitos, no sólo desconcierta a los miembros de la tripulación, sino que también reduce el rendimiento en los astronautas afectados. Además, no puede ignorarse el riesgo de vomitar mientras se utiliza un traje presurizado en el curso de AEV, por el riesgo evidente de avería del sistema de mantenimiento de la vida. Por estas razones, nunca se programan AEV para los tres primeros días de una misión espacial. Si es imprescindible efectuar una de estas actividades - por ejemplo, para llevar a cabo reparaciones de urgencia en la nave - la tripulación tendrá que correr el riesgo.

Gran parte de los estudios neurovestibulares se han encaminado a la búsqueda de un método para prevenir y tratar la EME. Se han probado diversas modalidades, como la aplicación de parches y píldoras anti-EME y la utilización de dispositivos de adaptación previos al vuelo, como las sillas giratorias, para habituar a los astronautas, con resultados muy limitados. No obstante, en los últimos años se ha descubierto que la inyección del antihistamínico fenergán es extremadamente eficaz. Por ello, se lleva a bordo en todos los vuelos y se administra según las necesidades. Su eficacia preventiva está aún por demostrar.

Otros síntomas neurovestibulares declarados por los astronautas son mareos, vértigo, desequilibrio e ilusiones de movimiento propio y del entorno, que en ocasiones dificultan la capacidad de andar durante un breve período posterior al vuelo. Los mecanismos que inducen estos fenómenos son muy complejos y no se comprenden plenamente. Son complicaciones potencialmente problemáticas, sobre todo después de un alunizaje que sigue a varios días o semanas en el espacio. Actualmente, no se conocen contramedidas eficaces.

Es muy probable que los fenómenos neurovestibulares se deban a una disfunción del oído interno (canales semicirculares, utrículo y sáculo) debida a la microgravedad. Quizá se envíen señales erróneas al sistema nervioso central o éste malinterpreta las que recibe. En cualquier caso, el resultado es la aparición de los síntomas mencionados. Una mejor conocimiento de estos mecanismos ayudará a formular contramedidas eficaces.

\section{Riesgos hematológicos}

La microgravedad afecta a los glóbulos rojos y blancos. Los primeros transportan el oxígeno a los tejidos, mientras que los segundos forman parte del sistema inmunitario, que protege frente a los organismos invasores. Por tanto, la disfunción de estas células es perjudicial. Por motivos que no se conocen, los astronautas pierden entre el 7 y el $17 \%$ de la masa de eritrocitos en las primeras fases de vuelo. La pérdida parece estabilizarse a lo largo de los meses, y el valor recupera la normalidad entre 4 y 8 semanas después de la misión.

Hasta la fecha, este fenómeno no ha tenido trascendencia clínica y se ha considerado más bien un resultado de laboratorio curioso. Sin embargo, su gravedad potencial es evidente. La posibilidad de que los glóbulos rojos se pierdan a mayor ritmo y en cantidades muy superiores en las misiones de larga duración previstas para el siglo XXI es motivo de preocupación. Si estos temores se confirmaran, los astronautas sufrirían anemias muy perjudiciales para su salud. Se espera que éste no sea el caso y que las pérdidas de eritrocitos sean muy limitadas, con independencia de la duración de la misión.

Por otra parte, varios componentes del sistema leucocitario se ven afectados por la microgravedad. Así, ésta provoca un aumento del número de leucocitos en general y de neutrófilos en particular, acompañado de reducción de la población linfocitaria. Asimismo, los datos indican que estas células no funcionan normalmente.

Hasta el momento, a pesar de todos estos cambios, no se ha atribuido ninguna enfermedad a la alteración de los glóbulos blancos. Se desconoce si en misiones de larga duración se 
perderían más leucocitos y se agravaría su disfunción. Si así fuera, la defensa inmunitaria del organismo se encontraría en peligro, los astronautas estarían más expuestos a sufrir infecciones y, posiblemente, quedarían incapacitados por enfermedades menores que un sistema inmunológico sano combatiría con facilidad.

Como en el caso de los eritrocitos, las alteraciones de los leucocitos, al menos en misiones de aproximadamente un año, carecen de trascendencia clínica. Debido al riesgo potencial de contraer enfermedades graves durante el vuelo o después de éste, es esencial seguir investigando los efectos de la microgravedad sobre el sistema hematológico.

\section{Riesgos endocrinológicos}

En los vuelos espaciales, se han detectado diversas alteraciones de fluidos y minerales en el organismo, debidas en parte a los cambios del sistema endocrino. En general, se pierden fluidos orgánicos, así como calcio y potasio. No se ha definido aún el mecanismo preciso de estos fenómenos, aunque la modificación de varios niveles hormonales constituye una explicación parcial. Para contribuir a la confusión, los resultados obtenidos en el laboratorio con distintos astronautas no suelen coincidir, lo que impide formular una hipótesis unitaria de la etiología de estas anomalías fisiológicas. Con independencia de la confusión, estos cambios no han tenido efectos perjudiciales conocidos sobre la salud de los astronautas ni han reducido su rendimiento en vuelo. Se ignora la importancia de estas alteraciones endocrinas en misiones de larga duración, así como el riesgo de que sean precursoras de secuelas de extrema gravedad.

Agradecimientos: los autores desean manifestar su gratitud a la Aerospace Medical Association.

\section{- HELICOPTEROS}

\section{David L. Huntzinger}

El helicóptero es un tipo de aeronave muy especial. Se utiliza en todo el mundo, en industrias y con fines muy variados. Su tamaño va desde los pequeños modelos monoplaza a los enormes aparatos de carga con pesos brutos superiores a $100.000 \mathrm{~kg}$ y dimensiones similares a las de un Boeing 757. En el presente artículo se analizan algunos de los problemas que plantea este vehículo en materia de salud y seguridad, las diferentes misiones civiles y militares en las que se emplea y su entorno operativo.

El helicóptero en sí plantea riesgos de salud y seguridad singulares. Todos los modelos funcionan con un rotor principal. Se trata del órgano elevador del aparato y cumple el mismo fin que las alas en un avión. Las palas del rotor constituyen un riesgo importante para las personas y las cosas debido a su tamaño, su masa y su velocidad de rotación que, además, las oculta a la vista bajo ciertos ángulos y en diversas condiciones de iluminación.

El rotor de cola representa otro factor de peligro. Suele ser mucho más pequeño que el principal y gira a gran velocidad, por lo que también es difícil verlo. A diferencia del principal, situado sobre el eje principal del helicóptero, el rotor de cola suele encontrarse cerca del suelo. Por tanto, para evitar el contacto con él, hay que acercarse al helicóptero por la parte frontal, a la vista del piloto. Deben adoptarse precauciones extremas para detectar y eliminar obstáculos (como arbustos o vallas) en zonas de aterrizaje provisionales o poco preparadas. El contacto con el rotor de cola puede provocar lesiones o la muerte a las personas y graves daños a las cosas y al propio helicóptero.

Los helicópteros hacen un ruido característico que muchas personas identifican fácilmente. Este ruido sólo se percibe cuando el aparato vuela hacia delante y no se considera un problema para la salud. El compresor del motor genera un ruido muy fuerte, a menudo superior a $140 \mathrm{dBA}$, por lo que debe evitarse la exposición sin protección. Hay que llevar dispositivos de protección acústica (tapones y auriculares o casco de atenuación) al trabajar en el interior de un helicóptero o en sus proximidades.

Hay otros riesgos que deben considerarse al trabajar con estos aparatos. Uno de ellos es el relacionado con los líquidos inflamables o combustibles. Todos los helicópteros necesitan combustible para que funcione el motor. En el motor y en las transmisiones de los rotores principal y de cola se utiliza aceite para lubricar y refrigerar. Algunos modelos disponen de uno o varios circuitos hidráulicos en los que se utilizan líquidos especiales.

Estos aparatos generan una carga eléctrica estática al volar siempre que gira el rotor. La carga se disipa en el momento en que el helicóptero toca tierra. En trabajos en explotaciones forestales, levantamiento de cargas externas u operaciones de rescate, el cable o la carga no deben tocarse antes de que hayan entrado en contacto con el suelo, para evitar descargas.

\section{Entorno operativo de los helicópteros}

Los helicópteros se utilizan en todo el mundo de diversas formas (véanse, por ejemplo las Figuras 102.5 y 102.6). Además, suelen operar muy cerca del suelo y otros obstáculos. Estas condiciones exigen una vigilancia constante por parte de los pilotos y demás ocupantes, así como de las personas que trabajan con estos aparatos. Por el contrario, el entorno de los aviones de ala fija es más predecible, ya que se desplazan (sobre todo los comerciales) fundamentalmente entre aeropuertos cuyo espacio aéreo se somete a un control estricto.

\section{Figura 102.5 • Un helicóptero H-46 aterriza en el desierto de Arizona, Estados Unidos.}

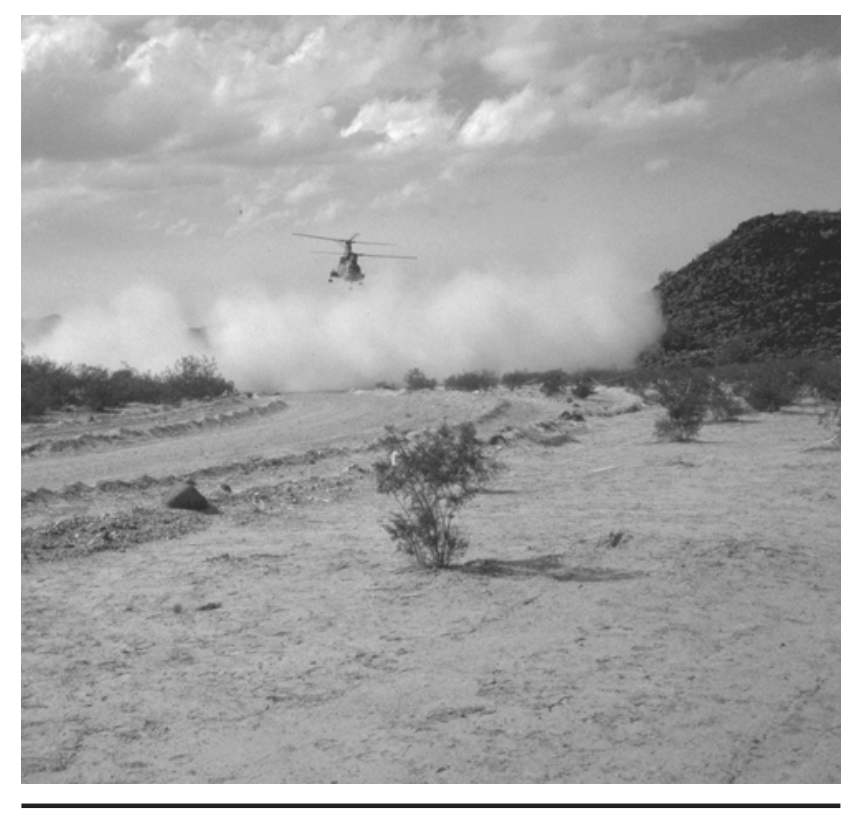




\section{Operaciones de helicópteros}

Las aplicaciones de los helicópteros son numerosas. Las diversas operaciones que efectúan pueden dividirse en dos categorías: civiles y militares.

\section{Actividades civiles}

Rescate/ambulancias aéreas. El helicóptero se concibió inicial mente para operaciones de rescate y una de sus funciones más generalizadas es su utilización como ambulancia. Estas actividades suelen llevarse a cabo en los lugares donde se ha producido un accidente o una catástrofe (véase la Figura 102.6) Pueden aterrizar en áreas restringidas y trasladar a bordo equipos médicos cualificados que prestan asistencia a los heridos sobre el terreno y en el viaje al centro sanitario. Los helicópteros se emplean también en vuelos no de urgencia cuando es necesario asegurar la velocidad del transporte o la comodidad del paciente.

Servicios auxiliares en las explotaciones petroliferas de alta mar. Los helicópteros se utilizan para facilitar el abastecimiento en las explotaciones petrolíferas en alta mar. Transportan personas y suministros entre la plataforma y tierra firme y entre plataformas.

Transporte de directivos y personal de otras categorías. El helicóptero se utiliza en el transporte entre escalas fijas. Esta actividad suele realizarse entre distancias cortas cuando la geografía o las condiciones de tráfico adversas impiden un transporte por carretera rápido. Las empresas construyen helipuertos en sus instalaciones para facilitar el acceso a aeropuertos o el transporte entre distintos centros.

Visitas turísticas. La utilización de helicópteros en el sector turístico ha experimentado un crecimiento continuo. Las excelentes vistas que pueden contemplarse desde este tipo de aeronaves, junto con su capacidad para acceder a áreas remotas, lo convierte en una atracción popular.

Orden público. Muchos departamentos de policía y organismos públicos utilizan helicópteros para velar por el manteimiento del orden público. La movilidad de estas aeronaves en áreas urbanas densamente pobladas y en zonas rurales remotas lo convierten en un instrumento de gran valor. El mayor helipuerto del mundo situado en una cubierta es el del Departamento de Policía de Los Angeles
Filmación de películas. Los helicópteros son un elemento básico de las películas de acción. Otro tipo de cintas y de ofertas de ocio basadas en la filmación se ruedan desde helicópteros.

Recopilación de información. Las emisoras de radio y televisión utilizan helicópteros para observar el tráfico y recopilar información. Su capacidad para aterrizar en el lugar donde se produce la notica les convierte en un instrumento eficaz. Muchas de estas aeronaves se equipan con transmisores-receptores de microondas, lo que permite el envío de información en directo a grandes distancias y en movimiento.

Elevación de cargas. Algunos helicópteros se diseñan para el transporte de bultos pesados enganchados al extremo de cables externos. El transporte de troncos por vía aérea pertenece a este ámbito. Los trabajadores de la construcción y de las explotaciones petrolíferas hacen un uso extensivo de la capacidad de estas aeronaves para elevar objetos grandes o voluminosos y colocarlos en su lugar correspondiente.

Pulverización aérea. Los helicópteros pueden equiparse con bombas de pulverización y cargarse para administrar herbicidas, pesticidas y fertilizantes. Pueden instalarse otros dispositivos para la extinción de incendios que rocían el terreno con agua o retardantes químicos

\section{Actividades militares}

Rescate/ambulancias aéreas. El helicóptero se utiliza ampliamente en las iniciativas de ayuda humanitaria. Muchos países de todo el mundo disponen de servicios de guardacostas que participan en tareas de rescate marítimo. Estas aeronaves se emplean además en la evacuación de enfermos y heridos de las zonas de combate y en el rescate y la recuperación de personas atrapadas tras las líneas enemigas.

Ataque. Los helicópteros pueden armarse y utilizarse como plataformas de ataque sobre la tierra o el mar. El armamento montado consiste en ametralladoras, cohetes y torpedos. Se emplean sistemas de detección de objetivos y orientación sofisticados para realizar seguimientos automáticos de los blancos y destruir éstos a larga distancia.

Transporte. Helicópteros de todos los tamaños se utilizan en el transporte de personas y suministros sobre la tierra o el mar. Muchos buques disponen de helipuertos para facilitar las operaciones en alta mar.
El entorno de combate plantea riesgos especiales. Los helicópteros militares también operan a bajo nivel y deben afrontar peligros semejantes. La proliferación de misiles baratos, dirigidos manualmente y guiados por el calor constituye otra fuente de riesgo para las aeronaves de rotor. Los modelos militares pueden utilizar el terreno para ocultarse o enmascarar sus características distintivas, pero a cielo abierto son vulnerables a los disparos de armas portátiles y a los misiles.

Los militares utilizan gafas de visión nocturna para mejorar la visibilidad del piloto en condiciones de baja luminosidad. Aunque estos dispositivos mejoran la capacidad de ver, presentan limitaciones operativas importantes. Una de las mayores dificultades es la falta de visión periférica, una deficiencia que ha provocado colisiones en el aire.

\section{Medidas de prevención de accidentes}

Las medidas preventivas se agrupan en varias categorías. Ninguna de ellas permitirá evitar los accidentes por sí sola. Todas deben aplicarse de manera concertada para maximizar su eficacia.

\section{Políticas operativas}

Las políticas operativas se formulan con anterioridad al inicio de las operaciones. Suele establecerlas la compañía que dispone del certificado de explotación. Se basan en reglamentaciones públicas, directrices recomendadas por los fabricantes, normas de la industria, buenas prácticas y sentido común. En general, han resultado ser eficaces en la prevención de incidentes y accidentes. Son las siguientes:

- Establecimiento de buenas prácticas y procedimientos. Los procedimientos son esenciales para prevenir accidentes. Cuando no se aplicaban, como en las primeras operaciones de helicópteros utilizados como ambulancia, las tasas de siniestralidad eran extremadamente elevadas. En ausencia de directrices reguladoras, los pilotos intentaban apoyar misiones humanitarias por la noche o en condiciones meteorológicas adversas, con una formación mínima y un equipamiento insuficiente para este tipo de vuelos; todo ello favorece los accidentes.

- Gestión de recursos de la tripulación (GRT). La GRT comenzó como "gestión de recursos de la cabina del piloto", pero finalmente 
se ha adoptado la denominación actual. Se basa en la idea de que los miembros de la tripulación deben comentar libremente entre sí cualquier situación para asegurar la correcta ejecución del vuelo. Aunque muchos helicópteros llevan un solo piloto, éste suele colaborar con otras personas situadas a bordo o en tierra. Cuando se produce esta forma de interacción, la GRT se convierte en gestión de recursos de la compañía. Este tipo de colaboración constituye una destreza adquirida y debe impartirse a los tripulantes, al personal de la empresa y a otras personas que trabajan dentro y alrededor de los helicópteros.

- Entorno de trabajo exento de peligros. Las operaciones efectuadas con helicópteros son a veces estacionales, lo que exige la realización de jornadas de trabajo prolongadas y extenuantes. Los tripulantes necesitan acabar sus tareas diarias sin temor a recriminaciones. Si se detectan otras deficiencias operativas, debe permitírseles identificarlas, analizarlas y corregirlas abiertamente.

- Conocimiento de los riesgos físicos. Un helicóptero plantea diversos riesgos. Los componentes dinámicos de la aeronave, es decir, sus rotores principal y de cola, deben evitarse. Todos los pasajeros y los tripulantes deben ser informados sobre su localización y el modo de prevenir el contacto con ellos. Las superficies de los componentes deben pintarse para mejorar su visibilidad. El helicóptero debe situarse de modo el acceso al rotor de cola sea difícil. Hay que facilitar protectores contra el ruido, sobre todo a las personas sometidas a exposición continua.

- Formación sobre condiciones anómalas. La formación, cuando se imparte, suele limitarse a la práctica de autorrotaciones para casos de parada del motor. Los simuladores exponen a una gama mucho más amplia de condiciones atípicas sin necesidad de someter a la tripulación o al aparato a situaciones reales.

\section{Prácticas de la tripulación}

- Procedimientos escritos. Un estudio ha puesto de manifiesto que, en más de la mitad de los casos, el accidente podría haberse evitado si el piloto hubiese seguido los procedimientos escritos.

- Gestión de los recursos de la tripulación. Debe aplicarse.
Figura 102.6 • Un helicóptero 5-76A Cougar aterriza sobre el terreno en el lugar de un accidente.

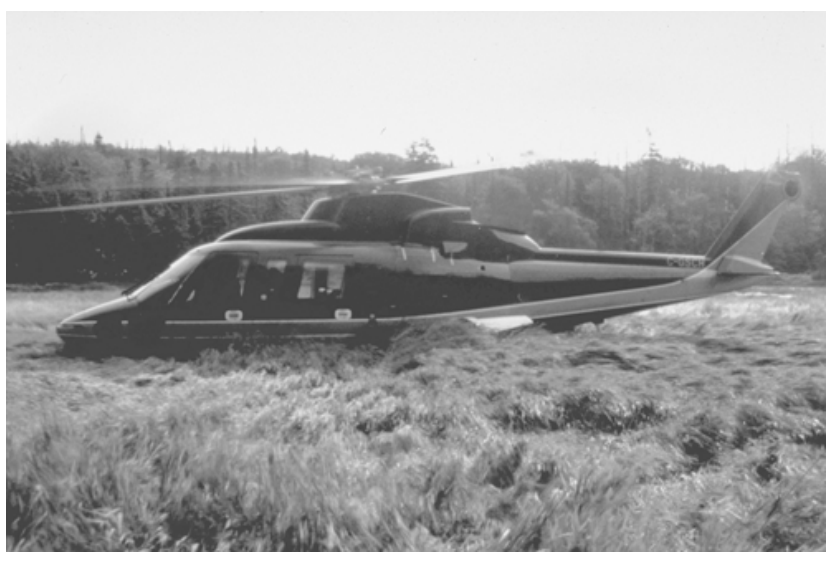

- Previsión y prevención de los problemas conocidos. La mayoría de los helicópteros no están equipados para volar a temperaturas inferiores a $0^{\circ} \mathrm{C}$ ni autorizados a operar con turbulencias moderadas o intensas; no obstante, muchos accidentes se deben a la actuación en estas condiciones. Los pilotos deben prever y evitar estas situaciones $y$ otras igualmente comprometidas.

- Operaciones especiales o no normalizadas. Los pilotos deben ser informados exhaustivamente en estos casos.

\section{Operaciones auxiliares}

A continuación se refieren operaciones auxiliares esenciales para la utilización de helicópteros en condiciones de seguridad:

- cumplimiento de los procedimientos escritos;

- información a todos los pasajeros antes de que suban al helicóptero;

- mantenimiento de las instalaciones libres de obstáculos, e

- iluminación adecuada de las instalaciones en caso de realización de operaciones nocturnas.

\section{TRANSPORTE POR CARRETERA}

\section{CONDUCGION DE CAMIONES Y AUTOBUSES}

Bruce A. Millies

El transporte por carretera mueve personas, animales y mercancías de todo tipo. En general, estos dos últimos tipos de carga se transportan en camiones, aunque los autobuses, además de paquetes y el equipaje de los pasajeros, desplazan a menudo aves y otros animales de pequeño tamaño. Las personas que viajan por carretera suelen utilizar el autobús, aunque, en muchas regiones, se emplean con este fin camiones de diversos modelos, entre los que figuran semirremolques, camiones cisterna, volquetes, combinaciones de remolques dobles y triples, grúas móviles, camiones de reparto y camionetas. Los pesos brutos de estos vehículos establecidos en la legislación (que dependen de la jurisdicción) oscilan entre 2.000 y más de $80.000 \mathrm{~kg}$. Transportan todo tipo de artículos: paquetes pequeños y grandes, maquinaria, piedras y arena, acero, leña, líquidos inflamables, gases comprimidos, explosivos, materiales radiactivos, sustancias químicas corrosivas y reactivas, líquidos criogénicos, productos alimenticios, alimentos congelados, cereales a granel y ganado ovino y bovino.

Además de conducir el vehículo, los camioneros lo revisan antes de cada viaje, comprueban los documentos de expedición, verifican la correcta colocación de placas y señales y mantienen el libro de ruta. Asimismo, son responsables del mantenimiento y la reparación del vehículo, de la carga y la descarga de la mercancía (a mano o con una carretilla elevadora, una grúa u otro dispositivo) y del cobro del dinero recibido a cambio de los artículos entregados. En caso de accidente, el conductor se ocupa de vigilar la mercancía y solicitar asistencia. Si en el incidente intervienen materiales peligrosos, intentar a veces controlar los derrames, detener las fugas o extinguir un incendio, incluso aunque carezca de la formación adecuada o del equipo necesario. 
Los conductores de autobús pueden transportar a unas pocas personas en una pequeña furgoneta o conducir vehículos de mediano o gran tamaño en los que se desplazan cien o más pasajeros. Son responsables de la subida y la bajada del pasaje en condiciones de seguridad, de la información y, en ocasiones, del cobro de billetes y el mantenimiento del orden. Asimismo, estos trabajadores pueden encargarse del mantenimiento y la reparación del vehículo y de la carga y descarga de mercancías y equipajes.

Los accidentes de los vehículos a motor constituyen uno de los riesgos más graves con que se enfrentan los conductores de camiones y autobuses. Este riesgo se agrava si el mantenimiento del vehículo no es el adecuado, sobre todo si los neumáticos están desgastados o el sistema de frenos falla. La fatiga provocada por horarios de trabajo prolongados o irregulares o por otros factores de estrés aumenta la probabilidad de accidente. Una velocidad excesiva o el transporte de cargas con pesos superiores a lo aconsejable agravan la situación, al igual que el tráfico denso y las condiciones meteorológicas adversas, que disminuyen la tracción y la visibilidad. Si en el accidente intervienen materiales peligrosos, el conductor y los pasajeros quedan expuestos a lesiones aún más graves (por exposición a productos tóxicos, quemaduras, etc.) y en ocasiones se ve afectada una zona extensa en torno al lugar del suceso.

Los conductores afrontan diversos riesgos ergonómicos. Los más obvios son las lesiones de espalda y de otro tipo por levantamiento de grandes pesos o por emplear técnicas de izado inadecuadas. Se ha generalizado el uso de cinturones de sujeción lumbar, aunque su eficacia es cuestionable y crean una falsa sensación de seguridad. La necesidad de cargar y descargar mercancías en lugares donde no se dispone de carretillas elevadoras, grúas o simples carretillas de ruedas y la gran variedad de pesos y configuraciones de los bultos contribuyen a agravar el riesgo de lesión por levantamiento.

Con frecuencia, los asientos del conductor están mal diseñados y no disponen de medios de ajuste para mejorar el apoyo y la comodidad en períodos prolongados, lo que da lugar a molestias de espalda y daños musculares y óseos. La costumbre de llevar el brazo durante mucho tiempo apoyado en la ventanilla en una posición elevada provoca, a consecuencia de las vibraciones, dolores en los hombros. La vibración que afecta a todo el cuerpo llega a dañar los riñones y la espalda. El uso reiterado de ciertos mandos del vehículo o de expendedores de billetes mal ubicados también es causa de lesiones.

Los conductores corren el riesgo de sufrir pérdidas auditivas por exposición prolongada al fuerte ruido emitido por el motor. El mantenimiento deficiente, los silenciadores defectuosos y el mal aislamiento de la cabina de conducción agravan este riesgo. La pérdida puede ser más pronunciada en el oído cercano a la ventanilla del conductor. Los conductores, sobre todo los de camiones de transporte de larga distancia, suelen trabajar un número excesivo de horas sin el descanso apropiado. El Convenio $\left(\mathrm{n}^{\circ}\right.$ 153) de la Organización Internacional del Trabajo (OIT) sobre duración del trabajo y períodos de descanso (transportes por carretera), 1979, establece un descanso cada cuatro horas de conducción, limita el tiempo total dedicado a ésta a nueve horas diarias y 48 semanales y exige al menos diez horas de descanso en cada período de 24. Asimismo, la mavoría de los países han promulgado leyes que regulan los períodos de conducción y de descanso y exigen a los conductores llevar libros de ruta para registrar las horas de trabajo y los descansos aplicados. No obstante, las expectativas de la patronal y la necesidad económica, así como ciertas modalidades de remuneración, como el pago por mercancía transportada o la falta de retribución por los viajes de vuelta sin carga, fuerzan a los conductores a prestar servicio durante un número de horas excesivo y a falsificar los apuntes en los registros. Una jornada muy prolongada produce estrés psicológico, agrava las deficiencias ergonómicas, multiplica el riesgo de accidentes (incluidos los debidos al sueño) y lleva a los conductores a consumir estimulantes artificiales adictivos.

A las deficiencias ergonómicas, los horarios de trabajo excesivos, el ruido y la ansiedad por cuestiones económicas se suman los factores de estrés psicológico y fisiológico y la fatiga provocados por el tráfico intenso, la deficiencia de los pavimentos, las condiciones meteorológicas desfavorables, la conducción nocturna, el miedo a asaltos y robos, la preocupación por el mal estado del vehículo y la concentración intensa y sostenida.

Algunos camioneros están expuestos a riesgos de carácter químico, radiactivo o biológico asociados con la carga que transportan. Los contenedores con fugas, las válvulas defectuosas de los depósitos y las emisiones durante las operaciones de carga y descarga llevan al trabajador a entrar en contacto con productos químicos tóxicos. Las deficiencias de embalaje, el blindaje insuficiente y el estibado incorrecto de mercancías radiactivas aumentan el riesgo de exposición. El transporte de animales vivos expone al conductor al riesgo de contagio de enfermedades infecciosas como la brucelosis. También los conductores de autobús corren el riesgo de contraer enfermedades infecciosas padecidas por sus pasajeros. En todos los casos, los conductores respiran vapores de combustible y gases de escape, sobre todo si el vehículo presenta fugas en los circuitos de alimentación o escape o si el conductor efectúa reparaciones o manipula la carga con el motor en marcha.

En caso de accidente durante el transporte de cargas peligrosas, el conductor corre el riesgo de exposición aguda a productos químicos y radiaciones, así como a lesiones debidas a incendio, explosión o reacción química. En general, los conductores carecen de la formación y el equipo necesarios para hacer frente a incidentes con este tipo de materiales. $\mathrm{Su}$ responsabilidad debe limitarse a su propia protección y a la petición de ayuda urgente. El conductor quedará expuesto a un riesgo todavía mayor si intenta adoptar medidas de emergencia para las que no están preparado ni equipado adecuadamente.

Los conductores pueden lesionarse al efectuar reparaciones mecánicas en su medio de transporte, o ser atropellados por otros vehículos mientras trabajan en su camión o su autobús junto a la carretera. Las ruedas con llantas deterioradas constituyen un importante riesgo de accidente. Utilizar gatos improvisados o de capacidad insuficiente es exponerse a sufrir una lesión por aplastamiento.

Los camioneros corren el riesgo de sufrir asaltos y robos, sobre todo si el vehículo transporta mercancías valiosas o si el conductor debe ocuparse de cobrar el precio de la carga entregada. Los conductores de autobús se enfrentan al robo de la recaudación y al comportamiento ofensivo y las agresiones de pasajeros impacientes o ebrios.

Muchos aspectos de la vida de un conductor contribuyen al deterioro de su salud. Las largas jornadas de trabajo y a la necesidad de comer en la carretera favorecen las deficiencias nutricionales. El estrés y la presión ejercida por los compañeros llevan al consumo de alcohol y drogas. La utilización de los servicios de prostitutas aumenta el riesgo de contraer SIDA y otras enfermedades de transmisión sexual. Los camioneros parecen constituir uno de los principales vectores de la propagación del SIDA en algunos países.

Todos los riesgos descritos son evitables o, al menos, controlables. Como ocurre con la mayoría de las cuestiones de salud y seguridad, hay que combinar remuneración adecuada, formación de los trabajadores, regulación sindical sólida y cumplimiento estricto de las normas por parte de la patronal. Si los 
conductores reciben una retribución proporcional a su labor, basada en horarios de trabajo razonables, disminuye el incentivo a elevar la velocidad, trabajar un número de horas excesivo, conducir vehículos poco seguros, transportar cargas de peso superior al permitido, ingerir drogas o falsificar apuntes en los registros. Las empresas deben exigir a los conductores que se atengan al conjunto de disposiciones en materia de seguridad, incluido llevar el diario de ruta con arreglo a las leyes.

Si la dirección de las empresas invierte en vehículos de fabricación óptima y asegura su inspección, reparación y mantenimiento periódicos, las averías y los accidentes se reducirán drásticamente. Las lesiones ergonómicas disminuyen cuando las empresas costean la dotación de cabinas de conducción bien diseñadas, con asientos plenamente ajustables y mandos correctamente colocados, mejoras éstas que ya se ofrecen en el mercado. El mantenimiento correcto, en especial de los circuitos de escape, atenúa la exposición al ruido.

Para reducir la exposición tóxica, la empresa propietaria debe exigir el cumplimiento de las normas de embalado, identificación, carga y señalización de materiales peligrosos. Las medidas que reducen el riesgo de accidentes de carretera también reducen el de incidentes con cargas peligrosas.

Hay que conceder a los conductores el tiempo que necesiten para inspeccionar con detalle su vehículo antes de partir y no deben ser objeto de sanción o desincentivo por negarse a conducir si su funcionamiento no es correcto. Asimismo, deben recibir una formación adecuada sobre conducción, inspección de vehículos, detección de riesgos y actuación rápida en caso de emergencia.

Si los conductores son responsables de la carga y la descarga, necesitan formación sobre técnicas de levantamiento adecuadas y han de disponer de carretillas, dispositivos elevadores, grúas u otros mecanismos apropiados para manipular la mercancía sin realizar esfuerzos excesivos. Si se les encarga la reparación de los vehículos, deben disponer de las herramientas y la preparación adecuadas. Es necesario adoptar las medidas de seguridad pertinentes para proteger a los conductores que transportan cargas valiosas o que cobran en efectivo el billete a los pasajeros o las mercancías transportadas a sus destinatarios. Los conductores de autobús deben disponer de los materiales necesarios para recoger o limpiar los fluidos corporales de pasajeros enfermos o heridos.

Por último, los conductores necesitan de un servicio médico, tanto para verificar su aptitud para el trabajo como para mantener su salud. Este servicio de atención médica se encargará asimismo de examinar a los conductores obligados a manipular cargas peligrosas o que hayan sufrido algún incidente con exposición a patógenos contagiados con la sangre o a productos peligrosos. Empresas y conductores deben cumplir las normas de evaluación de la capacidad física para el trabajo.

\section{ERGONOMIA DE LA CONDUCGION DE AUTOBUSES}

Alfons Grösbrink y Andreas Mahr

La conducción de autobuses se caracteriza por la influencia de factores de estrés psicológico y físico. Revisten especial importancia los relacionados con el tráfico en las grandes ciudades, debido a su densidad y la frecuencia de las paradas. En la mayoría de las empresas de transporte, los conductores, además de las responsabilidades propias de la conducción, desempeñan tareas como vender los billetes, vigilar la subida y bajada de los pasajeros y proporcionar información a éstos.
Los factores de estrés psicológico están vinculados a la responsabilidad que supone el transporte del pasaje en condiciones de seguridad, la escasas oportunidades de comunicación con los compañeros y la presión del horario fijo. El trabajo por turnos también resulta estresante desde el punto de vista psicológico y físico. Las deficiencias ergonómicas del puesto de conducción agravan el estrés físico.

Numerosos estudios de la actividad de estos profesionales han puesto de manifiesto que, considerados por separado, los factores de estrés no bastan para crear un riesgo inmediato para la salud. Sin embargo, su combinación y la tensión consiguiente sí basta para que los conductores de autobús padezcan problemas de salud con mayor frecuencia que otros trabajadores. Las enfermedades más frecuentes son las del estómago y el aparato digestivo, las de carácter motor (en especial de la columna vertebral) y las cardiovasculares. Estas dolencias impiden a menudo a los conductores alcanzar la edad de jubilación y les obligan a abandonar el trabajo por motivos de salud (Beiler y Tränkle 1993; Giesser-Weigt y Schmidt 1989; Haas, Petry y Schülein 1989; Meifort, Reiners y Schuh 1983; Reimann 1981).

Para mejorar la seguridad en el trabajo en el campo de la conducción comercial es necesario adoptar medidas técnicas y organizativas. Una práctica laboral muy recomendable es disponer los turnos de trabajo de forma que el estrés de los conductores se reduzca al mínimo y sus preferencias personales sean tenidos en cuenta en la medida de lo posible. Informar a los trabajadores sobre una conducta consciente desde el punto de vista sanitario y animarles a seguirla (dieta equilibrada, movimientos adecuados dentro y fuera del puesto de trabajo) contribuve decisivamente a fomentar la salud. Una medida técnica muy necesaria es el diseño óptimo del puesto de trabajo desde una perspectiva ergonómica. En el pasado, el diseño de la cabina de conducción se supeditaba a la satisfacción previa de

\section{Figura 102.7 • Puesto de conducción unificado y optimizado ergonómicamente de un autobús en Alemania.}

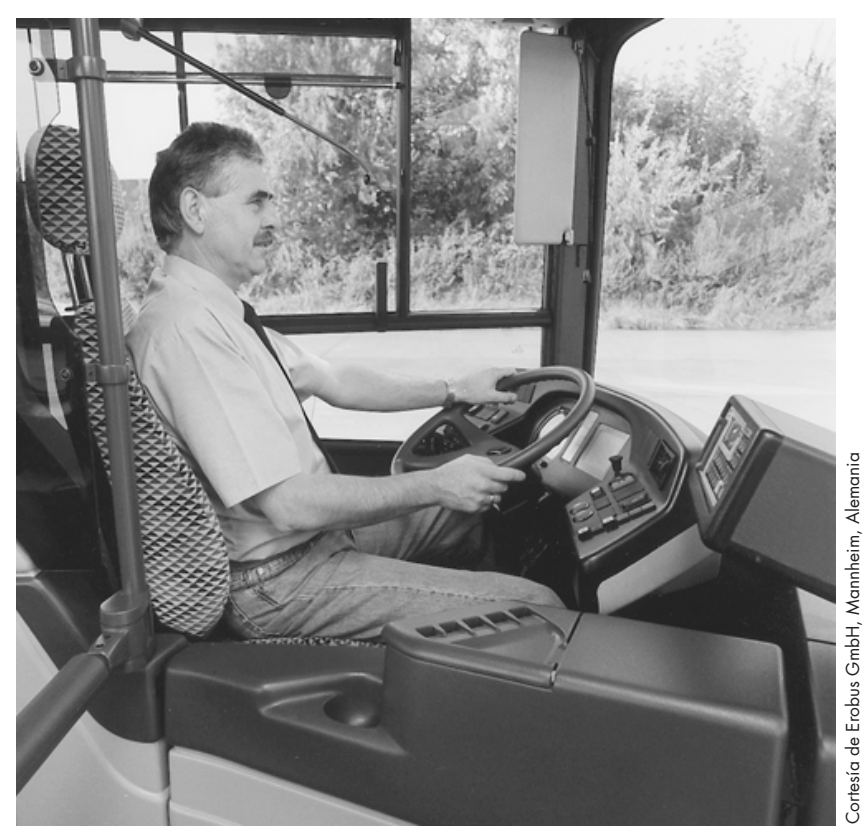

El tablero de instrumentos con controles puede ajustarse en coordinación con el volante. 
Tabla 102.1 • Medidas y escalas de ajuste del asiento de un conductor de autobús.

\begin{tabular}{|c|c|c|c|c|}
\hline Componente & Medida/escala de ajuste & $\begin{array}{l}\text { Valor estándar } \\
(\mathrm{mm})\end{array}$ & $\begin{array}{l}\text { Escala de ajuste } \\
(\mathrm{mm})\end{array}$ & Memorización \\
\hline \multirow[t]{2}{*}{ Asiento completo } & Horizontal & - & $\geq 200$ & Sí \\
\hline & Vertical & - & $\geq 100$ & Sí \\
\hline \multirow[t]{6}{*}{ Superficie del asiento } & Profundidad de la superficie del asiento & - & $390-450$ & Sí \\
\hline & Anchura de la superficie del asiento (total) & Mín. 495 & - & - \\
\hline & Anchura de la superficie del asiento (parte plana, en la zona pélvica) & 430 & - & - \\
\hline & Tapizado lateral en la zona pélvica (transversalmente) & $40-70$ & - & - \\
\hline & Profundidad del hueco del asiento & $10-20$ & - & - \\
\hline & Inclinación de la superficie del asiento & - & $\begin{array}{l}0-10^{\circ} \text { (elevado } \\
\text { hacia adelante) }\end{array}$ & Sí \\
\hline \multirow[t]{7}{*}{ Respaldo } & Altura del respaldo & & & \\
\hline & Altura mínima & 495 & - & - \\
\hline & Altura máxima & 640 & - & - \\
\hline & Anchura del respaldo (total) ${ }^{\star}$ & Mín. 475 & - & - \\
\hline & Anchura del respaldo (parte plana) & & & \\
\hline & —zona lumbar (inferior) & 340 & - & - \\
\hline & —zona de los hombros (superior) & 385 & - & - \\
\hline \multirow[t]{4}{*}{ Respaldo } & Tapizado lateral * (profundidad lateral) & & & \\
\hline & —zona lumbar (inferior) & 50 & - & - \\
\hline & -zona de los hombros (superior) & 25 & - & - \\
\hline & Inclinación del respaldo (respecto a la vertical) & - & $0^{\circ}-25^{\circ}$ & Sí \\
\hline \multirow[t]{3}{*}{ Reposacabezas } & $\begin{array}{l}\text { Altura del extremo superior del reposacabezas respecto a la } \\
\text { superficie del asiento }\end{array}$ & - & Min. 840 & - \\
\hline & Altura del reposacabezas & Mín. 120 & - & - \\
\hline & Anchura del reposacabezas & Mín. 250 & - & - \\
\hline \multirow[t]{2}{*}{ Refuerzo lumbar } & Arco delantero del soporte lumbar respecto a la superficie lumbar & - & $10-50$ & - \\
\hline & $\begin{array}{l}\text { Altura del extremo inferior del soporte lumbar respecto a la superficie } \\
\text { del asiento }\end{array}$ & - & $180-250$ & - \\
\hline \multicolumn{5}{|l|}{ - No aplicable } \\
\hline
\end{tabular}

otras necesidades, como el diseño de la zona de pasajeros. El diseño ergonómico del puesto de conducción es un componente necesario para la protección de la salud y la seguridad de los conductores. En años recientes se ha investigado sobre la optimización ergonómica de estos puestos de trabajo y otros aspectos de la conducción en Canadá, Suecia, Alemania y los Países Bajos (Canadian Urban Transit Association 1992; Peters y cols. 1992; Wallentowitz y cols. 1996; Streekvervoer Nederland 1991). Los resultados de un proyecto interdisciplinario realizado en Alemania se materializaron en la creación de un nuevo puesto de conducción normalizado (Verband Deutscher Verkehrsunternehmen 1996).

El puesto de conducción en los autobuses suele diseñarse en forma de cabina semiabierta. Sus medidas y el margen de ajuste del asiento y el volante deben estar dentro de unos límites aplicables a todos los conductores. En Europa central se utiliza un intervalo de estaturas comprendido entre 1,58 y $2,00 \mathrm{~m}$. También hay que tener en cuenta en el diseño circunstancias especiales, como el sobrepeso o unas extremidades manifiestamente largas o cortas.

Los ajustes del asiento y el volante deben coordinarse, de forma que todos los profesionales incluidos en la escala de diseño encuentren posiciones cómodas y ergonómicamente saludables para los brazos y las piernas. Con este fin, el respaldo del asiento debe inclinarse alrededor de $20^{\circ}$, un valor más alejado de la vertical de lo que anteriormente se aplicaba en vehículos comerciales. También el tablero de instrumentos debe ser graduable para optimizar el acceso a los mandos y la visibilidad de los instrumentos. El ajuste del tablero puede coordinarse con el del volante. La reducción del tamaño de éste mejora las relaciones entre espacios. El diámetro común en la actualidad parece heredado de la época en que la dirección asistida no era habitual en los autobuses. Véase la Figura 102.7.

El tablero de instrumentos y los mandos se ajusta en coordinación con el volante.

Dado que los tropiezos y las caídas son las causas más comunes de accidente en el lugar de trabajo para los conductores, hay que prestar especial atención al diseño de la entrada al puesto de conducción. Debe evitarse todo aquello en lo que pueda tropezarse. Los escalones de acceso deben tener todos la misma altura y una profundidad adecuada.

$\mathrm{El}$ asiento del conductor debe dotarse de un total de cinco mecanismos de ajuste: longitud y altura, ángulo del respaldo, ángulo de la base y profundidad. Es muy recomendable añadir 
Figura 102.8 • Imagen de un tablero de instrumentos.

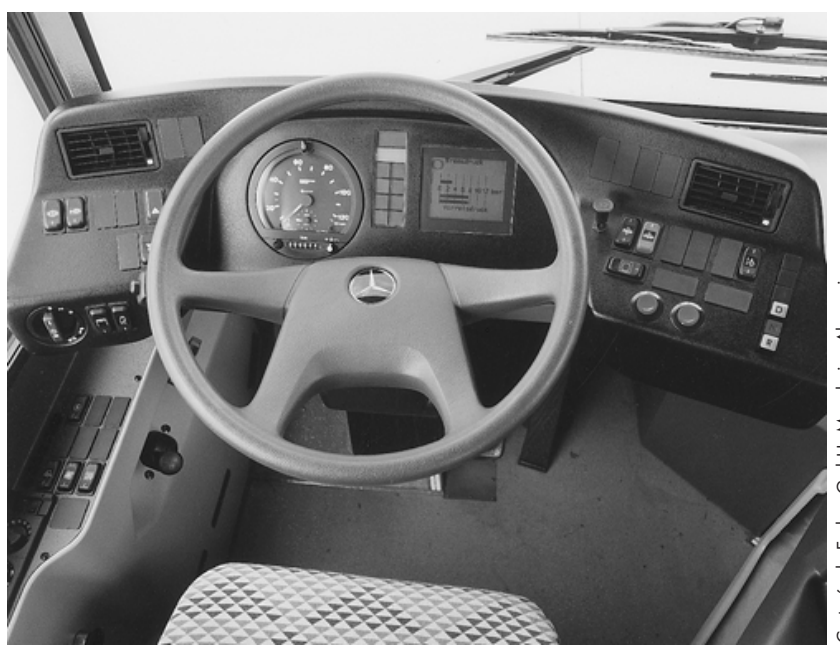

Con la excepción del velocímetro y algunas luces indicativas establecidas por la legislación, las funciones del cuadro de instrumentos e indicadores han sido asumidas por una pantalla de visualización central de cristal líquido. el ajuste del apoyo lumbar. Es aconsejable equipar el asiento con un cinturón de seguridad de tres puntos de anclaje y un reposacabezas, si es que la legislación no lo hace obligatorio. Ya que la experiencia demuestra que el ajuste manual hasta alcanzar la posición ergonómica idónea es laborioso, en el futuro debe utilizarse alguna forma de registro electrónico de las funciones de ajuste recogidas en la Tabla 102.1, lo que permitiría a cada conductor recuperar fácilmente todos sus ajustes (registrándolos en una tarjeta electrónica, por ejemplo).

La tensión derivada de la vibración del cuerpo en el puesto de conducción es moderada en los autobuses modernos en comparación con otros vehículos comerciales, y es muy inferior a lo establecido como máximo en las normas internacionales. La experiencia pone de manifiesto que el asiento del conductor de los autobuses no suelen graduarse de manera óptima respecto a la vibración real del vehículo. Se recomienda una adaptación idónea para evitar ciertas gamas de frecuencia que acentúan la vibración soportada por el conductor y reducen su productividad.

El nivel de ruido común en el puesto de conducción de un autobús no se considera peligroso para la capacidad auditiva. Los sonidos de alta frecuencia son irritantes y deben eliminarse, ya que dificultan la concentración.

Figura 102.9 • Ilustración de un tablero de instrumentos y leyenda.

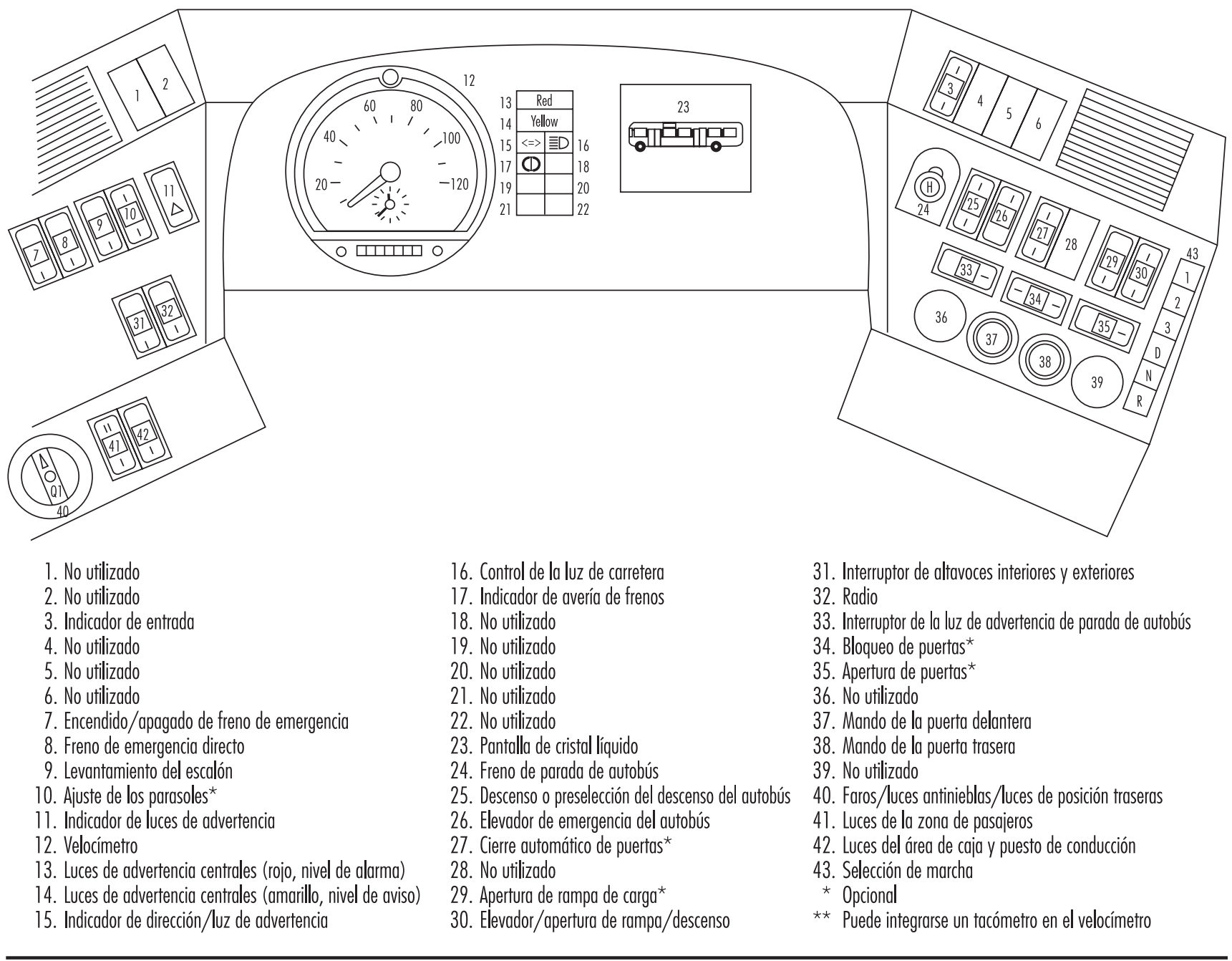


Todos los mandos de ajuste y reparación del puesto de conducción deben instalarse de manera que sean fácilmente accesibles. El número de estos mandos es a veces considerable, debido a los accesorios añadidos al vehículo. Por esta razón, los interruptores deben agruparse y combinarse de acuerdo con su uso. Los componentes de servicio utilizados con frecuencia, como los de apertura de las puertas, los frenos que se aplican en las paradas del autobús y los limpiaparabrisas, deben situarse en el área de acceso principal. Otros menos empleados pueden colocarse en otro sitio (en un tablero de control lateral, por ejemplo).

El análisis de los movimientos oculares demuestra que la conducción del vehículo en condiciones de tráfico normales y la observación de la entrada y salida de pasajeros en las paradas sobrecargan gravemente la atención del conductor. Por ello, la información que aportan los instrumentos y los testigos luminosos del vehículo debe limitarse a lo imprescindible. La informática aplicada a los vehículos permite sustituir numerosos instrumentos e indicadores por una pantalla informativa de cristal líquido montada en el centro del cuadro de mandos, como ilustran las Figuras 102.8 y 102.9.

Con los programas informáticos adecuados, la pantalla mostrará únicamente los datos necesarios en cada situación. En caso de avería, una descripción del fallo acompañada de instrucciones breves y claras, sin pictogramas difíciles de interpretar, proporcionará al conductor una asistencia muy valiosa. Las indicaciones de avería se pueden jerarquizar (por ejemplo: "información" en el caso de averías sin importancia, "alarma" si el vehículo debe detenerse de inmediato).

Los sistemas de calefacción instalados en autobuses suelen acondicionar el interior sólo con aire caliente. Pero para lograr verdadera comodidad conviene aumentar la proporción de calor radiante (por ejemplo, calentando las paredes laterales, cuya temperatura de superficie suele ser muy inferior a la de la atmósfera interior). Esto se logra haciendo circular aire caliente a través de paneles perforados que, de este modo, adquirirán la temperatura adecuada. En el puesto de conducción de los autobuses se emplean grandes superficies acristaladas para mejorar la visibilidad y también por motivos estéticos. Estas ventanas favorecen el recalentamiento del interior por acción de los rayos solares. En estas condiciones es aconsejable instalar aire acondicionado.

La calidad del aire en el puesto de conducción depende en gran media de la atmósfera exterior. Cuando el tráfico es intenso, se alcanzan con facilidad concentraciones transitorias elevadas de sustancias nocivas, como monóxido de carbono y emisiones de motores diesel. La situación mejora sustancialmente si las tomas de aire externas se sitúan en lugares más despejados, como el techo del vehículo en lugar del frontal; asimismo, hay que emplear filtros de retención de partículas.

En la mayoría de las empresas de transporte, una parte importante de la actividad de los conductores consiste en la venta de billetes, el manejo de los dispositivos de información a los pasajeros y la comunicación con la estación de control. Hasta la fecha se han utilizado para realizar estas actividades equipos independientes situados en el espacio de trabajo disponible y, con frecuencia, difíciles de alcanzar para el conductor. Hay que procurar desde un principio integrar todos los dispositivos en el diseño de manera ergonómica, sobre todo los controles de entrada y los paneles de información.

Por último, es fundamental la evaluación del área de conducción por parte de los propios conductores, cuyos intereses personales deben tenerse en cuenta. Detalles considerados menores, como la colocación de la bolsa del conductor o de huecos con llave para guardar efectos personales, son elementos importantes de la satisfacción de estos profesionales.

\section{OPERACIONES DE SUMINISTRO DE COMBUSTIBLE Y MANTENIMIENTO DE VEHICULOS DE MOTOR}

Richard S. Kraus

Los combustibles y lubricantes derivados del petróleo se venden directamente a los consumidores en estaciones de servicio con o sin personal encargado de repostar (y con o sin taller de reparaciones), instalaciones para el lavado de vehículos, centros de servicio a automóviles, agencias de vehículos de motor, paradas de camiones, talleres de reparación, almacenes de piezas de recambio para automóviles y establecimientos de venta de productos de horario amplio. Los empleados de las estaciones de servicio, los mecánicos y otros trabajadores que repostan, lubrican y prestan otros servicios a los vehículos de motor deben conocer los riesgos físicos y químicos de los combustibles, lubricantes y aditivos derivados del petróleo, así como de los residuos con los que entran en contacto, y atenerse a los procedimientos de trabajo seguros y las medidas de protección personal pertinentes. Estos mismos riesgos existen en otros establecimientos comerciales, como los gestionados por las flotas de camiones, agencias de alquiler de automóviles y empresas de autobuses para repostar y mantener sus propios vehículos.

Puesto que se trata de las instalaciones en las que se suministra directamente combustible a los vehículos de los usuarios, las estaciones de servicio en general, y las de autoservicio en particular, son los lugares donde los trabajadores y el público en su conjunto tienen más probabilidades de entrar en contacto directo con productos petrolíferos peligrosos. Aparte de los conductores que cambian el aceite y lubrican sus vehículos, la probabilidad de contacto de los automovilistas con lubricantes o aceite usado, salvo en el caso de accidente al comprobar los niveles de fluidos, es muy reducida.

\section{Operaciones en las estaciones de servicio}

\section{Isletas de abastecimiento de combustible y sistema de suministro}

Los trabajadores deben ser conscientes de los posibilidad de incendio y de los riesgos para la salud y la seguridad relacionados con la gasolina, el queroseno, el gasóleo y otros combustibles suministrados en las estaciones de servicio. Asimismo, deben conocer las precauciones oportunas, como el abastecimiento de combustible a vehículos y depósitos en condiciones de seguridad, la limpieza y eliminación de vertidos, la extinción de incendios incipientes y el drenaje seguro de combustibles. Las estaciones de servicio deben disponer de surtidores que funcionen únicamente cuando se retire la manguera de su soporte y se activen los interruptores de forma manual o automática. Los surtidores deben instalarse en isletas o protegidos de los daños producidos por choques mediante barreras o bordillos altos. Los equipos de suministro, las mangueras y las bocas deben inspeccionarse periódicamente para detectar, fugas, daños y averías. Los surtidores deben dotarse de mecanismos de seguridad, como los dispositivos de emergencia que retienen el líquido a ambos lados del punto de ruptura o las válvulas contra impactos con uniones fusibles en la base de los surtidores, que se cierran automáticamente en caso de golpe fuerte o incendio. 
Las normativas públicas y las políticas de las empresas pueden exigir la colocación de carteles en las áreas de suministro semejantes a los siguientes, utilizados en Estados Unidos:

- "Prohibido fumar - Apague el motor"

- "ATENCION: es ilegal y peligroso suministrar gasolina en recipientes no autorizados"

- "La legislación federal prohibe el suministro de gasolina con plomo o fósforo a los automóviles con la etiqueta SOLO GASOLINA SIN PLOMO"

- "GASOLINA SIN PLOMO", colocado en los surtidores de este tipo de combustible y "CONTIENE GOMPUESTOS DE PLOMO ANTIDETONANTES", situado en los surtidores de gasolina con plomo.

\section{Suministro de combustible a vehículos}

Los trabajadores de las estaciones de servicio deben conocer donde se encuentran los interruptores de emergencia de los surtidores y cómo activarlos, además de los riesgos potenciales y los procedimientos para abastecer de combustible a los vehículos en condiciones de seguridad, como los siguientes:

- Apagar el motor y no fumar mientras se reposta para reducir los riesgos de un movimiento accidental de los vehículos, derrames e ignición de los vapores del combustible.

- Al suministrar el combustible, la boca de la manguera debe insertarse en el depósito del vehículo y mantenerse en contacto con éste para establecer una conexión eléctrica hasta que la operación haya concluido. La boca no debe mantenerse abierta bloqueando el gatillo con un tapón de combustible u otro objeto. En su caso, se utilizarán con este fin enganches autorizados.

- Las hormigoneras, ciertos automóviles de recreo y otros vehículos dotados de motores de combustión interna auxiliares deben apagar estos motores auxiliares y el principal antes de repostar. Hay que tener cuidado al suministrar combustible a vehículos de recreo y de otro tipo equipados con hornos de gas, frigoríficos o calentadores de agua, para garantizar que los vapores de aquél no prendan por la acción de las luces testigo. Para abastecer de combustible a los camiones, los trabajadores no deben situarse en el larguero, en la plataforma ni en el depósito.

- Los depósitos de combustible de motocicletas, ciclomotores, carretillas elevadoras y vehículos similares no se deben llenar con el motor en marcha o con alguien sentado sobre los mismos. El suministro debe hacerse despacio, para evitar salpicaduras que puedan caer en el motor caliente e iniciar un incendio.

- Después de repostar, hay que colocar inmediatamente la boca de la manguera en su soporte del surtidor, apagar las bombas y cerrar el tapón del depósito o el recipiente.

\section{Suministro de combustible en recipientes portátiles}

Las estaciones de servicio deben establecer procedimientos como los siguientes para suministrar combustible en recipientes portátiles en condiciones de seguridad:

- Cuando así lo exija la normativa pública o las políticas de las empresas, el combustible sólo se suministrará en recipientes portátiles debidamente identificados y etiquetados, con o sin conductos, bocas o mangueras de abastecimiento y equipados con aberturas de ventilación y tapas roscadas o de cierre automático por gravedad, de resorte o mixto o con dispositivos de cierre de unión fusible diseñados para aliviar la presión.

- Los recipientes se depositan en el suelo y se llenan despacio para evitar las salpicaduras y el rebosamiento y para mantener el contacto con tierra. No se llenarán recipientes situados en vehículos o plataformas de camiones, sobre todo los revestidos de plástico, ya que no podrá conseguirse una puesta a tierra adecuada. Hay que facilitar y utilizar cables y pinzas de puesta a tierra o mantener el contacto entre las bocas de la manguera y los recipientes para garantizar la conexión durante el llenado, así como entre la boca o el embudo del recipiente y los depósitos donde se vierta el contenido de aquél.

- $\mathrm{Al}$ verter el combustible de recipientes que carezcan de boca incorporada, hay que utilizar un embudo para reducir al mínimo los derrames y evitar salpicaduras.

- Los recipientes portátiles que contengan combustible o vapores deben almacenarse adecuadamente en armarios autorizados o en locales alejadas de fuentes de calor e ignición.

\section{Depósitos de almacenamiento, conductos de llenado, cierres y válvulas de alivio}

Las válvulas de llenado y los aforadores de los depósitos de combustible situados bajo o sobre rasante deben mantenerse cerrados, salvo en las operaciones de llenado y medición, con el fin de reducir al mínimo la emisión de vapores de combustible. Si las aberturas de los aforadores están situadas en edificios, hay que instalar válvulas de comprobación cargadas por resorte o dispositivos similares para evitar el derramamiento de combustible y la emisión de vapores a través de dichas aberturas. Las válvulas de alivio de los depósitos deben ubicarse de acuerdo con las normativas públicas y la política de las empresas. Si se permite la salida directa al aire de las válvulas, los conductos de alivio procedentes de depósitos subterráneos o de superficie deben situarse en alto, de modo que los vapores inflamables se alejen de fuentes potenciales de combustión y no penetren por ventanas, tomas de aire o puertas ni queden atrapados bajo aleros o salientes.

La falta de identificación de los depósitos o la colocación incorrecta de los códigos de colores o las señales puede dar lugar a una combinación indebida de productos durante el abastecimiento. Tapas, conductos de llenado, válvulas e hileras o cuadros de llenado de los depósitos de almacenamiento deben identificarse en cuanto a productos y calidades para reducir el riesgo de errores en el abastecimiento. Los símbolos de identificación y los códigos de colores deben ser coherentes con los reglamentos públicos, las políticas de las empresas y las normas de la industria, como la Recomendación Practica 1637 del American Petroleum Institute (API), Using the API Color Symbol System to Mark Equipment and Vehicles for Product Identification at Service Stations and Distribution Terminals. En las estaciones de servicio habrá un cuadro con los símbolos y códigos de color vigentes para su consulta durante el abastecimiento.

\section{Suministro de combustible a las estaciones de servicio}

Las estaciones de servicio deben establecer y aplicar procedimientos como los indicados a continuación para el suministro seguro de combustible a sus depósitos de almacenamiento subterráneos o de superficie:

\section{Antes de la descarga}

- Los vehículos y otros objetos deben retirarse del área en la que se situarán el camión cisterna encargado del suministro y las mangueras utilizadas al efecto.

- Los camiones cisterna se situarán alejados de las zonas de tráfico y se colocarán conos o barreras para evitar el paso de vehículos por las proximidades del área de descarga o por encima de las mangueras mediante la utilización de conos o barreras. 
- Los depósitos de almacenamiento receptores del combustible se revisarán antes de la entrega para determinar si tienen capacidad suficiente o si hay agua en su interior.

- Los conductores deben tener la seguridad de que el combustible se carga en los depósitos correctos, de que las tapas de medición se colocan antes de iniciar el suministro y de que todas las salidas de los depósitos no utilizadas en la descarga permanecen tapadas.

- Cuando así lo exijan las políticas de las empresas o los reglamentos públicos, el sistema de recuperación de vapores de los camiones cisterna deben conectarse con el depósito de almacenamiento receptor antes de iniciar el suministro.

\section{Durante la descarga}

- Los conductores deben supervisar el área cercana a las válvulas de alivio del depósito receptor para detectar posibles fuentes de ignición y comprobar si dichas válvulas funcionan correctamente durante el suministro.

- Los conductores se situarán donde puedan observar el suministro y tengan la posibilidad de detenerlo o adoptar las medidas pertinentes en caso de emergencia, como salida de líquido por las válvulas o la activación de una alarma indicadora de rebosamiento o de fallo en una válvula de alivio.

\section{Después de la descarga}

- Se medirán los depósitos de almacenamiento para comprobar que cada uno ha recibido los productos correctos en las cantidades adecuadas, de acuerdo con la nota o el conocimiento de entrega. Pueden tomarse muestras de los depósitos tras el suministro con fines de control de calidad.

- En caso necesario, se drenarán los dispositivos de contención de derrames y volverán a colocarse los cierres de los medidores y las tapas de los depósitos.

\section{Otras funciones de las estaciones de servicio}

\section{Almacenamiento de líquidos inflamables y combustibles}

Los reglamentos de la administración pública y las normas de las empresas contienen normalmente disposiciones sobre almacenamiento, manipulación y suministro de líquidos inflamables y combustibles y sustancias químicas de automoción como pinturas, aditivos para el arranque, anticongelantes, ácidos de batería, líquidos para el limpiaparabrisas, disolventes y lubricantes en estaciones de servicio. Estos establecimientos deben almacenar los aerosoles y los líquidos inflamables en contenedores cerrados en áreas autorizadas y dotadas de ventilación

\section{Tabla 102.2 • Niveles de iluminación en las distintas} áreas de las estaciones de servicio.

\begin{tabular}{ll} 
Area de la estación de servicio & $\begin{array}{l}\text { Luminosidad propuesta } \\
\text { en bujías-pie }\end{array}$ \\
\hline $\begin{array}{l}\text { Areas de tráfico activo } \\
\text { Areas de almacenamiento y depósitos }\end{array}$ & 20 \\
Lavabos y áreas de espera & $30-20$ \\
$\begin{array}{l}\text { Zonas de repostaje, bancos de trabajo y áreas de } \\
\text { caja }\end{array}$ & 50 \\
Areas de servicio, reparación, lubricación y lavado & 100 \\
Oficinas & $100-150$ \\
\hline
\end{tabular}

adecuada, alejados de fuentes de calor o ignición, en salas, armarios o estantes apropiados o en edificios externos separados.

\section{Seguridad eléctrica e iluminación}

Los trabajadores de las estaciones de servicio deben conocer los principios fundamentales de seguridad eléctrica aplicables a este tipo de establecimientos, como los que se refieren a continuación:

- Las instalaciones, los equipos y los dispositivos eléctricos y de iluminación de la categoría pertinente deben ser utilizados y mantenidos de acuerdo con los códigos y reglamentos vigentes y no deben sustituirse por otros de categoría inferior.

- Las herramientas eléctricas, los enfriadores de agua, las máquinas de fabricación de hielo, los refrigeradores y otros equipos eléctricos similares deben dotarse de una toma de tierra adecuada. Las lámparas portátiles se protegerán contra la rotura para reducir al mínimo la posibilidad de que una chispa prenda los vapores inflamables en caso de que se rompa la bombilla.

Se dispondrá de una iluminación adecuada en los lugares oportunos de las estaciones de servicio con el fin de reducir la probabilidad de accidentes y lesiones. Son fuentes de consulta apropiadas para determinar los niveles de iluminación los reglamentos públicos, las políticas de la empresa y las normas sectoriales voluntarias. Véase la Tabla 102.2.

\section{Bloqueo y señalización}

Las estaciones de servicio deben establecer y aplicar procedimientos de bloqueo y señalización para evitar la liberación de formas de energía potencialmente peligrosas durante las operaciones de mantenimiento, reparación y prestación de servicio con herramientas, equipos, maquinaria y sistemas eléctricos, mecánicos, hidráulicos y neumáticos, como elevadores, montacargas, gatos, equipos de lubricación, surtidores y compresores. Los procedimientos de trabajo en condiciones de seguridad adoptados para evitar el arranque accidental de motores de vehículos durante su mantenimiento o reparación deben incluir la desconexión de la batería o la retirada de la llave de encendido.

\section{Líquidos en las estaciones de servicio}

Niveles de líquidos y refrigerantes

Antes de empezar a trabajar bajo el capó de un vehículo hay que cerciorarse de que se mantiene abierto comprobando el mecanismo tensor o sujetándolo con una barra. También hay que tomar precauciones al comprobar los niveles para evitar quemaduras por contacto con el colector de escape o el contacto accidental de la varilla de medición con terminales o cables eléctricos; asimismo, es necesario tener cuidado al verificar el nivel del aceite de la caja de cambios, ya que el motor debe estar en marcha. También es preciso atenerse a los procedimientos de trabajo seguros al abrir radiadores, dejando que se enfríen los que se encuentran presurizados, sujetando el tapón con un trapo grueso, utilizando EPI y girando la cara para evitar la inhalación de los humos o vapores que se liberen.

\section{Anticongelante y líquido lavaparabrisas}

Los trabajadores encargados de prestar servicio a los vehículos deben ser conscientes de los riesgos asociados a los anticongelantes de glicol y alcohol y a los líquidos concentrados empleados en el circuito del lavaparabrisas, así como del modo seguro de manipularlos. Se incluyen aquí precauciones como el almacenamiento de productos derivados del alcohol en bidones cerrados herméticamente o contenedores embalados, en salas o armarios aislados y alejados de los equipos de calefacción y la utilización de recipientes que eviten la contaminación de desagües y terrenos 
en caso de derrame o fuga de anticongelante de glicol. Los líquidos anticongelantes o lavaparabrisas se vierten desde un bidón en posición vertical con ayuda de una bomba de mano bien conectada y provista de un mecanismo antigoteo; nunca se utilizarán espitas o válvulas que obliguen a colocar el bidón horizontal, pues esto aumenta el riesgo de fugas, roturas y golpes. No debe utilizarse aire a presión para bombear anticongelante o lavaparabrisas concentrados. Los recipientes vacíos de estos productos deben vaciarse completamente antes de eliminarlos, y seguirse las normas gubernamentales aplicables a la eliminación de soluciones anticongelantes de glicol.

\section{Lubricación}

Las estaciones de servicio deben asegurarse de que sus trabajadores conozcan las características y los usos de los diversos combustibles, aceites, lubricantes, grasas, líquidos de automoción y sustancias químicas presentes en sus instalaciones, así como su correcta selección y aplicación. Deben utilizarse las herramientas adecuadas para desmontar los tapones de vaciado, los indicadores de nivel y los filtros de aceite del cárter, la caja de cambios y el diferencial, de forma que no se dañen los vehículos ni los equipos. Sólo deben utilizar llaves de tubo, alargadores y cortafríos los trabajadores que sepan abrir con seguridad tapones congelados u oxidados. Debido a los posibles riesgos, los dispositivos de lubricación de alta presión sólo se pondrán en marcha cuando las boquillas se hayan fijado firmemente a las tomas de aceite. Si es necesario efectuar una prueba antes del empleo real, la boquilla debe dirigirse a un bidón vacío o un recipiente similar y no a un trapo sostenido con la mano.

\section{Operaciones de izado}

Quienes trabajan dentro y en torno a las áreas de mantenimiento de vehículos deben conocer las situaciones poco seguras y atenerse a las buenas prácticas de trabajo, como evitar colocarse delante de los automóviles cuando éstos son conducidos a zonas de reparación, fosos de lubricación o plataformas elevadoras.

- Los vehículos deben alinearse correctamente en los elevadores de dos pistas, de rueda libre o de bastidor, ya que cualquier deslineado puede provocar una caída.

- Antes de poner en funcionamiento el elevador, hay que asegurarse de que no hay nadie dentro del vehículo y de que no hay ningún obstáculo sobre él.

- Una vez colocado el vehículo, debe aplicarse el dispositivo de parada de emergencia para evitar que el elevador caiga en caso de una bajada de presión. Si el elevador se sitúa de modo que el dispositivo mencionado no puede emplearse, se colocarán bajo el mismo o bajo el vehículo calzos o soportes de seguridad.

- Los elevadores hidráulicos deben equiparse con una válvula de control que impida el funcionamiento en caso de descenso del nivel de aceite en el depósito de suministro, ya que pueden producirse caídas accidentales en tal situación.

Cuando la lubricación de los cojinetes de las ruedas, la reparación de los frenos, el cambio de neumáticos y otros servicios se prestan en elevadores de rueda libre o de bastidor, los vehículos deben elevarse ligeramente sobre el suelo para que los trabajadores desarrollen su actividad en cuclillas y se reduzca así la posibilidad de lesiones en la espalda. Tras la elevación del vehículo, las ruedas deben bloquearse para impedir su giro, y deben colocarse soportes de seguridad para garantizar la posición en caso de avería del gato o del mecanismo de izado. Al desmontar las ruedas de vehículos en elevadores a los que se sube conduciendo, los vehículos deben bloquearse para impedir su desplazamiento. Si se utilizan gatos o soportes para izar y mantener los vehículos en posición elevada, estos instrumentos deben tener la capacidad adecuada, situarse en los lugares correctos y ser comprobados para verificar su estabilidad.

\section{Mantenimiento y reparación de neumáticos}

Los trabajadores deben aprender a comprobar presiones e hinchar neumáticos en condiciones de seguridad; hay que inspeccionar el desgaste de la banda de rodadura, no sobrepasar la presión máxima y permanecer de pie o de rodillas, a un lado del neumático y con la cara vuelta mientras se infla. Hay que ser consciente del riesgo y seguir métodos de trabajo seguros al reparar ruedas de camión y remolque con llanta de una o varias piezas o con pestañas de retención. $\mathrm{Al}$ reparar los neumáticos con compuestos o líquidos inflamables o tóxicos de pegar parches, hay que adoptar precauciones como evitar fuentes de ignición, usar EPI y contar con ventilación adecuada.

\section{Limpieza de componentes}

Los trabajadores de estaciones de servicio deben conocer los riesgos de incendio y para la salud derivados de la utilización de gasolina o de disolventes de punto de ignición bajo en la limpieza de componentes, y seguir prácticas seguras como el uso de disolventes autorizados con un punto de ignición superior a $60{ }^{\circ} \mathrm{C}$. Los dispositivos de lavado estarán provistos de una tapa protectora que ha de permanecer cerrada cuando no se utilizan; una vez abierta, necesita un dispositivo de sujeción o una unión fusible que la cierre automáticamente en caso de incendio. Los trabajadores deben adoptar precauciones para impedir que la gasolina u otros líquidos inflamables contaminen el disolvente de limpieza y reduzcan su punto de ignición, con el consiguiente riesgo de incendio. Los disolventes contaminados deben retirarse y colocarse en contenedores autorizados para su evacuación o reciclado. Los trabajadores dedicados a la limpieza de componentes y equipos que utilizan disolventes de limpieza deben evitar el contacto de éstos con la piel y los ojos y emplear el EPI apropiado. Los disolventes no deben utilizarse para lavarse las manos ni para la higiene personal.

\section{Aire comprimido}

Las estaciones de servicio deben establecer prácticas de trabajo seguras con compresores neumáticos y equipos de aire comprimido. Las mangueras deben emplearse sólo para inflar neumáticos y para servicios auxiliares, de lubricación, y de mantenimiento. Los trabajadores deben ser conscientes del riesgo de someter a presión depósitos de combustible, bocinas neumáticas, depósitos de agua y otros recipientes no diseñados para contener aire comprimido. Este no debe utilizarse para limpiar frenos, pues en muchos casos, sobre todo en modelos antiguos, los forros contienen amianto. Deben emplearse métodos más seguros como la limpieza por aspiración o la aplicación de soluciones líquidas.

\section{Mantenimiento y manipulación de baterías de acumuladores}

Las estaciones de servicio deben establecer procedimientos para garantizar que al almacenar, manipular y eliminar las baterías y los electrolitos que contienen se cumplen las normativas públicas y las políticas de las empresas. Los trabajadores deben ser conscientes del riesgo de cortocircuito eléctrico al cargar, sacar, instalar o manipular baterías; hay que desconectar el cable de masa (negativo) antes de sacar la batería y dejar para el final la conexión de ese cable al instalarla. Al sacar y sustituir baterías, hay que utilizar un dispositivo de transporte para facilitar su manipulación y evitar el contacto con la misma.

Para manipular las soluciones de las baterías, los trabajadores deben conocer las prácticas de seguridad siguientes: 
- Los recipientes con soluciones electrolíticas deben almacenarse a una temperatura comprendida entre 16 y $32{ }^{\circ} \mathrm{C}$, en áreas seguras donde no puedan volcarse. Los vertidos de estas soluciones sobre las baterías o en el área de llenado se eliminan con agua. Puede utilizarse bicarbonato sódico para neutralizar la acidez de estos líquidos.

- Para llenarlas de electrolito, las baterías nuevas se colocan en el suelo o en un banco de trabajo y se cierran con sus tapones antes de montarlas; nunca deben rellenarse estas baterías sin desmontarlas del vehículo.

- Pueden utilizarse mascarillas faciales, gafas, delantales y guantes de protección química para evitar la exposición a los líquidos de batería. Además, éstos deben manipularse siempre en lugares provistos de una fuente de agua potable $u$ otro líquido para el lavado ocular en caso de vertido o contacto con la piel o los ojos. Estos órganos no deben tratarse con líquidos neutralizadores.

- Al mantener baterías, hay que cepillar, lavar con agua limpia o neutralizar con bicarbonato sódico o similar las partículas corrosivas acumuladas en los bornes; es preciso evitar su contacto con los ojos o la ropa.

Los trabajadores deben comprobar el nivel de líquido en la batería antes de cargarla y vigilar la temperatura durante la carga para que no aumente en exceso. Una vez terminada la carga, se desconecta el cargador antes que los cables, para evitar chispas que puedan provocar la inflamación del hidrógeno que se genera durante la carga. Al montar baterías de carga rápida, hay que alejar el vehículo de la zona de suministro de combustible y desconectar el cable de masa (negativo) antes de conectar el equipo de carga. Hay que desmontar la batería si está en el compartimiento de pasajeros o bajo el suelo del vehículo.

Los trabajadores deben conocer los riesgos y los procedimientos seguros para arrancar vehículos con la batería descargada conectando ésta a otra, tanto para evitar averías en el circuito eléctrico como lesiones por explosión de la batería si los cables de conexión se instalan mal. Jamás deben conectarse a otra batería ni cargarse las baterías congeladas.

\section{Conducción y remolque de vehículos}

Los trabajadores deben disponer del permiso pertinente y estar capacitados y cualificados para conducir vehículos de los clientes o de la empresa, camiones de servicio o equipos de remolque, tanto en el interior como en el exterior de las instalaciones. Todos los vehículos deben conducirse de conformidad con las normativas públicas y las políticas de las empresas. Los operarios deben comprobar en primer lugar los frenos: los vehículos cuyo sistema de frenado sea defectuoso no deben conducirse. Los encargados de los vehículos de remolque deben conocer los métodos de trabajo seguros: manejo de la grúa, comprobación de la transmisión y el chasis del vehículo remolcado, capacidad de izado máxima, etc.

\section{Espacios confinados en las estaciones de servicio}

Los trabajadores de las estaciones de servicio deben ser conscientes de los riesgos propios de la entrada en espacios confinados, como depósitos situados por encima o por debajo del nivel del suelo, sumideros, fosos de bombeo, depósitos de almacenamiento de residuos, fosas sépticas y pozos colectores de protección del medio ambiente. No se permitirá el acceso no autorizado, y se establecerán procedimientos para la entrada en estos espacios, aplicables tanto a los trabajadores como a los operarios de los contratistas.

\section{Procedimientos de emergencia}

Las estaciones de servicio deben elaborar procedimientos de emergencia y los trabajadores deben saber cómo activar las alarmas, cómo notificar a las autoridades las situaciones de emergencia, cuándo y cómo proceder a una evacuación y qué medidas de respuesta deben adoptarse (como el cierre de los interruptores de emergencia en el caso de derrames o incendios en las áreas de suministro de combustible). Las estaciones de servicio pueden establecer programas de seguridad para dar a conocer a sus trabajadores las medidas oportunas de prevención de robos y actos de violencia, dependiendo de la localización de las instalaciones, los horarios de funcionamiento y las amenazas potenciales.

\section{Salud y seguridad en estaciones de servicio}

\section{Protección contra incendios}

Los vapores de gasolina son más pesados que el aire y pueden recorrer grandes distancias y alcanzar fuentes de ignición una vez liberados en las operaciones de llenado, por derrame, rebosamiento o reparación. Hay que garantizar la ventilación adecuada de los locales cerrados para disipar estos vapores. Pueden iniciarse incendios debidos a los derrames y rebosamientos que se producen al repostar o reparar vehículos o al verter combustible en los depósitos de las estaciones de servicio, sobre todo si no se prohibe fumar o si los motores de los vehículos permanecen en marcha al repostar. Para evitar incendios hay que alejar los vehículos de la zona de derrame y limpiar la gasolina vertida por debajo o cerca de ellos antes de arrancar el motor. Ningún vehículo debe entrar en zonas afectadas por vertidos ni circular por ellas.

Los trabajadores deben conocer otras causas de incendio en las estaciones de servicio, como la manipulación, el trasvase o el almacenamiento indebidos de líquidos inflamables y combustibles, los vertidos accidentales durante la reparación de los sistemas de suministro, la descarga electrostática al cambiar los filtros de los surtidores de gasolina y la utilización de luces de trabajo inadecuadas o desprotegidas. El drenaje de gasolina procedente de los depósitos de combustible de los vehículos puede resultar muy peligroso, debido a la posibilidad de que se liberen combustible y vapores, sobre todo en áreas de servicio cerradas con fuentes de ignición próximas.

Deben obtenerse permisos para trabajar en caliente cuando se realicen tareas distintas de la reparación y el mantenimiento de vehículos que obliguen a introducir fuentes de ignición en zonas con vapores inflamables. Los mecánicos deben ser conscientes del riesgo que supone cebar el carburador con el motor en marcha o cuando se arranca con el circuito de arranque eléctrico, pues el riesgo de ignición de los vapores del combustible es muy alto. Hay que seguir los procedimientos de seguridad, como cebar con líquido de arranque y no con gasolina y utilizar pinzas para mantener abierto el circuito de la bobina durante el arranque del motor.

Aunque las normativas públicas o las políticas de las empresas exijan la instalación de sistemas fijos de protección contra incendios, los extintores suelen constituir el medio fundamental utilizado con este fin en las estaciones de servicio. Estos lugares deben dotarse de extintores de la categoría adecuada para los riesgos previstos. Los extintores y los sistemas mencionados deben someterse a inspecciones, mantenimiento y reparación regulares, y los trabajadores deben saber cuándo, dónde y cómo utilizarlos o activarlos.

Debe haber interruptores de emergencia en los surtidores en lugares accesibles y claramente identificados, y el personal debe conocer la función, la localización y el funcionamiento de estos 
Figura 102.10 • Lista de comprobación de salud y seguridad en estaciones de servicio.

Esta lista de comprobación puede utilizarse como guía de las cuestiones que pueden considerarse al evaluar la protección contra incendios y las actividades en materia de salud y seguridad de una estación de servicio.

SALUD Y SEGURIDAD

Mantenimiento de registros y presentación de informes

- Asistencia médica y primeros auxilios

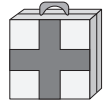

FORMACION, EDUCACION Y CUALIFICACION DE LOS TRABAJADORES $\square$ Sensibilización, prevención y protección de riesgos

Cualificaciones mecánicas

- Actuación en caso de emergencia

Métodos seguros de levantamiento de cargas

$\square$ Equipos de protección individual

Calzado, ropa y joyas utilizados por los trabajadores

PROTECCION Y PREVENCION DE INCENDIOS

$\checkmark$ Trabajo en caliente

Extintores de incendio

$\square$ Sistemas de protección fijos

$\square$ Interruptores de emergencia

$\square$ Almacenamiento, manipulación y suministro de líquidos inflamables y combustibles en recipientes

PREPARACION EN CASO DE EMERGENCIA

$\square$ Plan y procedimientos de actuación en caso de emergencia/incidente

- Números de teléfono de emergencia

Alarmas, vías de evacuación y salidas

SALUD, SEGURIDAD, PREVENCION DE INCENDIOS Y NOTAS, SEÑALES Y ETIQUETAS PREVISTAS POR LA LEGISLACION

$\square$ Comunicación de riesgos en estaciones de servicio

$\checkmark$ Señales y notas

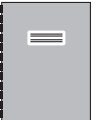

ZONAS DE SUMINISTRO DE COMBUSTIBLE

$\square$ Protección de las zonas de suministro

$\square$ Sistema de suministro de combusible

$\square$ Derrames y drenaje de combustible

- 5 Suministro de combustible a vehículos

Suministro de combustible a motoidtas $y$ pente

- Llenado de recipientes de combustible portátiles

$\square$ Limpieza de parabrisas

$\square$ Control de lubricantes, refrigerantes y niveles de líquidos

SEGURIDAD EN RELACION CON EL COMBUSTIBLE

$\square$ Riesgos relativos a los vapores de líquidos inflamables

$\square$ Cebado de carburadores

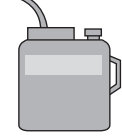

OPERACIONES DE ENTREGA

$\square$ Recepción y almacenamiento

$\square$ Depósitos de almacenamiento al descubierto y subterráneos

$\square$ Tuberías y compuertas de llenado de los depósitos de almacenamiento

$\square$ Respiraderos de los depósitos de almacenamiento

$\square$ Control de inventario

OPERACIONES GENERALES EN LAS ZONAS DE TALLER

$\square$ Operaciones de izado

$\square$ Aceites, grasas y fluidos

$\square$ Servicio de lubricación

Sustitución y evacuación de filtros

$\square$ Drenaje de aceite y líquidos de transmisión

REPARACIONES Y MANTENIMIENTO DE VEHICULOS Y EQUIPOS

$\square$ Bloqueo y señalización

$\square$ Herramientas de mano y mecánicas

$\square$ Correa del ventilador, correa de transmisión, etc.

$\square$ Reparaciones y sustitución del sistema de escape de gases

- Mantenimiento y reparación de bujías, carburador e inyección de combustible

$\square$ Gas comprimido para operaciones de soldadura autógena,

corte y soldadura

$\square$ Soldadura con arco eléctrico

$\checkmark$ Pulidoras de banco o de pedesta

L Líquidos y lavadoras de piezas de repuesto

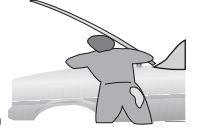

Operaciones de acabado con pintura pulverizado

$\square$ Relleno de resina plástica para carrocerías

MANTENIMIENTO DE RADIADORES

Comprobación de los niveles de refrigerante de radiador

Almacenamiento, manipulación y evacuación de anticongelante

$\square$ Reparación y sustitución de radiadores

COMPRESORES DE AIRE

- Funcionamiento, mantenimiento e inspección de compresores de aire

$\square$ Mangueras y bocas de los compresores de aire

MANTENIMIENTO DE FRENOS

Sensibilización respecto al amianto

$\square$ Utilización indebida del aire en tareas de limpiezo
MANTENIMIENTO DE BATERIAS

$\square$ Almacenamiento y manipulación de baterías

$\square$ Carga de baterías

$\square$ Cables de carga y arranque con cables de carga

L Líquidos de las baterías

$\square$ Retirada e instalación de baterías

OTRAS CUESTIONES RELATIVAS A LA SALUD Y LA SEGURIDAD EN EL LUGAR DE TRABAJO

$\square$ Lavado de vehículos

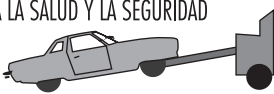

$\square$ Conducción de los vehículos de los clientes

$\square$ Remolque de vehículos

MANTENIMIENTO DE NEUMATICOS

$\checkmark$ Comprobación e inflado de neumáticos

$\square$ Retirada de neumáticos

$\square$ Reparación y montaje de neumáticos

$\square$ Depósito y almacenamiento de neumáticos

Neumáticos de camión

$\square$ Equilibrado y alineación de neumáticos

\section{CONDICIONES FISICAS}

$\square$ Conservación, mantenimiento y condiciones físicas

$\square$ luminación

$\square$ Manipulación y almacenamiento de mercancías

$\square$ Retirada de nieve, hielo y agua de lluvia

$\square$ Equipos de calefacción, ventilación y aire acondicionado

$\square$ Ventilación de vapores y gases de escape

$\square$ Escaleras

Espacios confinados en estaciones de servicio

$\square$ Seguridad eléctrica

$\square$ Manipulación y almacenamiento seguros de alimentos

(en su coso)

$\square$ Lavabos e higiene

\section{MEDIO AMBIENTE}

$\square$ Derrames, limpieza y evacuación

$\square$ Manipulación de aceite, líquidos, filtros y baterías utilizados

$\square$ Almacenamiento, manipulación y reciclado 0

evacuación de residuos peligrosos dispositivos. Para evitar combustiones espontáneas, los trapos manchados de grasa deben guardarse en contenedores de metal tapados hasta su reciclaje o eliminación.

\section{Seguridad}

Los trabajadores de las estaciones están expuestos a sufrir lesiones por uso incorrecto de herramientas, equipos y escaleras, por no llevar EPI, a consecuencia de caídas o resbalones, por trabajar en mala postura y por levantar y trasladar recipientes de forma incorrecta. Asimismo, se producen lesiones y accidentes por incumplimiento de las prácticas de seguridad al trabajar en radiadores calientes, transmisiones, motores y sistemas de escape de gases, al reparar neumáticos y baterías, al trabajar con elevadores, gatos, equipos eléctricos o maquinaria, a consecuencia de robos y asaltos y por uso inadecuado o exposición a limpiadores, disolventes y sustancias químicas de automoción.

Las estaciones de servicio deben desarrollar y aplicar programas de prevención de accidentes e incidentes imputables a deficiencias de las instalaciones o las prácticas de mantenimiento, almacenamiento y conservación. Otros factores que contribuyen a la accidentalidad en las estaciones de servicio son la falta de atención, formación o cualificación de los trabajadores, que propicia la utilización incorrecta de los equipos, las herramientas, los repuestos de automoción, los suministros y los materiales empleados en las operaciones de mantenimiento. En la Figura 102.10 se ofrece una lista de comprobación en materia de seguridad. 


\section{Violencia en las gasolineras}

Los empleados de las gasolineras ocupan el cuarto lugar en la clasificación de colectivos profesionales en función de las tasas de homicidios registrados en el lugar de trabajo en Estados Unidos y, en casi todos los casos, estas muertes se producen con ocasión de robos a mano armada y otros delitos (NIOSH 1993b). La tendencia reciente a sustituir los talleres de reparación por tiendas de artículos diversos y horario continuado ha agravado la situación. El estudio de las circunstancias en que trabajan estos establecimientos ha permitido la determinación de los siguientes factores de riesgo que explican esta violencia criminal:

- intercambio de dinero con el público;

- trabajo en solitario o con plantillas reducidas;

- trabajo a última hora de la noche y primeras de la mañana;

- prestación de servicio en zonas de criminalidad elevada;

- guarda de bienes o propiedades valiosos; y

- trabajo en barrios.

Otro factor de riesgo es la ubicación en lugares de fácil acceso y especialmente apropiados para una huida rápida.

Para defenderse de los intentos de robo, algunos empleados de gasolineras se han procurado bates de béisbol y otros instrumentos similares, e incluso han adquirido armas de fuego. La mayoría de las autoridades policiales se oponen a este tipo de medidas, ya que, en su opinión, es probable que provoquen reacciones violentas en los delincuentes. Se recomiendan las siguientes medidas preventivas como medios disuasorios más eficaces en casos de intento de robo:

- intensa iluminación de la áreas de surtidores y de aparcamiento, así como del interior de las tiendas y las zonas de caja;

- disposición de grandes ventanas despejadas y a prueba de balas para mejorar la visibilidad desde el interior de la tienda y dotación de cabinas cerradas de cristal antibalas para los cajeros;
- entradas independientes en el exterior a los servicios públicos, de forma que las personas que los utilicen no tengan que entrar en el establecimiento (un servicio propio en el interior sólo para el personal ofrecería privacidad a los empleados y evitaría la necesidad de salir a utilizar los públicos);

- utilización de cajas móviles y cajas fuertes de apertura temporizada para conservar una cantidad muy limitada de dinero en efectivo, y publicación de señales en lugares visibles que indique el empleo de estos dispositivos;

- formulación de una política de no facilitar cambio en las compras al contado durante la noche y primeras horas de la mañana;

- contratación de un trabajador adicional o de un guardia de seguridad para evitar que preste servicio un solo empleado llas empresas de las gasolineras y las tiendas anexas se quejan del aumento de costes);

- instalación de un sistema de alarma eléctrico o electrónico lactivado por pulsadores de emergencia de fácil accesol que emita señales de auxilio audibles y visibles que atraigan la atención de la policía u otro tipo de asistencia. Estos mecanismos pueden combinarse con una alarma conectada directamente a la comisaría de policía más cercana; e

- instalación de monitores de televisión de alta fidelidad para facilitar la identificación y, en última instancia, la detención de los delincuentes.

La consulta con las autoridades policiales locales y los expertos en la prevención de delitos simplifica la selección de los medios de disuasión más apropiados y eficaces en función del coste. Debe recordarse la necesidad de instalar adecuadamente los equipos y de someter éstos a operaciones periódicas de comprobación y mantenimiento, así como de instruir a los trabajadores en su utilización.

Leon J. Warshaw

Los robos constituyen un riesgo importante para la seguridad en las estaciones de servicio. Las precauciones y la formación adecuadas se analizan en el cuadro adjunto y en otros capítulos de la presente Enciclopedia.

\section{Salud}

Los empleados deben ser conscientes los riesgos para la salud propios del trabajo en estaciones de servicio. A continuación se describen algunos de ellos.

Monóxido de carbono. Los gases de escape de los motores de combustión interna contienen monóxido de carbono, un gas incoloro, inodoro y muy tóxico. El personal debe ser consciente de los peligros de la exposición a esta sustancia, sobre todo cuando los vehículos se encuentran en plataformas de reparación, garajes o instalaciones de lavado con el motor en marcha. Los gases de escape deben ser conducidos al exterior a través de mangueras flexibles y debe asegurarse la ventilación mediante un suministro adecuado de aire fresco. Los dispositivos y calentadores de fueloil deben ser comprobados para garantizar que el monóxido de carbono no penetra en lugares cerrados.

Toxicidad de los combustibles derivados del petróleo. Los trabajadores que entran en contacto con gasolina, gasóleo de automoción o calefacción o queroseno deben ser conscientes de los riesgos potenciales de la exposición a estas sustancias y conocer el modo de manipularlas con seguridad. La inhalación de una concentración suficiente de vapores de este tipo de combustibles durante períodos de tiempo prolongados provoca intoxicaciones leves, anestesia o afecciones más graves. Una exposición breve a concentraciones elevadas provoca mareos, cefaleas y náuseas, así como irritación de ojos, nariz y garganta. Los sifones utilizados para trasvasar gasolina, disolventes o gasóleos nunca deben cebarse con la boca, ya que la toxicidad de los hidrocarburos líquidos de baja viscosidad aspirados directamente a los pulmones es 200 veces superior a la registrada por ingestión. La aspiración accidental puede causar neumonía acompañada de edema pulmonar extenso y hemorragia, con la consecuencia de lesiones graves o muerte. No hay que provocar el vómito, y sí buscar asistencia médica inmediatamente.

Benceno. Los trabajadores de las estaciones de servicio deben conocer los riesgos potenciales del benceno, presente en la gasolina, y no inhalar los vapores de este combustible. Aunque la gasolina contiene benceno, no es probable que la exposición moderada a sus vapores provoque cáncer. Numerosos estudios científicos han puesto de manifiesto que el personal de las estaciones de servicio no está expuesto a niveles de benceno excesivo en el transcurso de su actividad laboral ordinaria; no obstante, siempre hay riesgo de sobreexposición.

Riesgos de dermatitis. Los trabajadores que manipulan y entran en contacto con productos derivados del petróleo como parte de su actividad deben conocer los riesgos de dermatitis y otras afecciones de la piel, así como las medidas de higiene y protección personal necesarias para controlar esta forma de exposición. En caso de contacto ocular con gasolina, lubricantes o anticongelantes, hay que lavarse los ojos con agua potable limpia y tibia y buscar asistencia médica. 
Figura 102.11 • Encapsulamiento portátil para la prevención de la exposición al polvo de amianto procedente de tambores de freno. Está equipado con una pistola de aire comprimido con una manga de algodón y conectado a un limpiador de vacío HEPA.

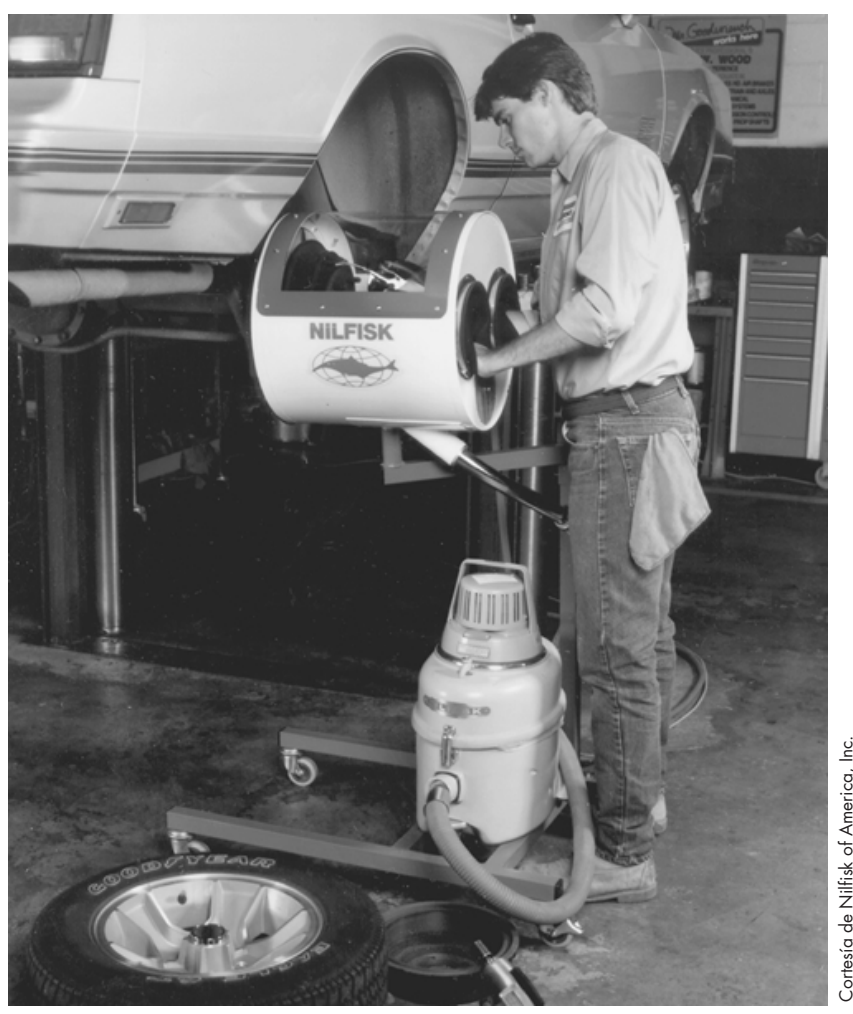

Lubricantes, aceites de motor usados y sustancias químicas de automoción. Los trabajadores que cambian el aceite y otros líquidos a los vehículos de motor, incluidos los anticongelantes, deben conocer los riesgos asociados y conocer el modo de reducir al mínimo la exposición a productos como la gasolina en el aceite de motor usado, el glicol en los anticongelantes y otros contaminantes en los líquidos de transmisión y lubricantes para engranajes, mediante la utilización de EPI y el recurso a buenas prácticas de higiene. En caso de descarga de una pistola de lubricación de aire comprimido contra el cuerpo de un trabajador, el área afectada debe examinarse de inmediato para comprobar si los productos petrolíferos han penetrado en la piel. Estas lesiones causan poco dolor o hemorragia, pero dan lugar a una separación casi instantánea de los tejidos dérmicos y, posiblemente, daños de mayor profundidad que deben ser objeto de atención médica inmediata. El médico encargado del caso debe ser informado de la causa y del producto implicado en la lesión.

Soldadura. La soldadura suma al riesgo de incendio el de contacto con pigmentos de plomo al operar en el exterior de automóviles, así como con vapores metálicos y otros gases. Es necesario instalar dispositivos de ventilación por aspiración local o de protección respiratoria.

Pintura por pulverización y productos de relleno para carrocerías. La pintura por pulverización puede dar lugar a la exposición a vapores de disolventes y partículas de pigmentos (p. ej., de cromato de plomo). Los productos de relleno para carrocerías suelen consistir en resinas epóxicas o de poliéster y pueden constituir un peligro para la piel y el aparato respiratorio. La pulverización de pintura debe efectuarse en cabinas en las que quepa el automóvil completo; los productos de relleno se aplican con extracción local de aire y protecciones para la piel y los ojos.

Baterías de acumuladores. Las baterías contienen soluciones electrolíticas corrosivas de ácido sulfúrico, que pueden provocar quemaduras y otras lesiones en los ojos y la piel. La exposición a este tipo de compuestos debe reducirse al mínimo mediante la utilización de EPI, incluidos guantes de goma y protectores oculares. Los trabajadores deben lavarse los ojos o la piel con agua potable u otro líquido específico durante al menos 15 minutos si estos órganos entran en contacto con dichas soluciones, y buscar atención médica de inmediato. Además, deben lavarse las manos concienzudamente después de trabajar con baterías y evitar el contacto de éstas con la cara y los ojos. Han de ser conscientes de que la sobrecarga de una batería puede generar cantidades explosivas y tóxicas de gas hidrógeno. Debido a los posibles efectos nocivos de la exposición al plomo, las baterías de acumuladores utilizadas deben eliminarse de forma adecuada o reciclarse de acuerdo con las normativas públicas y las políticas de las empresas.

Amianto. Los trabajadores que comprueban y reparan frenos deben conocer el riesgo que conlleva el amianto y el modo de detectar si las zapatas contienen esta sustancia, y adoptar las medidas de protección oportunas para reducir la exposición y acumular los residuos para su correcta evacuación (véase la Figura 102.11).

\section{Equipo de protección individual (EPI)}

Los trabajadores están expuestos a lesiones por contacto con combustibles, disolventes o sustancias químicas de automoción, o por quemaduras provocadas por estas últimas y debidas al contacto con ácidos de las baterías o soluciones cáusticas. El personal de las estaciones de servicio debe ser consciente de la necesidad de utilizar EPI como los siguientes:

- Calzado de trabajo con suela antideslizante y resistente al petróleo para efectuar las tareas generales en las estaciones de servicio, y calzado de seguridad autorizado y protegido en la puntera, con el mismo tipo de suela, cuando hay riesgo de sufrir lesiones en los pies por desplazamiento o caída de objetos o equipos.

- Gafas de seguridad y protectores respiratorios para prevenir la exposición a sustancias químicas, polvo o humos al pintar o trabajar con baterías y radiadores. Se emplearán gafas industriales de seguridad o máscaras faciales con gafas cuando haya posibilidad de exposición a materiales de impacto, como ocurre al trabajar con pulverizadores o muelas o ruedas de alambres para pulir, reparar o montar neumáticos o sustituir sistemas de escape. Hay que utilizar máscaras con filtros adecuados al cortar o soldar con el fin de evitar quemaduras por radiación térmica y lesiones provocadas por partículas.

- Deben utilizarse guantes, delantales, calzado, máscaras faciales y gafas inatacables al manipular sustancias químicas y disolventes, ácidos de batería y soluciones cáusticas, y al limpiar derrames químicos o de combustible. Se emplearán guantes de trabajo de cuero al manejar objetos cortantes como vidrios rotos, piezas de los vehículos o llantas y al vaciar cubos de basura.

- Puede ser necesario protegerse la cabeza al trabajar debajo de vehículos en fosos, al cambiar indicadores o luces elevadas o en otras zonas donde haya riesgo de sufrir lesiones en esa parte del cuerpo.

- El personal que trabaje con vehículos no debe llevar anillos, relojes de pulsera, pulseras o cadenas largas, ya que estos 
objetos pueden entrar en contacto con las componentes móviles o el sistema eléctrico de los vehículos y causar lesiones.

Para prevenir los incendios, la dermatitis y las quemaduras químicas de la piel, las ropas manchadas de gasolina, anticongelante o aceite deben retirarse de inmediato a una zona o una sala con ventilación adecuada en la que no haya fuentes de ignición como calentadores eléctricos, motores, cigarrillos, encendedores o secadores de manos eléctricos. Las áreas de la piel afectadas deben lavarse concienzudamente con jabón y agua caliente para eliminar todo rastro de contaminación. Antes de lavarlas, las prendas deben secarse al aire en el exterior o en zonas bien ventiladas lejos de las fuentes de ignición, con el fin de reducir al mínimo la contaminación de las redes de aguas residuales.

\section{Riesgos para el medio ambiente asociados con estaciones de servicio}

\section{Control de existencias en los depósitos de almacenamiento}

Las estaciones de servicio deben mantener y actualizar periódicamente un libro de existencias de todos los depósitos de almacenamiento de gasolina y gasóleo para controlar las fugas. Puede utilizarse la medición manual con varilla para comprobar la integridad de los depósitos subterráneos y de las tuberías de conexión. Cuando se emplee la medición automática o se instalen equipos de detección de fugas, su exactitud se verificará cada cierto tiempo mediante los sistemas de calibración manuales. Los depósitos y sistemas de almacenamiento de los que se sospeche una fuga deben ser investigados y, si finalmente se detecta la anomalía, hay que evitar que causen más daños o vaciarlos para su reparación, retirada o sustitución. Los trabajadores de las estaciones de servicio deben tener presente que las fugas de gasolina pueden recorrer grandes distancias bajo el suelo, contaminar redes de abastecimiento de agua, penetrar en redes de alcantarillado o de drenaje y provocar incendios y explosiones.

\section{Manipulación y evacuación de residuos}

Los residuos de lubricantes y sustancias químicas de automoción, el aceite para motor y los disolventes usados, la gasolina y el gasóleo derramados y las soluciones anticongelantes de glicol deben verterse en depósitos y contenedores autorizados y debidamente etiquetados y almacenarse hasta su eliminación o su reciclaje de acuerdo con las normativas públicas y las políticas de las empresas.

Puesto que los motores con cilindros desgastados u otros defectos favorecen la entrada de pequeñas cantidades de gasolina en el cárter, hay que adoptar precauciones para evitar que los vapores liberados en los depósitos y contenedores en los que se almacenan los aceites usados entren en contacto con fuentes de ignición.

Antes de evacuar los filtros de aceite y de líquidos de transmisión usados debe drenarse su contenido. Estos dispositivos, retirados de vehículos o de surtidores de combustible, deben drenarse en recipientes autorizados y almacenarse en lugares adecuadamente ventilados y alejados de fuentes de ignición, hasta que se hayan secado para su eliminación.

Los recipientes de electrolitos de batería usados deben enjuagarse exhaustivamente con agua antes de eliminarlos o reciclarlos. Las baterías usadas contienen plomo y deben someterse a las operaciones de eliminación o reciclaje oportunas.

La limpieza de grandes vertidos exige formación especial y utilización de EPI. El combustible recuperado puede devolverse a la planta de producción o almacenamiento de la que procede o eliminarse de otro modo de conformidad con las normativas públicas y las políticas de las empresas. Los lubricantes, el aceite usado, las grasas, los anticongelantes, el combustible derramado y otros materiales no deben ser barridos, fregados o vertidos en desagües, sumideros, retretes, alcantarillas, colectores u otras redes de drenaje, ni tampoco deben arrojarse a la calle. La grasa y el aceite acumulados deben retirarse de los desagües y sumideros para evitar que estas materias alcancen las alcantarillas. El polvo de amianto y los forros de los frenos usados de este material deben manipularse y evacuarse con arreglo a las normativas públicas y las políticas de las empresas. El personal debe ser consciente de la repercusión de estos residuos en el medio ambiente, la salud y la seguridad, así como del riesgo de incendio que suponen.

\section{TRANSPORTE FERROVIARIO}

\section{EXPLOTACIONES FERROVIARIAS}

\section{Neil McManus}

El ferrocarril es un medio de transporte fundamental en todo el mundo. Incluso con la competencia del transporte aéreo y por carretera, el ferrocarril sigue siendo una forma importante de desplazamiento terrestre de grandes cantidades de productos y materiales. Las operaciones ferroviarias se llevan a cabo en una amplísima gama de terrenos y climas, desde los hielos árticos a la selva ecuatorial, desde los bosques húmedos a los desiertos. La plataforma de grava y las vías de acero con traviesas de madera, cemento o acero son comunes a todos los ferrocarriles. Las traviesas y el balasto mantienen la posición de los raíles.

El tipo de material tractor utilizado en estas redes en todo el mundo (máquinas de vapor, diésel-eléctricas y eléctricas) marcan la evolución de este modo de transporte.

\section{Administración y operaciones ferroviarias}

La administración y las operaciones ferroviarias conforman el perfil público de este sector. Garantizan que las mercancías se desplacen del origen al destino. Las tareas de administración las realiza personal de oficina encargado de las funciones empresariales y técnicas y de la gestión. Las operaciones ferroviarias son responsabilidad de los supervisores de personal, los controladores del tráfico de trenes, el personal dedicado al mantenimiento de señales, la dotación de trabajadores a bordo del tren y el personal de talleres.

Los supervisores de personal se encargan de garantizar que se disponga de un equipo de trabajadores en el momento y el lugar oportunos. Los ferrocarriles funcionan 24 horas al día, 7 días a la semana durante todo el año. El personal encargado del tráfico ferroviario coordina los movimientos de los trenes. Son responsables de asignar las vías en la secuencia y el momento pertinentes. Esta función se ve dificultada por la necesidad de que ciertos trenes que se mueven en distintas direcciones compartan las mismas vías. Puesto que sólo un tren puede ocupar un tramo de vía en cada momento, el control del tráfico ferroviario debe asignar la ocupación de la vía principal y de las auxiliares de modo que se garantice la seguridad y se reduzcan al mínimo los retrasos.

Las señales ofrecen pistas visuales a los operadores ferroviarios, así como a los conductores de vehículos de transporte por carretera en los pasos a nivel. En el caso de los primeros, las 


\section{Metros}

Mientras que la seguridad ferroviaria depende de la jurisdicción de las administraciones nacionales, que promulgan normas y formulan políticas relativas a la regulación y la aplicación de medidas de seguridad, los metros suelen ser gestionados por las administraciones locales, que, en esencia, son autónomas.

Los billetes de metro no suelen cubrir los costes de explotación y, mediante la concesión de subvenciones, permanecen a ciertos niveles para mantener un servicio de transporte público al alcance de todos. El metro y otros sistemas urbanos de desplazamiento de población mejoran la accesibilidad de las vías urbanas y reducen la contaminación asociada al tráfico de automóviles en las ciudades.

Los recortes presupuestarios que se han generalizado en numerosos países en los últimos años también han afectado a los sistemas de transporte público. El personal dedicado al mantenimiento preventivo y la renovación de vías, señales y material móvil son los primeros periudicados. A menudo, las autoridades competentes en materia de control no están dispuestas o no son capaces de aplicar sus propios procedimientos de regulación en un sistema de transporte rápido sin subvenciones públicas. En tales circunstancias, es inevitable que un accidente que tenga como resultado una grave pérdida de vidas humanas en períodos de recorte presupuestario de lugar a una protesta pública en demanda de mejoras de la seguridad.

Aunque es cierto que existe una gran variedad de diseños, construcción y antigüedad de las instalaciones físicas de los sistemas de transporte rápido de Canadá, Estados Unidos y otros países, es necesario llevar a cabo ciertas operaciones de mantenimiento normalizadas para mantener en funcionamiento las vías, las estructuras de superficie y subterráneas, las estaciones de pasajeros y otros servicios afines en las condiciones de mayor seguridad posible.

\section{Funcionamiento y mantenimiento del metro}

Los metros difieren de los ferrocarriles de superficie en varios aspectos esenciales:

- la mayoría de los metros se desplazan por debajo del nivel del suelo a lo largo de túneles;

- funcionan con electricidad y no con combustible diesel o vapor (aunque también hay trenes eléctricos de superficie);

- su funcionamiento es mucho más frecuente que el de los trenes de superficie; y

- la eliminación de pintadas es un problema grave.

Estos factores influyen en el grado de riesgo al que hacen frente los operarios de los trenes y el personal de mantenimiento.

Los choques entre trenes en la misma vía y con personal de mantenimiento en ella constituyen un grave problema. Estas colisiones se evitan mediante una programación adecuada, la aplicación de sistemas de comunicación centralizados para alertar a los operarios de los trenes y la instalación de sistemas luminosos de señalización que indiquen a los maquinistas cuándo pueden avanzar con seguridad. Las averías de estos procedimientos de control que dan lugar a accidentes se deben a dificultades para la comunicación por radio, rotura o colocación errónea de luces de señalización que impiden a los conductores disponer del tiempo suficiente para detener el tren y fatiga debida al trabajo por turnos, al número excesivo de horas extraordinarias y la falta de atención.

Los equipos de mantenimiento supervisan las vías del metro, reparan vías, luces de señalización y otros dispositivos, recogen la basura acumulada y realizan otras tareas. Se exponen a riesgos eléctricos al entrar en contacto con el tercer carril que conduce la electricidad para el funcionamiento de los trenes, incendios y humos derivados de la quema de basuras, la posibilidad del inicio de fuegos de origen eléctrico, la inhalación de polvo de acero y otras partículas presentes en la atmósfera a causa de la acción de las ruedas de los trenes y los raíles y los choques con los vagones. Las inundaciones también pueden generar riesgos eléctricos y de incendio. Debido a la naturaleza subterránea del servicio, muchas de estas situaciones de riesgo se ven agravadas por su desarrollo en espacios confinados.

Una ventilación adecuada para eliminar los contaminantes atmosféricos, la aplicación de los procedimientos pertinentes en espacios confinados y otras medidas (p. ej., planes de evacuación) de emergencia en caso de incendio e inundación y la instalación de sistemas de comunicación adecuados, incluida la transmisión por radio y la colocación de luces de señalización para advertir a los conductores de los trenes de la presencia de equipos de mantenimiento en las vías, son esenciales para proteger a los trabajadores. Debe disponerse de abundantes refugios de emergencia en las paredes de los túneles y de suficiente espacio entre las vías para que el personal de mantenimiento pueda evitar a los vagones en movimiento.

La eliminación de pintadas del interior y el exterior de los vagones del metro es un riesgo añadido a la pintura y la limpieza periódica de los mismos. Los productos empleados en esta tarea suelen contener álcalis fuertes y disolventes peligrosos, y pueden constituir un riesgo por contacto con la piel y por inhalación. La eliminación de pintadas exteriores se realiza trasladando los vagones a una instalación de lavado donde se rocían con sustancias químicas, que también se aplican mediante cepillado y pulverización en el interior. Esta última actividad puede constituir un riesgo adicional por su desarrollo en espacios confinados.

Entre las medidas de precaución que pueden adoptarse figura la utilización de las sustancias químicas menos tóxicas disponibles, el empleo de equipos de protección individual y respiratoria y la aplicación de procedimientos adecuados para garantizar que los trabajadores conocen los productos químicos utilizados.

George J. McDonald señales deben trasladar un mensaje inequívoco sobre la situación de la vía. Actualmente se utilizan como mecanismo de ayuda en el control del tráfico ferroviario, al que también contribuye la comunicación por radio a través de canales que reciben las unidades de operación. Los encargados del mantenimiento de las señales deben garantizar el funcionamiento de estos dispositivos en todo momento, lo que, en ocasiones, exige la prestación de servicio en solitario en áreas remotas, en todo tipo de condiciones meteorológicas y a cualquier hora del día o de la noche.

Es obligación del personal de talleres garantizar que el material rodante esté preparado para recibir la carga correspon- diente, una función cada vez más importante en esta época de gestión de la calidad. Por ejemplo: los vagones de tres niveles dedicados al transporte de automóviles deben ser limpiados antes de su utilización y acondicionados para contener vehículos mediante la colocación de calzos en las posiciones adecuadas. La altura entre niveles en estos vagones es insuficiente para que una persona de estatura media pueda permanecer de pie, por lo que el trabajo debe realizarse agachado. Del mismo modo, los asideros de ciertos vagones obligan a los trabajadores de talleres a adoptar posturas incómodas al efectuar las maniobras de clasificación. 
Tabla 102.3 • Factores de riesgo asociados a la administración y a las operaciones ferroviarias.

\begin{tabular}{|c|c|c|}
\hline Factores & Grupos afectados & Observaciones \\
\hline Gases de escape & $\begin{array}{l}\text { Dotación de los trenes, supervisores, asesores } \\
\text { técnicos }\end{array}$ & $\begin{array}{l}\text { Las emisiones consisten fundamentalmente en dióxido de nitrógeno, óxido nítrico, monó- } \\
\text { xido de carbono, dióxido de azufre y partículas que contienen hidrocarburos aromáticos } \\
\text { policíclicos (HAP). La exposición es mayor en los tuneles no ventilados. }\end{array}$ \\
\hline Ruido & $\begin{array}{l}\text { Dotación de los trenes, supervisores, asesores } \\
\text { técnicos }\end{array}$ & El ruido en el puesto de conducción puede exceder los límites reglamentarios. \\
\hline Vibración de todo el cuerpo & Dotación de los trenes & $\begin{array}{l}\text { Vibración de las estructuras transmitida a través del suelo y los asientos del puesto de } \\
\text { conducción; tiene su origen en el motor y en el movimiento a lo largo de la vía y en los } \\
\text { golpes contra las separaciones entre carriles. }\end{array}$ \\
\hline Campos electromagnéticos & $\begin{array}{l}\text { Dotación de los trenes, personal de manteni- } \\
\text { miento de señales }\end{array}$ & $\begin{array}{l}\text { Pueden formarse campos de } C A \text { y CC, según el diseño de la unidad de generación de } \\
\text { energía y los motores de tracción. }\end{array}$ \\
\hline Campos de radiofrecuencia & Usuarios de radios bidireccionales & No se han determinado con precisión los efectos para los seres humanos. \\
\hline Condiciones meteorológicas & $\begin{array}{l}\text { Dotación de los trenes, trabajadores de taller, } \\
\text { personal de mantenimiento de señales }\end{array}$ & $\begin{array}{l}\text { La radiación ultravioleta puede causar quemaduras solares, cáncer de piel y cataratas. El } \\
\text { frío provoca estrés por frío y congelación. El calor causa estrés por calor. }\end{array}$ \\
\hline Trabajo por turnos & $\begin{array}{l}\text { Supervisores de personal, controladores del } \\
\text { tráfico ferroviario, dotación de los trenes, } \\
\text { personal de mantenimiento de señales }\end{array}$ & $\begin{array}{l}\text { Los miembros de las dotaciones de los trenes tienen con frecuencia horarios irregulares; la } \\
\text { remuneración suele basarse en el recorrido de una distancia fija en un determinado } \\
\text { período de tiempo. }\end{array}$ \\
\hline $\begin{array}{l}\text { Lesiones } \\
\text { musculosqueléticas }\end{array}$ & Dotación de los trenes, trabajadores de taller & $\begin{array}{l}\text { No son raras las lesiones de tobillo al bajar de los vagones y las de hombros al subir. } \\
\text { Pueden ocasionarse lesiones en diversos lugares al transportar piezas de empalme sobre } \\
\text { terreno irregular. El trabajo se lleva a cabo en posturas incómodas. }\end{array}$ \\
\hline $\begin{array}{l}\text { Pantallas de visualización } \\
\text { de datos }\end{array}$ & $\begin{array}{l}\text { Directivos, personal técnico y administrativo, } \\
\text { supervisores de personal, controladores del } \\
\text { tráfico ferroviario }\end{array}$ & $\begin{array}{l}\text { La utilización eficaz de los puestos de trabajo informatizados depende de la aplicación de } \\
\text { principios ergonómicos ópticos y relativos al trabajo en oficinas. }\end{array}$ \\
\hline Atropellos & Todos los trabajadores & $\begin{array}{l}\text { Un atropello puede producirse cuando una persona se sitúa en una vía activa y no percibe la } \\
\text { aproximación de trenes, equipos de trabajo en las vías o vagones en movimiento. }\end{array}$ \\
\hline
\end{tabular}

En largos recorridos, la dotación de un tren presta servicio entre los lugares de relevo designados. La dotación sustituta pasa a ocupar sus puestos en dichos lugares y continúa el viaje. La primera dotación debe esperar en los puntos de relevo a otro tren que realice el recorrido de vuelta. Los desplazamientos combinados y la espera del tren de regreso pueden llevar muchas horas.

El viaje de un tren a lo largo de un trayecto único es en ocasiones muy fragmentario, debido en parte a la planificación y en parte al trabajo en las vías o a la avería del equipo. En ocasiones las dotaciones vuelven a su lugar de origen en la cabina de la locomotora de tracción, en el furgón de cola (donde todavía se utilicen), o incluso en un taxi o en autobús.

Los deberes de la dotación de tren obligan a veces a desenganchar vagones y a recoger otros en ruta. Estas operaciones se llevan a cabo a cualquier hora del día o de la noche en cualquier condición meteorológica imaginable. Enganchar y desenganchar vagones son las únicas tareas de ciertos trabajadores de taller.

En ocasiones, se produce la avería de alguna de las juntas que unen los vagones o la rotura de un conducto del circuito neumático de frenado. Estas averías deben ser investigadas por alguno de los miembros de la dotación del tren, que determinará si es preciso reparar o sustituir la pieza defectuosa. La junta de repuesto (de unos $30 \mathrm{~kg}$ ) debe ser transportada a lo largo de la vía hasta el lugar de la reparación, y la pieza original debe desmontarse y sustituirse. Los trabajos entre vagones deben obedecer a una planificación y una preparación minuciosas, con el fin de garantizar que el tren no se desplace durante la intervención.

En zonas montañosas, las averías pueden producirse en un túnel. En estas condiciones, la locomotora debe mantener la potencia por encima del ralentí para mantener el sistema de frenado operativo y evitar el descarrilamiento del tren. El funcionamiento del motor dentro de un túnel provoca la acumulación de gases de escape (dióxido de nitrógeno, óxido nítrico, monóxido de carbono y dióxido de azufre).

En la Tabla 102.3 se resumen las situaciones peligrosas asociadas a la administración y las operaciones ferroviarias.

\section{Mantenimiento del material rodante y del material de vía}

El material rodante incluye locomotoras y vagones. El material de vía está compuesto por maquinaria especializada utilizada en el control, mantenimiento, construcción y rehabilitación de las vías. Dependiendo del tamaño de la vía férrea, el mantenimiento puede ir desde una operación sobre el terreno (reparaciones de pequeña escala) al levantamiento y restauración completos. El material rodante no debe averiarse durante su funcionamiento, ya que este tipo de deficiencias tiene consecuencias graves para la seguridad, el medio ambiente y la actividad empresarial. Si un vagón transporta una mercancía peligrosa, las consecuencias de no detectar y reparar sus deficiencias mecánicas pueden ser gravísimas.

Las grandes empresas ferroviarias disponen de talleres de explotación e instalaciones de desmontaje y renovación centralizadas. El material rodante se inspecciona y prepara para los viajes en dichos talleres. Las reparaciones de menor importancia se efectúan en los vagones y las locomotoras.

Los vagones son estructuras rígidas que disponen de puntos de giro en cada uno de sus extremos. Estos puntos aceptan un pasador vertical localizado en el bogie (el conjunto formado por las ruedas y su estructura de apoyo). En las reparaciones, el cuerpo del vagón se eleva para separarlo de los bogies. Las reparaciones menores afectan a la carrocería del coche o a sus 
accesorios o a los frenos y otros elementos de los bogies. Los planos de las ruedas se rectifican en un torno.

Las reparaciones de mayor importancia consisten en la eliminación y la sustitución de los revestimientos y estructuras metálicas deterioradas o corroídas, el tratamiento con chorro de arena y la restauración de la pintura o la renovación de pisos de madera. A veces hay que desmontar y restaurar los bogies, incluidos los ejes y rodamientos de las ruedas. Los componentes de fundición de los bogies se reparan mediante aportación de material con equipo de soldadura seguida de pulido con muela. Los ejes de las ruedas se reparan mediante mecanización para devolverles la geometría correcta.
Las locomotoras se limpian e inspeccionan antes de cada viaje. Además, pueden exigir reparaciones mecánicas. Son intervenciones menores el cambio de aceite y el mantenimiento de frenos y motores diesel. Otra intervención común es el desmontaje de un bogie para rectificar o igualar las ruedas. A veces la locomotora entra en el taller o sale de él con sus motores. Antes de la vuelta al servicio, una locomotora puede ser sometida a una prueba de carga, durante la cual el motor se pone en funcionamiento a plena potencia. Los mecánicos trabajan muy cerca del motor durante este procedimiento.

Las grandes operaciones de mantenimiento exigen en ocasiones el desmontaje completo de la locomotora. El motor

Tabla 102.4 • Factores de riesgo asociados al mantenimiento y los accidentes de transporte.

\section{Factores \\ Contaminación de la piel por residuos de aceites $y$ lubricantes \\ Gases de escape \\ Emisiones de soldadura autógena}

Emisiones de soldadura

Descomposición térmica de productos de procedentes de revestimientos

Residuos de las mercancías

Polvo de chorreo abrasivo

Vapores de disolventes

Aerosoles de pintura

Espacios confinados

\section{Ruido}

Vibración de manos y brazos

Campos electromagnéticos

Condiciones meteorológicas

Trabajo por turnos

Lesiones musculosqueléticas

Atropellos
Todos los trabajadores

\section{Grupos afectados}

Mecánicos de motores diesel, mecánicos de máquinas de tracción

Todos los trabajadores en los talleres dedicados a los motores diesel, instalaciones de lavado, área de repostaje, área de pruebas de carga

Soldadores, ayudantes de soldador, instaladores, operadores de grúas móviles

Electricistas que trabajen con motores de tracción

Soldadores, ayudantes de soldador, instaladores, pulidores, operarios de grúas móviles

Soldadores, ayudantes de soldador, instaladores, pulidores, mecánicos, achatarradores

Trabajadores que realizan esta tareas, personas presentes en el momento de llevarla a cabo

Pintores, personas presentes en el momento de la aplicación

Pintores, personas presentes en el momento de la aplicación

Todos los trabajadores de talleres

Todos los trabajadores de taller

Usuarios de herramientas de mano mecánicas y dispositivos manuales

Usuarios de equipos de soldadura eléctrica

Trabajadores en el exterior

Todos los trabajadores

Todos los trabajadores

\section{Observaciones}

La descomposición de hidrocarburos en contacto con superficies calientes produce hidrocarburos aromáticos policíclicos (HAP).

Las emisiones consisten principalmente en dióxido de nitrógeno, óxido nítrico, monóxido de carbono, dióxido de azufre y partículas que contienen HAP. La posibilidad de exposición es mayor donde las emisiones de escape quedan retenidas por estructuras.

Esta actividad exige esencialmente la utilización de acero al carbono; el aluminio y el acero inoxidable también se emplean.

Las emisiones consisten en gases y líquidos de protección, humos metálicos, ozono, dióxido de nitrógeno, radiación visible y ultravioleta.

Emisiones de cadmio y plomo de la aleación de soldadura.

Las emisiones pueden incluir monóxido de carbono, pigmentos inorgánicos que contienen plomo y otros cromatos, productos de descomposición de las resinas para pintura. Pueden haberse utilizado PCB con anterioridad a 1971. Estos puede formar furanos y dioxinas por calentamiento.

Los residuos reflejan el servicio prestado por el vagón; por ejemplo: transporte de metales pesados, carbón, azufre, lingotes de plomo, etc.

El polvo puede contener residuos de la mercancía, materiales de chorreo, polvo de pintura. La pintura aplicada con anterioridad a 1971 puede contener PCB.

Los vapores de disolvente se acumulan en áreas de almacenamiento y mezcla de pintura y cabinas para pintura; se forman a veces mezclas inflamables en espacios confinados, como recipientes y depósitos, durante las operaciones de pulverización.

Los aerosoles de pintura contienen pintura pulverizada y diluyentes; el disolvente en gotas y el vapor pueden formar mezclas inflamables; los preparados de resina pueden contener isocianatos, epoxias, aminos, peróxidos y otros reactivos intermedios.

Interior de algunos vagones, depósitos y tolvas, morro de las locomotoras, hornos, desengrasadoras, impregnadores de barniz, fosas, sumideros y otras estructuras total y parcialmente cerradas.

El ruido generado por numerosas fuentes y tareas puede exceder los límites reglamentarios.

La vibración se transmite a través de las empuñaduras.

Es posible la generación de campos de corriente alterna y continua, dependiendo del diseño de la unidad.

La energía ultravioleta puede provocar quemaduras solares, cáncer de piel y cataratas. El frío causa estrés por frío y congelación. El calor provoca estrés por calor.

Pueden establecerse horarios irregulares.

No son raras las lesiones de tobillo al bajar de los vagones y las de hombros al subir. El trabajo se lleva a cabo en posturas incómodas, sobre todo al soldar, quemar, cortar y utilizar herramientas de mano mecánicas.

Un atropello puede producirse cuando una persona se sitúa en una vía activa y no percibe la aproximación de equipos de mantenimiento de vías y vagones en movimiento. 
diesel y su compartimento, el compresor, el generador y los motores de tracción requieren una limpieza y un desengrasado exhaustivos debido a la intensidad del servicio prestado y al contacto del combustible y el lubricante con superficies calientes. Algunas piezas se desmontan y reacondicionan.

Los cárteres de los motores de tracción deben restaurarse mediante aportación de material por soldadura. Estatores y rotores se mecanizan para eliminar los aislantes viejos y se reparan e impregnan con una solución de barniz.

La maquinaria de mantenimiento de vías incluye coches y otros equipos que pueden funcionar en la carretera y en las vías férreas, así como equipos especializados que sólo operan en estas últimas. Las tareas pueden ser efectuadas por unidades muy especializadas, como las dedicadas a la inspección de las vías o las máquinas para el rectificado de raíles, que pueden ser modelos únicos, incluso en las grandes empresas ferroviarias. El mantenimiento de estos equipos se lleva a cabo en talleres o sobre el terreno. Los motores de estos equipos emiten muchos gases de escape, debido a los largos períodos transcurridos entre reparaciones y a la poca familiaridad que los mecánicos tienen con ellos. Estos factores pueden tener consecuencias importantes en materia de contaminación durante la actividad de esta maquinaria en espacios confinados, como túneles, hangares y formaciones geológicas cerradas.

En la Tabla 102.4 se resumen los posibles factores peligrosos vinculados al mantenimiento del material rodante y los equipos de mantenimiento de las vías, así como los accidentes de transporte.

\section{Mantenimiento de vías y plataformas}

El mantenimiento de vías y plataformas se hace casi siempre en el exterior, en condiciones muy variables: sol, lluvia, nieve, viento, aire frío o caliente, arena, picaduras de insectos, animales peligrosos, serpientes y plantas venenosas.

Estas tareas pueden consistir en la vigilancia de las vías, así como en el mantenimiento, la rehabilitación y la sustitución de edificios y estructuras, raíles y puentes, además del desempeño de funciones de servicio, como la retirada de nieve y la aplicación de herbicidas. Pueden ser efectuadas por unidades operativas locales o por grandes equipos de trabajo especializados que se ocupan de la sustitución de raíles, grava o traviesas. Se dispone de equipo para mecanizar casi por completo todas estas actividades. No obstante, los trabajos de escala reducida pueden requerir la intervención de pequeños dispositivos eléctricos o, incluso, consistir en actividades plenamente manuales.

Para llevar a cabo el mantenimiento de líneas en funcionamiento hay que disponer de cierto bloque de tiempo reservado para el trabajo. Este período puede corresponder a cualquier hora del día o de la noche, dependiendo de los horarios de los trenes, sobre todo en una línea de vía única. Por tanto, la premura de tiempo es una consideración fundamental al realizar este tipo de trabajos, ya que la línea debe volver a encontrarse operativa al final del período asignado. Durante ese tiempo hay que desplazar el material al lugar de que se trate, hacer el trabajo y dejar libre la vía.

La sustitución de grava, traviesas y raíles es una tarea compleja. En el caso del balasto, debe eliminarse en primer lugar el material contaminado o deteriorado para poner al descubierto la plataforma. Una unidad similar a una rastra o un arado, arrastrada por una locomotora, o una excavadora, se encarga de esta tarea. La excavadora utiliza una cadena de dientes continuos que aparta el balasto a un lado. Se utilizan otros equipos para retirar y sustituir las escarpias de carril, las abrazaderas de las traviesas y las placas de asiento de carril (placas de metal situadas entre el raíl y las traviesas) y las traviesas. El raíl continuo es semejante a un espagueti blando que puede doblarse y batirse y que se mueve con facilidad vertical y lateralmente. El balasto estabiliza el raíl. El tren que lo descarga lo coloca, además, en la posición adecuada. Los trabajadores caminan paralelamente a esta máquina y abren sistemáticamente tolvas situadas en la parte inferior de los vagones para que salga el balasto.

Después de verter el balasto, se pasa una vibradora dotada de dedos hidráulicos para compactar el balasto alrededor y debajo de las traviesas y elevar la vía. Una máquina alineadora clava un pasador en la plataforma para anclar la vía y desplaza los raíles hasta la posición deseada. El regulador nivela el balasto para establecer los contornos definitivos de la infraestructura y limpia la superficie de las traviesas y los raíles. Durante el vertido del balasto, la regulación y el barrido se levanta mucho polvo.

El trabajo de vía se desarrolla en medios muy variados: áreas abiertas, semicerradas, como desfiladeros y caras de montañas y acantilados, y cerradas, como túneles y hangares. Estas circunstancias tienen una influencia esencial en las condiciones de trabajo. En los espacios cerrados, por ejemplo, se concentran las emisiones de gases de escape, el polvo de grava o de trituración, los humos de la soldadura por aluminotermia, el ruido y otros agentes y factores peligrosos. En la soldadura por aluminotermia se utiliza aluminio y óxido de hierro pulverizados. Tras su ignición, el aluminio prende con intensidad y transforma el óxido de hierro en hierro fundido. Este se cuela en la separación entre raíles y los suelda.

Los cambios están asociados con las vías. Un cambio de vía tiene unos carriles móviles de perfil adelgazado (agujas) y unas guías que evitan el descarrilamiento de las ruedas (corazón). Ambos se fabrican con acero duro especial rico en manganeso y cromo. El corazón es una estructura ensamblada de varias piezas de raíl curvadas de manera específica. Las tuercas autoblocantes utilizadas para empernar éstas y otras estructuras ferroviarias pueden chaparse con cadmio. Los corazones se construyen con soldadura y se pulen durante su renovación, que puede llevarse a cabo sobre el terreno o en un taller.

La pintura de puentes es un aspecto importante del mantenimiento de infraestructuras. A menudo, los puentes se sitúan en lugares aislados, lo que complica considerablemente la instalación de los elementos de higiene personal necesarios para evitar la contaminación de las personas y el medio ambiente.

En la Tabla 102.5 se resumen los riesgos propios del mantenimiento de las vías y otras infraestructuras.

\section{Accidentes de transporte}

Posiblemente, el mayor motivo de preocupación relacionado con las operaciones ferroviarias son los accidentes de transporte. La gran cantidad de material que puede verse implicado provoca serios problemas de exposición del personal y del medio ambiente. La preparación para los accidentes de mayor gravedad nunca es suficiente. Por tanto, la reducción al mínimo de los riesgos y las consecuencias de estos sucesos es imprescindible. Los accidentes de transporte obedecen a diversas causas: colisiones en pasos a nivel, obstrucciones de la vía, averías y errores humanos.

Se previenen mediante una inspección y un mantenimiento concienzudos y constantes de las vías, las infraestructuras y los equipos. Las consecuencias de un accidente en el que resulta implicado un tren que transporta carga variada se atenúa colocando estratégicamente los vagones que contienen cargas compatibles. No obstante, esta ubicación estratégica no es posible en el caso de un tren que transporte un único producto. Las mercancías que despiertan mayor preocupación son el carbón pulverizado, el azufre, los gases de petróleo licuado 
Tabla 102.5 • Factores de riesgo asociados al mantenimiento de las vías y los pasos a nivel.

$\begin{array}{ll}\text { Factor } & \text { Grupos afectados } \\ \text { Emisiones de escape } & \text { Todos los trabajadores }\end{array}$

Polvo de lastre/carga derramada

Emisiones de soldadura, corte y pulido

Polvo de chorreo abrasivo

Vapores de disolvente

Aerosoles de pintura

Espacios confinados

Ruido

Vibración del cuerpo en su totalidad

Vibración de manos y brazos

Campos electromagnéticos

Campos de radiofrecuencio

Condiciones meteorológicas

Trabajo por turnos Todos los trabajadores

Lesiones musculosqueléticas Todos los trabajadores

Atropellos Todos los trabajadores llevarla a cabo de la aplicación de la aplicación

Todos los trabajadores

Todos los trabajadores

\section{Observaciones}

Las emisiones incluyen dióxido de nitrógeno, óxido nítrico, monóxido de carbono, dióxido de azufre y partículas que contienen hidrocarburos aromáticos policíclicos (HAP). La exposición es mayor en túneles sin ventilación y en otras circunstancias en las que los gases son retenidos por ciertas estructuras.

Dependiendo de la fuente, el polvo de lastre puede contener sílice (cuarzo), metales pesados 0 amianto. Los trabajos en las vías en torno a industrias que producen y manejan mercancías a granel puede provocar la exposición a productos como carbón, azufre, concentrados de metales pesados, etc.

En las operaciones de soldadura se utilizan fundamentalmente acero templado; las emisiones pueden constar de gases y líquidos de protección, humos metálicos, ozono, dióxido de nitrógeno, monóxido de carbono y energía visible y ultravioleta. El contacto con manganeso 0 cromo puede producirse al trabajar en los carriles; el cadmio puede estar presente en pernos y tuercas tratados con este metal.

El polvo contiene material producido en el chorreo y polvo de pintura; la pintura suele contener plomo y otros cromatos.

personas presentes en el momento de

Pintores, personas presentes en el momento

Pintores, personas presentes en el momento

Hay vapores de disolvente en áreas de almacenamiento y mezcla; a veces se forman mezclas inflamables dentro de las estructuras cerradas destinadas a la pulverización.

Estos aerosoles pueden contener pintura pulverizada y diluyentes; los disolventes en pequeñas gotas y vapor pueden formar mezclas inflamables; los preparados de resina pueden incluir isocianatos, epoxias, aminos, peróxidos y otros reactivos intermedios.

Interior de túneles, canales, recipientes, fosas, sumideros y otras estructuras parcial o totalmente cerradas.

El ruido generado por numerosas fuentes y tareas puede exceder los límites reglamentarios.

Conductores de camión, operarios de equipos de mantenimiento de las vías

Usuarios de herramientas de mano mecánicas y dispositivos de mano

Usuarios de equipos de soldadura eléctrica

Usuarios de radios bidireccionales

Trabajadores en el exterior

La vibración de las estructuras transmitida a través del suelo y el asiento del puesto de conducción se origina en el motor y en el desplazamiento por las carreteras y las vías y al paso por las separaciones entre carriles.

La vibración se transmite a través de las empuñaduras.

Es posible que se generen campos de corriente alterna y continua, dependiendo del diseño de cada unidad.

No se han determinado con precisión los efectos sobre los seres humanos.

La radiación ultravioleta provoca quemaduras solares, cáncer de piel y cataratas, el frío causa estrés por frío y congelación y el calor causa estrés por calor.

Se establecen horarios de trabajo irregulares debido a los problemas en la programación de períodos de actividad en las vías.

No son raras las lesiones de tobillo al bajar de los vagones y las de hombros al subir; se trabaja en posturas incómodas, sobre todo al soldar y utilizar herramientas de mano mecánicas.

Un atropello puede producirse cuando una persona se sitúa en una vía activa y no percibe la aproximación de equipos de mantenimiento de vías, trenes y vagones en movimiento. (combustible), los concentrados de metales pesados, los disolventes y las sustancias químicas industriales.

Todos los grupos que conforman una organización ferroviaria desempeñan un papel en relación con los accidentes de transporte. En las actividades de rehabilitación pueden participar, literalmente, todos los equipos que trabajan simultáneamente en la misma localización sobre el terreno. Por tanto, la coordinación de estas actividades reviste especial importancia, ya que se trata de evitar que las acciones de un grupo interfieran en las de otros.

En general, las mercancías peligrosas no se dispersan en los accidentes debido a la atención prestada a la resistencia a los impactos en el diseño de los contenedores y los vagones de transporte. En un accidente, los materiales contenidos son retirados de los vagones dañados por equipos de emergencia que actúan en nombre del expedidor. El personal encargado del mantenimiento de los equipos repara los daños en la medida de lo posible y, en su caso, vuelve a colocar los vagones afectados en la vía. No obstante, la vía situada bajo el vagón descarrilado puede haber quedado dañada. En tal caso, el siguiente paso consiste en la reparación o la sustitución de los raíles, utilizando secciones prefabricadas o técnicas similares a las antes descritas.

En algunas situaciones, se produce la pérdida de los materiales transportados en los contenedores o los vagones de 
Tabla 102.6 • Planteamientos de la industria ferroviaria respecto al control de los factores de riesgo.

\section{Factores de riesgo}

Emisiones de escape

Ruido

Vibración corporal

Campos electromagnéticos

Campos de radiofrecuencia

Condiciones meteorológicas

Trabajo por turnos

Lesiones musculosqueléticas

Pantallas de visualización de datos

Atropellos

\section{Observaciones y medidas de control}

Las locomotoras carecen de tubo de escape. Los gases se evacuan verticalmente desde la superficie superior. Los ventiladores de refrigeración, situados asimismo en esta zona de la máquina, dirigen el aire contaminado por gases de escape hacia la atmósfera de túneles y edificios. La exposición en los puestos de conducción durante el tránsito normal a través de túneles no excede los límites establecidos. La exposición durante las actividades estáticas en túneles, como la investigación de averías mecánicas, el encarrilamiento de trenes descarrilados o la reparación de las vías, puede superarlos con creces. La actividad estática en talleres también provoca un exceso de exposición significativa.

Los equipos de mantenimiento y tendido de vías y los vehículos pesados suelen disponer de tubos de escape verticales. La evacuación de gases de nivel bajo o la que se produce a través de deflectores horizontales es otro factor de sobreexposición. Los vehículos de pequeño tamaño y los equipos portátiles de motor de gasolina evacuan los gases de escape hacia abajo o carecen de tubo de escape. La proximidad a estas fuentes puede provocar sobreexposición.

Entre las medidas de control figuran:

- la ampliación de los tubos de escape de evacuación vertical

- la eliminación de las fugas de gases de escape

- la instalación en los edificios de ventiladores aspirantes en el techo

- el equipamiento con sistemas de aspiración local que recojan los gases en su fuente

- la instalación de ventiladores en los techos de los túneles para mejorar el flujo de aire natural en la parte superior de los mismos

- la adaptación de convertidores catalíticos en los sistemas de ventilación por extracción

- la parada de los motores de las locomotoras en el interior de edificios

- la utilización de protección respiratoria: los respiradores faciales completos equipados con cartuchos (en cumplimiento de las normas europeas) puede ofrecer una protección satisfactoria en este tipo de situaciones.

Las medidas de control consisten en:

- la incorporación en los puestos de conducción de técnicas de control del ruido

- la instalación de técnicas de control del ruido en los equipos existentes durante las operaciones de reacondicionamiento y regeneración

- Ia utilización de protección individual auditiva (consulta de los reglamentos para garantizar su cumplimiento durante el funcionamiento de trenes y vehículos).

Las medidas de control consisten en:

- la incorporación en los puestos de conducción de técnicas de control de la vibración

- la instalación de técnicas de control de la vibración en los equipos en uso durante las operaciones de reacondicionamiento y regeneración.

- Riesgo no reconocido por debajo de los límites actuales.

- Riesgo no reconocido por debajo de los límites actuales.

Las medidas de control consisten en:

- la utilización de ropa de trabajo que proteja contra el frío

- la utilización de ropa de trabajo que proteja contra la radiación solar

- la utilización de protección ocular que proteja contra la radiación solar

- la aplicación de filtros solares (debe consultarse al médico en caso de tratamientos prolongados).

Adaptación de los horarios de trabajo a los conocimientos actuales sobre ritmos circadianos.

Las medidas de control consisten en:

- el diseño de los equipos basado en los principios ergonómicos

- la formación en materia de acondicionamiento muscular, levantamiento de cargas y cuidado de la espalda

- elección de prácticas de trabajo que reduzcan al mínimo el padecimiento de lesiones musculosqueléticas.

Aplicación de los principios ergonómicos del trabajo en oficinas a la selección y la utilización de pantallas de visualización de datos.

Los equipos ferroviarios sólo actúan en las vías. Los no motorizados generan poco ruido al moverse. Las condiciones naturales pueden atenuar el ruido producido por estos equipos, y éste puede ahogar las señales acústicas de advertencia emitidas por un tren que se aproxima. En las operaciones en las estaciones de clasificación, las desviaciones pueden efectuarse por control remoto, con el resultado de la disponibilidad de la totalidad de las vías. Las medidas de control consisten en:

- la expedición de permisos de ocupación de vías (POV) y la instalación de señales que regulen el movimiento de trenes y equipos ferroviarios. El POV autoriza a la ocupación única de una sección de vía

- la instalación de alarmas en edificios para indicar el movimiento de equipos

- la adopción de prácticas y procedimientos para garantizar la seguridad de las actividades efectuadas en torno a las equipos ferroviarios.

Continúa en la página siguiente. 
Tabla 102.6 - Planteamientos de la industria ferroviaria respecto al control de los factores de riesgo.

Continuación.

\begin{tabular}{|c|c|}
\hline Factores de riesgo & Observaciones y medidas de control \\
\hline Operaciones con balasto/derrames de carga & $\begin{array}{l}\text { La humidificación del balasto antes de efectuar trabajos en las vías reduce la formación de polvo de éste y de los residuos de } \\
\text { la carga. Deben facilitarse equipos de protección personal y respiratoria. }\end{array}$ \\
\hline $\begin{array}{l}\text { Contaminación de la piel por la acción de los } \\
\text { residuos de aceites y lubricantes }\end{array}$ & $\begin{array}{l}\text { Los equipos deben limpiarse antes de su desmontaje para eliminar la contaminación. Deben utilizarse ropas, guantes y } \\
\text { lociones protectoras. }\end{array}$ \\
\hline $\begin{array}{l}\text { Emisiones de soldadura autógena, corte y } \\
\text { soldadura, polvo de pulido }\end{array}$ & $\begin{array}{l}\text { Las medidas de control consisten en: } \\
\text { - la instalación de sistemas de ventilación local por extracción } \\
\text { - la utilización de equipos de protección individual (EPI) } \\
\text { - el empleo de protección respiratoria } \\
\text { - la adopción de medidas de higiene personal } \\
\text { - la vigilancia médica (depende de la composición del metal base y del presente en cables o varillas). }\end{array}$ \\
\hline $\begin{array}{l}\text { Descomposición térmica de productos proce- } \\
\text { dentes de los revestimientos }\end{array}$ & $\begin{array}{l}\text { Las medidas de control consisten en: } \\
\text { - la instalación de sistemas de ventilación local por extracción } \\
\text { - la utilización de protección respiratoria } \\
\text { - la adopción de medidas de higiene personal } \\
\text { - la vigilancia médica (depende de la composición del revestimiento). }\end{array}$ \\
\hline Residuos de la carga & $\begin{array}{l}\text { Las medidas de control consisten en: } \\
\text { - el lavado de residuos de cada vagón antes de su puesta en servicio (según las circunstancias) } \\
\text { - la utilización de EPI (según las circunstancias) } \\
\text { - el empleo de protección respiratoria (según las circunstancias) } \\
\text { - la adopción de medidas de higiene personal (según las circunstancias) } \\
\text { - la vigilancia médica (en función de la carga). }\end{array}$ \\
\hline Polvo de chorreo abrasivo & $\begin{array}{l}\text { Las medidas de control consisten en: } \\
\text { - el cerramiento de las instalaciones dedicadas al chorreo abrasivo } \\
\text { - la robotización de la operación de chorreo } \\
\text { - la instalación de sistemas de extracción del polvo } \\
\text { - la utilización de EPI } \\
\text { - el empleo de protección respiratoria } \\
\text { - la adopción de medidas de higiene personal } \\
\text { - la vigilancia médica (depende de los residuos abrasivos, de revestimientos y de la carga). }\end{array}$ \\
\hline Vapores de disolvente, aerosoles de pintura & $\begin{array}{l}\text { Las medidas de control consisten en: } \\
\text { - la robotización del sistema de pintura para el interior de tolvas } \\
\text { - la aplicación de un sistema de pintura que emplee poco disolvente } \\
\text { - la mezcla previa de los materiales empleados para pintar } \\
\text { - la instalación de un sistema de transporte de pintura a través de tuberías } \\
\text { - la instalación de cabinas de pintura } \\
\text { - la utilización de EPI } \\
\text { - el empleo de protección respiratoria } \\
\text { - la vigilancia médica (según las circunstancias). }\end{array}$ \\
\hline Espacios confinados & $\begin{array}{l}\text { Las medidas de control consisten en: } \\
\text { - la aplicación de sistemas de ventilación portátiles } \\
\text { - la utilización de EPI } \\
\text { - el empleo de protección respiratoria. }\end{array}$ \\
\hline Vibración de manos y brazos & $\begin{array}{l}\text { Las medidas de control consisten en: } \\
\text { - la utilización de herramientas que cumplan las normas en la materia } \\
\text { - el empleo de guantes capaces de absorber la vibración. }\end{array}$ \\
\hline
\end{tabular}

transporte, que quedan esparcidos por el suelo. Si las sustancias se transportan en cantidades suficientes para requerir su señalización de acuerdo con la legislación sobre transporte, su identificación resulta fácil gracias a los conocimientos de embarque. Sin embargo, las sustancias altamente peligrosas que, al ser enviadas en cantidades menores, no requieren su inclusión en este tipo de documentos, pueden eludir la identificación y la caracterización durante un período considerable. Su retención en el lugar del accidente y la recogida del material vertido son responsabilidad del expedidor.

El personal ferroviario puede verse expuesto al contacto con materiales que quedan en la nieve, el suelo o la vegetación durante los trabajos de rehabilitación. La gravedad de la exposición depende de las propiedades y de la cantidad de la sustancia 
en cuestión, las características del lugar del accidente y las condiciones meteorológicas. Asimismo, la situación puede dar lugar a un incendio, una explosión o al contacto de sustancias reactivas o tóxicas con las personas, los animales y el medio ambiente

En algún momento posterior al accidente, el lugar donde se haya producido debe despejarse, de forma que la vía pueda volver a ponerse en servicio. La transferencia de la mercancía y la reparación de los equipos y la vía pueden estar aún pendientes. Estas actividades pueden complicarse enormemente por la incapacidad para contener la mercancía y la presencia de materiales derramados o desparramados. La adopción de medidas para abordar este tipo de situación requiere una exhaustiva planificación previa, en la que se tenga en cuenta la opinión de profesionales especializados con experiencia.

\section{Riesgos y precauciones}

En las Tablas 102.3, 102.4 y 102.5 se resumen los factores de riesgo asociados a los diversos grupos de trabajadores que participan en las operaciones ferroviarias. En la Tabla 102.6 se describen brevemente los tipos de precauciones adoptadas para controlar estos factores.

\section{TRANSPORTE FLUVIAL Y MARITIMO}

\section{TRANSPORTE FLUVIAL Y MARITIMO E INDUSTRIAS MARITIMAS}

\section{Timothy J. Ungs y Michael Adess}

La propia definición de entorno marítimo alude al trabajo y a la actividad vital que se desarrolla en o alrededor del mundo marítimo (en buques y barcazas, muelles y estaciones de carga). En primer lugar, las actividades laborales y vitales deben acomodarse a las condiciones ambientales de los océanos, los lagos y los cursos de agua en las que se llevan a cabo. Las embarcaciones sirven tanto de lugar de trabajo como de hogar, por lo que la mayoría de las exposiciones relacionadas con el hábitat y con el ámbito profesional coexisten y son inseparables.

El sector marino comprende varios subsectores: transporte de mercancías, servicios de pasajeros y transbordadores, pesca comercial, buques petroleros y transporte en pequeñas embarcaciones. Cada uno de estos subsectores engloba un conjunto de actividades comerciales que se caracterizan por el tipo de embarcación utilizada, los bienes y los servicios a los que se orienta, las prácticas y el área de operaciones típicos y la comunidad de propietarios, operadores y trabajadores. A su vez, estas actividades y el contexto en el que se desarrollan definen los riesgos profesionales y ambientales y las exposiciones experimentadas por los trabajadores del sector marítimo.

Las actividades marítimas comerciales organizadas se remontan a los primeros tiempos de la civilización. Las antiguas sociedades griega, egipcia y japonesa constituyen ejemplos de grandes civilizaciones en las que el desarrollo del poder y la influencia estaba estrechamente vinculado con una amplia presencia marítima. La importancia de las industrias marítimas en la consolidación del poder y la prosperidad nacionales se ha mantenido hasta la era moderna.

El sector naval dominante es el transporte, que sigue siendo el principal medio de comercio internacional. Las economías de la mayoría de los países con acceso al mar acusan enormemente la influencia de la recepción y la exportación de bienes y servicios por esta vía. No obstante, las economías nacionales y regionales que dependen en gran medida del transporte de mercancías por cursos de agua no son únicamente las de los países bañados por los océanos. Muchos países alejados del mar disponen de amplias redes de vías fluviales.

Los buques mercantes modernos pueden elaborar materiales u obtener productos además de transportarlos. La mundialización de las economías, la restricción en el uso de la tierra, una legislación fiscal favorable y la tecnología son algunos de los factores que han contribuido a la expansión de los buques que operan simultáneamente como fábricas y medios de transporte.
Las embarcaciones pesqueras dedicadas a la captura y el procesamiento son un buen ejemplo de esta tendencia. Estos buques factoría capturan, elaboran, envasan y entregan productos alimentarios marinos terminados en mercados regionales, como se analiza en el capítulo dedicado a la Industria pesquera.

\section{Buques mercantes}

Como ocurre con otros vehículos de transporte, la estructura, la forma y la función de estos buques se ajusta fielmente a su finalidad y a las principales circunstancias ambientales. Así, las embarcaciones que transportan líquidos en recorridos cortos a lo largo de vías de navegación interior diferirán sustancialmente en cuanto a forma y tripulación de las que transportan grandes volúmenes de áridos a granel en rutas transoceánicas. Hay embarcaciones móviles, semimóviles y fijas (como las plataformas de extracción de petróleo en alta mar), así como autopropulsadas y remolcadas. Las flotas combinan gran número de buques con una amplia gama de fechas de construcción, materiales y grados de modernidad.

El tamaño de las tripulaciones depende de la duración habitual de los viajes, de la finalidad y la tecnología de la embarcación, de las condiciones ambientales previstas y de la complejidad de las instalaciones costeras. Las tripulaciones numerosas exigen la planificación exhaustiva del alojamiento, la manutención, la higiene, la asistencia sanitaria y los servicios auxiliares. La tendencia en todo el mundo es hacia la construcción de buques cada vez más grandes y complejos, con tripulaciones reducidas y un grado de automatización, mecanización y agrupación de la carga en contenedores que no deja de aumentar. La Tabla 102.7 recoge una clasificación y un resumen descriptivo de los tipos de buques mercantes.

\section{Morbilidad y mortalidad en las industrias marítimas}

A los proveedores de asistencia sanitaria y a los epidemiólogos se les suele solicitar que distingan entre los estados de salud adversos debidos a las exposiciones de carácter profesional y los debidos a exposiciones fuera del lugar de trabajo. Esta dificultad aumenta en el sector naval, ya que las embarcaciones constituyen simultáneamente un lugar de trabajo y un hogar, y ambos se engloban en el entorno superior que constituye el medio marítimo en sí. Los límites físicos de la mayoría de los buques obligan a una convivencia estrecha y a compartir espacios de trabajo, salas de máquinas, áreas de almacenamiento, pasillos y otros compartimentos con los espacios vitales. A menudo, las embarcaciones disponen de un único sistema de distribución de agua, ventilación e higiene utilizado a la vez en el trabajo y en las actividades personales diarias. 
Tabla 102.7 - Tipos de buques mercantes.

\begin{tabular}{|c|c|c|}
\hline Tipo de embarcación & Descripción & $\begin{array}{l}\text { Tamaño de la } \\
\text { tripulación }\end{array}$ \\
\hline \multicolumn{3}{|l|}{ Buques mercantes } \\
\hline Buque granelero & $\begin{array}{l}\text { Embarcación de gran tamaño (61-183 m) que se caracteriza por la disposición de grandes bodegas y numerosos } \\
\text { compartimentos vacíos bajo cubierta; transporta cargas a granel como cereales o minerales; la mercancía se carga } \\
\text { mediante tolvas, cintas transportadoras o palas }\end{array}$ & $25-50$ \\
\hline Buque de carga fraccionada & $\begin{array}{l}\text { Embarcación de gran tamaño (61-183 m); transporta la mercancía en balas, palets, bolsas o cajas; bodegas ampliables } \\
\text { con entrepuentes; puede disponer de túneles }\end{array}$ & $25-60$ \\
\hline Buque portacontenedores & $\begin{array}{l}\text { Embarcación de gran tamaño }(61-183 \mathrm{~m}) \text { con bodegas abiertas; puede disponer o no de puntales de carga y grúas para } \\
\text { manejar las mercancías; los contenedores oscilan entre } 6,1 \text { y 12,2 m y son apilables }\end{array}$ & $25-45$ \\
\hline $\begin{array}{l}\text { Mineralero, granelero, } \\
\text { petrolero Buques OBO }\end{array}$ & $\begin{array}{l}\text { Embarcación de gran tamaño (6l-183 m); sus bodegas son extensas, conformadas para conservar minerales o petróleo } \\
\text { y estancas, puede disponer de bombas y tuberías; además de numerosos compartimentos vacíos bajo cubierta }\end{array}$ & $25-55$ \\
\hline Transporte de vehículos & $\begin{array}{l}\text { Embarcación de gran tamaño (61-183 m) con una gran superficie vertical de casco sobre la que ejerce presión el } \\
\text { viento; numerosos niveles; los vehículos pueden cargarse por sí mismos o con grúas }\end{array}$ & $25-40$ \\
\hline Ferry (ro/ro) & $\begin{array}{l}\text { Embarcación de gran tamaño (61-183 m) con una gran superficie vertical de casco; numerosos niveles; puede } \\
\text { transportar otras mercancías además de vehículos }\end{array}$ & $25-40$ \\
\hline \multicolumn{3}{|l|}{ Buques cisterna } \\
\hline Petroleros & $\begin{array}{l}\text { Embarcación de gran tamaño (61-305 m) con conducciones de carga a popa sobre cubierta; puede estar equipada con } \\
\text { puntales para el manejo de mangas y grandes espacios vacíos con muchos depósitos; puede transportar crudo o } \\
\text { petróleo elaborado, disolventes y otros productos petrolíferos }\end{array}$ & $25-50$ \\
\hline $\begin{array}{l}\text { Transportadores de sustan- } \\
\text { cias químicas }\end{array}$ & $\begin{array}{l}\text { Embarcación de gran tamaño ( } 61-305 \mathrm{~m} \text { ) similar a un petrolero, aunque con más conducciones y bombas para recibir } \\
\text { numerosos tipos de carga simultáneamente; los cargamentos pueden ser líquidos, gaseosos, áridos o sólidos } \\
\text { comprimidos }\end{array}$ & $25-50$ \\
\hline $\begin{array}{l}\text { Buques de depósitos } \\
\text { presurizados }\end{array}$ & $\begin{array}{l}\text { Suelen ser más pequeños (61-213,4 m) que los buques cisterna normales, disponen de menos depósitos y éstos están } \\
\text { presurizados o refrigerados; pueden transportar productos químicos o petrolíferos como el gas natural licuado; los } \\
\text { depósitos suelen estar cubiertos y aislados; cuenta con numerosos contenedores vacíos bajo cubierta, conducciones y } \\
\text { bombas }\end{array}$ & $15-30$ \\
\hline Remolcadores & Embarcaciones de pequeño y mediano tamaño $(24,4-61$ m); de puerto, empujadores, de navegación marítima & $3-15$ \\
\hline Gabarra & $\begin{array}{l}\text { Embarcación de mediano tamaño (30,5-106,7 m); pueden ser de carga en depósitos, en cubierta, cargueras } 0 \\
\text { transportadoras de vehículos; normalmente no son tripuladas ni autopropulsadas; numerosos contenedores vacíos bajo } \\
\text { cubierta }\end{array}$ & \\
\hline $\begin{array}{l}\text { Buques para perforaciones } \\
\text { submarinas y plataformas }\end{array}$ & $\begin{array}{l}\text { De gran tamaño, características similares a los buques graneleros; caracterizados por la disposición de grandes puntales } \\
\text { de carga; numerosos contenedores vacíos bajo cubierta, maquinaria, mercancías peligrosas y tripulaciones numerosas; } \\
\text { algunos son remolcados, otros, autopropulsados }\end{array}$ & $40-120$ \\
\hline Buques de pasajeros & $\begin{array}{l}\text { De todos los tamaños (15,2-213,4 m); caracterizados por el gran número de tripulantes y pasajeros } \\
\text { (hasta } 1.000 \text { o más) }\end{array}$ & $20-200$ \\
\hline
\end{tabular}

La estructura social a bordo de los buques suele jerarquizarse en oficiales (capitán, segundo oficial, etc.) y tripulantes. En general, los oficiales han recibido una mayor formación y disponen de más recursos económicos y de estabilidad profesional. No es infrecuente que los miembros de la tripulación de un barco sean de una nacionalidad o de una etnia totalmente diferente a la de los oficiales. Históricamente, las comunidades marítimas son más provisionales, heterogéneas y, en cierta medida, independientes que el resto. Los horarios de trabajo a bordo suelen estar más fragmentados y más entremezclados con los períodos de ocio que otros empleos desempeñados en tierra firme.

Hay razones por las que resulta difícil describir o cuantificar los problemas de salud en las industrias marítimas o asociar correctamente los problemas con las exposiciones. Los datos sobre morbilidad y mortalidad de la marinería no son completos ni representativos de todas las tripulaciones y subsectores. Otra carencia de muchos de estos datos y sistemas de información relativos a las industrias marítimas es la imposibilidad de diferenciar entre los problemas de salud debidos al trabajo, a la vida en la embarcación o a las condiciones ambientales. Como sucede con otras profesiones, la dificultad para obtener datos sobre morbilidad y mortalidad es evidente en el caso de las enfermedades crónicas (p. ej., trastornos cardiovasculares), sobre todo cuando tienen un período prolongado de latencia (como el cáncer).

El análisis de los datos del sector en Estados Unidos acumulados durante 11 años (1983 a 1993) ha puesto de manifiesto que la mitad de los fallecimientos debidos a accidentes marítimos, pero sólo el $12 \%$ de los accidentes no mortales, son atribuibles a las embarcaciones (colisiones y vuelcos). El resto de muertes y lesiones no mortales se deben a la actuación del personal (incidentes a bordo). Las causas declaradas de tal mortalidad y morbilidad se describen en las Figuras 102.12 y 102.13 respectivamente. No se dispone de datos comparables sobre mortalidad y morbilidad no vinculadas con accidentes.

Los datos combinados sobre bajas debidas a problemas de las embarcaciones y de las tripulaciones en Estados Unidos ponen de relieve que la mayor proporción $(42 \%)$ del total de fallecimientos (2.559) corresponde a los buques dedicados a la pesca 
Figura 102.12 Causas de los principales accidentes con resultado de muerte atribuidos a errores humanos (industrias marítimas de Estados Unidos, 1983-1993).

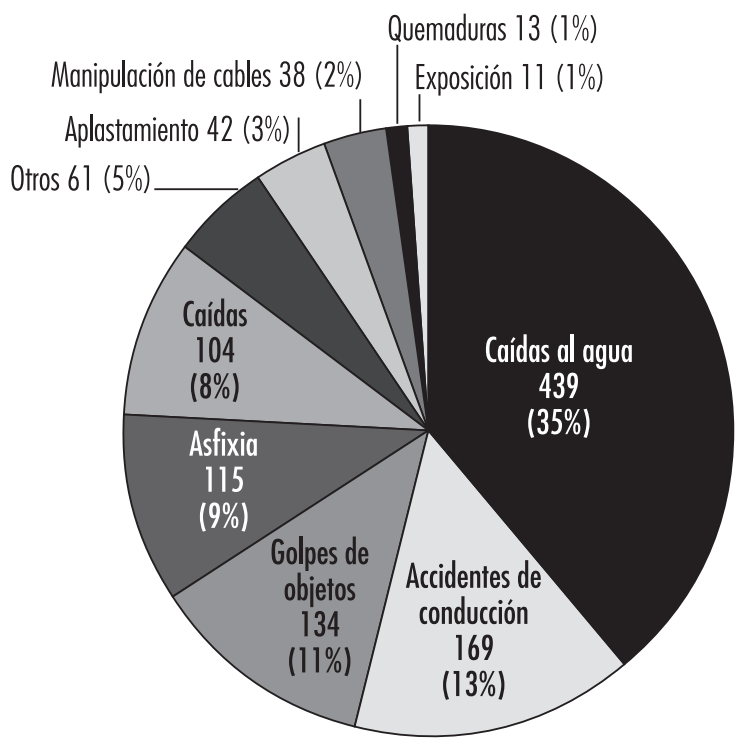

Total 1.270

Fuente: BLS 1996

comercial. Los siguientes grupos en esta clasificación son los remolcadores $(11 \%)$, los buques mercantes $(10 \%)$ y las embarcaciones de pasajeros $(10 \%)$.

El análisis de las lesiones profesionales declaradas correspondientes a las industrias marítimas muestra semejanzas en cuanto a las pautas registradas en las industrias de la fabricación y la construcción. Así, la mayoría de las lesiones se deben a caídas, golpes, cortes y contusiones o esguinces o sobreesfuerzos musculares. No obstante, es necesario interpretar estos datos con precaución, ya que se encuentran sesgados: es probable que las lesiones más graves figuren en exceso y que las de carácter crónico o latente, obviamente menos relacionadas con el trabajo, no se declaren en la medida pertinente.

\section{Riesgos profesionales y para el medio ambiente}

La mayoría de los riesgos para la salud en el entorno marítimo son semejantes a los experimentados en las actividades realizadas en tierra en los sectores de la fabricación, la construcción y la agricultura. La diferencia estriba en la restricción del espacio que provoca el ámbito marítimo, que obliga a una estrecha proximidad a los riesgos potenciales y a la mezcla de los espacios vitales y los lugares de trabajo con los depósitos de combustible, las salas de máquinas y las zonas reservadas a las mercancías y el almacenamiento.

En la Tabla 102.8 se resumen los riesgos para la salud comunes a todo tipo de embarcaciones. En la Tabla 102.9 se destacan aquellos que provocan mayor preocupación en cada tipo de buque específico. En los apartados siguientes de este capítulo se amplía el análisis de los riesgos para la salud de carácter medioambiental, físico y químico e higiénico.

\section{Riesgos medioambientales}

Puede sostenerse que la exposición más característica que define a las industrias marítimas consiste en la presencia abrumadora del agua. El entorno acuático más variable y que plantea mayores desafíos es el océano. Estos medios se caracterizan por una superficie continuamente ondulante, una meteorología extrema y unas condiciones hostiles para el desplazamiento, factores que se combinan para provocar un movimiento constante, turbulencias y superficies cambiantes y pueden dar lugar a perturbaciones vestibulares (enfermedad del movimiento), inestabilidad de los objetos (p. ej., cerrojos que se balancean y aparatos que se deslizan) y propensión a caer.

Las personas disponen de una capacidad limitada para sobrevivir en mar abierto; el ahogo y la hipotermia son amenazas inmediatas tras una inmersión. Los buques actúan como plataformas que permiten la presencia humana en el mar. Los barcos y otras embarcaciones marítimas suelen operar a cierta distancia de otros recursos. Por estas razones, los buques deben dedicar una gran proporción de su espacio total a los medios de mantenimiento de la vida, al combustible, a la integridad estructural y a la propulsión, a menudo a costa de la habitabilidad, la seguridad personal y las consideraciones relacionadas con el factor humano. Los modernos superpetroleros, que brindan un espacio más amplio para el desempeño de actividades de la vida ordinaria, constituyen una excepción.

La exposición a niveles de ruido excesivo es un problema habitual, ya que la energía sónica se transmite con facilidad a través de la estructura metálica de las embarcaciones a todos los espacios, y se emplea una cantidad limitada de materiales para la atenuación de ruidos. La contaminación sonora puede ser casi continua, sin disponibilidad de áreas de descanso. Las fuentes de ruido son los motores, los sistemas de propulsión, la maquinaria, los ventiladores, las bombas y el golpeo de las olas contra el casco.

Los marineros componen un grupo de riesgo identificado respecto al desarrollo de cánceres de piel, incluidos el melanoma maligno, el carcinoma de células escamosas y el carcinoma de

Figura 102.13 Causas de los principales accidentes sin resultado de muerte atribuidos a errores humanos (industrias marítimas de Estados Unidos, 1983-1993).

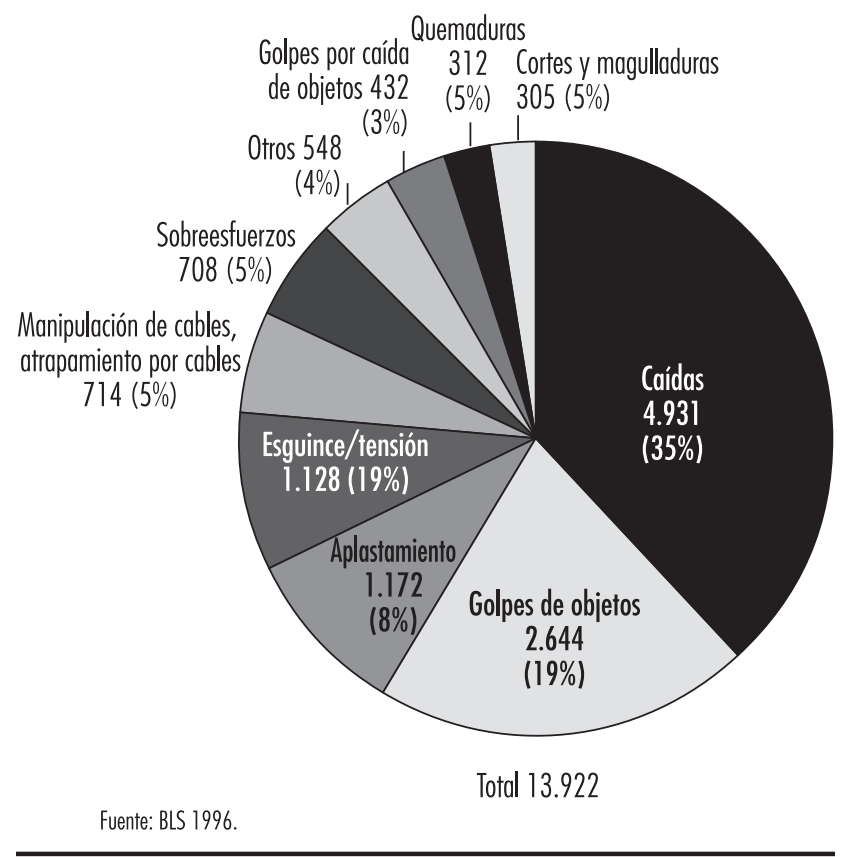


Tabla 102.8 • Riesgos para la salud comunes en todos los tipos de buques.

\begin{tabular}{|c|c|c|}
\hline Riesgos & Descripción & Ejemplos \\
\hline Mecánicos & $\begin{array}{l}\text { Objetos en movimiento sin protección o expuestos que pueden golpear, } \\
\text { perforar, aplastar } 0 \text { enredar. Pueden ser mecanizados (p. ej., carretilla } \\
\text { elevadora) o sencillos (puertas de bisagra). }\end{array}$ & $\begin{array}{l}\text { Cabrestantes, bombas, ventiladores, ejes motores, compresores, } \\
\text { hélices, compuertas, puertas, puntales, grúas, estachas de amarre, } \\
\text { mercancías en movimiento }\end{array}$ \\
\hline Eléctricos & $\begin{array}{l}\text { Fuentes de electricidad estáticas (p. ej., baterías) o activas (p. ej., genera- } \\
\text { dores), sus sistemas de distribución (p. ej., cableado) y dispositivos } \\
\text { mecánicos (p. ej., motores), que pueden provocar lesiones físicas } \\
\text { directas }\end{array}$ & $\begin{array}{l}\text { Baterías, generadores de los buques, fuentes eléctricas en los muelles, } \\
\text { motores eléctricos desprotegidos o no puestos a tierra (bombas, } \\
\text { ventiladores, etc.), cables desnudos, componentes electrónicos de } \\
\text { navegación y comunicación }\end{array}$ \\
\hline Térmicos & Lesiones provocadas por el calor o el frío & $\begin{array}{l}\text { Conductos de vapor, lugares para el almacenamiento en fría, gases de } \\
\text { escape de centrales de generación de energía, exposición a condi- } \\
\text { ciones meteorológicas de calor o frío sobre cubierta }\end{array}$ \\
\hline Ruido & $\begin{array}{l}\text { Problemas auditivos y fisiológicos de otro tipo debidos a la exposición a } \\
\text { una energía sonora excesiva y prolongada }\end{array}$ & $\begin{array}{l}\text { Sistema de propulsión de las embarcaciones, bombas, ventiladores, } \\
\text { cabrestantes, dispositivos impulsados por vapor, cintas } \\
\text { transportadoras }\end{array}$ \\
\hline Caídas & $\begin{array}{l}\text { Resbalones, tropezones y caídas que dan lugar a lesiones producidas por la } \\
\text { acción de la energía cinética }\end{array}$ & $\begin{array}{l}\text { Escaleras empinadas, bodegas profundas, falta de barandillas, pasillos } \\
\text { estrechos, plataformas elevadas }\end{array}$ \\
\hline Químicos & $\begin{array}{l}\text { Enfermedades agudas o crónicas y lesiones debidas a la exposición a } \\
\text { sustancias químicas orgánicas e inorgánicas y metales pesados }\end{array}$ & $\begin{array}{l}\text { Disolventes de limpieza, mercancías transportadas, detergentes, solda- } \\
\text { dura, procesos de oxidación/corrosión, refrigerantes, plaguicidas, } \\
\text { fumigantes }\end{array}$ \\
\hline Higiénicos & $\begin{array}{l}\text { Enfermedades relacionadas la escasa potabilidad del agua, la aplicación de } \\
\text { prácticas alimentarias deficientes o la evacuación inadecuada de residuos }\end{array}$ & $\begin{array}{l}\text { Agua potable contaminada, deterioro de los alimentos, sistema de } \\
\text { evacuación de residuos defectuoso }\end{array}$ \\
\hline Biológicos & $\begin{array}{l}\text { Causas de enfermedad vinculadas al contacto con seres vivos o sus } \\
\text { productos }\end{array}$ & $\begin{array}{l}\text { Polvo de cereales, productos de madera no tratada, balas de algodón, } \\
\text { fruta o carne a granel, alimentos marinos, patógenos infecciosos }\end{array}$ \\
\hline Radiación & Lesiones debidas a radiación no ionizante & $\begin{array}{l}\text { Luz solar intensa, soldadura con arco eléctrico, radares, comunica- } \\
\text { ciones por microondas }\end{array}$ \\
\hline Violencia & Violencia interpersonal & Asaltos, homicidios, conflictos entre los miembros de la tripulación \\
\hline Espacios confinados & $\begin{array}{l}\text { Lesiones tóxicas } 0 \text { anóxicas debidas a la entrada en un espacio confinado } \\
\text { con acceso limitado }\end{array}$ & $\begin{array}{l}\text { Bodegas, depósitos de lastre, sótanos de pequeña altura, depósitos de } \\
\text { combustible, calderas, salas de almacenamiento, bodegas } \\
\text { refrigeradas }\end{array}$ \\
\hline Trabajo físico & $\begin{array}{l}\text { Problemas de salud debido al exceso de trabajo o a prácticas laborales } \\
\text { inadecuadas }\end{array}$ & $\begin{array}{l}\text { Paleo de hielo en depósitos de pescado, transporte de mercancías de } \\
\text { difícil manejo en espacios restringidos, manipulación de cabos de } \\
\text { amarre pesados, períodos prolongados en tareas de vigilancia }\end{array}$ \\
\hline
\end{tabular}

células basales. El aumento del riesgo se debe a la exposición excesiva a la radiación solar ultravioleta directa y reflejada en la superficie del agua. Las zonas del cuerpo que corren mayor riesgo son las partes descubiertas de la cara, el cuello, las orejas y los antebrazos.

El aislamiento limitado, la ventilación insuficiente, la presencia de fuentes internas de calor o de frío (p. ej., salas de máquinas o de refrigeración) y la influencia de las superficies metálicas contribuyen al padecimiento de estrés térmico. Este agrava el de carácter psicológico sufrido por otras causas, lo que reduce el rendimiento físico y cognitivo. El estrés térmico no controlado adecuadamente o la ausencia de medidas de protección contra este tipo de trastorno puede dar lugar a lesiones inducidas por el calor o el frío.

\section{Riesgos físicos y químicos}

En la Tabla 102.9 se destacan los riesgos específicos o de especial interés relacionados con los diversos tipos de embarcaciones. Los de carácter físico son los más comunes y extendidos a bordo de los buques de cualquier categoría. Las limitaciones de espacio obligan a construir pasillos estrechos, escaleras empinadas y techos bajos. Además, obligan a montar la maquinaria, las tuberías, las aberturas de ventilación, los conductos, los depósitos, etc., con una separación física limitada. Los buques suelen disponer de aberturas que permiten el acceso vertical directo a todos los niveles. Los espacios interiores bajo cubierta se caracterizan por una combinación de grandes bodegas, salas compactas y compartimientos ocultos. Esta estructura física coloca a los miembros de las tripulaciones en una situación de riesgo de sufrir resbalones, tropezones y caídas, cortes y magulladuras, y de ser golpeados por objetos que se desplazan o caen.

Estas condiciones de restricción provocan una proximidad considerable con la maquinaria, el cableado eléctrico, depósitos y mangueras de alta presión y superficies peligrosamente calientes o frías. Si no se instalan dispositivos de protección o si se activan, el contacto con estos elementos puede producir quemaduras, abrasiones, contusiones, daños oculares, aplastamientos y lesiones más graves.

Puesto que las embarcaciones constituyen básicamente un conjunto de espacios contenidos en una envoltura estanca, la ventilación puede ser marginal o deficiente en ciertos lugares, lo que crea una situación de cerramiento espacial peligrosa. Si el oxígeno se agota, el aire es desplazado o entran gases tóxicos en estos espacios cerrados, el acceso a los mismos puede poner en peligro la vida.

En una embarcación es habitual encontrar refrigerantes, combustibles, disolventes, agentes limpiadores, pinturas, gases inertes y otras sustancias químicas. Las actividades normales en un buque, como soldadura, pintura o combustión de residuos pueden tener efectos tóxicos. Los buques de transporte 
(mercantes, de contenedores, petroleros) transportan productos químicos o biológicos variados, muchos de los cuáles resultan tóxicos por inhalación, ingestión o contacto con la piel desnuda. Otros pueden volverse tóxicos si se permite su degradación, contaminación o mezcla con otros agentes. La toxicidad puede ser aguda, como ponen de manifiesto las erupciones cutáneas y las quemaduras oculares, o crónica, como demuestran los trastornos neurológicos del comportamiento, la pérdida de fertilidad e, incluso, los efectos cancerígenos. Algunas exposiciones pueden amenazar la vida de inmediato. Son ejemplos de sustancias químicas transportadas por buques los productos petroquímicos que contienen benceno, el acrilonitrilo, el butadieno, el gas natural licuado, el tetracloruro de carbono, el cloroformo, el dibromuro de etileno, el óxido de etileno, las soluciones de formaldehído, el nitropropano, el 0 -toluidino y el cloruro de vinilo.

Tabla 102.9 • Principales riesgos físicos y químicos en determinados tipos de embarcaciones.

$\begin{array}{ll}\begin{array}{l}\text { Tipos de } \\ \text { embarcación }\end{array} & \text { Riesgos } \\ \text { Buques cisterna } & \begin{array}{l}\text { Benceno y diversos vapores de hidrocarburos, ácido sulfhí- } \\ \text { drico emitido por el petróleo crudo, gases inertes utili- } \\ \text { zados en los depósitos para crear atmósferas bajas en } \\ \text { oxígeno para el control de explosiones, incendios y } \\ \text { explosiones debidos a la combustión de hidrocarburos }\end{array}\end{array}$

Buques graneleros Acumulación de fumigantes utilizados en productos agrarios, personal que queda atrapado o se asfixia en mercancía suelta o movediza, riesgos de espacio confinado en cintas transportadoras y túneles del buque, deficiencia de óxigeno debida a la oxidación o fermentación de la carga

Transportadores de Ventilación de gases o polvos tóxicos, escapes de aire 0 sustancias químicas

Buques portacontenedores gas a presión, fuga de sustancias peligrosas de las bodegas de carga o de los conductos de transporte, incendio y explosión debidos a la combustión de mercancías químicas

Exposición a derrames o fugas debidos a averías o al almacenamiento inadecuado de sustancias peligrosas; escape de gases de inertización agrarios; ventilación de contenedores de sustancias químicas o gases; contacto con sustancias peligrosas mal etiquetadas; explosiones, incendios 0 exposiciones a sustancias tóxicas debidas a la combinación de sustancias independientes que forman un agente peligroso (p. ej., el ácido y el cianuro de sodio)

Buques de carga Condiciones inseguras debidas al movimiento de la carga 0 fraccionada al almacenamiento inadecuado; incendio, explosión y exposiciones a sustancias tóxicas debidos a la combinación de mercancías incompatibles; deficiencia de oxígeno debida a la oxidación y la fermentación de la carga; escape de gases refrigerantes

Buques de pasajeros Agua potable contaminada, prácticas de elaboración y almacenamiento de alimentos inadecuadas, dificultades de evacuación masiva, problemas de salud agudos de pasajeros determinados

Buques de pesca Riesgos térmicos vinculados con las bodegas refrigeradas, deficiencia de oxígeno debido a la descomposición de los alimentos marinos 0 a la utilización de conservantes antioxidantes, escape de gases refrigerantes, posibilidad de quedar atrapados en redes o sedales, contacto con peces y otros animales marinos tóxicos o peligrosos
Tabla 102.10 • Control y actividades de reducción de riesgos en embarcaciones.

Temas Actividades

Formulación y evalua- Determinar riesgos, a bordo y en los puertos. Evaluar lo ción de programas naturaleza, el alcance y la magnitud de las exposiciones potenciales. Identificar a los miembros de la tripulación en peligro. Determinar los métodos adecuados para controlar o eliminar los riesgos y proteger al personal. Desarrollar un sistema de vigiancia e información sobre salud. Evaluar y realizar un seguimiento del estado de salud de los miembros de la tripulación en situación de riesgo. Medir la eficacia de los programas. Adaptar y modificar los programas.

Determinación de Realizar un inventario de riesgos químicos, físicos, riesgos biológicos y ambientales a bordo de una embarcación, tanto en los lugares de trabajo, como en los espacios vitales (p. ej., barandillas rotas, utilización y almacenamiento de productos de limpieza, presencia de amianto). Investigar los riesgos vinculados a la carga y a los muelles.

Evaluación de la Comprender las prácticas de trabajo y las tareas de exposición cada puesto (tanto previstas como realizadas en la práctica). Calificar y cuantificar los niveles de exposición (p. ej., número de horas pasadas en áreas de almacenamiento de mercancías peligrosas, niveles de H2S en la atmósfera debido al escape de gases, tipo de organismos encontrados en el agua potable, niveles de ruido a bordo).

Personal en situación Revisar los diarios de trabajo, los registros de empleo y de riesgo

Control de riesgos y protección del personal os datos de control de la tripulación del barco, tanto estacional como fija.

Conocer las normas de exposición establecidas y recomendadas (p. ej., NIOSH, OIT, UE). Eliminar los riesgos cuando sea posible (sustituir las actividades de vigilancia realizadas por personas por dispositivos de seguimiento electrónico a distancia). Controlar los riesgos que no pueden eliminarse (p. ej., cerrar y aislar los cabrestantes en lugar de dejarlos expuestos, y colocar señales de advertencia). Facilitar los equipos de protección individual necesarios (llevar detectores de gas tóxico y 02 al entrar en espacios confinados).

Vigilancia sanitaria Desarrollar sistemas de recogida y comunicación de información sobre salud sobre todas las lesiones y enfermedades (p. ej., llevar un cuaderno de bitácora diario del buque).

Control de la salud de la Establecer un seguimiento de los aspectos de la salud tripulación relacionados con el trabajo, determinar normas de rendimiento y establecer criterios de capacidad física para el trabajo (p. ej., realización de pruebas pulmonares previas a la contratación y periódicas del personal encargado de la manipulación de cereales).

Control de riesgos y eficacia en su reducción

Formular y establecer las prioridades relativas a la consecución de objetivos (p. ej., reducción de las caídas a bordo). Establecer y medir los resultados respecto a los objetivos (reducción del número anual de días que los miembros de la tripulación no pueden trabajar debido a caídas a bordo). Determinar la eficacia de las iniciativas emprendidas para alcanzar los objetivos.

Evolución de los Modificar las actividades de prevención y control basánprogramas dose en el cambio de circunstanicas y en la determinación de prioridades. 
El amianto sigue representando un peligro en algunas embarcaciones, sobre todo en las construidas con anterioridad a la primera parte del decenio de 1970. El aislamiento térmico, la protección contra incendios, la durabilidad y el bajo coste del amianto hizo de esta sustancia un material favorito en la construcción de barcos. El riesgo fundamental deriva de su suspensión en el aire al ser alterado en operaciones de renovación, construcción o reparación.

\section{Higiene y riesgos de contraer enfermedades infecciosas}

Una de las realidades a bordo de un barco es que la tripulación suele permanecer en estrecho contacto. En los períodos de ocio y de trabajo y en los espacios vitales, la aglomeración de personas es una circunstancia frecuente que aumenta la necesidad de establecer un programa de higiene eficaz. Las áreas críticas son: los alojamientos, incluidas las instalaciones sanitarias y duchas, las zonas de servicio y almacenamiento de comida, la lavandería, las áreas de ocio y, en su caso, la peluquería. El control de plagas reviste asimismo una enorme importancia, ya que muchos de estos animales transmiten enfermedades. Los insectos y roedores disfrutan de un gran número de oportunidades para propagarse en un buque y, una vez asentados, son difíciles de controlar y erradicar, sobre todo durante los desplazamientos. Todas las embarcaciones deben aplicar un programa de control de plagas eficaz. Para ello, es necesario impartir formación y cursos anuales de actualización.

Las zonas de alojamiento deben mantenerse libres de residuos, ropa sucia y alimentos perecederos. La ropa de cama debe cambiarse al menos una vez a la semana (con mayor frecuencia si se mancha) y debe haber un servicio de lavandería ajustado al número de miembros de la tripulación. Las áreas de restauración deben ser objeto de un mantenimiento higiénico riguroso. El personal del servicio de comidas debe recibir formación sobre las técnicas apropiadas de elaboración y conservación de alimentos e higiene en la cocina, y debe disponer a bordo de instalaciones adecuadas para el almacenamiento. Este personal debe atenerse a las normas recomendadas para garantizar que los alimentos se preparan de una forma sana y están exentos de contaminación química o biológica. Cualquier epidemia declarada a bordo por ingestión de alimentos en mal estado puede ser grave. Una tripulación debilitada es incapaz de cumplir con sus obligaciones. Puede que no se disponga de los medicamentos suficientes para tratar a la tripulación, sobre todo durante un viaje, o del personal médico competente para abordar la enfermedad. Además, si el buque se ve obligado a modificar su lugar de destino, la compañía naviera puede sufrir pérdidas económicas considerables.

La integridad y el mantenimiento del sistema de agua potable de un barco también reviste gran importancia. Históricamente, los brotes de enfermedad por consumo de agua en mal estado han constituido la causa más habitual de discapacidad aguda y muerte entre los miembros de las tripulaciones. Por tanto, el suministro de este recurso debe proceder de una fuente aprobada (siempre que sea posible) y estar libre de contaminación química y biológica. Cuando estas condiciones no puedan cumplirse, las embarcaciones deben disponer de los medios para descontaminar eficazmente el agua y transformarla en apta para el consumo humano. El sistema de agua potable debe protegerse contra la contaminación derivada de toda fuente conocida, incluida su contaminación al mezclarse con líquidos no potables. Asimismo, el sistema debe protegerse de la contaminación química. Debe someterse a operaciones periódicas de limpieza y desinfección. El llenado del sistema con agua limpia que contenga al menos 100 partes por millón (ppm) de cloro y su mantenimiento en el mismo durante varias horas, tras las que debe purgarse con el mismo compuesto constituye un método de desinfección efectivo. A continuación, debe procederse a la limpieza con agua potable fresca. El suministro de este recurso debe mantener al menos $2 \mathrm{ppm}$ de cloro residual en todo momento, documentándose mediante la realización de pruebas periódicas.

La transmisión de enfermedades infecciosas a bordo de un barco constituye un problema potencial grave. La pérdida de horas de trabajo, el coste del tratamiento médico y la posibilidad de tener que evacuar a miembros de la tripulación la agravan. Además de los agentes patógenos más comunes (p. ej., los causantes de la gastroenteritis, como la salmonella, y de las enfermedades de las vías respiratorias altas, como el virus de la gripe), han vuelto a surgir aquéllos que se creían controlados o erradicados de la población general. La tuberculosis, cepas altamente patógenas de Escherichia coli y Streptococcus, además de la sífilis y la gonorrea han reaparecido con una incidencia y una virulencia cada vez mayores. Por otra parte, han surgido patógenos desconocidos o inhabituales como el virus VIH o el ebola, no sólo muy resistentes al tratamiento, sino también muy letales. Por tanto, es importante que se evalúe la oportunidad de efectuar una inmunización adecuada de las tripulaciones respecto a enfermedades como la polio, la difteria, el tétano, el sarampión y la hepatitis A y B. Puede que sea necesario efectuar otras inmunizaciones para exposiciones potenciales específicas o singulares, ya que las tripulaciones pueden visitar diversos puertos de todo el mundo y, al mismo tiempo, entrar en contacto con varios agentes patógenos.

Es fundamental que los miembros de las tripulaciones reciban formación periódica sobre la forma de evitar el contacto con los agentes causantes de las enfermedades. Deben abordarse los patógenos sanguíneos, las enfermedades de transmisión sexual (ETS), las enfermedades debidas a la ingestión de alimentos o de agua, la higiene personal, los síntomas de las enfermedades infecciosas más comunes y las acciones apropiadas que debe adoptar cada persona al descubrirlos. Los brotes infecciosos a bordo de una embarcación pueden tener un efecto devastador en su funcionamiento y provocar una elevada morbilidad en la tripulación, con riesgo de que se produzcan enfermedades debilitantes graves y, en algunos casos, fallecimientos. En ocasiones, ha sido necesario evacuar el barco, lo que ha dado lugar a grandes pérdidas económicas. El armador es el más interesado en formular un programa de prevención de enfermedades infecciosas eficaz y eficiente.

\section{Control y reducción de riesgos}

Conceptualmente, los principios de control y reducción de riesgos son similares a los de otros ámbitos profesionales y consisten en:

- identificación y caracterización de los riesgos;

- inventario y análisis de las exposiciones y los grupos de riesgo;

- eliminación o control de los riesgos;

- seguimiento y vigilancia del personal;

- prevención de enfermedades y lesiones e intervención en caso de que se produzcan; y

- evaluación y ajuste de programas (véase la Tabla 102.10).

No obstante, para que sean eficaces, los medios y los métodos elegidos para aplicar estos principios deben adaptarse al ámbito de interés específico de la industria marítima. Las actividades profesionales son complejas y se desarrollan en sistemas integrados (p. ej., operaciones en los buques, asociaciones entre trabajador y empresa, determinantes comerciales). La clave para lograr la prevención consiste en comprender estos sistemas y el contexto en que se desenvuelven, lo que requiere la interacción y la cooperación estrecha entre todos los niveles organizativos de 
la comunidad marítima, desde la marinería de base hasta los altos directivos de las empresas, pasando por los oficiales de los barcos. Hay muchos intereses públicos y normativos que repercuten en este sector. Las asociaciones entre la administración, los reguladores, los directivos y los trabajadores son esenciales para formular programas que mejoren el estado de salud y de seguridad en los sectores marítimos.

La OIT ha establecido diversos convenios y recomendaciones relativos al trabajo a bordo de embarcaciones, como el Convenio ( $\mathrm{n}^{\circ}$. 134) sobre prevención de accidentes (marineros), 1970 y la Recomendación ( $\mathrm{n}^{\circ}$. 142), 1970; el Convenio ( $\mathrm{n}^{\circ}$. 147) sobre la marina mercante (normas mínimas), 1976 y la Recomendación $\left(\mathrm{n}^{\circ} .155\right)$ sobre la marina mercante (mejora de las normas), 1976; y el Convenio ( $\mathrm{n}^{\circ}$. 164) sobre la protección de la salud y la asistencia médica (marineros), 1987. Asimismo, la OIT ha publicado un Código de Práctica relativo a la prevención de accidentes en el mar (OIT 1996).

En torno al $80 \%$ de las víctimas de accidentes acaecidos en buques se atribuyen a factores humanos. Del mismo modo, la mayoría de enfermedades y fallecimientos relacionados con accidentes obedecen a causas vinculadas con dichos factores. La reducción de estos sucesos en el ámbito marítimo requiere una aplicación eficaz de los principios relativos a tales factores en las actividades laborales y vitales a bordo de las embarcaciones. Para ello es necesario que se desarrollen las operaciones realizadas en los barcos, la ingeniería y el diseño navales, las actividades laborales, los sistemas y las políticas de gestión que integren la antropometría, la actuación, la percepción y el comportamiento humanos. Por ejemplo, la carga y la descarga de mercancías plantea riesgos potenciales. La consideración del factor humano pondría de manifiesto la necesidad de mejorar la comunicación y la visibilidad, procurar el ajuste ergonómico del trabajador a la tarea, asegurar la separación entre los trabajadores y la maquinaria y la mercancía en movimiento e impartir formación al personal, que perfeccionaría su conocimiento de los procesos de trabajo.

La prevención de enfermedades crónicas y de estados de salud adversos con períodos de latencia prolongados es más problemática que la prevención y el control de accidentes. Los sucesos en los que se producen lesiones agudas suelen presentar relaciones causa-efecto de más fácil determinación. Asimismo, la asociación de la causa y el efecto de la lesión con las prácticas y las condiciones de trabajo suele ser menos compleja que en el caso de los trastornos crónicos. Los datos sobre riesgos, exposiciones y salud específicos de las industrias marítimas son limitados. En general, los sistemas de vigilancia de la salud, los informes y los análisis correspondientes a este sector están menos desarrollados que los de otros muchos cuya actividad se lleva a cabo en tierra firme. La escasa disponibilidad de información sanitaria sobre enfermedades crónicas o latentes propia de las industrias marítimas dificulta la formulación y la aplicación de programas de prevención y control orientados.

\section{ALMACENAMIENTO}

\section{- ALMACENAMIENTO Y TRANSPORTE DE PETROLEO CRUDO, GAS NATURAL, PRODUCTOS DE PETROLEO LICUADOS Y OTRAS SUSTANCIAS QUIMICAS}

\section{Richard S. Kraus}

Oleoductos y gasoductos, buques mercantes, camiones cisterna, vagones cisterna y otros medios se utilizan para transportar petróleo crudo, hidrocarburos gaseosos comprimidos y licuados, productos de petróleo licuado y otras sustancias químicas desde su lugar de origen a las terminales de conducción, las refinerías, los distribuidores y los consumidores.

El petróleo crudo y los productos de petróleo licuados se transportan, manipulan y almacenan en su estado líquido natural. En el caso de los hidrocarburos gaseosos, todas estas operaciones se realizan tanto en estado gaseoso, como líquido, y los productos deben aislarse por completo en conductos, depósitos, bidones y otro tipo de recipientes antes de su utilización. La característica más importante de los hidrocarburos gaseosos licuados (HGL) es su almacenamiento, manipulación y transporte en estado líquido, lo que permite la ocupación de un espacio relativamente reducido, y su posterior expansión a forma gaseosa al ser utilizados. Por ejemplo, el gas natural licuado (GNL) se almacena a $-162^{\circ} \mathrm{C}$ y, cuando se libera, la diferencia entre las temperaturas de almacenamiento y atmosférica provoca su expansión y gasificación. Un galón $(3,8$ l) de GNL se transforma aproximadamente en $2,5 \mathrm{~m}^{3}$ de gas natural a temperatura y presión normales. Puesto que el grado de "concentración" del gas licuado es muy superior al del gas comprimido, es posible transportar una mayor cantidad de producto utilizable en un mismo recipiente.

\section{Conductos}

En general, el petróleo crudo, el gas natural, el gas natural licuado, el gas de petróleo licuado (GPL) y los productos derivados del petróleo fluyen a través de conductos en algún momento de su traslado del pozo a la refinería o la fábrica de gas, a los centros de distribución y, finalmente, a los usuarios. Por estos conductos aéreos, subacuáticos y subterráneos, cuyo diámetro va de algunos centímetros a un metro o más, se mueven grandes cantidades de petróleo crudo, gas natural, HGL y productos de petróleo licuados. Los oleoductos y gasoductos recorren todo el mundo, desde la tundra congelada de Alaska y Siberia, hasta los desiertos de Oriente Próximo; atraviesan ríos, lagos, mares, pantanos y bosques, montañas, ciudades y pueblos. Aunque la fabricación inicial de este tipo de canalizaciones resulta difícil y cara, una vez terminadas y sometidas a un mantenimiento y un funcionamiento adecuados, constituyen uno de los medios de transporte de estas mercancías más seguros y económicos.

El primer oleoducto para petróleo crudo que tuvo éxito, una tubería de hierro forjado de $5 \mathrm{~cm}$ de diámetro, $9 \mathrm{~km}$ de longitud y una capacidad de unos 800 barriles diarios, se inauguró en Pennsylvania (Estados Unidos) en 1865. Actualmente, dicho material, el gas natural comprimido y los productos de petróleo licuados recorren grandes distancias a través de estos conductos a velocidades que oscilan entre los 5,5 y los $9 \mathrm{~km}$ por hora, gracias a la acción de grandes bombas o compresores situados a lo largo de la conducción a intervalos que van de 90 a más de $270 \mathrm{~km}$. La distancia entre las estaciones de bombeo y compresión se determina en función de la capacidad de las bombas, la viscosidad del producto, el tamaño de la tubería y el tipo de terreno. Con independencia de estos factores, las presiones de bombeo en las conducciones y los caudales se controlan en todo el sistema, con el fin de mantener un movimiento constante del producto dentro de la conducción. 


\section{Tipos de canalización}

Los cuatro tipos básicos de canalización en la industria del petróleo y el gas son las tuberías de distribución, las tuberías colectoras, las canalizaciones principales de crudo y las canalizaciones principales de productos derivados del petróleo

- Tuberías de distribución. En las tuberías de distribución, el petróleo crudo o el gas natural se desplazan de los pozos de extracción a los depósitos de almacenamiento de la zona de explotación. Su tamaño oscila entre los $5 \mathrm{~cm}$ de diámetro de los conductos utilizados en los yacimientos más antiguos de baja presión con sólo unos pocos pozos, a las grandes canalizaciones empleadas en yacimientos de alta presión con numerosos pozos. En las plataformas de alta mar se aplican este tipo de tuberías para desplazar el crudo y el gas desde el lugar de extracción a sus instalaciones de almacenamiento y carga. Un conducto de explotación es un tipo de tubería de distribución que transporta todo el petróleo producido en un único yacimiento al depósito de almacenamiento.

- Tuberías colectoras y de alimentación. En las tuberías colectoras se recoge el petróleo y el gas procedente de varios lugares para su envío a los puntos de acumulación central, como ocurre en el caso del desplazamiento desde los depósitos de petróleo crudo de un yacimiento y las fábricas de gas hasta las dársenas portuarias. Las tuberías de alimentación recogen el petróleo y el gas de varios lugares para su envío directo a las canalizaciones principales, como en el caso del movimiento del crudo procedente de las plataformas de alta mar a las conducciones principales de crudo situadas en la costa. El diámetros de estos conductos suele ser superior al de las tuberías de distribución.

- Canalizaciones principales de crudo. El gas natural y el petróleo crudo recorren grandes distancias desde las áreas de producción o las dársenas portuarias hasta las refinerías, y de éstas, a las instalaciones de almacenamiento y distribución, encauzados en canalizaciones principales con diámetros de 1 a 3 metros o más.

- Canalizaciones principales de productos derivados del petróleo. En estos conductos se desplaza los productos de petróleo licuados, como la gasolina o el gasóleo, desde las refinerías y los terminales marítimos y de las conducciones a los centros de distribución. Asimismo, pueden distribuir productos desde las terminales a las fábricas y las instalaciones de almacenamiento para el consumo, y, en ocasiones, de las refinerías directamente a los usuarios. Estas canalizaciones se utilizan para transportar GPL de las refinerías a los centros de almacenamiento de los distribuidores o a grandes usuarios industriales.

\section{Reglamentos y normativas}

Las canalizaciones se construyen y explotan de acuerdo con normas ambientales y de seguridad establecidas por los organismos reguladores y las asociaciones industriales. En Estados Unidos, el Departamento de Transporte (DOT) regula el funcionamiento de los diversos conductos, la Environmental Protection Agency (EPA) regula lo relativo a vertidos y emisiones, la Occupational Safety and Health Administration (OSHA) promulga normas referentes a la salud y la seguridad de los trabajadores y la Interstate Commerce Commission (ICC) regula las conducciones de transporte comunes. Asimismo, varias organizaciones industriales, como el American Petroleum Institute y la American Gas Association, publican las prácticas recomendadas en relación con las operaciones efectuadas en las canalizaciones.

\section{Construcción de canalizaciones}

Los itinerarios de los conductos se planifican con mapas topográficos trazados mediante análisis fotogramétricos aéreos. Después de esta operación y de obtener los derechos de paso y los permisos necesarios, se establecen campamentos de base y se requiere la dotación de un medio de acceso para los equipos de construcción. Las tuberías pueden realizarse trabajando de un extremo a otro o simultáneamente, en tramos separados que más tarde se conectan.

El primer paso en la instalación de una canalización es la construcción de una carretera de servicio de 15 a 30 metros de ancho a lo largo del itinerario previsto, con el fin de disponer de una base estable para el equipo de instalación y conexión de la tubería, así como para la maquinaria de excavación y relleno en caso de que se trate de un conducto subterráneo. Las secciones del conducto se depositan sobre el terreno a lo largo de la carretera de servicio. Sus extremos se limpian, se procede al doblado horizontal o vertical de las tuberías, según proceda, y se colocan las secciones sobre soportes situados por encima del suelo. Estas secciones se unen mediante soldadura por arco eléctrico de varios cordones. Las soldaduras se comprueban visualmente y con rayos gamma para garantizar la ausencia de defectos. Las secciones conectadas se recubren con jabón líquido y se comprueban con aire a presión para detectar la presencia de fugas.

La conducción se limpia, se prepara y se recubre con un material caliente similar al alquitrán para evitar la corrosión y se envuelve con una capa exterior de cartón duro, lana mineral o plástico. Si la tubería debe enterrarse, el fondo de la zanja se acondiciona con arena o grava. A veces se tara con manguitos de hormigón para evitar que salga de las zanja impulsada por la presión de las aguas subterráneas. Una vez colocada la tubería, la zanja se rellena y la superficie del terreno vuelve a adoptar su apariencia normal. Después de su revestimiento y envoltura, las tuberías al descubierto se izan sobre soportes instalados al efecto, que pueden tener diversas características en cuanto a diseño, como la capacidad para la absorción de impactos en caso de terremoto. Las canalizaciones pueden aislarse o disponer de capacidad para el acondicionamiento térmico con el fin de mantener los productos a la temperatura deseada durante su transporte. Todas las secciones de los conductos son sometidas a pruebas hidrostáticas con anterioridad al acceso del gas o de hidrocarburos líquidos.

\section{Explotación de las canalizaciones}

Las canalizaciones pueden ser de propiedad y gestión privadas, en cuyo caso sólo se transportarán los productos de los propietarios, o de uso compartido, estando obligadas entonces a transportar los productos de cualquier compañía siempre que se cumplan los requisitos pertinentes y se abonen las tarifas fijadas. Las tres principales operaciones relacionadas con estas instalaciones son el control de las conducciones, la actividad de las estaciones de bombeo o compresión y la actividad de las terminales de abastecimiento. El almacenamiento, la limpieza, la comunicación y la carga constituyen asimismo funciones importantes.

- Control de las conducciones. Con independencia del producto que se transporte, el tamaño y la longitud de la canalización o el terreno, las estaciones de bombeo de la conducción, las presiones y los caudales se someten a un control exhaustivo con el fin de garantizar un caudal adecuado y la continuidad de las operaciones. Habitualmente, un operario y un ordenador controlan las bombas, las válvulas, los reguladores y los compresores de todo el sistema de conducción desde una estación central.

- Estaciones de bombeo de petróleo y de compresión de gas. Las estaciones de bombeo de petróleo crudo y de productos derivados del mismo , así como las de compresión de gas, se sitúan en las cabezas de pozo y a lo largo del itinerario de la conducción de acuerdo con las necesidades, con el fin de mantener la presión 
Figura 102.14 Un trabajador transfiere producto de la refinería Pasagoula a los depósitos de la terminal Deraville, cerca de Atlanta, Georgia, Estados Unidos.

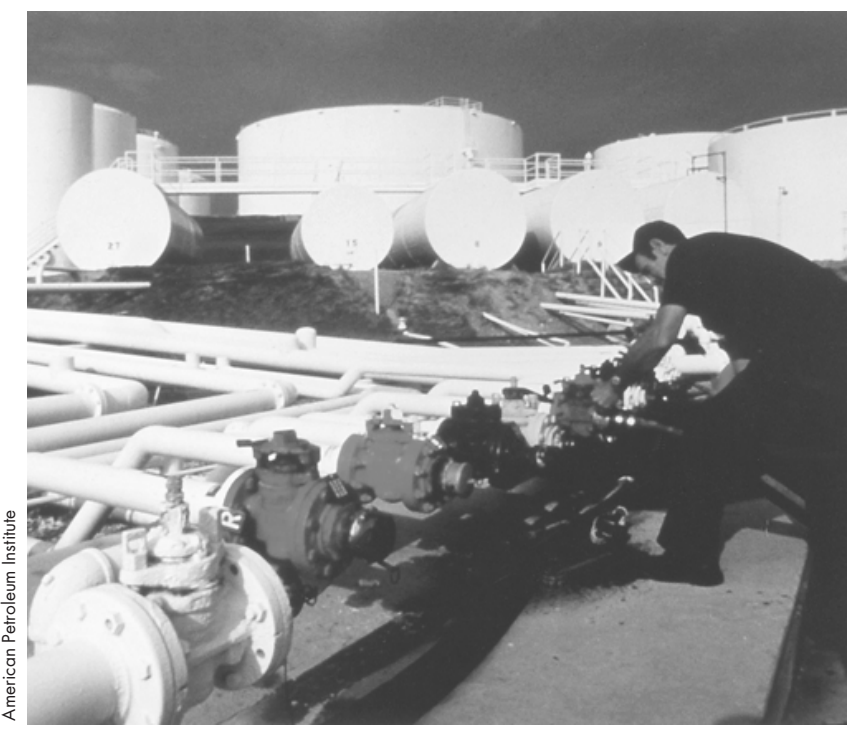

y el volumen. Las bombas son accionadas por motores eléctricos o diesel y las turbinas pueden obtener la energía para su funcionamiento del gasóleo, el gas o el vapor. Muchas de estas estaciones son controladas automáticamente y no disponen de personal en la mayoría de las ocasiones. Las bombas, con o sin conductos de retorno del vapor o de igualación de la presión, suelen utilizarse en canalizaciones de menor tamaño para el transporte de GNL, GPL y gas natural comprimido (GNC). Los detectores de caídas de presión se instalan para identificar la existencia de fugas en las canalizaciones, y las válvulas de exceso de flujo y otros dispositivos de limitación del caudal se utilizan para reducir al mínimo el caudal en caso de fuga. Los buques y los depósitos de almacenamiento pueden aislarse de los conductos principales mediante el accionamiento de válvulas operadas manualmente o por control remoto, o de conexión fusible.

- Almacenamiento de productos canalizados. Las terminales de los oleoductos disponen de depósitos de almacenamiento en caso de avería, a los que pueden desviarse los materiales transportados hasta que sean requeridos por una refinería, otra terminal o los usuarios (véase la Figura 102.14). Otros depósitos en las estaciones de bombeo de la canalización contienen combustible para poner en marcha bombas alimentadas con diesel o generadores eléctricos. Puesto que la producción en los yacimientos de gas es continua y las canalizaciones que transportan éste funcionan constantemente, incluso en períodos de demanda reducida como el verano, los gases de petróleo y el gas natural licuado se almacenan bajo tierra en cavidades naturales o en domos salinos hasta que sean necesarios.

- Limpieza de las canalizaciones. Las canalizaciones se limpian regularmente o de acuerdo con las necesidades, con el fin de mantener el flujo mediante la reducción de la fricción y mantener el diámetro interior en su dimensión original en la medida de lo posible. Un dispositivo especial de limpieza, denominado raspador o pistón rascador, se introduce en la tubería y es impulsado a lo largo de la misma por el flujo del petróleo, de una estación de bombeo a la siguiente. A su paso, extrae la suciedad, la cera y otros materiales depositados acumulados en el interior de los conductos. Al llegar a la estación de bombeo, es extraído, limpiado y reinsertado en el conducto para que lo recorra hasta la estación siguiente.

- Comunicaciones. Es importante que haya comunicación y acuerdo entre las estaciones y los operadores de la canalización y las personas encargadas de enviar y recibir el crudo, el gas y los productos derivados del petróleo, en lo que se refiere a los horarios, los índices y las presiones de bombeo y los procedimientos de emergencia. Algunas empresas explotadoras disponen de sistemas telefónicos privados que transmiten la señal a lo largo de la canalización, mientras que otras utilizan radios o teléfonos públicos. En muchos conductos se emplean sistemas de transmisión de microondas de frecuencias ultraaltas para la comunicación informática entre los centros de control y las estaciones de bombeo.

- Carga de los productos derivados del petróleo. Los productos derivados del petróleo pueden cargarse en las canalizaciones siguiendo diversos métodos. Una compañía que explote una refinería puede mezclar un tipo específico de su gasolina con los aditivos apropiados y enviar una remesa a través del oleoducto directamente a su propia terminal para su distribución a los clientes. Otro método consiste en que la refinería produzca una remesa de gasolina, denominada producto frangible o de especificación, que se mezcla para cumplir con las especificaciones de una compañía de transporte por canalización. La gasolina se introduce en el conducto para su envío a alguno de los terminales de la compañía conectados al sistema de canalización. De acuerdo con un tercer método, las empresas se intercambian remesas de producto enviadas a los terminales de cada una, con el fin de evitar operaciones de transporte y manipulación adicionales. Los productos frangibles y de intercambio suelen combinarse y mezclarse con aditivos en la terminal que recibe el producto procedente de la canalización para satisfacer los requisitos específicos de cada compañía que opera desde la terminal. Por último, ciertos productos son enviados desde las terminales y las refinerías a través de las conducciones directamente a los grandes consumidores comerciales, como en el caso del combustible de reactor a los aeropuertos, el gas a las empresas de distribución de este recurso, y el fueoil a las centrales eléctricas.

- Recepción y envío de productos. Los operadores de canalizaciones y terminales deben establecer conjuntamente programas que garanticen la seguridad en las tareas de recepción y transferencia de productos y coordinen las acciones pertinentes en caso de emergencias que requieran la detención o el desvío del producto. En las instrucciones relativas a la recepción de remesas a través de conductos debe incluirse la comprobación de la disponibilidad de los depósitos de almacenamiento para contener el envío, la apertura y alineación de las válvulas de los depósitos y los terminales previos a la entrega, la adopción de medidas de control para asegurar que el depósito adecuado recibe el producto inmediatamente después del inicio de la entrega, la realización de los muestreos y las pruebas necesarias de las remesas al principio de su entrega, la realización de las modificaciones de las remesas y de los cambios de depósitos oportunos, el control de los productos recibidos para garantizar que no se producen rebosamientos y el mantenimiento de la unión entre la canalización y la terminal. Debe considerarse la utilización de comunicaciones por escrito entre los trabajadores de la terminal, sobre todo cuando los cambios de turno se producen durante la transferencia del producto.

\section{Envíos de remesas e interconexión}

Aunque, inicialmente, las canalizaciones se utilizaron para trasladar petróleo crudo en exclusiva, estas instalaciones han evolucionado para transportar todo tipo de productos de petróleo 
líquido de diferente categoría. Puesto que los productos derivados del petróleo se transportan a través de los oleoductos por remesas enviadas sucesivamente, se producen mezclas en las interfases. Para controlarlas, se aplica alguno de los métodos siguientes: degradación, utilización de espaciadores líquidos o sólidos para separar, y reelaboración de la mezcla. Pueden introducirse en la conducción rastreadores radiactivos, tintes de color y espaciadores para determinar dónde se producen las interfases. Los sensores radioactivos, la observación visual y las pruebas de gravedad se utilizan en la instalación receptora para identificar las distintas remesas transportadas por la canalización.

Los productos derivados del petróleo suelen transportarse a través de oleoductos en remesas enviadas secuencialmente con petróleo crudo compatible o productos combinados. La degradación, método empleado para mantener la calidad y la integridad de los envíos, se aplica mediante la reducción de la interfase entre las dos remesas al nivel del producto menos afectado. Por ejemplo, una remesa de gasolina de primera calidad de alto poder antidetonante suele enviarse inmediatamente antes o después de otra compuesta por gasolina ordinaria de inferior octanaje. La pequeña cantidad de los dos productos que se entremezcle se degradará a la gasolina de inferior calidad. Cuando se envíe gasolina antes o después de remitir combustible diesel, se permite la mezcla de una cantidad limitada de la interfase de diesel con la gasolina, evitando la combinación de ésta con el combustible diesel, que podría reducir su punto de ignición. Las interfases de las remesas suelen detectarse mediante observación visual, gravimetría o toma de muestras.

Los espaciadores líquidos o sólidos y los raspadores pueden utilizarse para separar físicamente e identificar las distintas remesas de producto. Los espaciadores sólidos se detectan mediante una señal radiactiva y son desviados de la conducción hacia un receptáculo especial situado en la terminal cuando se produce el cambio de producto enviado. Los separadores líquidos pueden consistir en agua u otro producto que no se mezcle con ninguna de las remesas que trata de dividir y pueda extraerse y reelaborarse con posterioridad. El queroseno, que se degrada para convertirse en otro producto almacenado o se recicla, también puede utilizarse para separar remesas.

Un tercer método para controlar la interfase, utilizado a menudo en los extremos de los oleoductos que llegan a las refinerías, consiste en devolver aquélla para su reelaboración. Asimismo, los productos y las interfases contaminadas con agua pueden devolverse para someterse al mismo proceso.

\section{Protección ambiental}

Debido al gran volumen de productos transportados a través de las canalizaciones de manera continua, hay riesgo de que emisiones de los mismos provoquen daños ambientales. Dependiendo de los requisitos generales y de las empresas en materia de seguridad, así como de la construcción, la localización, las condiciones meteorológicas, la accesibilidad y el funcionamiento de la conducción, puede liberarse una cantidad considerable de producto en caso de rotura o fuga. Los operadores de las canalizaciones deben adoptar planes de actuación en caso de emergencia y de control de derrames y contar con materiales de contención y limpieza, personal y equipo disponibles en todo momento o previa solicitud. Las soluciones sencillas sobre el terreno, como la construcción de diques de tierra y zanjas de drenaje pueden aplicarse con rapidez por parte de operadores cualificados, con el fin de contener y desviar el producto derramado.

\section{Mantenimiento de las conducciones y de la salud y la seguridad de los trabajadores}

Los primeros oleoductos se fabricaron en hierro fundido. Las canalizaciones principales modernas se construyen en acero soldado de alta resistencia, capaz de soportar grandes presiones. Las paredes de los conductos se someten a pruebas periódicas para comprobar su grosor y determinar si se ha producido corrosión interna o se han creado depósitos. Las soldaduras se inspeccionan visualmente y con rayos gamma, con el fin de garantizar la ausencia de defectos. Las tuberías de plástico pueden emplearse en conducciones de flujo de baja presión y pequeño diámetro y en tuberías colectoras en los yacimientos de gas y de extracción de petróleo crudo, ya que el plástico es ligero y fácil de manejar, montar y desplazar.

Cuando un conducto se divide mediante corte, separación de las bridas, extracción de una válvula o apertura de una tubería, puede crearse un arco electrostático debido al voltaje de protección catódica por diferencia de potencial eléctrico, la corrosión, ánodos de sacrificio, líneas de alta tensión cercanas o corrientes terrestres parásitas. Este riesgo debe reducirse al mínimo mediante la puesta a tierra de la canalización, las desenergización de los rectificadores catódicos más próximos a ambos lados de la división y la conexión de un cable de puesta a masa en cada extremo del conducto antes de empezar a trabajar. Cuando se añadan secciones, válvulas y otros elementos a una conducción existente, o durante su construcción, éstos deben conectarse a tierra a las canalizaciones existentes.

Los trabajos en conducciones deben suspenderse durante las tormentas eléctricas. Los equipos utilizados para elevar y colocar la tubería no deben ponerse en funcionamiento a una distancia inferior a 3 metros de líneas de alta tensión. Los vehículos y los equipos que trabajen en la proximidad de este tipo de líneas deben disponer de tiras de conexión a masa unidas a sus carrocerías y estructuras. Las construcciones metálicas provisionales también deben conectarse a tierra.

Las canalizaciones se dotan de un revestimiento y una envoltura especiales para prevenir la corrosión. Asimismo, puede requerirse el equipamiento con una protección eléctrica catódica. Una vez revestidas y aisladas las secciones de los conductos, éstas se unen mediante abrazaderas especiales conectadas a ánodos metálicos. La canalización se somete a una fuente de corriente continua conectada a tierra de capacidad suficiente, de forma que el conducto actúe como cátodo y no se corroa.

Todas las secciones de la canalización son objeto de pruebas hidrostáticas antes de introducir en ellas gas o hidrocarburos líquidos y, en función de los requisitos legales o impuestos por las empresas, estas pruebas se repiten periódicamente a lo largo de la vida de la conducción. El aire debe eliminarse de las tuberías antes de someterlas a este tipo de pruebas, y la presión hidrostática debe elevarse y reducirse a ritmos seguros. Las conducciones son inspeccionadas con regularidad, normalmente mediante vigilancia aérea, con el fin de detectar fugas de forma visual, o desde los centros de control, para observar caídas de caudal o de presión que puedan indicar rotura de la canalización.

Los sistemas de conducción se dotan de mecanismos de advertencia y señalización para alertar a los operarios de la necesidad de adoptar acciones correctoras en caso de emergencia. Los conductos pueden disponer de sistemas de interrupción automática que activan válvulas de presión de emergencia cuando detectan un aumento o una reducción en la presión de los tubos. Las válvulas de aislamiento activadas de forma manual o automática suelen situarse cada cierta distancia en lugares estratégicos, como las estaciones de bombeo y a ambos lados de los pasos por ríos. 
Una consideración importante al poner en marcha canalizaciones es la instalación de un medio para advertir a los contratistas y otros agentes que puedan estar trabajando o realizando excavaciones a lo largo del itinerario de la conducción, con el fin de evitar que las tuberías sufran roturas o perforaciones que puedan dar lugar a explosiones por emisión de vapores o gases y a incendios. Esta circunstancia suele preverse en las normativas que exigen la solicitud de permisos de obra y por las asociaciones y empresas explotadoras, que facilitan un número central al que los contratistas pueden recurrir antes de iniciar una excavación

Puesto que el crudo y los productos inflamables derivados del petróleo se transportan a través de oleoductos, existe la posibilidad de que se produzcan incendios o explosiones en caso de rotura de la conducción o liberación de vapores o líquidos. La presión debe reducirse hasta alcanzar un nivel seguro antes de trabajar en conductos de alta presión. Deben realizarse pruebas de gas combustible y expedirse permisos antes de efectuar operaciones de mantenimiento que exijan el trabajo en caliente o la reparación en marcha de los oleoductos. Antes de iniciar las tareas, deben eliminarse los líquidos y vapores inflamables y los gases de las canalizaciones. Si un conducto no puede despejarse y se utiliza un obturador autorizado, deben establecerse procedimientos de trabajo seguros, que serán puestos en práctica por operarios cualificados. Las conducciones deben dotarse de respiraderos a una distancia segura del área de trabajo en caliente para atenuar el aumento de presión antes del obturador.

Deben adoptarse procedimientos de seguridad adecuados, que serán cumplidos por trabajadores cualificados cuando se proceda a la reparación de los oleoductos en marcha. Si la soldadura o la colocación de obturadores se efectúan en un área en la que se ha producido un derrame o una fuga, el exterior de la conducción se limpiará de líquidos, y la tierra contaminada se retirará o se cubrirá para evitar incendios.

Es muy importante notificar a los trabajadores de las estaciones de bombeo más cercanas situadas a cada lado de la canalización en funcionamiento dónde se realizan las operaciones de mantenimiento o reparación, por si es necesario interrumpir el caudal. Cuando los productores bombean petróleo crudo o gas a los conductos, sus operarios deben facilitarles instrucciones específicas respecto a las acciones que deben emprender durante los trabajos de reparación y mantenimiento y en los casos de emergencia. Por ejemplo, antes de la conexión de los depósitos y los conductos de producción a los oleoductos, todas sus válvulas de compuerta y purga deben cerrarse y bloquearse o sellarse hasta que la operación finalice.

\section{Figura 102.15• Petrolero SS Paul L. Fahrney.}

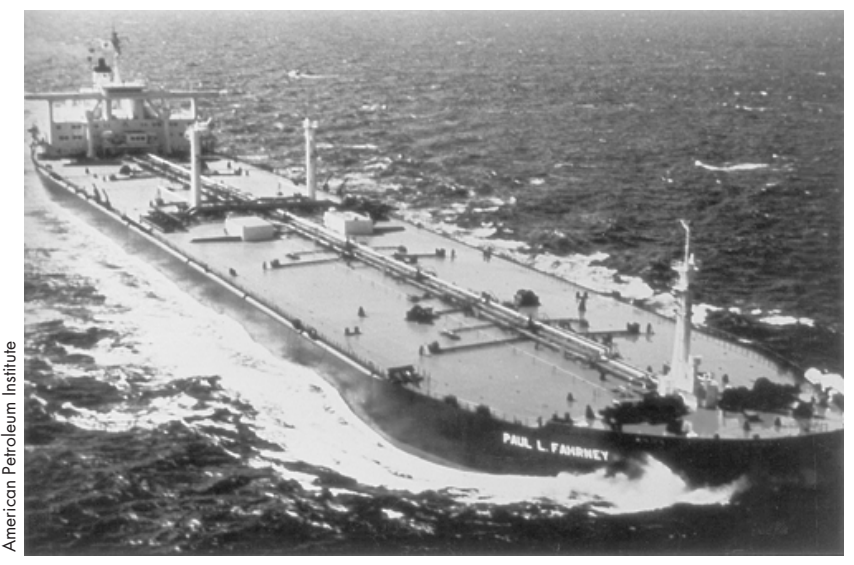

Figura 102.16 Carga del buque tanque dedicado al transporte de GNL Leo en Arun, Sumatra, Indonesia.

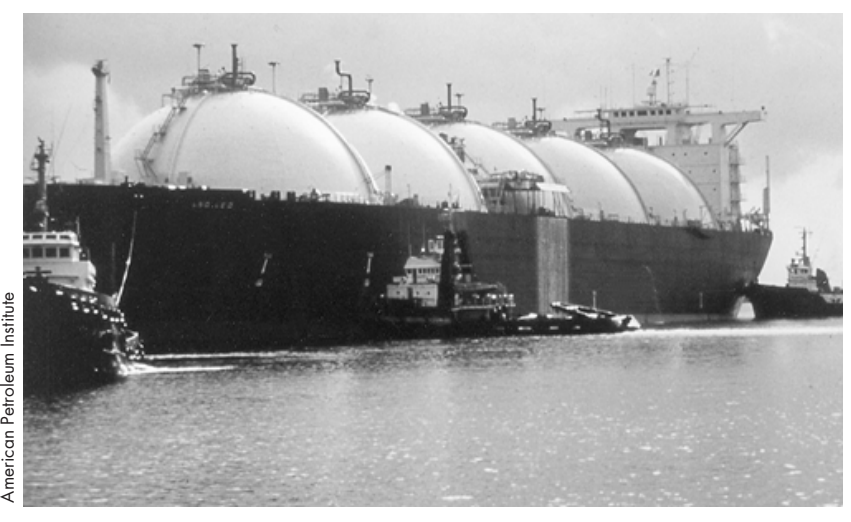

Las precauciones de seguridad habituales respecto a la manipulación de materiales y tuberías, exposiciones tóxicas y peligrosas, soldadura y excavación son aplicables durante la construcción de las canalizaciones. Los trabajadores dedicados a despejar el recorrido deben protegerse de las condiciones meteorológicas, las plantas venenosas, los insectos y las serpientes, la caída de árboles y rocas, etc. Las excavaciones y las zanjas deben formarse en talud o apuntalarse para evitar los derrumbamientos durante la construcción o la reparación de conducciones subterráneas (véase el artículo "Zanjas" incluido en el capítulo de Construcción). El personal debe atenerse a las prácticas de trabajo de seguridad al activar y desconectar transformadores e interruptores eléctricos.

Los trabajadores dedicados a la puesta en funcionamiento y el mantenimiento de las canalizaciones suele desarrollar su actividad en solitario y son responsables de grandes tramos de las mismas. Las pruebas atmosféricas y la utilización de equipos de protección personal y respiratoria son necesarias para determinar los niveles de oxígeno y de vapores inflamables y protegerse frente a exposiciones tóxicas al ácido sulfhídrico y al benceno producidas al comprobar depósitos, abrir conductos, limpiar vertidos, tomar muestras, efectuar pruebas, enviar y recibir remesas y llevar a cabo otras actividades en la canalización. Los trabajadores deben llevar dosímetros personales de radiación y evitar la exposición al trabajar con medidores de densidad y otros materiales radioactivos. Debe considerarse la utilización de equipos de protección individual y respiratoria para prevenir quemaduras por contacto con el alquitrán caliente utilizado en el revestimiento de las tuberías, así como la exposición a los vapores tóxicos que contienen hidrocarburos aromáticos polinucleares.

\section{Petroleros y barcazas}

La mayor parte del petróleo crudo mundial es transportado por petroleros desde regiones productoras como Oriente Próximo y Africa hasta las refinerías de las áreas de consumo como Europa, Japón y Estados Unidos. Los productos derivados del petróleo se transportaban inicialmente en grandes barriles a bordo de cargueros. El primer buque cisterna, construido en 1886, transportó unas 2.300 SDWT (2.240 libras por tonelada) de petróleo. Los superpetroleros actuales pueden tener una eslora de más de 300 metros y desplazar una cantidad de petróleo superior en casi 200 veces a la citada (véase la Figura 102.15). Las tuberías colectoras y de alimentación suelen desembocar en tinglados de carga de terminales marítimas o plataformas en alta mar, donde el 
crudo se carga en los petroleros u otras embarcaciones para su traslado a las conducciones principales o a refinerías. Los productos derivados del petróleo también se transportan de las refinerías a los terminales de distribución en este tipo de barcos. Después de la entrega de la mercancía, los buques regresan en lastre a las instalaciones de carga para repetir la operación.

El gas natural licuado se traslada en estado criogénico en buques mercantes especializados con compartimentos o depósitos fuertemente aislados (véase la Figura 102.16). En el puerto de entrega, el GNL se descarga en las instalaciones de almacenamiento o de regasificación. El gas de petróleo licuado puede transportarse en estado líquido en buques no aislados o como criógeno en embarcaciones aisladas. Además, el GNL en recipientes (gas embotellado) puede trasladarse como carga en buques mercantes.

\section{Buques dedicados al transporte de GPL y GNL}

Los tres tipos de buques mercantes dedicados al transporte de GPL y GNL son:

- los que disponen de depósitos a presión de hasta $2 \mathrm{mPa}$ (sólo GPL);

- los que disponen de depósitos termoaislados a una presión entre 0,3 y $0,6 \mathrm{mPa}$ (sólo GPL); y

- los buques criogénicos con depósitos termoaislados a una presión cercana a la atmosférica (GPL y GNL).

El transporte de HGL en buques mercantes requiere una sensibilización constante respecto a la seguridad. Las mangueras de carga deben adaptarse a las temperaturas y las presiones correctas de los HGL manipulados. Para evitar la combinación inflamable de vapores de gas y aire, se dotan los depósitos de una cubierta protectora de gas inerte (nitrógeno), y el área se somete a una vigilancia constante para detectar la presencia de fugas. Antes de cargar, los depósitos de almacenamiento deben inspeccionarse para garantizar que se encuentran libres de contaminantes. Si contienen gas inerte o aire, deben purgarse con vapor de HGL antes de la carga de éstos. Los depósitos deben someterse a un control constante para asegurar su integridad, y deben instalarse válvulas de seguridad para aliviar el vapor de HGL generado a la máxima carga de calor. Los buques mercantes cuentan con sistemas de extinción de incendios y disponen de procedimientos exhaustivos de actuación en caso de emergencia.

\section{Buques mercantes dedicados al transporte de crudo y productos derivados del petróleo}

Los petroleros y las barcazas llevan los motores y camarotes en la parte posterior y el resto de la embarcación se divide en compartimentos especiales (depósitos) para el transporte de crudo y productos derivados del petróleo a granel. Las bombas de la carga se sitúan en las salas de bombas y se dispone de sistemas de ventilación forzada e inertización para reducir el riesgo de incendio y explosiones en dichas salas y en los depósitos. Las barcazas y los petroleros modernos se construyen con cascos dobles y otras características de protección y seguridad exigidas por la Ley de contaminación por petróleo de los Estados Unidos, promulgada en 1990, y las normas de seguridad de petroleros de la Organización Marítima Internacional (OMI). En algunos diseños recientes, se extiende la duplicación del casco hacia la parte superior de los lados de las embarcaciones con el fin de ofrecer más protección. En general, los grandes petroleros transportan crudo y los pequeños y las barcazas se dedican al traslado de productos derivados del petróleo.

- Superpetroleros. Los buques de transporte "muy grandes" y "ultragrandes" (BTMG y BTUG) están obligados por su tamaño y calado a seguir itinerarios fijos. La capacidad de los BTUG supera los 300.000 SDWT y la de los BTMG oscila entre 160.000 y 300.000 SDWT. La mayoría de los grandes petroleros no son propiedad de empresas petroleras, sino que son fletados por empresas de transporte especializadas en la explotación de embarcaciones de gran tamaño.

- Petroleros. Los petroleros son más pequeños que los BTMG y, además de efectuar recorridos transoceánicos, pueden atravesar pasos restringidos como los canales de Suez y de Panamá, aguas costeras poco profundas y estuarios. Los grandes petroleros, cuya capacidad va de 25.000 a 160.000 SDWT, suelen transportar petróleo crudo o productos residuales pesados. Habitualmente, los buques de menor tamaño, con capacidades inferiores a 25.000 SDWT, transportan gasolina, gasóleo y lubricantes.

- Barcazas. Las barcazas operan fundamentalmente en zonas costeras, cursos de agua interiores y ríos, en solitario o en grupos de dos o más embarcaciones, y son autopropulsadas o arrastradas por un remolcador. Pueden transportar crudo a las refinerías, pero son utilizadas con mayor frecuencia como medio económico de trasladar productos derivados del petróleo desde las refinerías a las terminales de distribución. Las barcazas también se emplean para descargar en alta mar mercancía de petroleros que por su calado o tamaño no tienen acceso a los muelles.

\section{Carga y descarga de barcazas y otras embarcaciones}

Los operadores de las terminales y los buques mercantes deben establecer procedimientos de descarga de los buques, así como listas de comprobación y directrices de seguridad. En la International Safety Guide for Oil Tankers and Terminals (International Chamber of Shipping 1978) se recoge información y muestras de listas de comprobación, directrices, permisos y otros procedimientos relativos a la seguridad de las operaciones de carga y descarga de embarcaciones, que pueden ser utilizadas por ambas partes.

Aunque los buques mercantes se asientan sobre el agua y, por tanto, incorporan en su propia construcción la conexión a masa, es necesario protegerse de la electricidad estática que puede acumularse en las tareas de carga y descarga. Para lograrlo, deben conectarse los objetos metálicos presentes en los muelles o los equipos de carga y descarga con la parte metálica del buque. La conexión a masa se consigue asimismo mediante la utilización de mangueras o tuberías de carga conductoras. Una chispa electrostática de la intensidad necesaria para provocar una ignición puede ser generada al introducir equipos, termómetros o dispositivos de medición en los depósitos inmediatamente después de la carga; debe dejarse un período de tiempo suficiente para la disipación de la carga estática.

Las corrientes eléctricas del buque a la orilla, que difieren de la electricidad estática, pueden ser generadas por la protección catódica del casco del buque o de la dársena, o por las diferencias de potencial galvánico entre la embarcación y la orilla. Estas corrientes también se acumulan en los equipos metálicos de carga y descarga. Pueden instalarse dispositivos aislantes a lo largo del brazo de carga o en el lugar en el que las mangueras flexibles se conectan al sistema de conducción de tierra. Cuando se interrumpen las conexiones, es imposible que una chispa salte de una superficie metálica a otra.

Todos los buques y terminales deben acordar procedimientos de actuación de emergencia en caso de incendio o pérdida del producto, vapores o gases tóxicos. En éstos se recogerán las operaciones de emergencia, la detención del flujo de producto y la salida de los muelles de un buque en situaciones de emergencia. En estos planes deben considerarse las comunicaciones, la extinción de incendios, la mitigación de las nubes de vapores, 
la ayuda mutua, el rescate, la limpieza y las medidas paliativas. Los equipos portátiles y fijos de protección contra incendios deben ajustarse a las normativas públicas y los requisitos impuestos por las empresas, y al tamaño, la función, la posibilidad de exposición y el valor de las instalaciones portuarias. En la International Safety Guide for Oil Tankers and Terminals (International Chamber of Shipping 1978) se incluye un documento modelo que puede ser utilizado por las terminales como guía de referencia en materia de prevención de incendios en las dársenas portuarias.

\section{Salud y seguridad en los buques mercantes}

Además de los riesgos profesionales habituales en el ámbito marítimo, el transporte de petróleo crudo y líquidos inflamables en buques mercantes plantea diversas situaciones especiales en relación con la salud, la seguridad y la prevención de incendios. Son situaciones de este tipo la salida brusca y la expansión de la mercancía líquida, la generación de vapores inflamables durante el transporte y las operaciones de carga y descarga, la posibilidad de ignición pirofórica, las exposiciones tóxicas a materiales como el ácido sulfhídrico y el benceno y los problemas de seguridad al ventilar, limpiar con líquidos y en seco los depósitos. Los aspectos económicos de la explotación de los modernos petroleros exige que estos buques permanezcan en el mar durante períodos prolongados, estableciéndose únicamente intervalos limitados en puerto para cargar y descargar la mercancía. Este factor, junto con el elevado grado de automatización de estas embarcaciones, plantea demandas mentales y físicas singulares para los escasos miembros de las tripulaciones dedicadas a velar por el funcionamiento de los buques.

\section{Protección contra incendios y explosiones}

Deben formularse y aplicarse planes y procedimientos de emergencia adecuados al tipo de mercancía a bordo y otros riesgos potenciales. Deben facilitarse equipos de extinción de incendios. Los miembros de los equipos de actuación en caso de emergencia encargados de las operaciones de lucha contra incendios, rescate y limpieza de vertidos a bordo deben recibir formación, ejercitarse y equiparse para hacer frente a este tipo de situaciones. El agua, la espuma, las sustancias químicas secas, el halón, el dióxido de carbono y el vapor se utilizan como agentes de refrigeración, inhibición y extinción de incendios en los buques mercantes, si bien el halón es cada vez menos utilizado debido a consideraciones ambientales. Los requisitos de los equipos y sistemas de extinción aplicados en los buques los establece el país bajo cuya bandera naveguen, así como la política de cada naviera, aunque suelen seguirse las recomendaciones del Convenio Internacional para la Seguridad de la Vida Humana en el Mar (SOLAS), de 1974.

$\mathrm{El}$ control estricto de las llamas y las luces desnudas, los cigarrillos encendidos y otras fuentes de ignición, como chispas de soldadura o pulido, equipos eléctricos y bombillas desprotegidas, es necesario en los buques en todo momento, al objeto de reducir el riesgo de incendio y explosión. Antes de llevar a cabo trabajos en caliente a bordo, el área de operación debe examinarse y comprobarse para garantizar que las condiciones son seguras, y deben expedirse permisos para cada tarea específica autorizada.

Un método para prevenir las explosiones y los incendios en el espacio ocupado por vapores en los depósitos de la carga consiste en mantener el nivel de oxígeno por debajo del $11 \%$ mediante la inertización de la atmósfera con un gas no combustible. Las fuentes de gases inertes son el escape de las calderas de los buques o los generadores o turbinas de gas independientes equipadas con postquemadores. El Convenio SOLAS de 1974 exige que los buques que transportan mercancías con puntos de inflamación inferiores a $60^{\circ} \mathrm{C}$ dispongan de depósitos dotados de sistemas de inertización. Las embarcaciones que utilizan estos sistemas deben mantener tales depósitos en condiciones de ininflamabilidad en todo momento. Los depósitos de gas inerte deben vigilarse constantemente para garantizar su seguridad y no debe permitirse su transformación en inflamables, debido al peligro de ignición derivado de los depósitos pirofóricos.

\section{Espacios confinados}

Los espacios confinados de los buques mercantes, como los depósitos de mercancías, los pañoles de pinturas, las salas de máquinas, los depósitos de combustible y los espacios creados por los cascos dobles, deben tratarse del mismo modo que otros de idénticas características en lo que se refiere al acceso y a los trabajos en frío y en caliente. Debe comprobarse el contenido de oxígeno y la presencia de vapores inflamables y sustancias tóxicas, en ese orden, antes de entrar en un espacio confinado. Es necesario establecer y aplicar un sistema de permisos para el acceso y los tipos de actividad antes referidos, con el que se indique los niveles de exposición de seguridad y se exija la utilización de equipos de protección individual y respiratoria. En las aguas jurisdiccionales de Estados Unidos, estas pruebas deben ser realizadas por personal cualificado denominado "químicos marítimos".

Los compartimentos de los buques mercantes, como los depósitos de mercancías y las salas de máquinas, son espacios confinados; al proceder a la limpieza de aquéllos que se han inertizado o que tienen atmósferas formadas por vapores inflamables, tóxicas o desconocidas, deben ser comprobados, y deben aplicarse procedimientos especiales de seguridad y protección respiratoria. Tras la descarga del petróleo crudo, una pequeña cantidad de residuo, denominada sarro, permanece en las superficies interiores de los depósitos, que pueden ser lavados o llenados con agua como lastre. Un método de reducir la cantidad de residuo consiste en instalar equipos fijos encargados de eliminarlo hasta en un $80 \%$ mediante el lavado de las paredes de los depósitos inertizados con petróleo crudo durante la operación de descarga.

\section{Bombas, válvulas y equipos}

Es necesario expedir un permiso de trabajo y aplicar procedimientos de seguridad, como la conexión a masa, el drenaje y la eliminación de vapores, la comprobación de la exposición a vapores inflamables y sustancias tóxicas y la disposición de equipos de reserva para la extinción de incendios, cuando las operaciones de mantenimiento, reparación y de otra índole exijan la apertura de bombas de carga, conductos, válvulas o equipos a bordo de buques mercantes.

\section{Exposiciones tóxicas}

Los gases que escapan por los respiraderos, como los de combustión o el ácido sulfhídrico, pueden alcanzar las cubiertas de las embarcaciones, incluso a través de sistemas de ventilación especialmente diseñados. Deben realizarse pruebas continuas para determinar los niveles de gas inerte en todos los buques y los de dicho ácido en aquéllos que contienen o han transportado con anterioridad petróleo crudo sulfuroso o combustible residual. Asimismo, debe comprobarse la exposición al benceno en los barcos que trasladen crudo y gasolina. El agua residual utilizada en el lavado de gases inertes y el agua condensada es ácida y corrosiva; deben utilizarse EPI si hay posibilidad de contacto.

\section{Protección ambiental}

Los buques mercantes y las terminales marítimas deben establecer procedimientos y disponer de equipos que les permitan 
proteger el medio ambiente de vertidos en el agua y sobre el terreno, así como de emisiones de vapores a la atmósfera. La utilización de grandes sistemas de recuperación de vapores en las terminales marítimas es cada vez mayor. Debe prestarse atención al cumplimiento de los requisitos relativos a la contaminación atmosférica cuando los buques ventilen sus depósitos y espacios confinados. Es necesario formular procedimientos de actuación en caso de emergencia y debe disponerse de equipos y personal capacitados para actuar cuando se producen vertidos y derrames de petróleo crudo y de líquidos inflamables y combustibles. Debe designarse una persona responsable de garantizar la expedición de notificaciones a la compañía y las autoridades competentes en caso de vertido o derrame digno de comunicación.

En el pasado, el agua de lastre contaminada por el petróleo y el producto del lavado de depósitos se evacuaban de éstos al mar. En 1973, el Convenio Internacional para la Prevención de la Contaminación de las Embarcaciones estableció que, antes de la evacuación del agua al mar, debe separarse el residuo de petróleo y conservarse a bordo para su posterior tratamiento en tierra. Los petroleros modernos cuentan con sistemas de lastre separados, con conductos, bombas y depósitos distintos a los utilizados para la mercancía (de acuerdo con las recomendaciones internacionales), por lo que no hay posibilidad de contaminación. Los buques de mayor antigüedad siguen transportando el agua de lastre en los depósitos de la carga, por lo que, cuando se procede a la evacuación de estos residuos, deben aplicarse procedimientos especiales, como el bombeo del agua contaminada a los depósitos designados y las instalaciones de tratamiento situados en tierra, con el fin de prevenir la contaminación.

\section{Transporte por carretera y ferrocarril de productos derivados del petróleo}

En el pasado, el crudo y los productos derivados del petróleo se transportaban en furgones cisterna tirados por caballos; posteriormente comenzaron a trasladarse en vagones cisterna ferroviarios y, por último, en vehículos de motor. Tras su descarga en las terminales marítimas por los buques mercantes o procedentes de los oleoductos, los productos petrolíferos licuados a granel son distribuidos por camiones o vagones cisterna sin presión directamente a las estaciones de servicio y los usuarios o a terminales de menor tamaño, denominadas fábricas a granel, para su redistribución. Los GPL, los compuestos antidetonantes de gasolina, el ácido fluorhídrico y muchos otros productos, sustancias químicas y aditivos utilizados en las industrias del petróleo y el gas son transportados en vagones y camiones cisterna a presión. Además, el crudo puede ser transportado por camiones cisterna desde los pequeños pozos de extracción a los depósitos de recogida, y por éstos vehículos y vagones cisterna desde los depósitos de almacenamiento a las refinerías o los oleoductos principales. Los productos petrolíferos envasados en barriles o bidones a granel y en paletas y cajas de recipientes de menor tamaño se transportan en camiones y vagones para carga fraccionada.

\section{Normativas públicas}

El transporte de productos derivados del petróleo en vehículos de motor y vagones cisterna está regulado por los organismos públicos en la mayor parte del mundo. Entidades como el Departamento de Transporte de Estados Unidos y la Canadian Transport Commission (CTC) han establecido normativas que rigen el diseño, la fabricación, los dispositivos de seguridad, las pruebas, el mantenimiento preventivo, la inspección y la explotación de camiones y vagones cisterna. Las normas que regulan el funcionamiento de este tipo de vehículos suelen referirse a la comprobación y la certificación de los dispositivos instalados para controlar y aliviar la presión de los depósitos antes de su puesta en servicio inicial y posteriormente cada cierto tiempo. La Association of American Railroads y la National Fire Protection Association (NFPA) son dos casos típicos de organizaciones que publican especificaciones y requisitos para el funcionamiento de vagones y camiones cisterna en condiciones de seguridad. La mayoría de las administraciones han establecido normativas al respecto o se atienen a los convenios de las Naciones Unidas en los que se exige la identificación y la información relativa a los materiales peligrosos y a los productos petrolíferos transportados a granel o en recipientes. En los camiones y los vagones cisterna, así como en los camiones de carga fraccionada, se colocan placas para identificar los productos peligrosos transportados y ofrecer información para la actuación en caso de emergencia.

\section{Vagones cisterna}

Los vagones cisterna se fabrican en acero al carbono o aluminio y pueden estar presurizados o no. Los modelos modernos admiten hasta 171.000 litros de gas comprimido a presiones en torno a 600 psi (1,6 a 1,8 mPa). Los vehículos sin presión han evolucionado desde los primeros prototipos pequeños realizados en madera a finales del siglo XIX, hasta los modelos actuales de gran tonelaje capaces de transportar 1,31 millones de litros de producto a presiones de hasta 100 psi $(0,6 \mathrm{mPa})$. Pueden consistir en unidades individuales con uno o varios depósitos o en una cadena de vagones cisterna interconectados, denominados tren cisterna. Los vagones cisterna a presión y sin presión pueden calentarse, refrigerarse, aislarse o protegerse térmicamente contra incendios, en función del servicio que presten y de los productos que transporten.

Todos los vagones cisterna disponen de válvulas de líquidos o gases superiores e inferiores

para efectuar las operaciones de carga y de descarga, así como de compuertas para la limpieza. Asimismo, están equipados con dispositivos diseñados para prevenir el aumento de la presión interna en casos de exposición a condiciones anómalas. Se trata de válvulas de descarga de seguridad de resorte que se abren para aliviar la presión y que, a continuación, se cierran; aberturas de seguridad con discos de ruptura que estallan para atenuar la presión, pero no vuelven a cerrarse, o una combinación de ambos mecanismos. En los vagones cisterna sin presión se instala una válvula de anulación del vacío con el fin de evitar la formación de éste cuando se descarga desde la parte inferior. Tanto los modelos a presión como los sin presión disponen de revestimientos protectores en su parte superior rodeando las conexiones de carga, los conductos de toma de muestras, los termómetros y los dispositivos de medición. En algunos casos se instalan plataformas de carga en la parte superior de los vagones. Los modelos antiguos sin presión pueden constar de una o varias bóvedas de expansión. En la parte inferior se dispone de instrumentos de carga y descarga. En los extremos de los vagones se montan escudos de protección para evitar la perforación de la estructura por parte del gancho de unión de otro vagón en casos de descarrilamiento.

El GNL se carga como criógeno en camiones cisterna aislados y vagones cisterna a presión. Estos vehículos disponen de un depósito interior de acero inoxidable suspendido en un depósito exterior de acero al carbono. En el espacio anular se crea el vacío y se introducen aislantes para mantener una temperatura baja durante el transporte. Para evitar que los gases prendan en los depósitos, éstos se equipan con dos válvulas de cierre de emergencia en caso de avería manejadas por control remoto y situadas en las tuberías de carga y descarga, y con dispositivos de medición dentro y fuera de los depósitos.

El GPL se transporta en tierra en vagones cisterna de diseño especial (de hasta $130 \mathrm{~m}^{3}$ de capacidad) o en camiones cisterna (de hasta $40 \mathrm{~m}^{3}$ de capacidad). 
Estos vehículos suelen consistir en cilindros de acero no aislados de fondo esférico, equipados de medidores, termómetros, dos válvulas de alivio de seguridad, un indicador de nivel de gas y otro de llenado máximo y mamparas.

Los vagones cisterna que transportan GNL o GPL no deben sobrecargarse, ya que pueden permanecer en una vía de servicio durante cierto período de tiempo y exponerse a temperaturas ambientales elevadas, capaces de provocar un exceso de presión y la salida de gases. Las terminales de carga están equipados con cables de puesta a tierra para neutralizar y disipar la electricidad estática. Deben conectarse antes del inicio de las operaciones y no desconectarse hasta que éstas hayan concluido y todas las válvulas se hayan cerrado. Las instalaciones de carga de camiones y vagones suelen protegerse contra incendios mediante sistemas de pulverización de agua, nebulizadores y de extintores.

\section{Camiones cisterna}

Los depósitos de los camiones cisterna dedicados al transporte de productos petrolíferos y crudo suelen fabricarse de acero al carbono, aluminio o fibra de vidrio plastificada y su capacidad oscila entre los 1.900 litros de los modelos de pequeño tamaño y los 53.200 litros de los de gran tonelaje. La capacidad de estos vehículos es regulada por los organismos competentes y suele depender de las limitaciones relativas al transporte en autopista y al paso por puentes, así como del peso autorizado por eje o la cantidad total de producto permitida.

Existen camiones cisterna a presión y sin presión, aislados o no en función del servicio que presten y los productos que trasladen. Los modelos a presión suelen constar de un único depósito, mientras que los vehículos sin presión pueden disponer de más de uno. Con independencia del número de depósitos, cada uno de ellos debe ser objeto de un tratamiento individual, con sus propios dispositivos de carga, descarga y alivio de la presión. Pueden estar separados por paredes simples o dobles. Las normativas pueden exigir que los productos incompatibles y los líquidos inflamables o combustibles transportados en un mismo vehículo estén separados por paredes dobles. Al comprobar la presión de los depósitos, también debe examinarse el espacio entre ambos para detectar la presencia de líquidos o vapor.

Los camiones cisterna disponen de compuertas para carga superior, válvulas para la carga y descarga superior o inferior o ambos tipos de dispositivos. Todos los depósitos disponen de compuertas de acceso para la limpieza y están equipados con dispositivos de seguridad que permiten aliviar la presión interna en caso de exposición a condiciones anómalas. Se trata de válvulas de alivio de seguridad, fijadas por un resorte que puede abrirse para aliviar la presión y que, a continuación, se cierran; compuertas de seguridad en los depósitos sin presión que se abren si las válvulas mencionadas fallan, y discos de ruptura en los depósitos a presión. En los camiones cisterna sin presión se instala una válvula de anulación del vacío con el fin de evitar la formación de éste cuando se descarga desde la parte inferior. Este tipo de vehículos está equipado con barras situados en la parte superior para proteger las compuertas, válvulas de descarga y sistemas de recuperación del vapor en caso de vuelco. Los camiones cisterna suelen dotarse de dispositivos de rotura y cierre automático situados en los conductos de carga y descarga de la parte inferior de los depósitos, con el fin de evitar derrames en caso de vuelco o colisión.

\section{Carga y descarga de los vagones y los camiones cisterna}

Mientras que los vagones cisterna son cargados y descargados casi siempre por trabajadores encargados de estas tareas específicas, estas operaciones en el caso de los camiones cisterna pueden ser efectuadas por personal especializado o por los conductores. La carga se realiza en instalaciones denominadas terminales de carga, a través de compuertas o de conexiones cerradas situadas en la parte superior, de conexiones cerradas ubicadas en la parte inferior, o de una combinación de ambas.

\section{Carga}

Los trabajadores encargados de la carga y descarga de crudo, GPL, productos petrolíferos y ácidos y aditivos utilizados en las industrias del gas y el petróleo, deben haber adquirido un conocimiento básico de las características de los productos manejados, sus riesgos y exposiciones y los procedimientos operativos y prácticas de trabajo necesarios para desempeñar su tarea en condiciones de seguridad. Numerosos organismos públicos y empresas exigen la utilización y cumplimentación de formularios de inspección en el momento de la recepción y el envío de la mercancía y antes de su carga y descarga de los vagones y los camiones cisterna. Estos vehículos pueden cargarse a través de compuertas situadas en su parte superior o de accesorios y válvulas ubicados encima o debajo de cada depósito o compartimiento. Las conexiones cerradas son necesarias cuando se carga a presión y se dispone de sistemas de recuperación de vapor. Si los sistemas de carga no se activan por alguna razón (como el funcionamiento incorrecto de la recuperación de vapor o una avería de los mecanismos de conexión a tierra), la utilización de tubos de derivación no debe intentarse sin autorización previa. Todas las compuertas deben cerrarse y asegurarse con enganches durante el transporte.

Los trabajadores deben atenerse a las prácticas de trabajo de seguridad con el fin de evitar resbalones y caídas al cargar desde la parte superior de los depósitos. Si en los controles de carga se emplean dispositivos de medición prefijados, el personal encargado de la operación debe adoptar las precauciones necesarias para introducir los productos correctos en los depósitos y compartimientos asignados. Todas las compuertas deben cerrarse en las operaciones de carga inferior y, en las de carga superior, sólo se mantendrán abiertas las del compartimiento cargado. En las operaciones de carga superior, deben evitarse las salpicaduras mediante la colocación del tubo o la manguera empleados cerca del fondo del depósito y el inicio lento de la actividad, hasta que la apertura de estos dispositivos quede sumergida. En los procesos de carga manuales, el personal encargado permanecerá atento, no inmovilizará el control de interrupción de carga (dispositivo de detención automática) e impedirá el rebosamiento del depósito. Estos trabajadores deben evitar el contacto con el producto y sus vapores colocándose contra el viento, apartando la cabeza en las operaciones de carga superior a través de compuertas abiertas y utilizando equipos de protección al manipular aditivos, obtener muestras y drenar mangueras. Deben conocer y cumplir las medidas de actuación prescritas en caso de rotura de una manguera o un conducto, derrame, escape, incendio u otra emergencia.

\section{Descarga y entrega}

Al descargar vagones y camiones cisternas, es importante en primer lugar asegurarse de que cada producto se descarga en el depósito de almacenamiento designado y de que éste tiene capacidad suficiente para recibir la cantidad de producto entregada. Aunque las válvulas, tuberías de llenado, conductos y tapas de carga deben marcarse con un código de colores u otro método para identificar el producto contenido, el conductor seguirá siendo responsable de la calidad del producto durante su entrega. Un error en esta operación, la mezcla de sustancias o su contaminación deben comunicarse de inmediato al receptor de la carga y a la compañía para evitar consecuencias graves. Cuando se exija a los conductores u operarios añadir aditivos a los productos $u$ obtener muestras de los depósitos de almacenamiento tras la entrega, para garantizar la calidad del producto o por otras 
causas, deben seguirse todas las disposiciones en materia de salud y seguridad especificas de la exposición en cuestión. Las personas encargadas de las operaciones de entrega y descarga deben permanecer en todo momento cerca del lugar en el que se efectúen y saber qué medidas deben adoptarse en caso de emergencia, incluida la notificación, la detención del flujo de producto, la limpieza de derrames y la elección del momento para abandonar la zona.

Los depósitos presurizados se descargan con un compresor o una bomba, mientras que, en los no presurizados, esta operación se basará en la acción de la gravedad, o la utilización de una bomba del vehículo o del recipiente. En ocasiones, los camiones y vagones cisterna que transportan lubricantes o aceites industriales, aditivos y ácidos se descargan presurizando el depósito con gases inertes como el nitrógeno. Puede que estos vehículos necesiten ser calentados mediante el uso de vapor o electricidad con el fin de descargar petróleo crudo pesado, productos viscosos o ceras. Todas estas actividades plantean peligros y riesgos. Cuando así se establezca en la normativa, la descarga no debe comenzar hasta que las mangueras de recuperación de vapor hayan sido conectadas entre el depósito de entrega y el de almacenamiento. Al distribuir productos petrolíferos a residencias, explotaciones agrarias y establecimientos comerciales, los conductores deben inspeccionar los depósitos no equipados con una alarma de rebosamiento para evitar esta circunstancia.

\section{Protección contra incendios en las terminales de carga}

Los incendios y las explosiones en la parte superior e inferior de las terminales de carga de los vagones y los camiones cisterna pueden producirse por causas como la acumulación electrostática y una descarga de chispa incendiaria en una atmósfera inflamable, el trabajo en caliente no autorizado, la llamarada procedente de una unidad de recuperación de vapor, el consumo de tabaco y otras prácticas inseguras.

Las fuentes de ignición, como los cigarrillos encendidos, los motores de combustión interna en funcionamiento y el trabajo en caliente, deben someterse a un control continuo en las terminales de carga, sobre todo al cargar o realizar otras operaciones en las que puede producirse un derrame o un escape. Las terminales pueden equiparse con extintores portátiles y con sistemas de extinción de incendios basados en la utilización de espuma, agua o sustancias químicas secas y activados de forma manual o automática. Si se utilizan sistemas de recuperación de vapor, deben instalarse cortafuegos que prevengan la extensión del fuego de estos sistemas a las terminales de carga.

Deben instalarse mecanismos de drenaje en estas terminales para alejar los derrames de producto del personal cargador, del camión o el vagón cisterna y del soporte de las propias terminales. Los canales de desagüe deben dotarse de cortafuegos para evitar la propagación de las llamas y los vapores a través de la red de alcantarillado. Otros medidas de seguridad en las terminales de carga consisten en la colocación de controles de cierre de emergencia en los lugares de carga y otras ubicaciones estratégicas en la terminal, y de válvulas automáticas sensibles a la presión que interrumpan el flujo de producto a la terminal en caso de fuga en las conducciones. Algunas empresas han instalado sistemas de bloqueo de frenos automáticos en las conexiones de carga de sus camiones cisterna que impiden que el vehículo se mueva de la terminal hasta que los conductos de llenado hayan sido desconectados.

Riesgos de ignición electrostática

Algunos productos, como los destilados intermedios o los combustibles y disolventes de baja presión de vapor, tienden a acumular cargas electrostáticas. Al cargar vagones y camiones cisternas, siempre existe la posibilidad de que se generen este tipo de cargas por fricción, al atravesar el producto conductos y filtros, y por las salpicaduras provocadas. Este efecto se atenúa mediante el diseño de terminales de carga que permitan un período de relajación en el paso del flujo procedente de bombas y filtros.

Deben comprobarse los depósitos para asegurar que no contienen objetos no conectados a masa o flotantes que puedan actuar como acumuladores estáticos. Los depósitos de carga inferior pueden dotarse de cables internos que ayuden a disipar las cargas electrostáticas. Los contenedores de muestras, los termómetros y otros instrumentos no deben introducirse en los depósitos hasta que haya transcurrido un período de espera mínimo de un minuto, de forma que pueda disiparse la carga electrostática acumulada en el producto.

La puesta a masa y a tierra son una medida importante para disipar las cargas electrostáticas acumuladas durante las operaciones de carga. Al mantener la tubería de llenado en contacto con el lado metálico de la compuerta en los casos de carga superior, y mediante la utilización de brazos de carga metálicos o mangueras conductoras al proceder al llenado a través de conexiones cerradas, el camión o el vagón cisterna se conectan a la terminal de carga y se conserva la misma carga eléctrica entre los objetos, de forma que se impide la generación de una chispa al retirar el tubo o la manguera de carga. Asimismo, estos vehículos pueden conectarse a la terminal mediante el empleo de un cable de puesta a masa, que transporta la carga acumulada de un terminal del depósito a la terminal, donde se pone a tierra mediante un cable o una varilla. Es necesario adoptar precauciones similares al descargar vagones y camiones cisterna. Algunas terminales disponen de conectores y sensores electrónicos que impiden la activación de las bombas de carga hasta que se establezca una conexión a masa positiva.

En las tareas de limpieza, mantenimiento y reparación, los vagones y camiones cisterna de GPL presurizados suelen abrirse libremente, permitiendo el acceso del aire al depósito. Para prevenir la combustión debida a la acción de las cargas electrostáticas al cargar estos vehículos por primera vez después de dichas actividades, es necesario reducir el nivel de oxígeno por debajo del 9,5\%, rodeando el depósito con un gas inerte como el nitrógeno. Deben adoptarse precauciones para evitar que el nitrógeno líquido penetre en el depósito si éste se obtiene de recipientes portátiles.

\section{Cambio de carga}

El cambio de carga se produce cuando productos de presión de vapor baja o intermedia como el combustible diesel o el gasóleo se introducen en un depósito de un camión o un vagón cisterna que ha contenido previamente un producto inflamable como la gasolina. La carga electrostática generada durante la operación de carga puede activarse en una atmósfera en condiciones de inflamabilidad, lo que da lugar a la explosión y al incendio. Este riesgo puede controlarse en las operaciones de carga superior mediante la bajada del tubo de llenado al fondo del depósito y manteniendo un flujo lento hasta que el extremo del tubo se encuentre sumergido, con el fin de evitar las salpicaduras y la agitación. El contacto de metal a metal debe mantenerse durante la carga para establecer una conexión positiva entre el tubo de llenado y la compuerta del depósito. En el caso de la carga inferior, se utiliza un llenado inicial lento o deflectores contra salpicaduras para reducir la acumulación estática. Antes de proceder al cambio de carga, los depósitos que no pueden drenarse pueden rociarse con una pequeña cantidad del producto con el que van a llenarse, al objeto de eliminar residuos inflamables en sumideros, conductos, válvulas y bombas internas. 


\section{Transporte de productos en vagones de carga fraccionada y furgonetas de reparto}

Los productos derivados del petróleo son transportados por furgonetas de reparto y vagones de carga fraccionada en recipientes de metal, fibra o plástico de diversos tamaños, desde bidones de 55 galones (209 litros) a cubos de 5 galones (19 litros), pasando por otros recipientes de menor capacidad, desde 2,5 galones (9,5 litros) a 1 cuarto de galón (0,95 litros), embalados en cajas de cartón ondulado, normalmente dispuestas en paletas. Muchos productos petroliferos industriales y comerciales se trasladan en grandes contenedores intermedios a granel de metal, plástico o una combinación de materiales, cuya capacidad oscila entre los 380 y los 2.660 litros. El GPL se transporta en contenedores presurizados de tamaño variable. Además, las muestras de crudo, productos terminados y productos usados se remiten por correo o mensajería urgente a los laboratorios para su comprobación y análisis. Todos estos productos, recipientes y paquetes deben manipularse de acuerdo con las normativas públicas en materia de productos químicos peligrosos, líquidos inflamables y combustibles y materiales tóxicos. Con este fin, deben utilizarse declaraciones de materiales peligrosos, documentos de expedición, permisos, recibos y cumplirse otros requisitos reglamentarios, como el marcado de la parte exterior de los paquetes, recipientes, camiones y vagones con señales de identificación adecuadas y etiquetas de advertencia de peligro. Una utilización adecuada de los camiones y los vagones cisterna es importante para la industria del petróleo. Puesto que la capacidad de almacenamiento es finita, deben cumplirse los programas de distribución, tanto en la entrega de crudo para que las refinerías puedan mantenerse en funcionamiento, como en la de gasolina a las estaciones de servicio, de lubricantes a los clientes comerciales e industriales y de petróleo para calefacción a los hogares.

El GPL se suministra a los consumidores en camiones cisterna de gran tonelaje que lo bombean directamente a pequeños depósitos de almacenamiento in situ al descubierto o subterráneos (estaciones de servicio, explotaciones agrarias, consumidores comerciales e industriales). Asimismo, este tipo de gas se entrega a los consumidores con camiones o furgonetas que lo trasladan en recipientes (cilindros o botellas). El GNL se reparte en contenedores criogénicos especiales que disponen de un depósito de combustible interior rodeado por un aislante y una estructura de revestimiento exterior. En los vehículos y aparatos que utilizan el GNL como combustible se emplean contenedores similares. El gas natural comprimido suele entregarse en botellas convencionales, como las usadas en las carretillas elevadoras industriales.

Además de las precauciones de salud y seguridad habituales exigidas en los ferrocarriles y camiones de reparto, como las relativas al movimiento y la manipulación de objetos pesados y el funcionamiento de grandes vehículos industriales, los trabajadores deben conocer los riesgos asociados a los productos que manejan y entregan, y saber qué deben hacer en caso de vertido, escape u otra situación de emergencia. Por ejemplo, los bidones y los recipientes de tamaño intermedio a granel no deben dejarse caer de los vagones o de las puertas traseras de los camiones al suelo. Tanto las empresas como los organismos públicos han establecido normas y requisitos especiales para los conductores y los trabajadores que intervienen en el transporte y la entrega de productos petrolíferos inflamables y peligrosos.

Los conductores de camiones cisterna y furgonetas de reparto suelen trabajar en solitario y puede que tengan que recorrer grandes distancias durante varios días para entregar sus cargas. Prestan servicio día y noche en todo tipo de condiciones meteorológicas. La maniobra de camiones cisterna de gran tamaño en estaciones de servicio e instalaciones de clientes sin golpear a los vehículos aparcados u otros obstáculos fijos requiere paciencia, habilidad y experiencia. Estos profesionales deben reunir las características físicas y psicológicas necesarias para su actividad.

La conducción de camiones cisterna difiere de la de furgonetas de reparto en cuanto que el producto líquido tiende a desplazarse hacia delante en los primeros cuando el vehículo para, hacia atrás si acelera, y de un lado a otro si gira. Los depósitos de los camiones cisterna deben adaptarse con mamparas de protección que restrinjan el movimiento del producto durante su transporte. Los conductores deben demostrar una habilidad considerable para superar la inercia creada por este fenómeno, denominado "masa en movimiento". En ocasiones, deben extraer por bombeo el producto contenido en depósitos de almacenamiento. Esta actividad requiere la dotación de un equipo especial, incluida una manguera de succión y bombas de trasiego, así como la adopción de precauciones especiales, como la conexión a tierra para disipar la acumulación electrostática y evitar la liberación de vapores o líquidos.

\section{Acciones en casos de emergencia relacionados con vehículos de motor y vagones ferroviarios}

Los conductores y el resto de trabajadores deben conocer los requisitos de notificación y las acciones de emergencia en caso de incendio o escape de producto, gases o vapores. Las placas de identificación del producto y de advertencia de peligro, conforme a las normas de marcado impuestas a escala nacional, por el sector o por una asociación, se colocan en camiones y vagones para que las personas encargadas de emprender dichas acciones puedan determinar las medidas de precaución necesarias en caso de derrame o escape de vapores, gases o productos. Asimismo, puede que se exija a los conductores vehículos de motor y al personal responsable de los trenes que lleven consigo fichas técnicas de seguridad (FTS) u otros documentos en los que se describan los riesgos y las precauciones relativos a la manipulación de los productos transportados. Algunas empresas y organismos públicos exigen a los vehículos que transportan líquidos inflamables o materiales peligrosos que dispongan de equipos de primeros auxilios, extintores de incendios, materiales para la limpieza de vertidos y dispositivos de advertencia de peligro portátiles o señales que alerten a los conductores respecto a su detención en la carretera.

Es necesario contar con equipos y técnicas especiales si un vagón o un camión cisterna deben vaciarse del producto que transportan como consecuencia de un vuelco u otro tipo de accidente. Se prefiere la descarga a través de válvulas y conductos fijos o mediante la utilización de chapas extractoras situadas en las compuertas de los depósitos; no obstante, en ciertas condiciones, pueden practicarse agujeros en éstos siguiendo los procedimientos de trabajo seguros prescritos. Con independencia del método empleado en la extracción, los depósitos deben conectarse a masa y debe establecerse una conexión a tierra entre el depósito vaciado y el receptor.

\section{Limpieza de los vagones y los camiones cisterna}

La entrada en un depósito de un vagón o un camión cisterna para su inspección, limpieza, mantenimiento o reparación es una actividad peligrosa que requiere el cumplimiento de todas las normas relativas a ventilación, comprobación, liberación de gases, acceso a espacios confinados y concesión de permisos, con el fin de garantizar una actuación segura. La limpieza de los vagones y los camiones cisterna no difiere de la practicada en los depósitos de almacenamiento de productos petrolíferos, y son aplicables las mismas precauciones y procedimientos en materia de salud y seguridad. Los depósitos de los vagones y los camiones cisterna pueden contener residuos de materiales inflamables, peligrosos o tóxicos en sumideros y conductos de descarga, y pueden haber sido descargados utilizando un gas inerte como el 
nitrógeno; por tanto, lo que parece un espacio limpio y seguro quizá no lo sea. Es posible que los depósitos que han contenido petróleo crudo, residuos, asfalto o productos con un elevado punto de fusión tengan que someterse a operaciones de limpieza con vapor o sustancias químicas antes de su ventilación y del acceso a los mismos, o pueden plantear un riesgo pirofórico. La ventilación de depósitos para liberarlos de vapores y gases tóxicos o inertes puede lograrse mediante la apertura de la válvula o la conexión situadas en la posición más inferior y alejada de cada depósito o compartimento y colocando una salida de aire en la apertura superior ubicada en el otro extremo. Debe inspeccionarse el depósito antes de entrar en él sin protección respiratoria, al objeto de comprobar que todos los rincones y puntos inferiores del mismo, como los sumideros, han sido ventilados por completo, y la ventilación debe continuar mientras duren los trabajos.

\section{Almacenamiento de productos de petróleo líquido en depósitos al descubierto}

El petróleo crudo, el gas, el GNL y el GPL, los aditivos de elaboración, las sustancias químicas y los productos derivados del petróleo se almacenan en depósitos a presión y atmosféricos al descubierto y subterráneos. Estos se sitúan al final de las tuberías de alimentación y colectoras, a lo largo de las canalizaciones principales, en las instalaciones marítimas de carga y descarga y en refinerías, terminales y fábricas a granel. En esta sección se analizan los depósitos atmosféricos al descubierto ubicados en refinerías, terminales y parques de depósitos de fábricas a granel. (La información relativa a los depósitos a presión al descubierto se ofrece más adelante, y la que concierne a los depósitos subterráneos y los pequeños depósitos al descubierto se incluye en el artículo "Operaciones de suministro de combustible y mantenimiento de vehículos de motor".)

\section{Terminales y fábricas a granel}

Las terminales son instalaciones de almacenamiento que suelen recibir crudo y productos derivados del petróleo a través de conducciones principales o suministrados por buques mercantes. Almacenan y redistribuyen estas mercancías a refinerías, otras terminales, fábricas a granel, estaciones de servicio y consumidores a través de oleoductos, buques mercantes y vagones y camiones cisterna. Pueden ser propiedad de empresas petrolíferas, empresas de gestión de oleoductos, operadores independientes, grandes usuarios industriales o comerciales, o distribuidores de productos petrolíferos.

Las fábricas a granel suelen ser más pequeñas que las terminales y reciben habitualmente productos petrolíferos entregados por vagones o camiones cisterna y enviados por terminales y, en ocasiones, transferidos de manera directa por las refinerías. Almacenan y redistribuyen productos a las estaciones de servicio y a los consumidores en camiones y furgonetas cisterna (vehículos dotados de pequeños depósitos con una capacidad que oscila entre los 9.500 y los 1.900 litros). Su explotación puede correr a cargo de empresas petroleras, distribuidores o propietarios independientes.

\section{Parques de depósitos}

Estas instalaciones consisten en agrupaciones de depósitos de almacenamiento situadas en yacimientos, refinerías, terminales marítimas, de oleoductos y de distribución y fábricas a granel en los que se conserva el crudo y los productos derivados del petróleo. En estos parques, los depósitos individuales o grupos de dos o más unidades suelen rodearse por recintos denominados bermas, diques o muros contrafuegos. Estos recintos pueden variar en cuanto a forma de construcción y altura, desde las bermas de $45 \mathrm{~cm}$ situadas alrededor de las conducciones y las bombas ubicadas dentro de los diques, hasta los muros de hormigón de altura superior a los depósitos que rodean. Los diques pueden fabricarse de tierra, arcilla $u$ otros materiales, se cubren con grava, piedra caliza o conchas de moluscos para controlar la erosión, su altura es variable y su anchura es suficiente para que puedan desplazarse vehículos por encima. Las funciones principales de estos recintos son la contención, dirección y desviación del agua de lluvia, la separación física de los depósitos para evitar la propagación del fuego de un área a otra y la contención de vertidos, emisiones, fugas o rebosamientos de los depósitos, las bombas y las conducciones situadas en la zona que encierran.

Las normativas o las políticas de las empresas pueden exigir que los recintos basados en diques tengan un determinado tamaño y puedan contener una cantidad específica de producto. Por ejemplo, puede que uno de estos recintos deba ser capaz de contener al menos un $110 \%$ de la capacidad del depósito más grande ubicado en su interior, teniendo en cuenta el volumen desplazado por el resto de depósitos y la cantidad de producto que queda en el interior del primero después de alcanzar el equilibrio hidrostático. Asimismo, puede exigirse que los recintos de diques se construyan con arcilla impermeable o revestimientos plásticos para evitar que el producto derramado o vertido contamine la tierra o las aguas subterráneas.

\section{Depósitos de almacenamiento}

En los parques de depósitos hay diversos modelos de almacenamiento al descubierto, atmosféricos y a presión, verticales y horizontales, que contienen crudo, reservas petrolíferas, materiales intermedios o productos petrolíferos terminados. Su tamaño, forma, diseño, configuración y funcionamiento dependen de la cantidad y del tipo de productos almacenados y de los requisitos impuestos por las empresas y las normativas. Los depósitos verticales al descubierto pueden equiparse con doble fondo para evitar las fugas al terreno y con protectores catódicos con el fin de reducir al mínimo la corrosión. Los horizontales pueden fabricarse con paredes dobles o situarse en cámaras acorazadas para evitar cualquier fuga.

\section{Depósitos atmosféricos de techo cónico}

Los depósitos de techo cónico son contenedores atmosféricos cilíndricos, horizontales o verticales, cubiertos y situados sobre el nivel del suelo. Disponen de escaleras y plataformas externas y de un techo ligero que protege uniones, respiraderos, imbornales y salidas de desagüe; puede constar de otros accesorios, como tubos de medición, conductos y cámaras de espuma, sistemas de detección y señalización de rebosamiento, sistemas de medición automáticos, etc.

Cuando se almacena crudo volátil y productos de petróleo líquido inflamables en estos depósitos, puede ocurrir que el espacio ocupado por los vapores se sitúe dentro de la escala de inflamabilidad. Aunque el espacio entre el nivel superior del producto y la cubierta del depósito suele ser rico en vapor, la circunstancia antes descrita puede producirse cuando se introduce el producto por primera vez en un depósito vacío, al entrar aire en el mismo a través de los respiraderos o las válvulas de presión/vacío cuando se extrae el producto, o cuando el depósito despide vaho debido a los cambios de temperatura. Este tipo de depósitos puede conectarse a sistemas de recuperación de vapores.

Los depósitos de conservación constituyen una variante de los anteriores con una sección superior e inferior separada por una membrana flexible diseñada para contener los vapores producidos cuando el producto se calienta y expande debido a la exposición a la luz solar durante el día, y para devolver el vapor 
al depósito cuando el primero se condensa con el enfriamiento del segundo por la noche. Los depósitos de conservación suelen utilizarse para almacenar gasolina de aviación y productos similares.

\section{Depósitos atmosféricos de techo flotante}

Se trata de modelos atmosféricos y cilíndricos situados sobre el nivel del suelo, verticales, cubiertos o descubiertos y equipados con techos flotantes. El objetivo primordial de estos dispositivos es reducir al mínimo el espacio ocupado por el vapor entre su parte inferior y el nivel superior del producto, por lo que siempre es rico en vapor, impidiendo así la oportunidad de que se produzca una combinación de aire y vapor inflamable. Todos los depósitos de este tipo disponen de escaleras y plataformas externas, escaleras ajustables para el acceso al techo flotante desde la plataforma, y pueden equiparse con accesorios como derivadores que conectan eléctricamente el techo a la cubierta, tubos de medición, conductos y cámaras de espuma, sistemas de detección y señalización de rebosamientos, sistemas de medición automáticos, etc. Alrededor del perímetro de los techos flotantes se instalan precintos o fundas para evitar fugas del producto o el vapor y que éstos se acumulen en el techo o en el espacio situado encima del mismo.

Los techos flotantes disponen de patas que se colocan elevadas o bajas en función del tipo de operación. Suelen mantenerse en la posición baja para que pueda extraerse del depósito la máxima cantidad posible de producto sin crear un espacio de vapor entre el nivel superior de producto y la parte inferior del techo flotante. Puesto que los depósitos se ponen fuera de servicio antes de entrar en ellos para su inspección, mantenimiento, reparación o limpieza, es necesario ajustar dicha patas y situarlas en la posición elevada para dejar un espacio suficiente que permita trabajar bajo el techo una vez que el depósito se ha vaciado. Cuando el depósito vuelve a funcionar, y después de su llenado, las patas se colocan de nuevo en la posición baja.

Este tipo de depósitos se dividen en externos de techo flotante, internos de techo flotante y externos cubiertos de techo flotante.

Los depósitos de techo flotante externos (abiertos) suelen instalarse en depósitos de almacenamiento abiertos. Los techos flotantes externos suelen fabricarse en acero y disponen de pontones u otros dispositivos de flotación. Están equipados con tuberías de desagüe para eliminar el agua, con manguitos o fundas para evitar los escapes de vapor y con escaleras ajustables para acceder al techo desde la parte superior del depósito con independencia de su posición. Asimismo, pueden contar con precintos secundarios para reducir al mínimo la emisión de vapor a la atmósfera, protectores contra la intemperie para proteger los precintos y cerramientos de espuma para retener este material en la zona del precinto en caso de incendio o de fuga. El acceso a los techos flotantes externos para llevar a cabo tareas de medición, mantenimiento, etc. puede considerarse un caso de entrada en espacios confinados, dependiendo del nivel del techo por debajo de la parte superior del depósito, los productos contenidos en éste y las normativas públicas y las políticas de las empresas.

Los depósitos de techo flotante interno suelen consistir en modelos de techo cónico transformados mediante la instalación de plataformas flotantes, balsas o cubiertas flotantes internas dentro del depósito. Los techos flotantes internos suelen fabricarse en diversos tipos de chapas metálicas, aluminio, plástico o espuma plástica expandida cubierta de metal, y su construcción puede ser del tipo de pontón o de artesa, de material flotante macizo o una combinación de ambos. Los techos flotantes internos están equipados con precintos de perímetro para evitar que el vapor acceda al espacio del depósito situado entre la parte superior del techo flotante y el techo exterior. Las válvulas de presión/vacío y los respiraderos suelen situarse en la parte superior del depósito para controlar la presencia de vapores de hidrocarburos que puedan acumularse en el espacio situado sobre el flotador interno. En este tipo de depósitos se instalan escaleras para el acceso desde el techo cónico al techo flotante. La entrada en los techos flotantes internos, con independencia de la razón a la que obedezca, debe considerarse un acceso a un espacio confinado.

Los depósitos de techo flotante (externo) cubiertos consisten básicamente en modelos de techo flotante externo que han sido reconvertidos mediante la adaptación de una cúpula geodésica, una cubierta ligera o una estructura semifija similar, de forma que el techo flotante deja de estar abierto a la atmósfera. Los modelos de este depósito de nueva construcción pueden incorporar techos flotantes típicos diseñados para depósitos de techo flotante interno. El acceso a los techos flotantes externos cubiertos para efectuar tareas de medición, mantenimiento, etc. puede considerarse una entrada en un espacio confinado, dependiendo de la construcción de la cúpula o la cubierta, el nivel del techo por debajo de la parte superior del depósito, los productos contenidos en éste y las normativas públicas y las políticas de las empresas.

\section{Recepción de productos desde oleoductos y buques}

Una cuestión importante en materia de seguridad, calidad de producto y medio ambiente considerada en las instalaciones de almacenamiento consiste en evitar la mezcla de productos y el rebosamiento de los depósitos mediante la formulación y la aplicación de procedimientos operativos y prácticas de trabajo que garanticen la seguridad. El funcionamiento seguro de los depósitos de almacenamiento depende de la recepción del producto en unidades de la capacidad adecuada mediante su estudio con anterioridad a la entrega, la medición de los depósitos para determinar la capacidad disponible y la garantía de que la alineación de las válvulas es correcta y de que sólo el dispositivo de entrada del depósito receptor permanece abierto, de forma que la cantidad oportuna de producto se introduzca en la unidad asignada. Normalmente, los canales de desagüe ubicados en las áreas de diques que rodean a los depósitos deben mantenerse cerrados durante la recepción, en previsión de que se produzca un llenado excesivo o un derrame. La protección contra el rebosamiento y la prevención de este problema puede lograrse mediante el seguimiento de varias prácticas operativas de seguridad, incluida la aplicación de controles manuales y de la detección automática, la instalación de sistemas de señalización e interrupción de flujo como medio de comunicación, que deben ser aceptadas y comprendidas por el personal encargado del traslado del producto en el oleoducto, el buque mercante y la terminal marítima o la refinería.

Las normativas públicas o las políticas de las empresas pueden exigir la instalación de mecanismos automáticos de detección del nivel de producto y de sistemas de señalización e interrupción en los depósitos que reciben líquidos inflamables y otros productos procedentes de oleoductos principales o buques mercantes. En caso de que se proceda a la instalación, debe comprobarse la integridad de los sistemas electrónicos periódicamente o con anterioridad al trasvase del producto y, si el sistema falla, estos traslados deben someterse a los procedimientos manuales de recepción. Las remesas de producto deben controlarse de forma manual o automática, in situ o desde un centro de control remoto, con el fin de garantizar que las operaciones se llevan a cabo de acuerdo con las previsiones. A la finalización del trasvase, todas las válvulas deben volver a colocarse en su posición operativa normal o disponerse para la próxima recepción. Las bombas, válvulas, conexiones de tubos, conducciones de sangrado y muestreo, colectores, desagües y sumideros deben 
someterse a inspección y mantenimiento para garantizar su buen estado y evitar vertidos y fugas.

\section{Medición y toma de muestras de depósitos}

Las instalaciones de almacenamiento en depósitos deben establecer procedimientos y prácticas de trabajo seguras para la medición y la toma de muestras de crudo y productos petrolíferos en las que se tengan en cuenta los posibles riesgos asociados a cada producto almacenado y a cada tipo de depósito disponible. Aunque las mediciones suelen efectuarse con la ayuda de dispositivos mecánicos o electrónicos, deben emplearse métodos manuales cada cierto tiempo para garantizar la precisión de los sistemas automáticos.

Las operaciones manuales de medición y toma de muestras suelen obligar al trabajador a subir a la parte superior de los depósitos. Al evaluar modelos de techo flotante, la persona encargada debe descender a éste, salvo que el depósito disponga de tubos de medición y muestreo accesibles desde la plataforma. En el caso de las unidades de techo cónico, el responsable de la medición debe abrir una compuerta para introducir el dispositivo utilizado en el depósito. Estos trabajadores deben conocer los requisitos relativos al acceso a espacios confinados y los riesgos potenciales vinculados a la ubicación en techos flotantes cubiertos o descubiertos situados por debajo de los niveles de altura establecidos. Estas operaciones pueden exigir la utilización de dispositivos de vigilancia, como detectores de oxígeno, gas combustible y ácido sulfhídrico, así como de equipos de protección individual y respiratoria.

Las temperaturas y las muestras de producto pueden obtenerse simultáneamente cuando se efectúen operaciones de medición manual. Asimismo, las temperaturas pueden registrarse de manera automática y las muestras recogerse mediante conexiones incorporadas. Los métodos manuales deben restringirse cuando los depósitos reciban producto. A la conclusión de la recepción, se aplicará un período de relajación de 30 minutos a 4 horas, dependiendo del producto y de la política de la empresa, con el fin de permitir la disipación de la acumulación electrostática antes de llevar a cabo las tareas manuales de medición y toma de muestras. Algunas empresas exigen el establecimiento y mantenimiento de comunicación o contacto visual entre el personal encargado de la medición y otros trabajadores de la instalación durante las maniobras de descenso sobre techos flotantes. El acceso a los techos y las plataformas de los depósitos para efectuar tareas de medición, toma de muestras y otras actividades debe limitarse durante las tormentas.

\section{Ventilación y limpieza de depósitos}

Los depósitos de almacenamiento se ponen fuera de servicio para su inspección, comprobación, mantenimiento, reparación, renovación y limpieza, de acuerdo con las necesidades o a intervalos periódicos, en función de las normativas públicas, las políticas de las empresas y los requisitos del servicio operativo. Aunque la ventilación, la limpieza y el acceso a depósitos son operaciones potencialmente peligrosas, pueden llevarse a cabo sin incidentes, siempre que se establezcan los procedimientos adecuados y se sigan las prácticas de trabajo seguras. Sin estas precauciones, pueden producirse lesiones o daños a causa de explosiones, incendios, falta de oxígeno, exposiciones a sustancias tóxicas y riesgos físicos.

\section{Preparativos preliminares}

Es necesario llevar a cabo varios preparativos preliminares después de adoptar la decisión de que un determinado depósito necesita ser puesto fuera de servicio para su inspección, mantenimiento o limpieza. Se trata de: programar las alternativas de almacenamiento y suministro; revisar el historial de la unidad para determinar si ha contenido en algún momento productos con plomo o si ha sido limpiado con anterioridad y se ha certificado que no los contiene; establecer la cantidad y el tipo de productos contenidos, así como el volumen de residuos que permanecen en el depósito; inspeccionar la parte exterior de éste, el área que lo rodea y el equipo que se va a utilizar para retirar el producto, extraer el vapor y limpiar; asegurarse de que el personal está formado, cualificado y familiarizado con los procedimientos de seguridad y concesión de permisos de la instalación; asignar las tareas de acuerdo con los requisitos relativos a las autorizaciones para el acceso a espacios confinados, y el trabajo en caliente y en condiciones de seguridad; y celebrar una reunión entre el personal de la terminal y los trabajadores o los contratistas dedicados a la limpieza de los depósitos, antes de iniciar su construcción o su mantenimiento.

\section{Control de las fuentes de ignición}

Después de sacar todo el producto disponible del depósito por las tuberías fijas, y antes de la apertura de los conductos de extracción de agua y toma de muestras, todas las fuentes de ignición deben retirarse del área circundante hasta que el depósito quede libre de vapores. Las bombas, compresores y vehículos de aspiración, así como otros equipos de alimentación eléctrica o impulsados por motores deben situarse contra el viento, encima o fuera del área de diques o, si se colocan dentro de ésta, alejados al menos 20 metros del depósito y de cualquier otra fuente de vapores inflamables. Las actividades de preparación, ventilación y limpieza del depósito deben interrumpirse durante las tormentas eléctricas.

\section{Eliminación de residuos}

El siguiente paso consiste en eliminar en la medida de lo posible el producto restante y los residuos mediante las conexiones de las tuberías y de extracción de agua. Puede expedirse un permiso de trabajo seguro para esta actividad. Es posible inyectar agua o combustible destilado en el depósito a través de las conexiones fijas para ayudar a que el producto fluya fuera de la unidad. Los residuos retirados de los depósitos que han contenido crudo sulfuroso deben mantenerse húmedos hasta su evacuación para evitar la combustión espontánea.

\section{Aislamiento del depósito}

Después de que todo el producto disponible haya sido extraído a través de las conducciones fijas, las tuberías conectadas al depósito, incluidas las de entrada de producto, recuperación de vapor, canalización de espuma, tomas de muestra, etc. deben desconectarse mediante el cierre de las válvulas más cercanas al depósito e insertando pantallas en los conductos del lado de la válvula próxima al depósito, con el fin de evitar que los vapores accedan a éste desde las tuberías. La porción de éstas comprendida entre las pantallas y el depósito debe drenarse y limpiarse con agua. Las válvulas situadas fuera del área de diques deben cerrarse y bloquearse o señalizarse. Las bombas del depósito, los mezcladores internos, los sistemas de protección catódica, los dispositivos electrónicos de medición y detección de nivel y otros mecanismos deben desconectarse, desactivarse y bloquearse o señalizarse.

\section{Eliminación de vapores}

El depósito ya está preparado para quedar libre de vapores. Deben realizarse pruebas intermitentes o continuas para comprobar su nivel y la actividad en la zona debe restringirse durante las tareas de ventilación. No suele optarse por la de carácter natural, basada en la apertura de la unidad a la atmósfera, ya que no es ni tan rápida ni tan segura como la ventilación 
forzada. Hay varios métodos de ventilar mecánicamente un depósito, que dependen de su tamaño, construcción, condición y configuración interna. Uno de ellos, aplicado a depósitos de techo cónico, consiste en extraer el vapor con un ventilador montado en una compuerta de la parte superior de la unidad; la velocidad del ventilador aumenta progresivamente al tiempo que se abre una compuerta en la parte inferior.

Debe expedirse un permiso de trabajo seguro o en caliente relativo a las actividades de ventilación. Todos los ventiladores y extractores deben conectarse firmemente a la estructura del depósito para evitar la ignición electrostática. Por razones de seguridad, es preferible que estos dispositivos funcionen con aire comprimido; no obstante, se han utilizado motores eléctricos o de vapor a prueba de explosiones. Los depósitos de techo flotante interno pueden necesitar que se ventilen por separado las secciones situadas encima y debajo del techo. Si los vapores se evacuan a través de una compuerta inferior, es necesario instalar un tubo vertical de al menos 4 metros por encima del nivel del suelo y de una altura nunca menor a la del dique circundante, con el fin de evitar que los vapores se acumulen a niveles bajos o alcancen una fuente de ignición antes de disiparse. En caso necesario, pueden dirigirse al sistema de recuperación de vapor de la instalación.

A medida que avanza el proceso de ventilación, los residuos restantes pueden lavarse y eliminarse a través de la compuerta inferior abierta con la ayuda de mangueras de agua y de succión, que deben conectarse a tierra con la estructura del depósito para prevenir la ignición electrostática. Las unidades que hayan contenido crudo sulfuroso o productos residuales con alto contenido de azufre pueden generar calor espontáneo y arder al secarse durante la ventilación. Este riesgo debe evitarse humedeciendo el interior del depósito con agua para impedir que los sedimentos se combinen con el aire y que se eleve la temperatura. Los residuos de sulfuro de hierro deben extraerse a través de la compuerta abierta, al objeto de evitar la ignición de los vapores durante la ventilación. Los trabajadores dedicados a las actividades de lavado, extracción y humidificación deben utilizar equipos de protección individual y respiratoria adecuados.

\section{Acceso inicial, inspección y certificación}

Una indicación del avance de las tareas de extracción de vapores del depósito puede obtenerse mediante el análisis de éstos en el punto de extracción. Cuando la concentración de vapor inflamable se sitúe por debajo de lo establecido por los organismos reguladores y las políticas de las empresas, puede accederse al interior del depósito para su inspección y comprobación. La persona que entre debe utilizar equipos apropiados de protección individual y respiratoria con suministro de aire; después de evaluar la atmósfera en la compuerta y obtener un permiso de entrada, el trabajador podrá introducirse en el depósito para seguir realizando pruebas y proceder con la inspección. Esta debe comprender el control de obstrucciones, techos que amenacen caída, soportes débiles, perforaciones en el suelo y otros riesgos físicos.

\section{Limpieza, mantenimiento y reparación}

A medida que avanza la ventilación y se reducen los niveles de vapor en el depósito, pueden expedirse permisos a los trabajadores para que accedan al depósito con los equipos de protección personal y respiratoria adecuados, si son necesarios, y comiencen las tareas de limpieza. El control del oxígeno, los vapores inflamables y las atmósferas tóxicas debe continuar, y si los niveles dentro del depósito exceden los establecidos para autorizar el acceso, el permiso expirará automáticamente y los trabajadores abandonarán de inmediato la unidad hasta que se recuperen los niveles de seguridad y vuelva a expedirse un permiso. La ventilación debe proseguir durante las operaciones de limpieza siempre que quede algún residuo o sedimento en el depósito. Sólo se utilizarán luces de baja tensión o linternas autorizadas durante la inspección y la limpieza.

Una vez que los depósitos se han limpiado y secado, debe realizarse una inspección y una comprobación definitivas antes de iniciar las operaciones de mantenimiento, reparación o renovación. El examen exhaustivo de sumideros, pozos, chapas del piso, pontones del techo flotante, soportes y columnas es necesario para garantizar la inexistencia de fugas que permitan al producto introducirse en estos elementos o filtrarse a través del suelo. Los espacios existentes entre los precintos de espuma y las protecciones contra la intemperie o los recipientes secundarios también deben inspeccionarse y comprobarse para detectar la presencia de vapores. Si el depósito ha contenido previamente gasolina con plomo, o si se carece de su historial hay que efectuar una prueba de plomo en la atmósfera y certificarse que la unidad está libre de esta sustancia antes de que se permita a los trabajadores el acceso a su interior sin equipo de protección respiratoria con suministro de aire.

Debe expedirse un permiso de trabajo en caliente relativo a las tareas de soldadura, corte y afines, y otro de trabajo seguro que cubra otras actividades de reparación y mantenimiento. La soldadura y el trabajo en caliente pueden crear humos tóxicos o nocivos dentro del depósito, lo que exige su control, la utilización de protección respiratoria, y la ventilación continua. Cuando los depósitos se renuevan con la instalación de fondos dobles o techos flotantes internos, suele practicarse un gran orificio a un lado de los mismos para facilitar el acceso no restringido y evitar la necesidad de expedir permisos de entrada en espacios confinados.

Las operaciones de limpieza por chorro de aire y de pintura del exterior de los depósitos suelen seguir a la limpieza del interior y se completan antes de que se vuelvan a poner en servicio. Estas actividades, junto con la limpieza y la pintura de las tuberías del parque de depósitos, pueden realizarse con las unidades y los conductos en funcionamiento mediante la aplicación y cumplimiento de los procedimientos de seguridad prescritos, que consisten, por ejemplo, en la supervisión de los vapores de hidrocarburos y en la detención de la limpieza por chorro de aire cuando los depósitos cercanos reciben productos líquidos inflamables. La limpieza por chorro de arena puede plantear el riesgo de la exposición a la sílice; por tanto, numerosos organismos públicos y empresas exigen la utilización de materiales especiales no tóxicos para esta actividad o de arena, que puede recogerse, limpiarse y reciclarse. Pueden emplearse dispositivos de recogida al vacío tras la conclusión de esta tarea, al objeto de evitar la contaminación cuando se elimina pintura con plomo de los depósitos y las tuberías. Tras la limpieza por chorro de aire, los puntos de las paredes de los depósitos y de los conductos donde se sospecha la presencia de fugas y filtraciones deben comprobarse y repararse antes de ser pintados.

\section{Vuelta al servicio de los depósitos}

Como preparación para la vuelta al servicio tras la finalización de las tareas de limpieza, inspección, mantenimiento o reparación, las compuertas se cierran, se retiran las pantallas, y se vuelven a conectar las tuberías al depósito. Se procede al desbloqueo, apertura y ajuste de las válvulas y se reactivan los dispositivos mecánicos y eléctricos. Muchos organismos públicos y empresas exigen la comprobación hidrostática de los depósitos para garantizar la inexistencia de fugas antes de su puesta en funcionamiento. Puesto que se requiere una cantidad considerable de agua para alcanzar la presión necesaria para efectuar una prueba precisa, suele utilizarse una base de agua cubierta por combustible diesel. 
Tras la realización de la prueba, el depósito se vacía y se prepara para recibir el producto. Una vez completada la recepción y transcurrido el período de relajación, las alas de los depósitos de techo flotante vuelven a colocarse en una posición baja.

\section{Prevención y protección contra incendios}

Siempre que haya hidrocarburos en recipientes cerrados como los depósitos de refinerías, terminales y fábricas a granel, hay riesgo de fugas de líquidos y vapores. Estos pueden combinarse con el aire en condiciones de inflamabilidad y, si entran en contacto con una fuente de ignición, provocar una explosión o un incendio. Con independencia de la capacidad de los sistemas de protección contra incendios y del personal de la instalación, la clave en la lucha contra incendios es la prevención. Debe impedirse que los vertidos y escapes alcancen los sistemas de alcantarillado y desagüe. Los pequeños derrames deben cubrirse con mantas humedecidas, y los de gran importancia con espuma, con el fin de evitar que los vapores se propaguen y se combinen con el aire. Las fuentes de ignición en áreas donde puede haber vapores de hidrocarburos deben eliminarse o controlarse. Los extintores portátiles deben formar parte de la dotación de los vehículos de servicio y ubicarse en posiciones estratégicas y accesibles por toda la instalación.

El establecimiento y la aplicación de prácticas y procedimientos de trabajo seguros, como los sistemas de concesión de permisos para trabajo en caliente y seguro (en frío), los programas de clasificación eléctrica, los programas de bloqueo y señalización y la formación de los trabajadores y los contratistas son esenciales en la prevención de incendios. Las instalaciones deben desarrollar procedimientos de emergencia de acuerdo con una planificación previa, y los miembros del personal deben conocer sus responsabilidades en lo que respecta a la comunicación y la actuación en caso de incendio y a la evacuación. Los números de teléfono de los responsables y de los organismos que deben ser informados de las situaciones de emergencia deben colocarse en lugares visibles de las instalaciones y debe disponerse de un medio de comunicación. Los departamentos locales de bomberos y las organizaciones de actuación en caso de emergencia, seguridad pública y protección civil deben conocer los procedimientos oportunos, las instalaciones y sus riesgos.

Los incendios debidos a la combustión de hidrocarburos se controlan mediante la aplicación individual o combinada de los métodos siguientes:

- Eliminación del combustible. Uno de los métodos mejores y más sencillos para controlar y extinguir este tipo de incendios consiste en interrumpir el flujo de combustible mediante el cierre de una válvula, la desviación de su canalización o, si se trata de una pequeña cantidad de producto, el control de las exposiciones mientras se permite la combustión total del mismo. La espuma también puede utilizarse para cubrir los derrames de hidrocarburos y evitar la emisión de vapores y su combinación con el aire.

- Eliminación del oxígeno. Otro método es interrumpir el suministro de aire u oxígeno mediante la sofocación del incendio con espuma o agua nebulizada, o la aplicación de dióxido de carbono o nitrógeno para que desplacen al aire en espacios cerrados.

- Refrigeración. El agua nebulizada o pulverizada y el dióxido de carbono pueden utilizarse para extinguir ciertos fuegos de productos petrolíferos, situando la temperatura del incendio por debajo del punto de ignición del producto e impidiendo la formación de vapores y la combinación de éstos con el aire.

- Interrupción de la combustión. Las sustancias químicas como el polvo seco y el halón extinguen los incendios mediante la interrupción de la reacción química del fuego.

\section{Protección contra incendios en los depósitos de almacenamiento}

La protección y prevención de incendios en los depósitos de almacenamiento es una ciencia especializada que depende de la interrelación entre el tipo de depósito, el estado y el tamaño, el producto y la cantidad del mismo almacenada, la ubicación, la colocación de diques y el drenaje del depósito, las capacidades de protección y actuación contra incendios de la instalación, la asistencia externa, las normas de cada empresa, las normas industriales y las normativas públicas. Los incendios en este tipo de depósitos pueden resultar fáciles o muy difíciles de controlar y extinguir, dependiendo principalmente de la detección y el ataque de los mismos en la fase inicial de su desarrollo. Las personas encargadas del funcionamiento de los depósitos deben remitirse a las numerosas prácticas recomendadas y normas desarrolladas por organizaciones como el American Petroleum Institute (API), y la National Fire Protection Association (NFPA) de Estados Unidos, en las que se aborda la prevención y la protección contra incendios en depósitos de almacenamiento con gran detalle.

Si los depósitos descubiertos de techo flotante presentan excentricidad o si los precintos están desgastados o no garantizan la estanqueidad de los recipientes, los vapores se liberan y combinan con el aire y forman mezclas inflamables. Si en estas condiciones cae un rayo, es fácil que se inicie un incendio en el punto de unión de las guarniciones del techo con el armazón del depósito. Si se detectan a tiempo, estos pequeños fuegos se extinguen con un extintor manual de polvo seco o con espuma aplicada con una manguera o un sistema generador.

Si el incendio de un precinto no puede controlarse con estas herramientas, o si se desarrolla uno de grandes dimensiones, el techo se cubre de espuma proyectada con instalaciones fijas o semifijas o con equipos de gran capacidad. Es necesario adoptar precauciones al aplicar espuma a los techos flotantes, ya que si aumenta mucho el peso pueden inclinarse o hundirse, lo que determina la exposición al fuego de una gran superficie de producto. Los diques de espuma se utilizan en este tipo de techos para mantener dicho material en el área comprendida entre los precintos y la estructura del depósito. A medida que se asienta la espuma, el agua se filtra bajo los diques y debe ser extraída a través del sistema de drenaje del techo del depósito para evitar un exceso de peso y el posterior hundimiento del techo.

Dependiendo de las normativas públicas y las políticas de las empresas, los depósitos de almacenamiento pueden equiparse con sistemas fijos o semifijos de espuma que incluyen las conducciones hasta los depósitos, las cámaras o columnas instaladas en éstos, las toberas y los conductos de inyección sumergidos en el fondo de los depósitos, y los conductos de distribución y diques de espuma en la parte superior de los mismos. En los sistemas fijos, las soluciones de espuma y agua son generadas en recipientes de ubicación central y bombeados al depósito a través de las canalizaciones. En los sistemas semifijos, suelen utilizarse tanques de espuma portátiles, generadores y bombas que se desplazan al depósito, se conectan a un suministro de agua y a los conductos de espuma del depósito. Asimismo, las soluciones mencionadas pueden generarse y distribuirse desde una ubicación central de la instalación a través de un sistema de tuberías y tomas de agua, y las mangueras se utilizan para conectar la toma más cercana al sistema semifijo de espuma del depósito.

Cuando los depósitos no disponen de sistemas de espuma fijos o semifijos, ésta puede aplicarse desde la parte superior de los depósitos, utilizando proyectores, mangueras de incendios y toberas. Con independencia del método de aplicación, para controlar un incendio plenamente desarrollado en un depósito hay que suministrar una cantidad específica de espuma recurriendo a técnicas especiales, con una concentración y un caudal 
determinados durante un período de tiempo mínimo, que depende principalmente del tamaño del depósito, el producto de que se trate y la superficie del incendio. Si no se dispone de concentrado de espuma suficiente para satisfacer los criterios de aplicación establecidos, la posibilidad de control o extinción es mínima.

Sólo los bomberos capacitados y con experiencia deben ser autorizados para utilizar agua en la lucha contra incendios de depósitos de petróleo líquido. Pueden producirse erupciones o chorros de vapor hirviente cuando el agua se convierte en vapor al aplicarla directamente sobre los fuegos declarados en depósitos donde se consume crudo o productos petrolíferos pesados. Como el agua pesa más que la mayoría de los hidrocarburos, se desplaza al fondo del depósito y, si se aplica en una cantidad suficiente, llena éste y empuja al producto en llamas hacia arriba y fuera de la parte superior del depósito.

$\mathrm{El}$ agua suele utilizarse para controlar o extinguir incendios por vertido generados alrededor de la parte exterior de los depósitos, de forma que las válvulas puedan ser activadas para controlar el flujo de producto, refrigerar los lados de los depósitos afectados para evitar las explosiones de vapor en expansión generado por líquidos en ebullición (BLEVE; véase más adelante la sección "Riesgos de incendio de los HGL) y reducir el efecto del calor y la incidencia de las llamas sobre los depósitos y los equipos adyacentes. Debido a la necesidad de formación, materiales y equipos especializados, en vez de permitir a los trabajadores que intenten la extinción de este tipo de incendios, muchas terminales y fábricas a granel han adoptado la política de eliminar tanto producto como sea posible de los depósitos afectados, proteger las estructuras cercanas del calor y las llamas y dejar que el producto restante se queme en el depósito en condiciones controladas, hasta la total extinción del incendio.

\section{Salud y seguridad en terminales y fábricas a granel}

Los cimientos, soportes y tuberías de los depósitos de almacenamiento deben someterse a inspecciones periódicas para detectar la presencia de corrosión, erosión, sedimentación u otros daños visibles, con el fin de prevenir la pérdida o la degradación del producto. Las válvulas de presión-vacío, los precintos y las cubiertas, los respiraderos, las cámaras de espuma, los canales de desagüe de los techos, las válvulas de extracción de agua y los dispositivos de detección de rebosamiento deben ser objeto de operaciones de inspección, comprobación y mantenimiento cada cierto tiempo, incluida la retirada de hielo durante el invierno. Los cortafuegos instalados en los respiraderos o en los conductos de recuperación de vapor de los depósitos deben inspeccionarse y limpiarse con regularidad, además de mantenerse libres de escarcha en el invierno para garantizar un funcionamiento adecuado. Las válvulas situadas en las salidas del depósito dotadas de cierre automático en caso de incendio o caída de presión deben comprobarse para determinar su funcionalidad.

Las superficies de los diques deben drenar hacia el exterior de los depósitos, las bombas y las conducciones con el fin de alejar el producto derramado o vertido hacia una zona segura. Las paredes de los diques deben mantenerse en buenas condiciones, y las válvulas de drenaje han de permanecer cerradas, salvo en los momentos en que se extraiga el agua y se drenen las áreas de diques excavadas, según las necesidades relativas al mantenimiento de la capacidad establecida. Las escaleras fijas y de mano, rampas, plataformas y barandillas de las terminales de carga, diques y depósitos deben conservarse en perfectas condiciones, libres de hielo, nieve y petróleo. Las fugas de depósitos y conducciones deben repararse tan pronto como sea posible. No es aconsejable utilizar juntas victáulicas o similares en las tuberías situadas dentro de las áreas de diques que pueden verse expuestas al calor, para evitar el riesgo de que los conductos se abran durante los incendios.

Deben establecerse y aplicarse prácticas de trabajo y procedimientos seguros, e impartirse formación, de modo que los trabajadores de terminales y fábricas a granel, el personal de mantenimiento, los conductores de camiones cisterna y el personal contratado puedan desarrollar sus actividades con seguridad. En estos instrumentos debe incluirse, como mínimo, información relativa a los conceptos básicos de la ignición, el control y la extinción de incendios de hidrocarburos, a los riesgos y la protección frente a exposiciones de sustancias tóxicas como el ácido sulfhídrico y los compuestos aromáticos polinucleares presentes en el crudo y los combustibles residuales, el benceno de la gasolina y los aditivos como el tetraetilo de plomo y el metil-tert-butil éter (MTBE), planes de actuación en caso de emergencia y riesgos físicos y climáticos habituales asociados con esta actividad.

El amianto y otros aislantes pueden utilizarse en las instalaciones para la protección de depósitos y conductos. Deben establecerse y cumplirse las medidas oportunas relativas al trabajo seguro y a la utilización de protección individual en las operaciones de manipulación, eliminación y evacuación de estos materiales.

\section{Protección medioambiental}

Los directivos y trabajadores de las terminales deben conocer y cumplir las normativas públicas y las políticas de las empresas relativas a la protección del medio ambiente, las aguas subterráneas y de superficie, los suelos y la atmósfera frente a la contaminación provocada por líquidos y vapores de petróleo, así como a la manipulación y la evacuación de residuos peligrosos.

- Contaminación de las aguas. Muchas terminales disponen de dispositivos de separación del petróleo y el agua para manipular el agua contaminada procedente de las áreas de contención de los depósitos, de los desagües de terminales de carga y áreas de aparcamiento y de los drenajes de depósitos y techos de depósitos descubiertos. Las terminales pueden ser obligadas a cumplir las normas establecidas en lo que respecta a la calidad del agua y a obtener permisos antes de proceder a la evacuación de ésta.

- Contaminación atmosférica. La prevención de la contaminación atmosférica comprende la reducción al mínimo de las emisiones de vapores a través de válvulas y respiraderos. Las unidades de recuperación de vapores absorben éstos en las terminales de carga y las dársenas portuarias, incluso cuando los depósitos se ventilan con anterioridad al acceso a los mismos. Estos vapores se procesan y se devuelven a los depósitos de almacenamiento en forma líquida o se queman.

- Vertidos en el suelo y en el agua. Los organismos públicos y las empresas pueden exigir a las instalaciones de almacenamiento de petróleo que establezcan planes de prevención, control y actuación en casos de vertido, y al personal que reciba formación y conozca los riesgos potenciales, las notificaciones que deben efectuarse y las acciones que deben emprenderse en caso de vertido o escape. Además de la forma de abordar los vertidos en las instalaciones de las terminales, los trabajadores suelen ser instruidos y equipados para actuar en emergencias acaecidas fuera de las mismas, como el vuelco de un camión cisterna.

- Aguas residuales y residuos peligrosos. Las terminales pueden ser obligadas a cumplir la reglamentación en la materia y a obtener permisos para la evacuación de aguas residuales y residuos petrolíferos a centros de tratamiento de propiedad pública o privada. Son varias las normativas y los 
procedimientos establecidos por las empresas aplicables al almacenamiento y la manipulación in situ de residuos peligrosos como los aislamientos de amianto, los residuos de la limpieza de depósitos y los productos contaminados. Los trabajadores deben recibir formación para desempeñar esta actividad y deben ser informados de los posibles riesgos asociados a las eventuales exposiciones.

\section{Almacenamiento y manipulación de HGL}

\section{Depósitos de almacenamiento a granel}

Los HGL se almacenan en grandes depósitos en el lugar de explotación (yacimientos de gas y petróleo, fábricas de gas y refinerías) y en los puntos de distribución al consumidor (terminales y fábricas a granel). Los dos métodos más utilizados de almacenamiento a granel de HGL son:

- A alta presión y temperatura ambiente. Los HGL se almacenan en depósitos de acero a presión (de 1,6 a 1,8 $\mathrm{mPa}$ ) o en formaciones subterráneas salinas o rocosas impermeables.

- A presiones próximas a la atmosférica y baja temperatura. Los HGL se almacenan en depósitos de acero termoaislados de paredes delgadas; de hormigón armado subterráneos y al descubierto; y criogénicos subterráneos. La presión se mantiene próxima a la atmosférica $(0,005$ a $0,007 \mathrm{mPa})$ y a una temperatura de $-160{ }^{\circ} \mathrm{C}$ en el caso del GNL almacenado en depósitos criogénicos subterráneos.

Los depósitos de almacenamiento de GPL a granel son horizontales de forma cilíndrica (de 40 a $200 \mathrm{~m}^{3}$ ) o esféricos (hasta $8.000 \mathrm{~m}^{3}$ ). La refrigeración es habitual en almacenamientos de más de $2.400 \mathrm{~m}^{3}$. Tanto los depósitos horizontales, fabricados en talleres y transportados a su lugar de ubicación, como los esféricos, construidos in situ, se diseñan y construyen de acuerdo con especificaciones, normas y códigos estrictos.

La presión establecida para los depósitos de almacenamiento no debe ser inferior a la presión de vapor del HGL que se vaya a almacenar a la máxima temperatura de servicio. Los modelos diseñados para combinaciones de propano y butano deben estar diseñados para la máxima presión de propano. Hay que considerar la presión total, resultado de sumar la presión hidrostática del producto líquido a plena carga y la presión parcial de los gases no condensables acumulados en el espacio de vapor. En teoría, los depósitos de hidrocarburos gaseosos licuados deben diseñarse para un vacío completo. En caso contrario, deben instalarse válvulas de alivio del vacío. En las características de diseño debe incluirse asimismo el equipamiento con dispositivos de alivio de la presión, medidores de nivel de líquidos, indicadores de presión y temperatura, válvulas de cierre internas, obturadores de reflujo y válvulas de control de caudal excesivo. Asimismo, pueden instalarse válvulas de cierre de emergencia en caso de avería e indicadores de nivel máximo.

Los depósitos horizontales se instalan al descubierto, en montículos artificiales o en ubicaciones subterráneas, normalmente a sotavento de fuentes de ignición activas o potenciales. $\mathrm{Si}$ el extremo de un depósito de este tipo se rompe debido a un exceso de presión, la estructura se desplazará en sentido contrario Por tanto, es conveniente ubicar los depósitos descubiertos paralelos a otras estructuras importantes (de forma que ninguno de los extremos apunte hacia otras estructuras o equipamientos). Otros factores que deben considerarse son los espacios libres entre depósitos, la localización y la protección y prevención de incendios. En los códigos y normativas se especifican las distancias horizontales mínimas entre los depósitos de almacenamiento de hidrocarburos gaseosos licuados presurizados y las propiedades, depósitos y grandes estructuras adyacentes, así como las posibles fuentes de ignición, incluidos procesos, llamas, calentadores, conductos de transmisión de energía y transformadores, instalaciones de carga y descarga, motores de combustión interna y turbinas de gas.

El drenaje y la contención de vertidos son aspectos importantes del diseño y mantenimiento de las áreas de almacenamiento de HGL; los vertidos deben conducirse hacia zonas donde el riesgo para las instalaciones y áreas circundantes sea mínimo. La construcción de diques y balsas está indicada cuando los vertidos son peligrosos para otras instalaciones y para la población en general. Los depósitos de almacenamiento no suelen rodearse de diques, pero el terreno en el que se asientan se acondiciona de forma que los vapores y los líquidos no se acumulen debajo o alrededor de los mismos, para que no queden envueltos por vertidos en llamas.

\section{Bombonas}

Los HGL utilizados por los consumidores, sea GNL o GPL, se almacenan en botellas o bombonas a temperaturas superiores a su puntos de ebullición y a temperatura y presión normales. Estos recipientes se distribuyen siempre con aros protectores, válvulas de seguridad y tapas de válvula. Los tipos básicos de botellas para el consumo utilizadas actualmente son:

- bombonas de entrega de vapor (de 0,5 a $50 \mathrm{~kg}$ ), utilizadas por los consumidores finales; normalmente, las bombonas grandes vacías se devuelven al proveedor al adquirir otras llenas;

- bombonas de entrega de líquido para llenar otras menores recargables propiedad de los consumidores; y

- bombonas de combustible para vehículos de motor, entre las que figuran las de $40 \mathrm{~kg}$ instaladas permanentemente como depósitos de combustible en vehículos de motor y llenadas y utilizadas en posición horizontal, y las empleadas en camiones industriales y diseñadas para su almacenamiento, llenado y manipulación en posición vertical, aunque se usan en la horizontal.

\section{Propiedades de los hidrocarburos gaseosos}

De acuerdo con la NFPA, los gases inflamables (combustibles) son aquéllos que arden a las concentraciones normales de oxígeno en la atmósfera. La combustión de los gases inflamables es semejante a la de los vapores de hidrocarburos líquidos inflamables, ya que se requiere una temperatura de ignición especifica para iniciar la reacción de encendido, y cada uno de los gases arderá únicamente en una cierta relación definida de combinaciones de gas y aire. Los líquidos inflamables pueden caracterizarse por su punto de deflagración, que es la temperatura (siempre inferior al punto de ebullición) a la que se emite una cantidad suficiente de vapores de combustión. Los gases inflamables no presentan un punto de deflagración definido, pues suelen encontrarse a una temperatura muy superior al punto de ebullición, incluso en estado líquido, y por tanto también muy superior al punto de deflagración.

La NFPA (1976) define los gases comprimidos y licuados como sigue:

- "Los gases comprimidos son aquéllos que, a temperaturas atmosféricas normales dentro de sus recipientes, existen únicamente es estado gaseoso bajo presión."

- "Los gases licuados son aquéllos que, a temperaturas atmosféricas normales dentro de sus recipientes, existen en parte en estado líquido y en parte en estado gaseoso, y se encuentran bajo presión siempre que permanezca algo de líquido en el recipiente."

El factor principal que determina la presión dentro de un depósito es la temperatura del líquido almacenado. Cuando se expone a la acción de la atmósfera, el gas licuado se evapora con 
Tabla 102.11 • Propiedades de combustión aproximadas habituales en gases de hidrocarburos licuados.

\begin{tabular}{|c|c|c|c|c|c|c|}
\hline Tipo de gas & $\begin{array}{l}\text { Escala de inflamabilidad } \\
\text { (\% de gas en la atmósfera) }\end{array}$ & $\begin{array}{l}\text { Presión de vapor } \\
\text { (psig a } 21^{\circ} \mathrm{C} \text { ) }\end{array}$ & $\begin{array}{l}\text { Punto de ebullición } \\
\text { normal }\left({ }^{\circ} \mathrm{C}\right)\end{array}$ & $\begin{array}{l}\text { Peso específico } \\
(\mathrm{kg} / \mathrm{m} 3)\end{array}$ & julios/l & $\begin{array}{l}\text { Gravedad específica } \\
\text { (aire }=1 \text { ) }\end{array}$ \\
\hline GNL & $4,5-14$ & 1,47 & -162 & $419,4-479,3$ & 39.119 & $9,2-10$ \\
\hline GPL (propano) & $2,1-9,6$ & 132 & -46 & 508,1 & 93.282 & 1,52 \\
\hline GPL (butano) & $1,9-8,5$ & 17 & -9 & 576,4 & 119.220 & 2,0 \\
\hline
\end{tabular}

gran rapidez, desplazándose a lo largo de la superficie del terreno o del agua hasta su dispersión en el aire por la influencia del viento o de un movimiento atmosférico mecánico. A temperaturas atmosféricas normales, un tercio del líquido contenido en un recipiente se gasifica.

Los gases inflamables se dividen en combustibles e industriales. Los primeros, incluido el gas natural (metano) y los GPL (propano y butano), se queman con el aire para producir calor en hornos, calentadores de agua y calderas. Los gases industriales inflamables, como el acetileno, se utilizan en operaciones de fabricación, soldadura, corte y tratamiento con calor. Las diferencias en las propiedades de combustión de los GNL y los GPL se muestran en la Tabla 102.11.

\section{Riesgos para la seguridad de los GPL y los GNL}

Los riesgos para la seguridad aplicables a todos los HGL se asocian a la inflamabilidad, la reactividad química, la temperatura y la presión. El más importante consiste en el escape imprevisto de sus contenedores (recipientes o depósitos) y el contacto con una fuente de ignición. El escape puede producirse por avería del recipiente o de las válvulas debida a diversas razones, como el llenado en exceso o una ventilación con sobrepresión cuando el gas se expande a causa del calor.

La fase líquida de los GPL se caracteriza por un coeficiente de expansión elevado, como lo demuestra el hecho de que el propano se expanda 16 veces y el butano líquido 11 veces más que el agua con el mismo aumento de temperatura. Esta propiedad deben considerarse al llenar los recipientes, ya que debe dejarse espacio libre para la fase de vapor. La determinación de la cantidad correcta de llenado depende de diversas variables, incluida la naturaleza del gas licuado, la temperatura en el momento de la operación y las temperaturas ambiente previstas, y el tamaño, el tipo (aislado o no) y la localización del recipiente (subterráneo o al descubierto). Los códigos y las normativas establecen las cantidades permisibles, conocidas como "densidades de llenado", específicas para cada tipo de gas o familia de gases similares. Estas densidades pueden expresarse en función del peso, en valores absolutos, o del volumen líquido, medida que debe corregirse siempre en relación con la temperatura.

La cantidad máxima de líquido con la que deben llenarse los recipientes a presión de GPL es del $85 \%$ de su capacidad, a una temperatura de $40{ }^{\circ} \mathrm{C}$ (la proporción debe ser menor a temperaturas superiores). Puesto que el GNL se almacena a temperaturas inferiores, los recipientes de este tipo de gas pueden llenarse con líquido en una proporción que oscila entre el 90 y el $95 \%$. Todos los recipientes se equipan con dispositivos de alivio de la sobrepresión, que suelen descargar a presiones vinculadas a las temperaturas del líquido superiores a las atmosféricas normales. Como estas válvulas no pueden reducir la presión interna a los valores de la atmosférica, el líquido se mantendrá en todo momento a una temperatura superior a su punto de ebullición normal. Los hidrocarburos gaseosos licuados puros y comprimidos no corroen el acero ni la mayoría de las aleaciones del cobre. No obstante, la corrosión puede constituir un problema grave cuando el gas contiene compuestos sulfurosos e impurezas.

Los GPL son entre 1,5 y 2 veces más pesados que el aire y, cuando se liberan en la atmósfera, tienden a dispersarse rápidamente sobre el terreno o la superficie del agua y a acumularse en áreas bajas. No obstante, tan pronto como el vapor es diluido por el aire y forma una mezcla inflamable, su densidad es, en esencia, idéntica a la del aire y su pauta de dispersión varía. El viento reduce de manera significativa la distancia de dispersión en cualquier tipo de fuga. Los vapores de GNL reaccionan de forma diferente a los GPL. Dado que el gas natural tiene una densidad de vapor baja $(0,6)$, se combina y dispersa rápidamente al aire libre, reduciendo las posibilidades de que se formen nubes de vapor susceptibles de ignición. En la Figura 102.17 se indica el modo en que una nube de vapor de gas natural licuado se propaga a favor del viento en diversas situaciones de vertido.

Aunque el HGL es incoloro, una vez liberado en el aire sus vapores pueden apreciarse debido a la condensación y la congelación del vapor de agua contenido en la atmósfera con la que entra en contacto. Puede que este proceso no se produzca si el vapor se encuentra a una temperatura próxima a la ambiental y su presión es relativamente baja. Hay instrumentos que detectan la presencia de fugas de HGL y activan una alarma a concentraciones de sólo el 15 al $20 \%$ del límite de inflamabilidad inferior (LII). Asimismo, estos dispositivos pueden detener todas las

Figura 102.17 Propagación a favor del viento de una nube de vapor de GNL procedente de diversos derrames (velocidad del viento, $8,05 \mathrm{~km} / \mathrm{h})$.

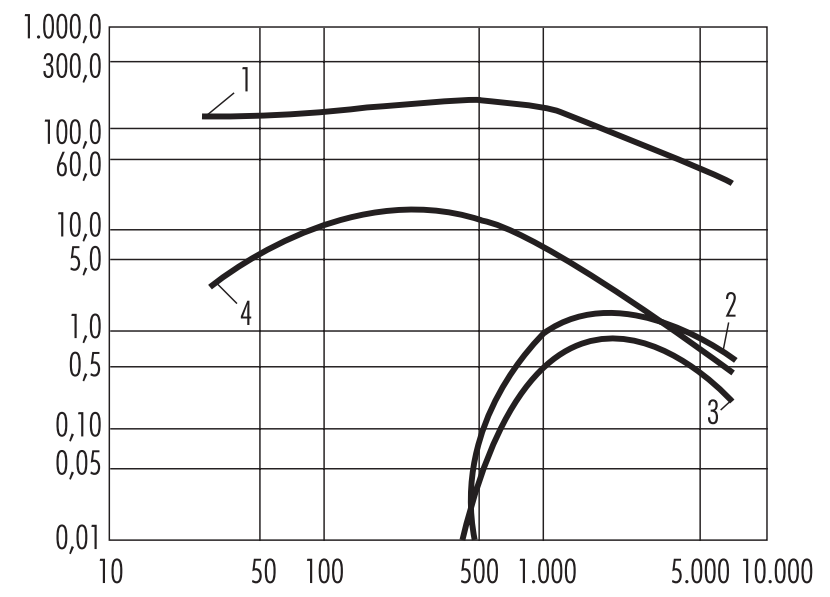

1. Vertido en el suelo dentro de un espacio de $175 \mathrm{~m}^{2}$ limitado por un dique de $5 \mathrm{~m}$ de altura.

2. Vertido en el suelo dentro de un espocio de $72 \mathrm{~m}^{2}$ limitado por un dique de $35 \mathrm{~m}$ de altura.

3. Depósito al descubierto de $62 \mathrm{~m}$ de diámetro $\left(100.000 \mathrm{~m}^{3}\right)$, con un escape de vapor de GNL de $35 \mathrm{~m}$ sobre el nivel del depósito

4. Depósito subterráneo de $50 \mathrm{~m}$ de diámetro $\left(100.000 \mathrm{~m}^{3}\right)$, con un escape de vapor de GNL de $6 \mathrm{~m}$ sobre el nivel del depósito 
Tabla 102.12 • Comparación de las características de los gases comprimidos y licuados.

\begin{tabular}{llllll}
\hline Tipo de gas & $\begin{array}{l}\text { Escala de inflamabilidad } \\
\text { (\% de gas en la atmósfera) }\end{array}$ & $\begin{array}{l}\text { Indice de emisión } \\
\text { de calor (kjulios/l) }\end{array}$ & $\begin{array}{l}\text { Estado de } \\
\text { almacenamiento }\end{array}$ & Riesgos de incendio & Riesgos para la salud \\
\hline Gas natural comprimido & $5,0-15$ & 5.631 & Gas de 2.400 a 4.000 psi & Gas inflamable & Asfixiante; sobrepresión \\
GNL & 23.495 & Líquido de 40 a 140 psi & $\begin{array}{l}\text { Gas inflamable, coeficiente Asfixiante; líquido } \\
\text { de expansión 625:1; BLEVE }\end{array}$ \\
\hline criogénico
\end{tabular}

operaciones y poner en marcha los sistemas de supresión si las concentraciones de gas alcanzan valores situados entre el 40 y el $50 \%$ del LII. En algunas instalaciones industriales se aplican sistemas de ventilación forzada con el fin de mantener las concentraciones de aire y combustible liberado por debajo del LII. Por otra parte, los quemadores de calentadores y hornos pueden estar equipados con dispositivos que detienen de forma automática el flujo de gas si la llama se apaga.

Las fugas de HGL de depósitos y recipientes pueden reducirse al mínimo mediante la utilización de dispositivos limitadores y de control de flujo. Cuando se descomprimen y liberan, los HGL salen de sus recipientes a presión negativa y baja temperatura. La temperatura de autorrefrigeración del producto a la presión inferior debe considerarse al seleccionar los materiales de construcción de recipientes y válvulas, con el fin de evitar la fragilización de los metales seguida de rotura o fallo por exposición a bajas temperaturas.

El HGL puede contener agua en sus fases líquida y gaseosa. $\mathrm{El}$ vapor de agua puede saturar el gas en una proporción específica a unos valores determinados de presión y temperatura. Si alguna de éstas varía, o el contenido de vapor de agua excede los límites de evaporación, el agua se condensa. Este efecto puede formar tapones de hielo en las válvulas y reguladores y cristales de hidratos de hidrocarburos en los conductos, los dispositivos y otros aparatos. Estos hidratos se descomponen cuando se calienta el gas, cuando se reduce la presión o con productos como el metanol, que disminuyen la presión del vapor de agua.

Hay diferencias en las características de los gases comprimidos y licuados que deben considerarse desde el punto de vista de la salud, la seguridad y la prevención de incendios. Por ejemplo, las diferentes características del gas natural comprimido y el GNL se recogen en la Tabla 102.12.

\section{Riesgos para la salud de los HGL}

El principal riesgo de lesión profesional relacionado con la utilización de HGL consiste en la posibilidad de congelación de la piel y los ojos debida al contacto con el líquido en actividades de manipulación y almacenamiento como la toma de muestras, la medición, el llenado, la recepción y la entrega. Como ocurre con otros gases combustibles, cuando se queman de forma incorrecta, los gases de hidrocarburos comprimidos y licuados emiten monóxido de carbono a concentraciones nocivas.

En condiciones de presión atmosférica y baja concentración, los gases de hidrocarburos comprimidos y licuados no suelen ser tóxicos, pero sí asfixiantes: desplazan el oxígeno (del aire) si se liberan en espacios confinados o restringidos. Pueden ser tóxicos si contienen compuestos sulfurosos, y en especial, ácido sulfhídrico. Dado que los HGL son incoloros e inodoros, las medidas de protección incluyen la incorporación de olores artificiales como los mercaptanos en los gases combustibles para el consumo, con el fin de facilitar la detección de fugas. Deben aplicarse prácticas de trabajo seguras para proteger a los trabajadores de la exposición a estas sustancias y otros aditivos durante su almacenamiento e inyección. El contacto con vapores de GPL a concentraciones iguales o superiores al LII puede provocar una depresión general del sistema nervioso central similar a la causada por los gases de anestesia o las bebidas alcohólicas.

\section{Riesgos de incendio de los HGL}

La avería de los recipientes de gas licuado (GNL y GPL) constituye un riesgo más grave que el derivado del fallo de recipientes de gas comprimido, ya que la cantidad liberada es superior. Cuando se calientan, los gases licuados reaccionan de forma diferente a los comprimidos, puesto que se trata de productos de dos fases (líquida y gaseosa). Con el aumento de la temperatura, la presión de vapor del líquido se eleva, lo que da lugar a un incremento de la presión dentro del recipiente. En primer lugar, la fase de vapor se expande, a lo que sigue la expansión del líquido, que comprime el vapor. Por tanto, en teoría, la presión establecida para los contenedores de HGL es próxima a la del gas a la temperatura ambiente más alta posible.

Cuando un recipiente de gas licuado se expone al fuego, puede producirse un accidente grave si se permite el calentamiento del metal correspondiente al espacio ocupado por el vapor. A diferencia de la fase líquida, la gaseosa absorbe poco calor. Este efecto permite un rápido calentamiento del metal, hasta que se alcanza un punto crítico en el que se produce una explosión instantánea y catastrófica del recipiente. Este fenómeno es conocido con las siglas BLEVE. La magnitud de una BLEVE depende de la cantidad de líquido que se vaporice en el momento del fallo del recipiente, del tamaño de las piezas de éste, de la distancia que recorran éstas y de las áreas en las que golpeen. Los recipientes de GPL no aislados pueden protegerse contra las BLEVE vertiendo agua fría en las zonas que se encuentran en fase gaseosa (no en contacto con el GPL).

Otros riesgos de incendio más comunes vinculados a los hidrocarburos gaseosos comprimidos y licuados son los relacionados con las descargas electrostáticas, las explosiones por combustión, las grandes explosiones al aire libre y las pequeñas fugas de juntas de bombas, recipientes, válvulas, conductos, mangueras y conexiones.

- Las cargas electrostáticas pueden generarse cuando el HGL se transporta a través de conductos, se carga o descarga, se mezcla o se filtra, así como en la limpieza de depósitos.

- Las explosiones por combustión se deben a los escapes de gas o vapor contenidos en un espacio o una estructura cerrada que se combinan con el aire creando una mezcla inflamable. Cuando esta combinación entra en contacto con una fuente de ignición, arde de forma instantánea y rápida y genera una enorme cantidad de calor. El aire a elevada temperatura se expande con prontitud y causa un aumento considerable de la presión. Si el espacio o la estructura no tienen la solidez suficiente para contener la presión, se produce la explosión por combustión. 
- Los incendios de gases inflamables se producen cuando los escapes de gas o vapor no se contienen y la ignición tiene lugar cuando sólo se ha liberado una pequeña cantidad de gas.

- Las grandes explosiones al aire libre ocurren cuando una avería importante de un recipiente da lugar a la emisión de una nube de gas vaporizado de gran volumen que arde antes de su dispersión.

El control de las fuentes de ignición en las zonas peligrosas es esencial para lograr una manipulación segura de los gases de hidrocarburos comprimidos y licuados. En este sentido, puede establecerse un sistema de concesión de permisos para autorizar y supervisar el trabajo en caliente, el consumo de tabaco, el funcionamiento de vehículos de motor $u$ otros motores de combustión interna y la utilización de llamas abiertas en áreas donde se transportan, almacenan o manipulan este tipo de gases. Otras medidas de seguridad consisten en el empleo de equipos eléctricos clasificados adecuadamente y de sistemas de puesta a masa para neutralizar y disipar la electricidad estática.

El mejor medio de atenuar el riesgo de incendio debido a la fuga de gases de hidrocarburos comprimidos y licuados es detener el escape o, si es posible, interrumpir el flujo de producto. Aunque la mayoría de los HGL se vaporizan al contacto con el aire, los GPL de presión de vapor inferior, como el butano, e incluso los de presión de vapor superior, como el propano, se acumulan en balsas si las temperaturas ambientales son bajas. No debe aplicarse agua a estas balsas, ya que crea turbulencias y aumenta el índice de vaporización. La evaporación de las balsas se controla con espuma. El agua, si se utiliza correctamente en las fugas de válvulas o en pequeñas roturas, puede congelarse por contacto con el HGL frío y bloquear el escape. Los fuegos de HGL requieren el control de la propagación de calor entre depósitos de almacenamiento y recipientes mediante la aplicación de agua de enfriamiento. Aunque los incendios debidos a la combustión de gases de hidrocarburos comprimidos y licuados pueden apagarse con extintores de pulverización de agua y de polvo seco, suele ser más prudente la combustión controlada para evitar la formación e ignición de una nube explosiva de vapor combustible si continúa el escape de gas después de la extinción del incendio.

\section{AlMACENAMIENTO}

\section{John Lund}

Hace tiempo que el almacenamiento constituye una industria global; los almacenes están vinculados al comercio y al transporte de mercancías por ferrocarril, mar, aire y carretera. Es posible clasificarlos en función del tipo de productos conservados: alimentos en seco, refrigerados y congelados, ropa y textiles en general, equipos y materiales de construcción, maquinaria y repuestos. Por ejemplo, en Estados Unidos en 1995, el número de trabajadores empleados en los sectores del transporte por carretera y el almacenamiento ascendía a 1.887.000 (BLS 1996). Actualmente, esta estadística no puede desagregarse por tipo o categoría de almacén. Estos establecimientos venden directamente a clientes externos (minoristas) o internos (mayoristas) a los que cobran por palets completos o incompletos (una o varias cajas de un palet). En ellos se utilizan medios mecánicos (carretillas elevadoras, máquinas transportadoras y sistemas de almacenamiento y recuperación automáticos (SARA)) para transportar cargas completas o incompletas o se realizan estas operaciones a mano. Con independencia de la naturaleza de cada explotación, los productos almacenados o el modo de transporte elegido por el almacén, las características básicas del sector son bastante uniformes, aunque es probable que la escala operativa, la terminología y la tecnología difieran. (Para más información sobre los SARA en la actividad de almacenamiento, véase Martin 1987.)

Los productos son entregados por expedidores o proveedores en un muelle de descarga, en el que se registran en un sistema de inventario manual o informatizado, se les asigna una ubicación en un estante o "plaza" (una dirección) y se transportan a la misma, normalmente con la ayuda de medios mecánicos (máquinas transportadoras, SARA, carretillas elevadoras o tractores). Una vez recibido el pedido de un cliente, los recipientes o las cajas deseadas deben recuperarse de su ubicación. Cuando se recuperan palets completos, se emplean los medios antes mencionados (véase la Figura 102.18). Si se trata de palets incompletos (una o varias cajas de una estante o plaza), es necesario recurrir a la operación manual, llevada a cabo por trabajadores denominados selectores, encargados de elegir el número deseado de cajas y colocarlas en un transportador mecánico de palets, un carrito de mano u otro dispositivo afín. El pedido de cada cliente se monta en un palet o un contenedor similar para su envío, al que se adjunta una etiqueta $u$ otro tipo de marca en el que figuren la factura y las instrucciones de ruta. Esta tarea puede ser efectuada por el selector del pedido, el operador de la carretilla elevadora o, en caso de que se utilicen máquinas transportadoras para la entrega de cajas individuales para su montaje definitivo, por un montador. Cuando el pedido está listo para su envío, se carga por medios mecánicos en un camión, un remolque, un vagón de ferrocarril o un buque (véase la Figura 102.19).

En torno al $60 \%$ de las actividades desarrolladas en un almacén están relacionadas directamente con el desplazamiento; la proporción restante se refiere a la manipulación de materiales. Aparte de la importante labor llevada a cabo por administrativos, repartidores, personal de limpieza, supervisores y gestores, el trabajo principal del almacén vinculado al transporte y la manipulación de mercancías es realizado fundamentalmente por dos tipos de trabajadores: operarios de carretillas elevadoras y selectores.

La intensa competencia internacional y la entrada rápida de nuevas empresas en el sector ha generado el impulso necesario

Figura 102.18 Carga de cajas de manzanas en una carretilla elevadora en un almacén del Reino Unido.

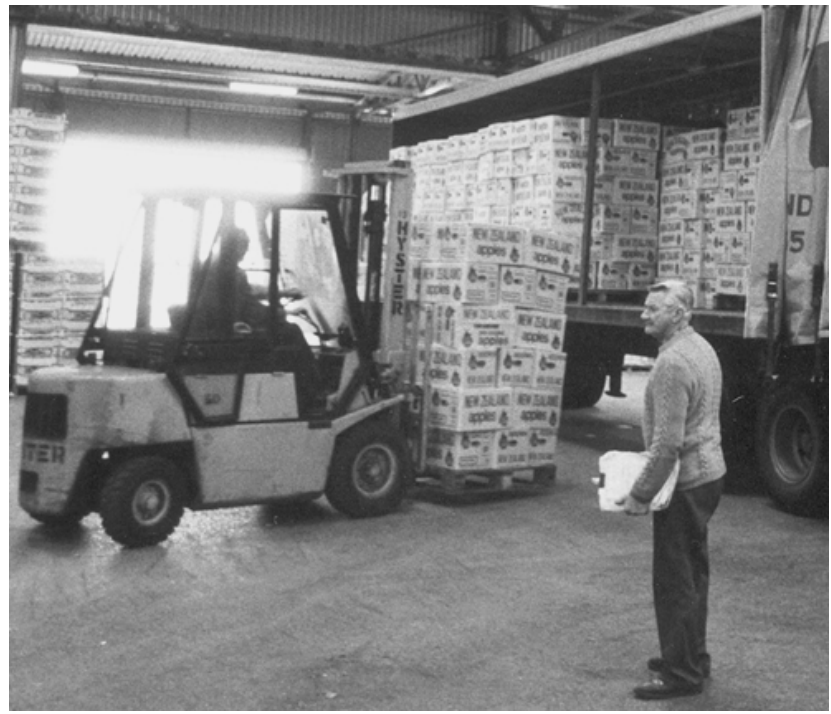


Figura 102.19• Un trabajador portuario en el Reino Unido utiliza máquinas elevadoras para trasladar cuartos traseros de ganado bovino.

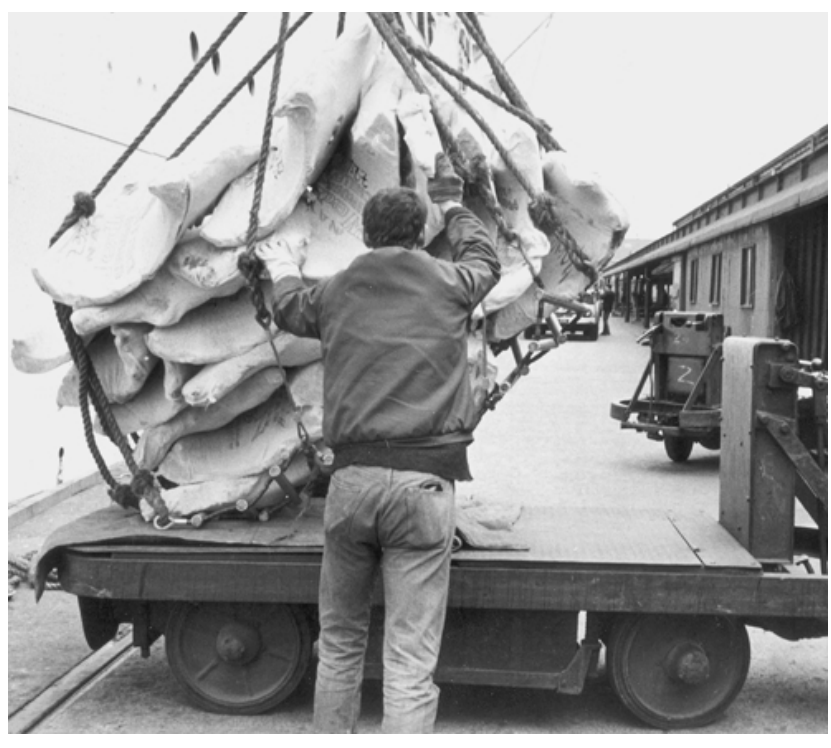

para mejorar la eficacia en la organización de la mano de obra y el espacio y engendrar una nueva disciplina a la que se hace referencia con la denominación de sistemas de gestión de almacén (SGA) (Register 1994). Estos sistemas son cada vez más económicos y potentes. Se basan en la aplicación de redes informáticas, códigos de barras, programas de ordenador y sistemas de comunicación de radiofrecuencia, con el fin de perfeccionar la gestión y el control de los inventarios y las operaciones efectuadas en los almacenes, lo que permite a éstos optimizar los períodos de respuesta a los clientes y su capacidad de adaptación, mejorar enormemente la exactitud de los inventarios y reducir costes (Firth 1995).

En esencia, los SGA informatizan los sistemas de inventario y expedición de pedidos. Cuando un producto remitido por un proveedor o un expedidor llega al muelle de carga, los lectores de código de barras registran su código y denominación, actualizando en el acto la base de datos de existencias y asignando a la mercancía una ubicación en el almacén. A continuación, se avisa a un operario de carretilla elevadora para recoger y entregar la carga a través de un sistema de comunicación por radiofrecuencia instalado en el vehículo.

Los pedidos de los clientes son registrados por otro programa informático que consulta la dirección del producto y la disponibilidad de cada artículo solicitado en la base de datos del inventario y, a continuación, encamina el pedido por la ruta más eficaz para reducir al mínimo los desplazamientos. Las etiquetas con el nombre, el código y la localización del producto se imprimen para su utilización por los selectores de pedido, que deben cumplimentarlo. Aunque estos avances contribuyen claramente a la mejora del servicio al cliente y de la eficacia, constituyen condiciones previas importantes relativas a las normas del trabajo planificado (NTP), que pueden plantear nuevos riesgos para la salud y la seguridad a los operarios de las carretillas elevadoras y los selectores de pedidos.

La información sobre cada pedido (número de cajas, distancias de los recorridos, etc.) generada por el programa de expedición de pedidos puede combinarse con los tiempos normales o permitidos de cada actividad para calcular un tiempo general normalizado necesario para la selección de un pedido concreto; resultaría extremadamente complejo y requeriría mucho tiempo obtener esta información sin utilizar bases de datos y equipos informáticos. Por tanto, el seguimiento efectuado por ordenador puede emplearse para registrar el tiempo dedicado a cada pedido, comparar el tiempo real con el utilizado y calcular un índice de eficacia a disposición de supervisores o gestores con sólo apretar unas cuantas teclas en su equipo informático.

Las NTP para almacenes se han extendido de Estados Unidos a Australia, Canadá, Reino Unido, Alemania, Austria, Finlandia, Suecia, Italia, Sudáfrica, Países Bajos y Bélgica. Aunque los sistemas de NTP no plantean necesariamente por sí mismos nuevos riesgos para la salud y la seguridad, hay datos significativos que indican que el aumento de la carga de trabajo, la falta de control sobre el ritmo de la actividad y la repercusión del aumento de la frecuencia de levantamiento contribuyen en gran medida al agravamiento del riesgo de lesión. Además, la presión sobre la disponibilidad de tiempo ejercida por las normas de trabajo puede obligar a los trabajadores a tomar atajos peligrosos y dejar de aplicar los métodos de trabajo seguros y adecuados. Estos riesgos y peligros se describen a continuación.

\section{Riesgos}

En el almacén más básico, con independencia del nivel de tecnología y de informatización, hay cientos de riesgos elementales para la salud y la seguridad. Los SGA modernos pueden vincularse a un variedad de éstos diferente.

Tabla 102.13 • Lesiones de espalda y generales y enfermedades en el lugar de trabajo de los selectores de pedidos de dos almacenes de alimentos analizados por el NIOSH, 1987-1992.

\begin{tabular}{lllll}
\hline Año & $\begin{array}{l}\text { Almacén A: total de lesiones } \\
\text { en (\%) }\end{array}$ & $\begin{array}{l}\text { Almacén B: total de lesiones } \\
\text { en (\%) }\end{array}$ & $\begin{array}{l}\text { Almacén A: sólo lesiones de } \\
\text { espalda en (\%) }\end{array}$ & $\begin{array}{l}\text { Almacén B: sólo lesiones de } \\
\text { espalda en (\%) }\end{array}$ \\
\hline 1987 & 79 & $\mathrm{~N} / \mathrm{D}$ & 28 & $\mathrm{~N} / \mathrm{D}$ \\
1988 & $\mathrm{~N} / \mathrm{D}$ & 31 & $\mathrm{~N} / \mathrm{D}$ \\
1989 & 88 & 62 & 39 & 21 \\
1990 & 87 & 62 & 31 & 31 \\
1991 & 81 & 83 & 28 & 29 \\
1992 & 52 & 86 & $\mathrm{~N} / \mathrm{D}$ & 17 \\
\hline
\end{tabular}

Fuentes: NIOSH 1993a, 1995. 


\section{Estudios de las lesiones de los selectores de pedidos de alimentos realizados por el NIOSH de Estados Unidos}

El National Institute for Occupational Safety and Health (NIOSH) llevó a cabo estudios sobre las lesiones por levantamiento de cargas y otras tareas afines en dos almacenes de alimentos la los que se hará referencia en adelante como "almacén A" y "almacén B") (NIOSH 1993a; NIOSH 1995). Ambos establecimientos habían establecido normas técnicas respecto a las cuales se medía el rendimiento de los selectores de pedidos; los trabajadores que obtenían resultados inferiores a lo estipulado en estas normas eran objeto de medidas disciplinarias. Los datos que figuran en la Tabla 102.13 se expresan en porcentajes del grupo de selectores solo, y se refieren tanto al conjunto de lesiones como sólo a las de espalda registradas cada año.

Con el riesgo de generalizar estos datos más allá de su contexto, con independencia del modo en que se estimen, la magnitud de los porcentajes de lesiones y enfermedades registradas en estos almacenes es considerablemente superior a la que corresponde a los datos totales del sector y al conjunto de las categorías profesionales. Mientras que el total de lesiones experimenta una ligera reducción en el almacén $A$, en el almacén $B$ se registra un aumento. Por su parte, las lesiones de espalda, con excepción de 1992 en el almacén $B$, son significativas y tienen una evolución estable. En general, estos datos indican que la probabilidd de que un selector de pedidos sufra una lesión de espalda que requiera tratamiento médico o suponga pérdida de horas de trabajo es del $30 \%$ anual.

El grupo industrial de Estados Unidos National Association of Grocery Warehouses of America (NAGWA), informó que las lesiones de espalda constituían un $30 \%$ del total de las lesiones registradas en almacenes de alimentos y que un tercio de los trabajadores de estos establecimientos (no sólo los selectores de pedidos) sufre una lesión susceptible de registro al año. Estos datos son coherentes con los estudios del NIOSH. Además, el NAGWA estimó que el coste de estas lesiones (fundamentalmente indemnizaciones a trabajadores) ascendía a 0,61 dólares por hora en el período comprendido entre 1990 y 1992 (casi 1.270 dólares por trabajador y año). Asimismo, determinó que el levantamiento manual constituía la principal causa de lesión en la espalda en un $54 \%$ de los casos analizados

Además de revisar las estadísticas sobre lesiones y enfermedades, el NIOSH propuso un cuestionario repartido a todos los selectores de pedidos de alimentos. En el almacén $\mathrm{A}$, de los 38 selectores a tiempo total encuestados, un $50 \%$ declaró haber sufrido al menos una lesión en los 12 meses anteriores, mientras que, en el caso de las lesiones específicas de espalda, la cifra correspondiente descendía al 18 \%. En el almacén B, esas mismas proporciones, estimadas con los datos de 19 selectores a tiempo total, fueron del 63 y del $47 \%$, respectivamente. Un $70 \%$ de los trabajadores a tiempo total del almacén $A$ y un $47 \%$ de los selectores de pedidos a tiempo total del almacén $B$ señalaron haber padecido dolores de espalda de intensidad considerable en el año anterior al estudio. Estos datos aportados por los miembros de las plantillas son muy similares a los obtenidos en las encuestas sobre lesiones y enfermedades.

Aparte de examinar los datos relativos a las lesiones de espalda, el NIOSH aplicó su ecuación revisada sobre levantamiento de cargas a una muestra de tareas vinculadas a esta actividad y realizadas por los selectores de pedidos y concluyó que, en todas las tareas analizadas, se sobrepasaba el límite de peso recomendado por márgenes significativos, lo que indica que estas labores eran altamente estresantes desde un punto de vista ergonómico. Además, se estimó que todas las fuerzas de compresión ejercidas sobre el disco vertebral $15 /$ S 1 excedían el límite biomecánico recomendado de 3,4 kN (kilonewtons), establecido como tope máximo para la protección de la mayoría de los trabajadores frente al riesgo de lesión lumbar.

Por último, el NIOSH, utilizando simultáneamente las metodologías de gasto de energía y de consumo de oxígeno, estimó la demanda de energía a la que hacían frente los selectores de pedidos de ambos almacenes. Las cifras medias de esta magnitud excedían el criterio establecido de $5 \mathrm{kcal} /$ minuto (4 METS) para jornadas de 8 horas, considerado equivalente a un trabajo entre moderado y pesado para la mayor parte de los trabajadores sanos. En el almacén $A$, la tasa metabólica de trabajo oscilaba entre 5,4 y $8,0 \mathrm{kcal} /$ minuto, y el índice cardiaco de trabajo iba de 104 a 131 pulsaciones por minuto; en el B, las cifras correspondientes variaban, respectivamente, de 2,6 a $6,3 \mathrm{kcal} /$ minuto, y de 138 a 146 pulsaciones por minuto. Es probable que las demandas de energía afrontadas por los selectores de pedido y debidas al ejercicio continuo provocado por una tasa de levantamientos de 4,1 a 4,9 por minuto causaran fatiga muscular, sobre todo en turnos de trabajo de 10 o más horas. Estos datos ilustran con claridad el coste fisiológico del trabajo realizado en los dos almacenes estudiados hasta la fecha. Al recapitular sus resultados, el NIOSH llego a las siguientes conclusiones respecto a los riesgos que corren los selectores de pedidos en los almacenes de alimentos:

En resumen, todos los selectores de pedidos corren un riesgo elevado de padecer trastornos musculoesqueléticos, incluidas molestias lumbares, debido a la combinación de factores profesionales adversos que contribuyen a la fatiga, la elevación de la carga metabólica y la incapacidad de los trabajadores para regular su ritmo de trabajo a causa de los requisitos de la actividad. De acuerdo con criterios admitidos que definen la capacidad de los trabajadores y el riesgo correspondiente de padecer lesiones lumbares, las tareas efectuadas por los selectores de pedidos en los lugares de trabajo analizados sitúan a estos profesionales, incluso al personal sometido a procesos rigurosos de selección, en una situación de riesgo potencial de desarrollar el tipo de lesiones mencionado. Además, consideramos que, en general, las normas vigentes sobre rendimiento fomentan y contribuyen a la exigencia de estos niveles excesivos de esfuerzo (NIOSH 1995).
Los riesgos básicos para la salud comienzan con los materiales potencialmente tóxicos que pueden conservarse en los almacenes, como los productos petrolíferos, los disolventes y los tintes. Estas sustancias requieren un etiquetado adecuado, la formación del trabajador y la formulación de un programa de comunicación de riesgos eficaz (incluidas las FTS) destinado a todos los trabajadores afectados, cuyos conocimientos sobre los efectos para su salud de los productos que manejan suelen ser insuficientes, y aún más escasos si se trata de los procedimientos de manipulación, control de vertidos y limpieza adecuados. (Véase, por ejemplo, el Convenio (núm. 170) de la OIT sobre sustancias químicas, 1990 y la Recomendación (núm. 177), 1990. Emiten ruidos las carretillas elevadoras de motor de gasolina o de gas licuado de petróleo, las cintas transportadoras, los sistemas de ventilación y los equipos accionados por aire comprimido. Además, los trabajadores que utilizan estos equipos 
pueden verse expuestos a vibraciones que afectan a todo el cuerpo. (Véase, por ejemplo, el Convenio (núm. 148) de la OIT sobre el medio ambiente de trabajo (contaminación del aire, ruido y vibraciones), 1977 y la Recomendación (núm. 156), 1977.)

Tanto los operarios de carretillas elevadoras como los selectores pueden verse expuestos a los gases de escape de motores diesel y de gasolina procedentes de estos vehículos y de los camiones de los muelles de carga y descarga. Puede que la iluminación no sea la adecuada para el tráfico de estas carretillas y otros vehículos o para garantizar la identificación oportuna de los productos solicitados por los clientes. El personal asignado a las áreas de almacenamiento de refrigeración y congelación pueden verse afectados por el estrés por frío debido a la exposición a temperaturas bajas y a los sistemas de recirculación del aire; las temperaturas en muchas de estas áreas puede acercarse a los $-20^{\circ} \mathrm{C}$, incluso sin considerar la influencia del viento. Por otra parte, dado que son pocos los almacenes que disponen de aire acondicionado durante los meses calurosos, su personal, sobre todo los dedicados a la manipulación manual de materiales, pueden padecer estrés por calor.

Los riesgos para la seguridad también son múltiples y variados. Aparte de los más obvios debidos a la presencia en la misma zona de trabajo de peatones y vehículos de motor, muchas de las lesiones sufridas por el personal de almacén se deben a resbalones, tropezones y caídas provocadas por el estado de suelos que no se limpian de hielo, agua o productos derramados o cuyo mantenimiento es deficiente. Algunos de los accidentes producidos afectan a operarios de carretillas elevadoras que resbalan o caen al cargar o descargar sus vehículos. Los trabajadores suelen exponerse a la caída de productos de los estantes superiores. Pueden resultar atrapados por los mástiles, las horquillas o la carga de las carretillas elevadoras, lo que provoca lesiones físicas graves. Los palets de madera manejados por los trabajadores tienen astillas y provocan fácilmente heridas punzantes. El empleo de cuchillos para desembalar cajas y otros recipientes suele provocar cortes y laceraciones. Los trabajadores que cargan y descargan cajas o contenedores en las máquinas transportadoras pueden exponerse a la acción de elementos punzantes en movimiento. Los selectores, montadores y otros trabajadores dedicados a la manipulación manual de materiales corren en diversos grados el riesgo de padecer lumbalgia y otras lesiones similares. Las normativas y los métodos recomendados respecto al izado de pesos se analizan en otros capítulos de la presente Enciclopedia.

Por ejemplo, los accidentes registrados y las jornadas de trabajo perdidas en el sector del almacenamiento en Estados Unidos son considerablemente superiores a los del resto de la industria.

Tabla 102.14 • Análisis de la seguridad en el trabajo: operarios de carretillas elevadoras.

Elementos del trabajo 0
tareas
Carga y descarga de carretillas
elevadoras

Conducción con y sin cargo

Elevación o descenso de las horquillas elevadoras con 0 sin carga

Llenado de depósitos de gas y cambio de baterías

\section{Riesgos}

Resbalones sobre el suelo (grasa, agua, cartones) durante las operaciones de carga y descarga; tensiones en la espalda o los hombros por la reiteración de entradas 0 salidas incorrectas y golpes de la cabeza en las estructuras de protección

Cruce repentino de las trayectorias de peatones y vehículos; iluminación insuficiente; ruido y vibración; giro del cuello adoptando posturas incómodas; tensión de la muñeca al sostener el volante, retorcimientos 0 fuerza excesiva; la situación de los pedales del freno y del acelerador suelen exigir la adopción de posturas incómodas de los pies y de las piernas, así como las operaciones de carga estática

\section{Medidas de protección recomendadas}

Mantenimiento y limpieza adecuados de los suelos, sobre todo en las áreas de mayor tráfico; adopción de precauciones al cargar y descargar; utilización del método de tres puntos para montar y desmontar del puesto de conducción de las carretillas, procurando no golpearse la cabeza en la estructura superior de protección: agarrar las barras del soporte de dicha estructura con ambas manos, colocar el pie izquierdo en su apoyo (si está instalado) y empujar con el pie derecho para salir del puesto de conducción.

Disminución de la velocidad en las áreas de tráfico elevado; espera y activación del claxon en todas las intersecciones con otras zonas; adopción de precauciones al cruzarse con peatones, observancia de los límites de velocidad; instalación de una iluminación adecuada y mantenimiento de la misma mediante inspecciones periódicas; instalación y mantenimiento de materiales que atenúen el ruido y la vibración en todos los vehículos y los equipos; realización de pruebas de ruido periódicas; conveniencia de girar el torso y la cintura, no el cuello, sobre todo al observar los espejos retrovisores instalados en la carretilla y en el conjunto de las instalaciones; adquisición, renovación y mantenimiento de los volantes de dirección asistida y ordinarios regulables en altura para facilitar su adaptación y evitar malas posturas; establecimiento de descansos frecuentes para recuperarse de la fatiga que provoca la carga estática; consideración del diseño de los pedales de los vehículos para reducir el ángulo del pie (extensión) mediante la articulación de los pedales del acelerador respecto al suelo

Inclinación y giro del cuello para ver la carga con claridad; Giros o inclinaciones de la cintura, no del cuello; selección de horquillas necesidad de estirarse para alcanzar los controles manuales con el resultado de una extensión o un retorcimiento excesivos elevadoras que faciliten una visibilidad adecuada sobre el mástil y que dispongan de controles manuales de fácil alcance (situados a un lado del operario, no en el panel de control cercano al volante), pero no ubicados tan cerca 0 en una posición tan elevada que obliguen a retorcerse; adaptación de estos equipos con el permiso del fabricante.

Utilización de al menos dos trabajadores para realizar las maniobras de levantamiento 0 aplicación de un elevador mecánico; plantear el rediseño de las horquillas elevadoras para facilitar una localización más accesible del depósito de combustible. baterías pueden exigir maniobras de levantamiento excesivas 0 incómodas 
Tabla 102.15 • Análisis de la seguridad en el trabajo: selectores de pedidos.

Elementos del puesto de trabajo o
tareas
Carga y descarga de los elevadores de
palets

Desplazamiento en las zonas de carga

\section{Riesgos}

Resbalones y tropezones en el suelo (grasa, agua, cartón) durante las operaciones de carga y descarga

Cruce repentino de las trayectorias de peatones y de otros vehículos; iluminación; ruido

Selección del embalaje en la estantería, desplazamiento hasta el palet, colocación en éste del embalaje
Lesiones por movimientos de elevación de pesos, tensiones de hombro, espalda y cuello; golpes de la cabeza contra las estanterías; estrés por calor; estrés por frío en congeladores y salas de refrigeración
Separar los palets para envolver, marcar 0 colocar en los muelles de carga
Resbalones y tropezones (grasa, agua, cartones en el suelo) durante las operaciones de carga y descarga

\section{Medidas de protección recomendadas}

Mantenimiento y limpieza adecuados de los suelos, sobre todo en las áreas de mayor tráfico; adoptando las medidas de precaución oportunas al cargar y descargar

Reducción de la velocidad en áreas de tráfico denso; espera y activación del claxon en todas las intersecciones con otras zonas; adopción de precauciones respecto a otros peatones; cumplimiento de los límites de velocidad; equipamiento y mantenimiento de la iluminación adecuada; instalación y mantenimiento de materiales que atenúen el ruido y la vibración en todos los vehículos y los equipos; realización de pruebas periódicas para comprobar los niveles de ruido

Colaboración con los proveedores para reducir el peso de los contenedores en la medida de lo posible e instalar asas o mejores asideros en productos voluminosos o pesados; almacenamiento de productos pesados a la altura de los nudillos o superior; no colocar productos cuya manipulación exija mucho esfuerzo por encima de la altura del hombro, o disposición de escaleras o plataformas; utilización de palets giratorios para evitar los estiramientos excesivos; modificación de los carros o los elevadores para que alcancen mayores alturas y, de este modo, reducir al mínimo la necesidad de doblarse e inclinarse al situar los productos en estos dispositivos; restricción de la altura de los palets para reducir al mínimo las elevaciones por encima del hombro; realización de un seguimiento periódico de los casos de estrés por calor y por frío; disposición de los líquidos adecuados, programas de acondicionamiento, ropas y descansos frecuentes

Mantenimiento y limpieza adecuados de los suelos, sobre todo en las áreas de tráfico elevado; adopción de precauciones al cargar y descargar
No hay datos nacionales ni internacionales sobre lesiones (y en particular, sobre las que afectan a la espalda) de los selectores de pedidos de alimentos, que constituyen el grupo con mayor riesgo de sufrir lesiones relacionadas con los levantamientos. No obstante, el NIOSH de Estados Unidos, ha estudiado éstas y otras lesiones en dos almacenes de alimentos en dicho país (véase el cuadro adjunto) y ha llegado a la conclusión de que "todos los selectores de pedidos corren un riesgo elevado de sufrir trastornos musculosqueléticos, entre ellos dolor de espalda, debido a la combinación de factores profesionales adversos que contribuyen a la fatiga, a una carga metabólica alta y a la incapacidad de los trabajadores para regular su ritmo de trabajo debido a las demandas planteadas por éste" (NIOSH 1995).

La aplicación exhaustiva de los principios ergonómicos a los almacenes no debe limitarse a los levantamientos y a los selectores de pedidos. Es necesario ampliar el número de cuestiones abordadas, perfeccionando el análisis de los puestos de trabajo, las mediciones y la evaluación (parte de este análisis comienza con los estudios de seguridad en el puesto de trabajo descritos más adelante). Debe considerarse desde una perspectiva más general el diseño de las estanterías, y conviene establecer una relación laboral más estrecha con los proveedores, con el fin de diseñar o renovar los controles de las carretillas elevadoras de forma que se reduzcan los factores de riesgo ergonómico (necesidad de estirarse para alcanzar los mandos, flexión y extensión de los pies, giro, posiciones incómodas de tronco y cuello), y desarrollar recipientes menos pesados y voluminosos, con asideros para reducir el riesgo asociado al izado de cargas.

\section{Acciones correctivas}

\section{Riesgos básicos para la salud}

Las empresas, los trabajadores y los sindicatos deben cooperar en el desarrollo y la aplicación de un programa de comunicación de riesgos eficaz en el que se haga hincapié en los tres principios fundamentales siguientes:

1. etiquetado adecuado de las sustancias tóxicas;

2. disponibilidad de FTS detalladas en las que se ofrezca información pormenorizada sobre efectos para la salud, prevención de incendios, reactividad, EPI, primeros auxilios, limpieza de vertidos y otros procedimientos de emergencia; y

3. formación periódica y adecuada de los trabajadores sobre la manipulación adecuada de estas sustancias.

La ausencia de un programa de comunicación de riesgos eficaz es una de las infracciones más frecuentes de las normas en este sector citada por la Occupational Safety and Health Administration (OSHA) de Estados Unidos.

El ruido y la vibración generados por equipos mecánicos, máquinas de transporte y otras fuentes exigen la realización de pruebas frecuentes y la formación de trabajadores, así como la imposición de controles técnicos cuando sea necesario. La mayor eficacia de estos controles se consigue mediante su aplicación en las fuentes en forma de aislantes, silenciadores y otros dispositivos (como la mayoría de los operarios de carretillas elevadoras se sientan encima del motor, la atenuación del ruido en este punto suele resultar sumamente eficaz). La iluminación debe comprobarse con frecuencia y mantenerse en niveles 
Figura 102.20 • Un dispositivo de protección superior instalado en una carretilla elevadora.

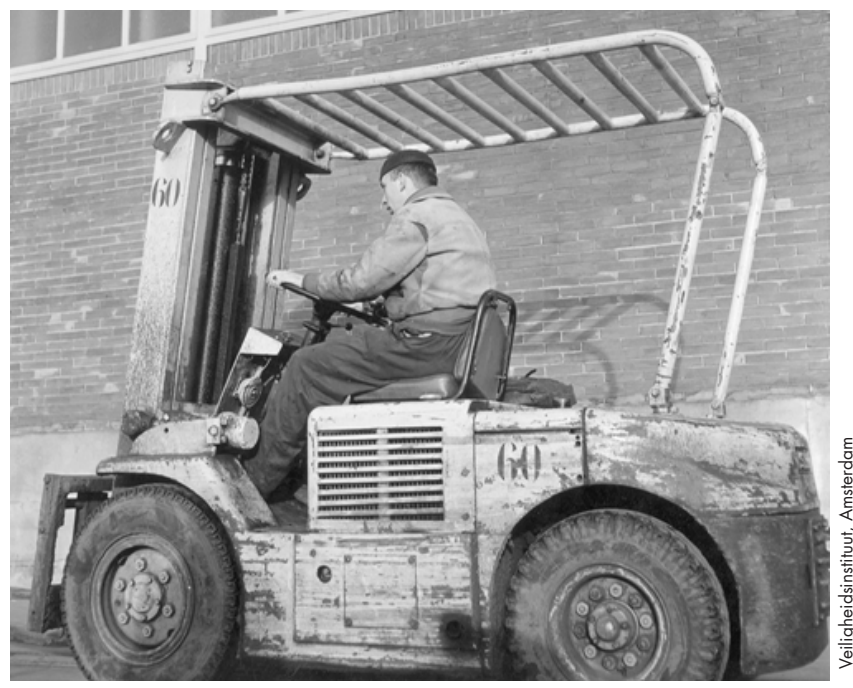

suficientes para reducir los accidentes entre peatones y vehículos y garantizar una lectura sencilla de las etiquetas de los productos y otras informaciones. Deben aplicarse programas de prevención del estrés por calor (o por frío) en lugares de trabajo situados en climas cálidos y húmedos y prestar especial atención a los selectores y operarios de carretillas elevadoras asignados a salas de almacenamiento mediante refrigeración y congelación, al objeto de garantizar que los trabajadores disfrutan de los descansos, las bebidas, la formación y la información esenciales y que se adoptan otras medidas preventivas. Por último, en los casos en que se utilicen combustibles diesel o petroquímicos, los sistemas de escape deben someterse a pruebas periódicas para analizar las emisiones de monóxido de carbono y óxidos de nitrógeno y asegurarse de que se mantienen en niveles seguros. Un mantenimiento correcto de los vehículos y la restricción de su uso a las áreas dotadas de ventilación adecuada también contribuirá a reducir el riesgo de sobreexposición a estas emisiones.

\section{Riesgos para la seguridad de operarios de carretillas elevadoras y otros vehículos}

Los accidentes entre peatones y vehículos constituyen un riesgo constante en cualquier almacén. Las vías de paso de los primeros deben señalizarse claramente y respetarse. Todos los conductores deben recibir formación sobre el funcionamiento seguro de los vehículos, incluidas las normas de tráfico y los límites de velocidad; asimismo, debe considerarse la oferta de cursos de reciclaje. Deben instalarse espejos en los cruces más transitados y en las esquinas sin visibilidad, para que los conductores puedan observar la presencia de peatones u otros vehículos y, después de hacer sonar su claxon, sigan adelante; además se considerará la instalación de señales acústicas u ópticas al accionar la marcha atrás. Las placas utilizadas en el transporte desde los muelles de carga y descarga a camiones, vagones o barcazas deben reunir las características adecuadas para soportar las mercancías y fijarse de manera adecuada.

En la Tabla 102.14 se ofrece un análisis de la seguridad en el puesto de trabajo de los operarios de carretillas elevadoras y se formulan recomendaciones.

La aplicación de soluciones ergonómicas exige una coordinación más estrecha con los fabricantes de carretillas elevadoras y vehículos; confiar únicamente en la formación del operario y en las normas de tráfico no eliminará los riesgos. Además, los organismos reguladores de la salud y la seguridad han elaborado normas de obligado cumplimiento para el diseño y la utilización de este tipo de carretillas (por ejemplo, la instalación de dispositivos de protección superior contra la caída de objetos (véase la Figura 102.20).

\section{Riesgos para la seguridad de los selectores de pedidos}

La Tabla 102.15 consta de un análisis de la seguridad en el trabajo en el que se refieren la mayor parte de las acciones correctoras necesarias para reducir los riesgos para la seguridad y relacionados con las operaciones de levantamiento de los selectores de pedidos. No obstante, al igual que la mejora del diseño de las carretillas elevadoras encaminada a atenuar los factores de riesgo ergonómico exige una coordinación más estrecha con los fabricantes de vehículos, la corrección de los riesgos que corren los selectores requiere una coordinación similar con los diseñadores de los sistemas de estanterías, los consultores que desarrollan e instalan los sistemas de control de almacenamiento y de normas técnicas y los proveedores que conservan sus productos en los almacenes. A estos últimos se les puede solicitar que proyecten productos menos voluminosos, de menor peso y con mejores asideros. Los fabricantes de estanterías pueden resultar de gran ayuda si conciben y adaptan sistemas que permitan al selector permanecer de pie al realizar su trabajo.

Es necesario sensibilizar a los consultores respecto a los riesgos para la salud y la seguridad vinculados al efecto de la intensificación del trabajo sobre las lesiones provocadas por la manipulación de materiales. El NIOSH (1993a, 1995) ha recomendado la utilización de formas más objetivas de determinar la tolerancia a la fatiga, como el consumo de oxígeno o el ritmo cardiaco. Asimismo, ha aconsejado que la altura de la paleta que se esté cargando se limite a un máximo de $150 \mathrm{~cm}$, y que se establezca una "interrupción de pedidos" después de la carga de una paleta por el selector, aumentando así la frecuencia de los períodos de recuperación entre pedidos. Además de la ampliación del número de descansos, el NIOSH ha recomendado la restricción de las horas extraordinarias basadas en las normas de trabajo planificado, así como la consideración de la rotación de trabajadores y la adopción de programas de "tareas ligeras" para los selectores de pedidos que vuelven a la actividad tras una lesión o un permiso. 


\section{Referencias}

American National Standards Institute (ANSI). 1967. Illumination. ANSI A11.1-1967. Nueva York: ANSI. Anton, DJ. 1988. Crash dynamics and restraint systems. En Aviation Medicine, $2^{\mathrm{a}}$ edición, dirigido por J Ernsting y PF King. Londres: Butterworth.

Beiler, H, U Tränkle. 1993. Fahrerarbeit als Lebensarbeitsperpektive. En Europäische Forschungsansätze zur Gestaltung der Fahrtätigkeit im ÖPNV (S. 94-98 Bundesanstat für Arbeitsschutz. Bremerhaven: Wirtschaftsverlag NW.

Bureau of Labor Statistics (BLS). 1996. Safety and Health Statistics. Washington, DC: BLS.

Canadian Urban Transit Association. 1992. Ergonomic Study of the Driver's Workstation in Urban Buses. Toronto: Canadian Urban Transit Association.

Decker, JA. 1994. Health Hazard Evaluation: Southwest Airlines, Houston Hobby Airport, Houston, Texas. HETA-93-0816-2371. Cincinnati, Ohio: NIOSH.

DeHart RL. 1992. Aerospace medicine. En Public Health and Preventive Medicine, 13 edición, dirigida por ML Last y RB Wallace. Norwalk, Connecticut: Appleton and Lange.

DeHart, R, KN Beers. 1985. Aircraft accidents, survival, and rescue. En Fundamentals of Aerospace Medicine, dirigido por RL DeHart. Filadelfia, Pensilvania: Lea and Febiger.

Eisenhardt, D, E Olmsted. 1996. Investigation of Jet Exhaust Infiltration into a Building Located on Fohn F. Kennedy (fFK) Airport Taxiway. Nueva York: US Department of Health and Human Services, Public Health Service, Division of Federal Occupational Health, Nueva York Field Office.

Firth, R. 1995. Steps to successfully installing a warehouse management system. Industrial Engineering 27(2):34-36

Friedberg, W, L Snyder, DN Faulkner, EB Darden, Jr., K O'Brien. 1992. Radiation Exposure of Air Carrier Crewemembers II. DOT/FAA/AM-92-2.19. Oklahoma City, OK: Civil Aeromedical Institute; Washington, DC: Federal Aviation Administration.

Gentry, JJ, J Semeijn, DB Vellenga. 1995. The future of road haulage in the new European Union-1995 and beyond. Logistics and Transportation Review 31(2):149.

Giesser-Weigt, M, G Schmidt. 1989. Verbesserung des Arbeitssituation von Fahrern im öffentlichen Personennahverkehr. Bremerhaven: Wirtschaftsverlag NW.

Glaister, DH. 1988a. The effects of long duration acceleration. En Aviation Medicine, $2^{\text {a }}$ edición, dirigida por J Ernsting y PF King. Londres: Butterworth. 1988b. Protection against long duration acceleration. En Aviation Medicine, $2^{a}$ edición, dirigida por J Ernsting y PF King. Londres: Butterworth.

Haas, J, H Petry y W Schühlein. 1989. Untersuchung zurVerringerung berufsbedingter Gesundheitsrisien im Fahrdienst des öffentlichen Personennahverkehr. Bremerhaven; Wirtschaftsverlag NW.

International Chamber of Shipping. 1978. International Safety Guide for Oil Tankers and Terminals. Londres: Witherby.

Joyner, KH, MJ Bangay. 1986. Exposure survey of civilian airport radar workers in Australia. Foumal of Microwave Power and Electromagnetic Energy 21(4):209-219

Landsbergis, PA, D Stein, D Iacopelli, J Fruscella. 1994. Work environment survey of air traffic controllers and development of an occupational safety and health training program. Presentado en la American Public Health Association, 1 noviembre, Washington, DC.

Leverett, SD, JE Whinnery. 1985. Biodynamics: Sustained acceleration. En Fundamentals of Aerospace
Medicine, dirigido por RL DeHart. Filadelfia, Pensilvania: Lea and Febiger.

Magnier, M. 1996. Experts: Japan has the structure but not the will for intermodalism. Fournal of $\mathrm{Com}^{-}$ merce and Commercial 407:15.

Martin, RL. 1987. AS/RS: From the warehouse to the factory floor. Manufacturing Engineering 99:49-56.

Meifort, J, H Reiners, J Schuh. 1983. Arbeitshedingungen von Linienbus- und Strassenbahnfahrern des Dortmunder Staatwerke Aktiengesellschaft. Bremen- haven: Wirtschaftsverlag.

Miyamoto, Y. 1986. Eye and respiratory irritants in jet engine exhaust. Aviation, Space and Environmental Medicine 57(11):1104-1108.

National Fire Protection Association (NFPA). 1976. Fire Protection Handbook, 14th edition. Quincy, Massachusetts: NFPA.

National Institute for Occupational Safety and Health (NIOSH). 1976. Documented Personnel Exposures from Airport Baggage Inspection Systems. DHHS (NIOSH) Publication 77-105. Cincinnati, Ohio: NIOSH.

1993a. Health Hazard Evaluation: Big Bear Grocery Warehouse. HETA 91-405-2340. Cincinnati, Ohio: NIOSH.

1993b. Alert: Preventing Homicide in the Workplace. DHHS (NIOSH) Publication 93-108. Cincinatti, Ohio: NIOSH.

1995. Health Hazard Evaluation: Kroger Grocery Warehouse. HETA 93-0920-2548. Cincinnati, Ohio: NIOSH.

National Safety Council. 1988. Aviation Ground Operation Safety Handbook, $4^{\mathrm{a}}$ edición. Chicago, Illinois: National Safety Council.

Nicogossian, AE, CL Huntoon, SL Pool (dirs.). 1994. Space Physiology and Medicine, $3^{\mathrm{a}}$ edición. Filadelfia, Pensilvania: Lea and Febiger.

Organización Internacional del Trabajo (OIT). 1992 Recent Developments in Inland Transportation. Report I Sectoral Activities Programme, Twelfth Session. Ginebra: OIT.

1996. Accident Prevention on Board Ship at Sea and in Port. Repertorio de Recomendaciones prácticas de la OIT. $2^{a}$ edición. Ginebra: OIT

Peters, Gustavsson, Morén, Nilsson, Wenäll. 1992. Forarplats I Buss, Etapp 3; Kravspecifikation. Linköping, Sweden: Väg och Trafikinstitutet.

Poitrast, BJ, deTreville. 1994. Occupational medical considerations in the aviation industry. En Occupational Medicine, $3^{\mathrm{a}}$ edición, dirigido por $\mathrm{C}$ Zenz, OB Dickerson y EP Hovarth. St. Louis, Misuri: Mosby.

Register, O. 1994. Make Auto-ID work in your world. Transportation and Distribution 35(10):102-112.

Reimann, J. 1981. Beanspruchung von Linienbusfahrern. Untersuchungen zur Beanspruchung von Linienbusfahrern im innerstädtischen Verkehr. Bremerhaven: Wirtschafts-verlag NW

Rogers, JW. 1980. Results of FAA Cabin Ozone Monitorin Program in Commercial Aircraft in 1978 and 1979 FAA-EE-80-10. Washington, DC: Federal Aviation Administration, Office of Environment and Energy.

Rose, RM, CD Jenkins, MW Hurst. 1978. Air Traffic Controller Health Change Study. Boston, Massachusetts: Boston University School of Medicine.

Sampson, RJ, MT Farris, DL Shrock. 1990. Domestic Transportation: Practice, Theory, and Policy, $6^{\mathrm{a}}$ edición. Boston, Massachusetts: Houghton Mifflin Company.

Streekvervoer Nederland. 1991. Chaufferscabine [Cabina del conductor]. Amsterdam, Países Bajos: Streekvervoer Nederland.
US Department of Transportation (DOT). 1995. Senate Report 103-310, June 1995. Washington, DC: GPO.

US Senate. 1970. Air Traffic Controllers (Corson Report). Senate Report 91-1012. 91st Congress, 2a sesión, 9 julio. Washington, DC: GPO.

Verband Deutscher Verkehrsunternehmen. 1996. Fahrerarbeitsplatz im Linienbus [Puesto de trabajo del conductor en los autobuses]. VDV Schrift 234 (Entwurf). Cologne, Germany: Verband Deutscher Verkehrsunternehmen.

Violland, M. 1996. Whither railways? OECD Observer No. 198,33

Wallentowitz H, M Marx, F Luczak, J Scherff. 1996. Forschungsprojekt. Fahrerarbeitsplatz im Limienbus Abschlußbericht [Proyecto de investigación. Puesto de trabajo de los conductores de autobus - Informe final]. Aquisgrán, Alemania: RWTH.

Wu, YX, XL Liu, BG Wang, XY Wang. 1989. Aircraft noise-induced temporary threshold shift. Aviation Space and Medicine 60(3):268-270.

\section{Otras lecturas recomendadas}

American Petroleum Institute (API). 1971. Chemistry and Petroleum for Classroom Use in Chemistry Courses. Washington, DC: API.

. 1973. Industrial Hygiene Monitoring Manual for Petroleum Refineries and Selected Petrochemical Operations. Washington, DC: API.

- 1980. Facts about Oil. Washington, DC: API.

. 1984. Safe Operation of Inland Bulk Plants. Washington, DC: API.

- 1984. Service Station Safety. Washington, DC: API. 1988. Design and Construction of LP Gas Installations. Washington, DC: API

- 1995. Overfill Protection for Storage Tanks in Petroleum Facilities. Recommended Practice 2350. Washington, DC: API.

. 1995. Using the API Color Symbol System to Mark Equipment and Vehicles for Product Identification at Service Stations and Distribution Terminals. Recommended Practice 1637. Washington, DC: API.

Armistead, G, Jr. 1950. Safety in Petroleum Refining and Related Industries. Nueva York: John G. Simmons \& Co.

Aschof, J. 1981. Circadian rhythms: Interference with and dependence on work-rest schedules. En Biological Rhythms, Sleep and Shift Work, dirigido por L Johnson. Nueva York: SP Medical and Scientific Books.

Association of American Railroads. 1982. Manual of Standards and Recommended Practices, Specifications for Tank Cars. Washington, DC: Association of American Railroads.

Benenson, AS (dir.). 1995. Control of Communicable Diseases Manual, 16 edición. Washington, DC: American Public Health Association.

Bowers, DG. 1983. What would make 11,500 people quit their jobs. Organizational Dynamics 5-19.

Chevron Corporation. 1983. It's Chevron Safety Time. San Francisco, California: Chevron Corporation.

Costa, G. 1992. A seven-point programme to reduce stress in air traffic controllers in Italy. En Preventing Stress at Work. Conditions of Work Digest. Vol. 11. Ginebra: OIT.

Davis, RG. 1987. Providing effective warehouse lighting. Plant Engineering 41:88-90.

Exxon Company. 1987. Encyclopedia for the User of Petroleum Products.Houston, Texas: Exxon Company.

Gentry, JJ, J Semeijn, DB Vellenga. 1995. The future of road haulage in the new European Union-1995 and beyond. Logistics and Transportation Review 31(2):149.

Graeber, RC. 1988. Aircrew fatigue and circadian rhythmicity. En Human Factors in Aviation, dirigido por Weiner and Nagel. San Diego, California: Academic Press. 
Gulf Publishing Company. 1964. Petroleum Marketing and Transportation. Houston, Texas: Gulf Publishing Company.

Hakkola, M. 1994. Neuropsychological symptoms among tanker drivers with exposure to solvents. Occupational Medicine 44(5):243-246.

Hertz, RP. 1988. Tractor-trailer driver fatality and the role of nonconsecutive rest in a sleeper berth Accident Analysis and Prevention 20(6):431-439.

Landsbergis, PA. 1986. Is air traffic control a stressful occupation? Labor Studies fournal 11:117-134

Lund, J. 1991. Computerised work performance monitoring and production standards: A review of labour law issues. Labor Law fournal 42(4): 195-202.

Marine Safety Agency. 1995. Merchant Shipping Notice No. M.1607: The Merchant Shipping and Fishing Vessel (Medical Stores) Regulations 1995. SI 1995 No 1802. Southampton, Reino Unido: Department of Transport.

Mobil Oil Corporation. 1972. Light Products Refining, Fuels Manufacture. Mobil Technical Bulletin. Fairfax, Virgina: Mobil Oil Corporation.

- 1974. The Language of Oil. Fairfax, Virginia: Mobil Oil Corporation.

- 1990. Handling, Storing and Dispensing Industrial Lubri cants. Mobil Technical Bulletin. Fairfax, Virginia: Mobil Oil Corporation.

- 1992. LPG Manual. Fairfax, Virginia: Mobil Oil Corporation.

National Fire Protection Association (NFPA). 1992. National Fuel Gas Code. NFPA 54. Quincy, Massachusetts: NFPA

- 1992. Liquified Petroleum Gases Handbook. Quincy, Massachusetts: NFPA.

1993. Automotive and Marine Service Station Code. NFPA 30A. Quincy, Massachusetts: NFPA.

- 1993. Flammable and Combustible Liquids Code. NFPA 30. Quincy, Massachusetts: NFPA.

- 1994. Liquified Natural Gas (LNG). NFPA 59A Quincy, Massachusetts: NFPA.
1995. Storage and Handling of Liquified Petroleum Gases. NFPA 58. Quincy, Massachusetts: NFPA.

National Institute for Occupational Safety and Health (NIOSH). 1975. Health and Safety Guide for Service Stations. Cincinnati, Ohio: NIOSH.

- 1994. Applications Manual for the Revised NIOSH Lifting Equation. NIOSH Publication 94-110. Cincinnati, Ohio: NIOSH.

- 1994. Workplace Use of Back Belts: Review and Recommendations. Cincinnati, Ohio: NIOSH.

National L-P Gas Association. 1968. LP Gas Safety Handbook. Chicago, Illinois: National L-P Gas Association.

National Research Council. 1986. The Airliner Cabin Environment: Air Quality and Safety. Washington, DC: Committee on Airliner Cabin Air Quality, Board on Environmental Studies and Toxicology, Commission on Life Sciences, National Research Council, National Academy Press.

National Safety Council. 1978. Service Sense: A Guide to Safety around the Automotive Shop. Itasca, Illinois: Naional Safety Council.

C. 1988. Motorized equipment. Accident Prevention Manual for Industrial Operations: Administration and Programs, $9^{\text {a }}$ edición. Itasca, Illinois: National Safety Council.

- 1995. Petroleum Section Safety and Health Fact Sheets: Service Station Safety Series, 1988-1995. Itasca, Illinois: National Safety Council.

Organización Internacional del Trabajo (OIT). 1977. Occupational Health and Safety in Civil Aviation. Tripartite technical meeting for civil aviation. Ginebra: OIT.

- 1993. Workers' Privacy, Part II: Monitoring and Surveillance in the Workplace. Conditions of Work Digest. Vol. 12. Ginebra: OIT.

- 1996. International Labour Conventions and Recommendations 1919-1995. 3 Vols. Ginebra: OIT.

Ribak, J, RB Rayman and P Froom (dirs.). 1995. Occupational Health in Aviation: Maintenance and Support Personnel. San Diego, California: Academic Press.
Rosa, RR, MH Bonnet, RR Bootzin, CI Eastman, T Monk, PE Penn, DI Tepas, JK Walsh. 1990. Intervention factors for promoting adjustment to nightwork and shiftwork. Occ Med: State Art Rev 5(2):391-414

Rosa, RR. 1993. Performance and alertness on $8 \mathrm{~h}$ and $12 \mathrm{~h}$ rotating shifts at a natural gas utility. Ergonomics 36:1177-1193

Schroeder, DJ, RR Rosa, LA Witt. Effects of 8- vs. 1-hour Work Schedules on the Performance/alterness of Air Traffic Control Specialists. Oklahoma City, Oklahoma: Civil Aeromedical Institute.

Shostak, AB, D Skocik. 1986. The Air Controllers Controversy. Nueva York: Human Sciences Press.

Transport and General Workers Union. 1993. Good Bu Cab Design. Code of Practice. Londres: Transport and General Workers Union.

US Coast Guard. 1992. Recommended Program for Protection of Merchant Mariners from Occupational Health Problems. Navigation and Vessel Inspection Circular No. 3-92. COMDTPUB P6700.4. Washington, DC: US Coast Guard.

- 1994. International Safety Management Code for the Safe Operations of Ships and for Pollution Prevention. Navigation and Vessel Inspection Circular No. 2-94. Washington, DC: US Coast Guard.

1996. Marine Safety Manual. COMDTINST M16465.6. Washington, DC: Department of Transportation, US Coast Guard.

US Department of Transportation (DOT). 1994. Haz ardous Materials Air Incidents by Date (fanuary 1, 1992 to December 31, 1993). Washington, DC: DOT, Hazardous Materials Safety, Hazardous Materials Information System.

-. 1996. Hazardous Materials Regulations. 49 CFR 171177. Washington, DC: DOT.

US Public Health Service. 1996. Ship's Medicine Chest and Medical Aid at Sea. Washington, DC: Deptartment of Health and Human Services.

Witt, CE. 1992. Warehouse lighting brightens path to productivity. Material Handling Engineering 47:65-6. 
ENCICLOPEDIA DE SALUD Y SEGURIDAD EN EL TRABAJO 



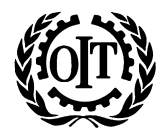

\title{
ENCICLOPEDIA DE SALUD Y SEGURIDAD EN EL TRABAJO
}

\author{
Directora de la publicación \\ Jeanne Mager Stellman, PhD
}

Subdirector general de la publicación

Michael McCann, PhD, $\mathrm{ClH}$

Subdirectores de la publicación

Leon Warshaw, MD Carole Brabant, PhD

Redactores principales

John Finklea, MD, Dr PH Jacqueline Messite, MD

Georges H. Coppée, MD Steven L. Sauter, PhD

Vilma R. Hunt, BDS, AM Jerry Spiegel, MA, MSC

Richard S. Kraus, PE, CSP Colin L. Soskolne, PhD

Wolfgang Laurig, Dr-Ing Benedetto Terracini, MD

Melvin L. Myers, BS, MPA

Gestión editorial

Chantal Dufresne, BA

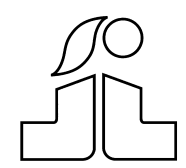


La edición original de esta obra ha sido publicada por la O ficina Internacional del Trabajo (G inebra) bajo el título "Encyclopaedia of 0 ccupational $\mathrm{H}$ ealth and Safety, fourth edition". Esta edición española se publica con la autorización de la O IT y bajo las condiciones del Acuerdo firmado entre la O ficina Internacional del Trabajo y el M inisterio de Trabajo y A suntos Sociales de España en materia de publicaciones.

Copyright @de la edición inglesa, O rganización Internacional del Trabajo, 1998

Copyright @de la edición española, M inisterio de Trabajo y A suntos Sociales, 1998

Las denominaciones empleadas, en concordancia con la práctica seguida en $\mathrm{N}$ aciones $\mathrm{U}$ nidas, y la forma en que aparecen presentados los datos en las publicaciones de la O IT no implican juicio alguno por parte de la O ficina Internacional del Trabajo sobre la condición jurídica de ninguno de los países, zonas o territorios citados o de sus autoridades, ni respecto de la delimitación de sus fronteras.

La responsabilidad de las opiniones expresadas en los artículos, estudios y otras colaboraciones firmadas incumbe exclusivamente a sus autores y su publicación no significa que la O IT las sancione.

El lector asume que las partes facilitan la presente documentación sin garantía de ningún tipo. Las partes no se hacen responsables de la validez ni de la integridad de ninguno de los datos, incluidos errores, inexactitudes u omisiones, ni de las posibles consecuencias que implique la utilización de dichos datos. $\mathrm{Ni}$ los autores ni la OIT, ni las instituciones colaboradoras son responsables de los daños ni de cualquier otra reclamación o demanda que se deriven de la utilización de estos datos.

Las referencias a firmas, procesos o productos comerciales no implica aprobación alguna por la 0 ficina Internacional del Trabajo, y el hecho de que no se mencionen firmas, procesos o productos comerciales no implica desaprobación alguna.

La presente edición es la versión española de la cuarta edición inglesa, revisada y enriquecida con las aportaciones ofrecidas y destinadas a la misma por la O IT y con las peculiaridades y conceptos incorporados al cuerpo de la enciclopedia por especialistas, con objeto de hacer su utilización más asequible en los países de habla hispana. En la traducción, coordinación y financiación de la presente edición han colaborado:

- M inisterio de Sanidad y Consumo

- Instituto Nacional de la Salud

- Instituto Nacional de M edicina y Seguridad en el Trabajo

- M inisterio de Trabajo y Asuntos Sociales

- Instituto Nacional de Seguridad eH igiene en el Trabajo

- Agencia E spañola de Cooperación Internacional

- O ficina Internacional del Trabajo

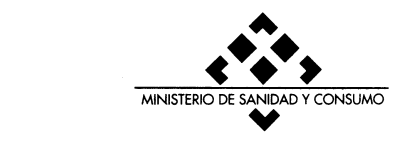

SIISAL INSALUD 6
NSTITUTO NACIONAL DE MEDICINA SEGURIDAD DEL TRABAJO
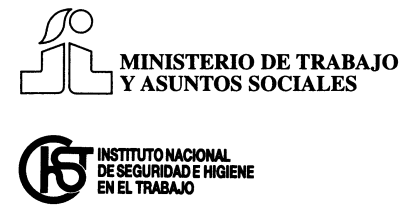

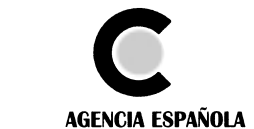

DE COOPERACION INTERNACIONAL

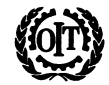

OFIIINA INTERNACIONAL

DEL TRABAJO

Los editores agradecen la colaboración y confianza demostradas por la A sociación de M utuas de Accidentes de Trabajo en la elaboración de esta obra.

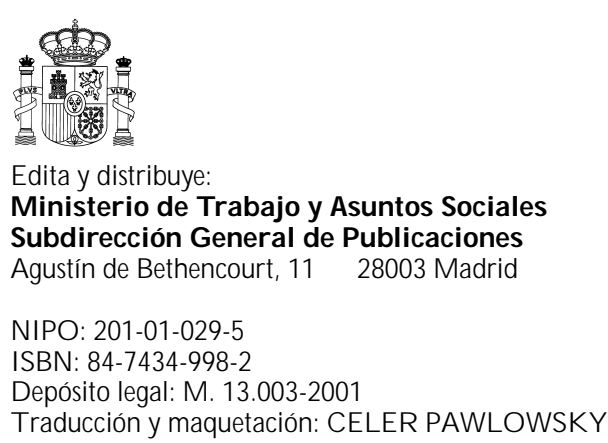




\section{AUTORES Y DIRECTORES}

Avraham Aladjem, DSC Instituto de Seguridad y Salud en el T rabajo de I srael

Tel Aviv

Israel

Janet L. Collins, M D , M PH

M edical Director

Division of $O$ ccupational M edicine

Sherman H ealth Systems

Elgin, Illinois

Estados U nidos

Alexander Donagi, DSC, M PH

Profesor

Facultad de M edicina

U niversidad de T el A viv

Director

Centro de Información

Instituto de Seguridad y Salud en el

Trabajo de Israel

Tel Aviv

Israel

Linda S. Forst, M S, M D , M PH

Assistant P rofessor

School of Public H ealth

U niversity of Illinois at C hicago

Chicago, Illinois

Estados U nidos

David L. Hinkamp, M D, M PH

Visiting Assistant P rofessor

School of Public H ealth

U niversity of $\mathrm{M}$ ichigan

Ann Arbor, Michigan

Estados U nidos
Niels Koehncke, BSC (hon), M D

$R$ esident, $O$ ccupational $M$ edicine P rogram

D epartment of Public $\mathrm{H}$ ealth Sciences

U niversity of A lberta

Edmonton, Alberta

Canadá

Kari Kurppa, M D PhD

Ayudante del D irector de D epartamento

D epartamento de E pidemiología y

Bioestadística

Instituto de Salud en el Trabajo

$\mathrm{H}$ elsinki

Finlandia

Pia Markkanen, M Sc, Eng

Experto asociado

O ficina Internacional del T rabajo

Bangkok

T ailandia

Debra Osinsky, M PH

E ditorial C onsultant

E ncyclopaedia of $\mathrm{O}$ ccupational $\mathrm{H}$ ealth and Safety

International L abour $O$ ffice

H ighland Park, Nueva Jersey

Estados U nidos

Beth Donovan Reh, M H S

Industrial $\mathrm{H}$ ygienist

$H$ azard Evaluations and T echnical

A ssistance Branch

$\mathrm{N}$ ational Institute for $\mathrm{O}$ ccupational Safety and $\mathrm{H}$ ealth

Cincinnati, Ohio

Estados U nidos
Menachem Schwartz, BSC, M Sc D irector General

Instituto de Seguridad y Salud en el Trabajo de I srael

Tel A viv

Israel

Jeanne M. Stellman, PhD

D irectora de la publicación

E nciclopedia de salud y seguridad en el trabajo

O ficina Internacional del Trabajo

Ginebra

Suiza

School of Public H ealth

Columbia U niversity

Nueva Y ork, Nueva Y ork

Estados U nidos

Steven D. Stellman, PhD, M PH

Chief

Division of Epidemiology

American $\mathrm{H}$ ealth Foundation

N ueva Y ork, Nueva Y ork

Estados U nidos 


\section{Para la versión inglesa original}

\author{
Sarah Alvarez \\ $M$ aria Arteta \\ $M$ ay Ballerio-H ofman \\ Lillian Benjamin \\ $M$ ichel Berka \\ W alter Benjamin \\ Christian Bolufer \\ Claude Chaperon \\ $K$ yle Creane \\ Denis Cullinan \\ Johanna de $V$ ries \\ R obert Dees \\ $M$ argaret Fennessy \\ $R$ aymond Figuières \\ Betty G oldman \\ Susan Guthridge \\ $\mathrm{K}$ athleen Susan H urst \\ Claudia H ommel \\ $\mathrm{R}$ achael $\mathrm{H}$ orner \\ Sanna Immonen \\ Lisa K ellner \\ Diana Signe K line \\ Nana-E kua L eigh \\ R obert Leuze \\ Elizabeth $\mathrm{M}$ ahiga \\ Christiane M elin \\ Jacky M erteau
}

\author{
John M cK enna \\ Julie N ayler \\ Catherine $\mathrm{H}$. Perring \\ Peter Perring \\ Bodhani Pieris \\ Giles R eed \\ K irsten R eed \\ John G. R odwan, Jr. \\ Nancy J. Rodwan \\ David Rosenweig \\ D avid R owley \\ $O$ riele $\mathrm{R}$ ovaletti \\ Daniel R uffieux \\ Jacques $P$. T remblet \\ Steven Sacks \\ Barbara Sandi \\ Gabor Sandi \\ Anneliese Shulte \\ Jonathon Stampf \\ Fred Stanton \\ Prabha Sundaram \\ Juan T enorio \\ Jennifer $V$ aldes \\ Tracy W eber \\ Berit W iding-Pry \\ Sydney G. Williams \\ Su Zen
}

\section{Para la versión española}

$\mathrm{H}$ an colaborado de forma desinteresada en las diversas fases de correcciones técnicas los/ las siguientes expertos/ expertas del Instituto Nacional de Seguridad e H igiene en el Trabajo, coordinados por D ña. M a C armen Guardiola H uertas:

R osa M a Alonso Espadalé

$M$ a josé Berenguer Subils

Angelina Constans A ubert

$R$ afael $D$ enia $C$ andel

C arlos D ie G oyanes

Alejo Fraile $C$ antalejo

Asunción Freixa Blanxart

Enrique Gadea Carrera

$M \stackrel{\mathrm{C}}{\mathrm{C}}$ armen G uardiola H uertas

Andrés $\mathrm{H}$ arto $\mathrm{C}$ astaño
Alicia H uici M ontagud

M argarita L ezcano N úñez

M a Carmen M artí Solé

Adoración Pascual Benés

Leandro R egidor Braojos

$M$ a Gracia R osell Farrás

Concepción Santolaya M artínez

$X$ avier Solans Lampurdanés

$M$ a C armen $T$ orres $L$ acalle

$\mathrm{M}$ a C armen $\mathrm{U}$ garte $\mathrm{O}$ terino 
Agencia Internacional para la Investigación sobre el

Cáncer (IARC)

150, cours Albert-T homas

69372 Lyon Cedex 08

Francia

Tel. +33-4 72738485

Fax +33-4 72738575

\section{American Health Foundation}

320 E ast 43rd Street

Nueva Y ork, NY 10017

Estados U nidos

Tel. +1-212 5512521

Fax +1-212 6872339

\section{American Industrial Hygiene Association (AlHA) \\ 2700 Prosperity A venue \\ Fairfax, V A 22031 \\ Estados U nidos \\ Tel. +1-703 8498888 \\ Fax +1-703 2073561}

\section{American Petroleum Institute}

1220 L Street NW

Washington DC 20005

Estados U nidos

Tel. +1-202 6828308

Fax +1-202 6828270

\section{Asociación Internacional de la Seguridad Social (AISS)}

4 , route des $M$ orillons

1211 G enève 22

Suiza

Tel. +41-22 7996617

Fax +41-22 7998509

\section{Berufsgenossenschaftliches Institut}

für Arbeitssicherheit (BIA)

Alte H eerstrasse 111

D-53754 Sankt A ugustin

Alemania

Tel. +49-2241 23102

Fax +49-2241 2312234

\section{Bundesanstalt für Arbeitsschutz und Arbeitsmedizin (BAuA)}

Fachbereich Arbeitsmedizin

Nöldnerstrasse 40/ 42

D-10317 Berlín

Alemania

Tel. +49-305154 8180

Fax +49-305154 8170

\section{Bundesanstalt für Arbeitsschutz} und Arbeitsmedizin

Fachbereich Arbeitsschutz

Friedrich-H enkel-Weg 1-25

D-44149 D ortmund

Alemania

Tel. +49-2319071340

Fax +49-231 9071454

\section{Canadian Auto Workers Union} (CAW)

205 Placer C ourt, N orth Y ork

Willowdale, $\mathrm{O}$ ntario $\mathrm{M} 2 \mathrm{H} 3 \mathrm{H} 9$

Canadá

Tel. +1-416 4974110

Fax +1-416 4953785

\section{Canadian Centre for Occupational Health and Safety (CCOHS)}

$250 \mathrm{M}$ ain Street East

$\mathrm{H}$ amilton, O ntario L 8N $1 \mathrm{H} 6$

Canadá

T el. +1-905 5722981

Fax +1-905 5722206

\section{Canadian Labour Congress}

2841 prom. R iverside $D$ rive

O ttawa, O ntario K IV 8X 7

Canadá

T el. +1-613 5213400

Fax +1-613 5214655

\section{Center to Protect Workers'} Rights

111 M assachusetts A venue NW

Washington DC 20001

Estados U nidos

Tel. +1-202 9628490

Fax +1-202962 8499

\section{CISL National Board}

Dipartimento Politiche Internazionale

V ia Po 21

Roma 00198

Italia

Tel. +39-6 8473357

Fax +39-6 8413782

\section{Columbia University}

School of Public H ealth

N ueva Y ork, NY 10032

Estados U nidos

Tel. +1-212 3053464

Fax +1-212 3053405

\section{Hauptverband der gewerblichen}

Berufsgenossenschaften (HVBG)

A lte H eerstrasse 111

D-53754 Sankt Augustin

Alemania

Tel. +49-2241 2311150

Fax +49-2241 2311391

Health and Safety Executive (HSE)

R ose Court

2 Southwark Bridge

L ondres SE $19 \mathrm{H} \mathrm{S}$

$R$ eino U nido

T el. +44-171 7176000

Fax +44-171 7176717
Institut de Recherche en Santé et en Sécurité du Travail (IRSST)

505, boulevard D e $M$ aisonneuve $O$ uest

M ontréal, Q uébec H 3A 3C2

Canadá

Tel. +1-514 2881551

Fax +1-514 2880998

\section{Institut für Arbeitsphysiologie} (IfADo)

U niversität D ortmund

A rdeystrasse 67

D -44139 D ortmund

Alemania

Tel. +49-231 1084361

Fax +49-231 1084402

Institut National de Recherche et de Sécurité (INRS)

30 , rue 0 livier N oyer

75680 Paris C edex 14

Francia

Tel. +33-1 40443000

Fax +33-1 40443099

Institut universitaire romand de Santé au Travail (IST)

1005 L ausanne

Suiza

Tel. +41-21 3147421

Fax +41-21 3147420

Institute of Occupational Medicine $C$ hinese A cademy of Preventive M edicine $29 \mathrm{~N}$ an W ei Road

Pekín 100050

R epública Popular China

Tel. +86-10 63014323

Fax +86-10 63014323

\section{Instituto de Investigación}

Científica de Salud en el Trabajo A cademia R usa de las Ciencias M édicas 31, Prospekt Budennogo

105275 M oscú

Federación Rusa

Tel. +7-0953650209

Fax +7-095366 0583

\section{Instituto de Medicina del Trabajo y Salud Ambiental}

$13 \mathrm{~K}$ oscielna Street

41-200 Sosnowiec

Polonia

Tel. +48-3 2660640

Fax +48-3 2661124

\section{Instituto de Seguridad y Salud en el Trabajo de I srael}

$22 \mathrm{M}$ aze Street

PO Box 1122

T el-A viv 61010

Israel

T el. +972-3 6297314

Fax +972-3 5252448 
Instituto Nacional de la

Vida Laboral

Ekelundsvägen 16

S-171 84 Solna

Suecia

Tel. +46-8 7309100

Fax +46-8 7301967

\section{Instituto Nacional de Seguridad} e Higiene en el Trabajo

Torrelaguna 73

28027 M adrid

España

T el. +34-1 4037000

Fax +34-1 4030050

\section{Instituto Nofer de la Medicina} en el Trabajo

$8 \mathrm{Sw}$. T eresy Street

PO Box 199

90-950 Lodz

Polonia

Tel. +48-42 314502

Fax +48-42 568331

\section{Instituto para la Ciencia del}

$$
\text { Trabajo }
$$

2-8-14 Sugao

M iyamae-ku

K awasaki 216-8501

Japón

Tel. +81-4 49772121

Fax +81-4 49777504

\section{Instituto Seguros Sociales}

Centro Administrativo Nacional

Diagonal 40, n.o 46-A-17

Bogotá

Colombia

T el. +57-1 2224491

Fax +57-1 2221315

\section{International Commission on \\ Occupational Health (ICOH)}

L ower K ent R idge R oad

Singapore 0511

Singapur

Tel. +657724290

Fax +65 7791489

Istituto di Medicina del Lavoro

U niversità degli Studi di M ilano

$\checkmark$ ia San Barnaba 8

I-20122 M ilán

I talia

Tel. +39-2 5511610

Fax +39-2 55187172
National Fire Protection

Association International

1 Batterymarch Park

PO Box 9101

Q uincy, M A 02269-9101

Estados U nidos

Tel. +1-617 7703000

Fax +1-617 7700700

\section{National Institute for}

Occupational Safety and

Health (NIOSH)

$\mathrm{H}$ ubert $\mathrm{H}$. H umphrey Building

200 Independence Avenue SW

W ashington DC 20201

Estados U nidos

T el. +1-202 4010721

Fax +1-202 2604464

\section{Occupational Safety and Health \\ Administration}

US D epartment of Labor

$N$ ational $O$ ffice

200 Constitution A venue NW

Washington DC 20010

Estados U nidos

Tel. +1-215 5961201

Fax +1-215 5964872

\section{Organización Internacional de}

Normalización (ISO)

1 , rue de $V$ arembé

PO Box 56

1211 G enève 20

Suiza

Tel. +41-22 7490111

Fax +41-22 7333430

Organización Mundial de la Salud (OMS)

20 , avenue A ppia

1211 G enève 27

Suiza

Tel. +41-22 7912111

Fax +41-22 7913111

\section{Schweizerische Unfall-}

versicherungs-Anstalt (SUVA)

Swiss 0 ccupational Accident I nsurance

PO Box 4358

6002 L uzern

Suiza

Tel. +41-41 4195111

Fax +41-41 4196170
Sheffield Occupational

Health Project

M udford's Buildings

37 Exchange Street

Sheffield S2 5T R

R eino U nido

Tel. +44-114 2755760

Fax +44-114 2491883

\section{Työterveyslaitos}

Instituto de Salud en el T rabajo

T opeliuksenkatu 41 a A

FIN -00250 H elsinki

Finlandia

Tel. +358-9 4747383

Fax +358-9 4747490

United Automobile, Aerospace and Agricultural Implement Workers of America (UAW)

8000 E ast J efferson Avenue

Detroit, M I 48214

Estados U nidos

T el. +1-313 9265563

Fax +1-313 8244473

\section{United Food and}

Commercial Workers

1775 K Street N W

Washington DC 20006-1598

Estados Unidos

Tel. +1-202 2233111

Fax +1-202 4661562

\section{University of Alberta}

Faculty of $\mathrm{M}$ edicine and $\mathrm{O}$ ral $\mathrm{H}$ ealth Sciences

D epartment of Public H ealth Sciences

13-103 Clinical Sciences Building

Edmonton, Alberta T 6G 2G3

Canadá

T el. +1-403 4926013

Fax +1-403 4920364 


\section{IV}

GUIAS

INDICES

DIRECTORIO DE EXPERTOS 



\section{SUMARIO}

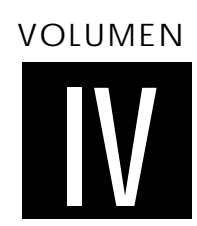

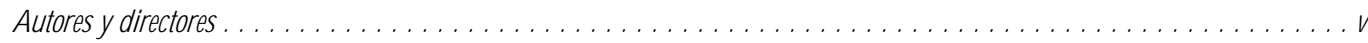

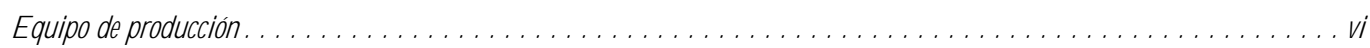

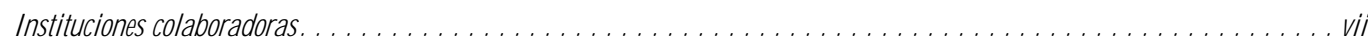

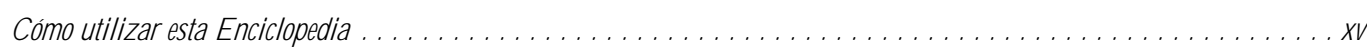

PARTE XVIII. GUIAS

103. Guía de profesiones . . . . . . . . . Alexander Donagi, Avraham Aladjem y Menachem Schwartz, Directores del capítulo

Sistematización de los riesgos profesionales

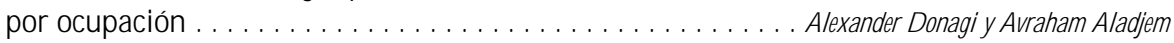

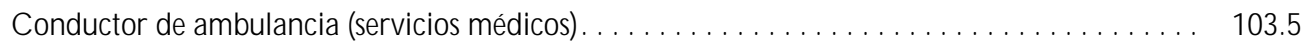

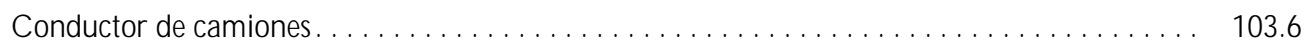

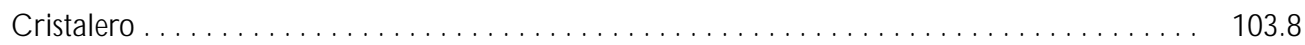

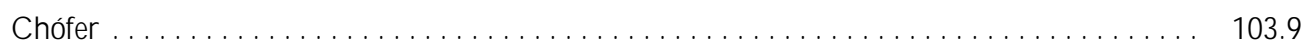

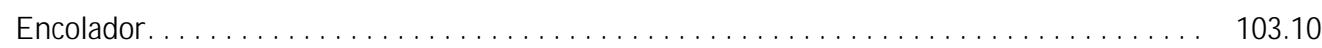

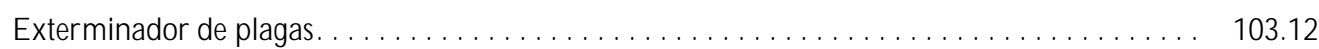

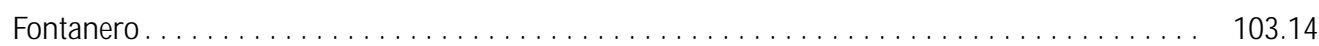

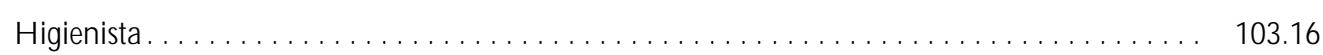

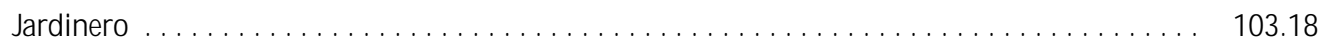

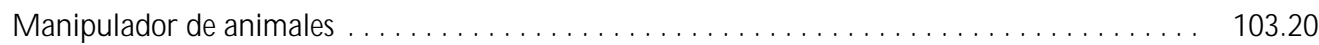

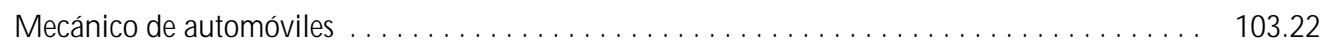

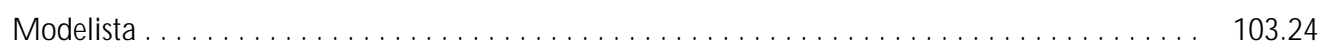

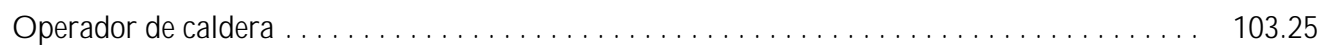

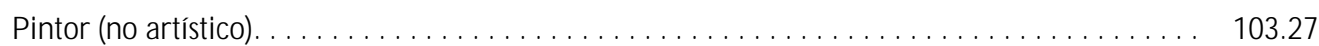

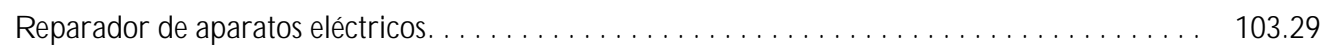

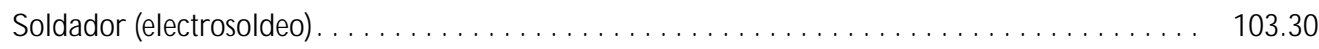

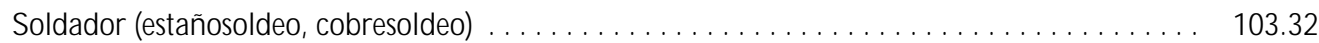

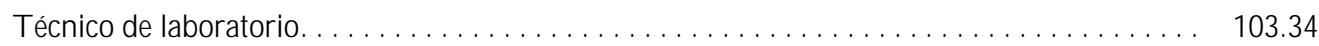

\section{Guía de productos químicos . J Jeanne Mager Stellman, Debra Osinsky}

Acidos inorgánicos.

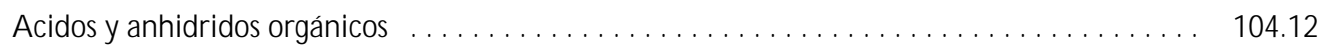

Alcoholes ............................................. 104.32

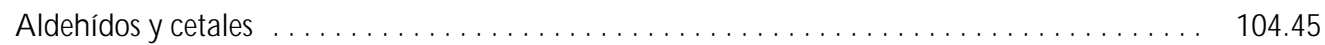

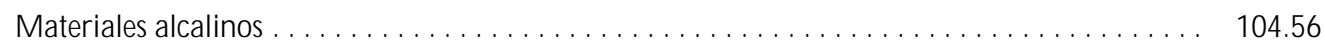

Amidas. .............................................. 104.73

Aminas alifáticas . . . . . . . . . . . . . . . . . . . . . . . . . . . . . . . . . . . 104.80

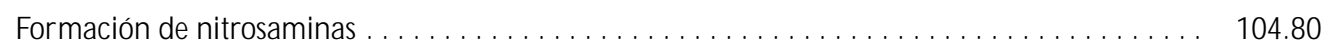

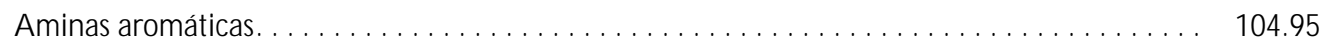


Azidas. . . . . . . . . . . . . . . . . . . . . . . . . . . . . . . . . . . . . . . 104.121

Compuestos de boro . . . . . . . . . . . . . . . . . . . . . . . . . . . . . . . . . . . . . . . . 104.130

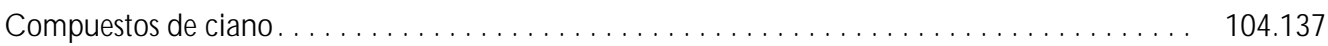

Compuestos epoxidicos . . . . . . . . . . . . . . . . . . . . . . . . . . . . . . . . . 104.152

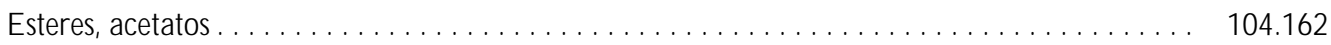

Esteres acrílicos . . . . . . . . . . . . . . . . . . . . . . . . . . . . . 104.172

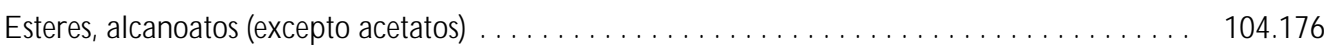

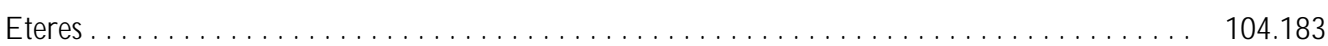

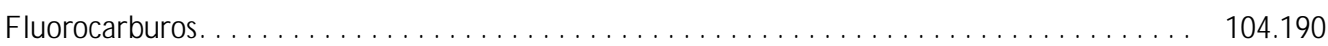

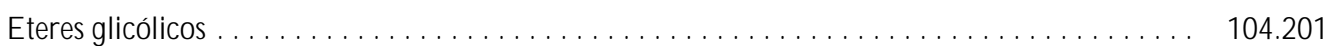

Gliceroles y glicoles . . . . . . . . . . . . . . . . . . . . . . . . . . . . . . . . . 104.209

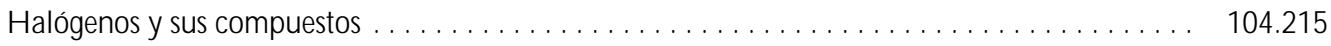

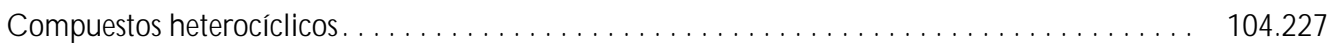

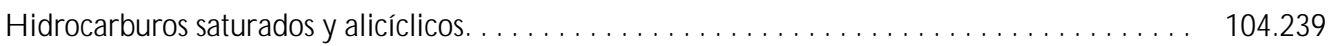

H idrocarburos, alifáticos y halogenados . . . . . . . . . . . . . . . . . . . . . . . . . . . . . . 104.249

H idrocarburos alifáticos insaturados . . . . . . . . . . . . . . . . . . . . . . . . . . . . . . . . . . . . 104.275

H idrocarburos aromáticos . . . . . . . . . . . . . . . . . . . . . . . . . . . . . . . . . . . 104.282

H idrocarburos aromáticos halogenados . . . . . . . . . . . . . . . . . . . . . . . . . . . . . . . . 104.296

H idrocarburos poliaromáticos . . . . . . . . . . . . . . . . . . . . . . . . . . . . . . . . . . . 104.310

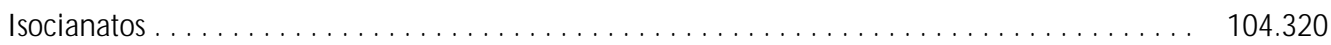

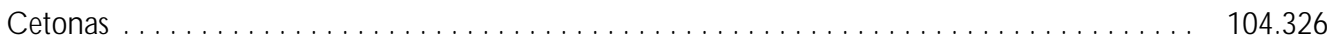

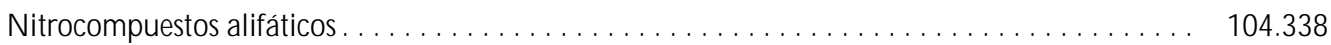

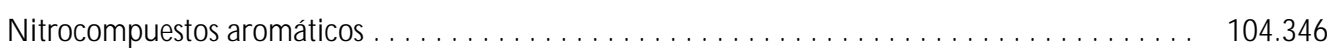

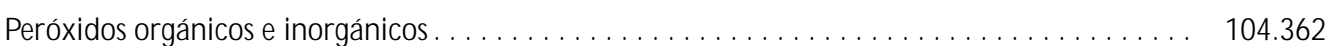

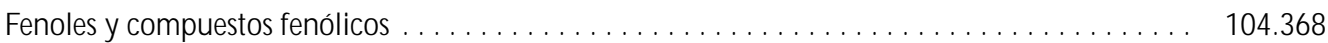

Fosfatos inorgánicos y orgánicos . . . . . . . . . . . . . . . . . . . . . . . . . . . . . . 104.382

Ftalatos. . . . . . . . . . . . . . . . . . . . . . . . . . . . . . . . . . . . . . . . . . . 104.394

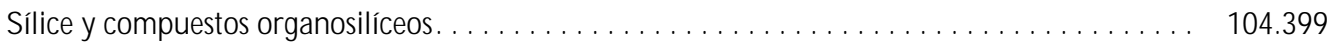

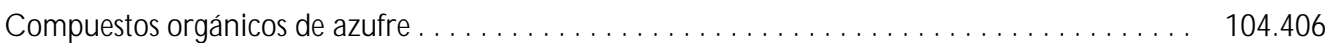

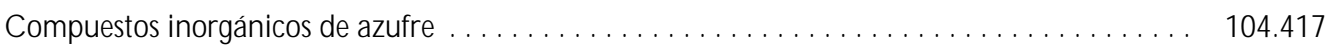

M onóxido de carbono . . . . . . . . . . . . . . . . . . . . . . . . . . . . . . . . . . . 104.429

\section{Guía de unidades y abreviaturas}

Sistema internacional de unidades . . . . . . . . . . . . . . . . . . . . . . . . . . . . . 105.2

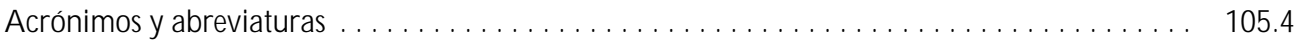

PARTE XIX. INDICES

A Indice temático $\ldots \ldots \ldots \ldots \ldots \ldots \ldots \ldots \ldots \ldots \ldots \ldots \ldots$

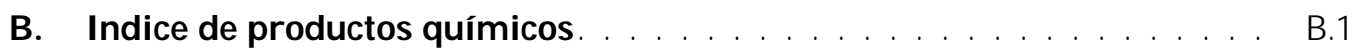

C. Indice de autores $\ldots \ldots \ldots \ldots \ldots \ldots \ldots \ldots \ldots \ldots \ldots \ldots, \ldots \ldots$ 
PARTE XX. DIRECTORIO DE EXPERTOS

\section{Directorio de expertos}

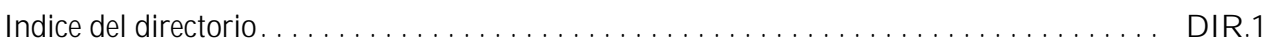

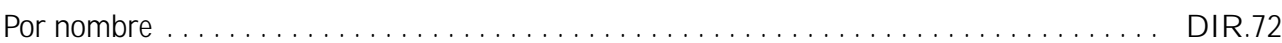

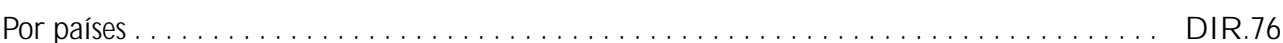

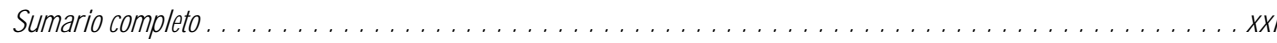

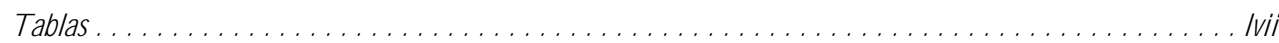

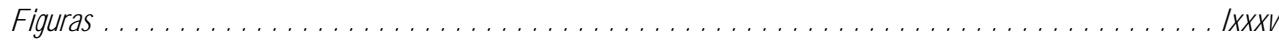




\section{UNAENCICLOPEDIA DE PARTES INTERRELACION ADAS}

os cuatro volúmenes de la cuarta edición de la E nciclopedia de salud y seguridad en el trabajo se han organizado en partes independientes pero interrelacionadas que, a su vez, se dividen en capítulos, secciones y artículos. Con la clasificación en partes se ha pretendido reflejar las principales reas disciplinarias o de estudio. Estas se han subdividido en capítulos, supervisados por uno o varios directores de edición. Los capítulos incluidos en cada parte ofrecen una visión general del área de estudio o de la disciplina en cuestión. Constan de artículos elaborados por expertos en la materia tratada. Asimismo, los de mayor extensión pueden dividirse en secciones lógicas. La intención es facilitar la revisión y el análisis de las tendencias y los temas principales. El contenido de cada volumen se esboza a continuación.

La obra consta de 105 capítulos numerados consecutivamente. Las páginas, figuras y tablas se han clasificado en función del capítulo (p. ej., la página 10.3 es la tercera del décimo capítulo). Al comienzo de cada volumen se incluye un índice. El índice específico de cada capítulo figura en la primera página del mismo. Además, cada volumen contiene una relación de las personas que han contribuido a su elaboración (autores y directores de edición), en la que se refiere sus datos profesionales. Los índices generales pueden consultarse en el volumen IV. LoS correspondientes a los volúmenes I, II y III se han incluido también al final del volumen IV, junto con una relación exhaustiva de las tablas y las figuras.

Los elementos gráficos de la presente Enciclopedia reflejan su estructura. Las denominaciones de las partes y los títulos de los artículos figuran, respectivamente, en el encabezado y en la esquina inferior de cada página. Los nombres de los capítulos aparecen en los marcadores colocados en el borde exterior de las páginas impares. Las barras de sección separan las distintas secciones que componen los capítulos.

\section{Volumen I}

En este volumen se ofrece información sobre las enfermedades y las lesiones de origen profesional; y la gestión y los sistemas sanitarios que se han desarrollado para reconocer, tratar y prevenir estos problemas. A simismo, se analizan las herramientas y los enfoques básicos utilizados para detectar, controlar y realizar un seguimiento de dichos trastornos. El volumen comprende cuatro partes y treinta y tres capítulos. Algunas cuestiones se abordan ampliamente en más de un capítulo. Estas relaciones principales se ilustran en la tabla adjunta.

Parte I. E I cuerpo humano consta de trece capítulos sobre sistemas orgánicos, cáncer de origen profesional y trastornos sistémicos, y ha sido redactada desde el punto de vista de la

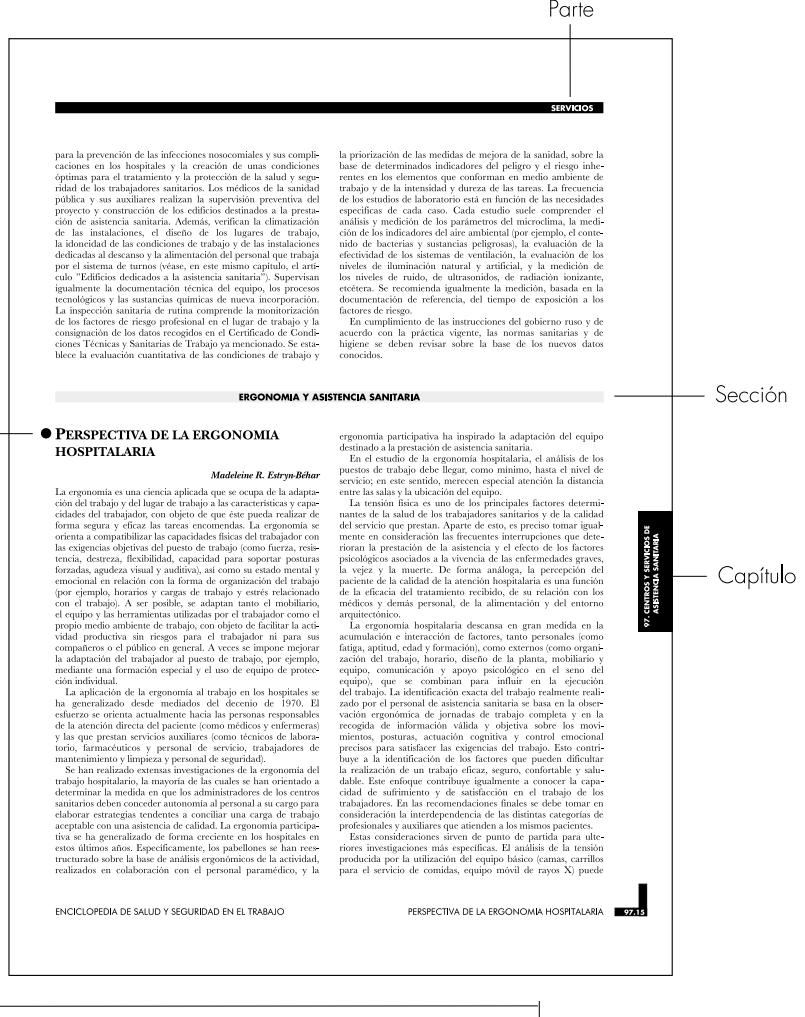

Título del artículo

medicina del trabajo. Estos capítulos remiten a las partes II, III y IV en lo que respecta a la información sobre los servicios de salud en el trabajo, los enfoques epidemiológicos, la vigilancia y el registro de datos, además de su medición y seguimiento. Se citan con frecuencia riesgos específicos con fines ilustrativos. En general, los riesgos, profesiones y sectores concretos asociados a disfunciones de sistemas orgánicos se abordan en los capítulos correspondientes de otros volúmenes.

Parte II. Asistencia sanitaria consta de tres capítulos sobre los servicios de salud en el trabajo, la protección y la promoción de la salud, y los primeros auxilios. En estos capítulos se establecen los principios básicos aplicables a los servicios de asistencia sanitaria.

Parte III. G estión y política comprende diez capítulos dedicados a la prevención y la gestión de la salud y la seguridad en el trabajo, en los que se analizan la discapacidad y la indemnización de los trabajadores, aspectos éticos, cuestiones de comercio y desarrollo y la naturaleza cambiante del trabajo y la población activa, las relaciones laborales y la gestión de los recursos humanos, la información y los marcos jurídico e institucional en los que se desarrollan.

Parte IV. H erramientas y enfoques consta de siete capítulos sobre los fundamentos científicos y de ingeniería de la salud y la seguridad en el trabajo, incluidos los relativos al control biológico y la toxicología, la ergonomía, la higiene industrial, los planteamientos respecto a la protección personal, la epidemiología, la estadística, la vigilancia y el sistema de registro de datos. 


\section{Volumen II}

Este volumen está dedicado al análisis de los riesgos físicos, psicosociales, ambientales y para la seguridad, así como de su naturaleza, frecuencia, prevención y gestión. Se describen brevemente los efectos específicos para la salud de ciertos riesgos. Para más información, el lector puede consultar el índice de materias y el volumen I. Los riesgos químicos se tratan en el volumen III y en la Guía de productos químicos (capítulo 104) incluida en el volumen IV. En el índice de productos químicos se ofrecen referencias a páginas específicas.

Parte V . Factores psicosociales y de organización consta de dos capítulos acerca de la estructura social y organizativa del trabajo, sus efectos y su gestión.

Parte VI. Riesgos generales comprende diecisiete capítulos en los que se analizan riesgos físicos y biológicos, horarios de trabajo, efectos asociados, detección y prevención.

Parte VII. EI medio ambiente incluye tres capítulos que ofrecen una visión general de la salud ambiental, su relación con la salud en el trabajo y los principios básicos de gestión y prevención.

Parte VIII. Accidentes y gestión de la seguridad consta de cinco capítulos en los que se abordan la teoría, la inspección, las auditorías y la prevención de accidentes en una amplia gama de circunstancias, así como los principios de política, dirección y gestión de la seguridad.

\section{Volumen III}

En este volumen se analizan diversos sectores y profesiones. En cada capítulo se ofrece una visión general de las características del proceso industrial en cuestión, los riesgos potenciales y la gestión preventiva indicada. Para más información sobre enfermedades y riesgos específicos, vigilancia e ingeniería, pueden consultarse los volúmenes I y II, así como las guías incluidas en el volumen IV.

Parte IX. Productos químicos consta de tres capítulos sobre seguridad en la manipulación y transporte, minerales y productos químicos para la agricultura y metales. (0 tras sustancias químicas se incluyen en la Guía de productos químicos que figura en el volumen IV.)

Parte $X$. Industrias basadas en recursos biológicos se divide en nueve capítulos dedicados al estudio de los recursos biológicos utilizados por las industrias de explotación animal y agraria, alimentación y bebidas, y productos de la madera (silvicultura, pasta de papel, papel y madera).
Parte XI. Industrias basadas en recursos naturales consta de cuatro capítulos sobre minerales (minería y explotación de canteras), hierro y acero, prospección y extracción petrolífera, y generación y distribución de energía.

Parte X II. Industrias químicas ofrece en cuatro capítulos una visión general de los procesos químicos y sus aplicaciones en las industrias del petróleo y el gas natural, de productos farmacéuticos y del caucho.

Parte X III. Industrias manufactureras consta de seis capítulos en los que se analizan las industrias manufactureras básicas (distintas del textil y el transporte, que se abordan en secciones específicas).

Parte XIV . Industrias textiles y de la confección comprende tres capítulos sobre confección y productos textiles, cueros, pieles y calzado.

Parte X V. Industrias de transporte estudia la fabricación y la reparación de vehículos de transporte. En sus tres capítulos se aborda la construcción y el mantenimiento aeroespacial, los vehículos de motor, la maquinaria pesada y la construcción y reparación de buques y embarcaciones.

Parte XVI. Construcción está constituida por un solo capítulo dividido en secciones acerca de la salud y la seguridad, la prevención y la gestión, los principales subsectores y sus riesgos asociados; y las herramientas, los equipos y los materiales utilizados en este sector.

Parte XVII. Servicios consta de nueve capítulos en los que se analiza una amplia gama de servicios privados y públicos, incluidos los de emergencia y las fuerzas armadas, las actividades artísticas, culturales y recreativas, los hoteles y restaurantes, las oficinas y el comercio minorista, el transporte y el almacenamiento.

\section{Volumen IV}

Este volumen contiene guías, un Directorio de expertos y los índices completos de la E nciclopedia.

Parte X VIII. Guías contiene la Guía de profesiones, un conjunto de "fichas de datos" correspondientes a una selección de profesiones ejercidas en diversos sectores, en las que se refieren las profesiones asociadas, las tareas, las fuentes de exposición y los riesgos; la Guía de productos químicos, en la que se informa de unas 2.000 sustancias organizadas en familias de productos químicos, y se incluyen tablas que contienen datos sobre identidad química, riesgos físicos, químicos y para la salud, y propiedades físicas; y la Guía de unidades y 
abreviaturas, que ofrece una visión general del sistema internacional de unidades de medida y se definen las abreviaturas y acrónimos empleados en la E nciclopedia.

Parte XIX. Indices incluye tres tipos diferenciados de índices:

- EI Indice por materias constituye una clasificación detallada de los contenidos de la Enciclopedia. Los números de página seguidos por una to una f en cursiva se refieren, respectivamente, a tablas y figuras. Las enfermedades y las partes del cuerpo humano figuran incluidas en el sistema orgánico correspondiente o como referencia independiente. En este índice aparecen asimismo familias de productos químicos y minerales; las sustancias químicas concretas pueden consultarse en un índice específico.

- En el Indice de productos químicos se clasifica cada una de las sustancias químicas referidas en la E nciclopedia. Se incluyen asimismo los minerales y las familias de productos químicos. Una misma sustancia puede aparecer en este índice con diversas denominaciones sinónimas; el uso en la página de referencia determina el modo en que se clasifica. (No se incluyen referencias cruzadas entre sinónimos. Estos se refieren en las tablas sobre identificación química correspondientes a cada familia de productos que figura en la Guía de productos químicos.) Como en el caso del índice de materias, una t 0 una $f$ a continuación de un número de página remite a una tabla o una figura en la página indicada. En el índice de productos químicos también se incluye una lista de los números de registro del Chemical Abstracts Service (CAS). Se ofrecen los números CAS de todas las sustancias referidas en las tablas de identificación química de cada familia de productos que figuran en la Guía de productos químicos, así como la página en la que comienzan las tablas respectivas. (Puede que los números CAS de algunas sustancias químicas citadas en los volúmenes I a III no aparezcan en este índice.)

- En el Indice de autores citados figura el apellido y las iniciales de cada autor y director de edición de la referencia citada, seguidos de los números de los capítulos en los que se menciona su obra. (En algunos casos, los autores figuran más de una vez si se les identifica con iniciales diferentes en las obras citadas.)

Parte XX. EI D irectorio de expertos es una lista alfabética no exhaustiva de los directores de edición, autores y consultores que han colaborado en la Enciclopedia, confeccionada con la información suministrada por cada experto. El Directorio se ha clasificado en función del nombre y el país de los expertos incluidos.

Además, este volumen contiene las listas de las tablas y las figuras de la Enciclopedia, así como un índice conjunto de los cuatro volúmenes. 
G uía del volumen I. Las principales relaciones entre capítulos se indican en negrita.

\begin{tabular}{|c|c|c|c|c|}
\hline $\begin{array}{l}\text { PARTE I. EL CUERPO } \\
\text { HUMANO }\end{array}$ & $\begin{array}{l}\text { Parte I. } \\
\text { El cuerpo } \\
\text { humano }\end{array}$ & $\begin{array}{l}\text { Parte II. } \\
\text { Asistencia } \\
\text { sanitaria }\end{array}$ & $\begin{array}{l}\text { Parte III. } \\
\text { Gestión y } \\
\text { política }\end{array}$ & $\begin{array}{l}\text { Parte IV. } \\
\text { Herramientas y } \\
\text { enfoques }\end{array}$ \\
\hline 1. Sangre & & & & 27 \\
\hline 2. Cáncer & $1,4,8,9,12$ & 15 & & $27, \mathbf{3 2}, \mathbf{3 3}$ \\
\hline $\begin{array}{l}\text { 3. Sistema } \\
\text { cardiovascular }\end{array}$ & & 15 & & $27,32,33$ \\
\hline 4. Aparato digestivo & & & & \\
\hline 5. Salud mental & & & & \\
\hline $\begin{array}{l}\text { 6. Sistema } \\
\text { musculosquelético }\end{array}$ & & & & 29 \\
\hline 7. Sistema nervioso & & & & 27 \\
\hline 8. Sistema renal-urinario & & & 19 & 27,33 \\
\hline 9. Sistema reproductor & & 15 & 24 & 27,33 \\
\hline 10. Aparato respiratorio & & & & \\
\hline 11. Organos sensoriales & 7,12 & 14 & & 31 \\
\hline $\begin{array}{l}\text { 12. Enfermedades de } \\
\text { la piel }\end{array}$ & 11 & & & 31 \\
\hline $\begin{array}{l}\text { 13. Condiciones } \\
\text { sistémicas }\end{array}$ & & & & \\
\hline
\end{tabular}

\section{PARTE II. ASISTENCIA}

SANITARIA

\section{Primeros auxilios y servicios médicos de emergencia} 15. Protección y promoción
de la salud

16. Servicios de salud en el trabajo

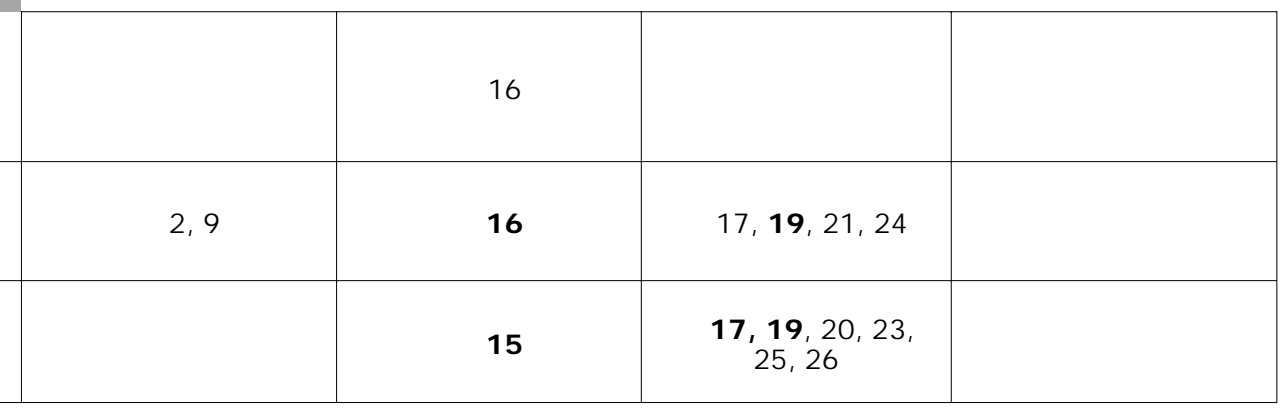




\begin{tabular}{|c|c|c|c|c|}
\hline $\begin{array}{l}\text { PARTE III. GESTION } \\
\text { Y POUTICA }\end{array}$ & $\begin{array}{l}\text { Parte I. } \\
\text { El cuerpo } \\
\text { humano }\end{array}$ & $\begin{array}{l}\text { Parte II. } \\
\text { Asistencia } \\
\text { sanitaria }\end{array}$ & $\begin{array}{l}\text { Parte III. } \\
\text { Gestión y } \\
\text { política }\end{array}$ & $\begin{array}{l}\text { Parte IV. } \\
\text { Herramientas y } \\
\text { enfoques }\end{array}$ \\
\hline 17. Discapacidad y trabajo & & 15,16 & $21,24, \mathbf{2 5}, \mathbf{2 6}$ & 29 \\
\hline \multicolumn{5}{|l|}{ 18. Educación y formación } \\
\hline $\begin{array}{l}\text { 19. Cuestiones relacionadas } \\
\text { con la ética }\end{array}$ & & 16 & & 28,32 \\
\hline $\begin{array}{l}\text { 20. Desarrollo, tecnología y } \\
\text { comercio }\end{array}$ & & 16 & 23,24 & \\
\hline $\begin{array}{l}\text { 21. Relaciones laborales y } \\
\text { gestión de recursos } \\
\text { humanos }\end{array}$ & & 16 & 23 & \\
\hline \multicolumn{5}{|l|}{$\begin{array}{l}\text { 22. Recursos: información y } \\
\text { salud y seguridad en el } \\
\text { trabajo }\end{array}$} \\
\hline $\begin{array}{l}\text { 23. Recursos institucionales, } \\
\text { estructurales y jurídicos }\end{array}$ & & 16 & 21, 24 & \\
\hline 24. Trabajo y trabajadores & & & $20,21,23$ & \\
\hline $\begin{array}{l}\text { 25. Indemnización a los } \\
\text { trabajadores: } \\
\text { visión general }\end{array}$ & & 16 & 17,26 & \\
\hline $\begin{array}{l}\text { 26. Indemnización a los } \\
\text { trabajadores: } \\
\text { temas relacionados }\end{array}$ & & & 25 & 32 \\
\hline
\end{tabular}

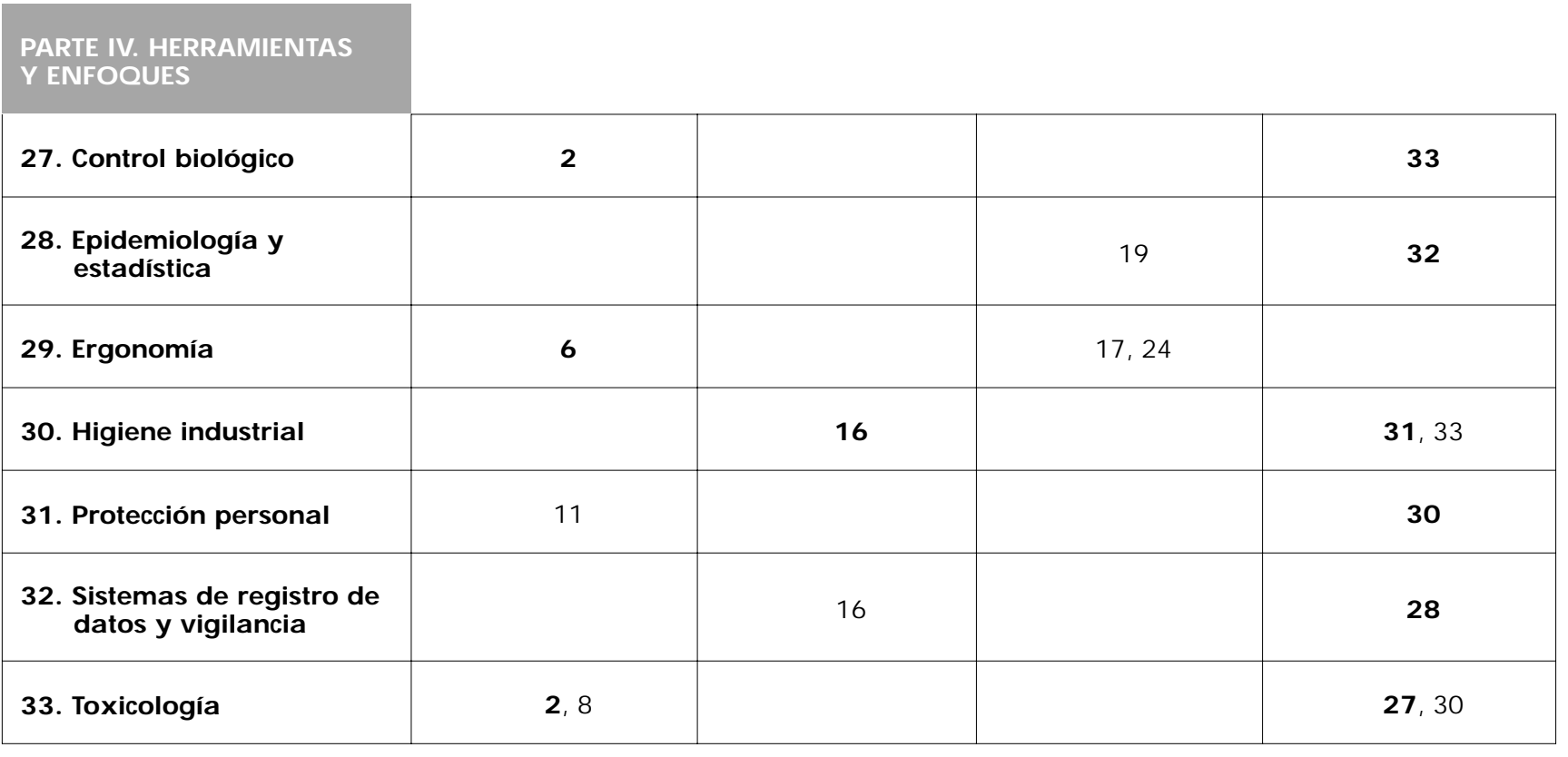




\section{GUIA DE PROFESIONES}

Directores del capítulo

Alexander D onagi,

Avraham Aladjem

M enachem Schwartz

\section{Sumario}

Sistematización de los riesgos profesionales por ocupación

Alexander D onagi y A vraham Aladjem . . . . . . . . . . . . . . . . . . . 103.2

Conductor de ambulancia (servicios médicos) . . . . . . . . 103.5

Conductor de camiones . . . . . . . . . . . . . . . . 103.6

Cristalero. . . . . . . . . . . . . . . . . . . . . . . . . . . . 103.8

Chófer .................................. 103.9

Encolador ............................. 103.10

Exterminador de plagas . . . . . . . . . . . . . . . . 103.12

Fontanero . . . . . . . . . . . . . . . . . . . . . 103.14

H igienista . . . . . . . . . . . . . . . . . . . . . 103.16

Jardinero . . . . . . . . . . . . . . . . . . . . . . 103.18

M anipulador de animales. . . . . . . . . . . . . . . . . . . 103.20

M ecánico de automóviles . . . . . . . . . . . . . . . . . . . 103.22

M odelista. . . . . . . . . . . . . . . . . . . . . . . . . . . . . . . . . 103.24

O perador de caldera . . . . . . . . . . . . . . . . . . . 103.25

Pintor (no artístico) . . . . . . . . . . . . . . . . . . . . 103.27

R eparador de aparatos eléctricos . . . . . . . . . . . . . . . . 103.29

Soldador (electrosoldeo) . . . . . . . . . . . . . . . . . . . . 103.30

Soldador (estañosoldeo, cobresoldeo) . . . . . . . . . . . . 103.32

Técnico de laboratorio . . . . . . . . . . . . . . . . . . . . . 103.34 


\section{SISTEMATIZACION DE LOS RIESG OS PROFESIONALES POR OCUPACION}

\author{
Alexander D onagi y Avraham Aladjem
}

\section{Antecedentes}

En la actualidad, no se dispone de libros de texto, manuales u otras fuentes específicas que contengan los datos esenciales sobre los distintos riesgos profesionales vinculados a cada ocupación. La diversidad de las profesiones es tan grande, que ni siquiera los especialistas reputados (ingenieros de seguridad, higienistas industriales, médicos del trabajo, consultores e investigadores) pueden conocer con precisión todos los riesgos propios de cada una de ellas. Por tanto, los expertos en salud y seguridad en el trabajo (SST ) deben recabar información en las amplísimas bibliografías y bases de datos disponibles al respecto y, en ocasiones, examinar los resultados reflejados en documentos técnicos. Estas consultas resultan suelen ser complejas, tediosas, llevan mucho tiempo y exigen el acceso a fuentes de información especializadas. Normalmente, quedan fuera del alcance de la capacidad y de los recursos de los profesionales de la SST (higienistas industriales, responsables de seguridad, inspectores, médicos del trabajo, personal sanitario, instructores), y más lejos aún de las posibilidades de los no profesionales (gestores de unidades industriales, miembros de los comités de seguridad 0 representantes de los trabajadores en los mismos). Como consecuencia, es muy habitual que los trabajadores dedicados a la SST accedan al lugar de trabajo sin haber recibido la preparación técnica preliminar adecuada.

Este problema se detectó hace muchos años. A.D. Brandt, en su obra de 1946, Industrial H ealth Engineering, realizó un primer intento de crear una lista práctica de riesgos en función de las profesiones. Brandt presentó una compilación de unas aproximadamente 1.300, distintas con los riesgos profesionales asociados a cada una. El número total de riesgos se situó en torno a los 150, en su mayoría de carácter químico. Tras el esfuerzo pionero de Brandt, no se llevó a cabo ningún trabajo sistemático sobre la materia, a excepción de unas pocas clasificaciones parciales relacionadas con aspectos limitados de los riesgos profesionales. No obstante, sí se emprendieron algunas iniciativas en este campo, como la obra de W. H addon, E.A. Suchman y D. K lein Accident Research: M ethods and Approaches de 1964, en la que intentaron clasificar los diversos tipos de accidentes; una "tabla de riesgos para la salud clasificados por profesión", incluida en la obra de 1973, W ork IS Dangerous to Y our H ealth, de J.M. Stellman y S.M. Daum; un conjunto de listados parciales de "posibles exposiciones profesionales" publicado en el la exhaustiva monografía del Instituto Nacional para la Salud y la Seguridad en el Trabajo (NIOSH ), O ccupational Diseases: A Guide to their Recognition; y una lista de unos 1.000 posibles riesgos para la salud que podrían afectar a unas 2.000 profesiones diferentes, recopilada en 1973 por la Facultad de M edicina de la U niversidad de T el-A viv.

Todos los proyectos mencionados presentan ciertas deficiencias: no están actualizados y las clasificaciones son parciales, se refieren a ámbitos específicos y no al conjunto del campo de estudio de la SST y se ocupan en su mayoría de cuestiones rutinarias en materia de la higiene industrial, descuidando en gran medida los aspectos agudos y de seguridad del problema. A demás, ninguna de estas clasificaciones se ofrece de una manera práctica y concisa, como un manual de bolsillo cuyo uso resulte sencillo o un conjunto de tarjetas independientes que puedan utilizarse directamente sobre el terreno.

Recientemente, el M inisterio de Sanidad israelí encargó la elaboración de una recopilación de 100 "tarjetas de riesgos" en hebreo, en las que se analizan los diversos riesgos a los que se ven expuestos los trabajadores de esta institución (en su mayoría, personal hospitalario y trabajadores de campo). Para preparar esta obra, se utilizaron algunos documentos de las $\mathrm{N}$ aciones U nidas y de la Organización Internacional del Trabajo (OIT), relativos a la clasificación de profesiones y actividades económicas, y otros publicados por la Comisión de las Comunidades Europeas (CCE) en el marco de su Programa Internacional de Seguridad de las Sustancias Q uímicas.

La experiencia acumulada adquirida en la realización del trabajo anterior suscitó la idea de iniciar un proyecto para la elaboración de Fichas técnicas de seguridad internacionales sobre profesiones (International Safety Datasheets on O ccupations), que ha sido avalado con posterioridad por el Centro Internacional de Información sobre Seguridad y Salud en el Trabajo (CIS) y se encuentra actualmente en curso. Para el presente capítulo de la Enciclopedia, se han seleccionado varias fichas técnicas con el fin de mostrar un planteamiento sistemático de aplicación generalizada y no limitado a un campo profesional específico. D esde este punto de vista, la selección se ha basado en dos criterios fundamentales: amplia diversidad de las profesiones seleccionadas respecto a los tipos de actividades en cuestión y el riesgo asociado correspondiente, y el carácter "transfronterizo" de cada profesión, es decir, su presencia en numerosos ámbitos de la economía.

\section{Aspectos metodológicos}

Se ha elaborado y aplicado un marco conceptual y de procedimiento coherente en la preparación de las fichas técnicas. Su organización se basa en una lista de comprobación o matriz utilizada como directriz para un análisis sistemático y exhaustivo de los riesgos vinculados a una determinada profesión. Además de ayudar a poner de relieve y evaluar los distintos riesgos que puedan estar relacionados con una ocupación, esta lista de comprobación cumple la función de plantilla con arreglo a la cuál se completa en la práctica cada ficha técnica de riesgos (véase la T abla 103.1).

La utilización de una plantilla normalizada y dividida adecuadamente en apartados permite disponer de una estructura uniforme para las fichas, lo que asegura una rápida familiarización y una fácil orientación de sus usuarios. 0 tro aspecto importante es el empleo de términos y expresiones normalizados para toda la gama de profesiones referidas, lo que favorece un reconocimiento instantáneo de los riesgos similares vinculados a ocupaciones diferentes.

La lista de comprobación (plantilla), junto con una serie de expresiones y palabras clave normalizadas, se utilizarán en el futuro como base para el desarrollo de una Guide for Compilers of $\mathrm{H}$ azard Datasheets, con un objetivo similar al de la Compiler's Guide for the Preparation of International Chemical Safety Cards, (un proyecto conjunto de la CCE, la OIT, la O rganización M undial de la Salud (OM S) y el Programa de las Naciones U nidas para el M edio A mbiente (PNU M A)).

La estructura de la ficha técnica de datos (data seet) consta de los apartados siguientes, de acuerdo con la plantilla:

- Denominación de la profesión: la denominación se obtiene del Dictionary of 0 ccupational T itles (DOT) o de la Clasificación internacional uniforme de ocupaciones (CIUO). [International Standard C lassification of O ccupations (ISCO)].

- Sinónimos: derivados del DOT y/o de otras fuentes, como tesauros del inglés

- Definición y/ o descripción: en su mayoría, se citan o se adaptan las incluidas en el DOT y en la CIUO. Algunas de las definiciones del DOT citadas contienen designaciones abreviadas de 
Tabla 103.1 • Lista de comprobación (plantilla) (C heeklist)

DENOMINACION DE LA PROFESION

\section{Sinónimos}

\section{Perfil del empleo}

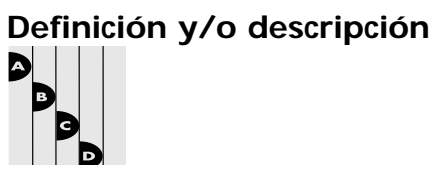

\section{Profesiones asociadas y específicas}
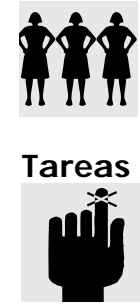

\section{Equipo básico utilizado}

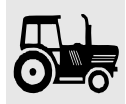

\section{Sectores en los que esta} profesión es común

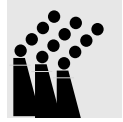

\section{Riesgos}

\section{Riesgos de accidente}

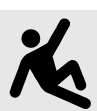

M ecánicosy generales

- Accidentes con maquinaria

- Accidentes de transporte

- Caída de personas (p. ej., resbaIones, tropiezos a ras de suelo, caídas desde altura, desde un vehículo en movimiento, etc.)

- Caídas de objetos pesados, materiales, derrumbamiento de paredesy muros, etc.

- Punzadas, cortes, amputaciones

- Choques o golpes con objetos (fracturas óseas, magulladuras)

- Tropiezos con objetos

- Quedar atrapado dentro de un objeto o entre dos objetos, incluidos los accidentes por aplastamiento y desgarro

- Recipientes a presión y al vacío (estallido, implosiones y explosiones mecánicas)

- Quemaduras y escaldaduras (por la acción de superficies o fluidos calientes o fríos)

- Penetración de partículas extrañas en los ojos

- Ingestión de sólidos no tóxicos voluminosos o de borde afilado

- Ahogamiento
- Lesiones agudas causadas por animales (p. ej., mordeduras, arañazos, patadas, compresión y pisoteo, picaduras, embestidas, etc.)

- M ovimientos forzadoso agotadores

Accidentes químicos

- T odas las lesiones agudas y los efectos derivados accidentalmente de la emisión, el derrame, la inhalación, la ingestión 0 el contacto con agentes químicos (excepto incendiosy explosiones)

Accidentes relacionados con la electricidad

- Todas las lesiones y los efectos relacionados con la corriente eléctrica y la electricidad estática

Incendiosy explosionesquímicas

Accidentes de radiación

- Lesiones vinculadas a la exposición accidental a dosis elevadas de ionización y radiación no ionizante, incluidos los rayos láser y la luz de gran intensidad, la radiación ultravioleta, etc.

\section{Riesgos físicos}

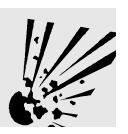

Radiación ionizante (como, p. ej.. los rayos $X$, la radiación alfa, beta y gamma, los rayos de neutrones y de partículas, el radón, etc.)

- Radiación no ionizante (incluido el espectro completo de radiación electromagnética no ionizante, como, p. ej., la luz visible, la luz ultravioleta e infrarroja, los rayos láser, $\mathrm{RF}$, $M W$, etc.); campos eléctricosy magnéticos

- Vibración (que afecta a todo el cuerpo; los riesgos relacionados con la vibración que afectan a órganos específicos aparecen en el apartado de "Factores ergonómicos y sociales")

R uido (incluidos asimismo los ultrasonidos y losinfrasonidos)

- Exposición a la intemperie, al calor o el frío extremos, a la reducción o el aumento de la presión atmosférica (incluidos el golpe de calor, la insolación, el estrés por calor, el estrés por frío, la congelación, etc.)

\section{Riesgos químicos*}

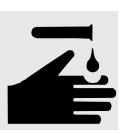

fectos directos/ inmediatos:

Irritación de las membranas mucosas, los ojos y el sistema respiratorio

Efectos sobre el sistema nervioso (migrañas, reducción de la capacidad de atención, intoxicación, etc.)

- Trastornos gastrointestinales

- Efectos sobre la piel (picor, eritema, aparición de ampollas, etc.)

Efectos de la exposición "rutinaria" en personas ultrasensibles; efecto de la combinación de factores "rutinarios", p. ej., formación no accidental de fosgeno al fumar en presencia de compuestos organoclorados - Asfixia
E fectos retardados, crónicos o a largo plazo:

- Intoxicación sistémica crónica

- O tros efectos sistémicos (p. ej., hematopoyéticos, sobre los sistemas gastrointestinal, urogentital, nervioso, etc.)

- Efectos sobre la piel (dermatosis, sensibilización dérmica y alergias, etc.)

- Efectos sobre los ojos (cataratas, deficiencias de visión, daños corrosivos, etc.)

- Efectos por inhalación (edema pulmonar, neumonitis de origen químico, neumoconiosis, reacciones asmáticas, etc.)

- Efectos por ingestión (irritación de garganta, dolores y calambres abdominales, diarrea, nauseas, vómitos, reducción de la conciencia, coma, etc.)

- Alergias de origen químico no referidas con anterioridad

- Efectos sobre el sistema reproductor, embarazo (aborto espontáneo, toxicidad para embriones y fetos), defectos de nacimiento

- Carcinogénesisy mutagénesis

\section{Riesgos biológicos}

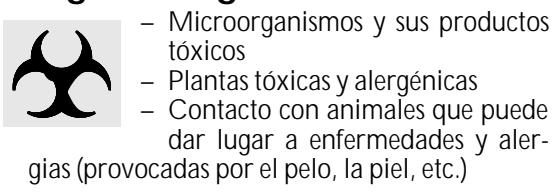

\section{Factores ergonómicos y sociales}

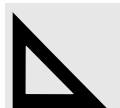

Riesgos relacionados con posturas adoptadas al trabajar, interacciones entre hombre y máquina, izado de pesos, estrés mental o físico, molestias e incomodidades (p. ej., síndrome del edificio enfermo, iluminación deficiente, contaminación atmosférica producida por fuentes no relacionadas con el lugar de trabajo, relaciones humanas, violencia, biorritmos, malos olores, vibración que afecta a órganos corporales específicos, como el síndrome del túnel del carpo bilateral, etc.)

\section{Información complementaria}

\section{Notas}

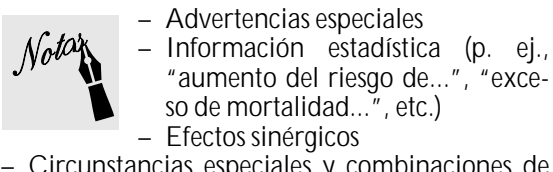

- Circunstancias especiales y combinaciones de factores

- Otra información importante y pertinente no incluida en otro apartado

\section{Referencias}

\section{Apéndices}

Lista de sustancias químicas, etc.

*R iesgos relacionados con la exposición no accidental a sustancias químicas 
diversos sectores, de acuerdo con el "Indice industrial" (DOT, Vol. 2). "Profesiones liberales y afines" ("Profesiones que exigen amplios estudios y experiencia en los campos de la práctica profesional liberal, los servicios técnicos, las ciencias, el arte y otros tipo de trabajo asociados") se designan por "Prof. lib. y af."; cuando las profesiones "no se clasifican en otra parte", se indica mediante "n.c.o.p.". La mayoría de las demás abreviaturas no requieren explicación.

- Profesiones asociadas y específicas: recopiladas en función del DOT, la CIU O, las consultas con expertos y los conocimientos personales.

- Tareas: datos obtenidos de diversas fuentes, incluido el R evised $\mathrm{H}$ andbook for A nalyzing J obs (R H AJ), el DOT, la CIU O, observaciones de expertos, etc., y clasificados por orden alfabético

- E quipo básico utilizado y sectores en los que esta profesión es común: La lista de herramientas, máquinas y sectores se recopiló con arreglo a las consultas con trabajadores sobre el terreno y expertos, así como a la información encontrada en diversas descripciones técnicas de puestos de trabajo; asimismo, se aprovecharon en gran medida los conocimientos personales de los expertos.
- Riesgos: Las listas de riesgos de distintos tipos se confeccionaron tras un análisis exhaustivo de un gran número de fuentes de información, a saber: listas previas de riesgos profesionales recopiladas por diversos investigadores; descripciones de puestos de trabajo incluidas en el DOT y la CIU O; documentos técnicos publicados por organizaciones nacionales de SST como INRS (Francia), HSE (Reino Unido), NIOSH (Estados Unidos), IIOSH (I srael), y otras; bibliografía profesional, incluida la E nciclopedia de salud y seguridad en el trabajo de la OIT; bases de datos informatizadas (p. ej., CISDOC, NIOSHTIC, HSELINE y TOXLINE); entrevistas con trabajadores sobre el terreno y profesionales de la SST, así como conocimientos personales y evaluaciones de expertos.

- Notas: todo tipo de información importante y pertinente no incluida en otra parte, como la relativa a efectos sinérgicos y advertencias sobre algunas situaciones de alto riesgo.

- Apéndices: datos auxiliares y complementarios, como listas de sustancias utilizadas en una determinada profesión, etc.

T ras su elaboración, todas las fichas técnicas se sometieron a la una revisión contrastada y comentada por al menos dos especialistas competentes.

\section{Referencias}

Brandt, AD. 1946. Industrial H ealth E ngineering. Nueva Y ork: John Wiley and Sons.

Comisión de las Comunidades Europeas (CCE). 1991-93. International Chemical Safety Cards. 10 vols. Luxemburgo: CCE.

-. 1993. Compiler's Guide for the Preparation of International Chemical Safety Cards (First Revision). Luxemburgo: Programa Internacional de la CCE sobre Seguridad Q uímica (U NEP/ IL O / WHO).

Donagi, AE (dir.). 1993. A Guide to $H$ ealth and Safety $\mathrm{H}$ azards in Various $\mathrm{O}$ ccupations: $\mathrm{T}$ he $\mathrm{H}$ ealth System. 2 vols. Instituto de Salud y Seguridad en el Trabajo de T el-A viv.

Donagi, AE y cols.. 1983. Potential H azards in Various $O$ ccupations, a Preliminary List [card file] Tel-Aviv: Escuela Universitaria de M edicina de T el-A viv, Instituto de Investigación de Salud Ambiental.

Haddon, W, EA Suchman, D K lein. 1964. Accident R esearch: M ethods and A pproaches. N ueva Y ork: $\mathrm{H}$ arpers and R ow.

International O ccupational Safety and $\mathrm{H}$ ealth Information Centre (CIS). 1995. International Safety Datasheets on $\mathrm{O}$ ccupations. Steering Committee meeting, 9-10 marzo. Ginebra : O rganización Internacional del Trabajo.

Naciones U nidas. 1971. Indexes to the International Standard Classification of All E conomic Activities. Publicación de las $\mathrm{N}$ aciones U nidas núm. WW .71.X VII 8. Nueva Y ork: U nited Nations Department of Economic and Social Affairs.

$\mathrm{N}$ ational Institute for $\mathrm{O}$ ccupational Safety and $\mathrm{H}$ ealth (NIOSH ). 1977. O ccupational D iseases: A Guide to
Their Recognition. DHHS (NIOSH) Núm. publicación: 77-181. Cincinnati, $\mathrm{OH}$ : NIOSH.

O rganización Internacional del Trabajo (OIT). 1978. Clasificación internacional uniforme de ocupaciones, edición revisada. Ginebra: OIT.

- 1990. Clasificación internacional uniforme de ocupaciones: CIU 0-88. Ginebra: OIT

Stellman, JM, SM Daum. 1973. W ork Is D angerous to Your $\mathrm{H}$ ealth. Nueva Y ork: $\mathrm{V}$ intage Books.

US Department of Labor (DOL). 1991. Dictionary of 0 ccupational Titles, 4a edición (revisada). Washington, DC: DOL.

- 1991. The Revised $H$ andbook for Analyzing Jobs. Washington, DC: DO L.

\section{0 tras lecturas recomendadas}

American Conference of Governmental Industrial H ygienists (ACGIH). 1997. Threshold Limit Values (T LV) for Chemical Substances and Physical Agents and Biological Exposure Indices (BEI). Cincinnati, $\mathrm{OH}$ : ACGIH

Bakar, A, C M an, D Gold. 1993. Safety and H ealth in the $U$ se of $C$ hemicals at $W$ ork: A T raining $M$ anual. Ginebra: OIT.

H ealth and Safety Executive (H SE). 1990. W ork-related U pper Limb Disorders: A Guide to Prevention. Publication HS(G ) 60. Londres: HSE Books.

- . 1994. G etting to $G$ rips with $M$ anual $H$ andling Problems. Londres: HSE Books.

-. 1994. $\mathrm{M}$ anual $\mathrm{H}$ andling: Solutions You $\mathrm{C}$ an $\mathrm{H}$ andle Publication HS(G) 115. Londres: H SE Books.

- . 1994. Essentials of $H$ ealth and Safety at W ork. Londres: HSE Books.
K irk, RE, DF Othmer. 1978-1984. Encyclopaedia of Chemical T echnology, $24+$ supl. vol., 3a dir.; 4a dir., 1991-1997 (24 de 27 vols. publicados hasta la fecha). N ueva Y ork: J ohn Wiley and Sons.

Lenga, RE. 1985. T he Sigma-Aldrich Library of Chemical Safety Data, $1^{a}$ dir. M ilwaukee, WI: Sigma-Aldrich Corp.

$M$ aterial Safety $D$ ata Sheets Collection. Actualizado con asiduidad. Schenectady, NY: G enium Publ. Co.

$M \mathrm{CG}$ raw-H ill Encyclopedia of Science and Technology, 3a dir., 15 vols., 1971. N ueva Y ork: M CG raw-H ill.

$\mathrm{N}$ ational Institute for $\mathrm{O}$ ccupational Safety and $\mathrm{H}$ ealth (NIOSH ). 1996. R egistry of Toxic Effects of Chemical Substances. R ockville, M D: NIOSH .

O rganización Internacional del Trabajo. 1993. Safety in the $\mathrm{U}$ se of Chemicals at W ork. Repertorio de recomendaciones prácticas de la OIT. Ginebra: OIT

-. Guide to $\mathrm{H}$ ealth and $\mathrm{H}$ ygiene in Agricultural W ork, 1979. Ginebra: OIT

OSH-ROM (incluye NIOSHTIC, CISDOC, HSELINE y M HIDAS databases). A ctualizado con asiduidad. Datos a partir de 1960. LondresAmsterdam-N orwood, M A: Silver Platter Information.

Patty, FA (dir.). 1995. Industrial H ygiene and T oxicology, 4a edición (revisada). Nueva Y ork: John Wiley and Sons.

R oyal Society of Chemistry (R SC). 1994. Dictionary of Substances and Their E ffects, 8 vols. Londres: R SC.

Sax, NI, RJ Lewis. 1996. Dangerous Properties of Industrial M aterials, ga dir. Nueva York: Van Nostrand R einhold. 
CONDUCTOR DE AMBULANCIA (Servicios médicos)

Sinónimos: Conductor de ambulancia (servicios públicos); conductor de ambulancia de la Cruz Roja (o de organizaciones similares)

\section{Perfil del empleo}

\section{Definición y/ o descripción}

A L Los conductores de ambulancia se ocupan de la conducción de este tipo de vehículos para el transporte de personas enfermas, lesionadas o convalecientes. Colocan a los pacientes en camillas e introducen éstas en la ambulancia, habitualmente con la ayuda de auxiliares (servicios médicos). Llevan a los enfermos 0 heridos al hospital y a los convalecientes a su lugar de destino, aplicando sus conocimientos y su destreza para evitar movimientos bruscos que puedan perjudicar a los pacientes. Cambian la ropa manchada utilizada en las camillas. Prestan primeros auxilios en caso necesario. En ocasiones deben atar a pacientes violentos. Pueden informar de los hechos relacionados con un accidente 0 una urgencia al personal hospitalario 0 a agentes del orden público (DOT). Asimismo, las personas que conducen vehículos (civiles o militares) dedicados a las urgencias médicas 0 a los servicios de ambulancia u hospitalarios pueden prestar su asistencia en partos efectuados en el interior de los mismos.

\section{Profesiones asociadas y específicas}

th

Auxiliar de ambulancia

miembro de equipo de ambu-

lancia/ auxiliar de enfermería conductor de coche fúnebre conductor de vehículos hospitalarios, conductor de servicios médicos; conductor de ambulancias militares; conductor de vehículos de motor (servicios médicos); conductor de ambulancias de la policía; conductor de ambulancias privadas.

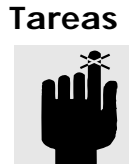

Administrar (medicinas oxígeno, etc.); prestar asis tencia; acarrear; cambiar limpiar; comunicar; conducir documentar; manejar; tocar e claxon; izar; cargar; localizar; registrar; mantener; arreglar; operar; colocar; tirar y empujar; reparar; informar; reducir reanimar; efectuar revisiones; atar; estirar; transportar; advertir; escribir.

\section{Riesgos}

\section{Riesgos de accidente}

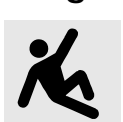

M ayor riesgo de sufrir accidentes de circulación debido a las velocidades alcanzadas en situaciones de urgencia (incluido el paso por cruces regulados por semáforos con luz roja y la conducción por aceras y superficies inclinadas al intentar llegar al lugar de destino evitando atascos de tráfico):

- R esbalones, tropiezos y caídas (en escaleras 0 en superficies llanas) al transportar camillas y cargar o asistir a los pacientes;

- Lesiones debidas al ejercicio de diversas funciones (tareas de reparación sobre e terreno, cambio de neumáticos, etc.) propias de un conductor de vehículos (véase los apartados correspondientes a conductor de camión, chófer, etc.);

- Emisión repentina de gases comprimidos (p. ej., oxígeno o gases anestésicos) en la ambulancia.

\section{Riesgos físicos}

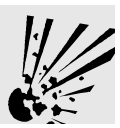

Exposición a niveles de ruido elevados producidos por la sirena de emergencia;

- Exposición a isótopos radiactivos (en algunos países en los que las ambulancias se utilizan en el transporte de radioisótopos a los hospitales).

\section{Riesgos químicos}

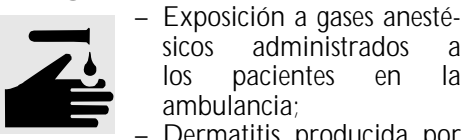

- Dermatitis producida por una utilización excesiva de agentes de aclarado, limpieza y desinfección.

\section{Riesgos biológicos}

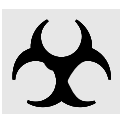

Exposición a enfermedades contagiosas de los pacientes;

- Exposición potencial a fluidos corporales de los pacientes (p. ej., sangre de heridas).

\section{Factores ergonómicos y} sociales

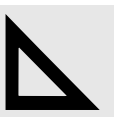

M olestias lumbares y otros trastornos musculares y óseos debidos a esfuerzos excesivos o malas posturas al levantar o mover los pacientes, conducir por vías en mal estado, reparar vehículos en la carretera, etc.;

- Estrés psicológico debido a una conducción peligrosa en situaciones de emergencia, el contacto con víctimas de accidente, pacientes terminales y cadáveres, horarios de trabajo irregulares, estados de alerta prolongados, etc.

\section{Informac. complementaria}

\section{Referencias}

International Occupational Safety and $\mathrm{H}$ ealth Information Centre (CIS). 1995. International Safety Datasheets on 0 ccupation. Steering Committee meeting. 9-10 marzo. Ginebra: OIT. 


\section{CONDUCTOR DE CAMIONES}

Sinónimos: Conductor de camiones pesados; conductor de vehículos de transporte por carretera; conductor de camiones con remolque; camionero

\section{Perfil del empleo}

\section{Definición y/o descripción}

A $\mid$ | Estos trabajadores conducen camiones de una capacidad superior a 3 toneladas para el transporte de materiales entre lugares de partida y de destino specificados. Para ello, aplican sus conocimientos sobre las normas de conducción comercial y las redes viarias. Preparan los recibos correspondientes a las cargas recogidas. Se ocupan de los cobros por los bienes entregados y los gastos de entrega. Entre sus posibles ocupaciones, figura el mantener un libro de registro conforme a la normativa aplicable, el contacto por teléfono o radio con su supervisor para recibir las instrucciones de entrega pertinentes, la carga y descarga del vehículo, la inspección de los equipos y los suministros del camión, como neumáticos, luces, frenos, combustible, aceite y agua. Además, pueden ocuparse de efectuar reparaciones de urgencia en carretera, como el cambio de neumáticos o la instalación de bombillas, cadenas o bujías, así como de calzar y atar la mercancía para asegurarla durante los desplazamientos. Cuando conducen camiones equipados con fines específicos, como la extinción de incendios, la excavación o la instalación y reparación de conducciones de empresas de servicios públicos, pueden recibir la denominación de conductores de coches de bomberos (petróleo y gas); conductor de vehículos excavadores (construcción; telecomunicaciones; servicios públicos). Si se especializan en la realización de entregas, pueden denominarse conductores de camiones pesados de reparto (todas las industrias). A simismo, pueden clasificarse de acuerdo con el tipo de vehículo conducido, como conductor de camión plataforma (explotación forestal), 0 del tipo de mercancía transportada, como conductor de camiones cisterna (explotación forestal) (DOT).

\section{Profesiones asociadas y específicas}

h⿻一亅八

Conductor de camiones ligeros (incluido conductor de vehículos de servicios de alimentación, conductor de vehículos de fertilizantes líquidos, etc.); conductor de vehículo hormigonera; conductor de camión volquete; conductor de vehículos de transporte de sustancias inflamables (explosivos, pólvora, camiones cisterna); conductor de camiones remolque (incluidos remolques tractores, remolques para el transporte de troncos, semirremolques y remolques de dos ejes, etc.); conductor de camiones pesados (incluidos los vehículos dedicados al transporte de leche 0 de agua, la recogida de basuras, camionetas, etc.); conductor de autobuses, tranvíasy trolebuses.

\section{Tareas}

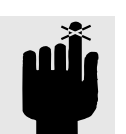

Ajustar; aplicar; arreglar; montar; asistir; adjuntar; enflejar: frenar; aparcar: acarrear; cambiar; comprobar; limpiar; recoger; comunicar; computar; conectar y desconectar; controlar; entregar; cavar; dirigir; desembragar; despachar; eliminar; distribuir; dividir; documentar; conducir; volcar; elevar; vaciar; examinar; asegurar; rellenar; repostar; calibrar; engrasar; manejar; remolcar; izar; tocar el claxon; inspeccionar; sacudir; levantar; cargar y descargar: localizar (direcciones de envío); registrar; lubricar; mantener; maniobrar; medir; dosificar; mezclar; controlar; desplazar; observar; poner en funcionamiento; embalar y desembalar; forrar; estacionar; ejecutar; colocar; posicionar; preparar; tirar y empujar; bombear; leer; recuperar; reponer; matricular; regular; expedir; reparar; sustituir; informar; invertir; encordar; tomar muestras; afianzar; efectuar revisiones; revestir; pulverizar; regar; apilar; orientar; esterilizar (recipientes de leche); almacenar; remitir; supervisar; comprobar; remolcar; transportar; atar; advertir; lavar; envolver; utilizar Ilaves de tuercas; escribir.

\section{Riesgos}

\section{Riesgos de accidente}

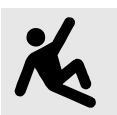

M ayor riesgo de accidentes de tráfico debido a los períodos de conducción prolongados (sobre todo en el caso de los conductores de camiones que realizan desplazamientos transcontinentales y otros largos recorridos), que incluyen trayectos nocturnos, bajo condiciones metereológicas desfavorables, por carreteras en mal estado y en situaciones de tráfico excesivo (el riesgo es mayor debido a la fatiga física y mental y al aburrimiento del conductor provocados por el gran número de horas de trabajo acumuladas, la brevedad de los períodos de descanso, la somnolencia, los horarios de comida irregulares y la inadecuación de la dieta, la ingestión excesiva de alcohol, la conducción a altas velocidades debido al sistema de pago de primas, etc.);

Accidentes de tráfico debidos a la pérdida de control al conducir camiones cargados en exceso por carreteras de grandes pendientes y resbaladizas, con temperaturas extremas y otras condiciones metereológicas;

- Accidentes de tráfico debidos a la utilización al conducir de tranquilizantes, estimulantes químicos o medicamentos indicados para enfermedades comunes, que producen efectos secundarios como somnolencia, sopor y deterioro de las funciones sensomotoras que reducen la capacidad de respuesta (sobre todo en lo que se refiere al retraso en las reacciones y la coordinación inadecuada);

- V uelco de camiones cargados en exceso debido a fallos mecánicos, condiciones difíciles de la vía o velocidades desmedidas, choques frontales, etc., con el resultado de que el conductor queda atrapado en la cabina o debajo del vehículo en una situación que puede poner en peligro su vida;

A ccidentes causados al desengancharse el dispositivo de bloqueo que mantiene unidos a la cabeza tractora con el remolque;

Resbalones, tropiezos y caídas desde una cabina elevada, una escalera de acceso a la misma o un remolque;

Peligro de quedar atrapado entre la unidad tractora y el remolque, o entre remolques, al intentar desengancharlos;

L esiones debidas al tropiezo accidental con componentes rígidos no protegidos del camión o de la mercancía;

- Lesiones producidas al efectuar diversas funciones propias de un conductor de camiones pesados ( $p$. ej., efectuar trabajos de reparación sobre el terreno, cambiar neumáticos, deshacer precintosy cuerdas muy ajustados, etc.);

- L esiones al utilizar diversas herramientas de mantenimiento y reparación: Ilaves, cuchillas, gatos, etc.;

- Explosiones, quemaduras químicas, intoxicaciones agudas debidas a sustancias químicas tóxicas; deterioro de la visión; etc.; causados por mercancías peligrosas como explosivos o inflamables, reactivos fuertes, sustancias tóxicas y sólidos a granel propensos a la formación de polvo;

Intoxicación aguda provocada por gases de escape como el monóxido de carbono;

R iesgos de incendio debidos a los derrames y las fugas de sustancias inflamables (normalmente en los camiones cisterna) que pueden arder al entrar en contacto con llamas vivas, superficies calientes, chispas eléctricas, descargas atmosféricas o electrostáticas, o como resultado de choques mecánicos debidos a colisiones de tráfico, vuelcos, etc. (en estos casos, también existe un riesgo para el medio ambiente); 
- Explosión de neumáticos hinchados en exceso;

- Traumatismos, como herniarse a causa de un esfuerzo físico excesivo (cambio de neumáticos, transporte de mercancías pesadas, atadura de cuerdas, etc.).

\section{Riesgos físicos}

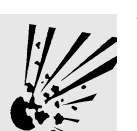

Exposición a niveles de ruido excesivo, de amplitud elevada (superior a $80 \mathrm{~dB}$ ) y/ 0 de baja frecuencia, generados por motores durante un período de tiempo prolongado, que producen efectos perniciosos inmediatos (migrañas agudas) o progresivos (pérdida de capacidad auditiva, etc.);

- Exposición a radiación ionizante al transportar radioisótopos (que suelen guardarse, por razones de seguridad, en la cabina del conductor):

- Exposición a la radiación (solar) ultravioleta directa y reflejada;

- Exposición a factores climáticos que pueden perjudicar la salud, como el frío o el calor extremos, o las combinaciones de temperatura, humedad y viento que dan lugar a congelaciones o golpes de calor;

- Exposición a cambios de temperatura re pentinos al entrar o salir de cabinas climatizadas, que dan lugar a enfriamientos y/ o efectos reumáticos;

- Vibraciones en todo el cuerpo que pue den deteriorar las funciones de los órganos del pecho y abdominales, y de sistema muscular y óseo, contribuir a la fatiga del conductor y reducir su capacidad de vigilancia.

\section{Riesgos químicos}

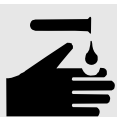

Exposición a diversas sustancias tóxicas (en estado sólido, líquido o gaseoso) a transportar mercancías peligrosas (se cuentan por miles y han sido clasificadas por las $\mathrm{N}$ acione Unidas en 9 grupos: explosivos, gases, líquidos inflamables, sólidos inflamables, sustancias oxidantes, sustancias tóxicas e infecciosas, sustancias radiactivas, corrosivos, otras sustancias peligrosas) que pueden tener efectos crónicos perniciosos para la salud, incluidos los de carácter cancerígeno, mutagénico, teratogénico, etc:;

- Enfermedades y trastornos de la piel (diversos tipos de dermatitis, sensibilización cutánea, eccema, acné de aceite, etc.) causadas por la exposición a sustancias químicas (p. ej., compuestos para limpiar y lavar, líquidos anticongelantes y para frenos, gasolina, gasoil, aceite, etc.);

- Efectos crónicos debidos a la inhalación de humos de gasolina y gasoil, y gases de escape que contienen monóxido de carbono, óxidos de nitrógeno $\left(\mathrm{NO}_{\mathrm{x}}\right)$, hidrocarburos, etc.

\section{Riesgos biológicos}

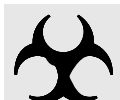

Contaminación e infección causados por la exposición de mercancías peligrosas desde e punto de vista biológico.

\section{Factores ergonómicos y sociales}

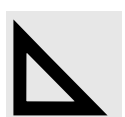

M olestias lumbares y dolores articulares (en piernas, manos y brazos) debidos a períodos de conducción prolongados, en ocasiones, por carreteras en mal estado y en asientos inadecuados;

- Trastornos reumáticos (como la artrosis escapulohumeral izquierda o la periartritis) debidos al hábito de apoyar el codo sobre el marco de la ventanilla al conducir;

- Trastornos del aparato digestivo causados por los horarios de comidas irregulares y los hábitos de alimentación inadecuados;

- Alucinaciones hipnóticas en períodos de somnolencia y trastornos psíquicos debidos a factores de estrés mental $y$ emocional

- Mayor incidencia del infarto de miocardio en el caso de los conductores obesos;
- Consumo de tabaco en la cabina de conducción, que contribuye al deterioro de la salud;

- Dificultades de visión y problemas oculares causados por una iluminación inadecuada y por la tensión ocular (sobre todo al conducir en la oscuridad por víasinterurbanas);

- Exposición a la violencia ejercida por compañeros de profesión (p. ej., en bares

- de carretera, etc.) y a la delincuencia menor y de bandas (incluida la organizada) atraída por las mercancías valiosas (sobre todo al conducir en países con fuerzas del orden público deficientes);

- Desarrollo de lumbago causado por las vibraciones, la inadecuada suspensión de los vehículos, la incomodidad de los asientos, etc.;

- Alteraciones patológicas y envejecimiento prematuro del segmento lumbosacro de la columna vertebral, que puede provocar la creación acelerada de discos lumbares intervertebrales (posiblemente, vinculada también a la manipulación rutinaria de cargas pesadas);

- Aumento de las probabilidades de contraer enfermedades de transmisión sexual (especialmente en el caso de los conductores que efectúan trayectos de largo recorrido y pasan mucho tiempo fuera de casa).

\section{Informac. complementaria}

\section{Referencias}

O rganización Internacional del Trabajo

(OIT ). 1972. W orking Conditions and

Safety Provisions Applying to Persons

E mployed in Road Transport. Inland

Transport Committee, ga sesión. Ginebra: OIT.

- 1977. H ours of W ork and Rest Periods in Road-transport. Informe VII(1) Conferencia Internacional del Trabajo, 64 sesión. Ginebra: O IT. 
Sinónimos: Instalador de cristales; montador de cristales; vidriero

\section{Perfil del empleo}

\section{Definición y/ o descripción}

A Los cristaleros instalan cristales - en aberturas (ventanas, puertas, escaparates, marcos, etc.) y superficies (paredes, techos, pantallas, mesas, etc.). Pueden cortar, tintar, decorar o tratar el cristal de otro modo antes de su instalación. Los que se dedican a la construcción instalan cristales en ventanas, tragaluces, escaparates y mostradores, además de en superficies como fachadas de edificios, paredes interiores, techos y mesas. M arcan los contornos o el diseño del cristal y cortan el vidrio utilizando un tallador. Eliminan el vidrio sobrante a mano o con una herramienta entallada. Fijan los paneles de cristal en los marcos de madera con puntas de vidrieros y extienden y allanan la masilla alrededor de los bordes con un cuchillo para sellar las juntas. Instalan espejos o cristales estructurales en las fachadas de edificios, tabiques, techos y mesas, utilizando masilla, tornillos o molduras decorativas. Colocan bisagras metálicas, cerraduras y otros dispositivos en las puertas de vidrio prefabricadas. Encajan puertas de cristal en su bastidor y ajustan las bisagras. Pueden instalar ventanas metálicas y bastidores de puertas en las que deben colocarse cristales. Asimismo, pueden colocar películas adhesivas plásticas en el cristal o pulverizar éste con una solución de tintura para evitar el reflejo de la luz. Pueden instalar vidrieras. M ontan e instalan mamparas de cristal con marco metálico en duchas, en cuyo caso reciben la denominación de instaladores de mamparas de baño (construcción). De acuerdo con el tipo de cristal instalado, pueden recibir la denominación de cristalero, instalador de cristal estructural (construcción) e instalador de lunas(construcción) (D OT).

\section{Profesiones asociadas y específicas}

wh Cristalero, instalador montador de cristales, denominado de acuerdo con el sector específico (cristalero (construcción); cristalero, carpintería metálica (mobiliario); cristalero de refrigeradores (maquinaria industrial); instalador de lunas (servicio de automoción); instalador de cristales (carpintería)), o del tipo de material utilizado (instalador de espejos (construcción); instalador de cristales tintados (productos de vidrio)). A simismo: biselador, manual (fabricación de vidrio ; productos de vidrio); biselador, retoque (productos de vidrio); marquista (productos de vidrio; productos de madera); reparador de marcos (productos de cristal); cortador de vidrio (de cualquier industria); decorador de cristales (fabricación de vidrio ; productos de vidrio); grabador de vidrio (fabricación de vidrio; productos de vidrio); pulidor de vidrio (productos de vidrio); lijador de vidrio, de correa (productos de vidrio); tintorero de vidrio (productos de vidrio) (DOT)

\section{Tareas}

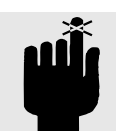

Ajustar; alinear; aplicar; montar; empernar; taladrar; cortar y eliminar el vidrio sobrante; calcular; comprobar; limpiar; recubrir; colorear; conectar; cubrir; cortar; decorar; determinar; perforar; conducir; biselar; estimar; grabar; asegurar; limar; dar el acabado; encajar; enmarcar; encristalar; encolar; amartillar; manipular; instalar; insertar; unir; colocar; izar; cargar y descargar; marcar, medir; desplazar; poner en funcionamiento (equipos); achaflanar; situar; pulir; posicionar; preparar; presionar; prevenir; enmasillar; reforzar; reparar; sustituir; eliminar; lijar; atornillar; trazar; sellar; seleccionar; disponer; dar forma; diseñar; allanar; soldar; pulverizar; extender; teñir; soldar por puntos; roscar; tintar; retocar; transportar; proteger contra la intemperie; limpiar.

\section{Riesgos}

\section{Riesgos de accidente}

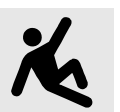

- Lesiones, en especial cortes graves en las manos y los pies y aplastamientos de los dedos de los pies causados por las hojas de vidrio y sus bordes afilados al cortar, trasladar, montar y otras operaciones de manipulación; - Cortes y punzadas debidas a la utilización de herramientas de trabajo como instrumentos de punta, cortadores de vidrio, cuchillas, etc.;

- Caídas desde superficies en altura producidas al montar cristales en ventanas, paredes y techos, etc., que dan lugar a traumatismos graves $y$, en ocasiones, a la muerte;

- Riesgo de aplastamiento bajo el peso de una o varias hojas de vidrio caídas

R esbalones, tropiezos y caídas en superficies sin cambio de nivel, especialmente en suelos húmedos, resbaladizos o sobre los que se ha derramado aceite, al desplazar hojas de vidrio;

- Lesiones oculares y cutáneas producidas por esquirlas;

- Intoxicación aguda y quemaduras químicas como consecuencia de la utilización de reactivos fuertes (p. ej., ácido fluorhídrico) para grabar el cristal y otros fines similares;

- Riesgo de incendio vinculado a la utilización de sustancias inflamables
Descargas eléctricas causadas por el contacto con equipos electromecánicos defectuosos;

\section{Riesgos físicos}

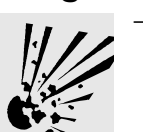

Exposición de la piel y los ojos a la radiación ultravioleta al trabajar bajo la luz solar directa;

Estrés por frío o calor (lo que genera efectos que van desde la incomodidad debida a la temperatura hasta la congelación o el golpe de calor, respectivamente) al trabajar en el exterior;

Efectos para la salud (p. ej., reuma, trastornos de las vías respiratorias, etc.) debido a la acción de corrientes de aire, permanencia de pie sobre suelos de hormigón durante períodos de tiempo prolongados, etc.

\section{Riesgos químicos}

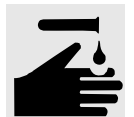

Intoxicación crónica y enfermedades cutáneas como resultado de la exposición a esquirlas de cristal que contienen plomo, arsénico y otros elementos tóxicos;

- Intoxicación crónica y enfermedades cutáneas ( $p$. ej., dermatitis) causadas por masillas, sellantes, adhesivos, disolventes (p. ej., al retirar un cristal de su marco), limpiadores, etc.;

- Efectos toxicológicos crónicos de la exposición a los humos de reactivos fuertes (p. ej., ácido fluorhídrico).

\section{Riesgos biológicos}

10 Los riesgos biológicos pueden afectar a los cristaleros que trabajan en un entorno en el que pueden verse expuestos a microorganismos, plantas alergénicas, pelo, pieles, etc.

\section{Factores ergonómicos y} sociales

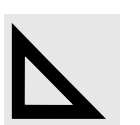

Lesiones musculares y óseas agudas causadas por un esfuerzo físico excesivo y posturas inadecuadas adoptadas al transportar 0 manipular hojas de vidrio voluminosas: - Trastornos traumáticos acumulativos, como el síndrome del tunel carpiano, causados por un trabajo repetitivo realizado durante mucho tiempo y que exige movimientos efectuados fundamentalmente con las manos, los brazos y los dedos;

Cansancio y malestar general;

- Estrés psicológico debido al miedo a caer desde superficies situadas en altura o de sufrir accidentes al cortar, manipular y montar hojas de vidrio de gran valor, etc. 


\section{CHOFER}

Sinónimos: Chófer privado; chófer de vehículos de motor privados; asimismo, se utiliza como denominación alternativa a "conductor de autobús" (DO T); además: conductor de limusina; conductor de vehículos de directivos; conductor de la flota de vehículos de una empresa

\section{Perfil del empleo}

\section{Definición y/o descripción}

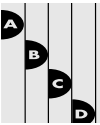

os chóferes conducen automóviles para trasladar personal administrativo y visitantes a establecimientos comerciales 0 industriales. Lleva a cabo otras tareas diversas, como el transporte de correo entre los centros de trabajo y la oficina postal. Puede prestar servicio durante la noche y efectuar desplazamientos de gran duración que requieran su disponibilidad en horarios irregulares Puede exigírseles la obtención de un permiso de conducir específico. Además pueden ocuparse de la limpieza del vehículo y realizar reparaciones y ajustes de poca importancia (D O T).

\section{Profesiones asociadas y específicas}

Conductor de autobuses taxista; conductor de camión conductor de camionetas y furgonetas; etc.

\section{Tareas}

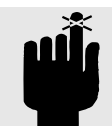

Ajustar; arreglar; asistir; llevar; cambiar; comprobar; limpiar; recoger; comunicar; realizar trayectos preestablecidos; dirigir; conducir; documentar; manipular; inspeccionar; izar; cargar y descargar; localizar; mantener; poner en funcionamiento; organizar; ejecutar; situar; tirar y empujar; regular; reparar, presentar informes; efectuar revisiones; transportar.

\section{Riesgos}

\section{Riesgos de accidente}

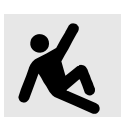

- Mayor riesgo de accidentes de tráfico como consecuencia de la conducción nocturna y los desplazamientos de irregulares; larga duración en horarios

- Resbalones, tropiezos y caídas al trans portar equipaje y paquetes:

- Lesiones sufridas como resultado del de sempeño de diversas funciones (p. ej., reparaciones sobre el terreno, cambio de neumáticos, etc.) del conductor de vehículos (véase asimismo conductor de camiones; conductor de autobuses, etc.

\section{Riesgos físicos}

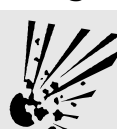

Los chóferes pueden exponerse riesgos físicos al trabajar en ciertas condiciones específicas (p. ej., a la radiación al transportar paquetes que contienen radioisótopos, etc.).

\section{Riesgos químicos}

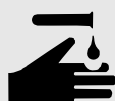

Pueden desarrollar dermatitis moderadas al utilizar limpiadores y detergentes.

\section{Riesgos biológicos}

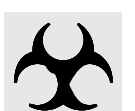

Posible exposición a enfermedades infecciosas al transportar pasajeros que las padecen

\section{Factores ergonómicos y}

\section{sociales}

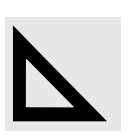

M olestias lumbares y dolores articulares (en piernas, manos y brazos) debidos a períodos de conducción prolongados en ocasiones, por carreteras en mal estado:

- Estrés psicológico e insatisfacción en el puesto de trabajo como resultado de desempeño de un papel subordinado y de la necesidad de atender diversas exigencias de los pasajeros, en ocasiones, nesperadas;

- En caso de ejercer funciones adicionales como guardaespaldas, los riesgos típicos de esta profesión

- Dificultades de visión y problemas oculares causados por una iluminación inadecuada y por la tensión ocular (sobre todo al conducir en la oscuridad por vías interurbanas). 


\section{ENCOLADOR}

Sinónimos: Especialista en adhesivos; aplicador de pegamentos; solador y empapelador (industria de la construcción); aplicador de adhesivos; engomador; especialista en chapeado (mobiliario)

\section{Perfil del empleo}

\section{Definición y/o descripción}

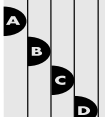

Estos trabajadores encolan materiales como papel, tela, cuero, madera, metal, vidrio, caucho o plástico, de acuerdo con procedimientos específicos. Aplican adhesivos en la superficie de los materiales mediante cepillado, pulverización, inmersión, rodillo, sosteniendo la pieza en cuestión contra un cepillo giratorio saturado o colocándola entre rodillos impregnados. U nen mediante presión los materiales encolados a mano, aseguran éstos con la ayuda de un rodillo de mano 0 los colocan en su lugar de montaje para fijarlos y aplican el adhesivo. Pueden llevar a cabo operaciones de montaje de material preencolado. Eliminan el material sobrante de las piezas encoladas. Pueden retirar con un trapo o una esponja el adhesivo aplicado en exceso en las juntas. Inspeccionan visualmente el trabajo realizado. De acuerdo con el elemento encolado, pueden recibir la denominación de encolador de elementos en punta de flecha (juguetes - equipamiento deportivo); encolador de juntas (fabricación de maquinaria); aplicador de muescas (juguetes - equipamiento deportivo); encolador de rellenos (todas las industrias); 0 de pulverizador de adhesivos (todas las industrias) con arreglo al método de encolado utilizado. 0 tras denominaciones posibles son: forrador de cajas, manual (artículos de papel); esparcidor de cola (mobiliario); confeccionador de filtros de papel (componentes electrónicos); encolador de goma (juguetes-equipamiento deportivo).

\section{Profesiones asociadas y específicas}

Aplicador de adhesivos; pulverizador de adhesivos; operador de máquinas de encolado: solador; aplicador de oseína; especialista en juntas encoladas: operador de equipos de fabricación de cola; mezclador de adhesivos; esparcidor de adhesivos; operador demáquinasdeencolar; etc.

\section{Tareas}

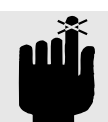

Adherir; aplicar (adhesivos); aspirar (disolventes); montar; unir (piezas de relleno); encuadernar (libros); aglutinar; cepillar; enmoquetar; acarrear; sujetar; limpiar y acondicionar; subir (escaleras de mano, andamios, etc.); revestir; cubrir; cortar (moquetas, bordes de papel pintado, etc.); sumergir; distribuir (cola); conducir; deshacerse (de residuos); secar; documentar; alimentar (máquinas); ajustar; formar; encolar; manejar; calentar (cola); sostener (herramientas); inyectar (cola); inspeccionar; instalar; aislar; juntar (superficies); arrodillarse (al enmoquetar, etc.); laminar; solar; izar y bajar; cargar y descargar; mantener; fabricar; mezclar (colas con varios componentes, etc.); moldear; abrir (recipientes, etc.); poner en funcionamiento (equipos); pedir (materiales); empaquetar y desempaquetar; empastar; ejecutar; colocar; verter; preparar; presionar; regular (el flujo de pulverización, etc.); reparar; sellar; afianzar; seleccionar; establecer; alisar (superficies); pulverizar; esparcir; apretar; almacenar; supervisar; roscar; comprobar (las juntas encoladas); transportar; dar el acabado; desatascar (boquillas); tapizar; utilizar (herramientas); lavar (equipos, manos, etc.); llevar (equipos deprotección personal); pesar; limpiar.

\section{Equipo básico utilizado}

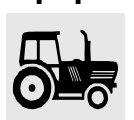

Cepillos de mano; rodillos (de mano o mecanizados); equipo de pulverización (de aire comprimido o no; de mano o automático): pistolas de inyección de cola aplicada en caliente; rociadores; aplicadoresa presión.

\section{Industrias en las que esta profesión es común}

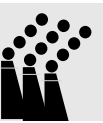

Cintas adhesivas; acondicionamiento de aire (fabricación e instalación): fabricación y mantenimiento de aeronaves; montaje de aparatos; encuadernación; fabricación y mantenimiento de automóviles; construcción (solado y empapelado); cartón ondulado; pañales desechables; electrónica; colchones de espuma; calzado; muebles; joyería; etiquetado y embalaje en diversas industrias y servicios; laminación (papel y cartón); cuero; fontanería (PVC y otras tuberías de plástico); refrigeración; caucho; fabricación de juguetes; tapicería.

\section{Riesgos}

\section{Riesgos de accidente}

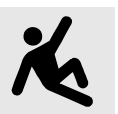

Lesiones producidas al trabajar con equipos mecanizados utilizados en la mezcla o la aplicación de colas (p. ej.. al enredarse ropas, cabellos o pelo de la barba o pillarse los dedos en mezcladoras mecánicas o en prensas);

Caídas de escaleras de mano (sobre todo en el caso de los empapeladores);

Caída de recipientes de cola pesados sobrelos pies;
Cortes sufridos al abrir ciertos tipos de recipientes de cola;

- Reventón de boquillas de pulverización a presión, con especial riesgo de daños oculares, sobre todo cuando se utilizan equipos sin presión de aire;

Explosión de recipientes a presión

- Q uemaduras y daños oculares en el caso de trabajos con adhesivos aplicados en caliente (en especial al pulverizar): quemaduras debidas al contacto con superficies calientes (p. ej., de secadores o de calentadores de activación).

Salpicaduras de líquidos irritantes, alergénicos y peligrosos por otras razones (disolventes; diluyentes, colas líquidas, emulsiones muy alcalinas, etc.) en los ojos o sobre la piel, con posibilidad de ingestión durante la mezcla, el transporte o la aplicación de los adhesivos;

- Intoxicación por fosgeno (véase la nota 1);

Posibilidad de que los dedos se queden pegados(véase la nota 2):

R iesgo de descarga eléctrica o electrocución debido a la utilización de herramientas eléctricas de mano ( $p$. ej., pistolas de aplicación de cola en caliente, ventiladores, ciertos instrumentos de pulverización), sobre todo al realizar trabajos con colas acuosas;

- Riesgo elevado de incendios y explosiones debido a la presencia de disolventes y otros materiales inflamables (p. ej., papel y cartón en los trabajos de encuadernación, madera y polvo de madera en la fabricación de muebles, algunas espumas inflamables en la aplicación de colas para aislamiento, etc.) y a la acumulación de vapores de disolvente, sobre todo en instalaciones pequeñas y mal ventiladas (véase el A péndice);

Explosiones de mezclas de hidrógeno y aire formadas al poner en contacto, por error 0 accidente, colas de un alto contenido alcalino con superficies de aluminio.

\section{Riesgos físicos}

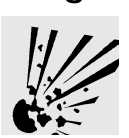

Exposición a la radiación de microondas y la luz infrarroja o ultravioleta si se utilizan en el secado de colas;

Niveles de ruido elevados, especialmente en las operaciones de pulverización.

\section{Riesgos químicos}

- Eritema, sensibilización de la piel, dermatosis de contacto y sistémicas como resultado de la exposición a numerosos disolventes $y$ sus vapores 0 a otros componentes de las colas, como las resinas epóxicas, el 
n-hexano, el tolueno, el cloruro de vinilo, etc.;

- Depigmentación cutánea por contacto (vitíligo) en trabajadores expuestos a las colas de neopreno;

- A parición de ampollas en la piel por contacto con colas que contienen epiclorohidrina (p. ej., colas epóxi);

- Irritación ocular debida a la acción de colas o vapores que contienen epiclorohidrina, disolventes clorados, tolueno o xileno;

- A sfixia en el caso de exposición a concentraciones elevadas de $n$-hexano;

- Irritación de la boca, la garganta y la cavidad nasal por la acción del tolueno, e tricloroetileno o el xileno

- Irritación del aparato respiratorio por el contacto con vapores de disolvente, en particular, de n-hexano;

- Intoxicación por monóxido de carbono procedente de los adhesivos aplicados en caliente a excesiva temperatura;

- Neumoconiosis debida a la exposición al polvo 0 a las fibras de algunos materiales aislantes inorgánicos encolados:

- Edema pulmonar como resultado de la inhalación de vapores de disolventes alifáticos mezclados y gasolina;

- Edema pulmonar, neumonitis química y hemorragias debidas a la aspiración de benceno líquido o xileno;

- Trastornos gastrointestinales como consecuencia de la ingestión de pequeñas cantidades de diversas colas, en especial en la aplicación de las basadas en vinilo

- Polineuropatía, sobre todo a causa del nhexano;

- Depresión del sistema nervioso centra con posibilidad de migrañas, mareos, falta de coordinación, estupor y coma como resultado de la inhalación de acrilonitrilo, ciclohexano, tolueno, xileno, 1,1,1-tricloroetano y tricloroetileno;

- R iesgo de aborto espontáneo o de daños al feto en las mujeres embarazadas ex puestas a disolventes organohalógenos;

- Cambios sanguíneos y anemia debidos a la exposición al benceno;

- Elevación de la tensión arterial a causa de la exposición a la dimetilformamida

- Daños del hígado como resultado de la acción de la dimetilformamida, el tetrahidrofurano y el cloruro de vinilo;

- Carcinogenicidad. Los siguientes componentes de las colas y disolventes han sido clasificados como cancerígenos animales (categoría A3) por la Conferencia A mericana de $\mathrm{H}$ igienistas Industriales del $\mathrm{Go}$ bierno (ACGIH): acrilamida; cloroformo; dinitrotolueno; epiclorohidrina; hexacloroetano; cloruro de metileno; 2 nitropropano. El acrilonitrilo y el acrilato de etilo se han clasificado como presuntos cancerígenos humanos (categoría A2). Se ha confirmado que el benceno constituye una sustancia cancerígena para el hombre (categoría A 1).

\section{Riesgos biológicos}

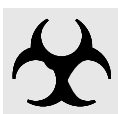

Exposición a microorganis mos patogénicos que pueden desarrollarse en ciertos tipos de colas (p. ej., oseína, caseína).

\section{Factores ergonómicos y sociales}

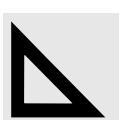

Problemas en muñecas, manos y brazos (p. ej., tenosino vitis como consecuencia de la realización de movimientos repetitivos al encolar mediante cepillado o aplicadores a presión):

- Cansancio (en particular en las piernas), que afecta especialmente a los encoladores que trabajan continuamente de pie, por ejemplo, en puestos de pulverización; - Calambres en las piernas y lesiones de rodilla en el caso de los soladores (instaladores de moqueta, parqué o tarima); la utilización de las rodillas para desplazar la moqueta al colocarla puede causar bursitis (conocida en este caso como "rodilla del instalador de moqueta")

- Tensiones y torceduras causadas por el levantamiento de recipientes de cola pesados;

- Exposición a olores desagradables, sobre todo los desprendidos por colas que contienen ciertos bactericidas.

\section{Informac. complementaria}

Notas

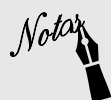

1. Se han registrado intoxicaciones graves e incluso con resultado de muerte en encoladores al fumar en presencia de colas que contienen disolventes organohalógenos. Al ser inhalados a través de un cigarrillo encendido, tales materiales se descomponen y se transforman parcialmente en fosgeno.

2. Un riesgo específico de los encoladore consiste en la posibilidad de que queden pegados los dedos entre sí, sobre todo al trabajar con cianoacrilato y algunas colas epóxicas.

3. Pueden producirse lesiones graves sobre todo al encolar mediante pulverización sin aire, por inyección cutánea de cola a alta presión en las manos o en los brazos.

4. El "esnifado de cola" y los efectos neurotóxicos y de intoxicación asociados a esta práctica constituyen un riesgo significativo debido a la facilidad de acceso al producto.

5. La utilización de benceno como disolvente de colas ha sido prohibido en numerosos países.

6. Se han producido lesiones oculares por el reventón de recipientes de cola (en particular de cianoacrilato) al apretar repetidamente tubos cuya abertura se encontraba atascada por una pequeña cantidad de producto endurecido.

7. Se ha registrado un aumento de la incidencia de cáncer sinonasal, rectal y de esclerosis múltiple en el caso de los encoladores.

\section{Apéndice}

Sustancias químicas utilizadas habitualmente como componentes o disolventes de las colas:

- Acetato de etilo
- n-A cetato de butilo

- Acetato de isopropilo

- Acetato de polivinilo

- Acetato de vinilo

- Acetona

A cido adípico

n-A crilato de butilo

- Acrilato de estireno

Acrilato de etilvinilo

- Acrilonitrilo

- Alcohol isobutílico

- Alcohol isopropílico

- Alcohol polivinílico

- Aminas alifáticas

- Anhídrido maleíco

- Benceno

- p-terc-Butilfenol

- Cianoacrilato de metilo

- Ciclohexano

- Ciclohexanona

- Cloroacetamida

- Clorobenceno

- Cloruro de metileno

- Cloruro de polivinilo

- Colágeno

- Colofonia (resina de trementina)

- Diaminodifenilmetano

- Dibutil maleinato

- o-Diclorobenceno

- 1,1-Dicloroetano

- Diclorometano (cloruro de metileno)

- Dicloropropano

- Diisocianato de tolueno

- 2,2-Dimetilbutano

- Disolvente de nafta

- Disolvente de Stoddard

- Etanol

- Etilbutilcetona

- Etilcianoacrilato

- Formaldehído

- Glicoles de polioxialkeno

- n-H eptano

- n-Hexano

- 2-H idroxipropil metacrilato

- H idroxitolueno butilado

- Isoforonediamina

- Látex natural

- M etacrilato de metilo

- M etanol

- M etil cloroformo

(1,1,1-tricloroetano)

- M etilbutilcetona

- M etiletilcetona

- Metilisobutilcetona

- M etilpentano

- N afta V M \&P

- Neopreno

- Nitrobenceno

- 2-N itropropano

- Pentaclorofenol

- Pentano

- Percloroetileno

- Polímeros de acrilamida

- Queroseno

- R esinas de fenol-formaldehído

- R esinas de poliéster

- R esinas de poliimida

- R esinas de poliuretano

- Resinas epóxi

- R esinas poliamida

- T etracloroetileno (percloetileno)

- T etrahidrofurano

- Tolueno

- 1,1,1-T ricloroetano

- Tricloroetileno

- Xileno 


\section{EXTERMINADOR DE PLAGAS}

Sinónimos: Aplicador de pesticidas; exterminador; exterminador de parásitos y roedores; fumigador y esterilizador; especialista en control de plagas; prospector (agricultura); pulverizador de pesticidas; pulverizador/ espolvoreador de pesticidas

\section{Perfil del empleo}

\section{Definición y/o descripción}

Los exterminadores de plagas - (servicios empresariales) se encargan de pulverizar soluciones químicas y gases toxicos, así como de disponer trampas mecánicas para acabar con las plagas que infestan los edificios y las áreas circundantes. Fumigan salas y edificios utilizando dichos gases. Pulverizan soluciones químicas o productos en polvo en habitaciones y áreas de trabajo. Colocan cebos venenosos y trampas mecánicas en los lugares afectados por las plagas. Pueden ocuparse de limpiar las áreas habitadas por las plagas con la ayuda de rastrillos, escobas, palas y fregonas, como operación previa a la fumigación. En ocasiones se les exige la obtención de un permiso estatal. De acuerdo con el tipo de plaga eliminada, puede recibir la denominación de exterminadores de roedores (servicios empresariales). (D OT).

\section{Profesiones asociadas y específicas}

th Piloto de aeronaves agrarias (piloto de aeroplanos, fumigación de cosechas; aplicador aéreo, piloto; control de plagas, piloto): inspector de sustancias químicas agrarias; operador de autoclaves; ayudante de exterminador; operador de pulverizadores manuales; manipulador de herbicidas; mezclador de insecticidas (química); pulverizador de insecticida, unidad móvil; pulverizador de productos contra mosquitos; pasteurizador; inspector de control de pesticidas; fabricante de pesticidas; exterminador sanitario; pulverizador de insecticidas; auxiliar de pulverización (agricultura); técnico de esterilización (bebidas; productos lácteos; plumas de ave; servicios médicos; etc.) supervisor de exterminación; supervisor, inspección de insectos y enfermedades; exterminador de termitas; inspector de herbicidas (DOT); trabajador agrario expuesto a residuos de pesticidas (jardinero, personal de enfermería y trabajadores de invernaderos); fumigador sobre el terreno; aplicador de pesticidas sobre el terreno; mezclador y/ o cargador de pesticidas; trabajador de almacenes de pesticidas; señalizador devuelo para aeronaves; etc.

\section{Tareas}

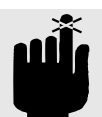

Añadir (sustancias químicas); asesorar (a los clientes); analizar; aplicar; asistir; autorizar; poner cebos; combinar; empernar; taladrar; informar (trabajadores, etc.); quemar (hierbas); calcular; llamar; acarrear; comprobar; sujetar; limpiar; subir; recoger; confiscar; controlar; coordinar; arrastrarse; cortar; destruir; detectar; determinar; cavar; dirigir; descargar (gases); distribuir; perforar; conducir; espolvorear; eliminar; atar; archivar; limpiar con agua; nebulizar; formular (mezclas de pesticidas); fumigar; gasear; dosificar; amartillar; manejar; identificar; prender; impregnar (suelo); iniciar; inyectar; insertar; inspeccionar; instalar; instruir; entrevistar; investigar; aislar; expedir; localizar; mantener; manipular (palancas); marcar; medir; mezclar; modificar; desplazar; notificar; observar; obtener; abrir; poner en funcionamiento; cerrar con candado; pintar; ejecutar; pilotar; colocar; apuntar (boquillas); envenenar; ubicar; fijar (carteles); verter; preparar; prevenir; producir; tirar y empujar; bombear; poner en cuarentena; izar; recomendar; registrar; emitir; retirar; sustituir; realizar informes; revisar; tomar muestras; serrar; sellar; indagar; resguardar; seleccionar; establecer; disparar; señalizar; pulverizar; difundir; esterilizar; estudiar: supervisar; examinar; medir con cinta; enseñar; conservar (máquinas); transerir; transportar; colocar trampas; tratar; hacer girar; actualizar; utilizar; visitar; pesar; envolver.

\section{Riesgos}

\section{Riesgos de accidente}

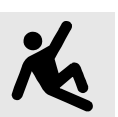

- Aumento del riesgo de accidente de tráfico debido a las períodos prolongados de conducción de vehículos cargados en exceso que, con frecuencia, arrastran remolques y equipos mecánicos de pulverización sobre carreteras en el campo con el firme en mal estado y en condiciones metereológicas desfavorables;

- Riesgos vinculados a los vuelos a bordo de aeronaves ligeras (incluidos helicópteros) a poca altitud (habitual en el caso de los exterminadores de plagas que realizan operaciones aéreas), como los accidentes de aviación y la exposición a los pesticidas al transportar éstos en la cabina e impregnarse en ropas y calzado, al atravesar en vuelo una nube de sustancias pulverizadas (nubes a la deriva), como resultado de la fuga de depósitos de alimentación, etc

- Riesgos para el personal en tierra que participa en la aplicación aérea de pesticidas (cargadores, señalizadores, trabajadores agrarios, etc.), como la posibilidad de ser golpeados por las aeronaves en el momento del despegue, el aterrizaje, al rodar por la pista o en vuelos a escasa altitud; la exposición accidental a pesticidas a consecuencia del siniestro de una aeronave cargada con estos productos, la fuga de los depósitos, etc.;

Posibilidad de ser atropellado por un tren al exterminar plagas entre los raíles de una vía férrea;

R esbalones, tropiezos y caídas (sobre superficies deslizantes y contra obstáculos, sobre todo al llevar máscaras protectoras que limitan el campo de visión); caídas de los ayudantes del exterminador desde el equipo remolcado; caídas de plataformas elevadas y escaleras, en especial al transportar recipientes y otras cargas pesadas;

Caída de cargas pesadas, sobre todo de recipientes, sobre los pies de los trabajadores;

- Punzadas y cortes causados por objetos afilados;

T ropiezos con objetos afilados abandonados al efectuar operaciones de pulverización sobre el terreno;

Explosión de recipientes de pulverización sometidos a una presión excesiva, lo que da lugar a la salpicadura de pesticidas que pueden alcanzar al operador;

M ordeduras de serpiente o picaduras de avispas o abejas sufridas al llevar a cabo trabajos de pulverización sobre el terreno;

- H ernias como resultado de un esfuerzo físico excesivo al izar y transportar cargas pesadas;

Intoxicación aguda al aplicar pesticidas (en especial a causa de la inhalación de aerosoles sin llevar máscara de protección, lo que puede resultar mortal), 0 como consecuencia de derrames e incendios en el transporte y almacenamiento de estos productos;

Contaminación 0 intoxicación accidental de los exterminadores al mezclar pesticidas peligrosos en concentraciones muy elevadas;

- Salpicaduras de pesticidas sobre la cara y las manos al preparar formulaciones de losmismos;

- Inhalación accidental de pesticidas pulverizados (causada por un cambio repentino en la dirección del viento o por una máscara de protección selectiva insuficiente y conservada deficientemente, etc.)

Ingestión accidental de pesticidas líquidos confundidos con agua, o de agua de riego contaminada con estos productos (en ocasiones, puede afectar a los trabajadores agrarios $y$, en particular, a los niños, que no participan directamente en los trabajos de exterminación, pero que se encuentran en el lugar donde se realizan), o bien a 
causa del contacto o la utilización de recipientes de pesticida vacíos y abandonados;

- Q uemaduras como resultado de una exposición excesiva de la piel a los pesticidas sin utilizar protección (p. ej., a soluciones de dibromuro de dicuat);

- D escargas eléctricas causadas por el contacto con equipos electromecánicos defectuosos;

- R iesgos eléctricos al exterminar plagas en las inmediaciones de torres metálicas para líneas de alto voltaje

- Intoxicación aguda como resultado de la emisión a la atmósfera de compuestos peligrosos (p. ej., $\mathrm{HCN}, \mathrm{SO}_{2}, \mathrm{NO}_{x}$ ) durante la quema accidental (incendios o explosiones) 0 intencionada (debida a una actuación poco fundamentada) de pesticidas 0 de sus recipientes en establecimientos de fabricación, almacenamiento, formulación o similares 0 en los lugares de aplicación

- Irritaciones cutáneas y oculares, opresión en el pecho, náuseas, entumecimiento de extremidades, asfixia, etc. en bomberos que participan en labores de extinción de incendios relacionados con pesticidas.

\section{Riesgos físicos}

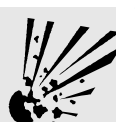

Electrocución producida por líneas de alto voltaje a pulverizar pesticidas en terrenosagrícolas;

Exposición a la radiación (solar) ultravioleta directa y reflejada a trabajar en el exterior, que puede dar lugar a eritemas, cáncer de piel, cataratas y fotoqueratitis;

- Exposición a factores climáticos potencialmente perjudiciales para la salud (con efectos que van desde la incomodidad por la temperatura hasta el golpe de calor) al trabajar en el exterior.

\section{Riesgos químicos}

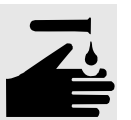

Intoxicaciones graves (no agudas) debidas a la exposición a diversos pesticidas que pueden dar lugar al padecimiento de enfermedades, a la discapacidad o a la muerte;

- Diversos efectos sobre la piel (prurito eritema, aparición de ampollas, irritación, sensibilización, fotosensibilización, etc.) como resultado de la exposición a pesticidas en forma de vapor, fumigación o pulverización; sobre todo a través del contacto directo con la piel (p. ej. ampollas y prurito producidos por el bromuro de metilo; eritema por el pire troide sintético; urticaria por el dietilfumarato, etc.);

- Dermatosis sistémicas y de contacto padecidas por los trabajadores que utilizan pesticidas, como los jardineros y los agricultores, los veterinarios, los manipuladores de frutas y verduras (expuestos a residuos de pesticidas) y, en especial, debidas a la exposición a los pesticidas fos fóricos orgánicos (OPP) y a los cianopiretroides;

- Acné clórico y porfiria cutánea tardía como resultado del contacto con pesticidas clorados;
- Irritación ocular de los trabajadores dedicados a la pulverización de pesticida (p. ej., al aplicar O PP)

Cataratas como resultado de la exposición a dibromuro de dicuat:

- Lesiones de la córnea y la conjuntiva causadas por losinsecticidas

- Quemaduras e irritación de boca y garganta (en pulverizadores)

- U Iceras bucales (en pulverizadores de jardines dedicados a la dilución de carbamatos):

- Asfixia causada por pesticidas fosfóricos orgánicos y carbamatos (en pulverizadoresagrícolas);

Diversas enfermedades pulmonares, como edema, neumonitis, reacciones asmáticas, alveolitis, neumoconiosis (causada por el espolvoreo de pesticida), etc.

- Trastornos gastrointestinales, como dolores abdominales, calambres, diarreas y náuseas, vértigo, mareos, migrañas, pérdida o reducción de conciencia, convulsiones, coma, etc.;

- Trastornos del sistema nervioso, como neurotoxicidad, inestabilidad de la postura, neuropatías, efectos sobre el comportamiento de origen nervioso, efectos sobre las funciones cognitivas, ansiedad, insomnio, etc. (causados por la exposición a pesticidas en general y a los pesticidas fosfóricos orgánicos en particular);

- Trastornos del sistema endocrino y de aparato reproductor, como la infertilidad, los abortos espontáneos, los nacimientos de niños muertos, la esterilidad, los defectos congénitos, los efectos embriotóxicos y fetotóxicos, los fallecimientos perinatales, etc.;

Efectos en el sistema sanguíneo y circulatorio causados por el contacto con pesticidas, sobre todo con hidrocarburos clorados;

- Problemas musculares, óseos y de los tejidosblandos de los usuarios de pesticidas; O tros efectos sistémicos causados por la exposición a diversos pesticidas:

- Efectos cancerígenos, incluidos los que dan lugar a cánceres de vejiga, cerebro hígado, pulmón, próstata, tracto gastrointestinal, sistema respiratorio, testícu los, etc., linfomas malignos, leucemia, mieloma múltiple y otros muchos, aś como distintas formas de mutagenicidad.

\section{Riesgos biológicos}

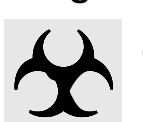

Posibilidad de infección por enfermedades zoonóticas transmitidas por pulgas $u$ otros insectos al efectuar trabajos de exterminación.

\section{Factores ergonómicos y sociales}

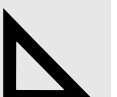

Dolores de espalda en los trabajadores que pulverizan a mano

- Lesiones musculares y óseas agudas causadas por un es fuerzo físico excesivo y posturas inadecuadas adoptadas al transportar y manipular recipientes y piezas de equipos pesados;

- Cansancio y malestar general

Estrés psicológico debido al miedo a la posibilidad de sobreexposición a pes ticidas y a no superar los reconocimientos médicos periódicos obligatorios

- Desarrollo de lumbago causado por las vibraciones, la inadecuada suspensión de los vehículos, la incomodidad de los asientos, el trabajo en condiciones de humedad elevada, etc.

\section{Referencias}

A gencia Internacional para la Investigación sobre el Cáncer (IAR C). 1991.

Occupational Exposures in Insecticide Application and Some Pesticides. M onográfico de la IARC sobre la evaluación de los riesgos cancerígenos en humanos. Vol. 53. Lyon: IARC

International Occupational Safety and $\mathrm{H}$ ealth Information Centre (CIS). 1995. International Safety Datasheets on 0 ccupations. Steering Committee meeting, 9-10 marzo. Ginebra: OIT. (Clasificado por "Laboratory A nimal R aiser".)

Organización Mundial de la Salud (O M S). 1990. Principles for the T oxicological Assessment of Pesticide $R$ esidues in Food. Environmental $\mathrm{H}$ ealth Criteria Series 104. G inebra: O M S.

\section{Apéndice}

Relación de pesticidas comunes:

- Aldrín

- Aldicarb

- Amitrol

- Arsénico

- Atrazine

- M etil-A cinfos

- Captán

- Carbaril

- Clordán

- Cloropicrina

- Clorpirifos

- Sulfato de cobre

- 2,4-D

DDT

- Diazinon

- Diclorvos

- Dieldrin

- Dicuat

- Endosulfán

- Endrin

- Etión

Dibromuro de etileno

- Fenamifos

- Fensulfotion

- Fention

- Fonofós

- Furfura

- Heptacloro

- Lindano

- Malatión

- Bromuro de metilo

- M evinfos

- Paracuat

- Paration

- Pentaclorofenol

- Permetrina

- Piretrina

- Rotenona

- Fluoracetato de sodio

- Sistox (2,4,5-T)

- Temefos

- TEPP

- Talio

- Tiram

- Warfarina 


\section{FONTANERO}

Sinónimos: Instalador; tubero; montador de tuberías; técnico de mantenimiento y reparación de tuberías

\section{Perfil del empleo}

\section{Definición y/o descripción}

A L Los fontaneros montan, B instalan y reparan tuberías, piezas y accesorios metálicos,
plásticos, cerámicos y de otros materiales de sistemas de calefacción, conducción de agua y desagüe. Abren rozas en las paredes y suelos para colocar tubos y accesorios, ayudándose de herramientas de mano y mecánicas. Cortan y roscan tuberías mediante la utilización de cortadoras de tubos; sopletes y roscadoras. Las doblan a mano o con la ayuda de máquinas de curvar. Montan e instalan válvulas, tubos y accesorios. Unen los conductos por medio de tornillos, pernos, empalmes, adhesivos, soldadura, latonado y juntas calafateadas. Instalan y reparan dispositivos como fregaderos, sanitarios, bañeras, depósitos de agua caliente, calefactores, lavavajillas, ablandadores de agua, unidades de evacuación de basuras, etc. Desatascan los desagües obturados. Arreglan las tuberías reventadas. Sustituyen las arandelas en los grifos que pierden. Afianzan las tuberías y los accesorios mediante soportes, abrazaderas y ganchos; pueden soldar los dispositivos de sujeción para consolidar los componentes estructurales. Pueden emplear equipos para localizar fugas, comprobar las tuberías y otros dispositivos de conducción para determinar su integridad estructural, etc. Asimismo pueden aislar las conducciones o los depósitos de agua en los sistemas de suministro de agua caliente o de vapor.

\section{Tareas}

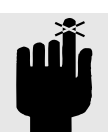

Alinear; montar; doblar y enderezar, taladrar; latonar; practicar rozas (paredes, suelos); quemar (antiguos aislamientos o revestimientos); acarrear (tubos, accesorios, equipos); calafatear; pegar; burilar; fijar; limpiar; revestir (tubos); conectar; cubrir; cortar (tubos y accesorios); cavar; sumergir; abrir zanjas; desmontar; drenar; perforar; conducir; verter; vaciar; excavar; atar; limar; rellenar; encajar; cortar a soplete; encolar; amartillar, calentar; sumergir; instalar; aislar; unir; empalmar; disponer; nivelar; izar; cargar y descargar; localizar (fugas, posición de los tubos); desobturar; marcar y medir; mantener; arreglar; utilizar (herramientas); abrir; pintar; colocar; aplicar (pegamentos); tirar y empujar; bombear; reparar; sustituir; raspar; limar; serrar; atornillar; restregar; asegurar; sellar; establecer; palear; instalar sifones; alisar; soldar; pulverizar (revestimientos, pintura); extender (argamasa); apretar; rodear con cinta; roscar; comprobar (fugas); roscar; hermetificar; transportar; ajustar; envolver; utilizar llaves de tuercas.

\section{Equipo básico utilizado}

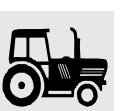

Taladros; buriles; perforadoras; martillos; faros; instrumentos de detección de fugas; curvadoras de tubos; enroscadoras; alicates; sierras; destornilladores; cizallas; palas; llaves de tuercas. El suministro de energía de algunas de las herramientas puede proceder de baterías 0 dela red.

\section{Industrias en las que esta profesión es común}

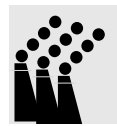
Agricultura; fabricación mantenimiento de calderas; industrias químicas y afines; construcción (incluidos el mantenimiento y la reparación de edificios); fabricación de equipos industriales; laboratorios; servicios municipales; construcción y mantenimiento de conducciones (líneas de suministro de agua, gas, petróleo, etc.); astilleros; fabricación de equipos para calentar agua; desalinización del agua.

\section{Riesgos}

\section{Riesgos de accidente}

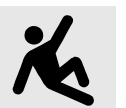

- Caídas desde altura (de escaleras de mano, andamios y tejados); caídas en zanjas; Caídas en superficies sin cambio de nivel, (resbalones y caídas en superficies húmedas y resbaladizas):

- Lesiones (y posibilidad de asfixia) como resultado del desprendimiento de tierras en zanjas;

- Cortes, punzadas, pellizcos y aplastamiento de dedos a causa de la utilización de herramientas de mano y maquinaria;

- Cortes y punzadas con fragmentos de loza sanitaria

Golpes en la cabeza con tuberías, barras situadas en alto, cantos, etc., sobre todo en espacios cerrados o en sótanos y pasillos de techo bajo:

- Partículas extrañas que se introducen en los ojos, en especial al efectuar operaciones de perforación o aislamiento (trabajos de desmontaje);

- Lesiones en los pies por caída de herramientas o de secciones de tubería:

Q uemaduras con líquidos calientes o corrosivos liberados al reventar tuberías 0 conexiones;
Q uemaduras al manejar lámparas de soldar y latonar portátiles;

- Descargas eléctricas y electrocución debidas a la utilización de lámparas portátiles y herramientas eléctricas:

- Incendios y explosiones como resultado de la utilización de lámparas o herramientas eléctricas móviles en espacios restringidos (p. ej., dentro de cisternas) que contienen residuos de gases combustibles;

- Posibilidad de ahogamiento en inundaciones accidentales de estaciones de bombeo (agua, aguas residuales);

T orceduras y lesiones de los órganos internos (p. ej., hernias, reventón de pequeños capilares sanguíneos) como resultado de un esfuerzo físico excesivo;

- Mordeduras y picaduras de insectos, roedores, ácaros, etc.;

Intoxicación por fosgeno emitido por disolventes clorados a temperaturas elevadas (p. ej., en presencia de llamas, arcos eléctricos, cigarrillos encendidos, etc.), sobre todo en espacios cerrados;

Intoxicación producida por los gases tóxicos liberados en los sistemas de tratamiento de aguas residuales (p. ej. dióxido de azufre, ácido sulfhídrico, indol, etc.).

\section{Riesgos químicos}

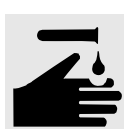

Dermatitis de contacto debidas a la exposición a diversos componentes de los líquidos de desagüe y de las aguas residuales y al contacto con disolventes y otros ingredientes de las colas y los líquidos utilizados en la limpieza de tuberías (especialmente al trabajar con conducciones de plástico)

- Irritaciones oculares y del sistema respiratorio a causa de la exposición a ácidos, álcalis, y diversos líquidos corrosivos patentados utilizados para desatascar tuberías;

- Deficiencia de oxígeno o exposición a gases asfixiantes al trabajar en espacios cerrados (p. ej., sótanos de altura reducida)

I rritación del aparato respiratorio y posibles lesiones pulmonares debidas a la exposición al amianto, fibras minerales y otras fibras y aerosoles inorgánicos al aplicar o desmontar aislamientos 0 conducciones de amianto.

\section{Riesgos biológicos}

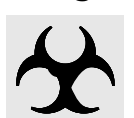
Exposición a una amplia gama de microorganismos parásitos, etc., presentes en aguas residuales, estancadas (sobre todo a temperaturas elevadas), instalaciones sanitarias, y otros 
medios, que pueden producir la enfermedad del legionario, giardiasis, dermatitis cutánea L arra migrans, etc.

\section{Factores ergonómicos y} sociales

- Exposición a la humedad, el frío y el calor en exceso (p. ej., en sótanos o en la construcción, la agricultura y otros trabajos sobre el terreno);

M olestias lumbares;

- Estrés por calor al utilizar trajes antivapores;
- Problemas de muñeca debidos a un esfuerzo físico excesivo al roscar y cortar callosidades en las rodillas ("rodilla de fontanero"), debidas a permanecer arrodillado al trabajar durante mucho tiempo.

\section{Informac. complementaria}

\section{Notas}

1. En el caso de los fontaneros, se ha detectado un aumento del riesgo de leptospirosis; carcinoma bronquial; cirrosis hepática; cáncer de pulmón; cáncer de esófago; cáncer bucal y bucofaríngeo; cáncer de hígado; linfoma no de Hodgkins; cáncer de laringe; mesotelioma pleural; cáncer de lengua; cáncer de próstata

2. Al trabajar en laboratorios, en la industria química 0 en sistemas de tratamiento de aguas residuales, los fontaneros se exponen a todos los riesgos químicos y biológicos propios de estos lugares de trabajo. En las operaciones de soldadura en latón 0 estaño, los fontaneros se exponen a los mismos riesgos que los profesionales que llevan a cabo estos trabajos. Lo mismo puede decirse en el caso del encolado. 


\section{HIGIENISTA}

Sinónimos: Inspector sanitario; inspector de sanidad; supervisor de sanidad; técnico ambiental; técnico en control de contaminación (DO T). A simismo: inspector de salud pública; inspector de salud ambiental; inspector de calidad ambiental; técnico/ auxiliar técnico a mbiental; higienista registrado/ autorizado

\section{Perfil del empleo}

\section{Definición y/o descripción}

A $1 \mid$ Los higienistas formulan, desarrollan y ejecutan programas de salud ambiental; organizan y gestionan programas de formación sobre prácticas de salud ambiental dirigidos a centros docentes y otros colectivos; determinan y establecen las normas de salud e higiene y aplican las normativas relativas al procesamiento de alimentos y los servicios de restauración, la recogida y evacuación de residuos sólidos, el tratamiento y la evacuación de aguas residuales, las instalaciones sanitarias, el control de vectores, las áreas recreativas, los hospitales y otras instituciones, el ruido, la ventilación, la contaminación atmosférica, la radiación y otros aspectos; mantiene contactos con las organizaciones públicas, comunitarias, industriales, de defensa civil y privadas para interpretar y promover los programas de salud ambiental; colabora con otro personal sanitario en las investigaciones y el control epidemiológicos. Asesora a los funcionarios de urbanismo y de otros ámbitos sobre el desarrollo de leyes y reglamentos sobre salud ambiental (DOT).

\section{Profesiones asociadas y específicas}

Ingeniero sanitario; técnico de m ambiental; inspector de alimentación y medicamentos; exterminador: exterminador de mosquitos (DOT).

\section{Tareas}

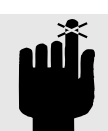

Analizar; montar e instalar; quemar (basuras, etc.); calcular; capturar (insectos, roedores, etc.); comprobar; construir; controlar; diseñar; determinar (cantidades, técnicas de tratamiento, etc.); desarrollar; cavar; desinfectar; evacuar; difundir (información); distribuir (información 0 material pedagógico); conducir; educar; aplicar; estimar (cantidades); erradicar (plagas); evaluar; examinar; ejecutar; exterminar; orientar; guiar; mejorar (técnicas de control, etc.); inspeccionar; investigar; medir; poner en funcionamiento; planificar; prevenir; preguntar; presentar informes; recoger muestras; higienizar; pulverizar; supervisar; estudiar; someter a prueba; transferir; advertir; atestiguar.

\section{Tareas auxiliares}

Administrar; asesorar; responder; aplicar; asistir; colaborar; recoger; compilar; computar; coordinar; debatir; archivar; fijar; iniciar; instruir; interpretar; dar conferencias; negociar; organizar; participar (en comités, programas, etc.); promover; revisar; programar; establecer normas; enseñar; formar; escribir.

\section{Riesgos}

\section{Riesgos de accidente}

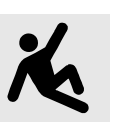

R esbalones, tropiezos y caídas de escaleras de mano y fijas, plataformas elevadas, etc., en visitas a fábricas y al inspección realizar operaciones de

Caídas en fosos abiertos y pozos de registro al inspeccionar sistemas de conducción de agua y evacuación de aguas residuales;

Intoxicación aguda provocada por gases (p. ej., dióxido de azufre y ácido sulfhídrico) al inspeccionar y limpiar los sistemas de evacuación de aguas residuales;

- Intoxicación aguda a causa de la operación y el manejo de recipientes y equipos de tratamiento con cloro y bromo del agua potable y de las piscinas;

- Intoxicación aguda causada por la utilización de diversos pesticidas (véase el apéndice) en las operaciones de exterminación y control de plagas;

Q uemaduras producidas al quemar basurasy utilizar incineradores;

- Riesgo relativamente elevado de verse afectado por accidentes de tráfico como resultado de la necesidad de conducir con frecuencia y durante períodos prolongados por carreteras en mal estado y caminos de tierra;

D escargas eléctricas como consecuencia de la utilización de equipos eléctricos y mecanizados de trabajo sobre el terreno;

Incendios y explosiones causados por sustancias inflamables y explosivas (p. ej., disolventes, gasolina, etc.)

\section{Riesgos físicos}

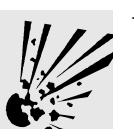

Exposición a un nivel de ruido excesivo (aplicable en el caso de los higienistas dedicados a la higiene industrial, los sistemas de calefacción y ventilación y la inspeccion de industrias "ruidosas" como la industria pesada, la textil y la gráfica);

- Exposición a la radiación ionizante (aplicable en el caso de los higienistas que participan en el control y la supervisión de la utilización de radioisótopos, equipos de rayos $X$ y residuos radiactivos):

Exposición a radiación no ionizante (p. ej., en la esterilización de agua mediante UV);

Exposición a condiciones metereológicas extremas al trabajar sobre el terreno.

\section{Riesgos químicos}

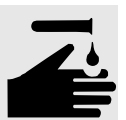

Intoxicación crónica como resultado de la exposición a diversos materiales tóxicos como los pesticidas (insecticidas, herbicidas, rodenticidas, fungicidas, algicidas, nematocidas, etc.), sus vapores y aerosoles en las operaciones de exterminación y de evacuación de recipientes con residuos tóxicos de este tipo de sustancias;

Contacto con oxidantes fuertes, sobre todo compuestos de cloro utilizados en la desinfección de agua potable y de piscinas;

Gases tóxicos presentes en los sistemas de evacuación de aguas residuales y en los centros industriales que carecen de sistemas de ventilación adecuados:

D ermatitis y eccemas producidos por el contacto con diversos aceites y disolventes utilizados en el control de plagas, las operaciones de quema de basuras y por otras sustancias químicas que suelen emplearse en los laboratorios sanitarios.

\section{Riesgos biológicos}

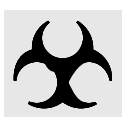

Exposición a diversos microorganismos al trabajar con residuos líquidos 0 sólidos;

- Mordeduras y picaduras de insectos (p. ej., abejas, moscas, pulgas, garrapatas, ácaros, mosquitos y avispas), serpientes, escorpiones, roedores, etc., en los trabajos sobre el terreno o en el laboratorio:

- Riesgo de contraer enfermedades infecciosasal trabajar en hospitales.

\section{Factores ergonómicos y sociales}

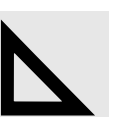

V iolencia física o verbal al llevar a cabo inspecciones sanitarias de edificios, empresas, establecimientos,

Intentos de las personas objeto de inspección de presentar quejas no justificadas que dan lugar a estrés psicológico, nerviosismo, etc. 


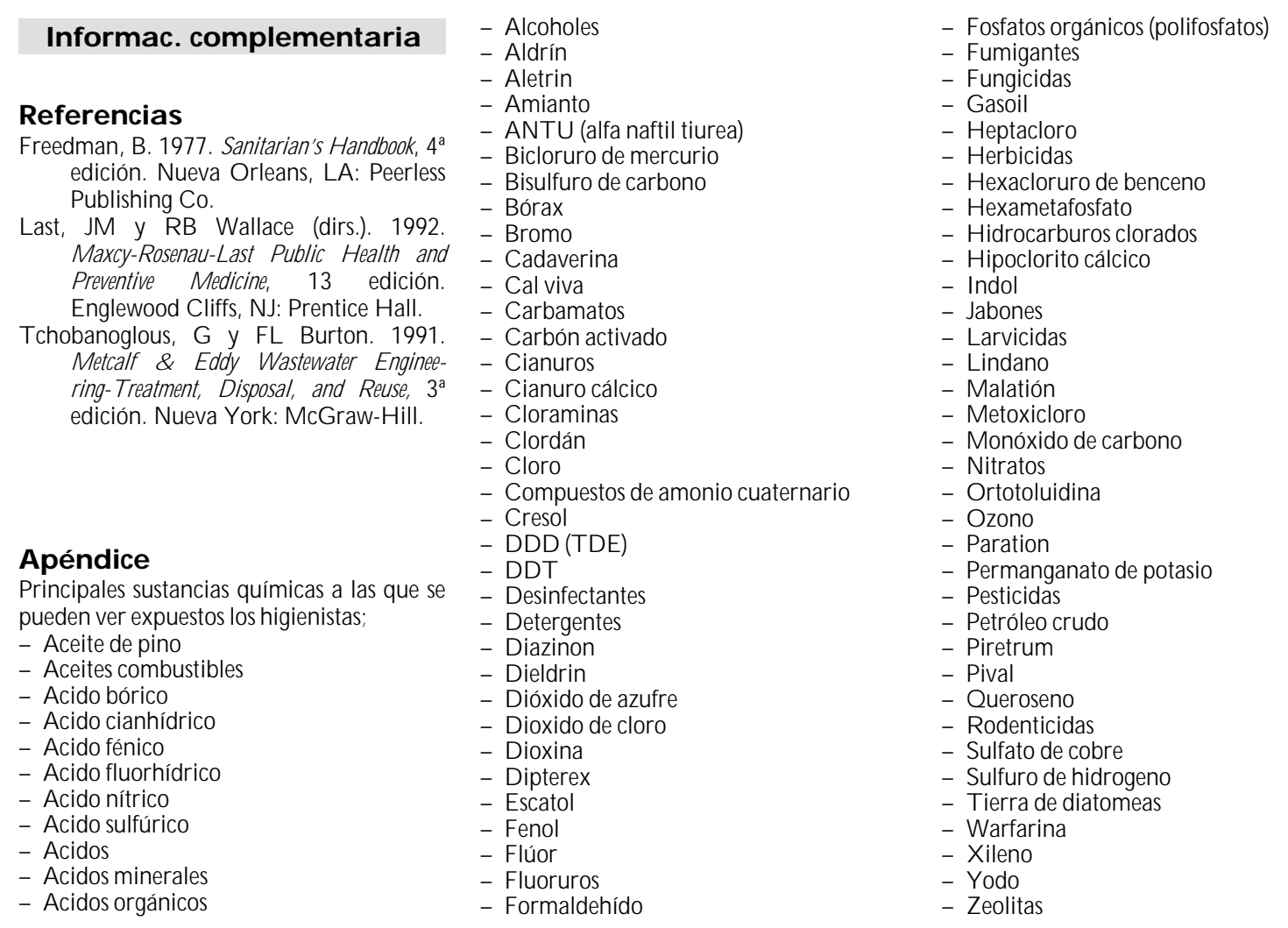




\section{JARDINERO}

Sinónimos: Cuidador de jardines; cuidador de zonas verdes; horticultor; paisajista; trabajador de parques y jardines

\section{Perfil del empleo}

\section{Definición y/o descripción}

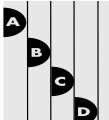

R ealizan jardines o trabajan en ellos. Se ocupan del mantenimiento de terrenos de propiedad pública, privada, industrial o comercial, llevando a cabo las tareas siguientes: acondicionan los suelos cavando, removiendo, arando, fertilizando, etc.; plantan hierba, flores, arbustos y árboles; riegan el césped, las flores y los arbustos; cortan el césped; realizan arreglos a lo largo de paseos, en macizos de flores y en muros; podan arbustos y árboles; pulverizan con insecticidas, herbicidas y fertilizantes; limpian, desinfectan o esterilizan las herramientas y los equipos de jardinería; formulan y preparan soluciones y mezclas de pesticidas, herbicidas, fertilizantes y aditivos para los suelos; retiran las hojas, ramas y leña menuda deterioradas; rastrillan y embolsan hojas; limpian el terreno y retiran la basura; acarrean para su eliminación o queman basura, hojas, papeles, etc.; retiran a pala la nieve de paseos y calzadas; además, pueden afilar las herramientas de jardinería, realizar reparaciones de menor importancia, arreglar y pintar vallas, muros, puertas y caminos, limpiar zanjas y canales de desagüe y medir el nivel de humedad del suelo.

\section{Tareas}

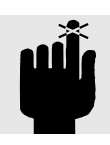

Embolsar (hojas); achicar iniciar; quemar; acarrear; limpiar; recortar; acondicionar (suelos); recolectar; cosechar frutos; cortar; despendonar; cavar; desinfectar; drenar; secar; espolvorear; ribetear; fertilizar; formular; fumigar; recoger; allanar (terrenos); injertar; rastriIlar; cosechar (en general); hacer zanjas; descortezar; irrigar; mantener; fabricar; medir (humedad, etc.); arreglar; cortar el cesped; abonar; pintar, realizar (tareas); plantar; arar; plantar en macetas; preparar (mezclas, etc.); propagar; segar; reparar; retirar; serrar; afilar; descascarillar; palear; clasificar; sembrar; clavar; rociar; desparramar; esterilizar; encordelar; diluir; trillar; labrar; transplantar; mondar; remover (tierra); regar; desherbar; aventar.

\section{Equipo básico utilizado}

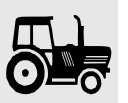

Cortador de césped (manual o motorizado): podadoras; desherbadoras; útiles de recortar; cizallas; arados; sierras; palas; pulverizadores; aspersores; esparcidoras; rastrillos; escobas; estacas; palas; desplantadores; cuchillas; máquinas cultivadoras; manqueras y depósitos de riego; horquillas en general y de ventear; útiles de techar; carretillas; tractores con diversos dispositivos auxiliares; sensores de agua.

\section{Riesgos}

\section{Riesgos de accidente}

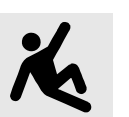

Caídas desde superficies en altura (p. ej., escaleras de mano, plataformas o tejados), resbalones y caídas sobre el terreno (en el barro, en suelos húmedos o sobre la hierba) y tropiezos y caídas en superficies desiguales o con diversos aperos de jardinería, que dan lugar a contusiones, conmociones, cortes y fracturas de huesos:

- Vuelcos de tractores y otros vehículos de trabajo y plataformas remolcadas, y caídas desde los mismos;

Enredo de ropas, cabellos o pelo de la barba con piezas móviles de la maquinaria eléctrica o accionada por motor;

Accidentes con útiles de jardinería (cuchillas, podadoras, cizallas, rastrillos, azadas, etc.), que se producen como resultado del resbalamiento de la herramienta, falta de atención, roturas, tropiezos o caídas sobre los utensilios, etc., y que causan punzadas, rasguños, aplastamientos, contusiones, heridas, amputación de dedos, etc.;

Proyección de partículas (arena, piedras, astillas, caucho o cuerda de nylon, etc.) al trabajar con sierras, cortadoras de césped, etc. motorizadas, lo que provoca lesiones oculares, contusiones, etc.;

Punzadas de plantas con espinas:

M ordeduras o picaduras de serpientes, escorpiones, abejas, avispas, roedores, insectos o perros, que causan heridas, dolores, hinchazón, intoxicación local o general, etc.;

Electrocución o descarga eléctrica debidas al contacto con cables con corriente (p. ej., líneas de alto voltaje aéreas al transportar tuberías de metal), o producidas al trabajar con equipos eléctricos de aislamiento deficiente

- Derrame de ácidos (p. ej., de ácido nítrico, utilizado para desinfectar herramientas) u otras sustancias químicas corrosivas sobre la piel o la ropa o en los ojos, lo que causa quemaduras químicas, erupciones, lesiones oculares graves, etc.;

- Intoxicación aguda debida a la ingestión - la inhalación accidental de pesticidas u otras sustancias químicas tóxicas utilizadas en agricultura.

\section{Riesgos físicos}

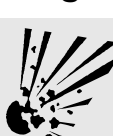

Niveles de ruido excesivos generados por equipos mecanizados (cortadoras de césped, sierras, etc.) que causan daños al tímpano con posible pérdida de capacidad auditiva;

- Sobreexposición a la luz solar, que produce quemaduras, golpes de calor, melanomas cutáneos, etc.;

- Exposición a condiciones metereológicas adversas (frío, lluvia, nieve, viento) que producen congelación, enfriamientos (con posibles complicaciones si se prolonga el trabajo en tales condiciones), etc.

\section{Riesgos químicos}

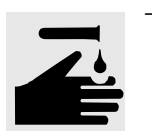

Dermatitis y otros trastornos cutáneos debidos al contacto prolongado con sustancias químicas agrarias o disolventes, 0 a los efectos sistémicos de la inhalación de dichas sustancias:

Intoxicación crónica como resultado de la inhalación, la absorción a través de la piel o la ingestión prolongadas de sustancias químicas agrarias que contengan metales pesados (p. ej., cadmio, mercurio, plomo y arsénico), compuestos organofosforados, aminos, etc.;

Aumento de los daños sufridos por pieles presensibilizadas por el contacto con sustancias químicas debidos a la exposición a la luz solar (efectos citofotoquímicos).

\section{Riesgos biológicos}

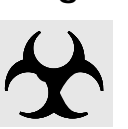
Contacto con plantas, flores, hierbas, etc. alergénicas (p. ej., Ficus benjamina, diversos cactus, etc.), que causa dermatosis, asma, etc.;

- Inhalación de polvo, polen, aceites, vapores, etc. alergénicos, que causan fiebre del heno, asma, etc.

Contacto de heridas abiertas con abono, parásitos, excrementos animales, insectos, etc., lo que provoca infecciones locales o generales como el tétanos, el ántrax y otras;

- Enfermedades zoonóticas (p. ej., tifus exantemático, fiebre Q );

Leptospirosis como resultado de la penetración de microorganismos del género Leptospira a través de las fisuras dela piel

- Enfermedades micóticas causadas por los hongos presentes en el suelo o en las hojas de las plantas (p. ej., aspergilosis alérgica, histoplasmosis (infección pulmonar), etc.); 
- Enfermedades parasitarias producidas por la mordedura de garrapatas, niguas y ácaros (p. ej.,sarna), o por larvas que penetran a través de las fisuras de la piel (p. ej., anquilostomiasis, ascariasis). En algunos casos, las infecciones pueden dar lugar a efectos neurotóxicos y a parálisis.

\section{Factores ergonómicos y sociales}

Los movimientos manuales repetitivos, las posturas incorrectas (p. ej., al plantar flores), el izado y transporte de cargas pesadas, etc., pueden causar molestias lumbares, trastornos de las extremidades superiores e inferiores y otros problemasmuscularesy óseos.

\section{Informac. complementaria}

\section{Notas}

1. Esta profesión suele desempeñarse en servicios municipales $y$ en terrenos públicos y privados, industriales y comerciales.

2. De acuerdo con los informes publicados, como resultado de la exposición a diversas sustancias químicas agrarias, es posible que los jardineros estén expuestos a un mayor riesgo de padecer efectos cancerígenos y mutagénicos; las mujeres embarazadas que desempeñan esta profesión pueden correr un mayor riesgo de sufrir abortos espontáneos y efectos tóxicos para el feto o teratogénicos.
3. Las sustancias químicas a las que se ve expuesto un jardinero incluyen una gran variedad de sustancias y compuestos químicos agrarios, como insecticidas (organosfosforados, organoclorados, carbamatos, piridina arsenicales, etc.), rodenticidas, fungicidas, fumigantes líquidos y gaseosos (p. ej., dibromoetano, bromuro de metilo), herbicidas, fertilizantes, etc.; combustibles y aceites lubricantes; ácidos, compuestos de limpieza y esterilización, disolventes (en particular queroseno en los compuestos pesticidas), etc.

\section{Referencias}

O rganización Internacional del Trabajo (OIT). 1979. Guide to $H$ ealth and $\mathrm{H}$ ygiene in Agricultural W ork. Ginebra (OIT).

Worksafe Australia. 1995. Agriculture and Services to Agriculture Industries. $0 \mathrm{ccu}-$ pational $\mathrm{H}$ ealth and Safety Performance $O$ verviews. Selected Industries, Issue No. 9. Canberra: Government of Australia. 
MANIPULADOR DE ANIMALES

Sinónimos: Asistente en el cuidado de animales; criador de animales, cuidador de animales, trabajador dedicado a la producción animal, trabajador de laboratorio de animales, reproductor de animales, trabajador agropecuario; trabajador de granjas de producción animal, etc.

\section{Perfil del empleo}

\section{Definición y/o descripción}

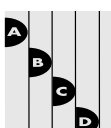

Se ocupa de las tareas que se refieren a continuación, relativas al cuidado de animales como ratones, canarios, cobayas, visones, perros y monos en granjas $u$ otras instalaciones como perreras, corrales, hospitales y laboratorios. Alimenta y da de beber a los animales de acuerdo con los horarios establecidos. Limpia y desinfecta jaulas, establos y corrales, y esteriliza los equipos de laboratorio y los instrumentos quirúrgicos. Examina los animales para detectar síntomas de enfermedad y los trata con arreglo a las instrucciones recibidas. Traslada los animales de un lugar a otro. Ajusta los controles de regulación de la temperatura y la humedad de la ubicación de los animales. Registra datos de genealogía, dieta, peso, medicación, alimentación, número de licencia, etc., de acuerdo con las instrucciones. Anestesia, inocula, rasura, baña y prepara a los animales. Repara jaulas, establos o corrales vallados. Puede ocuparse de sacrificar y desollar animales como en el caso del zorro y el conejo, y de empaquetar las pieles en cajas. Según el lugar donde preste sus servicios, el manipulador de animales puede recibir una denominación específica, como, por ej., auxiliar de perrera (servicios públicos); trabajador agropecuario dedicado a la producción peletera (agricultura); auxiliar de laboratorio de animales (farmacia); auxiliar de tienda de animales domésticos (comercio minorista) y auxiliar de hospital veterinario (servicios médicos). (D OT).

\section{Profesiones asociadas y específicas}

wh

Trabajador de matadero; carnicero; ganadero; trabajador agropecuario cualificado (asimismo: criadores de ganado y de animales productores de leche y sus derivados; de animales domésticos de pelo; piscicultores; trabajadores de producción animal combinada; criadores de animales de pelo no domesticados; de ganado porcino; de aves; de ganado ovino); veterinarios, etc. (CIUO)); cuidador de rebaños; supervisor de instalaciones para animales; apicultor; inseminador artificial; colmenero; vaquero; criador de animales de pelo; pastor; ranchero; auxiliar de instalación ganadera; ordeñador; desollador; criador/ productor avícola; auxiliar de establos; criador de ganado; supervisor de perreras; etc. (DOT y CIU O); trabajador encargado de la reproducción de animales (RHAJ); peluquero de animales; gaucho; mozo de establo; auxiliar/trabajador de parqueszoológicos, etc.

\section{Tareas}

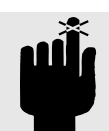

Ajustar (controles); administrar; anestesiar; aplicar (medicaciones); distribuir; asistir (al veterinario); asignar; prestar asistencia; capturar; desaguar; bañar; preparar lechos; atar; marcar; domar (caballos); criar; embridar; cepillar; construir (vallas, cobertizos, etc.); enfardar;sacrificar animales; comprar y vender; enjaular; calcular; mirar huevos al trasluz; caponar; prestar cuidados; acarrear; castrar; coger; cambiar; afianzar; limpiar; esquilar; cobrar (honorarios, donaciones, etc.); peinar; acondicionar; encerrar; acorralar; embalar; cultivar; curar (carne); despicar; descornar; repartir; realizar demostraciones (de animales a clientes, espectadores, etc.); tratar por inmersión (utensilios); desinfectar; descolar; domesticar (animales); suministrar medicamentos por vía oral; adiestrar; conducir; documentar; cercar; accionar; instalar; explorar (animales); ejercitar; exhibir (a efectos comerciales, educativos o de ocio); exterminar; engordar; alimentar; rellenar; lavar; suministrar pienso; apriscar; formular; fumigar; reunir; picar; apacentar; engrasar; moler; almohazar; desarrollar; guardar; guiar; manipular; enjaezar; cosechar; facilitar la incubación; remolcar; ayudar; llevar en manada; alquilar; enganchar (animales); identificar; informar; inyectar; inocular; inseminar; inspeccionar; investigar; aislar; conservar; sacrificar; etiquetar; fustigar; disponer los lechos (cuadra de animales); cargar y descargar; lubricar; mantener; gestionar; comercializar; medir; medicar; ordeñar; extraer líquido seminal; mezclar; montar y desmontar; trasladar; fabricar redes; muescar; notificar; observar; engrasar; abrir; operar; realizar pedidos; apaciguar; empaquetar; pintar; colocar; sembrar; verter; preparar; preservar; punzar; producir; propagar (animales); bombear; conducir con la aguijada (ganado); poner en cuarentena; estirar pieles; llevar la gestión de una granja; registrar; regular; eliminar, alquilar; reparar; reponer; realizar informes; refrenar; montar a caballo; ensillar; esparcir; descarnar; separar; seleccionar; sexar (aves); afilar; afeitar; expedir; herrar; palear; mostrar (animales a clientes, espectadores, etc.): desollar; tijeretear; clasificar; obtener la freza; rociar; espolear; esterilizar; aprovisionar; almacenar; despojar; supervisar; tatuar; ablandar; vigilar; instruir (perros de la policía y el ejercito para la detección de drogas y explosivos); transferir; tratar; asear; amarrar; utilizar; vacunar; pasear (perros); regar; pesar; azotar; uncir.

\section{Riesgos}

\section{Riesgos de accidente}

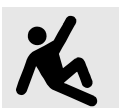

Resbalones, tropiezos y caídas (en superficies resbaladizas, escaleras, etc.); choques con objetos esparcidospor el suelo, etc.;

Cortes y pinchazos causados por objetos punzantes, vidrios rotos $y$ jeringuillas;

- Lesiones provocadas por puertas de vaivén;

- M ordeduras, cornadas u otro tipo de ataques de animales domésticos 0 salvajes;

- Coces, mordeduras, arañazos y picaduras de animales de laboratorio (primates, perros, gatos, cabras, conejos, cobayas, ratas, ratones, hamsters y otros roedores, serpientes, avispas, etc.) animales domésticos, animales de pelo, abejas, animales de parques zoológicos y mantenidos en otras instalaciones con fines educativos, comerciales, de ocio, recreativos, deportivos o de otro tipo, o dedicados a la investigación:

- Caídas de caballo y de otros animales de silla;

- Accidentes de tráfico producidos al transportar animales;

- Lesiones accidentales causadas por arma de fuego al cazar animales (destinados a parques zoológicos, etc.);

R iesgos de incendio en plantas de tratamiento de residuos de origen animal;

- Incendios y explosiones causadas por sustancias inflamables y explosivos;

Lesiones oculares producidas por fragmentos metálicos ( $p$. ej., en herrerías al clavar las herraduras a los caballos, 0 en las operaciones de marcado en caliente);

Q uemaduras causadas por objetos metálicos calientes ( $p$. ej., en herrerías al clavar las herraduras a los caballos);

Descargas eléctricas provocadas por equipos eléctricos y electromecánicos defectuosos u operados de forma incorrecta;

Explosiones de mezclas de alimentos de consumo animal en polvo, en suspensión en la atmósfera. 


\section{Riesgos físicos}

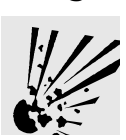

Exposición a radiación ionizante emitida por equipos veterinarios de rayos $X$ y por animales de laboratorio in radioisótopos;

vestigados 0 tratados con

- Exposición de la piel y los ojos a la radiación ultravioleta utilizada a efectos de esterilización y de otro tipo en laboratorios y otras instalaciones para la conservación de animales;

- Exposición a un nivel de ruido excesivo estrés por calor y vibraciones y sacudidas mecánicas en manos y brazos al efectuar operaciones de forjado y afines (en herrerías)

- Estrés por frío o calor (cuyos efectos van desde la incomodidad debida a la temperatura a la congelación y los golpes de calor, respectivamente) y exposición a cambios de temperatura bruscos y frecuentes (al entrar y salir de salas climatizadas) de los manipuladores de animales que trabajan parcial o mayoritariamente en el exterior sometidos a condiciones metereológicas extremas;

- Problemas de salud (p. ej., reuma, etc.) debido a las condiciones de los lugares de ubicación de los animales, como humedad elevada, suelos de hormigón, etc.

\section{Riesgos químicos}

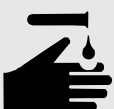

Intoxicación debida al contacto con sustancias químicas como pesticidas (sobre todo, insecticidas, germicidas y herbicidas), disolventes, ácidos y álcalis fuertes, detergentes, etc.;

- Dermatosis debidas al contacto con sus tancias químicas como pesticidas, disolventes, detergentes, desodorantes, medicamentos de uso animal, etc.;

- Alergias debidas al contacto con formaldehídos y otras sustancias sintéticas o alergénicas naturales;

- Riesgos para la salud provocados por la inhalación de vapores de formaldehído;

- R iesgos para la salud causados por la exposición a vapores metálicos, de disolventes y de otro tipo producidos al forjar, herrar y otras operaciones de cuidado de cascos (sobre todo en herrerías);

- Efectos sistémicos y gastrointestintales causados por la exposición a agentes citotóxicos (especialmente en el caso de los manipuladores de animales de laboratorio);

- Exposición a diversos agentes cancerígenos, mutágenos y teratógenos (sobre todo en el caso de los manipuladores de animales de laboratorio);
- Intoxicación por mercurio (en los trabajadores de la industria peletera).

\section{Riesgos biológicos}

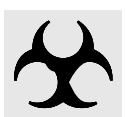

- Infecciones debidas al contacto con animales enfermos o portadores de patógenos, 0 causadas por la exposición a patógenos en suspensión en el aire, que dan lugar al desarrollo de enfermedades contagiosas (zoonosis), como el ántrax, blastomicosis, brucelosis (fiebrede $M$ alta), virus $B$ (enfermedad $B$ de los simios), fiebre por mordedura de gato, equinococosis (hidatidosis), encefalitis enteritis (adquirida zoonóticamente), erisipeloide, muermo, anquilostomiasis, leptospirosis, enfermedad del virus de $0 \mathrm{rf}$ ornitosis, pasteurelosis, peste, pseudovacuna, psitacosis, infecciones piogénicas, fiebre $\mathrm{Q}$, rabia, fiebre por mordedura de rata, enfermedades hemorrágicas virales (fiebres de R ift V alley), enfermedades por tiña, salmonelosis, enfermedad de los porqueros, enfermedades por tenia, toxoplasmosis, tuberculosis (bovina), tularemia, fiebre tifoidea, etc., así como otras enfermedades relacionadas con parásitos protozoicos, rickettsias y clamidias, infecciones virales y fúngicas, etc.;

- Alergias debidas al contacto con anima les de laboratorio (incluidas: asma de origen profesional, alveolitis alérgica, bronquitis, pneumonitis, rinitis, erupciones cutáneas, etc.) y enfermedades de las vías respiratorias causadas por la inhalación de polvo de alimentos de consumo animal que contienen diversos microorganismos y sus esporas, pelos animales (que producen la enfermedad del pulmón de peletero), residuos de aves (que causan la enfermedad del pulmón de criador de palomas), etc.

- Disfunciones pulmonares en trabajadores que prestan sus servicios en instalaciones de producción animal, debidas a la acción de diversos agentes, como la toxicidad por sulfuro de hidrógeno, la bronquitis, el asma no alérgica, el síndro me tóxico por polvo orgánico (ODTS); la irritación de membranas mucosas, así como de bioaerosolesy endotoxinas

- Efectos respiratorios debidos a la acción del polvo y de las endotoxinas en los trabajadores dedicados a la alimentación animal y a la cría de animales de pelo:

- Exposición de los trabajadores dedicados a la alimentación animal a aflatoxinas cancerígenas (causantes de cáncer de hígado primario);

- R iesgos de cáncer debidos a los agentes cancerígenos presentes en pesticidas, medicamentos de consumo animal, etc.;
- Efectos agudos para la salud causados por diversos productos insecticidas utilizados por los manipuladores de animales;

- Aumento del riesgo de contraer fiebre hemorrágica adquirida en laboratorio con síndrome renal provocada por ratas de laboratorio infectadas;

- Eccemas y dermatitis de contacto de origen profesional

- Aumento del riesgo de desarrollar leucemia linfática crónica y linfoma no de $\mathrm{H}$ odgkin en criadores de animales;

- Diversasinfecciones sépticas;

- Desarrollo de la enfermedad (viral) del síndrome de las vacas locas.

\section{Factores ergonómicos y}

\section{sociales}

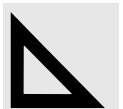

Trastornos musculares y óseos (sobre todo de espalda y rodillas) en los manipuladores de animales que deben montar a caballo durante períodos prolongados o arrodillarse (en especial en suelos de hormigón) al desarrollar su trabajo (p. ej., en herrerías);

- Incomodidad en el puesto relacionada con el entorno de trabajo (suciedad olores, etc.) y con el carácter fundamentalmente físico de la actividad;

- Exposición a los ataques de cuatreros ladrones de animales de compañía valiosos, etc.

- Exposición a las protestas y, posible mente, a la violencia, de grupos de defensores de los derechos de los animales;

- Peligro de desarrollar toxicomanías inducidas por la fácil disposición de me dicamentos de consumo animal.

\section{Informac. complementaria}

\section{Referencias}

Benenson, AS (dir.). 1990. Control of Communicable Diseases in $M$ an, 15a edición. Washington, DC: American Public $\mathrm{H}$ ealth Association.

O rganización Mundial de la Salud (O M S). 1979. Parasitic Z oonoses. Comité de expertos de la OM S con la participación de la FAO Technical Report Series No. 637. Ginebra: O M S

W orksafe Australia. 1995. A griculture and Services to Agriculture Industries. O ccupational $\mathrm{H}$ ealth and Safety Performance 0 verviews. Selected Industries, Issue No. 9. Canberra: Government of Australia. 


\section{MECANICO DE AUTOMOVILES}

\section{Sinónimos: Mecánico de automoción; mecánico de taller; mecánico de vehículos de motor}

\section{Perfil del empleo}

\section{Definición y/o descripción}

H Estos trabajadores se ocupan de reparar, prestar servicios de mantenimiento y revisar automóviles y otros vehículos de motor afines: examinan éstos para comprobar la naturaleza, la extensión y la localización de los defectos existentes; planifican su actividad utilizando gráficos y manuales técnicos; desmontan motores, sistemas de transmisión, diferenciales y otros componentes que requieran su atención; reparan o sustituyen piezas como pistones, bielas, engranajes, válvulas, rodamientos, interruptores o juntas, y accesorios como bujías; sustituyen el forro de las zapatas y ajustan los frenos, sueldan fugas del radiador, cambian los bujes del mecanismo de dirección y llevan a cabo otras reparaciones; ponen a punto el motor mediante el ajuste de la ignición, el carburador, las válvulas y el mecanismo de distribución; y ponen a prueba los vehículos reparados en el taller 0 en carretera. Pueden reconstruir componentes utilizando tornos, perfiles, equipos de soldadura y herramientas de mano. Además, pueden realizar reparaciones del sistema eléctrico y de la carrocería, así como pintar mediante pulverización. Pueden especializarse en el arreglo de un determinado tipo de motor, como los equipados en automóviles diesel; en este caso, reciben una denominación específica (CIU O).

\section{Profesiones asociadas y específicas}

mat

Profesionessimilaresdesignadas de acuerdo con una especialidad: mecánicos de autobuses; mecánico de motores diesel; mecánico de camiones; mecánico de reparación de motores; reparador de motores o autobuses, reparador de diferenciales; mecánico compresorista; reparador de culatas, etc.; o de acuerdo con un cargo: supervisor de taller; mecánico de inspección de autobuses; mecánico de transmisión; reparador de frenos, ayudante de mecánico demotoresdiesel, etc. (DOT)

\section{Tareas}

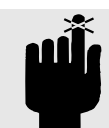

R aspar; ajustar; alinear; montar y desmontar; atornillar; pegar; calibrar; latonar; cepillar; soldar con soplete; consolidar; repelar; sujetar; limpiar; cortar; diagnosticar; tratar con baño; desarmar; taladrar; conducir; examinar; fabricar; fijar; limar; rellenar; acabar; encajar; oxicortar; forjar: molturar; encolar; martillar; calentar; insertar; inspeccionar; instalar; laminar; izar; lubricar; mecanizar; mantener; medir (con instrumentos); fundir; arreglar; fresar; revisar; pintar; perforar; planificar; posicionar; apretar; tirar; bombear; empujar; elevar; rectificar cilindros; cambiar los bujes; recargar; reacondicionar; sustituir forros; quitar; reparar: sustituir; remachar; rehacer instalaciones eléctricas; frotar (compuestos); lijar; rascar; colocar; soldar; pulverizar; apretar; grapar; roscar; comprobar; aterrajar; tensar; poner a punto; verificar (dimensiones).

\section{Riesgos}

\section{Riesgos de accidente}

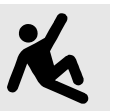

- Lesiones producidas al trabajar con equipos mecánicos como tornos, taladros, máquinas de taladrar y bruñir, discos, troqueles y diversas herramientas de corte y de mano ( $p$. ej., tenazas, llaves de tuercas, destornilladores, cinceles, martillos de dos manos, etc.);

- Lesiones debidas al desplome, la inclinación 0 el desplazamiento de equipos de gateamiento, elevación o alzado y a la caída de vehículos;

- Punzadas y cortes debidos a la acción de cuchillos, objetos punzantes, herramientas de mano, golpeo de piezas metálicas, pernos sueltos, etc., durante las operaciones de desmontaje, reparación y montaje;

R esbalones, tropiezos y caídas en escaleras de mano y fijas, plataformas elevadas, etc., y caídas en fosos de inspección (sobre todo cuando se transportan cargas);

- Caídas en superficies llanas, en especial cuando se ha derramado agua o aceite 0 se encuentra resbaladizo por otra causa;

A plastamiento de los dedos del pie debido a la caída de objetos pesados;

- Q uemaduras y escaldaduras como resultado del contacto con superficies calientes, tubos de escape o sustancias químicas fundidas; de la emisión repentina de agua caliente y vapor de conductos, radiadores y tuberías del sistema de refrigeración; 0 de operaciones de soldadura, etc.;

- Lesiones oculares provocadas por fragmentos y objetos proyectados durante las operaciones de moltura, mecanizado, abrasión, pulido, taladro y otras similares 0 al aplicar equipos de aire comprimido a la limpieza de tambores y frenos y otras tareas;

- Explosión de recipientes o conductos de aire comprimido; inyección accidental de materiales o aire comprimido a través de la piel o de los orificios corporales;

R eventones de neumáticos:

Accidentes debidos a una instalación deficiente y a un mantenimiento inapropiado de los limpiadores a presión de agua y de vapor;
- Lesiones causadas por equipos de comprobación de rodadurasy de frenos

Electrocución como resultado de defectos, cortocircuitos y una utilización incorrecta de equipos electromecánicos, o del contacto con cables con corriente (p. ej., descargas eléctricas generadas por herramientas mecánicas portátiles);

- Incendios y explosiones debidos a la acumulación de sustancias inflamables y explosivas (p. ej., gas de petróleo líquido, gasolina, disolventes, aceites, etc.) como resultado de derrames, fugas, negligencia, etc., a la ignición de hidrógeno emitido por las baterías, o a las llamas originadas en las operaciones de oxicorte y soldadura, etc.;

Intoxicación por monóxido de carbono de los trabajadores que desarrollan su actividad en fosos de inspección;

Accidentes de tráfico durante la reparación y la conducción de vehículos reparados.

\section{Riesgos físicos}

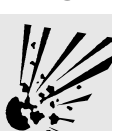

Nivel de ruido excesivo (superior a $90 \mathrm{~dB}$ ), sobre todo al trabajar en la carrocería de los vehículos; - Exposición a la radiación ultravioleta e infrarroja directa y reflejada;

Exposición a la radiación de microondas y radiofrecuencia, sobre todo en actividades como el sellado por calor de paneles y tapicería, el secado de vestiduras de base, etc.;

Exposición a bajas temperaturas y a la acción del viento, especialmente en talleres abiertos, lo que produce enfriamientos (la utilización de sistemas de calefacción improvisados puede causar asimismo incendios e intoxicacion por monóxido de carbono);

Exposición a rayos $X$ y radioisótopos en las pruebas no destructivas y de fabricación de automóviles;

- Desarrollo de "dedo blanco" por vibración como resultado de la utilización de herramientas motorizadas que producen este efecto.

\section{Riesgos químicos}

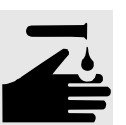

Intoxicación crónica como resultado de la exposición a una amplia gama de sustancias químicas industriales, como metales pesados (p. ej. , líquidos de frenos, desengrasadores, detergentes, lubricantes, limpiadores de metal, decapantes para pinturas, diluyentes, etc.) (véase el apéndice);

Enfermedades y trastornos de la piel (diversos tipos de dermatitis, sensibilización cutánea, eccema, acné de aceite, etc.) causadas por diversas 
sustancias químicas (p. ej., adhesivos, amianto, líquidos anticongelantes y de frenos, resinas epóxi, gasolina, aceites, níquel, colofonia, etc.);

- Irritaciones oculares, mareos, náuseas, problemas de respiración, migrañas, etc. causados por el contacto con sustancias químicas irritantes, polvos, humos, agentes antidetonantes (como el metilpentadienil manganeso tricarbonilo (M M T)), disolventes cetónicos (como la metilisobutilcetona (MIC)), etc.;

- Amiantosis y mesotelioma causados por el polvo de amianto producido por la limpieza y tratamiento de los tambores de freno;

- Saturnismo:

- Cambios hematológicos como resultado de la exposición a disolventes, como el benceno y sus homólogos, tolueno, xileno, etc.;

- Aumento del riesgo de cáncer debido a la inhalación de humos de escape de los motores diesel o el contacto con ciertos metales pesados y sus compuestos amianto, benceno, etc.;

- Aumento del riesgo de sufrir daños cere brales orgánicos debido a la inhalación de humos de escape de motores diesel;

- Irritaciones agudas de los ojos y las membranas mucosas, migrañas, dificultades de respiración, opresión en el pecho, etc. causadas por la inhalación de óxidos de nitrógeno $\left(\mathrm{NO}_{x}\right)$ y partículas respirables;

- Aumento del riesgo de aborto o de daños para el feto 0 el embrión en mujeres embarazadas expuestas a disolventes organohalógenos;

- Trastornos gastrointestinales como resultado de la ingestión accidental o crónica de adhesivos:

- Molestias debidas a los malos olores existentes al trabajar con ciertos adhesivos en disolventes base:

- Salpicaduras de sustancias químicas corrosivas y reactivas que pueden causar lesiones oculares y dérmicas, etc.

\section{Riesgos biológicos}

Infecciones como resultado de la contaminación y el crecimiento de microorganismos en ciertosadhesivos.

\section{Factores ergonómicos y} sociales

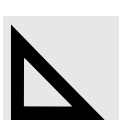

- Lesiones musculares y óseas agudas (hernia de disco intervertebral, rotura de tendones, hernia, etc.) causadas por un esfuerzo físico excesivo y una combinación incorrecta de peso y postura en las operaciones de izado y transporte de cargas pesadas;

- Trastornos por traumatismo acumulativo, como el síndrome del túnel carpiano, causados por trabajos repetitivos de larga duración;

- Cansancio y malestar general;

- Peligro de sufrir el ataque de personas (incluidos los clientes insatisfechos) en lugares de trabajo abiertos al público;

- Estrés psicológico al trabajar presionado por el tiempo.

\section{Informac. complementaria}

\section{Referencias}

H ealth and Safety Executive (H SE). 1991.

$H$ ealth and Safety in Tyre and Exhaust

Fitting Premises. HS (G) 62. Londres HSE Books.

-. 1991. Health and Safety in M otor Vehicle Repair. HS (G) 67. Londres: HSE Books.

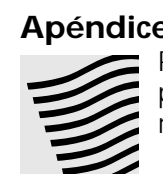

Principales sustancias a las que pueden verse expuestos los mecánicos de automóviles:

\section{- Aceites (incluidos los usados)}

- Aceleradoresy antioxidantes del caucho

- Acido oxálico

- Acroleina

- Adhesivos

- Alcalis

- Alcohol de diacetona

- Amianto

- Anhídrido ftálico
- Benceno

- Bencina mineral

- Bicromatos

- Bisfenol A

- Bisulfuro de molibdeno

- Butanol

- Butilacetato

- Colofonia (resina de trementina)

- Decapantes para pinturas

- Desengrasantes

- D etergentes (sintéticos)

- Diluyentes para pinturas (p. ej., aguarrás)

- Dioxano

- Disolventes (diversostipos)

- Etilacetato

- Etilenglicol

- Fibras de vidrio

- Fluidoshidráulicos

- Fundentes

- Gasolina y aditivos

- Grafito

- Grasas

- H idrocarburos clorados

- (p. ej., disolventes)

- Hidroquinona

- I socianatos

- Isopropanol

- Limpiadores de metal

- Líquidos anticongelantes

- Líquidos de frenos

- Líquidos para herramientas de corte

- Lubricantes

- M etanol

- M etilisobutilcetona

- Monóxido de carbono

- Níquel

- Oxidos de nitrógeno

- Pirorretardantes

- Plásticos

- Plomo tetraetilo

- Plomo y sus compuestos

- Polvosabrasivos

- Queroseno

- R esinas de poliester

- R esinas epóxi

- Timerosol

- Tolueno

- Tricarbonilo

- Xileno 


\section{Perfil del empleo}

\section{Definición y/o descripción}

A Estos profesionales elaboran B modelos a escala de objetos 0 - situaciones. Construyen y perfilan modelos utilizando arcilla, metal, madera, plástico, caucho y otros materiales, en función de la industria para la que se realicen. U tilizan su experiencia, destrezas y conocimientos especiales para comprender los requisitos de los clientes expresados en documentos, dibujos, bocetos, etc.; seleccionan los métodos, las herramientas y los procesos tecnológicos apropiados; diseñan y fabrican modelos y comprueban su conformidad con los requisitos y las especificaciones. Pueden realizar armazones, escaparates, etc., para los modelos y los acristalan. Pueden desmontar 0 destinar a otros fines los modelos que dejan de utilizarse. Asimismo, pueden reparar o modificar los modelos existentes, y probarlos, efectuar demostraciones y ponerlos en funcionamiento en los lugares de fabricación o en las instalaciones de los clientes. Pueden instruir a otros sobre el modo de utilizar un modelo.

\section{Profesiones asociadas y específicas}

Los modelistas pueden clasificarse en función de la industria I (p. ej., automoción, joyeria-platería, cerámica y porcelana), del principal material utilizado (p. ej., madera, chapa de metal), o de la clase específica de productos (mapas en relieve, aparatos domésticos, etc.) (D O T ).

\section{Tareas}

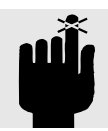

Abradir; ajustar; alinear; analizar; aplicar; averiguar; montar; sacar copias cianográficas; empernar; pegar; taladrar; latonar; cepillar; construir; tallar; comprobar; burilar; afianzar; limpiar; revestir; acordar; conectar; consultar; corregir; cubrir; cortar; desbarbar; efectuar demostraciones; diseñar; determinar; desmontar; desconectar; desarmar; dibujar; perforar; estimar; examinar; fabricar; atar; archivar; rellenar; dar el acabado; encajar; formar; estructurar; acristalar; moler; encolar; amartillar; acabar a mano; indicar; inspeccionar; instalar; instruir; interpretar (bocetos, etc.); enlazar; lacar; proyectar; izar; mecanizar; mantener; realizar; manufacturar; marcar;medir; fundir; arreglar; fresar; mezclar; modificar; moldear; desplazar; pintar; ejecutar; colocar; alisar; planificar; pulir; ubicar; verter; leer (especificaciones, etc.); reensamblar; refundir; reparar; sustituir; eliminar; remachar; lijar; raspar; atornillar; trazar; seleccionar; efectuar revisiones; armar; conformar; afilar; rasurar; esbozar; igualar; soldar; extender; estudiar; comprobar; transportar; recortar; adaptar; utilizar; verificar; encerar; cablear.

\section{Riesgos}

\section{Riesgos de accidente}

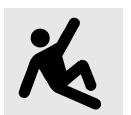

- Lesiones producidas al trabajar con equipos de fabricación, como tornos, taladradoras, discos, troqueles y diversas herramientas de mano y de cortar (p. ej., cuchillas, llaves, destornilladores, buriles, etc.);

- Cortes y punzadas causadas por cuchillos, objetos afilados, herramientas de mano, golpeo con piezas metálicas, etc.

R esbalones, tropiezos y caídas, sobre todo al desplazar materias primas y modelos acabados pesados;

- R esbalones, tropiezos y caídas en superficies sin cambio de nivel, sobre todo en suelos húmedos, resbaladizos o sobre los que se ha derramado aceite, al desplazar aparatos pesados

A plastamiento de los dedos de los pies como resultado de caídas de objetos pesados

- Q uemaduras y escaldaduras a causa del contacto con materiales calientes o herramientas calentadas; de la realización de operaciones de soldadura, etc.

- Lesiones oculares producidas por partículas y objetos proyectados al realizar operaciones de moler, mecanización, abrasión, pulido, taladro y otras similares; así como por salpicadura de sustancias químicas corrosivas y reactivas, etc.;

- Incendios y explosiones causados por sustancias inflamables y explosivas (p. ej., disolventes) o por llamas originadas en operaciones de corte con soplete 0 arco eléctrico, soldadura, etc.;

- Descargas eléctricas causadas por el contacto con equipos eléctricos y electromecánicos defectuosos;

\section{Riesgos físicos}

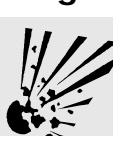

Estos riesgos suelen ser propios de cada tipo específico de industria (p. ej., la exposición a un calor excesivo geindustria cerámica).

\section{Riesgos químicos}

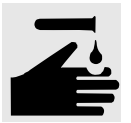

Intoxicación crónica y enfermedades de la piel como resultado de la exposición a una amplia gama de sustancias químicas (p. ej., disolventes, lacas, barnices, limpiadores, decapantes y diluyentes):

- Irritación ocular, mareos, náuseas, problemas respiratorios, migrañas, etc., causados por el contacto con sustancias irritantes (p. ej., polvos de madera y de metal, humos y disolventes);

- En algunas industrias, se registra un aumento acusado del riesgo de padecer cáncer debido a la exposición a productos de la madera, polvo, plásticos, disolventes, etc.

- Trastornos gastrointestinales como resultado de la ingestión crónica de adhesivos, pinturas, disolventes, etc.;

- Exposición excesiva al ozono durante las operaciones de soldadura con arco eléctrico.

\section{Riesgos biológicos}

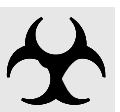
Los riesgos biológicos pueden afectar a los modelistas que trabajan en un entorno en el que se exponen potencialmente a microorganismos, plantas alergénicas, pelo, pieles, etc.

\section{Factores ergonómicos y sociales}

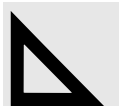

Lesiones musculares y óseas agudas causadas por un esfuerzo físico excesivo y por la combinación incorrecta de peso y postura al izar y trasladar cargas pesadas de materias primas y modelos terminados;

Trastornos traumáticos acumulativos, como el síndrome del túnel carpiano, causados por un trabajo repetitivo realizado durante mucho tiempo;

- Cansancio y malestar general

- Estrés psicológico ocasionado por el miedo a pasar por alto imperfecciones en el modelo que se trasladen a la producción en masa, y al intentar cumplir con especificaciones de trabajo difíciles o inusuales o con plazos de realización estrictos. 


\section{OPERADOR DE CALDERA}

Sinónimos: Auxiliar de caldera; trabajador de la sala de calderas; encargado del tratamiento del agua de caldera; operador del generador de vapor; operador de suministro de vapor

\section{Perfil del empleo}

\section{Definición y/ o descripción}

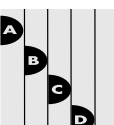

Estos trabajadores se ocupan de poner en funcionamiento calderas alimentadas por fueloi para generar vapor destinado al suministro de procesos indus triales, edificios, etc. Encienden calderas de gas, petróleo o combustibles sólidos utilizando fuentes de ignición; regulan el flujo de combustible y de agua que se introduce en la caldera. O bservan los paneles de control y regulan la temperatura, la presión, la aspiración y otros parámetros de funcionamiento. O bservan las calderas y las unidades auxiliares para detectar averías y realizar reparaciones. Cambian los quemadores, las tuberías y los empalmes de canalización. Comprueban y tratan el agua de alimentación de la caldera, utilizando sustancias químicas especiales, columnas de intercambio de iones, etc. Activan las bombas o los flujos de presión para retirar el polvo de cenizas de los dispositivos de alimentación y el agua contaminada de sistema, y limpian mediante descarga de agua los materiales depositados para su eliminación en el pulverizador de cenizas. Ayudan a los equipos de mantenimiento de calderas en las operaciones de conservación y reparación.

\section{Tareas}

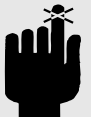

Activar (bombas); ajustar; montar y desmontar; cargar; comprobar; limpiar; (válvulas, depósitos de combustible) detectar (averías); rellenar encender; fijar; eliminar mediante descarga de agua (materiales depositados); instalar encender; cargar y descargar (combustible); mantener (aislamiento, etc.); medir; supervisar; poner en funcionamiento; regenerar (resinas del permutador de iones); regular (flujo, temperatura); eliminar (cenizas, residuos); reparar; sellar (fugas); atornillar; aprovisionar de combustible; comprobar (agua de alimentación); tratar (agua de alimentación); utilizar llaves de tuercas.

\section{Industrias en las que esta profesión es común}

Servicios y plantas de fabricación que requieren vapor para su funcionamiento; por ejemplo, en la industria química, la industria del plástico, las centrales eléctricas; los servicios de lavandería ; los hospitales; las industrias de la alimentación; la industria marítima; las instalaciones de desalinización; etc.

\section{Riesgos}

\section{Riesgos de accidente}

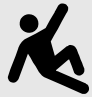

- Resbalones y caídas en superficies llanas, sobre todo cuando se ha derramado agua, combustible, aceite, etc.;

- Accidentes mecánicos al utilizar pulverizadores y atizadores en calderas de carbón;

- Explosión de calderas (debido a un sobrecalentamiento, al fallo de los componentes estructurales a causa de la fatiga de los metales, etc.), con probabilidad de incendio; lesiones producidas por la onda de la explosión o por los fragmentos despedidos, las llamas, el vapor, etc.;

- Incendios y explosiones de combustible (sobre todo debidos a fugas); trapos impregnados de combustible; explosiones de mezclas de gas y aire dentro de la caldera;

- Incendios provocados por el hollín;

- Q uemaduras producidas por el contacto con superficies calientes, agua a alta temperatura y fuga de vapor;

- Electrocución o descargas eléctricas;

- Asfixia debida al agotamiento del oxígeno respirable en la atmósfera circundante;

Intoxicación por monóxido de carbono u otros productos de combustión presentes en la atmósfera, sobre todo en el caso de una ventilación deficiente 0 un suministro de aire inadecuado a los quemadores (la intoxicación aguda por monóxido de carbono puede provocar migrañas, mareos, náuseas, pérdidas de conciencia, coma y muerte);

- Las salpicaduras de hidracina y sus derivados sobre la piel puede causar quemaduras profundas y dermatitis graves

- Las salpicaduras en los ojos de las sustancias químicas utilizadas en la regeneración de las columnas de permutación de iones y en las operaciones de desoxidación y desincrustación y, en especial, las de hidracina y sus derivados, pueden causar lesiones permanentes en la córnea.

\section{Riesgos físicos}

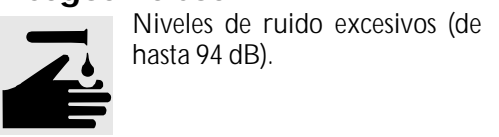

Riesgos químicos

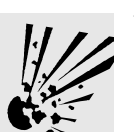

N eumoconiosis debida a la exposición al polvo con contenido de vanadio y a amianto procedente de aislamiento, sobre todo en los trabajos de mantenimiento y reparación, así como al contacto con cenizasen suspensión respirables;

- Dermatosis debidas a la exposición a combustibles y a los inhibidores de la corrosión (diversos compuestos orgánicos o metalorgánicos) y otros aditivos del agua;

- Irritaciones oculares, del aparato respiratorio y de la piel como resultado de la exposición a la hidracina y sus derivados, utilizados como aditivos del agua de la caldera; una exposición grave puede provocar ceguera temporal;

- Irritación de las vías respiratorias supe riores y tos como consecuencia de la inhalación de dioxido de azufre, en especial al quemar combustibles con un alto contenido de este metaloide;

- Exposición a sustancias químicas y compuestos aplicados al tratamiento del agua; en especial, inhibidores de la corrosión y eliminadores de oxígeno como la hidracina; sustancias químicas utilizadas en la regeneración de resinas de permutación de iones, tanto ácidos como bases; productos y disolventes de limpieza, desoxidación y desincrustación; monóxido de carbono; dióxido de carbono; oxidos de nitrógeno; dióxido de azufre; polvos que contienen óxidos refractariosy óxido de vanadio.

\section{Riesgos biológicos}

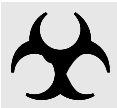
D esarrollo de hongos y crecimiento de bacterias en las salas de calderas debido a la elevada temperatura y humedad.

\section{Factores ergonómicos y} sociales

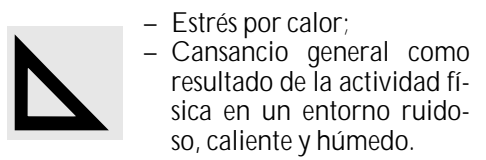

Informac. complementaria

Notas

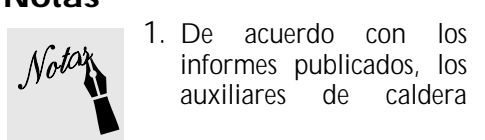


pueden estar sometidos a un mayor riesgo de cáncer de pecho o nasofaríngeo; además, la exposición de los operadores de caldera a la hidracina y sus derivados puede causar daños en los pulmones, el hígado y los riñones.

2. Existen riesgos especiales cuando se utilizan residuos como combustible; el operador de caldera puede entrar en contacto con una amplia gama de sustancias químicas peligrosas presentes en los mismos o formadas durante su combustión (p. ej., furanos, derivados de dióxidos, humos metálicos, fibras minerales, etc.). A simismo, el operador puede exponerse a las mordeduras y las picaduras de parásitos, insectos e, incluso, pequeños animales (p. ej., serpientes, escorpiones) presentes en los residuos, así como a infecciones bacterianas.

3. Puesto que las salas de calderas suelen ubicarse en sótanos, en algunas regiones existe el riesgo de exposición al radón.

\section{Referencias}

American National Standards Institute (ANSI). 1987. Gas-fired Low-pressure Steam and $\mathrm{H}$ ot $W$ ater Boilers. ANSI Standard Z21.13-87. Nueva Y ork: ANSI.

Parsons, RA (dir.). 1988. Boilers. En ASHRAE H andbook: Equipment. Atlanta, GA: American Society of $H$ eating, R efrigerating and Air-conditioning Engineers. 


\section{PINTOR (NO ARTISTICO)}

Sinónimos: Pintor de brocha; barnizador; pulverizador de pintura; especialista en pinturas

\section{Perfil del empleo}

\section{Definición y/o descripción}

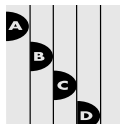

Estos trabajadores aplican pintura a las paredes y a superficies de madera, metal y de otro tipo que preparan con anterioridad. Cubren con telas suelos, máquinas y muebles. Instalan andamios o colocan escaleras de mano para trabajar por encima del nivel del suelo. Retiran los elementos fijados a la superficie de trabajo (como cuadros, clavos e interruptores). Eliminan las capas de pintura anteriores utilizando decapantes, rascadores, cepillos de alambre o lámparas de quemar. Tapan agujeros, grietas y juntas con plaste, masilla, yeso u otro material de relleno. Alisan las superficies con la ayuda de pape de lija, acero, madera y cepillos. Las lavan y tratan con agua u otros medios de limpieza. Seleccionan la pintura premezclada 0 mezclan sus componentes. A plican capas de pintura, barniz, tinte, esmalte o laca a las superficies mediante el empleo de brochas, pistolas pulverizadoras, rodillos 0 equipos electrostáticos. Pueden secar o endurecer la pintura en hornos especiales. Asimismo, pueden cortar patrones y pintar con broch o pulverizador elementos decorativos y rótulos sobre las superficies.

\section{Tareas}

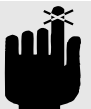

Secar con aire; aplicar (pintura); proyectar (aire seco); empernar; pegar; cepillar; quemar; calcular; acarrear calafatear: aplicar (aglutinante); limpiar; subir (a escaleras de mano, andamios); recubrir; cortar; decorar disolver; secar; depositar (electrostáticamente); esmaltar; instalar (andamios); rellenar; filtrar; dar el acabado; encolar moler; lacar; rotular; cargar y descargar marcar; utilizar estarcidos; armonizar medir; mezclar; desplazar; operar (pistolas de pulverización, etc.); pintar; engrudar; ornar con motivos; enyesar; verter; preparar (superficies); adquirir; emplastecer; regular (flujos): retirar (pintura, óxido, elementos fijados a las superficies, etc.); reparar; pasar el rodillo; raer; lijar; raspar; atornillar y destornillar; sellar; seleccionar; colocar (escaleras de mano, etc.); chorrear con granalla; alisar; pulverizar; extender; tintar; estampar (patrones y diseños); desmontar rodear con cinta; retocar; trazar; transferir transportar; barnizar; lavar; encerar enlucir; limpiar frotando; utilizar llaves de tuercas.

\section{Equipo básico utilizado}

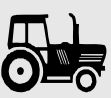

Brochas de mano; rodillos: dispositivos de pulverización (con presión de aire o sin aire; manuales 0 automáticos) equipos electrostáticos de pintura; hornos de secado para pintura; lámparas o ventiladores de aire caliente; mezcladoras de pintura; herramientas para el decapado de pintura (manuales o eléctricas).

\section{Riesgos}

\section{Riesgos de accidente}

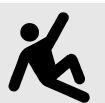

C aídas desde altura (de escaleras de mano, plataformas elevadas fijas y móviles, andamios, tejados, cubiertas de depósitos, a través de aper-

\section{turas en los tejados, etc.);}

Resbalones y caídas en superficies sin cambio de nivel, sobre todo en suelos deslizantes;

- Electrocución o descarga eléctrica (generadas por equipos eléctricos defectuosos, por el contacto de escaleras metálicas de mano con conductos eléctricos, durante el trabajo con equipos de pintura electrostáticos de alto voltaje, etc.):

- Inyección hipodérmica de pintura en los dedos, las manos y (con menor frecuencia) en otras partes del cuerpo al trabajar con equipos de pulverización a presión sin aire. Este tipo de inoculación puede dar lugar a una penetración profunda y a la amputación de los dedos afectados;

- Daños oculares graves de carácter mecánico producidos por chorro de pintura a alta presión;

- Incendios y explosiones de disolventes de pintura inflamables y otras sustancias, en especial al trabajar (pintando o mezclando) en espacios cerrados con una ventilación deficiente. Las lacas para muebles pueden contener nitrocelulosa, una sustancia explosiva que puede estallar por golpeo o calentamiento si se permite que los residuos de laca se sequen:

Incendios y explosiones como resultado de las descargas generadas al utilizar sistemas electrostáticos con pinturas en polvo, de las chispas producidas cuando las partículas metálicas ( $p$. ej.. en pinturas que contienen polvos de metal) impactan en la superficie metálica sobre la que se trabaja, o de la ignición de pinturas con aglutinantes que se oxidan al contacto con el aire;

- Ropas que se prenden, dentro o fuera de la zona de trabajo, al impregnarse con pinturas 0 aceites;
Salpicadura de pintura debida a la explosión de tubos o producida al intentar desatascar las boquillas de pulverización bloqueadas;

- Penetración de partículas extrañas en los ojos al preparar las superficies para pintar (p. ej., en las operaciones de chorreado con granalla o lijado):

- Cortes, punzadas, abrasiones, etc. en dedos y manos al preparar las superficies con la ayuda de medios mecánicos;

Penetración de astillas en la piel al preparar superficies de madera para pintar;

- Aplastamiento de miembros y golpes en otras partes del cuerpo al trabajar en una posición suspendida;

- Abrasiones de la piel con los peldaños de las escaleras de mano;

- Irritación ocular o daños en la córnea debido a la salpicadura de gotas de disolvente en los ojos:

- Asfixia en espacios cerrados como re sultado de una deficiencia de oxígeno agravada por la presencia de vapores de disolvente.

\section{Riesgos físicos}

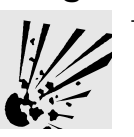

Ruido producido por pis tolas de pulverización equipos de chorreado con granalla;

Exposición a radiación ultravioleta o infrarroja y al calor producidos por los dispositivos de secado de pintura;

- Exposición al frío, la lluvia, la nieve y el viento en invierno, 0 al calor y la radiación solar en verano, sobre todo al efectuar trabajos en el exterior;

- Exposición a corrientes de aire en edificiosen construcción.

\section{Riesgos químicos}

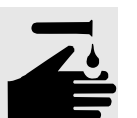

Dermatitis profesional de contacto como resultado de la exposición a diversos componentes de las pinturas y a disolventes; en particular, a hidrocarburos alifáticos y aromáticos, y a compuestos organohalógenos;

I rritación ocular (con posibilidad de daños permanentes de la capacidad visual) y del aparato respiratorio producida por diversos componentes de la pintura, como el tolueno y los diisocianatos de metileno:

Intoxicaciones agudas, fundamentalmente como resultado de la inhalación de disolventes, sobre todo en espacios cerrados con una ventilación inadecuada. Las intoxicaciones leves tienen un efecto narcótico que reduce la vigilancia y aumenta de forma acusada el ries- 
go de caídas y otro tipo de accidentes, en ocasiones con consecuencias graves. Las intoxicaciones graves pueden resultar mortales;

- Intoxicación por fosgenos formados por diversos disolventes clorados en contacto con una fuente de calor en condiciones de combustión parcial;

- Intoxicación por plomo existente en pinturas de imprimación y por otros componentes metálicos de las pinturas (p. ej.. compuestos de mercurio y arsénico utilizados como fungicidas en las pinturas de látex, compuestos organoestánnicos presentes en las pinturas antivegetativas utilizadas en embarcaciones; cromato de cinc incluido en distintas pinturas de imprimación sin plomo, etc.)

- Intoxicación por sustancias decapantes de pintura como el cloruro de metileno 0 disolventes mezclados;

- Intoxicación producida por componentes peligrosos de la pintura, dependiendo del tipo utilizado (p. ej., formaldehídos en las pinturas que los contienen y melamínicas, resinas epóxidicas, diisocianato de tolueno y de metileno en las pinturas de poliuretano, etc.);

- Efectos neurotóxicos debidos al trabajo con pinturas que contienen disolventes con hexano normal 0 pigmenos de plomo.

\section{Factores ergonómicos y sociales}

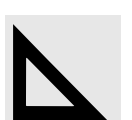

D olores de cuello u hombro, torceduras y distensiones de las extremidades superiores y trastornos musculares y óseos en general, como resultado de la adopción de posturas inadecuadas, sobre todo al pintar techos;

- Tensión ocular padecida por los pintores de artículos de pequeño tamaño
Dolores de rodilla y lesiones del cartílago de la articulación:

- Molestias cardiorrespiratorias al utilizar equipos de protección respiratoria.

\section{Informac. complementaria}

\section{Notas}

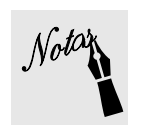

1. Se han publicado informes en los que se afirma que los pintores pueden estar expuestos a un mayor riesgo de cáncer de pulmón, vejiga, estómago, riñón, esófago e intestino grueso y de leucemia si utilizan pinturas que contienen benceno; de demencia presenil como resultado de la exposición a disolventes, de bronquitis crónica y enfermedades de obstrucción de las vías respiratorias; de neumoconiosis por inhalación de polvo de compuestos químicos; de deficiencia renal; y de daños en el cristalino como resultado de la exposición a disolventes durante períodos prolongados.

2. Existe un riesgo especial asociado al decapado mecánico o químico y a la combustión de pinturas antiguas. La utilización de pigmentos que contienen plomo, arsénico o mercurio en las pinturas modernas ha quedado muy restringido y en numerosos países está prohibida por la legislación (excepto en algunas aplicaciones especializadas); no obstante, las pinturas antiguas pueden contener una cantidad considerable de tales sustancias que, al decapar o quemar, son liberadas en la atmósfera en forma de polvo o de humos capaces de producir intoxicaciones.
3. Se ha observado que la exposición a éteres de etilenglicol y acetatos presentes en las pinturas puede tener un efecto perjudicial para el aparato reproductivo.

\section{Referencias}

$\mathrm{H}$ ealth and Safety Executive (HSE). 1991. H ealth and Safety in M otor-vehicle Repair: Painting. HSE Publication HS(G) 67. Londres: HSE.

0 'N eill, L. 1995. Health and safety in paints and painting. In Croner's $\mathrm{H}$ andbook of $\mathrm{O}$ ccupational $\mathrm{H}$ ygiene. $\mathrm{V}$ ol. 2 , part 8.19. K ingston-uponThames: Croner's Publications $L$ td.

\section{Apéndice}

Sustancias y productos químicos a los que un pintor puede verse expuesto: Las formulaciones decapantes de pintura contienen, en particular, cloruro de metileno, cresol, fenol, hidróxido de potasa, y/ o hidrocarburos alicíclicos (p. ej., metilciclohexano). Las pinturas pueden contener cadmio, plomo, compuestos organoestánnicos, compuestos de mercurio y arsénico, cromatos, epoxi, poliuretano, acrilato, vinilo y otras resinas y sus componentes. Los disolventes y los diluentes incluyen trementina, fracciones de petróleo (nafta, bencina, disolvente de Stoddard), hexano normal, tolueno, xileno, benceno, acetona, etilo de metilo y otras cetonas, alcoholes (metilo, etilo, isopropilo, amilo, etc.), formaldehído, fenol, etc. Las formulaciones de limpieza contienen ácidos (que pueden estar compuestos por diversos inhibidores orgánicos), álcalis, disolventesorgánicos, etc. 


\section{REPARADOR DE APARATOS ELECTRICOS}

Sinónimos: Representante del servicio de mantenimiento de aparatos eléctricos; reparador de pequeños aparatos electrodomésticos

\section{Perfil del empleo}

\section{Definición y/ o descripción}

A L Estos trabajadores se ocupan de reparar aparatos eléctricos como tostadores, dispositivos de cocción, cafeteras, lámparas y planchas, utilizando herramientas de mano e instrumentos de comprobación eléctrica. Detectan la presencia de defectos mecánicos en estos aparatos y los desmontan. Comprueban el cableado para determinar la existencia de circuitos abiertos o cortocircuitos, recurriendo a voltímetros, ohmímetros y otros galvanómetros. Sustituyen los cables y los componentes defectuosos, como los elementos de un tostador o el serpentín de una cafetera, con la ayuda de herramientas de mano, soldadores y equipos de soldadura eléctrica por puntos. Pueden cobrar por la mano de obra y los materiales empleados. Pueden colaborar con los servicios de reparación de dispositivos eléctricos (de cualquier sector) en el arreglo de aparatos como refrigeradoresy hornos (DOT).

\section{Profesiones asociadas y específicas}

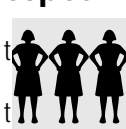

Reparador de aparatos elecrodomésticos (y profesiones afines de acuerdo con cada ipo de aparato; p. ej., reparador de mezcladores de alimentos; reparador de calentadores; reparador de tostadores; reparador de aspiradores; etc.) montador (de aparatos electrodomésticos); ajustador de aparatos eléctricos (y profesiones afines de acuerdo con cada tipo de aparato; p. ej., ajustador de cafeteras, ajustadores de refrigeradores eléctricos; ajustador de lavadoras; etc.) técnicos de mantenimiento de aparatos eléctricos (y profesiones afines de acuerdo con cada tipo de aparato); instalador de aparatos electrodomésticos; diagnosticador de averías; encargado de desembalaje.

\section{Tareas}

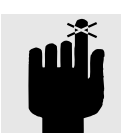

Ajustar; asesorar (clientes); alinear; aplicar; montar, desmontar y volver a montar asistir; doblar; empernar; taladrar; latonar; calcular (costes, parámetros de cableado, etc.); calibrar comprobar; limpiar; computar (gastos, etc.) conectar; cortar; efectuar demostraciones (de aparatos en funcionamiento); determinar (los requisitos de reparación) manejar; detectar (defectos); instalar insertar; aislar; unir; llevar (registros); izar; cargar y descargar; localizar (cortocircuitos y tomas de tierra, etc.); lubricar; mantener (existencias de piezas); marcar; medir (dimensiones, parámetros eléctricos); arreglar; mover (aparatos pesados); observar (los aparatos en funcionamiento, las lecturas de los instrumentos); poner en funcionamiento (aparatos, equipos); pintar; colocar; pulir; preparar; registrar (datos de la reparación); reparar; sustituir; eliminar; atornillar y destornillar; sellar; seleccionar; efectuar revisiones; regular; soldar; empalmar (cables); desforrar (hilos); probar; retocar (defectos de pintura); examinar (circuitos eléctricos); transportar; diagnosticar: desembalar; utilizar (herramientas, destrezas, etc.); lavar; cablear; envolve (cables con cinta).

\section{Riesgos}

\section{Riesgos de accidente}

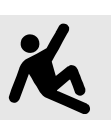

Cortes y punzadas causadas por herramientas de trabajo bordes afilados de piezas de los aparatos en reparación etc.;

R esbalones, tropiezos y caídas en superficies sin cambio de nivel, sobre todo en suelos húmedos, resbaladizos o sobre los que se ha derramado aceite, al desplazar aparatos pesados:

Caídas desde superficies en altura al ins talar o reparar unidades situadas en el exterior de aparatos de aire acondicionado "en dos piezas", ventiladores de techo, etc.

- Lesiones mecánicas debidas al contacto con piezas rotatorias de aparatos en reparación (p. ej., ventiladores);

Intoxicación aguda y quemaduras de origen químico como resultado de la utilización de disolventes, adhesivos y otras sustancias químicas;

R iesgo de incendio vinculado a la utilización de sustancias inflamables:

- Quemaduras causadas por el contacto con elementos calientes de los aparatos en reparación (p. ej., planchas), metales fundidos (al soldar) o como resultado de una emisión repentina de vapores (p. ej. de las cafeteras);

- Descargas eléctricas causadas por el contacto con cables con corriente;

Riesgo de accidentes de tráfico al dirigirse al lugar de prestación del servicio o a volver del mismo.

\section{Riesgos físicos}

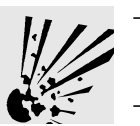

Exposición a la radiación de microondas al reparar los hornos que las utilizan:

Aumento del riesgo de exposición a la radiación.

Riesgos químicos

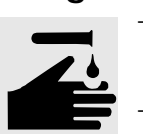

Efectos toxicológicos crónicos asociados a las operaciones de soldadura;

Intoxicación crónica como resultado de la exposición a fluorocarbonos, cloruro de metilo y otras sustancias utilizadas en los frigoríficos, aparatos de aire acondicionado, etc.

\section{Riesgos biológicos}

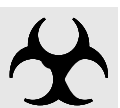

Pueden existir riesgos biológicos asociados a la reparación de aparatos que han sido utilizados por personas enfermas (p. ej., secadores de pelo, cepillos de dientes eléctricos, afeitadoras eléctricas, etc.), o se han puesto en funcionamiento en atmósferas contaminadas (p. ej., aspiradoras).

\section{Factores ergonómicos y} sociales

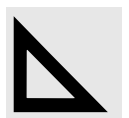

- Lesiones musculares y óseas agudas causadas por un esfuerzo físico excesivo y posturas inadecuadas adoptadas al desplazar e instalar aparatos pesados

- Trastornos traumáticos acumulativos, como el síndrome del túnel carpiano causado por trabajos repetitivos de larga duración que exigen, fundamentalmente, la realización de movimientos de manos, brazos y dedos (en el caso de reparadores de aparatos que prestan sus servicios en cadenas de montaje 0 en puestos de trabajo que requieren una actividad repetitiva),

- Cansancio y malestar general;

- Incomodidad visual y tensión ocular como resultado de la necesidad de observar piezas de pequeño tamaño en condiciones de iluminación deficientes (p. ej., dentro del aparato);

- Estrés psicológico como resultado del trabajo sometido a la presión del tiempo y del trato con clientes insatisfechos.

\section{Informac. complementaria}

Nota

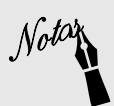

1. No existe un acuerdo generalizado respecto al peligro que constituye la radiación electromagnética de frecuencia muy baja y extre madamente baja. 
SOLDADOR (electrosoldeo)

\author{
Sinónimo: Soldador por fusión
}

\section{Perfil del empleo}

\section{Definición y/ o descripción}

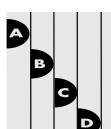

Los soldadores unen piezas metálicas mediante diversos procesos en los que las superficies de éstas suelen calentarse hasta su fusión, con 0 sin presión; los principales métodos de soldadura por fusión son la utilización de arco eléctrico (incluidos los arcos con electrodo metálico, con electrodos protegidos con gas inerte, con núcleo de fundente, con soplado de gas inerte ionizado y sumergidos en atmósfera inerte), la llama de gas (oxiacetileno, gas oxhídrico), la soldadura por resistencia eléctrica, el haz eléctrico, la inducción, el rayo láser, la aluminotermia, la soldadura con electroescoria y la soldadura en estado sólido (fricción, explosión, difusión, ultrasonidos y frío). Seleccionan e instalan equipos y materiales de soldadura manuales y automáticos de acuerdo con las especificaciones de trabajo o con las instrucciones de los supervisores. Examinan y preparan las superficies que deben unirse efectuando operaciones de limpieza, desengrasado, cepillado, limado, molturación y otras. Colocan las piezas de trabajo. Ajustan las válvulas o los interruptores eléctricos pertinentes para controlar el flujo de gas, corriente eléctrica, etc. Encienden 0 apagan la llama de gas, el arco eléctrico, la mezcla de termita u otras fuentes de calor. Guían y aplican la llama, el electrodo, la varilla de metal de aportación, el rayo láser, etc., a las piezas. Examinan las juntas soldadas para comprobar su calidad y su adecuación a las especificaciones.

\section{Profesiones asociadas y específicas}

nt

Cortador en caliente (oxicorte, corte con arco eléctrico, corte con haz de electrones); restaurador con soldadura; operador de electroerosionadora.

\section{Tareas}

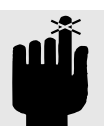

Ajustar (flujo, presión, etc.); alinear; recocer; aplicar (fundentes); cortar con arco eléctrico; soldar con arco eléctrico; montar y desmontar; doblar; empernar; pegar; cobresoldar; cepiIlar; calcular (corriente); desbarbar (metal sobrante); sujetar; limpiar (superficies); conectar (tubos y cables); controlar; cortar; desengrasar; sumergir; restaurar (electrodos); examinar (calidad de las juntas); limar; rellenar; fijar; oxicortar; derretir; moler; guiar (la varilla a lo largo de la llama); amartillar; manejar; tratar con calor; calentar y precalentar; sostener; prender; instalar; insertar; unir; golpear (soldaduras); trazar; levantar y bajar; cargar y descargar; mantener; marcar; fundir; arreglar; desplazar; colocar; pulir; ubicar; preparar; resoldar; eliminar (residuos); reparar; escarpar (soldaduras); atornillar y destornillar; asegurar; seleccionar (herramientas, materiales); separar; efectuar revisiones; establecer; estañosoldar; pulverizar; enderezar; encender y apagar; regular (controles); estañar; utilizar soplete; retocar; restaurar con soldadura; soldar por fusión.

\section{Riesgos}

\section{Riesgos de accidente}

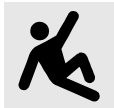

Caídas desde superficies en altura, sobre todo en la construcción;

Golpes por caída de piezas de gas, etc. metalicas pesadas, botellas

\section{Cortes y punza}

afilados, etc.;

- Quemaduras producidas por el contacto con superficies metálicas calientes, llamas, chispas proyectadas, gotas de metal fundido, radiación térmica, etc.

Partículas extrañas que se introducen en los ojos. Se trata de un riesgo muy común que puede concretarse incluso después de la extinción de la llama o del arco utilizadospara soldar;

Penetración de gotas de metal fundido o de chispas en los oídos (sobre todo al soldar por encima del nivel de la cabeza);

Incendios iniciados por chispas proyectadas, Ilamas, metales candentes, etc. Existe un riesgo específico de incendio cuando aumenta el nivel de oxígeno en la atmósfera circundante, ya que esta circunstancia favorece la ignición (p. ej., tanto las ropas como los lubricantes y los disolventes prenden con facilidad);

- Explosiones de polvo al soldar en instalaciones que contienen harina, cereales en polvo, etc.;

- Introducción de partículas metálicas proyectadas en la piel (de cara, cuello y manos);

Explosiones de neumáticos durante la soldadura de ruedas de vehículos;

- Ignición y explosión de hidrógeno (producidas por procesos de corrosión) y diversos gases combustibles residuales presentes en las mezclas con aire formadas en recipientes cerrados;

Intoxicación aguda a causa del fosgeno derivado de los hidrocarburos clorados que se utilizan para limpiar metales o como pintura, cola y otros disolventes, y de los gases peligrosos generados al soldar, en particular, el ozono, el monóxido de carbono y los óxidos de nitrógeno;

Electrocución o descargas en todos los procesos en que se aplican corrientes eléctricas; las corrientes de sobrevoltaje y la utilización de más de una fuente de suministro eléctrico al mismo tiempo conllevan riesgos específicos;

- Ignición de las prendas de vestir en procesos en que se emplean mezclas de gas y oxígeno, cuando la atmósfera circundante se enriquece con oxígeno ("se oxigena") voluntaria o involuntariamente, sobre todo si la ropa está impregnada de aceites o grasa;

Incendios y explosiones en el sistema de soldadura (tuberías, generador de acetileno) en procesos de oxisoldeo con mezclas de gas y oxígeno, especialmente debidos a retornos o retrogresiones de la llama a causa de la deficiencia de los equipos o un error humano;

- Incendios y explosiones debidos a una manipulación inadecuada del carburo de calcio o el acetileno en las operaciones de soldadura oxiacetilénica;

Posibilidad de que ropas, pelo, etc., se enreden, 0 dedos o brazos queden atrapados en soldadoras automáticas ("robotizadas").

\section{Riesgos físicos}

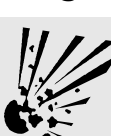

Exposición a niveles de ruido excesivos;

Exposición a calor o frío intensos, sobre todo en trabajos de construcción;

Exposición a rayos $X$ o gamma al inspeccionar las sueldas mediante radiografía;

- Exposición a los rayos $X$ generados por las soldadoras de haz de electrones;

Daños oculares crónicos, sequedad de la piel y otros problemas cutáneos ("erupción por calor") como resultado de la exposición a la luz actínica intensa (sobre todo a la ultravioleta) y al calor. Tales trastornos pueden agravarse si se dispone de un sistema de ventilación por aspiración adecuado, ya que éste elimina el efecto de pantalla del polvo.

\section{Riesgos químicos}

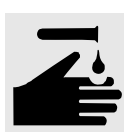

Exposición a humos de soldadura (véase la nota 3);

Intoxicación crónica como resultado de la exposición al cinc 0 al cadmio presentes en humos generados al soldar piezas tratadas con estos metales, a los bifenilos policlorados derivados de la descomposición de aceites anticorrosión, a los componentes de los productos de descomposición térmica obtenidos al soldar piezas pintadas, 0 al amianto resultante del oxicorte de piezas recubiertas con este material;

- Siderosis (un tipo de neumoconiosis), como resultado de la inhalación de óxido de hierro: 
- Daños del sistema nervioso central, los pulmones y el hígado debidos a la inhalación de fosfina (esta sustancia puede desprenderse en forma de vapor durante la generación de acetileno con carburo de calcio de baja pureza):

- Enfermedades respiratorias debidas a una elevada concentración de dióxido de carbono en la atmósfera y la deficiencia de oxígeno asociada a la misma, sobre todo en lugares cerrados y deficientemente ventilados (este problema puede agravarse en el caso de trabajadores con trastornos cardiovasculares o pulmonares);

- Irritaciones oculares y del sistema pulmonar causadas por los óxidos de nitrógeno y el ozono;

- Intoxicación por monóxido de carbono.

\section{Factores ergonómicos y sociales} - Lesiones por esfuerzo repeti-
tivo debidas al trabajo de carga estática;

- Trastornos musculares y óseos causados por el trabao en posturasinadecuadas

- Tensión ocular y cansancio;

- Cargas de trabajo físico extenuantes al levantar piezas pesadas;

- Estrés muscular y tensión en las manos a utilizar pistolas de soldadura pesadas, en especial al trabajar por encima del nive de la cabeza.

\section{Informac. complementa ria}

\section{Notas}

Notag

1. De acuerdo con los informes publicados, los soldadores se exponen a un mayor riesgo de padecer neumoconiosis (y, en particular, siderosis), cáncer de varios tipos (p. ej., de hígado, nasal, sinonasal y de estómago) y posibles pérdidas auditivas debidas al efecto combinado del ruido y el contacto con monóxido de carbono.

2. Los hombros y el cuello de los soldadores quedan expuestos en gran medida a la acción de las chispas y del calor.

3. La exposición a humos constituye el principal riesgo químico en la mayoría de los procesos de soldadura. Estos humos se forman en el aire al enfriarse y condensarse las sustancias volatilizadas por el calor en el proceso de soldadura y son generados por los metales de base soldados, por los electrodos y sus revestimientos, las varillas de aportación, los fundentes, etc., utilizados al trabajar, así como por los materiales "extraños", como los metales y capas de pintura presentes en el metal de base, los residuos de los materiales de limpieza y otros. Como norma, el tamaño de las partículas de los humos es micrométrico o submicrométrico, pero éstas pueden fusionarse y formar agregados mayores. La mayoría de las partículas de humo son "respirables" $y$, por tanto pueden penetrar profundamente en el sistema respiratorio y depositarse en el mismo. Los humos de soldadura suelen contener óxidos de los metales sobre los que se trabaja (en especial, en el caso de acero, el hierro, el cromo, el níquel, el manganeso, el vanadio y otros) y de los electrodos, silicio, aluminio magnesio y óxidos alcalinos y alcalinoterrosos (sobre todo de bario), y pueden incluir cantidades sustanciales de fluoridos y productos de descomposición y residuos de pintura, aceite y disolvente. Los humos producidos al utilizar electrodos toriados contienen óxido de torio. Al soldar metales no ferrosos, los humos generados pueden contener óxidos de éstos y pequeñas cantidades de impurezas altamente tóxicas, como compuestos de arsénico y antimonio. La cantidad de humos formados depende del tipo de proceso de soldadura, pero pueden alcanzarse niveles de 2-3 $\mathrm{g} / \mathrm{min} 0$ incluso superiores (p. ej., en la soldadura con arco eléctrico manual o con electrodos con núcleo de fundente). 


\section{SOLDADOR (estañosoldeo, cobresoldeo)}

Sinónimos: 0 perador de equipos de soldeo; especialista en soldadura fuerte; soldador con plata; soldador con aleaciones de cobre; la tonero

\section{Perfil del empleo}

\section{Definición y/ o descripción}

A Estos profesionales unen piezas metálicas mediante una aleación fusible ("estañosoldadura" o "cobresoldadura"; véase la Nota 1). Seleccionan e instalan equipos y materiales de soldadura manual 0 automática de acuerdo con las especificaciones de trabajo. Examinan y preparan las piezas que deben unirse efectuando operaciones de limpieza, desengrasado (pueden aplicar desengrasadores ultrasónicos), cepillado, limado y otras. Fijan dichas piezas en la posición adecuada para soldar. Encienden y controlan corrientes eléctricas y llamas de gas. Limpian la punta de los soldadores. Además de estas herramientas, aplican fundentes, soplete o llama, alambre de soldar, etc. a las piezas. Examinan éstas para comprobar su calidad y su adecuación a las especificaciones. Limpian la superficie de las piezas soldadas para eliminar el fundente que sobre y los residuos de soldadura. Pueden fundir y separar las juntas estañosoldadas para la reparación o la reutilización de las piezas.

\section{Tareas}

Ajustar (flujo, presión, etc.) alinear; recocer; aplicar (fundentes); cortar con arco eléctrico; soldar con arco eléctrico; montar y desmontar; doblar; empernar; pegar; cobresoldar; cepillar; calcular (corriente); sujetar; limpiar (superficies); conectar (tubos, cables); controlar; cortar; desengrasar; sumergir; examinar (calidad de las juntas); limar; rellenar; fijar; oxicortar; derretir; moler; guiar (la barra a lo largo de la llama); amartillar; manejar; tratar con calor; calentar y precalentar; sostener; prender; instalar; insertar; unir; golpear (soldaduras); trazar; levantar y bajar; cargar y descargar; mantener; marcar; fundir; arreglar; desplazar; colocar; pulir; ubicar; preparar; resoldar; eliminar (residuos); reparar; atornillar y destornillar; asegurar; seleccionar (herramientas, materiales); separar; efectuar revisiones; establecer; estañosoldar; pulverizar; enderezar; encender y apagar; regular (controles); estañar; utilizar soplete; retocar.

\section{Industrias en las que esta profesión es común}

El estañosoldeo y el cobresoldeo, como actividades desarrolladas a tiempo parcial 0 total, se llevan a cabo en un gran número de industrias, talleres, servicios técnicos, institutos de investigación, etc., como los que intervienen en la fabricación, el montaje, el mantenimiento y la reparación de todo tipo de componentes eléctricos y electrónicos; el acondicionamiento de aire y la refrigeración; la fabricación de recipientes, carcasas, depósitos de almacenamiento y contenedores metálicos; la instalación de líneas de suministro de gas y sustancias químicas; la fabricación y reparación de radiadores (en vehículos y hogares); la joyería; las actividades artísticas; los talleres de chapa de las instituciones de investigación; la fabricación y reparación de instrumentos musicales; los laboratorios dentales; numerosas industrias "domésticas", etc.

\section{Riesgos}

\section{Riesgos de accidente}

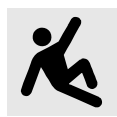

Golpes, sobre todo en los pies, debidos a la caída de piezas pesadas, secciones de tubería, etc.;

- Cortes y punzadas, especialmente en los dedos, con cantos afilados, salientes, limas (y otros instrumentos) al preparar las piezas para la soldadura y durante la limpieza de los productos soldados;

- Daños oculares como resultado de la penetración de partículas sólidas (sobre todo al utilizar cepillos giratorios de alambre 0 esmeriles para limpiar),de metal fundido 0 de gotas de fundente 0 de soluciones limpiadoras en los ojos:

- Electrocución y descargas al utilizar equipos de soldadura eléctrica;

Q uemaduras de la piel debidas al contacto con superficies calientes y salpicaduras de soldaduras o fundentes a elevada temperatura;

- Incendios como resultado de la ignición de disolventes y otras sustancias inflamables por la llama de soldeo o por chispas;

Incendios y explosiones, en especial al utilizar oxiacetileno, gas propano y otros procesos con lámpara de soldar;

Q uemaduras químicas como consecuencia de la salpicadura de las sustancias químicas corrosivas utilizadas en la limpieza de metales; sobre todo, de ácidos fuertes de mezclas de ácidos y soluciones oxidantes (p. ej., combinaciones de los ácidos sulfúrico y nítrico, o sulfúrico y crómico), de cremas limpiadoras de metales, etc.

- Intoxicaciones agudas (y, en ocasiones, mortales) por fosgeno y otros gases tóxicos formados por los disolventes clorados al contacto con una fuente de temperatura elevada, en especial al cobresoldar.

\section{Riesgos físicos}

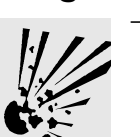

Exposición de los ojos a la uz intensa emitida en ciertos procesos de cobresoldeo realizados a temperaturas elevadas;

Erupciones como resultado de la exposición continua de la piel al calor generado en los procesos de estañosoldeo y cobresoldeo.

\section{Riesgos químicos}

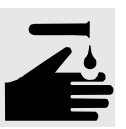

Alergias dérmicas como resultado de la exposición a disolventes, resina de trementina (colofonia), hidrazina, aminoetanolaminas y activadores contenidos en los fundentes;

Ulceración (y otros problemas dermatológicos) de las puntas de los dedos debida al manejo de piezas metálicas y el contacto con fundentes;

- Erupciones y dermatitis, en especial al utilizar fundentes líquidos;

- Irritaciones oculares, de las membranas mucosas y del aparato respiratorio como resultado de la exposición a aerosoles y gases generados en los procesos de limpieza con ácidos (p. ej.. óxidos de nitrógeno);

- Irritaciones oculares, de las membranas mucosas y del aparato respiratorio a causa del contacto con componentes de los fundetes o de los productos de descomposición liberados durante el soldeo (p. ej., ácido clorhídrico, cloruros de cinc y amoniaco), fluoruros, formaldehído (formado en la pirólisis de la soldadura con núcleo), fluoroboratos, resina de trementina, sales de hidracina, etc., o con el ozono y los óxidos de nitrógeno presentes en el aire durante ciertos procesos de cobresoldeo a alta temperatura;

- Trastornos neurotóxicos como resultado de la exposición a disolventes alifáticos, aromáticos y clorados utilizados en la limpieza de metales;

Intoxicación crónica debida a la exposición a diversos metales tóxicos presentes en la soldadura, como es el caso habitualmente del plomo, cadmio, cinc, antimonio e indio (y, en especial, a los humos emitidos durante la soldadura) 0 en las escorias y productos de desecho generados en las operaciones de soldeo;

Efectos coronarios perjudiciales derivados de la inhalación crónica de pequeñas cantidades de monóxido de carbono en ciertas operaciones de soldadura con soplete:

- Intoxicación por sustancias emitidas al limpiar o soldar con estaño o cobre piezas pintadas (p. ej., isocianatos). 


\section{Factores ergonómicos y} sociales

- Estrés por calor debido al trabajo en un entorno a temperatura elevada;

- Cansancio y dolores musculares a causa de la realización de actividades repetitivas; en especial al trabajar horas extraordinarias; - Tensión ocular al trabajar con una iluminación inadecuada;

- Cansancio en las piernas al permanecer de pie durante muchas horas.

\section{Informac. complementaria}

\section{Notas}

Notag

1. El proceso se denomina "estañosoldeo" cuando la soldadura tiene una temperatura de fusión inferior a los 426 C, y "cobresoldeo" o "soldadura fuerte" (en cada país se utilizan términos diferentes) cuando dicha temperatura es superior a la mencionada. En los procesos de soldadura manual se utilizan soldadores eléctricos, sopletes de gas, lámparas, y soldadores de cartucho químico y caldeados con gas, así como la inmersión en estaño; entre los procesos automáticos figuran la soldadura por flujo, por onda, por inmersión y con pistola de pulverización.
2. De acuerdo con los informes publicados, los soldadores dedicados al estañosoldeo y el cobresoldeo pueden estar expuestos a un mayor riesgo de sufrir abortos espontáneos, asma bronquial e hiperreactividad debido al contacto con humos y gases de soldadura, sobre todo a los vapores y productos de descomposición de la resina de trementina (colofonia) y a los tetrafluoruros.

\section{Referencias}

National Safety Council (NSC). 1994. Soldering and Brazing. Datasheet 445R ev-94. Washington, DC: NSC 
TECNICO DE LABORATORIO

Sinónimos: Auxiliar de laboratorio, trabajador de laboratorio

\section{Perfil del empleo}

Definición y/ o descripción

A L Técnico de laboratorio (en cualquier industria) es el término aplicado a los trabajadores que llevan a cabo tareas rutinarias, realizan pruebas especiales o investigan en ese tipo de instalaciones. De acuerdo con el tipo de trabajo efectuado, se pueden clasificar en bioquímicos (profesores y afines); catadores de alimentos (diversas industrias); comprobadores de laboratorio (diversas industrias) y ayudantes científicos (profesores y afines) (D O T). L os comprobadores de laboratorio llevan a cabo pruebas conforme a normas preestablecidas para determinar las características químicas y físicas o la composición de materiales sólidos, líquidos y gaseosos con fines como el control de calidad, el control de procesos o el desarrollo de productos. Instalan, ajustan y utilizan equipos e instrumentos de laboratorio como microscopios, centrifugadoras, mezcladoras, viscosímetros, balanzas químicas, espectrofotómetros, cromatógrafos de gas, colorímetros y otros dispositivos. Ponen a prueba materiales utilizados como componentes en adhesivos, pegamentos, combustibles, lubricantes, productos refractarios, caucho sintético, plásticos, pinturas, papel y textil, así como otros productos para determinar cualidades como pureza, estabilidad, viscosidad, densidad, absorción, velocidad de combustión y temperaturas de fusión y de inflamabilidad. Comprueban las soluciones utilizadas en procesos como la anodización, la impermeabilización, la limpieza, la decoloración y el tratamiento desoxidante, con el fin de establecer la concentración química, la gravedad específica y otras características. Prueban materiales para verificar la presencia y el contenido de elementos y sustancias como hidrocarburos, manganeso, grasa natural, tungsteno, azufre, cianuro, cenizas, polvo o impurezas. Examinan las muestras de productos manufacturados para controlar su conformidad con las especificaciones. R egistran los resultados de las pruebas en formularios normalizadosy redactan informes de prueba en los que describen los procedimientos utilizados. Limpian y esterilizan los equipos de laboratorio. Pueden elaborar gráficos y cuadros. Asimismo, pueden preparar soluciones químicas de acuerdo con fórmulas normalizadas y añadir sustancias químicas o materias brutas al objeto de procesar las soluciones o los lotes de producto y corregir - establecer la formulación requerida para satisfacer las especificaciones. Pueden calibrar los instrumentos de laboratorio. Es posible clasificarlos de acuerdo con el producto o el material comprobado (D OT).

\section{Profesiones asociadas y específicas}

mit

Auxiliar, ayudante, jefe de laboratorio, instalador de equipos, inspector, gestor, investigador, encargado de torio, etc. muestras, supervisor de labora-

\section{Tareas

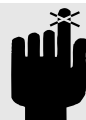

Añadir (sustancias químicas a una solución, etc.); ajustar (equipos); agitar; analizar; anestesiar; aplicar; estimar; asfixiar; aspirar; montar (sistemas); asistir; asegurar (calidad, coherencia, etc.); unir (tubos); atender; equilibrar (balanzas); decolorar; mezclar; hervir; quemar; calcular; calibrar (instrumentos); acarrear; centrifugar; clasificar; limpiar; subir (escaleras de mano, etc.); revestir (metales, etc.); recoger (muestras); comparar (respecto a normas, etc.); computar; condensar; realizar (pruebas); conectar y desconectar; controlar; enfriar; contar; moler; cortar (tejidos); describir; determinar (parámetros de prueba, etc.); diluir; sumergir; desinfectar; dividir (en partes alícuotas); destilar; documentar; secar; elevar; garantizar; evaluar; examinar; alimentar; filtrar; encajar; encender; lavar con agua; congelar (tejidos); soplado de vidrio; triturar; manejar; calentar; sostener (instrumentos, etc.); humidificar; identificar; sumergir; incubar; hinchar; inyectar; inocular; inspeccionar; instalar; instruir; investigar; etiquetar; izar; cargar y descargar; mantener; gestionar; manipular; marcar; medir; dosificar; mezclar; realizar seguimientos; desplazar; notificar; observar, poner en funcionamiento; realizar pedidos (sustancias químicas, etc.); efectuar (pruebas); pipetear; colocar; pulir; verter; preparar (muestras, etc.); procesar; pulverizar; bombear, adquirir; leer; registrar; investigar; tomar muestras; atornillar; sellar; fijar; seleccionar; separar; establecer; instalar; tamizar; soldar; esterilizar; almacenar; colar; estudiar; succionar; supervisar; rotular; comprobar; instruir; transferir; transportar; utilizar; ventilar; verificar (la conformidad con las normas, etc.); lavar; llevar (equipo de protección personal, etc.); pesar; redactar (informes).

\section{Equipo básico utilizado}

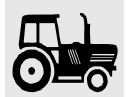

Equipos de vidrio y plástico desechables (matraces, botellas, pipetas, micropipetas, buretas, cubetas, grifos, tubos flexibles y rígidos, etc.); dispositivos de manipulación y fijación (pinzas, tenacillas, posicionadores, elevadores, alicates, soportes, destornilladores, etc.); instrumentos de distribución automática (p. ej., pipetas automáticas); escalas y balanzas; coladores, filtros, bombas y mezcladoras; dispositivos de toma de muestras gaseosas, líquidas y sólidas; instrumentos de cálculo de partículas; equipos de calentamiento, enfriamiento y medición o mantenimiento de temperatura (placas, camisas calefactoras, hornos, quemadores de gas, calefactores infrarrojos, calentadores de inmersión, refrigeradores, placas refrigeradoras por efecto Peltier, pirómetros, termómetros, termostatos, etc.); bombas de vacío, matrices, manómetros, etc:; calculadoras, grabadoras, ordenadores y dispositivos periféricos; equipo de protección personal, etc.; equipos especializados con fines específicos (p. ej., microscopios ópticos y electrónicos); medidores de $\mathrm{pH}$; electrodos selectores de iones; fuentes de energía, potenciostatos y galvanostatos; equipos para ensayos de inmunización, instrumentos de comprobación de materiales, incubadoras y autoclaves; medidores de humedad, flujómetros, colorímetros y calorímetros; cromatógrafos de gases y líquidos; espectrómetros de masas, espectroscopios IR y de Raman; analizadores de fluorescencia y de difracción de rayos $X$, láseres; fuentes de radiación, sondas, dosímetros y detectores de radiación; cajas de manipulación con guantes; campanas; micrótomos; etc.

\section{Industrias en las que esta profesión es común}

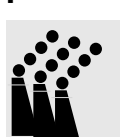

Química, petróleo y petroquímica, alimentación, caucho, polímeros, metalurgia y acabado de metales, papel y otras; universidades, centros escolares, institutos de investigación; hospitales y clínicas médicas; instituciones reguladoras; entidades públicas y privadas dedicadas a la realización de pruebas, laboratorios de inspección y de garantía de la calidad.

\section{Riesgos}

\section{Riesgos de accidente}

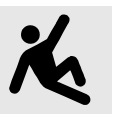

R esbalones y caídas sobre suelos húmedos; caídas de escaleras de mano;

Cortes y punzadas con

tos, etc.; bordes afilados, vidrios ro-

- Incendios y explosiones en el lugar de trabajo producidos por gases, líquidos y sólidosinflamables; 
- Incendios y explosiones debidos a reacciones químicas no controladas;

- Implosiones de equipos de generación del vacío;

- Caída de objetos pesados sobre la cabeza (situados en estanterías de almacenamiento) y los pies;

- Posibilidad de que la ropa o el pelo se enreden, o los dedos o los brazos queden atrapados en equipos rotativos o que realizan otro tipo de movimiento, como centrifugadoras, mezcladoras, etc.;

- Explosión de equipos que funcionan a una presión elevada;

- Electrocución y descargas eléctricas;

- Quemaduras y escaldaduras debidas al contacto con Ilamas, superficies calientes y gases y líquidos a temperatura elevada;

- Q uemaduras químicas producidas por líquidos corrosivos;

- Partículas en suspensión originadas al reventar centrifugadoras y autoclaves;

- Intoxicación aguda debida a una amplia gama de gases, líquidos y sólidos tóxicos utilizados como materias primas o liberados en reacciones químicas:

- Daños oculares producidos por rayos láser, salpicaduras de sustancias qúimicas, gases corrosivos y partículas proyectadas;

- Q uemaduras por congelación por el contacto de la piel con superficies o líquidos muy fríos (p. ej., gases licuados).

\section{Riesgos físicos}

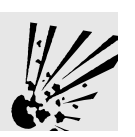

Radiación ionizante ultravioleta;

- Niveles de ruido elevado subsónicos o ultrasónicos bradores o rotativos. generados por equipos vi-

\section{Riesgos químicos}

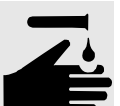

Exposición a una amplísima gama de sustancias químicas (los técnicos de laboratorios químicos pueden verse expuestos a todo tipo de agentes químicos conocidos y a combinaciones de los mismos) corrosivas, irritantes, tóxicas, neurotóxicas, asfixiantes, alergé nicas, cancerígenas, mutagénicas, teratogénicas, fetotóxicas, inhibidoras de las encimas, radiactivas y similares, mediante inhalación, ingestión, contacto cutáneo u ocular, etc. (véase el apéndice).

\section{Riesgos biológicos}

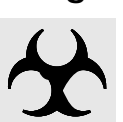

Exposición a muy diversos agentes biológicos(los técnicos de laboratorios biológicos pueden verse expuestos a todo tipo de de agentes biológicos conocidos y a combinaciones de los mismos), como virus, bacterias, hongos, parásitos, etc., mediante inhalación, ingestión, contacto cutáneo u ocular, transmisión por mordeduras o picaduras de animales de laboratorio, inoculación accidental, etc.

\section{Factores ergonómicos y} sociales

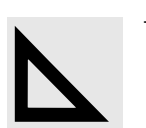

Tensión ocular debida al trabajo con microscopios ópticos y electrónicos, manipuladores telescópicos y terminales de ordenador, a la actividad en condiciones de oscuridad 0 semioscuridad, y a otros factores;

- Afecciones musculares y óseas producidas por el trabajo rutinario en una posición fija;

- Estrés y tensión en las manos debidas a la realización de operaciones manuales repetitivas (p. ej., al emplear pipetas, en los recuentos no automatizados, en el pulido a mano, etc.).

\section{Informac. complementaria}

\section{Nota

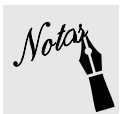

Existe un riesgo especial al trabajar con nuevas sustancias químicas (NSQ) cuyos efectos físicos, químicos, biológicos y de otro tipo no se han investigado adecuadamente. Las NSQ pueden ser explosivas 0 altamente inflamables, 0 formar mezclas explosivas con el aire y otras sustancias. Asimismo, pueden resultar sumamente tóxicas, corrosivas para la piel, los ojos o el sistema respiratorio o producir un efecto sinérgico con otras sustancias.

\section{Referencias}

Centers for Disease Control (CDC). 1984 B iosafety in M icrobiological and Biomedical laboratories. DHHS (CDC) Publication N o. 84-8395. Atlanta, GA: CDC.
M ahn, JW. 1991. F undamentals of laboratory Safety: Physical $\mathrm{H}$ azards in the A cademic Laboratory. Nueva York: Van Nostrand R einhold.

O rganización Mundial de la Salud (O M S). 1983. Laboratory Safety M anual. Ginebra:O M S.

Stricoff, RS y DB Walters. 1996. $\mathrm{H}$ andbook of Laboratory $\mathrm{H}$ ealth and Safety, 2a edición. Nueva York W iley-Interscience.

\section{Apéndice}

Clasificación de sustancias peligrosas de las $\mathrm{N}$ aciones U nidas:

\section{Clase 1: Explosivos}

1.1. Sustancias y productos que conllevan un riesgo de explosión masiva.

1.2. Sustancias y productos que conllevan un riesgo de proyección, pero no de explosión masiva.

1.3. Sustancias y productos que conllevan un riesgo de incendio, además de un riesgo de explosión y/o de proyección menor, pero no de explosión masiva.

1.4. Sustancias y productos que no representan un riesgo significativo.

1.5. Sustancias muy insensibles que conllevan un riesgo de explosión masiva.

1.6. Sustancias extremadamente insensibles que no conllevan un riesgo de explosión masiva.

\section{Clase 2: G ases}

Comprimidos, licuados, disueltos a presión o refrigeradosintensamente.

\section{Clase 3: Líquidosinflamables}

Clase 4: Sólidosinflamables 4.1. Sólidosinflamables 4.2. Sustancias propensas a la combustión espontánea.

4.3. Sustancias que, al contacto con el agua, emiten gases inflamables.

Clase 5: Sólidosoxidantes

Clase 6: Sustanciastóxicase infecciosas

Clase 7: $\mathrm{M}$ ateriales radiactivos

\section{Clase 8: Sustancias corrosivas}

Clase 9: Otras sustancias y productos peligrosos 



\section{GUIA DE PRODUCTOS QUIMICOS}

Directoras del capítulo

J eanne $M$ ager Stellman

Debra 0 sinsky

Pia M arkkanen

\section{Sumario}

A cidos inorgánicos . . . . . . . . . . . . . . . . . . . . . . . 104.5

A cidos y anhidridos orgánicos . . . . . . . . . . . . . . . . 104.12

Alcoholes ................................. 104.32

Aldehídos y cetales . . . . . . . . . . . . . . . . . . . . . . 104.45

M ateriales alcalinos. . . . . . . . . . . . . . . . . . . . . . . . . . 104.56

Amidas. . . . . . . . . . . . . . . . . . . . . . . . . . . . . . . . . 104.73

A minas alifáticas . . . . . . . . . . . . . . . . . . . . . . . . . . . . . . 104.80

Formación de nitrosaminas. . . . . . . . . . . . . . . . . . . . 104.80

A minas aromáticas . . . . . . . . . . . . . . . . . . . . . 104.95

Azidas . . . . . . . . . . . . . . . . . . . . . . . . . . . . . . . . . 104.121

Compuestos de boro . . . . . . . . . . . . . . . . . . . . . . . . 104.130

Compuestos de ciano . . . . . . . . . . . . . . . . . . . . . . . 104.137

Compuestos epoxidicos. . . . . . . . . . . . . . . . . . . . . . . 104.152

Esteres, acetatos. . . . . . . . . . . . . . . . . . . . . . . . . 104.162

Esteres acrílicos . . . . . . . . . . . . . . . . . . . . . . . . . . . . . 104.172

Esteres, alcanoatos (excepto acetatos) . . . . . . . . . . . . . . 104.176

Eteres. . . . . . . . . . . . . . . . . . . . . . . . . . . . . . . . . 104.183

Fluorocarburos . . . . . . . . . . . . . . . . . . . . . . . . 104.190

Eteres glicólicos. . . . . . . . . . . . . . . . . . . . . . . . . . . . 104.201

G liceroles y glicoles. . . . . . . . . . . . . . . . . . . . . . 104.209
H alógenos y sus compuestos. . . . . . . . . . . . . . . . . . . . 104.215

Compuestos heterocíclicos . . . . . . . . . . . . . . . . 104.227

H idrocarburos saturados y alicíclicos . . . . . . . . . . . . . 104.239

H idrocarburos, alifáticos y halogenados. . . . . . . . . . . 104.249

H idrocarburos alifáticos insaturados. . . . . . . . . . . . . . . 104.275

H idrocarburos aromáticos . . . . . . . . . . . . . . . . . . . 104.282

H idrocarburos aromáticos halogenados . . . . . . . . . . . 104.296

H idrocarburos poliaromáticos . . . . . . . . . . . . . . . . 104.310

I socianatos. . . . . . . . . . . . . . . . . . . . . . . . . . 104.320

Cetonas . . . . . . . . . . . . . . . . . . . . . . . . . . . . . . . . . . 104.326

Nitrocompuestos alifáticos. . . . . . . . . . . . . . . . . . . . . . 104.338

Nitrocompuestos aromáticos. . . . . . . . . . . . . . . . . . . . 104.346

Peróxidos orgánicos e inorgánicos . . . . . . . . . . . . . . . 104.362

Fenoles y compuestos fenólicos. . . . . . . . . . . . . . . . 104.368

Fosfatos inorgánicos y orgánicos. . . . . . . . . . . . . . . . 104.382

Ftalatos . . . . . . . . . . . . . . . . . . . . . . . . . . . . . . . . . . . 104.394

Sílice y compuestos organosilíceos . . . . . . . . . . . . . . . 104.399

Compuestos orgánicos de azufre. . . . . . . . . . . . . . . . . . 104.406

Compuestos inorgánicos de azufre . . . . . . . . . . . . . . . 104.417

M onóxido de carbono. . . . . . . . . . . . . . . . . . 104.429 


\section{Descripción general}

Esta $G$ uía de productos químicos tiene como finalidad permitir una rápida consulta sobre cerca de 2.000 productos químicos de interés comercial. Los productos químicos se han dividido en "familias" basándose en sus fórmulas químicas. Esta división es algo arbitraria, puesto que muchos productos químicos podrían formar parte de más de una familia.

El lector que busque un determinado producto químico debe consultar el índice de sustancias químicas de este volumen para saber si aparece o no en la guía y dónde buscarlo. Dicho índice contiene también referencias a otros capítulos de la Enciclopedia en donde puede encontrarse una descripción del producto químico en cuestión. El lector puede remitirse a los Capítulos Propiedades químicas y toxicidad de los metales y M inerales $y$ productos agroquímicos para una descripción sistemática de esos elementos y compuestos y al Capítulo Uso, almacenamiento y transporte de productos químicos para obtener información sobre la manipulación, el uso, el almacenamiento y el transporte seguros de los productos químicos.

Para cada familia química se ofrece una breve descripción con información toxicológica, epidemiológica y sobre seguridad química, además de cuatro tipos de tablas que resumen los datos químicos, físicos, toxicológicos y de seguridad utilizando siempre el mismo formato.

Por limitaciones de espacio no se han podido facilitar las referencias de la literatura utilizada para preparar el texto. El lector puede localizar la mayoría de las principales fuentes de datos consultando la Base de Datos de Sustancias Peligrosas (Hazardous Substances Database, HSDB), producida por la $\mathrm{N}$ ational Library of Medicine de Estados Unidos. Además de la 3 a edición de esta Enciclopedia y la literatura científica general, las HSE Reviews publicadas por el Health and Safety Executive del Reino Unido han servido como fuente de información. En el Capítulo Recursos: Información y salud y seguridad en el trabajo de esta Enciclopedia y en los capítulos mencionados antes pueden encontrarse otras referencias generales.

La información sobre los usos industriales de los productos químicos ha sido adaptada de la 3 a edición de esta Enciclopedia y la HSDB. (En los Capítulos Procesos químicos, Petróleo y gas natural, Industria farmacéutica e Industria del caucho, puede encontrarse una descripción más detallada de industrias químicas específicas.)

\section{Agradecimientos}

Este capítulo contiene una serie de materiales, algunos de ellos obtenidos de la 3 a edición de la Enciclopedia de salud y seguridad en el trabajo, que han sido actualizados y adaptados a forma to tabular.

Las siguientes personas han contribuido a esta 4 a edición: Janet L C ollins

Linda S. Forst

David L Hinkamp

$\mathrm{N}$ iels Koehncke

Kari Kurppa
Pia Markkanen

Debra 0 sinsky

Beth Donovan Reh

Jeanne M ager Stellman

Steven D. Stellman
Las estructuras químicas que aparecen en la tablas de identificación química se crearon utilizando el programa informático $C S$ ChemDraw Pro ${ }^{\circledR}$ y se obtuvieron de ChemFinder ${ }^{\text {Tm }}$ W eb Server, por cortesía de CambridgeSoft Corporation (www.camsoft.com).

Las siguientes personas contribuyeron a la 3 a edición:
M. V. Aldyreva
M. Lob
Z. Aleksieva
L Magos
D. D. Alexandrov
K. E. M alten
G . Armelli
Z. Bardodej
M. M. Manson
E. Bartalini
F. Bertolero
P. M anu
G. W. Boylen, Jr.
J. V. M arhold
D. M atheson
W. E. Broughton
T. V. M inajlova
A. M unn
E. Browning
G. T. Bryan
D. D. Bryson
S. Caccuri
B. Calesnick
N. Castellino
P. C atilina
A. Cavigneaux
W. B. Deichmann
S. N omura
K. N orpoth
E. V. 0 Imstead
L Parmeggiani
J. D. Paterson
F. L. M Pattison
M. Philbert
J. Piotrowski
J. Rantanen
D. DeRuggiero
P. Dervillee
D. W. Reed
E. Dervillee
J. Doignon
G. Reggiani
C. F. Reinhardt
V. E. Rose
H. Rossmann
V. K. Rowe
M. Evrard
D. Fassett
A. T. Fenlon
N. I. Sadkovskaja
T. S. Scott
L D. Fernandez-Conradi
G. Smagghe
G. C. Smith
I. Fleig
V. Foá
A. Forni
E. Fournier
I. D. G adaskina
E. G a ffuri
J. C. Gage
P. J. G ehring
H. W. G erarde
W. G. Goode
A. R. G regory
P. Hadengue
H. I. Hardy
H. Heimann
E. V. Henson
A. lannaccone
M. Ikeda
M. Inclan C uesta
T. Inoue
N. G. Ivanov
W. H. Jones
F. Kaloyanova-Simeonova
B. D. Karpov
K. Knobloch
H. Kondo
E. J. Largent
J. Levêque
A. L Linch
M. I Stasik
R. D. Stewart
W. G. Stocker
F. W. Sunderman, Jr.
O. N. Syrovadko
J. Teisinger
A. M. Thiess
A. A. Thomas
T. R. Torkelson
T. Toyama
D. C. Trainor
J. F. Treon
R. Truhaut
E. C. Vigliani
P. L Viola
N. I. Volkova
M. W assermann
D. W assermann
N. K. W eaver
D. W inter
C. M. W oodbury
R. C. W oodcock
S. Yamaguchi
J. A. Zapp, Jr.
M. R. Zavon
J. B. Zuzik 


\section{Notas sobre las tablas}

Los cuatro tipos de tablas que se facilitan para cada familia son:

\section{Identificación química}

En estas tablas se indica el nombre de los productos químicos, sus sinónimos, los códigos UN, los números CAS y las fórmulas químicas 0 estructurales. En la medida de lo posible se ha intentado utilizar la misma denominación química para un mismo producto en toda la Guía y la Enciclopedia. Sin embargo, no se ha utilizado exclusivamente el sistema de nomenclatura de la Unión Internacional de Q uímica Pura y Aplicada (IUPAC). En muchos casos la denominación de la IUPAC resulta poco familiar para aquellos que trabajan en un entorno comercial, razón por la cual se ha decidido utilizar un nombre menos complicado o más familiar. Por consiguiente, el nombre que aparece como denominación química en las tablas de cada familia es generalmente un nombre "familiar" más que el nombre de la IUPAC. La lista de sinónimos que aparecen en estas tablas no es exhaustiva, sino tan sólo un ejemplo de algunos de los nombres que se aplican al producto químico en cuestión. EI N úmero de Registro CAS es un identificador numérico utilizado en todas las tablas. El número CAS es único y se aplica tanto a productos químicos como a

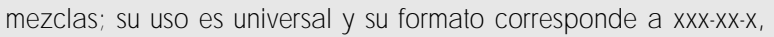
lo que facilita la búsqueda en las bases de datos. Chemical Abstracts Service es una entidad perteneciente a la American Chemical Society, una sociedad profesional de químicos con sede en Estados Unidos.

\section{Riesgos para la salud}

Los datos sobre los períodos cortos de exposición, los períodos largos de exposición, las vías de exposición y los síntomas asociados se han adaptado de la serie de Tarjetas Internacionales sobre la Seguridad de los Productos Q uímicos (International Chemical Safety Cards, IC SC) producida por el Programa Internacional de Seguridad de los Productos Q uímicos (IPCS), que ha sido desarrollado conjuntamente por la 0 rganización Mundial de la Salud (OMS), la O rganización Internacional del Trabajo (OIT) y el Programa de $\mathrm{N}$ aciones Unidas para el Medio Ambiente (PN UMA).

Se utilizan las siguientes abreviaturas: SN C = sistema nervioso central; SCV = sistema cardiovascular; $\mathrm{GI}=$ sistema gastrointestinal; SN P = sistema nervioso periférico; tract resp = tracto respiratorio.

Los restantes datos sobre órganos afectados, vías de entrada y síntomas asociados, se han obtenido de la N IO SH Pocket G uide to Chemical Hazards publicada por el $\mathrm{N}$ ational Institute for O ccupational Safety and Health de Estados Unidos (1994, N IO SH Publication N 0. 94-116).

Se utilizan las siguientes abreviaturas: abdom = abdominal; anor = anormal/ a nomalía; album = albuminuria; anes = anestesia; anor = anorexia; anos = anosmia (pérdida del olfato); a pre = aprensión; arrit = arritmias; aspir = aspiración; asfix = asfixia; $\mathrm{TA}=$ tensión arterial; resp = respiración; bron = bronquitis; bronconeu = bronconeumonia; bronespas = broncoespasmo; $\mathrm{BUN}=$ nitrógeno uréico en sangre; [carc] = posible carcinógeno laboral; card = cardíaco; $c o l=$ colinesterasa; cirr = cirrosis; $S N C=$ sistema nervioso central; conc = concentración; $\operatorname{conf}=$ confusión; conj = conjuntivitis; estre = estreñimiento; convuls = convulsiones; córn = córnea; $S C V=$ sistema cardiovascular; cian = cianosis; reduc $=$ reducido; depres $=$ depresivo $/$ depresión; derm $=$ derma titis; diarr = diarrea; trast $=$ trastorno; mar $=$ mareo; sop = sopor; disfunc = disfunción; dif resp = dificultad respiratoria; enfi = enfisema; eosin = eosinofilia; epilep = epileptiforme; epis = epistaxia (hemorragia nasal); equi = equilibrio; eri = eritema (irritación cutánea); euf = euforia; frac = fracaso; fasc = fasiculación; $\mathrm{VEF}=$ volumen espiratorio forzado; fib = fibrosis; fibri = fibrilación; ftg = fatiga; func = función; $G I$ = gastrointestinal; desv = desvanecimiento; alu = alucinaciones; cef = cefalea; hema = hematuria (sangre en la orina); hemato = hematopoyético; hemog = hemoglobinuria; hemorr = hemorragia; hiperpig = hiperpigmentación; hipox = hipoxemia (menor concentración de oxígeno en la sangre); desco = descoordinación; incr = incremento; embri = embriaguez; inflam = inflamación; les = lesión; insom $=$ insomnio; irreg = irregularidad/ irregularidades; irrit = irritación; irrita $b=$ irritabilidad; ict = ictericia; quera = queratitis (inflamación de la córnea); lag = lagrimeo; lar = laríngeo; las = lasitud (debilidad, cansancio); let = letargia (somnolencia 0 indiferencia); leucit = leucocitosis (aumento de leucocitos en la sangre); leupen = leucopenia (disminución de leucocitos en la sangre); atur = aturdimiento; liq = líquido; local = localizado; bajo-p = pérdida de peso; mal = malestar (sensación vaga de incomodidad); malnut $=$ malnutrición; methemo $=$ methemoglobinemia; monoci = monocitosis (aumento de monocitos en sangre); fund = fundido; muc $=$ mucosa; musc $=$ músculo $/$ muscular; narco $=$ narcosis; náu = náuseas; nec = necrosis; nef = nefritis; ner = nerviosismo; ent $=$ entumecimiento; opac $=$ opacidad; $p a l p=$ palpitaciones; pará $=$ parálisis; pares $=$ parestesia; perf $=$ perfo ración; neur peri $=$ neuropatía periférica; periorb $=$ periorbital (situado alrededor del ojo); far = faríngeo; foto = fotofobia (intolerancia visual anormal a la luz); neu = neumonia; neuitis = neumonitis; $\mathrm{SNP}=$ sistema nervioso periférico; polineur $=$ polineuropatía $;$ prot $=$ proteinuria; pulm = pulmonar; erit $=$ eritro citos; repro = reproductor; resp = respiratorio; inq = inquietud; retster = retrosternal (detrás del esternón); rin = rinorrea (excreción de moco nasal líquido); salv = salivación; sens = sensibilización; tem = temblores; dis = disnea; estor = estornudo; sol = sólido; soln = solución; som = somnolencia (sueño, somnolencia no natural); subes = subesternal (debajo del esternón); sud = sudor; hin = hinchazón; sis = sistema; tacar = taquicardia; sens dol = sensibilidad dolorosa; terato = teratogénico; $p$ uls = pulsátil; opr = opresión; traqbronc = traqueobronquitis; contr=contracción; incon = inconsciencia; va $p=$ vapor; fibven = fibrilación ventricular; vért = vértigo (sensación de movimiento); vesic = vesiculación; dist vis = distorsión visual; vómit = vómitos; deb = debilidad; resp sib=respiración sibilante.

\section{Riesgos físicos y químicos}

Los datos sobre los riesgos físicos y químicos se han adaptado de la serie de Tarjetas Internacionales sobre la Seguridad de los Productos Q uímicos (IC SC) producida por el Programa Internacional de Seguridad de los Productos Químicos (IPCS), que ha sido desarrollado conjuntamente por la 0 rganización M undial de la Salud (OMS), la O rganización Internacional del Trabajo (O IT) y el Programa de $\mathrm{N}$ aciones Unidas para el Medio Ambiente (PN UMA).

Los datos sobre la clasificación de riesgos se han obtenido de Recommendations on the Transport of Dangerous Goods, 9 a edición, elaboradas por el Comité de $\mathrm{N}$ aciones Unidas de 
Expertos sobre el Transporte de Sustancias Peligrosas y publicadas por $\mathrm{N}$ aciones Unidas (9 a edición, 1995).

Se utilizan los siguientes códigos: 1.5 = sustancia muy sensible con peligro de explosión masiva; 2.1 = gas inflamable; 2.3 = gas tóxico; 3 = líquido inflamable; 4.1 = sólido inflamable; 4.2 = sustancia capaz de combustión espontánea; $4.3=$ sustancia que en contacto con agua desprende gases inflamables; $5.1=$ sustancia oxidante; $6.1=$ sustancia tóxica; $7=$ sustancia radiactiva; 8 = sustancia corrosiva.

Las Recomendaciones están dirigidas a gobiernos y organizaciones internacionales que regulan el transporte de sustancias peligrosas. En ellas se establecen los principios para la clasificación y definición de clases, la lista de las principales sustancias peligrosas, los requisitos generales de embalaje, procedimientos de ensayo, marcaje, etiquetado o señalización y los documentos de transporte. Algunas recomendaciones especiales hacen referencia a ciertas clases de sustancias y no son aplicables a las sustancias a granel que, en la mayoría de los países, están sometidas a reglamentos especiales. Las siguientes clases y divisiones UN aparecen con frecuencia en las tablas de esta $G$ uía de productos químicos y en el $\mathrm{C}$ apítulo Propiedades químicas y toxicidad de los metales:

\section{Clase $2-G$ ases}

División 2.3- $G$ ases tóxicos: $G$ ases que (a) se sabe que son suficientemente tóxicos o corrosivos para el ser humano como para poner en peligro su salud 0 (b) se supone que son tóxicos 0 corrosivos para el ser humano debido a que su $\mathrm{CL}_{50}$ es igual 0 inferior a $5.000 \mathrm{ml} / \mathrm{m}^{3}$ (ppm) cuando se determina de acuerdo con 6.2.3. Los gases que cumplen los anteriores criterios debido a su corrosividad deben clasificarse como sustancias tóxicas con un riesgo corrosivo adicional.

Clase 4-Sólidos inflamables; sustancias capaces de arder espontáneamente; sustancias que en contacto con el agua desprenden gases infla mables

División 4.2-Sustancias capaces de arder espontáneamente: Sustancias que pueden calentarse espontáneamente en las condiciones normales encontradas durante su transporte, o que pueden calentarse en contacto con el aire, con peligro de incendio.

División 4.3-Sustancias que en contacto con el agua desprenden gases inflamables: Sustancias que, en contacto con el agua, pueden arder espontáneamente 0 desprender gases inflamables en cantidades peligrosas.
Clase 5-Sustancias oxidantes; peróxidos orgánicos

División 5.1 - Sustancias oxidantes: Sustancias que, aunque en sí mismas no sean inflamables, pueden causar o contribuir a la combustión de otro material, generalmente por liberación de oxígeno.

\section{Clase 6-Sustancias tóxicas e infecciosas}

División 6.1-Sustancias tóxicas: Sustancias capaces de causar la muerte o lesiones graves o que son nocivas para la salud humana cuando se ingieren, se inhalan o contactan con la piel.

\section{Clase 8-Sustancias corrosivas}

Sustancias que, por su acción química, pueden causar lesiones graves cuando entran en contacto con tejidos vivos o que, en el caso de fugas, pueden producir daños materiales 0 incluso destruir otros productos o medios de transporte; pueden también conllevar otros riesgos.

Los códigos UN, números identificativos asignados a sustancias peligrosas en su transporte por el Comité de $\mathrm{N}$ aciones Unidas de Expertos sobre el Transporte de Sustancias Peligrosas, permiten identificar fácilmente los materiales peligrosos en caso de producirse situaciones de emergencia durante su transporte. Los códigos precedidos por "N A" corresponden a descripciones no reconocidas en el ámbito del transporte internacional, salvo cuando se trata de transportes cuyo origen 0 destino es Canadá.

\section{Propiedades físicas y químicas}

La densidad relativa se mide a $20{ }^{\circ} \mathrm{C} / 4{ }^{\circ} \mathrm{C}$, la temperatura ambiente y la temperatura del agua, respectivamente, a no ser que se indique lo contrario.

Se utilizan las siguientes abreviaturas: p.e. $=$ punto de ebullición; p.f. = punto de fusión; p.m. = peso molecular; $s$ l $=$ soluble; lig sol = ligeramente soluble; muy sol = muy soluble; misc = miscible; insol = insoluble; Pvap = presión de vapor; limitinflam. = límite de inflamabilidad (vol-\% en el aire); li = límite inferior; $I s=$ límite superior; $p . i g .=$ punto de ignición; $c c=$ cubeta cerrada; $c a=$ cubeta abierta; p.autoig. = punto de autoignición. 


\section{ACIDOSINORGANICOS}

\section{David L. H inkamp}

Un ácido inorgánico es un compuesto de hidrógeno y uno o más elementos (a excepción del carbono) que, cuando se disuelve en agua u otro disolvente, se rompe o disocia, produciendo iones hidrógeno. La solución resultante tiene ciertas características, como la capacidad de neutralizar bases, tornar de color rojo el papel tornasol y producir determinados cambios de color cuando se combina con otros indicadores. A los ácidos inorgánicos se les denomina a menudo ácidos minerales. La forma anhidra puede ser gaseosa o sólida.

Un anhídrido inorgánico es un óxido de metaloide que puede combinarse con agua para formar un ácido inorgánico. Puede producirse por síntesis, como, por ejemplo, $\mathrm{S}+\mathrm{O}_{2} \rightarrow \mathrm{SO}_{2}$, que se transforma en ácido por adición de una molécula de agua (hidratación); o mediante eliminación de agua del correspondiente ácido, como por ejemplo:

$$
2 \mathrm{HMnO}_{4} \quad \mathrm{Mn}_{2} \mathrm{O}_{7}+\mathrm{H}_{2} \mathrm{O}
$$

Los anhídridos inorgánicos comparten, en general, las propiedades biológicas de sus ácidos, ya que en medios biológicos acuosos se produce rápidamente la hidratación.

\section{Usos}

L os ácidos inorgánicos se utilizan como sustancias químicas intermedias y catalizadores en reacciones químicas. Se encuentran en distintas industrias, como metalistería, madera, textiles, colorantes, petróleo y fotografía. En el trabajo de los metales se utilizan a menudo como agentes limpiadores antes de soldar, chapear o pintar. El ácido sulfámico, el ácido sulfúrico y el ácido clorhídrico se utilizan en galvanoplastia, y el ácido perclórico en el chapeado de metales.

El ácido clorhídrico, el ácido sulfúrico, el ácido perclórico y el ácido sulfámico se utilizan en muchas industrias. El ácido clorhídrico, o cloruro de hidrógeno en solución acuosa, se utiliza para la acidificación industrial, para el refinado de minerales de estaño y tantalio, para convertir el almidón de maíz en jarabe y para eliminar la capa de óxido de las calderas y equipos de intercambio de calor. También se utiliza como agente curtidor en la industria del cuero. El ácido sulfúrico se utiliza en papel encerado y en distintos procesos como la purificación de petróleo, el refinado de aceites vegetales, el carbonizado de tejidos de lana, la extracción de uranio a partir de pechblenda y el desoxidado de hierro y acero. El ácido sulfúrico y el ácido perclórico se utilizan en la industria de los explosivos. El ácido sulfámico es un retardante de llama en las industrias de la madera y textil y un blanqueador y bactericida en la industria de la pasta y el papel. También se emplea para la estabilización del cloro en las piscinas.

EI ácido nítrico se utiliza en la fabricación de nitrato amónico para fertilizantes y explosivos. Asimismo se utiliza en síntesis orgánicas, metalurgia, flotación de minerales, y para el reprocesado de combustible nuclear agotado.

\section{Riesgos}

L os riesgos específicos de los ácidos inorgánicos más importantes desde el punto de vista industrial se describen más adelante; no obstante, debe decirse que todos estos ácidos poseen ciertas propiedades peligrosas comunes a todos ellos. Las soluciones de ácidos inorgánicos no son inflamables por sí mismas, pero cuando entran en contacto con ciertos productos químicos 0 materiales combustibles, se pueden producir incendios o explosiones. Estos ácidos reaccionan con determinados metales liberando hidrógeno, que es una sustancia altamente inflamable y explosiva cuando se mezcla con el aire o con oxígeno. También pueden actuar como agentes oxidantes $y$, cuando contactan con productos orgánicos u otras sustancias oxidables, pueden reaccionar de forma violenta.

E fectos en la salud. Los ácidos inorgánicos son corrosivos, especialmente cuando se encuentran a altas concentraciones. Pueden destruir los tejidos corporales y producir quemaduras químicas cuando entran en contacto con la piel y las mucosas. Son especialmente peligrosos los accidentes oculares. Los vapores 0 nieblas de los ácidos inorgánicos irritan el tracto respiratorio y las mucosas, dependiendo el grado de irritación de su concentración; los trabajadores expuestos a estos ácidos pueden sufrir también decoloración o erosiones de los dientes. El contacto repetido con la piel provoca dermatitis. La ingestión accidental de ácidos inorgánicos concentrados causa grave irritación de la garganta y el estómago, así como destrucción tisular de los órganos internos, a veces mortal a no ser que se efectúe inmediatamente el tratamiento de urgencia adecuado. A lgunos ácidos inorgánicos actúan también como agentes tóxicos sistémicos.

\section{Medidas de salud y seguridad}

Siempre que sea posible, los ácidos muy corrosivos deben sustituirse por ácidos que presenten menos riesgos, siendo, además, esencial utilizarlos a la menor concentración necesaria. Cuando se utilicen ácidos inorgánicos, se deberán extremar las medidas de seguridad en cuanto a almacenamiento, manipulación, eliminación de residuos, ventilación, protección personal y primeros auxilios.

Almacenamiento. Siempre debe evitarse el contacto con otros ácidos y materiales combustibles $u$ oxidables. Las instalaciones eléctricas deben ser resistentes a los ácidos.

Las zonas dedicadas al almacenaje de estos productos deben estar separadas de las demás dependencias, bien ventiladas y protegidas de los rayos solares y otras fuentes de calor. EI suelo de estas áreas será de cemento y no contendrá sustancias que puedan reaccionar con un ácido. Los grandes almacenes deben estar rodeados por un muro, con el fin de retener el ácido en caso de derrame accidental, debiendo existir, además, los elementos precisos para neutralizarlo. Fuera de los almacenes deberá haber una boca de incendios y un equipo autónomo de protección respiratoria para casos de emergencia o para rescate. Los derrames se limpiarán inmediatamente con una manguera. En el caso de que se produzca un gran derrame, se mandará evacuar las instalaciones a todo el personal y después, una vez provistos del equipo de emergencia, se intentará neutralizar el ácido con agua 0 arena calcinada. Las instalaciones eléctricas deben ser resistente al agua y al ataque de los ácidos. Es conveniente contar con iluminación de seguridad.

Los envases deben mantenerse herméticamente cerrados y claramente etiquetados, indicando su contenido. Cuando sea preciso se tomarán medidas de descompresión. Todas las conducciones, uniones, juntas y válvulas deben ser de un material resistente al ácido nítrico. Los envases de cristal o plástico deben estar convenientemente protegidos contra impactos y por encima del nivel del suelo para facilitar el vaciado en caso de derrame. Los bidones se almacenarán sobre bastidores o caballetes y estarán debidamente calzados. Los cilindros de gas de ácidos anhidrosos gaseosos se deben almacenar en posición vertical y con la capucha puesta. Los envases llenos y los vacíos se 
almacenarán en lugares separados. Es muy importante la limpieza y un buen mantenimiento.

M anipulación. En la medida de lo posible, los ácidos deben ser bombeados mediante sistemas cerrados para prevenir todo peligro de contacto. Siempre que se proceda al transporte de los envases 0 al trasvase del producto, se empleará el equipo apropiado y sólo podrán realizar estos trabajos personas especializadas. El trasvase de los ácidos debe realizarse con sifones especiales, bombas de trasiego o plataformas basculantes para garrafas 0 bidones, etc. Los cilindros de gas ácido anhidro requieren válvulas de descarga o conexiones especiales.

L os trabajadores deben saber que si los ácidos se mezclan con otros productos químicos o con agua, pueden ocurrir reacciones violentas o peligrosas. Por ejemplo, un ácido concentrado debe añadirse lentamente al agua, y no a la inversa, para así evitar la generación de un calor excesivo o reacciones violentas que pueden provocar salpicaduras o contacto con la piel y los ojos.

Ventilación. Cuando, durante los procesos, se producen nieblas o vapores ácidos, como ocurre en la galvanoplastia, se deben instalar sistemas extractores de ventilación.

Protección personal. Las personas expuestas a salpicaduras peligrosas de ácidos inorgánicos deben utilizar equipos protectores resistentes a los ácidos en manos, brazos, ojos y cara, así como mandiles, monos y guardapolvos. Cuando se hayan adoptado procedimientos de trabajo seguros, no será necesario el uso de equipos de protección respiratoria, aunque siempre deberán estar disponibles para su uso en casos de emergencia, como derrames o fugas.

Cuando haya que introducirse en los tanques donde se encuentra almacenado el ácido, para su limpieza o reparación, primero tendrán que purgarse los tanques y adoptarse todas las precauciones necesarias para el acceso a espacios cerrados, según se describen en otros artículos de esta E nciclopedia.

F ormación. T odos los trabajadores que manipulen ácidos deben ser informados de sus propiedades peligrosas. Algunas actividades laborales, como las que se llevan a cabo en espacios cerrados o las que exigen la manipulación de grandes cantidades de ácidos, deben ser realizadas siempre por dos personas, una de ellas preparada para acudir en ayuda de la otra en caso necesario.

Instalaciones sanitarias. La higiene personal tiene una importancia fundamental cuando se produce contacto con ácidos inorgánicos. Los trabajadores deben disponer de unas instalaciones sanitarias y de lavado adecuadas y se les debe insistir para que se laven cuidadosamente antes de las comidas y al final de cada turno.

Primeros auxilios. El tratamiento más importante en caso de contaminación de la piel o de los ojos con ácidos inorgánicos consiste en lavar inmediatamente la zona afectada con agua corriente. Para este fin deben colocarse estratégicamente duchas de urgencia, fuentes para lavar los ojos, baños y botellas. Las salpicaduras en los ojos deben lavarse con agua abundante. L as ropas contaminadas deben retirarse en seguida y el personal debe conocer los procedimientos de emergencia para el tratamiento de la piel. Un procedimiento habitual es la neutralización del ácido en el área afectada con una solución alcalina, como bicarbonato sódico al 2-3\% o carbonato sódico al $5 \%$ e hiposulfito sódico al $5 \%$ o trietanolamina al $10 \%$.

Las personas que hayan inhalado vapores ácidos deben retirarse inmediatamente de la zona contaminada, impidiéndose que realicen ningún tipo de esfuerzo y solicitando atención médica inmediata. En caso de ingestión accidental, deberá administrarse a la víctima una sustancia neutralizante y efectuarla un lavado gástrico. En general no deben provocarse vómitos, ya que éstos podrían extender la lesión.

Supervisión médica. Los trabajadores deben someterse a exámenes médicos previos al empleo y, a partir de entonces, a reconocimientos periódicos. El examen previo al empleo debe enfocarse a la detección de enfermedades respiratorias, gastrointestinales o nerviosas crónicas, así como cualquier enfermedad de la piel y los ojos. Los reconocimientos periódicos deben realizarse a intervalos frecuentes, prestando especial atención al estado de la dentadura.

Contaminación de las aguas. La contaminación de las aguas debe prevenirse prohibiendo terminantemente el vertido de aguas residuales que contengan el ácido utilizado a cloacas 0 cursos fluviales en tanto que el pH (acidez) no se reduzca hasta 5,5-8,5.

\section{Acido clorhídrico}

El cloruro de hidrógeno anhidro no es corrosivo, si bien la solución acuosa ataca a casi todos los metales (salvo mercurio, plata, oro, platino, tantalio y ciertas aleaciones) con liberación de hidrógeno. El ácido clorhídrico reacciona con sulfuros para formar cloruros y sulfuro de hidrógeno. Es un compuesto muy estable, pero cuando se somete a a altas temperaturas se descompone, dando hidrógeno y cloro.

R iesgos. Los riesgos especiales del ácido clorhídrico son su acción corrosiva en la piel y las mucosas, la liberación de hidrógeno cuando entra en contacto con ciertos metales e hidruros metálicos, y su toxicidad. El ácido clorhídrico produce quemaduras en la piel y las mucosas cuya gravedad depende de la concentración de la solución. Estas quemaduras pueden ulcerarse quedando, más tarde, cicatrices queloides y retráctiles. EI contacto de este ácido con los ojos puede provocar reducción o pérdida total de la visión. Las quemaduras faciales pueden dejar graves cicatrices graves que desfiguren el rostro. El contacto frecuente con soluciones acuosas puede determinar la aparición de una dermatitis.

Los vapores del ácido clorhídrico producen un efecto irritante en el tracto respiratorio, causando laringitis, edema de glotis, bronquitis, edema pulmonar y muerte. También son frecuentes las enfermedades digestivas, caracterizándose por necrosis dental molecular, que consiste en un proceso por el cual los dientes pierden su brillo, se tornan amarillos, blandos y afilados y, finalmente, se rompen.

M edidas de salud y seguridad. Además de las medidas generales descritas antes, este ácido nunca debe almacenarse en la proximidad de sustancias oxidantes o inflamables, como ácido nítrico o cloratos, ni cerca de metales e hidruros metálicos que puedan ser atacados por él, con liberación de hidrógeno, cuyo límite de explosividad es de 4-75 por 100 de volumen de aire. Toda la instalación eléctrica será a prueba de llamas y estará protegida contra la acción corrosiva de los vapores.

\section{Acido nítrico}

El ácido nítrico es altamente corrosivo y ataca a una gran cantidad de metales. Las reacciones entre el ácido nítrico y diversas sustancias orgánicas son a menudo muy exotérmicas y explosivas, y las reacciones con metales pueden producir gases tóxicos. El ácido nítrico produce quemaduras en la piel y sus vapores son muy irritantes para la piel y las mucosas. La inhalación de cantidades significativas de estos vapores puede producir intoxicación aguda.

Incendios y explosiones. El ácido nítrico ataca a la mayor parte de las sustancias y a todos los metales, excepto a los metales nobles (oro, platino, iridio, torio, tantalio) y ciertas aleaciones. La magnitud de la reacción varía según el metal de que se trate y la concentración del ácido. Durante la reacción se producen gases como óxidos de nitrógeno, nitrógeno y amoníaco, pudiendo producir, todos ellos, efectos tóxicos o asfixiantes. Cuando el ácido nítrico entra en contacto con sodio o potasio, se produce una reacción violenta y peligrosa, liberándose nitrógeno. No obstante, en el caso de ciertos metales se forma una película de 
óxido protectora que previene ataques posteriores. El ácido nítrico puede reaccionar explosivamente con sulfuro de hidrógeno. Los nitratos obtenidos como resultado de la acción de este ácido sobre diferentes bases son poderosos agentes oxidantes.

Incluso cuando se trata de soluciones diluidas, el ácido nítrico es una sustancia fuertemente oxidante. Las soluciones con una concentración superior al $45 \%$ pueden provocar la ignición espontánea de materiales orgánicos como trementina, madera, paja, etc.

Riesgos para la salud. Las soluciones de ácido nítrico son muy corrosivas y producen lesiones en la piel, los ojos y las mucosas, cuya gravedad depende de la duración del contacto y de la concentración del ácido. Estas lesiones pueden ir desde una simple irritación hasta quemaduras y necrosis localizada después de un contacto prolongado. Los vapores de ácido nítrico son también corrosivos para la piel, las mucosas y el esmalte dental.

Los vapores de ácido nítrico contienen siempre, en diferentes proporciones, otros compuestos nitrogenados gaseosos (p. ej. óxidos de nitrógeno), dependiendo de la concentración del ácido y el tipo de operación de que se trate. Su inhalación puede causar intoxicación aguda y sobreaguda. La intoxicación sobreaguda es poco frecuente y produce la muerte rápidamente. $L a$ intoxicación aguda es más frecuente y generalmente consta de tres fases: la primera consiste en una irritación del tracto respiratorio superior (irritación de la garganta, tos, sensación de ahogo) y de los ojos, con lagrimeo. La segunda fase es desconcertante, puesto que hay ausencia de sintomatología durante varias horas. En la tercera fase reaparecen los trastornos respiratorios, pudiendo desarrollarse rápidamente un edema pulmonar, muchas veces mortal.

La ingestión accidental de ácido nítrico produce lesiones graves en la boca, la faringe, el esófago y el estómago, cuyas secuelas pueden ser graves.

M edidas de salud y seguridad. Según la cantidad y la concentración, el ácido nítrico debe almacenarse en envases de acero inoxidable, aluminio o vidrio. Las bombonas de vidrio o winchesters dispondrán de una protección metálica para que puedan resistir los golpes. Sin embargo, cuando se trate de ácido nítrico que contenga algún compuesto fluorado, no se podrá almacenar en envases de vidrio. Los materiales orgánicos como madera, paja, serrín, etc, deben mantenerse alejados del lugar donde se realicen operaciones con ácido nítrico. En los casos en que se tenga que diluir ácido nítrico en agua, se verterá el ácido sobre el agua, evitando así el calentamiento.

\section{Acido sulfúrico}

El ácido sulfúrico es un ácido fuerte que, cuando se calienta por encima de $30{ }^{\circ} \mathrm{C}$, desprende vapores y, por encima de $200^{\circ} \mathrm{C}$, emite trióxido de azufre. En frío, reacciona con todos los metales, incluido el platino; en caliente, su reactividad se intensifica. El ácido sulfúrico diluido disuelve el aluminio, el cromo, el cobalto, el cobre, el hierro, el manganeso, el níquel y el zinc, pero no el plomo ni el mercurio. T iene una gran afinidad por el agua, y es por esta razón que absorbe la humedad de la atmósfera y extrae el agua de las materias orgánicas, carbonizándolas. Descompone las sales de todos los demás ácidos, excepto las del ácido silícico.

El ácido sulfúrico se encuentra, en estado natural, en las proximidades de algunos volcanes $y$, sobre todo, en los gases volcánicos.

Riesgos. La acción del ácido sulfúrico en el organismo es la propia de un agente tóxico general y un potente cáustico. Cuando se introduce en el organismo, bien sea en forma líquida o vapor, produce gran irritación y quemaduras químicas en las mucosas de los tractos digestivo y respiratorio, los dientes, los ojos y la piel. En contacto con la piel, el ácido sulfúrico produce una intensa deshidratación, con liberación de calor suficiente para producir quemaduras similares a las térmicas, que pueden ser de primero, segundo o tercer grado. La profundidad de estas lesiones depende de la concentración del ácido y de la duración del contacto. La inhalación de vapores de esta sustancia produce los siguientes síntomas: secreción nasal, estornudos, sensación de quemazón en la garganta y la región retroesternal. Estos síntomas van seguidos por tos, dificultad respiratoria, a veces acompañada de espasmos de las cuerdas vocales, y sensación de quemazón en los ojos, con lagrimeo y congestión de la conjuntiva. L os vapores con altas concentraciones de ácido sulfúrico pueden causar secreciones nasales y esputos sanguinolentos, hematemesis, gastritis, etc. Son también frecuentes las lesiones dentales, que afectan sobre todo a los incisivos, los cuales se tornan de color marrón, con estriaciones en el esmalte, caries y destrucción rápida e indolora de la corona dental.

Las exposiciones profesionales a vapores de ácidos inorgánicos fuertes, como los del ácido sulfúrico, han sido clasificadas por la Agencia Internacional para la Investigación sobre el Cáncer (IAR C) como cancerígenos humanos.

Las lesiones que se encuentra con más frecuencia en los trabajadores empleados en los procesos de producción de ácido sulfúrico son las quemaduras químicas. Las soluciones concentradas causan quemaduras profundas en las mucosas y la piel. Inicialmente la zona que ha contactado con el ácido está blanquecina, tornándose más tarde de color marrón para, finalmente, aparecer una úlcera perfectamente definida sobre una zona ligeramente enrojecida. Estas lesiones tardan mucho tiempo en curar y, con frecuencia, dejan extensas cicatrices que producen impotencia funcional. Si la quemadura es muy extensa, el pronóstico puede ser fatal. El contacto repetido de la piel con soluciones poco concentradas de este ácido produce desecación de la piel, ulceraciones en las manos y panadizo o inflamación crónica purulenta alrededor de las uñas. Las salpicaduras de ácido sulfúrico en los ojos son particularmente graves, pudiendo causar ulceración profunda de la córnea, queratoconjuntivitis y lesiones palpebrales con graves secuelas.

La acción general tóxica del ácido sulfúrico determina una depleción alcalina del organismo, es decir, una acidosis que afecta al sistema nervioso central y produce agitación, marcha vacilante y debilidad generalizada.

M edidas de salud y seguridad. Las medidas más eficaces son el completo cerramiento de los procesos y la mecanización de los procedimientos de manipulación para evitar el contacto de los trabajadores con el ácido sulfúrico. Se prestará una atención especial a los procesos de almacenamiento, manipulación y aplicación, a la ventilación e iluminación de los puestos de trabajo, al mantenimiento y a la limpieza, y al uso de equipos de protección personal. Además de las precauciones generales antes indicadas, el ácido sulfúrico no debe almacenarse en la proximidad de cromatos, cloratos o sustancias similares, por el peligro de incendio o explosión.

Incendios y explosiones. El ácido sulfúrico y el ácido sulfúrico fumante no son inflamables por sí mismos, pero reaccionan violentamente con muchas sustancias, sobre todo materiales orgánicos, con liberación de calor suficiente como para provocar un incendio o explosión; además, el hidrógeno liberado durante la reacción con metales puede formar una mezcla explosiva con el aire.

Catalizadores. Cuando se utilice un catalizador de vanadio en el método de contacto, los trabajadores deberán protegerse de la exposición a emisiones de vanadiato amónico y pentóxido de vanadio, que se utilizan sobre un soporte de diatomita o gel de sílice. 
TABLAS DE ACIDOS INORGANICOS

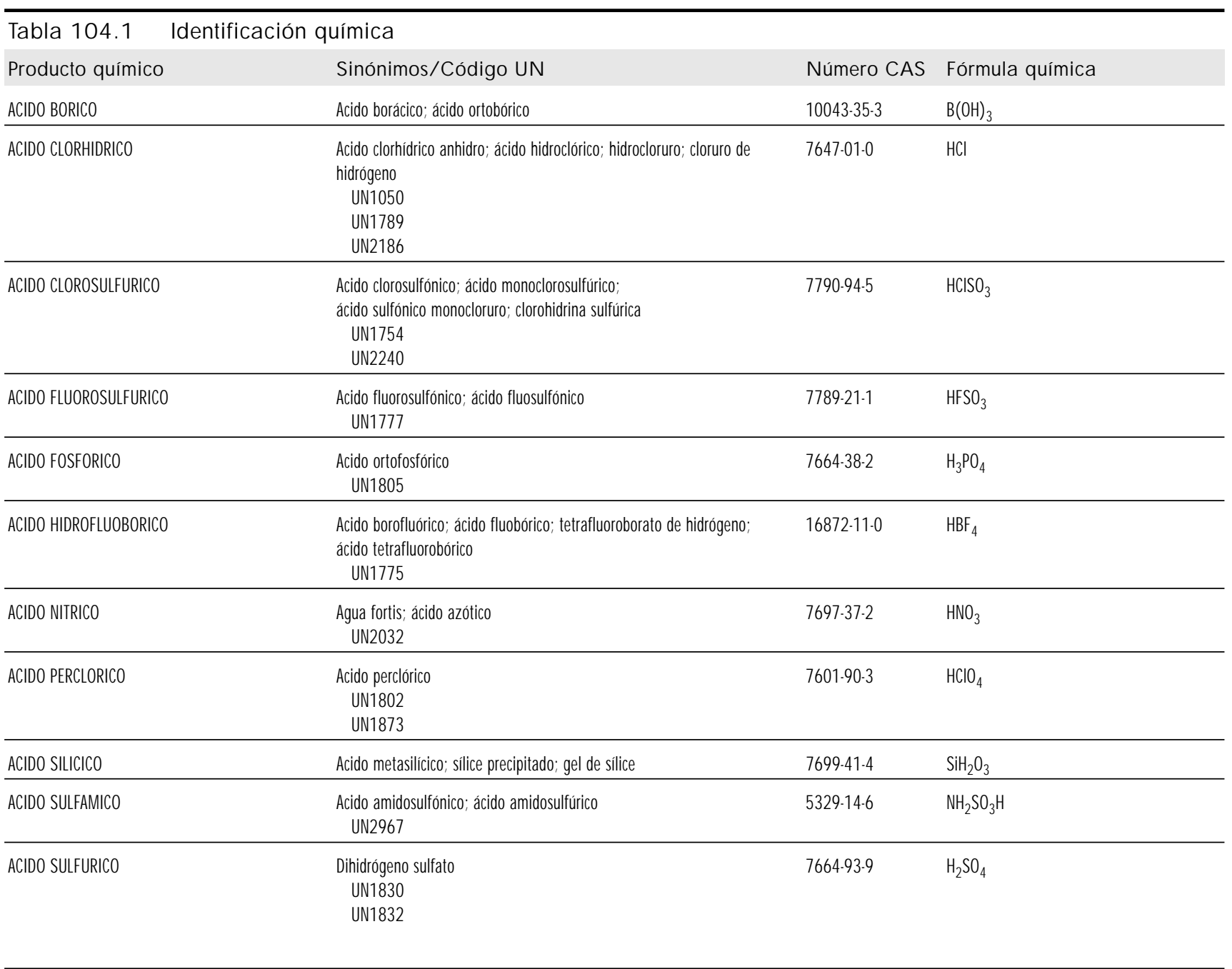

\begin{tabular}{|c|c|c|c|c|}
\hline \multirow[b]{2}{*}{$\begin{array}{l}\text { Denominación } \\
\text { química } \\
\text { N úmero CAS }\end{array}$} & \multicolumn{4}{|c|}{ Tarjetas Internacionales sobre la Seguridad de los Productos Q uímicos } \\
\hline & $\begin{array}{l}\text { Período } \\
\text { corto de } \\
\text { exposición }\end{array}$ & $\begin{array}{l}\text { Período } \\
\text { largo de } \\
\text { exposición }\end{array}$ & $\begin{array}{l}\text { Vías de } \\
\text { expo- } \\
\text { sición }\end{array}$ & Síntomas \\
\hline $\begin{array}{l}\text { ACIDO CLORHIDRICO } \\
7647-01-0\end{array}$ & \multicolumn{2}{|c|}{$\begin{array}{l}\text { ojos; piel; tract resp; pulmones; dientes } \\
\text { pulmones }\end{array}$} & Inhalación & $\begin{array}{l}\text { Corrosivo, sensación de quemazón, tos, } \\
\text { dificultad respiratoria y disnea, dolor de } \\
\text { garganta, los sintomas pueden tardar en } \\
\text { aparecer } \\
\text { Corrosivo, quemaduras graves en la piel, dolo } \\
\text { Corrosivo, dolor, visión borrosa, quemaduras } \\
\text { profundas graves }\end{array}$ \\
\hline
\end{tabular}

N IO SH (EE.UU.)

\begin{tabular}{|c|c|}
\hline $\begin{array}{l}\text { O rganos } \\
\text { afectados } \\
\text { Vías de } \\
\text { entrada }\end{array}$ & Síntomas \\
\hline $\begin{array}{l}\text { sis resp; ojos; piel } \\
\text { inh, ing, (soln), con }\end{array}$ & $\begin{array}{l}\text { Irrit nariz, garganta y laringe; } \\
\text { tos, ahogo; derm; soln: } \\
\text { quemaduras en ojos y piel; liq: } \\
\text { congelación; en animales: } \\
\text { espasmo lar, edema pulmonar }\end{array}$ \\
\hline
\end{tabular}




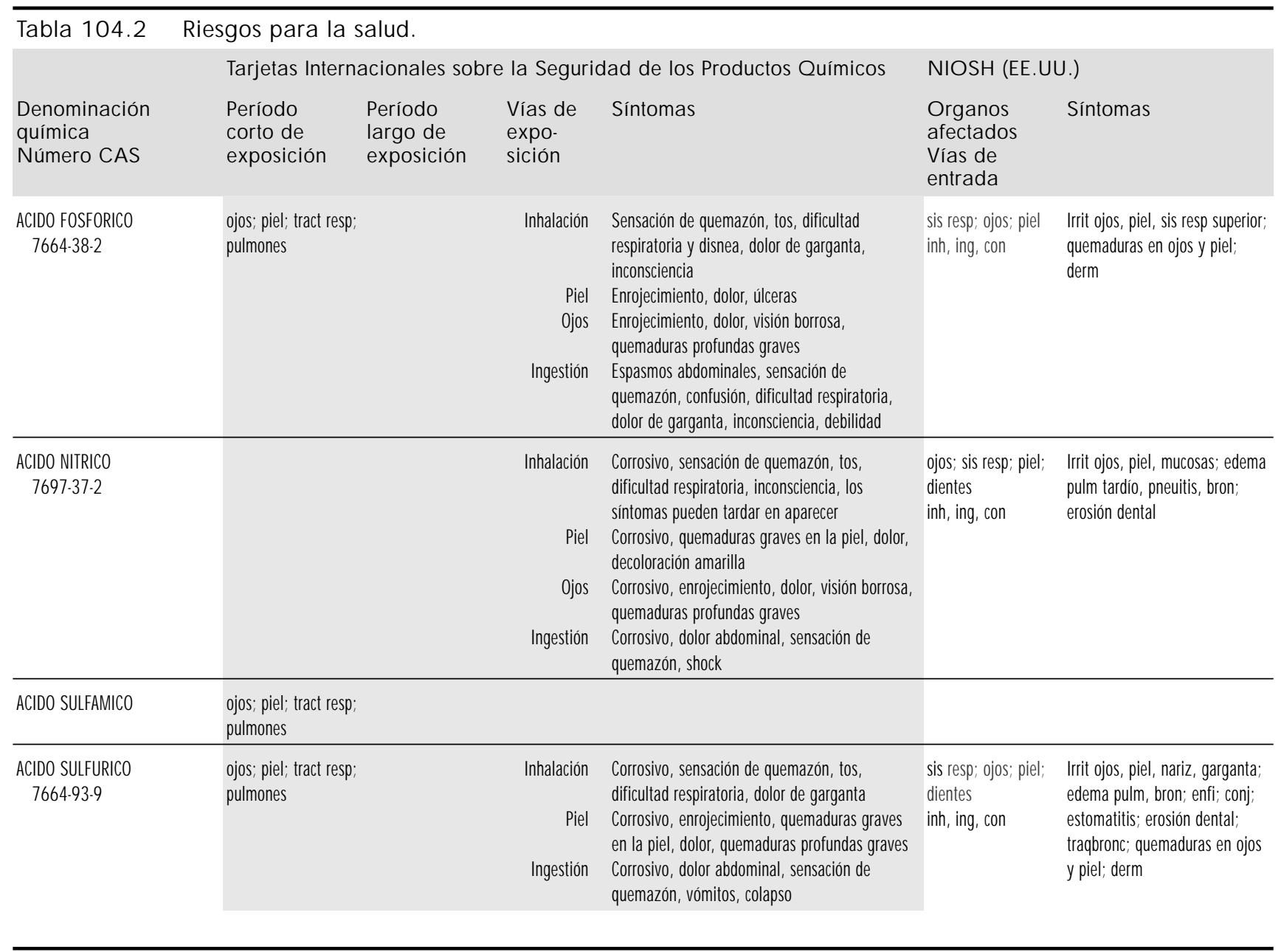

\begin{tabular}{|c|c|c|c|}
\hline $\begin{array}{l}\text { Denominación química } \\
\mathrm{N} \text { úmero CAS }\end{array}$ & Físicos & Q uímicos & $\begin{array}{l}\text { Clase o división } \\
\text { UN / Riesgos } \\
\text { subsidiarios }\end{array}$ \\
\hline $\begin{array}{l}\text { ACIDO CLORHIDRICO } \\
7647-01-0\end{array}$ & $\begin{array}{l}\text { El gas es más pesado } \\
\text { que el aire }\end{array}$ & $\begin{array}{l}\text { La solución en agua es muy ácida, reacciona violentamente con bases y es corrosiva } \\
\text { Reacciona violentamente con oxidantes, formando gases tóxicos (cloro) En contacto con el } \\
\text { aire emite vapores corrosivos (ácido clorhídrico) Ataca muchos metales, formando un gas } \\
\text { combustible (hidrógeno) }\end{array}$ & 8 \\
\hline $\begin{array}{l}\text { ACIDO CLOROSULFURICO } \\
7790-94-5\end{array}$ & & & 8 \\
\hline $\begin{array}{l}\text { ACIDO FLUOROSULFURICO } \\
7789-21-1\end{array}$ & & & 8 \\
\hline $\begin{array}{l}\text { ACIDO FOSFORICO } \\
7664-38-2\end{array}$ & & $\begin{array}{l}\text { Se polimeriza violentamente bajo la influencia de azocompuestos, epóxidos y otros compuestos } \\
\text { polimerizables En su combustión libera vapores tóxicos (óxidos de fósforo) Se descompone } \\
\text { en contacto con metales, alcoholes, aldehídos, cianuros, cetonas, fenoles, ésteres, sulfuros y } \\
\text { compuestos orgánicos halogenados, liberando vapores tóxicos Es un ácido de fuerza intermedia } \\
\text { Ataca los metales liberando gas hidrógeno inflamable. }\end{array}$ & \\
\hline
\end{tabular}

16872-11-0 


\begin{tabular}{|c|c|c|c|}
\hline \multicolumn{4}{|c|}{ Tabla 104.3 Riesgos químicos y físicos. } \\
\hline $\begin{array}{l}\text { Denominación química } \\
\mathrm{N} \text { úmero CAS }\end{array}$ & Físicos & Q uímicos & $\begin{array}{l}\text { Clase o división } \\
\text { UN / Riesgos } \\
\text { subsidiarios }\end{array}$ \\
\hline $\begin{array}{l}\text { ACIDO NITRICO } \\
7697-37-2\end{array}$ & & $\begin{array}{l}\text { Se descompone al calentarse produciendo óxidos de nitrógeno Es un oxidante fuerte y } \\
\text { reacciona violentamente con materiales combustibles y reductores, p. ej. trementina, carbón } \\
\text { vegetal, alcohol Es un ácido fuerte, reacciona violentamente con bases y corroe los } \\
\text { metales Reacciona muy violentamente con productos químicos orgánicos (p. ej. acetona, ácido } \\
\text { acético, anhídrido acético), con peligro de incendio y explosión Ataca algunos plásticos }\end{array}$ & 8 \\
\hline $\begin{array}{l}\text { ACIDO PERCLORICO } \\
7601-90-3\end{array}$ & & & $5.1 / 8$ \\
\hline $\begin{array}{l}\text { ACIDO SULFAMICO } \\
5329 \cdot 14 \cdot 6\end{array}$ & & & 8 \\
\hline $\begin{array}{l}\text { ACIDO SULFURICO } \\
7664-93.9\end{array}$ & & $\begin{array}{l}\text { En su combustión libera vapores tóxicos (óxidos de azufre) Es un oxidante fuerte y reacciona } \\
\text { violentamente con materiales combustibles y reductores Es un ácido fuerte, reacciona } \\
\text { violentamente con bases y corroe los metales más comunes, liberando un gas } \\
\text { inflamable/ explosivo (hidrógeno) Reacciona violentamente con agua y materiales orgánicos } \\
\text { con desprendimiento de calor Al calentarse emite vapores irritantes o tóxicos (óxidos de azufre) }\end{array}$ & 8 \\
\hline
\end{tabular}

\begin{tabular}{|c|c|c|c|c|c|c|c|c|c|c|}
\hline $\begin{array}{l}\text { Denominación } \\
\text { química } \\
\text { N úmero CAS }\end{array}$ & Color/ Forma & $\begin{array}{l}\text { p.e. } \\
\left({ }^{\circ} C\right)\end{array}$ & $\begin{array}{l}\text { p.f. } \\
(-\mathrm{C})\end{array}$ & $\begin{array}{l}\mathrm{p} . \mathrm{m} . / \\
\text { (g/ } \\
\mathrm{mol})\end{array}$ & $\begin{array}{l}\text { Solubilidad } \\
\text { en agua }\end{array}$ & $\begin{array}{l}\text { Densidad } \\
\text { relativa } \\
\text { (agua }=1 \text { ) }\end{array}$ & $\begin{array}{l}\text { Densidad } \\
\text { de vapor } \\
\text { relativa } \\
\text { (aire=1) }\end{array}$ & $\begin{array}{l}\text { Pvap/ } \\
(\mathrm{kPa})\end{array}$ & $\begin{array}{l}\text { Límit. } \\
\text { inflam. }\end{array}$ & $\begin{array}{ll}\text { p.ig. } & \text { p.aut } \\
(\stackrel{\circ}{ } \text { C }) & \text { ig. } \\
& (\stackrel{\circ}{ } \text { C })\end{array}$ \\
\hline $\begin{array}{r}\text { ACIDO BORICO } \\
10043-35-3\end{array}$ & $\begin{array}{l}\text { cristales incoloros, } \\
\text { transparentes o polvo o } \\
\text { gránulos blancos }\end{array}$ & 300 & 169 & 61,84 & $1 \mathrm{~g} / 18 \mathrm{ml}$ & $1,435 @ 15 \stackrel{\circ}{\circ}$ & & & & \\
\hline $\begin{array}{l}\text { ACIDO CARBONICO } \\
2582-30-1\end{array}$ & & & & 63,03 & sol & & & & & \\
\hline $\begin{array}{l}\text { ACIDO CLORHIDRICO } \\
\text { 7647-01-0 }\end{array}$ & líquido incoloro & -85 & -114 & 36,46 & $82,3 \mathrm{~g} / 100 \mathrm{ml}$ & $\begin{array}{l}1,05 \\
@ 15 \stackrel{\circ}{\circ} / 4 \stackrel{\circ}{ } \mathrm{C}\end{array}$ & 1,3 & & & \\
\hline $\begin{array}{l}\text { ACIDO CLOROSULFURICO } \\
7790-94-5\end{array}$ & $\begin{array}{l}\text { líquido incoloro } 0 \\
\text { ligeramente amarillo }\end{array}$ & $\begin{array}{l}151-152 @ \\
755 \mathrm{~mm} \mathrm{Hg}\end{array}$ & -80 & 116,53 & & 1,753 & 4,02 & $\begin{array}{l}1 \mathrm{~mm} \mathrm{Hg} \\
@ 32^{\circ} \mathrm{C}\end{array}$ & & \\
\hline $\begin{array}{l}\text { ACIDO FLUOROSULFURICO } \\
7789-21-1\end{array}$ & $\begin{array}{l}\text { líquido incoloro, de color } \\
\text { rojizo-marrón en acetona }\end{array}$ & 163 & .89 & 100,07 & & $\begin{array}{l}1,726 \\
@ 25 \stackrel{\circ}{\circ} 4 \stackrel{\circ}{-C}\end{array}$ & & & & \\
\hline $\begin{array}{l}\text { ACIDO FOSFORICO } \\
7664-38-2\end{array}$ & $\begin{array}{l}\text { cristales ortorrómbicos } \\
\text { inestables o líquido } \\
\text { meloso transparente; a } \\
20{ }^{\circ} \mathrm{C} \text {, las } \\
\text { concentraciones al } 50 \text { y } \\
75 \% \text { son líquidos } \\
\text { móviles; la concentración } \\
\text { al } 85 \% \text { tiene consistencia } \\
\text { melosa, mientras que el } \\
\text { ácido al } 100 \% \text { se } \\
\text { presenta en forma de } \\
\text { cristales; líquido viscoso, } \\
\text { incoloro, inodoro }\end{array}$ & 213 & 42,4 & 98,00 & muy sol & & 3,4 & 4,0 & & \\
\hline $\begin{array}{l}\text { ACIDO HIDROFLUOBORICO } \\
16872-11-0\end{array}$ & líquido incoloro & 130 & & 87,82 & misc & 1,84 & & & & \\
\hline $\begin{array}{c}\text { ACIDO NITRICO } \\
7697-37-2\end{array}$ & $\begin{array}{l}\text { líquido transparente } \\
\text { incoloro o amarillento }\end{array}$ & 83 & -42 & 63,01 & sol & $\begin{array}{l}1,5027 \\
@ 25 \stackrel{\circ}{\circ} / 4 \stackrel{\circ}{\mathrm{C}}\end{array}$ & $2-3$ & 6,4 & & \\
\hline
\end{tabular}




\begin{tabular}{|c|c|c|c|c|c|c|c|c|c|c|}
\hline Tabla 104.4 & Propiedades física & as y quír & cas. & & & & & & & \\
\hline $\begin{array}{l}\text { Denominación } \\
\text { química } \\
\text { N úmero CAS }\end{array}$ & Color/ Forma & $\begin{array}{l}\text { p.e. } \\
\left({ }^{\circ} \mathrm{C}\right)\end{array}$ & $\begin{array}{l}\text { p.f. } \\
(\stackrel{\circ}{ } \mathcal{C})\end{array}$ & $\begin{array}{l}\text { p.m.l } \\
\text { (g/ } \\
\text { mol) }\end{array}$ & $\begin{array}{l}\text { Solubilidad } \\
\text { en agua }\end{array}$ & $\begin{array}{l}\text { Densidad } \\
\text { relativa } \\
\text { (agua }=1 \text { ) }\end{array}$ & $\begin{array}{l}\text { Densidad } \\
\text { de vapor } \\
\text { relativa } \\
\text { (aire=1) }\end{array}$ & $\begin{array}{l}\text { Pvap/ } \\
(\mathrm{KPa})\end{array}$ & $\begin{array}{l}\text { Límit. } \\
\text { inflam. }\end{array}$ & $\begin{array}{ll}\text { p.ig. } & \text { p.aut } \\
(\stackrel{\circ}{ } C) & \text { ig. } \\
& (\stackrel{\circ}{ } C)\end{array}$ \\
\hline $\begin{array}{l}\text { ACIDO PERCLORICO } \\
7601-90-3\end{array}$ & líquido incoloro, oleoso & $\begin{array}{l}19 @ \\
11 \mathrm{~mm} \mathrm{Hg}\end{array}$ & -112 & 100,47 & misc & $1,768 @ 22 \stackrel{\circ}{\circ}$ & & & & \\
\hline $\begin{array}{l}\text { ACIDO SILICICO } \\
\text { 7699-41-4 }\end{array}$ & $\begin{array}{l}\text { al acidificar la solución de } \\
\text { silicato sódico se obtiene } \\
\text { un precipitado gelatinoso; } \\
\text { durante el secado, la } \\
\text { gelatina se convierte en } \\
\text { un polvo amorfo blanco }\end{array}$ & & & & & & & & & \\
\hline $\begin{array}{l}\text { ACIDO SULFAMICO } \\
5329-14-6\end{array}$ & $\begin{array}{l}\text { cristales ortorrómbicos; } \\
\text { sólido blanco cristalino }\end{array}$ & & 205 & 97,10 & sol & 2,15 & & & & \\
\hline $\begin{array}{l}\text { ACIDO SULFURICO } \\
7664-93-9\end{array}$ & $\begin{array}{l}\text { líquido transparente, } \\
\text { incoloro y oleoso cuando } \\
\text { está puro, pero marrón si } \\
\text { está impuro }\end{array}$ & 290 & 10,4 & 98,08 & sol & 1,841 & 3,4 & 0,13 & & \\
\hline
\end{tabular}




\section{ACIDOS Y ANHIDRIDOS ORGANICOS}

Los ácidos orgánicos y sus derivados constituyen un amplio grupo de sustancias químicas. Se utilizan en la fabricación de casi todos los productos químicos. La diferente estructura química de los ácidos orgánicos hace que sus efectos tóxicos sean muy variables. Estos compuestos ocasionan un efecto irritante primario cuya intensidad depende en parte de la disociación del ácido y su solubilidad en agua. Algunos pueden causar daños graves en los tejidos, similares a los producidos por los ácidos minerales fuertes. Puede aparecer también sensibilización, si bien ésta es más frecuente con los anhídridos que con los ácidos.

A los efectos de este artículo, los ácidos orgánicos se dividen en ácidos monocarboxílicos saturados e insaturados, ácidos alifáticos dicarboxílicos, ácidos acéticos halogenados, ácidos alifáticos monocarboxílicos y ácidos carboxílicos aromáticos. Son muchos los ácidos carboxílicos que tienen importancia debido a su uso en alimentos, bebidas, fármacos y distintos procesos de fabricación. Entre los más frecuentes se encuentran los siguientes: ácido adípico, ácido azelaico, ácido fumárico, ácido itacónico, ácido maleico, ácido málico, ácido oxálico, ácido pimélico, ácido sebácico, ácido succínico, ácido tartárico y ácido tiomálico.

Los ácidos monocarboxílicos saturados de cadena larga son los ácidos grasos y en su mayoría se obtienen de fuentes naturales. Tambien se fabrican ácidos grasos sintéticos mediante oxidación al aire de parafinas (hidrocarburos alifáticos) utilizando un metal como catalizador, o mediante oxidación de alcoholes con sosa cáustica.

\section{Usos}

Los ácidos orgánicos se utilizan en las industrias de plásticos, curtidos, textiles, papel, metales, productos farmacéuticos, alimentos, bebidas y cosméticos. T ambién se encuentran en perfumes, herbicidas, colorantes, lubricantes y productos de limpieza.

El ácido fórmico y el ácido acético son los principales productos químicos industriales del grupo de los ácidos monocarboxílicos saturados. El ácido fórmico se utiliza sobre todo en las industrias textil y del cuero. Actúa como agente agotador de tintes de diversas fibras naturales y sintéticas y como agente reductor en la tinción de cromo. El ácido fórmico se utiliza como agente descalcificante y neutralizante en la industria del cuero, como coagulante para látex de caucho y en la fabricación de fumigantese insecticidas. El ácido acético sirve de producto químico intermedio, agente descalcificante en el curtido del cuero, disolvente y acidificante de pozos de petróleo. Además se utiliza como aditivo en distintos alimentos y en el vidriado y como catalizador y agente de acabado en las industrias de colorantes y tejidos.

Con la fermentación aerobia (A cetobacter) de soluciones alcohólicas, se obtiene ácido acético a concentraciones bajas (el vinagre contiene aproximadamente entre un 4 y un $6 \%$ ). El ácido acético es uno de los ácidos orgánicos más utilizados. Se emplea en la producción de acetato de celulosa, acetato de vinilo, acetatos inorgánicos, acetatos orgánicos y anhídrido acético. El ácido acético como tal se utiliza en la industrias de colorantes, productos farmacéuticos, enlatado y conservación de alimentos y producción de pigmentos.

El ácido cloroacético se utiliza en las industrias farmacéutica, química y de fabricación de colorantes y como producto químico intermedio. El ácido salićlico sirve también como producto químico intermedio en la síntesis de aspirina y en las industrias de caucho y colorantes. El ácido benzoico, el ácido nonanoico, el ácido ascórbico y el ácido olèco (ácido 9-octadecenoico) son otros compuestos utilizados en las industrias de alimentos y bebidas y en la industria farmacéutica.

El ácido pal mítico y el ácido esteárico se emplean frecuentemente en jabones, cosméticos, detergentes, lubricantes, revestimientos protectores y productos químicos intermedios. El ácido propiónico se utiliza en síntesis orgánicas. T ambién es un inhibidor de hongos y un conservante alimentario. El ácido acrílico, el ácido metacrílico y el ácido crotónico se emplean en la fabricación de resinas y plastificantes en las industrias de papel, plásticos y pinturas. El ácido acrílico es también un ingrediente de formulaciones de cera para suelos. El ácido crotónico se utiliza en la fabricación de agentes de reblandecimiento para el caucho sintético. El ácido láctico, el ácido butírico y el ácido gálico se utilizan en la industria del cuero y los curtidos. EI ácido láctico también se emplea en adhesivos, plásticos y tejidos; sirve como acidulante alimentario y agente acidificante de pozos de petróleo. El ácido glicólico se utiliza en las industrias del cuero, tejidos, galvanoplastia, adhesivos y limpieza de metales.

Los ácidos dicarboxílicos (ácido succínico, ácido maleico, ácido fumárico, ácido adípico) y el ácido tricarboxílico (ácido cítrico) son útiles en las industrias de alimentos, bebidas y productos farmacéuticos. El ácido succínico se utiliza también en la fabricación de lacas y colorantes. El ácido maleico se emplea en la fabricación de resinas sintéticas y en síntesis orgánicas, actúa como conservante de aceites y grasas y sus sales se utilizan en la tinción de algodón, lana y seda. El ácido fumárico se utiliza en poliésteres y resinas alquílicas, revestimientos de plásticos, acidulantes alimentarios, tintas y síntesis orgánicas. El ácido adípico se utiliza sobre todo para la producción de nylon, aunque también se encuentran pequeñas cantidades en plastificantes, lubricantes sintéticos, poliuretanos y acidulantes alimentarios.

El ácido oxálico es un desengrasante utilizado en el acabado, desforramiento y limpieza de tejidos, así como un ingrediente de fórmulas para la limpieza de metales. Se emplea también en las industrias del papel, fotografía y caucho, en el estampado y tinción de telas de algodón, en la decoloración de sombreros de paja y cuero, y en la limpieza de madera. El ácido aminoacético se utiliza como tampón y en síntesis. El ácido peracético se utiliza como decolorante, catalizador y oxidante.

El ácido nafténico comercial suele ser una mezcla de ácidos nafténicos de color oscuro y olor fétido. Los ácidos nafténicos se derivan de las cicloparafinas del petróleo, probablemente por oxidación. Los ácidos comerciales son habitualmente mezclas líquidas viscosas en las que puede separarse una fracción de destilación de temperatura de ebullición alta y otra baja. Los pesos moleculares van desde 180 hasta 350. Se utilizan sobre todo en la preparación de secantes de pinturas donde las sales metálicas, como plomo, cobalto y manganeso, actúan como agentes oxidantes. L os ácidos nafténicos metálicos se utilizan como catalizadores de reacciones químicas. Una ventaja industrial es su solubilidad en aceite.

\section{Anhídridos de ácidos orgánicos}

Un anhídrido se define como un óxido que al combinarse con agua produce un ácido o una base. Los anhídridos ácidos se obtienen por eliminación del agua de dos moléculas del ácido correspondiente, como:

$$
2 \mathrm{H} \mathrm{MnO}_{4} \rightarrow \mathrm{M} \mathrm{n}_{2} \mathrm{O}_{7}+\mathrm{H}_{2} \mathrm{O}
$$

Los anhídridos más importantes en la industria son el acético y el ftálico. El anhídrido acético se utiliza en las industrias de plásticos, explosivos, perfumes, alimentos, tejidos y productos 
farmacéuticos y como producto químico intermedio. El anhídrido ftálico sirve de plastificante en la polimerización de cloruro de vinilo. T ambién se emplea en la producción de resinas de poliésteres saturados e insaturados, ácido benzoico, pesticidas, y ciertas esencias y perfumes. El anhídrido ftálico se utiliza en la producción de colorantes de ftalocianina y resinas alquídicas utilizadas en pinturas y lacas. El anhídrido maleico tiene también numerosas aplicaciones.

El anhídrido propiónico se usa en la fabricación de perfumes, resinas alquídicas, fármacos y colorantes, mientras que el anhídrido maleico, $\mathrm{e}$ anhídrido trimelítico y el anhídrido acético se utilizan en la industria de los plásticos. El anhídrido trimelítico (T M A) se emplea en las industrias de colorantes, impresión y tapicerías para automóviles. Se utiliza como agente de curado para resinas epoxi y de otros tipos, en plastificantes de vinilo, pinturas, revestimientos, colorantes, pigmentos y muchos otros productos manufacturados. 0 tras aplicaciones de estos productos son los plásticos termorresistentes, el aislamiento de cables y las juntas.

\section{Riesgos}

\section{Acidos monocarboxílicos}

Los ácidos monocarboxílicos de bajo peso molecular son irritantes primarios y producen graves lesiones en los tejidos. Es preciso adoptar precauciones estrictas en su manipulación y utilizar equipos protectores adecuados. Las salpicaduras en la piel y los ojos deben lavarse con agua abundante. Los ácidos más importantes de este grupo son el ácido acético y el ácido fórmico.

Los ácidos monocarboxílicos saturados de cadena larga (ácidos grasos) no son irritantes y exhiben una toxicidad muy baja. Su uso industrial plantea pocos problemas.

L os ácidos monocarboxílicos insaturados son sustancias muy reactivas y están reconocidos como irritantes graves de la piel, los ojos y el tracto respiratorio en solución concentrada. Las exposiciones agudas parecen entrañar más riesgos que las exposiciones crónicas.

La mayoría de estos ácidos presentan un riesgo mínimo cuando la exposición es crónica y a bajas concentraciones y muchos están presentes en los procesos normales del metabolismo humano. No obstante, algunos de estos ácidos tienen importantes efectos irritantes, particularmente cuando se encuentran en soluciones concentradas o en forma de polvo. La sensibilización es poco frecuente. Puesto que estos productos son sólidos a temperatura ambiente, el contacto se produce normalmente con polvo o cristales.

Acido acético. Los vapores de ácido acético pueden formar mezclas explosivas con el aire, constituyendo un riesgo de incendio, bien directamente o por liberación de hidrógeno. El ácido acético glacial y el ácido acético concentrado son muy irritantes para la piel y producen eritema (enrojecimiento), quemaduras químicas y ampollas. En casos de ingestión accidental, se han observado lesiones ulceronecróticas graves del tracto digestivo superior, con vómitos sanguinolentos, diarrea, shock y hemoglobinuria seguida de anuria y uremia.

L os vapores de ácido acético tienen una acción irritante en las mucosas, sobre todo en la conjuntiva, la rinofaringe y el tracto respiratorio superior. En una mujer que había inhalado vapores de ácido acético, produciéndole desvanecimiento, se desarrolló una bronconeumonía aguda.

T rabajadores expuestos durante varios años a concentraciones de ácido acético superiores a 200 ppm han llegado a sufrir edema palpebral, con hipertrofia de los ganglios linfáticos, hiperemia conjuntival, faringitis crónica, bronquitis catarral crónica y, en algunos casos, bronquitis asmática y signos de erosión en la superficie vestibular de los dientes (incisivos y caninos).
La aclimatación puede ser considerable, pero eso no significa que desaparezcan los efectos tóxicos. Por ejemplo, las exposiciones reiteradas pueden causar trastornos digestivos, con pirosis y estreñimiento. La piel de la palma de las manos es la que sufre una mayor exposición, llegando a secarse y agrietarse y tornándose hiperqueratótica, por lo que las pequeñas erosiones y cortes cicatrizan lentamente.

Acido fórmico. El principal riesgo de esta sustancia reside en su capacidad de producir graves lesiones en la piel, los ojos y las mucosas. Los casos de sensibilización son raros, pero pueden darse en personas previamente sensibilizadas al formaldehído. Las lesiones accidentales son las mismas que las producidas por otros ácidos relativamente fuertes. No se han observado efectos crónicos o retardados. El ácido fórmico es un líquido inflamable y sus vapores forman mezclas inflamables y explosivas con el aire.

El ácido propiónico en solución posee propiedades corrosivas sobre algunos metales. Es un irritante de los ojos, la piel y el sistema respiratorio. Se recomienda la adopción de las mismas precauciones que para la exposición a ácido fórmico, aunque teniendo en cuenta el menor punto de ignición del ácido propiónico.

El ácido maleico es un ácido fuerte que produce una marcada irritación de la piel y las mucosas. A partir de concentraciones del $5 \%$ puede producir algunos efectos graves, particularmente en los ojos. No se han descrito efectos tóxicos acumulativos en el ser humano. El principal riesgo en la industria es la irritación de las superficies expuestas que, en su caso, debe prevenirse con el uso del equipo de protección personal adecuado generalmente consistente en guantes o manoplas impermeables.

El ácido fumárico es un ácido relativamente débil y poco soluble en agua. Es un metabolito normal y menos tóxico por vía oral que el ácido tartárico. Produce una leve irritación de la piel y las mucosas y no se han descrito problemas relacionados con su manipulación industrial.

El ácido adípico no es irritante y su toxicidad por ingestión es muy baja.

\section{Acidos acéticos halogenados}

L os ácidos acéticos halogenados son muy reactivos. Entre ellos se encuentran el ácido cloroacético, el ácido dicloroacético (DCA), el ácido tricloroacético (T CA), el ácido bromoacético, el ácido iodoacético, el ácido fluoroacético y el ácido trifluoroacético (T FA).

Los ácidos acéticos halogenados causan graves lesiones en la piel y las mucosas y, cuando se ingieren, pueden interferir con sistemas enzimáticos esenciales del organismo. Su manipulación exige la adopción de precauciones estrictas. Estos ácidos deben prepararse y utilizarse en recintos cerrados que sólo se abrirán el tiempo necesario para su manipulación. D eberán existir extractores de aire para asegurar que los humos o vapores no escapen por otras aberturas que las establecidas para tal fin. Los trabajadores encargados de su manipulación deben utilizar equipos de protección personal y siempre deben disponer de equipos de protección ocular y respiratoria para utilizarlos en caso necesario.

Acido fluoroacético. Los ácidos di y trifluoroacético presentan un nivel de toxicidad menor que el ácido monofluoroacético lácido fluoroacético). El ácido monofluoroacético y sus compuestos son estables, muy tóxicos y perniciosos. Al menos cuatro plantas de Sudáfrica y Australia deben su toxicidad a este ácido (D ichapetalum cymosum, A cacia georginae, Palicourea marogravii) y recientemente se ha comprobado que más de 30 especies de $G$ astrolobium y 0 xylobrium en la zona oeste de Australia contienen cantidades variables de fluoroacetato.

EI mecanismo biológico responsable de los síntomas de intoxicación por fluoroacetato es la "síntesis letal" de ácido fluorocítrico, el cual, a su vez, bloquea el ciclo de los ácidos tricarboxílicos por inhibición de la enzima aconitasa. La privación resultante de energía al detenerse el ciclo de K rebs va seguida de 
disfunción celular y muerte. Por otro lado, es imposible especificar cuál es la dosis tóxica de ácido fluoroacético para el ser humano; probablemente esté comprendida entre 2 y $10 \mathrm{mg} / \mathrm{kg}$, si bien existen algunos fluoroacetatos mucho más tóxicos. En general, una o dos gotas del tóxico por inhalación, ingestión o absorción, a través de cortes 0 abrasiones de la piel 0 a través de la piel intacta, pueden resultar mortales.

De los estudios realizados en hospitales por casos de intoxicación parece deducirse que los principales efectos tóxicos de los fluoroacetatos en el ser humano afectan al sistema nervioso central y al sistema cardiovascular. Las víctimas sufren convulsiones epileptiformes graves que se alternan con coma y depresión. La muerte puede sobrevenir por asfixia durante una convulsión 0 por insuficiencia respiratoria. No obstante, los síntomas más característicos son las irregularidades cardíacas, una marcada fibrilación ventricular y parada cardíaca. Estos síntomas (que no se pueden diferenciar de todos los demás que se observan con frecuencia en la práctica clínica) suelen ir precedidos de un período inicial de latencia superior a 6 horas, caracterizado por náuseas, vómitos, sialorrea, entumecimiento, sensación de hormigueo, epigastralgias y opresión. Posteriormente pueden aparecer otros signos y síntomas, como contracturas musculares, descenso de la tensión arterial y visión borrosa.

A cido cloroacético. Esta sustancia es muy reactiva y debe manipularse con precaución. Cuando exista la posibilidad de que los trabajadores entren en contacto con soluciones concentradas, deberán ir protegidos obligatoriamente con guantes, gafas, botas de goma y mandiles impermeables.

\section{Otrosácidos}

El ácido glicólico es más fuerte que el acético y produce quemaduras químicas muy graves en la piel y los ojos. No se conocen efectos acumulativos y se cree que se metaboliza a glicina. En su manipulación deben adoptarse precauciones estrictas, similares a las recomendadas para el ácido acético. Las soluciones concentradas pueden provocar quemaduras en la piel y los ojos. Las personas que manipulen soluciones concentradas de este ácido deben utilizar equipos de protección individual.

El ácido sórbico se utiliza como fungicida en los alimentos. Es un irritante primario de la piel y puede provocar reacciones de sensibilización. Por esta razón se debe evitar todo contacto con la piel.

El ácido salićlico es un poderoso irritante de la piel y las mucosas. Los trabajadores deben adoptar precauciones estrictas para evitar el contacto con esta sustancia.

\section{Anhídridos}

Los anhídridos de ácidos tienen puntos de ebullición más altos que los correspondientes ácidos. Sus efectos fisiológicos generalmente recuerdan a los de los correspondientes ácidos, si bien son irritantes más potentes de los ojos cuando están en fase de vapor, pudiendo producir conjuntivitis crónica. Se hidrolizan lentamente en contacto con los tejidos corporales y ocasionalmente provocan sensibilización. Debe existir un sistema adecuado de ventilación y los trabajadores dispondrán de equipos de protección individual. En algunas circunstancias, sobre todo cuando tengan que realizarse labores de mantenimiento, los trabajadores tendrán que utilizar equipos adecuados de protección ocular y respiratoria.

Se han descrito algunos casos de conjuntivitis, secreciones nasales sanguinolentas, atrofia de la mucosa nasal, ronquera, tos y bronquitis en trabajadores empleados en la producción de ácido y anhídrido ftálico. Se ha reconocido que el anhídrido ftálico causa asma bronquial, y se han detectado casos de sensibilización de la piel después de una exposición prolongada a anhídrido ftálico. La lesión más frecuente es una dermatitis alérgica. También se ha identificado una IgE específica del anhídrido ftálico.

El anhídrido ftálico es inflamable y conlleva un peligro moderado de incendio. Su toxicidad es comparativamente baja en relación con otros anhídrido ácidos industriales, pero actúa como irritante de la piel, los ojos y el tracto respiratorio superior. Puesto que el anhídrido ftálico no tiene efecto alguno sobre la piel seca, pero produce quemaduras en la piel húmeda, es probable que el producto realmente irritante sea el ácido ftálico que se forma en contacto con el agua.

El anhídrido ftálico debe almacenarse en un lugar fresco y bien ventilado, alejado de llamas abiertas y sustancias oxidantes. En los lugares donde se manipule esta sustancia tiene que existir un buen sistema de ventilación local y general. En muchos procesos, el anhídrido ftálico se utiliza no en forma de copos sino en forma de líquido, que se envía a las industrias en tanques y se bombea directamente a un sistema de conducciones, con lo cual se evita el contacto directo con el producto y la contaminación del aire con el polvo. Este método ha tenido como resultado la completa desaparición de todas las manifestaciones irritativas en los trabajadores de este tipo de industrias. Sin embargo, debe tenerse siempre en cuenta que los vapores emitidos por el anhídrido ftálico líquido son tan irritantes como los copos o las escamas, por lo que debe prevenirse cualquier tipo de fuga en el sistema de conducciones. En caso de salpicaduras o contacto con la piel, ésta debe lavarse inmediatamente con agua abundante.

Los trabajadores que manipulan derivados del anhidrido ftálico deben mantenerse bajo control médico, prestando una atención especial a los síntomas de asma y sensibilización de la piel. Si se observa alguno de estos síntomas, el trabajador tendrá que ser asignado a otro puesto de trabajo. Sea como fuere, el contacto con la piel debe evitarse siempre. Se recomienda el uso de ropa protectora como guantes de goma. Los trabajadores deben someterse a un examen médico previo al empleo para tener la seguridad de que ninguna persona con asma bronquial, eczema u otras enfermedades alérgicas se vea expuestas al anhídrido ftálico.

Anhídrido acético. Cuando se expone al calor, el anhídrido acético libera humos tóxicos que pueden explotar en presencia de una llama. Reacciona violentamente con ácidos fuertes y oxidantes como ácido sulfúrico, ácido nítrico, ácido clorhídrido, permanganatos, trióxido de cromo y peróxido de hidrógeno, así como con sosa.

El anhídrido acético es un potente irritante y tiene propiedades corrosivas cuando contacta con los ojos, por regla general de forma retardada. EI contacto va seguido de lagrimeo, fotofobia, conjuntivitis y edema de córnea. La inhalación puede causar irritación de la nasofaringe y el tracto respiratorio superior, con sensación de quemazón, tos y disnea. Las exposiciones prolongadas pueden determinar la aparición de edema pulmonar. La ingestión de este producto causa dolor, náuseas y vómitos. En caso de contacto prolongado con la piel puede aparecer dermatitis.

Siempre que exista peligro de contacto con esta sustancia, se recomienda el uso de ropas y gafas protectoras y la disponibilidad de duchas e instalaciones para el lavado de los ojos. Para concentraciones de hasta $250 \mathrm{ppm}$ se recomienda el uso de respiradores con filtros químicos y para concentraciones de 1.000 ppm se recomienda el uso de máscaras integrales de protección respiratoria con suministro de aire. En caso de incendio tendrán que utilizarse aparatos respiradores autónomos.

El anhídrido butírico se obtiene mediante hidrogenación catalítica del ácido crotónico. El anhídrido butírico y el anhídrido propiónico presentan riesgos similares a los del anhídrido acético. 
EI anhídrido maleico produce quemaduras graves en la piel y los ojos por contacto de la piel húmeda con soluciones o escamas de anhídrido maleico. Es un compuesto que produce sensibilización de la piel y que exige la adopción de precauciones estrictas para evitar el contacto con la piel o los ojos. Los trabajadores deben llevar gafas adecuadas y prendas protectoras y es muy importante que tengan acceso a equipos de irrigación ocular. Cuando el anhídrido maleico se encuentra en suspensión en la atmósfera de trabajo, en forma de finas partículas, pueden formarse mezclas explosivas con el aire. Los condensadores donde el producto sublimado se deposita en forma de finos cristales deberán estar colocados en posición segura, fuera de las áreas ocupadas por el personal.

Se han dado algunos casos de edema pulmonar causado por el anhídrido trimeítico en trabajadores sometidos a una exposición aguda intensa, y de sensibilización de las vías respiratorias después de la exposición durante semanas o años, con rinitis o asma. Se han comunicado varios incidentes por exposición profesional a T M A. Se han descrito dos casos de edema pulmonar por exposición mediante inhalación múltiple a resinas epoxídicas que contenían TM A y que fueron pulverizadas sobre tuberías calientes. Aunque no se especificaron los niveles de exposición, la ausencia de irritación del tracto respiratorio superior durante la exposición podría indicar una reacción de hipersensibilidad. En otro informe, 14 trabajadores que participaban en la síntesis de TMA presentaron síntomas respiratorios por sensibilización a TM A. En este estudio se observaron tres respuestas distintas. La primera, rinitis o asma se desarrolló como consecuencia de una exposición durante semanas o años. U na vez sensibilizados, los trabajadores expuestos presentaron síntomas inmediatamente después del contacto con T M A, que remitieron al cesar la exposición. U na segunda respuesta, que también implicó sensibilización, produjo síntomas tardíos (tos, respiración sibilante y dificultosa) entre 4 y 8 horas después de que cesara la exposición. La tercera respuesta fue un efecto irritante después de exposiciones iniciales altas

EI National Institute for O ccupational Safety and $\mathrm{H}$ ealth (N IO SH ) de Estados U nidos realizó un estudio de los efectos adversos en la salud, con medición de las concentraciones de T M A en el aire. Treinta trabajadores que participaban en la fabricación de una pintura epoxídica presentaron irritación de los ojos, la piel, la nariz y la garganta, disnea, tos, ardor, náuseas y cefalea. Por término medio, los niveles de exposición profesional por contaminación ambiental fueron de $1,5 \mathrm{mg} / \mathrm{m}^{3}$ de TM A (intervalo desde indetectable a $4,0 \mathrm{mg} / \mathrm{m}^{3}$ ) durante las operaciones de procesado y de $2,8 \mathrm{mg} / \mathrm{m}^{3}$ de TMA (intervalo desde indetectable a $7,5 \mathrm{mg} / \mathrm{m}^{3}$ ) durante los procedimientos de descontaminación.

Estudios experimentales con ratas han demostrado la presencia de hemorragia intraalveolar con exposiciones subagudas a T M A a concentraciones de $0,08 \mathrm{mg} / \mathrm{m}^{3}$. La presión de vapor a $20 \stackrel{\circ}{ } \mathrm{C}$ $(4 \times 10-6 \mathrm{~mm} \mathrm{H} \mathrm{g})$ corresponde a una concentración algo mayor de $0,04 \mathrm{mg} / \mathrm{m}^{3}$.

A cido oxálico y sus derivados. El ácido oxálico es un ácido fuerte que, bien en forma sólida o en solución concentrada, produce quemaduras de la piel, los ojos y las mucosas. Las concentraciones de ácido oxálico de 5 a $10 \%$ son irritantes si la exposición es prolongada. Se han registrado algunos casos mortales por ingestión de cantidades tan pequeñas como $5 \mathrm{~g}$ de ácido oxálico. Los síntomas aparecen rápidamente y se caracterizan por un estado similar al shock, colapso y convulsiones. En estos casos puede observarse una insuficiencia renal marcada con precipitación de oxalato cálcico en los túbulos renales. Los episodios convulsivos se cree que son resultado de la hipocalcemia. Se ha comprobado que la exposición crónica de la piel a soluciones de ácido oxálico u oxalato potásico causa dolor localizado, cianosis en los dedos e, incluso, gangrena. Esto se debe aparentemente a una absorción localizada del ácido oxálico que produce arteritis. Las lesiones sistémicas crónicas por inhalación de ácido oxálico son poco frecuentes, aunque se ha descrito un caso de exposición a vapores calientes de ácido oxálico (que probablemente contenían un aerosol de ácido oxálico), con síntomas generalizados de pérdida de peso e inflamación crónica del tracto respiratorio superior. Debido a la naturaleza fuertemente ácida del polvo de ácido oxálico, la exposición al mismo debe controlarse rigurosamente y las concentraciones en el lugar de trabajo deben mantenerse dentro de unos límites aceptables para la salud.

EI oxalato de dietilo es ligeramente soluble en agua y miscible en cualquier proporción con muchos disolventes orgánicos. Se trata de un líquido incoloro, inestable y aceitoso obtenido mediante esterificación de alcohol etílico y ácido oxálico. Al igual que otros ésteres de oxalato líquidos, se utiliza como disolvente de muchas resinas naturales y sintéticas.

Los síntomas observados en ratas, tras la ingestión de grandes cantidades de dietil oxalato, fueron trastornos respiratorios y contracciones musculares bruscas. Se hallaron grandes depósitos de oxalato en los túbulos renales de ratas que habían recibido una dosis oral de $400 \mathrm{mg} / \mathrm{kg}$. Se ha notificado que los trabajadores expuestos durante varios meses a $0,76 \mathrm{mg} / \mathrm{I}$ de oxalato de dietilo desarrollaron un cuadro consistente en debilidad, cefaleas y náuseas, junto con pequeñas variaciones en el recuento de células sanguíneas. A causa de la baja presión de vapor de esta sustancia a temperatura ambiente, las concentraciones en el aire declaradas bien pudieron ser erróneas. Además, durante esta operación se utilizaron también algunas cantidades de acetato de diamilo y carbonato de dietilo.

\section{Medidas de salud y seguridad}

Todos los ácidos deben almacenarse lejos de fuentes de ignición y sustancias oxidantes. Las áreas de almacenamiento deben estar bien ventiladas para evitar la acumulación de concentraciones peligrosas. L os envases deben ser de acero inoxidable o cristal. En caso de fugas o derrames, el ácido acético debe neutralizarse con soluciones alcalinas. Se instalarán surtidores de agua para el lavado de los ojos y duchas de urgencia para la eliminación del ácido en caso de contacto con la piel o con los ojos. Es esencial que los envases estén correctamente etiquetados, y para todas las formas de transporte, el ácido acético se clasifica como sustancia peligrosa.

Para prevenir daños de las vías respiratorias y las mucosas, la concentración atmosférica de ácidos orgánicos y anhídridos con alta presión de vapor debe mantenerse por debajo de los niveles máximos permisibles mediante la utilización de dispositivos de higiene industrial, como extractores locales, ventilación general y determinación periódica de las concentraciones atmosféricas de ácido acético. En ausencia de vapores de otros ácidos, la detección y el análisis se realizan mediante borboteo en una solución alcalina y determinación del álcali residual; en presencia de otros ácidos, antes tenía que recurrirse a la destilación fraccionada, pero en la actualidad se dispone de un método de cromatografía de gases para la determinación en aire 0 agua. Las exposiciones a polvo deben reducirse al mínimo.

Las personas que trabajan con ácido puro o con soluciones concentradas deben utilizar ropas protectoras, además de elementos de protección para la cara, los ojos, las manos y los brazos. También utilizarán equipos de protección respiratoria. Deberán existir unas instalaciones sanitarias adecuadas y se fomentará una buena higiene personal. 
TABLAS DE ACIDOS Y ANHIDRIDOS ORGANICOS

\begin{tabular}{|c|c|c|}
\hline Producto químico & Sinónimos/ Código UN & $\mathrm{N}$ úmero CAS Fórmula estructural \\
\hline ACIDO ACRILICO & $\begin{array}{l}\text { Acido etilencarboxilico; ácido propenoico } \\
\text { UN2218 }\end{array}$ & $79-10-7$ \\
\hline ACIDO ADIPICO & $\begin{array}{l}\text { Acido adipínico; ácido 1,4-butanodicarboxilico; ácido hexanodioico; } \\
\text { ácido 1,6-hexanodioico }\end{array}$ & 124.04 .9 \\
\hline ACIDO L-ASCORBICO & $\begin{array}{l}\text { 3-Ceto--gulofuranolactona; lactona del ácido L-3-cetotreohexurónico; } \\
\text { vitamina C }\end{array}$ & $50-81-7$ \\
\hline ACIDO BENZOICO & $\begin{array}{l}\text { Acido bencenocarboxílico; ácido bencenofórmico; ácido bencenometanoico; } \\
\text { ácido fenil carboxilico; ácido fenilfórmico }\end{array}$ & $65-85-0$ \\
\hline ACIDO p-terc-BUTILBENZOICO & p-TBBA & $98-73-7$ \\
\hline ACIDO BUTIRICO & $\begin{array}{l}\text { Acido butánico; ácido butanoico; ácido n-butírico; ácido butírico; ácido } \\
\text { etilacético; ácido 1-propancarboxilico; ácido propilfórmico } \\
\text { UN2820 }\end{array}$ & $107-92.6$ \\
\hline ACIDO n-CAPROICO & $\begin{array}{l}\text { Acido butilacético; ácido caprónico; ácido n-hexanoico; ácido n-hexoico; } \\
\text { ácido pentanocarboxilico; ácido pentifórmico; ácido pentilfórmico } \\
\text { UN2829 }\end{array}$ & $142-62-1$ \\
\hline ACIDO CITRICO & $\begin{array}{l}\text { Citro; ácido 2-hidroxi-1,2,3-propantricarboxilico; ácido } \\
\text { b-hidroxitricarbalílico }\end{array}$ & $77-92-9$ \\
\hline ACIDO CLORENDICO & $\begin{array}{l}\text { Acido 1,4,5,6,7,7-hexacloro-5-norbornen-2,3-dicarboxilico; ácido } \\
\text { hexacloroo-endo-metilentetrahidroftálico }\end{array}$ & $115-28-6$ \\
\hline ACIDO CLOROACETICO & $\begin{array}{l}\text { Acido monocloroacético; ácido monocloroetanoico } \\
\text { UN1750 } \\
\text { UN1751 }\end{array}$ & $79-11-8$ \\
\hline ACIDO m-CLOROBENZOICO & Acido 3-clorobenzoico & $535-80.8$ \\
\hline ACIDO O-CLOROBENZOICO & 2-CBA; ácido 2-clorobenzoico & $118-91-2$ \\
\hline ACIDO p-CLOROBENZOICO & p-Carboxiclorobenzeno; ácido 4-clorobenzoico; ácido clorodracilico & $74-11-3$ \\
\hline ACIDO 2-CLOROPROPIONICO & $\begin{array}{l}\text { Acido } \alpha \text {-cloropropiónico } \\
\text { UN2511 }\end{array}$ & $598-78.7$ \\
\hline
\end{tabular}




\section{Tabla 104.5 • Identificación química.}

Producto químico

ACIDO 4-CLORO-0-TOLOXIACETICO

Sinónimos/ Código UN

Acido 4-cloro-0-cresoxiacético; ácido (4-cloro-2-metilfenoxi) acético; ácido 2-metil-4-clorofenoxiacético

$\mathrm{N}$ úmero CAS Fórmula estructural

94.74-6

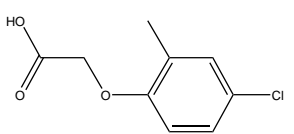

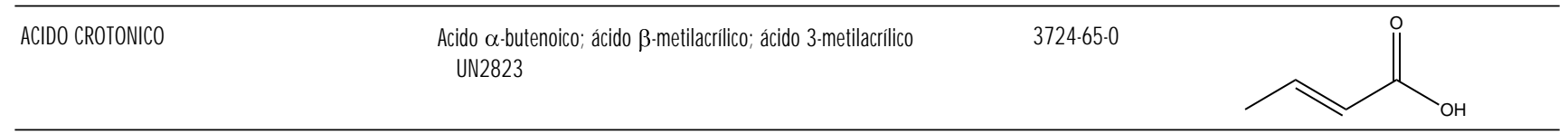

ACIDO 2,4-DICLORFENOXIACETICO

2,4-D; ácido diclorofenoxiacético

$94-75-7$

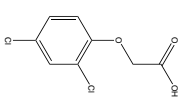

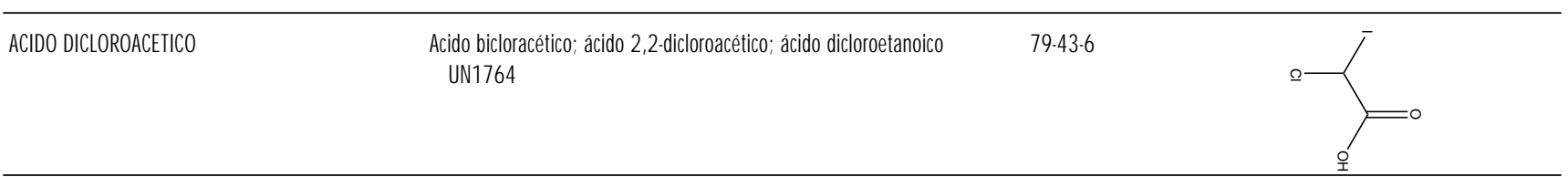

ACIDO ESTEARICO Acido cetilacético; ácido 1-heptadecancarboxilico; ácido octadecanoico 57-11-4

$57-11-4$

$\mathrm{Nin}^{\text {in }}$

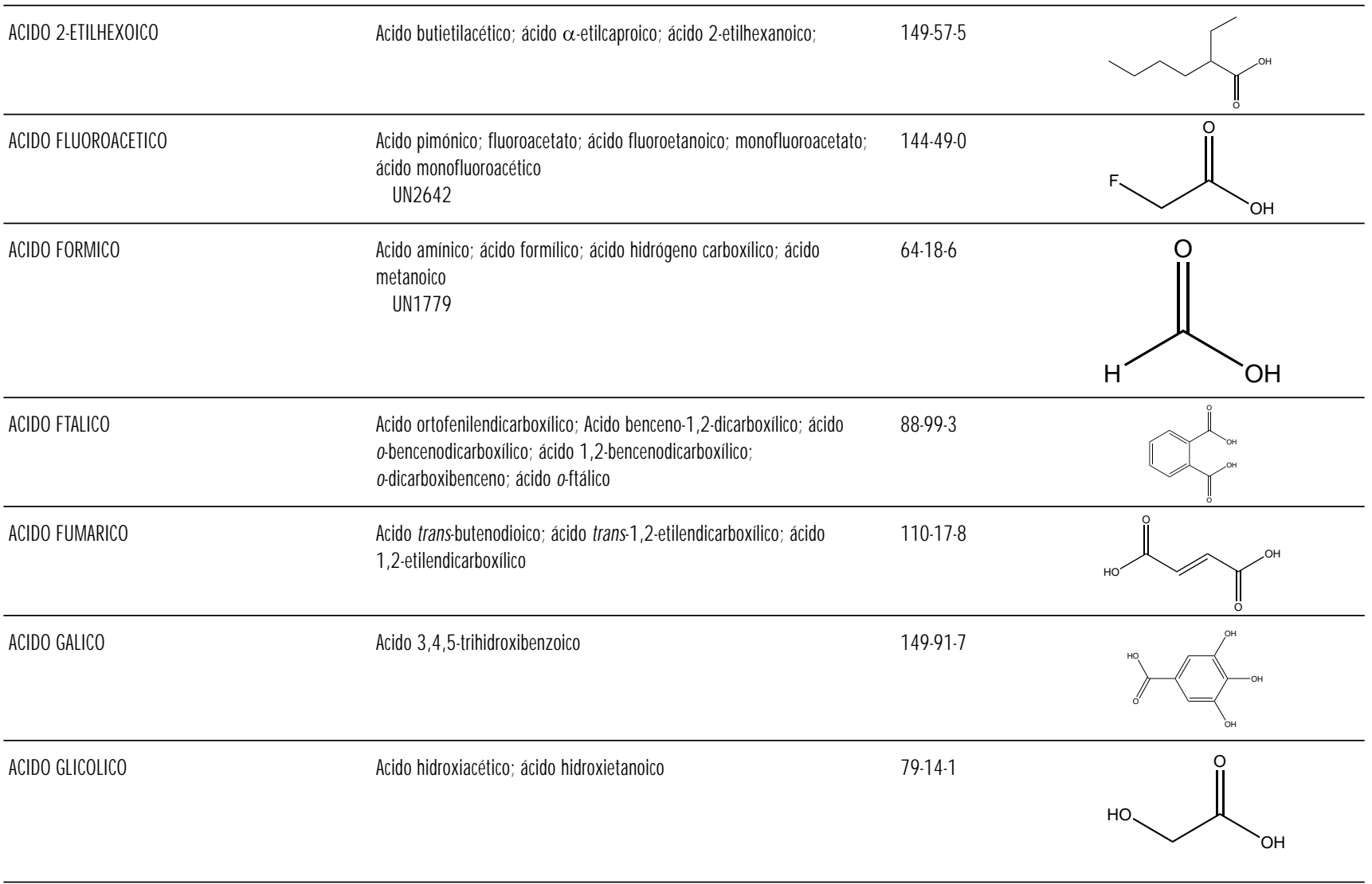

ACIDO HEPTANOICO

Acido n-heptoico; ácido heptílico; ácido 1-hexanocarboxilico; ácido

$111-14-8$

oenántico; ácido oenantílico

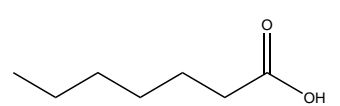




\begin{tabular}{|c|c|c|c|}
\hline Producto químico & Sinónimos/Código UN & $\mathrm{N}$ úmero $\mathrm{CAS}$ & Fórmula estructural \\
\hline ACIDO ISOBUTIRICO & $\begin{array}{l}\text { Acido dimetilacético; ácido isopropilfórmico; ácido 2-metilpropanoico; } \\
\text { ácido 2-metilpropiónico } \\
\text { UN2529 }\end{array}$ & $79-31-2$ & \\
\hline ACIDO ISOFTALICO & Acido m-fenilendicarboxilico; ácido m-bencenodicarboxilico; ácido m-ftálico & $121-91-5$ & \\
\hline ACIDO LAURICO & $\begin{array}{l}\text { Acido dodecanoico; ácido dodecoico; ácido duodećlilico; ácido } \\
\text { lauroesteárico; ácido 1-undecancarboxílico }\end{array}$ & $143 \cdot 07 \cdot 7$ & \\
\hline ACIDO MALEICO & $\begin{array}{l}\text { Acido cis-butenodioico; ácido cis-1,2-etilendicarboxílico; ácido } \\
\text { 1,2-etilendicarboxilico, ácido maleínico; ácido malénico; ácido toxílico }\end{array}$ & $110-16-7$ & \\
\hline ACIDO MALONICO & $\begin{array}{l}\text { Acido carboxiacético; dicarboximetano; ácido metanodicarboxilico; } \\
\text { ácido propanodioico }\end{array}$ & $141-82 \cdot 2$ & \\
\hline ACIDO MANDELICO & $\begin{array}{l}\text { Acido } \alpha \text {-hidroxifenilacético; ácido } \alpha \text {-hidroxi-toluico; ácido paramandélico; } \\
\text { ácido fenilglicólico; ácido fenilhidroxiacético }\end{array}$ & $90-64-2$ & \\
\hline ACIDO METACRILICO & $\begin{array}{l}\text { Acido acrílico, ácido metacrílico, ácido 2-metilpropenoico } \\
\text { UN2531 }\end{array}$ & $79-41-4$ & \\
\hline ACIDO NONANOICO & Acido n-nonílico; ácido 1-octancarboxilico; ácido pelargónico & $112.05-0$ & \\
\hline ACIDO 9-OCTADECENOICO & $\begin{array}{l}\text { Acido cis-9-octadecenoico; ácido 9,10-octadecenoico; ácido oleico; } \\
\text { ácido olénico }\end{array}$ & $112-80-1$ & \\
\hline ACIDO OXALICO & Acido etanodioico; ácido etanodiónico & $144-62 \cdot 7$ & \\
\hline ACIDO PALMITICO & $\begin{array}{l}\text { Acido cetílico; ácido hexadecanoico; ácido n-hexadecoico; ácido } \\
\text { hexadecilico; ácido-pentadecanocarboxílico }\end{array}$ & $57-10-3$ & \\
\hline ACIDO PIVALICO & $\begin{array}{l}\text { Acido 2,2-dimetilpropanoico; ácido } \alpha, \alpha \text {-dimetilpropiónico; ácido } \\
\text { 2,2-dimetilpropiónico; ácido neopentanoico; ácido terc-pentanoico; } \\
\text { ácido propanoico; ácido trimetilacético }\end{array}$ & $75-98-9$ & \\
\hline ACIDO PROPIONICO & $\begin{array}{l}\text { Carboxietano; ácido etanocarboxílico; ácido etilfórmico; ácido } \\
\text { metacetónico; ácido metil acético; ácido propanoico } \\
\text { UN1848 }\end{array}$ & $79-09-4$ & \\
\hline ACIDO SALICILICO & $\begin{array}{l}\text { Acido o-hidroxibenzoico; ácido 2-hidroxibenzoico; ácido } \\
\text { ortohidroxibenzoico }\end{array}$ & $69-72.7$ & \\
\hline ACIDO SUCCINICO & Acido butanodioico; ácido 1,2-etandicarboxilico; ácido etilensuccínico & $110-15-6$ & \\
\hline
\end{tabular}




\begin{tabular}{|c|c|c|c|}
\hline Producto químico & Sinónimos/ Código UN & $\mathrm{N}$ úmero CAS & Fórmula estructural \\
\hline ACIDO SULFANILICO & $\begin{array}{l}\text { Acido p-aminobencenosulfónico; 4-aminobencenosulfónico; ácido } \\
\text { p-aminofenilsulfónico; ácido anilina-p-sulfónico; ácido anilina-4-sulfónico }\end{array}$ & $121-57-3$ & \\
\hline ACIDO TARTARICO & Acido 2,3-dihidrosuccínico; ácido 2,3-dihidroxibutanodioico; ácido treárico & $87-69-4$ & \\
\hline ACIDO TEREFTALICO & Acido p-bencenodicarboxilico; ácido 1,4-bencenodicarboxílico & $100-21 \cdot 0$ & \\
\hline ACIDO p-TOLUENSULFONICO & $\begin{array}{l}\text { Acido p-metilbencenosulfónico; ácido 4-metilbencenosulfónico; ácido } \\
\text { p-metilfenilsulfónico; ácido toluensulfónico; ácido 4-toluensulfónico }\end{array}$ & $104-15-4$ & \\
\hline ACIDO TRICLOROACETICO & $\begin{array}{l}\text { TCA } \\
\text { UN1839 } \\
\text { UN2564 }\end{array}$ & $76-03-9$ & \\
\hline ACICO TRICLOROFENOXIACETICO & $2,4,5-\top$ & $93-76-5$ & \\
\hline ACIDO TRIFLUOROACETICO & $\begin{array}{l}\text { Acido perfluoroacético; ácido trifluoroetanoico; TFA } \\
\text { UN2699 }\end{array}$ & $76-05-1$ & \\
\hline ACIDO VALERICO & $\begin{array}{l}\text { Acido butanocarboxilico; ácido 1-butanocarboxílico; ácido pentanoico; } \\
\text { ácido propilacético }\end{array}$ & $109-52-4$ & \\
\hline ANHIDRIDO ACETICO & $\begin{array}{l}\text { Acetanhidruro; óxido acético; anhidrido de acetilo; éter de acetilo; } \\
\text { óxido de acetilo; anhidrato etanoico } \\
\text { UN1715 }\end{array}$ & $108-24-7$ & \\
\hline ANHIDRIDO DEL ACIDO TRIMELITICO & $\begin{array}{l}\text { Anhídrido 4-carboxiftálico; ácido 1,3-diox00-5-ftalancarboxílico; } \\
\text { ácido 5-ftalanacarboxilico; anhídrido 2,4-bencenotricarboxílico }\end{array}$ & $552-30-7$ & \\
\hline ANHIDRIDO FTALICO & $\begin{array}{l}\text { Anhídrido del ácido 1,2-bencenodicarboxílico; 1,3-dioxoftalan; } \\
\text { 1,3-isobenzofurandiona; ftalandiona; 1,3-ftalandiona; anhídrido del } \\
\text { ácido ftálico } \\
\text { UN2214 }\end{array}$ & $85-44-9$ & \\
\hline ANHIDRIDO MALEICO & $\begin{array}{l}\text { Anhídrido cis-butenodioico; } 2,5 \text {-furandiona; anhídrido del ácido maleico; } \\
\text { anhídrido tox́lico } \\
\text { UN2215 }\end{array}$ & $108-31-6$ & \\
\hline ANHIDRIDO PROPIONICO & $\begin{array}{l}\text { Anhídrido metilacético; anhídrido propanoico; anhídrido del ácido } \\
\text { propiónico; óxido de propionilo } \\
\text { UN2496 }\end{array}$ & $123-62-6$ & \\
\hline HIDRATO DE ACIDO CITRICO & Acido 2-hidroxi-1,2,3-propantricarboxílico, 2-hidroxi-, monohidrato & $5949-29-1$ & \\
\hline
\end{tabular}




\begin{tabular}{|c|c|c|c|c|c|c|}
\hline \multirow[b]{2}{*}{$\begin{array}{l}\text { Denominación química } \\
\mathrm{N} \text { úmero CAS }\end{array}$} & \multicolumn{4}{|c|}{ Tarjetas Internacionales sobre la Seguridad de los Productos Q uímicos } & \multicolumn{2}{|c|}{ N IO SH (EE.UU.) } \\
\hline & $\begin{array}{l}\text { Período } \\
\text { corto de } \\
\text { exposición }\end{array}$ & $\begin{array}{l}\text { Período } \\
\text { largo de } \\
\text { exposición }\end{array}$ & $\begin{array}{l}\text { Vías de } \\
\text { exposición }\end{array}$ & Síntomas & $\begin{array}{l}\text { O rganos } \\
\text { afectados } \\
\text { Vías de } \\
\text { entrada }\end{array}$ & Síntomas \\
\hline $\begin{array}{l}\text { ACIDO ACETICO } \\
64-19 \cdot 7\end{array}$ & $\begin{array}{l}\text { ojos; piel; } \\
\text { tract resp; } \\
\text { pulmones }\end{array}$ & piel & $\begin{array}{r}\text { Inhalación } \\
\text { Piel } \\
\text { 0jos } \\
\text { Ingestión }\end{array}$ & $\begin{array}{l}\text { Dolor de garganta, tos, disnea, los síntomas pueden } \\
\text { tardar en aparecer } \\
\text { Enrojecimiento, quemaduras graves en la piel, dolor. } \\
\text { Dolor, enrojecimiento, visión borrosa, quemaduras } \\
\text { profundas graves } \\
\text { Dolor abdominal, sensación de quemazón, diarrea, } \\
\text { dolor de garganta, vómitos }\end{array}$ & $\begin{array}{l}\text { Sis resp; piel; } \\
\text { ojos; dientes } \\
\text { Inh; con }\end{array}$ & $\begin{array}{l}\text { Irrit ojos, nariz, garganta; } \\
\text { quemaduras en piel y ojos; derm; } \\
\text { conj; tos; depres SNC; edema } \\
\text { pulm tardio; en animales: efectos } \\
\text { renales, repro, terato }\end{array}$ \\
\hline $\begin{array}{l}\text { ACIDO ACETILSALLCILICO } \\
50-78-2\end{array}$ & $\begin{array}{l}\text { ojos; piel; } \\
\text { tract resp }\end{array}$ & $\begin{array}{l}\text { hígado, riñones, } \\
\text { vejiga; tract Gl; } \\
\text { SCV; SNC; tract } \\
\text { resp }\end{array}$ & $\begin{array}{r}\text { Inhalación } \\
\text { Piel } \\
\text { 0jos }\end{array}$ & $\begin{array}{l}\text { Tos, embotamiento } \\
\text { Enrojecimiento } \\
\text { Enrojecimiento }\end{array}$ & $\begin{array}{l}\text { Ojos; piel; sis } \\
\text { resp; sangre; } \\
\text { hígado; riñón } \\
\text { Inh; ing; con }\end{array}$ & $\begin{array}{l}\text { Irrit ojos, piel, sis resp superior, } \\
\text { aumento del tiempo de } \\
\text { coagulación sanguínea; náu, } \\
\text { vómit; les hepáticas y renales }\end{array}$ \\
\hline $\begin{array}{l}\text { ACIDO ACRILICO } \\
79-10-7\end{array}$ & $\begin{array}{l}\text { ojos; piel; } \\
\text { tract resp; } \\
\text { pulmones }\end{array}$ & & $\begin{array}{r}\text { Inhalación } \\
\text { Piel } \\
\text { 0jos } \\
\text { Ingestión }\end{array}$ & $\begin{array}{l}\text { Sensación de quemazón, tos, secreción nasal, } \\
\text { dificultad respiratoria, dolor de garganta } \\
\text { Puese absorberse, enrojecimiento, dolor, ampollas } \\
\text { Enrojecimiento, dolor, pérdida de visión, quemaduras } \\
\text { profundas graves } \\
\text { Quemaduras graves en los labios, boca y garganta, } \\
\text { espasmos abdominales, diarrea, inconsciencia, shock }\end{array}$ & $\begin{array}{l}\text { Ojos, piel, sis } \\
\text { resp } \\
\text { Inh; abs; ing; } \\
\text { con }\end{array}$ & $\begin{array}{l}\text { Irrit ojos, piel, sis resp; } \\
\text { quemaduras en ojos y piel; sens } \\
\text { cut; en animales: les pulmonares, } \\
\text { hepáticas y renales }\end{array}$ \\
\hline $\begin{array}{l}\text { ACIDO ADIPICO } \\
124-04-9\end{array}$ & $\begin{array}{l}\text { ojos; piel; } \\
\text { tract resp }\end{array}$ & piel & $\begin{array}{r}\text { Inhalación } \\
\text { Piel } \\
\text { 0jos } \\
\end{array}$ & $\begin{array}{l}\text { Tos, dificultad respiratoria, dolor de garganta } \\
\text { Enrojecimiento } \\
\text { Enrojecimiento, dolor }\end{array}$ & & \\
\hline $\begin{array}{l}\text { ACIDO L-ASCORBICO } \\
50.81-7\end{array}$ & ojos, tract resp & & $\begin{array}{l}\text { Inhalación } \\
\text { Ojos } \\
\text { Ingestión }\end{array}$ & $\begin{array}{l}\text { Tos } \\
\text { Enrojecimiento } \\
\text { Sólo en caso de ingestión de grandes cantidades: } \\
\text { diarrea, vómitos }\end{array}$ & & \\
\hline $\begin{array}{l}\text { ACIDO BENZOICO } \\
65-85.0\end{array}$ & $\begin{array}{l}\text { ojos; piel; tract } \\
\text { resp }\end{array}$ & piel & $\begin{array}{r}\text { Inhalación } \\
\text { Piel } \\
\text { 0jos } \\
\text { Ingestión }\end{array}$ & $\begin{array}{l}\text { Tos, irritante } \\
\text { Enrojecimiento, irritante } \\
\text { Enrojecimiento, irritante, dolor } \\
\text { Dolor abdominal, náuseas, vómitos }\end{array}$ & & \\
\hline $\begin{array}{l}\text { ACIDO n-CAPROICO } \\
142-62-1\end{array}$ & $\begin{array}{l}\text { ojos; piel; tract } \\
\text { resp }\end{array}$ & piel & $\begin{array}{r}\text { Inhalación } \\
\text { Piel } \\
\text { 0jos } \\
\text { Ingestión }\end{array}$ & $\begin{array}{l}\text { Tos, dolor de garganta } \\
\text { Puede absorberse, enrojecimiento, sensación de } \\
\text { quemazón, dolor } \\
\text { Enrojecimiento, dolor, visión borrosa } \\
\text { Dolor abdominal, náuseas, dolor de garganta, } \\
\text { vómitos }\end{array}$ & & \\
\hline $\begin{array}{l}\text { ACIDO CITRICO } \\
77.92-9\end{array}$ & $\begin{array}{l}\text { ojos; piel; tract } \\
\text { resp }\end{array}$ & & $\begin{array}{r}\text { Inhalación } \\
\text { Piel } \\
\text { 0jos } \\
\text { Ingestión } \\
\end{array}$ & $\begin{array}{l}\text { Sensación de quemazón, tos, dificultad respiratoria } \\
\text { Enrojecimiento } \\
\text { Enrojecimiento, dolor } \\
\text { Tos }\end{array}$ & & \\
\hline $\begin{array}{l}\text { ACIDO CITRICO HIDRATO } \\
5949-29-1\end{array}$ & ojos; tract resp & & $\begin{array}{r}\text { Inhalación } \\
\text { Piel } \\
\text { 0jos } \\
\text { Ingestión } \\
\end{array}$ & $\begin{array}{l}\text { Tos, dolor de garganta } \\
\text { Enrojecimiento } \\
\text { Enrojecimiento, dolor } \\
\text { Dolor de garganta, sensación leve de quemazón }\end{array}$ & & \\
\hline $\begin{array}{l}\text { ACIDO CLOROACETICO } \\
79-11-8\end{array}$ & & & $\begin{array}{r}\text { Piel } \\
\text { Ojos } \\
\text { Ingestión }\end{array}$ & $\begin{array}{l}\text { Corrosivo, sensación de quemazón, tos, dificultad } \\
\text { respiratoria, dolor de garganta, los síntomas pueden } \\
\text { tardar en aparecer } \\
\text { Corrosivo, puede absorberse, enrojecimiento, dolor, } \\
\text { ampollas } \\
\text { Enrojecimiento, dolor, quemaduras profundas graves } \\
\text { Espasmos abdominales, sensación de quemazón, } \\
\text { colapso }\end{array}$ & & \\
\hline
\end{tabular}




\begin{tabular}{|c|c|c|c|c|c|c|}
\hline \multirow[b]{2}{*}{$\begin{array}{l}\text { Denominación química } \\
N \text { úmero } C A S\end{array}$} & \multicolumn{4}{|c|}{ Tarjetas Internacionales sobre la Seguridad de los Productos Q uímicos } & \multicolumn{2}{|c|}{ N IO SH (EE.UU.) } \\
\hline & $\begin{array}{l}\text { Período } \\
\text { corto de } \\
\text { exposición }\end{array}$ & $\begin{array}{l}\text { Período } \\
\text { largo de } \\
\text { exposición }\end{array}$ & $\begin{array}{l}\text { Vías de } \\
\text { exposición }\end{array}$ & Síntomas & $\begin{array}{l}\text { O rganos } \\
\text { afectados } \\
\text { Vías de } \\
\text { entrada }\end{array}$ & Síntomas \\
\hline $\begin{array}{l}\text { ACIDO CROTONICO } \\
3724-65-0\end{array}$ & $\begin{array}{l}\text { ojos; piel; tract } \\
\text { resp; pulmones }\end{array}$ & piel & $\begin{array}{r}\text { Inhalación } \\
\text { Piel } \\
\text { Ojos } \\
\text { Ingestión }\end{array}$ & $\begin{array}{l}\text { Sensación de quemazón, tos, cefalea, náuseas, } \\
\text { disnea, dolor de garganta, los síntomas pueden } \\
\text { tardar en aparecer } \\
\text { Quemaduras en la piel, sensación de quemazón, } \\
\text { dolor } \\
\text { Dolor, visión borrosa, quemaduras profundas graves. } \\
\text { Dolor, sensación de quemazón, diarrea, dolor de } \\
\text { garganta, vómitos }\end{array}$ & & \\
\hline $\begin{array}{l}\text { ACIDO DICLOROACETICO } \\
79-43-6\end{array}$ & $\begin{array}{l}\text { ojos; piel; tract } \\
\text { resp; pulmones }\end{array}$ & & $\begin{array}{l}\text { Inhalación } \\
\text { Piel } \\
\text { Ojos } \\
\text { Ingestión }\end{array}$ & $\begin{array}{l}\text { Sensación de quemazón, tos, dificultad respiratoria, } \\
\text { inconsciencia, los síntomas pueden tardar en } \\
\text { aparecer } \\
\text { Enrojecimiento, dolor, ampollas } \\
\text { Enrojecimiento, dolor, quemaduras profundas graves } \\
\text { Espasmos abdominales, sensación de quemazón, } \\
\text { dolor de garganta, inconsciencia, vómitos, debilidad }\end{array}$ & & \\
\hline $\begin{array}{l}\text { ACIDO } \\
\text { 2,4-DICLOROFENOXIACETICO } \\
94-75-7\end{array}$ & $\begin{array}{l}\text { ojos, piel, tract } \\
\text { resp }\end{array}$ & & $\begin{array}{r}\text { Inhalación } \\
\text { Piel } \\
\text { Ojos } \\
\text { Ingestión }\end{array}$ & $\begin{array}{l}\text { Cefalea, náuseas, debilidad } \\
\text { Enrojecimiento } \\
\text { Enrojecimiento } \\
\text { Dolor abdominal, sensación de quemazón, diarrea, } \\
\text { cefalea, náuseas, inconsciencia, vómitos, debilidad }\end{array}$ & $\begin{array}{l}\text { Piel; SNC; } \\
\text { hígado; riñones } \\
\text { Inh; abs; ing; } \\
\text { con }\end{array}$ & $\begin{array}{l}\text { Deb, estupor, hiporreflexia, contr } \\
\text { musc; convuls; derm; en animales: } \\
\text { les hepáticas y renales }\end{array}$ \\
\hline $\begin{array}{l}\text { ACIDO ESTEARICO } \\
57-11-4\end{array}$ & ojos & pulmones & $\begin{array}{r}\text { Inhalación } \\
\text { Ojos } \\
\text { Ingestión }\end{array}$ & $\begin{array}{l}\text { Tos, dificultad respiratoria } \\
\text { Enrojecimiento, dolor } \\
\text { Estreñimiento }\end{array}$ & & \\
\hline $\begin{array}{l}\text { ACIDO ETANODIOICO, DIHIDRATO } \\
6153-56-6\end{array}$ & $\begin{array}{l}\text { ojos, piel, tract } \\
\text { resp; pulmones; } \\
\text { riñones }\end{array}$ & riñones & $\begin{array}{r}\text { Inhalación } \\
\text { Piel } \\
\text { Ojos } \\
\text { Ingestión }\end{array}$ & $\begin{array}{l}\text { Tos, disnea, dolor de garganta } \\
\text { Puede absorberse, sequedad de piel, enrojecimiento, } \\
\text { quemaduras en la piel, dolor, ampollas } \\
\text { Enrojecimiento, dolor, quemaduras profundas graves } \\
\text { Espasmos abdominales, dolor de garganta, vómitos, } \\
\text { debilidad, convulsiones }\end{array}$ & & \\
\hline $\begin{array}{l}\text { ACIDO 2-ETILHEXANOICO } \\
149-57-5 \\
\end{array}$ & $\begin{array}{l}\text { ojos; piel; tract } \\
\text { resp }\end{array}$ & hígado & $\begin{array}{l}\text { Piel } \\
\text { Ojos }\end{array}$ & $\begin{array}{l}\text { Enrojecimiento } \\
\text { Enrojecimiento, dolor }\end{array}$ & & \\
\hline $\begin{array}{l}\text { ACIDO FLUOROACETICO } \\
144-49-0\end{array}$ & $\begin{array}{l}\text { ojos; piel; tract } \\
\text { resp; SCV; SNC; } \\
\text { riñones }\end{array}$ & & & & & \\
\hline $\begin{array}{l}\text { ACIDO FORMICO } \\
64-18-6\end{array}$ & $\begin{array}{l}\text { ojos; piel; tract } \\
\text { resp; pulmones }\end{array}$ & piel & $\begin{array}{r}\text { Inhalación } \\
\text { Piel } \\
\text { Ojos } \\
\text { Ingestión }\end{array}$ & $\begin{array}{l}\text { Sensación de quemazón, tos, dificultad respiratoria y } \\
\text { disnea, los síntomas pueden tardar en aparecer } \\
\text { Enrojecimiento, quemaduras graves en la piel, dolor } \\
\text { Enrojecimiento, dolor, visión borrosa, quemaduras } \\
\text { profundas graves } \\
\text { Dolor abdominal, sensación de quemazón, diarrea, } \\
\text { dolor de garganta, vómitos }\end{array}$ & $\begin{array}{l}\text { Ojos; piel; sis } \\
\text { resp } \\
\text { Inh; ing; con }\end{array}$ & $\begin{array}{l}\text { Irrit ojos, piel, garganta; } \\
\text { quemaduras en la piel; derm; lag; } \\
\text { rin; tos; disn; náu }\end{array}$ \\
\hline $\begin{array}{l}\text { ACIDO FTALICO } \\
88-99-3\end{array}$ & $\begin{array}{l}\text { ojos; piel; tract } \\
\text { resp }\end{array}$ & & $\begin{array}{r}\text { Inhalación } \\
\text { Piel } \\
\text { Ojos }\end{array}$ & $\begin{array}{l}\text { Tos } \\
\text { Enrojecimiento } \\
\text { Enrojecimiento, dolor }\end{array}$ & & \\
\hline $\begin{array}{l}\text { ACIDO LACTICO } \\
598-82-3\end{array}$ & $\begin{array}{l}\text { ojos; piel; tract } \\
\text { resp }\end{array}$ & & $\begin{array}{r}\text { Inhalación } \\
\text { Piel } \\
\text { Ojos } \\
\text { Ingestión }\end{array}$ & $\begin{array}{l}\text { Tos, disnea, dolor de garganta, los síntomas pueden } \\
\text { tardar en aparecer } \\
\text { Enrojecimiento, quemaduras en la piel, dolor } \\
\text { Enrojecimiento, dolor, quemaduras profundas graves } \\
\text { Dolor abdominal, sensación de quemazón, náuseas, } \\
\text { dolor de garganta, vómitos }\end{array}$ & & \\
\hline
\end{tabular}




\begin{tabular}{|c|c|c|c|c|c|c|}
\hline \multirow[b]{2}{*}{$\begin{array}{l}\text { Denominación química } \\
\mathrm{N} \text { úmero CAS }\end{array}$} & \multicolumn{4}{|c|}{ Tarjetas Internacionales sobre la Seguridad de los Productos Q uímicos } & \multicolumn{2}{|c|}{ N IO SH (EE.UU.) } \\
\hline & $\begin{array}{l}\text { Período } \\
\text { corto de } \\
\text { exposición }\end{array}$ & $\begin{array}{l}\text { Período } \\
\text { largo de } \\
\text { exposición }\end{array}$ & $\begin{array}{l}\text { Vías de } \\
\text { exposición }\end{array}$ & Síntomas & $\begin{array}{l}\text { O rganos } \\
\text { afectados } \\
\text { Vías de } \\
\text { entrada }\end{array}$ & Síntomas \\
\hline $\begin{array}{l}\text { ACIDO MALEICO } \\
110-16 \cdot 7\end{array}$ & $\begin{array}{l}\text { ojos; piel; tract } \\
\text { resp }\end{array}$ & piel; riñones & $\begin{array}{r}\text { Inhalación } \\
\text { Piel } \\
\text { 0jos } \\
\text { Ingestión } \\
\end{array}$ & $\begin{array}{l}\text { Tos, dificultad respiratoria } \\
\text { Enrojecimiento, quemaduras en la piel, irritante } \\
\text { grave } \\
\text { Enrojecimiento, dolor, visión borrosa } \\
\text { Sensación de quemazón, véase inhalación }\end{array}$ & & \\
\hline $\begin{array}{l}\text { ACIDO METACRILICO } \\
79-41-4\end{array}$ & $\begin{array}{l}\text { ojos; piel; } \\
\text { mucosas; tract } \\
\text { resp; pulmones }\end{array}$ & & $\begin{array}{r}\text { Inhalación } \\
\text { Piel } \\
\text { 0jos } \\
\text { Ingestión }\end{array}$ & $\begin{array}{l}\text { Sensación de quemazón, tos, dificultad respiratoria } \\
\text { Enrojecimiento, quemaduras en la piel, dolor, } \\
\text { ampollas } \\
\text { Enrojecimiento, dolor, pérdida de visión, quemaduras } \\
\text { profundas graves } \\
\text { Espasmos abdominales, dolor abdominal, sensación } \\
\text { de quemazón, debilidad }\end{array}$ & $\begin{array}{l}\text { Ojos; piel; sis } \\
\text { resp } \\
\text { Inh; abs; ing; } \\
\text { con }\end{array}$ & $\begin{array}{l}\text { Irrit ojos, piel, muc; quemaduras } \\
\text { en ojos y piel }\end{array}$ \\
\hline $\begin{array}{l}\text { ACIDO } \\
\text { 2-METIL-4-CLOROFENOACETICO } \\
94-74-6\end{array}$ & $\begin{array}{l}\text { ojos; piel; tract } \\
\text { resp }\end{array}$ & $\begin{array}{l}\text { defectos } \\
\text { congénitos }\end{array}$ & $\begin{array}{r}\text { Inhalación } \\
\text { Piel } \\
\text { 0jos } \\
\text { Ingestión }\end{array}$ & $\begin{array}{l}\text { Cefalea, náuseas } \\
\text { Enrojecimiento } \\
\text { Enrojecimiento } \\
\text { Dolor abdominal, náuseas, inconsciencia; vómitos; } \\
\text { debilidad }\end{array}$ & & \\
\hline $\begin{array}{l}\text { ACIDO OXALICO } \\
144-62 \cdot 7\end{array}$ & $\begin{array}{l}\text { ojos; piel; tract } \\
\text { resp; pulmones; } \\
\text { riñones }\end{array}$ & piel; riñones & $\begin{array}{l}\text { Inhalación } \\
\text { Piel } \\
\text { 0jos } \\
\text { Ingestión }\end{array}$ & $\begin{array}{l}\text { Sensación de quemazón, tos, dificultad respiratoria, } \\
\text { dolor de garganta, los sintomas pueden tardar en } \\
\text { aparecer } \\
\text { Enrojecimiento, quemaduras en la piel, dolor, } \\
\text { ampollas } \\
\text { Enrojecimiento, dolor, visión borrosa, pérdida de } \\
\text { visión, quemaduras profundas graves } \\
\text { Sensación de quemazón, sopor, dolor de garganta, } \\
\text { vómitos, shock, lumbago }\end{array}$ & $\begin{array}{l}\text { Sis resp; piel; } \\
\text { riñones; ojos } \\
\text { Inh; ing; con }\end{array}$ & $\begin{array}{l}\text { Irrit ojos, piel, muc; quemaduras } \\
\text { en ojos; dolor local, cian; shock, } \\
\text { colapso, convuls; lesiones renales }\end{array}$ \\
\hline $\begin{array}{l}\text { ACIDO PALMITICO } \\
57-10-3\end{array}$ & $\begin{array}{l}\text { ojos; piel; tract } \\
\text { resp; pulmones }\end{array}$ & piel & 0jos & Enrojecimiento & & \\
\hline $\begin{array}{l}\text { ACIDO PROPIONICO } \\
79-09-4\end{array}$ & $\begin{array}{l}\text { ojos; piel; tract } \\
\text { resp }\end{array}$ & & $\begin{array}{r}\text { Inhalación } \\
\text { Piel } \\
\text { 0jos } \\
\text { Ingestión }\end{array}$ & $\begin{array}{l}\text { Tos, dificultad respiratoria, dolor de garganta } \\
\text { Quemaduras en la piel, dolor, ampollas } \\
\text { Enrojecimiento, dolor, visión borrosa, quemaduras } \\
\text { profundas graves } \\
\text { Dolor abdominal, náuseas, dolor de garganta, } \\
\text { vómitos }\end{array}$ & $\begin{array}{l}\text { Ojos; piel; sis } \\
\text { resp } \\
\text { Inh; abs; ing; } \\
\text { con }\end{array}$ & $\begin{array}{l}\text { Irrit ojos, piel, nariz, garganta; } \\
\text { visión borrosa, quemaduras corn; } \\
\text { quemaduras en la piel; dolor } \\
\text { abdom, náu, vómit }\end{array}$ \\
\hline $\begin{array}{l}\text { ACIDO SALICILICO } \\
69-72.7\end{array}$ & $\begin{array}{l}\text { ojos; piel; tract } \\
\text { resp; SNC }\end{array}$ & piel & $\begin{array}{r}\text { Inhalación } \\
\text { Piel } \\
\text { 0jos } \\
\text { Ingestión } \\
\end{array}$ & $\begin{array}{l}\text { Tos, dolor de garganta } \\
\text { Puede absorberse, enrojecimiento, dolor } \\
\text { Enrojecimiento, dolor, visión borrosa } \\
\text { Náuseas, vómitos, zumbido de oídos }\end{array}$ & & \\
\hline $\begin{array}{l}\text { ACIDO SULFANILICO } \\
121-57-3\end{array}$ & $\begin{array}{l}\text { ojos; piel; tract } \\
\text { resp; sangre }\end{array}$ & piel; pulmones & $\begin{array}{l}\text { Inhalación } \\
\\
\text { Piel } \\
\text { 0jos } \\
\text { Ingestión }\end{array}$ & $\begin{array}{l}\text { Labios o uñas de las manos cianóticos, piel } \\
\text { cianótica, mareo, cefalea, dificultad respiratoria, } \\
\text { dolor de garganta } \\
\text { Enrojecimiento } \\
\text { Enrojecimiento } \\
\text { Labios o uñas de las manos cianóticos, piel } \\
\text { cianótica, mareo, cefalea, dificultad respiratoria }\end{array}$ & & \\
\hline $\begin{array}{l}\text { ACIDO TEREFTALICO } \\
100-21-0\end{array}$ & ojos; piel & & $\begin{array}{r}\text { Inhalación } \\
\text { Piel } \\
\text { 0jos }\end{array}$ & $\begin{array}{l}\text { Tos, irritante } \\
\text { Enrojecimiento, irritante leve } \\
\text { Enrojecimiento, irritante }\end{array}$ & & \\
\hline $\begin{array}{l}\text { ACIDO p-TOLUENSULFONICO } \\
\text { 104-15-4 }\end{array}$ & $\begin{array}{l}\text { ojos; piel; tract } \\
\text { resp; pulmones }\end{array}$ & & $\begin{array}{r}\text { Inhalación } \\
\text { Piel } \\
\text { Ojos } \\
\text { Ingestión }\end{array}$ & $\begin{array}{l}\text { Sensación de quemazón, tos, dificultad respiratoria } \\
\text { Enrojecimiento, dolor, ampollas } \\
\text { Enrojecimiento, dolor, visión borrosa } \\
\text { Sensación de quemazón, dolor de garganta }\end{array}$ & & \\
\hline
\end{tabular}




\begin{tabular}{|c|c|c|c|c|c|c|}
\hline \multirow[b]{2}{*}{$\begin{array}{l}\text { Denominación química } \\
N \text { úmero CAS }\end{array}$} & \multicolumn{4}{|c|}{ Tarjetas Internacionales sobre la Seguridad de los Productos Q uímicos } & \multicolumn{2}{|c|}{ N IO SH (EE.UU.) } \\
\hline & $\begin{array}{l}\text { Período } \\
\text { corto de } \\
\text { exposición }\end{array}$ & $\begin{array}{l}\text { Período } \\
\text { largo de } \\
\text { exposición }\end{array}$ & $\begin{array}{l}\text { Vías de } \\
\text { exposición }\end{array}$ & Síntomas & $\begin{array}{l}\text { O rganos } \\
\text { afectados } \\
\text { Vías de } \\
\text { entrada }\end{array}$ & Síntomas \\
\hline $\begin{array}{l}\text { ACIDO } \\
\text { 2,4,5-TRICLOROFENOXIACETICO } \\
93-76-5\end{array}$ & $\begin{array}{l}\text { ojos; piel; tract } \\
\text { resp }\end{array}$ & & & & $\begin{array}{l}\text { Piel; hígado, } \\
\text { tract Gllnh; ing; } \\
\text { con }\end{array}$ & $\begin{array}{l}\text { En animales: ataxia; irrit piel, } \\
\text { erupción tipo acné, lesiones } \\
\text { hepáticas }\end{array}$ \\
\hline $\begin{array}{l}\text { ACIDO VALERICO } \\
109-52-4\end{array}$ & $\begin{array}{l}\text { ojos; piel; tract } \\
\text { resp; pulmones; } \\
\text { SNC }\end{array}$ & & & & & \\
\hline $\begin{array}{l}\text { ANHIDRIDO ACETICO } \\
108-24-7\end{array}$ & $\begin{array}{l}\text { ojos; piel; } \\
\text { tract resp }\end{array}$ & piel & $\begin{array}{l}\text { Inhalación } \\
\text { Piel } \\
\text { Ojos } \\
\text { Ingestión }\end{array}$ & $\begin{array}{l}\text { Corrosivo, tos, dificultad respiratoria y disnea, dolor } \\
\text { de garganta, los síntomas pueden tardar en aparecer } \\
\text { Corrosivo, enrojecimiento, dolor, ampollas } \\
\text { Corrosivo, enrojecimiento, dolor, quemaduras } \\
\text { profundas graves } \\
\text { Corrosivo, dolor abdominal, dolor de garganta, } \\
\text { colapso }\end{array}$ & $\begin{array}{l}\text { Sis resp; piel; } \\
\text { ojos } \\
\text { Inh; con }\end{array}$ & $\begin{array}{l}\text { Conj, lag, edema córn, opac, foto; } \\
\text { irrit nasal, far; tos, disn, bron; } \\
\text { quemaduras en la piel, vesic, derm } \\
\text { sens }\end{array}$ \\
\hline $\begin{array}{l}\text { ANHIDRIDO FTALICO } \\
85-44-9\end{array}$ & $\begin{array}{l}\text { ojos; piel; tract } \\
\text { resp }\end{array}$ & piel; pulmones & & & $\begin{array}{l}\text { Sis resp; ojos; } \\
\text { piel; hígado, } \\
\text { riñones } \\
\text { Inh; ing; con }\end{array}$ & $\begin{array}{l}\text { Irrit ojos, piel, sis resp superior; } \\
\text { conj; sangrado de úlceras nasales; } \\
\text { bron, asma bronquial; derm; en } \\
\text { animales: lesiones hepáticas y } \\
\text { renales }\end{array}$ \\
\hline $\begin{array}{l}\text { ANHIDRIDO MALEICO } \\
108-31-6\end{array}$ & $\begin{array}{l}\text { ojos; piel; tract } \\
\text { resp }\end{array}$ & piel & $\begin{array}{r}\text { Inhalación } \\
\text { Piel } \\
\text { Ojos } \\
\text { Ingestión } \\
\end{array}$ & $\begin{array}{l}\text { Tos, cefalea, dificultad respiratoria, náuseas, disnea, } \\
\text { vómitos } \\
\text { Enrojecimiento, quemaduras en la piel } \\
\text { Enrojecimiento, dolor, lagrimeo, quemaduras } \\
\text { profundas graves } \\
\text { Dolor abdominal }\end{array}$ & $\begin{array}{l}\text { Ojos; piel; sis } \\
\text { resp } \\
\text { Inh; ing; con }\end{array}$ & $\begin{array}{l}\text { Irrit nariz, sis resp superior; conj; } \\
\text { foto, visión doble, asma bronquial, } \\
\text { derm }\end{array}$ \\
\hline $\begin{array}{l}\text { ANHIDRIDO PROPIONICO } \\
123-62.6\end{array}$ & $\begin{array}{l}\text { ojos; piel; tract } \\
\text { resp, pulmones }\end{array}$ & & $\begin{array}{l}\text { Inhalación } \\
\text { Piel } \\
\text { Ojos } \\
\text { Ingestión }\end{array}$ & $\begin{array}{l}\text { Sensación de quemazón, tos, dificultad respiratoria, } \\
\text { dolor de garganta, los síntomas pueden tardar en } \\
\text { aparecer } \\
\text { Enrojecimiento, quemaduras en la piel } \\
\text { Enrojecimiento, quemaduras profundas graves } \\
\text { Dolor de garganta, quemaduras }\end{array}$ & & \\
\hline $\begin{array}{l}\text { ANHIDRIDO TRIMELITICO } \\
552-30-7\end{array}$ & $\begin{array}{l}\text { ojos; piel; tract } \\
\text { resp; pulmones; } \\
\text { sangre }\end{array}$ & & $\begin{array}{r}\text { Inhalación } \\
\text { Piel } \\
\text { Ojos }\end{array}$ & $\begin{array}{l}\text { Tos, mareo, respiración sibilante, escalofríos } \\
\text { Enrojecimiento } \\
\text { Enrojecimiento, dolor }\end{array}$ & $\begin{array}{l}\text { Ojos; piel; abs } \\
\text { sis resp }\end{array}$ & $\begin{array}{l}\text { Irrit ojos, piel; nariz; sis resp; } \\
\text { edema pulm, sens resp; rinitis, } \\
\text { asma, tos, resp sib, disn, mal, } \\
\text { fiebre, dolores musc, estor }\end{array}$ \\
\hline
\end{tabular}

Tabla 104.7 • Riesgos físicos y químicos.

\begin{tabular}{|c|c|c|c|}
\hline $\begin{array}{l}\text { Denominación química } \\
\mathrm{N} \text { úmero CAS }\end{array}$ & Físicos & Q uímicos & $\begin{array}{l}\text { Clase o división } \\
\text { UN / Riesgos } \\
\text { subsidiarios }\end{array}$ \\
\hline $\begin{array}{l}\text { ACIDO ACETICO } \\
64-19-7\end{array}$ & & $\begin{array}{l}\text { Es un ácido de fuerza intermedia Reacciona violentamente con oxidantes como trióxido de } \\
\text { cromo y permanganato potásico Reacciona violentamente con bases fuertes }- \text { Ataca muchos } \\
\text { metales formando un gas combustible }\end{array}$ & 8 \\
\hline
\end{tabular}

ACIDO ACETILSALICILICO

$50-78-2$
Posibilidad de explosión Se descompone en contacto con agua caliente o cuando se disuelve en soluciones de hidróxidos pulverulenta cuando 0 carbonatos alcalinos Al calentarse libera vapores tóxicos Reacciona con oxidantes fuertes, encuentra en forma de ácidos fuertes, bases fuertes mezcla con aire 


\begin{tabular}{|c|c|c|c|}
\hline $\begin{array}{l}\text { Denominación química } \\
\mathrm{N} \text { úmero CAS }\end{array}$ & Físicos & Q uímicos & $\begin{array}{l}\text { Clase o división } \\
\text { UN / Riesgos } \\
\text { subsidiarios }\end{array}$ \\
\hline $\begin{array}{l}\text { ACIDO ACRILICO } \\
79-10-7\end{array}$ & $\begin{array}{l}\text { El vapor es más pesado } \\
\text { que el aire El vapor } \\
\text { forma una mezcla } \\
\text { explosiva con el aire }\end{array}$ & $\begin{array}{l}\text { Se polimeriza rápidamente por calentamiento, bajo la influencia de luz, oxígeno, agentes } \\
\text { oxidantes como peróxidos u otros activadores (ácidos, sales de hierro), con peligro de incendio o } \\
\text { explosión Al calentarse libera vapores tóxicos Es un ácido de fuerza intermedia Reacciona } \\
\text { violentamente con oxidantes, con peligro de incendio y explosión - Reacciona violentamente con } \\
\text { base fuertes y aminas - Ataca muchos metales, entre ellos níquel y cobre }\end{array}$ & $8 / 3$ \\
\hline $\begin{array}{l}\text { ACIDO ADIPICO } \\
124-04-9\end{array}$ & $\begin{array}{l}\text { - Posibilidad de explosión } \\
\text { pulverulenta cuando se } \\
\text { encuentra en forma de } \\
\text { polvo o gránulos y se } \\
\text { mezcla con el aire } \cdot \text { Si } \\
\text { está seco, puede cargarse } \\
\text { electrostáticamente por } \\
\text { agitación, transporte } \\
\text { neumático, vertido, etc. }\end{array}$ & $\begin{array}{l}\text { - Se descompone al calentarse, liberando vapores ácidos volátiles de ácido valérico y otras } \\
\text { sustancias - Es un ácido débil • Reacciona con materiales oxidantes }\end{array}$ & \\
\hline $\begin{array}{l}\text { ACIDO L-ASCORBICO } \\
50-81-7\end{array}$ & & $\begin{array}{l}\text { - La solución en agua es un ácido de fuerza intermedia } \text { • Ataca muchos metales en presencia de } \\
\text { agua }\end{array}$ & \\
\hline $\begin{array}{l}\text { ACIDO BENZOICO } \\
65-85-0\end{array}$ & $\begin{array}{l}\text { - Posibilidad de explosión } \\
\text { pulverulenta cuando se } \\
\text { encuentra en forma de } \\
\text { polvo o gránulos y se } \\
\text { mezcla con aire }\end{array}$ & - La solución en agua es un ácido débil • Reacciona con oxidantes & \\
\hline $\begin{array}{l}\text { ACIDO BUTIRICO } \\
107-92-6\end{array}$ & & & 8 \\
\hline $\begin{array}{l}\text { ACIDO n-CAPROICO } \\
142-62-1\end{array}$ & & $\begin{array}{l}\text { - Puede explotar al calentarse • En su combustión libera gases tóxicos/ irritantes • Es un ácido } \\
\text { de fuerza intermedia • Reacciona violentamente con oxidantes (por ejemplo trióxido de cromo) } \\
\text { con peligro de incendio y explosión • Reacciona vigorosamente con bases, con peligro de } \\
\text { calentamiento y aumento de presión • Ataca muchos metales, formando gases combustibles }\end{array}$ & 8 \\
\hline $\begin{array}{l}\text { ACIDO CITRICO } \\
77.92 .9\end{array}$ & $\begin{array}{l}\text { - Posibilidad de explosión } \\
\text { pulverulenta cuando se } \\
\text { encuentra en forma de } \\
\text { polvo o gránulos y se } \\
\text { mezcla con aire }\end{array}$ & - Reacciona con oxidantes, reductores, bases & \\
\hline $\begin{array}{l}\text { ACIDO CITRICO HIDRATO } \\
5949-29-1\end{array}$ & & $\begin{array}{l}\text { - La solución en agua es un ácido de fuerza intermedia - Reacciona violentamente con nitratos } \\
\text { metálicos • Reacciona con bases fuertes y oxidantes • Es corrosivo para cobre, zinc, aluminio, y } \\
\text { sus aleaciones }\end{array}$ & \\
\hline $\begin{array}{l}\text { ACIDO CLOROACETICO } \\
79-11-8\end{array}$ & & $\begin{array}{l}\text { - Se descompone al calentarse, liberando gases tóxicos y corrosivos (cloruro de hidrógeno, } \\
\text { fosgeno) - La solución en agua es un ácido fuerte, reacciona violentamente con bases y es } \\
\text { corrosiva }\end{array}$ & $6.1 / 8$ \\
\hline $\begin{array}{l}\text { ACIDO CROTONICO } \\
3724-65-0\end{array}$ & & $\begin{array}{l}\text { - Puede polimerizarse bajo la influencia de luz UV o humedad • La solución en agua es un } \\
\text { ácido débil • Reacciona violentamente con bases, oxidantes y agentes reductores, con peligro } \\
\text { de incendio y explosión }\end{array}$ & 8 \\
\hline $\begin{array}{l}\text { ACIDO DICLOROACETICO } \\
79-43-6\end{array}$ & & $\begin{array}{l}\text { - Se descompone al calentarse liberando vapores tóxicos y corrosivos (fosgeno, cloruro de } \\
\text { hidrógeno) - Es un ácido de fuerza intermedia • Ataca muchos metales formando gas hidrógeno } \\
\text { inflamable • Ataca el caucho }\end{array}$ & 8 \\
\hline $\begin{array}{l}\text { ACIDO 2,4-DICLOROFENOXIACETICO } \\
94-75-7\end{array}$ & & $\begin{array}{l}\text { - Se descompone al calentarse produciendo cloruro de hidrógeno y fosgeno • Es un ácido débil } \\
\text { - Reacciona con oxidantes fuertes con peligro de incendio y explosión }\end{array}$ & \\
\hline $\begin{array}{l}\text { ACIDO ESTEARICO } \\
57-11-4\end{array}$ & & $\begin{array}{l}\text { - Se descompone al calentarse liberando óxidos de carbono • Es un ácido débil • Reacciona con } \\
\text { bases, oxidantes y agentes reductores }\end{array}$ & \\
\hline $\begin{array}{l}\text { ACIDO ETANODIOICO, DIHIDRATO } \\
6153-56-6\end{array}$ & & $\begin{array}{l}\text { - Se descompone al calentarse rápidamente a aproximadamente } 150^{\circ} \mathrm{C} \text { produciendo gases } \\
\text { tóxicos } \cdot \text { La solución en agua es un ácido de fuerza intermedia que reacciona violentamente con } \\
\text { bases fuertes } \text { - Reacciona violentamente con oxidantes con peligro de incendio y explosión } \\
\text { - Reacciona con plata, formando productos explosivos }\end{array}$ & \\
\hline
\end{tabular}


Tabla 104.7 • Riesgos físicos y químicos.

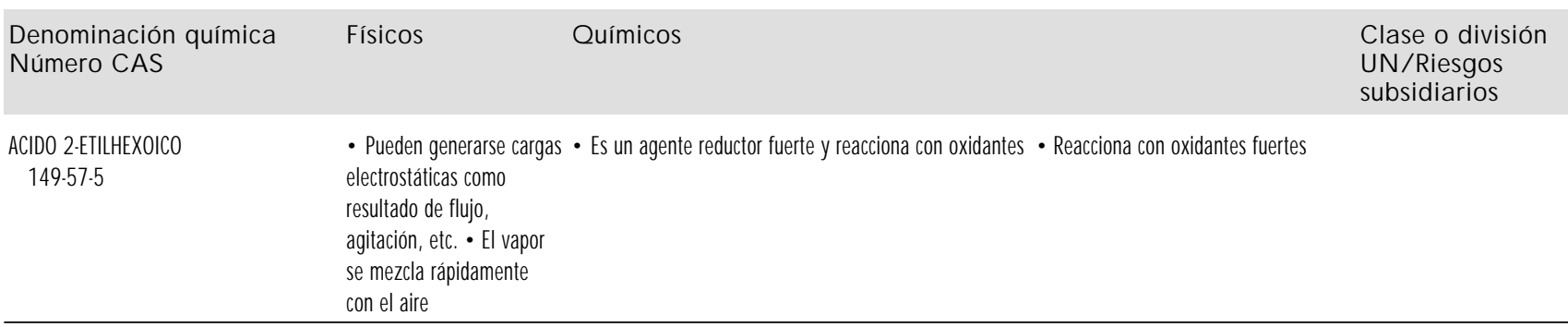

ACIDO FLUOROACETICO

6.1

144-49-0
ACIDO FORMICO
64-18-6

- Se descompone al calentarse produciendo monóxido de carbono - Es un ácido de fuerza

8

64-18-6 intermedia - Reacciona violentamente con oxidantes - Reacciona violentamente con bases fuertes con peligro de incendio y explosión - Ataca muchos metales en presencia de agua • Ataca muchos plásticos

ACIDO FTALLCO - La solución en agua es un ácido de fuerza intermedia
$88-99-3$

\begin{tabular}{|c|c|}
\hline $\begin{array}{l}\text { ACIDO ISOBUTIRICO } \\
79-31-2\end{array}$ & \\
\hline $\begin{array}{l}\text { ACIDO LACTICO } \\
598-82-3\end{array}$ & - Es un ácido de fuerza intermedia - Ataca muchos metales en presencia de agua \\
\hline $\begin{array}{l}\text { ACIDO MALEICO } \\
110-16 \cdot 7\end{array}$ & $\begin{array}{l}\text { - En su combustión libera humos irritantes (anhídrido maleico) • Se descompone al calentarse } \\
\text { liberando vapores altamente irritantes (anhídrido maleico) • La solución en agua es un ácido de } \\
\text { fuerza intermedia }\end{array}$ \\
\hline $\begin{array}{l}\text { ACIDO METACRILICO } \\
79-41-4\end{array}$ & $\begin{array}{l}\text { - Se polimeriza fácilmente al calentarse o en presencia de luz, oxígeno, agentes oxidantes como } \\
\text { peróxidos o trazas de ácido clorhídrido, con peligro de incendio o explosión - Se descompone al } \\
\text { calentarse liberando vapores acres } \text { Es un agente reductor fuerte y reacciona con oxidantes - Es } \\
\text { un ácido de fuerza intermedia - Ataca los metales }\end{array}$ \\
\hline $\begin{array}{l}\text { ACIDO 2-METLL-4-CLOROFENOXIACETICO } \\
\text { 94-74-6 }\end{array}$ & $\begin{array}{l}\text { - Se descompone al calentarse liberando vapores tóxicos y corrosivos, entre ellos cloruro de } \\
\text { hidrógeno - Es un ácido débil }\end{array}$ \\
\hline $\begin{array}{l}\text { ACIDO OXALLCO } \\
144-62 \cdot 7\end{array}$ & $\begin{array}{l}\text { - En contacto con superficies calientes o llamas, se descompone formando ácido fórmico y } \\
\text { monóxido de carbono } • \text { Es un agente reductor fuerte y reacciona con oxidantes } • \text { La solución en } \\
\text { agua es un ácido de fuerza intermedia • Reacciona violentamente con oxidantes fuertes con } \\
\text { peligro de incendio y explosión - Reacciona con algunos compuestos de plata para formar } \\
\text { oxalato de plata explosivo }\end{array}$ \\
\hline
\end{tabular}

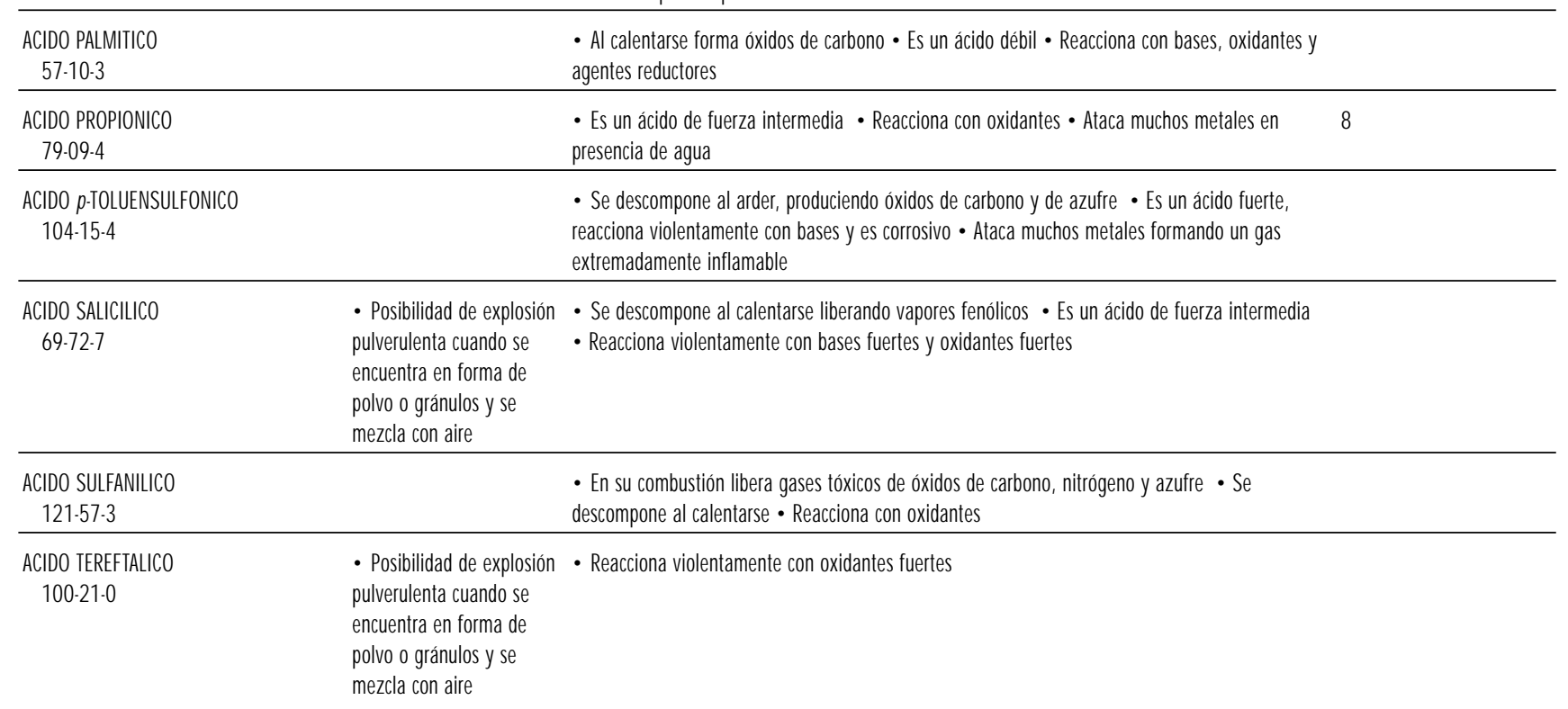




\begin{tabular}{|c|c|c|c|}
\hline $\begin{array}{l}\text { Denominación química } \\
\mathrm{N} \text { úmero CAS }\end{array}$ & Físicos & Q uímicos & $\begin{array}{l}\text { Clase o división } \\
\text { UN / Riesgos } \\
\text { subsidiarios }\end{array}$ \\
\hline $\begin{array}{l}\text { ACIDO 2,4,5-TRICLOROFENOXIACETICO } \\
93-76-5\end{array}$ & & & 6.1 \\
\hline $\begin{array}{l}\text { ACIDO TRIFLUOROACETICO } \\
76-05-1\end{array}$ & & & 8 \\
\hline $\begin{array}{l}\text { ANHIDRIDO ACETICO } \\
108-24-7\end{array}$ & & $\begin{array}{l}\text { Se descompone al calentarse, liberando vapores tóxicos y gases, entre ellos ácido acético } \\
\text { Reacciona violentamente con agua hirviendo, vapor, oxidantes fuertes, alcoholes, aminas, } \\
\text { bases fuertes y muchos otros compuestos Ataca muchos metales en presencia de agua El } \\
\text { líquido es muy corrosivo, especialmente en presencia de agua o humedad }\end{array}$ & $8 / 3$ \\
\hline $\begin{array}{l}\text { ANHIDRIDO FTALICO } \\
85-44-9\end{array}$ & & & 8 \\
\hline $\begin{array}{l}\text { ANHIDRIDO MALEICO } \\
108-31-6\end{array}$ & & $\begin{array}{l}\text { - La solución en agua es un ácido fuerte, reacciona violentamente con bases y es } \\
\text { corrosiva - Reacciona con oxidantes fuertes }\end{array}$ & 8 \\
\hline $\begin{array}{l}\text { ANHIDRIDO PROPIONICO } \\
123-62-6\end{array}$ & $\begin{array}{l}\text { - El vapor es más pesado } \\
\text { que el aire }\end{array}$ & - En su combustión libera gases tóxicos • Reacciona con oxidantes, bases y agua & 8 \\
\hline $\begin{array}{l}\text { ANHIDRIDO TRIMELITICO } \\
552-30-7\end{array}$ & $\begin{array}{l}\text { - Posibilidad de explosión } \\
\text { pulverulenta cuando se } \\
\text { encuentra en forma de } \\
\text { polvo o gránulos y se } \\
\text { mezcla con aire } \cdot \text { Si está } \\
\text { seco, puede cargarse } \\
\text { electrostáticamente por } \\
\text { agitación, transporte } \\
\text { neumático, vertido, etc. }\end{array}$ & $\begin{array}{l}\text { - Reacciona violentamente con oxidantes • Reacciona lentamente con agua para formar ácido } \\
\text { trimelítico }\end{array}$ & \\
\hline
\end{tabular}

\begin{tabular}{|c|c|c|c|c|c|c|c|c|c|c|c|}
\hline $\begin{array}{l}\text { Denominación química } \\
\mathrm{N} \text { úmero CAS }\end{array}$ & Color/ Forma & $\begin{array}{l}\text { p.e. } \\
\left({ }^{\circ} \mathrm{C}\right)\end{array}$ & $\begin{array}{l}\text { p.f. } \\
(\underline{O C})\end{array}$ & $\begin{array}{l}\text { p.m.l } \\
\text { (g/ } \\
\text { mol) }\end{array}$ & $\begin{array}{l}\text { Solubilidad } \\
\text { en agua }\end{array}$ & $\begin{array}{l}\text { Densidad } \\
\text { relativa } \\
\text { (agua }=1 \text { ) }\end{array}$ & $\begin{array}{l}\text { Densidad } \\
\text { de vapor } \\
\text { relativa } \\
\text { (aire=1) }\end{array}$ & $\begin{array}{l}\text { Pvap/ } \\
(\mathrm{kPa})\end{array}$ & $\begin{array}{l}\text { Límit. } \\
\text { inflam. }\end{array}$ & $\begin{array}{l}\text { p.ig. } \\
(\underline{O C})\end{array}$ & $\begin{array}{l}\text { p.aut } \\
\text { ig. } \\
(\stackrel{0}{ })\end{array}$ \\
\hline $\begin{array}{l}\text { ACIDO ACETICO } \\
64-19-7\end{array}$ & $\begin{array}{l}\text { cristales rómbicos } \\
(0,6 \stackrel{0}{ } \mathrm{C} \text { punto de } \\
\text { fusión); líquido } \\
\text { incoloro ( } 16,6 \stackrel{\circ}{ } \mathrm{C} \\
\text { punto de fusión) }\end{array}$ & 118 & 16,6 & 60,05 & misc & 1,0492 & 2,1 & 1,6 & $\begin{array}{l}4 \mathrm{li} \\
16 \mathrm{ls}\end{array}$ & $39 \mathrm{cc}$ & 426 \\
\hline $\begin{array}{l}\text { ACIDO ACETILSALICILICO } \\
50-78-2\end{array}$ & $\begin{array}{l}\text { cristales tabulares } \\
\text { monoclínicos o } \\
\text { cristales en forma de } \\
\text { aguja }\end{array}$ & & 135 & 180,15 & lig sol & 1,40 & & $\begin{array}{l}2,52 \times \\
10^{-5} \mathrm{~mm} \mathrm{Hg} \\
\text { @ } 25 \stackrel{\circ}{C}\end{array}$ & & & \\
\hline $\begin{array}{l}\text { ACIDO ACRILICO } \\
79-10-7\end{array}$ & líquido incoloro & 141 & 14 & 72,06 & misc & 1,0511 & 2,5 & 0,413 & $\begin{array}{l}2,9 \mathrm{li} \\
8 \mathrm{ls}\end{array}$ & $54 \mathrm{Ca}$ & 360 \\
\hline $\begin{array}{l}\text { ACIDO ADIPICO } \\
124-04-9\end{array}$ & $\begin{array}{l}\text { prismas monoclínicos } \\
\text { en acetato de etilo, } \\
\text { agua o acetona y } \\
\text { éter de petróleo; } \\
\text { cristales o polvo } \\
\text { blanco fino }\end{array}$ & 337,5 & 152 & 146,14 & lig sol & $\begin{array}{l}1,360 \\
@ 25 \stackrel{\circ}{0} 4 \stackrel{\circ}{\circ} \mathrm{C}\end{array}$ & 5,04 & $\begin{array}{l}0,010 \\
\text { @ } 18,5 \stackrel{\circ}{\circ}\end{array}$ & $\begin{array}{l}10 \mathrm{li} \\
15 \mathrm{mg} / \mathrm{l} \mathrm{ls}\end{array}$ & 196 cc & 422 \\
\hline
\end{tabular}




\begin{tabular}{|c|c|c|c|c|c|c|c|c|c|c|c|}
\hline $\begin{array}{l}\text { Denominación química } \\
\mathrm{N} \text { úmero CAS }\end{array}$ & Color/ Forma & $\begin{array}{l}\text { p.e. } \\
\left({ }^{\circ} \mathrm{C}\right)\end{array}$ & $\begin{array}{l}\text { p.f. } \\
(\stackrel{\circ}{ } C)\end{array}$ & $\begin{array}{l}\text { p.m.l } \\
\text { (g/ } \\
\text { mol) }\end{array}$ & $\begin{array}{l}\text { Solubilidad } \\
\text { en agua }\end{array}$ & $\begin{array}{l}\text { Densidad } \\
\text { relativa } \\
\text { (agua }=1 \text { ) }\end{array}$ & $\begin{array}{l}\text { Densidad } \\
\text { de vapor } \\
\text { relativa } \\
\text { (aire=1) }\end{array}$ & $\begin{array}{l}\text { Pvap/ } \\
(\mathrm{kPa})\end{array}$ & $\begin{array}{l}\text { Límit. } \\
\text { inflam. }\end{array}$ & 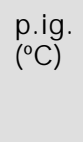 & $\begin{array}{l}\text { p.aut } \\
\text { ig. } \\
\left({ }^{\circ} \mathrm{C}\right)\end{array}$ \\
\hline $\begin{array}{l}\text { ACIDO L-ASCORBICO } \\
50-81.7\end{array}$ & $\begin{array}{l}\text { cristales } \\
\text { (normalmente } \\
\text { placas, a veces } \\
\text { agujas, sistema } \\
\text { monoclínico); } \\
\text { cristales o polvo } \\
\text { blanco o ligeramente } \\
\text { amarillo }\end{array}$ & & $\begin{array}{l}190- \\
192\end{array}$ & 176,12 & muy sol & $1,65 @ 25 \stackrel{\circ}{\circ}$ & & & & & \\
\hline $\begin{array}{l}\text { ACIDO BENZOICO } \\
65-85.0\end{array}$ & $\begin{array}{l}\text { cristales tabulares, } \\
\text { placas, laminillas } \\
\text { monoclínicos; } \\
\text { escamas blancas o } \\
\text { cristales en forma de } \\
\text { aguja }\end{array}$ & 249,2 & 122,4 & 122,13 & $\begin{array}{l}0,29 \mathrm{~g} / 100 \mathrm{ml} \\
@ 20 \stackrel{0}{0} \mathrm{C}\end{array}$ & $\begin{array}{l}1,2659 \\
@ 15^{\circ} \mathrm{C} / 4 \stackrel{\circ}{\circ} \mathrm{C}\end{array}$ & 4,21 & $\begin{array}{l}0,133 \\
@ 96 \stackrel{0}{ }=\end{array}$ & & $121 \mathrm{cc}$ & 570 \\
\hline $\begin{array}{l}\text { ACIDO p-terc-BUTILBENZOICO } \\
98-73-7\end{array}$ & $\begin{array}{l}\text { agujas en alcohol } \\
\text { diluido }\end{array}$ & & $\begin{array}{l}164,5- \\
165,5 \\
\end{array}$ & 178,2 & insol & & & & & & \\
\hline $\begin{array}{l}\text { ACIDO BUTIRICO } \\
107-92-6 \\
\end{array}$ & $\begin{array}{l}\text { líquido oleoso, } \\
\text { líquido incoloro }\end{array}$ & 165,5 & $-7,9$ & 88,10 & misc & 0,9577 & 3,0 & $\begin{array}{l}0,43 \mathrm{~mm} \\
\mathrm{Hg}\end{array}$ & $\begin{array}{l}2,0 \mathrm{li} \\
10,0 \mathrm{ls}\end{array}$ & $72 \mathrm{cc}$ & 443 \\
\hline $\begin{array}{l}\text { ACIDO n-CAPROICO } \\
142-62-1 \\
\end{array}$ & líquido oleoso & 205,8 & $-3,4$ & 116,16 & insol & 0,929 & 4,01 & 0,024 & $\begin{array}{l}1,3 \mathrm{li} \\
9,3 \mathrm{is}\end{array}$ & $102 \mathrm{ca}$ & 380 \\
\hline $\begin{array}{l}\text { ACIDO CITRICO } \\
77.92-9\end{array}$ & $\begin{array}{l}\text { cristales/ mono- } \\
\text { clínicos } \\
\text { holohédricos/ } \\
\text { cristaliza en solución } \\
\text { ac. concentrada } \\
\text { caliente; cristales } \\
\text { incoloros translúcidos } \\
\text { o polvo blanco } \\
\text { granular a cristalino } \\
\text { fino/ cristales } \\
\text { rómbicos en agua } \\
\text { con } 1 \text { mol de agua } \\
\text { de cristalización }\end{array}$ & descomp & 153 & 192,12 & muy sol & 1,665 & & & $\begin{array}{l}0,28 \mathrm{li} \\
2,29 \mathrm{ls}\end{array}$ & & \\
\hline $\begin{array}{l}\text { ACIDO CITRICO HIDRATO } \\
5949-29-1\end{array}$ & cristales & descomp & 100 & & sol & 1,5 & & & $\begin{array}{l}0,28 \mathrm{li} \\
2,29 \mathrm{ls} \\
\end{array}$ & & 1010 \\
\hline $\begin{array}{l}\text { ACIDO CLORENDICO } \\
115-28-6\end{array}$ & sólido cristalino & & & 388,84 & & & & & & & \\
\hline $\begin{array}{l}\text { ACIDO CLOROACETICO } \\
79-11-8\end{array}$ & $\begin{array}{l}\text { prismas } \\
\text { monoclínicos; } \\
\text { cristales incoloros o } \\
\text { blancos; cristales } \\
\text { incoloros o marrón } \\
\text { claro }\end{array}$ & 189 & $\begin{array}{l}\text { (alfa) 63; } \\
\text { (beta) } \\
55-56 ; \\
\text { (gamma) } \\
50\end{array}$ & 94,50 & muy sol & 1,6 & 3,26 & $\begin{array}{l}0,13 \\
@ 43 \stackrel{\circ}{0}\end{array}$ & $\begin{array}{l}8,0 \mathrm{li} \\
? \text { Is }\end{array}$ & 126 & 500 \\
\hline $\begin{array}{l}\text { ACIDO 0.CLOROBENZOICO } \\
118-91-2\end{array}$ & $\begin{array}{l}\text { prismas monoclínicos } \\
\text { en agua }\end{array}$ & sublima & 142 & 156,6 & sol & 1,544 & & $\begin{array}{l}6,6 \times 10-4 \\
\mathrm{~mm} \mathrm{Hg} @ \\
25 \stackrel{\circ}{-}\end{array}$ & & & \\
\hline $\begin{array}{l}\text { ACIDO m-CLOROBENZOICO } \\
535-80-8\end{array}$ & $\begin{array}{l}\text { cristales; prismas en } \\
\text { agua }\end{array}$ & sublima & 158 & 156,6 & muy sol & $\begin{array}{l}1,496 \\
@ 25 \stackrel{\circ}{ } \mathrm{C} / 4^{\circ} \mathrm{C}\end{array}$ & & $\begin{array}{l}8,475 \times 10-5 \\
\mathrm{~mm} \mathrm{Hg} \\
@ 25 \stackrel{\circ}{\mathrm{C}}\end{array}$ & & & \\
\hline $\begin{array}{l}\text { ACIDO p-CLOROBENZOICO } \\
74-11-3\end{array}$ & $\begin{array}{l}\text { prismas triclínicos en } \\
\text { alcohol y éter; polvo } \\
\text { grueso casi blanco }\end{array}$ & & 243 & 156,6 & insol & & & $\begin{array}{l}1,85 \times 10-3 \\
\mathrm{~mm} \mathrm{Hg} \\
\text { @ } 25 \stackrel{\circ}{\circ} \mathrm{C}\end{array}$ & & & \\
\hline
\end{tabular}




\begin{tabular}{|c|c|c|c|c|c|c|c|c|c|c|c|}
\hline $\begin{array}{l}\text { Denominación química } \\
\mathrm{N} \text { úmero CAS }\end{array}$ & Color/ Forma & $\begin{array}{l}\text { p.e. } \\
(\stackrel{C}{ } \mathrm{C})\end{array}$ & $\begin{array}{l}\text { p.f. } \\
(\stackrel{\circ}{ }=)\end{array}$ & $\begin{array}{l}\text { p.m.l } \\
\text { (g/ } \\
\text { mol) }\end{array}$ & $\begin{array}{l}\text { Solubilidad } \\
\text { en agua }\end{array}$ & $\begin{array}{l}\text { Densidad } \\
\text { relativa } \\
\text { (agua }=1 \text { ) }\end{array}$ & $\begin{array}{l}\text { Densidad } \\
\text { de vapor } \\
\text { relativa } \\
\text { (aire=1) }\end{array}$ & $\begin{array}{l}\mathrm{Pvap} / \\
(\mathrm{kPa})\end{array}$ & $\begin{array}{l}\text { Límit. } \\
\text { inflam. }\end{array}$ & $\begin{array}{l}\text { p.ig. } \\
(\underline{O C})\end{array}$ & $\begin{array}{l}\text { p.aut } \\
\text { ig. } \\
\left({ }^{\circ} \mathrm{C}\right)\end{array}$ \\
\hline $\begin{array}{l}\text { ACIDO 2-CLOROPROPIONICO } \\
598-78-7\end{array}$ & cristales & 186 & $-12,1$ & 108,53 & misc & 1,2585 & & & & & \\
\hline $\begin{array}{l}\text { ACIDO CROTONICO } \\
3724-65-0\end{array}$ & $\begin{array}{l}\text { agujas o prismas } \\
\text { monoclínicos (en } \\
\text { agua o éter de } \\
\text { petróleo); cristales } \\
\text { aciculares incoloros; } \\
\text { sólido cristalino } \\
\text { blanco }\end{array}$ & 185 & $\begin{array}{l}71,5- \\
71,7\end{array}$ & 86,09 & muy sol & $\begin{array}{l}1,018 \\
@ 15 \stackrel{\circ}{\circ} / 4 \stackrel{\circ}{\circ} C_{;} \\
0,964 \\
@ 80 \stackrel{\circ}{\circ} / 4 \stackrel{\circ}{\circ} \mathrm{C}\end{array}$ & 2,97 & 0,024 & & 88 & 396 \\
\hline $\begin{array}{l}\text { ACIDO DICLOROACETICO } \\
79-43-6\end{array}$ & líquido incoloro & 194 & 9,7 & 128,94 & misc & 1,56 & 4,45 & 0,019 & & & \\
\hline $\begin{array}{l}\text { ACIDO 2,4-DICLOROFENOXIACETICO } \\
94-75 \cdot 7\end{array}$ & $\begin{array}{l}\text { polvo cristalino } \\
\text { blanco a amarillo; el } \\
\text { color amarillo se } \\
\text { debe a impurezas } \\
\text { fenólicas; polvo } \\
\text { incoloro; blanco }\end{array}$ & $\begin{array}{l}160 @ 0,4 \\
\mathrm{~mm} \mathrm{Hg}\end{array}$ & 138 & 221,04 & insol & 1,6 & 7,6 & $\begin{array}{l}0,053 \\
@ 160 \stackrel{\circ}{0}\end{array}$ & & $88 \mathrm{ca}$ & \\
\hline $\begin{array}{l}\text { ACIDO 2,4-DICLOROFENOXI } \\
\text { PROPIONICO } \\
120-36-5\end{array}$ & $\begin{array}{l}\text { sólido cristalino } \\
\text { incoloro; sólido } \\
\text { cristalino blanco o } \\
\text { tostado }\end{array}$ & & $\begin{array}{l}117,5- \\
118,1\end{array}$ & 235,07 & & 1,42 & & & & & \\
\hline $\begin{array}{l}\text { ACIDO ESTEARICO } \\
57-11-4\end{array}$ & $\begin{array}{l}\text { láminas monoclínicas } \\
\text { en alcohol; polvo o } \\
\text { masas de cristales } \\
\text { blancos o } \\
\text { ligeramente amarillos }\end{array}$ & $\begin{array}{l}360 @ \\
15 \mathrm{~mm} \mathrm{Hg}\end{array}$ & 69 & 284,50 & insol & 0,9408 & 9,80 & $\begin{array}{l}1 \mathrm{~mm} \mathrm{Hg} \\
@ \\
173,7 \stackrel{\circ}{\mathrm{C}}\end{array}$ & & 196 & 395 \\
\hline $\begin{array}{l}\text { ACIDO ETANODIOICO, DIHIDRATO } \\
6153-56-6\end{array}$ & cristales incoloros & sublima & 102 & & $10 \mathrm{~g} / 100 \mathrm{ml}$ & 1,7 & 3,1 & & & & \\
\hline $\begin{array}{l}\text { ACIDO 2-ETILHEXOICO } \\
149-57-5\end{array}$ & líquido incoloro & 228 & .59 & 144,2 & sol & $\begin{array}{l}0,9031 \\
@ 25 \stackrel{\circ}{\circ} / 4 \stackrel{\circ}{\circ}\end{array}$ & 5,0 & 0,004 & $\begin{array}{l}0,8 \mathrm{li} \\
6,0 \mathrm{ls}\end{array}$ & $118 \mathrm{ca}$ & 310 \\
\hline $\begin{array}{l}\text { ACIDO FLUOROACETICO } \\
144-49-0\end{array}$ & $\begin{array}{l}\text { agujas; cristales } \\
\text { incoloros }\end{array}$ & 165 & 35,2 & 78,04 & sol & $\begin{array}{l}1,3693 \\
@ 36 \stackrel{0}{ }=\end{array}$ & & $\begin{array}{l}1,9 \mathrm{~mm} \mathrm{Hg} \\
@ 25 \stackrel{0}{0}\end{array}$ & & & \\
\hline $\begin{array}{l}\text { ACIDO FORMICO } \\
64-18-6 \\
\end{array}$ & líquido incoloro & 101 & 8,4 & 46,00 & misc & 1,22 & 1,6 & 4,4 & $\begin{array}{l}14 \mathrm{li} \\
34 \mathrm{ls} \\
\end{array}$ & 69 & $\begin{array}{l}480- \\
520 \\
\end{array}$ \\
\hline $\begin{array}{l}\text { ACIDO FTALICO } \\
88-99-3 \\
\end{array}$ & $\begin{array}{l}\text { cristales; placas en } \\
\text { agua }\end{array}$ & descomp & $210-211$ & 166,13 & lig sol & 1,59 & 5,73 & & & $168 \mathrm{ca}$ & \\
\hline $\begin{array}{l}\text { ACIDO FUMARICO } \\
110-17-8\end{array}$ & $\begin{array}{l}\text { agujas, prismas } \\
\text { monoclinicos o } \\
\text { laminillas en agua; } \\
\text { cristales incoloros; } \\
\text { polvo blanco } \\
\text { cristalino }\end{array}$ & $\begin{array}{l}165 \\
\text { sublima@1,7 } \\
\text { mm Hg }\end{array}$ & $300-302$ & 116,07 & lig sol & 1,635 & & & & & \\
\hline $\begin{array}{l}\text { ACIDO GALICO } \\
149-91.7\end{array}$ & $\begin{array}{l}\text { prismas en agua; } \\
\text { agujas en metanol } \\
\text { absoluto } 0 \\
\text { cloroformo }\end{array}$ & & 253 & 170,1 & lig sol & $\begin{array}{l}1,694 \\
@ 6 \stackrel{\circ}{ } \mathrm{C} / 4 \stackrel{\circ}{ } \mathrm{C}\end{array}$ & & & & & \\
\hline $\begin{array}{l}\text { ACIDO GLICOLICO } \\
79-14-1\end{array}$ & $\begin{array}{l}\text { cristales incoloros; } \\
\text { agujas rómbicas en } \\
\text { agua; láminas en } \\
\text { etanol }\end{array}$ & 100 & 80 & 76,05 & sol & & & & & & \\
\hline
\end{tabular}




\begin{tabular}{|c|c|c|c|c|c|c|c|c|c|c|c|}
\hline $\begin{array}{l}\text { Denominación química } \\
\mathrm{N} \text { úmero CAS }\end{array}$ & Color/ Forma & $\begin{array}{l}\text { p.e. } \\
(\stackrel{\circ}{ } C)\end{array}$ & $\begin{array}{l}\text { p.f. } \\
\left({ }^{\circ} \mathrm{C}\right)\end{array}$ & $\begin{array}{l}\text { p.m.l } \\
\text { (g/ } \\
\text { mol) }\end{array}$ & $\begin{array}{l}\text { Solubilidad } \\
\text { en agua }\end{array}$ & $\begin{array}{l}\text { Densidad } \\
\text { relativa } \\
\text { (agua }=1 \text { ) }\end{array}$ & $\begin{array}{l}\text { Densidad } \\
\text { de vapor } \\
\text { relativa } \\
\text { (aire }=1 \text { ) }\end{array}$ & $\begin{array}{l}\text { Pvap/ } \\
(\mathrm{kPa})\end{array}$ & $\begin{array}{l}\text { Límit. } \\
\text { inflam. }\end{array}$ & $\begin{array}{l}\text { p.ig. } \\
(\underline{O C})\end{array}$ & $\begin{array}{l}\text { p.aut } \\
\text { ig. } \\
\left({ }^{\circ} \mathrm{C}\right)\end{array}$ \\
\hline $\begin{array}{l}\text { ACIDO HEPTANOICO } \\
111-14-8\end{array}$ & $\begin{array}{l}\text { líquido oleoso } \\
\text { transparente }\end{array}$ & 223,01 & $-7,5$ & 130,2 & lig sol & 0,92 & & & & & \\
\hline $\begin{array}{l}\text { ACIDO ISOBUTIRICO } \\
79-31-2\end{array}$ & líquido incoloro & $152-155$ & -47 & 88,1 & muy sol & 0,950 & 3,0 & $\begin{array}{l}1 \mathrm{~mm} \mathrm{Hg} \\
\text { @ } 14,7 \stackrel{\circ}{-} \mathrm{C}\end{array}$ & & & \\
\hline $\begin{array}{l}\text { ACIDO ISOFTALICO } \\
121-91-5\end{array}$ & agujas & sublima & 347 & 166,13 & lig sol & & & & & & \\
\hline $\begin{array}{l}\text { ACIDO LACTICO } \\
598-82-3\end{array}$ & $\begin{array}{l}\text { líquido incoloro o } \\
\text { cristales incoloros }\end{array}$ & & $16,8-18$ & 90,08 & muy sol & & & & & 74 & \\
\hline $\begin{array}{l}\text { ACIDO LAURICO } \\
143 \cdot 07-7\end{array}$ & $\begin{array}{l}\text { sólido incoloro; polvo } \\
\text { blanco cristalino }\end{array}$ & 298,9 & 44,2 & 200,3 & insol & 0,883 & & $\begin{array}{l}1 \mathrm{~mm} \mathrm{Hg} \\
@ \\
121,0 \stackrel{\circ}{-C}\end{array}$ & & & \\
\hline $\begin{array}{l}\text { ACIDO MALEICO } \\
110-16-7\end{array}$ & $\begin{array}{l}\text { prismas monoclínicos } \\
\text { en agua; cristales } \\
\text { blancos en agua, } \\
\text { alcohol y benceno; } \\
\text { cristales incoloros }\end{array}$ & 135 & $138-139$ & 116,07 & $\begin{array}{l}788 \mathrm{~g} / \mathrm{I} @ \\
25 \mathrm{O} C\end{array}$ & 1,590 & 4,0 & & & & \\
\hline $\begin{array}{l}\text { ACIDO MALONICO } \\
141-82-2 \\
\end{array}$ & cristales blancos & descomp & $132-134$ & 104,06 & sol & 1,63 & & & & & \\
\hline $\begin{array}{l}\text { ACIDO METACRILICO } \\
79-41-4\end{array}$ & $\begin{array}{l}\text { cristales líquidos o } \\
\text { incoloros; líquido } \\
\text { incoloro }\end{array}$ & 163 & 16 & 86,09 & sol & 1,0153 & 2,97 & $\begin{array}{l}0,13 \\
@ 25 \stackrel{\circ}{\circ} \mathrm{C}\end{array}$ & & $77 \mathrm{ca}$ & \\
\hline $\begin{array}{l}\text { ACIDO METACRILICO, } \\
\text { 2-DIMETILAMINOETILO } \\
2867-47-2 \\
\end{array}$ & líquido & $62-65$ & -30 & 157,22 & sol & 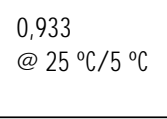 & 5,4 & & & $739 \mathrm{ca}$ & \\
\hline $\begin{array}{l}\text { ACIDO 2-METIL-4-CLOROFENOACETICO } \\
94-74-6\end{array}$ & $\begin{array}{l}\text { sólido marrón claro; } \\
\text { placas en benceno o } \\
\text { tolueno; sólido } \\
\text { blanco cristalino } \\
\text { (comp. puro); sólido } \\
\text { incoloro cristalino } \\
\text { (puro) }\end{array}$ & & 120 & 200,6 & lig sol & $\begin{array}{l}1,56 @ \\
25 \stackrel{\circ}{\circ} / 15,5 \stackrel{\circ}{\circ}\end{array}$ & 6,9 & $0,0002 \mathrm{~Pa}$ & & & \\
\hline $\begin{array}{l}\text { ACIDO NONANOICO } \\
112.05 .0\end{array}$ & $\begin{array}{l}\text { líquido incoloro y } \\
\text { oleoso a temperatura } \\
\text { normal; cristaliza } \\
\text { cuando se enfría; } \\
\text { aceite amarillento }\end{array}$ & 255 & 12,5 & 158,23 & insol & 0,9057 & & & & & \\
\hline $\begin{array}{l}\text { ACIDO OLEICO } \\
112-80-1\end{array}$ & $\begin{array}{l}\text { líquido incoloro o casi } \\
\text { incoloro (a más de } \\
5-7 \text { 이); líquido } \\
\text { amarillento y oleoso; } \\
\text { líquido acuoso blanco }\end{array}$ & $\begin{array}{l}286 @ \\
100 \mathrm{~mm} \mathrm{Hg}\end{array}$ & 16,3 & 282,45 & insol & $0,895 @ 25 \stackrel{\circ}{\circ} \mathrm{C}$ & & & & & 363 \\
\hline $\begin{array}{l}\text { ACIDO OXALICO } \\
144.62 \cdot 7\end{array}$ & $\begin{array}{l}\text { el ácido oxálico anh } \\
\text { cristaliza en ácido } \\
\text { acético glacial en el } \\
\text { sistema ortorrómbico, } \\
\text { los cristales son } \\
\text { piramidales u } \\
\text { octaédricos } \\
\text { alargados; cristales } \\
\text { incoloros y } \\
\text { transparentes o polvo } \\
\text { blanco }\end{array}$ & 157 & 189,5 & 90,04 & sol & $\begin{array}{l}1,900 \\
@ 17 \stackrel{\circ}{-C} / 4 \stackrel{\circ}{-} \mathrm{C}\end{array}$ & & & & & \\
\hline
\end{tabular}




\begin{tabular}{|c|c|c|c|c|c|c|c|c|c|c|c|}
\hline $\begin{array}{l}\text { Denominación química } \\
\mathrm{N} \text { úmero CAS }\end{array}$ & Color/ Forma & $\begin{array}{l}\text { p.e. } \\
\left({ }^{\circ} \mathrm{C}\right)\end{array}$ & $\begin{array}{l}\text { p.f. } \\
(\stackrel{\circ}{ }=)\end{array}$ & $\begin{array}{l}\text { p.m.l } \\
\text { (g/ } \\
\text { mol) }\end{array}$ & $\begin{array}{l}\text { Solubilidad } \\
\text { en agua }\end{array}$ & $\begin{array}{l}\text { Densidad } \\
\text { relativa } \\
\text { (agua }=1 \text { ) }\end{array}$ & $\begin{array}{l}\text { Densidad } \\
\text { de vapor } \\
\text { relativa } \\
\text { (aire=1) }\end{array}$ & $\begin{array}{l}\text { Pvap/ } \\
(\mathrm{kPa})\end{array}$ & $\begin{array}{l}\text { Límit. } \\
\text { inflam. }\end{array}$ & $\begin{array}{l}\text { p.ig. } \\
(\stackrel{\circ}{ } C)\end{array}$ & $\begin{array}{l}\text { p.aut } \\
\text { ig. } \\
(\stackrel{0}{ } \mathrm{C})\end{array}$ \\
\hline $\begin{array}{l}\text { ACIDO PALMITICO } \\
57-10-3\end{array}$ & $\begin{array}{l}\text { escamas cristalinas } \\
\text { blancas; agujas en } \\
\text { alcohol }\end{array}$ & $\begin{array}{l}351 @ 15 \\
\mathrm{~mm} \mathrm{Hg}\end{array}$ & $63-64$ & 256,5 & insol & $\begin{array}{l}0,853 @ 62 \\
\stackrel{0}{ } \mathrm{C} / 4 \stackrel{0}{ } \stackrel{\mathrm{C}}{ }\end{array}$ & & $\begin{array}{l}0,133 \\
@ 154 \stackrel{\circ}{C}\end{array}$ & & & \\
\hline $\begin{array}{l}\text { ACIDO PIVALICO } \\
75-98.9 \\
\end{array}$ & cristales coloreados & 164 & 35,5 & 102,13 & lig sol & $0,905 @ 50 \stackrel{\circ}{C}$ & & & & & \\
\hline $\begin{array}{l}\text { ACIDO PROPIONICO } \\
79-09-4 \\
\end{array}$ & $\begin{array}{l}\text { líquido incoloro; } \\
\text { líquido oleoso }\end{array}$ & 141 & $-20,8$ & 74,09 & misc & 0,9930 & 2,56 & 0,386 & $\begin{array}{l}2,9 \mathrm{li} \\
14,8 \mathrm{ls} \\
\end{array}$ & 544 & 955 \\
\hline $\begin{array}{l}\text { ACIDO SALLCILICO } \\
69.72 .7\end{array}$ & $\begin{array}{l}\text { cristales blancos, } \\
\text { finos, como agujas, o } \\
\text { polvo esponjoso } \\
\text { blanco cristalino; } \\
\text { agujas en agua; } \\
\text { prismas monoclínicos } \\
\text { en alcohol }\end{array}$ & 211 & 158 & 138,12 & lig sol & 1,443 & 4,8 & 0,114 & $\begin{array}{l}1,1 \text { is } \\
\text { ? Is }\end{array}$ & 157 & 540 \\
\hline $\begin{array}{l}\text { ACIDO SUCCINICO } \\
110-15-6\end{array}$ & $\begin{array}{l}\text { prismas monoclínicos } \\
\text { blancos diminutos; } \\
\text { prismas triclínicos o } \\
\text { monoclínicos }\end{array}$ & 235 & 188 & 118,09 & lig sol & $\begin{array}{l}1,572 \\
\text { @ } 25 \stackrel{\circ}{\circ} / 4 \stackrel{\circ}{\circ} \mathrm{C}\end{array}$ & & & & & \\
\hline $\begin{array}{l}\text { ACIDO SULFANILICO } \\
121-57-3\end{array}$ & $\begin{array}{l}\text { placas rómbicas o } \\
\text { cristales monoclínicos } \\
\text { en agua }\end{array}$ & & 288 & 173,2 & lig sol & $\begin{array}{l}1,485 @ \\
25 \stackrel{\circ}{\circ} / 4 \stackrel{\circ}{\circ} \mathrm{C}\end{array}$ & & & & & \\
\hline $\begin{array}{l}\text { ACIDO TARTARICO } \\
87-69-4\end{array}$ & & & 169 & 150,08 & & & & & & & \\
\hline $\begin{array}{l}\text { ACIDO TEREFTALLCO } \\
100-21 \cdot 0 \\
\end{array}$ & $\begin{array}{l}\text { agujas; polvo } 0 \\
\text { cristales blancos }\end{array}$ & 402 & & 166,13 & insol & 1,51 & & $<0.001$ & & 260 & 496 \\
\hline $\begin{array}{l}\text { ACIDO p-TOLUENSULFONICO } \\
\text { 104-15-4 }\end{array}$ & $\begin{array}{l}\text { laminillas o prismas } \\
\text { monoclínicos; } \\
\text { cristales incoloros }\end{array}$ & 140 & $106-107$ & 172,2 & muy sol & 1,24 & & & & $184 c C$ & \\
\hline $\begin{array}{l}\text { ACIDO TRICLOROACETICO } \\
76-03-9\end{array}$ & $\begin{array}{l}\text { cristales; incoloro; } \\
\text { sólido blanco }\end{array}$ & 197,55 & 58 & 163,40 & muy sol & $\begin{array}{l}1,62 \\
@ 25 \mathrm{C} / 4 \stackrel{0}{ } \mathrm{C}\end{array}$ & & $\begin{array}{l}1 \mathrm{~mm} \mathrm{Hg} \\
@ 51,0 \stackrel{\circ}{C}\end{array}$ & & & \\
\hline $\begin{array}{l}\text { ACIDO } \\
\text { 2,4,5-TRICLOROFENOXIACETICO } \\
93-76-5 \\
\end{array}$ & $\begin{array}{l}\text { sólido blanco; sólido } \\
\text { de color tostado claro }\end{array}$ & descomp & 153 & 255,5 & insol & 1,80 & & $<0,01 \mathrm{mPa}$ & & & \\
\hline $\begin{array}{l}\text { ACIDO TRIFLUOROACETICO } \\
\text { 76-05-1 }\end{array}$ & $\begin{array}{l}\text { líquido incoloro } \\
\text { fumante }\end{array}$ & 73 & $-15,2$ & 114,02 & sol & $\begin{array}{l}1,5351 \\
@ 25 \stackrel{\circ}{C}\end{array}$ & & & & & \\
\hline $\begin{array}{l}\text { ACIDO VALERICO } \\
109-52-4 \\
\end{array}$ & líquido incoloro & $186-187$ & $-34,5$ & 102,15 & sol & 0,939 & 3,5 & 0,020 & & $96 \mathrm{ca}$ & 400 \\
\hline $\begin{array}{l}\text { ANHIDRIDO ACETICO } \\
\text { 108-24-7 }\end{array}$ & $\begin{array}{l}\text { líquido incoloro, muy } \\
\text { móvil, fuertemente } \\
\text { refringente }\end{array}$ & 139 & .73 & 102,10 & muy sol & $1,080 @ 15 \stackrel{\circ}{ } \mathrm{C}$ & 3,5 & 0,5 & $\begin{array}{l}2,9 \mathrm{li} \\
10,3 \mathrm{ls}\end{array}$ & $49 \mathrm{cc}$ & 316 \\
\hline $\begin{array}{l}\text { ANHIDRIDO FTALICO } \\
85-44.9\end{array}$ & $\begin{array}{l}\text { agujas blancas } \\
\text { lustrosas; lascas } \\
\text { sólidas incoloras o } \\
\text { amarillo pálido; } \\
\text { agujas incoloras; } \\
\text { prismas monoclínicos } \\
\text { o rómbicos; agujas } \\
\text { blancas en alcohol y } \\
\text { benceno }\end{array}$ & 295 & 130,8 & 148,11 & lig sol & 1,527 & 5,1 & $0,27 \mathrm{~Pa}$ & $\begin{array}{l}1,7 \mathrm{li} \\
10,4 \mathrm{ls}\end{array}$ & & 570 \\
\hline
\end{tabular}


Tabla 104.8 - Propiedades físicas y químicas.

\begin{tabular}{|c|c|c|c|c|c|c|c|c|c|c|c|}
\hline $\begin{array}{l}\text { Denominación química } \\
\mathrm{N} \text { úmero CAS }\end{array}$ & Color/ Forma & $\begin{array}{l}\text { p.e. } \\
(\stackrel{0}{ } \mathrm{C})\end{array}$ & $\begin{array}{l}\text { p.f. } \\
(\stackrel{\circ}{ } C)\end{array}$ & $\begin{array}{l}\text { p.m.l } \\
\text { (g/ } \\
\text { mol) }\end{array}$ & $\begin{array}{l}\text { Solubilidad } \\
\text { en agua }\end{array}$ & $\begin{array}{l}\text { Densidad } \\
\text { relativa } \\
\text { (agua }=1 \text { ) }\end{array}$ & $\begin{array}{l}\text { Densidad } \\
\text { de vapor } \\
\text { relativa } \\
\text { (aire=1) }\end{array}$ & $\begin{array}{l}\text { Pvap/ } \\
(\mathrm{kPa})\end{array}$ & $\begin{array}{l}\text { Límit. } \\
\text { inflam. }\end{array}$ & $\begin{array}{l}\text { p.ig. } \\
(\underline{O C})\end{array}$ & $\begin{array}{l}\text { p.aut } \\
\text { ig. } \\
\left({ }^{\circ} \mathrm{C}\right)\end{array}$ \\
\hline $\begin{array}{l}\text { ANHIDRIDO MALEICO } \\
\text { 108-31-6 }\end{array}$ & $\begin{array}{l}\text { agujas ortorrómbicas } \\
\text { en cloroformo; clase } \\
\text { comercial en forma } \\
\text { fundida, como } \\
\text { briquetas; agujas } \\
\text { incoloras o grumos o } \\
\text { pelets blancos; } \\
\text { agujas en cloroformo } \\
\text { o éter }\end{array}$ & 202,0 & 52,8 & 98,06 & sol & 1,48 & 3,4 & $\begin{array}{l}0,025 \\
@ 25 \stackrel{\circ}{0}\end{array}$ & $\begin{array}{l}1,4 \mathrm{li} \\
7,1 \mathrm{is}\end{array}$ & 102 & 475 \\
\hline $\begin{array}{l}\text { ANHIDRIDO PROPIONICO } \\
123-62-6\end{array}$ & líquido incoloro & 167 & -45 & 130,2 & descomp & 1,01 & 4.5 & 100 & $\begin{array}{l}1,3 \mathrm{li} \\
9,5 \mathrm{is}\end{array}$ & 63 & 285 \\
\hline $\begin{array}{l}\text { ANHIDRIDO TRIMELLTICO } \\
552-30-7\end{array}$ & $\begin{array}{l}\text { cristales; sólido } \\
\text { incoloro }\end{array}$ & $240-245$ & $\begin{array}{l}161- \\
163.5\end{array}$ & 192,13 & reacciona & & 6,6 & $\begin{array}{l}<0,01 \\
@ 25 \stackrel{\circ}{\circ}\end{array}$ & $\begin{array}{l}1 \mathrm{li} \\
7 \mathrm{ls}\end{array}$ & & \\
\hline $\begin{array}{l}\text { CLORURO DE BUTIRILO } \\
141-75-3\end{array}$ & líquido incoloro & 101-102 & .89 & 106,55 & $\begin{array}{l}\text { lentamente con } \\
\text { descomp }\end{array}$ & $\begin{array}{l}1,0263 \\
@ 20,6 \stackrel{\circ}{\circ} / 4 \stackrel{\circ}{\circ} \mathrm{C}\end{array}$ & & & & $<21$ & \\
\hline
\end{tabular}

Continua $\ldots$ 


\section{AlCOHOLES}

Los alcoholes son compuestos orgánicos formados a partir de los hidrocarburos mediante la sustitución de uno o más grupos hidroxilo por un número igual de átomos de hidrógeno. EI término se hace también extensivo a diversos productos sustituidos que tienen carácter neutro y que contienen uno o más grupos alcoholes.

\section{Usos}

Los alcoholes se utilizan como productos químicos intermedios y disolventes en las industrias de textiles, colorantes, productos químicos, detergentes, perfumes, alimentos, bebidas, cosméticos, pinturas y barnices. Algunos compuestos se utilizan también en la desnaturalización del alcohol, en productos de limpieza, aceites y tintas de secado rápido, anticongelantes, agentes espumígenos y en la flotación de minerales.

El n-propanol es un disolvente utilizado en lacas, cosméticos, lociones dentales, tintas de impresión, lentes de contacto y líquidos de frenos. T ambién sirve como antiséptico, aromatizante sintético de bebidas no alcohólicas y alimentos, producto químico intermedio y desinfectante. El isopropanol es otro disolvente industrial importante que se utiliza como anticongelante, en aceites y tintas de secado rápido, en la desnaturalización de alcoholes y en perfumes. Se emplea como antiséptico y sustitutivo del alcohol etílico en cosméticos (p. ej. lociones para la piel, tónicos capilares y alcohol para fricciones), pero no puede utilizarse en productos farmacéuticos aplicados internamente. El isopropanol es un ingrediente de jabones líquidos, limpiacristales, aromatizante sintético de bebidas no alcohólicas y alimentos y producto químico intermedio.

El n-butanol se emplea como disolvente de pinturas, lacas, barnices, resinas naturales y sintéticas, gomas, aceites vegetales, tintes y alcaloides. Se utiliza como sustancia intermedia en la fabricación de productos químicos y farmacéuticos, y en las industrias de cuero artificial, textiles, gafas de seguridad, pastas de caucho, barnices de laca, impermeables, películas fotográficas y perfumes. El sec-butanol se utiliza también como disolvente y producto químico intermedio, y se encuentra en líquidos hidráulicos de frenos, limpiadores industriales, abrillantadores, decapantes de pinturas, agentes de flotación para minerales, esencias de frutas, perfumes y colorantes.

El isobutanol, un disolvente para revestimientos de superficie y adhesivos, se emplea en lacas, decapantes de pinturas, perfumes, productos de limpieza y líquidos hidráulicos. El terc-butanol se utiliza para la eliminación del agua de los productos, como disolvente en la fabricación de fármacos, perfumes y aromas, y como producto químico intermedio. También es un ingrediente de productos industriales de alcohol, un desnaturalizante de alcoholes y un cebador de octano en gasolinas. Los alcoholes amílicos actúan como espumígenos en la flotación de minerales. M uchos alcoholes, entre ellos el alcohol metilamílico, 2-etilbutanol, 2-etilhexanol, ciclohexanol, 2-octanol y metilciclohexanol, se utilizan en la fabricación de lacas. Además de sus numerosas aplicaciones como disolventes, el ciclohexanol y el metilciclohexanol son también útiles en la industria textil. El ciclohexanol se utiliza en el acabado de tejidos, el procesado del cuero y como homogeneizador de jabones y emulsiones detergentes sintéticas. EI metilciclohexanol es un componente de productos quitamanchas a base de jabón y un agente de mezcla en jabones y detergentes para tejidos especiales. El alcohol bencílico se utiliza en la preparación de perfumes, productos farmacéuticos, cosméticos, colorantes, tintas y ésteres bencílicos. Sirve también como disolvente de lacas, plastificante y desengrasante en productos para la limpieza de alfombras. EI 2-cloroetanol se emplea como agente de limpieza y disolvente de éteres de celulosa.

El etanol es la materia prima de numerosos productos, como acetaldehído, éter etílico y cloroetano. Se utiliza como anticongelante, aditivo alimentario y medio de crecimiento de levaduras, en la fabricación de revestimientos de superficie y en la preparación de mezclas de gasolina y alcohol etílico. La producción de butadieno a partir de alcohol etílico ha tenido una gran importancia en las industrias de los plásticos y el caucho sintético. El alcohol etílico puede disolver muchas sustancias $y$, por este motivo, se utiliza como disolvente en la fabricación de fármacos, plásticos, lacas, barnices, plastificantes, perfumes, cosméticos, aceleradores del caucho, etc.

EI metanol es un disolvente de tintas, colorantes, resinas y adhesivos. Se utiliza en la fabricación de película fotográfica, plásticos, jabones textiles, tintes de madera, tejidos con capa de resina sintética, cristal inastillable y productos impermeabilizantes. Sirve como materia prima para la fabricación de muchos productos químicos y es un ingrediente de decapantes de pinturas y barnices, productos desengrasantes, líquidos embalsamadores y mezclas anticongelantes.

El pentanol se utiliza en la fabricación de lacas, pinturas, barnices, decapantes, caucho, plásticos, explosivos, líquidos hidráulicos, pegamentos para calzado, perfumes, productos químicos y farmacéuticos, y en la extracción de grasas. Cuando se utilizan como disolventes, sirven perfectamente las mezclas de alcoholes, pero para síntesis químicas o extracciones más selectivas se requieren a menudo productos más puros.

Después del cloruro de alilo, el alcohol alílico es el compuestos alílico más importante en la industria. Se utiliza en la fabricación de productos farmacéuticos y en síntesis químicas en general, pero sobre todo para la producción de una serie de ésteres alílicos, los más importantes de los cuales son el ftalato de dialilo y el isoftalato de dialilo, que sirven de monómeros y repolímeros.

\section{Riesgos para la salud}

\section{M etanol}

Entre los muchos procesos de síntesis que existen para la producción de alcohol metílico se encuentra la reacción de FischerTropsch entre el monóxido de carbono y el hidrógeno, de la que se obtiene metanol como subproducto. También se produce mediante la oxidación directa de hidrocarburos o mediante un proceso de hidrogenación en dos etapas en el que se hidrogena el monóxido de carbono para dar formiato de metilo, que a su vez se hidrogena para obtener alcohol metílico. Sin embargo, la síntesis más importante es la realizada mediante hidrogenación catalítica a presión del monóxido de carbono o del dióxido de carbono, a presiones de $100-600 \mathrm{kgf} / \mathrm{cm}^{2}$ y temperaturas de $250-400 \stackrel{\circ}{\circ}$.

El alcohol metílico tiene propiedades tóxicas que pueden hacerse evidentes tanto por exposición aguda como crónica. LoS alcohólicos que ingieren este líquido o los trabajadores que inhalan sus vapores pueden sufrir lesiones. En experimentos con animales se ha demostrado que el alcohol metílico puede penetrar en la piel en cantidad suficiente como para causar una intoxicación mortal.

En casos de intoxicación grave, generalmente por ingestión, el alcohol metílico actúa de forma específica en el nervio óptico, 
causando ceguera como resultado de la degeneración del nervio óptico, acompañada de cambios degenerativos en las células ganglionares de la retina y trastornos circulatorios en la coroides. La ambliopía es normalmente bilateral y puede aparecer pocas horas después de la ingestión, mientras que la ceguera total no se instaura hasta pasada una semana. Las pupilas aparecen dilatadas, la esclerótica congestionada y el iris está pálido y presenta escotoma central; las funciones respiratorias y cardiovasculares están deprimidas y, en los casos muy graves, el paciente está inconsciente, si bien el coma puede ir precedido de delirio.

Las consecuencias de la exposición industrial a los vapores de alcohol metílico pueden variar considerablemente de un trabajador a otro. Bajo diferentes condiciones de intensidad y duración de la exposición, los síntomas de la intoxicación son: irritación de las mucosas, cefalea, zumbido de oídos, vértigo, insomnio, nistagmo, dilatación de las pupilas, visión borrosa, náuseas, vómitos, cólicos y estreñimiento. Pueden producirse lesiones cutáneas por la acción irritante y disolvente del alcohol metílico y también por la acción lesiva de los tintes y resinas disueltas en él. Estas lesiones se localizan preferentemente en las manos, las muñecas y los antebrazos. No obstante, la causa de estos efectos perjudiciales se debe en general a exposiciones prolongadas a concentraciones muy superiores a los límites recomendados por las autoridades para prevenir la intoxicación por inhalación de vapores de alcohol metílico.

Se ha sugerido que la exposición crónica combinada a metanol y monóxido de carbono es un factor causante de aterosclerosis cerebral.

La acción tóxica del alcohol metílico se atribuye a oxidación metabólica en ácido fórmico o formaldehído, producto éste que tiene un efecto nocivo específico en el sistema nervioso, y posiblemente a acidosis grave. Estos procesos de oxidación pueden ser inhibidos por el alcohol etílico.

\section{Etanol}

Un riesgo industrial frecuente es la exposición a vapores en la proximidad de un proceso en el que se utiliza alcohol etílico. La exposición prolongada a concentraciones superiores a 5.000 ppm causa irritación de los ojos y la nariz, cefalea, sopor, fatiga y narcosis. El alcohol etílico se oxida muy rápidamente en el organismo a dióxido de carbono y agua. El alcohol no oxidado se excreta en la orina y en el aire espirado, de manera que apenas se producen efectos acumulativos. Su efecto en la piel es similar al de todos los disolventes de grasas y, de no tomarse las debidas precauciones, puede producirse una dermatitis de contacto.

R ecientemente se ha sospechado la existencia de otro riesgo potencial en las personas expuestas a etanol sintético, por haberse demostrado que este producto es cancerígeno en ratones tratados con dosis altas. Un estudio epidemiológico posterior ha revelado una mayor incidencia de cáncer de laringe (cinco veces superior a la prevista) en un grupo de trabajadores empleados en una fábrica de etanol obtenido mediante ácidos fuertes. Parece ser que el agente causal fue el sulfato de dietilo, aunque también estaban implicados las alquil sulfonas y otros posibles cancerígenos.

El alcohol etílico es un líquido inflamable y sus vapores forman mezclas inflamables y explosivas con el aire a temperatura ambiente. Una solución acuosa con un $30 \%$ de alcohol puede producir una mezcla inflamable de vapor y aire a $29 \stackrel{\circ}{ } \mathrm{C}$. O tra que contenga solamente un $5 \%$ de alcohol puede producirla a $62 \stackrel{\circ}{\circ} \mathrm{C}$.

La ingestión es poco probable en el entorno industrial, pero posible en el caso de los alcohólicos. El peligro de este consumo anómalo depende de la concentración de etanol, que si es superior al $70 \%$ puede producir lesiones esofágicas y gástricas, y de la presencia de desnaturalizantes. Estos últimos se añaden para hacer que el alcohol tenga un sabor desagradable cuando se obtiene libre de impuestos para fines distintos al del consumo. Muchos de estos desnaturalizantes (p. ej. alcohol metílico, benceno, bases de piridina, metilisobutilcetona, queroseno, acetona, gasolina, dietilftalato, etc.) son más peligrosos para la persona que lo consuma que el propio alcohol etílico. Por todo ello es muy importante asegurarse de que no se produce consumo ilegal de alcohol etílico destinado a usos industriales.

\section{n-Propanol}

No se han notificado casos de intoxicación relacionados con el uso industrial de n-propanol. Para los animales de experimentación es moderadamente tóxico cuando se administra por vías respiratoria, oral o percutánea. I rrita las mucosas y deprime el sistema nervioso central. Cuando se inhala, produce una leve irritación del aparato respiratorio y ataxia. Es algo más tóxico que el alcohol isopropílico, pero aparentemente provoca los mismos efectos biológicos. Se conoce un caso de fallecimiento por ingestión de $400 \mathrm{ml}$ de n-propanol. Los cambios morfopatológicos observados fueron principalmente edema cerebral y pulmonar, también presentes con frecuencia en la intoxicación etílica. El n-propanol es inflamable y representa un riesgo moderado de incendio.

\section{Otros compuestos}

EI isopropanol es ligeramente tóxico para los animales de experimentación cuando se administra por vía dérmica y moderadamente tóxico por vía oral e intraperitoneal. No se conoce ningún caso de intoxicación industrial, aunque sí se ha detectado una mayor incidencia de cánceres de senos nasales y laringe en trabajadores que participaban en la producción de alcohol isopropílico. La causa podría ser el contacto con aceite isopropílico, que se obtiene como subproducto. La experiencia clínica demuestra que el alcohol isopropílico es más tóxico que el etanol, pero menos que el metanol. El isopropanol se metaboliza en el organismo dando acetona, que puede alcanzar concentraciones elevadas y, a su vez, es metabolizada y se excretada por los riñones y los pulmones. En el ser humano, las concentraciones de 400 ppm producen irritación leve de ojos, nariz y garganta.

El curso clínico de la intoxicación por isopropanol es semejante al de la intoxicación por etanol. La ingestión de hasta $20 \mathrm{ml}$ diluidos en agua causa solamente una suave sensación de calor y un ligero descenso de la presión sanguínea. No obstante, en dos casos mortales de intoxicación aguda, unas horas después de la ingestión se produjo parada respiratoria, coma profundo e hipotensión, lo que se considera un signo de mal pronóstico. El isopropanol es un líquido inflamable que conlleva peligro de incendio.

EI n-butanol es potencialmente más tóxico que cualquiera de sus homólogos inferiores, pero los riesgos prácticos asociados a su producción industrial y a su uso a temperatura ambiente son muy pequeños debido a su escasa volatilidad. Las altas concentraciones de vapor producen narcosis y muerte en los animales. La exposición del ser humano a los vapores puede causar irritación de las mucosas. Las concentraciones que producen irritación varían entre 50 y 200 ppm. Con más de 200 ppm pueden presentarse edema leve transitorio ocular de la conjuntiva y un recuento de eritrocitos ligeramente reducido. El contacto del líquido con la piel provoca irritación, dermatitis y absorción. Es ligeramente tóxico cuando se ingiere y conlleva también peligro de incendio.

La reacción de los animales a los vapores de sec-butanol es similar a la observada con n-butanol, si bien el primero es más narcótico y letal. Es un líquido inflamable con peligro de incendio. 
A elevadas concentraciones, la acción de los vapores de isobutanol es principalmente narcótica, como también ocurre con otros alcoholes. Produce irritación ocular cuando la concentración supera los 100 ppm. El contacto del líquido con la piel puede causar eritema. Es sligeramente tóxico por ingestión. Es un líquido inflamable con peligro de incendio.

Si bien los vapores de terc-butanol son más narcóticos que los del $n$ - o isobutanol para el ratón, hasta ahora se han notificado pocos casos de intoxicación relacionados con su uso industrial, salvo una leve irritación ocasional de la piel. Es ligeramente tóxico por ingestión. Además, es inflamable y constituye un riesgo importante de incendio.

La exposición prolongada a vapor de ciclohexanol puede producir cefalea e irritación de la conjuntiva, aunque no existen riesgos industriales graves. A una concentración de 100 ppm produce irritación de ojos, nariz y garganta. El contacto prolongado del líquido con la piel causa irritación, y el líquido se absorbe lentamente a través de la piel. Es ligeramente tóxico cuando se ingiere. El ciclohexanol se excreta en la orina, conjugado con ácido glucurónico. El líquido es inflamable y entraña un peligro moderado de incendio.

La exposición prolongada a los vapores de meilciclohexanol puede causar cefalea e irritación de los ojos y del tracto respiratorio superior. El contacto prolongado del líquido con la piel produce irritación, y el líquido se absorbe lentamente a través de la piel. Es ligeramente tóxico por ingestión y se excreta en la orina, conjugado con ácido glucurónico. Conlleva un peligro moderado de incendio.

La exposición a vapores altamente concentrados de una mezcla que contenía alcohol bencílico, benceno y ésteres como disolvente sólo produjo cefalea, vértigo, náuseas, diarrea y pérdida de peso, todos ellos pasajeros, sin que se haya producido ningún caso de enfermedad industrial relacionado con el alcohol bencílico. Esta sustancia produce una leve irritación de la piel y un leve lagrimeo. El líquido es inflamable y conlleva un peligro moderado de incendio.

El alcohol alílico es un líquido inflamable e irritante. Causa irritación en contacto con la piel, y la absorción a través de la piel da lugar a un dolor profundo en la región donde se ha producido la absorción, además de lesiones sistémicas. Si el líquido penetra en los ojos, puede producir quemaduras graves. Los vapores no poseen propiedades narcóticas serias, pero ejercen un efecto irritante sobre las mucosas y el sistema respiratorio cuando se inhalan como contaminante atmosférico. Su presencia en una atmósfera industrial puede causar lagrimeo, dolor en los ojos y visión borrosa (necrosis de la córnea, hematuria y nefritis).

\section{Alcoholes amílicos}

L os alcoholes pentílicos se presentan en varias formas isoméricas, y de las ocho estructuras isoméricas posibles, tres de ellas tienen también formas ópticamente activas. D e las formas estructurales, cuatro de ellas son alcoholes primarios- 1-pentanol (alcohol amílico), 2-metil-1-butanol, alcohol isopentílico (3-metil-1-butanol, alcohol isoamílico) y alcohol neopentílico (2,2-dimetil-1propanol); tres son alcoholes secundarios- 2-pentanol, 3-pentanol y 3-metil-2-butanol; y el último es un alcohol terciario-el alcohol terc-pentílico (2-metil-2-butanol).

El alcohol pentílico irrita las mucosas de los ojos, la nariz y la garganta cuando alcanza concentraciones de 100 ppm. Si bien se absorbe por vía digestiva, respiratoria y cutánea, la incidencia de enfermedades profesionales es muy baja. El producto crudo causa rápidamente irritación de las mucosas debido a la presencia de materiales volátiles extraños. Los síntomas de enfermedad generalizada son cefalea, mareo, náuseas, vómitos, diarrea, delirio y narcosis. El hecho de que el alcohol pentílico se utilice con frecuencia en estado impuro y mezclado con otros disolventes, hace imposible atribuir a este alcohol síntomas 0 hallazgos distintivos. La facilidad con la que se metabolizan los alcoholes decrece de los alcoholes primarios a los secundarios y terciarios. De los tres, los alcoholes terciarios son los que más se excretan sin sufrir cambios. A unque la toxicidad varía según la configuración química, puede afirmarse, en términos generales, que una mezcla de alcoholes pentílicos es aproximadamente diez veces más tóxica que el alcohol etílico. Este hecho se refleja en los límites de exposición recomendados para los dos alcoholes-100 ppm y 1.000 ppm, respectivamente. El riesgo de incendio de los alcoholes amílicos no es particularmente elevado. 
TABLAS DE ALCOHOLES

Tabla 104.9 • Identificación química.

\begin{tabular}{lll} 
Producto químico & Sinónimos/ Código UN & Número CAS Fórmula estructural \\
ALCOHOL ALLLCO & Alil alcohol; 2-propen-1-0l; propenol; alcohol propenílico \\
UN1098 & $107-18-6$ \\
\hline
\end{tabular}

ALCOHOL BENCILCO

Bencenocarbinol; bencenometanol; fenolcarbinol; fenilmetanol

$100-51-6$

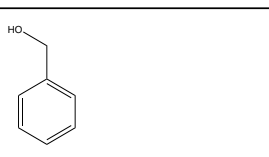

$\begin{array}{ll}\text { ALCOHOL BUTLILCO } & \begin{array}{l}\text { n-Buanol; alcohol 1-butílico; hidróxido de butilo; } 1 \text {-hidroxibutano; } \\ \text { propilcarbinol; propilmetanol }\end{array}\end{array}$

ALCOHOLSeC-BUTLLICO 2-Butanol; 2-hidroxibutano; metiletilcarbinol; 1-metil-1-propanol

ALCOHOL terc-BUTILICO terc-Butanol; 1,1-dimetiletanol; 2-metil-2-propanol; trimetilcarbinol

\begin{tabular}{ll}
\hline ALCOHOL 2-ETLBUTILICO & $\begin{array}{l}\text { 2-Etilbutanol; 2-etilbutanol-1; 2-etil-1-butanol; 2-etilbutil alcohol; alcohol 97-95-0 } \\
\text { Sec-hexílico; 3-metilolpentano; sec-pentilcarbinol; 3-pentilcarbinol; } \\
\text { alcohol pseudohexilico } \\
\text { UN2275 }\end{array}$ \\
\hline ALCOHOL ISOAMILICO & $\begin{array}{l}\text { Isobutilcarbinol; isopentanol; alcohol isopentilico; 3-metil butanol; } \\
\text { 3-metil-1-butanol }\end{array}$ \\
\hline
\end{tabular}

\begin{tabular}{lll}
\hline ALCOHOL ISOBUTLLCO & Isobutanol; 1-hidroximetilpropano; isopropilcarbinol; 2-metil propanol 78-83-1 \\
UN1212
\end{tabular}

ALCOHOL ISODECILICO ISOdecanol 25339-17-7

\begin{tabular}{lll}
\hline ALCOHOL ISOOCTILICO & Isooctanol \\
\hline ALCOHOL ISOPROPILCO & $\begin{array}{l}\text { Dimetilcarbinol; 2-hidroxipropano; isopropanol; n-propan-2-0l } \\
\text { UN1219 }\end{array}$ \\
\hline ALCOHOL OLELLICO & Oleol; cis-9-octadecen-1-0l ; alcohol de oliva & 26952-21-6 \\
\hline ALCOHOLterC-PENTILICO & Alcoholterc-amílico; dimetiletilcarbinol; etil dimetil carbinol; & 2-metil-2-butanol; 3-metilbutan-3-0l; terc-pentanol
\end{tabular}


Tabla 104.9 - Identificación química.

\begin{tabular}{|c|c|c|c|}
\hline Producto químico & Sinónimos/ Código UN & $\mathrm{N}$ úmero CAS & Fórmula estructural \\
\hline ALCOHOL PROPARGILLCO & Etinilcarbinol; metanol, etini-1; 1-propin-3-0l; alcohol 2-propinílico & 107-19-7 & \\
\hline ALCOHOL TETRAHIDROFURFURILICO & $\begin{array}{l}\text { Tetrahidro-2-furancarbinol; tetrahidro-2-furanmetanol ; } \\
\text { tetrahidro-2-furilmetanol; THFA }\end{array}$ & $97-99-4$ & \\
\hline CICLOHEXANOL & Alcohol ciclohexílico; hexahidrofenol; Hexalin; Hidralin; Naxol & $108-93.0$ & \\
\hline 2-CLOROETANOL & $\begin{array}{l}\text { Etileno clorohidrina; } \delta \text {-cloroetanol; alcohol } \beta \text {-cloroetílico; } \\
\text { alcohol 2-cloroetílico } \\
\text { UN1135 }\end{array}$ & 107-07-3 & \\
\hline 1,3-DICLORO-2-PROPANOL & $\begin{array}{l}\text { Diclorohidrina; } \alpha \text {-diclorohidrina; 1,3-dicloropropanol-2; } \\
\text { sim-glicerol diclorohidrina } \\
\text { UN2750 }\end{array}$ & $96-23-1$ & \\
\hline 2,2-DIMETIL-1-BUTANOL & 2,2,-Dimetilbutanol & $1185-33-7$ & \\
\hline 2,6-DIMETIL-4-HEPTANOL & Diisobutil carbinol; alcohol sec-nonilico & $108-82.7$ & \\
\hline
\end{tabular}

\begin{tabular}{ll}
\hline ETANOL & $\begin{array}{l}\text { Alcohol etílico; etil hidrato; etil hidróxido; } \\
\text { UN1170 } \\
\text { UN1986 } \\
\text { UN1987 }\end{array}$ \\
\hline 2-ETL-1-HEXANOL & Etilhexanol; 2-etilhexanol; alcohol 2-etilhexilico
\end{tabular}

FENILETANOL Bencil carbinol; Alcohol 2-fenetilico; 2-feniletanol; alcohol feniletílico $\quad 60-12-8$

\begin{tabular}{lll}
\hline HEPTANOL & 1-Heptanol; alcohol heptílico; 1-hidroxiheptano \\
\hline 2-HEPTANOL Amil metil carbinol; heptanol-2; 2-hidroxiheptano; metil amil carbinol & $543-49-7$
\end{tabular}

HEXANOL

1-Hexanol; alcohol hexílico; amilcarbinol; 1-hidroxihexano; pentilcarbinol

$111-27-3$

(1)


Tabla 104.9 - Identificación química.

\begin{tabular}{ll} 
Producto químico & Sinónimos/ Código UN \\
METANOL & $\begin{array}{c}\text { Alcohol metílico; metil hidrato; metil hidróxido; monohidroximetano } \\
\text { UN1230 }\end{array}$ \\
\hline 2-METL-1-BUTANOL & D,L-Sec-Butil carbinol; 2-metil-1-butanol \\
\hline METILICLOHEXANOL & $\begin{array}{c}\text { Hexahidrocresol; hexahidrometilfenol; metilciclohexanol } \\
\text { UN2617 }\end{array}$
\end{tabular}

n-METILCICLOHEXANOL

$591-23-1$

O-METLCICLOHEXANOL

\begin{tabular}{ll}
\hline 2-METLL-4.PENTANOL & Isobutilmetilcarbinol; isobutilmetilmetanol; MAOH; alcohol metil amílico \\
UN2053 & 108-11-2
\end{tabular}

Isobutilmetilcarbinol; isobutilmetilmetanol; MAOH; alcohol metil amílico 108-11-2
UN2053

$\mathrm{HO}^{-}$

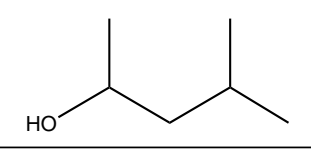

NONANOL

Alcohol n-nonílico; octil carbinol

$143-08-8$

Hо

\begin{tabular}{lll}
\hline OCTANOL Alcohol octílico; heptil carbinol; 1-hidroxioctano & $111-87-5$
\end{tabular}

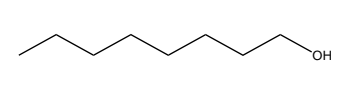

2-OCTANOL Alcohol caprílico

1.PENTANOL Alcohol amílico; n-butilcarbinol; alcohol pentílico

$71-41-0$

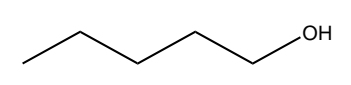

3.PENTANOL

\begin{tabular}{lll}
\hline PROPANOL & $\begin{array}{l}\text { Etil carbinol; 1-hidroxipropano; propil alcohol; alcohol propilico } \\
\text { UN1274 }\end{array}$ & 71-23-8
\end{tabular}

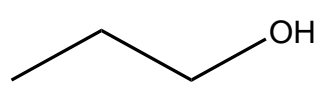




\begin{tabular}{|c|c|c|c|c|c|c|}
\hline \multirow[b]{2}{*}{$\begin{array}{l}\text { Denominación } \\
\text { química } \\
\text { N úmero CAS }\end{array}$} & \multicolumn{4}{|c|}{ Tarjetas Internacionales sobre la Seguridad de los Productos Q uímicos } & \multicolumn{2}{|c|}{ N IO SH (EE.UU.) } \\
\hline & $\begin{array}{l}\text { Período } \\
\text { corto de } \\
\text { exposición }\end{array}$ & $\begin{array}{l}\text { Período } \\
\text { largo de } \\
\text { exposición }\end{array}$ & $\begin{array}{l}\text { Vías de } \\
\text { exposición }\end{array}$ & Síntomas & $\begin{array}{l}\text { O rganos } \\
\text { afectados } \\
\text { Vías de } \\
\text { entrada }\end{array}$ & Síntomas \\
\hline $\begin{array}{l}\text { ALCOHOL ALLILCO } \\
\text { 107-18-6 }\end{array}$ & $\begin{array}{l}\text { ojos; piel; tract } \\
\text { resp; músculos; } \\
\text { hígado; riñones }\end{array}$ & & $\begin{array}{r}\text { Inhalación } \\
\text { Piel } \\
\text { 0jos } \\
\\
\text { Ingestión }\end{array}$ & $\begin{array}{l}\text { Cefalea, náuseas, vómitos } \\
\text { Puede absorberse, dolor, ampollas } \\
\text { Enrojecimiento, dolor, visión borrosa, pérdida } \\
\text { temporal de visión, quemaduras profundas } \\
\text { graves, sensibilidad a la luz } \\
\text { Dolor abdominal, inconsciencia }\end{array}$ & $\begin{array}{l}\text { Ojos; piel; sis resp } \\
\text { Inh, abs, ing, con }\end{array}$ & $\begin{array}{l}\text { Irrit ojos, les tisular; irrit sis } \\
\text { resp superior y piel; edema } \\
\text { pulm }\end{array}$ \\
\hline $\begin{array}{l}\text { ALCOHOL BENCLLICO } \\
100-51.6\end{array}$ & $\begin{array}{l}\text { ojos; piel; tract } \\
\text { resp; SNC }\end{array}$ & piel & $\begin{array}{r}\text { Inhalación } \\
\text { Piel } \\
\text { Ojos } \\
\text { Ingestión }\end{array}$ & $\begin{array}{l}\text { Tos, dolor de gargantaenrojecimiento } \\
\text { Enrojecimiento } \\
\text { Dolor abdominal, diarrea, sopor, náuseas, } \\
\text { Vómitos }\end{array}$ & & \\
\hline $\begin{array}{l}\text { ALCOHOL BUTLLICO } \\
71-36-3\end{array}$ & & & & & $\begin{array}{l}\text { Piel; ojos; sis resp; } \\
\text { SNC } \\
\text { Inh, abs, ing, con }\end{array}$ & $\begin{array}{l}\text { Irrit ojos, nariz, garganta; cef, } \\
\text { vért, sop; inflam córn, visión } \\
\text { borrosa, lag, foto; derm; } \\
\text { posible lesión del nervio } \\
\text { auditivo; pérdida de audición; } \\
\text { depres SNC }\end{array}$ \\
\hline $\begin{array}{l}\text { ALCOHOL sec-BUTILICO } \\
78-92 \cdot 2\end{array}$ & & & & & $\begin{array}{l}\text { Ojos; piel, sis resp; } \\
\text { SNC } \\
\text { Inh, ing, con }\end{array}$ & $\begin{array}{l}\text { Irrit ojos, piel, garganta; nariz; } \\
\text { narco }\end{array}$ \\
\hline $\begin{array}{l}\text { ALCOHOL terc-BUTILICO } \\
75-65-0\end{array}$ & & & & & $\begin{array}{l}\text { Ojos; piel, sis resp; } \\
\text { SNC } \\
\text { Inh, ing, con }\end{array}$ & $\begin{array}{l}\text { Irrit ojos, piel, nariz, garganta; } \\
\text { cef; enrojecimiento de la piel, } \\
\text { quemaduras }\end{array}$ \\
\hline $\begin{array}{l}\text { ALCOHOL ISOAMILICO } \\
123-51-3\end{array}$ & $\begin{array}{l}\text { ojos; tract resp; } \\
\text { SNC }\end{array}$ & piel & $\begin{array}{r}\text { Inhalación } \\
\text { Piel } \\
\text { 0jos } \\
\text { Ingestión }\end{array}$ & $\begin{array}{l}\text { Tos, mareo, sopor, cefalea, náuseas, dolor de } \\
\text { garganta } \\
\text { Sequedad de piel } \\
\text { Enrojecimiento, dolor } \\
\text { Dolor abdominal, inconsciencia }\end{array}$ & $\begin{array}{l}\text { Ojos; piel; sis resp; } \\
\text { SNC } \\
\text { Inh, ing, con }\end{array}$ & $\begin{array}{l}\text { Irrit ojos, piel, nariz; garganta; } \\
\text { cef, mar; tos, dis, náu, vómit, } \\
\text { diarr; agrietamiento de la piel; } \\
\text { en animales: narco }\end{array}$ \\
\hline $\begin{array}{l}\text { ALCOHOL SEC-ISOAMILICO } \\
\text { 528-75-4 }\end{array}$ & & & & & $\begin{array}{l}\text { Ojos; piel; sis resp; } \\
\text { SNC } \\
\text { Inh, ing, con }\end{array}$ & $\begin{array}{l}\text { Irrit ojos, piel, nariz, garganta; } \\
\text { cef, mar; tos, dis, náu, vómit, } \\
\text { diarr; agrietamiento de la piel; } \\
\text { en animales: narco }\end{array}$ \\
\hline $\begin{array}{l}\text { ALCOHOL ISOBUTILICO } \\
\text { 78-83-1 }\end{array}$ & $\begin{array}{l}\text { ojos; tract resp; } \\
\text { SNC }\end{array}$ & piel & & & $\begin{array}{l}\text { Ojos; piel; sis resp; } \\
\text { SNC Inh, ing, con }\end{array}$ & $\begin{array}{l}\text { Irrit ojos, garganta, cef, mar; } \\
\text { agrietamiento de la piel; en } \\
\text { animales: narco }\end{array}$ \\
\hline $\begin{array}{l}\text { ALCOHOL ISODECILICO } \\
25339-17-7\end{array}$ & $\begin{array}{l}\text { ojos; piel; tract } \\
\text { resp; SNC }\end{array}$ & piel & $\begin{array}{r}\text { Inhalación } \\
\text { Piel } \\
\text { Ojos } \\
\text { Ingestión }\end{array}$ & $\begin{array}{l}\text { Mareo, embotamiento, cefalea, náuseas } \\
\text { Enrojecimiento } \\
\text { Enrojecimiento, dolor } \\
\text { Diarrea, náuseas, vómitos }\end{array}$ & & \\
\hline $\begin{array}{l}\text { ALCOHOL ISOOCTILICO } \\
26952.21 .6\end{array}$ & $\begin{array}{l}\text { ojos; piel; tract } \\
\text { resp; SNC }\end{array}$ & piel & $\begin{array}{r}\text { Inhalación } \\
\text { Piel } \\
\text { 0jos } \\
\text { Ingestión } \\
\end{array}$ & $\begin{array}{l}\text { Mareo, embotamiento, cefalea, náuseas } \\
\text { Puede absorberse, enrojecimiento, quemaduras } \\
\text { en la piel } \\
\text { Enrojecimiento, dolor } \\
\text { Diarrea, náuseas, vómitos }\end{array}$ & $\begin{array}{l}\text { Ojos; piel; sis resp; } \\
\text { SNC; SCV } \\
\text { Inh, abs, ing, con }\end{array}$ & $\begin{array}{l}\text { Irrit ojos, piel, nariz, garganta; } \\
\text { quemaduras en ojos y piel }\end{array}$ \\
\hline $\begin{array}{l}\text { ALCOHOL ISOPROPILICO } \\
67.63 .0\end{array}$ & $\begin{array}{l}\text { ojos; piel; tract } \\
\text { resp; SNC }\end{array}$ & piel & $\begin{array}{r}\text { Inhalación } \\
\text { Piel } \\
\text { Ojos } \\
\text { Ingestión }\end{array}$ & $\begin{array}{l}\text { Tos, mareo, sopor, cefalea, náuseas, dolor de } \\
\text { garganta, vómitos } \\
\text { Enrojecimiento } \\
\text { Eenrojecimiento, dolor, visión borrosa } \\
\text { Mareo, sopor, náuseas, dolor de garganta, } \\
\text { vómitos }\end{array}$ & $\begin{array}{l}\text { Ojos; piel; sis resp; } \\
\text { SNC } \\
\text { Inh, ing, con }\end{array}$ & $\begin{array}{l}\text { Irrit ojos, nariz, garganta; sop, } \\
\text { mar, cef; agrietamiento de la } \\
\text { piel; en animales: narco }\end{array}$ \\
\hline
\end{tabular}


Tabla 104.10 - Riesgos para la salud.

\begin{tabular}{|c|c|c|c|c|c|c|}
\hline \multirow[b]{2}{*}{$\begin{array}{l}\text { Denominación } \\
\text { química } \\
\text { N úmero CAS }\end{array}$} & \multicolumn{4}{|c|}{ Tarjetas Internacionales sobre la Seguridad de los Productos Q uímicos } & \multicolumn{2}{|c|}{ N IO SH (EE.UU.) } \\
\hline & $\begin{array}{l}\text { Período } \\
\text { corto de } \\
\text { exposición }\end{array}$ & $\begin{array}{l}\text { Período } \\
\text { largo de } \\
\text { exposición }\end{array}$ & $\begin{array}{l}\text { Vías de } \\
\text { exposición }\end{array}$ & Síntomas & $\begin{array}{l}\text { O rganos } \\
\text { afectados } \\
\text { Vías de } \\
\text { entrada }\end{array}$ & Síntomas \\
\hline $\begin{array}{l}\text { ALCOHOL PROPARGILICO } \\
\text { 107-19-7 }\end{array}$ & $\begin{array}{l}\text { ojos; piel; } \\
\text { tract resp; hígado; } \\
\text { riñones; sangre }\end{array}$ & & $\begin{array}{r}\text { Inhalación } \\
\text { Piel } \\
\text { Ojos }\end{array}$ & $\begin{array}{l}\text { Sensación de quemazón } \\
\text { Puede absorberse, enrojecimiento } \\
\text { Dolor, quemaduras profundas graves }\end{array}$ & $\begin{array}{l}\text { Piel; sis resp; SNC; } \\
\text { hígado; riñones } \\
\text { Inh, abs, ing, con }\end{array}$ & $\begin{array}{l}\text { irrit piel, muc; depres SNC; en } \\
\text { animales: lesiones hepáticas y } \\
\text { renales }\end{array}$ \\
\hline $\begin{array}{l}\text { ALCOHOL } \\
\text { TETRAHIDROFURFURILICO } \\
97-99-4\end{array}$ & & & $\begin{array}{r}\text { Inhalación } \\
\text { Piel } \\
\text { 0jos } \\
\text { Ingestión }\end{array}$ & $\begin{array}{l}\text { Dolor de garganta, tos, cefalea, náuseas, } \\
\text { mareo, sopor, inconsciencia } \\
\text { Enrojecimiento, irritación, dolor } \\
\text { Enrojecimiento, irritación, dolor, } \\
\text { Dolor abdominal }\end{array}$ & & \\
\hline $\begin{array}{c}\text { CICLOHEXANOL } \\
108.93 .0\end{array}$ & $\begin{array}{l}\text { ojos; piel; tract } \\
\text { resp; SNC }\end{array}$ & piel & & & $\begin{array}{l}\text { Ojos; sis resp; piel } \\
\text { Inh, abs, ing, con }\end{array}$ & $\begin{array}{l}\text { Irrit ojos, piel, nariz, garganta; } \\
\text { piel; narco }\end{array}$ \\
\hline $\begin{array}{l}\text { 2-CLOROETANOL } \\
107-07-3\end{array}$ & $\begin{array}{l}\text { ojos; tract resp; } \\
\text { SNC; SCV; riñones; } \\
\text { hígado; puede } \\
\text { ocasionar la muerte }\end{array}$ & & $\begin{array}{r}\text { Inhalación } \\
\text { Piel } \\
\text { Ingestión }\end{array}$ & $\begin{array}{l}\text { Mucosas, náuseas } \\
\text { Vómitos, vértigos, descoordinación } \\
\text { Entumecimiento, distorsión visual, cefalea }\end{array}$ & $\begin{array}{l}\text { Sis resp; hígado; } \\
\text { riñones; SNC; piel; } \\
\text { SCV; ojos } \\
\text { Inh, abs, ing, con }\end{array}$ & $\begin{array}{l}\text { Irrit mucosas; náu, vómit; vért, } \\
\text { descoor; ent; dist vis; cef; sed; } \\
\text { delirio; TA baja; colapso, } \\
\text { shock, coma; lesiones } \\
\text { hepáticas y renales }\end{array}$ \\
\hline $\begin{array}{l}\text { ETANOL } \\
\quad 64-17-5\end{array}$ & $\begin{array}{l}\text { ojos; piel; tract } \\
\text { resp; SNC }\end{array}$ & $\begin{array}{l}\text { piel; SNC; hígado; } \\
\text { sangre }\end{array}$ & $\begin{array}{r}\text { Inhalación } \\
\text { Piel } \\
\text { Ojos } \\
\text { Ingestión }\end{array}$ & $\begin{array}{l}\text { Tos, sopor, cefalea, fatiga } \\
\text { Sequedad de piel } \\
\text { Enrojecimiento, dolor irritante, quemazón } \\
\text { irritante } \\
\text { Sensación de quemazón, confusión, mareo, } \\
\text { cefalea, inconsciencia }\end{array}$ & $\begin{array}{l}\text { Ojos; piel; sis resp; } \\
\text { SNC; hígado; } \\
\text { sangre; sis repro } \\
\text { Inh, ing, con }\end{array}$ & $\begin{array}{l}\text { Irrit ojos, piel, nariz; cef, sop, } \\
\text { ftg, narco; tos; lesiones } \\
\text { hepáticas; anemia; efectos } \\
\text { repro, terato }\end{array}$ \\
\hline $\begin{array}{l}\text { 2-ETIL-1-HEXANOL } \\
\text { 104-76-7 }\end{array}$ & ojos; piel & & $\begin{array}{r}\text { Inhalación } \\
\text { Piel } \\
\text { Ojos }\end{array}$ & $\begin{array}{l}\text { Mareo, cefalea, náuseas, debilidad } \\
\text { Puede absorberse, enrojecimiento } \\
\text { Enrojecimiento, dolor }\end{array}$ & & \\
\hline $\begin{array}{l}2 \text {-FENILETANOL } \\
60-12.8\end{array}$ & ojos; tract resp & SNC & $\begin{array}{r}\text { Inhalación } \\
\text { Ojos }\end{array}$ & $\begin{array}{l}\text { Tos } \\
\text { Enrojecimiento }\end{array}$ & & \\
\hline $\begin{array}{l}\text { HEPTANOL } \\
111-70-6 \\
\end{array}$ & ojos; piel; tract resp & $\begin{array}{l}\text { hígado; riñones; } \\
\text { defectos congénitos }\end{array}$ & & & & \\
\hline $\begin{array}{l}\text { HEXANOL } \\
626-93-7\end{array}$ & $\begin{array}{l}\text { ojos; piel; tract } \\
\text { resp; SNC }\end{array}$ & piel; SNC & $\begin{array}{r}\text { Inhalación } \\
\text { Piel } \\
\text { Ojos } \\
\text { Ingestión }\end{array}$ & $\begin{array}{l}\text { Tos, cefalea, dolor de garganta } \\
\text { Puede absorberse enrojecimiento } \\
\text { Enrojecimiento, dolor } \\
\text { Dolor abdominal, mareo, sopor, cefalea, } \\
\text { náuseas }\end{array}$ & & \\
\hline $\begin{array}{l}\text { METANOL } \\
67-56-1\end{array}$ & $\begin{array}{l}\text { ojos; piel; tract } \\
\text { resp; SNC }\end{array}$ & SNC & $\begin{array}{r}\text { Inhalación } \\
\text { Piel } \\
\text { Ojos } \\
\text { Ingestión }\end{array}$ & $\begin{array}{l}\text { Tos, mareo, cefalea, náuseas } \\
\text { Puede absorberse, sequedad de piel, } \\
\text { enrojecimiento } \\
\text { Enrojecimiento, dolor } \\
\text { Dolor abdominal, disnea, inconsciencia, } \\
\text { vómitos }\end{array}$ & $\begin{array}{l}\text { Ojos; piel, sis resp; } \\
\text { SNC; tract Gl } \\
\text { Inh, abs, ing, con }\end{array}$ & $\begin{array}{l}\text { Irrit ojos, piel, sis resp } \\
\text { superior; cef, mar, atur, náu, } \\
\text { vómit; dist vis, lesión del } \\
\text { nervio óptico (ceguera); derm }\end{array}$ \\
\hline $\begin{array}{l}\text { 2-METIL-1-BUTANOL } \\
\text { 137-32-6 }\end{array}$ & $\begin{array}{l}\text { ojos; piel; tract } \\
\text { resp; SNC }\end{array}$ & piel & $\begin{array}{r}\text { Inhalación } \\
\text { Piel } \\
\text { Ojos }\end{array}$ & $\begin{array}{l}\text { Tos, mareo, sopor, dolor de garganta } \\
\text { Sequedad de piel, enrojecimiento } \\
\text { Enrojecimiento, dolor, visión borrosa }\end{array}$ & & \\
\hline $\begin{array}{l}\text { METILCICLOHEXANOL } \\
25639-42-3\end{array}$ & $\begin{array}{l}\text { ojos; tract resp } \\
\text { superior }\end{array}$ & piel; SNC & $\begin{array}{r}\text { Inhalación } \\
\text { Piel } \\
\text { 0jos }\end{array}$ & $\begin{array}{l}\text { Tos, cefalea, } \\
\text { Sequedad de piel, enrojecimiento } \\
\text { Enrojecimiento }\end{array}$ & $\begin{array}{l}\text { Sis resp; piel; ojos; } \\
\text { hígado; riñones; } \\
\text { SNC } \\
\text { Inh, abs, ing, con }\end{array}$ & $\begin{array}{l}\text { Irrit ojos, piel, sis resp } \\
\text { superior; cef; en animales: } \\
\text { narco; lesiones hepáticas y } \\
\text { renales }\end{array}$ \\
\hline $\begin{array}{l}\text { M-METILCICLOHEXANOL } \\
\text { 591-23-1 }\end{array}$ & & piel & $\begin{array}{r}\text { Inhalación } \\
\text { Piel } \\
\text { Ojos }\end{array}$ & $\begin{array}{l}\text { Tos, cefalea } \\
\text { Sequedad de piel, enrojecimiento } \\
\text { Enrojecimiento }\end{array}$ & & \\
\hline
\end{tabular}




\begin{tabular}{|c|c|c|c|c|c|c|}
\hline \multirow[b]{2}{*}{$\begin{array}{l}\text { Denominación } \\
\text { química } \\
\text { N úmero CAS }\end{array}$} & \multicolumn{4}{|c|}{ Tarjetas Internacionales sobre la Seguridad de los Productos Q uímicos } & \multicolumn{2}{|c|}{ N IO SH (EE.UU.) } \\
\hline & $\begin{array}{l}\text { Período } \\
\text { corto de } \\
\text { exposición }\end{array}$ & $\begin{array}{l}\text { Período } \\
\text { largo de } \\
\text { exposición }\end{array}$ & $\begin{array}{l}\text { Vías de } \\
\text { exposición }\end{array}$ & Síntomas & $\begin{array}{l}\text { O rganos } \\
\text { afectados } \\
\text { Vías de } \\
\text { entrada }\end{array}$ & Síntomas \\
\hline $\begin{array}{l}\text { O-METILCICLOHEXANOL } \\
583.59 .5\end{array}$ & $\begin{array}{l}\text { ojos; tract resp } \\
\text { superior }\end{array}$ & piel; SNC & $\begin{array}{r}\text { Inhalación } \\
\text { Piel } \\
\text { 0jos } \\
\end{array}$ & $\begin{array}{l}\text { Tos, cefalea } \\
\text { Sequedad de piel, enrojecimiento } \\
\text { Enrojecimiento }\end{array}$ & & \\
\hline $\begin{array}{l}\text { 2-METIL-4.PENTANOL } \\
\text { 108-11-2 }\end{array}$ & $\begin{array}{l}\text { ojos; piel; tract } \\
\text { resp; pulmones; } \\
\text { SNC; hígado; } \\
\text { riñones }\end{array}$ & $\begin{array}{l}\text { piel; SNC; hígado; } \\
\text { riñones }\end{array}$ & $\begin{array}{r}\text { Inhalación } \\
\text { Piel } \\
\text { 0jos } \\
\text { Ingestión } \\
\end{array}$ & $\begin{array}{l}\text { Confusión, sopor, cefalea, náuseas, dolor de } \\
\text { garganta, inconsciencia } \\
\text { Puede absorberse, enrojecimiento, sensación } \\
\text { de quemazón } \\
\text { Enrojecimiento, dolor, } \\
\text { Dolor abdominal }\end{array}$ & $\begin{array}{l}\text { Ojos; piel; SNC } \\
\text { Inh, abs, ing, con }\end{array}$ & $\begin{array}{l}\text { Irrit ojos, piel; cef; sop; derm; } \\
\text { en animales: narco }\end{array}$ \\
\hline $\begin{array}{l}\text { 3-METOXI 1-BUTANOL } \\
\text { 2517-43-3 }\end{array}$ & $\begin{array}{l}\text { ojos; piel; tract } \\
\text { resp; pulmones }\end{array}$ & piel & $\begin{array}{l}\text { Inhalación } \\
\text { Piel } \\
\text { 0jos } \\
\text { Ingestión }\end{array}$ & $\begin{array}{l}\text { Tos, cefalea, los síntomas pueden tardar en } \\
\text { aparecer } \\
\text { Sequedad de piel, sensación de quemazón } \\
\text { Enrojecimiento } \\
\text { Dolor abdominal, embotamiento, náuseas, } \\
\text { vómitos }\end{array}$ & & \\
\hline $\begin{array}{l}\text { 1-PENTANOL } \\
71-41-0\end{array}$ & $\begin{array}{l}\text { ojos; piel; tract } \\
\text { resp; SNC }\end{array}$ & piel & $\begin{array}{r}\text { Inhalación } \\
\text { Piel } \\
\text { Ojos } \\
\text { Ingestión }\end{array}$ & $\begin{array}{l}\text { Tos, mareo, cefalea, náuseas } \\
\text { Enrojecimiento } \\
\text { Enrojecimiento, dolor, posible lesión de córnea } \\
\text { Tos, mareo, cefalea, náuseas, vómitos }\end{array}$ & & \\
\hline $\begin{array}{r}\text { 3-PENTANOL } \\
584-02-1\end{array}$ & $\begin{array}{l}\text { ojos; piel; tract } \\
\text { resp; SNC }\end{array}$ & piel & $\begin{array}{r}\text { Inhalación } \\
\text { Piel } \\
\text { 0jos } \\
\text { Ingestión } \\
\end{array}$ & $\begin{array}{l}\text { Tos, mareo, cefalea, náuseas, dolor de } \\
\text { garganta, vómitos, } \\
\text { Puede absorberse, enrojecimiento } \\
\text { Enrojecimiento, dolor, visión borrosa } \\
\text { Dolor abdominal, diarrea, náuseas, vómitos }\end{array}$ & & \\
\hline $\begin{array}{r}\text { PROPANOL } \\
71-23-8\end{array}$ & $\begin{array}{l}\text { ojos; piel; tract } \\
\text { resp; SNC }\end{array}$ & piel & $\begin{array}{r}\text { Inhalación } \\
\text { Piel } \\
\text { 0jos } \\
\text { Ingestión }\end{array}$ & $\begin{array}{l}\text { Tos, mareo, sopor, cefalea, náuseas, dolor de } \\
\text { garganta, vómitos } \\
\text { Enrojecimiento } \\
\text { Enrojecimiento, dolor, visión borrosa } \\
\text { Mareo, sopor, náuseas, dolor de garganta, } \\
\text { vómitos }\end{array}$ & $\begin{array}{l}\text { Piel; ojos; sis resp; } \\
\text { tract Gl; SNC } \\
\text { Inh, abs, ing, con }\end{array}$ & $\begin{array}{l}\text { Irrit ojos, nariz, garganta; piel } \\
\text { seca y agrietada; sop, cef; } \\
\text { ataxia, dolor Gl; espasmos } \\
\text { abdom, náu, vómit, diarr; en } \\
\text { animales: narco }\end{array}$ \\
\hline $\begin{array}{l}\text { 3,5,5-TRIMETLL-1.HEXANOL } \\
\text { 3452-97-9 }\end{array}$ & ojos; piel; tract resp & hígado; riñones & $\begin{array}{l}\text { Inhalación } \\
\text { Piel } \\
\text { 0jos } \\
\text { Ingestión }\end{array}$ & $\begin{array}{l}\text { Tos, cefalea, dolor de garganta } \\
\text { Puede absorberse, aspereza, sensación de } \\
\text { quemazón } \\
\text { Enrojecimiento, dolor } \\
\text { Cefalea, náuseas, vómitos }\end{array}$ & & \\
\hline
\end{tabular}

\begin{tabular}{|c|c|c|c|}
\hline $\begin{array}{l}\text { Denominación química } \\
\text { N úmero CAS }\end{array}$ & Físicos & Q uímicos & $\begin{array}{l}\text { Clase o división } \\
\text { UN / Riesgos } \\
\text { subsidiarios }\end{array}$ \\
\hline $\begin{array}{l}\text { ALCOHOL ALLILCO } \\
107-18-6\end{array}$ & $\begin{array}{l}\text { - El vapor es más pesado } \\
\text { que el aire y puede } \\
\text { desplazarse a ras del } \\
\text { suelo; posibilidad de } \\
\text { ignición a distancia }\end{array}$ & $\begin{array}{l}\text { - En su combustión forma monóxido de carbono • Al calentarse se liberan vapores tóxicos } \\
\text { - Reacciona con tetracloruro de carbono, ácido nítrico y ácido clorosulfónico, con peligro de } \\
\text { incendio y explosión }\end{array}$ & $6.1 / 3$ \\
\hline
\end{tabular}

ALCOHOL BENCILICO

$100-51.6$
- Reacciona violentamente con oxidantes y ácidos fuertes - Ataca muchos plásticos - Al calentarse puede atacar el hierro y el aluminio - Oxidación lenta en presencia de aire 
Tabla 104.11 • Riesgos físicos y químicos.

\begin{tabular}{|c|c|c|c|}
\hline $\begin{array}{l}\text { Denominación química } \\
\text { N úmero CAS }\end{array}$ & Físicos & Q uímicos & $\begin{array}{l}\text { Clase o división } \\
\text { UN / Riesgos } \\
\text { subsidiarios }\end{array}$ \\
\hline $\begin{array}{l}\text { ALCOHOLSec-BUTILICO } \\
78-92-2\end{array}$ & & & 3 \\
\hline $\begin{array}{l}\text { ALCOHOL terC-BUTILICO } \\
75-65-0\end{array}$ & & & 3 \\
\hline $\begin{array}{l}\text { ALCOHOL ISOAMILICO } \\
123-51-3\end{array}$ & $\begin{array}{l}\text { - El vapor se mezcla } \\
\text { rápidamente con aire }\end{array}$ & - Reacciona con oxidantes fuertes & \\
\hline $\begin{array}{l}\text { ALCOHOL ISOBUTILICO } \\
78-83-1\end{array}$ & & & 3 \\
\hline $\begin{array}{l}\text { ALCOHOL ISODECILICO } \\
25339-17-7\end{array}$ & & $\begin{array}{l}\text { - Se descompone al calentarse produciendo humo y vapores acres • Reacciona con oxidantes } \\
\text { fuertes }\end{array}$ & \\
\hline $\begin{array}{l}\text { ALCOHOL ISOOCTILICO } \\
26952-21-6\end{array}$ & & $\begin{array}{l}\text { - Se descompone al calentarse produciendo humo y vapores acres } \bullet \text { Reacciona con oxidantes } \\
\text { fuertes (analogía con alcohol isodecilíco) }\end{array}$ & \\
\hline $\begin{array}{l}\text { ALCOHOL ISOPROPILICO } \\
\quad 67-63.0\end{array}$ & $\begin{array}{l}\text { - El vapor se mezcla bien } \\
\text { con el aire; se forman } \\
\text { fácilmente mezclas } \\
\text { explosivas }\end{array}$ & - Reacciona con oxidantes fuertes & 3 \\
\hline $\begin{array}{l}\text { ALCOHOL PROPARGILICO } \\
107-19-7\end{array}$ & $\begin{array}{l}\text { - El vapor es más pesado } \\
\text { que el aire }\end{array}$ & $\begin{array}{l}\text { - Reacciona violentamente con oxidantes • Ataca muchos plásticos • En contacto con metales } \\
\text { pesados se forman sales poco solubles que pueden explotar al calentarse }\end{array}$ & \\
\hline $\begin{array}{l}\text { ALCOHOL TETRAHIDROFURFURILICO } \\
97-99-4\end{array}$ & & $\begin{array}{l}\text { - Presumiblemente puede formar peróxidos explosivos } \bullet \text { Se descompone al calentarse } \\
\text { produciendo humo y vapores acres } \bullet \text { Reacciona violentamente con oxidantes fuertes, varias } \\
\text { n-cloro y n-bromoimidas, con peligro de incendio y explosión • Ataca muchas resinas y materiales } \\
\text { orgánicos }\end{array}$ & \\
\hline
\end{tabular}

BUTIL ALCOHOL

$71-36-3$

3

2-CLOROETANOL

$6.1 / 3$

107-07-3

ETANOL

$64-17-5$

- El vapor se mezcla bien - En su combustión libera gases tóxicos • Reacciona lentamente con hipoclorito cálcico, óxido de 3

con aire; se forman

plata y amoníaco, con peligro de incendio y explosión • Reacciona violentamente con oxidantes

fácilmente mezclas

fuertes como ácido nítrico, nitrato de plata, nitrato mercúrico o perclorato magnésico, con peligro explosivas de incendio y explosión

\begin{tabular}{|c|c|c|c|}
\hline $\begin{array}{l}\text { 2-ETIL-1-HEXANOL } \\
\text { 104-76-7 }\end{array}$ & & - Reacciona vigorosamente con materiales oxidantes & \\
\hline $\begin{array}{l}2 \text {-FENILETANOL } \\
60-12-8\end{array}$ & & - Reacciona con oxidantes fuertes y ácidos fuertes & \\
\hline $\begin{array}{l}\text { HEXANOL } \\
111-27-3 \\
\end{array}$ & & & 3 \\
\hline $\begin{array}{l}\text { METANOL } \\
67-56-1\end{array}$ & $\begin{array}{l}\text { - El vapor se mezcla bien } \\
\text { con el aire; se forman } \\
\text { fácilmente mezclas } \\
\text { explosivas }\end{array}$ & - Reacciona violentamente con oxidantes, con peligro de incendio y explosión & $3 / 6.1$ \\
\hline $\begin{array}{l}\text { METILCICLOHEXANOL } \\
25639-42-3\end{array}$ & & - En su combustión libera gases tóxicos & 3 \\
\hline $\begin{array}{l}\text { m-METILCICLOHEXANOL } \\
\text { 591-23-1 }\end{array}$ & & & 3 \\
\hline
\end{tabular}

583-59-5 


\begin{tabular}{|c|c|c|c|}
\hline $\begin{array}{l}\text { Denominación química } \\
\mathrm{N} \text { úmero CAS }\end{array}$ & Físicos & Q uímicos & $\begin{array}{l}\text { Clase o división } \\
\text { UN / Riesgos } \\
\text { subsidiarios }\end{array}$ \\
\hline $\begin{array}{l}\text { 2-METIL-4.PENTANOL } \\
\text { 108-11-2 }\end{array}$ & $\begin{array}{l}\text { - El vapor es más pesado } \\
\text { que el aire y puede } \\
\text { desplazarse a ras del } \\
\text { suelo; posibilidad de } \\
\text { ignición a distancia }\end{array}$ & $\begin{array}{l}\text { - Reacciona con oxidantes } \bullet \text { Reacciona violentamente con metales alcalinos, con peligro de } \\
\text { incendio y explosión }\end{array}$ & 3 \\
\hline $\begin{array}{l}\text { 3-METOXI-1-BUTANOL } \\
\text { 2517-43-3 }\end{array}$ & & - Reacciona con oxidantes & \\
\hline $\begin{array}{l}\text { 1-PENTANOL } \\
71-41-0\end{array}$ & $\begin{array}{l}\text { - El vapor se mezcla bien } \\
\text { con el aire; se forman } \\
\text { fácilmente mezclas } \\
\text { explosivas }\end{array}$ & - Reacciona violentamente con oxidantes & 3 \\
\hline $\begin{array}{r}\text { 3-PENTANOL } \\
584-02-1\end{array}$ & $\begin{array}{l}\text { - El vapor es más pesado } \\
\text { que el aire y puede } \\
\text { desplazarse a ras del } \\
\text { suelo; posibilidad de } \\
\text { ignición a distancia }\end{array}$ & - Reacciona con oxidantes fuertes & 3 \\
\hline $\begin{array}{l}\text { PROPANOL } \\
71-23-8125\end{array}$ & $\begin{array}{l}\text { - El vapor se mezcla bien } \\
\text { con el aire; se forman } \\
\text { fácilmente mezclas } \\
\text { explosivas }\end{array}$ & - Reacciona con oxidantes fuertes (percloratos, nitratos) & 3 \\
\hline $\begin{array}{l}\text { 3,5,5-TRIMETLL-1-HEXANOL } \\
\text { 3452-97-9 }\end{array}$ & $\begin{array}{l}\text { - El vapor es más pesado } \\
\text { que el aire }\end{array}$ & $\begin{array}{l}\text { - Puede explotar al calentarse - Reacciona con oxidantes fuertes, ácidos inorgánicos, aldehídos, } \\
\text { alquenóxidos, anhídridos ácidos • Reacciona con caucho, PVC }\end{array}$ & \\
\hline
\end{tabular}

\begin{tabular}{|c|c|c|c|c|c|c|c|c|c|c|c|}
\hline $\begin{array}{l}\text { Denominación } \\
\text { química } \\
\text { N úmero CAS }\end{array}$ & Color/ Forma & $\begin{array}{l}\text { p.e. } \\
(\underline{O C})\end{array}$ & $\begin{array}{l}\text { p.f. } \\
\left({ }^{\circ} \mathrm{C}\right)\end{array}$ & $\begin{array}{l}\text { p.m.l } \\
\text { (g/ } \\
\text { mol) }\end{array}$ & $\begin{array}{l}\text { Solubilidad } \\
\text { en agua }\end{array}$ & $\begin{array}{l}\text { Densidad } \\
\text { relativa } \\
\text { (agua }=1 \text { ) }\end{array}$ & $\begin{array}{l}\text { Densidad } \\
\text { de vapor } \\
\text { relativa } \\
\text { (aire=1) }\end{array}$ & $\begin{array}{l}\text { Pvap/ } \\
(\mathrm{kPa})\end{array}$ & $\begin{array}{l}\text { Límit. } \\
\text { inflam. }\end{array}$ & $\begin{array}{l}\text { p.ig. } \\
(\underline{O C})\end{array}$ & $\begin{array}{l}\text { p.aut } \\
\text { ig. } \\
(\stackrel{\circ}{\circ})\end{array}$ \\
\hline $\begin{array}{l}\text { ALCOHOL ALLIICO } \\
107-18 \cdot 6\end{array}$ & $\begin{array}{l}\text { líquido móvil; líquido } \\
\text { incoloro }\end{array}$ & 97 & -129 & 58,08 & misc & 0,8540 & 2,00 & 2,5 & $\begin{array}{l}2,5 \mathrm{li} \\
18,0 \mathrm{ls}\end{array}$ & $21 \mathrm{cc}$ & 443 \\
\hline $\begin{array}{l}\text { ALCOHOL BENCILICO } \\
100-51-6\end{array}$ & líquido acuoso blanco & 205 & $-15,2$ & 108,13 & sol & 1,04535 & 3,72 & $\begin{array}{l}0,02 \\
@ 25 \mathrm{C}\end{array}$ & $\begin{array}{l}1,3 \mathrm{li} \\
13 \mathrm{Is}\end{array}$ & $93 \mathrm{cc}$ & 436 \\
\hline $\begin{array}{l}\text { ALCOHOL BUTILICO } \\
71-36-3 \\
\end{array}$ & líquido & 117,2 & $-89,5$ & 74,12 & sol & 0,8098 & 2,6 & $5,5 \mathrm{~mm} \mathrm{Hg}$ & $\begin{array}{l}1,4 \mathrm{li} \\
11,2 \mathrm{ls}\end{array}$ & $37 \mathrm{cc}$ & \\
\hline $\begin{array}{l}\text { ALCOHOLSEC-BUTLLICO } \\
78-92-2\end{array}$ & líquido incoloro & 99,5 & -115 & 74,12 & $15,4 \mathrm{~g} / 100 \mathrm{~g}$ & 0,8063 & 2,6 & $\begin{array}{l}23.9 \mathrm{~mm} \mathrm{Hg} \\
@ 30^{\circ} \mathrm{C}\end{array}$ & $\begin{array}{l}1,7 \mathrm{li} \\
9,85 @ \\
100 \stackrel{\circ}{C} \mathrm{Cls}\end{array}$ & $24 c c$ & 406 \\
\hline $\begin{array}{l}\text { ALCOHOL terc-BUTLLICO } \\
75-65-0\end{array}$ & $\begin{array}{l}\text { líquido incoloro, forma } \\
\text { cristales rómbicos; } \\
\text { prismas o placas } \\
\text { rómbicos }\end{array}$ & 82,4 & 25,4 & 74,12 & misc & 0,7887 & 2,55 & $\begin{array}{l}42,0 \mathrm{~mm} \mathrm{Hg} \\
@ 25 \stackrel{\circ}{\circ} \mathrm{C}\end{array}$ & $\begin{array}{l}2,35 @ \\
25 \cong \mathrm{Cli} \\
8 @ \\
55 \cong \mathrm{Cls}\end{array}$ & & \\
\hline $\begin{array}{l}\text { ALCOHOL 2-ETLBUTILICO } \\
97-95-0\end{array}$ & líquido incoloro & $\begin{array}{l}146,27^{\circ} \mathrm{C} @ \\
760 \mathrm{~mm} \mathrm{Hg}\end{array}$ & $\begin{array}{l}\text { menos de } \\
-15^{\circ} \mathrm{C}\end{array}$ & 102,18 & lig sol & $\begin{array}{l}0,8326 @ \\
20^{\circ} \mathrm{C} / 4^{\circ} \mathrm{C}\end{array}$ & & $\begin{array}{l}0,9 \mathrm{~mm} \mathrm{Hg} \\
@ 20^{\circ} \mathrm{C}\end{array}$ & & & \\
\hline $\begin{array}{l}\text { ALCOHOL ISOAMILICO } \\
123-51-3\end{array}$ & $\begin{array}{l}\text { líquido oleoso, } \\
\text { transparente }\end{array}$ & 131,0 & -117 & 88,1 & $\begin{array}{l}\text { moderada } \\
2 \mathrm{~g} / 100 \mathrm{ml} @ \\
14 \stackrel{\mathrm{C}}{ }\end{array}$ & 0,8092 & 3,04 & 0.32 & $\begin{array}{l}1,2 \mathrm{li} \\
9 @ \\
100 \stackrel{\circ}{O} \mathrm{Cls}\end{array}$ & 45 & 350 \\
\hline
\end{tabular}


Tabla 104.12 - Propiedades físicas y químicas.

\begin{tabular}{|c|c|c|c|c|c|c|c|c|c|c|c|}
\hline $\begin{array}{l}\text { Denominación } \\
\text { química } \\
\text { N úmero CAS }\end{array}$ & Color/ Forma & $\begin{array}{l}\text { p.e. } \\
(\underline{\underline{ }} \mathrm{C})\end{array}$ & $\begin{array}{l}\text { p.f. } \\
(\underline{o} C)\end{array}$ & $\begin{array}{l}\text { p.m.l } \\
(\mathrm{g} / \\
\mathrm{mol})\end{array}$ & $\begin{array}{l}\text { Solubilidad } \\
\text { en agua }\end{array}$ & $\begin{array}{l}\text { Densidad } \\
\text { relativa } \\
\text { (agua }=1 \text { ) }\end{array}$ & $\begin{array}{l}\text { Densidad } \\
\text { de vapor } \\
\text { relativa } \\
\text { (aire=1) }\end{array}$ & $\begin{array}{l}\text { Pvap/ } \\
(\mathrm{kPa})\end{array}$ & $\begin{array}{l}\text { Límit. } \\
\text { inflam. }\end{array}$ & $\begin{array}{l}\text { p.ig. } \\
(\underline{o} C)\end{array}$ & $\begin{array}{l}\text { p.aut } \\
\text { ig. } \\
(\stackrel{\circ}{ } C)\end{array}$ \\
\hline $\begin{array}{l}\text { ALCOHOLSEC-ISOAMILICO } \\
528-75-4\end{array}$ & líquido incoloro & 113 & -117 & & & 0,819 & & & & 394 & \\
\hline $\begin{array}{l}\text { ALCOHOL ISOBUTILICO } \\
78-83-1\end{array}$ & líquido incoloro & 107 & -108 & 74,1 & lig sol & 0,8 & 2,56 & 1,2 & $\begin{array}{l}1,7 \mathrm{li} \\
10,9 \mathrm{ls}\end{array}$ & 27 & 441 \\
\hline $\begin{array}{l}\text { ALCOHOL ISODECILICO } \\
25339-17-7\end{array}$ & líquido incoloro & 220 & 7 & 158,32 & insol & 0,841 & 5,5 & $\begin{array}{l}0,13 @ \\
70 \cong 0\end{array}$ & $\begin{array}{l}0,8 \mathrm{li} \\
? \text { Is }\end{array}$ & $104 \mathrm{ca}$ & 285 \\
\hline $\begin{array}{l}\text { ALCOHOL ISOOCTILICO } \\
26952-21-6\end{array}$ & líquido incoloro & $83-91$ & $<-76$ & 130,3 & $\begin{array}{l}640 \mathrm{mg} / \mathrm{I} @ \\
25 \stackrel{0}{0}\end{array}$ & 0,832 & 4,5 & 0,05 & $\begin{array}{l}0,9 \mathrm{li} \\
5,7 \mathrm{ls}\end{array}$ & $82 \mathrm{ca}$ & 277 \\
\hline $\begin{array}{l}\text { ALCOHOL ISOPROPILICO } \\
67.63 .0\end{array}$ & líquido & 83 & -90 & 60,09 & misc & 0,79 & 2,1 & 4,4 & $\begin{array}{l}2 \mathrm{li} \\
12 \mathrm{ls}\end{array}$ & 117 & 455 \\
\hline $\begin{array}{l}\text { ALCOHOL OLEILICO } \\
143-28-2\end{array}$ & $\begin{array}{l}\text { líquido oleoso, } \\
\text { habitualmente } \\
\text { amarillo claro, líquido } \\
\text { viscoso transparente }\end{array}$ & 333 & $13-19$ & 268,5 & insol & 0,8489 & & $\begin{array}{l}9,3 \times 10-5 \\
\mathrm{~mm} \mathrm{Hg} \\
\text { @ } 25 \stackrel{\circ}{\circ}\end{array}$ & & & \\
\hline $\begin{array}{l}\text { ALCOHOL terC-PENTILICO } \\
75-85-4\end{array}$ & líquido incoloro & 102 & $-8,8$ & 88,1 & sol & $\begin{array}{l}0,8059 @ \\
25 \stackrel{\circ}{ } \mathrm{C} / 4 \stackrel{\circ}{\circ} \mathrm{C}\end{array}$ & & & & $67 c c$ & 819 \\
\hline $\begin{array}{l}\text { ALCOHOL PROPARGILICO } \\
\text { 107-19-7 }\end{array}$ & $\begin{array}{l}\text { líquido claro o color } \\
\text { paja; líquido incoloro }\end{array}$ & 114- 115 & $-51,8$ & 56,1 & sol & 0,9715 & 1,93 & 1,54 & $\begin{array}{l}3,4 \mathrm{li} \\
70 \mathrm{ls}\end{array}$ & $33 \mathrm{ca}$ & \\
\hline $\begin{array}{l}\text { ALCOHOL } \\
\text { TETRAHIDROFURFURILICO } \\
97-99-4\end{array}$ & líquido incoloro & 178 & $<-80$ & 102,1 & misc & 1,054 & $3,5 \mathrm{~g} / \mathrm{l}$ & 0,306 & $\begin{array}{l}1,5 \mathrm{li} \\
9,7 \mathrm{ls}\end{array}$ & $75 \mathrm{ca}$ & 282 \\
\hline $\begin{array}{l}\text { CICLOHEXANOL } \\
108.93 .0\end{array}$ & $\begin{array}{l}\text { agujas incoloras o } \\
\text { líquido viscoso; } \\
\text { cristales higroscópicos }\end{array}$ & 161 & 25,1 & 100,2 & sol & 0,9624 & 3,5 & $\begin{array}{l}80 \mathrm{~mm} \mathrm{Hg} \\
\text { @ } 25 \stackrel{\circ}{-} \mathrm{C}\end{array}$ & & & \\
\hline $\begin{array}{l}\text { 2-CLOROETANOL } \\
107-07-3\end{array}$ & $\begin{array}{l}\text { líquido incoloro } \\
\text { semejante a glicerina }\end{array}$ & $\begin{array}{l}128-130^{\circ} \mathrm{C} \\
\text { @ } 760 \mathrm{~mm} \mathrm{Hg}\end{array}$ & $-67,5^{\circ} \mathrm{C}$ & 80,52 & sol & $\begin{array}{l}1,197 @ \\
20^{\circ} \mathrm{C} / 4^{\circ} \mathrm{C}\end{array}$ & 2,78 & $\begin{array}{l}4,9 \mathrm{~mm} \mathrm{Hg} \\
\text { @ } 20^{\circ} \mathrm{C}\end{array}$ & $\begin{array}{l}4,9 \% \text { li } \\
15,9 \% \text { ls }\end{array}$ & $\begin{array}{l}60^{\circ} \mathrm{C} \\
\mathrm{CC}\end{array}$ & $425^{\circ} \mathrm{C}$ \\
\hline $\begin{array}{l}\text { 1,3-DICLORO-2-PROPANOL } \\
96-23-1\end{array}$ & $\begin{array}{l}\text { líquido incoloro } \\
\text { ligeramente viscoso }\end{array}$ & 174,3 & -4 & 128,99 & muy sol & $\begin{array}{l}1,3506 @ \\
17 \stackrel{\circ}{C} / 4 \stackrel{0}{\circ}\end{array}$ & 4,4 & $7 \mathrm{~mm} \mathrm{Hg}$ & & & \\
\hline $\begin{array}{l}\text { 2,2-DIMETIL-1-BUTANOL } \\
\text { 1185-33-7 }\end{array}$ & & 136,5 & $<-15$ & 102,17 & lig sol & 0,8283 & & & & & \\
\hline $\begin{array}{l}\text { 2,6-DIMETIL-4-HEPTANOL } \\
\text { 108-82-7 }\end{array}$ & líquido incoloro & $176-177$ & $<-65$ & 144,3 & insol & 0,8114 & 4,97 & $0,21 \mathrm{~mm} \mathrm{Hg}$ & & & \\
\hline $\begin{array}{l}\text { 2,4-DIMETIL-3-PENTANOL } \\
600-36-2\end{array}$ & & 138,7 & 0 & 116,2 & lig sol & 0,8288 & & & & & \\
\hline $\begin{array}{l}\text { ETANOL } \\
64-17-5 \\
\end{array}$ & $\begin{array}{l}\text { líquido transparente, } \\
\text { incoloro, muy móvil }\end{array}$ & 78,5 & -114 & 46,07 & misc & 0,789 & 1,59 & $\begin{array}{l}40 \mathrm{~mm} \mathrm{Hg} \\
\text { @ } 19 \stackrel{\circ}{C}\end{array}$ & $\begin{array}{l}3,3 \mathrm{li} \\
19 \mathrm{ls}\end{array}$ & $13 \mathrm{cc}$ & 363 \\
\hline $\begin{array}{l}\text { 2-ETIL-1-HEXANOL } \\
\text { 104-76-7 }\end{array}$ & líquido incoloro & 184,6 & .76 & 130,22 & insol & 0,8344 & 4,5 & 0,020 & $\begin{array}{l}0,88 \mathrm{li} \\
9,7 \mathrm{Is}\end{array}$ & $81 \mathrm{cc}$ & 231 \\
\hline $\begin{array}{l}\text { 1-FENILETANOL } \\
98-84-1\end{array}$ & & & & 122,17 & & & & & & & \\
\hline $\begin{array}{l}2 \text {-FENILETANOL } \\
60-12.8\end{array}$ & $\begin{array}{l}\text { líquido incoloro, } \\
\text { viscoso }\end{array}$ & 218,2 & -27 & 122,16 & lig sol & 1,0202 & 4,21 & $\begin{array}{l}0,133 @ \\
58 \div C\end{array}$ & & 102 & \\
\hline $\begin{array}{l}\text { HEPTANOL } \\
111-70-6\end{array}$ & líquido incoloro & 176 & $-34,6$ & 116,2 & lig sol & 0,8219 & & & & 71 & \\
\hline $\begin{array}{l}\text { HEXANOL } \\
111-27-3\end{array}$ & líquido incoloro & 157 & $-51,6$ & 102,17 & lig sol & 0,8136 & 3,5 & $\begin{array}{l}1 \mathrm{~mm} \mathrm{Hg} @ \\
24,4 \stackrel{-C}{ }\end{array}$ & & & \\
\hline
\end{tabular}




\begin{tabular}{|c|c|c|c|c|c|c|c|c|c|c|c|}
\hline $\begin{array}{l}\text { Denominación } \\
\text { química } \\
\mathrm{N} \text { úmero CAS }\end{array}$ & Color/ Forma & $\begin{array}{l}\text { p.e. } \\
\left({ }^{\circ} \mathrm{C}\right)\end{array}$ & $\begin{array}{l}\text { p.f. } \\
\left({ }^{\circ} C\right)\end{array}$ & $\begin{array}{l}\text { p.m.l } \\
\text { (g/ } \\
\text { mol) }\end{array}$ & $\begin{array}{l}\text { Solubilidad } \\
\text { en agua }\end{array}$ & $\begin{array}{l}\text { Densidad } \\
\text { relativa } \\
\text { (agua }=1 \text { ) }\end{array}$ & $\begin{array}{l}\text { Densidad } \\
\text { de vapor } \\
\text { relativa } \\
(\text { aire }=1 \text { ) }\end{array}$ & $\begin{array}{l}\text { Pvap/ } \\
(\mathrm{kPa})\end{array}$ & $\begin{array}{l}\text { Límit. } \\
\text { inflam. }\end{array}$ & $\begin{array}{l}\text { p.ig. } \\
(\underline{O C})\end{array}$ & $\begin{array}{l}\text { p.aut } \\
\text { ig. } \\
(\stackrel{0}{ } \mathrm{C})\end{array}$ \\
\hline $\begin{array}{r}\text { 2-HEXANOL } \\
626.93 .7 \\
\end{array}$ & líquido & 136 & -23 & 102,18 & & 0,81 & & & & $41 \mathrm{cc}$ & \\
\hline $\begin{array}{l}\text { METANOL } \\
67-56-1 \\
\end{array}$ & líquido incoloro & 64,7 & .98 & 32,04 & misc & 0,7914 & 1,11 & 12,3 & $\begin{array}{l}6 \mathrm{li} \\
35,6 \mathrm{ls} \\
\end{array}$ & $12 c c$ & 385 \\
\hline $\begin{array}{l}\text { 2-METIL-1-BUTANOL } \\
137-32-6\end{array}$ & líquido incoloro & 128 & $<-70$ & 88,17 & lig sol & 0,816 & 3,0 & 0,42 & $\begin{array}{l}1,4 \mathrm{li} \\
9,0 \mathrm{ls}\end{array}$ & $50 \mathrm{Ca}$ & 385 \\
\hline $\begin{array}{l}\text { METILCICLOHEXANOL } \\
25639-42-3\end{array}$ & $\begin{array}{l}\text { líquido incoloro; } \\
\text { líquido viscoso }\end{array}$ & $155-180$ & -50 & 114,1 & $3-4 \%$ & $\begin{array}{l}0,924 @ \\
15 \stackrel{\circ}{C} 15\end{array}$ & 3,94 & $\begin{array}{l}0,2 @ \\
30 \stackrel{0}{C}\end{array}$ & & $68 c c$ & 296 \\
\hline $\begin{array}{l}\text { M-METILCICLOHEXANOL } \\
591-23-1\end{array}$ & líquido & 163 & & 114,2 & & 0,92 & & & & $62 c c$ & 295 \\
\hline $\begin{array}{l}\text { 0-METILCICLOHEXANOL } \\
583-59-5\end{array}$ & líquido & $163-166$ & $-9,5$ & 114,2 & insol & 0,93 & 3,9 & & & $58 \mathrm{cc}$ & 296 \\
\hline $\begin{array}{l}\text { 2-METIL-4.PENTANOL } \\
\text { 108-11-2 }\end{array}$ & líquido incoloro & 131,6 & -60 & 102,2 & lig sol & 0,8075 & 3,5 & $2,8 \mathrm{~mm} \mathrm{Hg}$ & $\begin{array}{l}1,0 \mathrm{li} \\
5,5 \mathrm{ls}\end{array}$ & 41 & \\
\hline $\begin{array}{l}\text { 3-METOXI 1-BUTANOL } \\
\text { 2517-43-3 }\end{array}$ & líquido & 160 & -85 & 104,14 & misc & 0,92 & 3,59 & 0,12 & $\begin{array}{l}1,9 \mathrm{li} \\
? \text { ls } \\
\end{array}$ & 74 & 335 \\
\hline $\begin{array}{l}\text { 2-METOXIPROPAN-1-0L } \\
\text { 1589-47-5 }\end{array}$ & & 130 & & 90,12 & & 0,938 & & & & & \\
\hline $\begin{array}{l}\text { NONANOL } \\
\quad 143-08-8\end{array}$ & $\begin{array}{l}\text { líquido incoloro a } \\
\text { amarillento }\end{array}$ & 215 & .5 & 144,3 & insol & 0,8279 & & & & & \\
\hline $\begin{array}{l}\text { OCTANOL } \\
111-87.5\end{array}$ & líquido incoloro & 195 & -16 & 130,22 & insol & 0,827 & 4,5 & $\begin{array}{l}7,94 \times 10-2 \\
\mathrm{~mm} \mathrm{Hg} \\
\text { @ } 25 \stackrel{\circ}{\circ} \mathrm{C}\end{array}$ & & & \\
\hline $\begin{array}{l}\text { 2-OCTANOL } \\
\quad 123-96-6\end{array}$ & incoloro & & & 130,22 & $\begin{array}{l}1120 \mathrm{mg} / \mathrm{I} @ \\
25 \stackrel{0}{ } \mathrm{C}\end{array}$ & & 4,5 & $\begin{array}{l}2,42 \times 10-1 \\
\mathrm{~mm} \mathrm{Hg} \\
\text { @ } 25 \stackrel{\circ}{\circ} \mathrm{C}\end{array}$ & & & \\
\hline $\begin{array}{l}\text { 1-PENTANOL } \\
71-41-0\end{array}$ & líquido incoloro & 137,5 & .79 & 88,15 & insol & 0,814 & 3,0 & 0,13 & $\begin{array}{l}1,2 \mathrm{li} \\
10,0 @ \\
100 \stackrel{\circ}{\mathrm{C}} \mathrm{ls}\end{array}$ & $33 c c$ & 300 \\
\hline $\begin{array}{r}\text { 3-PENTANOL } \\
584-02-1 \\
\end{array}$ & líquido incoloro & 116 & -8 & & $4,1 \mathrm{~g} / 100 \mathrm{ml}$ & 0,82 & 3,04 & $930 \mathrm{~Pa}$ & $\begin{array}{l}1,2 \mathrm{li} \\
8,0 \mathrm{ls}\end{array}$ & $40 \mathrm{cc}$ & 360 \\
\hline $\begin{array}{r}\text { PROPANOL } \\
71-23-8 \\
\end{array}$ & $\begin{array}{l}\text { líquido incoloro, } \\
\text { transparente }\end{array}$ & 97,2 & -127 & 60,09 & misc & 0,8053 & 2,1 & $\begin{array}{l}20,8 \mathrm{~mm} \mathrm{Hg} \\
@ 25^{\circ} \mathrm{C}\end{array}$ & $\begin{array}{l}2,29 \mathrm{li} \\
13,7 \mathrm{ls} \\
\end{array}$ & $23 c c$ & 412 \\
\hline $\begin{array}{r}\text { TRIDECANOL } \\
112 \cdot 70-9 \\
\end{array}$ & cristales & $\begin{array}{l}152 @ \\
14 \mathrm{~mm} \mathrm{Hg} \\
\end{array}$ & 32,5 & 200,4 & insol & $\begin{array}{l}0,8223 @ \\
31 \stackrel{\circ}{\circ} / 4 \stackrel{\circ}{\circ}\end{array}$ & & & & $121 \mathrm{ca}$ & \\
\hline $\begin{array}{l}\text { 3,5,5-TRIMETIL-1-HEXANOL } \\
\text { 3452-97-9 }\end{array}$ & líquido & 194 & .70 & 144,25 & $0,05 \mathrm{~g} / 100 \mathrm{ml}$ & 0,824 & 5,0 & 0,030 & & 76 & \\
\hline
\end{tabular}




\section{ALDEHIDOS Y CETALES}

Los aldehídos son miembros de un grupo de compuestos químicos orgánicos representados por la fórmula estructural general $\mathrm{R}-\mathrm{CHO}$. R puede ser hidrógeno 0 un radical hidrocarburo, sustituido o no sustituido. Las reacciones más importantes de los aldehídos son: oxidación (con formación de ácidos carboxílicos), reducción (con formación de alcohol), condensación aldólica (cuando dos moléculas de aldehído reaccionan en presencia de un catalizador para producir un hidroxialdehído) y la reacción de Cannizaro (con formación de un alcohol y la sal sódica de un ácido). Los cetales, o acetales, como también se denominan, son diésteres de hidratos de aldehídos o cetonas. Se producen por reacción de aldehídos con alcoholes.

\section{U sos}

Debido a su alta reactividad química, los aldehídos son importantes productos químicos intermedios para la fabricación de resinas, plastificantes, disolventes y tintes. Se utilizan en las industrias de tejidos, alimentos, caucho, plásticos, cuero, productos químicos y en asistencia sanitaria. Los aldehídos aromáticos se utilizan en la fabricación de perfumes y esencias.

EI acetaldehído se utiliza principalmente para fabricar ácido acético, pero también en la fabricación de acetato de etilo, ácido peracético, derivados de la piridina, perfumes, colorantes, plásticos y caucho sintético. El acetaldehído se emplea en el plateado de espejos, en el endurecimiento de fibras de gelatina, como desnaturalizante de alcoholes y como aroma sintético. El paralde hído, un trímero del acetaldehído, se utiliza en las industrias de colorantes y cueros y como agente hipnótico en medicina. En la industria sirve como disolvente, activador de caucho y antioxidante. EI metaldehído se utiliza como combustible en cocinillas de gas portátiles y también en jardinería y viveros para la lucha contra los caracoles. El glicidaldehído se emplea como agente de entramado para el acabado de la lana, para el curtido al aceite y para el engrasado de cuero y suturas quirúrgicas. EI propionaldehído se utiliza en la fabricación de polivinilo y otros plásticos y en la síntesis de productos químicos de caucho. También actúa como desinfectante y conservante. La acroleína se utiliza como material de partida para la fabricación de muchos compuestos orgánicos, entre ellos plásticos, perfumes, acrilatos, acabados textiles, fibras sintéticas y productos farmacéuticos. Se emplea también en mezclas de gases tóxicos bélicos y como combustible líquido, herbicida y biocida acuático, y fijador de tejidos en histología.

El formaldehído tiene numerosas aplicaciones relacionadas con sus propiedades disolventes y germicidas. Se utiliza en la producción de plásticos (p. ej. urea-formaldehído, fenol-formaldehído, resinas de melamina-formaldehído). Se utiliza también en la industria fotográfica, en tinción, en las industrias de caucho, seda artificial y explosivos, en el curtido, en recuperación de metales preciosos y en depuración de aguas residuales. El formaldehído es un potente antiséptico, germicida, fungicida y conservante, utilizado para desinfectar objetos inanimados, mejorar la la resistencia de los colorantes en los tejidos y proteger y revestir látex de caucho. Es también un producto químico intermedio, un agente para embalsamamiento y un fijador de muestras histológicas. El. paraformaldehído es el polímero comercial más habitual obtenido a partir de formaldehído y consiste en una mezcla de productos con distintos grados de polimerización. Se utiliza en fungicidas, desinfectantes, bactericidas y en la fabricación de adhesivos.
El butiraldenído se utiliza en síntesis orgánica, sobre todo para la fabricación de aceleradores de caucho, y como aroma sintético en alimentación. El isobutiraldehído es un producto químico intermedio para antioxidantes y aceleradores del caucho. Se emplea en la síntesis de aminoácidos y en la fabricación de perfumes, aromas, plastificantes y aditivos de la gasolina. El crotonaldehído se utiliza en la fabricación de n-butil alcohol y ácido crotónico y en la preparación de tensioactivos, pesticidas y productos quimioterapéuticos. Es un disolvente para el cloruro de polivinilo y se utiliza para controlar el peso molecular en la polimerización de cloruro de vinilo. El crotonaldehído se emplea en la preparación de aceleradores del caucho, en la purificación de aceites lubricantes, en el curtido del cuero, y como agente de advertencia en la detección de gases combustibles y roturas y fugas en tuberías.

El glutaraldehído es un importante agente esterilizante eficaz frente a todos los microorganismos, entre ellos virus y esporas. Se utiliza como desinfectante químico para la esterilización en frío de equipos e instrumentos en la industria sanitaria y como agente curtidor en la industria del cuero. T ambién es un componente de líquidos de embalsamamiento y un fijador de tejidos. El p-dioxano es un disolvente en el desfibrado de la madera y humectante y dispersante en el procesado de tejidos, baños de colorantes, tinciones y composiciones para impresión. Se utiliza en productos de limpieza y detergentes, adhesivos, cosméticos, fumigantes, lacas, pinturas, barnices, y decapantes de pintura y barniz.

Los cetales se encuentran en la industria como disolventes, plastificantes y productos químicos intermedios. Son capaces de endurecer adhesivos naturales, como cola o caseína. El metilal se emplea en unguentos, perfumes, combustibles especiales, y como disolvente para adhesivos y recubrimientos. El dicloroetil formal se utiliza como disolvente y como producto químico intermedio en la fabricación de caucho sintético polisulfurado.

\section{Medidas de seguridad}

M uchos aldehídos son líquidos volátiles e inflamables, que a temperaturas ambiente desprenden vapores que pueden alcanzar concentraciones explosivas. Las precauciones para evitar incendios y explosiones, según se describen en otro apartado de este capítulo, deben ser especialmente estrictas en el caso de los miembros inferiores de la familia de los aldehídos, y las medidas de seguridad frente a sus propiedades irritantes debe ser también más extensas en el caso de los miembros inferiores y los que presentan cadenas insaturadas o sustituidas.

El contacto con los aldehídos puede reducirse al mínimo con un diseño adecuado de la planta y un procedimiento correcto de manipulación. En la medida de lo posible deben evitarse los derrames; en caso de que éstos se produzcan, debe disponerse de agua y dispositivos de drenaje. Para la manipulación de productos químicos clasificados como cancerígenos conocidos 0 sospechosos, deben adoptarse las precauciones habituales para cancerígenos, descritas en otro lugar de este capítulo. M uchos de estos productos químicos son irritantes oculares potentes y los trabajadores deben utilizar obligatoriamente una protección ocular y facial aprobada frente a productos químicos. Las personas encargadas de las labores de mantenimiento deben llevar también protectores faciales de plástico. Cuando las condiciones así lo exijan, debe proporcionarse al personal prendas protectoras adecuadas, como mandiles, guantes y calzado impermeable. En la planta debe haber duchas de emergencia y aspersores para el lavado de los ojos. Los trabajadores deben recibir instrucción sobre el uso y el mantenimiento de todos los equipos protectores. 


\section{Riesgos para la salud}

La mayor parte de los aldehídos y cetales pueden causar irritación de la piel, los ojos y el sistema respiratorio, siendo este efecto más pronunciado en los miembros inferiores de una serie, en los miembros con la cadena alifática insaturada y en los miembros con sustitución halógena. Los aldehídos pueden tener un efecto anestésico, pero las propiedades irritantes de algunos de ellos posiblemente obligen al trabajador a limitar la exposición antes de que ésta sea suficiente como para que se manifiesten los efectos anestésicos. El efecto irritante en las mucosas puede estar relacionado con el efecto cilioestático que inhibe el movimiento de los cilios que tapizan el tracto respiratorio con funciones esencialmente de limpieza. El grado de toxicidad varía mucho en esta familia. Algunos aldehídos aromáticos y ciertos aldehídos alifáticos se metabolizan rápidamente y no producen efectos adversos, pudiendo utilizarse sin riesgos como aromas alimentarios. No obstante, otros miembros de la familia son cancerígenos conocidos o sospechosos y exigen la adopción de medidas de precaución siempre que exista posibilidad de contacto con ellos. Algunos son mutágenos químicos y otros, alergenos. También tienen la capacidad de producir un efecto hipnótico. En el texto siguiente y en las tablas adjuntas se facilitan más datos sobre miembros específicos de la familia.

El acetaldehído es un irritante de las mucosas y ejerce también una acción narcótica general en el sistema nervioso central. A bajas concentraciones causa irritación de ojos, nariz y vías respiratorias superiores, así como catarro bronquial. El contacto prolongado con esta sustancia puede dañar el epitelio de la córnea. A altas concentraciones produce cefalea, estupor, bronquitis y edema pulmonar. Su ingestión causa náuseas, vómitos, diarrea, narcosis e insuficiencia respiratoria, pudiendo producirse la muerte como consecuencia de lesiones renales y degeneración grasa del hígado y del músculo cardíaco. El acetaldehído se produce en la sangre como metabolito del alcohol etílico, y causa enrojecimiento facial, palpitaciones y otros síntomas desagradables. El fármaco D isulfiram (Antabuse) potencia este efecto, como también ocurre con la exposición a cianamida y dimetilformamida. Además de sus efectos agudos, el acetaldehído es un cancerígeno del grupo 2B; es decir, ha sido clasificado como posible cancerígeno para el ser humano y cancerígeno para animales por la A gencia Internacional de Investigación sobre el Cáncer (IARC). El acetaldehído ha provocado aberraciones cromosómicas e intercambio de cromátidas hermanas en varios sistemas de ensayo.

La exposición repetida a los vapores de acetaldehído causa dermatitis y conjuntivitis. En caso de exposición crónica, los síntomas se asemejan a los del alcoholismo crónico, con pérdida de peso, anemia, delirio, alucinaciones visuales y auditivas, deterioro intelectual y trastornos psíquicos.

La acroléna es un contaminante atmosférico común liberado por los humos de escape de los motores de combustión interna, que contienen distintos tipos de aldehídos. La concentración de acroleína aumenta cuando se utilizan gasoil o fueloil. A simismo, la acroleína se encuentra en cantidades considerables en el humo del tabaco, no solo en la fase particulada del humo, sino también, y en mayor cantidad, en la fase gaseosa. Junto con otros aldehídos (acetaldehído, propionaldehído, formaldehído, etc), alcanza una concentración tal (entre 50 y 150 ppm) que parece ser uno de los aldehídos más peligrosos del humo del tabaco. Por tanto, la acroleína representa un posible riesgo profesional y medioambiental.

La acroleína es tóxica y muy irritante, y su elevada presión de vapor puede dar lugar a la rápida acumulación de concentraciones atmosféricas peligrosas. Sus vapores provocan lesiones en el tracto respiratorio $y$, junto con la forma líquida, lesiones oculares. El contacto con la piel produce quemaduras graves. La acroleína se detecta fácilmente gracias a sus excelentes propiedades de advertencia, puesto que provoca irritación grave a concentraciones que no representan un riesgo agudo (su potente efecto lacrimógeno a concentraciones muy bajas en la atmósfera $\left(1 \mathrm{mg} / \mathrm{m}^{3}\right)$ obliga a las personas a salir del lugar contaminado en busca de equipos protectores). En consecuencia, es más probable que la exposición sea el resultado de fugas o derrames de tuberías 0 recipientes. Sin embargo, es posible que algunos efectos crónicos graves, como el cáncer, no se eviten del todo.

La inhalación constituye el riesgo más grave. Causa irritación de nariz y garganta, opresión torácica, dificultad respiratoria, náuseas y vómitos. El efecto broncopulmonar es muy grave; aunque la víctima se recupere de una exposición aguda, sufrirá secuelas radiológicas y funcionales permanentes. Experimentos con animales indican que la acroleína tiene acción vesicante, destruyendo la mucosa del tracto respiratorio de forma que la función respiratoria queda totalmente inhibida en el plazo de 2 a 8 días. El contacto repetido con la piel puede causar dermatitis, y se ha observado sensibilización de la piel.

El descubrimiento de las propiedades mutagénicas de la acroleína no es reciente. Rapaport lo observó ya en 1948 en D rosophila. Se han realizado investigaciones para determinar si el cáncer de pulmón, cuya conexión con el hábito de fumar es indiscutible, podría estar relacionado con la presencia de acroleína en el humo, y si ciertas formas de cáncer del aparato digestivo que se han relacionado con la absorción de aceites para cocinar quemados se deben a la acroleína contenida en dichos aceites. R ecientes estudios han demostrado que la acroleína es mutagénica para ciertas células (D rosophila, Salmonella, algas como D unaliella bioculata) pero no para otras (levaduras tales como Saccharomices cerevisiae). En los casos en que la acroleína es mutagénica para una célula, se observan cambios estructurales en el núcleo similares a los causados por los rayos $X$ en las algas. También produce distintos efectos en la síntesis de ADN por interferencia con ciertas enzimas.

La acroleína inhibe eficazmente la actividad de los cilios de las células bronquiales, cuya misión es mantener limpio el árbol bronquial. Este hecho, sumado a la acción favorecedora de la inflamación, hace muy probable que la acroleína pueda causar lesiones bronquiales crónicas.

EI cloroacetaldehído tiene propiedades muy irritantes, no sólo para las mucosas (es peligroso para los ojos incluso en fase de vapor y puede provocar daños irreversibles), sino también para la piel. Produce lesiones semejantes a quemaduras por contacto con una solución al $40 \%$, y una irritación apreciable por contacto prolongado o repetido con una solución al 0,1 \%. La prevención debe basarse en evitar el contacto y controlar la concentración atmosférica.

En el ser humano, el hidrato de cloral se excreta inicialmente como tricloroetanol y después, con el tiempo, como ácido tricloroacético, que puede alcanzar hasta la mitad de la dosis en exposiciones reiteradas. En exposiciones agudas graves, el hidrato de cloral actúa como narcótico y altera el centro respiratorio.

El crotonaldehído es una sustancia muy irritante que produce también quemaduras en la córnea y exhibe una toxicidad similar a la acroleína. Se han descrito casos de sensibilización en trabajadores, y algunos ensayos de mutagenicidad han dado resultados positivos.

Además del peligro de incendio que conlleva el $p$-dioxano, éste ha sido clasificado por la IAR C como cancerígeno del grupo $2 \mathrm{~B}$, esto es, como cancerígeno animal demostrado y posible cancerígeno humano. Los estudios de inhalación en animales indican que el vapor de p-dioxano produce narcosis, lesiones pulmonares, hepáticas y renales, irritación de las mucosas, congestión y edema pulmonar, cambios de comportamiento y recuentos hemáticos elevados. La administración de dosis elevadas de p-dioxano con el agua de beber se han relacionado con el desarrollo de tumores en 
ratas y cobayas. Experimentos con animales han demostrado también que el dioxano se absorbe rápidamente a través de la piel produciendo signos de descoordinación, narcosis, eritema y lesiones hepáticas y renales.

Estudios experimentales en seres humanos han demostrado irritación de ojos, nariz y garganta con concentraciones de entre 200 y 300 ppm. Se ha sugerido un umbral de olor de 3 ppm, aunque en otro estudio se obtuvo un umbral de olor de $170 \mathrm{ppm}$. Estudios con animales y seres humanos han demostrado que el dioxano se metaboliza a ácido $\beta$-hidroxietoxiacético. Según una investigación realizada en 1934 sobre la muerte de cinco trabajadores en un fábrica de seda artificial, los síntomas de la intoxicación por dioxano consisten en náuseas y vómitos, seguidos de una disminución de la orina y finalmente anuria. En la necropsia se observó hepatomegalia, hemorragia e inflamación en los riñones y edema pulmonar y cerebral.

Debe decirse que, a diferencia de muchos otros aldehídos, las propiedades irritantes que advierten de la presencia de p-dioxano no se consideran buenas.

Formaldehído y su derivado polimérico paraformaldehído. EI formaldehído se polimeriza rápidamente, tanto a estado sólido como líquido, para formar una mezcla de productos químicos denominada paraformaldehído. Este proceso de polimerización se retrasa en presencia de agua, razón por la cual los preparados comerciales de formaldehído (conocidos como formalina 0 formol) son soluciones acuosas que contienen entre un 37 y un $50 \%$ de formaldehído en peso; a estas soluciones acuosas se añade también entre un $10 \%$ y un $15 \%$ de alcohol metílico como inhibidor de la polimerización. El formaldehído es tóxico por ingestión e inhalación y puede causar lesiones en la piel. Se metaboliza a ácido fórmico. La toxicidad del formaldehído polimerizado es potencialmente similar a la del monómero, ya que el calentamiento produce la despolimerización.

La exposición a formaldehído se ha relacionado con efectos agudos y crónicos. El formaldehído es un cancerígeno animal clasificado como probable cancerígeno humano 1B por la IARC. En consecuencia, cuando se trabaja con formaldehído deben adoptarse las precauciones generales recomendadas para los cancerígenos

La exposición a bajas concentraciones atmosféricas de formaldehído produce irritación, especialmente de los ojos y el tracto respiratorio. La solubilidad del formaldehído en agua limita el efecto irritante a la parte superior del tracto respiratorio. U na concentración de entre 2 y 3 ppm produce un ligero hormigueo en los ojos, la nariz y la faringe; cuando la concentración sube a entre 4 y 5 ppm, las molestias aumentan rápidamente; a 10 ppm se tolera con dificultad, aún en exposiciones breves; entre 10 y $20 \mathrm{ppm}$ se produce dificultad respiratoria grave, quemazón de los ojos, la nariz y la tráquea, lagrimeo intenso y tos intensa. La exposición a concentraciones de entre 50 y 100 ppm produce sensación de opresión torácica, dolor de cabeza, palpitaciones y en casos extremos, muerte por edema o espasmo de glotis. T ambién puede producir quemaduras en los ojos.

El formaldehído reacciona rápidamente con las proteínas tisulares y desencadena reacciones alérgicas, entre ellas dermatitis de contacto, que también se produce por contacto con ropa tratada con esta sustancia. Pueden presentarse síntomas asmáticos por sensibilidad alérgica al formaldehído, incluso a concentraciones muy bajas. Cuando la exposición es excesiva y reiterada, puede causar lesiones renales. Se han descrito casos de dermatitis inflamatoria y alérgica, como distrofia de las uñas por contacto directo con soluciones, sólidos o resinas que contenían formaldehído libre. El contacto breve con grandes cantidades de formaldehído causa inflamación. U na vez sensibilizada la persona, ésta puede exhibir una reacción alérgica tras el contacto incluso con cantidades muy pequeñas.

El formaldehído reacciona con cloruro de hidrógeno y parece ser que, cuando dicha reacción tiene lugar en presencia de aire húmedo, genera una cantidad no despreciable de bis(clorometil)éter, BCME, un peligroso cancerígeno. En posteriores investigaciones se ha demostrado que, a temperatura y humedad ambiente e incluso a concentraciones muy altas, el formaldehído y el cloruro de hidrógeno no forman bis-(clorometil) éter al límite de detección de 0,1 ppb. No obstante, el National Institute for $\mathrm{O}$ ccupational Safety and $\mathrm{H}$ ealth (NIO SH) de Estados U nidos ha recomendado que el formaldehído se considere como un posible cancerígeno profesional, debido a que exhibe actividad mutagénica en varios sistemas de ensayo y provoca cáncer nasal en ratas y ratones, particularmente en presencia de vapores de ácido clorhídrico.

El glutaraldenído es un alergeno relativamente débil que puede causar dermatitis alérgica de contacto; la combinación de sus propiedades irritantes y alergénicas apunta también la posibilidad de alergias del sistema respiratorio. Es un irritante relativamente potente de la piel y los ojos.

El glicidaldehído es un producto químico muy reactivo clasificado por la IARC como un posible cancerígeno humano y un cancerígeno animal demostrado del grupo 2B. Por consiguiente, con este producto deben adoptarse las precauciones recomendadas para la manipulación de sustancias cancerígenas.

La ingestión de metaldehído provoca náuseas, vómitos intensos, dolor abdominal, rigidez muscular, convulsiones, coma y muerte por insuficiencia respiratoria. N ormalmente la ingestión de paraldehído produce somnolencia sin depresión de la respiración, aunque ocasionalmente la víctima fallece por insuficiencia respiratoria y circulatoria después de la exposición a dosis altas. El metilal puede causar alteraciones hepáticas y renales y actúa como irritante pulmonar en caso de exposición aguda. 
Tabla 104.13 - Identificación química.

$\begin{array}{lll}\text { Producto químico } & \text { Sinónimos/ Código UN } & \text { N úmero CAS Fórmula estructural } \\ \text { ACETAL } & \text { 1,1-Dietoxietano; dietil acetal; éter etiliden dietilico } \\ & \text { UN1088 } & 105-57-7\end{array}$

\begin{tabular}{llll}
\hline ACETALDEHIDO & $\begin{array}{c}\text { Aldehído acético; acetilaldehído; etanal; etil aldehído } \\
\text { UN1089 }\end{array}$ & A5-07-0 \\
\hline ACROLEINA & $\begin{array}{c}\text { Aldehído alílico; aldehído etilénico; propenal; 2-propenal } \\
\text { UN1062 }\end{array}$ \\
\hline
\end{tabular}

ALDEHIDO CINAMICO Cinamal; fenilacroleína; 3-fenilacrilaldehído; 3-fenil-2-propenal 14371-10-9

(1431.10.9

BENZALDEHIDO Benceno carbaldehído; bencenocarbonal; aldehído benzoico; fenilmetanal $\quad 100-52-7$

\begin{tabular}{|c|c|c|}
\hline BUTILALDEHIDO & $\begin{array}{l}\text { Butanal; butiral; n-butiraldehído; aldehído butírico } \\
\text { UN1129 }\end{array}$ & $123-72-8$ \\
\hline CLOROACETALDEHIDO & $\begin{array}{l}\text { 2-Cloroacetaldehído; 2-cloroetanal } \\
\text { UN2232 }\end{array}$ & $107-20-0$ \\
\hline o-CLOROBENZALDEHIDO & 2-Clorobenzaldehído; o-clorobencenocarboxaldehído & $89-98-5$ \\
\hline CROTONALDEHIDO & $\begin{array}{l}\text { 2-Butenal; aldehído crotónico; b-metilacroleína } \\
\text { UN1143 }\end{array}$ & $4170-30-3$ \\
\hline DICLOROETIL FORMAL & $\begin{array}{l}\text { Bis(2-cloroetoxi)-metano; bis( } \beta \text {-cloroetil) formal; } \\
\text { bis( } 2 \text {-cloroetil) formal; dicloroetil formal; } \\
\text { di-2-cloroetil formal; etano, 1, } 1^{\prime} \text {-(metilenbis( oxi)) bis(2-cloro-; } \\
\text { formaldehído bis ( } \beta \text {-cloroetil) acetal }\end{array}$ & $111-91-1$ \\
\hline DIMETILACETAL & $\begin{array}{l}\text { 1,1-Dimetoxietano; éter etiliden dimetilíco; } \\
\text { UN2377 }\end{array}$ & $534-15-6$ \\
\hline 2,2-DIMETIL-1,3-DIOXOLAN-4-METANOL & $\begin{array}{l}\text { 2,2-Dimetil-5-hidroximetil-1,3-dioxolano; } \\
\text { 2,2-dimetil-4-oximetil-1,3-dioxolano; glicerolactone; } \\
\text { 4-hidroximetil-2,2-dimetil-1,3-dioxolano; isopropiliden glicerol }\end{array}$ & $100-79-8$ \\
\hline
\end{tabular}


Tabla 104.13 - Identificación química.

\begin{tabular}{|c|c|c|c|}
\hline Producto químico & Sinónimos/ Código UN & $\mathrm{N}$ úmero $\mathrm{CAS}$ & Fórmula estructural \\
\hline p-DIOXANO & $\begin{array}{l}\text { 1,4-Dietilen dióxido; dietilen dióxido; éter dietilénico; dioxano; } \\
\text { 1,4-dioxano } \\
\text { UN1165 }\end{array}$ & $123-91-1$ & \\
\hline 2-ETILHEXANAL & $\begin{array}{l}\text { Butiletilacetaldehído; etilbutilacetaldehído; etilhexaldehído; } \\
\text { 2-etilhexaldehído }\end{array}$ & $123-05-7$ & \\
\hline FORMALDEHIDO & $\begin{array}{l}\text { Metanal; aldehído metílico; metilen glicol; óxido de metileno } \\
\text { UN1198 } \\
\text { UN2206 }\end{array}$ & $50-00-0$ & \\
\hline GLICIDALDEHIDO & $\begin{array}{l}\text { 2,3-Epoxipropanal; 2,3-epoxipropionaldehído; glicidal; propionaldehído } \\
\text { UN2622 }\end{array}$ & $765-34-4$ & \\
\hline GLUTARALDEHIDO & $\begin{array}{l}\text { Glutaral; glutardialdehído; dialdehído glutárico; 1,5-pentanodial; } \\
\text { 1,5-pentanodiona }\end{array}$ & $111-30-8$ & \\
\hline 3-HIDROXIBUTIRALDEHIDO & $\begin{array}{l}\text { Acetaldol; aldol; 3-butanolal; oxibutanal } \\
\text { UN2839 }\end{array}$ & $107-89-1$ & \\
\hline ISOBUTILALDEHIDO & $\begin{array}{l}\text { Isobutanal; isobutiral; isopropil formaldehído; metil propanal } \\
\text { UN2045 }\end{array}$ & $78-84-2$ & \\
\hline METALDEHIDO & $\begin{array}{l}\text { Metacetaldehído; 2,4,6,8-tetrametil-1,3,5,7-tetroxocano } \\
\text { UN1332 }\end{array}$ & $108-62-3$ & \\
\hline METILAL & $\begin{array}{l}\text { Dimetoximetano; formaldehído dimetilacetal; éter metilen dimetilíco } \\
\text { UN1234 }\end{array}$ & $109-87.5$ & \\
\hline 4-MORFOLINCARBOXALDEHIDO & N-Formilmorfolina; 4-formilmorfolina & $4394-85-8$ & \\
\hline PARAFORMALDEHIDO & $\begin{array}{l}\text { Paraform; triformol; trioximetileno } \\
\text { UN2213 }\end{array}$ & $30525-89-4$ & \\
\hline PARALDEHIDO & $\begin{array}{l}\text { Paracetaldehído; paral; 2,4,6-trimetil-1,3,5-trioxano } \\
\text { UN1264 }\end{array}$ & 123.63 .7 & \\
\hline PROPIONALDEHIDO & $\begin{array}{l}\text { Metilacetaldehído; propaldehído; propanal; aldehído propiónico; } \\
\text { propil aldehído } \\
\text { UN1275 }\end{array}$ & $123-38-6$ & \\
\hline SAFROL & $\begin{array}{l}\text { 5-Alil-1,3-benzodioxol; alildioxibenceno metilen éter; } \\
\text { 1-alil-3,4-metilendioxibenceno; 4-alil-1,2-metilendioxibenceno }\end{array}$ & $94-59-7$ & \\
\hline
\end{tabular}


Tabla 104.13 • Identificación química.

\begin{tabular}{lll} 
Producto químico & Sinónimos/ Código UN & Número CAS Fórmula estructural \\
3,5,5-TRIMETLLHEXANAL & terc-Butilisopentanal; isononilaldehído & \\
\hline TRIOXANO & Triformol; sim-trioxano; 1,3,5-trioxano; trioximetileno
\end{tabular}

VALERALDEHIDO Amil aldehído; butil formal; pentanal; aldehído valérico; valeral $\quad$ 110-62-3

\begin{tabular}{|c|c|c|c|c|c|c|}
\hline \multirow[b]{2}{*}{$\begin{array}{l}\text { Denominación } \\
\text { química } \\
\text { N úmero CAS }\end{array}$} & \multicolumn{4}{|c|}{ Tarjetas Internacionales sobre la Seguridad de los Productos Q uímicos } & \multicolumn{2}{|c|}{ N IO SH (EE.UU.) } \\
\hline & $\begin{array}{l}\text { Período } \\
\text { corto de } \\
\text { exposición }\end{array}$ & $\begin{array}{l}\text { Período } \\
\text { largo de } \\
\text { exposición }\end{array}$ & $\begin{array}{l}\text { Vías de } \\
\text { exposición }\end{array}$ & Síntomas & $\begin{array}{l}\text { O rganos } \\
\text { afectados } \\
\text { Vías de } \\
\text { entrada }\end{array}$ & Síntomas \\
\hline $\begin{array}{c}\text { ACETALDEHIDO } \\
75.07 .0\end{array}$ & $\begin{array}{l}\text { ojos; piel; tract Gl; } \\
\text { tract resp; } \\
\text { pulmones; SNC }\end{array}$ & $\begin{array}{l}\text { piel; pulmones; } \\
\text { SNC; hígado }\end{array}$ & $\begin{array}{r}\text { Inhalación } \\
\text { Piel } \\
\text { 0jos } \\
\text { Ingestión }\end{array}$ & $\begin{array}{l}\text { Tos, sopor, disnea, inconsciencia, los síntomas } \\
\text { pueden tardar en aparecer } \\
\text { Enrojecimiento, sensación de quemazón, dolor } \\
\text { Enrojecimiento, dolor, visión borrosa } \\
\text { Sensación de quemazón, diarrea, mareo, } \\
\text { náuseas, vómitos }\end{array}$ & $\begin{array}{l}\text { Ojos; piel; sis resp; } \\
\text { riñones; SNC; sis } \\
\text { repro [en animales: } \\
\text { cáncer nasal] } \\
\text { Inh, ing, con }\end{array}$ & $\begin{array}{l}\text { Irrit ojos, nariz, garganta, } \\
\text { quemaduras en ojos y piel; } \\
\text { derm; conj; tos; depres SNC; } \\
\text { edema pulm tardío; en } \\
\text { animales: efectos renales, } \\
\text { repro, terato; [ carc] }\end{array}$ \\
\hline $\begin{array}{c}\text { ACROLEINA } \\
107-02-8\end{array}$ & $\begin{array}{l}\text { ojos; piel; tract } \\
\text { resp; pulmones }\end{array}$ & & $\begin{array}{r}\text { Inhalación } \\
\text { Piel } \\
\text { 0jos } \\
\text { Ingestión }\end{array}$ & $\begin{array}{l}\text { Corrosivo, sensación de quemazón, tos, } \\
\text { dificultad respiratoria y disnea; dolor de } \\
\text { garganta, los síntomas pueden tardar en } \\
\text { aparecer } \\
\text { Corrosivo, enrojecimiento, quemaduras graves } \\
\text { en la piel, dolor, ampollas } \\
\text { Corrosivo, enrojecimiento, quemaduras graves } \\
\text { en la piel, dolor, ampollas } \\
\text { Corrosivo, enrojecimiento, dolor, quemaduras } \\
\text { profundas graves } \\
\text { espasmos abdominales, sensación de } \\
\text { quemazón, colapso }\end{array}$ & $\begin{array}{l}\text { Corazón; ojos; piel; } \\
\text { sis resp } \\
\text { Inh, ing, con }\end{array}$ & $\begin{array}{l}\text { Irrit ojos, piel, mucosas; dism } \\
\text { func pulm; edema pulm tardío; } \\
\text { enfermedad resp crónica }\end{array}$ \\
\hline $\begin{array}{c}\text { BENZALDEHIDO } \\
100-52 \cdot 7\end{array}$ & $\begin{array}{l}\text { ojos; piel; tract } \\
\text { resp, pulmones }\end{array}$ & piel & $\begin{array}{r}\text { Inhalación } \\
\text { Piel } \\
\text { 0jos } \\
\text { Ingestión }\end{array}$ & $\begin{array}{l}\text { Parálisis respiratoria, disnea, sensación de } \\
\text { quemazón en ojos y mucosa nasal, tos, mareo } \\
\text { Puede absorberse, enrojecimiento, pérdida de } \\
\text { sensación, dermatitis de contacto } \\
\text { Enrojecimiento, dolor } \\
\text { Sensación de quemazón, confusión, mareo, } \\
\text { sopor, cefalea, disnea, inconsciencia, vómitos, } \\
\text { convulsiones }\end{array}$ & & \\
\hline $\begin{array}{c}\text { BUTILALDEHIDO } \\
123-72-8\end{array}$ & $\begin{array}{l}\text { ojos; piel; tract } \\
\text { resp; pulmones }\end{array}$ & & $\begin{array}{r}\text { Inhalación } \\
\text { Piel } \\
\text { 0jos } \\
\text { Ingestión }\end{array}$ & $\begin{array}{l}\text { Sensación de quemazón, tos, dolor de } \\
\text { garganta } \\
\text { Enrojecimiento } \\
\text { Enrojecimiento, dolor } \\
\text { Sensación de quemazón }\end{array}$ & & \\
\hline
\end{tabular}


Tabla 104.14 - Riesgos para la salud.

\begin{tabular}{|c|c|c|c|c|c|c|}
\hline \multirow[b]{2}{*}{$\begin{array}{l}\text { Denominación } \\
\text { química } \\
\text { N úmero CAS }\end{array}$} & \multicolumn{4}{|c|}{ Tarjetas Internacionales sobre la Seguridad de los Productos Q uímicos } & \multicolumn{2}{|c|}{ N IO SH (EE.UU.) } \\
\hline & $\begin{array}{l}\text { Período } \\
\text { corto de } \\
\text { exposición }\end{array}$ & $\begin{array}{l}\text { Período } \\
\text { largo de } \\
\text { exposición }\end{array}$ & $\begin{array}{l}\text { Vías de } \\
\text { exposición }\end{array}$ & Síntomas & $\begin{array}{l}\text { O rganos } \\
\text { afectados } \\
\text { Vías de } \\
\text { entrada }\end{array}$ & Síntomas \\
\hline $\begin{array}{l}\text { 0-CLOROBENZALDEHIDO } \\
89-98-5\end{array}$ & $\begin{array}{l}\text { ojos; piel; hígado; } \\
\text { riñones }\end{array}$ & piel & $\begin{array}{r}\text { Inhalación } \\
\text { Piel } \\
\text { 0jos } \\
\text { Ingestión }\end{array}$ & $\begin{array}{l}\text { Sensación de quemazón, tos, dolor de } \\
\text { garganta } \\
\text { Puede absorberse, enrojecimiento, sensación } \\
\text { de quemazón, dolor } \\
\text { Enrojecimiento, dolor } \\
\text { Espasmos abdominales, sensación de } \\
\text { quemazón }\end{array}$ & & \\
\hline $\begin{array}{l}\text { 2,2-DIMETIL-1,3-DIOXOLAN-4- } \\
\text { METANOL } \\
\quad 100-79-8\end{array}$ & ojos; SNC & & $\begin{array}{r}\text { Inhalación } \\
\text { Ojos } \\
\text { Ingestión }\end{array}$ & $\begin{array}{l}\text { Tos, dolor de garganta } \\
\text { Enrojecimiento } \\
\text { Debilidad }\end{array}$ & & \\
\hline $\begin{array}{l}\text { p-DIOXANO } \\
123-91-1\end{array}$ & $\begin{array}{l}\text { ojos; tract resp; } \\
\text { SNC; hígado; } \\
\text { riñones }\end{array}$ & piel & $\begin{array}{l}\text { Inhalación } \\
\text { Piel } \\
\text { Ojos }\end{array}$ & $\begin{array}{l}\text { Cefalea, náuseas, tos, dolor de garganta, dolor } \\
\text { abdominal, mareo, sopor, vómitos, } \\
\text { inconsciencia } \\
\text { Puede absorberse, enrojecimiento } \\
\text { Enrojecimiento, irritante, dolor }\end{array}$ & $\begin{array}{l}\text { Hígado; riñones; } \\
\text { piel; ojos; sis resp } \\
\text { [en animales: } \\
\text { tumores } \\
\text { pulmonares, } \\
\text { hepáticos y de } \\
\text { cavidades nasales] } \\
\text { Inh, abs, ing, con }\end{array}$ & $\begin{array}{l}\text { Irrit ojos, piel, nariz, garganta; } \\
\text { sop, cef, náu, vómit; lesiones } \\
\text { hepáticas; insuficiencia renal; } \\
\text { [carc] }\end{array}$ \\
\hline $\begin{array}{l}\text { ETIL HEXALDEHIDO } \\
\text { 123-05-7 }\end{array}$ & ojos; piel; tract resp & piel & $\begin{array}{r}\text { Inhalación } \\
\text { Piel } \\
\text { Ojos } \\
\text { Ingestión }\end{array}$ & $\begin{array}{l}\text { Sensación de quemazón, tos, vómitos } \\
\text { Puede absorberse, enrojecimiento } \\
\text { Enrojecimiento, dolor } \\
\text { Dolor abdominal, náuseas, vómitos }\end{array}$ & & \\
\hline $\begin{array}{l}\text { FORMALDEHIDO } \\
50.00-0\end{array}$ & $\begin{array}{l}\text { ojos; piel; tract } \\
\text { resp; pulmones }\end{array}$ & piel & $\begin{array}{l}\text { Inhalación } \\
\text { Piel } \\
\text { Ojos }\end{array}$ & $\begin{array}{l}\text { Sensación de quemazón en nariz y garganta, } \\
\text { tos, cefalea, dificultad respiratoria, náuseas, } \\
\text { disnea } \\
\text { Enrojecimiento } \\
\text { Efectos tardíos, enrojecimiento, dolor, visión } \\
\text { borrosa, quemaduras profundas graves }\end{array}$ & $\begin{array}{l}\text { Sis resp; ojos; piel } \\
\text { [cáncer nasal] } \\
\text { Inh, con }\end{array}$ & $\begin{array}{l}\text { Irrit ojos, nariz, garganta, sis } \\
\text { resp; lag; tos, espasm bron; } \\
\text { [carc] }\end{array}$ \\
\hline $\begin{array}{l}\text { GLUTARALDEHIDO } \\
111-30-8\end{array}$ & ojos; piel; tract resp & piel; tract resp & & & $\begin{array}{l}\text { Ojos; piel; sis resp } \\
\text { Inh, abs, ing, con }\end{array}$ & $\begin{array}{l}\text { Irrit ojos, piel, sis resp; derm, } \\
\text { sens piel; tos; asma; náu, } \\
\text { vómit }\end{array}$ \\
\hline $\begin{array}{l}\text { HIDRATO DE CLORAL } \\
302-17-0\end{array}$ & $\begin{array}{l}\text { ojos; piel; tract } \\
\text { resp; SNC; riñones; } \\
\text { hígado; SCV }\end{array}$ & & $\begin{array}{r}\text { Inhalación } \\
\text { Piel } \\
\text { 0jos } \\
\text { Ingestión }\end{array}$ & $\begin{array}{l}\text { Confusión, sopor, náuseas, inconsciencia } \\
\text { Enrojecimiento } \\
\text { Enrojecimiento } \\
\text { Dolor abdominal, vómitos }\end{array}$ & & \\
\hline $\begin{array}{l}\text { METILAL } \\
109-87-5\end{array}$ & ojos; piel; tract resp & piel & $\begin{array}{r}\text { Inhalación } \\
\text { Piel } \\
\text { Ojos } \\
\text { Ingestión }\end{array}$ & $\begin{array}{l}\text { Tos, mareo, sopor, cefalea, dolor de garganta, } \\
\text { inconsciencia } \\
\text { Puede absorberse, sequedad de piel, } \\
\text { desengrasa la piel, enrojecimiento, dolor } \\
\text { Enrojecimiento, dolor } \\
\text { Dolor abdominal, náuseas, vómitos }\end{array}$ & $\begin{array}{l}\text { Ojos; piel; sis resp; } \\
\text { SNC } \\
\text { Inh, ing, con }\end{array}$ & $\begin{array}{l}\text { Irrit ojos, piel, sis resp } \\
\text { superior; anes }\end{array}$ \\
\hline $\begin{array}{l}\text { PARAFORMALDEHIDO } \\
30525-89-4\end{array}$ & ojos; piel; tract resp & piel & $\begin{array}{r}\text { Inhalación } \\
\text { Piel } \\
\text { 0jos }\end{array}$ & $\begin{array}{l}\text { Tos, dolor de garganta } \\
\text { Enrojecimiento } \\
\text { Enrojecimiento }\end{array}$ & & \\
\hline $\begin{array}{l}\text { PROPANAL } \\
123-38-6\end{array}$ & & & $\begin{array}{r}\text { Inhalación } \\
\text { Piel } \\
\text { 0jos } \\
\text { Ingestión }\end{array}$ & $\begin{array}{l}\text { Sensación de quemazón, tos, dificultad } \\
\text { respiratoria, dolor de garganta } \\
\text { Enrojecimiento } \\
\text { Enrojecimiento, dolor } \\
\text { Sensación de quemazón }\end{array}$ & $\begin{array}{l}\text { Ojos; piel; sis resp, } \\
\text { pulmones }\end{array}$ & \\
\hline
\end{tabular}




\begin{tabular}{|c|c|c|c|}
\hline $\begin{array}{l}\text { Denominación química } \\
\mathrm{N} \text { úmero CAS }\end{array}$ & Físicos & Q uímicos & $\begin{array}{l}\text { Clase o división } \\
\text { UN / Riesgos } \\
\text { subsidiarios }\end{array}$ \\
\hline $\begin{array}{l}\text { ACETAL } \\
105-57-7 \\
\end{array}$ & & & 3 \\
\hline $\begin{array}{l}\text { ACETALDEHIDO } \\
75-07-0\end{array}$ & $\begin{array}{l}\text { - El vapor es más pesado } \\
\text { que el aire y puede } \\
\text { desplazarse a ras del } \\
\text { suelo; posibilidad de } \\
\text { ignición a distancia }\end{array}$ & $\begin{array}{l}\text { - Puede formar peróxidos explosivos en contacto con el aire • Se polimeriza por la influencia de } \\
\text { ácidos y materiales alcalinos, como hidróxido sódico, en presencia de materiales traza (hierro) } \\
\text { con peligro de incendio o explosión • Es un agente reductor fuerte y reacciona violentamente con } \\
\text { oxidantes • Reacciona violentamente con algunas sustancias orgánicas, halógenos, ácido sulfúrico } \\
\text { y aminas, con peligro de incendio y explosión }\end{array}$ & \\
\hline $\begin{array}{l}\text { ACROLEINA } \\
\quad 107-02-8\end{array}$ & $\begin{array}{l}\text { - El vapor es más pesado } \\
\text { que el aire y puede } \\
\text { desplazarse a ras del } \\
\text { suelo; posibilidad de } \\
\text { ignición a distancia }\end{array}$ & $\begin{array}{l}\text { - Puede formar peróxidos explosivos • Puede polimerizarse con peligro de incendio y explosión } \\
\text { - Al calentarse libera vapores tóxicos • Reacciona con álcalis, ácidos, aminas, dióxido de azufre, } \\
\text { tiourea, sales metálicas y oxidantes, con peligro de incendio y explosión }\end{array}$ & $6.1 / 3$ \\
\hline $\begin{array}{l}\text { BUTILALDEHIDO } \\
123-72-8\end{array}$ & $\begin{array}{l}\text { - El vapor es más pesado } \\
\text { que el aire y puede } \\
\text { desplazarse a ras del } \\
\text { suelo; posibilidad de } \\
\text { ignición a distancia }\end{array}$ & $\begin{array}{l}\text { - Se polimeriza al calentarse bajo la influencia de ácidos o álcalis } \bullet \text { En su combustión libera } \\
\text { gases tóxicos } \bullet \text { Reacciona con oxidantes } \bullet \text { Reacciona violentamente con ácidos fuertes y bases }\end{array}$ & 3 \\
\hline $\begin{array}{l}\text { CLORAL } \\
75-87-6 \\
\end{array}$ & & & 6.1 \\
\hline $\begin{array}{l}\text { CLOROACETALDEHIDO } \\
\quad 107-20-0\end{array}$ & $\begin{array}{l}\text { - El vapor es más pesado } \\
\text { que el aire }\end{array}$ & $\begin{array}{l}\text { - Al calentarse libera vapores tóxicos • Reacciona con agua para formar un hidrato con } \\
\text { desprendimiento de calor • Reacciona con oxidantes y ácidos, con peligro de explosión } \bullet \text { En } \\
\text { reposo la sustancia anhidra puede polimerizarse }\end{array}$ & 6.1 \\
\hline $\begin{array}{l}\text { O-CLOROBENZALDEHIDO } \\
89.98 .5\end{array}$ & & $\begin{array}{l}\text { - Se descompone al calentarse, produciendo vapores tóxicos y corrosivos, entre ellos cloruro de } \\
\text { hidrógeno } \bullet \text { Reacciona con hierro, bases fuertes, oxidantes fuertes, agentes reductores fuertes y } \\
\text { humedad }\end{array}$ & \\
\hline $\begin{array}{l}\text { CROTONALDEHIDO } \\
\text { 4170-30-3 }\end{array}$ & & & $6.1 / 3$ \\
\hline $\begin{array}{l}\text { 2,2-DIMETIL-1,3-DIOXOLAN-4-METANOL } \\
\text { 100-79-8 }\end{array}$ & & - Reacciona con oxidantes & \\
\hline $\begin{array}{l}\text { p-DIOXANO } \\
123-91-1\end{array}$ & & $\begin{array}{l}\text { - Puede formar peróxidos explosivos } \bullet \text { Reacciona vigorosamente con oxidantes fuertes y ácidos } \\
\text { fuertes concentrados } \bullet \text { Reacciona explosivamente con algunos catalizadores (p. ej., níquel Raney } \\
\text { por encima de } 210^{\circ} \mathrm{C} \text { - Ataca muchos plásticos }\end{array}$ & 3 \\
\hline $\begin{array}{l}\text { 2-ETIL HEXALDEHIDO } \\
\text { 123-05-7 }\end{array}$ & $\begin{array}{l}\text { - El vapor es más pesado } \\
\text { que el aire }\end{array}$ & $\begin{array}{l}\text { - Puede formar peróxidos explosivos en contacto prolongado con oxígeno } 0 \text { aire } \bullet \text { Se polimeriza } \\
\text { en contacto con hidróxido sódico, amoníaco, butil y dibutilamina y ácidos inorgánicos • Reacciona } \\
\text { con oxidantes }\end{array}$ & \\
\hline
\end{tabular}

\begin{tabular}{lc}
\hline FENIL CLOROFORMATO & $6.1 / 8$ \\
$\begin{array}{l}\text { 1885-14-9 } \\
\text { FORMALDEHIDO } \\
50-00-0\end{array}$ & $3 / 8$ \\
\hline $\begin{array}{l}\text { GLICIDALDEHIDO } \\
\text { 765-34-4 }\end{array}$ & $3 / 6.1$ \\
\hline $\begin{array}{l}\text { GLUTARALDEHIDO } \\
\text { 111-30-8 }\end{array}$ & \\
\hline $\begin{array}{l}\text { 3-HIDROXIBUTIRALDEHIDO Produce humo y vapores acres (monóxido de carbono, dióxido de carbono) } \\
\text { 107-89-1 }\end{array}$ & 6.1 \\
\hline $\begin{array}{l}\text { ISOBUTIRALDEHIDO } \\
78-84-2\end{array}$ & 3
\end{tabular}




\begin{tabular}{|c|c|c|c|}
\hline $\begin{array}{l}\text { Denominación química } \\
\mathrm{N} \text { úmero CAS }\end{array}$ & Físicos & Q uímicos & $\begin{array}{l}\text { Clase o división } \\
\text { UN / Riesgos } \\
\text { subsidiarios }\end{array}$ \\
\hline $\begin{array}{l}\text { METILAL } \\
109-87-5\end{array}$ & $\begin{array}{l}\text { - El vapor es más pesado } \\
\text { que el aire y puede } \\
\text { desplazarse a ras del } \\
\text { suelo; posibilidad de } \\
\text { ignición a distancia }\end{array}$ & $\begin{array}{l}\text { - Presumiblemente puede formar peróxidos explosivos } \bullet \text { Puede explotar al calentar y al arder } \\
\text { produciendo dióxido de carbono y/ o monóxido de carbono } \bullet \text { Reacciona vigorosamente con } \\
\text { oxidantes fuertes con peligro de incendio y explosión }\end{array}$ & 3 \\
\hline $\begin{array}{l}\text { PARAFORMALDEHIDO } \\
\text { 30525-89-4 }\end{array}$ & $\begin{array}{l}\text { - Posibilidad de explosión } \\
\text { pulverulenta cuando se } \\
\text { encuentra en forma de } \\
\text { polvo o gránulos y se } \\
\text { mezcla con aire }\end{array}$ & $\begin{array}{l}\text { - Se descompone al calentarse produciendo formaldehído } \bullet \text { Reacciona con oxidantes } \bullet \text { Reacciona } \\
\text { con ácidos fuertes y bases fuertes produciendo formaldehído }\end{array}$ & 4.1 \\
\hline $\begin{array}{c}\text { PARALDEHIDO } \\
123-63.7 \\
\end{array}$ & & & 3 \\
\hline $\begin{array}{l}\text { PROPANAL } \\
\quad 123-38-6\end{array}$ & $\begin{array}{l}\text { - El vapor es más pesado } \\
\text { que el aire y puede } \\
\text { desplazarse a ras del } \\
\text { suelo; posibilidad de } \\
\text { ignición a distancia }\end{array}$ & $\begin{array}{l}\text { - Se polimeriza por calentamiento y bajo la influencia de ácidos caústicos } \bullet \text { En su combustión } \\
\text { libera gases tóxicos (óxidos de carbono) y gas combustible } \bullet \text { Reacciona violentamente con } \\
\text { oxidantes, ácidos y bases }\end{array}$ & 3 \\
\hline
\end{tabular}

VALERALDEHIDO

\begin{tabular}{|c|c|c|c|c|c|c|c|c|c|c|c|}
\hline $\begin{array}{l}\text { Denominación química } \\
\mathrm{N} \text { úmero CAS }\end{array}$ & Color/ Forma & $\begin{array}{l}\text { p.e. } \\
\left({ }^{\circ} \mathrm{C}\right)\end{array}$ & $\begin{array}{l}\text { p.f. } \\
(\stackrel{\circ}{ } C)\end{array}$ & $\begin{array}{l}\text { p.m.l } \\
\text { (g/ } \\
\text { mol) }\end{array}$ & $\begin{array}{l}\text { Solubilidad } \\
\text { en agua }\end{array}$ & $\begin{array}{l}\text { Densidad } \\
\text { relativa } \\
\text { (agua }=1 \text { ) }\end{array}$ & $\begin{array}{l}\text { Densidad } \\
\text { de vapor } \\
\text { relativa } \\
\text { (aire=1) }\end{array}$ & $\begin{array}{l}\text { Pvap/ } \\
(\mathrm{kPa})\end{array}$ & $\begin{array}{l}\text { Límit. } \\
\text { inflam. }\end{array}$ & $\begin{array}{l}\text { p.ig. } \\
(\underline{O C})\end{array}$ & $\begin{array}{l}\text { p.aut } \\
\text { ig. } \\
(\stackrel{0}{ } \text { C })\end{array}$ \\
\hline $\begin{array}{l}\text { ACETAL } \\
105.57 \cdot 7 \\
\end{array}$ & liquido incoloro & 102,2 & -100 & 118,17 & sol & 0,83 & 4,08 & $20 \mathrm{~mm} \mathrm{Hg}$ & $\begin{array}{l}1,6 \mathrm{li} \\
10,4 \mathrm{ls}\end{array}$ & $-21 \mathrm{cc}$ & 230 \\
\hline $\begin{array}{l}\text { ACETALDEHIDO } \\
75-07-0\end{array}$ & $\begin{array}{l}\text { líquido incoloro; gas } \\
\text { incoloro }\end{array}$ & 21 & -123 & 44,05 & misc & $\begin{array}{l}0,788 \\
@ 16 \stackrel{\circ}{\circ} / 4 \stackrel{\circ}{\circ} \mathrm{C}\end{array}$ & 1,52 & 99 & $\begin{array}{l}4 \mathrm{li} \\
57 \mathrm{ls}\end{array}$ & -39 & 185 \\
\hline $\begin{array}{l}\text { ACROLEINA } \\
\text { 107-02-8 }\end{array}$ & $\begin{array}{l}\text { líquido incoloro } 0 \\
\text { amarillento }\end{array}$ & 53 & -88 & 56,06 & muy sol & 0,84 & 1,94 & 29 & $\begin{array}{l}2,8 \mathrm{li} \\
31 \mathrm{is}\end{array}$ & $-26 c c$ & 234 \\
\hline $\begin{array}{l}\text { ALDEHIDO CINAMICO } \\
104-55-2\end{array}$ & $\begin{array}{l}\text { líquido oleoso } \\
\text { amarillento; líquido } \\
\text { amarillo-verdoso }\end{array}$ & 253 & $-7,5$ & 132,15 & $700 \mathrm{ml}$ & $\begin{array}{l}1,048 \cdot 1,052 \\
@ 25 \stackrel{\circ}{C} \mathrm{Cl} \\
25 \stackrel{\circ}{\circ} \mathrm{C}\end{array}$ & 4,6 & $\begin{array}{l}1 \mathrm{~mm} \mathrm{Hg} \\
\text { @ } 76 \stackrel{\circ}{\circ} \mathrm{C}\end{array}$ & & 120 & \\
\hline $\begin{array}{l}\text { BENZALDEHIDO } \\
100.52 .7\end{array}$ & líquido incoloro & 179 & .26 & 106,12 & lig sol & 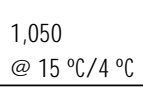 & 3,66 & $\begin{array}{l}1 \mathrm{~mm} \mathrm{Hg} \\
@ 26 \stackrel{\circ}{0}\end{array}$ & & $63 c c$ & 179 \\
\hline $\begin{array}{l}\text { BUTILALDEHIDO } \\
123-72-8 \\
\end{array}$ & $\begin{array}{l}\text { líquido incoloro; } \\
\text { líquido acuoso blanco }\end{array}$ & 74,8 & .99 & 72,10 & sol & 0,8 & 2,5 & 12,2 & $\begin{array}{l}1,9 \mathrm{li} \\
12,5 \mathrm{ls}\end{array}$ & $-667 \mathrm{cc}$ & 230 \\
\hline $\begin{array}{l}\text { CLORAL } \\
75-87-6\end{array}$ & líquido oleoso & $\begin{array}{l}97,8^{\circ} \mathrm{C} @ \\
760 \mathrm{~mm} \mathrm{Hg}\end{array}$ & $-57,5$ & 147,40 & sol & $\begin{array}{l}1,5121 \\
\text { @ } 20^{\circ} \mathrm{C} / 4^{\circ} \mathrm{C}\end{array}$ & 5,1 & $\begin{array}{l}35 \mathrm{~mm} \mathrm{Hg} \\
@ 20^{\circ} \mathrm{C}\end{array}$ & & & \\
\hline $\begin{array}{l}\text { CLOROACETALDEHIDO } \\
107-20.0\end{array}$ & $\begin{array}{l}\text { líquido incoloro y } \\
\text { transparente }\end{array}$ & 85,5 & $-16,3$ & 78,50 & misc & 1,19 & 2,7 & 13,3 & & $877 c c$ & 88 \\
\hline $\begin{array}{l}\text { 0-CLOROBENZALDEHIDO } \\
89-98-5\end{array}$ & $\begin{array}{l}\text { líquido incoloro a } \\
\text { amarillento }\end{array}$ & 211,9 & 12,4 & 140,6 & lig sol & 1,2483 & & 0,04 & & $90 \mathrm{cc}$ & 385 \\
\hline $\begin{array}{l}\text { CROTONALDEHIDO } \\
4170-30-3\end{array}$ & $\begin{array}{l}\text { líquido acuoso blanco } \\
\text { o color paja }\end{array}$ & 104,0 & $.76,5$ & 70,09 & $18,1 \mathrm{~g} / 100 \mathrm{~g}$ & 0,853 & 2,41 & $19 \mathrm{~mm} \mathrm{Hg}$ & $\begin{array}{l}2,1 \mathrm{li} \\
15,5 \mathrm{ls}\end{array}$ & $13 \mathrm{Ca}$ & 232,2 \\
\hline
\end{tabular}




\begin{tabular}{|c|c|c|c|c|c|c|c|c|c|c|c|}
\hline $\begin{array}{l}\text { Denominación química } \\
\mathrm{N} \text { úmero CAS }\end{array}$ & Color/ Forma & $\begin{array}{l}\text { p.e. } \\
\left({ }^{\circ} \mathrm{C}\right)\end{array}$ & $\begin{array}{l}\text { p.f. } \\
(\stackrel{\circ}{ } \mathrm{C})\end{array}$ & $\begin{array}{l}\text { p.m.l } \\
\text { (g/ } \\
\text { mol) }\end{array}$ & $\begin{array}{l}\text { Solubilidad } \\
\text { en agua }\end{array}$ & $\begin{array}{l}\text { Densidad } \\
\text { relativa } \\
\text { (agua }=1 \text { ) }\end{array}$ & $\begin{array}{l}\text { Densidad } \\
\text { de vapor } \\
\text { relativa } \\
\text { (aire=1) }\end{array}$ & $\begin{array}{l}\text { Pvap/ } \\
(\mathrm{kPa})\end{array}$ & $\begin{array}{l}\text { Límit. } \\
\text { inflam. }\end{array}$ & $\begin{array}{l}\text { p.ig. } \\
(\underline{O C})\end{array}$ & $\begin{array}{l}\text { p.aut } \\
\text { ig. } \\
\left({ }^{\circ} \mathrm{C}\right)\end{array}$ \\
\hline $\begin{array}{l}\text { DICLOROETIL FORMAL } \\
111-91-1\end{array}$ & líquido incoloro & 218,1 & $-32,8$ & 173,05 & $\begin{array}{l}81.000 \mathrm{mg} / \mathrm{l} \\
\text { @ } 25^{\circ} \mathrm{C}\end{array}$ & $\begin{array}{l}1,2339 \\
@ 20^{\circ} \mathrm{C} / 20^{\circ} \mathrm{C}\end{array}$ & 6,0 & $\begin{array}{l}0,1 \mathrm{~mm} \mathrm{Hg} \\
@ 20^{\circ} \mathrm{C}\end{array}$ & & $110^{\circ} \mathrm{C}$ & \\
\hline $\begin{array}{l}\text { DIMETILACETAL } \\
534-15-6\end{array}$ & $\begin{array}{l}\text { líquido incoloro; } \\
\text { líquido móvil }\end{array}$ & 64,5 & -113 & 90,1 & sol & 0,85015 & 3,1 & $61 \mathrm{~mm} \mathrm{Hg}$ & & & \\
\hline $\begin{array}{l}\text { 2,2-DIMETIL-1,3-DIOXOLAN- } \\
\text { 4-METANOL } \\
\text { 100-79-8 }\end{array}$ & líquido incoloro & $188-189$ & $-26,4$ & 132,2 & misc & 1,064 & 4,6 & & & $80 \mathrm{cc}$ & \\
\hline $\begin{array}{c}\text { p-DIOXANOt } \\
\text { 123-91-1 } \\
\end{array}$ & líquido incoloro & 101,0 & 11,8 & 88,10 & misc & 1,0337 & 3,03 & 4,1 & $\begin{array}{l}2,0 \mathrm{li} \\
22 \mathrm{ls}\end{array}$ & 12 & 180 \\
\hline $\begin{array}{l}\text { ETILHEXALDEHIDO } \\
123.05-7\end{array}$ & líquido incoloro & 163 & .76 & 128,22 & insol & 0,8540 & 4,4 & 0,2 & $\begin{array}{l}0,85 \\
@ 93{ }^{\circ} \mathrm{C}, \mathrm{li} \\
7,2 \\
@ 135 \stackrel{\circ}{\circ} \mathrm{Cls}\end{array}$ & $50-52$ & $\begin{array}{l}190 \\
210\end{array}$ \\
\hline $\begin{array}{l}\text { FORMALDEHIDO } \\
50.00 .0\end{array}$ & $\begin{array}{l}\text { gas o líquido } \\
\text { transparente, acuoso } \\
\text { blanco, muy } \\
\text { ligeramente ácido; la } \\
\text { solución de } \\
\text { formaldehído es un } \\
\text { líquido transparente, } \\
\text { incoloro o casi } \\
\text { incoloro }\end{array}$ & $-19,5$ & .92 & 30,03 & sol & 0,8 & 1,08 & & $\begin{array}{l}7,0 \mathrm{li} \\
73 \mathrm{ls}\end{array}$ & $\begin{array}{l}\text { gas } \\
\text { inflama } \\
\text { ble }\end{array}$ & 300 \\
\hline $\begin{array}{l}\text { GLICIDALDEHIDO } \\
765-34-4\end{array}$ & líquido incoloro & $112-113$ & .62 & 72,1 & misc & 1,1403 & 2,58 & $\begin{array}{l}27 \mathrm{~mm} \mathrm{Hg} \\
@ 25 \stackrel{\circ}{C} \mathrm{C}\end{array}$ & & & \\
\hline $\begin{array}{l}\text { GLUTARALDEHIDO } \\
111-30-8\end{array}$ & líquido incoloro & $187-189$ & -14 & 100,13 & sol & 0,72 & 3,4 & $17 \mathrm{~mm} \mathrm{Hg}$ & & & \\
\hline $\begin{array}{l}\text { HIDRATO DE CLORAL } \\
302-17 \cdot 0\end{array}$ & $\begin{array}{l}\text { cristales } \\
\text { transparentes e } \\
\text { incoloros; placas } \\
\text { anchas monoclínicas; } \\
\text { cristales incoloros o } \\
\text { blancos }\end{array}$ & $\begin{array}{l}96,3^{\circ} \mathrm{C} @ \\
764 \mathrm{~mm} \mathrm{Hg} \\
\text { (descomp) }\end{array}$ & $57^{\circ} \mathrm{C}$ & 165,42 & $\begin{array}{l}14,3 \mathrm{~g} / \mathrm{ml} \text { agua } \\
\text { a } 40^{\circ} \mathrm{C}\end{array}$ & $\begin{array}{l}1,908 @ \\
20^{\circ} \mathrm{C} / 4^{\circ} \mathrm{C}\end{array}$ & & & & & \\
\hline $\begin{array}{l}\text { 3-HIDROXIBUTIRALDEHIDO } \\
\text { 107-89-1 }\end{array}$ & $\begin{array}{l}\text { líquido meloso } \\
\text { transparente, blanco } \\
0 \text { amarillo; líquido } \\
\text { espeso incoloro }\end{array}$ & 83 & & 88,10 & misc & 1,103 & 3,00 & $21 \mathrm{~mm} \mathrm{Hg}$ & & & \\
\hline $\begin{array}{l}\text { ISOBUTILALDEHIDO } \\
78-84-2\end{array}$ & $\begin{array}{l}\text { líquido incoloro y } \\
\text { transparente }\end{array}$ & 64,5 & $-65,9$ & 72,10 & sol & 0,7938 & 2,48 & $\begin{array}{l}173 \mathrm{~mm} \mathrm{Hg} \\
@ 25 \stackrel{\mathrm{C}}{ }\end{array}$ & $\begin{array}{l}1,6 \mathrm{li} \\
10,6 \mathrm{ls}\end{array}$ & & 196 \\
\hline $\begin{array}{l}\text { METALDEHIDO } \\
108-62-3 \\
\end{array}$ & & 110 & 47 & 176,21 & & & & & & & \\
\hline $\begin{array}{l}\text { METILAL } \\
109-87-5\end{array}$ & $\begin{array}{l}\text { líquido incoloro y } \\
\text { transparente }\end{array}$ & 42 & -105 & 76,09 & sol & 0,8593 & 2,6 & 44 & $\begin{array}{l}1,6 \mathrm{li} \\
17,6 \mathrm{ls}\end{array}$ & $-18 \mathrm{ca}$ & 237 \\
\hline $\begin{array}{l}\text { 4-MORFOLINCARBOXIALDEHIDO } \\
\text { 4394-85-8 }\end{array}$ & & 236,5 & & 115,13 & & & & & & & \\
\hline $\begin{array}{l}\text { PARAFORMALDEHIDO } \\
30525-89-4\end{array}$ & $\begin{array}{l}\text { polvo blanco } \\
\text { cristalino; polvo } \\
\text { blanco amorfo }\end{array}$ & & $155-170$ & $\begin{array}{l}\text { polímero } \\
\text { variable }\end{array}$ & lig sol & $\begin{array}{l}1,46 @ 15 \text { @ C } \\
\text { (sólido) }\end{array}$ & & $\begin{array}{l}<0,2 \\
@ 25 \stackrel{\circ}{-C}\end{array}$ & $\begin{array}{l}7,0 \mathrm{li} \\
73,0 \mathrm{ls}\end{array}$ & $71 \mathrm{cc}$ & 300 \\
\hline $\begin{array}{c}\text { PARALDEHIDO } \\
123.63 .7\end{array}$ & $\begin{array}{l}\text { líquido incoloro } \\
\text { transparente }\end{array}$ & 124 & 12,6 & 132,16 & lig sol & 0,9943 & 4,5 & $\begin{array}{l}25,3 \mathrm{~mm} \\
\mathrm{Hg}\end{array}$ & $\begin{array}{l}1,3 \text { li } \\
? \text { ls }\end{array}$ & & \\
\hline
\end{tabular}


Tabla 104.16 - Propiedades físicas y químicas.

\begin{tabular}{|c|c|c|c|c|c|c|c|c|c|c|c|}
\hline $\begin{array}{l}\text { Denominación química } \\
\mathrm{N} \text { úmero CAS }\end{array}$ & Color/ Forma & $\begin{array}{l}\text { p.e. } \\
(\stackrel{0}{ } \mathrm{C})\end{array}$ & $\begin{array}{l}\text { p.f. } \\
(\underline{O C})\end{array}$ & $\begin{array}{l}\text { p.m.l } \\
\text { (g/ } \\
\text { mol) }\end{array}$ & $\begin{array}{l}\text { Solubilidad } \\
\text { en agua }\end{array}$ & $\begin{array}{l}\text { Densidad } \\
\text { relativa } \\
\text { (agua }=1 \text { ) }\end{array}$ & $\begin{array}{l}\text { Densidad } \\
\text { de vapor } \\
\text { relativa } \\
\text { (aire=1) }\end{array}$ & $\begin{array}{l}\text { Pvap/ } \\
(\mathrm{kPa})\end{array}$ & $\begin{array}{l}\text { Límit. } \\
\text { inflam. }\end{array}$ & $\begin{array}{l}\text { p.ig. } \\
(\underline{O} C)\end{array}$ & $\begin{array}{l}\text { p.aut } \\
\text { ig. } \\
(\stackrel{\circ}{ } \text { C })\end{array}$ \\
\hline $\begin{array}{l}\text { PROPANAL } \\
123-38-6 \\
\end{array}$ & líquido incoloro & 49 & -81 & 58,08 & sol & $\begin{array}{l}0,8071 \\
@ 25 \stackrel{\circ}{-} \mathrm{C}\end{array}$ & 2,0 & 31,3 & $\begin{array}{l}2,6 \mathrm{li} \\
16,1 \mathrm{Is}\end{array}$ & -30 & 207 \\
\hline $\begin{array}{l}\text { SAFROL } \\
94-59-7\end{array}$ & $\begin{array}{l}\text { aceite incoloro } \\
\text { amarillo claro; } \\
\text { cristales monoclínicos }\end{array}$ & 234,5 & 11,2 & 162,18 & insol & 1,1 & & $\begin{array}{l}1 \mathrm{~mm} \mathrm{Hg} \\
@ 63,8 \stackrel{\circ}{\mathrm{C}}\end{array}$ & & 97 & \\
\hline $\begin{array}{l}\text { TRIOXANO } \\
\quad 110-88-3\end{array}$ & $\begin{array}{l}\text { sólido cristalino; } \\
\text { agujas rómbicas en } \\
\text { éter; blanco }\end{array}$ & 114,5 & 64 & 90,08 & muy sol & $1,17 @ 650 \mathrm{C}$ & & & & 45 & \\
\hline $\begin{array}{l}\text { VALERALDEHIDO } \\
110-62.3\end{array}$ & líquido incoloro & 103 & $.91,5$ & 86,13 & lig sol & 0,8095 & 3,0 & $\begin{array}{l}50 \mathrm{~mm} \mathrm{Hg} \\
\text { @ } 25 \stackrel{\circ}{\mathrm{C}}\end{array}$ & & & \\
\hline
\end{tabular}




\section{MATERIALES ALCALINOS}

\section{David L. H inkamp}

Este artículo trata sobre el amoniaco, el sodio, el potasio, el calcio, el litio y sus compuestos. Con la excepción del amoniaco, son los metales alcalinos y alcalinotérreos más comunes.

\section{Usos}

El amoniaco es una fuente importante de varios compuestos nitrogenados. Se utilizan grandes cantidades de amoniaco en la producción de sulfato y nitrato amónicos, que son productos utilizados como fertilizantes. También se utiliza para la oxidación a ácido nítrico, la producción de urea sintética y sosa, y la preparación de soluciones acuosas utilizadas en la industria química y farmacéutica. Asimismo, se emplea en la industria de los explosivos, en medicina, en agricultura, en refrigeración para obtener temperaturas por debajo del punto de congelación y en la fabricación de hielo artificial.

El hidróxido amónico se utiliza en la industria textil, del caucho, farmacéutica, cerámica, fotográfica y alimentaria, así como en la fabricación de detergentes y en la extracción de metales como el cobre, el níquel y el molibdeno a partir de sus minerales. El hidróxido amónico es útil para decolorar y eliminar manchas. Es un agente limpiador de uso doméstico y un disolvente de la caseína en la industria papelera. El fosfato diamónico se utiliza en tejidos ignífugos y en productos de papel y madera. Se encuentra en los fertilizantes y en los fundentes para soldar metales. EI cloruro amónico se utiliza en los fundentes para el recubrimiento de láminas de acero con zinc, en explosivos de seguridad, en medicina y en el cemento para tuberías de hierro. Además, se utiliza en el estañado, el teñido, la galvanoplastia y el curtido.

El calcio constituye el quinto elemento de la naturaleza en orden de abundancia y el tercero entre los metales. En la naturaleza se encuentra ampliamente distribuido en forma de carbonato cálcico (caliza y mármol), sulfato cál cico (yeso), fluoruro cálcico (fluorita) y fosfato cálcico (apatita). L os minerales de calcio se encuentran en canteras o en minas. El calcio metálico se obtiene mediante la electrolisis del fluoruro o cloruro cálcico fundido. El calcio metálico se utiliza en la producción de uranio y torio y en la industria electrónica. Además, se emplea como desoxidante para el cobre, el berilio y el acero, como endurecedor en la producción de plomo y como catalizador industrial para fibras de poliéster.

El cloruro cálcico se obtiene como subproducto durante el proceso Solvay de producción de sosa amoniacal. Se usa como descongelante de pavimentos, como refrigerante y como agente secante en los sistemas de aire acondicionado. Asimismo, se emplea en la producción de cloruro de bario, calcio metálico y diferentes colorantes, para evitar la formación de polvo durante la construcción de carreteras, como agente acelerador del tiempo de fraguado del hormigón y para inhibir la combustión espontánea del carbón en las minas. EI nitrato cálcico se utiliza como fertilizante en agricultura y como agente oxidante en la fabricación de cerillas. También se emplea en la industria pirotécnica y en la fabricación de explosivos. El sulfito cálcico se utiliza como agente reductor en la producción de celulosa. El carburo cálcico se emplea en la producción industrial de acetileno, en la fabricación de cianamida cálcica, en la industria pirotécnica, en los generadores de acetileno de las lámparas de acetileno y en la soldadura y corte al oxiacetileno.

Cal es el término general con el que se denomina a los productos de la caliza, por ejemplo, el óxido y el hidróxido cálcicos.
El óxido cálcico se utiliza como material refractario, como fundente en la fabricación del acero, como agente aglutinante en la industria de la construcción y como materia prima para obtener el blanqueador hipoclorito cálcico. T ambién se emplea en la industria papelera, en el refinado del azúcar, en agricultura y en el curtido de la piel. EI hidróxido cálcico se utiliza en construcción y en ingeniería civil para los morteros, argamasas y cementos. Sirve para el tratamiento de suelos, para depilar el cuero y como compuesto contra incendios. Además, se utiliza en los lubricantes y en la industria papelera.

EI litio se utiliza como adsorbente metálico en los tubos de vacío, como componente de las soldaduras y aleaciones de bronce, como refrigerante 0 intercambiador de calor en reactores y como catalizador en la fabricación de caucho sintético y lubricantes. T ambién se utiliza en la fabricación de catalizadores para plásticos poliolefínicos, en la industria del metal y la cerámica, en gases especiales y en combustibles para aeronaves y misiles. EI cloruro de litio se utiliza en la producción de aguas minerales, en las soldaduras de aluminio, en la industria pirotécnica y como antidepresivo en medicina. El carbonato de litio se utiliza en la producción de barnices para porcelana y cerámicas eléctricas, en el recubrimiento de electrodos para soldadura al arco, como ingrediente de pinturas, barnices y colorantes luminiscentes $y$, en medicina, como fármaco estabilizador del estado de ánimo y antidepresivo. El hidruro de litio es una fuente de hidrógeno y se utiliza como escudo de protección nuclear.

El potasio se utiliza en la síntesis de compuestos inorgánicos de potasio y en la agricultura como componente de los fertilizantes. El potasio se emplea también en forma de aleación de sodio-potasio para la transferencia térmica en los reactores nucleares y en termómetros de lectura elevada.

EI hidróxido potásico se emplea en la fabricación de jabón líquido, como adsorbente de dióxido de carbono, en el mercerizado del algodón, en la producción de otros compuestos de potasio, en galvanoplastia, en litografía, como mordente para madera, en disolventes de pinturas y barnices y en tintas para impresión.

O tros compuestos de potasio son: bromato potásico, clorato potásico, nitrato potásico, perclorato potásico y permanganato potásico. Estos compuestos se utilizan en pirotecnia, en la industria de alimentos y explosivos y como agentes oxidantes. El clorato potásico es un componente de las cabezas de las cerillas y un agente blanqueador. Se utiliza en los tintes para pieles, algodón y lana, en la industria de los colorantes y en la industria papelera. EI clorato potásico se emplea en la fabricación de explosivos, cerillas, colorantes y en pirotecnia.

El bromato potásico se emplea como acondicionador de pasta, aditivo de alimentos, agente oxidante y en compuestos para el moldeado permanente del cabello. El nitrato potásico se utiliza en pirotecnia, en fundentes, en la fabricación de pólvora y cerillas y en las industrias del vidrio, el tabaco y la cerámica. T ambién se utiliza para la desoxidación de metales, para impregnar mechas de velas, como fertilizante en agricultura y como oxidante en los propulsores sólidos para cohetes. EI perclorato potásico se utiliza en la industria de explosivos, en pirotecnica, en fotografía y para el Ilenado de los airbags de los automóviles. El permanganato potásico se emplea como agente oxidante, como desinfectante, como agente blanqueador en la industria de cuero, metales y textiles, en la limpieza, separación y purificación de metales en minería y como agente de curtido en la industria del cuero.

El sodio se utiliza en la fabricación de compuestos de sodio, en síntesis orgánicas, como agente reductor de metales y como refrigerante en los reactores nucleares. También se encuentra en las 
lámparas de sodio y en los cables eléctricos. El clorato sódico es un agente oxidante en la industria de los colorantes y un agente oxidante y blanqueador en la industria papelera. Se utiliza en el teñido y estampado de tejidos, en el curtido y acabado de las pieles y en el procesado del uranio. También se utiliza como herbicida y como oxidante de combustibles para cohetes, así como en la fabricación de explosivos y cerillas y en la industria farmacéutica.

El hidróxido sódico se utiliza en la producción de rayón, algodón mercerizado, jabón, papel, explosivos y tintes, en la industria química, en la limpieza de metales, en la extracción electrolítica del zinc, en el estañado, en el lavado y en el blanqueado. El fosfato trisódico se emplea en la fabricación de reveladores fotográficos y detergentes, en la industria del papel, para el clarificado del azúcar, para eliminar las incrustaciones de las calderas, como ablandador del agua, en lavandería y para el curtido de pieles. Es también un agente para el tratamiento de aguas y un emulsificante en el proceso de fabricación de quesos. El fosfato disódico se utiliza en fertilizantes, productos farmacéuticos, cerámica y detergentes. En la industria textil, se utiliza en el engrosado de la seda y en el teñido y estampado de tejidos. También se emplea en el tratamiento ignífugo de la madera y el papel, como aditivo alimentario y como agente de curtido. El hipoclorito sódico es un blanqueador utilizado en los hogares, en las lavanderías y en las industrias papelera y textil. Se emplea como desinfectante para vidrio, cerámica y agua, y en las piscinas. El cloruro sódico se emplea en metalistería, en el curado del cuero, como anticongelante en las carreteras y como conservante alimentario. T ambién se emplea en fotografía, en cerámica, en la industria química, en la fabricación de jabón y en los reactores nucleares.

Las sales del ácido carbónico $\left(\mathrm{H}_{2} \mathrm{CO}_{3}\right) 0$ carbonatos se encuentran ampliamente distribuidas en la naturaleza en forma de minerales. Se utilizan en la construcción de edificios, en la fabricación de vidrio, en las industrias cerámica y química, así como en agricultura. El bicarbonato amónico se utiliza en la fabricación de plásticos, cerámica y colorantes, en la industria textil, como agente de espumado para la goma-espuma, como levadura en panadería, como fertilizante y como agente extintor de incendios. EI carbonato cálcico se utiliza principalmente como pigmento y en las industrias de pinturas, caucho, plásticos, papel, cosméticos, cerillas y lápices. También se emplea en la fabricación de cemento Portland, alimentos, barnices, cerámica, tintas e insecticidas. EI carbonato sódico se usa ampliamente en la fabricación de vidrio, sosa cáustica, bicarbonato sódico, aluminio, detergentes, sales y pinturas, así como para la desulfuración del hierro y el refino del petróleo. El bicarbonato sódico se utiliza en confitería, en la industria farmacéutica, del cuero y del caucho, en la fabricación de bebidas no alcohólicas y en la fabricación de extintores de incendios y aguas minerales. EI carbonato potásico se utiliza ampliamente en los fertilizantes de potasa, en la industria textil para la tinción de la lana, y en las industrias de vidrio, jabón y productos farmacéuticos.

\section{Alcalis}

L os álcalis son sustancias cáusticas que, disueltas en agua, forman soluciones con un pH bastante superior a 7. Entre estos productos tenemos: amoniaco, hidróxido amónico, hidróxido y óxido cálcicos, potasio, hidróxido y carbonato potásicos, sodio, carbonato, hidróxido, peróxido y silicatos sódicos y fosfato trisódico.

\section{Riesgos para la salud}

En general, los álcalis, ya sea en estado sólido o en soluciones concentradas, son más destructivos para los tejidos que la mayoría de los ácidos. Los polvos, nieblas o rocíos de cáusticos pueden producir irritación de los ojos y del aparato respiratorio, así como lesiones del tabique nasal. Los álcalis fuertes se combinan con los tejidos para formar albuminatos y con las grasas naturales para formar jabones. Gelatinizan los tejidos formando compuestos solubles que pueden producir destrucciones profundas y dolorosas. Los hidróxidos potásico y sódico son los dos productos más activos de este grupo. Incluso las soluciones diluidas de álcalis fuertes tienden a ablandar la epidermis y a emulsificar o disolver la grasa cutánea. Las exposiciones iniciales a atmósferas ligeramente contaminadas con álcalis pueden ser irritantes, pero esta irritación pronto deja de percibirse. C on frecuencia, las personas que trabajan en este tipo de atmósferas no muestran ninguna alteración, mientras que cuando se trata de individuos no habituados, la misma exposición puede producir tos, dolor de garganta e irritación nasal. El riesgo principal asociado con estos productos es la contaminación ocular por sal picaduras de soluciones o partículas.

H idróxido potásico e hidróxido sódico. Estos compuestos son muy peligrosos para los ojos, tanto en forma líquida como sólida. Como álcalis fuertes que son, destruyen los tejidos y producen graves quemaduras de tipo químico. La inhalación de polvos 0 nieblas de estos productos puede provocar graves lesiones a lo largo de todo el aparato respiratorio y la ingestión produce graves lesiones digestivas. Aunque no son inflamables ni combustibles, producen una gran cantidad de calor cuando el producto sólido se pone en contacto con agua. Por este motivo, siempre que se quiera hacer una solución tendrá que utilizarse agua fría, puesto que la solución puede hervir y salpicar el líquido corrosivo en una amplia zona.

Carbonatos y bicarbonatos. L os carbonatos más importantes son: el carbonato cálcico $\left(\mathrm{CaCO}_{3}\right)$, la magnesita $\left(\mathrm{M} \mathrm{gCO}_{3}\right)$, el carbonato sódico $\left(\mathrm{NaCO}_{3}\right)$, el bicarbonato sódico $\left(\mathrm{NaHCO}_{3}\right)$ y la potasa $\left(\mathrm{K}_{2} \mathrm{CO}_{3}\right)$. L os carbonatos normales (que contienen el anión $\mathrm{CO}_{3}$ ) y los carbonatos ácidos o bicarbonatos (que contienen el anión $\mathrm{HCO}_{3}$ ) son los compuestos más importantes. Todos los bicarbonatos son solubles en agua; de los carbonatos normales, sólo son solubles las sales de alcalimetales. Los carbonatos anhidros se descomponen cuando se calientan, antes de alcanzar el punto de fusión. Las soluciones de carbonatos producen reacciones alcalinas debido a la considerable hidrólisis que tiene lugar. Los bicarbonatos, al calentarse, se convierten en carbonatos normales:

$$
2 \mathrm{NaHCO}_{3}=\mathrm{Na}_{2} \mathrm{CO}_{3}+\mathrm{H}_{2} \mathrm{O}+\mathrm{CO}_{2}
$$

Los carbonatos normales se descomponen cuando entran en contacto con ácidos fuertes $\left(\mathrm{H}_{2} \mathrm{SO}_{4}, \mathrm{HCl}\right)$, liberando $\mathrm{CO}_{2}$.

Los carbonatos de sodio se presentan en las siguientes formas: sosa-carbonato sódico anhidro $\left(\mathrm{Na}_{2} \mathrm{CO}_{3}\right)$; sosa cristalizada-bicarbonato sódico $\left(\mathrm{NaHCO}_{3}\right)$ y carbonato sódico decahidrato $\left(\mathrm{Na}_{2} \mathrm{CO}_{3} \cdot 10 \mathrm{H}_{2} \mathrm{O}\right)$.

Los carbonatos alcalinos pueden causar una intensa irritación de la piel, la conjuntiva y las vías respiratorias altas durante el curso de diferentes procesos industriales (manipulación y almacenamiento o procesado). Los trabajadores que cargan y descargan sacos que contienen carbonatos pueden presentar en brazos y piernas zonas de piel necróticas del tamaño de una cereza. En ocasiones, después de desprenderse las costras marrones-negruzcas, se aprecian lesiones ulcerosas profundas. El contacto prolongado con soluciones de sosa puede causar eczema, dermatitis y ulceraciones.

Calcio y sus compuestos. El calcio es un constituyente esencial bien conocido del cuerpo humano y su metabolismo, solo o asociado con el fósforo, ha sido ampliamente estudiado, en especial como constituyente del sistema óseo y de las membranas celulares. Diversas condiciones pueden producir la pérdida de calcio, como 
la inmovilización, los trastornos digestivos, el descenso de la temperatura, la ingravidez en los vuelos espaciales, etc. La absorción del calcio presente en el ambiente de trabajo por inhalación de polvo de sus compuestos no aumenta significativamente el calcio que se ingiere con los vegetales y otros alimentos (normalmente más de $0,5 \mathrm{~g}$ ). Por otra parte, el calcio metálico posee propiedades alcalinas y reacciona con la humedad, produciendo quemaduras oculares y cutáneas. Expuesto al aire entraña un cierto riesgo de explosión.

Carburo cálcico. El carburo cálcico ejerce un fuerte efecto irritante debido a la formación de hidróxido cálcico por contacto con la humedad del aire o el sudor. El carburo seco, en contacto con la piel, produce dermatitis. En contacto con la piel húmeda y las mucosas, produce úlceras y cicatrices. Es especialmente peligroso para los ojos. C on frecuencia se ha observado un tipo peculiar de melanoderma con gran hiperpigmentación y numerosas telangiectasias. También son frecuentes las quemaduras producidas por el carburo cálcico caliente. Los tejidos se afectan hasta una profundidad de 1 a $5 \mathrm{~mm}$; las quemaduras evolucionan muy lentamente, son difíciles de tratar y con frecuencia requieren la escisión del tejido. Los trabajadores afectados sólo pueden volver al trabajo cuando la superficie de piel quemada está completamente cicatrizada. Las personas expuestas al carburo cálcico sufren con frecuencia queilitis, caracterizada por sequedad, hinchazón e hiperemia de los labios, con intensa descamación y formación de profundas fisuras radiales. En las comisuras de los labios se pueden observar lesiones erosivas con una tendencia a la supuración. Los trabajadores con una larga historia profesional suelen presentar lesiones en las uñas, es decir, oniquia y paroniquia de origen profesional. También pueden observarse lesiones oculares con hiperemia pronunciada de los párpados y la conjuntiva, con frecuencia acompañadas de secreciones mucopurulentas. En los casos de exposición más intensa, la sensibilidad de la conjuntiva y la córnea está notablemente reducida. La queratitis y la queratoconjuntivitis aparecen inicialmente sin síntomas, pero posteriormente degeneran en opacidades de la córnea.

En la producción del carburo cálcico, las impurezas pueden representar un riesgo adicional. El carburo cálcico contaminado con fosfato 0 arsenato cálcico, al humedecerse, desprende fosfina o hidruro de arsénico, que son sumamente tóxicos. El propio carburo cálcico, al exponerse al aire húmedo, libera acetileno, que es un compuesto moderadamente narcótico y asfixiante que comporta un considerable riesgo de incendio y explosión.

El cloruro cálcico tiene un poderoso efecto irritante sobre la piel y las mucosas. En los trabajadores encargados del envasado de cloruro cálcico seco, se han descrito casos de irritación acompañada de eritema y descamación de la piel del rostro, lagrimeo, alteraciones oculares, sensación de quemazón y dolor en las cavidades nasales, hemorragias nasales ocasionales y picor de garganta. También se han descrito casos de perforación del tabique nasal.

El nitrato cálcico ejerce una acción irritante y cauterizante sobre la piel y las mucosas. Es un potente agente oxidante y comporta un riesgo importante de incendio y explosión.

Sulfito cálcico. No se ha descrito ningún caso de intoxicación profesional por sulfito cálcico. La ingestión accidental de unos pocos gramos puede producir vómitos repetidos, diarrea violenta, alteraciones circulatorias y metahemoglobinemia.

\section{Amoniaco}

El amoniaco está presente en pequeñas cantidades en el aire, el agua, la tierra y en especial, en la materia orgánica en descomposición. Es un producto del metabolismo humano, animal y vegetal normal. El esfuerzo muscular y la excitación del sistema nervioso produce un aumento de la formación de amoniaco, cuya acumulación en los tejidos puede producir intoxicación. La formación endógena de amoniaco también aumenta durante el curso de muchas enfermedades. A través de los procesos vitales es combinado y excretado por el organismo, sobre todo en forma de sulfato amónico y urea. El amoniaco tiene también una gran importancia en el metabolismo del nitrógeno en las plantas.

EI amoniaco es ligeramente reactivo y oxidable, permitiendo fácilmente la sustitución (de los átomos de hidrógeno) y otras reacciones. Arde en presencia de aire o hidrógeno, formando nitrógeno. Un ejemplo de sustitución sería la formación de amidas de metales alcalinos o alcalinotérreos. En reacciones de adición, forma formas amoniacales (por ejemplo, $\mathrm{CaCl}_{2} \cdot 8 \mathrm{~N} \mathrm{H}_{3}$, $\mathrm{AgClNH}{ }_{3}$ ) y otros compuestos. Al disolverse en agua forma hidróxido amónico $\left(\mathrm{NH}_{4} \mathrm{OH}\right)$, que es una base débil que se disocia de la siguiente forma:

$$
\mathrm{NH}_{4} \mathrm{OH} \rightarrow \mathrm{NH}_{4}^{+}+\mathrm{OH}^{-}
$$

El radical $\mathrm{NH}_{4}{ }^{+}$no existe en forma libre, ya que se descompone en amoniaco e hidrógeno cuando se intenta aislar.

La intoxicación por amoniaco puede tener lugar durante su producción y también durante la producción de ácido nítrico, nitrato y sulfato amónicos, fertilizantes, urea y sosa, así como en refrigeración, fábricas de hielo, talleres de estampación de algodón, tintado de fibras, galvanoplastia, síntesis orgánicas, termotratamiento de metales (nitruración), laboratorios químicos y muchos otros procesos. El amoniaco se produce y emite también durante el procesado del guano, en la purificación de residuos, en las refinerías de azúcar y en las tenerías. T ambién se encuentra en el acetileno no purificado.

La intoxicación industrial es generalmente aguda, si bien, aunque menos común, también puede producirse de una forma crónica. Los efectos irritantes del amoniaco afectan especialmente a las vías respiratorias altas y, cuando se encuentra en concentraciones elevadas, afecta al sistema nervioso central, produciendo espasmos. La irritación del tracto respiratorio superior se produce con concentraciones superiores a $100 \mathrm{mg} / \mathrm{m}^{3}$, y la concentración máxima tolerable en 1 hora oscila entre 210 y $350 \mathrm{mg} / \mathrm{m}^{3}$. Las salpicaduras de agua amoniacal en los ojos son especialmente peligrosas. La rápida penetración del amoniaco en el tejido ocular puede ocasionar perforación de la córnea e incluso la destrucción del globo ocular. En cada sección de una fábrica de amoniaco existen riesgos específicos. En las secciones donde el gas se produce, se convierte (oxidación de $\mathrm{CO}$ a $\mathrm{CO}_{2}$ ), se comprime y se purifica, el problema principal es la emisión de monóxido de carbono y de sulfuro de hidrógeno. Durante la síntesis pueden desprenderse cantidades considerables de amoniaco. Las emisiones a la atmósfera pueden alcanzar límites explosivos.

\section{Cloratos y percloratos}

L os cloratos y percloratos son las sales del ácido clórico $\left(\mathrm{HClO}_{3}\right)$ y perclórico $\left(\mathrm{HClO}_{4}\right)$. Favorecen la combustión y sus principales riesgos se derivan de esta propiedad. Las sales potásicas y sódicas son las más comunes de este grupo y las más utilizadas en la industria.

R iesgo de incendio y explosión. Los cloratos son oxidantes potentes y sus principales riesgos son de incendio y explosión. A pesar de que no son explosivos en sí mismos, forman mezclas inflamables o explosivas con materia orgánica, azufre, sulfuros, metales en polvo y compuestos de amonio. La tela, el cuero, la madera y el papel son extremadamente inflamables cuando están impregnados con estos cloratos. 
Los percloratos también son oxidantes muy fuertes. Las sales de metales pesados y ácido perclórico son explosivas.

$R$ iesgos para la salud. Los cloratos son nocivos si se absorben por ingestión o por inhalación del polvo, pudiendo provocar dolor de garganta, tos, metahemoglobinemia con cianosis, mareo y desvanecimiento, y anemia. En caso de una absorción importante de clorato sódico, se observa un aumento del contenido sérico de sodio.

Los percloratos pueden penetrar en el organismo por inhalación, en forma de polvo o por ingestión. I rritan la piel, los ojos y las mucosas. Producen anemia hemolítica con metahemoglobinemia, cuerpos de H einz en los hematíes y lesiones hepáticas y renales. 
TABLAS DE MATERIALES ALCAUNOS

\begin{tabular}{|c|c|c|c|}
\hline Producto químico & Sinónimos/ Código UN & $\mathrm{N}$ úmero $\mathrm{CAS}$ & Fórmula química \\
\hline ACIDO CARBONICO, SAL CALCICA & Carbonato cálcico (1:1); monocarbonato cálcico & 471-34-1 & $\mathrm{CaCO}_{3}$ \\
\hline ACIDO PERCLORICO, SAL POTASICA & $\begin{array}{l}\text { Hipercloruro potásico; perclorato potásico } \\
\text { UN1489 }\end{array}$ & $7778-74-7$ & $\mathrm{KO}_{4} \mathrm{Cl}$ \\
\hline ACIDO PERCLORICO, SAL SODICA & $\begin{array}{l}\text { Perclorato sódico } \\
\text { UN1502 }\end{array}$ & $7601-89-0$ & $\mathrm{NaO}_{4} \mathrm{Cl}$ \\
\hline AMONIACO & $\begin{array}{l}\text { Amoniaco anhidro } \\
\text { UN1005 }\end{array}$ & $7664-41-7$ & $\mathrm{NH}_{3}$ \\
\hline BICARBONATO AMONICO & $\begin{array}{l}\text { Carbonato amónico; carbonato ácido de amonio; sal monoamónica del } \\
\text { ácido carbónico; carbonato monoamónico }\end{array}$ & $1066-33-7$ & $\left(\mathrm{NH}_{4}\right)_{2} \mathrm{CO}_{3}$ \\
\hline BICARBONATO SODICO & $\begin{array}{l}\text { Sosa cocida; carbonato monosódico; carbonato ácido de sodio; carbonato } \\
\text { hidrosódico }\end{array}$ & $144-55-8$ & $\mathrm{NaHCO}_{3}$ \\
\hline BROMATO CALCICO & & $10102 \cdot 75 \cdot 7$ & $\mathrm{CaBrO}_{3}$ \\
\hline BROMATO POTASICO & UN1484 & $7758-01-2$ & $\mathrm{KBrO}_{3}$ \\
\hline BROMATO SODICO & $\begin{array}{l}\text { Sal sódica del ácido brómico } \\
\text { UN1494 }\end{array}$ & $7789-38-0$ & $\mathrm{NaBrO}_{3}$ \\
\hline BROMURO POTASICO & Sal de bromo del potasio; Tribromuro tripotásico & $7758-02-3$ & $\mathrm{KBr}$ \\
\hline CALCIO & $\begin{array}{l}\text { Calcicat } \\
\text { UN1401 }\end{array}$ & $7440-70-2$ & $\mathrm{Ca}$ \\
\hline CARBONATO CALCICO & Domolita; caliza, mármol, piedra de Portland & $1317-65-3$ & $\mathrm{CaCO}_{3}$ \\
\hline CARBONATO DE LITIO & $\begin{array}{l}\text { Sal dilítica del ácido carbónico; sal de litio del ácido carbónico; } \\
\text { carbonato dilítico }\end{array}$ & $554-13-2$ & $\mathrm{Li}_{2}\left(\mathrm{CO}_{3}\right)$ \\
\hline CARBONATO POTASICO & Sal dipotásica del ácido carbónico; K-gran; ceniza en perlas; potasa & $584-08-7$ & $\mathrm{~K}_{2}\left(\mathrm{CO}_{3}\right)$ \\
\hline CARBONATO SODICO & $\begin{array}{l}\text { Carbonato de Crystol; carbonato disódico; lejía de sosa; sosa de Solvay; } \\
\text { Trona }\end{array}$ & $497-19-8$ & $\mathrm{Na}_{2} \mathrm{CO}_{3}$ \\
\hline CARBURO CALCICO & $\begin{array}{l}\text { Acetilenógeno; acetiluro cálcico; dicarburo cálico } \\
\text { UN1402 }\end{array}$ & $75-20-7$ & $\mathrm{CaC}_{2}$ \\
\hline CLORATO CALCICO & $\begin{array}{l}\text { Sal cálcica del ácido clórico } \\
\text { UN1452 } \\
\text { UN2429 }\end{array}$ & $10137-74-3$ & $\mathrm{Ca}\left(\mathrm{CO}_{3}\right)_{2}$ \\
\hline CLORATO POTASICO & $\begin{array}{l}\text { Clorato potásico } \\
\text { UN1485 } \\
\text { UN2427 }\end{array}$ & $3811-04-9$ & $\mathrm{KO}_{3} \mathrm{Cl}$ \\
\hline CLORATO SODICO & $\begin{array}{l}\text { Sal sódica del ácido clórico; sosa clorada } \\
\text { UN1495 } \\
\text { UN2428 }\end{array}$ & $7775-09-9$ & $\mathrm{NaO}_{3} \mathrm{Cl}$ \\
\hline CLORITO SODICO & $\begin{array}{l}\text { UN1496 } \\
\text { UN1908 }\end{array}$ & $7758-19-2$ & $\mathrm{ClO}_{2} \mathrm{Na}$ \\
\hline CLORURO AM ONICO & Salmiac & $12125-02-9$ & $\mathrm{NH}_{4} \mathrm{Cl}$ \\
\hline CLORURO CALCICO & & $10043-52-4$ & $\mathrm{CaCl}_{2}$ \\
\hline CLORURO DE LITIO & & 7447-41-8 & LiCl \\
\hline CLORURO DE TETRAMETILAM ONIO & & $75-57-0$ & $\mathrm{~N}\left(\mathrm{CH}_{3}\right)_{4} \mathrm{Cl}$ \\
\hline CLORURO SODICO & Sal común; sal marina; sal de mesa & $7647-14-5$ & $\mathrm{NaCl}$ \\
\hline ETILATO SODICO & Etóxido sódico; sal sódica de etanol; & 141.52 .6 & $\mathrm{NaOC}_{2} \mathrm{H}_{5}$ \\
\hline
\end{tabular}




\begin{tabular}{|c|c|c|c|}
\hline Producto químico & Sinónimos/ Código UN & $\mathrm{N}$ úmero CAS & Fórmula química \\
\hline FLUORURO AMONICO & $\begin{array}{l}\text { Fluoruro amónico } \\
\text { UN2505 }\end{array}$ & $12125-01-8$ & $\mathrm{NH}_{4} \mathrm{~F}$ \\
\hline FLUORURO POTASICO & UN1812 & $7789-23-3$ & $\mathrm{KF}$ \\
\hline FOSFATO SODICO & Fosfato sódico tribásico; ortofosfato trisódico; fosfato trisódico & $7601-54-9$ & $\mathrm{Na}_{3} \mathrm{PO}_{4}$ \\
\hline FOSFATO SODICO DIBASICO & $\begin{array}{l}\text { Fosfato disódico; ortofosfato disódico; sal disódica del ácido } \\
\text { ortofosfórico }\end{array}$ & $7558-79-4$ & $\mathrm{Na}_{2} \mathrm{HPO}_{4}$ \\
\hline HIDROXIDO AMONICO & $\begin{array}{l}\text { UN2073 } \\
\text { UN2672 }\end{array}$ & $1336-21-6$ & $\mathrm{NH}_{4} \mathrm{OH}$ \\
\hline HIDROXIDO CALCICO & Dihidróxido cálcico; hidrato cálcico; cal hidratada & $1305-62-0$ & $\mathrm{Ca}(\mathrm{OH})_{2}$ \\
\hline HIDROXIDO DE LITIO & $\begin{array}{l}\text { UN2679 } \\
\text { UN2680 }\end{array}$ & $1310-65-2$ & $\mathrm{LiOH}$ \\
\hline HIDROXIDO DE LITIO MONOHIDRATO & & $1310-66-3$ & $\mathrm{LiOH} \cdot \mathrm{H}_{2} \mathrm{O}$ \\
\hline HIDROXIDO POTASICO & $\begin{array}{l}\text { Potasa cáustica; hidrato potásico } \\
\text { UN1813 } \\
\text { UN1814 }\end{array}$ & $1310-58-3$ & $\mathrm{KOH}$ \\
\hline HIDROXIDO SODICO & $\begin{array}{l}\text { Sosa cáustica; hidrato de sodio; líquido cáustico } \\
\text { UN1823 } \\
\text { UN1824 }\end{array}$ & $1310-73-2$ & $\mathrm{NaOH}$ \\
\hline HIDRURO CALCICO & & $7789-78-8$ & $\mathrm{CaH}$ \\
\hline HIDRURO DE LITIO & $\begin{array}{l}\text { UN1414 } \\
\text { UN2805 } \\
\end{array}$ & $7580-67-8$ & LiH \\
\hline HIPOCLORITO SODICO & $\begin{array}{l}\text { Sal sódica del ácido hipocloroso } \\
\text { UN1791 }\end{array}$ & $7681-52-9$ & $\mathrm{NaOCl}$ \\
\hline LITIO & UN1415 & $7439-93-2$ & Li \\
\hline METILATO SODICO & $\begin{array}{l}\text { Metóxido sódico; sal sódica de metanol } \\
\text { UN1431 } \\
\text { UN1289 }\end{array}$ & $124-41-4$ & $\mathrm{NaOCH}_{3}$ \\
\hline NITRATO AMONICO & $\begin{array}{l}\text { Sal amónica del ácido nítrico } \\
\text { UN0222 } \\
\text { UN1942 } \\
\text { UN2426 }\end{array}$ & $6484-52-2$ & $\mathrm{HNO}_{3} \mathrm{NH}_{3}$ \\
\hline NITRATO CALCICO & $\begin{array}{l}\text { Dinitrato cálcico; salitre cálico } \\
\text { UN1454 }\end{array}$ & $10124-37-5$ & $\left(\mathrm{NO}_{3}\right)_{2} \mathrm{Ca}$ \\
\hline NITRATO POTASICO & $\begin{array}{l}\text { Sal potásica del ácido nítrico; salitre } \\
\text { UN1486 }\end{array}$ & $7757-79-1$ & $\mathrm{KNO}_{3}$ \\
\hline NITRATO SODICO & $\begin{array}{l}\text { Sal sódica del ácido nítrico; salitre sódico } \\
\text { UN1498 }\end{array}$ & $7631.99-4$ & $\mathrm{NaNO}_{3}$ \\
\hline NITRITO CALCICO & & $13780-06-8$ & $\mathrm{Ca}\left(\mathrm{NO}_{2}\right)_{2}$ \\
\hline NITRITO POTASICO & $\begin{array}{l}\text { Sal potásica del ácido nitroso } \\
\text { UN1488 }\end{array}$ & $7758-09-0$ & $\mathrm{KNO}_{2}$ \\
\hline NITRITO SODICO & $\begin{array}{l}\text { Sal sódica del ácido nitroso } \\
\text { UN1500 }\end{array}$ & $7632-00-0$ & $\mathrm{NaNO}_{2}$ \\
\hline OXIDO CALCICO & $\begin{array}{l}\text { Cal quemada; Calcia; Desical P; } \\
\text { cal; ceniza de cal } \\
\text { UN1910 }\end{array}$ & $1305-78-8$ & $\mathrm{CaO}$ \\
\hline OXIDO POTASICO & & $12136-45-7$ & KO \\
\hline PEROXIDO SODICO & $\begin{array}{l}\text { Dióxido disódico; peróxido disódico; dióxido sódico; oxido sódico }\left(\mathrm{Na}_{2} \mathrm{O}_{2}\right) \\
\text { UN1504 }\end{array}$ & $1313-60-6$ & $\mathrm{Na}_{2} \mathrm{O}_{2}$ \\
\hline
\end{tabular}




\begin{tabular}{|c|c|c|c|}
\hline Producto químico & Sinónimos/ Código UN & $\mathrm{N}$ úmero CAS & Fórmula química \\
\hline PERYODATO POTASICO & & $7790-21-8$ & $\mathrm{KIO}$ \\
\hline POTASIO & $\begin{array}{l}\text { UN1420 } \\
\text { UN2257 }\end{array}$ & $7440-09-7$ & K \\
\hline SODIO & UN1428 & $7440-23-5$ & $\mathrm{Na}$ \\
\hline TRIPOLIFOSFATO SODICO & $\begin{array}{l}\text { Trifosfato pentasódico; sal pentasódica del ácido trifosfórico; } \\
\text { Tripolifosfato pentasódico; fosfato sódico }\end{array}$ & $7758-29-4$ & $\mathrm{Na}_{5} \mathrm{P}_{3} \mathrm{O}_{10}$ \\
\hline YODATO POTASICO & Sal potásica del ácido yódico & $7758-05-6$ & $\mathrm{KIO}_{3}$ \\
\hline YODURO POTASICO & Knollide; Potide & $7681-11-0$ & $\mathrm{KI}$ \\
\hline YODURO SODICO & Yoduro sódico; monoyoduro sódico & $7681-82-5$ & $\mathrm{Nal}$ \\
\hline
\end{tabular}

Tabla 104.18 • Riesgos para la salud.

\begin{tabular}{|c|c|c|c|c|c|c|}
\hline \multirow[b]{2}{*}{$\begin{array}{l}\text { Denominación } \\
\text { química } \\
\mathrm{N} \text { úmero CAS }\end{array}$} & \multicolumn{4}{|c|}{ Tarjetas Internacionales sobre la Seguridad de los Productos Q uímicos } & \multicolumn{2}{|c|}{ N IO SH (EE.UU.) } \\
\hline & $\begin{array}{l}\text { Período } \\
\text { corto de } \\
\text { exposición }\end{array}$ & $\begin{array}{l}\text { Período } \\
\text { largo de } \\
\text { exposición }\end{array}$ & $\begin{array}{l}\text { Vías de } \\
\text { exposición }\end{array}$ & Síntomas & $\begin{array}{l}\text { O rganos } \\
\text { afectados } \\
\text { Vías de } \\
\text { entrada }\end{array}$ & Síntomas \\
\hline $\begin{array}{l}\text { ACIDO CARBONICO, SAL } \\
\text { CALCICA } \\
471-34-1 \\
\end{array}$ & ojos; tract resp & & $\begin{array}{r}\text { Inhalación } \\
\text { Piel } \\
\text { 0jos } \\
\end{array}$ & $\begin{array}{l}\text { Tos } \\
\text { Sequedad de piel } \\
\text { Enrojecimiento }\end{array}$ & & \\
\hline $\begin{array}{l}\text { ACIDO CLORICO, SAL CALCICA } \\
7775-09-9\end{array}$ & $\begin{array}{l}\text { ojos; piel; tract } \\
\text { resp; sangre; } \\
\text { riñones }\end{array}$ & piel & $\begin{array}{r}\text { Inhalación } \\
\text { Piel } \\
\text { Ojos } \\
\text { Ingestión }\end{array}$ & $\begin{array}{l}\text { Tos, dolor de garganta } \\
\text { Enrojecimiento } \\
\text { Enrojecimiento, dolor } \\
\text { Dolor abdominal, labios o uñas cianóticos, piel } \\
\text { cianótica, diarrea, náuseas, disnea, } \\
\text { inconsciencia, vómitos }\end{array}$ & & \\
\hline $\begin{array}{l}\text { ACIDO PERCLORICO, SAL } \\
\text { POTASICA } \\
7778-74-7\end{array}$ & ojos; piel; tract resp & sangre & $\begin{array}{r}\text { Inhalación } \\
\text { Piel } \\
\text { 0jos } \\
\end{array}$ & $\begin{array}{l}\text { Tos, dolor de garganta } \\
\text { Enrojecimiento } \\
\text { Enrojecimiento, dolor }\end{array}$ & & \\
\hline $\begin{array}{l}\text { AMONIACO } \\
7664-41-7\end{array}$ & $\begin{array}{l}\text { ojos; piel; tract } \\
\text { resp; pulmones }\end{array}$ & & $\begin{array}{r}\text { Inhalación } \\
\\
\text { Piel } \\
\text { 0jos } \\
\end{array}$ & $\begin{array}{l}\text { Sensación de quemazón, tos, dificultad } \\
\text { respiratoria, los síntomas pueden tener efectos } \\
\text { retardados } \\
\text { En contacto con el líquido: congelación } \\
\text { Quemaduras profundas graves }\end{array}$ & $\begin{array}{l}\text { Ojos; piel; sis resp } \\
\text { Inh, abs, ing (sol), } \\
\text { con (sol/ liq) }\end{array}$ & $\begin{array}{l}\text { Irrit ojos, nariz, garganta; dis, } \\
\text { bronespas, dolor torácico; } \\
\text { edema pulm; esputo espumoso } \\
\text { rosa; quemaduras en la piel, } \\
\text { vesic; líq: congelación }\end{array}$ \\
\hline $\begin{array}{l}\text { CARBONATO DE LITIO } \\
554-13-2\end{array}$ & $\begin{array}{l}\text { ojos; piel; tract } \\
\text { resp; SNC; SCV; } \\
\text { tracto GI }\end{array}$ & $\begin{array}{l}\text { piel; SNC; SCV; } \\
\text { estómago; riñones; } \\
\text { genes }\end{array}$ & $\begin{array}{r}\text { Inhalación } \\
\text { Piel } \\
\text { Ojos } \\
\text { Ingestión }\end{array}$ & $\begin{array}{l}\text { Sensación de quemazón, tos, dolor de } \\
\text { garganta } \\
\text { Enrojecimiento } \\
\text { Enrojecimiento, dolor } \\
\text { Espasmos abdominales, dolor abdominal, } \\
\text { confusión, diarrea, sopor, náuseas, vómitos }\end{array}$ & & \\
\hline $\begin{array}{l}\text { CARBURO CALCICO } \\
75-20.7\end{array}$ & $\begin{array}{l}\text { ojos; piel; tract } \\
\text { resp; pulmones }\end{array}$ & & $\begin{array}{r}\text { Inhalación } \\
\text { Piel } \\
\text { 0jos } \\
\text { Ingestión }\end{array}$ & $\begin{array}{l}\text { Tos, dificultad respiratoria, disnea, dolor de } \\
\text { garganta } \\
\text { Enrojecimiento, quemaduras en la piel, dolor } \\
\text { Enrojecimiento, dolor, visión borrosa, } \\
\text { quemaduras profundas graves } \\
\text { Espasmos abdominales, sensación de } \\
\text { quemazón }\end{array}$ & & \\
\hline
\end{tabular}


Tabla 104.18 • Riesgos para la salud.

\begin{tabular}{|c|c|c|c|c|c|c|}
\hline \multirow[b]{2}{*}{$\begin{array}{l}\text { Denominación } \\
\text { química } \\
\text { N úmero CAS }\end{array}$} & \multicolumn{4}{|c|}{ Tarjetas Internacionales sobre la Seguridad de los Productos Q uímicos } & \multicolumn{2}{|c|}{ N IO SH (EE.UU.) } \\
\hline & $\begin{array}{l}\text { Período } \\
\text { corto de } \\
\text { exposición }\end{array}$ & $\begin{array}{l}\text { Período } \\
\text { largo de } \\
\text { exposición }\end{array}$ & $\begin{array}{l}\text { Vías de } \\
\text { exposición }\end{array}$ & Síntomas & $\begin{array}{l}\text { O rganos } \\
\text { afectados } \\
\text { Vías de } \\
\text { entrada }\end{array}$ & Síntomas \\
\hline $\begin{array}{l}\text { CLORATO POTASICO } \\
3811-04-9\end{array}$ & $\begin{array}{l}\text { mucosas; tract resp } \\
\text { sup; sangre; } \\
\text { hígado; riñones; } \\
\text { SNC }\end{array}$ & piel & $\begin{array}{l}\text { Inhalación } \\
\text { Piel } \\
\text { 0jos } \\
\text { Ingestión }\end{array}$ & $\begin{array}{l}\text { Labios o uñas cianóticos, anemia, hemorragia } \\
\text { hemolítica, náuseas, disnea, inconsciencia, } \\
\text { vómitos; los síntomas pueden tardar en } \\
\text { aparecer } \\
\text { Enrojecimiento, sensación de quemazón } \\
\text { Enrojecimiento, dolor } \\
\text { Espasmos abdominales, dolor abdominal, } \\
\text { labios o uñas cianóticos, piel cianótica, } \\
\text { diarrea, cefalea, náuseas, disnea, dolor de } \\
\text { garganta, inconsciencia, vómitos, anuria, } \\
\text { colapso, convulsiones }\end{array}$ & & \\
\hline $\begin{array}{l}\text { CLORURO AM ONICO } \\
12125-02-9\end{array}$ & ojos; piel; tract resp & & $\begin{array}{r}\text { Inhalación } \\
\text { Piel } \\
\text { Ojos } \\
\text { Ingestión }\end{array}$ & $\begin{array}{l}\text { Tos } \\
\text { Enrojecimiento } \\
\text { Enrojecimiento } \\
\text { Náuseas, dolor de garganta, vómitos }\end{array}$ & $\begin{array}{l}\text { Ojos, piel, sis resp } \\
\text { Inh, con }\end{array}$ & $\begin{array}{l}\text { Irrit ojos, piel, sis resp; tos, } \\
\text { dis, sens pulm }\end{array}$ \\
\hline $\begin{array}{l}\text { CLORURO DE LITIO } \\
7447-41-8\end{array}$ & ojos; piel; tract resp & $\begin{array}{l}\text { piel; SNC; riñones; } \\
\text { genes }\end{array}$ & $\begin{array}{l}\text { Inhalación } \\
\text { Piel } \\
\text { Ojos }\end{array}$ & $\begin{array}{l}\text { Sensación de quemazón, tos, dolor de } \\
\text { garganta } \\
\text { Enrojecimiento, dolor } \\
\text { Enrojecimiento, dolor, visión borrosa }\end{array}$ & & \\
\hline $\begin{array}{l}\text { HIDROXIDO CALCICO } \\
1305-62.0\end{array}$ & piel; tract resp; ojos & piel & $\begin{array}{r}\text { Inhalación } \\
\text { Piel } \\
\text { Ojos } \\
\text { Ingestión }\end{array}$ & $\begin{array}{l}\text { Sensación de quemazón, tos } \\
\text { Enrojecimiento, aspereza, sensación de } \\
\text { quemazón } \\
\text { Enrojecimiento, dolor, visión borrosa } \\
\text { Espasmos abdominales, sensación de } \\
\text { quemazón, vómitos, debilidad }\end{array}$ & $\begin{array}{l}\text { Ojos, piel, sis resp } \\
\text { Inh, ing, con }\end{array}$ & $\begin{array}{l}\text { Irrit ojos, piel, tract resp sup; } \\
\text { quemaduras en la piel y los } \\
\text { ojos; vesic piel; tos, bron, neu }\end{array}$ \\
\hline $\begin{array}{l}\text { HIDROXIDO DE LITIO } \\
\text { MONOHIDRATO } \\
1310-66-3\end{array}$ & & & $\begin{array}{r}\text { Inhalación } \\
\text { Piel } \\
\text { Ojos } \\
\text { Ingestión }\end{array}$ & $\begin{array}{l}\text { Sensación de quemazón, tos, dificultad } \\
\text { respiratoria, disnea } \\
\text { Enrojecimiento, dolor, ampollas } \\
\text { Enrojecimiento, dolor, quemaduras profundas } \\
\text { graves } \\
\text { Espasmos abdominales, sensación de } \\
\text { quemazón, náuseas, vómitos, debilidad }\end{array}$ & & \\
\hline $\begin{array}{l}\text { HIDROXIDO DE LITIO } \\
\text { 1310-65-2 }\end{array}$ & & & $\begin{array}{r}\text { Inhalación } \\
\text { Piel } \\
\text { Ojos } \\
\text { Ingestión }\end{array}$ & $\begin{array}{l}\text { Sensación de quemazón, tos, dificultad } \\
\text { respiratoria, disnea } \\
\text { Enrojecimiento, dolor, ampollas } \\
\text { Enrojecimiento, dolor, quemaduras profundas } \\
\text { graves } \\
\text { Espasmos abdominales, sensación de } \\
\text { quemazón, náuseas, shock o colapso, vómitos, } \\
\text { debilidad }\end{array}$ & & \\
\hline $\begin{array}{l}\text { HIDROXIDO POTASICO } \\
1310-58-3\end{array}$ & $\begin{array}{l}\text { ojos; piel; tract } \\
\text { resp; pulmones }\end{array}$ & piel & $\begin{array}{r}\text { Inhalación } \\
\text { Piel } \\
\text { Ojos } \\
\text { Ingestión }\end{array}$ & $\begin{array}{l}\text { Corrosivo, sensación de quemazón, tos, } \\
\text { dificultad respiratoria } \\
\text { Corrosivo, enrojecimiento, quemaduras graves } \\
\text { en la piel, dolor } \\
\text { Corrosivo, enrojecimiento, dolor, visión } \\
\text { borrosa, quemaduras profundas graves } \\
\text { Corrosivo, dolor abdominal, sensación de } \\
\text { quemazón, diarrea, vómitos, colapso }\end{array}$ & $\begin{array}{l}\text { Ojos; piel; sis resp } \\
\text { Inh, ing, con }\end{array}$ & $\begin{array}{l}\text { Irrit ojos, piel, sis resp; tos, } \\
\text { estor; quemaduras en la piel y } \\
\text { los ojos; vómit, diarr }\end{array}$ \\
\hline
\end{tabular}




\begin{tabular}{|c|c|c|c|c|c|c|}
\hline \multirow[b]{2}{*}{$\begin{array}{l}\text { Denominación } \\
\text { química } \\
\text { N úmero CAS }\end{array}$} & \multicolumn{4}{|c|}{ Tarjetas Internacionales sobre la Seguridad de los Productos Q uímicos } & \multicolumn{2}{|c|}{ N IOSH (EE.UU.) } \\
\hline & $\begin{array}{l}\text { Período } \\
\text { corto de } \\
\text { exposición }\end{array}$ & $\begin{array}{l}\text { Período } \\
\text { largo de } \\
\text { exposición }\end{array}$ & $\begin{array}{l}\text { Vías de } \\
\text { exposición }\end{array}$ & Síntomas & $\begin{array}{l}\text { O rganos } \\
\text { afectados } \\
\text { Vías de } \\
\text { entrada }\end{array}$ & Síntomas \\
\hline $\begin{array}{l}\text { HIDROXIDO SODICO } \\
1310-73-2\end{array}$ & $\begin{array}{l}\text { ojos; piel; tract } \\
\text { resp; pulmones }\end{array}$ & piel & $\begin{array}{r}\text { Inhalación } \\
\text { Piel } \\
\text { 0jos } \\
\text { Ingestión }\end{array}$ & $\begin{array}{l}\text { Corrosivo, sensación de quemazón, tos, } \\
\text { dificultad respiratoria } \\
\text { Corrosivo, enrojecimiento, quemaduras graves } \\
\text { en la piel, dolor } \\
\text { Corrosivo, enrojecimiento, dolor, visión } \\
\text { borrosa, quemaduras profundas graves } \\
\text { Corrosivo, dolor intenso, dolor abdominal, } \\
\text { sensación de quemazón, diarrea, vómitos, } \\
\text { colapso }\end{array}$ & $\begin{array}{l}\text { Ojos; piel; sis resp } \\
\text { Inh, ing, con }\end{array}$ & $\begin{array}{l}\text { Irrit ojos, piel, muc; pneuitis; } \\
\text { quemaduras en la piel y los } \\
\text { ojos; caída temporal del } \\
\text { cabello }\end{array}$ \\
\hline $\begin{array}{l}\text { HIDRURO DE LTIOO } \\
7580-67.8\end{array}$ & $\begin{array}{l}\text { ojos; piel; tract } \\
\text { resp; pulmones }\end{array}$ & & $\begin{array}{l}\text { Inhalación } \\
\\
\text { Piel } \\
\text { Ojos } \\
\text { Ingestión }\end{array}$ & $\begin{array}{l}\text { Tos, náuseas, vómitos, temblor, calambres, } \\
\text { confusión, visión borrosa, dificultad } \\
\text { respiratoria, los síntomas pueden tardar en } \\
\text { aparecer } \\
\text { Enrojecimiento, quemaduras en la piel } \\
\text { Enrojecimiento, quemaduras profundas graves } \\
\text { Mareo, náuseas, vómitos, diarrea }\end{array}$ & $\begin{array}{l}\text { Ojos; piel; sis resp; } \\
\text { SNC } \\
\text { Inh, ing, con }\end{array}$ & $\begin{array}{l}\text { Irrit ojos, piel; quemaduras en } \\
\text { la piel y los ojos; quemaduras } \\
\text { en boca y esófago (en caso de } \\
\text { ingestión); náu; calambres } \\
\text { musc; conf mental; visión } \\
\text { borrosa }\end{array}$ \\
\hline $\begin{array}{l}\text { LITIO } \\
\quad 7439-93-2\end{array}$ & $\begin{array}{l}\text { ojos; piel; tract } \\
\text { resp; pulmones }\end{array}$ & & $\begin{array}{r}\text { Inhalación } \\
\text { Piel } \\
\text { 0jos } \\
\text { Ingestión }\end{array}$ & $\begin{array}{l}\text { Sensación de quemazón, tos, dificultad } \\
\text { respiratoria, disnea } \\
\text { Enrojecimiento, dolor, ampollas } \\
\text { Enrojecimiento, dolor, quemaduras profundas } \\
\text { graves } \\
\text { Espasmos abdominales, dolor abdominal, } \\
\text { sensación de quemazón, náuseas, shock o } \\
\text { colapso, vómitos, debilidad }\end{array}$ & & \\
\hline $\begin{array}{l}\text { METILATO SODICO } \\
124-41-4\end{array}$ & $\begin{array}{l}\text { ojos; piel; tract } \\
\text { resp; pulmones }\end{array}$ & & $\begin{array}{r}\text { Inhalación } \\
\text { Piel } \\
\text { Ojos } \\
\text { Ingestión }\end{array}$ & $\begin{array}{l}\text { Sensación de quemazón, tos, dificultad } \\
\text { respiratoria } \\
\text { Enrojecimiento, dolor, ampollas } \\
\text { Dolor, quemaduras profundas graves } \\
\text { Sensación de quemazón, dolor abdominal, } \\
\text { shock }\end{array}$ & & \\
\hline $\begin{array}{l}\text { NITRITO POTASICO } \\
7758-09-0\end{array}$ & $\begin{array}{l}\text { ojos; piel; tract } \\
\text { resp; sangre; SCV }\end{array}$ & & $\begin{array}{l}\text { Inhalación } \\
\text { Piel } \\
\text { Ojos } \\
\text { Ingestión }\end{array}$ & $\begin{array}{l}\text { Labios o uñas cianóticos, piel cianótica, tos, } \\
\text { mareo, cefalea, dificultad respiratoria, dolor de } \\
\text { garganta, inconsciencia } \\
\text { Enrojecimiento, dolor } \\
\text { Enrojecimiento, dolor } \\
\text { Labios o uñas cianóticos, piel cianótica, tos, } \\
\text { mareo, cefalea, dificultad respiratoria, dolor de } \\
\text { garganta, inconsciencia, vómitos, pulso rápido }\end{array}$ & & \\
\hline $\begin{array}{l}\text { NITRITO SODICO } \\
7632-00-0\end{array}$ & $\begin{array}{l}\text { ojos; piel; tract } \\
\text { resp; sangre; SNC; } \\
\text { riñones }\end{array}$ & & $\begin{array}{l}\text { Inhalación } \\
\\
\text { Piel } \\
\text { 0jos } \\
\text { Ingestión }\end{array}$ & $\begin{array}{l}\text { Labios y uñas cianóticos, piel cianótica, tos, } \\
\text { mareo, cefalea, dificultad respiratoria, dolor de } \\
\text { garganta, inconsciencia } \\
\text { Enrojecimiento, dolor } \\
\text { Enrojecimiento, dolor, puede adsorberse } \\
\text { Dolor abdominal, labios y uñas cianóticos, piel } \\
\text { cianótica, diarrea, mareo, cefalea, dificultad } \\
\text { respiratoria, inconsciencia }\end{array}$ & & \\
\hline $\begin{array}{c}\text { OXIDO CALCICO } \\
1305-78-8\end{array}$ & $\begin{array}{l}\text { ojos; piel; tract } \\
\text { resp; pulmones }\end{array}$ & piel & $\begin{array}{r}\text { Inhalación } \\
\text { Piel } \\
\text { Ojos } \\
\text { Ingestión }\end{array}$ & $\begin{array}{l}\text { Sensación de quemazón, tos, disnea } \\
\text { Enrojecimiento, quemaduras en la piel, } \\
\text { sensación de quemazón, dolor } \\
\text { Enrojecimiento, dolor, visión borrosa } \\
\text { Espasmos abdominales, dolor abdominal, } \\
\text { sensación de quemazón, diarrea, vómitos, } \\
\text { colapso }\end{array}$ & $\begin{array}{l}\text { Sis resp; piel; ojos } \\
\text { Inh, ing, con }\end{array}$ & $\begin{array}{l}\text { Irrit ojos, piel, tract resp sup; } \\
\text { ulcer, perf tabique nasal; neu; } \\
\text { derm }\end{array}$ \\
\hline
\end{tabular}


Tabla 104.18 - Riesgos para la salud.

\begin{tabular}{|c|c|c|c|c|c|c|}
\hline \multirow[b]{2}{*}{$\begin{array}{l}\text { Denominación } \\
\text { química } \\
\mathrm{N} \text { úmero CAS }\end{array}$} & \multicolumn{4}{|c|}{ Tarjetas Internacionales sobre la Seguridad de los Productos Q uímicos } & \multicolumn{2}{|c|}{ N IO SH (EE.UU.) } \\
\hline & $\begin{array}{l}\text { Período } \\
\text { corto de } \\
\text { exposición }\end{array}$ & $\begin{array}{l}\text { Período } \\
\text { largo de } \\
\text { exposición }\end{array}$ & $\begin{array}{l}\text { Vías de } \\
\text { exposición }\end{array}$ & Síntomas & $\begin{array}{l}\text { O rganos } \\
\text { afectados } \\
\text { Vías de } \\
\text { entrada }\end{array}$ & Síntomas \\
\hline $\begin{array}{c}\text { OXIDO POTASICO } \\
12136-45-7\end{array}$ & $\begin{array}{l}\text { ojos; piel; tract } \\
\text { resp; pulmones }\end{array}$ & & $\begin{array}{r}\text { Inhalación } \\
\text { Piel } \\
\text { 0jos } \\
\text { Ingestión }\end{array}$ & $\begin{array}{l}\text { Sensación de quemazón, tos, disnea } \\
\text { Quemaduras en la piel, dolor, ampollas } \\
\text { Enrojecimiento, dolor, quemaduras profundas } \\
\text { graves } \\
\text { Sensación de quemazón, shock, espasmos } \\
\text { abdominales }\end{array}$ & & \\
\hline
\end{tabular}

Tabla 104.19 • Riesgos físicos y químicos.

\begin{tabular}{|c|c|c|c|}
\hline $\begin{array}{l}\text { Denominación química } \\
\mathrm{N} \text { úmero CAS }\end{array}$ & Físicos & Q uímicos & $\begin{array}{l}\text { Clase o división } \\
\text { UN / Riesgos } \\
\text { subsidiarios }\end{array}$ \\
\hline $\begin{array}{l}\text { ACIDO CARBONICO, SAL CALCICA } \\
471-34-1\end{array}$ & & $\begin{array}{l}\text { Se descompone al calentarse a temperaturas elevadas, produciendo dióxido de carbono } \\
\text { Reacciona con ácidos, liberando dióxido de carbono }\end{array}$ & \\
\hline $\begin{array}{l}\text { ACIDO CLORICO, SAL CALCICA } \\
7775-09-9\end{array}$ & & $\begin{array}{l}\text { Al calentarse puede sufrir una combustión violenta o explosión Se descompone al calentarse } \\
\text { por encima de } 300^{\circ} \mathrm{C} \text { ol arder, produciendo humos tóxicos (cloro) y oxígeno, que aumenta el } \\
\text { riesgo de incendio Es un oxidante fuerte y reacciona violentamente con materiales combustibles } \\
\text { y reductores, con peligro de incendio y explosión Reacciona con ácidos fuertes, liberando } \\
\text { dióxido de carbono Reacciona con contaminantes orgánicos formando mezclas sensibles a los } \\
\text { golpes Ataca el zinc y el acero }\end{array}$ & 5.1 \\
\hline
\end{tabular}

\section{ACIDO PERCLORICO, SAL POTASICA \\ 7778-74-7}

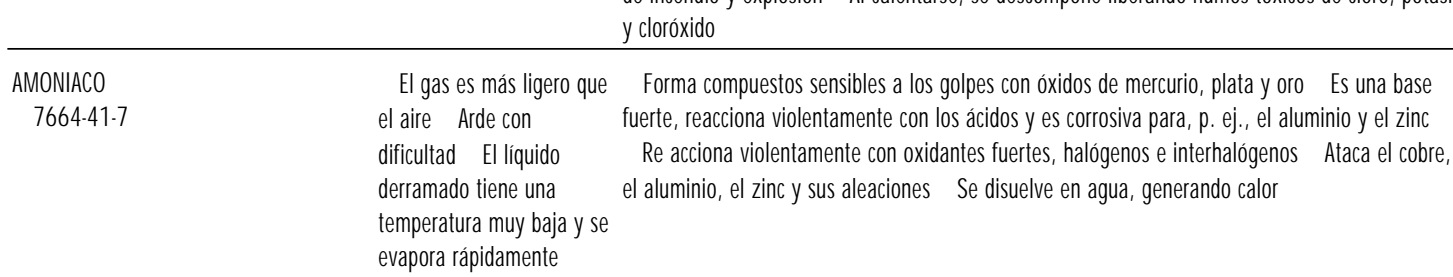

\begin{tabular}{|c|c|c|}
\hline $\begin{array}{l}\text { BROMATO POTASICO } \\
7758-01-2\end{array}$ & & 5.1 \\
\hline $\begin{array}{l}\text { BROM ATO SODICO } \\
7789-38-0\end{array}$ & & 5.1 \\
\hline $\begin{array}{l}\text { CALCIO } \\
\quad 7440-70-2\end{array}$ & & 4.3 \\
\hline $\begin{array}{l}\text { CARBONATO DE LITIO } \\
554-13-2\end{array}$ & $\begin{array}{l}\text { Se descompone al calentarse, produciendo monóxido y dióxido de carbono La solución en } \\
\text { agua es una base fuerte, reacciona violentamente con los ácidos y corroe el aluminio y zinc } \\
\text { Reacciona violentamente con flúor Ataca el aluminio y el zinc }\end{array}$ & \\
\hline
\end{tabular}

CARBONATO SODICO

497-19-8

CARBURO CALCICO

75-20-7

CLORATO CALCICO

10137-74-3

Se descompone al calentarse, liberando humos tóxicos (cloro, cloróxidos) Reacciona violentamente con metales en polvo y materiales combustibles, orgánicos u oxidables, con peligro de incendio y explosión Al calentarse, se descompone liberando humos tóxicos de cloro, potasio y cloróxido el aire Arde con dificultad El líquido derramado tiene una temperatura muy baja y se fuerte, reacciona violentamente con los ácidos y es corrosiva para, p. ej., el aluminio y el zinc Re acciona violentamente con oxidantes fuertes, halógenos e interhalógenos Ataca el cobre, el aluminio, el zinc y sus aleaciones Se disuelve en agua, generando calor 


\begin{tabular}{|c|c|c|c|}
\hline $\begin{array}{l}\text { Denominación química } \\
\mathrm{N} \text { úmero CAS }\end{array}$ & Físicos & Q uímicos & $\begin{array}{l}\text { Clase o división } \\
\text { UN / Riesgos } \\
\text { subsidiarios }\end{array}$ \\
\hline $\begin{array}{l}\text { CLORATO POTASICO } \\
3811-04-9\end{array}$ & & $\begin{array}{l}\text { Se descompone al calentarse, al arder o en contacto con sustancias orgánicas, materiales } \\
\text { combustibles, metales en polvo, ácido sulfúrico, sustancias que contengan amonio, y alcoholes, } \\
\text { produciendo dióxido de cloro, cloro y oxígeno, con peligro de incendio y explosión Al calentarse } \\
\text { desprende humos tóxicos Es un oxidante fuerte y reacciona violentamente con materiales } \\
\text { combustibles y reductores Es un potente agente reductor y reacciona con los oxidantes }\end{array}$ & 5.1 \\
\hline $\begin{array}{l}\text { CLORITO SODICO } \\
7758-19-2\end{array}$ & & & 5.1 \\
\hline $\begin{array}{l}\text { CLORURO AMONICO } \\
12125-02-9\end{array}$ & & $\begin{array}{l}\text { Se descompone al calentarse o al arder, produciendo humos tóxicos e irritantes (óxidos de } \\
\text { nitrógeno, amoniaco y cloruro de hidrógeno) La solución en agua es un ácido débil Reacciona } \\
\text { violentamente con nitrato amónico y clorato potásico, con peligro de incendio y explosión } \\
\text { Reacciona con ácidos muy concentrados formando cloruro de hidrógeno, y con bases fuertes } \\
\text { formando amoniaco Reacciona con sales de plata formando compuestos sensibles a los golpes } \\
\text { mecánicos Ataca el cobre y sus compuestos }\end{array}$ & \\
\hline $\begin{array}{l}\text { CLORURO DE LTIOO } \\
7447-41-8 \\
\end{array}$ & & La solución en agua es corrosiva para los metales & \\
\hline $\begin{array}{l}\text { FLUORURO AMONICO } \\
12125-01-8 \\
\end{array}$ & & & 6.1 \\
\hline $\begin{array}{l}\text { FLUORURO POTASICO } \\
7789-23-3\end{array}$ & & & 6.1 \\
\hline $\begin{array}{l}\text { HIDROXIDO AMONICO } \\
1336-21-6\end{array}$ & & & 8 \\
\hline $\begin{array}{l}\text { HIDROXIDO CALCICO } \\
1305-62-0\end{array}$ & & Se descompone al calentarse, produciendo óxido cálcico Es una base de fuerza intermedia & 8 \\
\hline $\begin{array}{l}\text { HIDROXIDO DE LITIO MONOHIDRATO } \\
\text { 1310-66-3 }\end{array}$ & & $\begin{array}{l}\text { La solución en agua da una base fuerte, reacciona violentamente con los ácidos y corroe el } \\
\text { aluminio y el zinc }\end{array}$ & 8 \\
\hline $\begin{array}{l}\text { HIDROXIDO DE LITIO } \\
1310-65-2\end{array}$ & & $\begin{array}{l}\text { La solución en agua da una base fuerte, reacciona violentamente con los ácidos y corroe el } \\
\text { aluminio y el zinc }\end{array}$ & \\
\hline $\begin{array}{l}\text { HIDROXIDO POTASICO } \\
\text { 1310-58-3 }\end{array}$ & & $\begin{array}{l}\text { Es una base fuerte, reacciona violentamente con los ácidos y, en ambientes húmedos, corroe } \\
\text { metales como zinc, aluminio, estaño y plomo, formando un gas combustible o explosivo } \\
\text { (hidrógeno) Absorbe rápidamente el dióxido de carbono y el agua del aire En contacto con el } \\
\text { agua o la humedad, genera calor }\end{array}$ & 8 \\
\hline
\end{tabular}

HIDROXIDO SODICO

$1310.73-2$

Es una base fuerte, reacciona violentamente con ácidos y, en ambientes húmedos, corroe 8 metales como zinc, aluminio, estaño y plomo, formando un gas combustible 0 explosivo (hidrógeno) Ataca algunos tipos de plástico, caucho y revestimientos Absorbe rápidamente el dióxido de carbono y la humedad del aire En contacto con el agua o la humedad, puede generar calor

\begin{tabular}{|c|c|c|}
\hline $\begin{array}{l}\text { HIDRURO CALCICO } \\
7789.78-8\end{array}$ & & \\
\hline $\begin{array}{l}\text { HIDRURO DE LTTIO } \\
7580-67-8\end{array}$ & $\begin{array}{l}\text { Posibilidad de explosión } \\
\text { pulverulenta cuando se } \\
\text { encuentra en forma de } \\
\text { polvo o gránulos y se } \\
\text { mezcla con el aire }\end{array}$ & $\begin{array}{l}\text { Puede arder espontáneamente en contacto con el aire Se descompone exotérmicamente al } \\
\text { calentarse a aprox. } 500^{\circ} \mathrm{C} \text { e en contacto con la humedad o con ácidos, produciendo un gas } \\
\text { inflamable Reacciona violentamente con oxidantes fuertes Reacciona con agua formando } \\
\text { hidróxido de litio, que es muy cáustico, y gas de hidrógeno inflamable Reacciona con alcoholes } \\
\text { secundarios, ácidos carboxílicos, cloro y amoniaco a } 400^{\circ} \mathrm{C} \text {, liberando gas de hidrógeno El } \\
\text { polvo de hidruro de litio y el oxígeno líquido son explosivos detonables }\end{array}$ \\
\hline
\end{tabular}

\begin{tabular}{lc}
\hline HIPOCLORITO SODICO & 8
\end{tabular}

LITIO Al calentarse puede sufrir una combustión violenta 0 explosión Puede arder espontáneamente 4.3
en contacto con el aire o cuando está finamente fragmentada Reacciona violentamente con oxidantes fuertes, ácidos y muchos otros compuestos (hidrocarburos, halógenos y halones), con peligro de incendio y explosión Reacciona violentamente con agua, formando un gas de hidrógeno muy inflamable y humos corrosivos de hidróxido de litio 


\begin{tabular}{|c|c|c|c|}
\hline $\begin{array}{l}\text { Denominación química } \\
\mathrm{N} \text { úmero CAS }\end{array}$ & Físicos & Q uímicos & $\begin{array}{l}\text { Clase o división } \\
\text { UN / Riesgos } \\
\text { subsidiarios }\end{array}$ \\
\hline $\begin{array}{l}\text { METILATO SODICO } \\
\text { 124-41-4 }\end{array}$ & $\begin{array}{l}\text { Posibilidad de explosión } \\
\text { pulverulenta cuando se } \\
\text { encuentra en forma de } \\
\text { polvo o gránulos y se } \\
\text { mezcla con el aire }\end{array}$ & $\begin{array}{l}\text { Al calentarse puede sufrir una combustión violenta o explosión Se descompone en contacto } \\
\text { con el agua, produciendo metanol, que aumenta el riesgo de incendio Es un potente agente } \\
\text { reductor y reacciona violentamente con los oxidantes Es una base fuerte, reacciona } \\
\text { violentamente con los ácidos y es corrosiva Ataca muchos metales en presencia de agua }\end{array}$ & 4.218 \\
\hline $\begin{array}{l}\text { NITRATO AMONICO } \\
6484-52-2\end{array}$ & & $\begin{array}{l}\text { Al calentarse puede sufrir una combustión violenta o explosión Se descompone al calentarse } \\
0 \text { al arder, liberando humos tóxicos (óxidos de nitrógeno) Es un oxidante fuerte y reacciona con } \\
\text { materiales combustibles y reductores }\end{array}$ & 5.1 \\
\hline $\begin{array}{l}\text { NITRATO CALCICO } \\
10124-37-5\end{array}$ & & & 5.1 \\
\hline $\begin{array}{l}\text { NITRATO POTASICO } \\
7757-79-1\end{array}$ & & $\begin{array}{l}\text { Se descompone al calentarse } 0 \text { al arder, produciendo óxidos de nitrógeno y oxígeno, que } \\
\text { aumenta el riesgo de incendio Es un oxidante fuerte y reacciona con materiales combustibles y } \\
\text { reductores }\end{array}$ & 5.1 \\
\hline $\begin{array}{l}\text { NITRATO SODICO } \\
7631-99-4\end{array}$ & & $\begin{array}{l}\text { Se descompone al calentarse } 0 \text { al arder, produciendo óxidos de nitrógeno y oxígeno, que } \\
\text { aumenta el riesgo de incendio Es un oxidante fuerte y reacciona con materiales combustibles y } \\
\text { reductores, con peligro de incendio y explosión }\end{array}$ & \\
\hline $\begin{array}{l}\text { NITRITO POTASICO } \\
7758-09-0\end{array}$ & & $\begin{array}{l}\text { Puede explotar si se calienta por encima de } 530^{\circ} \mathrm{C} \text { Se descompone en contacto con ácidos, } \\
\text { aunque sean débiles, liberando humos tóxicos (óxidos de nitrógeno) Es un oxidante fuerte y } \\
\text { reacciona con materiales combustibles y reductores, con peligro de incendio y explosión }\end{array}$ & 5.1 \\
\hline $\begin{array}{l}\text { NITRITO SODICO } \\
7632-00-0\end{array}$ & & $\begin{array}{l}\text { Puede explotar si se calienta por encima de } 530^{\circ} \mathrm{C} \text { Se descompone en contacto con ácidos, } \\
\text { aunque sean débiles, liberando humos tóxicos (óxidos de nitrógeno) Es un oxidante fuerte y } \\
\text { reacciona con materiales combustibles y reductores, con peligro de incendio y explosión }\end{array}$ & 5.1 \\
\hline $\begin{array}{l}\text { OXIDO CALCICO } \\
1305-78-8\end{array}$ & & $\begin{array}{l}\text { La solución en agua da una base de fuerza intermedia Reacciona violentamente con ácidos } \\
\text { fuertes, agua, cloro o trifluoruro de boro Reacciona con agua, generando suficiente calor como } \\
\text { para inflamar materiales combustibles }\end{array}$ & 8 \\
\hline $\begin{array}{l}\text { OXIDO POTASICO } \\
12136-45-7\end{array}$ & & $\begin{array}{l}\text { Se descompone en contacto con el agua, produciendo hidróxido potásico La solución en agua } \\
\text { da una base fuerte, reacciona violentamente con los ácidos y es corrosiva Ataca muchos } \\
\text { metales en presencia de agua }\end{array}$ & \\
\hline $\begin{array}{l}\text { PEROXIDO SODICO } \\
1313-60-6\end{array}$ & & & 5.1 \\
\hline $\begin{array}{l}\text { POTASIO } \\
7440-09-7 \\
\end{array}$ & & & 4.3 \\
\hline $\begin{array}{l}\text { SODIO } \\
7440-23-5\end{array}$ & & & 4.3 \\
\hline
\end{tabular}

\begin{tabular}{|c|c|c|c|c|c|c|c|c|c|c|}
\hline $\begin{array}{l}\text { Denominación } \\
\text { química } \\
\text { N úmero CAS }\end{array}$ & Color/ Forma & $\begin{array}{l}\text { p.e. } \\
\left({ }^{\circ} C\right)\end{array}$ & $\begin{array}{l}\text { p.f. } \\
\left({ }^{\circ} C\right)\end{array}$ & $\begin{array}{l}\text { p.m.l } \\
\text { (g/ } \\
\text { mol) }\end{array}$ & $\begin{array}{l}\text { Solubilidad } \\
\text { en agua }\end{array}$ & $\begin{array}{l}\text { Densidad } \\
\text { relativa } \\
\text { (agua=1) }\end{array}$ & $\begin{array}{l}\text { Densidad } \\
\text { de vapor } \\
\text { relativa } \\
(\text { aire }=1)\end{array}$ & $\begin{array}{l}\text { Pvap/ } \\
(\mathrm{kPa})\end{array}$ & $\begin{array}{l}\text { Límit. } \\
\text { inflam. }\end{array}$ & $\begin{array}{ll}\text { p.ig. } & \text { p.aut } \\
\left({ }^{\circ} \mathrm{C}\right) & \text { ig. } \\
& \left({ }^{\circ} \mathrm{C}\right)\end{array}$ \\
\hline $\begin{array}{l}\text { ACIDO CARBONICO, SAL DE } \\
\text { CALCIO } \\
471-34-1\end{array}$ & $\begin{array}{l}\text { polvo fino } \\
\text { microcristalino de color } \\
\text { blanco; polvo o cristales; } \\
\text { aragonita: } \\
\text { ortorrómbicos; calcita: } \\
\text { hexagonales } \\
\text { rombohédricos }\end{array}$ & & $\begin{array}{l}825 \text { se } \\
\text { descompone }\end{array}$ & 102,10 & insol & $2,7-2,9$ & & & & \\
\hline
\end{tabular}




\begin{tabular}{|c|c|c|c|c|c|c|c|c|c|c|c|}
\hline $\begin{array}{l}\text { Denominación } \\
\text { química } \\
\text { N úmero CAS }\end{array}$ & Color/ Forma & $\begin{array}{l}\text { p.e. } \\
(\stackrel{0}{ } C)\end{array}$ & $\begin{array}{l}\text { p.f. } \\
(\stackrel{\circ}{ } C)\end{array}$ & $\begin{array}{l}\text { p.m.l } \\
\text { (g/ } \\
\text { mol) }\end{array}$ & $\begin{array}{l}\text { Solubilidad } \\
\text { en agua }\end{array}$ & $\begin{array}{l}\text { Densidad } \\
\text { relativa } \\
\text { (agua }=1 \text { ) }\end{array}$ & $\begin{array}{l}\text { Densidad } \\
\text { de vapor } \\
\text { relativa } \\
\text { (aire=1) }\end{array}$ & $\begin{array}{l}\text { Pvap/ } \\
(\mathrm{kPa})\end{array}$ & $\begin{array}{l}\text { Límit. } \\
\text { inflam. }\end{array}$ & 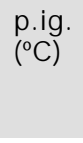 & $\begin{array}{l}\text { p.aut } \\
\text { ig. } \\
(\stackrel{\circ}{ } \text { C })\end{array}$ \\
\hline $\begin{array}{l}\text { ACIDO PERCLORICO, SAL } \\
\text { POTASICA } \\
7778-74-7\end{array}$ & $\begin{array}{l}\text { cristales incoloros o } \\
\text { polvo cristalino blanco; } \\
\text { cristales rómbicos } \\
\text { incoloros }\end{array}$ & & $\begin{array}{l}400 \text { se } \\
\text { descompone }\end{array}$ & 138,55 & sol en 65 partes & 2,52 & & & & & \\
\hline $\begin{array}{l}\text { AMONIACO } \\
7664-41-7\end{array}$ & gas o líquido incoloro & $-33,35$ & $.77,7$ & 17,03 & sol & 0,7710 & 0,59 & $\begin{array}{l}1013 \\
@ 26^{\circ} \mathrm{C}\end{array}$ & $\begin{array}{l}16 \mathrm{li} \\
25 \mathrm{ls}\end{array}$ & $\begin{array}{l}\text { gas } \\
\text { infla- } \\
\text { mable }\end{array}$ & 651 \\
\hline $\begin{array}{l}\text { BICARBONATO AMONICO } \\
1066-33-7\end{array}$ & $\begin{array}{l}\text { cristales incoloros, } \\
\text { rómbicos o } \\
\text { monoclínicos; masa } \\
\text { cristalina o prismas } \\
\text { brillantes, duros, } \\
\text { incoloros o blancos }\end{array}$ & & 107,5 & 79,06 & $14 \% @ 10^{\circ} \mathrm{C}$ & 1,57 & & & & & \\
\hline $\begin{array}{l}\text { BICARBONATO SODICO } \\
144-55-8\end{array}$ & $\begin{array}{l}\text { prismas monoclínicos } \\
\text { blancos; polvo cristalino } \\
\text { o gránulos blancos }\end{array}$ & & $\begin{array}{l}-\mathrm{CO2} \\
\text { @ } 270\end{array}$ & 84,01 & $\begin{array}{l}\text { sol en } 10 \text { partes } \\
@ 25^{\circ} \mathrm{C} ; 12 \\
\text { partes @ } 18^{\circ} \mathrm{C}\end{array}$ & 2,159 & & & & & \\
\hline $\begin{array}{c}\text { BROMATO CALCICO } \\
10102-75-7\end{array}$ & polvo blanco cristalino & 149 & 38,2 & 313,90 & muy sol & 3,329 & & & & & \\
\hline $\begin{array}{l}\text { BROMATO POTASICO } \\
7758-01-2\end{array}$ & $\begin{array}{l}\text { cristales o gránulos } \\
\text { blancos; cristales } \\
\text { trigonales incoloros }\end{array}$ & & 434 & 167,01 & $\begin{array}{l}7,53 \mathrm{~g} / 100 \mathrm{~g} \\
\text { @ } 25^{\circ} \mathrm{C}\end{array}$ & $\begin{array}{l}3,27 @ \\
17,5^{\circ} \mathrm{C}\end{array}$ & & & & & \\
\hline $\begin{array}{l}\text { BROMATO SODICO } \\
7789-38-0\end{array}$ & $\begin{array}{l}\text { cristales cúbicos } \\
\text { incoloros; polvo } \\
\text { cristalino } 0 \text { gránulos } \\
\text { blancos }\end{array}$ & & 381 & 150,90 & $\begin{array}{l}27,5 \mathrm{~g} / 100 \mathrm{ml} \\
@ 0^{\circ} \mathrm{C} \\
90.9 \mathrm{~g} / 100 \mathrm{ml} \\
@ 100{ }^{\circ} \mathrm{C}\end{array}$ & $\begin{array}{l}3,339 \\
@ 17,5^{\circ} \mathrm{C}\end{array}$ & & & & & \\
\hline $\begin{array}{l}\text { BROMURO POTASICO } \\
7758-02-3\end{array}$ & $\begin{array}{l}\text { cristales incoloros, } 0 \\
\text { gránulos o polvo blanco; } \\
\text { cristales cúbicos }\end{array}$ & 1435 & 730 & 119,01 & $1 \mathrm{~g} / 1,5 \mathrm{ml}$ & $2,75 @ 25^{\circ} \mathrm{C}$ & & & & & \\
\hline $\begin{array}{l}\text { CALCIO } \\
7440-70-2\end{array}$ & $\begin{array}{l}\text { superficie brillante, de } \\
\text { color blanco plateado } \\
\text { (recién cortada); } \\
\text { estructura cúbica } \\
\text { centrada en las caras } \\
\text { por debajo de } 300{ }^{\circ} \mathrm{C} \text {; } \\
\text { adquiere una coloración } \\
\text { azul grisácea cuando se } \\
\text { expone al aire húmedo }\end{array}$ & 1440 & 850 & 40,08 & & 1,54 & & $\begin{array}{l}10 \mathrm{~mm} \mathrm{Hg} \\
\text { @ } 983^{\circ} \mathrm{C}\end{array}$ & & & \\
\hline $\begin{array}{l}\text { CARBONATO CALCICO } \\
1317-65-3\end{array}$ & $\begin{array}{l}\text { polvo blanco o cristales } \\
\text { incoloros }\end{array}$ & $\begin{array}{l}825 \text { se } \\
\text { descompone }\end{array}$ & & & lig sol & $2,7-2,95$ & & & & & \\
\hline $\begin{array}{l}\text { CARBONATO DE LITIO } \\
554-13-2\end{array}$ & $\begin{array}{l}\text { polvo ligero blanco; } \\
\text { monoclínico }\end{array}$ & $\begin{array}{l}1310 \text { se } \\
\text { descompone }\end{array}$ & 618- 723 & 73,89 & insol & 2,11 & & & & & \\
\hline $\begin{array}{l}\text { CARBONATO POTASICO } \\
584-08-7\end{array}$ & $\begin{array}{l}\text { gránulos o polvo } \\
\text { granular; cristales } \\
\text { monoclínicos incoloros; } \\
\text { polvo granular blanco; } \\
\text { polvo granular } \\
\text { translúcido }\end{array}$ & & 891 & 140,82 & $\begin{array}{l}112 \mathrm{~g} / 100 \mathrm{ml} \\
\text { frío }\end{array}$ & 2,29 & & & & & \\
\hline $\begin{array}{l}\text { CARBONATO SODICO } \\
\text { 497-19-8 }\end{array}$ & $\begin{array}{l}\text { polvo blanco; polvo o } \\
\text { agregados } \\
\text { blancos-grisáceos con un } \\
\text { máximo de } 99 \% \text { de } \\
\text { carbonato sódico }\end{array}$ & & 851 & 106,00 & sol en 3,5 partes & 2,53 & & & & & \\
\hline
\end{tabular}


Tabla 104.20 Propiedades físicas y químicas.

\begin{tabular}{|c|c|c|c|c|c|c|c|c|c|c|}
\hline $\begin{array}{l}\text { Denominación } \\
\text { química } \\
\mathrm{N} \text { úmero CAS }\end{array}$ & Color/ Forma & $\begin{array}{l}\text { p.e. } \\
\left({ }^{\circ} C\right)\end{array}$ & $\begin{array}{l}\text { p.f. } \\
\left({ }^{\circ} \mathrm{C}\right)\end{array}$ & $\begin{array}{l}\text { p.m.l } \\
\text { (g/ } \\
\text { mol) }\end{array}$ & $\begin{array}{l}\text { Solubilidad } \\
\text { en agua }\end{array}$ & $\begin{array}{l}\text { Densidad } \\
\text { relativa } \\
\text { (agua }=1 \text { ) }\end{array}$ & $\begin{array}{l}\text { Densidad } \\
\text { de vapor } \\
\text { relativa } \\
\text { (aire=1) }\end{array}$ & $\begin{array}{l}\text { Pvap/ } \\
(\mathrm{kPa})\end{array}$ & $\begin{array}{l}\text { Límit. } \\
\text { inflam. }\end{array}$ & $\begin{array}{ll}\text { p.ig. } & \text { p.aut } \\
(\stackrel{\circ}{ }) & \text { ig. } \\
& (\stackrel{\circ}{ } \mathrm{C})\end{array}$ \\
\hline $\begin{array}{l}\text { CARBURO CALICOO } \\
75-20.7\end{array}$ & $\begin{array}{l}\text { agregados irregulares } 0 \\
\text { cristales ortorrómbicos } \\
\text { de color negro grisáceo; } \\
\text { cristales tetragonales } \\
\text { incoloros }\end{array}$ & & 2300 & 64,10 & reacciona & 2,22 & & & & \\
\hline $\begin{array}{c}\text { CLORATO CALCICO } \\
10137-74-3 \\
\end{array}$ & & & $340 \pm 10$ & 206,99 & sol & $2,710 @ 0{ }^{\circ} \mathrm{C}$ & & & & \\
\hline $\begin{array}{l}\text { CLORATO POTASICO } \\
3811.04 .9\end{array}$ & $\begin{array}{l}\text { cristales brillantes } \\
\text { incoloros, o gránulos } 0 \\
\text { polvo blanco }\end{array}$ & $\begin{array}{l}400 \text { se } \\
\text { descompone }\end{array}$ & 368 & 122,55 & $1 \mathrm{~g} / 16,5 \mathrm{ml}$ & 2,32 & & & & \\
\hline $\begin{array}{l}\text { CLORATO SODICO } \\
7775-09.9\end{array}$ & $\begin{array}{l}\text { cristales incoloros } \\
\text { cúbicos o trigonales; } \\
\text { polvo blanco; cristales } \\
\text { blancos o amarillo } \\
\text { pálido; polvo incoloro; } \\
\text { cristales incoloros o } \\
\text { gránulos blancos }\end{array}$ & 122 & 248 & 106,5 & & $\begin{array}{l}2,490 \mathrm{~g} / \mathrm{ml} \\
\text { @ } 15^{\circ} \mathrm{C}\end{array}$ & 3,7 & & & \\
\hline $\begin{array}{l}\text { CLORITO SODICO } \\
7758-19-2\end{array}$ & $\begin{array}{l}\text { sólido blanco cristalino; } \\
\text { cristales o escamas }\end{array}$ & & $180-200$ & 90,44 & $\begin{array}{l}34 \mathrm{~g} / 100 \mathrm{~g} \\
@ 5^{\circ} \mathrm{C} \\
39 \mathrm{~g} / 100 \mathrm{~g} \\
@ 17^{\circ} \mathrm{C}\end{array}$ & $\begin{array}{l}2,468 \mathrm{~g} / \mathrm{ml} \text { en } \\
\text { forma cristalina }\end{array}$ & & & & \\
\hline $\begin{array}{l}\text { CLORURO AM ONICO } \\
12125-02-9\end{array}$ & $\begin{array}{l}\text { cristales incoloros } 0 \\
\text { masa cristalina; } 0 \\
\text { polvo granular blanco; } \\
\text { cristales cúbicos; polvo } \\
\text { blanco cristalino, fino } 0 \\
\text { grueso }\end{array}$ & 520 & $\begin{array}{l}338 \text { se } \\
\text { descompone }\end{array}$ & 53,50 & sol & $\begin{array}{l}1,5274 @ \\
25^{\circ} \mathrm{C}\end{array}$ & & $\begin{array}{l}0,13 \\
\text { @ } 160^{\circ} \mathrm{C}\end{array}$ & & \\
\hline $\begin{array}{l}\text { CLORURO CALCICO } \\
10043-52-4\end{array}$ & $\begin{array}{l}\text { cristales cúbicos, } \\
\text { gránulos o masa } \\
\text { fusionada; incoloro }\end{array}$ & 1,935 & 772 & 110,98 & $74,5 \mathrm{~g} / 100 \mathrm{ml}$ & $\begin{array}{l}2,152 \\
@ 15^{\circ} \mathrm{C} / 4^{\circ} \mathrm{C}\end{array}$ & & & & \\
\hline $\begin{array}{l}\text { CLORURO DE LTIIO } \\
7447-41-8\end{array}$ & $\begin{array}{l}\text { cristales } \\
\text { cúbicos, gránulos o } \\
\text { polvo cristalino; blanco }\end{array}$ & 1360 & 613 & 42,40 & $1 \mathrm{~g} / 1,3 \mathrm{ml}$ & 2,07 & & & & \\
\hline $\begin{array}{l}\text { CLORURO DE } \\
\text { TETRAMETILAM ONIO } \\
75.57 .0\end{array}$ & Sólido blanco cristalino & & 420 & 109,6 & sol & 1,1690 & & & & \\
\hline $\begin{array}{l}\text { CLORURO SODICO } \\
7647-14-5\end{array}$ & $\begin{array}{l}\text { cristales transparentes } \\
\text { incoloros o polvo } \\
\text { cristalino blanco }\end{array}$ & 1413 & 801 & 58,44 & $\begin{array}{l}35,7 \mathrm{~g} / 100 \mathrm{ml} \\
@ 0^{\circ} \mathrm{C} \\
9,2 \mathrm{~g} / 100 \mathrm{ml} \\
@ 100{ }^{\circ} \mathrm{C}\end{array}$ & $\begin{array}{l}2,165 @ \\
25^{\circ} \mathrm{C} / 4^{\circ} \mathrm{C}\end{array}$ & & $\begin{array}{l}1 \mathrm{~mm} \mathrm{Hg} \\
\text { @ } 865^{\circ} \mathrm{C}\end{array}$ & & \\
\hline $\begin{array}{l}\text { ETILATO SODICO } \\
141.52 .6\end{array}$ & $\begin{array}{l}\text { polvo blanco o } \\
\text { amarillento; polvo } \\
\text { blanco con tonos pardos } \\
\text { en ocasiones }\end{array}$ & & & 68,06 & & & & & & \\
\hline $\begin{array}{l}\text { FLUORURO AMONICO } \\
\text { 12125-01-8 }\end{array}$ & $\begin{array}{l}\text { laminillas o agujas; } \\
\text { prismas hexagonales por } \\
\text { sublimación; cristales } \\
\text { hexagonales incoloros; } \\
\text { cristales blancos }\end{array}$ & & & 37,04 & $\begin{array}{l}45,3 \mathrm{~g} / 100 \mathrm{~g} \\
\text { @ } 25^{\circ} \mathrm{C}\end{array}$ & 1,015 & & & & \\
\hline $\begin{array}{l}\text { FLUORURO POTASICO } \\
7789-23-3\end{array}$ & $\begin{array}{l}\text { cristales cúbicos } \\
\text { incoloros y } \\
\text { delicuescentes }\end{array}$ & 1505 & 858 & 58,10 & muy sol & 2,48 & & & & \\
\hline
\end{tabular}




\begin{tabular}{|c|c|c|c|c|c|c|c|c|c|c|c|}
\hline $\begin{array}{l}\text { Denominación } \\
\text { química } \\
\mathrm{N} \text { úmero CAS }\end{array}$ & Color/ Forma & 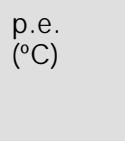 & $\begin{array}{l}\text { p.f. } \\
(\stackrel{\circ}{ } \mathrm{C})\end{array}$ & $\begin{array}{l}\mathrm{p} . \mathrm{m} . / \\
\text { (g/ } \\
\mathrm{mol})\end{array}$ & $\begin{array}{l}\text { Solubilidad } \\
\text { en agua }\end{array}$ & $\begin{array}{l}\text { Densidad } \\
\text { relativa } \\
\text { (agua }=1 \text { ) }\end{array}$ & $\begin{array}{l}\text { Densidad } \\
\text { de vapor } \\
\text { relativa } \\
\text { (aire=1) }\end{array}$ & $\begin{array}{l}\text { Pvap/ } \\
(\mathrm{kPa})\end{array}$ & $\begin{array}{l}\text { Límit. } \\
\text { inflam. }\end{array}$ & $\begin{array}{l}\text { p.ig. } \\
\left({ }^{\circ} \mathrm{C}\right)\end{array}$ & $\begin{array}{l}\text { p.aut } \\
\text { ig. } \\
(\stackrel{\circ}{\circ})\end{array}$ \\
\hline $\begin{array}{l}\text { FOSFATO DIAMONICO } \\
7783-28-0\end{array}$ & $\begin{array}{l}\text { polvo o cristales } \\
\text { blancos, incoloros, } \\
\text { monoclínicos }\end{array}$ & $\begin{array}{l}\text { se } \\
\text { descompone }\end{array}$ & $\begin{array}{l}155 \text { se } \\
\text { descompone }\end{array}$ & 132,07 & $1 \mathrm{~g} / 1,7 \mathrm{ml}$ & 1,619 & & & & & \\
\hline $\begin{array}{l}\text { FOSFATO SODICO DIBASICO } \\
7558-79-4\end{array}$ & $\begin{array}{l}\text { sal granular incolora } 0 \\
\text { blanca }\end{array}$ & & & 141,98 & $\begin{array}{l}\text { sol } 8 \text { partes } \\
25^{\circ} \mathrm{C}\end{array}$ & & & & & & \\
\hline $\begin{array}{l}\text { FOSFATO SODICO } \\
7601-54-9\end{array}$ & & & & 163,94 & $8,8 \mathrm{~g} / 100 \mathrm{ml}$ & $\begin{array}{l}2,536 \\
@ 17,5^{\circ} \mathrm{C}\end{array}$ & & & & & \\
\hline $\begin{array}{l}\text { HIDROXIDO AMONICO } \\
1336-21-6\end{array}$ & líquido incoloro & & .77 & 35,05 & misc & $0,90 @ 25^{\circ} \mathrm{C}$ & & & & & \\
\hline $\begin{array}{l}\text { HIDROXIDO CALCICO } \\
1305-62-0\end{array}$ & $\begin{array}{l}\text { cristales, gránulos } \\
\text { blandos o polvo; } \\
\text { incoloro, hexagonal; } \\
\text { cristales rómbicos, } \\
\text { trigonales, incoloros; } \\
\text { polvo blanco }\end{array}$ & $\begin{array}{l}580 \text { se } \\
\text { descompone }\end{array}$ & 580 & 74,10 & insol & 2,24 & & & & & \\
\hline $\begin{array}{l}\text { HIDROXIDO DE LITIO } \\
\text { MONOHIDRATO } \\
1310-66-3\end{array}$ & cristales & & $450-471$ & & $10,9 \mathrm{~g} / 100 \mathrm{ml}$ & 1,51 & & & & & \\
\hline $\begin{array}{l}\text { HIDROXIDO DE LITIO } \\
1310-65-2\end{array}$ & cristales & $\begin{array}{l}\text { se } \\
\text { descompone }\end{array}$ & $450-471$ & & $12,8 \mathrm{~g} / 100 \mathrm{ml}$ & 1,46 & & & & & \\
\hline $\begin{array}{l}\text { HIDROXIDO POTASICO } \\
\quad 1310-58-3\end{array}$ & $\begin{array}{l}\text { agregados, bastones, } \\
\text { gránulos, agujas, } \\
\text { escamas o masa } \\
\text { fusionada de color } \\
\text { blanco o ligeramente } \\
\text { amarillo; cristales } \\
\text { rómbicos blancos; } \\
\text { líquido acuoso incoloro }\end{array}$ & 1324 & 380 & 56,11 & $\begin{array}{l}100 \mathrm{~g} / 90 \mathrm{ml} \\
\text { @ } 25^{\circ} \mathrm{C}\end{array}$ & $2,044 \mathrm{mg} / \mathrm{ml}$ & & $\begin{array}{l}0,13 \\
\text { @ } 714^{\circ} \mathrm{C}\end{array}$ & & & \\
\hline $\begin{array}{l}\text { HIDROXIDO SODICO } \\
1310-73-2\end{array}$ & $\begin{array}{l}\text { agregados, astillas, } \\
\text { gránulos, bastones; } \\
\text { escamas o tarta de color } \\
\text { blanco; sólido fusionado } \\
\text { con fractura cristalina }\end{array}$ & 1390 & 318,4 & 40,01 & $1 \mathrm{~g} / 0,9 \mathrm{ml}$ & $2,13 @ 25^{\circ} \mathrm{C}$ & & $\begin{array}{l}0,13 \\
@ 739^{\circ} \mathrm{C}\end{array}$ & & & \\
\hline $\begin{array}{l}\text { HIDRURO CALCICO } \\
7789-78.8\end{array}$ & $\begin{array}{l}\text { agregados o cristales de } \\
\text { color blanco grisáceo }\end{array}$ & $\begin{array}{l}675 \text { se } \\
\text { descompone }\end{array}$ & & 42,10 & se descompone & 1,7 & & & & & \\
\hline $\begin{array}{l}\text { HIDRURO DE LITIO } \\
7580.67 .8\end{array}$ & $\begin{array}{l}\text { el producto comercial es } \\
\text { habitualmente gris; } \\
\text { polvo o masa cristalina } \\
\text { blanca, translúcida }\end{array}$ & $\begin{array}{l}850 \text { se } \\
\text { descompone }\end{array}$ & 680 & 7,95 & reacciona & $0,76-0,77$ & & $0 \mathrm{~mm} \mathrm{Hg}$ & & $\begin{array}{l}\text { muy } \\
\text { infla- } \\
\text { mable }\end{array}$ & 200 \\
\hline $\begin{array}{l}\text { HIPOCLORITO SODICO } \\
7681.52 .9\end{array}$ & $\begin{array}{l}\text { sólo en solución; líquido } \\
\text { amarillo verdoso }\end{array}$ & & & 74,44 & sol & 1,21 & & & & & \\
\hline $\begin{array}{l}\text { LITIO } \\
\quad 7439-93-2\end{array}$ & $\begin{array}{l}\text { metal blanco plateado; } \\
\text { estructura cúbica } \\
\text { centrada; se torna } \\
\text { amarillento en contacto } \\
\text { con la humedad del aire; } \\
\text { se torna blanco grisáceo } \\
\text { en contacto con el aire }\end{array}$ & 1342 & 180,54 & 6,941 & reacciona & 0,534 & & $\begin{array}{l}0,133 \\
\text { @ } 723^{\circ} \mathrm{C}\end{array}$ & & & \\
\hline $\begin{array}{l}\text { METLATO SODICO } \\
124-41-4\end{array}$ & polvo amorfo y fluido & & $\begin{array}{l}127 \text { se } \\
\text { descompone }\end{array}$ & 54,03 & reacciona & 0,45 & & & & & $70-80$ \\
\hline
\end{tabular}


Tabla 104.20 Propiedades físicas y químicas.

\begin{tabular}{|c|c|c|c|c|c|c|c|c|c|c|}
\hline $\begin{array}{l}\text { Denominación } \\
\text { química } \\
\mathrm{N} \text { úmero CAS }\end{array}$ & Color/ Forma & $\begin{array}{l}\text { p.e. } \\
(\stackrel{O}{ }=)\end{array}$ & $\begin{array}{l}\text { p.f. } \\
(\stackrel{\circ}{ } C)\end{array}$ & $\begin{array}{l}\text { p.m.l } \\
\text { (g/ } \\
\text { mol) }\end{array}$ & $\begin{array}{l}\text { Solubilidad } \\
\text { en agua }\end{array}$ & $\begin{array}{l}\text { Densidad } \\
\text { relativa } \\
\text { (agua }=1 \text { ) }\end{array}$ & $\begin{array}{l}\text { Densidad } \\
\text { de vapor } \\
\text { relativa } \\
\text { (aire=1) }\end{array}$ & $\begin{array}{l}\text { Pvap/ } \\
(\mathrm{kPa})\end{array}$ & $\begin{array}{l}\text { Límit. } \\
\text { inflam. }\end{array}$ & $\begin{array}{ll}\text { p.ig. } & \text { p.aut } \\
\left({ }^{\circ} C\right) & \text { ig. } \\
& \left({ }^{\circ} \mathrm{C}\right)\end{array}$ \\
\hline $\begin{array}{l}\text { NITRATO AMONICO } \\
6484.52-2\end{array}$ & $\begin{array}{l}\text { cristales rómbicos } \\
\text { incoloros; monoclínicos } \\
\text { a temperaturas por } \\
\text { encima de } 32,1^{\circ} \mathrm{C} ; \\
\text { cristales transparentes o } \\
\text { gránulos blancos, cinco } \\
\text { fases sólidas a presión } \\
\text { normal; ortorrómbicos a } \\
\text { temp. amb.; incoloros } \\
\text { (puros) o grises o } \\
\text { marrones (calidad de } \\
\text { fertilizante). }\end{array}$ & $\begin{array}{l}210 \text { se } \\
\text { descompone }\end{array}$ & 169,6 & 80,06 & $\begin{array}{l}118,3 \mathrm{~g} / \\
100 \mathrm{ml} \\
@ 0^{\circ} \mathrm{C} ; \\
871 \mathrm{~g} / 100 \mathrm{ml} \\
@ 100^{\circ} \mathrm{C}\end{array}$ & $1,725 @ 25^{\circ} \mathrm{C}$ & & & & \\
\hline $\begin{array}{l}\text { NITRATO CALCICO } \\
\text { 10124-37-5 }\end{array}$ & $\begin{array}{l}\text { gránulos; cristales } \\
\text { cúbicos incoloros; masa } \\
\text { blanca }\end{array}$ & & 560 & 164,10 & muy sol & $2,504 @ 18^{\circ} \mathrm{C}$ & & & & \\
\hline $\begin{array}{l}\text { NITRATO POTASICO } \\
7757-79-1\end{array}$ & $\begin{array}{l}\text { cristales incoloros, } \\
\text { rómbicos o trigonales; } \\
\text { polvo blanco granular o } \\
\text { cristalino }\end{array}$ & $\begin{array}{l}400 \text { se } \\
\text { descompone }\end{array}$ & 334 & 101,10 & $\begin{array}{l}1 \mathrm{~g} / 2,8 \mathrm{ml} @ \\
25^{\circ} \mathrm{C}\end{array}$ & $2,109 @ 16^{\circ} \mathrm{C}$ & & & & \\
\hline $\begin{array}{l}\text { NITRATO SODICO } \\
7631-99-4\end{array}$ & $\begin{array}{l}\text { cristales incoloros, } \\
\text { trigonales o } \\
\text { rombohédricos; gránulos } \\
\text { o polvo blanco }\end{array}$ & $\begin{array}{l}380 \text { se } \\
\text { descompone }\end{array}$ & 308 & 85,01 & $\begin{array}{l}92,1 \mathrm{~g} / 100 \mathrm{ml} \\
@ 25^{\circ} \mathrm{C}\end{array}$ & 2,26 & & & & \\
\hline $\begin{array}{c}\text { NITRITO CALCICO } \\
13780-06-8\end{array}$ & $\begin{array}{l}\text { cristales incoloros } 0 \\
\text { amarillentos }\end{array}$ & & 100 & 150,11 & sol & $2,23 @ 34^{\circ} \mathrm{C}$ & & & & \\
\hline $\begin{array}{l}\text { NITRITO POTASICO } \\
7758-09-0\end{array}$ & $\begin{array}{l}\text { gránulos } 0 \text { bastones } \\
\text { blancos o ligeramente } \\
\text { amarillos; prismas } \\
\text { blancos } 0 \text { amarillentos }\end{array}$ & & $\begin{array}{l}441 ; \text { se } \\
\text { descompone } \\
\text { @ } 351\end{array}$ & 85,10 & muy sol & 1,915 & & & & \\
\hline $\begin{array}{l}\text { NITRITO SODICO } \\
7632-00.0\end{array}$ & $\begin{array}{l}\text { prismas rombohédricos } \\
\text { incoloros o amarillentos; } \\
\text { gránulos, bastones o } \\
\text { polvo de color blanco } \\
\text { ligeramente amarillo; } \\
\text { cristales, gránulos, } \\
\text { astillas o polvo de color } \\
\text { blanco o ligeramente } \\
\text { amarillo }\end{array}$ & $\begin{array}{l}320 \text { se } \\
\text { descompone }\end{array}$ & 271 & 69,00 & sol & 2,26 & & & & \\
\hline $\begin{array}{c}\text { OXIDO CALCICO } \\
1305-78-8\end{array}$ & $\begin{array}{l}\text { cristales cúbicos } \\
\text { incoloros; polvo granular } \\
0 \text { agregados de color } \\
\text { blanco o blanco grisáceo }\end{array}$ & 2850 & 2570 & 56,08 & & $3,32-3,35$ & & & & \\
\hline $\begin{array}{l}\text { OXIDO POTASICO } \\
12136-45-7 \\
\end{array}$ & polvo cristalino & & 350 & & reacciona & 2,3 & & & & \\
\hline $\begin{array}{l}\text { PEROXIDO SODICO } \\
1313-60-6\end{array}$ & $\begin{array}{l}\text { polvo granular } \\
\text { amarillento a blanco; } \\
\text { polvo blanco que se } \\
\text { torna amarillo al } \\
\text { exponerse al aire; polvo } \\
\text { blanco amarillento que } \\
\text { se torna amarillo al } \\
\text { calentarse }\end{array}$ & $\begin{array}{l}657 \text { se } \\
\text { descompone }\end{array}$ & $\begin{array}{l}460 \text { se } \\
\text { descompone }\end{array}$ & 77,99 & muy sol & 2,805 & & & & \\
\hline
\end{tabular}




\begin{tabular}{|c|c|c|c|c|c|c|c|c|c|c|c|}
\hline $\begin{array}{l}\text { Denominación } \\
\text { química } \\
\mathrm{N} \text { úmero CAS }\end{array}$ & Color/ Forma & $\begin{array}{l}\text { p.e. } \\
\left({ }^{\circ} \mathrm{C}\right)\end{array}$ & $\begin{array}{l}\text { p.f. } \\
(\stackrel{\circ}{ } C)\end{array}$ & $\begin{array}{l}\text { p.m.l } \\
\text { (g/ } \\
\text { mol) }\end{array}$ & $\begin{array}{l}\text { Solubilidad } \\
\text { en agua }\end{array}$ & $\begin{array}{l}\text { Densidad } \\
\text { relativa } \\
\text { (agua }=1 \text { ) }\end{array}$ & $\begin{array}{l}\text { Densidad } \\
\text { de vapor } \\
\text { relativa } \\
\text { (aire=1) }\end{array}$ & $\begin{array}{l}\text { Pvap/ } \\
(\mathrm{kPa})\end{array}$ & $\begin{array}{l}\text { Límit. } \\
\text { inflam. }\end{array}$ & 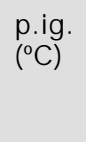 & $\begin{array}{l}\text { p.aut } \\
\text { ig. } \\
\left({ }^{\circ} C\right)\end{array}$ \\
\hline $\begin{array}{l}\text { PERYODATO POTASICO } \\
7790-21-8\end{array}$ & $\begin{array}{l}\text { pequeños cristales } \\
\text { incoloros o polvo } \\
\text { granular blanco }\end{array}$ & & 582 & 230 & lig sol & 3,168 & & & & 582 & \\
\hline $\begin{array}{l}\text { POTASIO } \\
\quad 7440-09-7\end{array}$ & $\begin{array}{l}\text { metal blando de color } \\
\text { blanco plateado; } \\
\text { estructura cúbica } \\
\text { centrada }\end{array}$ & 765,5 & 63,2 & 39,098 & & 0,856 & & $\begin{array}{l}8 \mathrm{~mm} \mathrm{Hg} \\
\text { @ } 432^{\circ} \mathrm{C}\end{array}$ & & & \\
\hline $\begin{array}{l}\text { SODI0 } \\
7440-23-5\end{array}$ & $\begin{array}{l}\text { metal ligero, } \\
\text { blanco-plateado; } \\
\text { estructura cúbica } \\
\text { centrada; brillante recién } \\
\text { cortado }\end{array}$ & 881,4 & 97,82 & 22,99 & & 0,968 & & $\begin{array}{l}1,2 \mathrm{~mm} \mathrm{Hg} \\
@ 400^{\circ} \mathrm{C}\end{array}$ & & & $\begin{array}{l}115 \\
\text { en aire } \\
\text { seco }\end{array}$ \\
\hline $\begin{array}{l}\text { TRIPOLLFOSFATO SODICO } \\
7758-29-4\end{array}$ & $\begin{array}{l}\text { polvo y gránulos; polvo } \\
\text { blanco }\end{array}$ & & & 367,86 & sol & & & & & & \\
\hline $\begin{array}{l}\text { YODATO POTASICO } \\
7758.05 .6\end{array}$ & $\begin{array}{l}\text { cristales blancos o polvo } \\
\text { cristalino; cristales } \\
\text { monoclínicos incoloros }\end{array}$ & & 560 & 214,02 & $4,74 \mathrm{~g} / 100 \mathrm{ml}$ & $\begin{array}{l}3,93 \\
\text { @ } 32{ }^{\circ} \mathrm{C} / 4^{\circ} \mathrm{C}\end{array}$ & & & & & \\
\hline $\begin{array}{l}\text { YODURO POTASICO } \\
7681-11-0\end{array}$ & $\begin{array}{l}\text { cristales cúbicos } \\
\text { incoloros o blancos, } \\
\text { gránulos o polvo blanco; } \\
\text { cristales hexahédricos } \\
\text { transparentes o } \\
\text { ligeramente opacos }\end{array}$ & 1330 & 680 & 166,02 & sol $1 \mathrm{~g} / 0,7 \mathrm{ml}$ & 3,13 & & & & & \\
\hline $\begin{array}{l}\text { YODURO SODICO } \\
7681-82.5\end{array}$ & $\begin{array}{l}\text { cristales cúbicos } \\
\text { incoloros; cristales o } \\
\text { gránulos blancos; polvo } \\
\text { blanco }\end{array}$ & 1304 & 651 & 149,92 & $184 \mathrm{~g} @ 25^{\circ} \mathrm{C}$ & 3,67 & & $\begin{array}{l}1 \mathrm{~mm} \mathrm{Hg} \\
@ 767{ }^{\circ} \mathrm{C}\end{array}$ & & & \\
\hline
\end{tabular}

Continua ... 


\section{AMIDAS}

Las amidas son un tipo de compuestos orgánicos que pueden considerarse derivados de ácidos o aminas. Por ejemplo, la amida alifática simple acetamida $\left(\mathrm{CH}_{3}-\mathrm{CO}-\mathrm{N} \mathrm{H}_{2}\right)$ está relacionada con el ácido acético en el sentido de que el grupo $\mathrm{BOH}$ del ácido acético se sustituye por un grupo $-\mathrm{NH}_{2}$. Recíprocamente, se puede considerar que la acetamida es un derivado del amoniaco por sustitución de un hidrógeno por un grupo acilo. Las amidas se derivan no sólo de los ácidos carboxílicos alifáticos o aromáticos, sino también de otros tipos de ácidos, como los que contienen azufre o fósforo.

El término amidas sustituidas se refiere a las amidas que tienen uno 0 ambos hidrógenos del nitrógeno reemplazados por otros grupos; por ejemplo, la $\mathrm{N}, \mathrm{N}$-dimetilacetamida. Este compuesto puede considerarse también como una amina, la acetildimetilamina.

Las amidas son, generalmente, de naturaleza neutra con respecto a su capacidad de reacción en comparación con los ácidos o aminas de los que se derivan y algunas de ellas son ligeramente resistentes a la hidrólisis. Las amidas simples de los ácidos carboxílicos alifáticos (con excepción de la formamida) se encuentran en estado sólido a temperatura ambiente, mientras que las amidas sustituidas de los ácidos carboxílicos alifáticos pueden ser líquidas, con puntos de ebullición relativamente altos. L as amidas de los ácidos carboxílicos aromáticos o sulfónicos son, generalmente, sólidas. Existe una gran variedad de métodos para la síntesis de las amidas.

\section{Usos}

Las amidas no sustituidas de los ácidos carboxílicos alifáticos se utilizan ampliamente como productos intermedios, estabilizantes, agentes de desmolde para plásticos, películas, surfactantes y fundentes. Las amidas sustituidas, como la dimetilformamida y la dimetilacetamida tienen propiedades disolventes muy poderosas.

L a dimetilformamida se utiliza principalmente como disolvente en procesos de síntesis orgánica y en la preparación de fibras sintéticas. T ambién constituye un medio selectivo para la extracción de compuestos aromáticos a partir del petróleo crudo y un disolvente para colorantes. T anto la dimetilformamida como la dimetilacetamida son componentes de disolventes de pinturas. La dimetilacetamida se emplea también como disolvente de plásticos, resinas y gomas y en numerosas reacciones orgánicas.

La acetamida se utiliza para la desnaturalización del alcohol y como disolvente de numerosos compuestos orgánicos, como plastificante y como aditivo para el papel. T ambién se encuentra en lacas, explosivos y fundentes. La formamida es un ablandador de papel y pegamentos y se utiliza como disolvente en la industria de plásticos y farmacéutica.

Algunas amidas alifáticas no saturadas, como la acrilamida, son monómeros reactivos que se utilizan en la síntesis de polímeros. La acrilamida se utiliza también en la síntesis de colorantes, adhesivos, en el engomado del papel y el apresto de textiles, en tejidos plisados y en el tratamiento del agua y las aguas residuales. En la industria del metal se utiliza para el procesado de minerales y en ingeniería civil, para la construcción de cimientos de presas y túneles. Las poliacrilamidas se utilizan ampliamente como agentes floculantes en el tratamiento del agua y las aguas residuales y como agentes reforzadores en los procesos de fabricación de papel en la industria papelera. L os compuestos de amidas aromáticas son importantes productos intermedios en la industria de los colorantes y en medicina. Algunos también son repelentes de insectos.

\section{Riesgos}

La gran variedad de estructuras químicas posibles de las amidas se refleja en la diversidad de sus efectos biológicos. Algunas son completamente inocuas, por ejemplo, las amidas de los ácidos grasos simples de cadena larga, como las amidas de los ácidos esteárico u oléico. Por otra parte, algunos miembros de esta familia han sido clasificados por la A gencia Internacional para la Investigación sobre el Cáncer (IARC) en el Grupo 2A (probable carcinógeno humano) 0 en el Grupo 2B (posible carcinógeno humano). Con la acrilamida se han observado efectos neurológicos en el hombre y en animales de experimentación. La dimetilformamida y la dimetilacetamida producen lesiones hepáticas en los animales y los efectos teratogénicos de la formamida y la monometilformamida se han demostrado experimentalmente.

$\mathrm{Si}$ bien existe una gran cantidad de información acerca del metabolismo de algunas amidas, la naturaleza de sus efectos tóxicos aún no se ha explicado a nivel molecular o celular. M uchas amidas simples son, probablemente, hidrolizadas por la acción de amidasas inespecíficas en el hígado y el ácido producido se excreta o se metaboliza a través de los mecanismos normales.

Algunas amidas aromáticas, como la $\mathrm{N}$-fenilacetamida (acetanilida), se hidroxilan en el anillo aromático y, seguidamente, se conjugan y se excretan. La capacidad de ciertas amidas de penetrar en el organismo a través de la piel intacta es especialmente importante para la adopción de medidas preventivas.

\section{E fectos neurológicos}

La acrilamida se obtuvo por primera vez en Alemania en el año 1893. Sin embargo, no fue sino hasta principios del decenio de 1950 cuando se inició su producción a escala industrial. Este desarrollo dio comienzo en Estados U nidos. A mediados de los años cincuenta se observó que los trabajadores expuestos a acrilamida desarrollaban alteraciones neurológicas características, asociadas principalmente con dificultades posturales y motoras. Los síntomas descritos fueron: hormigueo en los dedos, sensibilidad al tacto, enfriamiento de las extremidades, sudoración excesiva de las manos y de los pies, una alteración característica del color de la piel de las extremidades hacia un tono rojo azulado y una tendencia a la descamación de la piel de los dedos y de las manos. T odos estos síntomas se acompañaban de debilidad en las manos y en los pies, que dificultaba la marcha, la subida de escaleras, etc. La recuperación, en general, se consigue con sólo cesar la exposición a la sustancia. El tiempo necesario para la recuperación varía entre unas pocas semanas y un año.

El examen neurológico de las personas que padecen intoxicación por acrilamida muestra una neuropatía periférica típica con disminución o abolición de los reflejos tendinosos, una prueba de Romberg positiva, pérdida del sentido postural, disminución 0 pérdida del sentido de vibración, ataxia y atrofia de los músculos de las extremidades.

Tras la identificación del conjunto de síntomas asociado con la exposición a la acrilamida, se llevaron a cabo estudios con animales de experimentación para intentar documentar estos cambios. Se demostró que una serie de especies animales, como la rata, el gato y el papión, desarrollaban neuropatía periférica con alteraciones de la marcha y del equilibrio y pérdida del sentido postural. El examen histopatológico reveló una degeneración de los axones y de las vainas de mielina. Los nervios con los 
axones más largos y más gruesos fueron los más afectados, a diferencia de los cuerpos de las células nerviosas.

Se han propuesto varias teorías para explicar por qué se producen estos cambios. U na de ellas apunta a una posible interferencia con el metabolismo del cuerpo de la propia célula nerviosa; otra postula una interferencia con el sistema de transporte intracelular de la neurona. T ambién podría ocurrir que se produjera un efecto tóxico local sobre todo el axón, que lo hiciera más vulnerable a la acción de la acrilamida que el cuerpo neuronal. Los estudios realizados para investigar los cambios que tienen lugar en los axones y las vainas de mielina describen el proceso como un fenómeno de autodesecación, un término utilizado para describir gráficamente la evolución de los cambios observados en los nervios periféricos.

Aunque los síntomas y signos descritos de la neuropatía periférica característica asociada a la exposición a acrilamida se conocen perfectamente gracias a los casos de exposición industrial y a los estudios realizados en animales de experimentación, parece ser que, en el hombre, ante una ingestión de acrilamida, como ha ocurrido por beber agua contaminada con esta sustancia, los síntomas y signos están todos ellos relacionados con el sistema nervioso central. En estos casos se produjo somnolencia, alteraciones del equilibrio y trastornos mentales caracterizados por confusión, pérdida de memoria y alucinaciones. H asta más tarde no se presentaron síntomas de afectación neurológica periférica.

Se ha demostrado en esperimentación con conejos que esta sustancia se absorbe por vía percutánea, pudiendo ser ésta la principal responsable de los casos descritos de exposición profesional a la acrilamida en forma de monómero. Se piensa que el riesgo de inhalación estaría relacionado, principalmente, con la exposición a aerosoles de esta sustancia.

\section{Efectos hepatotóxicos}

Las buenas propiedades disolventes de la dimetilformamida hacen que, cuando se produce contacto con la piel, ésta se deshidrate y desengrase, provocando picor y descamación. Se han descrito algunos casos de irritación ocular tras la exposición profesional a los vapores. Los síntomas de los trabajadores expuestos fueron náuseas, vómitos y anorexia. También se ha descrito intolerancia al alcohol tras la exposición a dimetilformamida.

Los estudios de la acción de la dimetilformamida en animales de experimentación han demostrado la existencia de alteraciones hepáticas y renales en ratas, conejos y gatos. Estos efectos se observaron tanto si la administración se efectúo por vía intraperitoneal como si fue por inhalación. Los perros expuestos a concentraciones elevadas de vapores de esta sustancia desarrollaron policitemia, disminución del pulso y de la presión sistólica y evidencias histológicas de cambios degenerativos en el miocardio.

En el hombre, la dimetilformamida se absorbe rápidamente a través de la piel y la exposición reiterada causa efectos acumulativos. Además, al igual que ocurre con la dimetilacetamida, puede favorecer la absorción percutánea de otras sustancias disueltas en ella.

Debe recordarse que la dimetilformamida penetra rápidamente a través de los guantes de caucho (tanto natural como neopreno), por lo que no se recomienda el uso prolongado de este tipo de guantes. El polietileno confiere una mayor protección, si bien cualquier tipo de guante que se utilice para manipular este disolvente deberá lavarse después de cada contacto y se sustituirá con frecuencia.

La acción de la dimetilacetamida se ha estudiado en animales de experimentación, habiéndose demostrado que, tras una exposición reiterada o continua, su principal efecto tóxico se ejerce en el hígado. El contacto con la piel puede determinar la absorción de cantidades peligrosas de este compuesto.

\section{Carcinogénesis}

La acetamida y la tioacetamida se preparan calentando acetato amónico y sulfuro de aluminio y se utilizan en el laboratorio como reactivos analíticos. Se ha demostrado que ambos compuestos producen hepatomas en ratas tras su administración prolongada junto con los alimentos. La tioacetamida es más potente en este sentido; también tiene efectos carcinogénicos en ratones y puede inducir tumores del conducto biliar en ratas. Si bien no se dispone de datos sobre el efecto de estas sustancias químicas en el hombre, los estudios realizados en animales de experimentación son tan numerosos que, en la actualidad, estas sustancias se consideran posibles carcinógenos humanos. La tioacetamida se trata también en el artículo "Compuestos orgánicos de azufre" de este mismo capítulo. La IARC ha clasificado a la dimetilformamida en el Grupo $2 \mathrm{~B}$ como posible carcinógeno humano.

La IARC ha clasificado a la acrilamida como probable carcinógeno humano (Grupo 2A). Esa decisión se ha basado en los resultados de los bioensayos realizados en ratones con distintas vías de administración, que han demostrado el desarrollo de tumores en distintos órganos, así como en los datos de genotoxicidad y la capacidad de la acrilamida para formar aductos. La estructura química de la acrilamida también sugiere la posibilidad de que esta sustancia sea cancerígena para el ser humano.

\section{Medidas de salud y seguridad}

Las propiedades tóxicas potenciales de cualquier amida deben considerarse cuidadosamente antes de iniciar su uso o exposición. Como quiera que las amidas (especialmente las de bajo peso molecular) tienden, en general, a absorberse por vía percutánea, se debe evitar el contacto con la piel. La inhalación de polvos 0 vapores de estos productos también debe evitarse. Sería deseable que las personas expuestas a amidas se sometieran a reconocimientos médicos periódicos, prestando especial atención al funcionamiento del hígado y el sistema nervioso. La calificación de cancerígeno posible o probable de algunas de estas sustancias químicas obliga a imponer unas condiciones de trabajo extremadamente prudentes. 
TABLAS DE AMIDAS

\begin{tabular}{|c|c|c|c|}
\hline Producto químico & Sinónimos/ Código UN & $\mathrm{N}$ úmero CAS & Fórmula estructural \\
\hline ACETAMIDA & $\begin{array}{l}\text { Amida del ácido acético; ácido acetimídico; etanamida; } \\
\text { metanocarboxamida }\end{array}$ & $60-35-5$ & \\
\hline 2-ACETILAMINOFLUORENO & $\begin{array}{l}\text { 2-Acetaminofluoreno; acetoaminofluoreno; N-acetil-2-aminofluoreno; } \\
\text { 2-(acetilamino) fluoreno; 2-fluorenilacetamida }\end{array}$ & $53-96-3$ & \\
\hline ACRILAMIDA & $\begin{array}{l}\text { Amida acrilica; etilencarboxamida; propenamida; 2-propenamida; } \\
\text { vinilamida } \\
\text { UN2074 }\end{array}$ & $79-06-1$ & \\
\hline AMIDA SODICA & & $7782.92-5$ & $\mathrm{Na}-\mathrm{NH} 2$ \\
\hline BENZOTIACIL-2-CICLOHEXILSULFENAMIDA & $\begin{array}{l}\text { N-Ciclohexil-2-benzotiazolsulfenamida; } \\
\text { N-ciclohexil-2-benzotiacilsulfenamida }\end{array}$ & $95-33-0$ & \\
\hline CICLOFOSFAMIDA & $\begin{array}{l}\text { Ciclofosfano; diamida del éster del ácido } \\
\text { N,N-bis(2-cloroetil)-N',o-propilenfosfórico; } \\
\text { N,N-Dis(2-cloroetil)tetrahidro-2h-1,3,2-oxazafosforin-2-amina- } \\
\text { 2-óxido; éster de la bis(2-cloroetil) fosforamida-propanolamida cíclica }\end{array}$ & $50-18-0$ & \\
\hline CICLOHEXIMIDA & $\begin{array}{l}\beta-(2-\text {-3,5-Dimetil-2-20xociclohexil)-2-hidroxietil) glutarimida; } \\
\text { 3-(2-(3,5-dimetil-2-oxociclohexil)-2-hidroxietil) glutarimida }\end{array}$ & $66-81-9$ & \\
\hline 2-CLOROACETAMIDA & Cloroacetamida; $\alpha$-cloroacetamida; 2 -cloroetanamida & $79-07-2$ & \\
\hline 2-CLORO-N-HIDROXIMETILACETAMIDA & Cloracetamida-N-metolol & $2832-19-1$ & \\
\hline CLORURO DE DIETILCARBAMOILO & $\begin{array}{l}\text { Cloruro dietilcarbámico; cloruro de N,N-dietilcarbamoilo; cloruro de } \\
\text { dietilcarbamilo; dietilcloroformamida; N,N-dietilcloroformamida }\end{array}$ & $88-10-8$ & \\
\hline CLORURO DE DIMETILCARBAMOILO & $\begin{array}{l}\text { Dimetilamida del ácido clorofórmico; cloruro de (dimetilamino) carbonilo; } \\
\text { cloruro del ácido dimetillarbámico; cloururo dimetilcarbámico; } \\
\text { dimetilcloroformamida } \\
\text { UN2262 }\end{array}$ & $79-44-7$ & \\
\hline COLCHICINA & $\begin{array}{l}\text { Acetamida, N-(5,6,7,9-tetrahidro-1,2,3,10-tetrametoxi-9-oxobenzo- } \alpha \text { - } \\
\text { (heptalen-7-ill)-; éter metílico del ácido N-acetil trimetilcolchicínico; } \\
\text { benzo(a) heptalen-9(5h)-ona, 7-acetamido-6,7-dihidro-1,2,3,10- } \\
\text { tetrametoxi- }\end{array}$ & $64-86-8$ & \\
\hline 4,4'-DIACETILBENCIDINA & $\begin{array}{l}\text { 4,4'-Diacetamidodifenilo; 4,4'-diacetilaminodifenilo; diacetilbencidina; } \\
\text { N,N'-diacetilbencidina }\end{array}$ & $613-35-4$ & \\
\hline
\end{tabular}




\begin{tabular}{|c|c|c|c|}
\hline Producto químico & Sinónimos/ Código UN & $\mathrm{N}$ úmero $\mathrm{CAS}$ & Fórmula estructural \\
\hline DIMETILACETAMIDA & $\begin{array}{l}\text { Acetodimetilamida; dimetilamida del ácido acético; N,N-dimetilacetamida; } \\
\text { amida de la dimetilacetona; acetato de dimetilamida }\end{array}$ & $127-19-5$ & \\
\hline DIMETILFORMAMIDA & $\begin{array}{l}\text { N,N-dimetil formamida; N,N-dimetilmetanamida; N-formildimetilamina } \\
\text { UN2265 }\end{array}$ & $68-12-2$ & \\
\hline N,N'ETILEN BIS(ESTEARAMIDA) & $\begin{array}{l}\text { 1,2-Bis(octadecanamido) etano; N,N'-etilen distearilamida; } \\
\text { N,N'-etilen bis(octadecanamina) }\end{array}$ & $110-30-5$ & \\
\hline FORMAMIDA & Carbamaldehído; metanamida & $75-12 \cdot 7$ & \\
\hline METILFORMAMIDA & N-Metilformamida; monometilformamida & $123-39-7$ & \\
\hline
\end{tabular}

\begin{tabular}{|c|c|c|c|c|c|c|}
\hline \multirow[b]{2}{*}{$\begin{array}{l}\text { Denominación } \\
\text { química } \\
\text { N úmero CAS }\end{array}$} & \multicolumn{4}{|c|}{ Tarjetas Internacionales sobre la Seguridad de los Productos Q uímicos } & \multicolumn{2}{|c|}{ N IOSH (EE.UU.) } \\
\hline & $\begin{array}{l}\text { Período } \\
\text { corto de } \\
\text { exposición }\end{array}$ & $\begin{array}{l}\text { Período } \\
\text { largo de } \\
\text { exposición }\end{array}$ & $\begin{array}{l}\text { Vías de } \\
\text { exposición }\end{array}$ & Síntomas & $\begin{array}{l}\text { O rganos } \\
\text { afectados } \\
\text { Vías de } \\
\text { entrada }\end{array}$ & Síntomas \\
\hline $\begin{array}{c}\text { ACETAMIDA } \\
60-35-5\end{array}$ & ojos; piel; tract res: & & $\begin{array}{r}\text { Inhalación } \\
\text { Piel } \\
\text { Ojos } \\
\text { Ingestión }\end{array}$ & $\begin{array}{l}\text { Tos, disnea } \\
\text { Enrojecimiento, dolor } \\
\text { Dolor, enrojecimiento, visión borrosa } \\
\text { Dolor de garganta, sensación de quemazón }\end{array}$ & & \\
\hline $\begin{array}{l}\text { 2-ACETILAMINOFLUORENO } \\
53-96-3\end{array}$ & & & & & $\begin{array}{l}\text { Hígado; vejiga; } \\
\text { rin̂nones; páncreas; } \\
\text { piel; pulmones [en } \\
\text { animales: tumores } \\
\text { en el hígado; } \\
\text { vejiga, páncreas, } \\
\text { piel y pulmones] } \\
\text { Inh, abs, ing, con }\end{array}$ & $\begin{array}{l}\text { Deterioro funcional de hígado, } \\
\text { riñones, vejiga, páncreas } \\
\text { [carc] }\end{array}$ \\
\hline $\begin{array}{l}\text { ACRILAMIDA } \\
79-06-1\end{array}$ & $\begin{array}{l}\text { piel; tract resp; } \\
\text { SNC; hígado }\end{array}$ & SNP; SNC & $\begin{array}{r}\text { Inhalación } \\
\text { Piel } \\
\text { 0jos } \\
\text { Ingestión }\end{array}$ & $\begin{array}{l}\text { Tos, dolor de garganta, debilidad } \\
\text { Puede absorberse, enrojecimiento, dolor } \\
\text { Enrojecimiento, dolor } \\
\text { Dolor abdominal, debilidad }\end{array}$ & $\begin{array}{l}\text { SNC; SNP; piel; } \\
\text { ojos, sis repro [en } \\
\text { animales: tumores } \\
\text { en pulmones, } \\
\text { testículos, tiroides y } \\
\text { glándulas } \\
\text { suprarrenales] } \\
\text { Inh, abs, ing, con }\end{array}$ & $\begin{array}{l}\text { Irrit ojos y piel; ataxia, entu } \\
\text { de las extremidades, pares; } \\
\text { deb musc; ausencia de reflejos } \\
\text { tendinosos profundos; } \\
\text { sudoración de las manos; ftg, } \\
\text { let; efectos repro [carc] }\end{array}$ \\
\hline
\end{tabular}




\begin{tabular}{|c|c|c|c|c|c|c|}
\hline \multirow[b]{2}{*}{$\begin{array}{l}\text { Denominación } \\
\text { química } \\
\mathrm{N} \text { úmero CAS }\end{array}$} & \multicolumn{4}{|c|}{ Tarjetas Internacionales sobre la Seguridad de los Productos Q uímicos } & \multicolumn{2}{|c|}{ N IO SH (EE.UU.) } \\
\hline & $\begin{array}{l}\text { Período } \\
\text { corto de } \\
\text { exposición }\end{array}$ & $\begin{array}{l}\text { Período } \\
\text { largo de } \\
\text { exposición }\end{array}$ & $\begin{array}{l}\text { Vías de } \\
\text { exposición }\end{array}$ & Síntomas & $\begin{array}{l}\text { O rganos } \\
\text { afectados } \\
\text { Vías de } \\
\text { entrada }\end{array}$ & Síntomas \\
\hline $\begin{array}{l}\text { CICLOFOSFAMIDA } \\
\text { 50-18-0 }\end{array}$ & $\begin{array}{l}\text { ojos; piel; tract } \\
\text { resp; rinones; } \\
\text { vejiga; SCV; SNC; } \\
\text { tract Gl; hígado; } \\
\text { corazón; sangre }\end{array}$ & piel & $\begin{array}{r}\text { Inhalación } \\
\text { Piel }\end{array}$ & $\begin{array}{l}\text { Diarrea, mareo, caída del cabello, } \\
\text { oscurecimiento de la piel y las uñas, náuseas, } \\
\text { vómitos } \\
\text { Puede absorberse }\end{array}$ & & \\
\hline $\begin{array}{l}\text { 2-CLOROACETAMIDA } \\
\text { 79-07-2 }\end{array}$ & $\begin{array}{l}\text { ojos; piel; tract } \\
\text { resp; corazón; } \\
\text { hígado; bazo }\end{array}$ & piel & $\begin{array}{r}\text { Inhalación } \\
\text { Piel } \\
\text { 0jos } \\
\text { Ingestión } \\
\end{array}$ & $\begin{array}{l}\text { Sensación de quemazón, tos, dolor de } \\
\text { garganta } \\
\text { Enrojecimiento, dolor } \\
\text { Enrojecimiento, dolor } \\
\text { Dolor de garganta }\end{array}$ & & \\
\hline $\begin{array}{l}\text { DIMETILACETAMIDA } \\
\text { 127-19-5 }\end{array}$ & ojos; piel; tract resp & $\begin{array}{l}\text { piel; hígado; } \\
\text { riñones }\end{array}$ & $\begin{array}{r}\text { Inhalación } \\
\text { Piel } \\
\text { 0jos }\end{array}$ & $\begin{array}{l}\text { Cefalea, náuseas, vómitos } \\
\text { Puede absorberse, enrojecimiento } \\
\text { Los vapores se absorben, enrojecimiento, dolor }\end{array}$ & $\begin{array}{l}\text { SNC; hígado; piel } \\
\text { Inh, abs, ing, con }\end{array}$ & $\begin{array}{l}\text { irrit piel; ict, les hepáticas; } \\
\text { depres, let, alu, delirio }\end{array}$ \\
\hline $\begin{array}{l}\text { DIMETILFORMAMIDA } \\
68-12-2\end{array}$ & $\begin{array}{l}\text { ojos; piel; tract } \\
\text { resp; hígado; SNC }\end{array}$ & hígado & $\begin{array}{l}\text { Inhalación } \\
\begin{array}{r}\text { Piel } \\
\text { 0jos }\end{array}\end{array}$ & $\begin{array}{l}\text { Pérdida de apetito, dolor abdominal, diarrea, } \\
\text { mareo, náuseas, vómitos, nerviosismo, rubor } \\
\text { facial e intolerancia al alcohol } \\
\text { Puede absorberse, sequedad de piel, } \\
\text { enrojecimiento, aspereza } \\
\text { Enrojecimiento, dolor }\end{array}$ & $\begin{array}{l}\text { Ojos; hígado; } \\
\text { riñones; SCV; piel; } \\
\text { sis resp } \\
\text { Inh, abs, ing, con }\end{array}$ & $\begin{array}{l}\text { Irrit ojos, piel, sis resp; náu, } \\
\text { vómit, cólico; les hepáticas, } \\
\text { aumento de tamaño del } \\
\text { hígado; aumento de la TA; } \\
\text { rubor facial; derm; en } \\
\text { animales: lesiones renales y } \\
\text { cardíacas }\end{array}$ \\
\hline $\begin{array}{l}\text { FORMAMIDA } \\
75-12 \cdot 7\end{array}$ & pulmones; SNC & hígado & $\begin{array}{r}\text { Inhalación } \\
\text { Piel } \\
\text { Ojos } \\
\text { Ingestión }\end{array}$ & $\begin{array}{l}\text { Sopor, cefalea, náuseas, inconsciencia } \\
\text { Puede absorberse, enrojecimiento } \\
\text { Enrojecimiento } \\
\text { Dolor abdominal }\end{array}$ & $\begin{array}{l}\text { Ojos; piel; sis resp; } \\
\text { SNC; sis repro } \\
\text { Inh, ing, con }\end{array}$ & $\begin{array}{l}\text { Irrit ojos, piel y muc; sop, ftg; } \\
\text { náu, acidosis; erupciones } \\
\text { cutáneas; en animales: efectos } \\
\text { repro }\end{array}$ \\
\hline
\end{tabular}

\begin{tabular}{|c|c|c|c|}
\hline $\begin{array}{l}\text { Denominación química } \\
\mathrm{N} \text { úmero CAS }\end{array}$ & Físicos & Q uímicos & $\begin{array}{l}\text { Clase o división } \\
\text { UN / Riesgos } \\
\text { subsidiarios }\end{array}$ \\
\hline $\begin{array}{l}\text { ACETAMIDA } \\
60-35-5\end{array}$ & & $\begin{array}{l}\text { Se descompone al calentarse, liberando humos tóxicos La solución en agua es una base } \\
\text { fuerte, reacciona violentamente con ácidos y es corrosiva Reacciona con oxidantes, agentes } \\
\text { reductores, bases y ácidos }\end{array}$ & \\
\hline $\begin{array}{l}\text { ACRILAMIDA } \\
79-06-1\end{array}$ & & $\begin{array}{l}\text { Se polimeriza violentamente al calentarse o por influencia de la luz Se descompone al } \\
\text { calentarse liberando gases tóxicos (óxidos nitrosos) Reacciona violentamente con los oxidantes }\end{array}$ & 6.1 \\
\hline $\begin{array}{l}\text { CICLOFOSFAMIDA } \\
50-18-0\end{array}$ & & $\begin{array}{l}\text { Se descompone al calentarse y en contacto con la humedad o la luz, produciendo humos } \\
\text { tóxicos Reacciona con oxidantes fuertes, ácidos fuertes y bases fuertes }\end{array}$ & \\
\hline $\begin{array}{l}\text { 2-CLOROACETAMIDA } \\
79-07-2\end{array}$ & & $\begin{array}{l}\text { Se descompone al calentarse liberando humos tóxicos, como óxidos de nitrógeno y cloro } \\
\text { Reacciona con oxidantes fuertes, agentes reductores fuertes, ácidos fuertes y bases fuertes. }\end{array}$ & \\
\hline $\begin{array}{l}\text { CLORURO DE DIMETILCARBAMOILO } \\
79-44-7\end{array}$ & & & 8 \\
\hline $\begin{array}{l}\text { DIMETILACETAMIDA } \\
127-19-5\end{array}$ & & $\begin{array}{l}\text { Se descompone al calentarse, liberando humos tóxicos (óxidos de nitrógeno) Ataca muchos } \\
\text { plásticos }\end{array}$ & \\
\hline $\begin{array}{l}\text { DIMETILFORMAMIDA } \\
68-12-2\end{array}$ & & $\begin{array}{l}\text { En su combustión libera gases tóxicos (monóxido de carbono, dimetilamina y óxidos de } \\
\text { nitrógeno) Reacciona con oxidantes }\end{array}$ & 3 \\
\hline
\end{tabular}




\begin{tabular}{|c|c|c|c|}
\hline $\begin{array}{l}\text { Denominación química } \\
\mathrm{N} \text { úmero CAS }\end{array}$ & Físicos & Q uímicos & $\begin{array}{l}\text { Clase o división } \\
\text { UN / Riesgos } \\
\text { subsidiarios }\end{array}$ \\
\hline $\begin{array}{l}\text { N,N'ETLLEN BIS(ESTEARAMIDA) } \\
110-30.5\end{array}$ & $\begin{array}{l}\text { Posibilidad de explosión } \\
\text { pulverulenta cuando se } \\
\text { encuentra en forma de } \\
\text { polvo o gránulos y se } \\
\text { mezcla con el aire }\end{array}$ & $\begin{array}{l}\text { En su combustión libera gases tóxicos Se descompone al calentarse y al arder, produciendo } \\
\text { humos tóxicos (óxidos de nitrógeno) Reacciona con oxidantes fuertes }\end{array}$ & \\
\hline $\begin{array}{l}\text { FORMAMIDA } \\
75-12 \cdot 7\end{array}$ & & $\begin{array}{l}\text { En su combustión libera gases tóxicos( (óxidos de nitrógeno) Se descompone al calentarse a } \\
200^{\circ} \mathrm{C} \text { o más, produciendo amoniaco, agua, monóxido de carbono y cianuro de hidrógeno } \\
\text { Reacciona vigorosamente con materiales oxidantes Ataca el cobre y el caucho natural } \\
\text { Incompatible con yodo, piridina y trióxido de azufre }\end{array}$ & \\
\hline
\end{tabular}

\begin{tabular}{|c|c|c|c|c|c|c|c|c|c|c|}
\hline $\begin{array}{l}\text { Denominación química } \\
\mathrm{N} \text { úmero CAS }\end{array}$ & Color/ Forma & $\begin{array}{l}\text { p.e. } \\
(\because C)\end{array}$ & $\begin{array}{l}\text { p.f. } \\
\left({ }^{\circ} \mathrm{C}\right)\end{array}$ & $\begin{array}{l}\mathrm{p} . \mathrm{m} . / \\
\text { (g/ } \\
\mathrm{mol})\end{array}$ & $\begin{array}{l}\text { Solubilidad } \\
\text { en agua }\end{array}$ & $\begin{array}{l}\text { Densidad } \\
\text { relativa } \\
\text { (agua }=1 \text { ) }\end{array}$ & $\begin{array}{l}\text { Densidad } \\
\text { de vapor } \\
\text { relativa } \\
\text { (aire=1) }\end{array}$ & $\begin{array}{l}\text { Pvap/ } \\
(\mathrm{kPa})\end{array}$ & $\begin{array}{l}\text { Límit. } \\
\text { inflam. }\end{array}$ & $\begin{array}{ll}\text { p.ig. } & \text { p.aut } \\
\left({ }^{\circ} \mathrm{C}\right) & \text { ig. } \\
& \left({ }^{\circ} \mathrm{C}\right)\end{array}$ \\
\hline $\begin{array}{l}\text { ACETAMIDA } \\
60-35-5\end{array}$ & $\begin{array}{l}\text { cristales hexagonales } \\
\text { delicuescentes; } \\
\text { cristales trigonales } \\
\text { monoclínicos }\end{array}$ & 222 & 81 & 59,07 & $1 \mathrm{~g} / 0,5 \mathrm{ml}$ & 1,159 & & $<0,1$ & & \\
\hline $\begin{array}{l}\text { 2-ACETILAMINOFLUORENO } \\
53.96-3\end{array}$ & sólido cristalino pardo & & 194 & 223,26 & insol & & & & & \\
\hline $\begin{array}{l}\text { ACRILAMIDA } \\
79-06-1\end{array}$ & $\begin{array}{l}\text { cristales tipo escama } \\
\text { en benceno; sólido } \\
\text { cristalino de color } \\
\text { blanco; cristales } \\
\text { laminares en benceno }\end{array}$ & 125 & 84,5 & 71,08 & muy sol & 1,122 & 2,45 & $1 \mathrm{~Pa}$ & & 138 cc 424 \\
\hline $\begin{array}{l}\text { AMIDA SODICA } \\
7782-92.5 \\
\end{array}$ & polvo blanco cristalino & 400 & 210 & 39,02 & sol & 1,39 & & & & \\
\hline $\begin{array}{l}\text { BENZOTIACIL-2-CICLOHEXIL } \\
\text { SULFENAMIDA } \\
95-33.0\end{array}$ & polvo color crema & & $93-100$ & 264,41 & insol & 1,27 & & & & \\
\hline $\begin{array}{l}\text { CICLOFOSFAMIDA } \\
\text { 50-18.0 }\end{array}$ & $\begin{array}{l}\text { polvo fino cristalino } \\
\text { de color blanco, que } \\
\text { se licúa al perder el } \\
\text { agua de cristalización }\end{array}$ & & $49,5-53$ & 261,10 & 1/ 25 partes & & & & & 112 \\
\hline $\begin{array}{l}\text { CICLOHEXIMIDA } \\
66-81-9\end{array}$ & $\begin{array}{l}\text { Láminas de } \\
\text { amilacetato, agua } 0 \\
\text { metanol al } 30 \% ; \\
\text { cristales incoloros }\end{array}$ & & $\begin{array}{l}119,5- \\
121\end{array}$ & 281,34 & & & & & & \\
\hline $\begin{array}{l}\text { 2-CLOROACETAMIDA } \\
\text { 79-07-2 }\end{array}$ & cristales & 225 & 120 & 93,5 & sol & & 3,2 & 0,007 & & \\
\hline $\begin{array}{l}\text { CLORURO DE DIETLLCARBAMOILO } \\
88-10-8\end{array}$ & líquido & 187 & -44 & 135,6 & sol & & 4,1 & & & \\
\hline $\begin{array}{l}\text { CLORURO DE } \\
\text { DIMETILCARBAMOILO } \\
\quad 79-44-7\end{array}$ & líquido & 167 & -33 & 107,5 & & 1,1678 & 3,73 & & & \\
\hline $\begin{array}{l}\text { COLCHICINA } \\
64-86-8\end{array}$ & & & 156 & 399,42 & muy sol & & & & & \\
\hline
\end{tabular}




\begin{tabular}{|c|c|c|c|c|c|c|c|c|c|c|c|}
\hline $\begin{array}{l}\text { Denominación química } \\
\mathrm{N} \text { úmero CAS }\end{array}$ & Color/ Forma & $\begin{array}{l}\text { p.e. } \\
(\circ \mathrm{C})\end{array}$ & $\begin{array}{l}\text { p.f. } \\
(\underline{O C})\end{array}$ & $\begin{array}{l}\mathrm{p} . \mathrm{m} . / \\
\text { (g/ } \\
\mathrm{mol})\end{array}$ & $\begin{array}{l}\text { Solubilidad } \\
\text { en agua }\end{array}$ & $\begin{array}{l}\text { Densidad } \\
\text { relativa } \\
\text { (agua }=1 \text { ) }\end{array}$ & $\begin{array}{l}\text { Densidad } \\
\text { de vapor } \\
\text { relativa } \\
\text { (aire=1) }\end{array}$ & $\begin{array}{l}\text { Pvap/ } \\
(\mathrm{kPa})\end{array}$ & $\begin{array}{l}\text { Límit. } \\
\text { inflam. }\end{array}$ & $\begin{array}{l}\text { p.ig. } \\
(\underline{O C})\end{array}$ & $\begin{array}{l}\text { p.aut } \\
\text { ig. } \\
(\stackrel{\circ}{ } \text { C })\end{array}$ \\
\hline $\begin{array}{l}\text { 4, '-DIACETILBENCIDINA } \\
613-35-4\end{array}$ & & & 328,3 & 268,30 & & & & & & & \\
\hline $\begin{array}{l}\text { DIMETIL ACETAMIDA } \\
\text { 127-19-5 } \\
\end{array}$ & $\begin{array}{l}\text { líquido aceitoso } \\
\text { incoloro }\end{array}$ & 165 & -20 & 87,12 & misc & $\begin{array}{l}0,9366 \\
@ 25^{\circ} \mathrm{C} / 4^{\circ} \mathrm{C}\end{array}$ & 3,01 & 0,33 & $\begin{array}{l}1,8 \mathrm{li} \\
11,5 \mathrm{ls}\end{array}$ & $70 \mathrm{ca}$ & 490 \\
\hline $\begin{array}{l}\text { DIMETLLFORMAMIDA } \\
68-12-2\end{array}$ & $\begin{array}{l}\text { líquido incoloro o } \\
\text { amarillo muy pálido; } \\
\text { líquido acuoso } \\
\text { transparente }\end{array}$ & 153 & $.60,4$ & 73,09 & misc & $\begin{array}{l}0,9445 \\
@ 25^{\circ} \mathrm{C} / 4^{\circ} \mathrm{C}\end{array}$ & 2,51 & 0,36 & $\begin{array}{l}2,2 \mathrm{li} \\
15,2 \mathrm{ls}\end{array}$ & $67 \mathrm{ca}$ & 354 \\
\hline $\begin{array}{l}\text { N,N'-ETILEN BIS(ESTEARAMIDA) } \\
110-30-5\end{array}$ & sólido & & $135-146$ & 593,04 & insol & 0,97 & & & & $280 \mathrm{ca}$ & \\
\hline $\begin{array}{l}\text { FORMAMIDA } \\
75-12 \cdot 7\end{array}$ & $\begin{array}{l}\text { líquido aceitoso } \\
\text { incoloro, ligeramente } \\
\text { viscoso }\end{array}$ & $\begin{array}{l}210,5 \text { se } \\
\text { descompone }\end{array}$ & 2,55 & 45,04 & misc & 1,1334 & 1,6 & $2 \mathrm{~Pa}$ & & 154 ca & 500 \\
\hline $\begin{array}{l}\text { METILFORMAMIDA } \\
123-39-7\end{array}$ & & $180-185$ & $-3,8$ & 59,07 & muy sol & $1,011 @ 19^{\circ} \mathrm{C}$ & & $\begin{array}{l}3,08 \mathrm{x} \\
10^{-2} \mathrm{~mm} \mathrm{Hg} \\
\text { @ } 25^{\circ} \mathrm{C}\end{array}$ & & & \\
\hline
\end{tabular}




\section{AMIN AS ALIFATICAS}

Las aminas alifáticas se forman cuando uno o más átomos de hidrógeno del amoníaco ( $\left.\mathrm{NH}_{3}\right)$ son sustituidos por uno, dos o tres radicales alquil 0 alcanol. Las aminas alifáticas inferiores son gases como el amoníaco y perfectamente solubles en agua, pero los homólogos superiores son insolubles en agua. Todas las aminas alifáticas son básicas disoluciones y forman sales, siendo estas últimas sólidos no volátiles, inodoros y perfectamente solubles en agua.

En función del número de hidrógenos sustituidos, las aminas pueden ser primarias $\left(\mathrm{NH}_{2} \mathrm{R}\right)$, secundarias $\left(\mathrm{NHR}_{2}\right) 0$ terciarias $\left(\mathrm{NR}_{3}\right)$.

\begin{abstract}
Usos
Las aminas alifáticas se emplean en las industrias química, farmacéutica, de caucho, plásticos, colorantes, tejidos, cosméticos y metales. Sirven como productos químicos intermedios, disolventes, aceleradores del caucho, catalizadores, emulsionantes, lubricantes sintéticos para cuchillas, inhibidores de la corrosión y agentes de flotación. M uchas de ellas se emplean en la fabricación de herbicidas, pesticidas y colorantes. En la industria fotográfica, la trietilamina y la metilamina se utilizan como aceleradores para reveladores. La dietilamina se utiliza como inhibidor de la corrosión en las industrias metalúrgicas y como disolvente en la industria del petróleo. En las industrias de curtidos y cuero, la hexametilentetramina se utiliza como conservante de curtidos; la metilamina, la etanolamina y la diisopropanolamina son agentes reblandecedores de pieles y cuero.
\end{abstract}

\section{Formación de nitrosaminas}

Las nitrosaminas son aminas que contienen un grupo funcional nitroso $(-\mathrm{N}-\mathrm{N}=0)$. Estos compuestos se forman cuando un nitrógeno $(N)$ y un oxígeno $(0)$ de un compuesto "nitrosante" se unen al nitrógeno del grupo amino $(\mathrm{N})$ de un compuesto amínico. Por ejemplo, las sales de nitrato y nitrito utilizadas en los baños de sal para la fabricación de caucho siven de agentes nitrosantes y se combinan con aminas en el compuesto de caucho, formando nitrosaminas. Las nitrosaminas se forman también in vivo durante el metabolismo de los alimentos que contienen nitratos o nitritos. Entre los compuestos de caucho precursores de nitrosaminas se encuentran las sulfonamidas, las sulfonamidas secundarias, los ditiocarbamatos, los tiuranos y las dietilhidroxilaminas. Algunos compuestos de caucho contienen una nitrosamina, como la nitrosodifenilamina (N DPhA), un retardador, o dinitrosopentametilentetramina (DN PT), un agente espumante. Estas nitrosaminas son débilmente cancerígenas, pero pueden "transnitrosar" o transferir sus grupos nitrosos a otras aminas, formando nitrosaminas más cancerígenas. Algunas nitrosaminas detectadas en las operaciones de baño de sal son: nitrosodimetilamina (N DMA), nitrosopiperidina (N PIP), nitrosomorfolina (N M O R), nitrosodietila mina (N DEA) y nitrosopirrolidina (N PYR).

La formación de nitrosaminas es preocupante desde el punto de vista sanitario, ya que se sospecha que las nitrosaminas son cancerígenos humanos. Aunque todavía no se ha demostrado una clara asociación causal entre la exposición a nitrosaminas y el cáncer humano, existen pruebas de que las nitrosaminas podrían provocar cáncer en el ser humano. Las nitrosaminas son potentes cancerígenos a nimales; a proximadamente el $90 \%$ de las 300 nitrosaminas ensayadas han demostrado efectos cancerígenos en animales de laboratorio. Se han estudiado aproximadamente 40 especies animales, entre ellas mamíferos, aves, peces y anfibios, y ninguna de ellas ha mostrado resistencia. Los efectos de las nitrosaminas se han demostrado en mucho órganos; la localización del tumor depende de la nitrosamina específica, las especies ensayadas y la vía de administración.

Las investigaciones bioquímicas, patológicas y experimentales de las nitrosaminas aportan pocos indicios de que la especie humana sea resistente al potencial cancerígeno de las nitrosaminas. Se ha demostrado que los tejidos humanos metabolizan las nitrosaminas para formar compuestos que se unen al ADN, un proceso conside- rado como el primer paso en el desarrollo de muchos cánceres, y parece ser que el tejido hepático humano metaboliza las nitrosaminas con una actividad similar al tejido hepático de los roedores. Algunos estudios con aductos de ADN humanos han observado unos niveles más altos de aductos de ADN relacionados con las nitrosaminas en los casos de cáncer que en los controles, y estudios con animales de experimentación han demostrado la formación de aductos de ADN similares a los detectados en estudios humanos.

La Agencia Internacional para la Investigación sobre el Cáncer (IARC) ha clasificado NDMA y NDEA como cancerígenos del grupo 2A (probables cancerígenos humanos), y N MOR, N PIP y N PYR como cancerígenos del grupo 2B (posibles cancerígenos humanos). El N ational Toxicology Program (N TP) de Estados Unidos ha clasificado estas cinco nitrosaminas como sustancias que pueden considerarse razonablemente cancerígenos humanos. En los Estados Unidos, tanto la $\mathrm{O}$ ccupational Safety and $\mathrm{Health} \mathrm{Admi}$ nistration (O SHA) como el $\mathrm{N}$ ational Institute for 0 ccupational Safety and Health $(\mathrm{N} / \mathrm{OSH})$ consideran la nitrosodimetilamina (N DMA) como un cancerígeno profesional, pero aún no se ha establecido ningún límite de exposición. En Alemania, el Der Ausschub für $G$ efahrstoffe (AGS) aplica normas estrictas en materia de exposición profesional a las nitrosaminas. En general, la exposición total a nitrosaminas en la industria no puede sobrepasar $1 \mathrm{mg} / \mathrm{m}^{3}$. En algunos procesos, como la vulcanización de caucho, la exposición total a nitrosaminas no puede sobrepasar $2,5 \mathrm{mg} / \mathrm{m}^{3}$.

La formación de nitrosaminas en operaciones como las de la industria del caucho puede evitarse reformulando los compuestos de caucho o utilizando métodos alternativos, como aire caliente con perlas de vidrio o curado con microondas. Este tipo de modificaciones requiere una cierta labor de investigación y desarrollo para asegurarse de que el producto final tenga todas las mismas propiedades deseables que el producto de caucho al que pretende susttuir. 0 tra posibilidad para reducir las exposiciones es la ventilación por extracción localizada (VEL). No solamente son necesarios el aislamiento y la adecuada ventilación de los baños de sal, sino que además deben instalarse unos controles técnicos adecuados en otras zonas de la línea de producción, como los lugares donde se corta 0 taladra el producto, para garantizar que las exposiciones de los trabajadores se mantengan reducidas.

Beth Donovan Reh 
EI 2-dimetilaminoetanol sirve para controlar la acidez del agua de las calderas. La trietanolamina, la isopropanolamina, la ciclohexilamina y la diciclohexilamina se utilizan en jabones para limpieza en seco. L a trietanolamina se emplea extensamente en la industria para la fabricación de tensoactivos, ceras, barnices, herbicidas y lubricantes para cuchillas. Asimismo se utiliza para recuperar el sulfuro de hidrógeno de gas natural y crudo de petróleo con grandes proporciones de azufre. La etanolamina extrae tanto el dióxido de carbono como el sulfuro de hidrógeno del gas natural.

La etilamina actúa como estabilizante para látex de caucho y como producto intermedio de tintes, mientras que la butilamina es un pesticida y un líquido alcalino fuerte utilizado en las industrias del caucho, productos farmacéuticos y colorantes. La etilendiamina es otro líquido alcalino fuerte utilizado en la preparación de colorantes, aceleradores del caucho, fungicidas, ceras sintéticas, productos farmacéuticos, resinas, insecticidas y agentes humectantes para asfaltos. La dimetilamina y la isobutanolamina se utilizan en la industria del caucho como aceleradores de la vulcanización. L a dimetilamina se usa también en la industria de curtidos y en la fabricación de jabones detergentes.

La etilenimina es un compuesto importante empleado en las industrias de papel, tejidos, petróleo, lacas y barnices, cosméticos y fotografía. La dietanolamina es un agente depurante de gases, un producto químico intermedio y un emulsionante de productos agroquímicos, cosméticos y farmacéuticos. 0 tros agentes emulsionantes muy utilizados son la isobutanolamina, la isopropanolamina y la ciclohexilamina.

\section{Riesgos}

Las aminas son bases y forman soluciones fuertemente alcalinas, por lo que pueden resultar dañinas si salpican los ojos o si contaminan la piel. N o obstante, carecen de propiedades tóxicas específicas, y las aminas alifáticas inferiores son constituyentes normales de los tejidos corporales, estando presentes en un gran número de alimentos, particularmente el pescado, al que dan su olor característico. U na preocupación actual es la posibilidad de que algunas aminas alifáticas puedan reaccionar con nitratos 0 nitritos in vivo para formar compuestos nitrosos, muchos de los cuales son cancerígenos potentes en animales, como se comenta con más detalle en el cuadro adjunto.
Alilamina. Sus vapores son muy irritantes. En animales se ha demostrado que afecta al corazón y al sistema circulatorio, con lesiones miocárdicas y vasculares. Parte de la toxicidad de la alilamina se atribuye a la formación de acroleína in vivo. Existe también un riesgo claro de explosión con un amplio rango de concentraciones en el aire.

La butilamina es el isómero de mayor importancia comercial. Se ha demostrado que sus vapores tienen efectos graves en el sistema nervioso central (SN C) de los animales expuestos. Produce efectos intensos en el ser humano. Es extremadamente irritante para los ojos y el tracto respiratorio. Afecta también al SNC y puede causar depresión e incluso inconsciencia. También se han descrito dolores torácicos y tos intensa. La butilamina se absorbe fácilmente a través de la piel y se metaboliza en seguida.

U no de los principales efectos tóxicos de la ciclohexilamina es su acción irritante. Puede lesionar y sensibilizar la piel. La ciclohexilamina es un débil inductor de la metahemoglobina. Esta amina es también el principal metabolito del ciclamato.

La dietanolamina es irritante para la piel y mucosas. La exposición a esta sustancia puede provocar náuseas y vómitos.

Los vapores de dimetilamina son inflamables e irritantes. Las soluciones que forma son muy alcalinas.

La etanolamina provoca una ligera irritación, pero no se asocia a efectos tóxicos importantes en el ser humano.

La eilamina puede provocar irritación ocular. Las personas expuestas a sus vapores pueden sufrir daños en la córnea. En el ser humano, el compuesto se excreta sin modificar.

La etilendiamina daña los ojos, la piel y el tracto respiratorio. La exposición a sus vapores puede provocar reacciones de sensibilización.

La metilamina es una base más fuerte que el amoníaco, y sus vapores irritan los ojos y el tracto respiratorio. Se han descrito casos de sensibilización (bronquial). Las propiedades de advertencia de este compuesto no son buenas, ya que provoca fatiga olfatoria.

El vapor de propilamina puede lesionar los ojos y el tracto respiratorio. Se han descrito alteraciones visuales transitorias.

La trietanolamina es poco tóxica para el ser humano y se añade habitualmente a muchos cosméticos y productos similares. 
TABLAS DE AMINAS AUFATICAS

\begin{tabular}{|c|c|c|c|}
\hline Producto químico & Sinónimos/Código UN & $\mathrm{N}$ úmero $\mathrm{CAS}$ & Fórmula estructural \\
\hline ACETALDEHIDO OXIMA & $\begin{array}{l}\text { Acetaldoxima; aldoxima; etanal oxima; etilidenhidroxilamina } \\
\text { UN2332 }\end{array}$ & $107-29-9$ & \\
\hline ALILAMINA & $\begin{array}{l}\text { Alilamina; 3-aminopropeno; 3-aminopropileno; monoalilamina; } \\
\text { 2-propenamina } \\
\text { UN2334 }\end{array}$ & $107-11-9$ & \\
\hline 1,3-BUTANDIAMINA & 1,3-Diaminobutano & $590-88-5$ & \\
\hline BUTILAMINA & $\begin{array}{l}\text { 1-Aminobutano; 1-butanamina; monobutilamina } \\
\text { UN1125 }\end{array}$ & $109-73-9$ & \\
\hline Sec-BUTILAMINA & 2-Aminobutano; 2-butanamina; 1-metilpropilamina, & $13952-84.6$ & \\
\hline terc-BUTILAMINA & $\begin{array}{l}\text { 2-Aminoisobutano; 2-amino-2-metilpropano; 1,1-dimetiletilamina; } \\
\text { trimetilaminometano }\end{array}$ & $75-64-9$ & \\
\hline CICLOHEXILAMINA & $\begin{array}{l}\text { Aminociclohexano; aminohexahidrobenceno; ciclohexanamina; } \\
\text { hexahidroanilina } \\
\text { UN2357 }\end{array}$ & $108-91-8$ & \\
\hline CLORHIDRATO DE DIMETILAMINA & $\begin{array}{l}\text { Cloruro de dimetilamonio ; ácido clorhídrico dimetilamina; clorhidrato de } \\
\text { N-metilmetanamina }\end{array}$ & $506-59-2$ & \\
\hline & & & $\mathrm{H}-\mathrm{Cl}$ \\
\hline DIALILAMINA & $\begin{array}{l}\text { Di-2-propenilamina ; N-2-propenil 2-propen-1-amina } \\
\text { UN2359 }\end{array}$ & $124 \cdot 02 \cdot 7$ & \\
\hline 3,3'-DIAMINODIPROPILAMINA & $\begin{array}{l}\text { Aminobis( propilamina); dipropilentriamina; iminobis( propilamina); } \\
\text { 3,3'-iminobis( propilamina) } \\
\text { UN2269 }\end{array}$ & $56-18-8$ & \\
\hline DIBUTILAMINA & $\begin{array}{l}\text { Butil-1-1-butanamina; N-dibutilamina } \\
\text { UN2248 }\end{array}$ & $111-92-2$ & \\
\hline 2-DIBUTILAMINOETANOL & $\begin{array}{l}\text { Dibutilaminoetanol; N,N-dibutiletanolamina; } \\
\text { N,N-dibutil-N-(2-hidroxietil) amina } \\
\text { UN2873 }\end{array}$ & $102-81-8$ & \\
\hline DICICLOHEXILAMINA & $\begin{array}{l}\text { N-Ciclohexilciclohexanamina; N,N-diclohexilamina; dodecahidrodifenilamina } \\
\text { UN2565 }\end{array}$ & $101-83-7$ & \\
\hline
\end{tabular}




\begin{tabular}{|c|c|c|}
\hline Producto químico & Sinónimos/ Código UN & $\mathrm{N}$ úmero CAS Fórmula estructural \\
\hline 2,2'-DICLORO-N-METILDIETILAMINA & $\begin{array}{l}\text { Bis(2-cloroetil) metilamina; 2-cloro-n-(2-chloroetil)-N-metiletanamina; } \\
\text { N,N-di(cloroetil) metilamina; metilbis(2-cloroetil) amina }\end{array}$ & $51-75-2$ \\
\hline DIETANOLAMINA & $\begin{array}{l}\text { Bis(2-hidroxietil)amina; dietanolamina; dietilolamina; } \\
\text { 2,2'-dihidroxidietilamina ; di(2-hidroxietil) amina }\end{array}$ & $111-42-2$ \\
\hline DIETILAMINA & $\begin{array}{l}\text { Dietamina; N,N-dietilamina; N-etil etanamina } \\
\text { UN1154 }\end{array}$ & $109-89-7$ \\
\hline
\end{tabular}

\begin{tabular}{ll}
\hline 2-DIETILAMINOETANOL & $\begin{array}{c}\text { Dietilaminoetanol; dietiletanolamina; N,N-dietiletanolamina } \\
\text { UN2686 }\end{array}$ \\
\hline
\end{tabular}

\begin{tabular}{|c|c|c|c|c|}
\hline DIETILENTRIAMINA & $\begin{array}{l}\text { Aminoetiletandiamina; bis(2-aminoetil) amina; 2,2'-diaminodietilamina; } \\
\text { etilamina, 2,2'-iminobis-; etilendiamina-N-(2-aminoetil)- } \\
\text { UN2079 }\end{array}$ & $111-40-0$ & & \\
\hline DIISOPROPANOLAMINA & $\begin{array}{l}\text { Bis(2-propanol) amina; bis(2-hidroxipropil) amina; DIPA; } \\
\text { 1,1'-iminobis-2-propanol; 1,1'-iminodi-2-propanol }\end{array}$ & $110-97-4$ & $\mathrm{OH}$ & $\mathrm{OH}$ \\
\hline DIISOPROPILAMINA & $\begin{array}{l}\text { N-(1-Metiletil)-2-propanamina } \\
\text { UN1158 }\end{array}$ & $108-18-9$ & & \\
\hline
\end{tabular}

\begin{tabular}{lll}
\hline DIMETILAMINA & DMA; metanamina, N-metilmetanamina \\
& UN1032 \\
& UN1160 & $124-40-3$ \\
\hline 2-DIMETILAMINOETANOL & $\begin{array}{l}\text { Dimetilaminoetanol; dimetiletanolamina; } \\
\text { N,N-dimetil-N-(2-hidroxietil) amina; DMAE } \\
\text { UN2051 }\end{array}$ & $108-01-0$ \\
\hline
\end{tabular}

BIS(2-DIM ETILAMINOETIL) ETER Etilamina, 2,2'-oxibis(N,N-dimetil); NIAX catalizador A1 3033-62-3

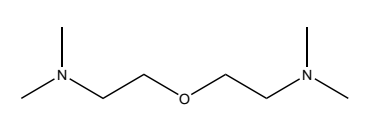

\begin{tabular}{ll}
\hline 3-DIMETILAMINOPROPILAMINA & 1-Amino-3-dimetilaminopropano; N,N-dimetil-1,3-propanodiamina; \\
N,N-dimetil-n-(3-aminopropil) amina; 3-(dimetilamino) propilamina; & 109-55-7 \\
N,N-dimetil-1,3-propilendiamina &
\end{tabular}

\begin{tabular}{lll}
\hline DIPENTILAMINA & Diamil amina; di-N-amilamina; 1-pentanamina, N-pentil \\
UN2841 & 2050-92-2
\end{tabular}
UN2841

\begin{tabular}{ll}
\hline 2-Aminoetanol; etanolamina; glicinol; 2-hidroxietilamina; & 141-43-5 \\
monoetanolamina &
\end{tabular}

$$
\text { UN2491 }
$$

$1-43-5$<smiles>NCCO</smiles> 


\begin{tabular}{|c|c|c|c|}
\hline Producto químico & Sinónimos/Código UN & $\mathrm{N}$ úmero $\mathrm{CAS}$ & Fórmula estructural \\
\hline ETILAMINA & $\begin{array}{l}\text { Aminoetano; 1-aminoetano; etanamina; monoetilamina } \\
\text { UN1036 } \\
\text { UN2270 }\end{array}$ & $75-04-7$ & \\
\hline ETILENDIAMINA & $\begin{array}{l}\text { 1,2-Diaminoetano; dimetilendiamina; 1,2-etanodiamina; etilenodiamina; } \\
\text { 1,2-etilenodiamina } \\
\text { UN1604 }\end{array}$ & $107-15-3$ & \\
\hline ETILENIMINA & $\begin{array}{l}\text { Dihidroazireno; dihidro-1H-azirina; dimetilenimina; dimetilenimina } \\
\text { UN1185 }\end{array}$ & $151-56-4$ & \\
\hline 2-ETILHEXILAMINA & $\begin{array}{l}\text { 2-Etil hexilamina } \\
\text { UN2276 }\end{array}$ & $104-75-6$ & \\
\hline ETLLMETILCETONA OXIMA & 2-Butanona, oxima; etil metil cetoxima; MEK-oxima; metil etil cetoxima & $96-29-7$ & \\
\hline HEXAMETILENDIAMINA & $\begin{array}{l}\text { 1,6-Diaminohexano; hexametilendiamina; } 1 \text {,6-hexametilendiamina } \\
\text { UN1783 } \\
\text { UN2280 }\end{array}$ & $124-09-4$ & \\
\hline HEXAMETILENTETRAMINA & $\begin{array}{l}\text { Formamina; hexaform; 1,6-hexanodiamina; hexamina; metamina; } \\
\text { metenamina } \\
\text { UN1328 }\end{array}$ & $100-97-0$ & \\
\hline HIDROXIETILETILENDIAMINA & $\begin{array}{l}\text { N-Aminoetiletanolamina; etanoletilen diamina; } \\
\text { N-hidroxietil-1,2-etanodiamina monoetanoletilenodiamina; } \\
\text { 2-((2-aminoetil)amino) etanol }\end{array}$ & $111-41-1$ & \\
\hline 1,3-BIS(HIDROXIMETIL)UREA & $\begin{array}{l}\text { N,N'-Bis(hidroximetil) urea; N,N'-dihidroximetilurea; dimetanol urea; } \\
\text { dimetilolurea; N,N'-dimetilolurea; 1,3-dimetilolurea; oximeturea }\end{array}$ & $140-95-4$ & \\
\hline ISOBUTANOLAMINA & $\begin{array}{l}\text { 2-Aminodimetiletanol; 2-amino-2-metilpropanol; 2-amino-2-propanol; } \\
\text { isobutanol-2-amina }\end{array}$ & $124-68-5$ & \\
\hline ISOBUTILAMINA & $\begin{array}{l}\text { 1-Amino-2-metilpropano; monoisobutilamina; 1-propanamina, 2-metil- } \\
\text { UN1214 }\end{array}$ & $78-81-9$ & \\
\hline ISOPROPANOLAMINA & $\begin{array}{l}\alpha \text {-Aminoisopropil alcohol; 2-hidroxipropilamina; isopropanolamina; } \\
\text { 1-metil-2-aminoetanol; mono-iso-propanolamina }\end{array}$ & $78-96-6$ & \\
\hline ISOPROPILAMINA & $\begin{array}{l}\text { 1-Metiletilamina; monoisopropilamina; 2-propanamina; sec-propilamina; } \\
\text { 2-propilamina } \\
\text { UN1221 }\end{array}$ & $75-31-0$ & \\
\hline
\end{tabular}




\begin{tabular}{|c|c|c|c|}
\hline Producto químico & Sinónimos/ Código UN & $\mathrm{N}$ úmero CAS & Fórmula estructural \\
\hline METILAMINA & $\begin{array}{l}\text { Aminometano; carbinamina; mercurialin; monometilamina } \\
\text { UN1061 } \\
\text { UN1235 }\end{array}$ & $74-89-5$ & \\
\hline 2-METILAMINOETANOL & N-Metilaminoetanol; metiletanolamina; monometilaminoetanol & 109-83-1 & \\
\hline 1,5-PENTANODIAMINA & $\begin{array}{l}\text { Cadaverina; 1,5-diaminopentano; pentametilendiamina; } \\
\text { 1,5-pentametilendiamina }\end{array}$ & $462-94-2$ & \\
\hline 1,3-PROPANDIAMINA & 1,3-Diaminopropano; 1,3-propilendiamina; trimetilendiamina & $109-76-2$ & \\
\hline PROPILAMINA & $\begin{array}{l}\text { 1-Aminopropano; monopropilamina; propanamina; 1-propilamina } \\
\text { UN1277 }\end{array}$ & 107-10-8 & \\
\hline PROPILENDIAMINA-1,2-PROPANODIAMINA & $\begin{array}{l}\text { 1,2-Diaminopropano;1,2-propanodiamina; 1,2-propilendiamina; } \\
\text { propilendiamina } \\
\text { UN2258 }\end{array}$ & $78-90-0$ & \\
\hline TETRAETILENPENTAMINA & $\begin{array}{l}\text { D.E.H. 26; 1,4,7,10,13-pentaazatridecano; } \\
\text { 1,2-etanodiamina, N-(2-aminoetil)-N'-(2-(2-aminoetil) amino) etil } \\
\text { UN2320 }\end{array}$ & $112-57-2$ & \\
\hline TRIALILAMINA & $\begin{array}{l}\text { N,N-Di-2-propenil-2-propen-1-amina; 2-propen-1-amina; N,N-di-2-propenil- } \\
\text { UN2610 }\end{array}$ & $102 \cdot 70-5$ & \\
\hline TRIBUTILAMINA & $\begin{array}{l}\text { Tributilamina; tri-N-butilamina; tris-N-butilamina } \\
\text { UN2542 }\end{array}$ & $102-82-9$ & \\
\hline TRIETANOLAMINA & $\begin{array}{l}\text { Nitrilo-2,2',2"-trietanol; trietanolamina; } \\
\text { tri(hidroxietil) amina; trihidroxitrietilamina }\end{array}$ & $102-71-6$ & \\
\hline TRIETILAMINA & $\begin{array}{l}\text { Dietilaminoetano; N,N-dietiletanamina; etanamina, N,N-dietil } \\
\text { UN1296 }\end{array}$ & $121-44-8$ & \\
\hline TRIETILENTETRAMINA & $\begin{array}{l}\text { N,N-Bis(2-aminoetil)-1,2-diaminoetano; } \\
\text { N,N'-bis(2-aminoetil) etilendiamina; } \\
\text { 1,2-etanodiamina, N,N'-bis(2-aminoetil)-; } \\
\text { etilendiamina, N,N'-bis(2-aminoetil)- } \\
\text { UN2259 }\end{array}$ & $112-24-3$ & \\
\hline TRIISOPROPANOLAMINA & $\begin{array}{l}\text { Triisopropanolamina; tris(2-hidroxipropil) amina; } \\
\text { tris(2-hidroxi-1-propil) amina }\end{array}$ & $122-20-3$ & \\
\hline
\end{tabular}




\begin{tabular}{lll}
\hline Tabla 104.25 & $\bullet$ & \\
Producto químico & Sinónimos/ Código UN & Número CAS Fórmula estructural \\
TRIMETLLAMINA & Metanamina, N,N-dimetil-; TMA \\
& UN1083 \\
& UN1297 & $75-50-3$ \\
\hline TRIPROPILAMINA & N,N-Dipropil-1-propanamina \\
UN2260 & $102-69-2$ \\
\hline
\end{tabular}

\begin{tabular}{|c|c|c|c|c|c|c|}
\hline \multirow[b]{2}{*}{$\begin{array}{l}\text { Denominación } \\
\text { química } \\
\text { N úmero CAS }\end{array}$} & \multicolumn{4}{|c|}{ Tarjetas Internacionales sobre la Seguridad de los Productos Q uímicos } & \multicolumn{2}{|c|}{ N IO SH (EE.UU.) } \\
\hline & $\begin{array}{l}\text { Período } \\
\text { corto de } \\
\text { exposición }\end{array}$ & $\begin{array}{l}\text { Período } \\
\text { largo de } \\
\text { exposición }\end{array}$ & $\begin{array}{l}\text { Vías de } \\
\text { exposición }\end{array}$ & Síntomas & $\begin{array}{l}\text { O rganos } \\
\text { afectados } \\
\text { Vías de } \\
\text { entrada }\end{array}$ & Síntomas \\
\hline $\begin{array}{l}\text { ALILAMINA } \\
107-11-9\end{array}$ & $\begin{array}{l}\text { ojos; piel; tract } \\
\text { resp; pulmones; } \\
\text { corazón }\end{array}$ & piel & $\begin{array}{r}\text { Inhalación } \\
\text { Piel } \\
\text { 0jos } \\
\text { Ingestión }\end{array}$ & $\begin{array}{l}\text { Sensación de quemazón, tos, dolor torácico, } \\
\text { disnea, dolor de garganta } \\
\text { Puede absorberse, enrojecimiento, dolor, } \\
\text { ampollas } \\
\text { Irritación intensa de los ojos, enrojecimiento, } \\
\text { dolor, lagrimeo, visión borrosa, pérdida de } \\
\text { visión } \\
\text { Sensación de quemazón, cefalea, náuseas, } \\
\text { debilidad }\end{array}$ & & \\
\hline $\begin{array}{l}\text { 1-AMINO-2-PROPANOL } \\
\text { 78-96-6 }\end{array}$ & $\begin{array}{l}\text { ojos; piel; tract } \\
\text { resp; pulmones }\end{array}$ & & Inhalación & $\begin{array}{l}\text { Sensación de quemazón, tos, cefalea, } \\
\text { dificultad respiratoria, náuseas, dolor de } \\
\text { garganta }\end{array}$ & & \\
\hline $\begin{array}{r}\text { BUTILAMINA } \\
109-73-9\end{array}$ & $\begin{array}{l}\text { ojos; piel; tract } \\
\text { resp; pulmones; } \\
\text { SNC }\end{array}$ & piel & $\begin{array}{r}\text { Inhalación } \\
\text { Piel } \\
\text { Ojos } \\
\text { Ingestión }\end{array}$ & $\begin{array}{l}\text { Sensación de quemazón, tos, mareo, } \\
\text { inconsciencia } \\
\text { Puede absorberse, enrojecimiento, aspereza, } \\
\text { quemaduras en la piel, sensación de } \\
\text { quemazón, ampollas } \\
\text { Dolor, quemaduras, pérdida de visión } \\
\text { Tos, mareo, náusea, inconsciencia, vómitos }\end{array}$ & $\begin{array}{l}\text { Sis resp ; ojos; piel } \\
\text { Inh, abs, ing, con }\end{array}$ & $\begin{array}{l}\text { Irrit ojos, piel, nariz, garganta; } \\
\text { cef; enrojecimiento de la piel, } \\
\text { quemaduras }\end{array}$ \\
\hline $\begin{array}{c}\text { SeC-BUTILAMINA } \\
13952-84-6\end{array}$ & $\begin{array}{l}\text { ojos; piel; tract } \\
\text { resp; pulmones }\end{array}$ & piel & $\begin{array}{r}\text { Inhalación } \\
\text { Piel } \\
\text { 0jos } \\
\text { Ingestión }\end{array}$ & $\begin{array}{l}\text { Tos, dificultad respiratoria, dolor de garganta; } \\
\text { los síntomas pueden tardar en aparecer } \\
\text { Enrojecimiento, quemaduras en la piel, dolor } \\
\text { Enrojecimiento, dolor, visión borrosa, } \\
\text { quemaduras profundas graves } \\
\text { Diarrea, dolor de garganta, vómitos }\end{array}$ & & \\
\hline $\begin{array}{l}\text { CICLOHEXILAMINA } \\
108-91.8\end{array}$ & $\begin{array}{l}\text { ojos; piel; tract } \\
\text { resp; pulmones; } \\
\text { SNC }\end{array}$ & piel & & & $\begin{array}{l}\text { Ojos; piel; sis resp; } \\
\text { SNC } \\
\text { Inh, abs, ing, con }\end{array}$ & $\begin{array}{l}\text { Irrit ojos, piel, mucosas, sis } \\
\text { resp; quemaduras en ojos y } \\
\text { piel; sens piel; tos, edema } \\
\text { pulm; sop; atur, mar, diarr, } \\
\text { náu, vómit }\end{array}$ \\
\hline $\begin{array}{c}\text { DIALILAMINA } \\
124-02 \cdot 7\end{array}$ & $\begin{array}{l}\text { ojos; piel; tract } \\
\text { resp; pulmones; } \\
\text { corazón }\end{array}$ & & Inhalación & $\begin{array}{l}\text { Sensación de quemazón, tos, dolor de } \\
\text { garganta, dolor torácico, disnea }\end{array}$ & & \\
\hline $\begin{array}{l}\text { DIETANOLAMINA } \\
111-42-2\end{array}$ & ojos; piel; tract re & piel; tract resp & $\begin{array}{r}\text { Inhalación } \\
\text { Piel } \\
\text { 0jos } \\
\text { Ingestión }\end{array}$ & $\begin{array}{l}\text { Sensación de quemazón, cefalea, náuseas, } \\
\text { dolor de garganta, vómitos } \\
\text { Enrojecimiento, sensación de quemazón } \\
\text { Enrojecimiento, dolor, quemaduras profundas } \\
\text { graves } \\
\text { Dolor abdominal, sensación de quemazón }\end{array}$ & $\begin{array}{l}\text { Ojos; piel; sis resp } \\
\text { Ing, ing, con }\end{array}$ & $\begin{array}{l}\text { irrit ojos, piel, nariz, garganta; } \\
\text { quemaduras en ojos, nec córn; } \\
\text { quemaduras en la piel; lag, } \\
\text { tos, estor }\end{array}$ \\
\hline
\end{tabular}


Tabla 104.26 • Riesgos para la salud.

\begin{tabular}{|c|c|c|c|c|c|c|}
\hline \multirow[b]{2}{*}{$\begin{array}{l}\text { Denominación } \\
\text { química } \\
\mathrm{N} \text { úmero CAS }\end{array}$} & \multicolumn{4}{|c|}{ Tarjetas Internacionales sobre la Seguridad de los Productos Q uímicos } & \multicolumn{2}{|c|}{ N IO SH (EE.UU.) } \\
\hline & $\begin{array}{l}\text { Período } \\
\text { corto de } \\
\text { exposición }\end{array}$ & $\begin{array}{l}\text { Período } \\
\text { largo de } \\
\text { exposición }\end{array}$ & $\begin{array}{l}\text { Vías de } \\
\text { exposición }\end{array}$ & Síntomas & $\begin{array}{l}\text { O rganos } \\
\text { afectados } \\
\text { Vías de } \\
\text { entrada }\end{array}$ & Síntomas \\
\hline $\begin{array}{l}\text { DIETILAMINA } \\
\text { 109-89-7 }\end{array}$ & $\begin{array}{l}\text { ojos; piel; tract } \\
\text { resp; pulmones }\end{array}$ & piel & $\begin{array}{r}\text { Inhalación } \\
\text { Piel } \\
\text { 0jos } \\
\text { Ingestión }\end{array}$ & $\begin{array}{l}\text { Sensación de quemazón, tos, dolor torácico } \\
\text { Aspereza, quemaduras en la piel, dolor } \\
\text { Dolor, visión borrosa, quemaduras profundas } \\
\text { graves } \\
\text { Espasmos abdominales, dolor abdominal, } \\
\text { sensación de quemazón, tos, dolor de } \\
\text { garganta }\end{array}$ & $\begin{array}{l}\text { Ojos; piel; sis resp; } \\
\text { SNC } \\
\text { Inh, abs, ing, con }\end{array}$ & $\begin{array}{l}\text { Irrit ojos, piel, sis resp; en } \\
\text { animales: degeneración } \\
\text { miocárdica }\end{array}$ \\
\hline $\begin{array}{l}\text { 2-DIETILAMINOETANOL } \\
100-37-8\end{array}$ & & & Inhalación & $\begin{array}{l}\text { Tos, dificultad respiratoria, náuseas, disnea, } \\
\text { dolor de garganta, vómitos }\end{array}$ & $\begin{array}{l}\text { Sis resp; piel; ojos } \\
\text { Inh, abs, ing, con }\end{array}$ & $\begin{array}{l}\text { Irrit ojos, piel, sis resp; náu, } \\
\text { vómit }\end{array}$ \\
\hline $\begin{array}{l}\text { DIETILENTRIAMINA } \\
\quad 111-40.0\end{array}$ & $\begin{array}{l}\text { ojos; piel; tract } \\
\text { resp; pulmones }\end{array}$ & piel; tract resp & $\begin{array}{l}\text { Inhalación } \\
\\
\text { Piel } \\
\text { 0jos } \\
\text { Ingestión } \\
\end{array}$ & $\begin{array}{l}\text { Sensación de quemazón, tos, cefalea, } \\
\text { dificultad respiratoria, náuseas, dolor de } \\
\text { garganta, los síntomas pueden tardar en } \\
\text { aparecer } \\
\text { Quemaduras graves en la piel, dolor } \\
\text { Dolor, pérdida de visión, quemaduras } \\
\text { profundas graves } \\
\text { Dolor abdominal, dolor de garganta }\end{array}$ & $\begin{array}{l}\text { Ojos; piel; sis resp } \\
\text { Inh, abs, ing, con }\end{array}$ & $\begin{array}{l}\text { Irrit ojos, piel, muc, sis resp } \\
\text { superior; derm, sens piel; nec } \\
\text { ojos, piel; tos, dis, sens pulm }\end{array}$ \\
\hline $\begin{array}{l}\text { DIISOPROPANOLAMINA } \\
110-97-4\end{array}$ & ojos; piel & piel & $\begin{array}{l}\text { Piel } \\
\text { Ojos }\end{array}$ & $\begin{array}{l}\text { Enrojecimiento, sensación de quemazón } \\
\text { Enrojecimiento, dolor, visión borrosa }\end{array}$ & & \\
\hline $\begin{array}{l}\text { DIISOPROPILAMINA } \\
\quad 108-18-9\end{array}$ & $\begin{array}{l}\text { ojos; tract resp; } \\
\text { pulmones }\end{array}$ & piel & $\begin{array}{r}\text { Inhalación } \\
\text { Piel } \\
\text { 0jos } \\
\text { Ingestión }\end{array}$ & $\begin{array}{l}\text { Tos, dificultad respiratoria, náuseas, dolor de } \\
\text { garganta } \\
\text { Puede absorberse, sequedad de piel, } \\
\text { enrojecimiento, sensación de quemazón } \\
\text { Enrojecimiento, dolor, pérdida de visión } \\
\text { temporal o incluso permanente } \\
\text { Corrosivo, espasmos abdominales, tos, } \\
\text { náuseas, dolor de garganta }\end{array}$ & $\begin{array}{l}\text { Ojos; piel; sis resp } \\
\text { Inh, abs, ing, con }\end{array}$ & $\begin{array}{l}\text { Irrit ojos, piel, sis resp; náu, } \\
\text { vómit; cef; dist vis }\end{array}$ \\
\hline $\begin{array}{l}\text { DIMETILAMINA } \\
\text { 124-40-3 }\end{array}$ & $\begin{array}{l}\text { ojos; piel; tract } \\
\text { resp; pulmones }\end{array}$ & piel & $\begin{array}{l}\text { Inhalación } \\
\\
\text { Piel } \\
\text { 0jos }\end{array}$ & $\begin{array}{l}\text { Dolor abdominal, sensación de quemazón, tos, } \\
\text { diarrea, dificultad respiratoria y disnea, dolor } \\
\text { de garganta } \\
\text { Enrojecimiento, quemaduras en la piel, dolor } \\
\text { Enrojecimiento, dolor, visión borrosa, } \\
\text { quemaduras profundas graves }\end{array}$ & $\begin{array}{l}\text { Sis resp; piel; ojos } \\
\text { Inh, con, (liq) }\end{array}$ & $\begin{array}{l}\text { Irrit nariz, garganta; estor, tos, } \\
\text { dis; edema pulm; conj; derm; } \\
\text { liq: congelación }\end{array}$ \\
\hline $\begin{array}{l}\text { 2-DIMETILAMINOETANOL } \\
\text { 108-01-0 }\end{array}$ & $\begin{array}{l}\text { ojos; piel; tract } \\
\text { resp; pulmones }\end{array}$ & piel & $\begin{array}{r}\text { Inhalación } \\
\text { Piel } \\
\text { 0jos } \\
\text { Ingestión } \\
\end{array}$ & $\begin{array}{l}\text { Tos, dificultad respiratoria, los síntomas } \\
\text { pueden tardar en aparecer } \\
\text { Puede absorberse, enrojecimiento, dolor } \\
\text { Dolor, quemaduras profundas graves } \\
\text { Dolor abdominal, náuseas, vómitos }\end{array}$ & & \\
\hline $\begin{array}{l}\text { DIPENTILAMINA } \\
2050-92.2\end{array}$ & ojos; piel; tract resp & & Inhalación & Tos & & \\
\hline $\begin{array}{l}\text { 1,2-ETANODIAMINA } \\
\text { 107-15-3 }\end{array}$ & $\begin{array}{l}\text { ojos; piel; tract } \\
\text { resp; pulmones; } \\
\text { hígado; riñones }\end{array}$ & piel; tract resp & $\begin{array}{r}\text { Inhalación } \\
\text { Piel } \\
\text { 0jos } \\
\text { Ingestión }\end{array}$ & $\begin{array}{l}\text { Sensación de quemazón, tos, dificultad } \\
\text { respiratoria y disnea, dolor de garganta } \\
\text { Puede absorberse, enrojecimiento, quemaduras } \\
\text { en la piel, dolor } \\
\text { Enrojecimiento, dolor, visión borrosa } \\
\text { Dolor abdominal, diarrea, dolor de garganta, } \\
\text { vómitos }\end{array}$ & $\begin{array}{l}\text { Sis resp; hígado; } \\
\text { riñones; piel } \\
\text { Inh, abs, ing, con }\end{array}$ & $\begin{array}{l}\text { Irrit nariz, sis resp; sens derm; } \\
\text { asma; lesiones hepáticas y } \\
\text { renales }\end{array}$ \\
\hline $\begin{array}{l}\text { ETANOLAMINA } \\
141-43-5\end{array}$ & & & & & $\begin{array}{l}\text { Sis resp; piel; ojos; } \\
\text { SNC } \\
\text { Inh, ing, con }\end{array}$ & Irrit ojos, piel, sis resp; let \\
\hline $\begin{array}{r}\text { ETILAMINA } \\
75-04-7\end{array}$ & ojos; piel; tract resp & riñones; pulmones & $\begin{array}{r}\text { Inhalación } \\
\text { Piel } \\
\text { 0jos } \\
\text { Ingestión }\end{array}$ & $\begin{array}{l}\text { Tos, dificultad respiratoria, dolor de garganta } \\
\text { Puede absorberse, enrojecimiento, sensación } \\
\text { de quemazón } \\
\text { Enrojecimiento, dolor } \\
\text { Dolor abdominal, sensación de quemazón }\end{array}$ & $\begin{array}{l}\text { Sis resp; ojos; piel } \\
\text { Inh, abs (liq), ing } \\
\text { (liq), con (liq) }\end{array}$ & $\begin{array}{l}\text { Irrit ojos, piel, sis resp; } \\
\text { quemaduras en la piel; derm }\end{array}$ \\
\hline
\end{tabular}




\begin{tabular}{|c|c|c|c|c|c|c|}
\hline \multirow[b]{2}{*}{$\begin{array}{l}\text { Denominación } \\
\text { química } \\
\text { N úmero CAS }\end{array}$} & \multicolumn{4}{|c|}{ Tarjetas Internacionales sobre la Seguridad de los Productos Q uímicos } & \multicolumn{2}{|c|}{ N IO SH (EE.UU.) } \\
\hline & $\begin{array}{l}\text { Período } \\
\text { corto de } \\
\text { exposición }\end{array}$ & $\begin{array}{l}\text { Período } \\
\text { largo de } \\
\text { exposición }\end{array}$ & $\begin{array}{l}\text { Vías de } \\
\text { exposición }\end{array}$ & Síntomas & $\begin{array}{l}\text { O rganos } \\
\text { afectados } \\
\text { Vías de } \\
\text { entrada }\end{array}$ & Síntomas \\
\hline $\begin{array}{l}\text { ETILENIMINA } \\
\text { 151-56-4 }\end{array}$ & $\begin{array}{l}\text { ojos; piel; tract } \\
\text { resp; pulmones; } \\
\text { SNC; riñones; } \\
\text { hígado }\end{array}$ & piel & $\begin{array}{r}\text { Inhalación } \\
\text { Piel } \\
\text { 0jos } \\
\text { Ingestión }\end{array}$ & $\begin{array}{l}\text { Tos, mareo, cefalea, dificultad respiratoria, } \\
\text { náuseas, vómitos, los síntomas pueden tardar } \\
\text { en aparecer } \\
\text { Puede absorberse, enrojecimiento, quemaduras } \\
\text { en la piel, ampollas } \\
\text { Enrojecimiento, dolor, quemaduras profundas } \\
\text { graves } \\
\text { Vómitos }\end{array}$ & $\begin{array}{l}\text { Ojos; pulmones; } \\
\text { piel; hígado; } \\
\text { riñones; sis resp; En } \\
\text { animales: tumores } \\
\text { pulmonares y } \\
\text { hepáticos } \\
\text { Ing, abs, ing, con }\end{array}$ & $\begin{array}{l}\text { Irrit ojos, piel, nariz, garganta; } \\
\text { náu, vómit; cef, mar; edema } \\
\text { pulm; lesiones hepáticas y } \\
\text { renales; quemaduras en la } \\
\text { piel; sens piel [carc] }\end{array}$ \\
\hline $\begin{array}{l}\text { HEXAMETILENDIAMINA } \\
\text { 124-09-4 }\end{array}$ & ojos; piel; tract res & piel & $\begin{array}{r}\text { Inhalación } \\
\text { Piel } \\
\text { Ojos } \\
\text { Ingestión } \\
\end{array}$ & $\begin{array}{l}\text { Tos, dificultad respiratoria y disnea } \\
\text { Enrojecimiento, dolor } \\
\text { Enrojecimiento, dolor } \\
\text { Espasmos abdominales, dolor abdominal }\end{array}$ & & \\
\hline $\begin{array}{l}\text { ISOBUTANOLAMINA } \\
\text { 124-68-5 } \\
\end{array}$ & $\begin{array}{l}\text { ojos; piel; tract } \\
\text { resp; pulmones }\end{array}$ & & & & & \\
\hline $\begin{array}{l}\text { ISOFORONA DIAMINA } \\
2855-13-2\end{array}$ & $\begin{array}{l}\text { ojos; piel; tract } \\
\text { resp; pulmones }\end{array}$ & piel; pulmones & $\begin{array}{r}\text { Inhalación } \\
\text { Piel } \\
\text { 0jos } \\
\text { Ingestión }\end{array}$ & $\begin{array}{l}\text { Sensación de quemazón, tos, cefalea, } \\
\text { disritmia cardíaca, los síntomas pueden tardar } \\
\text { en aparecer } \\
\text { Puede absorberse, enrojecimiento, quemaduras } \\
\text { en la piel, sensación de quemazón, dolor } \\
\text { Enrojecimiento, dolor, visión borrosa, pérdida } \\
\text { de visión, quemaduras profundas graves } \\
\text { Dolor abdominal, sensación de quemazón, } \\
\text { dolor de garganta }\end{array}$ & & \\
\hline $\begin{array}{l}\text { ISOPROPILAMINA } \\
75-31.0\end{array}$ & & & & & $\begin{array}{l}\text { Sis resp; piel; ojos } \\
\text { Inh, abs, ing, con }\end{array}$ & $\begin{array}{l}\text { Irrit ojos, piel, nariz, garganta; } \\
\text { edema pulm; dist vis; } \\
\text { quemaduras en ojos y piel; } \\
\text { derm }\end{array}$ \\
\hline $\begin{array}{l}\text { METILAMINA } \\
74-89.5\end{array}$ & $\begin{array}{l}\text { ojos; piel; tract } \\
\text { resp; pulmones }\end{array}$ & piel & $\begin{array}{r}\text { Inhalación } \\
\\
\text { Piel } \\
\text { 0jos } \\
\text { Ingestión }\end{array}$ & $\begin{array}{l}\text { Espasmos abdominales, tos, diarrea, dificultad } \\
\text { respiratoria y disnea, dolor de garganta, } \\
\text { vómitos } \\
\text { Enrojecimiento, dolor } \\
\text { Enrojecimiento, dolor } \\
\text { Espasmos abdominales }\end{array}$ & $\begin{array}{l}\text { Sis resp; ojos; piel } \\
\text { Inh, abs (sol), ing } \\
\text { (sol), con (liq/ sol) }\end{array}$ & $\begin{array}{l}\text { Irrit ojos, piel, sis resp; tos; } \\
\text { quemaduras en piel y } \\
\text { mucosas; derm; conj; liq: } \\
\text { congelación }\end{array}$ \\
\hline $\begin{array}{c}\text { PROPILAMINA } \\
107-10-8 \\
\end{array}$ & $\begin{array}{l}\text { ojos; piel; tract } \\
\text { resp; pulmones }\end{array}$ & & Inhalación & $\begin{array}{l}\text { Sensación de quemazón, tos, dolor de } \\
\text { garganta, disnea }\end{array}$ & & \\
\hline $\begin{array}{l}\text { TRIETILAMINA } \\
121-44-8\end{array}$ & & & & & $\begin{array}{l}\text { Sis resp; ojos; piel; } \\
\text { SCV; hígado, } \\
\text { riñones } \\
\text { Ing, abs, ing, con }\end{array}$ & $\begin{array}{l}\text { Irrit ojos, piel, sis resp; en } \\
\text { animales: lesiones } \\
\text { miocárdicas, renales y } \\
\text { hepáticas }\end{array}$ \\
\hline $\begin{array}{l}\text { TRIETLEENTETRAMINA } \\
112-24-3\end{array}$ & $\begin{array}{l}\text { ojos; piel; tract } \\
\text { resp; pulmones }\end{array}$ & piel & $\begin{array}{r}\text { Inhalación } \\
\text { Piel } \\
\text { 0jos } \\
\text { Ingestión }\end{array}$ & $\begin{array}{l}\text { Sensación de quemazón, tos, dificultad } \\
\text { respiratoria } \\
\text { Enrojecimiento, dolor, ampollas } \\
\text { Enrojecimiento, dolor, quemaduras profundas } \\
\text { graves } \\
\text { Dolor abdominal, sensación de quemazón, } \\
\text { debilidad }\end{array}$ & & \\
\hline $\begin{array}{l}\text { TRIISOPROPANOLAMINA } \\
122-20-3\end{array}$ & $\begin{array}{l}\text { ojos; piel; tract } \\
\text { resp; pulmones }\end{array}$ & & Inhalación & $\begin{array}{l}\text { Sensación de quemazón, tos, dificultad } \\
\text { respiratoria, dolor de garganta }\end{array}$ & & \\
\hline $\begin{array}{l}\text { TRIMETILAMINA } \\
75-50-3\end{array}$ & & & $\begin{array}{l}\text { Piel } \\
\text { 0jos }\end{array}$ & $\begin{array}{l}\text { Dolor abdominal, sensación de quemazón, tos, } \\
\text { diarrea, dificultad respiratoria y disnea, dolor } \\
\text { de garganta } \\
\text { Enrojecimiento, quemaduras en la piel, dolor } \\
\text { Enrojecimiento, dolor, visión borrosa, } \\
\text { quemaduras profundas graves }\end{array}$ & $\begin{array}{l}\text { Ojos; piel; sis resp } \\
\text { Inh, ing (sol), con }\end{array}$ & $\begin{array}{l}\text { Irrit ojos, piel, nariz, garganta, } \\
\text { sis resp; tos, dis, edema pulm } \\
\text { tardí; visión borrosa, nec } \\
\text { córn; quemaduras en la piel; } \\
\text { liq: congelación }\end{array}$ \\
\hline
\end{tabular}




\begin{tabular}{|c|c|c|c|}
\hline $\begin{array}{l}\text { Denominación química } \\
\mathrm{N} \text { úmero CAS }\end{array}$ & Físicos & Q uímicos & $\begin{array}{l}\text { Clase o división } \\
\text { UN / Riesgos } \\
\text { subsidiarios }\end{array}$ \\
\hline $\begin{array}{l}\text { ACETALDEHIDO-OXIMA } \\
107-29.9\end{array}$ & & & 3 \\
\hline $\begin{array}{l}\text { ALILAMINA } \\
\text { 107-11-9 }\end{array}$ & $\begin{array}{l}\text { El vapor es más pesado } \\
\text { que el aire y puede } \\
\text { desplazarse a ras del } \\
\text { suelo; posibilidad de } \\
\text { ignición a distancia }\end{array}$ & $\begin{array}{l}\text { Se descompone al calentarse y al arder liberando vapores tóxicos (óxidos de nitrógeno) } \\
\text { Reacciona violentamente con oxidantes con peligro de explosión Reacciona violentamente } \\
\text { con ácidos y anhídridos ácidos Corrosivo para el cobre (aleaciones), aluminio, zinc } \\
\text { (aleaciones) y acero }\end{array}$ & $6.1 / 3$ \\
\hline $\begin{array}{r}\text { BUTILAMINA } \\
109-73-9\end{array}$ & $\begin{array}{l}\text { El vapor es más pesado } \\
\text { que el aire y puede } \\
\text { desplazarse a ras del } \\
\text { suelo; posibilidad de } \\
\text { ignición a distancia }\end{array}$ & $\begin{array}{l}\text { En su combustión forma monóxido de carbono y óxidos de nitrógeno Reacciona con } \\
\text { oxidantes fuertes, ácidos }\end{array}$ & $3 / 8$ \\
\hline $\begin{array}{l}\text { SeC-BUTILAMINA } \\
13952-84-6\end{array}$ & $\begin{array}{l}\text { El vapor es más pesado } \\
\text { que el aire y puede } \\
\text { desplazarse a ras del } \\
\text { suelo; posibilidad de } \\
\text { ignición a distancia }\end{array}$ & $\begin{array}{l}\text { Se descompone al arder produciendo vapores y gases tóxicos (amoníaco, óxidos de nitrógeno) } \\
\text { Es una base débil, formando ácidos sales solubles en agua Reacciona con oxidantes fuertes y } \\
\text { ácidos fuertes Corrosivo para el estaño, aluminio y algunos aceros }\end{array}$ & \\
\hline $\begin{array}{l}\text { CILOHEXILAMINA } \\
\text { 108-91-8 }\end{array}$ & $\begin{array}{l}\text { El vapor en más pesado } \\
\text { que el aire }\end{array}$ & $\begin{array}{l}\text { Se descompone al calentarse produciendo gases tóxicos (óxidos de nitrógeno) Es una base } \\
\text { fuerte, reacciona violentamente con ácidos y es corrosivo Reacciona violentamente con } \\
\text { oxidantes fuertes con peligro de incendio }\end{array}$ & $8 / 3$ \\
\hline $\begin{array}{l}\text { DIALLLAMINA } \\
124 \cdot 02 \cdot 7\end{array}$ & $\begin{array}{l}\text { El vapor se mezcla bien } \\
\text { con el aire, se forman } \\
\text { fácilmente mezclas } \\
\text { explosivas }\end{array}$ & $\begin{array}{l}\text { Puede explotar al calentarse En contacto con superficies calientes o llamas, se descompone } \\
\text { liberando vapores tóxicos y corrosivos (óxidos de nitrógeno) Es una base de fuerza intermedia } \\
\text { Reacciona violentamente con oxidantes y ácidos Ataca cobre, estaño, aluminio y zinc Las } \\
\text { soluciones de dialilamina en agua pueden atacar el vidrio }\end{array}$ & $6.1 / 3$ \\
\hline $\begin{array}{l}\text { DIBUTILAMINA } \\
111-92.2\end{array}$ & & & $8 / 3$ \\
\hline $\begin{array}{l}\text { DICICLOHEXILAMINA } \\
\text { 101-83-7 }\end{array}$ & & & 8 \\
\hline $\begin{array}{l}\text { DIETANOLAMINA } \\
111-42-2\end{array}$ & $\begin{array}{l}\text { El vapor es más pesado } \\
\text { que el aire }\end{array}$ & $\begin{array}{l}\text { Se descompone al calentarse produciendo vapores tóxicos La solución en agua es una base } \\
\text { de fuerza intermedia Reacciona violentamente con oxidantes Reacciona violentamente con } \\
\text { ácidos fuertes y anhídridos Ataca el cobre }\end{array}$ & \\
\hline $\begin{array}{l}\text { DIETILAMINA } \\
109-89-7\end{array}$ & $\begin{array}{l}\text { El vapor es más pesado } \\
\text { que el aire y puede } \\
\text { desplazarse a ras del } \\
\text { suelo; posibilidad de } \\
\text { ignición a distancia }\end{array}$ & $\begin{array}{l}\text { En su combustión forma monóxido de carbono y óxidos de nitrógeno Al calentarse libera } \\
\text { vapores tóxicos La solución en agua es una base de fuerza intermedia Reacciona con } \\
\text { oxidantes, con peligro de incendio y explosión }\end{array}$ & $3 / 8$ \\
\hline $\begin{array}{l}\text { 2-DIETLLAMINOETANOL } \\
\text { 100-37-8 }\end{array}$ & & $\begin{array}{l}\text { En su combustión forma gases tóxicos (óxidos de nitrógeno) Reacciona violentamente con } \\
\text { oxidantes, ácidos, cloruros ácidos, e isocianatos Ataca metales ligeros y cobre }\end{array}$ & 3 \\
\hline $\begin{array}{l}\text { DIETLENTRIAMINA } \\
\quad 111-40.0\end{array}$ & $\begin{array}{l}\text { El vapor es más pesado } \\
\text { que el aire }\end{array}$ & $\begin{array}{l}\text { Se descompone al arder liberando vapores tóxicos La solución en agua es una base fuerte, } \\
\text { reacciona violentamente con ácido y es corrosiva Reacciona violentamente con oxidantes } \\
\text { fuertes, ácido nítrico, y nitrocompuestos orgánicos Ataca muchos metales en presencia de agua }\end{array}$ & 8 \\
\hline $\begin{array}{l}\text { DIISOPROPILAMINA } \\
\text { 108-18-9 }\end{array}$ & $\begin{array}{l}\text { El vapor es más pesado } \\
\text { que el aire y puede } \\
\text { desplazarse a ras del } \\
\text { suelo; posibilidad de } \\
\text { ignición a distancia }\end{array}$ & $\begin{array}{l}\text { Se descompone al calentarse y al arder liberando vapores tóxicos y corrosivos ( } p \text {. ej. Nox) } \\
\text { Es una base de fuerza intermedia y reacciona violentamente con ácidos fuertes Reacciona } \\
\text { violentamente con oxidantes fuertes Reacciona con muchos compuestos como cloruros } \\
\text { orgánicos, nitrilos, óxidos, etc. Ataca muchos metales formando gas combustible (hidrógeno): } \\
\text { aluminio, zinc, cobre y estaño }\end{array}$ & $3 / 8$ \\
\hline $\begin{array}{l}\text { DIMETILAMINA } \\
124-40-3\end{array}$ & $\begin{array}{l}\text { El vapor es más pesado } \\
\text { que el aire y puede } \\
\text { desplazarse a ras del } \\
\text { suelo; posibilidad de } \\
\text { ignición a distancia }\end{array}$ & $\begin{array}{l}\text { Se descompone al arder liberando vapores tóxicos (óxidos de nitrógeno) Es una base de } \\
\text { fuerza intermedia Reacciona violentamente con oxidantes fuertes, como cloro Reacciona } \\
\text { violentamente con mercurio con peligro de incendio y explosión Ataca plásticos, caucho y } \\
\text { revestimientos }\end{array}$ & 2.1 \\
\hline
\end{tabular}




\begin{tabular}{|c|c|c|c|}
\hline $\begin{array}{l}\text { Denominación química } \\
\mathrm{N} \text { úmero CAS }\end{array}$ & Físicos & Q uímicos & $\begin{array}{l}\text { Clase o división } \\
\text { UN / Riesgos } \\
\text { subsidiarios }\end{array}$ \\
\hline $\begin{array}{l}\text { DIMETILETANOLAMINA } \\
\text { 108-01-0 }\end{array}$ & $\begin{array}{l}\text { El vapor es más pesado } \\
\text { que el aire }\end{array}$ & $\begin{array}{l}\text { Reacciona con oxidantes fuertes y muchas otras sustancias, con peligro de incendio y explosión } \\
\text { Ataca el cobre }\end{array}$ & $8 / 3$ \\
\hline $\begin{array}{l}\text { 3,3'-DIAMINODIPROPILAMINA } \\
56-18-8\end{array}$ & & & 6.1 \\
\hline $\begin{array}{l}\text { DIISOPROPANOLAMINA } \\
110-97-4\end{array}$ & $\begin{array}{l}\text { Posibilidad de explosión } \\
\text { pulverulenta cuando se } \\
\text { encuentra en forma de } \\
\text { polvo o gránulos y se } \\
\text { mezcla con aire }\end{array}$ & $\begin{array}{l}\text { Se descompone al calentarse y al arder liberando gases tóxicos (óxidos de nitrógeno) Es un } \\
\text { oxidante fuerte y reacciona con materiales combustibles y oxidantes La solución en agua es una } \\
\text { base de fuerza intermedia y reacciona con ácidos fuertes Reacciona violentamente con } \\
\text { oxidantes fuertes con peligro de incendio y explosión }\end{array}$ & \\
\hline $\begin{array}{l}\text { ETANOLAMINA } \\
141-43-5 \\
\end{array}$ & & & 8 \\
\hline $\begin{array}{r}\text { ETILAMINA } \\
75-04-7\end{array}$ & $\begin{array}{l}\text { El vapor es más pesado } \\
\text { que el aire y puede } \\
\text { desplazarse a ras del } \\
\text { suelo; posibilidad de } \\
\text { ignición a distancia No } \\
\text { debe utilizarse aire } \\
\text { comprimido durante } \\
\text { operaciones de llenado, } \\
\text { vaciado o procesado }\end{array}$ & $\begin{array}{l}\text { Se descompone al calentarse liberando gases tóxicos, como óxidos de nitrógeno La solución } \\
\text { en agua es una base fuerte Reacciona violentamente con oxidantes fuertes ácidos y } \\
\text { compuestos orgánicos con peligro de incendio y explosión Ataca muchos metales no ferrosos y } \\
\text { plásticos }\end{array}$ & $3 / 8$ \\
\hline $\begin{array}{l}\text { ETILENDIAMINA } \\
\text { 107-15-3 }\end{array}$ & & $\begin{array}{l}\text { Se descompone al calentarse liberando vapores tóxicos (óxidos de nitrógeno Es una base de } \\
\text { fuerza intermedia Reacciona violentamente con oxidantes fuertes orgánicos clorados }\end{array}$ & $8 / 3$ \\
\hline $\begin{array}{c}\text { ETILENIMINA } \\
151-56-4\end{array}$ & $\begin{array}{l}\text { El vapor es más pesado } \\
\text { que el aire y puede } \\
\text { desplazarse a ras del } \\
\text { suelo; posibilidad de } \\
\text { ignición a distancia El } \\
\text { vapor se mezcla bien con } \\
\text { el aire; se forman } \\
\text { fácilmente mezclas } \\
\text { explosivas }\end{array}$ & $\begin{array}{l}\text { Se polimeriza bajo la influencia de condiciones ácidas acuosas, ácidos y materiales oxidantes } \\
\text { En su combustión forma vapores tóxicos e irritantes, como óxidos de nitrógeno Es una base } \\
\text { de fuerza intermedia }\end{array}$ & $6.1 / 3$ \\
\hline $\begin{array}{l}\text { HEXAMETILENDIAMINA } \\
\text { 124-09-4 }\end{array}$ & & $\begin{array}{l}\text { Al calentarse libera vapores tóxicos La solución en agua es una base fuerte, reacciona } \\
\text { violentamente con ácidos y es corrosiva Reacciona con oxidantes Ataca muchos metales en } \\
\text { presencia de agua }\end{array}$ & 8 \\
\hline $\begin{array}{l}\text { ISOBUTILAMINA } \\
78-81-9\end{array}$ & & & $3 / 8$ \\
\hline $\begin{array}{l}\text { ISOFORONA DIAMINA } \\
\text { 2855-13-2 }\end{array}$ & & $\begin{array}{l}\text { Puede explotar al calentarse Reacciona con bronce, cobre, zinc y estaño Reacciona } \\
\text { violentamente con ácidos Ataca muchos metales }\end{array}$ & 8 \\
\hline $\begin{array}{l}\text { ISOPROPANOLAMINA } \\
78-96-6\end{array}$ & & En su combustión forma oxido nitroso Reacciona con oxidantes fuertes & \\
\hline $\begin{array}{l}\text { ISOPROPILAMINA } \\
75-31.0\end{array}$ & & & 3 \\
\hline $\begin{array}{l}\text { METILAMINA } \\
74-89.5\end{array}$ & $\begin{array}{l}\text { El gas es más pesado } \\
\text { que el aire y puede } \\
\text { desplazarse a ras del } \\
\text { suelo; posibilidad de } \\
\text { ignición a distancia }\end{array}$ & $\begin{array}{l}\text { Se descompone al calentarse liberando vapores tóxicos (óxidos de nitrógeno) Es una base } \\
\text { de fuerza intermedia Reacciona violentamente con mercurio con peligro de incendio y explosión } \\
\text { Reacciona violentamente con oxidantes fuertes, como cloro }\end{array}$ & 2.1 \\
\hline $\begin{array}{l}\text { DIPENTILAMINA } \\
2050-92-2\end{array}$ & & $\begin{array}{l}\text { Se descompone al calentarse liberando gases tóxicos e irritantes (óxidos de nitrógeno) } \\
\text { Reacciona con oxidantes }\end{array}$ & \\
\hline
\end{tabular}




\begin{tabular}{|c|c|c|c|}
\hline $\begin{array}{l}\text { Denominación química } \\
\mathrm{N} \text { úmero CAS }\end{array}$ & Físicos & Q uímicos & $\begin{array}{l}\text { Clase o división } \\
\text { UN / Riesgos } \\
\text { subsidiarios }\end{array}$ \\
\hline $\begin{array}{l}\text { PROPILAMINA } \\
107-10-8\end{array}$ & $\begin{array}{l}\text { El vapor es más pesado } \\
\text { que el aire y puede } \\
\text { desplazarse a ras del } \\
\text { suelo; posibilidad de } \\
\text { ignición a distancia }\end{array}$ & $\begin{array}{l}\text { Se descompone al calentarse } 0 \text { al arder liberando gases tóxicos (óxidos de nitrógeno) Es una } \\
\text { base de fuerza intermedia Reacciona violentamente con oxidantes y mercurio con peligro de } \\
\text { incendio y explosión Reacciona violentamente con ácidos concentrados, nitroparafinas, } \\
\text { hidrocarburos halogenados, alcoholes y muchos otros compuestos Ataca muchos metales y } \\
\text { aleaciones, especialmente cobre Es corrosivo para el cobre (aleaciones) aluminio, zinc } \\
\text { (aleaciones) y superficies galvanizadas Las soluciones de propilamina en agua pueden atacar el } \\
\text { vidrio }\end{array}$ & $3 / 8$ \\
\hline $\begin{array}{l}\text { TETRAETILENPENTAMINA } \\
112-57-2\end{array}$ & & & 8 \\
\hline $\begin{array}{l}\text { TRIALLLAMINA } \\
102-70-5 \\
\end{array}$ & & & $3 / 8$ \\
\hline $\begin{array}{l}\text { TRIBUTILAMINA } \\
102-82-9 \\
\end{array}$ & & & 8 \\
\hline $\begin{array}{l}\text { TRIETLLAMINA } \\
121-44-8 \\
\end{array}$ & & & $3 / 8$ \\
\hline $\begin{array}{l}\text { TRIETILENTETRAMINA } \\
\text { 112-24-3 }\end{array}$ & & $\begin{array}{l}\text { En su combustión libera vapores tóxicos de monóxido de carbono y óxidos de nitrógeno Es } \\
\text { una base de fuerza intermedia Reacciona violentamente con oxidantes con peligro de incendio } \\
\text { y explosión Reacciona con cloruros ácidos, anhídridos ácidos, aldehídos, cetonas, compuestos } \\
\text { orgánicos halogenados y acrilatos Ataca metales como aluminio, zinc, cobre y sus aleaciones }\end{array}$ & \\
\hline $\begin{array}{l}\text { TRIISOPROPANOLAMINA } \\
122-20-3\end{array}$ & & $\begin{array}{l}\text { En su combustión forma gases tóxicos de óxidos de carbono y nitrógeno Reacciona con } \\
\text { ácidos y oxidantes fuertes }\end{array}$ & \\
\hline $\begin{array}{l}\text { TRIMETILAMINA } \\
75-50-3\end{array}$ & $\begin{array}{l}\text { El gas es más pesado } \\
\text { que el aire y puede } \\
\text { desplazarse a ras del } \\
\text { suelo; posibilidad de } \\
\text { ignición a distancia }\end{array}$ & $\begin{array}{l}\text { Se descompone al arder liberando gases tóxicos (óxidos de nitrógeno) Es una base de fuerza } \\
\text { intermedia Reacciona violentamente con mercurio con peligro de incendio y explosión } \\
\text { Reacciona violentamente con oxidantes fuertes como cloro }\end{array}$ & 2.1 \\
\hline
\end{tabular}

Tabla 104.28 Propiedades físicas y químicas.

\begin{tabular}{|c|c|c|c|c|c|c|c|c|c|c|c|}
\hline $\begin{array}{l}\text { Denominación química } \\
\mathrm{N} \text { úmero CAS }\end{array}$ & Color/ Forma & $\begin{array}{l}\text { p.e. } \\
(\stackrel{\circ}{ } C)\end{array}$ & $\begin{array}{l}\text { p.f. } \\
(\stackrel{\circ}{ } C)\end{array}$ & $\begin{array}{l}\text { p.m.l } \\
\text { (g/ } \\
\text { mol) }\end{array}$ & $\begin{array}{l}\text { Solubilidad } \\
\text { en agua }\end{array}$ & $\begin{array}{l}\text { Densidad } \\
\text { relativa } \\
\text { (agua }=1 \text { ) }\end{array}$ & $\begin{array}{l}\text { Densidad } \\
\text { de vapor } \\
\text { relativa } \\
\text { (aire=1) }\end{array}$ & $\begin{array}{l}\text { Pvap/ } \\
(\mathrm{kPa})\end{array}$ & $\begin{array}{l}\text { Límit } \\
\text { inflam. }\end{array}$ & $\begin{array}{l}\text { p.ig. } \\
(\because 0 C)\end{array}$ & $\begin{array}{l}\text { p. aut } \\
\text { ig. } \\
\left({ }^{\circ} \mathrm{C}\right)\end{array}$ \\
\hline $\begin{array}{l}\text { ACETALDEHIDO OXIMA } \\
\text { 107-29-9 }\end{array}$ & $\begin{array}{l}\text { agujas; dos } \\
\text { modificaciones } \\
\text { cristalinas }\end{array}$ & 115 & 47 & 59,07 & sol & 0,9656 & & $\begin{array}{l}10 \mathrm{~mm} \mathrm{Hg} \\
@ 25,8 \stackrel{\circ}{\circ} \mathrm{C}\end{array}$ & & & \\
\hline $\begin{array}{l}\text { ALLLAMINA } \\
107-11-9 \\
\end{array}$ & $\begin{array}{l}\text { líquido incoloro a } \\
\text { amarillo claro }\end{array}$ & $55-58$ & -88 & 57,09 & misc & 0,76 & 2,0 & 26,4 & $\begin{array}{l}2,2 \mathrm{li} \\
22 \mathrm{Is}\end{array}$ & $.29 c c$ & 370 \\
\hline $\begin{array}{l}\text { 1,3-BUTANODIAMINA } \\
\text { 590-88-5 }\end{array}$ & líquido acuoso blanco & $143-150$ & & & & 0,858 & & & & 516 & \\
\hline $\begin{array}{r}\text { BUTILAMINA } \\
109-73-9 \\
\end{array}$ & $\begin{array}{l}\text { líquido transparente e } \\
\text { incoloro }\end{array}$ & 77,8 & .50 & 73,1 & misc & 0,7414 & 2,5 & 10,9 & $\begin{array}{l}1,7 \mathrm{li} \\
9,80 \mathrm{ls}\end{array}$ & $-1 \mathrm{ca}$ & 312 \\
\hline $\begin{array}{c}\text { SeC-BUTLLAMINA } \\
\text { 13952-84-6 }\end{array}$ & líquido incoloro & 63 & -104 & 73,14 & misc & 0,724 & 2,52 & 18 & $\begin{array}{l}1,7 \mathrm{li} \\
9,8 \mathrm{ls}\end{array}$ & .9 & 378 \\
\hline $\begin{array}{l}\text { terc-BUTILAMINA } \\
75-64.9\end{array}$ & líquido incoloro & 44 & $.72,65$ & 73,1 & misc & 0,6951 & 2,5 & $\begin{array}{l}362 \mathrm{~mm} \mathrm{Hg} \\
\text { @ } 25^{\circ} \mathrm{C} \text {. }\end{array}$ & $\begin{array}{l}1,7 \mathrm{li} \\
8,9 \mathrm{ls}\end{array}$ & 10 & 380 \\
\hline
\end{tabular}




\begin{tabular}{|c|c|c|c|c|c|c|c|c|c|c|c|}
\hline $\begin{array}{l}\text { Denominación química } \\
\mathrm{N} \text { úmero CAS }\end{array}$ & Color/ Forma & $\begin{array}{l}\text { p.e. } \\
\left({ }^{\circ} \mathrm{C}\right)\end{array}$ & 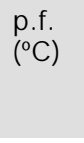 & $\begin{array}{l}\text { p.m.l } \\
\text { (g/ } \\
\text { mol) }\end{array}$ & $\begin{array}{l}\text { Solubilidad } \\
\text { en agua }\end{array}$ & $\begin{array}{l}\text { Densidad } \\
\text { relativa } \\
\text { (agua }=1 \text { ) }\end{array}$ & $\begin{array}{l}\text { Densidad } \\
\text { de vapor } \\
\text { relativa } \\
\text { (aire=1) }\end{array}$ & $\begin{array}{l}\text { Pvap/ } \\
(\mathrm{kPa})\end{array}$ & $\begin{array}{l}\text { Límit } \\
\text { inflam. }\end{array}$ & $\begin{array}{l}\text { p.ig. } \\
\left({ }^{\circ} C\right)\end{array}$ & $\begin{array}{l}\text { p.aut } \\
\text { ig. } \\
(\stackrel{0}{ })\end{array}$ \\
\hline $\begin{array}{l}\text { CICLOHEXILAMINA } \\
\text { 108-91-8 }\end{array}$ & $\begin{array}{l}\text { líquido incoloro a } \\
\text { amarillo }\end{array}$ & 134 & $-17,7$ & 99,17 & sol & 0,8191 & 3,42 & 1,2 & $\begin{array}{l}1,5 \mathrm{li} \\
9,4 \mathrm{is}\end{array}$ & $31 \mathrm{cc}$ & 293 \\
\hline $\begin{array}{l}\text { CLORHIDRATO DE DIMETILAMINA } \\
506-59-2\end{array}$ & & & 171 & 81,54 & muy sol & & & & & & \\
\hline $\begin{array}{c}\text { DIALLLAMINA } \\
124-02 \cdot 7 \\
\end{array}$ & líquido & 111 & $-88,4$ & 97,2 & $8,6 \mathrm{~g} / 100 \mathrm{ml}$ & $\begin{array}{l}0,7627 \\
@ 10 \stackrel{\circ}{0} / 4 \stackrel{\circ}{ } \mathrm{C}\end{array}$ & 3,35 & 2,4 & & 21 & \\
\hline $\begin{array}{l}\text { 3,3'-DIAM INODIPROPILAMINA } \\
56-18-8\end{array}$ & & $15 @ 50 \stackrel{\circ}{C}$ & & 131,22 & & $0,938 @ 25 \stackrel{\circ}{\circ}$ & & & & & \\
\hline $\begin{array}{l}\text { DIBUTILAMINA } \\
111-92-2 \\
\end{array}$ & líquido; incoloro & 160 & .60 .59 & 129,24 & sol & 0,7670 & 4,46 & $1,9 \mathrm{~mm} \mathrm{Hg}$ & 1,1 & $57 \mathrm{Ca}$ & \\
\hline $\begin{array}{l}\text { 2-DIBUTILAMINOETANOL } \\
\text { 102-81-8 }\end{array}$ & líquido incoloro & $224-232$ & & 173,29 & & 0,859 & & & & 933 & \\
\hline $\begin{array}{l}\text { DICICLOHEXILAMINA } \\
101-83.7 \\
\end{array}$ & líquido incoloro & 256 & $-0,1$ & 181,31 & lig sol & 0,9123 & 6,25 & & & 110 & \\
\hline $\begin{array}{l}\text { 2,2'-DICLORO-N-METILIETI- } \\
\text { LAMINA } \\
51-75-2 \\
\end{array}$ & líquido móvil & $\begin{array}{l}87 @ \\
18 \mathrm{~mm} \mathrm{Hg}\end{array}$ & -60 & 156,07 & lig sol & $\begin{array}{l}1,118 \\
@ 25 \stackrel{\circ}{0} / 4 \stackrel{\circ}{C}\end{array}$ & & & & & \\
\hline $\begin{array}{l}\text { DIETANOLAMINA } \\
111-42-2\end{array}$ & $\begin{array}{l}\text { prismas; } \\
\text { habitualmente en } \\
\text { forma de líquido } \\
\text { viscoso; sólido } \\
\text { cristalino }\end{array}$ & 268,8 & 28 & 105,1 & muy sol & 1,0966 & 3,65 & 0,001 & & $134 \mathrm{ca}$ & 660 \\
\hline $\begin{array}{c}\text { DIETILAMINA } \\
109-89-7 \\
\end{array}$ & líquido incoloro & 55,5 & $-49,8$ & 73,1 & muy sol & 0,71 & 2,53 & 25,9 & $\begin{array}{l}1,8 \mathrm{li} \\
10,1 \mathrm{is}\end{array}$ & $-26 c c$ & 312 \\
\hline $\begin{array}{l}\text { 2-DIETILAMINOETANOL } \\
\text { 100-37-8 }\end{array}$ & líquido incoloro & 163 & .70 & 117,19 & misc & 0,8921 & 4,03 & 0,19 & $\begin{array}{l}6,7 \mathrm{li} \\
11,7 \mathrm{ls} \\
\end{array}$ & $52 \mathrm{cc}$ & 250 \\
\hline $\begin{array}{l}\text { DIETILENTRIAMINA } \\
111-40-0\end{array}$ & líquido amarillo & 207 & -39 & 103,2 & misc & 0,96 & 3,56 & 0,037 & $\begin{array}{l}1 \mathrm{li} \\
10 \mathrm{ls}\end{array}$ & $\begin{array}{l}97- \\
102 \text { ca }\end{array}$ & $\begin{array}{l}390 \\
395\end{array}$ \\
\hline $\begin{array}{l}\text { DIISOPROPANOLAMINA } \\
\text { 110-97-4 }\end{array}$ & cristales & $\begin{array}{l}249-250 \\
\text { @ } \\
745 \mathrm{~mm} \mathrm{Hg}\end{array}$ & 44,5 & 133,2 & sol & 0,989 & 4,6 & $\begin{array}{l}0,003 @ \\
42^{\circ} \mathrm{C}\end{array}$ & $\begin{array}{l}1,1 \mathrm{li} \\
5,4 \mathrm{ls}\end{array}$ & 127 & 374 \\
\hline $\begin{array}{l}\text { DIISOPROPILAMINA } \\
108-18.9 \\
\end{array}$ & líquido incoloro & 84 & .61 & 101,19 & lig sol & 0,7169 & 3,5 & 8,0 & $\begin{array}{l}0,8 \mathrm{li} \\
7,1 \mathrm{is}\end{array}$ & $-1 \mathrm{ca}$ & 316 \\
\hline $\begin{array}{l}\text { DIMETILAMINA } \\
124-40-3 \\
\end{array}$ & $\begin{array}{l}\text { gas a temperatura } \\
\text { ordinaria; gas incoloro }\end{array}$ & 7 & .92 & 45,08 & muy sol & 0,680 & 1,6 & 206 & $\begin{array}{l}2,8 \mathrm{li} \\
14,4 \mathrm{ls}\end{array}$ & & 402 \\
\hline $\begin{array}{l}\text { 3-DIMETILAMINOPROPILAMINA } \\
109-55-7\end{array}$ & líquido incoloro & 123 & .70 & 102,2 & sol & $\begin{array}{l}0,8100 \\
@ 30 \stackrel{\circ}{\circ}\end{array}$ & 3,5 & & & & \\
\hline $\begin{array}{l}\text { DIMETILETANOLAMINA } \\
108-01-0\end{array}$ & líquido incoloro & 135 & .59 & 89,1 & misc & 0,8866 & 3,03 & 560 & & $41 c a$ & 220 \\
\hline $\begin{array}{l}\text { DIPENTILAMINA } \\
2050.92-2 \\
\end{array}$ & $\begin{array}{l}\text { líquido incoloro a } \\
\text { amarillo claro }\end{array}$ & 202 & -44 & 157,3 & lig sol & 0,7771 & 5,4 & & & 52 & \\
\hline $\begin{array}{l}\text { ETANOLAMINA } \\
141-43-5\end{array}$ & $\begin{array}{l}\text { líquido viscoso, } \\
\text { transparente, } \\
\text { higroscópico; líquido } \\
\text { viscoso }\end{array}$ & 171 & 10,5 & 61,08 & misc & 1,0180 & 2,1 & $\begin{array}{l}0,26 \mathrm{~mm} \mathrm{Hg} \\
@ 25^{\circ} \mathrm{C}\end{array}$ & & $85 \mathrm{cc}$ & 410 \\
\hline ETIL METIL CETONA OXIMA & & 152,5 & $-29,5$ & 87,12 & sol & 0,9232 & & & & & \\
\hline
\end{tabular}

ETIL METIL CETONA OXIMA

96-29.7 


\begin{tabular}{|c|c|c|c|c|c|c|c|c|c|c|c|}
\hline $\begin{array}{l}\text { Denominación química } \\
\mathrm{N} \text { úmero } \mathrm{CAS}\end{array}$ & Color/ Forma & $\begin{array}{l}\text { p.e. } \\
\left({ }^{\circ} \mathrm{C}\right)\end{array}$ & $\begin{array}{l}\text { p.f. } \\
(\stackrel{\circ}{ })\end{array}$ & $\begin{array}{l}\mathrm{p} . \mathrm{m} . / \\
\text { (g/ } \\
\mathrm{mol})\end{array}$ & $\begin{array}{l}\text { Solubilidad } \\
\text { en agua }\end{array}$ & $\begin{array}{l}\text { Densidad } \\
\text { relativa } \\
\text { (agua }=1 \text { ) }\end{array}$ & $\begin{array}{l}\text { Densidad } \\
\text { de vapor } \\
\text { relativa } \\
\text { (aire=1) }\end{array}$ & $\begin{array}{l}\text { Pvap/ } \\
(\mathrm{kPa})\end{array}$ & $\begin{array}{l}\text { Límit } \\
\text { inflam. }\end{array}$ & $\begin{array}{l}\text { p.ig. } \\
(\underline{O C})\end{array}$ & $\begin{array}{l}\text { p.aut } \\
\text { ig. } \\
\left({ }^{\circ} \mathrm{C}\right)\end{array}$ \\
\hline $\begin{array}{r}\text { ETILAMINA } \\
75-04-7\end{array}$ & líquido o gas incoloro & 17 & .81 & 45,08 & misc & $\begin{array}{l}0,689 @ 15 \\
\stackrel{\circ}{ } \mathrm{C} / 15 \stackrel{\circ}{ } \stackrel{\mathrm{C}}{ }\end{array}$ & 1,55 & 121 & $\begin{array}{l}3,5 \mathrm{li} \\
14 \mathrm{ls}\end{array}$ & $-17 \mathrm{cc}$ & 725 \\
\hline $\begin{array}{l}\text { ETLLENDIAMINA } \\
107-15-3\end{array}$ & $\begin{array}{l}\text { líquido incoloro; } \\
\text { líquido acuoso blanco }\end{array}$ & 117 & 8,5 & 60,10 & muy sol & 0,8979 & 2,07 & 1,2 & $\begin{array}{l}4,2 \mathrm{li} \\
14,4 \mathrm{ls}\end{array}$ & $34 \mathrm{cc}$ & 385 \\
\hline $\begin{array}{c}\text { ETILENIMINA } \\
151-56-4\end{array}$ & $\begin{array}{l}\text { incoloro; líquido } \\
\text { móvil; aceite }\end{array}$ & $56-57$ & $-71,5$ & 43,08 & sol & $\begin{array}{l}0,8321 \\
@ 24 \stackrel{\circ}{\mathrm{C}} / 4 \stackrel{\circ}{-} \mathrm{C}\end{array}$ & 1,48 & 21,3 & $\begin{array}{l}3,6 \mathrm{li} \\
46 \mathrm{ls}\end{array}$ & $11 \mathrm{cc}$ & 322 \\
\hline $\begin{array}{l}\text { 2.ETILHEXILAMINA } \\
\text { 104-75-6 }\end{array}$ & líquido incoloro & & & 129,24 & sol & & & 1,2 & & $60 \mathrm{ca}$ & \\
\hline $\begin{array}{l}\text { HEXAMETILENDIAMINA } \\
\text { 124-09-4 }\end{array}$ & $\begin{array}{l}\text { laminillas incoloras; } \\
\text { placas bipiramidales } \\
\text { rómbicas }\end{array}$ & 205 & 42 & 116,20 & muy sol & 0,93 & 4,01 & $\begin{array}{l}200 \mathrm{~Pa} \\
@ 50 \stackrel{\circ}{-} \mathrm{C}\end{array}$ & $\begin{array}{l}0,7 \mathrm{li} \\
6,3 \mathrm{is}\end{array}$ & 71 & 310 \\
\hline $\begin{array}{l}\text { HEXAMETILENTETRAMINA } \\
\text { 100-97-0 }\end{array}$ & $\begin{array}{l}\text { cristales rómbicos en } \\
\text { alcohol; cristales o } \\
\text { gránulos o polvo; } \\
\text { cristales lustrosos } \\
\text { incoloros o polvo } \\
\text { blanco cristalino }\end{array}$ & & & 140,19 & $1 \mathrm{~g} / 1,5 \mathrm{ml}$ & $1,331 @-5 \stackrel{0}{0} \mathrm{C}$ & & & & & \\
\hline $\begin{array}{l}\text { HIDROXIETIL ETILENEDIAMINA } \\
\text { 111-41-1 }\end{array}$ & líquido incoloro & $238-40$ & & 104,15 & misc & 1,0286 & 3,59 & $\begin{array}{l}8,19 \times 10^{-4} \\
\mathrm{~mm} \mathrm{Hg} \\
@ 25 \stackrel{\circ}{\circ} \mathrm{C}\end{array}$ & & $135 c c$ & \\
\hline $\begin{array}{l}\text { ISOBUTANOLAMINA } \\
124-68-5\end{array}$ & masa cristalina & 165 & 31 & 89,1 & misc & 0,934 & 3,0 & & & $67 \mathrm{cc}$ & \\
\hline $\begin{array}{l}\text { ISOBUTILAMINA } \\
78-81-9\end{array}$ & líquido incoloro & 68 & .85 & 73,1 & muy sol & $\begin{array}{l}0,724 \\
@ 25 \stackrel{\circ}{\circ} / 4 \stackrel{\circ}{=} \mathrm{C}\end{array}$ & 2,5 & $\begin{array}{l}100 \mathrm{~mm} \mathrm{Hg} \\
@ 18,8 \stackrel{\circ}{\circ} \mathrm{C}\end{array}$ & $\begin{array}{l}3,4 \mathrm{li} \\
9 \mathrm{ls}\end{array}$ & & 378 \\
\hline $\begin{array}{l}\text { ISOFORONA DIAMINA } \\
2855-13-2\end{array}$ & líquido incoloro & 247 & 10 & 170,30 & muy sol & 0,92 & & $2 \mathrm{~Pa}$ & & 110 & \\
\hline $\begin{array}{l}\text { ISOPROPANOLAMINA } \\
78.96 .6\end{array}$ & líquido & 159,46 & 1,74 & 75,11 & sol & 0,9611 & 2,6 & 0,2 & & 77 & 374 \\
\hline $\begin{array}{l}\text { ISOPROPILAMINA } \\
75-31.0\end{array}$ & líquido incoloro & 33- 34 & -101 & 59,1 & misc & $\begin{array}{l}0,694 \\
@ 15 \stackrel{\circ}{-} / 4 \stackrel{\circ}{\circ}\end{array}$ & 2,04 & $\begin{array}{l}579,6 \mathrm{~mm} \\
\mathrm{Hg} @ 25 \stackrel{\circ}{\circ} \mathrm{C}\end{array}$ & $\begin{array}{l}2,3 \mathrm{li} \\
12 \mathrm{ls}\end{array}$ & $-37 \mathrm{ca}$ & 402 \\
\hline $\begin{array}{l}\text { METILAMINA } \\
74-89-5\end{array}$ & gas o líquido incoloro & $-6,3$ & .94 & 31,1 & muy sol & 0,6628 & 1,07 & 290 & $\begin{array}{l}4,9 \mathrm{li} \\
20,7 \mathrm{ls}\end{array}$ & & 430 \\
\hline $\begin{array}{l}\text { 2-METLLAMINOETANOL } \\
\text { 109-83-1 }\end{array}$ & líquido viscoso & $155-156$ & $-4,5$ & 75,11 & misc & 0,937 & 2,6 & $0,7 \mathrm{~mm} \mathrm{Hg}$ & & $74 \mathrm{ca}$ & \\
\hline $\begin{array}{l}\text { 1,5.PENTANODIAMINA } \\
462.94-2\end{array}$ & & 179 & 9 & 102,17 & sol & $\begin{array}{l}0,873 \\
@ 25 \stackrel{\circ}{C}\end{array}$ & & & & & \\
\hline $\begin{array}{l}\text { 1,3-PROPANODIAMINA } \\
109-76-2\end{array}$ & & 140 & & 74,12 & sol & 0,884 & & & & & \\
\hline $\begin{array}{l}\text { PROPILAMINA } \\
\text { 107-10-8 }\end{array}$ & líquido incoloro & 48- 49 & .83 & 59,11 & sol & 0,72 & 2,0 & 33,1 & $\begin{array}{l}2,0 \mathrm{li} \\
10,4 \mathrm{ls}\end{array}$ & $7 \mathrm{Ca}$ & 317 \\
\hline $\begin{array}{l}\text { PROPILENDIAMINA } \\
78-90-0\end{array}$ & & 119,5 & & 74,12 & muy sol & $0,878 @ 15 \stackrel{\circ}{\circ} \mathrm{C}$ & & & & & \\
\hline $\begin{array}{l}\text { TETRAETILENPENTAMINA } \\
112.57-2\end{array}$ & $\begin{array}{l}\text { líquido viscoso } \\
\text { higroscópico; líquido } \\
\text { amarillo }\end{array}$ & 340 & -30 & 189,3 & sol & 0,9980 & 6,53 & $\begin{array}{l}8,0 \times 10^{-7} \\
\mathrm{~mm} \mathrm{Hg} \\
@ 25 \stackrel{\circ}{0} \mathrm{C}\end{array}$ & & $163 \mathrm{ca}$ & 321 \\
\hline $\begin{array}{l}\text { TRIALLLAMINA } \\
102.70 .5\end{array}$ & líquido & 155,5 & .70 & 137,2 & $0,25 \mathrm{~g} / 100 \mathrm{ml}$ & 0,809 & 4,73 & & & $39 \mathrm{ca}$ & \\
\hline
\end{tabular}




\begin{tabular}{|c|c|c|c|c|c|c|c|c|c|c|c|}
\hline $\begin{array}{l}\text { Denominación química } \\
\mathrm{N} \text { úmero CAS }\end{array}$ & Color/ Forma & $\begin{array}{l}\text { p.e. } \\
(\stackrel{\circ}{ } \mathrm{C})\end{array}$ & $\begin{array}{l}\text { p.f. } \\
\left({ }^{\circ} \mathrm{C}\right)\end{array}$ & $\begin{array}{l}\text { p.m.l } \\
\text { (g/ } \\
\text { mol) }\end{array}$ & $\begin{array}{l}\text { Solubilidad } \\
\text { en agua }\end{array}$ & $\begin{array}{l}\text { Densidad } \\
\text { relativa } \\
\text { (agua }=1 \text { ) }\end{array}$ & $\begin{array}{l}\text { Densidad } \\
\text { de vapor } \\
\text { relativa } \\
\text { (aire=1) }\end{array}$ & $\begin{array}{l}\text { Pvap/ } \\
(\mathrm{KPa})\end{array}$ & $\begin{array}{l}\text { Límit } \\
\text { inflam. }\end{array}$ & $\begin{array}{l}\text { p.ig. } \\
(\underline{O C})\end{array}$ & $\begin{array}{l}\text { p.aut } \\
\text { ig. } \\
\left({ }^{\circ} \text { C }\right)\end{array}$ \\
\hline $\begin{array}{l}\text { TRIBUTILAMINA } \\
102-82.9\end{array}$ & $\begin{array}{l}\text { líquido incoloro; } \\
\text { líquido amarillo claro }\end{array}$ & 216,5 & .70 & 185,34 & lig sol & 0,78 & 6,39 & $\begin{array}{l}0,29 \mathrm{~mm} \mathrm{Hg} \\
\text { @ } 25^{\circ} \mathrm{C}\end{array}$ & & $86 \mathrm{ca}$ & \\
\hline $\begin{array}{l}\text { TRIETANOLAMINA } \\
102-71.6\end{array}$ & $\begin{array}{l}\text { líquido viscoso; } \\
\text { incoloro a amarillo } \\
\text { claro }\end{array}$ & 335 & 20,5 & 149,2 & misc & 1,1242 & 5,1 & $0,01 \mathrm{~mm} \mathrm{Hg}$ & & & \\
\hline $\begin{array}{l}\text { TRIETILAMINA } \\
121-44-8\end{array}$ & líquido incoloro & 89 & -115 & 101,19 & sol & 0,7275 & 3,49 & $\begin{array}{l}400 \mathrm{~mm} \mathrm{Hg} \\
@ 31,5 \stackrel{\circ}{C}\end{array}$ & $\begin{array}{l}1,2 \mathrm{li} \\
8,0 \mathrm{ls}\end{array}$ & $-667 \mathrm{ca}$ & \\
\hline $\begin{array}{l}\text { TRIETLENTETRAMINA } \\
112-24-3\end{array}$ & $\begin{array}{l}\text { líquido amarillento } \\
\text { moderadamente } \\
\text { viscoso }\end{array}$ & 266,5 & 12 & 146,2 & muy sol & 0,9818 & 5,04 & $1,3 \mathrm{~Pa}$ & $\begin{array}{l}1,1 \mathrm{li} \\
6,4 \mathrm{ls}\end{array}$ & $\begin{array}{l}118-14 \\
3 c c\end{array}$ & 338 \\
\hline $\begin{array}{l}\text { TRIISOPROPANOLAMINA } \\
122-20-3\end{array}$ & cristales & 305 & 45 & 191,3 & sol & 1,0 & & 0,001 & & 160 & 320 \\
\hline $\begin{array}{l}\text { TRIMETILAMINA } \\
75-50-3\end{array}$ & gas incoloro & 3 & -117 & 59,11 & muy sol & 0,6356 & 2,0 & 220 & $\begin{array}{l}2,0 \mathrm{li} \\
11,6 \mathrm{ls}\end{array}$ & $12 \ll c$ & 190 \\
\hline $\begin{array}{l}\text { TRIPROPILAMINA } \\
102.69-2\end{array}$ & líquido acuoso blanco & $150-156$ & .94 & 143,28 & & 0,7558 & & & & 405 & \\
\hline
\end{tabular}




\section{AMINAS AROMATICAS}

Las aminas aromáticas pertenecen a una clase de productos químicos derivados de los hidrocarburos aromáticos, como benceno, tolueno, naftaleno, antraceno y difenilo, por sustitución de al menos un átomo de hidrógeno por un grupo amino $-\mathrm{NH}_{2}$. Los compuestos que presentan un grupo amino libre se describen como aminas primarias. Cuando uno de los átomos de hidrógeno del grupo $-\mathrm{NH}_{2}$ se sustituye por un grupo alquilo o arilo, el compuesto resultante es una amina secundaria; cuando se sustituyen los dos átomos de hidrógeno, se obtiene una amina terciaria. El hidrocarburo puede tener uno o dos grupos amino 0 , más raramente, tres. De esta manera se puede obtener una gran cantidad de compuestos y, realmente, las aminas aromáticas constituyen un amplio grupo de compuestos químicos de gran interés desde el punto de vista técnico y comercial.

La anilina es la amina aromática más simple; consta de un grupo $-\mathrm{NH}_{2}$ unido a un anillo de benceno y es la que más se emplea en la industria. Entre los compuestos de un solo anillo más comunes están la dimetilanilina y la dietilanilina, las cloroanilinas, las nitroanilinas, las toluidinas, las clorotoluidinas, las fenilendiaminas y la acetanilida. Las aminas aromáticas con varios anillos más importantes desde el punto de vista de la medicina del trabajo son la bencidina, la o-tolidina, la o-dianisidina, la 3,3'-diclorobencidina y el 4-aminodifenilo. De los compuestos con estructura anular, las naftilaminas y los aminoantracenos han atraído mucho la atención de los expertos por problemas de carcinogenicidad. Con muchos de los integrantes de esta familia de compuestos se deben adoptar las precauciones estrictas necesarias para manipular carcinógenos.

\section{Colorantes azoicos y diazoicos}

El término colorante azoico se aplica a un grupo de colorantes que tienen un grupo azo $(-\mathrm{N}=\mathrm{N}-)$ en su estructura molecular. Este grupo puede dividirse en subgrupos de colorantes monoazoicos, diazoicos y triazoicos según el número de grupos azo que posea la molécula. Desde el punto de vista toxicológico es importante tener en cuenta que los colorantes de calidad comercial contienen generalmente hasta un $20 \%$ o más de impurezas. La composición y la cantidad de impurezas varía dependiendo de varios factores, como la pureza de los materiales de partida utilizados, el proceso de síntesis y las necesidades de los usuarios.

\section{Producción}

Los colorantes azoicos se obtienen mediante diazotización o tetrazotización de monoaminas o diaminas aromáticas con nitrito sódico en un medio $\mathrm{ClH}$, seguido por acoplamiento con productos intermedios colorantes, como pueden ser compuestos aromáticos o heterocíclicos. Cuando el componente de acoplamiento posee un grupo amino, se pueden obtener colorantes poliazoicos de cadena larga repitiendo el proceso de diazotización y acoplamiento. La fórmula estructural general de los tres primeros miembros de esta familia es:

$$
\begin{aligned}
& R-N=N-R^{\prime} \\
& R-N=N-R^{\prime}-N=N-R^{\prime \prime} \\
& R-N=N-R^{\prime}-N=N-R^{\prime \prime}-N=N-R^{\prime \prime}
\end{aligned}
$$

colorante monoazoico colorante diazoico colorante triazoico

La tetrazotización de la bencidina y el acoplamiento con el ácido naftiónico produce el conocido colorante R ojo Congo.

\section{U sos}

Las aminas aromáticas se utilizan principalmente como compuestos intermedios en la fabricación de tintes y pigmentos. La principal clase de tintes es la de los colorantes azoicos, que se obtienen por diazotización, un proceso mediante el cual se hace reaccionar una amina aromática primaria con ácido nitroso en presencia de un exceso de ácido mineral para producir compuestos diazoicos $(-\mathrm{N}=\mathrm{N}$-); seguidamente, estos compuestos reaccionan con un fenol o con una amina. 0 tra importante clase de colorantes a base de trifenilmetano, se obtiene también a partir de aminas aromáticas. Además de utilizarse como compuestos químicos intermedios en la industria de los colorantes, algunos de estos productos se utilizan también como colorantes 0 productos intermedios en las industrias de productos farmacéuticos, tejidos, peletería, peluquería y fotografía.

El o-aminofenol se utiliza como tinte en peluquería y peletería, como revelador en la industria fotográfica y como producto intermedio en la industria farmacéutica. El p-aminofenol se utiliza para teñir telas, cabello, pieles y plumas, en el revelado fotográfico, en la industria farmacéutica y en la fabricación de antioxidantes y aditivos para el aceite. El 2,4-diaminoanisol proporciona una posibilidad de oxidación para teñir pieles. La o-toluidina, la p-fenilendiamina, la difenilamina y la N-fenil-2-naftilamina se utilizan también como antioxidantes en la industria del caucho.

La difenilamina se emplea en la industria farmacéutica, en la fabricación de explosivos y como pesticida. La N -fenil-2-naftilamina sirve como acelerador en la vulcanización, como estabilizante de esmaltes de silicona y como lubricante. Es, además, un componente de los combustibles para cohetes, de la escayola quirúrgica, de los baños de estañado y de algunos colorantes. El 2,4-diaminotolueno y el 4,4'-diaminodifenilmetano son productos intermedios en la fabricación de isotiocianatos, el principal material de partida para la obtención de poliuretanos.

La bencidina se emplea sobre todo en la fabricación de colorantes. Esta sustancia se tetrazotiza y reacciona con otros productos intermedios para formar tintes. Su uso en la industria del caucho se ha abandonado. La auramina se utiliza en tintas para imprenta y como antiséptico y fungicida.

La o-fenilendiamina es un revelador fotográfico y un componente de los tintes para el cabello, y la p-fenilendiamina se utiliza en fotografía y como tinte en peletería y peluquería. No obstante, algunos países han prohibido su uso como agente oxidante en los tintes para el cabello. Es también un acelerador de la vulcanización y un componente de los antioxidantes de la gasolina. La m-fe nilendiamina tiene numerosos usos en las industrias de los colorantes, el caucho y los textiles, así como en peluquería y fotografía. Se utiliza como agente de curado de caucho y en resinas de intercambio iónico y decolorantes, uretanos, fibras textiles, aditivos del petróleo, inhibidores de la corrosión y tintes para el cabello. Además, se emplea como promotor para adherir hilos de neumáticos al caucho.

La xilidina se emplea como aditivo de la gasolina y como materia prima en la fabricación de colorantes y productos farmacéuticos. La melamina se utiliza en compuestos para moldear, resinas para el tratamiento de telas y papel y resinas adhesivas para pegar madera, contrachapados y revestimientos de pisos. También se emplea en síntesis orgánicas y en el curtido del cuero. La o-tolidina se usa como reactivo para la detección del oro.

\section{Anilinas}

Las anilinas se utilizan principalmente como productos intermedios en la fabricación de colorantes y pigmentos. Algunas de ellas 
son también sustancias intermedias en la fabricación de productos farmacéuticos, herbicidas, insecticidas y sustancias químicas para el procesado del caucho. La propia anilina se utiliza ampliamente en la fabricación de colorantes sintéticos, tintas para imprenta y tintes textiles, así como en la fabricación de resina, barnices, perfumes, colorantes para zapatos, productos químicos para fotografía, explosivos, herbicidas y fungicidas. La anilina se emplea en la fabricación del caucho y como agente de vulcanización, antioxidante y agente antiozono. O tra aplicación importante de la anilina es en la fabricación del p, $p^{\prime}$-metilen-bisfenildiisocianato (MDI), que se utiliza para preparar resinas de poliuretano y fibras spandex y para adherir caucho a rayón y nylon.

La cloroanilina existe en tres formas isoméricas: orto, meta y para, de las cuáles, sólo la primera y la última son importantes en la fabricación de colorantes, medicamentos y pesticidas. La p-nitroanilina es un producto intermedio en la fabricación de antioxidantes, colorantes, pigmentos, inhibidores del espesado de la gasolina y productos farmacéuticos. Se utiliza en forma diazotizada para obtener colores resistentes al lavado. La 4,4'-metilen-bis(2-cloroanilina), M bO CA, se emplea como agente de curado con polímeros que contienen isocianato para la fabricación de poliuretanos resistentes a la abrasión sólida y artículos foam de poliuretano semirrígido moldeados con un revestimiento que le da dureza. Estos materiales se utilizan en una amplia gama de productos, como ruedas, muelas trituradoras, poleas de cintas transportadoras, conectores y sellados de cables, suelas de zapatos, montajes antivibratorios y componentes acústicos. La p-nitroso- $\mathrm{N}, \mathrm{N}$,-dimetilanilina y la 5-cloro-o-toluidina se emplean como productos intermedios en la fabricación de colorantes. La N,N-dietilanilina y la N,N-dimetilanilina se utilizan en la síntesis de colorantes y otros productos intermedios. $\mathrm{La} \mathrm{N}, \mathrm{N}$-dimetilanilina se utiliza también como endurecedor catalítico en algunas resinas de fibra de vidrio.

\section{Compuestos azoicos}

Los compuestos azoicos son algunos de los colorantes más comunes de diversos tipos, como colorantes directos, ácidos, básicos, de naftol, mordentes ácidos, dispersos, etc. y se utilizan ampliamente en tejidos, telas, artículos de piel, productos de papel, plásticos y muchos otros artículos.

\section{Riesgos}

La fabricación y utilización industrial de determinadas aminas aromáticas puede constituir un riesgo grave y, en ocasiones, inesperado. Sin embargo, a medida que han sido mejor conocidos todos estos riesgos, en los últimos años ha habido la tendencia de sustituirlas por otras sustancias 0 , si no, a tomar las precauciones necesarias para reducir el riesgo que presentan. Asimismo, existe una polémica sobre la posibilidad de que las aminas aromáticas tengan efectos en la salud, bien cuando se presentan como impurezas de un producto acabado, bien cuando se liberan de resultas de una reacción química que tenga lugar durante la utilización de un derivado o/ y éste es un caso totalmente diferente como resultado de una degradación metabólica en el organismo de individuos que han absorbido derivados más complejos.

\section{Vías de absorción}

En general, el principal riesgo de absorción corresponde a la vía percutánea, puesto que casi todas las aminas aromáticas son liposolubles. Este riesgo es el más importante, ya que en la práctica industrial pasa fácilmente inadvertido. No obstante, la vía respiratoria también constituye una importante puerta de entrada del tóxico, tanto si se realiza por inhalación de vapores, aunque la mayoría de estas aminas son poco volátiles a temperatura normal, como si se realiza por inhalación de polvos de productos sólidos. Este último sería el caso de las sales de aminas, como los sulfatos o los clorhidratos, que presentan una volatilidad y una solubilidad en lípidos muy bajas. Desde un punto de vista práctico, el riesgo profesional de estas sales es menor, si bien su toxicidad es similar a la de la amina correspondiente, por lo que la inhalación de partículas en suspensión o incluso el contacto con la piel deben considerarse peligrosos.

La absorción por vía digestiva constituye un peligro potencial si no se cuenta con instalaciones sanitarias y comedores adecuados, o si los trabajadores no realizan una correcta higiene personal. La contaminación de los alimentos y el fumar con las manos sucias son dos ejemplos de posibles vías de ingestión.

M uchas de las aminas aromáticas son inflamables y comportan un riesgo moderado de incendio. Con frecuencia, los productos de su combustión son muy tóxicos. El principal riesgo para la salud de la exposición industrial a las anilinas se debe a la facilidad con que éstas se absorben, ya sea por vía respiratoria 0 percutánea. Por ello, la prevención de la intoxicación por anilinas exige un conocimiento exhaustivo de las normas de higiene personal e industrial. La principal medida para prevenir los derrames o la contaminación del ambiente de trabajo con estos compuestos es el diseño adecuado de las plantas de producción. El sistema de ventilación para controlar el contaminante debe diseñarse de tal forma que quede lo más cerca posible de la fuente contaminante. Los trabajadores deberán cambiarse la ropa de trabajo a diario y existirán las instalaciones adecuadas para una ducha obligatoria al final de la jornada de trabajo. La piel o las ropas contaminadas se lavarán inmediatamente y las personas expuestas se mantendrán bajo supervisión médica. T anto los trabajadores como los supervisores deberán conocer la naturaleza y el grado de riesgo al que están expuestos y sabrán cómo realizar su trabajo de manera limpia y segura. EI trabajo de mantenimiento deberán realizarse siempre eliminando previamente todas las posibles fuentes de contacto con las sustancias químicas peligrosas.

Puesto que muchos casos de intoxicación por anilinas se producen por la contaminación de la piel o la ropa, con la subsiguiente absorción por vía percutánea, se procederá a quitar y lavar la ropa contaminada cuanto antes. Incluso cuando la intoxicación se produce por inhalación, es probable que también estén contaminadas las ropas, por lo que habrá que quitarlas. T oda la superficie corporal, incluido el cabello y las uñas, se lavará cuidadosamente con jabón y agua tibia. En caso de metahemoglobinemia se adoptarán las medidas de emergencia apropiadas y el servicio de medicina en el trabajo estará plenamente equipado y perfectamente entrenado para atender este tipo de urgencias. EI personal de lavandería deberá adoptar las debidas precauciones para evitar la contaminación con los compuestos de anilina.

\section{M eta bolismo}

Las aminas sufren un proceso de metabolización en el organismo y los verdaderos agentes activos son sus metabolitos, algunos de los cuales producen metahemoglobinemia, mientras que otros son cancerígenos. Estos metabolitos son generalmente hidroxilaminas ( $\mathrm{R}-\mathrm{NHOH}$ ) que se convierten en aminofenoles $\left(\mathrm{H}_{2} \mathrm{~N}-\mathrm{R}-\mathrm{OH}\right)$ durante el proceso de desintoxicación. Su excreción constituye un medio útil para estimar el grado de contaminación cuando el nivel de exposición ha sido lo suficientemente alto como para hacerlos detectables.

\section{E fectos en la salud}

L as aminas aromáticas tienen efectos patológicos diversos y diferentes para cada una de ellas, por lo que deben considerarse de 
forma individualizada. No obstante, muchas de ellas comparten algunos efectos importantes, que pueden resumirse en:

- cáncer de las vías urinarias, especialmente de la vejiga

- riesgo de intoxicación aguda, en especial de metahemoglobinemia, que puede afectar a los hematíes

- sensibilización, principalmente de la piel, pero en ocasiones también respiratoria.

Los efectos tóxicos de estos compuestos están también relacionados con sus características químicas. Por ejemplo, a pesar de que la sal de anilina exhibe una toxicidad muy similar a la de la propia anilina, no es hidrosoluble ni liposoluble y, por tanto, no se absorbe tan fácilmente por vía percutánea o respiratoria, razón por la cual las intoxicaciones por exposición industrial a sales de anilina son poco frecuentes.

La intoxicación aguda se produce generalmente por inhibición de la función de la hemoglobina a través de la formación de metahemoglobina, que produce una situación llamada metahemoglobinemia, descrita con más detalle en el capítulo Sangre. L a metahemoglobinemia es más frecuente en los casos de intoxicación por aminas aromáticas de un solo anillo. La metahemoglobina está normalmente presente en la sangre en un nivel de aproximadamente un 1-2 \% de la hemoglobina total. La cianosis de la mucosa oral comienza a ser aparente con niveles de $10-15 \%$, aunque generalmente no se observan los primeros síntomas hasta que se alcanzan niveles de metahemoglobina del orden del $30 \%$. Por encima de este nivel, la piel del paciente se oscurece; después aparece dolor de cabeza, debilidad, malestar, anoxia y, si la exposición continúa, coma, insuficiencia cardíaca y muerte. La mayoría de las víctimas de una intoxicación aguda reaccionan favorablemente al tratamiento y la metahemoglobina desaparece completamente en el plazo de dos o tres días. El consumo de alcohol favorece y agrava la intoxicación aguda por metahemoglobina. T ras una intoxicación grave se puede detectar hemólisis de los eritrocitos, seguida de un proceso de regeneración que se demuestra por la presencia de reticulocitos. En ocasiones también se detecta la presencia de cuerpos de $\mathrm{H}$ einz en los corpúsculos de los eritrocitos.

Cáncer. L os potentes efectos cancerígenos de las aminas aromáticas se descubrieron por primera vez en el ámbito laboral al detectarse una incidencia anormalmente elevada de esta enfermedad en los trabajadores de una fábrica de colorantes, por lo que se denominó "cáncer por tintes". N o obstante, análisis posteriores demostraron muy pronto que su origen era, en realidad, las materias primas utilizadas, de entre las cuales la más importante era la anilina, por cuya razón se cambió la antigua denominación por la de "cánceres por anilina". Fue más tarde cuando se identificó la verdadera causa de estos cánceres, a saber: $\beta$-naftilamina y la bencidina. Sin embargo, la confirmación experimental fue larga y difícil. L os trabajos experimentales con miembros de esta familia han demostrado que algunos de ellos son cancerígenos en animales, pero las evidencias existentes en seres humanos son todavía insuficientes y la Agencia Internacional para la Investigación sobre el Cáncer (IARC) ha clasificado a la mayoría de estas sustancias en el Grupo 2B, es decir, como probables carcinógenos humanos, lo que significa que existen suficientes pruebas de carcinogenicidad en animales, pero insuficientes en el hombre. En algunos casos, los trabajos de laboratorio han llevado al descubrimiento de cánceres en el hombre, como sucedió con el 4-amino-difenilo, con respecto al cual primero se comprobó que era cancerígeno para los animales de experimentación (cáncer de hígado) y solo después se descubrieron una serie de casos de cáncer de vejiga en personas.

D ermatitis. Por su naturaleza alcalina, algunas aminas, en especial las aminas primarias, constituyen un riesgo directo de dermatitis. M uchas aminas aromáticas pueden causar dermatitis alérgica del tipo de las producidas por las "para-aminas" (p-aminofenol $y$, especialmente, $p$-fenilendiamina). También es posible que se produzca sensibilidad cruzada.

Alergia respiratoria. Se han descrito varios casos de asma por sensibilización a p-fenilendiamina, por ejemplo.

Las exposiciones intensas a o-toluidina, a p-toluidina y, en especial, a sus derivados clorados como la cloro-5-0-toluidina, pueden provocar cistitis hemorrágica. Estas hematurias son de corta duración y no se ha podido comprobar su relación con el desarrollo de tumores de vejiga.

Lesiones hepáticas. Algunas diaminas, como la toluendiamina y el diaminodifenilmetano, ejercen potentes efectos hepatotóxicos en los animales de experimentación, si bien no se han descrito muchos casos de lesiones hepáticas graves derivadas de la exposición profesional a estos compuestos. No obstante, en el año 1966 se describieron 84 casos de ictericia tóxica por ingestión de pan fabricado con harina contaminada por 4,4'-diaminodifenilmetano y también se han descrito casos de hepatitis tóxica tras la exposición profesional a esta sustancia.

A continuación se comentan algunas de las propiedades toxicológicas de las aminas aromáticas. D ebido a que esta familia de compuestos es muy numerosa, es imposible citarlos a todos y el lector debe saber que existen muchos otros no mencionados aquí que también exhiben propiedades tóxicas.

\section{Aminofenoles}

Los isómeros o- y p-aminofenol, que son sólidos cristalinos poco volátiles, no se absorben fácilmente a través de la piel, aunque ambos pueden actuar como sensibilizantes cutáneos y causar dermatitis de contacto, siendo éstos, al parecer, los principales riesgos derivados de su uso en la industria. Ambos isómeros pueden causar una metahemoglobinemia grave que incluso ponga en peligro la vida, pero ésta rara vez se produce como consecuencia de exposiciones de carácter industrial ya que, por sus propiedades físicas, ninguno de estos compuestos penetra fácilmente en el organismo. El principal metabolito de la anilina en el hombre es el $p$-aminofenol, que se excreta en la orina en forma conjugada. T ambién se ha descrito asma bronquial producida por el isómero orto.

La IARC considera al p-aminodifenilo como un carcinógeno humano demostrado. Este fue el primer compuesto del que se demostró su capacidad cancerígena en animales de experimentación antes de conocerse los primeros casos de tumores de vejiga en los trabajadores expuestos a él, cuando se utilizaba como antioxidante en la industria del caucho. Esta sustancia es claramente un potente carcinógeno de vejiga, ya que en una fábrica con 315 trabajadores, 55 desarrollaron tumores, al igual que el $11 \%$ de los 171 trabajadores en otra fábrica de 4-aminodifenilo. Los tumores aparecieron entre 5 y 19 años después de la exposición y la supervivencia osciló entre 1,25 y 10 años.

\section{Anilina y sus derivados}

Se ha demostrado experimentalmente que los vapores de anilina pueden introducirse en el organismo por vía percutánea o respiratoria en, aproximadamente, igual cantidad. Sin embargo, la velocidad de absorción del líquido a través de la piel es aproximadamente 1.000 veces mayor que la de los vapores. La causa más frecuente de intoxicación industrial es la contaminación accidental de la piel, ya sea por contacto accidental directo o de forma indirecta al manejar ropas o calzados contaminados. EI uso de prendas protectoras limpias y adecuadas y el lavado rápido en caso de contacto accidental constituyen la mejor protección. A pesar de que el $\mathrm{N}$ ational Institute for $\mathrm{O}$ ccupational 
$\mathrm{H}$ ealth and Safety (NIOSH) de Estados U nidos recomienda que la anilina se manipule como un posible carcinógeno humano, la IARC Io ha catalogado como un producto químico del Grupo 3, es decir, una sustancia de cuya carcinogenicidad no existen pruebas suficientes en animales ni en el hombre.

L a p-cloroanilina es un potente formador de metahemoglobina y un irritante ocular. Los experimentos en animales no han podido demostrar sus efectos cancerígenos. La 4,4'-metilen bis(2-cloroanilina), o M bO CA, se puede absorber por contacto con el polvo o por inhalación de los humos y, en la industria, la vía percutánea puede constituir otro importante medio de absorción. Los estudios de laboratorio demuestran que la M bO CA o sus metabolitos producen alteraciones genéticas en distintos organismos. Además, la administración subcutánea prolongada en ratas produjo tumores hepáticos y pulmonares. Por todo ello, la M bOCA se considera un carcinógeno en animales y un probable carcinógeno humano.

$\mathrm{L}$ a N,N-dietilanilina y la N,N-dimetilanilina se absorben fácilmente por vía percutánea, pero también puede producirse una intoxicación por inhalación de los vapores. Sus riesgos se consideran similares a los de la anilina y, en particular, son potentes formadoras de metahemoglobina.

N itroanilinas. De las tres mono-nitroanilinas, la más importante es la p-nitroanilina. T odas ellas se utilizan como productos intermedios en la fabricación de colorantes, aunque los isómeros o- y msólo a pequeña escala. La p-nitroanilina se absorbe rápidamente a través de la piel y por inhalación del polvo o los vapores. Es un potente formador de metahemoglobina y se piensa que, en los casos graves, también produce hemolisis e, incluso, lesiones hepáticas. Se han dado casos de intoxicación y cianosis tras la exposición a esta sustancia durante la limpieza de derrames. Las cloronitroanilinas son también potentes formadoras de metahemoglobina, producen hemólisis y son hepatotóxicas. Además, pueden causar dermatitis por sensibilización.

La p-nitroso- $\mathrm{N}, \mathrm{N}$-dimetilanilina es un irritante cutáneo primario y produce sensibilización cutánea, siendo una causa frecuente de dermatitis de contacto. Aunque algunos de los trabajadores que desarrollan dermatitis pueden seguir trabajando con este compuesto sin presentar nuevos problemas, la mayoría sufre recidivas graves de las lesiones cutáneas al reanudar la exposición y, en general, se recomienda asignar a estas personas a otro tipo de trabajo para evitar nuevos contactos.

La 5-cloro-o-toluidina se absorbe fácilmente por vía cutánea y respiratoria. T anto ella como algunos de sus isómeros pueden producir la formación de metahemoglobina, pero su característica más sobresaliente es la irritación de las vías urinarias, con cistitis hemorrágica caracterizada por hematuria dolorosa y micción frecuente. En los varones expuestos a este compuesto puede observarse hematuria microscópica antes de que se manifieste la cistitis. Esta sustancia no tiene efectos cancerígenos en el ser humano, pero los experimentos de laboratorio han suscitado dudas sobre el potencial carcinogénico de otros isómeros en algunas especies animales.

\section{Bencidina y sus derivados}

La bencidina es un carcinógeno confirmado. Se han dado muchos casos de papilomas y carcinomas de las vías urinarias relacionados con su fabricación y uso industrial. En algunos grupos de trabajadores, más del $20 \%$ han desarrollado la enfermedad. Los estudios recientes indican que la bencidina puede aumentar la incidencia de cáncer en otros órganos, pero este punto es todavía motivo de controversia. La bencidina es un sólido cristalino con una presión de vapor alta (es decir, que se transforma en vapor rápidamente). La penetración a través de la piel parece ser la principal vía de absorción, aunque también existe riesgo de inhalación de vapores o partículas finas. La actividad carcinogénica de esta sustancia ha quedado demostrada por la gran cantidad de casos registrados de tumores de vejiga en trabajadores expuestos y por inducción experimental en animales. Según la clasificación de la IARC, pertenece al Grupo 1 de carcinógenos humanos demostrados y su uso se ha abandonado en casi todo el mundo.

La 3,3'-diclorobencidina es un probable carcinógeno humano (Grupo 2B de la IAR C). Esta conclusión se basa en el aumento estadísticamente significativo de la incidencia de tumores observado en ratas, ratones y perros y en los datos positivos sobre su genotoxicidad. Su relación estructural con la bencidina, un carcinógeno de la vejiga humana conocido y potente, aumenta la posibilidad de que sea también un carcinógeno humano.

D iamino-4,4'-diaminodifenilmetano. La demostración más patente de la toxicidad de este compuesto fue cuando 84 personas sufrieron hepatitis tóxica como consecuencia de haber comido pan fabricado con harina contaminada con este producto. T ambién se detectaron otros casos tras exposiciones de carácter profesional en las que se había producido una absorción percutánea del mismo. Este compuesto puede causar dermatitis alérgica. Los experimentos en animales hacen sospechar que se trata de un posible carcinógeno, pero aún no se han obtenido resultados definitivos. Se ha demostrado que los derivados del diaminodifenilmetano son carcinógenos para los animales de laboratorio.

Dimeilaminoazobenceno. El metabolismo del DAB ha sido objeto de numerosos estudios y se ha comprobado que sufre reducción y ruptura del grupo azoico, desmetilación, hidroxilación aromática, $\mathrm{N}$-hidroxilación, $\mathrm{N}$-acetilación, unión a proteínas y unión a ácidos nucléicos. EI DAB exhibe propiedades mutagénicas después de su activación. Es carcinogénico por distintas vías en ratas y ratones (carcinoma hepático) y por vía oral produce carcinoma de vejiga en perros. La única observación relacionada con la salud de los trabajadores expuestos a esta sustancia se refiere a dermatitis de contacto por la manipulación de DAB.

Las medidas técnicas deben ir encaminadas a evitar todo contacto con la piel y las mucosas. Los trabajadores expuestos a $D A B$ deben utilizar equipos de protección personal y realizar su trabajo exclusivamente en áreas restringidas. Las ropas y equipos utilizados deben colocarse en recipientes impermeables para su descontaminación 0 desecho. Los reconocimientos médicos previos al empleo y los exámenes periódicos deben centrarse en la función hepática. En Estados Unidos, la OSHA ha considerado que el DAB es un posible cancerígeno humano.

$D$ ifenilamina. Esta sustancia química es levemente irritante. En condiciones industriales normales no es peligrosa, pero el potente carcinógeno 4-aminodifenilo puede estar presente como impureza durante el proceso de fabricación. Este compuesto alcanza concentraciones considerables en los alquitranes producidos en la etapa de destilación y comporta un riesgo de cáncer de vejiga. A pesar de que los procedimientos modernos de fabricación han permitido reducir considerablemente la cantidad de impurezas de este compuesto en el producto comercial, se deben adoptar las precauciones adecuadas para evitar el contacto innecesario con él.

\section{Naftilaminas}

Las naftilaminas pueden presentarse en dos formas isoméricas: $\alpha$-naftilamina y $\beta$-naftilamina. La $\alpha$-naftilamina se absorbe a través de la piel y por inhalación. En contacto con esta sustancia produce quemaduras en la piel y los ojos. No se conocen casos de intoxicación aguda como consecuencia de su uso en la industria, pero la exposición al producto de grado comercial produjo, en tiempos pasados, muchos casos de papilomas y carcinomas de 
vejiga. La posibilidad de que estos tumores pudieran atribuirse a la gran cantidad de impurezas que contenía la $\beta$-naftilamina originó una polémica que fue más allá de los círculos académicos, pues hizo que la $\alpha$-naftilamina de hoy en día tenga una proporción mucho menor de $\beta$-naftilamina como impureza.

La $\beta$-naftilamina es un conocido carcinógeno de vejiga en el hombre. La intoxicación aguda produce metahemoglobinemia y cistitis hemorrágica aguda. Si bien hubo un tiempo en que esta sustancia se utilizaba mucho como producto intermedio en la fabricación de colorantes y antioxidantes, en la actualidad casi se ha abandonado tanto su producción como su uso por considerarse demasiado peligrosa su manipulación sin medidas preventivas que, por otra parte, eran prohibitivas. Esta sustancia se absorbe rápidamente por vía cutánea y respiratoria. La cuestión de sus efectos tóxicos agudos queda relegada a segundo término por su alto poder cancerígeno.

\section{Fenilendiaminas}

Existen varias formas isoméricas de las fenilendiaminas, pero sólo los isómeros $\mathrm{m}$ - y p-tienen importancia industrial. A pesar de que la $\mathrm{p}$-fenilendiamina puede actuar como formadora de metahemoglobina in vitro, no se ha dado ningún caso de metahemoglobinemia por exposición industrial. La p-fenilendiamina es un producto notorio por su acción sensibilizante de la piel y el aparato respiratorio. EI contacto frecuente con la piel causa rápidamente dermatitis de contacto. También se ha descrito acné y leucoderma. El antiguo problema de la "dermatitis de los peleteros" es actualmente mucho menos frecuente gracias a las mejoras introducidas en los procesos de tintado, que permiten eliminar cualquier vestigio de $\mathrm{p}$-fenilendiamina en los productos acabados. De forma análoga, el asma, que era un proceso frecuente entre los tintoreros de pieles que utilizaban esta sustancia, es actualmente relativamente rara gracias a las mejoras en el control del polvo ambiental. Incluso cuando se utilizan controles, resulta útil realizar una prueba cutánea preliminar antes de la posible exposición profesional. La m-fenilendiamina es un potente irritante de la piel, los ojos y el tracto respiratorio. Las conclusiones obtenidas de los experimentos realizados con las fenilendiaminas y sus derivados (como N-fenil o 4- ó 2-nitro) para determinar el potencial carcinogénico han sido, hasta el momento, insuficientes, dudosas 0 negativas. Los derivados clorados que se han investigado parece ser que tienen efectos cancerígenos en los animales de experimentación.

En el pasado, el potencial carcinogénico de las mezclas comerciales era un motivo de preocupación debido a la presencia de $\beta$-naftilamina como impureza en cantidades considerables (decenas o incluso centenas de ppm) en algunas de las primeras preparaciones y por el descubrimiento, en el caso concreto de la $\mathrm{N}$-fenil-2-naftilamina, PBNA, de la excreción metabólica de $\beta$-naftilamina, aunque en cantidades infinitesimales. Los experimentos han sugerido un cierto potencial cancerígeno de esta sustancia en los animales de experimentación, pero todavía no han podido extraerse conclusiones definitivas ni se sabe la importancia de los hallazgos metabólicos. Los estudios epidemiológicos realizados sobre un gran número de personas que trabajaban en condiciones diferentes no han podido demostrar un aumento significativo de la incidencia de cáncer en los trabajadores expuestos a estos compuestos. La cantidad de $\beta$-naftilamina presente actualmente en los productos comerciales es muy pequeña (menos de $1 \mathrm{ppm}$ y, con frecuencia, 0,5 ppm). En este momento no se puede extraer ninguna conclusión sobre el riesgo real de cáncer, motivo por el cual deben adoptarse todo tipo de precauciones, entre ellas la eliminación de las impurezas sospechosas y el uso de medidas técnicas protectoras en la fabricación y el uso de estos compuestos.

\section{Otros compuestos}

La toluidina se presenta en tres formas isoméricas, aunque sólo tienen importancia industrial los isómeros o- y p-. La o-toluidina y la $p$-toluidina se absorben con suma facilidad a través de la piel 0 por inhalación de polvos, humos o vapores. Estos compuestos son potentes formadores de metahemoglobina y la intoxicación aguda puede ir acompañada de hematuria microscópica 0 macroscópica, aunque son irritantes de la vejiga mucho menos potentes que la 5-cloro-0-toluidina. Existen pruebas suficientes de su efecto cancerígeno en animales como para clasificar a la o-toluidina y a la p-toluidina como posibles carcinógenos humanos

T oluendiaminas. De los seis isómeros de la toluendiamina, el más frecuente es el 2,4-, que constituye el $80 \%$ de los productos intermedios utilizados en la producción de diisotiocianato de tolueno, estando representado el otro $20 \%$ por el isómero 2,6-, que es una de las sustancias básicas de los poliuretanos. Este producto es objeto de especial atención desde el descubrimiento de su potencial cancerígeno en los animales de experimentación. Sin embargo, no se dispone de datos humanos.

Xilidinas. Los resultados de los experimentos realizados con animales indican que se tratan, principalmente, de toxinas hepáticas que actúan de forma secundaria sobre la sangre. No obstante, en otros estudios se ha observado que inducen la formación de metahemoglobina y cuerpos de $\mathrm{H}$ einz en gatos, pero no así en conejos.

\section{Colorantes azoicos}

En general, los colorantes azoicos, como tal grupo, representan un riesgo bajo de toxicidad. M uchos de ellos tienen una $D L_{50}$ por vía oral superior a $1 \mathrm{~g} / \mathrm{kg}$ en ratas y ratones y los roedores pueden consumir durante toda su vida dietas de laboratorio con más de $1 \mathrm{~g}$ del compuesto por $\mathrm{kg}$ de alimento. Algunos pueden causar dermatitis de contacto pero, en general, con escasas manifestaciones. En la práctica resulta bastante difícil determinar si las lesiones cutáneas se deben al propio colorante 0 a otros productos que coexisten con él. Por el contrario, cada vez se presta más atención al potencial cancerígeno de los compuestos azoicos. A pesar de que aún existen pocas observaciones epidemiológicas que lo confirmen, los resultados obtenidos en estudios a largo plazo indican que algunos colorantes azoicos son cancerígenos para los animales de laboratorio. El principal órgano afectado en estas condiciones experimentales es el hígado, seguido por la vejiga urinaria. En algunos casos también se encuentra afectado el intestino. Con todo, es muy difícil extrapolar estos resultados al hombre.

La mayoría de los colorantes azoicos carcinogénicos no lo son de forma directa, sino como precarcinógenos, debiendo transformarse mediante una activación metabólica in vivo, para pasar de precarcinógenos a carcinógenos finales. Por ejemplo, el metilaminoazobenceno experimenta primero una $\mathrm{N}$-hidroxilación y una $\mathrm{N}$-desmetilación en el grupo amino y después se conjuga el grupo sulfato con el derivado $\mathrm{N}$-hidroxi para formar el carcinógeno final, que reacciona con los ácidos nucléicos.

Es importante señalar que los colorantes diazoicos derivados de la bencidina pueden transformarse en el potente carcinógeno bencidina a través de los procesos metabólicos normales del organismo. El propio organismo o las bacterias del intestino reducenin vivo los dos grupos azo a bencidina. Por este motivo, los colorantes azoicos deben manipularse con prudencia.

\section{Medidas de salud y seguridad}

La principal medida para prevenir los derrames o la contaminación del ambiente de trabajo con estos compuestos es el diseño adecuado de las plantas. EI sistema de ventilación para controlar 
el contaminante debe diseñarse de tal forma que quede lo más cerca posible de la fuente contaminante. Los trabajadores deberán cambiarse la ropa de trabajo a diario y existirán las instalaciones adecuadas para una ducha obligatoria al final de la jornada de trabajo. La piel o las ropas contaminadas se lavarán inmediatamente y las personas expuestas se mantendrán bajo supervisión médica. T anto los trabajadores como los supervisores deberán conocer la naturaleza y el grado de riesgo al que están expuestos y sabrán cómo realizar su trabajo de manera limpia y segura. Las labores de mantenimiento deberán realizarse siempre eliminando previamente todas las posibles fuentes de contacto con las sustancias químicas peligrosas. 
TABLAS DE AMINAS AROMATICAS

\begin{tabular}{|c|c|c|}
\hline Producto químico & Sinónimos/ Código UN & N úmero CAS Fórmula estructural \\
\hline O-ACETOTOLUIDINA & 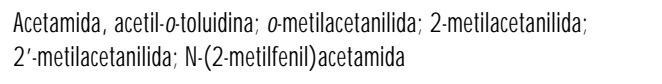 & $120-66-1$ \\
\hline 4-AMINODIFENILO & p-Aminodifenilo; 4-aminodifenilo; p-aminodifenilo; difenilamina & $92-67-1$ \\
\hline p-AMINOFENOL & $\begin{array}{l}\text { 4-Amino-1-hidroxibenceno; 4-aminofenol; azol; BASF Ursol P base; } \\
\text { p-hidroxianilina; 4-hidroxianilina } \\
\text { UN2512 }\end{array}$ & $123-30-8$ \\
\hline O-AMINOFENOL & $\begin{array}{l}\text { 2-Amino-1-hidroxibenceno; 2-aminofenol; o-hidroxianilina; 2-hidroxianilina; } \\
\text { Amarillo Nako 3GA } \\
\text { UN2512 }\end{array}$ & $95-55-6$ \\
\hline 1-AMINO-2-METILANTRAQUINONA & $\begin{array}{l}\text { Acetato naranja rápido } \mathrm{R} ; \text { Acetoquinona naranja claro JL; } \\
\text { 1-amino-2-metil-9,10-antracenodiona }\end{array}$ & $82-28-0$ \\
\hline ANILINA & $\begin{array}{l}\text { Aminobenceno; bencenamina; fenilamina } \\
\text { UN1547 }\end{array}$ & $62-53-3$ \\
\hline O-ANISIDINA & $\begin{array}{l}\text { o-Aminoanisol; 2-aminoanisol; 1-amino-2-metoxibenceno; 2-anisidina; } \\
\text { 2-metoxi-1-aminobenceno; metoxifenilamina }\end{array}$ & $90-04-0$ \\
\hline p-ANISIDINA & $\begin{array}{l}\text { p-Aminoanisol; 4-aminoanisol; 1-amino-4-metoxibenceno; 4-anisidina; } \\
\text { 4-metoxi-1-aminobenceno; metoxibencenamina }\end{array}$ & $104-94-9$ \\
\hline
\end{tabular}

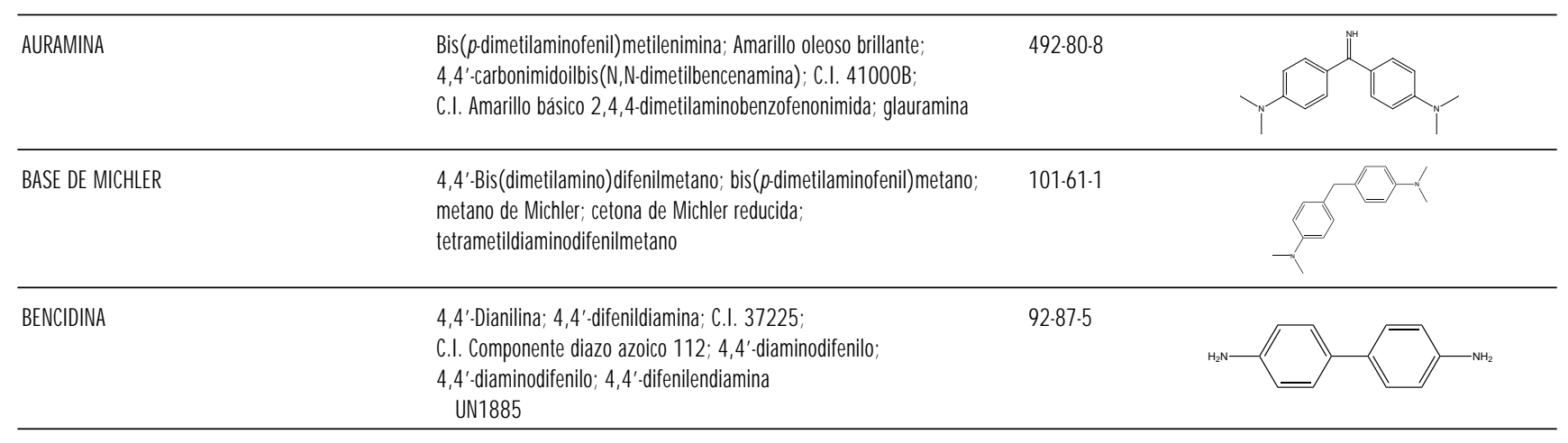

m-BROMOANILINA

591-19-5

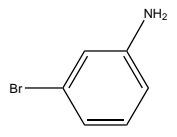

CETONA DE MICHLER

$\operatorname{Bis}(p-$ - N,N-dimetilamino) fenil) cetona;

$90-94.8$

bis(4-(dimetilamino) fenil) metanona; 4,4'-bis(dimetilamino) benzofenona;

tetrametildiaminobenzofenona

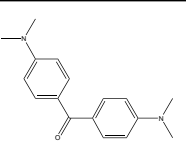




\begin{tabular}{|c|c|c|c|}
\hline Producto químico & Sinónimos/ Código UN & $\mathrm{N}$ úmero CAS & Fórmula estructural \\
\hline CLORHIDRATO DE ANILINA & $\begin{array}{l}\text { Cloruro de anilina; clorhidrato de bencenamida; clorhidrato de fenilamina } \\
\text { UN1548 }\end{array}$ & $142-04-1$ & \\
\hline O-CLORHIDRATO DE ANISIDINA & $\begin{array}{l}\text { Clorhidrato de 2-aminoanisol; clorhidrato de o-aminoanisol; clorhidrato } \\
\text { de o-anisilamina; C.I. 37115; Rojo rápido BB base; clorhidrato de } \\
\text { 2-metoxi-1-aminobenceno; clorhidrato de o-metoxianilina; clorhidrato de } \\
\text { 2-metoxianilina }\end{array}$ & $134-29-2$ & \\
\hline CLORHIDRATO DE p-FENILENDIAMINA & $\begin{array}{l}\text { Diclorhidrato de p-aminoanilina; diclorhidrato de 4-aminoanilina; } \\
\text { diclorhidrato de p-bencendiamina; diclorhidrato de 1,4-bencendiamina; } \\
\text { C.I. 76061; C.I. base de oxidación 10A; diclorhidrato de } \\
\text { p-diaminobenceno; diclorhidrato de 1,4-diaminobenceno }\end{array}$ & $624-18 \cdot 0$ & \\
\hline m-CLOROANILINA & $\begin{array}{l}\text { m-Aminoclorobenceno; 1-amino-3-clorobenceno; 3-cloroanilina; } \\
\text { 3-clorobencenamina }\end{array}$ & $108-42-9$ & \\
\hline 0-CLOROANILINA & 1-Amino-2-clorobenceno; 2-cloroanilina; 2-clorobencenamina & $95-51-2$ & \\
\hline p-CLOROANILINA & 1-Amino-4-lorobenceno; 4-clorobencenamina; 4-clorofenilamina & $106-47-8$ & \\
\hline 4-CLORO-0-FENILENDIAMINA & $\begin{array}{l}\text { 2-Amino-4-cloroanilina; C.I. 76015; 4-cloro-1,2-bencendiamina; } \\
\text { 4-cloro-1,2-diaminobenceno; 4-cloro-1,2-fenilendiamina; } \\
\text { 1,2-diamino-4-clorobenceno; 3,4-diaminoclorobenceno; } \\
\text { 3,4-diamino-1-clorobenceno }\end{array}$ & $95-83-0$ & \\
\hline 2-CLORO-4-NITROANILINA & & $121-87-9$ & \\
\hline 4-CLORO-0-TOLUIDINA & $\begin{array}{l}\text { 2-Amino-5-clorotolueno; Azógeno rojo rápido TR; 3-cloro-6-aminotolueno; } \\
\text { 5-cloro-2-aminotolueno; 4-cloro-2-metilanilina; 4-cloro-6-metilanilina; } \\
\text { 2-metil-4-cloroanilina }\end{array}$ & $95-69-2$ & \\
\hline 5-CLORO-0-TOLUIDINA & $\begin{array}{l}\text { 2H-1-Benzopiran-2-ona; 2-oxo-2H-1-benzopirano; benzopirona; } \\
\text { 1,2-benzopirona; } \delta \text {-lactona del ácido o-hidroxicinámico; lactona del ácido } \\
\text { cis-o-cumarínico; anhídrido cumarínico; cumarina; lactona del } \\
\text { ácidoo-hidroxicinámico ; lactona del ácido o-hidroxicinámico; NCl } \mathrm{C0} 7103 ; \\
\text { 2-oxo-1,2-benzopirano; Rattex; Alcanfor de Tonka }\end{array}$ & $95-79-4$ & \\
\hline p-CRESIDINA & $\begin{array}{l}\text { Ester metílico de 3-amino-p-cresol; 1-amino-2-metoxi-5-metillbenceno; } \\
\text { 3-amino-4-metoxitolueno; 2-amino-4-metilanisol; 5-metil-0-anisidina; Rojo } \\
\text { azoico } 36\end{array}$ & $120-71-8$ & \\
\hline 2,4-DIAMINOANISOL & $\begin{array}{l}\text { C.I. 76050; m-diaminoanisol; 1,3-diamino-4-metoxibenceno; } \\
\text { 2,4-diamino-1-metoxibenceno; Furro I; 4-metoxi-1,3-bencendiamina }\end{array}$ & $615-05-4$ & \\
\hline
\end{tabular}




\begin{tabular}{|c|c|c|c|}
\hline Producto químico & Sinónimos/Código UN & $\mathrm{N}$ úmero CAS & Fórmula estructural \\
\hline 3,3'-DIAM INOBENCIDINA & 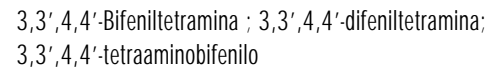 & $91-95-2$ & \\
\hline
\end{tabular}

\begin{tabular}{ll}
\hline 2,4-DIAMINOTOLUENO & 3-Amino-p-toluidina; 5-amino-0-toluidina; Revelador de azógeno Hh; $\quad 95-80-7$ \\
& Benzofur MT; C.I. 76035; 1,3-diamino-4-metilbenceno; \\
& 2,4-diamino-1-metilbenceno
\end{tabular}

ino-1-metilbenceno

UN1709

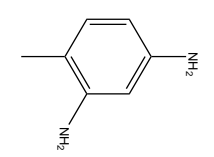

2,6-DIAMINOTOLUENO 2-Metil-1,3-bencendiamina; 2,6-toluilendiamina; 2,6-tolilendiamina $823-40-5$

N,N-DIBUTILANILINA

$613-29 \cdot 6$

$\begin{array}{ll}\text { DICICLOHEXILAMINONITRITO } & \begin{array}{l}\text { Nitrito de N-ciclohexilciclohexanamina; Dechan; Diana; nitrito de } \\ \text { diciclohexilamonio } \\ \text { UN2687 }\end{array}\end{array}$

DICLORHIDRATO DE 2,4-DIAMINOFENOL ACrol; amidol; clorhidrato de 2,4-diaminofenol; dianol; NCI-C60026 137-09-7

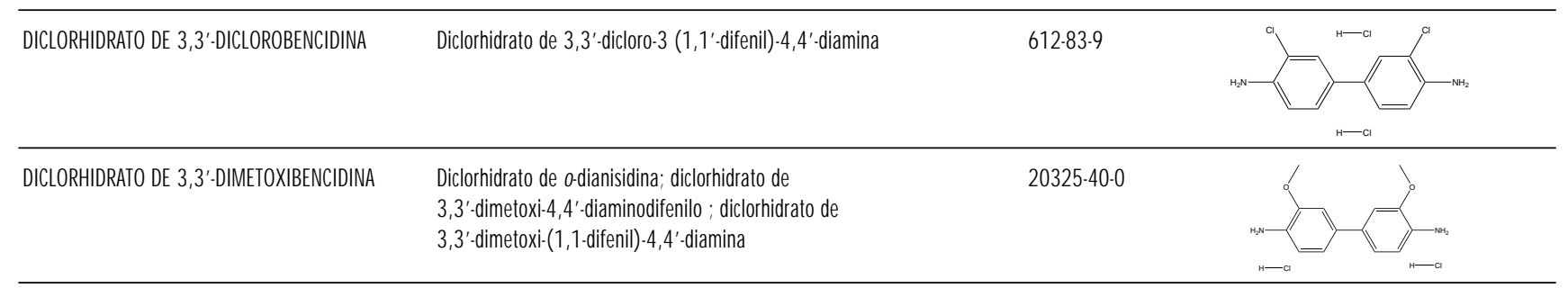

2,3-DICLOROANILINA

2,6-DICLOROANILINA




\section{Tabla 104.29 • Identificación química.}

$\begin{array}{ll}\text { Producto químico } & \text { Sinónimos/ Código UN } \\ 3,3^{\prime} \text {-DICLOROBENCIDINA } & \text { C.I. } 23060 \text {; Curithane C126; DCB; 4,4'-diamino-3,3'-diclorodifenilo; } \\ & \text { diclorobencidina; 3,3'-dicloro-4,4'-difenildiamina }\end{array}$

$\mathrm{N}$ úmero CAS Fórmula estructural diclorobencidina; 3,3'-dicloro-4,4'-difenildiamina

$91-94-1$

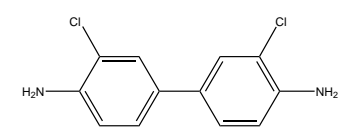

m-DIETILAMINOFENOL

3-(Dietilamino)fenol

$91-68-9$

$91-66-7$

N,N-Dietilaminobenceno; dietilanilina; N,N-dietilbencenamina; dietilfenilamina UN2432

N,N-DIETILANILINA N,N-Dietilaminobenceno; dietilanilina; N,N-dietilbencenamina;
dietilfenilamina
UN2432

DIFENILAMINA

Anilinobenceno; benceno C.I. 10355; No scald; No scald DPA 283; $\mathrm{N}$-fenilanilina; N-fenilbencenamina

$122-39-4$

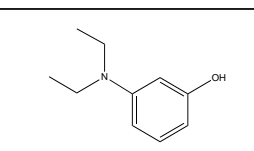
$\begin{array}{ll}\text { N,N'-DIFENIL-p-FENILENDIAMINA } & \text { Agerita; Agerita DPPD; 1,4-bis(fenilamino) benceno; difenil-p-fenilendiamina 74-31-7 } \\ \text { DPPD; Flexamina g; JZF; Nonox DPPD }\end{array}$

\begin{tabular}{|c|c|c|}
\hline 1,3-DIFENILGUANIDINA & Difenilguanidina; N,N'-difenilguanidina & $102-06-7$ \\
\hline DIMETILAMINOAZOBENCENO & $\begin{array}{l}\text { p-Dimetilaminoazobenceno; N,N-dimetil-4-aminoazobenceno; } \\
\text { bencenazodimetilanilina; 4-dimetilaminoazobenceno; } \\
\text { 4-dimetilaminoazobenzol; DAB }\end{array}$ & $60-11-7$ \\
\hline N,N-DIMETIL-p-TOLUIDINA & N,N,4-Trimetil-bencenamina; N,N,4-trimetilanilina; p-N,N-trimetilanilina & $99-97-8$ \\
\hline DIMETILANILINA & $\begin{array}{l}\text { Dimetilaminobenceno; N,N-dimetilbencenamidina; dimetilfenilamina } \\
\text { UN2253 }\end{array}$ & $121-69-7$ \\
\hline 2,4-DINITROANILINA & 2,4-Dinitroanilina; 2,4-dinitrobencenamina & $97-02-9$ \\
\hline N-ETILANILINA & $\begin{array}{l}\text { Anilinoetano; N-etilaminobenceno; etilanilina; N-etilbencenamina; } \\
\text { etilfenilamina } \\
\text { UN2272 }\end{array}$ & $103-69-5$ \\
\hline N-FENIL-1-NAFTILAMINA & 1-Anilinonaftaleno; fenilnaftilamina; fenil- $\alpha$-naftilamina & $90-30-2$ \\
\hline N-FENIL- $\beta$-NAFTILAMINA & $\begin{array}{l}\text { Anilinonaftaleno; 2-anilinonaftaleno; N-(2-naftil) anilina; } \\
\text { fenilaminonaftaleno }\end{array}$ & $135-88-6$ \\
\hline
\end{tabular}




\begin{tabular}{|c|c|c|c|}
\hline Producto químico & Sinónimos/ Código UN & $\mathrm{N}$ úmero $\mathrm{CAS}$ & Fórmula estructural \\
\hline m-FENILENBIS(METILAMINA) & $\begin{array}{l}\text { 1,3-Bis(aminometil) benceno; MXDA; m-xilen- } \alpha, \alpha^{\prime} \text {-diamina; } \\
\text { m-xililendiamina }\end{array}$ & $1477-55-0$ & \\
\hline m-FENILENDIAMINA & $\begin{array}{l}\text { m-Aminoalina; 3-aminoanilina; m-bencendiamina; 1,3-bencendiamina; } \\
\text { C.I. 76025; revelador 11; m-diaminobenceno; 1,3-diaminobenceno; } \\
\text { m-fenilendiamina; metafenilendiamina; 1,3-fenilendiamina } \\
\text { UN1673 }\end{array}$ & $108-45-2$ & \\
\hline 0-FENILENDIAMINA & $\begin{array}{l}\text { 2-Aminoanilina; o-bencendiamina; 1,2-bencendiamina; C.I. 76010; } \\
\text { C.I. Base de oxidación 16; o-diaminobenceno; 1,2-diaminobenceno; } \\
\text { o-fenilendiamina; 1,2-fenilendiamina } \\
\text { UN1673 }\end{array}$ & $95-54-5$ & \\
\hline p-FENILENDIAMINA & $\begin{array}{l}\text { p-Aminoanilina; 4-aminoanilina; p-bencendiamina; 1,4-bencendiamina; } \\
\text { Benzofur D; C.I. 76060; Pelagol D } \\
\text { UN1673 }\end{array}$ & $106-50-3$ & \\
\hline N-FENILETANOLAMINA & N-(2-hidroxietil)-anilina; 2-(fenilamino) etanol; N-feniletanolamina & $122-98-5$ & \\
\hline
\end{tabular}

N-ISOPROPILANILINA

768.52 .5

\begin{tabular}{|c|c|c|}
\hline N-ISOPROPIL-N'FENIL-p-FENILENDIAMINA & $\begin{array}{l}\text { Cyzone; Elastozone 34; Flexzone 3C; 4-isopropilaminodifenilamina; } \\
\text { N-fenil-N'-isopropil-p-fenilendiamina; N-2-propil-N'-fenil-p-fenilendiamina; } \\
\text { Santoflex } 36\end{array}$ & $101-72-4$ \\
\hline MELAMINA & $\begin{array}{l}\text { Aero; Ammelide; cianuramida; triamida cianúrica; } \\
\text { 4,6-triamino-1,3,5-triacina; 1,3,5-triacin-2,4,6-triamina }\end{array}$ & $108-78-1$ \\
\hline p-METILAMINOFENOL & 4-(Metilamino) fenol & $150-75-4$ \\
\hline METILANILINA & $\begin{array}{l}\text { Anilinometano; (metilamino) benceno; metilfenilamina; monometilanilina } \\
\text { UN2294 }\end{array}$ & $100-61-8$ \\
\hline 4,4'-METILEN-BIS (CLOROANILINA) & $\begin{array}{l}\text { Bis-amina; bis-amina A; bisamina S; bis(4-amino-3-clorofenil)metano; } \\
\text { bis(3-cloro-4-aminofenil)metano; CL-MDA; Buamine M; MbOCA; MOCA }\end{array}$ & 101-14-4 \\
\hline 4,4'-METILENBIS(2-METILANILINA) & $\begin{array}{l}\text { Bis(4-amino-3-metilfenil) metano; 3,3'-dimetil-4,4'-diaminodifenilmetano; } \\
\text { MBOT; Me-MDA; 4,4'-metilenbis(2-metilbencenamina) }\end{array}$ & $838-88 \cdot 0$ \\
\hline 2,4'-METILENDIANILINA & $\begin{array}{l}\text { 2',4-Bis(aminofenil) metano; o, } \mathbf{p}^{\prime} \text {-diaminodifenilmetano; } \\
\text { 2,4'-diaminodifenilmetano; 2,4'-difenilmetanodiamina' }\end{array}$ & $1208-52-2$ \\
\hline
\end{tabular}




\begin{tabular}{|c|c|c|c|}
\hline Producto químico & Sinónimos/ Código UN & $\mathrm{N}$ úmero CAS & Fórmula estructural \\
\hline 4,4-METILENDIANILINA & $\begin{array}{l}\text { Ancamine TL; Araldite endurecedor 972; bis( p-aminofenil)metano; } \\
\text { bis(4-aminofenil)metano; Curithane; DADPM; DAPM; DDM; } \\
\text { diaminodifenilmetano; dianilinometano; 4,4'-difenilmetanodiamina } \\
\text { UN2651 }\end{array}$ & 101-77-9 & \\
\hline 1,5-NAFTALENDIAMINA & 1,5-Diaminonaftaleno; 1,5-naftilendiamina; NCI-C03021 & $2243-62-1$ & \\
\hline N,N'-DI-2-NAFTIL-p-FENILENDIAMINA & 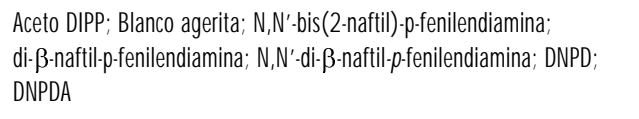 & $93-46-9$ & \\
\hline$\alpha$-NAFTILAMINA & $\begin{array}{l}\text { 1-Naftilamina; 1-aminonaftaleno; C.I. Componente diazo azoico 114; } \\
\text { naftalidam; naftalidina } \\
\text { UN2077 }\end{array}$ & $134-32-7$ & \\
\hline$\beta$-NAFTILAMINA & $\begin{array}{l}\text { 2-Aminonaftaleno; C.I. 37270; Base escarlata rápida B; 2-naftilamina; } \\
\text { 2-naftalenamina; 6-naftilamina } \\
\text { UN1650 }\end{array}$ & $91-59-8$ & \\
\hline m-NITROANILINA & $\begin{array}{l}\text { 1-Amino-3-nitrobenceno; nitranilina; m-nitroanilina; 3-nitroanilina; } \\
\text { 3-nitrobencenamina } \\
\text { UN1661 }\end{array}$ & $99-09-2$ & \\
\hline o-NITROANILINA & $\begin{array}{l}\text { 1-Amino-2-nitrobenceno; 2-nitroanilina } \\
\text { UN1661 }\end{array}$ & $88-74-4$ & \\
\hline p-NITROANILINA & $\begin{array}{l}\text { p-Aminonitrobenceno; 1-amino-4-nitrobenceno; 4-nitroanilina; } \\
\text { 4-nitrobencenamina } \\
\text { UN1661 }\end{array}$ & $100-01-6$ & \\
\hline $4,4^{\prime}-$ OXIDIANILINA & $\begin{array}{l}\text { Eter 4-aminofenílico; éter diaminodifenílico; óxido 4,4'-diaminofenílico; } \\
\text { 4,4'-oxibisanilina; 4,4'-oxibisbencenamina }\end{array}$ & $101-80-4$ & \\
\hline 0-TOLIDINA & $\begin{array}{l}\text { Bianisidina; (1,1'-difenil)-4,4'-diamino-3,3'-dimetil-; 4,4' -di-o-toluidina; } \\
\text { C.I. 37230; C.l. componente diazo azoico 113; } \\
\text { 4,4'-diamino-3,3'-dimetildifenil; 4,4'-diamino-3,3'-dimetildifenilo; } \\
\text { 3,3'-dimetilbencidina }\end{array}$ & $119-93-7$ & \\
\hline m-TOLUIDINA & $\begin{array}{l}\text { 3-Amino-1-metilbenceno; 3-aminofenilmetano; m-aminotolueno; } \\
\text { 3-aminotolueno; m-metilanilina; 3-metilanilina } \\
\text { UN1708 }\end{array}$ & 108-44-1 & \\
\hline O-TOLUIDINA & $\begin{array}{l}\text { 1-Amino-2-metilbenceno; 0-aminotolueno; 2-aminotolueno; C.I. 37077; } \\
\text { 1-metil-2-aminobenceno; 0-metilanilina } \\
\text { UN1708 }\end{array}$ & $95-53-4$ & \\
\hline p-TOLUIDINA & $\begin{array}{l}\text { 4-Amino-1-metilbenceno; p-aminotolueno; 4-aminotolueno; C.I. 37107; } \\
\text { C.I. Componente azoico de acoplamiento 107; p-metilanilina; } \\
\text { 4-metilanilina; p-metilbencenamina; 4-metilbencenamina } \\
\text { UN1708 }\end{array}$ & $106-49-0$ & \\
\hline
\end{tabular}




\begin{tabular}{|c|c|c|}
\hline Producto químico & Sinónimos/ Código UN & N úmero CAS Fórmula estructural \\
\hline TRIFENILAMINA & N,N-Difenilanilina; N,N-difenilbencenamina & $603-34-9$ \\
\hline 2,4,5-TRIMETILANILINA & $\begin{array}{l}\text { 1-Amino-2,4,5-trimetilbenceno; 1,2,4-trimetil-5-aminobenceno; } \\
\text { 2,4,5-trimetilanilina }\end{array}$ & $137-17-7$ \\
\hline XILIDINA & $\begin{array}{l}\text { Marrón cuero ácido 2G; Naranja ácido 24; aminodimetilbenceno; } \\
\text { dimetilaminobenceno; dimetilanilina; dimetilfenilamina } \\
\text { UN1711 }\end{array}$ & $1300-73-8$ \\
\hline 2,3-XILIDINA & $\begin{array}{l}\text { 2,3-Dimetilanilina; 2,3-dimetilbencenamina; 2,3-dimetilfenilamina; } \\
\text { o-xilidina; 2,3-xililamina }\end{array}$ & $87-59-2$ \\
\hline $2,4-X \mid L I D I N A$ & $\begin{array}{l}\text { 1-Amino-2,4-dimetilbenceno; 4-amino-1,3-dimetilbenceno; } \\
\text { 4-amino-3-metiltolueno; 4-amino-1,3-x-lleno; 2,4-dimetilanilina; } \\
\text { 2,4-dimetilbencenamina }\end{array}$ & $95-68-1$ \\
\hline 3,4-XILIDINA & $\begin{array}{l}\text { 3,4-Dimetilaminobenceno; 3,4-dimetilanilina; 3,4-dimetilbencenamina; } \\
\text { 3,4-dimetilfenilamina; 3,4-xililamina }\end{array}$ & $95-64-7$ \\
\hline
\end{tabular}

\begin{tabular}{|c|c|c|c|c|c|c|}
\hline \multirow[b]{2}{*}{$\begin{array}{l}\text { Denominación } \\
\text { química } \\
\text { N úmero CAS }\end{array}$} & \multicolumn{4}{|c|}{ Tarjetas Internacionales sobre la Seguridad de los Productos Q uímicos } & \multicolumn{2}{|c|}{ N IO SH (EE.UU.) } \\
\hline & $\begin{array}{l}\text { Período } \\
\text { corto de } \\
\text { exposición }\end{array}$ & $\begin{array}{l}\text { Período } \\
\text { largo de } \\
\text { exposición }\end{array}$ & $\begin{array}{l}\text { Vías de } \\
\text { exposición }\end{array}$ & Síntomas & $\begin{array}{l}\text { O rganos } \\
\text { afectados } \\
\text { Vías de } \\
\text { entrada }\end{array}$ & Síntomas \\
\hline $\begin{array}{l}\text { 4-AMINODIFENILO } \\
\text { 92-67-1 }\end{array}$ & ojos; vejiga & & $\begin{array}{r}\text { Inhalación } \\
\text { Piel } \\
\text { 0jos }\end{array}$ & $\begin{array}{l}\text { Embotamiento, cefalea } \\
\text { Puede absorberse } \\
\text { Enrojecimiento }\end{array}$ & $\begin{array}{l}\text { Vejiga; piel [cáncer } \\
\text { de vejiga] } \\
\text { Inh; abs; ing; con }\end{array}$ & $\begin{array}{l}\text { Cef, mar; let, dis; atax, deb; } \\
\text { metahem; ardor al orinar; } \\
\text { cistitis hemorrágica aguda; } \\
\text { [carc] }\end{array}$ \\
\hline $\begin{array}{l}\text { O-AMINOFENOL } \\
95.55 .6\end{array}$ & sangre & piel & $\begin{array}{r}\text { Inhalación } \\
\text { 0jos } \\
\end{array}$ & $\begin{array}{l}\text { Labios o uñas cianóticos, piel cianótica, tos, } \\
\text { mareo, cefalea, dificultad respiratoria, } \\
\text { inconsciencia, los síntomas pueden tardar en } \\
\text { aparecer } \\
\text { Enrojecimiento }\end{array}$ & & \\
\hline $\begin{array}{l}\text { ANILINA } \\
62-53-3\end{array}$ & ojos; sangre; SNC & $\begin{array}{l}\text { hígado; riñones; } \\
\text { bazo; piel; sangre }\end{array}$ & 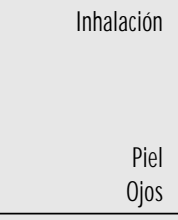 & $\begin{array}{l}\text { Labios o uñas cianóticos, piel cianótica, } \\
\text { cefalea, mareo, dificultad respiratoria, } \\
\text { convulsiones, aumento de la frecuencia } \\
\text { cardíaca, vómitos, debilidad, inconsciencia } \\
\text { Puede absorberse } \\
\text { Enrojecimiento }\end{array}$ & $\begin{array}{l}\text { Sangre; SCV; ojos; } \\
\text { hígado; riñones; sis } \\
\text { resp [en animales: } \\
\text { tumores del bazo] } \\
\text { Inh; abs; ing; con }\end{array}$ & $\begin{array}{l}\text { Cef; deb; mar; cian; atax; disn } \\
\text { por esfuerzo; taqui; irrit ocul; } \\
\text { metahem; cirr; [carc] }\end{array}$ \\
\hline $\begin{array}{l}\text { 0-ANISIDINA } \\
90-04-0\end{array}$ & sangre & sangre & $\begin{array}{r}\text { Inhalación } \\
\text { Piel }\end{array}$ & $\begin{array}{l}\text { Labios o uñas ciannóticos, piel cianótica, mareo, } \\
\text { sopor, cefalea, náuseas, vómitos } \\
\text { Puede absorberse }\end{array}$ & $\begin{array}{l}\text { Sangre; riñones; } \\
\text { hígado; SCV; SNC } \\
\text { Inh; abs; ing; con }\end{array}$ & $\begin{array}{l}\text { Cef, mar; cian; cuerpos de } \\
\text { Heinz en eritr; [carc] }\end{array}$ \\
\hline
\end{tabular}




\begin{tabular}{|c|c|c|c|c|c|c|}
\hline \multirow[b]{2}{*}{$\begin{array}{l}\text { Denominación } \\
\text { química } \\
\mathrm{N} \text { úmero CAS }\end{array}$} & \multicolumn{4}{|c|}{ Tarjetas Internacionales sobre la Seguridad de los Productos Q uímicos } & \multicolumn{2}{|c|}{ N IO SH (EE.UU.) } \\
\hline & $\begin{array}{l}\text { Período } \\
\text { corto de } \\
\text { exposición }\end{array}$ & $\begin{array}{l}\text { Período } \\
\text { largo de } \\
\text { exposición }\end{array}$ & $\begin{array}{l}\text { Vías de } \\
\text { exposición }\end{array}$ & Síntomas & $\begin{array}{l}\text { O rganos } \\
\text { afectados } \\
\text { Vías de } \\
\text { entrada }\end{array}$ & Síntomas \\
\hline $\begin{array}{r}\text { p-ANISIDINA } \\
104-94-9\end{array}$ & sangre & sangre & $\begin{array}{l}\text { Inhalación } \\
\text { Piel } \\
\text { Ingestión }\end{array}$ & $\begin{array}{l}\text { Labios o uñas cianóticos, piel cianótica, mareo, } \\
\text { sopor, cefalea, dificultad respiratoria, náuseas, } \\
\text { vómitos } \\
\text { Puede absorberse, labios o uñas cianóticos, } \\
\text { piel cianótica } \\
\text { Labios o uñas cianóticos, piel cianótica }\end{array}$ & $\begin{array}{l}\text { Sangre; riñones; } \\
\text { hígado; SCV; SNC } \\
\text { Inh; abs; ing; con }\end{array}$ & $\begin{array}{l}\text { Cef, mar; cian; cuerpos de } \\
\text { Heinz en eritr; [carc] }\end{array}$ \\
\hline $\begin{array}{l}\text { BENCIDINA } \\
92.87-5\end{array}$ & & & & & $\begin{array}{l}\text { Vejiga; riñones; } \\
\text { hígado; piel; sangre } \\
\text { [ cáncer de hígado, } \\
\text { riñón y vejiga] } \\
\text { Inh; abs; ing; con }\end{array}$ & $\begin{array}{l}\text { Hema; anemia secundaria por } \\
\text { hemólisis; cistitis aguda; } \\
\text { trastornos hepáticos agudos; } \\
\text { derm; micción irregular y } \\
\text { dolorosa; [carc] }\end{array}$ \\
\hline $\begin{array}{l}\text { CLORHIDRATO DE ANILINA } \\
\text { 142-04-1 }\end{array}$ & $\begin{array}{l}\text { ojos; piel; tract } \\
\text { resp; sangre }\end{array}$ & $\begin{array}{l}\text { piel; bazo; riñones; } \\
\text { sangre }\end{array}$ & 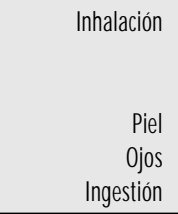 & $\begin{array}{l}\text { Labios o uñas cianóticos, piel cianótica, tos, } \\
\text { mareo, cefalea, náuseas, disnea, dolor de } \\
\text { garganta, inconsciencia, vómitos, debilidad } \\
\text { Puede absorberse, enrojecimiento } \\
\text { Enrojecimiento, dolor } \\
\text { Dolor abdominal }\end{array}$ & & \\
\hline $\begin{array}{l}\text { CLORHIDRATO DE } \\
\text { p-FENILENDIAMINA } \\
624-18-0\end{array}$ & $\begin{array}{l}\text { ojos; piel; tract } \\
\text { resp; sangre; } \\
\text { cerebro; riñones }\end{array}$ & $\begin{array}{l}\text { piel; tract resp; } \\
\text { higado }\end{array}$ & $\begin{array}{r}\text { Inhalación } \\
\text { Piel } \\
\text { 0jos } \\
\text { Ingestión }\end{array}$ & $\begin{array}{l}\text { Tos, mareo, dificultad respiratoria, véase } \\
\text { ingestión } \\
\text { Enrojecimiento } \\
\text { Visión borrosa, incluso pérdida permanente de } \\
\text { la visión } \\
\text { Dolor abdominal, labios o uñas cianóticos, piel } \\
\text { cianótica, vómitos, debilidad, hinchazón de la } \\
\text { cara y el cuello, convulsiones, coma, muerte }\end{array}$ & & \\
\hline $\begin{array}{l}\text { m-CLOROANILINA } \\
108-42-9\end{array}$ & $\begin{array}{l}\text { ojos; piel; tract } \\
\text { resp; hígado; } \\
\text { riñones }\end{array}$ & sangre & $\begin{array}{r}\text { Inhalación } \\
\text { Piel } \\
\text { 0jos } \\
\text { Ingestión }\end{array}$ & $\begin{array}{l}\text { Labios o uñas cianóticos, piel cianótica, mareo, } \\
\text { sopor, cefalea, náuseas, disnea, inconsciencia } \\
\text { Puede absorberse, enrojecimiento, sensación } \\
\text { de quemazón } \\
\text { Enrojecimiento, dolor, quemaduras profundas } \\
\text { graves } \\
\text { Dolor abdominal, }\end{array}$ & & \\
\hline $\begin{array}{l}\text { 0-CLOROANILINA } \\
95-51.2\end{array}$ & ojos; piel & $\begin{array}{l}\text { piel; hígado; } \\
\text { riñones; sangre }\end{array}$ & 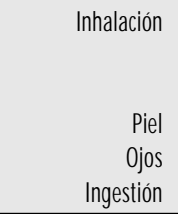 & $\begin{array}{l}\text { Labios o uñas cianóticos, piel cianótica, } \\
\text { convulsiones, diarrea, mareo, cefalea, } \\
\text { náuseas, disnea, vómitos, debilidad } \\
\text { Puede absorberse, enrojecimiento } \\
\text { Enrojecimiento, dolor } \\
\text { Dolor abdominal }\end{array}$ & & \\
\hline $\begin{array}{l}p-C L O R O A N I L I N A \\
106-47-8\end{array}$ & $\begin{array}{l}\text { ojos; piel; tract } \\
\text { resp; sangre }\end{array}$ & $\begin{array}{l}\text { piel; sangre; } \\
\text { hígado; riñones; } \\
\text { bazo; médula ósea }\end{array}$ & $\begin{array}{l}\text { Inhalación } \\
\text { Piel } \\
\text { 0jos } \\
\text { Ingestión }\end{array}$ & $\begin{array}{l}\text { Labios o uñas cianóticos, piel cianótica, mareo, } \\
\text { cefalea, dificultad respiratoria } \\
\text { Puede absorberse, enrojecimiento } \\
\text { Enrojecimiento, dolor } \\
\text { Náuseas }\end{array}$ & & \\
\hline $\begin{array}{l}\text { 2,4-DIAMINOTOLUENO } \\
\text { 95-80-7 }\end{array}$ & $\begin{array}{l}\text { ojos; piel; tract } \\
\text { resp; pulmones; } \\
\text { corazón; hígado; } \\
\text { sangre }\end{array}$ & piel & $\begin{array}{r}\text { Piel } \\
\text { Ojos } \\
\text { Ingestión }\end{array}$ & $\begin{array}{l}\text { Labios o uñas cianóticos, piel cianótica, mareo, } \\
\text { aumento de la frecuencia cardíaca, dificultad } \\
\text { respiratoria, náuseas, vómitos, convulsiones, } \\
\text { depresión respiratoria } \\
\text { Puede absorberse, enrojecimiento en contacto } \\
\text { con el material fundido - quemaduras en la } \\
\text { piel, ampollas } \\
\text { Enrojecimiento } \\
\text { Dolor abdominal, piel cianótica, cefalea, } \\
\text { náuseas, vómitos }\end{array}$ & $\begin{array}{l}\text { Ojos, piel, sis resp, } \\
\text { sangre, SCV, } \\
\text { hígado, SNC [en } \\
\text { animales: tumores } \\
\text { de hígado, piel y } \\
\text { glándulas } \\
\text { mamarias] } \\
\text { Inh; abs; ing; con }\end{array}$ & $\begin{array}{l}\text { Irrit ojos, piel, nariz y } \\
\text { garganta; derm; atax, taqui, } \\
\text { náu, vómit, convuls, depres } \\
\text { resp; metahem, cian, cef, ftg, } \\
\text { mar, piel cianótica; les } \\
\text { hepáticas; [carc] }\end{array}$ \\
\hline
\end{tabular}




\begin{tabular}{|c|c|c|c|c|c|c|}
\hline \multirow[b]{2}{*}{$\begin{array}{l}\text { Denominación } \\
\text { química } \\
\mathrm{N} \text { úmero CAS }\end{array}$} & \multicolumn{4}{|c|}{ Tarjetas Internacionales sobre la Seguridad de los Productos Q uímicos } & \multicolumn{2}{|c|}{ N IO SH (EE.UU.) } \\
\hline & $\begin{array}{l}\text { Período } \\
\text { corto de } \\
\text { exposición }\end{array}$ & $\begin{array}{l}\text { Período } \\
\text { largo de } \\
\text { exposición }\end{array}$ & $\begin{array}{l}\text { Vías de } \\
\text { exposición }\end{array}$ & Síntomas & $\begin{array}{l}\text { O rganos } \\
\text { afectados } \\
\text { Vías de } \\
\text { entrada }\end{array}$ & Síntomas \\
\hline $\begin{array}{l}\text { 2,6-DIAMINOTOLUENO } \\
823-40-5\end{array}$ & $\begin{array}{l}\text { ojos; piel; tract } \\
\text { resp; sangre }\end{array}$ & piel & $\begin{array}{r}\text { Inhalación } \\
\text { Piel } \\
\text { 0jos } \\
\text { Ingestión } \\
\end{array}$ & $\begin{array}{l}\text { Labios o uñas cianóticos, piel cianótica, tos, } \\
\text { mareo, cefalea, disnea } \\
\text { Enrojecimiento } \\
\text { Enrojecimiento, dolor } \\
\text { Dificultad respiratoria }\end{array}$ & & \\
\hline $\begin{array}{l}\text { 2,3-DICLOROANILINA } \\
608-27-5\end{array}$ & hígado; riñones & piel; sangre & $\begin{array}{r}\text { Inhalación } \\
\\
\text { Piel } \\
\text { 0jos } \\
\end{array}$ & $\begin{array}{l}\text { Labios o uñas cianóticos, piel cianótica, } \\
\text { convulsiones, diarrea, mareo, cefalea, disnea, } \\
\text { vómitos, debilidad } \\
\text { Puede absorberse, enrojecimiento } \\
\text { Enrojecimiento, dolor }\end{array}$ & & \\
\hline $\begin{array}{l}\text { 2,4-DICLOROANILINA } \\
\text { 554-00-7 }\end{array}$ & hígado; riñones & piel; sangre & $\begin{array}{r}\text { Inhalación } \\
\text { Piel } \\
\text { 0jos } \\
\text { Ingestión }\end{array}$ & $\begin{array}{l}\text { Cianosis, mareo, cefalea, disnea } \\
\text { Puede absorberse, enrojecimiento, quemaduras } \\
\text { en la piel } \\
\text { Enrojecimiento, dolor, quemaduras profundas } \\
\text { graves } \\
\text { Dolor abdominal, náuseas }\end{array}$ & & \\
\hline $\begin{array}{l}2,5-\text { DICLOROANILINA } \\
95-82-9\end{array}$ & hígado; riñones & piel; sangre & $\begin{array}{r}\text { Inhalación } \\
\text { Piel } \\
\text { 0jos } \\
\text { Ingestión }\end{array}$ & $\begin{array}{l}\text { Cianosis, mareo, cefalea, disnea } \\
\text { puede absorberse, enrojecimiento, quemaduras } \\
\text { En la piel } \\
\text { Enrojecimiento, dolor, quemaduras profundas } \\
\text { graves } \\
\text { Dolor abdominal, náuseas }\end{array}$ & & \\
\hline $\begin{array}{l}\text { 2,6-DICLOROANILINA } \\
\text { 608-31-1 }\end{array}$ & hígado; riñones & piel; sangre & $\begin{array}{r}\text { Inhalación } \\
\text { Piel } \\
\text { 0jos } \\
\end{array}$ & $\begin{array}{l}\text { Cianosis, mareo, cefalea, disnea } \\
\text { Puede absorberse, enrojecimiento } \\
\text { Enrojecimiento, dolor }\end{array}$ & & \\
\hline $\begin{array}{l}\text { 3,4-DICLOROANILINA } \\
95-76-1\end{array}$ & hígado; riñones & piel; sangre & $\begin{array}{r}\text { Inhalación } \\
\text { Piel } \\
\text { 0jos } \\
\text { Ingestión }\end{array}$ & $\begin{array}{l}\text { Cianosis, mareo, cefalea, disnea } \\
\text { Puede absorberse, enrojecimiento, sensación } \\
\text { de quemazón } \\
\text { Enrojecimiento, dolor, quemaduras profundas } \\
\text { graves } \\
\text { Dolor abdominal, náuseas }\end{array}$ & & \\
\hline $\begin{array}{l}\text { 3,3'-DICLOROBENCIDINA } \\
91-94-1\end{array}$ & tract resp & piel; hígado & $\begin{array}{r}\text { Inhalación } \\
\text { Piel }\end{array}$ & $\begin{array}{l}\text { Tos, dolor de garganta } \\
\text { Puede absorberse }\end{array}$ & $\begin{array}{l}\text { Vejiga; hígado; } \\
\text { pulmones; piel; } \\
\text { tract GI [en } \\
\text { animales: cáncer de } \\
\text { hígado y vejiga] } \\
\text { Inh; abs; ing; con } \\
\end{array}$ & $\begin{array}{l}\text { Sens cutánea, derm; cef, mar; } \\
\text { quemaduras cáusticas; micción } \\
\text { frecuente, disuria; hema; trast } \\
\text { Gl; infección resp superior; } \\
\text { [carc] }\end{array}$ \\
\hline $\begin{array}{l}\text { DIFENILAMINA } \\
\text { 122-39-4 }\end{array}$ & ojos; piel; tract re & riñones & $\begin{array}{r}\text { Inhalación } \\
\text { Piel } \\
\text { 0jos }\end{array}$ & $\begin{array}{l}\text { Tos, dolor de garganta } \\
\text { Enrojecimiento } \\
\text { Enrojecimiento }\end{array}$ & $\begin{array}{l}\text { Ojos; piel; sis resp; } \\
\text { SCV; sangre; vejiga; } \\
\text { sis repro } \\
\text { Inh; abs; ing; con }\end{array}$ & $\begin{array}{l}\text { Irrit ojos, piel y muc; eczema; } \\
\text { taqui, hipertensión; tos, } \\
\text { estorn; metahem; aum TA, } \\
\text { frecuencia cardíaca; prot, } \\
\text { hema, lesiones de la vejiga; } \\
\text { en animales: efectos terato }\end{array}$ \\
\hline $\begin{array}{l}\text { N,N-DIMETIL-p-TOLUIDINA } \\
\text { 99-97-8 }\end{array}$ & $\begin{array}{l}\text { sangre; cerebro; } \\
\text { riñones }\end{array}$ & & $\begin{array}{r}\text { Inhalación } \\
\text { Piel }\end{array}$ & $\begin{array}{l}\text { Labios o uñas cianóticos, piel cianótica, mareo, } \\
\text { cefalea, disnea, debilidad } \\
\text { Puede absorberse }\end{array}$ & & \\
\hline $\begin{array}{l}\text { DIMETILAMINOAZOBENCENO } \\
60-11-7\end{array}$ & & & & & $\begin{array}{l}\text { Piel; sis resp; } \\
\text { hígado; riñones; } \\
\text { vejiga [en } \\
\text { animales: tumores } \\
\text { de hígado y vejiga] } \\
\text { Inh; abs; ing; con }\end{array}$ & $\begin{array}{l}\text { Hepatomegalia; disfun } \\
\text { hepática y renal; derm de } \\
\text { contacto; tos, resp sib, dis; } \\
\text { esputos con sangre; } \\
\text { secreciones bronquiales; } \\
\text { micción frecuente, hema, } \\
\text { disuria; [carc] }\end{array}$ \\
\hline
\end{tabular}




\begin{tabular}{|c|c|c|c|c|c|c|}
\hline \multirow[b]{2}{*}{$\begin{array}{l}\text { Denominación } \\
\text { química } \\
\text { N úmero CAS }\end{array}$} & \multicolumn{4}{|c|}{ Tarjetas Internacionales sobre la Seguridad de los Productos Q uímicos } & \multicolumn{2}{|c|}{ N IO SH (EE.UU.) } \\
\hline & $\begin{array}{l}\text { Período } \\
\text { corto de } \\
\text { exposición }\end{array}$ & $\begin{array}{l}\text { Período } \\
\text { largo de } \\
\text { exposición }\end{array}$ & $\begin{array}{l}\text { Vías de } \\
\text { exposición }\end{array}$ & Síntomas & $\begin{array}{l}\text { O rganos } \\
\text { afectados } \\
\text { Vías de } \\
\text { entrada }\end{array}$ & Síntomas \\
\hline $\begin{array}{l}\text { DIMETILANILINA } \\
\text { 121-69-7 }\end{array}$ & sangre & piel & $\begin{array}{r}\text { Inhalación } \\
\\
\\
\text { Piel } \\
\text { 0jos } \\
\end{array}$ & $\begin{array}{l}\text { Dolor abdominal, piel cianótica, mareo, } \\
\text { cefalea, zumbido de oídos, dificultad } \\
\text { respiratoria, inconsciencia, vómitos, trastornos } \\
\text { visuales } \\
\text { Puede absorberse, enrojecimiento } \\
\text { Enrojecimiento, dolor }\end{array}$ & $\begin{array}{l}\text { Sangre; riñones; } \\
\text { hígado; SCV } \\
\text { Inh; abs; ing; con }\end{array}$ & $\begin{array}{l}\text { Síntomas de anox; cian, deb, } \\
\text { mar, atax; metahem }\end{array}$ \\
\hline $\begin{array}{l}\text { 2,4-DINITROANILINA } \\
\text { 97-02-9 }\end{array}$ & $\begin{array}{l}\text { ojos; piel; tract } \\
\text { resp; sangre }\end{array}$ & sangre & $\begin{array}{r}\text { Inhalación } \\
\text { Piel } \\
\text { 0jos } \\
\text { Ingestión }\end{array}$ & $\begin{array}{l}\text { Labios o uñas cianóticos, piel cianótica, tos, } \\
\text { mareo, cefalea, dificultad respiratoria, } \\
\text { náuseas, dolor de garganta } \\
\text { Puede absorberse, enrojecimiento, labios o } \\
\text { uñas cianóticos, piel cianótica } \\
\text { Enrojecimiento, dolor } \\
\text { Inconsciencia }\end{array}$ & & \\
\hline $\begin{array}{l}\text { p-FENILENDIAMINA } \\
106-50-3\end{array}$ & $\begin{array}{l}\text { tract resp; sangre; } \\
\text { riñones }\end{array}$ & piel; tract resp & $\begin{array}{r}\text { Inhalación } \\
\text { Piel } \\
\text { Ojos } \\
\text { Ingestión }\end{array}$ & $\begin{array}{l}\text { Tos, mareo, cefalea, dificultad respiratoria } \\
\text { Enrojecimiento } \\
\text { Enrojecimiento, visión borrosa, incluso pérdida } \\
\text { permanente de la visión } \\
\text { Dolor abdominal, labios o uñas cianóticos, piel } \\
\text { cianótica, vómitos, debilidad, convulsiones, } \\
\text { coma, muerte }\end{array}$ & $\begin{array}{l}\text { Sis resp; piel } \\
\text { Inh; abs; ing; con }\end{array}$ & $\begin{array}{l}\text { Irrit faringe y laringe; asma } \\
\text { bronquial; sens dérm }\end{array}$ \\
\hline $\begin{array}{l}\text { N-FENIL-1-NAFTILAMINA } \\
90-30-2\end{array}$ & & piel & Piel & Enrojecimiento & & \\
\hline $\begin{array}{l}\text { N-ISOPROPILANILINA } \\
768-52.5\end{array}$ & $\begin{array}{l}\text { piel; sangre; } \\
\text { cerebro; riñones }\end{array}$ & piel; sangre & $\begin{array}{r}\text { Inhalación } \\
\text { Piel } \\
\text { 0jos } \\
\text { Ingestión }\end{array}$ & $\begin{array}{l}\text { Labios o uñas cianóticos, piel cianótica, mareo, } \\
\text { cefalea, dificultad respiratoria } \\
\text { Puede absorberse, labios o uñas cianóticos, } \\
\text { piel cianótica } \\
\text { Enrojecimiento, dolor, visión borrosa } \\
\text { Náuseas }\end{array}$ & $\begin{array}{l}\text { Ojos; piel; sis resp; } \\
\text { sangre; SCV; } \\
\text { hígado; rinones } \\
\text { Inh; abs; ing; con }\end{array}$ & $\begin{array}{l}\text { Irrit ojos y piel; cef, deb, mar; } \\
\text { cian; atax; disn por esfuerzo; } \\
\text { taqui; metahem }\end{array}$ \\
\hline $\begin{array}{l}\text { N-ISOPROPIL-N'FENIL- } \\
\text { p-FENILENDIAMINA } \\
101-72-4 \\
\end{array}$ & ojos; piel & piel & $\begin{array}{r}\text { Inhalación } \\
\text { Piel } \\
\text { 0jos } \\
\end{array}$ & $\begin{array}{l}\text { Tos, irritante } \\
\text { Enrojecimiento, irritante } \\
\text { Enrojecimiento, irritante }\end{array}$ & & \\
\hline $\begin{array}{l}\text { METILANILINA } \\
\text { 100-61-8 }\end{array}$ & $\begin{array}{l}\text { ojos; piel; tract } \\
\text { resp; sangre; } \\
\text { cerebro; riñones }\end{array}$ & piel; sangre & $\begin{array}{l}\text { Inhalación } \\
\text { Piel } \\
\text { 0jos } \\
\text { Ingestión }\end{array}$ & $\begin{array}{l}\text { Labios o uñas cianóticos, piel cianótica, tos, } \\
\text { mareo, cefalea, dificultad respiratoria, dolor de } \\
\text { garganta } \\
\text { Puede absorberse, enrojecimiento, dolor } \\
\text { Enrojecimiento, dolor, visión borrosa } \\
\text { Dolor abdominal, labios o uñas cianóticos, piel } \\
\text { cianótica, mareo, cefalea, dificultad } \\
\text { respiratoria, náuseas }\end{array}$ & $\begin{array}{l}\text { Sis resp; hígado; } \\
\text { riñones; sangre; } \\
\text { SNC } \\
\text { Inh; abs; ing; con }\end{array}$ & $\begin{array}{l}\text { deb, mar, cef; dis, cian; } \\
\text { metahem; edema pulm; les } \\
\text { hepáticas y renales }\end{array}$ \\
\hline $\begin{array}{l}\text { 1,5-NAFTALENDIAMINA } \\
\text { 2243-62-1 }\end{array}$ & & piel & Piel & Puede absorberse & & \\
\hline $\begin{array}{l}\alpha \text {-NAFTILAMINA } \\
134-32 \cdot 7\end{array}$ & & & & & $\begin{array}{l}\text { Vejiga; piel [cáncer } \\
\text { de vejiga] } \\
\text { Inh; abs; ing; con }\end{array}$ & $\begin{array}{l}\text { Derm; cistitis hemorrágica; dis, } \\
\text { atax, metahem; hema; disuria; } \\
\text { [ carc] }\end{array}$ \\
\hline $\begin{array}{l}\beta \text {-NAFTILAMINA } \\
91-59-8\end{array}$ & & & & & $\begin{array}{l}\text { Vejiga; piel [cáncer } \\
\text { de vejiga] } \\
\text { Inh; abs; ing; con }\end{array}$ & $\begin{array}{l}\text { Derm; cistitis hemorrágica; dis; } \\
\text { atax; metahem, hema; disuria; } \\
\text { [carc] }\end{array}$ \\
\hline $\begin{array}{l}\text { m-NITROANILINA } \\
\text { 99-09-2 }\end{array}$ & sangre & & Inhalación & $\begin{array}{l}\text { Labios o uñas cianóticos, piel cianótica, mareo, } \\
\text { sopor, cefalea, dificultad respiratoria, náuseas, } \\
\text { disnea, inconsciencia, debilidad } \\
\text { Puede absorberse, labios o uñas cianóticos, } \\
\text { piel cianótica }\end{array}$ & & \\
\hline
\end{tabular}




\begin{tabular}{|c|c|c|c|c|c|c|}
\hline \multirow[b]{2}{*}{$\begin{array}{l}\text { Denominación } \\
\text { química } \\
\mathrm{N} \text { úmero CAS }\end{array}$} & \multicolumn{4}{|c|}{ Tarjetas Internacionales sobre la Seguridad de los Productos Q uímicos } & \multicolumn{2}{|c|}{ N IO SH (EE.UU.) } \\
\hline & $\begin{array}{l}\text { Período } \\
\text { corto de } \\
\text { exposición }\end{array}$ & $\begin{array}{l}\text { Período } \\
\text { largo de } \\
\text { exposición }\end{array}$ & $\begin{array}{l}\text { Vías de } \\
\text { exposición }\end{array}$ & Síntomas & $\begin{array}{l}\text { O rganos } \\
\text { afectados } \\
\text { Vías de } \\
\text { entrada }\end{array}$ & Síntomas \\
\hline $\begin{array}{l}\text { 0-NITROANILINA } \\
\text { 88-74-4 }\end{array}$ & sangre & & $\begin{array}{l}\text { Inhalación } \\
\text { Piel }\end{array}$ & $\begin{array}{l}\text { Labios o uñas cianóticos, piel cianótica, mareo, } \\
\text { sopor, cefalea, dificultad respiratoria, náuseas, } \\
\text { disnea, inconsciencia, debilidad } \\
\text { Puede absorberse, labios o uñas cianóticos, } \\
\text { piel cianótica }\end{array}$ & & \\
\hline $\begin{array}{l}\text { p-NITROANILINA } \\
100-01-6\end{array}$ & sangre & hígado & $\begin{array}{l}\text { Inhalación } \\
\text { Piel }\end{array}$ & $\begin{array}{l}\text { Labios o uñas cianóticos, piel cianótica, mareo, } \\
\text { sopor, cefalea, dificultad respiratoria, náuseas, } \\
\text { disnea, inconsciencia, debilidad } \\
\text { Puede absorberse, labios o uñas cianóticos, } \\
\text { piel cianótica }\end{array}$ & $\begin{array}{l}\text { Sis resp; sangre; } \\
\text { corazón; hígado } \\
\text { Inh; abs; ing; con }\end{array}$ & $\begin{array}{l}\text { Irrit nariz y garganta; cian, } \\
\text { atax; taqui, taquipnea; disp; } \\
\text { irrti; vómit, diarr; convuls; } \\
\text { parada resp; anemia; } \\
\text { metahemo; ict }\end{array}$ \\
\hline $\begin{array}{l}\text { 0-TOLIDINA } \\
119.93 .7\end{array}$ & ojos; piel; tract res & piel; sangre & $\begin{array}{r}\text { Inhalación } \\
\text { Piel }\end{array}$ & $\begin{array}{l}\text { Tos, irritante débil } \\
\text { Puede absorberse }\end{array}$ & $\begin{array}{l}\text { Ojos; sis resp; } \\
\text { hígado; riñones; [en } \\
\text { animales: tumores } \\
\text { en hígado, vejiga y } \\
\text { glándulas } \\
\text { mamarias] } \\
\text { Inh; abs; ing; con }\end{array}$ & $\begin{array}{l}\text { Irrit ojos y nariz; en animales: } \\
\text { les hepáticas y renales; [carc] }\end{array}$ \\
\hline $\begin{array}{l}\text { 0-TOLUIDINA } \\
\text { 95-53-4 }\end{array}$ & & & & & $\begin{array}{l}\text { Ojos; piel; sangre; } \\
\text { riñones; hígado; } \\
\text { SCV [en animales: } \\
\text { tumores en hígado, } \\
\text { vejiga y glándulas } \\
\text { mamarias] } \\
\text { Inh; abs; ing; con }\end{array}$ & $\begin{array}{l}\text { Irrit ojos; anox, cef, cian; deb, } \\
\text { mar, sop; microhema, } \\
\text { quemaduras en los ojos; derm; } \\
\text { [carc] }\end{array}$ \\
\hline $\begin{array}{l}\text { XILIDINA } \\
1300-73-8\end{array}$ & $\begin{array}{l}\text { ojos; piel; tract } \\
\text { resp; sangre }\end{array}$ & $\begin{array}{l}\text { riñones; hígado; } \\
\text { eritrocitos }\end{array}$ & $\begin{array}{r}\text { Inhalación } \\
\text { Piel } \\
\text { Ojos } \\
\text { Ingestión }\end{array}$ & $\begin{array}{l}\text { Labios o uñas cianóticos, piel cianótica, mareo, } \\
\text { cefalea, dificultad respiratoria } \\
\text { Puede absorberse } \\
\text { Enrojecimiento, dolor, visión borrosa } \\
\text { Labios o uñas cianóticos, piel cianótica, mareo, } \\
\text { cefalea }\end{array}$ & $\begin{array}{l}\text { Sis resp; sangre; } \\
\text { hígado; riñones; } \\
\text { SCV } \\
\text { Inh; abs; ing; con }\end{array}$ & $\begin{array}{l}\text { Anox, cian, metahem; les } \\
\text { pulmonares, hepáticas y } \\
\text { renales }\end{array}$ \\
\hline
\end{tabular}

Tabla 104.31 • Riesgos físicos y químicos.

\begin{tabular}{|c|c|c|c|}
\hline $\begin{array}{l}\text { Denominación química } \\
\mathrm{N} \text { úmero CAS }\end{array}$ & Físicos & Q uímicos & $\begin{array}{l}\text { Clase o división } \\
\text { UN / Riesgos } \\
\text { subsidiarios }\end{array}$ \\
\hline $\begin{array}{l}\text { 4-AMINODIFENILO } \\
\text { 92-67-1 }\end{array}$ & & $\begin{array}{l}\text { - En su combustión libera gases tóxicos: } \mathrm{CO}_{x}, \mathrm{NO}_{x} \text { La solución en agua es una base débil } \\
\text { Reacciona con oxidantes fuertes } \quad \text { Forma sales con ácidos como el clorhídrico, el sulfúrico, etc. }\end{array}$ & \\
\hline $\begin{array}{l}\text { O-AMINOFENOL } \\
95-55-6\end{array}$ & & $\begin{array}{l}\text { - Se descompone al calentarse produciendo humos tóxicos (óxidos de nitrógeno) Reacciona } \\
\text { violentamente con oxidantes, con peligro de incendio y explosión }\end{array}$ & 6.1 \\
\hline $\begin{array}{l}\text { P-AMINOFENOL } \\
123-30-8\end{array}$ & & & 6.1 \\
\hline $\begin{array}{l}\text { ANILINA } \\
62.53-3\end{array}$ & & $\begin{array}{l}\text { - Se descompone al calentarse a temperaturas superiores a } 190^{\circ} \mathrm{C} \text { o al arder, liberando humos } \\
\text { tóxicos y corrosivos (amoniaco y óxidos de nitrógeno) y vapores inflamables Es una base débil } \\
\text { Reacciona violentamente con oxidantes fuertes, ácidos, anhídrido acético, monómeros de } \\
\text { cloromelamina, beta propilactona y epiclorhidrina, con peligro de incendio y explosión } \\
\text { Reacciona con metales, como sodio, potasio y calcio, produciendo gas de hidrógeno inflamable } \\
\text { Ataca el cobre y sus aleaciones }\end{array}$ & 6.1 \\
\hline
\end{tabular}




\begin{tabular}{|c|c|c|c|}
\hline $\begin{array}{l}\text { Denominación química } \\
\text { N úmero CAS }\end{array}$ & Físicos & Q uímicos & $\begin{array}{l}\text { Clase o división } \\
\text { UN / Riesgos } \\
\text { subsidiarios }\end{array}$ \\
\hline $\begin{array}{l}\text { O-ANISIDINA } \\
\text { 90-04-0 }\end{array}$ & & $\begin{array}{l}\text { - Se descompone al calentarse produciendo humos tóxicos (óxidos de nitrógeno) Reacciona } \\
\text { con oxidantes fuertes, con peligro de incendio y explosión Reacciona con ácidos, cloruros de } \\
\text { ácidos, anhídridos de ácidos y cloroformiatos Ataca ciertos tipos de plásticos, caucho y } \\
\text { revestimientos }\end{array}$ & 6.1 \\
\hline $\begin{array}{l}\text { p-ANISIDINA } \\
104-94-9\end{array}$ & & $\begin{array}{l}\text { - Se descompone al calentarse, liberando humos tóxicos (óxidos de nitrógeno) Reacciona con } \\
\text { oxidantes fuertes, con peligro de incendio y explosión Reacciona con ácidos, cloruros de ácidos, } \\
\text { anhídridos de ácidos y cloroformiatos }\end{array}$ & 6.1 \\
\hline $\begin{array}{c}\text { BENCIDINA } \\
92-87.5 \\
\end{array}$ & & & 6.1 \\
\hline $\begin{array}{l}\text { CLORHIDRATO DE ANILINA } \\
\text { 142-04-1 }\end{array}$ & $\begin{array}{l}\text { - El vapor es más pesado } \\
\text { que el aire }\end{array}$ & $\begin{array}{l}\text { - En su combustión libera humos tóxicos, como óxidos de nitrógeno En contacto con superficies } \\
\text { calientes o una llama, se descompone desprendiendo humos tóxicos y corrosivos de anilina, } \\
\text { compuestos clorados y gases nitrogenados Se descompone al calentarse o en contacto con } \\
\text { ácidos, produciendo humos tóxicos como anilina y ácido clorhídrico Reacciona violentamente } \\
\text { con oxidantes, con peligro de incendio y explosión }\end{array}$ & \\
\hline $\begin{array}{l}\text { CLORHIDRATO DE O-ANISIDINA } \\
\text { 134-29-2 }\end{array}$ & & & 6.1 \\
\hline $\begin{array}{l}\text { m-CLOROANILINA } \\
108-42-9\end{array}$ & & $\begin{array}{l}\text { - Se descompone al arder, liberando humos tóxicos (óxidos nitrosos, cloruro de hidrógeno) La } \\
\text { solución en agua es una base débil Reacciona violentamente con oxidantes, con peligro de } \\
\text { incendio y explosión }\end{array}$ & 6.1 \\
\hline $\begin{array}{l}\text { 0-CLOROANILINA } \\
95-51.2\end{array}$ & & - Se descompone al arder, liberando humos tóxicos (óxidos nitrosos, cloruro de hidrógeno) & 6.1 \\
\hline $\begin{array}{l}\text { p-CLOROANILINA } \\
106-47-8\end{array}$ & & $\begin{array}{l}\text { - Se descompone al calentarse por encima de } 160^{\circ} \mathrm{C} \text { y al arder, produciendo humos tóxicos y } \\
\text { corrosivos de óxidos de nitrógeno y cloruro de hidrógeno Reacciona violentamente con } \\
\text { oxidantes }\end{array}$ & 6.1 \\
\hline $\begin{array}{l}\text { 2-CLORO-4-NITROANILINA } \\
\text { 121-87-9 }\end{array}$ & & & 6.1 \\
\hline $\begin{array}{l}\text { 5-CLORO-0-TOLUIDINA } \\
\text { 95-79-4 }\end{array}$ & & & 6.1 \\
\hline $\begin{array}{c}\text { p-CRESIDINA } \\
120-71-8 \\
\end{array}$ & & & 8 \\
\hline $\begin{array}{l}\text { 2,4-DIAMINOTOLUENO } \\
95-80-7\end{array}$ & & $\begin{array}{l}\text { - En su combustión libera gases y humos tóxicos (monóxido de carbono y óxidos de nitrógeno) } \\
\text { Reacciona con oxidantes, ácidos, anhídridos y cloruros de ácidos }\end{array}$ & 6.1 \\
\hline $\begin{array}{l}\text { 2,6-DIAMINOTOLUENO } \\
\text { 823-40-5 }\end{array}$ & & - En su combustión libera humos tóxicos de óxidos de nitrógeno & \\
\hline $\begin{array}{l}\text { DICICLOHEXILAMINONITRITO } \\
3129.91 .7\end{array}$ & & & 4.1 \\
\hline $\begin{array}{l}\text { DICLORHIDRATO DE 1,4-BENCENDIAMINA } \\
624-18-0 \\
\end{array}$ & $\begin{array}{l}\text { - Posibilidad de explosión } \\
\text { pulverulenta cuando se } \\
\text { encuentra en forma de } \\
\text { polvo o gránulos y se } \\
\text { mezcla con el aire }\end{array}$ & $\begin{array}{l}\text { - Se descompone al calentarse, liberando humos tóxicos y corrosivos (óxidos de nitrógeno, } \\
\text { cloruro de hidrógeno) }\end{array}$ & \\
\hline $\begin{array}{l}\text { 2,3-DICLOROANILINA } \\
608-27-5\end{array}$ & & $\begin{array}{l}\text { - Se descompone al calentarse, desprendiendo humos tóxicos (óxidos nitrosos, cloruro de } \\
\text { hidrógeno) }\end{array}$ & 6.1 \\
\hline $\begin{array}{l}\text { 2,4-DICLOROANILINA } \\
554-00-7\end{array}$ & & - Se descompone al calentarse, liberando humos tóxicos (óxidos nitrosos, cloruro de hidrógeno) & 6.1 \\
\hline $\begin{array}{l}\text { 2,5-DICLOROANILINA } \\
95-82.9\end{array}$ & & - Se descompone al calentarse, liberando humos tóxicos (óxidos nitrosos, cloruro de hidrógeno) & 6.1 \\
\hline
\end{tabular}


Tabla 104.31 • Riesgos físicos y químicos.

\begin{tabular}{|c|c|c|c|}
\hline $\begin{array}{l}\text { Denominación química } \\
\mathrm{N} \text { úmero CAS }\end{array}$ & Físicos & Q uímicos & $\begin{array}{l}\text { Clase o división } \\
\text { UN / Riesgos } \\
\text { subsidiarios }\end{array}$ \\
\hline $\begin{array}{l}\text { 2,6-DICLOROANILINA } \\
\text { 608-31-1 }\end{array}$ & & - Se descompone al calentarse, liberando humos tóxicos (óxidos nitrosos, cloruro de hidrógeno) & 6.1 \\
\hline $\begin{array}{l}\text { 3,4-DICLOROANILINA } \\
95-76-1\end{array}$ & & - Se descompone al calentarse, liberando humos tóxicos (óxidos nitrosos, cloruro de hidrógeno) & 6.1 \\
\hline $\begin{array}{l}\text { 3,3'-DICLOROBENCIDINA } \\
91-94-1\end{array}$ & & $\begin{array}{l}\text { - Se descompone al calentarse, liberando humos tóxicos y corrosivos como óxidos de nitrógeno y } \\
\text { cloruro de hidrógeno Produce las reacciones habituales de los derivados de la bencidina, por } \\
\text { ejemplo, formación de sales de diazonio y derivados aćlicos y alquílicos }\end{array}$ & \\
\hline $\begin{array}{l}\text { N,N-DIETILANILINA } \\
91-66-7\end{array}$ & & & 6.1 \\
\hline $\begin{array}{l}\text { DIFENILAMINA } \\
\text { 122-39-4 }\end{array}$ & $\begin{array}{l}\text { - Posibilidad de explosión } \\
\text { pulverulenta cuando se } \\
\text { encuentra en forma de } \\
\text { polvo o gránulos y se } \\
\text { mezcla con el aire }\end{array}$ & $\begin{array}{l}\text { - En su combustión libera gases tóxicos de carbono y óxidos de nitrógeno Reacciona con } \\
\text { oxidantes fuertes y ácidos }\end{array}$ & \\
\hline
\end{tabular}

\begin{tabular}{|c|c|}
\hline $\begin{array}{l}\text { DIMETILANILINA } \\
121-69-7\end{array}$ & $\begin{array}{l}\text { - Se descompone al calentarse } 0 \text { al arder, desprendiendo humos muy tóxicos (anilina, óxidos de } \\
\text { nitrógeno) Es una base débil Reacciona con oxidantes }\end{array}$ \\
\hline $\begin{array}{l}\text { N,N-DIMETIL-p-TOLUIDINA } \\
99-97-8\end{array}$ & $\begin{array}{l}\text { - En su combustión libera gases tóxicos y corrosivos }\left(\mathrm{NO}_{\mathrm{x}}\right) \text { Reacciona violentamente con } \\
\text { oxidantes fuertes, con peligro de incendio y explosión Reacciona con ácidos, anhídridos y } \\
\text { cloruros Ataca muchos plásticos }\end{array}$ \\
\hline $\begin{array}{l}\text { 2,4-DINITROANILINA } \\
97-02-9\end{array}$ & $\begin{array}{l}\text { - Puede explotar por efecto del calor, la fricción o la contaminación Se descompone al } \\
\text { calentarse, produciendo humos tóxicos (óxidos de nitrógeno) Reacciona violentamente con } \\
\text { oxidantes Reacciona violentamente con cloro y ácido clorhídrico, emitiendo gases }\end{array}$ \\
\hline
\end{tabular}

N-ETILANILINA

6.1

103-69-5

\begin{tabular}{|c|c|}
\hline $\begin{array}{l}\text { 0.FENILENDIAMINA } \\
95-54-5\end{array}$ & \\
\hline $\begin{array}{l}\text { P-FENILENDIAMINA } \\
106-50-3\end{array}$ & $\begin{array}{l}\text { - Se descompone al calentarse y al arder, desprendiendo humos tóxicos (óxidos de } \\
\text { nitrógeno) Es un potente agente reductor y reacciona violentamente con oxidantes }\end{array}$ \\
\hline $\begin{array}{l}\text { N-FENIL-1-NAFTILAMINA } \\
90-30-2\end{array}$ & $\begin{array}{l}\text { - En su combustión libera humos tóxicos }\left(\mathrm{NO}_{\mathrm{X}}\right) \text { Se descompone al calentarse } \mathrm{o} \text { al arder, } \\
\text { desprendiendo humos tóxicos (óxidos de nitrógeno) }\end{array}$ \\
\hline $\begin{array}{l}\text { N-ISOPROPIL-N'-FENIL- } \\
\text { p-FENILENDIAMINA } \\
\text { 101-72-4 }\end{array}$ & $\begin{array}{l}\text { - En su combustión libera gases tóxicos }\left(\mathrm{NO}_{x^{\prime}} \mathrm{CO}_{x}\right) \text { Se descompone produciendo humos tóxicos } \\
\text { (óxidos de nitrógeno) }\end{array}$ \\
\hline
\end{tabular}

$101-72-4$

D-METILAMINOFENOL

150-75-4

METILANILINA

100-61-8

- Se descompone al calentarse y al arder, produciendo humos tóxicos como anilina y óxidos de nitrógeno Reacciona violentamente con ácidos fuertes y oxidantes Ataca algunos plásticos

1,5-NAFTALENDIAMINA

2243-62-1

- Se descompone al calentarse, liberando humos tóxicos (óxidos de nitrógeno) 


\begin{tabular}{|c|c|c|c|}
\hline $\begin{array}{l}\text { Denominación química } \\
\mathrm{N} \text { úmero CAS }\end{array}$ & Físicos & Q uímicos & $\begin{array}{l}\text { Clase o división } \\
\text { UN / Riesgos } \\
\text { subsidiarios }\end{array}$ \\
\hline $\begin{array}{l}\text { m-NITROANILINA } \\
99 \cdot 09-2\end{array}$ & $\begin{array}{l}\text { - Posibilidad de explosión } \\
\text { pulverulenta cuando se } \\
\text { encuentra en forma de } \\
\text { polvo o gránulos y se } \\
\text { mezcla con el aire }\end{array}$ & $\begin{array}{l}\text { - En su combustión libera humos tóxicos de óxidos de nitrógeno Es un oxidante fuerte y } \\
\text { reacciona con materiales combustibles y reductores Reacciona con materiales orgánicos en } \\
\text { presencia de humedad, con peligro de incendio }\end{array}$ & 6.1 \\
\hline $\begin{array}{l}\text { 0-NITROANILINA } \\
\text { 88-74-4 }\end{array}$ & $\begin{array}{l}\text { - Posibilidad de explosión } \\
\text { pulverulenta cuando se } \\
\text { encuentra en forma de } \\
\text { polvo o gránulos y se } \\
\text { mezcla con el aire }\end{array}$ & $\begin{array}{l}\text { - En su combustión libera humos tóxicos de óxidos de nitrógeno Es un oxidante fuerte y } \\
\text { reacciona con materiales combustibles y reductores Reacciona con materiales orgánicos en } \\
\text { presencia de humedad, con peligro de incendio }\end{array}$ & 6.1 \\
\hline $\begin{array}{l}\text { p-NITROANILINA } \\
100-01-6\end{array}$ & $\begin{array}{l}\text { - Posibilidad de explosión } \\
\text { pulverulenta cuando se } \\
\text { encuentra en forma de } \\
\text { polvo o gránulos y se } \\
\text { mezcla con el aire }\end{array}$ & $\begin{array}{l}\text { - Puede explotar si se calienta En su combustión libera humos tóxicos de óxidos de nitrógeno } \\
\text { Es un oxidante fuerte y reacciona con materiales combustibles y reductores Reacciona con } \\
\text { materiales orgánicos en presencia de humedad, con peligro de incendio }\end{array}$ & 6.1 \\
\hline $\begin{array}{l}\text { 0-TOLIDINA } \\
\text { 119-93-7 }\end{array}$ & & $\begin{array}{l}\text { - Se descompone al calentarse y al arder, liberando humos tóxicos, como óxidos de nitrógeno } \\
\text { Se degrada por acción de la luz solar }\end{array}$ & \\
\hline $\begin{array}{c}\text { m-TOLUIDINA } \\
\text { 108-44-1 } \\
\end{array}$ & & & 6.1 \\
\hline $\begin{array}{l}\text { 0-TOLUIDINA } \\
95-53-4\end{array}$ & & & 6.1 \\
\hline $\begin{array}{c}\text { P-TOLUIDINA } \\
106-49-0\end{array}$ & & & 6.1 \\
\hline $\begin{array}{l}\text { XILIDINA } \\
1300-73-8\end{array}$ & & $\begin{array}{l}\text { - Se descompone al arder, liberando óxidos de nitrógeno peligrosos Reacciona con oxidantes } \\
\text { fuertes Reacciona con hipocloritos, formando cloraminas explosivas }\end{array}$ & 6.1 \\
\hline $\begin{array}{l}2,3-X \mid \text { XIIINA } \\
87-59-2\end{array}$ & & & 6.1 \\
\hline $\begin{array}{l}2,4-X \mid L I D I N A \\
95-68-1\end{array}$ & & & 6.1 \\
\hline $\begin{array}{l}3,4-X \mid L I D I N A \\
95-64-7\end{array}$ & & & 6.1 \\
\hline
\end{tabular}

\begin{tabular}{|c|c|c|c|c|c|c|c|c|c|}
\hline $\begin{array}{l}\text { Denominación química } \\
\mathrm{N} \text { úmero CAS }\end{array}$ & Color/ Forma & $\begin{array}{l}\text { p.e. } \\
(\stackrel{\circ}{ } \mathrm{C})\end{array}$ & $\begin{array}{l}\text { p.f. } \\
(\stackrel{\circ}{ } C)\end{array}$ & $\begin{array}{l}\text { p.m.l } \\
\text { (g/ } \\
\text { mol) }\end{array}$ & $\begin{array}{l}\text { Solubilidad } \\
\text { en agua }\end{array}$ & $\begin{array}{l}\text { Densidad } \\
\text { relativa } \\
\text { (agua =1) }\end{array}$ & $\begin{array}{l}\text { Densidad } \\
\text { de vapor } \\
\text { relativa } \\
\text { (aire=1) }\end{array}$ & $\begin{array}{l}\text { Pvap/ } \\
(\mathrm{kPa})\end{array}$ & 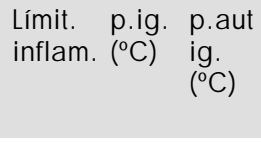 \\
\hline $\begin{array}{l}\text { 0-ACETOLUIDINA } \\
120-66-1 \\
\end{array}$ & cristales; incoloros & 296 & 110 & 149,2 & lig sol & $1,168 @ 15^{\circ} \mathrm{C}$ & & & \\
\hline $\begin{array}{l}\text { 1-AMINO-2-METILANTRAQUINONA } \\
82-28-0\end{array}$ & & & 205,5 & 237,3 & insol & & & & \\
\hline $\begin{array}{l}\text { 2-AMINOANTRAQUINONA } \\
\text { 177-79-3 }\end{array}$ & $\begin{array}{l}\text { agujas de color rojo } \\
\text { naranja-marrón }\end{array}$ & sublima & 303,6 & 233,23 & insol & & & & \\
\hline
\end{tabular}


Tabla 104.32 • Propiedades físicas y químicas.

\begin{tabular}{|c|c|c|c|c|c|c|c|c|c|c|c|}
\hline $\begin{array}{l}\text { Denominación química } \\
\mathrm{N} \text { úmero CAS }\end{array}$ & Color/ Forma & $\begin{array}{l}\text { p.e. } \\
(\stackrel{0}{ } \mathrm{C})\end{array}$ & $\begin{array}{l}\text { p.f. } \\
(\because C)\end{array}$ & $\begin{array}{l}\text { p.m.l } \\
\text { (g/ } \\
\text { mol) }\end{array}$ & $\begin{array}{l}\text { Solubilidad } \\
\text { en agua }\end{array}$ & $\begin{array}{l}\text { Densidad } \\
\text { relativa } \\
\text { (agua }=1 \text { ) }\end{array}$ & $\begin{array}{l}\text { Densidad } \\
\text { de vapor } \\
\text { relativa } \\
\text { (aire=1) }\end{array}$ & $\begin{array}{l}\text { Pvap/ } \\
(\mathrm{kPa})\end{array}$ & $\begin{array}{l}\text { Límit. } \\
\text { inflam. }\end{array}$ & $\begin{array}{l}\text { p.ig. } \\
(\stackrel{\circ}{ } \mathrm{C})\end{array}$ & $\begin{array}{l}\text { p.aut } \\
\text { ig. } \\
\left({ }^{\circ} \mathrm{C}\right)\end{array}$ \\
\hline $\begin{array}{l}\text { 4-AMINODIFENILO } \\
\text { 92.67-1 }\end{array}$ & $\begin{array}{l}\text { cristales incoloros que } \\
\text { adquieren una } \\
\text { coloración violeta en } \\
\text { contacto con el aire }\end{array}$ & 302 & 53 & 169,2 & lig sol & 1,160 & $\begin{array}{l}5,8 @ \text { punto } \\
\text { de ebullición }\end{array}$ & & & $153 \mathrm{cc}$ & 450 \\
\hline $\begin{array}{l}\text { O-AMINOFENOL } \\
95-55.6\end{array}$ & $\begin{array}{l}\text { cristales que se } \\
\text { vuelven marrones } \\
\text { rápidamente; agujas } \\
\text { rómbicas } \\
\text { bipiramidales blancas } \\
\text { en benceno; agujas o } \\
\text { placas rómbicas } \\
\text { incoloras }\end{array}$ & $\begin{array}{l}153 \\
\text { sublima }\end{array}$ & 174 & 109,12 & sol & 1,328 & & & & 190 & \\
\hline $\begin{array}{l}\text { p-AMINOFENOL } \\
123-30-8\end{array}$ & $\begin{array}{l}\text { placas ortorrómbicas } \\
\text { en agua; placas } \\
\text { blancas en agua; } \\
\text { cristales incoloros; } \\
\text { cristales blancos o } \\
\text { amarillo-rojizos }\end{array}$ & $\begin{array}{l}284 \text { se } \\
\text { descompo } \\
\text { ne }\end{array}$ & 188 & 109,13 & lig sol & & & & & & \\
\hline $\begin{array}{l}\text { ANILINA } \\
62-53-3\end{array}$ & $\begin{array}{l}\text { líquido aceitoso, } \\
\text { incoloro cuando está } \\
\text { puro; incoloro con } \\
\text { una fluorescencia } \\
\text { azulada cuando se } \\
\text { acaba de destilar }\end{array}$ & 184 & -6 & 93,12 & sol & 1,022 & 3,22 & 0,04 & $\begin{array}{l}1,2 \mathrm{li} \\
11 \mathrm{is}\end{array}$ & $70 \mathrm{cc}$ & 615 \\
\hline $\begin{array}{l}\text { 0-ANISIDINA } \\
90-04.0\end{array}$ & $\begin{array}{l}\text { líquido amarillento } \\
\text { pálido; aceite de color } \\
\text { rojizo o amarillento; } \\
\text { líquido incoloro o } \\
\text { rosáceo }\end{array}$ & 225 & 5 & 123,2 & lig sol & 1,0923 & 4,25 & $\begin{array}{l}<.133 \\
@ 30^{\circ} \mathrm{C}\end{array}$ & & $118 \mathrm{ca}$ & \\
\hline $\begin{array}{r}\text { p-ANISIDINA } \\
104-94-9\end{array}$ & $\begin{array}{l}\text { cristales tabulares en } \\
\text { agua, placas } \\
\text { rómbicas; cristales; } \\
\text { masa cristalina } \\
\text { fundida }\end{array}$ & 246 & 57 & 123,15 & sol & $\begin{array}{l}1,071 \\
@ 57^{\circ} \mathrm{C} / 4^{\circ} \mathrm{C}\end{array}$ & 4,28 & $<13 \mathrm{~Pa}$ & & 107 & \\
\hline $\begin{array}{l}\text { AURAMINA } \\
\quad 492-80-8\end{array}$ & $\begin{array}{l}\text { placas amarillas o } \\
\text { incoloras en alcohol }\end{array}$ & & 136 & 267,4 & insol & & & $\begin{array}{l}2,5 \times 10^{-6} \\
\mathrm{~mm} \mathrm{Hg} \\
\text { @ } 25^{\circ} \mathrm{C}\end{array}$ & & & \\
\hline $\begin{array}{l}\text { BASE DE MICHLER } \\
101-61-1\end{array}$ & $\begin{array}{l}\text { laminillas brillantes; } \\
\text { laminillas } \\
\text { amarillentas o placas } \\
\text { brillantes }\end{array}$ & 390 & 91,5 & 254,36 & insol & & & & & & \\
\hline $\begin{array}{l}\text { BENCIDINA } \\
92-87-5\end{array}$ & $\begin{array}{l}\text { polvo cristalino blanco } \\
\text { o ligeramente rojizo; } \\
\text { agujas, polvo } \\
\text { cristalino amarillo } \\
\text { grisáceo }\end{array}$ & 400 & 120 & 184,23 & lig sol & 1,250 & 6,36 & & & & \\
\hline $\begin{array}{l}\text { CETONA DE MICHLER } \\
90-94.8\end{array}$ & $\begin{array}{l}\text { laminillas entre } \\
\text { blancas y verdosas; } \\
\text { láminas en alcohol, } \\
\text { agujas en benceno }\end{array}$ & $\begin{array}{l}360 \text { se } \\
\text { descompo } \\
\text { ne }\end{array}$ & 172 & 268,35 & insol & & & & & & \\
\hline $\begin{array}{l}\text { CLORHIDRATO DE ANILINA } \\
142-04-1\end{array}$ & cristales & 245 & 198 & 526,8 & muy sol & 1,22 & 4,46 & & & 193 & \\
\hline
\end{tabular}




\begin{tabular}{|c|c|c|c|c|c|c|c|c|c|c|c|}
\hline $\begin{array}{l}\text { Denominación química } \\
\mathrm{N} \text { úmero CAS }\end{array}$ & Color/ Forma & $\begin{array}{l}\text { p.e. } \\
\left({ }^{\circ} \mathrm{C}\right)\end{array}$ & $\begin{array}{l}\text { p.f. } \\
(\stackrel{\circ}{ } C)\end{array}$ & $\begin{array}{l}\text { p.m.l } \\
\text { (g/ } \\
\text { mol) }\end{array}$ & $\begin{array}{l}\text { Solubilidad } \\
\text { en agua }\end{array}$ & $\begin{array}{l}\text { Densidad } \\
\text { relativa } \\
\text { (agua }=1 \text { ) }\end{array}$ & $\begin{array}{l}\text { Densidad } \\
\text { de vapor } \\
\text { relativa } \\
\text { (aire=1) }\end{array}$ & $\begin{array}{l}\text { Pvap/ } \\
(\mathrm{kPa})\end{array}$ & $\begin{array}{l}\text { Límit. } \\
\text { inflam. }\end{array}$ & $\begin{array}{l}\text { p.ig. } \\
(\stackrel{\circ}{ } \mathrm{C})\end{array}$ & $\begin{array}{l}\text { p.aut } \\
\text { ig. } \\
\left({ }^{\circ} C\right)\end{array}$ \\
\hline $\begin{array}{l}\text { CLORHIDRATO DE HIDROXILAMINA } \\
5470-11-1\end{array}$ & cristales & & $\begin{array}{l}\text { se } \\
\text { descompone }\end{array}$ & & $\begin{array}{l}83 \mathrm{~g} / 100 \mathrm{ml} \\
\text { @ } 17^{\circ} \mathrm{C}\end{array}$ & 1,7 & & & & & \\
\hline $\begin{array}{l}\text { m-CLOROANILINA } \\
108-42-9\end{array}$ & $\begin{array}{l}\text { líquido incoloro o } \\
\text { ligeramente ámbar }\end{array}$ & 230,5 & -10 & 127,57 & insol & 1,2161 & 4,4 & $9 \mathrm{~Pa}$ & & $118 c c$ & 540 \\
\hline $\begin{array}{l}\text { 0-CLOROANILINA } \\
95.51 .2\end{array}$ & líquido color ámbar & 208,8 & -14 & 127,57 & insol & $\begin{array}{l}1,2114 \\
@ 22^{\circ} \mathrm{C} / 4^{\circ} \mathrm{C}\end{array}$ & 4,41 & 0,05 & & 108 & 500 \\
\hline $\begin{array}{l}p \text {-CLOROANILINA } \\
106-47-8\end{array}$ & $\begin{array}{l}\text { cristales } \\
\text { ortorrómbicos en } \\
\text { alcohol o éter de } \\
\text { petróleo; prismas } \\
\text { rombohédricos; } \\
\text { cristales incoloros }\end{array}$ & 232 & 72,5 & 127,6 & sol & 1,4 & 4,4 & $2 \mathrm{~Pa}$ & $\begin{array}{l}2,2 \mathrm{li} \\
? \text { Is }\end{array}$ & $\begin{array}{l}120 \\
123\end{array}$ & 685 \\
\hline $\begin{array}{l}\text { 4-CLORO-0.FENILENDIAMINA } \\
\text { 95-83-0 }\end{array}$ & & & 76 & 142,6 & lig sol & & & & & & \\
\hline $\begin{array}{l}\text { 2-CLORO-4-NITROANILINA } \\
121-87-9\end{array}$ & $\begin{array}{l}\text { agujas amarillas en } \\
\text { éter de } \\
\text { petróleo-disulfuro de } \\
\text { carbono, agua, ácido } \\
\text { acético al } 20 \%\end{array}$ & & 108 & 172,57 & misc & & & & & & \\
\hline $\begin{array}{l}\text { 5-CLORO-0-TOLUIDINA } \\
\text { 95-79-4 }\end{array}$ & sólido blanco grisáceo & $\begin{array}{l}237 @ \\
722 \mathrm{~mm} \\
\mathrm{Hg}) \\
\end{array}$ & 26 & 141,6 & & & & & & & \\
\hline $\begin{array}{c}\text { p-CRESIDINA } \\
120-71-8\end{array}$ & cristales blancos & 235 & 52 & 137,2 & lig sol & & & $\begin{array}{l}1,02 \times 10^{-2} \\
\mathrm{~mm} \mathrm{Hg} \\
@ 25^{\circ} \mathrm{C}\end{array}$ & & & \\
\hline $\begin{array}{l}\text { 2,4-DIAMINOANISOL } \\
\text { 615-05-4 }\end{array}$ & & & 67,5 & 138,16 & & & & & & & \\
\hline $\begin{array}{l}\text { 3,3'-DIAM INOBENCIDINA } \\
91-95-2\end{array}$ & sólido & & $\begin{array}{l}178 \\
180\end{array}$ & & & & & & & & \\
\hline $\begin{array}{l}\text { 4,4'-DIAMINODIFENILMETANO } \\
\text { 101-77-9 }\end{array}$ & & $398-399$ & 92,5 & 198,25 & lig sol & & & & & & \\
\hline $\begin{array}{l}\text { 2,4-DIAMINOTOLUENO } \\
95-80-7\end{array}$ & $\begin{array}{l}\text { agujas del agua o } \\
\text { cristales en alcohol; } \\
\text { prismas; cristales } \\
\text { incoloros }\end{array}$ & 292 & 99 & 122,2 & muy sol & & 4,2 & $\begin{array}{l}0,13 \\
@ 106,5{ }^{\circ} \mathrm{C}\end{array}$ & & 149 & \\
\hline $\begin{array}{l}\text { 2,6-DIAMINOTOLUENO } \\
823-40-5\end{array}$ & cristales incoloros & 289 & 106 & 122,17 & sol & & & $\begin{array}{l}2,13 \\
@ 150^{\circ} \mathrm{C}\end{array}$ & & & \\
\hline $\begin{array}{l}\text { N,N-DIBUTILANILINA } \\
613-29-6\end{array}$ & líquido color ámbar & $267-275$ & & & insol & 0,904 & & & & 110 & \\
\hline $\begin{array}{l}\text { DICLORHIDRATO DE } \\
\text { 1,4-BENCENDIAMINA } \\
624-18-0\end{array}$ & cristales & & & 181,06 & sol & & 6,2 & & & & \\
\hline $\begin{array}{l}\text { DICLORHIDRATO DE } \\
2,4-\text { DIAMINOFENOL } \\
137-09-7\end{array}$ & $\begin{array}{l}\text { cristales } \\
\text { blanco-grisáceos; } \\
\text { agujas }\end{array}$ & & 205 & 197,08 & muy sol & & & & & & \\
\hline $\begin{array}{l}\text { 2,3-DICLOROANILINA } \\
608-27-5\end{array}$ & $\begin{array}{l}\text { agujas en éter de } \\
\text { petróleo icsc: cristales } \\
\text { incoloros }\end{array}$ & 252 & 24 & 162,02 & insol & & 5,6 & $\begin{array}{l}<0,01 \mathrm{~Pa} \\
@ 25^{\circ} \mathrm{C}\end{array}$ & & $112 c c$ & \\
\hline
\end{tabular}


Tabla 104.32 • Propiedades físicas y químicas.

\begin{tabular}{|c|c|c|c|c|c|c|c|c|c|c|c|}
\hline $\begin{array}{l}\text { Denominación química } \\
\mathrm{N} \text { úmero CAS }\end{array}$ & Color/ Forma & $\begin{array}{l}\text { p.e. } \\
\left({ }^{\circ} \mathrm{C}\right)\end{array}$ & $\begin{array}{l}\text { p.f. } \\
(\underline{O C})\end{array}$ & $\begin{array}{l}\text { p.m.l } \\
\text { (g/ } \\
\text { mol) }\end{array}$ & $\begin{array}{l}\text { Solubilidad } \\
\text { en agua }\end{array}$ & $\begin{array}{l}\text { Densidad } \\
\text { relativa } \\
\text { (agua }=1 \text { ) }\end{array}$ & $\begin{array}{l}\text { Densidad } \\
\text { de vapor } \\
\text { relativa } \\
\text { (aire=1) }\end{array}$ & $\begin{array}{l}\text { Pvap/ } \\
(\mathrm{kPa})\end{array}$ & $\begin{array}{l}\text { Límit. } \\
\text { inflam. }\end{array}$ & $\begin{array}{l}\text { p.ig. } \\
(\stackrel{C}{ })\end{array}$ & $\begin{array}{l}\text { p.aut } \\
\text { ig. } \\
\left({ }^{\circ} \mathrm{C}\right)\end{array}$ \\
\hline $\begin{array}{l}\text { 2,4-DICLOROANILINA } \\
554-00-7\end{array}$ & $\begin{array}{l}\text { prismas en acetona; } \\
\text { agujas en alcohol } \\
\text { diluido o éter de } \\
\text { petróleo }\end{array}$ & 245 & 64 & 162,0 & lig sol & 1,567 & 5,6 & $\begin{array}{l}<1 \mathrm{~Pa} \\
@ 25^{\circ} \mathrm{C}\end{array}$ & & & \\
\hline $\begin{array}{l}2,5 \text {-DICLOROANILINA } \\
95-82-9\end{array}$ & $\begin{array}{l}\text { masa cristalina color } \\
\text { ámbar o ligeramente } \\
\text { marrón; agujas en } \\
\text { éter de petróleo }\end{array}$ & 251 & 50 & 162,0 & lig sol & 1,54 & 5,6 & $\begin{array}{l}<1 \mathrm{~Pa} \\
@ 25^{\circ} \mathrm{C}\end{array}$ & & 139 & 540 \\
\hline $\begin{array}{l}\text { 2,6-DICLOROANILINA } \\
\text { 608-31-1 }\end{array}$ & cristales & 97 & 39 & & insol & & 5,6 & & & & \\
\hline $\begin{array}{l}\text { 3,4-DICLOROANILINA } \\
95-76-1\end{array}$ & $\begin{array}{l}\text { agujas en éter de } \\
\text { petróleo; cristales } \\
\text { finos, ligeramente } \\
\text { pardos }\end{array}$ & 272 & $71-72$ & 162,03 & insol & 1,36 & 5,6 & $2 \mathrm{~Pa}$ & $\begin{array}{l}2,8 \\
@ 152^{\circ} \\
\mathrm{Cli} \\
7,2 \\
@ 179^{\circ} \\
\mathrm{Cls}\end{array}$ & 166 ca & 269 \\
\hline $\begin{array}{l}\text { 3,3'-DICLOROBENCIDINA } \\
91-94-1\end{array}$ & $\begin{array}{l}\text { agujas en alcohol o } \\
\text { benceno; sólido } \\
\text { cristalino gris o } \\
\text { violeta. }\end{array}$ & 402 & $\begin{array}{l}132- \\
133\end{array}$ & 253,13 & insol & & & $6 \times 10^{-7} \mathrm{~Pa}$ & & & 350 \\
\hline $\begin{array}{l}\text { M-DIETILAMINOFENOL } \\
91-68.9\end{array}$ & $\begin{array}{l}\text { sólido cristalino } \\
\text { blanco }\end{array}$ & $276-280$ & 78 & 165,23 & sol & & & & & & \\
\hline $\begin{array}{l}\text { N,N-DIETILANILINA } \\
91.66-7\end{array}$ & $\begin{array}{l}\text { líquido incoloro o } \\
\text { amarillento; líquido } \\
\text { aceitoso marrón }\end{array}$ & 216 & -38 & 149,23 & lig sol & 0,9307 & 1,0 & & & & \\
\hline $\begin{array}{l}\text { DIFENILAMINA } \\
\text { 122-39-4 }\end{array}$ & $\begin{array}{l}\text { laminillas } \\
\text { monoclínicas en } \\
\text { alcohol diluido; } \\
\text { cristales; sólido o } \\
\text { líquido de color entre } \\
\text { ámbar muy claro y } \\
\text { marrón }\end{array}$ & 302 & 53 & 169,2 & insol & 1,16 & 5,82 & $\begin{array}{l}133 \mathrm{~Pa} \\
\text { @ } 108^{\circ} \mathrm{C}\end{array}$ & & $153 \mathrm{ca}$ & 634 \\
\hline $\begin{array}{l}\text { N,N'-DIFENIL-PFENILENDIAMINA } \\
74-31-7\end{array}$ & $\begin{array}{l}\text { laminillas incoloras en } \\
\text { alcohol; la calidad } \\
\text { comercial es } \\
\text { marrón-verdosa; polvo } \\
\text { gris }\end{array}$ & $\begin{array}{l}220-225 \\
@ \\
0,5 \mathrm{~mm} \mathrm{H} \\
g\end{array}$ & 150- 151 & 260,32 & insol & 1,20 & 9,0 & & & & \\
\hline $\begin{array}{l}\text { 1,3-DIFENILGUANIDINA } \\
102-06-7\end{array}$ & $\begin{array}{l}\text { agujas monoclínicas; } \\
\text { polvo blanco }\end{array}$ & $170 \mathrm{D}$ & 150 & 211,3 & lig sol & 1,13 & & & & & \\
\hline $\begin{array}{l}\text { DIMETILAMINOAZOBENCENO } \\
60-11-7\end{array}$ & $\begin{array}{l}\text { laminillas cristalinas } \\
\text { amarillas }\end{array}$ & $\begin{array}{l}\text { se } \\
\text { descompo } \\
\text { ne }\end{array}$ & $\begin{array}{l}114- \\
117\end{array}$ & 225,28 & $13,6 \mathrm{ppm}$ & & & $\begin{array}{l}3,3 \times 10^{-7} \\
\mathrm{~mm} \mathrm{Hg} \\
\text { (est). }\end{array}$ & & & \\
\hline $\begin{array}{l}\text { DIMETILANILINA } \\
121-69-7\end{array}$ & $\begin{array}{l}\text { líquido oleoso de } \\
\text { color amarillo pálido }\end{array}$ & 194 & 2,5 & 121,2 & lig sol & 0,956 & 4,17 & $67 \mathrm{~Pa}$ & & 62 & 371 \\
\hline $\begin{array}{l}\text { N,N-DIMETIL-p-TOLUIDINA } \\
\text { 99-97-8 }\end{array}$ & líquido & 211 & & 135,20 & insol & 0,9366 & 4,7 & 0,02 & $\begin{array}{l}1,2 \mathrm{li} \\
7 \mathrm{ls}\end{array}$ & 83 & \\
\hline $\begin{array}{l}\text { 2,4-DINITROANILINA } \\
\text { 97-02-9 }\end{array}$ & $\begin{array}{l}\text { agujas amarillas en } \\
\text { acetona } \\
\text { diluida, placas } \\
\text { amarillo verdosas en } \\
\text { alcohol. }\end{array}$ & 56,7 & 188 & 183,12 & insol & $\begin{array}{l}1,615 \mathrm{~g} / \mathrm{ml} \\
@ 14{ }^{\circ} \mathrm{C}\end{array}$ & 6,31 & $\begin{array}{l}5,94 \times 10^{-7} \\
\mathrm{~mm} \mathrm{Hg} \\
\text { @ } 25^{\circ} \mathrm{C}\end{array}$ & & $224 \mathrm{cc}$ & \\
\hline
\end{tabular}




\begin{tabular}{|c|c|c|c|c|c|c|c|c|c|c|}
\hline $\begin{array}{l}\text { Denominación química } \\
\mathrm{N} \text { úmero CAS }\end{array}$ & Color/ Forma & $\begin{array}{l}\text { p.e. } \\
\left({ }^{\circ} \mathrm{C}\right)\end{array}$ & $\begin{array}{l}\text { p.f. } \\
(\stackrel{\circ}{ } \mathrm{C})\end{array}$ & $\begin{array}{l}\mathrm{p} . \mathrm{m} . / \\
\text { (g/ } \\
\mathrm{mol})\end{array}$ & $\begin{array}{l}\text { Solubilidad } \\
\text { en agua }\end{array}$ & $\begin{array}{l}\text { Densidad } \\
\text { relativa } \\
\text { (agua }=1 \text { ) }\end{array}$ & $\begin{array}{l}\text { Densidad } \\
\text { de vapor } \\
\text { relativa } \\
\text { (aire=1) }\end{array}$ & $\begin{array}{l}\text { Pvap/ } \\
(\mathrm{kPa})\end{array}$ & $\begin{array}{l}\text { Límit. } \\
\text { inflam. }\end{array}$ & $\begin{array}{ll}\text { p.ig. p.aut } \\
\left({ }^{\circ} \mathrm{C}\right) & \text { ig. } \\
& \left({ }^{\circ} \mathrm{C}\right)\end{array}$ \\
\hline $\begin{array}{l}\text { N-ETILANILINA } \\
\text { 103-69-5 }\end{array}$ & $\begin{array}{l}\text { líquido incoloro; } \\
\text { aceite transparente } \\
\text { de color entre } \\
\text { amarillo marronáceo } \\
\text { y pajizo }\end{array}$ & 204,5 & $.63,5$ & 121,2 & insol & 0,9625 & 4,2 & $\begin{array}{l}1 \mathrm{~mm} \mathrm{Hg} \\
@ 38,5^{\circ} \mathrm{C}\end{array}$ & & \\
\hline $\begin{array}{l}\text { m.FENILENBIS(METILAMINA) } \\
\text { 1477-55-0 }\end{array}$ & líquido incoloro & 247 & & 136,2 & muy sol & 1,052 & & $\begin{array}{l}0,03 \mathrm{~mm} \\
\mathrm{Hg} \\
@ 25^{\circ} \mathrm{C}\end{array}$ & & \\
\hline $\begin{array}{l}\text { m-FENILENDIAMINA } \\
108-45-2\end{array}$ & $\begin{array}{l}\text { cristales blancos que } \\
\text { se tornan rojos en } \\
\text { contacto con el aire; } \\
\text { agujas incoloras; } \\
\text { cristales rómbicos en } \\
\text { alcohol; agujas } \\
\text { rómbicas incoloras }\end{array}$ & 285 & 63,5 & 108,14 & muy sol & 1,139 & $\begin{array}{l}1,1309 \\
@ 50 C\end{array}$ & $\begin{array}{l}<1 \mathrm{~mm} \mathrm{Hg} \\
\text { @ } 99,8^{\circ} \mathrm{C}\end{array}$ & & \\
\hline $\begin{array}{l}\text { 0-FENILENDIAMINA } \\
\quad 95.54 .5\end{array}$ & $\begin{array}{l}\text { láminas de color } \\
\text { amarillo-marrón en } \\
\text { agua; placas en } \\
\text { cloroformo }\end{array}$ & 257 & 103 & 108,14 & sol & & & & $\begin{array}{l}1,5 \mathrm{li} \\
? \text { ls }\end{array}$ & \\
\hline $\begin{array}{l}\text { p-FENILENDIAMINA } \\
106-50-3\end{array}$ & $\begin{array}{l}\text { cristales blancos o } \\
\text { ligeramente rojizos; } \\
\text { placas blancas en } \\
\text { benceno o éter }\end{array}$ & 267 & 146 & 108,14 & lig sol & 1,14 & 3,72 & $\begin{array}{l}<1 \mathrm{~mm} @ \\
21^{\circ} \mathrm{C}\end{array}$ & $\begin{array}{l}1,5 \mathrm{li} \\
? \text { Is }\end{array}$ & 156 \\
\hline $\begin{array}{l}\text { N-FENILETANOLAMINA } \\
122-98.5\end{array}$ & & 286 & & 137,17 & lig sol & 1,0945 & & & & \\
\hline $\begin{array}{l}\text { N-FENIL-1-NAFTILAMINA } \\
90-30-2\end{array}$ & polvo & 335 & 62 & 219,27 & lig sol & 1,2 & & & & \\
\hline $\begin{array}{l}\text { N-FENIL-NAFTILAMINA } \\
\text { 135-88-6 }\end{array}$ & $\begin{array}{l}\text { agujas en metanol; } \\
\text { cristales blancos o } \\
\text { amarillentos; escamas } \\
\text { o polvo de color gris } \\
\text { o pardo }\end{array}$ & 395,5 & 108 & 219,29 & insol & 1,24 & & & & \\
\hline $\begin{array}{l}\text { HIDROXILAMINA } \\
7803-49-8\end{array}$ & $\begin{array}{l}\text { escamas grandes o } \\
\text { agujas de color } \\
\text { blanco; líquido } \\
\text { incoloro }\end{array}$ & $\begin{array}{l}56,5 \\
@ 22 \mathrm{~mm} \\
\mathrm{Hg}\end{array}$ & 32,05 & 33,04 & muy sol & $\begin{array}{l}1,2255 \\
@ 0^{\circ} \mathrm{C} / 4^{\circ} \mathrm{C}\end{array}$ & & & & \\
\hline $\begin{array}{l}\text { N-ISOPROPILANILINA } \\
768-52.5\end{array}$ & líquido amarillento & 203 & & 135,2 & insol & $0,952625^{\circ} \mathrm{C}$ & & & & 878 \\
\hline $\begin{array}{l}\text { N-ISOPROPIL-N'FENIL- } \\
\text { p-FENILENDIAMINA } \\
101-72-4\end{array}$ & $\begin{array}{l}\text { escamas de color gris } \\
\text { oscuro o negro }\end{array}$ & & 72,5 & 226,3 & insol & $1,04 @ 25^{\circ} \mathrm{C}$ & & & & \\
\hline $\begin{array}{c}\text { MELAMINA } \\
108-78-1 \\
\end{array}$ & $\begin{array}{l}\text { prismas monoclínicos; } \\
\text { incoloros; blancos }\end{array}$ & & & 126,13 & lig sol & $1,573 @ 14{ }^{\circ} \mathrm{C}$ & 4,34 & $\begin{array}{l}50 \mathrm{~mm} \mathrm{Hg} \\
\text { @ } 315^{\circ} \mathrm{C} \\
\end{array}$ & & \\
\hline $\begin{array}{l}\text { P-METILAMINOFENOL } \\
\text { 150-75-4 }\end{array}$ & agujas incoloras & & 87 & 123,17 & sol & & & $\begin{array}{l}5,77 \times 10^{-2} \\
\mathrm{~mm} \mathrm{Hg} \\
\text { @ } 25^{\circ} \mathrm{C} \\
\end{array}$ & & \\
\hline $\begin{array}{l}\text { METILANILINA } \\
100-61-8\end{array}$ & $\begin{array}{l}\text { líquido aceitoso entre } \\
\text { incoloro y } \\
\text { marrón-rojizo }\end{array}$ & 196 & -57 & 107,15 & insol & 0,989 & 3,70 & $\begin{array}{l}133 \mathrm{~Pa} \\
@ 36^{\circ} \mathrm{C}\end{array}$ & & $795 \mathrm{cc}$ \\
\hline
\end{tabular}


Tabla 104.32 • Propiedades físicas y químicas.

\begin{tabular}{|c|c|c|c|c|c|c|c|c|c|}
\hline $\begin{array}{l}\text { Denominación química } \\
\mathrm{N} \text { úmero CAS }\end{array}$ & Color/ Forma & $\begin{array}{l}\text { p.e. } \\
\left({ }^{\circ} C\right)\end{array}$ & $\begin{array}{l}\text { p.f. } \\
\left({ }^{\circ} C\right)\end{array}$ & $\begin{array}{l}\text { p.m.l } \\
\text { (g/ } \\
\text { mol) }\end{array}$ & $\begin{array}{l}\text { Solubilidad } \\
\text { en agua }\end{array}$ & $\begin{array}{l}\text { Densidad } \\
\text { relativa } \\
\text { (agua }=1 \text { ) }\end{array}$ & $\begin{array}{l}\text { Densidad } \\
\text { de vapor } \\
\text { relativa } \\
\text { (aire=1) }\end{array}$ & $\begin{array}{l}\text { Pvap/ } \\
(\mathrm{kPa})\end{array}$ & $\begin{array}{l}\text { Límit. p.ig. } \\
\text { inflam. (으) }\end{array}$ \\
\hline $\begin{array}{l}\text { 4,4'-METILEN BIS(2-CLOROANILINA) } \\
\text { 101-14-4 }\end{array}$ & $\begin{array}{l}\text { gránulos de color } \\
\text { pardo }\end{array}$ & & 110 & 267,15 & insol & 1,44 & & $\begin{array}{l}1,3 \times 10^{-3} \\
\text { torr } \\
@ 60^{\circ} \mathrm{C}\end{array}$ & \\
\hline
\end{tabular}

\begin{tabular}{|c|c|c|c|c|c|c|c|c|c|}
\hline $\begin{array}{l}\text { 1,5-NAFTALENDIAMINA } \\
\text { 2243-62-1 }\end{array}$ & cristales incoloros & sublima & 190 & 158,2 & lig sol & 1,4 & & & \\
\hline $\begin{array}{l}\text { N,N'-DI-2-NAFTIL- } \\
\text { p-FENILENDIAMINA } \\
93-46-9\end{array}$ & & & 235 & 360,43 & & & & & \\
\hline $\begin{array}{c}\alpha \text {-NAFTILAMINA } \\
134-32.7\end{array}$ & $\begin{array}{l}\text { agujas en etanol } \\
\text { dilluido y éter; agujas } \\
\text { rómbicas amarillas; } \\
\text { cristales blancos; } \\
\text { agujas que viran a } \\
\text { rojo al exponerse al } \\
\text { aire o masa cristalina } \\
\text { rojiza }\end{array}$ & 300,8 & 50 & 143,18 & lig sol & 1,0228 & 4,93 & $\begin{array}{l}1 \mathrm{~mm} \mathrm{Hg} \\
@ 104,3^{\circ} \mathrm{C}\end{array}$ & $157 \mathrm{CC}$ \\
\hline $\begin{array}{l}\begin{array}{l}\beta \text {-NAFTILAMINA } \\
91.59-8\end{array}\end{array}$ & $\begin{array}{l}\text { cristales incoloros que } \\
\text { se tornan de un color } \\
\text { púrpura-rojizo en } \\
\text { contacto con el aire }\end{array}$ & 306 & 113 & 143,18 & sol & $\begin{array}{l}1,061 \\
@ 98^{\circ} \mathrm{C} / 4^{\circ} \mathrm{C}\end{array}$ & 4,95 & $\begin{array}{l}1 \mathrm{~mm} \mathrm{Hg} \\
@ 108,0^{\circ} \mathrm{C}\end{array}$ & 157 \\
\hline
\end{tabular}

\begin{tabular}{|c|c|c|c|c|c|c|c|c|c|c|}
\hline $\begin{array}{l}\text { NITRITO DE DICICLOHEXILAMINA } \\
3129.91 .7\end{array}$ & & & & 228,32 & & & & & & \\
\hline $\begin{array}{l}\text { m-NITROANILINA } \\
\text { 99-09-2 }\end{array}$ & $\begin{array}{l}\text { cristales amarillos en } \\
\text { agua; agujas } \\
\text { rómbicas amarillas }\end{array}$ & 306 & 114 & 138,1 & lig sol & $\begin{array}{l}0,9011 \\
@ 25^{\circ} \mathrm{C} / 4^{\circ} \mathrm{C}\end{array}$ & & $\begin{array}{l}0,005 \mathrm{~Pa} \\
@ 25^{\circ} \mathrm{C}\end{array}$ & & \\
\hline $\begin{array}{l}\text { O-NITROANILINA } \\
88-74-4\end{array}$ & $\begin{array}{l}\text { cristales de color } \\
\text { amarillo-naranja en } \\
\text { agua hirviendo; } \\
\text { placas o agujas; } \\
\text { sólido naranja }\end{array}$ & 284 & 71 & 138,1 & lig sol & $\begin{array}{l}0,9015 \\
@ 25^{\circ} \mathrm{C} / 4^{\circ} \mathrm{C}\end{array}$ & & $\begin{array}{l}133 \mathrm{~Pa} \\
\text { @ } 104{ }^{\circ} \mathrm{C}\end{array}$ & 168 & 521 \\
\hline $\begin{array}{l}\text { p-NITROANILINA } \\
\text { 100-01-6 }\end{array}$ & $\begin{array}{l}\text { agujas monoclínicas } \\
\text { amarillas; polvo } \\
\text { amarillo brillante }\end{array}$ & 332 & 146 & 138,12 & $1 \mathrm{~g} / 1250 \mathrm{ml}$ & 1,424 & 4,77 & $0,2 \mathrm{~Pa}$ & 199 & 180 \\
\hline $\begin{array}{l}\text { 4,4'-OXIDIANILINA } \\
\text { 101-80-4 }\end{array}$ & cristales incoloros & 300 & $\begin{array}{l}186- \\
187\end{array}$ & 200,2 & insol & & & $\begin{array}{l}3,07 \times 10^{-7} \\
\mathrm{~mm} \mathrm{Hg} \\
\text { @ } 25^{\circ} \mathrm{C}\end{array}$ & & \\
\hline $\begin{array}{l}\text { SULFATO DE HIDROXILAMINA } \\
10039-54-0\end{array}$ & cristales incoloros & & 177 & & sol & & & & & \\
\hline $\begin{array}{l}\text { 0-TOLIDINA } \\
\text { 119-93-7 }\end{array}$ & $\begin{array}{l}\text { cristales o polvo } \\
\text { cristalino de color } \\
\text { blanco o rojizo }\end{array}$ & 300 & 131,5 & 212,28 & lig sol & 1 & & & & \\
\hline $\begin{array}{c}\text { m-TOLUIDINA } \\
\text { 108-44-1 }\end{array}$ & líquido incoloro & 203 & $-30,4$ & 107,15 & lig sol & 0,9889 & 3,90 & $\begin{array}{l}1 \mathrm{~mm} \mathrm{Hg} \\
@ 41^{\circ} \mathrm{C}\end{array}$ & 861 & \\
\hline $\begin{array}{l}\text { 0-TOLUIDINA } \\
\text { 95-53-4 }\end{array}$ & $\begin{array}{l}\text { líquido amarillo pálido } \\
\text { que se torna marrón } \\
\text { rojizo al exponerse al } \\
\text { aire y a la luz; líquido } \\
\text { incoloro }\end{array}$ & 200,2 & $\begin{array}{l}-14,7- \\
-16,3\end{array}$ & 107,15 & lig sol & 1,008 & 3,69 & 0,32 torr & & \\
\hline
\end{tabular}




\begin{tabular}{|c|c|c|c|c|c|c|c|c|c|c|c|}
\hline $\begin{array}{l}\text { Denominación química } \\
\mathrm{N} \text { úmero CAS }\end{array}$ & Color/ Forma & $\begin{array}{l}\text { p.e. } \\
(\stackrel{\circ}{ } \mathrm{C})\end{array}$ & $\begin{array}{l}\text { p.f. } \\
(\stackrel{O}{ } \mathrm{C})\end{array}$ & $\begin{array}{l}\mathrm{p} . \mathrm{m} . / \\
\text { (g/ } \\
\mathrm{mol})\end{array}$ & $\begin{array}{l}\text { Solubilidad } \\
\text { en agua }\end{array}$ & $\begin{array}{l}\text { Densidad } \\
\text { relativa } \\
\text { (agua }=1 \text { ) }\end{array}$ & $\begin{array}{l}\text { Densidad } \\
\text { de vapor } \\
\text { relativa } \\
\text { (aire=1) }\end{array}$ & $\begin{array}{l}\text { Pvap/ } \\
(\mathrm{kPa})\end{array}$ & $\begin{array}{l}\text { Límit. } \\
\text { inflam. }\end{array}$ & $\begin{array}{l}\text { p.ig. } \\
(\stackrel{\circ}{ } \mathrm{C})\end{array}$ & $\begin{array}{l}\text { p.aut } \\
\text { ig. } \\
(\stackrel{\circ}{\circ})\end{array}$ \\
\hline $\begin{array}{l}\text { p-TOLUIDINA } \\
106-49-0\end{array}$ & $\begin{array}{l}\text { placas o laminillas } \\
\text { brillantes; sólido } \\
\text { blanco; laminillas } \\
\text { incoloras }\end{array}$ & 200,5 & 44 & 107,15 & lig sol & 1,046 & 3,9 & 0,34 torr & & & \\
\hline $\begin{array}{l}\text { TRIFENILAMINA } \\
603-34-9\end{array}$ & $\begin{array}{l}\text { cristales monoclínicos } \\
\text { en metanol, } \\
\text { etilacetato o benceno; } \\
\text { incoloros }\end{array}$ & 365 & 127 & 245,3 & insol & $\begin{array}{l}0,774 \\
000^{\circ} \mathrm{C} / 0^{\circ} \mathrm{C}\end{array}$ & & & & & \\
\hline $\begin{array}{l}\text { 2,4,5-TRIMETILANILINA } \\
\text { 137-17-7 }\end{array}$ & $\begin{array}{l}\text { cristales blancos; } \\
\text { agujas obtenidas con } \\
\text { agua como disolvente }\end{array}$ & 235 & 68 & 135,2 & insol & $0,957 @ 25^{\circ} \mathrm{C}$ & & & & & \\
\hline $\begin{array}{l}\text { XILIDINA } \\
1300-73-8\end{array}$ & $\begin{array}{l}\text { existe en } 6 \text { formas } \\
\text { isoméricas que van } \\
\text { desde un líquido } \\
\text { amarillo pálido a } \\
\text { marrón; todos los } \\
\text { isómeros, con } \\
\text { excepción del la } \\
\text { orto-4-xilidina, son } \\
\text { líquidos por encima } \\
\text { de los } 27^{\circ} \mathrm{C}\end{array}$ & $213-226$ & $\begin{array}{l}-15- \\
+51\end{array}$ & 121,18 & lig sol & $0,97-0,99$ & 4,17 & $20 \mathrm{~Pa}$ & $\begin{array}{l}1 \mathrm{li} \\
7 \mathrm{is}\end{array}$ & 91 & 405 \\
\hline $\begin{array}{c}2,3-X \mid L I D I N A \\
87-59-2 \\
\end{array}$ & líquido & 221,5 & -15 & 121,2 & lig sol & 0,9931 & & $\begin{array}{l}0,1 \mathrm{~mm} \mathrm{Hg} \\
@ 25^{\circ} \mathrm{C}\end{array}$ & $\begin{array}{l}1,0 \mathrm{li} \\
? \mathrm{ls} \\
\end{array}$ & $97 \mathrm{cc}$ & \\
\hline $\begin{array}{l}2,4-X \mid \text { XIIDINA } \\
95-68-1\end{array}$ & líquido incoloro & 214 & $-14,3$ & 121,2 & lig sol & 0,9723 & & $\begin{array}{l}1 \mathrm{~mm} \mathrm{Hg} \\
@ 52,6^{\circ} \mathrm{C}\end{array}$ & & & \\
\hline $\begin{array}{l}\text { 3,4-XILIDINA } \\
95-64-7\end{array}$ & $\begin{array}{l}\text { placas prismáticas en } \\
\text { éter de petróleo }\end{array}$ & 226 & 51 & 121,2 & lig sol & $1,076 @ 18{ }^{\circ} \mathrm{C}$ & & & & & \\
\hline
\end{tabular}

Continua ... 


\section{AZIDAS}

\section{Usos}

Las azidas tienen diversos usos en las industrias de productos químicos, colorantes, plásticos, caucho y metales. $V$ arios de estos compuestos se utilizan para el tratamiento de aguas residuales y como productos químicos intermedios, aditivos alimentarios y agentes desinfectantes en detergentes para lavavajillas y piscinas.

La 1,1'-azobis(formamida) es un agente de soplado para el caucho sintético y natural y para los polímeros de acetato de etilen vinilo. También es útil como agente espumante y como aditivo para aumentar la porosidad de los plásticos. El ácido tricloro isocianúrico y el dicloroisocianurato sódico se utilizan como agentes desinfectantes para piscinas y como principios activos de detergentes, lejías de uso comercial y doméstico y compuestos para lavavajillas. El dicloroisocianurato sódico se utiliza también para el tratamiento del agua y de las aguas residuales.

El ácido edético (EDTA) tiene un gran número de funciones en las industrias alimentaria, química, textil, metalúrgica, fotográfica y sanitaria. Es un antioxidante que se añade a los alimentos. El EDTA se utiliza como agente quelante para eliminar los iones metálicos no deseados en el agua de las calderas y de refrigeración y en los procesos de niquelado y de obtención de pulpa de papel. T ambién se emplea como decolorante en el procesado de películas en la industria fotográfica, como mordiente para los acabados metálicos y como agente de tinción en la industria textil. EI EDTA se encuentra en detergentes para ropa, germicidas industriales, fluidos de corte, en la producción de semiconductores, jabones líquidos, champús, productos farmacéuticos y cosméticos. T ambién se emplea en medicina para tratar la intoxicación por plomo.

La fenilhidracina, el aminoazotolueno y la hidracina se utilizan en la industria de los colorantes. La fenilhidracina se utiliza también en la preparación de productos farmacéuticos. La hidracina es un reactivo utilizado en las células de combustible para uso militar y un agente reductor en la extracción del plutonio de los residuos de los reactores. Se utiliza en procesos de niquelado, tratamiento de aguas residuales, galvanoplastia de metales sobre vidrio y plásticos, reciclaje de combustibles nucleares y como componente de combustibles de alta energía. Es un inhibidor de la corrosión en el agua de las calderas y el agua de refrigeración de los reactores. T ambién es un producto químico intermedio y un propelente de cohetes. El diazometano es un potente agente metilante para los compuestos ácidos, como los ácidos carboxílicos y los fenoles.

La azida sódica se utiliza en la síntesis orgánica, en la fabricación de explosivos y como propelente en los airbags de los automóviles. El ácido hidrazoico se emplea para fabricar explosivos de contacto, como la azida de plomo.

0 tras azidas, como la metilhidracina, el hidrazobenceno, la 1,1-dime tilhidracina, el sulfato de hidracina y el diazometano, se utilizan en numerosas industrias. La metilhidracina es un disolvente, un producto químico intermedio y un propelente de misiles, mientras que el hidrazobenceno es un producto químico intermedio y un aditivo para evitar la formación de sedimentos en los aceites para motores. La 1,1-dimetilhidracina se utiliza en las formulaciones de combustibles para cohetes. Es un estabilizante de los peróxidos orgánicos añadidos a los combustibles, un absorbente de gases ácidos y un componente de los combustibles de aviones de reacción. El sulfato de hidracina se utiliza para el cálculo gravimétrico de níquel, cobalto y cadmio como oxidante en los fundentes para soldar metales ligeros, como germicida y como agente reductor en el análisis de minerales y escorias.

\section{Riesgos}

\section{Diazometano}

R iesgo de incendio y explosión. En estado líquido o gaseoso, el diazometano explota con llamarada y el líquido puede detonar incluso a $-80^{\circ} \mathrm{C}$. Sin embargo, estas explosiones no se producen cuando el diazometano se prepara y se conserva en disolventes como el éter etílico.

Riesgos para la salud. Este compuesto fue descrito por primera vez en el año 1894 por Von Pechmann, quien indicó que era sumamente tóxico y que causaba axfisia y dolor torácico. Posteriormente, otros investigadores observaron síntomas de mareo y zumbidos. Se vio que la exposición cutánea al diazometano producía descamación de la piel y las mucosas y que su efecto era similar al del sulfatodimetilo. T ambién se observó que los vapores de la solución del gas en éter eran irritantes para la piel y dejaban los dedos tan sensibles que era difícil hasta agarrar un alfiler. En 1930, la exposición de dos personas provocó dolor torácico, fiebre y síntomas asmáticos graves aproximadamente 5 horas después de la exposición a sólo trazas de este gas.

Es posible que la primera exposición al gas no produzca reacciones iniciales importantes. No obstante, las siguientes exposiciones, incluso a cantidades mínimas, pueden producir crisis asmáticas sumamente graves y otros síntomas. Los síntomas pulmonares se explicarían bien como resultado de una sensibilidad alérgica real tras la exposición reiterada al gas, especialmente en las personas con alergia hereditaria o bien como consecuencia de una potente acción irritante del gas sobre las mucosas.

Se han descrito al menos 16 casos de intoxicación aguda por diazometano, incluidas muertes por edema pulmonar, en químicos y trabajadores de laboratorio. En todos los casos, los síntomas de la intoxicación fueron tos irritativa, fiebre y malestar de intensidad variable dependiendo del grado y la duración de la exposición. En algunos casos, las exposiciones posteriores provocaron una reacción de hipersensibilidad.

En animales, la exposición a 175 ppm de diazometano durante 10 minutos produjo enfisema hemorrágico y edema pulmonar en gatos, provocando la muerte en 3 días.

T oxicidad. La toxicidad del diazometano se ha atribuido a la formación intracelular de formaldehído. El diazometano reacciona lentamente con el agua formando alcohol metílico y liberando nitrógeno. El formaldehído, en cambio, se forma por oxidación del alcohol metílico. $\mathrm{H}$ ay que tener en cuenta la posibilidad de liberación in vivo de alcohol metílico o de reacción del diazometano con compuestos carboxílicos para formar ésteres metílicos tóxicos; por otra parte, los efectos nocivos del diazometano pueden deberse principalmente a la fuerte acción irritante de este gas sobre el aparato respiratorio.

Se ha demostrado que el diazometano es un carcinógeno pulmonar en ratones y ratas. También se ha demostrado que la aplicación en la piel y la inyección subcutánea, así como la inhalación de este compuesto, favorecen el desarrollo de tumores en animales de experimentación. Los estudios en bacterias han demostrado efectos mutagénicos. No obstante, la A gencia Internacional para la Investigación sobre el Cáncer (IARC) lo ha colocado en el Grupo 3, es decir, inclasificable como carcinógeno humano. 
El diazometano es un insecticida eficaz para el control químico de las plagas por T riatoma. T ambién resulta útil como algicida. Cuando el componente ictiotóxico de las algas verdes Chaetomorpha minima se metila con diazometano, se obtiene un sólido que conserva su toxicidad letal para los peces. R esulta significativo que en el metabolismo de los cancerígenos dimetilnitrosamina y circasina, uno de los productos intermedios sea el diazometano.

\section{Hidracina y sus derivados}

La posibilidad de inflamación, explosión y toxicidad son los principales riesgos de las hidracinas. Por ejemplo, cuando la hidracina se mezcla con nitrometano, se forma un potente explosivo que es más peligroso que el TNT. Todas las hidracinas que se mencionan aquí tienen una presión de vapor suficientemente alta como para representar un riesgo grave para la salud por inhalación. Estos compuestos tienen un olor amoniacal, similar al del pescado, que resulta repulsivo e indica la presencia de concentraciones peligrosas en los casos de exposición accidental breve. A bajas concentraciones, como las que pueden producirse durante los procesos de producción o transporte, el olor puede no ser suficiente para impedir la exposición profesional crónica a concentraciones bajas en las personas que manipulan combustibles.

Las concentraciones moderadas 0 altas de vapores de hidracina son muy irritantes para los ojos, la nariz y el aparato respiratorio. Con las hidracinas utilizadas como propelentes, la irritación de la piel es importante y el contacto directo con el líquido produce quemaduras e incluso un tipo de dermatitis por sensibilización, sobre todo en el caso de la fenilhidracina. Las salpicaduras en los ojos producen una intensa irritación y la hidracina puede causar lesiones permanentes en la córnea.

Además de sus propiedades irritantes, las hidracinas también producen efectos sistémicos pronunciados sea cual sea la vía de absorción. Después de la inhalación, la absorción a través de la piel es la vía de intoxicación más importante. Todas las hidracinas son de moderadas a muy tóxicas para el sistema nervioso central y producen temblores, aumento de la excitabilidad del sistema nervioso central y, en dosis suficientemente altas, convulsiones. Estos síntomas pueden progresar hasta producir depresión, parada respiratoria y muerte. Otros efectos sistémicos producidos por las hidracinas son las alteraciones del sistema hematopoyético, el hígado y los riñones. Cada hidracina varía considerablemene en su grado de toxicidad sistémica, así como con respecto a los órganos afectados por ellas.

Los efectos hematológicos se explican por sí mismos sobre la base de una actividad hemolítica. Estos efectos dependen de la dosis y, con la única excepción de la monometilhidracina, son los más llamativos en los casos de intoxicación crónica. Con la fenilhidracina se producen alteraciones hiperplásicas de la médula ósea y también se ha observado hematopoyesis extramedular. La monometilhidracina es un potente formador de metahemoglobina y se eliminan pigmentos sanguíneos en la orina. Las alteraciones hepáticas son principalmente del tipo de degeneración grasa, que rara vez progresa a necrosis y, generalmente, son reversibles cuando se trata de las hidracinas de los propelentes. La monometilhidracina y la fenilhidracina, en dosis elevadas, pueden causar graves lesiones renales. Las lesiones del músculo cardíaco son principalmente de carácter graso. Las náuseas observadas con todas estas hidracinas son de origen central y refractarias a todo tipo de tratamiento. Los convulsivos más potentes de esta serie son la monometilhidracina y la 1,1-dimetilhidracina. La hidracina produce principalmente depresión $y$, con mucha menor frecuencia, convulsiones.

T odas las hidracinas parecen ejercer algún tipo de efecto oncogénico en una u otra especie de animales de laboratorio y por una u otra vía de entrada (administración con el agua de beber, sonda gástrica 0 inhalación). La IARC las clasifica en el Grupo 2B, como posibles carcinógenos humanos. En los animales de laboratorio, con la excepción de un derivado que no se trata aquí, la 1,2-dimetilhidracina (o dimetilhidracina simétrica), existe una clara relación dosis-respuesta. La clasificación de estas sustancias en el grupo 2B obliga a reducir al mínimo cualquier exposición humana mediante el uso de equipos protectores aducados y la descontaminación de derrames accidentales.

\section{Fenilhidracina}

La patología debida a la fenilhidracina se ha estudiado por medio de experimentos con animales y observaciones clínicas. La información sobre los efectos de la fenilhidracina en el hombre se ha obtenido a partir del uso del clorhidrato de fenilhidracina con fines terapeúticos. Los efectos observados fueron anemia hemolítica, con hiperbilirrubinemia y urobilinuria, aparición de cuerpos de $\mathrm{H}$ einz, lesiones hepáticas con hepatomegalia, ictericia y orina muy oscura por contener fenoles y también, en ocasiones, manifestaciones renales. Los efectos hematológicos fueron cianosis, anemia hemolítica con metahemoglobinemia y leucocitosis. LoS síntomas generales más frecuentes fueron fatiga, vahídos, diarrea y disminución de la presión sanguínea. En un estudiante que recibió 300 g de esta sustancia en el abdomen y los muslos, se observó colapso cardíaco y coma durante varias horas. Las personas con deficiencia hereditaria de glucosa-6-fosfato deshidrogenasa (G 6PDH ) son mucho más sensibles a los efectos hemolíticos de la fenilhidracina y deben evitar la exposición a esta sustancia.

En lo que se refiere a las lesiones cutáneas, se ha descrito eczema agudo con erupción vesicular y eczema crónico en las manos y los antebrazos de los trabajadores que fabrican antipirina. T ambién se describió un caso de dermatosis vesicular con producción de flictenas en las muñecas de un auxiliar químico. La dermatosis apareció 5 ó 6 horas después de manipular el producto y tardó 2 semanas en curarse. Un ingeniero químico que manipuló esta sustancia presentó únicamente algunas pequeñas pústulas, que desaparecieron en 2 ó 3 días. Por tanto, se considera que la fenilhidracina es un potente sensibilizante cutáneo. Se absorbe muy rápidamente a través de la piel.

A la vista de los informes publicados sobre los efectos carcinogénicos de la fenilhidracina en ratones, el National Institute of $\mathrm{O}$ ccupational Safety and $\mathrm{H}$ ealth (NIOSH) ha recomendado que se regule como un carcinógeno humano. V arios estudios en bacterias y cultivos tisulares han demostrado que es mutagénica. La inyección intraperitoneal en hembras preñadas de ratón provocó ictericia grave, anemia y deficiencias en la conducta adquirida en las crías.

\section{Azida sódica y ácido hidrazoico}

La azida sódica se obtiene combinando sodamida con óxido nitroso. Reacciona con el agua produciendo ácido hidrazoico, por lo que pueden existir vapores de ácido hidrazoico cuando se manipula la azida sódica. A escala comercial, el ácido hidrazoico se obtiene mediante reacción de un ácido con azida sódica.

La toxicidad aguda de la azida sódica parece ser ligeramente menor que la del cianuro sódico. La absorción por vía respiratoria, digestiva o percutánea puede causar la muerte. EI contacto con esta sustancia produce quemaduras en la piel y los ojos. Un técnico de laboratorio ingirió accidentalmente lo que se consideró una "cantidad muy pequeña" de azida sódica y presentó síntomas de taquicardia, hiperventilación e hipotensión. Parece ser que la dosis hipotensora mínima en el hombre oscila entre 0,2 y $0,4 \mu \mathrm{g} / \mathrm{kg}$.

El tratamiento de personas normales con 3,9 mg/ día de azida sódica durante 10 días sólo produjo una sensación de latidos muy fuertes del corazón. Algunos pacientes hipertensos desarrollaron sensibilidad a la azida con 0,65 mg/ día. 
Los trabajadores expuestos a 0,5 ppm de ácido hidrazoico presentaron cefalea y congestión nasal. Tras la exposición a 3 ppm durante menos de 1 hora se describió, además, debilidad e irritación ocular y nasal. El pulso fue variable y la presión sanguínea, baja o normal. En trabajadores que fabricaban azida de plomo se describieron síntomas similares y una clara hipotensión, sobre todo durante la jornada laboral, que remitía al abandonar el lugar de trabajo.

Los estudios en animales han mostrado una disminución rápida y temporal de la tensión arterial con la administración de dosis orales únicas de $2 \mathrm{mg} / \mathrm{kg} 0$ más de azida sódica. Con la administración por vía intravenosa de $1 \mathrm{mg} / \mathrm{kg}$ en gatos, se observó hematuria e irregularidades cardíacas. Los síntomas observados en animales tras la administración de dosis relativamente altas de azida sódica fueron estimulación respiratoria y convulsiones, seguidas por depresión y muerte. $L a D_{50}$ de la azida sódica es de $45 \mathrm{mg} / \mathrm{kg}$ en ratas y de $23 \mathrm{mg} / \mathrm{kg}$ en ratones.

La exposición a los vapores de ácido hidrazoico en roedores produce inflamación aguda del pulmón. Los vapores de ácido hidrazoico son unas ocho veces menos tóxicos que el cianuro de hidrógeno, y una concentración de 1.024 ppm produce la muerte de los ratones en 60 minutos (frente a 135 ppm en el caso del cianuro de hidrógeno).

La azida sódica es mutagénica en bacterias, aunque este efecto se reduce en presencia de enzimas metabólicas. También ha exhibido efectos mutagénicos en los estudios realizados con células de mamíferos. 
TABLAS DE AZIDAS

\begin{tabular}{|c|c|c|}
\hline Producto químico & Sinónimos/ Código UN & N úmero CAS Fórmula estructural \\
\hline ACIDO EDETICO & $\begin{array}{l}\text { 3,6-bis( carboximetil)-; N,N'-1,2-etanodilibis( (N-(carboximetil)glicina); ácido } \\
\text { 3,6-diazaoctanodioico; ácido etilenediaminotetraacético; ácido } \\
\text { etilenediamino-N,N,N'N,N'-tetraacético }\end{array}$ & $60-00-4$ \\
\hline ACIDO HIDRAZOICO & Azoimida; diazoimida; azida de hidrógeno; ácido hidronítrico & $-\mathrm{N}=\mathrm{N}^{+} \mathrm{N}^{-}$ \\
\hline ACIDO TRICLOROISOCIANURICO & $\begin{array}{l}\text { Acido tricloroisocianúrico; ácido tricloroisociánico; tricloroisocianurato; ácido } \\
\text { 1,3,5-tricloroisocianúrico; } 1,3,5 \text {-tricloro-2,4,6-trioxohexahidro-sim-triazina } \\
\text { UN2468 }\end{array}$ & $87-90-1$ \\
\hline AMINOAZOTOLUENO & $\begin{array}{l}\text { 0-Aminoazotolueno; 2-amino-5-azotolueno; } \\
\text { 4-amino-2',3-dimetilazobenceno; 4'-amino-2,3'-dimetilazobenceno; } \\
\text { 2-metil-4-( (2-metilfenil) azo) bencenamina; toluazotoluidina; } \\
\text { 4-(0-tolilazo)-0-toluidina }\end{array}$ & $97-56-3$ \\
\hline 3-AMIN0-9-ETILCARBAZOL & 3-Amino-N-etilcarbazol & $132-32-1$ \\
\hline 3-AMINO-1,2,4-TRIAZOL & $\begin{array}{l}\text { Aminotriazol; 2-aminotriazol; 3-aminotriazol; 3-amino-s-triazol; } \\
\text { 3-amino-1,2,4-triazol; 2-amino-1,3,4-triazol; 3-amino-1h-1,2,4-triazol; } \\
\text { Amitrol; Amitrol-t; triazolamina; 1h-1,2,4-triazol-3-amina }\end{array}$ & $61-82-5$ \\
\hline AZASERINA & Azaserina; diazoacetato (éster) L-serina; L-diazoacetato (éster) serina & $115 \cdot 02 \cdot 6$ \\
\hline AZIDA SODICA & UN1687 & $26628-22-8$ \\
\hline AZOBENCENO & $\begin{array}{l}\text { Azobencida; azobenzol; azodibencenazofume; azofume; } \\
\text { bencenazobenceno; azodibenceno; benzofume; diazobenceno; } \\
\text { difenildiaceno; 1,2-difenildiaceno; difenildiimida }\end{array}$ & $103-33-3$ \\
\hline 1,1'-AZOBIS(FORMAMIDA) & Azobiscarboxamida; azodicarbamida; diamida del ácido azodicarboxilico & $123-77-3$ \\
\hline CLORHIDRATO DE FENILHIDRACINA & Fenilhidracina clorhidrato; cloruro de fenilhidracinio & $59-88-1$ \\
\hline CLORHIDRATO DE HIDRACINA & Monocloruro de hidracina; cloruro de hidracinio; monocloruro de hidracinio & $2644-70-4$ \\
\hline CLORHIDRATO DE METLLHIDRACINA & & $7339-53-9$ \\
\hline
\end{tabular}




\begin{tabular}{|c|c|c|c|}
\hline Producto químico & Sinónimos/ Código UN & $\mathrm{N}$ úmero CAS & Fórmula estructural \\
\hline CLORURO CIANURICO & $\begin{array}{l}\text { Clorotriacina; cianurcloruro; cloruro del ácido cianúrico; triclorocianidina; } \\
\text { 1,3,5-triclorotriacina; 2,4,6-tricloro-1,3,5-triacina; cloruro tricianógeno } \\
\text { UN2670 }\end{array}$ & $108-77 \cdot 0$ & \\
\hline DIAZOMETANO & Azimetileno; diacirina; diazometano & $334-88-3$ & \\
\hline DICLOROCIANURATO SODICO & $\begin{array}{l}\text { Sal sódica del ácido dicloroisocianúrico; } \\
\text { sal sódica del ácido dicloroisocianúrico; diclorisocianurato sódico; } \\
\text { dicloroisocianurato sódico; sal sódica de } \\
\text { sim-triaciin-2,4,6(1H,3H,5H)-triona, dicloro- }\end{array}$ & $2893-78-9$ & \\
\hline 1,2-DIETILHIDRACINA & N-N'-dietilhidracina; hidrazoetano; hidroazoetano & $1615-80-1$ & \\
\hline 1,1-DIMETILHIDRACINA & $\begin{array}{l}\text { Dimetilhidracina; N,N-dimetilhidracina } \\
\text { UN1163 }\end{array}$ & $57-14-7$ & \\
\hline 1,2-DIMETILHIDRACINA & $\begin{array}{l}\text { N,N'-dimetilhidracina; sim-dimetilhidracina; hidrazometano } \\
\text { UN2382 }\end{array}$ & $540-73-8$ & \\
\hline FENILHIDRACINA & $\begin{array}{l}\text { Hidracina-benceno; hidracinobenceno } \\
\text { UN2572 }\end{array}$ & $100-63-0$ & \\
\hline HIDRACINA & UN2029 & $302 \cdot 01-2$ & \\
\hline 2-HIDRACINOETANOL & Hidroxietil hidracina; $\beta$-hidroxietilhidracina; N-(2-hidroxietil) hidracina & $109-84-2$ & \\
\hline HIDRATO DE HIDRACINA & Hidracina, monohidrato & $7803-57-8$ & \\
\hline HIDRAZOBENCENO & $\begin{array}{l}\text { N,N'-difenilhidracina; sim-difenilhidracina; 1,2-difenilhidracina; } \\
\text { hidracina, 1,2-difenil- }\end{array}$ & $122-66-7$ & \\
\hline METILHIDRACINA & $\begin{array}{l}\text { Hidrazometano; 1-Metilhidracina; Monometilhidracina } \\
\text { UN1244 }\end{array}$ & $60-34-4$ & \\
\hline SULFATO DE HIDRACINA & Monosulfato de hidracina; sulfato de hidracinio; sulfato de hidrazonio & $10034-93-2$ & \\
\hline 1,2,4-TRIAZOL & sim-Triazol & $288-88-0$ & \\
\hline
\end{tabular}




\begin{tabular}{|c|c|c|c|c|c|c|}
\hline \multirow[b]{2}{*}{$\begin{array}{l}\text { Denominación } \\
\text { química } \\
\text { N úmero CAS }\end{array}$} & \multicolumn{4}{|c|}{ Tarjetas Internacionales sobre la Seguridad de los Productos Q uímicos } & \multicolumn{2}{|c|}{ N IO SH (EE.UU.) } \\
\hline & $\begin{array}{l}\text { Período } \\
\text { corto de } \\
\text { exposición }\end{array}$ & $\begin{array}{l}\text { Período } \\
\text { largo de } \\
\text { exposición }\end{array}$ & $\begin{array}{l}\text { Vías de } \\
\text { exposición }\end{array}$ & Síntomas & $\begin{array}{l}\text { O rganos } \\
\text { afectados } \\
\text { Vías de } \\
\text { entrada }\end{array}$ & Síntomas \\
\hline $\begin{array}{l}\text { ACIDO EDETICO } \\
60-00-4\end{array}$ & ojos; piel; tract resp & & $\begin{array}{r}\text { Inhalación } \\
\text { Piel } \\
\text { Ojos } \\
\text { Ingestión } \\
\end{array}$ & $\begin{array}{l}\text { Sensación de quemazón, tos } \\
\text { Enrojecimiento } \\
\text { Enrojecimiento } \\
\text { Sensación de quemazón }\end{array}$ & & \\
\hline $\begin{array}{l}\text { AZIDA SODICA } \\
26628-22-8\end{array}$ & $\begin{array}{l}\text { ojos; piel; tract } \\
\text { resp; SNC }\end{array}$ & SNC; genes & $\begin{array}{l}\text { Inhalación } \\
\text { Piel } \\
\text { Ojos } \\
\text { Ingestión }\end{array}$ & $\begin{array}{l}\text { Tos, cefalea, congestión nasal, visión borrosa, } \\
\text { disnea, inconsciencia, disminución de la } \\
\text { frecuencia cardíaca, disminución de la tensión } \\
\text { arterial } \\
\text { Enrojecimiento, ampollas } \\
\text { Enrojecimiento, dolor } \\
\text { Dolor abdominal, cefalea, náuseas, } \\
\text { inconsciencia, sudoración }\end{array}$ & $\begin{array}{l}\text { Ojos; piel; SNC; } \\
\text { CVS; riñones } \\
\text { Inh; abs; ing; con }\end{array}$ & $\begin{array}{l}\text { Irrit ojos y piel; cef, deb, mar, } \\
\text { visión borrosa; dis; TA baja, } \\
\text { bradicardia; les renales }\end{array}$ \\
\hline $\begin{array}{l}\text { 1,1'-AZOBIS(FORMAMIDA) } \\
123-77-3\end{array}$ & ojos; tract resp & piel; tract resp & $\begin{array}{r}\text { Inhalación } \\
\text { Piel } \\
\text { 0jos } \\
\end{array}$ & $\begin{array}{l}\text { Tos, cefalea, fatiga, disnea, dolor de garganta, } \\
\text { calambres } \\
\text { Enrojecimiento } \\
\text { Enrojecimiento, dolor }\end{array}$ & & \\
\hline $\begin{array}{l}\text { DIAZOMETANO } \\
334-88-3\end{array}$ & & & & & $\begin{array}{l}\text { ojos; sis resp } \\
\text { Inh; con (liq) }\end{array}$ & $\begin{array}{l}\text { Irrit ojos; tos, dis; cef, ftg; } \\
\text { rubor, fiebre; dolor torác, } \\
\text { edema pulm, neuitis; asma; } \\
\text { líq: congelación }\end{array}$ \\
\hline $\begin{array}{l}\text { DICLOROCIANURATO SODICO } \\
2893-78.9\end{array}$ & $\begin{array}{l}\text { ojos; piel; tract } \\
\text { resp; pulmones }\end{array}$ & piel; pulmones & $\begin{array}{l}\text { Inhalación } \\
\text { Piel } \\
\text { 0jos } \\
\text { Ingestión }\end{array}$ & $\begin{array}{l}\text { Tos, embotamiento, cefalea, náuseas, disnea, } \\
\text { dolor de garganta, vómitos, los síntomas } \\
\text { pueden tardar en aparecer } \\
\text { Enrojecimiento, quemaduras en la piel, dolor } \\
\text { Enrojecimiento, dolor, pérdida de visión, } \\
\text { quemaduras profundas graves } \\
\text { Sensación de quemazón, tos, cefalea, dolor de } \\
\text { garganta }\end{array}$ & & \\
\hline $\begin{array}{l}\text { DIMETIL } \\
\text {-P-AMINOAZOBENCENO } \\
60-11-7\end{array}$ & & & & & $\begin{array}{l}\text { Hígado; piel; vejiga; } \\
\text { riñones; sis resp [en } \\
\text { animales: tumores } \\
\text { de hígado y vejiga] } \\
\text { Inh; abs; ing; con }\end{array}$ & $\begin{array}{l}\text { Hepatomegalia; disfunc } \\
\text { hígado, riñon; derm de } \\
\text { contacto; tos, resp sib, dis; } \\
\text { esputos con sangre; } \\
\text { secreciones bronquiales; } \\
\text { micción frecuente, hema, } \\
\text { disuria; [ carc] }\end{array}$ \\
\hline $\begin{array}{l}\text { FENILHIDRACINA } \\
100-63.0\end{array}$ & $\begin{array}{l}\text { ojos; piel; tract } \\
\text { resp; sangre; } \\
\text { riñones }\end{array}$ & piel; sangre & $\begin{array}{r}\text { Inhalación } \\
\text { Piel } \\
\text { 0jos } \\
\text { Ingestión }\end{array}$ & $\begin{array}{l}\text { Tos, dificultad respiratoria, dolor de garganta, } \\
\text { cianosis } \\
\text { Puede absorberse, sequedad de piel, } \\
\text { enrojecimiento, dolor } \\
\text { Enrojecimiento, dolor, visión borrosa } \\
\text { Dolor abdominal, diarrea, náuseas, vómitos, } \\
\text { debilidad, vértigo }\end{array}$ & $\begin{array}{l}\text { Sangre; sis resp; } \\
\text { hígado; riñones; } \\
\text { piel [en animales: } \\
\text { tumores en } \\
\text { pulmones, hígado, } \\
\text { vasos sanguíneos e } \\
\text { intestino] } \\
\text { Inh; abs; ing; con }\end{array}$ & $\begin{array}{l}\text { Sens cutánea, anemia } \\
\text { hemolítica, dis, cian; ict; les } \\
\text { renales; trombosis vascular; } \\
\text { [carc] }\end{array}$ \\
\hline $\begin{array}{l}\text { HIDRACINA } \\
302.01-2\end{array}$ & $\begin{array}{l}\text { ojos; piel; tract } \\
\text { resp; higado; } \\
\text { riñones; SNC }\end{array}$ & $\begin{array}{l}\text { piel; hígado; } \\
\text { riñones; SNC; genes }\end{array}$ & & & $\begin{array}{l}\text { Ojos; piel; sis resp; } \\
\text { SNC; hígado; } \\
\text { riñones [en } \\
\text { animales: tumores } \\
\text { en pulmones, } \\
\text { hígado, vasos } \\
\text { sanguíneos e } \\
\text { intestino] } \\
\text { Inh; ing; abs; con }\end{array}$ & $\begin{array}{l}\text { Irrit ojos, piel, nariz y } \\
\text { garganta; ceguera temporal; } \\
\text { mar, náu; derm; quemaduras } \\
\text { en la piel y los ojos; en } \\
\text { animales: bron, edema pulm; } \\
\text { les hepáticas y renales; } \\
\text { convuls; [carc] }\end{array}$ \\
\hline
\end{tabular}


Tabla 104.34 - Riesgos para la salud.

\begin{tabular}{|c|c|c|c|c|c|c|}
\hline \multirow[b]{2}{*}{$\begin{array}{l}\text { Denominación } \\
\text { química } \\
\text { N úmero CAS }\end{array}$} & \multicolumn{4}{|c|}{ Tarjetas Internacionales sobre la Seguridad de los Productos Q uímicos } & \multicolumn{2}{|c|}{ N IO SH (EE.UU.) } \\
\hline & $\begin{array}{l}\text { Período } \\
\text { corto de } \\
\text { exposición }\end{array}$ & $\begin{array}{l}\text { Período } \\
\text { largo de } \\
\text { exposición }\end{array}$ & $\begin{array}{l}\text { Vías de } \\
\text { exposición }\end{array}$ & Síntomas & $\begin{array}{l}\text { O rganos } \\
\text { afectados } \\
\text { Vías de } \\
\text { entrada }\end{array}$ & Síntomas \\
\hline $\begin{array}{l}\text { METILHIDRACINA } \\
60-34-4\end{array}$ & & & & & $\begin{array}{l}\text { SNC; sis resp; } \\
\text { hígado; sangre; } \\
\text { CVS; ojos; piel } \\
\text { Inh; abs; ing; con }\end{array}$ & $\begin{array}{l}\text { Irrit ojos, piel, sis resp; vómit, } \\
\text { diarr, temblores, ataxia; } \\
\text { anoxia, cian; convuls; [carc] }\end{array}$ \\
\hline $\begin{array}{c}\text { 1,2,4-TRIAZOL } \\
288-88-0\end{array}$ & ojos; piel & & & & & \\
\hline
\end{tabular}

Tabla 104.35 • Riesgos físicos y químicos.

\begin{tabular}{|c|c|c|c|}
\hline $\begin{array}{l}\text { Denominación química } \\
\mathrm{N} \text { úmero CAS }\end{array}$ & Físicos & Q uímicos & $\begin{array}{l}\text { Clase o división } \\
\text { UN / Riesgos } \\
\text { subsidiarios }\end{array}$ \\
\hline $\begin{array}{l}\text { ACIDO EDETICO } \\
60-00-4\end{array}$ & & $\begin{array}{l}\text { Se descompone al calentarse, produciendo óxidos nitrosos Reacciona con oxidantes fuertes, } \\
\text { bases fuertes, cobre, aleaciones de cobre y níquel }\end{array}$ & \\
\hline $\begin{array}{l}\text { ACIDO TRICLOROISOCIANURICO } \\
87-90-1\end{array}$ & & & 5.1 \\
\hline $\begin{array}{l}\text { AZIDA SODICA } \\
26628-22-8\end{array}$ & & $\begin{array}{l}\text { Puede explotar si se calienta por encima del punto de fusión, sobre todo si se calienta } \\
\text { rápidamente, con peligro de incendio y explosión La solución en agua es una base débil } \\
\text { Reacciona con cobre, plomo, plata, mercurio y disulfuro de carbono, formando compuestos } \\
\text { particularmente sensibles a los impactos Reacciona con ácidos, formando azida de hidrógeno } \\
\text { tóxica y explosiva Muy corrosiva para el aluminio }\end{array}$ & 6.1 \\
\hline
\end{tabular}

\begin{tabular}{|c|c|c|c|}
\hline $\begin{array}{l}1,1^{\prime}-A Z O B I S(F O R M A M I D A) \\
123-77-3\end{array}$ & & Se descompone al calentarse 0 al arder, liberando humos tóxicos (óxidos de nitrógeno) & \\
\hline $\begin{array}{l}\text { CLORHIDRATO DE FENILHIDRACINA } \\
59-88-1\end{array}$ & & & 6.1 \\
\hline $\begin{array}{l}\text { CLORHIDRATO DE METILHIDRACINA } \\
7339.53 .9\end{array}$ & & & $6.1 / 3 / 8$ \\
\hline $\begin{array}{l}\text { CLORURO CIANURICO } \\
108-77-0\end{array}$ & & & 8 \\
\hline $\begin{array}{l}\text { DICLOROCIANURATO SODICO } \\
\text { 2893-78-9 }\end{array}$ & & $\begin{array}{l}\text { Se descompone al calentarse en contacto con agua, produciendo humos tóxicos Es un } \\
\text { oxidante fuerte y reacciona violentamente con materiales combustibles y reductores Es un } \\
\text { potente agente reductor y reacciona con oxidantes La solución en agua es un ácido débil } \\
\text { Reacciona violentamente con muchas sustancias, con peligro de incendio y explosión }\end{array}$ & 5.1 \\
\hline $\begin{array}{l}\text { 1,1-DIMETILHIDRACINA } \\
57-14-7\end{array}$ & $\begin{array}{l}\text { Los vapores son más } \\
\text { pesados que el aire y } \\
\text { pueden desplazarse a ras } \\
\text { del suelo; posibilidad de } \\
\text { ignición a distancia }\end{array}$ & $\begin{array}{l}\text { Puede arder espontáneamente en contacto con el aire en presencia de agentes oxidantes } \\
\text { Reacciona violentamente con materiales oxidantes, como el aire; los vapores son inflamables } \\
\text { en contacto con el aire En combustión libera humos tóxicos o inflamables, como óxidos de } \\
\text { nitrógeno, hidrógeno, amoniaco, dimetilamina y ácido hidrazoico Es un potente agente reductor } \\
\text { y reacciona violentamente con oxidantes, como tetróxido de nitrógeno, peróxido de hidrógeno y } \\
\text { ácido nítrico Es una base fuerte, reacciona violentamente con ácidos y es corrosiva Reacciona } \\
\text { con el oxígeno, con peligro de incendio y explosión Ataca los plásticos }\end{array}$ & 3 \\
\hline $\begin{array}{l}\text { 1,2-DIMETILHIDRACINA } \\
540-73-8\end{array}$ & & & $6.1 / 3$ \\
\hline $\begin{array}{l}\text { FENILHIDRACINA } \\
100-63-0\end{array}$ & & $\begin{array}{l}\text { Se descompone al calentarse } 0 \text { al arder, desprendiendo humos tóxicos, como óxidos de } \\
\text { nitrógeno Reacciona con oxidantes Reacciona violentamente con dióxido de plomo }\end{array}$ & 6.1 \\
\hline $\begin{array}{l}\text { HIDRACINA } \\
302-01-2\end{array}$ & & & $3 / 3 / 6.1$ \\
\hline
\end{tabular}




\begin{tabular}{|c|c|c|c|c|}
\hline $\begin{array}{l}\text { Denominación química } \\
\mathrm{N} \text { úmero CAS }\end{array}$ & Físicos & Q uímicos & & $\begin{array}{l}\text { Clase o división } \\
\text { UN / Riesgos } \\
\text { subsidiarios }\end{array}$ \\
\hline $\begin{array}{l}\text { METILHIDRACINA } \\
60-34-4\end{array}$ & & & & $6.1 / 3 / 8$ \\
\hline $\begin{array}{c}\text { 1,2,4-TRIAZOL } \\
288-88-0\end{array}$ & $\begin{array}{l}\text { Posibilidad de explosión } \\
\text { polvorienta cuando se } \\
\text { encuentra en forma de } \\
\text { polvo o gránulos y se } \\
\text { mezcla con el aire }\end{array}$ & $\begin{array}{l}\text { Se descompone al hervir Al calentarse, libera humos tóxicos } \\
\text { bases fuertes }\end{array}$ & Reacciona con oxidantes y & \\
\hline
\end{tabular}

\begin{tabular}{|c|c|c|c|c|c|c|c|c|c|c|}
\hline $\begin{array}{l}\text { Denominación química } \\
\mathrm{N} \text { úmero CAS }\end{array}$ & Color/ Forma & $\begin{array}{l}\text { p.e. } \\
\left({ }^{\circ} \mathrm{C}\right)\end{array}$ & $\begin{array}{l}\text { p.f. } \\
(\stackrel{\circ}{ })\end{array}$ & $\begin{array}{l}\text { p.m.l } \\
\text { (g/ } \\
\text { mol) }\end{array}$ & $\begin{array}{l}\text { Solubilidad } \\
\text { en agua }\end{array}$ & $\begin{array}{l}\text { Densidad } \\
\text { relativa } \\
\text { (agua }=1 \text { ) }\end{array}$ & $\begin{array}{l}\text { Densidad } \\
\text { de vapor } \\
\text { relativa } \\
\text { (aire=1) }\end{array}$ & $\begin{array}{l}\mathrm{Pvap} / \\
(\mathrm{kPa})\end{array}$ & $\begin{array}{l}\text { Límit. } \\
\text { inflam. }\end{array}$ & 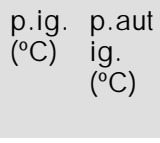 \\
\hline $\begin{array}{l}\text { ACIDO EDETICO } \\
60-00-4\end{array}$ & $\begin{array}{l}\text { polvo blanco } \\
\text { cristalino }\end{array}$ & & $\begin{array}{l}240 \text { se } \\
\text { descompone }\end{array}$ & 292,24 & $\begin{array}{l}0,50 \mathrm{~g} / \mathrm{l} \\
@ 25^{\circ} \mathrm{C}\end{array}$ & & & & & \\
\hline $\begin{array}{l}\text { ACIDO HIDRAZOICO } \\
7782.79-8\end{array}$ & $\begin{array}{l}\text { líquido volátil e } \\
\text { incoloro }\end{array}$ & 37 & -80 & & & & & & & \\
\hline $\begin{array}{l}\text { ACIDO TRICLOROISOCIANURICO } \\
87-90-1\end{array}$ & $\begin{array}{l}\text { agujas en cloruro de } \\
\text { etileno; gránulos o } \\
\text { polvo cristalino } \\
\text { blanco }\end{array}$ & & $\begin{array}{l}246,7 \text { se } \\
\text { descompone }\end{array}$ & 232,4 & sol & $>1$ (sólido) & & & & \\
\hline $\begin{array}{l}\text { 3-AMIN0-9-ETILCARBAZOL } \\
\text { 132-32-1 }\end{array}$ & compuesto cristalino & & 127 & 210,3 & & & & & & \\
\hline $\begin{array}{l}\text { AMINOAZOTOLUENO } \\
97-56-3\end{array}$ & $\begin{array}{l}\text { cristales dorados; } \\
\text { cristales de color } \\
\text { marrón-rojizo o } \\
\text { amarillo; láminas } \\
\text { amarillas en alcohol }\end{array}$ & & 102 & 225,28 & $\begin{array}{l}7,64 \mathrm{mg} / \mathrm{l} \\
\text { @ } 25^{\circ} \mathrm{C}\end{array}$ & & & $\begin{array}{l}7,5 \times 10^{-7} \\
\mathrm{~mm} \mathrm{Hg} \\
\text { @ } 25^{\circ} \mathrm{C}\end{array}$ & & \\
\hline $\begin{array}{l}\text { AZASERINA } \\
115.02-6\end{array}$ & $\begin{array}{l}\text { cristales ortorómbicos } \\
\text { de color amarillo } \\
\text { pálido ó verde en } \\
\text { etanol al } 90 \% \text {. }\end{array}$ & & 157 & 173,13 & $\begin{array}{l}1,36 \times 10^{5} \mathrm{mg} / \mathrm{l} \\
@ 25^{\circ} \mathrm{C}\end{array}$ & & & $\begin{array}{l}1,53 \times 10^{-10} \\
\mathrm{~mm} \mathrm{Hg} \\
\text { @ } 25^{\circ} \mathrm{C} .\end{array}$ & & \\
\hline $\begin{array}{l}\text { AZIDA SODICA } \\
26628-22-8\end{array}$ & $\begin{array}{l}\text { sólido cristalino } \\
\text { blanco; cristales } \\
\text { hexagonales } \\
\text { incoloros }\end{array}$ & & $\begin{array}{l}275 \text { se } \\
\text { descompone }\end{array}$ & 65,02 & muy sol & 1,846 & & & & \\
\hline $\begin{array}{l}\text { AZOBENCENO } \\
103-33-3\end{array}$ & $\begin{array}{l}\text { laminillas de color } \\
\text { rojo-naranja; sólido, } \\
\text { cristales rojo-naranja; } \\
\text { cristales amarillos o } \\
\text { naranjas }\end{array}$ & 293 & 68 & 182,22 & insol en agua & $\begin{array}{l}1,203 @ 20 \cong \\
C / 4 \cong C\end{array}$ & & $\begin{array}{l}1 \mathrm{~mm} \mathrm{Hg} \\
@ 103 \cong \mathrm{C}\end{array}$ & & \\
\hline $\begin{array}{l}\text { 1,1'-AZOBIS(FORMAMIDA) } \\
123-77-3\end{array}$ & $\begin{array}{l}\text { cristales de color } \\
\text { rojo-naranja, polvo } \\
\text { amarillo }\end{array}$ & & $\begin{array}{l}212 \text { se } \\
\text { descompone }\end{array}$ & 116,08 & lig sol & 1,65 & & & & \\
\hline $\begin{array}{l}\text { CLORHIDRATO DE FENILHIDRACINA } \\
59-88-1\end{array}$ & & sublima & $\begin{array}{l}\text { 243-246 se } \\
\text { descompone }\end{array}$ & 144,60 & muy sol & & & & & \\
\hline
\end{tabular}




\begin{tabular}{|c|c|c|c|c|c|c|c|c|c|c|c|}
\hline $\begin{array}{l}\text { Denominación química } \\
\mathrm{N} \text { úmero } \mathrm{CAS}\end{array}$ & Color/ Forma & $\begin{array}{l}\text { p.e. } \\
\left({ }^{\circ} \mathrm{C}\right)\end{array}$ & $\begin{array}{l}\text { p.f. } \\
\left({ }^{\circ} \mathrm{C}\right)\end{array}$ & $\begin{array}{l}\text { p.m.l } \\
\text { (g/ } \\
\text { mol) }\end{array}$ & $\begin{array}{l}\text { Solubilidad } \\
\text { en agua }\end{array}$ & $\begin{array}{l}\text { Densidad } \\
\text { relativa } \\
\text { (agua=1) }\end{array}$ & $\begin{array}{l}\text { Densidad } \\
\text { de vapor } \\
\text { relativa } \\
\text { (aire=1) }\end{array}$ & $\begin{array}{l}\mathrm{Pvap} / \\
(\mathrm{kPa})\end{array}$ & $\begin{array}{l}\text { Límit. } \\
\text { inflam. }\end{array}$ & $\begin{array}{l}\text { p.ig. } \\
(\underline{O C})\end{array}$ & $\begin{array}{l}\text { p.aut } \\
\text { ig. } \\
(\stackrel{\circ}{ } \mathrm{C})\end{array}$ \\
\hline $\begin{array}{l}\text { CLORHIDRATO DE HIDRACINA } \\
2644-70-4\end{array}$ & $\begin{array}{l}\text { escamas cristalinas } \\
\text { blancas }\end{array}$ & $\begin{array}{l}190 \text { se } \\
\text { des- } \\
\text { compone }\end{array}$ & 81- 87 & & sol & & & & & & \\
\hline $\begin{array}{l}\text { CLORURO CIANURICO } \\
108.77 .0\end{array}$ & $\begin{array}{l}\text { cristales en éter o } \\
\text { benceno; cristales } \\
\text { monoclínicos } \\
\text { incoloros }\end{array}$ & 190 & 154 & 184,41 & insol & 1,32 & 6,36 & $\begin{array}{l}2 \mathrm{~mm} \mathrm{Hg} \\
@ 70^{\circ} \mathrm{C}\end{array}$ & & & \\
\hline $\begin{array}{l}\text { DIAZOMETANO } \\
334-88-3\end{array}$ & gas amarillo & .23 & -145 & 42,04 & & 1,45 & 1,45 & & & & \\
\hline $\begin{array}{l}\text { DICLOROCIANURATO SODICO } \\
\text { 2893-78-9 }\end{array}$ & $\begin{array}{l}\text { polvo cristalino } \\
\text { blanco }\end{array}$ & & $\begin{array}{l}\text { 240-250 se } \\
\text { descompone }\end{array}$ & $-220,96$ & $25 \mathrm{~g} / 100 \mathrm{ml}$ & $>1$ & & & & & \\
\hline $\begin{array}{l}\text { 1,2-DIETILHIDRACINA } \\
\text { 1615-80-1 }\end{array}$ & & 85,5 & & 88,15 & & $0,797 @ 26^{\circ} \mathrm{C}$ & & & & & \\
\hline $\begin{array}{l}\text { 1,1-DIMETILHIDRACINA } \\
57-14-7\end{array}$ & $\begin{array}{l}\text { líquido transparente e } \\
\text { incoloro }\end{array}$ & 63,9 & -58 & 60,1 & muy sol & $\begin{array}{l}0,7914 \\
@ 22^{\circ} \mathrm{C} / 4^{\circ} \mathrm{C}\end{array}$ & 1,94 & 16,4 & $\begin{array}{l}2 \mathrm{li} \\
95 \mathrm{ls}\end{array}$ & $-15 \mathrm{cc}$ & 249 \\
\hline $\begin{array}{l}\text { 1,2-DIMETILHIDRACINA } \\
540-73-8\end{array}$ & $\begin{array}{l}\text { líquido transparente e } \\
\text { incoloro }\end{array}$ & $\begin{array}{l}81 @ \\
753 \\
\mathrm{~mm} \mathrm{Hg}\end{array}$ & .9 & 60,10 & misc & 0,8274 & & $\begin{array}{l}68 \\
\mathrm{~mm} \mathrm{Hg} @ \\
24,46^{\circ} \mathrm{C}\end{array}$ & & $<23 c c$ & \\
\hline $\begin{array}{l}\text { FENILHIDRACINA } \\
100-63.0\end{array}$ & $\begin{array}{l}\text { prismas monoclínicos } \\
0 \text { aceite; líquido } \\
\text { aceitoso incoloro; } \\
\text { sólido o líquido } \\
\text { incoloro o amarillo } \\
\text { pálido }\end{array}$ & 243,5 & 19,5 & 108,14 & sol & 1,098 & 3,7 & $\begin{array}{l}0,133 \\
@ 71,8^{\circ} \mathrm{C}\end{array}$ & & $88 \mathrm{cc}$ & 174 \\
\hline $\begin{array}{l}\text { HIDRACINA } \\
302.01 .2\end{array}$ & $\begin{array}{l}\text { líquido aceitoso } \\
\text { incoloro; cristales } \\
\text { blancos }\end{array}$ & 113 & 2,0 & 32,05 & misc & $\begin{array}{l}1,011 \\
@ 15^{\circ} \mathrm{C} / 4\end{array}$ & 1,1 & 2,1 & $\begin{array}{l}4 \mathrm{li} \\
100 \mathrm{ls}\end{array}$ & $38 \mathrm{cc}$ & 270 \\
\hline $\begin{array}{l}\text { 2-HIDRACINOETANOL } \\
\text { 109-84-2 }\end{array}$ & & $\begin{array}{l}218- \\
220 @ \\
754 \\
\mathrm{~mm} \mathrm{Hg}\end{array}$ & .70 & 76,10 & muy sol & $1,119 @ 25^{\circ} \mathrm{C}$ & & & & & \\
\hline $\begin{array}{l}\text { HIDRAZOBENCENO } \\
122.66 .7\end{array}$ & $\begin{array}{l}\text { cristales tabulares en } \\
\text { alcohol y éter }\end{array}$ & & 131 & 184,2 & & $\begin{array}{l}1,158 \\
\text { @ } 16^{\circ} \mathrm{C} / 4^{\circ} \mathrm{C}\end{array}$ & & $\begin{array}{l}1 \text { torr } \\
\text { @ } 103^{\circ} \mathrm{C}\end{array}$ & & & \\
\hline $\begin{array}{l}\text { METILHIDRACINA } \\
60-34-4\end{array}$ & líquido incoloro & 87,5 & $.52,4$ & 46,07 & sol & $0,874 @ 25^{\circ} \mathrm{C}$ & 1,6 & $\begin{array}{l}49,6 \\
\mathrm{~mm} \mathrm{Hg} \\
@ 25{ }^{\circ} \mathrm{C}\end{array}$ & $\begin{array}{l}2,5 \mathrm{li} \\
97 \mathrm{ls}\end{array}$ & $\mathrm{OCa}$ & 194 \\
\hline $\begin{array}{l}\text { SULFATO DE HIDRACINA } \\
10034-93-2\end{array}$ & $\begin{array}{l}\text { cristales } \\
\text { ortorómbicos; placas } \\
\text { o prismas semejantes } \\
\text { al vidrio; polvo } \\
\text { cristalino blanco; } \\
\text { cristales rómbicos } \\
\text { incoloros }\end{array}$ & & 254 & 130,12 & muy sol & $1,378 @ 25^{\circ} \mathrm{C}$ & & & & & \\
\hline $\begin{array}{l}\text { 1,2,4-TRIAZOL } \\
288-88-0\end{array}$ & agujas & 260 & $120-121$ & & muy sol & & & & & & \\
\hline
\end{tabular}




\section{COMPUESTOS DE BORO}

David L. H inkamp

\begin{abstract}
U sos
El boro y sus sales tienen diversos usos en las industria electrónica, metalúrgica, química, cerámica, textil y papelera, así como en construcción. En la industria electrónica, el boro, el tribromuro de boro y el tricloruro de boro se utilizan como semiconductores. EI boro sirve como ignitor en los tubos de radio y como agente desgasificador en metalurgia. T ambién se utiliza en pirotecnia. El diborano, el pentaborano y el decaborano se utilizan en combustibles de alta energía. El tricloruro de boro, el diborano y el decaborano se emplean como propulsores de cohetes y el trietilboro y el boro, como ignitores para motores de cohetes y aviones de propulsión a chorro. El ${ }^{10}$ boro se emplea en la industria nuclear como componente del blindaje contra neutrones en los reactores.

En la industria metalúrgica, muchos de los boranos se utilizan en procesos de soldadura y bronceado. Otros compuestos se emplean como retardadores de llama y como decolorantes en la industria textil, papelera y de pinturas y barnices. El óxido de boro es un aditivo antiinflamable en pinturas y barnices y el tetraborato sódico, el bórax y el trimetil borato se emplean para el tratamiento ignífugo de tejidos. Tanto el bórax como el tetraborato sódico se utilizan para el tratamiento ignífugo y el envejecimiento artificial de la madera. En el sector de la construcción, son componentes de los aislantes de fibra de vidrio. El tetraborato sódico se utiliza también como algicida en aguas industriales y como agente en el curtido y la conservación de pieles. EI bórax se emplea como germicida en productos de limpieza, como inhibidor de la corrosión en anticongelantes y como insecticida en polvo para el tratamiento de las grietas en las zonas donde se manipulan alimentos. El decaborano se utiliza para quitar el brillo al rayón y como agente antipolilla en la industria textil. El borohidruro sódico es un agente blanqueador para la pasta papelera.

En la industria cerámica, el óxido bórico y el bórax forman parte de los vidriados y el tetraborato sódico es un componente de los esmaltes y vidriados de la porcelana. EI perborato sódico se utiliza para blanquear tejidos y en galvanoplastia. T ambién se emplea en jabones, desodorantes, detergentes, colutorios bucales y en los colorantes para el teñido en cubas. EI trifluoruro de boro se emplea en el envasado de alimentos, en electrónica y en los reactores nucleares que producen material fisionable.
\end{abstract}

\section{Riesgos para la salud}

El boro es una sustancia presente en la naturaleza que se encuentra con frecuencia en los alimentos y el agua potable. En cantidades traza, es esencial para el crecimiento de las plantas y ciertos tipos de algas. A pesar de que también se encuentra en los tejidos humanos, su función se desconoce. El boro se considera generalmente una sustancia segura para utilizarse como aditivo indirecto en los alimentos (por ejemplo, durante el envasado), pero los compuestos que contienen boro pueden ser muy tóxicos. El boro está presente en una serie de compuestos útiles desde el punto de vista industrial, como los boratos, los boranos y los haluros de boro.

En el hombre, la toxicidad del boro se manifiesta principalmente tras el uso crónico de medicamentos que contienen ácido bórico y en casos de ingestión accidental, especialmente en niños de corta edad. La toxicidad de origen profesional se deriva generalmente de la exposición del aparato respiratorio o de heridas abiertas a polvos, gases o vapores de los compuestos de boro.
El contacto con casi todos estos materiales en concentraciones habituales puede producir irritación aguda de los ojos, la piel y el tracto respiratorio. La absorción afecta a la sangre, el tracto respiratorio y digestivo, los riñones, el hígado y el sistema nervioso central y, en casos extremos, puede originar la muerte.

El ácido bórico es el más común de los boratos, que son compuestos formados por boro, oxígeno y otros elementos. La exposición aguda al ácido bórico en forma líquida o sólida produce irritación, cuya gravedad dependerá de la concentración y la duración de la exposición. La inhalación de polvos o nieblas de boratos puede irritar directamente la piel, los ojos y el sistema respiratorio.

Los síntomas de esta irritación consisten en molestias oculares, sequedad de boca, dolor de garganta y tos productiva. L os trabajadores habitualmente presentan estos síntomas después de una exposición aguda a concentraciones superiores a $10 \mathrm{mg} / \mathrm{m}^{3}$ de ácido bórico. No obstante, la exposición crónica a menos de la mitad de esta concentración también puede producir síntomas de irritación.

Los trabajadores expuestos al polvo de bórax (borato sódico) presentan tos productiva crónica y, en los casos de exposición prolongada, se han detectado anomalías obstructivas, aunque no está claro que estén relacionadas con la exposición.

Los boratos se absorben rápidamente a través de las heridas abiertas en la piel y por vía respiratoria y digestivo. D espués de absorberse, actúan principalmente sobre la piel, el sistema nervioso central y el tracto digestivo. Los síntomas suelen aparecer en poco tiempo, aunque en el caso de la exposición cutánea pueden tardar horas en manifestarse. Tras la absorción, la piel 0 las mucosas pueden presentar un enrojecimiento anormal (eritema) o un desprendimiento del tejido superficial. La exposición crónica se ha asociado a eczema, caída del cabello en parches e hinchazón alrededor de los ojos. Estos efectos dermatológicos pueden tardar varios días en presentarse después de la exposición. La persona experimenta dolor abdominal, náuseas, vómitos y diarrea. Los vómitos y la diarrea pueden tener una coloración azul-verdosa y contener sangre. También pueden presentarse cefaleas, excitación o depresión, convulsiones, letargo y coma.

En los casos de intoxicación aguda, se ha observado anemia, acidosis y deshidratación, acompañados por una disminución rápida del pulso y la presión sanguínea. Estos efectos pueden ir seguidos por un ritmo cardíaco irregular, shock, insuficiencia renal y, en casos raros, lesiones hepáticas. L as víctimas aparecen pálidas, sudorosas y muy enfermas. La mayoría de estos síntomas graves se presentan justo antes de la muerte por intoxicación aguda con boratos. Sin embargo, cuando las víctimas reciben un diagnóstico y un tratamiento rápidos, los efectos son generalmente reversibles.

L os efectos de los boratos sobre la reproducción no se conocen claramente. La exposición al ácido bórico inhibe la movilidad espermática en las ratas y, a concentraciones altas, produce atrofia testicular. Los estudios de genotoxicidad en animales y tejidos han dado resultados negativos, pero se ha demostrado infertilidad en machos y hembras tras la exposición crónica a ácido bórico en los alimentos. Las crías muestran un desarrollo tardío y anormal, con un crecimiento anormal de las costillas. En cuanto al hombre, sólo existen indicios de una disminución de la fertilidad en los pocos trabajadores que han sido evaluados en estudios no controlados.

Los trihaluros de boro (trifluoruro de boro, cloruro de boro y bromuro de boro) pueden reaccionar violentamente con el agua, liberando 
haluros de hidrógeno, como los ácidos clorhídrico y fluorhídrico. El trifluoruro de boro es un potente irritante de los pulmones, los ojos y la piel. Los estudios realizados en animales de experimentación han indicado que tras la exposición letal aparece insuficiencia renal y lesiones en los túbulos renales, irritación pulmonar y neumonía. La exploración de un pequeño número de trabajadores expuestos indicó una disminución de la función pulmonar, aunque no está claro que se debiera a la exposición.

Los boranos o hidruros de boro (diborano, pentaborano y decaborano), son compuestos sumamente reactivos que pueden explotar en contacto con oxígeno o con agentes oxidantes. En conjunto, son potentes irritantes que pueden causar rápidamente neumonía química, edema pulmonar y otras lesiones respiratorias. Además, se ha visto que los boranos producen convulsiones y lesiones neurológicas, con déficit neurológico y síntomas psicológicos prolongados. Estos compuestos deben manipularse con extrema precaución.

$\mathrm{Ni}$ los experimentos de exposición crónica en animales ni los estudios de personas expuestas han podido demostrar que el boro o sus sales produzcan cáncer. 


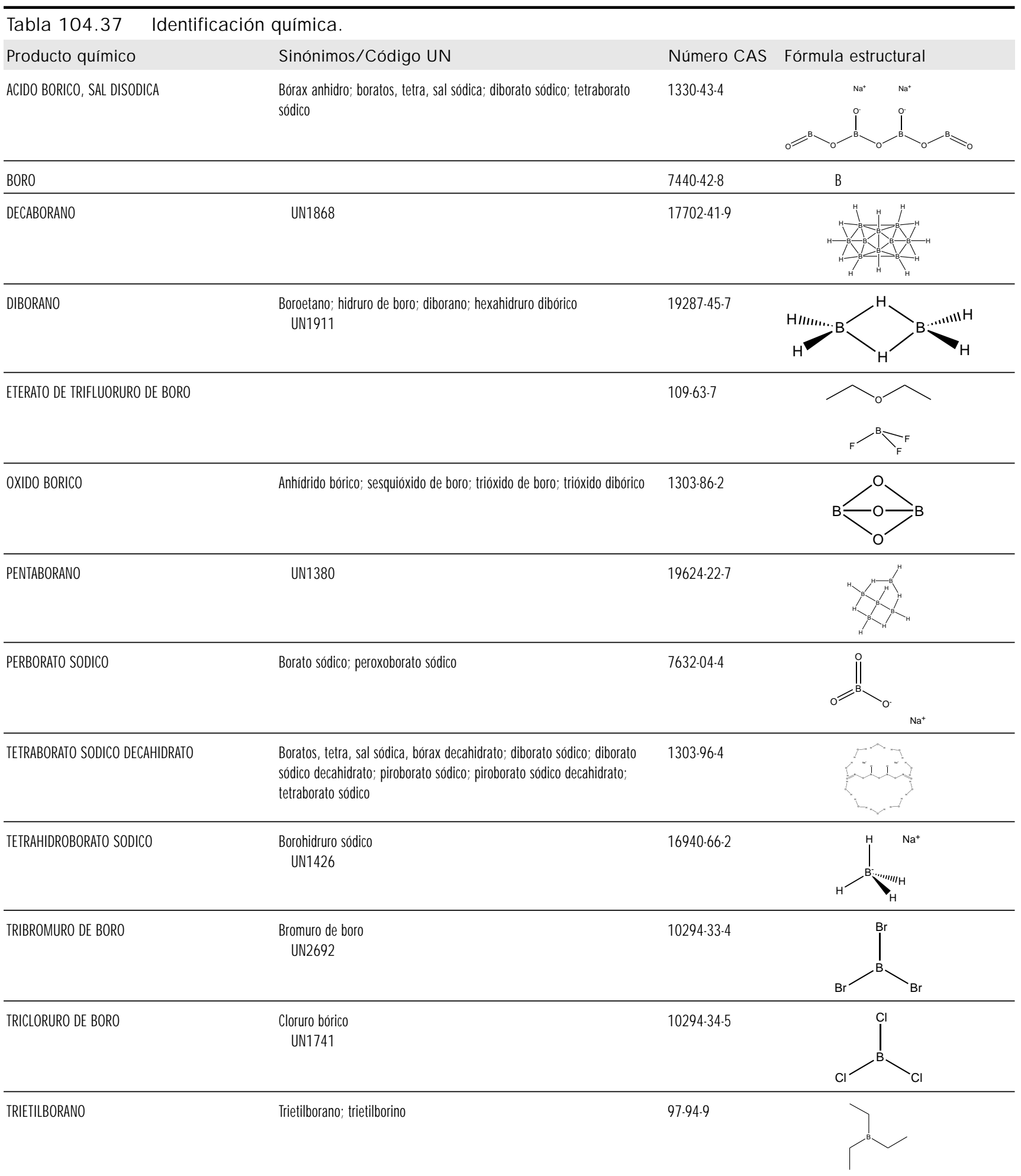




\begin{tabular}{lcc}
\hline Tabla 104.37 & Identificación química. & Número CAS Fórmula estructural \\
Producto químico & Sinónimos/ Código UN & $7637-07-2$ \\
TRIFLUORURO DE BORO & $\begin{array}{c}\text { Fluoruro bórico } \\
\text { UN1008 }\end{array}$ & \\
\hline TRIMETLL BORATO & $\begin{array}{c}\text { Ester trimetílico del ácido bórico; metil borato; trimetoxiborino; } \\
\text { trimetil borato } \\
\text { UN2416 }\end{array}$ & $121-43-7$ \\
\hline
\end{tabular}

Tabla 104.38 - Riesgos para la salud.

\begin{tabular}{|c|c|c|c|c|c|c|}
\hline \multirow[b]{2}{*}{$\begin{array}{l}\text { Denominación } \\
\text { química } \\
\text { Número CAS }\end{array}$} & \multicolumn{4}{|c|}{ Tarjetas Internacionales sobre la Seguridad de los Productos Q uímicos } & \multicolumn{2}{|c|}{ N IO SH (EE.UU.) } \\
\hline & $\begin{array}{l}\text { Período } \\
\text { corto de } \\
\text { exposición }\end{array}$ & $\begin{array}{l}\text { Período } \\
\text { largo de } \\
\text { exposición }\end{array}$ & $\begin{array}{l}\text { Vías de } \\
\text { exposición }\end{array}$ & Síntomas & $\begin{array}{l}\text { O rganos } \\
\text { afectados } \\
\text { Vías de } \\
\text { entrada }\end{array}$ & Síntomas \\
\hline $\begin{array}{l}\text { DECABORANO } \\
17702-41-9\end{array}$ & $\begin{array}{l}\text { ojos; tract resp; } \\
\text { SNC }\end{array}$ & SNC & Inhalación & $\begin{array}{l}\text { Tos, mareo, sopor, cefalea, temblores, } \\
\text { convulsiones, náuseas, debilidad, } \\
\text { descoordinación, los síntomas pueden tardar } \\
\text { en aparecer }\end{array}$ & $\begin{array}{l}\text { SNC; hígado; } \\
\text { riñones } \\
\text { Inh; abs; ing; con }\end{array}$ & $\begin{array}{l}\text { Mar, cef, náu, mar, sop; } \\
\text { desco, espasmos musc locales, } \\
\text { temblores, convuls; ftg; en } \\
\text { animales: deb; dis; les } \\
\text { hepáticas y renales }\end{array}$ \\
\hline $\begin{array}{l}\text { DIBORANO } \\
19287-45-7\end{array}$ & $\begin{array}{l}\text { ojos; piel; tract } \\
\text { resp; pulmones }\end{array}$ & pulmones & $\begin{array}{l}\text { Inhalación } \\
\text { Piel } \\
\text { Ojos }\end{array}$ & $\begin{array}{l}\text { Tos, mareo, dificultad respiratoria, náuseas, } \\
\text { dolor de garganta, debilidad } \\
\text { Congelación grave } \\
\text { Quemaduras profundas graves }\end{array}$ & $\begin{array}{l}\text { Sis resp; SNC; } \\
\text { hígado; riñones } \\
\text { Inh }\end{array}$ & $\begin{array}{l}\text { Opr torác, dolor precordial, dis, } \\
\text { tos no productiva, náu; cef, } \\
\text { atur, mar, escalofríos, fiebre, } \\
\text { ftg, deb, temblores, fasc musc; } \\
\text { en animales: les hepáticas y } \\
\text { renales; edema pulm; hemorr }\end{array}$ \\
\hline $\begin{array}{c}\text { OXIDO BORICO } \\
1303-86-2\end{array}$ & ojos; piel; tract resp & riñones & $\begin{array}{r}\text { Inhalación } \\
\text { Piel } \\
\text { Ojos } \\
\text { Ingestión }\end{array}$ & $\begin{array}{l}\text { Tos, dolor de garganta } \\
\text { Enrojecimiento } \\
\text { Enrojecimiento, dolor } \\
\text { Espasmos abdominales, diarrea, náuseas, } \\
\text { vómitos, shock }\end{array}$ & $\begin{array}{l}\text { Ojos, piel; sis resp } \\
\text { Inh; ing; con }\end{array}$ & $\begin{array}{l}\text { Irrit ojos, piel, sis resp; tos; } \\
\text { conj; erit cutáneo }\end{array}$ \\
\hline $\begin{array}{r}\text { PENTABORANO } \\
19624-22-7\end{array}$ & tract resp; SNC & & $\begin{array}{l}\text { Inhalación } \\
\text { Ingestión }\end{array}$ & $\begin{array}{l}\text { Náuseas, sopor, cefalea, mareo, visión } \\
\text { borrosa, temblores, convulsiones; los síntomas } \\
\text { pueden tardar en aparecer } \\
\text { Náuseas, vómitos }\end{array}$ & $\begin{array}{l}\text { SNC; ojos; piel } \\
\text { Inh; abs; ing; con }\end{array}$ & $\begin{array}{l}\text { Irrit ojos y piel; mar, cef, sop, } \\
\text { atur, desco, temblores, } \\
\text { convuls, cambios de } \\
\text { comportamiento; espasmos } \\
\text { tónicos en cara, cuello, } \\
\text { abdomen y extremidades }\end{array}$ \\
\hline $\begin{array}{l}\text { TETRABORATO SODICO } \\
\text { DECAHIDRATO } \\
\text { 1303-96-4 }\end{array}$ & $\begin{array}{l}\text { mucosas; ojos; } \\
\text { hígado; riñones; } \\
\text { SNC }\end{array}$ & piel & $\begin{array}{r}\text { Inhalación } \\
\text { Piel } \\
\text { Ojos } \\
\text { Ingestión }\end{array}$ & $\begin{array}{l}\text { Hemorragia nasal, tos, opresión torácica, } \\
\text { disnea, dolor de garganta } \\
\text { Sequedad de la piel } \\
\text { Enrojecimiento } \\
\text { Dolor abdominal, confusión, diarrea, sopor, } \\
\text { cefalea, náuseas, vómitos, debilidad }\end{array}$ & $\begin{array}{l}\text { Ojos, piel, sis resp } \\
\text { Inh; ing; con }\end{array}$ & $\begin{array}{l}\text { Irrit ojos, piel y sis resp sup; } \\
\text { derm; epis; tos, dis }\end{array}$ \\
\hline $\begin{array}{l}\text { TRIBROMURO DE BORO } \\
\text { 10294-33-4 }\end{array}$ & $\begin{array}{l}\text { ojos; piel; tract } \\
\text { resp; pulmones }\end{array}$ & & $\begin{array}{r}\text { Inhalación } \\
\text { Piel } \\
\text { 0jos } \\
\text { Ingestión }\end{array}$ & $\begin{array}{l}\text { Tos, dificultad respiratoria, dolor de garganta } \\
\text { Enrojecimiento, quemaduras, dolor } \\
\text { Enrojecimiento, dolor, quemaduras profundas } \\
\text { graves } \\
\text { Quemaduras en la boca y el tracto } \\
\text { gastrointestinal superior, dolor abdominal, } \\
\text { sensación de quemazón, vómitos }\end{array}$ & $\begin{array}{l}\text { Ojos, piel; sis resp } \\
\text { Inh; ing; con }\end{array}$ & $\begin{array}{l}\text { Irrit ojos, piel, sis resp; } \\
\text { quemaduras en la piel y los } \\
\text { ojos; disn, edema pulm }\end{array}$ \\
\hline
\end{tabular}




\begin{tabular}{|c|c|c|c|c|c|c|}
\hline \multirow[b]{2}{*}{$\begin{array}{l}\text { Denominación } \\
\text { química } \\
\mathrm{N} \text { úmero CAS }\end{array}$} & \multicolumn{4}{|c|}{ Tarjetas Internacionales sobre la Seguridad de los Productos Q uímicos } & \multicolumn{2}{|c|}{ N IO SH (EE.UU.) } \\
\hline & $\begin{array}{l}\text { Período } \\
\text { corto de } \\
\text { exposición }\end{array}$ & $\begin{array}{l}\text { Período } \\
\text { largo de } \\
\text { exposición }\end{array}$ & $\begin{array}{l}\text { Vías de } \\
\text { exposición }\end{array}$ & Síntomas & $\begin{array}{l}\text { Organos } \\
\text { afectados } \\
\text { Vías de } \\
\text { entrada }\end{array}$ & Síntomas \\
\hline $\begin{array}{l}\text { TRICLORURO DE BORO } \\
10294-34-5\end{array}$ & $\begin{array}{l}\text { ojos; piel; tracto } \\
\text { resp. }\end{array}$ & & $\begin{array}{r}\text { Inhalación } \\
\text { Piel } \\
\text { 0jos }\end{array}$ & $\begin{array}{l}\text { Sensación de quemazón, tos, dificultad } \\
\text { respiratoria, disnea, dolor de garganta } \\
\text { Enrojecimiento, quemaduras, sensación de } \\
\text { quemazón, dolor, ampollas } \\
\text { Enrojecimiento, dolor, pérdida de visión }\end{array}$ & & \\
\hline $\begin{array}{l}\text { TRIFLUORURO DE BORO } \\
7637-07-2\end{array}$ & $\begin{array}{l}\text { ojos; piel; tract } \\
\text { resp; pulmones }\end{array}$ & pulmones; riñones & $\begin{array}{r}\text { Inhalación } \\
\text { Piel } \\
\text { 0jos }\end{array}$ & $\begin{array}{l}\text { Corrosivo, sensación de quemazón, tos, } \\
\text { dificultad respiratoria } \\
\text { Enrojecimiento, sensación de quemazón, dolor, } \\
\text { en contacto con el líquido: congelación } \\
\text { Enrojecimiento, dolor, visión borrosa }\end{array}$ & $\begin{array}{l}\text { Sis resp; riñones; } \\
\text { ojos; piel } \\
\text { Inh; con }\end{array}$ & $\begin{array}{l}\text { Irrit ojos, piel, nariz, sis resp; } \\
\text { epis; quemaduras en la piel y } \\
\text { los ojos; en animales: neu; les } \\
\text { renales }\end{array}$ \\
\hline $\begin{array}{l}\text { TRIMETIL BORATO } \\
121-43-7\end{array}$ & ojos; tract resp & & $\begin{array}{l}\text { Inhalación } \\
\text { Ingestión }\end{array}$ & $\begin{array}{l}\text { Tos, dolor de garganta } \\
\text { Dolor abdominal, sensación de quemazón }\end{array}$ & & \\
\hline
\end{tabular}

\begin{tabular}{|c|c|c|c|}
\hline $\begin{array}{l}\text { Denominación química } \\
\text { Número CAS }\end{array}$ & Físicos & Q uímicos & $\begin{array}{l}\text { Clase o división } \\
\text { UN / Riesgos } \\
\text { subsidiarios }\end{array}$ \\
\hline $\begin{array}{l}\text { BOROHIDRURO DE SODIO } \\
\text { 16940-66-2 }\end{array}$ & & & 4.3 \\
\hline $\begin{array}{l}\text { DECABORANO } \\
17702-41-9\end{array}$ & $\begin{array}{l}\text { Posibilidad de explosión } \\
\text { pulverulenta cuando se } \\
\text { encuentra en forma de } \\
\text { polvo o gránulos y se } \\
\text { mezcla con el aire }\end{array}$ & $\begin{array}{l}\text { Puede explotar si se calienta, o en contacto con el fuego Se descompone lentamente al } \\
\text { calentarse hasta } 300^{\circ} \mathrm{C} \text {, formando boro y el gas inflamable hidrógeno, y al arder, desprendiendo } \\
\text { humos tóxicos (óxidos de boro) Reacciona con compuestos halogenados y éteres, formando } \\
\text { materiales sensibles a los impactos La reacción con los oxidantes es explosiva Reacciona con } \\
\text { el agua o la humedad, formando un gas inflamable (hidrógeno) Ataca el caucho natural, } \\
\text { algunos cauchos sintéticos, algunas grasas y algunos lubricantes Arde en presencia de oxígeno } \\
\text { a } 100{ }^{\circ} \mathrm{C} \text { Reacciona con amidas, acetona, butiraldehído y acetonitrilo a temperatura ambiente }\end{array}$ & $4.1 / 6.1$ \\
\hline $\begin{array}{l}\text { DIBORANO } \\
\quad 19287-45-7\end{array}$ & $\begin{array}{l}\text { El gas se mezcla con el } \\
\text { aire y se forma fácilmente } \\
\text { mezclas explosivas Arde } \\
\text { espontáneamente en } \\
\text { contacto con aire húmedo } \\
\text { a temperatura ambiente }\end{array}$ & $\begin{array}{l}\text { Se polimeriza formando pentaborano líquido Se descompone al rojo en boro e hidrógeno y, a } \\
\text { temperaturas más bajas, en hidrógeno e hidruros de boro Reacciona espontáneamente con el } \\
\text { cloro y forma hidruros con aluminio y litio, que pueden arder espontáneamente en contacto con el } \\
\text { aire Es un potente agente reductor y eacciona con muchas superficies oxidables }\end{array}$ & $2.3 / 2.1$ \\
\hline $\begin{array}{l}\text { ETERATO DE TRIFLUORURO DE BORO } \\
109-63-7\end{array}$ & & & $8 / 3$ \\
\hline $\begin{array}{l}\text { OXIDO BORICO } \\
1303-86-2\end{array}$ & & $\begin{array}{l}\text { Reacciona lentamente con el agua para formar ácido bórico Corrosivo para los metales en } \\
\text { presencia de oxígeno }\end{array}$ & \\
\hline $\begin{array}{r}\text { PENTABORANO } \\
19624-22 \cdot 7\end{array}$ & $\begin{array}{l}\text { El vapor es más pesado } \\
\text { que el aire }\end{array}$ & $\begin{array}{l}\text { Se descompone lentamente al calentarse a } 150^{\circ} \mathrm{C} \text {, formando boro y el gas inflamable } \\
\text { hidrógeno, y al arder, produciendo humos tóxicos (óxidos de boro) Reacciona con oxidantes y } \\
\text { halógenos, con peligro de incendio y explosión El material con impurezas arde } \\
\text { espontáneamente en contacto con el aire Con disolventes como cetonas, éteres y ésteres forma } \\
\text { soluciones sensibles a los impactos }\end{array}$ & 4.216 .1 \\
\hline $\begin{array}{l}\text { TETRABORATO SODICO DECAHIDRATO } \\
\text { 1303-96-4 }\end{array}$ & & $\begin{array}{l}\text { Se descompone al calentarse por encima de } 400^{\circ} \mathrm{C} \text {, produciendo metaboratos Es una base } \\
\text { débil }\end{array}$ & \\
\hline $\begin{array}{l}\text { TRIBROMURO DE BORO } \\
\text { 10294-33-4 }\end{array}$ & $\begin{array}{l}\text { El vapor es más pesado } \\
\text { que el aire }\end{array}$ & $\begin{array}{l}\text { Puede explotar si se calienta Se descompone en contacto con el alcohol, produciendo humos } \\
\text { tóxicos y corrosivos (bromuro de hidrógeno) La solución en agua es un ácido fuerte, reacciona } \\
\text { violentamente con las bases y es corrosivo para metales, caucho y madera Reacciona } \\
\text { violentamente con agua, produciendo gas de hidrógeno, con peligro de explosión }\end{array}$ & 8 \\
\hline
\end{tabular}




\begin{tabular}{|c|c|c|c|}
\hline $\begin{array}{l}\text { Denominación química } \\
\text { N úmero CAS }\end{array}$ & Físicos & Q uímicos & $\begin{array}{l}\text { Clase o división } \\
\text { UN / Riesgos } \\
\text { subsidiarios }\end{array}$ \\
\hline $\begin{array}{l}\text { TRICLORURO DE BORO } \\
10294-34-5\end{array}$ & $\begin{array}{l}\text { El gas es más pesado } \\
\text { que el aire }\end{array}$ & $\begin{array}{l}\text { Reacciona violentamente con el agua En contacto con el aire, se desprende cloruro de } \\
\text { hidrógeno Ataca muchos metales en presencia de agua }\end{array}$ & $2.3 / 8$ \\
\hline $\begin{array}{l}\text { TRIFLUORURO DE BORO } \\
7637-07-2\end{array}$ & $\begin{array}{l}\text { El gas es más pesado } \\
\text { que el aire }\end{array}$ & $\begin{array}{l}\text { Polimeriza compuestos no saturados Se descompone en contacto con el agua y la humedad, } \\
\text { produciendo humos tóxicos y corrosivos como fluoruro de hidrógeno, ácido fluorobórico y ácido } \\
\text { bórico Reacciona violentamente con metales como sodio, potasio y calcio y con los alquil } \\
\text { nitratos Ataca muchos metales en presencia de agua }\end{array}$ & 2.318 \\
\hline $\begin{array}{l}\text { TRIMETILBORATO } \\
121-43-7\end{array}$ & $\begin{array}{l}\text { El vapor es más pesado } \\
\text { que el aire y puede } \\
\text { desplazarse a ras del } \\
\text { suelo; posibilidad de } \\
\text { ignición a distancia }\end{array}$ & $\begin{array}{l}\text { En su combustión libera gases tóxicos de carbono y óxidos de boro Reacciona con oxidantes, } \\
\text { con peligro de incendio y explosión Reacciona con el agua, el aire húmedo y los ácidos, } \\
\text { formando metanol y ácido bórico }\end{array}$ & 3 \\
\hline
\end{tabular}

\begin{tabular}{|c|c|c|c|c|c|c|c|c|c|c|c|}
\hline $\begin{array}{l}\text { Denominación química } \\
\mathrm{N} \text { úmero CAS }\end{array}$ & Color/ Forma & $\begin{array}{l}\text { p.e. } \\
\left({ }^{\circ} \mathrm{C}\right)\end{array}$ & $\begin{array}{l}\text { p.f. } \\
(\stackrel{\circ}{ })\end{array}$ & $\begin{array}{l}\text { p.m.l } \\
\text { (g/ } \\
\mathrm{mol})\end{array}$ & $\begin{array}{l}\text { Solubilidad } \\
\text { en agua }\end{array}$ & $\begin{array}{l}\text { Densidad } \\
\text { relativa } \\
\text { (agua }=1 \text { ) }\end{array}$ & $\begin{array}{l}\text { Densidad } \\
\text { de vapor } \\
\text { relativa } \\
\text { (aire }=1 \text { ) }\end{array}$ & $\begin{array}{l}\text { Pvap/ } \\
(\mathrm{kPa})\end{array}$ & $\begin{array}{l}\text { Límit. } \\
\text { inflam. }\end{array}$ & $\begin{array}{l}\text { p.ig. } \\
\left({ }^{\circ} \mathrm{C}\right)\end{array}$ & $\begin{array}{l}\text { p.aut } \\
\text { ig. } \\
\left({ }^{\circ} \text { C }\right)\end{array}$ \\
\hline $\begin{array}{l}\text { ACIDO BORICO, SAL DISODICA } \\
1330-43-4\end{array}$ & $\begin{array}{l}\text { polvo o placas } \\
\text { similares al vidrio; } \\
\text { cristales sueltos de } \\
\text { color blanco; sólido } \\
\text { gris claro }\end{array}$ & 1575 & 741 & 201,3 & $2,56 \mathrm{~g} / 100 \mathrm{~g}$ & 2,367 & & & & & \\
\hline $\begin{array}{l}\text { BORO } \\
\quad 7440-42-8\end{array}$ & $\begin{array}{l}\text { polimórfico: cristales } \\
\text { transparentes y rojos } \\
\text { de la forma alfa } \\
\text { rombohédrica; } \\
\text { cristales negros de la } \\
\text { forma beta } \\
\text { rombohédrica; } \\
\text { cristales opacos, } \\
\text { negros y con un brillo } \\
\text { metálico de forma } \\
\text { alfa tetragonal; polvo } \\
\text { negro o marrón } \\
\text { oscuro de forma } \\
\text { amorfa; otras formas } \\
\text { cristalinas conocidas }\end{array}$ & 2550 & 2300 & 10,81 & insol & $\begin{array}{l}\text { Amorfo, } \\
2,3 \mathrm{~g} / \mathrm{cm}^{3} ; \text { alfa } \\
\text { rombohédrico, } \\
2,46 \mathrm{~g} / \mathrm{cm}^{3} ; \\
\text { alfa tetragonal, } \\
2,31 \mathrm{~g} / \mathrm{cm}^{3} ; \\
\text { beta } \\
\text { rombohédrico, } \\
2,35 \mathrm{~g} / \mathrm{cm}^{3}\end{array}$ & & $\begin{array}{l}1,56 \times 10^{-5} \\
@ 2140^{\circ} \mathrm{C}\end{array}$ & & & 580 \\
\hline $\begin{array}{l}\text { DECABORANO } \\
17702-41-9\end{array}$ & $\begin{array}{l}\text { cristales blancos; } \\
\text { cristales } \\
\text { ortorrómbicos; agujas } \\
\text { cristalinas blancas o } \\
\text { incoloras }\end{array}$ & 213 & 99,5 & 122,21 & lig sol & $\begin{array}{l}\text { sólido: } 0,94 \\
\text { @ } 25^{\circ} \mathrm{C} ; \\
\text { líquido: } 0,78 \\
\text { @ } 100^{\circ} \mathrm{C}\end{array}$ & 4,2 & $\begin{array}{l}6,65 \mathrm{~Pa} \\
@ 25^{\circ} \mathrm{C}\end{array}$ & & $80 c c$ & 149 \\
\hline $\begin{array}{l}\text { DIBORANO } \\
\quad 19287-45-7\end{array}$ & gas incoloro & $-92,5$ & -165 & 27,69 & lig sol & $0,210 @ 15^{\circ} \mathrm{C}$ & 0,96 & $\begin{array}{l}224 \mathrm{~mm} \mathrm{Hg} \\
@-1122^{\circ} \mathrm{C}\end{array}$ & $\begin{array}{l}0,8 \mathrm{li} \\
88 \mathrm{ls}\end{array}$ & $\begin{array}{l}\text { gas } \\
\text { infla- } \\
\text { mable }\end{array}$ & $40-50$ \\
\hline $\begin{array}{l}\text { ETERATO DE TRIFLUORURO DE BORO } \\
109.63 .7\end{array}$ & líquido; incoloro & 125,7 & $.60,4$ & 141,94 & & 1,3572 & & & & $64 \mathrm{ca}$ & \\
\hline
\end{tabular}




\begin{tabular}{|c|c|c|c|c|c|c|c|c|c|c|}
\hline $\begin{array}{l}\text { Denominación química } \\
\mathrm{N} \text { úmero CAS }\end{array}$ & Color/ Forma & $\begin{array}{l}\text { p.e. } \\
\left({ }^{\circ} C\right)\end{array}$ & $\begin{array}{l}\text { p.f. } \\
(\because 0 C)\end{array}$ & $\begin{array}{l}\text { p.m.l } \\
\text { (g/ } \\
\mathrm{mol})\end{array}$ & $\begin{array}{l}\text { Solubilidad } \\
\text { en agua }\end{array}$ & $\begin{array}{l}\text { Densidad } \\
\text { relativa } \\
\text { (agua }=1 \text { ) }\end{array}$ & $\begin{array}{l}\text { Densidad } \\
\text { de vapor } \\
\text { relativa } \\
\text { (aire=1) }\end{array}$ & $\begin{array}{l}\mathrm{Pvap} / \\
(\mathrm{kPa})\end{array}$ & $\begin{array}{l}\text { Límit. } \\
\text { inflam. }\end{array}$ & $\begin{array}{ll}\text { p.ig. } & \text { p.aut } \\
\left({ }^{\circ} \mathrm{C}\right) & \text { ig. } \\
& \left({ }^{\circ} \mathrm{C}\right)\end{array}$ \\
\hline $\begin{array}{l}\text { OXIDO BORICO } \\
1303-86-2\end{array}$ & $\begin{array}{l}\text { cristales rómbicos; } \\
\text { agregados } \\
\text { semitransparentes } \\
\text { incoloros o cristales } \\
\text { duros blancos }\end{array}$ & 1860 & 450 & 69,6 & $2,77 \mathrm{~g} / 100 \mathrm{~g}$ & $\begin{array}{l}1,8 \text { (amorfo); } \\
2,46 \text { (cristalino) }\end{array}$ & & & & \\
\hline $\begin{array}{r}\text { PENTABORANO } \\
19624-22 \cdot 7 \\
\end{array}$ & líquido incoloro & 60 & $-46,6$ & 63,2 & reacciona & $\begin{array}{l}0,61 \\
\text { @ } 0^{\circ} \mathrm{C} / 4^{\circ} \mathrm{C}\end{array}$ & 2,2 & 22,8 & $\begin{array}{l}0,42 \mathrm{li} \\
98 \mathrm{ls}\end{array}$ & $30 \mathrm{cc} \quad 35$ \\
\hline $\begin{array}{l}\text { PERBORATO SODICO } \\
7632-04-4\end{array}$ & polvo blanco amorfo & & & 81,80 & & & & & & \\
\hline $\begin{array}{l}\text { TETRABORATO SODICO DECAHIDRATO } \\
\text { 1303-96-4 }\end{array}$ & $\begin{array}{l}\text { cristales monoclínicos } \\
\text { incoloros; cristales } \\
\text { duros, gránulos o } \\
\text { polvo cristalino; listas } \\
\text { blancas, azuladas o } \\
\text { blanco verdosas, } \\
\text { opacas o vidriosas }\end{array}$ & 320 & 75 & 381,4 & $5,92 \mathrm{~g} / 100 \mathrm{~g}$ & 1,73 & & & & \\
\hline $\begin{array}{l}\text { TETRAHIDROBORATO SODICO } \\
\text { 16940-66-2 }\end{array}$ & $\begin{array}{l}\text { cristales cúbicos } \\
\text { blancos; polvo } \\
\text { microcristalino o } \\
\text { agregados blancos o } \\
\text { blanco-grisáceos }\end{array}$ & $\begin{array}{l}\text { se } \\
\text { descompone } \\
\text { lentamente a } \\
400 \text { y } \\
\text { rápidamente a } \\
500\end{array}$ & 36 & 37.8 & muy sol & 1,07 & & & & \\
\hline $\begin{array}{l}\text { TRIBROMURO DE BORO } \\
\text { 10294-33-4 }\end{array}$ & líquido incoloro & 90 & $-46,0$ & 250,57 & reacciona & $\begin{array}{l}2,6431 @ \\
18,4^{\circ} \mathrm{C} / 4^{\circ} \mathrm{C}\end{array}$ & 8,6 & $\begin{array}{l}5,3 \\
@ 14{ }^{\circ} \mathrm{C}\end{array}$ & & \\
\hline $\begin{array}{l}\text { TRICLORURO DE BORO } \\
10294-34-5 \\
\end{array}$ & & 12,5 & -107 & 117,16 & & $\begin{array}{l}1,35 \\
@ 12{ }^{\circ} \mathrm{C} / 4\end{array}$ & 4,03 & $\begin{array}{l}2,99 \mathrm{~Pa} \\
@ 12,4^{\circ} \mathrm{C}\end{array}$ & & \\
\hline $\begin{array}{l}\text { TRIETILBORANO } \\
97.94-9\end{array}$ & líquido incoloro & $95-96$ & $-92,9$ & 98,00 & & $\begin{array}{l}0,6961 \mathrm{~mm} \mathrm{Hg} \\
@ 23^{\circ} \mathrm{C}\end{array}$ & & & & \\
\hline $\begin{array}{l}\text { TRIFLUORURO DE BORO } \\
7637.07-2\end{array}$ & gas incoloro & $-99,9$ & $-126,8$ & 67,82 & reacciona & $\begin{array}{l}3,08 \mathrm{~g} / 1,571 \\
@ 4{ }^{\circ} \mathrm{C}\end{array}$ & 2,4 & $\begin{array}{l}10 \mathrm{~mm} \mathrm{Hg} \\
@-141{ }^{\circ} \mathrm{C} \text {. } \\
\text { (sólido); } \\
760 \mathrm{~mm} \mathrm{Hg} \\
110,7^{\circ} \mathrm{C} \\
\text { (líquido) }\end{array}$ & & \\
\hline $\begin{array}{l}\text { TRIMETILBORATO } \\
121-43-7\end{array}$ & líquido color de agua & $67-68$ & $-29,3$ & 103,9 & reacciona & 0,91 & 3,6 & $\begin{array}{l}137 \mathrm{~mm} \mathrm{Hg} \\
@ 25 \stackrel{\circ}{\circ} \mathrm{C}\end{array}$ & & $<27 \mathrm{CC}$ \\
\hline
\end{tabular}




\section{PROPIEDADES DE LOS COMPUESTOS DE CIANO}

\section{COMPUESTOS DE CIANO}

Esta clase de compuestos se caracteriza por la presencia de un grupo $\mathrm{C} \equiv \mathrm{N}$ (ciano) e incluye a los cianuros, los nitrilos $(\mathrm{R}-\mathrm{C} \equiv \mathrm{N})$ y sustancias químicas relacionadas, como los cianógenos, isocianatos y cianamidas. La toxicidad de este grupo se debe principalmente al ión cianuro que, cuando se libera en el organismo, es capaz de inhibir a muchas enzimas y, en especial, a la citocromo oxidasa. La muerte, más o menos rápida dependiendo de la velocidad a la que se libere el ión cianuro, se produce como resultado de asfixia química a nivel celular.

\section{Cianuros inorgánicos}

L os cianuros inorgánicos se hidrolizan rápidamente en presencia de agua y se descomponen por acción del dióxido de carbono y los ácidos minerales, formando cianuro de hidrógeno, que también es producido por algunas bacterias. El cianuro de hidrógeno se produce durante la fabricación del coque y el acero y puede generarse también en incendios en los que se quema espuma de poliuretano (por ejemplo, al arder muebles, tabiques, etc.). T ambién puede generarse accidentalmente por la acción de ácidos sobre residuos que contengan cianuro (el lactonitrilo forma ácido cianhídrico en contacto con álcalis, por ejemplo), o intencionadamente, como en las cámaras de gas utilizadas para aplicar la pena capital, en las que se introducen pastillas de cianuro en recipientes con ácido para crear una atmósfera letal.

\section{Nitrilos}

Los nitrilos (también llamados cianuros orgánicos) son cianuros orgánicos que contienen un grupo ciano $(-\mathrm{C} \equiv \mathrm{N})$ como característica funcional y la fórmula general RCN. Pueden considerarse como derivados de hidrocarburos mediante sustitución de tres átomos de hidrógeno unidos a un carbono primario por un grupo nitrilo, o como derivados de ácidos carboxílicos ( $\mathrm{R}-\mathrm{COOH})$ mediante sustitución de los radicales oxo e hidroxilo por un grupo nitrilo $(\mathrm{R}-\mathrm{C} \equiv \mathrm{N})$. La hidrólisis de un nitrilo produce un ácido que contiene el mismo número de átomos de carbono y que, en consecuencia, suele designarse por analogía con el ácido, más que como derivado de un cianuro de hidrógeno. Estos compuestos son muy peligrosos cuando se calientan hasta la descomposición, ya que liberan cianuro de hidrógeno.

Los nitrilos alifáticos saturados hasta el $\mathrm{C}_{14}$ son líquidos que desprenden un olor bastante agradable, parecido al de los éteres. L os nitrilos de $\mathrm{C}_{14}$ o más son sólidos inodoros y, en general, incoloros. La mayoría de los nitrilos hierven sin descomponerse a temperaturas inferiores a las de los ácidos correspondientes. Son muy reactivos y se utilizan ampliamente como productos intermedios en síntesis orgánicas y como materiales de partida para la síntesis de distintos ácidos grasos, productos farmacéuticos, vitaminas, resinas sintética, plásticos y colorantes.

\section{U sos}

Los compuestos inorgánicos de cianuro tienen diversos usos en la industria química, en metalúrgica y en la fabricación de plásticos y caucho. Se utilizan como productos químicos intermedios, pesticidas, limpiadores de metales y agentes para extraer oro y plata de los minerales.

El acrionitrilo (cianuro de vinilo, cianoetileno, propenonitrilo), un líquido incoloro inflamable y explosivo, se encuentra en revestimientos de superficie y adhesivos y se utiliza como producto químico intermedio en la síntesis de antioxidantes, productos farmacéuticos, pesticidas, colorantes y agentes tensoactivos.
La cianamida cálcica (nitrolim, carbamida cálcica, cianamida) es un polvo gris-negruzco brillante que se utiliza en agricultura como fertilizante, herbicida y pesticida y como desfoliador en las plantaciones de algodón. T ambién se utiliza en el endurecimiento del acero y como agente desulfurante en la industria del hierro y el acero. Asimismo, se emplea en la fabricación de cianuro cálcico y diciandiamida, el material de partida para la producción de melamina.

El cianógeno, el bromuro de cianógeno y el cloruro de cianógeno se utilizan en síntesis orgánicas. El cianógeno se emplea también como fumigante y como gas combustible para la soldadura y corte de metales resistentes al calor. También se utiliza como propelente de cohetes y misiles, mezclado con ozono o fluoruros, y puede estar presente en los gases de los altos hornos. El bromuro de cianógeno se utiliza para el tratamiento de tejidos, como fumigante y pesticida y en los procesos de extracción del oro. El cloruro cianógeno se utiliza como agente avisador en los gases fumigantes.

EI cianuro de hidrógeno se emplea en la fabricación de fibras sinté ticas y plásticos, en agentes para el pulido de metales, en soluciones de galvanoplastia, en los procesos metalúrgicos y fotográficos y en la producción de sales de cianuro. El cianuro sódico y el cianuro potásico se utilizan en galvanoplastia, en el endurecimiento del acero, en la extracción de oro y plata de los minerales y en la fabricación de colorantes y pigmentos. Además, el cianuro sódico se utiliza como agente en la separación de minerales por el método de flotación por espuma.

El ferricianuro potásico (rojo prusia de potasa) se utiliza en fotografía y para copias al ferroprusiato, como atemperante de metales, en galvanoplastia y en la fabricación de pigmentos. EI ferrocianuro potásico (amarillo prusia de potasa) se utiliza para la atemperación del acero, en los procesos de grabado, en la fabricación de pigmentos y como reactivo químico.

El cianuro cálcico, el malononitrilo, la cianhidrina de acetona (2-hidroxi-2-meil-proprionitrilo), la cianamida y el acrilonitrilo son compuestos utilizados en las industrias química, metalúrgica, de los plásticos y del caucho. El cianuro cálcico y el malononitrilo se utilizan en la lixiviación del oro. Además, el cianuro cálcico se emplea como fumigante, pesticida, estabilizador del cemento y en la fabricación de acero inoxidable. La cianhidrina de acetona es un agente complejante que se utiliza en el refinado y la separación de metales. La cianamida se utiliza en limpiadores de metales, en el refinado de minerales y en la producción de caucho sintético. El tiocianato de amonio se utiliza en la fabricación de cerillas, en la industria fotográfica, para la doble tinción de tejidos y para aumentar la resistencia de las sedas junto con sales de estaño. También se emplea como estabilizante de pegamentos, como trazador en yacimientos petrolíferos y como componente de pesticidas y propelentes líquidos para cohetes. El cianuro potásico se utiliza como producto químico intermedio y como herbicida.

Algunos de los nitrilos orgánicos más importantes desde el punto de vista industria son: acrionitrilo (vinilcianamida, cianoetileno, propenonitrilo), acetonitrilo (metilcianamida, etanonitrilo, cianometano), cianhidrina de etileno, proprionitrilo (cianuro de etilo), lactonitrilo, el glicolonitrilo (cianhidrina de formaldehído, hidroxiacetonitrilo, hidroximetilcianuro, cianhidrina de metileno), 2-metil-lactonitrilo y adiponitrilo.

\section{Riesgos}

La toxicidad de los compuestos de cianuro depende del grado en que liberen ión cianuro. La exposición aguda puede causar la muerte por asfixia, como resultado de la exposición a concentra- 
ciones letales de cianuro de hidrógeno $(\mathrm{HCN})$, ya sea por inhalación, ingestión o absorción percutánea, aunque en este último caso la dosis requerida es mayor. La exposición crónica a concentraciones más bajas de cianuros no produce complicaciones clínicas series, pero puede causar una serie de problemas. En los trabajadores de la industria de la galvanoplastia se ha observado dermatitis, acompañada con frecuencia de reacciones pruriginosas, eruptivas y papulosas, además de una intensa irritación de la nariz, con tendencia a la obstrucción, hemorragias, escaras y, en ocasiones, perforación del tabique nasal. En los fumigadores, la intoxicación leve por cianuros produce síntomas de déficit de oxígeno, dolor de cabeza, aceleración del pulso y náuseas, que remiten completamente al cesar la exposición.

La intoxicación sistémica crónica por cianuros puede existir pero es difícil de detectar debido al comienzo gradual del malestar y a la aparición de síntomas que pueden corresponder a otras patologías. Se ha sugerido que el exceso de tiocianato en el líquido extracelular podría explicar las afecciones crónicas debidas al cianuro, ya que los síntomas descritos son similares a los observados cuando se utilizaba el tiocianato como medicamento. Se han descrito síntomas de enfermedad crónica en trabajadores de galvanoplastia y bruñido de plata después de varios años de exposición. Los síntomas más llamativos fueron: debilidad motora de las extremidades, cefalea y trastornos tiroideos. Todos estos síntomas aparecen también como complicaciones del tratamiento con tiocianato.

\section{Toxicidad}

\section{Cianuros}

El ión cianuro de los compuestos solubles de cianuro es absorbido rápidamente por todas las vías de entrada al organismo: inhalación, ingestión o absorción percutánea. Las propiedades tóxicas de estos compuestos se deben a su capacidad de formar complejos con iones de metales pesados que inhiben las enzimas necesarias para la respiración celular, en especial la citocromo oxidasa. De esta forma se impide la captación de oxígeno por parte de los tejidos y se produce la muerte por asfixia. La sangre retiene el oxígeno, lo que explica el color rojo cereza característico de las víctimas de la intoxicación aguda por cianuros. El cianuro se combina, aproximadamente, con el $2 \%$ de la metahemoglobina presente en condiciones normales, hecho que ha contribuido al desarrollo del tratamiento de las intoxicaciones por cianuro.

Si la dosis inicial no es mortal, parte de ella se exhala sin modificar, mientras que la rodanasa, una enzima ampliamente distribuida en el organismo, convierte el resto a tiocianato, un ión mucho menos nocivo, que permanece en los líquidos extracelulares del organismo hasta que finalmente se excreta en la orina. Los niveles de tiocianato en la orina se han utilizado para medir el grado de intoxicación, pero no son específicos y se encuentran elevados en los fumadores. Debido a la afinidad del ión tiocianato por el yodo, también pueden existir efectos sobre la función tiroidea.

Los efectos biológicos de los compuestos de este grupo son variables. En concentraciones bajas, el cianuro de hidrógeno (ácido cianhídrico o prúsico) y los compuestos de cianuro halogenados (como el cloruro y el bromuro de cianógeno) en forma de vapor son irritantes para los ojos y el tracto respiratorio. Los efectos respiratorios, como el edema pulmonar, pueden tardar en manifestarse. Los efectos sistémicos consisten en: debilidad, cefalea, confusión, náuseas y vómitos. En los casos leves, la presión sanguínea permanece normal a pesar de que el pulso se acelera. La frecuencia respiratoria depende de la intensidad de la exposición, siendo más rápida en las exposiciones leves y más lenta y entrecortada en las exposiciones graves.

\section{Nitrilos}

La toxicidad de los nitrilos varía considerablemente según la estructura molecular, pudiendo ser comparativamente no tóxicos (como los nitrilos de ácidos grasos saturados) o sumamente tóxicos, como los $\alpha$-aminonitrilos y las $\alpha$-cianhidrinas, que se consideran tan tóxicas como el mismo ácido cianhídrico. Los nitrilos halogenados son muy tóxicos e irritantes y producen un intenso lagrimeo. Los nitrilos, como el acrilonitrilo, el propionitrilo y el fumaronitrilo, son tóxicos y pueden causar dermatitis graves y dolorosas cuando la piel se expone a ellos.

La exposición a nitrilos tóxicos puede ocasionar rápidamente la muerte por asfixia de forma similar a la resultante de la exposición al cianuro de hidrógeno. La personas que han sobrevivido a una exposición a concentraciones elevadas de nitrilos no muestran indicios de efectos fisiológicos residuales tras la recuperación del episodio agudo, lo que ha llevado a pensar que tras la exposición a los nitrilos, la persona sucumbe 0 se recupera completamente.

Los trabajadores que puedan verse expuestos a nitrilos deben mantenerse bajo vigilancia médica y someterse a reconocimientos previos al empleo y a exámenes periódicos orientados a detectar posibles trastornos de la piel, de los aparatos cardiovascular y pulmonar y del sistema nervioso central. Cualquier antecedente de desvanecimientos o trastornos convulsivos pueden suponer un riesgo adicional para las personas que trabajan con nitrilos.

Todos los nitrilos deberán manejarse en condiciones rigurosamente controladas y sólo por personas debidamente adiestradas que conozcan las técnicas de manipulación en condiciones adecuadas de seguridad. No se utilizará el cuero como material para las prendas protectoras, los guantes y el calzado, ya que el acrilonitrilo y otros compuestos similares pueden atravesarlo. Los equipos protectores de goma deberán lavarse e inspeccionarse con frecuencia para detectar posibles deterioros. Asimismo, deberá utilizarse protección ocular y equipo de protección respiratoria y, en caso de salpicaduras, se procederá a un lavado inmediato y cuidadoso.

A crilonitrilo. El acrilonitrilo produce asfixia química, al iqual que el cianuro de hidrógeno. I rrita la piel y las mucosas, y puede causar lesiones graves en la córnea si no se lavan los ojos rápidamente con agua abundante. La Agencia Internacional para la Investigación sobre el Cáncer (IARC) ha clasificado esta sustancia como un carcinógeno del Grupo 2A (probable carcinógeno humano) basándose en pruebas limitadas de carcinogenicidad en el hombre y pruebas suficientes de carcinogenicidad en animales.

El acrilonitrilo se puede absorber por inhalación o por vía percutánea. En los casos de exposición gradual, las víctimas muestran niveles significativos de cianuro en la sangre ya antes de que aparezcan los síntomas. Estos síntomas se producen por anoxia de los tejidos y consisten, en orden aproximado de aparición, en: debilidad de las extremidades, disnea, sensación de quemazón en la garganta, mareo, confusión mental, cianosis y náuseas. En los últimos estadios puede producirse colapso, respiración irregular, convulsiones y parada cardíaca súbita. Algunos pacientes padecen histeria o se muestran agresivos, pudiendo indicar este tipo de alteraciones de la conducta una intoxicación por acrilonitrilo.

La irritación de la piel por contacto reiterado o prolongado con acrilonitrilo puede tardar varias horas en aparecer. D ebido a que esta sustancia atraviesa fácilmente el cuero y las prendas de vestir, puede causar ampollas a menos que las prendas contaminadas se retiren rápidamente y se lave la zona de piel en contacto con estas prendas. Las ropas de goma debe inspeccionarse y lavarse con frecuencia, debido a que se ablandan y se hinchan.

El acrilonitrilo comporta un riesgo considerable de incendio y explosión. El bajo punto de ignición de esta sustancia determina 
la posibilidad de que se produzcan vapores suficientes a temperaturas normales como para formar una mezcla inflamable con el aire. El acrilonitrilo se polimeriza espontáneamente por efecto de la luz solar o el calor, pudiendo causar una explosión, incluso aunque se mantenga en envases cerrados. Por ello, nunca debe almacenarse sin haber sido inhibido. El peligro de incendio y explosión se intensifica por la naturaleza letal de los humos y vapores emitidos, como amoniaco y cianuro de hidrógeno.

Cianamida cálcica. La cianamida cálcica se encuentra principalmente en forma de polvo. Su inhalación provoca rinitis, faringitis, laringitis y bronquitis. En casos de exposición prolongada se ha descrito perforación del tabique nasal. En los ojos puede producir conjuntivitis, queratitis y ulceraciones de la córnea. En la piel causa dermatitis pruriginosa que, después de cierto tiempo, puede derivar en úlceras de cicatrización lenta en las palmas de la mano y en los espacios interdigitales. También puede producir sensibilización de la piel.

Su efecto sistémico más significativo es una reacción motora característica con eritema difuso del cuerpo, la cara y los brazos, que puede ir acompañada de fatiga, náuseas, vómitos, diarrea, mareo y sensación de frío. En los casos más graves, estos síntomas pueden ir seguidos de un colapso respiratorio. El consumo de alcohol desencadena o potencia esta reacción vasomotora.

Además de un sistema adecuado de extracción de aire y el uso de equipos de protección personal, los trabajadores deben aplicarse una crema protectora resistente al agua sobre la cara y la piel expuesta. También es muy importante una buena higiene personal, con ducha y cambio de ropa después de cada turno.

Cianatos. Algunos de los cianatos más importantes que se utilizan en la industria son los de sodio, potasio, amonio, plomo y plata. Los cianatos de elementos tales como bario, boro, cadmio, cobalto, cobre, silicio, azufre y talio pueden prepararse por medio de reacciones entre soluciones de un cianato y la sal metálica correspondiente. Estos cianatos son peligrosos porque liberan cianuro de hidrógeno cuando se calientan hasta la descomposición o cuando entran en contacto con ácidos o vapores de ácidos. El personal que manipule estos materiales debe contar con la protección respiratoria y cutánea adecuada.

El cianato sódico se utiliza en síntesis orgánicas, en el tratamiento térmico del acero y como intermedio en la fabricación de productos farmacéuticos. Se considera moderadamente tóxico y los trabajadores deben protegerse contra la inhalación de polvo y la contaminación de la piel.

La toxicidad de los compuestos de cianato es variable y, por consiguiente, deben ser manejados en condiciones seguras, adoptando procedimientos normalizados de trabajo que protejan al personal de la exposición. Cuando se calientan hasta la descomposición o cuando entran en contacto con ácidos o vapores ácidos, emiten gases muy tóxicos. D eberá existir una ventilación adecuada y se vigilará estrechamente la calidad del aire en el lugar de trabajo. El personal no debe inhalar aire contaminado y debe evitarse el contacto de la piel con estas sustancias. U na buena higiene personal es indispensable para las personas que trabajen en las zonas donde se manipulan estos compuestos.

\section{Medidas de salud y seguridad}

Se debe prestar una atención escrupulosa a la ventilación. Se recomienda que los procesos se lleven a cabo completamente en cerrado, con un sistema adicional de extracción de gases. D eben colocarse señales de advertencia cerca de los accesos a las zonas en las que pueda liberarse cianuro de hidrógeno al aire. Todos los envases utilizados para el transporte y el almacenamiento de cianuro de hidrógeno o de sales de cianuro deberán llevar una etiqueta de advertencia con instrucciones de primeros auxilios, se almacenarán en áreas bien ventiladas y se manipularán con extremo cuidado.

Las personas que trabajen con sales de cianuro deben conocer perfectamente los riesgos. Deben recibir la formación necesaria para reconocer el olor característico del cianuro de hidrógeno y, en caso de detectarlo, se procederá inmediatamente a evacuar el área de trabajo. L os trabajadores que entren en un área contaminada deben contar con respiradores autónomos o provistos de suministro de aire y cartuchos específicos para cianuros, gafas 0 máscaras faciales completas y ropa protectora impermeable.

Las personas que trabajen con acrilonitrilo deberán adoptar las precauciones habituales para la manipulación de carcinógenos y líquidos muy inflamables. Asimismo, se adoptarán las medidas necesarias para eliminar el riesgo de ignición por fuentes como equipos eléctricos, electricidad estática y fricción. Debido a la naturaleza tóxica e inflamable de los vapores de esta sustancia, deberán tomarse medidas para evitar el escape de vapores al aire del lugar de trabajo, mediante el confinamiento de los procesos y la instalación de un sistema de extracción de aire. Será necesario controlar de forma continua el aire del lugar de trabajo para comprobar la eficacia de los sistemas de control. Cuando exista posibilidad de exposición en el curso de una operación normal, pero no rutinaria, como el recambio de una bomba, se utilizarán sistema de protección respiratoria, preferiblemente del tipo de presión positiva, y ropa protectora impermeable. No debe utilizarse el cuero como material para los equipos protectores, ya que el acrilonitrilo lo atraviesa fácilmente. Los equipos de goma o de otros materiales deberán inspeccionarse y lavarse con frecuencia.

Los trabajadores que manipulen acrilonitrilo deben recibir la formación necesaria sobre los riesgos químicos y sobre las actividades de rescate, descontaminación, primeros auxilios y administración de nitrato de amilo. En los casos de emergencia se requerirá asistencia médica experimentada. EI principal requisito es contar con un sistema de alarma y con personal que haya sido entrenado debidamente para que pueda colaborar con los profesionales sanitarios. D eberán existir suministros de antídotos específicos tanto en la propia planta como en los centros hospitalarios cercanos.

La vigilancia médica de los trabajadores potencialmente expuestos a cianuros debe centrarse en los aparatos respiratorio y cardiovascular, en el sistema nervioso central, en la función hepática, renal y tiroidea, en el estado de la piel y en los antecedentes de desvanecimiento o mareos. Los trabajadores con enfermedades crónicas renales, del tracto respiratorio, de la piel o de tiroides, tienen un riesgo mayor de desarrollar los efectos tóxicos de los cianuros que los trabajadores sanos.

El control médico exige una formación adecuada en técnicas de reanimación artificial y el uso de fármacos para el tratamiento de urgencia de la intoxicación aguda (por ejemplo, la inhalación de nitrito de amilo). La ropa, los guantes y el calzado contaminados deberán quitarse lo antes posible y lavar la piel para evitar que la absorción continúe. Deberán existir equipos de primeros auxilios, con fármacos y jeringas, en lugares accesibles y adecuados y se deberá comprobar su contenido con frecuencia.

Desafortunadamente, algunos manuales ampliamente distribuidos sugieren el uso de azul de metileno en las intoxicaciones por cianuros debido a que, a ciertas concentraciones, forma metahemoglobina, pudiendo ésta, gracias a su afinidad por el ión cianuro, reducir su efecto tóxico. Sin embargo, no se recomienda el uso de azul de metileno ya que, a otras concentraciones, produce el efecto contrario, es decir, convierte la metahemoglobina en hemoglobina, y en las situaciones de emergencia que constituyen las intoxicaciones por cianuro no se dispone de tiempo para realizar los análisis necesarios para determinar su concentración. 


\section{Tratamiento}

Las personas expuestas a niveles tóxicos de nitrilos deben llevarse inmediatamente a un área segura y hacerlas inhalar nitrito de amilo. Cualquier indicio de problemas respiratorios exigirá la inhalación de oxígeno y, en algunos casos, reanimación cardiopulmonar. La víctima deberá ser despojada de toda la ropa contaminada y las zonas de piel expuestas se lavarán con agua abundante. En caso de lagrimeo o irritación de la conjuntiva, se recomienda lavar extensamente los ojos con soluciones neutras 0 agua. Deberá solicitarse inmediatamente la presencia de médicos, enfermeras o personal sanitario de urgencia para que administren a la víctima un tratamiento definitivo y la mantengan bajo estrecha vigilancia hasta su recuperación completa. 
TABLAS DE COMPUESTOS DE CIANO

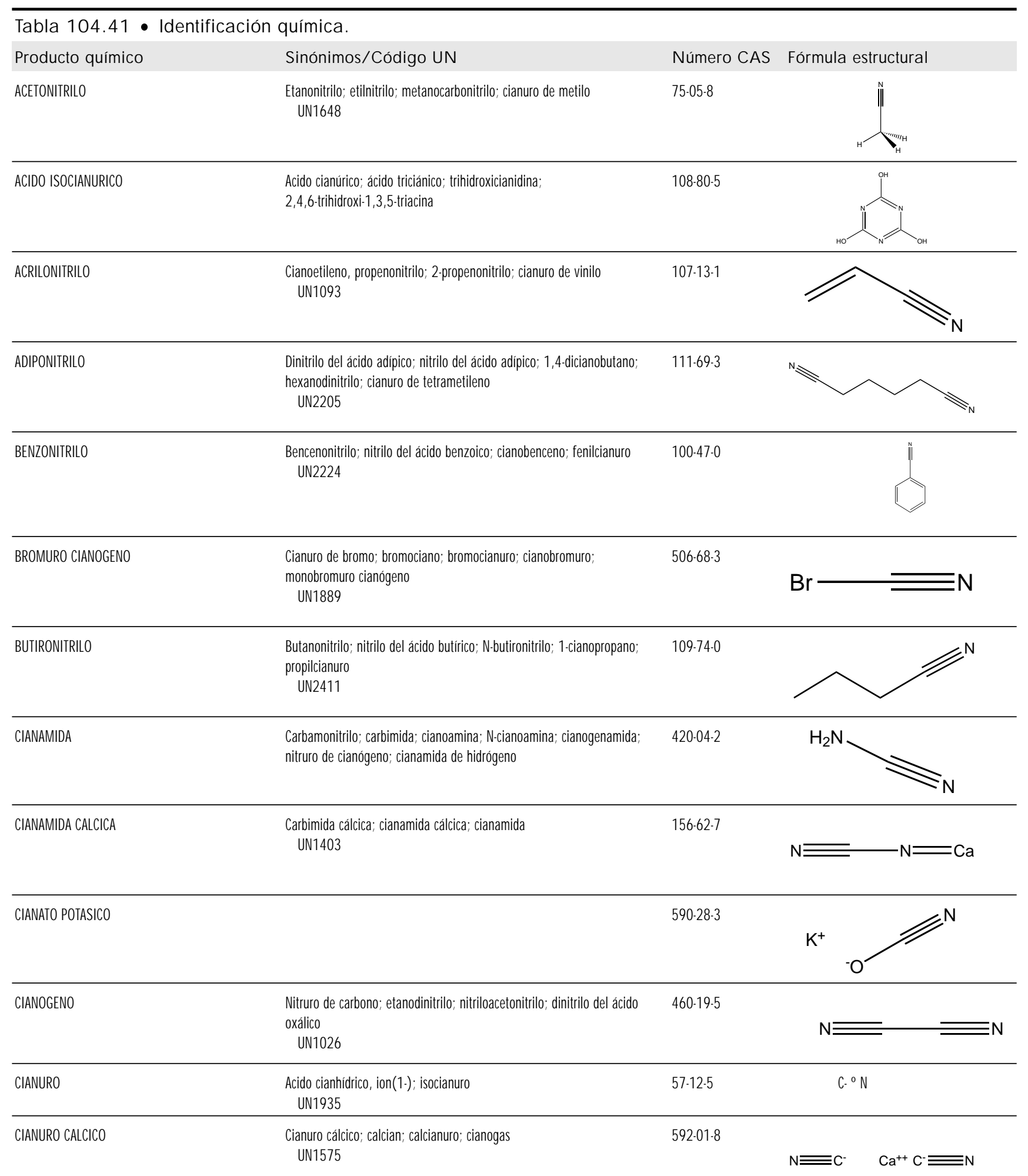




\begin{tabular}{|c|c|c|c|}
\hline Producto químico & Sinónimos/ Código UN & $\mathrm{N}$ úmero $\mathrm{CAS}$ & Fórmula estructural \\
\hline CIANURO DE HIDROGENO & $\begin{array}{l}\text { Hidruro nitruro de carbono; ácido cianhídrico } \\
\text { UN1051 } \\
\text { UN1613 } \\
\text { UN1614 }\end{array}$ & $74-90-8$ & $\cong N$ \\
\hline CIANURO POTASICO & $\begin{array}{l}\text { Sal potásica del ácido cianhídrico } \\
\text { UN1680 }\end{array}$ & $151-50-80$ & $\mathrm{~N} \cong \mathrm{C}-\quad \mathrm{K}+$ \\
\hline CIANURO SODICO & $\begin{array}{l}\text { Sal sódica del ácido cianhídrico } \\
\text { UN1689 }\end{array}$ & $143-33-9$ & $\mathrm{~N} \cong \mathrm{C}-\quad \mathrm{Nat}$ \\
\hline CIANURO DE YODO & Yoduro cianógeno; yodociano & $506-78.5$ & \\
\hline CLOROACETONITRILO & $\begin{array}{l}\text { 2-Cloroacetonitrilo; clorometilcianuro; monocloroacetonitrilo; } \\
\text { monoclorometilcianuro } \\
\text { UN2668 }\end{array}$ & $107-14-2$ & \\
\hline O-CLOROBENCILIDEN MALONONITRILO & $\begin{array}{l}\text { 2-clorobenzalmalononitrilo; 2-clorobenciliden malononitrilo; } \\
\text { propanodinitrilo de ((2-clorofenil) metileno) }\end{array}$ & 2698-41-1 & \\
\hline CLORURO CIANOGENO & $\begin{array}{l}\text { Cianuro de cloro; clorociano; clorocianuro; clorocianógeno } \\
\text { UN1589 }\end{array}$ & $506-77-4$ & $\mathrm{~N} \overline{\bar{\equiv}}$ \\
\hline DIALILCIANURATO & & $1081-69-2$ & \\
\hline DICIANODIAMIDA & Cianoguanidina; diciandiamida & $461-58.5$ & \\
\hline ETIL-2-CIANURATO & $\begin{array}{l}\text { ACE-E 50; ACE-EE; ácido acrilico, adhesivo 502; Aron alfa D; negro max; } \\
\text { cianoacrilato de etilo; alfa-cianoacrilato de etilo; 2-ciano-2-propenoato de } \\
\text { etilo; Super glue }\end{array}$ & $7085-85-0$ & \\
\hline FENILACETONITRILO & $\begin{array}{l}\text { Bencenoacetonitrilo }(9 \mathrm{Cl}) \text {; cianuro de bencilo; bencilnitrilo; } \\
\text { cianometilbenceno; } \alpha \text {-cianotolueno; o-cianotolueno; } \\
\text { fenilacetonitrilo líquido; } 2 \text {-fenilacetonitrilo; nitrilo del ácido fenílico; } \\
\alpha \text {-cianotolueno; } \alpha \text {-tolunitrilo } \\
\text { UN2470 }\end{array}$ & $140-29-4$ & \\
\hline m-FTALODINITRILO & $\begin{array}{l}\text { m-Dicianobenceno; 1,3-dicianobenceno; isoftalodinitrilo; isoftalonitrilo; } \\
\text { m-talodinitrilo; 1,3-bencenodicarbonitrilo }\end{array}$ & $626-17-5$ & \\
\hline FTALONITRILO & $\begin{array}{l}\text { o-Dicianobenceno; 1,2-dicianobenceno; dinitrilo del ácido ftálico; } \\
\text { ftalodinitrilo; o-ftalodinitrilo }\end{array}$ & $91-15-6$ & \\
\hline HIDRACRILONITRILO & $\begin{array}{l}\text { 2-Cianoetanol; Cianhidrina de etileno; 3-hidroxipropanonitrilo; } \\
\text { 3-hidroxipropionitrilo; metanolacetonitrilo }\end{array}$ & $109-78-4$ & \\
\hline
\end{tabular}




\begin{tabular}{|c|c|c|c|}
\hline Producto químico & Sinónimos/ Código UN & $\mathrm{N}$ úmero $\mathrm{CAS}$ & Fórmula estructural \\
\hline 2-HIDROXI-2-METILPROPIONITRILO & $\begin{array}{l}\text { Cianhidrina de acetona; 2-metil-laconitrilo } \\
\text { UN1541 }\end{array}$ & $75-86-5$ & \\
\hline HIDROXIACETONITRILO & $\begin{array}{l}\text { Cianometanol; cianhidrina de formaldehído; nitrilo glicólico; } \\
\text { 2-hidroxiacetonitrilo; hidroximetilnitrilo }\end{array}$ & $107-16-4$ & \\
\hline ISOBUTIRONITRILO & $\begin{array}{l}\text { 2-Cianopropano; dimetilacetonitrilo; cianuro de isopropilo; } \\
\text { 2-metilpropanonitrilo; 2-metilpropionitrilo } \\
\text { UN2284 }\end{array}$ & $78-82-0$ & \\
\hline ISOTIOCIANATO DE ALILO & $\begin{array}{l}\text { Isosulfocianato de alilo; isotiocianato de alilo; 3-isotiocianato-1-propeno; } \\
\text { 2-propenil isotiocianato } \\
\text { UN1545 }\end{array}$ & $57-06-7$ & \\
\hline LACTONITRILO & & $78-97-7$ & \\
\hline MALONONITRILO & $\begin{array}{l}\text { Cianoacetonitrilo; dicianometano; dinitrilo del ácido malónico; dinitrilo } \\
\text { malónico } \\
\text { UN2647 }\end{array}$ & $109-77-3$ & \\
\hline MANDELONITRILO & $\begin{array}{l}\text { Hidroxifenilacetonitrilo; cianhidrina de benzaldehído; fenilglicolonitrilo; } \\
\text { nitrilo del ácido mandélico }\end{array}$ & $532-28.5$ & \\
\hline METIL-2-CIANOACRILATO & $\begin{array}{l}\text { Ester metílico del ácido 2-cianoacrilico; cianoacrilato de metilo; } \\
\text { alfa-cianoacrilato de metilo; }\end{array}$ & $137-05-3$ & \\
\hline METILACRILONITRILO & $\begin{array}{l}\text { 2-Cianopropeno-1; isopropencianuro; isopropenilnitrilo; } \\
\text { 2-metilpropenonitrilo } \\
\text { UN3079 }\end{array}$ & $126-98-7$ & \\
\hline 4-MORFOLINACETONITRILO & Acetonitrilo, morfolin-; N-cianometilmorfolina & $5807-02-3$ & \\
\hline PROPIONITRILO & $\begin{array}{l}\text { Cianoetano; cianuro de etilo; éter cianhídrico; propanonitrilo; nitrilo } \\
\text { propiónico } \\
\text { UN2404 }\end{array}$ & $107-12-0$ & \\
\hline SUCCINONITRILO & $\begin{array}{l}\text { Butanodinitrilo; cianuro de etileno; dicianuro de etileno; dinitrilo del ácido } \\
\text { sucćinico; succinodinitrilo }\end{array}$ & $110-61-2$ & \\
\hline TETRAMETILSUCCINONITRILO & $\begin{array}{l}\text { Tetrametilbutanodinitrilo; dinitrilo del ácido tetrametilsuccínico; } \\
\text { tetrametilsuccinodinitrilo }\end{array}$ & $3333-52-6$ & \\
\hline
\end{tabular}




\begin{tabular}{|c|c|c|c|}
\hline Producto químico & Sinónimos/Código UN & $\mathrm{N}$ úmero $\mathrm{CAS}$ & Fórmula estructural \\
\hline TIOCIANATO DE AMONIO & $\begin{array}{l}\text { Rodanato de amonio; sulfocianuro de amonio; tiocianato de amonio; sal } \\
\text { amónica del ácido tiociánico }\end{array}$ & $1762-95-4$ & \\
\hline TIOCIANATO POTASICO & $\begin{array}{l}\text { Isotiocianato potásico; rodanato potásico; sulfocianato potásico; tiocianuro } \\
\text { potásico }\end{array}$ & $333-20-0$ & $\mathrm{~K}^{+}$ \\
\hline
\end{tabular}

\begin{tabular}{|c|c|c|c|c|c|c|}
\hline \multirow[b]{2}{*}{$\begin{array}{l}\text { Denominación } \\
\text { química } \\
\text { N úmero CAS }\end{array}$} & \multicolumn{4}{|c|}{ Tarjetas Internacionales sobre la Seguridad de los Productos Q uímicos } & \multicolumn{2}{|c|}{ N IO SH (EE.UU.) } \\
\hline & $\begin{array}{l}\text { Período } \\
\text { corto de } \\
\text { exposición }\end{array}$ & $\begin{array}{l}\text { Período } \\
\text { largo de } \\
\text { exposición }\end{array}$ & $\begin{array}{l}\text { Vías de } \\
\text { exposición }\end{array}$ & Síntomas & $\begin{array}{l}\text { O rganos } \\
\text { afectados } \\
\text { Vías de } \\
\text { entrada }\end{array}$ & Síntomas \\
\hline $\begin{array}{l}\text { ACETONITRILO } \\
75-05-8\end{array}$ & ojos; piel; tract resp & & $\begin{array}{l}\text { Inhalación } \\
\\
\\
\text { Piel } \\
\text { 0jos }\end{array}$ & $\begin{array}{l}\text { Dolor abdominal, convulsiones, dificultad } \\
\text { respiratoria, dolor de garganta, inconsciencia, } \\
\text { vómitos, debilidad, los síntomas pueden tardar } \\
\text { en aparecer } \\
\text { Puede absorberse, enrojecimiento } \\
\text { Enrojecimiento, dolor }\end{array}$ & $\begin{array}{l}\text { Riñones; hígado; } \\
\text { SCV; SNC; } \\
\text { pulmones; piel; } \\
\text { ojos; sis resp } \\
\text { Inh; abs; ing; con }\end{array}$ & $\begin{array}{l}\text { Irrit nariz y garganta; asfix; } \\
\text { náu, vómit; dolor torác; deb; } \\
\text { estupor, convuls; en animales: } \\
\text { lesiones hepáticas y renales }\end{array}$ \\
\hline $\begin{array}{l}\text { ACRILONITRILO } \\
\text { 107-13-1 }\end{array}$ & $\begin{array}{l}\text { ojos; piel; tract } \\
\text { resp; higado; SNC }\end{array}$ & SNC; hígado & $\begin{array}{l}\text { Inhalación } \\
\text { Piel } \\
\text { 0jos } \\
\text { Ingestión }\end{array}$ & $\begin{array}{l}\text { Mareo, cefalea, náuseas, vómitos, debilidad, } \\
\text { temblores y descoordinación en los } \\
\text { movimientos } \\
\text { Puede absorberse, enrojecimiento, dolor, } \\
\text { ampollas } \\
\text { Enrojecimiento, dolor, visión borrosa } \\
\text { Dolor abdominal, cefalea, náuseas, disnea, } \\
\text { vómitos, debilidad }\end{array}$ & $\begin{array}{l}\text { SCV; hígado; } \\
\text { riñones; SNC; piel; } \\
\text { ojos [tumores } \\
\text { cerebrales, cáncer } \\
\text { de pulmón e } \\
\text { intestino] } \\
\text { Inh; abs; ing; con }\end{array}$ & $\begin{array}{l}\text { Irrit ojos y piel; asfix; cef; } \\
\text { estor; náu, vómit; deb, mar; } \\
\text { vesic piel; derm con } \\
\text { descamación; [carc] }\end{array}$ \\
\hline $\begin{array}{l}\text { BENZONITRILO } \\
100-47.0\end{array}$ & ojos; tract resp; & & $\begin{array}{r}\text { Inhalación } \\
\text { Ojos } \\
\text { Ingestión } \\
\end{array}$ & $\begin{array}{l}\text { Cefalea, dificultad respiratoria, inconsciencia } \\
\text { Enrojecimiento, dolor } \\
\text { Náuseas, vómitos }\end{array}$ & & \\
\hline $\begin{array}{l}\text { BROMURO CIANOGENO } \\
506-68-3\end{array}$ & $\begin{array}{l}\text { ojos; piel; tract } \\
\text { resp; pulmones }\end{array}$ & pulmones & $\begin{array}{r}\text { Piel } \\
\text { 0jos } \\
\text { Ingestión }\end{array}$ & $\begin{array}{l}\text { Dolor abdominal, sensación de quemazón, } \\
\text { confusión, convulsiones, mareo, cefalea, } \\
\text { dificultad respiratoria, disnea, inconsciencia, } \\
\text { vómitos, asfixia, ansiedad, frecuencia cardíaca } \\
\text { irregular } \\
\text { Puede absorberse, enrojecimiento, dolor, } \\
\text { ampollas } \\
\text { Enrojecimiento, dolor, quemaduras profundas } \\
\text { graves, lagrimeo } \\
\text { Espasmos abdominales, sensación de } \\
\text { quemazón }\end{array}$ & & \\
\hline $\begin{array}{l}\text { CIANAMIDA } \\
420-04-2\end{array}$ & ojos; piel; tract resp & piel; reproducción & $\begin{array}{r}\text { Inhalación } \\
\text { Piel } \\
\text { Ojos } \\
\text { Ingestión }\end{array}$ & $\begin{array}{l}\text { Tos, disnea } \\
\text { Puede absorberse, enrojecimiento } \\
\text { Enrojecimiento, dolor } \\
\text { Dolor abdominal }\end{array}$ & $\begin{array}{l}\text { Ojos; piel; sis resp; } \\
\text { SNC } \\
\text { Inh; abs; ing; con }\end{array}$ & $\begin{array}{l}\text { Irrit ojos, piel, sis resp; } \\
\text { quemaduras en la piel y los } \\
\text { ojos; miosis, salv, lag, } \\
\text { calambres musc; efectos tipo } \\
\text { Antabuse }\end{array}$ \\
\hline
\end{tabular}


Tabla 104.42 • Riesgos para la salud.

\begin{tabular}{|c|c|c|c|c|c|c|}
\hline \multirow[b]{2}{*}{$\begin{array}{l}\text { Denominación } \\
\text { química } \\
\mathrm{N} \text { úmero CAS }\end{array}$} & \multicolumn{4}{|c|}{ Tarjetas Internacionales sobre la Seguridad de los Productos Q uímicos } & \multicolumn{2}{|c|}{ N IO SH (EE.UU.) } \\
\hline & $\begin{array}{l}\text { Período } \\
\text { corto de } \\
\text { exposición }\end{array}$ & $\begin{array}{l}\text { Período } \\
\text { largo de } \\
\text { exposición }\end{array}$ & $\begin{array}{l}\text { Vías de } \\
\text { exposición }\end{array}$ & Síntomas & $\begin{array}{l}\text { O rganos } \\
\text { afectados } \\
\text { Vías de } \\
\text { entrada }\end{array}$ & Síntomas \\
\hline $\begin{array}{l}\text { CIANURO CALCICO } \\
592-01-8\end{array}$ & $\begin{array}{l}\text { ojos; piel; tract } \\
\text { resp; pulmones; } \\
\text { SNC; sangre; } \\
\text { corazón }\end{array}$ & piel; reproducción & $\begin{array}{l}\text { Inhalación } \\
\\
\text { Piel } \\
\text { 0jos } \\
\text { Ingestión }\end{array}$ & $\begin{array}{l}\text { Sensación de quemazón, tos, mareo, cefalea, } \\
\text { coloración rojiza de la piel, dificultad } \\
\text { respiratoria, náuseas, disnea, inconsciencia, } \\
\text { vómitos, convulsiones, coma, muerte } \\
\text { Puede absorberse, quemaduras en la piel, } \\
\text { dolor, prurito, pápulas } \\
\text { Dolor, visión borrosa, posible pérdida } \\
\text { permanente de visión, quemaduras profundas } \\
\text { graves } \\
\text { Confusión, sensación de quemazón en la boca; } \\
\text { entumecimiento u opresión en la garganta, } \\
\text { salivación, convulsiones seguidas de parálisis }\end{array}$ & & \\
\hline $\begin{array}{l}\text { CIANURO DE HIDROGENO } \\
74-90-8\end{array}$ & & & $\begin{array}{l}\text { Inhalación } \\
\\
\text { Piel } \\
\text { 0jos } \\
\text { Ingestión }\end{array}$ & $\begin{array}{l}\text { Entumecimiento u opresión en la garganta y } \\
\text { rigidez en la mandíbula inferior, confusión, } \\
\text { mareo, cefalea, dificultad respiratoria, } \\
\text { náuseas, inconsciencia, vómitos, debilidad } \\
\text { Puede absorberse } \\
\text { El vapor se absorbe; véase inhalación } \\
\text { Sensación de quemazón }\end{array}$ & $\begin{array}{l}\text { SCV; SNC; tiroides; } \\
\text { sangre } \\
\text { Inh; abs; ing; con }\end{array}$ & $\begin{array}{l}\text { Asfix; deb, cef, conf; náu, } \\
\text { vómit; aumento de la } \\
\text { frecuencia y la profundidad de } \\
\text { la respiración o respiración } \\
\text { lenta y entrecortada; cambios } \\
\text { en tiroides y sangre }\end{array}$ \\
\hline $\begin{array}{l}\text { CIANURO POTASICO } \\
151-50-8\end{array}$ & ojos; piel; tract resp & glándula tiroides & $\begin{array}{l}\text { Inhalación } \\
\\
\text { Piel } \\
\text { 0jos } \\
\text { Ingestión }\end{array}$ & $\begin{array}{l}\text { Confusión, convulsiones, mareo, cefalea, } \\
\text { dificultad respiratoria, náuseas, disnea, } \\
\text { inconsciencia, vómitos, debilidad, asfixia, } \\
\text { ansiedad, frecuencia cardíaca irregular, } \\
\text { opresión torácica } \\
\text { Puede absorberse, enrojecimiento } \\
\text { Los vapores se absorben, enrojecimiento } \\
\text { Salivación, espasmos abdominales, sensación } \\
\text { de quemazón }\end{array}$ & $\begin{array}{l}\text { SCV; SNC; ojos; } \\
\text { piel; tiroides; } \\
\text { sangre } \\
\text { Inh; abs; ing; con }\end{array}$ & $\begin{array}{l}\text { Irrit ojos, piel, sis resp sup; } \\
\text { asfix; deb, cef, conf; náu, } \\
\text { vómit; aumento frecuencia } \\
\text { resp; resp lenta y } \\
\text { entrecortada; cambios en } \\
\text { tiroides y sangre }\end{array}$ \\
\hline $\begin{array}{l}\text { CIANURO SODICO } \\
143-33-9\end{array}$ & & & $\begin{array}{r}\text { Inhalación } \\
\text { Piel } \\
\text { 0jos } \\
\text { Ingestión } \\
\end{array}$ & $\begin{array}{l}\text { Sensación de quemazón, cefalea, disnea, dolor } \\
\text { de garganta, inconsciencia, debilidad, } \\
\text { convulsiones } \\
\text { Puede absorberse, quemaduras en la piel, } \\
\text { sensación de quemazón, dolor } \\
\text { Dolor, quemaduras profundas graves } \\
\text { Dolor abdominal, diarrea, vómitos }\end{array}$ & $\begin{array}{l}\text { Ojos; piel; SCV; } \\
\text { SNC; tiroides; } \\
\text { sangre } \\
\text { Inh; abs; ing; con }\end{array}$ & $\begin{array}{l}\text { Irrit ojos y piel; asfix; deb, cef, } \\
\text { conf; náu, vómit; aumento de } \\
\text { la frecuencia resp; resp lenta y } \\
\text { entrecortada; cambios en } \\
\text { tiroides y en sangre }\end{array}$ \\
\hline $\begin{array}{l}\text { CIANURO DE YODO } \\
506-78-5\end{array}$ & $\begin{array}{l}\text { ojos; piel; tract } \\
\text { resp; pulmones; } \\
\text { metabolismo de } \\
\text { oxígeno intracelular }\end{array}$ & & $\begin{array}{l}\text { Inhalación } \\
\text { Piel } \\
\text { 0jos } \\
\text { Ingestión }\end{array}$ & $\begin{array}{l}\text { Confusión, tos, mareo, cefalea, dificultad } \\
\text { respiratoria, náuseas, inconsciencia, vómitos, } \\
\text { debilidad } \\
\text { Puede absorberse, enrojecimiento } \\
\text { Enrojecimiento } \\
\text { Confusión, mareo, dificultad respiratoria, } \\
\text { inconsciencia, vómitos }\end{array}$ & & \\
\hline $\begin{array}{l}\text { CLOROACETONITRILO } \\
107-14-2\end{array}$ & ojos; piel; tract resp & & $\begin{array}{r}\text { Inhalación } \\
\text { Piel } \\
\text { 0jos } \\
\text { Ingestión } \\
\end{array}$ & $\begin{array}{l}\text { Ttos, cefalea, dificultad respiratoria, dolor de } \\
\text { garganta, inconsciencia } \\
\text { Puede absorberse, enrojecimiento } \\
\text { Enrojecimiento } \\
\text { Sensación de quemazón }\end{array}$ & & \\
\hline $\begin{array}{l}\text { 0-CLOROBENCILIDEN } \\
\text { MALONONITRILO } \\
2698-41-1\end{array}$ & & & & & $\begin{array}{l}\text { Sis resp; piel; ojos } \\
\text { Inh; abs; ing; con }\end{array}$ & $\begin{array}{l}\text { Dolor, quemaduras en los ojos, } \\
\text { lagr, conj; erit en los } \\
\text { párpados, blefarospasmo; irrit } \\
\text { de garganta, tos, opresión } \\
\text { torác; cef; erit, vesic piel }\end{array}$ \\
\hline
\end{tabular}




\begin{tabular}{|c|c|c|c|c|c|c|}
\hline \multirow[b]{2}{*}{$\begin{array}{l}\text { Denominación } \\
\text { química } \\
\text { N úmero CAS }\end{array}$} & \multicolumn{4}{|c|}{ Tarjetas Internacionales sobre la Seguridad de los Productos Q uímicos } & \multicolumn{2}{|c|}{ N IO SH (EE.UU.) } \\
\hline & $\begin{array}{l}\text { Período } \\
\text { corto de } \\
\text { exposición }\end{array}$ & $\begin{array}{l}\text { Período } \\
\text { largo de } \\
\text { exposición }\end{array}$ & $\begin{array}{l}\text { Vías de } \\
\text { exposición }\end{array}$ & Síntomas & $\begin{array}{l}\text { O rganos } \\
\text { afectados } \\
\text { Vías de } \\
\text { entrada }\end{array}$ & Síntomas \\
\hline $\begin{array}{l}\text { CLORURO CIANOGENO } \\
506-77-4\end{array}$ & $\begin{array}{l}\text { ojos; piel; tract } \\
\text { resp; pulmones; piel }\end{array}$ & & $\begin{array}{l}\text { Inhalación } \\
\text { Piel } \\
\text { 0jos }\end{array}$ & $\begin{array}{l}\text { Confusión, sopor, náuseas, dolor de garganta, } \\
\text { irritación, inconsciencia, vómitos, los síntomas } \\
\text { pueden tardar en aparecer } \\
\text { Enrojecimiento, dolor, el líquido puede } \\
\text { absorberse, en contacto con el líquido: } \\
\text { congelación } \\
\text { En contacto con el líquido: congelación, } \\
\text { enrojecimiento, dolor }\end{array}$ & $\begin{array}{l}\text { Ojos; piel; sis resp; } \\
\text { SNC; SCV } \\
\text { Inh; abs (líq); con } \\
\text { (líq) }\end{array}$ & $\begin{array}{l}\text { Irrit ojos y sis resp sup; tos, } \\
\text { edema pulm tardío; deb, cef, } \\
\text { desv, mar, conf, náu, vómit; } \\
\text { frec cardíaca irreg; irrit piel } \\
\text { (líq) }\end{array}$ \\
\hline $\begin{array}{l}\text { DICIANODIAMIDA } \\
\text { 461-58-5 }\end{array}$ & & & $\begin{array}{r}\text { Inhalación } \\
\text { Piel } \\
\text { 0jos }\end{array}$ & $\begin{array}{l}\text { Dolor abdominal, mareo, náuseas, disnea } \\
\text { Enrojecimiento, quemaduras en la piel } \\
\text { Pérdida de visión, quemaduras profundas } \\
\text { graves }\end{array}$ & & \\
\hline $\begin{array}{l}\text { 2-HIDROXI-2-METILPROPIONITR } \\
\text { ILO } \\
\quad 75-86-5\end{array}$ & $\begin{array}{l}\text { ojos; piel; tract } \\
\text { resp; metabolismo } \\
\text { de oxígeno } \\
\text { intracelular }\end{array}$ & & $\begin{array}{l}\text { Inhalación } \\
\text { Piel } \\
\text { 0jos } \\
\text { Ingestión }\end{array}$ & $\begin{array}{l}\text { Confusión, mareo, cefalea, dificultad } \\
\text { respiratoria, náuseas, inconsciencia, vómitos, } \\
\text { debilidad } \\
\text { Puede absorberse, enrojecimiento } \\
\text { Enrojecimiento } \\
\text { Confusión, mareo, dificultad respiratoria, } \\
\text { inconsciencia, vómitos }\end{array}$ & $\begin{array}{l}\text { Ojos; piel; sis resp; } \\
\text { SNC; SCV; hígado; } \\
\text { riñones; tracto Gl } \\
\text { Inh; abs; ing; con }\end{array}$ & $\begin{array}{l}\text { Irrit ojos, piel, sis resp; mar, } \\
\text { deb, cef, conf, convuls; les } \\
\text { hepáticas y renales; edema } \\
\text { pulm, asfix }\end{array}$ \\
\hline $\begin{array}{l}\text { ISOTIOCIANATO DE ALILO } \\
57.06 .7\end{array}$ & ojos; piel; tract resp & piel & $\begin{array}{r}\text { Inhalación } \\
\text { Piel } \\
\text { Ojos } \\
\text { Ingestión }\end{array}$ & $\begin{array}{l}\text { Dolor de garganta, tos, dificultad respiratoria } \\
\text { Enrojecimiento, dolor } \\
\text { Dolor, enrojecimiento, visión borrosa } \\
\text { Dolor de garganta, sensación de quemazón, } \\
\text { náuseas, vómitos }\end{array}$ & & \\
\hline $\begin{array}{l}\text { PROPIONITRILO } \\
107-12 \cdot 0\end{array}$ & $\begin{array}{l}\text { ojos; piel; tract } \\
\text { resp; metabolismo } \\
\text { celular; SNC }\end{array}$ & $\begin{array}{l}\text { piel; defectos } \\
\text { congénitos }\end{array}$ & $\begin{array}{r}\text { Inhalación } \\
\text { Piel } \\
\text { 0jos } \\
\text { Ingestión } \\
\end{array}$ & $\begin{array}{l}\text { Confusión, asfixia, mareo, embotamiento, } \\
\text { cefalea, náuseas, vómitos } \\
\text { Puede absorberse, sequedad de piel, dolor } \\
\text { Quemaduras profundas graves } \\
\text { Inconsciencia }\end{array}$ & $\begin{array}{l}\text { Ojos; piel; sis resp; } \\
\text { SNC; hígado; } \\
\text { riñones } \\
\text { Inh; abs; ing; con }\end{array}$ & $\begin{array}{l}\text { Irrit ojos, piel, sis resp; náu, } \\
\text { vómit; dolor torác; deb; } \\
\text { estupor; convuls; en animales: } \\
\text { lesiones hepáticas y renales }\end{array}$ \\
\hline $\begin{array}{l}\text { TETRAMETILSUCCINONITRILO } \\
3333-52-6\end{array}$ & SNC & & $\begin{array}{r}\text { Inhalación } \\
\text { Piel }\end{array}$ & $\begin{array}{l}\text { Convulsiones, mareo, cefalea, náuseas, } \\
\text { inconsciencia, vómitos } \\
\text { Puede absorberse }\end{array}$ & $\begin{array}{l}\text { SNC; hígado; } \\
\text { riñones; tracto Gl } \\
\text { Inh; abs; ing; con }\end{array}$ & $\begin{array}{l}\text { Cef, náu; convuls, coma; } \\
\text { hígado, riñones, efectos Gl }\end{array}$ \\
\hline
\end{tabular}

Tabla 104.43 • Riesgos físicos y químicos.

\begin{tabular}{|c|c|c|}
\hline $\begin{array}{l}\text { Denominación química } \\
\mathrm{N} \text { úmero CAS }\end{array}$ & Físicos & Q uímicos \\
\hline $\begin{array}{l}\text { ACETONITRILO } \\
75-05-8\end{array}$ & $\begin{array}{l}\text { El vapor es más pesado } \\
\text { que el aire y puede } \\
\text { desplazarse a ras del } \\
\text { suelo; posibilidad de } \\
\text { ignición a distancia El } \\
\text { vapor se mezcla } \\
\text { fácilmente con el aire y } \\
\text { forma mezclas } \\
\text { explosivas Se pueden } \\
\text { generar cargas } \\
\text { electrostáticas como } \\
\text { consecuencia de flujo, } \\
\text { agitación, etc. }\end{array}$ & $\begin{array}{l}\text { En su combustión libera humos tóxicos de cianuro de hidrógeno y óxidos de nitrógeno Se } \\
\text { descompone en contacto con ácidos, agua y vapor de agua, produciendo humos tóxicos y vapores } \\
\text { inflamables En contacto con oxidantes fuertes produce riesgo de incendio y explosión Ataca } \\
\text { algunos tipos de plásticos, caucho y revestimientos }\end{array}$ \\
\hline
\end{tabular}

Clase o división UN / Riesgos subsidiarios

\section{3}

(1)


Tabla 104.43 • Riesgos físicos y químicos.

\begin{tabular}{|c|c|c|c|}
\hline $\begin{array}{l}\text { Denominación química } \\
\mathrm{N} \text { úmero CAS }\end{array}$ & Físicos & Q uímicos & $\begin{array}{l}\text { Clase o división } \\
\text { UN / Riesgos } \\
\text { subsidiarios }\end{array}$ \\
\hline $\begin{array}{l}\text { ACIDO ISOCIANURICO } \\
108-80-5\end{array}$ & & & $6.1 / 8$ \\
\hline $\begin{array}{l}\text { ACRILONITRILO } \\
\text { 107-13-1 }\end{array}$ & $\begin{array}{l}\text { El vapor es más pesado } \\
\text { que el aire y puede } \\
\text { desplazarse a ras del } \\
\text { suelo; posibilidad de } \\
\text { ignición a distancia }\end{array}$ & $\begin{array}{l}\text { Se polimeriza por efecto del calor, la luz solar y el contacto con bases y peróxidos al } \\
\text { calentarse puede suffir una combustión violenta o explosión Se descompone al calentarse, } \\
\text { liberando humos tóxicos como óxidos de nitrógeno y cianuro de hidrógeno Reacciona } \\
\text { violentamente con oxidantes fuertes y bases fuertes, con peligro de incendio y explosión }\end{array}$ & $3 / 6.1$ \\
\hline $\begin{array}{l}\text { ADIPONITRILO } \\
111-69-3 \\
\end{array}$ & & & 6.1 \\
\hline $\begin{array}{l}\text { BENZONITRILO } \\
100-47.0\end{array}$ & & $\begin{array}{l}\text { Se descompone al calentarse o al arder en contacto con ácidos, desprendiendo humos muy } \\
\text { tóxicos (cianuro de hidrógeno, óxidos nitrosos) Reacciona violentamente con ácidos fuertes, } \\
\text { produciendo cianuro de hidrógeno, muy tóxico Ataca algunos plásticos }\end{array}$ & 6.1 \\
\hline $\begin{array}{l}\text { BROMURO CIANOGENO } \\
506-68-3\end{array}$ & $\begin{array}{l}\text { El vapor es más pesado } \\
\text { que el aire }\end{array}$ & $\begin{array}{l}\text { Se descompone al calentarse o en contacto con ácidos, produciendo cianuro de hidrógeno, muy } \\
\text { tóxico e inflamable, y bromuro de hidrógeno corrosivo Reacciona lentamente con el agua y el } \\
\text { vapor de agua, formando bromuro y cianuro de hidrógeno }\end{array}$ & \\
\hline
\end{tabular}

BUTIRONITRILO

$109-74-0$

CIANAMIDA

$420-04-2$

Puede polimerizarse a temperaturas superiores a $122{ }^{\circ} \mathrm{C}$ Se descompone al calentarse por encima de $49^{\circ} \mathrm{C}$, en contacto con ácidos, bases y humedad, produciendo humos tóxicos, como óxidos de nitrógeno y cianuros Reacciona con ácidos, oxidantes fuertes, agentes reductores fuertes y agua, con peligro de toxicidad y explosión Ataca algunos metales

CIANAMIDA CALCICA

4.3

$156-62 \cdot 7$

CIANOGENO

460-19-5

CIANURO CALCICO

592-01-8

Se descompone al calentarse por encima de $350^{\circ} \mathrm{C}$, liberando humos tóxicos (cianuro de

carbono, ácidos y sales de ácidos, produciendo cianuro de hidrógeno, muy tóxico e inflamable
Reacciona violentamente al calentarse con nitritos, nitratos, cloratos y percloratos

CIANURO DE HIDROGENO

$74-90-8$
El gas se mezcla con el aire, formando fácilmente mezclas explosivas

La sustancia puede polimerizarse si se calienta por encima de $184^{\circ} \mathrm{C}$, por efecto de bases 0

agua al 2- $5 \% 0$ si no se estabiliza químicamente, con peligro de incendio o explosión En su combustión se forma monóxido de carbono y óxidos de nitrógeno Se descompone en contacto con bases, con peligro de incendio y explosión Es un ácido débil La solución en agua es un ácido débil Reacciona violentamente con un exceso de ácidos fuertes, con peligro de incendio y explosión Ataca muchos metales en presencia de agua

CIANURO POTASICO

$151-50-8$

CIANURO SODICO

$143-33-9$

Se descompone en contacto con agua, humedad, carbonatos alcalinos y ácidos, produciendo un 6.1 gas muy tóxico (cianuro de hidrógeno) La solución en agua es una base fuerte, reacciona violentamente con ácidos y es corrosiva

Se descompone al arder, liberando humos tóxicos (óxidos de nitrógeno) Es una base fuerte, 6.1 reacciona violentamente con los ácidos y corroe los metales (aluminio y zinc) Reacciona violentamente con oxidantes fuertes, como nitratos y cloratos, con peligro de incendio y explosión

Se descompone en presencia de aire, humedad o dióxido de carbono, produciendo un gas muy tóxico e inflamable (cianuro de hidrógeno) En contacto con ácidos y sales de ácidos forma inmediatamente un gas muy tóxico e inflamable (cianuro de hidrógeno)

\title{
CIANURO DE YODO
}

$506-78.5$

Puede polimerizarse al calentarse 0 en contacto con ácidos, produciendo un gas muy tóxico (cianuro de hidrógeno) Se descompone lentamente en contacto con el agua o la humedad, produciendo un gas muy tóxico (cianuro de hidrógeno) Reacciona violentamente con oxidantes fuertes Se puede descomponer si se expone a la luz

\section{CLOROACETONITRILO}

107-14-2
El vapor es más pesado que el aire
En contacto con superficies calientes o llamas, se descompone emitiendo vapores tóxicos e inflamables Reacciona con oxidantes fuertes, agentes reductores, ácidos, bases y vapor de agua, liberando humos muy tóxicos e inflamables

$2.3 / 2.1$

6.1

$6.1 / 3$

.




\begin{tabular}{|c|c|c|c|}
\hline $\begin{array}{l}\text { Denominación química } \\
\text { N úmero CAS }\end{array}$ & Físicos & Q uímicos & $\begin{array}{l}\text { Clase o división } \\
\text { UN / Riesgos } \\
\text { subsidiarios }\end{array}$ \\
\hline $\begin{array}{l}\text { CLORURO DE CIANOGENO } \\
506-77-4\end{array}$ & $\begin{array}{l}\text { El gas es más pesado } \\
\text { que el aire }\end{array}$ & $\begin{array}{l}\text { Puede polimerizarse violentamente si se contamina con cloruro de hidrógeno o de amonio Se } \\
\text { descompone al calentarse produciendo humos tóxicos y corrosivos (cianuro de hidrógeno, ácido } \\
\text { clorhídrico, óxidos de nitrógeno) Reacciona lentamente con el agua y el vapor de agua, } \\
\text { formando cloruro de hidrógeno Ataca el cobre y el bronce }\end{array}$ & \\
\hline $\begin{array}{l}\text { DIALLLCIANURATO } \\
\text { 1081-69-2 }\end{array}$ & & & 2.318 \\
\hline $\begin{array}{l}\text { DICIANODIAMIDA } \\
461-58-5\end{array}$ & & $\begin{array}{l}\text { Se descompone al calentarse, produciendo gases tóxicos Reacciona violentamente con } \\
\text { oxidantes fuertes, con peligro de incendio y explosión Reacciona con ácidos, formando gases } \\
\text { tóxicos }\end{array}$ & $2.3 / 2.1$ \\
\hline $\begin{array}{l}\text { FENILACETONITRILO } \\
140-29-4 \\
\end{array}$ & & & 6.1 \\
\hline $\begin{array}{l}\text { 2-HIDROXI-2-METLLPROPIONITRILO } \\
75-86-5\end{array}$ & & $\begin{array}{l}\text { Se descompone al calentarse y al arder, produciendo cianuro de hidrógeno Reacciona con } \\
\text { oxidantes fuertes, bases fuertes y ácidos fuertes Reacciona violentamente con metales } \\
\text { alcalinos, con peligro de incendio y explosión }\end{array}$ & 6.1 \\
\hline $\begin{array}{l}\text { ISOBUTIRONITRILO } \\
78-82.0\end{array}$ & & & $3 / 6.1$ \\
\hline $\begin{array}{l}\text { ISOTIOCIANATO DE ALLLO } \\
57.06 .7\end{array}$ & & $\begin{array}{l}\text { Se descompone al calentarse, liberando vapores de ácido cianhídrico Reacciona con oxidantes } \\
\text { fuertes }\end{array}$ & 6.1 \\
\hline $\begin{array}{l}\text { MALONONITRILO } \\
109-77 \cdot 3\end{array}$ & & & 6.1 \\
\hline $\begin{array}{l}\text { METILACRILONITRILO } \\
126-98.7\end{array}$ & & & $3 / 6.1$ \\
\hline $\begin{array}{l}\text { PROPIONITRILO } \\
107-12-0\end{array}$ & $\begin{array}{l}\text { El vapor se mezcla } \\
\text { fácilmente con el aire; se } \\
\text { forman fácilmente mezclas } \\
\text { explosivas }\end{array}$ & $\begin{array}{l}\text { Se descompone al calentarse, desprendiendo humos tóxicos como óxidos de nitrógeno y } \\
\text { cianuro de hidrógeno Reacciona violentamente con oxidantes fuertes, con peligro de incendio y } \\
\text { explosión Reacciona con ácidos, vapor de agua y agua caliente, emitiendo cianuro de } \\
\text { hidrógeno, tóxico e inflamable }\end{array}$ & $3 / 6.1$ \\
\hline $\begin{array}{l}\text { TETRAMETILSUCCINONITRILO } \\
3333-52-6\end{array}$ & & $\begin{array}{l}\text { Se descompone al calentarse, produciendo humos tóxicos (cianuro de hidrógeno, óxidos de } \\
\text { nitrógeno) Reacciona con oxidantes fuertes, con peligro de incendio y explosión }\end{array}$ & \\
\hline
\end{tabular}

\begin{tabular}{|c|c|c|c|c|c|c|c|c|c|c|c|}
\hline $\begin{array}{l}\text { Denominación química } \\
\mathrm{N} \text { úmero CAS }\end{array}$ & Color/ Forma & $\begin{array}{l}\text { p.e. } \\
(\underline{O C})\end{array}$ & $\begin{array}{l}\text { p.f. } \\
(\underline{O} C)\end{array}$ & $\begin{array}{l}\text { p.m.l } \\
\text { (g/ } \\
\text { mol) }\end{array}$ & $\begin{array}{l}\text { Solubilidad } \\
\text { en agua }\end{array}$ & $\begin{array}{l}\text { Densidad } \\
\text { relativa } \\
\text { (agua }=1 \text { ) }\end{array}$ & $\begin{array}{l}\text { Densidad } \\
\text { de vapor } \\
\text { relativa } \\
\text { (aire=1) }\end{array}$ & $\begin{array}{l}\text { Pvap/ } \\
(\mathrm{kPa})\end{array}$ & $\begin{array}{l}\text { Límit. } \\
\text { inflam. }\end{array}$ & $\begin{array}{l}\text { p.ig. } \\
(\underline{O C})\end{array}$ & $\begin{array}{l}\text { p.aut } \\
\text { ig. } \\
(\stackrel{\circ}{\circ})\end{array}$ \\
\hline $\begin{array}{l}\text { ACETONITRILO } \\
75-05-8\end{array}$ & $\begin{array}{l}\text { líquido límpido e } \\
\text { incoloro }\end{array}$ & 81,6 & -45 & 41,05 & misc & 0,7857 & 1,42 & $\begin{array}{l}87 \mathrm{~mm} \mathrm{Hg} \\
\text { @ } 24 \mathrm{C}\end{array}$ & $\begin{array}{l}3,0 \mathrm{li} \\
16,0 \mathrm{ls}\end{array}$ & $128 \mathrm{cc}$ & 524 \\
\hline $\begin{array}{l}\text { ACIDO ISOCIANURICO } \\
108-80-5\end{array}$ & $\begin{array}{l}\text { cristales anhidros en } \\
\text { ácido clorhídrico o } \\
\text { sulfúrico } \\
\text { concentrados; polvo } \\
\text { cristalino }\end{array}$ & & 360 & 129,08 & $1 \mathrm{~g} / 200 \mathrm{ml}$ & 2,500 & & & & & \\
\hline $\begin{array}{l}\text { ACRILONITRILO } \\
\text { 107-13-1 }\end{array}$ & $\begin{array}{l}\text { líquido transparente e } \\
\text { incoloro }\end{array}$ & 77,3 & $-83,5$ & 53,06 & $7 \mathrm{~g} / 100 \mathrm{ml}$ & 0,8060 & $\begin{array}{l}1,13 \\
\text { @ } 25^{\circ} \mathrm{C}\end{array}$ & 11,0 & $\begin{array}{l}3 \mathrm{li} \\
17 \mathrm{ls}\end{array}$ & $-1 c c$ & 481 \\
\hline $\begin{array}{l}\text { ADIPONITRILO } \\
111-69-3\end{array}$ & $\begin{array}{l}\text { agujas en éter; } \\
\text { líquido incoloro }\end{array}$ & 295 & 1 & 108,1 & lig sol & 0,9676 & 3,73 & $\begin{array}{l}6,8 \times 10^{-4} \\
\mathrm{~mm} \mathrm{Hg} \\
@ 25^{\circ} \mathrm{C}\end{array}$ & $\begin{array}{l}1,0 \\
@ 200^{\circ} \mathrm{C}\end{array}$ & & 550 \\
\hline
\end{tabular}




\begin{tabular}{|c|c|c|c|c|c|c|c|c|c|c|c|}
\hline $\begin{array}{l}\text { Denominación química } \\
\mathrm{N} \text { úmero CAS }\end{array}$ & Color/ Forma & $\begin{array}{l}\text { p.e. } \\
(\stackrel{0}{ } \mathrm{C})\end{array}$ & $\begin{array}{l}\text { p.f. } \\
(\stackrel{\circ}{ } C)\end{array}$ & $\begin{array}{l}\text { p.m.l } \\
\text { (g/ } \\
\text { mol) }\end{array}$ & $\begin{array}{l}\text { Solubilidad } \\
\text { en agua }\end{array}$ & $\begin{array}{l}\text { Densidad } \\
\text { relativa } \\
\text { (agua }=1 \text { ) }\end{array}$ & $\begin{array}{l}\text { Densidad } \\
\text { de vapor } \\
\text { relativa } \\
\text { (aire=1) }\end{array}$ & $\begin{array}{l}\text { Pvap/ } \\
(\mathrm{kPa})\end{array}$ & $\begin{array}{l}\text { Límit. } \\
\text { inflam. }\end{array}$ & $\begin{array}{l}\text { p.ig. } \\
(\stackrel{C}{ })\end{array}$ & $\begin{array}{l}\text { p.aut } \\
\text { ig. } \\
(\stackrel{\circ}{ } \mathrm{C})\end{array}$ \\
\hline $\begin{array}{l}\text { BENZONITRILO } \\
100-47-0 \\
\end{array}$ & $\begin{array}{l}\text { líquido; aceite } \\
\text { transparente incoloro }\end{array}$ & 191 & -13 & 103,1 & lig sol & $\begin{array}{l}1,010 \\
@ 15^{\circ} \mathrm{C} / 15^{\circ} \mathrm{C}\end{array}$ & 3,6 & 0,1 & & $75 \mathrm{cc}$ & 550 \\
\hline $\begin{array}{l}\text { BROMURO CIANOGENO } \\
506-68-3\end{array}$ & $\begin{array}{l}\text { cubos incoloros o } \\
\text { cristales blancos con } \\
\text { forma de aguja }\end{array}$ & 61,5 & 52 & 105,0 & sol & 2,015 & 3,62 & 12,3 & & & \\
\hline $\begin{array}{l}\text { BUTIRONITRILO } \\
\text { 109-74-0 }\end{array}$ & líquido incoloro & 117,5 & -112 & 69,10 & lig sol & 0,7936 & 2,4 & $\begin{array}{l}19,5 \mathrm{~mm} \\
\mathrm{Hg} \\
@ 25^{\circ} \mathrm{C} \\
\end{array}$ & $\begin{array}{l}1,65 \mathrm{li} \\
? \text { ls }\end{array}$ & & 501 \\
\hline $\begin{array}{l}\text { CIANAMIDA } \\
420-04-2\end{array}$ & $\begin{array}{l}\text { cristales alargados } \\
\text { ortorrómbicos, } \\
\text { alargados y } \\
\text { hexagonales en } \\
\text { dimetilftalato; } \\
\text { cristaliza en distintos } \\
\text { solventes como } \\
\text { cristales incoloros, } \\
\text { ortorrómbicos, } \\
\text { delicuescentes, } \\
\text { ligeramente } \\
\text { inestables }\end{array}$ & $\begin{array}{l}83 \\
@ 0,5 \mathrm{~mm} \mathrm{Hg}\end{array}$ & $45-46$ & 42,04 & muy sol & 1,282 & 1,45 & & & 141 & \\
\hline $\begin{array}{l}\text { CIANAMIDA CALCICA } \\
156-62.7\end{array}$ & $\begin{array}{l}\text { la cianamida cálcica } \\
\text { pura se presenta } \\
\text { como cristales } \\
\text { hexagonales } \\
\text { brillantes que } \\
\text { pertenecen al sistema } \\
\text { rombohédrico; polvo } \\
\text { o cristales incoloros }\end{array}$ & & 1340 & 80,11 & insol & 2,29 & & & & & \\
\hline $\begin{array}{l}\text { CIANATO POTASICO } \\
590-28-3\end{array}$ & $\begin{array}{l}\text { polvo cristalino } \\
\text { blanco; cristales } \\
\text { tetragonales incoloros }\end{array}$ & & 315 & 81,12 & $\begin{array}{l}75 \mathrm{~g} / 100 \mathrm{cc} @ \\
25^{\circ} \mathrm{C}\end{array}$ & $2,056 @ 20^{\circ} \mathrm{C}$ & & & & & \\
\hline $\begin{array}{r}\text { CIANOGENO } \\
460-19-5\end{array}$ & gas incoloro & $-21,1$ & $-27,9$ & 52,0 & sol & $\begin{array}{l}0,9537 @ \\
-21,17^{\circ} \mathrm{C} / \\
4{ }^{\circ} \mathrm{C}\end{array}$ & 1,8 & $\begin{array}{l}760 \mathrm{~mm} \mathrm{Hg} \\
\text { @ - }-21,0^{\circ} \mathrm{C}\end{array}$ & $\begin{array}{l}6,6 \mathrm{li} \\
32 \mathrm{ls}\end{array}$ & & \\
\hline $\begin{array}{l}\text { CIANURO CALCICO } \\
592.01 .8\end{array}$ & $\begin{array}{l}\text { polvo blanco; cristales } \\
\text { rombohédricos o } \\
\text { polvo }\end{array}$ & & $\begin{array}{l}>350 \text { se } \\
\text { descompo } \\
\text { ne }\end{array}$ & 92,12 & sol & 1,853 (sólido) & & & & & \\
\hline $\begin{array}{l}\text { CIANURO DE HIDROGENO } \\
74-90-8\end{array}$ & $\begin{array}{l}\text { gas o líquido incoloro; } \\
\text { líquido color agua a } \\
\text { temperaturas } \\
\text { inferiores a } 26,5^{\circ} \mathrm{C} \text {; } \\
\text { líquido incoloro o } \\
\text { blanco azulado }\end{array}$ & & $-13,4$ & 27,0 & misc & 0,6876 & 0,94 & 81,8 & $\begin{array}{l}5,6 \mathrm{li} \\
40,0 \mathrm{ls}\end{array}$ & $\begin{array}{l}-1778 \\
c c\end{array}$ & 538 \\
\hline $\begin{array}{l}\text { CIANURO POTASICO } \\
151.50-8\end{array}$ & $\begin{array}{l}\text { polvo granular o } \\
\text { fragmentos } \\
\text { fusionados de color } \\
\text { blanco; masa } \\
\text { cristalina o agregados } \\
\text { amorfos de color } \\
\text { blanco; cubos } \\
\text { incoloros }\end{array}$ & & 634 & 65,11 & se descompone & 1,553 & & & & & \\
\hline
\end{tabular}




\begin{tabular}{|c|c|c|c|c|c|c|c|c|c|c|}
\hline $\begin{array}{l}\text { Denominación química } \\
\mathrm{N} \text { úmero CAS }\end{array}$ & Color/ Forma & $\begin{array}{l}\text { p.e. } \\
(\stackrel{0}{ })\end{array}$ & $\begin{array}{l}\text { p.f. } \\
\left({ }^{\circ} \mathrm{C}\right)\end{array}$ & $\begin{array}{l}\text { p.m.l } \\
\text { (g/ } \\
\text { mol) }\end{array}$ & $\begin{array}{l}\text { Solubilidad } \\
\text { en agua }\end{array}$ & $\begin{array}{l}\text { Densidad } \\
\text { relativa } \\
\text { (agua }=1 \text { ) }\end{array}$ & $\begin{array}{l}\text { Densidad } \\
\text { de vapor } \\
\text { relativa } \\
\text { (aire=1) }\end{array}$ & $\begin{array}{l}\text { Pvap/ } \\
(\mathrm{kPa})\end{array}$ & $\begin{array}{l}\text { Límit. } \\
\text { inflam. }\end{array}$ & $\begin{array}{ll}\text { p.ig. } & \text { p.aut } \\
\left({ }^{\circ} \mathrm{C}\right) & \text { ig. } \\
& \left({ }^{\circ} \mathrm{C}\right)\end{array}$ \\
\hline $\begin{array}{l}\text { CIANURO SODICO } \\
143-33-9\end{array}$ & $\begin{array}{l}\text { cubos incoloros; } \\
\text { sólido blanco en } \\
\text { forma de gránulos, } \\
\text { escamas o elipsoides }\end{array}$ & 1496 & 563,7 & 49,02 & $\begin{array}{l}48 \mathrm{~g} / 100 \mathrm{ml} \\
\text { @ } 10^{\circ} \mathrm{C}\end{array}$ & 1,6 & & & & \\
\hline $\begin{array}{l}\text { CIANURO DE YODO } \\
506-78.5\end{array}$ & cristales & $>45$ sublima & 146,5 & 152,92 & reacciona & $2,84 @ 18{ }^{\circ} \mathrm{C}$ & 5,3 & $\begin{array}{l}0,13 \\
\text { @ } 25,2^{\circ} \mathrm{C}\end{array}$ & & \\
\hline $\begin{array}{l}\text { CLOROACETONITRILO } \\
\text { 107-14-2 }\end{array}$ & líquido incoloro & 126 & & 75,50 & insol & 1,1930 & 2,61 & 1,15 & $\begin{array}{l}1,0 \mathrm{li} \\
? \text { Is }\end{array}$ & 56 \\
\hline $\begin{array}{l}\text { O-CLOROBENCILIDEN MALONONITRILO } \\
2698-41-1\end{array}$ & $\begin{array}{l}\text { sólido cristalino } \\
\text { blanco }\end{array}$ & $310-315$ & $93-95$ & 188,62 & insol & & & $\begin{array}{l}3,4 \times 10.5 \mathrm{~m} \\
\mathrm{~m} \mathrm{Hg}\end{array}$ & & \\
\hline $\begin{array}{l}\text { CLORURO CIANOGENO } \\
506-77-4\end{array}$ & líquido o gas incoloro & 13 & $-6,5$ & 61,5 & sol & 1,186 & 2,16 & $\begin{array}{l}1987 \\
@ 21,1^{\circ} \mathrm{C}\end{array}$ & & \\
\hline $\begin{array}{l}\text { DICIANODIAMIDA } \\
461-58-5\end{array}$ & $\begin{array}{l}\text { cristales prismáticos } \\
\text { monoclínicos en agua } \\
\text { y alcohol; cristales } \\
\text { puros blancos }\end{array}$ & & 211 & 84,08 & sol & $\begin{array}{l}1,400 \\
@ 25^{\circ} \mathrm{C} / 4^{\circ} \mathrm{C}\end{array}$ & & & & \\
\hline $\begin{array}{l}\text { FENILACETONITRILO } \\
140-29-4 \\
\end{array}$ & $\begin{array}{l}\text { líquido aceitoso } \\
\text { incoloro }\end{array}$ & 233,5 & $-23,8$ & 117,14 & insol & $\begin{array}{l}1,0214 \\
@ 15^{\circ} \mathrm{C} / 15^{\circ} \mathrm{C}\end{array}$ & & $\begin{array}{l}1 \mathrm{~mm} \mathrm{Hg} \\
@ 60,0^{\circ} \mathrm{C}\end{array}$ & & \\
\hline $\begin{array}{l}\text { m-FTALODINITRILO } \\
626-17 \cdot 5 \\
\end{array}$ & & 265 sublima & 162 & 128,13 & lig sol & $0,992 @ 40^{\circ} \mathrm{C}$ & & & & \\
\hline $\begin{array}{l}\text { FTALONITRLLO } \\
91-15-6\end{array}$ & $\begin{array}{l}\text { agujas en agua o éter } \\
\text { de petróleo; cristales } \\
\text { color crema }\end{array}$ & & 141 & 128,1 & lig sol & & & & & \\
\hline $\begin{array}{l}\text { HIDRACRILONITRILO } \\
\quad 109-78-4\end{array}$ & $\begin{array}{l}\text { líquido color agua } 0 \\
\text { color pajizo }\end{array}$ & 230 & -46 & 71,08 & misc & 1,041 & 2,45 & $\begin{array}{l}0,08 \mathrm{~mm} \\
\mathrm{Hg} \\
@ 25{ }^{\circ} \mathrm{C} \\
\end{array}$ & & $\begin{array}{l}1294 \quad 505 \\
\text { ca }\end{array}$ \\
\hline $\begin{array}{l}\text { HIDROXIACETONITRILO } \\
\text { 107-16-4 }\end{array}$ & $\begin{array}{l}\text { líquido aceitoso } \\
\text { incoloro o color agua }\end{array}$ & $\begin{array}{l}183 \text { se } \\
\text { descompone }\end{array}$ & $<-72$ & 57,06 & muy sol & 1,10 & 1,96 & $\begin{array}{l}1 \mathrm{~mm} \mathrm{Hg} \\
@ 63^{\circ} \mathrm{C}\end{array}$ & & \\
\hline $\begin{array}{l}\text { 2-HIDROXI-2-METILPROPIONITRILO } \\
75-86-5\end{array}$ & líquido incoloro & 95 & -19 & 85,10 & muy sol & $\begin{array}{l}0,9267 \\
@ 25^{\circ} \mathrm{C} / 4 \\
\end{array}$ & 2,93 & $106 \mathrm{~Pa}$ & $\begin{array}{l}2,2 \mathrm{li} \\
12,0 \mathrm{ls}\end{array}$ & $\begin{array}{l}63-74 \quad 688 \\
\text { cc }\end{array}$ \\
\hline $\begin{array}{l}\text { ISOBUTIRONITRILO } \\
78-82.0\end{array}$ & líquido incoloro & 103,8 & $.71,5$ & 69,1 & lig sol & $\begin{array}{l}0,7608 \\
@ 30^{\circ} \mathrm{C} / 4^{\circ} \mathrm{C}\end{array}$ & 2,38 & $\begin{array}{l}32,7 \mathrm{~mm} \mathrm{Hg} \\
\text { @ } 25^{\circ} \mathrm{C}\end{array}$ & & $8 \mathrm{cc} \quad 482$ \\
\hline $\begin{array}{l}\text { ISOTIOCIANATO DE ALLLO } \\
57.06 .7\end{array}$ & $\begin{array}{l}\text { líquido aceitoso } \\
\text { incoloro } 0 \text { amarillo } \\
\text { pálido }\end{array}$ & 152 & .80 & 99,15 & lig sol & 1,0126 & 3,41 & $\begin{array}{l}1,3 \mathrm{~Pa} \\
@ 38,3{ }^{\circ} \mathrm{C}\end{array}$ & & 461 \\
\hline $\begin{array}{l}\text { LACTONITRILO } \\
78-97-7 \\
\end{array}$ & $\begin{array}{l}\text { líquido amarillo; } \\
\text { l'iquido color pajizo }\end{array}$ & $\begin{array}{l}102^{\circ} \mathrm{C} \\
@ 30 \mathrm{~mm} \mathrm{Hg}\end{array}$ & -40 & 71,1 & sol & $\begin{array}{l}0,9877 \\
@ 20^{\circ} \mathrm{C} / 4^{\circ} \mathrm{C}\end{array}$ & & $\begin{array}{l}17 \mathrm{~mm} \mathrm{Hg} \mathrm{a} \\
90^{\circ} \mathrm{C}\end{array}$ & & \\
\hline $\begin{array}{l}\text { MALONONITRILO } \\
109-77-3 \\
\end{array}$ & $\begin{array}{l}\text { polvo blanco; sólido } \\
\text { incoloro }\end{array}$ & 218,5 & 32 & 66,06 & sol & 1,1910 & & $\begin{array}{l}11 \mathrm{~mm} \mathrm{Hg} \\
@ 99^{\circ} \mathrm{C}\end{array}$ & & \\
\hline $\begin{array}{l}\text { MANDELONITRILO } \\
532-28-5 \\
\end{array}$ & $\begin{array}{l}\text { líquido aceitoso } \\
\text { amarillo }\end{array}$ & 170 & -10 & & & 1,1165 & & & & \\
\hline $\begin{array}{l}\text { METIL 2-CIANOACRILATO } \\
\text { 137-05-3 }\end{array}$ & $\begin{array}{l}\text { líquido viscoso } \\
\text { incoloro }\end{array}$ & $\begin{array}{l}47-48 \\
@ 1,8 \mathrm{~mm} \mathrm{Hg}\end{array}$ & & 111,10 & $\begin{array}{l}2,95 \\
x 10+5 \mathrm{mg} / \mathrm{I}\end{array}$ & 1,1012 & & $\begin{array}{l}0,179 \mathrm{~mm} \\
\mathrm{Hg} \\
\text { @ } 25^{\circ} \mathrm{C} .\end{array}$ & & \\
\hline $\begin{array}{l}\text { METILACRILONITRILO } \\
\text { 126-98-7 }\end{array}$ & líquido incoloro & 90,3 & $-35,8$ & 67,10 & insol & 0,8001 & 2,31 & $\begin{array}{l}71,2 \mathrm{~mm} \\
\mathrm{Hg} \\
@ 25^{\circ} \mathrm{C}\end{array}$ & $\begin{array}{l}2 \mathrm{li} \\
6,8 \mathrm{ls}\end{array}$ & $13 \mathrm{ca}$ \\
\hline
\end{tabular}


Tabla 104.44 • Propiedades físicas y químicas.

\begin{tabular}{|c|c|c|c|c|c|c|c|c|c|c|}
\hline $\begin{array}{l}\text { Denominación química } \\
\mathrm{N} \text { úmero CAS }\end{array}$ & Color/ Forma & $\begin{array}{l}\text { p.e. } \\
\left({ }^{\circ} \mathrm{C}\right)\end{array}$ & $\begin{array}{l}\text { p.f. } \\
\left({ }^{\circ} C\right)\end{array}$ & $\begin{array}{l}\text { p.m.l } \\
\text { (g/ } \\
\text { mol) }\end{array}$ & $\begin{array}{l}\text { Solubilidad } \\
\text { en agua }\end{array}$ & $\begin{array}{l}\text { Densidad } \\
\text { relativa } \\
\text { (agua }=1 \text { ) }\end{array}$ & $\begin{array}{l}\text { Densidad } \\
\text { de vapor } \\
\text { relativa } \\
\text { (aire=1) }\end{array}$ & $\begin{array}{l}\text { Pvap/ } \\
(\mathrm{kPa})\end{array}$ & $\begin{array}{l}\text { Límit. } \\
\text { inflam. }\end{array}$ & $\begin{array}{l}\text { p.ig. } \\
(\stackrel{\circ}{ } \mathrm{C})\end{array}$ \\
\hline $\begin{array}{l}\text { PROPIONITRILO } \\
107-12-0\end{array}$ & líquido incoloro & 97,1 & .92 & 55,08 & muy sol & 0,7818 & 1,9 & 5,2 & $\begin{array}{l}3,1 \mathrm{li} \\
? \mathrm{ls}\end{array}$ & $6 c c$ \\
\hline $\begin{array}{l}\text { SUCCINONITRILO } \\
110-61-2\end{array}$ & & 266 & 54,5 & 80,09 & muy sol & $\begin{array}{l}0,9867 \\
@ 60^{\circ} \mathrm{C}\end{array}$ & & & & \\
\hline $\begin{array}{l}\text { TETRAMETILSUCCINONITRILO } \\
3333-52.6\end{array}$ & sólido & 1,070 & 170 sub & 136,19 & insol & $1,070 @ 2{ }^{\circ} \mathrm{C}$ & 4,7 & & & \\
\hline $\begin{array}{l}\text { TIOCIANATO DE AMONIO } \\
\text { 1762-95-4 }\end{array}$ & $\begin{array}{l}\text { cristales monoclínicos } \\
\text { incoloros }\end{array}$ & & 149,6 & 76,12 & $\begin{array}{l}128 \mathrm{~g} / 100 \mathrm{ml} \\
@ 0^{\circ} \mathrm{C} \text {; muy } \\
\text { sol en agua } \\
\text { caliente }\end{array}$ & $1,3057 \mathrm{~g} / \mathrm{ml}$ & & & & \\
\hline
\end{tabular}




\section{COMPUEST OS EPOXIDICOS}

Janet L. Collins

Los compuestos epoxi constan de uno o más anillos oxiranos. Un anillo oxirano es básicamente un átomo de oxígeno unido a dos átomos de carbono. Estos compuestos reaccionan con los grupos amino, hidroxilo y carboxilo, así como con los ácidos inorgánicos, para dar sustancias relativamente estables.

\section{Usos}

Los compuestos epoxi se utilizan ampliamente en la industria como productos químicos intermedios en la fabricación de disolventes, plastificantes, cementos, adhesivos y resinas sintéticas. Se usan en distintas industrias como recubrimientos protectores para el metal y la madera. Los compuestos alfa epoxi, que tienen el grupo epoxi (C-O-C) en posición 1,2 , son los más reactivos y los más utilizados en aplicaciones industriales. Las resinas epoxi, cuando reaccionan con un agente endurecedor, se convierten en productos muy versátiles y termoestables, que se utilizan en muy diversas aplicaciones, como recubrimiento de superficies, electrónica (productos encapsulados), estructuras laminares y unión de materiales muy diversos.

Los óxidos de butileno (1,2-epoxibutano y 2,3-epoxibutano) se utilizan en la producción de butilenglicoles y sus derivados, además de en la fabricación de agentes tensoactivos. La epiclorhidrina se utiliza como producto químico intermedio, insecticida, fumigante y disolvente de pinturas, barnices, esmaltes de uñas y lacas. T ambién se utiliza en los polímeros de recubrimiento de las redes de abastecimiento de agua y como materia prima en la producción de resinas de alta resistencia a la humedad en la industria papelera. El glicidol (o 2,3-epoxipropanol) se utiliza como estabilizante de aceites naturales y polímeros de vinilo, como agente de rotulado de tintes y como emulsionante.

1,2,3,4-D iepoxibutano. En los estudios de inhalación a corto plazo (4 horas) realizados en ratas se produjo lagrimeo, opacidad corneal, disnea y congestión pulmonar. Los experimentos en otras especies animales han demostrado que el diepoxibutano, al igual que muchos otros compuestos epoxi, puede producir irritación ocular, quemaduras y ampollas en la piel e irritación del sistema pulmonar. En el hombre, una exposición accidental "leve" provocó Oblefaritis, irritación de las vías respiratorias altas e irritación ocular dolorosa 6 horas después de la exposición.

En ratones, la aplicación cutánea de las formas $D, L$ - y meso- del 1,2,3,4-diepoxibutano produjo tumores de la piel, como carcinomas de células escamosas. En ratones y ratas, los isómeros $D$ - y L- produjeron sarcomas locales por inyección subcutánea e intraperitoneal, respectivamente.

Algunos compuestos epoxi se utilizan en la industria sanitaria y alimentaria. El óxido de etileno se utiliza para esterilizar instrumental quirúrgico y equipos médicos, tejidos, productos de papel, sábanas y artículos de aseo personal. También se utiliza como fumigante de alimentos y tejidos, como propelente de cohetes y como acelerador del crecimiento de las hojas de tabaco. El óxido de etileno se emplea como intermediario en la producción de etilenglicol, películas y fibras de poliéster de tereftalato de polietileno y otros compuestos orgánicos. El guayacol se utiliza como anestésico local, antioxidante, expectorante y como producto químico intermedio en la producción de otros expectorantes. También se emplea como aromatizante en bebidas no alcohólicas y alimentos. El óxido de propileno o 1,2-epoxipropano, sirve como fumigante para esterilizar alimentos envasados y otros materiales.
Es un intermediario muy reactivo en la producción de poliéteres polioles que, a su vez, se emplean para fabricar espumas de poliuretano. Asimismo, se utiliza en la producción de propilenglicol y sus derivados.

El dióxido de vinilciclohexeno se utiliza como diluyente reactivo para otros diepóxidos y para las resinas derivadas de la epiclorhidrina y el bisfenol A. También se ha investigado su uso para la preparación de poliglicoles que contienen grupos epoxi libres 0 para la polimerarización en resinas tridimensionales.

El furfural se utiliza en análisis de orina, en el refinado con disolventes de los aceites de petróleo y en la fabricación de barnices. T ambién se emplea como aromatizante sintético, como disolvente para el algodón nitrado, como componente de los adhesivos a base de caucho y como agente humectante en la fabricación de ruedas abrasivas y guarniciones de frenos. El alcohol furfurílico se emplea como aromatizante, como propelente líquido y como disolvente de colorantes y resinas, aś como en sellados y adhesivos resistentes a la corrosión y en los núcleos de fundición. El tetrahidrofurano se utiliza en histología, en síntesis químicas y en la fabricación de artículos para envasado, transporte y conservación de alimentos. También se utiliza como disolvente de grasas y caucho no vulcanizado. El diepoxibutano se ha utilizado para evitar la descomposición de alimentos, como agente endurecedor de polímeros y como agente reticulante de fibras textiles.

\section{Riesgos}

Los compuestos epoxídicos se utilizan ampliamente en la actualidad. L os más importantes se comentan individualmente a continuación. Como grupo, sin embargo, comparten ciertos riesgos característicos. En general, la toxicidad de un sistema de resinas es el resultado de una complicada interrelación entre los efectos tóxicos de sus distintos componentes. Los compuestos epoxi son sensibilizantes conocidos de la piel, sobre todo los de bajo peso molecular. EI bajo peso molecular también se asocia, en general, con una mayor volatilidad. Se han dado casos de dermatitis alérgica epóxica tanto retardada como inmediata, así como dermatitis epóxica irritante. La dermatitis suele aparecer en las manos y en los espacios interdigitales y su intensidad va desde un simple eritema hasta una erupción bullosa importante. 0 tros órganos afectados por la exposición a los compuestos epoxi son el sistema nervioso central (SNC), los pulmones, los riñones, los órganos reproductores, la sangre y los ojos. T ambién existen pruebas del potencial mutagénico de algunos compuestos epoxi. En un estudio, 39 de los 51 compuestos epoxi considerados provocaron una respuesta positiva en la prueba de Ames/Salmonella. Se ha demostrado que otros epóxidos inducen intercambios de cromátidas hermanas en los linfocitos humanos. Actualmente se están realizando estudios en animales para determinar la relación entre la exposición a epóxidos y el cáncer.

Es importante señalar que algunos de los agentes de curado, endurecedores y otros agentes de procesado utilizados en la producción de los compuestos finales exhiben también una acción tóxica. Uno de ellos en particular, la 4,4-metilendianilina (M DA), produce hepatotoxicidad y lesiones en la retina, además de ser carcinógena en animales. 0 tro es el anhídrido trimelítico (AT M ). A mbos se tratan más adelante en este capítulo.

Se ha visto que la epiclorhidrina, un compuesto epoxi, produce un aumento significativo del cáncer pulmonar en los trabajadores expuestos. La Agencia Internacional para la Investigación sobre el Cáncer (IARC) ha clasificado a esta sustancia en el Grupo 2A como probable carcinógeno humano. Los resultados de un 
estudio epidemiológico a largo plazo de los trabajadores expuestos a epiclorhidrina en dos plantas de la empresa Shell Chemical Company en Estados U nidos, pusieron de manifiesto un aumento estadísticamente significativo $(p<0,05)$ de la mortalidad por cáncer del aparato respiratorio. Al igual que otros compuestos epoxi, la epiclorhidrina irrita los ojos, la piel y el tracto respiratorio de las personas expuestas. Los estudios realizados en el hombre y en animales demuestran que la epiclorhidrina provoca lesiones cutáneas graves e intoxicación sistémica tras el contacto prolongado con la piel. Se ha visto que la exposición a $40 \mathrm{ppm}$ de epiclorhidrina durante $1 \mathrm{~h}$ produce una irritación de los ojos y la garganta que puede durar $48 \mathrm{~h}$, y con 20 ppm aparecen quemaduras en los ojos y los conductos nasales. Además, se ha comprobado que la epiclorhidrina produce esterilidad en los animales, así como lesiones hepáticas y renales.

La inyección subcutánea de epiclorhidrina en el ratón produjo tumores en el sitio de la inyección, algo que no ocurrió cuando esta sustancia se aplicó con un pincel sobre la piel. Los estudios de inhalación realizados en ratas han demostrado un aumento estadísticamente significativo de los cánceres nasales. La epiclorhidrina induce mutaciones (sustitución de pares de bases) en microorganismos. También se ha detectado un aumento de aberraciones cromosómicas en los leucocitos de trabajadores expuestos a epiclorhidrina. En 1996, la Conferencia A mericana de Higienistas Industriales del Gobierno (ACGIH) estableció un V alor Límite U mbral (T LV) de 0,5 ppm para la epiclorhidrina y se considera un carcinógeno del Grupo A3 (carcinógeno en animales).

1,2-E poxibutano e isómeros (óxidos de butileno). Estos compuestos son menos volátiles y menos tóxicos que el óxido de propileno. L os principales efectos adversos descritos en el hombre son irritación de los ojos, los conductos nasales y la piel. En animales se han observado también problemas respiratorios, hemorragia pulmonar, nefrosis y lesiones de la cavidad nasal con la exposición aguda a concentraciones muy elevadas de 1,2-epoxibutano, pero no ha podido demostrarse claramente que esta sustancia tenga efectos teratogénicos. La IARC ha decidido que las pruebas que existen del potencial carcinogénico del 1,2-epoxibutano en animales de experimentación son insuficientes.

EI 1,2-epoxipropano (óxido de propileno) es muchos menos tóxico para el hombre que el óxido de etileno, otro compuesto epoxi utilizado con frecuencia para esterilizar material quirúrgico y hospitalario. La exposición a esta sustancia produce efectos irritantes en los ojos, la piel y el tracto respiratorio, depresión del SNC, ataxia, estupor y coma (hasta el momento, estos últimos sólo se han demostrado claramente en animales). Además, el 1,2-epoxipropano actúa como un agente alquilante directo en varios tejidos, lo que aumenta la posibilidad de potencial carcinógeno. $V$ arios estudios realizados en animales han relacionado este compuesto con efectos carcinogénicos. Los principales efectos adversos que se han demostrado claramente en el hombre hasta el momento son quemaduras 0 ampollas en la piel por contacto prolongado con la sustancia no volatilizada, incluso a concentraciones bajas de óxido de propileno. También se han descrito quemaduras de la córnea atribuidas a este compuesto.

Dióxido de vinilciclohexeno. La irritación producida por la aplicación de este compuesto puro en la piel de conejo es similar al edema y al enrojecimiento de las quemaduras de primer grado. La aplicación cutánea de dióxido de vinilciclohexeno en ratones produjo un efecto carcinogénico (carcinomas de células escamosas o sarcomas). La administración intraperitoneal en ratas tuvo un efecto análogo (sarcomas de la cavidad peritoneal). Se ha demostrado que esta sustancia es mutagénica para la cepa TA 100 de Salmonella typhimurium y también produce un aumento significativo de las mutaciones en las células de ovario de hámster chino. El dióxido de vinilciclohexeno debe manejarse como un posible cancerígeno y obliga a instalar controles técnicos y adoptar medidas de higiene adecuadas.

En lo que se refiere a su uso industrial, se ha demostrado que el dióxido de vinilciclohexeno irrita la piel y produce dermatitis. Un trabajador que utilizó calzado contaminado con este compuesto sufrió vesiculación grave en ambos piés. Las lesiones oculares constituyen también un riesgo bien conocido. Por el momento no se han realizado estudios sobre los efectos crónicos de esta sustancia.

2,3-E poxipropanol. En los estudios experimentales realizados en ratones y ratas, el glicidol produjo irritación ocular y pulmonar. La $C_{50}$ para una exposición de 4 horas en ratones fue de 450 ppm, y para una exposición de 8 horas en ratas, 580 ppm. No obstante, las ratas expuestas durante 7 horas diarias a 400 ppm de glicidol durante 50 días no mostraron signos de toxicidad sistémica. Después de las primeras exposiciones se percibió una ligera irritación ocular y sufrimiento respiratorio.

El óxido de etileno (OTE) es una sustancia química muy peligrosa y tóxica. R eacciona exotérmicamente y puede explotar cuando se calienta o cuando entra en contacto con hidróxidos alcalimetálicos o con superficies catalíticas muy activas. Por este motivo, debe controlarse estrictamente y utilizarse sólo en procesos industriales cerrados o automatizados. La forma líquida del óxido de etileno es relativamente estable. Sus vapores, en concentraciones de tan sólo un $3 \%$, son muy inflamables y pueden explotar en presencia de calor o llamas.

Se dispone de mucha información sobre los efectos para la salud de este compuesto en el hombre. El óxido de etileno es un irritante respiratorio, cutáneo y ocular. A concentraciones altas produce depresión del sistema nervioso central. Algunas personas expuestas a concentraciones elevadas de esta sustancia han descrito un sabor extraño en la boca tras la exposición. Los efectos tardíos de la exposición aguda a concentraciones elevadas son: cefalea, náuseas, vómitos, disnea, cianosis y edema pulmonar. 0 tros síntomas que se han descrito tras la exposición aguda son sopor, fatiga, debilidad y descoordinación. La solución de óxido de etileno puede causar un tipo de quemadura característico en la piel expuesta, que aparece entre 1 y 5 horas después de la exposición. Estas quemaduras evolucionan con frecuencia de ampollas a vesículas coalescentes y descamación. Casi siempre las lesiones cutáneas remiten espontáneamente, dejando un área más pigmentada en el lugar de la quemadura.

La exposición crónica o prolongada a concentraciones bajas 0 moderadas de óxido de etileno se ha asociado a una actividad mutagénica. Se sabe que este compuesto actúa como agente alquilante en los sistemas biológicos, uniéndose al material gené tico y a otros sitios donantes de electrones, como la hemoglobina, y causando mutaciones y problemas funcionales. Se ha comprobado también que el óxido de etileno induce aberraciones cromosómicas. En un estudio de personas expuestas, la capacidad de autorreparación del ADN resultó negativamente afectada por la exposición prolongada a concentraciones bajas de esta sustancia. En algunos estudios se ha observado una relación entre la exposición a óxido de etileno y un aumento del recuento absoluto de linfocitos en los trabajadores expuestos. Sin embargo, esta relación no ha podido ser demostrada en estudios más recientes.

El potencial carcinogénico del óxido de etileno se ha demostrado en varios modelos animales. La IARC lo ha clasificado en el Grupo 1 (carcinógeno humano conocido). La inhalación prolongada de óxido de etileno en ratas y monos produce leucemia, mesotelioma peritoneal y algunos tumores cerebrales. Los estudios de exposición en ratones han asociado la exposición por inhalación con cánceres pulmonares y linfomas. Tanto el $\mathrm{N}$ ational Institute of $\mathrm{O}$ ccupational Safety and $\mathrm{H}$ ealth $(\mathrm{NIOSH})$ como la O ccupational Safety and Health Administration (OSH A) de Estados Unidos consideran que el óxido de etileno es 
cancerígeno para el hombre. EI NIO SH llevó a cabo un estudio a gran escala en el que participaron más de 18.000 trabajadores expuestos a óxido de etileno durante un período de 16 años y concluyó que, en la población expuesta, la tasa de cánceres de sangre y linfomas era superior a la esperada. Sin embargo, estudios posteriores no han encontrado una mayor incidencia de estos cánceres en los trabajadores expuestos. U no de los principales problemas de estos estudios, y una de las posibles causas de su naturaleza contradictoria, es la imposibilidad de cuantificar con exactitud los niveles de exposición. Por ejemplo, la mayor parte de los estudios sobre los efectos carcinogénicos del óxido de etileno en el hombre se han centrado en el personal encargado de la esterilización de los hospitales. Es más que probable que las personas que realizaban este tipo de trabajo antes del decenio de 1970 experimentaran una mayor exposición al gas de óxido de etileno debido a la tecnología existente y a la ausencia de medidas de control en aquella época. ( $L$ as medidas de seguridad para el uso del óxido de etileno en los centros sanitarios se comentan en el Capítulo Centros y servicios de asistencia sanitaria de este mismo volumen).

Se ha visto también que el óxido de etileno tiene efectos adversos en el sistema reproductor tanto de animales como del hombre. En machos y hembras de ratón y rata expuestos a óxido de etileno, las mutaciones letales dominantes en las células reproductoras determinaron un aumento de la tasa de mortalidad embrionaria en las crías. Algunos estudios han asociado la exposición a óxido de etileno con una mayor tasa de abortos en el hombre.

Se han descrito también efectos adversos neurológicos y neuropsiquiátricos derivados de la exposición al óxido de etileno tanto en animales como en el hombre. Las ratas, conejos y monos expuestos a 357 ppm de OTE durante un período de 48 a 85 días desarrollaron deficiencias en las funciones sensoriales y motoras, así como desgaste muscular y debilidad de las extremidades posteriores. Un estudio demostró que los trabajadores expuestos a OTE mostraban deficiencias en la respuesta sensorial a la vibración e hipoactividad en los reflejos tendinosos profundos. No se ha demostrado claramente que las personas expuestas durante largos períodos de tiempo a concentraciones bajas de óxido de etileno sufran trastornos neuropsiquiátricos. Algunos estudios y un volumen cada vez mayor de pruebas anecdóticas sugieren que el OTE induce una disfunción del SNC y deficiencias cognitivas como, por ejemplo, dificultad para pensar, problemas de memoria y tiempos de reacción más lentos en algunos tipos de pruebas.

Un estudio de personas expuestas a óxido de etileno en un entorno hospitalario ha indicado una asociación entre la exposición y el desarrollo de cataratas.

0 tro riesgo relacionado con la exposición al óxido de etileno es la posibilidad de que se forme etilenclorhidrina (2-cloroetanol) en presencia de humedad y de iones cloro. La etilenclorhidrina ejerce una intensa acción tóxica generalizada y algunas personas han muerto como consecuencia de la exposición a sus vapores.

El tetrahidrofurano (T H F) forma peróxidos explosivos en contacto con el aire. Las explosiones pueden ocurrir también cuando el compuesto entra en contacto con aleaciones de litio-aluminio. Sus vapores y peróxidos irritan las mucosas y la piel y la sustancia es un potente narcótico.

Aunque se dispone de información limitada sobre la exposición industrial a THF, los investigadores que han realizado experimentos con este compuesto en animales sufrieron fuertes cefaleas occipitales y embotamiento después de cada experimento. Los animales expuestos a dosis letales de tetrahidrofurano cayeron rápidamente en narcosis, acompañada de hipotonía muscular y supresión de los reflejos de la córnea, coma y muerte. La exposición a dosis tóxicas únicas produjo desvanecimiento, irritación de las mucosas con salivación y mucosidad abundante, vómitos, una marcada disminución de la presión sanguínea y relajación muscular, seguido por un sueño prolongado. En general, los animales se recuperaron de estas dosis y no mostraron indicios de cambios biológicos. T ras la exposición reiterada se observó irritación de las mucosas y, en algunos casos, alteraciones renales y hepáticas. Las bebidas alcohólicas potencian el efecto tóxico de esta sustancia.

\section{Medidas de salud y seguridad}

El principal objetivo de las medidas de control de los compuestos epoxi será la reducción del riesgo de inhalación y contacto con la piel. Siempre que sea factible se intensificará el control de la misma fuente de contaminación. Para ello es posible que los procesos tengan que realizarse en sistemas cerrados o con ventilación aspirante local. Cuando estos controles técnicos no sean suficientes para reducir las concentraciones ambientales hasta niveles aceptables, será necesario utilizar equipos de protección respiratoria para evitar la irritación pulmonar y la sensibilización de los trabajadores expuestos. Estos equipos consisten en máscaras para gases provistas de cartuchos y filtros para partículas sólidas de alto rendimiento, o bien, respiradores con suministro de aire. Toda la superficie corporal deberá protegerse contra posibles contactos con compuestos epoxi mediante la utilización de guantes, mandiles, pantallas faciales, gafas y tantos otros equipos y prendas de protección como fuere necesario. Las ropas contaminadas deberán retirarse lo antes posible y las zonas de la piel afectadas se lavarán con agua y jabón.

En aquellas zonas donde se manipulen cantidades apreciables de compuestos epoxi deberán existir duchas de seguridad, fuentes para el lavado de los ojos y extintores de incendios. Todos los trabajadores que tengan relación con estos productos dispondrán, asimismo, de instalaciones para lavarse las manos con agua y jabón.

El riesgo potencial de incendio asociado a los compuestos epoxi aconseja que en las zonas donde se almacenen o manipulen este tipo de compuestos no existan llamas ni otras fuentes de ignición, como pueden ser cigarrillos encendidos.

Los trabajadores afectados deberán ser necesariamente retirados de cualquier situación de emergencia y, en caso de contaminación de los ojos o la piel, se procederá a su lavado con agua abundante. Las ropas contaminadas se retirarán rápidamente. Si la exposición hubiera sido grave, se recomienda la hospitalización de la víctima para su observación durante 72 horas, por la posibilidad de que se presente un edema pulmonar tardío.

Cuando se trata de compuestos epoxi muy volátiles, como el óxido de etileno, deben adoptarse medidas de seguridad estrictas para evitar incendios y explosiones, entre ellas el control de las fuentes de ignición, como la electricidad estática, la disponibilidad de extintores de incendios a base de espuma, dióxido de carbono o polvo seco (si en los incendios masivos se utiliza agua para su extinción, las mangueras deberán estar equipadas con boquillas aspersoras), la utilización de vapor de agua 0 agua caliente para calentar el óxido de etileno o sus mezclas, y su almacenaje en zonas protegidas del calor y alejadas de oxidantes fuertes, ácidos fuertes, álcalis, cloruros anhidros o hierro, aluminio o estaño, óxidos de hierro y óxidos de aluminio.

Además, existirá un plan de emergencia adecuado y se dispondrá de equipos protectores para actuar en caso de derrames o fugas de óxido de etileno. En caso de derrame, la primera medida que debe adoptarse es la evacuación de todo el personal, con excepción de los encargados de las operaciones de limpieza. Todas las fuentes de ignición que existan en el área se quitarán o clausurarán y procurará ventilarse bien la zona. Las cantidades pequeñas de líquido derramado pueden absorberse 
con trapos o papel y dejar que se evapore en un lugar seguro, como debajo de una campana de extracción de vapores químicos. No debe permitirse que el óxido de etileno penetre en espacios confinados, como puede ser un sumidero. Los trabajadores no deben entrar en espacios confinados en los que se haya almacenado óxido de etileno sin adoptar las medidas oportunas para tener la seguridad de que no existan concentraciones tóxicas o explosivas. Siempre que sea posible, el óxido de etileno se almacenará y utilizará en sistemas cerrados o provistos de una ventilación local aspirante adecuada.
Todas las sustancias que poseen propiedades carcinogénicas, como el óxido de etileno y el dióxido de vinilciclohexeno, deben manipularse con extrema precaución para evitar el contacto con la piel del trabajador o la inhalación durante su producción y uso. La prevención del contacto se logra también con un diseño adecuado de las instalaciones de trabajo y de las plantas de procesado que impida las fugas del producto (aplicación de una ligera presión negativa, procesos herméticamente cerrados, etc.). Las medida de precaución recomendadas para estos casos se comentan con más detalle en otros artículos de esta E nciclopedia. 
TABLAS DE COMPUESTOS EPOXIDICOS

\begin{tabular}{|c|c|c|c|}
\hline Producto químico & Sinónimos/ Código UN & $\mathrm{N}$ úmero $\mathrm{CAS}$ & Fórmula estructural \\
\hline ALCOHOL FURFURILICO & $\begin{array}{l}\text { Furanmetanol; alcohol furfurálico; furfuralcohol; furilalcohol } \\
\text { UN2874 }\end{array}$ & $98-00-0$ & \\
\hline CLORURO DE (2,3-EPOXIPROPIL)TRIMETILAMONIO & $\begin{array}{l}\text { Cloruro de glicidiltrimetilamonio; cloruro de } \\
\text { oxiranometanaminio, trimetilglicidilamonio; cloruro de } \\
\text { N,N,N-N-rimetiloxiranometanaminio }\end{array}$ & $3033-77-0$ & \\
\hline DIBENZO-p-DIOXINA & $\begin{array}{l}\text { Dibenzodioxina; dibenzo(1,4) dioxina; dibenzo(b,e) }(1,4) \text { dioxina; dióxido } \\
\text { de difenileno }\end{array}$ & $262-12-4$ & \\
\hline 1,2,3,4-DIEPOXIBUTANO & $\begin{array}{l}\text { Diepóxido de butadieno; diepóxido de 1,3-butadieno; diepoxibutano; } \\
\text { 2,4-diepoxibutano }\end{array}$ & $1464-53-5$ & \\
\hline DIOXIDO DE VINILCICLOHEXENO & $\begin{array}{l}\text { 1,2-Epoxi-4-(epoxietil)ciclohexano; 1-epoxietil-3,4-epoxiciclohexano; } \\
\text { 4-vinil-1,2-ciclohexen-diepóxido; dióxido de 1-vinil-3-ciclohexeno; dióxido } \\
\text { de 4-vinil-1-ciclohexeno }\end{array}$ & $106-87.6$ & \\
\hline EPICLORHIDRINA & $\begin{array}{l}\text { 3-Cloro-1,2-epoxipropano; 1-cloro-2,3-epoxipropano; óxido de } \\
\text { (clorometil) etileno; óxido de 3-cloro-1,2-propano } \\
\text { UN2023 }\end{array}$ & $106-89-8$ & \\
\hline 1,2-EPOXIBUTANO & $\begin{array}{l}\text { 1-Butenóxido; óxido de butileno; óxido de 1,2-butileno; epoxibutano } \\
\text { UN3022 }\end{array}$ & 106-88-7 & \\
\hline 1,2-EPOXIETILBENCENO & $\begin{array}{l}\text { 1,2-Epoxi-1-feniletano; epoxiestireno; 1-fenil-1,2-epoxietano; óxido de } \\
\text { feniletileno; fenil oxirano }\end{array}$ & $96-09-3$ & \\
\hline 1,2-EPOXIPROPANO & $\begin{array}{l}\text { 2,3-Epoxipropano; óxido de metiletileno; propenóxido; óxido de propileno } \\
\text { UN1280 }\end{array}$ & $75-56-9$ & \\
\hline 2,3-EPOXIPROPANOL & $\begin{array}{l}\text { Alcohol epihidrínico; 2,3-epoxi-1-propanol; alcohol glicidílico; } \\
\text { 3-hidroxi-1,2-epoxipropano }\end{array}$ & $556-52-5$ & \\
\hline ETER ALILGLICIDILICO & $\begin{array}{l}\text { Eter alil-2,3-epoxipropílico; 1-(aliloxi)-2,3-epoxipropano; } \\
\text { 1,2-epoxi-3-aliloxipropano; éter glicidilalílico } \\
\text { UN2219 }\end{array}$ & $106-92-3$ & \\
\hline ETER BUTILGLICIDILICO & $\begin{array}{l}\text { Eter butilglicidílico; éter 2,3-epoxipropilbutílico; éter } \\
\text { butill-2,3-epoxipropilico; butilglicidiliéter; éter glicidilibutililico }\end{array}$ & $2426-08-6$ & \\
\hline ETER CRESILGLICIDILICO & $\begin{array}{l}\text { Eter cresil glicid́lilico; cresilglicídiléter; éter glicidilmetilfenílico; } \\
\text { 1,2-epoxi-3-(toliloxi)-propano }\end{array}$ & $26447-14-3$ & \\
\hline
\end{tabular}




\begin{tabular}{|c|c|c|c|}
\hline Producto químico & Sinónimos/ Código UN & $\mathrm{N}$ úmero $\mathrm{CAS}$ & Fórmula estructural \\
\hline ETER DIGLICIDILICO & Eter di(2,3-epoxi) propílico & $2238-07-5$ & \\
\hline ETER DIGLICIDLLICO DE HIDROQUINONA & & $2425-01-6$ & \\
\hline ETER DIGLICIDILICO DE RESORCINOL & $\begin{array}{l}\text { 1,3-Bis(2,3-epoxipropoxi) benceno; m-bis ( glicidiloxi) benceno; } \\
\text { 1,3-diglicidilloxibenceno; éter de digglicidiliresorcinol; éter } \\
\text { resorcinildiglicidílico }\end{array}$ & $101-90-6$ & \\
\hline 1,1-ETER DIMETILETILGLICIDILICO & $\begin{array}{l}\text { Eter terc-butil glicidílico; 1-terc-butoxi-2,3-epoxi-propano; } \\
\text { ((1,1-dimetiletoxi) metil)-oxirano }\end{array}$ & $7665-72.7$ & \\
\hline 2-ETER ETILHEXILGLICIDILICO & Eter glicidil-2-etilhexilico & $2461-15-6$ & \\
\hline ETER FENILGLICIDILICO & $\begin{array}{l}\text { 1,2-Epoxi-3-fenoxipropano; éter 2,3-epoxipropilfenílico; éter } \\
\text { fenolglicidilico; 3-fenoxi-1,2-epoxipropano; éter fenil-2,3-epoxipropilico }\end{array}$ & $122-60-1$ & \\
\hline ETER ISOPROPILGLICIDILICO & $\begin{array}{l}\text { Eter glicidilisopropílico; éter isopropilglicidílico; óxido de } \\
\text { 3-isopropiloxipropileno; ((1-Metiletoxi)metil)oxirano }\end{array}$ & $4016-14-2$ & \\
\hline FURFURAL & $\begin{array}{l}\text { 2-Furanaldehído; } 2 \text {-furancarbonal; } 2 \text {-furancarboxaldehído; } 2 \text {-furfural; } \\
\text { 2-furilaldehido } \\
\text { UN1199 }\end{array}$ & $98-01-1$ & \\
\hline GUAYACOL & Hidroxianisol & $90-05-1$ & \\
\hline OXIDO DE ETILENO & $\begin{array}{l}\text { Oxido de dimetileno; epoxietano; 1,2-epoxietano; etenóxido } \\
\text { UN1040 }\end{array}$ & $75-21-8$ & \\
\hline TETRAHIDRODIMETILFURANO & Tetrahidrodimetilfurano & $1320-94-1$ & \\
\hline TETRAHIDROFURANO & $\begin{array}{l}\text { Oxido de butileno; óxido de ciclotetrametileno; óxido de dietileno; } \\
\text { 1,4-epoxibutano; óxido de tetrametileno } \\
\text { UN2056 }\end{array}$ & $109-99-9$ & \\
\hline
\end{tabular}




\begin{tabular}{|c|c|c|c|c|c|c|}
\hline \multirow[b]{2}{*}{$\begin{array}{l}\text { Denominación } \\
\text { química } \\
\text { N úmero CAS }\end{array}$} & \multicolumn{4}{|c|}{ Tarjetas Internacionales sobre la Seguridad de los Productos Q uímicos } & \multicolumn{2}{|c|}{ N IO SH (EE.UU.) } \\
\hline & $\begin{array}{l}\text { Período } \\
\text { corto de } \\
\text { exposición }\end{array}$ & $\begin{array}{l}\text { Período } \\
\text { largo de } \\
\text { exposición }\end{array}$ & $\begin{array}{l}\text { Vías de } \\
\text { exposición }\end{array}$ & Síntomas & $\begin{array}{l}\text { O rganos } \\
\text { afectados } \\
\text { Vías de } \\
\text { entrada }\end{array}$ & Síntomas \\
\hline $\begin{array}{l}\text { ALCOHOL FURFURILICO } \\
98-00-0\end{array}$ & $\begin{array}{l}\text { ojos; piel; tract } \\
\text { resp; pulmones }\end{array}$ & piel & $\begin{array}{r}\text { Inhalación } \\
\text { Piel } \\
\text { 0jos } \\
\text { Ingestión }\end{array}$ & $\begin{array}{l}\text { Tos, disnea, dolor de garganta } \\
\text { Puede absorberse, sequedad de piel, } \\
\text { enrojecimiento } \\
\text { Enrojecimiento, dolor, lagrimeo, visión borrosa, } \\
\text { hinchazón de los párpados } \\
\text { Inconsciencia }\end{array}$ & $\begin{array}{l}\text { Sis resp; ojos; piel; } \\
\text { SNC } \\
\text { Inh; abs; ing; con }\end{array}$ & $\begin{array}{l}\text { Irrit ojos y muc; mar; náu, } \\
\text { diarr; diuresis; depr resp y de } \\
\text { la temperatura corporal; } \\
\text { vómit; derm }\end{array}$ \\
\hline $\begin{array}{l}\text { DIOXIDO DE } \\
\text { VINILCICLOHEXENO } \\
106-87-6\end{array}$ & $\begin{array}{l}\text { ojos; piel; tract } \\
\text { resp; pulmones }\end{array}$ & & $\begin{array}{r}\text { Inhalación } \\
\text { Piel } \\
\text { 0jos }\end{array}$ & $\begin{array}{l}\text { Dificultad respiratoria, dolor de garganta } \\
\text { Puede absorberse, enrojecimiento, hinchazón } \\
\text { Enrojecimiento }\end{array}$ & $\begin{array}{l}\text { Ojos; piel; sis resp; } \\
\text { sangre; timo; sis } \\
\text { repro [en animales: } \\
\text { tumores en la piel] } \\
\text { Inh; abs; ing; con }\end{array}$ & $\begin{array}{l}\text { En animales: irrit ojos, piel y } \\
\text { sis resp; atrofia testicular; } \\
\text { leucopen; nec tímica; sens } \\
\text { cutánea; [carc] }\end{array}$ \\
\hline $\begin{array}{l}\text { EPICLORHIDRINA } \\
106-89-8\end{array}$ & $\begin{array}{l}\text { ojos; piel; tract } \\
\text { resp; pulmones; } \\
\text { SNC }\end{array}$ & $\begin{array}{l}\text { piel; asma; genes; } \\
\text { sistema reproductor }\end{array}$ & $\begin{array}{l}\text { Inhalación } \\
\text { Piel } \\
\text { 0jos } \\
\text { Ingestión }\end{array}$ & $\begin{array}{l}\text { Dolor, sensación de quemazón, tos, dificultad } \\
\text { respiratoria, disnea, vómitos, cefalea, } \\
\text { inconsciencia } \\
\text { Puede absorberse, dolor, enrojecimiento, } \\
\text { quemaduras graves en la piel } \\
\text { Dolor, visión borrosa, quemaduras profundas } \\
\text { graves } \\
\text { Sensación de quemazón, espasmos } \\
\text { abdominales, náuseas, vómitos, inconsciencia }\end{array}$ & $\begin{array}{l}\text { Sis resp; piel; } \\
\text { riñones; ojos; } \\
\text { hígado; sis repro } \\
\text { [en animales: } \\
\text { cáncer nasal] } \\
\text { Inh; abs; ing; con }\end{array}$ & $\begin{array}{l}\text { Irrit ojos y piel, con dolor } \\
\text { profundo; náu, vómit; dolor } \\
\text { abdom; sufrimiento resp, tos; } \\
\text { cian; efectos repro; [carc] }\end{array}$ \\
\hline $\begin{array}{l}\text { 1,2-EPOXIBUTANO } \\
106-88-7\end{array}$ & $\begin{array}{l}\text { ojos; piel; tract } \\
\text { resp; pulmones }\end{array}$ & & $\begin{array}{l}\text { Inhalación } \\
\\
\text { Piel } \\
\text { 0jos } \\
\text { Ingestión }\end{array}$ & $\begin{array}{l}\text { Sensación de quemazón, confusión, cefalea, } \\
\text { dificultad respiratoria, náuseas, inconsciencia, } \\
\text { los síntomas pueden tardar en aparecer } \\
\text { Puede absorberse, enrojecimiento } \\
\text { Enrojecimiento } \\
\text { Dolor abdominal }\end{array}$ & & \\
\hline $\begin{array}{l}\text { 1,2-EPOXIPROPANO } \\
\text { 75-56-9 }\end{array}$ & & & & & $\begin{array}{l}\text { Ojos; piel; sis resp } \\
\text { [en animales: } \\
\text { tumores nasal] } \\
\text { Inh; ing; con }\end{array}$ & $\begin{array}{l}\text { Irrit de ojos, piel y sis resp; } \\
\text { ampollas, quemaduras; [carc] }\end{array}$ \\
\hline $\begin{array}{l}\text { 2,3-EPOXIPROPANOL } \\
556-52.5\end{array}$ & $\begin{array}{l}\text { ojos; piel; tract } \\
\text { resp; pulmones; } \\
\text { SNC }\end{array}$ & piel & $\begin{array}{l}\text { Inhalación } \\
\text { Piel } \\
\text { 0jos } \\
\text { Ingestión }\end{array}$ & $\begin{array}{l}\text { Tos, irritante, mareo, narcosis, dificultad } \\
\text { respiratoria } \\
\text { Puede absorberse, enrojecimiento, irritante } \\
\text { Enrojecimiento, potente irritante, dolor } \\
\text { Dolor abdominal, irritante }\end{array}$ & $\begin{array}{l}\text { Ojos; piel; sis resp; } \\
\text { SNC } \\
\text { Inh; ing; con }\end{array}$ & $\begin{array}{l}\text { Irrit ojos, piel, nariz y } \\
\text { garganta; narco }\end{array}$ \\
\hline $\begin{array}{l}\text { ETER ALLILGLICIDILICO } \\
\text { 106-92-3 }\end{array}$ & ojos; piel; tract re & piel & & & $\begin{array}{l}\text { Ojos; sis resp; piel; } \\
\text { hígado; riñones } \\
\text { Inh; abs; ing; con }\end{array}$ & $\begin{array}{l}\text { Irrit ojos, piel, nariz, muc; } \\
\text { edema pulm; en animales: les } \\
\text { hepáticas y renales }\end{array}$ \\
\hline $\begin{array}{l}\text { ETER BUTILGLICIDILICO } \\
2426-08-6\end{array}$ & piel & & & & $\begin{array}{l}\text { Ojos; piel; sis resp; } \\
\text { SNC; sangre } \\
\text { Inh; ing; con }\end{array}$ & $\begin{array}{l}\text { Irrit ojos, piel y nariz; sens; } \\
\text { narco; posibles efectos } \\
\text { hemato; depres SNC }\end{array}$ \\
\hline $\begin{array}{l}\text { ETER DIGLICIDILICO } \\
2238.07 .5\end{array}$ & & & & & $\begin{array}{l}\text { Piel; ojos; sis resp; } \\
\text { sis repro [en } \\
\text { animales: tumores } \\
\text { en la piel] } \\
\text { Inh; abs; ing; con }\end{array}$ & $\begin{array}{l}\text { Irrit ojos, piel, sis resp; } \\
\text { quemaduras en la piel; en } \\
\text { animales: les en el sist } \\
\text { hemato, pulmonar, hepático, } \\
\text { renal; efectos repro; [carc] }\end{array}$ \\
\hline $\begin{array}{l}\text { ETER FENILGLICIDILICO } \\
122-60-1\end{array}$ & & & & & $\begin{array}{l}\text { Ojos; piel; SNC; sist } \\
\text { hemato; sis repro } \\
\text { [en animales: } \\
\text { cáncer nasal] } \\
\text { Inh; abs; ing; con }\end{array}$ & $\begin{array}{l}\text { Irrit ojos, piel y sis resp sup; } \\
\text { sens cutánea; narco; posibles } \\
\text { efectos repro y hemato; [carc] }\end{array}$ \\
\hline
\end{tabular}


Tabla 104.46 • Riesgos para la salud.

\begin{tabular}{|c|c|c|c|c|c|c|}
\hline \multirow[b]{2}{*}{$\begin{array}{l}\text { Denominación } \\
\text { química } \\
\text { N úmero CAS }\end{array}$} & \multicolumn{4}{|c|}{ Tarjetas Internacionales sobre la Seguridad de los Productos Q uímicos } & \multicolumn{2}{|c|}{ N IO SH (EE.UU.) } \\
\hline & $\begin{array}{l}\text { Período } \\
\text { corto de } \\
\text { exposición }\end{array}$ & $\begin{array}{l}\text { Período } \\
\text { largo de } \\
\text { exposición }\end{array}$ & $\begin{array}{l}\text { Vías de } \\
\text { exposición }\end{array}$ & Síntomas & $\begin{array}{l}\text { O rganos } \\
\text { afectados } \\
\text { Vías de } \\
\text { entrada }\end{array}$ & Síntomas \\
\hline $\begin{array}{l}\text { ETER ISOPROPILGLCIDILICO } \\
\text { 4016-14-2 }\end{array}$ & $\begin{array}{l}\text { ojos; piel; tract } \\
\text { resp; SNC }\end{array}$ & & & & $\begin{array}{l}\text { Ojos; piel; sis resp; } \\
\text { sangre; sis repro } \\
\text { Inh; ing; con }\end{array}$ & $\begin{array}{l}\text { Irrit ojos, piel y sis resp sup; } \\
\text { sens piel; posibles efectos } \\
\text { repro y hemato }\end{array}$ \\
\hline $\begin{array}{r}\text { FURFURAL } \\
98-01-1\end{array}$ & $\begin{array}{l}\text { ojos; piel; tract } \\
\text { resp; pulmones; } \\
\text { SNC }\end{array}$ & $\begin{array}{l}\text { piel; hígado; } \\
\text { riñones }\end{array}$ & $\begin{array}{r}\text { Inhalación } \\
\text { Piel } \\
\text { 0jos } \\
\text { Ingestión }\end{array}$ & $\begin{array}{l}\text { Tos, cefalea, dificultad respiratoria, disnea, } \\
\text { dolor de garganta } \\
\text { Puede absorberse, enrojecimiento, dolor } \\
\text { Enrojecimiento, dolor } \\
\text { Dolor abdominal, diarrea, cefalea, dolor de } \\
\text { garganta, vómitos }\end{array}$ & $\begin{array}{l}\text { Ojos; sis resp; piel } \\
\text { Inh; abs; ing; con }\end{array}$ & $\begin{array}{l}\text { Irrit de ojos, piel y sis resp } \\
\text { sup; cefalea; derm }\end{array}$ \\
\hline $\begin{array}{l}\text { OXIDO DE ETILENO } \\
75-21-8\end{array}$ & & & & & $\begin{array}{l}\text { Ojos; sangre; sis } \\
\text { resp; hígado; SNC; } \\
\text { riñones; piel; sis } \\
\text { repro [ cáncer } \\
\text { peritoneal, } \\
\text { leucemia] } \\
\text { Inh; ing (líq); con }\end{array}$ & $\begin{array}{l}\text { Irrit ojos, piel, nariz y } \\
\text { garganta; sabor extraño; cef; } \\
\text { náu, vómit, diarr; dis, cian, } \\
\text { edema pulm; sop; desco; EKG } \\
\text { anor; quemaduras en ojos y } \\
\text { piel (líq o alta conc de vap); } \\
\text { l'íq: congelación; efectos repro; } \\
\text { [carc]; en animales: convuls; } \\
\text { lesiones hepáticas y renales }\end{array}$ \\
\hline $\begin{array}{l}\text { TETRAHIDROFURANO } \\
109-99-9\end{array}$ & $\begin{array}{l}\text { ojos; piel; tract } \\
\text { resp; SNC }\end{array}$ & $\begin{array}{l}\text { piel; hígado; } \\
\text { riñones }\end{array}$ & $\begin{array}{r}\text { Inhalación } \\
\text { Piel } \\
\text { 0jos }\end{array}$ & $\begin{array}{l}\text { Mareo, cefalea, náuseas, inconsciencia } \\
\text { Sequedad de piel, enrojecimiento, aspereza } \\
\text { Enrojecimiento, dolor }\end{array}$ & $\begin{array}{l}\text { Sis resp; piel; ojos; } \\
\text { SNC } \\
\text { Inh; ing; con }\end{array}$ & $\begin{array}{l}\text { Irrit ojos y sis resp sup; náu, } \\
\text { mar; cef, depres SNC }\end{array}$ \\
\hline
\end{tabular}

\begin{tabular}{|c|c|c|c|}
\hline $\begin{array}{l}\text { Denominación química } \\
\mathrm{N} \text { úmero CAS }\end{array}$ & Físicos & Q uímicos & $\begin{array}{l}\text { Clase o división } \\
\text { UN / Riesgos } \\
\text { subsidiarios }\end{array}$ \\
\hline $\begin{array}{l}\text { ALCOHOL FURFURILICO } \\
98-00-0\end{array}$ & & $\begin{array}{l}\text { Se polimeriza por la influencia de ácidos Reacciona violentamente con oxidantes fuertes } 0 \\
\text { ácidos fuertes, con peligro de incendio y explosión }\end{array}$ & 6.1 \\
\hline $\begin{array}{l}\text { DIOXIDO DE VINILCICLOHEXENO } \\
\text { 106-87.6 }\end{array}$ & & $\begin{array}{l}\text { En su combustión libera humos acres e irritantes Reacciona con compuestos de hidrógeno } \\
\text { activos (como alcoholes y aminas) }\end{array}$ & \\
\hline $\begin{array}{l}\text { EPICLORHIDRINA } \\
106-89-8\end{array}$ & & $\begin{array}{l}\text { Se polimeriza por efecto del calor o por la influencia de ácidos fuertes, bases y contaminantes } \\
\text { En su combustión libera humos tóxicos y corrosivos Se descompone lentamente en contacto } \\
\text { con el agua Reacciona violentamente con oxidantes fuertes Reacciona violentamente con } \\
\text { aluminio, zinc, polvo de metales, alcoholes, fenoles, aminas (en especial anilina) y ácidos } \\
\text { orgánico, con peligro de incendio y explosión Ataca el acero en presencia de agua }\end{array}$ & 6.1 \\
\hline $\begin{array}{l}\text { 1,2-EPOXIBUTANO } \\
\text { 106-88-7 }\end{array}$ & $\begin{array}{l}\text { El vapor es más pesado } \\
\text { que el aire y puede } \\
\text { desplazarse a ras del } \\
\text { suelo; posibilidad de } \\
\text { ignición a distancia El } \\
\text { vapor se mezcla con el } \\
\text { aire y forma fácilmente } \\
\text { mezclas explosivas } \\
\text { Puede generar cargas } \\
\text { electrostáticas como } \\
\text { resultado de flujo, la } \\
\text { agitación, etc. }\end{array}$ & $\begin{array}{l}\text { Puede polimerizarse en contacto con ácidos, álcalis, estaño y cloruros de aluminio y hierro, con } \\
\text { peligro de incendio o explosión }\end{array}$ & 3 \\
\hline
\end{tabular}




\begin{tabular}{|c|c|c|c|}
\hline $\begin{array}{l}\text { Denominación química } \\
\mathrm{N} \text { úmero CAS }\end{array}$ & Físicos & Q uímicos & $\begin{array}{l}\text { Clase o división } \\
\text { UN / Riesgos } \\
\text { subsidiarios }\end{array}$ \\
\hline $\begin{array}{l}\text { 1,2-EPOXIPROPANO } \\
\text { 75-56-9 }\end{array}$ & & & 3 \\
\hline $\begin{array}{l}\text { 2,3-EPOXIPROPANOL } \\
556-52.5\end{array}$ & & $\begin{array}{l}\text { Se descompone en contacto con ácidos y bases fuertes, sales (cloruro de aluminio, cloruro } \\
\text { férrico) o metales (cobre, zinc), con peligro de incendio y explosión Ataca el plástico y el } \\
\text { caucho }\end{array}$ & \\
\hline $\begin{array}{l}\text { ETER ALLLGLICIDILLCO } \\
106-92-3\end{array}$ & & & 3 \\
\hline $\begin{array}{r}\text { FURFURAL } \\
98-01-1\end{array}$ & $\begin{array}{l}\text { El vapor es más pesado } \\
\text { que el aire }\end{array}$ & $\begin{array}{l}\text { Se polimeriza por la influencia de ácidos o bases, con peligro de incendio o explosión } \\
\text { Reacciona violentamente con oxidantes Ataca muchos plásticos }\end{array}$ & 3 \\
\hline $\begin{array}{l}\text { OXIDO DE ETILENO } \\
75-21-8 \\
\end{array}$ & & & $6.1 / 2.1$ \\
\hline $\begin{array}{l}\text { TETRAHIDROFURANO } \\
109-99-9\end{array}$ & $\begin{array}{l}\text { El vapor es más pesado } \\
\text { que el aire y puede } \\
\text { desplazarse a ras del } \\
\text { suelo; posibilidad de } \\
\text { ignición a distancia }\end{array}$ & $\begin{array}{l}\text { Puede formar peróxidos explosivos En su combustión se forma monóxido de carbono } \\
\text { Reacciona violentamente con oxidantes fuertes, con peligro de incendio y explosión }\end{array}$ & 3 \\
\hline
\end{tabular}

\begin{tabular}{|c|c|c|c|c|c|c|c|c|c|c|c|}
\hline $\begin{array}{l}\text { Denominación química } \\
\mathrm{N} \text { úmero CAS }\end{array}$ & Color/ Forma & $\begin{array}{l}\text { p.e. } \\
\left({ }^{\circ} \mathrm{C}\right)\end{array}$ & $\begin{array}{l}\text { p.f. } \\
(\stackrel{\circ}{ } \mathrm{C})\end{array}$ & $\begin{array}{l}\text { p.m.l } \\
\text { (g/ } \\
\text { mol) }\end{array}$ & $\begin{array}{l}\text { Solubilidad } \\
\text { en agua }\end{array}$ & $\begin{array}{l}\text { Densidad } \\
\text { relativa } \\
\text { (agua }=1 \text { ) }\end{array}$ & $\begin{array}{l}\text { Densidad } \\
\text { de vapor } \\
\text { relativa } \\
\text { (aire=1) }\end{array}$ & $\begin{array}{l}\text { Pvap/ } \\
(\mathrm{kPa})\end{array}$ & $\begin{array}{l}\text { Límit. } \\
\text { inflam. }\end{array}$ & $\begin{array}{l}\text { p.ig. } \\
(\mathrm{O} C)\end{array}$ & $\begin{array}{l}\text { p.aut } \\
\text { ig. } \\
\left({ }^{\circ} \mathrm{C}\right)\end{array}$ \\
\hline $\begin{array}{l}\text { ALCOHOL FURFURILICO } \\
98-00-0\end{array}$ & $\begin{array}{l}\text { líquido incoloro o } \\
\text { amarillento; líquido } \\
\text { móvil transparente }\end{array}$ & 171 & $-14,6$ & 98,10 & misc & 1,1296 & 1,003 & 0,051 & $\begin{array}{l}1,8 \mathrm{li} \\
16,3 \mathrm{ls}\end{array}$ & $75 \mathrm{ca}$ & 490 \\
\hline $\begin{array}{l}\text { DIBENZO-p-DIOXINA } \\
\text { 262-12-4 }\end{array}$ & & & $122-123$ & 184,2 & 1 ppm @ $25 \stackrel{\circ}{\circ}$ & & & $\begin{array}{l}4,125 \times 10^{-4} \\
\mathrm{~mm} \mathrm{Hg} \\
\text { @ } 25 \stackrel{\circ}{-C}\end{array}$ & & & \\
\hline $\begin{array}{l}\text { 1,2,3,4-DIEPOXIBUTANO } \\
\text { 1464-53-5 }\end{array}$ & & 138 & -19 & 86,09 & muy sol & 1,113 & & $\begin{array}{l}6,9 \mathrm{~mm} \mathrm{Hg} \\
\text { @ } 25^{\circ} \mathrm{C} \text {. }\end{array}$ & & & \\
\hline $\begin{array}{l}\text { DIOXIDO DE VINILCICLOHEXENO } \\
106-87.6\end{array}$ & líquido incoloro & 227 & $<-55$ & 140,18 & muy sol & 1,0986 & 4,8 & 0,13 & & $110 \mathrm{ca}$ & \\
\hline $\begin{array}{l}\text { EPICLORHIDRINA } \\
106-89-8\end{array}$ & $\begin{array}{l}\text { líquido móvil e } \\
\text { incoloro }\end{array}$ & 116 & -48 & 92,5 & misc & 1,1801 & 3,29 & 1,6 & $\begin{array}{l}3,8 \mathrm{li} \\
21,0 \mathrm{ls}\end{array}$ & $34 c c$ & 385 \\
\hline $\begin{array}{l}\text { 1,2-EPOXIBUTANO } \\
106-88-7\end{array}$ & líquido incoloro & 63,3 & -150 & 72,12 & $\begin{array}{l}95000 \mathrm{ppm} \\
@ 25 \stackrel{\circ}{C} \mathrm{C}\end{array}$ & $\begin{array}{l}0,837 \\
\text { @ } 17 \stackrel{\circ}{\circ} \mathrm{Cl} 4 \stackrel{\circ}{\mathrm{C}} \mathrm{C}\end{array}$ & 2,2 & 18,8 & $\begin{array}{l}3,1 \mathrm{li} \\
25,1 \mathrm{Is}\end{array}$ & -17 & 439 \\
\hline $\begin{array}{l}\text { 1,2-EPOXIETILBENCENO } \\
96-09-3\end{array}$ & $\begin{array}{l}\text { líquido incoloro o } \\
\text { color pajizo pálido }\end{array}$ & 194,1 & $-35,6$ & 120,1 & insol & $\begin{array}{l}1,0523 \\
@ 16 \stackrel{\circ}{\circ} / 4 \stackrel{\circ}{=} \mathrm{C}\end{array}$ & 4,30 & $0,3 \mathrm{~mm} \mathrm{Hg}$ & & 822 ca & 498 \\
\hline $\begin{array}{l}\text { 1,2-EPOXIPROPANO } \\
75-56-9\end{array}$ & $\begin{array}{l}\text { líquido etéreo } \\
\text { incoloro }\end{array}$ & 34,23 & $-112,13$ & 58,08 & muy sol & 0,8304 & 2,0 & $445 \mathrm{~mm} \mathrm{Hg}$ & $\begin{array}{l}2,3 \mathrm{li} \\
36 \mathrm{ls}\end{array}$ & & 449 \\
\hline $\begin{array}{l}\text { 2,3-EPOXIPROPANOL } \\
556-52.5\end{array}$ & $\begin{array}{l}\text { líquido incoloro, } \\
\text { ligeramente viscoso }\end{array}$ & $\begin{array}{l}\text { 166-167 se } \\
\text { descompone }\end{array}$ & -45 & 74,08 & misc & 1,115 & 2,15 & $\begin{array}{l}0,12 \\
@ 25^{\circ} \mathrm{C}\end{array}$ & & $72 \mathrm{cc}$ & 415 \\
\hline $\begin{array}{l}\text { ETER ALILGLICIDILICO } \\
106-92-3\end{array}$ & líquido incoloro & 154 & -100 & 114,1 & $14,1 \%$ & 0,9698 & $\begin{array}{l}3,32 \\
@ 25 \stackrel{\circ}{\circ}\end{array}$ & $\begin{array}{l}4,7 \mathrm{~mm} \mathrm{Hg} \\
\text { @ } 25 \stackrel{\circ}{\circ} \mathrm{C}\end{array}$ & & & \\
\hline $\begin{array}{l}\text { ETER BUTILGLICIDILICO } \\
2426-08 \cdot 6\end{array}$ & $\begin{array}{l}\text { líquido transparente } \\
\text { incoloro }\end{array}$ & 164 & & 130,2 & $2 \%$ sol & 0,918 & $\begin{array}{l}3,78 \\
@ 25 \stackrel{\circ}{\circ}\end{array}$ & 0,2 & & $74 \mathrm{cc}$ & \\
\hline
\end{tabular}


Tabla 104.48 • Propiedades físicas y químicas.

\begin{tabular}{|c|c|c|c|c|c|c|c|c|c|c|c|}
\hline $\begin{array}{l}\text { Denominación química } \\
\mathrm{N} \text { úmero CAS }\end{array}$ & Color/ Forma & $\begin{array}{l}\text { p.e. } \\
(\stackrel{O}{ } \mathrm{C})\end{array}$ & $\begin{array}{l}\text { p.f. } \\
(\stackrel{\circ}{ } C)\end{array}$ & $\begin{array}{l}\text { p.m.l } \\
\text { (g/ } \\
\text { mol) }\end{array}$ & $\begin{array}{l}\text { Solubilidad } \\
\text { en agua }\end{array}$ & $\begin{array}{l}\text { Densidad } \\
\text { relativa } \\
\text { (agua }=1 \text { ) }\end{array}$ & $\begin{array}{l}\text { Densidad } \\
\text { de vapor } \\
\text { relativa } \\
(\text { aire }=1)\end{array}$ & $\begin{array}{l}\text { Pvap/ } \\
(\mathrm{kPa})\end{array}$ & $\begin{array}{l}\text { Límit. } \\
\text { inflam. }\end{array}$ & $\begin{array}{l}\text { p.ig. } \\
(\stackrel{\circ}{ } \mathrm{C})\end{array}$ & $\begin{array}{l}\text { p.aut } \\
\text { ig. } \\
\left({ }^{\circ} \mathrm{C}\right)\end{array}$ \\
\hline $\begin{array}{l}\text { ETER CRESILGLICIDILLCO } \\
\text { 26447-14-3 }\end{array}$ & líquido incoloro & & & 164,20 & & & & & & $93 \mathrm{ca}$ & \\
\hline $\begin{array}{l}\text { ETER DIGLICIDILICO DE RESORCINOL } \\
101-90.6\end{array}$ & líquido amarillo paja & $\begin{array}{l}172 @ \\
0,8 \mathrm{~mm} \mathrm{Hg} \\
\end{array}$ & $32-33$ & 222,2 & & $1,21 @ 25^{\circ} \mathrm{C}$ & & & & $177 \mathrm{ca}$ & \\
\hline $\begin{array}{l}\text { ETER DIGLICIDILICO } \\
2238-07.5\end{array}$ & líquido incoloro & 260 & & 130,16 & & 1,1195 & $\begin{array}{l}3,78 \\
@ 25 \cong C\end{array}$ & $\begin{array}{l}0,09 \mathrm{~mm} \mathrm{Hg} \\
\text { @ } 25 \stackrel{\circ}{\circ} \mathrm{C}\end{array}$ & & & \\
\hline $\begin{array}{l}\text { 1,1-ETER DIMETILETLGLICIDILLCO } \\
7665-72 \cdot 7\end{array}$ & & 152 & .70 & 130,18 & & 0,898 & & & & & \\
\hline $\begin{array}{l}\text { ETER FENILGLICIDILICO } \\
122-60-1\end{array}$ & líquido incoloro & 245 & 3,5 & 150,1 & $0,24 \%$ & 1,1092 & 4,37 & $0,01 \mathrm{~mm} \mathrm{Hg}$ & & & \\
\hline $\begin{array}{l}\text { ETER ISOPROPILGLICIDILICO } \\
4016-14-2 \\
\end{array}$ & líquido móvil incoloro & 137 & & 116,18 & $18,8 \%$ & 0,9186 & 4,15 & $\begin{array}{l}9,4 \mathrm{~mm} \mathrm{Hg} \\
\text { @ } 25 \stackrel{0}{\mathrm{C}}\end{array}$ & & & \\
\hline $\begin{array}{l}\text { FURFURAL } \\
98-01-1\end{array}$ & $\begin{array}{l}\text { líquido color ámbar; } \\
\text { líquido incoloro } \\
\text { recién preparado; } \\
\text { líquido aceitoso entre } \\
\text { incoloro y marrón } \\
\text { rojizo }\end{array}$ & 161,7 & $-36,5$ & 96,08 & sol & 1,1594 & 3,3 & 0,144 & $\begin{array}{l}2,1 \mathrm{li} \\
19,3 \mathrm{Is}\end{array}$ & $60 \mathrm{cc}$ & 316 \\
\hline $\begin{array}{l}\text { GUAYACOL } \\
90-05-1\end{array}$ & $\begin{array}{l}\text { masa cristalina entre } \\
\text { blanca y ligeramente } \\
\text { amarilla o entre } \\
\text { incolora y } \\
\text { amarillenta; prismas } \\
\text { hexagonales; } \\
\text { cristales o líquido }\end{array}$ & 205 & 32 & 124,13 & lig sol & $\begin{array}{l}1,1287 \\
@ 21 \stackrel{\circ}{0} / 4 \stackrel{\circ}{\circ} \mathrm{C}\end{array}$ & & $\begin{array}{l}0,103 \mathrm{~mm} \\
\mathrm{Hg} \\
\text { @ } 25 \stackrel{\circ}{\circ} \mathrm{C}\end{array}$ & & & \\
\hline $\begin{array}{l}\text { OXIDO DE ETILENO } \\
75-21-8\end{array}$ & $\begin{array}{l}\text { gas incoloro a } \\
\text { temperatura y } \\
\text { presión ambiente } \\
\text { normales, líquido a } \\
\text { temperaturas } \\
\text { inferiores a } 12{ }^{\circ} \mathrm{C}\end{array}$ & 10,7 & $-112,5$ & 44,06 & sol & $\begin{array}{l}0,8222 \\
@ 10^{\circ} \mathrm{Cl} \\
10{ }^{\circ} \mathrm{C}\end{array}$ & 1,49 & $\begin{array}{l}1095 \mathrm{~mm} \\
\mathrm{Hg}\end{array}$ & $\begin{array}{l}3 \mathrm{li} \\
100 \mathrm{Is}\end{array}$ & & \\
\hline $\begin{array}{l}\text { TETRAHIDROFURANO } \\
109.99-9\end{array}$ & líquido móvil incoloro & 66 & $-108,3$ & 72,1 & sol & 0,8892 & 2,5 & 19,3 & $\begin{array}{l}2 \mathrm{li} \\
11,8 \mathrm{ls}\end{array}$ & -145 & 321 \\
\hline
\end{tabular}




\section{ESTERES, ACETATOS}

Los acetatos se obtienen por esterificación del alcohol correspondiente con ácido acético 0 un compuesto anhidro que contenga un grupo acetato, eliminándose agua durante la reacción. Así, el acetato de metilo se obtiene mediante la esterificación del alcohol metílico con ácido acético, en presencia de ácido sulfúrico como catalizador. Esta reacción es reversible y por ello debe ser controlada con calor y eliminando el agua formada durante la misma. El acetato de etilo se obtiene mediante esterificación directa del alcohol etílico con ácido acético, un proceso que consiste en mezclar ácido acético con alcohol etílico en exceso y añadir pequeñas cantidades de ácido sulfúrico. El éster se separa y se purifica por destilación. EI acetato de etilo se hidroliza fácilmente en agua, dando una reacción ligeramente ácida. En otro proceso, las moléculas del acetaldehído anhidro reaccionan en presencia de etóxido de aluminio para producir el éster, que se purifica mediante destilación. L os ésteres acetato de propilo y acetato de isopropilo se obtienen por reacción del ácido acético con el alcohol propílico correspondiente, en presencia de un catalizador.

Tanto el acetato de butilo como el acetato de amilo están formados por mezclas de isómeros. Así, el acetato de butilo está formado por acetato de n-butilo, acetato de sec-butilo y acetato de isobutilo. Se obtiene mediante la esterificación del n-butanol con ácido acético en presencia de ácido sulfúrico. El n-butanol se obtiene por fermentación del almidón con Clostridium acetobutylicum. El acetato de amilo es principalmente una mezcla de acetato de n-amilo y acetato de isoamilo. Su composición y sus características dependen de su grado. El punto de ignición de los distintos grados varía entre 17 y $35^{\circ} \mathrm{C}$.

\section{Usos}

Los acetatos se utilizan como disolventes de nitrocelulosa, lacas, acabados de cuero, pinturas y plásticos. También se utilizan como aromatizantes y conservantes en la industria alimentaria, y como fragancias y disolventes en perfumería y cosmética. El acetato de metilo, mezclado generalmente con acetona y alcohol metílico, se utiliza en la industria de los plásticos y pieles artificiales, así como en la producción de perfumes, colorantes y lacas. El acetato de etilo es un buen disolvente de nitrocelulosa, grasas, barnices, tintas y barnices impermeabilizantes para aviones. También se utiliza en la producción de polvo fumífugo, pieles artificiales, perfumes, películas y placas fotográficas y seda artificial, como agente limpiador en la industria textil y como aromatizante en productos farmacéuticos y alimentos.

El acetato de n-propilo y el acetato de isopropilo se utilizan como disolventes de plásticos, tintes y nitrocelulosa en la producción de lacas. T ambién se emplean en la fabricación de perfumes e insecticidas y en síntesis orgánicas. El acetato de butilo es un disolvente ampliamente utilizado en la producción de lacas de nitrocelulosa. También se emplea en la fabricación de resinas vinílicas, pieles artificiales, películas fotográficas, perfumes y en la conservación de alimentos.

En su forma comercial, el acetato de amilo, una mezcla de isómeros, se utiliza como disolvente de nitrocelulosa en la fabricación de lacas y como aromatizante, debido a que tiene un olor parecido al del plátano. T ambién se emplea en la fabricación de pieles artificiales, películas fotográficas, vidrio artificial, celuloide, seda artificial y barnices para muebles. El acetato de isoamilo se utiliza en la tinción y el terminado de tejidos, para perfumar las ceras para calzado y para fabricar sedas, pieles y perlas artificiales, películas fotográficas, adhesivos de celuloide, barnices impermeables y pinturas metálicas. También se emplea en la fabricación de vidrio artificial y sombreros de paja y como componente de lacas y soluciones endurecedoras. EI acetato sódico se utiliza en el curtido del cuero, en fotografía, en galvanoplastia y como conservante cárnico, así como en la fabricación de jabones y productos farmacéuticos.

El acetato de vinilo se utiliza principalmente como producto químico intermedio en la producción de alcohol y acetales polivinílicos. También se emplea en lacas para el cabello y en la producción de pinturas en emulsión, materiales para acabados e impregnación y pegamentos. El acetato de 2-pentilo tiene los mismos usos que los demás acetatos y se emplea como disolvente de caucho clorado, pinturas metálicas, adhesivos, linóleo, papel lavable para paredes, perlas y recubrimiento de perlas artificiales.

\section{Riesgos}

El acetato de metilo es inflamable y sus vapores forman mezclas explosivas con el aire a temperaturas normales. Estos vapores, a concentraciones elevadas, pueden causar irritación de los ojos y las mucosas, así como cefalea, sopor, mareo, quemaduras en los ojos, lagrimeo, palpitaciones, sensación de opresión torácica y disnea. Se han producido algunos casos de ceguera por contacto de esta sustancia con los ojos.

El acetato de etilo es un líquido inflamable y produce un vapor que forma mezclas explosivas con el aire a temperaturas normales. El acetato de etilo irrita la conjuntiva y las mucosas del tracto respiratorio. Los experimentos en animales demuestran que, a concentraciones muy elevadas, este éster tiene efectos narcóticos y letales. A concentraciones de entre 20.000 y 43.000 ppm puede producir edema pulmonar con hemorragia, síntomas de depresión del sistema nervioso central, anemia secundaria y alteraciones hepáticas. En personas expuestas a concentraciones más bajas se ha observado irritación de la nariz y la faringe, así como irritación de la conjuntiva con opacidad temporal de la córnea. Rara vez la exposición produce sensibilización de las mucosas y erupciones cutáneas.

El efecto irritante del acetato de etilo es menos intenso que el de los acetatos de propilo o de butilo. Estos dos isómeros del acetato de propilo son inflamables y sus vapores forman mezclas explosivas con el aire a temperaturas normales. A concentraciones de 200 ppm pueden causar irritación ocular y, a concentraciones superiores, irritan también la nariz y la laringe Se han descrito casos de irritación de la conjuntiva, opresión torácica y tos en trabajadores expuestos por motivos profesionales a estos ésteres, pero sin efectos permanentes o sistémicos. El contacto reiterado del líquido con la piel puede ocasionar su desengrasado y agrietamiento.

A cetato de amilo. Todos los isómeros y grados del acetato de amilo son inflamables y sus vapores forman mezclas inflamables con el aire. A concentraciones altas (10.000 ppm durante $5 \mathrm{~h}$ ) puede resultar letal para las cobayas. Los principales síntomas descritos en casos de exposición profesional son cefalea e irritación de las mucosas de la nariz y de la conjuntiva, así como vértigo, palpitaciones, trastornos gastrointestinales, anemia, lesiones cutáneas, dermatitis y lesiones hepáticas. El acetato de amilo también provoca el desengrasado de la piel y la exposición prolongada a esta sustancia puede causar dermatitis. EI acetato de butilo es considerablemente más irritante que el acetato de etilo. Además, puede provocar cambios de conducta similares a los observados con el acetato de amilo. 
EI acetato de hexilo y el acetato de bencilo se utilizan en la industria y son inflamables, pero puesto que su presión de vapor es baja, a menos que se calienten no es probable que den lugar a concentraciones de vapores inflamables. Los experimentos realizados en animales indican que las propiedades tóxicas de estos acetatos son más pronunciadas que las del acetato de amilo. N o obstante, en la práctica su escasa volatilidad determina que el efecto en los trabajadores afectados se limite a una irritación local. No se dispone de información suficiente para evaluar los riesgos de esta sustancia.

El acetato de ciclohexilo puede ejercer un efecto narcótico sumamente intenso en animales $y$, experimentalmente, parece ser un irritante más potente que el acetato de amilo. Sin embargo, tampoco en este caso existen datos suficientes sobre la exposición humana para evaluar los riesgos. Esta sustancia no tiende a acumularse en el organismo y muchos de sus efectos parecen ser reversibles.

EI acetato de vinilo se transforma metabólicamente en acetaldehído, lo que hace pensar en un posible efecto carcinogénico. Por este motivo y por los resultados positivos obtenidos en los estudios con animales, la Agencia Internacional para la Investigación sobre el Cáncer (IARC) lo ha clasificado en el Grupo 2B como posible carcinógeno humano. Además, esta sustancia química irrita el tracto respiratorio superior y los ojosy desengrasa la piel. 
TABLAS DE ACETATOS

\begin{tabular}{|c|c|c|c|}
\hline Producto químico & Sinónimos/Código UN & $\mathrm{N}$ úmero CAS & Fórmula estructural \\
\hline ACETATO DE AMILO & $\begin{array}{l}\text { Ester amílico del ácido acético; éster entílico del ácido acético; éster } \\
\text { amiloacético; aceite de pera; acetato de pentilo } \\
\text { UN1104 }\end{array}$ & $628-63.7$ & \\
\hline ACETATO DE SEC-AMILO & $\begin{array}{l}\text { 2-Acetoxipentano; acetato de 1-metilbutilo; éster 2-pentílico del ácido } \\
\text { acético; acetato de 2-pentilo } \\
\text { UN1104 }\end{array}$ & $626-38-0$ & $\mathrm{O}$ \\
\hline ACETATO DE BENCILO & $\begin{array}{l}\text { Ester fenilmetílico del ácido acético; } \alpha \text {-acetoxitolueno; benciletanoato; } \\
\text { acetato de fenilmetilo }\end{array}$ & $140-11-4$ & \\
\hline ACETATO DE BUTILO & $\begin{array}{l}\text { Ester } n \text {-butílico del ácido acético; éster butílico del ácido acético; } \\
\text { n-butillacetato; 1-butilacetato; butil etanoato } \\
\text { UN1123 }\end{array}$ & $123-86-4$ & \\
\hline ACETATO DE SECBUTTLO & $\begin{array}{l}\text { Ester 2-butoxi del ácido acético; acetato de 2-butanol; sec-butilacetato; } \\
\text { 2-butilacetato; éster sec-butilico del ácido acético } \\
\text { UN1123 }\end{array}$ & $105-46-4$ & \\
\hline ACETATO DE terCBUTILO & $\begin{array}{l}\text { Ester terc-butílico del ácido acético; éster 1,1-dimetiletilico del ácido } \\
\text { acético; apreciador de plomo Texaco; TLA } \\
\text { UN1123 }\end{array}$ & $540-88-5$ & \\
\hline ACETATO DE CALCIO & $\begin{array}{l}\text { Acetato marrón; diacetato cálcico; acetato gris; acetato de calcita; } \\
\text { calcita pirolignita; Sorbo-calcio; Teltozan; sales de vinagre }\end{array}$ & $62-54-4$ & \\
\hline ACETATO DE CICLOHEXILO & $\begin{array}{l}\text { Ester ciclohexílico del ácido acético; acetato de ciclohexanilo } \\
\text { UN2243 }\end{array}$ & $622-45-7$ & \\
\hline ACETATO DE ETILO & $\begin{array}{l}\text { Ester etílico del ácido acético; éter acético; acetidina; acetoxietano; éster } \\
\text { etilacético; etiletanoato; nafta de vinagre } \\
\text { UN1173 }\end{array}$ & $141-78-6$ & \\
\hline ACETATO DE FENILO & Acetilfenol; fenolacetato; éster fenílico del ácido acético & $122 \cdot 79-2$ & \\
\hline ACETATO DE SECHEXILO & $\begin{array}{l}\text { Ester 1,3-dimetilbutílico del ácido acético; acetato de 1,3-dimetilbutilo; } \\
\text { MAAC; acetato de metilamilo; acetato de metilisoamilo } \\
\text { UN1233 }\end{array}$ & $108-84-9$ & \\
\hline ACETATO DE ISOAMILO & $\begin{array}{l}\text { Ester isopentilico del ácido acético; aceite de plátano; isoamiletanoato; } \\
\text { acetato de alcohol isopentílico; acetato de isopentilo; acetato de } \\
\text { 3-metilbutilo; aceite de pera }\end{array}$ & $123-92-2$ & \\
\hline ACETATO DE ISOBUTILO & $\begin{array}{l}\text { Ester isobutílico del ácido acético; éster 2-metilpropílico del ácido acético; } \\
\text { acetato de } 2 \text {-metilpropilo } \\
\text { UN1213 }\end{array}$ & $110-19-0$ & \\
\hline
\end{tabular}




\begin{tabular}{|c|c|c|c|}
\hline Producto químico & Sinónimos/Código UN & $\mathrm{N}$ úmero CAS & Fórmula estructural \\
\hline ACETATO DE ISOPROPILO & $\begin{array}{l}\text { Ester isopropílico del ácido acético; éster 1-metiletílico del ácido acético; } \\
\text { 2-propilacetato } \\
\text { UN1220 }\end{array}$ & $108-21-4$ & P \\
\hline ACETATO DE METILO & $\begin{array}{l}\text { Ester metilico del ácido acético; Devoton; Tereton } \\
\text { UN1231 }\end{array}$ & $79-20-9$ & \\
\hline ACETATO DE 1-METOXI-2-PROPILO & $\begin{array}{l}\text { Ester 2-metoxi-1-metiletílico del ácido acético; Dowanol (r); PMA; acetato } \\
\text { de glicoléter; 1-metoxi-2-acetoxipropano; acetato del éter } \\
\text { propilenglicolmonometílico; }\end{array}$ & $108 \cdot 65 \cdot 6$ & \\
\hline ACETATO DE 2-METOXI-1-PROPILO & Ester 2-metoxipropílico del ácido acético & $70657-70-4$ & \\
\hline ACETATO POTASICO & Sal diurética; sal potásica del ácido acético & $127-08-2$ & \\
\hline ACETATO DE PROPILO & $\begin{array}{l}\text { Ester propílico del ácido acético; acetato de 1-propilo } \\
\text { UN1276 }\end{array}$ & $109-60-4$ & \\
\hline ACETATO SODICO & Sal sódica del ácido acético; acetato sódico anhidro & $127-09-3$ & \\
\hline ACETATO DE VINILO & $\begin{array}{l}\text { Ester etenílico del ácido acético; éter etilénico del ácido acético; } \\
\text { 1-acetoxietileno; éster etenílico del ácido etanoico; acetato de etenilo; } \\
\text { eteniletanoato } \\
\text { UN1301 }\end{array}$ & $108-05-4$ & \\
\hline ACETOACETATO DE ETILO & $\begin{array}{l}\text { Ester etilico del ácido acetoacético; éter diacético; EAA; acetato de } \\
\text { etilacetilo; etilacetilacetonato; etil-3-0xobutanoato; etil-3-0xobutirato; éster } \\
\text { etílico del ácido 3-oxobutanoico }\end{array}$ & $141-97-9$ & \\
\hline ACETOACETATO DE METILO & $\begin{array}{l}\text { Ester metílico acetoacético; metilacetoacetato; acetilacetato de metilo; } \\
\text { Metilacetilacetonato; 3-oxobutanoato de metilo; 3-oxobutirato de metilo }\end{array}$ & $105-45-3$ & \\
\hline CLOROACETATO DE ETILO & $\begin{array}{l}\text { Etilcloroacetato; etil- } \alpha \text {-cloroacetato; etilcloroetanoato; } \\
\text { etilmonocloroacetato } \\
\text { UN1181 }\end{array}$ & 105-39-5 & \\
\hline 0-CRESOL-4,6-DINITROACETATO & Ester 4,6-dinitro-0-creślico del ácido acético & $18461-55-7$ & \\
\hline DIACETATO DE 1,2-PROPANODIOL & Diacetato de propilenglicol; diacetato de $\alpha$ - propilenglicol & $623-84-7$ & \\
\hline $\begin{array}{l}\text { ESTER ((3,5,6-TRICLORO-2-PIRIDINIL) OXI)-; } \\
\text { 2-BUTOXIETLICO DEL ACIDO ACETICO }\end{array}$ & $\begin{array}{l}\text { Garlon 4; Garlon 4e; M 4021; éster 2-butoxietílico del ácido } \\
\text { ((3,5,6-tricloro-2-piridinil) oxi) acético }\end{array}$ & $64700-56-7$ & \\
\hline
\end{tabular}




\begin{tabular}{|c|c|c|c|}
\hline Producto químico & Sinónimos/ Código UN & $\mathrm{N}$ úmero CAS & Fórmula estructural \\
\hline FLUOROACETATO SODICO & $\begin{array}{l}\text { Sal sódica del ácido fluoroacético; monofluoroacetato sódico } \\
\text { UN2629 }\end{array}$ & $62.74-8$ & $\mathrm{Na}^{+}$ \\
\hline TRIACETINA & $\begin{array}{l}\text { Enzactina; Fungacetina; triacetato de glicerol; triacetato de } \\
\text { 1,2,3-propanotriol; triacetina; triacetilglicerina; Vanay }\end{array}$ & $102-76-1$ & \\
\hline $\begin{array}{l}\text { TRICLOROACETATO SODICO; ACIDO } \\
\text { TRICLOROACETICO, SAL SODICA }\end{array}$ & $\begin{array}{l}\text { Herbicida ACP; TCA sódico Allied Arcadian; Antiperz; Antyperz; TCA; } \\
\text { TCA Varitox }\end{array}$ & $650-51-1$ & \\
\hline
\end{tabular}

\begin{tabular}{|c|c|c|c|c|c|c|}
\hline \multirow[b]{2}{*}{$\begin{array}{l}\text { Denominación } \\
\text { química } \\
N \text { úmero CAS }\end{array}$} & \multicolumn{4}{|c|}{ Tarjetas Internacionales sobre la Seguridad de los Productos Q uímicos } & \multicolumn{2}{|c|}{ N IO SH (EE.UU.) } \\
\hline & $\begin{array}{l}\text { Período } \\
\text { corto de } \\
\text { exposición }\end{array}$ & $\begin{array}{l}\text { Período } \\
\text { largo de } \\
\text { exposición }\end{array}$ & $\begin{array}{l}\text { Vías de } \\
\text { exposición }\end{array}$ & Síntomas & $\begin{array}{l}\text { O rganos } \\
\text { afectados } \\
\text { Vías de } \\
\text { entrada }\end{array}$ & Síntomas \\
\hline $\begin{array}{l}\text { ACETATO DE AMILO } \\
628.63 .7\end{array}$ & ojos; piel; tract resp & piel & $\begin{array}{r}\text { Inhalación } \\
\text { Piel } \\
\text { Ojos } \\
\text { Ingestión }\end{array}$ & $\begin{array}{l}\text { Mareo, sopor, cefalea, dolor de garganta } \\
\text { Sequedad de piel, enrojecimiento } \\
\text { Enrojecimiento } \\
\text { Náuseas, dolor de garganta }\end{array}$ & $\begin{array}{l}\text { Ojos; piel; sis resp; } \\
\text { SNC } \\
\text { Inh; ing; con }\end{array}$ & $\begin{array}{l}\text { Irrit ojos, nariz; derm; posible } \\
\text { depres SNC, narco }\end{array}$ \\
\hline $\begin{array}{l}\text { ACETATO DE SeC-AMILO } \\
626-38-0\end{array}$ & ojos; piel; tract resp & piel & $\begin{array}{r}\text { Inhalación } \\
\text { Piel } \\
\text { Ojos } \\
\text { Ingestión } \\
\end{array}$ & $\begin{array}{l}\text { Mareo, sopor, cefalea, dolor de garganta } \\
\text { Sequedad de piel, enrojecimiento } \\
\text { Enrojecimiento } \\
\text { Náuseas, dolor de garganta }\end{array}$ & $\begin{array}{l}\text { Sis resp; ojos; piel } \\
\text { Inh; con }\end{array}$ & $\begin{array}{l}\text { Irrit ojos, piel, sis resp; tos, } \\
\text { dis, sens pulm }\end{array}$ \\
\hline $\begin{array}{l}\text { ACETATO DE BUTLLO } \\
123-86-4\end{array}$ & ojos; piel; tract resp & piel & $\begin{array}{r}\text { Inhalación } \\
\text { Piel } \\
\text { 0jos } \\
\end{array}$ & $\begin{array}{l}\text { Tos, mareo, cefalea, náuseas } \\
\text { Sequedad de piel, enrojecimiento } \\
\text { Enrojecimiento, dolor }\end{array}$ & $\begin{array}{l}\text { Ojos; piel; sis resp; } \\
\text { SNC } \\
\text { Inh; ing; con }\end{array}$ & $\begin{array}{l}\text { Irrit ojos, piel, sis resp sup; } \\
\text { cef; sop, narco }\end{array}$ \\
\hline $\begin{array}{l}\text { ACETATO DE SEC-BUTLLO } \\
105-46-4\end{array}$ & $\begin{array}{l}\text { ojos; tract resp; } \\
\text { SNC }\end{array}$ & piel & $\begin{array}{r}\text { Inhalación } \\
\text { Piel } \\
\text { 0jos }\end{array}$ & $\begin{array}{l}\text { Sopor, cefalea, dolor de garganta, } \\
\text { inconsciencia, debilidad } \\
\text { Sequedad de piel } \\
\text { Enrojecimiento, dolor }\end{array}$ & $\begin{array}{l}\text { Ojos; piel; sis resp; } \\
\text { SNC } \\
\text { Inh; ing; con }\end{array}$ & $\begin{array}{l}\text { Irrit ojos; cef; sop; sequedad } \\
\text { del sis resp sup, piel; narco }\end{array}$ \\
\hline $\begin{array}{l}\text { ACETATO DE terc-BUTLLO } \\
540-88-5\end{array}$ & & & & & $\begin{array}{l}\text { Sis resp; ojos; piel; } \\
\text { SNC } \\
\text { Inh; ing; con }\end{array}$ & $\begin{array}{l}\text { Prurito, inflam ocular; irrit tract } \\
\text { resp sup; cef; narco; derm }\end{array}$ \\
\hline $\begin{array}{l}\text { ACETATO DE CICLOHEXILO } \\
622-45-7\end{array}$ & $\begin{array}{l}\text { ojos; piel; tract } \\
\text { resp; pulmones }\end{array}$ & & $\begin{array}{r}\text { Inhalación } \\
\\
\text { Piel } \\
\text { 0jos }\end{array}$ & $\begin{array}{l}\text { Sensación de quemazón, tos, cefalea, } \\
\text { náuseas, dolor de garganta } \\
\text { Enrojecimiento } \\
\text { Enrojecimiento }\end{array}$ & & \\
\hline $\begin{array}{l}\text { ACETATO DE ETILO } \\
141-78.6\end{array}$ & $\begin{array}{l}\text { ojos; piel; tract } \\
\text { resp; SNC }\end{array}$ & piel & $\begin{array}{r}\text { Inhalación } \\
\text { Piel } \\
\text { Ojos } \\
\text { Ingestión }\end{array}$ & $\begin{array}{l}\text { Tos, mareo, sopor, cefalea, náuseas, disnea, } \\
\text { dolor de garganta, inconsciencia, debilidad } \\
\text { Enrojecimiento, dolor } \\
\text { Enrojecimiento, dolor } \\
\text { Dolor abdominal, mareo, náuseas, dolor de } \\
\text { garganta, debilidad }\end{array}$ & $\begin{array}{l}\text { Ojos; piel; sis resp } \\
\text { Inh; ing; con }\end{array}$ & $\begin{array}{l}\text { Irrit ojos, piel, nariz y } \\
\text { garganta; narco; derm }\end{array}$ \\
\hline $\begin{array}{l}\text { ACETATO DE FENILO } \\
122-79-2\end{array}$ & & & $\begin{array}{l}\text { Piel } \\
\text { 0jos }\end{array}$ & $\begin{array}{l}\text { Puede absorberse, enrojecimiento } \\
\text { Enrojecimiento }\end{array}$ & & \\
\hline
\end{tabular}


Tabla 104.50 - Riesgos para la salud.

\begin{tabular}{|c|c|c|c|c|c|c|}
\hline \multirow[b]{2}{*}{$\begin{array}{l}\text { Denominación } \\
\text { química } \\
\text { N úmero CAS }\end{array}$} & \multicolumn{4}{|c|}{ Tarjetas Internacionales sobre la Seguridad de los Productos Q uímicos } & \multicolumn{2}{|c|}{ N IOSH (EE.UU.) } \\
\hline & $\begin{array}{l}\text { Período } \\
\text { corto de } \\
\text { exposición }\end{array}$ & $\begin{array}{l}\text { Período } \\
\text { largo de } \\
\text { exposición }\end{array}$ & $\begin{array}{l}\text { Vías de } \\
\text { exposición }\end{array}$ & Síntomas & $\begin{array}{l}\text { O rganos } \\
\text { afectados } \\
\text { Vías de } \\
\text { entrada }\end{array}$ & Síntomas \\
\hline $\begin{array}{l}\text { ACETATO DE SEC-HEXILO } \\
108-84-9\end{array}$ & & & & & $\begin{array}{l}\text { Sis resp; SNC; ojos; } \\
\text { piel } \\
\text { Inh; ing; con }\end{array}$ & $\begin{array}{l}\text { Irrit ojos, piel, nariz y } \\
\text { garganta; cef; en animales: } \\
\text { narco }\end{array}$ \\
\hline $\begin{array}{l}\text { ACETATO DE ISOAMILO } \\
123-92.2\end{array}$ & ojos; tract resp & piel & $\begin{array}{r}\text { Inhalación } \\
\text { Piel } \\
\text { Ojos } \\
\text { Ingestión }\end{array}$ & $\begin{array}{l}\text { Sopor, cefalea, dolor de garganta, debilidad } \\
\text { Sequedad de piel } \\
\text { Enrojecimiento } \\
\text { Dolor abdominal, náuseas, dolor de garganta }\end{array}$ & $\begin{array}{l}\text { Sis resp; SNC; ojos; } \\
\text { piel } \\
\text { Inh; ing; con }\end{array}$ & $\begin{array}{l}\text { Irrit ojos, piel, nariz y } \\
\text { garganta; cef; en animales: } \\
\text { narco }\end{array}$ \\
\hline $\begin{array}{l}\text { ACETATO DE ISOBUTILO } \\
110-19-0\end{array}$ & ojos; piel; tract resp & piel & $\begin{array}{r}\text { Inhalación } \\
\text { Piel } \\
\text { 0jos }\end{array}$ & $\begin{array}{l}\text { Tos, mareo, cefalea, náuseas, dolor de } \\
\text { garganta, inconsciencia, vómitos } \\
\text { Sequedad de piel } \\
\text { Enrojecimiento, dolor }\end{array}$ & $\begin{array}{l}\text { Sis resp; SNC; ojos; } \\
\text { piel } \\
\text { Inh; ing; con }\end{array}$ & $\begin{array}{l}\text { Irrit ojos, piel, sis resp sup; } \\
\text { cef, sop, anes; en animales: } \\
\text { narco }\end{array}$ \\
\hline $\begin{array}{l}\text { ACETATO DE ISOPROPILO } \\
108-21-4\end{array}$ & $\begin{array}{l}\text { ojos; tract resp; } \\
\text { pulmones }\end{array}$ & piel & $\begin{array}{r}\text { Inhalación } \\
\text { Piel } \\
\text { Ojos } \\
\text { Ingestión }\end{array}$ & $\begin{array}{l}\text { Tos, sopor, cefalea } \\
\text { Sequedad de piel, enrojecimiento } \\
\text { Enrojecimiento, dolor } \\
\text { Dolor abdominal, mareo }\end{array}$ & $\begin{array}{l}\text { Sis resp; SNC; ojos; } \\
\text { piel } \\
\text { Inh; ing; con }\end{array}$ & $\begin{array}{l}\text { Irrit ojos, piel y nariz; derm; } \\
\text { en animales: narco }\end{array}$ \\
\hline $\begin{array}{l}\text { ACETATO DE METLLO } \\
79-20-9\end{array}$ & $\begin{array}{l}\text { ojos; piel; tract } \\
\text { resp; pulmones; } \\
\text { SNC }\end{array}$ & piel & $\begin{array}{l}\text { Inhalación } \\
\\
\text { Piel } \\
\text { Ojos } \\
\text { Ingestión }\end{array}$ & $\begin{array}{l}\text { Tos, embotamiento, cefalea, dolor de } \\
\text { garganta, inconsciencia, vómitos, los síntomas } \\
\text { pueden tardar en aparecer } \\
\text { Sequedad de piel, enrojecimiento, aspereza } \\
\text { Enrojecimiento, dolor, visión borrosa } \\
\text { Dolor abdominal, embotamiento, náuseas, } \\
\text { vómitos, debilidad }\end{array}$ & $\begin{array}{l}\text { Sis resp; piel; ojos; } \\
\text { SNC } \\
\text { Inh; ing; con }\end{array}$ & $\begin{array}{l}\text { Irrit ojos, piel, nariz y } \\
\text { garganta; cef, sop; atrofia del } \\
\text { nervio óptico; opres. torác; en } \\
\text { animales: narco }\end{array}$ \\
\hline $\begin{array}{l}\text { ACETATO DE } \\
\text { 1-METOXI-2-PROPILO } \\
\text { 108-65-6 }\end{array}$ & $\begin{array}{l}\text { ojos; tract resp; } \\
\text { SNC }\end{array}$ & piel & $\begin{array}{r}\text { Inhalación } \\
\text { Piel } \\
\text { Ojos } \\
\text { Ingestión }\end{array}$ & $\begin{array}{l}\text { Tos, mareo, sopor, cefalea, náuseas } \\
\text { Sequedad de piel, enrojecimiento } \\
\text { Enrojecimiento, dolor } \\
\text { Dolor abdominal, diarrea, inconsciencia }\end{array}$ & & \\
\hline $\begin{array}{l}\text { ACETATO POTASICO } \\
127-08-2\end{array}$ & ojos; piel; tract resp & & $\begin{array}{r}\text { Inhalación } \\
\text { Piel } \\
\text { Ojos }\end{array}$ & $\begin{array}{l}\text { Dolor de garganta } \\
\text { Enrojecimiento } \\
\text { Enrojecimiento }\end{array}$ & & \\
\hline $\begin{array}{l}\text { ACETATO DE PROPILO } \\
109-60-4\end{array}$ & $\begin{array}{l}\text { ojos; tract resp; } \\
\text { SNC }\end{array}$ & piel & $\begin{array}{r}\text { Inhalación } \\
\text { Piel } \\
\text { 0jos }\end{array}$ & $\begin{array}{l}\text { Sensación de opresión torácica, náuseas, } \\
\text { inconsciencia, vómitos } \\
\text { Sequedad de piel } \\
\text { Enrojecimiento, dolor }\end{array}$ & $\begin{array}{l}\text { Sis resp; ojos; piel; } \\
\text { SNC } \\
\text { Inh; ing; con }\end{array}$ & $\begin{array}{l}\text { En animales: irrit ojos, nariz y } \\
\text { garganta; derm; narco }\end{array}$ \\
\hline $\begin{array}{l}\text { ACETATO SODICO } \\
127-09-3\end{array}$ & ojos; piel; tract resp & & $\begin{array}{r}\text { Inhalación } \\
\text { Piel } \\
\text { 0jos }\end{array}$ & $\begin{array}{l}\text { Dolor de garganta } \\
\text { Enrojecimiento } \\
\text { Enrojecimiento }\end{array}$ & & \\
\hline $\begin{array}{l}\text { ACETOACETATO DE ETILO } \\
141.97-9\end{array}$ & & & $\begin{array}{r}\text { Inhalación } \\
\text { Piel } \\
\text { 0jos }\end{array}$ & $\begin{array}{l}\text { Sensación de quemazón, tos, dolor de } \\
\text { garganta } \\
\text { Enrojecimiento } \\
\text { Enrojecimiento }\end{array}$ & & \\
\hline $\begin{array}{l}\text { FLUOROACETATO SODICO } \\
62.74-8\end{array}$ & & & $\begin{array}{r}\text { Inhalación } \\
\text { Piel } \\
\text { 0jos } \\
\text { Ingestión }\end{array}$ & $\begin{array}{l}\text { Cconvulsiones, dificultad respiratoria, } \\
\text { inconsciencia, vómitos } \\
\text { Puede absorberse } \\
\text { Visión borrosa } \\
\text { Espasmos abdominales, dolor abdominal }\end{array}$ & $\begin{array}{l}\text { SCV; sis resp; } \\
\text { riñones; SNC; } \\
\text { hígado } \\
\text { Inh; abs; ing; con }\end{array}$ & $\begin{array}{l}\text { Vómit; apre, alu auditivas; } \\
\text { pares facial; contracción de los } \\
\text { musc faciales; pulso irregular, } \\
\text { latido cardíaco ectópico, taqui, } \\
\text { fib ven; edema pulm; } \\
\text { nistagmo; convuls; les } \\
\text { hepáticas y renales }\end{array}$ \\
\hline
\end{tabular}




\begin{tabular}{|c|c|c|c|c|c|c|}
\hline \multirow[b]{2}{*}{$\begin{array}{l}\text { Denominación } \\
\text { química } \\
\mathrm{N} \text { úmero CAS }\end{array}$} & \multicolumn{4}{|c|}{ Tarjetas Internacionales sobre la Seguridad de los Productos Q uímicos } & \multicolumn{2}{|c|}{ N IO SH (EE.UU.) } \\
\hline & $\begin{array}{l}\text { Período } \\
\text { corto de } \\
\text { exposición }\end{array}$ & $\begin{array}{l}\text { Período } \\
\text { largo de } \\
\text { exposición }\end{array}$ & $\begin{array}{l}\text { Vías de } \\
\text { exposición }\end{array}$ & Síntomas & $\begin{array}{l}\text { O rganos } \\
\text { afectados } \\
\text { Vías de } \\
\text { entrada }\end{array}$ & Síntomas \\
\hline $\begin{array}{l}\text { 2-METOXIACETATO DE ETILO } \\
\text { 110-49-6 }\end{array}$ & SNC & $\begin{array}{l}\text { piel; hígado; } \\
\text { riñones sangre }\end{array}$ & $\begin{array}{r}\text { Inhalación } \\
\text { Piel } \\
\text { 0jos } \\
\text { Ingestión }\end{array}$ & $\begin{array}{l}\text { Confusión, mareo, cefalea, náuseas, } \\
\text { inconsciencia, vómitos, debilidad } \\
\text { Puede absorberse, mareo, cefalea, náuseas, } \\
\text { vómitos } \\
\text { Visión borrosa } \\
\text { Dolor abdominal, sensación de quemazón, } \\
\text { confusión, mareo, cefalea, náuseas, } \\
\text { inconsciencia }\end{array}$ & $\begin{array}{l}\text { Riñones; cerebro; } \\
\text { SNC; SNP; ojos, sis } \\
\text { resp, sis repro; sist } \\
\text { hemato } \\
\text { Inh; abs; ing; con }\end{array}$ & $\begin{array}{l}\text { Irrit ojos, nariz y garganta; les } \\
\text { renales y cerebrales; en } \\
\text { animales: narco; efectos repro } \\
\text { y terato }\end{array}$ \\
\hline
\end{tabular}

\begin{tabular}{|c|c|c|c|}
\hline $\begin{array}{l}\text { Denominación química } \\
\mathrm{N} \text { úmero CAS }\end{array}$ & Físicos & Q uímicos & $\begin{array}{l}\text { Clase o división } \\
\text { UN / Riesgos } \\
\text { subsidiarios }\end{array}$ \\
\hline $\begin{array}{l}\text { ACETATO DE AMILO } \\
628-63-7\end{array}$ & $\begin{array}{l}\text { El vapor es más pesado } \\
\text { que el aire }\end{array}$ & Reacciona con oxidantes, con peligro de incendio y explosión Ataca muchos plásticos & 3 \\
\hline $\begin{array}{l}\text { ACETATO DE SeCAMILO } \\
626-38-0\end{array}$ & $\begin{array}{l}\text { El vapor es más pesado } \\
\text { que el aire }\end{array}$ & $\begin{array}{l}\text { Se descompone al arder, liberando gases y vapores tóxicos Reacciona violentamente con } \\
\text { ácidos fuertes, oxidantes fuertes y bases fuertes Ataca muchos plásticos }\end{array}$ & 3 \\
\hline $\begin{array}{l}\text { ACETATO DE BUTLLO } \\
123-86-4\end{array}$ & & $\begin{array}{l}\text { Se descompone lentamente en contacto con el aire o la humedad, produciendo ácido acético y } \\
\text { n-butanol Reacciona violentamente con oxidantes fuertes, con peligro de incendio y explosión } \\
\text { Ataca muchos plásticos y resinas }\end{array}$ & 3 \\
\hline $\begin{array}{l}\text { ACETATO DE SEC-BUTILO } \\
105-46-4\end{array}$ & $\begin{array}{l}\text { El vapor se mezcla con } \\
\text { el aire y forman fácilmente } \\
\text { mezclas explosivas }\end{array}$ & $\begin{array}{l}\text { En su combustión libera gases y vapores tóxicos (como monóxido de carbono) Reacciona } \\
\text { violentamente con nitratos, oxidantes fuertes, bases fuertes y ácidos fuertes, con peligro de } \\
\text { incendio y explosión Ataca muchos plásticos }\end{array}$ & 3 \\
\hline $\begin{array}{l}\text { ACETATO DE terc-BUTILO } \\
540-88-5\end{array}$ & & & 3 \\
\hline $\begin{array}{l}\text { ACETATO DE CICLOHEXILO } \\
622-45-7\end{array}$ & & $\begin{array}{l}\text { Reacciona con oxidantes Reacciona en contacto con agua o humedad, produciendo ácido } \\
\text { acético, con riesgo de corrosión lenta de los envases metálicos }\end{array}$ & 3 \\
\hline $\begin{array}{l}\text { ACETATO DE ETILO } \\
141-78.6\end{array}$ & $\begin{array}{l}\text { El vapor es más pesado } \\
\text { que el aire y puede } \\
\text { desplazarse a ras del } \\
\text { suelo; posibilidad de } \\
\text { ignición a distancia }\end{array}$ & $\begin{array}{l}\text { Al calentarse puede sufrir una combustión violenta o explosión Se descompone por influencia } \\
\text { de la luz UV, las bases y los ácidos Al calentarse desprende humos tóxicos La solución en } \\
\text { agua es un ácido débil Reacciona con oxidantes, bases o ácidos fuertes Ataca muchos } \\
\text { metales en presencia de agua Ataca los plásticos }\end{array}$ & 3 \\
\hline $\begin{array}{l}\text { ACETATO DE FENILO } \\
122-79-2\end{array}$ & & Reacciona con oxidantes & \\
\hline $\begin{array}{l}\text { ACETATO DE SEC-HEXILO } \\
108-84-9\end{array}$ & & & 3 \\
\hline $\begin{array}{l}\text { ACETATO DE ISOAMILO } \\
123-92.2\end{array}$ & $\begin{array}{l}\text { El vapor se mezcla con } \\
\text { el aire y se forma } \\
\text { fácilmente mezclas } \\
\text { explosivas }\end{array}$ & Reacciona violentamente con oxidantes fuertes, con peligro de incendio y explosión & \\
\hline $\begin{array}{l}\text { ACETATO DE ISOBUTILO } \\
110-19-0\end{array}$ & & $\begin{array}{l}\text { Reacciona con oxidantes fuertes, nitratos, bases y ácidos fuertes, con peligro de incendio y } \\
\text { explosión }\end{array}$ & 3 \\
\hline
\end{tabular}




\begin{tabular}{|c|c|c|c|}
\hline $\begin{array}{l}\text { Denominación química } \\
\text { N úmero CAS }\end{array}$ & Físicos & Q uímicos & $\begin{array}{l}\text { Clase o división } \\
\text { UN / Riesgos } \\
\text { subsidiarios }\end{array}$ \\
\hline $\begin{array}{l}\text { ACETATO DE ISOPROPILO } \\
\text { 108-21-4 }\end{array}$ & $\begin{array}{l}\text { El vapor es más pesado } \\
\text { que el aire y puede } \\
\text { desplazarse a ras del } \\
\text { suelo; posibilidad de } \\
\text { ignición a distancia }\end{array}$ & $\begin{array}{l}\text { Se descompone lentamente en contacto con el acero al exponerse al aire, produciendo ácido } \\
\text { acético y alcohol isopropílico Reacciona violentamente con materiales oxidantes Ataca } \\
\text { muchos plásticos }\end{array}$ & 3 \\
\hline $\begin{array}{l}\text { ACETATO DE METLOO } \\
79-20-9\end{array}$ & $\begin{array}{l}\text { El vapor es más pesado } \\
\text { que el aire y puede } \\
\text { desplazarse a ras del } \\
\text { suelo; posibilidad de } \\
\text { ignición a distancia; se } \\
\text { puede acumular en } \\
\text { espacios de techos bajos, } \\
\text { produciendo deficiencia de } \\
\text { oxígeno }\end{array}$ & $\begin{array}{l}\text { Se descompone al calentarse o por efecto del aire, la luz UV o en contacto con bases, } \\
\text { oxidantes fuertes } 0 \text { agua, con peligro de incendio y explosión Es un potente agente reductor y } \\
\text { reacciona con oxidantes Ataca muchos metales en presencia de agua Ataca los plásticos }\end{array}$ & 3 \\
\hline $\begin{array}{l}\text { ACETATO DE 1-METOXI-2.PROPILO } \\
\text { 108-65-6 }\end{array}$ & & Reacciona con oxidantes fuertes & \\
\hline $\begin{array}{l}\text { ACETATO POTASICO } \\
127-08-2\end{array}$ & $\begin{array}{l}\text { Posibilidad de explosión } \\
\text { pulverulenta cuando se } \\
\text { encuentra en forma de } \\
\text { polvo o gránulos y se } \\
\text { mezcla con el aire }\end{array}$ & $\begin{array}{l}\text { En su combustión se producen óxidos de potasio y carbono Se descompone al calentarse; en } \\
\text { contacto con ácidos fuertes produce humos de ácido acético La solución en agua es una base de } \\
\text { fuerza intermedia }\end{array}$ & \\
\hline $\begin{array}{l}\text { ACETATO DE PROPILO } \\
109-60-4\end{array}$ & $\begin{array}{l}\text { El gas se mezcla con el } \\
\text { aire y se forman } \\
\text { fácilmente mezclas } \\
\text { explosivas }\end{array}$ & $\begin{array}{l}\text { Se descompone al arder, produciendo gases tóxicos o irritantes Puede reaccionar } \\
\text { violentamente con materiales oxidantes Ataca los plásticos }\end{array}$ & 3 \\
\hline $\begin{array}{l}\text { ACETATO SODICO } \\
127-09-3\end{array}$ & $\begin{array}{l}\text { Posibilidad de explosión } \\
\text { pulverulenta cuando se } \\
\text { encuentra en forma de } \\
\text { polvo o gránulos y se } \\
\text { mezcla con el aire }\end{array}$ & $\begin{array}{l}\text { Se descompone al calentarse por encima de los } 120^{\circ} \mathrm{C} 0 \text { en contacto con ácidos fuertes, } \\
\text { produciendo ácido acético La solución en agua es una base de fuerza intermedia }\end{array}$ & \\
\hline $\begin{array}{l}\text { ACETATO DE VINILO } \\
\text { 108-05-4 }\end{array}$ & & & 3 \\
\hline $\begin{array}{l}\text { ACETOACETATO DE ETILO } \\
141-97-9\end{array}$ & $\begin{array}{l}\text { El vapor es más pesado } \\
\text { que el aire }\end{array}$ & $\begin{array}{l}\text { Al calentarse desprende humos tóxicos Reacciona con oxidantes fuertes Reacciona } \\
\text { violentamente con oxidantes, bases y ácidos }\end{array}$ & \\
\hline $\begin{array}{l}\text { CLOROACETATO DE ETILO } \\
\text { 105-39-5 }\end{array}$ & & & 6.1 \\
\hline $\begin{array}{l}\text { FLUOROACETATO SODICO } \\
62-74-8\end{array}$ & & & 6.1 \\
\hline $\begin{array}{l}\text { 2-METOXIACETATO DE ETILO } \\
\text { 110-49-6 }\end{array}$ & $\begin{array}{l}\text { El vapor es más pesado } \\
\text { que el aire }\end{array}$ & Reacciona con oxidantes fuertes, con peligro de incendio y explosión & 3 \\
\hline
\end{tabular}




\begin{tabular}{|c|c|c|c|c|c|c|c|c|c|c|c|}
\hline $\begin{array}{l}\text { Denominación química } \\
\mathrm{N} \text { úmero CAS }\end{array}$ & Color/ Forma & $\begin{array}{l}\text { p.e. } \\
(\stackrel{0}{ } \mathrm{C})\end{array}$ & $\begin{array}{l}\text { p.f. } \\
(\stackrel{\circ}{ } C)\end{array}$ & $\begin{array}{l}\text { p.m.l } \\
\text { (g/ } \\
\text { mol) }\end{array}$ & $\begin{array}{l}\text { Solubilidad } \\
\text { en agua }\end{array}$ & $\begin{array}{l}\text { Densidad } \\
\text { relativa } \\
\text { (agua }=1 \text { ) }\end{array}$ & $\begin{array}{l}\text { Densidad } \\
\text { de vapor } \\
\text { relativa } \\
\text { (aire=1) }\end{array}$ & $\begin{array}{l}\mathrm{Pvap} / \\
(\mathrm{kPa})\end{array}$ & $\begin{array}{l}\text { Límit. } \\
\text { inflam. }\end{array}$ & $\begin{array}{l}\text { p.ig. } \\
(\underline{O C})\end{array}$ & $\begin{array}{l}\text { p.aut } \\
\text { ig. } \\
(\mathrm{O} C)\end{array}$ \\
\hline $\begin{array}{l}\text { ACETATO DE AMILO } \\
628-63-7 \\
\end{array}$ & líquido & 149 & .71 & 130,2 & lig sol & 0,88 & 4,5 & $\begin{array}{l}0,65 \\
@ 25^{\circ} \mathrm{C}\end{array}$ & $\begin{array}{l}1,1 \mathrm{ls} \\
7,5 \mathrm{li}\end{array}$ & $25 \mathrm{cc}$ & 375 \\
\hline $\begin{array}{l}\text { ACETATO DE SECAMILO } \\
626-38-0\end{array}$ & líquido & $130-131$ & -148 & & lig sol & 0,86 & 4,5 & 0,93 & $\begin{array}{l}1,0 \mathrm{li} \\
7,5 \mathrm{ls}\end{array}$ & 32 & 380 \\
\hline $\begin{array}{l}\text { ACETATO DE BENCILO } \\
140-11-4\end{array}$ & líquido de color agua & 213 & -51 & 150,17 & lig sol & 1,0550 & 5,2 & $\begin{array}{l}1,9 \mathrm{~mm} \mathrm{Hg} \\
\text { @ } 600^{\circ} \mathrm{C}\end{array}$ & & $90 \mathrm{cc}$ & 460 \\
\hline $\begin{array}{l}\text { ACETATO DE BUTILO } \\
123-86-4 \\
\end{array}$ & líquido incoloro & 126 & .77 & 116,2 & lig sol & 0,8826 & 4,0 & $2 @ 25^{\circ} \mathrm{C}$ & $\begin{array}{l}1,7 \mathrm{li} \\
7,6 \mathrm{is}\end{array}$ & $22 \mathrm{cc}$ & 420 \\
\hline $\begin{array}{l}\text { ACETATO DE SEC-BUTILO } \\
105-46-4\end{array}$ & líquido incoloro & 112 & $.73,5$ & 116,16 & insol & 0,8716 & 4,0 & 2,53 & $\begin{array}{l}1,7 \mathrm{li} \\
9,8 \mathrm{is}\end{array}$ & $167 c c$ & \\
\hline $\begin{array}{l}\text { ACETATO DE terc-BUTILO } \\
\text { 540-88-5 }\end{array}$ & líquido incoloro & $97-98$ & & 116,1 & insol & 0,8665 & $4,0 @ p e$ & & $\begin{array}{l}1,5 \mathrm{li} \\
? \text { Is }\end{array}$ & & \\
\hline $\begin{array}{l}\text { ACETATO DE CICLOHEXILO } \\
622-45-7 \\
\end{array}$ & líquido & 177 & .77 & 142,2 & insol & 0,97 & 4,9 & 2 & & 57 & 330 \\
\hline $\begin{array}{l}\text { ACETATO DE ETILO } \\
141-78.6 \\
\end{array}$ & líquido transparente & 77 & -84 & 88,10 & sol & 0,9003 & 3,04 & 10 & $\begin{array}{l}2,2 \mathrm{li} \\
9 \mathrm{is}\end{array}$ & $72 \mathrm{ca}$ & 427 \\
\hline $\begin{array}{l}\text { ACETATO DE FENILO } \\
122.79-2\end{array}$ & $\begin{array}{l}\text { líquido móvil } \\
\text { incoloro; líquido de } \\
\text { color agua }\end{array}$ & 196 & & 136,14 & lig sol & 1,0780 & 4,7 & & & 80 & \\
\hline $\begin{array}{l}\text { ACETATO DE SEC-HEXXLO } \\
108-84.9\end{array}$ & líquido incoloro & 147,5 & .64 & 144,2 & $0,08 \mathrm{~g} / 100 \mathrm{ml}$ & $\begin{array}{l}0,8805 \\
@ 25^{\circ} \mathrm{C}\end{array}$ & 5,0 & $3 \mathrm{~mm} \mathrm{Hg}$ & $\begin{array}{l}0,9 \mathrm{li} \\
5,0 \mathrm{is}\end{array}$ & 433 ca & \\
\hline $\begin{array}{l}\text { ACETATO DE ISOAMILO } \\
123-92-2\end{array}$ & líquido incoloro & 142 & $.78,5$ & 130,18 & lig sol & 0,8670 & 4,5 & 0,53 & $\begin{array}{l}1,0 \mathrm{li} \\
? \text { Is } \\
\end{array}$ & $25 \mathrm{cc}$ & 379 \\
\hline $\begin{array}{l}\text { ACETATO DE ISOBUTILO } \\
\text { 110-19-0 }\end{array}$ & líquido incoloro & 117 & .99 & 116,2 & lig sol & 0,8712 & 4,0 & 1,7 & $\begin{array}{l}1,3 \mathrm{li} \\
10,5 \mathrm{ls}\end{array}$ & $178 c c$ & 423 \\
\hline $\begin{array}{l}\text { ACETATO DE ISOPROPILO } \\
108-21-4\end{array}$ & líquido incoloro & 90 & $.73,4$ & 102,13 & sol & 0,8718 & 3,52 & $\begin{array}{l}5,3 \\
@ 17^{\circ} \mathrm{C}\end{array}$ & $\begin{array}{l}1,8 \mathrm{li} \\
7,8 \mathrm{Is}\end{array}$ & $2 c c$ & 460 \\
\hline $\begin{array}{l}\text { ACETATO DE METLLO } \\
79-20.9\end{array}$ & $\begin{array}{l}\text { líquido volátil } \\
\text { incoloro }\end{array}$ & 57 & .98 & 74,08 & muy sol & 0,9330 & 2,8 & 21,7 & $\begin{array}{l}3,1 \mathrm{li} \\
16,0 \mathrm{ls}\end{array}$ & $-10 c c$ & 501 \\
\hline $\begin{array}{l}\text { ACETATO DE 1-METOXI-2-PROPILO } \\
\text { 108-65-6 }\end{array}$ & líquido & 146 & & & $18,5 \mathrm{~g} / 100 \mathrm{ml}$ & 0,96 & 4,6 & $\begin{array}{l}0,5 \\
@ 25^{\circ} \mathrm{C}\end{array}$ & $\begin{array}{l}1,5 \mathrm{li} \\
7,0 \\
@ 200 \mathrm{ls} \\
\end{array}$ & $47-48$ & \\
\hline $\begin{array}{l}\text { ACETATO POTASICO } \\
127-08-2 \\
\end{array}$ & polvo cristalino & & 292 & 98,14 & muy sol & $1,57 @ 25^{\circ} \mathrm{C}$ & & & & & \\
\hline $\begin{array}{l}\text { ACETATO DE PROPILO } \\
109-60-4\end{array}$ & líquido incoloro & 101,6 & .92 & 102,13 & lig sol & 0,836 & 3,5 & 3,3 & $\begin{array}{l}2,0 \mathrm{li} \\
8 \mathrm{Is}\end{array}$ & $14 \mathrm{cc}$ & 450 \\
\hline $\begin{array}{l}\text { ACETATO SODICO } \\
127-09-3\end{array}$ & $\begin{array}{l}\text { polvo granular blanco } \\
\text { o cristales } \\
\text { monoclínicos } \\
\text { incoloros }\end{array}$ & & 324 & 82,0 & muy sol & $1,528 @ 25^{\circ} \mathrm{C}$ & & & & & 611 \\
\hline $\begin{array}{l}\text { ACETATO DE VINILO } \\
108-05-4\end{array}$ & $\begin{array}{l}\text { líquido móvil } \\
\text { incoloro; blanco } \\
\text { (inestable) }\end{array}$ & 72,5 & $-93,2$ & 86,09 & insol & 0,932 & 3,0 & $\begin{array}{l}115 \mathrm{~mm} \mathrm{Hg} \\
\text { @ } 25^{\circ} \mathrm{C}\end{array}$ & $\begin{array}{l}2,6 \mathrm{li} \\
13,4 \mathrm{Is}\end{array}$ & $-8 c c$ & 402 \\
\hline $\begin{array}{l}\text { ACETOACETATO DE ETILO } \\
141-97-9\end{array}$ & líquido incoloro & 180,8 & -45 & 130,14 & muy sol & 1,0282 & 4,48 & 0,1 & $\begin{array}{l}1,0 \mathrm{li} \\
54 \mathrm{is}\end{array}$ & $844 c c$ & 295 \\
\hline $\begin{array}{l}\text { ACETOACETATO DE METLLO } \\
\text { 105-45-3 }\end{array}$ & líquido incoloro & 171,7 & $27-28$ & 116,11 & $38 \mathrm{~g} / 100 \mathrm{ml}$ & 1,0762 & 4,0 & $0,7 \mathrm{~mm} \mathrm{Hg}$ & & $77 \mathrm{ca}$ & 280 \\
\hline
\end{tabular}


Tabla 104.52 • Propiedades físicas y químicas.

\begin{tabular}{|c|c|c|c|c|c|c|c|c|c|c|c|}
\hline $\begin{array}{l}\text { Denominación química } \\
\mathrm{N} \text { úmero CAS }\end{array}$ & Color/ Forma & $\begin{array}{l}\text { p.e. } \\
\left({ }^{\circ} \mathrm{C}\right)\end{array}$ & $\begin{array}{l}\text { p.f. } \\
(\underline{O C})\end{array}$ & $\begin{array}{l}\text { p.m.l } \\
\text { (g/ } \\
\text { mol) }\end{array}$ & $\begin{array}{l}\text { Solubilidad } \\
\text { en agua }\end{array}$ & $\begin{array}{l}\text { Densidad } \\
\text { relativa } \\
\text { (agua }=1 \text { ) }\end{array}$ & $\begin{array}{l}\text { Densidad } \\
\text { de vapor } \\
\text { relativa } \\
\text { (aire=1) }\end{array}$ & $\begin{array}{l}\text { Pvap/ } \\
(\mathrm{kPa})\end{array}$ & $\begin{array}{l}\text { Límit. } \\
\text { inflam. }\end{array}$ & $\begin{array}{l}\text { p.ig. } \\
(\stackrel{C}{ })\end{array}$ & $\begin{array}{l}\text { p.aut } \\
\text { ig. } \\
(\stackrel{\circ}{ } \text { C })\end{array}$ \\
\hline $\begin{array}{l}\text { CLOROACETATO DE ETILO } \\
\text { 105-39-5 }\end{array}$ & $\begin{array}{l}\text { líquido móvil de color } \\
\text { agua }\end{array}$ & 144 & -21 & 122,6 & insol & 1,1585 & $4,23-4,46$ & $\begin{array}{l}10 \mathrm{~mm} \mathrm{Hg} \\
@ 37,5^{\circ} \mathrm{C}\end{array}$ & & 54 & \\
\hline $\begin{array}{l}\text { FLUOROACETATO SODICO } \\
62-74-8\end{array}$ & polvo blanco & & $\begin{array}{l}200 \text { se } \\
\text { descompone }\end{array}$ & 100,02 & sol & & & $0,0 \mathrm{~mm} \mathrm{Hg}$ & & & \\
\hline $\begin{array}{l}\text { TRIACETINA } \\
102-76-1\end{array}$ & líquido incoloro & 259 & .78 & 218,20 & lig sol & 1,1596 & 7,52 & $\begin{array}{l}0,00248 \\
\mathrm{~mm} \mathrm{Hg} \\
\text { @ } 25^{\circ} \mathrm{C}\end{array}$ & $\begin{array}{l}1,8 \mathrm{li} \\
? \text { Is }\end{array}$ & $138 \mathrm{cc}$ & 433 \\
\hline
\end{tabular}




\section{ESTERES ACRILICOS}

\begin{abstract}
U sos
Los ésteres acrílicos se utilizan en la fabricación de resinas para el acabado del cuero y recubrimientos de materias textiles, plástico y papel. El acrilato de metilo, que produce la resina más dura de todos los ésteres acrílicos, se utiliza en la fabricación de fibras acrílicas como un comonómero del acrilonitrilo, puesto que su presencia facilita el hilado de las fibras. Se utiliza en odontología, medicina y farmacia y para la polimerización de residuos radiactivos. Esta sustancia se emplea también en la depuración de efluentes industriales y en la liberación programada y la desintegración de pesticidas. El acrilato de etilo es un componente de polímeros producidos por emulsión y solución para el recubrimiento superficial de materias textiles, papel y cuero. Asimismo, se emplea en la síntesis de aromas y fragancias; como aditivo en pastas para abrillantasuelos y selladores; en cremas para zapatos; y en la producción de fibras, adhesivos y aglomerantes acrílicos.

M ás del $50 \%$ del metacrilato de metilo producido se utiliza para fabricar polímeros acrílicos. En forma de polimetacrilato de metilo y otras resinas, se usa principalmente en forma de láminas plásticas, polvo de moldeo y extrusión, resinas de recubrimiento superficial, polímeros de emulsión, fibras, tintas y películas. EI metacrilato de metilo sirve también para la fabricación de los productos conocidos como Plexiglas o L ucite que se emplean en prótesis dentarias plásticas, lentes de contacto duras y cementos. El metacrilato de n-butilo es un monómero para resinas, revestimientos, disolventes, adhesivos y aditivos para aceites y se utiliza en emulsiones para materias textiles, acabado de cuero y papel y en la fabricación de lentes de contacto.
\end{abstract}

\section{Riesgos}

Como ocurre con muchos monómeros es decir, compuestos químicos que se polimerizan para formar plásticos y resinas, la reactividad de los acrilatos puede plantear riesgos para la salud y la seguridad en el trabajo cuando existen niveles de exposición suficientes. El acrilato de metilo es muy irritante y puede provocar sensibilización. Se han descrito algunos casos de lesiones hepáticas y renales asociadas a exposiciones crónicas. No existen pruebas concluyentes de carcinogénesis (Grupo 3: inclasificable, según la Agencia Internacional para la Investigación sobre el Cáncer (IARC)). Por el contrario, el acrilato de etilo está considerado como un carcinógeno del Grupo 2B (posible carcinógeno humano). Sus vapores son muy irritantes para la nariz, los ojos y el tracto respiratorio. Puede provocar lesiones de córnea y la inhalación de sus vapores en altas concentraciones causa edema pulmonar. Se han descrito algunos casos de sensibilización cutánea por contacto con acrilato de etilo líquido. EI acrilato butílico exhibe propiedades biológicas similares a las de los acrilatos de etilo y metilo, si bien la toxicidad parece disminuir con el aumento de su peso molecular. También es una sustancia irritante que puede provocar sensibilización por contacto de la piel con el líquido.

Los metacrilatos se parecen a los acrilatos, pero su actividad biológica es menor. No ha podido demostrarse que provoquen cáncer en los animales. El metacrilato de metilo puede actuar como depresor del sistema nervioso central y se han dado casos de sensibilización en los trabajadores expuestos al monómero. EI metacrilato de etilo comparte las propiedades del metacrilato de metilo, pero es mucho menos irritante. Al igual que los acrilatos, la potencia biológica de los metacrilatos disminuye con el aumento del peso molecular y el metacrilato de butilo, aunque es irritante, lo es menos que el metacrilato de etilo. 
TABLAS DE ACRILATOS

\begin{tabular}{|c|c|c|c|}
\hline Producto químico & Sinónimos/ Código UN & $\mathrm{N}$ úmero CAS & Fórmula estructural \\
\hline ACRILATO DE BUTILO & $\begin{array}{l}\text { Ester butílico del ácido acrílico; éster butílico del ácido 2-propenoico; } \\
\text { acrilato de n-butilo; 2-propenoato de butilo } \\
\text { UN2348 }\end{array}$ & $141-32-2$ & \\
\hline ACRILATO DE DECILO & $\begin{array}{l}\text { Ester decílico del ácido acrílico; acrilato de n-decilo; éster decílico del ácido } \\
\text { 2-propenoico }\end{array}$ & $2156-96-9$ & \\
\hline ACRILATO DE ETILO & $\begin{array}{l}\text { Ester etílico del ácido acrílico; Carboset 511; etoxicarboniletileno; } \\
\text { propenoato de etilo; 2-propenoato de etilo } \\
\text { UN1917 }\end{array}$ & $140-88-5$ & \\
\hline ACRILATO DE METILO & $\begin{array}{l}\text { Ester metilico del ácido acrílico; Curithane 103; metoxicarboniletileno; } \\
\text { metilpropenato } \\
\text { UN1919 }\end{array}$ & $96-33-3$ & \\
\hline DIACRILATO DE 1,3-BUTANODIOL & $\begin{array}{l}\text { Diéster 1,3-butilenglicólico del ácido acrilico; éster 1-metiltrimetilénico del } \\
\text { ácido acrilico; diacrilato de 1,3-butileno; diacrilato de 1,3-butilenglicol }\end{array}$ & $19485-03-1$ & \\
\hline 2-ETILHEXIL ACRILATO & $\begin{array}{l}\text { Ester 2-etilhexilíco del ácido acrilico; 2-etilhexil-2-propenoato; acrilato de } \\
\text { 2-etil-1-hexanol; octilacrilato; ácido 2-propenoico }\end{array}$ & $103-11-7$ & \\
\hline 2-HIDROXIPROPIL ACRILATO & $\begin{array}{l}\text { Ester 2-hidroxipropilíco del ácido acrílico; HPA; 1,2-propanodiol-1-acrilato; } \\
\text { ácido 2-propenoico }\end{array}$ & $999-61-1$ & \\
\hline METACRILATO DE BUTILO & $\begin{array}{l}\text { Ester butílico del ácido metacrílico; 2-metacrilato de butilo; } \\
\text { 2-metil-2-propenoato de butillo; 2-metilbutilacrilato; éster 2-metilbutílico del } \\
\text { ácido 2-propenoico } \\
\text { UN2227 }\end{array}$ & $97-88-1$ & \\
\hline METACRILATO DE ETILO & $\begin{array}{l}\text { 2-metilacrilato de etilo; 2-metil-2-propenoato de etilo; éster etilico del } \\
\text { ácido metacrilico; éster 2-metiletililico del ácido 2-propenoico } \\
\text { UN2277 }\end{array}$ & $97-63-2$ & \\
\hline METACRILATO DE METILO & $\begin{array}{l}\text { Diakon; éster metílico del ácido metacrílico; metilacrilato de metilo; } \\
\text { metil-2-metil-2-propenoato; éster metilico del ácido 2-metil-2-propenoico; } \\
\text { MME } \\
\text { UN1247 }\end{array}$ & 80.62 .6 & \\
\hline
\end{tabular}




\begin{tabular}{|c|c|c|c|c|c|c|}
\hline \multirow[b]{2}{*}{$\begin{array}{l}\text { Denominación } \\
\text { química } \\
\text { y número CAS }\end{array}$} & \multicolumn{4}{|c|}{ Tarjetas Internacionales sobre la Seguridad de los Productos Q uímicos } & \multicolumn{2}{|c|}{ N IO SH (EE.UU.) } \\
\hline & $\begin{array}{l}\text { Período } \\
\text { corto de } \\
\text { exposición }\end{array}$ & $\begin{array}{l}\text { Período } \\
\text { largo de } \\
\text { exposición }\end{array}$ & $\begin{array}{l}\text { Vías de } \\
\text { exposición }\end{array}$ & Síntomas & $\begin{array}{l}\text { O rganos } \\
\text { afectados } \\
\text { Vías de } \\
\text { entrada }\end{array}$ & Síntomas \\
\hline $\begin{array}{l}\text { ACRILATO DE ETLLO } \\
\text { 140-88-5 }\end{array}$ & $\begin{array}{l}\text { ojos; piel; } \\
\text { tract resp; } \\
\text { pulmones }\end{array}$ & $\begin{array}{l}\text { piel; hígado; } \\
\text { riñones }\end{array}$ & $\begin{array}{r}\text { Inhalación } \\
\text { Piel } \\
\text { 0jos } \\
\text { Ingestión }\end{array}$ & $\begin{array}{l}\text { Sensación de quemazón, tos, dificultad } \\
\text { respiratoria, disnea, dolor de garganta } \\
\text { Enrojecimiento, quemaduras en la piel, dolor } \\
\text { Enrojecimiento, dolor, visión borrosa } \\
\text { Dolor abdominal, dolor de garganta, vómitos }\end{array}$ & $\begin{array}{l}\text { Sis resp; ojos; piel } \\
\text { [en animales: } \\
\text { tumores del aparato } \\
\text { digestivo] } \\
\text { Inh; abs; ing; con }\end{array}$ & Irrit ojos, piel, sis resp; [carc] \\
\hline $\begin{array}{l}\text { ACRILATO DE METILO } \\
96-33-3\end{array}$ & ojos; piel; tract resp & $\begin{array}{l}\text { piel; hígado; } \\
\text { riñones; pulmones }\end{array}$ & $\begin{array}{r}\text { Inhalación } \\
\text { Piel } \\
\text { Ojos } \\
\text { Ingestión }\end{array}$ & $\begin{array}{l}\text { Mareo, cefalea, dificultad respiratoria, dolor de } \\
\text { garganta } \\
\text { Puede absorberse, sensación de quemazón, } \\
\text { dolor, mareo, cefalea } \\
\text { Enrojecimiento, dolor, sensación de quemazón } \\
\text { Sensación de quemazón, vómitos }\end{array}$ & $\begin{array}{l}\text { Sis resp; ojos; piel } \\
\text { Inh; abs; ing; con }\end{array}$ & Irrit ojos, piel, sis resp superior \\
\hline $\begin{array}{l}\text { ETILHEXIL 2-ACRILATO } \\
\text { 103-11-7 }\end{array}$ & $\begin{array}{l}\text { ojos; piel; } \\
\text { tract resp; } \\
\text { pulmones }\end{array}$ & piel & $\begin{array}{r}\text { Inhalación } \\
\text { Piel } \\
\text { Ojos } \\
\text { Ingestión }\end{array}$ & $\begin{array}{l}\text { Sopor, cefalea, náuseas } \\
\text { Puede absorberse, enrojecimiento } \\
\text { Enrojecimiento, dolor } \\
\text { Dolor abdominal, diarrea, mareo, dificultad } \\
\text { respiratoria, vómitos }\end{array}$ & & \\
\hline $\begin{array}{l}\text { 2-HIDROXIPROPIL ACRILATO } \\
\text { 999-61-1 }\end{array}$ & $\begin{array}{l}\text { ojos; piel; } \\
\text { tract resp; } \\
\text { pulmones }\end{array}$ & piel & $\begin{array}{r}\text { Inhalación } \\
\text { Piel } \\
\text { 0jos } \\
\text { Ingestión }\end{array}$ & $\begin{array}{l}\text { Sensación de quemazón, tos, dificultad } \\
\text { respiratoria, dolor de garganta } \\
\text { Enrojecimiento, dolor, ampollas } \\
\text { Dolor, visión borrosa, quemaduras profundas } \\
\text { graves } \\
\text { Espasmos abdominales, sensación de } \\
\text { quemazón, debilidad }\end{array}$ & $\begin{array}{l}\text { Ojos; piel; sis resp } \\
\text { Inh; abs; ing; con }\end{array}$ & $\begin{array}{l}\text { Irrit ojos, piel, sis resp; } \\
\text { quemaduras en piel, ojos; tos, }\end{array}$ \\
\hline $\begin{array}{l}\text { METACRILATO DE ETILO } \\
97.63-2\end{array}$ & ojos; piel; tract resp & piel & $\begin{array}{r}\text { Inhalación } \\
\text { Piel } \\
\text { Ojos } \\
\text { Ingestión }\end{array}$ & $\begin{array}{l}\text { Sensación de quemazón, tos, mareo, sopor, } \\
\text { cefalea, náuseas, inconsciencia } \\
\text { Sequedad de piel, enrojecimiento, aspereza, } \\
\text { sensación de quemazón } \\
\text { Lagrimeo, enrojecimiento, dolor } \\
\text { Confusión, vómitos }\end{array}$ & & \\
\hline $\begin{array}{l}\text { METACRILATO DE METILO } \\
80-62-6\end{array}$ & ojos; piel; pulmones & $\begin{array}{l}\text { piel; hígado; } \\
\text { riñones }\end{array}$ & & & $\begin{array}{l}\text { Ojos; sis resp; piel } \\
\text { Inh; ing; con }\end{array}$ & $\begin{array}{l}\text { Irrit ojos, piel, nariz, garganta; } \\
\text { derm }\end{array}$ \\
\hline
\end{tabular}

\begin{tabular}{|c|c|c|c|}
\hline $\begin{array}{l}\text { Denominación química } \\
\mathrm{N} \text { úmero CAS }\end{array}$ & Físicos & Q uímicos & $\begin{array}{l}\text { Clase o división } \\
\text { UN / Riesgos } \\
\text { subsidiarios }\end{array}$ \\
\hline $\begin{array}{l}\text { ACRILATO DE BUTILO } \\
141-32-2\end{array}$ & & & 3 \\
\hline $\begin{array}{l}\text { ACRILATO DE ETILO } \\
\text { 140-88-5 }\end{array}$ & $\begin{array}{l}\text { El vapor es más pesado que el aire y puede } \\
\text { desplazarse a ras del suelo; posibilidad de ignición a } \\
\text { distancia Los vapores no se inhiben y pueden formar } \\
\text { polímeros en respiraderos o parallamas, provocando } \\
\text { taponamientos }\end{array}$ & $\begin{array}{l}\text { Se polimeriza espontáneamente por calentamiento y en presencia } \\
\text { de luz }\end{array}$ & 3 \\
\hline $\begin{array}{l}\text { ACRILATO DE METILO } \\
96-33-3\end{array}$ & $\begin{array}{l}\text { El vapor es más pesado que el aire y puede } \\
\text { desplazarse a ras del suelo; posibilidad de ignición a } \\
\text { distancia }\end{array}$ & $\begin{array}{l}\text { Se polimeriza por calentamiento o por efecto de la luz Reacciona } \\
\text { con oxidantes fuertes, con peligro de incendio y explosión }\end{array}$ & 3 \\
\hline
\end{tabular}


Tabla 104.55 • Riesgos físicos y químicos.

\begin{tabular}{|c|c|c|c|}
\hline $\begin{array}{l}\text { Denominación química } \\
\mathrm{N} \text { úmero CAS }\end{array}$ & Físicos & Q uímicos & $\begin{array}{l}\text { Clase o división } \\
\text { UN / Riesgos } \\
\text { subsidiarios }\end{array}$ \\
\hline $\begin{array}{l}\text { 2-ETILHEXIL ACRILATO } \\
\text { 103-11-7 }\end{array}$ & & $\begin{array}{l}\text { Se polimeriza por calentamiento en presencia de ácidos, álcalis, } \\
\text { aminas, peróxidos u oxidantes }\end{array}$ & \\
\hline $\begin{array}{l}\text { 2-HIDROXIPROPIL ACRILATO } \\
\text { 999-61-1 }\end{array}$ & & $\begin{array}{l}\text { Se polimeriza por calentamiento o por efecto de iniciadores o luz } \\
\text { UV Se descompone al calentarse, liberando humos acres (ácido } \\
\text { acrílico, acroleína) }\end{array}$ & 8 \\
\hline $\begin{array}{l}\text { METACRILATO DE BUTILO } \\
97-88-1\end{array}$ & & & 3 \\
\hline $\begin{array}{l}\text { METACRILATO DE ETILO } \\
97.63-2\end{array}$ & $\begin{array}{l}\text { El vapor se mezcla bien con el aire, formándose } \\
\text { fácilmente mezclas explosivas }\end{array}$ & $\begin{array}{l}\text { Se polimeriza violentamente por calentamiento y en presencia de } \\
\text { luz o por contacto con oxidantes fuertes }\end{array}$ & 3 \\
\hline $\begin{array}{l}\text { METACRILATO DE METILO } \\
80-62.6\end{array}$ & & & 3 \\
\hline
\end{tabular}

\begin{tabular}{|c|c|c|c|c|c|c|c|c|c|c|c|}
\hline $\begin{array}{l}\text { Denominación química } \\
\mathrm{N} \text { úmero CAS }\end{array}$ & Color/ forma & $\begin{array}{l}\text { p.e. } \\
(\stackrel{0}{ } \mathrm{C})\end{array}$ & $\begin{array}{l}\text { p.f. } \\
(\stackrel{\circ}{ } \mathrm{C})\end{array}$ & $\begin{array}{l}\mathrm{p} . \mathrm{m} . / \\
\text { (g/ } \\
\mathrm{mol})\end{array}$ & $\begin{array}{l}\text { Solubilidad } \\
\text { en agua }\end{array}$ & $\begin{array}{l}\text { Densidad } \\
\text { relativa } \\
\text { (agua }=1 \text { ) }\end{array}$ & $\begin{array}{l}\text { Densidad } \\
\text { relativa } \\
\text { del vapor } \\
\text { (aire }=1 \text { ) }\end{array}$ & $\begin{array}{l}\text { Pvap/ } \\
(\mathrm{kPa})\end{array}$ & $\begin{array}{l}\text { Límit. } \\
\text { inflam. }\end{array}$ & $\begin{array}{l}\text { p.ig. } \\
(-\mathrm{C})\end{array}$ & $\begin{array}{l}\text { p.aut } \\
\text { ig. } \\
(\stackrel{\circ}{ } \text { C })\end{array}$ \\
\hline $\begin{array}{l}\text { ACRILATO DE BUTILO } \\
141-32-2\end{array}$ & $\begin{array}{l}\text { líquido incoloro; } \\
\text { monómero de color } \\
\text { de agua }\end{array}$ & 145 & $-64,6$ & 128,2 & insol & 0,8898 & 4,8 & $4,9 \mathrm{~mm} \mathrm{Hg}$ & $\begin{array}{l}1,5 \mathrm{li} \\
9,9 \mathrm{is}\end{array}$ & $49 \mathrm{ca}$ & 292 \\
\hline $\begin{array}{l}\text { ACRILATO DE DECILO } \\
2156-96-9\end{array}$ & & $\begin{array}{l}158 \\
@ 50 \mathrm{~mm} \mathrm{Hg}\end{array}$ & & 212,37 & lig sol & 0,8781 & & & & $227 \mathrm{ca}$ & \\
\hline $\begin{array}{l}\text { ACRILATO DE ETILO } \\
140-88-5\end{array}$ & líquido; incoloro & 99,4 & $.71,2$ & 100,11 & lig sol & 0,9234 & 3,45 & 3,9 & $\begin{array}{l}1,4 \mathrm{li} \\
14,0 \mathrm{ls}\end{array}$ & $10 \mathrm{ca}$ & 372 \\
\hline $\begin{array}{l}\text { ACRILATO DE METILO } \\
96-33-3\end{array}$ & $\begin{array}{l}\text { líquido; } \\
\text { prácticamente } \\
\text { incoloro }\end{array}$ & 80,5 & $-76,5$ & 86,09 & lig sol & 0,9561 & 2,97 & 9,0 & $\begin{array}{l}2,8 \mathrm{li} \\
25,0 \mathrm{ls}\end{array}$ & $-3 c c$ & 468 \\
\hline $\begin{array}{l}\text { DIACRILATO DE 1,3-BUTANODIOL } \\
\text { 19485-03-1 }\end{array}$ & & & & 198,21 & & & & & & & \\
\hline $\begin{array}{l}\text { 2-ETILHEXIL ACRILATO } \\
\text { 103-11-7 }\end{array}$ & líquido incoloro & $214-218$ & .90 & 184,3 & $0,01 \mathrm{~g} / 100 \mathrm{~g}$ & 0,8869 & 6,35 & $<0,1 \mathrm{~Pa}$ & $\begin{array}{l}0,8 \mathrm{li} \\
6,4 \mathrm{Is}\end{array}$ & 82 & 252 \\
\hline $\begin{array}{l}\text { 2.HIDROXIPROPIL ACRILATO } \\
\text { 999-61-1 }\end{array}$ & líquido & 225 & & 130,2 & misc & 1,06 & 4,5 & $5 \mathrm{~Pa}$ & & 99 & \\
\hline $\begin{array}{l}\text { METACRILATO DE BUTILO } \\
\text { 97-88-1 }\end{array}$ & líquido incoloro & 160 & .75 & 142,2 & insol & 0,8936 & 4,8 & $\begin{array}{l}4,9 \mathrm{~mm} \mathrm{Hg} \\
\mathrm{C}\end{array}$ & $\begin{array}{l}2,0 \mathrm{li} \\
8,0 \mathrm{ls}\end{array}$ & & \\
\hline $\begin{array}{l}\text { METACRILATO DE ETILO } \\
97.63-2\end{array}$ & líquido incoloro & 117 & $<-75$ & 114,1 & lig sol & 0,9135 & 3,9 & 2 & $\begin{array}{l}1,8 \mathrm{li} \\
? \text { Is }\end{array}$ & $35 \mathrm{Ca}$ & 393 \\
\hline $\begin{array}{l}\text { METACRILATO DE METILO } \\
80-62 \cdot 6\end{array}$ & líquido incoloro & 100,5 & -48 & 100,1 & lig sol & 0,9440 & 3,6 & $\begin{array}{l}40 \mathrm{~mm} \mathrm{Hg} \\
\text { @ } 25,5^{\circ} \mathrm{C}\end{array}$ & $\begin{array}{l}1,7 \mathrm{li} \\
8,2 \mathrm{ls}\end{array}$ & $10 \mathrm{ca}$ & \\
\hline
\end{tabular}




\section{ESTERES, ALCAN O AT OS (EXCEPTO ACETATOS)}

Los ésteres son compuestos orgánicos obtenidos por reacción entre un ácido orgánico o inorgánico y un alcohol, con eliminación de agua. También se pueden obtener por medio de otras reacciones, entre ellas las siguientes: haluros de ácidos con alcoholes o fenoles; cetonas con alcoholes o fenoles; 0 ácidos libres con diazoderivados alifáticos, especialmente el diazometano.

L os ésteres de ácidos minerales son líquidos. Los resultantes de ácidos alifáticos con alcoholes saturados son líquidos de olor agradable y fácilmente solubles en agua. Los ésteres aromáticos son menos volátiles y poseen un olor agradable. Los ésteres bencílicos son más irritantes que los correspondientes ésteres alifáticos. La mayoría de los poliésteres aromáticos son líquidos con una presión de vapor baja y un punto de ebullición muy alto. Dada la estabilidad de estos últimos compuestos, se utilizan mucho en la industria de los plásticos.

El formiato de metilo se obtiene calentando alcohol metílico con formiato sódico y ácido clorhídrico. El formiato de metilo así obtenido se separa por destilación. Es un buen disolvente de grasas, ácidos grasos, colodión y celuloide. U tilizado como disolvente industrial general, suele mezclarse con otros ésteres como el formiato de etilo, el acetato de metilo y el acetato de etilo.

\section{Riesgos}

El formiato de butilo es inflamable y su vapor forma mezclas explosivas con el aire a temperaturas normales. Irrita los ojos y las mucosas. Se absorbe por los pulmones y el tracto gastrointestinal. En estudios con animales se ha comprobado que provoca narcosis y edema pulmonar a concentraciones muy altas, pero no se ha registrado ningún caso de intoxicación industrial 0 accidental en seres humanos.

El formiato de etilo se obtiene calentando alcohol etílico con ácido fórmico en presencia de ácido sulfúrico y destilando el producto resultante. Es un líquido inflamable y sus vapores forman mezclas explosivas con el aire a temperaturas normales.
En experimentos con animales, la inhalación de los vapores de esta sustancia causó temblores, depresión progresiva del sistema nervioso central y muerte por insuficiencia circulatoria y respiratoria, siendo la dosis narcótica semejante a la dosis letal. La intoxicación por formiato de etilo industrial no está bien documentada, aunque a concentraciones de 330 ppm, los trabajadores experimentan irritación de la conjuntiva y de las mucosas, que en ocasiones persiste varias horas después de haber cesado el contacto.

El oxalato de etilo se obtiene por un procedimiento estandarizado de esterificación, utilizando alcohol etílico y ácido oxálico. Es un líquido combustible, pero no produce concentraciones inflamables de sus vapores a temperatura ambiente. En el organismo se hidroliza para formar ácido oxálico, siendo éste último el responsable de los efectos tóxicos. No se conoce ningún caso de intoxicación letal por oxalato de etilo en la industria, pero siempre deben tenerse en cuenta sus posibles efectos tóxicos. En caso de exposición crónica en los seres humanos, se observa una disminución del recuento sanguíneo de hematíes y leucocitos, junto con una ligera eosinofilia y neutropenia.

El formiato de meilo es un líquido inflamable. El vapor forma mezclas explosivas con el aire a temperatura normal. Este éster puede ser absorbido por el organismo a través de los sistemas respiratorio y digestivo y también por vía percutánea. Tiene un efecto irritante y narcótico y, a concentraciones altas, puede producir narcosis, disnea, convulsiones, coma y muerte en animales de experimentación. En estas condiciones, los pulmones fueron los órganos más afectados (congestión, enfisema y edema), con hiperemia en los riñones, las glándulas suprarrenales, el hígado y las meninges. Puesto que el formiato de metilo suele utilizarse como ingrediente de mezclas de disolventes, es difícil determinar exactamente su sintomatología específica. T rabajadores expuestos a los vapores de un disolvente con $30 \%$ de formiato de metilo sufrieron irritación de las mucosas, sensación de opresión torácica y disnea de intensidad variable; algunos experimentaron euforia, otros depresión. Un joven al que se le aplicó el éster en la cabeza como parasiticida desarrolló cianosis en 20 minutos y falleció por insuficiencia cardíaca. 


\section{TABLAS DE ALCANOATOS (EXCEPTO ACETATOS)}

\begin{tabular}{|c|c|c|c|}
\hline Producto químico & Sinónimos/ Código UN & $\mathrm{N}$ úmero CAS & Fórmula estructural \\
\hline BENZOATO DE BENCILO & $\begin{array}{l}\text { Ester fenilmetílico de ácido benzoico; éster benzoico de alcohol bencílico; } \\
\text { bencenocarboxilato de bencilo; fenilformiato de bencilo; benilato }\end{array}$ & $120-51-4$ & \\
\hline BENZOATO DE BUTILO & Ester n-butílico de ácido benzoico; benzoato de n-butilo & $136-60-7$ & \\
\hline BENZOATO DE ETILO & Eter benzoico; éster etílico de ácido benzoico & $93-89-0$ & \\
\hline BENZOATO DE METILO & $\begin{array}{l}\text { Ester metílico de ácido benzoico; bencenocarboxilato de metilo; benzoato } \\
\text { de metilo } \\
\text { UN2938 }\end{array}$ & $93-58-3$ & \\
\hline BUTIRATO DE BUTILO & $\begin{array}{l}\text { n-Butanoato de n-butilo; éster butílico de ácido butírico; butirato } \\
\text { de n-butilo }\end{array}$ & $109-21-7$ & \\
\hline$\beta$-BUTIROLACTONA & $\begin{array}{l}\beta \text {-Lactona de ácido 3-hidroxibutanoico; lactona de ácido hidroxibutírico; } \\
\text { lactona de ácido 3-hidroxibutírico; 4-metil-2-oxetanona; 2-oxetanona de } \\
\text { 4-metilo }\end{array}$ & $3068-88-0$ & \\
\hline CARBOFURANO & $\begin{array}{l}\text { 2,3-Dihidro-2,2-dimetilbenzofuranil-7-N-metilcarbamato; } \\
\text { metilcarbamato de 2,3-dihidro-2,2-dimetilbenzofuran-7-ilo; } \\
\text { 2,2-dimetil-7-cumaranil-N-metilcarbamato; } \\
\text { 2,2-dimetil-2,3-dihidro-7-benzofuranil-N-metilcarbamato; éster } \\
\text { 2,3-dihidro-2,2-dimetil-7-benzofuranilico de ácido metilcarbámico }\end{array}$ & $1563-66-2$ & \\
\hline CARBONATO DE DIETILO & $\begin{array}{l}\text { Ester dietílico de ácido carbónico; carbonato dietílico; anhídrido } \\
\text { etoxifórmico; carbonato etílico } \\
\text { UN2366 }\end{array}$ & $105-58-8$ & \\
\hline CARBONATO DE DIMETILO & $\begin{array}{l}\text { Ester dimetílico de ácido carbónico; carbonato de metilo } \\
\text { UN1161 }\end{array}$ & $616-38-6$ & \\
\hline CLOROFORMIATO DE DECILO & & $55488-51-2$ & \\
\hline CLOROFORMIATO ESTEARILICO & & $51637-93-5$ & \\
\hline CLOROFORMIATO DE ETILO & $\begin{array}{l}\text { Ester etílico de ácido clorofórmico; ECF; clorocarbonato de etilo } \\
\text { UN1182 }\end{array}$ & $541-41-3$ & \\
\hline CLOROFORMIATO DE FENILO & $\begin{array}{l}\text { Ester fenílico de ácido clorofórmico; clorocarbonato de fenilo } \\
\text { UN2746 }\end{array}$ & $1885-14-9$ & \\
\hline
\end{tabular}




\begin{tabular}{|c|c|c|}
\hline Producto químico & Sinónimos/ Código UN & N úmero CAS Fórmula estructural \\
\hline CLOROFORMIATO LAURILICO & & $24460-74.0$ \\
\hline CLOROFORMIATO DE METILO & $\begin{array}{l}\text { Ester metilico de ácido clorocarbónico; éster metílico de ácido clorofórmico; } \\
\text { MCF; cloruro de metoxicarbonilo; clorocarbonato de metilo } \\
\text { UN1238 }\end{array}$ & $79-22-1$ \\
\hline
\end{tabular}

CLOROFORMIATO MIRISTLLICO

$56677-60-2$

禹

\begin{tabular}{ll}
\hline DIBENZOATO DE DIETILENGLICOL & Diéster de ácido benzoico con dietilenglicol; éster dietilenglicólico de \\
dibenzoilo
\end{tabular}

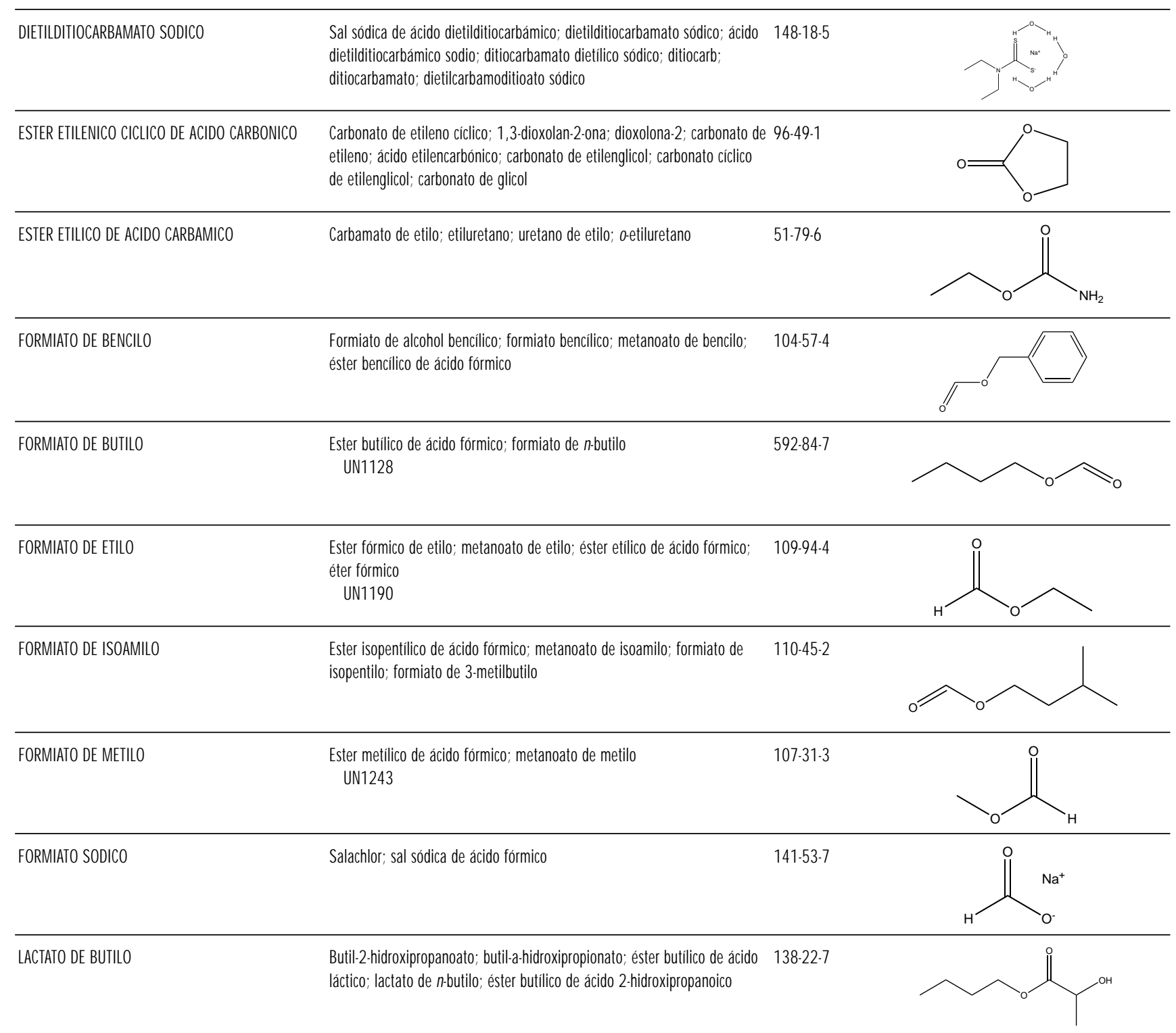




\begin{tabular}{|c|c|c|}
\hline Producto químico & Sinónimos/ Código UN & $\mathrm{N}$ úmero CAS Fórmula estructural \\
\hline LACTONA DE ACIDO BUTIRICO & $\begin{array}{l}\text { 4-Butanoluro; 1,2-butanoluro; 1,4-butanoluro; } \gamma \text {-lactona de ácido } \\
\text { 4-hidroxibutírico; butirolactona; 4-butirolactona; butirilactona; lactona de } \\
\text { butirilo; 2-(3H)-furanona dihidro }\end{array}$ & $96-48-0$ \\
\hline MALONATO DE DIETILO & $\begin{array}{l}\text { Ester carbetoxiacético; dicarbetoximetano; éster dietílico de ácido } \\
\text { malónico; propanodiato dietilico; malonato de etilo; éster malónico; éster } \\
\text { dietélico de ácido metanodicarboxilico; éster dietilico de ácido } \\
\text { propanodioico }\end{array}$ & $105-53-3$ \\
\hline OXALATO DE AMONIO & Sal diamónica de ácido etanodioico; sal diamónica de ácido oxálico & $1113-38-8$ \\
\hline OXALATO DE ETILO & $\begin{array}{l}\text { Etanodiato dietílico; oxalato dietílico; oxalato etílico } \\
\text { UN } 2525\end{array}$ & $95-92-1$ \\
\hline PROPIOLACTONA & $\begin{array}{l}\beta \text {-Lactona de ácido hidracrílico; lactona de ácido 3-hidroxipropionico; } \\
\text { propanoluro; 3-propanoluro; 1,3-propiolactona; 3-propiolactona }\end{array}$ & $57-57-8$ \\
\hline PROPIONATO DE BUTILO & $\begin{array}{l}\text { Ester butílico de ácido propiónico } \\
\text { UN1914 }\end{array}$ & $590-01-2$ \\
\hline PROPIONATO DE ETILO & $\begin{array}{l}\text { Propionato etílico; éster etílico de ácido propanoico; éter propiónico } \\
\text { UN1195 }\end{array}$ & $105-37-3$ \\
\hline PROPIONATO DE METILO & $\begin{array}{l}\text { Propilato de metilo; éster metílico de ácido propanoico } \\
\text { UN1248 }\end{array}$ & $554-12-1$ \\
\hline SAL SODICA DEL ACIDO PROPIONICO & $\begin{array}{l}\text { Impedex; Mycoban; Napropion; Ocuseptine; sal sódica de ácido } \\
\text { propanoico; propionato sódico }\end{array}$ & $137-40-6$ \\
\hline SUCCINATO DE DIETILO & $\begin{array}{l}\text { Ester dietílico de ácido butanodioico; succinato de etilo; éster dietilico de } \\
\text { ácido succínico }\end{array}$ & $123-25-1$ \\
\hline TRIBUTIRINA & $\begin{array}{l}\text { Ester 1,2,3-propanotrílico de ácido butanoico; triglicérido butirílico; } \\
\text { glicerol-tributirato; tributiroina; glicérido tributiŕlico }\end{array}$ & $60-01-5$ \\
\hline
\end{tabular}




\begin{tabular}{|c|c|c|c|c|c|c|}
\hline \multirow[b]{2}{*}{$\begin{array}{l}\text { Denominación } \\
\text { química } \\
\text { N úmero CAS }\end{array}$} & \multicolumn{4}{|c|}{ Tarjetas Internacionales sobre la Seguridad de los Productos Q uímicos } & \multicolumn{2}{|c|}{ N IO SH (EE.UU.) } \\
\hline & $\begin{array}{l}\text { Período } \\
\text { corto de } \\
\text { exposición }\end{array}$ & $\begin{array}{l}\text { Período } \\
\text { largo de } \\
\text { exposición }\end{array}$ & $\begin{array}{l}\text { Vías de } \\
\text { exposición }\end{array}$ & Síntomas & $\begin{array}{l}\text { O rganos } \\
\text { afectados } \\
\text { Vías de } \\
\text { entrada }\end{array}$ & Síntomas \\
\hline $\begin{array}{l}\text { CLOROFORMIATO DE ETILO } \\
541-41-3\end{array}$ & $\begin{array}{l}\text { ojos; piel; } \\
\text { tract resp; } \\
\text { pulmones }\end{array}$ & & $\begin{array}{r}\text { Inhalación } \\
\text { Piel } \\
\text { 0jos } \\
\text { Ingestión }\end{array}$ & $\begin{array}{l}\text { Sensación de quemazón, tos, dificultad } \\
\text { respiratoria, náuseas, disnea, dolor de } \\
\text { garganta } \\
\text { Enrojecimiento, quemaduras en la piel, } \\
\text { sensación de quemazón, dolor, ampollas } \\
\text { Enrojecimiento, dolor, quemaduras profundas } \\
\text { graves } \\
\text { Espasmos abdominales, dolor abdominal, } \\
\text { debilidad }\end{array}$ & & \\
\hline $\begin{array}{l}\text { CLOROFORMIATO DE METILO } \\
79-22-1\end{array}$ & $\begin{array}{l}\text { ojos; piel; } \\
\text { tract resp; } \\
\text { pulmones }\end{array}$ & & $\begin{array}{l}\text { Inhalación } \\
\text { Piel } \\
\text { 0jos } \\
\text { Ingestión }\end{array}$ & $\begin{array}{l}\text { Sensación de quemazón, tos, dificultad } \\
\text { respiratoria, náuseas, los síntomas pueden } \\
\text { tardar en aparecer } \\
\text { Enrojecimiento, dolor, ampollas } \\
\text { Enrojecimiento, dolor, quemaduras profundas } \\
\text { graves } \\
\text { Dolor abdominal, sensación de quemazón, } \\
\text { vómitos, debilidad, shock }\end{array}$ & & \\
\hline $\begin{array}{l}\text { FORMIATO DE BUTILO } \\
592-84-7\end{array}$ & $\begin{array}{l}\text { ojos; piel; } \\
\text { tract resp; } \\
\text { pulmones; CNS }\end{array}$ & & $\begin{array}{l}\text { Inhalación } \\
\\
\text { Piel } \\
\text { 0jos } \\
\text { Ingestión }\end{array}$ & $\begin{array}{l}\text { Tos, embotamiento, sensación de quemazón } \\
\text { en la garganta, dificultad respiratoria, disnea, } \\
\text { dolor de garganta, inconsciencia, vómitos, los } \\
\text { síntomas pueden tardar en aparecer } \\
\text { Enrojecimiento, dolor } \\
\text { Enrojecimiento, dolor, visión borrosa, } \\
\text { quemaduras profundas graves } \\
\text { Dolor abdominal, diarrea }\end{array}$ & & \\
\hline $\begin{array}{l}\text { FORMIATO DE ETILO } \\
\text { 109-94-4 }\end{array}$ & $\begin{array}{l}\text { ojos; piel; } \\
\text { tract resp; } \\
\text { pulmones; SNC; } \\
\text { hígado; riñones }\end{array}$ & $\begin{array}{l}\text { piel; hígado; } \\
\text { riñones }\end{array}$ & $\begin{array}{r}\text { Inhalación } \\
\text { Piel } \\
\text { Ojos } \\
\text { Ingestión }\end{array}$ & $\begin{array}{l}\text { Sensación de quemazón, tos, sopor, cefalea, } \\
\text { disnea, dolor de garganta, inconsciencia } \\
\text { Puede ser absorbido, enrojecimiento, sensación } \\
\text { de quemazón } \\
\text { Enrojecimiento, dolor } \\
\text { Dolor abdominal, sensación de quemazón }\end{array}$ & $\begin{array}{l}\text { Ojos; sist resp; SNC } \\
\text { Inh; ing; con }\end{array}$ & $\begin{array}{l}\text { Irrit ojos, sist resp superior; en } \\
\text { animales: narc }\end{array}$ \\
\hline $\begin{array}{l}\text { FORMIATO DE METILO } \\
\text { 107-31-3 }\end{array}$ & & & $\begin{array}{r}\text { Inhalación } \\
\text { Ojos } \\
\text { Piel }\end{array}$ & $\begin{array}{l}\text { Tos, mareo, embotamiento, cefalea, dificultad } \\
\text { respiratoria, disnea, inconsciencia } \\
\text { Enrojecimiento } \\
\text { Enrojecimiento }\end{array}$ & $\begin{array}{l}\text { Ojos; sis resp; SNC } \\
\text { Inh; abs; ing; con }\end{array}$ & $\begin{array}{l}\text { Irrit ojos, nariz; opresión } \\
\text { torácica; dis; alt vis; depres } \\
\text { SNC; en animales: edema } \\
\text { pulm; narc }\end{array}$ \\
\hline $\begin{array}{l}\text { FORMIATO SODICO } \\
141.53 \cdot 7\end{array}$ & & & $\begin{array}{r}\text { Inhalación } \\
\text { Ojos } \\
\text { Ingestión }\end{array}$ & $\begin{array}{l}\text { Tos, disnea } \\
\text { Enrojecimiento, dolor } \\
\text { Dolor abdominal, vómitos }\end{array}$ & & \\
\hline $\begin{array}{l}\text { NITRATO DE n-PROPILO } \\
627-13-4\end{array}$ & & & & & $\begin{array}{l}\text { Ojos; piel; sangre } \\
\text { Inh; ing; con }\end{array}$ & $\begin{array}{l}\text { En animales: Irrit ojos, piel; } \\
\text { metahem, anoxia, cian; dis; } \\
\text { deb, mar, cef }\end{array}$ \\
\hline $\begin{array}{l}\text { PROPIONATO DE BUTILO } \\
590-01-2\end{array}$ & ojos; piel; tract resp & & $\begin{array}{r}\text { Inhalación } \\
\text { Piel } \\
\text { Ojos } \\
\text { Ingestión }\end{array}$ & $\begin{array}{l}\text { Sensación de quemazón, tos, dolor de } \\
\text { garganta } \\
\text { Enrojecimiento } \\
\text { Enrojecimiento, dolor } \\
\text { Dolor abdominal, mareo, náuseas }\end{array}$ & & \\
\hline $\begin{array}{l}\text { SAL SODICA DEL ACIDO } \\
\text { PROPIONICO } \\
137-40-6\end{array}$ & $\begin{array}{l}\text { ojos; piel; } \\
\text { tract resp. }\end{array}$ & & & & & \\
\hline
\end{tabular}


Tabla 104.59 • Riesgos físicos y químicos.

\begin{tabular}{|c|c|c|c|}
\hline $\begin{array}{l}\text { Denominación química } \\
\mathrm{N} \text { úmero CAS }\end{array}$ & Físicos & Q uímicos & $\begin{array}{l}\text { Clase o división } \\
\text { UN / Riesgos } \\
\text { subsidiarios }\end{array}$ \\
\hline $\begin{array}{l}\text { BENZOATO DE BENCILO } \\
120-51-4\end{array}$ & $\begin{array}{l}\text { El vapor es más pesado } \\
\text { que el aire }\end{array}$ & En su combustión libera vapores tóxicos e irritantes & \\
\hline $\begin{array}{l}\text { BENZOATO DE BENCILO DIETILENICO } \\
\quad 120-55-8\end{array}$ & $\begin{array}{l}\text { El vapor es más pesado } \\
\text { que el aire }\end{array}$ & En su combustión libera vapores acres & \\
\hline $\begin{array}{l}\text { BENZOATO DE METILO } \\
93-58-3\end{array}$ & & & 6.1 \\
\hline $\begin{array}{l}\text { CARBOFURANO } \\
1563-66-2\end{array}$ & & Se descompone al calentarse 0 al arder & \\
\hline $\begin{array}{l}\text { CARBONATO DE DIETILO } \\
\text { 105-58-8 }\end{array}$ & $\begin{array}{l}\text { El vapor se mezcla bien } \\
\text { con el aire; se forman } \\
\text { fácilmente mezclas } \\
\text { explosivas }\end{array}$ & $\begin{array}{l}\text { Reacciona con materiales reductores y bases fuertes Reacciona violentamente con oxidantes } \\
\text { fuertes, con peligro de incendio y explosión Ataca muchos plásticos y resinas }\end{array}$ & 3 \\
\hline $\begin{array}{l}\text { CARBONATO DE DIMETILO } \\
616-38-6\end{array}$ & & & 3 \\
\hline $\begin{array}{l}\text { CLOROFORMIATO DE ETILO } \\
541-41-3\end{array}$ & $\begin{array}{l}\text { El vapor es más pesado } \\
\text { que el aire y puede } \\
\text { desplazarse a ras del } \\
\text { suelo; posibilidad de } \\
\text { ignición a distancia }\end{array}$ & $\begin{array}{l}\text { En contacto con superficies calientes o llamas, se descompone y forma cloruro de hidrógeno y } \\
\text { fosgeno Se descompone al calentarse, liberando vapores tóxicos e irritantes, entre ellos cloruro } \\
\text { de hidrógeno y fosgeno Reacciona en contacto con agua o vapor produciendo hidrógeno tóxico } \\
\text { y corrosivo Reacciona violentamente con oxidantes fuertes, con peligro de incendio y explosión } \\
\text { Ataca muchos metales, especialmente en presencia de humedad }\end{array}$ & $6.1 / 3 / 8$ \\
\hline $\begin{array}{l}\text { CLOROFORMIATO DE METILO } \\
79-22-1\end{array}$ & $\begin{array}{l}\text { El vapor es más pesado } \\
\text { que el aire y puede } \\
\text { desplazarse a ras del } \\
\text { suelo; posibilidad de } \\
\text { ignición a distancia }\end{array}$ & $\begin{array}{l}\text { En su combustión libera vapores tóxicos ( } \mathrm{HCl} \text {, fosgeno) Se descompone al calentarse o al } \\
\text { arder en contacto con superficies calientes o llamas, liberando vapores tóxicos y corrosivos } \\
\text { (cloruro de hidrógeno, fosgeno), con peligro de incendio Reacciona con oxidantes fuertes } \\
\text { Reacciona gradualmente con el agua, formando una sustancia corrosiva (cloruro de hidrógeno) }\end{array}$ & $6.1 / 3$ \\
\hline $\begin{array}{l}\text { ESTER ETILICO DEL ACIDO CARBAMICO } \\
51-79-6\end{array}$ & & Se descompone al calentarse, liberando vapores tóxicos (óxidos de nitrógeno) & \\
\hline $\begin{array}{l}\text { FORMIATO DE BUTILO } \\
592-84-7\end{array}$ & $\begin{array}{l}\text { El vapor se mezcla bien } \\
\text { con el aire; se forman } \\
\text { fácilmente mezclas } \\
\text { explosivas Se pueden } \\
\text { generar cargas } \\
\text { electrostáticas como } \\
\text { resultado de flujo, } \\
\text { agitación, etc. }\end{array}$ & $\begin{array}{l}\text { Se descompone al calentarse } 0 \text { al arder, liberando vapores acres e irritantes Reacciona } \\
\text { violentamente con oxidantes fuertes }\end{array}$ & \\
\hline $\begin{array}{l}\text { FORMIATO DE ETILO } \\
\text { 109-94-4 }\end{array}$ & $\begin{array}{l}\text { El vapor es más pesado } \\
\text { que el aire y puede } \\
\text { desplazarse a ras del } \\
\text { suelo; posibilidad de } \\
\text { ignición a distancia }\end{array}$ & Reacciona violentamente con oxidantes fuertes, ácidos y bases & \\
\hline $\begin{array}{l}\text { FORMIATO DE METILO } \\
\text { 107-31-3 }\end{array}$ & $\begin{array}{l}\text { El vapor es más pesado } \\
\text { que el aire y puede } \\
\text { desplazarse a ras del } \\
\text { suelo; posibilidad de } \\
\text { ignición a distancia El } \\
\text { vapor se mezcla bien con } \\
\text { el aire, se forman } \\
\text { fácilmente mezclas } \\
\text { explosivas }\end{array}$ & Reacciona vigorosamente con oxidantes & 3 \\
\hline
\end{tabular}

\begin{tabular}{lc}
\hline $\begin{array}{l}\text { FORMIATO SODICO } \\
141-53-7\end{array}$ & $\begin{array}{c}\text { Se descompone en oxalato sódico, hidrógeno y monóxido de carbono cuando se calienta a más } \\
\text { de } 253^{\circ} \mathrm{C} \text { y en contacto con ácidos, produciendo vapores de ácido fórmico }\end{array}$ \\
\hline PROPIONATO DE BUTILO & Reacciona con oxidantes fuertes
\end{tabular}

Reacciona con oxidantes fuertes

$590-01-2$ 


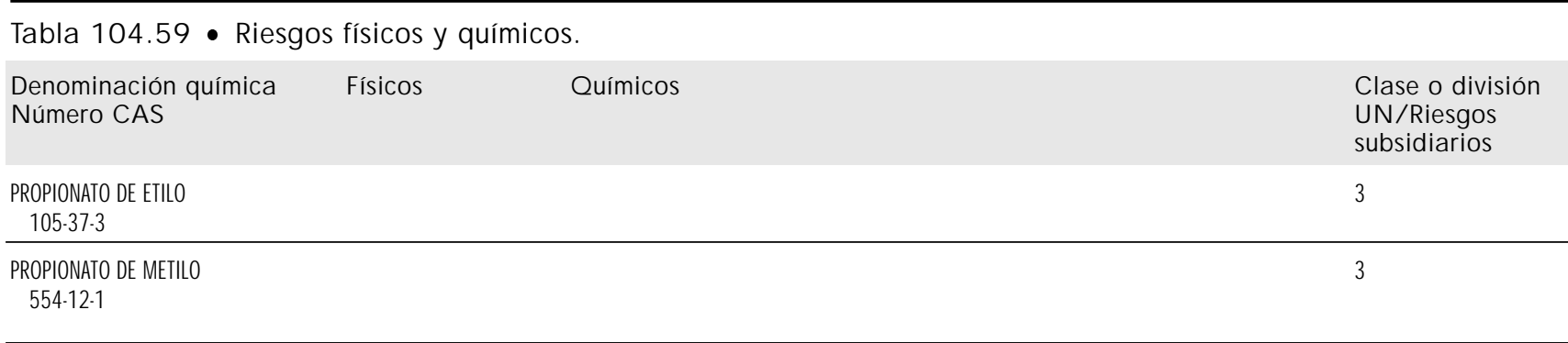

\begin{tabular}{|c|c|c|c|c|c|c|c|c|c|c|c|}
\hline $\begin{array}{l}\text { Denominación química } \\
\mathrm{N} \text { úmero CAS }\end{array}$ & Color/ forma & $\begin{array}{l}\text { p.e. } \\
(\stackrel{\circ}{ })\end{array}$ & $\begin{array}{l}\text { p.f. } \\
(\stackrel{\circ}{ }) \text { ) }\end{array}$ & $\begin{array}{l}\text { p.m.l } \\
\text { (g/ } \\
\text { mol) }\end{array}$ & $\begin{array}{l}\text { Solubilidad } \\
\text { en agua }\end{array}$ & $\begin{array}{l}\text { Densidad } \\
\text { relativa } \\
\text { (agua }=1 \text { ) }\end{array}$ & $\begin{array}{l}\text { Densidad } \\
\text { relativa } \\
\text { del vapor } \\
\text { (aire=1) }\end{array}$ & $\begin{array}{l}\text { Pvap/ } \\
(\mathrm{kPa})\end{array}$ & $\begin{array}{l}\text { Límit. } \\
\text { inflam. }\end{array}$ & $\begin{array}{l}\text { p.ig. } \\
(\underline{O C})\end{array}$ & $\begin{array}{l}\text { P.aut } \\
\text { ig. } \\
(\stackrel{\circ}{ } \mathrm{C})\end{array}$ \\
\hline $\begin{array}{l}\text { BUTIRATO DE BUTILO } \\
109-21-7\end{array}$ & & 166 & $-91,5$ & 144,21 & insol & 0,8700 & & & & & \\
\hline $\begin{array}{l}\text { CLOROFORMIATO DE ETILO } \\
541-41-3\end{array}$ & $\begin{array}{l}\text { líquido acuoso } \\
\text { transparente }\end{array}$ & 95 & $-80,6$ & 108,5 & insol & 1,1403 & 3,7 & 5,5 & $\begin{array}{l}3,2 \mathrm{li} \\
27,5 \mathrm{ls} \\
\end{array}$ & $16 c c$ & 500 \\
\hline $\begin{array}{l}\text { CLOROFORMIATO DE METILO } \\
79-22-1\end{array}$ & líquido transparente & 71 & -61 & 94,50 & insol & 1,223 & 3,26 & 13,7 & 6,7 & $13 \mathrm{cc}$ & 510 \\
\hline $\begin{array}{l}\text { DIACETATO DE a-PROPILENGLICOL } \\
623-84-7 \\
\end{array}$ & & 190,5 & & 160,16 & muy sol & 1,059 & & & & & \\
\hline $\begin{array}{l}\text { FORMIATO DE BENCILO } \\
104-57-4\end{array}$ & & $202-203$ & & 136,14 & insol & 1,081 & & & & & \\
\hline $\begin{array}{l}\text { FORMIATO DE BUTILO } \\
592-84-7 \\
\end{array}$ & líquido & 106 & $-91,5$ & 102,13 & lig sol & 0,8885 & 3,5 & $\begin{array}{l}5,33 \\
\text { @ } 31,6^{\circ} \mathrm{C}\end{array}$ & $\begin{array}{l}1,7 \mathrm{li} \\
8,0 \mathrm{ls}\end{array}$ & $18 \mathrm{cc}$ & 322 \\
\hline $\begin{array}{l}\text { FORMIATO DE ETILO } \\
109-94-4\end{array}$ & $\begin{array}{l}\text { líquido móvil líquido } \\
\text { acuoso transparente }\end{array}$ & 54,4 & -80 & 74,1 & sol & 0,9168 & 2,56 & 25,6 & $\begin{array}{l}2,8 \mathrm{li} \\
16,0 \mathrm{ls}\end{array}$ & $-20 \mathrm{cc}$ & 440 \\
\hline $\begin{array}{l}\text { FORMIATO DE ISOAMILO } \\
110-45-2 \\
\end{array}$ & & 123,5 & $-93,5$ & 116,15 & lig sol & 0,8857 & & & & & \\
\hline $\begin{array}{l}\text { FORMIATO DE METILO } \\
107-31-3 \\
\end{array}$ & líquido incoloro & 32 & $-99,8$ & 60,05 & muy sol & 0,9742 & 2,07 & 64 & $\begin{array}{l}5 \mathrm{li} \\
23 \mathrm{ls}\end{array}$ & $-19 c c$ & 449 \\
\hline $\begin{array}{l}\text { FORMIATO SODICO } \\
141.53 .7\end{array}$ & $\begin{array}{l}\text { cristales monocíclicos } \\
\text { incoloros; polvo } \\
\text { cristalino } 0 \text { gránulos } \\
\text { blancos }\end{array}$ & $\begin{array}{l}253 \text { se } \\
\text { descompone }\end{array}$ & 253 & 68,02 & $97,2 \mathrm{~g} / 100 \mathrm{ml}$ & 1,92 & & & & & \\
\hline $\begin{array}{l}\text { GLICEROL-TRIBUTIRATO } \\
60-01-5\end{array}$ & $\begin{array}{l}\text { líquido oleaginoso; } \\
\text { incoloro }\end{array}$ & $305-310$ & .75 & 302,4 & insol & 1,0350 & & & $\begin{array}{l}0,5 \mathrm{li} \\
? \text { Is }\end{array}$ & & \\
\hline $\begin{array}{l}\text { OXALATO DE ETILO } \\
95-92-1\end{array}$ & $\begin{array}{l}\text { líquido oleaginoso e } \\
\text { incoloro }\end{array}$ & $\begin{array}{l}185,7 \text { 으 @ } \\
760 \mathrm{~mm} \mathrm{Hg}\end{array}$ & $-38,5^{\circ} \mathrm{C}$ & 146,14 & $\begin{array}{l}\text { lig sol; se } \\
\text { descompone }\end{array}$ & $\begin{array}{l}1,0785 \\
@ 20 \stackrel{\circ}{\circ} / 4 \stackrel{\circ}{\circ}\end{array}$ & 5,04 & $\begin{array}{l}1 \mathrm{~mm} \mathrm{Hg} \\
@ 47 \stackrel{\circ}{-C}\end{array}$ & & & \\
\hline $\begin{array}{l}\text { PROPIONATO DE BUTILO } \\
590-01-2\end{array}$ & líquido & 146 & -89 & 130,2 & lig sol & 0,8754 & 4,5 & 0,38 & & 32 & 425 \\
\hline $\begin{array}{l}\text { PROPIONATO DE ETILO } \\
\text { 105-37-3 }\end{array}$ & líquido incoloro & 99 & .73 & 102,1 & lig sol & 0,891 & 3,5 & & $\begin{array}{l}1,9 \mathrm{il} \\
11 \mathrm{is} \\
\end{array}$ & $12 c c$ & 440 \\
\hline $\begin{array}{l}\text { PROPIONATO DE METILO } \\
\text { 554-12-1 }\end{array}$ & líquido incoloro & 79,7 & .87 & 88,10 & lig sol & 0,915 & 3,03 & $\begin{array}{l}84,04 \mathrm{~mm} \\
\mathrm{Hg} \\
@ 25^{\circ} \mathrm{C}\end{array}$ & $\begin{array}{l}2,5 \mathrm{li} \\
13,0 \mathrm{ls}\end{array}$ & $-2 c c$ & 469 \\
\hline $\begin{array}{l}\text { SAL SODICA DEL ACIDO PROPIONICO } \\
137-40-6\end{array}$ & $\begin{array}{l}\text { polvo granulado } \\
\text { blanco; cristales } \\
\text { transparentes, } \\
\text { gránulos }\end{array}$ & & & 96,07 & lig sol & & & & & & \\
\hline
\end{tabular}




\section{PROPIEDADES DE LOS ETERES}

\section{ETERES}

L os éteres son compuestos orgánicos en los que el oxígeno actúa de enlace entre dos radicales orgánicos. La mayoría de los éteres de importancia industrial son líquidos, aunque el éter metílico es un gas y algunos éteres, como los de celulosa, son sólidos.

\section{Riesgos}

L os éteres de bajo peso molecular (méílico, dietílico, isopropílico, vinílico y vinilisopropílico) son altamente inflamables, con puntos de ignición por debajo de las temperaturas ambientales normales. En consecuencia, exigen la adopción de medidas para evitar la liberación de vapores en áreas donde puedan existir fuentes de ignición. Entre otras medidas de control, deben eliminarse todas las fuentes de ignición en las zonas donde puedan acumularse concentraciones apreciables de vapores de éter durante las operaciones normales, como el secado de hornos, o cuando pueda producirse la liberación accidental del éter, ya sea en forma líquida o gaseosa.

Al almacenarlos durante períodos prolongados en presencia de aire o bajo la acción de la luz solar, los éteres pueden formar peróxidos, con el consiguiente peligro de explosión. En los laboratorios, los recipientes de vidrio ámbar confieren protección, excepto frente a la radiación ultravioleta o la luz solar directa. Los inhibidores del tipo de la malla de cobre o la adición de una pequeña cantidad de un agente reductor no siempre son eficaces. Si no se necesita un éter seco, puede añadirse agua hasta un $10 \%$ del volumen de éter. La agitación con sulfato ferroso al $5 \%$ elimina los peróxidos. La característica toxicológica principal de los éteres no sustituidos es su efecto narcótico, pudiendo provocar pérdida de consciencia cuando la exposición es considerable y, como buenos disolventes de grasas que son, provocan dermatitis por contacto repetido o prolongado con la piel. La exposición a concentraciones excesivas puede evitarse recurriendo al confinamiento y a la ventilación. Las cremas protectoras y los guantes impermeables ayudan a evitar la irritación cutánea. En caso de pérdida de consciencia, debe retirarse a la persona afectada del lugar contaminado y proporcionarle respiración artificial y oxígeno.

El principal efecto fisiológico de los éteres no halogenados que aparecen en las tablas adjuntas es la anestesia. Las exposiciones repetidas a concentraciones superiores a $400 \mathrm{ppm}$ de éter etílico producen irritación nasal, inapetencia, cefalea, mareo y excitación, seguidos de somnolencia. El contacto repetido con la piel puede secarla y agrietarla. Se han descrito algunos casos de trastornos mentales como consecuencia de exposiciones prolongadas.

\section{E teres halogenados}

Al contrario que los éteres no halogenados, los éteres halogenados suponen un grave riesgo industrial. Comparten la propiedad química de ser agentes alquilantes; es decir, pueden inducir la formación de enlaces químicos de grupos alquilos como grupos etílicos y metílicos con segmentos radicales de electrones (p. ej., - $\mathrm{NH}_{2}$ en material genético y hemoglobina). Se cree que esta alquilación está estrechamente relacionada con el cáncer y se trata con más detalle en otros artículos de la E nciclopedia.

El éter bis-(clorometilíco) (BCME) es un conocido carcinógeno humano (perteneciente al Grupo 1 de la clasificación de la Agencia Internacional para la Investigación sobre el Cáncer $($ (IARC)). También es una sustancia extremadamente irritante. Los efectos carcinógenos del BCM E se han demostrado en trabajadores expuestos a la sustancia durante un período de tiempo relativamente corto. Es probable que este reducido período de latencia se deba a la gran potencia del agente.

El éter clorometilmetílico (CM M E) es también un conocido carcinógeno humano que, además, produce una intensa irritación. La exposición a vapores del CM ME, incluso a concentraciones de tan solo 100 ppm, pueden poner en peligro la vida. Los trabajadores expuestos a estas concentraciones han experimentado graves efectos respiratorios, entre ellos edema pulmonar.

Salvo que existan evidencias de lo contrario, la prudencia dicta manipular todos los éteres halogenados con precaución y considerar a todos los agentes alquilantes como posibles cancerígenos. L os éteres glicidílicos se consideran en la familia de "compuestos epoxídicos". 


\begin{tabular}{|c|c|c|}
\hline Producto químico & Sinónimos/ Código UN & N úmero CAS Fórmula estructural \\
\hline ANISOL & $\begin{array}{l}\text { Metoxibenceno; éter metilfenílico; éter fenilmetilico } \\
\text { UN2222 }\end{array}$ & $100-66-3$ \\
\hline terc-BUTIL-4-HIDROXIANISOL & $\begin{array}{l}\text { Antyoxine B; Antrancine 12; BHA; hidroxianisol butilado; butilhidroxianisol; } \\
\text { terc-butilhidroxianisol; 1,1-dimetiletil-4-metoxifenol; Embanox; } \\
\text { Nipantios 1-F; Protex; Pemerge plus; Sustane; Sustane 1-F; Vertac; } \\
\text { Tenox BHA }\end{array}$ & $25013-16-5$ \\
\hline ETER ALLIFENILICO & (2-Propeniloxi)-benceno; USAF DO-23 & $1746-13-0$ \\
\hline ETER BENCILICO & Eter dibencílico & $103-50-4$ \\
\hline
\end{tabular}

\begin{tabular}{lll}
\hline ETER n-BUTILICO DE TRIETILENGLICOL $\quad$ Butoxitrietilenglicol; butoxitriglicol; éter monobutílico de trietilenglicol $\quad 143-22-6$
\end{tabular}

\begin{tabular}{ll}
\hline ETER DIALLLICO & Aliléter; dialiléter; 3,3'-0xibis-(1-propeno); éter propenílico \\
UN2360 & $557-40-4$
\end{tabular}
UN2360

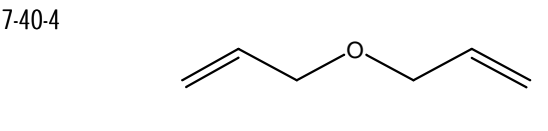

ETER DIBUTLLCO $\quad$ 1-Butoxibutano; éter butilico; óxido de dibutilo; 1,1'-0xibis-(butano) $\quad$ 142-96-1

\begin{tabular}{|c|c|c|}
\hline ETER DIETILICO & $\begin{array}{l}\text { Oxido de dietilo; etoxietano; éter etílico } \\
\text { UN1155 }\end{array}$ & $60-29.7$ \\
\hline ETER DIPROPILLCO & $\begin{array}{l}\text { Oxido de dipropilo; 1,1'-oxibispropano } \\
\text { UN2384 }\end{array}$ & $111-43-3$ \\
\hline ETER ETILBUTILICO & $\begin{array}{l}\text { Eter butiletílico } \\
\text { UN1179 }\end{array}$ & $628-81-9$ \\
\hline ETER ETILMETILICO & $\begin{array}{l}\text { Metoxietano; etoximetano; éter metiletílico } \\
\text { UN1039 }\end{array}$ & $540-67-0$ \\
\hline ETER ISOPROPILICO & $\begin{array}{l}\text { Eter diisopropílico; óxido de diisopropilo; 2-isopropoxipropano; } \\
\text { isopropiléter } \\
\text { UN1159 }\end{array}$ & $108-20-3$ \\
\hline ETER METILICO & $\begin{array}{l}\text { Eter dimetílico; éter de la madera } \\
\text { UN1033 }\end{array}$ & $115-10-6$ \\
\hline
\end{tabular}




\begin{tabular}{|c|c|c|}
\hline Producto químico & Sinónimos/ Código UN & $\mathrm{N}$ úmero CAS Fórmula estructural \\
\hline ETER METILPROPILICO & $\begin{array}{l}\text { 1-Metoxipropano; Metopryl; Neothyl } \\
\text { UN2612 }\end{array}$ & 557-17-5 \\
\hline ETER METIL-terc-BUTILLCO & $\begin{array}{l}\text { Eter terc-butilmetílico; 2-metoxi-2-metilpropano; } \\
\text { éter metil-1,1-dimetilletilico } \\
\text { UN2398 }\end{array}$ & $1634-04-4$ \\
\hline ETER METILVINILICO & $\begin{array}{l}\text { Metoxieteno; éter vinilmetílico } \\
\text { UN1087 }\end{array}$ & $107-25-5$ \\
\hline ETER PENTILICO & Eter amílico; éter diamílico; éter dipentílico; 1,1'-oxibispentano & $693-65-2$ \\
\hline
\end{tabular}

Tabla 104.62 - Riesgos para la salud.

\begin{tabular}{|c|c|c|c|c|c|c|}
\hline \multirow[b]{2}{*}{$\begin{array}{l}\text { Denominación } \\
\text { química } \\
\text { N úmero CAS }\end{array}$} & \multicolumn{4}{|c|}{ Tarjetas Internacionales sobre la Seguridad de los Productos Q uímicos } & \multicolumn{2}{|c|}{ NIO SH (EE.UU.) } \\
\hline & $\begin{array}{l}\text { Período } \\
\text { corto de } \\
\text { exposición }\end{array}$ & $\begin{array}{l}\text { Período } \\
\text { largo de } \\
\text { exposición }\end{array}$ & $\begin{array}{l}\text { Vías de } \\
\text { exposición }\end{array}$ & Síntomas & $\begin{array}{l}\text { O rganos } \\
\text { afectados } \\
\text { Vías de } \\
\text { entrada }\end{array}$ & Síntomas \\
\hline $\begin{array}{l}\text { ETER n-BUTILICO DE } \\
\text { TRIETILENGLICOL } \\
143-22-6\end{array}$ & $\begin{array}{l}\text { ojos; piel; tract } \\
\text { resp; pulmones }\end{array}$ & piel & $\begin{array}{r}\text { Inhalación } \\
\text { Piel } \\
\text { Ojos } \\
\text { Ingestión }\end{array}$ & $\begin{array}{l}\text { Tos, irritación } \\
\text { Puede absorberse, aspereza } \\
\text { Irritación, dolor, visión borrosa, erosión } \\
\text { Tos, mareo, sopor, náuseas }\end{array}$ & & \\
\hline $\begin{array}{l}\text { ETER DIBUTILICO } \\
142-96-1\end{array}$ & $\begin{array}{l}\text { ojos; piel; tract } \\
\text { resp; SNC; hígado }\end{array}$ & piel & $\begin{array}{r}\text { Inhalación } \\
\text { Piel } \\
\text { Ojos } \\
\text { Ingestión }\end{array}$ & $\begin{array}{l}\text { Tos, sopor, dolor de garganta } \\
\text { Sequedad de piel, enrojecimiento } \\
\text { Enrojecimiento, dolor } \\
\text { Sensación de quemazón en la boca, irritación } \\
\text { bucal y abdominal, náuseas, dolor de garganta }\end{array}$ & & \\
\hline $\begin{array}{l}\text { ETER DIETILICO } \\
60-29.7\end{array}$ & $\begin{array}{l}\text { ojos; piel; } \\
\text { tract resp; } \\
\text { pulmones; SNC }\end{array}$ & SNC & $\begin{array}{r}\text { Inhalación } \\
\text { Piel } \\
\text { Ojos } \\
\text { Ingestión }\end{array}$ & $\begin{array}{l}\text { Sopor, cefalea, narcosis, inconsciencia, } \\
\text { vómitos, anestesia } \\
\text { Sequedad de piel } \\
\text { Enrojecimiento, dolor } \\
\text { Mareo, sopor, vómitos }\end{array}$ & $\begin{array}{l}\text { SNC; piel; sis resp; } \\
\text { ojos } \\
\text { Inh; ing; con }\end{array}$ & $\begin{array}{l}\text { Irrit ojos, piel, sis resp } \\
\text { superior; mar, sop, cef, } \\
\text { excitación, narco; náu, vóm }\end{array}$ \\
\hline $\begin{array}{l}\text { ETER ISOPROPILICO } \\
108-20-3\end{array}$ & $\begin{array}{l}\text { ojos; piel; tract } \\
\text { resp; pulmones }\end{array}$ & piel & $\begin{array}{r}\text { Inhalación } \\
\text { Piel } \\
\text { Ojos }\end{array}$ & $\begin{array}{l}\text { Tos, sopor, dolor de garganta } \\
\text { Enrojecimiento } \\
\text { Enrojecimiento }\end{array}$ & $\begin{array}{l}\text { Sis resp; piel; ojos; } \\
\text { SNC } \\
\text { Inh; ing; con }\end{array}$ & $\begin{array}{l}\text { Irrit ojos, piel, nariz; molestias } \\
\text { resp; derm; en animales: sop, } \\
\text { mar, incon, narco }\end{array}$ \\
\hline $\begin{array}{l}\text { ETER METIL-terc-BUTILICO } \\
\text { 1634-04-4 }\end{array}$ & & & $\begin{array}{r}\text { Inhalación } \\
\text { Piel } \\
\text { Ojos } \\
\text { Ingestión }\end{array}$ & $\begin{array}{l}\text { Tos, mareo, sopor, náuseas, } \\
\text { inconsciencia, debilidad } \\
\text { Sequedad de piel } \\
\text { Enrojecimiento, dolor } \\
\text { Dolor abdominal, mareo, náuseas, vómitos }\end{array}$ & & \\
\hline
\end{tabular}




\begin{tabular}{|c|c|c|c|}
\hline $\begin{array}{l}\text { Denominación química } \\
\mathrm{N} \text { úmero } \mathrm{CAS}\end{array}$ & Físicos & Q uímicos & $\begin{array}{l}\text { Clase o división } \\
\text { UN / Riesgos } \\
\text { subsidiarios }\end{array}$ \\
\hline $\begin{array}{l}\text { ANISOL } \\
\quad 100-66-3\end{array}$ & & & 3 \\
\hline $\begin{array}{l}\text { ETER DI-n-BUTILICO } \\
142-96-1\end{array}$ & $\begin{array}{l}\text { Pueden generarse cargas } \\
\text { electrostáticas por flujo, } \\
\text { agitación, etc. }\end{array}$ & $\begin{array}{l}\text { Puede formar peróxidos explosivos, especialmente en forma de anhidro Se descompone al } \\
\text { calentarse, liberando humos y vapores acres Reacciona con oxidantes Reacciona } \\
\text { violentamente con el tricloruro de nitrógeno }\left(\mathrm{NCl}_{3}\right)\end{array}$ & 3 \\
\hline $\begin{array}{l}\text { ETER DIETILICO } \\
60-29.7\end{array}$ & $\begin{array}{l}\text { El vapor es más pesado } \\
\text { que el aire y puede } \\
\text { desplazarse a ras del } \\
\text { suelo; posibilidad de } \\
\text { ignición a distancia } \\
\text { Pueden generarse cargas } \\
\text { electrostáticas por flujo, } \\
\text { agitación, etc. }\end{array}$ & $\begin{array}{l}\text { Puede formar peróxidos explosivos por efecto de la luz y del aire Reacciona violentamente } \\
\text { con oxidantes, con peligro de incendio y explosión }\end{array}$ & 3 \\
\hline $\begin{array}{l}\text { ETER DIPROPILICO } \\
111-43-3\end{array}$ & & & 3 \\
\hline $\begin{array}{l}\text { ETER ETILBUTILICO } \\
628-81-9\end{array}$ & & & 3 \\
\hline $\begin{array}{l}\text { ETER ETLLMETILICO } \\
540-67-0\end{array}$ & & & 2.1 \\
\hline $\begin{array}{l}\text { ETER FENILLCO } \\
101-84-8\end{array}$ & & Reacciona con oxidantes fuertes, con peligro de incendio y explosión & \\
\hline $\begin{array}{l}\text { ETER ISOPROPILICO } \\
108-20-3\end{array}$ & $\begin{array}{l}\text { El vapor es más pesado } \\
\text { que el aire y puede } \\
\text { desplazarse a ras del } \\
\text { suelo; posibilidad de } \\
\text { ignición a distancia }\end{array}$ & Puede formar fácilmente peróxidos explosivos cuando se desestabiliza y explotar al agitarse & 3 \\
\hline $\begin{array}{l}\text { ETER METILPROPILICO } \\
557-17-5\end{array}$ & & & 3 \\
\hline $\begin{array}{l}\text { ETER METIL-EerC-BUTILICO } \\
\text { 1634-04-4 }\end{array}$ & $\begin{array}{l}\text { El vapor es más pesado } \\
\text { que el aire y puede } \\
\text { desplazarse a ras del } \\
\text { suelo; posibilidad de } \\
\text { ignición a distancia El } \\
\text { vapor se mezcla bien con } \\
\text { el aire; se forman } \\
\text { fácilmente mezclas } \\
\text { explosivas Pueden } \\
\text { generarse cargas } \\
\text { electrostáticas por flujo, } \\
\text { agitación, etc. }\end{array}$ & Reacciona violentamente con oxidantes fuertes, con peligro de incendio & 3 \\
\hline
\end{tabular}




\begin{tabular}{|c|c|c|c|c|c|c|c|c|c|c|c|}
\hline $\begin{array}{l}\text { Denominación química } \\
\mathrm{N} \text { úmero CAS }\end{array}$ & Color/ Forma & $\begin{array}{l}\text { p.e. } \\
(\stackrel{O}{ } C)\end{array}$ & $\begin{array}{l}\text { p.f. } \\
(\stackrel{\circ}{ } C)\end{array}$ & $\begin{array}{l}\text { p.m.l } \\
\text { (g/ } \\
\text { mol) }\end{array}$ & $\begin{array}{l}\text { Solubilidad } \\
\text { en agua }\end{array}$ & $\begin{array}{l}\text { Densidad } \\
\text { relativa } \\
\text { (agua }=1 \text { ) }\end{array}$ & $\begin{array}{l}\text { Densidad } \\
\text { relativa } \\
\text { del vapor } \\
\text { (air=1) }\end{array}$ & $\begin{array}{l}\text { Pvap/ (k } \\
\mathrm{Pa})\end{array}$ & $\begin{array}{l}\text { Límit. } \\
\text { inflam. }\end{array}$ & $\begin{array}{l}\text { p.ig. } \\
(\because 0)\end{array}$ & $\begin{array}{l}\text { p.aut } \\
\text { ig. } \\
(\because 0 \mathrm{C})\end{array}$ \\
\hline $\begin{array}{l}\text { ANISOL } \\
\quad 100-66-3\end{array}$ & $\begin{array}{l}\text { líquido móvil, color } \\
\text { pajizo transparente }\end{array}$ & 155 & 37,3 & 108,13 & insol & 0,9961 & 3,72 & $\begin{array}{l}10 \mathrm{~mm} \mathrm{Hg} \\
@ 42,2^{\circ} \mathrm{C}\end{array}$ & & & 475 \\
\hline $\begin{array}{l}\text { ETER ALILFENILICO } \\
1746-13-0\end{array}$ & & 191,7 & & 134,17 & insol & 0,9811 & & & & & \\
\hline $\begin{array}{l}\text { ETER ALLLICO } \\
557-40-4\end{array}$ & & 94 & & 98,14 & insol & 0,8260 & & & & & \\
\hline $\begin{array}{l}\text { ETER BENCLLLCO } \\
103-50-4\end{array}$ & $\begin{array}{l}\text { líquido incoloro; } \\
\text { amarillo muy pálido }\end{array}$ & 298 & 3,6 & 198,25 & insol & 1,0428 & & & & & \\
\hline $\begin{array}{l}\text { ETER n-BUTLLICO DE TRIETILENGLICOL } \\
\quad 143-22-6\end{array}$ & líquido & 278 & $-35,2$ & 206,3 & misc & 0,9890 & & $\begin{array}{l}0,0025 \\
\mathrm{~mm} \mathrm{Hg} \\
@ 25^{\circ} \mathrm{C}\end{array}$ & & $143 c c$ & \\
\hline $\begin{array}{l}\text { ETER DI-n-BUTILICO } \\
\quad 142-96-1\end{array}$ & líquido incoloro & 142 & $-95,3$ & 130,2 & insol & 0,7689 & 4,48 & 0,64 & $\begin{array}{l}1,5 \mathrm{li} \\
7,6 \mathrm{is}\end{array}$ & 37 & 194 \\
\hline $\begin{array}{l}\text { ETER DIETLLICO } \\
60-29-7\end{array}$ & $\begin{array}{l}\text { líquido móvil, } \\
\text { incoloro, } \\
\text { transparente }\end{array}$ & 34,6 & $-116,3$ & 74,12 & lig sol & 0,7134 & 2,55 & 58,6 & $\begin{array}{l}1,9 \mathrm{li} \\
36,0 \mathrm{ls}\end{array}$ & $-45 \mathrm{cc}$ & $\begin{array}{l}180- \\
190\end{array}$ \\
\hline $\begin{array}{l}\text { ETER DIMETILICO } \\
115-10-6\end{array}$ & & $-24,8$ & $-141,5$ & 46,07 & sol & & & & & & \\
\hline $\begin{array}{l}\text { ETER DIPROPILICO } \\
111-43-3\end{array}$ & líquido móvil & 90 & -122 & 102,17 & lig sol & 0,7360 & 3,53 & $\begin{array}{l}62,5 \\
\mathrm{~mm} \mathrm{Hg} \\
@ 25{ }^{\circ} \mathrm{C} \\
\end{array}$ & & $21 \mathrm{cc}$ & 188 \\
\hline $\begin{array}{l}\text { ETER ETILBUTILICO } \\
628-81.9\end{array}$ & & 92,3 & -124 & 102,17 & insol & 0,7490 & & & & & \\
\hline $\begin{array}{l}\text { ETER ETILMETILLCO } \\
540.67 .0 \\
\end{array}$ & incoloro & 10,8 & -113 & 60,1 & sol & $\begin{array}{l}0,7252 \\
@ 0^{\circ} \mathrm{C} / 0^{\circ} \mathrm{C}\end{array}$ & 2,1 & $\begin{array}{l}760 \mathrm{~mm} \mathrm{Hg} \\
@ 7,5^{\circ} \mathrm{C} \\
\end{array}$ & $\begin{array}{l}2 \mathrm{li} \\
10,1 \mathrm{ls}\end{array}$ & & \\
\hline $\begin{array}{l}\text { ETER FENILICO } \\
101-84-8\end{array}$ & $\begin{array}{l}\text { cristales rómbicos } \\
\text { monoclínicos; líquido } \\
\text { o cristales incoloros }\end{array}$ & 258 & 28 & 170,20 & insol & 1,075 & 5,86 & $2,8 \mathrm{~Pa}$ & $\begin{array}{l}0,8 \mathrm{li} \\
1,5 \mathrm{ls}\end{array}$ & 115 & 618 \\
\hline $\begin{array}{l}\text { ETER ISOPROPILICO } \\
\quad 108-20-3 \\
\end{array}$ & líquido incoloro & 68,5 & .60 & 102,17 & lig sol & 0,7258 & 3,5 & 15,9 & $\begin{array}{l}1,4 \mathrm{li} \\
7,9 \mathrm{is}\end{array}$ & $-18 \mathrm{~F}$ & 443 \\
\hline $\begin{array}{l}\text { ETER METILPROPILICO } \\
557-17-5\end{array}$ & & 39,1 & & 74,12 & sol & 0,738 & & & & & \\
\hline $\begin{array}{l}\text { ETER METLL-terC-BUTLLICO } \\
\text { 1634-04-4 }\end{array}$ & líquido incoloro & 55,2 & -109 & 88,1 & sol & 0,7405 & 3,0 & $\begin{array}{l}32,7 \\
@ 25^{\circ} \mathrm{C}\end{array}$ & $\begin{array}{l}1,6 \mathrm{li} \\
15,1 \mathrm{ls} \\
\end{array}$ & -28 & 224 \\
\hline $\begin{array}{l}\text { ETER METILVINILICO } \\
\quad 107-25-5\end{array}$ & $\begin{array}{l}\text { gas comprimido } \\
\text { incoloro o líquido } \\
\text { incoloro }\end{array}$ & 12 & -122 & 58,08 & lig sol & $\begin{array}{l}0,7725 \\
@ 00^{\circ} \mathrm{C} / 4^{\circ} \mathrm{C}\end{array}$ & 2,0 & $\begin{array}{l}1052 \\
\mathrm{~mm} \mathrm{Hg}\end{array}$ & $\begin{array}{l}2,6 \mathrm{li} \\
39 \mathrm{is}\end{array}$ & & 287 \\
\hline $\begin{array}{l}\text { MEZCLA DE ETER FENILICO Y } \\
\text { BIFENILO } \\
\quad 8004-13-5\end{array}$ & $\begin{array}{l}\text { líquido entre incoloro } \\
\text { y pajizo }\end{array}$ & 257,4 & 12 & 324,42 & insol & $\begin{array}{l}1,06 @ 25^{\circ} \mathrm{Cl} \\
25^{\circ} \mathrm{C}\end{array}$ & & $\begin{array}{l}0,08 \\
\mathrm{~mm} \mathrm{Hg} \\
@ 25^{\circ} \mathrm{C}\end{array}$ & & $124 \mathrm{ca}$ & \\
\hline
\end{tabular}


TABLAS DE ETERES HALOGENADOS

\begin{tabular}{|c|c|c|c|}
\hline Producto químico & Sinónimos/Código UN & $\mathrm{N}$ úmero CAS & Fórmula estructural \\
\hline ETER BIS-(4-AMINO-3-CLOROFENILICO) & $\begin{array}{l}\text { Eter 3,3'-dicloro-4,4'-diaminodifenilíco; 4,4'-oxibis-(2-cloroanilina); } \\
\text { 4,4'-oxibis-(2-cloro-bencenamina) }\end{array}$ & $28434-86-8$ & \\
\hline ETER BIS-(CLOROMETILICO) & $\begin{array}{l}\text { Cloro (clorometoxi) metano; éter clorometílico; éter 1,1'-diclorodimetilíco; } \\
\text { dimetil-1,1'-dicloroéter; oxibis-(cloro) metano } \\
\text { UN2249 }\end{array}$ & $542-88-1$ & $\mathrm{Cl}$ \\
\hline ETER CLOROMETILMETILICO & $\begin{array}{l}\text { Dimetilcloroéter; éter metilclorometilico; éter monoclorodimetilico } \\
\text { UN1239 }\end{array}$ & $107-30-2$ & \\
\hline ETER DICLOROETLLICO & $\begin{array}{l}\text { Eter bis-(2-cloroetilico); éter 1-cloro-2,2,2'-dicloroetílico; éter } \\
\text { 2,2'-diclorodietílico; éter di-(2-cloroetilico); óxido de dicloroetilo; } \\
\text { 1,1'-oxibis-(2-cloro) etano } \\
\text { UN1916 }\end{array}$ & $111-44-4$ & \\
\hline ETER DICLOROFENILLCO & Eter diclorodifeńlico; óxido de diclorodifenilo; dicloroéter fenílico & $28675-08-3$ & \\
\hline ETER DICLOROISOPROPILICO & $\begin{array}{l}\text { Eter bis-(2-cloroisopropílico); éter bis-(2-cloro-1-metiletílico); éter } \\
\text { bis-(1-cloro-2-propilico); éter (2-cloro-1-metiletilico) } \\
\text { UN2490 }\end{array}$ & $108-60-1$ & \\
\hline ETER PENTACLOROFENILICO & $\begin{array}{l}\text { Eter pentaclorodifeńlilico; óxido de pentaclorodifenilo; éter fenilico } \\
\text { pentaclorado }\end{array}$ & $42279-29-8$ & \\
\hline ETER TETRACLOROFENILICO & $\begin{array}{l}\text { Eter fenílico tetraclorado; éter tetraclorodifenílico; óxido de } \\
\text { tetraclorodifenilo }\end{array}$ & $31242-94-1$ & \\
\hline OXIDO DE DIFENILO CLORADO & $\begin{array}{l}\text { Eter hexaclorofenílico; éter hexaclorodifenílico; óxido de hexaclorodifenilo; } \\
\text { éter triclorodifenílico; óxido de triclorodifenilo }\end{array}$ & $31242.93-0$ & \\
\hline
\end{tabular}

Tabla 104.66 • Riesgos para la salud.

\begin{tabular}{|c|c|c|c|c|c|c|}
\hline \multirow[b]{2}{*}{$\begin{array}{l}\text { Denominación } \\
\text { química } \\
\mathrm{N} \text { úmero CAS }\end{array}$} & \multicolumn{4}{|c|}{ Tarjetas Internacionales sobre la Seguridad de los Productos Q uímicos } & \multicolumn{2}{|c|}{ N IO SH (EE.UU.) } \\
\hline & $\begin{array}{l}\text { Período } \\
\text { corto de } \\
\text { exposición }\end{array}$ & $\begin{array}{l}\text { Período } \\
\text { largo de } \\
\text { exposición }\end{array}$ & $\begin{array}{l}\text { Vías de } \\
\text { exposición }\end{array}$ & Síntomas & $\begin{array}{l}\text { O rganos } \\
\text { afectados } \\
\text { Vías de } \\
\text { entrada }\end{array}$ & Síntomas \\
\hline $\begin{array}{l}\text { BIS-(CLOROMETIL) ETER } \\
542-88-1\end{array}$ & $\begin{array}{l}\text { ojos; piel; tract } \\
\text { resp; piel; SNC; } \\
\text { corazón }\end{array}$ & piel & $\begin{array}{r}\text { Inhalación } \\
\text { Piel } \\
\text { Ojos } \\
\text { Ingestión }\end{array}$ & $\begin{array}{l}\text { Sensación de quemazón, tos, mareo, cefalea, } \\
\text { náuseas, los síntomas pueden tardar en } \\
\text { aparecer } \\
\text { Enrojecimiento, sensación de quemazón } \\
\text { Enrojecimiento, dolor, visión borrosa } \\
\text { Espasmos abdominales, dolor de garganta, } \\
\text { vómitos }\end{array}$ & $\begin{array}{l}\text { Sis resp; ojos; piel } \\
\text { [cáncer de pulmón] } \\
\text { Inh; abs; ing; con }\end{array}$ & $\begin{array}{l}\text { Irrit ojos, piel, muc, sis resp; } \\
\text { congestión pulm, edema; } \\
\text { lesión córn, nec; función pulm } \\
\text { dism, tos, disn, resp sib; } \\
\text { esputos sanguinolentos, } \\
\text { secreciones bronquiales; [carc] }\end{array}$ \\
\hline
\end{tabular}


Tabla 104.66 • Riesgos para la salud.

\begin{tabular}{|c|c|c|c|c|c|c|}
\hline \multirow[b]{2}{*}{$\begin{array}{l}\text { Denominación } \\
\text { química } \\
\mathrm{N} \text { úmero CAS }\end{array}$} & \multicolumn{4}{|c|}{ Tarjetas Internacionales sobre la Seguridad de los Productos Q uímicos } & \multicolumn{2}{|c|}{ N IO SH (EE.UU.) } \\
\hline & $\begin{array}{l}\text { Período } \\
\text { corto de } \\
\text { exposición }\end{array}$ & $\begin{array}{l}\text { Período } \\
\text { largo de } \\
\text { exposición }\end{array}$ & $\begin{array}{l}\text { Vías de } \\
\text { exposición }\end{array}$ & Síntomas & $\begin{array}{l}\text { O rganos } \\
\text { afectados } \\
\text { Vías de } \\
\text { entrada }\end{array}$ & Síntomas \\
\hline $\begin{array}{l}\text { CLOROMETLMETILETER } \\
107-30-2\end{array}$ & $\begin{array}{l}\text { ojos; piel; tract } \\
\text { resp; pulmones; } \\
\text { SNC }\end{array}$ & hígado; riñones & $\begin{array}{r}\text { Inhalación } \\
\text { Piel } \\
\text { 0jos } \\
\text { Ingestión }\end{array}$ & $\begin{array}{l}\text { Sensación de quemazón, tos, mareo, cefalea, } \\
\text { dificultad respiratoria, náuseas, dolor de } \\
\text { garganta } \\
\text { Enrojecimiento, quemaduras en la piel, dolor, } \\
\text { ampollas } \\
\text { Enrojecimiento, dolor, visión borrosa, pérdida } \\
\text { de visión, quemaduras profundas graves } \\
\text { Espasmos abdominales, vómitos }\end{array}$ & $\begin{array}{l}\text { Sis resp; piel; ojos; } \\
\text { mucosas [en } \\
\text { animales: cáncer de } \\
\text { piel y de pulmón] } \\
\text { Inh; abs; ing; con }\end{array}$ & $\begin{array}{l}\text { Irrit ojos, piel, muc; edema } \\
\text { pulm, congestión pulm, neum; } \\
\text { quemaduras en la piel, nec; } \\
\text { tos, resp sib, esputos } \\
\text { sanguinolentos; bajo-p; } \\
\text { secreciones bronquiales; [carc] }\end{array}$ \\
\hline $\begin{array}{l}\text { ETER DICLOROETILICO } \\
111-44-4\end{array}$ & & & & & $\begin{array}{l}\text { Sis resp; hígado; } \\
\text { ojos [ en animales: } \\
\text { tumores hepáticos] } \\
\text { Inh; abs; ing; con }\end{array}$ & $\begin{array}{l}\text { Irrit nariz, garganta, sis resp; } \\
\text { lag; tos; náu, vómit; en } \\
\text { animales: edema pulm; } \\
\text { lesiones hepáticas; [carc] }\end{array}$ \\
\hline
\end{tabular}

Tabla 104.67 • Riesgos físicos y químicos.

\begin{tabular}{|c|c|c|c|}
\hline $\begin{array}{l}\text { Denominación química } \\
\mathrm{N} \text { úmero CAS }\end{array}$ & Físicos & Q uímicos & $\begin{array}{l}\text { Clase o división } \\
\text { UN / Riesgos } \\
\text { subsidiarios }\end{array}$ \\
\hline $\begin{array}{l}\text { BIS-(CLOROMETIL) ETER } \\
542-88-1\end{array}$ & $\begin{array}{l}\text { El vapor se mezcla bien } \\
\text { con el aire; se forman } \\
\text { fácilmente mezclas } \\
\text { explosivas }\end{array}$ & $\begin{array}{l}\text { Se descompone al calentarse y en contacto con agua, liberando vapores tóxicos y corrosivos de } \\
\text { cloruro de hidrógeno y formaldehído Ataca muchos metales, resinas y plásticos }\end{array}$ & 6.1 \\
\hline $\begin{array}{l}\text { CLOROMETILMETLETER } \\
107-30-2\end{array}$ & $\begin{array}{l}\text { El vapor es más pesado } \\
\text { que el aire y puede } \\
\text { desplazarse a ras del } \\
\text { suelo; posibilidad de } \\
\text { ignición a distancia }\end{array}$ & $\begin{array}{l}\text { En su combustión libera gases y vapores tóxicos (fosgeno y cloruro de hidrógeno) Se } \\
\text { descompone en contacto con agua, produciendo cloruro de hidrógeno y formaldehído Ataca } \\
\text { muchos metales en presencia de agua }\end{array}$ & $6.1 / 3$ \\
\hline
\end{tabular}

ETER DICLOROETLILCO

6.1 111-44-4

Tabla 104.68 • Propiedades físicas y químicas.

\begin{tabular}{|c|c|c|c|c|c|c|c|c|c|c|c|}
\hline $\begin{array}{l}\text { Denominación química } \\
\mathrm{N} \text { úmero CAS }\end{array}$ & Color/ Forma & $\begin{array}{l}\text { p.e. } \\
(\because 0 C)\end{array}$ & $\begin{array}{l}\text { p.f. } \\
(\stackrel{\circ}{ } C)\end{array}$ & $\begin{array}{l}\text { p.m.l } \\
\text { (g/ } \\
\text { mol) }\end{array}$ & $\begin{array}{l}\text { Solubilidad } \\
\text { en agua }\end{array}$ & $\begin{array}{l}\text { Densidad } \\
\text { relativa } \\
\text { (agua }=1 \text { ) }\end{array}$ & $\begin{array}{l}\text { Densidad } \\
\text { relativa } \\
\text { del vapor } \\
\text { (aire=1) }\end{array}$ & $\begin{array}{l}\text { Pvap/ } \\
(\mathrm{kPa})\end{array}$ & $\begin{array}{l}\text { Límit. } \\
\text { inflam. }\end{array}$ & $\begin{array}{l}\text { p.ig. } \\
(\underline{O C})\end{array}$ & $\begin{array}{l}\text { p.aut } \\
\text { ig. } \\
\left({ }^{\circ} \mathrm{C}\right)\end{array}$ \\
\hline $\begin{array}{l}\text { BIS-(CLOROMETIL) ETER } \\
542-88-1\end{array}$ & líquido incoloro & 106 & $-41,5$ & 114,97 & reacciona & $\begin{array}{l}1,323 @ \\
15 \stackrel{\circ}{\circ} / 4 \stackrel{\circ}{\circ} \mathrm{C}\end{array}$ & 4,0 & $14 \mathrm{~Pa}$ & & $c c$ & \\
\hline $\begin{array}{l}\text { CLOROMETILMETILETER } \\
107-30-2\end{array}$ & líquido incoloro & 59 & $-103,5$ & 80,5 & se descompone & 1,0605 & 2,8 & 25,3 & & $O O C$ & \\
\hline $\begin{array}{l}\text { ETER DICLOROETILICO } \\
\quad 111-44-4\end{array}$ & $\begin{array}{l}\text { líquido incoloro, } \\
\text { transparente }\end{array}$ & 178 & $-51,9$ & 143,01 & insol & 1,22 & 4,93 & $0,7 \mathrm{~mm} \mathrm{Hg}$ & & $63 \mathrm{cc}$ & 369 \\
\hline $\begin{array}{l}\text { ETER DICLOROISOPROPILICO } \\
\text { 108-60-1 }\end{array}$ & líquido incoloro & 187 & $\begin{array}{l}-96,8 \text { a } \\
-101,8\end{array}$ & 171,07 & insol & 1,103 & 5,9 & $\begin{array}{l}0,71-0,85 \\
\mathrm{~mm} \mathrm{Hg}\end{array}$ & & & \\
\hline
\end{tabular}




\section{FLUOROCARBUROS}

Los fluorocarburos se derivan de los hidrocarburos mediante sustitución por flúor de todos o algunos de sus átomos de hidrógeno. Los hidrocarburos en los que se ha reemplazado alguno de los átomos de hidrógeno por cloro o bromo, además de los que fueron por flúor (es decir, clorofluorhidrocarburos, bromofluorhidrocarburos) suelen incluirse en la clasificación de fluorocarburos; por ejemplo, el bromoclorodifluorometano (C CIBrF 2).

El primer fluorocarburo económicamente importante fue el diclorodifluorometano (CCI2F2), que se comenzó a utilizar en 1931 como un refrigerante mucho menos tóxico que el dióxido de azufre, el amoníaco o el clorometano, que eran los refrigerantes utilizados en aquella época.

\section{U sos}

Los fluorocarburos se han utilizado como refrigerantes, propulsores para aerosoles, disolventes, agentes expulsores para espumas extintoras de incendios y productos químicos intermedios de polímeros. Tal como se explica más adelante, la preocupación por el efecto de los clorofluorocarburos en la destrucción de la capa de ozono de la atmósfera ha llevado a prohibir el uso de estos productos químicos.

El triclorofluorometano y el dicloromonofluorometano se utilizaban antigüamente como propulsores para aerosoles. EI triclorofluorome tano se utiliza hoy en día como agente limpiador y desengrasante, como refrigerante y como agente expulsor para poliuretanos. También se utiliza en extintores de incendios y aislamientos eléctricos y como fluído dieléctrico. El dicloromonofluorometano se utiliza en la fabricación de botellas de vidrio, en líquidos intercambiadores de calor, como refrigerante para máquinas centrífugas, como disolvente y como agente espumante.

El diclorotetrafluoretano es un disolvente, diluyente, agente limpiador y desengrasante para circuitos impresos. Se utiliza como agente expulsor para espumas extintoras de incendios y como refrigerante en sistemas de refrigeración y aire acondicionado, así como para el refinado de magnesio, como inhibidor de la erosión de los metales en fluídos hidráulicos y como material de refuerzo en botellas. El diclorodifluorometano se empleaba también en la fabricación de botellas de vidrio, como aerosol para cosméticos, pinturas e insecticidas, y para la depuración de agua, cobre y aluminio. El tetrafluoruro de carbono es un propulsor para cohetes y para el guiado de satélites y el tetrafluoretileno se utiliza en la preparación de propulsores para aerosoles alimentarios. EI cloropentafluoretano es un propulsor para aerosoles alimentarios y un refrigerante para aparatos domésticos y aparatos portátiles de aire acondicionado. El clorotrifluorometano, el clorodifluorometano, el trifluorometano, el 1,1-difluoretano y el 1,1,-clorodifluorđano son también refrigerantes.

Muchos de los fluorocarburos se utilizan como productos químicos intermedios y disolventes en diversas industrias, como las de tejidos, limpieza en seco, fotografía y plásticos. Algunos de ellos tienen además funciones específicas como inhibidores de la corrosión y detectores de fugas. El teflón se utiliza en la fabricación de plásticos de alta resistencia térmica, prendas protectoras, tubos y láminas para laboratorios químicos, aislantes eléctricos, interruptores automáticos, cables, hilos y revestimientos antiadherentes. El clorotrifluorometano se utiliza para endurecer metales y el 1,1,1,2-tetracloro-2,2-difluoretano y el diclorodifluorometano sirven para detectar grietas superficiales y defectos en los metales.

EI halotano, el isoflurano y el enflurano se utilizan como anestésicos administrados por vía respiratoria.

\section{Riesgos para el medio ambiente}

En los decenios de 1970 y 1980 se fueron acumulando evidencias de que los fluorocarburos estables y otros productos químicos, como el bromuro metílico y el 1,1,1-tricloroetano, una vez liberados a la atmósfera, se propagaban lentamente hacia las capas superiores, llegando a la estratosfera, donde la intensa radiación ultravioleta podía hacer que estas moléculas liberasen átomos de cloro libres, que reaccionarían con el oxígeno de la forma siguiente:

$$
\begin{gathered}
\mathrm{Cl}+\mathrm{O}_{3}=\mathrm{ClO}+\mathrm{O}_{2} \\
\mathrm{ClO}+\mathrm{O}=\mathrm{Cl}+\mathrm{O}_{2} \\
\mathrm{O}+\mathrm{O}_{3}=2 \mathrm{O}_{2}
\end{gathered}
$$

Puesto que en esta reacción se regeneran los átomos de cloro, quedarían libres para repetir el ciclo. El resultado evidente sería una reducción significativa del ozono estratosférico que protege a la T ierra de los efectos nocivos de la radiación ultravioleta solar. El aumento de la radiación ultravioleta provocaría un aumento del cáncer de piel y afectaría a las cosechas, a la productividad forestal y a los ecosistemas marinos. Los estudios de la atmósfera superior realizados en la última década han demostrado la existencia de agujeros en la capa de ozono.

Como consecuencia de esta inquietud, a partir de 1979 se prohibió en todo el mundo la mayoría de los aerosoles que contenían clorofluorocarburos. En 1987 se firmó un acuerdo internacional, el "Protocolo de Montreal relativo a las sustancias destructoras de la capa de ozono", para controlar la producción y el consumo de sustancias que destruyen el ozono. En este protocolo se estableció el año 1996 como fecha límite para abandonar totalmente la producción y el consumo de clorofluorocarburos en los países desarrollados. Los países en vías de desarrollo disponen de 10 años más para el cumplimiento de este requisito. También se establecieron controles para los haluros, el tetracloruro de carbono, el 1,1,1-tricloroetano (metil cloroformo), los hidroclorofluorocarburos (H CFC), los hidrobromofluorocarburos (H BFC) y el bromuro metílico. Estos productos químicos sólo se permiten para usos esenciales y siempre que no existan alternativas técnica y económicamente viables.

\section{Riesgos}

L os fluorocarburos son, en general, menos tóxicos que los correspondientes hidrocarburos clorados o bromados. Esta menor toxicidad puede deberse a una mayor estabilidad del enlace C-F $y$, tal vez también, a la menor solubilidad lipoide de las sustancias más fluoradas. Gracias a su bajo nivel de toxicidad, ha sido posible seleccionar fluorocarburos que sean seguros para los usos a los que se destinan. No obstante, la supuesta seguridad de los fluorocarburos en estas aplicaciones ha hecho que se divulgara la falsa creencia de que los fluorocarburos son completamente inocuos en cualquier condición de exposición.

En realidad, los fluorocarburos volátiles poseen propiedades narcóticas similares a las de los hidrocarburos clorados, aunque más débiles. La inhalación aguda de 2.500 ppm de triclorotrifluoretano provoca intoxicación y descoordinación psicomotriz en el ser 
humano, un efecto que también se observa con concentraciones de 10.000 ppm (1 \%) de diclorodifluorometano. La inhalación de diclorodifluorometano a concentraciones de 150.000 ppm (15\%) provoca pérdida de la consciencia. Se han registrado más de 100 muertes relacionadas con la inhalación de fluorocarburos como consecuencia de la pulverización de aerosoles que contenían diclorodifluorometano como propulsor en el interior de una bolsa de papel y su posterior inhalación. EI TLV de 1.000 ppm establecido por la Conferencia Americana de $\mathrm{H}$ igienistas Industriales del Gobierno (ACGIH) no produce efectos narcóticos en el ser humano.

Los fluorometanos y fluoretanos tampoco producen efectos tóxicos, como lesiones hepáticas o renales, por exposición repetida. Los fluoralquenos, como el tetrafluoretileno, el hexafluoropropileno 0 el clorotrifluoretileno, pueden causar lesiones hepáticas y renales en animales de experimentación tras exposiciones prolongadas y repetidas a las concentraciones apropiadas.

No obstante, la toxicidad aguda de los fluoralquenos es sorprendente en algunos casos. El perfluorisobutileno es un buen ejemplo de ello. C on una $C L_{50}$ de 0,76 ppm para cuatro horas de exposición en el caso de las ratas, es más tóxico que el fosgeno. Al igual que este último producto, produce edema pulmonar agudo. Por su parte, el fluoruro de vinilo y el fluoruro de vinilideno son fluoralcanos de muy baja toxicidad.

De la misma forma que muchos otros vapores de disolventes y anestésicos utilizados en cirugía, los fluorocarburos volátiles también pueden producir arritmia o parada cardíaca cuando el organismo libera una cantidad anormalmente elevada de adrenalina (como en situaciones de angustia, miedo, excitación o ejercicio violento). Las concentraciones necesarias para producir este efecto son muy superiores a las que se encuentran normalmente en la industria.

En perros y monos, tanto el clorodifluorometano como el diclorodifluorometano provocan rápidamente depresión respiratoria, broncoconstricción, taquicardia, depresión miocárdica e hipotensión a concentraciones de entre un 5 y un $10 \%$. El clorodifluorometano, al contrario que el diclorodifluorometano, no provoca arritmias cardíacas en monos (aunque sí en ratones) y tampoco reduce la función pulmonar.

$M$ edidas de salud y seguridad. Todos los fluorocarburos sufren descomposición térmica cuando se exponen a la acción de la llama o de metales calentados al rojo. Los productos de la descomposición de los clorofluorocarburos son los ácidos fluorhídrico y clorhídrico, junto con cantidades más pequeñas de fosgeno y fluoruro de carbonilo. Este último compuesto es muy inestable a la hidrólisis y rápidamente se transforma en ácido fluorhídrico y dióxido de carbono en presencia de humedad.

Los estudios de mutagenicidad y teratogenicidad realizados de los tres fluorocarburos más importantes desde el punto de vista industrial (triclorofluorometano, diclorodifluorometano y triclorotrifluore tano), han dado resultados negativos.

El clorodifluorometano, que en un tiempo se consideró como posible propulsor para aerosoles, resultó ser mutágeno en los estudios de mutagénesis bacteriana. Los estudios de exposición a lo largo de toda la vida aportaron ciertas evidencias de carcinogénesis en ratas macho expuestas a concentraciones de 50.000 ppm (5\%), pero no a concentraciones de 10.000 ppm (1\%). Este efecto no se apreció en ratas hembra ni en otras especies. $L a$ Agencia Internacional para la Investigación sobre el Cáncer (IARC) ha clasificado esta sustancia en el Grupo 3 (evidencias limitadas de carcinogénesis en animales). También se obtuvieron ciertas pruebas de teratogenicidad en ratas expuestas a $50.000 \mathrm{ppm}(5 \%)$, pero no a $10.000 \mathrm{ppm}(1 \%)$, ni en conejos expuestos a concentraciones de hasta $50.000 \mathrm{ppm}$.
Las víctimas de la exposición a fluorocarburos deben ser evacuadas del área contaminada y recibir un tratamiento sintomático. No se les administrará adrenalina, pues existe la posibilidad de provocar arritmias o parada cardíaca.

\section{T etrafluoretileno}

Los riesgos principales del monómero tetrafluoretileno son su inflamabilidad en un amplio rango de concentraciones (del 11 al $60 \%$ ) y su peligro de explosión. El tetrafluoretileno no inhibido puede experimentar polimerización o dimerización espontáneas, siendo ambas reacciones exotérmicas. El consiguiente aumento de presión en un envase cerrado puede provocar una explosión y se han registrado varios accidentes de este tipo. Se cree que estas reacciones espontáneas son iniciadas por impurezas activas tales como el oxígeno.

El tetrafluoretileno no comporta un gran riesgo de toxicidad aguda per se, siendo la $\mathrm{CL}_{50}$ en ratas expuestas durante 4 horas de $40.000 \mathrm{ppm}$. Las ratas que fallecen como consecuencia de exposiciones letales no sólo presentan lesiones pulmonares, sino también cambios degenerativos en el riñón, siendo esto último característico de otros fluoralquenos, pero no de los fluoralcanos.

O tro posible riesgo está relacionado con las impurezas tóxicas que se forman durante la preparación o pirólisis del tetrafluoretileno, en especial el octafluorisobutileno, que tiene una concentración letal aproximada de tan solo 0,76 ppm en ratas para exposiciones de 4 horas. Se han registrado algunos casos mortales por exposición a estas "grandes calderas". Debido a su peligrosidad, los experimentos con tetrafluoroetileno no deben ser nunca realizados por personas que no estén debidamente entrenadas.

$M$ edidas de salud y seguridad. El tetrafluoretileno se transporta en cilindros de acero a presión elevada. En estas condiciones, el monómero tiene que inhibirse para prevenir su polimerización o dimerización espontáneas. Los cilindros estarán equipados con válvulas de seguridad, si bien habrá que cuidar que estas válvulas no se atasquen con el polímero.

El télón (politetrafluoretileno) se sintetiza por polimerización del tetrafluoretileno con un catalizador redox. El teflón no es peligroso a temperatura ambiente. Sin embargo, cuando se calienta a una temperatura de entre 300 y $500{ }^{\circ} \mathrm{C}$, se obtienen fluoruro de hidrógeno y octafluorisobutileno como productos de la pirólisis $A$ temperaturas más elevadas, entre 500 y $800 \stackrel{\circ}{ } \mathrm{C}$, se produce fluoruro de carbonilo. Por encima de $650^{\circ} \mathrm{C}$, se producen tetrafluoruro de carbono y dióxido de carbono, que pueden provocar fiebre causada por el humo de polímeros, una enfermedad parecida a la gripe. La causa más común de esta enfermedad es el encendido de cigarrillos contaminados con polvo de teflón. También se han registrado casos de edema pulmonar.

Fluorocarburos anestésicos. El halotano es un anestésico inhalable utilizado desde antigüo, a menudo en combinación con óxido nitroso. El isoflurano y el enflurano se utilizan cada vez más, ya que producen menos efectos secundarios que el halotano.

El halotano es anestésico a concentraciones superiores a $6.000 \mathrm{ppm}$. La exposición a concentraciones de 1.000 ppm durante 30 minutos produce anomalías en el comportamiento que no aparecen con concentraciones de 200 ppm. A concentraciones subanestésicas no se han registrado casos de irritación 0 sensibilización cutánea, ocular ni respiratoria, pero sí algunos casos de hepatitis. Algunos pacientes expuestos repetidamente a concentraciones anestésicas han sufrido hepatitis graves. La toxicidad en el higado no se ha encontrado por exposiciones laborales al isoflurano o al enflurano, pero sí algunos casos de hepatitis en pacientes expuestos a dosis de enflurano iguales 0 superiores a $6.000 \mathrm{ppm}$ y en trabajadores que habían utilizado isoflurano, aunque la contribución de éste no ha podido ser demostrada. 
En un estudio de toxicidad hepática en animales, no se observaron efectos tóxicos en ratas expuestas repetidamente a 100 ppm de halotano en el aire. En otro estudio se observó al microscopio electrónico necrosis cerebral, hepática y renal con concentraciones de $10 \mathrm{ppm}$. No se detectaron efectos en ratones expuestos a $1.000 \mathrm{ppm}$ de enflurano durante 4 horas diarias a lo largo de unos 70 días y sólo se observó una ligera disminución de la ganancia de peso cuando se les expuso a 3.000 ppm durante 4 horas diarias, 5 días a la semana a lo largo de hasta 78 semanas. En otro estudio se registraron grandes pérdidas de peso y numerosas muertes en ratones expuestos continuamente a 700 ppm de enflurano durante períodos de hasta 17 días; en ese mismo estudio no se apreciaron efectos en ratas ni cobayas expuestos durante 5 semanas. La exposición continua de ratones a dosis de 150 ppm o superiores de isoflurano en el aire provocó una disminución de la ganancia de peso. A concentraciones de 1.500 ppm se observaron efectos similares en cobayas, pero no en ratas. No se apreciaron efectos significativos en ratones expuestos a concentraciones de hasta $1.500 \mathrm{ppm}$ durante 4 horas diarias, 5 días a la semana a lo largo de 9 semanas.

Los estudios realizados en animales no han podido demostrar que el enflurano 0 el isoflurano tengan efectos mutagénicos 0 carcinogénicos, como ha ocurrido con los estudios epidemiológicos de halotano. Los primeros estudios epidemiológicos que sugirieron efectos teratogénicos del halotano y otros anestésicos inhalables no han sido corroborados por estudios posteriores de exposición al halotano.
No existen evidencias claras de efectos fetales en ratas expuestas a concentraciones de halotano de hasta 800 ppm; tampoco se han observado efectos en la fertilidad con exposiciones repetidas a concentraciones de hasta $1.700 \mathrm{ppm}$. Se ha observado cierta fetotoxicidad (pero no teratogenicidad) a concentraciones de $1.600 \mathrm{ppm}$ y superiores. En ratones, se observó fetotoxicidad a 1.000 ppm, pero no a 500 ppm. En los estudios realizados con enflurano no se observaron efectos en la fertilidad de los ratones a concentraciones de hasta 10.000 ppm, pero sí se obtuvieron ciertas evidencias de anomalías espermáticas a concentraciones de 12.000 ppm.T ampoco se hallaron evidencias de teratogenicidad en ratones expuestos a concentraciones de hasta $7.500 \mathrm{ppm}$, ni en ratas expuestas a concentraciones de hasta $5.000 \mathrm{ppm}$. Se apreció una ligera embrio/ fetotoxicidad en ratas preñadas expuestas a $1.500 \mathrm{ppm}$. Con el isoflurano, la exposición de ratones macho a concentraciones de hasta 4.000 ppm durante 4 horas diarias a lo largo de 42 días no tuvo efecto alguno en la fertilidad. No se apreciaron efectos fetotóxicos en hembras de ratón preñadas expuestas a 4.000 ppm durante 4 horas diarias a lo largo de 2 semanas, si bien la exposición de ratas preñadas a una concentración de 10.500 ppm produjo una ligera pérdida de peso de los fetos. En otro estudio se observó una disminución del tamaño de la camada y del peso corporal fetal, así como efectos en el desarrollo de los fetos, en ratones expuestos a $6.000 \mathrm{ppm}$ de isoflurano durante 4 horas diarias en los días 60 a 15 de la gestación. Estos efectos no se observaron con concentraciones de 60 ó 600 ppm. 
TABLAS DE FLUOROCARBUROS

Tabla 104.69 - Identificación química.

\begin{tabular}{|c|c|c|c|}
\hline Producto químico & Sinónimos/ Código UN & $\mathrm{N}$ úmero CAS & Fórmula estructural \\
\hline BROMOTRIFLUOROMETANO & $\begin{array}{l}\text { Bromofluoroformo; bromotrifluorometano; F-13B1; Freón 13B1; } \\
\text { Halón 1301; R13B1; trifluorobromometano; trifluoromonobromometano } \\
\text { UN1009 }\end{array}$ & $75-63-8$ & \\
\hline 1-CLORO-1,1-DIFLUORETANO & $\begin{array}{l}\text { CFC 142B; fluoruro de cloroetilideno; 1,1-diflúor-1-cloroetano; Freón 142; } \\
\text { Freón 142B; hidroclorofluorocarburo 142B; R142B } \\
\text { UN2517 }\end{array}$ & $75-68-3$ & \\
\hline CLORODIFLUOROBROMOMETANO & $\begin{array}{l}\text { Bromoclorodifluorometano; Flugex 12B1; fluorocarburo 1211; } \\
\text { Freón 12B1; Halón 1211; R12B1 } \\
\text { UN1974 }\end{array}$ & $353-59-3$ & \\
\hline CLORODIFLUOROMETANO & $\begin{array}{l}\text { CFC 22; difluoroclorometano; difluoromonoclorometano; Eskimon 22; } \\
\text { F 22; FC } 22 \\
\text { UN1018 }\end{array}$ & $75-45-6$ & $F$ \\
\hline CLOROFLUOROMETANO & $\begin{array}{l}\text { CFC 31; FC 31; Freón 31; monocloromonofluorometano; R 31; } \\
\text { R } 31 \text { (refrigerante) }\end{array}$ & $593-70-4$ & \\
\hline CLOROPENTAFLUORETANO & $\begin{array}{l}\text { Cloropentafluoretano; fluorocarbonoo-115; Freón 115; Genetron 115; } \\
\text { Halocarbono 115; monocloropentafluoretano; R115 } \\
\text { UN1020 }\end{array}$ & $76-15-3$ & \\
\hline CLOROTRIFLUORETILENO & $\begin{array}{l}\text { 1-Cloro-1,2,2-trifluoretileno; 2-cloro-1,1,2-trifluoretileno; CTFE; R1113; } \\
\text { trifluorocloroetileno; 1,1,2-trifluor-2-cloroetileno } \\
\text { UN1082 }\end{array}$ & $79-38-9$ & \\
\hline CLOROTRIFLUOROMETANO & $\begin{array}{l}\text { Arcton 3; F 13; Freón 13; Genetron 13; monoclorotrifluorometano; R 13; } \\
\text { trifluoroclorometano; cloruro de trifluorometilo; trifluoromonoclorocarbono } \\
\quad \text { UN1022 }\end{array}$ & $75-72-9$ & \\
\hline 1,2-DICLORO-1,1,2,2-TETRAFLUORETANO & $\begin{array}{l}\text { Criofluorano; diclorotetrafluoretano; F 114; FC 114; Fluorano 114; } \\
\text { Fluorocarbono 114; R 114; 1,1,2,2-tetrafluor-1,2-dicloroetano }\end{array}$ & $76-14-2$ & \\
\hline DICLORODIFLUOROMETANO & $\begin{array}{l}\text { Arcton 6; Arcton 12; difluorodiclorometano; Electro-CF 12; F 12; FC 12; } \\
\text { Fluorocarbono-12; Freón 12; Eskimon 12; Freón f-12 } \\
\text { UN1028 }\end{array}$ & $75-71-8$ & \\
\hline DICLOROFLUOROMETANO & $\begin{array}{l}\text { Algofreno tipo 5; Arcton 7; fluorodiclorometano; Freón 21; Genetron 21; } \\
\text { FC-21; R21 } \\
\text { UN1029 }\end{array}$ & $75-43-4$ & \\
\hline DIFLUORETANO & $\begin{array}{l}\text { Algofreno tipo 67; fluoruro de etileno; difluoruro de etilideno; fluoruro de } \\
\text { etilideno; FC 152A; Freón 152; Genetron 100; Genetron 152A; } \\
\text { Halocarbono 152A }\end{array}$ & $75-37-6$ & \\
\hline DIFLUORODIBROMOMETANO & $\begin{array}{l}\text { Dibromodifluorometano; Freón 12-b2; Halón 1202; R12B2 } \\
\text { UN1941 }\end{array}$ & $75-61-6$ & \\
\hline
\end{tabular}


Tabla 104.69 - Identificación química.

\begin{tabular}{lll} 
Producto químico & Sinónimos/ Código UN & N úmero CAS Fórmula estructural \\
ENFLURANO & $\begin{array}{l}\text { 2-Cloro-1-(difluorometoxi)-1,1,2-trifluoretano; éter diffluorometílico de } \\
\text { 2-cloro-1,1,2-trifluoretilo; etrano; metilfluoréter }\end{array}$ \\
\hline ETER VINILICO DE 2,2,2-TRIFLUORETILO & (2,2,2-Trifluoretoxi)-eteno; fluoroxenofluoroxeno; fluoroxeno
\end{tabular}

FLUORURO DE VINILIDENO

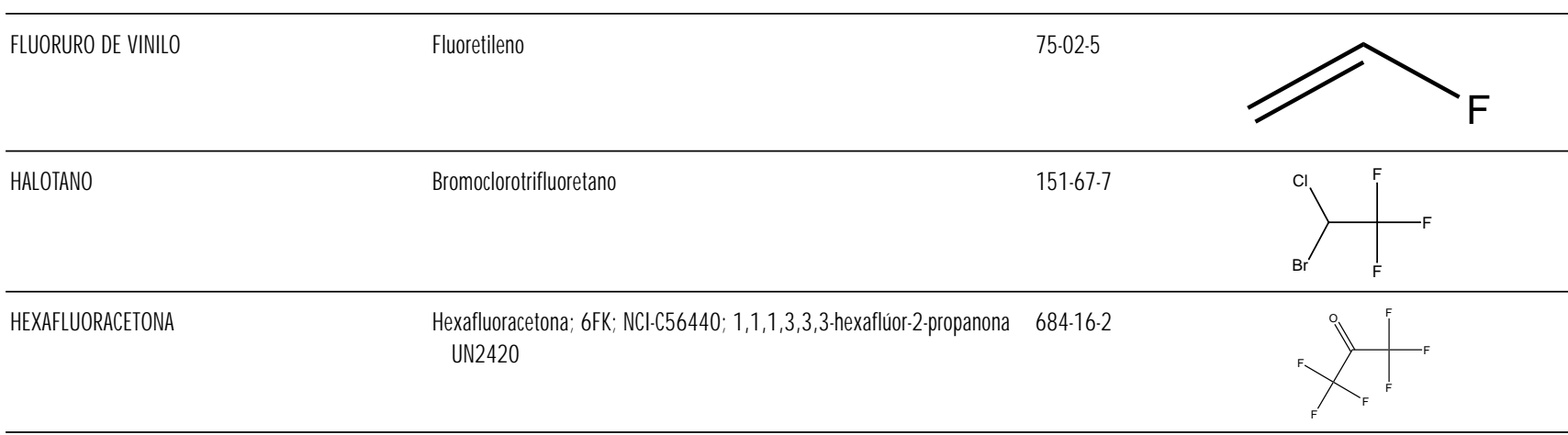

OCTAFLUORISOBUTILENO

$382-21-8$

PERFLUORISOBUTILENO Octafluorisobuteno; Octafluorisobutileno; octafluor-sec-buteno; $\quad 382-21-8$

1,1,3,3,3-pentafluor-2-trifluorometil-1-propeno PFIB

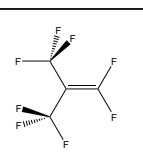

1,1,3,3,3-pentafluor-2-trifluorometil-1-propeno PFIB

TEFLON Poli(etileno tetrafluoruro); politetrafluoreteno; politetrafluoretileno; PTFE $\quad 9002-84-0$

\begin{tabular}{lll}
\hline 1,1,2,2-TETRACLORO-1,2-DIFLUORETANO & $\begin{array}{l}\text { 1,2-Difluor-1,1,2,2-tetracloroetano; F-112; } \mathrm{FC} \mathrm{112;} \mathrm{Freón} \mathrm{112;} \\
\text { Freón } \mathrm{r} 112 ; \text { halocarbono 112; Refrigerante 112; 1,1,2,2-tetracloro-1, } \\
\text { 2-difluoretano }\end{array}$ & Halocarbono 112A; refrigerante 112A \\
\hline 1,1,1,2-TETRACLORO-2,2-DIFLUORETANO & $\begin{array}{c}\text { Fluoroplast 4; perfluoreteno; perfluoretileno; tetrafluoretileno } \\
\text { UN1081 }\end{array}$ &
\end{tabular}

\begin{tabular}{ll}
\hline TETRAFLUOROMETANO & Arcton 0; fluoruro de carbono; tetrafluoruro de carbono; F 14; FC 14; $75-73-1$ \\
Freón 14; Halocarbono 14; Halón 14; perfluorometano; tetrafluorocarbono \\
UN1982
\end{tabular}

1,1,2-TRICLORO-1,2,2-TRIFLUORETANO F 113; FC 113; Freón 113; Halocarburo 113; Isceon 113; $\quad$ 76-13-1
triclorotrifluoretano; 1,1,2-triclorotrifluoretano; 1,2,2-triclorotrifluoretano
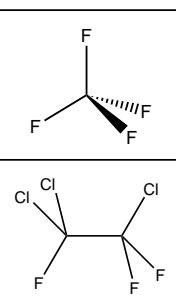
Tabla 104.69 • Identificación química.

\begin{tabular}{|c|c|c|}
\hline Producto químico & Sinónimos/Código UN & $\mathrm{N}$ úmero CAS Fórmula estructural \\
\hline TRICLOROFLUOROMETANO & $\begin{array}{l}\text { Eskimon 11; FC 11; Freón 11; Freón 11a; Freón 11b; Freón HE; } \\
\text { Freón MF }\end{array}$ & $75-69-4$ \\
\hline TRIFLUOROMETANO & $\begin{array}{l}\text { Arcton; trifluoruro de carbono; fluoroformo; fluorilo; Freón 23; Freón f-23; } \\
\text { Genetron-23; Halocarbono 23; trifluoruro de metilo; R } 23 \\
\text { UN1984 y UN3136 }\end{array}$ & $75-46-7$ \\
\hline TRIFLUORO- $\alpha, \alpha, \alpha-T O L U E N O$ & $\begin{array}{l}\text { Fluoruro de bencenilo; benzotrifluoruro; fluoruro de bencilidina; } \\
\text { feniffluoroformo; (trifluorometil) benceno } \\
\text { UN2338 }\end{array}$ & $98-08-8$ \\
\hline
\end{tabular}

Tabla 104.70 - Riesgos para la salud.

\begin{tabular}{|c|c|c|c|c|c|c|}
\hline \multirow[b]{2}{*}{$\begin{array}{l}\text { Denominación } \\
\text { química } \\
\text { N úmero CAS }\end{array}$} & \multicolumn{4}{|c|}{ Tarjetas Internacionales sobre la Seguridad de los Productos Q uímicos } & \multicolumn{2}{|c|}{ N IO SH (EE.UU.) } \\
\hline & $\begin{array}{l}\text { Período } \\
\text { corto de } \\
\text { exposición }\end{array}$ & $\begin{array}{l}\text { Período } \\
\text { largo de } \\
\text { exposición }\end{array}$ & $\begin{array}{l}\text { Vías de } \\
\text { exposición }\end{array}$ & Síntomas & $\begin{array}{l}\text { O rganos } \\
\text { afectados } \\
\text { Vías de } \\
\text { entrada }\end{array}$ & Síntomas \\
\hline $\begin{array}{l}\text { BROMOTRIFLUOROMETANO } \\
75.63 .8\end{array}$ & & & $\begin{array}{r}\text { Inhalación } \\
\text { Piel } \\
\text { 0jos }\end{array}$ & $\begin{array}{l}\text { Mareo } \\
\text { Enrojecimiento, en contacto con el líquido: } \\
\text { congelación } \\
\text { Quemaduras profundas graves }\end{array}$ & $\begin{array}{l}\text { Corazón; SNC } \\
\text { Inh; con (líq) }\end{array}$ & $\begin{array}{l}\text { Atur; arrit card; líq: } \\
\text { congelación }\end{array}$ \\
\hline $\begin{array}{l}\text { CLORODIFLUOROBROMO- } \\
\text { METANO } \\
353-59-3\end{array}$ & piel & & $\begin{array}{r}\text { Inhalación } \\
\text { Piel } \\
\text { 0jos }\end{array}$ & $\begin{array}{l}\text { Somnolencia, inconsciencia } \\
\text { En contacto con el líquido: congelación } \\
\text { Quemaduras profundas graves }\end{array}$ & & \\
\hline $\begin{array}{l}\text { CLORODIFLUOROMETANO } \\
75-45-6\end{array}$ & $\begin{array}{l}\text { tract resp; piel; } \\
\text { SNC; SCV }\end{array}$ & & $\begin{array}{r}\text { Inhalación } \\
\text { Piel } \\
\text { 0jos }\end{array}$ & $\begin{array}{l}\text { Confusión, sopor, inconsciencia } \\
\text { En contacto con el líquido: congelación } \\
\text { Enrojecimiento, dolor }\end{array}$ & $\begin{array}{l}\text { Sis resp; SCV; SNC; } \\
\text { hígado; bazo; } \\
\text { riñones } \\
\text { Inh; con (líq) }\end{array}$ & $\begin{array}{l}\text { Irrit sis resp; conf, sop, } \\
\text { zumbido de oídos; palpit, arrit } \\
\text { card; asfi; lesiones en higado, } \\
\text { riñones y bazo; líq: } \\
\text { congelación }\end{array}$ \\
\hline $\begin{array}{l}\text { CLOROPENTAFLUORETANO } \\
76 \cdot 15-3\end{array}$ & piel & & $\begin{array}{r}\text { Inhalación } \\
\text { Piel } \\
\text { 0jos }\end{array}$ & $\begin{array}{l}\text { Mareo, inconsciencia } \\
\text { En contacto con el líquido: congelación } \\
\text { Quemaduras profundas graves }\end{array}$ & $\begin{array}{l}\text { Piel; SNC; SCV } \\
\text { Inh; con (líq) }\end{array}$ & $\begin{array}{l}\text { Disn; mar, descoord, narco; } \\
\text { náu, vóm; palpit, arrit card, } \\
\text { asfi; líq: congelación, derm }\end{array}$ \\
\hline $\begin{array}{l}\text { CLOROTRIFLUOROMETANO } \\
75-72.9\end{array}$ & & & $\begin{array}{r}\text { Inhalación } \\
\text { Piel }\end{array}$ & $\begin{array}{l}\text { Confusión, cefalea } \\
\text { En contacto con el líquido: congelación }\end{array}$ & & \\
\hline $\begin{array}{l}\text { DICLORODIFLUOROMETANO } \\
75-71-8\end{array}$ & $\begin{array}{l}\text { tract resp; piel; } \\
\text { SNC; SCV; } \\
\text { pulmones }\end{array}$ & piel & $\begin{array}{r}\text { Inhalación } \\
\text { Piel } \\
\text { 0jos }\end{array}$ & $\begin{array}{l}\text { Confusión, sopor, inconsciencia } \\
\text { En contacto con el líquido: congelación } \\
\text { Enrojecimiento, dolor }\end{array}$ & $\begin{array}{l}\text { SCV; SNP } \\
\text { Inh; con (líq) }\end{array}$ & $\begin{array}{l}\text { Mar, temblores, asfi, incons, } \\
\text { arrit card, parada card; líq: } \\
\text { congelación }\end{array}$ \\
\hline $\begin{array}{l}\text { DICLOROFLUOROMETANO } \\
75-43-4\end{array}$ & piel; SNC; SCV & & $\begin{array}{r}\text { Inhalación } \\
\text { Piel }\end{array}$ & $\begin{array}{l}\text { Somnolencia, inconsciencia } \\
\text { En contacto con el líquido: congelación }\end{array}$ & $\begin{array}{l}\text { Sis resp; SCV } \\
\text { Inh; con (líq) }\end{array}$ & $\begin{array}{l}\text { Asfi, arrit card, parada card; } \\
\text { líq: congelación }\end{array}$ \\
\hline $\begin{array}{l}\text { DIFLUORODIBROMOMETANO } \\
75-61.6\end{array}$ & & & & & $\begin{array}{l}\text { Sis resp; SNC; } \\
\text { hígado } \\
\text { Inh; ing; con }\end{array}$ & $\begin{array}{l}\text { En animales: irrit sis resp; } \\
\text { síntomas del SNC; lesiones } \\
\text { hepáticas }\end{array}$ \\
\hline $\begin{array}{l}\text { ENFLURANO } \\
\quad 13838-16-9\end{array}$ & SNC & hígado & Inhalación & Somnolencia, debilidad & $\begin{array}{l}\text { Ojos; SNC } \\
\text { Inh; ing; con }\end{array}$ & $\begin{array}{l}\text { Irrit ojos; depres SNC, } \\
\text { analgesia, anes, temblores, } \\
\text { crisis resp }\end{array}$ \\
\hline $\begin{array}{l}\text { FLUORURO DE VINILLIDENO } \\
75-38-7\end{array}$ & & & $\begin{array}{r}\text { Inhalación } \\
\text { Piel } \\
\text { 0jos }\end{array}$ & $\begin{array}{l}\text { Mareo, sopor, disnea } \\
\text { En contacto con el líquido: congelación } \\
\text { Quemaduras profundas graves }\end{array}$ & $\begin{array}{l}\text { SNC } \\
\text { Inh; con (líq) }\end{array}$ & Mar, cef, náu; líq: congelación \\
\hline
\end{tabular}




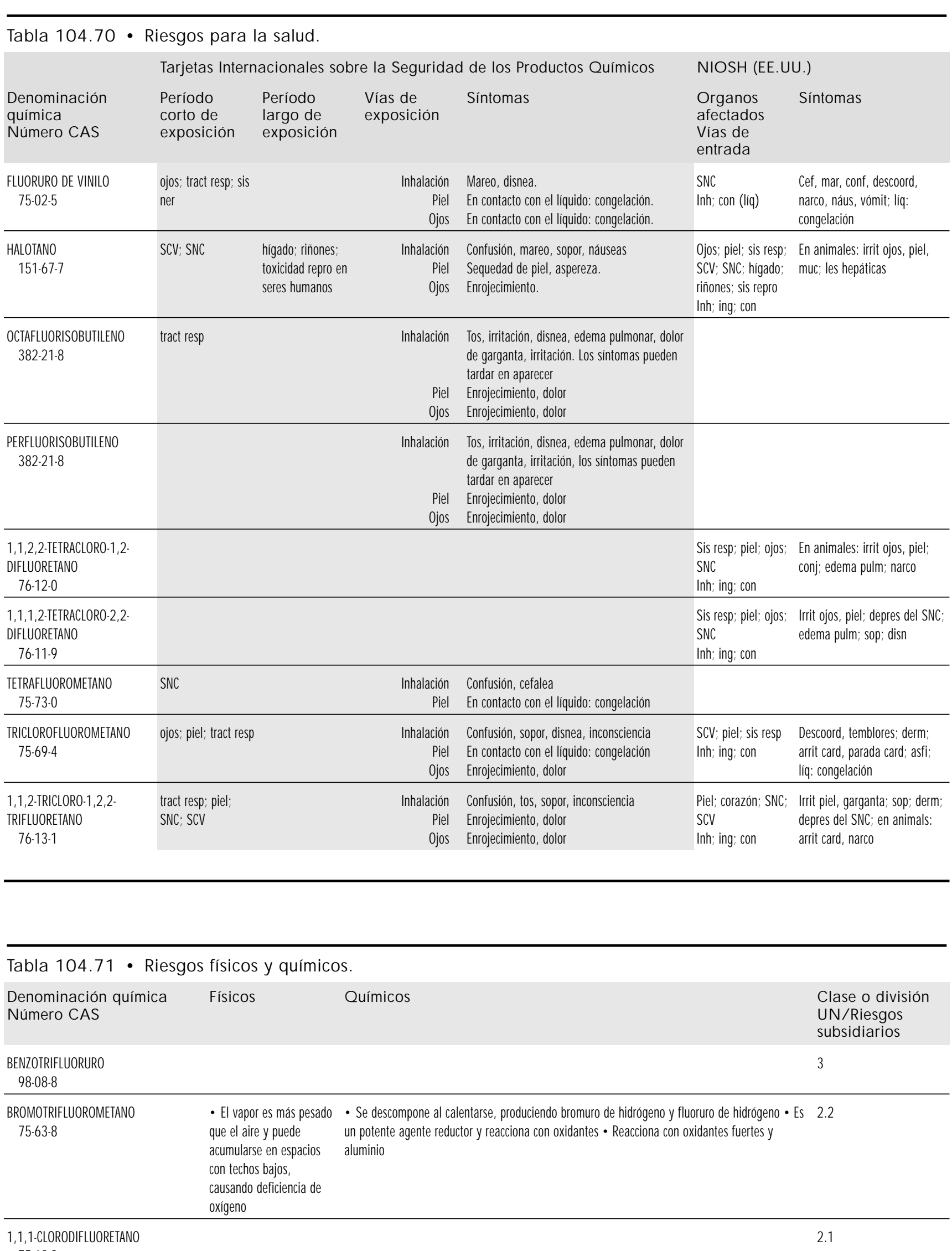

\begin{tabular}{|c|c|c|c|}
\hline $\begin{array}{l}\text { Denominación química } \\
\mathrm{N} \text { úmero CAS }\end{array}$ & Físicos & Q uímicos & $\begin{array}{l}\text { Clase o división } \\
\text { UN / Riesgos } \\
\text { subsidiarios }\end{array}$ \\
\hline $\begin{array}{l}\text { BENZOTRIFLUORURO } \\
98-08.8\end{array}$ & & & 3 \\
\hline $\begin{array}{l}\text { BROMOTRIFLUOROMETANO } \\
75-63-8\end{array}$ & $\begin{array}{l}\text { - El vapor es más pesado } \\
\text { que el aire y puede } \\
\text { acumularse en espacios } \\
\text { con techos bajos, } \\
\text { causando deficiencia de } \\
\text { oxígeno }\end{array}$ & $\begin{array}{l}\text { - Se descompone al calentarse, produciendo bromuro de hidrógeno y fluoruro de hidrógeno • ES } \\
\text { un potente agente reductor y reacciona con oxidantes } \cdot \text { Reacciona con oxidantes fuertes y } \\
\text { aluminio }\end{array}$ & 2.2 \\
\hline
\end{tabular}




\begin{tabular}{|c|c|c|c|}
\hline $\begin{array}{l}\text { Denominación química } \\
\mathrm{N} \text { úmero CAS }\end{array}$ & Físicos & Q uímicos & $\begin{array}{l}\text { Clase o división } \\
\text { UN / Riesgos } \\
\text { subsidiarios }\end{array}$ \\
\hline $\begin{array}{l}\text { CLORODIFLUOROBROMOMETANO } \\
353-59-3\end{array}$ & $\begin{array}{l}\text { - El gas es más pesado } \\
\text { que el aire y puede } \\
\text { acumularse en espacios } \\
\text { con techos bajos, } \\
\text { causando deficiencia de } \\
\text { oxígeno }\end{array}$ & $\begin{array}{l}\text { - Se descompone en contacto con llamas abiertas o superficies muy calientes, produciendo gases } \\
\text { tóxicos }\end{array}$ & 2.2 \\
\hline $\begin{array}{l}\text { CLORODIFLUOROMETANO } \\
75-45-6\end{array}$ & $\begin{array}{l}\text { - El gas es más pesado } \\
\text { que el aire y puede } \\
\text { acumularse en espacios } \\
\text { con techos bajos, } \\
\text { causando deficiencia de } \\
\text { oxígeno }\end{array}$ & $\begin{array}{l}\text { - En contacto con superficies calientes o llamas, se descompone liberando vapores corrosivos y } \\
\text { muy tóxicos (cloruro de hidrógeno; fosgeno; cloro; fluoruro de hidrógeno) • Reacciona } \\
\text { violentamente con metales en polvo como el aluminio y el zinc, con peligro de incendio y } \\
\text { explosión - Ataca el magnesio y sus aleaciones }\end{array}$ & 2.2 \\
\hline $\begin{array}{l}\text { CLOROPENTAFLUORETANO } \\
76-15-3\end{array}$ & $\begin{array}{l}\text { - El vapor es más pesado } \\
\text { que el aire y puede } \\
\text { acumularse en espacios } \\
\text { con techos bajos, } \\
\text { causando deficiencia de } \\
\text { oxígeno }\end{array}$ & $\begin{array}{l}\text { - Se descompone al calentarse, produciendo cloruro de hidrógeno y fluoruro de hidrógeno } \\
\text { - Reacciona con oxidantes fuertes }\end{array}$ & 2.2 \\
\hline $\begin{array}{l}\text { CLOROTRIFLUOROMETANO } \\
75-72-9\end{array}$ & & $\begin{array}{l}\text { - En contacto con superficies calientes o llamas, se descompone formando HCl, HF y haluros de } \\
\text { carbonilo } \cdot \text { Se descompone por efecto del fuego o en contacto con ciertos metales, formando } \\
\text { productos tóxicos }\end{array}$ & 2.2 \\
\hline $\begin{array}{l}\text { DICLORODIFLUOROMETANO } \\
75-71-8\end{array}$ & $\begin{array}{l}\text { - El gas es más pesado } \\
\text { que el aire y puede } \\
\text { acumularse en espacios } \\
\text { con techos bajos, } \\
\text { causando deficiencia de } \\
\text { oxígeno }\end{array}$ & $\begin{array}{l}\text { - En contacto con superficies calientes o llamas, se descompone liberando vapores corrosivos y } \\
\text { muy tóxicos (cloruro de hidrógeno; fosgeno; cloro; fluoruro de hidrógeno) } \cdot \text { Reacciona } \\
\text { violentamente con metales como calcio, magnesio, potasio, sodio, zinc y aluminio en polvo } \\
\text { - Ataca el magnesio y sus aleaciones }\end{array}$ & 2.2 \\
\hline $\begin{array}{l}\text { DICLOROFLUOROMETANO } \\
75-43-4\end{array}$ & $\begin{array}{l}\text { - El gas es más pesado } \\
\text { que el aire }\end{array}$ & $\begin{array}{l}\text { - Se descompone al calentarse liberando vapores corrosivos y muy tóxicos (cloruro de hidrógeno, } \\
\text { fluoruro de hidrógeno y fosgeno) - Reacciona violentamente con metales químicamente activos } \\
\text { - Reacciona con ácidos o vapores ácidos liberando vapores muy tóxicos (cloro, flúor) - Ataca } \\
\text { algunos tipos de plástico, caucho y revestimientos }\end{array}$ & 2.2 \\
\hline $\begin{array}{l}\text { DICLOROTETRAFLUORETANO } \\
1320-37-2\end{array}$ & & & 2.2 \\
\hline $\begin{array}{l}\text { 1,1-DIFLUORETANO } \\
\text { 75-37-6 }\end{array}$ & & & 2.1 \\
\hline $\begin{array}{l}\text { DIFLUORODIBROMOMETANO } \\
75-61-6\end{array}$ & & & 9 \\
\hline $\begin{array}{l}\text { ENFLURANO } \\
\quad 13838-16-9\end{array}$ & & $\begin{array}{l}\text { - Se descompone al calentarse o al arder liberando vapores tóxicos y corrosivos (cloruro de } \\
\text { hidrógeno, fluoruro de hidrógeno, fosgeno) }\end{array}$ & \\
\hline $\begin{array}{l}\text { FLUORURO DE VINILIDENO } \\
75-38-7\end{array}$ & $\begin{array}{l}\text { - El gas es más pesado } \\
\text { que el aire y puede } \\
\text { desplazarse a ras del } \\
\text { suelo; posibilidad de } \\
\text { ignición a distancia; puede } \\
\text { acumularse en espacios } \\
\text { con techos bajos, } \\
\text { causando deficiencia de } \\
\text { oxígeno - Pueden } \\
\text { generarse cargas } \\
\text { electrostáticas por flujo, } \\
\text { agitación, etc. }\end{array}$ & $\begin{array}{l}\text { - Puede formar peróxidos explosivos - Puede polimerizarse con peligro de incendio o explosión } \\
\text { - Al calentarse puede arder violentamente } 0 \text { explotar • Se descompone al arder produciendo } \\
\text { fluoruro de hidrógeno • Reacciona violentamente con oxidantes y cloruro de hidrógeno }\end{array}$ & \\
\hline
\end{tabular}




\begin{tabular}{|c|c|c|c|}
\hline $\begin{array}{l}\text { Denominación química } \\
\mathrm{N} \text { úmero CAS }\end{array}$ & Físicos & Q uímicos & $\begin{array}{l}\text { Clase o división } \\
\text { UN / Riesgos } \\
\text { subsidiarios }\end{array}$ \\
\hline $\begin{array}{l}\text { HEXAFLUORACETONA } \\
684-16-2\end{array}$ & & & $2.3 / 8$ \\
\hline $\begin{array}{l}\text { 1,1,2,2-TETRACLORO-1,2-DIFLUOR- } \\
\text { ETANO } \\
76-12-0\end{array}$ & & & 2.2 \\
\hline $\begin{array}{l}\text { 1,1,1,2-TETRACLORO-2,2-DIFLUOR- } \\
\text { ETANO } \\
\quad 76-11-9\end{array}$ & & & 2.2 \\
\hline $\begin{array}{l}\text { TETRAFLUOROMETANO } \\
75.73 .0\end{array}$ & $\begin{array}{l}\text { - El gas es más pesado } \\
\text { que el aire y puede } \\
\text { acumularse en espacios } \\
\text { con techos bajos, } \\
\text { causando deficiencia de } \\
\text { oxígeno }\end{array}$ & - En contacto con superficies calientes o llamas, se descompone formando ácido fluorhídrico & 2.2 \\
\hline $\begin{array}{l}\text { TRICLOROFLUOROMETANO } \\
75-69-4\end{array}$ & $\begin{array}{l}\text { - El gas es más pesado } \\
\text { que el aire - El vapor es } \\
\text { más pesado que el aire y } \\
\text { puede acumularse en } \\
\text { espacios con techos bajos, } \\
\text { causando deficiencia de } \\
\text { oxígeno }\end{array}$ & $\begin{array}{l}\text { - En contacto con superficies calientes o llamas, se descompone liberando vapores corrosivos y } \\
\text { muy tóxicos (cloruro de hidrógeno; fosgeno; cloro; fluoruro de hidrógeno) } \bullet \text { Reacciona } \\
\text { violentamente con metales y algunos metales en polvo, como aluminio, bario, calcio, magnesio y } \\
\text { sodio }\end{array}$ & \\
\hline $\begin{array}{l}\text { 1,1,2-TRICLORO-1,2,2-TRIFLUOR- } \\
\text { ETANO } \\
\text { 76-13-1 }\end{array}$ & $\begin{array}{l}\text { - El vapor es más pesado } \\
\text { que el aire y puede } \\
\text { acumularse en espacios } \\
\text { con techos bajos, } \\
\text { causando deficiencia de } \\
\text { oxígeno }\end{array}$ & $\begin{array}{l}\text { - En contacto con superficies calientes o llamas, se descompone liberando vapores corrosivos y } \\
\text { muy tóxicos (carbonilfluoruro; cloruro de hidrógeno; fosgeno; cloro; fluoruro de hidrógeno) } \\
\text { - Reacciona violentamente con calcio, potasio, sodio y metales en polvo como alumino, berilio, } \\
\text { magnesio y zinc, con peligro de incendio y explosión - Ataca aleaciones que contienen más de } \\
\text { un } 2 \% \text { de magnesio }\end{array}$ & \\
\hline
\end{tabular}

\begin{tabular}{|c|c|c|c|c|c|c|c|c|c|c|}
\hline $\begin{array}{l}\text { Denominación química } \\
\mathrm{N} \text { úmero CAS }\end{array}$ & Color/ Forma & $\begin{array}{l}\text { p.e. } \\
(\stackrel{\circ}{ } \mathrm{C})\end{array}$ & $\begin{array}{l}\text { p.f. } \\
(\stackrel{\circ}{ } \mathcal{C})\end{array}$ & $\begin{array}{l}\mathrm{p} . \mathrm{m} . / \\
\text { (g/ } \\
\mathrm{mol})\end{array}$ & $\begin{array}{l}\text { Solubilidad } \\
\text { en agua }\end{array}$ & $\begin{array}{l}\text { Densidad } \\
\text { relativa } \\
\text { (agua }=1 \text { ) }\end{array}$ & $\begin{array}{l}\text { Densidad } \\
\text { relativa } \\
\text { del vapor } \\
\text { (aire=1) }\end{array}$ & $\begin{array}{l}\text { Pvap/ } \\
(\mathrm{kPa})\end{array}$ & $\begin{array}{l}\text { Límit. } \\
\text { inflam. }\end{array}$ & $\begin{array}{ll}\text { p.ig. } & \text { p.aut } \\
\left({ }^{\circ} \mathrm{C}\right) & \text { ig. } \\
& \left({ }^{\circ} \mathrm{C}\right)\end{array}$ \\
\hline $\begin{array}{l}\text { BENZOTRIFLUORURO } \\
98-08-8\end{array}$ & $\begin{array}{l}\text { líquido de color de } \\
\text { agua }\end{array}$ & 103,46 & $-29,05$ & 146,11 & & 1,1886 & 5,04 & $\begin{array}{l}11 \mathrm{~mm} \mathrm{Hg} \\
@ 0^{\circ} \mathrm{C}\end{array}$ & & $12 \ll$ \\
\hline $\begin{array}{l}\text { BROMOTRIFLUOROMETANO } \\
75-63-8 \\
\end{array}$ & gas incoloro & $-57,86$ & -166 & 148,92 & insol & 1,5800 & 3,8 & & & \\
\hline $\begin{array}{l}\text { 1,1,1-CLORODIFLUORETANO } \\
\text { 75-68-3 }\end{array}$ & gas incoloro & $-9,2$ & $-130,8$ & & $\begin{array}{l}9,18 \times 10+3 \\
\mathrm{mg} / \mathrm{I} \\
@ 25^{\circ} \mathrm{C}\end{array}$ & $1.194 @-9{ }^{\circ} \mathrm{C}$ & & $\begin{array}{l}2.528 \\
\mathrm{~mm} \mathrm{Hg} \\
@ 25^{\circ} \mathrm{C} \\
\end{array}$ & $\begin{array}{l}6,2 \mathrm{li} \\
17,9 \mathrm{ls}\end{array}$ & \\
\hline $\begin{array}{l}\text { CLORODIFLUOROBROMOMETANO } \\
353-59-3\end{array}$ & gas incoloro & -4 & -161 & 165,37 & insol & $\begin{array}{l}1,850 \\
@ 15{ }^{\circ} \mathrm{C} \\
\text { (líquido) } \\
\end{array}$ & 5,7 & & & \\
\hline $\begin{array}{l}\text { CLORODIFLUOROMETANO } \\
75-45-6\end{array}$ & gas incoloro & $-40,8$ & -146 & 86,47 & muy sol & $\begin{array}{l}1,209 \\
@ 21^{\circ} \mathrm{C}\end{array}$ & 2,98 & 908 & & \\
\hline
\end{tabular}


Tabla 104.72 • Propiedades físicas y químicas.

\begin{tabular}{|c|c|c|c|c|c|c|c|c|c|c|c|}
\hline $\begin{array}{l}\text { Denominación química } \\
\mathrm{N} \text { úmero CAS }\end{array}$ & Color/ Forma & $\begin{array}{l}\text { p.e. } \\
(\because 0)\end{array}$ & 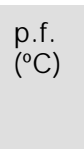 & $\begin{array}{l}\mathrm{p} . \mathrm{m} . / \\
\text { (g/ } \\
\mathrm{mol})\end{array}$ & $\begin{array}{l}\text { Solubilidad } \\
\text { en agua }\end{array}$ & $\begin{array}{l}\text { Densidad } \\
\text { relativa } \\
\text { (agua }=1 \text { ) }\end{array}$ & $\begin{array}{l}\text { Densidad } \\
\text { relativa } \\
\text { del vapor } \\
\text { (aire }=1 \text { ) }\end{array}$ & $\begin{array}{l}\text { Pvap/ } \\
(\mathrm{kPa})\end{array}$ & $\begin{array}{l}\text { Límit. } \\
\text { inflam. }\end{array}$ & $\begin{array}{l}\text { p.ig. } \\
(\underline{O C})\end{array}$ & $\begin{array}{l}\text { p.aut } \\
\text { ig. } \\
(\underline{O} \text { C })\end{array}$ \\
\hline $\begin{array}{l}\text { CLOROFLUOROMETANO } \\
593 \cdot 70-4\end{array}$ & & $-9,1$ & -133 & 68,48 & & & & & & & \\
\hline $\begin{array}{l}\text { CLOROPENTAFLUORETANO } \\
76-15-3\end{array}$ & gas incoloro & -38 & -106 & 154,47 & insol & $\begin{array}{l}1,526 \mathrm{~kg} / \mathrm{I} \\
\text { líquido } \\
@-20^{\circ} \mathrm{C}\end{array}$ & 5,54 & 711,7 & & & \\
\hline $\begin{array}{l}\text { CLOROTRIFLUORETANO } \\
1330-45-6\end{array}$ & & 6,93 & $-105,5$ & 118,49 & & $\begin{array}{l}1,389 \\
@ 0^{\circ} \mathrm{C} / 4^{\circ} \mathrm{C}\end{array}$ & & & & & \\
\hline $\begin{array}{l}\text { CLOROTRIFLUORETILENO } \\
79-38-9\end{array}$ & gas incoloro & $-27,9$ & $-157,5$ & 116,47 & & 1,305 & & & $\begin{array}{l}8,4 \mathrm{li} \\
38,7 \mathrm{ls}\end{array}$ & & \\
\hline $\begin{array}{l}\text { CLOROTRIFLUOROMETANO } \\
75-72.9\end{array}$ & gas incoloro & $-81,1$ & -181 & 104,46 & insol & 1,3 & 3,65 & $\begin{array}{l}2.735 \\
@ 15^{\circ} \mathrm{C}\end{array}$ & & & \\
\hline $\begin{array}{l}\text { DICLORODIFLUOROMETANO } \\
75-71-8\end{array}$ & $\begin{array}{l}\text { gas incoloro; gas } \\
\text { comprimido licuado }\end{array}$ & $-29,8$ & -158 & 120,91 & sol & $\begin{array}{l}1,486 \\
@-29,8^{\circ} \mathrm{C}\end{array}$ & 4,1 & 568 & & & \\
\hline $\begin{array}{l}\text { DICLOROFLUOROMETANO } \\
75-43-4\end{array}$ & gas pesado incoloro & 9 & -135 & 102,92 & insol & $\begin{array}{l}1,405 \mathrm{~g} / \mathrm{ml} \\
@ g^{\circ} \mathrm{C}\end{array}$ & 3,82 & 160 & & & 522 \\
\hline $\begin{array}{l}\text { DICLOROTETRAFLUORETANO } \\
1320-37-2 \\
\end{array}$ & gas incoloro & 3,6 & .94 & 170,92 & insol & $\begin{array}{l}1,455 \\
\text { @ } 25^{\circ} \mathrm{C} \\
\end{array}$ & & & & & \\
\hline $\begin{array}{l}\text { 1,1-DIFLUORETANO } \\
\text { 75-37-6 }\end{array}$ & gas incoloro & $-24,7$ & -117 & 66,05 & insol & 0,95 & 2,3 & $\begin{array}{l}4.437,1 \\
\mathrm{~mm} \mathrm{Hg} \\
@ 25^{\circ} \mathrm{C} \\
\end{array}$ & $\begin{array}{l}3,7 \mathrm{li} \\
18 \mathrm{ls}\end{array}$ & & \\
\hline $\begin{array}{l}\text { DIFLUORODIBROMOMETANO } \\
75-61-6\end{array}$ & $\begin{array}{l}\text { líquido pesado } \\
\text { incoloro; gas incoloro }\end{array}$ & 25 & -146 & 209,83 & sol & $\begin{array}{l}2,288 \\
@ 15^{\circ} \mathrm{C} / 4^{\circ} \mathrm{C}\end{array}$ & 7,2 & & & & \\
\hline $\begin{array}{l}\text { ENFLURANO } \\
13838-16-9 \\
\end{array}$ & líquido & 56,5 & & & lig sol & 1,52 & & & & & \\
\hline $\begin{array}{l}\text { FLUORURO DE VINILIDENO } \\
75-38-7\end{array}$ & gas incoloro & .83 & -144 & 64,04 & insol & 0,617 & 2,2 & 3.600 & $\begin{array}{l}5,5 \mathrm{li} \\
21,3 \mathrm{ls}\end{array}$ & $\begin{array}{l}\text { Gas } \\
\text { infla- } \\
\text { mable }\end{array}$ & \\
\hline $\begin{array}{l}\text { FLUORURO DE VINILO } \\
\text { 75-02-5 }\end{array}$ & gas incoloro & $.72,2$ & $-160,5$ & 46,05 & insol & 1,58 & & & $\begin{array}{l}2,6 \% \text { vol li } \\
21,7 \% \text { vol } \\
\text { ls }\end{array}$ & & \\
\hline $\begin{array}{l}\text { HALOTANO } \\
151-67-7 \\
\end{array}$ & $\begin{array}{l}\text { líquido volátil } \\
\text { incoloro }\end{array}$ & 50,2 & & 197,39 & $3.900 \mathrm{mg} / \mathrm{l}$ & $\begin{array}{l}1,871 @ 20^{\circ} \\
\mathrm{C} / 4^{\circ} \mathrm{C}\end{array}$ & & $\begin{array}{l}243 \mathrm{~mm} \mathrm{Hg} \\
\text { @ } 20^{\circ} \mathrm{C}\end{array}$ & & & \\
\hline $\begin{array}{l}\text { HEXAFLUORACETONA } \\
684-16-2\end{array}$ & gas incoloro & -27 & -122 & 166,03 & & $\begin{array}{l}1,33 \mathrm{~g} / \mathrm{ml} \\
@ 25^{\circ} \mathrm{C} \\
\text { (líquido) }\end{array}$ & & & & & \\
\hline $\begin{array}{l}\text { HEXAFLUOROPROPILENO } \\
116-15-4 \\
\end{array}$ & gas & $-29,4$ & $-156,2$ & 150,02 & & $\begin{array}{l}1,583 \mathrm{a} \\
-40^{\circ} \mathrm{C} / 4^{\circ} \mathrm{C}\end{array}$ & & & & & \\
\hline $\begin{array}{l}\text { PERFLUORISOBUTLLENO } \\
382-21-8 \\
\end{array}$ & gas & 7 & & 200,03 & & $\begin{array}{l}1,5297 \\
@ 0^{\circ} \mathrm{C} \\
\end{array}$ & & & & & \\
\hline $\begin{array}{l}\text { TEFLON } \\
9002-84-0\end{array}$ & $\begin{array}{l}\text { láminas finas } \\
\text { transparentes de } \\
\text { color blanco } \\
\text { grisáceo; sólido } \\
\text { blando, ceroso, de } \\
\text { color blanco lechoso; } \\
\text { polvo blanco }\end{array}$ & & & & & 2,25 & & & & & \\
\hline $\begin{array}{l}\text { 1,1,2,2-TETRACLORO-1,2-DI- } \\
\text { FLUORETANO }\end{array}$ & $\begin{array}{l}\text { sólido o líquido } \\
\text { incoloro }\end{array}$ & 93 & 25 & 203,83 & insol & $\begin{array}{l}1,6447 \\
@ 25^{\circ} \mathrm{C} / 4^{\circ} \mathrm{C}\end{array}$ & 7,03 & 40 torr & & & \\
\hline
\end{tabular}




\begin{tabular}{|c|c|c|c|c|c|c|c|c|c|c|}
\hline $\begin{array}{l}\text { Denominación química } \\
\mathrm{N} \text { úmero CAS }\end{array}$ & Color/ Forma & $\begin{array}{l}\text { p.e. } \\
\left({ }^{\circ} \mathrm{C}\right)\end{array}$ & $\begin{array}{l}\text { p.f. } \\
(\stackrel{\circ}{ } C)\end{array}$ & $\begin{array}{l}\text { p.m.l } \\
\text { (g/ } \\
\text { mol) }\end{array}$ & $\begin{array}{l}\text { Solubilidad } \\
\text { en agua }\end{array}$ & $\begin{array}{l}\text { Densidad } \\
\text { relativa } \\
\text { (agua }=1 \text { ) }\end{array}$ & $\begin{array}{l}\text { Densidad } \\
\text { relativa } \\
\text { del vapor } \\
\text { (aire=1) }\end{array}$ & $\begin{array}{l}\text { Pvap/ } \\
(\mathrm{KPa})\end{array}$ & $\begin{array}{l}\text { Límit. } \\
\text { inflam. }\end{array}$ & $\begin{array}{ll}\text { p.ig. } & \text { p.aut } \\
\left({ }^{\circ} \mathrm{C}\right) & \text { ig. } \\
& \left({ }^{\circ} \mathrm{C}\right)\end{array}$ \\
\hline $\begin{array}{l}\text { 1,1,1,2-TETRACLORO-2,2-DI- } \\
\text { FLUORETANO } \\
\text { 76-11-9 }\end{array}$ & $\begin{array}{l}\text { sólido o líquido } \\
\text { incoloro }\end{array}$ & 91,5 & 40,6 & 203,82 & insol & 1,65 & 7,0 & $40 \mathrm{~mm} \mathrm{Hg}$ & & \\
\hline $\begin{array}{l}\text { TETRAFLUORETILENO } \\
116-14-3 \\
\end{array}$ & gas incoloro & $-76,3$ & $-142,5$ & 100,02 & insol & $\begin{array}{l}1,519 \\
@-76.3^{\circ} \mathrm{C}\end{array}$ & 3,87 & & $\begin{array}{l}10,0 \mathrm{li} \\
50,0 \mathrm{ls}\end{array}$ & 180 \\
\hline $\begin{array}{l}\text { TETRAFLUOROMETANO } \\
75-73.0\end{array}$ & gas incoloro & $-127,8$ & $-183,6$ & 88,01 & lig sol & $\begin{array}{l}3,034 \\
@ 25^{\circ} \mathrm{C}\end{array}$ & 3,04 & & & $>1.100$ \\
\hline $\begin{array}{l}\text { TRICLOROFLUOROMETANO } \\
\text { 75-69-4 }\end{array}$ & líquido incoloro & 23,7 & -111 & 137,4 & $\begin{array}{l}1 \mathrm{~g} / 1 \mathrm{I} @ \\
25^{\circ} \mathrm{C}\end{array}$ & $\begin{array}{l}1,494 \\
@ 17,2^{\circ} \mathrm{Cl} \\
4^{\circ} \mathrm{C} \text { (líquido) }\end{array}$ & 4,7 & 89 & $\begin{array}{l}\text { no } \\
\text { inflamable }\end{array}$ & \\
\hline $\begin{array}{l}\text { 1,1,2-TRICLORO-1,2,2-TRIFLUORETANO } \\
\text { 76-13-1 }\end{array}$ & $\begin{array}{l}\text { gas incoloro; líquido } \\
\text { volátil }\end{array}$ & 47,7 & $-36,4$ & 187,38 & $0,017 \mathrm{~g} / 100 \mathrm{~g}$ & $\begin{array}{l}1,5635 \\
\text { @ } 25^{\circ} \mathrm{C} / 4^{\circ} \mathrm{C}\end{array}$ & 6,5 & 36 & & 350 \\
\hline $\begin{array}{l}\text { TRIFLUOROMETANO } \\
75-46-7\end{array}$ & gas incoloro & $-84,4$ & -160 & 70,02 & sol & $\begin{array}{l}1,52 \mathrm{~g} / \mathrm{ml} \\
@-100{ }^{\circ} \mathrm{C} \\
\text { (líquido) }\end{array}$ & & $\begin{array}{l}30.000 \\
\mathrm{~mm} \mathrm{Hg}\end{array}$ & & \\
\hline
\end{tabular}




\section{ETERES GLICOLICOS}

\section{Usos}

L os éteres glicólicos se utilizan mucho como disolventes gracias a su solubilidad tanto en agua como en líquidos orgánicos. Sus principales usos son las tintas y colorantes, los esmaltes, las pinturas y como agentes limpiadores para la limpieza en seco y la limpieza de cristales. Estos compuestos se emplean también como disolventes y limpiadores en la fabricación de semiconductores.

Los éteres de etilenglicol se emplean como disolventes de resinas, lacas, pinturas, barnices, tintas y colorantes, y como componentes de pastas de pintura, productos de limpieza, jabones líquidos, cosméticos y líquidos hidráulicos. L os éteres de propilenglicol y butilenglicol sirven como agentes dispersores y como disolventes de lacas, pinturas, resinas, colorantes, aceites y grasas.

EI éter monoetílico de etilenglicol se utiliza como disolvente en las industrias de lacado, imprenta, metalurgia y química. T ambién se emplea para la tinción y el estampado de tejidos, como agente de acabado del cuero, como anticongelante en los combustibles de los aviones y como componente de decapantes de pinturas y soluciones limpiadoras. EI éter monometílico de dietilengl icol y el acetato del éter monobutílico de etilenglicol se utilizan en la industria como disolventes de alto punto de ebullición. El éter monometílico de dietilenglicol se utiliza en tintes para la madera que no resaltan las vetas, en lacas de olores suaves para su aplicación con pincel, en tintas para tampones y en el acabado del cuero. En la industria de las pinturas, se utiliza como agente coalescente para pintura de látex. En la industria textil se utiliza para el estampado de tejidos, como ingrediente de jabones textiles y pastas colorantes, y para fijar la torsión y acondicionar hilos y telas.

EI éter monometílico de dietilenglicol, el éter monotélico de dietilenglicol y el éter mono-n-butílico de dietilenglicol son disolventes que sirven como diluyentes de líquidos hidráulicos para frenos. El 2-fenoxietanol se utiliza como fijador en perfumes, cosméticos y jabones, como soporte de colorantes para tejidos y como disolvente en productos de limpieza, tintas, germicidas y productos farmacéuticos. EI 2-metoxietanol también es un fijador de perfumes. Se utiliza en la fabricación de películas fotográficas, como anticongelante en combustibles para reactores, como disolvente de las resinas utilizadas en la industria electrónica y para la tinción del cuero. EI 2-metoxietanol y el éter metílico de propilenglicol son útiles para el sellado de celofán con disolventes. El éter mono-n-butílico de etilenglicol es un disolvente para revestimientos protectores y limpiametales. Se utiliza en la industria textil para evitar manchas durante el estampado o la tinción.

\section{Riesgos}

En términos generales, los efectos agudos de los éteres glicólicos se limitan al sistema nervioso central y son parecidos a la toxicidad aguda de los disolventes. Estos efectos consisten en mareo, cefalea, confusión, fatiga, desorientación, habla tibuteante y, si son suficientemente intensos, depresión respiratoria y pérdida de consciencia. La exposición durante largos períodos de tiempo produce irritación de la piel, anemia, supresión de la médula ósea, encefalopatía y toxicidad reproductiva. El 2-metoxietanol y el 2-etoxietanol (y sus acetatos) son tóxicos en grado sumo. Debido a su volatilidad relativamente baja, la exposición suele producirse por contacto de la piel con los líquidos o por inhalación de los vapores en espacios cerrados.
La mayoría de los éteres del etilenglicol son más volátiles que sus compuestos precursores $y$, en consecuencia, resulta menos fácil controlar la exposición a sus vapores. T odos ellos son más tóxicos que el etilenglicol y producen un cuadro sintomatológico parecido.

E ter monometílico de etilenglicol (M etilcellosolve; Dowanol EM; 2-metoxietanol). $L a D_{50}$ del éter monometílico de etilenglicol administrado por vía oral a ratas produce muertes tardías con edema pulmonar, lesiones hepáticas leves y lesiones renales extensas. $L a$ insuficiencia renal probablemente sea la causa de la muerte en respuesta a dosis orales repetidas. Este éter glicólico produce una irritación moderada de los ojos, dolor agudo, inflamación de las mucosas y opacidad corneal durante varias horas. Aunque el éter monometílico de etilenglicol no es un irritante cutáneo importante, puede absorberse por vía percutánea en cantidades tóxicas. La experiencia con la exposición humana al éter monometílico de etilenglicol ha demostrado que puede dar lugar a la aparición de leucocitos inmaduros, anemia monocítica y alteraciones neurológicas y de la conducta. Se ha constatado también que la exposición humana por inhalación causa problemas de memoria, cambios de la personalidad, debilidad, letargo y cefalea. En animales, la inhalación de concentraciones mayores puede causar degeneración testicular, lesiones en el bazo y hematuria. Los estudios con animales han demostrado la presencia de anemia y lesiones en el timo y la médula con concentraciones de 300 ppm. También la exposición de animales a concentraciones de $50 \mathrm{ppm}$ produce importantes anomías fetales durante el embarazo. El efecto más importante para la salud parece ser el que se ejerce en el sistema reproductor humano, con una disminución de la espermatogénesis. Por ello, resulta evidente que el éter monometílico de etilenglicol es un compuesto moderadamente tóxico y que debe evitarse el contacto repetido con la piel y la inhalación de sus vapores.

E ter monoetílico de etilenglicol (disolvente de cellosolve; Dowanol $E E ;$ 2-etoxietanol). El éter monoetílico de etilenglicol es menos tóxico que el éter metílico (véase más arriba). Su efecto tóxico más importante lo ejerce en la sangre y rara vez aparecen síntomas neurológicos. Por lo demás, su acción tóxica es similar a la del éter monometílico del etilenglicol. La exposición excesiva puede ocasionar irritación moderada del sistema respiratorio, edema pulmonar, depresión del sistema nervioso central y glomerulitis acusada. En estudios con animales se ha observado fetotoxicidad y teratogenicidad con concentraciones superiores a 160 ppm, así como cambios evidentes de comportamiento en la prole tras exponer a la madre a una concentración de 100 ppm.

Otros éteres de etilenglicol. El éter monobutílico de etilenglicol merece una mención especial por su amplia utilización en la industria. En ratas, se producen muertes en respuesta a una sola dosis oral, que son atribuibles a narcosis, mientras que las muertes tardías se producen por congestión pulmonar e insuficiencia renal. El contacto directo de los ojos con este éter provoca dolor intenso, marcada irritación de la conjuntiva y opacidad corneal, que puede durar varios días. Como en el caso del éter monometílico, el contacto con la piel no ocasiona mucha irritación, pero pueden absorberse cantidades tóxicas por vía percutánea. Los estudios de inhalación han demostrado que las ratas pueden tolerar 30 exposiciones de 7 horas a concentraciones de 54 ppm, pero a 100 ppm aparecen algunas lesiones. A concentraciones superiores, las ratas presentan hemorragia pulmonar, congestión visceral, lesiones hepáticas, hemoglobinuria e intensa fragilidad de los eritrocitos. Se ha detectado fetotoxicidad en ratas expuestas a concentraciones de $100 \mathrm{ppm}$, pero no a 50 ppm, así como un aumento evidente de la fragilidad de los 
eritrocitos por exposición a concentraciones superiores a 50 ppm de éter monobutílico de etilenglicol. Los seres humanos parecen ser algo menos susceptibles que los animales de laboratorio, por la aparente resistencia a su efecto hemolítico. Aunque la exposición a concentraciones por encima de 100 ppm causa cefalea e irritación ocular y nasal en el ser humano, no se aprecian daños en los hematíes.

Tanto el éter isopropílico como el n-propílico de etilenglicol entrañan riesgos particulares. Estos éteres glicólicos poseen valores bajos de $\mathrm{DL}_{50}$ cuando se administran dosis orales únicas y pueden ocasionar graves lesiones renales y hepáticas. La hematuria es un signo precoz de afectación renal grave. La muerte suele producirse en el plazo de unos pocos días. En el conejo, el contacto ocular produce una rápida irritación de la conjuntiva y opacidad corneal parcial que remite aproximadamente en una semana. Como la mayoría de los demás éteres de etilenglicol, los derivados propílicos sólo son irritantes cutáneos leves, pero pueden absorberse cantidades tóxicas por vía percutánea. Además, son muy tóxicos cuando se inhalan. Afortunadamente, el éter monoisopropílico de etilenglicol es un compuesto de escasa importancia comercial.

E teres de dietilenglicol. Los éteres de dietilenglicol son menos tóxicos que los éteres de etilenglicol, aunque exhiben características similares.

Polietilenglicoles. Los glicoles de trietileno, tetraetileno y polietilenglicoles de cadena larga son compuestos especialmente inocuos con una baja presión de vapor.

É teres de propilenglicol. El éter monometílico de propilenglicol es relativamente poco tóxico. En ratas, la $D L_{50}$ en dosis oral única produjo la muerte por depresión generalizada del sistema nervioso central, probablemente con parada respiratoria. La administración de dosis orales repetidas $(3 \mathrm{~g} / \mathrm{kg}$ ) durante un período de 35 días, también en ratas, sólo indujo la aparición de alteraciones histopatológicas leves en el hígado y los riñones. EI contacto ocular produjo una ligera irritación transitoria. Este compuesto no es un irritante cutáneo importante, pero la aplicación de grandes cantidades sobre la piel del conejo produce depresión del sistema nervioso central. La inhalación de sus vapores no comporta un riesgo importante para la salud. En animales expuestos a exposiciones intensas por inhalación, la muerte parece deberse a narcosis profunda. En el hombre, este éter irrita los ojos y el tracto respiratorio superior a concentraciones que no son peligrosas para la salud, razón por la cual puede decirse que posee algunas propiedades que advierten de su presencia.
Los éteres de di- y tripropilenglicol exhiben propiedades toxicológicas similares a las de los derivados monopropilénicos, pero prácticamente no entrañan ningún riesgo por inhalación de los vapores o por contacto con la piel.

Polibutilenglicoles. Los polibutilenglicoles que se han estudiado pueden ocasionar lesiones renales en dosis excesivas, pero no afectan a los ojos ni a la piel, ni se absorben en cantidades tóxicas.

E steres, diésteres, y éter ésteres acéticos. E stos derivados de los glicoles comunes tienen una especial importancia en virtud de su utilización como disolventes de plásticos y resinas en diversos productos. M uchos explosivos contienen éster de etilenglicol para disminuir el punto de congelación. Por lo que se refiere a su toxicidad, los ésteres de ácidos grasos y éter de glicol son considerablemente más irritantes para las mucosas que los compuestos precursores antes citados. Sin embargo, una vez absorbidos, los ésteres de ácidos grasos poseen propiedades tóxicas prácticamente idénticas a las de los compuestos precursores, ya que se saponifican en medios biológicos para dar el ácido graso y el correspondiente glicol o éter de glicol.

\section{Medidas de salud y seguridad}

Las medidas recomendadas para controlar y limitar la exposición a los éteres glicólicos son básicamente las mismas que las adoptadas para controlar la exposición a disolventes, ya comentadas en otros artículos de esta E nciclopedia. La sustitución de un material por otro menos tóxico, en caso de ser posible, es siempre un buen punto de partida. Es importante disponer de sistemas eficaces de ventilación para reducir la concentración del material en la zona de respiración. Siempre que exista peligro de explosión 0 incendio, deberán evitarse las chispas o llamas desnudas y los materiales se almacenarán en recipientes "a prueba de explosiones". Aunque es importante utilizar equipos de protección personal, como respiradores, guantes y prendas protectoras, no conviene depender exclusivamente de ellos. Siempre que exista riesgo de exposición a salpicaduras, se utilizarán gafas protectoras. L os trabajadores que manipulan éter monometílico de etilenglicol deben utilizar gafas de seguridad química y trabajar en áreas con una ventilación adecuada. También se recomienda el uso de protección ocular ante cualquier posibilidad de contacto de los ojos con el éter monobutílico de etilenglicol. Debe evitarse la inhalación de los vapores y el contacto cutáneo, esto último sobre todo cuando se trabaja con 2-metoxietanol y 2-etoxietanol. 
TABLAS DE ETERES GUCOUCOS

Tabla 104.73 • Identificación química.

$\begin{array}{ll}\text { Producto químico } & \text { Sinónimos/ Código UN } \\ \text { ACETATO DE ETER ETILICO DE ETILENGLICOL } & \begin{array}{l}\text { Cellosolve; Dowanol EE; 2-etoxietanol; etilcellosolve; éter monoetílico de } \\ \text { glicol; hidroxiéter } \\ \text { UN1171 }\end{array}\end{array}$

N úmero CAS Fórmula estructural

$110-80-5$ licol; hidroxiéter

$\overbrace{\mathrm{O}}^{\mathrm{OH}}$

ACETATO DE ETER MONOBUTILETILICO

DE ETILENGLICOL

$112-07-2$

\begin{tabular}{|c|c|}
\hline $\begin{array}{l}\text { ACETATO DE ETER MONOBUTILICO } \\
\text { DE DIETILENGLICOL }\end{array}$ & $\begin{array}{l}\text { Ester 2-(2-butoxietoxi)etílico de ácido acético; acetato de } \\
\text { 2-(2-butoxietoxi) etilo; acetato de butilicarbitol; acetato de éter butilico de } \\
\text { dietilenglicol; }\end{array}$ \\
\hline $\begin{array}{l}\text { ACETATO DE ETER MONOETLLCO } \\
\text { DE ETLENGLICOL }\end{array}$ & $\begin{array}{l}\text { Acetato de cellosolve; etoxiacetato; acetato de etoxietilo } \\
\text { UN1172 }\end{array}$ \\
\hline $\begin{array}{l}\text { ACETATO DE ETER MONOMETILLCO } \\
\text { DE ETILENGLICOL }\end{array}$ & $\begin{array}{l}\text { Ester 2-metoxietílico de ácido acético; acetato de éter metílico de } \\
\text { etilenglicol; acetato EM de éter glicólico; acetato de éter monometílico de } \\
\text { glicol; Mecsac; acetato de 2-metoxietanol; acetato de 2-metoxietilo; } \\
\text { acetato de metilicellosolve; acetato de metilglicol; monoacetato de } \\
\text { metilglicol } \\
\text { UN1189 }\end{array}$ \\
\hline
\end{tabular}

Dimetoxietano; dimetilcellosolve; 2,5-dioxahexano; éter etilendimetilíic;
éter dimetílico de etilenglicol
UN2252

$110-71-4$

$124-17-4$

$111-15-9$
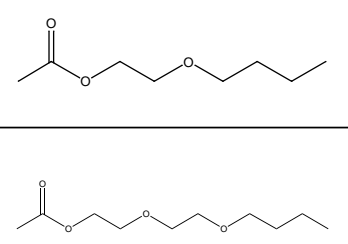

ETER DIETILICO DE DIETILENGLICOL Eter bis-(2-etoxietilíco); dietilcarbitol; 3,6,9-trioxaundecano $\quad$ 112-36-7

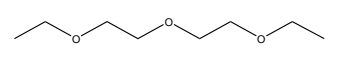

$\begin{array}{lcl}\text { ETER DIETILICO DE ETLENGLCOL } & \begin{array}{l}\text { 1,2-Dietoxietano; dietilcellosolve; éter dietilico de glicol } \\ \text { UN1153 }\end{array}\end{array}$

\begin{tabular}{|c|c|c|}
\hline ETER DIGLICIDILICO DE 1,4-BUTANODIOL & $\begin{array}{l}\text { 1,4-Bis-(2,3-epoxipropoxi) butano; 1,4-bis-( glicidiloxi) butano; } \\
\text { éter diglicidílico de 1,4-butano; éter diglicidilílico de butanodiol; éter } \\
\text { diglicidílico de butano-1,4-diol; } \\
\text { 2,2'-(1,4-butanodilbis( (oximetilen) ) bisoxirano; 1,4-diglicidoloxibutano }\end{array}$ & $2425-79-8$ \\
\hline ETER DIGLICIDLLCO DE DIETLENGLICOL & $\begin{array}{l}\text { Eter bis-(2-(2,3-epoxipropoxi) etilíico); } \\
\text { 2,2'-(oxibis-(2,1-etanodiloximetilen))-bis-(9Cl)-oxirano; } \\
\text { 2,2'-(oxibis-(2,1-etanodiloximetilen))-bisoxirano }\end{array}$ & $4206-61-5$ \\
\hline ETER FENILLCO DE ETLLENGLICOL & $\begin{array}{l}\text { Arosol; Dowanol EP; Dowanol EPH; 2-fenoxietanol; éter monofenólico de } \\
\text { glicol; fenilcellosolve }\end{array}$ & $122-99-6$ \\
\hline ETER METILICO DE DIPROPILENGLICOL & $\begin{array}{l}\text { Arcosolve; dipropileno Dowanol DPM; Dowanol-50B; } \\
\text { 1-(2-metoxiisopropoxi)-2-propanol }\end{array}$ & $34590-94-8$ \\
\hline
\end{tabular}


Tabla 104.73 • Identificación química.

\begin{tabular}{lll} 
Producto químico & Sinónimos/ Código UN & N úmero CAS Fórmula estructural \\
ETER METLLICO DE ETLENGLICOL & $\begin{array}{l}\text { Eter glicólico monometilico; 2-metoxietanol; metoxihidroxietano; } \\
\text { metilcellosolve } \\
\text { UN1188 }\end{array}$ & Eter etilmetílico de dietilenglicol \\
\hline ETER 2-METOXIETLICO DE 2-ETOXIETILO & $1009-86-4$
\end{tabular}

ETER MONOBUTILICO DE DIETLENGLICOL B Butoxidietilenglicol; butoxidiglicol; 2-(2-butoxietoxi)etanol; butilcarbitol; $\quad$ 112-34-5 éter glicol-n-butílico; éter monobutílico de diglicol

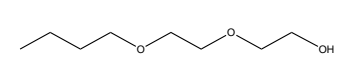

\begin{tabular}{|c|c|c|}
\hline ETER MONOBUTILLCO DE ETLLENGLICOL & $\begin{array}{l}\text { Butoxietanol; butilicellosolve; 2-butoxietanol; éter butílico de glicol; éter } \\
\text { monobutílico de glicol; éter monobutilico glicólico } \\
\text { UN2369 }\end{array}$ & $111-76 \cdot 2$ \\
\hline ETER MONOETILICO DE DIETILENGLICOL & Carbitol cellosolve; dietilenglicol etílico; 2-(2-etoxietoxi) etanol & $111-90-0$ \\
\hline ETER MONOMETILICO DE DIETILENGLICOL & $\begin{array}{l}\text { Eter monometílico de glicol dietilénico; Dowanol DM; éter monometílico de } \\
\text { etilendiglicol; metoxidiglicol }\end{array}$ & $111-77-3$ \\
\hline ETER MONOMETILICO DE PROPILENGLICOL & $\begin{array}{l}\text { Eter glicólico PM; metoxiéter del propilenglicol; 1-metoxi-2-propanol; } \\
\text { disolvente Propasol M; éter metílico de propilenglicol; } \\
\text { éter monometilico de propilenglicol } \\
\text { UN3092 }\end{array}$ & $107-98-2$ \\
\hline ETER MONOPROPILICO DE ETILENGLICOL & Ektasolve EP; 2-propoxietanol; propilcellosolve & $2807-30-9$ \\
\hline
\end{tabular}

\begin{tabular}{|c|c|c|c|c|c|c|}
\hline \multirow[b]{2}{*}{$\begin{array}{l}\text { Denominación } \\
\text { química } \\
\text { N úmero CAS }\end{array}$} & \multicolumn{4}{|c|}{ Tarjetas Internacionales sobre la Seguridad de los Productos Q uímicos } & \multicolumn{2}{|c|}{ N IO SH (EE.UU.) } \\
\hline & $\begin{array}{l}\text { Período } \\
\text { corto de } \\
\text { exposición }\end{array}$ & $\begin{array}{l}\text { Período } \\
\text { largo de } \\
\text { exposición }\end{array}$ & $\begin{array}{l}\text { Vías de } \\
\text { exposición }\end{array}$ & Síntomas & $\begin{array}{l}\text { O rganos } \\
\text { afectados } \\
\text { Vías de } \\
\text { entrada }\end{array}$ & Síntomas \\
\hline $\begin{array}{l}\text { ACETATO DE ETER ETILICO DE } \\
\text { ETILENGLCOL } \\
111-15-9\end{array}$ & SNC; sangre & hígado; riñones & $\begin{array}{r}\text { Inhalación } \\
\text { Piel } \\
\text { 0jos } \\
\text { Ingestión }\end{array}$ & $\begin{array}{l}\text { Tos, sopor, cefalea, náuseas, disnea, dolor de } \\
\text { garganta, vómitos } \\
\text { Puede absorberse, mareo, cefalea, náuseas y } \\
\text { vómitos } \\
\text { Visión borrosa } \\
\text { Dolor abdominal, sopor, cefalea, náuseas, } \\
\text { vómitos }\end{array}$ & $\begin{array}{l}\text { Sis resp; ojos; tract } \\
\text { Gl; sis repro; sis } \\
\text { hemat } \\
\text { Inh; abs; ing; con }\end{array}$ & $\begin{array}{l}\text { Irrit ojos, nariz; vómit; } \\
\text { lesiones renales; pará; en } \\
\text { animales: efectos repro, terato }\end{array}$ \\
\hline $\begin{array}{l}\text { ACETATO DE ETER } \\
\text { MONOBUTILICO DE } \\
\text { ETILENGLICOL } \\
112.07-2\end{array}$ & $\begin{array}{l}\text { ojos; piel; } \\
\text { tract resp; riñones; } \\
\text { sangre }\end{array}$ & $\begin{array}{l}\text { piel; hígado; } \\
\text { médula osea }\end{array}$ & $\begin{array}{r}\text { Inhalación } \\
\text { Piel } \\
\text { 0jos }\end{array}$ & $\begin{array}{l}\text { Tos, cefalea, náuseas } \\
\text { Enrojecimiento } \\
\text { Enrojecimiento }\end{array}$ & $\begin{array}{l}\text { Ojos; piel; sis resp; } \\
\text { SNC; sis hemato; } \\
\text { sangre; riñones; } \\
\text { hígado; sis linf } \\
\text { Inh }\end{array}$ & $\begin{array}{l}\text { Irrit ojos, piel, nariz, garganta; } \\
\text { hemólisis, hemog; depres } \\
\text { SNC, cef, vómit }\end{array}$ \\
\hline
\end{tabular}


Tabla 104.74 - Riesgos para la salud

Tarjetas Internacionales sobre la Seguridad de los Productos Q uímicos

\begin{tabular}{|c|c|c|c|c|c|c|}
\hline $\begin{array}{l}\text { Denominación } \\
\text { química } \\
\mathrm{N} \text { úmero CAS }\end{array}$ & $\begin{array}{l}\text { Período } \\
\text { corto de } \\
\text { exposición }\end{array}$ & $\begin{array}{l}\text { Período } \\
\text { largo de } \\
\text { exposición }\end{array}$ & $\begin{array}{l}\text { Vías de } \\
\text { exposición }\end{array}$ & Síntomas & $\begin{array}{l}\text { O rganos } \\
\text { afectados } \\
\text { Vías de } \\
\text { entrada }\end{array}$ & Síntomas \\
\hline $\begin{array}{l}\text { ACETATO DE ETER } \\
\text { MONOMETILICO DE } \\
\text { ETILENGLICOL } \\
110-49-6\end{array}$ & SNC & $\begin{array}{l}\text { piel; hígado; } \\
\text { riñones; sangre }\end{array}$ & $\begin{array}{r}\text { Inhalación } \\
\text { Piel } \\
\text { 0jos } \\
\text { Ingestión }\end{array}$ & $\begin{array}{l}\text { Confusión, mareo, cefalea, náuseas, } \\
\text { inconsciencia, vómitos, debilidad } \\
\text { Vértigos, dolor de cabeza, náuseas, vómitos } \\
\text { Visión borrosa } \\
\text { Dolor abdominal, sensación de quemazón, } \\
\text { confusión, mareo, cefalea, náuseas, } \\
\text { inconsciencia }\end{array}$ & $\begin{array}{l}\text { Ojos; sis resp; } \\
\text { riñones; cerebro; } \\
\text { SNC; SNP; sis repro; } \\
\text { sis hemato } \\
\text { Inh; abs; ing; con }\end{array}$ & $\begin{array}{l}\text { Irrit ojos, nariz, garganta; } \\
\text { lesiones renales, cerebrales; } \\
\text { en animales: narco; efectos } \\
\text { repro, terato }\end{array}$ \\
\hline $\begin{array}{l}\text { ETER DIETILICO DE } \\
\text { DIETILENGLLCOL } \\
112-36-7\end{array}$ & ojos; piel; tract resp & & $\begin{array}{r}\text { Inhalación } \\
\text { Piel } \\
\text { Ojos } \\
\text { Ingestión }\end{array}$ & $\begin{array}{l}\text { Tos } \\
\text { Enrojecimiento } \\
\text { Enrojecimiento } \\
\text { Diarrea, cefalea, náuseas, vómitos }\end{array}$ & & \\
\hline
\end{tabular}

\begin{tabular}{|c|c|c|c|c|c|c|}
\hline $\begin{array}{l}\text { ETER DIGLICIDILICO } \\
\text { DE 1,4-BUTANODIOL }\end{array}$ & $\begin{array}{l}\text { ojos; pies; } \\
\text { tract resp; } \\
\text { pulmones }\end{array}$ & piel & & & & \\
\hline $\begin{array}{l}\text { ETER DIGLICIDILICO } \\
\text { DE DIETILENGLICOL } \\
4206-61-5\end{array}$ & pulmones & $\begin{array}{l}\text { piel; SNC; sangre; } \\
\text { riñones }\end{array}$ & & & & \\
\hline $\begin{array}{l}\text { ETER FENILICO DE } \\
\text { ETILENGLICOL } \\
122-99.6\end{array}$ & ojos; piel & & $\begin{array}{r}\text { Inhalación } \\
\text { Piel } \\
\text { Ojos } \\
\text { Ingestión }\end{array}$ & $\begin{array}{l}\text { Dolor de garganta } \\
\text { Enrojecimiento } \\
\text { Enrojecimiento, dolor } \\
\text { Dolor abdominal, dolor de garganta }\end{array}$ & & \\
\hline $\begin{array}{l}\text { ETER METILICO DE } \\
\text { DIPROPILENGLICOL } \\
34590-94-8 \\
\end{array}$ & & & Piel & Sequedad de piel & $\begin{array}{l}\text { Sis resp; ojos; SNC } \\
\text { Inh; abs; ing; con }\end{array}$ & $\begin{array}{l}\text { Irrit ojos, nariz, garganta; deb, } \\
\text { atur, cef }\end{array}$ \\
\hline $\begin{array}{l}\text { ETER METILICO } \\
\text { DE ETILENGLICOL } \\
109-86-4\end{array}$ & $\begin{array}{l}\text { ojos; tract resp; } \\
\text { SNC; hígado; } \\
\text { riñones }\end{array}$ & & $\begin{array}{l}\text { Inhalación } \\
\text { Piel } \\
\text { Ojos }\end{array}$ & $\begin{array}{l}\text { Confusión, mareo, cefalea, náuseas, } \\
\text { inconsciencia, vómitos, debilidad } \\
\text { Puede absorberse } \\
\text { Visión borrosa }\end{array}$ & $\begin{array}{l}\text { Ojos; sis resp; SNC; } \\
\text { sangre; riñones; sis } \\
\text { repro; sis hemato } \\
\text { Inh; abs; ing; con }\end{array}$ & $\begin{array}{l}\text { Irrit ojos, nariz, garganta; cef, } \\
\text { sop, deb; ataxia, temblores, } \\
\text { som; palidez anémica, en } \\
\text { animales: efectos repro, terato }\end{array}$ \\
\hline $\begin{array}{l}\text { ETER MONOBUTILICO } \\
\text { DE DIETILENGLICOL } \\
112-34-5\end{array}$ & ojos; piel; SNC & piel & $\begin{array}{r}\text { Piel } \\
\text { Ojos } \\
\text { Ingestión } \\
\end{array}$ & $\begin{array}{l}\text { Puede absorberse, enrojecimiento } \\
\text { Enrojecimiento, dolor } \\
\text { Cefalea, inconsciencia, vómitos }\end{array}$ & & \\
\hline $\begin{array}{l}\text { ETER MONOBUTILICO } \\
\text { DE ETILENGLICOL } \\
\quad 111-76-2\end{array}$ & $\begin{array}{l}\text { ojos; piel; } \\
\text { tract resp; SNC; } \\
\text { hígado; riñones }\end{array}$ & piel & $\begin{array}{r}\text { Inhalación } \\
\text { Piel } \\
\text { Ojos } \\
\text { Ingestión }\end{array}$ & $\begin{array}{l}\text { Tos, sopor, cefalea, náuseas } \\
\text { Puede absorberse, sequedad de piel } \\
\text { Enrojecimiento, dolor, visión borrosa } \\
\text { Dolor abdominal, diarrea, náuseas, vómitos }\end{array}$ & $\begin{array}{l}\text { Hígado; riñones; sis } \\
\text { linf; piel; sangre; } \\
\text { ojos; sis resp; sist } \\
\text { hemato; SNC } \\
\text { Inh; abs; ing; con. }\end{array}$ & $\begin{array}{l}\text { Irrit ojos, piel, nariz, garganta; } \\
\text { hemólisis, hemog; depres } \\
\text { SNC, cef, vómit }\end{array}$ \\
\hline
\end{tabular}

\begin{tabular}{|c|c|c|c|c|c|c|}
\hline $\begin{array}{l}\text { ETER MONOETILICO } \\
\text { DE DIETILENGLICOL } \\
111-90-0\end{array}$ & pulmones & piel & & & & \\
\hline $\begin{array}{l}\text { ETER MONOMETILICO } \\
\text { DE DIETILENGLICOL } \\
111-77-3\end{array}$ & ojos; piel; tract resp & $\begin{array}{l}\text { piel; pulmones; } \\
\text { puede deteriorar la } \\
\text { fertilidad masculina }\end{array}$ & $\begin{array}{l}\text { Piel } \\
\text { Ojos }\end{array}$ & $\begin{array}{l}\text { Enrojecimiento, aspereza } \\
\text { Enrojecimiento }\end{array}$ & & \\
\hline $\begin{array}{l}\text { ETER MONOMETILICO } \\
\text { DE PROPILENGLICOL } \\
107-98-2\end{array}$ & $\begin{array}{l}\text { ojos; piel; } \\
\text { tract resp; nariz; } \\
\text { garganta; SNC }\end{array}$ & & $\begin{array}{r}\text { Inhalación } \\
\text { Piel } \\
\text { 0jos } \\
\text { Ingestión }\end{array}$ & $\begin{array}{l}\text { Mareo, sopor, cefalea, náuseas } \\
\text { Sequedad de piel, enrojecimiento } \\
\text { Lagrimeo, enrojecimiento } \\
\text { Diarrea, sopor, cefalea, náuseas, vómitos, } \\
\text { descoordinación o posible inconsciencia }\end{array}$ & $\begin{array}{l}\text { Ojos; piel; sis resp; } \\
\text { SNC } \\
\text { Inh; ing; con }\end{array}$ & $\begin{array}{l}\text { Irrit ojos, piel, nariz, garganta; } \\
\text { cef, náu, atur, sop, desco, } \\
\text { vómit, diarr. }\end{array}$ \\
\hline
\end{tabular}




\begin{tabular}{|c|c|c|c|c|c|c|}
\hline \multirow[b]{2}{*}{$\begin{array}{l}\text { Denominación } \\
\text { química } \\
\mathrm{N} \text { úmero CAS }\end{array}$} & \multicolumn{4}{|c|}{ Tarjetas Internacionales sobre la Seguridad de los Productos Q uímicos } & \multicolumn{2}{|c|}{ N IO SH (EE.UU.) } \\
\hline & $\begin{array}{l}\text { Período } \\
\text { corto de } \\
\text { exposición }\end{array}$ & $\begin{array}{l}\text { Período } \\
\text { largo de } \\
\text { exposición }\end{array}$ & $\begin{array}{l}\text { Vías de } \\
\text { exposición }\end{array}$ & Síntomas & $\begin{array}{l}\text { O rganos } \\
\text { afectados } \\
\text { Vías de } \\
\text { entrada }\end{array}$ & Síntomas \\
\hline $\begin{array}{l}\text { ETER MONOPROPILLCO } \\
\text { DE ETILENGLICOL } \\
2807-30-9\end{array}$ & $\begin{array}{l}\text { ojos; piel; } \\
\text { tract resp; } \\
\text { pulmones }\end{array}$ & $\begin{array}{l}\text { sangre; bazo; } \\
\text { riñones }\end{array}$ & $\begin{array}{r}\text { Inhalación } \\
\text { Piel } \\
\text { Ojos } \\
\text { Ingestión }\end{array}$ & $\begin{array}{l}\text { Confusión, tos, cefalea, náuseas, dolor de } \\
\text { garganta, los síntomas pueden tardar en } \\
\text { aparecer } \\
\text { Enrojecimiento, sensación de quemazón } \\
\text { Enrojecimiento, dolor } \\
\text { Confusión, diarrea, cefalea, náuseas, vómitos }\end{array}$ & & \\
\hline $\begin{array}{c}\text { 2-ETOXIETANOL } \\
110-80-5\end{array}$ & $\begin{array}{l}\text { ojos; piel; } \\
\text { tract resp; SNC; } \\
\text { hígado; riñones }\end{array}$ & $\begin{array}{l}\text { piel; fertilidad } \\
\text { masculina; defectos } \\
\text { congénitos }\end{array}$ & $\begin{array}{r}\text { Inhalación } \\
\text { Piel } \\
\text { 0jos } \\
\text { Ingestión }\end{array}$ & $\begin{array}{l}\text { Tos, sopor, cefalea, disnea, dolor de garganta, } \\
\text { debilidad } \\
\text { Puede absorberse } \\
\text { Visión borrosa } \\
\text { Dolor abdominal, náuseas, vómitos }\end{array}$ & $\begin{array}{l}\text { Sis resp; ojos; } \\
\text { sangre; riñones; } \\
\text { hígado; sis repro; } \\
\text { sis hemato } \\
\text { Inh; abs; ing; con }\end{array}$ & $\begin{array}{l}\text { En animales: irrit ojos, sis } \\
\text { resp; cambios hemáticos; } \\
\text { lesiones hepáticas, renales, } \\
\text { pulmonares; efectos repro, } \\
\text { terato }\end{array}$ \\
\hline
\end{tabular}

\begin{tabular}{|c|c|c|c|}
\hline $\begin{array}{l}\text { Denominación química } \\
N \text { úmero CAS }\end{array}$ & Físicos & Q uímicos & $\begin{array}{l}\text { Clase o división } \\
\text { UN / Riesgos } \\
\text { subsidiarios }\end{array}$ \\
\hline $\begin{array}{l}\text { ACETATO DE ETER ETILICO DE } \\
\text { ETILENGLICOL } \\
111-15-9\end{array}$ & $\begin{array}{l}\text { - El vapor es más pesado } \\
\text { que el aire }\end{array}$ & - Reacciona con oxidantes fuertes, con peligro de incendio y explosión & 3 \\
\hline $\begin{array}{l}\text { ACETATO DE ETER MONOBUTILICO } \\
\text { DE ETILENGLICOL } \\
112-07-2\end{array}$ & $\begin{array}{l}\text { - El vapor se mezcla bien } \\
\text { con el aire }\end{array}$ & - Reacciona con oxidantes fuertes, con peligro de incendio y explosión & \\
\hline $\begin{array}{l}\text { ACETATO DE ETER MONOMETILICO } \\
\text { DE ETILENGLICOL } \\
110-49 \cdot 6\end{array}$ & & & 3 \\
\hline $\begin{array}{l}\text { ETER DIETILLCO DE DIETILENGLICOL } \\
\text { 112-36-7 }\end{array}$ & & $\begin{array}{l}\text { - Puede formar peróxidos explosivos • Al calentarse } 0 \text { al arder, produce humos acres y vapores } \\
\text { irritantes • Reacciona con oxidantes fuertes }\end{array}$ & \\
\hline $\begin{array}{l}\text { ETER DIETLLICO DE ETLLENGLICOL } \\
\text { 629-14-1 }\end{array}$ & & & 3 \\
\hline $\begin{array}{l}\text { ETER FENLLICO DE ETLLENGLICOL } \\
122-99.6\end{array}$ & $\begin{array}{l}\text { - El vapor es más pesado } \\
\text { que el aire }\end{array}$ & - Reacciona con oxidantes & \\
\hline $\begin{array}{l}\text { ETER METILICO DE DIETILENGLICOL } \\
111-77 \cdot 3\end{array}$ & & - Presumiblemente puede formar peróxidos explosivos $\bullet$ Reacciona con oxidantes fuertes & \\
\hline $\begin{array}{l}\text { ETER METILICO DE DIPROPILENGLICOL } \\
\text { 34590-94-8 }\end{array}$ & & $\begin{array}{l}\text { - Presumiblemente puede formar peróxidos explosivos en contacto con el aire • Reacciona } \\
\text { violentamente con oxidantes fuertes }\end{array}$ & \\
\hline $\begin{array}{l}\text { ETER METILICO DE ETLLENGLICOL } \\
\text { 109-86-4 }\end{array}$ & & $\begin{array}{l}\text { - Puede formar peróxidos explosivos } \bullet \text { Se descompone al arder y en contacto con cáusticos } \\
\text { fuertes, produciendo vapores tóxicos • Reacciona con oxidantes fuertes, con peligro de incendio } \\
\text { y explosión }\end{array}$ & 3 \\
\hline $\begin{array}{l}\text { ETER MONOBUTILLCO DE DIETILENGLICOL } \\
112-34-5\end{array}$ & & - Reacciona con oxidantes fuertes, con peligro de incendio y explosión & \\
\hline $\begin{array}{l}\text { ETER MONOBUTLLICO DE ETLLENGLICOL } \\
111.76 .2\end{array}$ & & $\begin{array}{l}\text { - Puede formar peróxidos explosivos } \bullet \text { Se descompone liberando vapores tóxicos } \bullet \text { Reacciona } \\
\text { con oxidantes fuertes, con peligro de incendio y explosión }\end{array}$ & 6.1 \\
\hline $\begin{array}{l}\text { ETER MONOMETLLCO DE } \\
\text { PROPILENGLICOL } \\
107-98-2\end{array}$ & & - Presumiblemente puede formar peróxidos explosivos • Reacciona con oxidantes fuertes & \\
\hline
\end{tabular}




\begin{tabular}{|c|c|c|c|}
\hline $\begin{array}{l}\text { Denominación química } \\
\text { N úmero CAS }\end{array}$ & Físicos & Q uímicos & $\begin{array}{l}\text { Clase o división } \\
\text { UN / Riesgos } \\
\text { subsidiarios }\end{array}$ \\
\hline $\begin{array}{l}\text { ETER MONOPROPILICO DE ETILENGLICOL } \\
2807-30-9\end{array}$ & $\begin{array}{l}\text { - El vapor es más pesado } \\
\text { que el aire y puede } \\
\text { desplazarse a ras de suelo; } \\
\text { posibilidad de ignición a } \\
\text { distancia }\end{array}$ & & \\
\hline $\begin{array}{c}\text { 2-ETOXIETANOL } \\
110-80-5\end{array}$ & & $\begin{array}{l}\text { - Puede formar peróxidos explosivos } \bullet \text { Se descompone al arder liberando vapores tóxicos } \\
\text { - Reacciona con oxidantes fuertes, con peligro de incendio y explosión } \bullet \text { Ataca muchos plásticos } \\
\text { y caucho }\end{array}$ & 3 \\
\hline
\end{tabular}

Tabla 104.76 • Propiedades físicas y químicas.

\begin{tabular}{|c|c|c|c|c|c|c|c|c|c|c|c|}
\hline $\begin{array}{l}\text { Denominación química } \\
\mathrm{N} \text { úmero CAS }\end{array}$ & Color/ Forma & $\begin{array}{l}\text { p.e. } \\
\left({ }^{\circ} \mathrm{C}\right)\end{array}$ & $\begin{array}{l}\text { p.f. } \\
(\underline{O C})\end{array}$ & $\begin{array}{l}\text { p.m.l } \\
\text { (g/ } \\
\text { mol) }\end{array}$ & $\begin{array}{l}\text { Solubilidad } \\
\text { en agua }\end{array}$ & $\begin{array}{l}\text { Densidad } \\
\text { relativa } \\
\text { (agua }=1 \text { ) }\end{array}$ & $\begin{array}{l}\text { Densidad } \\
\text { relativa } \\
\text { del vapor } \\
\text { (aire=1) }\end{array}$ & $\begin{array}{l}\text { Pvap/ } \\
(\mathrm{kPa})\end{array}$ & $\begin{array}{l}\text { Límit. } \\
\text { inflam. }\end{array}$ & $\begin{array}{l}\text { p.ig. } \\
(\stackrel{\circ}{ } \mathrm{C})\end{array}$ & $\begin{array}{l}\text { p.aut } \\
\text { ig. } \\
\left({ }^{\circ} \mathrm{C}\right)\end{array}$ \\
\hline $\begin{array}{l}\text { ACETATO DE ETER ETILICO DE } \\
\text { ETLENGLICOL } \\
111-15-9\end{array}$ & líquido incoloro & 156 & $-61,7$ & 132,2 & muy sol & 0,9740 & 4,72 & 0,16 & $\begin{array}{l}1,7 \mathrm{li} \\
13,0 \mathrm{ls}\end{array}$ & $52 \mathrm{cc}$ & 379 \\
\hline $\begin{array}{l}\text { ACETATO DE ETER MONOBUTILICO } \\
\text { DE DIETILENGLICOL } \\
\text { 124-17-4 }\end{array}$ & líquido transparente & 245 & -32 & 204,30 & sol & 0,985 & & $\begin{array}{l}<0,01 \\
\mathrm{~mm} \mathrm{Hg}\end{array}$ & & & \\
\hline $\begin{array}{l}\text { ACETATO DE ETER MONOBUTILICO } \\
\text { DE ETILENGLICOL } \\
112.07-2\end{array}$ & líquido incoloro & 192,3 & $.64,5$ & 160,24 & $1,1 \mathrm{~g} / 100 \mathrm{~g}$ & 0,9422 & 5,5 & $30-40 \mathrm{~Pa}$ & $\begin{array}{l}0,88 \\
@ 93{ }^{\circ} \mathrm{Cli} \\
8,54 \\
@ 135^{\circ} \mathrm{C} \\
\text { ls }\end{array}$ & $71 \mathrm{cc}$ & 340 \\
\hline $\begin{array}{l}\text { ACETATO DE ETER MONOMETILICO } \\
\text { DE ETILENGLICOL } \\
110-49-6\end{array}$ & líquido incoloro & 143 & $-65,1$ & 118,13 & muy sol & $\begin{array}{l}1,0090 \\
@ 19^{\circ} \mathrm{Cl} \\
19^{\circ} \mathrm{C}\end{array}$ & 4,1 & 0,44 & $\begin{array}{l}1,7 \mathrm{li} \\
8,2 \mathrm{is}\end{array}$ & $45 \mathrm{cc}$ & 394 \\
\hline $\begin{array}{l}\text { ETER DIETILICO DE DIETLLENGLICOL } \\
112-36-7\end{array}$ & líquido incoloro & 189 & $-44,3$ & 162,22 & muy sol & 0,907 & 5,6 & $79 \mathrm{~Pa}$ & & $71 \mathrm{cc}$ & 174 \\
\hline $\begin{array}{l}\text { ETER DIETILICO DE DIETILENGLICOL } \\
\text { 629-14-1 }\end{array}$ & líquido incoloro & 123,5 & .74 & 118,2 & $2 \%$ & 0,8484 & 4,07 & $9,4 \mathrm{~mm} \mathrm{Hg}$ & & & \\
\hline $\begin{array}{l}\text { ETER DIGLICIDILLCO DE } \\
\text { 1,4-BUTANODIOL } \\
2425-79-8\end{array}$ & & 266 & & $-202,28$ & & $1,1 @ 25^{\circ} \mathrm{C}$ & & & & & \\
\hline $\begin{array}{l}\text { ETER FENILLCO DE ETLLENGLICOL } \\
122.99-6\end{array}$ & $\begin{array}{l}\text { líquido oleaginoso; } \\
\text { líquido incoloro }\end{array}$ & 245 & 14 & 138,16 & insol & 1,1094 & 4,8 & 5,2 & $\begin{array}{l}1,4 \mathrm{li} \\
9,0 \mathrm{is}\end{array}$ & 121 & \\
\hline $\begin{array}{l}\text { ETER METLLICO DE } \\
\text { DIPROPILENGLCOL } \\
34590-94-8\end{array}$ & líquido incoloro & 190 & -80 & 148,2 & misc & $0,95 @ 25^{\circ} \mathrm{C}$ & 5,11 & $\begin{array}{l}53,2 \mathrm{~Pa} \\
@ 26^{\circ} \mathrm{C}\end{array}$ & $\begin{array}{l}1,3 \mathrm{li} \\
10,4 \mathrm{ls}\end{array}$ & $85 \mathrm{cc}$ & 270 \\
\hline $\begin{array}{l}\text { ETER METLLICO DE ETILENGLICOL } \\
109-86-4\end{array}$ & líquido incoloro & 125 & $-85,1$ & 76,09 & misc & 0,9647 & 2,62 & 0,83 & $\begin{array}{l}2,3 \mathrm{li} \\
24,5 \mathrm{ls}\end{array}$ & $42 \mathrm{cc}$ & 285 \\
\hline $\begin{array}{l}\text { ETER MONOBUTILICO } \\
\text { DE DIETILENGLICOL } \\
112-34-5\end{array}$ & líquido incoloro & 230,4 & $-68,1$ & 162,2 & misc & 0,9553 & 5,58 & $2,99 \mathrm{~Pa}$ & & 78 & 225 \\
\hline
\end{tabular}




\begin{tabular}{|c|c|c|c|c|c|c|c|c|c|c|c|}
\hline $\begin{array}{l}\text { Denominación química } \\
\text { N úmero CAS }\end{array}$ & Color/ Forma & $\begin{array}{l}\text { p.e. } \\
\left({ }^{\circ} \mathrm{C}\right)\end{array}$ & $\begin{array}{l}\text { p.f. } \\
(\underline{O C})\end{array}$ & $\begin{array}{l}\mathrm{p} . \mathrm{m} . / \\
\text { (g/ } \\
\mathrm{mol})\end{array}$ & $\begin{array}{l}\text { Solubilidad } \\
\text { en agua }\end{array}$ & $\begin{array}{l}\text { Densidad } \\
\text { relativa } \\
\text { (agua }=1 \text { ) }\end{array}$ & $\begin{array}{l}\text { Densidad } \\
\text { relativa } \\
\text { del vapor } \\
\text { (aire=1) }\end{array}$ & $\begin{array}{l}\text { Pvap/ } \\
(\mathrm{kPa})\end{array}$ & $\begin{array}{l}\text { Límit. } \\
\text { inflam. }\end{array}$ & $\begin{array}{l}\text { p.ig. } \\
\left({ }^{\circ} \mathrm{C}\right)\end{array}$ & $\begin{array}{l}\text { p.aut } \\
\text { ig. } \\
\left({ }^{\circ} \mathrm{C}\right)\end{array}$ \\
\hline $\begin{array}{l}\text { ETER MONOBUTLLICO } \\
\text { DE ETILENGLICOL } \\
111.76-2\end{array}$ & líquido incoloro & $171-172$ & .75 & 118,2 & misc & 0,9015 & 4,1 & 0,10 & $\begin{array}{l}1,1 \\
@ 93{ }^{\circ} \mathrm{Cli} \\
12,7 \\
@ 135^{\circ} \mathrm{C} \\
\text { Is }\end{array}$ & $61 \mathrm{cc}$ & 238 \\
\hline $\begin{array}{l}\text { ETER MONOETLLICO } \\
\text { DE DIETLENGLICOL } \\
111-90-0\end{array}$ & líquido incoloro & 196 & & 134,17 & misc & 0,9881 & 4,62 & $\begin{array}{l}19 \mathrm{~Pa} \\
@ 25^{\circ} \mathrm{C}\end{array}$ & $\begin{array}{l}1,2 \\
@ 135{ }^{\circ} \mathrm{C} \\
\text { li } \\
23,5 \\
@ 182{ }^{\circ} \mathrm{C} \\
\text { Is }\end{array}$ & $96 \mathrm{ca}$ & 204 \\
\hline $\begin{array}{l}\text { ETER MONOMETILLCO } \\
\text { DE DIETILENGLICOL } \\
111-77-3\end{array}$ & líquido incoloro & 193 & $<-84$ & 120,1 & misc & 1,0270 & 4,14 & $30 \mathrm{~Pa}$ & $\begin{array}{l}1,6 \mathrm{li} \\
18,1 \mathrm{ls}\end{array}$ & $93 \mathrm{ca}$ & 215 \\
\hline $\begin{array}{l}\text { ETER MONOMETILICO } \\
\text { DE PROPILENGLICOL } \\
107-98.2\end{array}$ & líquido incoloro & $\begin{array}{l}118-118,5 \\
@ 740 \mathrm{~mm} \mathrm{Hg}\end{array}$ & $-96,7$ & 90,1 & muy sol & 0,9620 & 3,11 & 1,6 & $\begin{array}{l}1,6 \mathrm{li} \\
13,8 \mathrm{ls}\end{array}$ & $38 \mathrm{ca}$ & \\
\hline $\begin{array}{l}\text { ETER MONOPROPILICO } \\
\text { DE ETILENGLICOL } \\
2807-30-9\end{array}$ & líquido volátil & 149,8 & $<.70$ & 104,1 & sol & 0,9112 & 3,6 & $200 \mathrm{~Pa}$ & $\begin{array}{l}5,5 \mathrm{li} \\
23 \mathrm{ls}\end{array}$ & 49 & 230 \\
\hline $\begin{array}{c}\text { 2-ETOXIETANOL } \\
110-80-5\end{array}$ & líquido incoloro & 135 & .70 & 90,12 & muy sol & 0,9297 & 3,1 & 0,5 & $\begin{array}{l}1,7 \\
@ 93^{\circ} \mathrm{Cli} \\
15,6 \\
@ 93^{\circ} \mathrm{Cls}\end{array}$ & $44 \mathrm{CC}$ & 235 \\
\hline
\end{tabular}




\section{GLICEROLES Y GLICOLES}

\section{Usos}

M uchas de las aplicaciones industriales de los glicoles y los gliceroles se basan en su propiedad de ser disolventes orgánicos completamente hidrosolubles. Estos compuestos se utilizan como disolventes de colorantes, pinturas, resinas, tintas, insecticidas y productos farmacéuticos. Además, los dos grupos hidroxilo químicamente reactivos hacen de los glicoles intermediarios químicos importantes. Entre los muchos usos de los glicoles y poliglicoles, los más importantes son la disminución del punto de congelación, la lubricación y la solubilización. Los glicoles se emplean también como aditivos alimentarios directos o indirectos y como ingredientes en la preparación de explosivos y resinas alquídicas, humos teatrales y cosméticos.

EI propilenglicol se utiliza mucho en productos farmacéuticos, en cosméticos, como humectante de ciertos alimentos y como lubricante. También se emplea como líquido de termotransferencia cuando existe el riesgo de que una fuga pueda entrar en contacto con alimentos; por ejemplo, refrigerantes para equipos de refrigeración de productos lácteos. También se utiliza como disolvente de colorantes y aromas alimentarios, como anticongelante en fábricas cerveceras y establecimientos y como aditivo para mejorar la estabilidad de las pinturas de látex frente a la congelación-descongelación. El propilenglicol, el etilenglicol y el 1,3-butanodiol son componentes de líquidos descongelantes utilizados en aeronáutica. El tripropilenglicol y el 2,3-butanodiol son disolventes de colorantes. Los butanodioles (butilenglicoles) se utilizan en la producción de resinas de poliéster.

El etilenglicol se emplea como anticongelante en sistemas de refrigeración y calefacción, como disolvente en las industrias de pinturas y plásticos y como ingrediente de los líquidos descongelantes utilizados en las pistas de los aeropuertos. Se utiliza en líquidos hidráulicos para frenos, en la dinamita de bajo punto de congelación, en tintes para madera, en adhesivos, en tintes para el cuero y en el tabaco. También sirve como deshidratante del gas natural, como disolvente de tintas y pesticidas y como ingrediente de condensadores electrolíticos. El dietilenglicol es un humectante para el tabaco, la caseína, las esponjas sintéticas y los productos de papel. También se encuentra en compuestos de corcho, adhesivos de encuadernación, líquidos de freno, lacas de barnizado, cosméticos y soluciones anticongelantes para sistemas de aspersión. El dietilenglicol se utiliza en las juntas hidráulicas de los depósitos de gas, para la lubricación y el acabado de tejidos, como disolvente de colorantes de tina y como agente deshidratante del gas natural. El trietilenglicol es un disolvente y lubricante para el teñido y la estampación de tejidos. También se utiliza para la desinfección del aire y para mejorar la flexibilidad de algunos plásticos. El trietilenglicol sirve como humectante en la industria del tabaco y es un producto químico intermedio en la fabricación de plastificantes, resinas, emulsionantes, lubricantes y explosivos.

La versatilidad del glicerol se refleja en los casi 1.700 usos de este compuesto y sus derivados. El glicerol se utiliza en alimentos, productos farmacéuticos, artículos de perfumería y cosméticos. La naturaleza higroscópica de esta sustancia hace que sea ideal para su uso como humectante en muchos productos, como, por ejemplo, el tabaco, el hielo, las cremas dérmicas y las pastas de dientes, productos todos ellos que, de otra forma, podrían deteriorarse durante su almacenamiento a causa de la desecación.
Además, el glicerol es un lubricante que se añade a los chicles para facilitar su procesado, un plastificante del coco defibrado húmedo y un aditivo para mantener la humedad y suavidad de los productos farmacéuticos. Se emplea para evitar la formación de escarcha en los parabrisas y como anticongelante para automóviles, gasómetros y gatos hidráulicos. No obstante, el principal uso del glicerol es en la producción de resinas alquídicas para revestimientos superficiales. Estos se preparan condensando glicerol con un ácido dicarboxílico o anhídrido (normalmente anhídrido ftálico) y ácidos grasos. 0 tra aplicación importante del glicerol es la producción de explosivos, entre ellos la nitroglicerina y la dinamita.

\section{Glicerol}

El glicerol es un alcohol trihídrico y experimenta todas las reacciones características de los alcoholes. Los grupos hidroxilo poseen diversos grados de reactividad, siendo más reactivos los que ocupan las posiciones 1 y 3 que los de la posición 2. A provechando estas diferencias de reactividad y variando la proporción de los reactivos, se pueden obtener mono-, di- o tri-derivados. El glicerol se obtiene mediante hidrólisis de grasas o sintéticamente a partir del propileno. Los principales componentes de casi todos los aceites y grasas animales y vegetales son triglicéridos de ácidos grasos.

La hidrólisis de esos glicéridos produce ácidos grasos libres y glicerol. Se emplean dos técnicas: la hidrólisis alcalina (saponificación) y la hidrólisis neutra (fraccionamiento). En la saponificación, la grasa se hierve con hidróxido sódico y cloruro sódico, dando lugar a la formación de glicerol y sales sódicas de los ácidos grasos (jabones).

En la hidrólisis neutra, las grasas se hidrolizan en un horno 0 un autoclave a alta presión en un proceso semicontinuo o por lotes, o también en una torre a alta presión mediante una técnica de contracorriente continua. Existen dos procesos principales para la síntesis de glicerol a partir de propileno. En el primero, se trata el propileno con cloro para obtener cloruro de alilo, el cual reacciona con una solución de hipoclorito sódico para dar glicerol-diclorohidrina, a partir de la cual se obtiene el glicerol por hidrólisis alcalina. El segundo proceso consiste en oxidar el propileno para formar acroleína, la cual se reduce a alcohol alílico. Este compuesto puede hidroxilarse con peróxido de hidrógeno en solución acuosa para obtener glicerol directamente, o tratarse con hipoclorito sódico para obtener glicerol-monoclorohidrina que más tarde, mediante hidrólisis alcalina, se convierte en glicerol.

\section{Riesgos}

El glicerol es muy poco tóxico (en el ratón, la $\mathrm{DL}_{50}$ por vía oral es de $31,5 \mathrm{~g} / \mathrm{kg}$ ) y en general se le considera inofensivo en las condiciones normales de uso. La glicerina produce una leve diuresis en individuos sanos que reciben una única dosis oral igual o inferior a $1,5 \mathrm{~g} / \mathrm{kg}$. Los efectos nocivos que produce la administración oral de glicerina consisten en un ligero dolor de cabeza, mareo, náuseas, vómitos, sed y diarrea.

Cuando el glicerol se presenta en forma de niebla, la Conferencia Americana de Higienistas Industriales del Gobierno (ACGIH) lo ha clasificado como "partícula molesta", asignándole un TLV de $10 \mathrm{mg} / \mathrm{m}^{3}$. Además, la reactividad del glicerol le hace peligroso y propenso a explotar en contacto con oxidantes fuertes como el permanganato potásico, el clorato potásico, etc. Por ello, nunca debe almacenarse cerca de ese tipo de sustancias. 


\section{Los glicoles y sus derivados}

Los glicoles de interés comercial son compuestos alifáticos que poseen dos grupos hidroxilo por molécula. Son líquidos viscosos, incoloros y prácticamente inodoros. El etilenglicol y el dietilenglicol son los más importantes de todos los glicoles y sus derivados. Al final de este artículo se comenta la toxicidad y los riesgos que comportan ciertos grupos y compuestos importantes. Ninguno de los glicoles ni sus derivados estudiados han demostrado ser mutágenos, cancerígenos o teratógenos.

Los glicoles y sus derivados son líquidos inflamables. Sin embargo, sus puntos de ignición están por encima de la temperatura ambiente normal y sus vapores alcanzan concentraciones situadas dentro del rango inflamable o explosivo sólo cuando se calientan (p. ej., en hornos), razón por la cual entrañan un riesgo moderado de incendio.

Síntesis. El etilenglicol se produce para fines comerciales mediante oxidación al aire de etileno, seguida por la hidratación del óxido de etileno resultante. El dietilenglicol se obtiene como subproducto de la producción de etilenglicol. De manera similar, el propilenglicol y el 1,2-butanodiol se obtienen mediante hidratación del óxido de propileno y del óxido de butileno, respectivamente. El 2,3-butanodiol se obtiene mediante hidratación del 2,3-epoxibutano; el 1,3-butanodiol se obtiene mediante hidrogenación catalítica del aldol utilizando níquel Raney; y el 1,4-butanodiol se obtiene mediante reacción del acetileno con formaldehído, seguida de hidrogenación del 2-butino-1,4-diol resultante.

\section{Riesgos de los glicoles comunes}

E tilenglicol. La toxicidad oral del etilenglicol en animales es muy baja. Sin embargo, basándose en la experiencia clínica se ha estimado que la dosis letal para el ser humano adulto es de unos $100 \mathrm{~cm}^{3} 0$ alrededor de $1,6 \mathrm{~g} / \mathrm{kg}$, lo que indicaría que su potencia tóxica es mayor en el hombre que en los animales de laboratorio. Esta toxicidad se debe a los metabolitos, que varían según las diferentes especies. Los efectos típicos de la ingesta oral excesiva de etilenglicol son narcosis, depresión del centro respiratorio y afectación renal progresiva. Se han mantenido monos durante 3 años con dietas que contenían entre un 0,2 y un $0,5 \%$ de etilenglicol, sin que aparecieran efectos nocivos; en la vejiga de estos animales no se encontraron tumores, pero sí cristales de oxalato y litiasis. El etilenglicol generalmente produce una leve irritación de los ojos y la piel, pero en cantidades tóxicas, puede absorberse a través de la piel. La exposición de ratas y ratones durante 8 horas al día a lo largo de 16 semanas a concentraciones de entre 0,35 y $3,49 \mathrm{mg} /$ I no provocó lesiones orgánicas. A las concentraciones más altas, se formaron nieblas y gotas. Según eso, la exposición repetida del hombre a estos vapores a temperatura ambiente no parece entrañar ningún riesgo importante. En condiciones industriales razonables, ni la inhalación de vapores de etilenglicol a temperatura ambiente, ni el contacto oral o cutáneo, parecen comportar un riesgo marcado. No obstante, la inhalación de etilenglicol calentado o vigorosamente agitado (con formación de niebla), el contacto cutáneo importante o la ingestión durante períodos prolongados, podrían generar riesgos profesionales. El principal riesgo del etilenglicol para la salud está relacionado con la ingestión de grandes cantidades de este producto.
Dietilenglicol. El dietilenglicol es muy similar al etilenglicol en cuanto a su toxicidad, si bien no produce ácido oxálico y es más directamente tóxico para los riñones que el etilenglicol. Los síntomas característicos de la ingesta de dosis excesivas consisten en diuresis, sed, pérdida de apetito, narcosis, hipotermia, insuficiencia renal y muerte, dependiendo del grado de exposición. $R$ atones y ratas expuestos a concentraciones de dietilenglicol de $5 \mathrm{mg} / \mathrm{m}^{3}$ durante períodos de entre 3 y 7 meses experimentaron cambios en los sistemas nervioso central y endocrino y en sus órganos internos, así como otros cambios patológicos. Aunque el dietilenglicol no plantea problemas para la salud en la práctica, los animales alimentados con altas dosis de etilenglicol presentaron litiasis vesical y tumores, probablemente secundarios a las litiasis. Las litiasis podrían deberse al monoetilenglicol presente en las muestras. Al igual que el etilenglicol, el dietilenglicol no parece comportar un riesgo importante por inhalación de vapores a temperatura ambiente, ni por contacto cutáneo u oral en condiciones industriales razonables.

Propilenglicol. El propilenglicol es poco tóxico e higroscópico. En un estudio de 866 sujetos humanos resultó ser un irritante primario en algunas personas, probablemente por deshidratación. También puede provocar reacciones cutáneas alérgicas en más de un $2 \%$ de personas con eczema. La exposición prolongada de animales a atmósferas saturadas con propilenglicol no produce efectos detectables. Por su baja toxicidad, el propilenglicol se utiliza mucho en preparados farmacéuticos, cosméticos $\mathrm{y}$, con ciertas limitaciones, en productos alimenticios.

El dipropilenglicol es muy poco tóxico. No irrita la piel ni los ojos $y$, por su baja presión de vapor y su escasa toxicidad, no plantea problemas en caso de inhalación a menos que se calienten grandes cantidades en el interior de un espacio cerrado y de dimensiones reducidas.

Butanodioles. Existen cuatro isómeros, todos ellos solubles en agua, alcohol etílico y éter etílico. Son poco volátiles, de manera que su inhalación no plantea problemas en condiciones industriales normales. Con excepción del isómero 1,4-, los butanodioles no comportan riesgos industriales significativos.

En ratas, la exposición oral masiva por vía oral a 1,2-butanodiol provoca narcosis profunda e irritación del tracto digestivo, pudiendo aparecer también necrosis congestiva renal. Se piensa que la muerte puede sobrevenir por narcosis o bien, de forma tardía, por una insuficiencia renal progresiva. EI contacto de los ojos con 1,2-butanodiol puede provocar lesiones en la córnea pero, en cambio, el contacto prolongado con la piel suele ser inocuo por lo que se refiere a irritación primaria y toxicidad por absorción. No se han descrito efectos nocivos por la inhalación de vapores.

El 1,3-butanodiol carece prácticamente de toxicidad, salvo en dosis orales masivas, que producen narcosis.

Se sabe poco acerca de la toxicidad del 2,3-butanodiol, pero los escasos estudios animales publicados parecen indicar que ocupa un lugar intermedio entre los butanodioles 1,2- y 1,3-.

Las pruebas de toxicidad aguda realizadas indican que el 1,4-butanodiol es unas ocho veces más tóxico que el isómero 1,2-. La ingestión aguda produce narcosis grave y posibles lesiones renales. La muerte probablemente se deba al fracaso de los sistemas nerviosos simpático y parasimpático. No es un irritante primario, ni se absorbe fácilmente por vía percutánea. 
TABLAS DE GUCOLES Y GUCEROLES

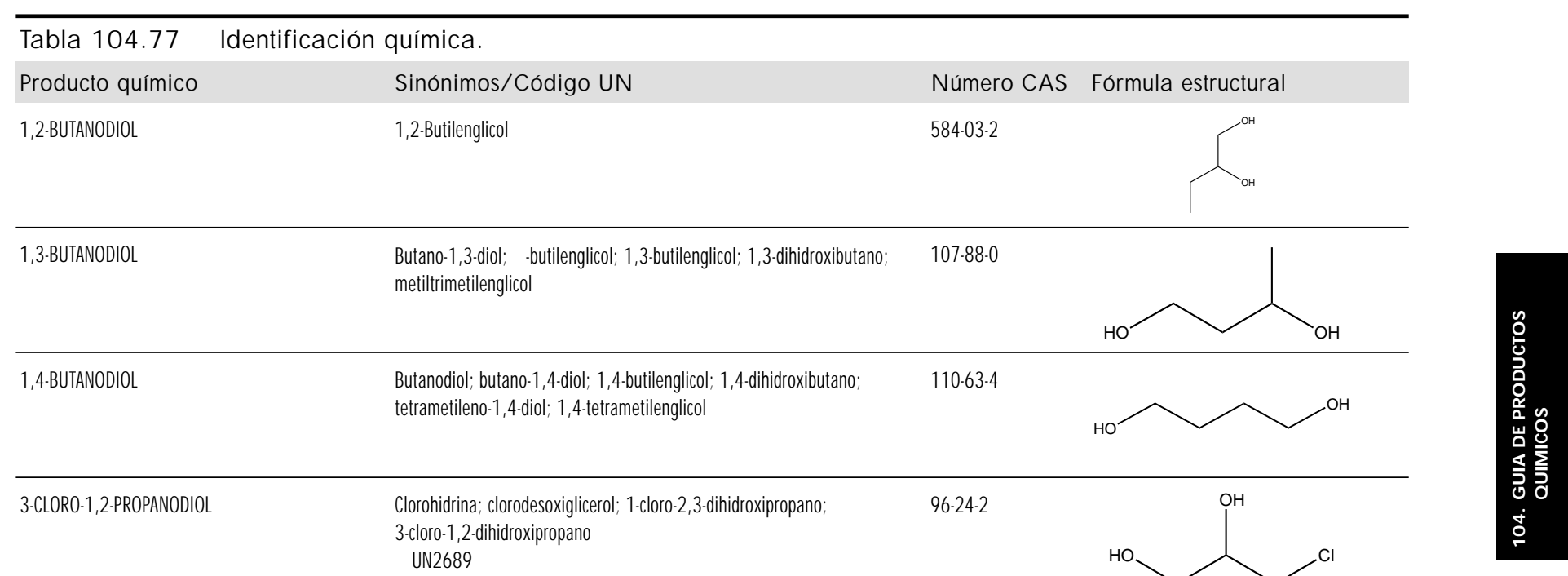

\begin{tabular}{ll}
\hline DIETILENGLICOL & Eter bis-(2-hidroxietilíco); éter dihidroxidietílico; éter 2,2'-dihidroxietilíco; $111-46-6$ \\
& etilendiglicol; éter glicólico; éter etílico de glicol; 3-oxapentano-1,5-diol; \\
3-0xa-1,5-pentanodiol; 2,2'-oxibisetanol; 2,2'-oxidietanol
\end{tabular}

DIMETILENGLICOL 2,3-Butanodiol; 2,3-butilenglicol; 2,3-dihidroxibutano

\begin{tabular}{lll}
\hline DIPROPILENGLICOL & Eter 2,2'-dihidroxidipropilíco; éter 2,2'-dihidroxiisopropilico; & $110-98-5$ \\
$1,1^{\prime}-$-oxidi-2-propanol &
\end{tabular}
$1,1^{\prime}$-oxidi-2-propanol

$110-98-5$

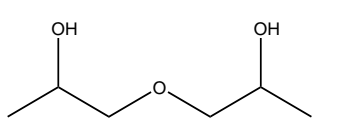

ETILENGLICOL

1,2-Dihidroxietano; 1,2-etandiol; 1,2-etanodiol; etano-1,2-diol; alcohol etilénico; dihidrato etilénico; glicol; alcohol glicólico; monoetilenglicol

$107-21-1$

Etilhexanodiol; 2-etilhexano-1,3-diol; 2-etilhexanodiol-1,3; $\quad 94-96-2$

\begin{tabular}{ll}
\hline 2-ETL-1,3-HEXANODIOL & $\begin{array}{l}\text { Etilhexanodiol; 2-etilhexano-1,3-diol; 2-etilhexanodiol-1,3; } \\
\text { etilhexilenglicol; 2-etil-3-propil-1,3-propanodiol; } \\
\text { 3-hidroximetil-n-heptano-4-0;; octilenglicol }\end{array}$ \\
\hline GLICEROL & $\begin{array}{l}\text { Glicerina; alcohol glicílico; 1,2,3-propanotriol; Star; Superol; glicerina } \\
\text { sintética; trihidroxipropano; 1,2,3-trihidroxipropano }\end{array}$ \\
\hline
\end{tabular}

\begin{tabular}{lll}
\hline $1,6-H E X A N O D I O L$ & Hexametilenglicol & $629-11-8$
\end{tabular}

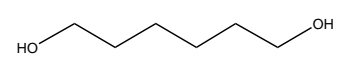

2,5-HEXANODIOL

$2935-44-6$

2,4-Dihidroxi-2-metilpentano; 2-metilpentano-2,4-diol;
HEXILENGLICOL<smiles>CC(O)CCC(C)O</smiles>

2,4-Dihidroxi-2-metilpen

$107-41-5$<smiles>CC(O)CC(C)(C)O</smiles> 


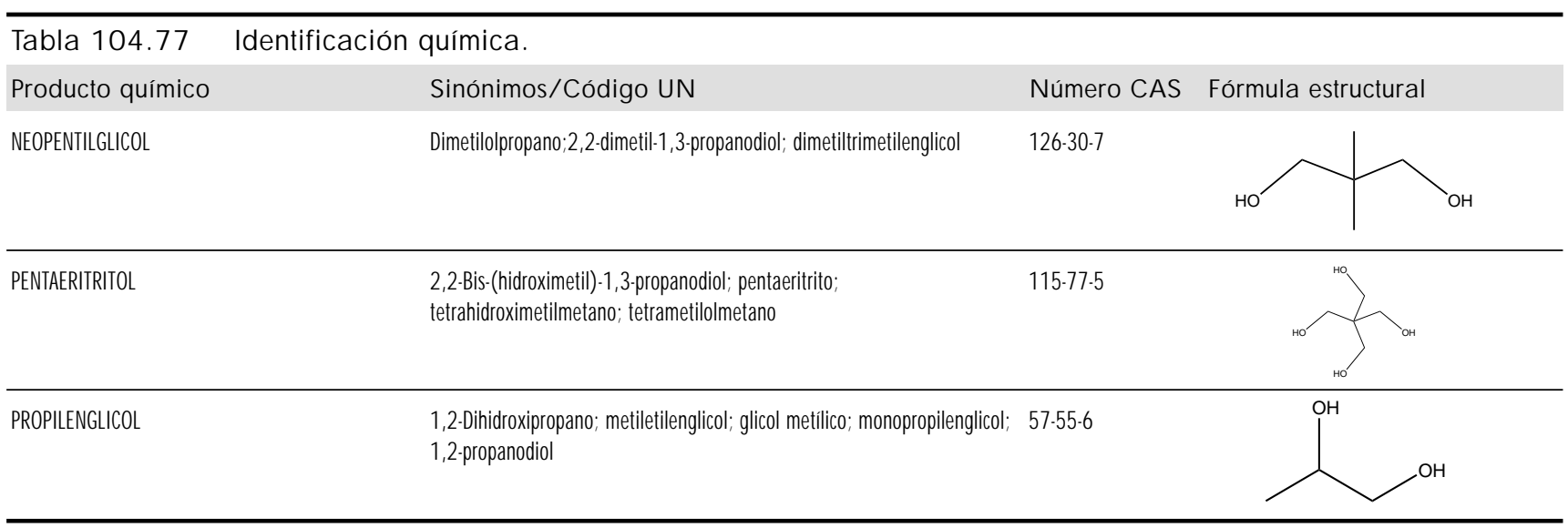

\begin{tabular}{|c|c|c|c|c|c|c|}
\hline \multirow[b]{2}{*}{$\begin{array}{l}\text { Denominación } \\
\text { química } \\
\text { N úmero CAS }\end{array}$} & \multicolumn{4}{|c|}{ Tarjetas Internacionales sobre la Seguridad de los Productos Q uímicos } & \multicolumn{2}{|c|}{ N IO SH (EE.UU.) } \\
\hline & $\begin{array}{l}\text { Período } \\
\text { corto de } \\
\text { exposición }\end{array}$ & $\begin{array}{l}\text { Período } \\
\text { largo de } \\
\text { exposición }\end{array}$ & $\begin{array}{l}\text { Vías de } \\
\text { exposición }\end{array}$ & Síntomas & $\begin{array}{l}\text { O rganos } \\
\text { afectados } \\
\text { Vías de } \\
\text { entrada }\end{array}$ & Síntomas \\
\hline $\begin{array}{l}\text { 1,3-BUTANODIOL } \\
107-88-0\end{array}$ & ojos; piel; tract resp & & $\begin{array}{r}\text { Inhalación } \\
\text { Piel } \\
\text { 0jos }\end{array}$ & $\begin{array}{l}\text { Tos } \\
\text { Enrojecimiento } \\
\text { Picores }\end{array}$ & & \\
\hline $\begin{array}{l}\text { 1,4-BUTANODIOL } \\
110-63-4\end{array}$ & $\begin{array}{l}\text { ojos; tract resp; } \\
\text { SNC; riñones }\end{array}$ & & $\begin{array}{r}\text { Inhalación } \\
\text { Ojos } \\
\text { Ingestión }\end{array}$ & $\begin{array}{l}\text { Tos, mareo, cefalea, inconsciencia } \\
\text { Enrojecimiento, irritación } \\
\text { Inconsciencia }\end{array}$ & & \\
\hline $\begin{array}{l}\text { DIETILENGLICOL } \\
111-46-6\end{array}$ & $\begin{array}{l}\text { ojos; piel; } \\
\text { tract resp; SNC; } \\
\text { hígado; riñones }\end{array}$ & higado; riñones & $\begin{array}{r}\text { Piel } \\
\text { Ojos } \\
\text { Ingestión }\end{array}$ & $\begin{array}{l}\text { Enrojecimiento } \\
\text { Enrojecimiento } \\
\text { Confusión, diarrea, mareo, sopor } \\
\text { náuseas, inconsciencia, vómitos }\end{array}$ & & \\
\hline $\begin{array}{l}\text { DIPROPILENGLICOL } \\
\text { 110-98.5 }\end{array}$ & ojos; piel; tract resp & piel & $\begin{array}{r}\text { Inhalación } \\
\text { Piel } \\
\text { 0jos }\end{array}$ & $\begin{array}{l}\text { Tos } \\
\text { Enrojecimiento } \\
\text { Enrojecimiento }\end{array}$ & & \\
\hline $\begin{array}{l}\text { ETILENGLICOL } \\
107-21-1\end{array}$ & $\begin{array}{l}\text { ojos; piel; } \\
\text { tract resp; riñones; } \\
\text { SNC }\end{array}$ & SNC; ojos & $\begin{array}{r}\text { Inhalación } \\
\text { Piel } \\
\text { 0jos } \\
\text { Ingestión }\end{array}$ & $\begin{array}{l}\text { Tos, mareo, cefalea } \\
\text { Sequedad de piel, enrojecimiento } \\
\text { Enrojecimiento } \\
\text { Dolor abdominal, embotamiento, náuseas, } \\
\text { inconsciencia, vómitos }\end{array}$ & $\begin{array}{l}\text { Ojos; piel; sis resp; } \\
\text { SNC } \\
\text { Inh; ing; con }\end{array}$ & $\begin{array}{l}\text { Irrit ojos, piel, nariz, garganta } \\
\text { náu, vómi, dolor abdom; deb; } \\
\text { mar, estupor, convuls, depres } \\
\text { SNC; sens cutánea }\end{array}$ \\
\hline $\begin{array}{l}\text { 1,6-HEXANODIOL } \\
\text { 629-11-8 }\end{array}$ & ojos; tract resp & & $\begin{array}{r}\text { Inhalación } \\
\text { 0jos }\end{array}$ & $\begin{array}{l}\text { Tos } \\
\text { Irritación, enrojecimiento }\end{array}$ & & \\
\hline $\begin{array}{l}2,5 \text {-HEXANODIOL } \\
2935-44-6\end{array}$ & ojos; piel; tract resp & piel; SNC & & & & \\
\hline $\begin{array}{l}\text { HEXILENGLICOL } \\
107-41-5\end{array}$ & ojos; piel & piel; riñones & $\begin{array}{r}\text { Inhalación } \\
\text { Piel } \\
\text { 0jos } \\
\text { Ingestión }\end{array}$ & $\begin{array}{l}\text { Tos } \\
\text { Sequedad de piel, enrojecimiento } \\
\text { Enrojecimiento } \\
\text { Espasmos abdominales, diarrea, náuseas, } \\
\text { vómitos }\end{array}$ & $\begin{array}{l}\text { Ojos; piel; sis resp } \\
\text { Inh; ing; con }\end{array}$ & $\begin{array}{l}\text { Irrit ojos, piel, sis resp; cef, } \\
\text { mar, náu, desco, depres SNC; } \\
\text { derm, sens cutánea }\end{array}$ \\
\hline $\begin{array}{l}\text { NEOPENTLLGLICOL } \\
126-30.7\end{array}$ & $\begin{array}{l}\text { ojos; piel; } \\
\text { tract resp; } \\
\text { pulmones }\end{array}$ & pulmones; riñones & & & & \\
\hline $\begin{array}{l}\text { PROPILENGLICOL } \\
57-55.6\end{array}$ & ojos & & 0jos & Dolor & & \\
\hline
\end{tabular}


Tabla 104.79 • Riesgos físicos y químicos.

\begin{tabular}{|c|c|c|c|}
\hline $\begin{array}{l}\text { Denominación química } \\
\mathrm{N} \text { úmero CAS }\end{array}$ & Físicos & Q uímicos & $\begin{array}{l}\text { Clase o división } \\
\text { UN / Riesgos } \\
\text { subsidiarios }\end{array}$ \\
\hline $\begin{array}{l}\text { 1,4-BUTANODIOL } \\
110-63-4\end{array}$ & & - En su combustión libera vapores tóxicos ( $\mathrm{CO}$ ) • Reacciona con oxidantes fuertes & \\
\hline $\begin{array}{l}\text { DIETILENGLICOL } \\
111-46-6\end{array}$ & & - Reacciona violentamente con oxidantes fuertes • Ataca muchos plásticos & \\
\hline $\begin{array}{l}\text { ETILENGLICOL } \\
107-21-1\end{array}$ & & - En su combustión libera gases tóxicos • Reacciona con oxidantes fuertes y bases fuertes & \\
\hline $\begin{array}{l}\text { 1,6-HEXANODIOL } \\
629-11-8\end{array}$ & $\begin{array}{l}\text { - Posibilidad de explosión } \\
\text { pulverulenta cuando se } \\
\text { encuentra en forma } \\
\text { granular o en polvo y se } \\
\text { mezcla con el aire }\end{array}$ & - En su combustión libera gases tóxicos & \\
\hline $\begin{array}{l}\text { HEXILENGLICOL } \\
107-41-5\end{array}$ & & - Se polimeriza $\bullet$ Reacciona con oxidantes fuertes & \\
\hline $\begin{array}{l}\text { PROPILENGLICOL } \\
57-55-6\end{array}$ & $\begin{array}{l}\text { - El vapor es más pesado } \\
\text { que el aire }\end{array}$ & $\begin{array}{l}\text { - Reacciona con oxidantes fuertes, p. ej., perclorato de potasio, con peligro de incendio y } \\
\text { explosión }\end{array}$ & \\
\hline
\end{tabular}

Tabla 104.80 • Propiedades físicas y químicas.

\begin{tabular}{|c|c|c|c|c|c|c|c|c|c|c|c|}
\hline $\begin{array}{l}\text { Denominación química } \\
\mathrm{N} \text { úmero CAS }\end{array}$ & Color/ Forma & $\begin{array}{l}\text { p.e. } \\
(\stackrel{O}{ } \mathrm{C})\end{array}$ & $\begin{array}{l}\text { p.f. } \\
(\stackrel{O}{ } C)\end{array}$ & $\begin{array}{l}\text { p.m.l } \\
\text { (g/ } \\
\text { mol) }\end{array}$ & $\begin{array}{l}\text { Solubilidad } \\
\text { en agua }\end{array}$ & $\begin{array}{l}\text { Densidad } \\
\text { relativa } \\
\text { (agua }=1 \text { ) }\end{array}$ & $\begin{array}{l}\text { Densidad } \\
\text { relativa } \\
\text { del vapor } \\
\text { (aire=1) }\end{array}$ & $\begin{array}{l}\text { Pvap/ } \\
(\mathrm{kPa})\end{array}$ & $\begin{array}{l}\text { Límit. } \\
\text { inflam. }\end{array}$ & 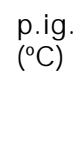 & $\begin{array}{l}\text { p.aut } \\
\text { ig. } \\
(\stackrel{0}{ } \text { C })\end{array}$ \\
\hline $\begin{array}{l}\text { 1,3-BUTANODIOL } \\
107-88-0\end{array}$ & $\begin{array}{l}\text { líquido viscoso; el } \\
\text { compuesto puro es } \\
\text { incoloro }\end{array}$ & 207,5 & $<50$ & 90,12 & sol & 1,002 & 3,2 & $8 \mathrm{~Pa}$ & & 121 & 394 \\
\hline $\begin{array}{l}\text { 1,4-BUTANODIOL } \\
\text { 110-63-4 }\end{array}$ & $\begin{array}{l}\text { líquido viscoso e } \\
\text { incoloro }\end{array}$ & 230 & 20,1 & 90,12 & misc & 1,0171 & 3,1 & $\begin{array}{l}0,13 \\
\text { @ } 37,7^{\circ} \mathrm{C}\end{array}$ & & $121 \mathrm{ca}$ & 350 \\
\hline $\begin{array}{l}\text { DIETLENGLICOL } \\
111-46.6\end{array}$ & $\begin{array}{l}\text { líquido incoloro; } \\
\text { líquido meloso }\end{array}$ & 245,8 & $-10,4$ & 106,1 & sol & 1,18 & 3,66 & $5 \mathrm{~Pa}$ & $\begin{array}{l}1,6 \mathrm{li} \\
10,8 \mathrm{ls} \\
\end{array}$ & 143 & 400 \\
\hline $\begin{array}{l}\text { DIMETLLENGLICOL } \\
513-85-9\end{array}$ & $\begin{array}{l}\text { Sólido o líquido casi } \\
\text { incoloro }\end{array}$ & & & 90,12 & & & 3,1 & & & & 402 \\
\hline $\begin{array}{l}\text { DIPROPILENGLICOL } \\
110.98 .5\end{array}$ & $\begin{array}{l}\text { líquido incoloro, } \\
\text { ligeramente viscoso }\end{array}$ & 233 & & 134,17 & misc & 1,0252 & 4,63 & $\begin{array}{l}4 \mathrm{~Pa} \\
@ 25^{\circ} \mathrm{C}\end{array}$ & & 137 & \\
\hline $\begin{array}{l}\text { ETILENGLICOL } \\
107-21-1\end{array}$ & $\begin{array}{l}\text { líquido ligeramente } \\
\text { viscoso; líquido } \\
\text { meloso transparente } \\
\text { e incoloro }\end{array}$ & 197,6 & -13 & 62,07 & misc & 1,1135 & 2,14 & $7 \mathrm{~Pa}$ & $\begin{array}{l}3,2 \mathrm{li} \\
15,3 \mathrm{ls}\end{array}$ & $111 \mathrm{cc}$ & 398 \\
\hline $\begin{array}{l}\text { 2-ETLL-1,3-HEXANODIOL } \\
\text { 94-96-2 }\end{array}$ & $\begin{array}{l}\text { líquido ligeramente } \\
\text { oleaginoso; líquido } \\
\text { incoloro }\end{array}$ & 244 & -40 & 146,22 & lig sol & $\begin{array}{l}0,9325 \\
@ 22^{\circ} \mathrm{C} / 4^{\circ} \mathrm{C}\end{array}$ & 5,03 & $\begin{array}{l}<0,01 \\
\mathrm{~mm} \mathrm{Hg}\end{array}$ & & $110 \mathrm{ca}$ & 335 \\
\hline $\begin{array}{l}\text { GLICEROL } \\
56-81.5\end{array}$ & $\begin{array}{l}\text { líquido meloso } \\
\text { transparente e } \\
\text { incoloro }\end{array}$ & 290 & 18 & 92,09 & sol & 1,2613 & & & & 320 & 392 \\
\hline $\begin{array}{l}\text { 1,6-HEXANODIOL } \\
629-11-8\end{array}$ & cristales & 208 & 42,8 & 118,17 & sol & $\begin{array}{l}0,967 \\
@ 0^{\circ} \mathrm{C} / 4^{\circ} \mathrm{C}\end{array}$ & 4,07 & $\begin{array}{l}0,0005 \\
\mathrm{~mm} \mathrm{Hg} \\
@ 25^{\circ} \mathrm{C} \\
\text { (est.) }\end{array}$ & & 101 & 320 \\
\hline
\end{tabular}




\begin{tabular}{|c|c|c|c|c|c|c|c|c|c|c|c|}
\hline $\begin{array}{l}\text { Denominación química } \\
\mathrm{N} \text { úmero CAS }\end{array}$ & Color/ Forma & $\begin{array}{l}\text { p.e. } \\
(\stackrel{0}{ } \mathrm{C})\end{array}$ & $\begin{array}{l}\text { p.f. } \\
(\because 0)\end{array}$ & $\begin{array}{l}\text { p.m.l } \\
\text { (g/ } \\
\mathrm{mol})\end{array}$ & $\begin{array}{l}\text { Solubilidad } \\
\text { en agua }\end{array}$ & $\begin{array}{l}\text { Densidad } \\
\text { relativa } \\
\text { (agua }=1 \text { ) }\end{array}$ & $\begin{array}{l}\text { Densidad } \\
\text { relativa } \\
\text { del vapor } \\
\text { (aire=1) }\end{array}$ & $\begin{array}{l}\text { Pvap/ } \\
(\mathrm{kPa})\end{array}$ & $\begin{array}{l}\text { Límit. } \\
\text { inflam. }\end{array}$ & $\begin{array}{l}\text { p.ig. } \\
(\underline{O} \mathrm{C})\end{array}$ & $\begin{array}{l}\text { p.aut } \\
\text { ig. } \\
\left({ }^{\circ} \text { C }\right)\end{array}$ \\
\hline $\begin{array}{l}2,5 \text {-HEXANODIOL } \\
2935-44-6\end{array}$ & & $216-218$ & 43 & 118,17 & sol & 0,9610 & & & & & \\
\hline $\begin{array}{l}\text { HEXILENGLICOL } \\
107-41-5 \\
\end{array}$ & líquido incoloro & 198 & -50 & 118,2 & sol & $\begin{array}{l}0,9254 \\
@ 17^{\circ} \mathrm{C}\end{array}$ & 4,1 & $6,7 \mathrm{~Pa}$ & $\begin{array}{l}1,3 \mathrm{li} \\
7,4 \mathrm{Is}\end{array}$ & 93 & 260 \\
\hline $\begin{array}{l}\text { NEOPENTILGLLCOL } \\
126-30-7\end{array}$ & & 208 & 130 & 104,14 & sol. & & & & & & \\
\hline $\begin{array}{l}\text { PENTAERITRITOL } \\
115-77.5\end{array}$ & $\begin{array}{l}\text { cristales } \\
\text { ditetragonales en } \\
\text { ácido clorhídrico } \\
\text { diluido; polvo blanco } \\
\text { cristalino }\end{array}$ & sublima & 260 & 136,1 & sol & $\begin{array}{l}1,399 \\
@ 25^{\circ} \mathrm{C} / 4^{\circ} \mathrm{C}\end{array}$ & & & & & \\
\hline $\begin{array}{l}\text { PROPILENGLICOL } \\
57.55-6\end{array}$ & $\begin{array}{l}\text { líquido viscoso } \\
\text { incoloro }\end{array}$ & 187,6 & .59 & 76,1 & misc & 1,0361 & 2,6 & $106,6 \mathrm{~Pa}$ & $\begin{array}{l}2,6 \mathrm{li} \\
12,5 \mathrm{ls}\end{array}$ & $99 \mathrm{cc}$ & 371 \\
\hline
\end{tabular}




\section{HALOGEN OS Y SUS COMPUESTOS}

El flúor, el cloro, el bromo, el yodo y el elemento radiactivo, el astato, constituyen la familia de elementos denominados halógenos. Excepto el astato, las propiedades físicas y químicas de estos elementos han sido objeto exhaustivo de estudio. 0 cupan el grupo VII en la tabla periódica y presentan una gradación casi perfecta de propiedades físicas.

La familia de los halógenos se relaciona también por la similitud de las propiedades químicas de los elementos, una similitud que está asociada con la disposición de siete electrones en la órbita externa de la estructura atómica de cada uno de los elementos del grupo. Todos los miembros forman compuestos con el hidrógeno y la facilidad con que se realiza esta unión decrece a medida que aumenta el peso atómico del halógeno. De igual manera, la facilidad de formación de diferentes sales decrece a medida que aumenta el peso atómico del halógeno. Las propiedades de los ácidos halogenados y sus sales muestran una estrecha relación; la similitud es evidente en los compuestos orgánicos halogenados, si bien al aumentar la complejidad química, las caracterísicas y las influencias de otros componentes de la molécula pueden enmascarar o modificar el grado de las propiedades.

\section{U sos}

Los halógenos se utilizan en las industrias química, de tratamiento de aguas, de plásticos, farmacéutica, papelera, textil, militar y petrolífera. El bromo, el cloro, el flúor y el yodo son productos químicos intermedios, agentes blanqueadores y desinfectantes. El bromo y el cloro se utilizan en la industria textil para blanquear y tratar la lana para que no encoja. EI bromo también se emplea en los procesos de extracción minera de oro y en la perforación de pozos de petróleo y de gas. Es un retardador de la llama en la industria del plástico y un intermedio en la fabricación de fluidos hidráulicos, agentes refrigerantes y deshumidificantes y preparados para moldear el cabello. El bromo es también un componente de gases militares y fluidos para la extinción de incendios.

El cloro se utiliza como desinfectante de detritus y para la depuración y el tratamiento de agua para beber y piscinas. Es un agente blanqueador empleado en lavanderías y en la industria papelera. El cloro se emplea en la fabricación de pilas especialese hidrocarburos clorados y en el procesamiento de carnes, verduras, pescados y frutas. A demás, actúa como retardador de llama. El dióxido de cloro se utiliza en el tratamiento de aguas potables y de piscinas para depurar y controlar el sabor y el olor de las mismas. Se emplea como agente blanqueador en las industrias alimentaria, del cuero, textil y papelera, como oxidante, como bactericida y como antiséptico. Se utiliza también para limpiar y destanificar el cuero y para blanquear celulosa, aceites y cera de abeja. El tricloruro de nitrógeno se utilizaba antiguamente como blanqueador y "mejorador" de la harina. El yodo también es un desinfectante para el tratamiento de las aguas y actúa como producto químico intermedio en la síntesis de yoduros inorgánicos, yoduro potásico y compuestos orgánicos de yodo.

El flúor, el monóxido de flúor, el pentafluoruro de bromo y el trifluoruro de cloro sirven como oxidantes en los combustibles para cohetes. El flúor también se emplea para transformar tetrafluoruro de uranio en hexafluoruro de uranio, y el trifluoruro de cloro se utiliza en la fabricación de combustibles para reactores nucleares y en los pozos petrolíferos.
El fluoruro cálcico, cuya forma mineral es la fluorita o espatoflúor, es la principal fuente de obtención de flúor y sus compuestos. Se utiliza en la industria metalúrgica como fundente. También se emplea en las industrias óptica, del vidrio y de la electrónica.

El bromuro de hidrógeno y sus soluciones acuosas sirven para obtener bromuros orgánicos e inorgánicos y como agentes reductores y catalizadores. T ambién se emplean en la alquilación de compuestos aromáticos. El bromuro potásico se utiliza para fabricar placas y papeles fotográficos. El gas fosgeno es necesario en grandes cantidades para numerosas síntesis industriales, como en la fabricación de colorantes. T ambién se emplea en la fabricación de gases militares y productos farmacéuticos. Además, se encuentra en insecticidas y fumigantes.

\section{Riesgos}

La similitud que presentan estos elementos con respecto a sus propiedades químicas se evidencia en sus efectos fisiológicos. Los gases (flúor y cloro) y los vapores de bromo y yodo son irritantes del aparato respiratorio. L a inhalación de concentraciones relativamente bajas de estos gases y vapores produce una sensación desagradable y picante que va seguida por sensación de ahogo, tos y sensación de opresión torácica. Las lesiones del tejido pulmonar asociadas a estos productos pueden determinar la aparición de un edema pulmonar, que puede ser mortal.

\section{El flúor y sus compuestos}

\section{Fuentes}

La mayor parte del flúor y sus compuestos se obtienen directa 0 indirectamente a partir de fluoruro cálcico (espatoflúor) y fosfato mineral (fluorapatita) o productos químicos derivados de ellos. El fluoruro presente en el fosfato mineral limita la utilidad de este último y, por ello, se debe eliminar casi por completo en la preparación de fósforo elemental o fosfato cálcico para alimentos y parcialmente en la conversión de fluorapatita para fertilizantes. Estos fluoruros se recuperan en algunos casos como soluciones acuosas de ácidos o como sales cálcicas o sódicas del flúor liberado (probablemente una mezcla de fluoruro de hidrógeno y de tetrafluoruro de sílice) o se liberan a la atmósfera.

\section{Riesgos de incendio y explosión}

M uchos de los compuestos fluorados representan un riesgo de incendio y explosión. El flúor reacciona con casi todos los productos, incluso con los metales de los envases y de las conducciones cuando se deteriora la película inerte. La reacción con metales puede producir hidrógeno gaseoso. En los sistemas de transporte es preciso que exista una perfecta limpieza para evitar las reacciones localizadas y el consiguiente riesgo de incendio. Para prevenir que se produzcan reacciones con los lubricantes, se utilizan válvulas especiales sin lubricante. El difluoruro de oxígeno es explosivo en mezclas gaseosas con agua, sulfuro de hidrógeno o hidrocarburos. Al calentarse, muchos compuestos fluorados liberan gases tóxicos y vapores corrosivos.

\section{Riesgos para la salud}

Acido fluorhídrico. El contacto del ácido hidrofluórico anhidro con la piel produce graves quemaduras que se sienten inmediatamente. Las soluciones acuosas concentradas de este ácido también causan una rápida sensación de dolor, pero las soluciones diluidas no siempre producen efectos visibles inmediatos. El contacto externo con el líquido o los vapores provoca una 
intensa irritación de los ojos y los párpados que puede ocasionar defectos visuales prolongados o permanentes o la destrucción total de los ojos. Se han dado casos de fallecimiento por exposición cutánea en tan sólo un $2,5 \%$ de la superficie corporal total.

En caso de contacto con ácido fluorhídrico, es esencial administrar rápidamente un tratamiento, que consistirá en lavar la zona afectada con agua abundante de camino al hospital y, cuando sea posible, sumergirla en una solución helada de sulfato magnésico al $25 \%$. El tratamiento normal de las quemaduras leves o moderadas consiste en la aplicación de un gel de gluconato cálcico. Las quemaduras más graves pueden precisar la inyección de una solución de sulfato magnésico o gluconato cálcico al $10 \%$ en y alrededor de la zona afectada. A veces es necesaria la anestesia local para calmar el dolor.

La inhalación de nieblas concentradas de ácido fluorhídrico concentrado o fluoruro de hidrógeno anhidro provocan irritación respiratoria y una exposición de tan sólo 5 minutos suele ser fatal en el plazo de 2 a 10 horas por la aparición de edema pulmonar hemorrágico. Las exposiciones cutáneas también pueden ir acompañadas de inhalación.

Flúor y otros gases fluorados. El flúor elemental, el trifluoruro de cloro y el difluoruro de oxígeno son tres oxidantes fuertes que pueden ser muy destructivos. Cuando se encuentran a altas concentraciones, son extremadamente corrosivos para los tejidos animales. Sin embargo, el trifluoruro de nitrógeno es mucho menos irritante. El flúor gaseoso en contacto con el agua forma ácido fluorhídrico, que produce graves quemaduras y úlceras en la piel.

La exposición aguda a concentraciones de flúor de 10 ppm provoca ligera irritación cutánea, ocular y nasal. La exposición a concentraciones por encima de $25 \mathrm{ppm}$ resulta intolerable, si bien las exposiciones repetidas pueden determinar una cierta adaptación. La exposición a concentraciones elevadas produce edema pulmonar diferido, hemorragias, lesiones renales y, posiblemente, la muerte. El difluoruro de oxígeno tiene efectos similares.

En un estudio de inhalación aguda de trifluoruro de cloro realizado en ratas, la exposición a 800 ppm durante 15 minutos 0 400 ppm durante 25 minutos provocó la muerte. La toxicidad aguda de este compuesto es similar a la del fluoruro de hidrógeno. En un estudio de larga duración realizado con dos especies, la concentración de 1,17 ppm causó irritación respiratoria y ocular y, en algunos animales, la muerte. En estudios de larga duración con animales de la inhalación repetida de flúor, se observaron efectos tóxicos en los pulmones, el hígado y los testículos con una concentración de 16 ppm, así como irritación de las mucosas y los pulmones con una concentración de $2 \mathrm{ppm}$. El flúor se toleró en concentraciones de $1 \mathrm{ppm}$. En un estudio posterior realizado con varias especies, no se observaron efectos derivados de la exposición durante 60 minutos a concentraciones de hasta 40 ppm.

Se dispone de escasa información sobre la exposición industrial de trabajadores al flúor y aún menos experiencia acerca de la exposición prolongada al trifluoruro de cloro y al difluoruro de oxígeno.

\section{Fluoruros}

La ingestión de fluoruros solubles en cantidades de entre 5 y 10 gramos es, con casi total seguridad, mortal para una persona adulta. Se han producido casos mortales por ingestión de fluoruro de hidrógeno, fluoruro sódico y fluosilicatos. Se han registrado tambien casos de enfermedad no mortal como consecuencia de la ingestión de éstos y otros fluoruros, entre ellos una sal tan poco soluble como es la criolita (fluoruro de aluminio y sodio).
En la industria, los polvos que contienen fluoruros juegan un papel importante en muchos de los casos de exposición real 0 potencial a los fluoruros, y la ingestión de estos polvos puede constituir un factor significativo. La exposición a fluoruros en el trabajo puede deberse a fluoruros gaseosos, pero incluso en estos casos, la ingestión no puede desestimarse completamente, bien sea por contaminación de los alimentos o las bebidas que se consumen en el lugar de trabajo, bien sea porque los fluoruros se expectoren con la tos y seguidamente sean deglutidos. En las exposiciones a una mezcla de fluoruros gaseosos y en forma de partículas, tanto la inhalación como la ingestión pueden ser factores importantes en la absorción de fluoruros.

En la fluorosis o intoxicación crónica por flúor, este elemento se deposita en el tejido óseo, tanto de los animales como del hombre. Los síntomas de la fluorosis de los huesos consisten en aumento de su opacidad radiológica, formación de gruesas excrecencias en las costillas y calcificación de los ligamentos intervertebrales. T ambién se observan manchas en los dientes. La relación exacta entre los niveles de fluoruro en la orina y las correspondientes cifras de fijación de fluoruros en los huesos no está perfectamente determinada. No obstante, puede decirse que los niveles de fluoruro urinario en los trabajadores no deben superar los $4 \mathrm{ppm}$. Cuando dichos niveles sean de $6 \mathrm{ppm}$, será preciso realizar una supervisión y/ o un control más estrictos. Cuando el nivel sea de 8 ppm o más, cabe esperar que, si esa situación se mantiene durante muchos años, se producirá una fijación de flúor en los huesos que determinará una opacificación radiológica de éstos.

El caso de los fluoboratos es el único en que el ión de fluoborato absorbido se excreta casi por completo en la orina. Esto quiere decir que la disociación del fluoruro a partir del ión de fluoroborato es muy pequeña o nula, por lo que virtualmente no se produce la fijación en el esqueleto que cabría esperar con este fluoruro.

En un estudio de los trabajadores de la criolita, casi la mitad de ellos se quejaron de inapetencia y disnea; una proporción menor mencionó estreñimiento, dolor localizado en la región del hígado y otros síntomas. Se detectó una leve fluorosis en los trabajadores de la criolita expuestos durante dos o dos años y medio, signos más marcados en los expuestos durante casi 5 años y fluorosis moderada en los expuestos durante más de 11 años.

Los niveles de fluoruro se han asociado a asma de origen profesional en los trabajadores empleados en la reducción del aluminio.

Fluoruro cálcico. Los riesgos del espatoflúor se deben principalmente a los efectos perjudiciales del contenido de flúor. Los efectos crónicos consisten en enfermedades de los dientes, los huesos y otros órganos. Se han descrito lesiones pulmonares en personas que inhalaron polvo con un contenido del 92 al $96 \%$ de fluoruro cálcico y un 3,5\% de sílice. Se llegó a la conclusión de que el fluoruro cálcico intensifica el efecto fibrógeno de la sílice en los pulmones. Se han dado casos de bronquitis y silicosis en las personas que trabajan en las minas de espatoflúor.

\section{Riesgos para el medio ambiente}

Las plantas industriales que utilizan grandes cantidades de compuestos fluorados, como las industrias siderúrgicas, las fundiciones de aluminio, las fábricas de superfosfatos, etc., pueden liberar a la atmósfera gases, humos o polvos que contengan flúor. Se han descrito casos de daño ambiental en animales que pastaban en la hierba contaminada, incluso fluorosis con manchas dentales, depósito óseo y excreción. También se ha descrito la corrosión de los cristales de las ventanas de las casas vecinas. 


\section{B romo y sus compuestos}

El bromo está muy extendido en la naturaleza en forma de compuestos inorgánicos tales como los minerales, en el agua de mar y en los lagos salados. Los tejidos animales y vegetales también contienen pequeñas cantidades de bromo. Se obtiene a partir de lagos salados y pozos de sondeo, del agua del mar y de las aguas madres que quedan tras el tratamiento de las sales potásicas (silvita, carnalita).

El bromo es un líquido muy corrosivo, cuyos vapores son extremadamente irritantes para los ojos, la piel y las mucosas. En contacto prolongado con los tejidos, el bromo puede provocar quemaduras profundas que tardan mucho en cicatrizar $y$, a menudo, se ulceran. Asimismo, es tóxico por vía digestiva, respiratoria o percutánea.

En caso de existir exposición prolongada al bromo, su concentración en la atmófera de trabajo no debe superar los $0,5 \mathrm{mg} / \mathrm{m}^{3}$. Cuando esta concentración es igual o superior a $3-4 \mathrm{mg} / \mathrm{m}^{3}$, resulta imposible trabajar sin un equipo de protección respiratoria. U na concentración de 11 a $23 \mathrm{mg} / \mathrm{m}^{3}$ produce intenso ahogo y se acepta unánimamente que las concentraciones de 30 a $60 \mathrm{mg} / \mathrm{m}^{3}$ son muy peligrosas para el ser humano. Cualquier concentración en torno a $200 \mathrm{mg} / \mathrm{m}^{3}$ produce la muerte en muy poco tiempo.

El bromo posee propiedades acumulativas, depositándose en los tejidos en forma de bromuros y desplazando a otros halógenos (yodo y cloro). Los efectos a largo plazo incluyen trastornos del sistema nervioso.

Las personas expuestas habitualmente a concentraciones entre tres y seis veces superiores al límite de exposición para un año presentarán dolor de cabeza, dolor precordial, mayor irritabilidad, pérdida de apetito, dolor en las articulaciones y dispepsia. Durante el quinto o sexto año de trabajo en tales circunstancias, puede producirse una pérdida de reflejos corneales, faringitis, alteraciones de índole vegetativa e hiperplasia tiroidea acompañada de alteraciones funcionales de esta glándula. También pueden presentarse complicaciones cardiovasculares en forma de degeneración miocárdica e hipotensión, y alteraciones funcionales y secretoras del tracto digestivo. En la sangre se aprecian signos de inhibición de la leucopoyesis y leucocitosis. La concentración de bromo en sangre varía entre $0,15 \mathrm{mg} / 100 \mathrm{~cm}^{3}$ y $1,5 \mathrm{mg} / 100 \mathrm{~cm}^{3}$ con independencia del grado de intoxicación.

El bromuro de hidrógeno gaseoso puede detectarse a concentraciones de 2 ppm que no producen irritación. El ácido bromhídrico, en solución acuosa al $47 \%$, es un líquido corrosivo, de color amarillo pálido y olor intenso, que se oscurece cuando se expone al aire y a la luz.

El efecto tóxico del ácido bromhídrico es entre dos y tres veces menor que el del bromo, pero más agudo que el del cloruro de hidrógeno. T anto la forma gaseosa como la acuosa irritan la mucosa del tracto respiratorio superior a concentraciones de 5 ppm. La intoxicación crónica se caracteriza por inflamación de las vías respiratorias altas y dispepsia, ligeras alteraciones de los reflejos y disminución del recuento de hematíes. Asimismo, puede presentarse una disminución de la sensibilidad olfativa. EI contacto con la piel y las mucosas puede provocar quemaduras.

Ácido brómico y ácido hipobromoso. Los ácidos oxigenados del bromo sólo se encuentran en forma de soluciones o de sus sales. Su acción en el organismo es similar a la del ácido bromhídrico.

Bromuro ferroso-férrico. Los bromuros ferroso-férricos son sustancias sólidas utilizadas en las industrias química y farmacéutica, así como en la industria de fabricación de productos fotográficos. Estos compuestos se obtienen haciendo pasar una mezcla de bromo y vapor de agua a través de un lecho de partículas de hierro. La sal de bromo caliente y de consistencia siruposa que se obtiene se introduce en contenedores de hierro, donde se solidifica. El bromo húmedo (es decir, el bromo que contiene más de 20 ppm de agua) es corrosivo para la mayoría de los metales y el bromo elemental ha de transportarse en estado de absoluta deshidratación en envases de monel, níquel o plomo herméticamente cerrados. Para evitar el problema de la corrosión, el bromo suele transportarse en forma de sal ferroso-férrica.

Bromofosgeno. Este es un producto de la descomposición del bromoclorometano que se genera durante los procesos de obtención de violeta de genciana. Se produce combinando monóxido de carbono y bromo en presencia de cloruro amónico anhidro.

Los efectos tóxicos del bromofosgeno son similares a los del fosgeno (véase el apartado dedicado al fosgeno más adelante en este mismo artículo).

Bromuro de cianógeno. El bromuro de cianógeno es un sólido utilizado para la extracción de oro y como pesticida. Reacciona con agua para producir ácido cianhídrico y bromuro de hidrógeno. Sus efectos tóxicos son similares a los del ácido cianhídrico y probablemente tenga una toxicidad similar.

El bromuro de cianógeno también tiene un acción irritante y, a altas concentraciones, puede provocar edema y hemorragias pulmonares. La exposición a 20 ppm durante 1 minuto u 8 ppm durante 10 minutos resulta intolerable. En gatos y ratones, la exposición a $70 \mathrm{ppm}$ provoca parálisis en el plazo de 3 minutos y la exposición a $230 \mathrm{ppm}$ produce la muerte.

\section{Cloro y sus compuestos inorgánicos}

Los compuestos clorados están muy extendidos en la naturaleza, constituyendo alrededor del $2 \%$ de la superficie terrestre, principalmente en forma de cloruro sódico en el agua del mar y en depósitos naturales como los de carnalita y silvina.

El cloro gaseoso es principalmente un irritante respiratorio. En concentración suficiente, irrita las mucosas, el tracto respiratorio y los ojos. En casos extremos, la dificultad respiratoria puede aumentar hasta el punto de producirse la muerte por colapso respiratorio o insuficiencia pulmonar. La presencia de cloro en la atmósfera es, hasta cierto punto, detectable debido a su olor penetrante característico. Además, a altas concentraciones es un gas visible por su color amarillo verdoso. El contacto del cloro líquido con la piel o los ojos provoca quemaduras químicas y/ o congelación.

Los efectos del cloro pueden agravarse en las 36 horas siguientes a la exposición. La estrecha vigilancia de los individuos expuestos debe forma parte del programa de actuación médica.

Exposición crónica. La mayoría de los estudios indican que la exposición crónica a bajas concentraciones de cloro no produce efectos nocivos significativos para la salud. Un estudio finlandés realizado en 1983 demostró en los trabajadores expuestos un aumento de la tos crónica y una tendencia a la hipersecreción de las mucosas. Sin embargo, ni las pruebas ni las radiografías de tórax realizadas demostraron anomalías en la función pulmonar de estos trabajadores.

En un estudio realizado en 1993 por el Instituto de Toxicología Q uímica Industrial (C hemical Industry Institute of T oxicology) sobre la inhalación crónica de cloro, ratas y ratones fueron expuestos a concentraciones de $0,4,1,0 \circ 2,5 \mathrm{ppm}$ del gas cloro hasta 6 horas al día, entre 3 y 5 días a la semana durante un período de hasta 2 años. No se hallaron evidencias de cáncer. La exposición a todas las concentraciones de cloro produjo lesiones nasales. Puesto que los roedores sólo respiran por la nariz, no está claro cómo deben extrapolarse estos resultados al ser humano.

El cloro puede estar presente en concentraciones considerablemente superiores a los valores umbral actuales sin que se perciba inmediatamente. Las personas pierden en poco tiempo su capacidad para detectar el olor del cloro a pequeñas concentraciones. 
Se ha observado que la exposición prolongada a una concentración atmosférica de cloro de 5 ppm provoca afectación bronquial y predisposición a la tuberculosis, y los estudios pulmonares han indicado que las concentraciones de 0,8-1,0 ppm producen una reducción permanente, aunque moderada, de la función pulmonar. También es frecuente el acné en personas expuestas durante largos períodos de tiempo a bajas concentraciones de cloro, que comúnmente se conoce como "cloracné". También puede dañarse el esmalte dental.

\section{Oxidos}

En total existen cinco óxidos de cloro. Son el monóxido de dicloro, el monóxido de cloro, el dióxido de cloro, el hexóxido de cloro y el heptóxido de cloro. Todos ellos producen más o menos idénticos efectos en el organismo humano y requieren las mismas medidas de seguridad que el cloro. El más utilizado en la industria es el dióxido de cloro, que es un irritante ocular y respiratorio similar al cloro, pero más potente. Las exposiciones agudas por inhalación provocan bronquitis y edema pulmonar, y en los trabajadores expuestos los síntomas observados consisten en tos, respiración sibilante, dificultad respiratoria, secreción nasal e irritación de los ojos y la garganta.

El tricloruro de nitrógeno es un potente irritante para la piel y las mucosas de los ojos y el tracto respiratorio. Sus vapores son tan corrosivos como el cloro. Es altamente tóxico cuando se ingiere.

La concentración letal media $\left(\mathrm{CL}_{50}\right)$ de tricloruro de nitrógeno en ratas es de $12 \mathrm{ppm}$, según se ha determinado en un estudio de exposición de ratas a concentraciones de entre 0 y 157 ppm durante 1 hora. Los perros alimentados con harina blanqueada con tricloruro de nitrógeno desarrollan rápidamente ataxia y convulsiones epileptiformes. El examen histológico de animales experimentales ha demostrado necrosis de la corteza cerebral y alteraciones de las células de Purkinje en el cerebelo. Los núcleos de los hematíes también pueden verse afectados.

El tricloruro de nitrógeno puede explotar como consecuencia de impactos, exposición al calor, ondas supersónicas e incluso espontáneamente. La presencia de ciertas impurezas puede aumentar el riesgo de explosión. También explota en contacto con cantidades traza de algunos compuestos orgánicos, en especial, la trementina. Su descomposición crea productos clorados altamente tóxicos.

Fosgeno. El fosgeno de uso comercial $\left(\mathrm{COCl}_{2}\right)$ se obtiene por reacción de cloro y monóxido de carbono. También se forma fosgeno como subproducto no deseado cuando ciertos hidrocarburos clorados (especialmente el diclorometano, el tetracloruro de carbono, el cloroformo, el tricloroetileno, el percloroetileno y el hexacloroetano) entran en contacto con una llama desnuda 0 un metal caliente, como en procesos de soldadura. La descomposición de los hidrocarburos clorados en cuartos cerrados puede provocar la acumulación de concentraciones peligrosas de fosgeno, como, por ejemplo, cuando se utiliza tetracloruro de carbono como producto para la extinción de incendios o tetracloroetileno como lubricante en la maquinaria para fabricación de acero de alta calidad.

El fosgeno anhidro no es corrosivo para los metales, pero en presencia de agua reacciona formando ácido clorhídrico, que sí es corrosivo.

El fosgeno es uno de los gases más tóxicos utilizados en la industria. La inhalación de $50 \mathrm{ppm}$ durante un corto período de tiempo es mortal para los animales de experimentación. En el caso del hombre, la inhalación prolongada de 2-5 ppm es peligrosa. Otra propiedad peligrosa del fosgeno es la ausencia de todo tipo de signos de advertencia durante su inhalación, ya que ésta produce, a lo sumo, una ligera irritación de las mucosas del tracto respiratorio y de los ojos en concentraciones de 4 a 10 ppm. La exposición a $1 \mathrm{pmm}$ durante períodos largos de tiempo puede provocar edema pulmonar tardío. Los casos leves de intoxicación van seguidos de bronquitis pasajera. En los casos graves, puede producirse edema pulmonar diferido, que aparece tras un período de latencia de varias horas, normalmente entre 5 y 8 , y muy rara vez más de 12 . En la mayoría de los casos, el paciente permanece consciente hasta el final. La muerte se produce por asfixia o parada cardíaca. Si el paciente logra sobrevivir los 2 ó 3 primeros días, el pronóstico es generalmente favorable. El fosgeno en altas concentraciones provoca inmediatamente lesiones pulmonares y causa en poco tiempo la muerte por asfixia y detención de la circulación a través de los pulmones.

\section{Protección del medio a mbiente}

EI cloro libre destruye la vegetación y, como puede encontrarse en concentraciones que causen este tipo de daños en condiciones climáticas desfavorables, debe prohibirse su liberación a la atmósfera. Si no es posible utilizar el cloro liberado para producir ácido clorhídrico o productos similares, deberán adoptarse siempre las medidas necesarias para captar el cloro, por ejemplo, mediante una torre depuradora de cal. Se adoptarán también medidas técnicas de seguridad especiales, con sistemas automáticos de alarma en las fábricas y sus alrededores, siempre que exista el riesgo de que puedan escapar cantidades apreciables de cloro a la atmósfera de los alrededores.

Desde el punto de vista de la contaminación ambiental, debe prestarse especial atención a las botellas u otros envases utilizados para el transporte de cloro o de sus compuestos, a las medidas para controlar los posibles riesgos y a los pasos que se darán en situaciones de emergencia.

\section{El yodo y sus compuestos}

El yodo no se encuentra en estado libre en la naturaleza, sino que se presenta formando yoduros y/o yodatos como vestigios de impurezas en los depósitos de otras sales. Los depósitos de nitrato de $C$ hile contienen la suficiente cantidad de yodato (aproximadamente un $0,2 \%$ de yodato sódico) como para que su explotación comercial resulte rentable. I gualmente, existen algunos saladares naturales, especialmente en Estados U nidos, que contienen yoduros en cantidades considerables. El yoduro del agua del mar se concentra por la acción de algunas plantas marinas (kelpo), cuyas cenizas constituyeron en su tiempo una fuente de producción de considerable importancia en Francia, Reino Unido y Japón.

El yodo es un potente oxidante. Puede provocar una explosión cuando entra en contacto con materiales tales como el acetileno 0 el amoníaco.

Los vapores de yodo, incluso a bajas concentraciones, son extremadamente irritantes para el tracto respiratorio, los ojos y, en menor medida, la piel. Las concentraciones de sólo 0,1 ppm en el aire pueden producir irritación ocular cuando la exposición es prolongada. Las concentraciones atmosféricas superiores a 0,1 ppm provocan irritación ocular cada vez más grave, junto con irritación del tracto respiratorio y, en los casos extremos, edema pulmonar. O tras lesiones sistémicas producidas por la inhalación de vapores de yodo son poco probables a menos que la persona expuesta padezca de antemano alguna alteración de la glándula tiroides. El yodo se absorbe por vía pulmonar, convirtiéndose en yoduro en el interior del organismo, y se excreta principalmente por vía urinaria. El yodo en forma cristalizada o en soluciones concentradas es un potente irritante cutáneo, siendo bastante difícil eliminarlo de la piel y, una vez que se ha 
producido el contacto, tiende a penetrar y a producir lesiones continuas. Las lesiones cutáneas provocadas por el yodo se parecen mucho a las quemaduras por calor, con la sola diferencia de que en el primer caso las zonas quemadas aparecen coloreadas de marrón. Como el yodo se queda adherido a los tejidos, pueden producirse úlceras de lenta curación.

Posiblemente, la dosis letal media del yodo por vía oral es de 2-3 g en adultos, debido a su efecto corrosivo en el aparato digestivo. En términos generales, los productos que contienen yodo (ya sean orgánicos o inorgánicos) parecen ser más tóxicos que los análogos bromados o clorados. A demás de la toxicidad que posee por ser un halógeno, el yodo se concentra en la glándula tiroides (la base para el tratamiento del cáncer de tiroides con $\left.\right|^{131}$ ) y, por ello, es fácil que se produzcan alteraciones metabólicas como resultado de una exposición excesiva a este elemento. La absorción crónica del yodo provoca "yodismo", una enfermedad caracterizada por taquicardia, temblores, pérdida de peso, insomnio, diarrea, conjuntivitis, rinitis y bronquitis. Además, puede desarrollarse una hipersensibilidad al yodo, caracterizada por erupciones cutáneas y posiblemente rinitis y/ 0 asma.

Radiactividad. El yodo tiene un número atómico de 53 y un peso atómico que oscila entre 117 y 139. Su único isótopo estable tiene una masa de 127 (126,9004). Sus isótopos radiactivos tienen períodos de semidesintegración que varían desde algunos segundos (pesos atómicos de 136 y superiores) hasta millones de años (I ${ }^{129}$ ). En las reacciones que caracterizan el proceso de fisión en un reactor nuclear, se forma I ${ }^{131}$ en abundancia. Este isótopo tiene un período de semidesintegración de 8,070 días; emite negatrones y radiación gamma con energías principales a 0,606 M eV (máx) y 0,36449 M eV, respectivamente.

Cuando penetra en el organismo, sea cual sea la vía, el yodo inorgánico (yoduro) se concentra en la glándula tiroides. Este hecho, sumado a la abundante formación de $\mathrm{I}^{131}$ en los procesos de fisión nuclear, lo convierte en uno de los materiales más peligrosos que puede liberar un reactor nuclear, ya sea deliberadamente o por accidente. 
TABLAS DE HALOGENOS Y SUS COMPUESTOS

Tabla 104.81 • Identificación química de algunos halógenos y sus compuestos.

\begin{tabular}{llcc} 
Producto químico & Sinónimos/ Código UN & N úmero CAS & Fórmula estructural \\
BROMO & $\begin{array}{c}\text { Bromo } \\
\text { UN1744 }\end{array}$ & $7726-95-6$ & $\mathrm{Br}-\mathrm{Br}$ \\
\hline BROMURO DE HIDROGENO & $\begin{array}{c}\text { Acido bromhídrico anhidro; solución de ácido bromhídrico } \\
\text { UN1788 }\end{array}$ & $10035-10-6$ & $\mathrm{H}-\mathrm{Br}$ \\
\hline CLORO & $\begin{array}{l}\text { Cloro molecular } \\
\text { UN1017 }\end{array}$ & $7782-50-5$ & $\mathrm{Cl}-\mathrm{Cl}$ \\
\hline
\end{tabular}

CLORURO DE AZUFRE Dicloruro disulfúrico; monocloruro de azufre; subcloruro de azufre; dicloruro 10025-67-9 tiosulfuroso<smiles>ClSSCl</smiles>

CLORURO DE NITROGENO Nitruro de cloro; tricloruro de nitrógeno; tricloramina; nitruro de tricloro $10025-85-1$

\begin{tabular}{lll}
\hline DICLORURO DE AZUFRE & \\
\hline DIFLUORURO DE OXIGENO & $\begin{array}{c}\text { Monóxido de flúor; óxido de flúor; fluoruro de oxígeno } \\
\text { UN2190 }\end{array}$ \\
\hline FLUOR & $\begin{array}{l}\text { Flúor } \\
\text { UN1045 }\end{array}$ & $7782-41-4$ \\
\hline
\end{tabular}

FLUORURO CALCICO

$7789-75-5$

\section{$\mathrm{Ca}^{++}$}

$\mathrm{F}^{-} \quad \mathrm{F}^{-}$

\begin{tabular}{ll}
\hline FLUORURO DE CARBONILO & $\begin{array}{l}\text { Oxido de difluoruro de carbono; óxido de fluoruro de carbono; oxifluoruro } \\
\text { de carbono; difluoruro de carbonilo; difluoroformaldehído; fluofosgeno; } \\
\text { fluoruro de fluoroformilo; fluorofosgeno } \\
\text { UN2417 }\end{array}$ \\
\hline $\begin{array}{l}\text { Acido fluorhídrico; hidrofluoruro } \\
\text { UN1052; UN1790 }\end{array}$ & $\begin{array}{l}\text { Oxido de clorofluoruro; oxifluoruro de cloro } \\
\text { UN3083 }\end{array}$ \\
\hline FLUORORURO DE HIDROGENO & $\begin{array}{l}\text { Oxifluoruro sulfúrico } \\
\text { UN2191 }\end{array}$ \\
\hline FLUORURO DE SULFURILO &
\end{tabular}

FOSGENO


Tabla 104.81 • Identificación química de algunos halógenos y sus compuestos.

$\begin{array}{llll}\text { Producto químico } & \text { Sinónimos/ Código UN } & \text { N úmero CAS Fórmula estructural } \\ \text { HEXAFLUORURO DE AZUFRE } & \text { Fluoruro de azufre } & \text { UN1080 } & 2551-62-4\end{array}$

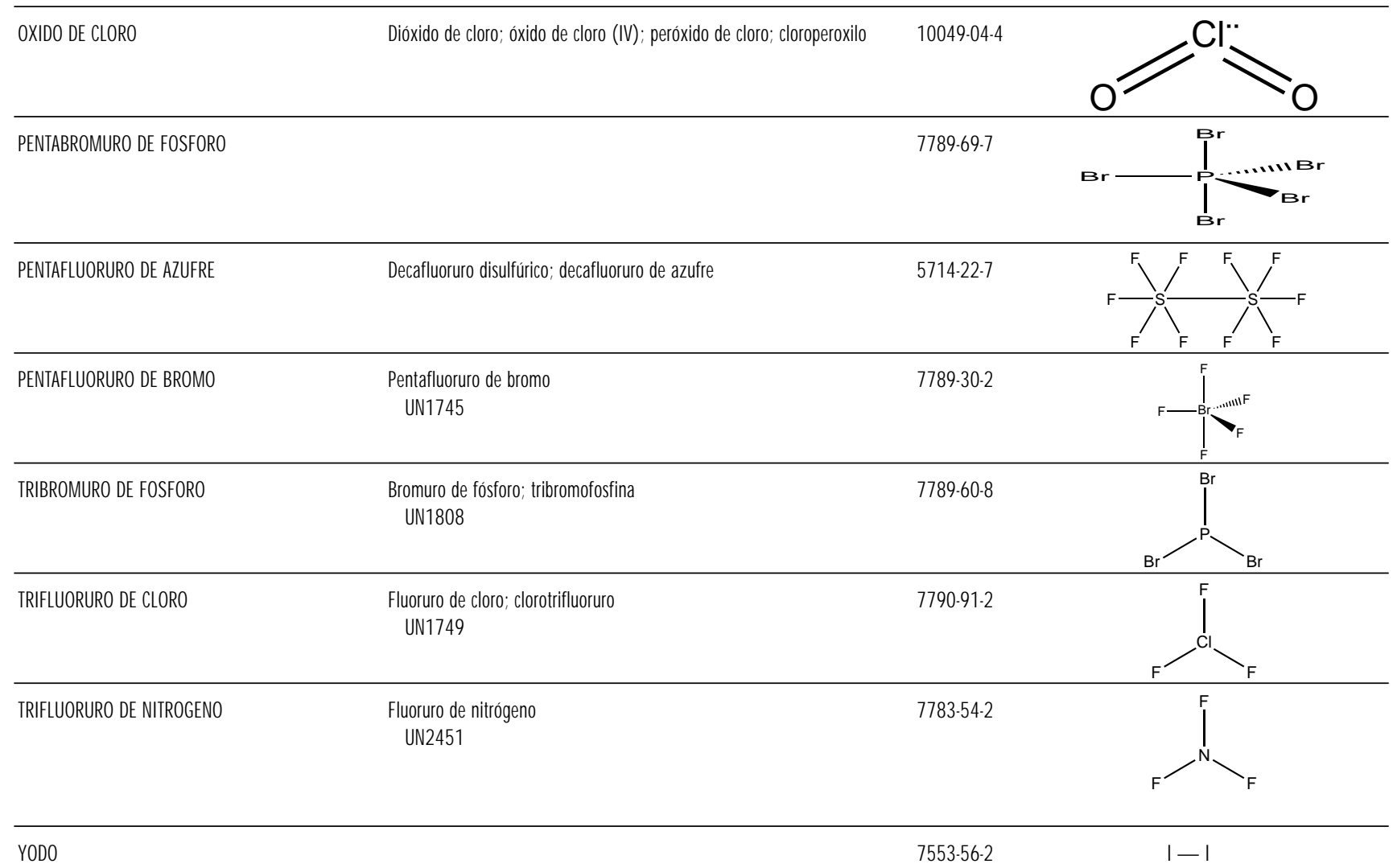

Tabla 104.82 - Riesgos para la salud.

\begin{tabular}{|c|c|c|c|c|c|c|}
\hline \multirow[b]{2}{*}{$\begin{array}{l}\text { Denominación } \\
\text { química } \\
\text { N úmero CAS }\end{array}$} & \multicolumn{4}{|c|}{ Tarjetas Internacionales sobre la Seguridad de los Productos Q uímicos } & \multicolumn{2}{|c|}{ N IO SH (EE.UU.) } \\
\hline & $\begin{array}{l}\text { Período } \\
\text { corto de } \\
\text { exposición }\end{array}$ & $\begin{array}{l}\text { Período } \\
\text { largo de } \\
\text { exposición }\end{array}$ & $\begin{array}{l}\text { Vías de } \\
\text { exposición }\end{array}$ & Síntomas & $\begin{array}{l}\text { O rganos } \\
\text { afectados } \\
\text { Vías de } \\
\text { entrada }\end{array}$ & Síntomas \\
\hline $\begin{array}{l}\text { BROMO } \\
7726-95-6\end{array}$ & $\begin{array}{l}\text { ojos; piel; } \\
\text { tract resp; } \\
\text { pulmones }\end{array}$ & piel; pulmones & $\begin{array}{r}\text { Inhalación } \\
\text { Piel } \\
\text { 0jos } \\
\text { Ingestión }\end{array}$ & $\begin{array}{l}\text { Corrosivo, sensación de quemazón, tos, } \\
\text { mareo, cefalea, dificultad respiratoria, dolor de } \\
\text { garganta } \\
\text { Corrosivo, enrojecimiento, quemaduras en la } \\
\text { piel, dolor } \\
\text { Corrosivo, enrojecimiento, dolor, quemaduras } \\
\text { profundas graves } \\
\text { Corrosivo, espasmos abdominales, sensación } \\
\text { de quemazón, dolor de garganta, colapso }\end{array}$ & $\begin{array}{l}\text { Sis resp; ojos; SNC; } \\
\text { piel } \\
\text { Inh; ing; con }\end{array}$ & $\begin{array}{l}\text { Mar, cef; lag, epis; tos, } \\
\text { sensación de opresión, edema } \\
\text { pulm, neum; dolor abdom, } \\
\text { diarr; erupciones como el } \\
\text { sarampión; quemaduras en } \\
\text { ojos y piel }\end{array}$ \\
\hline
\end{tabular}




\begin{tabular}{|c|c|c|c|c|c|c|}
\hline \multirow[b]{2}{*}{$\begin{array}{l}\text { Denominación } \\
\text { química } \\
\text { N úmero CAS }\end{array}$} & \multicolumn{4}{|c|}{ Tarjetas Internacionales sobre la Seguridad de los Productos Q uímicos } & \multicolumn{2}{|c|}{ N IO SH (EE.UU.) } \\
\hline & $\begin{array}{l}\text { Período } \\
\text { corto de } \\
\text { exposición }\end{array}$ & $\begin{array}{l}\text { Período } \\
\text { largo de } \\
\text { exposición }\end{array}$ & $\begin{array}{l}\text { Vías de } \\
\text { exposición }\end{array}$ & Síntomas & $\begin{array}{l}\text { O rganos } \\
\text { afectados } \\
\text { Vías de } \\
\text { entrada }\end{array}$ & Síntomas \\
\hline $\begin{array}{l}\text { CLORO } \\
\quad 7782-50-5\end{array}$ & $\begin{array}{l}\text { ojos; piel; } \\
\text { tract resp; } \\
\text { pulmones; piel }\end{array}$ & pulmones & $\begin{array}{l}\text { Inhalación } \\
\\
\\
\text { Piel } \\
\text { 0jos }\end{array}$ & $\begin{array}{l}\text { Corrosivo, sensación de quemazón, tos, } \\
\text { cefalea, dificultad respiratoria, náuseas, } \\
\text { disnea, dolor de garganta, los síntomas } \\
\text { pueden tardar en aparecer } \\
\text { Corrosivo, quemaduras en la piel, dolor } \\
\text { Corrosivo, dolor, visión borrosa, quemaduras } \\
\text { profundas graves }\end{array}$ & $\begin{array}{l}\text { Sis resp, ojos, piel } \\
\text { Inh; con }\end{array}$ & $\begin{array}{l}\text { Quemaduras en ojos, nariz, } \\
\text { boca; lag, rin; tos, ahogo, } \\
\text { dolor subest; náu, vómit; cef, } \\
\text { mar; síncope; edema pulm; } \\
\text { neum; hipox; derm; líq: } \\
\text { congelación }\end{array}$ \\
\hline $\begin{array}{l}\text { CLORURO DE AZUFRE } \\
10025-67-9\end{array}$ & $\begin{array}{l}\text { ojos; piel; } \\
\text { tract resp; } \\
\text { pulmones; corrosivo } \\
\text { en caso de } \\
\text { ingestión }\end{array}$ & piel & $\begin{array}{r}\text { Inhalación } \\
\text { Piel } \\
\text { 0jos }\end{array}$ & $\begin{array}{l}\text { Sensación de quemazón, tos, cefalea, } \\
\text { dificultad respiratoria, náuseas, vómitos } \\
\text { Enrojecimiento, quemaduras en la piel, } \\
\text { sensación de quemazón, dolor, ampollas } \\
\text { Enrojecimiento, dolor, quemaduras profundas } \\
\text { graves }\end{array}$ & $\begin{array}{l}\text { Sis resp; piel; ojos } \\
\text { Inh; ing; con }\end{array}$ & $\begin{array}{l}\text { Irrit ojos, piel, muc; lag; tos; } \\
\text { quemaduras en ojos, piel; } \\
\text { edema pulm }\end{array}$ \\
\hline $\begin{array}{l}\text { DIFLUORURO DE OXIGENO } \\
7783-41-7\end{array}$ & $\begin{array}{l}\text { ojos; piel; } \\
\text { tract resp; } \\
\text { pulmones }\end{array}$ & & $\begin{array}{l}\text { Inhalación } \\
\text { Piel }\end{array}$ & $\begin{array}{l}\text { Tos, dificultad respiratoria, dolor de garganta } \\
\text { En contacto con el líquido: congelación }\end{array}$ & $\begin{array}{l}\text { Sis resp; ojos; piel } \\
\text { Inh; con }\end{array}$ & $\begin{array}{l}\text { Irrit ojos, piel, sis resp; cef; } \\
\text { edema pulm; quemaduras en } \\
\text { ojos, piel (por contacto con el } \\
\text { gas a presión) }\end{array}$ \\
\hline $\begin{array}{l}\text { FLUOR } \\
\quad 7782-41-4\end{array}$ & $\begin{array}{l}\text { ojos; piel; } \\
\text { tract resp; } \\
\text { pulmones }\end{array}$ & piel & $\begin{array}{r}\text { Inhalación } \\
\text { Piel } \\
\text { 0jos }\end{array}$ & $\begin{array}{l}\text { Corrosivo, tos, disnea, dolor de garganta, } \\
\text { ahogo } \\
\text { Corrosivo, enrojecimiento, quemaduras graves } \\
\text { en la piel, en contacto con el líquido: } \\
\text { congelación } \\
\text { Enrojecimiento, quemaduras profundas graves }\end{array}$ & $\begin{array}{l}\text { Sis resp; ojos; } \\
\text { hígado; riñones } \\
\text { Inh; con }\end{array}$ & $\begin{array}{l}\text { Irrit ojos, nariz, sis resp; } \\
\text { espasmo lar, espasmo bron; } \\
\text { edema pulm; quemaduras en } \\
\text { ojos y piel; en animales: } \\
\text { lesiones hepáticas, renales }\end{array}$ \\
\hline $\begin{array}{l}\text { FLUORURO DE CARBONILO } \\
\text { 353-50-4 }\end{array}$ & $\begin{array}{l}\text { ojos; piel; } \\
\text { tract resp; } \\
\text { pulmones; piel }\end{array}$ & sangre & $\begin{array}{l}\text { Inhalación } \\
\text { Pies } \\
\text { 0jos }\end{array}$ & $\begin{array}{l}\text { Tos, dificultad respiratoria, dolor de garganta, } \\
\text { los síntomas pueden tardar en aparecer } \\
\text { Enrojecimiento, en contacto con el líquido: } \\
\text { congelación } \\
\text { Enrojecimiento }\end{array}$ & $\begin{array}{l}\text { Ojos; piel; sis resp; } \\
\text { huesos } \\
\text { Inh; con }\end{array}$ & $\begin{array}{l}\text { Irrit ojos, piel, muc, sis resp; } \\
\text { quemaduras en ojos y piel; } \\
\text { lag; tos; edema pulm, disn; } \\
\text { exposición crónica: dolor Gl, } \\
\text { fibr musc, fluorosis } \\
\text { esquelética; líq: congelación }\end{array}$ \\
\hline $\begin{array}{l}\text { FLUORURO DE HIDROGENO } \\
7664-39-3\end{array}$ & $\begin{array}{l}\text { ojos; piel; } \\
\text { tract resp; } \\
\text { pulmones }\end{array}$ & & $\begin{array}{r}\text { Inhalación } \\
\text { Piel } \\
\text { 0jos } \\
\text { Ingestión }\end{array}$ & $\begin{array}{l}\text { Tos, dificultad respiratoria, dolor de garganta, } \\
\text { los síntomas pueden tardar en aparecer } \\
\text { Puede adsorberse, quemaduras graves en la } \\
\text { piel } \\
\text { Enrojecimiento, dolor, visión borrosa } \\
\text { Dolor abdominal, diarrea, dolor de garganta, } \\
\text { vómitos, los sintomas pueden tener efectos } \\
\text { retardados }\end{array}$ & $\begin{array}{l}\text { Ojos; sis resp; piel; } \\
\text { huesos } \\
\text { Inh; abs (líq); ing } \\
\text { (disol); con }\end{array}$ & $\begin{array}{l}\text { Irrit ojos, piel, nariz, garganta; } \\
\text { edema pulm; quemaduras en } \\
\text { ojos, piel; rinitis; bron; } \\
\text { cambios óseos }\end{array}$ \\
\hline $\begin{array}{l}\text { FLUORURO DE PERCLORILO } \\
7616-94-6\end{array}$ & tract resp; piel & sangre & $\begin{array}{r}\text { Inhalación } \\
\text { Piel } \\
\text { 0jos }\end{array}$ & $\begin{array}{l}\text { Cefalea } \\
\text { En contacto con el líquido: congelación } \\
\text { Quemaduras profundas graves }\end{array}$ & $\begin{array}{l}\text { Sis resp; piel; } \\
\text { sangre } \\
\text { Inh; con (líq) }\end{array}$ & $\begin{array}{l}\text { Irrit sis resp; líq: congelación; } \\
\text { en animales: metahem; cian; } \\
\text { deb; mar, cef; edema pulm; } \\
\text { neuitis; anoxia }\end{array}$ \\
\hline $\begin{array}{l}\text { FOSGENO } \\
75-44-5\end{array}$ & $\begin{array}{l}\text { ojos; piel; } \\
\text { tract resp; } \\
\text { pulmones }\end{array}$ & pulmones & Inhalación & $\begin{array}{l}\text { Corrosivo, sensación de quemazón, tos, } \\
\text { dificultad respiratoria, disnea, dolor de } \\
\text { garganta }\end{array}$ & $\begin{array}{l}\text { Sis resp; piel; ojos } \\
\text { Inh; con (líq) }\end{array}$ & $\begin{array}{l}\text { Irrit ojos; sequedad, ardor de } \\
\text { garganta; vómit; tos, esputos } \\
\text { espumosos, disn, dolor torac, } \\
\text { cian; líq: congelación }\end{array}$ \\
\hline $\begin{array}{l}\text { HEXAFLUORURO DE AZUFRE } \\
2551-62-4\end{array}$ & piel & & $\begin{array}{l}\text { Piel } \\
\text { Ojos }\end{array}$ & $\begin{array}{l}\text { En contacto con líquido: congelación } \\
\text { Daños en la córnea }\end{array}$ & $\begin{array}{l}\text { Sis resp } \\
\operatorname{lnh}\end{array}$ & $\begin{array}{l}\text { Asfix: aceleración de la } \\
\text { respiración, del pulso; ligera } \\
\text { desco musc, alteraciones } \\
\text { emocionales; ftg, náu, vómit, } \\
\text { convuls }\end{array}$ \\
\hline
\end{tabular}


Tabla 104.82 - Riesgos para la salud.

\begin{tabular}{|c|c|c|c|c|c|c|}
\hline \multirow[b]{2}{*}{$\begin{array}{l}\text { Denominación } \\
\text { química } \\
\text { N úmero CAS }\end{array}$} & \multicolumn{4}{|c|}{ Tarjetas Internacionales sobre la Seguridad de los Productos Q uímicos } & \multicolumn{2}{|c|}{ N IO SH (EE.UU.) } \\
\hline & $\begin{array}{l}\text { Período } \\
\text { corto de } \\
\text { exposición }\end{array}$ & $\begin{array}{l}\text { Período } \\
\text { largo de } \\
\text { exposición }\end{array}$ & $\begin{array}{l}\text { Vías de } \\
\text { exposición }\end{array}$ & Síntomas & $\begin{array}{l}\text { O rganos } \\
\text { afectados } \\
\text { Vías de } \\
\text { entrada }\end{array}$ & Síntomas \\
\hline $\begin{array}{l}\text { OXIDO DE CLORO } \\
10049-04-4\end{array}$ & $\begin{array}{l}\text { ojos; piel; } \\
\text { tract resp; } \\
\text { pulmones; piel }\end{array}$ & pulmones & $\begin{array}{r}\text { Inhalación } \\
\text { Piel }\end{array}$ & $\begin{array}{l}\text { Corrosivo, tos, cefalea, dificultad respiratoria, } \\
\text { náuseas, disnea, dolor de garganta, los } \\
\text { sintomas pueden tardar en aparecer } \\
\text { Corrosivo, enrojecimiento, quemaduras graves } \\
\text { en la piel, dolor }\end{array}$ & $\begin{array}{l}\text { Sis resp; ojos } \\
\text { Inh; ing (lía); con }\end{array}$ & $\begin{array}{l}\text { Irrit ojos, nariz, garganta; tos, } \\
\text { resp sib, bron, edema pulm; } \\
\text { bron crónica }\end{array}$ \\
\hline $\begin{array}{l}\text { PENTAFLUORURO DE AZUFRE } \\
5714-22.7\end{array}$ & & & & & $\begin{array}{l}\text { Sis resp; SNC; ojos; } \\
\text { piel } \\
\text { Inh; ing; con }\end{array}$ & $\begin{array}{l}\text { Irrit ojos, piel, sis resp; en } \\
\text { animales: hemorr, edema pulm }\end{array}$ \\
\hline $\begin{array}{l}\text { PENTAFLUORURO DE BROMO } \\
7789-30-2\end{array}$ & $\begin{array}{l}\text { ojos; piel; } \\
\text { tract resp; } \\
\text { pulmones }\end{array}$ & $\begin{array}{l}\text { hígado; riñones; } \\
\text { tract resp }\end{array}$ & $\begin{array}{r}\text { Inhalación } \\
\text { Piel } \\
\text { 0jos } \\
\text { Ingestión }\end{array}$ & $\begin{array}{l}\text { Sensación de quemazón, disnea, dolor de } \\
\text { garganta } \\
\text { Quemaduras en la piel, dolor, ampollas } \\
\text { Dolor, visión borrosa, quemaduras profundas } \\
\text { graves } \\
\text { Dolor abdominal, sensación de quemazón }\end{array}$ & $\begin{array}{l}\text { Ojos; piel; sis resp; } \\
\text { hígado; riñones } \\
\text { Inh; ing; con }\end{array}$ & $\begin{array}{l}\text { Irrit ojos, piel, sis resp; nec } \\
\text { córn; quemaduras en la piel; } \\
\text { tos; disn, edema pulm; } \\
\text { lesiones hepáticas y renales }\end{array}$ \\
\hline $\begin{array}{l}\text { TRIFLLORURO DE CLORO } \\
7790-91-2\end{array}$ & $\begin{array}{l}\text { ojos; piel; } \\
\text { tract resp; } \\
\text { pulmones }\end{array}$ & & $\begin{array}{r}\text { Inhalación } \\
\text { Piel } \\
\text { 0jos }\end{array}$ & $\begin{array}{l}\text { Tos, dificultad respiratoria, dolor de garganta } \\
\text { Corrosivo, enrojecimiento, quemaduras graves } \\
\text { en la piel, dolor } \\
\text { Pérdida de visión permanente, quemaduras } \\
\text { profundas graves, ceguera }\end{array}$ & $\begin{array}{l}\text { Piel; ojos; sis resp } \\
\text { Inh; ing. (líq); con }\end{array}$ & $\begin{array}{l}\text { Quemaduras en ojos, piel (líq } \\
\text { o vap alta conc); irrit resp; en } \\
\text { animales: lag; ulceras corn; } \\
\text { edema pulm }\end{array}$ \\
\hline
\end{tabular}

\begin{tabular}{|c|c|c|c|}
\hline $\begin{array}{l}\text { Denominación química } \\
\text { y número CAS }\end{array}$ & Físicos & Q uímicos & $\begin{array}{l}\text { Tipo o división } \\
\text { UN / Riesgos } \\
\text { subsidiarios }\end{array}$ \\
\hline $\begin{array}{l}\text { BROMO } \\
7726-95-6\end{array}$ & $\begin{array}{l}\text { - El vapor es más pesado } \\
\text { que el aire }\end{array}$ & $\begin{array}{l}\text { - Al calentarse, forma vapores tóxicos • Es un oxidante fuerte y reacciona violentamente con } \\
\text { sustancias combustibles y reductoras • Reacciona violentamente con amoníaco acuoso, } \\
\text { oxidantes, metales, compuestos orgánicos y fósforo, con peligro de incendio y explosión • Ataca } \\
\text { algunos tipos de plástico, caucho y revestimientos }\end{array}$ & $3 / 6.1$ \\
\hline $\begin{array}{l}\text { BROMURO DE HIDROGENO } \\
10035-10-6\end{array}$ & $\begin{array}{l}\text { - El gas es más pesado } \\
\text { que el aire }\end{array}$ & $\begin{array}{l}\text { - La solución en agua es un ácido fuerte, reacciona violentamente con bases y es corrosiva } \\
\text { - Reacciona violentamente con oxidantes fuertes y muchos compuestos orgánicos, con peligro de } \\
\text { incendio y explosión - Ataca muchos metales, formando gas hidrógeno inflamable }\end{array}$ & 8 \\
\hline $\begin{array}{l}\text { CLORO } \\
\quad 7782-50-5\end{array}$ & $\begin{array}{l}\text { - El gas es más pesado } \\
\text { que el aire }\end{array}$ & $\begin{array}{l}\text { - Reacciona violentamente con muchos compuestos orgánicos, amoníaco y metales finamente } \\
\text { divididos, con peligro de incendio y explosión - Ataca muchos metales en presencia de agua } \\
\text { - Ataca plásticos, caucho y revestimientos }\end{array}$ & $2.3 / 5.1 / 8$ \\
\hline $\begin{array}{l}\text { CLORURO DE AZUFRE } \\
10025-67-9\end{array}$ & & $\begin{array}{l}\text { - Al arder, desprende gases y vapores tóxicos (cloruro de hidrógeno, dióxido de azufre, sulfuro } \\
\text { de hidrógeno) • Se descompone dando cloro gaseoso tóxico y azufre sólido al calentarse por } \\
\text { encima de } 300{ }^{\circ} \mathrm{C} \text { - Reacciona con peróxidos, óxidos de fósforo y algunos compuestos } \\
\text { orgánicos, con peligro de incendio y explosión • Reacciona con el aire húmedo desprendiendo } \\
\text { vapores corrosivos (ácido clorhídrico) • El contacto con el agua provoca una reacción violenta, } \\
\text { con formación de cloruro de hidrógeno gaseoso (o ácido clorhídrico), dióxido de azufre, azufre, } \\
\text { sulfito, tiosulfato y sulfuro de hidrógeno, que pueden corroer los envases metálicos y formar gas } \\
\text { hidrógeno inflamable }\end{array}$ & 8 \\
\hline
\end{tabular}




\begin{tabular}{|c|c|c|c|}
\hline $\begin{array}{l}\text { Denominación química } \\
\text { y número CAS }\end{array}$ & Físicos & Q uímicos & $\begin{array}{l}\text { Tipo o división } \\
\text { UN / Riesgos } \\
\text { subsidiarios }\end{array}$ \\
\hline $\begin{array}{l}\text { DIFLUORURO DE OXIGENO } \\
7783-41-7\end{array}$ & $\begin{array}{l}\text { - El gas es más pesado } \\
\text { que el aire }\end{array}$ & $\begin{array}{l}\text { - Se descompone al calentarse por encima de } 250^{\circ} \mathrm{C} \text {, produciendo vapores tóxicos (flúor) } \\
\text { - Es un oxidante fuerte y reacciona violentamente con materiales combustibles y reductores } \\
\text { - Reacciona explosivamente con sulfuro de hidrógeno a temperatura ambiente, y con cloro, } \\
\text { bromo y yodo al calentarse } \bullet \text { Ataca el mercurio • Explota en contacto con el vapor de agua • La } \\
\text { reacción del difluoruro de oxígeno con compuestos no metálicos, como polvo de boro y fósforo } \\
\text { rojo y silicio, alúmina u otros tensoactivos sólidos similares, es exotérmica y puede ser explosiva }\end{array}$ & $2.3 / 5.1 / 8$ \\
\hline $\begin{array}{l}\text { FLUOR } \\
7782-41-4\end{array}$ & $\begin{array}{l}\text { - El gas es más pesado } \\
\text { que el aire }\end{array}$ & $\begin{array}{l}\text { - Es un potente oxidante y reacciona violentamente con materiales combustibles y reductores } \\
\text { - Reacciona violentamente con el agua, produciendo vapores tóxicos y corrosivos: ozono y } \\
\text { fluoruro de hidrógeno • Reacciona violentamente con amoníaco, metales, oxidantes y muchos } \\
\text { otros materiales, con peligro de incendio y explosión }\end{array}$ & $2.3 / 5.1 / 8$ \\
\hline $\begin{array}{l}\text { FLUORURO DE CARBONILO } \\
353-50-4\end{array}$ & $\begin{array}{l}\text { - El gas es más pesado } \\
\text { que el aire }\end{array}$ & $\begin{array}{l}\text { - Se descompone al calentarse a } 450-490^{\circ} \mathrm{C} \text {, produciendo gases tóxicos } \bullet \text { En contacto con el } \\
\text { agua se hidroliza rápidamente formando dióxido de carbono y fluoruro de hidrógeno }\end{array}$ & $2.3 / 8$ \\
\hline $\begin{array}{l}\text { FLUORURO DE HIDROGENO } \\
7664-39-3\end{array}$ & & $\begin{array}{l}\text { - La solución en agua es un ácido fuerte, reacciona violentamente con bases y es corrosiva } \\
\text { - Reacciona violentamente con muchos compuestos, con peligro de incendio y explosión • En } \\
\text { contacto con el aire, desprende vapores corrosivos que son más pesados que el aire y se } \\
\text { propagan a ras del suelo • Ataca el vidrio y otros compuestos silíicicos }\end{array}$ & $3 / 6.1$ \\
\hline $\begin{array}{l}\text { FLUORURO DE PERCLORILO } \\
7616-94-6\end{array}$ & & $\begin{array}{l}\text { - Se descompone al calentarse, liberando vapores tóxicos (flúor, óxidos de flúor, cloro, óxidos } \\
\text { de cloro) • Es un oxidante fuerte y reacciona violentamente con materiales combustibles y } \\
\text { reductores, con peligro de incendio y explosión • Ataca algunos tipos de plásticos, caucho } \\
\text { y revestimientos }\end{array}$ & $2.3 / 5.1$ \\
\hline $\begin{array}{l}\text { FLUORURO DE SULFURILO } \\
2699-79-8\end{array}$ & & & 2.3 \\
\hline $\begin{aligned} \text { FOSGENO } \\
75-44-5\end{aligned}$ & $\begin{array}{l}\text { - El vapor es más pesado } \\
\text { que el aire y puede } \\
\text { desplazarse a ras del suelo }\end{array}$ & $\begin{array}{l}\text { - Se descompone al calentarse por encima de } 300^{\circ} \mathrm{C} \text {, liberando gases tóxicos y corrosivos: } \\
\text { cloruro de hidrógeno, monóxido de carbono, vapores de cloro • Reacciona violentamente con } \\
\text { oxidantes fuertes } \bullet \text { Reacciona lentamente con agua, produciendo gases corrosivos, acres y } \\
\text { tóxicos • Reacciona violentamente con aminas y aluminio • Ataca muchos metales en presencia } \\
\text { de agua } \bullet \text { Ataca los metales, los plásticos y el caucho }\end{array}$ & $2.3 / 8$ \\
\hline $\begin{array}{l}\text { HEXAFLUORURO DE AZUFRE } \\
2551-62-4\end{array}$ & $\begin{array}{l}\text { - El gas es más pesado } \\
\text { que el aire y puede } \\
\text { acumularse en espacios } \\
\text { con techos bajos, } \\
\text { provocando deficiencia de } \\
\text { oxígeno }\end{array}$ & $\begin{array}{l}\text { - Se descompone al arder, liberando vapores tóxicos de óxidos de azufre y fluoruro de hidrógeno, } \\
\text { y en contacto con superficies calientes, produciendo } \mathrm{SO2} \text { - Al calentarse, desprende vapores } \\
\text { tóxicos • Reacciona con oxidantes fuertes y con álcali y tierra alcalina }\end{array}$ & 2.2 \\
\hline $\begin{array}{l}\text { OXIDO DE CLORO } \\
10049-04-4\end{array}$ & $\begin{array}{l}\text { - El gas es más pesado } \\
\text { que el aire }\end{array}$ & $\begin{array}{l}\text { - Puede descomponerse explosivamente como consecuencia de un impacto, fricción o sacudida } \\
\text { - Puede explotar al calentarse } \bullet \text { Es un potente oxidante y reacciona violentamente con } \\
\text { materiales combustibles y reductores } \bullet \text { Reacciona violentamente con mercurio, fósforo, azufre y } \\
\text { muchos compuestos, con peligro de incendio y explosión • Reacciona con el agua, produciendo } \\
\text { ácido clorhídrico y ácido clórico }\end{array}$ & \\
\hline $\begin{array}{l}\text { PENTABROMURO DE FOSFORO } \\
7789-69-7\end{array}$ & & & 8 \\
\hline $\begin{array}{l}\text { PENTAFLUORURO DE BROMO } \\
7789-30-2\end{array}$ & $\begin{array}{l}\text { - El vapor es más pesado } \\
\text { que el aire }\end{array}$ & $\begin{array}{l}\text { - Se descompone al calentarse por encima de } 460^{\circ} \mathrm{C} \text { y en contacto con ácidos o vapores ácidos, } \\
\text { produciendo vapores muy tóxicos de flúor y bromo • Reacciona violentamente con combustibles } \\
\text { y compuestos orgánicos, así como con sustancias que contengan hidrógeno (amoníaco, ácido } \\
\text { acético, grasa, papel), con peligro de incendio y explosión • Reacciona explosivamente con agua } \\
\text { o vapor de agua, liberando vapores tóxicos y corrosivos • Reacciona con todos los elementos } \\
\text { conocidos, excepto el nitrógeno, el oxígeno y los gases nobles }\end{array}$ & $5.1 / 6.1 / 8$ \\
\hline
\end{tabular}


Tabla 104.83 • Riesgos físicos y químicos.

\begin{tabular}{|c|c|c|c|}
\hline $\begin{array}{l}\text { Denominación química } \\
\text { y número CAS }\end{array}$ & Físicos & Q uímicos & $\begin{array}{l}\text { Tipo o división } \\
\text { UN / Riesgos } \\
\text { subsidiarios }\end{array}$ \\
\hline $\begin{array}{l}\text { TRIFLUORURO DE CLORO } \\
7790.91-2\end{array}$ & $\begin{array}{l}\text { - El gas es más pesado } \\
\text { que el aire y corrosivo }\end{array}$ & $\begin{array}{l}\text { - Se descompone al calentarse por encima de } 220^{\circ} \mathrm{C} \text {, produciendo gases tóxicos (compuestos } \\
\text { clorados y fluorados) } \bullet \text { Reacciona violentamente con agua, arena, compuestos silicicos, vidrio y } \\
\text { amianto } \bullet \text { Reacciona con todo tipo de plásticos, caucho y resinas, excepto los polímeros } \\
\text { altamente fluorados } \bullet \text { La mayoría de los materiales combustibles arden espontáneamente en } \\
\text { contacto con esta sustancia } \bullet \text { Reacciona violentamente con materiales oxidables, metales y } \\
\text { óxidos metálicos } \bullet \text { Explota en contacto con materiales orgánicos } \bullet \text { Emite vapores altamente } \\
\text { tóxicos en contacto con ácidos }\end{array}$ & $2.3 / 5.1 / 8$ \\
\hline
\end{tabular}

\begin{tabular}{|c|c|c|c|c|c|c|c|c|c|c|}
\hline $\begin{array}{l}\text { Denominación química } \\
\mathrm{N} \text { úmero CAS }\end{array}$ & Color/ forma & $\begin{array}{l}\text { p.e. } \\
(\stackrel{0}{ } \mathrm{C})\end{array}$ & $\begin{array}{l}\text { p.f. } \\
(\stackrel{\circ}{ } C)\end{array}$ & $\begin{array}{l}\text { p.m.l } \\
\text { (g/ } \\
\text { mol) }\end{array}$ & $\begin{array}{l}\text { Solubilidad } \\
\text { en agua }\end{array}$ & $\begin{array}{l}\text { Densidad } \\
\text { relativa } \\
\text { (agua =1) }\end{array}$ & $\begin{array}{l}\text { Densidad } \\
\text { relativa } \\
\text { del vapor } \\
\text { (air=1) }\end{array}$ & $\begin{array}{l}\text { Pvap/ } \\
(\mathrm{kPa})\end{array}$ & $\begin{array}{l}\text { Límit. } \\
\text { inflam. }\end{array}$ & $\begin{array}{ll}\text { p.ig. } & \text { p.aut } \\
\left({ }^{\circ} \mathrm{C}\right) & \text { ig. } \\
& \left({ }^{\circ} \mathrm{C}\right)\end{array}$ \\
\hline $\begin{array}{l}\text { BROMO } \\
\quad 7726-95-6\end{array}$ & $\begin{array}{l}\text { líquido de color } \\
\text { marrón rojizo oscuro; } \\
\text { vapor de color } \\
\text { marrón rojizo; } \\
\text { cristales rómbicos }\end{array}$ & 58,78 & $-7,25$ & 159,808 & $3,58 \mathrm{~g} / 100 \mathrm{ml}$ & $\begin{array}{l}3,1023 \\
\text { @ } 25^{\circ} \mathrm{C} / 4^{\circ} \mathrm{C}\end{array}$ & $\begin{array}{l}5,51 \\
@ 15^{\circ} \mathrm{C}\end{array}$ & 23,3 & & \\
\hline $\begin{array}{l}\text { CLORO } \\
7782-50-5\end{array}$ & $\begin{array}{l}\text { gas diatómico de } \\
\text { color amarillo } \\
\text { verdoso }\end{array}$ & $-34,6$ & $-100,98$ & 70,906 & $\begin{array}{l}0,57 \mathrm{~g} / 100 \mathrm{ml} \\
@ 30^{\circ} \mathrm{C}\end{array}$ & $1,159 @ 25^{\circ} \mathrm{C}$ & 2,5 & 638 & & \\
\hline $\begin{array}{l}\text { CLORURO DE AZUFRE } \\
10025-67-9\end{array}$ & $\begin{array}{l}\text { líquido oleaginoso de } \\
\text { color ámbar claro o } \\
\text { rojo amarillento }\end{array}$ & 135,6 & .77 & 135,03 & reacciona & $\begin{array}{l}1,6885 \\
@ 15,5^{\circ} \mathrm{Cl} \\
15,5^{\circ} \mathrm{C}\end{array}$ & 4,66 & 0,906 & & 118 cc 234 \\
\hline $\begin{array}{l}\text { CLORURO DE NITROGENO } \\
10025-85-1\end{array}$ & $\begin{array}{l}\text { cristales rómbicos } 0 \\
\text { aceite de color } \\
\text { amarillo }\end{array}$ & $<71$ & $<-40$ & 120,37 & $\begin{array}{l}\text { insol en agua } \\
\text { fría, se } \\
\text { descompone en } \\
\text { agua caliente }\end{array}$ & 1,653 & & & & \\
\hline $\begin{array}{l}\text { DICLORURO DE AZUFRE } \\
10545-99-0\end{array}$ & $\begin{array}{l}\text { líquido de color rojo } \\
\text { oscuro; líquido } \\
\text { marrón rojizo }\end{array}$ & $\begin{array}{l}59 \text { (se } \\
\text { descompone) }\end{array}$ & .78 & 102,96 & & $\begin{array}{l}1,621 @ \\
15^{\circ} \mathrm{C} / 15^{\circ} \mathrm{C}\end{array}$ & 3,55 & $\begin{array}{l}7,6 \mathrm{~mm} \mathrm{Hg} \\
@-23^{\circ} \mathrm{C}\end{array}$ & & \\
\hline $\begin{array}{l}\text { DIFLUORURO DE OXIGENO } \\
7783-41-7\end{array}$ & $\begin{array}{l}\text { gas incoloro; líquido } \\
\text { de color marrón } \\
\text { amarillento }\end{array}$ & $-144,8$ & $-223,8$ & 54,00 & $\begin{array}{l}\text { insol en agua } \\
\text { caliente; lig sol y } \\
\text { se descompone } \\
\text { en agua fría }\end{array}$ & $\begin{array}{l}1,90 \\
\text { @ }-233,8^{\circ} \mathrm{C} \\
\text { (líquido) }\end{array}$ & 1,8 & $\begin{array}{l}760 \mathrm{~mm} \mathrm{Hg} \\
@ \\
-144,6{ }^{\circ} \mathrm{C}\end{array}$ & & \\
\hline $\begin{array}{l}\text { FLUOR } \\
\quad 7782-41-4\end{array}$ & $\begin{array}{l}\text { amarillo pálido; gas } \\
\text { amarillo verdoso }\end{array}$ & $-188,13$ & $-219,61$ & 37,99 & reacciona & $\begin{array}{l}1,51 \\
@-188,2{ }^{\circ} \mathrm{C}\end{array}$ & 1,3 & $\begin{array}{l}1 \mathrm{~mm} \mathrm{Hg} \\
@ \\
-223,0^{\circ} \mathrm{C} ; \\
10 \mathrm{~mm} \mathrm{Hg} \\
@ \\
-214,1^{\circ} \mathrm{C}\end{array}$ & & \\
\hline $\begin{array}{l}\text { FLUORURO DE CARBONILO } \\
\text { 353-50-4 }\end{array}$ & gas incoloro & .83 & -114 & 66,01 & reacciona & $1,139 @ 25^{\circ} \mathrm{C}$ & 2,3 & & & \\
\hline $\begin{array}{l}\text { FLUORURO DE HIDROGENO } \\
7664-39-3\end{array}$ & líquido incoloro & 20 & .83 & 20,0 & misc & $\begin{array}{l}0,991 \\
@ 19,54{ }^{\circ} \mathrm{C}\end{array}$ & $\begin{array}{l}0,922 \mathrm{~g} / \mathrm{l} \\
\text { @ } 0^{\circ} \mathrm{C}\end{array}$ & $\begin{array}{l}400 \mathrm{~mm} \mathrm{Hg} \\
@ 2,5^{\circ} \mathrm{C}\end{array}$ & & \\
\hline $\begin{array}{l}\text { FLUORURO DE PERCLORILO } \\
7616-94-6\end{array}$ & gas incoloro & $-46,8$ & -146 & 102,45 & misc & $\begin{array}{l}0,637 \text { (gas); } \\
1,434 \text { (líquido) }\end{array}$ & 3,5 & 1,06 & & \\
\hline
\end{tabular}




\begin{tabular}{|c|c|c|c|c|c|c|c|c|c|c|}
\hline $\begin{array}{l}\text { Denominación química } \\
\mathrm{N} \text { úmero CAS }\end{array}$ & Color/ forma & 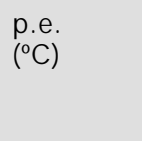 & $\begin{array}{l}\text { p.f. } \\
(\stackrel{\circ}{ } \mathrm{C})\end{array}$ & $\begin{array}{l}\mathrm{p} . \mathrm{m} . / \\
(\mathrm{g} / \\
\mathrm{mol})\end{array}$ & $\begin{array}{l}\text { Solubilidad } \\
\text { en agua }\end{array}$ & $\begin{array}{l}\text { Densidad } \\
\text { relativa } \\
\text { (agua }=1 \text { ) }\end{array}$ & $\begin{array}{l}\text { Densidad } \\
\text { relativa } \\
\text { del vapor } \\
\text { (air=1) }\end{array}$ & $\begin{array}{l}\text { Pvap/ } \\
(\mathrm{kPa})\end{array}$ & $\begin{array}{l}\text { Límit. } \\
\text { inflam. }\end{array}$ & $\begin{array}{ll}\text { p.ig. } & \text { p.aut } \\
\left({ }^{\circ} \mathrm{C}\right) & \text { ig. } \\
& \left({ }^{\circ} \mathrm{C}\right)\end{array}$ \\
\hline $\begin{array}{l}\text { FLUORURO DE SULFURILO } \\
2699-79-8\end{array}$ & gas incoloro & $-55,38$ & $-135,82$ & 102,07 & $\begin{array}{l}4-5 \mathrm{ml} \text { gas/ } \\
100 \mathrm{ml}\end{array}$ & $\begin{array}{l}3,72 \mathrm{~g} / \mathrm{I} \text { (gas), } \\
1,7 \mathrm{~g} / \mathrm{I} \\
\text { (líquido) }\end{array}$ & 3,5 & $\begin{array}{l}1,7 \mathrm{mPa} \\
@ 25^{\circ} \mathrm{C}\end{array}$ & & \\
\hline $\begin{array}{r}\text { FOSGENO } \\
75-44.5 \\
\end{array}$ & gas incoloro & 8 & -118 & 98,92 & lig sol & 1,381 & 3,4 & 161,6 & & \\
\hline $\begin{array}{l}\text { HEXAFLUOROSILICATO SODICO } \\
16893-85-9\end{array}$ & $\begin{array}{l}\text { polvo granulado } \\
\text { blanco }\end{array}$ & & & 188,05 & sol & 2,68 & & & & \\
\hline $\begin{array}{l}\text { HEXAFLUORURO DE AZUFRE } \\
2551-62-4\end{array}$ & $\begin{array}{l}\text { gas incoloro; líquido } \\
\text { a }-50,5^{\circ} \mathrm{C}\end{array}$ & $-63,8$ sublima & $-50,8$ & 146,06 & lig sol & $\begin{array}{l}1,88 @-50^{\circ} \mathrm{C} \\
\text { (líquido) }\end{array}$ & 5,1 & 2.140 & & \\
\hline $\begin{array}{l}\text { OXIDO DE CLORO } \\
10049-04-4\end{array}$ & $\begin{array}{l}\text { gas amarillo o } \\
\text { amarillo rojizo a } \\
\text { temp. ambiente; el } \\
\text { dióxido de cloro } \\
\text { sólido es una masa } \\
\text { cristalina de color } \\
\text { rojo amarillento; el } \\
\text { líquido es de color } \\
\text { marrón rojizo }\end{array}$ & 11 & .59 & 67,46 & $\begin{array}{l}3,01 \mathrm{~g} / \mathrm{I} \\
@ 25^{\circ} \mathrm{Cy} \\
34,5 \mathrm{~mm} \mathrm{Hg}\end{array}$ & $1,642 @ 0{ }^{\circ} \mathrm{C}$ & 2,3 & 10 & $>10$ & \\
\hline $\begin{array}{l}\text { PENTABROMURO DE FOSFORO } \\
7789-69-7\end{array}$ & $\begin{array}{l}\text { masa cristalina } \\
\text { amarilla }\end{array}$ & $\begin{array}{l}106 \text { se } \\
\text { descompone }\end{array}$ & & 430,49 & se descompone & & & & & \\
\hline $\begin{array}{l}\text { PENTAFLUORURO DE BROMO } \\
7789-30-2\end{array}$ & $\begin{array}{l}\text { líquido incoloro; gas } \\
\text { incoloro por encima } \\
\text { de } 40,3^{\circ} \mathrm{C}\end{array}$ & 40,76 & $-60,5$ & 174,90 & reacciona & $\begin{array}{l}2,4604 \\
@ 25^{\circ} \mathrm{C}\end{array}$ & 6,05 & $\begin{array}{l}53,5 \\
@ 25,5^{\circ} \mathrm{C}\end{array}$ & & \\
\hline $\begin{array}{l}\text { TRIBROMURO DE FOSFORO } \\
7789-60-8\end{array}$ & $\begin{array}{l}\text { líquido incoloro; } \\
\text { líquido amarillo } \\
\text { pálido }\end{array}$ & 173,2 & $-41,5$ & 270,73 & & $2,85 @ 15^{\circ} \mathrm{C}$ & & $\begin{array}{l}10 \mathrm{~mm} \mathrm{Hg} \\
\text { @ } 47,8{ }^{\circ} \mathrm{C}\end{array}$ & & \\
\hline $\begin{array}{l}\text { TRIFLUORURO DE CLORO } \\
7790-91.2\end{array}$ & $\begin{array}{l}\text { gas incoloro; el } \\
\text { líquido es de color } \\
\text { verde-amarillo; el } \\
\text { sólido es blanco }\end{array}$ & 11,75 & $.76,34$ & 92,46 & reacciona & $1,77 @ 13^{\circ} \mathrm{C}$ & 3,18 & $\begin{array}{l}400 \mathrm{~mm} \mathrm{Hg} \\
@-4,9^{\circ} \mathrm{C} ; \\
740 \mathrm{~mm} \mathrm{Hg} \\
@ 11,5^{\circ} \mathrm{C}\end{array}$ & & \\
\hline $\begin{array}{l}\text { TRIFLUORURO DE NITROGENO } \\
7783-54-2\end{array}$ & gas incoloro & -129 & $-208,5$ & 71,01 & lig sol & $\begin{array}{l}1,885 \\
@-129^{\circ} \mathrm{C} \\
\text { (líquido) }\end{array}$ & & & & \\
\hline $\begin{array}{l}\text { YODO } \\
\quad 7553-56-2\end{array}$ & $\begin{array}{l}\text { escamas o placas de } \\
\text { color negro azulado; } \\
\text { diatómicas; cristales } \\
\text { rómbicos de color } \\
\text { negro-violeta con } \\
\text { lustre metálico }\end{array}$ & 184,35 & 113,50 & 253,81 & & $\begin{array}{l}4,93 @ 25^{\circ} \mathrm{C} \\
\text { (sólido) }\end{array}$ & $\begin{array}{l}6,75 \mathrm{~g} / \mathrm{l} \\
\text { (gas) }\end{array}$ & $\begin{array}{l}1 \mathrm{~mm} \mathrm{Hg} \\
\text { @ } 38,7^{\circ} \mathrm{C} \\
\text { (sólido) }\end{array}$ & & \\
\hline
\end{tabular}




\section{COMPUESTOS HETEROCICLICOS}

LoS compuestos heterocíclicos se utilizan como productos químicos intermedios y disolventes en industrias farmacéuticas, químicas, textiles, petrolíferas, fotográficas y de tintes. Algunos de ellos sirven además como aceleradores de la vulcanización del caucho.

La acridina y la benzantrona se enplean como materias primas y productos químicos intermedios en la fabricación de tintes. $L$ a benzantrona se utiliza también en la industria pirotécnica. La propilenimina se emplea en floculantes para el refinado de petróleo y como modificador para combustibles propelentes de cohetes. Asimismo, sirve como aditivo de lubricantes para modificar el control de la viscosidad y mejorar su rendimiento a alta presión y su resistencia a la oxidación. L a 3-metilpiridina y la 4-metilpiridina se emplean como agentes impermeabilizantes en la industria textil. La 4-metilpiridina es un disolvente utilizado en la síntesis de productos farmacéuticos, resinas, tintes, aceleradores del caucho, pesticidas y agentes impermeabilizantes. La 2-pirrolidona también se utiliza en preparados farmacéuticos y actúa como disolvente de alto punto de ebullición en la transformación del petróleo. Se encuentra en tintas de imprenta especializadas y en algunos abriIlantasuelos. La 4,4'-ditiodimorfolina se utiliza en la industria del caucho como protector antimanchas y como agente vulcanizante. En la industria del caucho, la 2-vinilpiridina se convierte en un terpolímero que se utiliza en adhesivos para encolar hilos para neumáticos al caucho.

Algunos compuestos heterocíclicos, como la morfolina, el mercaptobenzotiazol, la piperazina, el 1,2,3-benzotriazol y la quinoleina, actúan como inhibidores de la corrosión en el tratamiento de aguas industriales y del cobre. El mercaptobenzotiazol es también un inhibidor de la corrosión para aceites de corte y productos derivados del petróleo y un aditivo de presión extrema en lubricantes. La morfolina es un disolvente para resinas, ceras, caseína y tintesy un agente desespumante en las industrias del papel y los cartonajes. Además, se encuentra en insecticidas, fungicidas, herbicidas, anestésicos locales y antisépticos. El 1,2,3-benzotriazol es un agente retardador, revelador y antivelo para emulsiones fotográficas, un componente de líquidos descongelantes para aviones militares y un agente estabilizante en la industria del plástico.

La piridina se utiliza en numerosas industrias como producto químico intermedio y como disolvente. Se emplea para elaborar vitaminas, fármacos, desinfectantes, tintes y explosivos y como auxiliar de la tinción en la industria textil. La piridina también es útil en las industrias del caucho y la pintura, en la perforación de pozos de gas y petróleo y en las industrias alimentaria y de bebidas no alcohólicas como agente aromatizante. Las vinilpiridinas se emplean en la producción de polímeros. El sulfolano, un disolvente y plastificante, se utiliza para extraer hidrocarburos aromáticos de las corrientes de las refinerías de petróleo, para el acabado de textiles y como componente de líquidos hidráulicos. El tetrahidrotiofeno es un disolvente y odorante de gases combustibles que se utiliza en sistemas de detección de fugas para la prevención de incendios en minas subterráneas. La piperidina se utiliza en la fabricación de productos farmacéuticos, agentes humectantes y germicidas. Es un endurecedor de resinas epoxi y un componente traza del gasóleo.

\section{Riesgos}

La acridina es un potente irritante que, en contacto con la piel o las mucosas, provoca picores, quemaduras, estornudos, lagrimeo e irritación de la conjuntiva. Los trabajadores expuestos al polvo de cristales de acridina en concentraciones de entre 0,02 y $0,6 \mathrm{mg} / \mathrm{m}^{3}$ se quejaron de dolores de cabeza, alteraciones del sueño, irritabilidad y fotosensibilización y presentaron edema en los párpados, conjuntivitis, erupciones cutáneas, leucocitosis y aumento de la sedimentación de los hematíes. Estos síntomas no aparecieron con una concentración de acridina en suspensión en el aire de $1,01 \mathrm{mg} / \mathrm{m}^{3}$. Al calentarse, la acridina emite vapores tóxicos. La acridina y muchos de sus derivados han demostrado poseer propiedades mutágenas e inhibir la reparación del ADN y el crecimiento de las células en algunas especies.

En animales, las dosis cuasiletales de aminopiridinas producen un aumento de la excitabilidad a los ruidos y al tacto y provocan temblores, convulsiones clónicas y tetania, así como contracción de la musculatura esquelética y lisa, con vasoconstricción y aumento de la tensión arterial. Se ha observado que las aminopiridinas y algunas alquilpiridinas ejercen un efecto inotrópico y cronotrópico en el corazón. Las vinilpiridinas provocan convulsiones menos intensas. La intoxicación aguda puede deberse a la inhalación de polvo o vapor a concentraciones relativamente bajas o a la absorción cutánea.

Un riesgo común de la benzantrona es la sensibilización cutánea por exposición al polvo de benzantrona. La sensibilidad varía de una persona a otra, pero tras una exposición que puede durar entre algunos meses y varios años, las personas sensibles, especialmente las que son rubias o pelirrojas, desarrollan un eczema que puede ser intenso y cuya fase aguda puede dejar una pigmentación de color avellana o gris pizarra, especialmente alrededor de los ojos. Al microscopio se observa atrofia de la piel. LoS problemas cutáneos producidos por la benzantrona son más frecuentes en la estación cálida y se agravan significativamente con el calor y la luz.

La morfolina es un compuesto moderadamente tóxico por vía digestiva y cutánea; la morfolina no diluida es un potente irritante de la piel y de los ojos, aunque no parece tener efectos tóxicos crónicos. Comporta un riesgo moderado de incendio cuando se expone al calor y en su descomposición térmica libera vapores que contienen óxidos de nitrógeno.

La fenotiazina exhibe propiedades irritantes nocivas y la exposición industrial puede provocar fotosensibilización y lesiones cutáneas, entre ellas queratitis fotosensible. Por lo que se refiere a sus efectos sistémicos, se han descrito casos de intoxicación grave en aplicaciones terapéuticas, caracterizados por anemia hemolítica y hepatitis tóxica. La baja solubilidad de este compuesto determina que la velocidad de absorción en el tracto gastrointestinal dependa del tamaño de las partículas. La forma micronizada del fármaco se absorbe rápidamente. La toxicidad de esta sustancia varía mucho de un animal a otro, siendo la $D L_{50}$ por vía oral en ratas de $5 \mathrm{~g} / \mathrm{kg}$.

Aunque la fenotiazina se oxida con bastante facilidad cuando se expone al aire, el riesgo de incendio no es elevado. Aún así, cuando se ve involucrada en un incendio, desprende óxidos de azufre y nitrógeno altamente tóxicos, que son peligrosos irritantes pulmonares.

La piperidina puede absorberse por vía respiratoria, digestiva 0 cutánea, produciendo en los animales una respuesta tóxica similar a la de las aminopiridinas. En dosis altas bloquea la conducción ganglionar. En pequeñas dosis provoca estimulación simpática y parasimpática por su efecto en los ganglios. Los síntomas de intoxicación consisten en un aumento de la tensión arterial y del ritmo cardíaco, náuseas, vómitos, salivación, dificultad respiratoria, debilidad muscular, parálisis y convulsiones. 
Esta sustancia es altamente inflamable y desprende concentraciones explosivas de vapor a temperatura ambiente normal. Con ella deben adoptarse las mismas precauciones recomendadas para la piridina.

Piridina y sus homólogos. Los estudios clínicos de exposición humana han facilitado cierta información sobre la piridina, principalmente relacionada con tratamientos médicos o exposición a sus vapores. La piridina se absorbe por vía digestiva, cutánea 0 respiratoria. Los síntomas clínicos de intoxicación consisten en alteraciones gastrointestinales, con diarrea, dolor abdominal y náuseas, debilidad, cefalea, insomnio y nerviosismo. La exposición a concentraciones inferiores a las necesarias para producir signos clínicos evidentes puede causar lesiones hepáticas de grado variable, con degeneración grave del lóbulo central, congestión e infiltración celular. Las exposiciones repetidas a concentraciones bajas de piridina provocan cirrosis. El riñón parece ser menos sensible que el hígado a los daños inducidos por esta sustancia. En general, las piridinas y sus derivados producen irritación local cuando contactan con la piel, las mucosas y la córnea. Las lesiones hepáticas pueden producirse por exposición a concentraciones demasiado pequeñas como para provocar una respuesta del sistema nervioso, de manera que no siempre los trabajadores expuestos pueden advertir la presencia de esta sustancia. A demás, aunque el olor de la piridina se detecta fácilmente a concentraciones de vapor inferiores a 1 ppm, no se puede confiar en el sentido del olfato porque rápidamente se adormece.

La piridina en estado líquido y gaseoso comporta un grave riesgo de incendio y explosión cuando se expone a las llamas; también puede reaccionar violentamente con sustancias oxidantes. Si se calienta hasta su descomposición, desprende vapores de cianuro.

El pirrol y la pirrolidina. El pirrol es un líquido inflamable que, al arder, libera óxidos de nitrógeno peligrosos. Este producto ejerce una acción depresora sobre el sistema nervioso central y, en caso de intoxicación grave, provoca lesiones hepáticas. Aunque se dispone de poca información sobre el grado de riesgo laboral de esta sustancia, siempre deben adoptarse medidas de protección y prevención contra incendios y se dispondrá de los medios adecuados para su extinción. Las personas que participen en la extinción de un incendio relacionado con el pirrol deberán utilizar equipos de protección respiratoria.

Existe también poca información sobre la exposición humana a pirrolidina. Su administración prolongada en ratas produjo disminución de la diuresis, inhibición de la espermatogénesis, disminución de la hemoglobinemia y excitación nerviosa. Como ocurre con muchos compuestos nitrogenados, la acidez del estómago puede hacer que la pirrolidina se transforme en $\mathrm{N}$-nitrosopirrolidina, un compuesto que ha demostrado ser cancerígeno para los animales de laboratorio. Algunos trabajadores expuestos a esta sustancia han sufrido cefalea y vómitos.

EI líquido puede desprender concentraciones inflamables de vapor a temperaturas de trabajo normales y, en consecuencia, en aquellas zonas donde se utilice deberán eliminarse todas las llamas desnudas y demás agentes que puedan inflamar los vapores. Al arder, la pirrolidina desprende óxidos de nitrógeno peligrosos, y las personas expuestas a estos productos de combustión deben utilizar equipos adecuados de protección respiratoria. Para prevenir la diseminación del líquido en caso de accidente, habrá que construir muros y brocales alrededor de los tanques de almacenaje y de los vasos de reacción.

La quinoleina se absorbe a través de la piel (vía percutánea). Los síntomas clínicos de toxicidad son letargo, dificultad respiratoria y postración que puede llevar al coma. Esta sustancia es irritante para la piel y puede causar lesiones graves e irreversibles en la córnea. Es cancerígena para algunas especies animales, pero no se disponen de datos suficientes sobre el riesgo de cáncer en el ser humano. Aunque es moderadamente inflamable, no desprende concentraciones inflamables de vapores a temperaturas por debajo de $99 \stackrel{\circ}{\circ}$.

Vinilpiridina. Una breve exposición a los vapores de esta sustancia provoca irritación de ojos, nariz y garganta, cefalea, náuseas, nerviosismo y anorexia, con carácter transitorio. El contacto con la piel provoca un dolor ardiente seguido de quemaduras cutáneas graves. Puede aparecer sensibilización. El riesgo de incendio es moderado y la descomposición por calor va acompañada de la liberación de vapores peligrosos de cianuro.

\section{Medidas de salud y seguridad}

D eben adoptarse las precauciones de seguridad normales para la manipulación de los polvos y vapores de los productos químicos de este grupo. Puesto que algunos de ellos provocan sensibilización cutánea, es muy importante que existan unas instalaciones sanitarias y de lavado adecuadas. También es importante que los trabajadores tengan acceso a zonas limpias para comer. 
TABLAS DE COMPUESTOS HETEROCICUCOS

\begin{tabular}{|c|c|c|c|}
\hline Producto químico & Sinónimos/ Código UN & $\mathrm{N}$ úmero CAS & Fórmula estructural \\
\hline N-ACETILCAPROLACTAMA & Acetilcaprolactama; 1-acetilhexahidro-2H-azepin-2-ona & 1888-91-1 & \\
\hline ACIDO 3,6-DICLOROPICOLINICO & $\begin{array}{l}\text { Acido 3,6-dicloro-2-piridincarboxílico; ácido 2-piridincarboxílico, } \\
\text { 3,6-dicloro-(9Cl) }\end{array}$ & $1702-17-6$ & \\
\hline ACRIDINA & $\begin{array}{l}\text { Benzo(b) quinoleina; 2,3-benzoquinoleina; dibenzo(b,e) piridina } \\
\text { UN2713 }\end{array}$ & $260-94-6$ & \\
\hline N-AMINOETILPIPERAZINA & $\begin{array}{l}\text { N-(2-Aminoetil) piperazina; 1-(2-aminoetil) piperazina } \\
\quad \text { UN2815 }\end{array}$ & $140-31-8$ & \\
\hline 2-AMINOPIRIDINA & $\begin{array}{l}\text { o-Aminopiridina; } \alpha \text {-aminopiridina; amino-2-piridina; } \alpha \text {-piridinamina; } \\
\alpha \text {-piridilamina; } 2 \text {-piridilamina } \\
\quad \text { UN2671 }\end{array}$ & $504-29-0$ & \\
\hline BENZOGUANAMINA & $\begin{array}{l}\text { 4,6-Diamino-2-fenil-s-triazina; 2-fenil-4,6-diamino-s-triazina; } \\
\text { 2-fenil-4,6-diamino-1,3,5-triazina }\end{array}$ & $91-76-9$ & \\
\hline 1,2,3-BENZOTRIAZOL & $\begin{array}{l}\text { 1,2,-Aminozofenileno; aziminobenceno; azimida bencénica; benzisotriazol; } \\
\text { benzotriazol; } 1 \text { H-triazaindeno }\end{array}$ & $95-14-7$ & \\
\hline CUMARINA & & $91-64-5$ & \\
\hline $3,4,5,6$-DIBENZOCARBAZOL & $\begin{array}{l}\text { 3,4,5,6-Dibenzcarbazol; 3,4,5,6-dinaftacarbazol; } \\
\text { 7H-dibenzo(c,g) carbazol }\end{array}$ & $194-59-2$ & \\
\hline DIHIDROCLORURO DE PIPERAZINA & $\begin{array}{l}\text { Sal dihidrocloruro de dietilendiamina; Dowzene DHC; hidrocloruro de } \\
\text { piperazina }\end{array}$ & $142-64-3$ & \\
\hline DISULFURO DE 2-MERCAPTOBENZOTIAZOL & $\begin{array}{l}\text { Disulfuro de 2-benzotiazolilo; disulfuro de benzotiazilo; } \\
\text { bis-(benzotiazolil)-disulfuro; bis-(2-benzotiazil)-disulfuro; disulfuro de } \\
\text { dibenzotiazolilo; disulfuro de dibenzotiazilo; disulfuro de dibenzoilotiazilo; } \\
\text { disulfuro de dibenztiazilo; 2,2'-ditiobis-(benzotiazol); disulfuro de } \\
\text { 2-mercaptobenzotiazilo }\end{array}$ & $120-78-5$ & \\
\hline N-ETILMORFOLINA & 4-Etilmorfolina & $100-74-3$ & \\
\hline FENAZOPIRIDINA & $\begin{array}{l}\text { 2,6-Diamino-3-fenilazopiridina; fenazodina; } \\
\text { 3-(fenilazo)-2,6-piridindiamina; 3-(fenilazo)-2,6-piridindiamina; piridium; } \\
\text { piripiridium }\end{array}$ & $94-78-0$ & \\
\hline
\end{tabular}




\begin{tabular}{|c|c|c|}
\hline Producto químico & Sinónimos/ Código UN & $\mathrm{N}$ úmero CAS Fórmula estructural \\
\hline FENILENPIRENO & $\begin{array}{l}\text { Indeno-(1,2,3-c,d)-pireno; 0-fenilenpireno; 2,3-; 2,3-o-fenilenpireno; } \\
\text { 1,10-(0-fenilen)-pireno; 1,10-(1,2-fenilen)-pireno }\end{array}$ & $193-39-5$ \\
\hline FENOTIAZINA & Dibenzoparatiazina; dibenzotiazina; dibenzo-1,4-tiazina & $92-84-2$ \\
\hline 2-MERCAPTOBENZOTIAZOL & $\begin{array}{l}\text { Benzotiazol-2-tiona; } 2 \text { (3H)-benzotiazoletiona; mercaptano de } \\
\text { 2-benzotiazolilo; mercaptobenzotiazol }\end{array}$ & $149-30-4$ \\
\hline N-METILMORFOLINA & $\begin{array}{l}\text { Metilmorfolina; 4-metilmorfolina } \\
\text { UN2535 }\end{array}$ & $109-02-4$ \\
\hline 1-METIL-2-PIRROLIDINONA & $\begin{array}{l}\text { N-Metilpirrolidinona; N-metil-2-pirrolidinona; 1-metil-5-pirrolidinona; } \\
\text { N-metilpirrolidona; N-metil-a-pirrolidona; 1-metil-2-pirrolidona }\end{array}$ & $872-50-4$ \\
\hline 2-METILPIRIDINA & $\alpha$-Metilpiridina; 2-picolina; $\alpha$-picolina & $109-06-8$ \\
\hline 3-METILPIRIDINA & 3-Picolina & $108-99-6$ \\
\hline 4-METILPIRIDINA & $\gamma$-Picolina; 4-picolina & $108-89-4$ \\
\hline MORFOLINA & $\begin{array}{l}\text { Oxido de dietilenimida; dietilenimidóxido; dietilenoximida; óxido de } \\
\text { dietilenimida; drewamina; tetrahidro-p-isoxazina; tetrahidro-; } \\
\text { tetrahidro-1,4-isoxazina; tetrahidro-1,4-0xazina } \\
\text { UN2054 }\end{array}$ & $110-91-8$ \\
\hline NICOTINA & $\begin{array}{l}\text { 1-Metil-2-(3-piridil)-pirrolidina; 3-(N-metilpirrolidino) piridina; L-nicotina; } \\
\text { 3-(tetrahidro-1-metilpirrol-2-llo); } \alpha \text {-piridil- } \alpha \text {-N-metilpirrolidina; } \\
\text { 1-metil-2-2-(3-piridal)-pirrolidina; tetrahidronicotirina } \\
\text { UN1654 }\end{array}$ & $54-11-5$ \\
\hline N-NITROSONORNICOTINA & $\begin{array}{l}\text { 1'-Nitroso-1'-demetilnicotina; 1-nitroso-2-(3-piridil)-pirrolidina; } \\
\text { 3-(1-nitroso-2-pirrolidinil)-piridina; } \\
\text { (s)-NNN-3-(1-nitroso-2-pirrolidinil)-piridina }\end{array}$ & $16543-55-8$ \\
\hline PIPERAZINA & $\begin{array}{l}\text { 1,4-Dietilendiamina; hexahidro-1,4-diazina; hexahidropirazina; } \\
\text { piperazidina; piperazina anhidro; hexahidruro de pirazina } \\
\text { UN2579 }\end{array}$ & $110-85-0$ \\
\hline PIPERIDINA & $\begin{array}{l}\text { Azaciclohexano; ciclopentimina; hexahidropiridina; hexazano; } \\
\text { pentametilenimina; hexahidropiridina } \\
\text { UN2401 }\end{array}$ & $110-89-4$ \\
\hline PIRIDINA & UN1282 & $110-86-1$ \\
\hline
\end{tabular}




\begin{tabular}{|c|c|c|}
\hline Producto químico & Sinónimos/ Código UN & $\mathrm{N}$ úmero CAS Fórmula estructural \\
\hline PIRIMIDINA & 1,3-Diazabenceno; m-diazina; metadiazina & $289-95-2$ \\
\hline PIRROLIDINA & $\begin{array}{l}\text { Azaciclopentano; azolidina; prolamina; tetrahidropirrol; tetrahidropirrol; } \\
\text { tetrametilenimina } \\
\text { UN1922 }\end{array}$ & $123-75-1$ \\
\hline 2.PIRROLIDINONA & $\begin{array}{l}\text { Lactama del ácido 4-aminobutírico; butirolactama; 2-oxopirrolidina; } \\
\alpha \text {-pirrolidinona; pirrolidona; 2-pirrolidona }\end{array}$ & $616-45-5$ \\
\hline PROPILENIMINA & $\begin{array}{l}\text { 2-Metilazaciclopropano; 2-metilaziridina; metiletilenimina; } \\
\text { 2-metiletilenimina; 1,2-propilenimina } \\
\text { UN1921 }\end{array}$ & $75-55-8$ \\
\hline QUINOLINA & $\begin{array}{l}\text { 1-Azanaftaleno; 1-benzacina; 1-bencina; benzo-(b)-piridina; } \\
\text { UN2656 }\end{array}$ & $91-22-5$ \\
\hline SULFOLANO & $\begin{array}{l}\text { Sulfona de tetrametileno cíclico; sulfona de ciclotetrametileno; } \\
\text { sulfona de dihidrobutadieno; 1,1-dioxidotetrahidrotiofurano; } \\
\text { 1,1-dioxidotetrahidrotiofeno; sulfalona; sulfolán; dióxido de } \\
\text { tetrahidrotiofeno }\end{array}$ & $126-33-0$ \\
\hline SULFONA DE 1,3-PROPANO & $\begin{array}{l}\text { Sulfona de ácido 3-hidroxi-1-propanosulfónico; } \\
\text { sulfona de ácido 3-hidroxi-1-propanosulfónico; 2,2-dioxido de } \\
\text { 1,2-oxatrolano }\end{array}$ & $1120-71-4$ \\
\hline TARTRATO NICOTINICO & $\begin{array}{l}\text { Tartrato ácido nicotínico; bitartrato nicotínico; tartrato de nicotina } \\
\text { UN1659 }\end{array}$ & $65-31-6$ \\
\hline TETRAHIDROTIOFENO & $\begin{array}{l}\text { Tetrametilensulfuro; tiaciclopentano; tilano; tiofano } \\
\text { UN2412 }\end{array}$ & $110-01-0$ \\
\hline TIOFENO & $\begin{array}{l}\text { Sulfuro de divinileno; tiaciclopentadieno; tiafeno; tiofurano; tiofuram; } \\
\text { tiofurfurano; tiol; tiofén } \\
\text { UN2414 }\end{array}$ & $110-02-1$ \\
\hline 2-VINILPIRIDINA & & $100-69-6$ \\
\hline
\end{tabular}




\begin{tabular}{|c|c|c|c|c|c|c|}
\hline \multirow[b]{2}{*}{$\begin{array}{l}\text { Denominación } \\
\text { química } \\
\text { N úmero CAS }\end{array}$} & \multicolumn{4}{|c|}{ Tarjetas Internacionales sobre la Seguridad de los Productos Q uímicos } & \multicolumn{2}{|c|}{ N IO SH (EE.UU.) } \\
\hline & $\begin{array}{l}\text { Período } \\
\text { corto de } \\
\text { exposición }\end{array}$ & $\begin{array}{l}\text { Período } \\
\text { largo de } \\
\text { exposición }\end{array}$ & $\begin{array}{l}\text { Vías de } \\
\text { exposición }\end{array}$ & Síntomas & $\begin{array}{l}\text { O rganos } \\
\text { afectados } \\
\text { Vías de } \\
\text { entrada }\end{array}$ & Síntomas \\
\hline $\begin{array}{l}\text { ACIDO } \\
3,6-D I C L O R O P I C O L I N I C O \\
1702-17-6 \\
\end{array}$ & ojos; tract resp & hígado; riñones & Inhalación & Tos, embotamiento & & \\
\hline $\begin{array}{l}\text { 2-AMINOPIRIDINA } \\
504-29-0\end{array}$ & & & Inhalación & $\begin{array}{l}\text { Convulsiones, mareo, cefalea, náuseas, } \\
\text { disnea, debilidad, aumento de la tensión } \\
\text { arterial, colapso }\end{array}$ & $\begin{array}{l}\text { SNC; sis resp } \\
\text { Inh; abs; ing; con }\end{array}$ & $\begin{array}{l}\text { Irrit ojos, nariz, garganta; cef, } \\
\text { mar, excitación; náu; PA alta; } \\
\text { dif resp; deb; convuls; estupor }\end{array}$ \\
\hline $\begin{array}{l}\text { DISULFURO DE } \\
\text { 2-MERCAPTOBENZOTIAZOL } \\
\text { 120-78-5 }\end{array}$ & ojos; piel; tract resp & piel & $\begin{array}{r}\text { Inhalación } \\
\text { Piel } \\
\text { 0jos }\end{array}$ & $\begin{array}{l}\text { Tos, dolor de garganta } \\
\text { Puede absorberse, enrojecimiento } \\
\text { Enrojecimiento }\end{array}$ & & \\
\hline $\begin{array}{l}\text { FENILENPIRENO } \\
193-39-5 \\
\end{array}$ & & & Piel & Puede absorberse & & \\
\hline $\begin{array}{l}\text { FENOTIAZINA } \\
92-84-2\end{array}$ & $\begin{array}{l}\text { ojos; piel; } \\
\text { tract resp; sangre; } \\
\text { hígado }\end{array}$ & piel & $\begin{array}{r}\text { Inhalación } \\
\text { Piel } \\
\text { 0jos }\end{array}$ & $\begin{array}{l}\text { Tos, dolor de garganta } \\
\text { Puede absorberse, enrojecimiento, dolor, } \\
\text { picores, piel de color amarillo-marrón } \\
\text { Enrojecimiento, dolor, visión borrosa }\end{array}$ & $\begin{array}{l}\text { Piel; SCV; hígado; } \\
\text { riñones } \\
\text { Inh; abs; ing; con }\end{array}$ & $\begin{array}{l}\text { Picores, piel enrojecida, irrit; } \\
\text { hepatitis, anemia hemolítica, } \\
\text { espasmos abdom, tacar; } \\
\text { lesiones renales; fotosens } \\
\text { cutánea }\end{array}$ \\
\hline $\begin{array}{l}\text { 2-MERCAPTOBENZOTIAZOL } \\
\text { 149-30-4 }\end{array}$ & ojos & piel & $\begin{array}{r}\text { Inhalación } \\
\text { Piel } \\
\text { 0jos } \\
\end{array}$ & $\begin{array}{l}\text { Tos } \\
\text { Enrojecimiento } \\
\text { Enrojecimiento, dolor }\end{array}$ & & \\
\hline $\begin{array}{l}\text { 2-METILPIRIDINA } \\
\text { 109-06-8 }\end{array}$ & ojos; piel; tract resp & piel; SNC & $\begin{array}{r}\text { Inhalación } \\
\text { Piel } \\
\text { 0jos } \\
\text { Ingestión }\end{array}$ & $\begin{array}{l}\text { Sensación de quemazón, tos, mareo, sopor, } \\
\text { cefalea, dificultad respiratoria, náuseas, dolor } \\
\text { de garganta, inconsciencia, debilidad } \\
\text { Puede absorberse, sequedad de piel, } \\
\text { enrojecimiento, sensación de quemazón, dolor, } \\
\text { ampollas } \\
\text { Dolor, visión borrosa, quemaduras profundas } \\
\text { graves } \\
\text { Dolor abdominal, sensación de quemazón, } \\
\text { diarrea, vómitos }\end{array}$ & & \\
\hline $\begin{array}{l}\text { 3-METLLPIRIDINA } \\
\text { 108-99.6 }\end{array}$ & ojos; piel; tract resp & piel; SNC & $\begin{array}{r}\text { Inhalación } \\
\text { Piel } \\
\text { 0jos } \\
\text { Ingestión }\end{array}$ & $\begin{array}{l}\text { Sensación de quemazón, tos, mareo, sopor, } \\
\text { cefalea, dificultad respiratoria, náuseas, dolor } \\
\text { de garganta, inconsciencia, debilidad } \\
\text { Puede absorberse, sequedad de piel, } \\
\text { enrojecimiento, sensación de quemazón, dolor, } \\
\text { ampollas } \\
\text { Dolor, visión borrosa, quemaduras profundas } \\
\text { graves } \\
\text { Dolor abdominal, sensación de quemazón, } \\
\text { diarrea, vómitos }\end{array}$ & & \\
\hline $\begin{array}{l}\text { 4-METILPIRIDINA } \\
\text { 108-89-4 }\end{array}$ & ojos; piel; tract resp & piel; SNC & $\begin{array}{r}\text { Inhalación } \\
\text { Piel } \\
\text { 0jos } \\
\text { Ingestión }\end{array}$ & $\begin{array}{l}\text { Sensación de quemazón, tos, mareo, sopor, } \\
\text { cefalea, dificultad respiratoria, náuseas, dolor } \\
\text { de garganta, inconsciencia, debilidad } \\
\text { Puede absorberse, sequedad de piel, } \\
\text { enrojecimiento, sensación de quemazón, dolor, } \\
\text { ampollas } \\
\text { Dolor, visión borrosa, quemaduras profundas } \\
\text { graves } \\
\text { Dolor abdominal, sensación de quemazón, } \\
\text { diarrea, vómitos }\end{array}$ & & \\
\hline
\end{tabular}


Tabla 104.86 • Riesgos para la salud.

\begin{tabular}{|c|c|c|c|c|c|c|}
\hline \multirow[b]{2}{*}{$\begin{array}{l}\text { Denominación } \\
\text { química } \\
\text { N úmero CAS }\end{array}$} & \multicolumn{4}{|c|}{ Tarjetas Internacionales sobre la Seguridad de los Productos Q uímicos } & \multicolumn{2}{|c|}{ N IO SH (EE.UU.) } \\
\hline & $\begin{array}{l}\text { Período } \\
\text { corto de } \\
\text { exposición }\end{array}$ & $\begin{array}{l}\text { Período } \\
\text { largo de } \\
\text { exposición }\end{array}$ & $\begin{array}{l}\text { Vías de } \\
\text { exposición }\end{array}$ & Síntomas & $\begin{array}{l}\text { O rganos } \\
\text { afectados } \\
\text { Vías de } \\
\text { entrada }\end{array}$ & Síntomas \\
\hline $\begin{array}{l}\text { 1-METLL-2-PIRROLIDONA } \\
872-50-4\end{array}$ & tract resp; ojos & $\begin{array}{l}\text { pulmones; médula } \\
\text { ósea; sistema } \\
\text { linfático }\end{array}$ & $\begin{array}{r}\text { Inhalación } \\
\text { Piel } \\
\text { 0jos } \\
\text { Ingestión }\end{array}$ & $\begin{array}{l}\text { Tos, dificultad respiratoria } \\
\text { Puede absorberse } \\
\text { Enrojecimiento, dolor, visión borrosa, pérdida } \\
\text { de visión } \\
\text { Espasmos abdominales, diarrea, dificultad } \\
\text { respiratoria }\end{array}$ & & \\
\hline $\begin{array}{r}\text { MORFOLINA } \\
110-91-8\end{array}$ & $\begin{array}{l}\text { ojos; piel; } \\
\text { tract resp; } \\
\text { pulmones }\end{array}$ & hígado; riñones & $\begin{array}{r}\text { Inhalación } \\
\text { Piel } \\
\text { 0jos } \\
\text { Ingestión }\end{array}$ & $\begin{array}{l}\text { Sensación de quemazón, tos, dificultad } \\
\text { respiratoria, disnea, dolor de garganta } \\
\text { Puede absorberse, enrojecimiento, quemaduras } \\
\text { en la piel, dolor } \\
\text { Enrojecimiento, dolor, visión borrosa } \\
\text { Dolor abdominal, tos, diarrea, vómitos }\end{array}$ & $\begin{array}{l}\text { Sis resp; ojos; piel; } \\
\text { hígado; riñones } \\
\text { Inh; abs; ing; con }\end{array}$ & $\begin{array}{l}\text { Irrit ojos, piel, nariz, sis resp; } \\
\text { dist vis; tos; en animales: } \\
\text { lesiones hepáticas y renales }\end{array}$ \\
\hline $\begin{array}{l}\text { NICOTINA } \\
54-11-5\end{array}$ & & & Inhalación & $\begin{array}{l}\text { Dolor abdominal, cefalea, náuseas, vómitos, } \\
\text { temblores, convulsiones }\end{array}$ & $\begin{array}{l}\text { SNC; SCV; } \\
\text { pulmones; tract Gl; } \\
\text { sis repro } \\
\text { Inh; abs; ing; con }\end{array}$ & $\begin{array}{l}\text { Náu, saliv, dolor abdom, vómi, } \\
\text { diarr; cef, mar, dist vis y aud; } \\
\text { conf, deb, inco; fibri auricular } \\
\text { paroxísmica; convuls, dis; en } \\
\text { animales: efectos terato }\end{array}$ \\
\hline $\begin{array}{r}\text { PIPERIDINA } \\
110-89-4 \\
\end{array}$ & & & Inhalación & $\begin{array}{l}\text { Sensación de quemazón, tos, dificultad } \\
\text { respiratoria }\end{array}$ & & \\
\hline $\begin{array}{l}\text { PIRIDINA } \\
\quad 110-86-1\end{array}$ & $\begin{array}{l}\text { ojos; piel; } \\
\text { tract resp; tract Gl; } \\
\text { SNC; SCV }\end{array}$ & $\begin{array}{l}\text { piel; hígado; } \\
\text { riñones }\end{array}$ & $\begin{array}{l}\text { Inhalación } \\
\text { Piel } \\
\text { 0jos } \\
\text { Ingestión }\end{array}$ & $\begin{array}{l}\text { Tos, mareo, cefalea, náuseas, disnea, } \\
\text { inconsciencia } \\
\text { Puede absorberse, enrojecimiento } \\
\text { Enrojecimiento, dolor } \\
\text { Dolor abdominal, diarrea, vómitos, debilidad }\end{array}$ & $\begin{array}{l}\text { Ojos; piel; SNC; } \\
\text { hígado; riñones; } \\
\text { tract GI } \\
\text { Inh; abs; ing; con }\end{array}$ & $\begin{array}{l}\text { Irrit ojos; cef, nerv, mar, } \\
\text { insom; náu, anor, derm; } \\
\text { lesiones hepáticas y renales }\end{array}$ \\
\hline $\begin{array}{l}\text { 2-PIRROLIDINONA } \\
616-45-5\end{array}$ & ojos & & & & & \\
\hline $\begin{array}{l}\text { PROPILENIMINA } \\
75-55-8\end{array}$ & $\begin{array}{l}\text { ojos; piel; } \\
\text { tract resp; } \\
\text { pulmones; SNC }\end{array}$ & piel & $\begin{array}{r}\text { Inhalación } \\
\text { Piel } \\
\text { 0jos } \\
\text { Ingestión }\end{array}$ & $\begin{array}{l}\text { Tos, mareo, cefalea, dificultad respiratoria, } \\
\text { disnea, inconsciencia } \\
\text { Puede absorberse, enrojecimiento, quemaduras } \\
\text { en la piel, picores, ampollas } \\
\text { Enrojecimiento, dolor, visión borrosa } \\
\text { Sensación de quemazón en el tracto digestivo, } \\
\text { mareo, cefalea, náuseas, vómitos }\end{array}$ & $\begin{array}{l}\text { Ojos; piel [en } \\
\text { animales: tumores } \\
\text { nasales] } \\
\text { Inh; abs; ing; con }\end{array}$ & $\begin{array}{l}\text { Quemaduras en ojos y piel; } \\
\text { [carc] }\end{array}$ \\
\hline $\begin{array}{l}\text { QUINOLEINA } \\
91-22.5\end{array}$ & $\begin{array}{l}\text { ojos; tract resp; } \\
\text { SNC }\end{array}$ & $\begin{array}{l}\text { hígado; riñones; } \\
\text { retina }\end{array}$ & $\begin{array}{r}\text { Inhalación } \\
\text { Piel } \\
\text { 0jos }\end{array}$ & $\begin{array}{l}\text { Tos, dificultad respiratoria, náuseas, disnea, } \\
\text { vómitos, debilidad } \\
\text { Puede absorberse, enrojecimiento, quemaduras } \\
\text { en la piel } \\
\text { Enrojecimiento, dolor, visión borrosa }\end{array}$ & & \\
\hline $\begin{array}{l}\text { TARTRATO NICOTINICO } \\
65-31-6\end{array}$ & ojos; piel; SNC & & $\begin{array}{r}\text { Inhalación } \\
\text { Piel } \\
\text { 0jos } \\
\end{array}$ & $\begin{array}{l}\text { Dolor abdominal, cefalea, náuseas, vómitos, } \\
\text { temblores, convulsiones } \\
\text { Puede absorberse } \\
\text { Enrojecimiento, dolor }\end{array}$ & & \\
\hline $\begin{array}{l}\text { TETRAHIDROTIOFENO } \\
110.01-0\end{array}$ & $\begin{array}{l}\text { ojos; piel; } \\
\text { tract resp; SNC }\end{array}$ & piel & $\begin{array}{r}\text { Inhalación } \\
\text { Piel } \\
\text { 0jos } \\
\text { Ingestión }\end{array}$ & $\begin{array}{l}\text { Sensación de quemazón, tos, cefalea, dolor de } \\
\text { garganta } \\
\text { Puede absorberse, enrojecimiento, sequedad } \\
\text { de piel, sensación de quemazón } \\
\text { Enrojecimiento, dolor de ojos } \\
\text { Dolor abdominal }\end{array}$ & & \\
\hline $\begin{array}{l}\text { TIOFENO } \\
\quad 110-02-1\end{array}$ & ojos; piel; tract resp & & $\begin{array}{r}\text { Inhalación } \\
\text { Piel } \\
\text { 0jos }\end{array}$ & $\begin{array}{l}\text { Tos, dolor de garganta } \\
\text { Puede absorberse } \\
\text { Enrojecimiento, dolor }\end{array}$ & & \\
\hline
\end{tabular}




\begin{tabular}{|c|c|c|c|}
\hline $\begin{array}{l}\text { Denominación química } \\
\mathrm{N} \text { úmero CAS }\end{array}$ & Físicos & Q uímicos & $\begin{array}{l}\text { Clase o división } \\
\text { UN / Riesgos } \\
\text { subsidiarios }\end{array}$ \\
\hline $\begin{array}{l}\text { ACIDO 3,6-DICLOROPICOLINICO } \\
1702-17 \cdot 6\end{array}$ & & $\begin{array}{l}\text { - Se descompone al arder, liberando gases tóxicos y corrosivos • Reacciona con bases, } \\
\text { formando sales • En solución es corrosivo para el aluminio, el hierro y el estaño }\end{array}$ & \\
\hline $\begin{array}{l}\text { N-AMINOETILPIPERAZINA } \\
\text { 140-31-8 }\end{array}$ & & & 8 \\
\hline $\begin{array}{l}\text { 2-AMINOPIRIDINA } \\
504-29-0\end{array}$ & $\begin{array}{l}\text { - Posibilidad de explosión } \\
\text { pulverulenta cuando se } \\
\text { encuentra en forma de } \\
\text { polvo o gránulos y se } \\
\text { mezcla con el aire }\end{array}$ & $\begin{array}{l}\text { - Se descompone al arder liberando gases y vapores tóxicos, entre ellos óxidos nitrosos } \\
\text { - Reacciona con oxidantes fuertes con peligro de incendio y explosión • Es una base fuerte } \\
\text { soluble en agua }\end{array}$ & 6.1 \\
\hline
\end{tabular}

BENZOGUANAMINA

6.1

91.76 .9

\begin{tabular}{|c|c|c|c|}
\hline \multicolumn{2}{|l|}{$\begin{array}{l}\text { DISULFURO DE } \\
\text { 2-MERCAPTOBENZOTIAZOL } \\
\text { 120-78-5 }\end{array}$} & \multicolumn{2}{|l|}{$\begin{array}{l}\text { - En su combustión libera gases tóxicos: óxidos de carbono, azufre y nitrógeno • Reacciona con } \\
\text { ácidos fuertes y oxidantes }\end{array}$} \\
\hline $\begin{array}{l}\text { FENILENPIRENO } \\
193-39-5 \\
\end{array}$ & & - Al calentarse, desprende vapores tóxicos & \\
\hline $\begin{array}{l}\text { FENOTIAZINA } \\
92-84-2\end{array}$ & & $\begin{array}{l}\text { - Se descompone al calentarse y al arder, liberando vapores tóxicos e irritantes, entre ellos } \\
\text { óxidos de nitrógeno y óxidos de azufre }\end{array}$ & \\
\hline $\begin{array}{l}\text { 2-MERCAPTOBENZOTIAZOL } \\
\text { 149-30-4 }\end{array}$ & & $\begin{array}{l}\text { - En su combustión libera gases tóxicos (monóxido de carbono y compuestos de azufre) } \bullet \text { Se } \\
\text { descompone al calentarse y al arder, produciendo vapores tóxicos e irritantes (óxidos de azufre y } \\
\text { nitrógeno) • Reacciona con ácidos, desprendiendo vapores altamente tóxicos de compuestos de } \\
\text { azufre } \text { Reacciona con ácidos o vapores ácidos, produciendo vapores tóxicos (compuestos } \\
\text { azufrados) }\end{array}$ & \\
\hline $\begin{array}{l}\text { 2-METILPIRIDINA } \\
\text { 109-06-8 }\end{array}$ & & $\begin{array}{l}\text { - Se descompone al calentarse, produciendo vapores tóxicos (óxidos de nitrógeno) • Reacciona } \\
\text { con ácidos fuertes y oxidantes • Ataca el cobre y sus aleaciones }\end{array}$ & 3 \\
\hline $\begin{array}{l}\text { 3-METILPIRIDINA } \\
\text { 108-99-6 }\end{array}$ & & $\begin{array}{l}\text { - Se descompone al calentarse, produciendo vapores tóxicos (óxidos de nitrógeno) • Reacciona } \\
\text { con ácidos fuertes y oxidantes }\end{array}$ & 3 \\
\hline $\begin{array}{l}\text { 4-METILPIRIDINA } \\
\text { 108-89-4 }\end{array}$ & & $\begin{array}{l}\text { - Se descompone al calentarse, produciendo vapores tóxicos (óxidos de nitrógeno) • Reacciona } \\
\text { con ácidos fuertes y oxidantes }\end{array}$ & 3 \\
\hline $\begin{array}{l}\text { 1-METIL-2-PIRROLIDONA } \\
872-50-4\end{array}$ & & $\begin{array}{l}\text { - Se descompone al calentarse por encima de } 315^{\circ} \mathrm{C} \text {, produciendo vapores tóxicos } \bullet \text { Reacciona } \\
\text { con ácidos fuertes } \bullet \text { Ataca el aluminio }\end{array}$ & \\
\hline $\begin{array}{r}\text { MORFOLINA } \\
110-91-8\end{array}$ & & $\begin{array}{l}\text { - Se descompone al calentarse, produciendo vapores tóxicos (óxidos de nitrógeno) • Es una } \\
\text { base débil • Reacciona con oxidantes fuertes, con peligro de incendio • Ataca el cobre y sus } \\
\text { compuestos }\end{array}$ & 3 \\
\hline $\begin{aligned} \text { NICOTINA } \\
54-11-5\end{aligned}$ & & $\begin{array}{l}\text { - Se descompone al calentarse, produciendo vapores tóxicos } \bullet \text { Reacciona violentamente con } \\
\text { oxidantes fuertes • Ataca el caucho y algunos plásticos }\end{array}$ & \\
\hline $\begin{array}{r}\text { PIPERAZINA } \\
110-85-0\end{array}$ & & & 8 \\
\hline $\begin{array}{r}\text { PIPERIDINA } \\
110-89-4\end{array}$ & $\begin{array}{l}\text { - El vapor es más pesado } \\
\text { que el aire y puede } \\
\text { desplazarse a ras del } \\
\text { suelo; posibilidad de } \\
\text { ignición a distancia }\end{array}$ & $\begin{array}{l}\text { - Se descompone al calentarse y al arder, liberando gases tóxicos como óxidos de nitrógeno } \\
\text { - Es una base de fuerza intermedia } \bullet \text { Reacciona violentamente con oxidantes }\end{array}$ & $3 / 8$ \\
\hline $\begin{array}{l}\text { PIRIDINA } \\
\quad 110-86-1\end{array}$ & $\begin{array}{l}\text { - El vapor es más pesado } \\
\text { que el aire y puede } \\
\text { desplazarse a ras del } \\
\text { suelo; posibilidad de } \\
\text { ignición a distancia }\end{array}$ & $\begin{array}{l}\text { - En su combustión libera vapores tóxicos (aminas) • Se descompone al calentarse } 0 \text { al arder, } \\
\text { produciendo vapores tóxicos (óxidos de nitrógeno y cianuro de hidrógeno) • Reacciona } \\
\text { violentamente con oxidantes fuertes y ácidos fuertes }\end{array}$ & 3 \\
\hline
\end{tabular}


Tabla 104.87 • Riesgos físicos y químicos.

\begin{tabular}{|c|c|c|c|}
\hline $\begin{array}{l}\text { Denominación química } \\
\mathrm{N} \text { úmero CAS }\end{array}$ & Físicos & Q uímicos & $\begin{array}{l}\text { Clase o división } \\
\text { UN / Riesgos } \\
\text { subsidiarios }\end{array}$ \\
\hline $\begin{array}{c}\text { PIRROLIDINA } \\
\text { 123-75-1 }\end{array}$ & & & $3 / 8$ \\
\hline $\begin{array}{l}\text { 2-PIRROLLDINONA } \\
616-45-5\end{array}$ & & $\begin{array}{l}\text { - Se descompone al calentarse, produciendo vapores tóxicos • Reacciona con ácidos fuertes, } \\
\text { compárese con la metilpirrolidona • Ataca el aluminio }\end{array}$ & \\
\hline $\begin{array}{l}\text { PROPILENIMINA } \\
75-55-8 \\
\end{array}$ & & & 3 \\
\hline $\begin{array}{l}\text { QUINOLINA } \\
91-22-5\end{array}$ & & $\begin{array}{l}\text { - La sustancia se descompone al calentarse y al arder, produciendo vapores tóxicos de óxidos de } \\
\text { nitrógeno • Reacciona con oxidantes fuertes y anhídrido maleico }\end{array}$ & 6.1 \\
\hline $\begin{array}{l}\text { TARTRATO NICOTINICO } \\
\text { 65-31-6 }\end{array}$ & & $\begin{array}{l}\text { - Con esta sustancia se forman compuestos sensibles a impactos } \bullet \text { Se descompone al calentarse, } \\
\text { produciendo vapores tóxicos } \bullet \text { Es un agente reductor fuerte y reacciona con oxidantes }\end{array}$ & 6.1 \\
\hline $\begin{array}{l}\text { TETRAHIDROTIOFENO } \\
110-01-0\end{array}$ & $\begin{array}{l}\text { - El vapor es más pesado } \\
\text { que el aire y puede } \\
\text { desplazarse a ras del } \\
\text { suelo; posibilidad de } \\
\text { ignición a distancia }\end{array}$ & $\begin{array}{l}\text { • En su combustión libera vapores tóxicos } \bullet \text { Reacciona violentamente con oxidantes fuertes y } \\
\text { ácido nítrico • Ataca el caucho }\end{array}$ & 3 \\
\hline $\begin{array}{l}\text { TIOFENO } \\
110-02-1\end{array}$ & $\begin{array}{l}\text { - El vapor es más pesado } \\
\text { que el aire y puede } \\
\text { desplazarse a ras del } \\
\text { suelo; posibilidad de } \\
\text { ignición a distancia } \\
\text { - Pueden generarse cargas } \\
\text { electrostáticas por flujo, } \\
\text { agitación, etc. }\end{array}$ & $\begin{array}{l}\text { - Se descompone al calentarse y al arder, produciendo vapores tóxicos e irritantes (óxidos de } \\
\text { azufre) • Reacciona violentamente con materiales oxidantes, entre ellos el ácido nítrico fumante }\end{array}$ & 3 \\
\hline $\begin{array}{l}\text { 2-VINILPIRIDINA } \\
100-69-6\end{array}$ & & & $6.1 / 3$ \\
\hline
\end{tabular}

Tabla 104.88 • Propiedades físicas y químicas.

\begin{tabular}{|c|c|c|c|c|c|c|c|c|c|c|}
\hline $\begin{array}{l}\text { Denominación química } \\
\mathrm{N} \text { úmero CAS }\end{array}$ & Color/ Forma & $\begin{array}{l}\text { p.e. } \\
(\because-C)\end{array}$ & $\begin{array}{l}\text { p.f. } \\
(\stackrel{O}{ } C)\end{array}$ & $\begin{array}{l}\text { p.m.l } \\
\text { (g/ } \\
\text { mol) }\end{array}$ & $\begin{array}{l}\text { Solubilidad } \\
\text { en agua }\end{array}$ & $\begin{array}{l}\text { Densidad } \\
\text { relativa } \\
\text { (agua }=1 \text { ) }\end{array}$ & $\begin{array}{l}\text { Densidad } \\
\text { relativa } \\
\text { del vapor } \\
\text { (aire=1) }\end{array}$ & $\begin{array}{l}\text { Pvap/ } \\
(\mathrm{kPa})\end{array}$ & $\begin{array}{l}\text { Límit. } \\
\text { inflam. }\end{array}$ & $\begin{array}{ll}\text { p.ig. } & \text { p.aut } \\
\left({ }^{\circ} C\right) & \text { ig. } \\
& \left({ }^{\circ} \mathrm{C}\right)\end{array}$ \\
\hline $\begin{array}{l}\text { ACIDO 3,6-DICLOROPICOLINICO } \\
1702-17 \cdot 6\end{array}$ & $\begin{array}{l}\text { sólido cristalino blanco; } \\
\text { cristales incoloros }\end{array}$ & & $151-152$ & 192,0 & $\begin{array}{l}1.000 \mathrm{ppm} \\
@ 25^{\circ} \mathrm{C}\end{array}$ & 0,8 & & $0,003 \mathrm{~Pa}$ & & \\
\hline $\begin{array}{l}\text { ACRIDINA } \\
260-94-6\end{array}$ & $\begin{array}{l}\text { agujas o prismas } \\
\text { romboédricos en } \\
\text { alcohol; monoclínicos, } \\
\text { ortorrómbicos; agujas } \\
\text { incoloras pequénas; } \\
\text { placas ortorrómbicas, } \\
\text { agujas en alcohol } \\
\text { diluido; pequeños } \\
\text { cristales incoloros o de } \\
\text { color amarillo pálido }\end{array}$ & 346 & 111 & 179,21 & lig sol & 1,005 & & $\begin{array}{l}1 \mathrm{~mm} \mathrm{Hg} \\
\text { @ } 129^{\circ} \mathrm{C}\end{array}$ & & \\
\hline $\begin{array}{l}\text { N-AMINOETILPIPERAZINA } \\
\text { 140-31-8 }\end{array}$ & líquido & 220 & $-17,6$ & 129,2 & sol & 0,9837 & 4,4 & & & 93 oc \\
\hline
\end{tabular}




\begin{tabular}{|c|c|c|c|c|c|c|c|c|c|c|}
\hline $\begin{array}{l}\text { Denominación química } \\
\mathrm{N} \text { úmero CAS }\end{array}$ & Color/ Forma & $\begin{array}{l}\text { p.e. } \\
(\stackrel{0}{ } \mathrm{C})\end{array}$ & $\begin{array}{l}\text { p.f. } \\
(\stackrel{\circ}{ } \mathcal{C})\end{array}$ & $\begin{array}{l}\mathrm{p} . \mathrm{m} . / \\
\text { (g/ } \\
\mathrm{mol})\end{array}$ & $\begin{array}{l}\text { Solubilidad } \\
\text { en agua }\end{array}$ & $\begin{array}{l}\text { Densidad } \\
\text { relativa } \\
\text { (agua }=1 \text { ) }\end{array}$ & $\begin{array}{l}\text { Densidad } \\
\text { relativa } \\
\text { del vapor } \\
\text { (aire=1) }\end{array}$ & $\begin{array}{l}\text { Pvap/ } \\
(\mathrm{kPa})\end{array}$ & $\begin{array}{l}\text { Límit. } \\
\text { inflam. }\end{array}$ & $\begin{array}{ll}\text { p.ig. } & \text { p.aut } \\
\left({ }^{\circ} \mathrm{C}\right) & \text { ig. } \\
& \left({ }^{\circ} \mathrm{C}\right)\end{array}$ \\
\hline $\begin{array}{l}\text { 2-AMINOPIRIDINA } \\
504-29-0\end{array}$ & $\begin{array}{l}\text { laminillas blancas o } \\
\text { cristales grandes } \\
\text { incoloros; cristales o } \\
\text { polvo blanco }\end{array}$ & 211 & 58 & 94,11 & misc & & 3,25 & 0,13 & & $68 \mathrm{cc}$ \\
\hline $\begin{array}{l}\text { BENZOGUANAMINA } \\
91.76 .9\end{array}$ & cristales & & 227 & 187,20 & $0,6 \%$ & $\begin{array}{l}1,40 \\
@ 25^{\circ} \mathrm{C} / 4^{\circ} \mathrm{C}\end{array}$ & & & & \\
\hline $\begin{array}{l}\text { 1,2,3-BENZOTRIAZOL } \\
\text { 95-14-7 }\end{array}$ & $\begin{array}{l}\text { agujas en benceno; } \\
\text { polvo cristalino entre } \\
\text { blanco y ligeramente } \\
\text { tostado }\end{array}$ & $\begin{array}{l}204 \\
@ 15 \mathrm{~mm} \mathrm{Hg}\end{array}$ & 98,5 & 119,12 & lig sol & & & & & \\
\hline $\begin{array}{r}\text { CUMARINA } \\
91-64-5\end{array}$ & $\begin{array}{l}\text { cristales romboidales, } \\
\text { piramidales en éter; } \\
\text { placas ortorrómbicas } \\
\text { rectangulares; sólido } \\
\text { blanco, cristalino }\end{array}$ & 301,72 & 71 & 146,14 & $\begin{array}{l}1 \mathrm{~g} / 400 \mathrm{ml} \\
\text { (en frío) }\end{array}$ & $\begin{array}{l}0,935 \mathrm{a} \\
20 / 4^{\circ} \mathrm{C}\end{array}$ & & $\begin{array}{l}1 \mathrm{~mm} \mathrm{Hga} \\
106,0^{\circ} \mathrm{C}\end{array}$ & & \\
\hline $\begin{array}{l}\text { 3,4,5,6-DIBENZOCARBAZOL } \\
194-59-2\end{array}$ & agujas en etanol & & 158 & 267,34 & & & & & & \\
\hline $\begin{array}{l}\text { DIHIDROCLORURO DE PIPERAZINA } \\
142-64-3\end{array}$ & $\begin{array}{l}\text { polvo cristalino color } \\
\text { crema; agujas blancas }\end{array}$ & & & 159,07 & $41 \%$ & & & & & \\
\hline $\begin{array}{l}\text { DISULFURO DE } \\
\text { 2-MERCAPTOBENZOTIAZOL } \\
\text { 120-78-5 }\end{array}$ & $\begin{array}{l}\text { agujas de color amarillo } \\
\text { pálido en benceno; } \\
\text { polvo fluyente }\end{array}$ & & 180 & 332,46 & insol & 1,50 & & & & \\
\hline $\begin{array}{l}\text { N-ETILMORFOLINA } \\
100-74-3\end{array}$ & líquido incoloro & 138,5 & $-62,78$ & 115,2 & misc & 0,8996 & 4,0 & $\begin{array}{l}6,1 \mathrm{~mm} \mathrm{Hg} \\
@ 20^{\circ} \mathrm{C}\end{array}$ & & \\
\hline $\begin{array}{l}\text { FENAZOPIRIDINA } \\
94-78.0\end{array}$ & $\begin{array}{l}\text { cristales de color } \\
\text { amarillo-marrón }\end{array}$ & & 139 & 213,25 & $\begin{array}{l}388 \mathrm{mg} / \mathrm{I} \\
\text { @ } 25^{\circ} \mathrm{C} \text { (est.) }\end{array}$ & & & $\begin{array}{l}4,57 \times 10-12 \\
\mathrm{~mm} \mathrm{Hg} \\
\text { @ } 25^{\circ} \mathrm{C}\end{array}$ & & \\
\hline $\begin{array}{l}\text { FENILENPIRENO } \\
193-39-5\end{array}$ & $\begin{array}{l}\text { agujas o placas } \\
\text { amarillas en fracciones } \\
\text { ligeras de petróleo }\end{array}$ & 530 & $\begin{array}{l}162,5- \\
164\end{array}$ & & insol & & & $\begin{array}{l}1,0 \times 10-10 \\
\text { torr }\end{array}$ & & \\
\hline $\begin{array}{l}\text { FENOTIAZINA } \\
92-84-2\end{array}$ & $\begin{array}{l}\text { laminillas rómbicas } \\
\text { amarillas o placas con } \\
\text { forma de diamante en } \\
\text { tolueno o butanol; } \\
\text { prismas amarillos en } \\
\text { alcohol; polvo, gránulos } \\
\text { o escamas de color } \\
\text { verde grisáceo o } \\
\text { amarillo verdoso }\end{array}$ & 371 & 185,1 & 186,26 & insol & & & & & \\
\hline $\begin{array}{l}\text { 2-MERCAPTOBENZOTIAZOL } \\
149-30-4\end{array}$ & $\begin{array}{l}\text { agujas o laminillas } \\
\text { monoclínicas de color } \\
\text { amarillo pálido; polvo } \\
\text { amarillento; agujas en } \\
\text { alc. o metanol diluido; } \\
\text { polvo cristalino entre } \\
\text { amarillento y tostado }\end{array}$ & & 181 & 167,2 & insol & 1,42 & & & & \\
\hline $\begin{array}{l}\text { N-METILMORFOLINA } \\
\text { 109-02-4 }\end{array}$ & & $115-116$ & & 101,14 & sol & 0,9051 & & & & \\
\hline $\begin{array}{l}\text { 2-METILPIRIDINA } \\
\text { 109-06-8 }\end{array}$ & líquido incoloro & 129 & .70 & 93,12 & muy sol & 0,9443 & 3,2 & 1,2 & $\begin{array}{l}1,4 \mathrm{li} \\
8,6 \mathrm{ls}\end{array}$ & 535 \\
\hline
\end{tabular}




\begin{tabular}{|c|c|c|c|c|c|c|c|c|c|c|c|}
\hline $\begin{array}{l}\text { Denominación química } \\
\mathrm{N} \text { úmero CAS }\end{array}$ & Color/ Forma & $\begin{array}{l}\text { p.e. } \\
\left({ }^{\circ} \mathrm{C}\right)\end{array}$ & $\begin{array}{l}\text { p.f. } \\
\left({ }^{\circ} C\right)\end{array}$ & $\begin{array}{l}\text { p.m.l } \\
\text { (g/ } \\
\text { mol) }\end{array}$ & $\begin{array}{l}\text { Solubilidad } \\
\text { en agua }\end{array}$ & $\begin{array}{l}\text { Densidad } \\
\text { relativa } \\
\text { (agua }=1 \text { ) }\end{array}$ & $\begin{array}{l}\text { Densidad } \\
\text { relativa } \\
\text { del vapor } \\
\text { (aire=1) }\end{array}$ & $\begin{array}{l}\text { Pvap/ } \\
(\mathrm{kPa})\end{array}$ & $\begin{array}{l}\text { Límit. } \\
\text { inflam. }\end{array}$ & $\begin{array}{l}\text { p.ig. } \\
(\because C)\end{array}$ & $\begin{array}{l}\text { p.aut } \\
\text { ig. } \\
\left({ }^{\circ} \text { C }\right)\end{array}$ \\
\hline $\begin{array}{l}\text { 3-METILPIRIDINA } \\
\text { 108-99-6 }\end{array}$ & líquido incoloro & $143-144$ & $-18,3$ & 93,12 & misc & $\begin{array}{l}0,9613 \\
@ 15^{\circ} \mathrm{C} / 4^{\circ} \mathrm{C}\end{array}$ & 3,2 & $\begin{array}{l}6,05 \\
\mathrm{~mm} \mathrm{Hg} \\
@ 25^{\circ} \mathrm{C} \\
\end{array}$ & $\begin{array}{l}1,3 \mathrm{li} \\
8,7 \mathrm{ls}\end{array}$ & $38 \mathrm{cc}$ & \\
\hline $\begin{array}{l}\text { 4-METILPIRIDINA } \\
108-89-4\end{array}$ & líquido incoloro & 145 & 3,6 & 93,12 & misc & 0,9548 & 3,2 & $\begin{array}{l}1,3 \\
@ 25^{\circ} \mathrm{C}\end{array}$ & $\begin{array}{l}1,3 \mathrm{li} \\
8,7 \mathrm{ls}\end{array}$ & $57 \mathrm{ca}$ & \\
\hline $\begin{array}{l}\text { 1-METIL-2-PIRROLIDONA } \\
872-50-4\end{array}$ & líquido incoloro & 202 & 24 & 99,13 & muy sol & $\begin{array}{l}1,0260 \\
@ 25^{\circ} \mathrm{Cl} \\
25^{\circ} \mathrm{C}\end{array}$ & 3,4 & $\begin{array}{l}66 \mathrm{~Pa} \\
@ 25^{\circ} \mathrm{C}\end{array}$ & $\begin{array}{l}0,99 \mathrm{li} \\
3,9 \mathrm{ls}\end{array}$ & 91 & 270 \\
\hline $\begin{array}{r}\text { MORFOLINA } \\
110-91-8 \\
\end{array}$ & $\begin{array}{l}\text { líquido incoloro; líquido } \\
\text { móvil }\end{array}$ & 128,9 & $-4,9$ & 87,12 & misc & 1,0007 & 3 & 1,06 & $\begin{array}{l}2,0 \mathrm{li} \\
11,2 \mathrm{ls} \\
\end{array}$ & 38 oc & 310 \\
\hline $\begin{array}{l}\text { NICOTINA } \\
54-11-5\end{array}$ & $\begin{array}{l}\text { líquido oleaginoso } \\
\text { incoloro o amarillo } \\
\text { pálido; aceite espeso } \\
\text { de color agua que se } \\
\text { vuelve marrón }\end{array}$ & $\begin{array}{l}246,7 @ \\
745 \mathrm{~mm} \mathrm{Hg}\end{array}$ & .79 & 162,23 & misc & 1,0097 & 5,61 & $\begin{array}{l}133 \mathrm{~Pa} \\
@ 62^{\circ} \mathrm{C}\end{array}$ & $\begin{array}{l}0,7 \mathrm{li} \\
4,0 \mathrm{ls}\end{array}$ & 95 & 244 \\
\hline $\begin{array}{l}\text { N-NITROSONORNICOTINA } \\
\text { 16543-55-8 }\end{array}$ & aceite amarillo & $\begin{array}{l}154 @ \\
0,2 \mathrm{~mm} \mathrm{Hg} \\
\end{array}$ & 47 & 177,23 & & & & $\begin{array}{l}0,2 \mathrm{~mm} \mathrm{Hg} \\
@ 154^{\circ} \mathrm{C} \\
\end{array}$ & & & \\
\hline $\begin{array}{r}\text { PIPERAZINA } \\
110-85-0\end{array}$ & $\begin{array}{l}\text { laminillas o placas en } \\
\text { etanol; grumos } 0 \\
\text { escamas blancas o } \\
\text { ligeramente } \\
\text { blancuzcas; cristales } \\
\text { aciculares incoloros y } \\
\text { transparentes }\end{array}$ & 146 & 106 & 86,14 & muy sol & 1,1 & 3,0 & & & $81 \mathrm{ca}$ & \\
\hline $\begin{array}{r}\text { PIPERIDINA } \\
110-89-4 \\
\end{array}$ & $\begin{array}{l}\text { líquido incoloro y } \\
\text { transparente }\end{array}$ & $\begin{array}{l}106 @ 760 \\
\mathrm{~mm} \mathrm{Hg}\end{array}$ & .7 & 85,15 & muy sol & 0,8622 & 3,0 & $\begin{array}{l}5,3 \\
\text { @ } 29,2{ }^{\circ} \mathrm{C} \\
\end{array}$ & & $16 c c$ & \\
\hline $\begin{array}{l}\text { PIRIDINA } \\
110-86-1 \\
\end{array}$ & $\begin{array}{l}\text { líquido incoloro; } \\
\text { ligeramente amarillo }\end{array}$ & 115,2 & -42 & 79,10 & misc & 0,9819 & 2,73 & 2,0 & $\begin{array}{l}1,8 \mathrm{li} \\
12,4 \mathrm{ls}\end{array}$ & $17 \mathrm{cc}$ & 482 \\
\hline $\begin{array}{r}\text { PIRIMIDINA } \\
289-95-2 \\
\end{array}$ & & 123,8 & 22 & 80,09 & misc & & & & & & \\
\hline $\begin{array}{l}\text { PIRROLIDINA } \\
123-75-1\end{array}$ & $\begin{array}{l}\text { líquido incoloro } 0 \\
\text { amarillo pálido }\end{array}$ & $88,5-89$ & $.57,8$ & 71,12 & misc & $\begin{array}{l}0,8520 @ \\
22,5^{\circ} \mathrm{C} / 4^{\circ} \mathrm{C}\end{array}$ & 2,45 & $\begin{array}{l}128 \mathrm{~mm} \mathrm{Hg} \\
\text { @ } 39^{\circ} \mathrm{C}\end{array}$ & $\begin{array}{l}2,9 \mathrm{li} @ \\
-2^{\circ} \mathrm{C} \\
13,0 \mathrm{ls} @ \\
29,8^{\circ} \mathrm{C} \\
\end{array}$ & & \\
\hline $\begin{array}{l}\text { 2.PIRROLIDINONA } \\
616-45-5 \\
\end{array}$ & líquido & $\begin{array}{l}250 @ \\
742 \mathrm{~mm} \mathrm{Hg} \\
\end{array}$ & 25 & 85,1 & muy sol & 1,120 & 2,93 & & & $110 \mathrm{cc}$ & \\
\hline $\begin{array}{l}\text { PROPILENIMINA } \\
75-55-8 \\
\end{array}$ & $\begin{array}{l}\text { líquido oleaginoso } \\
\text { incoloro }\end{array}$ & 66 & -65 & 57,1 & sol & $\begin{array}{l}0,812 @ 16 \\
{ }^{\circ} \mathrm{C} / 4^{\circ} \mathrm{C}\end{array}$ & 2,0 & 14,9 & & $-39 \mathrm{cc}$ & \\
\hline $\begin{array}{l}\text { QUINOLINA } \\
91-22-5 \\
\end{array}$ & $\begin{array}{l}\text { líquido incoloro } 0 \\
\text { marrón }\end{array}$ & 237,7 & -15 & 129,16 & insol & 1,0929 & 4,45 & 0,1 & $\begin{array}{l}1,2 \mathrm{li} \\
7 \mathrm{ls}\end{array}$ & 99 & 480 \\
\hline $\begin{array}{r}\text { SULFOLANO } \\
126-33.0\end{array}$ & $\begin{array}{l}\text { polvo cristalino blanco } \\
\text { o blanco cremoso }\end{array}$ & 285 & $\begin{array}{l}27,4- \\
27,8\end{array}$ & 120,16 & misc & $\begin{array}{l}1,2606 \\
@ 30^{\circ} \mathrm{C} / 4^{\circ} \mathrm{C}\end{array}$ & & $\begin{array}{l}0,0062 \\
\mathrm{~mm} \mathrm{Hg} \\
\text { @ } 27,6^{\circ} \mathrm{C}\end{array}$ & & $177 \mathrm{ca}$ & \\
\hline $\begin{array}{l}\text { SULFONA DE 1,3-PROPANO } \\
\text { 1120-71-4 }\end{array}$ & $\begin{array}{l}\text { líquido incoloro } 0 \\
\text { cristales blancos }\end{array}$ & $\begin{array}{l}180 @ \\
0,039 \mathrm{~atm} .\end{array}$ & 31 & 122,1 & $100 \mathrm{~g} / \mathrm{l}$ & $\begin{array}{l}1,393 \\
@ 40^{\circ} \mathrm{C} / 4^{\circ} \mathrm{C}\end{array}$ & & & & & \\
\hline $\begin{array}{l}\text { TARTRATO NICOTINICO } \\
65-31-6\end{array}$ & placas blancas & & 90 & 462,46 & sol & & & & & & \\
\hline
\end{tabular}


Tabla 104.88 • Propiedades físicas y químicas.

\begin{tabular}{|c|c|c|c|c|c|c|c|c|c|c|c|}
\hline $\begin{array}{l}\text { Denominación química } \\
\mathrm{N} \text { úmero CAS }\end{array}$ & Color/ Forma & $\begin{array}{l}\text { p.e. } \\
(\underline{O} C)\end{array}$ & $\begin{array}{l}\text { p.f. } \\
(\stackrel{\circ}{ })\end{array}$ & $\begin{array}{l}\text { p.m./ } \\
\text { (g/ } \\
\mathrm{mol})\end{array}$ & $\begin{array}{l}\text { Solubilidad } \\
\text { en agua }\end{array}$ & $\begin{array}{l}\text { Densidad } \\
\text { relativa } \\
\text { (agua }=1 \text { ) }\end{array}$ & $\begin{array}{l}\text { Densidad } \\
\text { relativa } \\
\text { del vapor } \\
\text { (aire=1) }\end{array}$ & $\begin{array}{l}\text { Pvap/ } \\
(\mathrm{kPa})\end{array}$ & $\begin{array}{l}\text { Límit. } \\
\text { inflam. }\end{array}$ & $\begin{array}{l}\text { p.ig. } \\
(\underline{O C})\end{array}$ & $\begin{array}{l}\text { p.aut } \\
\text { ig. } \\
\left({ }^{\circ} \mathrm{C}\right)\end{array}$ \\
\hline $\begin{array}{l}\text { TETRAHIDROTIOFENO } \\
110-01.0\end{array}$ & $\begin{array}{l}\text { líquido de color de } \\
\text { agua }\end{array}$ & 121,0 & $-96,1$ & 88,2 & insol & 0,9987 & 3,05 & $\begin{array}{l}2,4 \\
@ 25^{\circ} \mathrm{C}\end{array}$ & $\begin{array}{l}1,1 \mathrm{li} \\
12,1 \mathrm{ls}\end{array}$ & 12 & 200 \\
\hline $\begin{array}{l}\text { TIOFENO } \\
110-02-1\end{array}$ & líquido incoloro & 84,16 & $-38,25$ & 84,14 & insol & 1,06494 & 2,9 & $\begin{array}{l}5,3 \\
@ 12,5^{\circ} \mathrm{C}\end{array}$ & & -1 & \\
\hline $\begin{array}{l}\text { 2-VINILPIRIDINA } \\
100-69.6\end{array}$ & líquido incoloro & $159-160$ & $159-160$ & 105,1 & lig sol & 0,9983 & & $\begin{array}{l}10 \mathrm{~mm} \mathrm{Hg} \\
\text { @ } 44,5{ }^{\circ} \mathrm{C}\end{array}$ & & & \\
\hline
\end{tabular}




\section{HIDROCARBUROS SATURADOSY ALICICLICOS}

Los hidrocarburos alifáticos son compuestos formados por carbono e hidrógeno. Pueden ser moléculas ramificadas o lineales de cadena abierta, saturada o insaturada, siendo su nomenclatura la siguiente:

- parafinas (o alcanos)- hidrocarburos saturados

- olefinas (o alquenos)- hidrocarburos insaturados con uno 0 más dobles enlaces

- acetilenos (o alquinos)- hidrocarburos insaturados con uno o más triples enlaces

Las fórmulas generales son $\mathrm{C}_{n} \mathrm{H}_{2 n+2}$ para las parafinas, $\mathrm{C}_{n} \mathrm{H}_{2 n}$ para las olefinas, y $\mathrm{C}_{n} \mathrm{H}_{2 n-2}$ para los acetilenos.

Las moléculas más pequeñas son gases a temperatura ambiente $\left(\mathrm{C}_{1}\right.$ a $\left.\mathrm{C}_{4}\right)$. Al aumentar el tamaño y la complejidad estructural de la molécula, ésta se hace líquida y su viscosidad aumenta con el número de carbonos $\left(\mathrm{C}_{5} \mathrm{a}_{16}\right)$. Por último, los hidrocarburos de alto peso molecular son sólidos a temperatura ambiente (mayores de $\mathrm{C}_{16}$ ).

Los hidrocarburos alifáticos de uso industrial derivan principalmente del petróleo, que es una mezcla compleja de hidrocarburos. Se obtienen por craqueado, destilación y fraccionamiento del petróleo crudo.

El metano, el miembro inferior de la serie, constituye un $85 \%$ del gas natural, que puede ser extraído directamente de bolsas 0 reservorios existentes cerca de los yacimientos de petróleo. La condensación fraccionada de gas natural permite obtener grandes cantidades de pentano.

\section{U sos}

Los hidrocarburos saturados se utilizan en la industria como combustibles, lubricantes y disolventes. Una vez sometidos a procesos de alquilación, isomerización y deshidrogenación, pueden actuar también como materias primas para la síntesis de pinturas, revestimientos protectores, plásticos, caucho sintético, resinas, pesticidas, detergentes sintéticos y una gran variedad de productos petroquímicos.

Los combustibles, lubricantes y disolventes son mezclas que contienen muchos hidrocarburos diferentes. El gas natural se ha distribuido durante mucho tiempo en forma gaseosa para su uso como gas ciudad. Actualmente se licúa en grandes cantidades, se transporta refrigerado y se almacena como líquido refrigerado hasta que se introduce, sin modificar o reformado, en un sistema de distribución de gas ciudad. Los gases licuados de petróleo (LPGs), constituidos principalmente por propano y butano, se transportan y almacenan a presión o como líquidos refrigerados y se utilizan también para aumentar el suministro de gas ciudad. Se emplean directamente como combustibles, sobre todo en trabajos metalúrgicos de alta calidad que requieren un combustible exento de azufre, en trabajos de soldadura y corte al oxipropano, y en todas aquellas circunstancias en que el aumento de la demanda de combustibles gaseosos por parte de la industria pesada no pueda ser cubierto por el suministro público. Los depósitos utilizados para su almacenamiento varían en tamaño desde aproximadamente 2 toneladas hasta varios miles de toneladas. Los gases licuados del petróleo se utilizan también como propulsores en muchos tipos de aerosoles, y los miembros superiores de la serie, desde el heptano en adelante, se utilizan como combustibles para motores y como disolventes. El isobutano se emplea para controlar la volatilidad de la gasolina y es un componente del líquido de calibración de instrumentos. El isooctano es el combustible utilizado como patrón de referencia para el octanaje de combustibles, y el octano es un ingrediente de los combustibles antidetonantes para motores. Además de ser un componente de la gasolina, el nonano es también un componente de los detergentes biodegradables.

El principal uso del hexano es como disolvente de gomas, cementos y adhesivos para la producción de calzado, tanto de cuero como de plástico. Se usa también como disolvente de colas en el montaje de muebles, como adhesivo para papeles de pared, como disolvente de colas en la producción de bolsos y maletas de cuero y cuero artificial, en la fabricación de impermeables, en el recauchutado de neumáticos y en la extracción de aceites vegetales. En muchos casos, el hexano ha sido sustituido por heptano debido a la toxicidad del n-hexano.

Es imposible enumerar todas las ocasiones en las que el hexano puede estar presente en el medio ambiente de trabajo. Como regla general, su presencia puede sospecharse en disolventes volátiles y desengrasantes que contengan hidrocarburos derivados del petróleo. El hexano se utiliza también como agente limpiador en las industrias de tejidos, muebles y cuero.

Los hidrocarburos alifáticos utilizados como materias primas de productos intermedios para síntesis pueden ser compuestos individuales de gran pureza o mezclas relativamente simples.

\section{Riesgos}

\section{Incendio y explosión}

La construcción de grandes complejos para almacenar gas metano y después LPG se ha asociado a explosiones de gran magnitud y efectos catastróficos, que han puesto de manifiesto el peligro que su pone un derrame masivo de estas sustancias. La mezcla inflamable de gas y aire puede recorrer grandes distancias, incluso superando las distancias que se consideran adecuadas en términos de seguridad, con el resultado de que la mezcla inflamable puede arder por la presencia de un fuego doméstico 0 el motor de un automóvil situados fuera del perímetro de la zona considerada de riesgo. El vapor puede incendiarse en una gran área, y la propagación de la llama por la mezcla puede realizarse con una violencia explosiva. Muchos incendios y explosiones menores, aunque importantes, se han producido durante el uso de estos hidrocarburos gaseosos.

L os mayores incendios causados por los hidrocarburos líquidos se han producido como consecuencia de escapes masivos de líquidos, que alcanzaron una parte de la fábrica con una fuente de ignición o se extendieron sobre una gran superficie y se evaporaron rápidamente. La explosión de Flixborough (R eino U nido) se atribuyó a un escape de ciclohexano.

\section{Riesgos para la salud}

Los dos primeros elementos de la serie, el metano y el etano, son farmacológicamente "inertes" y pertenecen a un grupo de gases llamado "asfixiantes simples". Estos gases pueden ser tolerados en altas concentraciones en el aire inspirado sin producir efectos sistémicos. Cuando la concentración es lo bastante alta como para diluir o desplazar el oxígeno normalmente presente en el aire, sus efectos se producen por ausencia de oxígeno y asfixia. EI metano es inodoro y, por tanto, difícil de detectar. Su baja densidad hace que tienda a acumularse en zonas mal ventiladas, donde produce una atmósfera asfixiante. El etano, a concentra- 
ciones inferiores a 50.000 ppm (5 \%) en la atmósfera, no produce efectos sistémicos por inhalación.

Desde el punto de vista farmacológico, los hidrocarburos superiores al etano pueden considerarse dentro del grupo de los anestésicos generales, en esa larga lista de sustancias conocidas como depresores del sistema nervioso central. Los vapores de estos hidrocarburos producen una ligera irritación de las mucosas. La intensidad de la irritación aumenta de pentano a octano. En general, la toxicidad de los alcanos aumenta al hacerlo el número de carbonos de la molécula. Asimismo, los alcanos de cadena lineal son más tóxicos que los isómeros ramificados.

Los hidrocarburos parafínicos líquidos son disolventes de grasas e irritantes primarios de la piel. El contacto repetido o prolongado con la piel, la seca y desengrasa, con resultado de irritación y dermatitis. El contacto directo de los hidrocarburos líquidos con el tejido pulmonar (por aspiración) produce neumonitis química, edema pulmonar y hemorragia. La intoxicación crónica por n-hexano o mezclas que contengan n-hexano puede causar polineuropatía.

La exposición breve a concentraciones de propano de 10.000 ppm (1 \%) no produce síntomas en el ser humano. La concentración de 100.000 ppm (10 \%) no es irritante para los ojos, la nariz ni el tracto respiratorio, si bien produce un ligero mareo al cabo de unos minutos. El gasbutano causa sopor, pero no efectos sistémicos, con exposiciones a 10.000 ppm (1 \%) durante 10 minutos.

El pentano es el miembro inferior de la serie que es líquido a temperatura y presión ambiente. En estudios realizados en sujetos humanos, una exposición de 10 minutos a 5.000 ppm $(0,5 \%)$ no produjo irritación de las mucosas ni otros síntomas.

El heptano causó un ligero mareo en hombres expuestos durante 6 minutos a 1.000 ppm $(0,1 \%)$ y durante 4 minutos a 2.000 ppm $(0,2 \%)$. La exposición durante 4 minutos a 5.000 ppm $(0,5 \%)$ de heptano causó un intenso mareo, incapacidad de caminar en línea recta, hilaridad y descoordinación. Estos efectos sistémicos se produjeron en ausencia de irritación de las mucosas. La exposición durante 15 minutos a esa concentración de heptano produjo un estado de intoxicación caracterizado por hilaridad incontrolada en algunos individuos, y en otros produjo estupor, que duró hasta 30 minutos después de cesar la exposición. En muchos casos, estos síntomas se intensificaron o manifestaron por primera vez al entrar en una atmósfera no contaminada. Los individuos presentaron también pérdida de apetito, leves náuseas, y un sabor semejante a gasolina durante varias horas después de la exposición a heptano.

El octano a concentraciones de entre 6.600 y 13.700 ppm (de 0,66 a 1,37 \% ) causó narcosis en ratones durante 30-90 minutos. La exposición a concentraciones menores de 13.700 ppm $(1,37 \%)$ no provocó muerte ni convulsiones.

Ante la posibilidad de que, en una mezcla de alcanos, sus componentes tengan efectos tóxicos aditivos, el National Institute for O ccupational Safety and H ealth (N IO SH ) de Estados U nidos ha recomendado mantener un valor límite umbral para alcanos totales $\left(C_{5}\right.$ a $\left.C_{8}\right)$ de $350 \mathrm{mg} / \mathrm{m}^{3}$ como media ponderada en el tiempo, con un valor máximo para 15 minutos de $1.800 \mathrm{mg} / \mathrm{m}^{3}$. El n-hexano se considera por separado debido a su neurotoxicidad.

\section{n-H exano}

EI n-hexano es un hidrocarburo alifático (o alcano) de cadena lineal y saturado, con la fórmula general $\mathrm{C}_{n} \mathrm{H}_{2 n+2}$ y uno de la serie de hidrocarburos con puntos de ebullición bajos (entre 40 y $90 \stackrel{\circ}{ } \mathrm{C}$ ) que pueden obtenerse del petróleo mediante diversos procesos (craqueo, rectificación). Estos hidrocarburos son una mezcla de alcanos y cicloalcanos con cinco a siete átomos de carbono (n-pentano, n-hexano, n-heptano, isopentano, ciclopentano, 2-metilpentano, 3-metilpentano, ciclohexano, metilciclopentano). Su destilación fraccionada permite obtener hidrocarburos simples con diversos grados de pureza.

El hexano se vende comercialmente como una mezcla de isómeros con seis átomos de carbono y un punto de ebullición comprendido entre 60 y $70 \stackrel{\circ}{\circ}$. Los isómeros más comunes son 2-metilpentano, 3-metilpentano, 2,3-dimetilbutano y 2,2-dimetilbutano. El término hexano técnico de uso comercial se refiere a una mezcla que contiene no sólo n-hexano y sus isómeros, sino también otros hidrocarburos alifáticos con cinco a siete átomos de carbono (pentano, heptano y sus isómeros).

Los hidrocarburos con seis átomos de carbono, entre ellos el n-hexano, están presentes en los siguientes derivados del petróleo: éter de petróleo, gasolina, nafta y ligroína, y combustibles para reactores.

La exposición a n-hexano puede ser o no de origen profesional. En el entorno de trabajo puede ocurrir como resultado de la utilización de disolventes para colas, cementos, adhesivos y líquidos desengrasantes. El contenido de $n$-hexano de estos disolventes varía. En pegamentos para calzado y caucho, puede llegar hasta el 40 ó $50 \%$ del disolvente en peso. Los usos aquí mencionados son los que han causado enfermedades profesionales en el pasado $y$, en algunos casos, el hexano ha sido ya sustituido por heptano. Puede también producirse exposición profesional a n-hexano por inhalación de vapores de petróleo en depósitos de combustible o talleres de reparación de automóviles. No obstante, el peligro de esta forma de exposición profesional es muy pequeño, puesto que la concentración de n-hexano en la gasolina para automóviles se mantiene por debajo del $10 \%$ debido a la necesidad de un alto índice de octanaje.

La exposición no profesional se produce sobre todo en niños o drogadictos que esnifan pegamento o gasolina. En este caso, el contenido de $n$-hexano varía desde un alto porcentaje en el pegamento hasta $10 \%$ o menos en la gasolina.

\section{Riesgos}

EI n-hexano puede penetrar en el organismo por dos vías: por inhalación o a través de la piel. Sea cual sea la vía, la absorción es lenta. De hecho, las medidas de la concentración en equilibrio de n-hexano en el aire espirado han demostrado el paso de los pulmones a la sangre de una fracción del $n$-hexano inhalado de entre el 5,6 y el $15 \%$. La absorción a través de la piel es extremadamente lenta.

El n-hexano produce los mismos efectos en la piel que los descritos previamente para otros hidrocarburos alifáticos líquidos. El hexano tiende a evaporarse cuando se ingiere o aspira en el árbol traqueobronquial. El resultado puede ser su rápida dilución en el aire alveolar y un descenso marcado del contenido de oxígeno, con asfixia y consiguiente lesión cerebral o parada cardíaca. Las lesiones irritativas pulmonares que se producen después de la aspiración de homólogos superiores (p. ej. octano, nonano, decano, etc.) y de mezclas de los mismos (p. ej. queroseno) no parecen deberse al hexano. Los efectos agudos 0 crónicos se producen casi siempre por inhalación. El hexano exhibe una toxicidad aguda tres veces mayor que el pentano. Los efectos agudos se producen por exposición a altas concentraciones de vapor de $n$-hexano y van desde mareo después de una exposición breve a concentraciones de aproximadamente $5.000 \mathrm{ppm}$, hasta convulsiones y narcosis observadas en animales a concentraciones de aproximadamente 30.000 ppm. En el ser humano, la exposición durante 10 minutos a una concentración de $2.000 \mathrm{ppm}(0,2 \%)$ no produce síntomas. La exposición a 880 ppm durante 15 min puede causar irritación de los ojos y el tracto respiratorio superior. 
Los efectos crónicos se producen por exposición prolongada a dosis que no producen síntomas agudos aparentes y tienden a desaparecer lentamente cuando finaliza la exposición. A finales del decenio de 1960 y principios del decenio de 1970, se detectaron algunos brotes de polineuropatías sensorimotoras y sensoriales en trabajadores expuestos a mezclas de disolventes que contenían n-hexano en concentraciones de entre 500 y 1.000 ppm, con algunos picos mayores y algunos casos de sintomatología con concentraciones de tan sólo 50 ppm. Se observaron también algunos casos de atrofia muscular y afectación de nervios craneales, con trastornos visuales y parálisis facial. A proximadamente un 50 \% mostró desnervación y regeneración de los nervios. También se notificó sensación de hormigueo, entumecimiento y debilidad de las extremidades, principalmente en las piernas. A menudo se observó marcha vacilante. Los reflejos del tendón de Aquiles desaparecieron; la sensación de tacto y calor disminuyeron. El tiempo de conducción se redujo en los nervios motores y sensoriales de brazos y piernas.

El curso de la enfermedad es, en general, muy lento. D espués de la aparición de los primeros síntomas, suele producirse un deterioro del cuadro clínico por agravamiento de la deficiencia motora de las regiones afectadas en un principio y su extensión a aquellas que hasta entonces se habían mantenido intactas. Este deterioro puede persistir varios meses después de haber cesado la exposición. La lesión suele extenderse de los miembros inferiores a los superiores. En casos muy graves aparece parálisis motora ascendente con deficiencia funcional de los músculos respiratorios. La recuperación puede durar entre 1 y 2 años; generalmente es completa, aunque en algunos casos persiste la disminución de los reflejos tendinosos, en particular los del tendón de Aquiles pese a un estado de salud aparentemente bueno.

En casos graves de intoxicación con n-hexano, se han observado síntomas en el sistema nervioso central (defectos de la función visual o de la memoria) relacionados con una degeneración del núcleo visual y las estructuras hipotalámicas, que pueden ser permanentes.

Con respecto a las pruebas de laboratorio, los análisis hematológicos y hematoquímicos más habituales no muestran cambios característicos; tampoco los análisis de orina, que sólo detectan un aumento de la creatinuria en casos graves de parálisis con hipotrofia muscular.

En el examen del líquido cefalorraquídeo no se producen hallazgos característicos, manométricos ni cualitativos, excepto en casos raros de aumento del contenido de proteínas. Al parecer, solamente el sistema nervioso muestra cambios característicos. Los electroencefalogramas (EEG) suelen ser normales. No obstante, en casos graves de enfermedad se pueden detectar disrritmias, molestias generalizadas o subcorticales e irritabilidad. La prueba más útil es la electromiografía (EM G). Los hallazgos indican lesiones mielínicas y axonales de los nervios distales. La velocidad de conducción motora (MCV) y la velocidad de conducción sensitiva (SCV) se reducen, la latencia distal (LD) se altera y el potencial sensorial (SPA) disminuye.

EI diagnóstico diferencial con respecto a otras polineuropatías periféricas se basa en la simetría de la parálisis, en la bajísima frecuencia de pérdida sensorial, en la ausencia de cambios en el líquido cefalorraquídeo y, sobre todo, en el conocimiento de que se ha producido una exposición a disolventes que contienen n-hexano y en la aparición de más de un caso con síntomas similares en el mismo lugar de trabajo.

Experimentalmente, el n-hexano de grado técnico causa trastornos en los nervios periféricos de los ratones a concentraciones iguales o superiores a 250 ppm después de 1 año de exposición. Los estudios metabólicos han demostrado que, en cobayas, el n-hexano y la metil butil cetona (MBK) se metabolizan a los mismos compuestos neurotóxicos (2-hexanodiol y 2,5-hexanodiona).

En biopsias musculares se han observado modificaciones anatómicas de los nervios que explican las manifestaciones clínicas antes descritas, tanto en animales de laboratorio como en sujetos humanos enfermos. Schaumberg y Spencer consiguieron por primera vez en 1976 reproducir experimentalmente la polineuritis por $n$-hexano. Las modificaciones anatómicas de los nervios se asocian a degeneración axonal. Esta degeneración axonal y la desmielinización resultante de las fibras comienza en la periferia, en particular en las fibras más largas, y tiende a avanzar hacia el centro, aunque la neurona no muestre signos de degeneración. El cuadro anatómico no es específico de la patología del n-hexano, si no común a una serie de enfermedades nerviosas causadas por venenos de uso industrial y no industrial.

Un aspecto muy interesante de la toxicología del n-hexano es la identificación de los metabolitos activos de la sustancia y sus relaciones con la toxicología de otros hidrocarburos. En primer lugar parece ser que la patología nerviosa está causada solamente por n-hexano y no por sus isómeros ni por $n$-pentano o n-heptano puros.

En la Figura 104.1 se muestra la ruta metabólica de n-hexano y metil $n$-butil cetona en el ser humano. Puede observarse que los dos compuestos tienen una ruta metabólica común y que la M BK puede formarse a partir de n-hexano. La patología nerviosa se ha reproducido con 2-hexanol, 2,5-hexanodiol y 2,5-hexanodiona. E s evidente, como se ha demostrado en experimentos animales y en la práctica clínica, que la MBK también es neurotóxica. El más tóxico de los metabolitos de n-hexano es la 2,5-hexanodiona. 0 tro aspecto importante de la relación entre el metabolismo del n-hexano y la toxicidad es el efecto sinérgico que ha demostrado tener la metil etil cetona (M EK) en la neurotoxicidad producida por n-hexano y MBK. La MEK no es neurotóxica en sí misma para animales ni seres humanos, pero causa lesiones de los sistemas nerviosos periféricos en animales tratados con $n$-hexano o M BK, que aparecen más rápidamente que las lesiones similares provocadas sólo por dichas sustancias. La explicación más probable es una interferencia metabólica de MEK con la ruta que convierte n-hexano y M BK en los metabolitos neurotóxicos mencionados antes.

Figura 104.1 Ruta metabólica del n-hexano y la metil-n-butil cetona.

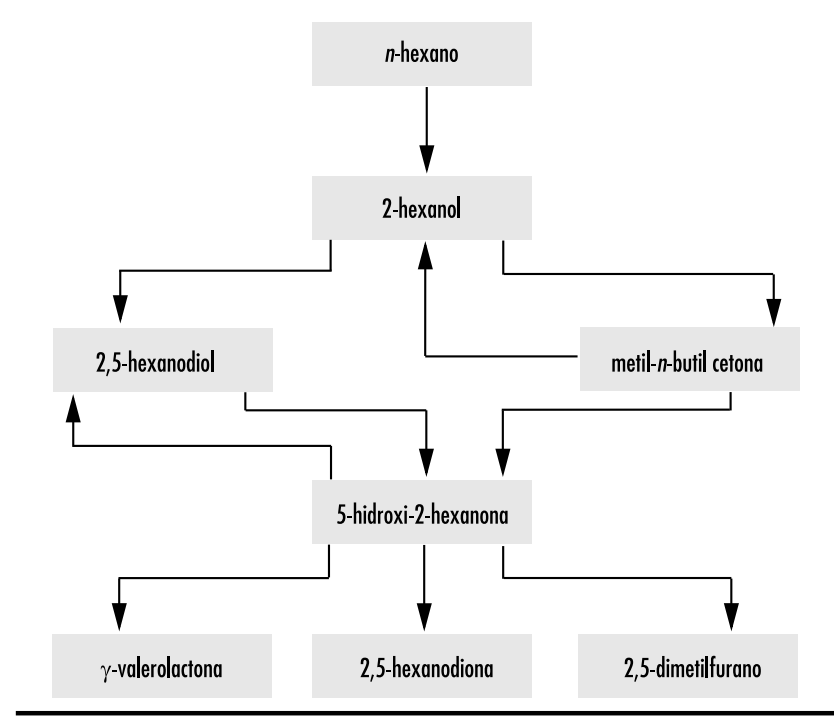




\section{Medidas de salud y seguridad}

De las observaciones anteriores se deduce que debe evitarse la asociación de n-hexano con M BK o MEK en disolventes de uso industrial. Siempre que sea posible, se sustituirá heptano por hexano.

Con respecto a los TLV en vigor para n-hexano, se han observado alteraciones EM G en trabajadores expuestos a concentraciones de $144 \mathrm{mg} / \mathrm{ml}$ (40 ppm) que están ausentes en los trabajadores no expuestos a n-hexano. El seguimiento médico de los trabajadores expuestos se basa en los datos relativos a la concentración de n-hexano en la atmósfera y en observaciones clínicas, principalmente en el campo neurológico. El seguimiento biológico de la 2,5-hexanodiona en la orina es el indicador más útil de la exposición, aunque la MBK puede interferir con esta medición. En caso necesario, la medición de n-hexano en el aire espirado al final del turno de trabajo puede confirmar la exposición.

\section{Cicloparafinas (cicloalcanos)}

Las cicloparafinas son hidrocarburos alicíclicos en los que tres 0 más átomos de carbono de cada molécula se unen formando una estructura en anillo y cada uno de los átomos de carbono del anillo se unen a dos átomos de hidrógeno o grupos alquilo. Los miembros de este grupo tienen la fórmula general $\mathrm{C}_{n} \mathrm{H}_{2 n}$. Entre los derivados de estas cicloparafinas se encuentran compuestos como el metilciclohexano $\left(\mathrm{C}_{6} \mathrm{H}_{11} \mathrm{CH}_{3}\right)$. D esde el punto de vista de la seguridad y la salud en el trabajo, los más importantes de ellos son el ciclohexano, el ciclopropano y el metilciclohexano.

El ciclohexano se utiliza en decapantes y barnices; como disolvente de lacas y resinas, caucho sintético, y grasas y ceras en la industria de perfumes; como producto químico intermedio en la fabricación de ácido adípico, benceno, cloruro de ciclohexilo, nitrociclohexano, ciclohexanol y ciclohexanona; y para determinaciones de peso molecular en química analítica. EI ciclopropano es un anestésico general.

\section{Riesgos}

Las cicloparafinas y sus derivados son líquidos inflamables, y sus vapores forman concentraciones explosivas con el aire a temperatura ambiente normal.

Pueden producir efectos tóxicos por inhalación e ingestión, y tienen una acción irritante y desengrasante de la piel. En general, las cicloparafinas son anestésicos y depresores del sistema nervioso central, pero su toxicidad aguda es escasa y al ser eliminadas casi por completo del organismo, el peligro de intoxicación crónica es relativamente pequeño.

Ciclohexano. La toxicidad aguda del ciclohexano es muy pequeña. En ratones, la exposición a una concentración de $18.000 \mathrm{ppm}(61,9 \mathrm{mg} / \mathrm{l})$ de vapor de ciclohexano en el aire produjo temblores al cabo de 5 minutos, alteraciones del equilibrio al cabo de 15 minutos, y postración completa al cabo de 25 minutos. En conejos, los temblores aparecieron a los 6 minutos, las alteraciones del equilibrio a los 15 minutos y la postración completa a los 30 minutos. No se observaron cambios tóxicos en los tejidos de los conejos después de una exposición durante 50 períodos de $6 \mathrm{~h}$ a concentraciones de $1,46 \mathrm{mg} / \mathrm{I}$ (434 ppm). La concentración de 300 ppm de ciclohexano pudo detectarse por su olor y produjo una cierta irritación de los ojos y las mucosas. Los vapores de ciclohexano causan un leve y corto efecto anestésico, pero más potente que el del hexano.

Los experimentos con animales han demostrado que el ciclohexano es mucho menos nocivo que el benceno, su análogo cíclico aromático de seis miembros y, en concreto, no ataca el sistema hematopoyético como lo hace el benceno. Se cree que la ausencia virtual de efectos nocivos en los tejidos hematopoyéticos se debe, al menos en parte, a diferencias en el metabolismo del ciclohexano y el benceno. Se han identificado dos metabolitos del ciclohexano, ciclohexano y ciclohexanol; el primero de ellos se oxida parcialmente a ácido adípico. Ninguno de los derivados fenólicos característicos de la toxicidad de benceno se han encontrado como metabolitos en animales expuestos a ciclohexano, lo que ha llevado a proponer la sustitución de benceno por ciclohexano como disolvente.

EI metilciclohexano tiene efectos tóxicos similares, pero menos intensos, que el ciclohexano. La exposición reiterada de conejos a 1.160 ppm durante 10 semanas no produjo efectos, y solamente se observaron lesiones leves hepáticas y renales con 3.330 ppm. La exposición prolongada a 370 ppm resultó ser inofensiva para los monos. No se han notificado efectos tóxicos por exposición industrial a metilciclohexano ni intoxicación causada por este compuesto en seres humanos.

Estudios realizados con animales demuestran que la mayor parte de esta sustancia que penetra en el torrente circulatorio se conjuga con ácidos sulfúrico y glucurónico y se excreta en la orina como sulfatos o glucurónidos, sobre todo glucurónido de trans-4-metilciclohexanol. 


\section{TABLAS DE HIDROCARBUROS SATURADOS Y AUCICUCOS}

\begin{tabular}{|c|c|c|c|}
\hline Producto químico & Sinónimos/ Código UN & $\mathrm{N}$ úmero $\mathrm{CAS}$ & Fórmula estructural \\
\hline BUTANO & $\begin{array}{l}\text { n-Butano; dietilo; metiletilmetano } \\
\text { UN1011 }\end{array}$ & $106-97-8$ & \\
\hline CICLOHEXANO & $\begin{array}{l}\text { Hexahidrobenceno; hexametileno; hexanafteno } \\
\text { UN1145 }\end{array}$ & $110-82.7$ & \\
\hline CICLOPENTANO & $\begin{array}{l}\text { Pentametileno } \\
\text { UN1146 }\end{array}$ & $287-92-3$ & \\
\hline CICLOPROPANO & $\begin{array}{r}\text { Trimetileno } \\
\text { UN1027 }\end{array}$ & $75-19-4$ & \\
\hline DECANO & UN2247 & $124-18-5$ & \\
\hline 2,2-DIMETILBUTANO & & $75-83-2$ & \\
\hline 2,3-DIMETILBUTANO & $\begin{array}{l}\text { 2,3-Dimetilbutano } \\
\text { UN2457 }\end{array}$ & $79-29-8$ & \\
\hline 2,2-DIMETILPROPANO & $\begin{array}{l}\text { Neopentano } \\
\text { UN2044 }\end{array}$ & $463-82-1$ & \\
\hline ETANO & $\begin{array}{l}\text { Bimetilo; dimetilo; hidruro de etilo; metilmetano } \\
\text { UN1035 } \\
\text { UN1961 }\end{array}$ & $74-84-0$ & \\
\hline HEPTANO & $\begin{array}{l}\text { Dipropil metano; n-heptano; hidruro de heptilo } \\
\text { UN1206 }\end{array}$ & $142-82-5$ & \\
\hline HEXANO & $\begin{array}{l}\text { n-Hexano; hidruro de hexilo } \\
\text { UN1208 }\end{array}$ & $110-54-3$ & \\
\hline ISOBUTANO & $\begin{array}{l}\text { 2-Metilo-propano } \\
\text { UN1969 }\end{array}$ & $75-28-5$ & \\
\hline ISOHEXANO & & $107-83-5$ & \\
\hline
\end{tabular}




\begin{tabular}{|c|c|c|}
\hline Producto químico & Sinónimos/ Código UN & N úmero CAS Fórmula estructural \\
\hline 2-METILBUTANO & $\begin{array}{l}\text { Etildimetilmetano; isoamilhidruro; isopentano } \\
\text { UN1265 }\end{array}$ & $78-78-4$ \\
\hline METILCICLOHEXANO & $\begin{array}{l}\text { Ciclohexilmetano; hexahidrotolueno; tolueno hexahidro } \\
\text { UN2296 }\end{array}$ & $108-87-2$ \\
\hline 2-METLLHEPTANO & & $592-27-8$ \\
\hline 3-METILPENTANO & & $96-14 \cdot 0$ \\
\hline NONANO & n-Nonano & $111-84-2$ \\
\hline OCTANO & $\begin{array}{l}\text { n-Octano } \\
\text { UN1262 }\end{array}$ & $111-65-9$ \\
\hline PENTANO & UN1265 & $109-66-0$ \\
\hline PROPANO & $\begin{array}{l}\text { Dimetilmetano; hidruro de propilo } \\
\text { UN1978 }\end{array}$ & $74-98-6$ \\
\hline 2,2,4-TRIMETLLPENTANO & Isobutiltrimetilmetano; isooctano & $540-84-1$ \\
\hline
\end{tabular}

Tabla 104.90 - Riesgos para la salud.

\begin{tabular}{|c|c|c|c|c|c|c|}
\hline \multirow[b]{2}{*}{$\begin{array}{l}\text { Denominación } \\
\text { química } \\
\text { N úmero CAS }\end{array}$} & \multicolumn{4}{|c|}{ Tarjetas Internaciones sobre la Seguridad de los Productos Q uímicos } & \multicolumn{2}{|c|}{ N IO SH (EE.UU.) } \\
\hline & $\begin{array}{l}\text { Período } \\
\text { corto de } \\
\text { exposición }\end{array}$ & $\begin{array}{l}\text { Período } \\
\text { largo de } \\
\text { exposición }\end{array}$ & $\begin{array}{l}\text { Vías de } \\
\text { exposición }\end{array}$ & Síntomas & $\begin{array}{l}\text { O rganos } \\
\text { afectados } \\
\text { Vías de } \\
\text { entrada }\end{array}$ & Síntomas \\
\hline $\begin{array}{l}\text { BUTANO } \\
\quad 106-97-8\end{array}$ & & & $\begin{array}{r}\text { Inhalación } \\
\text { Piel } \\
\text { 0jos }\end{array}$ & $\begin{array}{l}\text { Sopor } \\
\text { En contacto con el líquido: congelación } \\
\text { En contacto con el líquido: congelación }\end{array}$ & $\begin{array}{l}\text { SNC } \\
\text { inh; con (liq) }\end{array}$ & $\begin{array}{l}\text { Sop, narco, asfix; liq: } \\
\text { congelación }\end{array}$ \\
\hline $\begin{array}{l}\text { CICLOHEXANO } \\
110-82 \cdot 7\end{array}$ & $\begin{array}{l}\text { ojos; piel; tract } \\
\text { resp superior; } \\
\text { pulmones }\end{array}$ & piel & $\begin{array}{r}\text { Inhalación } \\
\text { Piel } \\
\text { 0jos }\end{array}$ & $\begin{array}{l}\text { Mareo, cefalea, náuseas } \\
\text { Enrojecimiento } \\
\text { Enrojecimiento }\end{array}$ & $\begin{array}{l}\text { Ojos; sis resp; piel; } \\
\text { SNC } \\
\text { Inh; ing; con }\end{array}$ & $\begin{array}{l}\text { Irrit ojos, piel, sis resp; sop; } \\
\text { derm; narco, coma }\end{array}$ \\
\hline
\end{tabular}


Tabla 104.90 - Riesgos para la salud.

\begin{tabular}{|c|c|c|c|c|c|c|}
\hline \multirow[b]{2}{*}{$\begin{array}{l}\text { Denominación } \\
\text { química } \\
\text { N úmero CAS }\end{array}$} & \multicolumn{4}{|c|}{ Tarjetas Internaciones sobre la Seguridad de los Productos Q uímicos } & \multicolumn{2}{|c|}{ N IOSH (EE.UU.) } \\
\hline & $\begin{array}{l}\text { Período } \\
\text { corto de } \\
\text { exposición }\end{array}$ & $\begin{array}{l}\text { Período } \\
\text { largo de } \\
\text { exposición }\end{array}$ & $\begin{array}{l}\text { Vías de } \\
\text { exposición }\end{array}$ & Síntomas & $\begin{array}{l}\text { O rganos } \\
\text { afectados } \\
\text { Vías de } \\
\text { entrada }\end{array}$ & Síntomas \\
\hline $\begin{array}{l}\text { CICLOPENTANO } \\
287-92.3\end{array}$ & $\begin{array}{l}\text { ojos; piel; tract } \\
\text { resp superior; } \\
\text { pulmones; SNC }\end{array}$ & piel & $\begin{array}{l}\text { Inhalación } \\
\text { Piel } \\
\text { Ojos } \\
\text { Ingestión }\end{array}$ & $\begin{array}{l}\text { Mareo, cefalea, náuseas, inconsciencia, } \\
\text { debilidad } \\
\text { Enrojecimiento } \\
\text { Enrojecimiento } \\
\text { Dolor abdominal, diarrea, mareo, náuseas, } \\
\text { dolor de garganta }\end{array}$ & $\begin{array}{l}\text { Ojos; piel; sis resp; } \\
\text { SNC } \\
\text { Inh; ing; con }\end{array}$ & $\begin{array}{l}\text { Irrit ojos, piel, nariz, garganta; } \\
\text { atur, vért, euf, desco, náu, } \\
\text { vómit, estupor; piel seca y } \\
\text { agrietada }\end{array}$ \\
\hline $\begin{array}{l}\text { DECANO } \\
124-18-5\end{array}$ & pulmones & piel; riñones; sangre & $\begin{array}{r}\text { Inhalación } \\
\text { Piel } \\
\text { 0jos }\end{array}$ & $\begin{array}{l}\text { Confusión, sopor } \\
\text { Piel seca, enrojecimiento } \\
\text { Enrojecimiento, dolor }\end{array}$ & & \\
\hline $\begin{array}{l}\text { ETANO } \\
\quad 74-84-0\end{array}$ & piel & & $\begin{array}{r}\text { Inhalación } \\
\text { Piel } \\
\text { 0jos }\end{array}$ & $\begin{array}{l}\text { Asfixiante simple } \\
\text { En contacto con el líquido: congelación } \\
\text { En contacto con el líquido: congelación }\end{array}$ & & \\
\hline $\begin{array}{l}\text { HEPTANO } \\
\quad 142-82-5\end{array}$ & $\begin{array}{l}\text { ojos; piel; } \\
\text { tract resp; } \\
\text { pulmones; SNC }\end{array}$ & piel & $\begin{array}{r}\text { Inhalación } \\
\text { Piel } \\
\text { Ojos } \\
\text { Ingestión }\end{array}$ & $\begin{array}{l}\text { Embotamiento, cefalea } \\
\text { Piel seca, sensación de quemazón } \\
\text { Enrojecimiento, dolor, } \\
\text { Espasmos abdominales, náuseas, vómitos }\end{array}$ & $\begin{array}{l}\text { Piel; sis resp; SNC } \\
\text { Inh; ing; con }\end{array}$ & $\begin{array}{l}\text { Atur, desv, estupor, vért, } \\
\text { desco; pérdida de apetito, } \\
\text { náu; derm; neu química (aspir } \\
\text { liq); incon }\end{array}$ \\
\hline $\begin{array}{l}\text { HEXANO } \\
\quad 110-54-3\end{array}$ & $\begin{array}{l}\text { ojos; piel; } \\
\text { tract resp; } \\
\text { pulmones; SNC; } \\
\text { hígado }\end{array}$ & piel; SNP; genes & $\begin{array}{l}\text { Inhalación } \\
\\
\text { Piel } \\
\text { 0jos }\end{array}$ & $\begin{array}{l}\text { Mareo, sopor, embotamiento, cefalea, } \\
\text { dificultad respiratoria, náuseas, inconsciencia, } \\
\text { debilidad } \\
\text { Sequedad de piel, enrojecimiento } \\
\text { Enrojecimiento, dolor }\end{array}$ & $\begin{array}{l}\text { Piel; ojos; sis resp; } \\
\text { SNC; SNP } \\
\text { Inh; ing; con }\end{array}$ & $\begin{array}{l}\text { Irrit ojos, nariz; atur; náu, cef; } \\
\text { neur peri: ent extremidades, } \\
\text { deb musc; derm; desv; neu } \\
\text { química (aspir liq) }\end{array}$ \\
\hline $\begin{array}{l}\text { 2-METLLBUTANO } \\
\text { 78-78-4 }\end{array}$ & $\begin{array}{l}\text { ojos; piel; } \\
\text { tract resp; } \\
\text { pulmones; corazón }\end{array}$ & piel & $\begin{array}{r}\text { Inhalación } \\
\text { Piel } \\
\text { 0jos } \\
\text { Ingestión }\end{array}$ & $\begin{array}{l}\text { Tos, mareo, sopor, cefalea, disnea, dolor de } \\
\text { garganta, latido irregular } \\
\text { Sequedad de piel, desengrasa la piel, } \\
\text { enrojecimiento } \\
\text { Enrojecimiento, dolor } \\
\text { Dolor abdominal, náuseas, vómitos }\end{array}$ & & \\
\hline $\begin{array}{l}\text { METILCICLOHEXANO } \\
108-87-2\end{array}$ & pulmones; SNC & piel & $\begin{array}{r}\text { Inhalación } \\
\text { Piel } \\
\text { Ojos } \\
\text { Ingestión }\end{array}$ & $\begin{array}{l}\text { Mareo, sopor } \\
\text { Enrojecimiento } \\
\text { Enrojecimiento } \\
\text { Náuseas }\end{array}$ & $\begin{array}{l}\text { Sis resp; piel; ojos; } \\
\text { SNC } \\
\text { Inh; ing; con }\end{array}$ & $\begin{array}{l}\text { Irrit ojos, piel, nariz, garganta; } \\
\text { atur, sop; en animales: narco }\end{array}$ \\
\hline $\begin{array}{l}\text { 2-METILHEPTANO } \\
592-27-8\end{array}$ & piel & & Piel & Enrojecimiento & & \\
\hline $\begin{array}{l}\text { OCTANO } \\
\quad 111-65-9\end{array}$ & $\begin{array}{l}\text { ojos; piel; } \\
\text { tract resp: } \\
\text { pulmones }\end{array}$ & piel & $\begin{array}{l}\text { Inhalación } \\
\text { Piel } \\
\text { Ojos } \\
\text { Ingestión }\end{array}$ & $\begin{array}{l}\text { Confusión, mareo, sopor, cefalea, dificultad } \\
\text { respiratoria, náuseas, inconsciencia } \\
\text { Sequedad de piel, enrojecimiento } \\
\text { Enrojecimiento, dolor } \\
\text { Vómitos }\end{array}$ & $\begin{array}{l}\text { Piel; ojos; sis resp; } \\
\text { SNC } \\
\text { Inh; ing; con }\end{array}$ & $\begin{array}{l}\text { Irrit ojos, nariz; sop; derm; } \\
\text { neu química (aspir liq); en } \\
\text { animales: narco }\end{array}$ \\
\hline $\begin{array}{l}\text { PENTANO } \\
109.66-0\end{array}$ & pulmones; SNC & & $\begin{array}{r}\text { Inhalación } \\
\text { Piel }\end{array}$ & $\begin{array}{l}\text { Mareo, sopor, cefalea, náuseas, inconsciencia, } \\
\text { vómitos } \\
\text { Sequedad de piel }\end{array}$ & $\begin{array}{l}\text { Piel; ojos; sis resp; } \\
\text { SNC } \\
\text { Inh; ing; con }\end{array}$ & $\begin{array}{l}\text { Irrit ojos, piel, nariz; derm; } \\
\text { neu química (aspir liq); sop; } \\
\text { en animales: narco }\end{array}$ \\
\hline $\begin{array}{l}\text { PROPANO } \\
74-98-6\end{array}$ & piel & & $\begin{array}{r}\text { Inhalación } \\
\text { Piel } \\
\text { 0jos } \\
\end{array}$ & $\begin{array}{l}\text { Asfixiante simple. } \\
\text { En contacto con el líquido: congelación } \\
\text { En contacto con el líquido: congelación }\end{array}$ & $\begin{array}{l}\text { SNC } \\
\text { Inh; con (liq) }\end{array}$ & $\begin{array}{l}\text { Mar, conf, excitación, asfix; } \\
\text { liq: congelación }\end{array}$ \\
\hline $\begin{array}{l}\text { 2,2,4-TRIMETILPENTANO } \\
\text { 540-84-1 }\end{array}$ & $\begin{array}{l}\text { ojos; piel; } \\
\text { tract resp; riñones; } \\
\text { hígado }\end{array}$ & $\begin{array}{l}\text { piel; riñones; } \\
\text { hígado }\end{array}$ & $\begin{array}{r}\text { Inhalación } \\
\text { Piel } \\
\text { Ojos } \\
\text { Ingestión }\end{array}$ & $\begin{array}{l}\text { Confusión, mareo, cefalea, náuseas, vómitos } \\
\text { Enrojecimiento, dolor } \\
\text { Enrojecimiento } \\
\text { Vómitos }\end{array}$ & & \\
\hline
\end{tabular}




\begin{tabular}{|c|c|c|c|}
\hline $\begin{array}{l}\text { Denominación química } \\
\mathrm{N} \text { úmero CAS }\end{array}$ & Físicos & Q uímicos & $\begin{array}{l}\text { Clase o división } \\
\text { UN / Riesgos } \\
\text { subsidiarios }\end{array}$ \\
\hline $\begin{array}{l}\text { BUTANO } \\
\quad 106-97-8\end{array}$ & $\begin{array}{l}\text { - El gas es más pesado que el aire y puede } \\
\text { desplazarse a ras del suelo; posibilidad de } \\
\text { ignición a distancia; puede acumularse en } \\
\text { espacios con techos bajos causando deficiencia de } \\
\text { oxígeno }\end{array}$ & - En su combustión libera gases tóxicos; COx & 2.1 \\
\hline $\begin{array}{l}\text { CICLOHEXANO } \\
110-82.7\end{array}$ & $\begin{array}{l}\text { - El vapor es más pesado que el aire y puede } \\
\text { desplazarse a ras del suelo; posibilidad de } \\
\text { ignición a distancia } \bullet \text { Pueden generarse cargas } \\
\text { electrostáticas como resultado de flujo, agitación, } \\
\text { etc. }\end{array}$ & & 3 \\
\hline $\begin{array}{l}\text { CICLOPENTANO } \\
287-92-3\end{array}$ & $\begin{array}{l}\text { - El vapor es más pesado que el aire y puede } \\
\text { desplazarse a ras del suelo; posibilidad de } \\
\text { ignición a distancia • Pueden generarse cargas } \\
\text { electrostáticas como resultado de flujo, agitación, } \\
\text { etc. }\end{array}$ & & 3 \\
\hline $\begin{array}{l}\text { CICLOPROPANO } \\
75-19-4 \\
\end{array}$ & & & 2.1 \\
\hline $\begin{array}{l}\text { DECANO } \\
124-18-5\end{array}$ & & - Reacciona con materiales oxidantes & 3 \\
\hline $\begin{array}{l}\text { 2,3-DIMETILBUTANO } \\
\text { 79-29-8 }\end{array}$ & & & 3 \\
\hline $\begin{array}{l}\text { ETANO } \\
74-84.0\end{array}$ & $\begin{array}{l}\text { - El gas se mezcla bien con el aire; se forman } \\
\text { fácilmente mezclas explosivas }\end{array}$ & - En su combustión libera gases tóxicos & 2.1 \\
\hline $\begin{array}{l}\text { HEPTANO } \\
\quad 142-82-5\end{array}$ & $\begin{array}{l}\text { - El vapor es más pesado que el aire y puede } \\
\text { desplazarse a ras del suelo; posibilidad de } \\
\text { ignición a distancia • Si está seco, puede } \\
\text { cargarse electrostáticamente por agitación, } \\
\text { transporte neumático, vertido, etc. }\end{array}$ & - Reacciona violentamente con oxidantes fuertes Ataca muchos plásticos & 3 \\
\hline $\begin{array}{l}\text { HEXANO } \\
\quad 110-54-3\end{array}$ & $\begin{array}{l}\text { - El vapor es más pesado que el aire y puede } \\
\text { desplazarse a ras del suelo; posibilidad de } \\
\text { ignición a distancia }\end{array}$ & - Reacciona con oxidantes fuertes con peligro de incendio y explosión & 3 \\
\hline $\begin{array}{c}\text { ISOBUTANO } \\
75-28-5 \\
\end{array}$ & & & 2.1 \\
\hline $\begin{array}{l}\text { 2-METILBUTANO } \\
\text { 78-78-4 }\end{array}$ & $\begin{array}{l}\text { - El vapor es más pesado que el aire y puede } \\
\text { desplazarse a ras del suelo; posibilidad de } \\
\text { ignición a distancia } ~-\text { Pueden generarse cargas } \\
\text { electrostáticas como resultado de flujo, agitación, } \\
\text { etc. }\end{array}$ & $\begin{array}{l}\text { - Puede explotar al calentarse • En su combustión libera humo acre y vapores } \\
\text { irritantes Reacciona violentamente con oxidantes }\end{array}$ & 3 \\
\hline $\begin{array}{l}\text { METILCICLOHEXANO } \\
108-87-2\end{array}$ & 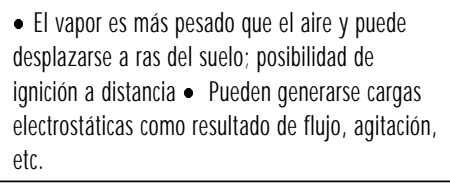 & $\begin{array}{l}\text { - Reacciona violentamente con oxidantes fuertes con peligro de incendio y } \\
\text { explosión }\end{array}$ & 3 \\
\hline $\begin{array}{l}\text { 2-METLLHEPTANO } \\
592-27-8\end{array}$ & $\begin{array}{l}\text { - El vapor es más pesado que el aire y puede } \\
\text { desplazarse a ras del suelo; posibilidad de } \\
\text { ignición a distancia }\end{array}$ & - Al calentarse se forman vapores tóxicos $\bullet$ Reacciona con oxidantes & \\
\hline $\begin{array}{l}\text { 3-METILPENTANO } \\
96-14-0\end{array}$ & & & 3 \\
\hline $\begin{array}{l}\text { NONANO } \\
\quad 111-84-2\end{array}$ & & & 3 \\
\hline
\end{tabular}




\begin{tabular}{|c|c|c|c|}
\hline $\begin{array}{l}\text { Denominación química } \\
\mathrm{N} \text { úmero CAS }\end{array}$ & Físicos & Q uímicos & $\begin{array}{l}\text { Clase o división } \\
\text { UN / Riesgos } \\
\text { subsidiarios }\end{array}$ \\
\hline $\begin{array}{l}\text { OCTANO } \\
\quad 111-65-9\end{array}$ & $\begin{array}{l}\text { - El vapor es más pesado que el aire y puede } \\
\text { desplazarse a ras del suelo; posibilidad de } \\
\text { ignición a distancia } \bullet \text { Pueden generarse cargas } \\
\text { electrostáticas como resultado de flujo, agitación, } \\
\text { etc. }\end{array}$ & $\begin{array}{l}\text { - Reacciona con oxidantes fuertes con peligro de incendio y explosión • Ataca } \\
\text { algunas formas de plásticos, cauchos y revestimientos }\end{array}$ & 3 \\
\hline $\begin{array}{l}\text { PENTANO } \\
\quad 109.66 .0\end{array}$ & $\begin{array}{l}\text { - El vapor es más pesado que el aire y puede } \\
\text { desplazarse a ras del suelo; posibilidad de } \\
\text { ignición a distancia }\end{array}$ & $\begin{array}{l}\text { - En su combustión libera gases tóxicos de óxidos de carbono } \bullet \text { Reacciona con } \\
\text { oxidantes fuertes (p. ej,. peróxidos, nitratos y percloratos), con peligro de } \\
\text { incendio y explosión • Ataca algunos tipos de plásticos, caucho y revestimientos }\end{array}$ & 3 \\
\hline $\begin{array}{l}\text { PROPANO } \\
74-98-6\end{array}$ & $\begin{array}{l}\text { - El gas es más pesado que el aire y puede } \\
\text { desplazarse a ras del suelo; posibilidad de } \\
\text { ignición a distancia } \bullet \text { Puede acumularse en } \\
\text { espacios con techos bajos causando deficiencia de } \\
\text { oxígeno }\end{array}$ & - En su combustión libera vapores tóxicos & 2.1 \\
\hline $\begin{array}{l}\text { 2,2,4-TRIMETLPPENTANO } \\
\text { 540-84-1 }\end{array}$ & $\begin{array}{l}\text { - El vapor es más pesado que el aire y puede } \\
\text { desplazarse a ras del suelo; posibilidad de } \\
\text { ignición a distancia • Pueden generarse cargas } \\
\text { electrostáticas como resultado de flujo, agitación, } \\
\text { etc. }\end{array}$ & $\begin{array}{l}\text { - Al calentarse puede arder violentamente o producir una explosión • Reacciona } \\
\text { con oxidantes fuertes }\end{array}$ & 3 \\
\hline
\end{tabular}

\begin{tabular}{|c|c|c|c|c|c|c|c|c|c|c|c|}
\hline $\begin{array}{l}\text { Denominación química } \\
\mathrm{N} \text { úmero CAS }\end{array}$ & Color/ Forma & $\begin{array}{l}\text { p.e. } \\
(\because 0 \mathrm{C})\end{array}$ & $\begin{array}{l}\text { p.f. } \\
(\stackrel{\circ}{ } \mathrm{C})\end{array}$ & $\begin{array}{l}\text { p.m.l } \\
\text { (g/ } \\
\text { mol) }\end{array}$ & $\begin{array}{l}\text { Solubilidad } \\
\text { en agua }\end{array}$ & $\begin{array}{l}\text { Densidad } \\
\text { relativa } \\
\text { (agua }=1 \text { ) }\end{array}$ & $\begin{array}{l}\text { Densidad } \\
\text { de vapor } \\
\text { relativa } \\
\text { (aire=1) }\end{array}$ & $\begin{array}{l}\text { Pvap/ } \\
(\mathrm{kPa})\end{array}$ & $\begin{array}{l}\text { Límit. } \\
\text { inflam. }\end{array}$ & $\begin{array}{l}\text { p.ig. } \\
(\underline{O C})\end{array}$ & $\begin{array}{l}\text { p.aut } \\
\text { ig. } \\
\left({ }^{\circ} \mathrm{C}\right)\end{array}$ \\
\hline $\begin{array}{l}\text { BUTANO } \\
\quad 106-97-8\end{array}$ & gas incoloro & $-0,5$ & -138 & 58,12 & sol & 0,5788 & $2,07 @ 0 \stackrel{0}{0}$ & $\begin{array}{l}213,7 \\
@ 21,1 \stackrel{\circ}{C}\end{array}$ & $\begin{array}{l}1,6 \mathrm{li} \\
8,4 \mathrm{ls}\end{array}$ & $\begin{array}{l}\text { gas } \\
\text { infla- } \\
\text { mable }\end{array}$ & 287 \\
\hline $\begin{array}{l}\text { CICLOHEXANO } \\
110-82.7\end{array}$ & líquido móvil incoloro & 80,7 & 6,5 & 84,2 & insol & 0,778 & 2,98 & 12,7 & $\begin{array}{l}1,3 \mathrm{li} \\
8,4 \mathrm{ls}\end{array}$ & $-18 \mathrm{cc}$ & 260 \\
\hline $\begin{array}{l}\text { CICLOPENTANO } \\
287-92-3\end{array}$ & líquido incoloro & 49 & .94 & 70,2 & insol & 0,7457 & 2,42 & 45 & $\begin{array}{l}1,1 \mathrm{li} \\
8,7 \mathrm{ls}\end{array}$ & $-37 \mathrm{cc}$ & 361 \\
\hline $\begin{array}{l}\text { CICLOPROPANO } \\
75-19-4\end{array}$ & gas incoloro & -33 & $-127,6$ & 42,08 & sol & $\begin{array}{l}1,879 \mathrm{~g} / \mathrm{l} \\
@ 0 \stackrel{0}{0} \mathrm{C}\end{array}$ & 1,88 & & $\begin{array}{l}2,4 \mathrm{li} \\
10,3 \mathrm{ls}\end{array}$ & & 497 \\
\hline $\begin{array}{l}\text { DECANO } \\
124-18-5\end{array}$ & líquido incoloro & 174,1 & $-29,7$ & 142,3 & insol & 0,7300 & 4,90 & $\begin{array}{l}0,17 \\
@ 25 \stackrel{\circ}{-C}\end{array}$ & $\begin{array}{l}0,8 \mathrm{il} \\
5,4 \mathrm{is}\end{array}$ & $46 c c$ & 210 \\
\hline $\begin{array}{l}\text { 2,2-DIMETILBUTANO } \\
75-83-2\end{array}$ & líquido incoloro & 49,7 & $-99,9$ & 86,2 & insol & 0,6485 & 3,0 & $\begin{array}{l}400 \mathrm{~mm} \mathrm{Hg} \\
\text { @ } 31,0 \stackrel{\circ}{\circ} \mathrm{C}\end{array}$ & $\begin{array}{l}1,2 \mathrm{li} \\
7,0 \mathrm{is}\end{array}$ & $-48 c c$ & 405 \\
\hline $\begin{array}{l}\text { 2,3-DIMETLLUUTANO } \\
\text { 79-29-8 }\end{array}$ & líquido incoloro & 58,0 & $-128,53$ & 86,2 & insol & 0,6616 & 3,0 & $\begin{array}{l}400 \mathrm{~mm} \mathrm{Hg} \\
@ 39,0 \stackrel{\circ}{C}\end{array}$ & $\begin{array}{l}1,2 \mathrm{li} \\
7,0 \mathrm{ls}\end{array}$ & $-29 \mathrm{cc}$ & 405 \\
\hline $\begin{array}{l}\text { 2,2-DIMETILPROPANO } \\
\text { 463-82-1 }\end{array}$ & líquido o gas & 9,5 & $-16,6$ & 72,15 & insol & 0,613 & 2,5 & $\begin{array}{l}1100 \mathrm{~mm} \\
\mathrm{Hg} \\
@ 21 \stackrel{\circ}{\mathrm{C}}\end{array}$ & $\begin{array}{l}1,4 \mathrm{li} \\
7,5 \mathrm{is}\end{array}$ & $<-7$ & 450 \\
\hline $\begin{array}{l}\text { ETANO } \\
74-84-0\end{array}$ & gas incoloro & .89 & -183 & 30,1 & $\begin{array}{l}60,2 \mathrm{ppm} \\
@ 25 \stackrel{\circ}{C} \mathrm{C}\end{array}$ & $\begin{array}{l}0,446 \\
@ 0 \stackrel{\circ}{C} / 4 \stackrel{\circ}{C}\end{array}$ & 1,04 & 3850 & $\begin{array}{l}3,0 \mathrm{li} \\
12,5 \mathrm{ls}\end{array}$ & $\begin{array}{l}\text { gas } \\
\text { infla- } \\
\text { mable }\end{array}$ & 472 \\
\hline $\begin{array}{l}\text { HEPTANO } \\
142-82.5\end{array}$ & líquido & 98 & .90 & 100,2 & insol & 0,68 & 3,46 & 4,8 & $\begin{array}{l}1,1 \mathrm{li} \\
6,7 \mathrm{is}\end{array}$ & -1 & 215 \\
\hline
\end{tabular}




\begin{tabular}{|c|c|c|c|c|c|c|c|c|c|c|c|}
\hline $\begin{array}{l}\text { Denominación química } \\
\mathrm{N} \text { úmero CAS }\end{array}$ & Color/ Forma & $\begin{array}{l}\text { p.e. } \\
(\stackrel{0}{ } \mathrm{C})\end{array}$ & $\begin{array}{l}\text { p.f. } \\
(\because 0 \mathrm{C})\end{array}$ & $\begin{array}{l}\mathrm{p} . \mathrm{m} . / \\
\text { (g/ } \\
\mathrm{mol})\end{array}$ & $\begin{array}{l}\text { Solubilidad } \\
\text { en agua }\end{array}$ & $\begin{array}{l}\text { Densidad } \\
\text { relativa } \\
\text { (agua }=1 \text { ) }\end{array}$ & $\begin{array}{l}\text { Densidad } \\
\text { de vapor } \\
\text { relativa } \\
\text { (aire=1) }\end{array}$ & $\begin{array}{l}\text { Pvap/ } \\
(\mathrm{kPa})\end{array}$ & $\begin{array}{l}\text { Límit. } \\
\text { inflam. }\end{array}$ & $\begin{array}{l}\text { p.ig. } \\
(\underline{\circ C})\end{array}$ & $\begin{array}{l}\text { p.aut } \\
\text { ig. } \\
\left({ }^{\circ} \mathrm{C}\right)\end{array}$ \\
\hline $\begin{array}{l}\text { HEXANO } \\
\quad 110-54-3\end{array}$ & líquido incoloro & 69 & .95 & 86,2 & insol & 0,66 & 2,97 & 16 & $\begin{array}{l}1,1 \mathrm{li} \\
7,5 \mathrm{ls}\end{array}$ & $-22 c c$ & 240 \\
\hline $\begin{array}{c}\text { ISOBUTANO } \\
75-28-5 \\
\end{array}$ & gas incoloro & $-11,63$ & $-138,3$ & 58,12 & lig sol & 0,5572 & 2,0 & & $\begin{array}{l}1,8 \mathrm{li} \\
8,4 \mathrm{ls}\end{array}$ & & \\
\hline $\begin{array}{r}\text { ISOHEXANO } \\
107-83-5 \\
\end{array}$ & líquido incoloro & 60 & $-153,7$ & 86,2 & insol & 0,6532 & 3,00 & $\begin{array}{l}400 \mathrm{~mm} \mathrm{Hg} \\
@ 1,6 \stackrel{\circ}{\circ} \mathrm{C}\end{array}$ & $\begin{array}{l}1,2 \mathrm{li} \\
7,0 \mathrm{ls}\end{array}$ & $<-7 \mathrm{CC}$ & 306 \\
\hline $\begin{array}{l}\text { 2-METLLBUTANO } \\
\text { 78-78-4 }\end{array}$ & líquido incoloro & 28 & $-159,9$ & 72,15 & insol & 0,6201 & 2,48 & 79 & $\begin{array}{l}1,4 \mathrm{li} \\
7,6 \mathrm{ls}\end{array}$ & $\begin{array}{l}<-51 \\
\mathrm{CC}\end{array}$ & 420 \\
\hline $\begin{array}{l}\text { METILCICLOHEXANO } \\
108-87-2 \\
\end{array}$ & líquido incoloro & 100,9 & $-126,6$ & 98,2 & insol & 0,7694 & 3,39 & $\begin{array}{l}5,76 \\
@ 25 \stackrel{\circ}{ }\end{array}$ & $\begin{array}{l}1,2 \mathrm{li} \\
6,7 \mathrm{is}\end{array}$ & $-6 \mathrm{ca}$ & 258 \\
\hline $\begin{array}{l}\text { 2-METILHEPTANO } \\
592-27-8 \\
\end{array}$ & líquido & 116 & -109 & 114,2 & insol & 0,6980 & 3,9 & $\begin{array}{l}5,3 \\
@ 38 \stackrel{\circ}{ }=\mathrm{C}\end{array}$ & $\begin{array}{l}1,0 \mathrm{li} \\
? \text { Is }\end{array}$ & 44 & \\
\hline $\begin{array}{l}\text { 3-METILPENTANO } \\
\text { 96-14.0 }\end{array}$ & líquido incoloro & 63,2 & -163 & 86,2 & insol & 0,6645 & 3,0 & & $\begin{array}{l}1,2 \mathrm{li} \\
7,0 \mathrm{ls}\end{array}$ & & \\
\hline $\begin{array}{l}\text { NONANO } \\
\quad 111-84-2\end{array}$ & líquido incoloro & 150,8 & -51 & 128,3 & insol & 0,7176 & 4,41 & $\begin{array}{l}4,45 \mathrm{~mm} \\
\mathrm{Hg} @ \\
25 \stackrel{\circ}{\mathrm{C}}\end{array}$ & $\begin{array}{l}0,8 \mathrm{il} \\
2,9 \mathrm{is}\end{array}$ & & \\
\hline $\begin{array}{l}\text { OCTANO } \\
\quad 111-65-9 \\
\end{array}$ & líquido incoloro & 125,6 & $-56,8$ & 114,22 & insol & 0,7028 & 3,86 & 1,47 & $\begin{array}{l}1,0 \mathrm{li} \\
6,5 \mathrm{is}\end{array}$ & $13 \mathrm{cc}$ & 220 \\
\hline $\begin{array}{l}\text { PENTANO } \\
\quad 109-66-0\end{array}$ & líquido incoloro & 36,0 & -130 & 72,15 & lig sol & 0,6262 & 2,49 & 56,8 & $\begin{array}{l}1,5 \mathrm{li} \\
7,8 \mathrm{is}\end{array}$ & $-49 c c$ & 309 \\
\hline $\begin{array}{l}\text { PROPANO } \\
74-98-6\end{array}$ & gas incoloro & $-42,1$ & $-189,7$ & 44,09 & sol & $\begin{array}{l}0,5853 \\
@-45 \stackrel{\circ}{\circ} / 4 \stackrel{\circ}{C} \mathrm{C}\end{array}$ & $1,56 @ 0 \stackrel{0}{0}$ & $\begin{array}{l}760 \mathrm{~mm} \mathrm{Hg} \\
@ 25 \stackrel{\circ}{\circ} \mathrm{C}\end{array}$ & $\begin{array}{l}2,1 \mathrm{li} \\
9,5 \mathrm{is}\end{array}$ & $\begin{array}{l}\text { gas } \\
\text { infla- } \\
\text { mable }\end{array}$ & 450 \\
\hline $\begin{array}{l}\text { 2,2,4-TRIMETLLPENTANO } \\
540-84-1\end{array}$ & $\begin{array}{l}\text { líquido móvil; líquido } \\
\text { incoloro }\end{array}$ & 99,2 & -107 & 114,22 & insol & 0,6919 & 3,93 & 5,1 & $\begin{array}{l}1,1 \mathrm{li} \\
6,0 \mathrm{ls}\end{array}$ & $45 \mathrm{ca}$ & 417 \\
\hline
\end{tabular}




\section{HIDROCARBUROS, ALIFATICOSY HALO GENADOS}

L os hidrocarburos alifáticos halogenados son productos químicos orgánicos en los que uno o más átomos de hidrógeno han sido sustituidos por un halógeno (es decir, se han fluorado, clorado, bromado 0 yodado). Los productos químicos alifáticos no contienen un anillo de benceno.

L os hidrocarburos alifáticos clorados se obtienen mediante la cloración de hidrocarburos, la adición de cloro o cloruro de hidrógeno a compuestos insaturados, la reacción entre cloruro de hidrógeno o hipoclorito de calcio y alcoholes, aldehídos o cetonas y, excepcionalmente, la cloración de disulfuro de carbono o algún otro proceso. En algunos casos se necesitan más etapas (p. ej., cloración con subsiguiente eliminación de cloruro de hidrógeno) para obtener el derivado deseado y, generalmente, se obtiene una mezcla de la que habrá de separarse la sustancia deseada. Los hidrocarburos alifáticos bromados se obtienen de forma similar, mientras que para la producción de los hidrocarburos yodados y, sobre todo, de los fluorados, se suelen utilizar otros métodos, como la producción electrolítica de yodoformo.

Puesto que el punto de ebullición de las sustancias es, en general, mayor cuanto mayor sea su masa molecular y, a su vez, aumenta por halogenación, sólo los hidrocarburos alifáticos halogenados con un grado de fluoración no muy alto (hasta el decafluorobutano inclusive), el clorometano, el diclorometano, el cloroetano, el cloroetileno y el bromometano, son gaseosos a temperatura ambiente. La mayoría de los demás compuestos de este grupo son líquidos. Los compuestos clorados más pesados, así como el tetrabromometano y el triyodometano, son sólidos. El olor de los hidrocarburos suele aumentar con la halogenación y algunos miembros volátiles del grupo no sólo tienen un olor desagradable, sino además un marcado sabor dulzón (p. ej. el cloroformo y los derivados del etano y del propano con un alto grado de halogenación).

\section{U sos}

L os hidrocarburos alifáticos y alicíclicos halogenados insaturados se utilizan en la industria como disolventes, productos químicos intermedios, fumigadores e insecticidas. Se encuentran en las industrias de productos químicos, pinturas y barnices, textiles, caucho, plásticos, colorantes, productos farmacéuticos y limpieza en seco.

Las aplicaciones industriales de los hidrocarburos alifáticos y alicíclicos halogenados saturados son numerosas, pero las más importantes son su uso como disolventes, productos químicos intermedios, compuestos para extinción de incendios y productos limpiametales. Estos compuestos se encuentran en las industrias del caucho, plásticos, metalistería, pinturas, barnices, asistencia sanitaria y textiles. Algunos son componentes de insecticidas y fumigadores de tierras y otros son agentes vulcanizadores del caucho.

El 1,2,3-tricloropropano y el 1,1-dicloroetano son disolventes e ingredientes de productos decapantes de pinturas y barnices, mientras que elbromuro de metilo es un disolvente de colorantes anilínicos. El bromuro de metilo también se utiliza en el desengrasado de la lana, la esterilización de alimentos para el control de plagas y la extracción de aceites de flores. El cloruro de metilo es un disolvente y diluyente del caucho butílico, un componente de los líquidos para equipos termométricos y termostáticos y un agente espumante para plásticos. EI 1,1,1-triclorotano se utiliza principalmente para la limpieza de metales en frío y como refrigerante y lubricante para cuchillas. Es un agente limpiador de instrumentos mecánicos de precisión, un disolvente de colorantes y un componente de líquidos quitamanchas en la industria textil; en la industria de los plásticos, el 1,1,1-tricloroetano se utiliza para la limpieza de los moldes de plástico. El 1,1-dicloroetano es un disolvente, limpiador y desengrasante utilizado en adhesivos de caucho, pulverizadores de insecticidas, extintores de incendios y gasolinas, así como en el caucho de alto vacío, en la flotación de minerales, en los plásticos y en el ensanchado de tejidos en la industria textil. La termodesintegración del 1,1-dicloroetano produce cloruro de vinilo. El 1,1,2,2-tetracloroetano tiene diversas funciones como disolvente no inflamable en las industrias del caucho, pinturas y barnices, metales y pieles. También es un agente antipolilla para tejidos y se utiliza en películas fotográficas, en la fabricación de seda y perlas artificiales y para estimar el agua que contiene el tabaco.

El dicloruro de etileno tiene usos limitados como disolvente y como producto químico intermedio. Se encuentra en decapantes de pinturas, barnices y lustres y se utiliza como aditivo en la gasolina para reducir el contenido de plomo. EI diclorometano ocloruro de metileno se utiliza principalmente como disolvente en formulaciones industriales y decapantes de pinturas, y en ciertos aerosoles, entre ellos pesticidas y productos cosméticos. Sirve como disolvente de proceso en las industrias farmacéutica, de los plásticos y alimentaria. El cloruro de metileno también se emplea como disolvente de adhesivos y en análisis de laboratorio. La principal aplicación del 1,2-dibromoetano es en la formulación de agentes antidetonantes a base de plomo que se mezclan con la gasolina. También se utiliza en la síntesis de otros productos y como componente de líquidos que tengan índice de refracción.

El cloroformo sirve como producto químico intermedio, producto de limpieza en seco y disolvente del caucho. El hexacloroetano es un agente desgasificador para metales como aluminio y magnesio. Se utiliza para eliminar impurezas de metales fundidos y para inhibir la explosividad del metano y la combustión del perclorato amónico. Se emplea en pirotecnia, en explosivos y en aplicaciones militares.

El bromoformo es un disolvente, retardador de llama y agente de flotación. Se utiliza en la separación de minerales, en la vulcanización del caucho y en la síntesis de productos químicos. Eltetracloruro de carbono se utilizaba antiguamente como disolvente desengrasante y en líquidos de limpieza en seco, productos antimanchas para tejidos y agentes extintores de incendios, pero su toxicidad ha obligado a abandonar su uso en productos de consumo y de fumigación. Puesto que en gran parte se utiliza para la fabricación de clorofluorocarburos, que a su vez se están retirando de la gran mayoría de las aplicaciones comerciales, el uso del tetracloruro de carbono seguirá disminuyendo en el futuro. Actualmente se utiliza en la fabricación de semiconductores, en cables, en la recuperación de metales, como catalizador, como agente de secado azeotrópico para bujías húmedas, como fragancia para jabones y en la extracción de aceites de flores.

Aunque sustituido por el tetracloroetileno en la mayoría de sus aplicaciones, el tricloroetileno actúa como agente desengrasante, disolvente y diluyente de pinturas. Sirve como agente para eliminar hilos de hilvanar en la industria textil, como anestésico en odontología y como agente humectante para la tinción de poliéster. El tricloroetileno también se utiliza en el desengrasado al vapor de piezas metálicas. Se ha empleado en líquidos correctores para mecanografía y como disolvente para la extracción de caféna. El tricloroetileno, el 3-cloro-2-metil-1-propeno y el bromuro de 
alilo se encuentran en productos fumigadores e insecticidas. EI 2-cloro-1,3-butadieno se emplea como producto químico intermedio en la fabricación de caucho artificial. EI hexacloro-1,3-butadieno se utiliza como disolvente, como intermedio en la producción de lubricantes y caucho y como pesticida para fumigación.

El cloruro de vinilo se utiliza principalmente en la industria de los plásticos y en la síntesis de cloruro de polivinilo (PVC). A ntiguamente se utilizaba mucho como refrigerante, disolvente de extracción y propelente de aerosoles. Es un componente de las baldosas de vinilo-amianto. 0 tros hidrocarburos insaturados se utilizan principalmente como disolventes, retardadores de llama, líquidos de intercambio calorífico y productos de limpieza en muy diversas industrias. El teracloroetileno se utiliza en síntesis químicas y en el acabado, apresto y desencolado de telas. También se emplea en la limpieza en seco y en los líquidos aislantes y los gases refrigerantes de los transformadores. EI cis-1,2-dicloroetileno es un disolvente para perfumes, tintes, lacas de barnizar, termoplásticos y caucho. El bromuro de vinilo es un retardador de llama para materiales de refuerzo de alfombras, ropa de cama y artículos para el hogar. El cloruro de alilo se utiliza en resinas termoestables para barnices y plásticos y como producto químico intermedio. El 1,1-dicloroetileno se utiliza en el envasado de alimentos y el 1,2-dicloroetileno es un agente de extracción a bajas temperaturas de sustancias termosensibles, como los aceites esenciales y la cafeína del café.

\section{Riesgos}

La producción y el uso de hidrocarburos alifáticos halogenados crean serios problemas para la salud. Sus efectos tóxicos locales y sistémicos son numerosos, siendo los más graves su carcinogenicidad y mutagenicidad, sus efectos en el sistema nervioso y las lesiones que producen en órganos vitales, especialmente el hígado. A pesar de la relativa simplicidad química del grupo, sus efectos tóxicos son muy variables y no es fácil establecer una relación entre la estructura y el efecto producido.

Cáncer. Desde hace mucho tiempo existen evidencias experimentales de la carcinogenicidad de algunos hidrocarburos alifáticos halogenados ( $p$. ej., cloroformo y tetracloruro de carbono). El apéndice del C apítulo T oxicología de la presente Enciclopedia contiene las clasificaciones de carcinogenicidad de la Agencia Internacional para la Investigación sobre el Cáncer (IARC). Algunos hidrocarburos alifáticos halogenados presentan además propiedades mutágenas y teratógenas.

La depresión de sistema nervioso central (SNC) es el efecto agudo más destacado de muchos hidrocarburos alifáticos halogenados. La reacción típica es un estado de embriaguez y excitación, seguido por narcosis, razón por la cual muchos de los productos químicos de este grupo se han utilizado como anestésicos e incluso como drogas. Su efecto narcótico es variable: algunos producen efectos narcóticos muy acusados y otro muy débiles. En exposiciones agudas graves siempre existe peligro de muerte por insuficiencia respiratoria o parada cardíaca, ya que los hidrocarburos alifáticos halogenados aumentan la susceptibilidad cardíaca a las catecolaminas.

Los efectos neurológicos de algunos compuestos, como el cloruro de metilo y el bromuro de metilo, así como otros compuestos bromados o yodados de este grupo, son mucho más intensos, especialmente cuando la exposición es repetida o crónica. Sus efectos en el sistema nervioso central no pueden describirse como una simple depresión del sistema nervioso, ya que los síntomas pueden ser extremos y consistir en cefalea, náuseas, ataxia, temblores, dislalia, alteraciones visuales, convulsiones, parálisis, delirio, manías o apatía. Estos efectos pueden ser duraderos y de recuperación muy lenta y pueden producirse lesiones neurológicas permanentes. Los efectos asociados a los diferentes productos químicos reciben nombres tales como "encefalopatía por cloruro de metilo" o "encefalomielitis por cloropreno". Los nervios periféricos también pueden resultar afectados, como ocurre en la polineuritis por tetracloroetano o dicloroacetileno.

E fectos sistémicos. Prácticamente todos los hidrocarburos alifáticos halogenados son nocivos para el hígado, los riñones y otros órganos, si bien el alcance de las lesiones varía notablemente de uno a otro miembro del grupo. Puesto que las lesiones no se manifiestan inmediatamente, algunas veces se ha considerado que son sustancias de efectos retardados. El curso de la intoxicación aguda suele describirse como bifásico: en la primera fase se aprecian signos de un efecto reversible razonable (narcosis), y en la segunda fase se presentan signos de lesiones orgánicas. O tros efectos, como el cáncer, pueden tener períodos de latencia extremadamente largos. Sin embargo, no siempre es posible establecer una clara distinción entre los efectos tóxicos de una exposición crónica o repetida y los efectos retardados de la intoxicación aguda. No existe una relación sencilla entre la intensidad de los efectos inmediatos y retardados de algunos hidrocarburos alifáticos halogenados. Algunas sustancias de este grupo ejercen un efecto narcótico muy marcado y efectos retardados débiles, mientras que otras son muy peligrosas porque provocan lesiones irreversibles en los órganos sin que muestren efectos inmediatos intensos. Casi nunca se ve afectado un solo órgano o sistema. En particular, las lesiones rara vez se producen únicamente en el hígado o los riñones, ni siquiera en el caso de los compuestos considerados típicamente hepatotóxicos (p. ej., tetracloruro de carbono) o nefrotóxicos (p. ej., bromuro de metilo).

Las propiedades como irritantes locales de estas sustancias son especialmente acusadas en el caso de algunos de los miembros insaturados. No obstante, existen diferencias sorprendentes entre compuestos muy similares (p. ej., el octafluorisobutileno es muchísimo más irritante que el isómero octafluoro-2-buteno). En el caso de otros compuestos de este grupo, el riesgo principal de la exposición aguda por inhalación es el de irritación pulmonar (p. ej., cloruro de alilo) y algunos de ellos son lacrimógenos (p. ej., tetrabromuro de carbono). Las altas concentraciones de vapores o las salpicaduras de líquidos pueden ser peligrosas para los ojos en determinados casos. No obstante, las lesiones que producen la mayor parte de los hidrocarburos alifáticos halogenados más utilizados remiten espontáneamente y sólo la exposición prolongada de la córnea provoca lesiones permanentes. Algunas de estas sustancias, como el 1,2-dibromometano y el 1,3-dicloropropano, son irritantes y lesivas para la piel, provocando enrojecimiento, vesiculación y necrosis incluso aunque el contacto haya sido muy breve.

Como buenos disolventes que son, todos estos productos químicos dañan la piel y la desengrasan, tornándola reseca, vulnerable y agrietada, especialmente cuando se producen contactos repetidos.

\section{Riesgos de compuestos específicos}

EI tetracloruro de carbono es un producto químico extremadamente peligroso que ha causado la muerte por intoxicación de trabajadores sometidos a exposiciones agudas al mismo. La IARC Io ha clasificado en el Grupo 2B como posible carcinógeno humano y muchas autoridades, como la British $\mathrm{H}$ ealth and Safety Executive, han exigido que se abandone progresivamente su uso en la industria. Puesto que una gran parte del tetracloruro de carbono se utilizaba en la producción de clorofluorocarburos, la práctica eliminación de estos productos químicos ha hecho también que disminuya el uso de este disolvente en la industria.

La mayoría de las intoxicaciones por tetracloruro de carbono se han producido por inhalación de sus vapores. No obstante, esta sustancia se absorbe fácilmente por vía digestiva. Al ser un buen disolvente de grasas, el contacto del tetracloruro de carbono con la piel la desengrasa, lo que puede dar lugar a la aparición de 
una dermatitis séptica secundaria. Como se absorbe por vía percutánea, deben tomarse precauciones para evitar el contacto prolongado y repetido de esta sustancia con la piel. El contacto con los ojos puede causar irritación pasajera, pero no provoca lesiones graves

EI tetracloruro de carbono exhibe propiedades anestésicas y la exposición a altas concentraciones de vapores pueden causar la rápida pérdida de consciencia. Las personas expuestas a concentraciones de vapores de tetracloruro de carbono inferiores a las anestésicas presentan con frecuencia otros efectos en el sistema nervioso, como mareo, vértigos, cefalea, depresión, confusión mental y descoordinación. A concentraciones más altas provoca arritmias cardíacas y fibrilación ventricular. Algunas personas expuestas a concentraciones de vapores sorprendentemente bajas sufren trastornos gastrointestinales, como náuseas, vómitos, dolores abdominales y diarrea.

Los efectos del tetracloruro de carbono en el hígado y los riñones merecen una atención especial cuando se evalúan los riesgos potenciales a los que están expuestas las personas que trabajan con este compuesto. D ebe recordarse que el consumo del alcohol potencia sus efectos nocivos. La respuesta inicial consiste en oliguria 0 anuria, seguida en pocos días por diuresis. La orina recogida durante el período de diuresis tiene una baja densidad relativa y suele contener proteínas, albúmina, cilindros pigmentados y hematíes. El aclaramiento renal de insulina, diodrast y ácido $p$-aminohipúrico disminuye, lo cual indica una reducción del flujo sanguíneo a través del riñón, así como daños glomerulares y tubulares. La función renal retorna gradualmente a la normalidad y, en el plazo de entre 100 y 200 días después de la exposición, alcanza el límite inferior de normalidad. El examen histopatológico de los riñones revela diversos grados de deterioro del epitelio tubular

Cloroformo. El cloroformo es uno de los hidrocarburos clorados volátiles más peligrosos. Es nocivo cuando penetra en el organismo por inhalación, por ingestión o por contacto con la piel y puede provocar narcosis, parálisis respiratoria, parada cardíaca 0 muerte tardía por lesiones hepáticas y renales. Algunas personas lo esnifan. El cloroformo líquido desengrasa la piel y produce quemaduras químicas. En la rata y el ratón tiene efectos teratógenos y cancerígenos. Cuando el cloroformo reacciona con oxidantes fuertes, se forma fosgeno.

El cloroformo es un producto químico ampliamente utilizado en productos comerciales y se forma espontáneamente por cloración de compuestos orgánicos, como en el agua potable clorada. El cloroformo atmosférico se deriva al menos en parte de la degradación fotoquímica del tricloroetileno. En presencia de luz solar, se descompone lentamente en fosgeno, cloro y cloruro de hidrógeno.

Basándose en las evidencias experimentales disponibles, la IAR C ha clasificado el cloroformo en el Grupo 2B como posible carcinógeno humano. $L a L_{50}$ por vía oral para perros y ratas es aproximadamente de $1 \mathrm{~g} / \mathrm{kg}$. Las ratas de dos semanas se mostraron dos veces más susceptibles que las ratas adultas. El ratón es más susceptible que la rata, siendo la causa de la muerte las lesiones hepáticas que se producen. En ratas, cobayas y perros expuestos durante 6 meses ( 7 horas al día, 5 días a la semana) a concentraciones de $25 \mathrm{ppm}$ en el aire, se produjeron alteraciones histopatológicas en el hígado y los riñones. Se observó infiltración grasa, degeneración granular centrilobular con áreas de necrosis en el hígado y alteración de las actividades enzimáticas en el suero, así como inflamación del epitelio de los túbulos, proteinuria, glucosuria y disminución de la excreción de sulfofenolftaleina. En una serie de estudios se vio que el cloroformo no tiene apenas capacidad para provocar anomalías cromosómicas, por lo que se cree que su carcinogenicidad se debe a mecanismos no genotóxicos. El cloroformo también provoca ciertas anomalías fetales en los animales de experimentación y todavía no se ha establecido una concentración sin efectos.

Las personas expuestas a vapores de cloroformo manifiestan síntomas diferentes dependiendo de la concentración y la duración de la exposición: cefalea, sopor, sensación de embriaguez, laxitud, mareo, náuseas, excitación, inconsciencia, depresión respiratoria, coma y muerte en estado de narcosis. La muerte suele producirse por parálisis respiratoria o parada cardíaca. EI cloroformo sensibiliza al miocardio frente a las catecolaminas. Una concentración de 10.000-15.000 ppm de cloroformo en el aire inhalado produce anestesia y una concentración de 15.000-18.000 ppm puede ser letal. Las concentraciones hemáticas que producen narcosis varían entre 30 y $50 \mathrm{mg} / 100 \mathrm{ml}$. Los niveles de $50-70 \mathrm{mg} / 100 \mathrm{ml}$ de sangre son letales. Es posible que, en los casos de exposición intensa a esta sustancia, y tras una recuperación transitoria, se produzca la muerte por fracaso de las funciones hepática y renal. Se han descrito efectos del cloroformo en el miocardio. La inhalación de concentraciones muy altas puede provocar parada cardíaca súbita (muerte por shock).

Los trabajadores expuestos a concentraciones bajas en el aire durante largos períodos de tiempo y las personas que han desarrollado una dependencia del cloroformo pueden sufrir síntomas neurológicos y gastrointestinales semejantes a los que se dan en el alcoholismo crónico. También se han observado alteraciones hepáticas, con hepatomegalia, hepatitis tóxica y degeneración grasa del hígado.

El 2-cloropropano es un potente anestésico, pero no se ha utilizado demasiado, ya que provoca vómitos y arritmia cardíaca en las personas y lesiones hepáticas y renales en los animales de experimentación. Las salpicaduras en la piel o en los ojos pueden provocar efectos graves, pero transitorios. Esta sustancia comporta un grave riesgo de incendio.

El diclorometano (cloruro de metileno) es muy volátil y en las zonas mal ventiladas pueden acumularse grandes concentraciones atmosféricas capaces de provocar la pérdida de consciencia de los individuos expuestos. Sin embargo, esta sustancia tiene un olor dulzón detectable a concentraciones superiores a 300 ppm, por lo que es fácil percibir su presencia antes de que se alcancen concentraciones con efectos agudos. Aunque no se disponen de datos suficientes en el hombre, la IARC ha considerado que existen datos suficientes en animales como para clasificar al diclorometano como posible carcinógeno humano.

Se han dado casos de intoxicación mortal en trabajadores que entraron en espacios cerrados donde existían altas concentraciones de diclorometano. U no de estos casos mortales se produjo durante la extracción de una oleorresina por medio de un proceso en el que la mayoría de las operaciones se realizaron en un sistema cerrado. Sin embargo, el trabajador se intoxicó por los vapores que escapaban por el respiradero interno de suministro del tanque y por los filtros. Se comprobó que la pérdida de diclorometano del sistema alcanzaba los 3.750 litros semanales.

El diclorometano ejerce su principal acción tóxica en el sistema nervioso central, produciendo narcosis y, a concentraciones altas, efectos anestésicos que se evidencian por una intensa fatiga, mareo, sopor e incluso inconsciencia. El margen de seguridad entre estos efectos graves y otros de menor importancia es muy pequeño. Los efectos narcóticos provocan pérdida de apetito, cefalea, mareo, irritabilidad, estupor, entumecimiento y hormigueo en las extremidades. La exposición prolongada a las concentraciones narcóticas más bajas puede producir, después de un período de latencia de varias horas, disnea, tos seca e improductiva con intenso dolor y, posiblemente, edema pulmonar. Algunos autores han observado también alteraciones hemáticas, con disminución del recuento de hematíes y del nivel de hemoglobina, así como congestión local de los vasos cerebrales y dilatación cardíaca. 
Con todo, la intoxicación leve no parece producir ninguna discapacidad permanente y la toxicidad hepática potencial del diclorometano es mucho menor que la de otros hidrocarburos halogenados (en especial, el tetracloruro de carbono), si bien los resultados de los experimentos con animales son contradictorios a este respecto. El diclorometano rara vez se utiliza en estado puro, mezclándose a menudo con otros compuestos que sí ejercen un efecto hepatotóxico. Y a en 1972 se demostró que las personas expuestas a diclorometano presentan concentraciones elevadas de carboxihemoglobina (10\% una hora después de la exposición durante dos horas a $1.000 \mathrm{ppm}$ de diclorometano y $3,9 \%$ 17 horas más tarde) debido a la conversión endógena del diclorometano en monóxido de carbono. En aquella época, la exposición a concentraciones de diclorometano que no superaran una media ponderada en el tiempo (T W A) de 500 ppm podría dar lugar a un nivel de carboxihemoglobina superior al permitido para el monóxido de carbono (un 7,9\% de $\mathrm{COHb}$ es el nivel de saturación correspondiente a una exposición a $50 \mathrm{ppm}$ de $\mathrm{CO}$ ); y $100 \mathrm{ppm}$ de diclorometano producirían el mismo nivel de $\mathrm{CO} \mathrm{H} \mathrm{b}$ o la misma concentración de $\mathrm{CO}$ en el aire alveolar que 50 ppm de CO.

El contacto directo con esta sustancia puede provocar irritación de la piel y los ojos, pero los principales problemas industriales que ocasiona la exposición excesiva son los síntomas de embriaguez y descoordinación que produce la intoxicación por diclorometano, y los actos inseguros y los consiguientes accidentes que pueden provocar estos síntomas.

El diclorometano atraviesa la barrera placentaria y puede detectarse en los tejidos del embrión tras la exposición de la madre. También se excreta en la leche materna. En la actualidad, no se dispone de datos suficientes sobre su toxicidad reproductiva.

EI dicloruro de etileno es inflamable y comporta un grave peligro de incendio. La IARC lo ha clasificado en el Grupo 2B como posible carcinógeno humano. El dicloruro de etileno puede absorberse por vía respiratoria, percutánea y digestiva. Se metaboliza en 2-cloroetanol y ácido monocloroacético, siendo estos dos metabolitos más tóxicos que el compuesto original. El umbral de olor de esta sustancia para el hombre, determinado en condiciones controladas de laboratorio, oscila entre 2 y 6 ppm. No obstante, la adaptación parece producirse relativamente pronto, de manera que al cabo de 1 ó 2 minutos, el olor producido por una concentración de 50 ppm apenas se detecta. El dicloruro de etileno es muy tóxico para el ser humano. Concentraciones de entre 80 y $100 \mathrm{ml}$ son suficientes para provocar la muerte en un plazo de 24 ó 48 horas. La inhalación de 4.000 ppm provoca lesiones graves. A elevadas concentraciones produce irritación inmediata de los ojos, la nariz, la garganta y la piel.

Un importante uso de este producto químico es en la fabricación de cloruro de vinilo mediante un proceso en su mayor parte cerrado. No obstante, pueden producirse y se producen fugas que entrañan un riesgo para el trabajador expuesto. El mayor riesgo de exposición se produce durante el vaciado de envases que contienen dicloruro de etileno en el interior de cubetas abiertas, desde donde se utiliza posteriormente para la fumigación de cereales. T ambién se producen exposiciones por fugas durante su fabricación, en la aplicación de pinturas, en la extracción de disolventes y en operaciones de vertido de residuos. El dicloruro de etileno se fotooxida rápidamente en el aire y no se acumula en el medio ambiente. T ampoco parece bioconcentrarse en ninguna cadena alimentaria ni acumularse en los tejidos humanos.

La clasificación del cloruro de etileno como carcinógeno del Grupo $2 B$ se basa en el aumento significativo de la tasa de tumores observado en ratas y ratones de ambos sexos. M uchos de los tumores, como el hemangiosarcoma, son de tipos poco comunes que rara vez se encuentran en los animales de control.
El "tiempo transcurrido hasta la aparición de un tumor" en los animales tratados es menor que en los controles. Al haberse demostrado que produce enfermedades malignas progresivas de varios órganos en dos especies de animales, el dicloruro de etileno debe considerarse un posible cancerígeno humano.

H exaclorobutadieno (HCBD). Se han dado pocos casos de enfermedades de origen profesional relacionadas con esta sustancia. Trabajadores agrícolas que fumigaban viñedos y se vieron expuestos simultáneamente a concentraciones de $0,8-30 \mathrm{mg} / \mathrm{m}^{3}$ de HCBD y 0,12-6,7 mg/ $\mathrm{m}^{3}$ de policlorobutano en la atmósfera presentaron hipotensión, trastornos cardíacos, bronquitis crónica, lesiones hepáticas crónicas y alteraciones funcionales del sistema nervioso. En otros trabajadores expuestos se observaron lesiones cutáneas probablemente debidas al H CBD.

EI hexacloroetano posee un efecto narcótico. No obstante, al ser sólido y tener una presión de vapor bastante baja en condiciones normales, el riesgo de depresión del sistema nervioso central por inhalación es pequeño. Irrita la piel y las mucosas. Se ha observado irritación producida por polvo de esta sustancia y se han descrito casos de trabajadores expuestos a vapores calientes de hexacloroetano que desarrollaron blefarospasmo, fotofobia, lagrimeo y enrojecimiento de la conjuntiva, pero sin lesiones corneales ni secuelas permanentes. En animales se ha demostrado que el hexacloroetano puede provocar cambios distróficos en el hígado y en otros órganos.

La IARC ha asignado el HCBD al Grupo 3 de compuestos inclasificables en términos de carcinogenicidad.

El cloruro de meilo es un gas inodoro y, por consiguiente, no advierte de su presencia, razón por la cual puede producirse una exposición considerable sin que los afectados se den cuenta. T ambién existe riesgo de susceptibilidad individual incluso con exposiciones leves. En animales se ha demostrado que el HCBD ejerce efectos muy diferentes según la especie, afectándose tanto más cuanto mayor sea el desarrollo del sistema nervioso central, lo que hace presumir que en el hombre provoque grados de susceptibilidad superiores. Un riesgo que comporta la exposición crónica a pequeñas concentraciones es la posibilidad de que la "borrachera", el mareo y la lenta recuperación de una intoxicación ligera impida que se reconozca la causa o se sospeche la existencia de fugas, lo que provocaría exposiciones prolongadas y accidentes. La mayoría de los casos mortales registrados se produjeron por derrame del líquido de los refrigerados domésticos o por defectos de las plantas de refrigeración. El clorometano comporta también un grave peligro de incendio y explosión.

La intoxicación aguda se caracteriza por un período de latencia de algunas horas entre la exposición y la aparición de los síntomas. Estos síntomas son cefalea, fatiga, náuseas, vómitos y dolor abdominal. Es posible que la persona afectada haya sufrido mareos y sopor durante algún tiempo antes de que se precipite el ataque más agudo por un accidente repentino. Se han descrito pocos casos de intoxicación crónica por exposiciones más leves, posiblemente porque los síntomas desaparecen poco tiempo después de cesar la exposición. Las molestias en los casos leves consisten en mareo, dificultad para caminar, cefalea, náuseas y vómitos. Los síntomas objetivos más frecuentes son marcha tambaleante, nistagmo, trastornos del habla, hipotensión arterial y reducción y alteración de la actividad eléctrica cerebral. U na intoxicación leve prolongada puede provocar lesiones permanentes del músculo cardíaco y del sistema nervioso central, con cambio de la personalidad, depresión, irritabilidad y, ocasionalmente, alucinaciones visuales y auditivas. El aumento del contenido de albúmina en el líquido cefalorraquídeo, con posibles lesiones piramidales y extrapiramidales, puede sugerir un diagnóstico de meningoencefalitis. En los casos de muerte, la autopsia ha demostrado la existencia de congestión pulmonar, hepática y renal. 
El teracloroetano es un potente narcótico y, además, es tóxico para el sistema nervioso central y para el hígado. La lenta eliminación del tetracloroetano del organismo podría explicar su toxicidad. La principal vía de absorción de los vapores de esta sustancia suele ser la vía respiratoria, si bien se han dado casos de absorción percutánea. Se ha especulado sobre la posibilidad de que la absorción percutánea produzca algunos efectos en el sistema nervioso (p. ej., temblores). T ambién es un irritante de la piel y puede producir dermatitis.

La mayoría de las exposiciones laborales al tetracloroetano se deben a su empleo como disolvente. Entre 1915 y 1920 se produjeron una serie de casos mortales durante los procesos de fabricación de aviones y perlas artificiales, en los que se empleaba tetracloroetano. 0 tros casos mortales de intoxicación por tetracloroetano han estado relacionados con la fabricación de gafas de seguridad, la industria del cuero artificial, la industria del caucho y una industria bélica no especificada. Se han producido algunos casos no mortales en la fabricación de seda artificial, en el desengrasado de la lana, en la producción de penicilina y en la industria de joyería.

El tetracloroetano es un potente narcótico, dos o tres veces más potente que el cloroformo en animales. En as personas se han producido casos de muerte por ingestión de tetracloroetano. En todos estos casos, la muerte sobrevino en las 12 horas siguientes a la ingestión. También se han registrado casos no mortales con pérdida de consciencia, pero sin efectos secundarios graves. En comparación con el tetracloruro de carbono, los efectos narcóticos del tetracloroetano son mucho más graves, pero los efectos nefrotóxicos son menos acusados. La intoxicación crónica por tetracloroetano puede adoptar dos formas: efectos en el sistema nervioso central, como temblores, vértigo y dolor de cabeza; y síntomas hepatodigestivos como náuseas, vómitos, dolores gástricos, ictericia y aumento del tamaño del hígado.

EI 1,1,1-tricloroetano se absorbe rápidamente por vía respiratoria y digestiva. Puede absorberse también por vía percutánea, pero esto raramente tiene importancia sistémica, a menos que la sustancia se localice en la superficie cutánea bajo una barrera impermeable. La primera manifestación clínica de sobreexposición es una depresión funcional del sistema nervioso central, que comienza con mareos, descoordinación y prueba de Romberg positiva (el individuo tiene que mantenerse en equilibrio sobre un pie, con los ojos cerrados y los brazos en cruz), que progresa a anestesia y parada del centro respiratorio. La depresión del SNC es proporcional a la magnitud de la exposición y típica de un agente anestésico, de ahí el peligro de sensibilización cardíaca a la epinefrina con aparición de arritmia. T ras una intensa sobreexposición, se han observado alteraciones transitorias en el hígado y los riñones y en las autopsias se han detectado lesiones pulmonares. La salpicadura de varias gotas directamente sobre la córnea puede provocar una conjuntivitis leve, que remite por sí sola en pocos días. El contacto prolongado o repetido con la piel produce eritema transitorio y una ligera irritación, debido a la acción desgrasante del disolvente.

Tras la absorción de 1,1,1-tricloroetano, un pequeño porcentaje se metaboliza en dióxido de carbono, mientras que el resto aparece en la orina como glucurónido de 2,2,2-tricloroetanol.

Exposición aguda. Las personas expuestas a 900-1.000 ppm experimentaron irritación ocular leve y transitoria y una alteración inmediata, aunque mínima, de la coordinación. Las exposiciones de esta magnitud también pueden provocar cefalea y laxitud. 0 casionalmente se han observado alteraciones del equilibrio en individuos "susceptibles" expuestos a concentraciones de 300 $500 \mathrm{ppm}$. U na de las pruebas clínicas más sensibles de intoxicación ligera durante la exposición es la incapacidad de realizar normalmente una prueba de R omberg modificada. Por encima de 1.700 ppm ya se evidencian claras alteraciones del equilibrio.
La mayoría de los pocos casos mortales documentados en la bibliografía se produjeron por exposición a concentraciones anestésicas del disolvente, por depresión del centro respiratorio o por arritmia resultante de la sensibilización cardíaca a la epinefrina.

La IARC considera que el 1,1,1-tricloroetano es inclasificable (G rupo 3) en términos de carcinogenicidad.

El isómero 1,1,2-tricloroetano se utiliza como producto químico intermedio y como disolvente. La principal respuesta farmacológica a este compuesto es la depresión del SNC. Su toxicidad aguda parece ser menor que la del isómero 1,1,2-. Aunque la IARC lo considera una sustancia inclasificable en términos de carcinogenicidad (Grupo 3), algunos organismos públicos lo tratan como posible carcinógeno humano (p. ej., el National Institute of $\mathrm{O}$ ccupational Safety and $\mathrm{H}$ ealth $(\mathrm{N}$ IO SH ) de Estados U nidos).

T ricloroetileno. En condiciones normales de uso, el tricloroetileno no es inflamable ni explosivo, pero puede descomponerse a altas temperaturas dando ácido clorhídrico, fosgeno (en presencia de oxígeno atmosférico) y otros compuestos. Estas condiciones (temperaturas superiores a $300 \stackrel{\circ}{\circ}$ ) pueden darse en los metales calentados, en la soldadura al arco y en las llamas desnudas. En presencia de álcalis fuertes (p. ej., hidróxido sódico), puede formarse dicloroacetileno, un compuesto tóxico, explosivo e inflamable.

El tricloroetileno tiene principalmente un efecto narcótico. La exposición a altas concentraciones de vapores (superiores a $1.500 \mathrm{mg} / \mathrm{m}^{3}$ ) produce un cuadro de excitación o euforia que irá seguido de mareo, confusión, sopor, náuseas, vómitos y, posiblemente, pérdida de consciencia. Cuando se produce la ingestión accidental de tricloroetileno, estos síntomas van precedidos por una sensación de quemazón en la garganta y el esófago. En caso de intoxicación por inhalación, la mayoría de las manifestaciones desaparecen cuando se respira aire no contaminado y se elimina el disolvente y sus metabolitos. No obstante, se han producido algunas muertes como consecuencia de accidentes de trabajo. EI contacto prolongado de pacientes inconscientes con tricloroetileno líquido puede provocar vesiculación de la superficie cutánea. 0 tras posibles complicaciones de la intoxicación por tricloroetileno son neumonitis química y lesiones hepáticas y renales. Las salpicaduras de tricloroetileno en los ojos producen irritación (ardor, lagrimeo y otros síntomas).

Tras el contacto repetido con tricloroetileno líquido, puede producirse dermatitis grave (sequedad, enrojecimiento, aspereza y cuarteamiento de la piel), seguida de infección secundaria y sensibilización.

La IAR C ha clasificado el tricloroetileno en el Grupo 2A como probable carcinógeno humano. Además, el sistema nervioso central es el principal órgano afectado por la toxicidad crónica. Conviene distinguir dos tipos de efectos: (a) el efecto narcótico del tricloroetileno y su metabolito tricloroetanol mientras se encuentran en el organismo; y (b) las secuelas a largo plazo como consecuencia de sobreexposiciones repetidas. Estas secuelas pueden durar varias semanas o incluso meses después de finalizar la exposición al tricloroetileno. Los principales síntomas son laxitud, mareo, irritabilidad, cefalea, trastornos digestivos, intolerancia al alcohol (embriaguez tras consumir pequeñas cantidades de alcohol, enrojecimiento de la superficie de la piel por vasodilatación síntoma conocido como "rubicundez de los desengrasadores") y confusión metal. Estos síntomas pueden ir acompañados de signos neurológicos de carácter menor (principalmente del cerebro y del sistema nervioso autónomo, rara vez de los nervios periféricos) y deterioro psicológico. En algunos casos se observan irregularidades del ritmo cardíaco y ligera afectación hepática. El efecto eufórico que produce la inhalación de tricloroetileno puede provocar deseo de consumo, habituación y esnifado. 


\section{Compuestos alílicos}

Los compuestos alílicos son análogos insaturados de los compuestos propílicos correspondientes y se representan con la fórmula general $\mathrm{CH}_{2}: \mathrm{CHCH}_{2} \mathrm{X}$, donde $\mathrm{X}$ suele ser un halógeno, un hidroxilo 0 un radical ácido orgánico. Al igual que en el caso de los compuestos vinílicos estrechamente emparentados, las propiedades reactivas del doble enlace han demostrado su utilidad para síntesis químicas y polimerizaciones.

Este doble enlace de los compuestos alílicos se asocia también a ciertos efectos fisiológicos importantes para la higiene industrial. Se ha observado que los ésteres alifáticos insaturados presentan propiedades irritantes y lacrimógenas de las que carecen (al menos en la misma medida) los ésteres saturados correspondientes, y la $D L_{50}$ aguda por diversas vías tiende a ser menor en el caso del éster insaturado que en el del compuesto saturado. En estos aspectos se observan diferencias notables entre el acetato de alilo y el acetato de propilo. Sin embargo, las propiedades irritantes no se limitan a los ésteres alílicos, encontrándose en diferentes clases de compuestos alílicos.

El cloruro de alilo (cloropreno) tiene propiedades inflamables y tóxicas. Aunque produce un efecto narcótico débil, es muy tóxico. Provoca una intensa irritación de los ojos y de las vías respiratorias superiores. Tanto la exposición aguda como la crónica pueden ocasionar lesiones pulmonares, hepáticas y renales. La exposición crónica también se ha asociado a una disminución de la presión sistólica y de la tonicidad de los vasos cerebrales. En contacto con la piel provoca irritación leve, pero su absorción por vía percutánea causa un dolor muy localizado en la zona de contacto y puede ocasionar lesiones sistémicas.

Los estudios con animales han obtenido resultados contradictorios con respecto a la carcinogenicidad, mutagenicidad y toxicidad reproductiva de esta sustancia. La IARC ha asignado el cloruro de alilo al G rupo 3 como inclasificable.

\section{Compuestos clorados de vinilo y vinilideno}

Los vinilos son productos químicos intermedios y se utilizan principalmente como monómeros en la fabricación de plásticos. M uchos de ellos se obtienen mediante la adición del compuesto apropiado al acetileno. Como ejemplos de monómeros de vinilo pueden citarse el bromuro de vinilo, el cloruro de vinilo, el fluoruro de vinilo, el acetato de vinilo, los éteres vinílicos y los ésteres vinílicos. Los polímeros son productos de alto peso molecular obtenidos mediante polimerización, un proceso que puede definirse como la combinación de monómeros iguales para producir otro compuesto que contiene los mismos elementos en las mismas proporciones, pero con un peso molecular superior y diferentes características físicas.

Cloruro de vinilo. El cloruro de vinilo (CV) es inflamable y forma una mezcla explosiva con el aire en proporciones de entre un 4 y un $22 \%$ en volumen. Al arder, se descompone en ácido clorhídrico gaseoso, monóxido de carbono y dióxido de carbono. Penetra fácilmente en el organismo humano a través del sistema respiratorio, desde donde pasa a la circulación sanguínea y de ahí a los distintos órganos y tejidos. T ambién se absorbe a través del sistema digestivo como contaminante de alimentos y bebidas, y por vía percutánea. Sin embargo, estas dos vías de entrada carecen de interés desde el punto de vista de las intoxicaciones de origen profesional.

EI CV absorbido se transforma y excreta por diversas vías, dependiendo de la cantidad acumulada. Cuando está presente en altas concentraciones, hasta un $90 \%$ del producto puede eliminarse sin sufrir cambios a través del aire exhalado, junto con pequeñas cantidades de $\mathrm{CO}_{2}$. EI resto sufre biotransformación y se excreta con la orina. Si, por el contrario, se encuentra a bajas concentraciones, la cantidad de monómero exhalado sin modificar es muy pequeña y la proporción reducida a $\mathrm{CO}_{2}$ representa aproximadamente el $12 \%$. EI resto se transforma. EI centro principal del proceso metabólico es el hígado, donde el monómero sufre una serie de procesos oxidativos, catalizados en parte por la alcohol deshidrogenasa y en parte por una catalasa. La principal ruta metabólica es la microsómica, a través de la cual el CV se oxida para formar óxido de cloroetileno, un epóxido inestable que se transforma espontáneamente en cloroacetaldehído.

Sea cual sea la ruta metabólica seguida, el producto final es siempre cloroacetaldehído, que seguidamente se combina con glutatión y cisteína. Los principales metabolitos excretados en la orina son la hidroxietilcisteína, la carboxietilcisteína (como tal o $\mathrm{N}$-acetilada) y trazas de ácido monocloroacético y ácido tiodiglicólico. Una pequeña proporción de los metabolitos se excreta junto con la bilis al intestino.

Intoxicación aguda. En el ser humano, la exposición prolongada a CV produce un estado de intoxicación que puede seguir un curso agudo o crónico. Las concentraciones atmosféricas de alrededor de $100 \mathrm{ppm}$ no son perceptibles, ya que el umbral del olor se sitúa entre 2.000 y 5.000 ppm. Estas altas concentraciones del monómero se perciben por un olor dulzón, no desagradable. La exposición a concentraciones elevadas produce un estado de exaltación, seguido de astenia, sensación de pesadez en las piernas y somnolencia. L as concentraciones de entre 8.000 y 10.000 ppm provocan vértigos; a 16.000 ppm se deterioran el oído y la vista; a 70.000 ppm se experimenta pérdida de consciencia y narcosis y las concentraciones superiores a 120.000 ppm pueden ser fatales para el ser humano.

E fecto carcinógeno. El cloruro de vinilo ha sido clasificado por la IARC dentro del Grupo 1 como carcinógeno humano demostrado y ha sido regulado por numerosas autoridades de todo el mundo como carcinógeno humano conocido. En el hígado puede provocar el desarrollo de un tumor maligno extremadamente raro, conocido como angiosarcoma, hemangioblastoma, hemangioendotelioma maligno o mesenquimoma angiomatoso. EI período medio de latencia es de unos 20 años. E voluciona asintomáticamente y sólo se manifiesta en las últimas fases, con síntomas de hepatomegalia, dolor, deterioro del estado general de salud y posiblemente signos de fibrosis hepática concomitante, hipertensión portal, venas esofágicas varicosas, ascitis, hemorragia del tracto digestivo, anemia hipocrómica, colestasis con aumento de la fosfatasa alcalina, hiperbilirrubinemia, aumento del tiempo de retención de BSP (bromosulftaleína), hiperfunción esplénica caracterizada principalmente por trombocitopenia y reticulocitosis y afección de las células hepáticas con disminución de la concentración plasmática de albúmina y fibrinógeno.

Los períodos largos de exposición a concentraciones suficientemente altas provocan un síndrome denominado "enfermedad por cloruro de vinilo". Esta entidad se caracteriza por síntomas neurotóxicos, modificaciones de la microcirculación periférica (fenómeno de R aynaud), alteraciones cutáneas de tipo esclerodérmico, alteraciones óseas (acrosteolisis), alteraciones del hígado y el bazo (fibrosis hepatoesplénica), síntomas genotóxicos acusados y cáncer. Pueden producirse afecciones cutáneas, como esclerodermia en el dorso de las manos a nivel de las articulaciones metacarpianas y falángicas y en la cara interna de los antebrazos. Las manos aparecen pálidas, frías, húmedas y sudorosas, por causa del intenso edema. La piel pierde su elasticidad, es difícil de pellizcar y se cubre de pequeñas pápulas, microvesículas y formaciones urticaroides. Estas alteraciones se han observado en pies, cuello, cara y espalda, así como en manos y brazos.

Acrosteolisis. Se trata de una afección esquelética que suele localizarse en las falanges distales de las manos. Se debe a una necrosis aséptica del hueso, de origen isquémico, provocada por una arteriolitis ósea estenosante. Las imágenes radiológicas 
muestran un proceso de osteolisis con bandas transversales o con estrechamiento de las falanges ungulares.

Alteraciones hepáticas. En todos los casos de intoxicación por CV se observan alteraciones hepáticas, que suelen comenzar con digestiones pesadas, sensación de pesadez en la región epigástrica y meteorismo. El tamaño del hígado está aumentado, pero su consistencia es normal y no aparece dolor en las maniobras de palpación. Las pruebas funcionales hepáticas raramente están alteradas. La hepatomegalia desaparece una vez que cesa la exposición. Las personas expuestas durante períodos de tiempo más largos, es decir, de 2 a 20 años, pueden desarrollar fibrosis hepática, en ocasiones aislada, pero más frecuentemente asociada a esplenomegalia, que puede complicarse con hipertensión portal, varices esofágicas y, como consecuencia, hemorragias del aparato digestivo. La fibrosis hepática y esplénica no se asocia necesariamente con un aumento del tamaño de estos órganos. L as pruebas de laboratorio son poco indicativas, aunque la experiencia ha demostrado la conveniencia de realizar una prueba de BSP (bromosulftaleína), así como la determinación de SGOT (transaminasa glutamicooxalacética en suero) y la SG PT (transaminasa glutamicopirúvica en suero), gamma GT y bilirrubinemia. La única prueba fiable es una laparoscopia con biopsia. La superficie del hígado aparece irregular debido a la presencia de granulaciones y zonas escleróticas. La estructura general del hígado rara vez sufre modificaciones y el parénquima se ve poco afectado, si bien se encuentran células hepáticas con degeneración y necrosis de hepatocitos, siendo evidente un cierto polimorfismo de los núcleos celulares. Las alteraciones mesenquimatosas son más específicas, ya que siempre se observa fibrosis de la cápsula de Glisson que se extiende por los espacios portales y penetra en los intersticios de las células hepáticas. Cuando el bazo resulta afectado, se observa fibrosis capsular con hiperplasia folicular, dilatación de los sinusoides y congestión de la pulpa roja. No es raro encontrar una ascitis discreta. Tras retirar al sujeto de la exposición, la hepatomegalia y la esplenomegalia disminuyen, las alteraciones del parénquima hepático remiten y los cambios mesenquimáticos pueden continuar su progresión 0 pueden ceder en su evolución.

B romuro de vinilo. Aunque la toxicidad aguda del bromuro de vinilo es menor que la de muchos otros productos químicos de este grupo, la IARC lo considera un probable carcinógeno humano (Grupo $2 A$ ) y debe manipularse como un posible carcinógeno en el lugar de trabajo. En el conejo, el bromuro de vinilo en estado líquido produce una irritación moderada de los ojos, pero no de la piel. Las ratas, conejos y monos expuestos a concentraciones de 250 ó 500 ppm durante 6 horas diarias, 5 días a la semana durante 6 meses, no presentaron ningún tipo de alteración. Se ha realizado un experimento con ratas a las que se expuso durante un año a concentraciones de 1.250 ó 250 ppm (6 horas diarias, 5 días a la semana). Al cabo de ese tipo se había producido un aumento de la mortalidad, pérdida de peso, angiosarcoma de hígado y carcinomas de las glándulas de Zimbal. Se ha comprobado que esta sustancia es mutágena para las colonias de Salmonella typhimurium con y sin activación metabólica.

Cloruro de vinilideno (CVD). Si el cloruro de vinilideno puro se mantiene entre $-40{ }^{\circ} \mathrm{C}$ y $+25{ }^{\circ} \mathrm{C}$ en presencia de aire 0 de oxígeno, se forma un peróxido muy explosivo cuya estructura no se ha determinado, que puede detonar por la acción de cualquier estímulo mecánico ligero o por la acción del calor. Los vapores producen una irritación moderada de los ojos y la exposición a altas concentraciones provoca efectos similares a los de una borrachera, que pueden progresar hasta producirse inconsciencia. En estado líquido, este producto es irritante para la piel, acción ésta que, en parte, puede deberse al inhibidor fenólico que se añade para evitar su polimerización incontrolada y su explosión. T ambién exhibe propiedades sensibilizantes.
El potencial carcinógeno del CVD en animales sigue siendo objeto de debate. La IARC no lo ha clasificado como carcinógeno posible o probable (en 1996), pero el NIOSH de Estados Unidos ha recomendado el mismo límite de exposición para el CVD que para el cloruro de vinilo monómero, esto es, 1 ppm. $\mathrm{H}$ asta la fecha, no se han realizado estudios epidemiológicos importantes respecto a la carcinogenicidad para las personas de los copolímeros de cloruro de vinilo-CVD.

EI CVD presenta una actividad mutágena que varía según su concentración. Cuando la concentración es baja, se ha visto que dicha actividad es mayor que la del cloruro de vinilo monómero. Sin embargo, parece ser que disminuye cuando se trata de dosis elevadas, probablemente como resultado de la inhibición de las enzimas microsómicas responsables de su activación metabólica.

\section{Hidrocarburos alifáticos bromados}

B romoformo. La mayor parte de la experiencia que se tiene de casos de intoxicación en personas procede de la administración oral de bromoformo y resulta difícil determinar la importancia de su toxicidad en aplicaciones industriales. El bromoformo se ha utilizado como sedante y, sobre todo, como antitusígeno, durante muchos años. $\mathrm{L}$ a ingestión de dosis superiores a las terapéuticas (entre 0,1 y 0,5 g) provoca estupor, hipotensión y coma. Además del efecto narcótico, también tiene una potente acción irritante y lacrimógena. La exposición a los vapores de bromoformo provoca una intensa irritación de las vías respiratorias, lagrimeo y sialorrea. El bromoformo puede causar lesiones hepáticas y renales y, en ratones, provoca tumores tras su aplicación intraperitoneal. Se absorbe también a través de la piel. La exposición a concentraciones de hasta $100 \mathrm{mg} / \mathrm{m}^{3}$ (10 ppm) produce cefalea, mareo, dolor en la región del hígado y alteración de la función hepática.

El dibromuro de etileno (dibromoetano) es un producto químico potencialmente peligroso con una dosis letal mínima estimada para el ser humano de $50 \mathrm{mg} / \mathrm{kg}$. De hecho, la ingestión de $4,5 \mathrm{~cm}^{3}$ de D ow-fume $\mathrm{W}-85$, que contiene un $83 \%$ de dibromoetano, provocó la muerte de una mujer adulta de $55 \mathrm{~kg}$ de peso. La IARC lo ha clasificado en el Grupo $2 \mathrm{~A}$ como carcinógeno humano probable.

Los síntomas que provoca este producto químico dependen de que se haya producido contacto directo con la piel, inhalación de vapores o ingestión oral. Como su forma líquida es un potente irritante, el contacto prolongado con la piel produce enrojecimiento, edema y vesículas, que pueden ulcerarse. La inhalación de vapores provoca lesiones en el aparato respiratorio, con congestión pulmonar, edema y neumonía. También se produce depresión del sistema nervioso central, con sopor. En caso de muerte, ésta suele producirse por fracaso cardiopulmonar. La ingestión oral de este compuesto produce lesiones hepáticas y, aunque de menor importancia, renales, tanto en animales de experimentación como en seres humanos. En estos casos, la muerte suele deberse a lesiones hepáticas extensas. 0 tros síntomas que se observan tras la ingestión o inhalación de dibromuro de etileno son excitación, cefalea, zumbido de oídos, debilidad generalizada, pulso débil y vómitos intensos y prolongados.

La administración oral del dibromoetano a través de una sonda gástrica provocó carcinomas de células escamosas en el cardias de ratas y ratones, cánceres de pulmón en ratones, hemangiosarcomas esplénicos en ratas macho y cáncer de hígado en ratas hembra. No se han descrito casos en el hombre ni se han realizado estudios epidemiológicos en seres humanos.

Recientemente se ha detectado en ratas una grave interacción tóxica entre dibromoetano inhalado y disulfiram administrado por vía oral, que produce tasas de mortalidad muy altas con una elevada incidencia de tumores, como hemangiosarcomas hepáticos, esplénicos y renales. Por ello, el NIOSH de Estados U nidos 
recomienda que (a) los trabajadores no se expongan al dibromoetano cuando estén recibiendo tratamiento con sulfiram (A ntabuse o R osulfiram utilizados para ayudar a abandonar el consumo de alcohol) y (b) ningún trabajador se exponga al mismo tiempo al dibromoetano y al disulfiram (este último se utiliza también en la industria como acelerador en la fabricación de caucho, como fungicida y como insecticida).

Afortunadamente, la aplicación de dibromoetano como fumigante de tierras se realiza normalmente bajo la superficie del suelo utilizando un inyector, lo que permite reducir al mínimo el riesgo de contacto directo con el líquido y los vapores. A simismo, la baja presión de vapor de este producto reduce la posibilidad de inhalación de grandes cantidades del mismo.

El olor del dibromoetano puede detectarse a una concentración de $10 \mathrm{ppm}$. Con este producto deben adoptarse las mismas precauciones ya indicadas en este capítulo que para la manipulación de cualquier sustancia cancerígena. El uso de prendas protectoras y guantes de nylon-neopreno ayuda a evitar el contacto con la piel y una posible absorción. En caso de contacto directo con la superficie cutánea, se retirará la ropa que cubra la zona y se procederá a lavar la piel con agua abundante y jabón. Cuanto antes se realice esta operación, más se evitará la aparición de lesiones cutáneas. En caso de contaminación de los ojos por el producto líquido o por sus vapores, se irrigarán estos con agua abundante. La ingestión de dibromoetano produce graves lesiones hepáticas, razón por la cual es imprescindible realizar un vaciado urgente de estómago y un lavado gástrico minucioso. EI tratamiento para prevenir lesiones hepáticas debe consistir en procedimientos tan tradicionales como una dieta alta en hidratos de carbono con suplementos vitamínicos, especialmente de vitaminas $B, C$ y K.

El bromuro de metilo es uno de los haluros orgánicos más tóxicos y no despide un olor que avise de su presencia. En la atmósfera se dispersa lentamente. Por todo ello, es uno de los compuestos más peligrosos que se utilizan en la industria. Se introduce en el organismo sobre todo por inhalación, siendo el grado de absorción percutánea probablemente insignificante. A menos que se produzca una narcosis severa, los síntomas suelen tardar horas 0 incluso días en manifestarse. Se han producido algunas muertes relacionadas con la fumigación de este producto, que plantea un problema especial por su uso continuado. O tros casos mortales han ocurrido por fugas en las plantas refrigeradoras o por el uso de extintores de incendios. El contacto prolongado de la piel con ropa contaminada por salpicaduras puede producir quemaduras de segundo grado.
El bromuro de metilo daña el cerebro, el corazón, los pulmones, el bazo, el hígado, las glándulas suprarrenales y los riñones. En estos órganos se han encontrado alcohol metílico, formaldehído y bromuro en cantidades que oscilan entre 32 y $62 \mathrm{mg}$ por cada $300 \mathrm{~g}$ de tejido. El erebro puede sufrir una congestión aguda, con edema y degeneración cortical. La congestión pulmonar puede no existir o ser extrema. La degeneración de los túbulos renales produce uremia. Las hemorragias pulmonares y cerebrales indican lesiones en el sistema vascular. Parece ser que el bromuro de metilo se hidroliza en el organismo, formando bromuro inorgánico. Los efectos sistémicos de esta sustancia pueden ocasionar una forma inusual de bromidismo con penetración intracelular del bromo. En estos casos, las lesiones pulmonares son menos graves.

Se ha observado una dermatitis acneiforme en personas sometidas a exposiciones reiteradas. Se han descrito también efectos acumulativos, casi siempre con alteraciones del sistema nervioso central, tras la inhalación repetida de concentraciones moderadas de bromuro de metilo.

\section{Medidas de salud y seguridad}

Ante todo, y siempre que sea posible, debe evitarse el uso de los compuestos más peligrosos de este grupo, sustituyéndolos por sustancias menos nocivas. Por ejemplo, siempre que sea posible debe sustituirse el bromometano por sustancias de menor riesgo en refrigeradores y extintores de incendios. Además de las precauciones de salud y seguridad aplicables a los productos químicos volátiles de toxicidad similar, se recomiendan también las siguientes:

Incendio y explosión. Solamente no son inflamables ni explosivos los miembros más altos de las series de hidrocarburos alifáticos halogenados. Algunos de ellos son incombustibles y se utilizan como agentes extintores de incendios. Por el contrario, los miembros más bajos de las series son inflamables y, en algunos casos, altamente inflamables (por ejemplo, el 2-cloropropano) y forman mezclas explosivas con el aire. Además, algunos miembros insaturados (p. ej., el dicloroetileno) pueden formar peróxidos altamente explosivos incluso a temperaturas muy bajas. La descomposición térmica de los hidrocarburos halogenados puede formar compuestos tóxicos peligrosos.

Las medidas preventivas de carácter técnico e higiénico deben complementarse con exploraciones médicas periódicas y pruebas de laboratorio dirigidas a detectar lesiones en los órganos afectados, sobre todo en el hígado y los riñones. 


\section{TABLAS DE HIDROCARBUROS HALOGENADOS SATURADOS}

\begin{tabular}{|c|c|c|c|}
\hline Producto químico & Sinónimos/ Código UN & $\mathrm{N}$ úmero CAS & Fórmula estructural \\
\hline 1-BROMOBUTANO & $\begin{array}{l}\text { 1-Bromobutano; bromuro de n-butilo } \\
\text { UN } 1126\end{array}$ & $109-65-9$ & \\
\hline 1-BROM 0-2-CLOROETANO & & 107-04-0 & \\
\hline BROMOFORMO & $\begin{array}{l}\text { Tribromuro de metenilo; tribromuro de metilo; tribromometano } \\
\text { UN2515 }\end{array}$ & $75-25-2$ & \\
\hline BROMURO DE ETILO & $\begin{array}{l}\text { Eter brómico; bromoetano; etil bromuro; éter bromhídrico } \\
\text { UN1891 }\end{array}$ & $74-96-4$ & \\
\hline BROMURO DE METILO & $\begin{array}{l}\text { Bromometano; Metafume; monobromometano metogás } \\
\text { UN1062 }\end{array}$ & $74-83-9$ & \\
\hline CLOROBROMOMETANO & $\begin{array}{l}\text { Bromoclorometano; Halón 1011; clorobromuro de metileno; } \\
\text { monocloromonobromometano } \\
\text { UN1887 }\end{array}$ & $74-97-5$ & \\
\hline 1-CLORO-3-BROMOPROPANO & $\begin{array}{l}\text { 1-Bromo-3-cloropropano; cloruro de 3-bromopropilo; bromuro de } \\
\text { 3-cloropropilo; cloruro-bromuro de trimetileno; clorobromuro de trimetileno } \\
\text { UN2688 }\end{array}$ & $109-70-6$ & \\
\hline 1-CLOROBUTANO & Cloruro de butilo; cloruro de n-butilo; cloruro de n-propilcarbinilo & $109-69-3$ & \\
\hline CLOROFORMIATO DE ISOPROPILO & & $108-23-6$ & \\
\hline CLOROFORMO & $\begin{array}{l}\text { Tricloruro de metano; tricloruro de metilo; tricloroformo; triclorometano } \\
\text { UN1888 }\end{array}$ & $67-66-3$ & \\
\hline 2-CLORO-2-METILPROPANO & Cloruro de terc-butilo; 2-cloroisobutano; trimetilclorometano & $507-20-0$ & \\
\hline 2-CLOROPROPANO & $\begin{array}{l}\text { Isopropilcloruro } \\
\text { UN2356 }\end{array}$ & $75-29-6$ & \\
\hline CLORURO DE ETILO & $\begin{array}{l}\text { Cloroetano; cloretilo; éter clorado; éter clorhídrico; monocloroetano } \\
\text { UN1037 }\end{array}$ & $75-00-3$ & \\
\hline CLORURO DE ISOBUTILO & & $513-36-0$ & \\
\hline
\end{tabular}




\begin{tabular}{|c|c|c|c|}
\hline Producto químico & Sinónimos/ Código UN & $\mathrm{N}$ úmero $\mathrm{CAS}$ & Fórmula estructural \\
\hline CLORURO DE METILENO & $\begin{array}{l}\text { Diclorometano; dicloruro de metano; dicloruro de metileno } \\
\text { UN1593 }\end{array}$ & $75-09-2$ & \\
\hline CLORURO DE METILO & $\begin{array}{l}\text { Metil cloruro; monoclorometano } \\
\text { UN1063 }\end{array}$ & $74-87-3$ & \\
\hline 1,2-DIBROMO-3-CLOROPROPANO & $\begin{array}{l}\text { 1-Cloro-2,3-dibromopropano; 3-cloro-1,2-dibromopropano; } \\
\text { dibromocloropropano; 1-2-dibrom0-3-cloropropano } \\
\text { UN2872 }\end{array}$ & $96-12-8$ & \\
\hline DIBROMOMETANO & $\begin{array}{l}\text { Dibromometano; bromuro de metileno; dibromuro de metileno } \\
\text { UN2664 }\end{array}$ & 74-95-3 & \\
\hline DIBROMURO DE ETLLENO & $\begin{array}{l}\text { Dibromoetano; sim-dibromoetano; 1,2-dibromoetano } \\
\text { UN1605 }\end{array}$ & $106-93-4$ & \\
\hline 1,1-DICLOROETANO & $\begin{array}{l}\text { Eter clorhídrico clorado; 1,1-dicloretano; cloruro de etilideno; dicloruro de } \\
\text { etilideno } \\
\text { UN2362 }\end{array}$ & $75-34-3$ & \\
\hline 1,1-DICLOROPROPANO & Cloruro de propilideno & $78-99-9$ & \\
\hline 1,2-DICLOROPROPANO & $\begin{array}{l}\alpha-\beta \text {-Dicloropropano; } 1,2 \text {-dicloropropano, cloruro de propileno } \\
\text { UN1279 }\end{array}$ & $78-87-5$ & \\
\hline 1,3-DICLOROPROPANO & Dicloruro de trimetileno & $142-28-9$ & \\
\hline DICLORURO DE ETILENO & $\begin{array}{l}\text { 1,2-Dicloroetano; 1,2-DCE; } 1 \text { dicloremulsión; 1,2-dicloretano; } \\
\text { dicloroetileno; cloruro de propilo } \\
\text { UN1184 }\end{array}$ & 107-06-2 & $\mathrm{Cl}^{\prime}$ \\
\hline HEPTACLOR & $\begin{array}{l}\text { Heptaclorano; 3,4,5,6,7,8,8-heptaclorodiciclopentadieno; } \\
\text { 1,4,5,6,7,10,10-heptacloro-4, 7,8,9-tetrahidro-4,7-metilenindeno }\end{array}$ & $76-44-8$ & \\
\hline HEXACLOROCICLOHEXANO & Hexacloruro de benceno; hexaclor; 1,2,3,4,5,6-hexaclorociclohexano & $608-73-1$ & \\
\hline$\alpha$-HEXACLOROCICLOHEXANO & $\begin{array}{l}\text { Hexacloruro de } \alpha \text {-benceno; ENT 9,232; } \alpha \text {-HCH; a-hexaclorano; } \\
\alpha-1,2,3,4,5,6 \text {-hexaclorociclohexano }\end{array}$ & $319-84-6$ & \\
\hline$\beta$-HEXACLOROCICLOHEXANO & $\begin{array}{l}\text { Hexacloruro de trans- } \alpha \text {-benceno; } \beta \text {-isómero; } \\
\beta-1,2,3,4,5,6 \text {-hexaclorociclohexano; 1- } \alpha-2-\beta, 3-\alpha-4-\beta-\beta, 5-\alpha \\
-6-\beta-\text {-hexaclorociclohexano }\end{array}$ & $319-85-7$ & \\
\hline
\end{tabular}




\begin{tabular}{|c|c|c|c|}
\hline Producto químico & Sinónimos/ Código UN & $\mathrm{N}$ úmero CAS & Fórmula estructural \\
\hline$\delta$-HEXACLOROCICLOHEXANO & $\begin{array}{l}\delta-1,2,3,4,5,6 \text {-Hexaclorociclohexano; } 1-\alpha, 2-\alpha, 3-\alpha, 4-\beta, 5-\alpha, \\
\text { 6- } \beta \text {-hexaclorociclohexano; } \delta \text {-indano }\end{array}$ & $319-86-8$ & \\
\hline HEXACLOROETANO & $\begin{array}{l}\text { Hexacloruro de etano; hexacloruro de etileno; hexacloretano; } \\
\text { hexacloroetano; 1,1,1,2,2,2-hexacloroetano; percloroetano }\end{array}$ & $67-72-1$ & \\
\hline PENTACLOROETANO & $\begin{array}{l}\text { Pentacloruro de etano } \\
\text { UN1669 }\end{array}$ & $76-01-7$ & \\
\hline TETRABROMURO DE ACETLENO & $\begin{array}{l}\text { Líquido de Muthmann; TBE; tetrabromoacetileno; sim-tetrabromoetano; } \\
\text { 1,1,2,2-tetrabromoetano }\end{array}$ & $79-27-6$ & \\
\hline TETRABROMURO DE CARBONO & $\begin{array}{l}\text { Bromuro de carbono; tetrabromuro de metano; tetrabromometano } \\
\text { UN2516 }\end{array}$ & $558-13-4$ & \\
\hline TETRACLOROETANO & $\begin{array}{l}\text { Tetracloroetano } \\
\text { UN1702 }\end{array}$ & $25322-20-7$ & \\
\hline 1,1,1,2-TETRACLOROETANO & & $630-20-6$ & \\
\hline 1,1,2,2-TETRACLOROETANO & 1,1-Dicloro-2,2-dicloroetano; tetracloretano; 1,1,2,2-tetracloroetano & $79-34-5$ & \\
\hline TETRACLORURO DE CARBONO & $\begin{array}{l}\text { Bencinoformo; tetraclorocarbono; tetraclorometano } \\
\text { UN1846 }\end{array}$ & $56-23-5$ & \\
\hline 1,1,1-TRICLOROETANO & $\begin{array}{l}\text { Cloroeteno; metilcloroformo; metiltriclorometano; tricloroetano; } \\
\alpha \text {-tricloroetano; triclorometilmetano } \\
\text { UN2831 }\end{array}$ & $71-55-6$ & \\
\hline 1,1,2-TRICLOROETANO & Tricloruro de etano; tricloruro de vinilo & $79-00-5$ & \\
\hline 1,2,3-TRICLOROPROPANO & $\begin{array}{l}\text { Tricloruro de alilo; glicerol triclorohidrina; gliceril triclorohidrina; } \\
\text { triclorohidrina }\end{array}$ & $96-18-4$ & \\
\hline YODOFORMO & Triyodometano & $75-47-8$ & \\
\hline YODURO DE ETLLO & Eter yodhídrico; yodoetano & $75-03.6$ & \\
\hline YODURO DE METILO & $\begin{array}{l}\text { Yodometano } \\
\text { UN2644 }\end{array}$ & $74-88-4$ & \\
\hline
\end{tabular}




\begin{tabular}{|c|c|c|c|c|c|c|}
\hline \multirow[b]{2}{*}{$\begin{array}{l}\text { Denominación } \\
\text { química } \\
\text { N úmero CAS }\end{array}$} & \multicolumn{4}{|c|}{ Tarjetas Internacionales sobre la Seguridad de los Productos Q uímicos } & \multicolumn{2}{|c|}{ N IO SH (EE.UU.) } \\
\hline & $\begin{array}{l}\text { Período } \\
\text { corto de } \\
\text { exposición }\end{array}$ & $\begin{array}{l}\text { Período } \\
\text { largo de } \\
\text { exposición }\end{array}$ & $\begin{array}{l}\text { Vías de } \\
\text { exposición }\end{array}$ & Síntomas & $\begin{array}{l}\text { O rganos } \\
\text { afectados } \\
\text { Vías de } \\
\text { entrada }\end{array}$ & Síntomas \\
\hline $\begin{array}{l}\text { BROMOFORMO } \\
75-25-2\end{array}$ & $\begin{array}{l}\text { ojos; piel; } \\
\text { tract resp; puede } \\
\text { afectar al SNC; } \\
\text { hígado; riñones; } \\
\text { corazón; sangre }\end{array}$ & piel & $\begin{array}{l}\text { Inhalación } \\
\\
\\
\text { Piel } \\
\text { 0jos } \\
\text { Ingestión }\end{array}$ & $\begin{array}{l}\text { Enrojecimiento de la cara, salivación, } \\
\text { alteración de los movimientos, convulsiones, } \\
\text { tos, mareo, cefalea, dificultad respiratoria, } \\
\text { inconsciencia, pérdida de memoria, shock, los } \\
\text { síntomas pueden tardar en aparecer } \\
\text { Puede absorberse, enrojecimiento } \\
\text { Enrojecimiento, dolor } \\
\text { Sensación de quemazón }\end{array}$ & $\begin{array}{l}\text { Ojos; piel; hígado; } \\
\text { riñones; sis resp; } \\
\text { SNC } \\
\text { Inh; abs; ing; con }\end{array}$ & $\begin{array}{l}\text { Irrit ojos, piel, sis resp; depres } \\
\text { SNC; lesiones hepáticas y } \\
\text { renales }\end{array}$ \\
\hline $\begin{array}{l}\text { BROMURO DE ETLLO } \\
74.96-4\end{array}$ & & & & & $\begin{array}{l}\text { Piel; hígado; } \\
\text { riñones; sis resp; } \\
\text { SVC; SNC; ojos } \\
\text { Inh; ing; con }\end{array}$ & $\begin{array}{l}\text { Irrit ojos, piel, sis resp; depres } \\
\text { SNC; edema pulm; lesiones } \\
\text { hepáticas y renales; arrit card, } \\
\text { parada card }\end{array}$ \\
\hline $\begin{array}{l}\text { BROMURO DE METILO } \\
74-83.9\end{array}$ & $\begin{array}{l}\text { ojos; tract resp; } \\
\text { pulmones; puede } \\
\text { afectar al SNC }\end{array}$ & $\begin{array}{l}\text { piel; pulmones; } \\
\text { SNC; hígado; } \\
\text { riñones; cerebro }\end{array}$ & $\begin{array}{l}\text { Inhalación } \\
\text { Piel } \\
\text { 0jos }\end{array}$ & $\begin{array}{l}\text { Mareo, cefalea, dolor abdominal, dolor } \\
\text { torácico, vómitos, debilidad, alucinaciones, } \\
\text { pérdida del habla, descoordinación, dificultad } \\
\text { respiratoria, edema pulmonar, convulsiones } \\
\text { Puede absorberse, picores, hormigueo, } \\
\text { sensación de quemazón, enrojecimiento, } \\
\text { ampollas, dolor, en contacto con el líquido: } \\
\text { congelación } \\
\text { Enrojecimiento, dolor, visión borrosa, pérdida } \\
\text { temporal de la visión, ceguera durante } 12 \\
\text { horas }\end{array}$ & $\begin{array}{l}\text { SNC; sis resp; piel; } \\
\text { ojos [en animales: } \\
\text { tumores de pulmón, } \\
\text { riñón y cardias] } \\
\text { Inh; abs (líq); con } \\
\text { (líq) }\end{array}$ & $\begin{array}{l}\text { Irrit ojos, piel, sis resp; deb } \\
\text { musc, desco, dis vis, mar; náu, } \\
\text { vómit, cef; mal; temblor de las } \\
\text { manos; convul; disn; vesic en } \\
\text { la piel; líq: congelación; [carc] }\end{array}$ \\
\hline $\begin{array}{l}\text { CLOROBROMOMETANO } \\
74.97 .5\end{array}$ & $\begin{array}{l}\text { ojos; piel; } \\
\text { tract resp; SNC }\end{array}$ & riñones; hígado & $\begin{array}{r}\text { Inhalación } \\
\text { Piel } \\
\text { 0jos }\end{array}$ & $\begin{array}{l}\text { Confusión, mareo, sopor, cefalea, } \\
\text { inconsciencia } \\
\text { Sequedad de piel, enrojecimiento, aspereza } \\
\text { Enrojecimiento, dolor, visión borrosa }\end{array}$ & $\begin{array}{l}\text { Piel; hígado; } \\
\text { rinones; sis resp; } \\
\text { ojos; SNC } \\
\text { Inh; ing; con }\end{array}$ & $\begin{array}{l}\text { Irrit ojos, piel, garganta; conf, } \\
\text { mar, depres SNC; edema pulm }\end{array}$ \\
\hline $\begin{array}{l}\text { CLOROFORMIATO DE } \\
\text { ISOPROPILO } \\
\text { 108-23-6 }\end{array}$ & $\begin{array}{l}\text { ojos; piel; } \\
\text { tract resp; } \\
\text { pulmones }\end{array}$ & pulmones & & & & \\
\hline $\begin{array}{l}\text { CLOROFORMO } \\
67-66-3\end{array}$ & $\begin{array}{l}\text { ojos; piel; } \\
\text { tract resp; puede } \\
\text { afectar al SNC; } \\
\text { SCV; tract GI; } \\
\text { hígado; riñones }\end{array}$ & piel & $\begin{array}{r}\text { Inhalación } \\
\text { Piel } \\
\text { Ojos } \\
\text { Ingestión }\end{array}$ & $\begin{array}{l}\text { Tos, sopor, cefalea, náuseas } \\
\text { Puede absorberse, enrojecimiento, dolor } \\
\text { Enrojecimiento, dolor } \\
\text { Dolor abdominal, vómitos }\end{array}$ & $\begin{array}{l}\text { Hígado; riñones; } \\
\text { corazón; ojos; piel; } \\
\text { SNC [en animales: } \\
\text { cáncer de hígado y } \\
\text { riñón] } \\
\text { Inh; abs; ing; con }\end{array}$ & $\begin{array}{l}\text { Irrit ojos, piel; mar, embo } \\
\text { mental, náu, conf; cef, ftg; } \\
\text { anes; dilatación del higado; } \\
\text { [carc] }\end{array}$ \\
\hline $\begin{array}{l}\text { 2-CLORO-2-METILPROPANO } \\
507-20-0\end{array}$ & & & & & Ojos; piel; sis resp & \\
\hline $\begin{array}{l}\text { CLORURO DE ETILO } \\
75-00-3\end{array}$ & & & $\begin{array}{r}\text { Inhalación } \\
\text { Piel } \\
\text { 0jos }\end{array}$ & $\begin{array}{l}\text { Espasmos abdominales, mareo, } \\
\text { embotamiento, cefalea } \\
\text { Puede absorberse, en contacto con el líquido: } \\
\text { congelación } \\
\text { Enrojecimiento, dolor, visión borrosa }\end{array}$ & $\begin{array}{l}\text { Hígado; riñones; sis } \\
\text { resp; SVC } \\
\text { Inh; abs (líq); ing } \\
\text { (líq); con }\end{array}$ & $\begin{array}{l}\text { Desco, embri; espasmos } \\
\text { abdom; arrit card, parada } \\
\text { card; lesiones hepáticas y } \\
\text { renales }\end{array}$ \\
\hline
\end{tabular}

\begin{tabular}{ll}
\hline CLORURO DE ISOBUTILO & ojos; piel; \\
$513-36-0$ & tract resp; puede \\
& afectar al SNC
\end{tabular}


Tabla 104.94 - Riesgos para la salud.

\begin{tabular}{|c|c|c|c|c|c|c|}
\hline \multirow[b]{2}{*}{$\begin{array}{l}\text { Denominación } \\
\text { química } \\
\text { N úmero CAS }\end{array}$} & \multicolumn{4}{|c|}{ Tarjetas Internacionales sobre la Seguridad de los Productos Q uímicos } & \multicolumn{2}{|c|}{ N IO SH (EE.UU.) } \\
\hline & $\begin{array}{l}\text { Período } \\
\text { corto de } \\
\text { exposición }\end{array}$ & $\begin{array}{l}\text { Período } \\
\text { largo de } \\
\text { exposición }\end{array}$ & $\begin{array}{l}\text { Vías de } \\
\text { exposición }\end{array}$ & Síntomas & $\begin{array}{l}\text { O rganos } \\
\text { afectados } \\
\text { Vías de } \\
\text { entrada }\end{array}$ & Síntomas \\
\hline $\begin{array}{l}\text { CLORURO DE METILENO } \\
75-09-2\end{array}$ & $\begin{array}{l}\text { ojos; piel; } \\
\text { tract resp; } \\
\text { pulmones }\end{array}$ & $\begin{array}{l}\text { piel; SNC; hígado; } \\
\text { cerebro }\end{array}$ & $\begin{array}{r}\text { Inhalación } \\
\text { Piel } \\
\text { 0jos } \\
\text { Ingestión }\end{array}$ & $\begin{array}{l}\text { Mareo, sopor, cefalea, náuseas, inconsciencia, } \\
\text { debilidad, muerte } \\
\text { Sequedad, enrojecimiento, sensación de } \\
\text { quemazón } \\
\text { Enrojecimiento, dolor, quemaduras profundas } \\
\text { graves } \\
\text { Dolor abdominal }\end{array}$ & $\begin{array}{l}\text { piel; SVC; ojos; SNC } \\
\text { [en animales: } \\
\text { tumores de pulmón, } \\
\text { hígado y glándulas } \\
\text { salivales y } \\
\text { mamarias] } \\
\text { Inh; abs; ing; con }\end{array}$ & $\begin{array}{l}\text { Irrit ojos, piel; ftg, deb, somn, } \\
\text { atur, hormigueo y entu de los } \\
\text { miembros; náu; [carc] }\end{array}$ \\
\hline $\begin{array}{l}\text { CLORURO DE METILO } \\
74-87-3\end{array}$ & $\begin{array}{l}\text { SNC: lesiones } \\
\text { cerebrales; hígado; } \\
\text { riñones; médula } \\
\text { ósea }\end{array}$ & & $\begin{array}{l}\text { Inhalación } \\
\\
\text { Piel }\end{array}$ & $\begin{array}{l}\text { Confusión, diarrea, mareo, cefalea, marcha } \\
\text { bamboleante, náuseas, inconsciencia, vómitos, } \\
\text { convulsiones e insuficiencia respiratoria } \\
\text { Puede absorberse, en contacto con el líquido: } \\
\text { congelación }\end{array}$ & $\begin{array}{l}\text { SNC; hígado; } \\
\text { riñones; sis repro } \\
\text { [en animales: } \\
\text { tumores de pulmón, } \\
\text { riñón y cardias] } \\
\text { Inh; con (líq.) }\end{array}$ & $\begin{array}{l}\text { Mar, náu, vómit; dis vis, habla } \\
\text { tibuteante, convul, coma; } \\
\text { lesiones hepáticas y renales; } \\
\text { líq: congelación; efectos repro, } \\
\text { terato; [carc] }\end{array}$ \\
\hline $\begin{array}{l}\text { 1,2-DIBROMO3-CLORO- } \\
\text { PROPANO } \\
96-12-8\end{array}$ & $\begin{array}{l}\text { ojos; piel; } \\
\text { tract resp; } \\
\text { pulmones; hígado; } \\
\text { riñones }\end{array}$ & hígado; riñones & $\begin{array}{l}\text { Inhalación } \\
\\
\text { Piel } \\
\text { 0jos } \\
\text { Ingestión }\end{array}$ & $\begin{array}{l}\text { Extremadamente irritante, sensación de } \\
\text { quemazón, tos, cefalea, disnea, dolor de } \\
\text { garganta, debilidad } \\
\text { Puede absorberse, enrojecimiento } \\
\text { Enrojecimiento, dolor, visión borrosa } \\
\text { Sensación de quemazón, náuseas, dolor de } \\
\text { garganta, vómitos }\end{array}$ & $\begin{array}{l}\text { SNC; piel; hígado; } \\
\text { riñones; bazo; sis } \\
\text { repro; tract GI; sis } \\
\text { resp; sis digestivo } \\
\text { [en animales: } \\
\text { cáncer de cavidad } \\
\text { nasal, lengua, } \\
\text { faringe, pulmones, } \\
\text { estómago, } \\
\text { glandulas } \\
\text { suprarrenales y } \\
\text { mamarias] } \\
\text { Inh; abs; ing; con }\end{array}$ & $\begin{array}{l}\text { Irrit ojos, piel, nariz, garganta; } \\
\text { sop; náu, vómi; edema pulm; } \\
\text { lesiones hepáticas y renales; } \\
\text { esterilidad; [carc] }\end{array}$ \\
\hline
\end{tabular}

\begin{tabular}{|c|c|c|c|c|c|c|}
\hline $\begin{array}{l}\text { DIBROMOETANO } \\
74-95-3\end{array}$ & $\begin{array}{l}\text { ojos; piel; } \\
\text { tract resp; puede } \\
\text { afectar al SNC; } \\
\text { riñones; hígado }\end{array}$ & piel & $\begin{array}{l}\text { Inhalación } \\
\text { Piel } \\
\text { Ojos } \\
\text { Ingestión }\end{array}$ & $\begin{array}{l}\text { Mareo, insuficiencia respiratoria, náuseas, } \\
\text { cefalea, vómitos, narcosis, diarrea, } \\
\text { embotamiento } \\
\text { Puede absorberse, sequedad de piel, } \\
\text { Enrojecimiento } \\
\text { Irritación gastrointestinal }\end{array}$ & & \\
\hline $\begin{array}{l}\text { 1,2-DIBROMOETANO } \\
106-93-4\end{array}$ & $\begin{array}{l}\text { ojos; piel; tract } \\
\text { resp; SNC }\end{array}$ & $\begin{array}{l}\text { pulmones; hígado; } \\
\text { riñones; } \\
\text { carcinógeno para } \\
\text { humanos; } \\
\text { reproducción } \\
\text { humana }\end{array}$ & $\begin{array}{r}\text { Inhalación } \\
\text { Piel } \\
\text { 0jos } \\
\text { Ingestión }\end{array}$ & $\begin{array}{l}\text { Sensación de quemazón, tos, dificultad } \\
\text { respiratoria, disnea, inconsciencia } \\
\text { Puede absorberse, dolor, enrojecimiento, } \\
\text { ampollas } \\
\text { Dolor, enrojecimiento, quemaduras profundas } \\
\text { graves } \\
\text { Espasmos abdominales, confusión, diarrea, } \\
\text { cefalea (véase también Inhalación) }\end{array}$ & $\begin{array}{l}\text { Sis resp; hígado; } \\
\text { riñones; piel; ojos; } \\
\text { sis repro [ en } \\
\text { animales: tumores } \\
\text { cutáneos y } \\
\text { pulmonares] } \\
\text { Inh; abs; ing; con }\end{array}$ & $\begin{array}{l}\text { Irrit ojos, piel, sis resp; derm } \\
\text { con vesic; lesiones en hígado, } \\
\text { corazón, bazo y riñones; } \\
\text { efectos repro; [carc] }\end{array}$ \\
\hline $\begin{array}{l}\text { DIBROMURO DE ETILENO } \\
\text { 106-93-4 }\end{array}$ & $\begin{array}{l}\text { ojos; piel; } \\
\text { tract resp; SNC }\end{array}$ & $\begin{array}{l}\text { pulmones; hígado; } \\
\text { riñones; sistema } \\
\text { reproductivo }\end{array}$ & $\begin{array}{r}\text { Inhalación } \\
\text { Piel } \\
\text { Ojos } \\
\text { Ingestión }\end{array}$ & $\begin{array}{l}\text { Sensación de quemazón, tos, dificultad } \\
\text { respiratoria, disnea, inconsciencia } \\
\text { Puede absorberse, dolor, enrojecimiento, } \\
\text { ampollas } \\
\text { Dolor, enrojecimiento, quemaduras profundas y } \\
\text { graves } \\
\text { Espasmos abdominales, confusión, diarrea, } \\
\text { cefalea }\end{array}$ & $\begin{array}{l}\text { Sis resp; hígado; } \\
\text { riñones; piel; ojos; } \\
\text { sis repro [en } \\
\text { animales: tumores } \\
\text { de piel y de } \\
\text { pulmón] } \\
\text { Inh; abs; ing; con }\end{array}$ & $\begin{array}{l}\text { Irrit ojos, piel, sis resp; derm } \\
\text { con vesic; lesiones en hígado, } \\
\text { corazón, bazo y riñones; } \\
\text { efectos repro; [ carc] }\end{array}$ \\
\hline $\begin{array}{l}\text { 1,1-DICLOROETANO } \\
\text { 75-34-3 }\end{array}$ & $\begin{array}{l}\text { ojos; tract resp; } \\
\text { SNC }\end{array}$ & $\begin{array}{l}\text { piel; hígado; } \\
\text { riñones }\end{array}$ & $\begin{array}{r}\text { Inhalación } \\
\text { Piel } \\
\text { Ojos } \\
\text { Ingestión }\end{array}$ & $\begin{array}{l}\text { Mareo, sopor, embotamiento, náuseas, } \\
\text { inconsciencia } \\
\text { Sequedad de piel, aspereza } \\
\text { Enrojecimiento, dolor } \\
\text { Sensación de quemazón }\end{array}$ & $\begin{array}{l}\text { Piel; hígado; } \\
\text { riñones; pulmones; } \\
\text { SNC } \\
\text { Inh; ing; con }\end{array}$ & $\begin{array}{l}\text { Irrit piel; depres SNC; lesiones } \\
\text { hepáticas, renales y } \\
\text { pulmonares }\end{array}$ \\
\hline
\end{tabular}




\begin{tabular}{|c|c|c|c|c|c|c|}
\hline \multirow[b]{2}{*}{$\begin{array}{l}\text { Denominación } \\
\text { química } \\
\text { N úmero CAS }\end{array}$} & \multicolumn{4}{|c|}{ Tarjetas Internacionales sobre la Seguridad de los Productos Q uímicos } & \multicolumn{2}{|c|}{ N IO SH (EE.UU.) } \\
\hline & $\begin{array}{l}\text { Período } \\
\text { corto de } \\
\text { exposición }\end{array}$ & $\begin{array}{l}\text { Período } \\
\text { largo de } \\
\text { exposición }\end{array}$ & $\begin{array}{l}\text { Vías de } \\
\text { exposición }\end{array}$ & Síntomas & $\begin{array}{l}\text { O rganos } \\
\text { afectados } \\
\text { Vías de } \\
\text { entrada }\end{array}$ & Síntomas \\
\hline $\begin{array}{l}\text { 1,1-DICLOROPROPANO } \\
\text { 78-99.9 }\end{array}$ & $\begin{array}{l}\text { el aerosol irrita los } \\
\text { ojos y la piel }\end{array}$ & & Piel & Enrojecimiento, dolor & & \\
\hline $\begin{array}{l}\text { 1,2-DICLOROPROPANO } \\
\text { 78-87-5 }\end{array}$ & $\begin{array}{l}\text { ojos; piel; tract } \\
\text { resp; sistema } \\
\text { nervioso }\end{array}$ & $\begin{array}{l}\text { dermatitis; hígado; } \\
\text { sangre; } \\
\text { malformaciones } \\
\text { congénitas }\end{array}$ & $\begin{array}{r}\text { Inhalación } \\
\text { Piel } \\
\text { 0jos } \\
\text { Ingestión }\end{array}$ & $\begin{array}{l}\text { Anorexia, diarrea, sopor, cefalea, dolor de } \\
\text { garganta } \\
\text { Sequedad, enrojecimiento, dolor } \\
\text { Enrojecimiento, dolor } \\
\text { Dolor abdominal, diarrea, sopor, cefalea, } \\
\text { náuseas, vómitos }\end{array}$ & $\begin{array}{l}\text { Ojos; piel; sis resp; } \\
\text { hígado; riñones; } \\
\text { SNC [en animales: } \\
\text { tumores en el } \\
\text { hígado y en las } \\
\text { glándulas } \\
\text { mamarias] } \\
\text { Inh; abs; ing; con }\end{array}$ & $\begin{array}{l}\text { Irrit ojos, piel, sis resp; mar, } \\
\text { atur; lesiones hepáticas y } \\
\text { renales; en animales: depres } \\
\text { SNC; [carc] }\end{array}$ \\
\hline $\begin{array}{l}\text { 1,3-DICLOROPROPANO } \\
\text { 142-28-9 }\end{array}$ & $\begin{array}{l}\text { ojos; piel; } \\
\text { tract resp; } \\
\text { pulmones; puede } \\
\text { afectar a la sangre; } \\
\text { SNC; hígado }\end{array}$ & piel & Piel & Enrojecimiento, dolor & & \\
\hline $\begin{array}{l}\text { DICLORURO DE ETILENO } \\
107-06-2\end{array}$ & & & & & $\begin{array}{l}\text { Riñones; hígado; } \\
\text { ojos; piel; } \\
\text { SNC; SVC [en } \\
\text { animales: cáncer de } \\
\text { cardias, glándulas } \\
\text { mamarias y sis } \\
\text { circulatorio] } \\
\text { Inh; abs; ing; con }\end{array}$ & $\begin{array}{l}\text { Irrit ojos, opac córn; depres } \\
\text { SNC; náu, vómit; derm; } \\
\text { lesiones hepáticas, renales y } \\
\text { del SVC; [ carc] }\end{array}$ \\
\hline $\begin{array}{l}\text { HEXACLOROCICLOHEXANO } \\
608-73-1\end{array}$ & $\begin{array}{l}\text { ojos; piel; } \\
\text { tract resp; puede } \\
\text { afectar al SNC }\end{array}$ & $\begin{array}{l}\text { piel; SNC; médula } \\
\text { ósea; hígado; } \\
\text { hormonas sexuales; } \\
\text { genitales }\end{array}$ & $\begin{array}{r}\text { Inhalación } \\
\text { Piel } \\
\text { 0jos } \\
\text { Ingestión }\end{array}$ & $\begin{array}{l}\text { Confusión, mareo, cefalea, vómitos, debilidad, } \\
\text { irritabilidad, temblores, parestesia } \\
\text { Puede absorberse, enrojecimiento } \\
\text { Enrojecimiento } \\
\text { Mareo, sopor, dificultad respiratoria, vómitos, } \\
\text { temblores, espasmos musculares, } \\
\text { convulsiones, depresión }\end{array}$ & & \\
\hline $\begin{array}{l}\alpha \text {-HEXACLOROCICLOHEXANO } \\
319-84-6\end{array}$ & $\begin{array}{l}\text { ojos; piel; } \\
\text { tract resp; SNC }\end{array}$ & sangre; hígado & $\begin{array}{r}\text { Inhalación } \\
\text { Piel } \\
\text { 0jos } \\
\text { Ingestión }\end{array}$ & $\begin{array}{l}\text { Debilidad, temblores } \\
\text { Puede absorberse, enrojecimiento } \\
\text { Enrojecimiento } \\
\text { Diarrea, mareo, cefalea, náuseas, vómitos }\end{array}$ & & \\
\hline $\begin{array}{l}\beta \text {-HEXACLOROCICLOHEXANO } \\
319-85-7\end{array}$ & $\begin{array}{l}\text { ojos; piel; } \\
\text { tract resp; SNC }\end{array}$ & $\begin{array}{l}\text { sangre; hígado; } \\
\text { riñones }\end{array}$ & $\begin{array}{r}\text { Inhalación } \\
\text { Piel } \\
\text { 0jos } \\
\text { Ingestión } \\
\end{array}$ & $\begin{array}{l}\text { Debilidad, temblores, convulsiones } \\
\text { Puede absorberse, enrojecimiento } \\
\text { Enrojecimiento } \\
\text { Diarrea, mareo, cefalea, náuseas, vómitos }\end{array}$ & & \\
\hline $\begin{array}{l}\text { HEXACLOROETANO } \\
67-72 \cdot 1\end{array}$ & SNC & $\begin{array}{l}\text { hígado; riñones; } \\
\text { SNC }\end{array}$ & Piel & Puede absorberse & $\begin{array}{l}\text { Ojos; piel; sis resp; } \\
\text { riñones [en } \\
\text { animales: cáncer de } \\
\text { hígado] } \\
\text { Inh; abs; ing; con }\end{array}$ & $\begin{array}{l}\text { Irrit ojos, piel, muc; en } \\
\text { animales: lesiones hepáticas; } \\
\text { [carc] }\end{array}$ \\
\hline $\begin{array}{l}\text { TETRABROMURO DE CARBONO } \\
558-13-4\end{array}$ & $\begin{array}{l}\text { ojos; piel; } \\
\text { tract resp; SNC; } \\
\text { hígado; riñones }\end{array}$ & hígado & $\begin{array}{r}\text { Piel } \\
\text { Ojos } \\
\text { Ingestión }\end{array}$ & $\begin{array}{l}\text { Dolor de garganta, tos, dificultad respiratoria, } \\
\text { embotamiento, sopor, los síntomas pueden } \\
\text { tardar en aparecer } \\
\text { Enrojecimiento, dolor, quemaduras graves en } \\
\text { la piel } \\
\text { Enrojecimiento, dolor, visión borrosa } \\
\text { Dolor de garganta, dolor abdominal, diarrea, } \\
\text { embotamiento }\end{array}$ & $\begin{array}{l}\text { Ojos; piel; sis resp; } \\
\text { riñones; hígado } \\
\text { Inh; ing; con }\end{array}$ & $\begin{array}{l}\text { Irrit ojos, piel, sis resp; lag; } \\
\text { lesiones pulmonares, hepáticas } \\
\text { y renales; en animales: daños } \\
\text { en la córnea }\end{array}$ \\
\hline
\end{tabular}


Tabla 104.94 • Riesgos para la salud.

\begin{tabular}{|c|c|c|c|c|c|c|}
\hline \multirow[b]{2}{*}{$\begin{array}{l}\text { Denominación } \\
\text { química } \\
\mathrm{N} \text { úmero CAS }\end{array}$} & \multicolumn{4}{|c|}{ Tarjetas Internacionales sobre la Seguridad de los Productos Q uímicos } & \multicolumn{2}{|c|}{ N IO SH (EE.UU.) } \\
\hline & $\begin{array}{l}\text { Período } \\
\text { corto de } \\
\text { exposición }\end{array}$ & $\begin{array}{l}\text { Período } \\
\text { largo de } \\
\text { exposición }\end{array}$ & $\begin{array}{l}\text { Vías de } \\
\text { exposición }\end{array}$ & Síntomas & $\begin{array}{l}\text { O rganos } \\
\text { afectados } \\
\text { Vías de } \\
\text { entrada }\end{array}$ & Síntomas \\
\hline $\begin{array}{l}\text { 1,1,2,2-TETRACLOROETANO } \\
79-34-5\end{array}$ & ojos; piel; tract resp & $\begin{array}{l}\text { piel; hígado; } \\
\text { riñones; SNC }\end{array}$ & & & $\begin{array}{l}\text { Piel; hígado; } \\
\text { riñones; SNC; tract } \\
\text { GI [en animales: } \\
\text { tumores hepáticos] } \\
\text { Inh; abs; ing; con }\end{array}$ & $\begin{array}{l}\text { Náu, vómi, dolor abdom; } \\
\text { temblor de dedos; ict, } \\
\text { hepatitis, sens dol del hígado; } \\
\text { derm; monoci; lesiones } \\
\text { hepáticas; [carc] }\end{array}$ \\
\hline $\begin{array}{l}\text { TETRACLORURO DE CARBONO } \\
56-23.5\end{array}$ & $\begin{array}{l}\text { ojos; SNC; hígado; } \\
\text { riñones }\end{array}$ & piel; SNC & $\begin{array}{r}\text { Inhalación } \\
\text { Piel } \\
\text { Ojos } \\
\text { Ingestión }\end{array}$ & $\begin{array}{l}\text { Mareo, sopor, cefalea, náuseas } \\
\text { Puede absorberse, enrojecimiento, dolor } \\
\text { Enrojecimiento, dolor } \\
\text { Dolor abdominal, diarrea }\end{array}$ & $\begin{array}{l}\text { SNC; ojos; } \\
\text { pulmones; hígado; } \\
\text { riñones; piel [en } \\
\text { animales: cáncer de } \\
\text { hígado] } \\
\text { Inh; abs; ing; con }\end{array}$ & $\begin{array}{l}\text { Irrit ojos, piel; depres SNC; } \\
\text { náu, vómit; lesiones hepáticas } \\
\text { y renales; sop, mar, desco; } \\
\text { [carc] }\end{array}$ \\
\hline $\begin{array}{l}\text { 1,1,1-TRICLOROETANO } \\
\text { 71-55-6 }\end{array}$ & $\begin{array}{l}\text { ojos; piel; } \\
\text { tract resp; la } \\
\text { inhalación puede } \\
\text { provocar disnea; } \\
\text { puede afectar al } \\
\text { SNC; hígado; } \\
\text { riñones }\end{array}$ & $\begin{array}{l}\text { piel; hígado; } \\
\text { riñones }\end{array}$ & & & $\begin{array}{l}\text { Piel; SVC; SNC; } \\
\text { ojos; hígado } \\
\text { Inh; ing; con }\end{array}$ & $\begin{array}{l}\text { Irrit ojos, piel; cef, las, depres } \\
\text { SNC, equi defic; derm; arrit } \\
\text { card; lesiones hepáticas }\end{array}$ \\
\hline $\begin{array}{l}\text { 1,1,2-TRICLOROETANO } \\
\text { 79-00-5 }\end{array}$ & $\begin{array}{l}\text { ojos; piel; } \\
\text { tract resp; puede } \\
\text { afectar al SNC; } \\
\text { hígado; riñones }\end{array}$ & skin & & & $\begin{array}{l}\text { SNC; ojos; nariz; } \\
\text { hígado; riñones } \\
\text { Inh; abs; ing; con }\end{array}$ & $\begin{array}{l}\text { Irrit ojos, nariz; depres SNC; } \\
\text { lesiones hepáticas y renales; } \\
\text { derm; [ } \text { carc] }\end{array}$ \\
\hline $\begin{array}{l}\text { 1,2,3-TRICLOROPROPANO } \\
\text { 96-18-4 }\end{array}$ & $\begin{array}{l}\text { ojos; piel; } \\
\text { tract resp; puede } \\
\text { afectar al hígado }\end{array}$ & & $\begin{array}{r}\text { Inhalación } \\
\text { Piel } \\
\text { 0jos }\end{array}$ & $\begin{array}{l}\text { Cefalea, inconsciencia } \\
\text { Enrojecimiento } \\
\text { Enrojecimiento }\end{array}$ & $\begin{array}{l}\text { Ojos; sis resp; piel; } \\
\text { SNC; hígado; } \\
\text { riñones [en } \\
\text { animales: cáncer de } \\
\text { cardias, hígado y } \\
\text { glándulas } \\
\text { mamarias] } \\
\text { Inh; abs; ing; con }\end{array}$ & $\begin{array}{l}\text { Irrit ojos, nariz, garganta; } \\
\text { depres SNC; en animales: } \\
\text { lesiones hepáticas y renales; } \\
\text { [carc] }\end{array}$ \\
\hline
\end{tabular}

\begin{tabular}{|c|c|c|c|c|}
\hline $\begin{array}{l}\text { YODURO DE ETLLO } \\
75.03 .6\end{array}$ & $\begin{array}{l}\text { ojos; piel; } \\
\text { tract resp; } \\
\text { pulmones; SNC; } \\
\text { riñones; tiroides; } \\
\text { hígado }\end{array}$ & $\begin{array}{l}\text { Inhalación } \\
\text { Piel } \\
\text { 0jos }\end{array}$ & $\begin{array}{l}\text { Sabor desagradable, confusión, tos, sopor, } \\
\text { disnea, inconsciencia, dolor en las } \\
\text { extremidades } \\
\text { Puede absorberse, quemaduras en la } \\
\text { piel,ampollas } \\
\text { El vapor se absorbe, quemaduras profundas } \\
\text { graves }\end{array}$ & \\
\hline $\begin{array}{l}\text { YODURO DE METILO } \\
74-88-4\end{array}$ & & & & $\begin{array}{l}\text { SNC; piel; ojos; sis Irrit ojos, piel, sis resp; náu, } \\
\text { repro [en animales: vómit; mar, ataxia; habla } \\
\text { tumores de pulmón, titubeante, sop; derm; [carc] } \\
\text { riñón y cardias] } \\
\text { Inh; abs; ing; con }\end{array}$ \\
\hline
\end{tabular}




\begin{tabular}{|c|c|c|c|}
\hline $\begin{array}{l}\text { Denominación química } \\
\text { N úmero CAS }\end{array}$ & Físicos & Q uímicos & $\begin{array}{l}\text { Clase o división } \\
\text { UN / Riesgos } \\
\text { subsidiarios }\end{array}$ \\
\hline $\begin{array}{l}\text { BROMOFORMO } \\
75-25-2\end{array}$ & & $\begin{array}{l}\text { - Se descompone al calentarse, produciendo vapores tóxicos y corrosivos como bromuro de } \\
\text { hidrógeno y bromo } \bullet \text { Es un ácido fuerte, reacciona violentamente con bases y es corrosivo para la } \\
\text { mayoría de los metales } \bullet \text { Es un ácido de fuerza intermedia } \bullet \text { Es un ácido débil • Reacciona } \\
\text { violentamente con oxidantes y bases en forma de polvo y es corrosivo para la mayoría de los } \\
\text { metales } \bullet \text { Reacciona con metales alcalinos, aluminio, zinc y magnesio en polvo y acetona en } \\
\text { condiciones básicas, con peligro de incendio y explosión • Ataca algunos tipos de plástico, caucho } \\
\text { y revestimientos } \bullet \text { Incompatible con sodio, potasio, calcio, aluminio en polvo, zinc, magnesio, } \\
\text { cáusticos fuertes, aleación de potasio sódico, acetona e hidróxido potásico }\end{array}$ & 6.1 \\
\hline $\begin{array}{l}\text { BROMURO DE METILO } \\
74.83-9\end{array}$ & $\begin{array}{l}\text { - El gas es más pesado } \\
\text { que el aire, y puede } \\
\text { desplazarse a ras del } \\
\text { suelo; posibilidad de } \\
\text { ignición a distancia }\end{array}$ & - Al calentarse, desprende vapores tóxicos $\bullet$ Reacciona con oxidantes fuertes, aluminio y caucho & 2.3 \\
\hline $\begin{array}{l}\text { CLOROBROMOMETANO } \\
74-97.5\end{array}$ & & $\begin{array}{l}\text { - Se descompone al calentarse, produciendo cloruro de hidrógeno, cloro, fosgeno, bromuro de } \\
\text { hidrógeno } \bullet \text { Reacciona con oxidantes } \bullet \text { Reacciona con acero, aluminio, magnesio y zinc, salvo } \\
\text { que se inhiba }\end{array}$ & 6.1 \\
\hline $\begin{array}{l}\text { 1-CLORO-3-BROMOPROPANO } \\
109-70-6\end{array}$ & & & 6.1 \\
\hline $\begin{array}{l}\text { 1-CLOROBUTANO } \\
\text { 109-69-3 }\end{array}$ & & & 3 \\
\hline $\begin{array}{l}\text { CLOROFORMIATO DE ISOPROPILO } \\
108-23-6\end{array}$ & & & $6.1 / 3 / 8$ \\
\hline $\begin{array}{l}\text { CLOROFORMO } \\
67.66-3\end{array}$ & $\begin{array}{l}\text { - El vapor es más pesado } \\
\text { que el aire }\end{array}$ & $\begin{array}{l}\text { - En contacto con superficies calientes o llamas, se descompone y forma vapores tóxicos e } \\
\text { irritantes (cloruro de hidrógeno; fosgeno; cloro) } \bullet \text { Se descompone lentamente por efecto del aire } \\
\text { y de la luz } \bullet \text { Reacciona violentamente con bases fuertes, oxidantes fuertes y algunos metales, } \\
\text { como aluminio, litio, magnesio, potasio, sodio y acetona, con peligro de incendio y explosión } \\
\text { - Ataca el plástico, el caucho y los revestimientos }\end{array}$ & 6.1 \\
\hline $\begin{array}{l}\text { 2-CLOROPROPANO } \\
75-29-6 \\
\end{array}$ & & & 3 \\
\hline $\begin{array}{l}\text { CLORURO DE ETILO } \\
\text { 75-00-3 }\end{array}$ & $\begin{array}{l}\text { - El gas es más pesado } \\
\text { que el aire y puede } \\
\text { desplazarse a ras del } \\
\text { suelo; posibilidad de } \\
\text { ignición a distancia }\end{array}$ & $\begin{array}{l}\text { - Se descompone al calentarse o al arder, produciendo gases tóxicos (cloruro de hidrógeno) } \\
\text { - Reacciona violentamente con oxidantes, metales alcalinos, calcio, magnesio, polvo de aluminio } \\
\text { y zinc } \bullet \text { Reacciona con agua o vapor, liberando vapores corrosivos de cloruro de hidrógeno }\end{array}$ & 2.1 \\
\hline $\begin{array}{l}\text { CLORURO DE METILENO } \\
75-09-2\end{array}$ & $\begin{array}{l}- \text { El vapor es más pesado } \\
\text { que el aire } \bullet \text { Pueden } \\
\text { generarse cargas } \\
\text { electrostáticas como } \\
\text { consecuencia de flujo, } \\
\text { agitación, etc. }\end{array}$ & $\begin{array}{l}\text { - En contacto con superficies calientes o llamas, se descompone y forma vapores tóxicos y } \\
\text { corrosivos • Reacciona violentamente con metales como aluminio, magnesio, sodio, potasio y } \\
\text { litio, bases y oxidantes fuertes, con peligro de incendio y explosión • Ataca algunos tipos de } \\
\text { plásticos, caucho y revestimientos }\end{array}$ & 6.1 \\
\hline $\begin{array}{l}\text { CLORURO DE METILO } \\
74-87-3\end{array}$ & $\begin{array}{l}\text { - El gas es más pesado } \\
\text { que el aire y puede } \\
\text { desplazarse a ras del } \\
\text { suelo; posibilidad de } \\
\text { ignición a distancia }\end{array}$ & $\begin{array}{l}\text { - Se descompone al arder formando cloruro de hidrógeno y fosgeno y en contacto con materias } \\
\text { oxidantes, amidas, aminas y aluminio, produciendo cloruro de hidrógeno y fosgeno } \bullet \text { Es un } \\
\text { oxidante fuerte y reacciona con materiales combustibles y reductores } \bullet \text { Es un agente reductor } \\
\text { fuerte y reacciona con oxidantes }\end{array}$ & 2.1 \\
\hline $\begin{array}{l}\text { 1,2-3-DIBROMOCLOROPROPANO } \\
96-12-8\end{array}$ & $\begin{array}{l}\text { - El vapor es más pesado } \\
\text { que el aire y puede } \\
\text { desplazarse a ras del } \\
\text { suelo; posibilidad de } \\
\text { ignición a distancia }\end{array}$ & $\begin{array}{l}\text { - Se descompone al calentarse por encima del punto de ebullición y al arder, produciendo } \\
\text { vapores tóxicos (bromuro de hidrógeno, cloruro de hidrógeno, monóxido de carbono) } \bullet \text { Reacciona } \\
\text { con aluminio, magnesio, estaño y sus aleaciones en presencia de agua } \bullet \text { Reacciona en contacto } \\
\text { con álcali, produciendo alcohol 2-bromoalílico • Ataca algunos tipos de caucho y revestimientos }\end{array}$ & 6.1 \\
\hline $\begin{array}{l}\text { DIBROMOETANO } \\
74-95-3\end{array}$ & $\begin{array}{l}\text { - El vapor es más pesado } \\
\text { que el aire }\end{array}$ & $\begin{array}{l}\text { - En contacto con superficies calientes o llamas, se descompone y forma vapores irritantes } \\
\text { (bromuro de hidrógeno) - Se descompone al calentarse, produciendo vapores irritantes (bromuro } \\
\text { de hidrógeno) }\end{array}$ & 6.1 \\
\hline
\end{tabular}




\section{Tabla 104.95 • Riesgos físicos y químicos.}

\begin{tabular}{|c|c|c|c|}
\hline $\begin{array}{l}\text { Denominación química } \\
\text { N úmero CAS }\end{array}$ & Físicos & Q uímicos & $\begin{array}{l}\text { Clase o división } \\
\text { UN / Riesgos } \\
\text { subsidiarios }\end{array}$ \\
\hline $\begin{array}{l}\text { DIBROMURO DE ETILENO } \\
106-93-4\end{array}$ & & & 6.1 \\
\hline $\begin{array}{l}\text { 1,1-DICLOROETANO } \\
\text { 75-34-3 }\end{array}$ & $\begin{array}{l}\text { - El vapor es más pesado } \\
\text { que el aire y puede } \\
\text { desplazarse a ras del } \\
\text { suelo; posibilidad de } \\
\text { ignición a distancia }\end{array}$ & $\begin{array}{l}\text { - Se descompone al calentarse y al arder, liberando vapores tóxicos y corrosivos, entre ellos } \\
\text { fosgeno y cloruro de hidrógeno } \bullet \text { Reacciona violentamente con oxidantes fuertes, metales } \\
\text { alcalinos y metales de álcalis terrosos y metales en polvo, con peligro de incendio y explosión } \\
\text { - Ataca el aluminio, el hierro y el polietileno • En contacto con un cáustico fuerte, forma gas } \\
\text { acetaldehído tóxico e inflamable }\end{array}$ & 3 \\
\hline $\begin{array}{l}\text { 1,1-DICLOROPROPANO } \\
\text { 78-99-9 }\end{array}$ & $\begin{array}{l}\text { - El vapor es más pesado } \\
\text { que el aire y puede } \\
\text { desplazarse a ras del } \\
\text { suelo; posibilidad de } \\
\text { ignición a distancia }\end{array}$ & $\begin{array}{l}\text { - Se descompone al calentarse, produciendo el cloruro de hidrógeno } \bullet \text { Reacciona con oxidantes } \\
\text { fuertes y bases fuertes }\end{array}$ & \\
\hline $\begin{array}{l}\text { 1,2-DICLOROPROPANO } \\
\text { 78-87-5 }\end{array}$ & $\begin{array}{l}\text { - El vapor es más pesado } \\
\text { que el aire y puede } \\
\text { desplazarse a ras del } \\
\text { suelo; posibilidad de } \\
\text { ignición a distancia }\end{array}$ & $\begin{array}{l}\text { - En su combustión libera gases y vapores tóxicos y corrosivos (cloruro de hidrógeno y fosgeno) } \\
\text { - Reacciona violentamente con oxidantes fuertes, ácidos y bases, con peligro de incendio y } \\
\text { explosión • Es corrosivo para aleaciones de aluminio }\end{array}$ & 3 \\
\hline $\begin{array}{l}\text { 1,3-DICLOROPROPANO } \\
142-28-9\end{array}$ & $\begin{array}{l}\text { - El vapor es más pesado } \\
\text { que el aire y puede } \\
\text { desplazarse a ras del } \\
\text { suelo; posibilidad de } \\
\text { ignición a distancia }\end{array}$ & $\begin{array}{l}\text { - Se descompone al calentarse, produciendo cloruro de hidrógeno y fosgeno } \bullet \text { Reacciona con } \\
\text { oxidantes, ácidos, bases y alúmina }\end{array}$ & \\
\hline
\end{tabular}

DICLORURO DE ETILENO

107-06-2
HEPTACLOR

- Se descompone al calentarse, liberando vapores tóxicos de cloro y cloruro de hidrógeno

HEXACLOROCICLOHEXANO

- Reacciona con oxidantes fuertes

608-73-1

- Se descompone al calentarse 0 al arder, liberando vapores altamente tóxicos (fosgeno, cloro y cloruro de hidrógeno), y en contacto con álcalis • Deshidrocloración a temperatura ambiente; deshidrocloración cuando se calienta, produciendo pentaclorociclohexano y triclorobencenos

\begin{tabular}{|c|c|c|c|}
\hline $\begin{array}{l}\text { a-HEXACLOROCICLOHEXANO } \\
319-84-6\end{array}$ & & $\begin{array}{l}\text { - Se descompone al calentarse } 0 \text { al arder, liberando vapores tóxicos (fosgeno, cloruro de } \\
\text { hidrógeno) • Reacciona violentamente con dimetilformamida en presencia de hierro }\end{array}$ & \\
\hline $\begin{array}{l}\beta \text {-HEXACLOROCICLOHEXANO } \\
319-85-7\end{array}$ & & $\begin{array}{l}\text { - Se descompone al calentarse } 0 \text { al arder, liberando vapores tóxicos (fosgeno, cloruro de } \\
\text { hidrógeno) }\end{array}$ & \\
\hline $\begin{array}{l}\text { HEXACLOROETANO } \\
67-72 \cdot 1\end{array}$ & & $\begin{array}{l}\text { - Se descompone al calentarse por encima de } 300^{\circ} \mathrm{C} \text {, produciendo vapores tóxicos y corrosivos, } \\
\text { fosgeno y cloruro de hidrógeno } \bullet \text { Reacciona violentamente con zinc, aluminio en polvo y sodio } \\
\text { - Ataca el hierro en presencia de humedad }\end{array}$ & \\
\hline $\begin{array}{l}\text { PENTACLOROETANO } \\
76.01 .7\end{array}$ & & & 6.1 \\
\hline $\begin{array}{l}\text { TETRABROMURO DE CARBONO } \\
558-13-4\end{array}$ & & $\begin{array}{l}\text { - Se descompone en contacto con una llama o una superficie caliente, liberando gases tóxicos } \\
\text { (bromo) • Explota por impacto cuando se mezcla con litio }\end{array}$ & 6.1 \\
\hline $\begin{array}{l}\text { 1,1,1,2-TETRACLOROETANO } \\
630-20-6\end{array}$ & & & 6.1 \\
\hline $\begin{array}{l}\text { 1,1,2,2-TETRACLOROETANO } \\
\text { 79-34-5 }\end{array}$ & & & 6.1 \\
\hline $\begin{array}{l}\text { TETRACLORURO DE CARBONO } \\
56-23.5\end{array}$ & $\begin{array}{l}\text { - El vapor es más pesado } \\
\text { que el aire }\end{array}$ & $\begin{array}{l}\text { - En contacto con superficies calientes o llamas, se descompone formando vapores tóxicos e } \\
\text { irritantes (cloruro de hidrógeno; cloro; fosgeno) • Reacciona violentamente con algunos metales } \\
\text { como aluminio, bario, magnesio, potasio, sodio, flúor y otras sustancias, con peligro de incendio y } \\
\text { explosión • Ataca el cobre, el plomo y el zinc }\end{array}$ & $\begin{array}{l}6.1 \\
y\end{array}$ \\
\hline
\end{tabular}




\begin{tabular}{|c|c|c|c|}
\hline $\begin{array}{l}\text { Denominación química } \\
\mathrm{N} \text { úmero CAS }\end{array}$ & Físicos & Q uímicos & $\begin{array}{l}\text { Clase o división } \\
\text { UN / Riesgos } \\
\text { subsidiarios }\end{array}$ \\
\hline $\begin{array}{l}\text { 1,2,3-TRICLOROPROPANO } \\
96 \cdot 18-4\end{array}$ & $\begin{array}{l}- \text { El gas es más pesado } \\
\text { que el aire } \bullet \text { El vapor es } \\
\text { más pesado que el aire }\end{array}$ & $\begin{array}{l}\text { - Se descompone al calentarse, liberando vapores tóxicos de cloro y fosgeno } \bullet \text { Reacciona } \\
\text { violentamente con metales } \bullet \text { Incompatible con metales activos, cáusticos fuertes y oxidantes } \\
\text { fuertes }\end{array}$ & \\
\hline $\begin{array}{l}\text { YODURO DE ETILO } \\
75-03-6\end{array}$ & $\begin{array}{l}\text { - El vapor es más pesado } \\
\text { que el aire }\end{array}$ & $\begin{array}{l}\text { - En su combustión se forma monóxido de carbono, yodo y yoduro de hidrógeno } \bullet \text { Se } \\
\text { descompone al arder, produciendo yodo y yoduro de hidrógeno } \bullet \text { Reacciona con oxidantes } \\
\text { - Reacciona violentamente con cloruro de plata, con peligro de incendio y explosión }\end{array}$ & \\
\hline
\end{tabular}

\begin{tabular}{|c|c|c|c|c|c|c|c|c|c|c|c|}
\hline $\begin{array}{l}\text { Denominación química } \\
\mathrm{N} \text { úmero CAS }\end{array}$ & Color/ Forma & $\begin{array}{l}\text { p.e. } \\
(\underline{O C})\end{array}$ & $\begin{array}{l}\text { p.f. } \\
(\stackrel{\circ}{ }=)\end{array}$ & $\begin{array}{l}\text { p.m.l } \\
\text { (g/l } \\
\text { mol) }\end{array}$ & $\begin{array}{l}\text { Solubilidad } \\
\text { en agua }\end{array}$ & $\begin{array}{l}\text { Densidad } \\
\text { relativa } \\
\text { (agua }=1 \text { ) }\end{array}$ & $\begin{array}{l}\text { Densidad } \\
\text { relativa } \\
\text { del vapor } \\
\text { (aire=1) }\end{array}$ & $\begin{array}{l}\text { Pvap/ } \\
(\mathrm{kPa})\end{array}$ & $\begin{array}{l}\text { Límit. } \\
\text { inflam. }\end{array}$ & $\begin{array}{l}\text { p.ig. } \\
(\underline{O} C)\end{array}$ & $\begin{array}{l}\text { p.aut } \\
\text { ig. } \\
(\mathrm{o} C)\end{array}$ \\
\hline $\begin{array}{l}\text { 1-BROMOBUTANO } \\
\text { 109-65.9 }\end{array}$ & $\begin{array}{l}\text { líquido incoloro; } \\
\text { líquido de color } \\
\text { pajizo pálido }\end{array}$ & 101,3 & -112 & 137,03 & insol & $\begin{array}{l}1,2686 @ \\
25^{\circ} \mathrm{C} / 4^{\circ} \mathrm{C}\end{array}$ & 4,72 & & & $\begin{array}{l}65^{\circ} \mathrm{F} \\
\mathrm{Ca}\end{array}$ & 265 \\
\hline $\begin{array}{l}\text { 1-BROMO-2-CLOROETANO } \\
\text { 107-04-0 }\end{array}$ & líquido incoloro & 107 & $-16,7$ & 143,4 & $\begin{array}{l}0,69 \mathrm{~g} / 100 \mathrm{~g} \\
@ 30^{\circ} \mathrm{C}\end{array}$ & $\begin{array}{l}1,7392 @ 20 \\
{ }^{\circ} \mathrm{C} / 4^{\circ} \mathrm{C}\end{array}$ & 4,94 & $\begin{array}{l}760 \mathrm{~mm} \mathrm{Hg} \\
@ 82,7^{\circ} \mathrm{C} \\
\end{array}$ & & & \\
\hline $\begin{array}{l}\text { BROMOFORMO } \\
75-25-2\end{array}$ & $\begin{array}{l}\text { líquido denso; } \\
\text { escamas } \\
\text { hexagonales; líquido } \\
\text { incoloro } 0 \text { amarillo }\end{array}$ & 149,1 & 8,0 & 252,73 & lig sol & 2,8899 & 8,7 & 0,7 & & & \\
\hline $\begin{array}{l}\text { BROMURO DE ETILO } \\
74-96-4\end{array}$ & líquido incoloro & 38,2 & -119 & 108,98 & lig sol & 1,4612 & 3,76 & $\begin{array}{l}467 \mathrm{~mm} \mathrm{Hg} \\
\text { @ } 25^{\circ} \mathrm{C}\end{array}$ & $\begin{array}{l}6,8 \mathrm{li} \\
8,0 \mathrm{ls} \\
\end{array}$ & $-20 c c$ & 511 \\
\hline $\begin{array}{l}\text { BROMURO DE METILO } \\
74-83.9\end{array}$ & gas incoloro & 3,55 & $.93,66$ & 94,95 & $1,75 \mathrm{~g} / 100 \mathrm{~g}$ & $3,974 \mathrm{~g} / \mathrm{I}$ (gas) & 3,3 & $\begin{array}{l}1420 \\
\mathrm{~mm} \mathrm{Hg}\end{array}$ & $\begin{array}{l}13,5 \mathrm{li} \\
14,5 \mathrm{ls} \\
\end{array}$ & & 537 \\
\hline $\begin{array}{l}\text { CLOROBROMOMETANO } \\
74.97 .5\end{array}$ & $\begin{array}{l}\text { líquido incoloro y } \\
\text { transparente; líquido } \\
\text { amarillo pálido }\end{array}$ & 68 & -88 & 129,38 & insol & 1,9344 & 4,5 & 15,8 & & & \\
\hline $\begin{array}{l}\text { 1-CLORO-3-BROMOPROPANO } \\
109-70-6\end{array}$ & líquido incoloro & 143,3 & $-58,9$ & 157,44 & insol & 1,5969 & & & & & \\
\hline $\begin{array}{l}\text { 1-CLOROBUTANO } \\
109-69-3 \\
\end{array}$ & líquido incoloro & 78,6 & $-123,1$ & 92,56 & insol & 0,8862 & 3,2 & $\begin{array}{l}80,1 \\
\mathrm{~mm} \mathrm{Hg}\end{array}$ & $\begin{array}{l}1,8 \mathrm{li} \\
10,1 \mathrm{ls}\end{array}$ & $-9 c c$ & 460 \\
\hline $\begin{array}{l}\text { CLOROFORMIATO DE ISOPROPILO } \\
108-23.6\end{array}$ & líquido incoloro & 105 & & 122,55 & insol & $1,08 \mathrm{~g} / \mathrm{ml}$ & 4,2 & & & 156 & \\
\hline $\begin{array}{l}\text { CLOROFORMO } \\
67-66-3 \\
\end{array}$ & $\begin{array}{l}\text { líquido incoloro y } \\
\text { transparente }\end{array}$ & 61,5 & .64 & 119,39 & lig sol & 1,4832 & 4,12 & 21,2 & & & \\
\hline $\begin{array}{l}\text { 2-CLORO-2-METILPROPANO } \\
507-20-0\end{array}$ & & 50,9 & -26 & 92,56 & lig sol & 0,8420 & & & & & \\
\hline $\begin{array}{l}\text { 2-CLOROPROPANO } \\
75-29-6 \\
\end{array}$ & líquido incoloro & 35,7 & $-117,2$ & 78,54 & lig sol & 0,8617 & 2,7 & $\begin{array}{l}523 \mathrm{~mm} \mathrm{Hg} \\
@ 25^{\circ} \mathrm{C} \\
\end{array}$ & & & \\
\hline $\begin{array}{l}\text { CLORURO DE ETLLO } \\
\text { 75-00-3 }\end{array}$ & líquido incoloro & 12,3 & $-138,7$ & 64,5 & lig sol & 0,8978 & 2,22 & 133,3 & $\begin{array}{l}3,8 \mathrm{li} \\
15,4 \mathrm{ls}\end{array}$ & $-50 \mathrm{cc}$ & 510 \\
\hline $\begin{array}{l}\text { CLORURO DE ISOBUTILO } \\
513-36-0\end{array}$ & & 68,5 & $-130,3$ & 92,56 & & 0,8810 & & & & & \\
\hline
\end{tabular}




\begin{tabular}{|c|c|c|c|c|c|c|c|c|c|c|c|}
\hline $\begin{array}{l}\text { Denominación química } \\
\mathrm{N} \text { úmero CAS }\end{array}$ & Color/ Forma & $\begin{array}{l}\text { p.e. } \\
\left({ }^{\circ} \mathrm{C}\right)\end{array}$ & $\begin{array}{l}\text { p.f. } \\
\left({ }^{\circ} C\right)\end{array}$ & $\begin{array}{l}\text { p.m.l } \\
\text { (g/ } \\
\text { mol) }\end{array}$ & $\begin{array}{l}\text { Solubilidad } \\
\text { en agua }\end{array}$ & $\begin{array}{l}\text { Densidad } \\
\text { relativa } \\
\text { (agua }=1 \text { ) }\end{array}$ & $\begin{array}{l}\text { Densidad } \\
\text { relativa } \\
\text { del vapor } \\
\text { (aire=1) }\end{array}$ & $\begin{array}{l}\text { Pvap/ } \\
(\mathrm{kPa})\end{array}$ & $\begin{array}{l}\text { Límit. } \\
\text { inflam. }\end{array}$ & $\begin{array}{l}\text { p.ig. } \\
\left({ }^{\circ} C\right)\end{array}$ & $\begin{array}{l}\text { p.aut } \\
\text { ig. } \\
(\stackrel{0}{ } \text { C })\end{array}$ \\
\hline $\begin{array}{l}\text { CLORURO DE METILENO } \\
75-09-2\end{array}$ & líquido incoloro & 40 & $-95,1$ & 84,9 & lig sol & 1,3266 & 2,9 & 47,4 & $\begin{array}{l}14 \mathrm{li} \\
25 \mathrm{ls}\end{array}$ & & 640 \\
\hline $\begin{array}{l}\text { CLORURO DE METILO } \\
74-87-3\end{array}$ & $\begin{array}{l}\text { gas incoloro; se } \\
\text { condensa en un } \\
\text { líquido incoloro }\end{array}$ & 24,0 & $-97,7$ & 50,49 & sol & 0,9159 & 2,47 & 475 & $\begin{array}{l}8,1 \mathrm{li} \\
17,4 \mathrm{ls}\end{array}$ & $\begin{array}{l}-46 \text { gas } \\
\text { infla- } \\
\text { mable }\end{array}$ & 634 \\
\hline $\begin{array}{l}\text { 1,2-DIBROMO-3-CLOROPROPANO } \\
96-12-8\end{array}$ & $\begin{array}{l}\text { líquido incoloro en } \\
\text { estado puro }\end{array}$ & 196 & 5 & 236,36 & $0,1 \mathrm{~g} / 100 \mathrm{ml}$ & $2,093 @ 14^{\circ} \mathrm{C}$ & 8,2 & 0,1 & & 77 & \\
\hline $\begin{array}{l}\text { DIBROMOETANO } \\
74-95-3 \\
\end{array}$ & $\begin{array}{l}\text { líquido incoloro y } \\
\text { transparente }\end{array}$ & 97 & $-52,5$ & 173,83 & lig sol & 2,4970 & 6,05 & 5 & & & \\
\hline $\begin{array}{l}\text { DIBROMURO DE ETLEENO } \\
\text { 106.93-4 }\end{array}$ & $\begin{array}{l}\text { líquido denso e } \\
\text { incoloro }\end{array}$ & $131-132$ & 9,8 & 187,88 & $\begin{array}{l}0,34 \mathrm{~g} / 100 \mathrm{ml} \\
\text { a } 20{ }^{\circ} \mathrm{C} ; \\
* 0,404 \mathrm{~g} / \\
100 \mathrm{~g} \text { a } 20{ }^{\circ} \mathrm{C} ;\end{array}$ & $2,172 \mathrm{~g} / \mathrm{ml}$ & 6,5 & $\begin{array}{l}11 \mathrm{~mm} \mathrm{Hg} \\
\text { a } 20^{\circ} \mathrm{C}\end{array}$ & & & \\
\hline $\begin{array}{l}\text { 1,1-DICLOROETANO } \\
\text { 75-34-3 }\end{array}$ & $\begin{array}{l}\text { líquido oleaginoso; } \\
\text { líquido incoloro }\end{array}$ & 57 & .98 & 98,97 & lig sol & 1,175 & 3,44 & 24 & $\begin{array}{l}5,6 \mathrm{li} \\
11,4 \mathrm{ls} \\
\end{array}$ & $-6 c c$ & 458 \\
\hline $\begin{array}{l}\text { 1,1-DICLOROPROPANO } \\
\text { 78-99-9 }\end{array}$ & líquido & 88,1 & & 112,98 & insol & 1,1321 & 3,90 & & $\begin{array}{l}3,4 \mathrm{li} \\
14,5 \mathrm{ls} \\
\end{array}$ & $21 \mathrm{cc}$ & \\
\hline $\begin{array}{l}\text { 1,2-DICLOROPROPANO } \\
\text { 78-87-5 }\end{array}$ & líquido incoloro & 96,4 & $-100,4$ & 112,99 & $\begin{array}{l}0,26 \% \text { en peso } \\
\text { a } 20^{\circ} \mathrm{C}\end{array}$ & $\begin{array}{l}1,159 \mathrm{a} \\
25^{\circ} \mathrm{C} / 25^{\circ} \mathrm{C}\end{array}$ & 3,9 & $\begin{array}{l}50 \mathrm{~mm} \mathrm{Hg} \\
\text { a } 25^{\circ} \mathrm{C}\end{array}$ & $\begin{array}{l}3,4 \% \text { li } \\
14,5 \% \text { is }\end{array}$ & $21 \mathrm{ca}$ & 557 \\
\hline $\begin{array}{l}\text { 1,3-DICLOROPROPANO } \\
142-28-9\end{array}$ & líquido incoloro & 120,4 & $-99,5$ & 112,99 & $0,3 \mathrm{~g} / 100 \mathrm{ml}$ & 1,1876 & 3,90 & 18 torr & $\begin{array}{l}3,4 \mathrm{li} \\
14,5 \mathrm{ls}\end{array}$ & $21 \mathrm{cc}$ & \\
\hline $\begin{array}{l}\text { DICLORURO DE ETILENO } \\
107-06-2\end{array}$ & $\begin{array}{l}\text { líquido oleaginoso } \\
\text { incoloro y } \\
\text { transparente }\end{array}$ & & & & $\begin{array}{l}0,869 \mathrm{~g} / \\
100 \mathrm{ml} \text { de agua } \\
@ 20^{\circ} \mathrm{C}\end{array}$ & 1,2351 a $20^{\circ} \mathrm{C}$ & 3,42 & & $\begin{array}{l}6,2 \% \mathrm{li} \\
16 \% \mathrm{ls}\end{array}$ & $\begin{array}{l}13^{\circ} \mathrm{C} \\
\mathrm{CC} \\
18^{\circ} \mathrm{C} \\
\mathrm{Ca}\end{array}$ & 413 \\
\hline $\begin{array}{l}\text { HEPTACLOR } \\
76-44-8\end{array}$ & $\begin{array}{l}\text { blanco; sólido ceroso } \\
\text { blanco o ligeramente } \\
\text { tostado }\end{array}$ & $135-145$ & 95,5 & 373,35 & insol & 1,65 & & $\begin{array}{l}0,053 \mathrm{~Pa} \\
@ 25^{\circ} \mathrm{C}\end{array}$ & & & \\
\hline $\begin{array}{l}\text { HEXACLOROCICLOHEXANO } \\
608-73-1\end{array}$ & $\begin{array}{l}\text { polvo o escamas de } \\
\text { color blanco o } \\
\text { amarillento; polvo } \\
\text { amorfo entre marrón } \\
\text { y blanco }\end{array}$ & & 65 & 290,80 & insol & 1,87 & 1,85 & $4,2 \mathrm{~Pa}$ & & & \\
\hline $\begin{array}{l}\alpha \text {-HEXACLOROCICLOHEXANO } \\
319-84-6\end{array}$ & polvo cristalino & 288 & $156-161$ & & insol & 1,87 & & $3 \mathrm{~Pa}$ & & & \\
\hline $\begin{array}{l}\beta \text {-HEXACLOROCICLOHEXANO } \\
319-85-7\end{array}$ & polvo cristalino & $60 @ 0,50$ & 312 & 290,83 & insol & $1,89 @ 19^{\circ} \mathrm{C}$ & & $0,7 \mathrm{~Pa}$ & & & \\
\hline $\begin{array}{l}\delta \text {-HEXACLOROCICLOHEXANO } \\
319-86-8\end{array}$ & placas & & $141-2$ & 290,83 & & & & & & & \\
\hline $\begin{array}{l}\text { HEXACLOROETANO } \\
67-72.1\end{array}$ & $\begin{array}{l}\text { cristales rómbicos en } \\
\text { alcohol y éter; } \\
\text { cristales incoloros; } \\
\text { polvo cristalino; } \\
\text { sólido incoloro; } \\
\text { estructura del cristal: } \\
\text { rómbica hasta } \\
46^{\circ} \mathrm{C} \text {; triclínica a } \\
46-71^{\circ} \mathrm{C}\end{array}$ & 187 & 187 & 236,74 & insol & 2,091 & 8,16 & $53 \mathrm{~Pa}$ & & & \\
\hline $\begin{array}{l}\text { PENTACLOROETANO } \\
76-01.7\end{array}$ & líquido incoloro & $161-162$ & -29 & 202,29 & insol & 1,6796 & 7,0 & $\begin{array}{l}3,5 \mathrm{~mm} \mathrm{Hg} \\
\text { @ } 25^{\circ} \mathrm{C}\end{array}$ & & & \\
\hline
\end{tabular}




\begin{tabular}{|c|c|c|c|c|c|c|c|c|c|c|c|}
\hline $\begin{array}{l}\text { Denominación química } \\
\mathrm{N} \text { úmero CAS }\end{array}$ & Color/ Forma & $\begin{array}{l}\text { p.e. } \\
(\underline{O C})\end{array}$ & $\begin{array}{l}\text { p.f. } \\
(\underline{O C})\end{array}$ & $\begin{array}{l}\mathrm{p} . \mathrm{m} . / \\
\text { (g/ } \\
\mathrm{mol})\end{array}$ & $\begin{array}{l}\text { Solubilidad } \\
\text { en agua }\end{array}$ & $\begin{array}{l}\text { Densidad } \\
\text { relativa } \\
\text { (agua }=1 \text { ) }\end{array}$ & $\begin{array}{l}\text { Densidad } \\
\text { relativa } \\
\text { del vapor } \\
\text { (aire=1) }\end{array}$ & $\begin{array}{l}\text { Pvap/ } \\
(\mathrm{kPa})\end{array}$ & $\begin{array}{l}\text { Límit. } \\
\text { inflam. }\end{array}$ & $\begin{array}{l}\text { p.ig. } \\
(\underline{O C})\end{array}$ & $\begin{array}{l}\text { p.aut } \\
\text { ig. } \\
(\stackrel{\circ}{-})\end{array}$ \\
\hline $\begin{array}{l}\text { TETRABROMURO DE CARBONO } \\
\text { 558-13-4 }\end{array}$ & $\begin{array}{l}\text { cristales tabulares } \\
\text { monoclínicos en } \\
\text { alcohol diluido; } \\
\text { cristales incoloros }\end{array}$ & 189,5 & 90 & 331,63 & insol & 2,9609 & 11,4 & $\begin{array}{l}5,33 \\
@ 96{ }^{\circ} \mathrm{C}\end{array}$ & & & \\
\hline $\begin{array}{l}\text { TETRACLOROETANO } \\
25322 \cdot 20-7 \\
\end{array}$ & $\begin{array}{l}\text { líquido incoloro } \\
\text { denso y corrosivo }\end{array}$ & 146,5 & -43 & & & & & & & & \\
\hline $\begin{array}{l}\text { 1,1,1,2-TETRACLOROETANO } \\
630-20-6\end{array}$ & $\begin{array}{l}\text { cristales de color rojo } \\
\text { amarillento }\end{array}$ & 130,5 & $-70,2$ & 167,85 & lig sol & 1,5406 & & & & & \\
\hline $\begin{array}{l}\text { 1,1,2,2-TETRACLOROETANO } \\
\text { 79-34-5 }\end{array}$ & $\begin{array}{l}\text { líquido incoloro puro } \\
0 \text { amarillo pálido }\end{array}$ & 146,5 & -44 & 167,86 & lig sol & 1,5953 & 5,79 & $\begin{array}{l}0,78 \\
@ 25^{\circ} \mathrm{C}\end{array}$ & & & \\
\hline $\begin{array}{l}\text { TETRACLORURO DE CARBONO } \\
56-23-5\end{array}$ & $\begin{array}{l}\text { líquido incoloro, } \\
\text { transparente y denso }\end{array}$ & 76,5 & .23 & 153,8 & insol & 1,5940 & 5,32 & 12,2 & & & \\
\hline $\begin{array}{l}\text { 1,1,1-TRICLOROETANO } \\
71-55 \cdot 6\end{array}$ & líquido incoloro & 74,0 & $-30,4$ & 133,4 & lig sol & 1,3376 & 4,63 & 13,3 & $\begin{array}{l}7 \mathrm{li} \\
16 \mathrm{ls} \\
\end{array}$ & & 537 \\
\hline $\begin{array}{l}\text { 1,1,2-TRICLOROETANO } \\
\text { 79-00-5 }\end{array}$ & líquido incoloro & 113,8 & $-36,5$ & 133,4 & insol & 1,4416 & $4,21 \mathrm{~g} / \mathrm{l}$ & 2,5 & $\begin{array}{l}6 \mathrm{li} \\
15,5 \mathrm{ls}\end{array}$ & & \\
\hline $\begin{array}{l}\text { 1,2,3-TRICLOROPROPANO } \\
\text { 96-18-4 }\end{array}$ & $\begin{array}{l}\text { líquido incoloro o } \\
\text { pajizo }\end{array}$ & 157 & $-14,7$ & 147,43 & lig sol & 1,3889 & 5,1 & 0,267 & $\begin{array}{l}3,2 \mathrm{li} \\
12,6 \mathrm{ls}\end{array}$ & 82 & 304 \\
\hline $\begin{array}{l}\text { YODOFORMO } \\
75-47-8\end{array}$ & $\begin{array}{l}\text { polvo o cristales } \\
\text { amarillos; polvo o } \\
\text { cristales pequeños, } \\
\text { de color amarillo } \\
\text { verdoso o lustrosos; } \\
\text { agujas o prismas } \\
\text { hexagonales } \\
\text { amarillos en acetona }\end{array}$ & 218 & 119 & 393,7 & insol & $4,008 @ 25^{\circ} \mathrm{C}$ & 13,6 & & & & \\
\hline $\begin{array}{l}\text { YODURO DE ETILO } \\
75-03.6\end{array}$ & líquido & 72 & -108 & 155,97 & lig sol & 1,9358 & 5,4 & $\begin{array}{l}18,3 \\
@ 25^{\circ} \mathrm{C}\end{array}$ & & & \\
\hline $\begin{array}{l}\text { YODURO DE METLLO } \\
74-88-4\end{array}$ & $\begin{array}{l}\text { líquido incoloro y } \\
\text { transparente }\end{array}$ & 42,5 & $.66,5$ & 141,94 & lig sol & 2,28 & 4,9 & $\begin{array}{l}400 \mathrm{~mm} \mathrm{Hg} \\
\text { @ } 25^{\circ} \mathrm{C}\end{array}$ & & & \\
\hline
\end{tabular}




\section{TABLAS DE HIDROCARBUROS HALOGENADOS INSATURADOS}

\begin{tabular}{|c|c|c|c|}
\hline Producto químico & Sinónimos/ código UN & $\mathrm{N}$ úmero CAS & Estructura química \\
\hline BROMURO DE ALILO & $\begin{array}{l}\text { Bromalileno; 1-bromo-2-propeno; 3-bromopropeno; 3-bromopropileno; } \\
\text { UN1099 }\end{array}$ & $106-95-6$ & \\
\hline BROMURO DE PROPARGILO & $\begin{array}{l}\gamma \text {-bromoalileno; 1-bromo-2-propino; 3-bromopropino; } \\
\text { 3-bromo-1-propino } \\
\text { UN2345 }\end{array}$ & $106-96-7$ & \\
\hline BROMURO DE VINILO & $\begin{array}{l}\text { Bromoeteno; bromoetileno } \\
\text { UN1085 }\end{array}$ & $593-60-2$ & \\
\hline 2-CLORO-1,3-BUTADIENO & $\begin{array}{l}\text { Clorobutadieno; 2-clorobuta-1,3-dieno; cloropreno; b-loropreno } \\
\text { UN1991 }\end{array}$ & $126-99-8$ & \\
\hline 1-CLORO-2-METIL-1-PROPENO & & $513-37-1$ & \\
\hline 3-CLORO-2-METILPROPENO & $\begin{array}{l}\gamma \text {-cloroisobutileno; 1-cloro-2-metil-2-propeno; 3-cloro-2-metil-propeno } \\
\text { UN2554 }\end{array}$ & $563-47-3$ & \\
\hline CLORURO DE ALLLO & $\begin{array}{l}\text { Cloralileno; 3-cloropreno; 1-cloropropeno-2; 3-cloropropeno-1; } \\
\text { 3-cloropropeno; 1-cloro-2-propeno; a-cloropropileno; 3-cloropropileno }\end{array}$ & $107-05-1$ & \\
\hline CLORURO DE PROPARGILO & & $624-65-7$ & \\
\hline CLORURO DE VINILIDENO & $\begin{array}{l}\text { 1,1-dicloroetileno; 1,1-dicloroeteno; CVD } \\
\text { UN1303 }\end{array}$ & $75-35-4$ & \\
\hline CLORURO DE VINILO & $\begin{array}{l}\text { Cloretileno; cloroeteno; cloroetileno } \\
\text { UN1086 }\end{array}$ & 75-01-4 & \\
\hline DICLOROACETILENO & Dicloroetino & $7572-29-4$ & \\
\hline 1,4-DICLORO-2-BUTENO & DCB; 1,4-DCB; 1,4-diclorobuteno-2 & $764-41-0$ & \\
\hline cis-1,2-DICLOROETILENO & cis-Dicloroetileno; cis-1,2-dicloroetileno & $156-59-2$ & \\
\hline
\end{tabular}




\section{Tabla 104.97 • Identificación química.}

Producto químico

Sinónimos/ código UN

1,2-DICLOROETILENO

Dicloruro de acetileno; sim-dicloroetileno; 1,2-dicloroetileno; dioformo
N úmero CAS Estructura química

$540-59-0$

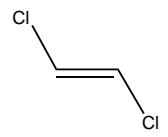

trans-1,2-DICLOROETILENO

Dicloruro de trans-acetileno; trans-dicloroetileno

$156-60-5$

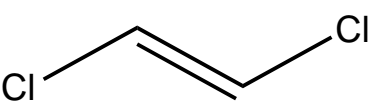

1,2-DICLORO-2-PROPENO

$78-88-6$<smiles>C=C(Cl)CCl</smiles>

1,3-DICLOROPROPENO

Cloruro de $\alpha$-cloroalilo; cloruro de $\gamma$-cloroalilo; cloruro de 3-cloroalilo; cloruro de 3-cloropropenilo; dicloropropeno

$542 \cdot 75 \cdot 6$

cho de 3icrapropenilo; didoropropeno

Cis-1,3-DICLOROPROPENO

1,3-dicloropropeno; 1,3-dicloro-1-propeno; cis-1,3-dicloropropileno

10061-01-5

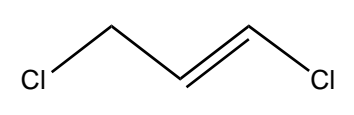

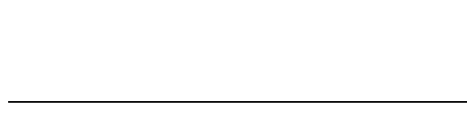

\begin{tabular}{ll}
\hline trans-1,3-DICLOROPROPENO & 1,3-dicloropropeno; 1,3-dicloro-1-propeno; trans-1,3-dicloropropileno; \\
& 1,3-dicloro-1-propeno \\
& \\
\hline HEXACLOROBUTADIENO & Dolen-pur; GP-40-66:120; HCBD; hexaclorobutadieno; \\
& 1,3-hexaclorobutadieno; 1,1,2,3,4,4-hexacloro-1,3-butadieno; \\
& 1,2,3,4,5,5-hexacloropentadieno \\
\hline HEXACLOROCICLOPENTADIENO & Hexacloro-1,3-ciclopentadieno; hexaclorociclopentadieno; \\
& perclorociclopentadieno \\
& UN2646
\end{tabular}

HEXACLOROPROPENO

$1888-71-7$

$10061-02-6$

$87.68-3$

1,3-hexaclorobutadieno; 1,1,2,3,4,4-hexacloro-1,3-butadieno;

1,2,3,4,5,5-hexacloropentadieno

$77-47-4$

perclorociclopentadieno

$77-47.4$

$\mathrm{Cl}$

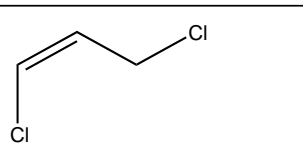

HCXCLOROPROPENO

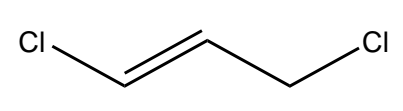

TETRACLOROETILENO

Anquilostín; Antisol 1; bicloruro de carbono; dicloruro de carbono; percleno; 127-18-4 percleno D; percloroetileno; tetracloretileno; tetracloroeteno;

1,1,2,2-tetracloroetileno UN1897

\begin{tabular}{ll}
\hline 2,3,4-TRICLORO-1-BUTENO & 2,3,4-Triclorobuteno-1 \\
& \\
\hline TRICLOROETLENO & Tricloruro de acetileno; algileno; Anamenth; bencinol; Blacosolv; \\
& Blancosolv; 1,1-dicloro-2-cloroetileno; tricloroeteno; 1,1,2-tricloroetileno; \\
& 1,2,2-tricloroetileno \\
UN1710
\end{tabular}

$2431-50-7$

79-01-6

Blancosolv; 1,1-dicloro-2-cloroetileno; tricloroeteno; 1,1,2-tricloroetileno;

UN1710

\subsection{0 .7}
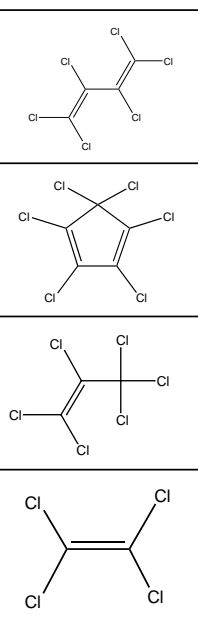

$.01-6$
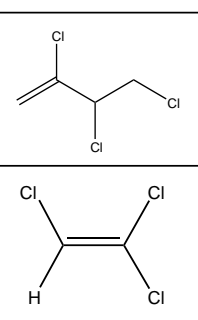


\begin{tabular}{|c|c|c|c|c|c|c|}
\hline \multirow[b]{2}{*}{$\begin{array}{l}\text { Denominación } \\
\text { química } \\
\mathrm{N} \text { úmero CAS }\end{array}$} & \multicolumn{4}{|c|}{ Tarjetas Internacionales sobre la Seguridad de los Productos Q uímicos } & \multicolumn{2}{|c|}{ N IO SH (EE.UU.) } \\
\hline & $\begin{array}{l}\text { Período } \\
\text { corto de } \\
\text { exposición }\end{array}$ & $\begin{array}{l}\text { Período } \\
\text { largo de } \\
\text { exposición }\end{array}$ & $\begin{array}{l}\text { Vías de } \\
\text { exposición }\end{array}$ & Síntomas & $\begin{array}{l}\text { O rganos } \\
\text { afectados } \\
\text { Vías de } \\
\text { entrada }\end{array}$ & Síntomas \\
\hline $\begin{array}{l}\text { CLORURO DE ALLLO } \\
\text { 107-05-1 }\end{array}$ & $\begin{array}{l}\text { ojos; piel; tract } \\
\text { resp; pulmones; } \\
\text { riñones; SNC }\end{array}$ & $\begin{array}{l}\text { puede afectar al } \\
\text { hígado; riñones; } \\
\text { SNP }\end{array}$ & $\begin{array}{l}\text { Inhalación } \\
\text { Piel } \\
\text { 0jos } \\
\text { Ingestión }\end{array}$ & $\begin{array}{l}\text { Tos, dolor de garganta, cefalea, mareo, } \\
\text { espasmos abdominales, sensación de } \\
\text { quemazón, vómitos, dificultad respiratoria, } \\
\text { inconsciencia } \\
\text { Puede absorberse, enrojecimiento, sensación } \\
\text { de quemazón, dolor, dolor óseo intenso varias } \\
\text { horas después del contacto } \\
\text { Enrojecimiento, dolor, visión borrosa } \\
\text { Dolor abdominal, sensación de quemazón, } \\
\text { vómitos }\end{array}$ & $\begin{array}{l}\text { Sis resp; piel; ojos; } \\
\text { hígado; rinones } \\
\text { Inh; abs; ing; con }\end{array}$ & $\begin{array}{l}\text { Irrit ojos, piel, nariz, muc; } \\
\text { edema pulm; en animales: } \\
\text { lesiones hepáticas, renales }\end{array}$ \\
\hline $\begin{array}{l}\text { CLORURO DE VINILIDENO } \\
75-35-4\end{array}$ & $\begin{array}{l}\text { ojos; piel; tract } \\
\text { resp; pulmones; } \\
\text { SNC }\end{array}$ & $\begin{array}{l}\text { piel; hígado; } \\
\text { riñones }\end{array}$ & $\begin{array}{r}\text { Inhalación } \\
\text { Piel } \\
\text { 0jos } \\
\text { Ingestión }\end{array}$ & $\begin{array}{l}\text { Mareo, sopor, inconsciencia } \\
\text { Enrojecimiento, quemaduras en la piel } \\
\text { Enrojecimiento, dolor } \\
\text { Dolor abdominal, dolor de garganta }\end{array}$ & $\begin{array}{l}\text { Ojos; piel; sis resp; } \\
\text { SNC; hígado; } \\
\text { riñones [en } \\
\text { animales: tumores } \\
\text { de hígado y riñón] } \\
\text { Inh; abs; ing; con }\end{array}$ & $\begin{array}{l}\text { Irrit ojos, piel, garganta; mar, } \\
\text { cef, náu; disn; disfunc } \\
\text { hepática, renal; neuitis;; [carc] }\end{array}$ \\
\hline $\begin{array}{l}\text { CLORURO DE VINILO } \\
75.01-4\end{array}$ & ojos; piel; SNC & $\begin{array}{l}\text { hígado; vasos } \\
\text { sanguíneos; tejido } \\
\text { conectivo }\end{array}$ & $\begin{array}{r}\text { Inhalación } \\
\text { Piel } \\
\text { 0jos }\end{array}$ & $\begin{array}{l}\text { Mareo, sopor, cefalea, inconsciencia } \\
\text { En contacto con el líquido: congelación } \\
\text { Enrojecimiento, dolor }\end{array}$ & $\begin{array}{l}\text { Hígado; SNC; } \\
\text { sangre; sis resp; sis } \\
\text { linfático [cáncer de } \\
\text { hígado] } \\
\text { Inh; con (líq) }\end{array}$ & $\begin{array}{l}\text { Deb; dolor abdom, hemorragia } \\
\text { Gl; hígado agrandado; palidez } \\
\text { o cian en las extremidades; } \\
\text { líq: congelación; [carc] }\end{array}$ \\
\hline $\begin{array}{l}\text { HEXACLOROBUTADIENO } \\
87-68-3\end{array}$ & $\begin{array}{l}\text { ojos; piel; tract } \\
\text { resp; riñones; } \\
\text { glándula suprarrenal }\end{array}$ & & $\begin{array}{r}\text { Inhalación } \\
\text { Piel } \\
\text { 0jos } \\
\text { Ingestión }\end{array}$ & $\begin{array}{l}\text { Mareo, embotamiento, cefalea, coma, } \\
\text { temblores } \\
\text { Puede absorberse, enrojecimiento } \\
\text { Enrojecimiento, dolor } \\
\text { Náuseas, vómitos }\end{array}$ & $\begin{array}{l}\text { Ojos; piel; sis resp; } \\
\text { riñones [en } \\
\text { animales: tumores } \\
\text { de riñón] } \\
\text { Inh; abs; ing; con }\end{array}$ & $\begin{array}{l}\text { En animales: irrit ojos, piel, sis } \\
\text { resp; lesiones renales; [carc] }\end{array}$ \\
\hline $\begin{array}{l}\text { TETRACLOROETILENO } \\
127-18-4\end{array}$ & $\begin{array}{l}\text { ojos; piel; tract } \\
\text { resp; pulmones; } \\
\text { SNC }\end{array}$ & $\begin{array}{l}\text { piel; hígado; } \\
\text { riñones }\end{array}$ & $\begin{array}{r}\text { Inhalación } \\
\text { Piel } \\
\text { 0jos } \\
\text { Ingestión }\end{array}$ & $\begin{array}{l}\text { Descoordinación, exhilaración, mareo, sopor, } \\
\text { cefalea, náuseas, debilidad, inconsciencia } \\
\text { Sequedad de piel, enrojecimiento, quemaduras } \\
\text { en la piel, ampollas } \\
\text { Enrojecimiento, dolor } \\
\text { Dolor abdominal }\end{array}$ & $\begin{array}{l}\text { Hígado; riñones; } \\
\text { ojos; sis resp; SNC; } \\
\text { piel [en animales: } \\
\text { tumores de hígado] } \\
\text { Inh; abs; ing; con }\end{array}$ & $\begin{array}{l}\text { Irrit ojos, nariz, garganta; náu; } \\
\text { rubor de cara y cuello; vért, } \\
\text { mar, desco; cef, somn; eri cut; } \\
\text { lesiones hepáticas; [ carc] }\end{array}$ \\
\hline $\begin{array}{l}\text { TRICLOROETILENO } \\
79.01 .6\end{array}$ & $\begin{array}{l}\text { ojos; piel ; } \\
\text { pulmones; SNC }\end{array}$ & $\begin{array}{l}\text { piel; hígado; } \\
\text { riñones }\end{array}$ & $\begin{array}{r}\text { Inhalación } \\
\text { Piel } \\
\text { 0jos } \\
\text { Ingestión }\end{array}$ & $\begin{array}{l}\text { Mareo, sopor, cefalea, debilidad, inconsciencia } \\
\text { Sequedad de piel, enrojecimiento } \\
\text { Enrojecimiento, dolor } \\
\text { Dolor abdominal }\end{array}$ & $\begin{array}{l}\text { Sis resp; corazón; } \\
\text { hígado; riñones; } \\
\text { SNC; piel; ojos [en } \\
\text { animales: cáncer de } \\
\text { hígado y riñón] } \\
\text { Inh; abs; ing; con }\end{array}$ & $\begin{array}{l}\text { Irrit ojos, piel; cef, vért; dist } \\
\text { vis, ftg, desv, temblores, som, } \\
\text { náu, vómit; derm; arrit card, } \\
\text { pares; lesiones hepáticas; } \\
\text { [carc] }\end{array}$ \\
\hline
\end{tabular}




\begin{tabular}{|c|c|c|c|}
\hline $\begin{array}{l}\text { Denominación química } \\
\mathrm{N} \text { úmero CAS }\end{array}$ & Físicos & Q uímicos & $\begin{array}{l}\text { Clase o división } \\
\text { UN / Riesgos } \\
\text { subsidiarios }\end{array}$ \\
\hline $\begin{array}{l}\text { BROMURO DE ALLLO } \\
106-95.6\end{array}$ & & & $3 / 6.1$ \\
\hline $\begin{array}{l}\text { BROMURO DE PROPARGILO } \\
106-96-7\end{array}$ & & & 3 \\
\hline $\begin{array}{l}\text { BROMURO DE VINILO } \\
593-60-2 \\
\end{array}$ & & & 2.1 \\
\hline $\begin{array}{l}\text { 2-CLORO-1,3-BUTADIENO } \\
126-99-8 \\
\end{array}$ & & & $3 / 6.1$ \\
\hline $\begin{array}{l}\text { 3-CLORO-2-METILPROPENO } \\
\text { 563-47-3 }\end{array}$ & & & 3 \\
\hline $\begin{array}{l}\text { CLORURO DE ALLLO } \\
\text { 107-05-1 }\end{array}$ & $\begin{array}{l}\text { - El vapor es más pesado } \\
\text { que el aire y puede } \\
\text { desplazarse a ras del } \\
\text { suelo; posibilidad de } \\
\text { ignición a distancia }\end{array}$ & $\begin{array}{l}\text { - Puede polimerizarse al calentarse o por efecto de diferentes metales, cloruros metálicos y ácido } \\
\text { sulfúrico, con peligro de incendio o explosión • Al arder, se forman vapores tóxicos y corrosivos } \\
\text { (cloruro de hidrógeno) • Reacciona violentamente con oxidantes fuertes y metales como } \\
\text { aluminio, magnesio y zinc, con peligro de incendio y explosión • Ataca plásticos, caucho y } \\
\text { revestimientos }\end{array}$ & $3 / 6.1$ \\
\hline $\begin{array}{l}\text { CLORURO DE VINILIDENO } \\
75-35-4\end{array}$ & $\begin{array}{l}\text { - El gas es más pesado } \\
\text { que el aire y puede } \\
\text { desplazarse a ras del } \\
\text { suelo; posibilidad de } \\
\text { ignición a distancia }\end{array}$ & $\begin{array}{l}\text { - Puede formar peróxidos explosivos • Se polimeriza al calentarse y por efecto del oxígeno, la } \\
\text { luz solar, el cobre o el aluminio, con peligro de incendio o explosión • Puede explotar al } \\
\text { calentarse } 0 \text { en contacto con llamas } \bullet \text { Se descompone al arder, produciendo fluoruro de hidrógeno } \\
\text { - Reacciona violentamente con oxidantes y cloruro de hidrógeno }\end{array}$ & 2.1 \\
\hline $\begin{array}{l}\text { CLORURO DE VINILO } \\
75.01-4\end{array}$ & $\begin{array}{l}\text { - El gas es más pesado } \\
\text { que el aire y puede } \\
\text { desplazarse a ras del } \\
\text { suelo; posibilidad de } \\
\text { ignición a distancia }\end{array}$ & $\begin{array}{l}\text { - En determinadas circunstancias puede formar peróxidos, iniciando una polimerización explosiva } \\
\text { - Se polimeriza fácilmente al calentarse y por efecto del aire, de la luz solar y en contacto con } \\
\text { catalizadores, agentes oxidantes fuertes y metales como cobre y aluminio, con peligro de } \\
\text { incendio y explosión - Se descompone al arder, liberando vapores tóxicos y corrosivos (cloruro de } \\
\text { hidrógeno y fosgeno) }\end{array}$ & 2.1 \\
\hline $\begin{array}{l}\text { 1,1-DICLOROETENO } \\
\text { 75-35-4 }\end{array}$ & $\begin{array}{l}\text { - El vapor es más pesado } \\
\text { que el aire y puede } \\
\text { desplazarse a ras del } \\
\text { suelo; posibilidad de } \\
\text { ignición a distancia }\end{array}$ & $\begin{array}{l}\text { - Puede formar peróxidos fácilmente explosivos } \bullet \text { Se polimeriza al calentarse o por efecto del } \\
\text { oxígeno, la luz solar, el cobre } 0 \text { el aluminio, con peligro de incendio o explosión } \bullet \text { Puede explotar } \\
\text { al calentarse } 0 \text { en contacto con llamas } \bullet \text { Se descompone al arder, liberando vapores tóxicos y } \\
\text { corrosivos (cloruro de hidrógeno, fosgeno y cloro) • Reacciona violentamente con oxidantes }\end{array}$ & 3 \\
\hline $\begin{array}{l}\text { 1,2-DICLOROETILENO } \\
540-59-0\end{array}$ & $\begin{array}{l}\text { - El vapor es más pesado } \\
\text { que el aire y puede } \\
\text { desplazarse a ras del } \\
\text { suelo; posibilidad de } \\
\text { ignición a distancia }\end{array}$ & $\begin{array}{l}\text { - En contacto con superficies calientes o llamas, se descompone liberando gases y vapores } \\
\text { tóxicos (cloruro de hidrógeno, fosgeno y monóxido de carbono) • Reacciona con oxidantes } \\
\text { fuertes, con peligro de incendio y explosión }\end{array}$ & 3 \\
\hline $\begin{array}{l}\text { Cis-1,2-DICLOROETLLENO } \\
156-59-2\end{array}$ & & & 3 \\
\hline $\begin{array}{l}\text { trans-1,2-DICLOROETILENO } \\
156-60-5\end{array}$ & & & 3 \\
\hline $\begin{array}{l}\text { 1,2-DICLORO-2-PROPENO } \\
78-88-6 \\
\end{array}$ & & & 3 \\
\hline $\begin{array}{l}\text { 1,3-DICLOROPROPENO } \\
542 \cdot 75 \cdot 6 \\
\end{array}$ & & & 3 \\
\hline $\begin{array}{l}\text { Cis-1,3-DICLOROPROPENO } \\
\text { 10061-01-5 }\end{array}$ & & & 3 \\
\hline $\begin{array}{l}\text { trans-1,3-DICLOROPROPENO } \\
\text { 10061-02-6 }\end{array}$ & & & 3 \\
\hline
\end{tabular}




\begin{tabular}{|c|c|c|c|}
\hline $\begin{array}{l}\text { Denominación química } \\
\mathrm{N} \text { úmero CAS }\end{array}$ & Físicos & Q uímicos & $\begin{array}{l}\text { Clase o división } \\
\text { UN / Riesgos } \\
\text { subsidiarios }\end{array}$ \\
\hline $\begin{array}{l}\text { HEXACLOROBUTADIENO } \\
87.68-3\end{array}$ & $\begin{array}{l}\text { - El vapor es más pesado } \\
\text { que el aire }\end{array}$ & - Se descompone al arder, produciendo gases irritantes o venenosos (fosgeno) & 6.1 \\
\hline $\begin{array}{l}\text { TETRACLOROETILENO } \\
\text { 127-18-4 }\end{array}$ & $\begin{array}{l}\text { - El vapor es más pesado } \\
\text { que el aire }\end{array}$ & $\begin{array}{l}\text { - En contacto con superficies calientes o llamas, se descompone liberando vapores tóxicos y } \\
\text { corrosivos ( cloruro de hidrógeno, fosgeno, cloro) } \bullet \text { Se descompone lentamente en contacto con la } \\
\text { humedad, produciendo ácido tricloroacético y ácido clorhídrico } \bullet \text { Reacciona con metales como } \\
\text { aluminio, litio, bario y berilio }\end{array}$ & 6.1 \\
\hline $\begin{array}{l}\text { TRICLOROETILENO } \\
79-01-6\end{array}$ & $\begin{array}{l}\text { - El vapor es más pesado } \\
\text { que el aire } \bullet \text { Pueden } \\
\text { generarse cargas } \\
\text { electrostáticas como } \\
\text { consecuencia de flujo, } \\
\text { agitación, etc. }\end{array}$ & $\begin{array}{l}\text { - En contacto con superficies calientes o llamas, se descompone liberando vapores tóxicos y } \\
\text { corrosivos (fosgeno, cloruro de hidrógeno, cloro) • Se descompone en contacto con álcalis } \\
\text { fuertes, produciendo dicloroacetileno, que aumenta el riesgo de incendio • Reacciona } \\
\text { violentamente con metales como litio, magnesio, aluminio, titanio, bario y sodio } \bullet \text { Se } \\
\text { descompone lentamente por efecto de la luz en presencia de humedad, con formación de ácido } \\
\text { clorhídrico corrosivo }\end{array}$ & 6.1 \\
\hline
\end{tabular}

\begin{tabular}{|c|c|c|c|c|c|c|c|c|c|c|c|}
\hline $\begin{array}{l}\text { Denominación química } \\
\mathrm{N} \text { úmero CAS }\end{array}$ & Color/ forma & $\begin{array}{l}\text { p.e. } \\
(\stackrel{O}{ } \mathrm{C})\end{array}$ & $\begin{array}{l}\text { p.f. } \\
(\stackrel{0}{ })\end{array}$ & $\begin{array}{l}\text { p.m.l } \\
\text { (g/ } \\
\text { mol) }\end{array}$ & $\begin{array}{l}\text { Solubilidad } \\
\text { en agua }\end{array}$ & $\begin{array}{l}\text { Densidad } \\
\text { relativa } \\
\text { (agua }=1 \text { ) }\end{array}$ & $\begin{array}{l}\text { Densidad } \\
\text { relativa } \\
\text { del vapor } \\
\text { (aire=1) }\end{array}$ & $\begin{array}{l}\mathrm{Pvap} / \\
(\mathrm{kPa})\end{array}$ & $\begin{array}{l}\text { Límit. } \\
\text { inflam. }\end{array}$ & $\begin{array}{l}\text { p.ig. } \\
(\underline{O C})\end{array}$ & $\begin{array}{l}\text { p.aut } \\
\text { ig. } \\
(\circ 0)\end{array}$ \\
\hline $\begin{array}{l}\text { BROMURO DE ALILO } \\
106-95-6\end{array}$ & $\begin{array}{l}\text { líquido incoloro } 0 \\
\text { amarillo claro }\end{array}$ & 71,3 & -119 & 120 & insol & 1,398 & 4,2 & & $\begin{array}{l}4,4 \mathrm{li} \\
7,3 \mathrm{ls}\end{array}$ & -11 & 295 \\
\hline $\begin{array}{l}\text { BROMURO DE PROPARGILO } \\
106.96-7\end{array}$ & $\begin{array}{l}\text { líquido incoloro o } \\
\text { color ámbar claro }\end{array}$ & 89 & & 118 & insol & $1,579 @ 18 \cong 0$ & & & $\begin{array}{l}3,0 \mathrm{li} \\
? \text { Is }\end{array}$ & $100 c c$ & 328 \\
\hline $\begin{array}{l}\text { BROMURO DE VINILO } \\
\text { 593-60-2 }\end{array}$ & $\begin{array}{l}\text { gas en condiciones } \\
\text { atmosféricas } \\
\text { normales, líquido } \\
\text { incoloro a presión }\end{array}$ & 15,8 & -139 & 106,96 & insol & 1,4933 & 3,7 & $\begin{array}{l}1033 \\
\mathrm{~mm} \mathrm{Hg} \\
@ 25 \stackrel{\circ}{\circ} \mathrm{C}\end{array}$ & $\begin{array}{l}9 \mathrm{li} \\
15 \mathrm{ls}\end{array}$ & & 530 \\
\hline $\begin{array}{l}\text { 2-CLORO-1,3-BUTADIENO } \\
126-99-8\end{array}$ & líquido incoloro & 59,4 & -130 & 88,54 & lig sol & 0,9583 & 3,0 & $20 @ 26,7$ & $\begin{array}{l}2,1 \mathrm{li} \\
11,5 \mathrm{ls}\end{array}$ & $-22 \mathrm{ca}$ & 320 \\
\hline $\begin{array}{l}\text { 1-CLORO-2-METLL-1-PROPENO } \\
\text { 513-37-1 }\end{array}$ & líquido & $\begin{array}{l}68{ }^{\circ} \mathrm{C} @ \\
754 \mathrm{~mm} \mathrm{Hg}\end{array}$ & & 90,55 & & $\begin{array}{l}0,9186 @ \\
20^{\circ} \mathrm{C} / 4^{\circ} \mathrm{C}\end{array}$ & & & & & \\
\hline $\begin{array}{l}\text { 3-CLORO-2-METILPROPENO } \\
563-47-3\end{array}$ & $\begin{array}{l}\text { líquido incoloro } 0 \\
\text { color pajizo }\end{array}$ & 71,5 & -12 & 90,55 & insol & 0,9165 & 3,1 & 13,53 & & $\begin{array}{l}-161 \\
\text { ca }\end{array}$ & \\
\hline $\begin{array}{l}\text { CLORURO DE ALLLO } \\
107-05-1\end{array}$ & $\begin{array}{l}\text { líquido incoloro; } \\
\text { líquido incoloro o de } \\
\text { color rojo o marrón } \\
\text { amarillento }\end{array}$ & 45 & $-134,5$ & 76,53 & insol & 0,938 & 2,64 & 39,3 & $\begin{array}{l}2,9 \mathrm{li} \\
11,2 \mathrm{ls}\end{array}$ & $-317 c c$ & 390 \\
\hline $\begin{array}{l}\text { CLORURO DE PROPARGILO } \\
624-65-7\end{array}$ & líquido & 57,1 & $.76,9$ & 74,51 & insol & 1,0297 & & & & 183 & \\
\hline $\begin{array}{l}\text { CLORURO DE VINILIDENO } \\
75-35-4\end{array}$ & líquido incoloro & 31,7 & $-122,5$ & 96,94 & insol & 1,2129 & 3,25 & 66,5 & $\begin{array}{l}5,6 \mathrm{li} \\
16 \mathrm{ls}\end{array}$ & 56 & 570 \\
\hline $\begin{array}{l}\text { CLORURO DE VINILO } \\
75-01-4\end{array}$ & gas o líquido incoloro & $-13,37$ & $-153,8$ & 62,50 & lig sol & 0,9106 & 2,15 & 343 & $\begin{array}{l}3,6 \mathrm{li} \\
33,0 \mathrm{ls}\end{array}$ & $.78 \mathrm{cc}$ & 472 \\
\hline $\begin{array}{l}\text { DICLOROACETILENO } \\
7572-29-4\end{array}$ & & $32-33$ & .66 & 94,93 & insol & 1,261 & & & & & \\
\hline $\begin{array}{l}\text { 1,4-DICLORO-2-BUTENO } \\
764-41-0\end{array}$ & líquido incoloro & & & 125 & insol & & & $\begin{array}{l}20 \mathrm{~mm} \mathrm{Hg} \\
\text { @ } 55,5 \stackrel{\circ}{\circ} \mathrm{C}\end{array}$ & $\begin{array}{l}1,5 \mathrm{li} \\
4,0 \mathrm{ls}\end{array}$ & & \\
\hline
\end{tabular}




\begin{tabular}{|c|c|c|c|c|c|c|c|c|c|c|c|}
\hline $\begin{array}{l}\text { Denominación química } \\
\mathrm{N} \text { úmero CAS }\end{array}$ & Color/ forma & $\begin{array}{l}\text { p.e. } \\
(\stackrel{0}{ } \mathrm{C})\end{array}$ & $\begin{array}{l}\text { p.f. } \\
(\stackrel{\circ}{ })\end{array}$ & $\begin{array}{l}\text { p.m.l } \\
\text { (g/ } \\
\text { mol) }\end{array}$ & $\begin{array}{l}\text { Solubilidad } \\
\text { en agua }\end{array}$ & $\begin{array}{l}\text { Densidad } \\
\text { relativa } \\
\text { (agua }=1 \text { ) }\end{array}$ & $\begin{array}{l}\text { Densidad } \\
\text { relativa } \\
\text { del vapor } \\
(\text { aire }=1 \text { ) }\end{array}$ & $\begin{array}{l}\text { Pvap/ } \\
(\mathrm{kPa})\end{array}$ & $\begin{array}{l}\text { Límit. } \\
\text { inflam. }\end{array}$ & $\begin{array}{l}\text { p.ig. } \\
(\underline{O C})\end{array}$ & $\begin{array}{l}\text { p.aut } \\
\text { ig. } \\
\left({ }^{\circ} \mathrm{C}\right)\end{array}$ \\
\hline $\begin{array}{l}\text { 1,2-DICLOROETILENO } \\
540-59-0\end{array}$ & líquido incoloro & 45 & -81 & 96,95 & insol & 1,27 & 3,34 & $24,0-35,3$ & $\begin{array}{l}9,7 \mathrm{li} \\
12,8 \mathrm{ls}\end{array}$ & $22-39$ & 460 \\
\hline $\begin{array}{l}\text { Cis-1,2-DICLOROETILENO } \\
156-59-2\end{array}$ & líquido incoloro & 60,3 & -80 & 96,94 & lig sol & 1,2837 & $3,54 \mathrm{~g} / \mathrm{l}$ & $\begin{array}{l}273 \mathrm{~mm} \mathrm{Hg} \\
@ 30^{\circ} \mathrm{C}\end{array}$ & $\begin{array}{l}9,7 \mathrm{li} \\
12,8 \mathrm{IS}\end{array}$ & & 460 \\
\hline $\begin{array}{l}\text { trans-1,2-DICLOROETILENO } \\
156-60-5\end{array}$ & & 48,7 & .50 & 96,94 & lig sol & 1,2565 & $3,67 \mathrm{~g} / \mathrm{l}$ & $\begin{array}{l}395 \mathrm{~mm} \mathrm{Hg} \\
\text { @ } 30 \stackrel{\mathrm{C}}{ }\end{array}$ & $\begin{array}{l}9,7 \mathrm{li} \\
12,8 \mathrm{ls}\end{array}$ & 2 & 460 \\
\hline $\begin{array}{l}\text { 1,2-DICLORO-2-PROPENO } \\
\text { 78-88-6}\end{array}$ & $\begin{array}{l}\text { líquido de color } \\
\text { pajizo }\end{array}$ & 94 & & 110,97 & $0,0194 \mathrm{~g} / \mathrm{l}$ & $\begin{array}{l}1,211 \mathrm{a} \\
20^{\circ} \mathrm{C} / 4{ }^{\circ} \mathrm{C}\end{array}$ & 3,8 & $\begin{array}{l}53 \mathrm{~mm} \mathrm{Hg} \\
\text { a } 25^{\circ} \mathrm{C}\end{array}$ & $\begin{array}{l}5,3 \% \mathrm{li} \\
14,5 \% \text { is }\end{array}$ & & \\
\hline $\begin{array}{l}\text { 1,3-DICLOROPROPENO } \\
542 \cdot 75 \cdot 6\end{array}$ & $\begin{array}{l}\text { líquido incoloro } 0 \\
\text { color pajizo }\end{array}$ & 108 & $<-50$ & 110,98 & $0,15 \%$ & $1,220 @ 25 \stackrel{\circ}{0}$ & 3,8 & $3,7 \mathrm{~Pa}$ & $\begin{array}{l}2,6 \mathrm{li} \\
7,8 \mathrm{Is}\end{array}$ & $25 \mathrm{cc}$ & \\
\hline $\begin{array}{l}\text { Cis-1,3-DICLOROPROPENO } \\
\text { 10061-01-5 }\end{array}$ & líquido incoloro & 104,3 & & 110,97 & insol & 1,217 & $\begin{array}{l}1,4 @ \\
37,8 \stackrel{\circ}{-C}\end{array}$ & $\begin{array}{l}43 \mathrm{~mm} \mathrm{Hg} \\
@ 25 \stackrel{\circ}{ } \mathrm{C}\end{array}$ & $\begin{array}{l}2,6 \mathrm{li} \\
7,8 \mathrm{Is}\end{array}$ & $35 \mathrm{Ca}$ & \\
\hline $\begin{array}{l}\text { trans-1,3-DICLOROPROPENO } \\
\text { 10061-02-6 }\end{array}$ & líquido incoloro & 112 & & 110,97 & insol & 1,224 & $1,4 @ 37,8 \mathrm{C}$ & 2,47 & $\begin{array}{l}2,6 \mathrm{li} \\
7,8 \mathrm{Is}\end{array}$ & $35 \mathrm{Ca}$ & \\
\hline $\begin{array}{l}\text { FLUORURO DE VINILLIDENO } \\
75-38-7\end{array}$ & gas incoloro & .83 & -144 & 64,04 & insol & 0,617 & 2,2 & 3600 & $\begin{array}{l}5,5 \mathrm{li} \\
21,3 \mathrm{ls}\end{array}$ & $\begin{array}{l}\text { gas } \\
\text { infla- } \\
\text { mable }\end{array}$ & \\
\hline $\begin{array}{l}\text { FLUORURO DE VINILO } \\
72-02-5\end{array}$ & gas incoloro & $\cdot 72,2$ & $-160,5$ & 46,04 & insol & & & & & & \\
\hline $\begin{array}{l}\text { HEXACLOROBUTADIENO } \\
87.68-3\end{array}$ & $\begin{array}{l}\text { líquido incoloro y } \\
\text { transparente }\end{array}$ & 215 & -21 & 260,76 & insol & 1,5542 & 8,99 & $\begin{array}{l}2,93 \\
\text { @ } 100\left({ }^{\circ} \mathrm{C}\right)\end{array}$ & & & 610 \\
\hline $\begin{array}{l}\text { HEXACLORO-1,3-CICLOPENTADIENO } \\
77-47-4\end{array}$ & $\begin{array}{l}\text { líquido verde } \\
\text { amarillento; líquido } \\
\text { oleaginoso denso }\end{array}$ & $\begin{array}{l}239 @ \\
753 \mathrm{~mm} \mathrm{Hg}\end{array}$ & .9 & 272,77 & & $\begin{array}{l}1,7019 @ \\
25 \stackrel{\circ}{\circ} / 4 \stackrel{\circ}{-} \mathrm{C}\end{array}$ & 9,4 & $\begin{array}{l}0,080 \\
\mathrm{~mm} \mathrm{Hg} \\
@ 25 \stackrel{\circ}{-} \mathrm{C} \\
\end{array}$ & & & \\
\hline $\begin{array}{l}\text { HEXACLOROPROPENO } \\
1888.71 .7\end{array}$ & $\begin{array}{l}\text { líquido de color de } \\
\text { agua }\end{array}$ & 210 & & 248,73 & insol & & & & & & \\
\hline $\begin{array}{l}\text { TETRACLOROETILENO } \\
\text { 127-18-4 } \\
\end{array}$ & líquido incoloro & 121 & .22 & 165,83 & insol & 1,6227 & 5,7 & 1,9 & & & \\
\hline $\begin{array}{l}\text { 2,3,4-TRICLORO-1-BUTENO } \\
\text { 2431-50-7 }\end{array}$ & & 60 & & 159,44 & insol & 1,3430 & & & & & \\
\hline $\begin{array}{l}\text { TRICLOROETLEENO } \\
79-01.6\end{array}$ & $\begin{array}{l}\text { líquido móvil } \\
\text { transparente, } \\
\text { incoloro o azul }\end{array}$ & 87 & .73 & 131,40 & lig sol & 1,4649 & 4,53 & 7,8 & $\begin{array}{l}8 \mathrm{li} \\
10,5 \mathrm{ls}\end{array}$ & & 410 \\
\hline
\end{tabular}




\section{HIDRO CARBUROS ALIFATICOS INSATURADOS}

\begin{abstract}
U sos
Los hidrocarburos insaturados tienen importancia comercial como materias primas para la fabricación de numerosos productos químicos y polímeros, como plásticos, caucho y resinas. La vasta producción de la industria petroquímica se basa en la reactividad de estas sustancias.

El 1-penteno es un agente de mezclado para combustibles de alto octanaje de motores, y el isopreno se utiliza en la fabricación de caucho sintético y caucho butílico. El propileno se utiliza también en la fabricación de caucho sintético y en forma polimerizada como plástico de polipropileno. El isobutileno es un antioxidante en las industrias de alimentos y conservas. EI 1-hexeno se utiliza en la síntesis de aromas, perfumes y colorantes. El etileno, el cis-2-buteno y el trans-2-buteno son disolventes, y el propadieno es un compuesto de gas combustible utilizado en metalistería

El principal uso industrial del etileno es como ingrediente de materias primas que a su vez se utilizan para fabricar una gran variedad de sustancias y productos. El etileno se utiliza también en la soldadura oxietilénica, el cortado de metales y en el gas mostaza. Actúa como refrigerante, anestésico por inhalación, acelerador del crecimiento de las plantas y madurador de frutas. No obstante, las cantidades utilizadas con estos fines son más pequeñas que las utilizadas en la fabricación de otros productos químicos. U no de los principales productos químicos derivados del etileno es el polietileno, obtenido mediante polimerización catalítica del etileno y utilizado en la fabricación de diversos productos de plástico moldeados. El óxido de etileno se produce mediante oxidación catalítica y a su vez se utiliza para preparar etilen glicol y etanolaminas. La mayor parte del alcohol etílico industrial se obtiene por hidratación de etileno. Su cloración produce monómero de cloruro de vinilo y 1,2-dicloroetano. Cuando reacciona con benceno, se obtiene monómero de estireno. También puede obtenerse acetaldehído por oxidación de etileno.
\end{abstract}

\section{Riesgos}

\section{Riesgos para la salud}

Como sus homólogos saturados, los hidrocarburos alifáticos insaturados inferiores u olefinas son asfixiantes simples, pero a medida que aumenta el peso molecular, las propiedades narcóticas e irritantes son más pronunciadas que las de sus análogos saturados. Por ejemplo, el etileno, el propileno y el amileno se han utilizado como anestésicos en cirugía, pero requieren grandes concentraciones $(60 \%)$ y por ello se administran con oxígeno. L as diolefinas son más narcóticas que las monoolefinas y también más irritantes para las mucosas y los ojos.

1,3-B utadieno. L os riesgos físicoquímicos del butadieno se deben a su alta inflamabilidad y extrema reactividad. Puesto que fácilmente se alcanza una mezcla inflamable con concentraciones de entre 2 y 11,5\% de butadieno en el aire, esta sustancia conlleva peligro de incendio y explosión cuando se expone a calor, chispas, Ilamas y oxidantes. C uando se expone a aire u oxígeno, el butadieno forma rápidamente peróxidos, que pueden experimentar combustión espontánea.

A pesar de que durante muchos años la experiencia de los trabajadores expuestos a butadieno y los experimentos con seres humanos y animales parecían indicar que este compuesto es poco tóxico, estudios epidemiológicos han demostrado que el 1,3-butadieno es un probable cancerígeno humano (Grupo 2A de la Agencia Internacional para la Investigación sobre el Cáncer $($ (IARC)). La exposición a concentraciones muy altas de gas produce efectos irritantes y anestésicos. Las personas pueden tolerar concentraciones de hasta 8.000 ppm durante 8 horas sin más efectos que una leve irritación de ojos, nariz y garganta. Se ha observado que la exposición a butadieno líquido y a su gas de evaporación provoca dermatitis (y también quemaduras por congelación). Algunos casos de inhalación de concentraciones excesivas que pueden producir anestesia, parálisis respiratoria y muerte se han debido a derrames y fugas de recipientes a presión, válvulas y bombas en zonas con una ventilación inadecuada. El butadieno se comenta con más detalle en el Capítulo Industria del caucho de este volumen.

El isopreno, que no presenta toxicidad salvo a concentraciones muy altas, se considera también ahora un posible cancerígeno humano. Grupo 2B de la IAR C.

E tileno. El principal riesgo del etileno es el de incendio y explosión. El etileno explota espontáneamente por efecto de la luz del sol en presencia de cloro y puede reaccionar vigorosamente con tetracloruro de carbono, dióxido de nitrógeno, cloruro de aluminio y sustancias oxidantes en general. Las mezclas etilenoaire arden cuando se exponen a cualquier fuente de ignición, como chispas estáticas, de fricción o eléctricas, llamas abiertas 0 calor excesivo. Algunas mezclas confinadas explotan violentamente como consecuencia de estas fuentes de ignición. A menudo el etileno se manipula y transporta en forma de líquido a presión. El contacto de la piel con el líquido puede causar una "quemadura por frío". En los procesos de fabricación existen pocas posibilidades de exposición a etileno, ya que tienen lugar en sistemas cerrados. La exposición puede ocurrir como resultado de fugas, derrames $u$ otros accidentes que hacen que se libere gas al aire. L os tanques y recipientes vacíos que han contenido etileno constituyen otra fuente potencial de exposición.

En el aire, el etileno actúa principalmente como asfixiante. Las concentraciones de etileno necesarias para producir un efecto fisiológico marcado reducen el contenido de oxígeno a un nivel muy bajo e incompatible con la vida. Por ejemplo, el aire que contiene un $50 \%$ de etileno contendrá solamente un $10 \%$ de oxígeno.

Cuando el aire contiene aproximadamente un $11 \%$ de oxígeno, se produce pérdida de conciencia y si dicho porcentaje desciende todavía más, se produce la muerte en el acto. No existen pruebas que indiquen que la exposición prolongada a bajas concentraciones de etileno cause efectos crónicos. La exposición prolongada a altas concentraciones puede causar efectos permanentes debido a la privación de oxígeno.

El etileno exhibe una toxicidad sistémica muy baja. C uando se utiliza como anestésico en cirugía, se administra siempre con oxígeno. En dichos casos, su acción es la de un anestésico simple con una acción rápida y una recuperación igualmente rápida. $L a$ inhalación prolongada de aproximadamente una concentración de $85 \%$ en oxígeno es ligeramente tóxica, provocando un descenso lento de la tensión arterial; la concentración de etileno del $94 \%$ en oxígeno es letal.

\section{Medidas de salud y seguridad}

C on respecto a los productos químicos sin carcinogenicidad ni efectos tóxicos similares, debe mantenerse una ventilación adecuada para prevenir la exposición de los trabajadores a una 
concentración que supere los límites de seguridad recomendados. Los trabajadores deben saber que algunos síntomas, como escozor de ojos, irritación respiratoria, cefalea y vértigo, pueden indicar una concentración en la atmósfera poco segura. Las bombonas de butadieno deben almacenarse boca arriba en un lugar fresco, seco y bien ventilado, alejado de fuentes de calor, llamas abiertas y chispas.

El área de almacenamiento debe estar separada de fuentes de oxígeno, cloro, otros materiales oxidantes y gases y materiales combustibles. Puesto que el butadieno es más pesado que el aire y el gas procedente de fugas se acumula en las zonas bajas, debe evitarse el almacenamiento en fosas y sótanos. Los contenedores de butadieno deben estar debidamente etiquetados, indicando claramente que se trata de un gas explosivo. Las bombonas deben estar construidas para resistir la presión y evitar las fugas y no deben sufrir golpes durante su manipulación. Estas bombonas están habitualmente provistas de una válvula de seguridad. Las bombonas no deben someterse a temperaturas superiores a $55 \stackrel{\circ}{\circ}$. Para detectar posibles fugas, lo mejor es empapar la zona sospechosa con una solución jabonosa, de manera que en caso de existir algún escape de gas, se formen pompas visibles; en ningún caso se utilizarán cerillas o llamas para detectar fugas.

Con respecto a los posibles o probables cancerígenos, deben adoptarse todas las precauciones adecuadas y necesarias para su manipulación.

Tanto en su fabricación como en su uso, el butadieno debe manipularse en un sistema cerrado y correctamente diseñado. Generalmente se le añaden antioxidantes e inhibidores (como terc-butilcatecol en una proporción aproximada del 0,02 \% en peso) para prevenir la formación de polímeros y peróxidos peligrosos. La extinción de los incendios de butadieno es difícil y peligrosa. Los pequeños incendios pueden apagarse con dióxido de carbono o extintores de incendios con productos químicos en polvo. Los grandes incendios y las áreas adyacentes deben rociarse con agua. En la medida de lo posible, los incendios deben controlarse cerrando todas las fuentes de combustible. EI butadieno no requiere la realización de exámenes médicos previos al empleo ni reconocimientos periódicos de los trabajadores que lo manipulan.

Los miembros inferiores de la serie (etileno, propileno y butileno) son gases a temperatura ambiente y muy inflamables 0 explosivos cuando se mezclan con aire u oxígeno. El resto de los miembros son líquidos volátiles e inflamables que pueden dar lugar a concentraciones explosivas de vapor en el aire a las temperaturas normales de trabajo. En contacto con el aire, las diolefinas pueden formar peróxidos orgánicos que, si se concentran o calientan, pueden detonar violentamente. La mayor parte de las diolefinas producidas comercialmente están en general inhibidas contra la formación de peróxidos.

Debe evitarse el contacto con toda fuente de ignición. Las instalaciones y equipos eléctricos deben ser resistentes a las explosiones. Todas las salas o áreas en la que se manipule etileno deben estar debidamente ventiladas. No debe permitirse la entrada a espacios confinados que hayan contenido etileno hasta que los análisis de gases indiquen que son seguros y una persona autorizada haya firmado un permiso de acceso.

Las personas que puedan verse expuestas a etileno deben recibir una instrucción adecuada y conocer los métodos para una manipulación segura y adecuada. Debe prestarse atención al peligro de incendio, a las "quemaduras por frío" debido al contacto con el material líquido, al uso de equipos protectores y a las medidas de emergencia. 


\section{TABLAS DE HIDROCARBUROS AUFATICOS INSATURADOS}

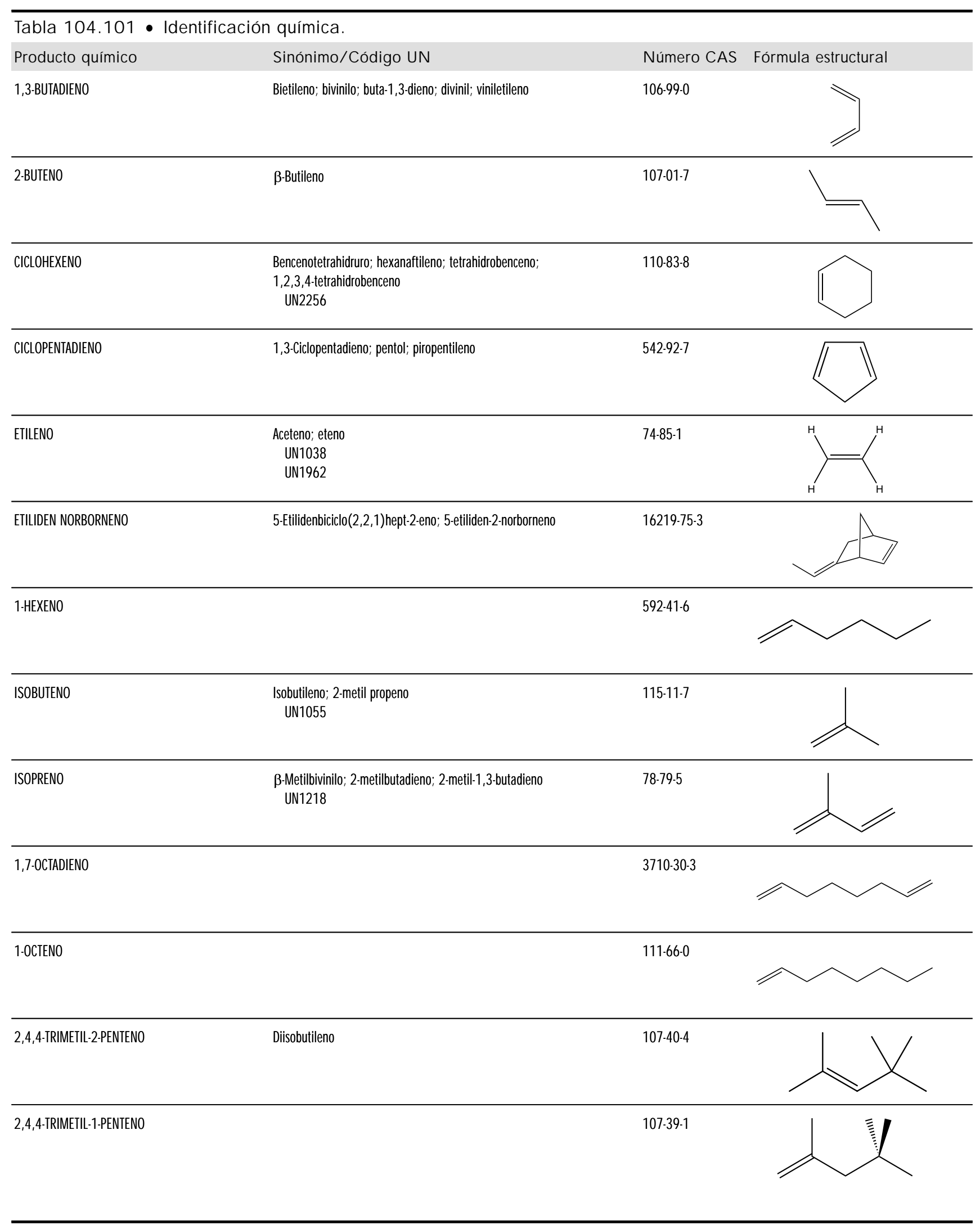




\begin{tabular}{|c|c|c|c|c|c|c|}
\hline \multirow[b]{2}{*}{$\begin{array}{l}\text { Denominación } \\
\text { química } \\
\mathrm{N} \text { úmero CAS }\end{array}$} & \multicolumn{4}{|c|}{ Tarjetas Internacionales sobre la Seguridad de los Productos Q uímicos } & \multicolumn{2}{|c|}{ N IO SH (EE.UU.) } \\
\hline & $\begin{array}{l}\text { Período } \\
\text { corto de } \\
\text { exposición }\end{array}$ & $\begin{array}{l}\text { Período } \\
\text { largo de } \\
\text { exposición }\end{array}$ & $\begin{array}{l}\text { Vías de } \\
\text { exposición }\end{array}$ & Síntomas & $\begin{array}{l}\text { O rganos } \\
\text { afectados } \\
\text { Vías de } \\
\text { entrada }\end{array}$ & Síntomas \\
\hline $\begin{array}{l}\text { 1,3-BUTADIENOR } \\
106-99-0\end{array}$ & $\begin{array}{l}\text { ojos; tract resp; } \\
\text { piel; SNC }\end{array}$ & $\begin{array}{l}\text { médula ósea; } \\
\text { higado; } \\
\text { reproducción }\end{array}$ & $\begin{array}{r}\text { Inhalación } \\
\text { Piel } \\
\text { 0jos }\end{array}$ & $\begin{array}{l}\text { Tos; sopor, visión borrosa; náuseas, dolor de } \\
\text { garganta, inconsciencia, parálisis respiratoria } \\
\text { En contacto con el líquido: congelación } \\
\text { Enrojecimiento; dolor; visión borrosa }\end{array}$ & $\begin{array}{l}\text { Ojos; sis resp; SNC; } \\
\text { sis repro [cáncer } \\
\text { hemato] } \\
\text { Inh; con (liq) }\end{array}$ & $\begin{array}{l}\text { Irrit ojos, nariz, garganta; sop, } \\
\text { atur; liq: congelación; efectos } \\
\text { terato, repro; [carc] }\end{array}$ \\
\hline $\begin{array}{l}\text { 2-BUTENO } \\
107-01-7 \\
\end{array}$ & tract resp & piel & $\begin{array}{r}\text { Inhalación } \\
\text { Piel } \\
\end{array}$ & $\begin{array}{l}\text { Mareo, inconsciencia } \\
\text { En contacto con el líquido: congelación }\end{array}$ & & \\
\hline $\begin{array}{c}\text { cis-2-BUTENO } \\
590-18-1 \\
\end{array}$ & tract resp & piel & $\begin{array}{r}\text { Inhalación } \\
\text { Piel } \\
\end{array}$ & $\begin{array}{l}\text { Mareo; inconsciencia } \\
\text { En contacto con el líquido: congelación }\end{array}$ & & \\
\hline $\begin{array}{l}\text { trans-2-BUTENO } \\
624-64-6 \\
\end{array}$ & tract resp & piel & $\begin{array}{r}\text { Inhalación } \\
\text { Piel } \\
\end{array}$ & $\begin{array}{l}\text { Mareo, inconsciencia } \\
\text { En contacto con el líquido: congelación }\end{array}$ & & \\
\hline $\begin{array}{l}\text { CICLOHEXADIENOR } \\
592-57-4\end{array}$ & ojos; piel; tract res & & $\begin{array}{r}\text { Inhalación } \\
\text { Piel } \\
\text { 0jos } \\
\end{array}$ & $\begin{array}{l}\text { Tos, dolor de garganta } \\
\text { Enrojecimiento } \\
\text { Enrojecimiento }\end{array}$ & & \\
\hline $\begin{array}{l}\text { CICLOHEXENO } \\
110-83-8\end{array}$ & ojos; piel; tract res & & $\begin{array}{r}\text { Inhalación } \\
\text { Piel } \\
\text { Ojos } \\
\text { Ingestión } \\
\end{array}$ & $\begin{array}{l}\text { Tos } \\
\text { Enrojecimiento } \\
\text { Enrojecimiento } \\
\text { Sopor, dificultad respiratoria, náuseas } \\
\end{array}$ & $\begin{array}{l}\text { Ojos; piel; sis resp; } \\
\text { SNC } \\
\text { Inh; ing; con }\end{array}$ & Irrit ojos, piel, sis resp; sop \\
\hline $\begin{array}{l}\text { CICLOPENTADIENO } \\
542.92 .7\end{array}$ & ojos; tract resp & piel & $\begin{array}{r}\text { Inhalación } \\
\text { Ojos } \\
\text { Ingestión }\end{array}$ & $\begin{array}{l}\text { Sopor } \\
\text { Enrojecimiento, dolor } \\
\text { Insconsciencia }\end{array}$ & $\begin{array}{l}\text { Ojos; sis resp } \\
\text { Inh; ing; con }\end{array}$ & Irrit ojos, nariz \\
\hline $\begin{array}{l}\text { ETILENO } \\
74-85-1 \\
\end{array}$ & & & Inhalación & Mareo, sopor, cefalea, inconsciencia & & \\
\hline $\begin{array}{l}\text { ETLLIDEN NORBORNENO } \\
16219-75-3\end{array}$ & $\begin{array}{l}\text { ojos; piel; } \\
\text { tract resp; } \\
\text { pulmones }\end{array}$ & hígado; riñones & $\begin{array}{r}\text { Inhalación } \\
\text { Piel } \\
\text { 0jos } \\
\text { Ingestión }\end{array}$ & $\begin{array}{l}\text { Confusión, tos, cefalea, disnea, dolor de } \\
\text { garganta } \\
\text { Enrojecimiento, dolor } \\
\text { Enrojecimiento, dolor } \\
\text { Náuseas, vómitos }\end{array}$ & $\begin{array}{l}\text { Ojos; piel; sis resp; } \\
\text { SNC; hígado; } \\
\text { riñones; sis } \\
\text { urogenital; médula } \\
\text { ósea } \\
\text { Inh; abs; ing; con }\end{array}$ & $\begin{array}{l}\text { Irrit ojos, piel, nariz, garganta; } \\
\text { cef; tos; dis; náu, vómit; } \\
\text { alteración del olfato y el } \\
\text { gusto; neu química (aspir liq); } \\
\text { en animales: lesiones } \\
\text { hepáticas, renales y } \\
\text { urogenitales; efectos en la } \\
\text { médula ósea }\end{array}$ \\
\hline $\begin{array}{l}\text { 1-HEXENO } \\
592-41-6\end{array}$ & mucosas; SNC & & $\begin{array}{r}\text { Inhalación } \\
\text { Piel } \\
\text { 0jos } \\
\end{array}$ & $\begin{array}{l}\text { Mareo, inconsciencia, vómitos } \\
\text { Enrojecimiento } \\
\text { Enrojecimiento }\end{array}$ & & \\
\hline $\begin{array}{r}\text { ISOPRENO } \\
78.79 .5\end{array}$ & ojos; piel; tract res & & $\begin{array}{r}\text { Inhalación } \\
\text { Piel } \\
\text { 0jos }\end{array}$ & $\begin{array}{l}\text { Mareo, inconsciencia, vómitos } \\
\text { Enrojecimiento } \\
\text { Enrojecimiento }\end{array}$ & & \\
\hline $\begin{array}{l}\text { 1,7-0CTADIENO } \\
3710-30-3\end{array}$ & ojos; piel; tract res & piel; pulmones & $\begin{array}{r}\text { Inhalación } \\
\text { Piel } \\
\text { 0jos }\end{array}$ & $\begin{array}{l}\text { Confusión, mareo, sopor, cefalea, náuseas, } \\
\text { inconsciencia } \\
\text { Puede absorberse, enrojecimiento, quemaduras } \\
\text { en la piel, dolor, ampollas } \\
\text { Enrojecimiento, dolor, visión borrosa, } \\
\text { quemaduras profundas graves }\end{array}$ & & \\
\hline $\begin{array}{l}\text { 1-OCTENO } \\
\quad 111-66.0 \\
\end{array}$ & $\begin{array}{l}\text { puede afectar al } \\
\text { SNC }\end{array}$ & piel & $\begin{array}{l}\text { Piel } \\
\text { Ojos }\end{array}$ & $\begin{array}{l}\text { Sequedad de piel } \\
\text { Enrojecimiento }\end{array}$ & & \\
\hline $\begin{array}{l}\text { 2,2,4-TRIMETIL-1-PENTENO } \\
\text { 107-39-1 }\end{array}$ & $\begin{array}{l}\text { ojos; piel; } \\
\text { tract resp; } \\
\text { pulmones }\end{array}$ & & $\begin{array}{r}\text { Inhalación } \\
\text { Piel } \\
\text { 0jos } \\
\end{array}$ & $\begin{array}{l}\text { Confusión, mareo, sopor, embotamiento, } \\
\text { cefalea } \\
\text { Enrojecimiento } \\
\text { Enrojecimiento, dolor }\end{array}$ & & \\
\hline $\begin{array}{l}\text { 2,2,4-TRIMETIL-2-PENTENO } \\
\text { 107-40-4 }\end{array}$ & piel; SNC & & $\begin{array}{l}\text { Piel } \\
\text { Ojos }\end{array}$ & $\begin{array}{l}\text { Enrojecimiento, dolor } \\
\text { Enrojecimiento, dolor }\end{array}$ & & \\
\hline
\end{tabular}


Tabla 104.103 • Riesgos físicos y químicos.

\begin{tabular}{|c|c|c|c|}
\hline $\begin{array}{l}\text { Denominación química } \\
\mathrm{N} \text { úmero CAS }\end{array}$ & Físicos & Q uímicos & $\begin{array}{l}\text { Clase o división } \\
\text { UN / Riesgos } \\
\text { subsidiarios }\end{array}$ \\
\hline $\begin{array}{l}\text { 1,3-BUTADIENO } \\
106-99-0\end{array}$ & $\begin{array}{l}\text { - El gas es más pesado que el aire y } \\
\text { puede desplazarse a ras del suelo; } \\
\text { posibilidad de ignición a distancia • El } \\
\text { 1,3-butadieno líquido flota y hierve en } \\
\text { agua }\end{array}$ & $\begin{array}{l}\text { - En algunas circunstancias puede formar peróxidos, iniciando una polimerización } \\
\text { explosiva • Se polimeriza por calentamiento con riesgo de incendio } 0 \text { explosión } \\
\text { - Con cobre y sus aleaciones forma compuestos sensibles al impacto • Se } \\
\text { descompone explosivamente al calentarse rápidamente bajo presión } \bullet \text { Reacciona } \\
\text { vigorosamente con oxidantes y muchas otras sustancias, con peligro de incendio y } \\
\text { explosión }\end{array}$ & 2.1 \\
\hline $\begin{array}{l}\text { 2-BUTENO } \\
\quad 107-01-7\end{array}$ & $\begin{array}{l}\text { - El vapor es más pesado que el aire y } \\
\text { puede desplazarse a ras del suelo; } \\
\text { posibilidad de ignición a distancia } \\
\text { - Pueden generarse cargas } \\
\text { electrostáticas como resultado de flujo, } \\
\text { agitación, etc. }\end{array}$ & $\begin{array}{l}\text { - Se polimeriza en contacto con ácidos orgánicos e inorgánicos, halógenos y } \\
\text { sustancias halogénicas }\end{array}$ & \\
\hline $\begin{array}{l}\text { cis-2-BUTENO } \\
590-18-1\end{array}$ & $\begin{array}{l}\text { - El gas es más pesado que el aire y } \\
\text { puede desplazarse a ras del suelo; } \\
\text { posibilidad de ignición a distancia; puede } \\
\text { acumularse en espacios con techos bajos } \\
\text { causando deficiencia de oxígeno } \\
\text { - Pueden generarse cargas } \\
\text { electrostáticas como resultado de flujo, } \\
\text { agitación, etc. }\end{array}$ & & \\
\hline $\begin{array}{l}\text { trans-2-BUTENO } \\
624-64-6\end{array}$ & $\begin{array}{l}\text { - El gas es más pesado que el aire y } \\
\text { puede desplazarse a ras del suelo; } \\
\text { posibilidad de ignición a distancia; y } \\
\text { puede acumularse en espacios con } \\
\text { techos bajos causando deficiencia de } \\
\text { oxígeno • Pueden generarse cargas } \\
\text { electrostáticas como resultado de flujo, } \\
\text { agitación, etc. }\end{array}$ & & \\
\hline $\begin{array}{l}\text { n-BUTENO } \\
106-98-9\end{array}$ & $\begin{array}{l}\text { - El gas es más pesado que el aire y } \\
\text { puede desplazarse a ras del suelo; } \\
\text { posibilidad de ignición a distancia }\end{array}$ & $\begin{array}{l}\text { - Puede polimerizarse } \bullet \text { Puede explotar al calentarse } \bullet \text { Reacciona violentamente } \\
\text { con oxígeno y oxidantes, con peligro de incendio y explosión }\end{array}$ & 2.1 \\
\hline $\begin{array}{l}\text { 1,3-CICLOHEXADIENO } \\
592-57-4\end{array}$ & - El vapor es más pesado que el aire & $\begin{array}{l}\text { - En contacto con el aire puede formar peróxidos explosivos } \bullet \text { En su combustión } \\
\text { libera gases tóxicos • Reacciona con oxidantes fuertes con peligro de incendio y } \\
\text { explosión }\end{array}$ & \\
\hline $\begin{array}{l}\text { CICLOHEXENO } \\
110-83-8\end{array}$ & $\begin{array}{l}\text { - El vapor es más pesado que el aire y } \\
\text { puede desplazarse a ras del suelo; } \\
\text { posibilidad de ignición a distancia } \\
\text { - Pueden generarse cargas } \\
\text { electrostáticas como resultado de flujo, } \\
\text { agitación, etc. }\end{array}$ & $\begin{array}{l}\text { - Puede formar peróxidos explosivos } \bullet \text { Se polimeriza en ciertas condiciones } \\
\text { - Reacciona con oxidantes fuertes con peligro de incendio y explosión }\end{array}$ & 3 \\
\hline $\begin{array}{l}\text { CICLOPENTADIENO } \\
542.92 \cdot 7\end{array}$ & - El vapor es más pesado que el aire & $\begin{array}{l}\text { - Reacciona con ácido nítrico, ácido sulfúrico y oxidantes fuertes, con peligro de } \\
\text { incendio y explosión • Se dimeriza espontáneamente o en contacto con peróxido o } \\
\text { ácido tricloroacético }\end{array}$ & \\
\hline $\begin{array}{l}\text { ETLENO } \\
74-85-1\end{array}$ & - El gas es más ligero que el aire & $\begin{array}{l}\text { - Se polimeriza formando compuestos aromáticos por calentamiento a } 600{ }^{\circ} \mathrm{C} \\
\text { - Reacciona violentamente con cloro a la luz natural con peligro de incendio y } \\
\text { explosión • Reacciona con oxidantes con riesgo de explosión }\end{array}$ & \\
\hline $\begin{array}{l}\text { ETLLIDENO NORBORNENO } \\
16219-75-3\end{array}$ & $\begin{array}{l}\text { - Pueden generarse cargas } \\
\text { electrostáticas como resultado de flujo, } \\
\text { agitación, etc. }\end{array}$ & - Puede polimerizarse $\bullet$ Reacciona violentamente con oxidantes fuertes & \\
\hline $\begin{array}{l}\text { 1-HEXENO } \\
592-41.6\end{array}$ & $\begin{array}{l}\text { - El vapor es más pesado que el aire y } \\
\text { puede desplazarse a ras del suelo; } \\
\text { posibilidad de ignición a distancia; puede } \\
\text { acumularse en espacios con techos bajos } \\
\text { causando deficiencia de oxígeno }\end{array}$ & - Reacciona vigorosamente con oxidantes & 3 \\
\hline
\end{tabular}




\begin{tabular}{|c|c|c|c|}
\hline $\begin{array}{l}\text { Denominación química } \\
\mathrm{N} \text { úmero CAS }\end{array}$ & Físicos & Q uímicos & $\begin{array}{l}\text { Clase o división } \\
\text { UN / Riesgos } \\
\text { subsidiarios }\end{array}$ \\
\hline $\begin{array}{r}\text { ISOBUTENO } \\
115-11-7\end{array}$ & $\begin{array}{l}\text { - El gas es más pesado que el aire y } \\
\text { puede desplazarse a ras del suelo; } \\
\text { posibilidad de ignición a distancia; puede } \\
\text { acumularse en espacios con techos bajos } \\
\text { causando deficiencia de oxígeno } \\
\text { - Pueden generarse cargas } \\
\text { electrostáticas como resultado de flujo, } \\
\text { agitación, etc. }\end{array}$ & $\begin{array}{l}\text { - Presumiblemente puede formar peróxidos explosivos • Puede polimerizarse con } \\
\text { riesgo de incendio o explosión • Reacciona violentamente con oxidantes, cloro, } \\
\text { flúor, óxidos de nitrógeno, cloruro de hidrógeno, bromuro de hidrógeno, con peligro } \\
\text { de incendio y explosión • Ataca algunos plásticos y el caucho natural }\end{array}$ & 2.1 \\
\hline $\begin{array}{r}\text { ISOPRENO } \\
78-79-5\end{array}$ & $\begin{array}{l}\text { - El vapor es más pesado que el aire y } \\
\text { puede desplazarse a ras del suelo; } \\
\text { posibilidad de ignición a distancia } \\
\text { - Pueden generarse cargas } \\
\text { electrostáticas como resultado de flujo, } \\
\text { agitación, etc. }\end{array}$ & $\begin{array}{l}\text { - Puede formar rápidamente peróxidos explosivos } \bullet \text { Puede polimerizarse con } \\
\text { peligro de incendio o explosión • El calentamiento puede provocar combustión o } \\
\text { explosión violenta } \bullet \text { Reacciona con oxidantes fuertes, reductores fuertes, ácidos } \\
\text { fuertes, bases fuertes, cloruros ácidos, alcoholes, metales alcalinos }\end{array}$ & 3 \\
\hline $\begin{array}{l}\text { 1,7-OCTADIENO } \\
3710-30-3\end{array}$ & $\begin{array}{l}\text { - El vapor es más pesado que el aire y } \\
\text { puede desplazarse a ras del suelo; } \\
\text { posibilidad de ignición a distancia }\end{array}$ & $\begin{array}{l}\text { - Se polimeriza bajo la influencia de sustancias generadoras de radicales } \bullet \text { En su } \\
\text { combustión libera vapores tóxicos e irritantes } \bullet \text { Reacciona con oxidantes }\end{array}$ & \\
\hline $\begin{array}{l}1.0 C T E N O \\
111-66-0\end{array}$ & $\begin{array}{l}\text { - El vapor se mezcla bien con el aire, } \\
\text { formándose fácilmente mezclas } \\
\text { explosivas • Pueden generarse cargas } \\
\text { electrostáticas como resultado de flujo, } \\
\text { agitación }\end{array}$ & $\begin{array}{l}\text { - Presumiblemente puede formar peróxidos explosivos } \bullet \text { Reacciona violentamente } \\
\text { con oxidantes fuertes } \bullet \text { Reacciona con ácidos }\end{array}$ & \\
\hline $\begin{array}{l}\text { 2,4,4-TRIMETLL-1-PENTENO } \\
\text { 107-39-1 }\end{array}$ & $\begin{array}{l}\text { - El vapor es más pesado que el aire y } \\
\text { puede desplazarse a ras del suelo; } \\
\text { posibilidad de ignición a distancia } \\
\text { - Pueden generarse cargas } \\
\text { electrostáticas como resultado de flujo, } \\
\text { agitación, etc. }\end{array}$ & $\begin{array}{l}\text { - En su combustión libera vapores tóxicos } \bullet \text { Al calentarse se forman vapores } \\
\text { tóxicos } \bullet \text { Reacciona violentamente con oxidantes }\end{array}$ & \\
\hline $\begin{array}{l}\text { 2,4,4-TRIMETLL-2-PENTENO } \\
\text { 107-40-4 }\end{array}$ & $\begin{array}{l}\text { - El vapor es más pesado que el aire y } \\
\text { puede desplazarse a ras del suelo; } \\
\text { posibilidad de ignición a distancia }\end{array}$ & - Al calentarse se forman vapores tóxicos $\bullet$ Reacciona con oxidantes & \\
\hline
\end{tabular}

\begin{tabular}{|c|c|c|c|c|c|c|c|c|c|c|c|}
\hline $\begin{array}{l}\text { Denominación química } \\
\mathrm{N} \text { úmero CAS }\end{array}$ & Color/ Forma & $\begin{array}{l}\text { p.e. } \\
\left({ }^{\circ} \mathrm{C}\right)\end{array}$ & $\begin{array}{l}\text { p.f. } \\
(\stackrel{\circ}{ } C)\end{array}$ & $\begin{array}{l}\text { p.m.l } \\
\text { (g/ } \\
\text { mol) }\end{array}$ & $\begin{array}{l}\text { Solubilidad } \\
\text { en agua }\end{array}$ & $\begin{array}{l}\text { Densidad } \\
\text { relativa } \\
\text { (agua }=1 \text { ) }\end{array}$ & $\begin{array}{l}\text { Densidad } \\
\text { de vapor } \\
\text { relativa } \\
\text { (aire=1) }\end{array}$ & $\begin{array}{l}\text { Pvap/ } \\
(\mathrm{kPa})\end{array}$ & $\begin{array}{l}\text { Límit. } \\
\text { inflam. }\end{array}$ & $\begin{array}{l}\text { p.ig. } \\
\left({ }^{\circ} \mathrm{C}\right)\end{array}$ & $\begin{array}{l}\text { p.aut } \\
\text { ig. } \\
\left({ }^{\circ} \text { C }\right)\end{array}$ \\
\hline $\begin{array}{l}\text { BICICLOHEPTADIENO } \\
121-46-0\end{array}$ & & 89,5 & $-19,1$ & 92,13 & insol & 0,9064 & & & & & \\
\hline $\begin{array}{l}\text { 1,3-BUTADIENO } \\
106-99-0\end{array}$ & gas incoloro & $-4,5$ & $-108,9$ & 54,09 & insol & 0,6211 & 1,87 & 245 & $\begin{array}{l}2,0 \mathrm{li} \\
11,5 \mathrm{ls}\end{array}$ & 76 & 414 \\
\hline $\begin{array}{c}\text { cis-2-BUTENO } \\
590-18-1 \\
\end{array}$ & gas incoloro & 3,73 & $-139,3$ & 56,10 & insol & 0,6213 & 1,94 & $\begin{array}{l}188 @ \\
21^{\circ} \mathrm{C}\end{array}$ & $\begin{array}{l}1,7 \mathrm{li} \\
9,0 \mathrm{is}\end{array}$ & & 324 \\
\hline $\begin{array}{l}\text { trans-2-BUTENO } \\
624-64-6 \\
\end{array}$ & gas licuado & 0,8 & -105 & 56,10 & & 0,60 & 1,94 & $\begin{array}{l}212 \\
@ 21{ }^{\circ} \mathrm{C}\end{array}$ & $\begin{array}{l}1,8 \mathrm{li} \\
9,7 \mathrm{is}\end{array}$ & & 324 \\
\hline $\begin{array}{l}\text { CICLOHEXENO } \\
110-83-8\end{array}$ & líquido incoloro & 82,98 & $-103,5$ & 82,14 & insol & 0,8102 & 2,8 & 8,9 & $\begin{array}{l}1,2 \mathrm{li} \\
4,8 \mathrm{ls}\end{array}$ & $-6 c c$ & 310 \\
\hline
\end{tabular}


Tabla 104.104 • Propiedades físicas y químicas.

\begin{tabular}{|c|c|c|c|c|c|c|c|c|c|c|c|}
\hline $\begin{array}{l}\text { Denominación química } \\
\mathrm{N} \text { úmero CAS }\end{array}$ & Color/ Forma & $\begin{array}{l}\text { p.e. } \\
(\stackrel{\circ}{ } \mathrm{C})\end{array}$ & $\begin{array}{l}\text { p.f. } \\
(\stackrel{\circ}{ } C)\end{array}$ & $\begin{array}{l}\text { p.m.l } \\
\text { (g/ } \\
\mathrm{mol})\end{array}$ & $\begin{array}{l}\text { Solubilidad } \\
\text { en agua }\end{array}$ & $\begin{array}{l}\text { Densidad } \\
\text { relativa } \\
\text { (agua }=1 \text { ) }\end{array}$ & $\begin{array}{l}\text { Densidad } \\
\text { de vapor } \\
\text { relativa } \\
\text { (aire=1) }\end{array}$ & $\begin{array}{l}\text { Pvap/ } \\
(\mathrm{kPa})\end{array}$ & $\begin{array}{l}\text { Límit. } \\
\text { inflam. }\end{array}$ & $\begin{array}{l}\text { p.ig. } \\
\left({ }^{\circ} \mathrm{C}\right)\end{array}$ & $\begin{array}{l}\text { p.aut } \\
\text { ig. } \\
\left({ }^{\circ} \mathrm{C}\right)\end{array}$ \\
\hline $\begin{array}{l}\text { CICLOPENTADIENO } \\
542-92.7\end{array}$ & líquido incoloro & 41 & .85 & 66,11 & insol & 0,8021 & 2,3 & $\begin{array}{l}58,4 @ \\
25{ }^{\circ} \mathrm{C}\end{array}$ & & $25 \mathrm{Ca}$ & 640 \\
\hline $\begin{array}{l}\text { ETILENO } \\
74-85-1\end{array}$ & gas incoloro & -104 & -169 & 28,05 & insol & $0,465 @ 25 \cong C$ & 0,978 & $\begin{array}{l}8100 \\
@ 15^{\circ} \mathrm{C}\end{array}$ & $\begin{array}{l}2,7 \mathrm{li} \\
36,0 \mathrm{ls}\end{array}$ & & 450 \\
\hline $\begin{array}{l}\text { ETILLDENO NORBORNENO } \\
16219-75-3\end{array}$ & $\begin{array}{l}\text { líquido incoloro; } \\
\text { líquido blanco }\end{array}$ & 67 & -80 & 120,21 & insol & 0,8958 & 4,1 & 0,61 & & $38 \mathrm{ca}$ & \\
\hline $\begin{array}{l}\text { 1-HEXENO } \\
592-41-6\end{array}$ & líquido incoloro & 63,35 & $-139,8$ & 84,16 & insol & 0,6731 & 3,0 & $\begin{array}{l}40 @ \\
38{ }^{\circ} \mathrm{C}\end{array}$ & $\begin{array}{l}1,2 \mathrm{li} \\
6,9 \mathrm{ls}\end{array}$ & -26 & \\
\hline $\begin{array}{r}\text { ISOPRENO } \\
78.79-5\end{array}$ & líquido incoloro & 34,067 & -146 & 68,13 & insol & 0,681 & 2,4 & 61,8 & $\begin{array}{l}1,5 \mathrm{li} \\
8,9 \mathrm{ls}\end{array}$ & $54 \mathrm{cc}$ & 427 \\
\hline $\begin{array}{l}\text { 1-OCTENO } \\
111-66-0\end{array}$ & líquido incoloro & 121,3 & $-101,7$ & 112,22 & insol & 0,7149 & 3,87 & $\begin{array}{l}4,8 \\
@ 38^{\circ} \mathrm{C}\end{array}$ & $\begin{array}{l}0,7 \mathrm{li} \\
3,9 \mathrm{is}\end{array}$ & 21 & 230 \\
\hline $\begin{array}{l}\text { 2,4,4-TRIMETIL-1.PENTENO } \\
\quad 107-39-1 \\
\end{array}$ & líquido incoloro & 101,4 & $-93,5$ & 112,22 & insol & 0,7150 & 3,8 & $\begin{array}{l}10 @ \\
38^{\circ} \mathrm{C}\end{array}$ & $\begin{array}{l}0,8 \mathrm{li} \\
4,8 \mathrm{ls}\end{array}$ & -5 & 391 \\
\hline $\begin{array}{l}\text { 2,4,4-TRIMETIL-2.PENTENO } \\
\text { 107-40-4 }\end{array}$ & líquido incoloro & 104,91 & $-106,3$ & 112,22 & insol & 0,7218 & 3,8 & $\begin{array}{l}11,02 \\
@ 38^{\circ} \mathrm{C}\end{array}$ & $\begin{array}{l}0,9 \mathrm{li} \\
? \text { ls }\end{array}$ & $17 \mathrm{Ca}$ & 305 \\
\hline
\end{tabular}

Continua ... 


\section{HIDROCARBUROS AROMATICOS}

Los hidrocarburos aromáticos son aquellos hidrocarburos que poseen las propiedades especiales asociadas con el núcleo 0 anillo del benceno, en el cual hay seis grupos de carbono-hidrógeno unidos a cada uno de los vértices de un hexágono. Los enlaces que unen estos seis grupos al anillo presentan características intermedias, respecto a su comportamiento, entre los enlaces simples y los dobles. Así, aunque el benceno puede reaccionar para formar productos de adición, como el ciclohexano, la reacción característica del benceno no es una reacción de adición, sino de sustitución, en la cual el hidrógeno es reemplazado por otro sustituto, ya sea un elemento univalente 0 un grupo.

L os hidrocarburos aromáticos y sus derivados son compuestos cuyas moléculas están formadas por una o más estructuras de anillo estables del tipo antes descrito y pueden considerarse derivados del benceno de acuerdo con tres procesos básicos:

1. por sustitución de los átomos de hidrógeno por radicales de hidrocarburos alifáticos,

2. por la unión de dos o más anillos de benceno, ya sea directamente o mediante cadenas alifáticas u otros radicales intermedios,

3. por condensación de los anillos de benceno.

Cada una de las estructuras anulares puede constituir la base de series homólogas de hidrocarburos, en las que una sucesión de grupos alquilo, saturados o no saturados, sustituye a uno o más átomos de hidrógeno de los grupos de carbono-hidrógeno.

Las principales fuentes de hidrocarburos aromáticos son la destilación de la hulla y una serie de procesos petroquímicos, en particular la destilación catalítica, la destilación del petróleo crudo y la alquilación de hidrocarburos aromáticos de las series más bajas. Los aceites esenciales, que contienen terpenos y $p$-cimeno, también pueden obtenerse de los pinos, los eucaliptos y las plantas aromáticas y son un subproducto de las industrias papeleras que utilizan pulpa de pino. Los hidrocarburos policíclicos se encuentran en las atmósferas urbanas.

\section{U sos}

La importancia económica de los hidrocarburos aromáticos ha aumentado progresivamente desde que a principios del siglo X IX se utilizaba la nafta de alquitrán de hulla como disolvente del caucho. En la actualidad, los principales usos de los compuestos aromáticos como productos puros son: la síntesis química de plásticos, caucho sintético, pinturas, pigmentos, explosivos, pesticidas, detergentes, perfumes y fármacos. T ambién se utilizan, principalmente en forma de mezclas, como disolventes y como constituyentes, en proporción variable, de la gasolina.

El cumeno se utiliza como componente de alto octanaje en los combustibles de los aviones, como disolvente de pinturas y lacas de celulosa, como materia prima para la síntesis de fenol y acetona y para la producción de estireno por pirólisis. T ambién se encuentra en muchos disolventes comerciales derivados del petróleo, con puntos de ebullición que oscilan entre 150 y $160{ }^{\circ} \mathrm{C}$. Es un buen disolvente de grasas y resinas $\mathrm{y}$, por este motivo, se ha utilizado como sustituto del benceno en muchos de sus usos industriales. EI p-cimeno se encuentra en muchos aceites esenciales y se puede obtener porhidrogenación de los terpenos monocíclicos. Es un subproducto del proceso de fabricación de pasta de papel al sulfito y se utiliza principalmente, junto con otros disolventes e hidrocarburos aromáticos, como diluyente de lacas y barnices.

La cumarina se utiliza como desodorante o como potenciador del olor en jabones, tabaco, productos de caucho y perfumes. T ambién se utiliza en preparados farmacéuticos.

El benceno se ha prohibido como componente de productos destinados al uso doméstico y en muchos países también se ha prohibido su uso como disolvente y componente de los líquidos de limpieza en seco. El benceno se ha utilizado ampliamente en la fabricación de estireno, fenoles, anhídrido maleico, detergentes, explosivos, productos farmacéuticos y colorantes. También se ha empleado como combustible, reactivo químico y agente de extracción para semillas y frutos secos. L os derivados mono, di y trialquilados del benceno se utilizan principalmente como disolventes y diluyentes y en la fabricación de perfumes y productos intermedios en la producción de colorantes. Estas sustancias se encuentran en algunos petróleos y en los destilados del alquitrán de hulla. El pseudocumeno se utiliza en la fabricación de perfumes y el 1,3,5-trimetilbenceno y el pseudocumeno se emplean también como productos intermedios en la producción de colorantes, aunque el uso industrial más importante de estas sustancias es como disolventes y diluyentes de pinturas.

El tolueno es un disolvente de aceites, resinas, caucho natural (mezclado con ciclohexano) y sintético, alquitrán de hulla, asfalto, brea y acetilcelulosas (en caliente, mezclado con etanol). También se utiliza como disolvente y diluyente de pinturas y barnices de celulosa y como diluyente de las tintas de fotograbado. Al mezclarse con el agua, forma mezclas azeotrópicas que tienen un efecto deslustrante. El tolueno se encuentra en mezclas que se utilizan como productos de limpieza en distintas industrias y en artesanía. También se utiliza en la fabricación de detergentes y cuero artificial y es una importante materia prima para síntesis orgánicas, como las de cloruro de benzoilo y bencilideno, sacarina, cloramina $T$, trinitrotolueno y un gran número de colorantes. El tolueno es un componente del combustible para aviones y de la gasolina para automóviles. EI Reglamento 594/ 91/ CE del Consejo ha prohibido el uso de esta sustancia en la Unión Europea.

El naftaleno se utiliza como material de partida para la síntesis orgánica de una amplia gama de sustancias químicas, como antipolillas, y en conservantes de madera. También se emplea en la fabricación de índigo y se aplica externamente al ganado o las aves para controlar los insectos parásitos.

El estireno se utiliza en la fabricación de una amplia gama de polímeros (como el poliestireno) y elastómeros copolímeros, como el caucho de butadieno-estireno o el acrilonitrilo-butadieno-estireno ( $A B S)$, que se obtienen mediante la copolimerización del estireno con 1,3-butadieno y acrilonitrilo. El estireno se utiliza ampliamente en la producción de plásticos transparentes. El eilbenceno es un producto intermedio en síntesis orgánicas, especialmente en la producción de estireno y caucho sintético. Se utiliza como disolvente o diluyente, como componente de los combustibles para automóviles y aviones y en la fabricación de acetato de celulosa.

Existen tres isómeros del xileno: orto- (o-), para- (p-) y meta- (m-). EI producto comercial es una mezcla de estos isómeros, con el isómero meta- en mayor proporción (hasta un 60 a $70 \%$ ) y el para- en menor proporción (hasta un $5 \%$ ). El xileno se utiliza como diluyente de pinturas y barnices, en productos farmacéuticos, como aditivo de alto octanaje en combustibles de aviones, en la síntesis de colorantes y en la producción de ácidos ftálicos. Debido a que el xileno es un buen disolvente de la parafina, el 
bálsamo de Canadá y el poliestireno, también se utiliza en histología.

Los terfenilos se utilizan como productos químicos intermedios en la producción de lubricantes densos y como refrigerantes en los reactores nucleares. Los terfenilos y difenilos se utilizan como agentes de transferencia de calor, en síntesis orgánicas y en la fabricación de perfumes. El difenilmetano, por ejemplo, se utiliza como perfume en la industria del jabón y como disolvente de lacas de celulosa. También tiene algunas aplicaciones como pesticida.

\section{Riesgos}

La absorción de los hidrocarburos aromáticos tiene lugar por inhalación, ingestión y, en cantidades pequeñas, por vía cutánea. En general, los derivados monoalquilados del benceno son más tóxicos que los dialquilados, y los derivados de cadena ramificada son más tóxicos que los de cadena simple. Los hidrocarburos aromáticos se metabolizan mediante la biooxidación del anillo. Si existen cadenas laterales, preferiblemente de grupos metilo, éstas se oxidan y el anillo permanece sin modificar. En gran parte se convierten en compuestos hidrosolubles y posteriormente se conjugan con glicina, ácido glucurónico o ácido sulfúrico y se eliminan en la orina.

Los hidrocarburos aromáticos pueden causar efectos agudos y crónicos en el sistema nervioso central. La intoxicación aguda por estos compuestos produce cefalea, náuseas, mareo, desorientación, confusión e inquietud. La exposición aguda a dosis altas puede incluso provocar pérdida de consciencia y depresión respiratoria. U no de los efectos agudos más conocidos es la irritación respiratoria (tos y dolor de garganta). T ambién se han observado síntomas cardiovasculares, como palpitaciones y mareos. Los síntomas neurológicos de la exposición crónica pueden ser: cambios de conducta, depresión, alteraciones del estado de ánimo y cambios de la personalidad y de la función intelectual. T ambién se sabe que la exposición crónica produce o contribuye a producir neuropatía distal en algunos pacientes. EI tolueno se ha asociado con un síndrome persistente de ataxia cerebelar. 0 tros efectos crónicos son sequedad, irritación y agrietamiento de la piel y dermatitis. La exposición, sobre todo a los compuestos clorados de este grupo, puede causar hepatotoxicidad. EI benceno es un carcinógeno humano demostrado que favorece el desarrollo de todo tipo de leucemias y, en particular, de la leucemia no linfocítica aguda. También puede causar anemia aplástica y pancitopenia reversible.

L os hidrocarburos aromáticos, en conjunto, entrañan un riesgo considerable de ignición. La N ational Fire Prevention Association (NFPA) de Estados Unidos ha clasificado a la mayoría de los compuestos de este grupo con un código de inflamabilidad de 3 (donde 4 representa un riesgo grave). Con estas sustancias deben adoptarse las medidas necesarias para evitar la acumulación de vapores en los lugares de trabajo y para atacar rápidamente las fugas y los derrames. En presencia de vapores se deben evitar las fuentes de calor extremo.

\section{Benceno}

EI benceno se conoce generalmente como "Benzol" cuando se encuentra en forma comercial (que es una mezcla de benceno y sus homólogos) y no debe confundirse con la bencina, un disolvente comercial compuesto por una mezcla de hidrocarburos alifáticos.

M ecanismo de acción. La absorción del benceno tiene lugar principalmente por vía respiratoria y digestiva. Esta sustancia no penetra fácilmente por vía cutánea, a menos que la exposición sea excepcionalmente alta. U na pequeña cantidad del benceno se exhala sin cambios. El benceno se distribuye ampliamente por todo el organismo y se metaboliza principalmente en fenol, que se excreta en la orina tras su conjugación. U na vez que cesa la exposición, los niveles en los tejidos corporales disminuyen rápidamente.

Desde el punto de vista biológico, parece ser que las alteraciones hemáticas y de la médula ósea encontradas en los casos de intoxicación crónica con benceno pueden atribuirse a la conversión del benceno en epóxido de benceno. Se ha sugerido que el benceno podría oxidarse directamente a epóxido en las células de la médula ósea, como los eritroblastos. En lo que se refiere al mecanismo de toxicidad, los metabolitos del benceno parecen interferir con los ácidos nucléicos. T anto en las personas como en los animales expuestos al benceno, se ha detectado un aumento de la frecuencia de aberraciones cromosómicas. Cualquier factor que inhiba el metabolismo del epóxido de benceno y las reacciones de conjugación, especialmente las alteraciones hepáticas, tenderá a potenciar los efectos tóxicos del benceno. Estos factores son importantes cuando se consideran las susceptibilidades individuales a este agente tóxico. El benceno se trata con más detalle en otros artículos de esta E nciclopedia.

Incendio y explosión. El benceno es un líquido inflamable y sus vapores forman mezclas inflamables o explosivas con el aire en una amplia gama de concentraciones. EI benceno líquido puede emitir vapores a temperaturas tan bajas como $-11^{\circ} \mathrm{C}$. Por ello, si no se observan las necesarias precauciones durante el almacenamiento, la manipulación o el uso del benceno líquido, es seguro que, a las temperaturas normales de trabajo, se formarán concentraciones inflamables. Este riesgo aumentará cuando se produzcan salpicaduras o derrames accidentales.

\section{T olueno y sus derivados}

M etabolismo. El tolueno se absorbe en el organismo principalmente a través del tracto respiratorio y, en menor proporción, a través de la piel. Traspasa la membrana alveolar. La mezcla sangre/ aire se mantiene en una proporción de 11,2 a 15,6 a $37^{\circ} \mathrm{C} y$, entonces, se distribuye por los distintos tejidos en cantidades variables que dependen de sus características de perfusión y solubilidad, respectivamente. La proporción tejido/ sangre es de 1:3, excepto en el caso de los tejidos ricos en grasas, que presentan un coeficiente de 80/100. A continuación, el tolueno es oxidado en su cadena lateral por los microsomas hepáticos (mono-oxigenación microsomal). El producto más importante de esta transformación, que representa aproximadamente un $68 \%$ del tolueno absorbido, es el ácido hipúrico (AH ), que aparece en la orina debido a la excreción renal que suele producirse en los túbulos proximales. También pueden detectarse en la orina pequeñas cantidades de 0 -cresol $(0,1 \%)$ y $p$-cresol $(1 \%)$, como resultado de la oxidación del núcleo aromático, según se explica en el C apítulo Control biológico de esta E nciclopedia.

La vida media biológica del AH es muy corta, del orden de 1 a 2 horas. El nivel de tolueno en el aire espirado, en reposo, es del orden de 18 ppm durante una exposición a 100 ppm, y disminuye rápidamente al cesar la exposición. La cantidad de tolueno retenida en el organismo está en función del porcentaje de grasa presente. Las personas obesas retienen más tolueno que las delgadas.

En el hígado, los mismos sistemas enzimáticos son los encargados de oxidar el tolueno, el estireno y el benceno. Por ello, estas tres sustancias tienden a inhibirse mutuamente de forma competitiva. Si se administra a ratas una cantidad importante de tolueno y benceno, se observa una disminución de la concentración de los metabolitos del benceno en los tejidos y en la orina y un aumento de benceno en el aire espirado. En el caso del tricloroetileno, la inhibición no es competitiva, ya que estas dos sustancias no son oxidadas por el mismo sistema enzimático. La exposición simultánea produce una disminución del $\mathrm{AH}$ y la aparición de compuestos triclorados en la orina. La absorción 
de tolueno es mucho mayor durante un esfuerzo que en reposo. Con un rendimiento de 50 watios, los valores detectados en la sangre arterial y en el aire alveolar se duplican con respecto a los obtenidos en reposo.

Riesgos agudos y crónicos para la salud. La toxicidad aguda del tolueno es ligeramente más intensa que la del benceno. En concentraciones de aproximadamente 200 ó 240 ppm, produce en el plazo de 3-7 h, vértigos, mareo, dificultad para mantener el equilibrio y cefalea. Las concentraciones más altas pueden provocar un coma narcótico.

Los síntomas de toxicidad crónica son los que se observan habitualmente con la exposición a los disolventes de uso común y son: irritación de las mucosas, euforia, cefalea, vértigo, náuseas, pérdida de apetito e intolerancia al alcohol. Estos síntomas aparecen generalmente al final del día, se agravan hacia el final de la semana y disminuyen o desaparecen durante el fin de semana o los días festivos.

El tolueno no ejerce acción alguna sobre la médula ósea. Los casos registrados se debieron a una exposición simultánea a tolueno y benceno, o no existen datos claros sobre este extremo. En teoría, el tolueno podría ocasionar un cuadro hepatotóxico, pero este cuadro no se ha llegado a probar nunca. Algunos autores indican la posibilidad de que cause una enfermedad autoinmune similar a la del síndrome de G oodpasture (glomerulonefritis autoinmune).

$\mathrm{H}$ ay que hacer referencia a algunos casos de muerte súbita que se han producido, especialmente en niños o adolescentes que tenían la costumbre de "esnifar pegamento", inhalando así los vapores de pegamentos que contenían tolueno además de otros disolventes. En estos casos, la muerte sobrevino por un paro cardíaco secundario a fibrilación ventricular y pérdida de catecolaminas. Los estudios en animales han demostrado que el tolueno sólo es teratogénico a dosis elevadas.

Incendio y explosión. El tolueno emite vapores sumamente inflamables a todas las temperaturas normales de trabajo. En las zonas donde se manipule este líquido o donde pueda encontrarse, aunque sea por accidente, estarán prohibidas todas las llamas desnudas y otros elementos capaces de incendiar los vapores. Esta sustancia exige unas instalaciones adecuadas para su almacenamiento y transporte.

Otros derivados monoalquilados de benceno. El propilbenceno produce depresión del sistema nervioso central, con efectos lentos pero prolongados. El dodecilbenocensulfonato sódico se obtiene mediante la reacción catalítica entre el tetrapropileno y el benceno, la acidificación con ácido sulfúrico y el tratamiento con sosa cáustica. EI contacto reiterado de esta sustancia con la piel puede causar dermatitis y, si la exposición es prolongada, puede producir una ligera irritación de las mucosas.

p-terc-B utiltol ueno. Los vapores de este compuesto pueden detectarse por su olor a partir de concentraciones de $5 \mathrm{ppm}$. T ras la exposición a concentraciones de 5-8 ppm, se produce una irritación leve de la conjuntiva. La exposición a los vapores provoca cefalea, náuseas, malestar y signos de distonia neurovegetativa. EI metabolismo de esta sustancia es probablemente similar al del tolueno. C uando se utilice $\mathrm{p}$-terc-butiltolueno, tendrán que adoptarse las mismas precauciones con relación a la salud y los incendios que en el caso del tolueno.

\section{Xileno}

Al igual que el benceno, el xileno es un narcótico, por lo que la exposición prolongada al mismo provoca alteraciones de los órganos hematopoyéticos y del sistema nervioso central. EI cuadro clínico de la intoxicación aguda es similar al de la intoxicación por benceno. Los síntomas son: fatiga, mareo, sensación de borrachera, temblores, disnea y, en ocasiones, náuseas y vómitos. En los casos más graves puede producirse pérdida de la consciencia. También se observa irritación de la mucosas oculares, de las vías respiratorias altas y de los riñones.

La exposición crónica produce debilidad general, excesiva fatiga, mareo, cefalea, irritabilidad, insomnio, pérdida de memoria y zumbidos en los oídos. L os síntomas típicos son alteraciones cardiovasculares, sabor dulzón en la boca, náuseas, en ocasiones vómitos, pérdida del apetito, mucha sed, sensación de quemazón en los ojos y hemorragia nasal. En algunos casos se han observado alteraciones funcionales del sistema nervioso central asociadas con efectos neurológicos pronunciados (por ejemplo, distonía), alteración de la síntesis de proteínas y deterioro de la actividad inmunológica.

Las mujeres pueden sufrir alteraciones en los ciclos menstruales (menorragia o metrorragia). Se ha visto que las trabajadoras expuestas a tolueno y xileno en concentraciones que sobrepasaban periódicamente los límites de exposición, también se vieron afectadas por problemas durante sus embarazos (toxicosis, amenaza de aborto, hemorragias durante el parto) y esterilidad.

Las alteraciones hematológicas se manifiestan en forma de anemia, poiquilocitosis, anisocitosis (en ocasiones leucocitosis) con linfocitosis relativa $y$, a veces, una trombocitopenia muy pronunciada. Existen datos sobre diferencias en la susceptibilidad individual al xileno. En algunos trabajadores expuestos durante varias décadas al xileno no se han producido intoxicaciones por este compuesto, mientras que una tercera parte del personal que trabajaba en las mismas condiciones de exposición presentó síntomas de intoxicación crónica por xileno y fueron inhabilitados. La exposición prolongada al xileno puede reducir la resistencia del organismo y hacerlo más vulnerable a diversos tipos de factores patógenos. Los análisis de orina muestran la presencia de proteínas, sangre, urobilina y urobilinógeno en la orina.

Se han producido casos mortales consecutivos a intoxicaciones crónicas, sobre todo en trabajadores de imprenta, aunque también en otros sectores de la industria. Asimismo, se han descrito casos de intoxicación grave y mortal en trabajadoras embarazadas con hemofilia y aplasia de la médula ósea. El xileno también puede causar alteraciones cutáneas, particularmente eczema.

En los casos de intoxicación crónica se detectan vestigios de xileno en todos los órganos y, en especial, en las glándulas suprarrenales, la médula ósea, el bazo y el tejido nervioso. El xileno se oxida en el organismo para formar ácidos toluicos (ácidos o-, m- y p-metilbenzoico), que a su vez reaccionan con la glicina y el ácido glucurónico.

Durante la producción o el uso del xileno pueden darse concentraciones elevadas en la atmósfera del lugar de trabajo si las instalaciones no son totalmente estancas 0 si se realizan procesos abiertos, en ocasiones con grandes superficies de evaporación. También pueden liberarse al ambiente grandes cantidades de xileno durante las labores de reparación y limpieza de los equipos.

El contacto con el xileno que haya podido contaminar las superficies del lugar de trabajo, los equipos o las prendas protectoras puede determinar su absorción por vía cutánea. La velocidad de absorción por esta vía en el hombre es de $4-10 \mathrm{mg} / \mathrm{cm}^{2}$ por hora.

La exposición a concentraciones de 100 ppm durante un máximo de 30 minutos produce una ligera irritación de las vías respiratorias altas. Con 300 ppm, resultan afectados el equilibrio, la visión y el tiempo de reacción. La exposición a 700 ppm durante 60 minutos puede causar cefalea, mareo y náuseas.

0 tros derivados dialquílicos del benceno. El p-cimeno comporta un cierto riesgo de incendio y es también un irritante primario de la piel. El contacto con el líquido puede causar sequedad, pérdida de la protección grasa de la piel y eritema. No existen pruebas 
concluyentes de que pueda afectar a la médula ósea. La exposición aguda al p-terc-butiltolueno, en concentraciones iguales 0 superiores a 20 ppm, provoca náuseas, sabor metálico, irritación ocular y desvanecimiento. En los casos de exposiciones repetidas se observa disminución de la presión sanguínea, aumento de la frecuencia cardíaca, ansiedad, temblores, ligera anemia con leucopenia y eosinofilia, así como leve irritación de la piel por eliminación de la grasa. Los estudios de toxicidad en animales han demostrado los efectos de esta sustancia en el sistema nervioso central (SNC), con lesiones en el cuerpo calloso y la médula espinal.

E stireno y etilbenceno. Las intoxicaciones por estireno y por etilbenceno son muy similares y, por tanto, se tratan conjuntamente aquí. El estireno puede penetrar en el organismo por inhalación de sus vapores y, al ser liposoluble, por vía cutánea. U na vez en el organismo, al que satura rápidamente (en 30 ó 40 min), se distribuye por todos los órganos y se elimina rápidamente $(85 \%$ en $24 \mathrm{~h}$ ), ya sea en la orina (71 \% en forma de productos de oxidación del grupo vinilo: ácidos hipúrico y mandélico) o en el aire espirado (10\%). En cuanto al etilbenceno, el $70 \%$ se elimina en la orina en forma de distintos metabolitos: ácido fenilacético, alcohol $\alpha$-feniletílico, ácido mandélico y ácido benzoico.

La presencia del doble enlace en la cadena lateral del estireno aumenta considerablemente las propiedades irritantes del anillo de benceno. Con todo, el efecto tóxico general del estireno es menos pronunciado que el del etilbenceno. El estireno líquido produce un efecto local en la piel. Los experimentos en animales demuestran que el estireno líquido irrita la piel y produce ampollas y necrosis tisular. La exposición a los vapores de estireno también puede causar irritación cutánea.

L os vapores de etilbenceno y estireno en concentraciones superiores a $2 \mathrm{mg} / \mathrm{ml}$ provocan intoxicación aguda en animales de laboratorio. Los síntomas iniciales son irritación de las mucosas de las vías respiratorias altas, los ojos y la boca. Poco después puede producirse narcosis, contracciones musculares y muerte por parálisis de los centros respiratorios. L os principales hallazgos patológicos son edema cerebral y pulmonar, necrosis epitelial de los túbulos renales y distrofia hepática.

El etilbenceno es más volátil que el estireno y su producción se asocia a un mayor riesgo de intoxicación aguda. Ambas sustancias son tóxicas cuando se ingieren. Los experimentos en animales han demostrado que la ingestión de estireno produce síntomas de intoxicación similares a los que se producen por inhalación. Las dosis letales son de $8 \mathrm{~g} / \mathrm{kg}$ de peso corporal para el estireno y de $6 \mathrm{~g} / \mathrm{kg}$ para el etilbenceno. Las concentraciones letales por inhalación oscilan entre 45 y $55 \mathrm{mg} / \mathrm{l}$.

En la industria, la intoxicación aguda por estireno o etilbenceno puede producirse como resultado de una operación errónea o mal planteada. Las reacciones de polimerización en las que se pierde el control se acompañarán de una liberación rápida de calor y precisarán la rápida evacuación del producto del vaso de reacción. Es indispensable contar con controles técnicos que impidan un aumento repentino de las concentraciones de estireno y etilbenceno en la atmósfera del lugar de trabajo; en caso contrario, los trabajadores podrían verse expuestos a concentraciones peligrosas y sufrir secuelas como encefalopatía y hepatitis tóxica, a menos que se protejan con equipos de respiración adecuados.

T oxicidad crónica. T anto el estireno como el etilbenceno pueden causar intoxicación crónica. La exposición prolongada a los vapores de estireno o etilbenceno en concentraciones superiores a los niveles permitidos puede causar alteraciones funcionales del sistema nervioso, irritación de las vías aéreas superiores, alteraciones hematológicas (en particular leucopenia y linfocitosis) y trastornos hepáticos y de las vías biliares. Los reconocimientos médicos de trabajadores empleados durante más de 5 años en plantas de poliestireno y caucho sintético, donde las concentraciones atmosféricas de estireno y etilbenceno eran de aproximadamente $50 \mathrm{mg} / \mathrm{m}^{3}$, detectaron casos de hepatitis tóxica. La exposición prolongada a concentraciones de estireno inferiores a $50 \mathrm{mg} / \mathrm{m}^{3}$ produjo alteraciones de algunas funciones hepáticas (proteínas, pigmentos, glucógeno). T ambién se han observado, en trabajadores y trabajadoras en la producción de poliestireno, casos de astenia e inflamación de la mucosa nasal así como trastornos menstruales y de la ovulación.

Los estudios experimentales en ratas han demostrado que el estireno produce efectos embriotóxicos en concentraciones de $1,5 \mathrm{mg} / \mathrm{m}^{3}$. Su metabolito, el óxido de estireno, es mutagénico y reacciona con los microsomas, las proteínas y los ácidos nucléicos de las células hepáticas. El óxido de estireno es químicamente activo y mucho más tóxico que el propio estireno para las ratas. La IARC ha clasificado al óxido de estireno en el Grupo $2 \mathrm{~A}$, como probable carcinógeno. El propio estireno se considera un compuesto del G rupo 2B: posible carcinógeno humano.

Los experimentos realizados en animales sobre la toxicidad crónica del etilbenceno han demostrado que las concentraciones elevadas $\left(1.000\right.$ y $\left.100 \mathrm{mg} / \mathrm{m}^{3}\right)$ pueden ser nocivas y producir alteraciones funcionales y orgánicas (trastornos del sistema nervioso, hepatitis tóxica y problemas del tracto respiratorio superior). En concentraciones de tan solo $10 \mathrm{mg} / \mathrm{m}^{3}$, puede causar inflamación catarral de la mucosa de las vías respiratorias altas. Las concentraciones de $1 \mathrm{mg} / \mathrm{m}^{3}$ causan alteraciones de la función hepática.

Derivados trialquílicos del benceno. En los trimetilbencenos se sustituyen tres átomos de hidrógeno del núcleo de benceno por tres grupos metilo para formar otro grupo de hidrocarburos aromáticos. El uso de estos líquidos representa un riesgo para la salud y un riesgo de incendio. Los tres isómeros son inflamables. EI punto de ignición del pseudocumeno es de $45,5{ }^{\circ} \mathrm{C}$, pero estos líquidos se utilizan comúnmente en la industria como componentes del disolvente nafta de alquitrán de hulla, que puede tener un punto de ignición desde menos de $23^{\circ} \mathrm{C}$ hasta $32^{\circ} \mathrm{C}$. Si no se toman las debidas precauciones, puede producirse una concentración inflamable de vapores cuando se utilizan los líquidos en procesos de disolución y dilución.

R iesgos para la salud. La mayor parte de la información que se dispone sobre los efectos tóxicos de los trimetilbencenos, el 1,3,5-trimetilbenceno y el pseudocumeno, tanto en animales como en seres humanos, procede de estudios sobre un disolvente y diluyente de pinturas que contiene un $80 \%$ de estas sustancias en su composición. Estas sustancias actúan como depresores del sistema nervioso central y pueden afectar a la coagulación sanguínea. A proximadamente el $70 \%$ de los trabajadores expuestos a concentraciones elevadas se quejaron de bronquitis asmática, cefalea, fatiga y sopor. U na gran parte del 1,3,5-trimetilbenceno se oxida en el organismo a ácido mesitilénico, que se conjuga con glicina y se excreta en la orina. El pseudocumeno se oxida a ácido p-xílico y también se excreta en la orina.

Cumeno. Siempre que se utilice cumeno en procesos industriales, tendrán que tenerse en cuenta los riesgos para la salud y el riesgo de incendio de esta sustancia. El cumeno es irritante para la piel y se puede absorber lentamente a través de la piel. También tiene un potente efecto narcótico en animales y la narcosis se desarrolla más lentamente y dura más tiempo que con benceno o tolueno. T ambién suele producir lesiones pulmonares, hepáticas y renales, aunque no se han descrito este tipo de lesiones en seres humanos.

El cumeno líquido no emite vapores en concentraciones inflamables a menos que la temperatura alcance los $43,9{ }^{\circ} \mathrm{C}$. Por tanto, sólo podrán formarse mezclas inflamables de vapores y aire durante operaciones no controladas en las que se utilicen temperaturas más elevadas. Si se calientan las soluciones o revestimientos que contienen cumeno durante un proceso (en una 
estufa de secado, por ejemplo), pueden incendiarse rápidamente $y$, en ciertas condiciones, provocar una explosión.

\section{Medidas de salud y seguridad}

Puesto que la principal vía de entrada al organismo es la pulmonar, es muy importante evitar la presencia de estos compuestos en el aire respirado. U no de los métodos más importantes para evitar la inhalación excesiva es el uso de sistemas eficaces de extracción localizada. Los envases abiertos se deben mantener tapados o cerrados cuando no se utilicen. Estas precauciones para evitar que se acumulen concentraciones nocivas de vapores en la atmósfera de trabajo evitan también la formación de mezclas inflamables en el aire en condiciones normales. Para evitar el riesgo de fugas o derrames accidentales de líquidos en los envases donde se almacenen estos compuestos o en los vasos de reacción, deberán adoptarse precauciones adicionales, como la construcción de una solera con talud en las entradas de los depósitos para retener los líquidos que puedan derramarse. En las zonas donde se utilicen o almacenen estos compuestos se eliminarán todas las llamas y fuentes de ignición. D eberá existir un procedimiento eficaz para limpiar los derrames y las fugas.

L os respiradores, pese a ser eficaces, deben utilizarse sólo como una medida adicional (o en casos de emergencia) y dependen completamente del usuario. La protección de la segunda vía principal de exposición, la piel, puede lograrse mediante el uso de prendas protectoras como guantes, protectores y máscaras faciales y mandiles. Además, deberán utilizarse gafas protectoras en caso de que exista riesgo de recibir salpicaduras en los ojos de estas sustancias. Los trabajadores no deben utilizar lentes de contacto cuando trabajen en áreas con riesgo de exposición (especialmente de la cara y los ojos), ya que las lentes de contacto, si no se quitan inmediatamente, pueden potenciar el efecto nocivo de estas sustancias y hacer que los lavados oculares sean menos eficaces.
En caso de contacto de estas sustancias con la piel, se procederá inmediatamente a lavar la zona afectada con agua y jabón. La ropa contaminada se retirará rápidamente. Las salpicaduras de hidrocarburos aromáticos en los ojos deben eliminarse mediante irrigación con agua durante al menos 15 minutos. Las quemaduras producidas por salpicaduras de los compuestos líquidos requieren asistencia médica lo antes posible. En caso de exposición grave, debe llevarse al paciente a un sitio al aire libre y dejarlo descansar hasta que llegue el médico. Si la víctima tiene dificultades para respirar, se le administrará oxígeno. La mayoría de las personas se recuperan rápidamente cuando salen al aire libre y el tratamiento sintomático sólo es necesario en rarasocasiones.

Sustitución de benceno. Actualmente se admite que el uso del benceno con fines industriales o comerciales debe abandonarse cuando exista una sustancia eficaz y menos dañina disponible, aunque con frecuencia esto no es posible cuando el benceno se utiliza como reactivo en un proceso de síntesis química. Por otra parte, se ha demostrado que se pueden encontrar sustitutos para casi todas las operaciones, muy numerosas, en las que se utilizaba benceno como disolvente. En ocasiones, el sustituto no es un disolvente tan bueno como el benceno, pero puede ser preferible debido a que las precauciones necesarias son menos costosas. Estos sustitutos pueden ser homólogos del benceno (en especial tolueno y xileno), ciclohexano, hidrocarburos alifáticos (ya sea puros, como en el caso del hexano, o en forma de mezclas, como la amplia gama de disolventes del petróleo), naftas como disolventes (que son mezclas relativamente complejas y de composición variable, obtenidas de la hulla) o algunos derivados del petróleo. Estos compuestos prácticamente no contienen benceno y contienen muy poco tolueno. Sus principales componentes son homólogos de estos dos hidrocarburos en proporciones variables dependiendo del origen de la mezcla. Existen varios disolventes más que pueden elegirse en función del material que se desee disolver y el proceso industrial, como alcoholes, cetonas, ésteres y derivados clorados del etileno. 


\section{TABLAS DE HIDROCARBUROS AROMATICOS}

\begin{tabular}{|c|c|c|}
\hline Producto químico & Sinónimos/ Código UN & $\mathrm{N}$ úmero CAS Fórmula estructural \\
\hline BENCENO & $\begin{array}{l}\text { Hidruro de fenilo; pirobenzol } \\
\text { UN1114 }\end{array}$ & $71-43-2$ \\
\hline p-terc-BUTILTOLUENO & p-metil-terc-butilbenceno; 1-metil-4-terc-butilbenceno; ТВT & $98-51-1$ \\
\hline p-CIMENO & $\begin{array}{l}\text { p-sopropilmetilbenceno; 4-isopropil-1-metilbenceno; p-sopropiltolueno; } \\
\text { p-metilisopropilbenceno }\end{array}$ & $99-87-6$ \\
\hline CUMENO & $\begin{array}{l}\text { Isopropilbenceno; (1-metiletil) benceno; 2-fenilpropano } \\
\text { UN1918 }\end{array}$ & $98-82-8$ \\
\hline DECAHIDRONAFTALENO & $\begin{array}{l}\text { Naftalano; naftano; perhidronaftaleno } \\
\text { UN1147 }\end{array}$ & $91-17-8$ \\
\hline DIETILBENCENO & $\begin{array}{l}\text { Dietilbenzol } \\
\text { UN2049 }\end{array}$ & $25340-17-4$ \\
\hline DIFENILO & Dibenceno; 1,1'-difenilo; bifenilo; limoneno; fenilbenceno & $92.52-4$ \\
\hline DIVINILBENCENO & Vinilestireno & $1321-74-0$ \\
\hline DODECILBENCENO & 1-Fenildodecano & $123-01-3$ \\
\hline ESTIRENO & $\begin{array}{l}\text { Etenilbenceno; fenileteno; feniletileno; vinilbenceno } \\
\text { UN2055; }\end{array}$ & $100-42-5$ \\
\hline ETILBENCENO & $\begin{array}{l}\text { Etilbenzol; feniletano } \\
\text { UN1175 }\end{array}$ & $100-41-4$ \\
\hline 1-ETLLAFTALENO & & $1127 \cdot 76-0$ \\
\hline 2-ETLNAFTALENO & & $939-27-5$ \\
\hline
\end{tabular}




\begin{tabular}{|c|c|c|c|}
\hline Producto químico & Sinónimos/ Código UN & $\mathrm{N}$ úmero CAS & Fórmula estructural \\
\hline O-FENILFENOL SODICO & $\begin{array}{l}\text { Sal sódica de 2-hidroxidifenilo; sal sódica de 2-fenilfenol; } \\
\text { (2-difenililoxi) sodio; 2-hidroxidifenilo sódico; offenilfenato sódico; } \\
\text { 2-fenilfenato sódico }\end{array}$ & $132-27-4$ & \\
\hline INDENO & Indonafteno & $95-13-6$ & \\
\hline LIMONENO & $\begin{array}{l}\text { p-menta-1,8-dieno; 1-metil-4-isopropenil-1-1-ciclohexeno; Nesol } \\
\text { UN2052 }\end{array}$ & $138-86-3$ & \\
\hline D-LIMONENO & D-4-isopropenil-1-metilciclohexeno & $5989-27-5$ & \\
\hline L-LIMONENO & L-1-Metil-4-(1-metiletenil) ciclohexeno; L(-)-p-menta-1,8-dieno & $5989-54-8$ & \\
\hline METILESTIRENO & $\begin{array}{l}\text { Viniltolueno } \\
\text { UN2618 }\end{array}$ & $25013-15-4$ & \\
\hline$\alpha$-METLLESTIRENO & $\begin{array}{l}\text { Isopropenilbenceno; } 2 \text {-fenilpropeno; } 2 \text {-fenilpropileno; } \beta \text {-fenilpropileno } \\
\text { UN2303 }\end{array}$ & $98-83-9$ & \\
\hline
\end{tabular}

M-METLESTIRENO 1-Etenil-3-metilbenceno; 3-metilestireno; m-viniltolueno; 3-viniltolueno 100-80-1

\begin{tabular}{lll}
\hline O-METLESTIRENO & 1-Etenil-2-metilbenceno; 2-metilestireno; 0-viniltolueno; 2-viniltolueno & $611-15-4$ \\
\hline p-METILESTIRENO & 1-Etenil-4-metilbenceno; 1-p-tolieteno; p-viniltolueno; 4-viniltolueno & $622-97-9$ \\
\hline
\end{tabular}

\begin{tabular}{ll}
\hline METILNAFTALENO & $1321-94-4$
\end{tabular}

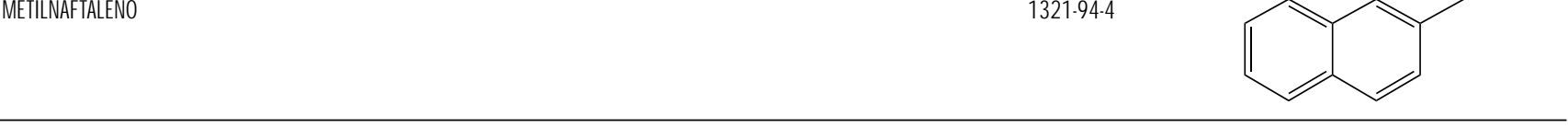

\begin{tabular}{lcl}
\hline NAFTALENO & $\begin{array}{c}\text { Naftalina; nafteno } \\
\text { UN1334 } \\
\text { UN2304 }\end{array}$ \\
\hline PROPENILBENCENO & trans-1-Fenilpropeno; trans-1-propenilbenceno & $91-20-3$ \\
\hline n-PROPILBENCENO & $873-66-5$ \\
\hline
\end{tabular}




\begin{tabular}{|c|c|c|}
\hline Producto químico & Sinónimos/ Código UN & $\mathrm{N}$ úmero CAS Fórmula estructural \\
\hline 1,2,3,4-TETRAHIDRONAFTALENO & $\begin{array}{l}\text { Naftaleno 1,2,3,4-tetrahidruro; d(sup 5,7,9)-naftantrieno; } \\
\text { tetrahidronaftaleno }\end{array}$ & $119-64-2$ \\
\hline TOLUENO & $\begin{array}{l}\text { Metilbenceno; metilbenzol; fenilmetano } \\
\text { UN1294 }\end{array}$ & $108-88-3$ \\
\hline 1,3,5-TRIMETILBENCENO & $\begin{array}{l}\text { Trimetilbenceno; mesitileno; trimetilbenzol } \\
\text { UN2325 }\end{array}$ & $108-67-8$ \\
\hline m-XILENO & $\begin{array}{l}\text { m-Dimetilbenceno; 1,3-dimetilbenceno; 1,3-xileno } \\
\text { UN1307 }\end{array}$ & $108-38-3$ \\
\hline O-XILENO & $\begin{array}{l}\text { 0-Dimetilbenceno; 1,2-dimetilbenceno; 0-metiltolueno; 1,2-xileno } \\
\text { UN1307 }\end{array}$ & $95-47-6$ \\
\hline p-XILENO & $\begin{array}{l}\text { p-Dimetilbenceno; 1,4-dimetilbenceno; p-metiltolueno; 1,4-xileno } \\
\text { UN1307 }\end{array}$ & $106-42-3$ \\
\hline
\end{tabular}

\section{Tabla 104.106 • Riesgos para la salud.}

\begin{tabular}{|c|c|c|c|c|c|c|}
\hline \multirow[b]{2}{*}{$\begin{array}{l}\text { Denominación } \\
\text { química } \\
\mathrm{N} \text { úmero CAS }\end{array}$} & \multicolumn{4}{|c|}{ Tarjetas Internacionales sobre la Seguridad de los Productos Q uímicos } & \multicolumn{2}{|c|}{ N IO SH (EE.UU.) } \\
\hline & $\begin{array}{l}\text { Período } \\
\text { corto de } \\
\text { exposición }\end{array}$ & $\begin{array}{l}\text { Período } \\
\text { largo de } \\
\text { exposición }\end{array}$ & $\begin{array}{l}\text { Vías de } \\
\text { exposición }\end{array}$ & Síntomas & $\begin{array}{l}\text { O rganos } \\
\text { afectados } \\
\text { Vías de } \\
\text { entrada }\end{array}$ & Síntomas \\
\hline $\begin{array}{l}\text { BENCENO } \\
71-43-2\end{array}$ & $\begin{array}{l}\text { piel; tract resp; } \\
\text { pulmones; SNC }\end{array}$ & $\begin{array}{l}\text { piel; sangre; } \\
\text { hígado; sistema } \\
\text { inmune }\end{array}$ & $\begin{array}{r}\text { Inhalación } \\
\text { Piel } \\
\text { Ingestión }\end{array}$ & $\begin{array}{l}\text { Mareo, sopor, cefalea, náuseas, disnea, } \\
\text { convulsiones, inconsciencia } \\
\text { Puede absorberse, sequedad de piel } \\
\text { Dolor abdominal, dolor de garganta, vómitos }\end{array}$ & $\begin{array}{l}\text { sangre; SNC; piel; } \\
\text { médula ósea; ojos; } \\
\text { sis resp } \\
\text { inh, abs, ing, con }\end{array}$ & $\begin{array}{l}\text { Irrit ojos, piel, nariz, sis resp; } \\
\text { mar; cef, náu, andar vacilante; } \\
\text { ftg, anor, las; derm; depres } \\
\text { médula ósea; [carc] }\end{array}$ \\
\hline $\begin{array}{l}\text { p-terc-BUTILTOLUENO } \\
98-51-1\end{array}$ & & & & & $\begin{array}{l}\text { SCV; SNC; piel; } \\
\text { médula ósea; ojos; } \\
\text { sis resp sup; } \\
\text { hígado; riñones } \\
\text { inh, ing, con }\end{array}$ & $\begin{array}{l}\text { Irrit ojos y piel; sequedad de } \\
\text { nariz y garganta; cef; TA baja, } \\
\text { taqui, estrés SCV anor; SNC, } \\
\text { depres hemato; sabor } \\
\text { metálico; les hepáticas y } \\
\text { renales }\end{array}$ \\
\hline $\begin{array}{r}\text { P-CIMENO } \\
99-87-6\end{array}$ & ojos; piel & & Inhalación & Mareo, sopor, vómitos, inhalación & & \\
\hline $\begin{array}{l}\text { CUMENO } \\
98-82-8\end{array}$ & & & & & $\begin{array}{l}\text { ojos; sis resp sup; } \\
\text { piel; SNC } \\
\text { inh, abs, ing, con }\end{array}$ & $\begin{array}{l}\text { Irrit ojos, piel, muc; derm; cef, } \\
\text { narco, coma }\end{array}$ \\
\hline $\begin{array}{c}\text { DIETILBENCENO } \\
25340-17-4\end{array}$ & $\begin{array}{l}\text { ojos; piel; tract } \\
\text { resp; pulmones; } \\
\text { SNC }\end{array}$ & $\begin{array}{l}\text { piel; riñones; } \\
\text { hígado }\end{array}$ & $\begin{array}{r}\text { Inhalación } \\
\text { Piel } \\
\text { Ojos } \\
\text { Ingestión }\end{array}$ & $\begin{array}{l}\text { Mareo, embotamiento, cefalea, náuseas } \\
\text { Sequedad de piel, enrojecimiento } \\
\text { Enrojecimiento, dolor } \\
\text { Espasmos abdominales, mareo, } \\
\text { embotamiento, cefalea, náuseas }\end{array}$ & & \\
\hline
\end{tabular}




\begin{tabular}{|c|c|c|c|c|c|c|}
\hline \multirow[b]{2}{*}{$\begin{array}{l}\text { Denominación } \\
\text { química } \\
\text { N úmero CAS }\end{array}$} & \multicolumn{4}{|c|}{ Tarjetas Internacionales sobre la Seguridad de los Productos Q uímicos } & \multicolumn{2}{|c|}{ N IO SH (EE.UU.) } \\
\hline & $\begin{array}{l}\text { Período } \\
\text { corto de } \\
\text { exposición }\end{array}$ & $\begin{array}{l}\text { Período } \\
\text { largo de } \\
\text { exposición }\end{array}$ & $\begin{array}{l}\text { Vías de } \\
\text { exposición }\end{array}$ & Síntomas & $\begin{array}{l}\text { O rganos } \\
\text { afectados } \\
\text { Vías de } \\
\text { entrada }\end{array}$ & Síntomas \\
\hline $\begin{array}{l}\text { DIFENILO } \\
92-52-4\end{array}$ & $\begin{array}{l}\text { ojos; piel; tract } \\
\text { resp; hígado }\end{array}$ & piel; SNC; hígado & $\begin{array}{r}\text { Inhalación } \\
\text { Ojos }\end{array}$ & $\begin{array}{l}\text { Tos, náuseas, vómitos } \\
\text { Enrojecimiento, dolor }\end{array}$ & $\begin{array}{l}\text { hígado; piel; SNC; } \\
\text { sis resp sup; ojos } \\
\text { inh, abs, ing, con }\end{array}$ & $\begin{array}{l}\text { Irrit ojos, garganta; cef; náu, } \\
\text { ftg, entu de las extremidades; } \\
\text { les hepáticas }\end{array}$ \\
\hline $\begin{array}{l}\text { DIVINILBENCENO } \\
1321-74-0\end{array}$ & $\begin{array}{l}\text { ojos; piel; tract } \\
\text { resp; pulmones }\end{array}$ & piel & $\begin{array}{r}\text { Inhalación } \\
\text { Piel } \\
\text { 0jos }\end{array}$ & $\begin{array}{l}\text { Tos, dolor de garganta } \\
\text { Enrojecimiento } \\
\text { Enrojecimiento }\end{array}$ & $\begin{array}{l}\text { ojos; piel; sis resp; } \\
\text { sangre } \\
\text { inh, ing, con }\end{array}$ & $\begin{array}{l}\text { Irrit ojos, piel, sis resp; } \\
\text { quemaduras en la piel; en } \\
\text { animales: depres SNC }\end{array}$ \\
\hline $\begin{array}{l}\text { DODECILBENCENO } \\
123-01.3\end{array}$ & piel; ojos & piel & $\begin{array}{r}\text { Inhalación } \\
\text { Piel } \\
\text { Ojos } \\
\text { Ingestión }\end{array}$ & $\begin{array}{l}\text { Tos, dolor de garganta } \\
\text { Puede absorberse, enrojecimiento, irritante } \\
\text { enrojecimiento, irritante } \\
\text { Náuseas }\end{array}$ & & \\
\hline $\begin{array}{l}\text { ESTIRENO } \\
\quad 100-42-5\end{array}$ & $\begin{array}{l}\text { ojos; piel; tract } \\
\text { resp; pulmones }\end{array}$ & piel; pulmones; SNC & $\begin{array}{r}\text { Inhalación } \\
\text { Piel } \\
\text { Ojos } \\
\text { Ingestión }\end{array}$ & $\begin{array}{l}\text { Mareo, sopor, cefalea, náuseas, debilidad } \\
\text { Enrojecimiento } \\
\text { Enrojecimiento, dolor } \\
\text { Dolor abdominal }\end{array}$ & $\begin{array}{l}\text { SNC; sis resp; ojos; } \\
\text { piel } \\
\text { inh, abs, ing, con }\end{array}$ & $\begin{array}{l}\text { Irrit ojos, nariz; sis resp; cef, } \\
\text { ftg, mar, conf, mal, sop, deb, } \\
\text { andar vacilante; narco; derm } \\
\text { por desengrasado; posibles les } \\
\text { hepáticas, efectos repro }\end{array}$ \\
\hline $\begin{array}{l}\text { ETILBENCENO } \\
100-41-4\end{array}$ & $\begin{array}{l}\text { ojos; piel; tract } \\
\text { resp; pulmones; } \\
\text { SNC }\end{array}$ & piel & & & $\begin{array}{l}\text { ojos; sis resp sup; } \\
\text { piel; SNC } \\
\text { inh, ing, con }\end{array}$ & $\begin{array}{l}\text { Irrit ojos, piel, muc; cef; derm; } \\
\text { narco; coma }\end{array}$ \\
\hline $\begin{array}{l}\text { D-LIMONENO } \\
5989-27-5\end{array}$ & ojos; piel; tract resp & piel & $\begin{array}{r}\text { Inhalación } \\
\text { Piel } \\
\text { 0jos }\end{array}$ & $\begin{array}{l}\text { Tos } \\
\text { Enrojecimiento } \\
\text { Enrojecimiento }\end{array}$ & & \\
\hline $\begin{array}{c}\text { METILESTIRENO } \\
25013-15-4\end{array}$ & $\begin{array}{l}\text { ojos; piel; tract } \\
\text { resp; SNC }\end{array}$ & piel; hígado & $\begin{array}{r}\text { Inhalación } \\
\text { Piel } \\
\text { Ojos } \\
\text { Ingestión }\end{array}$ & $\begin{array}{l}\text { Mareo, sopor, embotamiento, cefalea, dolor de } \\
\text { garganta } \\
\text { Puede absorberse, enrojecimiento, dolor } \\
\text { Enrojecimiento, dolor } \\
\text { Dolor abdominal, náuseas, vómitos }\end{array}$ & $\begin{array}{l}\text { ojos; piel; tract resp } \\
\text { inh, ing, con }\end{array}$ & Ojos, piel, sis resp, SNC \\
\hline $\begin{array}{l}\alpha-M E T I L E S T I R E N O \\
98.83 .9\end{array}$ & ojos; piel; tract resp & & Inhalación & Tos, dolor de garganta & $\begin{array}{l}\text { ojos; tract resp; piel } \\
\text { inh, ing, con }\end{array}$ & 0jos, piel, sis resp, SNC \\
\hline $\begin{array}{l}\text { m-METILESTIRENO } \\
\text { 100-80-1 }\end{array}$ & $\begin{array}{l}\text { ojos; piel; tract } \\
\text { resp; SNC }\end{array}$ & piel & $\begin{array}{r}\text { Inhalación } \\
\text { Piel } \\
\text { Ojos } \\
\text { Ingestión } \\
\end{array}$ & $\begin{array}{l}\text { Mareo, sopor, embotamiento, cefalea, dolor de } \\
\text { garganta } \\
\text { Puede absorberse, enrojecimiento } \\
\text { Enrojecimiento } \\
\text { Dolor abdominal, náuseas, vómitos }\end{array}$ & & \\
\hline $\begin{array}{l}\text { o-METILESTIRENO } \\
611-15-4\end{array}$ & $\begin{array}{l}\text { ojos; piel; tract } \\
\text { resp; riñones; SNC }\end{array}$ & piel & $\begin{array}{r}\text { Inhalación } \\
\text { Piel } \\
\text { Ojos } \\
\text { Ingestión }\end{array}$ & $\begin{array}{l}\text { Mareo, sopor, embotamiento, cefalea, dolor de } \\
\text { garganta } \\
\text { Puede absorberse, enrojecimiento, irritante } \\
\text { Enrojecimiento } \\
\text { Dolor abdominal, náuseas, vómitos }\end{array}$ & & \\
\hline $\begin{array}{l}\text { p-METILESTIRENO } \\
622-97-9\end{array}$ & $\begin{array}{l}\text { ojos; piel; tract } \\
\text { resp; SNC }\end{array}$ & piel & $\begin{array}{r}\text { Inhalación } \\
\text { Piel } \\
\text { Ojos } \\
\text { Ingestión }\end{array}$ & $\begin{array}{l}\text { Mareo, sopor, embotamiento, cefalea, dolor de } \\
\text { garganta } \\
\text { Puede absorberse, enrojecimiento, irritante de } \\
\text { la piel } \\
\text { Enrojecimiento } \\
\text { Dolor abdominal, náuseas, vómitos }\end{array}$ & & \\
\hline $\begin{array}{l}\text { METILNAFTALENO } \\
1321-94-4\end{array}$ & ojos; tract resp & & $\begin{array}{r}\text { Inhalación } \\
\text { Piel } \\
\text { Ojos }\end{array}$ & $\begin{array}{l}\text { Tos } \\
\text { Enrojecimiento } \\
\text { Enrojecimiento }\end{array}$ & & \\
\hline
\end{tabular}




\begin{tabular}{|c|c|c|c|c|c|c|}
\hline \multirow[b]{2}{*}{$\begin{array}{l}\text { Denominación } \\
\text { química } \\
\mathrm{N} \text { úmero CAS }\end{array}$} & \multicolumn{4}{|c|}{ Tarjetas Internacionales sobre la Seguridad de los Productos Q uímicos } & \multicolumn{2}{|c|}{ N IO SH (EE.UU.) } \\
\hline & $\begin{array}{l}\text { Período } \\
\text { corto de } \\
\text { exposición }\end{array}$ & $\begin{array}{l}\text { Período } \\
\text { largo de } \\
\text { exposición }\end{array}$ & $\begin{array}{l}\text { Vías de } \\
\text { exposición }\end{array}$ & Síntomas & $\begin{array}{l}\text { O rganos } \\
\text { afectados } \\
\text { Vías de } \\
\text { entrada }\end{array}$ & Síntomas \\
\hline $\begin{array}{l}\text { NAFTALENO } \\
91-20-3\end{array}$ & & & & & $\begin{array}{l}\text { ojos; sangre; } \\
\text { higado; riñones; } \\
\text { piel; SNC } \\
\text { inh, abs, ing, con }\end{array}$ & $\begin{array}{l}\text { Irrit ojos; cef, conf, excitación, } \\
\text { mal; náu, vómit, dolor; irrit } \\
\text { vejiga; sudoración abundante; } \\
\text { ict; hema, hemog, fallo renal; } \\
\text { derm; neuritis óptica, les córn }\end{array}$ \\
\hline $\begin{array}{l}\text { PROPENILBENCENO } \\
873.66-5\end{array}$ & piel & & & & & \\
\hline $\begin{array}{l}\text { TOLUENO } \\
108-88-3\end{array}$ & $\begin{array}{l}\text { ojos; tract resp; } \\
\text { pulmones; SNC; } \\
\text { SCV }\end{array}$ & piel; SNC; corazón & $\begin{array}{r}\text { Inhalación } \\
\text { Piel } \\
\text { Ojos } \\
\text { Ingestión }\end{array}$ & $\begin{array}{l}\text { Mareo, sopor, cefalea, náuseas, inconsciencia } \\
\text { Sequedad de piel, enrojecimiento } \\
\text { Enrojecimiento, dolor } \\
\text { Dolor abdominal, sensación de quemazón }\end{array}$ & $\begin{array}{l}\text { SNC; hígado; } \\
\text { riñones; piel; ojos; } \\
\text { sis resp } \\
\text { inh, abs, ing, con }\end{array}$ & $\begin{array}{l}\text { Irrit ojos, nariz; ftg, deb, conf, } \\
\text { euf, mar, cef; pupilas } \\
\text { dilatadas, lag; ner, ftg musc, } \\
\text { insom; pares; derm; les } \\
\text { hepáticas y renales }\end{array}$ \\
\hline $\begin{array}{l}\text { m-XILENO } \\
108-38-3\end{array}$ & $\begin{array}{l}\text { garganta, ojos; } \\
\text { pulmones; SNC }\end{array}$ & piel; pulmones; SNC & $\begin{array}{r}\text { Inhalación } \\
\text { Piel } \\
\text { Ojos } \\
\text { Ingestión }\end{array}$ & $\begin{array}{l}\text { Mareo, sopor, cefalea, inconsciencia } \\
\text { Sequedad de piel, enrojecimiento } \\
\text { Enrojecimiento, dolor } \\
\text { Dolor abdominal, sensación de quemazón }\end{array}$ & $\begin{array}{l}\text { Ojos; piel; sis resp; } \\
\text { SNC; tracto Gl; } \\
\text { sangre; hígado; } \\
\text { riñones } \\
\text { inh, abs, ing, con }\end{array}$ & $\begin{array}{l}\text { Irrit ojos, piel, nariz, garganta; } \\
\text { mar, excitación, sop, desco, } \\
\text { andar vacilante; vacuolización } \\
\text { de la córnea; anor, náu, vómit, } \\
\text { dolor abdom; derm }\end{array}$ \\
\hline $\begin{array}{l}\text { O-XILENO } \\
95-47-6\end{array}$ & $\begin{array}{l}\text { garganta, ojos; } \\
\text { pulmones; SNC }\end{array}$ & $\begin{array}{l}\text { piel; pulmones: } \\
\text { SNC }\end{array}$ & $\begin{array}{r}\text { Inhalación } \\
\text { Piel } \\
\text { 0jos } \\
\text { Ingestión }\end{array}$ & $\begin{array}{l}\text { Mareo, sopor, cefalea, inconsciencia } \\
\text { Sequedad de piel, enrojecimiento } \\
\text { Enrojecimiento, dolor } \\
\text { Dolor abdominal, sensación de quemazón }\end{array}$ & $\begin{array}{l}\text { Ojos; piel; sis resp; } \\
\text { SNC; tracto Gl; } \\
\text { sangre; hígado; } \\
\text { riñones } \\
\text { inh, abs, ing, con }\end{array}$ & $\begin{array}{l}\text { Irrit ojos, piel, nariz, garganta; } \\
\text { mar, excitación, sop, desco, } \\
\text { andar vacilante; vacuolización } \\
\text { de la córnea; anor, náu, vómit, } \\
\text { dolor abdom; derm }\end{array}$ \\
\hline $\begin{array}{l}\text { p-XILENO } \\
106-42-3\end{array}$ & $\begin{array}{l}\text { garganta, ojos; } \\
\text { pulmones; SNC }\end{array}$ & piel; pulmones; SNC & $\begin{array}{r}\text { Inhalación } \\
\text { Piel } \\
\text { Ojos } \\
\text { Ingestión }\end{array}$ & $\begin{array}{l}\text { Mareo, sopor, cefalea, inconsciencia } \\
\text { Sequedad de piel, enrojecimiento } \\
\text { Enrojecimiento, dolor } \\
\text { Dolor abdominal, sensación de quemazón }\end{array}$ & $\begin{array}{l}\text { Ojos; piel; sis resp; } \\
\text { SNC; tracto Gl; } \\
\text { sangre; hígado; } \\
\text { riñones } \\
\text { inh, abs, ing, con }\end{array}$ & $\begin{array}{l}\text { Irrit ojos, piel, nariz y } \\
\text { garganta; mar, excitación, sop, } \\
\text { desco, andar vacilante; } \\
\text { vacuolización de la córnea; } \\
\text { anor, náu, vómit, dolor } \\
\text { abdom; derm }\end{array}$ \\
\hline
\end{tabular}

\begin{tabular}{|c|c|c|c|}
\hline $\begin{array}{l}\text { Denominación química } \\
\mathrm{N} \text { úmero CAS }\end{array}$ & Físicos & Q uímicos & $\begin{array}{l}\text { Clase o división } \\
\text { UN / Riesgos } \\
\text { subsidiarios }\end{array}$ \\
\hline $\begin{array}{l}\text { BENCENO } \\
71-43-2\end{array}$ & $\begin{array}{l}\text { El vapor es más pesado } \\
\text { que el aire y puede } \\
\text { desplazarse a ras del } \\
\text { suelo; posibilidad de } \\
\text { ignición a distancia }\end{array}$ & Reacciona violentamente con oxidantes y halógenos, con peligro de incendio y explosión & 3 \\
\hline $\begin{array}{l}\text { p-terc-BUTILTOLUENO } \\
98-51-1\end{array}$ & & & 6.1 \\
\hline $\begin{array}{l}\text { p-CIMENO } \\
99-87-6\end{array}$ & $\begin{array}{l}\text { El vapor es más pesado } \\
\text { que el aire }\end{array}$ & Reacciona con oxidantes Ataca el caucho & 3 \\
\hline $\begin{array}{l}\text { CUMENO } \\
98.82-8\end{array}$ & & & 3 \\
\hline $\begin{array}{l}\text { DECAHIDRONAFTALENO } \\
91-17-8\end{array}$ & & & 3 \\
\hline
\end{tabular}




\begin{tabular}{|c|c|c|c|}
\hline $\begin{array}{l}\text { Denominación química } \\
\text { N úmero CAS }\end{array}$ & Físicos & Q uímicos & $\begin{array}{l}\text { Clase o división } \\
\text { UN / Riesgos } \\
\text { subsidiarios }\end{array}$ \\
\hline $\begin{array}{l}\text { DIETLLBENCENO } \\
25340-17-4\end{array}$ & $\begin{array}{l}\text { Pueden generarse cargas } \\
\text { electrostáticas como } \\
\text { resultado del flujo, la } \\
\text { agitación, etc. }\end{array}$ & Reacciona con oxidantes fuertes, con peligro de incendio y explosión & 3 \\
\hline $\begin{array}{l}\text { DIFENILO } \\
92-52-4\end{array}$ & $\begin{array}{l}\text { Posibilidad de explosión } \\
\text { pulverulenta cuando se } \\
\text { encuentra en forma de } \\
\text { polvo o gránulos y se } \\
\text { mezcla con el aire }\end{array}$ & $\begin{array}{l}\text { Se descompone al calentarse, liberando gases tóxicos y humos acres Reacciona con } \\
\text { oxidantes, con peligro de incendio y explosión }\end{array}$ & \\
\hline $\begin{array}{l}\text { DIVINILBENCENO } \\
1321-74.0\end{array}$ & & $\begin{array}{l}\text { Puede polimerizarse al calentarse, con peligro de incendio o explosión Reacciona } \\
\text { violentamente con oxidantes }\end{array}$ & \\
\hline $\begin{array}{l}\text { DODECILBENCENO } \\
123-01-3\end{array}$ & $\begin{array}{l}\text { El vapor es más pesado } \\
\text { que el aire }\end{array}$ & & \\
\hline $\begin{array}{l}\text { ESTIRENO } \\
\quad 100-42-5\end{array}$ & $\begin{array}{l}\text { Pueden generarse cargas } \\
\text { electrostáticas como } \\
\text { resultado de flujo, } \\
\text { agitación, etc. }\end{array}$ & $\begin{array}{l}\text { Puede formar peróxidos explosivos Puede polimerizarse al calentarse, por efecto de la luz } \\
\text { solar y en contacto con muchos compuestos, como oxígeno, agentes oxidantes, peróxidos y } \\
\text { ácidos fuertes, con peligro de incendio o explosión Se descompone al arder, liberando humos } \\
\text { tóxicos (óxido de estireno) Ataca el cobre y las aleaciones de cobre }\end{array}$ & 3 \\
\hline $\begin{array}{c}\text { ETILBENCENO } \\
100-41-4 \\
\end{array}$ & & & 3 \\
\hline $\begin{array}{r}\text { D-LIMONENO } \\
5989-27-5 \\
\end{array}$ & & En su combustión emite gases tóxicos $\left(\mathrm{CO}_{x}\right)$ Tiende a oxidarse con la exposición prolongada & \\
\hline $\begin{array}{l}\text { L-LIMONENO } \\
5989-54-8 \\
\end{array}$ & & & 3 \\
\hline $\begin{array}{l}\text { METLEESTIRENO } \\
25013-15-4\end{array}$ & & $\begin{array}{l}\text { Si no se estabiliza, se polimeriza generando calor Se debe evitar el contacto con } \\
\text { catalizadores, como peróxidos, ácidos fuertes o cloruro de aluminio Se descompone al } \\
\text { calentarse, liberando gases y humos tóxicos (monóxido de carbono) Es un potente agente } \\
\text { reductor y reacciona violentamente con oxidantes }\end{array}$ & 3 \\
\hline 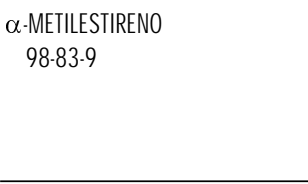 & $\begin{array}{l}\text { El vapor es más pesado } \\
\text { que el aire y puede } \\
\text { desplazarse a ras del } \\
\text { suelo; posibilidad de } \\
\text { ignición a distancia }\end{array}$ & $\begin{array}{l}\text { Se descompone al calentarse, produciendo monóxido de carbono Reacciona con oxidantes } \\
\text { fuertes }\end{array}$ & 3 \\
\hline $\begin{array}{l}\text { m-METLLESTIRENO } \\
100-80-1\end{array}$ & & $\begin{array}{l}\text { Si no se estabiliza, se polimeriza Se descompone al calentarse, liberando gases y humos } \\
\text { tóxicos (monóxido de carbono) Reacciona con oxidantes fuertes y ácidos fuertes }\end{array}$ & 3 \\
\hline $\begin{array}{l}\text { O-METILESTIRENO } \\
611-15-4\end{array}$ & & $\begin{array}{l}\text { Si no se estabiliza, se polimeriza Se descompone al calentarse, liberando gases y humos } \\
\text { tóxicos (monóxido de carbono) Reacciona con oxidantes fuertes y ácidos fuertes }\end{array}$ & 3 \\
\hline $\begin{array}{l}\text { p-METILESTIRENO } \\
622-97-9\end{array}$ & $\begin{array}{l}\text { El vapor es más pesado } \\
\text { que el aire }\end{array}$ & $\begin{array}{l}\text { Si no se estabiliza, se polimeriza Se descompone al calentarse, liberando gases y humos } \\
\text { tóxicos (monóxido de carbono) Es un oxidante fuerte y reacciona con materiales combustibles y } \\
\text { reductores Es un potente agente reductor y reacciona con oxidantes Reacciona con oxidantes } \\
\text { fuertes y ácidos fuertes }\end{array}$ & 3 \\
\hline $\begin{array}{l}\text { METILNAFTALENO } \\
1321-94-4\end{array}$ & & Se descompone al calentarse, desprendiendo humos irritantes & \\
\hline $\begin{array}{l}\text { PROPENILBENCENO } \\
873-66-5\end{array}$ & $\begin{array}{l}\text { El vapor es más pesado } \\
\text { que el aire }\end{array}$ & $\begin{array}{l}\text { Se descompone al calentarse, liberando gases y humos tóxicos (monóxido de carbono) } \\
\text { Reacciona con oxidantes fuertes }\end{array}$ & \\
\hline
\end{tabular}




\begin{tabular}{|c|c|c|c|}
\hline $\begin{array}{l}\text { Denominación química } \\
\mathrm{N} \text { úmero CAS }\end{array}$ & Físicos & Q uímicos & $\begin{array}{l}\text { Clase o división } \\
\text { UN / Riesgos } \\
\text { subsidiarios }\end{array}$ \\
\hline $\begin{array}{l}\text { TOLUENO } \\
108-88-3\end{array}$ & $\begin{array}{l}\text { El vapor es más pesado } \\
\text { que el aire y puede } \\
\text { desplazarse a ras del } \\
\text { suelo; posibilidad de } \\
\text { ignición a distancia } \\
\text { Pueden generarse cargas } \\
\text { electrostáticas como } \\
\text { resultado de flujo, } \\
\text { agitación, etc. }\end{array}$ & Reacciona violentamente con oxidantes fuertes, con peligro de incendio y explosión & 3 \\
\hline $\begin{array}{l}\text { 1,3,5-TRIMETILBENCENO } \\
108-67-8\end{array}$ & & & 3 \\
\hline $\begin{array}{l}\text { m-XILENO } \\
\quad 108-38-3\end{array}$ & $\begin{array}{l}\text { Pueden generarse cargas } \\
\text { electrostáticas como } \\
\text { resultado de flujo, } \\
\text { agitación, etc. }\end{array}$ & Reacciona violentamente con oxidantes fuertes, como el ácido nítrico & 3 \\
\hline $\begin{array}{l}\text { O-XILENO } \\
95-47-6\end{array}$ & $\begin{array}{l}\text { Pueden generarse cargas } \\
\text { electrostáticas como } \\
\text { resultado de flujo, } \\
\text { agitación, etc. }\end{array}$ & Reacciona violentamente con oxidantes fuertes, con peligro de incendio y explosión & 3 \\
\hline $\begin{array}{l}p \text {-XILENO } \\
106-42-3\end{array}$ & $\begin{array}{l}\text { Pueden generarse cargas } \\
\text { electrostáticas como } \\
\text { resultado de flujo, } \\
\text { agitación, etc. }\end{array}$ & Reacciona violentamente con oxidantes fuertes, como el ácido nítrico & 3 \\
\hline
\end{tabular}

\begin{tabular}{|c|c|c|c|c|c|c|c|c|c|c|c|}
\hline $\begin{array}{l}\text { Denominación química } \\
\mathrm{N} \text { úmero CAS }\end{array}$ & Color/ Forma & $\begin{array}{l}\text { p.e. } \\
\left({ }^{\circ} \mathrm{C}\right)\end{array}$ & $\begin{array}{l}\text { p.f. } \\
(\stackrel{O}{ } C)\end{array}$ & $\begin{array}{l}\text { p.m.l } \\
\text { (g/ } \\
\mathrm{mol})\end{array}$ & $\begin{array}{l}\text { Solubilidad } \\
\text { en agua }\end{array}$ & $\begin{array}{l}\text { Densidad } \\
\text { relativa } \\
\text { (agua }=1 \text { ) }\end{array}$ & $\begin{array}{l}\text { Densidad } \\
\text { de vapor } \\
\text { relativa } \\
\text { (aire=1) }\end{array}$ & $\begin{array}{l}\text { Pvap/ } \\
(\mathrm{kPa})\end{array}$ & $\begin{array}{l}\text { Límit. } \\
\text { inflam. }\end{array}$ & $\begin{array}{l}\text { p.ig. } \\
(\stackrel{\circ}{ }) \text {. }\end{array}$ & $\begin{array}{l}\text { p.aut } \\
\text { ig. } \\
(\stackrel{\circ}{ } \text { C })\end{array}$ \\
\hline $\begin{array}{l}\text { BENCENO } \\
71-43-2\end{array}$ & $\begin{array}{l}\text { líquido transparente } \\
\text { e incoloro; prismas } \\
\text { romboédricos }\end{array}$ & 80 & 5,5 & 78,11 & lig sol & 0,8765 & 2,7 & 10 & $\begin{array}{l}1,3 \mathrm{li} \\
7,1 \mathrm{lu}\end{array}$ & $-11 c c$ & 500 \\
\hline $\begin{array}{l}\text { p-terc-BUTILTOLUENO } \\
98-51-1\end{array}$ & $\begin{array}{l}\text { líquido transparente } \\
\text { incoloro }\end{array}$ & 193 & .52 & 148,2 & insol & 0,8612 & 4,62 & $\begin{array}{l}0,65 \\
\mathrm{~mm} \mathrm{Hg} \\
@ 25^{\circ} \mathrm{C} \\
\end{array}$ & & & \\
\hline $\begin{array}{r}p-C I M E N O \\
99-87.6 \\
\end{array}$ & líquido incoloro & 177,1 & $-67,94$ & 134,2 & insol & 0,8573 & 4,62 & 0,2 & $\begin{array}{l}0,7 \mathrm{li} \\
5,6 \mathrm{ls}\end{array}$ & $47 \mathrm{cc}$ & 436 \\
\hline $\begin{array}{l}\text { 0-CLOROESTIRENO } \\
2039-87-4\end{array}$ & líquido & 188,7 & $-63,1$ & 138,60 & & 1,1000 & & $\begin{array}{l}9,6 \times 10^{-1} \\
\mathrm{~mm} \mathrm{Hg} \\
@ 25^{\circ} \mathrm{C}\end{array}$ & & & \\
\hline $\begin{array}{l}\text { CUMENO } \\
98-82-8 \\
\end{array}$ & líquido incoloro & 152,4 & $-96,0$ & 120,19 & insol & 0,862 & 4,2 & $\begin{array}{l}10 \mathrm{~mm} \mathrm{Hg} \\
@ 38,3^{\circ} \mathrm{C}\end{array}$ & $\begin{array}{l}0,9 \mathrm{li} \\
6,5 \mathrm{ls}\end{array}$ & & \\
\hline $\begin{array}{l}\text { DECAHIDRONAFTALENO } \\
91-17-8\end{array}$ & $\begin{array}{l}\text { líquido transparente } \\
\text { incoloro }\end{array}$ & 155,5 & -43 & 138,24 & $0,9 \mathrm{ppm}$ & 0,8965 & 4,8 & $\begin{array}{l}2,3 \mathrm{~mm} \mathrm{Hg} \\
@ 25^{\circ} \mathrm{C}\end{array}$ & $\begin{array}{l}0,7 \mathrm{li} \\
4,9 \\
@ 100{ }^{\circ} \mathrm{C} \\
\text { ls }\end{array}$ & $58 \mathrm{cc}$ & $\begin{array}{l}250 ; \\
255 \\
\text { isómero } \\
\text { trans }\end{array}$ \\
\hline $\begin{array}{c}\text { DIETILBENCENO } \\
25340-17-4\end{array}$ & líquido & 181- 184 & $<-20$ & & insol & 0,9 & 4,6 & 0,13 & $\begin{array}{l}0,8 \mathrm{li} \\
5 \mathrm{ls}\end{array}$ & 56 & $\begin{array}{l}395- \\
450\end{array}$ \\
\hline
\end{tabular}




\begin{tabular}{|c|c|c|c|c|c|c|c|c|c|c|c|}
\hline $\begin{array}{l}\text { Denominación química } \\
\mathrm{N} \text { úmero CAS }\end{array}$ & Color/ Forma & $\begin{array}{l}\text { p.e. } \\
(\stackrel{0}{ } \mathrm{C})\end{array}$ & $\begin{array}{l}\text { p.f. } \\
(\stackrel{\circ}{ } C)\end{array}$ & $\begin{array}{l}\text { p.m.l } \\
\text { (g/ } \\
\text { mol) }\end{array}$ & $\begin{array}{l}\text { Solubilidad } \\
\text { en agua }\end{array}$ & $\begin{array}{l}\text { Densidad } \\
\text { relativa } \\
\text { (agua }=1 \text { ) }\end{array}$ & $\begin{array}{l}\text { Densidad } \\
\text { de vapor } \\
\text { relativa } \\
\text { (aire=1) }\end{array}$ & $\begin{array}{l}\text { Pvap/ } \\
(\mathrm{kPa})\end{array}$ & $\begin{array}{l}\text { Límit. } \\
\text { inflam. }\end{array}$ & $\begin{array}{l}\text { p.ig. } \\
(\underline{O C})\end{array}$ & $\begin{array}{l}\text { p.aut } \\
\text { ig. } \\
(\stackrel{\circ}{ } \text { C })\end{array}$ \\
\hline $\begin{array}{l}\text { DIFENILO } \\
92-52-4\end{array}$ & $\begin{array}{l}\text { escamas blancas; } \\
\text { láminas en alcohol } \\
\text { dil; laminillas } \\
\text { incoloras }\end{array}$ & 256 & 69 & 154,20 & insol & 1,041 & 5,31 & $\begin{array}{l}0,13 \\
@ 71^{\circ} \mathrm{C}\end{array}$ & $\begin{array}{l}0,6 \\
@ 232 \\
\mathrm{~mm} \mathrm{Hg} \\
5,8 @ \\
311 \mathrm{~mm} \mathrm{Hg}\end{array}$ & $113 c c$ & 540 \\
\hline $\begin{array}{l}\text { DIVINILBENCENO } \\
1321-74.0\end{array}$ & líquido incoloro & 195 & $\begin{array}{l}-66,9 a \\
-52\end{array}$ & 130,19 & insol & 0,9 & 4,48 & $\begin{array}{l}0,133 \\
@ 32,7^{\circ} \mathrm{C}\end{array}$ & $\begin{array}{l}1,1 \mathrm{il} \\
6,2 \mathrm{is}\end{array}$ & 169 ca & 500 \\
\hline $\begin{array}{l}\text { DODECILBENCENO } \\
123-01-3\end{array}$ & líquido incoloro & 328 & 3 & 246,4 & insol & 0,9 & 8,47 & $<10 \mathrm{~Pa}$ & & 1406 & \\
\hline $\begin{array}{l}\text { ESTIRENO } \\
\quad 100-42-5\end{array}$ & $\begin{array}{l}\text { líquido aceitoso } \\
\text { incoloro o } \\
\text { amarillento; líquido } \\
\text { viscoso; con } \\
\text { propiedades } \\
\text { disolventes, elástico }\end{array}$ & 145 & -31 & 104,14 & insol & 0,906 & 3,6 & 0,7 & $\begin{array}{l}0,9 \mathrm{li} \\
6,8 \mathrm{is}\end{array}$ & $\begin{array}{l}344- \\
367\end{array}$ & 490 \\
\hline $\begin{array}{c}\text { ETILBENCENO } \\
100-41-4 \\
\end{array}$ & líquido incoloro & 136 & .95 & 106,16 & insol & 0,8670 & 3,66 & 0,9 & $\begin{array}{l}1,6 \mathrm{li} \\
7 \mathrm{Is} \\
\end{array}$ & $128 \mathrm{cc}$ & 432 \\
\hline $\begin{array}{l}\text { 1-ETILNAFTALENO } \\
1127-76-0\end{array}$ & & 258,6 & $-13,9$ & 156,22 & insol & 1,0082 & & & & & \\
\hline $\begin{array}{l}\text { 2-ETILNAFTALENO } \\
939-27-5\end{array}$ & & 258 & $-7,4$ & 156,22 & insol & 0,9922 & & & & & \\
\hline $\begin{array}{l}\text { INDENO } \\
95-13-6 \\
\end{array}$ & $\begin{array}{l}\text { líquido; agujas } \\
\text { amarillas }\end{array}$ & 182 & $-1,8$ & 116,15 & insol & 0,9968 & & & & & \\
\hline $\begin{array}{l}\text { LIMONENO } \\
\quad 138-86-3 \\
\end{array}$ & líquido móvil incoloro & $175,5-176,5$ & $-95,5$ & 136,23 & $\begin{array}{l}13,8 \mathrm{mg} / \mathrm{l} \\
@ 25^{\circ} \mathrm{C}\end{array}$ & 0,8402 & 4,7 & $\begin{array}{l}20 \mathrm{~mm} \mathrm{Hg} \\
@ 68,2{ }^{\circ} \mathrm{C}\end{array}$ & $\begin{array}{l}0,7 \mathrm{li} \\
6,1 \mathrm{is}\end{array}$ & $45 \mathrm{cc}$ & 237 \\
\hline $\begin{array}{l}\text { D-LIMONENO } \\
5989-27-5\end{array}$ & líquido & 178 & $.74,35$ & 136,23 & insol & 0,8411 & 4,7 & $\begin{array}{l}0,4 \\
@ 14,4^{\circ} \mathrm{C}\end{array}$ & $\begin{array}{l}0,7 \mathrm{li} \\
6,1 @ \\
302^{\circ} \mathrm{Cls} \\
\end{array}$ & 48 & 237 \\
\hline $\begin{array}{l}\text { L-LIMONENO } \\
5989-54-8 \\
\end{array}$ & & 177,5 & & 136,23 & & 0,8422 & & & & & \\
\hline $\begin{array}{c}\text { METILESTIRENO } \\
25013-15-4 \\
\end{array}$ & líquido incoloro & $170-171$ & $.76,67$ & 118,18 & insol & $\begin{array}{l}0,890 @ 25^{\circ} \mathrm{C} \\
125^{\circ} \mathrm{C}\end{array}$ & 4,08 & 0,15 & $\begin{array}{l}0,8 \mathrm{li} \\
11 \mathrm{is}\end{array}$ & 544 & 494 \\
\hline $\begin{array}{l}\alpha \text {-METILESTIRENO } \\
98.83 .9\end{array}$ & líquido incoloro & 164 & $-23,2$ & 118,2 & insol & 0,91 & 4,08 & $29 \mathrm{~Pa}$ & $\begin{array}{l}0,9 \mathrm{li} \\
6,6 \mathrm{ls}\end{array}$ & $8389 c c$ & 574 \\
\hline $\begin{array}{l}\text { m-METLLESTIRENO } \\
100-80-1 \\
\end{array}$ & líquido & 172 & $-86,3$ & 118,17 & insol & 0,91 & 4,1 & & & & \\
\hline $\begin{array}{l}\text { O-METILESTIRENO } \\
611-15-4\end{array}$ & líquido & 170 & .69 & 118,17 & insol & 0,91 & 4,1 & & & 51 & \\
\hline $\begin{array}{l}\text { p-METILESTIRENO } \\
622-97-9\end{array}$ & líquido incoloro & 173 & -34 & 118,2 & insol & 0,8764 & 4,1 & 0,1 & $\begin{array}{l}1,1 \mathrm{li} \\
5,3 \mathrm{is}\end{array}$ & 45 & 515 \\
\hline $\begin{array}{l}\text { METILNAFTALENO } \\
1321-94-4\end{array}$ & líquido incoloro & 241-244 & .22 & 142,21 & insol & 1,0 & & & & 82.97 & \\
\hline NAFTALENO & $\begin{array}{l}\text { sólido o escamas } \\
\text { cristalinas blancas; } \\
\text { escamas, esferas, } \\
\text { polvo o agregados de } \\
\text { color blanco; placas } \\
\text { monoclínicas en } \\
\text { alcohol }\end{array}$ & 217,9 & 80,2 & 128,16 & insol & 1,0253 & 4,42 & 0,01 & $\begin{array}{l}0,9 \mathrm{li} \\
5,9 \mathrm{is}\end{array}$ & & 526 \\
\hline
\end{tabular}


Tabla 104.108 • Propiedades físicas y químicas.

\begin{tabular}{|c|c|c|c|c|c|c|c|c|c|c|c|}
\hline $\begin{array}{l}\text { Denominación química } \\
\mathrm{N} \text { úmero CAS }\end{array}$ & Color/ Forma & $\begin{array}{l}\text { p.e. } \\
\left({ }^{\circ} \mathrm{C}\right)\end{array}$ & $\begin{array}{l}\text { p.f. } \\
(\stackrel{\circ}{ } \mathrm{C})\end{array}$ & $\begin{array}{l}\mathrm{p} . \mathrm{m} . / \\
\text { (g/ } \\
\mathrm{mol})\end{array}$ & $\begin{array}{l}\text { Solubilidad } \\
\text { en agua }\end{array}$ & $\begin{array}{l}\text { Densidad } \\
\text { relativa } \\
\text { (agua }=1 \text { ) }\end{array}$ & $\begin{array}{l}\text { Densidad } \\
\text { de vapor } \\
\text { relativa } \\
\text { (aire=1) }\end{array}$ & $\begin{array}{l}\text { Pvap/ } \\
(\mathrm{kPa})\end{array}$ & $\begin{array}{l}\text { Límit. } \\
\text { inflam. }\end{array}$ & $\begin{array}{l}\text { p.ig. } \\
(\underline{O} C)\end{array}$ & $\begin{array}{l}\text { p.aut } \\
\text { ig. } \\
(\mathrm{O} C)\end{array}$ \\
\hline $\begin{array}{l}\text { PROPENILBENCENO } \\
873-66-5 \\
\end{array}$ & líquido & 175 & $-29,3$ & 118,2 & insol & 0,911 & 4,1 & & $\begin{array}{l}0,9 \mathrm{li} \\
? \text { Is }\end{array}$ & 53 & \\
\hline $\begin{array}{l}\text { n-PROPILBENCENO } \\
103-65-1\end{array}$ & líquido incoloro & $\begin{array}{l}159,2^{\circ} \mathrm{Ca} \\
760 \mathrm{~mm} \mathrm{Hg}\end{array}$ & $-99,2$ & 120,19 & $0,06 \mathrm{~g} / \mathrm{l}$ & $\begin{array}{l}\text { d. esp: } 0,8620 \\
\text { @ } 20^{\circ} \mathrm{C} / 4^{\circ} \mathrm{C}\end{array}$ & 4,14 & $\begin{array}{l}1 \mathrm{~mm} \mathrm{Hg} \mathrm{a} \\
6,3^{\circ} \mathrm{C}\end{array}$ & $0,8-6 \%$ & & \\
\hline $\begin{array}{l}\text { 1,2,3,4-TETRAHIDRONAFTALENO } \\
\text { 119-64-2 }\end{array}$ & líquido incoloro & 207,6 & $-35,7$ & 132,20 & insol & 0,9702 & 4,6 & $\begin{array}{l}0,368 \\
\mathrm{~mm} \mathrm{Hg} \\
@ 25^{\circ} \mathrm{C}\end{array}$ & $\begin{array}{l}? \mathrm{li} \\
5,0 \\
@ 150^{\circ} \mathrm{C} \\
\text { is }\end{array}$ & $\begin{array}{l}77 \mathrm{ca} \\
82 \mathrm{cc}\end{array}$ & \\
\hline $\begin{array}{l}\text { TOLUENO } \\
108-88-3 \\
\end{array}$ & líquido incoloro & 111 & -95 & 92,13 & insol & 0,866 & 3,2 & 2,9 & $\begin{array}{l}1,2 \mathrm{li} \\
7,1 \mathrm{is}\end{array}$ & $4 \mathrm{cc}$ & 480 \\
\hline $\begin{array}{l}\text { 1,3,5-TRIMETLLBENCENO } \\
\text { 108-67-8 }\end{array}$ & $\begin{array}{l}\text { líquido transparente } \\
\text { e incoloro }\end{array}$ & 164,7 & $-44,7$ & 120,19 & insol & 0,8637 & 1,006 & $\begin{array}{l}1,86 \\
\mathrm{~mm} \mathrm{Hg}\end{array}$ & & & \\
\hline $\begin{array}{l}\text { m-XILENO } \\
108-38-3 \\
\end{array}$ & $\begin{array}{l}\text { líquido transparente } \\
\text { e incoloro; móvil }\end{array}$ & 139,3 & $-47,8$ & 106,17 & insol & $\begin{array}{l}0,8684 \\
@ 15^{\circ} \mathrm{C} / 4^{\circ} \mathrm{C}\end{array}$ & 3,7 & $\begin{array}{l}760 \mathrm{~mm} \mathrm{Hg} \\
@-47,9^{\circ} \mathrm{C}\end{array}$ & $\begin{array}{l}1,1 \mathrm{li} \\
7,0 \mathrm{ls}\end{array}$ & $27 c c$ & 527 \\
\hline $\begin{array}{l}\text { O-XILENO } \\
95-47-6 \\
\end{array}$ & líquido incoloro & 144 & .25 & 106,16 & insol & 0,880 & 3,7 & 0,7 & $\begin{array}{l}1,0 \mathrm{li} \\
7,0 \mathrm{ls}\end{array}$ & $32 c c$ & 463 \\
\hline $\begin{array}{l}p-X \mid L E N O \\
106-42-3\end{array}$ & $\begin{array}{l}\text { placas o prismas } \\
\text { incoloros a } \\
\text { temperaturas bajas; } \\
\text { líquido incoloro }\end{array}$ & 138,3 & 13 & 106,2 & insol & 0,861 & 3,7 & 0,9 & $\begin{array}{l}1,1 \mathrm{li} \\
7,0 \mathrm{ls}\end{array}$ & $27 \mathrm{cc}$ & 528 \\
\hline
\end{tabular}




\section{HIDROCARBUROS AROMATICOS HALO GENADOS}

Los hidrocarburos aromáticos halogenados son productos químicos que contienen uno o más átomos de un halógeno (cloro, flúor, bromo, yodo) y un anillo de benceno.

\section{Usos}

Clorobenceno (y derivados como el diclorobenceno; el m-diclorobenceno; el p-diclorobenceno; el 1,2,3-triclorobenceno; el 13,5-triclorobenceno; el 1,2,4-triclorobenceno; el hexaclorobenceno; el 1-cloro-3-nitrobenceno; el 1-bromo-4-clorobenceno). EI monoclorobenceno y los diclorobencenos se utilizan mucho como disolventes y productos químicos intermedios. Los diclorobencenos, especialmente el isómero $\mathrm{p}-$, se usan como fumigantes, insecticidas y desinfectantes. A simismo, para combatir las termitas se utiliza una mezcla de isómeros de triclorobenceno. Antiguamente se utilizaban el 1,2,3-triclorobenceno y el 1,3,5-triclorobenceno como medios de transferencia térmica, líquidos para transformadores y disolventes.

El hexaclorobenceno es un fungicida y un producto químico intermedio para colorantes y hexafluorobenceno. También es la materia prima para la producción de caucho sintético, un plastificante para el cloruro de polivinilo, un aditivo para compuestos pirotécnicos militares y un agente de control de la porosidad en la fabricación de electrodos.

El cloruro de bencilo sirve como producto químico intermedio en la fabricación de compuestos bencílicos. Se utiliza en la fabricación de cloruros amónicos cuaternarios, colorantes, agentes de curtido, productos farmacéuticos y perfumes. El cloruro de benzoilo se utiliza en las industrias textil y de tinte para mejorar la resistencia del color en fibras o tejidos teñidos.

Los cloronaftalenos de uso industrial son mezclas de tri-, tetra-, penta- y hexacloronaftalenos. Muchos de estos compuestos se utilizaban antiguamente como medios de transferencia térmica, disolventes, aditivos para lubricantes, líquidos dieléctricos y material de aislamiento eléctrico (pentacloronaftaleno, octacloronaftaleno, tricloronaftaleno, hexacloronaftaleno y tetracloronaftaleno). En la mayoría de los casos, los naftalenos clorados han sido sustituidos por plásticos.

EI DDT se ha utilizado muchísimo para el control de insectos que son parásitos o vectores de organismos patógenos para el hombre. Entre las enfermedades que pueden transmitir estos vectores se encuentran la malaria, la fiebre amarilla, el dengue, la filariasis, el tifus exantemático transmitido por los piojos y la fiebre recurrente transmitida por los piojos. T odos los vectores de estas enfermedades son artrópodos vulnerables al DDT. Aunque en los países europeos, en Estados U nidos y en Japón se ha abandonado el uso del DDT, esta sustancia sigue siendo utilizada por las autoridades encargadas de la salud pública y por los militares para controlar enfermedades transmitidas por vectores, para fines de cuarentena y en fármacos administrados contra las ladillas.

EI hexaclorofeno es un antiinfeccioso tópico, un detergente y un agente antibacteriano en jabones, productos de limpieza empleados en cirugía, equipos médicos y cosméticos. Se utiliza como fungicida para verduras y plantas decorativas. El cloruro de benzatonio se emplea como antiinfeccioso tópico en medicina, como germicida para la limpieza de utensilios con los que se manipulan alimentos y productos lácteos y como agente algicida para las piscinas. También es un aditivo para desodorantes y productos de peluquería.

Bifenilos policlorados (PCBS). La producción de PCBs de grado técnico con fines comerciales aumentó en 1929, cuando estos compuestos comenzaron a utilizarse como aceites no inflamables en condensadores y transformadores eléctricos. Así, por ejemplo, se estima que en Estados U nidos se fabricaron 1,4 billones de libras de PCBs desde finales del decenio de 1920 hasta mediados del decenio de 1970. Las principales propiedades de los PCBs que los hacen útiles para la producción de una gran diversidad de artículos son: su baja solubilidad en agua, su miscibilidad con disolventes orgánicos y polímeros, su elevada constante dieléctrica, su estabilidad química (degradación muy lenta), sus altos puntos de ebullición, su baja presión de vapor, su termoestabilidad y su resistencia a las llamas. Los PCBs también son bacteriostáticos, fungostáticos y sinergéticos pesticidas.

Los PCB se han utilizado en sistemas "cerrados" o "semicerrados", como transformadores eléctricos, condensadores, sistemas de transferencia térmica, reactancias de lámparas fluorescentes, líquidos hidráulicos, aceites lubricantes, cables e hilos eléctricos aislados, etc., y en sistemas "abiertos", como plastificantes de materiales plásticos, adhesivos para revestimientos murales impermeables, tratamientos de superficie para tejidos, tratamientos de superficie para madera, metal y hormigón, productos de calafateado, pinturas, tintas de imprenta, papel, papel autocopiativo, papeles impregnados para la envoltura de cítricos, aceites de corte, medios de montaje y aceites de inmersión para microscopia, antiempañantes, retardadores de llama, y también en productos insecticidas y bactericidas.

\section{Riesgos}

La exposición a hidrocarburos aromáticos halogenados entraña numerosos riesgos. Los efectos pueden variar considerablemente según el tipo de compuesto. En conjunto, la toxicidad de los hidrocarburos aromáticos halogenados se caracteriza por irritación aguda de los ojos, las mucosas y los pulmones, así como síntomas gastrointestinales y neurológicos (náuseas, cefalea y depresión del sistema nervioso central). T ambién pueden presentarse acné (cloracné) y disfunciones hepáticas (hepatitis, ictericia, porfiria). Se han registrado alteraciones reproductivas (abortos, mortinatos y recién nacidos de bajo peso) y también ciertos efectos carcinogénicos. Seguidamente se realiza un análisis más detenido de los efectos específicos que producen algunos productos químicos de este grupo.

La Agencia Internacional para la Investigación sobre el Cáncer (IARC) ha clasificado a los toluenos clorados (cloruro de bencilo, benzalcloruro y benzotricloruro) como carcinógenos del Grupo 2A. Debido a sus propiedades fuertemente irritantes, la concentraciones de cloruro de bencilo de $6-8 \mathrm{mg} / \mathrm{m}^{3}$ causan una ligera conjuntivitis a los cinco minutos de exposición. Las concentraciones de $50-100 \mathrm{mg} / \mathrm{m}^{3}$ en suspensión en el aire causan de inmediato lagrimeo y parpadeo $y$, a concentraciones de $160 \mathrm{mg} / \mathrm{m3}$, la irritación de los ojos y la mucosa nasal resulta insoportable. Los trabajadores expuestos a concentraciones de $10 \mathrm{mg} / \mathrm{m}^{3}$ o más de cloruro de bencilo sufrieron debilidad, fatiga rápida, dolores de cabeza persistentes, irritabilidad creciente, calor intenso, pérdida de sueño y apetito y, en algunos casos, picores en la piel. Los exámenes médicos de estos trabajadores revelaron astenia, distonía del sistema nervioso autónomo (hiperhidrosis, temblores en los párpados y los dedos, inseguridad en la prueba de R omberg, dermografismo positivo, etc.). Pueden producirse también trastornos de la función hepática, con 
aumento del contenido de bilirrubina en sangre y resultados positivos en las pruebas de T akata-A ra y W eltmann, disminución del número de leucocitos y tendencia a enfermedades como resfriados y rinitis alérgicas. No se han registrado casos de intoxicaciones agudas. El cloruro de bencilo puede provocar dermatitis $y$, si penetra en los ojos, provoca una quemadura intensa, lagrimeo y conjuntivitis.

EI clorobenceno y sus derivados provocan irritación aguda de los ojos, la nariz y la piel. La exposición a concentraciones altas produce dolores de cabeza y crisis respiratorias. Dentro de este grupo, el hexaclorobenceno merece una mención especial. Entre 1955 y 1958 se produjo una grave epidemia en Turquía como consecuencia de la ingestión de trigo que había sido contaminado con el fungicida hexaclorobenceno. M iles de personas desarrollaron porfiria, que comenzó con lesiones bullosas que progresaron hasta convertirse en úlceras, con escaras pigmentadas. En niños, las lesiones iniciales recordaban a los comedones y miltos. El diez por ciento de los afectados fallecieron. En los lactantes que ingirieron leche materna contaminada con hexaclorobenceno, la tasa de mortalidad fue del $95 \%$ Se detectaron descargas masivas de porfirinas en la orina y las heces de los pacientes. Incluso 20 ó 25 años después, entre el 70 y el $85 \%$ de supervivientes seguían presentando hiperpigmentación y cicatrices residuales en la piel, así como artritis y trastornos musculares. La IARC ha clasificado el hexaclorobenceno como carcinógeno del Grupo 2B (posible carcinógeno humano).

La toxicidad de los cloronaftalenos aumenta con el grado de cloración. Los principales problemas provocados por la exposición a esta sustancia son el cloracné y la hepatitis tóxica. Los naftalenos más clorados pueden provocar lesiones hepáticas graves, caracterizadas por atrofia aguda amarilla o necrosis subaguda. L os cloronaftalenos también tienen un efecto fotosensibilizante sobre la piel.

Los PCBs pueden penetrar en el organismo humano por vía percutánea, respiratoria o digestiva durante la fabricación y/ o manipulación de estos compuestos. Son sustancias muy lipofílicas que se difunden rápidamente en el tejido adiposo. Se metabolizan en el hígado, tanto más despacio cuanto mayor sea el contenido de cloro del isómero. De ahí que estos compuestos tarden mucho en eliminarse y puedan detectarse en el tejido adiposo años después de la exposición. Los isómeros bifenílicos con un elevado índice de cloración son metabolizados muy lentamente en el organismo, de manera que sus tasas de eliminación son muy bajas (se excretó menos del $20 \%$ del 2,4,5,2',4',5'-hexaclorobifenilo durante el tiempo que vivieron una serie de ratas a las que se administró una sola dosis intravenosa de este compuesto).

Aunque la fabricación, distribución y utilización de PCBs se prohibió en Estados U nidos en 1977 y posteriormente en otros países, la exposición accidental (por fugas o contaminación ambiental) sigue siendo motivo de preocupación. No es raro que los transformadores que contienen PCBs se incendien o exploten, contaminando el medio ambiente con PCBs y productos tóxicos originados en su descomposición. En algunos trabajadores expuestos, el perfil de la cromatografía de gases correspondiente a los residuos de PC Bs es diferente al de la población general. $L a$ dieta, la exposición concomitante a otros xenobióticos y determinadas características bioquímicas individuales también pueden influir en los perfiles de la cromatografía de gases de los PCBS. La dsminución de los niveles plasmáticos de PCBs tras cesar la exposición fue relativamente rápida en los trabajadores expuestos durante cortos períodos de tiempo y muy lenta en los expuestos durante más de 10 años y/ o en los expuestos a mezclas de PCBs con un alto índice de cloración.

En las personas expuestas a PCBs por razones profesionales se ha detectado un amplio abanico de efectos nocivos para la salud, como alteraciones de la piel y las mucosas; inflamación de los párpados, quemaduras en los ojos y lagrimeo excesivo. T ambién pueden aparecer sensación de quemazón y edema en la cara y las manos, erupciones eritematosas simples con prurito, eczema agudo de contacto (erupciones vesiculoeritematosas), cloracné (una forma de acné extremadamente rebelde), hiperpigmentación de la piel y las mucosas (conjuntiva, palpebral y gingival), decoloración de las uñas y engrosamiento de la piel. En muchos casos se produce irritación de las vías respiratorias altas y, en un porcentaje relativamente alto de los trabajadores expuestos en una fábrica de condensadores eléctricos, se detectó una disminución de la capacidad vital forzada, sin que se acompañara de alteraciones radiológicas.

Pueden también producirse síntomas digestivos tales como: dolor abdominal, anorexia, náuseas, vómitos e ictericia y, rara vez, coma y muerte del paciente. En estos últimos casos mortales, las autopsias han revelado la existencia de atrofia amarilla aguda del hígado.

A simismo, se han encontrado en diferentes proporciones otros síntomas neurológicos como: cefaleas, mareos, depresión, nerviosismo, etc. y, en ocasiones, fatiga, pérdida de peso, disminución de la líbido, mialgias y altralgias.

La IARC ha asignado los PC Bs al Grupo 2A (probables carcinógenos humanos). T ras el desastre ecológico ocurrido en $Y$ usho, Japón, donde los PCBs contaminaron aceites comestibles, se observó un aumento de la tasa de tumores malignos. Los embarazos patológicos (toxemia, abortos, mortinatos, recién nacidos de bajo peso, etc.) se relacionaron con un aumento de los niveles séricos de PCBs en los enfermos de Yusho y en la población general.

Los PBBs (bifenilos polibromados) son análogos químicos de los PCBs con bromo en lugar de cloro en los anillos bifenílicos. Al igual que en los PCBs, existen numerosos isómeros, aunque los PBBs comerciales son, en su mayoría, hexabromados y se han utilizado principalmente como retardadores de llama. Son lipofílicos y se acumulan en el tejido adiposo. Se metabolizan muy despacio en el organismo, razón por la cual también se excretan lentamente. Sus efectos en la salud humana se conocen bien debido a un episodio ocurrido en M ichigan en 1973 en el que se mezclaron inadvertidamente unos $900 \mathrm{~kg}$ de PBBs con pienso para el ganado, tras lo cual numerosas familias granjeras estuvieron expuestas a productos lácteos y cárnicos contaminados. Se observaron efectos tóxicos como acné, sequedad y oscurecimiento de la piel, náuseas, dolores de cabeza, visión borrosa, mareo, depresión, fatiga inusual, nerviosismo, somnolencia, debilidad, parestesia, pérdida del equilibrio, dolores en las articulaciones, en la espalda y en las extremidades inferiores, aumento de los niveles de las enzimas hepáticas SG PT y SGOT y disminución de la función inmunológica. Se ha detectado la presencia de PBBs en el plasma y el tejido adiposo de personas que trabajan en la producción de PBBs, así como en la leche materna, en la sangre del cordón umbilical, en el líquido biliar y en las heces de mujeres y lactantes expuestos a través de la dieta.

La IARC ha clasificado los PBBs como posibles carcinógenos humanos (Grupo 2B).

\section{Dioxina}

$L$ a dioxina -2,3,7,8-tetraclorodibenzo-p-dioxina (TCDD)- no se produce a escala comercial, si bien se encuentra como impureza en el 2,4,5-triclorofenol (TCP). Asimismo, pueden existir vestigios de esta sustancia en el herbicida 2,4,5-T y en el agente antibacteriano hexaclorofeno, que se obtiene a partir del triclorofenol.

La T CDD se forma, como subproducto, durante la síntesis de 2,4,5-triclorofenol a partir de 1,2,4,5-tetraclorobenceno en condiciones alcalinas por condensación de dos moléculas de 
triclorofenato sódico. Cuando se mantiene un control estricto de la temperatura y la presión a medida que avanza la reacción, el 2,4,5-triclorofenol crudo contiene entre $1 \mathrm{mg} / \mathrm{kg}$ y $5 \mathrm{mg} / \mathrm{kg}$ de T CDD (1-5 ppm). A temperaturas más altas $\left(230\right.$ a $\left.260^{\circ} \mathrm{C}\right)$, la formación del producto aumenta.

La estructura química de la TCDD fue identificada en el año 1956 por Sandermann y sus colaboradores, quienes sintetizaron esta sustancia por primera vez. Un técnico de laboratorio que trabajaba en la síntesis fue hospitalizado con cloracné muy severo.

Existen 22 isómeros posibles de la tetraclorodibenzo-p-dioxina. La dreviatura TCDD se utiliza normalmente para referirse a la 2,3,7,8-tetraclorodibenzo-p-dioxina, sin excluir la existencia de los otros 21 tetraisómeros. La TCDD puede obtenerse para grados químico y toxicológico mediante la condensación catalítica de 2,4,5-triclorofenato potásico.

La TCDD es una sustancia sólida poco soluble en agua y en los disolventes comunes $(0,2 \mathrm{ppb})$ y muy estable frente a la degradación térmica. En presencia de un donante de hidrógeno, se descompone rápidamente por la acción de la luz. Cuando se incorpora a la tierra o a las aguas, prácticamente no se altera.

\section{Incidencia}

La principal fuente de formación de TCDD en el medio ambiente es la reacción térmica, bien durante los procesos químicos de producción de 2,4,5-triclorofenol, bien durante la combustión de productos químicos que puedan contener precursores de las dioxinas en general.

La exposición laboral a TCDD puede ocurrir durante la producción del triclorofenol y sus derivados $(2,4,5-T$ y hexaclorofeno), durante su incineración y durante el uso y el manejo de estos productos químicos y sus residuos.

Asimismo, es posible que se produzca exposición de la población general como consecuencia de programas de aplicación de herbicidas, por la bioacumulación de TCDD en la cadena alimentaria, por inhalación de polvos de cenizas o gases emanados de incineradores municipales e instalaciones industriales, durante la combustión de carbón que contiene esta sustancia en presencia de cloro, por el desenterramiento de residuos químicos, y por contacto con personas que lleven las ropas contaminadas.

\section{Toxicidad}

La TCDD es extremadamente tóxica para los animales de experimentación. Todavía no se comprende el mecanismo por el que se produce la muerte de los mismos y la sensibilidad a los efectos tóxicos varía según la especie. La dosis letal por vía oral oscila entre $0,5 \mathrm{mg} / \mathrm{kg}$ para los cobayas y más de $1.000 \mathrm{mg} / \mathrm{kg}$ para los hámsters. Los efectos letales son lentos y duran varios días 0 semanas desde la administración de una dosis única.

El cloracné y la hiperqueratosis son dos características típicas de la toxicidad por TCDD que se observa en conejos, monos y ratones sin pelo, y en el hombre. La TCDD tiene efectos teratógenos y/ 0 embriotóxicos en los roedores. En conejos, la toxicidad parece afectar principalmente al hígado. En monos, el primer signo de toxicidad se manifiesta en la piel, mientras que el hígado permanece relativamente normal. Algunas especies sufren alteraciones del metabolismo de la porfirina hepática. T ambién se han observado inmunosupresión, carcinogénesis, inducción enzimática y mutagénesis en condiciones experimentales. La vida media en ratas y cobayas es de aproximadamente 31 días y la principal vía de excreción son las heces.

K.H. Schulz descubrió en 1957 en Hamburgo que la TCDD era el agente tóxico responsable de las lesiones y los síntomas observados en el ser humano tras la exposición al triclorofenol o al ácido 2,4,5-triclorofenoxiacético. Este investigador demostró posteriormente las propiedades cloracnegénicas y hepatotóxicas de la TCDD en conejos. En una prueba de autoadministración cutánea (10 mg aplicados dos veces) se demostró también el efecto de la TCDD en la piel humana. Klingmann repitió un experimento humano en 1970 y volvió a comprobar que la aplicación en el hombre de $70 \mathrm{mg} / \mathrm{kg}$ producía cloracné evidente.

Se han registrado efectos tóxicos producidos por la TCDD en seres humanos como consecuencia de exposiciones laborales repetidas durante la producción industrial de triclorofenol y 2,4,5-T y exposiciones agudas en fábricas y sus alrededores donde se habían producido accidentes durante la producción de estas sustancias.

\section{Exposición industrial}

Se ha estimado que la producción mundial anual de 2,4,5-triclorofenol en el año 1979 fue de unas 7.000 toneladas, la mayor parte de las cuales se destinaron a la producción del herbicida 2,4,5-T y sus sales. Dicho herbicida se aplica con periodicidad anual para controlar el crecimiento de hierbas en los bosques, montes y zonas industriales, urbanas y acuáticas. EI uso general de 2,4,5-T se ha suspendido parcialmente en Estados U nidos. En algunos países se ha prohibido su utilización (Italia, Holanda, Suecia); en otros, como R eino U nido, C anadá, Australia y N ueva Zelanda, este herbicida se sigue utilizando. La aplicación normal de 2,4,5-T y sus sales $(0,9 \mathrm{~kg} /$ acre) podría dispersar no más de $90 \mathrm{mg}$ de TCDD por cada acre tratado con la concentración más alta permitida de 0,1 ppm de TCDD en 2,4,5-T de grado técnico. En el tiempo transcurrido desde que se inició la producción comercial de 2,4,5-T a escala comercial hasta la actualidad (1946-1947), se han producido varios episodios industriales de exposición a TCDD. La mayoría de estas exposiciones han ocurrido durante la manipulación de productos intermedios contaminados, es decir, triclorofenol. En ocho ocasiones, se produjeron explosiones durante la producción de triclorofenato sódico y los trabajadores se vieron expuestos a TCDD en el mismo momento del accidente, durante las tareas de limpieza o por contaminación posterior del ambiente de trabajo. En la literatura se mencionan otros cuatro episodios, si bien no se facilitan datos acerca de las personas afectadas.

\section{Características clínicas}

En estos episodios se han visto envueltas alrededor de 1.000 personas. Se han descrito lesiones y síntomas muy diversos relacionados con la exposición a este producto y se ha descrito la existencia de una relación causal para algunos de ellos. Como síntomas cabe citar:

- dermatológicos: cloracné, porfiria cutánea tardía, hiperpigmentación e hirsutismo

- internos: lesiones hepáticas (fibrosis ligera, degeneración grasa, depósito de hemofucsina y degeneración parenquimatosa celular), aumento de los niveles plasmáticos de enzimas hepáticas, alteraciones del metabolismo de las grasas, alteraciones del metabolismo de los hidratos de carbono, alteraciones cardiovasculares, alteraciones del tracto urinario, alteraciones del aparato respiratorio, alteraciones pancreáticas

- neurológicos: (a) periféricos: polineuropatías, alteraciones sensoriales (vista, oído, olfato, gusto); (b) centrales: cansancio, debilidad, impotencia, pérdida de líbido

R ealmente, sólo en unos pocos casos se ha producido exposición únicamente a la TCDD. Casi siempre, la contaminación y los síntomas pueden deberse a productos químicos que se utilizan para la fabricación de T CP y sus derivados; es decir, tetraclorobenceno, hidróxido sódico o potásico, etilenglicol o metanol, triclorofenato sódico, monocloracetato sódico y algunos otros 
compuestos dependiendo del proceso de fabricación. La acción tóxica de la TCDD está probablemente relacionada con cuatro signos clínicos, todos ellos sugeridos por los estudios realizados en animales u observados en varios episodios. E stos síntomas son:

- cloracné, presente en la gran mayoría de los casos registrados

- hepatomegalia y, en ocasiones, deterioro de la función hepática

- síntomas neuromusculares ocasionales

- alteración del metabolismo de la porfirina en algunos casos.

Cloracné. Desde el punto de vista clínico, el cloracné es una erupción de puntos negros, habitualmente acompañada de pequeños quistes de color amarillo pálido, que en todos los casos, salvo en los más graves, tienen un tamaño que va desde el de una cabeza de alfiler hasta el de una lenteja. En los casos graves pueden aparecer pápulas (manchas rojas) o incluso pústulas (nódulos con pus). Esta enfermedad tiene predilección por la piel de la cara y, especialmente, por la zona malar debajo de los ojos y detrás de las orejas en los casos muy benignos. A medida que aumenta la gravedad, se ve afectado el resto de la cara y del cuello, en tanto que la zona externa de las extremidades superiores, el tórax, la espalda, el abdomen, la cara externa de los muslos y los genitales se ven afectados en diversos grados en los peores casos. Por lo demás, la enfermedad es asintomática y se limita a una desfiguración. Su duración depende en gran medida de la gravedad y en los casos graves pueden quedar lesiones activas incluso 15 años después de que haya cesado el contacto. En las personas estudiadas, diez días después de comenzar la exposición se produjo enrojecimiento de la piel y un ligero aumento de la queratina en los conductos de las glándulas sebáceas que, en la segunda semana, fue seguido de taponamiento del infundíbulo. A continuación desaparecen las células sebáceas y son reemplazadas por quistes de queratina y comedones que persisten durante muchas semanas.

El cloracné se produce frecuentemente como consecuencia del contacto cutáneo con el producto químico causante, pero también aparece tras su ingestión o inhalación. En estos casos casi siempre es grave y puede ir acompañado de signos de lesiones sistémicas. El cloracné, por sí mismo, carece de gravedad, pero es indicativo de que la persona ha estado expuesta, aunque sea mínimamente, a una toxina cloracnegénica. Por esta razón constituye el indicador más sensible que existe para identificar a las personas que están sometidas a una sobreexposición a TCDD. Sin embargo, la ausencia de cloracné no indica ausencia de exposición.

$\mathrm{H}$ epatomegalia y alteraciones de la función hepática. T ras la exposición a esta sustancia, en dgunos casos puede detectarse un aumento de los valores séricos de transaminasas que, por regla general, se normalizan en pocas semanas o meses. No obstante, las pruebas de función hepática pueden ser normales incluso en casos de exposición a concentración ambientales de TCDD de 1.000 ppm que producen cloracné grave. En el $50 \%$ de los casos se han observado también signos clínicos de disfunción hepática como trastornos abdominales, gastropatías, pérdida de apetito, intolerancia a ciertos alimentos y hepatomegalia.

La laparoscopia y la biopsia del hígado mostraron ligeras alteraciones fibrosas, depósitos de hemofucsina, degeneración grasa y ligera degeneración de las células del parénquima en algunos de estos casos. Las lesiones hepáticas causadas por TCDD no se caracterizan necesariamente por hiperbilirrubinemia.

Los estudios de seguimiento de los casos que en la actualidad aún presentan lesiones acneiformes después de 20 años 0 más, han indicado que la hepatomegalia y la alteración de las pruebas funcionales hepáticas desaparecen. En casi todos los animales de experimentación, las lesiones hepáticas no son de magnitud suficiente como para provocar la muerte.
E fectos neuromusculares. Las manifestaciones más discapacitantes parecen ser, en algunos casos, la existencia de intensos dolores musculares que se agravan con el ejercicio, especialmente en la pelvis y los muslos, así como en la zona torácica, fatiga, debilidad de los miembros inferiores y alteraciones sensoriales.

En los animales, el sistemas nervioso central y el periférico no se ven afectados por la toxicidad de la TCDD. No se han realizado estudios en animales que justifiquen la presencia de adinamia muscular 0 alteración de la función musculoesquelética en las personas expuestas a T CDD. Por consiguiente, este efecto podría estar relacionado con la exposición simultánea a otros productos químicos.

Alteración del metabolismo de la porfirina. La exposición a TCDD se ha asociado a alteraciones del metabolismo intermediario de los lípidos, los hidratos de carbono y las porfirinas. En animales, la TCDD produjo una acumulación de uroporfirina en el hígado, con aumento del ácido $\delta$-aminolevulínico (ALA) y de la excreción de uroporfirina en la orina. En los trabajadores expuestos a TCDD se ha observado un aumento de la excreción de uroporfirinas. Esta anomalía se traduce en un aumento cuantitativo de la excreción urinaria de uroporfirinas y un cambio en la proporción con la coproporfirina.

\section{Efectos crónicos}

La TCDD produce diversos efectos perjudiciales en la salud de animales y seres humanos, como inmunotoxicidad, teratogenicidad, carcinogenicidad y letalidad. Los efectos agudos en animales pueden originar la muerte por emaciación, a menudo acompañada de atrofia del timo, una glándula que desempeña un papel activo en la función inmunológica de los animales adultos (pero no de las personas adultas). La TCDD provoca cloracné, un síndrome cutáneo grave, en animales y seres humanos y altera la función inmunológica en muchas especies. Las dioxinas provocan malformaciones congénitas y otros problemas reproductivos en los roedores, como el paladar hendido y la deformación de los riñones.

En los trabajadores sometidos a exposiciones intensas, se ha observado cloracné y otros síndromes cutáneos, porfiria cutánea tardía, aumento de los niveles plasmáticos de las enzimas hepáticas, alteraciones del metabolismo de las grasas y los hidratos de carbono, polineuropatías, debilidad, pérdida de líbido e impotencia.

Teratogenicidad y embriotoxicidad. La TCDD es un teratógeno extremadamente potente en roedores, especialmente en ratones, provocando paladar hendido e hidronefrosis. La TCDD causa toxicidad reproductiva, como disminución de la producción de esperma en mamíferos. En grandes dosis, la T CDD es embriotóxica (letal para el feto en desarrollo) en muchas especies. Sin embargo, existen pocos estudios de toxicidad reproductiva en el ser humano. Los escasos datos disponibles sobre la población expuesta a TCDD como consecuencia del accidente de Seveso, ocurrido en 1976, no indican que se haya producido un aumento de la tasa de malformaciones congénitas, si bien el número de casos estudiados fue demasiado pequeño como para poder detectar un aumento de malformaciones muy raras. La ausencia de datos históricos y la posibilidad de que los informes fueran desvirtuados hace difícil evaluar la frecuencia de abortos espontáneos en esta población.

Carcinogenicidad. En animales de laboratorio, la TCDD provoca cáncer en distintas zonas, como los pulmones, la cavidad buconasal, las glándulas suprarrenales, el tiroides y el hígado de las ratas y los pulmones, el hígado, el tejido subcutáneo, la glándula tiroides y el sistema linfático de los ratones. Por esta razón, muchos estudios de trabajadores expuestos a dioxinas se han centrado en la incidencia de cáncer. Ha sido más difícil realizar estudios concluyentes en seres humanos porque los trabajadores 
suelen verse expuestos a mezclas contaminadas por dioxinas (como los fenoxiherbicidas), más que a dioxina pura. Por ejemplo, en estudios de casos y controles se ha observado que los trabajadores agrícolas y forestales expuestos a herbicidas tienen un mayor riesgo de sufrir sarcoma de los tejidos blandos y linfoma no hodgkiniano.

Se han realizado numerosos estudios de cohortes humanas, si bien pocos de ellos han obtenido resultados concluyentes debido al número relativamente pequeño de trabajadores empleados en cualquier planta de producción. En 1980, la Agencia Internacional para la Investigación sobre el Cáncer (IARC) emprendió un estudio de mortalidad en una cohorte multinacional en el que actualmente participan más de 30.000 trabajadores y trabajadoras de 12 países, cuyo empleo se extiende desde 1939 hasta la actualidad. Un informe publicado en 1997 apuntaba a una tasa dos veces superior a la normal de sarcoma de los tejidos blandos y un aumento pequeño, pero significativo, de la mortalidad global por cáncer (710 fallecimientos, tasa de mortalidad ajustada = 1,12; intervalo de confianza del $95 \%=1,04-1,21$ ). L as tasas de mortalidad por linfoma no hodgkiniano y cáncer de pulmón también fueron ligeramente superiores a lo normal, sobre todo en trabajadores expuestos a herbicidas contaminados por TCDD. En un estudio de casos y controles anidados en esta cohorte, la exposición a fenoxiherbicidas se asoció a un riesgo diez veces mayor de sarcoma de tejidos blandos.

\section{Diagnóstico}

El diagnóstico de la contaminación por T CDD realmente se basa en la historia lógica de la posibilidad (correlación cronológica y geográfica) de exposición a sustancias que se sabe que contienen TCDD como contaminante y en la demostración de contaminación por TCDD en el ambiente mediante análisis químico.

Los síntomas y signos clínicos de la toxicidad no están lo suficientemente diferenciados como para permitir su reconocimiento clínico. Se sabe que en el ser humano el cloracné, que es el indicador más sensible de la exposición a T CDD, puede estar producido por:

- cloronaftalenos (CN)

- bifenilos policlorados (PCB)

- bifenilos polibromados (PBB)

- dibenzo-p-dioxinas policloradas (PCDD)

- dibenzofuranos policlorados (PCDF)

- 3,4,3,4-tetraclorazobenceno (TCAB)

- 3,4,3,4-tetraclorazoxibenceno (T CAO B).

La determinación en laboratorio de la TCDD en el organismo humano (sangre, órganos, sistemas, tejidos y grasa) solamente sirve para demostrar el depósito real de TCDD en el organismo, pero se desconoce el nivel al que es capaz de provocar toxicidad en el hombre.

\section{Medidas de salud y seguridad}

Las medidas de salud y seguridad son similares a las recomendadas para los disolventes. En general, debe reducirse al mínimo el contacto con la piel y la inhalación de vapores. Para ello, la medida más eficaz es el aislamiento del proceso de fabricación y la existencia de un sistema eficaz de ventilación junto con extractores locales en los principales focos de exposición. Los equipos de protección personal deberán consistir en respiradores con filtros industriales y protectores del rostro, los ojos, las manos y los brazos. Las ropas de trabajo deberán inspeccionarse y lavarse con frecuencia. U na buena higiene personal, incluida la ducha diaria, es muy importante para los trabajadores que manipulan cloronaftalenos. Con algunos productos, como el cloruro de bencilo, deben realizarse exámenes médicos periódicos. A conti- nuación se comentan algunos aspectos específicos de los PCBs relacionados con la salud y la seguridad.

\section{Bifenilos policlorados}

En el pasado, la concentración de PCBs en las atmósferas de trabajo de las industrias donde se manipulan estos productos eran variables, pero a menudo superaban los $10 \mathrm{mg} / \mathrm{m}^{3}$. A la vista de los efectos tóxicos observados con esas concentraciones, en Estados U nidos (Código de Reglamentos Federales de Estados Unidos, 1974) y en otros países se adoptó un TLV de $1 \mathrm{mg} / \mathrm{m}^{3}$ para los bifenilos con un bajo índice de cloración (42\%) y de $0,5 \mathrm{mg} / \mathrm{m}^{3}$ para los de alto índice de cloración (54\%). Estos límites siguen vigentes en la actualidad.

La concentración de PCBs en los ambientes de trabajo debe controlarse anualmente para comprobar la eficacia de las medidas preventivas encaminadas a mantener dichas concentraciones dentro de los niveles recomendados. Los análisis deben repetirse en los 30 días siguientes a cualquier cambio que se realice en los procesos tecnológicos que pueda aumentar la exposición de los trabajadores a PCBs.

En caso de producirse fugas o derrames de PCBs, habrá que proceder a una evacuación inmediata del personal. Para ello, las salidas de emergencia deberán estar convenientemente señalizadas y existirán instrucciones claras respecto a los procedimientos de emergencia que deben seguirse, teniendo en cuenta las características tecnológicas especiales de cada industria. Sólo podrá penetrar en la zona contaminada personal convenientemente entrenado y siempre que vaya provisto de equipos de protección adecuados. Las tareas que debe realizar el personal de emergencia son: reparación de las fugas, limpieza de los derrames (se echará arena o tierra sobre toda la superficie del derrame) y extinción de incendios.

Los trabajadores recibirán información sobre los efectos adversos para la salud derivados de la exposición profesional a los PCBs, así como sobre los efectos cancerígenos comprobados en animales expuestos experimentalmente a PCB y los efectos negativos sobre la actividad reproductora de mamíferos y del hombre con niveles de $P C B s$ relativamente altos. $L$ as mujeres en estado de gestación deberán evitar las zonas contaminadas con PBCs, puesto que estos compuestos pueden ser nocivos para su salud y para el feto, ya que atraviesan la barrera placentaria y ejercen efectos fetotóxicos. A estas trabajadoras se les debe ofrecer la posibilidad de realizar otros trabajos durante el embarazo y la lactancia, si bien esta última se desaconseja debido a la gran cantidad de PCBs que se excretan en la leche materna (la cantidad de PCB transmitidos al lactante a través de la leche es mayor que la que atraviesa la placenta). Se ha observado una correlación significativa entre los niveles plasmáticos de PCBs en madres expuestas en sus trabajos a estos compuestos y los niveles de PCBs en la leche. Si estas madres amamantan a sus hijos durante más de 3 meses, los niveles de PCBs en los niños superan a los de sus respectivas madres y quedan retenidos en los organismos de los niños durante muchos años. N o obstante, la extracción y el desecho de leche puede ayudar a disminuir el contenido de PC Bs en el organismo de las madres.

EI acceso a las zonas donde se trabaje con PCBs debe restringirse al personal autorizado. Estos trabajadores pasarán provistos de ropas protectoras adecuadas: monos de trabajo con mangas largas, botas, cubrebotas y mandiles de tipo babero que lleguen a cubrir la parte alta de las botas. A simismo, tendrán que utilizar guantes para reducir la absorción cutánea durante tareas especiales. Se prohibirá terminantemente manipular sin guantes materiales que contengan PCBs fríos o calientes. (La cantidad de PCBs que se absorbe a través de la piel intacta puede ser igual 0 , incluso, mayor que la absorbida por inhalación.) T odos los días se proveerá al personal de ropa de trabajo limpia, que se 
inspeccionará periódicamente para detectar posibles deterioros. Para la protección de los ojos se utilizarán gafas provistas de protección lateral. Los equipos de protección respiratoria (que deben cumplir los requisitos legales) se utilizarán en aquellas zonas donde existan vapores de PCBs y durante las operaciones de instalación y reparación de depósitos y en trabajos de emergencia, cuando se desconozca la concentración de PCBs o ésta supere el TLV . La ventilación de las naves de trabajo evitará la acumulación de vapores. (U na vez usados, los equipos de protección respiratoria se deben limpiar y almacenar en un lugar adecuado.)

L os empleados deben lavarse las manos antes de comer, beber o fumar, y abstenerse de realizar estas actividades en las naves contaminadas. Las ropas de calle se guardarán en taquillas separadas de las ropas de trabajo y, antes de cambiarse, los trabajadores deberán ducharse. En las cercanías de los puestos de trabajo existirán duchas, fuentes para el lavado de los ojos e instalaciones sanitarias.

Será necesario realizar exámenes clínicos periódicos de los trabajadores (al menos una vez al año), en los que se prestará la máxima atención a posibles dermopatías, alteraciones de la función hepática y posibles efectos en la reproducción.

\section{Dioxina}

La experiencia de exposición laboral a TCDD, bien sea por un accidente durante los procesos de producción de triclorofenol y sus derivados, bien como consecuencia de procesos industriales normales, ha demostrado que las lesiones que provoca esta sustancia pueden incapacitar por completo a los trabajadores durante varias semanas o incluso meses. L a resolución y cicatrización de las lesiones puede llegar a lograrse, pero en algunas casos las lesiones cutáneas y viscerales se hacen tórpidas y reducen la capacidad laboral del individuo en un 20-50 \% durante más de 20 años. La toxicidad por TCDD puede evitarse mediante un control estricto de los procesos químicos donde interviene este producto. U nas buenas prácticas de fabricación pueden eliminar el riesgo de exposición de los trabajadores que manipulan los productos y de la población general. En caso de accidente, es decir, si el proceso de síntesis del 2,4,5-triclorofenol queda fuera de control y se liberan grandes cantidades de TCDD, los afectados deberán quitarse las ropas contaminadas inmediatamente para evitar la contaminación de la piel y de otras partes del cuerpo. Las zonas expuestas se lavarán cuanto antes y repetidamente hasta que se obtenga atención médica. Se recomienda que los trabajadores que se ocupen de las labores de descontaminación después de un accidente, utilicen equipos de protección desechables para proteger la superficie cutánea y prevenir la exposición al polvo y a los vapores de los materiales contaminados. Asimismo, se usarán máscaras contra gases si se sospecha que durante alguna tarea pudiera producirse inhalación de productos contaminados en suspensión aérea.

Todos los trabajadores estarán obligados a ducharse a diario al final de la jornada laboral. Las ropas y el calzado de calle no debe entrar nunca en contacto con las ropas y el calzado de trabajo. La experiencia ha demostrado que varias esposas de trabajadores afectados por cloracné también desarrollaron la enfermedad aunque nunca hubieran estado en la fábrica donde se producía triclorofenol. Algunos de los hijos también sufrieron una experiencia similar. En el caso del personal de laboratorio que trabaja con TCDD o con productos contaminados y del personal sanitario, como enfermeras y auxiliares sanitarios, que tratan con trabajadores enfermos o personas contaminadas, tendrán que adoptarse las mismas medidas preventivas recomendadas para los trabajadores en caso de accidente. El personal encargado del cuidado de los animales de experimentación 0 cualquier personal técnico que tenga contacto con materiales contaminados o con instrumentos y material de vidrio utilizado para los análisis de TCDD, debe ser consciente de la toxicidad de esta sustancia y manejarla debidamente. La eliminación de residuos, incluidos los cadáveres de los animales de experimentación, requiere métodos especiales de incineración. El material de vidrio, las encimeras, los instrumentos y las herramientas deben controlarse con regularidad, mediante pruebas de arrastre (arrastrar sobre un papel filtrante y determinar la cantidad de TCDD). Los envases de TCDD, así como el material de vidrio y las herramientas, estarán separados y toda la zona de trabajo permanecerá aislada.

Para la protección del público en general y, especialmente, de aquellas personas (aplicadores de herbicidas, personal de hospitales, etcétera) más expuestas a posibles riesgos, los organismos reguladores de todo el mundo impusieron en 1971 una especificación, en la fabricación, de un máximo de 0,1ppm de TCDD. G racias a las mejoras constantes en los procesos de fabricación, el grado comercial del producto contenía en 1980 0,01 ppm de TCDD o menos.

Esta especificación pretende evitar toda exposición a cantidades que puedan plantear un riesgo importante para las personas y su acumulación en la cadena alimentaria humana. Además, para evitar la contaminación de la cadena alimentaria humana, aunque sea por cantidades mínimas de TCDD que pudieran estar presentes en pastos o pastizales inmediatamente después de la aplicación de 2,4,5-T, no debe permitirse que los animales destinados a la producción láctea pasten en las zonas tratadas con este producto hasta que pasen entre una y seis semanas desde la fecha de su aplicación. 
TABLAS DE HIDROCARBUROS AROMATICOS HALOGENADOS

\begin{tabular}{|c|c|c|c|c|}
\hline Producto químico & Sinónimos/ Código UN & $\mathrm{N}$ úmero $\mathrm{CAS}$ & Fórmula estructural & \\
\hline BENZALCLORURO & $\begin{array}{l}\text { Dicloruro de bencilo; cloruro de bencileno; cloruro de bencilideno; } \\
\text { clorobenzal } \\
\text { UN1886 }\end{array}$ & $98-87-3$ & & \\
\hline BIFENILO POLICLORADO (AROCLOR 1242) & Clorodifenilo (42 \% de cloro) & $53469-21-9$ & & $\begin{array}{l}1<=x<=5 \\
1<=y<=5\end{array}$ \\
\hline BIFENILO POLICLORADO (AROCLOR 1254) & Clorodifenilo (54\% de cloro); PCB & $11097-69-1$ & & \\
\hline BIFENILOS POLIBROMADOS & Hexabromobifenilo (grado técnico); PBB & $59536-65-1$ & & $\begin{array}{l}1<=x<=5 \\
1<=y<=5\end{array}$ \\
\hline BROMOBENCENO & $\begin{array}{l}\text { Bromobenceno; monobromobenceno; bromuro de fenilo } \\
\text { UN2514 }\end{array}$ & $108-86-1$ & & \\
\hline BROMURO DE BENCILO & $\begin{array}{l}\alpha \text {-Bromotolueno; bromometilbenceno; bromofenilmetano } \\
\text { UN1737 }\end{array}$ & $100-39-0$ & & \\
\hline CANFENO CLORADO & Toxafeno; clorocanfeno; octaclorocanfeno; PCC & $8001-35-2$ & & \\
\hline CLOROBENZLLATO & $\begin{array}{l}\text { 4,4'-Diclorobenzilato; éster etílico del ácido 4,4'-diclorobenćlilico; } \\
\text { etil-p,p'p'-diclorobenzilato; etil-4,4'-diclorobenzilato }\end{array}$ & $510-15-6$ & & \\
\hline CLOROFORMIATO DE BENCILO & $\begin{array}{l}\text { Cloruro de bencilcarbonilo; bencilclorocarbonato; BZCF; } \\
\text { carbobenzoxicloruro } \\
\text { UN1739 }\end{array}$ & $501-53-1$ & & \\
\hline 4-CLOROMETILBIFENILO & $\begin{array}{l}\text { 4-(Clorometil)-1'-bifenilo; 4-CMB; p-fenilbencilcloruro; } \\
\text { 4-fenilbencilcloruro }\end{array}$ & $1667-11-4$ & & \\
\hline 1-CLORONAFTALENO & $\alpha$-Cloronaftaleno & $90-13-1$ & & \\
\hline O-CLOROTOLUENO & $\begin{array}{l}\text { 1-Cloro-2-metilbenceno; 2-cloro-1-metilbenceno; 0-clorotolueno; } \\
\text { 2-clorotolueno; 1-metil-2-clorobenceno; 2-metilclorobenceno } \\
\text { UN2238 }\end{array}$ & $95-49-8$ & & \\
\hline CLORURO DE BENCENO & $\begin{array}{l}\text { Clorbenceno; clorbenzol; clorobenceno; monoclorbenceno; } \\
\text { monoclorobenceno; cloruro de fenilo } \\
\text { UN1134 }\end{array}$ & $108-90-7$ & & \\
\hline CLORURO DE BENCILO & $\begin{array}{l}\text { Clorometilbenceno; clorofenilmetano; a-clorotolueno; } \\
\text { cloruro de tolilo } \\
\text { UN1738 }\end{array}$ & $100-44-7$ & & \\
\hline
\end{tabular}




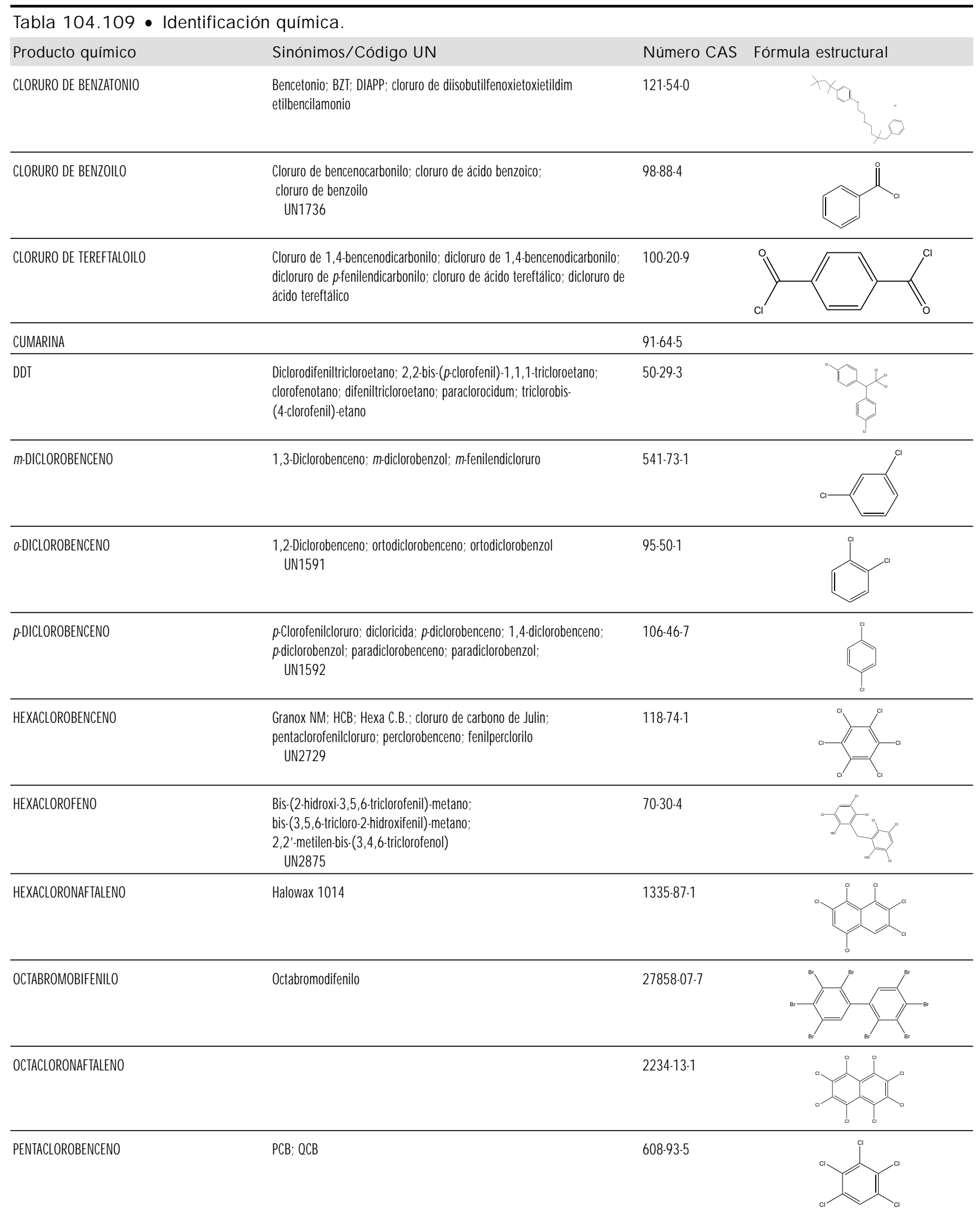




\begin{tabular}{|c|c|c|c|}
\hline Producto químico & Sinónimos/ Código UN & $\mathrm{N}$ úmero $\mathrm{CAS}$ & Fórmula estructural \\
\hline PENTACLORONAFTALENO & & $1321-64-8$ & \\
\hline 1,2,4,5-TETRACLOROBENCENO & Tetracloruro de benceno; sim-tetraclorobenceno & $95-94-3$ & \\
\hline 2,3,7,8-TETRACLORODIBENZO-p-DIOXINA & $\begin{array}{l}\text { Dioxina; TCDBD; TCDD; 2,3,7,8-TCDD; 2,3,7,8-tetraclorodibenzo- } \\
\text { 1,4-dioxina; tetradioxina }\end{array}$ & $1746-01-6$ & \\
\hline TETRACLORONAFTALENO & Halowax; tetracloronaftaleno & $1335-88-2$ & \\
\hline 1,2,3-TRICLOROBENCENO & vic-Triclorobenceno; 1,2,6-triclorobenceno & $87-61-6$ & \\
\hline 1,2,4-TRICLOROBENCENO & $\begin{array}{l}\text { 1,2,4-Triclorobenceno; 1,2,5-triclorobenceno; 1,3,4-triclorobenceno; } \\
\text { 1,2,4-triclorobenzol }\end{array}$ & $120-82-1$ & \\
\hline 1,3,5-TRICLOROBENCENO & sim-Triclorobenceno & $108-70-3$ & \\
\hline TRICLOROMETLLBENCENO & $\begin{array}{l}\text { Cloruro de bencenilo; tricloruro de bencenilo; tricloruro benzoico; } \\
\text { benzotricloruro; tricloruro de bencilo } \\
\text { UN2226 }\end{array}$ & $98-07-7$ & \\
\hline
\end{tabular}

\begin{tabular}{|c|c|c|c|c|c|c|}
\hline \multirow[b]{2}{*}{$\begin{array}{l}\text { Denominación } \\
\text { química } \\
\text { N úmero CAS }\end{array}$} & \multicolumn{4}{|c|}{ Tarjetas Internacionales sobre la Seguridad de los Productos Q uímicos } & \multicolumn{2}{|c|}{ N IO SH (EE.UU.) } \\
\hline & $\begin{array}{l}\text { Período } \\
\text { corto de } \\
\text { exposición }\end{array}$ & $\begin{array}{l}\text { Período } \\
\text { largo de } \\
\text { exposición }\end{array}$ & $\begin{array}{l}\text { Vías de } \\
\text { exposición }\end{array}$ & Síntomas & $\begin{array}{l}\text { O rganos } \\
\text { afectados } \\
\text { Vías de } \\
\text { entrada }\end{array}$ & Síntomas \\
\hline $\begin{array}{c}\text { BENZALCLORURO } \\
98-87.3\end{array}$ & $\begin{array}{l}\text { ojos; piel; tract } \\
\text { resp; SNC }\end{array}$ & & $\begin{array}{r}\text { Inhalación } \\
\text { Piel } \\
\text { Ojos } \\
\text { Ingestión }\end{array}$ & $\begin{array}{l}\text { Tos, dificultad respiratoria, náuseas, dolor de } \\
\text { garganta } \\
\text { Enrojecimiento, dolor irritante, irritante } \\
\text { Enrojecimiento, dolor irritante } \\
\text { Sensación de quemazón, vómitos }\end{array}$ & & \\
\hline $\begin{array}{l}\text { BIFENILO POLLCLORADO } \\
\text { (AROCLOR 1254) } \\
11097-69-1\end{array}$ & ojos & piel; hígado & $\begin{array}{r}\text { Piel } \\
\text { Ojos } \\
\text { Ingestión }\end{array}$ & $\begin{array}{l}\text { Puede absorberse, sequedad de piel, } \\
\text { enrojecimiento, cloracné } \\
\text { Enrojecimiento, dolor } \\
\text { Cefalea, entumecimiento, fiebre }\end{array}$ & $\begin{array}{l}\text { Piel; ojos; hígado; } \\
\text { sis repro [ en } \\
\text { animales: tumores } \\
\text { de la glándula } \\
\text { pituitaria y de } \\
\text { hígado, leucemia] } \\
\text { Inh; abs; ing; con }\end{array}$ & $\begin{array}{l}\text { Irrit ojos; cloracné; les } \\
\text { hepáticas; efectos repro; } \\
\text { [carc] }\end{array}$ \\
\hline
\end{tabular}




\begin{tabular}{|c|c|c|c|c|c|c|}
\hline \multirow[b]{2}{*}{$\begin{array}{l}\text { Denominación } \\
\text { química } \\
\text { N úmero CAS }\end{array}$} & \multicolumn{4}{|c|}{ Tarjetas Internacionales sobre la Seguridad de los Productos Q uímicos } & \multicolumn{2}{|c|}{ N IO SH (EE.UU.) } \\
\hline & $\begin{array}{l}\text { Período } \\
\text { corto de } \\
\text { exposición }\end{array}$ & $\begin{array}{l}\text { Período } \\
\text { largo de } \\
\text { exposición }\end{array}$ & $\begin{array}{l}\text { Vías de } \\
\text { exposición }\end{array}$ & Síntomas & $\begin{array}{l}\text { O rganos } \\
\text { afectados } \\
\text { Vías de } \\
\text { entrada }\end{array}$ & Síntomas \\
\hline $\begin{array}{l}\text { CANFENO CLORADO } \\
8001-35-2\end{array}$ & SNC & & $\begin{array}{r}\text { Piel } \\
\text { Ojos } \\
\text { Ingestión }\end{array}$ & $\begin{array}{l}\text { Puede absorberse, enrojecimiento } \\
\text { Enrojecimiento } \\
\text { Convulsiones, mareo, náuseas, vómitos }\end{array}$ & $\begin{array}{l}\text { Piel; SNC [ en } \\
\text { animales: cáncer de } \\
\text { hígado] } \\
\text { Inh; abs; ing; con }\end{array}$ & $\begin{array}{l}\text { Náu, conf, agitación, } \\
\text { temblores, convuls, desco; piel } \\
\text { seca, enrojecida; [carc] }\end{array}$ \\
\hline $\begin{array}{l}\text { CLORURO DE BENCENO } \\
108-90-7\end{array}$ & pulmones & $\begin{array}{l}\text { piel; SNC; sangre; } \\
\text { hígado; riñones; } \\
\text { malformaciones } \\
\text { congénitas }\end{array}$ & $\begin{array}{r}\text { Inhalación } \\
\text { Piel } \\
\text { Ojos } \\
\text { Ingestión }\end{array}$ & $\begin{array}{l}\text { Sopor, cefalea, náuseas, inconsciencia } \\
\text { Puede absorberse, sequedad de piel, } \\
\text { enrojecimiento, rugosidad } \\
\text { Enrojecimiento } \\
\text { Dolor abdominal }\end{array}$ & $\begin{array}{l}\text { sis resp; ojos; piel; } \\
\text { SNC; hígado } \\
\text { Inh; ing; con }\end{array}$ & $\begin{array}{l}\text { Irrit ojos, piel, nariz; sop, } \\
\text { desco; depres SNC; en } \\
\text { animales: les hepáticas, } \\
\text { pulmonares, renales }\end{array}$ \\
\hline $\begin{array}{l}\text { CLORURO DE BENCILO } \\
100-44-7\end{array}$ & $\begin{array}{l}\text { ojos; piel; tract } \\
\text { resp; SNC }\end{array}$ & $\begin{array}{l}\text { hígado; riñones; } \\
\text { reproducción } \\
\text { humana }\end{array}$ & $\begin{array}{r}\text { Inhalación } \\
\text { Piel } \\
\text { 0jos } \\
\text { Ingestión }\end{array}$ & $\begin{array}{l}\text { Sensación de quemazón, tos, náuseas, } \\
\text { cefalea, disnea, mareo } \\
\text { Enrojecimiento, dolor, Puede absorberse } \\
\text { Enrojecimiento, dolor, visión borrosa, lesiones } \\
\text { en la córnea o daños oculares permanentes, } \\
\text { quemaduras profundas graves } \\
\text { Dolor abdominal, diarrea, vómitos, sensación } \\
\text { de quemazón detrás del esternón }\end{array}$ & $\begin{array}{l}\text { Ojos; sis resp; piel; } \\
\text { SNC } \\
\text { Inh; ing; con }\end{array}$ & $\begin{array}{l}\text { Irrit ojos, piel, nariz; deb; irrit; } \\
\text { cef; erupción cutánea, edema } \\
\text { pulm }\end{array}$ \\
\hline $\begin{array}{l}\text { CLORURO DE BENZATONIO } \\
121-54-0\end{array}$ & $\begin{array}{l}\text { ojos; piel; } \\
\text { tract resp }\end{array}$ & piel & $\begin{array}{r}\text { Inhalación } \\
\text { Piel } \\
\text { Ojos } \\
\text { Ingestión }\end{array}$ & $\begin{array}{l}\text { Tos, dolor de garganta } \\
\text { Enrojecimiento } \\
\text { Enrojecimiento, lesiones en la córnea } \\
\text { Diarrea, náuseas, vómitos, colapso, } \\
\text { convulsiones, coma }\end{array}$ & & \\
\hline $\begin{array}{l}\text { CLORURO DE TEREFTALOILO } \\
100-20-9\end{array}$ & ojos; piel; tract resp & & $\begin{array}{r}\text { Inhalación } \\
\text { Piel } \\
\text { 0jos } \\
\text { Ingestión } \\
\end{array}$ & $\begin{array}{l}\text { Tos, náuseas } \\
\text { Enrojecimiento } \\
\text { Enrojecimiento, dolor } \\
\text { Sensación de quemazón, tos, vómitos }\end{array}$ & & \\
\hline $\begin{array}{r}\text { CUMARINA } \\
91-64.5 \\
\end{array}$ & sangre & & & & & \\
\hline $\begin{array}{l}\text { DDT } \\
50-29-3\end{array}$ & & & & & $\begin{array}{l}\text { SNC; riñones; } \\
\text { hígado; piel; ojos; } \\
\text { SNP [en animales: } \\
\text { tumores hepáticos, } \\
\text { pulmonares y } \\
\text { linfáticos] } \\
\text { Inh; abs; ing; con } \\
\end{array}$ & $\begin{array}{l}\text { Irrit ojos, piel; pares en } \\
\text { lengua, labios, rostro; } \\
\text { temblores; apre, mar, conf, } \\
\text { mal, cef, ftg; convuls; pares } \\
\text { en manos; vómit; [carc] }\end{array}$ \\
\hline $\begin{array}{l}\text { p-DICLOROBENCENO } \\
106-46-7\end{array}$ & $\begin{array}{l}\text { ojos; piel; tract } \\
\text { resp; hígado; } \\
\text { riñones }\end{array}$ & $\begin{array}{l}\text { hígado; riñones; } \\
\text { pulmones; piel }\end{array}$ & $\begin{array}{r}\text { Inhalación } \\
\text { Piel } \\
\text { 0jos } \\
\text { Ingestión }\end{array}$ & $\begin{array}{l}\text { Sensación de quemazón, tos, sopor, cefalea, } \\
\text { náuseas, disnea, vómitos } \\
\text { Enrojecimiento } \\
\text { Dolor } \\
\text { Sensación de quemazón, convulsiones, diarrea }\end{array}$ & $\begin{array}{l}\text { Hígado; sis resp; } \\
\text { ojos; riñones; piel } \\
\text { [en animales: } \\
\text { cáncer de hígado y } \\
\text { riñón] } \\
\text { Inh; abs; ing; con }\end{array}$ & $\begin{array}{l}\text { Irrit ojos, hinchazón periorb; } \\
\text { rinitis profusa; cef, anor, náu, } \\
\text { vómit; bajo-p, ict, cirr; en } \\
\text { animales: les hepáticas, } \\
\text { renales; [carc] }\end{array}$ \\
\hline $\begin{array}{l}\text { HEXACLOROBENCENO } \\
118-74-1\end{array}$ & & hígado; piel; SNC & Piel & Puede absorberse & & \\
\hline $\begin{array}{l}\text { PENTACLOROBENCENO } \\
608-93.5\end{array}$ & SNC & $\begin{array}{l}\text { riñones; hígado; } \\
\text { sistema reproductor }\end{array}$ & $\begin{array}{l}\text { Inhalación } \\
\text { Ingestión }\end{array}$ & $\begin{array}{l}\text { Véase ingestión } \\
\text { Vómitos, debilidad, temblores }\end{array}$ & & \\
\hline $\begin{array}{l}\text { PENTACLORONAFTALENO } \\
1321-64-8\end{array}$ & ojos; piel; tract resp & piel; hígado & $\begin{array}{r}\text { Inhalación } \\
\text { Piel } \\
\text { 0jos } \\
\end{array}$ & $\begin{array}{l}\text { Dolor de garganta } \\
\text { Enrojecimiento } \\
\text { Enrojecimiento, dolor }\end{array}$ & $\begin{array}{l}\text { Hígado; piel; SNC } \\
\text { Inh; abs; ing; con }\end{array}$ & $\begin{array}{l}\text { Cef, ftg, vért, anor; prurito, } \\
\text { erupciones cutáneas } \\
\text { acneiformes; ict, necr hepática }\end{array}$ \\
\hline $\begin{array}{l}1,2,4,5-\text { TETRACLOROBENCENO } \\
95-94-3\end{array}$ & piel; tract resp & & $\begin{array}{l}\text { Inhalación } \\
\text { Ingestión }\end{array}$ & $\begin{array}{l}\text { Sensación de quemazón, tos, disnea } \\
\text { Mareo, náuseas, inconsciencia, vómitos, } \\
\text { debilidad }\end{array}$ & & \\
\hline $\begin{array}{l}\text { 1,2,4-TRICLOROBENCENO } \\
\text { 120-82-1 }\end{array}$ & ojos; piel; tract resp & piel & $\begin{array}{r}\text { Inhalación } \\
\text { Piel } \\
\text { Ojos } \\
\text { Ingestión }\end{array}$ & $\begin{array}{l}\text { Tos, dolor de garganta } \\
\text { Enrojecimiento, aspereza } \\
\text { Enrojecimiento, dolor } \\
\text { Vómitos }\end{array}$ & $\begin{array}{l}\text { Ojos; piel; sis repro; } \\
\text { hígado; sis resp } \\
\text { Inh; abs; ing; con }\end{array}$ & $\begin{array}{l}\text { Irrit ojos, piel, muc; en } \\
\text { animales: les hepáticas, } \\
\text { renales; posibles efectos terato }\end{array}$ \\
\hline
\end{tabular}




\begin{tabular}{|c|c|c|c|c|c|c|}
\hline \multirow[b]{2}{*}{$\begin{array}{l}\text { Denominación } \\
\text { química } \\
\text { N úmero CAS }\end{array}$} & \multicolumn{4}{|c|}{ Tarjetas Internacionales sobre la Seguridad de los Productos Q uímicos } & \multicolumn{2}{|c|}{ N IO SH (EE.UU.) } \\
\hline & $\begin{array}{l}\text { Período } \\
\text { corto de } \\
\text { exposición }\end{array}$ & $\begin{array}{l}\text { Período } \\
\text { largo de } \\
\text { exposición }\end{array}$ & $\begin{array}{l}\text { Vías de } \\
\text { exposición }\end{array}$ & Síntomas & $\begin{array}{l}\text { O rganos } \\
\text { afectados } \\
\text { Vías de } \\
\text { entrada }\end{array}$ & Síntomas \\
\hline $\begin{array}{l}\text { 1,3,5-TRICLOROBENCENO } \\
108-70-3\end{array}$ & $\begin{array}{l}\text { piel; tract resp; } \\
\text { pulmones }\end{array}$ & $\begin{array}{l}\text { piel; hígado; } \\
\text { riñones }\end{array}$ & $\begin{array}{r}\text { Inhalación } \\
\text { Piel } \\
\text { 0jos } \\
\text { Ingestión }\end{array}$ & $\begin{array}{l}\text { Tos, embotamiento, disnea, dolor de garganta } \\
\text { Puede absorberse, enrojecimiento, dolor, } \\
\text { desengrasa la piel } \\
\text { Enrojecimiento, dolor } \\
\text { Dolor abdominal, náuseas, dolor de garganta }\end{array}$ & & \\
\hline $\begin{array}{l}\text { TRICLOROMETILENCENO } \\
98.07 .7\end{array}$ & $\begin{array}{l}\text { ojos; piel; tract } \\
\text { resp; pulmones }\end{array}$ & & $\begin{array}{l}\text { Inhalación } \\
\text { Piel } \\
\text { 0jos }\end{array}$ & $\begin{array}{l}\text { Tos, embotamiento, disnea, dolor de garganta, } \\
\text { inconsciencia, síntomas de efectos retardados } \\
\text { Enrojecimiento, dolor } \\
\text { Enrojecimiento, dolor, visión borrosa, pérdida } \\
\text { de visión }\end{array}$ & & \\
\hline $\begin{array}{l}\text { TRICLORONAFTALENO } \\
1321-65.9\end{array}$ & ojos; piel & piel; hígado & $\begin{array}{r}\text { Piel } \\
\text { Ojos } \\
\text { Ingestión }\end{array}$ & $\begin{array}{l}\text { Puede absorberse, enrojecimiento } \\
\text { Enrojecimiento, dolor } \\
\text { Náuseas, vómitos }\end{array}$ & $\begin{array}{l}\text { Piel; hígado } \\
\text { Inh; abs; ing; con }\end{array}$ & $\begin{array}{l}\text { Anor, náu; vért; ict, les } \\
\text { hepáticas }\end{array}$ \\
\hline
\end{tabular}

\begin{tabular}{|c|c|c|c|}
\hline $\begin{array}{l}\text { Denominación química } \\
\mathrm{N} \text { úmero CAS }\end{array}$ & Físicos & Q uímicos & $\begin{array}{l}\text { Clase o división } \\
\text { (UN)/ Riesgos } \\
\text { subsidiarios }\end{array}$ \\
\hline $\begin{array}{l}\text { BENZALCLORURO } \\
98-87-3\end{array}$ & & $\begin{array}{l}\text { En contacto con superficies calientes o llamas, se descompone liberando vapores tóxicos de } \\
\text { compuestos clorados Reacciona violentamente con oxidantes fuertes o metales En contacto } \\
\text { con el aire, emite vapores corrosivos (cloruro de hidrógeno) }\end{array}$ & 6.1 \\
\hline $\begin{array}{l}\text { BIFENILO POLLCLORADO } \\
\text { (AROCLOR 1254) } \\
11097-69-1\end{array}$ & & Se descompone en contacto con el fuego, produciendo gases tóxicos e irritantes & 9 \\
\hline $\begin{array}{l}\text { BROMOBENCENO } \\
108-86-1\end{array}$ & & & 3 \\
\hline $\begin{array}{l}\text { BROMURO DE BENCILO } \\
100-39-0\end{array}$ & & & $6.1 / 8$ \\
\hline $\begin{array}{l}\text { CANFENO CLORADO } \\
8001-35-2\end{array}$ & & $\begin{array}{l}\text { Se descompone al calentarse, al arder o por efecto de álcalis, luz solar intensa y catalizadores } \\
\text { como el hierro, produciendo vapores tóxicos Ataca el hierro Incompatible con pesticidas } \\
\text { fuertemente alcalinos }\end{array}$ & \\
\hline $\begin{array}{l}\text { CLOROBENZILATO } \\
510-15-6\end{array}$ & & & 6.1 \\
\hline $\begin{array}{l}\text { CLOROFORMIATO DE BENCILO } \\
501-53-1\end{array}$ & & & 8 \\
\hline $\begin{array}{l}\text { 0-CLOROTOLUENO } \\
95-49-8\end{array}$ & & & 3 \\
\hline $\begin{array}{l}\text { 5-CLORO-0-TOLUIDINA } \\
95-79-4\end{array}$ & & & 6.1 \\
\hline $\begin{array}{l}\text { CLORURO DE BENCENO } \\
108-90-7\end{array}$ & $\begin{array}{l}\text { El vapor es más pesado } \\
\text { que el aire y puede } \\
\text { desplazarse por el suelo; } \\
\text { posible ignición a distancia }\end{array}$ & $\begin{array}{l}\text { Se descompone al calentarse, al arder y en contacto con superficies calientes, produciendo } \\
\text { vapores tóxicos y corrosivos Reacciona con oxidantes fuertes Reacciona violentamente con } \\
\text { cloratos, dimetilsulfóxido y metales alcalinos, con peligro de incendio y explosión Ataca el } \\
\text { caucho }\end{array}$ & 3 \\
\hline $\begin{array}{l}\text { CLORURO DE BENCILO } \\
100-44-7\end{array}$ & & $\begin{array}{l}\text { Se polimeriza bajo la influencia de todos los metales comunes excepto el níquel y el plomo, } \\
\text { produciendo vapores corrosivos (cloruro de hidrógeno), con peligro de incendio o explosión En } \\
\text { su combustión se forman vapores tóxicos y corrosivos (cloruro de hidrógeno) Reacciona } \\
\text { violentamente con oxidantes fuertes Reacciona con agua, produciendo vapores corrosivos } \\
\text { (cloruro de hidrógeno) Ataca muchos metales en presencia de agua }\end{array}$ & $6.1 / 8$ \\
\hline $\begin{array}{l}\text { CLORURO DE BENZATONIO } \\
121-54-0\end{array}$ & & $\begin{array}{l}\text { En su combustión libera gases tóxicos e irritantes (cloruro de hidrógeno, óxidos de nitrógeno y } \\
\text { carbono) Desprende vapores tóxicos en contacto con el fuego }\end{array}$ & \\
\hline
\end{tabular}


Tabla 104.111 • Riesgos físicos y químicos.

\begin{tabular}{|c|c|c|c|}
\hline $\begin{array}{l}\text { Denominación química } \\
\mathrm{N} \text { úmero CAS }\end{array}$ & Físicos & Q uímicos & $\begin{array}{l}\text { Clase o división } \\
\text { (UN )/ Riesgos } \\
\text { subsidiarios }\end{array}$ \\
\hline $\begin{array}{l}\text { CLORURO DE BENZOILO } \\
98-88-4\end{array}$ & $\begin{array}{l}\text { El vapor es más pesado } \\
\text { que el aire }\end{array}$ & $\begin{array}{l}\text { En contacto con superficies calientes o llamas, se descompone liberando gases altamente } \\
\text { tóxicos y corrosivos (fosgeno y HCl) Se descompone violentamente al calentarse o en contacto } \\
\text { con álcalis, aminas, otros compuestos básicos y DMSO, con peligro de incendio y explosión } \\
\text { Reacciona violentamente con oxidantes fuertes Reacciona con agua o vapor de agua } \\
\text { desprendiendo calor y vapores tóxicos y corrosivos Ataca muchos metales con formación de gas } \\
\text { hidrógeno inflamable, y también en contacto con sales metálicas, alcoholes, aminas y bases } \\
\text { fuertes }\end{array}$ & 8 \\
\hline $\begin{array}{l}\text { p-DICLOROBENCENO } \\
106-46-7\end{array}$ & $\begin{array}{l}\text { El vapor es más pesado } \\
\text { que el aire }\end{array}$ & $\begin{array}{l}\text { En su combustión libera vapores tóxicos y corrosivos como el fosgeno y el cloruro de hidrógeno } \\
\text { Se descompone en contacto con ácidos o vapores ácidos, produciendo vapores altamente } \\
\text { tóxicos Reacciona con oxidantes fuertes, agentes reductores fuertes y metales alcalinos, con } \\
\text { peligro de incendio y explosión Ataca algunos tipos de plásticos, caucho y revestimientos }\end{array}$ & \\
\hline $\begin{array}{l}\text { HEXACLOROFENO } \\
70-30-4\end{array}$ & & & 6.1 \\
\hline $\begin{array}{l}\text { HEXACLOROBENCENO } \\
118-74-1\end{array}$ & & $\begin{array}{l}\text { Se descompone al calentarse, produciendo vapores tóxicos Reacciona violentamente con } \\
\text { dimetilformamida por encima de } 65^{\circ} \mathrm{C}\end{array}$ & 6.1 \\
\hline $\begin{array}{l}\text { OCTACLORONAFTALENO } \\
\text { 2234-13-1 }\end{array}$ & & Se descompone al calentarse, produciendo vapores tóxicos (cloro) & \\
\hline $\begin{array}{l}\text { PENTACLOROBENCENO } \\
608-93-5 \\
\end{array}$ & & $\begin{array}{l}\text { Se descompone al calentarse o en contacto con ácidos o vapores ácidos, produciendo vapores } \\
\text { tóxicos e irritantes (cloruro de hidrógeno) }\end{array}$ & 4.1 \\
\hline $\begin{array}{l}\text { PENTACLORONAFTALENO } \\
1321-64-8\end{array}$ & & $\begin{array}{l}\text { En contacto con superficies calientes o llamas, se descompone y produce vapores tóxicos de } \\
\text { cloro }\end{array}$ & \\
\hline $\begin{array}{l}\text { 1,2,4,5-TETRACLOROBENCENO } \\
95-94-3\end{array}$ & $\begin{array}{l}\text { Posibilidad de explosión } \\
\text { pulverulenta cuando se } \\
\text { encuentra en forma de } \\
\text { polvo } 0 \text { gránulos y se } \\
\text { mezcla con el aire }\end{array}$ & $\begin{array}{l}\text { En su combustión se produce fosgeno Se descompone al calentarse o al arder, desprendiendo } \\
\text { vapores tóxicos y corrosivos como el cloruro de hidrógeno y el fosgeno Reacciona } \\
\text { violentamente con bases y oxidantes fuertes, con peligro de explosión Cuando se calienta con } \\
\text { hidróxido sódico y un disolvente (metanol o etilenglicol) para producir triclorofenol, se pueden } \\
\text { producir explosiones violentas }\end{array}$ & 3 \\
\hline $\begin{array}{l}\text { 1,2,3-TRICLOROBENCENO } \\
87-61-6\end{array}$ & & & 6.1 \\
\hline $\begin{array}{l}\text { 1,2,4-TRICLOROBENCENO } \\
120-82 \cdot 1\end{array}$ & & $\begin{array}{l}\text { Se descompone al calentarse } 0 \text { al arder, produciendo vapores tóxicos e irritantes (fosgeno, } \\
\text { cloro y cloruro de hidrógeno) Reacciona violentamente con oxidantes, ácidos y vapores ácidos }\end{array}$ & 6.1 \\
\hline $\begin{array}{l}\text { 1,3,5-TRICLOROBENCENO } \\
108-70-3\end{array}$ & & & 6.1 \\
\hline $\begin{array}{l}\text { TRICLOROMETLLEENCENO } \\
98-07-7\end{array}$ & & & 8 \\
\hline $\begin{array}{l}\text { TRICLORONAFTALENO } \\
1321-65-9\end{array}$ & & $\begin{array}{l}\text { Se descompone al calentarse y al arder, liberando vapores tóxicos y corrosivos (incluidos el } \\
\text { cloruro de hidrógeno y el fosgeno) Reacciona con oxidantes fuertes, con peligro de incendio y } \\
\text { explosión }\end{array}$ & \\
\hline
\end{tabular}

Tabla 104.112 • Propiedades físicas y químicas.

\begin{tabular}{|c|c|c|c|c|c|c|c|c|c|c|}
\hline $\begin{array}{l}\text { Denominación química } \\
\mathrm{N} \text { úmero CAS }\end{array}$ & Color/ Forma & $\begin{array}{l}\text { p.e. } \\
(\underline{O C})\end{array}$ & $\begin{array}{l}\text { p.f. } \\
(\stackrel{\circ}{ })\end{array}$ & $\begin{array}{l}\text { p.m.l } \\
\text { (g/ } \\
\text { mol) }\end{array}$ & $\begin{array}{l}\text { Solubilidad } \\
\text { en agua }\end{array}$ & $\begin{array}{l}\text { Densidad } \\
\text { relativa } \\
\text { (agua }=1 \text { ) }\end{array}$ & $\begin{array}{l}\text { Densidad } \\
\text { relativa } \\
\text { del vapor } \\
\text { (aire=1) }\end{array}$ & $\begin{array}{l}\text { Pvap/ } \\
(\mathrm{kPa})\end{array}$ & $\begin{array}{l}\text { Límit. } \\
\text { inflam. }\end{array}$ & $\begin{array}{ll}\text { p.ig. } & \text { p.aut } \\
(\stackrel{\circ}{ } \mathrm{C}) & \text { ig. } \\
& \left({ }^{\circ} \mathrm{C}\right)\end{array}$ \\
\hline $\begin{array}{l}\text { BENZALCLORURO } \\
98-87-3\end{array}$ & $\begin{array}{l}\text { líquido oleaginoso } \\
\text { incoloro }\end{array}$ & 205 & -17 & 161,03 & insol & 1,26 & 5,6 & 0,04 & $\begin{array}{l}1 \mathrm{li} \\
11 \mathrm{ls}\end{array}$ & 93 \\
\hline $\begin{array}{l}\text { BENZOTRICLORURO } \\
98.07 .7\end{array}$ & $\begin{array}{l}\text { líquido transparente, } \\
\text { incoloro o } \\
\text { amarillento; líquido } \\
\text { oleaginoso }\end{array}$ & 221 & -5 & 195,48 & reacciona & 1,3756 & 6,77 & $20 \mathrm{~Pa}$ & $\begin{array}{l}2,1 \mathrm{li} \\
6,5 \mathrm{ls}\end{array}$ & 127 cc 211 \\
\hline
\end{tabular}




\begin{tabular}{|c|c|c|c|c|c|c|c|c|c|c|c|}
\hline $\begin{array}{l}\text { Denominación química } \\
\mathrm{N} \text { úmero CAS }\end{array}$ & Color/ Forma & $\begin{array}{l}\text { p.e. } \\
\left({ }^{\circ} \mathrm{C}\right)\end{array}$ & $\begin{array}{l}\text { p.f. } \\
\left({ }^{\circ} \mathrm{C}\right)\end{array}$ & $\begin{array}{l}\text { p.m.l } \\
\text { (g/ } \\
\text { mol) }\end{array}$ & $\begin{array}{l}\text { Solubilidad } \\
\text { en agua }\end{array}$ & $\begin{array}{l}\text { Densidad } \\
\text { relativa } \\
\text { (agua }=1 \text { ) }\end{array}$ & $\begin{array}{l}\text { Densidad } \\
\text { relativa } \\
\text { del vapor } \\
\text { (aire=1) }\end{array}$ & $\begin{array}{l}\text { Pvap/ } \\
(\mathrm{kPa})\end{array}$ & $\begin{array}{l}\text { Límit. } \\
\text { inflam. }\end{array}$ & $\begin{array}{l}\text { p.ig. } \\
\left({ }^{\circ} \mathrm{C}\right)\end{array}$ & $\begin{array}{l}\text { p.aut } \\
\text { ig. } \\
\left({ }^{\circ} \mathrm{C}\right)\end{array}$ \\
\hline $\begin{array}{l}\text { BIFENILO POLICLORADO } \\
\text { (AROCLOR 1242) } \\
53469-21.9\end{array}$ & aceite móvil incoloro & $325-366$ & & 261 & & & & & & & \\
\hline $\begin{array}{l}\text { BIFENILO POLICLORADO } \\
\text { (AROCLOR 1254) } \\
11097-69-1\end{array}$ & $\begin{array}{l}\text { líquido viscoso } \\
\text { amarillo claro }\end{array}$ & $365-390$ & & 327 & insol & 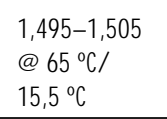 & & $\begin{array}{l}0,01 \mathrm{~Pa} \\
@ 25^{\circ} \mathrm{C}\end{array}$ & & $>141$ & \\
\hline $\begin{array}{l}\text { BROMOBENCENO } \\
108-86-1\end{array}$ & $\begin{array}{l}\text { líquido móvil; } \\
\text { incoloro }\end{array}$ & 156 & $-30,6$ & 157,02 & insol & 1,4950 & 5,41 & $\begin{array}{l}10 \mathrm{~mm} \mathrm{Hg} \\
@ 40 \stackrel{\circ}{-} \mathrm{C}\end{array}$ & & 51 & \\
\hline $\begin{array}{l}\text { BROMURO DE BENCILO } \\
100-39-0\end{array}$ & $\begin{array}{l}\text { líquido transparente; } \\
\text { líquido incoloro o } \\
\text { amarillo }\end{array}$ & 198- 199 & $-4,0$ & 171,04 & insol & 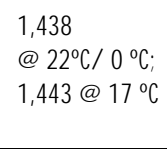 & 5,9 & $\begin{array}{l}1, \mathrm{~mm} \mathrm{Hg} \\
@ 32,2 \circ \mathrm{O}, \\
10 \mathrm{~mm} \mathrm{Hg} \\
@ 73,4 \stackrel{\circ}{\circ} \mathrm{C}\end{array}$ & & & \\
\hline $\begin{array}{l}\text { CANFENO CLORADO } \\
8001-35-2\end{array}$ & $\begin{array}{l}\text { sólido ceroso } \\
\text { amarillo; sólido } \\
\text { ceroso ámbar }\end{array}$ & & $65-90$ & 414 & insol & $1,65 @ 25 \stackrel{\circ}{ } \mathrm{C}$ & 14,3 & $\begin{array}{l}53 \mathrm{~Pa} \\
@ 25\left({ }^{\circ} \mathrm{C}\right)\end{array}$ & & 135 & \\
\hline $\begin{array}{l}\text { CLOROBENZILATO } \\
510-15-6\end{array}$ & sólido incoloro (puro) & $\begin{array}{l}146-148 @ \\
0,04 \mathrm{~mm} \mathrm{Hg}\end{array}$ & $\begin{array}{l}36- \\
37,3\end{array}$ & 325,20 & $10 \mathrm{mg} / \mathrm{l}$ & 1,2816 & & $\begin{array}{l}2,2 \times 10^{-6} \\
\mathrm{~mm} \mathrm{Hg}\end{array}$ & & & \\
\hline $\begin{array}{l}\text { CLOROFORMIATO DE BENCILO } \\
\text { 501-53-1 }\end{array}$ & $\begin{array}{l}\text { líquido oleaginoso; } \\
\text { líquido incoloro o } \\
\text { amarillo pálido }\end{array}$ & 103 & & 170,60 & & 1,20 & & & & & \\
\hline $\begin{array}{l}\text { 4-CLOROMETILBIFENILO } \\
\text { 1667-11-4 }\end{array}$ & & & 72 & 202,67 & & & & & & & \\
\hline $\begin{array}{l}\text { 1-CLORONAFTALENO } \\
\text { 90-13-1 }\end{array}$ & $\begin{array}{l}\text { líquido oleaginoso; } \\
\text { cristales en alcohol, } \\
\text { acetona }\end{array}$ & 259 & $-2,5$ & 162,61 & insol & 1,19382 & 5,6 & $\begin{array}{l}0,029 \\
\mathrm{~mm} \mathrm{Hg} \\
@ 25 \stackrel{\circ}{-C}\end{array}$ & & & $>558$ \\
\hline $\begin{array}{l}\text { O-CLOROTOLUENO } \\
95-49-8\end{array}$ & líquido incoloro & 159 & 35,1 & 126,6 & insol & 1,0826 & & $\begin{array}{l}3,6 \mathrm{~mm} \mathrm{Hg} \\
@ 25 \stackrel{\circ}{\circ} \mathrm{C}\end{array}$ & & & \\
\hline $\begin{array}{l}\text { CLORURO DE BENCENO } \\
108-90-7\end{array}$ & líquido incoloro & 132 & -45 & 112,56 & insol & 1,1058 & 3,88 & 1,17 & $\begin{array}{l}1,8 \mathrm{il} \\
9,6 \mathrm{is}\end{array}$ & 27 & 638 \\
\hline $\begin{array}{l}\text { CLORURO DE BENCILO } \\
100-44-7\end{array}$ & $\begin{array}{l}\text { líquido incoloro o } \\
\text { ligeramente amarillo }\end{array}$ & 179 & -45 & 126,58 & insol & 1,100 & 4,4 & $120 \mathrm{~Pa}$ & $\begin{array}{l}1,1 \mathrm{li} \\
14,0 \mathrm{ls}\end{array}$ & $67 \mathrm{cc}$ & 585 \\
\hline $\begin{array}{l}\text { CLORURO DE BENZATONIO } \\
121-54-0\end{array}$ & cristales incoloros & & $164-166$ & 448,10 & muy sol & & & & & & \\
\hline $\begin{array}{l}\text { CLORURO DE BENZOILO } \\
\text { 98-88-4 }\end{array}$ & $\begin{array}{l}\text { líquido incoloro } \\
\text { transparente; líquido } \\
\text { ligeramente marrón }\end{array}$ & 197 & $-1,0$ & 140,57 & se descompone & 1,2120 & 4,9 & $50 \mathrm{~Pa}$ & $\begin{array}{l}1,2 \mathrm{li} \\
4,9 \mathrm{Is}\end{array}$ & 88 & 197 \\
\hline $\begin{array}{l}\text { CLORURO DE TEREFTALOILO } \\
100-20-9\end{array}$ & agujas incoloras & 259 & 83,5 & 203,02 & reacciona & & 7,0 & $\mathrm{~Pa}$ & & 180 & \\
\hline $\begin{array}{l}\text { DDT } \\
50-29-3\end{array}$ & $\begin{array}{l}\text { cristales tabulares } \\
\text { alargados biaxiales; } \\
\text { la p,p-DDT } \\
\text { químicamente pura } \\
\text { consta de agujas } \\
\text { blancas; cristales } \\
\text { incoloros o polvo } \\
\text { blanco o ligeramente } \\
\text { blancuzco }\end{array}$ & 260 & 108,5 & 354,50 & insol & 0,98 & & $\begin{array}{l}1,5 \times 10^{-7} \\
\mathrm{~mm} \mathrm{Hg}\end{array}$ & & & \\
\hline $\begin{array}{l}\text { m-DICLOROBENCENO } \\
541-73-1\end{array}$ & líquido incoloro & 173 & $-24,7$ & 147,00 & insol & 1,2884 & & $\begin{array}{l}2,3 \mathrm{~mm} \mathrm{Hg} \\
@ 25 \stackrel{\circ}{\circ} \mathrm{C}\end{array}$ & & & \\
\hline
\end{tabular}




\begin{tabular}{|c|c|c|c|c|c|c|c|c|c|c|c|}
\hline $\begin{array}{l}\text { Denominación química } \\
\mathrm{N} \text { úmero CAS }\end{array}$ & Color/ Forma & $\begin{array}{l}\text { p.e. } \\
(\stackrel{0}{ } \mathrm{C})\end{array}$ & $\begin{array}{l}\text { p.f. } \\
(\stackrel{\circ}{ } C)\end{array}$ & $\begin{array}{l}\text { p.m.l } \\
\text { (g/ } \\
\text { mol) }\end{array}$ & $\begin{array}{l}\text { Solubilidad } \\
\text { en agua }\end{array}$ & $\begin{array}{l}\text { Densidad } \\
\text { relativa } \\
\text { (agua }=1 \text { ) }\end{array}$ & $\begin{array}{l}\text { Densidad } \\
\text { relativa } \\
\text { del vapor } \\
\text { (aire=1) }\end{array}$ & $\begin{array}{l}\text { Pvap/ } \\
(\mathrm{kPa})\end{array}$ & $\begin{array}{l}\text { Límit. } \\
\text { inflam. }\end{array}$ & $\begin{array}{l}\text { p.ig. } \\
(\underline{O C})\end{array}$ & $\begin{array}{l}\text { p.aut } \\
\text { ig. } \\
(\stackrel{O}{ } \mathrm{C})\end{array}$ \\
\hline $\begin{array}{l}\text { O-DICLOROBENCENO } \\
95-50-1\end{array}$ & líquido incoloro & 181 & -17 & 147,01 & insol & 1,3048 & 5,05 & $\begin{array}{l}1,47 \\
\mathrm{~mm} \mathrm{Hg} @ \\
25 \stackrel{\circ}{\circ}\end{array}$ & $\begin{array}{l}2 \mathrm{li} \\
9 \mathrm{is}\end{array}$ & & \\
\hline $\begin{array}{l}\text { p-DICLOROBENCENO } \\
106-46-7\end{array}$ & $\begin{array}{l}\text { cristales blancos; } \\
\text { prismas } \\
\text { monoclínicos, } \\
\text { láminas en acetona; } \\
\text { disponible en forma } \\
\text { de cristales puros }\end{array}$ & 174 & 53 & 147,01 & insol & 1,2475 & 5,08 & $\begin{array}{l}1,33 \\
@ 55^{\circ} \mathrm{C}\end{array}$ & $\begin{array}{l}2,5 \mathrm{li} \\
16 \mathrm{is}\end{array}$ & $66 c c$ & 413 \\
\hline $\begin{array}{l}\text { HEXACLOROBENCENO } \\
118-74-1\end{array}$ & $\begin{array}{l}\text { agujas en alcohol } \\
\text { benćlico; agujas } \\
\text { blancas }\end{array}$ & 325 & 231 & 284,80 & insol & $\begin{array}{l}1,5691 @ \\
23,6 \stackrel{\circ}{\circ}\end{array}$ & 9,83 & $<0,1 \mathrm{~Pa}$ & & 242 & \\
\hline $\begin{array}{l}\text { HEXACLOROFENO } \\
70-30-4\end{array}$ & $\begin{array}{l}\text { agujas en benceno; } \\
\text { polvo cristalino } \\
\text { blanco o ligeramente } \\
\text { tostado }\end{array}$ & & 164 & 406,92 & insol & & & & & & \\
\hline $\begin{array}{l}\text { HEXACLORONAFTALENO } \\
1335-87-1\end{array}$ & sólido blanco & $344-388$ & 137 & 334,74 & insol & 1,78 & 11,6 & $\begin{array}{l}3 \times 10^{-8} \\
\mathrm{~mm} \mathrm{Hg} @ \\
25 \stackrel{\circ}{-C}\end{array}$ & & & \\
\hline $\begin{array}{l}\text { OCTACLORONAFTALENO } \\
2234-13-1\end{array}$ & $\begin{array}{l}\text { amarillo pálido; } \\
\text { aguas en benceno y } \\
\text { tetracloruro de } \\
\text { carbono; sólido } \\
\text { ceroso amarillo }\end{array}$ & 440 & 192 & 403,74 & insol & 2,00 & 13,9 & $<0,13$ & & & \\
\hline $\begin{array}{l}\text { PENTACLOROBENCENO } \\
608-93-5\end{array}$ & $\begin{array}{l}\text { sólido cristalino } \\
\text { incoloro }\end{array}$ & 277 & 86 & 250,14 & insol & $\begin{array}{l}1,8342 @ \\
16,5 \stackrel{\circ}{\circ}\end{array}$ & 8,6 & $2,2 \mathrm{~Pa}$ & & & \\
\hline $\begin{array}{l}\text { PENTACLORONAFTALENO } \\
1321-64-8\end{array}$ & $\begin{array}{l}\text { sólido blanco; polvo } \\
\text { blanco; sólido } \\
\text { amarillo pálido }\end{array}$ & $327-371$ & 120 & 300,41 & insol & 1,7 & 10,4 & $<133 \mathrm{~Pa}$ & & & \\
\hline $\begin{array}{l}\text { 1,2,4,5-TETRACLOROBENCENO } \\
95-94-3\end{array}$ & $\begin{array}{l}\text { escamas, cristales } \\
\text { blancos }\end{array}$ & 245 & 139,5 & 215,90 & insol & 1,9 & 7,4 & $\begin{array}{l}0,3 \mathrm{~Pa} \\
@ 25^{\circ} \mathrm{C}\end{array}$ & & $155 c c$ & \\
\hline $\begin{array}{l}\text { 2,3,7,8-8TETRACLORO-DIBENZO- } \\
\text { p-DIOXINA } \\
\text { 1746-01-6 }\end{array}$ & agujas incoloras & & $305-306$ & 322 & & & & $\begin{array}{l}7,4 \times 10^{-10} \\
\mathrm{~mm} \mathrm{Hg} \\
\text { @ } 25^{\circ} \mathrm{C}\end{array}$ & & & \\
\hline $\begin{array}{l}\text { TETRACLORONAFTALENO } \\
1335-88-2\end{array}$ & $\begin{array}{l}\text { cristales; sólido } \\
\text { amarillo pálido; } \\
\text { sólido incoloro o } \\
\text { amarillo pálido }\end{array}$ & $312-360$ & 182 & 265,94 & insol & $1,59-1,65$ & 9,2 & $\begin{array}{l}1 \times 10^{-6} \\
\mathrm{~mm} \mathrm{Hg} \\
\text { @ } 25^{\circ} \mathrm{C}\end{array}$ & & $210 \mathrm{ca}$ & \\
\hline $\begin{array}{l}\text { 1,2,3-TRICLOROBENCENO } \\
87-61-6 \\
\end{array}$ & $\begin{array}{l}\text { plaquetas en alcohol; } \\
\text { cristales blancos }\end{array}$ & 221 & 52,6 & 181,46 & insol & 1,69 & 6,26 & $\begin{array}{l}1 \mathrm{~mm} \mathrm{Hg} \\
@ 40 \stackrel{\circ}{C}\end{array}$ & & $\begin{array}{l}1127 \\
C C\end{array}$ & \\
\hline $\begin{array}{l}\text { 1,2,4-TRICLOROBENCENO } \\
\text { 120-82-1 }\end{array}$ & $\begin{array}{l}\text { líquido incoloro; } \\
\text { cristales rómbicos }\end{array}$ & 214 & 17 & 181,46 & insol & 1,5 & 6,26 & $\begin{array}{l}40 \mathrm{~Pa} \\
@ 25^{\circ} \mathrm{C}\end{array}$ & $\begin{array}{l}2,5 \mathrm{li} \\
6,6 \mathrm{is}\end{array}$ & 105 & 571 \\
\hline $\begin{array}{l}\text { 1,3,5-TRICLOROBENCENO } \\
108-70-3\end{array}$ & $\begin{array}{l}\text { cristales blancos; } \\
\text { agujas alargadas }\end{array}$ & 208 & 63,5 & 181,45 & insol & & 6,26 & $\begin{array}{l}0,13 @ \\
78{ }^{\circ} \mathrm{C}\end{array}$ & & $>110$ & \\
\hline $\begin{array}{l}\text { TRICLORONAFTALENO } \\
1321.65-9\end{array}$ & $\begin{array}{l}\text { sólido incoloro } 0 \\
\text { amarillo pálido }\end{array}$ & $304-354$ & 92,78 & 231,5 & insol & 1,58 & 8,0 & $<133 \mathrm{~Pa}$ & & $200 \mathrm{ca}$ & \\
\hline
\end{tabular}




\section{HIDROCARBUROS POLIAROMATICOS}

Los hidrocarburos aromáticos políciclos (H AP) son compuestos orgánicos formados por tres o más anillos aromáticos condensados, en donde algunos atómos de carbono son comunes a dos 0 tres anillos. Esta estructura se denomina también sistema de anillos fusionados. Los anillos pueden estar en línea recta, angulados o racimados. Además, el término hidrocarburo indica que la molécula contiene sólo carbono e hidrógeno. La estructura condensada más sencilla, formada por sólo dos anillos aromáticos condensados, es el naftaleno. A los anillos aromáticos pueden unirse otros tipos de anillos, como los de cinco átomos de carbono o los que contienen otros átomos (oxígeno, nitrógeno 0 azufre) en lugar del carbono. Estos últimos compuestos se conocen como compuestos heteroaromáticos o heterocíclicos y no se considerarán aquí. En la literatura sobre los HAPs se pueden encontrar muchas otras denominaciones, como APN (aromáticos polinucleares), CAP (compuestos aromáticos policíclicos) o M O P (materias orgánicas policíclicas). Esta última denominación suele englobar a los compuestos heteroaromáticos. Entre los HAPs se encuentran cientos de compuestos que han sido objeto de gran atención por ser muchos de ellos cancerígenos, especialmente los H APs que contienen entre cuatro y seis anillos aromáticos.

La ausencia de una nomenclatura uniforme en la literatura puede confundir al lector de trabajos procedentes de distintos países y publicados en épocas distintas. La IU PAC (U nión Internacional de Q uímica Pura y Aplicada) ha adoptado una nomenclatura que es la más utilizada en la actualidad. A continuación se ofrece un breve resumen de la misma:

Se han seleccionado algunos de los principales HAP y se han mantenido sus nombres vulgares. Se dibujan tantos anillos como sea posible en una línea horizontal y el mayor número de los anillos sobrantes se colocan en el cuadrante superior derecho. La numeración comienza por el primer atómo de carbono que no sea común a dos anillos, en el anillo situado a la derecha de la primera línea. Los siguientes atómos de carbono unidos a un hidrógeno se numeran en el sentido de las agujas del reloj. A los lados más externos de los anillos se les asignan letras en orden alfabético, empezando por el lado situado entre C 1 y C 2 .

Como ejemplo de la nomenclatura de los H APs hemos tomado el benzo(a)pireno. Benzo(a) - indica que hay un anillo aromático unido al pireno en la posición a. Un anillo puede unirse también a las posiciones $b$, e, etc. N o obstante, las posiciones $a, b, h$ e i son equivalentes, y lo mismo ocurre con e y 1 . En consecuencia, sólo hay dos isómeros, benzo(a)pireno y benzo(e)pireno. Sólo se utiliza la primera letra y las fórmulas se escriben aplicando las anteriores reglas. En las posiciones $\mathrm{cd}, \mathrm{fg}$, etc. del pireno también puede unirse un anillo. Sin embargo, esta sustancia, el $2 \mathrm{H}$-benzo(cd)pireno, está saturada en la posición 2, lo que se indica con una $\mathrm{H}$.

Propiedades fisicoquímicas de los H APs. Los sistemas conjugados II-electrón de los HAPs son los responsables de su estabilidad química. Son sólidos a temperatura ambiente y su volatibilidad es muy pequeña. Dependiendo de su carácter aromático, los H APs absorben luz ultravioleta y producen un espectro fluorescente característico. Son solubles en muchos disolventes orgánicos, pero muy poco solubles en agua, tanto menos cuanto mayor sea su peso molecular. Sin embargo, los detergentes y compuestos que forman emulsiones en agua, o los H APs adsorbidos en partículas en suspensión, pueden aumentar el contenido de HAPs en aguas residuales o naturales. D esde el punto de vista químico, los HAPs reaccionan por sustitución del hidrógeno o por adición cuando se produce su saturación. Generalmente se conserva el sistema de anillos. La mayoría de los HAPs se fotooxidan, una reacción importante para eliminarlos de la atmósfera. La reacción de fotooxidación más frecuente es la formación de endoperóxidos, que pueden convertirse a quinonas. Por razones estéricas, un endoperóxido no puede formarse por fotooxidación del benzo(a)pireno; en este caso se forman 1,6-diona, 3,6-diona y 6,12-diona. Se ha observado que la fotooxidación de los HAPS adsorbidos es mayor que la de los HAPs en disolución. Este hecho debe tenerse en cuenta al analizar los HAPs mediante cromatografía en capa fina, especialmente si se utilizan capas de gel de sílice, donde muchos H APs se fotooxidan rápidamente cuando se iluminan con luz ultravioleta. Para la eliminación de Ios HAPs existentes en los lugares de trabajo, las reacciones de oxidación no tienen interés. Los HAPs reaccionan rápidamente con óxidos de nitrógeno $\mathrm{OHNO}_{3}$. Por ejemplo, el antraceno puede oxidarse a antraquinona por acción del $\mathrm{HNO}_{3} \mathrm{O}$ dar un derivado nitrogenado mediante una reacción de sustitución con $\mathrm{NO}_{2}$. Los HAPs pueden reaccionar con $\mathrm{SO}_{2}, \mathrm{SO}_{3}$ y $\mathrm{H}_{2} \mathrm{SO}_{4}$ para formar ácidos sulfínico y sulfónico. EI hecho de que los HAPs cancerígenos reaccionen con otras sustancias no significa necesariamente que se inactiven como tales; por el contrario, muchos H APs que contienen sustituyentes son carcinógenos más potentes que el correspondiente compuesto progenitor. Aquí se describen algunos de los H APs más importantes.

Formación. Los HAPs se forman por pirólisis o combustión incompleta de materia orgánica que contiene carbono e hidrógeno. A elevadas temperatuas, la pirólisis de compuestos orgánicos produce fragmentos de moléculas y radicales que se combinan para formar HAPs. La composición de los productos resultantes de la pirosíntesis depende del combustible, la temperatura y el tiempo de estancia en la zona de caldeo. L os combustibles que forman HAPs son metano, otros hidrocarburos, hidratos de carbono, ligninas, péptidos, etc. Sin embargo, los compuestos que contienen cadenas laterales, los compuestos insaturados y las estructuras cíclicas suelen favorecer la formación de HAPs. Evidentemente, los HAPs se liberan de la zona de combustión en forma de vapores. Debido a sus bajas presiones de vapor, la mayoría de los H APs se condensan en el acto sobre partículas de hollín o forman ellos mismos partículas muy pequeñas. Los H APs liberados a la atmósfera en forma de vapor son adsorbidos por las partículas presentes en ella. Por ello, se producirá una diseminación de aerosoles que contienen HAPs, que pueden ser transportados a grandes distancias por los vientos.

\section{Producción y usos}

M uchos HAPs pueden obtenerse a partir de alquitrán de hulla. Las sustancias puras no tienen aplicaciones técnicas importantes, salvo el naftaleno y el antraceno. No obstante, se utilizan indirectamente en el alquitrán de hulla y el petróleo, que contienen mezclas de distintos HAPs.

L os H APs pueden encontrarse casi en todas partes, en el aire, en la tierra y en el agua, procedentes de fuentes naturales 0 antropogénicas. La contribución de las fuentes naturales, como los incendios forestales y los volcanes, es mínima si la comparamos con las emisiones causadas por el ser humano. La combustión de combustibles fósiles es la principal fuente de emisiones de HAPs. O tras emisiones proceden de la combustión de residuos y madera, así como de los vertidos de petróleo crudo o refinado que en sí mismo contiene HAPs. Los HAPs están también 
presentes en el humo del tabaco y en los alimentos a la parrilla, ahumados y fritos.

La principal fuente de HAP en el aire de las atmósferas de trabajo es el alquitrán de hulla, que se forma por pirólisis de la hulla en fábricas de gas y coque, donde se producen emisiones de humos procedentes de la brea calentada. Los trabajadores que permanecen cerca de los hornos están altamente expuestos a estos HAPs. La mayoría de las investigaciones de HAPs en los lugares de trabajo se han llevado a cabo en fábricas de gas y coque. En la mayoría de los casos sólo se ha analizado el benzo(a)pireno, aunque también se han realizado algunas investigaciones sobre otros HAPs. Generalmente, el contenido de benzo(a)pireno es máximo en el aire situado en la parte superior de los hornos. El aire situado en la parte superior de los canales de humos y del precipitador de alquitrán es extremadamente rico en benzo(a) pireno, habiéndose medido concentraciones de hasta $500 \mathrm{mg} / \mathrm{m}^{3}$. Mediante técnicas de muestreo personal, se ha podido comprobar que la mayor exposición la sufren los conductores de camiones, los trabajadores encargados de asegurar y zafar las amarras de los buques, los trabajadores que realizan operaciones de deshollinado y los trabajadores del alquitrán. EI naftaleno, el fenantreno, el fluoranteno, el pireno y el antraceno predominan entre los HAPs aislados de las muestras de aire tomadas. Es evidente que algunos de los trabajadores de la industria del gas y del coque están expuestos a altos niveles de HAPs, incluso en las instalaciones modernas. En estas industrias no es raro que muchos trabajadores hayan estado expuestos a estas sustancias durante años. Las investigaciones clínicas han demostrado que estos trabajadores tienen un alto riesgo de desarrollar cáncer de pulmón. El alquitrán de hulla se utiliza en otros procesos industriales, donde se calienta y libera HAPs al aire ambiente.

Los hidrocarburos poliarilos se utilizan principalmente en la fabricación de colorantes y en síntesis químicas. EI antraceno se utiliza en la producción de antraquinona, una importante materia prima para la fabricación de colorantes rápidos. Se emplea también como diluyente para conservantes de la madera y en la producción de fibras sintéticas, plásticos y monocristales. El fenantreno se emplea en la fabricación de colorantes y explosivos, en la investigación clínica y en la síntesis de fármacos.

EI benzofurano se utiliza en la fabricación de resinas de cumarona-indeno. El fluoranteno es un componente del asfalto derivado del alquitrán y del petróleo que se utiliza como material de revestimiento para proteger el interior de las tuberías de agua potable de acero y hierro dúctil y los tanques de almacenamiento.

El aluminio se produce mediante un proceso electrolítico a temperaturas de unos $970{ }^{\circ} \mathrm{C}$. Existen dos tipos de ánodos: el ánodo de Söderberg y el de grafito ("precocido"). El primero de ellos, que es el más utilizado, es la principal causa de exposición a H AP en la industria del aluminio. Este ánodo está formado por una mezcla de coque y alquitrán de hulla. Durante la electrolisis se grafita ("cuece") en su parte inferior, más caliente, y finalmente se consume por oxidación electrolítica para formar óxidos de carbono. Desde arriba se va añadiendo pasta fresca de ánodo, a modo de electrodo continuo. Los H APs se liberan del alquitrán cuando éste alcanza temperaturas elevadas, escapando a la atmósfera de trabajo a pesar de los mecanismos de ventilación. En muchos trabajos diferentes de las fundiciones de aluminio, tales como el desembornado, el izado de rejillas, y la adición de pasta de ánodo, las exposiciones pueden ser considerables. También el apisonado de los cátodos es causa de exposición a HAPs, puesto que se utiliza alquitrán en el apisonado con varilla y en las ranuras.

Los electrodos de grafito se utilizan en las plantas de reducción de aluminio, en los hornos eléctricos de acero y en otros procesos metalúrgicos. La materia prima para la fabricación de estos electrodos suele ser coque de petróleo mezclado con alquitrán como ligante. El cocido de los mismos se realiza calentando esta mezcla en hornos, a temperaturas superiores a $1.000 \stackrel{\circ}{\circ}$. En una segunda fase de calentamiento en la que se alcanzan hasta $2.700^{\circ} \mathrm{C}$ se produce el grafitado. Durante el proceso de cocido se liberan grandes cantidades de HAPs de la masa de los electrodos. La segunda fase conlleva una liberación de HAPs más bien baja, puesto que los componentes volátiles ya se han liberado durante el primer calentamiento.

En los trabajos siderometalúrgicos y en las fundiciones se produce exposición a H APs liberados por los productos de alquitrán al entrar en contacto con el metal fundido. Los preparados de brea se utilizan en hornos, canales de colada y lingoteras.

El asfalto que se utiliza para pavimentar las calles y las carreteras procede principalmente de los residuos de destilación del petróleo crudo. El asfalto de petróleo contiene pocos H APs superiores. No obstante, en algunos casos este asfalto se mezcla con alquitrán de hulla, lo que aumenta el riesgo de exposición a H APs cuando se trabaja con el asfalto caliente. En otros trabajos en los que se utiliza alquitrán derretido y se rocía sobre una gran superficie, los trabajadores pueden sufrir una intensa exposición a HAPs. Tales operaciones incluyen los trabajos de recubrimiento de oleoductos, el aislamiento de paredes y el calafateado de tejados.

\section{Riesgos}

En 1775, un médico inglés, Sir Percival Pott, describió por primera vez un cáncer de origen profesional. Asoció el cáncer de escroto de los deshollinadores con su prolongada exposición a alquitrán y hollín, en condiciones deficientes de higiene personal. Cien años más tarde se describió el cáncer de piel en los trabajadores expuestos a alquitrán 0 aceites bituminosos. En el decenio de 1930 se describió el cáncer de pulmón en los trabajadores de la industria del acero y en la del coque. A finales del decenio de 1910 se describió el desarrollo experimental de cáncer de pulmón en animales de laboratorio tras la aplicación repetida de alquitrán de hulla. En 1933 se demostró que un hidrocarburo aromático cíclico aislado del alquitrán de hulla era cancerígeno. EI compuesto aislado resultó ser benzo(a)pireno. D esde entonces se han descrito cientos de H APs cancerígenos. Los estudios epidemiológicos indican una mayor frecuencia de cáncer de pulmón en los trabajadores de las industrias de coque, aluminio y acero. A proximadamente un siglo después se han regulado algunos de los H APs como cancerígenos laborales.

El largo período de latencia entre la primera exposición y la aparición de los síntomas, junto con muchos otros factores, han hecho que el establecimiento de valores límite umbral para los H APs en la atmósfera del lugar de trabajo sea una tarea ardúa y difícil. También existe un largo período de latencia para la formulación de normas. Hasta 1967, prácticamente no existían Valores Límite U mbral (TLVs) para los HAPs, año en el que la Conferencia Americana de $\mathrm{H}$ igienistas Industriales del Gobierno (ACGIH) adoptó un TLV de $0,2 \mathrm{mg} / \mathrm{m}^{3}$ para los alquitranes de hulla volátiles, definiéndose como el peso de una fracción soluble en benceno de las partículas recogidas en un filtro. En el decenio de 1970, la U RSS estableció una concentración máxima admisible (M AC) para el benzo(a)pireno basándose en estudios de laboratorio realizados con animales. En 1978 se estableció en Suecia un TLV de $10 \mathrm{~g} / \mathrm{m}^{3}$ para el BaP. En 1997, la $\mathrm{O}$ ccupational Safety and $\mathrm{H}$ ealth Administration (OSHA) de Estados Unidos estableció un límite de exposición permisible (PEL) para el BaP de $0,2 \mathrm{mg} / \mathrm{m}^{3}$. La ACGIH no ha establecido una concentración media ponderada en el tiempo (TWA), puesto que el $\mathrm{BaP}$ es un carcinógeno humano sospechado. El límite de 
exposición recomendado (REL) por el National Institute for O ccupational Safety and Health (NIO SH ) de Estados U nidos es de $0,1 \mathrm{mg} / \mathrm{m}^{3}$ (fracción extraíble en ciclohexano).

Las fuentes de HAPs en el trabajo, además del alquitrán de hulla y el asfalto, son el negro de humo, la creosota, los aceites minerales, los humos y hollines procedentes de diversas combustiones y los gases de escape de los vehículos. Los aceites minerales contienen cantidades muy pequeñas de HAPs, pero muchos de sus usos aumentan considerablemente su contenido de HAPs. Algunos ejemplos son los aceites lubricantes para motores, los aceites de corte y los aceites que se utilizan en máquinas de descarga eléctrica. No obstante, puesto que los HAPs permanecen en los aceites, el riesgo de exposición se limita al contacto con la piel. Los gases de escape de los vehículos contienen proporciones muy bajas de HAPs en comparación con los humos de alquitrán mineral y asfalto. En la siguiente lista se han utilizado las mediciones de benzo(a)pireno en distintos tipos de lugares de trabajo para clasificarlos según el grado de exposición:

- exposición muy alta a benzo(a)pireno (más de $10 \mathrm{mg} / \mathrm{m}^{3}$ )trabajos en fábricas de gas y coque; plantas de aluminio; fábricas de electrodos de grafito; manipulación de alquitranes y breas calentados

- exposición moderada $\left(0,1\right.$ a $\left.10 \mathrm{~g} / \mathrm{m}^{3}\right)$ - trabajos en fábricas de gas y coque; acerías; fábricas de electrodos de grafito; plantas de aluminio; fundiciones

- exposición baja (menos de 0,1 g/ m³)-fundiciones; producción de asfaltos; plantas de producción de aluminio con electrodos precocidos; talleres de reparación de automóviles y garajes; minas de hierro y construcción de túneles.

\section{Riesgos asociados a algunos H APs}

El antraceno es un hidrocarburo aromático polinuclear con anillos condensados que forma antraquinona cuando se oxida y 9,10-dihidroantraceno cuando se reduce. Los efectos tóxicos del antraceno son similares a los del alquitrán de hulla y sus productos de destilación, y dependen de la proporción de fracciones pesadas que contenga. EI antraceno es fotosensibilizante. Produce dermatitis aguda y crónica con síntomas de quemazón, picor y edema, que son más pronunciados en las regiones de la piel expuesta. Las lesiones cutáneas se asocian a irritación de la conjuntiva y de las vías aéreas superiores. 0 tros síntomas son lagrimeo, fotofobia, edema de los párpados e hiperemia conjuntival. Los síntomas agudos desaparecen varios días después de cesar el contacto. La exposición prolongada causa pigmentación de las zonas de piel expuesta, con cornificación de las capas superficiales y telangioectasis. El efecto fotodinámico del antraceno industrial es más pronunciado que el del antraceno puro, lo que evidentemente se debe al uso de mezclas de acridina, carbazol, fenantreno y otros hidrocarburos pesados. Los efectos sistémicos se manifiestan en cefalea, náuseas, inapetencia, reacciones lentas y adinamia. Las exposiciones prolongadas pueden causar inflamación del tracto gastrointestinal.

No se ha demostrado que el antraceno puro sea cancerígeno, pero algunos de sus derivados y el antraceno industrial (que contiene impurezas) sí lo son. El 1,2-benzantraceno y algunos de sus derivados monometilados y dimetilados son también cancerígenos. Los derivados dimetilados y trimeilados del 1,2-benzantraceno son cancerígenos más potentes que los monometilados, especialmente el 9,10-dimetil-1,2-benzantraceno, que produce cáncer de piel en ratones en menos de 43 días. Los derivados 5,9- y 5,10dimetilados son también muy cancerígenos. $L$ a carcinogenicidad de los derivados 5,9,10- y 6,9,10-trimetilados es menos pronunciada. El 20-metilcolantreno, que tiene una estructura similar a la del 5,6,10-trimetil-1,2-benzantraceno, es un cancerígeno muy potente. Ninguno de los derivados dimetilados con grupos metilos sustituidos en el anillo adicional de benceno (en las posiciones $1,2,3,4)$ lo son. Se ha observado que la carcinogenicidad de algunos grupos de derivados alquilados de 1,2-benzantraceno disminuye a medida que aumenta la longitud de sus cadenas de carbonos.

El benz(a)antraceno está presente en el alquitrán de hulla en una concentración de hasta $12,5 \mathrm{~g} / \mathrm{kg}$; en la madera y el humo del tabaco en una concentración de entre 12 y $140 \mathrm{ng}$ en el humo de un cigarrillo; en aceites minerales; en el aire exterior, en una concentración de 0,6 a $361 \mathrm{ng} / \mathrm{m}^{3}$ y en las fábricas de gas en una concentración de 0,7 a $14 \mathrm{mg} / \mathrm{m}^{3}$. El benz(a)antraceno es un cancerígeno débil, pero algunos de sus derivados lo son mucho más, como los 6-, 7-, 8- y 12-metilbenz(a)antracenos y algunos de sus derivados dimetilados, como el 7,12-dimetilbenz(a)antraceno. La introducción de un anillo de cinco miembros entre las posiciones 7 y 8 del benz(a)antraceno forma colantreno ((benz(j)aceantrileno), que conjuntamente con su derivado 3-metilado, es un cancerígeno extremadamente potente. EI dibenz (a,h)antraceno fue el primer H AP puro cuya actividad carcinogénica quedó demostrada.

El criseno aparece en el alquitrán de hulla en concentraciones de hasta $10 \mathrm{~g} / \mathrm{kg}$. Se han medido concentraciones de entre 1,8 y $361 \mathrm{ng} / \mathrm{m}^{3}$ en el aire y de entre 3 y $17 \mathrm{mg} / \mathrm{m}^{3}$ en los gases de escape de los motores diesel. El humo de un cigarillo puede contener hasta $60 \mathrm{ng}$ de criseno. El dibenzo(b,d,e,f)-criseno y el dibenzo(d,e,f,p)-criseno son cancerígenos. El criseno exhibe una débil actividad carcinogénica.

Difenilos. Se dispone de poca información sobre los efectos tóxicos del difenilo y sus derivados, con la excepción de los bifenilos policlorados (PCBS). D ebido a su baja presión de vapor y a su olor, la exposición por inhalación a temperatura ambiente no suele entrañar un riesgo grave. Sin embargo, en un estudio de observación de trabajadores que realizaban la impregnación de papel de envolver con un polvo fungicida fabricado con difenilo, se detectaron brotes de tos, náuseas y vómitos. La exposición repetida a una solución de difenilo en aceite de parafina a $90 \stackrel{\circ}{\circ}$ y concentraciones ambiente muy superiores a $1 \mathrm{mg} / \mathrm{m}^{3}$, provocó la muerte de un trabajador por atrofia aguda del hígado y ocho trabajadores sufrieron lesiones de los sistemas nerviosos central y periférico y lesiones hepáticas. Estos trabajadores se quejaron de cefalea, trastornos gastrointestinales, síntomas polineuríticos y fatiga general.

EI difenilo fundido puede causar quemaduras graves. La absorción a través de la piel conlleva también un riesgo moderado. El contacto con los ojos produce irritación leve o moderada. El procesamiento y manipulación del éter de difenilo representa un pequeño riesgo para la salud. Su olor es desagradable y la exposición excesiva produce irritación de los ojos y la garganta.

El contacto con esta sustancia puede causar dermatitis.

La mezcla de éter de difenilo y difenilo a concentraciones de entre 7 y 10 ppm no afecta seriamente a los animales de experimentación sometidos a exposición repetida. Sin embargo, en el ser humano puede causar irritación de los ojos y la vías aéreas, así como náuseas. La ingestión accidental de este compuesto produce graves lesiones en el hígado y los riñones.

El fluoranteno está presente en el alquitrán de hulla, el humo del tabaco y los H A Ps atmosféricos. No es una sustancia cancerígena, pero sus isómeros benzo(b)-, benzo(j)- y benzo(k)- isómeros sí lo son.

El naftaceno está presente en el humo del tabaco y el alquitrán de hulla. Pigmenta algunas sustancias incoloras aisladas del alquitrán de hulla, como el antraceno.

EI naftaleno arde fácilmente $\mathrm{y}$, bien en partículas 0 vapores, forma mezclas explosivas con el aire. Su acción tóxica se ha observado principalmente en casos de intoxicación 
gastrointestinal en niños que confundieron las bolas de naftalina con caramelos y se manifiesta por anemia hemolítica aguda con lesiones hepáticas y renales y congestión vesical.

Se han publicado informes sobre casos de intoxicación grave en trabajadores que habían inhalado vapores de naftaleno; los síntomas más comunes fueron anemia hemolítica con cuerpos de $H$ einz, trastornos hepáticos y renales y neuritis óptica. La absorción prolongada de naftaleno puede ocasionar también pequeñas opacidades puntiformes en la periferia del cristalino, sin deterioro funcional. El contacto de los ojos con vapores y microcristales condensados puede causar queratitis puntiforme e incluso coriorretinitis.

Se ha observado que el contacto con la piel produce dermatitis eritematosa exudativa, si bien estos casos se han atribuido al contacto con naftaleno crudo que todavía contenía fenol, siendo éste el agente causal de la dermatitis en los pies observada en los trabajadores que descargaban bandejas de naftaleno cristalizado.

El fenantreno se obtiene a partir del alquitrán de hulla y puede sintetizarse haciendo pasar difeniletileno a través de un tubo calentado al rojo. Está presente en el humo del tabaco y se encuentra entre los H APs presentes en el aire. No parece exhibir actividad cancerígena, al contrario que algunos de los derivados alquilados del benzo(c)fenantreno. El fenantreno es una excepción recomendada al sistema de numeración; 1 y 2 se indican en la fórmula.

El pireno está presente en el alquitrán mineral, el humo del tabaco y los HAPs atmosféricos. También está presente en los productos derivados del petróleo en una concentración de 0,1 a $12 \mathrm{mg} / \mathrm{ml}$. El pireno no tiene actividad cancerígena, pero sus derivados benzo(a) y dibenzo son cancerígenos muy potentes. En el aire exterior se han medido concentraciones de benzo(a)pireno $(\mathrm{BaP})$ de $0,1 \mathrm{ng} / \mathrm{m}^{3}$ o menores en zonas no contaminadas y valores hasta varios miles de veces superiores en atmósferas urbanas contaminadas. EI BaP se encuentra en asfaltos, alquitrán de hulla, alquitrán de madera, gases de escape de los automóviles, humo del tabaco, aceites minerales, aceites de motor usados y aceites usados de equipos eléctricos. EI BaP y muchos de sus derivados alquilados son carcinógenos muy potentes.

Los vapores de terfenilo producen irritación de la conjuntiva y algunos efectos sistémicos. En animales de experimentación, el p-terfenilo se absorbe mal por vía oral y parece tener sólo un ligero efecto tóxico; los meta- y especialmente los orto-terfenilos son peligrosos para los riñones y éste último puede también deteriorar las funciones hepáticas. Se han descrito alteraciones morfológicas de las mitocondrias (pequeñas estructuras celulares que realizan funciones respiratorias y otras funciones enzimáticas esenciales para la síntesis biológica) en ratas expuestas a $50 \mathrm{mg} / \mathrm{m}^{3}$. Los agentes de intercambio de calor fabricados con terfenilos hidrogenados, mezclas de terfenilo e isopropil-meta-terfenilo, producen cambios funcionales del sistema nervioso, los riñones y la sangre en los animales de experimentación, con algunas lesiones orgánicas. Se ha demostrado la existencia de riesgo carcinogénico en ratones expuestos al refrigerante irradiado, si bien la mezcla no irradiada parece ser segura.

\section{Medidas de salud y seguridad}

Los HAPs se encuentran principalmente como contaminantes atmosféricos en una gran diversidad de lugares de trabajo. LoS análisis demuestran siempre el mayor contenido de HAPs en las muestras de aire tomadas en lugares donde existen humos 0 vapores visibles. Un método general para evitar la exposición es reducir dichas emisiones. En la industria del coque, esto se logra evitando las fugas mediante sistemas herméticos, aumentando la ventilación o utilizando cabinas con filtros de aire. En la industria del aluminio se tienen que adoptar medidas similares. En algunos casos tienen que instalarse sistemas de evacuación de humos y vapores. El uso de electrodos precocidos elimina casi por completo las emisiones de H APs. En las fundiciones y acerías, las emisiones de HAPs pueden reducirse evitando los preparados que contienen alquitrán. No es necesario adoptar medidas especiales para eliminar los HAPs de garajes, minas, etc. donde se emiten gases de escape de los automóviles; los sistemas de ventilación necesarios para eliminar otras sustancias más tóxicas reducen al mismo tiempo la exposición a HAPs. EI contacto de la piel con aceites usados que contienen HAPs puede evitarse utilizando guantes y cambiándose de ropa cuando ésta se contamine.

Deben aplicarse las mismas medidas relativas a controles técnicos, equipos de protección individual, formación e instalaciones sanitarias que se describen en otros artículos de esta E nciclopedia. Puesto que muchos miembros de esta familia son cancerígenos demostrados o sospechados, debe tenerse un cuidado especial en adoptar todas las precauciones recomendadas para una manipulación segura de las sustancias cancerígenas. 
TABLAS DE LOS HIDROCARBUROS

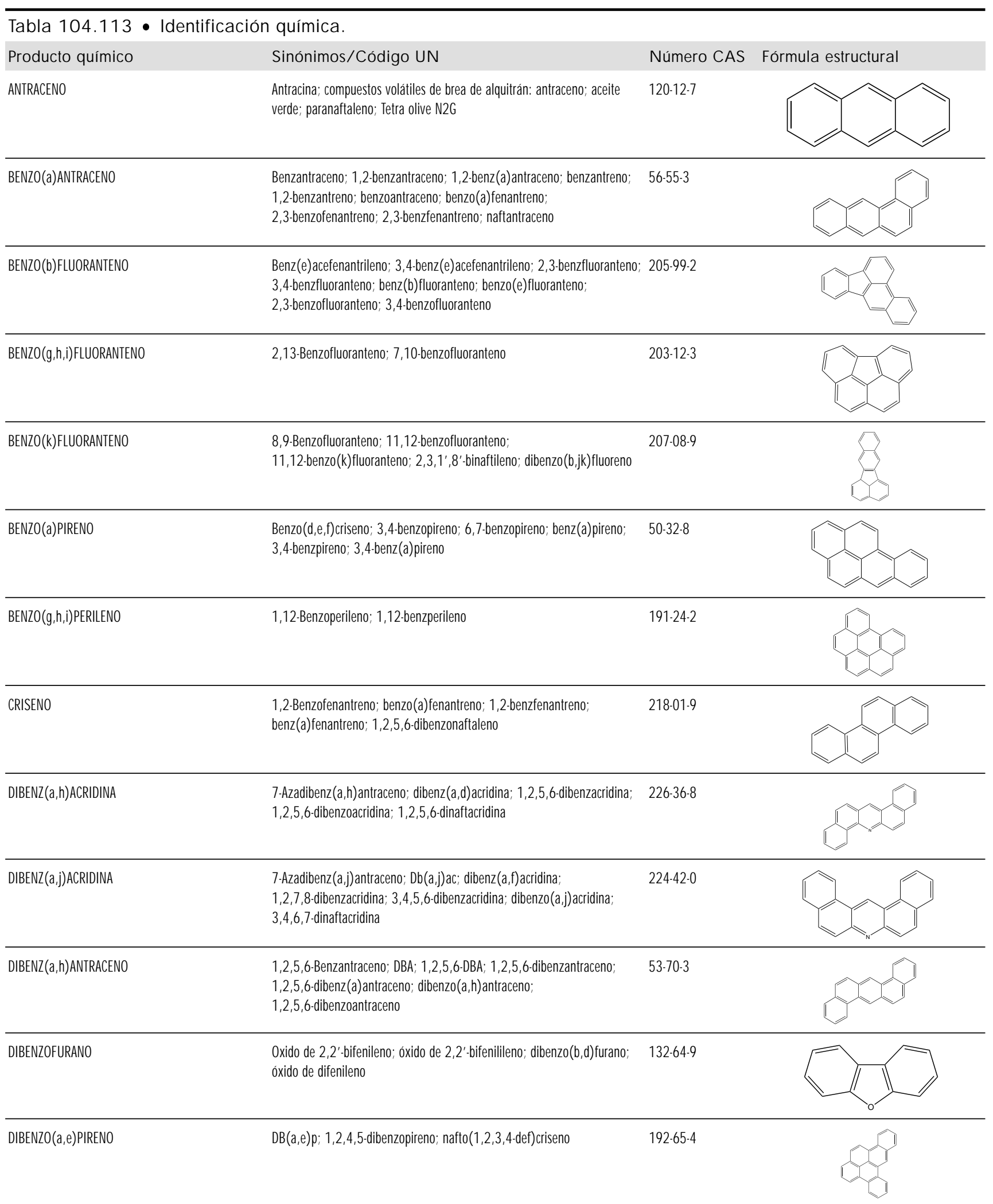




\begin{tabular}{|c|c|c|}
\hline Producto químico & Sinónimos/ Código UN & $\mathrm{N}$ úmero CAS Fórmula estructural \\
\hline DIBENZO(a,h) PIRENO & $\begin{array}{l}\mathrm{DB}(\mathrm{a}, \mathrm{h}) \mathrm{p} \text {; dibenzo( } \mathrm{b}, \mathrm{d}, \mathrm{e}, \mathrm{f}) \text { criseno; 1,2,6,7-dibenzopireno; } \\
\text { 3,4,8,9-dibenzopireno }\end{array}$ & $189-64-0$ \\
\hline DIBENZO(a,i) PIRENO & $\begin{array}{l}\text { Benzo(rst) pentafeno; dibenzo (b,h) pireno; 1,2,7,8-dibenzopireno; } \\
\text { 3,4,9,10-dibenzopireno; dibenz(a,i) pireno; 1,2,7,8-dibenzpireno; } \\
\text { 3,4,9,10-dibenzpireno }\end{array}$ & $189-55-9$ \\
\hline FENANTRENO & Compuestos volátiles de brea de alquitrán: fenantreno; fenantrino & $85-01-8$ \\
\hline FLUORANTENO & $\begin{array}{l}\text { 1,2-Benzacenafteno; benceno, 1,2-(1,8-naftileno)-; benzo(jk) fluoreno; } \\
\text { 1,2-(1,8-naftalenodil) benzeno; 1,2-(1,8-naftileno) benceno }\end{array}$ & $206-44-0$ \\
\hline NAFTACENO & $\begin{array}{l}\text { Acenaftileno, 1,2-dihidro-1,8-etilenonaftaleno; naftilenetileno; } \\
\text { perietilenonaftaleno }\end{array}$ & $83-32-9$ \\
\hline PERILENO & Dibenz(de,kl) antraceno; peri-dinaftaleno; perileno & $198-55-0$ \\
\hline PIRENO & Benzo(def)fenantreno; compuestos volátiles de brea de alquitrán: pireno & $129-00-0$ \\
\hline
\end{tabular}

\begin{tabular}{|c|c|c|c|c|c|c|}
\hline \multirow[b]{2}{*}{$\begin{array}{l}\text { Denominación } \\
\text { química } \\
\mathrm{N} \text { úmero CAS }\end{array}$} & \multicolumn{4}{|c|}{ Tarjetas Internacionales sobre la Seguridad de los Productos Q uímicos } & \multicolumn{2}{|c|}{ N IO SH (EE.UU.) } \\
\hline & $\begin{array}{l}\text { Período } \\
\text { corto de } \\
\text { exposición }\end{array}$ & $\begin{array}{l}\text { Período } \\
\text { largo de } \\
\text { exposición }\end{array}$ & $\begin{array}{l}\text { Vías de } \\
\text { exposición }\end{array}$ & Síntomas & $\begin{array}{l}\text { O rganos } \\
\text { afectados } \\
\text { Vías de } \\
\text { entrada }\end{array}$ & Síntomas \\
\hline $\begin{array}{r}\text { ANTRACENO } \\
120 \cdot 12 \cdot 7\end{array}$ & $\begin{array}{l}\text { ojos; piel; } \\
\text { tract resp; tract Gl }\end{array}$ & piel & $\begin{array}{r}\text { Inhalación } \\
\text { Piel } \\
\text { Ojos } \\
\text { Ingestión }\end{array}$ & $\begin{array}{l}\text { Tos, dificultad respiratoria, dolor de garganta } \\
\text { Puede absorberse, enrojecimiento } \\
\text { Enrojecimiento, dolor } \\
\text { Dolor abdominal }\end{array}$ & & \\
\hline $\begin{array}{l}\text { BENZO(a) ANTRACENO } \\
56-55-3\end{array}$ & & & Piel & Puede absorberse & & \\
\hline $\begin{array}{l}\text { BENZO(b) FLUORANTENO } \\
205-99-2\end{array}$ & & & Piel & Puede absorberse & & \\
\hline $\begin{array}{l}\text { BENZO }(g, h, i) \text { FLUORANTENO } \\
203-12-3\end{array}$ & & & Piel & Puede absorberse & & \\
\hline $\begin{array}{l}\text { BENZO(k) FLUORANTENO } \\
\text { 207-08-9 }\end{array}$ & & & Piel & Puede absorberse & & \\
\hline $\begin{array}{l}\operatorname{BENZO}(g, h, i) \text { PERILENO } \\
191-24-2\end{array}$ & & & Piel & Puede absorberse & & \\
\hline
\end{tabular}




\begin{tabular}{|c|c|c|c|c|c|c|}
\hline \multirow[b]{2}{*}{$\begin{array}{l}\text { Denominación } \\
\text { química } \\
\text { N úmero CAS }\end{array}$} & \multicolumn{4}{|c|}{ Tarjetas Internacionales sobre la Seguridad de los Productos Q uímicos } & \multicolumn{2}{|c|}{ N IO SH (EE.UU.) } \\
\hline & $\begin{array}{l}\text { Período } \\
\text { corto de } \\
\text { exposición }\end{array}$ & $\begin{array}{l}\text { Período } \\
\text { largo de } \\
\text { exposición }\end{array}$ & $\begin{array}{l}\text { Vías de } \\
\text { exposición }\end{array}$ & Síntomas & $\begin{array}{l}\text { O rganos } \\
\text { afectados } \\
\text { Vías de } \\
\text { entrada }\end{array}$ & Síntomas \\
\hline $\begin{array}{l}\text { BENZO(a) PIRENO } \\
50-32-8\end{array}$ & & \multicolumn{2}{|c|}{$\begin{array}{l}\text { defectos genéticos y } \\
\text { congénitos }\end{array}$} & & & \\
\hline $\begin{array}{l}\text { DIBENZO(a,h) ANTRACENO } \\
53-70-3\end{array}$ & ojos; piel; tract r & piel & $\begin{array}{l}\text { Piel } \\
\text { 0jos }\end{array}$ & $\begin{array}{l}\text { Fotosensibilización } \\
\text { Enrojecimiento, dolor }\end{array}$ & & \\
\hline
\end{tabular}

\begin{tabular}{|c|c|c|c|}
\hline $\begin{array}{l}\text { Denominación química } \\
\mathrm{N} \text { úmero CAS }\end{array}$ & Físicos & Q uímicos & $\begin{array}{l}\text { Clase o división } \\
\text { UN / Riesgos } \\
\text { subsidiarios }\end{array}$ \\
\hline $\begin{array}{r}\text { ANTRACENO } \\
120-12 \cdot 7\end{array}$ & $\begin{array}{l}\text { Posibilidad de ignición a } \\
\text { distancia cuando se } \\
\text { encuentra en forma de } \\
\text { polvo o granular y se } \\
\text { mezcla con el aire }\end{array}$ & $\begin{array}{l}\text { Se descompone al calentarse, por contacto con la luz solar y por influencia de oxidantes } \\
\text { fuertes, produciendo humos tóxicos acres, con peligro de incendio y explosión }\end{array}$ & 3 \\
\hline $\begin{array}{l}\text { BENZO(b) FLUORANTENO } \\
\text { 205-99-2 }\end{array}$ & & Al calentarse, se forman humos tóxicos & \\
\hline $\begin{array}{l}\text { BENZO }(g, h, i) \text { FLUORANTENO } \\
203-12-3\end{array}$ & & Al calentarse, se forman humos tóxicos & \\
\hline $\begin{array}{l}\text { BENZO(k)FLUORANTENO } \\
\text { 207-08-9 }\end{array}$ & & Al calentarse, se forman humos tóxicos Reacciona con oxidantes fuertes & \\
\hline $\begin{array}{l}\text { BENZO }(g, h, i) \text { PERILENO } \\
191-24-2\end{array}$ & & $\begin{array}{l}\text { Al calentarse, se forman humos tóxicos Reacciona con } \mathrm{NO} \text { y NO}{ }_{2} \text { para formar derivados } \\
\text { nitrosos }\end{array}$ & \\
\hline $\begin{array}{l}\text { DIBENZO(a, h) ANTRACENO } \\
53-70-3\end{array}$ & & Reacciona con oxidantes fuertes & 4.1 \\
\hline
\end{tabular}


Tabla 104.116 • Propiedades físicas y químicas.

\begin{tabular}{|c|c|c|c|c|c|c|c|c|c|c|}
\hline $\begin{array}{l}\text { Denominación química } \\
\mathrm{N} \text { úmero CAS }\end{array}$ & Color/ Forma & $\begin{array}{l}\text { p.e. } \\
(\stackrel{\circ}{ } \mathrm{C})\end{array}$ & $\begin{array}{l}\text { p.f. } \\
(\stackrel{o}{ } C)\end{array}$ & $\begin{array}{l}\text { p.m.l } \\
\text { (g/ } \\
\text { mol) }\end{array}$ & $\begin{array}{l}\text { Solubilidad } \\
\text { en agua }\end{array}$ & $\begin{array}{l}\text { Densidad } \\
\text { relativa } \\
\text { (agua }=1 \text { ) }\end{array}$ & $\begin{array}{l}\text { Densidad } \\
\text { relativa } \\
\text { del vapor } \\
\text { (aire=1) }\end{array}$ & $\begin{array}{l}\text { Pvap/ } \\
(\mathrm{kPa})\end{array}$ & $\begin{array}{l}\text { Límit. } \\
\text { inflam. }\end{array}$ & $\begin{array}{ll}\text { p.ig. } & \text { p.aut } \\
(\mathrm{O} C) & \text { ig. } \\
& (\stackrel{\circ}{ } \mathrm{C})\end{array}$ \\
\hline $\begin{array}{r}\text { ANTRACENO } \\
120-12-7\end{array}$ & $\begin{array}{l}\text { placas monoclínicas } \\
\text { por recristalización } \\
\text { en alcohol; en estado } \\
\text { puro es incoloro, con } \\
\text { fluorescencia violeta; } \\
\text { cuando se cristaliza } \\
\text { en benceno, se } \\
\text { forman placas } \\
\text { incoloras brillantes } \\
\text { con fluorescencia } \\
\text { azul; cristales } \\
\text { amarillos con } \\
\text { fluorescencia amarilla }\end{array}$ & 342 & 218 & 178,22 & insol & $1,283 @ 25^{\circ} \mathrm{C}$ & 6,15 & $\begin{array}{l}1 \mathrm{~mm} \mathrm{Hg} \\
\text { @ } 145^{\circ} \mathrm{C}\end{array}$ & $\begin{array}{l}0,6 \mathrm{li} \\
? \text { Is }\end{array}$ & 121 cc 540 \\
\hline $\begin{array}{l}\text { BENZ(a) ANTRACENO } \\
56-55-3\end{array}$ & $\begin{array}{l}\text { placas incoloras } \\
\text { recristalizadas en } \\
\text { ácido acético glacial } \\
0 \text { alcohol }\end{array}$ & 400 & 162 & 228,3 & $\begin{array}{l}0,014 \mathrm{mg} / \mathrm{l} \\
@ 25^{\circ} \mathrm{C}\end{array}$ & & & $5 \times 10^{-9}$ torr & & \\
\hline $\begin{array}{l}\text { BENZO(b)FLUORANTENO } \\
\text { 205-99-2 }\end{array}$ & $\begin{array}{l}\text { agujas } \\
\text { (recristalizadas en } \\
\text { benceno), agujas } \\
\text { incoloras } \\
\text { (recristalizadas en } \\
\text { tolueno o ácido } \\
\text { acético glacial) }\end{array}$ & & 168 & 252,3 & insol & & & $<10 \mathrm{~Pa}$ & & \\
\hline $\begin{array}{l}\text { BENZO }(g, h, i) \text { FLUORANTENO } \\
\text { 203-12-3 }\end{array}$ & cristales & & 149 & & insol & & & $<10 \mathrm{~Pa}$ & & \\
\hline $\begin{array}{l}\text { BENZO(k) FLUORANTENO } \\
\text { 207-08.9 }\end{array}$ & $\begin{array}{l}\text { agujas de color } \\
\text { amarillo claro en } \\
\text { benceno }\end{array}$ & 480 & 217 & 252,3 & insol & & & $\begin{array}{l}9,59 \times 10^{-11} \\
\text { torr }\end{array}$ & & \\
\hline $\begin{array}{l}\operatorname{BENZO}(g, h, i) \text { PERILENO } \\
191-24-2\end{array}$ & $\begin{array}{l}\text { placas grandes de } \\
\text { color amarillo } \\
\text { verduzco claro } \\
\text { (recristalizadas en } \\
\text { xileno) }\end{array}$ & 550 & 277 & 276,3 & insol & & & $\begin{array}{l}1,0 \times 10^{-10} \\
\mathrm{~mm} \mathrm{Hg} \\
@ 25^{\circ} \mathrm{C}\end{array}$ & & \\
\hline $\begin{array}{l}\text { BENZO(a) PIRENO } \\
50-32-8\end{array}$ & $\begin{array}{l}\text { agujas monoclínicas } \\
\text { de color amarillo } \\
\text { claro en benceno y } \\
\text { metanol; los cristales } \\
\text { pueden ser } \\
\text { monoclínico y } \\
\text { ortorrómbicos; placas } \\
\text { amarillentas (en } \\
\text { benceno y ligroína) }\end{array}$ & $>360$ & $\begin{array}{l}179- \\
179,3\end{array}$ & 252,30 & insol & 1,351 & 8,7 & $>1 \mathrm{~mm} \mathrm{Hg}$ & & \\
\hline $\begin{array}{l}\text { CRISENO } \\
218-01-9\end{array}$ & $\begin{array}{l}\text { placas rómbicas rojas } \\
\text { con fluorescencia roja } \\
0 \text { azul en beceno y } \\
\text { ácido acético; placas } \\
\text { bipiramidales } \\
\text { ortorrómbicas en } \\
\text { benceno; láminas } \\
\text { incoloras con } \\
\text { fluorescencia azul }\end{array}$ & 448 & $255-256$ & 228,28 & insol & 1,274 & & $\begin{array}{l}6,3 \times 10^{-7} \\
\mathrm{~mm} \mathrm{Hg}\end{array}$ & & \\
\hline $\begin{array}{l}\text { DIBENZ(a,h) ACRIDINA } \\
226-36-8\end{array}$ & cristales amarillos & & 228 & 279,35 & & & & & & \\
\hline
\end{tabular}




\begin{tabular}{|c|c|c|c|c|c|c|c|c|c|c|}
\hline $\begin{array}{l}\text { Denominación química } \\
\mathrm{N} \text { úmero } \mathrm{CAS}\end{array}$ & Color/ Forma & $\begin{array}{l}\text { p.e. } \\
(\stackrel{0}{ } \mathrm{C})\end{array}$ & $\begin{array}{l}\text { p.f. } \\
\left({ }^{\circ} \mathrm{C}\right)\end{array}$ & $\begin{array}{l}\text { p.m.l } \\
\text { (g/ } \\
\mathrm{mol})\end{array}$ & $\begin{array}{l}\text { Solubilidad } \\
\text { en agua }\end{array}$ & $\begin{array}{l}\text { Densidad } \\
\text { relativa } \\
\text { (agua }=1 \text { ) }\end{array}$ & $\begin{array}{l}\text { Densidad } \\
\text { relativa } \\
\text { del vapor } \\
\text { (aire=1) }\end{array}$ & $\begin{array}{l}\text { Pvap/ } \\
(\mathrm{kPa})\end{array}$ & $\begin{array}{l}\text { Límit. } \\
\text { inflam. }\end{array}$ & 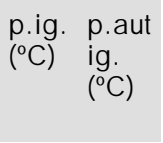 \\
\hline $\begin{array}{l}\text { DIBENZ(a,j)ACRIDINA } \\
224-42-0\end{array}$ & $\begin{array}{l}\text { agujas o prismas de } \\
\text { color amarillo }\end{array}$ & & 216 & 279,35 & & & & & & \\
\hline $\begin{array}{l}\text { DIBENZ( }(a, h) \text { ANTRACENO } \\
53-70-3\end{array}$ & $\begin{array}{l}\text { placas o laminillas } \\
\text { incoloras } \\
\text { recristalizadas en } \\
\text { ácido acético; la } \\
\text { solución en ácido } \\
\text { sulfúrico concentrado } \\
\text { es roja; los cristales } \\
\text { pueden ser } \\
\text { monoclínicos u } \\
\text { ortorrómbicos }\end{array}$ & 524 & 266 & 278,33 & insol & 1,282 & & $\begin{array}{l}1 \times 10^{-10} \\
\mathrm{~mm} \mathrm{Hg}\end{array}$ & & \\
\hline $\begin{array}{l}\text { DIBENZOFURANO } \\
132-64-9\end{array}$ & $\begin{array}{l}\text { láminas o agujas en } \\
\text { alcohol; cristales } \\
\text { blancos; sólido } \\
\text { cristalino }\end{array}$ & 287 & & 168,19 & $\begin{array}{l}10 \mathrm{ppm} \\
@ 25^{\circ} \mathrm{C}\end{array}$ & $\begin{array}{l}1,0886 \\
@ 99^{\circ} \mathrm{C} / 4^{\circ} \mathrm{C}\end{array}$ & 5,8 & $\begin{array}{l}0,0044 \\
\mathrm{~mm} \mathrm{Hg} \\
@ 25^{\circ} \mathrm{C}\end{array}$ & & \\
\hline $\begin{array}{l}\text { DIBENZO(a,e)PIRENO } \\
192-65-4\end{array}$ & $\begin{array}{l}\text { agujas de color } \\
\text { amarillo claro en } \\
\text { xileno; de color } \\
\text { amarillo-rojo en } \\
\text { solución de ácido } \\
\text { sulfúrico concentrado }\end{array}$ & & 234 & 302,4 & & & & & & \\
\hline $\begin{array}{l}\text { DIBENZO }(a, h) \text { PIRENO } \\
\quad 189-64.0\end{array}$ & $\begin{array}{l}\text { placas amarillas } \\
\text { doradas en xileno o } \\
\text { triclorobenceno; en } \\
\text { solución de } \mathrm{H}_{2} \mathrm{SO}_{4} \\
\text { tiene color rojo, } \\
\text { cambiando después a } \\
\text { violeta } 0 \text { azul }\end{array}$ & & 308 & 302,38 & & & & & & \\
\hline $\begin{array}{l}\text { DIBENZO(a,i) PIRENO } \\
189-55-9\end{array}$ & $\begin{array}{l}\text { agujas, prismas o } \\
\text { lamelas de color } \\
\text { amarillo verduzco }\end{array}$ & $\begin{array}{l}275 \\
@ 0,05 \mathrm{~mm} \\
\mathrm{Hg}\end{array}$ & 281 & 302,4 & & & & $\begin{array}{l}2,39 \times 10^{-14} \\
\mathrm{~mm} \mathrm{Hg}\end{array}$ & & \\
\hline $\begin{array}{l}\text { FENANTRENO } \\
85.01-8\end{array}$ & $\begin{array}{l}\text { placas monoclínicas } \\
\text { en alcohol; cristales } \\
\text { brillantes incoloros; } \\
\text { laminillas }\end{array}$ & 340 & 101 & 178,22 & insol & $0,9800 @ 4{ }^{\circ} \mathrm{C}$ & 6,15 & $\begin{array}{l}1 \mathrm{~mm} \mathrm{Hg} \\
@ \\
118,2^{\circ} \mathrm{C}\end{array}$ & & $171 \mathrm{ca}$ \\
\hline $\begin{array}{l}\text { FLUORANTENO } \\
206-44-0\end{array}$ & $\begin{array}{l}\text { agujas coloreadas; } \\
\text { agujas o placas de } \\
\text { color amarillo claro } \\
\text { en alcohol }\end{array}$ & 375 & 111 & 202,2 & insol & $\begin{array}{l}1,252 \\
\text { (a) } 0^{\circ} \mathrm{C} / 4^{\circ} \mathrm{C}\end{array}$ & & $\begin{array}{l}0,01 \\
\mathrm{~mm} \mathrm{Hg}\end{array}$ & & \\
\hline $\begin{array}{c}\text { NAFTACENO } \\
83-32-9\end{array}$ & $\begin{array}{l}\text { agujas blancas; } \\
\text { agujas bipiramidales } \\
\text { ortorrómbicas en } \\
\text { alcohol }\end{array}$ & 279 & 95 & 154,21 & insol & $\begin{array}{l}1,0242 \mathrm{a} \\
90^{\circ} \mathrm{C} / 4^{\circ} \mathrm{C}\end{array}$ & 5,32 & $\begin{array}{l}10 \mathrm{~mm} \mathrm{Hg} \\
\text { a } 131,2{ }^{\circ} \mathrm{C}\end{array}$ & & \\
\hline
\end{tabular}


Tabla 104.116 • Propiedades físicas y químicas.

\begin{tabular}{|c|c|c|c|c|c|c|c|c|c|c|c|}
\hline $\begin{array}{l}\text { Denominación química } \\
\mathrm{N} \text { úmero CAS }\end{array}$ & Color/ Forma & $\begin{array}{l}\text { p.e. } \\
\left({ }^{\circ} \mathrm{C}\right)\end{array}$ & $\begin{array}{l}\text { p.f. } \\
\left({ }^{\circ} C\right)\end{array}$ & $\begin{array}{l}\text { p.m.l } \\
\text { (g/ } \\
\text { mol) }\end{array}$ & $\begin{array}{l}\text { Solubilidad } \\
\text { en agua }\end{array}$ & $\begin{array}{l}\text { Densidad } \\
\text { relativa } \\
\text { (agua }=1 \text { ) }\end{array}$ & $\begin{array}{l}\text { Densidad } \\
\text { relativa } \\
\text { del vapor } \\
\text { (aire=1) }\end{array}$ & $\begin{array}{l}\text { Pvap/ } \\
(\mathrm{kPa})\end{array}$ & $\begin{array}{l}\text { Límit. } \\
\text { inflam. }\end{array}$ & $\begin{array}{l}\text { p.ig. } \\
(\stackrel{\circ}{ } C)\end{array}$ & $\begin{array}{l}\text { p.aut } \\
\text { ig. } \\
\left({ }^{\circ} \mathrm{C}\right)\end{array}$ \\
\hline $\begin{array}{l}\text { PIRENO } \\
\quad 129-00-0\end{array}$ & $\begin{array}{l}\text { cristales tabulares } \\
\text { prismáticos } \\
\text { monoclínicos en } \\
\text { alcohol o por } \\
\text { sublimación; el } \\
\text { pireno puro es } \\
\text { incoloro; placas de } \\
\text { color amarillo claro } \\
\text { (cuando se } \\
\text { recristalizan en } \\
\text { tolueno); sólido } \\
\text { incoloro (las } \\
\text { impurezas de } \\
\text { tetraceno dan color } \\
\text { amarillo) }\end{array}$ & 393 & 156 & 202,2 & insol & $1,271 @ 23 \stackrel{\circ}{0}$ & & $\begin{array}{l}6,85 \times 10^{-7} \\
\text { torr } \\
\text { @ } 20 \stackrel{\circ}{\circ} \mathrm{C}\end{array}$ & & & \\
\hline
\end{tabular}




\section{ISOCIANATOS}

Los isocianatos, más comúnmente conocidos por poliuretanos, entran en la composición de la mayoría de los productos industriales denominados de esta forma. Constituyen un grupo de derivados neutros de las aminas primarias con la fórmula general $\mathrm{R}-\mathrm{N}=\mathrm{C}=0$. Entre los isocianatos más utilizados en la actualidad se encuentran el tolueno-2,4-diisocianato (TDI), el tolueno-2,6-diisocianato y el difenilmetano-4,4'-diisocianato. EI hexametileno-diisocianato y el 1,5-naftileno-diisocianato se utilizan menos.

Los isocianatos reaccionan espontáneamente con compuestos que contienen átomos de hidrógeno activos, los cuales emigran al nitrógeno. Los compuestos que contienen grupos hidroxilo forman espontáneamente ésteres de dióxido de carbono sustituido o uretanos.

\section{U sos}

U no de los principales usos de los isocianatos es la síntesis de poliuretanos en productos industriales. La durabilidad y resistencia del metilen-bis(4-fenil-isocianato) y el tolueno-2,4-diisocianato (TDI) los hacen adecuados para la fabricación de revestimientos de aviones, camiones cisterna y remolques. EI metilen-bis(4-fenil-isocianato) se utiliza para adherir caucho a rayon y nylon y para fabricar revestimientos lacados de poliuretano que se aplican a ciertos componentes de los automóviles y al charol. El tolueno-2,4-diisocianato se emplea en revestimientos de poliuretano para sellados y acabados de suelos y madera, pinturas y sellados de hormigón. Se utiliza también en la fabricación de espumas de poliuretano y elastómeros de poliuretano para impermeabilización de tejidos y sellados de tuberías de arcilla. EI hexametileno-diisocianato es un agente reticulante en la preparación de materiales dentales, lentes de contacto y adsorbentes médicos. Se utiliza también como ingrediente de pinturas para coches.

\section{Riesgos}

Los isocianatos irritan la piel y las mucosas, produciendo afecciones cutáneas que van desde una irritación localizada hasta un eczema más o menos extendido. Las afecciones oculares son menos frecuentes $y$, aunque los isocianatos suelen causar lagrimeo, rara vez producen conjuntivitis. Los problemas más comunes y graves son los que afectan al sistema respiratorio. La gran mayoría de los autores mencionan formas de rinitis o rinofaringitis y se han descrito también afecciones pulmonares, principalmente manifestaciones asmáticas que varían desde una ligera dificultad para respirar hasta ataques agudos de asma, en ocasiones acompañados de pérdida súbita de la consciencia. Las personas que desarrollan sensibilidad a este tipo de compuestos pueden reaccionar con síntomas graves de asma tras su exposición a concentraciones muy bajas de isocianatos (incluso inferiores a 0,02 ppm). Además, las personas sensibilizadas pueden reaccionar a estímulos medioambientales como el ejercicio y el aire frío. El asma por sensibilización está generalmente mediada por la IgE (sólo cuando se trata de sustancias de alto peso molecular, puesto que para las sustancias de bajo peso molecular no se conoce todavía bien el mecanismo). Por el contrario, el asma inducida por sustancias irritantes es típicamente secundaria a la inflamación de las vías respiratorias y a efectos tóxicos locales directos con hiperrespuestas inespecíficas, aunque todavía no se conoce bien el mecanismo que la desencadena. Las respuestas alérgicas se describen con más detalle en otros artículos de esta Encicl opedia.

Muchos isocianatos son volátiles y sus vapores pueden ser detectados por el olfato a una concentración de 0,1 ppm, si bien este nivel tan bajo es ya peligroso para algunas personas.

T olueno-2,4-diisocianato (T DI). Esta es la sustancia que más se utiliza en la industria y la responsable del mayor número de manifestaciones patológicas, porque es extremadamente volátil y porque, a menudo, se utiliza en altas concentraciones. La sintomatología correspondiente a las alteraciones producidas por la inhalación de esta sustancia es típica. Al final de un período, que puede ir desde unos pocos días hasta 2 meses, se presentan los siguientes síntomas: irritación de la conjuntiva, lagrimeo e irritación de la faringe. M ás adelante aparecen problemas respiratorios, con una desagradable tos seca por la noche, dolor torácico, sobre todo retroesternal, dificultad para respirar y malestar. Estos síntomas empeoran por la noche y desaparecen por la mañana, con una ligera expectoración mucosa. D espués de varios días de reposo, el estado del paciente mejora, pero el regreso a la actividad laboral suele acompañarse de la reaparición de las mismas alteraciones, es decir, tos, dolor torácico, disnea con roncus y sibilancias y malestar. Los estudios radiológicos y humorales suelen dar resultados negativos.

L as afecciones respiratorias que se sabe que están causadas por el TDI son bronquitis, asma de origen profesional y deterioro de la función respiratoria, tanto en el trabajo como con carácter crónico. En otros casos se producen catarros recurrentes 0 un eczema particularmente pruriginoso que aparece en muchas zonas diferentes de la piel. Algunos pacientes sufren al mismo tiempo problemas cutáneos y respiratorios.

Además de estas consecuencias típicas de la intoxicación, existen otros efectos, si bien raros, derivados de la exposición a concentraciones muy bajas de isocianatos durante largos períodos de tiempo, incluso años. Entre estas alteraciones podemos señalar casos de asma típicos, combinados con bradipnea espiratoria y eosinofilia en el esputo.

La fisiopatología de la intoxicación aún no se conoce perfectamente. Algunos autores creen que se produce una irritación primaria; otros piensan que se trata de un mecanismo inmunitario y lo cierto es que en algunos casos se ha demostrado la presencia de anticuerpos. La sensibilización puede demostrarse con pruebas de provocación, pero éstas deben siempre ser realizadas por un médico con experiencia y con gran precaución para evitar una sensibilización todavía mayor del paciente. No obstante, muchas de las pruebas alergológicas (con acetilcolina 0 los alergenos habituales, por ejemplo) suelen dar resultados negativos. Con respecto a las pruebas de la función pulmonar, el índice VEF/ CVF parece ser el que mejor refleja los problemas respiratorios. Sin embargo, los exámenes funcionales rutinarios, que se realizan lejos de una zona de exposición al riesgo, dan resultados normales.

D ifenilmetano-4,4'-diisocianato (M DI). Esta sustancia es menos volátil y sus vapores son peligrosos sólo cuando la temperatura alcanza los $75 \stackrel{\circ}{\circ}$, aunque se han descrito casos de intoxicación similares, la mayoría de ellos relacionados con aerosoles, puesto que el M DI puede utilizarse en forma líquida para atomizadores.

$H$ exameileno-diisocianato. Esta sustancia se utiliza menos, pero es altamente irritante para la piel y los ojos. El problema más común atribuido a ella es la blefaroconjuntivitis. Se cree que el metilisocianato es el compuesto químico responsable del desastre de Bhopal. 
1,5- $\mathrm{N}$ aftileno-diisocianato. Este isocianato se utiliza poco en la industria. Se han descrito algunos casos de intoxicación después de la exposición a vapores calentados a más de $100 \stackrel{0}{C}$.

\section{Medidas de salud y seguridad}

La ventilación, el uso de equipos protectores y la formación de los trabajadores en materia de salud y seguridad, según se describe en otros artículos de esta E nciclopedia, son aspectos todos ellos necesarios cuando se trabaja con isocianatos. Es imprescindible que existan instalaciones adecuadas para extraer los vapores de isocianato. El mecanismo de extracción debe estar colocado lo más cerca posible de la fuente donde se generan los vapores. Siempre que se diseñe un proceso industrial, deberá tenerse en cuenta la posible descomposición y liberación de isocianatos a partir de espumas y colas de poliuretano.

Prevención médica. El reconocimiento médico previo al empleo debe incluir un cuestionario y una exploración clínica completa para prevenir la exposición de personas con antecedentes de alergia cutánea o respiratoria a los isocianatos. Los trabajadores expuestos deben mantenerse en observación y, entre otras instalaciones sanitarias, deben disponer de duchas. 
TABLAS DE ISOCIANATOS

\begin{tabular}{|c|c|c|c|}
\hline Producto químico & Sinónimos/ Código UN & $\mathrm{N}$ úmero CAS & Fórmula estructural \\
\hline ACIDO ISOCIANICO, NITROIMINODIETLEENDI- & 3-Nitro-3-azapentano-1,5-diisocianato; ácido nitroiminodietilendiisociánico & $7046-61-9$ & \\
\hline CICLOHEXIL ISOCIANATO & $\begin{array}{l}\text { Ester ciclohexílico del ácido isociánico; isocianato de ciclohexano; } \\
\text { isocianatociclohexano } \\
\text { UN2488 }\end{array}$ & $3173-53-3$ & \\
\hline DIANISIDINA DIISOCIANATO & $\begin{array}{l}\text { 1,1'-Bifenilo, 4,4'-diisocianato-3,3'-dimetoxi-; } \\
\text { 4,4'-diisocianato-3,3'-dimetoxi-1, 1'-bifenilo; } \\
\text { 3,3'-dimetoxibencidina-4,4'-disocianato; éster } \\
\text { 3,3'-dimetoxi-4,4'-bifenílico del ácido isociánico }\end{array}$ & $91-93-0$ & \\
\hline ETIL ISOCIANATO & $\begin{array}{l}\text { Ester etilico del ácido isociánico; isocianatoetano } \\
\text { UN2481 }\end{array}$ & $109-90-0$ & \\
\hline FENIL ISOCIANATO & $\begin{array}{l}\text { Isocianato de benceno; Mondur } P \text {; fenilcarbimida; fenilcarbonimida } \\
\text { UN2487 }\end{array}$ & $103-71-9$ & \\
\hline HEXAMETILENO-DIISOCIANATO & $\begin{array}{l}\text { Desmodur H; Desmodur N; diisocianato de hexametileno; } \\
\text { hexametilen-1,6-diisocianato; 1,6-hexametileno-diisocianato; } \\
\text { 1,6-hexanodiol-disocianato; HMDI; TI } 78 \\
\text { UN2281 }\end{array}$ & $822-06-0$ & \\
\hline ISOFORONA DIISOCIANATO & $\begin{array}{l}\text { 5-Isocianato-1-(isocianatometill-1,3,3-trimetilciclohexano; IPDI; } \\
\text { 3-socianatometil-3,5,5-trimetil ciclohexil isocianato; éster } \\
\text { metilen(3,5,5-trimetil-3,1-ciclohexilénico) del ácido isociánico; } \\
\text { isoforona diamina diisocianato } \\
\text { UN2906 } \\
\text { UN2290 }\end{array}$ & $4098-71-9$ & \\
\hline METIL ISOCIANATO & $\begin{array}{l}\text { Ester metílico del ácido isociánico; isocianatometano; MIC } \\
\text { UN2480 }\end{array}$ & $624-83-9$ & \\
\hline METILENBISFENIL ISOCIANATO & $\begin{array}{l}\text { Ester metilendi-p-fenilénico del ácido isociánico; } \\
\text { bis( p-isocianatofenil)metano; Caradate 30; Desmodur 44; } \\
\text { difenilmetano 4,4'-diisocianato; difenilmetano dilisocianato; Hylene M 50; } \\
\text { isonato; isonato 125M; 4,4'-metilenbis(fenil isocianato) } \\
\text { UN2489 }\end{array}$ & $101-68-8$ & \\
\hline 1,5-NAFTALENO-DIISOCIANATO & $\begin{array}{l}\text { 1,5-Diisocianato-naftaleno; éster 1,5-naftilénico del ácido isociánico; } \\
\text { 1,5-naftaleno-diisocianato; 1,5-diisocianato-de naftaleno }\end{array}$ & $3173-72-6$ & \\
\hline TOLUENO-DIISOCIANATO & $\begin{array}{l}\text { 1,3-Diisociano metilbenceno; Desmodur T100; diisocianato metilbenceno; } \\
\text { diisocianato-tolueno; Hylene-T; éster metilfenilénico del ácido isociánico; } \\
\text { Mondur-TD; Nacconate-100; Niax isocianato TDI } \\
\text { UN2078 }\end{array}$ & $26471-62-5$ & \\
\hline TOLUENO-2,4-DIISOCIANATO & $\begin{array}{l}\text { Cresorcinol diisocianato; Desmodur T80; diisociano-tolueno; } \\
\text { 2,4-disocianato-1-metilbenceno (9 CI); 2,4-diisocianato-tolueno; Hylene T; } \\
\text { Mondur TD; Rubinate TDI 80;20; TDI; 2,4-TDI; TDI-80; TDI }\end{array}$ & $584-84-9$ & \\
\hline
\end{tabular}




\begin{tabular}{|c|c|c|}
\hline Producto químico & Sinónimos/ Código UN & N úmero CAS Fórmula estructural \\
\hline TOLUENO-2,6-DIISOCIANATO & $\begin{array}{l}\text { 2,6-Diisocianato-1-metilbenceno; 2,6-diisocianato-tolueno; Hylene TCPA; } \\
\text { éster 2-metil-m-fenilénico del ácido isociánico; } \\
\text { 2-metil-m-fenileno-diisocianato; 2-metil-m-fenileno-isocianato; Niax TDI; } \\
\text { Niax TDI-p; 2,6-TDI }\end{array}$ & $91-08-7$ \\
\hline
\end{tabular}

\begin{tabular}{|c|c|c|c|c|c|c|}
\hline \multirow[b]{2}{*}{$\begin{array}{l}\text { Denominación } \\
\text { química } \\
\text { N úmero CAS }\end{array}$} & \multicolumn{4}{|c|}{ Tarjetas Internacionales sobre la Seguridad de los Productos Q uímicos } & \multicolumn{2}{|c|}{ N IO SH (EE.UU.) } \\
\hline & $\begin{array}{l}\text { Período } \\
\text { corto de } \\
\text { exposición }\end{array}$ & $\begin{array}{l}\text { Período } \\
\text { largo de } \\
\text { exposición }\end{array}$ & $\begin{array}{l}\text { Vías de } \\
\text { exposición }\end{array}$ & Síntomas & $\begin{array}{l}\text { O rganos } \\
\text { afectados } \\
\text { Vías de } \\
\text { entrada }\end{array}$ & Síntomas \\
\hline $\begin{array}{l}\text { CICLOHEXIL ISOCIANATO } \\
\text { 3173-53-3 }\end{array}$ & ojos; piel; tract resp & piel & $\begin{array}{r}\text { Inhalación } \\
\text { Piel } \\
\text { 0jos } \\
\\
\text { Ingestión } \\
\end{array}$ & $\begin{array}{l}\text { Sensación de quemazón, tos, dificultad } \\
\text { respiratoria, disnea; véase ingestión } \\
\text { Enrojecimiento } \\
\text { Lagrimeo, enrojecimiento, dolor, visión } \\
\text { borrosa, quemaduras profundas graves } \\
\text { Espasmos abdominales, diarrea, vómitos }\end{array}$ & & \\
\hline $\begin{array}{l}\text { HEXAMETILENO-DIISOCIANATO } \\
822-06-0\end{array}$ & ojos; piel; tract resp & piel & $\begin{array}{r}\text { Inhalación } \\
\text { Piel } \\
\text { 0jos } \\
\end{array}$ & $\begin{array}{l}\text { Sensación de quemazón, tos, dificultad } \\
\text { respiratoria, disnea, dolor de garganta } \\
\text { Puede absorberse, enrojecimiento, quemaduras } \\
\text { en la piel, ampollas } \\
\text { Enrojecimiento, dolor, hinchazón de párpados }\end{array}$ & $\begin{array}{l}\text { Ojos; piel; sis resp } \\
\text { Inh; ing; con }\end{array}$ & $\begin{array}{l}\text { Irrit ojos, piel, sis resp; tos, } \\
\text { dis, bron, resp sib, edema } \\
\text { pulm, asma; lesión córn, } \\
\text { ampollas en la piel }\end{array}$ \\
\hline $\begin{array}{l}\text { ISOFORONA DIISOCIANATO } \\
\text { 4098-71-9 }\end{array}$ & ojos; piel; tract resp & piel; pulmones & $\begin{array}{r}\text { Inhalación } \\
\text { Piel } \\
\text { 0jos }\end{array}$ & $\begin{array}{l}\text { Tos, dolor de garganta, los síntomas pueden } \\
\text { tardar en aparecer } \\
\text { Enrojecimiento } \\
\text { Enrojecimiento }\end{array}$ & $\begin{array}{l}\text { Ojos; piel; sis resp } \\
\text { Inh; abs; ing; con }\end{array}$ & $\begin{array}{l}\text { Irrit ojos, piel, sis resp; opr } \\
\text { torácica, dis, tos, dolor de } \\
\text { garganta; bron, resp sib, } \\
\text { edema pulm; posible sens } \\
\text { resp; asma }\end{array}$ \\
\hline $\begin{array}{l}\text { METIL ISOCIANATO } \\
624-83.9\end{array}$ & $\begin{array}{l}\text { ojos; piel; } \\
\text { tract resp; } \\
\text { pulmones }\end{array}$ & piel; pulmones & $\begin{array}{r}\text { Inhalación } \\
\text { Piel } \\
\text { 0jos } \\
\text { Ingestión }\end{array}$ & $\begin{array}{l}\text { Tos, mareo, dificultad respiratoria, disnea, } \\
\text { dolor de garganta, inconsciencia, vómitos } \\
\text { Puede absorberse, quemaduras en la piel, } \\
\text { dolor } \\
\text { Dolor, pérdida de visión, quemaduras } \\
\text { profundas graves } \\
\text { Espasmos abdominales, dolor de garganta, } \\
\text { vómitos }\end{array}$ & $\begin{array}{l}\text { Sis resp; ojos; piel } \\
\text { Inh; abs; ing; con }\end{array}$ & $\begin{array}{l}\text { Irrit ojos, piel, nariz, garganta; } \\
\text { sens resp, tos, secreciones } \\
\text { pulm, dolor torácico, dis; } \\
\text { asma; lesiones en ojos y piel; } \\
\text { en animales: edema pulm }\end{array}$ \\
\hline $\begin{array}{l}\text { METILEN BISFENIL ISOCIANATO } \\
\quad 101-68-8\end{array}$ & $\begin{array}{l}\text { ojos; piel; } \\
\text { tract resp; } \\
\text { pulmones }\end{array}$ & piel & $\begin{array}{r}\text { Inhalación } \\
\text { Piel } \\
\text { 0jos }\end{array}$ & $\begin{array}{l}\text { Cefalea, náuseas, disnea, dolor de garganta } \\
\text { Enrojecimiento } \\
\text { Dolor, posibles lesiones de la córnea }\end{array}$ & $\begin{array}{l}\text { Sis resp; ojos } \\
\text { Inh; ing; con }\end{array}$ & $\begin{array}{l}\text { Irrit ojos, nariz, garganta; sens } \\
\text { resp, tos, secreciones pulm, } \\
\text { dolor torácico, dis; asma }\end{array}$ \\
\hline $\begin{array}{l}\text { 1,5-NAFTILENO-DIISOCIANATO } \\
3173-72-6\end{array}$ & ojos; piel; tract resp & piel; pulmones & $\begin{array}{r}\text { Inhalación } \\
\text { Piel } \\
\text { 0jos } \\
\end{array}$ & $\begin{array}{l}\text { Tos, dificultad respiratoria, dolor de garganta } \\
\text { Enrojecimiento, dolor } \\
\text { Enrojecimiento, dolor }\end{array}$ & $\begin{array}{l}\text { Ojos, sis resp } \\
\text { Inh; ing; con }\end{array}$ & $\begin{array}{l}\text { Irrit ojos, nariz, garganta; sens } \\
\text { resp, tos, secreciones pulm, } \\
\text { dolor torácico, dis; asma }\end{array}$ \\
\hline $\begin{array}{l}\text { TOLUENO-2,4-DIISOCIANATO } \\
584-84-9\end{array}$ & $\begin{array}{l}\text { ojos; piel; } \\
\text { tract resp; nariz }\end{array}$ & piel; pulmones & & & $\begin{array}{l}\text { Ojos; sis resp; piel } \\
\text { Inh; ing; con }\end{array}$ & $\begin{array}{l}\text { Irrit ojos, piel, nariz, garganta; } \\
\text { ahogo, tos paroxísmica; dolor } \\
\text { torácico, dolor retroest; náu, } \\
\text { vómit, dolor abdom; } \\
\text { broncoespasmo, edema pulm; } \\
\text { dis, asma; conj, lag; derm, } \\
\text { sens cutánea; [carc] }\end{array}$ \\
\hline
\end{tabular}




\begin{tabular}{|c|c|c|c|}
\hline $\begin{array}{l}\text { Denominación química } \\
\mathrm{N} \text { úmero CAS }\end{array}$ & Físicos & Q uímicos & $\begin{array}{l}\text { Clase o división } \\
\text { UN / Riesgos } \\
\text { subsidiarios }\end{array}$ \\
\hline $\begin{array}{l}\text { CICLOHEXIL ISOCIANATO } \\
\text { 3173-53-3125 }\end{array}$ & $\begin{array}{l}\text { El vapor es más pesado } \\
\text { que el aire y puede } \\
\text { desplazarse a ras del } \\
\text { suelo; posibilidad de } \\
\text { ignición a distancia }\end{array}$ & $\begin{array}{l}\text { Puede polimerizarse al calentarsae o por influencia de materiales incompatibles Se } \\
\text { descompone al arder liberando humos tóxicos (óxidos de nitrógeno) Reacciona con oxidantes y } \\
\text { bases fuertes, agua, alcohol, ácidos y aminas }\end{array}$ & 6.1 \\
\hline $\begin{array}{l}\text { ETLL ISOCIANATO } \\
109-90-0 \\
\end{array}$ & & & $3 / 6.1$ \\
\hline $\begin{array}{l}\text { FENIL ISOCIANATO } \\
103-71.9\end{array}$ & & & 6.1 \\
\hline $\begin{array}{l}\text { HEXAMETILENO-DIISOCIANATO } \\
822.06 .0\end{array}$ & & $\begin{array}{l}\text { Se polimeriza por influencia de temperaturas superiores a } 93^{\circ} \mathrm{C} \text { En su combustión libera } \\
\text { humos tóxicos y corrosivos, entre ellos óxidos de nitrógeno y cianuro de hidrógeno Se } \\
\text { descompone en contacto con el agua para formar aminas y poliureas Reacciona violentamente } \\
\text { con ácidos, alcoholes, aminas, bases y oxidantes, con peligro de incendio y explosión Ataca el } \\
\text { cobre }\end{array}$ & 6.1 \\
\hline $\begin{array}{l}\text { ISOFORONA DIISOCIANATO } \\
\text { 4098-71-9 }\end{array}$ & & $\begin{array}{l}\text { Se descompone al calentarse liberando humos tóxicos (óxidos de nitrógeno) Reacciona con } \\
\text { oxidantes, ácidos, alcoholes, aminas, amidas, mercaptanos Ataca muchos metales, plásticos y } \\
\text { caucho }\end{array}$ & 6.1 \\
\hline $\begin{array}{l}\text { METLL ISOCIANATO } \\
624-83-9\end{array}$ & $\begin{array}{l}\text { El vapor es más pesado } \\
\text { que el aire y puede } \\
\text { desplazarse a ras del } \\
\text { suelo; posibilidad de } \\
\text { ignición a distancia El } \\
\text { vapor se mezcla bien con } \\
\text { el aire y se forman } \\
\text { fácilmente mezclas } \\
\text { explosivas }\end{array}$ & $\begin{array}{l}\text { Puede polimerizarse al calentarse o por influencia de agua y catalizadores Se descompone al } \\
\text { calentarse liberando gases tóxicos (cianuro de hidrógeno, óxidos de nitrógeno, monóxido de } \\
\text { carbono) Reacciona con oxidantes fuertes Reacciona violentamente con agua, ácidos, } \\
\text { alcoholes, aminas, hierro, acero, zinc, estaño, cobre ( } 0 \text { aleaciones de estos metales), con peligro } \\
\text { de incendio y explosión Ataca ciertos tipos de plásticos, caucho y revestimientos }\end{array}$ & $6.1 / 3$ \\
\hline $\begin{array}{l}\text { METILEN BISFENIL ISOCIANATO } \\
\text { 101-68-8 }\end{array}$ & & $\begin{array}{l}\text { Puede polimerizarse cuando se calienta por encima de } 204^{\circ} \mathrm{C} \text { o por influencia de temperaturas } \\
\text { superiores a } 204^{\circ} \mathrm{C} \text { En su combustión libera humos tóxicos y corrosivos, entre ellos óxidos de } \\
\text { nitrógeno y cianuro de hidrógeno Reacciona fácilmente con agua para formar poliureas } \\
\text { insolubles Reacciona violentamente con ácidos, alcoholes, aminas, bases y oxidantes, con } \\
\text { peligro de incendio y explosión }\end{array}$ & 6.1 \\
\hline $\begin{array}{l}\text { 1,5-NAFTILENO-DIISOCIANATO } \\
\text { 3173-72-6 }\end{array}$ & & Se descompone con el calor produciendo humos tóxicos (óxidos de nitrógeno) & \\
\hline $\begin{array}{l}\text { TOLUENO-DIISOCIANATO } \\
26471-62-5\end{array}$ & & & 6.1 \\
\hline $\begin{array}{l}\text { TOLUENO-2,4-DIISOCIANATO } \\
584-84-9\end{array}$ & & & 6.1 \\
\hline $\begin{array}{l}\text { TOLUENO-2,6-DIISOCIANATO } \\
91-08-7\end{array}$ & & & 6.1 \\
\hline
\end{tabular}


Tabla 104.120 • Propiedades físicas y químicas.

\begin{tabular}{|c|c|c|c|c|c|c|c|c|c|c|c|}
\hline $\begin{array}{l}\text { Denominación química } \\
\mathrm{N} \text { úmero } \mathrm{CAS}\end{array}$ & Color/ Forma & $\begin{array}{l}\text { p.e. } \\
(\stackrel{\circ}{ } C)\end{array}$ & $\begin{array}{l}\text { p.f. } \\
(\stackrel{\circ}{ } C)\end{array}$ & $\begin{array}{l}\text { p.m.l } \\
\text { (g/ } \\
\text { mol) }\end{array}$ & $\begin{array}{l}\text { Solubilidad } \\
\text { en agua }\end{array}$ & $\begin{array}{l}\text { Densidad } \\
\text { relativa } \\
\text { (agua }=1 \text { ) }\end{array}$ & $\begin{array}{l}\text { Densidad } \\
\text { relativa } \\
\text { del vapor } \\
\text { (aire=1) }\end{array}$ & $\begin{array}{l}\text { Pvap/ } \\
(\mathrm{kPa})\end{array}$ & $\begin{array}{l}\text { Límit. } \\
\text { inflam. }\end{array}$ & $\begin{array}{l}\text { p.i. } \\
(\stackrel{\circ}{ } \mathrm{C})\end{array}$ & $\begin{array}{l}\text { p. aut } \\
\text { ig. } \\
\left({ }^{\circ} \mathrm{C}\right)\end{array}$ \\
\hline $\begin{array}{l}\text { CICLOHEXIL ISOCIANATO } \\
\text { 3173-53-3 }\end{array}$ & líquido & 168 & & 125,16 & reacciona & 0,98 & 4,3 & & & $48 \mathrm{cc}$ & \\
\hline $\begin{array}{l}\text { DIANISIDINA DIISOCIANATO } \\
91.93 .0\end{array}$ & polvo gris a marrón & & 112 & 296,30 & & & & & & & \\
\hline $\begin{array}{l}\text { ETLL ISOCIANATO } \\
109-90-0 \\
\end{array}$ & & 60 & & 71,1 & insol & 0,9031 & & & & & \\
\hline $\begin{array}{l}\text { FENIL ISOCIANATO } \\
103.71-9 \\
\end{array}$ & líquido & $158-168$ & -30 & 119,12 & & $\begin{array}{l}1,0956 @ \\
19,6^{\circ} \mathrm{C} / 4^{\circ} \mathrm{C}\end{array}$ & & & & & \\
\hline $\begin{array}{l}\text { HEXAMETILENO-DIISOCIANATO } \\
822-06-0\end{array}$ & líquido & 255 & .67 & 168,2 & reacciona & 1,0528 & 5,81 & $\begin{array}{l}7 \mathrm{~Pa} \\
@ 25^{\circ} \mathrm{C}\end{array}$ & $\begin{array}{l}0,9 \mathrm{li} \\
9,5 \mathrm{is}\end{array}$ & $140 \mathrm{ca}$ & 454 \\
\hline $\begin{array}{l}\text { ISOFORONA DIISOCIANATO } \\
\text { 4098-71-9 }\end{array}$ & $\begin{array}{l}\text { líquido incoloro } 0 \\
\text { ligeramente amarillo }\end{array}$ & $\begin{array}{l}158 @ 10 \\
\text { torr }\end{array}$ & -60 & 222,32 & reacciona & $1,062 \mathrm{~g} / \mathrm{ml}$ & & $0,04 \mathrm{~Pa}$ & & $\begin{array}{l}155- \\
161\end{array}$ & 430 \\
\hline $\begin{array}{l}\text { METIL ISOCIANATO } \\
624-83.9 \\
\end{array}$ & líquido incoloro & 39,5 & -45 & 57,1 & muy sol & 0,9599 & 1,42 & 46,4 & $\begin{array}{l}5,3 \mathrm{li} \\
26 \mathrm{is} \\
\end{array}$ & $.7 \mathrm{CC}$ & 534 \\
\hline $\begin{array}{l}\text { METILEN BISFENIL ISOCIANATO } \\
\text { 101-68-8 }\end{array}$ & $\begin{array}{l}\text { sólido condensado de } \\
\text { color amarillo claro; } \\
\text { cristales }\end{array}$ & $\begin{array}{l}\text { e } 196 \\
@ 5 \text { mm Hg }\end{array}$ & 37 & 250,27 & $0,2 \mathrm{~g} / 100 \mathrm{ml}$ & $\begin{array}{l}1,197 \\
@ 70^{\circ} \mathrm{C}\end{array}$ & 8,6 & & & $196 c c$ & 240 \\
\hline $\begin{array}{l}\text { 1,5-NAFTILENO-DIISOCIANATO } \\
3173-72-6\end{array}$ & cristales & & 130 & 210,19 & & & & & & & \\
\hline $\begin{array}{l}\text { TOLUENO-DIISOCIANATO } \\
26471-62-5\end{array}$ & $\begin{array}{l}\text { líquido transparente } \\
\text { incoloro a amarillo } \\
\text { claro. }\end{array}$ & 251 & $11-14$ & & & $\begin{array}{l}1,22 \mathrm{~g} / \mathrm{ml} \\
@ 25^{\circ} \mathrm{C}\end{array}$ & & 0,01 torr & & & \\
\hline $\begin{array}{l}\text { TOLUENO-2,4-DIISOCIANATO } \\
584-84-9\end{array}$ & $\begin{array}{l}\text { líquido incoloro que } \\
\text { se vuelve amarillento } \\
\text { con el tiempo; } \\
\text { líquido o cristales } \\
\text { transparentes o } \\
\text { ligeramente } \\
\text { amarillos; sólido o } \\
\text { líquido incoloro o } \\
\text { amarillo claro }\end{array}$ & 251 & 20,5 & 174,15 & reacciona & 1,2244 & 6,0 & $1,3 \mathrm{~Pa}$ & $\begin{array}{l}0,9 \mathrm{li} \\
9,5 \mathrm{ls}\end{array}$ & $132 c c$ & 620 \\
\hline $\begin{array}{l}\text { TOLUENO-2,6-DIISOCIANATO } \\
91-08-7\end{array}$ & & $\begin{array}{l}129-133 \\
@ 18 \mathrm{~mm} \mathrm{Hg}\end{array}$ & & & & & & & & & \\
\hline
\end{tabular}




\section{CetONAS}

La estructura química de las cetonas se caracteriza por la presencia de un grupo carbonilo $(-\mathrm{C}=0)$ unido a dos átomos de carbono. Las cetonas están representadas por la fórmula general $\mathrm{R}-\mathrm{CO}-\mathrm{R}^{\prime}$, donde $\mathrm{R}$ y $\mathrm{R}^{\prime}$ son habitualmente grupos alquilos 0 arilos. Los diferentes métodos utilizados para obtener estos compuestos son muy parecidos, al igual que lo son sus propiedades biológicas y químicas.

\section{Usos}

Las cetonas se obtienen mediante deshidrogenación catalítica u oxidación de alcoholes secundarios. En la industria petroquímica suelen obtenerse mediante hidratación de olefinas. Se utilizan principalmente como disolventes industriales de colorantes, resinas, gomas, breas, lacas, ceras y grasas. Actúan también como productos intermedios en síntesis químicas y como disolventes en la extracción de aceites lubricantes. Las cetonas se utilizan como disolventes en la producción de plásticos, seda artificial, explosivos, cosméticos, perfumes y productos farmacéuticos.

El disolvente acetona se utiliza en la producción de pinturas, lacas y barnices, caucho, plásticos, colorantes y explosivos, así como en la industria fotográfica. Se emplea también en la producción de aceites lubricantes y en la fabricación de seda artificial y cuero sintético. En la industria química, la acetona es un productos químico intermedio en la producción de numerosas sustancias químicas, como las cetenas, anhídrido acético, metiln-butilcetona, isoforona, cloroformo, yodoformo y vitamina C.

El principal uso de la metiletilcetona (M EK ) es en la aplicación de adhesivos y revestimientos protectores, lo que refleja sus excelentes características como disolvente. Se utiliza también como disolvente en la producción de cintas magnéticas, el desparafinado de aceites lubricantes y el procesamiento de alimentos. Es un componente habitual de barnices y colas, así como de muchas mezclas de disolventes orgánicos.

EI óxido de mesitilo, la metilbutilcetona (M BK) y la metilisobutilcetona (MIBK) se utilizan como disolventes en la producción de pinturas, barnices y lacas. La 4-metil-3-penten-2-ona es un componente de los decapantes de pinturas y barnices y un disolvente de lacas, tintas y esmaltes. Se utiliza también como repelente de insectos, disolvente de resinas y gomas de nitrocelulosa-vinilo, producto químico intermedio en la preparación de metilisobutilcetona y un agente aromatizante. La metilbutilcetona es un disolvente evaporador del medio para los revestimientos de acrilatos y alquilos de nitrocelulosa. La metilisobutilcetona es un desnaturalizante del alcohol etílico y un disolvente de nitrocelulosa, lacas y barnices y revestimientos protectores. Se utiliza en la fabricación del alcohol metilamilo, en la extracción de uranio a partir de productos de fisión y en el desparafinado de aceites minerales.

L as cetonas halogenadas se utilizan en gases lacrimógenos. La cloroacetona, obtenida por cloración de la acetona, se emplea también como pesticida y en acopladores para la fotografía en color. La bromoacetona, obtenida por tratamiento de la acetona acuosa con bromo y clorato sódico a una temperatura de entre 30 y $40 \stackrel{\circ}{ } \mathrm{C}$, se utiliza en síntesis orgánica. Las cetonas alicíclicas como la ciclohexanona y la isoforona sirven como disolventes para diversos compuestos, entre ellos resinas y nitrocelulosa. A demás, la ciclohexanona es un producto químico intermedio en la fabricación de ácido adípico para nylon. Las cetonas aromáticas como la acetofenona y la benzoquinona son disolventes y productos químicos intermedios. La acetofenona se utiliza como fragancia en perfumes, jabones y cremas, y como agente aromatizante en alimentos, bebidas no alcohólicas y tabaco. La benzoquinona sirve como acelerante del caucho, agente de curtido en la industria del cuero y agente oxidante en la industria fotográfica.

\section{Riesgos}

L as cetonas son sustancias inflamables y las más volátiles de ellas pueden liberar vapores en cantidad suficiente, a temperatura ambiente, como para formar mezclas explosivas con el aire. Aunque la principal vía de absorción durante las exposiciones profesionales es la vía respiratoria, algunas cetonas se absorben fácilmente a través de la piel intacta. Por regla general, las cetonas se excretan con rapidez, en su mayor parte con el aire espirado. Su metabolismo suele realizarse mediante hidroxilación oxidativa, seguida de reducción a alcohol secundario. L as cetonas poseen propiedades narcóticas cuando se inhalan en grandes concentraciones. A concentraciones más bajas pueden provocar náuseas y vómitos y son irritantes para los ojos y el sistema respiratorio. L os umbrales de percepción son incluso más bajos. Estos efectos fisiológicos tienden a potenciarse en las cetonas insaturadas y en las más altas de la serie.

Además de deprimir el sistema nervioso central (SNC), la exposición excesiva a cetonas puede también producir efectos en el sistema nervioso periférico, tanto sensoriales como motores. Causa asimismo una irritación moderada de la piel, siendo probablemente la metil-n-amil cetona la más irritante de todas.

A cetona. Es muy volátil y puede inhalarse en grandes cantidades cuando se encuentra en altas concentraciones. Pasa a la sangre a través de los pulmones y se difunde por todo el organismo. T ambién se pueden absorber pequeñas cantidades a través de la piel.

Los síntomas típicos que aparecen después de la exposición a acetona consisten en narcosis, ligera irritación de la piel e irritación más pronunciada de las mucosas. La exposición a altas concentraciones produce una sensación de malestar, seguida de colapso progresivo acompañado de estupor, respiración irregular $y$, finalmente, coma. También pueden aparecer náuseas y vómitos, seguidos en ocasiones por hematemesis. En algunos casos, la presencia de albúmina, hematíes y leucocitos en la orina indica la posibilidad de lesiones renales. Cuando se encuentran niveles altos de urobilina y aparición precoz de bilirrubina, debe pensarse en la posibilidad de alteraciones hepáticas. Cuanto más larga es la exposición, más disminuye la frecuencia respiratoria y el pulso. Estos cambios son más o menos proporcionales a la concentración de acetona. Los casos de intoxicación crónica producidos por la exposición prolongada a pequeñas concentraciones de acetona son poco frecuentes; no obstante, en algunos casos de exposición repetida a pequeñas concentraciones, los individuos se quejaron de cefalea, sopor, vértigo, irritación de garganta y tos.

1-B romo-2-propanona (bromoacetona). Es tóxica y muy irritante para la piel y las mucosas. Debe almacenarse en una zona ventilada $y$, siempre que sea posible, manipularse en sistemas cerrados. Los recipientes deben mantenerse cerrados y debidamente etiquetados. Los trabajadores potencialmente expuestos a sus vapores deben utilizar gafas de seguridad química herméticas a los gases y equipos de protección respiratoria. En algunos países, esta sustancia se clasifica como un residuo peligroso, exigiendo por tanto unos requisitos especiales para su manipulación. 
2-Cloroacetofenona. Es muy irritante para los ojos y provoca lagrimeo. La exposición aguda puede producir lesiones permanentes en la córnea. La irritación parece ser el principal efecto de este compuesto químico. Al calentarse se descompone liberando humos tóxicos

Ciclohexanona. La exposición de animales de experimentación a altas dosis de ciclohexanona produjo cambios degenerativos en el hígado, los riñones y el músculo cardíaco; la aplicación repetida sobre la piel produjo cataratas. La ciclohexanona resultó ser también embriotóxica para los huevos de pollo. No obstante, en las personas expuestas a concentraciones mucho menores, su principal efecto parece ser una irritación moderada.

1-Cloro-2-propanona (cloroacetona). Es un líquido cuyo vapor produce un intenso lagrimeo, así como irritación de la piel y el tracto respiratorio. Sus efectos como irritante ocular y lacrimógeno son tan intensos que se ha utilizado como gas bélico. U na concentración de $0,018 \mathrm{mg} / \mathrm{l}$ es suficiente para producir lagrimeo y una concentración de 0,11 mg/ I no puede, en general, soportarse durante más de 1 min. En su manipulación y almacenamiento deben tomarse las mismas precauciones que con el cloro.

Diacetona. Tiene propiedades irritantes para los ojos y las vías aéreas superiores; a concentraciones mayores produce excitación y somnolencia. La exposición prolongada puede causar lesiones renales y hepáticas, así como cambios hematológicos.

$\mathrm{H}$ exafluoroacetona [CAS 684-16-2]. Es un gas muy irritante, especialmente para los ojos. La exposición a concentraciones relativamente altas causa trastornos respiratorios y hemorragia en la conjuntiva. Una serie de estudios experimentales han demostrado sus efectos adversos en el sistema reproductor masculino, entre ellos una alteración de la espermatogénesis. Se han observado también cambios en el hígado, los riñones y el sistema linfopoyético. Las propiedades irritantes de esta sustancia exigen la adopción de precauciones especiales durante su manipulación.

I soforona. Además de producir una intensa irritación de los ojos, la nariz y las mucosas, este compuesto químico puede afectar al sistema nervioso central y hacer que la persona expuesta sufra una sensación de ahogo. Los otros síntomas de su efecto en el SNC son mareo, fatiga y embriaguez. La exposición reiterada en animales de experimentación produjo efectos tóxicos en los pulmones y los riñones; una exposición única a altas dosis causó narcosis y parálisis del centro respiratorio.

0 xido de mesitilo. Es un potente irritante, tanto por contacto con el líquido como con sus vapores y puede causar necrosis de la córnea. Las exposiciones cortas producen efectos narcóticos, mientras que las exposiciones prolongadas o repetidas pueden causar lesiones en el hígado, los riñones y los pulmones. Se absorbe fácilmente a través de la piel intacta.

M etilamilcetona. Es irritante para la piel y produce narcosis a altas concentraciones, pero no parece ser neurotóxica.
M etilbutilcetona (M BK). En una fábrica de tejidos estampados, varios casos de neuropatía periférica fueron atribuidos a la exposición a este disolvente, donde se había sustituido la metil-n-butiIcetona por metilisobutilcetona en las máquinas de estampado antes de detectarse problemas neurológicos. Esta cetona tiene dos metabolitos (5-hidroxi-2-hexanona y 2,5-hexanediona) en común con el n-hexano, que también se considera un agente causante de neuropatías periféricas y que se describe en otros artículos de esta E nciclopedia. Los síntomas de neuropatía periférica consisten en debilidad muscular y hallazgos electromiográficos anormales. L os primeros síntomas de intoxicación pueden ser hormigueo, entumecimiento y debilidad en los pies.

2-M etilciclohexanona. El contacto con esta sustancia produce una intensa irritación de los ojos y la piel; su inhalación irrita las vías aéreas superiores. La exposición reiterada puede causar lesiones en los riñones, el hígado y los pulmones. La metilciclohexanona reacciona violentamente con el ácido nítrico.

M etiletilcetona (M EK ). La exposición breve de los trabajadores a una concentración atmosférica de 500 ppm de MEK provocó naúseas y vómitos; a concentraciones algo menores, los trabajadores experimentaron irritación de la garganta y dolor de cabeza. A concentraciones altas se han descrito casos de afección neurológica, con neuropatía simétrica e indolora, predominio de lesiones sensoriales y posible afectación de los miembros superiores 0 inferiores. En algunos casos se han visto afectados los dedos de la mano por inmersión de la mano desnuda en el líquido. Se han descrito también casos de dermatitis, tanto por inmersión en el líquido como por exposición a vapores concentrados

M eilisobutilcetona (M IBK). Esta sustancia comparte los efectos irritantes y los efectos en el SNC de muchas otras cetonas. La exposición a altas concentraciones produce vértigo, cefalea y fatiga.

\section{Medidas de salud y seguridad}

Deben adoptarse las medidas recomendadas para las sustancias inflamables. Los métodoss de trabajo y las técnicas de higiene industrial pueden reducir la volatilización de las cetonas en la atmósfera del lugar de trabajo de manera que no se sobrepasen los límites de exposición.

Además, en la medida de lo posible, se sustituirán las cetonas con propiedades neurotóxicas (como la metiletilcetona y la metil-n-butilcetona) por productos menos tóxicos. Se recomienda realizar un reconocimiento médico previo al empleo, así como exámenes periódicos a partir de entonces, con especial atención al SN C y al sistema nervioso periférico, el sistema respiratorio, los ojos, los riñones y la función hepatica. La exploración electrodiagnóstica mediante electromiografía y determinación de la velocidad de conducción nerviosa está especialmente indicada en los trabajadores expuestos a metil-n-butilcetona. 
TABLAS DE CETONAS

\begin{tabular}{|c|c|c|c|}
\hline Producto químico & Sinónimos/Código UN & $\mathrm{N}$ úmero $\mathrm{CAS}$ & Fórmula estructural \\
\hline ACETILBROMURO & $\begin{array}{l}\text { Acido acético, bromuro; etanoilbromuro } \\
\text { UN1716 }\end{array}$ & $506-96-7$ & \\
\hline ACETILCLORURO & $\begin{array}{l}\text { Acido acético, cloruro; cloruro acético; etanoilcloruro } \\
\text { UN1717 }\end{array}$ & $75-36-5$ & \\
\hline ACETOFENONA & $\begin{array}{l}\text { Acetilbenceno; benzoil metilo; Dymex; etanona, hipnona; Hipnona; } \\
\text { metilfenilcetona; 1-feniletanona; fenilmetilcetona }\end{array}$ & $98-86-2$ & \\
\hline ACETONA & $\begin{array}{l}\text { Dimetilformaldehído; dimetilcetona; cetona propano; metilcetona; } \\
\text { propanona; 2-propanona } \\
\text { UN1090; UN1091 }\end{array}$ & $67-64-1$ & \\
\hline BENZOFENONA & $\begin{array}{l}\text { Benzoilbenceno; difenilcetona; difenilmetanona; cetona, difenil; } \\
\alpha \text {-oxodifenilmetano; } \alpha \text {-0xoditano; fenilcetona }\end{array}$ & $119-61-9$ & \\
\hline p-BENZOQUINONA & $\begin{array}{l}\text { 1,4-Benzoquinona; benzoquinona; ciclohexadiendiona; } \\
\text { 1,4-ciclohexadiendiona; 2,5-ciclohexadieno-1,4-diona; dióxido de } \\
\text { 1,4-ciclohexadieno; 1,4-dioxibenceno } \\
\text { UN2587 }\end{array}$ & $106-51-4$ & \\
\hline 1-BROMO-2.PROPANONA & $\begin{array}{l}\text { Acetonilbromuro; acetilmetilbromuro; bromometilmetilcetona; } \\
\text { bromo-2-propanona; bromoacetona } \\
\text { UN1569 }\end{array}$ & $598-31-2$ & \\
\hline CETENA & Carbometeno; etenona; cetoetileno & $463-51-4$ & $C=0$ \\
\hline CICLOHEXANONA & $\begin{array}{l}\text { Ciclohexilcetona; Hytrol 0; cetohexametileno; Nadone } \\
\text { UN1915 }\end{array}$ & 108-94-1 & \\
\hline CICLOPENTANONA & $\begin{array}{l}\text { Cetona adípica; Dumasin; cetociclopentano; cetopentametileno } \\
\text { UN2245 }\end{array}$ & $120-92-3$ & \\
\hline 2-CLOROACETOFENONA & $\begin{array}{l}\text { Q-Cloroacetofenona; 1-cloroacetofenona; clorometilfenilcetona } \\
\text { UN1679 }\end{array}$ & $532-27-4$ & \\
\hline 1-CLORO-2-PROPANONA & $\begin{array}{l}\text { Acetonilcloruro; cloroacetona; 1-cloro-2-cetopropano; 1-cloro-2-0xopropano; } \\
\text { cloropropanona; monocloroacetona } \\
\text { UN1695 }\end{array}$ & $78-95-5$ & \\
\hline CLORURO CLOROACETICO & $\begin{array}{l}\text { Cloruro del ácido cloroacético; monocloroacetilloruro } \\
\text { UN1752 }\end{array}$ & $79-04-9$ & \\
\hline DIACETONA & $\begin{array}{l}\text { Alcohol de diacetona; alcohol de dicetona; 4-hidroxi-4-metil-2-pentanona } \\
\text { UN1148 }\end{array}$ & $123-42-2$ & \\
\hline
\end{tabular}




\begin{tabular}{|c|c|c|c|}
\hline Producto químico & Sinónimos/Código UN & $\mathrm{N}$ úmero $\mathrm{CAS}$ & Fórmula estructural \\
\hline DICETENA & $\begin{array}{l}\text { 3-Buteno-beta-lactona; dicetena, dímero; 4-metilen-2-oxetanona; 4-metilen } \\
\text { 2-oxetanona; 4-metileno; 4-metoxi-4-metil-2-pentanona } \\
\text { UN2521 }\end{array}$ & $674-82-8$ & \\
\hline DICLOROACETILCLORURO & $\begin{array}{l}\alpha, \alpha \text {-Dicloroacetilcloruro; 2,2-dicloroacetilcloruro; dicloroetanoilcloruro } \\
\text { UN1765 }\end{array}$ & $79-36-7$ & \\
\hline DIETILCETONA & $\begin{array}{l}\text { DEK; 3-pentanona; dimetilacetona; metacetona; propiona } \\
\text { UN1156 }\end{array}$ & $96-22-0$ & \\
\hline 2,6-DIMETIL-4-HEPTANONA & $\begin{array}{l}\text { Diisobutilcetona; sim-diisopropilacetona; isobutil cetona; isovalerona; } \\
\text { valerona } \\
\text { UN1157 }\end{array}$ & $108-83-8$ & \\
\hline DIPROPILCETONA & $\begin{array}{l}\text { Butirona; GBL; 4-heptanona; heptan-4-ona; propilcetona } \\
\text { UN2710 }\end{array}$ & $123 \cdot 19-3$ & \\
\hline ETILAMILCETONA & $\begin{array}{l}\text { 3-Octanona; amiletilcetona; EAK } \\
\text { UN2271 }\end{array}$ & $106-68-3$ & \\
\hline ETILBUTILCETONA & n-Etilbutilcetona, 3-heptanona & $106-35-4$ & \\
\hline 2,5-HEXANODIONA & $\begin{array}{l}\text { Acetona, acetonil-; acetonilacetona; diacetonil; } \alpha, \beta \text {-diacetiletano; } \\
\text { 1,2-diacetiletano; } 2,5 \text {-dicetohexano }\end{array}$ & $110-13-4$ & \\
\hline ISOFORONA & $\begin{array}{l}\text { Isoacetoforona; 1,1,3-trimetil-3-ciclohexen-5-ona; } \\
\text { 3,5,5-trimetil-2-ciclohexen-1-ona; 3,3,5-trimetil-5-ciclohexen-1-ona }\end{array}$ & $78-59-1$ & \\
\hline METILAMILCETONA & $\begin{array}{l}\text { Amilmetilcetona; 2-heptanona; n-amilmetilcetona; metilpentilcetona } \\
\text { UN1110 }\end{array}$ & $110-43-0$ & \\
\hline METILBUTILCETONA & 2-Hexanona; butilmetilcetona, 2-oxohexano; MBK & $591-78-6$ & \\
\hline 2-METILCICLOHEXANONA & o-Metilciclohexanona & $583-60-8$ & \\
\hline METIL ETIL CETONA & $\begin{array}{l}\text { 2-Butanona; butanona; 3-butanona; MEK; metilacetona; etilmetilcetona } \\
\text { UN1193 }\end{array}$ & $78-93-3$ & \\
\hline 5-METIL-3-HEPTANONA & Etil-sec-amilcetona; etilamilcetona; 3-metil-5-heptanona & $541-85-5$ & \\
\hline
\end{tabular}




\begin{tabular}{|c|c|c|c|}
\hline Producto químico & Sinónimos/ Código UN & $\mathrm{N}$ úmero CAS & Fórmula estructural \\
\hline 5-METLL-2-HEXANONA & $\begin{array}{l}\text { Isoamilmetilcetona; isopentilmetilcetona; 2-metil-5-hexanona; } \\
\text { metilisoamilcetona; MIAK } \\
\text { UN2302 }\end{array}$ & $110-12-3$ & \\
\hline METILISOBUTILCETONA & $\begin{array}{l}\text { Hexona; isopropilacetona; 2-pentanona, 4-metil-; 2-metil-4-pentanona; } \\
\text { 4-metil-2-pentanona; MIBK; MIK } \\
\text { UN1245 }\end{array}$ & 108-10-1 & \\
\hline METILISOPROPILCETONA & $\begin{array}{l}\text { 2-Acetilpropano; 3-metil-2-butanona; metilisopropilcetona; MIPK } \\
\text { UN2397 }\end{array}$ & $563-80-4$ & \\
\hline METILPROPILCETONA & Etilacetona; metil-N-propilcetona; 2-pentanona & 107-87-9 & \\
\hline METILVINILCETONA & $\begin{array}{l}\text { Acetona, metileno; acetiletileno; 3-buten-2-ona; butenona; } \\
\text { metilvinilcetona } \\
\text { UN1251 }\end{array}$ & $78-94-4$ & \\
\hline 4-METOXI-4-METIL-2-PENTANONA & UN2293 & $107-70-0$ & \\
\hline OXIDO DE MESITILO & $\begin{array}{l}\text { Acetona, isopropilideno; isobutenilmetilcetona; isopropiliden acetona; } \\
\text { 4-metil-3-penten-2-ona } \\
\text { UN1229 }\end{array}$ & $141-79-7$ & \\
\hline OXIMOCICLOHEXANONA & (Hidroximino) ciclohexano & $100-64-1$ & \\
\hline 2,4-PENTANODIONA & $\begin{array}{l}\text { Acetoacetona; acetilacetona; acetil-2-propanona; diacetilmetano; } \\
\text { pentanodiona } \\
\text { UN2310 }\end{array}$ & $123-54-6$ & \\
\hline
\end{tabular}




\begin{tabular}{|c|c|c|c|c|c|c|}
\hline \multirow[b]{2}{*}{$\begin{array}{l}\text { Denominación } \\
\text { química } \\
\text { N úmero CAS }\end{array}$} & \multicolumn{4}{|c|}{ Tarjetas Internacionales sobre la Seguridad de los Productos Q uímicos } & \multicolumn{2}{|c|}{ N IOSH (EE.UU.) } \\
\hline & $\begin{array}{l}\text { Período } \\
\text { corto de } \\
\text { exposición }\end{array}$ & $\begin{array}{l}\text { Período } \\
\text { largo de } \\
\text { exposición }\end{array}$ & $\begin{array}{l}\text { Vías de } \\
\text { exposición }\end{array}$ & Síntomas & $\begin{array}{l}\text { O rganos } \\
\text { afectados } \\
\text { Vías de } \\
\text { entrada }\end{array}$ & Síntomas \\
\hline $\begin{array}{l}\text { ACETILBROMURO } \\
506-96-7\end{array}$ & tract resp; piel & & $\begin{array}{r}\text { Inhalación } \\
\text { Piel } \\
\text { 0jos } \\
\text { Ingestión }\end{array}$ & $\begin{array}{l}\text { Tos, dolor de garganta, dificultad respiratoria, } \\
\text { disnea, síntomas de efectos diferidos } \\
\text { Enrojecimiento, dolor, quemaduras en la piel } \\
\text { Dolor, enrojecimiento, visión borrosa, } \\
\text { quemaduras profundas graves } \\
\text { Sensación de quemazón, espasmos } \\
\text { abdominales, vómitos }\end{array}$ & & \\
\hline $\begin{array}{l}\text { ACETONA } \\
67-64-1\end{array}$ & $\begin{array}{l}\text { ojos; tract resp; } \\
\text { SNC; hígado; } \\
\text { riñones; estómago }\end{array}$ & $\begin{array}{l}\text { piel; SNC; células } \\
\text { sanguíneas }\end{array}$ & $\begin{array}{r}\text { Inhalación } \\
\text { Piel } \\
\text { 0jos } \\
\text { Ingestión }\end{array}$ & $\begin{array}{l}\text { Salivación, confusión, tos, mareo, sopor, } \\
\text { cefalea, cabeza congestionada, dolor de } \\
\text { garganta, inconsciencia } \\
\text { Enrojecimiento } \\
\text { Enrojecimiento, dolor, visión borrosa, posibles } \\
\text { lesiones en la córnea } \\
\text { Náuseas, vómitos }\end{array}$ & $\begin{array}{l}\text { Sis resp; piel; 0jos; } \\
\text { SNC } \\
\text { Inh; ing; con }\end{array}$ & $\begin{array}{l}\text { Irrit ojos, nariz, garganta; cef, } \\
\text { mar, depres SNC; derm }\end{array}$ \\
\hline $\begin{array}{l}\text { BENZOFENONA } \\
119.61-9\end{array}$ & $\begin{array}{l}\text { ojos; piel; } \\
\text { tract resp; SNC }\end{array}$ & & $\begin{array}{r}\text { Inhalación } \\
\text { Piel } \\
\text { 0jos } \\
\end{array}$ & $\begin{array}{l}\text { Dolor de garganta } \\
\text { Enrojecimiento } \\
\text { Enrojecimiento }\end{array}$ & & \\
\hline $\begin{array}{l}\text { p-BENZOQUINONA } \\
106-51-4\end{array}$ & $\begin{array}{l}\text { ojos; piel; } \\
\text { tract resp; SNC; } \\
\text { hígado; riñones }\end{array}$ & $\begin{array}{l}\text { piel; tract resp; } \\
\text { hígado; riñones }\end{array}$ & $\begin{array}{r}\text { Inhalación } \\
\text { Piel } \\
\text { 0jos } \\
\text { Ingestión }\end{array}$ & $\begin{array}{l}\text { Sensación de quemazón, tos, hemorragias } \\
\text { nasales, dificultad respiratoria, disnea, dolor } \\
\text { de garganta } \\
\text { Puede absorberse; enrojecimiento, dolor, } \\
\text { manchas marrones, ampollas } \\
\text { Enrojecimiento, dolor, pérdida de visión, } \\
\text { manchas marrones } \\
\text { Dolor abdominal, sensación de quemazón, } \\
\text { diarrea, vómitos, muerte }\end{array}$ & $\begin{array}{l}\text { Ojos; piel } \\
\text { Inh; ing; con }\end{array}$ & Irrit ojos; conj; quera; irrit piel \\
\hline $\begin{array}{l}\text { CETENA } \\
\quad 463-51-4\end{array}$ & & & $\begin{array}{r}\text { Inhalación } \\
\text { Piel } \\
\text { 0jos }\end{array}$ & $\begin{array}{l}\text { Tos, disnea } \\
\text { Enrojecimiento } \\
\text { Enrojecimiento }\end{array}$ & $\begin{array}{l}\text { Ojos, piel, sis resp } \\
\text { Inh; con }\end{array}$ & $\begin{array}{l}\text { Irrit ojos, piel, nariz, garganta, } \\
\text { sis resp; edema pulm }\end{array}$ \\
\hline $\begin{array}{l}\text { CICLOHEXANONA } \\
108-94-1\end{array}$ & ojos; tract resp; piel & & $\begin{array}{r}\text { Inhalación } \\
\text { Piel } \\
\text { 0jos } \\
\text { Ingestión }\end{array}$ & $\begin{array}{l}\text { Tos, mareo, sopor, embotamiento, dolor de } \\
\text { garganta, inconsciencia } \\
\text { Puede absorberse, sequedad de piel, } \\
\text { enrojecimiento } \\
\text { Lagrimeo, enrojecimiento, dolor, opacidad de } \\
\text { la córnea } \\
\text { Dolor abdominal, sensación de quemazón, } \\
\text { sopor, embotamiento, inconsciencia }\end{array}$ & $\begin{array}{l}\text { Ojos; piel; sis resp; } \\
\text { SNC; hígado; } \\
\text { riñones }\end{array}$ & $\begin{array}{l}\text { Irrit ojos; piel; muc; cef; narco; } \\
\text { coma; derm; en animales: } \\
\text { lesiones hepáticas y renales }\end{array}$ \\
\hline $\begin{array}{l}\text { CICLOPENTANONA } \\
120-92-3\end{array}$ & ojos; piel; tract resp & piel & $\begin{array}{r}\text { Inhalación } \\
\text { Piel } \\
\text { 0jos }\end{array}$ & $\begin{array}{l}\text { Tos, dolor de garganta } \\
\text { Enrojecimiento } \\
\text { Enrojecimiento, dolor }\end{array}$ & & \\
\hline $\begin{array}{l}\text { 2-CLOROACETOFENONA } \\
532-27-4\end{array}$ & $\begin{array}{l}\text { ojos; piel; } \\
\text { tract resp; SNC }\end{array}$ & piel & $\begin{array}{r}\text { Inhalación } \\
\text { Piel } \\
\text { 0jos } \\
\text { Ingestión } \\
\end{array}$ & $\begin{array}{l}\text { Sensación de quemazón en el pecho, tos, } \\
\text { cefalea, dificultad respiratoria, disnea, } \\
\text { vómitos, respiración sibilante } \\
\text { Enrojecimiento, dolor } \\
\text { Enrojecimiento, dolor, visión borrosa, pérdida } \\
\text { parcial permanente de visión } \\
\text { Inconsciencia, pérdida de reflejos }\end{array}$ & $\begin{array}{l}\text { Sis resp; piel; ojos } \\
\text { Inh; ing; con }\end{array}$ & $\begin{array}{l}\text { Irrit ojos, piel, sis resp; edema } \\
\text { pulm }\end{array}$ \\
\hline $\begin{array}{l}\text { 1-CLORO-2.PROPANONA } \\
\text { 78-95-5 }\end{array}$ & $\begin{array}{l}\text { ojos; piel; } \\
\text { tract resp; } \\
\text { pulmones }\end{array}$ & piel & $\begin{array}{r}\text { Inhalación } \\
\text { Piel } \\
\text { 0jos }\end{array}$ & $\begin{array}{l}\text { Tos, sensación de quemazón, dificultad } \\
\text { respiratoria, dolor de garganta } \\
\text { Puede absorberse, enrojecimiento, quemaduras } \\
\text { en la piel, sensación de quemazón, dolor, } \\
\text { efectos diferidos: ampollas } \\
\text { Enrojecimiento, dolor, visión borrosa }\end{array}$ & & \\
\hline
\end{tabular}




\begin{tabular}{|c|c|c|c|c|c|c|}
\hline \multirow[b]{2}{*}{$\begin{array}{l}\text { Denominación } \\
\text { química } \\
\text { N úmero CAS }\end{array}$} & \multicolumn{4}{|c|}{ Tarjetas Internacionales sobre la Seguridad de los Productos Q uímicos } & \multicolumn{2}{|c|}{ N IO SH (EE.UU.) } \\
\hline & $\begin{array}{l}\text { Período } \\
\text { corto de } \\
\text { exposición }\end{array}$ & $\begin{array}{l}\text { Período } \\
\text { largo de } \\
\text { exposición }\end{array}$ & $\begin{array}{l}\text { Vías de } \\
\text { exposición }\end{array}$ & Síntomas & $\begin{array}{l}\text { O rganos } \\
\text { afectados } \\
\text { Vías de } \\
\text { entrada }\end{array}$ & Síntomas \\
\hline $\begin{array}{l}\text { DIACETONA } \\
\quad 123-42-2\end{array}$ & & & & & $\begin{array}{l}\text { Ojos; piel; sis resp; } \\
\text { SNC; hígado } \\
\text { Inh; ing; con }\end{array}$ & $\begin{array}{l}\text { Irrit ojos, piel, nariz, garganta; } \\
\text { lesiones córn; en animales: } \\
\text { narco, lesiones hepáticas }\end{array}$ \\
\hline $\begin{array}{l}\text { DICETENA } \\
\quad 674-82-8\end{array}$ & & & $\begin{array}{r}\text { Inhalación } \\
\text { Piel } \\
\text { Ojos } \\
\text { Ingestión }\end{array}$ & $\begin{array}{l}\text { Tos, cefalea, disnea, mareo, embotamiento } \\
\text { Sequedad de piel, enrojecimiento, dolor } \\
\text { Enrojecimiento, dolor } \\
\text { Espasmos abdominales, mareo, } \\
\text { embotamiento, cefalea }\end{array}$ & & \\
\hline $\begin{array}{l}\text { DICLOROACETILCLORURO } \\
79-36-7\end{array}$ & $\begin{array}{l}\text { ojos; piel; tract } \\
\text { resp superior }\end{array}$ & & $\begin{array}{r}\text { Inhalación } \\
\text { Piel } \\
\text { 0jos } \\
\text { Ingestión }\end{array}$ & $\begin{array}{l}\text { Sensación de quemazón, tos, dificultad } \\
\text { respiratoria } \\
\text { Enrojecimiento, dolor, ampollas } \\
\text { Enrojecimiento, dolor, quemaduras profundas } \\
\text { graves } \\
\text { Espasmos abdominales, sensación de } \\
\text { quemazón, debilidad }\end{array}$ & & \\
\hline $\begin{array}{l}\text { DIETILCETONA } \\
96-22-0\end{array}$ & $\begin{array}{l}\text { ojos; piel; tract } \\
\text { resp; pulmones }\end{array}$ & pulmones & $\begin{array}{r}\text { Inhalación } \\
\text { Piel } \\
\text { 0jos } \\
\end{array}$ & $\begin{array}{l}\text { Tos, disnea } \\
\text { Enrojecimiento } \\
\text { Enrojecimiento }\end{array}$ & $\begin{array}{l}\text { Sis resp; ojos; piel } \\
\text { Inh; ing; con }\end{array}$ & $\begin{array}{l}\text { Irrit ojos, piel, muc, sis resp; } \\
\text { tos, estornudos }\end{array}$ \\
\hline $\begin{array}{l}\text { 2,6-DIMETIL-4-HEPTANONA } \\
\text { 108-83-8 }\end{array}$ & $\begin{array}{l}\text { ojos; tract resp; } \\
\text { pulmones }\end{array}$ & $\begin{array}{l}\text { piel; hígado; } \\
\text { riñones }\end{array}$ & $\begin{array}{r}\text { Inhalación } \\
\text { Piel } \\
\text { 0jos }\end{array}$ & $\begin{array}{l}\text { Cefalea, mareo, náuseas, vómitos, dolor de } \\
\text { garganta } \\
\text { Enrojecimiento, embotamiento } \\
\text { Enrojecimiento }\end{array}$ & $\begin{array}{l}\text { Ojos; piel; sis resp; } \\
\text { SNC; hígado; } \\
\text { riñones } \\
\text { Inh; ing; con }\end{array}$ & $\begin{array}{l}\text { Irrit ojos, piel, nariz, garganta; } \\
\text { cef, mar, derm; lesiones } \\
\text { hepáticas y renales }\end{array}$ \\
\hline $\begin{array}{l}\text { ETILBUTILCETONA } \\
106-35-4\end{array}$ & ojos; piel; tract resp & $\begin{array}{l}\text { piel; hígado; } \\
\text { riñones }\end{array}$ & $\begin{array}{r}\text { Inhalación } \\
\text { Piel } \\
\text { 0jos } \\
\end{array}$ & $\begin{array}{l}\text { Cefalea, mareo, dolor de garganta, } \\
\text { inconsciencia } \\
\text { Enrojecimiento } \\
\text { Enrojecimiento, dolor }\end{array}$ & $\begin{array}{l}\text { Sis resp; ojos; piel; } \\
\text { SNC } \\
\text { Inh; ing; con }\end{array}$ & $\begin{array}{l}\text { Irrit ojos, piel, muc; cef, narco, } \\
\text { coma; derm }\end{array}$ \\
\hline $\begin{array}{l}\text { ISOFORONA } \\
78-59-1\end{array}$ & ojos; piel & piel & & & $\begin{array}{l}\text { Ojos; piel; sis resp; } \\
\text { SNC; hígado; } \\
\text { riñones } \\
\text { Inh; ing; con }\end{array}$ & $\begin{array}{l}\text { Irrit ojos, nariz, garganta; cef, } \\
\text { náu, mar, ftg, mal, narco; } \\
\text { derm; en animales: lesiones } \\
\text { renales y hepáticas }\end{array}$ \\
\hline $\begin{array}{l}\text { METILAMILCETONA } \\
\quad 110-43-0\end{array}$ & & & $\begin{array}{r}\text { Inhalación } \\
\text { 0jos }\end{array}$ & $\begin{array}{l}\text { Cefalea, mareo, visión borrosa, inconsciencia } \\
\text { Enrojecimiento }\end{array}$ & $\begin{array}{l}\text { Ojos; piel; sis resp; } \\
\text { SNC; SNP } \\
\text { Inh; ing; con }\end{array}$ & $\begin{array}{l}\text { Irrit ojos, piel, muc; cef, narco, } \\
\text { coma; derm }\end{array}$ \\
\hline $\begin{array}{l}\text { METILBUTILCETONA } \\
591-78-6\end{array}$ & ojos; piel; tract resp & & $\begin{array}{r}\text { Inhalación } \\
\text { Piel } \\
\text { Ojos } \\
\text { Ingestión }\end{array}$ & $\begin{array}{l}\text { Tos, sopor, cefalea, inconsciencia } \\
\text { Puede absorberse, sequedad de piel, } \\
\text { enrojecimiento } \\
\text { Enrojecimiento, dolor, visión borrosa } \\
\text { Dolor abdominal, diarrea, náuseas, dolor de } \\
\text { garganta }\end{array}$ & & \\
\hline $\begin{array}{l}\text { 2-METILCICLOHEXANONA } \\
\text { 583-60-8 }\end{array}$ & $\begin{array}{l}\text { ojos; piel; } \\
\text { tract resp; SNC }\end{array}$ & piel; SNC & & & $\begin{array}{l}\text { SNC; piel; sis resp; } \\
\text { hígado; riñones } \\
\text { Inh; abs; ing; con }\end{array}$ & $\begin{array}{l}\text { En animales: irrit ojos, muc; } \\
\text { narco; derm }\end{array}$ \\
\hline $\begin{array}{l}\text { METILETLCETONA } \\
78-93-3\end{array}$ & & & & & $\begin{array}{l}\text { Ojos; piel; sis resp; } \\
\text { SNC } \\
\text { Inh; ing; con }\end{array}$ & $\begin{array}{l}\text { Irrit ojos, piel, nariz; cef, mar; } \\
\text { vómit; derm }\end{array}$ \\
\hline $\begin{array}{l}\text { 5-METLL-3-HEPTANONA } \\
\text { 541-85-5 }\end{array}$ & $\begin{array}{l}\text { ojos; piel; } \\
\text { tract resp; } \\
\text { pulmones }\end{array}$ & piel & & & $\begin{array}{l}\text { Ojos; piel; sis resp; } \\
\text { SNC }\end{array}$ & $\begin{array}{l}\text { Irrit ojos, piel, muc; cef, narco, } \\
\text { coma; derm }\end{array}$ \\
\hline
\end{tabular}




\begin{tabular}{|c|c|c|c|c|c|c|}
\hline \multirow[b]{2}{*}{$\begin{array}{l}\text { Denominación } \\
\text { química } \\
\mathrm{N} \text { úmero CAS }\end{array}$} & \multicolumn{4}{|c|}{ Tarjetas Internacionales sobre la Seguridad de los Productos Q uímicos } & \multicolumn{2}{|c|}{ NIOSH (EE.UU.) } \\
\hline & $\begin{array}{l}\text { Período } \\
\text { corto de } \\
\text { exposición }\end{array}$ & $\begin{array}{l}\text { Período } \\
\text { largo de } \\
\text { exposición }\end{array}$ & $\begin{array}{l}\text { Vías de } \\
\text { exposición }\end{array}$ & Síntomas & $\begin{array}{l}\text { O rganos } \\
\text { afectados } \\
\text { Vías de } \\
\text { entrada }\end{array}$ & Síntomas \\
\hline $\begin{array}{l}\text { 5-METIL-2-HEXANONA } \\
\text { 110-12-3 }\end{array}$ & ojos; piel; tract resp & piel; ojos & $\begin{array}{l}\text { Inhalación } \\
\text { Piel } \\
\text { Ojos } \\
\text { Ingestión }\end{array}$ & $\begin{array}{l}\text { Cefalea, mareo, sopor } \\
\text { Enrojecimiento } \\
\text { Enrojecimiento } \\
\text { Náuseas, vómitos }\end{array}$ & $\begin{array}{l}\text { Ojos; piel; sis resp; } \\
\text { SNC; hígado; } \\
\text { riñones } \\
\text { Inh; ing; con }\end{array}$ & $\begin{array}{l}\text { Irrit ojos, piel, muc; cef, narco, } \\
\text { coma; derm; en animales: } \\
\text { lesiones hepáticas y renales }\end{array}$ \\
\hline $\begin{array}{l}\text { METLILSOBUTILCETONA } \\
\text { 108-10-1 }\end{array}$ & $\begin{array}{l}\text { ojos; piel; } \\
\text { tract resp; SNC }\end{array}$ & $\begin{array}{l}\text { piel; timo; } \\
\text { pulmones; cerebro; } \\
\text { conducto nasal }\end{array}$ & $\begin{array}{r}\text { Inhalación } \\
\\
\text { Piel } \\
\text { 0jos }\end{array}$ & $\begin{array}{l}\text { Sensación de quemazón, diarrea, cefalea, } \\
\text { náuseas, dolor de garganta, inconsciencia, } \\
\text { vómitos, debilidad } \\
\text { Sequedad de piel, sensación de quemazón } \\
\text { Enrojecimiento, dolor }\end{array}$ & $\begin{array}{l}\text { Ojos; piel; sis resp; } \\
\text { SNC; PNS } \\
\text { Inh; abs; ing; con }\end{array}$ & $\begin{array}{l}\text { Irrit ojos, nariz; neur peri; deb, } \\
\text { pares; derm; cef, sop }\end{array}$ \\
\hline $\begin{array}{l}\text { METILISOPROPILCETONA } \\
563-80-4\end{array}$ & & & $\begin{array}{r}\text { Inhalación } \\
\text { Piel } \\
\text { Ojos } \\
\text { Ingestión }\end{array}$ & $\begin{array}{l}\text { Tos, cefalea, dolor de garganta, debilidad } \\
\text { Puede absorberse } \\
\text { Enrojecimiento } \\
\text { Náuseas, vómitos }\end{array}$ & $\begin{array}{l}\text { Ojos; piel; sis resp } \\
\text { Inh; ing; con }\end{array}$ & $\begin{array}{l}\text { Irrit ojos, piel, muc, sis resp; } \\
\text { tos }\end{array}$ \\
\hline $\begin{array}{l}\text { METILPROPILCETONA } \\
107-87-9\end{array}$ & $\begin{array}{l}\text { ojos; piel; } \\
\text { tract resp; SNC }\end{array}$ & $\begin{array}{l}\text { piel; hígado; } \\
\text { riñones; sangre }\end{array}$ & $\begin{array}{r}\text { Inhalación } \\
\text { Piel } \\
\text { Ojos } \\
\text { Ingestión } \\
\end{array}$ & $\begin{array}{l}\text { Embotamiento, sopor } \\
\text { Sequedad de piel, enrojecimiento } \\
\text { Enrojecimiento, dolor } \\
\text { Náuseas, vómitos }\end{array}$ & $\begin{array}{l}\text { Ojos; piel; sis resp; } \\
\text { SNC } \\
\text { Inh; ing; con }\end{array}$ & $\begin{array}{l}\text { Irrit ojos, piel, muc; cef; derm; } \\
\text { narco, coma }\end{array}$ \\
\hline $\begin{array}{l}\text { 2,4-PENTANODIONA } \\
\text { 123-54-6 }\end{array}$ & ojos; piel; tract resp & piel & $\begin{array}{r}\text { Inhalación } \\
\text { Piel } \\
\text { 0jos } \\
\text { Ingestión }\end{array}$ & $\begin{array}{l}\text { Mareo, sopor, cefalea, dificultad respiratoria, } \\
\text { náuseas, vómitos, ataxia y temblores } \\
\text { Puede absorberse, enrojecimiento } \\
\text { Enrojecimiento, dolor } \\
\text { Diarrea, náuseas, vómitos, debilidad, ataxia }\end{array}$ & $\begin{array}{l}\text { Sis resp; ojos; piel; } \\
\text { SNC }\end{array}$ & \\
\hline
\end{tabular}

\begin{tabular}{|c|c|c|c|}
\hline $\begin{array}{l}\text { Denominación química } \\
\mathrm{N} \text { úmero CAS }\end{array}$ & Físicos & Q uímicos & $\begin{array}{l}\text { Clase o división } \\
\text { UN / Riesgos } \\
\text { subsidiarios }\end{array}$ \\
\hline $\begin{array}{l}\text { ACETLLBROMURO } \\
506-96-7\end{array}$ & & $\begin{array}{l}\text { Se descompone al calentarse liberando humos tóxicos y corrosivos Reacciona violentamente } \\
\text { con agua y alcoholes, con peligro de incendio y explosión }\end{array}$ & \\
\hline $\begin{array}{l}\text { ACETILCLORURO } \\
75-36-5\end{array}$ & & & 3 \\
\hline $\begin{array}{l}\text { ACETONA } \\
67-64-1\end{array}$ & $\begin{array}{l}\text { El vapor es más pesado } \\
\text { que el aire y puede } \\
\text { desplazarse a ras del } \\
\text { suelo; posibilidad de } \\
\text { ignición a distancia }\end{array}$ & Puede formar peróxidos explosivos en contacto con oxidantes fuertes Ataca muchos plásticos & 3 \\
\hline $\begin{array}{c}\text { BENZOFENONA } \\
119-61-9\end{array}$ & & Reacciona con oxidantes fuertes & \\
\hline $\begin{array}{l}\text { p-BENZOQUINONA } \\
106-51-4\end{array}$ & $\begin{array}{l}\text { Posibilidad de explosión } \\
\text { pulverulenta cuando se } \\
\text { encuentra en forma de } \\
\text { polvo o granular y se } \\
\text { mezcla con el aire En } \\
\text { seco puede cargarse } \\
\text { electrostáticamente como } \\
\text { consecuencia de } \\
\text { turbulencias, transporte } \\
\text { neumático, vertidos, etc. }\end{array}$ & $\begin{array}{l}\text { Reacciona con oxidantes fuertes con peligro de incendio y explosión Reacciona violentamente } \\
\text { con bases fuertes Por encima de } 60^{\circ} \mathrm{C} \text { en ambientes húmedos se autocalienta y descompone } \\
\text { liberando gases tóxicos (monóxido de carbono) }\end{array}$ & 6.1 \\
\hline
\end{tabular}




\begin{tabular}{|c|c|c|c|}
\hline $\begin{array}{l}\text { Denominación química } \\
\mathrm{N} \text { úmero CAS }\end{array}$ & Físicos & Q uímicos & $\begin{array}{l}\text { Clase o división } \\
\text { UN / Riesgos } \\
\text { subsidiarios }\end{array}$ \\
\hline $\begin{array}{l}\text { CETENA } \\
\quad 463-51-4\end{array}$ & $\begin{array}{l}\text { El gas es más pesado } \\
\text { que el aire y puede } \\
\text { desplazarse a ras del } \\
\text { suelo; posibilidad de } \\
\text { ignición a distancia }\end{array}$ & $\begin{array}{l}\text { Se polimeriza fácilmente Reacciona violentamente con muchos compuestos orgánicos } \\
\text { Reacciona con agua para formar ácido acético Se descompone en alcohol y amoníaco }\end{array}$ & \\
\hline $\begin{array}{l}\text { CICLOHEXANONA } \\
108-94-1\end{array}$ & $\begin{array}{l}\text { El vapor es más pesado } \\
\text { que el aire y puede } \\
\text { desplazarse a ras del } \\
\text { suelo; posibilidad de } \\
\text { ignición a distancia }\end{array}$ & $\begin{array}{l}\text { En su combustión libera monóxido de carbono Reacciona con oxidantes y ácido nítrico, con } \\
\text { peligro de incendio y explosion }\end{array}$ & 3 \\
\hline $\begin{array}{l}\text { CICLOPENTANONA } \\
120-92-3\end{array}$ & $\begin{array}{l}\text { El vapor es más pesado } \\
\text { que el aire }\end{array}$ & $\begin{array}{l}\text { Se polimeriza fácilmente por influencia de ácidos En su combustión libera gases tóxicos } \\
\text { (óxidos de carbono) Reacciona con ácidos }\end{array}$ & 3 \\
\hline $\begin{array}{l}\text { 2-CLOROACETOFENONA } \\
532-27-4\end{array}$ & & $\begin{array}{l}\text { En su combustión libera vapores tóxicos y corrosivos Se descompone al calentarse } \\
\text { produciendo gases corrosivos (cloruro de hidrógeno) }\end{array}$ & \\
\hline $\begin{array}{l}\text { 1-CLORO-2.PROPANONA } \\
\text { 78-95-5 }\end{array}$ & & $\begin{array}{l}\text { Se polimeriza lentamente por influencia de la luz En su combustión libera gases tóxicos y } \\
\text { corrosivos (óxidos de carbono, cloruro de hidrógeno, fosgeno) Reacciona con oxidantes fuertes }\end{array}$ & \\
\hline $\begin{array}{r}\text { DIACETONA } \\
123-42-2 \\
\end{array}$ & & & 3 \\
\hline $\begin{array}{l}\text { DICETENA } \\
674-82-8\end{array}$ & & & 3 \\
\hline $\begin{array}{l}\text { DICLORACETILCLORURO } \\
\text { 79-36-7 }\end{array}$ & & $\begin{array}{l}\text { Se descompone al calentarse en contacto con humedad, metales alcalinos, metales } \\
\text { alcalino-térreos, polvo metálicos, produciendo cloruro de hidrógeno y fosgeno, con peligro de } \\
\text { incendio y explosión Reacciona con oxidantes fuertes, alcoholes y agua Ataca muchos } \\
\text { metales formando un gas combustible }\end{array}$ & \\
\hline $\begin{array}{l}\text { DIETILCETONA } \\
96-22-0\end{array}$ & $\begin{array}{l}\text { El vapor es más pesado } \\
\text { que el aire y puede } \\
\text { desplazarse a ras del } \\
\text { suelo; posibilidad de } \\
\text { ignición a distancia El } \\
\text { vapor se mezcla bien con } \\
\text { el aire; se forman } \\
\text { fácilmente mezclas } \\
\text { explosivas }\end{array}$ & $\begin{array}{l}\text { Reacciona violentamente con oxidantes, con peligro de incendio y explosión Ataca muchos } \\
\text { plásticos }\end{array}$ & 3 \\
\hline $\begin{array}{l}\text { 2,6-DIMETIL-4-HEPTANONA } \\
\text { 108-83-8 }\end{array}$ & & Reacciona con oxidantes Ataca algunos tipos de plásticos & 3 \\
\hline $\begin{array}{l}\text { DIPROPILCETONA } \\
123-19-3\end{array}$ & & & 3 \\
\hline $\begin{array}{l}\text { ETILAMILCETONA } \\
106-68-3 \\
\end{array}$ & & & 3 \\
\hline $\begin{array}{l}\text { METLLAMILCETONA } \\
110-43-0 \\
\end{array}$ & & Reacciona con materiales oxidantes Ataca algunos tipos de plásticos & 3 \\
\hline $\begin{array}{l}\text { METILBUTILCETONA } \\
591-78-6\end{array}$ & & $\begin{array}{l}\text { Reacciona violentamente con oxidantes y puede formar peróxidos inestables Ataca los } \\
\text { plásticos }\end{array}$ & \\
\hline $\begin{array}{l}\text { METILETLLETONA } \\
78-93-3\end{array}$ & & & 3 \\
\hline $\begin{array}{l}\text { 5-METLL-2-HEXANONA } \\
110-12-3\end{array}$ & & & 3 \\
\hline
\end{tabular}




\begin{tabular}{|c|c|c|c|}
\hline $\begin{array}{l}\text { Denominación química } \\
\text { N úmero CAS }\end{array}$ & Físicos & Q uímicos & $\begin{array}{l}\text { Clase o división } \\
\text { UN / Riesgos } \\
\text { subsidiarios }\end{array}$ \\
\hline $\begin{array}{l}\text { METILISOBUTILCETONA } \\
\text { 108-10-1 }\end{array}$ & $\begin{array}{l}\text { El vapor es más pesado } \\
\text { que el aire y puede } \\
\text { desplazarse a ras del } \\
\text { suelo; posibilidad de } \\
\text { ignición a distancia }\end{array}$ & Puede formar peróxidos explosivos En su combustión libera monóxido de carbono & 3 \\
\hline $\begin{array}{l}\text { METILISOPROPILCETONA } \\
563-80-4\end{array}$ & $\begin{array}{l}\text { El vapor es más pesado } \\
\text { que el aire y puede } \\
\text { desplazarse a ras del } \\
\text { suelo; posibilidad de } \\
\text { ignición a distancia }\end{array}$ & $\begin{array}{l}\text { Se descompone al calentarse liberando humos acres y vapores tóxicos Reacciona } \\
\text { violentamente con oxidantes fuertes }\end{array}$ & 3 \\
\hline $\begin{array}{l}\text { METILPROPILCETONA } \\
107-87-9\end{array}$ & $\begin{array}{l}\text { El vapor se mezcla bien } \\
\text { con el aire; se forman } \\
\text { fácilmente mezclas } \\
\text { explosivas }\end{array}$ & Puede reaccionar violentamente con agentes oxidantes & 3 \\
\hline $\begin{array}{l}\text { 4-METOXI-4-METLL-2-PENTANONA } \\
\text { 107-70-0 }\end{array}$ & & & 3 \\
\hline $\begin{array}{l}\text { OXIDO DE MESITILO } \\
141-79-7\end{array}$ & & $\begin{array}{l}\text { Puede formar peróxidos explosivos Reacciona violentamente con oxidantes fuertes Ataca } \\
\text { muchos plásticos }\end{array}$ & 3 \\
\hline $\begin{array}{l}\text { 2,4-PENTANODIONA } \\
\text { 123-54-6 }\end{array}$ & $\begin{array}{l}\text { El vapor es más pesado } \\
\text { que el aire }\end{array}$ & $\begin{array}{l}\text { Se polimeriza por influencia de la luz En su combustión libera óxidos de carbono tóxicos } \\
\text { Reacciona con oxidantes fuertes, bases y agentes reductores }\end{array}$ & \\
\hline
\end{tabular}

\begin{tabular}{|c|c|c|c|c|c|c|c|c|c|c|}
\hline $\begin{array}{l}\text { Denominación química } \\
\mathrm{N} \text { úmero } \mathrm{CAS}\end{array}$ & Color/ Forma & $\begin{array}{l}\text { p.e. } \\
\left({ }^{\circ} C\right)\end{array}$ & $\begin{array}{l}\text { p.f. } \\
\left({ }^{\circ} C\right)\end{array}$ & $\begin{array}{l}\text { p.m.l } \\
\text { (g/ } \\
\text { mol) }\end{array}$ & $\begin{array}{l}\text { Solubilidad } \\
\text { en agua }\end{array}$ & $\begin{array}{l}\text { Densidad } \\
\text { relativa } \\
\text { (agua }=1 \text { ) }\end{array}$ & $\begin{array}{l}\text { Densidad } \\
\text { de vapor } \\
\text { relativa } \\
\text { (aire=1) }\end{array}$ & $\begin{array}{l}\text { Pvap/ } \\
(\mathrm{kPa})\end{array}$ & $\begin{array}{l}\text { Límit. } \\
\text { inflam. }\end{array}$ & $\begin{array}{l}\text { p.ig. p.aut } \\
\text { (ㅇ) ig. } \\
\\
\left({ }^{\circ} \mathrm{C}\right)\end{array}$ \\
\hline $\begin{array}{l}\text { ACETILBROMURO } \\
506-96-7\end{array}$ & líquido incoloro & 76 & .96 & 122,96 & sol & $1,52 @ 9^{\circ} \mathrm{C}$ & & $\begin{array}{l}14,3 \\
@ 21 \\
\end{array}$ & & \\
\hline $\begin{array}{l}\text { ACETOFENONA } \\
98-86-2\end{array}$ & $\begin{array}{l}\text { láminas o prismas } \\
\text { monoclínicos; líquido } \\
\text { ligeramente aceitoso; } \\
\text { líquido incoloro; el } \\
\text { líquido forma cristales } \\
\text { laminares a baja } \\
\text { temperatura }\end{array}$ & 202 & 20,5 & 120,16 & insol & $\begin{array}{l}1,033 \\
@ 15\left({ }^{\circ} \mathrm{C}\right) / \\
15^{\circ} \mathrm{C}\end{array}$ & 4,14 & $\begin{array}{l}0,059 \\
@ 25^{\circ} \mathrm{C}\end{array}$ & & 82 ca 570 \\
\hline $\begin{array}{l}\text { ACETONA } \\
67-64-1 \\
\end{array}$ & líquido incoloro & 56,2 & $-95,35$ & 58,08 & misc & 0,7899 & & 2,0 & $\begin{array}{l}2,15 \mathrm{li} \\
13,0 \mathrm{ls} \\
\end{array}$ & $-20 \quad 465$ \\
\hline $\begin{array}{l}\text { BENZOFENONA } \\
119.61-9 \\
\end{array}$ & cristales blancos & 305 & 49 & 182,2 & insol & 1,1 & & & & \\
\hline $\begin{array}{l}\text { p-BENZOQUINONA } \\
106-51-4\end{array}$ & $\begin{array}{l}\text { primas monoclínicos } \\
\text { amarillos en agua o } \\
\text { éter de petróleo; } \\
\text { sólido de color } \\
\text { verduzco-amarillento }\end{array}$ & & 115,7 & 108,09 & lig sol & $\begin{array}{l}1,318 @ \\
20^{\circ} \mathrm{C} / 4^{\circ} \mathrm{C}\end{array}$ & 3,7 & $\begin{array}{l}0,013 \\
@ 25^{\circ} \mathrm{C}\end{array}$ & & $\begin{array}{l}38-9 \quad 560 \\
3 \mathrm{cc}\end{array}$ \\
\hline $\begin{array}{l}\text { 1-BROMO-2-PROPANONA } \\
598-31-2\end{array}$ & $\begin{array}{l}\text { líquido incoloro; se } \\
\text { torna rápidamente } \\
\text { violeta incluso en } \\
\text { ausencia de aire }\end{array}$ & 137 & $-36,5$ & 136,99 & lig sol & $1,634 @ 23^{\circ} \mathrm{C}$ & 4,75 & 1,20 & & \\
\hline
\end{tabular}




\begin{tabular}{|c|c|c|c|c|c|c|c|c|c|c|c|}
\hline $\begin{array}{l}\text { Denominación química } \\
\mathrm{N} \text { úmero CAS }\end{array}$ & Color/ Forma & $\begin{array}{l}\text { p.e. } \\
(\underline{O C})\end{array}$ & $\begin{array}{l}\text { p.f. } \\
(\stackrel{\circ}{ } \mathrm{C})\end{array}$ & $\begin{array}{l}\text { p.m.l } \\
\text { (g/ } \\
\text { mol) }\end{array}$ & $\begin{array}{l}\text { Solubilidad } \\
\text { en agua }\end{array}$ & $\begin{array}{l}\text { Densidad } \\
\text { relativa } \\
\text { (agua }=1 \text { ) }\end{array}$ & $\begin{array}{l}\text { Densidad } \\
\text { de vapor } \\
\text { relativa } \\
\text { (aire=1) }\end{array}$ & $\begin{array}{l}\text { Pvap/ } \\
(\mathrm{kPa})\end{array}$ & $\begin{array}{l}\text { Límit. } \\
\text { inflam. }\end{array}$ & $\begin{array}{l}\text { p.ig. } \\
(\stackrel{\circ}{ } \mathrm{C})\end{array}$ & $\begin{array}{l}\text { p.aut } \\
\text { ig. } \\
\left({ }^{\circ} \mathrm{C}\right)\end{array}$ \\
\hline $\begin{array}{l}\text { CETENA } \\
\quad 463-51-4\end{array}$ & gas incoloro & .56 & -150 & 42,0 & reacciona & & 1,4 & & & $\begin{array}{l}\text { Gas } \\
\text { infla- } \\
\text { mable }\end{array}$ & \\
\hline $\begin{array}{l}\text { CICLOHEXANONA } \\
108-94-1\end{array}$ & $\begin{array}{l}\text { líquido aceitoso; } \\
\text { líquido de color } \\
\text { blanco-agua o } \\
\text { amarillo claro }\end{array}$ & 155,6 & 16,4 & 98,14 & sol & $\begin{array}{l}0,9421 \\
@ 25^{\circ} \mathrm{C}_{i} \\
0,9478\end{array}$ & 3,4 & $\begin{array}{l}0,67 \\
@ \\
C^{-26,4^{\circ}}\end{array}$ & $\begin{array}{l}1,1 \text { li } \\
9,4 \text { is }\end{array}$ & $63 c c$ & 420 \\
\hline $\begin{array}{l}\text { CICLOPENTANONA } \\
120-92-3\end{array}$ & $\begin{array}{l}\text { líquido móvil de color } \\
\text { blanco-agua }\end{array}$ & 130,6 & $-51,3$ & 84,12 & insol & 0,948 & 2,3 & $\begin{array}{l}1,51 \\
@ 25^{\circ} \mathrm{C}\end{array}$ & & $31 \mathrm{cc}$ & \\
\hline $\begin{array}{l}\text { CLOROACETILCLORURO } \\
75-36-5\end{array}$ & $\begin{array}{l}\text { líquido incoloro } 0 \\
\text { ligeramente amarillo }\end{array}$ & 106 & 21,77 & 112,95 & & 1,4202 & & 2,35 & & & \\
\hline $\begin{array}{l}\text { 2-CLOROACETOFENONA } \\
532-27-4\end{array}$ & $\begin{array}{l}\text { cristales incoloros } \\
0 \text { grisáceos }\end{array}$ & 247 & 56,5 & 154,6 & insol & $\begin{array}{l}1,324 \\
@ 15^{\circ} \mathrm{C}\end{array}$ & 5,3 & $<10 \mathrm{~Pa}$ & & 118 & \\
\hline $\begin{array}{l}\text { 1-CLORO-2.PROPANONA } \\
78-95-5\end{array}$ & líquido incoloro & 119,7 & $-44,5$ & 92,53 & sol & $1,123 @ 25^{\circ} \mathrm{C}$ & & & & $40 \mathrm{ca}$ & \\
\hline $\begin{array}{l}\text { DIACETONA } \\
123-42-2\end{array}$ & líquido incoloro & 167,9 & -44 & 116,16 & misc & $\begin{array}{l}0,9306 \\
@ 25^{\circ} \mathrm{C}\end{array}$ & 4,0 & 0,13 & $\begin{array}{l}1,8 \mathrm{li} \\
6,9 \mathrm{sl}\end{array}$ & $66 \mathrm{ca}$ & $\begin{array}{l}\text { sin ace- } \\
\text { tona } \\
603 \\
\text { comer- } \\
\text { cial } \\
643\end{array}$ \\
\hline $\begin{array}{l}\text { DICETENA } \\
674-82-8\end{array}$ & $\begin{array}{l}\text { líquido transparente } \\
\text { incoloro cuando es } \\
\text { puro }\end{array}$ & 127,4 & $-6,5$ & 84,08 & sol & 1,0897 & 2,9 & & & $34 \mathrm{ca}$ & \\
\hline $\begin{array}{l}\text { DICLOROACETILCLORURO } \\
79-36.7\end{array}$ & $\begin{array}{l}\text { líquido fumante } \\
\text { incoloro } 0 \text { amarillo }\end{array}$ & 107- 108 & & 147,4 & se descompone & 1,53 & 5,09 & 3,06 & $\begin{array}{l}11,9 \mathrm{li} \\
? \text { Is }\end{array}$ & 66 & 585 \\
\hline $\begin{array}{l}\text { DIETILCETONA } \\
96-22.0\end{array}$ & líquido móvil incoloro & 101,7 & $-39,8$ & 86,13 & muy sol & 0,814 & 3,0 & $\begin{array}{l}4,72 \\
@ 25^{\circ} \mathrm{C}\end{array}$ & 1,6 & $13 \mathrm{ca}$ & 452 \\
\hline $\begin{array}{l}\text { 2,6-DIMETIL-4-HEPTANONA } \\
\text { 108-83-8 }\end{array}$ & líquido incoloro & 168 & -42 & 142,2 & insol & 0,805 & 4,9 & 0,23 & $\begin{array}{l}0,8 \text { li } \\
6,2 \\
@ 93{ }^{\circ} \mathrm{C} \\
\text { is }\end{array}$ & $49 c c$ & 396 \\
\hline $\begin{array}{l}\text { DIPROPILCETONA } \\
\text { 123-19-3 }\end{array}$ & & 144 & -33 & 114,18 & insol & 1,407 & & & & & \\
\hline $\begin{array}{l}\text { ETILAMILCETONA } \\
106-68-3\end{array}$ & & 167,5 & & 128,21 & insol & $\begin{array}{l}0,882 @ \\
25^{\circ} \mathrm{C}\end{array}$ & & & & & \\
\hline $\begin{array}{l}\text { ETLBUTILCETONA } \\
106-35-4 \\
\end{array}$ & líquido transparente & $\begin{array}{l}147 @ \\
765 \mathrm{~mm} \mathrm{Hg}\end{array}$ & -39 & 114,21 & insol & 0,8183 & & $\begin{array}{l}0,19 \\
@ 25^{\circ} \mathrm{C}\end{array}$ & & $46 \mathrm{ca}$ & \\
\hline $\begin{array}{l}\text { 2,5-HEXANODIONA } \\
\text { 110-13-4 }\end{array}$ & & 194 & $-5,5$ & 114,4 & muy sol & 0,737 & & & & & \\
\hline $\begin{array}{l}\text { ISOFORONA } \\
78.59-1\end{array}$ & $\begin{array}{l}\text { líquido transparente } \\
\text { como el agua }\end{array}$ & $\begin{array}{l}214 \\
@ 754 \mathrm{~mm} \\
\mathrm{Hg}\end{array}$ & $-8,1$ & 138,2 & lig sol & 0,9229 & 4,77 & $\begin{array}{l}0,059 \\
@ 25^{\circ} \mathrm{C}\end{array}$ & $\begin{array}{l}0,8 \mathrm{li} \\
3,8 \mathrm{ls}\end{array}$ & $84 c c$ & 460 \\
\hline $\begin{array}{l}\text { METLLAMILCETONA } \\
110-43-0\end{array}$ & $\begin{array}{l}\text { líquido transparente } \\
\text { como el agua }\end{array}$ & 151,5 & $-35,5$ & 114,18 & muy sol & $\begin{array}{l}0,8197 \\
@ 15^{\circ} \mathrm{C} ; \\
0,8068 \\
@ 30{ }^{\circ} \mathrm{C}\end{array}$ & 3,9 & $\begin{array}{l}0,21 \\
@ 25{ }^{\circ} \mathrm{C}\end{array}$ & $\begin{array}{l}1,1 \\
@ 66^{\circ} \mathrm{C} \\
\text { li } \\
7,9 \\
@ 121^{\circ} \\
\mathrm{Cls}\end{array}$ & $39 \mathrm{cc}$ & 393 \\
\hline
\end{tabular}




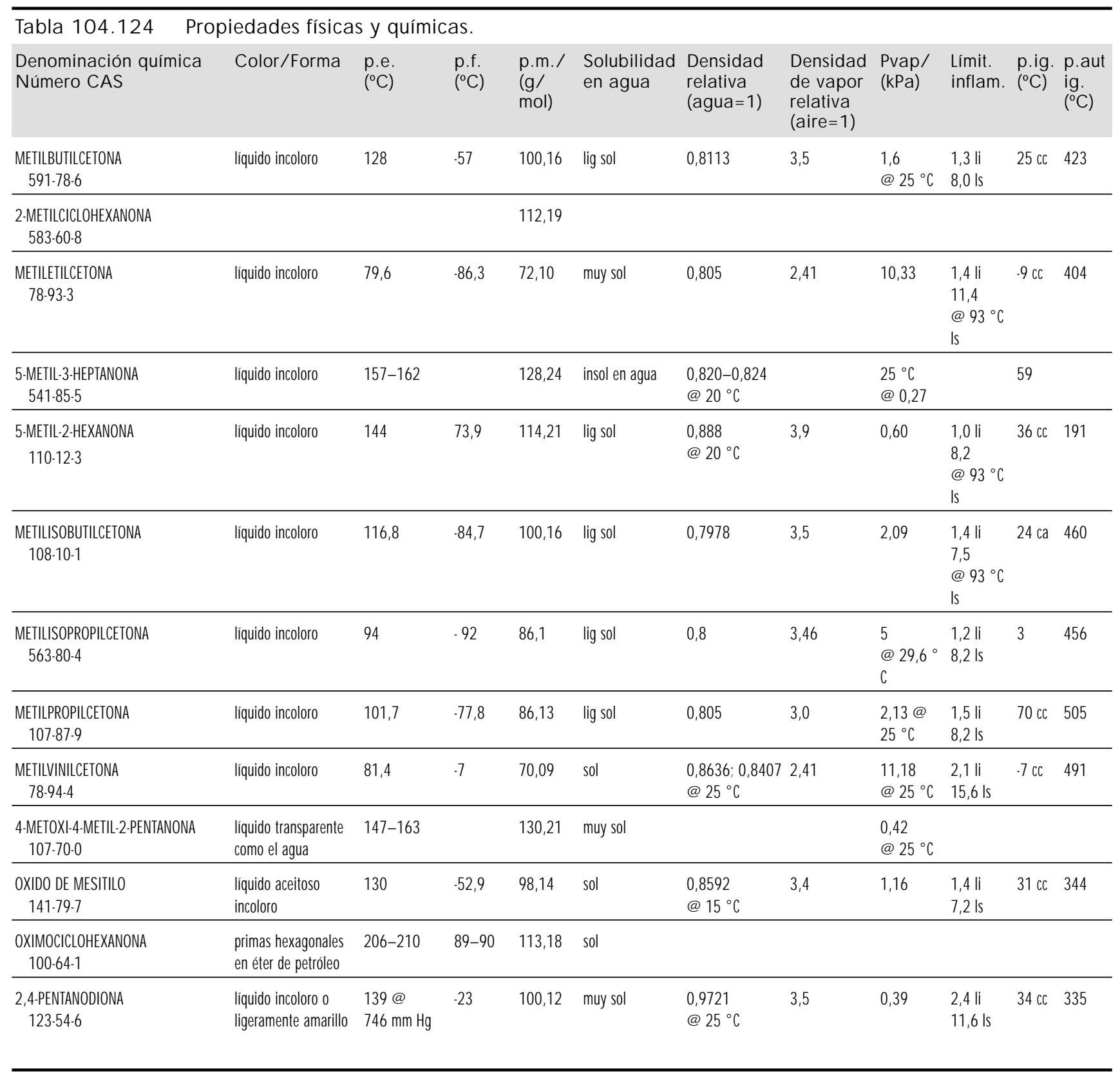

Continua ... 


\section{NITROCOMPUESTOS ALIFATICOS}

Los nitrocompuestos se caracterizan por poseer un enlace $\mathrm{C}-\mathrm{NO}_{2}$ y en este grupo se incluyen las mononitroparafinas, las polinitroparafinas, las nitroolefinas, y los alquil nitritos y nitratos.

Las mononitroparafinas se obtienen por nitración directa de las correspondientes parafinas en fase de vapor y se utilizan principalmente como disolventes de ésteres de celulosa, otras resinas, y aceites, grasas, ceras y colorantes. Entre los grupos especiales de mononitroparafinas se encuentran las cloronitroparafinas.

\section{Usos}

Los nitrocompuestos alifáticos se utilizan como disolventes, explosivos, propulsores de cohetes, fumigantes y aditivos de gasolina. Algunos de ellos se emplean en las industrias del caucho, textil, pinturas y barnices.

El pentaeritritol tetranitrato, el etilenglicol dinitrato (EGDN), el tetranitrometano, la nitroglicerina y el 2-nitropropano son componentes de explosivos. El etilenglicol dinitrato es un explosivo detonante, pero tiene también la propiedad de disminuir el punto de congelación de la nitroglicerina. En la mayoría de países con un clima templado o frío, la dinamita se prepara con una mezcla de nitroglicerina y EGDN. La nitroglicerina se utiliza en explosivos detonantes y en la producción de dinamita y otros explosivos, aunque ha sido sustituida gradualmente por nitrato amónico. La nitroglicerina se utiliza también para combatir incendios en pozos de petróleo y, en medicina, como vasodilatador en casos de espasmo de la arteria coronaria.

La nitroglicerina, el 2-nitropropano, el tetranitrometano y el nitrometano se emplean como propulsores de cohetes. EI 1-nitropropano y el 2-nitropropano son disolventes y aditivos de la gasolina, y el tetranitrometano es un propulsor para gasóleo. El 2-nitropropano se aplica como depresor de humo en el gasóleo y como componente de combustibles para coches de carreras y decapantes de pinturas y barnices.

La cloropicrina se emplea como rodenticida y como arma química, mientras que el nitrometano y el nitroetano se utilizan como propulsores en ingeniería militar. El ácido nitrilotriacético tiene numerosos usos en el tratamiento de aguas, textiles y caucho, así como en las industrias de pasta y de papel. También se utiliza como aditivo para el agua de alimentación de calderas y como agente quelante en la limpieza y separación de metales.

Las nitroparafinas cloradas se utilizan sobre todo como disolventes y productos intermedios en la industria química y en la fabricación de caucho sintético. Se emplean también como pesticidas, especialmente fumigantes, fungicidas y ovicidas para mosquitos.

Las nitro-olefinas se obtienen por deshidratación de nitroalcoholes o por adición directa de óxidos de nitrógeno a olefinas. No tienen mucha aplicación industrial.

Los alquil nitritos se obtienen por reacción de nitritos y alcoholes en presencia de ácido sulfúrico diluido, o a partir de mononitroparafinas, por reacción de haluros de alquilo y nitritos. EI principal uso de los alquil nitritos ha sido en explosivos industriales y militares, aunque estas sustancias se utilizan también en síntesis orgánicas y como agentes terapéuticos (vasodilatadores) en medicina. Se hidrolizan fácilmente liberando ácido nitroso, y producen reacciones de intercambio cuando se disuelven en alcoholes. Los alquil nitratos se forman por la interacción de alcoholes y ácido nítrico. EI nitrato de etilo y en cierta medida el nitrato de metilo se utilizan en síntesis orgánicas como agentes nitrantes para compuestos aromáticos. EI nitrato de metilo se utiliza también como combustible para cohetes.

\section{Riesgos}

Los efectos de los nitrocompuestos alifáticos se producen tras su absorción por cualquier vía (p. ej. inhalación, ingestión, absorción por la piel). La irritación se produce como resultado del contacto con la piel. A menudo el riesgo industrial más importante es la inhalación de vapores, ya que las presiones de vapor suelen ser lo bastante altas como para producir concentraciones considerables de vapor en el lugar de trabajo. Cuando se exponen a altas temperaturas, llamas o impactos, algunos nitrocompuestos alifáticos conllevan peligro de incendio y explosión. También pueden producirse reacciones químicas exotérmicas espontáneas. Algunos de los síntomas de exposición son irritación de mucosas, náuseas, vómitos, cefaleas, disnea y mareo. La exposición crónica a estas sustancias puede aumentar el riesgo de carcinogenicidad (en animales), enfermedad cardíaca isquémica y muerte súbita.

\section{Nitroparafinas}

Las nitroparafinas tienen un efecto depresor del sistema nervioso central y también pueden provocar lesiones en el hígado y los riñones. Las polinitroparafinas son considerablemente más tóxicas que las mononitroparafinas. La exposición industrial a $30 \mathrm{ppm}$ de nitropropano (una mononitroparafina) causa síntomas como cefalea, náuseas, vómitos y diarrea. No se han observado síntomas a concentraciones entre 10 y 20 ppm. Los efectos del tetranitrometano (una polinitroparafina) observados en trabajadores son irritación del sistema respiratorio, disnea, mareo y, con exposiciones repetidas, anemia, cianosis y bradicardia. Su potencial cancerígeno se comenta más adelante. En condiciones normales, el nitrometano (una mononitroparafina) es relativamente estable, pero puede explotar por impacto o por calor. Los daños causados por la explosión separada de dos vagones cisterna de nitrometano fueron considerables $y$, como resultado de estas experiencias, ahora el nitrometano se almacena y transporta preferentemente en tambores, mejor que a granel. La inhalación de nitrometano produce irritación leve y toxicidad antes de que se manifiesten sus efectos narcóticos; la exposición repetida puede causar lesiones hepáticas. Esta sustancia debe manipularse en zonas bien ventiladas, preferiblemente con extracción localizada, y los trabajadores deben utilizar equipos de protección personal.

Aunque el nitroetano es menos explosivo que el nitrometano, puede explotar cuando se dan ciertas condiciones de contaminación y confinamiento, y requiere la adopción de métodos seguros para su manipulación. Es un irritante moderado del tracto respiratorio, pero no se ha notificado ningún caso de lesiones graves en la industria. Siempre debe manipularse en lugares con una buena ventilación.

\section{Nitroolefinas}

Las nitroolefinas se consideran altamente tóxicas por la intensa irritación local que causa el contacto con líquidos o vapores a concentraciones de entre 0,1 y 1 ppm (p. ej., nitrobuteno, nitrohexeno 0 nitrononeno), y por la rápida absorción de estos compuestos a través de cualquier vía. Los efectos tóxicos aparecen inmediatamente después de la exposición e incluyen hiperexcitabilidad, convulsiones, taquicardia, hipernea, depresión, ataxia, cianosis y asfixia. Los cambios patológicos son más pronunciados en los pulmones, con independencia de la vía de absorción. 


\section{Alquil nitritos y nitratos}

Los alquil nitritos se consideran tóxicos por su efecto en la formación de iones nitrito, que son agentes oxidantes fuertes. LoS alquil nitratos y nitritos pueden ocasionar la formación de metahemoglobina en la sangre. Al calentarse pueden descomponer liberando óxidos de nitrógeno muy tóxicos. A elevadas concentraciones, los alquil nitritos son narcóticos. Los alquil nitratos son muy tóxicos y a dosis altas pueden ocasionar mareo, espasmos abdominales, vómitos, diarrea hemática, debilidad, convulsiones y colapso. Dosis pequeñas y repetidas producen debilidad, depresión general, cefalea y alteraciones mentales.

Los vapores de cloropicrina son muy irritantes para los ojos, causando lagrimeo intenso, y para la piel y el tracto respiratorio. La cloropicrina produce náuseas, vómitos, cólicos y diarrea si llega al estómago.

L os datos sobre los efectos de la cloropicrina proceden principalmente de las experiencias con armas químicas durante la primera Guerra M undial. Es un irritante pulmonar con una toxicidad mayor que la del cloro, pero menor que la del fosgeno. Los datos militares indican que la exposición a 4 ppm durante unos segundos es suficiente para dejar a una persona incapacitada para la acción, y la exposición a 15 ppm durante 60 segundos causa lesiones bronquiales o pulmonares importantes. En concreto, daña los bronquios pequeños y medianos la causa de la muerte es frecuentemente el edema pulmonar. Al reaccionar con grupos sulfhidrilo, interfiere con el transporte de oxígeno y puede producir latidos débiles e irregulares, ataques de asma recurrentes y anemia. Una concentración de aproximadamente 1 ppm causa lagrimeo intenso y es una buena señal de advertencia de la exposición; a concentraciones mayores la irritación de la piel es evidente. La ingestión puede deberse a la deglución de saliva que contiene cloropicrina disuelta y produce vómitos y diarrea. La cloropicrina no es combustible, pero cuando se calienta o sufre un impacto que sobrepasa el umbral crítico, puede explotar.

Etilenglicol dinitrato (EGDN). Cuando el etilenglicol dinitrato se introdujo por primera vez en la industria de la dinamita, los únicos cambios observados fueron similares a los que afectaban a los trabajadores expuestos a nitroglicerina: cefalea, sudoración, rubor facial, hipotensión arterial, palpitaciones y mareo, sobre todo al iniciar el trabajo los lunes por la mañana o después de una baja laboral. EI EGDN, que es absorbido por el tracto respiratorio y la piel, ejerce una marcada acción hipotensora aguda. Cuando empezaron a producirse algunos casos de muerte súbita entre los trabajadores de la industria de los explosivos, nadie sospechó en un principio el origen profesional de esos accidentes hasta que, en 1952, Symansky atribuyó numerosos casos de mortalidad ya observados en las fábricas de dinamita de Estados U nidos, R eino U nido y la R epública Federal de Alemania a intoxicación crónica por EGDN. Posteriormente se observaron, 0 al menos se sospecharon, otros casos en varios países, como Japón, I talia, N oruega y Canadá.

Después de un período de exposición que a menudo varía entre 6 y 10 años, los trabajadores expuestos a mezclas de nitroglicerina y EGDN pueden presentar dolor súbito torácico, semejante al de la angina de pecho, y/o morir súbitamente, habitualmente entre 30 y 64 horas después de finalizar la exposición, durante el sueño o después de realizar los primeros esfuerzos físicos del día al llegar al lugar de trabajo. La muerte es, en general, tan repentina que normalmente no se puede realizar un examen minucioso de las víctimas durante el ataque.

El tratamiento de urgencia con dilatadores coronarios y, en particular nitroglicerina, no es efectivo. En la mayor parte de los casos la autopsia dio resultados negativos y, aparentemente, las lesiones miocárdicas y coronarias no eran más prevalentes ni extensas que en la población general. Los electrocardiogramas también han dado resultados decepcionantes. D esde un punto de vista clínico, se ha observado hipotensión sistólica, más señalada durante las horas de trabajo, acompañada de aumento de la presión diastólica, a veces con signos modestos de hiperexcitabilidad del sistema piramidal; con menos frecuencia se han observado signos de acrocianosis, con algunos cambios en la reacción vasomotora. Se han descrito también casos de parestesia periférica, particularmente por la noche, atribuidos a espasmos arteriales y/ o neuropatías periféricas, así como algunos casos de sensibilización cutánea.

Nitroglicerina. La nitroglicerina es una sustancia altamente explosiva y muy sensible a los impactos mecánicos; también explota fácilmente por calor o reacción química espontánea. La sensibilidad de los explosivos comerciales se reduce añadiendo un absorbente como pasta de madera y productos químicos como etilenglicol dinitrato y nitrato amónico. En su forma pura o como dinamita amoniacal, la sustancia presenta solamente un riesgo moderado de explosión.

La nitroglicerina puede penetrar en el organismo por ingestión, inhalación o a través de la piel intacta. Produce dilatación arterial, aumento del ritmo cardíaco y reducción de la tensión arterial y del pulso. Se han descrito casos de muerte súbita en trabajadores que manipulaban explosivos y estaban expuestos a nitroglicerina; no obstante, la mayoría de estas muertes se han atribuido a la acción del etilenglicol dinitrato mezclado con nitroglicerina en la fabricación de dinamita.

La mayoría de trabajadores se adaptan rápidamente a la acción hipotensora de la nitroglicerina, pero la interrupción de la exposición (aunque sea sólo durante unos pocos días, tales como el fin de semana) puede hacer que esa adaptación se pierda y algunos trabajadores sufren náuseas al volver al trabajo los lunes por la mañana; otros no se llegan nunca a adaptar y deben ser retirados de la exposición después de un período de prueba de entre 2 y 3 semanas. La exposición prolongada a nitroglicerina puede causar trastornos neurológicos, y la ingestión de grandes cantidades provoca habitualmente colapso mortal.

Los síntomas iniciales de la exposición son cefalea, embotamiento y reducción de la tensión arterial, seguidos por náuseas, vómitos con fatiga y pérdida de peso, cianosis y alteraciones nerviosas centrales que pueden ser intensas, como manía aguda. En casos de intoxicación grave se han observado confusión, agresividad, alucinaciones y manifestaciones maníacas. Las bebidas alcohólicas pueden precipitar la intoxicación y aumentar su gravedad. En la intoxicación crónica se producen molestias digestivas, temblores y neuralgias.

La nitroglicerina puede causar irritación moderada en el punto de aplicación, habiéndose observado erupciones en las palmas y los espacios interdigitales y úlceras bajo las uñas en trabajadores que manipulan esta sustancia.

Nitroparafinas cloradas. Cuando se exponen al calor o a llamas, las nitroparafinas cloradas se descomponen fácilmente liberando vapores peligrosos, como fosgeno y óxidos de nitrógeno. Estos vapores altamente tóxicos pueden irritar las mucosas y producir lesiones pulmonares con grados variables de edema agudo y muerte. Aún así, no se han notificado exposiciones accidentales de seres humanos.

La toxicidad de algunas de estas sustancias no ha sido elucidada claramente. Con todo, las exposiciones experimentales a altas concentraciones producen lesiones no solo en el sistema respiratorio, sino posiblemente también en el hígado, los riñones y el sistema cardiovascular. Además, la ingestión causa congestión del tracto gastrointestinal, y el contacto con grandes cantidades, irritación de la piel. No se han registrado casos de intoxicación local o sistémica crónica de trabajadores en la industria. 
Entre las nitroparafinas cloradas se incluyen: cloronitrometano, dicloronitrometano, 1-cloro-1-nitroetano, 1,1-dicloro-1-nitro-etano, 1-cloro1-nitropropano, 1-cloro-2-nitropropano, 2-cloro-1-nitropropano y 2-cloro2-nitropropano.

\section{2-Nitropropano (2-NP)}

Los estudios de seres humanos expuestos accidentalmente a 2-N P indican que la exposición breve a altas concentraciones puede ser nociva. Un informe atribuye la muerte de un trabajador y las lesiones hepáticas observadas en otro a la exposición a altos niveles de 2-N P mientras pintaban el interior de un tanque con una pintura de zinc-epoxi diluida con 2-N P y etilglicol (2-etoxietanol). 0 tro informe describe la muerte de cuatro hombres que trabajaban en espacios confinados con pinturas, revestimientos de superficies y resinas de poliéster que contenían 2-NP. LOS cuatro trabajadores presentaban lesiones hepáticas y destrucción de hepatocitos. Los autores atribuyeron las muertes a una sobreexposición a 2-N P, aunque no descartaron el posible papel de otros disolventes, ya que no se identificó 2-NP en el análisis toxicológico. La exposición continuada a concentraciones de entre 20 y 45 ppm de 2-NP causó náuseas, vómitos, diarrea, anorexia y cefaleas intensas en los trabajadores de una fábrica. En otro caso se detectó un brote de hepatitis tóxica en trabajadores de la construcción que aplicaban resinas epoxi a las paredes de una central nuclear. Aunque la hepatitis se atribuyó a una hepatotoxina conocida, la p, $p^{\prime}$-metilendianilina $(4,4$ '-diaminodifenilmetano), también podría haberse debido al 2-NP que los hombres utilizaron para lavar las resinas epoxi de su piel.

L os trabajadores no pueden detectar fácilmente la presencia de 2-NP por su olor, ni siquiera en presencia de concentraciones potencialmente peligrosas. Según un informe, el umbral de detección del 2-N P por su olor se sitúa en concentraciones de 83 ppm. O tro informe indica que no puede detectarse 2-NP por su olor hasta una concentración de aproximadamente 160 ppm. No obstante, en 1984 se publicó un estudio según el cual el olor de 2-NP se detectaba a concentraciones de 3,1-5 ppm.

Estudios de carcinogenicidad. El 2-NP es cancerígeno en ratas. Algunos estudios han demostrado que la exposición a 100 ppm de 2-N P durante 18 meses (7 horas al día, 5 días a la semana) causa destrucción hepática y carcinoma hepatocelular en algunos machos. El aumento de la exposición a 2-NP aumentó la incidencia de cáncer hepático y causó lesiones hepáticas más rápidas. En 1979 se publicó un estudio epidemiológico de 1.481 trabajadores de una empresa química expuestos a 2-NP. Los autores concluyeron que "el análisis de estos datos no sugiere una mayor tasa de mortalidad por cáncer $u$ otras enfermedades en este grupo de trabajadores". No obstante, señalaron que "debido al pequeño tamaño de la cohorte y que el período de latencia era para la mayoría relativamente corto, estos datos no nos permiten descartar que el 2-NP sea cancerígeno para el ser humano". Tampoco pudieron explicar algunos hallazgos relacionados con la tasa de mortalidad por cáncer observada en trabajadores que la empresa consideraba no expuestos a 2-N P. Combinando las cifras de mortalidad correspondientes a todos los trabajadores varones, con independencia de la categoría de exposición, había cuatro muertes por cáncer linfático, cuando el número esperado era de sólo una muerte. Entre las 147 trabajadoras se produjeron ocho muertes en total, en comparación con las 2,9 muertes esperadas, y cuatro muertes por cáncer en comparación con las 0,8 esperadas. Finalmente, los autores informaron que en la pequeña cohorte estudiada se produjeron siete muertes por sarcoma, una enfermedad maligna relativamente rara. Si bien este número parece demasiado alto, no pudo establecerse el número esperado de muertes para comparar y determinar estadísticamente si el número de cánceres sarcomatosos era muy alto, puesto que no puede desglosarse como categoría según el método habitual de notificación y clasificación de defunciones. En resumen, hasta la fecha no existen pruebas de que el 2-NP sea cancerígeno para el ser humano. En 1982 la IARC concluyó que existían "pruebas suficientes" para afirmar que el 2-NP es cancerígeno en ratas. En la misma época la ACGIH lo clasificó como sospechoso cancerígeno humano. Actualmente se clasifica como cancerígeno A3 (cancerígeno en animales).

\section{Medidas de salud y seguridad}

Los métodos más importantes de control técnico para prevenir riesgos son la ventilación general o la extracción localizada. La ventilación general consiste en diluir el aire contaminado con aire fresco mediante el uso de ventiladores en el medio ambiente de trabajo. La extracción localizada consiste en retirar los contaminantes del medio ambiente en el punto en que se generan los vapores nocivos. En las zonas de trabajo, la concentración de contaminantes debe mantenerse por debajo de los límites de exposición utilizando cualquiera de estos dos métodos.

Si estos métodos de ventilación no son suficientes para reducir las cantidades excesivas de contaminantes presentes en el aire, se recomienda el confinamiento de los procesos o la segregación del personal. Los aparatos en los que se producen o procesan nitrocompuestos alifáticos deben estar sellados. Los trabajadores deben utilizar equipos de protección respiratoria y protección para la piel. También es necesaria la adopción de medidas contra incendios y explosiones y se recomienda una supervisión médica general que incluya exámenes médicos periódicos de los trabajadores.

En la medida de lo posible, la cloropicrina debe sustituirse por algún otro producto químico menos tóxico. Siempre que exista riesgo de exposición (p. ej. en la fumigación del suelo), los trabajadores deben ir adecuadamente protegidos con protectores oculares, equipos de protección respiratoria, preferiblemente con suministro de aire y, en caso de altas concentraciones, prendas protectoras para evitar la exposición de la piel. La mezcla y dilución de cloropricina deben realizarse con un cuidado extremo; en invernaderos cuyo suelo haya sido tratado con esta sustancia debe colocarse un cartel de advertencia e impedir el acceso a su interior a personas no protegidas.

La primera consideración en la producción y el uso de EGDN es la prevención de explosiones; es por tanto necesario adoptar las mismas medidas de seguridad que en la fabricación de nitroglicerina y en la industria de explosivos en general. En este sentido, se ha conseguido un progreso considerable gracias al control remoto (por medios ópticos, mecánicos o electrónicos) de las operaciones más peligrosas (en particular la trituración) y la automatización de numerosos procesos como la nitración, el mezclado, el llenado de cartuchos, etc. Estas modificaciones presentan asimismo la ventaja de reducir al mínimo el número de trabajadores expuestos al contacto directo con EGDN y los tiempos de exposición asociados.

En los casos en que sigue produciéndose la exposición de los trabajadores a EGDN, se hace necesario la adopción de una serie de medidas de salud y seguridad. En particular, la concentración de EGDN en la mezcla de explosivos debe reducirse en función de la temperatura ambiente; en países de clima templado no debe sobrepasarse un 20-25\% y durante la estación cálida puede ser conveniente prescindir por completo del EGDN. No obstante, deben evitarse los cambios demasiado frecuentes en la concentración de EGDN para evitar que se produzcan síntomas de abstinencia. El riesgo de inhalación se reduce controlando la concentración atmosférica en el lugar de trabajo mediante sistemas de ventilación general y, en caso necesario, inducción de aire, puesto que la extracción localizada entraña riesgo de explosión. 
La absorción por la piel puede reducirse mediante la adopción de métodos de trabajo adecuados y el uso de prendas protectoras, incluyendo guantes de polietileno; el nitroglicol atraviesa fácilmente el neopreno, el caucho y el cuero, razón por la cual estos materiales no confieren una protección adecuada. La empresa debe asegurarse de que los equipos se laven al menos dos veces por semana. D ebe promoverse la higiene personal y hacer que los trabajadores se duchen al final de cada turno. El uso de un jabón indicador de sulfito podría servir para detectar restos de la mezcla nitroglicerina/ EGDN en la piel. La ropa de trabajo debe mantenerse totalmente separada de la ropa personal. En algunas circunstancias puede que sea necesario el uso de equipos de protección respiratoria, así como en el trabajo en espacios confinados

En la fabricación de nitroglicerina es esencial adoptar las medidas recomendadas para la manipulación de explosivos, según se describen en otro capítulo de esta E nciclopedia. Debe prestarse una atención especial al control efectivo del proceso de nitración, que implica una reacción altamente exotérmica. Los recipientes de nitración deben estar provistos de serpentines refrigerantes o dispositivos similares, y deben disponer de un sistema para anegar completamente la carga en caso de que se produzca una situación peligrosa. En la planta no debe utilizarse vidrio ni metal expuesto y, normalmente, se excluyen los equipos eléctricos.

Siempre que sea posible, el proceso debe estar completamente automatizado, con controles remotos y vigilancia mediante circuitos cerrados de televisión. En los lugares donde sea necesario trabajar con nitroglicerina, debe instalarse extracción localizada, respaldada por una buena ventilación general. Cada trabajador debe recibir al menos tres conjuntos completos de ropa de trabajo, incluido un gorro, de cuya limpieza se encargará la empresa. Estas ropas deben cambiarse como mínimo al principio de cada turno; en ningún caso se dará la vuelta a las perneras 0 a las mangas, y solamente se llevará calzado autorizado y en buen estado. La nitroglicerina atraviesa el caucho delgado, de manera que los trabajadores deben utilizar guantes de nylon o polietileno con una capa de algodón para absorber el sudor.

En los lugares donde se sospechen concentraciones atmosféricas excesivamente altas de nitroglicerina, los trabajadores deben utilizar equipos de protección respiratoria. Los encargados de limpiar cubas de control, maquinaria y pozos de tensión, deben utilizar un respirador neumático. En ningún caso se permitirá el consumo de alimentos, bebidas o tabaco en el lugar de trabajo y los trabajadores deben lavarse cuidadosamente las manos antes de las comidas.

El 2-nitropropano debe manipularse en el lugar de trabajo como si fuera un potencial cancerígeno humano.

Prevención médica. Consiste en un examen previo a la contratación para evaluar el estado general de salud, el sistema cardiovascular (es esencial el examen electrocardiográfico en reposo y durante el ejercicio), el sistema neurológico, la orina y la sangre. Las personas con presión sistólica superior a 150 o inferior a $100 \mathrm{~mm} \mathrm{Hg} 0$ con presión diastólica superior a 90 o inferior a $60 \mathrm{~mm} \mathrm{Hg}$ no deben, en principio, considerarse adecuadas para la exposición profesional a nitroglicol. Tampoco se aconseja la exposición de mujeres embarazadas. Además de los exámenes periódicos, los trabajadores que se reincorporen al trabajo después de una larga baja por enfermedad deberán someterse también a este tipo de exploración. Los electrocardiogramas deben repetirse al menos una vez al año.

Los trabajadores que padezcan enfermedades cardíacas, hipertensión, trastornos hepáticos, anemia o trastornos neurológicos, especialmente del sistema vasomotor, no deben exponerse a mezclas de nitroglicerina/ EGDN. Se recomienda también trasladar a otros puestos de trabajo a las personas que lleven más de 5 ó 6 años realizando tareas peligrosas, y evitar los cambios demasiados frecuentes en la intensidad de la exposición. 
TABLAS DE NITROCOMPUESTOS AUFATICOS

\begin{tabular}{|c|c|c|c|}
\hline Producto químico & Sinónimos/ Código UN & $\mathrm{N}$ úmero CAS & Fórmula estructural \\
\hline ACIDO NITRILOTRIACETICO & $\begin{array}{l}\text { Acido aminotriacético ; N,N-bis( carboximetil) glicina; triglicina; ácido } \\
\text { triglicolámico }\end{array}$ & $139-13-9$ & \\
\hline 1-CLORO-1-NITROETANO & & $598-92.5$ & \\
\hline 1-CLORO-1-NITROPROPANO & Cloronitropropano & $600-25-9$ & \\
\hline 2-CLORO-2-NITROPROPANO & $\begin{array}{l}\text { Nitrito de etilo ; soluciones de nitrito de etilo (DOT); nitrosil etóxido; éter } \\
\text { nitroso; nitroso etil éter } \\
\text { UN1194 }\end{array}$ & $594-71-8$ & \\
\hline CLOROPICRINA & $\begin{array}{l}\text { Nitrocloroformo; nitrotriclorometano; tricloronitrometano } \\
\text { UN1580 } \\
\text { UN1583 }\end{array}$ & $76-06-2$ & \\
\hline 1,1-DICLORO-1-NITROETANO & $\begin{array}{l}\text { Dicloronitroetano } \\
\text { UN2650 }\end{array}$ & $594-72-9$ & \\
\hline DIETLLEN GLICOL DINITRATO & $\begin{array}{l}\text { Di(hidroxietil) éter dinitrato } \\
\text { UN0075 }\end{array}$ & $693-21-0$ & \\
\hline ETILEN GLICOL DINITRATO & $\begin{array}{l}\text { Dinitroglicol; etilen dinitrato; etilen nitrato; glicol dinitrato; nitroglicol, } \\
\text { EGDN }\end{array}$ & $628-96-6$ & \\
\hline $\begin{array}{l}\text { ETILEN GLICOL DINITRATO mezclado con } \\
\text { NITROGLICERINA (1:1) }\end{array}$ & & $53569-64.5$ & \\
\hline NITRATO DE ETLLO & Ester propílico del ácido nítrico; nitrato de propilo; nitrato de n-propilo & $625-58-1$ & \\
\hline NITRATO DE PROPILO & Ester propílico del ácido nítrico; nitrato de n-propilo & $627-13-4$ & \\
\hline NITRITO DE AMILO & $\begin{array}{l}\text { Nitrito de isoamilo ; nitrito de 3-metilbutanol; nitrito de 3-metilbutil; } \\
\text { nitramilo; éster 3-metilbutilíco del ácido nitroso }\end{array}$ & $110-46-3$ & \\
\hline NITRITO DE ETLLO & Ester propílico del ácido nítrico; nitrato de propilo; nitrato de n-propilo & $109-95-5$ & \\
\hline
\end{tabular}




\begin{tabular}{|c|c|c|c|}
\hline Producto químico & Sinónimos/ Código UN & $\mathrm{N}$ úmero CAS & Fórmula estructural \\
\hline NITROETANO & UN2842 & $79-24-3$ & \\
\hline NITROGLICERINA & $\begin{array}{l}\text { Glicerol trinitrato; nitrato de glicerilo ; trinitrato de glicerilo ; nitroglicerol } \\
\text { UN0143 } \\
\text { UN0144 } \\
\text { UN1204 } \\
\text { UN3064 }\end{array}$ & $55-63-0$ & \\
\hline NITROMETANO & $\begin{array}{r}\text { Nitrocarbol } \\
\text { UN1261 }\end{array}$ & $75-52-5$ & \\
\hline 1-NITROPROPANO & & $108-03-2$ & \\
\hline 2-NITROPROPANO & Dimetilnitrometano; isonitropropano; nitroisopropano & $79-46-9$ & \\
\hline PENTAERITRITOL TETRANITRATO & $\begin{array}{l}\text { 2,2-Bis( ( nitrooxi) metil)-1,3-propanediol dinitrato (éster); } \\
\text { 2,2-bis( hidroximetil)-1,3-propanodiol tetranitrato; neopentanotetril nitrato; } \\
\text { nitropentaeritrito } \\
\text { UN0411 }\end{array}$ & $78-11-5$ & \\
\hline 1,2-PROPILEN GLICOL DINITRATO & Propilen dinitrato; propilen glicol 1,2-dinitrato; 1,2-propanodiol, dinitrato & $6423-43-4$ & \\
\hline TETRANITROMETANO & UN1510 & $509-14-8$ & \\
\hline
\end{tabular}

\begin{tabular}{|c|c|c|c|c|c|c|}
\hline \multirow[b]{2}{*}{$\begin{array}{l}\text { Denominación } \\
\text { química } \\
\text { N úmero CAS }\end{array}$} & \multicolumn{4}{|c|}{ Tarjetas Internacionales sobre la Seguridad de los Productos Q uímicos } & \multicolumn{2}{|c|}{ N IO SH (EE.UU.) } \\
\hline & $\begin{array}{l}\text { Período } \\
\text { corto de } \\
\text { exposición }\end{array}$ & $\begin{array}{l}\text { Período } \\
\text { largo de } \\
\text { exposición }\end{array}$ & $\begin{array}{l}\text { Vías de } \\
\text { exposición }\end{array}$ & Síntomas & $\begin{array}{l}\text { O rganos } \\
\text { afectados } \\
\text { Vías de } \\
\text { entrada }\end{array}$ & Síntomas \\
\hline $\begin{array}{l}\text { ETILEN GLICOL DINITRATO } \\
628.96-6\end{array}$ & SCV & SCV & $\begin{array}{r}\text { Inhalación } \\
\text { Piel }\end{array}$ & $\begin{array}{l}\text { Mareo, cefalea, náuseas, debilidad, los } \\
\text { síntomas pueden tardar en aparecer } \\
\text { Puede absorberse }\end{array}$ & $\begin{array}{l}\text { SCV; sangre, piel; } \\
\text { hígado; riñones } \\
\text { Inh, abs, ing, con }\end{array}$ & $\begin{array}{l}\text { Cef pulsátil; mar; náu, vómit, } \\
\text { dolor abdom; hipotensión, } \\
\text { sofocos, palp, angina; } \\
\text { metahem; delirio, depres SNC; } \\
\text { irrit piel; en animales: anemia; } \\
\text { lesiones hepáticas y renales }\end{array}$ \\
\hline $\begin{array}{l}\text { NITROETANO } \\
79-24-3\end{array}$ & \multicolumn{2}{|l|}{ ojos; piel; tract resp } & $\begin{array}{r}\text { Inhalación } \\
\text { Piel } \\
\text { Ojos } \\
\text { Ingestión } \\
\end{array}$ & $\begin{array}{l}\text { Tos, cefalea } \\
\text { Enrojecimiento } \\
\text { Enrojecimiento } \\
\text { Dolor abdominal, dolor de garganta }\end{array}$ & $\begin{array}{l}\text { Piel; sis resp; SNC; } \\
\text { riñones; hígado } \\
\text { Inh, ing, con }\end{array}$ & $\begin{array}{l}\text { Derm; en animales: lag; dis, } \\
\text { estertores y edema pulm; } \\
\text { lesiones hepáticas y renales; } \\
\text { narco }\end{array}$ \\
\hline $\begin{array}{l}\text { NITROMETANO } \\
75-52.5\end{array}$ & SNC & $\begin{array}{l}\text { piel; riñones; } \\
\text { hígado }\end{array}$ & $\begin{array}{l}\text { Inhalación } \\
\text { Piel } \\
\text { 0jos }\end{array}$ & $\begin{array}{l}\text { Tos, mareo, cefalea, náuseas, inconsciencia, } \\
\text { vómitos } \\
\text { Sequedad de piel } \\
\text { Enrojecimiento }\end{array}$ & $\begin{array}{l}\text { Ojos; piel; SNC; } \\
\text { hígado } \\
\text { Inh, ing, con }\end{array}$ & $\begin{array}{l}\text { Derm; en animales: irrit ojos, } \\
\text { sis resp; convuls, narco; } \\
\text { lesiones hepáticas }\end{array}$ \\
\hline
\end{tabular}




\begin{tabular}{|c|c|c|c|}
\hline $\begin{array}{l}\text { Denominación química } \\
\mathrm{N} \text { úmero CAS }\end{array}$ & Físicos & Q uímicos & $\begin{array}{l}\text { Clase o división } \\
\text { UN / Riesgos } \\
\text { subsidiarios }\end{array}$ \\
\hline $\begin{array}{l}\text { ETILEN GLICOL DINITRATO } \\
628.96 .6\end{array}$ & & $\begin{array}{l}\text { Al calentarse puede arder o explotar violentamente liberando vapores tóxicos (óxidos de } \\
\text { nitrógeno) Puede descomponerse explosivamente por impacto, fricción o sacudida Reacciona } \\
\text { con ácidos }\end{array}$ & \\
\hline $\begin{array}{l}\text { NITROETANO } \\
79-24-3\end{array}$ & & $\begin{array}{l}\text { Al calentarse, puede arder o explotar violentamente Puede explotar al calentarse } \\
\text { rápidamente a altas temperaturas con álcalis fuertes, ácidos o combinación de aminas y óxidos } \\
\text { de metales pesados Forma compuestos sensibles a impactos En su combustión libera gases } \\
\text { tóxicos (dióxido de nitrógeno) Se descompone al calentarse a más de } 300{ }^{\circ} \mathrm{C} \text { produciendo } \\
\text { humos tóxicos (óxidos de nitrógeno) Es un agente reductor fuerte y reacciona con oxidantes } \\
\text { Puede atacar algunos plásticos }\end{array}$ & 3 \\
\hline $\begin{array}{l}\text { NITROMETANO } \\
75-52.5\end{array}$ & $\begin{array}{l}\text { El vapor es más pesado } \\
\text { que el aire y puede } \\
\text { desplazarse a ras del } \\
\text { suelo; posibilidad de } \\
\text { ignición a distancia }\end{array}$ & $\begin{array}{l}\text { Puede descomponerse explosivamente por impacto, fricción o sacudida Puede explotar al } \\
\text { calentarse Se descompone al calentarse produciendo óxidos de nitrógeno Reacciona con } \\
\text { álcalis formando compuestos que cuando se secan presentan riesgo de explosión Forma con } \\
\text { aminas una mezcla sensible a los impactos }\end{array}$ & 3 \\
\hline $\begin{array}{l}\text { PENTAERITRITOL TETRANITRATO } \\
\text { 78-11-5 }\end{array}$ & & & 1.10 \\
\hline
\end{tabular}

Tabla 104.128 Propiedades físicas y químicas.

\begin{tabular}{|c|c|c|c|c|c|c|c|c|c|c|}
\hline $\begin{array}{l}\text { Denominación química } \\
\mathrm{N} \text { úmero CAS }\end{array}$ & Color/ Forma & $\begin{array}{l}\text { p.e. } \\
(\stackrel{0}{ } \mathrm{C})\end{array}$ & $\begin{array}{l}\text { p.f. } \\
(\stackrel{\circ}{ })\end{array}$ & $\begin{array}{l}\text { P.m.l } \\
\text { (g/ } \\
\text { mol) }\end{array}$ & $\begin{array}{l}\text { Solubilidad } \\
\text { en agua }\end{array}$ & $\begin{array}{l}\text { Densidad } \\
\text { relativa } \\
\text { (agua }=1 \text { ) }\end{array}$ & $\begin{array}{l}\text { Densidad } \\
\text { de vapor } \\
\text { relativa } \\
\text { (aire=1) }\end{array}$ & $\begin{array}{l}\mathrm{Pvap} / \\
(\mathrm{kPa})\end{array}$ & $\begin{array}{l}\text { Límit. } \\
\text { inflam. }\end{array}$ & $\begin{array}{ll}\text { p.ig. } & \text { p.aut } \\
\left({ }^{\circ} C\right) & \text { ig. } \\
& \left({ }^{\circ} \mathrm{C}\right)\end{array}$ \\
\hline $\begin{array}{l}\text { ACIDO NITRILOTRIACETICO } \\
\text { 139-13-9 }\end{array}$ & $\begin{array}{l}\text { cristales prismáticos } \\
\text { en agua caliente, } \\
\text { polvo blanco } \\
\text { cristalino }\end{array}$ & & 242 & 191,1 & lig sol & 1 & & & & \\
\hline $\begin{array}{l}\text { 1-CLORO-1-NITROETANO } \\
598-92-5\end{array}$ & & 124,5 & & 109,51 & insol & 1,2837 & & & & \\
\hline $\begin{array}{l}\text { 1-CLORO-1-NITROPROPANO } \\
600-25-9\end{array}$ & líquido & 143 & & 123,54 & $0,5 \mathrm{ml} / 100 \mathrm{ml}$ & 1,209 & 0,3 & $\begin{array}{l}5,8 \mathrm{~mm} \mathrm{Hg} \\
\text { @ } 25 \stackrel{\circ}{\circ} \mathrm{C}\end{array}$ & & $62 \mathrm{ca}$ \\
\hline $\begin{array}{l}\text { 2-CLORO-2-NITROPROPANO } \\
594-71-8\end{array}$ & líquido & 133,6 & & 123,55 & $\begin{array}{l}0,5 \mathrm{ml} \mathrm{sol} \mathrm{en} \\
100 \mathrm{ml} @ \\
20{ }^{\circ} \mathrm{C}\end{array}$ & $\begin{array}{l}1,197 @ \\
20^{\circ} \mathrm{C} / 20^{\circ} \mathrm{C}\end{array}$ & 4,3 & $\begin{array}{l}8,5 \mathrm{~mm} \mathrm{Hg} \\
@ 25^{\circ} \mathrm{C}\end{array}$ & & $\begin{array}{l}57^{\circ} \mathrm{C} \\
\mathrm{Ca}\end{array}$ \\
\hline $\begin{array}{l}\text { CLOROPICRINA } \\
76-06-2\end{array}$ & $\begin{array}{l}\text { líquido ligeramente } \\
\text { oleoso; incoloro; } \\
\text { líquido amarillo } \\
\text { pálido }\end{array}$ & 112 & $.69,2$ & 164,4 & sol & 1,6558 & 5,7 & $\begin{array}{l}5,7 \mathrm{~mm} \mathrm{Hg} \\
@ 0 \stackrel{0}{0}\end{array}$ & & \\
\hline $\begin{array}{l}\text { 1,1-DICLORO-1-NITROETANO } \\
594-72-9\end{array}$ & líquido incoloro & 124 & & 143,9 & $\begin{array}{l}0,25 \mathrm{ml} / \\
100 \mathrm{ml}\end{array}$ & 1,4271 & 5,0 & $\begin{array}{l}16,0 \\
\mathrm{~mm} \mathrm{Hg} \\
@ 25 \stackrel{\circ}{-} \mathrm{C}\end{array}$ & & $76 \mathrm{ca}$ \\
\hline $\begin{array}{l}\text { DIETILEN GLICOL DINITRATO } \\
693-21-0\end{array}$ & líquido & 161 & $-11,6$ & & lig sol & $1,377 @ 25 \stackrel{\circ}{C}$ & & & & \\
\hline $\begin{array}{l}\text { ETILEN GLICOL DINITRATO mezclado } \\
\text { con NITROGLICERINA (1:1) } \\
53569-64-5\end{array}$ & $\begin{array}{l}\text { líquido viscoso, } \\
\text { amarillo pálido }\end{array}$ & $197-200$ & $-22,3$ & 152,06 & lig sol & 1,4978 & & & & 218 \\
\hline $\begin{array}{l}\text { ETLEEN GLICOL DINITRATO } \\
628-96.6\end{array}$ & $\begin{array}{l}\text { líquido amarillento y } \\
\text { oleoso; incoloro }\end{array}$ & $197-200$ & $-22,3$ & 152,06 & insol & 1,4918 & 5,24 & $7 \mathrm{~Pa}$ & & 215 cc 114 \\
\hline
\end{tabular}




\begin{tabular}{|c|c|c|c|c|c|c|c|c|c|c|c|}
\hline $\begin{array}{l}\text { Denominación química } \\
\mathrm{N} \text { úmero CAS }\end{array}$ & Color/ Forma & $\begin{array}{l}\text { p.e. } \\
(\stackrel{0}{ } \mathrm{C})\end{array}$ & $\begin{array}{l}\text { p.f. } \\
(\stackrel{0}{ } C)\end{array}$ & $\begin{array}{l}\text { P.m./ } \\
\text { (g/ } \\
\text { mol) }\end{array}$ & $\begin{array}{l}\text { Solubilidad } \\
\text { en agua }\end{array}$ & $\begin{array}{l}\text { Densidad } \\
\text { relativa } \\
\text { (agua }=1 \text { ) }\end{array}$ & $\begin{array}{l}\text { Densidad } \\
\text { de vapor } \\
\text { relativa } \\
\text { (aire=1) }\end{array}$ & $\begin{array}{l}\text { Pvap/ } \\
(\mathrm{kPa})\end{array}$ & $\begin{array}{l}\text { Límit. } \\
\text { inflam. }\end{array}$ & $\begin{array}{l}\text { p.ig. } \\
(\because C)\end{array}$ & $\begin{array}{l}\text { p.aut } \\
\text { ig. } \\
(\mathrm{O} C)\end{array}$ \\
\hline $\begin{array}{l}\text { NITRATO DE ETILO } \\
625-58-1\end{array}$ & líquido incoloro & $\begin{array}{l}87,2^{\circ} \mathrm{Ca} \\
762 \mathrm{~mm} \mathrm{Hg}\end{array}$ & $94,6^{\circ} \mathrm{C}$ & 91,07 & $\begin{array}{l}1,3 \mathrm{~g} \text { en } \\
100 \mathrm{ml} \\
@ 55^{\circ} \mathrm{C}\end{array}$ & $\begin{array}{l}1,1084 \mathrm{a} \\
20^{\circ} \mathrm{C} / 4^{\circ} \mathrm{C}\end{array}$ & 3,1 & & $\begin{array}{l}\text { Inferior, } \\
4,0 \% \text { en } \\
\text { volumen }\end{array}$ & 10 & \\
\hline $\begin{array}{l}\text { NITRATO DE PROPILO } \\
627-13-4\end{array}$ & & 110 & & 105,09 & lig sol & 1,0538 & & & & & \\
\hline $\begin{array}{l}\text { NITRITO DE AMILO } \\
110-46-3\end{array}$ & $\begin{array}{l}\text { líquido amarillento, } \\
\text { transparente }\end{array}$ & 99 & & 117,1 & lig sol & 0,8828 & 4,0 & & & & \\
\hline $\begin{array}{l}\text { NITRITO DE ETILO } \\
\text { 109-95-5 }\end{array}$ & $\begin{array}{l}\text { líquido transparente } \\
\text { incoloro o } \\
\text { amarillento }\end{array}$ & 17 & .50 & 75,07 & lig sol & $\begin{array}{l}0,90 @ \\
15^{\circ} \mathrm{C} / 15^{\circ} \mathrm{C}\end{array}$ & 2,6 & & $\begin{array}{l}4,0 \% \text { li } \\
50,0 \% \text { is en } \\
\text { volumen en } \\
\text { aire }\end{array}$ & $-35^{\circ} \mathrm{C}$ & $\begin{array}{l}90 \text { (se } \\
\text { des-- } \\
\text { compo- } \\
\text { ne), }\end{array}$ \\
\hline $\begin{array}{l}\text { NITROETANO } \\
79-24-3\end{array}$ & $\begin{array}{l}\text { líquido oleoso; } \\
\text { líquido incoloro }\end{array}$ & 114 & -50 & 75,07 & lig sol & $\begin{array}{l}1,0448 \\
@ 25 \stackrel{\circ}{\circ} / 4 \stackrel{\circ}{C}\end{array}$ & 2,58 & 2,08 & $\begin{array}{l}4,0 \mathrm{li} \\
? \text { Is }\end{array}$ & 28 & 414 \\
\hline $\begin{array}{l}\text { NITROGLICERINA } \\
55-63-0\end{array}$ & $\begin{array}{l}\text { cristales triclínicos o } \\
\text { rómbicos de color } \\
\text { amarillo pálido por } \\
\text { debajo del punto de } \\
\text { fusión; líquido } \\
\text { viscoso; líquido } \\
\text { oleoso, amarillo } \\
\text { pálido }\end{array}$ & 260 & 13 & 227,1 & lig sol & 1,5931 & 7,8 & $\begin{array}{l}0,0025 \\
\mathrm{~mm} \mathrm{Hg}\end{array}$ & & & 270 \\
\hline $\begin{array}{l}\text { NITROMETANO } \\
75-52.5 \\
\end{array}$ & $\begin{array}{l}\text { líquido incoloro; } \\
\text { líquido oleoso }\end{array}$ & 101,1 & -29 & 61,04 & sol & 1,14 & 2,11 & 3,5 & $\begin{array}{l}7,3 \mathrm{li} \\
? \text { Is } \\
\end{array}$ & $35 \mathrm{cc}$ & 417 \\
\hline $\begin{array}{l}\text { 1-NITROPROPANO } \\
\text { 108-03-2 }\end{array}$ & líquido incoloro & 131,6 & -108 & 89,09 & lig sol & $\begin{array}{l}0,9934 @ \\
25 \stackrel{\circ}{\circ} / 4 \stackrel{\circ}{-} \mathrm{C}\end{array}$ & 3,1 & $7,5 \mathrm{~mm} \mathrm{Hg}$ & 2,2 & 34 & \\
\hline $\begin{array}{l}\text { 2-NITROPROPANO } \\
\text { 79-46-9 }\end{array}$ & líquido incoloro & 120 & .93 & 89,09 & lig sol & 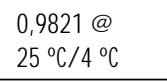 & 3,06 & $\begin{array}{l}20 \mathrm{~mm} \mathrm{Hg} \\
@ 25 \stackrel{\circ}{\mathrm{C}}\end{array}$ & $\begin{array}{l}2,6 \mathrm{li} \\
11,0 \mathrm{ls}\end{array}$ & $24 c c$ & 428 \\
\hline $\begin{array}{l}\text { PENTAERITRITOL TETRANITRATO } \\
\text { 78-11-5 }\end{array}$ & $\begin{array}{l}\text { prismas blancos } \\
\text { cristalinos; } \\
\text { (acetona-alcohol) } \\
\end{array}$ & $\begin{array}{l}180 \\
@ 50 \mathrm{~mm} \mathrm{Hg}\end{array}$ & 140 & 316,1 & lig sol & 1,773 & & & & & \\
\hline $\begin{array}{l}\text { 1,2-PROPILEN GLICOL DINITRATO } \\
6423-43-4\end{array}$ & líquido incoloro & 121 & $-27,7$ & 166,09 & sol & 0,9234 & & & & 361 & \\
\hline $\begin{array}{l}\text { TETRANITROMETANO } \\
509-14-8\end{array}$ & $\begin{array}{l}\text { líquido amarillo claro; } \\
\text { líquido oleoso } \\
\text { incoloro }\end{array}$ & 126 & 13,8 & 196,0 & insol & 1,6229 & 0,8 & $\begin{array}{l}13 \mathrm{~mm} \mathrm{Hg} \\
@ 25 \stackrel{\circ}{\circ} \mathrm{C}\end{array}$ & & & \\
\hline
\end{tabular}




\section{NITROCOMPUESTOS AROMATICOS}

Los nitrocompuestos aromáticos constituyen un grupo de productos químicos orgánicos encabezados por el nitrobenceno $\left(\mathrm{C}_{6} \mathrm{H}_{5} \mathrm{NO}_{2}\right)$ y derivados del benceno y sus homólogos (tolueno y xileno), el naftaleno y el antraceno, por sustitución de uno o más átomos de hidrógeno por un grupo nitro $\left(\mathrm{NO}_{2}\right)$. Este grupo nitro puede ser sustituido a su vez por un halógeno y ciertos radicales alquilos en casi todas las posiciones del anillo.

Los nitrocompuestos más importantes desde el punto de vista industrial son el nitrobenceno, el mononitrolueno, el dinitrotolueno, el trinitrotolueno (T NT), el tetrilo, los mononitroclorobencenos, las nitroanilinas, los nitroclorotoluenos, el nitronaftaleno, el dinitrofenol, el ácido pícrico (trinitrofenol) y el dinitrocresol. La acción de todos estos compuestos en el organismo humano se ha estudiado lo suficiente como para establecer una relación de sus propiedades tóxicas y las medidas de control necesarias para evitar sus efectos nocivos.

$\mathrm{H}$ ay que considerar que existen muchos otros compuestos de este grupo, como son todos aquellos derivados que nunca se han producido en cantidad suficiente como para realizar una evaluación completa de los riesgos. Entre estos derivados están los dinitroclorobencenos, dicloronitrobencenos, nitroxilenos, nitrotoluidinas, nitrocloroanilinas, nitroanisoles, nitrofenetoles y nitroanisidinas.

\section{U sos}

Los nitrocompuestos aromáticos tienen pocos usos directos que no sean en la fabricación de explosivos o como disolventes. Su mayor consumo corresponde a la reducción a derivados de la anilina que se utilizan en la fabricación de colorantes, pigmentos, insecticidas, textiles (poliamida resistente al calor: "Nomex"), plásticos, resinas, elastómeros (poliuretano), productos farmacéuticos, reguladores del crecimiento de las plantas, aditivos para combustibles, aceleradores del caucho y antioxidantes.

Los dinitrotoluenos se utilizan en la síntesis orgánica, colorantes, explosivos y como aditivos de propelentes. Los nitrotoluenos se emplean en la fabricación de colorantes, explosivos, toluidinas y ácidos nitrobenzoicos. T ambién se encuentran en algunas formulaciones de detergentes, agentes de flotación y en la fabricación de neumáticos. Los nitrotoluenos se utilizan en la síntesis de protectores solares y en la producción de inhibidores de la gasolina. EI 2,4,6-trinitrotolueno es un explosivo militar e industrial. EI nitrobenceno se emplea en la fabricación de anilina, como disolvente de éteres de celulosa y como componente de productos para el pulido de metales, en ceras para suelos y calzados y en la fabricación de jabones. El nitrobenceno se utiliza también en el refino de aceites lubricantes y en la producción de isocianatos, pesticidas, productos químicos derivados del caucho y productos farmacéuticos.

El m-nitrofenol se utiliza en peletería como fungicida y el p-nitrofenol, como producto químico intermedio en la producción de conservantes de pieles. El 2,4-dinitrofenol se utiliza en la fabricación de reveladores fotográficos, como conservante de madera y como insecticida. La 2-nitro-p-fenilendiamina y el 4-amino-2-nitrofenol se emplean como componentes de productos para el moldeado permanente del cabello y de tintes para pieles.

La p-nitrosodifenilamina actúa como acelerador de la vulcanización del caucho y como inhibidor de la polimerización en la fabricación de monómeros de vinilo. El ácido pícrico tiene numerosos usos en la industria textil, del vidrio y del cuero. También se utiliza en explosivos, colorantes, germicidas, fungicidas, baterías eléctricas y combustibles de cohetes, así como para el grabado del cobre y como producto químico intermedio. El tetrilo se utiliza como agente detonante intermedio para otros explosivos menos sensibles y como carga multiplicadora en equipos militares.

\section{Riesgos}

\section{Salud}

EI riesgo agudo para la salud más importante de los nitrocompuestos aromáticos es la cianosis, y la manifestación crónica es la anemia. Los nitrocompuestos liposolubles se absorben muy rápidamente a través de la piel intacta. Una cierta cantidad se excreta sin cambios a través de los riñones, pero la mayor parte se reduce para dar derivados nitrocianógenos e hidroxilamínicos, que a su vez se degradan a los análogos orto y para-aminofenol y se excretan en la orina. T res de cada cuatro casos de cianosis muestran el aspecto azul o gris cenizo típico, pero sólo una tercera parte de las víctimas presentan síntomas de anoxia (cefalea, fatiga, náuseas, vértigo, dolor torácico, entumecimiento, dolor abdominal, dolor, palpitaciones, afonía, nerviosismo, disnea e irritabilidad). La intoxicación puede confirmarse mediante análisis de sangre y orina, detectándose cuerpos de $\mathrm{H}$ einz en los hematíes. La metahemoglobinemia se trata con más detalle en otros artículos de esta E nciclopedia.

El potencial cianogénico depende en gran parte de la naturaleza y la posición de los grupos sustituyentes en el anillo de benceno. Además de su potencial cianogénico, los nitroclorobencenos también son irritantes. Los dinitroclorobencenos producen dermatitis por sensibilización en la mayoría de las personas incluso después de un contacto leve. El grado de toxicidad de los dicloronitrobencenos es intermedio.

Los efectos a largo plazo son más insidiosos y sólo pueden detectarse mediante registros médicos bien documentados. LoS análisis de sangre bimensuales revelarán la presencia de anemia durante varios años, incluso en ausencia de cianosis detectable 0 de una excreción urinaria significativamente elevada.

EI 2,4-dinitrotolueno afecta a las enzimas que metabolizan los fármacos en los microsomas hepáticos y se ha demostrado que es un carcinógeno hepático en la rata. No existen datos disponibles en lo referente a su potencial carcinogénico en el hombre.

La 1- y la 2-nitronaftilamina se han aislado como metabolitos urinarios del 1-y del 2-nitronaftaleno, respectivamente, en ratas. Este hecho tiene repercusiones importantes en cuanto al posible potencial carcinogénico de los nitronaftalenos.

El dinitrofenol (DNF) es un agente tóxico agudo que altera el metabolismo celular en todos los tejidos al interferir con el proceso esencial de fosforilación oxidativa. Si la víctima no sucumbe a la intoxicación, los efectos desparecen rápida y completamente. La exposición puede tener lugar por inhalación de vapores, polvo o nieblas de soluciones de DNF. Esta sustancia se absorbe a través de la piel intacta pero, gracias a su color amarillo intenso, la contaminación de la piel es muy fácil de reconocer. Se han producido casos de intoxicación sistémica tanto durante su producción como durante su uso. EI DNF sólido es explosivo y han ocurrido accidentes durante su producción y uso, por lo que debe manipularse con extrema precaución.

La intoxicación produce sudoración excesiva y una sensación de calor con debilidad y fatiga. En los casos graves, la respiración se hace rápida, existe taquicardia incluso en reposo y la temperatura corporal puede aumentar. Si se produce la muerte, ésta es 
rápida y el rigor mortis se instaura casi de inmediato. EI DNF ejerce su efecto tóxico por una alteración general del metabolismo celular que produce la necesidad de consumir cantidades excesivas de oxígeno para poder sintetizar los nucleótidos de adenina necesarios para la supervivencia de las células del cerebro, el corazón o los músculos. Si por ello la producción de calor es superior a su pérdida, puede producirse una hipertermia fatal. Estos efectos son más graves en los lugares de trabajo con ambientes cálidos.

EI DNF se reduce rápidamente a aminofenol, un compuesto mucho menos tóxico, pero no inocuo, que se excreta como tal en la orina. Puesto que el D NF se metaboliza y excreta rápidamente, y como la intoxicación no produce lesiones estructurales en los tejidos, la absorción de pequeñas dosis durante largos períodos de tiempo no produce efectos crónicos ni acumulativos. La intoxicación puede confirmarse determinando el DNF o el aminofenol en la orina mediante el método de Derrien. No se produce metahemoglobinemia.

EI dinitrobenceno es una sustancia química potente con efectos multisistémicos (como mínimo afecta al sistema nervioso central (SNC), la sangre, el hígado, el sistema cardiovascular y los ojos). Puede producir anemia grave y metahemoglobinemia.

EI nitrobenceno puede penetrar en el organismo por vía respiratoria o percutánea (por ejemplo, por el uso de zapatos teñidos de negro con un colorante que contenga nitrobenceno o por la contaminación de la ropa de los trabajadores encargados de la producción de nitrobenceno). El efecto tóxico más importante del nitrobenceno es su capacidad de producir metahemoglobinemia. Su aparición es insidiosa y la cianosis sólo se presenta cuando el nivel de metahemoglobina en la sangre alcanza un $15 \%$ o más. En caso de metahemoglobinemia grave, el paciente sufre, en estadios más avanzados, hipotensión, cefalea, náuseas, vértigo, entumecimiento de las extremidades, una intensa debilidad general grave y trastornos corticales. EI nitrobenceno también es tóxico para el sistema nervioso central y, en algunos casos, produce excitación y temblores, seguidos de depresión grave, inconsciencia y coma. El análisis de orina de las personas expuestas muestra la presencia de nitro y aminofenoles, cuyos niveles pueden ser paralelos a los de la metahemoglobinemia. $L a$ exposición reiterada puede derivar en insuficiencia hepática que progresa a atrofia amarilla, ictericia hemolítica, anemia en distintos grados y presencia de cuerpos de $\mathrm{H}$ einz en los hematíes. El nitrobenceno también provoca dermatitis por irritación primaria o sensibilización.

Acido pícrico y derivados. Los derivados del ácido pícrico de importancia industrial son los picratos metálicos (de hierro, níquel, bario, cromo, plomo y potasio) y las sales de amoniaco y guanidina. Algunas de estas sales metálicas (bario, plomo 0 potasio) se han utilizado para la fabricación de mezclas detonantes y reforzadoras en bombas, minas y balas de cañón. Los efectos tóxicos pueden producirse por contacto cutáneo o por inhalación o ingestión del polvo de ácido pícrico o de sus sales. EI contacto con la piel produce además dermatosis. Algunas de las sales metálicas también representan un riesgo de incendio y explosión.

T ras la ingestión de algunos gramos de ácido pícrico, que tiene un sabor sumamente amargo, puede producirse gastroenteritis aguda, hepatitis tóxica, nefritis, hematuria y otros síntomas urinarios. La piel y la conjuntiva se tornan de color amarillo, principalmente debido al ácido, pero también en parte, a causa de la ictericia. Puede producirse una visión amarilla. La muerte, cuando se produce, se debe a lesiones renales y anuria. En raras ocasiones, la muerte va precedida de ictericia y coma. T ras la absorción de esta sustancia por vía percutánea aparece cefalea, vértigo, náuseas, vómitos y erupciones cutáneas.
En la industria, sobre todo en la fabricación de explosivos, el principal problema de salud es la aparición de dermopatías, en tanto que los casos de intoxicación sistémica son raros. Se ha visto que el ácido pícrico en forma sólida es irritante para la piel, pero en solución acuosa sólo irrita las pieles hipersensibles, produciendo una dermatitis por sensibilización similar a la producida por el picrato amónico. G eneralmente afecta a la cara $y$, en especial, a la zona peribucal y los flancos de la nariz. Se aprecia edema, pápulas, vesículas y, por último, descamación. La zona aparece endurecida, como ocurre con el tetrilo o el trinitrotolueno. L os trabajadores que manipulan ácido pícrico o sus sales presentan la superficie cutánea y el pelo de un color amarillento.

La exposición intensa de animales de experimentación a polvo de picrato amónico durante períodos de hasta 12 meses produjo lesiones que demostraban alteraciones irreversibles en ciertos tejidos. El polvo del ácido pícrico puede causar no sólo irritación de la piel, sino también de la mucosa nasal. La inhalación de concentraciones elevadas de polvo produce pérdida de la consciencia momentáneamente, seguida de debilidad, mialgia, anuria y, posteriormente, poliuria. Los efectos del ácido pícrico en los ojos son: irritación, lesiones en la córnea, efectos visuales extraños (como el aspecto amarillo de los objetos) y coloración amarilla de los tejidos.

El ácido pícrico y sus derivados inflamables y explosivos deben almacenarse en cantidades pequeñas y en una zona fresca y bien ventilada, alejada de cualquier riesgo de incendio y de potentes agentes oxidantes y, preferiblemente, en un local aislado y separado del resto de las instalaciones.

T etrilo. Los riesgos de explosión asociados a la producción de tetrilo son fundamentalmente los mismos que los de otros productos de la industria de explosivos, aunque el tetrilo, por ser relativamente estable, no puede considerarse como uno de los explosivos más peligrosos.

Durante la fabricación de tetrilo, los trabajadores pueden verse expuestos a óxidos de nitrógeno y a vapores ácidos en caso de ocurrir alguna fuga en los reactores de nitración. $\mathrm{H}$ ay exposición a cantidades apreciables de polvo de tetrilo durante la fabricación de los detonadores y en las operaciones subsiguientes de manejo, especialmente en el mezclado, pesaje, prensado de tabletas, eliminación de polvo y carga y montaje de los ingenios explosivos. Las principales manifestaciones de la exposición son irritación de las mucosas, pigmentación y decoloración de la piel y el cabello, dermatitis y, en casos de exposición intensa y prolongada, intoxicación sistémica debida a la inhalación y a la absorción cutánea.

La exposición inicial al tetrilo produce una irritación aguda de las mucosas de la nariz y la faringe. Al cabo de unos días, las manos, la cara, el cuero cabelludo y el cabello de los trabajadores expuestos se tiñen de un color amarillento. En las exposiciones más graves resulta afectada la conjuntiva y casi siempre se observa edema periorbital y palpebral inyectado de sangre. Durante las primeras 2 ó 3 semanas de exposición, los trabajadores pueden desarrollar dermatitis en forma de eritema, especialmente en la región del cuello, el pecho, la espalda y la cara interna de los antebrazos. D espués de unos días, el eritema puede remitir, dejando una descamación moderada. Los trabajadores que pueden continuar trabajando a pesar de la dermatitis desarrollan tolerancia o resistencia al tetrilo. Sin embargo, la exposición prolongada o en personas con mala higiene personal o piel muy fina, la dermatitis puede extenderse a otras zonas del cuerpo y convertirse en papular, vesicular y eczematosa.

Después de sólo 3 ó 4 días de exposición a concentraciones elevadas de polvo, los trabajadores pueden llegar a quejarse de dolores de cabeza seguidos por hemorragias nasales periódicas. La irritación del tracto respiratorio superior no se extiende con frecuencia a los bronquios debido a que los cristales de tetrilo, 
por su gran tamaño, no suelen llegar tan lejos; no obstante, en algunos casos se ha observado tos seca y espasmos bronquiales. O casionalmente pueden presentarse diarrea y trastornos menstruales.

M uchas de las alteraciones causadas por el tetrilo pueden atribuirse a la acción irritante de los cristales. En algunos casos la dermatitis es alérgica y en muchos casos se han sugerido mecanismos tales como la liberación local de histamina.

Después de una exposición intensa y prolongada, el tetrilo produce intoxicación crónica con trastornos digestivos como pérdida de apetito, dolor abdominal y vómitos, pérdida de peso, hepatitis crónica, irritación del sistema nervioso central con insomnio, hiperreflexia y excitación mental. Se han dado algunos casos de leucocitosis con ligera anemia ocasional. También se han descrito casos de trastornos menstruales. Los experimentos realizados con animales indican daños en los túbulos renales.

El trinitrotolueno, comúnmente conocido como TNT, es también un inductor de metahemoglobina. Durante la Primera Guerra M undial se observó que los trabajadores que participaban en la fabricación de municiones desarrollaban efectos hepáticos graves y anemia y al menos el $25 \%$ de los cerca de 500 casos descritos terminaron con la muerte del trabajador. Durante la Segunda Guerra M undial también se observaron efectos adversos. Presumiblemente, las condiciones han mejorado de tal forma que, en la actualidad, la exposición es mucho más limitada y no deberían producirse casos de intoxicación grave. También se han descrito alteraciones del ciclo menstrual, problemas del tracto urinario y cataratas.

\section{Incendio y explosión}

Los nitrocompuestos aromáticos son inflamables y los di y trinitroderivados son explosivos en condiciones favorables (calor e impactos). Las bombas en funcionamiento que encuentran una válvula de descarga cerrada o una conducción taponada producen la suficiente cantidad de calor friccional con mononitrotolueno y nitroclorobencenos como para provocar explosiones. Los nitrocompuestos aromáticos, excepto el nitrobenceno, no deben calentarse en condiciones alcalinas. L os dinitrocompuestos pueden formar sales nitrólicas sensibles a los impactos y se han llegado a producir incendios por calentar carbonato potásico en o-nitrotolueno.

Durante el almacenamiento y el transporte debe evitarse el contacto con agentes reductores fuertes como sulfuro sódico, polvo de zinc, hidrosulfito sódico, hidruros metálicos y oxidantes fuertes como son los dicromatos, los peróxidos y los cloratos. Aquellos derivados que contengan átomos de cloro reactivos requieren unas condiciones muy especiales de almacenamiento y transporte. Los procesos de reducción química se utilizarán para la adición de nitrocompuestos a un sistema reductor (reducción ácida del hierro, sulfuro alcalino, etc.) en pequeños incrementos sobre una cantidad y a una velocidad que permita evitar el sobrecalentamiento o la acumulación de una excesiva cantidad de nitrocompuestos. Además de conocer los riesgos inherentes al uso de ácido nítrico y sulfúrico concentrados, se debe tener mucho cuidado al desechar las mezclas de ácidos usadas, puesto que contienen compuestos orgánicos muy inestables durante el almacenamiento y calentamiento. El producto terminado deberá lavarse perfectamente y se neutralizará para evitar la corrosión de los metales y la descomposición espontánea.

\section{Medidas de salud y seguridad}

Un programa de salud eficaz encaminado a evitar daños en ésta debido a la exposición a nitrocompuestos aromáticos requiere una serie de medidas relacionadas con el control de la exposición y con la supervisión médica de los trabajadores. Como requisitos mínimos, deberán realizarse análisis en los puestos de trabajo para garantizar la idoneidad de los procedimientos de manipulación de los productos, del diseño de los equipos utilizados para los procesos y las labores de mantenimiento y del sistema de ventilación, realizándose un control de la contaminación ambiental. Siempre es preferible que los procesos se realicen en sistema cerrado. En algunas circunstancias puede que sea necesario realizar análisis del aire, pero en general, los resultados pueden inducir a error debido a la baja presión de vapor de los derivados del nitrobenceno y a la contaminación de las superficies donde se produce el contacto cutáneo. No obstante, las nieblas liberadas de las operaciones de carga en caliente, conducciones de fuga, operaciones de vaporización, canales de drenaje en caliente, etc., no pueden ignorarse como posibles fuentes de intensa exposición cutánea y de contaminación del ambiente de trabajo.

Las medidas de protección necesarias, en orden ascendente de eficacia, son: protección respiratoria, rotación de los puestos de trabajo, limitación del tiempo de exposición, uso de ropa protectora y protección integral del cuerpo. La protección respiratoria tiene una aplicación limitada y el principal problema es el de la absorción percutánea. Los equipos protectores deben seleccionarse cuidadosamente para garantizar que sean impermeables a las sustancias químicas que se van a utilizar.

Para reducir al mínimo el riesgo de exposición crónica, que prive al individuo de una tolerancia limitada a los agentes cianogénicos, será preciso que exista un alto grado de higiene personal, sobre todo en lo que se refiere a la ducha diaria con agua y jabón abundante aplicado vigorosamente al final de cada turno de trabajo. Como consecuencia de la sospecha de ser potencialmente carcinógeno para el ser humano, la exposición profesional a los 1- y 2-nitronaftalenos debe mantenerse la más bajo nivel posible.

Cuando sea factible, se reemplazarán el ácido pícrico y sus derivados por otras sustancias inocuas o menos peligrosas. Si ello no fuese posible, se procederá a modificar los procesos, aislándolos o realizándolos en cerrado, mediante técnicas automáticas o mecánicas. A simismo, se instalarán sistemas de extracción localizada y se recurrirá a los métodos húmedos, con el fin de reducir al mínimo la concentración atmosférica del producto. De cualquier forma, habrá que evitar el contacto directo con estas sustancias químicas. 
TABLAS DE NITROCOMPUESTOS AROMATICOS

\begin{tabular}{|c|c|c|c|}
\hline Tabla 104.129 & química. & & \\
\hline Producto químico & Sinónimos/ Código UN & $\mathrm{N}$ úmero CAS & Fórmula estructural \\
\hline ACIDO PICRICO & $\begin{array}{l}\text { 2-Hidroxi-1,3,5-trinitrobenceno; 1,3,5-trinitrofenol; 2,4,6-trinitrofenol } \\
\text { UN0154 } \\
\text { UN1344 }\end{array}$ & $88-89-1$ & \\
\hline 1-AMINO-2-METIL-5-NITROBENCENO & $\begin{array}{l}\text { 2-Amino-4-nitrotolueno; 2-metil-5-nitroanilina; 6-metil-3-nitroanilina; } \\
\text { 2-metil-5-nitro-bencenamina }\end{array}$ & $99-55-8$ & \\
\hline 4-AMINO-2-NITROFENOL & 4-Hidroxi-3-nitroanilina; o-nitro-p-aminofenol; 2-nitro-4-aminofenol & 119-34-6 & \\
\hline 1-CLORO-2,4-DINITROBENCENO & $\begin{array}{l}\text { 4-Cloro-1,3-dinitrobenceno; 6-cloro-1,3-dinitrobenceno; } \\
\text { 1,3-dinitro-4-clorobenceno; 2,4-dinitroclorobenceno }\end{array}$ & $97-00-7$ & \\
\hline 1-CLORO-2-NITROBENCENO & $\begin{array}{l}\text { Cloro-o-nitrobenceno; 0-cloronitrobenceno; 2-cloronitrobenceno; } \\
\text { o-nitroclorobenceno } \\
\text { UN1578 }\end{array}$ & $88-73-3$ & \\
\hline 1-CLORO-3-NITROBENCENO & $\begin{array}{l}\text { Cloro-m-nitrobenceno; m-nitroclorobenceno } \\
\text { UN1578 }\end{array}$ & $121-73-3$ & \\
\hline 1-CLORO-4-NITROBENCENO & $\begin{array}{l}\text { p-Cloronitrobenceno; 4-cloronitrobenceno; 4-cloro-1-nitrobenceno; } \\
\text { p-nitroclorobenceno } \\
\text { UN1578 }\end{array}$ & $100-00-5$ & \\
\hline 3,5-CLORURO DE DINITROBENZOILO & Cloruro del ácido 3,5-dinitrobenzoico & $99-33-2$ & \\
\hline 1,2-DICLORO-3-NITROBENCENO & 2,3-Dicloronitrobenceno & $3209-22-1$ & \\
\hline 1,2-DICLORO-4-NITROBENCENO & 3,4-Dicloronitrobenceno & $99-54-7$ & \\
\hline 2,4-DICLORO-1-NITROBENCENO & 2,4-Dicloronitrobenceno & $611-06-3$ & \\
\hline DINITROBENCENO & UN1597 & 25154-54-5 & \\
\hline m-DINITROBENCENO & $\begin{array}{l}\text { 1,3-Dinitrobenceno; 2,4-dinitrobenceno } \\
\text { UN1597 }\end{array}$ & $99-65-0$ & \\
\hline
\end{tabular}




\begin{tabular}{|c|c|c|}
\hline Tabla 104.129 & Identificación química. & \\
\hline Producto químico & Sinónimos/ Código UN & $\mathrm{N}$ úmero CAS Fórmula estructural \\
\hline O-DINITROBENCENO & $\begin{array}{l}\text { 1,2-Dinitrobenceno } \\
\text { UN1597 }\end{array}$ & $528-29.0$ \\
\hline p-DINITROBENCENO & UN1597 & $100-25-4$ \\
\hline 2,3-DINITROFENOL & & $66-56-8$ \\
\hline 2,4-DINITROFENOL & 2,4-DNP; 1-hidroxi-2,4-dinitrobenceno & $51-28-5$ \\
\hline DINITRONAFTALENO & & $27478-34-8$ \\
\hline 1,5-DINITRONAFTALENO & & $605-71.0$ \\
\hline 1,3-DINITROPIRENO & & $75321-20-9$ \\
\hline 1,6-DINITROPIRENO & & $42397-64-8$ \\
\hline 1,8-DINITROPIRENO & & $42397-65-9$ \\
\hline DINITROTOLUENO & $\begin{array}{l}\text { Dinitrofenilmetano; metildinitrobenceno } \\
\text { UN2038 }\end{array}$ & $25321-14-6$ \\
\hline 2,3-DINITROTOLUENO & 1-Metil-2,3-dinitrobenceno & $602-01-7$ \\
\hline 2,4-DINITROTOLUENO & Dinitrotolueno; 2,4-dinitrotoluol; 1-metil-2,4-dinitrobenceno & $121-14-2$ \\
\hline 2,5-DINITROTOLUENO & 2-Metil-1,4-dinitrobenceno & $619-15-8$ \\
\hline 2,6-DINITROTOLUENO & 2-M etil-1,3-dinitrobenceno & $606-20-2$ \\
\hline
\end{tabular}




\begin{tabular}{|c|c|c|}
\hline Tabla 104.129 Id & química. & \\
\hline Producto químico & Sinónimos/Código UN & $\mathrm{N}$ úmero CAS Fórmula estructural \\
\hline 3,4-DINITROTOLUENO & 4-Metil-1,2-dinitrobenceno & $610-39-9$ \\
\hline 3,5-DINITRO-0-TOLUIDINA & 2-Amino-4,6-dinitrotolueno; 2-metil-3,5-dinitrobencenamina & $35572-78-2$ \\
\hline 3,5-DINITRO-p-TOLUIDINA & $\begin{array}{l}\text { Amino-2,6-dinitrotolueno; 3,5-dinitro-4-metilbencenamina; 4- } \\
\text { 4-metil-3,5-dinitrobencenamina }\end{array}$ & $19406-51.0$ \\
\hline 1-FLUORO-2,4-DINITROBENCENO & $\begin{array}{l}\text { 2,4-Dinitrofluorobenceno; 2,4-dinitro-1-fluorobenceno; } \\
\text { 1,2,4-fluorodinitrobenceno }\end{array}$ & $70-34-8$ \\
\hline 4-METIL-2,6-DINITROANILINA & $\begin{array}{l}\text { 4-Amino-3,5-dinitrotolueno; 4-metil-2,6-dinitrobencenamina -; } \\
\text { 2,6-dinitro-p-toluidina }\end{array}$ & $6393-42.6$ \\
\hline 2-METIL-1-NITROANTRAQUINONA & 2-Metil-1-nitro-9,10-antracenodiona; 1-nitro-2-metilantraquinona & 129-15-7 \\
\hline N-METIL-N-NITROSOANILINA & $\begin{array}{l}\text { Metilnitrosoanilina; N-metil-N-nitrosobencenamina; metilfenilnitrosamina; } \\
\text { nitrosometilanilina; N-nitroso-N-metilanilina }\end{array}$ & $614-00-6$ \\
\hline 5-NITROACENAFTENO & 1,2-Dihidro-5-nitro-acenaftileno; 5-nitronaftalenotileno & $602-87-9$ \\
\hline 5-NITRO-0-ANISIDINA & $\begin{array}{l}\text { 2-Amino-1-metoxi-4-nitrobenceno; 3-amino-4-metoxinitrobenceno; } \\
\text { 2-amino-4-nitroanisol; 2-metoxi-5-nitroanilina }\end{array}$ & $99-59-2$ \\
\hline NITROBENCENO & $\begin{array}{l}\text { Nitrobenceno; nitrobenzol } \\
\text { UN1662 }\end{array}$ & $98-95-3$ \\
\hline 4-NITRODIFENILAMINA & 4-Nitro-N-fenilbencenamina; p-nitrodifenilamina; p-nitrofenilfenilamina & $836-30-6$ \\
\hline 4-NITRODIFENILO & 4-Nitrodifenilo; p-nitrodifenilo; p-fenil-nitrobenceno; 4-fenil-nitrobenceno & $92-93-3$ \\
\hline NITROFEN & $\begin{array}{l}\text { Eter 2',4'-dicloro-4-nitrodifenílico; éter 2,4-dicloro-4'-nitrodifeńlico; } \\
\text { 2,4-dicloro-1-(4-nitrofenoxi) benceno; éter 2,4-diclorofenil-p-nitrofeńlico }\end{array}$ & $1836-75-5$ \\
\hline 2-NITRO-p-FENILENDIAMINA & $\begin{array}{l}\text { 4-Amino-2-nitroanilina; 1,4-diamino-2-nitrobenceno; } \\
\text { 2-nitro-1,4-bencendiamina; 2-nitro-1,4-diaminobenceno; } \\
\text { 2-nitro-1,4-fenilendiamina }\end{array}$ & $5307-14-2$ \\
\hline
\end{tabular}




\begin{tabular}{|c|c|c|c|}
\hline Tabla 104.129 Id & n química. & & \\
\hline Producto químico & Sinónimos/ Código UN & $\mathrm{N}$ úmero $\mathrm{CAS}$ & Fórmula estructural \\
\hline m-NITROFENOL & $\begin{array}{l}\text { m-Hidroxinitrobenceno; 3-hidroxinitrobenceno; 3-Nitrofenol } \\
\text { UN2648 }\end{array}$ & $554-84-7$ & \\
\hline O-NITROFENOL & $\begin{array}{l}\text { 2-Hidroxinitrobenceno; 2-nitrofenol } \\
\text { UN1663 }\end{array}$ & $88-75-5$ & \\
\hline p-NITROFENOL & $\begin{array}{l}\text { 4-Hidroxinitrobenceno; 4-nitrofenol } \\
\text { UN1663 }\end{array}$ & $100-02.7$ & \\
\hline 1-NITRONAFTALENO & $\alpha-$ Nitronaftaleno & $86-57-7$ & \\
\hline 2-NITRONAFTALENO & $\beta$-Nitronaftaleno & $581-89-5$ & \\
\hline 1-NITROPIRENO & 3-Nitropireno & $5522-43-0$ & \\
\hline p-NITROSODIFENILAMINA & $\begin{array}{l}\text { 4-Nitrosodifenilamina; p-nitroso-N-fenilanilina; 4-nitroso-N-fenilanilina; } \\
\text { 4-nitroso-N-fenilbencenamina }\end{array}$ & $156-10-5$ & \\
\hline m-NITROTOLUENO & $\begin{array}{l}\text { 3-Metilnitrobenceno; m-metilnitrobenceno; 3-nitrotolueno } \\
\text { UN1664 }\end{array}$ & $99-08-1$ & \\
\hline O-NITROTOLUENO & $\begin{array}{l}\text { 0-Metilnitrobenceno; 2-metilnitrobenceno; 2-nitrotolueno } \\
\text { UN1664 }\end{array}$ & $88-72.2$ & \\
\hline p-NITROTOLUENO & $\begin{array}{l}\text { p-Metilnitrobenceno; 4-metilnitrobenceno; p-nitrotolueno; 4-nitrotolueno } \\
\text { UN1664 }\end{array}$ & $99-99-0$ & \\
\hline TETRILO & $\begin{array}{l}\text { N-Metil-N, 2,4,6-tetranitroanilina; N-metil-N,2,4,6-tetranitrobencenamina; } \\
\text { trinitrofenilmetilnitramina; 2,4,6-trinitrofenilmetilnitramina } \\
\text { UN0208 }\end{array}$ & $479-45-8$ & \\
\hline 2,4,7-TRINITROFLUOREN-9-ONA & 2,4,7-Trinitro-9-fluorenona & $129-79-3$ & \\
\hline 1,3,6-TRINITROPIRENO & & $75321-19-6$ & \\
\hline 2,4,6-TRINITROTOLUENO & $\begin{array}{l}\text { 2-Metil-1,3,5-trinitrobenceno; trinitrotolueno, TNT } \\
\text { UN0209 } \\
\text { UN1356 }\end{array}$ & $118-96-7$ & \\
\hline
\end{tabular}




\begin{tabular}{|c|c|c|c|c|c|c|}
\hline \multirow[b]{2}{*}{$\begin{array}{l}\text { Denominación } \\
\text { química } \\
\text { N úmero CAS }\end{array}$} & \multicolumn{4}{|c|}{ Tarjetas Internacionales sobre la Seguridad de los Productos Q uímicos } & \multicolumn{2}{|c|}{ N IO SH (EE.UU.) } \\
\hline & $\begin{array}{l}\text { Período } \\
\text { corto de } \\
\text { exposición }\end{array}$ & $\begin{array}{l}\text { Período } \\
\text { largo de } \\
\text { exposición }\end{array}$ & $\begin{array}{l}\text { Vías de } \\
\text { exposición }\end{array}$ & Síntomas & $\begin{array}{l}\text { O rganos } \\
\text { afectados } \\
\text { Vías de } \\
\text { entrada }\end{array}$ & Síntomas \\
\hline $\begin{array}{l}\text { ACIDO PICRICO } \\
88-89-1\end{array}$ & ojos; piel & piel & $\begin{array}{r}\text { Inhalación } \\
\text { Piel } \\
\text { Ojos } \\
\text { Ingestión }\end{array}$ & $\begin{array}{l}\text { Tos, dolor de garganta, debilidad } \\
\text { Puede absorberse, enrojecimiento } \\
\text { Enrojecimiento, dolor } \\
\text { Diarrea, mareo, cefalea, náuseas, vómitos }\end{array}$ & $\begin{array}{l}\text { Riñones; hígado; } \\
\text { sangre; piel; ojos } \\
\text { Inh; abs; ing; con }\end{array}$ & $\begin{array}{l}\text { Irrit ojos y piel; derm sens; } \\
\text { coloración amarilla del cabello } \\
\text { y la piel; deb, mialgia, anuria, } \\
\text { poliuria; sabor amargo, trast } \\
\text { Gl; hepatitis, hema, album, } \\
\text { nef }\end{array}$ \\
\hline $\begin{array}{l}\text { 1-CLORO-2,4-DINITROBENCENO } \\
97-00-7\end{array}$ & ojos; piel; tract resp & piel; ojos & $\begin{array}{l}\text { Inhalación } \\
\text { Piel } \\
\text { Ojos } \\
\text { Ingestión }\end{array}$ & $\begin{array}{l}\text { Coloración azulada de los labios o uñas, piel } \\
\text { azulada, mareo, cefalea, dificultad } \\
\text { respiratoria, náuseas, vómitos, trastornos } \\
\text { visuales } \\
\text { Puede absorberse, enrojecimiento, dolor } \\
\text { Enrojecimiento, dolor } \\
\text { Dolor abdominal, piel azulada, mareo, cefalea, } \\
\text { dificultad respiratoria, náuseas, vómitos }\end{array}$ & & \\
\hline $\begin{array}{l}\text { 1-CLORO-2-NITROBENCENO } \\
88-73-3\end{array}$ & $\begin{array}{l}\text { ojos; piel; tract } \\
\text { resp; sangre }\end{array}$ & $\begin{array}{l}\text { sangre; hígado; } \\
\text { riñones; bazo }\end{array}$ & $\begin{array}{l}\text { Inhalación } \\
\text { Piel } \\
\text { Ojos }\end{array}$ & $\begin{array}{l}\text { Labios o uñas cianóticos, piel cianótica, mareo, } \\
\text { cefalea, náuseas, respiración entrecortada } \\
\text { Puede absorberse, enrojecimiento } \\
\text { Enrojecimiento, dolor }\end{array}$ & & \\
\hline $\begin{array}{l}\text { 1-CLORO-4-NITROBENCENO } \\
100-00-5\end{array}$ & sangre & piel; sangre & $\begin{array}{r}\text { Inhalación } \\
\text { Piel }\end{array}$ & $\begin{array}{l}\text { Cefalea, desvanecimiento, vértigo, debilidad } \\
\text { Puede absorberse }\end{array}$ & $\begin{array}{l}\text { Sangre; hígado; } \\
\text { riñones; SCV; bazo; } \\
\text { médula ósea; sis } \\
\text { repro [en animales: } \\
\text { tumores vasculares } \\
\text { y hepáticos] } \\
\text { Inh; abs; ing; con }\end{array}$ & $\begin{array}{l}\text { Anox; sabor desagradable; } \\
\text { anemia; metahemo; en } \\
\text { animales: hema, hemog; } \\
\text { cambios en bazo, riñones y } \\
\text { médula ósea; efectos repro; } \\
\text { [carc] }\end{array}$ \\
\hline $\begin{array}{l}\text { 1,2-DICLORO-3-NITRO- } \\
\text { BENCENO } \\
\text { 3209-22-1 }\end{array}$ & sangre & $\begin{array}{l}\text { piel; hígado; } \\
\text { riñones }\end{array}$ & $\begin{array}{r}\text { Inhalación } \\
\text { Piel } \\
\text { Ingestión }\end{array}$ & $\begin{array}{l}\text { Labios o uñas cianóticos } \\
\text { Puede absorberse, enrojecimiento, labios o } \\
\text { uñas cianóticos } \\
\text { Labios o uñas cianóticos, piel cianótica, } \\
\text { confusión, cefalea, vómitos, debilidad }\end{array}$ & & \\
\hline $\begin{array}{l}\text { 1,2-DICLORO-4-NITRO- } \\
\text { BENCENO } \\
\text { 99-54-7 }\end{array}$ & $\begin{array}{l}\text { ojos; piel; tract } \\
\text { resp; pulmones }\end{array}$ & $\begin{array}{l}\text { piel; riñones; } \\
\text { hígado }\end{array}$ & $\begin{array}{r}\text { Inhalación } \\
\text { Piel } \\
\text { Ojos } \\
\text { Ingestión }\end{array}$ & $\begin{array}{l}\text { Labios o uñas cianóticos, sensación de } \\
\text { quemazón en la garganta, cefalea, disnea } \\
\text { Puede absorberse, enrojecimiento, sensación } \\
\text { de quemazón, dolor, labios o uñas cianóticos } \\
\text { Enrojecimiento, dolor } \\
\text { Labios o uñas cianóticos }\end{array}$ & & \\
\hline $\begin{array}{l}\text { 2,4-DICLORO-1-NITRO- } \\
\text { BENCENO } \\
\quad 611-06-3\end{array}$ & sangre & hígado; riñones & $\begin{array}{r}\text { Inhalación } \\
\text { Piel } \\
\text { Ojos } \\
\text { Ingestión }\end{array}$ & $\begin{array}{l}\text { Labios o uñas cianóticos } \\
\text { Puede absorberse, enrojecimiento, labios o } \\
\text { uñas cianóticos } \\
\text { Enrojecimiento } \\
\text { Labios o uñas cianóticos, piel cianótica, } \\
\text { confusión, cefalea, vómitos, debilidad }\end{array}$ & & \\
\hline $\begin{array}{l}\text { DINITROBENCENO } \\
25154-54-5\end{array}$ & $\begin{array}{l}\text { ojos; piel; tract } \\
\text { resp; pulmones; } \\
\text { sangre }\end{array}$ & $\begin{array}{l}\text { hígado; puede } \\
\text { reducir la fertilidad } \\
\text { masculina }\end{array}$ & $\begin{array}{r}\text { Piel } \\
\text { Ojos } \\
\text { Ingestión }\end{array}$ & $\begin{array}{l}\text { Labios o uñas cianóticos, piel cianótica, } \\
\text { sensación de quemazón, mareo, cefalea, } \\
\text { dificultad respiratoria, dolor de garganta, } \\
\text { debilidad, trastornos visuales } \\
\text { Puede absorberse, enrojecimiento, coloración } \\
\text { amarilla de la piel } \\
\text { Enrojecimiento } \\
\text { Dolor abdominal, piel cianótica, diarrea, } \\
\text { mareo, cefalea, dificultad respiratoria, } \\
\text { náuseas, vómitos }\end{array}$ & & \\
\hline
\end{tabular}




\begin{tabular}{|c|c|c|c|c|c|c|}
\hline \multirow[b]{2}{*}{$\begin{array}{l}\text { Denominación } \\
\text { química } \\
\text { N úmero CAS }\end{array}$} & \multicolumn{4}{|c|}{ Tarjetas Internacionales sobre la Seguridad de los Productos Q uímicos } & \multicolumn{2}{|c|}{ N IO SH (EE.UU.) } \\
\hline & $\begin{array}{l}\text { Período } \\
\text { corto de } \\
\text { exposición }\end{array}$ & $\begin{array}{l}\text { Período } \\
\text { largo de } \\
\text { exposición }\end{array}$ & $\begin{array}{l}\text { Vías de } \\
\text { exposición }\end{array}$ & Síntomas & $\begin{array}{l}\text { O rganos } \\
\text { afectados } \\
\text { Vías de } \\
\text { entrada }\end{array}$ & Síntomas \\
\hline $\begin{array}{l}\text { 1,3-DINITROBENCENO } \\
99-65-0\end{array}$ & ojos; piel; tract resp & $\begin{array}{l}\text { hígado; puede } \\
\text { causar alteraciones } \\
\text { de la fertilidad } \\
\text { masculina }\end{array}$ & $\begin{array}{l}\text { Inhalación } \\
\text { Piel } \\
\text { 0jos } \\
\text { Ingestión }\end{array}$ & $\begin{array}{l}\text { Labios o uñas cianóticos, piel cianótica, mareo, } \\
\text { cefalea, dificultad respiratoria, debilidad, } \\
\text { sensación de quemazón en la boca, sequedad } \\
\text { de garganta, sed, trastornos visuales } \\
\text { Puede absorberse, enrojecimiento, quemaduras } \\
\text { en la piel, coloración amarilla de la piel } \\
\text { Enrojecimiento, quemaduras } \\
\text { Dolor abdominal, piel cianótica, diarrea, } \\
\text { mareo, cefalea, dificultad respiratoria, } \\
\text { náuseas, vómitos }\end{array}$ & $\begin{array}{l}\text { Ojos; piel; sangre; } \\
\text { hígado; SCV; SNC } \\
\text { Inh; abs; ing; con }\end{array}$ & $\begin{array}{l}\text { Anox, cian; dist vis, escotomas } \\
\text { centrales; sabor desagradable, } \\
\text { sensación de quemazón en la } \\
\text { boca, sequedad de boca, sed; } \\
\text { coloración amarilla del cabello } \\
\text { y la piel; anemia; les } \\
\text { hepáticas }\end{array}$ \\
\hline $\begin{array}{l}\text { O-DINITROBENCENO } \\
528-29.0\end{array}$ & $\begin{array}{l}\text { ojos; piel; tract } \\
\text { resp; pulmones; } \\
\text { sangre }\end{array}$ & hígado & $\begin{array}{l}\text { Inhalación } \\
\\
\text { Piel } \\
\text { 0jos } \\
\text { Ingestión }\end{array}$ & $\begin{array}{l}\text { Labios o uñas cianóticos, piel cianótica, } \\
\text { sensación de quemazón, mareo, cefalea, } \\
\text { dificultad respiratoria, debilidad, trastornos } \\
\text { visuales } \\
\text { Suede absorberse } \\
\text { Enrojecimiento } \\
\text { Dolor abdominal, piel cianótica, diarrea, } \\
\text { mareo, cefalea, dificultad respiratoria, } \\
\text { náuseas, vómitos }\end{array}$ & $\begin{array}{l}\text { Ojos; piel; sangre; } \\
\text { hígado; SCV; SNC } \\
\text { Inh; abs; ing; con }\end{array}$ & $\begin{array}{l}\text { Anox, cian; dist vis, escotomas } \\
\text { centrales; sabor desagradable, } \\
\text { sensación de quemazón en la } \\
\text { boca, sequedad de garganta, } \\
\text { sed; coloración amarilla del } \\
\text { cabello, los ojos y la piel; } \\
\text { anemia; les hepáticas }\end{array}$ \\
\hline $\begin{array}{l}p \text { p-DINITROBENCENO } \\
100-25-4\end{array}$ & ojos; piel; tract resp & & $\begin{array}{l}\text { Inhalación } \\
\\
\text { Piel } \\
\text { 0jos } \\
\text { Ingestión }\end{array}$ & $\begin{array}{l}\text { Labios o uñas cianóticos, piel cianótica, mareo, } \\
\text { cefalea, dificultad respiratoria, debilidad, } \\
\text { sensación de quemazón en la boca, sequedad } \\
\text { de garganta, sed, trastornos visuales } \\
\text { Puede absorberse, enrojecimiento, coloración } \\
\text { amarilla de la piel } \\
\text { Enrojecimiento, quemaduras } \\
\text { Dolor abdominal, piel cianótica, diarrea, } \\
\text { mareo, cefalea, dificultad respiratoria, } \\
\text { náuseas, vómitos }\end{array}$ & $\begin{array}{l}\text { Ojos, piel; sangre; } \\
\text { hígado; SCV; SNC } \\
\text { Inh; abs; ing; con }\end{array}$ & $\begin{array}{l}\text { Anox, cian; dist vis, escotomas } \\
\text { centrales; sabor desagradable, } \\
\text { sensación de quemazón en la } \\
\text { boca, sequedad de garganta, } \\
\text { sed; coloración amarilla del } \\
\text { cabello, los ojos y la piel; } \\
\text { anemia; les hepáticas }\end{array}$ \\
\hline $\begin{array}{l}\text { 2,4-DINITROFENOL } \\
\text { 51-28-5 }\end{array}$ & Tract GI & $\begin{array}{l}\text { piel; SNC; sangre; } \\
\text { ojos; }\end{array}$ & $\begin{array}{r}\text { Inhalación } \\
\text { Piel } \\
\end{array}$ & $\begin{array}{l}\text { Sudoración, palpitaciones, náuseas, vómitos, } \\
\text { colapso y muerte } \\
\text { Puede absorberse }\end{array}$ & & \\
\hline $\begin{array}{l}\text { DINITROTOLUENO } \\
25321-14-6\end{array}$ & sangre & $\begin{array}{l}\text { hígado; fertilidad } \\
\text { masculina y } \\
\text { femenina }\end{array}$ & $\begin{array}{r}\text { Inhalación } \\
\text { Piel }\end{array}$ & $\begin{array}{l}\text { Sopor, náuseas, vómitos, debilidad } \\
\text { Puede absorberse, labios o uñas cianóticos, } \\
\text { piel azulada, piel metahemoglobinémica }\end{array}$ & $\begin{array}{l}\text { Sangre; hígado; } \\
\text { SCV; sis repro [en } \\
\text { animales: tumores } \\
\text { de hígado, piel y } \\
\text { renales] } \\
\text { Inh; abs; ing; con }\end{array}$ & $\begin{array}{l}\text { Anox, cian; anemia, ict; } \\
\text { efectos repro [carc] }\end{array}$ \\
\hline $\begin{array}{l}\text { 2,3-DINITROTOLUENO } \\
602-01-7\end{array}$ & SNC; SCV; sangre & & $\begin{array}{r}\text { Piel } \\
\text { Ingestión }\end{array}$ & $\begin{array}{l}\text { Puede absorberse } \\
\text { Labios o uñas cianóticos; cefalea, náuseas, } \\
\text { dolor de garganta; vómitos }\end{array}$ & & \\
\hline $\begin{array}{l}\text { 2,4-DINITROTOLUENO } \\
\text { 121-14-2 }\end{array}$ & SNC; SCV; sangre & & $\begin{array}{l}\text { Inhalación } \\
\text { Piel } \\
\text { Ingestión }\end{array}$ & $\begin{array}{l}\text { Labios o uñas cianóticos, cefalea, náuseas, } \\
\text { dolor de garganta, vómitos } \\
\text { Puede absorberse } \\
\text { Labios o uñas cianóticos, cefalea, náuseas, } \\
\text { dolor de garganta, vómitos }\end{array}$ & & \\
\hline $\begin{array}{l}\text { 2,6-DINITROTOLUENO } \\
606-20-2\end{array}$ & sangre & $\begin{array}{l}\text { posible carcinógeno } \\
\text { humano }\end{array}$ & $\begin{array}{r}\text { Inhalación } \\
\text { Piel } \\
\end{array}$ & $\begin{array}{l}\text { Labios o uñas cianóticos, piel cianótica, } \\
\text { diarrea, mareo, sopor } \\
\text { Puede absorberse }\end{array}$ & & \\
\hline $\begin{array}{l}\text { 3,4-DINITROTOLUENO } \\
\text { 610-39-9 }\end{array}$ & SNC; SCV; sangre; & & $\begin{array}{r}\text { Piel } \\
\text { Ingestión }\end{array}$ & $\begin{array}{l}\text { Puede absorberse } \\
\text { Labios o uñas cianóticos, cefalea, náuseas, } \\
\text { dolor de garganta, vómitos }\end{array}$ & & \\
\hline
\end{tabular}




\begin{tabular}{|c|c|c|c|c|c|c|}
\hline \multirow[b]{2}{*}{$\begin{array}{l}\text { Denominación } \\
\text { química } \\
\text { N úmero CAS }\end{array}$} & \multicolumn{4}{|c|}{ Tarjetas Internacionales sobre la Seguridad de los Productos Q uímicos } & \multicolumn{2}{|c|}{ N IO SH (EE.UU.) } \\
\hline & $\begin{array}{l}\text { Período } \\
\text { corto de } \\
\text { exposición }\end{array}$ & $\begin{array}{l}\text { Período } \\
\text { largo de } \\
\text { exposición }\end{array}$ & $\begin{array}{l}\text { Vías de } \\
\text { exposición }\end{array}$ & Síntomas & $\begin{array}{l}\text { O rganos } \\
\text { afectados } \\
\text { Vías de } \\
\text { entrada }\end{array}$ & Síntomas \\
\hline $\begin{array}{l}\text { NITROBENCENO } \\
98-95-3\end{array}$ & ojos; sangre; SNC & $\begin{array}{l}\text { piel; sangre; } \\
\text { hígado; SNC; bazo; } \\
\text { puede reducir la } \\
\text { fertilidad masculina }\end{array}$ & $\begin{array}{l}\text { Inhalación } \\
\text { Piel }\end{array}$ & $\begin{array}{l}\text { Labios o uñas cianóticos, piel cianótica, mareo, } \\
\text { cefalea, náuseas, inconsciencia, debilidad } \\
\text { Puede absorberse }\end{array}$ & $\begin{array}{l}\text { Ojos; piel; sangre; } \\
\text { hígado; riñones; } \\
\text { SCV; sis repro } \\
\text { Inh; abs; ing; con }\end{array}$ & $\begin{array}{l}\text { Irrit ojos, piel; anox; derm; } \\
\text { anemia; metahemo; en } \\
\text { animales: les hepáticas y } \\
\text { renales; efectos testiculares }\end{array}$ \\
\hline $\begin{array}{l}\text { 4-NITRODIFENILAMINA } \\
\quad 836-30-6\end{array}$ & $\begin{array}{l}\text { ojos; piel; tract } \\
\text { resp; sangre; } \\
\text { cerebro }\end{array}$ & sangre & $\begin{array}{r}\text { Inhalación } \\
\text { Piel } \\
\text { Ojos } \\
\text { Ingestión }\end{array}$ & $\begin{array}{l}\text { Sensación de quemazón, tos, dolor de } \\
\text { garganta, véase ingestión } \\
\text { Véase ingestión } \\
\text { Enrojecimiento, dolor } \\
\text { Labios o uñas cianóticos, piel cianótica, mareo, } \\
\text { cefalea, dificultad respiratoria }\end{array}$ & & \\
\hline $\begin{array}{l}\text { NITROFEN } \\
1836-75-5\end{array}$ & ojos; piel; tract resp & $\begin{array}{l}\text { piel; sangre; SNC; } \\
\text { sis reproductor } \\
\text { humano }\end{array}$ & $\begin{array}{r}\text { Inhalación } \\
\text { Piel } \\
\text { Ojos } \\
\text { Ingestión }\end{array}$ & $\begin{array}{l}\text { Tos, dificultad respiratoria, dolor de garganta } \\
\text { Enrojecimiento, dolor } \\
\text { Enrojecimiento, dolor, visión borrosa } \\
\text { Dolor abdominal }\end{array}$ & & \\
\hline $\begin{array}{l}\text { P-NITROFENOL } \\
100-02-7\end{array}$ & $\begin{array}{l}\text { ojos; piel; tract } \\
\text { resp; SNC; sangre; } \\
\text { riñones }\end{array}$ & $\begin{array}{l}\text { SNC; hígado; } \\
\text { riñones; sangre; }\end{array}$ & $\begin{array}{r}\text { Inhalación } \\
\text { Piel } \\
\text { Ojos } \\
\text { Ingestión }\end{array}$ & $\begin{array}{l}\text { Piel cianótica, mareo, cefalea, fiebre, náuseas, } \\
\text { disnea, debilidad, sudoración } \\
\text { Puede absorberse, enrojecimiento, costras } \\
\text { Enrojecimiento, dolor } \\
\text { Dolor como de quemazón en la boca y la } \\
\text { garganta, dolor abdominal, mareo, } \\
\text { inconsciencia }\end{array}$ & & \\
\hline $\begin{array}{l}\text { O-NITROTOLUENO } \\
88-72.2\end{array}$ & $\begin{array}{l}\text { ojos; piel; tract } \\
\text { resp; sangre }\end{array}$ & hígado; sangre & $\begin{array}{l}\text { Inhalación } \\
\text { Piel } \\
\text { Ojos } \\
\text { Ingestión }\end{array}$ & $\begin{array}{l}\text { Labios o uñas cianóticos, piel cianótica, tos, } \\
\text { mareo, cefalea, dificultad respiratoria, dolor de } \\
\text { garganta } \\
\text { Puede absorberse, enrojecimiento, dolor } \\
\text { Enrojecimiento, dolor } \\
\text { Dolor abdominal, labios o uñas cianóticos, piel } \\
\text { cianótica, mareo, cefalea, dificultad } \\
\text { respiratoria }\end{array}$ & $\begin{array}{l}\text { Sangre; SNC; SCV; } \\
\text { piel; tract GI } \\
\text { Inh; abs; ing; con }\end{array}$ & $\begin{array}{l}\text { Anox, cian; cef, deb, mar; } \\
\text { atax; dis; taquil; náu, vómit }\end{array}$ \\
\hline $\begin{array}{l}\text { p-NITROTOLUENO } \\
99.99 .0\end{array}$ & ojos; piel; tract resp & hígado; riñones & $\begin{array}{l}\text { Inhalación } \\
\text { Piel } \\
\text { Ojos } \\
\text { Ingestión }\end{array}$ & $\begin{array}{l}\text { Labios o uñas cianóticos, piel cianótica, tos, } \\
\text { mareo, cefalea, dificultad respiratoria, dolor de } \\
\text { garganta } \\
\text { Puede absorberse, enrojecimiento, dolor } \\
\text { Enrojecimiento, dolor } \\
\text { Dolor abdominal, labios o uñas cianóticos, piel } \\
\text { cianótica, mareo, cefalea, dificultad } \\
\text { respiratoria, dolor de garganta, inconsciencia }\end{array}$ & $\begin{array}{l}\text { Sangre; SNC; SCV; } \\
\text { piel; tract GI } \\
\text { Inh; abs; ing; con }\end{array}$ & $\begin{array}{l}\text { Anox, cian; cef, deb, mar; } \\
\text { ataxia; dis; taqui; náu, vómit }\end{array}$ \\
\hline $\begin{array}{l}\text { TETRILO } \\
479-45-8\end{array}$ & $\begin{array}{l}\text { ojos; piel; tract } \\
\text { resp; riñones; } \\
\text { hígado; sangre }\end{array}$ & piel & $\begin{array}{r}\text { Inhalación } \\
\text { Piel } \\
\text { Ojos } \\
\text { Ingestión }\end{array}$ & $\begin{array}{l}\text { Insomnio, tos, cefalea, dolor de garganta, } \\
\text { hemorragias nasales } \\
\text { Enrojecimiento, manchas amarillas en la piel y } \\
\text { el cabello } \\
\text { Enrojecimiento, dolor } \\
\text { Dolor abdominal, mareo, cefalea, náuseas }\end{array}$ & $\begin{array}{l}\text { sis resp; ojos; SNC; } \\
\text { piel; hígado; } \\
\text { riñones } \\
\text { Inh; abs; ing; con }\end{array}$ & $\begin{array}{l}\text { Derm sens, prurito, erit; } \\
\text { edema de los pliegues } \\
\text { nasales, mejillas y cuello; } \\
\text { quera, estor; anemia; ftg; tos, } \\
\text { coriza; irrit; mal, cef, las, } \\
\text { insom; náu, vómit; les } \\
\text { hepáticas y renales }\end{array}$ \\
\hline $\begin{array}{l}\text { 2,4,6-TRINITROTOLUENO } \\
\text { 118-96-7 }\end{array}$ & $\begin{array}{l}\text { ojos; piel; tract } \\
\text { resp; sangre }\end{array}$ & hígado; sangre; ojos & Ojos & Enrojecimiento, dolor & $\begin{array}{l}\text { Ojos; piel; sis resp; } \\
\text { sangre; hígado; } \\
\text { SCV; SNC; riñones } \\
\text { Inh; abs; ing; con }\end{array}$ & $\begin{array}{l}\text { Irrit piel y muc; les hepáticas, } \\
\text { ict; cian; estorn; tos, dolor de } \\
\text { garganta; neur peri, dolor } \\
\text { musc; les renales, cataratas; } \\
\text { derm sens; leucocit; anemia; } \\
\text { irreg card }\end{array}$ \\
\hline
\end{tabular}




\begin{tabular}{|c|c|c|c|}
\hline $\begin{array}{l}\text { Denominación química } \\
\mathrm{N} \text { úmero CAS }\end{array}$ & Físicos & Q uímicos & $\begin{array}{l}\text { Clase o división } \\
\text { UN / Riesgos } \\
\text { subsidiarios }\end{array}$ \\
\hline $\begin{array}{l}\text { ACIDO PICRICO } \\
88-89-1\end{array}$ & & $\begin{array}{l}\text { Puede descomponerse violentamente como consecuencia de un impacto, fricción o sacudida } \\
\text { Puede explotar si se calienta Forma compuestos sensibles a los impactos con los metales, } \\
\text { principalmente cobre, plomo, mercurio y zinc En su combustión produce óxidos tóxicos de } \\
\text { carbono y nitrógeno Reacciona violentamente con materiales oxidantes y reductores }\end{array}$ & $1.1 \mathrm{D}$ \\
\hline $\begin{array}{l}\text { 1-AMINO-2-METIL-5-NITROBENCENO } \\
99-55-8\end{array}$ & & & 6.1 \\
\hline $\begin{array}{l}\text { 1-CLORO-2,4-DINITROBENCENO } \\
97-00-7\end{array}$ & & $\begin{array}{l}\text { Puede sufrir una combustión violenta o explosión cuando se calienta a aproximadamente } \\
149{ }^{\circ} \mathrm{C} \text { Puede explotar si se calienta en espacios cerrados o sufre un golpe Se descompone } \\
\text { al calentarse, liberando gases tóxicos (óxidos de nitrógeno, cloro, cloruro de hidrógeno, fosgeno) } \\
\text { Es un oxidante fuerte y reacciona con materiales combustibles y reductores Es un potente } \\
\text { agente reductor y reacciona con los oxidantes Reacciona con oxidantes fuertes y bases fuertes }\end{array}$ & 6.1 \\
\hline $\begin{array}{l}\text { 1-CLORO-2-NITROBENCENO } \\
88-73-3\end{array}$ & $\begin{array}{l}\text { Posibilidad de explosión } \\
\text { pulverulenta cuando se } \\
\text { encuentra en forma de } \\
\text { polvo o gránulos y se } \\
\text { mezcla con el aire }\end{array}$ & $\begin{array}{l}\text { Se descompone al calentarse o al arder, desprendiendo humos tóxicos y corrosivos (óxidos de } \\
\text { nitrógeno, cloro, cloruro de hidrógeno, fosgeno) Reacciona violentamente con materiales } \\
\text { reductores, con peligro de incendio y explosión }\end{array}$ & 6.1 \\
\hline
\end{tabular}

\begin{tabular}{|c|c|c|c|}
\hline $\begin{array}{l}\text { 1-CLORO-3-NITROBENCENO } \\
121-73-3\end{array}$ & & & 6.1 \\
\hline $\begin{array}{l}\text { 1-CLORO-4-NITROBENCENO } \\
100-00-5\end{array}$ & & $\begin{array}{l}\text { Se descompone al calentarse, liberando gases tóxicos (óxidos de nitrógeno, ácido clorhídrico, } \\
\text { fosgeno y cloro) Es un oxidante fuerte y reacciona violentamente con materiales combustibles y } \\
\text { reductores Reacciona con muchas sustancias, con peligro de incendio y explosión }\end{array}$ & \\
\hline $\begin{array}{l}\text { DINITROBENCENO } \\
25154.54 .5\end{array}$ & $\begin{array}{l}\text { Posibilidad de explosión } \\
\text { pulverulenta cuando se } \\
\text { encuentra en forma de } \\
\text { polvo o gránulos y se } \\
\text { mezcla con el aire }\end{array}$ & $\begin{array}{l}\text { Puede explotar si se calienta en espacios cerrados En su combustión libera gases y humos } \\
\text { tóxicos Reacciona violentamente con oxidantes fuertes, bases fuertes y agentes reductores, con } \\
\text { peligro de incendio y explosión Las mezclas con ácido nítrico son muy explosivas }\end{array}$ & 6.1 \\
\hline $\begin{array}{l}\text { 1,3-DINITROBENCENO } \\
99-65-0\end{array}$ & $\begin{array}{l}\text { Posibilidad de explosión } \\
\text { pulverulenta cuando se } \\
\text { encuentra en forma de } \\
\text { polvo o gránulos y se } \\
\text { mezcla con el aire }\end{array}$ & $\begin{array}{l}\text { Puede explotar si se calienta en espacios cerrados En su combustión desprende gases y } \\
\text { humos tóxicos Reacciona violentamente con oxidantes fuertes, bases fuertes y metales } \\
\text { reductores (estaño y zinc), con peligro de incendio y explosión Las mezclas con ácido nítrico } \\
\text { son muy explosivas }\end{array}$ & 6.1 \\
\hline $\begin{array}{l}\text { 0-DINITROBENCENO } \\
528-29-0\end{array}$ & $\begin{array}{l}\text { Posibilidad de explosión } \\
\text { pulverulenta cuando se } \\
\text { encuentra en forma de } \\
\text { polvo o gránulos y se } \\
\text { mezcla con el aire }\end{array}$ & $\begin{array}{l}\text { Puede explotar si se calienta en espacios cerrados En su combustión libera gases y humos } \\
\text { tóxicos Reacciona violentamente con oxidantes fuertes, bases fuertes y metales reductores, } \\
\text { como estaño y zinc, con peligro de incendio y explosión Las mezclas con ácido nítrico son muy } \\
\text { explosivas }\end{array}$ & 6.1 \\
\hline $\begin{array}{l}\text { p-DINITROBENCENO } \\
100-25-4\end{array}$ & $\begin{array}{l}\text { Posibilidad de explosión } \\
\text { pulverulenta cuando se } \\
\text { encuentra en forma de } \\
\text { polvo o gránulos y se } \\
\text { mezcla con el aire }\end{array}$ & $\begin{array}{l}\text { Puede explotar si se calienta en espacios cerrados En su combustión emite gases y humos } \\
\text { tóxicos Reacciona violentamente con oxidantes fuertes, bases fuertes y metales, como estaño y } \\
\text { zinc, con peligro de incendio y explosión Las mezclas con ácido nítrico son muy explosivas }\end{array}$ & 6.1 \\
\hline $\begin{array}{l}\text { 2,4-DINITROFENOL } \\
\text { 51-28-5 }\end{array}$ & $\begin{array}{l}\text { Posibilidad de explosión } \\
\text { pulverulenta cuando se } \\
\text { encuentra en forma de } \\
\text { polvo o gránulos y se } \\
\text { mezcla con el aire }\end{array}$ & $\begin{array}{l}\text { Puede descomponerse explosivamente por impacto, fricción o golpes Puede explotar si se } \\
\text { calienta }\end{array}$ & \\
\hline $\begin{array}{l}\text { DINITROTOLUENO } \\
25321-14-6\end{array}$ & $\begin{array}{l}\text { El vapor es más pesado } \\
\text { que el aire Posibilidad } \\
\text { de explosión pulverulenta } \\
\text { cuando se encuentra en } \\
\text { forma de polvo o gránulos } \\
\text { y se mezcla con el aire }\end{array}$ & $\begin{array}{l}\text { Puede formar peróxidos explosivos Puede explotar si se calienta o se expone a una llama } \\
\text { Se descompone al calentarse desprendiendo gases y humos tóxicos (monóxido de carbono y } \\
\text { óxidos de nitrógeno) Reacciona violentamente con oxidantes fuertes, con peligro de incendio } \\
\text { y explosión Reacciona con bases fuertes y metales como estaño y zinc, pudiendo producir calor } \\
\text { y un aumento de la presión Ataca algunos tipos de plásticos, caucho y revestimientos }\end{array}$ & 6.1 \\
\hline
\end{tabular}


Tabla 104.131 Riesgos físicos y químicos.

\begin{tabular}{|c|c|c|c|c|}
\hline $\begin{array}{l}\text { Denominación química } \\
\mathrm{N} \text { úmero CAS }\end{array}$ & Físicos & Q uímicos & & $\begin{array}{l}\text { Clase o división } \\
\text { UN / Riesgos } \\
\text { subsidiarios }\end{array}$ \\
\hline $\begin{array}{l}\text { 2,3-DINITROTOLUENO } \\
602-01-7\end{array}$ & $\begin{array}{l}\text { Posibilidad de explosión } \\
\text { pulverulenta cuando se } \\
\text { encuentra en forma de } \\
\text { polvo o gránulos y se } \\
\text { mezcla con el aire }\end{array}$ & $\begin{array}{l}\text { Puede explotar si se calienta } \\
\text { carbono y óxidos de nitrógeno }\end{array}$ & $\begin{array}{l}\text { Se descompone al calentarse, produciendo monóxido de } \\
\text { Reacciona con bases fuertes, oxidantes y agentes reductores }\end{array}$ & 6.1 \\
\hline $\begin{array}{l}\text { 2,4-DINITROTOLUENO } \\
\text { 121-14-2 }\end{array}$ & $\begin{array}{l}\text { Posibilidad de explosión } \\
\text { pulverulenta cuando se } \\
\text { encuentra en forma de } \\
\text { polvo o gránulos y se } \\
\text { mezcla con el aire }\end{array}$ & $\begin{array}{l}\text { Puede explotar si se calienta } \\
\text { carbono y óxidos de nitrógeno }\end{array}$ & $\begin{array}{l}\text { Se descompone al calentarse, produciendo monóxido de } \\
\text { Reacciona con bases fuertes, oxidantes y agentes reductores }\end{array}$ & 6.1 \\
\hline $\begin{array}{l}\text { 2,6-DINITROTOLUENO } \\
606-20-2\end{array}$ & $\begin{array}{l}\text { Posibilidad de explosión } \\
\text { pulverulenta cuando se } \\
\text { encuentra en forma de } \\
\text { polvo o gránulos y se } \\
\text { mezcla con el aire }\end{array}$ & $\begin{array}{l}\text { Puede explotar si se calienta } \\
\text { carbono y óxidos de nitrógeno }\end{array}$ & $\begin{array}{l}\text { Se descompone al calentarse, produciendo monóxido de } \\
\text { Reacciona con bases fuertes, oxidantes y agentes reductores }\end{array}$ & 6.1 \\
\hline $\begin{array}{l}\text { 3,4-DINITROTOLUENO } \\
\quad 610-39-9\end{array}$ & $\begin{array}{l}\text { Posibilidad de explosión } \\
\text { pulverulenta cuando se } \\
\text { encuentra en forma de } \\
\text { polvo o gránulos y se } \\
\text { mezcla con el aire }\end{array}$ & $\begin{array}{l}\text { Puede explotar si se calienta } \\
\text { carbono y óxidos de nitrógeno }\end{array}$ & $\begin{array}{l}\text { Se descompone al calentarse, produciendo monóxido de } \\
\text { Reacciona con bases fuertes, oxidantes y agentes reductores }\end{array}$ & 6.1 \\
\hline
\end{tabular}

5-NITRO-O-ANISIDINA

$99-59-2$

NITROBENCENO

98-95-3

En su combustión libera humos corrosivos, como óxidos de nitrógeno Reacciona

violentamente con oxidantes fuertes y agentes reductores, con peligro de incendio y explosión Ataca muchos plásticos Forma sustancias o mezclas explosivas (térmicamente inestables) con muchos compuestos orgánicos e inorgánicos como oxidantes, cloruro de aluminio con fenol, hidróxido potásico anhidro o con pequeñas cantidades de metanol, anilina con glicerol, pentacloruro de fósforo, ácido nítrico, ácido sulfúrico o potasio

\begin{tabular}{|c|c|c|c|}
\hline $\begin{array}{l}\text { 4-NITRODIFENILAMINA } \\
836-30-6\end{array}$ & & $\begin{array}{l}\text { Se descompone al calentarse } 0 \text { al arder, desprendiendo humos tóxicos (óxidos de nitrógeno) } \\
\text { Reacciona con oxidantes fuertes Incompatible con agentes oxidantes fuertes y bases fuertes }\end{array}$ & \\
\hline $\begin{array}{l}\text { m-NITROFENOL } \\
554-84-7\end{array}$ & & & 6.1 \\
\hline $\begin{array}{l}\text { O-NITROFENOL } \\
88-75-5\end{array}$ & & & 6.1 \\
\hline $\begin{array}{l}\text { p-NITROFENOL } \\
100-02-7\end{array}$ & $\begin{array}{l}\text { Posibilidad de explosión } \\
\text { pulverulenta cuando se } \\
\text { encuentra en forma de } \\
\text { polvo o gránulos y se } \\
\text { mezcla con el aire }\end{array}$ & $\begin{array}{l}\text { Puede explotar si se calienta Se descompone al calentarse o al arder, liberando humos } \\
\text { tóxicos como óxidos de nitrógeno, con peligro de incendio y explosión Es un oxidante fuerte y } \\
\text { reacciona violentamente con materiales combustibles y reductores Las mezclas con hidróxido } \\
\text { potásico son explosivas }\end{array}$ & 6.1 \\
\hline
\end{tabular}

1-NITRONAFTALENO

86.57 .7

m-NITROTOLUENO

6.1

99-08-1
O-NITROTOLUENO
$88-72-2$

$88-72.2$

Se descompone en contacto con oxidantes fuertes, ácido sulfúrico, agentes reductores, ácidos 06.1 bases, produciendo humos tóxicos, con peligro de incendio y explosión Ataca algunos tipos de plásticos, caucho y revestimientos

p-NITROTOLUENO

$99-99-0$
Se descompone al calentarse, desprendiendo humos tóxicos (óxidos de nitrógeno) Reacciona 6.1 violentamente con oxidantes fuertes 0 ácido sulfúrico, con peligro de incendio y explosión Ataca algunos tipos de plásticos, caucho y revestimientos 


\begin{tabular}{|c|c|c|c|}
\hline $\begin{array}{l}\text { Denominación química } \\
\mathrm{N} \text { úmero } \mathrm{CAS}\end{array}$ & Físicos & Q uímicos & $\begin{array}{l}\text { Clase o división } \\
\text { UN / Riesgos } \\
\text { subsidiarios }\end{array}$ \\
\hline $\begin{array}{l}\text { TETRILO } \\
479-45-8\end{array}$ & $\begin{array}{l}\text { Posibilidad de explosión } \\
\text { pulverulenta cuando se } \\
\text { encuentra en forma de } \\
\text { polvo o gránulos y se } \\
\text { mezcla con el aire }\end{array}$ & $\begin{array}{l}\text { Puede descomponerse violentamente como consecuencia de un impacto, fricción o sacudida } \\
\text { Se descompone violentamente al calentarse a } 187^{\circ} \mathrm{C} \text { El contacto del tetrilo con algunos } \\
\text { materiales oxidables puede causar incendios y explosiones Explota espontáneamente en } \\
\text { contacto con trioxigendiffluoruro Al arder o explotar puede liberar gases y vapores tóxicos (como } \\
\text { óxidos de nitrógeno) }\end{array}$ & 1.10 \\
\hline $\begin{array}{l}\text { 2,4,6-TRINITROTOLUENO } \\
118-96-7\end{array}$ & & $\begin{array}{l}\text { Puede descomponerse violentamente como consecuencia de un impacto, fricción o sacudida Al } \\
\text { calentarse emite humos tóxicos Reacciona violentamente con agentes reductores, con peligro } \\
\text { de incendio y explosión Reacciona con metales pesados Explota al calentarse a } 240^{\circ} \mathrm{C}\end{array}$ & 1.10 \\
\hline
\end{tabular}

Tabla 104.132 • Propiedades físicas y químicas.

\begin{tabular}{|c|c|c|c|c|c|c|c|c|c|c|c|}
\hline $\begin{array}{l}\text { Denominación química } \\
N \text { úmero CAS }\end{array}$ & Color/ Forma & $\begin{array}{l}\text { p.e. } \\
\left({ }^{\circ} \mathrm{C}\right)\end{array}$ & $\begin{array}{l}\text { p.f. } \\
(\stackrel{\circ}{ }) \text { ) }\end{array}$ & $\begin{array}{l}\text { p.m.l } \\
\text { (g/ } \\
\text { mol) }\end{array}$ & $\begin{array}{l}\text { Solubilidad } \\
\text { en agua }\end{array}$ & $\begin{array}{l}\text { Densidad } \\
\text { relativa } \\
\text { (agua }=1 \text { ) }\end{array}$ & $\begin{array}{l}\text { Densidad } \\
\text { de vapor } \\
\text { relativa } \\
\text { (aire=1) }\end{array}$ & $\begin{array}{l}\text { Pvap/ } \\
(\mathrm{kPa})\end{array}$ & $\begin{array}{l}\text { Límit. } \\
\text { inflam. }\end{array}$ & $\begin{array}{l}\text { p.ig. } \\
(\underline{O C})\end{array}$ & $\begin{array}{l}\text { p.aut } \\
\text { ig. } \\
(\stackrel{\circ}{ } C)\end{array}$ \\
\hline $\begin{array}{l}\text { ACIDO PICRICO } \\
88-89-1\end{array}$ & cristales amarillos & 300 & 122,5 & 229,1 & lig sol & 1,763 & 7,90 & $<1$ torr & & 150 & 300 \\
\hline $\begin{array}{l}\text { 1-AMINO-2-METIL-5-NITROBENCENO } \\
\text { 99-55-8 }\end{array}$ & $\begin{array}{l}\text { prismas monoclínicos } \\
\text { amarillos en alcohol }\end{array}$ & & 105,5 & 152,2 & lig sol & & & $\begin{array}{l}1,3 \times 10^{-5} \\
\mathrm{~mm} \mathrm{Hg}\end{array}$ & & & \\
\hline $\begin{array}{l}\text { 4-AMINO-2-NITROFENOL } \\
\text { 119-34-6 }\end{array}$ & $\begin{array}{l}\text { placas o agujas de } \\
\text { color rojo oscuro en } \\
\text { agua y alcohol }\end{array}$ & & 131 & 154,1 & sol & & & & & & \\
\hline $\begin{array}{l}\text { 1-CLORO-2,4-DINITROBENCENO } \\
97-00-7\end{array}$ & cristales amarillos & 315 & 53 & 202,6 & insol & 1,7 & 6,98 & & $\begin{array}{l}2,0 \mathrm{li} \\
22,0 \mathrm{ls}\end{array}$ & & \\
\hline $\begin{array}{l}\text { 1-CLORO-3-NITROBENCENO } \\
88-73-3\end{array}$ & $\begin{array}{l}\text { cristales amarillos; } \\
\text { agujas monoclínicas }\end{array}$ & $245-246$ & $32-33$ & 157,56 & insol & 1,305 & & & 261 & & \\
\hline $\begin{array}{l}\text { 1-CLORO-4-NITROBENCENO } \\
\text { 100-00-5 }\end{array}$ & $\begin{array}{l}\text { prismas } \\
\text { monoclínicos; } \\
\text { cristales amarillos }\end{array}$ & 242 & 83,5 & 157,6 & insol & 1,3 & 5,44 & $\begin{array}{l}20 \mathrm{~Pa} \\
@ 30 \stackrel{\circ}{-C}\end{array}$ & & $127 c c$ & 510 \\
\hline $\begin{array}{l}\text { 2-CLORO-3-NITROBENCENO } \\
\text { 121-73-3 }\end{array}$ & $\begin{array}{l}\text { prismas } \\
\text { ortorrómbicos de } \\
\text { color amarillo pálido } \\
\text { en alcohol }\end{array}$ & 236 & 46 & 157,6 & insol & 1,534 & & & & & \\
\hline $\begin{array}{l}\text { 3,5-CLORURO DE DINITROBENZOILO } \\
99-33-2\end{array}$ & & 196 & 74 & 230,56 & & & & & & & \\
\hline $\begin{array}{l}\text { 1,2-DICLORO-4-NITROBENCENO } \\
\text { 99-54-7 }\end{array}$ & $\begin{array}{l}\text { agujas en alcohol y } \\
\text { tetracloruro de } \\
\text { carbono; líquido; } \\
\text { sólido }\end{array}$ & 255,5 & 43 & 192,00 & insol & $\begin{array}{l}1,4558 \\
@ 75 \stackrel{\circ}{C} / 4 \stackrel{\circ}{C} \mathrm{C}\end{array}$ & 6,63 & $\begin{array}{l}0,014 \\
\mathrm{~mm} \mathrm{Hg}\end{array}$ & & & \\
\hline $\begin{array}{l}\text { 2,4-DICLORO-1-NITROBENCENO } \\
611-06-3\end{array}$ & & 258,5 & 34 & 192,00 & insol & $\begin{array}{l}1,4790 \\
@ 80 \stackrel{\circ}{C}\end{array}$ & & & & & \\
\hline $\begin{array}{l}\text { DINITROBENCENO } \\
25154-54-5\end{array}$ & $\begin{array}{l}\text { sólido amarillo } \\
\text { pálido; sólido } \\
\text { cristalino blanco }\end{array}$ & 300 & $75-85$ & 168 & insol & 1,6 & 5,8 & $<0,1$ & & 150 & \\
\hline $\begin{array}{l}\text { 1,3-DINITROBENCENO } \\
99-65-0\end{array}$ & $\begin{array}{l}\text { cristales amarillentos; } \\
\text { placas rombohédricas } \\
\text { en alcohol; sólido de } \\
\text { color amarillo pálido }\end{array}$ & $300-303$ & 90 & 168,1 & lig sol & $\begin{array}{l}1,575 \\
@ 18 \stackrel{\circ}{\circ} / 4 \stackrel{\circ}{\circ}\end{array}$ & 5,8 & $<.1$ & & 149 & \\
\hline
\end{tabular}




\begin{tabular}{|c|c|c|c|c|c|c|c|c|c|c|}
\hline $\begin{array}{l}\text { Denominación química } \\
\mathrm{N} \text { úmero CAS }\end{array}$ & Color/ Forma & $\begin{array}{l}\text { p.e. } \\
\left({ }^{\circ} \mathrm{C}\right)\end{array}$ & $\begin{array}{l}\text { p.f. } \\
(\stackrel{O}{ } C)\end{array}$ & $\begin{array}{l}\text { p.m.l } \\
\text { (g/ } \\
\text { mol) }\end{array}$ & $\begin{array}{l}\text { Solubilidad } \\
\text { en agua }\end{array}$ & $\begin{array}{l}\text { Densidad } \\
\text { relativa } \\
\text { (agua }=1 \text { ) }\end{array}$ & $\begin{array}{l}\text { Densidad } \\
\text { de vapor } \\
\text { relativa } \\
\text { (aire=1) }\end{array}$ & $\begin{array}{l}\text { Pvap/ } \\
(\mathrm{kPa})\end{array}$ & $\begin{array}{l}\text { Límit. } \\
\text { inflam. }\end{array}$ & $\begin{array}{ll}\text { p.ig. } & \text { p.aut } \\
\left({ }^{\circ} \mathrm{C}\right) & \text { ig. } \\
& \left({ }^{\circ} \mathrm{C}\right)\end{array}$ \\
\hline $\begin{array}{l}\text { 0-DINITROBENCENO } \\
528-29-0\end{array}$ & $\begin{array}{l}\text { cristales, agujas o } \\
\text { placas amarillos o } \\
\text { incoloros; agujas en } \\
\text { benceno, placas; } \\
\text { cristales blancos; } \\
\text { sólido de color } \\
\text { amarillo pálido }\end{array}$ & 319 & 118 & 168,1 & insol & 1,3119120 & 5,79 & $<0,1$ & & $150 \mathrm{cc}$ \\
\hline $\begin{array}{l}\text { p-DINITROBENCENO } \\
100-25-4\end{array}$ & $\begin{array}{l}\text { cristales blancos; } \\
\text { agujas en alc; agujas } \\
\text { monoclínicas } \\
\text { incoloras o amarillas; } \\
\text { sólido de color } \\
\text { amarillo pálido; } \\
\text { cristales amarillos }\end{array}$ & 299 & 174 & 168,1 & insol & $\begin{array}{l}1,625 \\
@ 18 \stackrel{\circ}{0} / 4 \stackrel{\circ}{\circ}\end{array}$ & 5,8 & $<0,1$ & & 150 \\
\hline $\begin{array}{l}\text { 2,3-DINITROFENOL } \\
66-56-8\end{array}$ & & & 144,5 & 184,10 & lig sol & 1,681 & & & & \\
\hline $\begin{array}{l}\text { 2,4-DINITROFENOL } \\
\text { 51-28-5 }\end{array}$ & $\begin{array}{l}\text { cristales } \\
\text { ortorrómbicos } \\
\text { amarillentos a } \\
\text { amarillos }\end{array}$ & & $112-114$ & 184,1 & lig sol & $\begin{array}{l}1,683 \mathrm{~g} / \mathrm{ml} \\
@ 24 \stackrel{\circ}{\mathrm{C}}\end{array}$ & 6,35 & $\begin{array}{l}2 \times 10^{-5} \\
\mathrm{~mm} \mathrm{Hg} \\
@ 25^{\circ} \mathrm{C}\end{array}$ & & \\
\hline $\begin{array}{l}\text { 1,5-DINITRONAFTALENO } \\
605-71-0\end{array}$ & & & 219 & 218,16 & insol & & & & & \\
\hline $\begin{array}{l}\text { DINITROTOLUENO } \\
25321-14-6 \\
\end{array}$ & líquido aceitoso & $250-300$ & 54- 93 & 182,14 & insol & 1,3 & 6,28 & 0,13 & & $207 c c$ \\
\hline $\begin{array}{l}\text { 2,3-DINITROTOLUENO } \\
602-01-7\end{array}$ & cristales amarillos & $250-300$ & 63 & 182,1 & insol & 1,3 & 6,28 & & & \\
\hline $\begin{array}{l}\text { 2,4-DINITROTOLUENO } \\
\text { 121-14-2 }\end{array}$ & $\begin{array}{l}\text { cristales o líquido } \\
\text { aceitoso }\end{array}$ & 300 & 71 & 182,1 & insol & $\begin{array}{l}1,3208 \mathrm{~g} / \mathrm{ml} \\
@ 71 \stackrel{\circ}{\circ}\end{array}$ & 6,27 & $\begin{array}{l}0,13 \\
@ 103 \stackrel{\circ}{C}\end{array}$ & & $207 \mathrm{ca}$ \\
\hline $\begin{array}{l}\text { 2,5-DINITROTOLUENO } \\
\text { 619-15-8 }\end{array}$ & & & 52,5 & 182,13 & & $1,282 @ 111$ & & & & \\
\hline $\begin{array}{l}\text { 2,6-DINITROTOLUENO } \\
\text { 606-20-2 }\end{array}$ & $\begin{array}{l}\text { agujas rómbicas en } \\
\text { alcohol; sólido entre } \\
\text { amarillo y rojo }\end{array}$ & 285 & 66 & 182,1 & & $\begin{array}{l}1,2833 \\
@ 111 \stackrel{\circ}{\circ}\end{array}$ & 6,28 & $\begin{array}{l}5,67 \times 10^{-4} \\
\mathrm{~mm} \mathrm{Hg}\end{array}$ & & $207 c c$ \\
\hline $\begin{array}{l}\text { 3,4-DINITROTOLUENO } \\
\text { 610-39-9 } \\
\end{array}$ & cristales 0 agujas & $250-300$ & 58 & 182,1 & insol & 1,26 & 6,28 & & & 110 \\
\hline $\begin{array}{l}\text { 3,5-DINITRO-p-TOLUIDINA } \\
\text { 19406-51-0 }\end{array}$ & & & 171 & 197,14 & & & & & & \\
\hline $\begin{array}{l}\text { 1-FLUORO-2,4-DINITROBENCENO } \\
70-34-8\end{array}$ & $\begin{array}{l}\text { cristales de color } \\
\text { amarillo pálido en } \\
\text { alcohol }\end{array}$ & 296 & 25,8 & 186,10 & & $\begin{array}{l}1,4718 @ \\
84 \stackrel{\circ}{\circ} \mathrm{C}\end{array}$ & & & & \\
\hline $\begin{array}{l}\text { 2-METLL-1-NITROANTRAQUINONA } \\
\text { 129-15-7 }\end{array}$ & $\begin{array}{l}\text { agujas de color } \\
\text { amarillo pálido }\end{array}$ & & 270,5 & 267,2 & insol & & & & & \\
\hline $\begin{array}{l}\text { N-METIL-N-NITROSOANILINA } \\
614-00-6\end{array}$ & & 225 & 14,7 & 136,15 & insol & 1,1240 & & & & \\
\hline $\begin{array}{l}\text { 5-NITROACENAFTENO } \\
602-87-9\end{array}$ & & & 103,5 & 199,2 & sol & & & & & \\
\hline $\begin{array}{l}\text { 5-NITRO-0-ANISIDINA } \\
\text { 99-59-2 }\end{array}$ & $\begin{array}{l}\text { agujas rojas o } \\
\text { naranja en alc, éter } 0 \\
\text { agua }\end{array}$ & & 118 & 168,2 & sol & $\begin{array}{l}1,2068 \\
@ 156 \stackrel{\circ}{ } \mathrm{C}\end{array}$ & & $\begin{array}{l}1,3 \times 10^{-4} \\
\mathrm{~mm} \mathrm{Hg} \\
@ 25^{\circ} \mathrm{C}\end{array}$ & & \\
\hline
\end{tabular}




\begin{tabular}{|c|c|c|c|c|c|c|c|c|c|c|}
\hline $\begin{array}{l}\text { Denominación química } \\
\mathrm{N} \text { úmero CAS }\end{array}$ & Color/ Forma & $\begin{array}{l}\text { p.e. } \\
\left({ }^{\circ} \mathrm{C}\right)\end{array}$ & $\begin{array}{l}\text { p.f. } \\
(\stackrel{\circ}{ } C)\end{array}$ & $\begin{array}{l}\text { p.m.l } \\
\text { (g/ } \\
\text { mol) }\end{array}$ & $\begin{array}{l}\text { Solubilidad } \\
\text { en agua }\end{array}$ & $\begin{array}{l}\text { Densidad } \\
\text { relativa } \\
\text { (agua }=1 \text { ) }\end{array}$ & $\begin{array}{l}\text { Densidad } \\
\text { de vapor } \\
\text { relativa } \\
\text { (aire=1) }\end{array}$ & $\begin{array}{l}\text { Pvap/ } \\
(\mathrm{kPa})\end{array}$ & $\begin{array}{l}\text { Límit. } \\
\text { inflam. }\end{array}$ & $\begin{array}{ll}\text { p.ig. } & \text { p.aut } \\
(\stackrel{O}{ } C) & \text { ig. } \\
& \left({ }^{\circ} \mathrm{C}\right)\end{array}$ \\
\hline $\begin{array}{l}\text { NITROBENCENO } \\
98-95-3\end{array}$ & $\begin{array}{l}\text { cristales amarillo } \\
\text { verdosos } 0 \text { amarillos, } \\
\text { líquido aceitoso }\end{array}$ & 210,8 & 5,7 & 123,11 & lig sol & 1,2037 & 4,3 & $20 \mathrm{~Pa}$ & $\begin{array}{l}1,8 \mathrm{li} \\
40 \mathrm{ls}\end{array}$ & $88 c c \quad 480$ \\
\hline $\begin{array}{l}\text { 4-NITRODIFENILO } \\
\text { 92-93-3 }\end{array}$ & $\begin{array}{l}\text { agujas amarillas; } \\
\text { agujas blancas }\end{array}$ & 340 & 114 & 199,2 & insol & & & & & \\
\hline $\begin{array}{l}\text { NITROFEN } \\
\quad 1836-75-5\end{array}$ & $\begin{array}{l}\text { sólido blanco; } \\
\text { cristales; sólido } \\
\text { cristalino; sólido } \\
\text { cristalino amarillo; } \\
\text { sólido fluyente de } \\
\text { color marrón oscuro }\end{array}$ & $\begin{array}{l}180-190 @ \\
0.25 \mathrm{~mm} \mathrm{Hg}\end{array}$ & $70-71$ & 284,10 & insol & $1,33 @ 90 \cong \mathrm{C}$ & & $\begin{array}{l}<0,1 \mathrm{~Pa} \\
@ 40 \stackrel{\stackrel{C}{C}}{ }\end{array}$ & & \\
\hline $\begin{array}{l}\text { 4-NITROFENILBENZANAMINA } \\
\text { 836-30-6 }\end{array}$ & $\begin{array}{l}\text { cristales tabulares } 0 \\
\text { agujas de color } \\
\text { amarillo en } \\
\text { tetracloruro de } \\
\text { carbono }\end{array}$ & $\begin{array}{l}211 @ \\
30 \mathrm{~mm} \mathrm{Hg}\end{array}$ & 133,5 & 214,23 & insol & & 7,4 & & & \\
\hline $\begin{array}{l}\text { 2-NITRO-p-FENILENDIAMINA } \\
5307-14-2\end{array}$ & $\begin{array}{l}\text { agujas casi negras } \\
\text { con un brillo negro } \\
\text { verdoso }\end{array}$ & & 137 & 153,1 & sol & & & & & \\
\hline $\begin{array}{l}\text { M-NITROFENOL } \\
554-84-7\end{array}$ & $\begin{array}{l}\text { prismas monoclínicos } \\
\text { en éter y ácido } \\
\text { clorhídrico diluido; } \\
\text { cristales monoclínicos } \\
\text { incoloros o amarillos }\end{array}$ & $\begin{array}{l}194 \\
\text { @ } 70 \mathrm{~mm} \mathrm{Hg}\end{array}$ & 97 & 139,1 & lig sol & $\begin{array}{l}1,2797 \\
@ 100 \stackrel{\circ}{ } \mathrm{C} / 4 \stackrel{\circ}{ } \mathrm{C}\end{array}$ & & 0,75 torr & & \\
\hline $\begin{array}{l}\text { O-NITROFENOL } \\
88-75-5\end{array}$ & $\begin{array}{l}\text { agujas o prismas } \\
\text { amarillo claro; } \\
\text { monoclínicos }\end{array}$ & 216 & 44,8 & 139,1 & lig sol & $1,495 @ 14 \stackrel{0}{C}$ & & $\begin{array}{l}1 \mathrm{~mm} \mathrm{Hg} \\
@ 49,3 \stackrel{\circ}{\mathrm{C}}\end{array}$ & & \\
\hline $\begin{array}{l}\text { p-NITROFENOL } \\
100-02.7\end{array}$ & $\begin{array}{l}\text { cristales incoloros o } \\
\text { ligeramente } \\
\text { amarillos; prismas } \\
\text { monoclínicos } \\
\text { amarillos en tolueno; } \\
\text { sólido entre amarillo } \\
\text { y marrón }\end{array}$ & 279 & 113,8 & 139,1 & lig sol & 1,270 & 4,8 & $0,0032 \mathrm{~Pa}$ & & 169 \\
\hline $\begin{array}{l}\text { 1-NITRONAFTALENO } \\
\text { 86-57-7 }\end{array}$ & cristales amarillos & 304 & 61,5 & 173,2 & insol & 1,332 & & $\begin{array}{l}4,8 \times 10^{-4} \\
\mathrm{~mm} \mathrm{Hg} \\
@ 25 \stackrel{\circ}{-} \mathrm{C}\end{array}$ & & $164 c c$ \\
\hline $\begin{array}{l}\text { 2-NITRONAFTALENO } \\
581-89.5\end{array}$ & & 312,5 & 79 & 173,16 & insol & & & & & \\
\hline $\begin{array}{l}\text { p-NITROSODIFENILAMINA } \\
\text { 156-10-5 }\end{array}$ & $\begin{array}{l}\text { placas verdes con } \\
\text { brillo azulado (en } \\
\text { benceno) o prismas o } \\
\text { placas de color azul } \\
\text { acero (en éter o } \\
\text { agua); placas o } \\
\text { líquido de color } \\
\text { amarillo; cristales } \\
\text { verdosos }\end{array}$ & & 143 & 198,2 & lig sol & & & & & \\
\hline $\begin{array}{l}\text { m-NITROTOLUENO } \\
\text { 99-08-1 }\end{array}$ & líquido amarillo & 232 & 15,5 & 137,1 & insol & 1,1581 & 4,73 & $\begin{array}{l}0,207 \\
\mathrm{~mm} \mathrm{Hg} \\
@ 25 \stackrel{\circ}{0} \mathrm{C}\end{array}$ & & 106 \\
\hline
\end{tabular}


Tabla 104.132 • Propiedades físicas y químicas.

\begin{tabular}{|c|c|c|c|c|c|c|c|c|c|c|}
\hline $\begin{array}{l}\text { Denominación química } \\
\mathrm{N} \text { úmero CAS }\end{array}$ & Color/ Forma & $\begin{array}{l}\text { p.e. } \\
(\stackrel{O}{ } \mathrm{C})\end{array}$ & $\begin{array}{l}\text { p.f. } \\
(\stackrel{O}{ } C)\end{array}$ & $\begin{array}{l}\text { p.m.l } \\
\text { (g/ } \\
\text { mol) }\end{array}$ & $\begin{array}{l}\text { Solubilidad } \\
\text { en agua }\end{array}$ & $\begin{array}{l}\text { Densidad } \\
\text { relativa } \\
\text { (agua }=1 \text { ) }\end{array}$ & $\begin{array}{l}\text { Densidad } \\
\text { de vapor } \\
\text { relativa } \\
\text { (aire=1) }\end{array}$ & $\begin{array}{l}\text { Pvap/ } \\
(\mathrm{kPa})\end{array}$ & $\begin{array}{l}\text { Límit. } \\
\text { inflam. }\end{array}$ & $\begin{array}{ll}\text { p.ig. p.aut } \\
\left({ }^{\circ} \mathrm{C}\right) & \text { ig. } \\
& \left({ }^{\circ} \mathrm{C}\right)\end{array}$ \\
\hline $\begin{array}{l}\text { O-NITROTOLUENO } \\
88-72-2 \\
\end{array}$ & líquido amarillento & 222 & -10 & 137,13 & insol & 1,1629 & 4,73 & $\begin{array}{l}0,133 \\
@ 50 \stackrel{0}{0}\end{array}$ & $\begin{array}{l}2,2 \mathrm{li} \\
? \mathrm{ls} \\
\end{array}$ & $106 c c$ \\
\hline $\begin{array}{l}\text { p-NITROTOLUENO } \\
99-99-0\end{array}$ & $\begin{array}{l}\text { cristales amarillentos; } \\
\text { agujas rómbicas } \\
\text { incoloras; cristales } \\
\text { ortorrómbicos en } \\
\text { alcohol y éter }\end{array}$ & 238,3 & $53-54$ & 137,1 & insol & $\begin{array}{l}1,1038 @ 75 / \\
4 \stackrel{C}{C}\end{array}$ & 4,72 & $\begin{array}{l}0,173 \\
@ 65 \stackrel{\circ}{\circ}\end{array}$ & & 106 \\
\hline $\begin{array}{l}\text { TETRILO } \\
479-45-8\end{array}$ & $\begin{array}{l}\text { sólido incoloro a } \\
\text { amarillo; cristales } \\
\text { monoclínicos; } \\
\text { prismas amarillos en } \\
\text { alcohol }\end{array}$ & 187 & 131,5 & 287,15 & insol & 1,57 & & $<0,1 \mathrm{~Pa}$ & & 187 \\
\hline $\begin{array}{l}\text { 2,4,7-TRINITROFLUOREN-9-ONA } \\
\text { 129-79-3 }\end{array}$ & $\begin{array}{l}\text { agujas de color } \\
\text { amarillo pálido en } \\
\text { ácido acético } 0 \\
\text { benceno }\end{array}$ & & 176 & 315,19 & lig sol & & & & & \\
\hline $\begin{array}{l}\text { 2,4,6-TRINITROTOLUENO } \\
\text { 118-96-7 }\end{array}$ & $\begin{array}{l}\text { rombohedros } \\
\text { monoclínicos; los } \\
\text { cristales comerciales } \\
\text { (agujas) son } \\
\text { amarillos; sólido } \\
\text { incoloro o amarillo } \\
\text { claro en forma de } \\
\text { cristales, escamas, } \\
\text { gránulos, o bloques o } \\
\text { placas fundidas; } \\
\text { escamas trituradas }\end{array}$ & 240 & 80,1 & 227,13 & insol & 1,654 & 7,85 & $<0,1 \mathrm{~Pa}$ & & \\
\hline
\end{tabular}




\section{Peroxidos ORGANICOSE INORGANICOS}

La estructura química de los peróxidos se caracteriza por la presencia de dos moléculas de oxígeno unidas por un enlace covalente sencillo (compuestos peroxídicos). Esta estructura es, en sí misma, inestable. Los peróxidos se descomponen rápidamente en radicales libres muy reactivos. El anión peróxido sirve como iniciador de numerosas reacciones químicas. Esta reactividad es esencial para la utilidad de algunos peróxidos en la industria y explica los riesgos que conllevan en materia de seguridad.

\section{U sos}

Los peróxidos orgánicos se utilizan sobre todo en las industrias químicas, de los plásticos y el caucho. Actúan como iniciadores para reacciones de polimerización de radicales libres, de monómeros para obtener polímeros termoplásticos, para resinas de poliéster termoestables y para elastómeros entrecruzados y polietileno. Los peróxidos orgánicos se utilizan como fuente de radicales libres en muchas síntesis orgánicas.

El peróxido de 2-butanona es un endurecedor de fibra de vidrio y plásticos reforzados y un agente de curado de resinas de poliéster insaturadas. El peróxido de ciclohexanona se utiliza como catalizador para el endurecimiento de ciertas resinas de fibra de vidrio, como blanqueador de harina, aceites vegetales, grasas y ceras, como agente de polimerización en la industria de los plásticos y como agente de vulcanización en la industria del caucho. El peróxido de dilaurilo se utiliza en las industrias cosmética y farmacéutica y en la combustión de hilos de acetato. Además de servir como catalizador de polimerizaciones, el peróxido de terc-butilo actúa como acelerador de la ignición de combustibles diesel.

El peróxido de benzoilo se utiliza principalmente en la producción de polímeros para iniciar los procesos de polimerización y copolimerización de radicales libres de cloruro de vinilo, estireno, acetato vinílico y acrílicos. Se utiliza también para el curado de resinas de poliéster termoestables y gomas de silicona y para el endurecimiento de algunas resinas de fibra de vidrio. El peróxido de benzoilo se utiliza en medicina para el tratamiento del acné. Es el blanqueador preferido para la harina y se utiliza también para decolorar quesos, aceites vegetales, ceras, grasas, etc. EI hidroperóxido de cumeno se utiliza en la fabricación de fenoles y acetona. El ácido peracético es un bactericida y fungicida empleado especialmente en el procesamiento de los alimentos. Sirve también como decolorante de tejidos, papel, aceites, ceras y almidón, y como catalizador de polimerizaciones.

El peróxido de hidrógeno tiene numerosas aplicaciones, la mayoría de ellas basadas en sus propiedades como agente oxidante y blanqueante. Actúa también como reactivo en la síntesis de compuestos químicos. El peróxido de hidrógeno tiene diferentes usos dependiendo de su concentración: las soluciones al $3 \%$ y $6 \%$ se utilizan con fines medicinales y cosméticos; la solución al $30 \%$ se usa como reactivo de laboratorio; las soluciones al $35 \%$ y $50 \%$ se utilizan en la mayoría de las aplicaciones industriales; la solución al 70 \% se utiliza en oxidaciones orgánicas y la solución al $90 \%$ tiene algunas aplicaciones industriales y sirve también como propelente en programas militares y espaciales. Las soluciones superiores al 90 \% se usan sólo para fines militares especiales.

El peróxido de hidrógeno se emplea en la producción de glicerina, plastificantes, agentes blanqueantes, productos farmacéuticos, cosméticos, agentes secantes para grasas, aceites y ceras y óxidos de amina para detergentes de lavavajillas. Se utiliza en la industria textil para blanquear tejidos, especialmente el algodón, y en la industria papelera para blanquear la pulpa mecánica obtenida de la madera. En minería, el peróxido de hidrógeno se utiliza para aumentar la solubilidad del uranio en la solución lixiviadora. Es también útil en la industria electrónica para la erosión catódica y la oxidación de metales y para el tratamiento de superficies metálicas. Además, el peróxido de hidrógeno se utiliza como esterilizante en la industria de los alimentos y como fuente de oxígeno en los equipos de protección respiratoria.

\section{Riesgos}

Los principales riesgos son los incendios y las explosiones. LOS peróxidos orgánicos son excelentes combustibles que entran fácilmente en ignición y arden con fuerza. Los enlaces oxígeno-oxígeno son térmicamente inestables, descomponiéndose exotérmicamente, de forma creciente a medida que aumenta la temperatura. La inestabilidad térmica es muy variable. Las temperaturas de los peróxidos orgánicos para una vida media de 10 horas oscilan entre $25^{\circ} \mathrm{C}$ y $172 \stackrel{\circ}{\circ}$. L L os productos de descomposición son generalmente vapores inflamables que pueden formar mezclas explosivas con el aire; si la descomposición es rápida, puede alcanzarse una temperatura suficiente como para que se produzca la autoignición al entrar en contacto con el aire. La descomposición puede iniciarse por acción del calor, por fricción, por choques mecánicos o por contaminación, si bien la sensibilidad a estos estímulos varía mucho. Si el calor producido por la descomposición no se disipa con rapidez suficiente, puede producirse una reacción que va desde un ligero desprendimiento de gas hasta una descomposición espontánea violenta, con la consiguiente deflagración o explosión. Los peróxidos formados espontáneamente en diversos éteres y aldehídos de bajo peso molecular son extremadamente sensibles a la fricción y a los choques. El peróxido de metiletilcetona y el ácido peroxiacético son extremadamente sensibles a los choques y tienen que diluirse para poder ser manipulados sin riesgos. El peróxido de benzoilo seco es también sensible a los choques. El peróxido de dicumilo, por el contrario, no es sensible a los choques ni a la fricción. $L a$ sensibilidad a los choques puede aumentar con la temperatura. La descomposición violenta puede ser provocada por cantidades traza de una gran diversidad de contaminantes, como ácidos fuertes, bases, metales, aleaciones de metales, sales metálicas, compuestos azufrados, aminas, aceleradores 0 agentes reductores. E sto es especialmente cierto en el caso de los peróxidos de metiletilcetona y benzoilo, cuya descomposición puede provocarse inintencionadamente a temperatura ambiente cuando se utilizan pequeñas cantidades de aceleradores. La violencia de la descomposición se ve muy afectada por la cantidad y el tipo de peróxido, por la velocidad del aumento de la temperatura, por la cantidad y el tipo de contaminación y por el grado de confinamiento.

La seguridad de muchos peróxidos orgánicos mejora considerablemente cuando se dispersan en diluyentes disolventes 0 no disolventes que absorben el calor de la descomposición ( $p$. ej., agua 0 un plastificante) o reducen la sensibilidad a los impactos (p. ej., dimetilftalato). Estas mezclas son, en general, mucho menos inflamables que los peróxidos puros, y algunas de ellas no son inflamables. No obstante, el uso de un diluyente tóxico puede aumentar considerablemente la toxicidad de la solución de peróxidos.

El principal efecto tóxico de la mayoría de los peróxidos es la irritación de la piel, las mucosas y los ojos. El contacto prolongado 0 intenso con la piel o las salpicaduras en los ojos pueden 
causar lesiones graves. Algunos vapores de peróxidos orgánicos son irritantes y pueden causar también cefaleas, intoxicación similar a la del alcohol y edema pulmonar cuando se inhalan en grandes concentraciones. Otros, como los hidroperóxidos de cumeno, son sensibilizantes conocidos de la piel. Los peróxidos de dialquilo no suelen ser tan irritantes y los peróxidos de diacilo son los menos irritantes de todos los peróxidos. Los hidroperóxidos, los peroxiácidos y especialmente el peróxido de metiletilcetona son mucho más peligrosos. Son extremadamente irritantes y corrosivos para los ojos, con riesgo de ceguera, y pueden causar graves lesiones o la muerte si se ingieren en cantidad suficiente.

La carcinogenicidad de los peróxidos ha sido objeto de investigación, pero por el momento no se han obtenido resultados concluyentes. La Agencia Internacional para la Investigación sobre el Cáncer (IARC) ha asignado al Grupo 3 (sustancias no clasificables por su carcinogenicidad) al peróxido de benzoilo, al cloruro de benzoilo y al peróxido de hidrógeno.

Peróxido de benzoilo. Los peligros del peróxido de benzoilo seco se reducen considerablemente cuando éste se dispersa en diluyentes no disolventes capaces de absorber el calor liberado por su descomposición y que, además, confieren otras ventajas. El peróxido de benzoilo se produce habitualmente en forma granular hidratada, con un contenido en agua del $20-30 \%$ de agua, y en forma de pastas diversas que contienen en torno al $50 \%$ de un plastificante y otros diluyentes. Estas formulaciones han reducido considerablemente la inflamabilidad y la sensibilidad al impacto en comparación con el peróxido de benzoilo seco. Algunas son ignífugas. Los endurecedores utilizados con cargas de resinas plásticas, como las imprimaciones para carrocerías de automóviles, contienen normalmente un $50 \%$ de peróxido de benzoilo. L os blanqueadores de harina contienen un $32 \%$ de peróxido de benzoilo, con un $68 \%$ de almidón en grano y sulfato cálcico dihidratado o fosfato dicálcico dihidratado y se consideran no inflamables. Las cremas para combatir el acné, que tampoco son inflamables, contienen entre un $5 \%$ y un $10 \%$ de peróxido de benzoilo.

Peróxido de hidrógeno. Esta sustancia se vende en soluciones acuosas, normalmente al 35\%,50\% (grado industrial), $70 \%$ y $90 \%$ (grado alto) en peso, aunque también está disponible en soluciones al $3 \%, 6 \%, 27,5 \%$ y $30 \%$. Asimismo, se vende según "volúmenes" (lo que significa la cantidad de gas oxígeno que se liberará por ml de solución). El peróxido de hidrógeno se estabiliza durante su fabricación para evitar la contaminación por metales y otras impurezas; pese a ello, el aditivo no podrá inhibir la descomposición si se produce una contaminación excesiva.

La exposición humana por inhalación provoca irritacion e inflamación extremas de la nariz, la garganta y el tracto respiratorio; edema pulmonar, cefalea, mareo, náuseas, vómitos, diarrea, irritabilidad, insomnio, hiperreflexia; temblores y entumecimiento de las extremidades, convulsiones, pérdida de la consciencia y shock. Estos últimos síntomas son el resultado de una intoxicación sistémica grave. La exposición a neblinas 0 pulverizaciones de peróxido de hidrógeno causa picor y lagrimeo de los ojos. Si el peróxido de hidrógeno salpica los ojos, puede producir lesiones graves, como ulceración de la córnea; en algunas raras ocasiones ésta aparece hasta una semana después de la exposición.

El contacto de la piel con el peróxido de hidrógeno en forma líquida produce una decoloración pasajera de la piel y, si la contaminación no cesa, es posible que se produzca eritema y vesiculación.

Aunque la ingestión de peróxido de hidrógeno es poco frecuente, cuando se produce puede causar irritación del tracto gastrointestinal superior. Su descomposición produce la rápida liberación de $\mathrm{O}_{2}$, provocando la distensión del esófago o el estómago $\mathrm{y}$, posiblemente, graves lesiones y hemorragias internas.
La descomposición del peróxido de hidrógeno es un proceso continuo que tiene lugar incluso a velocidad lenta cuando el compuesto está inhibido y, por tanto, debe almacenarse en un lugar adecuado y en envases ventilados. El peróxido de hidrógeno de grado alto es un producto altamente energético. C uando se descompone en oxígeno y agua, se libera gran cantidad de calor, lo que produce a su vez un aumento de la velocidad de la descomposición. La velocidad se multiplica por casi 2,2 veces con cada $10 \stackrel{\circ}{ } \mathrm{C}$ de aumento de la temperatura entre 20 y $100 \stackrel{\circ}{ } \mathrm{C}$. Aunque las soluciones puras de peróxido de hidrógeno no suelen ser explosivas a presión atmosférica, las concentraciones de vapor del peróxido de hidrógeno en equilibrio por encima de $26 \mathrm{~mol} \%$ ( $40 \%$ en peso) se hacen explosivas a temperaturas por debajo del punto de ebullición del líquido.

Puesto que el compuesto es un oxidante muy potente, cuando se derrama sobre materiales combustibles puede provocar un incendio. Cuando el peróxido se mezcla con compuestos orgánicos incompatibles (la mayoría), puede producirse una detonación. Las soluciones con concentraciones inferiores al $45 \%$ se dilatan al congelarse, mientras que las que tienen una concentración superior al $65 \%$, se contraen. Cuando se produce una descomposición rápida cerca de materiales combustibles, puede ocurrir una detonación con exposiciones que causen irritación intensa de la piel, los ojos y las mucosas. Las soluciones de peróxido de hidrógeno superiores al $8 \%$ se clasifican como líquidos corrosivos.

El peróxido de hidrógeno no es en sí mismo inflamable, pero puede causar la combustión espontánea de sustancias inflamables y mantener la combustión, puesto que libera oxígeno al descomponerse. Aunque no se considera una sustancia explosiva, cuando se mezcla con productos químicos orgánicos pueden formarse compuestos peligrosos sensibles a los impactos. Los materiales con catalizadores metálicos pueden provocar una descomposición explosiva del peróxido de hidrógeno.

La contaminación del peróxido de hidrógeno con metales como cobre, cobalto, manganeso, cromo, niquel, hierro y plomo, y sus sales, o con polvo, suciedad, aceites, distintas enzimas, herrumbe y agua no destilada, aumenta la velocidad de descomposición. Con la descomposición se libera oxígeno y calor. Cuando la solución se diluye, el calor que se genera es rápidamente absorbido por el agua. En soluciones más concentradas, el calor aumenta la temperatura de la solución y la velocidad de descomposición, con el consiguiente peligro de explosión. La contaminación con materiales que contienen catalizadores metálicos puede causar una descomposición inmediata y una ruptura explosiva del envase si éste no está debidamente ventilado. El uso de peroxidisulfato amónico para la producción de peróxido de hidrógeno entraña un riesgo de sensibilización bronquial y cutánea.

\section{Medidas de seguridad}

L os derrames se limpiarán con prontitud, para lo que habrá que utilizar herramientas que no produzcan chispas y un diluyente inerte húmedo, como vermiculita 0 arena. El material barrido puede introducirse en contenedores abiertos 0 sacos de polietileno y la zona se lavará con agua y detergente. Los peróxidos derramados, contaminados, desechados o en dudoso estado deben destruirse. La mayoría de los peróxidos pueden hidrolizarse añadiendo lentamente una cantidad aproximada de 10 veces su peso de una solución de hidróxido sódico frío al $10 \%$ mientras se mezcla con una varilla o agitador. La operación puede requerir varias horas. Los envases rígidos de edad 0 aspecto incierto no deben nunca abrirse, sino quemarse con precaución desde una distancia segura.

Las personas que manipulen peróxidos deben utilizar gafas ajustadas de seguridad, gafas protectoras o pantallas faciales para 
protegerse los ojos. Asimismo, existirán fuentes para el lavado de urgencia de los ojos. Para evitar el contacto con la piel, se usarán guantes, mandiles y otras prendas protectoras. No deben utilizarse prendas de vestir y equipos que generen electricidad estática. Estará prohibido fumar. Los peróxidos no deben almacenarse en los mismos refrigeradores que contengan alimentos 0 bebidas. Las reacciones de laboratorio se realizarán siempre detrás de una pantalla de seguridad.

Las zonas donde se almacenen y manipulen estos productos deben estar protegidas contra incendios mediante un sistema de rociado 0 aspersores (puede utilizarse un sistema de rociado con nitrógeno líquido para la protección de los peróxidos que sólo son estables por debajo del punto de congelación del agua). En caso de incendio, se aplicará agua desde una distancia segura mediante un sistema de aspersores 0 con manguera, preferiblemente provista de una boquilla aspersora. Sin embargo, si el peróxido está diluido en un disolvente inflamable de baja densidad, será necesario utilizar espuma. No deben utilizarse extintores portátiles, salvo en el caso de incendios muy pequeños. Los peróxidos amenazados por un incendio deben humedecerse desde una distancia segura para enfriarlos.

En caso de producirse el contacto de la piel con peróxidos, la zona afectada debe lavarse rápidamente para evitar su irritación. En caso de contacto con los ojos, éstos deben lavarse inmediatamente con agua abundante, poniendo a la víctima bajo vigilancia médica. Si no se actúa rápidamente, la exposición a irritantes corrosivos como el peróxido de metiletilcetona puede causar ceguera. En caso de ingestión accidental, debe solicitarse también asistencia médica. Si se produjera sensibilización, habría que evitar ulteriores contactos con peróxidos. 
TABLAS DE PEROXIDOS ORGANICOS E INORGANICOS

\begin{tabular}{|c|c|c|c|}
\hline Producto químico & Sinónimos/ Código UN & $\mathrm{N}$ úmero CAS & Fórmula estructural \\
\hline HIDROPEROXIDO DE terC-BUTILO & Cadox TBH; hidroperóxido de 1,1-dimetiletilo ; perbutilo H & $75-91-2$ & \\
\hline HIDROPEROXIDO DE CUMENO & $\begin{array}{l}\text { Cumenil hidroperóxido; cumil hidroperóxido; hidroperóxido de } \alpha \text {-cumilo; } \\
\text { hidroperóxido de } \alpha, \alpha \text {-dimetilbenzilo; hidroperóxido de isopropilbenceno }\end{array}$ & $80-15-9$ & \\
\hline PEROXIDICARBONATO DE DIISOPROPILO & & $105-64-6$ & \\
\hline PEROXIDO DE BENZOILO & $\begin{array}{l}\text { BP0; benoxil; peróxido del ácido benzoico; benzoperóxido; benzoilo; } \\
\text { superóxido de benzoilo; loción Clearasil de peróxido de benzoilo; } \\
\text { tratamiento para el acné Clearasil BP }\end{array}$ & $94-36-0$ & \\
\hline PEROXIDO DE DICUMILO & & $80-43-3$ & \\
\hline PEROXIDO DE DODECANOILO & $\begin{array}{l}\text { Peróxido de dilauroilo; peróxido de dilaurilo; DYP-97F; Laurox; peróxido } \\
\text { de lauroilo; lauridol; peróxido de bis(1-0xododecilo) }\end{array}$ & $105-74-8$ & \\
\hline PEROXIDO DE HIDROGENO & $\begin{array}{l}\text { Dióxido de hidrógeno; Peroxan; peróxido } \\
\text { UN2015 }\end{array}$ & $7722-84-1$ & \\
\hline
\end{tabular}

\begin{tabular}{|c|c|c|c|c|c|c|}
\hline \multirow[b]{2}{*}{$\begin{array}{l}\text { Denominación } \\
\text { química } \\
\text { N úmero CAS }\end{array}$} & \multicolumn{4}{|c|}{ Tarjetas Internacionales sobre la Seguridad de los Productos Q uímicos } & \multicolumn{2}{|c|}{ N IO SH (EE.UU.) } \\
\hline & $\begin{array}{l}\text { Período } \\
\text { corto de } \\
\text { exposición }\end{array}$ & $\begin{array}{l}\text { Período } \\
\text { largo de } \\
\text { exposición }\end{array}$ & $\begin{array}{l}\text { Vías de } \\
\text { exposición }\end{array}$ & Síntomas & $\begin{array}{l}\text { O rganos } \\
\text { afectados } \\
\text { Vías de } \\
\text { entrada }\end{array}$ & Síntomas \\
\hline $\begin{array}{l}\text { HIDROPEROXIDO DE } \\
\text { terc-BUTILO } \\
75-91-2\end{array}$ & \multicolumn{2}{|l|}{ ojos; piel; tract resp } & $\begin{array}{r}\text { Inhalación } \\
\text { Piel } \\
\text { Ojos } \\
\text { Ingestión }\end{array}$ & $\begin{array}{l}\text { Sensación de quemazón, tos, disnea } \\
\text { Enrojecimiento, dolor, ampollas } \\
\text { Enrojecimiento, dolor, quemaduras profundas } \\
\text { graves } \\
\text { Espasmos abdominales, sensación de } \\
\text { quemazón, debilidad }\end{array}$ & & \\
\hline $\begin{array}{l}\text { HIDROPEROXIDO DE CUMENO } \\
80-15-9\end{array}$ & \multicolumn{2}{|l|}{$\begin{array}{l}\text { ojos; piel; } \\
\text { tract resp; } \\
\text { pulmones }\end{array}$} & $\begin{array}{r}\text { Inhalación } \\
\text { Piel } \\
\text { 0jos } \\
\\
\text { Ingestión }\end{array}$ & $\begin{array}{l}\text { Sensación de quemazón, tos, disnea } \\
\text { Enrojecimiento, quemaduras en la piel, dolor } \\
\text { Enrojecimiento, dolor, quemaduras profundas } \\
\text { graves } \\
\text { Dolor abdominal, sensación de quemazón }\end{array}$ & & \\
\hline
\end{tabular}




\begin{tabular}{|c|c|c|c|c|c|c|}
\hline \multirow[b]{2}{*}{$\begin{array}{l}\text { Denominación } \\
\text { química } \\
\text { N úmero CAS }\end{array}$} & \multicolumn{4}{|c|}{ Tarjetas Internacionales sobre la Seguridad de los Productos Q uímicos } & \multicolumn{2}{|c|}{ N IO SH (EE.UU.) } \\
\hline & $\begin{array}{l}\text { Período } \\
\text { corto de } \\
\text { exposición }\end{array}$ & $\begin{array}{l}\text { Período } \\
\text { largo de } \\
\text { exposición }\end{array}$ & $\begin{array}{l}\text { Vías de } \\
\text { exposición }\end{array}$ & Síntomas & $\begin{array}{l}\text { O rganos } \\
\text { afectados } \\
\text { Vías de } \\
\text { entrada }\end{array}$ & Síntomas \\
\hline $\begin{array}{l}\text { PEROXIDO DE BENZOILO } \\
94-36-0\end{array}$ & & & $\begin{array}{r}\text { Inhalación } \\
\text { Piel } \\
\text { 0jos } \\
\text { Ingestión }\end{array}$ & $\begin{array}{l}\text { Tos, dolor de garganta } \\
\text { Enrojecimiento } \\
\text { Enrojecimiento } \\
\text { Dolor abdominal }\end{array}$ & $\begin{array}{l}\text { Piel; sis resp; ojos } \\
\text { Inh; ing; con }\end{array}$ & Irrit ojos, piel, muc; derm sens \\
\hline $\begin{array}{l}\text { PEROXIDO DE DODECANOILO } \\
105-74-8\end{array}$ & $\begin{array}{l}\text { ojos; tract resp; } \\
\text { pulmones }\end{array}$ & & & & & \\
\hline $\begin{array}{l}\text { PEROXIDO DE HIDROGENO } \\
7722-84-1\end{array}$ & & & $\begin{array}{c}\text { Piel } \\
\text { Ojos } \\
\text { Ingestión }\end{array}$ & $\begin{array}{l}\text { Corrosivo, tos, mareo, cefalea, dificultad } \\
\text { respiratoria, naúseas, respiración entrecortada, } \\
\text { dolor de garganta, los síntomas pueden tardar } \\
\text { en aparecer } \\
\text { Corrosivo, enrojecimiento, quemaduras en la } \\
\text { piel, dolor } \\
\text { Corrosivo, enrojecimiento, dolor, visión } \\
\text { borrosa, quemaduras profundas graves, } \\
\text { ulceración de la córnea, perforación } \\
\text { Dolor abdominal, náuseas, dolor de garganta, } \\
\text { vómitos, distensión abdominal }\end{array}$ & $\begin{array}{l}\text { Piel; sis resp; ojos } \\
\text { Inh; ing; con }\end{array}$ & $\begin{array}{l}\text { Irrit ojos, nariz, garganta; } \\
\text { ulcer córn; erit, vesic piel; } \\
\text { decoloración del cabello }\end{array}$ \\
\hline
\end{tabular}

\begin{tabular}{|c|c|c|c|}
\hline $\begin{array}{l}\text { Denominación química } \\
\mathrm{N} \text { úmero CAS }\end{array}$ & Físicos & Q uímicos & $\begin{array}{l}\text { Clase o división } \\
\text { UN / Riesgos } \\
\text { subsidiarios }\end{array}$ \\
\hline $\begin{array}{l}\text { HIDROPEROXIDO DE terC-BUTILO } \\
75-91-2\end{array}$ & & $\begin{array}{l}\text { Puede explotar al calentarse Es un oxidante fuerte y reacciona violentamente con } \\
\text { materiales combustibles y reductores, compuestos metálicos y de azufre }\end{array}$ & \\
\hline $\begin{array}{l}\text { HIDROPEROXIDO DE CUMENO } \\
\text { 80-15-9 }\end{array}$ & & $\begin{array}{l}\text { Puede explotar al calentarse a unos } 150^{\circ} \mathrm{C} \text { En su combustión libera gases tóxicos Al } \\
\text { calentarse se forman humos tóxicos Es un oxidante fuerte y reacciona violentamente con } \\
\text { materiales combustibles y reductores, con peligro de incendio y explosión El contacto con } \\
\text { aleaciones de cobre o plomo y minerales ácidos puede producir su descomposición violenta }\end{array}$ & 5.2 \\
\hline \multicolumn{4}{|c|}{$\begin{array}{l}\text { PEROXIDICARBONATO DE DIISOPROPILO } \\
105-64-6\end{array}$} \\
\hline $\begin{array}{l}\text { PEROXIDO DE BENZOILO } \\
94-36-0\end{array}$ & & $\begin{array}{l}\text { Puede descomponerse violentamente por choque, fricción o sacudida Puede explotar al } \\
\text { calentarse En su combustión libera humos y gases tóxicos e irritantes de ácido benzoico y } \\
\text { monóxido de carbono Se descompone al calentarse a } 103^{\circ} \mathrm{C} \text { Es un oxidante fuerte y } \\
\text { reacciona violentamente con materiales combustibles y reductores Reacciona violentamente } \\
\text { con muchos ácidos orgánicos e inorgánicos, alcoholes y aminas, con peligro de incendio y } \\
\text { explosión Ataca algunos tipos de pláticos, caucho y revestimientos; puede ocasionar } \\
\text { incendios y explosiones }\end{array}$ & \\
\hline \multicolumn{4}{|l|}{$\begin{array}{l}\text { PEROXIDO DE DICUMILO } \\
80-43-3\end{array}$} \\
\hline $\begin{array}{l}\text { PEROXIDO DE DODECANOILO } \\
105-74-8\end{array}$ & & & 5.2 \\
\hline $\begin{array}{l}\text { PEROXIDO DE HIDROGENO } \\
7722-84-1\end{array}$ & & $\begin{array}{l}\text { Se decompone al calentarse o por influencia de la luz produciendo oxígeno, lo que } \\
\text { aumenta el peligro de incendio Es un oxidante fuerte y reacciona violentamente con } \\
\text { materiales combustibles y reductores, con peligro de incendio y explosión, particularmente } \\
\text { en presencia de metales Ataca muchas sustancias orgánicas, p. ej., tejidos y papeles }\end{array}$ & \\
\hline
\end{tabular}


Tabla 104.136 • Propiedades físicas y químicas.

\begin{tabular}{|c|c|c|c|c|c|c|c|c|c|c|c|}
\hline $\begin{array}{l}\text { Denominación química } \\
\mathrm{N} \text { úmero CAS }\end{array}$ & Color/ Forma & $\begin{array}{l}\text { p.e. } \\
(\stackrel{\circ}{ } \mathrm{C})\end{array}$ & $\begin{array}{l}\text { p.f. } \\
(\stackrel{\circ}{ } C)\end{array}$ & $\begin{array}{l}\text { p.m.l } \\
\text { (g/ } \\
\text { mol) }\end{array}$ & $\begin{array}{l}\text { Solubilidad } \\
\text { en agua }\end{array}$ & $\begin{array}{l}\text { Densidad } \\
\text { relativa } \\
\text { (agua }=1 \text { ) }\end{array}$ & $\begin{array}{l}\text { Densidad } \\
\text { relativa } \\
\text { del vapor } \\
\text { (aire=1) }\end{array}$ & $\begin{array}{l}\text { Pvap/ } \\
(\mathrm{kPa})\end{array}$ & $\begin{array}{l}\text { Límit. } \\
\text { Inflam. }\end{array}$ & $\begin{array}{l}\text { p.ig. } \\
(\stackrel{\circ}{ } C)\end{array}$ & $\begin{array}{l}\text { p.aut } \\
\text { ig. } \\
(\underline{0} \text { C })\end{array}$ \\
\hline $\begin{array}{l}\text { HIDROPEROXIDO DE terC-BUTILO } \\
75-91-2\end{array}$ & $\begin{array}{l}\text { líquido acuoso } \\
\text { transparente }\end{array}$ & $\begin{array}{l}89 \text { se } \\
\text { descompone }\end{array}$ & -8 & 90,12 & sol & 0,8960 & 2,07 & 3,07 & $\begin{array}{l}5 \mathrm{li} \\
10 \mathrm{ls}\end{array}$ & 43 & 238 \\
\hline $\begin{array}{l}\text { HIDROPEROXIDO DE CUMENO } \\
80-15-9\end{array}$ & $\begin{array}{l}\text { líquido incoloro o } \\
\text { amarillo claro }\end{array}$ & 153 & -10 & 152,2 & lig sol & 1,05 & & $32 \mathrm{~Pa}$ & $\begin{array}{l}0,9 \mathrm{li} \\
6,5 \mathrm{ls} \\
\end{array}$ & 79 & 221 \\
\hline $\begin{array}{l}\text { PEROXIDICARBONATO DE } \\
\text { DIISOPROPILO } \\
105-64-6 \\
\end{array}$ & $\begin{array}{l}\text { sólido cristalino de } \\
\text { grano grueso; } \\
\text { incoloro }\end{array}$ & & $8-10$ & 206,22 & insol & $\begin{array}{l}1,080 @ \\
15,5^{\circ} \mathrm{C} / 4^{\circ} \mathrm{C}\end{array}$ & & & & & \\
\hline $\begin{array}{l}\text { PEROXIDO DE BENZOILO } \\
94-36-0\end{array}$ & $\begin{array}{l}\text { cristales; } \\
\text { polvo blanco granular }\end{array}$ & explota & $\begin{array}{l}103-106 \\
\text { se des- } \\
\text { compone }\end{array}$ & 242,2 & lig sol & $1,334 @ 25^{\circ} \mathrm{C}$ & 8,4 & 0,1 & & & 80 \\
\hline $\begin{array}{l}\text { PEROXIDO DE DICUMILO } \\
80-43-3\end{array}$ & $\begin{array}{l}\text { sólido granular de } \\
\text { color blanco o } \\
\text { amarillo claro }\end{array}$ & & 28 & 270,40 & & 1,02 & & & & & \\
\hline $\begin{array}{l}\text { PEROXIDO DE DODECANOILO } \\
105-74-8\end{array}$ & $\begin{array}{l}\text { polvo grueso blanco; } \\
\text { láminas blancas }\end{array}$ & descompone & 49 & 398,70 & insol & $\begin{array}{l}0,91 @ 25^{\circ} \mathrm{C} \\
\text { (sólido) }\end{array}$ & & & & & 112 \\
\hline $\begin{array}{l}\text { PEROXIDO DE HIDROGENO } \\
7722-84-1\end{array}$ & $\begin{array}{l}\text { líquido transparente } \\
\text { incoloro; sólido } \\
\text { cristalino a bajas } \\
\text { temperaturas }\end{array}$ & 152 & $-0,43$ & 34,02 & misc & $\begin{array}{l}1,463 \\
@ 00^{\circ} \mathrm{C} / 4^{\circ} \mathrm{C}\end{array}$ & 1,0 & $\begin{array}{l}0,2 \\
(90 \%) \\
0,1(70 \%)\end{array}$ & & & \\
\hline
\end{tabular}




\section{FENOLES Y COMPUEST OS FEN OLICOS}

Los fenoles son derivados del benceno que se caracterizan por la presencia de un grupo hidroxilo $(-\mathrm{OH})$ unido al anillo de benceno.

\section{Usos}

Los fenoles se utilizan en la industria como antioxidantes, productos químicos intermedios, desinfectantes, agentes de curtido, reveladores fotográficos y aditivos de lubricantes y gasolina. Se emplean ampliamente en las industrias de fotografía, petróleo, pinturas, explosivos, caucho, productos farmacéuticos y productos agrícolas. Los tres principales usos de los fenoles son la fabricación de resinas fenólicas, bisfenol A y caprolactamo.

El fenol se utiliza en la fabricación de diversos compuestos, como medicamentos, tintes y resinas artificiales incoloras 0 de colores claros. Es un desinfectante general para cuartos de baño, establos, pozos negros, suelos y alcantarillas, así como un disolvente extractivo para el refinado del petróleo. El fenol se encuentra en pinturas germicidas, bactericidas antimoho y colas. El catecol se utiliza principalmente como antioxidante en las industrias del caucho, química, fotografía, colorantes, grasas y aceites, así como en cosméticos y en algunos productos farmacéuticos.

El resorcinol se utiliza en las industrias de curtidos, cosméticos, productos farmacéuticos y fotografía, así como en la fabricación de explosivos, colorantes, sustancias químicas orgánicas y antisépticos. Es también un ingrediente de adhesivos para neumáticos, caucho y madera. El resorcinol es un polímero que se añade de forma indirecta a los alimentos como componente básico de las superficies en contacto con alimentos de uso único o repetido. La hidroquinona es un agente reductor utilizado ampliamente como revelador fotográfico, antioxidante y estabilizante en pinturas, barnices, combustibles para motores y aceites. M uchos derivados de la hidroquinona se han utilizado como agentes bactericidas. EI ácido pirogálico sirve también como revelador fotográfico, mordiente de madera, colorante de pieles y pelo, antioxidante en aceites lubricantes y agente reductor de sales de oro, plata y mercurio. Se utiliza para la tinción del cuero, la fabricación de fármacos sintéticos y el mantenimiento de las condiciones anaeróbicas para el crecimiento bacteriano. Su utilidad se debe principalmente a su tendencia a la oxidación en soluciones alcalinas (incluso por acción del oxígeno atmosférico).

El 2,4-dimetilfenol se utiliza en la fabricación de productos farmacéuticos, plásticos, insecticidas, fungicidas, compuestos químicos de caucho, agentes humectantes y colorantes. Actúa como disolvente, desinfectante, germicida y esterilizante en las mezclas comerciales utilizadas para desinfectar todas las zonas, instrumentos y equipos de los hospitales. El o-fenilfenol tiene numerosas funciones como fungicida, germicida y desinfectante de uso doméstico. Se utiliza en las industrias del caucho y el procesamiento de alimentos y sirve como vehículo de los colorantes de fibras de poliéster y como desinfectante de lubricantes para cuchillas, madera y papel.

Los cresoles tienen una gran diversidad de aplicaciones en las industrias de resinas fenólicas, explosivos, petróleo, fotografía pintura y agricultura. Son ingredientes de muchos de los productos desinfectantes de uso doméstico. Los cresoles se utilizan también como aditivos de los aceites lubricantes y como ingredientes de compuestos desengrasantes y limpiadores de pinceles. El m-cresol es un detergente para la ropa; el o-cresol se utiliza para el curtido, el tratamiento de fibras y el desengrasado de metales; el p-cresol sirve como disolvente de esmaltes metálicos, agente para la limpieza de metales y la flotación de minerales y componente de aromatizantes sintéticos y perfumes.

Los clorofenoles son productos químicos intermedios en la síntesis de colorantes, pigmentos y resinas fenólicas. Algunos clorofenoles se utilizan directamente como inhibidores de mohos, antisépticos, desinfectantes y agentes para evitar el espesamiento de la gasolina. El pentaclorofenol y su sal sódica se utilizan para proteger diversos productos industriales del ataque microbiológico. Entre ellos se encuentran la madera y otros productos celulósicos, almidones, adhesivos, proteínas, cuero, hilos y tejidos aprestados, soluciones fotográficas, aceites, pinturas, látex y caucho. El pentaclorofenol se utiliza en la construcción de barcos y edificios, para el control de mohos en las prospecciones y explotaciones petrolíferas, y como agente antibacteriano en desinfectantes y productos de limpieza. Es también útil para el tratamiento de revestimientos de cables, correas de lona, redes, poleas y agua de las torres de refrigeración. EI pentaclorofenol es igualmente importante para controlar las termitas en madera y tableros aislantes, la carcoma de polvo de salvadera y otros insectos que se alimentan de la madera, así como el fango y las algas. Se emplea en la producción de herbicidas y como agente para inhibir la fermentación de diversos materiales.

Algunos clorofenoles se utilizan como productos químicos intermedios y conservantes en las industrias de pinturas, tejidos, cosmética y cuero. El 2-clorofenol y el 2,4-diclorofenol se utilizan en síntesis orgánicas. El 2-clorofenol se emplea en la fabricación de colorantes y en el proceso de extracción de compuestos de azufre y nitrógeno del carbón. El 2,4,5-triclorofenol es un conservante para adhesivos, tejidos sintéticos, caucho, madera, pinturas y papel, y el 2,4,6-triclorofenol es un conservante para madera y pegamento. Los tetraclorofenoles (y sus sales sódicas) sirven como fungicidas y conservantes de la madera.

\section{Riesgos}

\section{Fenol}

El fenol se absorbe fácilmente a través de la piel y por vía digestiva, en tanto que los vapores de este producto lo hacen también con rapidez por vía pulmonar. Tras la absorción de una dosis subletal, la mayor parte del fenol se oxida o conjuga con ácido sulfúrico, ácido glucurónico y otros ácidos, y se excreta con la orina en forma de fenol "conjugado". U na pequeña parte se excreta como fenol "libre". Los efectos tóxicos del fenol están directamente relacionados con la concentración de fenol libre en la sangre.

En el ser humano, la intoxicación aguda de fenol produce vasodilatación, depresión cardíaca, hipotermia, coma y parada respiratoria. La ingestión de fenol causa un dolor abdominal intenso y quemaduras en la boca. T ambién puede ocasionar insuficiencia renal aguda. En animales, los síntomas de intoxicación aguda son muy similares, con independencia del lugar o el modo de administración de este compuesto. Los efectos predominantes se ejercen en los centros motores de la médula espinal, produciendo temblores y fuertes convulsiones. En la actualidad, el número de casos notificados de intoxicación crónica por fenol es comparativamente menor. Los casos graves se caracterizan por trastornos sistémicos, como problemas digestivos con vómitos, dificultad para tragar, ptialismo, diarrea y anorexia; trastornos nerviosos, con cefalea, fatiga, vértigo y alteración mental; y posiblemente ocronosis y erupción cutánea. EI pronóstico es grave 
cuando se producen lesiones extensas en el hígado y los riñones. $\mathrm{La}$ ingestión de una dosis de $1 \mathrm{~g}$ de fenol es letal para el ser humano. Casi todos los segundos casos notificados de intoxicación aguda por fenol (en una misma persona) han tenido consecuencias mortales.

En términos generales, los síntomas de la intoxicación por di y trihidroxifenoles (resorcinol, hidroquinona, pirogalol) son similares a los del fenol, si bien la acción antipirética del resorcinol es más marcada que la del fenol. La aplicación cutánea de soluciones 0 pomadas con un 3-5\% de resorcinol produce hiperemia local, dermatitis pruriginosa, edema y destrucción de las capas superficiales de la piel. La dosis letal aproximada de resorcinol en solución acuosa para los conejos es $0,75 \mathrm{~g} / \mathrm{kg}$, y para las ratas y cobayas, $0,37 \mathrm{~g} / \mathrm{kg}$. La hidroquinona es más tóxica que el fenol. Se han comunicado dosis letales de $0,2 \mathrm{~g} / \mathrm{kg}$ (conejo) y $0,08 \mathrm{~g} / \mathrm{kg}$ (gato). La aplicación dérmica de pirogalol produce destrucción e irritación de la piel. Los contactos repetidos pueden llegar a producir sensibilización de la piel. Los síntomas observados en intoxicaciones agudas de seres humanos son similares a los que aparecen en los animales de experimentación, entre ellos vómitos, hipotermia, temblores ligeros, debilidad, descoordinación muscular, diarrea, pérdida de reflejos, coma, asfixia y muerte por insuficiencia respiratoria. La dosis letal estimada de pirogalol acuoso es de $1,1 \mathrm{~g} / \mathrm{kg}$ (por vía oral) para el conejo, $0,35 \mathrm{~g} / \mathrm{kg}$ (por vía subcutánea) para el gato y el perro, y $0,09 \mathrm{~g} / \mathrm{kg}$ (por vía intravenosa) para el perro.

El pentaclorofenol y su sal sódica producen malestar y efectos locales o sistémicos. Es muy probable que la piel se irrite tras una única exposición relativamente breve a una solución con aproximadamente un $10 \%$ de esta sustancia. Una solución al $1 \%$ puede causar irritación si el contacto se repite. U na solución al $0,1 \%$ o menos puede causar efectos adversos después de un contacto prolongado. Los síntomas de intoxicación sistémica grave consisten en pérdida de apetito, dificultad respiratoria, anestesia, hiperpirexia, sudoración, disnea y coma de rápida progresión.

El polvo fino y las pulverizaciones de pentaclorofenol o pentaclorofenato sódico causan una irritación dolorosa de los ojos, del tracto respiratorio y de la nariz. Las concentraciones atmosféricas superiores a $1 \mathrm{mg} / \mathrm{m}^{3}$ de aire causan ese dolor en personas no habituadas. El pentaclorofenol ha sido clasificado por la IARC como un posible carcinógeno humano del G rupo 2B.

0 tros clorofenoles. Se han descrito casos de dermatosis humana por exposición a tetraclorofenol y su sal sódica, con lesiones papulofoliculares, quistes sebáceos e hiperqueratosis marcada. La exposición profesional a clorofenoles aumenta el riesgo de sarcoma de tejidos blandos. Los derivados clorofenóxidos, entre ellos el ácido 2,4-diclorofenoxiacético, el ácido 2,4,5-triclorofenoxiacético, el ácido 2,4,5-triclorofenoxipropiónico y las sales y esteres de 2,4-D se describen en otras partes de este capítulo y en otros artículos de la E nciclopedia.

Los síntomas de intoxicación por o-, m- y p-clorofenol en ratas consisten en inquietud y aumento de la frecuencia respiratoria, evolucionando rápidamente a debilidad motora, temblores, convulsiones clónicas, disnea y coma. Los 2,4- y 2,6-diclorofenoles y los 2,4,6- y 2,4,5-triclorofenoles producen también estos síntomas, pero la reducción de la actividad y la debilidad motora no se manifiestan con tanta rapidez. Los temblores son mucho menos intensos pero, también en este caso, continúan hasta unos minutos antes de la muerte. Los tetraclorofenoles ocupan un lugar intermedio entre los homólogos de cadena más corta y el pentaclorofenol. Estos compuestos provocan también síntomas similares a los causados por los mono-, di- y triclorofenoles, si bien no suelen producir hiperpirexia.

En el ser humano se han descrito casos de dermatosis, entre ellas dermatitis fotoalérgica de contacto, tras la exposición a 2,4,5-triclorofenol, cloro-2-fenilfenol y tetraclorofenoles. LoS síntomas observados son lesiones papulofoliculares, comedones, quistes sebáceos e hiperqueratoris marcada (cloracné).

B romo- y yodofenoles. L os bromo- y yodofenoles se absorben rápidamente del tracto gastrointestinal. La dosis oral letal aproximada de pentabromofenol es de $200 \mathrm{mg} / \mathrm{kg}$ en la rata; la de 2,4,6-tribromofenol, 2,0 g/ kg en la rata; y la de 2,4,6-triyodofenol, entre 2,0 y $2,5 \mathrm{~g} / \mathrm{kg}$ en la rata. $E n$ ratas y cobayas, las $L D_{50}$ subcutáneas de 0 -bromofenol son 1,5 y $1,8 \mathrm{~g} / \mathrm{kg}$, respectivamente. En términos generales, los síntomas son similares a los del pentaclorofenol. EI pentabromofenol produce también temblores y convulsiones.

En virtud de los resultados obtenidos en experimentos con animales, los fenoles halogenados, el pentabromofenol y el pentaclorofenato sódico y cúprico se consideran seguros para su uso como molusquicidas siempre que se tomen las debidas precauciones durante su aplicación.

Catecol (pirocatecol). Se sabe que el contacto de esta sustancia con la piel produce una dermatitis eczematosa. En algunos raros casos, la absorción a través de la piel ha producido síntomas tóxicos muy similares a los del fenol, con la excepción de algunos efectos centrales marcados (convulsiones). Las dosis tóxicas 0 letales provocan síntomas similares a los del fenol en los animales de experimentación. No obstante, al contrario que el fenol, la administración de dosis altas de pirocatecol produce una depresión predominante del sistema nervioso central y una elevación sostenida de la tensión arterial. Esta última parece deberse a una vasoconstricción periférica.

La absorción repetida de dosis subletales en animales provoca metahemoglobinemia, leucopenia y anemia. La muerte sobre viene aparentemente por insuficiencia respiratoria.

El pirocatecol produce una mayor toxicidad aguda que el fenol. $\mathrm{La}$ dosis oral letal aproximada es de $0,3 \mathrm{~g} / \mathrm{kg}$ en perros y $0,16 \mathrm{~g} / \mathrm{kg}$ en cobayas. El pirocatecol se absorbe fácilmente del tracto gastrointestinal y a través de la piel intacta. T ras su absorción, una parte del catecol se oxida por acción de la polifenol oxidasa para dar o-benzoquinona. 0 tra parte se conjuga en el organismo con ácido hexurónico, ácido sulfúrico y otros ácidos, mientras que una pequeña cantidad se excreta en la orina como pirocatecol libre. La fracción conjugada se hidroliza en la orina liberándose el compuesto libre, que se oxida con la formación de sustancias de color oscuro que son responsables del aspecto turbio de la orina. Aparentemente, el pirocatecol actúa por mecanismos similares a los descritos para el fenol.

Q uinona. En animales, la absorción de grandes dosis de quinona a través de los tejidos subcutános 0 el tracto gastroentérico produce cambios locales, Ilanto, convulsiones clónicas, dificultad respiratoria, descenso de la tensión arterial y muerte por parálisis de los centros medulares. La asfixia parece desempeñar un papel fundamental como causa de la muerte, debido a las lesiones pulmonares producidas por la excreción de quinona en los alvéolos y a ciertos efectos todavía no bien conocidos de la quinona en la hemoglobina. La orina de los animales gravemente intoxicados contiene proteínas, sangre, cilindros e hidroquinona libre y conjugada.

En el ser humano, el contacto de las partes expuestas del cuerpo (especialmente superficies húmedas) con quinona, ya sea en forma de material cristalino, solución o vapores condensados, provoca lesiones locales graves en la piel y las mucosas. Los cambios locales consisten en despigmentación, irritación intensa con eritema, hinchazón y formación de pápulas y vesículas. EI contacto prolongado con la piel puede causar necrosis. La condensación de vapores en los ojos provoca graves trastornos de la visión. La lesión suele extenderse por toda la conjuntiva y se caracteriza por un depósito de pigmento. La pigmentación, que va desde un marrón difuso hasta la aparición de glóbulos de color 
negro marrón, se localiza principalmente en las zonas que se extienden desde los canthi en dirección medial hasta los bordes de la córnea. La lesión afecta a todas las capas de la córnea, con la consiguiente decoloración, que puede ser blanca y opaca o marrón verduzca y traslúcida. La lesión de la córnea puede seguir existiendo una vez que el pigmento ha desaparecido. Algunos casos de ulceración de la córnea se han producido después de tan sólo una breve exposición a altas concentraciones de vapor de quinona o tras la exposición reiterada a concentraciones moderadamente altas.

Cresoles y sus derivados. El cresol puro es una mezcla de isómeros orto- (0-), meta- (m-) y para (p-), mientras que el ácido cresílico, utilizado algunas veces como sinónimo de mezcla de cresoles, es una mezcla de cresoles, xilenoles y fenol en la que el $50 \%$ del material tiene un punto de ebullición superior a $204 \stackrel{\circ}{\circ}$. L a concentración relativa de isómeros en el cresol puro depende de la fuente. Los efectos tóxicos del cresol son similares a los del fenol. Puede absorberse a través de la piel, el sistema respiratorio y el sistema digestivo. La velocidad de penetración a través de la piel depende más del área de la superficie que de la concentración.

Al igual que el fenol, es un veneno protoplásmico general y tóxico para todas las células. Las soluciones concentradas producen corrosión local de la piel y de las membranas mucosas, mientras que las soluciones diluidas producen irritación, vesiculación y ulceración de la piel. El contacto con la piel puede causar también neuritis periférica facial, deterioro de la función renal e incluso necrosis del hígado y de los riñones. En personas susceptibles puede aparecer dermatitis por sensibilización tras su exposición a soluciones inferiores al 0,1\%. A nivel sistémico, es un potente depresor de los sistemas cardiovascular y nervioso central, actuando sobre todo en la columna vertebral y la médula. La administración oral produce una sensación de quemazón en la boca y el esófago, pudiendo causar vómitos. La concentración de vapor alcanzada a temperaturas relativamente altas causa irritación de las vías aéreas superiores y de la mucosa nasal. La absorción sistémica va seguida de colapso vascular, shock, hipotermia, inconsciencia, insuficiencia respiratoria y muerte. Se han descrito también complicaciones pancreáticas. La dosis oral tóxica media para animales de pequeño tamaño es $1 \mathrm{mg} / \mathrm{kg}, y$, específicamente, $0,6 \mathrm{mg} / \mathrm{kg}$ para el p-cresol, $0,9 \mathrm{mg} / \mathrm{kg}$ para el 0-cresol, y 1,0 mg/ kg para el m-cresol. Por su similitud con el fenol, la dosis letal en el hombre puede estimarse en unos $10 \mathrm{~g}$. En el organismo, una pequeña parte se oxida a hidroquinona y pirocatequina, mientras que el resto se excreta tal cual o se conjuga con ácido glucurónico o sulfúrico. Al analizar la orina se observan células hemáticas, cilindros y albúmina. El cresol conlleva también un peligro moderado de incendio.

\section{Medidas de salud y seguridad}

Estas sustancias deben manipularse con precaución. Para prevenir sus efectos tópicos y su absorción, debe evitarse la inhalación de los vapores y el contacto del polvo y la piel con soluciones de estos materiales. Debe prevenirse también la ingestión de incluso cantidades traza. Si la exposición al polvo no puede evitarse del todo, la nariz y la boca deben protegerse con un respirador o un paño doblado y utilizar gafas herméticas para proteger los ojos. Deben utilizarse también prendas protectoras, como guantes de goma (no de algodón). Los trabajadores deben cambiarse inmediatamente de ropa si ésta se contamina con algún vertido. Toda la ropa utilizada durante una operación de nebulización debe lavarse antes de ser utilizada de nuevo. Las precauciones normales consisten en lavarse las manos, los brazos y la cara con agua y jabón antes de comer, beber o fumar. Al final de cada jornada, los trabajadores deben ducharse y ponerse ropa limpia.

Entre las medidas que deben adoptarse con respecto al fenol y sus derivados, pueden citarse las siguientes:

- una cuidadosa instrucción de las personas que participan en la fabricación, manipulación, almacenamiento y transporte de fenol

- una ventilación eficaz

- una eliminación adecuada de los residuos fenólicos para evitar la posible contaminación de la atmósfera, los cursos fluviales y las aguas subterráneas, puesto que las especies acuáticas son especialmente sensibles a los efectos de esta familia de compuestos químicos

- precauciones especiales durante la limpieza de los tanques, no debiendo realizarse ésta sin un equipo adecuado, con suministro de aire a presión, arnés de seguridad, cabo salvavidas, máscara con respirador, botas, mandil y guantes de caucho, y un "vigilante" apostado a la entrada del tanque

- vigilancia continua por parte del higienista o el médico para detectar síntomas de intoxicación aguda o crónica (local o sistémica)

- precauciones para la prevención de incendios.

Primeros auxilios. La velocidad en la administración del tratamiento es esencial en caso de producirse una exposición aguda. El agente tóxico debe eliminarse de la piel, para lo cual lo mejor es lavar la zona afectada con agua abundante. Al cabo de unos minutos de lavado, la zona afectada debe limpiarse o rociarse con polietilenglicol-300 hasta que haya pasado el peligro de colapso. Si la zona expuesta está cubierta con ropa, ésta debe retirarse debajo de la ducha. Las quemaduras provocadas por el fenol deben cubrirse suavemente con un apósito limpio y blanco. No deben utilizarse grasas, pomadas 0 ungüentos en el tratamiento inicial de este tipo de quemaduras. El tratamiento hospitalario consiste en sedación, retirada del tejido muerto, reposición de líquidos y administracion de antibióticos y vitaminas. Si el fenol ha salpicado los ojos, será necesario lavarlos con agua abundante durante al menos 15 minutos. Todas las lesiones oculares, salvo las más triviales, deben ser vistas por un oftalmólogo.

$L$ a velocidad es también esencial en caso de ingestión de fenol. En el lugar de trabajo debe disponerse de un equipo adecuado de primeros auxilios y los servicios médicos locales deben ser informados de la posibilidad de este tipo de accidentes, de manera que estén preparados para dispensar un tratamiento médico de urgencia. El tratamiento de la intoxicación crónica por fenol es sintomático una vez que la víctima ha sido retirada del lugar de exposición. 
TABLAS DE FENOLES Y COMPUESTOS FENOUCOS

\begin{tabular}{|c|c|c|c|}
\hline Producto químico & Sinónimos/ Código UN & $\mathrm{N}$ úmero $\mathrm{CAS}$ & Fórmula estructural \\
\hline 2,6-DI-terc-BUTIL-p-CRESOL & $\begin{array}{l}\text { 2,6-Bis(1,1-dimetiletil)-4-metilfenol; hidroxitolueno butilado; } \\
\text { butilhidroxitolueno; DBMP; DBPC; 2,6-di-terc-butil-1-hidroxi-4-metillbenceno; } \\
\text { 3,5-di-terc-butil-4-hidroxitolueno; 2,6-di-terc-butil-p-metillfenol; } \\
\text { 2,6-di-terc-butil-4-metilfenol; 4-hidroxi-3,5-di-terc-butiltolueno }\end{array}$ & 128-37-0 & \\
\hline 2,6-DI-terc-BUTILFENOL & 2,6-Bis( terc-butil) fenol; & $128-39-2$ & \\
\hline p-terc-BUTILFENOL & $\begin{array}{l}\text { 4-terc-Butilfenol; 4-(1,1-dimetiletil) fenol; 1-hidroxi-4-terc-butilbenceno; } \\
\text { fenol, 4-(1,1-dimetiletil)-; PTBP }\end{array}$ & $98-54-4$ & \\
\hline 4 -terc-BUTILPIROCATECOL & $\begin{array}{l}\text { 1,2-Bencenodiol, 4-(1,1-dimetiletil)-; 4-terc-butil-1,2-bencenodiol; } \\
\text { 4-terc-butilcatecol; p-terc-butilpirocatecol; 4-terc-butilpirocatecol }\end{array}$ & $98-29-3$ & \\
\hline CATECOL & $\begin{array}{l}\text { o-Bencenodiol; 1,2-bencenodiol; catecol; o-dihidroxibenceno; } \\
\text { 1,2-dihidroxibenceno; o-dioxibenceno; 0-difenol; o-hidroquinona; } \\
\text { o-hidroxifenol; 2-hidroxifenol; o-fenilenediol }\end{array}$ & $120-80-9$ & \\
\hline$p$-CLORO-m-CRESOL & $\begin{array}{l}\text { 4-Clor-m-cresol; clorocresol; p-clorocresol; 6-cloro-m-cresol; } \\
\text { 2-cloro-hidroxitolueno }\end{array}$ & $59-50-7$ & \\
\hline m-CLOROFENOL & 3-Clorofenol & $108-43-0$ & \\
\hline O-CLOROFENOL & 2-Clorofenol & $95-57-8$ & \\
\hline p-CLOROFENOL & 4-Clorofenol & $106-48-9$ & \\
\hline m-CRESOL & $\begin{array}{l}\text { 3-Cresol; ácido m-cresillico; 1-hidroxi-3-metilbenceno; m-hidroxitolueno; } \\
\text { 3-hidroxitolueno; m-metilfenol; 3-metilfenol } \\
\text { UN2076 }\end{array}$ & $108-39-4$ & \\
\hline O-CRESOL & $\begin{array}{l}\text { 2-Cresol; ácido o-cresílico; 1-hidroxi-2-metilbenceno; o-hidroxitolueno; } \\
\text { 2-hidroxitolueno; o-metilfenol; 2-metilfenol; o-metilfenilol; 0-oxitolueno; } \\
\text { fenol } \\
\text { UN2076 }\end{array}$ & $95-48-7$ & \\
\hline$p$-CRESOL & $\begin{array}{l}\text { 4-Cresol; ácido p-cresilico; 1-hidroxi-4-metilbenceno; p-hidroxitolueno; } \\
\text { 4-hidroxitolueno; p-metilhidroxibenceno; 1-metil-4-hidroxibenceno; } \\
\text { p-metilfenol; 4-metilfenol } \\
\text { UN2076 }\end{array}$ & $106-44-5$ & \\
\hline CRESOL, TODOS LOS ISOMEROS & $\begin{array}{l}\text { Acido cresílico; ácido cresílico; metilfenol; Tekresol; Ar-toluenol; tricresol } \\
\text { UN2022 }\end{array}$ & $1319-77-3$ & \\
\hline
\end{tabular}




\begin{tabular}{|c|c|c|c|}
\hline Producto químico & Sinónimos/ Código UN & $\mathrm{N}$ úmero $\mathrm{CAS}$ & Fórmula estructural \\
\hline 2,4-DICLOROFENOL & 2,4-DCP; 2,4-diclorohidroxibenceno & $120-83-2$ & \\
\hline 2,5-DICLOROFENOL & & $583-78-8$ & \\
\hline 3,5-DICLOROFENOL & & $591-35-5$ & \\
\hline 2,4-DIMETILFENOL & 4,6-Dimetilfenol; 1-hidroxi-2,4-dimetilbenceno; m-xilenol; 2,4-xilenol & $105 \cdot 67 \cdot 9$ & \\
\hline DINITRO-O-CRESOL & $\begin{array}{l}\text { Dinitrocresol; 2,4-dinitro-0-cresol; 4,6-dinitro-o-cresol; dinitrodendtroxal; } \\
\text { 3,5-dinitro-2-hidroxitolueno; dinitrol; dinitrometilciclohexiltrienol; } \\
\text { 2,4-dinitro-6-metilfenol; DNOC; 2-metil-4,6-dinitrofenol; Nitrador } \\
\text { UN1598 }\end{array}$ & $534-52-1$ & \\
\hline FENOL & $\begin{array}{l}\text { Bencenol; ácido carbólico; hidroxibenceno; monohidroxibenceno; } \\
\text { monofenol; oxibenceno; ácido fénico; alcohol fenol; hidrato de fenilo; } \\
\text { hidróxido de fenilo; ácido fenilico; alcohol fenílico } \\
\text { UN1671 } \\
\text { UN2312 } \\
\text { UN2821 }\end{array}$ & $108-95-2$ & \\
\hline HIDROQUINONA & $\begin{array}{l}\text { p-Bencenodiol; 1,4-bencenodiol; benzohidroquinona; benzoquinol; } \\
\text { dihidroxibenceno; p-dihidroxibenceno; 1,4-dihidroxibenceno; } \\
\text { p-dioxobenceno; p-dioxibenceno; p-hidroquinona } \\
\text { UN2662 }\end{array}$ & $123-31-9$ & \\
\hline 2-HIDROXIBIFENILO & $\begin{array}{l}\text { o-Bifenilol; 2-bifenilol; o-difenilol; o-hidroxidifenilo; 2-hidroxidifenilo; } \\
\text { ortohidroxidifenilo }\end{array}$ & $90-43-7$ & \\
\hline 4-METOXIFENOL & $\begin{array}{l}\text { Eter monometílico de hidroquinona; p-metoxifenol; 4-metoxifenol; MME; } \\
\text { éter monometílico de hidroquinona }\end{array}$ & $150-76.5$ & \\
\hline NONIL FENOL, TODOS LOS ISOMEROS & Hidroxilo no. 253 & $25154-52-3$ & \\
\hline PENTACLOROFENOL & $\begin{array}{l}\text { Dowicide 7; antimicrobiano Dow pentaclorofenol DP-2 ; Durotox; EP 30; } \\
\text { 1-hidroxipentaclorobenceno; Lauxtol; Lauxtol A; Liroprem }\end{array}$ & $87-86-5$ & \\
\hline PENTACLOROFENOL, SAL SODICA & $\begin{array}{l}\text { Pentaclorofenato sódico; pentaclorofenoxi sódico; pentafenato; } \\
\text { pentaclorofenato sódico; pentaclorofenol sódico; } \\
\text { UN2567 }\end{array}$ & $131-52-2$ & \\
\hline PIROGALOL & $\begin{array}{l}\text { 1,2,3-Trihidroxi-benceno; 1,2,3-bencenotriol; Fouramine Brown AP; } \\
\text { Fourrine PG; Fourrine 85; ácido pirogálico; 1,2,3-trihidroxibenceno }\end{array}$ & $87-66-1$ & \\
\hline
\end{tabular}




\begin{tabular}{|c|c|c|c|}
\hline Producto químico & Sinónimos/ Código UN & $\mathrm{N}$ úmero CAS & Fórmula estructural \\
\hline RESORCINOL & $\begin{array}{l}\text { m-Bencenodiol; 1,3-bencenodiol; m-dihidroxibenceno; } \\
\text { 1,3-dihidroxibenceno; m-dioxibenceno; m-hidroquinona; } \\
\text { 3-hidroxiciclohexadien-1-ona; m-hidroxifenol; 3-hidroxifenol; } \\
\text { m-hidroxi-fenol } \\
\text { UN2876 }\end{array}$ & $108-46-3$ & \\
\hline 2,3,5,6-TETRACLOROFENOL & & $935-95-5$ & \\
\hline 2,4,5,6-TETRACLOROFENOL & Dowicide 6; TCP; 2,3,4,6-tetraclorofenol & $58-90-2$ & \\
\hline 4,4'-TIOBIS(6-terc-BUTLL-m-CRESOL) & $\begin{array}{l}\text { Bis(3-terc-butil-4-hidroxi-6-metilfenil) sulfuro; } \\
\text { Bis(4-hidroxi-5-terc-butil-2-metilfenilo) sulfuro; } \\
\text { 4,4'-tiobis(6-terc-butil-m-cresol) }\end{array}$ & $96-69-5$ & \\
\hline 2,3,4-TRICLOROFENOL & & $15950-66-0$ & \\
\hline 2,3,5-TRICLOROFENOL & & $933-78-8$ & \\
\hline 2,3,6-TRICLOROFENOL & & $933-75-5$ & \\
\hline 2,4,5-TRICLOROFENOL & Collunosol; Dowicide 2; Dowicide B; Nurelle; Preventol I & $95-95-4$ & \\
\hline 2,4,6-TRICLOROFENOL & & $88-06-2$ & \\
\hline XYLENOL & $\begin{array}{l}\text { Dimetilfenol; fenol, dimetil- } \\
\text { UN2261 }\end{array}$ & $1300-71-6$ & \\
\hline
\end{tabular}




\begin{tabular}{|c|c|c|c|c|c|c|}
\hline \multirow[b]{2}{*}{$\begin{array}{l}\text { Denominación } \\
\text { química } \\
\text { N úmero CAS }\end{array}$} & \multicolumn{4}{|c|}{ Tarjetas Internacionales sobre la Seguridad de los Productos Q uímicos } & \multicolumn{2}{|c|}{ N IO SH (EE.UU.) } \\
\hline & $\begin{array}{l}\text { Período } \\
\text { corto de } \\
\text { exposición }\end{array}$ & $\begin{array}{l}\text { Período } \\
\text { largo de } \\
\text { exposición }\end{array}$ & $\begin{array}{l}\text { Vías de } \\
\text { exposición }\end{array}$ & Síntomas & $\begin{array}{l}\text { O rganos } \\
\text { afectados } \\
\text { Vías de } \\
\text { entrada }\end{array}$ & Síntomas \\
\hline $\begin{array}{l}\text { ACIDO PIROGALICO } \\
87-66-1\end{array}$ & $\begin{array}{l}\text { ojos; piel; } \\
\text { tract resp; hígado; } \\
\text { riñones; sangre }\end{array}$ & piel & $\begin{array}{l}\text { Inhalación } \\
\text { Piel } \\
\text { 0jos } \\
\text { Ingestión }\end{array}$ & $\begin{array}{l}\text { Labios o uñas cianóticos, piel cianótica, tos, } \\
\text { mareo, cefalea, dificultad respiratoria, } \\
\text { náuseas, disnea, dolor de garganta } \\
\text { Puede absorberse, enrojecimiento, dolor, } \\
\text { despigmentación local } \\
\text { Enrojecimiento, dolor } \\
\text { Dolor abdominal, náuseas, vómitos, debilidad }\end{array}$ & & \\
\hline $\begin{array}{l}\text { 2,6-DI-terc-BUTIL-p-CRESOL } \\
\text { 128-37-0 }\end{array}$ & ojos; piel; tract resp & piel & $\begin{array}{r}\text { Inhalación } \\
\text { Piel } \\
\text { Ojos } \\
\text { Ingestión }\end{array}$ & $\begin{array}{l}\text { Tos, dolor de garganta } \\
\text { Puede absorberse, enrojecimiento, dolor } \\
\text { Enrojecimiento, dolor } \\
\text { Dolor abdominal, diarrea, mareo, cefalea, } \\
\text { vómitos }\end{array}$ & $\begin{array}{l}\text { Ojos, piel } \\
\text { Inh; ing; con }\end{array}$ & $\begin{array}{l}\text { Irrit ojos, piel; en animales: } \\
\text { menor tasa de crec, incr peso } \\
\text { del hígado }\end{array}$ \\
\hline $\begin{array}{l}\text { CATECOL } \\
\quad 120-80-9\end{array}$ & $\begin{array}{l}\text { ojos; piel; } \\
\text { tract resp; tracto Gl; } \\
\text { SNC; sangre }\end{array}$ & piel & $\begin{array}{r}\text { Inhalación } \\
\text { Piel } \\
\text { Ojos } \\
\text { Ingestión }\end{array}$ & $\begin{array}{l}\text { Tos, dificultad respiratoria } \\
\text { Puede absorberse, enrojecimiento } \\
\text { Enrojecimiento, quemaduras profundas graves } \\
\text { Dolor abdominal, diarrea, vómitos }\end{array}$ & $\begin{array}{l}\text { Ojos; piel; sis resp; } \\
\text { SNC; riñones } \\
\text { Inh; abs; ing; con }\end{array}$ & $\begin{array}{l}\text { Irrit ojos, piel, sis resp; sens } \\
\text { piel, derm; lag, quemaduras } \\
\text { en los ojos; convuls, incr TA, } \\
\text { les renales }\end{array}$ \\
\hline $\begin{array}{l}\text { p-CLOROFENOL } \\
106-48-9\end{array}$ & $\begin{array}{l}\text { ojos; piel; } \\
\text { tract resp; SNC; } \\
\text { vejiga }\end{array}$ & $\begin{array}{l}\text { hígado; pulmones; } \\
\text { riñones; sangre; } \\
\text { corazón }\end{array}$ & $\begin{array}{r}\text { Inhalación } \\
\text { Piel } \\
\text { 0jos } \\
\text { Ingestión } \\
\end{array}$ & $\begin{array}{l}\text { Tos, mareo, cefalea, dificultad respiratoria, } \\
\text { dolor de garganta } \\
\text { Puede absorberse, enrojecimiento } \\
\text { Enrojecimiento } \\
\text { Dolor abdominal }\end{array}$ & & \\
\hline $\begin{array}{l}\text { m-CRESOL } \\
108-39-4\end{array}$ & SNC & $\begin{array}{l}\text { piel; pulmones; } \\
\text { hígado; riñones; } \\
\text { SNC }\end{array}$ & $\begin{array}{r}\text { Inhalación } \\
\text { Piel } \\
\text { 0jos } \\
\text { Ingestión }\end{array}$ & $\begin{array}{l}\text { Tos, cefalea, dificultad respiratoria, náuseas, } \\
\text { inconsciencia } \\
\text { Puede absorberse, aspereza } \\
\text { Quemaduras profundas graves } \\
\text { Mareo, embotamiento, cefalea, inconsciencia }\end{array}$ & $\begin{array}{l}\text { Ojos; piel; sis resp; } \\
\text { SNC; hígado; } \\
\text { riñones; SCV; } \\
\text { páncreas } \\
\text { Inh; abs; ing; con }\end{array}$ & $\begin{array}{l}\text { Irrit ojos, piel, muc; efectos en } \\
\text { el SNC: conf, depres, insuf } \\
\text { resp; dis, resp rápida irreg, } \\
\text { pulso débil; quemaduras en } \\
\text { ojos y piel; derm; lesiones en } \\
\text { pulmones, hígado, riñones, } \\
\text { páncreas }\end{array}$ \\
\hline $\begin{array}{l}\text { O-CRESOL } \\
95-48-7\end{array}$ & $\begin{array}{l}\text { ojos; piel; } \\
\text { tract resp; } \\
\text { pulmones; SNC }\end{array}$ & $\begin{array}{l}\text { piel; pulmones; } \\
\text { hígado; riñones }\end{array}$ & $\begin{array}{r}\text { Inhalación } \\
\text { Piel } \\
\text { 0jos } \\
\text { Ingestión }\end{array}$ & $\begin{array}{l}\text { Sensación de quemazón, tos, cefalea, } \\
\text { dificultad respiratoria, náuseas, vómitos } \\
\text { Puede absorberse, enrojecimiento, dolor, } \\
\text { ampollas } \\
\text { Enrojecimiento, dolor, quemaduras profundas } \\
\text { graves } \\
\text { Espasmos abdominales, sensación de } \\
\text { quemazón, colapso }\end{array}$ & $\begin{array}{l}\text { Ojos, piel, sis resp, } \\
\text { SNC, hígado, } \\
\text { riñones, páncreas, } \\
\text { SCV } \\
\text { Inh; abs; ing; con }\end{array}$ & $\begin{array}{l}\text { Irrit ojos, piel, muc; efectos en } \\
\text { el SNC: conf, depres, insuf } \\
\text { resp; dis, resp rápida irreg, } \\
\text { pulso débil; quemaduras en } \\
\text { ojos y piel; derm; lesiones en } \\
\text { pulmones, hígado, riñones, } \\
\text { páncreas }\end{array}$ \\
\hline $\begin{array}{l}\text { p-CRESOL } \\
106-44-5\end{array}$ & $\begin{array}{l}\text { ojos; piel; } \\
\text { tract resp; } \\
\text { pulmones; SNC }\end{array}$ & $\begin{array}{l}\text { piel; pulmones; } \\
\text { hígado; riñones }\end{array}$ & $\begin{array}{r}\text { Inhalación } \\
\text { Piel } \\
\text { 0jos } \\
\text { Ingestión }\end{array}$ & $\begin{array}{l}\text { Sensación de quemazón, tos, cefalea, } \\
\text { dificultad respiratoria, náuseas, vómitos } \\
\text { Puede absorberse, enrojecimiento, dolor, } \\
\text { ampollas } \\
\text { Enrojecimiento, dolor, quemaduras profundas } \\
\text { graves } \\
\text { Espasmos abdominales, sensación de } \\
\text { quemazón, colapso }\end{array}$ & $\begin{array}{l}\text { Ojos, piel; sis resp; } \\
\text { SNC; hígado; } \\
\text { riñones; páncreas; } \\
\text { SCV } \\
\text { Inh; abs; ing; con }\end{array}$ & $\begin{array}{l}\text { Irrit ojos, piel, muc; efectos en } \\
\text { el SNC: conf, depres, insuf } \\
\text { resp; dis, resp rápida irreg, } \\
\text { pulso débil; quemaduras en } \\
\text { ojos y piel; derm; lesiones en } \\
\text { pulmones, hígado, riñones, } \\
\text { páncreas }\end{array}$ \\
\hline $\begin{array}{l}\text { CRESOL, TODOS LOS } \\
\text { ISOMEROS } \\
\quad 1319-77-3\end{array}$ & $\begin{array}{l}\text { ojos; piel; } \\
\text { tract resp; } \\
\text { pulmones; SNC }\end{array}$ & $\begin{array}{l}\text { piel; pulmones; } \\
\text { riñones; hígado }\end{array}$ & $\begin{array}{r}\text { 0jos } \\
\text { Ingestión }\end{array}$ & $\begin{array}{l}\text { Confusión, tos, mareo, cefalea, disnea, dolor } \\
\text { de garganta, inconsciencia, debilidad, los } \\
\text { síntomas pueden tardar en aparecer } \\
\text { Puede causar efectos tóxicos en 20-30 } \\
\text { minutos después del contacto con la piel, } \\
\text { puede absorberse, enrojecimiento, quemaduras } \\
\text { graves en la piel, dolor } \\
\text { Enrojecimiento, dolor, quemaduras profundas } \\
\text { graves } \\
\text { Dolor abdominal, diarrea, vómitos }\end{array}$ & & \\
\hline
\end{tabular}


Tabla 104.138 • Riesgos para la salud.

\begin{tabular}{|c|c|c|c|c|c|c|}
\hline \multirow[b]{2}{*}{$\begin{array}{l}\text { Denominación } \\
\text { química } \\
\text { N úmero CAS }\end{array}$} & \multicolumn{4}{|c|}{ Tarjetas Internacionales sobre la Seguridad de los Productos Q uímicos } & \multicolumn{2}{|c|}{ N IO SH (EE.UU.) } \\
\hline & $\begin{array}{l}\text { Período } \\
\text { corto de } \\
\text { exposición }\end{array}$ & $\begin{array}{l}\text { Período } \\
\text { largo de } \\
\text { exposición }\end{array}$ & $\begin{array}{l}\text { Vías de } \\
\text { exposición }\end{array}$ & Síntomas & $\begin{array}{l}\text { O rganos } \\
\text { afectados } \\
\text { Vías de } \\
\text { entrada }\end{array}$ & Síntomas \\
\hline $\begin{array}{l}\text { 2,4-DICLOROFENOL } \\
\quad 120-83-2\end{array}$ & & & Ingestión & $\begin{array}{l}\text { Mareo, cefalea, convulsiones, cambio de la } \\
\text { temperatura corporal }\end{array}$ & & \\
\hline $\begin{array}{l}2,5-D I C L O R O F E N O L \\
583-78-8\end{array}$ & ojos; piel; tract resp & & $\begin{array}{r}\text { Inhalación } \\
\text { Piel } \\
\text { 0jos } \\
\text { Ingestión }\end{array}$ & $\begin{array}{l}\text { Véase ingestión } \\
\text { Puede absorberse, enrojecimiento, quemaduras } \\
\text { en la piel, dolor } \\
\text { Enrojecimiento, dolor, quemaduras profundas } \\
\text { graves } \\
\text { Dolor abdominal, sensación de quemazón, } \\
\text { diarrea, mareo, cefalea, dificultad respiratoria, } \\
\text { náuseas, vómitos, debilidad, pérdida de } \\
\text { coordinación }\end{array}$ & & \\
\hline $\begin{array}{l}\text { 3,5-DICLOROFENOL } \\
\text { 591-35-5 }\end{array}$ & piel; ojos; tract resp & & $\begin{array}{r}\text { Inhalación } \\
\text { Piel } \\
\text { Ojos } \\
\text { Ingestión }\end{array}$ & $\begin{array}{l}\text { Véase ingestión } \\
\text { Puede absorberse, enrojecimiento, quemaduras } \\
\text { en la piel, dolor } \\
\text { Enrojecimiento, dolor } \\
\text { Dolor abdominal, sensación de quemazón, } \\
\text { diarrea, mareo, cefalea, dificultad respiratoria, } \\
\text { náuseas, vómitos, debilidad, pérdida de } \\
\text { coordinación }\end{array}$ & & \\
\hline $\begin{array}{l}\text { DINITRO-0-CRESOL } \\
534-52-1\end{array}$ & & & & & $\begin{array}{l}\text { SCV; sis endocrino; } \\
\text { ojos } \\
\text { Inh; abs; ing; con }\end{array}$ & $\begin{array}{l}\text { Sensación de bienestar; cef, } \\
\text { fiebre, las, sudoración } \\
\text { abundante, sed intensa, tacar, } \\
\text { hipernea, tos, disnea, coma }\end{array}$ \\
\hline $\begin{array}{l}\text { FENOL } \\
108-95-2\end{array}$ & $\begin{array}{l}\text { ojos; piel; } \\
\text { tract resp; } \\
\text { pulmones; SNC; } \\
\text { hígado; riñones }\end{array}$ & $\begin{array}{l}\text { piel; riñones; } \\
\text { hígado }\end{array}$ & $\begin{array}{r}\text { Inhalación } \\
\text { Piel } \\
\text { 0jos } \\
\text { Ingestión }\end{array}$ & $\begin{array}{l}\text { Sensación de quemazón, tos, mareo, cefalea, } \\
\text { náuseas, disnea, inconsciencia, vómitos, los } \\
\text { síntomas pueden tardar en aparecer } \\
\text { Puede absorberse, quemaduras graves en la } \\
\text { piel, shock, colapso, coma, convulsiones, } \\
\text { efecto anestésico local, muerte } \\
\text { Pérdida permanente de la visión, quemaduras } \\
\text { profundas graves } \\
\text { Dolor abdominal, convulsiones, diarrea, shock } \\
\text { o colapso, dolor de garganta, orina de color } \\
\text { gris o verde oscuro }\end{array}$ & $\begin{array}{l}\text { Hígado; riñones; } \\
\text { piel; ojos, sis resp } \\
\text { Inh; abs; ing; con }\end{array}$ & $\begin{array}{l}\text { Irrit ojos, nariz, garganta; } \\
\text { anor, bajo peso; deb, dolor } \\
\text { musc, dolor; orina oscura; } \\
\text { cian; lesiones en hígado y } \\
\text { riñones; quemaduras en la } \\
\text { piel; derm; ocronosis; } \\
\text { temblores, convuls, contr }\end{array}$ \\
\hline $\begin{array}{l}\text { HIDROQUINONA } \\
\text { 123-31-9 }\end{array}$ & ojos; piel; tract resp & piel & $\begin{array}{r}\text { Inhalación } \\
\text { Piel } \\
\text { Ojos } \\
\text { Ingestión }\end{array}$ & $\begin{array}{l}\text { Tos, dificultad respiratoria } \\
\text { Enrojecimiento } \\
\text { Enrojecimiento, dolor, visión borrosa } \\
\text { Piel cianótica, mareo, cefalea, náuseas, } \\
\text { disnea, convulsiones, vómitos, zumbido de } \\
\text { oídos }\end{array}$ & $\begin{array}{l}\text { Ojos; sis resp; piel; } \\
\text { SNC } \\
\text { Inh; ing; con }\end{array}$ & $\begin{array}{l}\text { Irrit ojos, conj, quera; } \\
\text { excitación SNC; orina } \\
\text { coloreada, náu, mar, sofoco, } \\
\text { resp rápida; contr musc, } \\
\text { delirio; colapso; piel irrit, sens, } \\
\text { derm }\end{array}$ \\
\hline $\begin{array}{l}\text { 2-HIDROXIBIFENILO } \\
\quad 90-43-7\end{array}$ & ojos; piel; tract resp & & $\begin{array}{r}\text { Inhalación } \\
\text { Piel } \\
\text { Ojos } \\
\text { Ingestión }\end{array}$ & $\begin{array}{l}\text { Véase ingestión } \\
\text { Enrojecimiento } \\
\text { Enrojecimiento } \\
\text { Espasmos abdominales, dolor abdominal, tos, } \\
\text { dificultad respiratoria }\end{array}$ & & \\
\hline $\begin{array}{l}\text { NONILFENOL, TODOS LOS } \\
\text { ISOMEROS } \\
25154-52-3\end{array}$ & $\begin{array}{l}\text { ojos; piel; } \\
\text { tract resp; } \\
\text { pulmones }\end{array}$ & & $\begin{array}{r}\text { Inhalación } \\
\text { Piel } \\
\text { Ojos } \\
\text { Ingestión }\end{array}$ & $\begin{array}{l}\text { Sensación de quemazón, tos, dificultad } \\
\text { respiratoria, dolor de garganta, inconsciencia } \\
\text { Enrojecimiento, quemaduras en la piel, dolor } \\
\text { Enrojecimiento, dolor, visión borrosa } \\
\text { Dolor abdominal, diarrea, náuseas, dolor de } \\
\text { garganta }\end{array}$ & & \\
\hline
\end{tabular}




\begin{tabular}{|c|c|c|c|c|c|c|}
\hline \multirow[b]{2}{*}{$\begin{array}{l}\text { Denominación } \\
\text { química } \\
\mathrm{N} \text { úmero CAS }\end{array}$} & \multicolumn{4}{|c|}{ Tarjetas Internacionales sobre la Seguridad de los Productos Q uímicos } & \multicolumn{2}{|c|}{ N IO SH (EE.UU.) } \\
\hline & $\begin{array}{l}\text { Período } \\
\text { corto de } \\
\text { exposición }\end{array}$ & $\begin{array}{l}\text { Período } \\
\text { largo de } \\
\text { exposición }\end{array}$ & $\begin{array}{l}\text { Vías de } \\
\text { exposición }\end{array}$ & Síntomas & $\begin{array}{l}\text { O rganos } \\
\text { afectados } \\
\text { Vías de } \\
\text { entrada }\end{array}$ & Síntomas \\
\hline $\begin{array}{l}\text { PENTACLOROFENOL } \\
87-86.5\end{array}$ & $\begin{array}{l}\text { ojos; piel; } \\
\text { tract resp; } \\
\text { pulmones; corazón }\end{array}$ & $\begin{array}{l}\text { piel; pulmones; SNC } \\
\text { hígado; riñones }\end{array}$ & $\begin{array}{r}\text { Inhalación } \\
\text { Piel } \\
\text { Ojos } \\
\text { Ingestión }\end{array}$ & $\begin{array}{l}\text { Tos, mareo, sopor, cefalea, dificultad } \\
\text { respiratoria, dolor de garganta } \\
\text { Puede absorberse, enrojecimiento, ampollas } \\
\text { Enrojecimiento, dolor } \\
\text { Espasmos abdominales, diarrea, náuseas, } \\
\text { inconsciencia, vómitos, debilidad }\end{array}$ & $\begin{array}{l}\text { SCV; sis resp; ojos; } \\
\text { hígado; riñones; } \\
\text { piel; SNC } \\
\text { Inh; abs; ing; con }\end{array}$ & $\begin{array}{l}\text { Irrit ojos, nariz, garganta; } \\
\text { estor, tos; deb, anor, bajo } \\
\text { peso; sudor; cef, mar; náu, } \\
\text { vómit; dis, dolor torac; fiebre } \\
\text { alta; derm }\end{array}$ \\
\hline $\begin{array}{l}\text { PENTACLOROFENOL, SAL } \\
\text { SODICA } \\
131-52-2\end{array}$ & $\begin{array}{l}\text { ojos; piel; } \\
\text { tract resp; } \\
\text { pulmones }\end{array}$ & $\begin{array}{l}\text { piel; SNC; } \\
\text { pulmones; hígado; } \\
\text { riñones }\end{array}$ & $\begin{array}{r}\text { Inhalación } \\
\text { Piel } \\
\text { 0jos } \\
\text { Ingestión }\end{array}$ & $\begin{array}{l}\text { Tos, mareo, sopor, cefalea, sudoración, } \\
\text { dificultad respiratoria, dolor de garganta } \\
\text { Puede absorberse, enrojecimiento, quemaduras } \\
\text { en la piel, sensación de quemazón } \\
\text { Enrojecimiento, dolor, pérdida de visión } \\
\text { Fiebre, sudoración, excitación, convulsiones, } \\
\text { coma }\end{array}$ & & \\
\hline $\begin{array}{l}\text { 2,3,5,6-TETRACLOROFENOL } \\
\text { 935-95-5 }\end{array}$ & & & $\begin{array}{r}\text { Inhalación } \\
\text { Piel } \\
\text { Ojos } \\
\text { Ingestión }\end{array}$ & $\begin{array}{l}\text { Tos, dolor de garganta } \\
\text { Puede absorberse, enrojecimiento, dolor } \\
\text { Enrojecimiento, dolor } \\
\text { Dolor abdominal, diarrea, mareo, cefalea, } \\
\text { náuseas, fatiga, espasmos musculares, } \\
\text { aumento de la temperatura corporal y } \\
\text { sudoración }\end{array}$ & & \\
\hline $\begin{array}{l}\text { 2,3,5-TRICLOROFENOL } \\
\text { 933-78-8 }\end{array}$ & & piel & $\begin{array}{r}\text { Inhalación } \\
\text { Piel } \\
\text { Ojos } \\
\text { Ingestión }\end{array}$ & $\begin{array}{l}\text { Tos, dolor de garganta } \\
\text { Enrojecimiento, dolor } \\
\text { Enrojecimiento, dolor } \\
\text { Convulsiones, dolor abdominal, diarrea, } \\
\text { mareo, cefalea, vómitos, debilidad, fatiga, } \\
\text { espasmos musculares, aumento de la } \\
\text { temperatura corporal y sudoración }\end{array}$ & & \\
\hline $\begin{array}{l}\text { 2,3,6-TRICLOROFENOL } \\
\text { 933-75-5 }\end{array}$ & ojos; piel; tract resp & piel & $\begin{array}{r}\text { Inhalación } \\
\text { Piel } \\
\text { Ojos } \\
\text { Ingestión }\end{array}$ & $\begin{array}{l}\text { Tos, dolor de garganta } \\
\text { Enrojecimiento, dolor } \\
\text { Enrojecimiento, dolor } \\
\text { Dolor abdominal, diarrea, mareo, cefalea, } \\
\text { vómitos, debilidad, fatiga, espasmos } \\
\text { musculares, aumento de la temperatura } \\
\text { corporal y sudoración }\end{array}$ & & \\
\hline $\begin{array}{l}\text { 2,4,5-TRICLOROFENOL } \\
\text { 95-95-4 }\end{array}$ & ojos; piel; tract resp & $\begin{array}{l}\text { piel; hígado; } \\
\text { riñones }\end{array}$ & $\begin{array}{r}\text { Inhalación } \\
\text { Piel } \\
\text { Ojos } \\
\text { Ingestión }\end{array}$ & $\begin{array}{l}\text { Tos, dolor de garganta } \\
\text { Puede absorberse, enrojecimiento } \\
\text { Enrojecimiento, visión borrosa } \\
\text { Dolor abdominal, diarrea, mareo, cefalea, } \\
\text { vómitos, debilidad, fatiga, sudoración }\end{array}$ & & \\
\hline $\begin{array}{l}\text { 2,4,6-TRICLOROFENOL } \\
88-06-2\end{array}$ & ojos; piel; tract resp & hígado & $\begin{array}{l}\text { Inhalación } \\
\text { Piel } \\
\text { Ojos } \\
\text { Ingestión }\end{array}$ & $\begin{array}{l}\text { Tos } \\
\text { Puede absorberse, enrojecimiento } \\
\text { Enrojecimiento } \\
\text { Diarrea, náuseas, vómitos, debilidad }\end{array}$ & & \\
\hline
\end{tabular}


Tabla 104.139 • Riesgos físicos y químicos.

\begin{tabular}{|c|c|c|c|}
\hline $\begin{array}{l}\text { Denominación química } \\
\mathrm{N} \text { úmero CAS }\end{array}$ & Físicos & Q uímicos & $\begin{array}{l}\text { Clase o división } \\
\text { UN / Riesgos } \\
\text { subsidiarios }\end{array}$ \\
\hline $\begin{array}{l}\text { ACIDO PIROGALICO } \\
87.66-1\end{array}$ & & $\begin{array}{l}\text { Al calentarse libera humos tóxicos Es un ácido débil Reacciona con oxidantes } \\
\text { y bases }\end{array}$ & \\
\hline $\begin{array}{l}\text { 2,6-Dl-terC-BUTIL-p-CRESOL } \\
128-37-0\end{array}$ & & Se descompone al calentarse y por contacto con materiales oxidantes & \\
\hline $\begin{array}{l}\text { CATECOL } \\
120-80-9\end{array}$ & & En su combustión libera humos acres e irritantes Reacciona con oxidantes & \\
\hline $\begin{array}{l}\text { p-CLORO-m-CRESOL } \\
59-50-7\end{array}$ & & & 6.1 \\
\hline $\begin{array}{l}\text { 2-CLOROFENOL } \\
95-57-8\end{array}$ & $\begin{array}{l}\text { El vapor es más pesado } \\
\text { que el aire }\end{array}$ & $\begin{array}{l}\text { Se descompone al calentarse liberando humos tóxicos y corrosivos (acido clorhídrico, } \\
\text { cloro) Reacciona con oxidantes }\end{array}$ & 6.1 \\
\hline $\begin{array}{l}\text { 3-CLOROFENOL } \\
108-43-0\end{array}$ & & $\begin{array}{l}\text { Se descompone al calentarse liberando humos tóxicos y corrosivos (ácido clorhídrico, } \\
\text { cloro) Reacciona con oxidantes }\end{array}$ & \\
\hline $\begin{array}{l}\text { 4-CLOROFENOL } \\
106-48-9\end{array}$ & $\begin{array}{l}\text { El vapor es más pesado } \\
\text { que el aire }\end{array}$ & $\begin{array}{l}\text { Se descompone al calentarse liberando humos tóxicos y corrosivos (ácido clorhídrico, } \\
\text { cloro) Reacciona con oxidantes }\end{array}$ & 6.1 \\
\hline $\begin{array}{c}\text { m-CRESOL } \\
108-39-4\end{array}$ & & $\begin{array}{l}\text { Se descompone al arder liberando humos tóxicos e irritantes Reacciona con oxidantes } \\
\text { fuertes }\end{array}$ & $6.1 / 8$ \\
\hline $\begin{array}{l}0 . \text { CRESOL } \\
95-48-7\end{array}$ & & $\begin{array}{l}\text { En su combustión libera humos tóxicos Reacciona violentamente con agentes oxidantes } \\
\text { fuertes, con peligro de incendio y explosión Se oxida fácilmente en contacto con el aire }\end{array}$ & $6.1 / 8$ \\
\hline $\begin{array}{l}\text { P-CRESOL } \\
106-44-5\end{array}$ & & $\begin{array}{l}\text { En su combustión libera humos tóxicos Reacciona violentamente con agentes oxidantes } \\
\text { fuertes, con peligro de incendio y explosión }\end{array}$ & $6.1 / 8$ \\
\hline $\begin{array}{l}\text { CRESOL, TODOS LOS ISOMEROS } \\
1319-77-3\end{array}$ & & $\begin{array}{l}\text { Se descompone al calentarse produciendo ácidos y bases fuertes, con peligro de incendio y } \\
\text { explosión Ataca muchos metales }\end{array}$ & $6.1 / 8$ \\
\hline $\begin{array}{l}\text { 2,4-DICLOROFENOL } \\
\text { 120-83-2 }\end{array}$ & $\begin{array}{l}\text { El vapor es más pesado } \\
\text { que el aire }\end{array}$ & $\begin{array}{l}\text { En su combustión libera gases corrosivos (cloruro de hidrógeno) Reacciona violentamente } \\
\text { con oxidantes fuertes Libera humos tóxicos en un incendio }\end{array}$ & 6.1 \\
\hline $\begin{array}{l}\text { 2,5-DICLOROFENOL } \\
583-78-8\end{array}$ & & $\begin{array}{l}\text { Se descompone al arder liberando gases irritantes y tóxicos Reacciona con oxidantes, } \\
\text { cloruros ácidos y anhídridos ácidos }\end{array}$ & 6.1 \\
\hline $\begin{array}{l}\text { 3,5-DICLOROFENOL } \\
591-35-5\end{array}$ & & $\begin{array}{l}\text { Se descompone al arder liberando gases irritantes y tóxicos, cloruros ácidos y anhidros } \\
\text { ácidos Reacciona con oxidantes }\end{array}$ & 6.1 \\
\hline $\begin{array}{l}\text { 2,4-DIMETILFENOL } \\
\text { 105-67-9 }\end{array}$ & & & 6.1 \\
\hline $\begin{array}{l}\text { 0-DINITROCRESOL } \\
534-52-1\end{array}$ & & & 6.1 \\
\hline $\begin{array}{l}\text { FENOL } \\
108-95-2\end{array}$ & $\begin{array}{l}\text { El vapor es más pesado } \\
\text { que el aire y puede } \\
\text { desplazarse a ras del } \\
\text { suelo; posibilidad de } \\
\text { ignición a distancia }\end{array}$ & $\begin{array}{l}\text { Puede explotar al calentarse por encima de } 78{ }^{\circ} \mathrm{C} \text { En su combustión libera humos tóxicos } \\
\text { (monóxido de carbono) Al calentarse se forman humos tóxicos La solución en agua es un } \\
\text { ácido débil Reacciona con oxidantes, con peligro de incendio y explosión }\end{array}$ & 6.1 \\
\hline $\begin{array}{l}\text { HIDROQUINONA } \\
123-31-9\end{array}$ & $\begin{array}{l}\text { Posibilidad de explosión } \\
\text { pulverulenta cuando se } \\
\text { encuentra en forma de } \\
\text { polvo o gránulos y se } \\
\text { mezcla con el aire }\end{array}$ & Reacciona violentamente con hidróxido sódico & 6.1 \\
\hline $\begin{array}{l}\text { 2-HIDROXIBIFENILO } \\
90-43-7\end{array}$ & $\begin{array}{l}\text { Posibilidad de explosión } \\
\text { pulverulenta cuando se } \\
\text { encuentra en forma de } \\
\text { polvo o granular y se } \\
\text { mezcla con el aire }\end{array}$ & $\begin{array}{l}\text { Explota, produciendo monóxido de carbono, neblina acre y humos irritantes Reacciona con } \\
\text { bases fuertes y oxidantes fuertes }\end{array}$ & \\
\hline
\end{tabular}




\begin{tabular}{|c|c|c|c|}
\hline $\begin{array}{l}\text { Denominación química } \\
\mathrm{N} \text { úmero CAS }\end{array}$ & Físicos & Q uímicos & $\begin{array}{l}\text { Clase o división } \\
\text { UN / Riesgos } \\
\text { subsidiarios }\end{array}$ \\
\hline $\begin{array}{l}\text { PENTACLOROFENOL } \\
87-86.5\end{array}$ & & $\begin{array}{l}\text { Se descompone al calentarse por encima de } 200{ }^{\circ} \mathrm{C} \text {, produciendo humos y gases tóxicos, } \\
\text { entre ellos cloruro de hidrógeno, dioxinas y fenoles clorados Reacciona violentamente con } \\
\text { oxidantes fuertes y agua, con peligro de incendio y explosión }\end{array}$ & 6.1 \\
\hline $\begin{array}{l}\text { PENTACLOROFENOL, SAL SODICA } \\
\quad 131-52-2\end{array}$ & & $\begin{array}{l}\text { Al contactar con superficies calientes o llamas, se descompone liberando hidrocarburos } \\
\text { clorados, fenoles clorados, monóxido de carbono y } \mathrm{Na}_{2} \mathrm{O} \text { Reacciona con oxidantes fuertes } \\
\text { con peligro de incendio y explosión }\end{array}$ & 6.1 \\
\hline $\begin{array}{c}\text { RESORCINOL } \\
108-46-3 \\
\end{array}$ & & & 6.1 \\
\hline $\begin{array}{l}2,3,4,6-\text { TETRACLOROFENOL } \\
58-90-2\end{array}$ & & & 6.1 \\
\hline $\begin{array}{l}\text { 2,3,5,6-TETRACLOROFENOL } \\
\text { 935-95-5 }\end{array}$ & $\begin{array}{l}\text { El vapor es más pesado } \\
\text { que el aire }\end{array}$ & $\begin{array}{l}\text { Se descompone al calentarse y por contacto con oxidantes fuertes, liberando vapores y } \\
\text { humos tóxicos e irritantes, así como cloruro de hidrógeno y fosgeno Es un ácido débil }\end{array}$ & 6.1 \\
\hline $\begin{array}{l}\text { 2,3,4-TRICLORO FENOL } \\
15950-66.0\end{array}$ & & $\begin{array}{l}\text { Se descompone al calentarse produciendo monóxido de carbono y cloruro de hidrógeno } \\
\text { Reacciona con oxidantes, anhídridos ácidos y cloruros ácidos }\end{array}$ & \\
\hline $\begin{array}{l}\text { 2,3,5-TRICLORO FENOL } \\
\text { 933-78-8 }\end{array}$ & & $\begin{array}{l}\text { Se descompone al calentarse, al arder o por contacto con oxidantes fuertes, produciendo } \\
\text { vapores y humos tóxicos e irritantes (cloruro de hidrógeno y fosgeno) Es un ácido débil } \\
\text { Reacciona con oxidantes fuertes }\end{array}$ & \\
\hline $\begin{array}{l}\text { 2,3,6-TRICLOROFENOL } \\
\text { 933-75-5 }\end{array}$ & & $\begin{array}{l}\text { Puede explotar al calentarse Se descompone al calentarse o por contacto con oxidantes } \\
\text { fuertes, liberando vapores y humos tóxicos e irritantes (cloruro de hidrógeno y fosgeno) Es un } \\
\text { ácido débil Reacciona con oxidantes fuertes }\end{array}$ & \\
\hline $\begin{array}{l}\text { 2,4,5-TRICLOROFENOL } \\
95-95-4\end{array}$ & & $\begin{array}{l}\text { Puede explotar al calentarse hasta su descomposición Se descompone al calentarse y por } \\
\text { contacto con oxidantes fuertes, liberando humos tóxicos e irritantes (cloro, ácido clorhídrico) ES } \\
\text { un ácido débil Reacciona con oxidantes fuertes Reacciona en medio alcalino a elevadas } \\
\text { temperaturas produciendo dioxinas cloradas altamente tóxicas }\end{array}$ & \\
\hline $\begin{array}{l}\text { 2,4,6-TRICLOROFENOL } \\
88-06-2\end{array}$ & & $\begin{array}{l}\text { En su combustión libera humos tóxicos ( } \mathrm{HCl}, \mathrm{CO} \text { ) Se descompone al calentarse } 0 \text { al arder, } \\
\text { liberando humos tóxicos y corrosivos (cloruro de hidrógeno y cloro) Reacciona violentamente } \\
\text { con oxidantes fuertes }\end{array}$ & \\
\hline
\end{tabular}

\begin{tabular}{|c|c|c|c|c|c|c|c|c|c|c|}
\hline $\begin{array}{l}\text { Denominación química } \\
\mathrm{N} \text { úmero CAS }\end{array}$ & Color/ Forma & $\begin{array}{l}\text { p.e. } \\
(-\mathrm{C})\end{array}$ & $\begin{array}{l}\text { p.f. } \\
(\underline{O C})\end{array}$ & $\begin{array}{l}\text { p.m.l } \\
\text { (g/ } \\
\text { mol) }\end{array}$ & $\begin{array}{l}\text { Solubilidad } \\
\text { en agua }\end{array}$ & $\begin{array}{l}\text { Densidad } \\
\text { relativa } \\
\text { (agua =1) }\end{array}$ & $\begin{array}{l}\text { Densidad } \\
\text { relativa } \\
\text { del vapor } \\
\text { (aire=1) }\end{array}$ & $\begin{array}{l}\text { Pvap/ } \\
(\mathrm{KPa})\end{array}$ & $\begin{array}{l}\text { Límit. } \\
\text { inflam. }\end{array}$ & $\begin{array}{ll}\text { p.ig. } & \text { p.aut } \\
\left({ }^{\circ} C\right) & \text { ig. } \\
& \left({ }^{\circ} C\right)\end{array}$ \\
\hline $\begin{array}{l}\text { ACIDO PIROGALICO } \\
87-66-1\end{array}$ & $\begin{array}{l}\text { cristales blancos; } \\
\text { ortorrómbicos; } \\
\text { laminillas o agujas } \\
\text { en benceno }\end{array}$ & 309 & 133 & 126,11 & muy sol & 1,45 & & $\begin{array}{l}1,33 \\
\text { @ } 168^{\circ} \mathrm{C}\end{array}$ & & \\
\hline $\begin{array}{l}\text { 2,6-DI-terc-BUTIL-p-CRESOL } \\
\text { 128-37-0 }\end{array}$ & $\begin{array}{l}\text { sólido cristalino } \\
\text { blanco; polvo } \\
\text { cristalino de color } \\
\text { amarillo claro }\end{array}$ & 265 & 70 & 220,34 & insol & 1,048 & 7,6 & & & $127 \mathrm{cc}$ \\
\hline $\begin{array}{l}\text { 2,6-DI-terc-BUTILFENOL } \\
\text { 128-39-2 }\end{array}$ & & 133 & 39 & 206,31 & & & & & & \\
\hline p-terc-BUTILFENOL & & 237 & 98 & 150,21 & sol & $0,908 @ 80^{\circ}$ & & & & \\
\hline
\end{tabular}




\begin{tabular}{|c|c|c|c|c|c|c|c|c|c|c|c|}
\hline $\begin{array}{l}\text { Denominación química } \\
\mathrm{N} \text { úmero CAS }\end{array}$ & Color/ Forma & $\begin{array}{l}\text { p.e. } \\
(\stackrel{0}{ } \mathrm{C})\end{array}$ & $\begin{array}{l}\text { p.f. } \\
(\stackrel{0}{ } C)\end{array}$ & $\begin{array}{l}\mathrm{p} . \mathrm{m} . / \\
\text { (g/ } \\
\mathrm{mol})\end{array}$ & $\begin{array}{l}\text { Solubilidad } \\
\text { en agua }\end{array}$ & $\begin{array}{l}\text { Densidad } \\
\text { relativa } \\
\text { (agua }=1 \text { ) }\end{array}$ & $\begin{array}{l}\text { Densidad } \\
\text { relativa } \\
\text { del vapor } \\
\text { (aire=1) }\end{array}$ & $\begin{array}{l}\text { Pvap/ } \\
(\mathrm{kPa})\end{array}$ & $\begin{array}{l}\text { Límit. } \\
\text { inflam. }\end{array}$ & 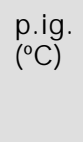 & $\begin{array}{l}\text { p.aut } \\
\text { ig. } \\
\left({ }^{\circ} C\right)\end{array}$ \\
\hline $\begin{array}{l}\text { 4-terc-BUTILPIROCATECOL } \\
98-29-3\end{array}$ & & 285 & 53,5 & 166,21 & & & & & & & \\
\hline $\begin{array}{l}\text { CATECOL } \\
\quad 120-80-9\end{array}$ & $\begin{array}{l}\text { Tabletas } \\
\text { monoclínicas, } \\
\text { prismas en tolueno; } \\
\text { cristales incoloros; } \\
\text { cristales incoloros } \\
\text { que adquieren una } \\
\text { tonalidad marrón } \\
\text { cuando se exponen } \\
\text { al aire y la luz, } \\
\text { especialmente en } \\
\text { ambientes húmedos }\end{array}$ & 245 & 105 & 110,11 & muy sol & 1,344 & 3,79 & $\begin{array}{l}3 \times 10^{-2} \\
\mathrm{~mm} \mathrm{Hg}\end{array}$ & & $127 c c$ & 510 \\
\hline $\begin{array}{l}\text { p-CLORO-m-CRESOL } \\
59-50-7\end{array}$ & $\begin{array}{l}\text { cristales dimorfos; } \\
\text { agujas en éter de } \\
\text { petróleo; cristales } \\
\text { blancos o rosáceos }\end{array}$ & 235 & 67 & 142,58 & lig sol & & & & & & \\
\hline $\begin{array}{l}\text { 2-CLOROFENOL } \\
95-57-8\end{array}$ & $\begin{array}{l}\text { líquido de color } \\
\text { ambar claro; líquido } \\
\text { incoloro o marrón } \\
\text { amarillento }\end{array}$ & 174,9 & 9,3 & 128,6 & lig sol & 1,2634 & 4,4 & 0,23 & & $64 \mathrm{cc}$ & \\
\hline $\begin{array}{c}\text { 3-CLOROFENOL } \\
108-43-0\end{array}$ & $\begin{array}{l}\text { agujas; cristales } \\
\text { blancos }\end{array}$ & 214 & 33 & 128,6 & lig sol & $1,268 @ 25 \stackrel{\circ}{ } \mathrm{C}$ & & $\begin{array}{l}0,13 \\
@ 44,2 \stackrel{\circ}{ } \mathrm{C}\end{array}$ & & 112 & \\
\hline $\begin{array}{l}\text { 4-CLOROFENOL } \\
106-48-9\end{array}$ & $\begin{array}{l}\text { cristales con forma } \\
\text { de aguja y color } \\
\text { blanco } 0 \text { amarillento; } \\
\text { cristales rosas }\end{array}$ & 220 & 43 & 128,6 & lig sol & $\begin{array}{l}1,2238 \\
@ 78 \stackrel{\circ}{\mathrm{C} / 4} 4 \stackrel{\circ}{\mathrm{C}}\end{array}$ & 4,43 & $13 \mathrm{~Pa}$ & & $121 c c$ & \\
\hline $\begin{array}{l}\text { m-CRESOL } \\
108-39-4 \\
\end{array}$ & $\begin{array}{l}\text { líquido incoloro o } \\
\text { amarillento }\end{array}$ & 202 & 12 & 108,1 & lig sol & 1,034 & 3,72 & $\begin{array}{l}20 \mathrm{~Pa} \\
@ 25^{\circ} \mathrm{C}\end{array}$ & $\begin{array}{l}1,1 \text { ii } \\
? \text { Is }\end{array}$ & $86 \mathrm{cc}$ & 558 \\
\hline $\begin{array}{l}\text { 0-CRESOL } \\
95-48-7\end{array}$ & $\begin{array}{l}\text { compuesto cristalino } \\
\text { incoloro; } \\
\text { líquido/ cristales } \\
\text { blancos }\end{array}$ & 191 & 31 & 108,1 & sol & 1,047 & 3,72 & $\begin{array}{l}33 \mathrm{~Pa} \\
@ 25^{\circ} \mathrm{C}\end{array}$ & $\begin{array}{l}1,35 \mathrm{li} \\
? \text { Is }\end{array}$ & $81 \mathrm{cc}$ & 599 \\
\hline $\begin{array}{l}\text { p-CRESOL } \\
106-44-5\end{array}$ & $\begin{array}{l}\text { cristales; prismas; } \\
\text { incoloros; cristales } \\
\text { blancos; masa } \\
\text { cristalina }\end{array}$ & 201,9 & 35 & 108,13 & lig sol & 1,0178 & 3,72 & $\begin{array}{l}15 \mathrm{~Pa} \\
@ 25^{\circ} \mathrm{C}\end{array}$ & $\begin{array}{l}1,1 \text { ii } \\
? \text { Is }\end{array}$ & $86 \mathrm{cc}$ & 559 \\
\hline $\begin{array}{l}\text { CRESOL, TODOS LOS ISOMEROS } \\
1319-77-3\end{array}$ & $\begin{array}{l}\text { líquido incoloro, } \\
\text { amarillento, marrón } \\
\text { amarillento o rosado }\end{array}$ & 191-203 & $11-35$ & 108,13 & 50 partes & $\begin{array}{l}1,030-1,038 \\
@ 25^{\circ} \mathrm{Cl} \\
25^{\circ} \mathrm{C}\end{array}$ & 3,72 & $\begin{array}{l}14-32 \mathrm{~Pa} \\
@ 25^{\circ} \mathrm{C}\end{array}$ & $\begin{array}{l}1,1 \mathrm{li} \\
? \text { is }\end{array}$ & $43-82$ & 559 \\
\hline $\begin{array}{l}\text { 2,4-DICLOROFENOL } \\
120-83-2\end{array}$ & $\begin{array}{l}\text { cristales incoloros; } \\
\text { agujas hexagonales } \\
\text { en benceno; sólido } \\
\text { blanco }\end{array}$ & 210 & 45 & 163,00 & lig sol & $\begin{array}{l}1,383 \\
@ 60 \stackrel{\circ}{\mathrm{C} / 25} \stackrel{\circ}{\circ} \mathrm{C}\end{array}$ & 5,62 & $\begin{array}{l}0,075 \\
\mathrm{~mm} \mathrm{Hg} \\
\text { @ } 25,0 \cong \mathrm{C}\end{array}$ & & 114 & \\
\hline $\begin{array}{l}\text { 2,5-DICLOROFENOL } \\
583-78-8\end{array}$ & $\begin{array}{l}\text { prismas en benceno y } \\
\text { éter de petróleo }\end{array}$ & $\begin{array}{l}211 @ \\
744 \mathrm{~mm} \mathrm{Hg}\end{array}$ & 59 & 163,0 & lig sol & & 5,6 & $\begin{array}{l}16,6 \mathrm{~Pa} \\
@ 25 \stackrel{\circ}{-} \mathrm{C}\end{array}$ & & & \\
\hline $\begin{array}{l}\text { 3,5-DICLOROFENOL } \\
591-35-5 \\
\end{array}$ & $\begin{array}{l}\text { prismas en éter de } \\
\text { petróleo }\end{array}$ & $\begin{array}{l}233 @ \\
757 \mathrm{~mm} \mathrm{Hg}\end{array}$ & 68 & 163,00 & lig sol & & 5,6 & $\begin{array}{l}1,1 \mathrm{~Pa} \\
@ 25 \stackrel{\circ}{-} \mathrm{C}\end{array}$ & & & \\
\hline $\begin{array}{l}\text { 2,4-DIMETILFENOL } \\
\text { 105-67-9 }\end{array}$ & $\begin{array}{l}\text { cristales; agujas en } \\
\text { agua; agujas } \\
\text { incoloras }\end{array}$ & $\begin{array}{l}211,5 @ \\
766 \mathrm{~mm} \mathrm{Hg}\end{array}$ & $25,4-26$ & 122,16 & lig sol & 0,9650 & & $\begin{array}{l}10 \mathrm{~mm} \mathrm{Hg} \\
@ 92,3^{\circ} \mathrm{C}\end{array}$ & & & \\
\hline
\end{tabular}




\begin{tabular}{|c|c|c|c|c|c|c|c|c|c|c|c|}
\hline $\begin{array}{l}\text { Denominación química } \\
\mathrm{N} \text { úmero CAS }\end{array}$ & Color/ Forma & $\begin{array}{l}\text { p.e. } \\
(\stackrel{0}{ } \mathrm{C})\end{array}$ & $\begin{array}{l}\text { p.f. } \\
\left({ }^{\circ} \mathrm{C}\right)\end{array}$ & $\begin{array}{l}\text { p.m.l } \\
\text { (g/ } \\
\text { mol) }\end{array}$ & $\begin{array}{l}\text { Solubilidad } \\
\text { en agua }\end{array}$ & $\begin{array}{l}\text { Densidad } \\
\text { relativa } \\
\text { (agua }=1 \text { ) }\end{array}$ & $\begin{array}{l}\text { Densidad } \\
\text { relativa } \\
\text { del vapor } \\
\text { (aire=1) }\end{array}$ & $\begin{array}{l}\text { Pvap/ } \\
(\mathrm{kPa})\end{array}$ & $\begin{array}{l}\text { Límit. } \\
\text { inflam. }\end{array}$ & $\begin{array}{l}\text { p.ig. } \\
(\stackrel{C}{ }=)\end{array}$ & $\begin{array}{l}\text { p.aut } \\
\text { ig. } \\
(\stackrel{0}{ } \text { C })\end{array}$ \\
\hline $\begin{array}{l}\text { DINITRO-0-CRESOL } \\
534-52-1\end{array}$ & & 312 & 87 & 198,13 & lig sol & & 6,8 & $\begin{array}{l}1,05 \times 10^{-4} \\
\mathrm{~mm} \mathrm{Hg} \\
@ 25^{\circ} \mathrm{C}\end{array}$ & & & \\
\hline $\begin{array}{l}\text { FENOL } \\
\quad 108-95-2\end{array}$ & $\begin{array}{l}\text { cristales aciculares } \\
\text { incoloros o masa } \\
\text { cristalina blanca; } \\
\text { cristales aciculares } \\
\text { incoloros o } \\
\text { ligeramente rosas, } \\
\text { entrelazados o } \\
\text { separados, o masa } \\
\text { cristalina de color } \\
\text { rosa claro }\end{array}$ & 181,8 & 43 & 94,11 & sol & 1,0576 & 3,24 & $47 \mathrm{~Pa}$ & $\begin{array}{l}1,7 \mathrm{li} \\
8,6 \mathrm{ls}\end{array}$ & $79 \mathrm{cc}$ & 715 \\
\hline $\begin{array}{l}\text { HIDROQUINONA } \\
\quad 123-31.9\end{array}$ & $\begin{array}{l}\text { prismas hexagonales } \\
\text { incoloros; cristales } \\
\text { blancos; prismas } \\
\text { monoclínicos } \\
\text { (sublimación); agujas } \\
\text { en agua; prismas en } \\
\text { metanol }\end{array}$ & $285-287$ & 172 & 110,11 & sol & 1,332 & 3,81 & $0,12 \mathrm{~Pa}$ & & 165 & 515 \\
\hline $\begin{array}{l}\text { 2-HIDROXIBIFENILO } \\
\text { 90-43-7 }\end{array}$ & $\begin{array}{l}\text { agujas en éter de } \\
\text { petróleo; cristales } \\
\text { rosáceos; cristales } \\
\text { lamelares blancos; } \\
\text { cristales incoloros }\end{array}$ & 286 & 59 & 170,20 & insol & $\begin{array}{l}1,213 \\
@ 25^{\circ} \mathrm{C} / 4^{\circ} \mathrm{C}\end{array}$ & & $\begin{array}{l}2,7 @ \\
163^{\circ} \mathrm{C}\end{array}$ & & $124 c c$ & 530 \\
\hline $\begin{array}{l}\text { 4-METOXIFENOL } \\
150-76.5 \\
\end{array}$ & $\begin{array}{l}\text { láminas en agua; } \\
\text { sólido ceroso blanco }\end{array}$ & 243 & 57 & 124,14 & sol & 1,55 & & & & $132 \mathrm{ca}$ & 421 \\
\hline $\begin{array}{l}\text { NONILFENOL, TODOS LOS ISOMEROS } \\
25154-52-3\end{array}$ & $\begin{array}{l}\text { líquido espeso de } \\
\text { color amarillo claro o } \\
\text { pajizo }\end{array}$ & 293-297 & -10 & 220,39 & insol & 0,950 & 7,59 & 0,01 & $\begin{array}{l}1,0 \mathrm{li} \\
? \text { Is }\end{array}$ & $140 \mathrm{cc}$ & 370 \\
\hline $\begin{array}{l}\text { PENTACLOROFENOL } \\
87.86 .5\end{array}$ & $\begin{array}{l}\text { cristales incoloros } \\
\text { (puro); polvo o } \\
\text { escamas de color gris } \\
\text { oscuro (producto } \\
\text { crudo); perlas o } \\
\text { escamas sólidas; } \\
\text { sólido cristalino } \\
\text { monoclínico blanco; } \\
\text { cristales con forma } \\
\text { de aguja }\end{array}$ & 309- 310 & $190-191$ & 266,3 & lig sol & $\begin{array}{l}1,978 @ \\
22 \stackrel{\circ}{\circ} / 4 \stackrel{\circ}{\circ} \mathrm{C}\end{array}$ & 9,20 & $0,02 \mathrm{~Pa}$ & & & \\
\hline $\begin{array}{l}\text { PENTACLOROFENOL, SAL SODICA } \\
131.52 .2\end{array}$ & $\begin{array}{l}\text { escamas de color } \\
\text { amarillo claro; polvo } \\
\text { blanco o color canela }\end{array}$ & & & 288,34 & $33 \% @ 25 \stackrel{\circ}{\circ}$ & & & & & & \\
\hline $\begin{array}{l}\text { RESORCINOL } \\
108-46-3\end{array}$ & $\begin{array}{l}\text { cristales aciculares } \\
\text { blancos; agujas en } \\
\text { benceno; láminas en } \\
\text { agua; cristales } \\
\text { tabulares rómbicos y }\end{array}$ & 280 & 111 & 110,11 & sol & 1,2717 & 1,0739 & $\begin{array}{l}1 \mathrm{~mm} \mathrm{Hg} \\
@ \\
108,4^{\circ} \mathrm{C}\end{array}$ & $\begin{array}{l}1,4 \\
@ 200^{\circ} \mathrm{C} \\
\text { li } \\
? \text { Is }\end{array}$ & & \\
\hline
\end{tabular}

piramidales; polvo 
Tabla 104.140 • Propiedades físicas y químicas.

\begin{tabular}{|c|c|c|c|c|c|c|c|c|c|c|c|}
\hline $\begin{array}{l}\text { Denominación química } \\
\mathrm{N} \text { úmero CAS }\end{array}$ & Color/ Forma & $\begin{array}{l}\text { p.e. } \\
(\stackrel{O}{ } \mathrm{C})\end{array}$ & $\begin{array}{l}\text { p.f. } \\
(\stackrel{\circ}{ } C)\end{array}$ & $\begin{array}{l}\text { p.m.l } \\
\text { (g/ } \\
\mathrm{mol})\end{array}$ & $\begin{array}{l}\text { Solubilidad } \\
\text { en agua }\end{array}$ & $\begin{array}{l}\text { Densidad } \\
\text { relativa } \\
\text { (agua }=1 \text { ) }\end{array}$ & $\begin{array}{l}\text { Densidad } \\
\text { relativa } \\
\text { del vapor } \\
\text { (aire=1) }\end{array}$ & $\begin{array}{l}\text { Pvap/ } \\
(\mathrm{kPa})\end{array}$ & $\begin{array}{l}\text { Límit. } \\
\text { inflam. }\end{array}$ & $\begin{array}{l}\text { p.ig. } \\
(\stackrel{\circ}{ } \text { C })\end{array}$ & $\begin{array}{l}\text { p.aut } \\
\text { ig. } \\
\left({ }^{\circ} \mathrm{C}\right)\end{array}$ \\
\hline $\begin{array}{l}\text { 2,3,4,6-TETRACLOROFENOL } \\
58-90-2\end{array}$ & $\begin{array}{l}\text { agujas en ligroina, } \\
\text { ácido acético; } \\
\text { escamas marrones o } \\
\text { masa sublimada; } \\
\text { masa de color } \\
\text { marrón claro }\end{array}$ & $\begin{array}{l}150 @ \\
15 \mathrm{~mm} \mathrm{Hg}\end{array}$ & 70 & 231,89 & insol & $\begin{array}{l}1,83 @ 25 \\
\stackrel{\circ}{C} / 4 \stackrel{\circ}{-} \mathrm{C}\end{array}$ & & $\begin{array}{l}1 \mathrm{~mm} \mathrm{Hg} \\
@ \\
100,0 \stackrel{0}{ } \mathrm{C}\end{array}$ & & & \\
\hline $\begin{array}{l}\text { 2,3,5,6-TETRACLOROFENOL } \\
\text { 935-95-5 }\end{array}$ & láminas en ligroina & 288 & 115 & 231,89 & lig sol & 1,7 & 8,1 & $\mathrm{~Pa}$ & & & \\
\hline $\begin{array}{l}\text { 4,4'-TIO-BIS-(6-terc-BUTIL-m- } \\
\text { CRESOL) } \\
96-69-5\end{array}$ & $\begin{array}{l}\text { polvo gris claro; } \\
\text { cristales blancos } \\
\text { delgados }\end{array}$ & & 150 & 358,58 & $0,08 \%$ & & & & & & \\
\hline $\begin{array}{l}\text { 2,3,4-TRICLOROFENOL } \\
15950-66-0\end{array}$ & $\begin{array}{l}\text { polvo } 0 \text { agujas de } \\
\text { color blanco }\end{array}$ & & $\begin{array}{l}83,5 \\
\text { sublima }\end{array}$ & 197,5 & & & & & & & \\
\hline $\begin{array}{l}\text { 2,3,5-TRICLOROFENOL } \\
933-78-8\end{array}$ & cristales incoloros & $248-249$ & 62 & 197,4 & insol & & 6,8 & & & & \\
\hline $\begin{array}{l}\text { 2,3,6-TRICLOROFENOL } \\
\text { 933-75-5 }\end{array}$ & $\begin{array}{l}\text { agujas en alcohol } \\
\text { diluido, éter de } \\
\text { petróleo; agujas } \\
\text { incoloras }\end{array}$ & 253 & 58 & 197,44 & lig sol & 1,5 & 6,82 & & & 78 & \\
\hline $\begin{array}{l}\text { 2,4,5-TRICLOROFENOL } \\
\text { 95-95-4 }\end{array}$ & $\begin{array}{l}\text { agujas en alcohol o } \\
\text { ligroina; escamas } \\
\text { grises en masa } \\
\text { sublimada; agujas } \\
\text { incoloras }\end{array}$ & 253 & 67 & 197,4 & lig sol & $\begin{array}{l}1,678 \\
@ 25 \stackrel{\circ}{\circ} / 4 \stackrel{\circ}{C}\end{array}$ & & $\begin{array}{l}2,9 \mathrm{~Pa} \\
@ 25 \stackrel{\circ}{\varrho} \mathrm{C}\end{array}$ & & & \\
\hline $\begin{array}{l}\text { 2,4,6-TRICLOROFENOL } \\
88-06-2\end{array}$ & $\begin{array}{l}\text { cristales en ligroina; } \\
\text { escamas amarillas; } \\
\text { agujas rómbicas en } \\
\text { ácido acético; agujas } \\
\text { incoloras }\end{array}$ & 246 & 69 & 197,45 & $\begin{array}{l}800 \mathrm{mg} / \mathrm{l} \\
\text { @ } 25 \stackrel{\circ}{\mathrm{C}}\end{array}$ & 1,4901 & 6,8 & $\begin{array}{l}133 \mathrm{~Pa} \\
@ 76,5 \stackrel{\circ}{\circ} \mathrm{C}\end{array}$ & & & \\
\hline
\end{tabular}




\section{FO SFAT O S INORGANICOS Y ORGANICOS}

\section{Presencia y usos}

El fósforo no está presente en la naturaleza en estado libre, sino combinado con numerosos compuestos vegetales y animales. Se encuentra también en formaciones rocosas que contienen fosfato, como la apatita (una forma de fosfato cálcico). En Estados U nidos (T ennessee y Florida), algunas zonas del norte de Africa y algunas islas del Pacífico, existen grandes depósitos de fosfatos en forma mineral.

L os fosfatos inorgánicos y orgánicos se utilizan ampliamente en la industria como aditivos de lubricantes, retardadores de llama, plastificantes y productos químicos intermedios. Se utilizan también en las industrias de caucho, plástico, papel, barnices y metal y como ingredientes de pesticidas y productos de limpieza.

El dibutilfenil fosfato y el tributil fosfato son componentes de los líquidos hidráulicos utilizados en los motores de los aviones, y la hexametil fosforamida es un descongelante que se añade a los combustibles de los reactores. El dibutil fosfato se utiliza en la separación y extracción de metales y como catalizador en la fabricación de fenol y resinas uréicas. El trimetil fosfato se emplea en la industria automovilística como antiincrustante de las bujías y como aditivo de la gasolina para controlar la ignición de superficie y el autoencendido.

El ácido fosfórico es un componente de cemento dental, látex de caucho, agentes controladores de llama y lodos de inyección de pozos de petróleo. Se utiliza como aromatizante de bebidas no alcohólicas, para la tinción del algodón, para el tratamiento de las aguas, como componente de ladrillos refractarios, en la fabricación de fertilizantes con superfosfatos, en la limpieza de los metales antes de pintarlos, como aditivo en la gasolina y como ligante en la cerámica.

El tricresil fosfato (T CP) se utiliza como disolvente de ésteres de nitrocelulosa y numerosas resinas naturales. Es un plastificante de caucho clorado, plásticos vinílicos, poliestireno y ésteres poliacrílicos y polimetracrílicos. El tricresil fosfato actúa también como ligante de resinas y nitrocelulosas, mejorando las propiedades de resistencia, elasticidad y pulido de los revestimientos. En solitario o combinado con hidrocarburos, se utiliza como aditivo antidesgaste y antifricción en numerosos lubricantes sintéticos, incorrectamente llamados "aceites" por su aspecto. Se utiliza también como líquido hidráulico. C uando se incorpora a la gasolina, el tricresil fosfato contrarresta los efectos nocivos de los depósitos de plomo. Además, es un excelente retardante de la llama en numerosas industrias.

El pirofosfato tetrasódico tiene una gran diversidad de aplicaciones en las industrias del papel, la alimentación, los tejidos y el caucho. Se utiliza también en la perforación de pozos de petróleo, tratamiento de aguas, emulsificación de quesos, producción de detergentes para ropa y deposición galvanoplástica de metales. El pirofosfato tetrasódico se utiliza para la tinción de tejidos, el lavado de lana y el procesamiento de arcilla y papel. EI tributil fosfato sirve como plastificante de ésteres de celulosa, lacas, plásticos y resinas vinílicas. Es también un agente acomplejante en la extracción de metales pesados y un agente antiespumante en procesos de separación del minerales. El trifenil fosfato es un plastificante retardador de la llama para materiales celulósicos y un plastificante para adhesivos aplicados en caliente. Es también útil en las industrias de tapicería y de cartón alquitranado.
Algunos fosfatos orgánicos se utilizan para la producción de materiales pirotécnicos, explosivos y pesticidas. EI fosfuro cálcico se utiliza en señales de fuego, torpedos, pirotécnia y como rodenticida. El sulfuro de fósforo se utiliza en la fabricación de cerillas de seguridad, compuestos de ignición, aditivos de aceites lubricantes y pesticidas. La fosfina se utiliza para el control de roedores y como insecticida aplicado en la fumigación de piensos, tabaco almacenado en hojas y vagones utilizados para el transporte de animales.

El fósforo blanco se utiliza en la fabricación de raticidas; el fósforo rojo se emplea en pirotécnia, en la fabricación de cerillas de seguridad, en la síntesis de compuestos químicos, en pesticidas, proyectiles incendiarios, balas trazadoras y bombas de humo. El trisulfuro de tetrafósforo se utiliza para fabricar las cabezas de cerillas y las cintas de rozamiento de las cajas de cerillas de "seguridad".

El pentóxido de fósforo se añade al asfalto en el proceso de refinado al aire para elevar su punto de fusión y se utiliza en la fabricación de vidrios especiales para tubos de vacío. El tricloruro de fósforo es un componente de los agentes de acabado de los tejidos y un producto químico intermedio o reactivo en la fabricación de muchos compuestos químicos industriales, entre ellos insecticidas, agentes tensioactivos sintéticos y productos para el pulido de la plata. El oxicloruro de fósforo y el pentacloruro de fósforo sirven como agentes clorantes de compuestos orgánicos.

\section{Fósforo}

El fósforo (P) existe en tres formas alotrópicas: blanco (0 amarillo), rojo y negro, este último sin importancia industrial. EI fósforo blanco es un sólido incoloro o de aspecto céreo que se oscurece con la exposición a la luz y brilla en la oscuridad (fosforescencia). A rde espontáneamente en contacto con el aire produciendo una llama azul y un olor desagradable característico parecido al del ajo. La forma roja es más estable.

\section{Importancia histórica}

El fósforo como elemento se extrajo por primera vez a partir de productos animales, especialmente de los huesos, a principios de siglo XIX. En seguida se descubrió su utilidad para fabricar cerillas que podían encenderse en cualquier superficie y, como resultado, surgió una gran demanda de este producto. Poco después comenzó a aparecer una grave enfermedad en las personas que lo manipulaban; los primeros casos se detectaron en 1845, con necrosis del maxilar inferior en los trabajadores que procesaban el fósforo. Esta enfermedad desfigurante y grave, que en el siglo XIX era mortal en el $20 \%$ de los casos, fue pronto reconocida y se adoptaron medidas para combatirla, entre ellas la sustitución del fósforo blanco por fósforo rojo y sesquisulfuro de fósforo, relativamente más seguros. Los países europeos firmaron un acuerdo (el Convenio de Berna de 1906) para dejar de fabricar e importar cerillas fabricadas con fósforo blanco.

No obstante, en muchos países el fósforo siguió constituyendo un grave riesgo asociado a su uso en la industria pirotécnica hasta que se alcanzó un acuerdo con esos fabricantes para que dejaran de utilizarlo. En la actualidad, los riesgos para la salud del fósforo blanco siguen poniendo en peligro a los trabajadores que participan en las distintas etapas de la producción y fabricación de este compuesto.

El mecanismo por el cual se producen lesiones maxilares no se ha explicado del todo. Algunos autores creen que se debe al efecto local del fósforo en la cavidad oral y que la infección sobreviene por la presencia constante de organismos patógenos en la boca y alrededor de los dientes. De hecho, se ha observado que 
las personas expuestas a fósforo con dientes cariados tienen más probabilidades de sufrir esta afección, si bien resulta difícil explicar la presencia de esta enfermedad en trabajadores sin dientes.

Una segunda explicación más plausible es que la necrosis producida por el fósforo en los maxilares es la manifestación de una enfermedad sistémica que afecta a muchos órganos y tejidos y principalmente a los huesos. En favor de esta teoría abogan los siguientes hechos:

- Como ya se ha dicho con anterioridad, se ha visto que personas sin dentadura presentaron necrosis maxilar cuando sufrieron exposición al fósforo en su trabajo, incluso aunque su "higiene dental" pudiera considerarse buena.

- Los animales de experimentación jóvenes y en período de crecimiento sufren alteraciones en las áreas "de crecimiento" de los huesos (metáfisis) cuando reciben dosis suficientes de fósforo blanco.

- En ocasiones, los huesos lesionados por traumatismo en los adultos expuestos al fósforo se curan muy despacio.

\section{Riesgos}

Riesgos para la salud. La intoxicación aguda por vapores de fósforo amarillo liberados en su combustión espontánea produce irritación de los ojos, con fotofobia, lagrimeo y blefaroespasmo; irritación intensa del tracto respiratorio y quemaduras profundas y penetrantes de la piel. El contacto directo de la piel con el fósforo, que puede ocurrir durante su producción o en período de guerra, produce quemaduras muy profundas de primero y segundo grado, similares a las producidas por el fluoruro de hidrógeno. Se han descrito casos de hemolisis masiva, seguida de hematuria, oliguria e insuficiencia renal, aunque este conjunto de episodios se debía probablemente al tratamiento con sulfato de cobre que se recomendaba anteriormente.

Tras su ingestión, el fósforo produce quemaduras en la boca y el tracto gastrointestinal (GI), con sensación de quemazón en la boca, vómitos, diarrea y dolor abdominal intenso. Las quemaduras progresan a segundo y tercer grado. Puede aparecer oliguria secundaria, deshidratación y mala perfusión renal; en los casos menos graves, los túbulos renales proximales sufren lesiones transitorias. U na característica típica es la ausencia de azúcar en el líquido cerebrospinal.

Tras su absorción por vía digestiva, el fósforo amarillo ejerce efectos directos en el miocardio, el sistema circulatorio de las extremidades (vasculatura periférica), el hígado, los riñones y el cerebro. Se han descrito casos de hipotensión y miocardiopatía dilatada y en las autopsias se ha observado la presencia de edema miocárdico intersticial con infiltración celular. La síntesis intracelular de proteínas parece estar deprimida en el corazón y el hígado.

Se han descrito tres estadios clínicos después de la ingestión de fósforo. En el estadio I, inmediatamente después de la ingestión, aparecen náuseas y vómitos, dolor abdominal, ictericia y aliento con olor a ajo. Los vómitos fosforescentes pueden ser peligrosos para el personal médico que atiende a la víctima. El estadio II se caracteriza por un período de latencia de 2-3 días durante el cual el paciente es asintomático, si bien puede producirse dilatación cardíaca e infiltración grasa en el hígado y los riñones. El estadio III se caracteriza por vómitos intensos con sangre, hemorragia en numerosos tejidos, uremia y anemia marcada como preludio de la muerte.

La ingesta prolongada (entre 10 meses y 18 años) puede causar necrosis de la mandíbula y el maxilar con afectación del hueso; la extirpación de esta afectación produce deformidad facial ("fosfonecrosis de la mandíbula"). Los primeros síntomas consisten en dolor de muelas y un exceso de salivación. Además puede aparecer anemia, caquexia y toxicidad hepática. En la literatura de principios del siglo $X X$ se describieron numerosos casos de necrosis de la mandíbula con deformación facial como consecuencia de la exposición crónica al fósforo. Algunos autores han descrito este fenómeno en trabajadores de la producción y fabricantes de rodenticidas. No se han descrito efectos reproductores ni carcinogénicos

El gas fosfina $\left(\mathrm{PH}_{3}\right)$ se produce por reacción del ácido fosfórico calentado con metales tratados para su limpieza (similar al fosgeno), por calentamiento del tricloruro de fósforo, por humedecimiento del fosfato alumínico, en la fabricación de bengalas utilizando fosfuro cálcico y en la producción de acetileno. Su inhalación causa una grave irritación de las mucosas, con tos, disnea y edema pulmonar hasta 3 días después de la exposición. El efecto fisiopatológico se debe a la inhibición de la respiración mitocondrial, así como a citoxicidad directa.

La fosfina se libera también accidental o deliberadamente del fosfito alumínico por interacción química con el ácido clorhídrico del estómago. En la India se han descrito numerosos casos de ingestión suicida de este rodenticida. La fosfina se utiliza también como fumigante y se han descrito numerosos casos de muerte accidental por su inhalación en zonas próximas a la fumigación de cereales almacenados. Los efectos tóxicos sistémicos consisten en náuseas, vómitos, dolor abdominal, excitación del sistema nervioso central (inquietud), edema pulmonar, shock cardíaco, pericarditis aguda, infarto auricular, lesiones renales, insuficiencia hepática e hipoglucemia. La prueba del nitrato de plata dio positiva en el aspirado gástrico y en el aire espirado (esta última con menos sensibilidad). La medición de los niveles de aluminio en sangre puede servir para identificar a esta toxina. El tratamiento consiste en un lavado gástrico, con administración de agentes vasodepresores, respiración asistida, administración de antiarrítmicos y altas dosis de infusión de sulfato magnésico.

El fosfuro de zinc, utilizado ampliamente como rodenticida, se ha relacionado con la intoxicación grave de animales que ingieren pienso fumigado o cadáveres de animales envenenados. En el estómago se libera gas fosfina por acción de los ácidos gástricos.

\section{Compuesto organofosforados}

Los tricresil fosfatos (TCPS) forman parte de una serie de compuestos organofosforados que producen neurotoxicidad diferida. El brote de parálisis "por el jengibre" en 1930 estuvo causado por la contaminación de extracto de jengibre por cresil fosfatos utilizados en su procesamiento. Desde entonces se han producido algunos casos de intoxicación accidental de alimentos por tri-o-cresil fosfato (TOCP). En la literatura se encuentran algunos casos casos descritos de exposición profesional. Las exposiciones profesionales agudas parecen causar síntomas gastrointestinales seguidos por un período de latencia que puede durar entre días y 4 semanas, después del cual el dolor y el temblor de las extremidades evoluciona hasta la parálisis motora de las extremidades inferiores, extendiéndose hasta los muslos y de las extremidades superiores hasta los codos. R ara vez se produce pérdida sensorial. El paciente puede tardar varios años en recuperarse total o parcialmente. Se han producido algunas muertes por ingestión de altas dosis. Las células del asta anterior de la médula y los tractos piramidales se ven afectados, con observación necrópsica de desmielinización y lesión de las células del asta anterior. En el ser humano, la dosis oral letal es de $1,0 \mathrm{~g} / \mathrm{kg}$ y con dosis de entre 6 y $7 \mathrm{mg} / \mathrm{kg}$ se produce parálisis grave. No se han descrito casos de irritación de la piel o los ojos, aunque el TOCP se absorbe a través de la piel. La inhibición de la actividad de la colinesterasa no parece estar relacionada con los síntomas o el grado de exposición. La exposición de gatos y gallinas se asoció a lesiones en la médula espinal y los nervios ciáticos, con afección de las células de Schwann y las vainas de 
mielina como resultado de la destrucción de los axones más largos. No se obtuvieron evidencias de teratogenicidad en ratas que recibieron dosis de hasta $350 \mathrm{mg} / \mathrm{kg} /$ día.

T res moléculas de 0 -, m- o $p$-cresol esterifican una molécula de ácido fosfórico y, puesto que el cresol comercial es normalmente una mezcla de los tres isómeros con un contenido del isómero orto que varía entre 25 y $40 \%$ según la fuente, el TCP resultante es una mezcla de los tres isómeros simétricos, que son muy difíciles de separar. N o obstante, puesto que la toxicidad del T CP comercial se debe a la presencia del isómero orto, muchos países obligan a que la fracción fenólica esterificada no contenga más de un $3 \%$ de 0 -cresol. La dificultad radica en seleccionar un cresol libre del isómero orto. EI T CP preparado a partir de m- o p-cresol exhibe las mismas propiedades que el producto técnico, pero el coste de separar y purificar estos isómeros es prohibitivo.

0 tros dos estéres que contienen fosfato,el cresil difenil fosfato y elo-isopropilfenildifenil fosfato, son también neurotóxicos para algunas especies, entre ellas el hombre, la gallina y el gato. Los animales adultos son, en general, más susceptibles que los jóvenes. Entre 8 y 10 días después de un único período largo de exposición a estos compuestos organofosforados neurotóxicos, aparecen lesiones axonales. La exposición crónica a pequeñas concentraciones puede causar también neurotoxicidad. Los axones de los nervios periféricos y los tractos ascendente y descendente de la médula espinal se ven afectados por un mecanismo diferente al de la inhibición de la colinesterasa. Aunque algunos de los insecticidas organofosforados que inhiben la colinesterasa causan este efecto (diisopropil fluorofosfato, leptofos y mipafox), la neuropatía diferida se produce aparentemente por un mecanismo diferente al de la inhibición de la colinesterasa. Existe una débil correlación entre la inhibición de pseudocolinesterasa o colinesterasa verdadera y el efecto neurotóxico.

El trifenil fosfato puede causar una ligera inhibición de la colinesterasa, pero por lo demás es poco tóxico para el ser humano. Este compuesto aparece en ocasiones conjuntamente con tri-0-cresil fosfato (TOCP). No se ha observado teratogenicidad en ratas alimentadas con dietas que contenían un $1 \%$ de este compuesto. La administración por vía intraperitoneal de entre 0,1 y $0,5 \mathrm{~g} / \mathrm{kg}$ en gatos causó parálisis al cabo de 16 ó 18 días. No se ha demostrado que produzca irritación de la piel ni se han descrito efectos en los ojos.

El trifenil fosfito(T PP) causa una neurotoxicidad en los animales de laboratorio similar a la descrita para el T O CP. L os estudios en ratas demostraron hiperexcitabilidad precoz y temblores seguidos por parálisis flácida, con las extremidades inferiores más afectadas que las superiores. La lesión patológica indicó daño de la médula espinal con una ligera inhibición de la colinesterasa. Un estudio en gatos que recibieron inyecciones de trifenil fosfito obtuvo prácticamente los mismos resultados clínicos. Se ha demostrado también que el TPP es irritante y sensibilizador de la piel.

El tributil fosfato causa irritación de la piel y las mucosas, así como edema pulmonar en los animales de laboratorio. Las ratas expuestas a una formulación comercial (bapros) de 123 ppm durante 6 horas sufrieron irritación de las vías respiratoria. T ras su ingestión, la $L D_{50}$ fue de $3 \mathrm{~g} / \mathrm{kg}$, con debilidad, disnea, edema pulmonar y contracción mucular. Inhibe débilmente a la colinesterasa presente en el plasma y en los eritrocitos.

Se ha demostrado que la hexametil fosforamida produce cáncer de la cavidad nasal cuando se administra a ratas en concentraciones de entre 50 y 4.000 ppb durante períodos entre 6 y 24 meses. Se observó metaplasia escamosa en la cavidad nasal y en la tráquea, esta última con la dosis más alta. 0 tros hallazgos fueron un incremento dependiente de la dosis en la inflamación y descamación de la tráquea, hiperplasia eritropoyética de la médula ósea, atrofia testicular y degeneración de los túbulos contorneados del riñón.

\section{0 tros compuestos fosfatados inorgánicos}

El pentóxido de fósforo (fósforo anhidro), el pentacloruro de fósforo, el oxicloruro de fósforo y el tricloruro de fósforo tienen propiedades irritantes, causando una serie de efectos leves, como corrosión de los ojos, quemaduras en la piel y las mucosas y edema pulmonar. La exposición crónica o sistémica no suele ser tan importante debido a la escasa tolerancia al contacto directo con estos compuestos químicos.

La neblina de ácido fosfórico es ligeramente irritante para la piel, los ojos y el tracto respiratorio superior. Se ha demostrado en grupos de trabajadores que los humos de pentóxido de fósforo (anhídrido del ácido fosfórico) pueden detectarse, pero no causan molestias, a concentraciones de entre 0,8 y $5,4 \mathrm{mg} / \mathrm{m}^{3}$, producen tos a concentraciones de entre 3,6 y $11,3 \mathrm{mg} / \mathrm{m}^{3}$, y resultan intolerables para los trabajadores no habituados a una concentración de $100 \mathrm{mg} / \mathrm{m}^{3}$. La inhalación de la neblina entraña un pequeño riesgo de edema pulmonar. El contacto de la piel con la neblina produce una ligera irritación, pero no toxicidad sistémica. La disolución de ácido fosfórico al 75 \% produce quemaduras graves si salpica la piel. En el estudio de una cohorte de trabajadores expuestos a ácido fosfórico, no se observó un incremento de la mortalidad específica por esta causa.

Se ha estimado que la concentración letal media del oxicloruro de fósforo y sus productos de neutralización con amoníaco es de 48,4 y 44,4 micromoles por mol de aire en ratas y 52,5 y 41,3 en cobayas. El $15 \%$ del oxicloruro de fósforo se hidroliza. La mayoría de las publicaciones sobre los efectos en la salud del oxicloruro de fósforo incluyen también la exposición a otros compuestos fosforados. En solitario, el oxicloruro de fósforo parece causar necrosis del estómago por ingestión, necrosis del tracto respiratorio por inhalación, ulceración de la piel por aplicación directa y ulceración de los ojos con pérdida de visión en conejos. La exposición crónica de los animales produjo alteración del metabolismo de los minerales y osteoporosis con eliminación de cantidades excesivas de fósforo inorgánico, sales de calcio y cloruros del organismo. En combinación con otros compuestos fosforados, algunos estudios publicados indican que el oxicloruro fosfórico produce asma y bronquitis.

El pentasulfuro de fósforo se hidroliza produciendo sulfuro de hidrógeno y ácido fosfórico, ocasionando los efectos de estas sustancias en contacto con las mucosas (véase ácido fosfórico, más arriba, y también sulfuro de hidrógeno en otros artículos de esta $E$ nciclopedia). $L a L_{50}$ oral fue de $389 \mathrm{mg} / \mathrm{kg}$ en ratas. La instilación de 20 miligramos en los ojos de conejos produjo una grave irritación al cabo de 24 horas. La aplicación de $500 \mathrm{mg}$ sobre la piel de conejos causó una irritación moderada al cabo de 24 horas.

L os vapores de tricloruro de fósforo son muy irritantes para las mucosas, los ojos y la piel. Al igual que el pentasulfuro de fósforo, su efecto se debe principalmente a la hidrólisis del ácido clorhídrico y el ácido fosfórico en contacto con las mucosas. La inhalación de vapores produce irritación de la garganta, broncoespasmo y/ o edema pulmonar hasta 24 horas después de la exposición, dependiendo de la dosis. El síndrome de enfermedad reactiva de las vías aéreas, con síntomas prolongados de respiración sibilante y tos, puede estar causado por la exposición aguda o repetida a estos vapores. El tricloruro de fósforo produce quemaduras por contacto con los ojos, la piel y las mucosas. La ingestión, accidental o suicida, produce quemaduras en el tracto gastrointestinal. Setenta personas que se vieron expuestas a tricloruro fosfórico y a los productos de su hidrólisis después de un accidente con un buque cisterna fueron sometidas a evaluación médica. Las que se encontraban más cerca del lugar del vertido 
sufrieron disnea, tos, náuseas, vómitos, irritación de los ojos y lagrimeo. En seis de ellas se observó una elevación transitoria de la lactato deshidrogenasa. Aunque las radiografías torácicas fueron normales, las pruebas de la función pulmonar indicaron una reducción significativa de la capacidad vital forzada y el $V E F_{1}$. En los 17 pacientes que fueron examinados de nuevo un mes más tarde, se observó una mejora de estos parámetros. La $\mathrm{LC}_{50}$ fue de 104 ppm a las 4 horas en ratas. El principal hallazgo en las autopsias consistió en nefrosis, con lesiones pulmonares negligibles.

La inhalación de humo de pentacloruro de fósforo produce irritación grave del tracto respiratorio, con bronquitis documentada. La aparición diferida de edema pulmonar es posible, aunque no se ha descrito nunca. La exposición de los ojos a este humo produce también irritación grave y cabría esperar que el contacto con la piel produjera dermatitis por contacto. La LC 50 correspondiente a 4 horas de inhalación es de $205 \mathrm{mg} / \mathrm{m3}$.

Fosfatos y superfosfatos. El principal problema de los fosfatos en el medio ambiente es que producen eutrofización en lagos y estanques. Los fosfatos se introducen en las masas de agua a través de la escorrentía de la agricultura (sus fuentes son los compuestos fosforados utilizados como fertilizantes y pesticidas, y la descomposición de plantas y animales) y los detergentes utilizados en viviendas particulares y en la industria. También se produce un crecimiento excesivo de algas verdeazuladas, puesto que el fósforo es generalmente el nutriente limitante esencial para su crecimiento. La proliferación de algas afecta al uso de los lagos para fines pesqueros y recreativos. Por otra parte, complica el proceso de purificación del agua potable.

\section{Toxicidad de los fosfatos}

Las minas de fosfatos se han asociado a traumas físicos. La neumoconiosis no es un problema en este caso, ya que la cantidad de polvo que se genera es pequeña. El polvo de fosfato se crea en el proceso de secado y plantea un problema por ser causa de neumoconiosis en los trabajadores que manipulan y transportan el material. Este polvo puede contener también fluoruros tóxicos.

El polvo de fosfato se origina también durante la producción de superfosfatos utilizados como fertilizantes. Un estudio en mujeres que trabajaban en la fabricación de superfosfatos detectó trastornos en la función menstrual. Se han descrito lesiones oculares graves y ceguera en seres humanos y animales por contacto directo con superfosfatos.

\section{Medidas de salud y seguridad}

Peligro de incendio. El fósforo puede arder espontáneamente en contacto con el aire, produciendo incendios y explosiones. El contacto con la piel genera chispas y pequeños fragmentos de fósforo blanco que arden después de secarse, produce quemaduras graves.

Debido a su inflamabilidad en contacto con el aire, el fósforo blanco debe mantenerse siempre cubierto de agua. Además, las partículas sueltas deben mojarse con agua, para evitar que se sequen y empiecen a arder. Los incendios producidos por el fósforo pueden controlarse con agua (nebulizada o rociada), cubriéndolos con arena o tierra, o con extintores de dióxido de carbono. Este producto debe almacenarse en una zona fresca, ventilada, aislada y alejada de oxidantes fuertes, peligros agudos de incendio y de los rayos solares directos.

En caso de contacto de la piel con fragmentos de fósforo ardiendo, éstos deben mojarse con una disolución de sulfato de cobre al 1-5 \% acuoso para apagar la llama y formar un compuesto no inflamable. U na vez aplicado este tratamiento, los fragmentos de fósforo pueden eliminarse con cantidades mayores de agua. La aplicación de una disolución jabonosa blanda con una concentración similar de sulfato de cobre puede resultar más eficaz que una simple disolución acuosa. 
TABLAS DE FOSFATOS INORGANICOS Y ORGANICOS

\begin{tabular}{|c|c|c|c|}
\hline Producto químico & Sinónimos/ Código UN & $\mathrm{N}$ úmero CAS & Fórmula estructural \\
\hline CLORURO DE FOSFORO & $\begin{array}{l}\text { Tricloruro de fósforo; triclorofosforina } \\
\text { UN1809 }\end{array}$ & $7719-12 \cdot 2$ & \\
\hline DIBUTIL FENIL FOSFATO & Ester dibutil fenílico del ácido fosfórico & $2528-36-1$ & \\
\hline DIBUTIL FOSFATO & $\begin{array}{l}\text { Fosfato del ácido dibutílico; dibutil hidrógeno fosfato; dibutil fosfato; } \\
\text { éster dibutilico del ácido fosfórico }\end{array}$ & $107-66-4$ & \\
\hline DIETIL TIOFOSFORIL CLORURO & $\begin{array}{l}\text { 0,0-Dietil fosfocloridotioato; dietil clorotiofosfato; éster cloro, 0,0-dietilíco } \\
\text { del ácido fosfonotioico } \\
\text { UN2751 }\end{array}$ & $2524-04-1$ & \\
\hline DIMETIL HIDROGENOFOSFITO & $\begin{array}{l}\text { Oxido de bis( hidroximetil) fosfina; óxido de dimetoxifosfina; fosfito del } \\
\text { ácido dimetilico; dimetil fosfito; dimetil fosfonato; ácido } \\
\text { fosfórico dimetilico; hidrógeno dimetil fosfito; éster dimetilico del ácido } \\
\text { fosfónico }\end{array}$ & $868-85-9$ & \\
\hline FENILFOSFINA & & $638-21-1$ & \\
\hline FOSFINA & $\begin{array}{l}\text { Gas-ex-B; fosfuro de hidrógeno; trihidruro fosfórico } \\
\text { UN2199 }\end{array}$ & $7803-51-2$ & \\
\hline FOSFORO (rojo) & $\begin{array}{l}\text { Fósforo, amorfo } \\
\text { UN1338 }\end{array}$ & $7723-14-0$ & $P$ \\
\hline \multirow[t]{2}{*}{ FOSFURO CALCICO } & \multirow[t]{2}{*}{$\begin{array}{l}\text { Photophor cálcico; Photophor } \\
\text { UN1360 }\end{array}$} & \multirow[t]{2}{*}{$1305-99-3$} & ${ }^{\mathrm{Ca}^{++}}{ }_{\mathrm{Ca}^{++}}^{\mathrm{P}}$ \\
\hline & & & $\mathrm{Ca}^{++}$ \\
\hline HEXAMETIL FOSFORAMIDA & $\begin{array}{l}\text { Hexametapol; hexametil fosforamida; triamida del ácido } \\
\text { hexametilfosfórico; triamida hexametilfosfórica; óxido de } \\
\text { tris( dimetilamino)fosfina; óxido de tris( dimetilamino)fósforo }\end{array}$ & $680-31-9$ & \\
\hline OXICLORURO DE FOSFORO & $\begin{array}{l}\text { Oxitricloruro de fósforo; fosforil cloruro } \\
\text { UN1810 }\end{array}$ & $10025-87-3$ & \\
\hline OXIDO DE FOSFORO & $\begin{array}{l}\text { Pentóxido de difósforo; óxido de fósforo(V); pentaóxido de fósforo; } \\
\text { pentóxido de fósforo } \\
\text { UN1807 }\end{array}$ & $1314-56-3$ & \\
\hline PENTACLORURO DE FOSFORO & $\begin{array}{l}\text { Cloruro de fósforo; percloruro de fósforo } \\
\text { UN1806 }\end{array}$ & $10026-13-8$ & \\
\hline PENTASULFURO DE FOSFORO & $\begin{array}{l}\text { Sulfuro de fósforo; persulfuro de fósforo; fosfuro de azufre; anhídrido } \\
\text { de trifósforo } \\
\text { UN1340 }\end{array}$ & $1314-80-3$ & \\
\hline
\end{tabular}




\begin{tabular}{|c|c|c|c|}
\hline Producto químico & Sinónimos/ Código UN & $\mathrm{N}$ úmero CAS & Fórmula estructural \\
\hline PIROFOSFATO TETRAPOTASICO & $\begin{array}{l}\text { Sal tetrapotásica del ácido difosfórico; pirofosfato potásico; } \\
\text { difosforato tetrapotásico; TKPP }\end{array}$ & $7320-34-5$ & \\
\hline PIROFOSFATO TETRASODICO & $\begin{array}{l}\text { Pirofosfato tetrasódico anhidro; Phosphotex; pirofosfato; } \\
\text { pirofosfato sódico; difosfato tetrasódico; pirofosfato tetrasódico, } \\
\text { anhidro; TSPP }\end{array}$ & $7722-88-5$ & $\begin{array}{llll}\mathrm{Na}^{+} & \mathrm{Na}^{+} & \mathrm{Na}^{+} & \mathrm{Na}{ }^{+}\end{array}$ \\
\hline TIOFOSFORIL CLORURO & $\begin{array}{l}\text { Tricloruro fosforotióico; tricloruro fosforotiónico; sulfocloruro fosfórico; } \\
\text { tiocloruro de fósforo; tricloruro tiofosfórico; tiofosforil tricloruro } \\
\text { UN1837 }\end{array}$ & $3982-91.0$ & \\
\hline TRIBUTIL FOSFATO & Butil fosfato, tri; TBP; tributil fosfato & $126-73-8$ & \\
\hline TRICRESIL FOSFATO & $\begin{array}{l}\text { Plastificante Flexol; TCP; éster tritolílico del ácido fosfórico; óxido de } \\
\text { tris(toliloxi)fosfina; tritolil fosfato } \\
\text { UN2574 }\end{array}$ & $1330-78-5$ & \\
\hline TRI-O-CRESIL FOSFATO & $\begin{array}{l}\text { o-Cresil fosfato; éster tri-o-tolílico del ácido fosfórico; TOCP; TOFK; } \\
\text { o-tolil fosfato; TOTP; tricresil fosfato; triocresil fosfato; } \\
\text { tri-2-metilfenil fosfato; tris( o-cresill)fosfato; tris ( o-metilfenil) fosfato; } \\
\text { tris( o-tolil)fosfato; tri-o-tolil fosfato; tri-2-tolil fosfato }\end{array}$ & $78-30-8$ & \\
\hline TRIETIL FOSFATO & Etil fosfato; éster trietílico del ácido fosfórico; TEP & $78-40-0$ & \\
\hline TRIETIL FOSFITO & $\begin{array}{l}\text { Ester trietílico del ácido fosfórico } \\
\text { UN2323 }\end{array}$ & $122-52-1$ & \\
\hline TRIFENIL FOSFATO & Celluflex TPP; TPP & $115-86-6$ & \\
\hline TRIFENIL FOSFINA & & $603-35-0$ & \\
\hline TRIFENIL FOSFITO & & $101-02-0$ & \\
\hline TRIMETLL FOSFATO & $\begin{array}{l}\text { Metil fosfato; NCI-C03781; éster trimetílico del ácido fosfórico; TMP; } \\
\text { 0,0,o-trimetil fosfato }\end{array}$ & $512-56-1$ & \\
\hline TRIMETLL FOSFITO & $\begin{array}{l}\text { Metil fosfito; trimetoxifosfina; éster trimetilico del ácido fosfórico } \\
\text { UN2329 }\end{array}$ & $121-45-9$ & \\
\hline
\end{tabular}




\begin{tabular}{|c|c|c|c|}
\hline Producto químico & Sinónimos/ Código UN & $\mathrm{N}$ úmero CAS & Fórmula estructural \\
\hline TRIS(2,3-DIBROMOPROPIL) FOSFATO & $\begin{array}{l}\text { 2,3-Dibromo1 propanol fosfato; (2,3-dibromopropil) fosfato; Fyrol HB32; } \\
\text { NCI-C03270; éster tris(2,3-dibromoproṕlico) del ácido fosfórico; } \\
\text { 1-propanol, 2,3-dibromo, fosfato (3:1); TDBPP; T 23P; Tris; TrisBP; } \\
\text { tris(dibromopropil) fosfato; éster tris(2,3-dibromopropilico) del ácido } \\
\text { fosfórico; Tris (retardante de llama); Zetifex ZN }\end{array}$ & $126-72.7$ & \\
\hline TRIS(2-ETILHEXIL) FOSFATO & $\begin{array}{l}\text { 2-Etil-1-hexanol fosfato; 1-hexanol, 2-etil-, fosfato; éster } \\
\text { tris( 2-etilhexilico) del ácido fosforico; TOF; trietilhexil fosfato; } \\
\text { trioctil fosfato }\end{array}$ & $78-42-2$ & \\
\hline TRISULFURO DE TETRAFOSFORO & & $1314-85-8$ & \\
\hline
\end{tabular}

\begin{tabular}{|c|c|c|c|c|c|c|}
\hline \multirow[b]{2}{*}{$\begin{array}{l}\text { Denominación } \\
\text { química } \\
\mathrm{N} \text { úmero CAS }\end{array}$} & \multicolumn{4}{|c|}{ Tarjetas Internacionales sobre la Seguridad de los Productos Q uímicos } & \multicolumn{2}{|c|}{ N IO SH (EE.UU.) } \\
\hline & $\begin{array}{l}\text { Período } \\
\text { corto de } \\
\text { exposición }\end{array}$ & $\begin{array}{l}\text { Período } \\
\text { largo de } \\
\text { exposición }\end{array}$ & $\begin{array}{l}\text { Vías de } \\
\text { exposición }\end{array}$ & Síntomas & $\begin{array}{l}\text { O rganos } \\
\text { afectados } \\
\text { Vías de } \\
\text { entrada }\end{array}$ & Síntomas \\
\hline $\begin{array}{l}\text { DIBUTIL FOSFATO } \\
107-66-4\end{array}$ & & & & & $\begin{array}{l}\text { Sis resp; piel; ojos } \\
\text { Inh; ing; con }\end{array}$ & Irrit ojos, piel, sis resp; cef \\
\hline $\begin{array}{l}\text { DIETILTIOFOSFORIL CLORURO } \\
\text { 2524-04-1 }\end{array}$ & $\begin{array}{l}\text { ojos; piel; } \\
\text { tract resp; } \\
\text { pulmones }\end{array}$ & & $\begin{array}{r}\text { Inhalación } \\
\text { Piel } \\
\text { 0jos } \\
\text { Ingestión }\end{array}$ & $\begin{array}{l}\text { Sensación de quemazón, confusión, tos, } \\
\text { mareo, cefalea, náuseas, disnea, dolor de } \\
\text { garganta, inconsciencia, vómitos, debilidad, } \\
\text { los síntomas pueden tardar en aparecer } \\
\text { Puede absorberse, enrojecimiento, sensación } \\
\text { de quemazón, dolor } \\
\text { El vapor se absorbe, enrojecimiento, dolor, } \\
\text { visión borrosa, pérdida de visión, quemaduras } \\
\text { profundas graves } \\
\text { Confusión, diarrea, cefalea, náuseas, vómitos }\end{array}$ & & \\
\hline $\begin{array}{l}\text { FOSFINA } \\
7803-51-2\end{array}$ & $\begin{array}{l}\text { ojos; piel; } \\
\text { tract resp; } \\
\text { pulmones; SNC; } \\
\text { sangre; hígado; } \\
\text { riñones; corazón }\end{array}$ & & $\begin{array}{l}\text { Inhalación } \\
\begin{array}{r}\text { Piel } \\
\text { 0jos }\end{array}\end{array}$ & $\begin{array}{l}\text { Sensación de quemazón, diarrea, mareo, } \\
\text { embotamiento, cefalea, temblores, dificultad } \\
\text { respiratoria, náuseas, dolor de garganta } \\
\text { Enrojecimiento, dolor, congelación por contacto } \\
\text { con el líquido } \\
\text { En caso de congelación: inflamación, dolor }\end{array}$ & $\begin{array}{l}\text { Sis resp } \\
\text { Inh; con (liq) }\end{array}$ & $\begin{array}{l}\text { Náu, vómit, dolor abdom, } \\
\text { diarr; sed; opresión en el } \\
\text { tórax, dis; dolor musc, } \\
\text { temblores; estupor o síncope; } \\
\text { edema pulm; liq: congelación }\end{array}$ \\
\hline $\begin{array}{l}\text { FOSFORO } \\
77723-14-0\end{array}$ & $\begin{array}{l}\text { ojos; piel; } \\
\text { tract resp; } \\
\text { pulmones; hígado; } \\
\text { riñones }\end{array}$ & huesos & $\begin{array}{r}\text { Inhalación } \\
\text { Piel } \\
\text { 0jos } \\
\text { Ingestión }\end{array}$ & $\begin{array}{l}\text { Sensación de quemazón, inconsciencia, los } \\
\text { síntomas pueden tardar en aparecer } \\
\text { Quemaduras en la piel, dolor } \\
\text { Dolor, pérdida de visión, quemaduras } \\
\text { profundas graves } \\
\text { Espasmos abdominales, inconsciencia }\end{array}$ & $\begin{array}{l}\text { Sis resp; hígado; } \\
\text { riñones; mandíbula, } \\
\text { dientes; sangre; } \\
\text { ojos; piel } \\
\text { Inh; ing; con }\end{array}$ & $\begin{array}{l}\text { Irrit ojos, tract resp; } \\
\text { quemaduras en ojos y piel; } \\
\text { dolor abdom, náu, ict; anemia; } \\
\text { caquexia; dolor dental, salv, } \\
\text { dolor mandibular, hin }\end{array}$ \\
\hline $\begin{array}{l}\text { PENTACLORURO DE FOSFORO } \\
10026-13-8\end{array}$ & & & $\begin{array}{r}\text { Inhalación } \\
\text { Piel } \\
\text { 0jos } \\
\text { Ingestión }\end{array}$ & $\begin{array}{l}\text { Sensación de quemazón, tos, disnea, vómitos, } \\
\text { los síntomas pueden tardar en aparecer } \\
\text { Puede absorberse, aspereza, quemaduras } \\
\text { graves en la piel } \\
\text { Dolor, quemaduras profundas graves } \\
\text { Espasmos abdominales, dolor abdominal, } \\
\text { sensación de quemazón, debilidad }\end{array}$ & $\begin{array}{l}\text { Sis resp; ojos; piel } \\
\text { Inh; ing; con }\end{array}$ & $\begin{array}{l}\text { Irrit ojos, piel, sis resp; bron; } \\
\text { derm }\end{array}$ \\
\hline
\end{tabular}




\begin{tabular}{|c|c|c|c|c|c|c|}
\hline \multirow[b]{2}{*}{$\begin{array}{l}\text { Denominación } \\
\text { química } \\
\text { N úmero CAS }\end{array}$} & \multicolumn{4}{|c|}{ Tarjetas Internacionales sobre la Seguridad de los Productos Q uímicos } & \multicolumn{2}{|c|}{ N IO SH (EE.UU.) } \\
\hline & $\begin{array}{l}\text { Período } \\
\text { corto de } \\
\text { exposición }\end{array}$ & $\begin{array}{l}\text { Período } \\
\text { largo de } \\
\text { exposición }\end{array}$ & $\begin{array}{l}\text { Vías de } \\
\text { exposición }\end{array}$ & Síntomas & $\begin{array}{l}\text { O rganos } \\
\text { afectados } \\
\text { Vías de } \\
\text { entrada }\end{array}$ & Síntomas \\
\hline $\begin{array}{l}\text { PENTASULFURO DE FOSFORO } \\
1314-80-3\end{array}$ & & & & & $\begin{array}{l}\text { Sis resp; SNC; ojos; } \\
\text { piel } \\
\text { Inh; ing; con }\end{array}$ & $\begin{array}{l}\text { Irrit ojos, piel, sis resp; apnea, } \\
\text { coma, convuls; dolor conj, lag, } \\
\text { foto, querato-conj, vesic córn; } \\
\text { mar; cef; ftg; irrit, insom; tract } \\
\text { Gl }\end{array}$ \\
\hline $\begin{array}{l}\text { PENTOXIDO DE FOSFORO } \\
1314-56-3\end{array}$ & $\begin{array}{l}\text { ojos; piel; } \\
\text { tract resp; } \\
\text { pulmones }\end{array}$ & & $\begin{array}{r}\text { Inhalación } \\
\text { Piel } \\
\text { Ojos } \\
\text { Ingestión } \\
\end{array}$ & $\begin{array}{l}\text { Sensación de quemazón, tos, disnea } \\
\text { Enrojecimiento, quemaduras en la piel, dolor } \\
\text { Enrojecimiento, dolor, quemaduras profundas } \\
\text { graves } \\
\text { Dolor abdominal, diarrea, náuseas, vómitos }\end{array}$ & & \\
\hline $\begin{array}{l}\text { PIROFOSFATO TETRAPOTASICO } \\
7320-34.5\end{array}$ & $\begin{array}{l}\text { ojos; piel; } \\
\text { tract resp; } \\
\text { pulmones }\end{array}$ & & $\begin{array}{r}\text { Inhalación } \\
\text { Piel } \\
\text { 0jos } \\
\text { Ingestión }\end{array}$ & $\begin{array}{l}\text { Sensación de quemazón, tos, dificultad } \\
\text { respiratoria } \\
\text { Enrojecimiento, dolor, ampollas } \\
\text { Enrojecimiento, dolor, quemaduras profundas } \\
\text { graves } \\
\text { Sensación de quemazón, dolor de garganta, } \\
\text { espasmos abdominales, debilidad }\end{array}$ & & \\
\hline $\begin{array}{l}\text { PIROFOSFATO TETRASODICO } \\
7722-88-5\end{array}$ & ojos; piel; tract resp & & $\begin{array}{r}\text { Inhalación } \\
\text { Piel } \\
\text { Ojos } \\
\text { Ingestión } \\
\end{array}$ & $\begin{array}{l}\text { Ssensación de quemazón, tos } \\
\text { Enrojecimiento, dolor } \\
\text { Enrojecimiento, dolor } \\
\text { Náuseas, vómitos, diarrea }\end{array}$ & $\begin{array}{l}\text { Ojos; piel; sis resp } \\
\text { Inh; ing; con }\end{array}$ & $\begin{array}{l}\text { Irrit ojos, piel, nariz, garganta; } \\
\text { derm }\end{array}$ \\
\hline $\begin{array}{l}\text { TIOFOSFORIL CLORURO } \\
3982.91 .0\end{array}$ & $\begin{array}{l}\text { ojos; piel; } \\
\text { tract resp; } \\
\text { pulmones }\end{array}$ & pulmones & $\begin{array}{l}\text { Inhalación } \\
\text { Piel } \\
\text { 0jos } \\
\text { Ingestión }\end{array}$ & $\begin{array}{l}\text { Sensación de quemazón, confusión, tos, } \\
\text { cefalea, resp sib, dificultad respiratoria, } \\
\text { disnea, dolor de garganta, inconsciencia, } \\
\text { vómitos, debilidad, los síntomas pueden tardar } \\
\text { en aparecer } \\
\text { Puede absorberse, quemaduras en la piel, } \\
\text { dolor } \\
\text { Dolor, pérdida de visión, quemaduras } \\
\text { profundas graves } \\
\text { Espasmos abdominales, dolor abdominal, } \\
\text { sensación de quemazón, confusión, tos, } \\
\text { cefalea, náuseas, disnea, dolor de garganta, } \\
\text { inconsciencia, vómitos }\end{array}$ & & \\
\hline $\begin{array}{l}\text { TRIBUTIL FOSFATO } \\
126-73-8\end{array}$ & $\begin{array}{l}\text { ojos; piel; } \\
\text { tract resp; } \\
\text { pulmones; SNC }\end{array}$ & piel; sangre & $\begin{array}{r}\text { Inhalación } \\
\text { Piel } \\
\text { Ojos } \\
\text { Ingestión }\end{array}$ & $\begin{array}{l}\text { Mareo, cefalea, convulsiones, dificultad } \\
\text { respiratoria, náuseas, dolor de garganta } \\
\text { Puede absorberse, enrojecimiento, aspereza, } \\
\text { sensación de quemazón } \\
\text { Enrojecimiento, dolor } \\
\text { Espasmos abdominales, diarrea, dificultad } \\
\text { respiratoria, náuseas, inconsciencia, vómitos, } \\
\text { debilidad, hipersalivación }\end{array}$ & $\begin{array}{l}\text { Sis resp; piel; ojos } \\
\text { Inh; ing; con }\end{array}$ & $\begin{array}{l}\text { Irrit ojos, piel, sis resp; cef; } \\
\text { náu }\end{array}$ \\
\hline $\begin{array}{l}\text { TRICLORURO DE FOSFORO } \\
7719-12-2\end{array}$ & & & $\begin{array}{r}\text { Inhalación } \\
\text { Piel } \\
\text { 0jos } \\
\text { Ingestión } \\
\end{array}$ & $\begin{array}{l}\text { Sensación de quemazón, tos, diarrea, mareo, } \\
\text { cefalea, disnea, dolor de garganta, vómitos } \\
\text { Quemaduras graves en la piel, dolor, ampollas } \\
\text { Enrojecimiento, visión borrosa, quemaduras } \\
\text { profundas graves } \\
\text { Sensación de quemazón, dolor de garganta }\end{array}$ & $\begin{array}{l}\text { Sis resp; ojos; piel } \\
\text { Inh; ing; con }\end{array}$ & $\begin{array}{l}\text { Irrit ojos, piel, nariz, garganta; } \\
\text { edema pulm; quemaduras en } \\
\text { ojos y piel }\end{array}$ \\
\hline $\begin{array}{l}\text { TRII-0-CRESIL FOSFATO } \\
\text { 78-30-8 }\end{array}$ & & & $\begin{array}{r}\text { Inhalación } \\
\text { Piel } \\
\text { Ingestión }\end{array}$ & $\begin{array}{l}\text { Cefalea, náuseas, vómitos, dolor muscular, los } \\
\text { síntomas pueden tardar en aparecer } \\
\text { Puede absorberse, enrojecimiento, dolor } \\
\text { Dolor abdominal, náuseas, vómitos }\end{array}$ & $\begin{array}{l}\text { SNP; SNC } \\
\text { Inh; abs; ing; con }\end{array}$ & $\begin{array}{l}\text { trast Gl; neur peri; calambres } \\
\text { en las pantorillas; pares en } \\
\text { pies o manos; debilidad en los } \\
\text { pies, muñeca péndula, pará }\end{array}$ \\
\hline
\end{tabular}




\begin{tabular}{|c|c|c|c|c|c|c|}
\hline \multirow[b]{2}{*}{$\begin{array}{l}\text { Denominación } \\
\text { química } \\
\mathrm{N} \text { úmero CAS }\end{array}$} & \multicolumn{4}{|c|}{ Tarjetas Internacionales sobre la Seguridad de los Productos Q uímicos } & \multicolumn{2}{|c|}{ N IO SH (EE.UU.) } \\
\hline & $\begin{array}{l}\text { Período } \\
\text { corto de } \\
\text { exposición }\end{array}$ & $\begin{array}{l}\text { Período } \\
\text { largo de } \\
\text { exposición }\end{array}$ & $\begin{array}{l}\text { Vías de } \\
\text { exposición }\end{array}$ & Síntomas & $\begin{array}{l}\text { O rganos } \\
\text { afectados } \\
\text { Vías de } \\
\text { entrada }\end{array}$ & Síntomas \\
\hline $\begin{array}{l}\text { TRIETIL FOSFITO } \\
122-52-1\end{array}$ & $\begin{array}{l}\text { ojos; piel; } \\
\text { tract resp; } \\
\text { pulmones; SNC }\end{array}$ & & $\begin{array}{r}\text { Inhalación } \\
\text { Piel } \\
\text { Ojos } \\
\text { Ingestión }\end{array}$ & $\begin{array}{l}\text { Sensación de quemazón, cefalea, náuseas, } \\
\text { dolor de garganta, los síntomas pueden tardar } \\
\text { en aparecer } \\
\text { Puede absorberse, enrojecimiento } \\
\text { Enrojecimiento, dolor } \\
\text { Dolor abdominal }\end{array}$ & & \\
\hline $\begin{array}{l}\text { TRIFENIL FOSFATO } \\
115-86.6\end{array}$ & & & & & $\begin{array}{l}\text { Sangre; SNP } \\
\text { Inh; ing }\end{array}$ & $\begin{array}{l}\text { Ligeros cambios en enzimas de } \\
\text { la sangre; en animales: deb } \\
\text { musc, pará }\end{array}$ \\
\hline $\begin{array}{l}\text { TRIFENIL FOSFITO } \\
101.02 .0\end{array}$ & $\begin{array}{l}\text { ojos; piel; } \\
\text { tract resp; SNC }\end{array}$ & & $\begin{array}{r}\text { Inhalación } \\
\text { Piel } \\
\text { 0jos } \\
\end{array}$ & $\begin{array}{l}\text { Sensación de quemazón, tos, irritante } \\
\text { inconsciencia } \\
\text { Enrojecimiento, dolor } \\
\text { Enrojecimiento, dolor }\end{array}$ & & \\
\hline $\begin{array}{l}\text { TRIFENILFOSFINA } \\
603-35-0\end{array}$ & ojos; piel; tract resp & & $\begin{array}{r}\text { Inhalación } \\
\text { Piel } \\
\text { Ojos } \\
\text { Ingestión }\end{array}$ & $\begin{array}{l}\text { Tos, dolor de garganta } \\
\text { Enrojecimiento } \\
\text { Enrojecimiento, dolor } \\
\text { Tos }\end{array}$ & & \\
\hline $\begin{array}{l}\text { TRIMETLL FOSFATO } \\
512-56-1\end{array}$ & SNC & SNC; genes & & & & \\
\hline $\begin{array}{l}\text { TRIS(2-ETILHEXIL FOSFATO) } \\
78-42-2\end{array}$ & piel & & $\begin{array}{l}\text { Piel } \\
\text { Ojos }\end{array}$ & $\begin{array}{l}\text { Enrojecimiento } \\
\text { Enrojecimiento }\end{array}$ & & \\
\hline
\end{tabular}

\begin{tabular}{|c|c|c|c|}
\hline $\begin{array}{l}\text { Denominación química } \\
\mathrm{N} \text { úmero CAS }\end{array}$ & Físicos & Q uímicos & $\begin{array}{l}\text { Clase o división } \\
\text { UN / Riesgos } \\
\text { subsidiarios }\end{array}$ \\
\hline $\begin{array}{l}\text { DIETILTIOFOSFORIL CLORURO } \\
\text { 2524-04-1 }\end{array}$ & & Se descompone al calentarse liberando humos tóxicos & 8 \\
\hline $\begin{array}{l}\text { FOSFINA } \\
\quad 7803-51-2\end{array}$ & $\begin{array}{l}\text { El gas es más pesado } \\
\text { que el aire }\end{array}$ & $\begin{array}{l}\text { Puede arder espontáneamente en contacto con el aire En su combustión libera humos } \\
\text { tóxicos de óxidos fosfóricos Reacciona con agua, halógenos, ácido nítrico, óxidos nitrosos, } \\
\text { oxígeno y cobre, con peligro de incendio y explosión En contacto con el aire emite humos } \\
\text { tóxicos de óxidos fosfóricos }\end{array}$ & $6.1 / 2.1$ \\
\hline $\begin{array}{l}\text { FOSFORO } \\
7723-14-0\end{array}$ & & $\begin{array}{l}\text { Puede arder espontáneamente en contacto con el aire produciendo humos tóxicos (óxidos } \\
\text { fosfóricos) Reacciona violentamente con oxidantes, halógenos y azufre, con peligro de } \\
\text { incendio y explosión Reacciona con bases fuertes liberando gases tóxicos (fosfina) }\end{array}$ & 4.216 .1 \\
\hline $\begin{array}{l}\text { FOSFURO CALCICO } \\
1305-99-3 \\
\end{array}$ & & & $4.3 / 6.1$ \\
\hline $\begin{array}{l}\text { OXICLORURO DE FOSFORO } \\
10025-87-3\end{array}$ & & & 8 \\
\hline $\begin{array}{l}\text { PENTACLORURO DE FOSFORO } \\
10026-13-8\end{array}$ & & $\begin{array}{l}\text { En su combustión libera gases tóxicos la solución en agua es un ácido fuerte, reacciona } \\
\text { violentamente con bases y es corrosiva Reacciona con agua, produciendo humos de cloruro } \\
\text { de hidrógeno y neblina de ácido fosfórico En contacto con el aire emite humos corrosivos } \\
\text { Ataca los plásticos y el caucho }\end{array}$ & 8 \\
\hline
\end{tabular}


Tabla 104.143 • Riesgos físicos y químicos.

\begin{tabular}{|c|c|c|c|}
\hline $\begin{array}{l}\text { Denominación química } \\
\text { N úmero CAS }\end{array}$ & Físicos & Q uímicos & $\begin{array}{l}\text { Clase o división } \\
\text { UN / Riesgos } \\
\text { subsidiarios }\end{array}$ \\
\hline $\begin{array}{l}\text { PENTOXIDO DE FOSFORO } \\
1314-56-3\end{array}$ & & $\begin{array}{l}\text { La solución en agua es un ácido fuerte, reacciona violentamente con bases y es corrosiva } \\
\text { Reacciona violentamente con ácido perclórico, con peligro de incendio y explosión } \\
\text { Reacciona violentamente con agua formando ácido fosfórico con generación de calor En } \\
\text { presencia de agua, reacciona con metales formando gases inflamables o tóxicos (hidrógeno } \\
\text { o fosfina) }\end{array}$ & 8 \\
\hline
\end{tabular}

\begin{tabular}{lll}
\hline $\begin{array}{l}\text { PIROFOSFATO TETRAPOTASICO } \\
7320-34-5\end{array}$ & La solución en agua es una base de fuerza intermedia Reacciona con ácidos fuertes \\
\hline $\begin{array}{ll}\text { PIROFOSFATO TETRASODICO } \\
7722-88-5\end{array}$ & $\begin{array}{l}\text { En su combustión libera gases tóxicos } \\
\text { con ácidos }\end{array}$ \\
\hline $\begin{array}{l}\text { TIOFOSFORIL CLORURO solución en agua es una base débil } \\
\text { 3982-91-0 }\end{array}$ & $\begin{array}{l}\text { El vapor es más pesado } \\
\text { que el aire }\end{array}$ & $\begin{array}{l}\text { Se descompone en contacto con el agua o la humedad produciendo ácido fosfórico, cloruro } \\
\text { de hidrógeno y sulfuro de hidrógeno, que son tóxicos e inflamables Al calentarse se forman } \\
\text { humos tóxicos Reacciona con oxidantes fuertes y alcoholes } \\
\text { presencia de agua }\end{array}$ \\
\hline
\end{tabular}

TRIBUTIL FOSFATO
$126-73-8$

TRICLORURO DE FOSFORO

7719-12-2
Se descompone al calentarse 0 al arder produciendo vapores y gases tóxicos (óxidos de carbono y fósforo, y fosfina) Ataca algunos tipos de plásticos, caucho y revestimientos

El vapor es más pesado En su combustión libera humos tóxicos, corrosivos e inflamables de óxidos fosfóricos, que el aire cloruro de hidrógeno y fósforo Se descompone al calentarse y por contacto con el agua produciendo humos y gases ácidos tóxicos (fosfina) y es corrosivo para muchos metales

Es un oxidante fuerte y reacciona con materiales combustibles y reductores La solución en agua es un ácido fuerte, reacciona violentamente con bases y es corrosiva para muchos metales Reacciona violentamente con bases, con peligro de incendio y explosión Reacciona con alcoholes y fenoles En contacto con el aire, libera humos corrosivos Ataca muchos metales formando gas inflamable (hidrógeno) Ataca muchos materiales

\begin{tabular}{|c|c|c|c|}
\hline $\begin{array}{l}\text { TRICRESIL FOSFATO } \\
\quad 1330-78.5 \\
\end{array}$ & & & 6.1 \\
\hline $\begin{array}{l}\text { TRI-0.CRESIL FOSFATO } \\
78-30-8\end{array}$ & & $\begin{array}{l}\text { Se descompone al calentarse } 0 \text { al arder liberando humos tóxicos (entre ellos óxidos } \\
\text { fosfóricos) Reacciona con oxidantes }\end{array}$ & 6.1 \\
\hline $\begin{array}{l}\text { TRIETIL FOSFITO } \\
122-52-1\end{array}$ & & $\begin{array}{l}\text { Se descompone al arder liberando humos tóxicos Reacciona con oxidantes y bases } \\
\text { fuertes }\end{array}$ & 3 \\
\hline $\begin{array}{l}\text { TRIFENIL FOSFITO } \\
101.02 .0\end{array}$ & & $\begin{array}{l}\text { En su combustión libera humos tóxicos }\left(\mathrm{PO}_{\mathrm{x}}\right) \\
\text { arder liberando humos tóxicos (óxidos fosforicos) } \\
\text { Reacciona con oxidantes fuertes }\end{array}$ & \\
\hline $\begin{array}{l}\text { TRIFENILFOSFINA } \\
603-35-0\end{array}$ & $\begin{array}{l}\text { Posibilidad de explosión } \\
\text { pulverulenta cuando se } \\
\text { encuentra en forma de } \\
\text { polvo o granular y se } \\
\text { mezcla con el aire }\end{array}$ & $\begin{array}{l}\text { Se descompone al calentarse liberando humos altamente tóxicos de óxidos fosfóricos } \\
\text { y fosfina Reacciona con ácidos fuertes y oxidantes fuertes }\end{array}$ & \\
\hline $\begin{array}{l}\text { TRIMETLL FOSFATO } \\
512-56-1\end{array}$ & & Se descompone al calentarse liberando humos tóxicos de $\mathrm{PO}_{\mathrm{x}}$ & \\
\hline $\begin{array}{l}\text { TRIMETLL FOSFITO } \\
121-45-9\end{array}$ & & & 3 \\
\hline $\begin{array}{l}\text { TRIS(2-ETILHEXIL) FOSFATO } \\
78-42-2\end{array}$ & & $\begin{array}{l}\text { Se descompone al calentarse produciendo fosfina y óxidos fosfóricos Reacciona con } \\
\text { oxidantes fuertes }\end{array}$ & \\
\hline $\begin{array}{l}\text { TRISULFURO DE TETRAFOSFORO } \\
\text { 1314-85-8 }\end{array}$ & & & 4.1 \\
\hline
\end{tabular}




\begin{tabular}{|c|c|c|c|c|c|c|c|c|c|c|c|}
\hline $\begin{array}{l}\text { Denominación } \\
\text { química } \\
\mathrm{N} \text { úmero CAS }\end{array}$ & Color/ Forma & $\begin{array}{l}\text { p.e. } \\
(\because 0 \mathrm{C})\end{array}$ & $\begin{array}{l}\text { p.f. } \\
\left({ }^{\circ} C\right)\end{array}$ & $\begin{array}{l}\text { p.m.l } \\
\text { (g/ } \\
\text { mol) }\end{array}$ & $\begin{array}{l}\text { Solubilidad } \\
\text { en agua }\end{array}$ & $\begin{array}{l}\text { Densidad } \\
\text { relativa } \\
\text { (agua }=1 \text { ) }\end{array}$ & $\begin{array}{l}\text { Densidad } \\
\text { relativa } \\
\text { del vapor } \\
\text { (aire=1) }\end{array}$ & $\begin{array}{l}\text { Pvap/ } \\
(\mathrm{kPa})\end{array}$ & $\begin{array}{l}\text { Límit. } \\
\text { ilnflam. }\end{array}$ & $\begin{array}{l}\text { p.ig. } \\
(\because 0 C)\end{array}$ & $\begin{array}{l}\text { p.aut } \\
\text { ig. } \\
(\stackrel{0}{ })\end{array}$ \\
\hline $\begin{array}{l}\text { DIBUTIL FENIL FOSFATO } \\
2528-36-1 \\
\end{array}$ & $\begin{array}{l}\text { líquido transparente } \\
\text { ligeramente amarillo }\end{array}$ & $131-132$ & & 286,34 & lig sol & $\begin{array}{l}1,0691 @ \\
25^{\circ} \mathrm{Cl} 25^{\circ} \mathrm{C}\end{array}$ & & $\begin{array}{l}0,007 \text { torr } \\
@ 25{ }^{\circ} \mathrm{C}\end{array}$ & & $\begin{array}{l}129 \mathrm{cc} ; \\
177 \mathrm{ca}\end{array}$ & \\
\hline $\begin{array}{l}\text { DIBUTIL FOSFATO } \\
107-66-4 \\
\end{array}$ & $\begin{array}{l}\text { líquido de color ámbar } \\
\text { claro }\end{array}$ & & & 210,21 & insol & 1,06 & & $1 \mathrm{~mm} \mathrm{Hg}$ & & & \\
\hline $\begin{array}{l}\text { DIETILTIOFOSFORIL CLORURO } \\
\text { 2524-04-1 }\end{array}$ & $\begin{array}{l}\text { líquido incoloro o de color } \\
\text { ámbar claro }\end{array}$ & $>110$ & $<-75$ & 188,62 & insol & $\begin{array}{l}1,196 @ \\
25^{\circ} \mathrm{Cl} 25^{\circ} \mathrm{C}\end{array}$ & & $\begin{array}{l}0,25 @ \\
50^{\circ} \mathrm{C} \\
\end{array}$ & & 110 & \\
\hline $\begin{array}{l}\text { DIMETIL HIDROGENO FOSFITO } \\
868-85-9\end{array}$ & líquido móvil incoloro & $\begin{array}{l}72-73 @ \\
25 \mathrm{~mm} \mathrm{Hg} \\
\end{array}$ & & 110,05 & sol & 1,200 & & & & & \\
\hline $\begin{array}{l}\text { FENILFOSFINA } \\
638-21-1 \\
\end{array}$ & & 160,5 & & 110,09 & & $1001 @ 15^{\circ} \mathrm{C}$ & & & & & \\
\hline $\begin{array}{l}\text { FOSFINA } \\
7803-51-2\end{array}$ & gas incoloro & $-87,7$ & -133 & 34,00 & lig sol & 0,75 & 1,17 & 3530 & $\begin{array}{l}1,79 \mathrm{li} \\
? \text { ls }\end{array}$ & $\begin{array}{l}\text { gas } \\
\text { infla- } \\
\text { mable }\end{array}$ & $\begin{array}{l}100- \\
150\end{array}$ \\
\hline $\begin{array}{l}\text { FOSFORIL OXICLORURO } \\
10025-87-3 \\
\end{array}$ & $\begin{array}{l}\text { líquido aceitoso incoloro o } \\
\text { ligeramente amarillento }\end{array}$ & 105,8 & 1,25 & 153,33 & & $\begin{array}{l}1,645 @ \\
25^{\circ} \mathrm{C} / 4^{\circ} \mathrm{C} \\
\end{array}$ & 5.3 & $\begin{array}{l}40 \mathrm{~mm} \mathrm{Hg} \\
@ 27,3{ }^{\circ} \mathrm{C} \\
\end{array}$ & & & \\
\hline $\begin{array}{l}\text { FOSFORO } \\
\quad 7723-14-0\end{array}$ & $\begin{array}{l}\text { blanco: sólido incoloro o } \\
\text { blanco, transparente, } \\
\text { cristalino; aspecto ceroso; } \\
\text { amarillo: sólido blanco o } \\
\text { amarillo, blando, ceroso; } \\
\text { negro: forma cristalina } \\
\text { polimórfica, ortorrómbica, } \\
\text { forma amorfa; rojo: polvo } \\
\text { rojo o violeta; } \\
\text { polimorfismo; violeta: } \\
\text { monoclínico violeta }\end{array}$ & $\begin{array}{l}\text { Amarillo: 280; } \\
\text { Rojo: 280 } \\
\text { (ignición a } \\
\text { @ 200) }\end{array}$ & $\begin{array}{l}\text { Amarillo: } \\
44,1 ; \\
\text { Violeta: } \\
590 ; \\
\text { Rojo: } 590 \\
\text { @ } 43 \\
\text { atm }\end{array}$ & 30,9737 & insol & $\begin{array}{l}\text { Rojo: } 2,34 ; \\
\text { Violeta: } 2,36 ; \\
\text { Negro: } 2,70 ; \\
\text { Amarillo: } 1,82\end{array}$ & $\begin{array}{l}\text { Rojo: } 4,77 ; \\
\text { Blanco: } 4,42\end{array}$ & $3,5 \mathrm{~Pa}$ & & & $\begin{array}{l}\text { Rojo: } \\
260 ; \\
\text { Blanco: } \\
30\end{array}$ \\
\hline $\begin{array}{l}\text { FOSFURO CALCICO } \\
1305-99-3\end{array}$ & $\begin{array}{l}\text { polvo cristalino de color } \\
\text { marrón rojizo o grumos } \\
\text { grises }\end{array}$ & & 1600 & 182,20 & & 2,51 & & & & & \\
\hline $\begin{array}{l}\text { HEXAM ETLL FOSFORAMIDA } \\
680-31-9\end{array}$ & líquido móvil incoloro & 233 & $5-7$ & 179,24 & misc & 1,03 & 6,18 & $\begin{array}{l}0,03 \\
\mathrm{~mm} \mathrm{Hg}\end{array}$ & & & \\
\hline $\begin{array}{l}\text { PENTACLORURO DE FOSFORO } \\
10026-13-8\end{array}$ & $\begin{array}{l}\text { masa cristalina de color } \\
\text { blanco o amarillo claro; } \\
\text { cristales tetragonales }\end{array}$ & 160 & 148 & 208,27 & & $\begin{array}{l}4,65 \mathrm{~g} / \mathrm{I} @ \\
296^{\circ} \mathrm{C}(\mathrm{GAS})\end{array}$ & & $\begin{array}{l}133 \mathrm{~Pa} @ \\
55,5^{\circ} \mathrm{C}\end{array}$ & & & \\
\hline $\begin{array}{l}\text { PENTASULFURO DE FOSFORO } \\
1314-80-3\end{array}$ & $\begin{array}{l}\text { cristales de color gris } \\
\text { amarillento; cristales } \\
\text { triclínicos de color } \\
\text { amarillo claro; escamas } \\
\text { sólidas o polvo; color gris } \\
\text { verduzco }\end{array}$ & 513- 515 & $286-290$ & 222,29 & insol & & & $\begin{array}{l}1 \mathrm{~mm} \mathrm{Hg} \\
@ 300^{\circ} \mathrm{C}\end{array}$ & & & $\begin{array}{l}260- \\
290 \\
\text { polvo; } \\
275 \\
\text { líquido }\end{array}$ \\
\hline $\begin{array}{l}\text { PENTOXIDO DE FOSFORO } \\
1314-56-3\end{array}$ & $\begin{array}{l}\text { cristales pulverulentos o } \\
\text { monocíclicos blancos; } \\
\text { existen distintas } \\
\text { modificaciones cristalinas } \\
\text { y amorfas; forma } \\
\text { comercial hexagonal }\end{array}$ & 300 sublima & $580-5$ & 141,96 & muy sol & 2,39 & & $\begin{array}{l}1 @ \\
384^{\circ} \mathrm{C}\end{array}$ & & & \\
\hline $\begin{array}{l}\text { PIROFOSFATO TETRAPOTASICO } \\
7320-34-5\end{array}$ & $\begin{array}{l}\text { gránulos o polvo de color } \\
\text { blanco }\end{array}$ & & 1090 & & muy sol & & & & & & \\
\hline
\end{tabular}




\begin{tabular}{|c|c|c|c|c|c|c|c|c|c|c|c|}
\hline $\begin{array}{l}\text { Denominación } \\
\text { química } \\
\text { N úmero CAS }\end{array}$ & Color/ Forma & $\begin{array}{l}\text { p.e. } \\
(\stackrel{\circ}{ } C)\end{array}$ & $\begin{array}{l}\text { p.f. } \\
(\stackrel{O}{ } C)\end{array}$ & $\begin{array}{l}\text { p.m.l } \\
\text { (g/ } \\
\mathrm{mol})\end{array}$ & $\begin{array}{l}\text { Solubilidad } \\
\text { en agua }\end{array}$ & $\begin{array}{l}\text { Densidad } \\
\text { relativa } \\
\text { (agua }=1 \text { ) }\end{array}$ & $\begin{array}{l}\text { Densidad } \\
\text { relativa } \\
\text { del vapor } \\
\text { (aire=1) }\end{array}$ & $\begin{array}{l}\text { Pvap/ } \\
(\mathrm{kPa})\end{array}$ & $\begin{array}{l}\text { Límit. } \\
\text { ilnflam. }\end{array}$ & $\begin{array}{l}\text { p.ig. } \\
(\stackrel{\circ}{ } C)\end{array}$ & $\begin{array}{l}\text { p.aut } \\
\text { ig. } \\
(\stackrel{\circ}{\circ})\end{array}$ \\
\hline $\begin{array}{l}\text { PIROFOSFATO TETRASODICO } \\
7722-88-5\end{array}$ & $\begin{array}{l}\text { cristales; cristales } \\
\text { transparentes incoloros o } \\
\text { polvo blanco }\end{array}$ & & 988 & 265,94 & $\begin{array}{l}2,61 \mathrm{~g} / 100 \mathrm{ml} \\
@ 0^{\circ} \mathrm{C} ; \\
6,7 \mathrm{~g} / 100 \mathrm{ml} \\
@ 25^{\circ} \mathrm{C}\end{array}$ & 2,534 & & & & & \\
\hline $\begin{array}{l}\text { TIOFOSFORIL CLORURO } \\
3982.91 .0\end{array}$ & $\begin{array}{l}\text { líquido incoloro; cristaliza } \\
\text { como forma alfa a } \\
-40,8^{\circ} \mathrm{Co} \text { como forma } \\
\text { beta a - } 36,2^{\circ} \mathrm{C}\end{array}$ & 125 & -35 & 169,41 & se descompone & 1,635 & 5,86 & $\begin{array}{l}2,9 @ \\
25^{\circ} \mathrm{C}\end{array}$ & & & \\
\hline $\begin{array}{l}\text { TRIBUTLL FOSFATO } \\
126-73.8 \\
\end{array}$ & líquido incoloro & 289 & $<80$ & 266,32 & sol & $\begin{array}{l}0,976 @ \\
25^{\circ} \mathrm{Cl} 25^{\circ} \mathrm{C}\end{array}$ & 9,20 & $\begin{array}{l}17 @ \\
177^{\circ} \mathrm{C}\end{array}$ & & 146 & 410 \\
\hline $\begin{array}{l}\text { TRICLORURO DE FOSFORO } \\
7719-12-2\end{array}$ & $\begin{array}{l}\text { líquido transparente } \\
\text { incoloro }\end{array}$ & 76 & -112 & 137,35 & reacciona & $1,574 @ 20^{\circ} \mathrm{C}$ & 4,75 & 12,7 & & & \\
\hline $\begin{array}{l}\text { TRICRESIL FOSFATO } \\
1330-78.5 \\
\end{array}$ & $\begin{array}{l}\text { líquido prácticamente } \\
\text { incoloro }\end{array}$ & 420 & & & $\begin{array}{l}0,36 \mathrm{mg} / \mathrm{I} @ \\
25^{\circ} \mathrm{C}\end{array}$ & $\begin{array}{l}1,162 @ \\
25 / 25^{\circ} \mathrm{C}\end{array}$ & & & & & 410 \\
\hline $\begin{array}{l}\text { TRI-0-CRESIL FOSFATO } \\
\text { 78-30-8 }\end{array}$ & $\begin{array}{l}\text { líquido incoloro o amarillo } \\
\text { claro }\end{array}$ & 410 & 11 & 368,37 & insol & 1,1955 & 12,7 & $\begin{array}{l}10 \mathrm{~mm} \mathrm{Hg} \\
@ 265^{\circ} \mathrm{C}\end{array}$ & & 225 & 385 \\
\hline $\begin{array}{l}\text { TRIETIL FOSFATO } \\
78-40.0\end{array}$ & líquido; incoloro & 215,5 & $-56,4$ & 182,16 & sol & 1,0695 & 6,28 & $\begin{array}{l}1 \mathrm{~mm} \mathrm{Hg} \\
\text { @ } 39,6^{\circ} \mathrm{C}\end{array}$ & & & \\
\hline $\begin{array}{l}\text { TRIETLL FOSFITO } \\
122-52-1 \\
\end{array}$ & líquido incoloro & 157,9 & -112 & 166,16 & insol & 0,9629 & & 0,6 & & 52 & 250 \\
\hline $\begin{array}{l}\text { TRIFENIL FOSFATO } \\
115-86-6\end{array}$ & $\begin{array}{l}\text { cristales en alcohol } \\
\text { absoluto-ligroina, prismas } \\
\text { en alcohol, agujas en } \\
\text { éter-ligroina; polvo } \\
\text { cristalino incoloro; placas } \\
\text { pequeñas blancas }\end{array}$ & $\begin{array}{l}245 @ \\
11 \mathrm{~mm} \mathrm{Hg}\end{array}$ & 50 & 326,28 & insol & $\begin{array}{l}1,2055 @ \\
50^{\circ} \mathrm{C} / 4^{\circ} \mathrm{C}\end{array}$ & 1,19 & $\begin{array}{l}1 \mathrm{~mm} \mathrm{Hg} \\
@ \\
193,5^{\circ} \mathrm{C}\end{array}$ & & & \\
\hline $\begin{array}{l}\text { TRIFENIL FOSFINA } \\
603-35-0\end{array}$ & $\begin{array}{l}\text { plaquetas monoclínicas o } \\
\text { prismas en éter; sólido } \\
\text { cristalino blanco }\end{array}$ & $>360$ & 80,5 & 262,28 & insol & $\begin{array}{l}1,075 @ \\
80^{\circ} \mathrm{C} / 4^{\circ} \mathrm{C}\end{array}$ & 9,0 & & & $180 \mathrm{Ca}$ & \\
\hline $\begin{array}{l}\text { TRIFENIL FOSFITO } \\
101-02-0\end{array}$ & $\begin{array}{l}\text { sólido o líquido aceitoso } \\
\text { de color blanco o amarillo } \\
\text { claro }\end{array}$ & 360 & 25 & 310,29 & insol & 1,1844 & & & & $218 \mathrm{ca}$ & \\
\hline $\begin{array}{l}\text { TRIMETLL FOSFATO } \\
512.56-1\end{array}$ & líquido incoloro & 197,2 & -46 & 140,08 & muy sol & 1,2144 & & & & & \\
\hline $\begin{array}{l}\text { TRIMETIL FOSFITO } \\
121-45-9\end{array}$ & líquido incoloro & 111,5 & & 124,08 & & 1,0520 & 4,3 & & & & \\
\hline $\begin{array}{l}\text { TRIS-2,3-DIBROMOPROPIL } \\
\text { FOSFATO } \\
126-72-7\end{array}$ & $\begin{array}{l}\text { líquido viscoso amarillo } \\
\text { claro; líquido denso casi } \\
\text { incoloro }\end{array}$ & & FP 5,5 & 697,93 & $8,0 \mathrm{mg} / \mathrm{l}$ & $2,27 @ 25^{\circ} \mathrm{C}$ & & $\begin{array}{l}0,00019 \\
\mathrm{~mm} \mathrm{Hg} @ \\
25^{\circ} \mathrm{C}\end{array}$ & & & \\
\hline $\begin{array}{l}\text { TRIS(2-ETILHEXIL) FOSFATO } \\
78-42-2\end{array}$ & líquido viscoso & $\begin{array}{l}220 @ \\
5 \mathrm{~mm} \mathrm{Hg}\end{array}$ & .74 & 434,72 & insol & 0,926 & 14,95 & $\begin{array}{l}0,25 @ \\
200{ }^{\circ} \mathrm{C}\end{array}$ & & 207 & \\
\hline $\begin{array}{l}\text { TRISULFURO DE TETRAFOSFORO } \\
\text { 1314-85-8 }\end{array}$ & $\begin{array}{l}\text { agujas rómbicas largas de } \\
\text { color amarillo verduzco en } \\
\text { benceno }\end{array}$ & 407,5 & 172,5 & 220,08 & insol & $\begin{array}{l}2,03 @ 20^{\circ} \mathrm{Cl} \\
4{ }^{\circ} \mathrm{C}\end{array}$ & & & & & 100 \\
\hline
\end{tabular}




\section{Ftalatos}

Los ftalatos son ésteres de ácido ftálico y diversos alcoholes. Algunos diésteres tienen especial importancia práctica, como los diésteres de metanol, etanol, butanol, isobutanol, isooctanol, 2-etilhexanol, isononanol e isodecanol y alfoles de cadena lineal. Los ftalatos se sintetizan a partir de anhídrido ftálico y dos moléculas del alcohol correspondiente.

\section{Usos}

Los ésteres ftalicos se utilizan en productos no plastificados como perfumes y cosméticos, en productos plastificados como piscinas de vinilo, asientos de vinilo plastificados para muebles y vehículos y en prendas de vestir tales como cazadoras, impermeables y botas. Estos compuestos se utilizan principalmente en la industria de los plásticos, que consume alrededor del $87 \%$ de todos los ésteres ftalicos para producir "PVC blando". EI $13 \%$ restante se destina a la fabricación de barnices, dispersiones, celulosa, poliestiroles, colorantes, caucho natural y sintético, lubricantes, poliamidas, repelentes de insectos, fijadores para perfumes, congelantes para explosivos y fluidos de trabajo para bombas de alto vacío. De entre los ftalatos, el di-sec-octilftalato (DO P) y el diisononilftalato forman parte de los descalcificadores habituales.

El dimetilftalato y el dibutilftalato (DBP) tienen otros usos en numerosas industrias, como las de textiles, colorantes, cosméticos y vidrio. El dimetilftalato es un soporte para colorantes y un plastificante de lacas para el cabello y cristales de seguridad. EI dibutilftalato se emplea como repelente de insectos para la impregnación de prendas de vestir y como plastificante de barnices de nitrocelulosa, elastómeros, explosivos, lacas de uñas y propelentes sólidos para cohetes. Sirve como disolvente para aceites esenciales, como fijador para perfumes y como lubricante para textiles. Además, se utiliza en la fabricación de cristales de seguridad, tintas de imprenta, revestimientos para papel, materiales para impresión dental y como componente del plastisol de PV C utilizado como refuerzo en el reverso de las alfombras.

M uchos compuestos de dialilftalato se usan con fines militares y en aplicaciones eléctricas y electrónicas de alta fiabilidad que tienen que resistir condiciones ambientales adversas, durante largos períodos de tiempo. Estos compuestos se utilizan en conectores eléctricos para comunicaciones, ordenadores y sistemas aeroespaciales, así como en circuitos impresos, aislantes y potenciómetros.

\section{Riesgos}

El primer paso en la biotransformación de los ésteres de ácido ftálico es su escisión en monoésteres. El siguiente paso en los mamíferos es la oxidación del alcohol resultante del monoéster. En la orina pueden detectarse los correspondientes productos de excreción.

L os ftalatos, especialmente los que tienen una cadena corta de alcohol, pueden absorberse por vía cutánea. Veinticuatro horas después de la aplicación dérmica de dietilftalato radiactivo (DEP), el $9 \%$ de la radioactividad se detectó en la orina y, pasados 3 días, se hallaron rastros del compuesto radiactivo en varios órganos. Al parecer, existe una cierta relación entre el metabolismo y la toxicidad de los ftalatos, puesto que los ftalatos que poseen una cadena corta de alcohol, los cuales tienen una toxicidad más elevada, se fraccionan con especial rapidez para dar monoésteres y muchos de los efectos tóxicos de los ftalatos en los animales de experimentación están provocados por los monoésteres.
T oxicidad aguda. La toxicidad aguda de los ftalatos es muy ligera $y$, en general, es tanto menor cuanto mayor sea el peso molecular. Según los estudios publicados, la $D L_{50}$ por vía oral en ratas del DBP varía entre 8 y $23 \mathrm{~g} / \mathrm{kg}$ y la del DOP, entre 30,6 y $34 \mathrm{~g} / \mathrm{kg}$. En los conejos, los ftalatos no provocan inflamación de la piel ni de los ojos. No se ha descrito ningún caso de sensibilización cutánea, pero sí se ha visto que los ftalatos provocan una ligera irritación de la mucosa del tracto respiratorio. La combinación de una toxicidad baja y una presión de vapor también baja hace que, en términos generales, estos compuestos presenten un riesgo de inhalación más reducido.

T oxicidad crónica. En los estudios realizados para determinar la toxicidad crónica y subcrónica, los ftalatos exhiben una toxicidad relativamente baja en general. La administración diaria a ratas de DOP en dosis de $65 \mathrm{mg} / \mathrm{kg}$ de peso corporal, no mostró efectos adversos después de 2 años. T ampoco se ha comprobado la existencia de efectos adversos de otros ftalatos en experimentos que duraron 1 ó 2 años con ratas y perros a los que se administraron dosis de entre 14 y $1.250 \mathrm{mg}$ por kg de peso y día. No obstante, recientemente se han detectado cambios testiculares y aumento de peso del hígado en ratas que habían recibido DO P al $0,2 \%$ junto con el alimento durante un período de 17 semanas, por lo que posiblemente tenga que modificarse la "dosis sin efectos adversos".

La administración de DOP y DBP en cantidades superiores a la "dosis sin efectos adversos" produce un retraso de la ganancia de peso, alteraciones hepáticas y renales, alteraciones de las actividades enzimáticas en el tejido hepático y degeneración testicular. Este último efecto puede atribuirse a una interferencia con el metabolismo del zinc. Sin embargo, podría estar provocado no sólo por el DBP, sino también por el monoéster y el DOP. Tanto el DOP como el monoéster producen alteraciones tisulares hepáticas similares. Según este estudio, el DOP y el isómero de cadena recta di-n-octilftalato son los compuestos que presentan una mayor toxicidad de entre las ocho sustancias estudiadas. 0 tros dos ésteres del ácido ftálico, el bis-(2-metoxietil)ftalato y el butilcarboximetilftalato, tienen una toxicidad acumulativa relativamente baja (con factores de 2,53 y 2,06 , respectivamente). Ahora bien, se desconoce si los efectos acumulativos observados son importantes también para dosis bajas 0 sólamente en los casos en que la capacidad de las enzimas que participan en la biotransformación es insuficiente para lograr una velocidad de eliminación adecuada tras la administración parenteral de dosis altas.

I rritación local. EI DOP sin diluir no provocó inflamación de la piel ni de los ojos en conejos, ni tampoco necrosis de la córnea. Calley y sus colaboradores detectaron reacciones inflamatorias tras la inyección intradérmica de la sustancia. Estos resultados no han sido confirmados por otros autores, por lo que se piensa que podrían deberse al uso de disolventes inadecuados. N o obstante, sí se ha podido volver a demostrar la ausencia de irritación ocular en los conejos. Los estudios realizados en humanos, ninguno de los 23 voluntarios mostró señal alguna de irritación de la piel de la espalda tras mantenerla en contacto con el producto durante 7 días, ni tampoco pudo demostrarse la supuesta sensibilización por aplicación repetida en el mismo sitio. O bviamente, tanto la absorción del compuesto a través de la piel intacta como la irritación local son leves.

T oxicidad por inhalación. En los estudios de inhalación con ratas, éstas toleraron aire saturado de vapores de D O P durante 2 horas sin que falleciera ninguna de ellas. Cuando se amplió el tiempo de exposición, todos los animales murieron durante las dos horas 
siguientes. En otro experimento, se hizo pasar aire a $50{ }^{\circ} \mathrm{C}$ a través de una solución de DOP y el vapor se enfrió y se introdujo en una cámara de inhalación. En dicha cámara se expusieron ratones a los vapores tres veces por semana y durante una hora cada vez, a lo largo de 12 semanas. Todos los animales sobrevivieron. Los ratones fueron sacrificados a las doce semanas $y$, cuando se realizaron estudios histológicos en 20 de ellos, no pudo demostrarse la existencia de neumonía crónica difusa.

E mbriotoxicidad y teratogenicidad. Algunos ftalatos son embriotóxicos y teratógenos para embriones de pollo y ratas preñadas cuando se administran a dosis altas (una décima parte de la $D L_{50}$ aguda $010 \mathrm{ml} / \mathrm{kg}$ de DOP por vía intraperitoneal). El efecto nocivo para los embriones aumenta con la solubilidad de los ftalatos. EI DEP y el DO P pueden llegar al embrión a través de la placenta de la rata. Al contrario que otros seis ftalatos, el DO P y el di-n-octilftalato de cadena lineal no producen anomalías en el esqueleto de la prole de ratas Sprague-D awley.

M utagenicidad. EI DOP superó en capacidad mutágena al dimetoxietilftalato en la prueba realizada en ratones y mostró un evidente efecto mutágeno cuando se administraron dosis de un tercio, un medio y dos tercios de la $\mathrm{DL}_{50}$ aguda. 0 tros estudios de teratogenicidad han puesto de manifiesto una tendencia opuesta respecto a los efectos adversos. Aunque en los ensayos con el test de Ames para determinar la actividad mutágena in vitro se obtuvieron resultados dispares, cabe suponer que existe una débil actividad mutágena. Este efecto dependería, entre otros factores, de la facilidad del fraccionamiento del éster in vitro.

Carcinogenicidad. En los estudios de administración de ftalatos conjuntamente con el alimento en ratas y ratones, se han obtenido tasas mayores de cambios hepatocelulares en ambos sexos. Los datos obtenidos de sujetos humanos son insuficientes para valorar el riesgo; sin embargo, la Agencia Internacional para la Investigación sobre el Cáncer (IARC) ha clasificado el DOP como probable carcinógeno humano.

Datos obtenidos en humanos. Tras la administración de $10 \mathrm{~g}$ de DOP por vía oral a un voluntario, se presentaron ligeras molestias gástricas y diarrea. U n segundo voluntario toleró la administración oral de $5 \mathrm{~g}$ sin mostrar síntoma alguno. Algunos autores han observado una ausencia de irritación 0, como mucho, una ligera irritación de la piel tras la aplicación tópica de DOP en voluntarios. Cuando se aplicó el producto por segunda vez sobre la misma zona, no se produjo signo alguno de sensibilización.

La exposición durante un período medio de 12 años (con períodos de entre 4 meses y 35 años) a concentraciones de entre 0,0006 y $0,001 \mathrm{ppm}$ de DOP en el ambiente de trabajo, no provocó alteraciones de la salud ni aumentó la tasa de aberraciones cromosómicas en el personal expuesto. Los plásticos que contienen ésteres de ácido ftálico, especialmente el DOP, se utilizan mucho en equipos médicos, como por ejemplo en envases de sangre para hemodiálisis. Por ello se ha estudiado a fondo el problema de la posible absorción de ftalatos por vía intravenosa directa. La sangre almacenada en envases de plástico a $4{ }^{\circ} \mathrm{C}$ presentó una concentración de DOP de entre 5 y $20 \mathrm{mg}$ por cada $100 \mathrm{ml}$ de sangre después de transcurrir 21 días. Esto podría dar lugar a un aporte de DOP de $300 \mathrm{mg} \mathrm{o} \mathrm{4,3} \mathrm{mg/} \mathrm{kg}$ en una transfusión total de sangre a un hombre de $70 \mathrm{~kg}$. Consideraciones teóricas apuntan hacia un posible aporte de $150 \mathrm{mg}$ de DO P durante una hemodiálisis de 5 horas. 
TABLAS DE FTALATOS

\begin{tabular}{|c|c|c|c|}
\hline Producto químico & Sinónimos/ Código UN & $\mathrm{N}$ úmero CAS & Fórmula estructural \\
\hline DIALILFTALATO & $\begin{array}{l}\text { Ester di-2-propenílico del ácido 1,2-bencenodicarboxilico; éster dialílico } \\
\text { del ácido ftálico; éster dialílico del ácido o-ftálico }\end{array}$ & 131-17-9 & \\
\hline DIBUTILFTALATO & $\begin{array}{l}\text { Ester dibutílico del ácido o-bencenodicarboxílico; éster di-n-butilico del } \\
\text { ácido benceno-o-dicarboxilico; DBP; } 1,2 \text {-bencenodicarboxilato de dibutilo; } \\
\text { ftalato de dibutilo; ftalato de di-n-butilo; n-butiliftalato; Polycizer DBP }\end{array}$ & $84-74-2$ & \\
\hline DICICLOHEXILFTALATO & $\begin{array}{l}\text { Ester diciclohexilico del ácido 1,2-bencenodicarboxilico; éster } \\
\text { diciclohexilico de ácido ftálico }\end{array}$ & $84-61-7$ & \\
\hline DIETILFTALATO & $\begin{array}{l}\text { Ester dietílico del ácido 1,2-bencenodicarboxílico; etilftalato; Neantine; } \\
\text { Palatinol a; ftalol }\end{array}$ & $84-66-2$ & \\
\hline DIHEPTILFTALATO & Ftalato de di-n-heptilo; ftalato de heptilo & $3648-21-3$ & \\
\hline DIISODECILFTALATO & $\begin{array}{l}\text { Bis-(isodecil) ftalato del ácido 1,2-bencenodicarboxílico; DIDP } \\
\text { (plastificante); ftalato dilisodećlico; éster dilisodecílico de ácido ftálico }\end{array}$ & $26761-40-0$ & \\
\hline DIMETLLFTALATO & $\begin{array}{l}\text { Ester dimetílico de 1,2-bencenodicarboxílico; } \\
\text { dimetil-1,2-bencenodicarboxilato; DMP; ftalato de metilo; éster metílico } \\
\text { del ácido ftálico }\end{array}$ & 131-11-3 & \\
\hline DI-sec-OCTILFTALATO & $\begin{array}{l}\text { Bis-(2-etilhexil)éster de ácido 1,2-bencenodicarboxilico; } \\
\text { bis-(2-etilhexil)-1,2-bencenodicarboxilato; bis-(2-etilhexil) ftalato; } \\
\text { di(2-etilhexil) ortoftalato }\end{array}$ & $117-81 \cdot 7$ & \\
\hline ESTER DIETILICO DE ACIDO TEREFTALICO & Ester dietílico del 1,4-bencenodicarboxilico; tereftalato de dietilo & $636-09-9$ & \\
\hline ESTER DIISOBUTILICO DE ACIDO FTALICO & DIBP; ftalato de diisobutilo; Hexaplas M;1B; Palatinol IC & $84-69-5$ & \\
\hline ESTER DIISOOCTILICO DE ACIDO FTALICO & $\begin{array}{l}\text { Ester diisooctílico del ácido 1,2-bencenodicarboxilico; ftalato de } \\
\text { dilisooctilo; ftalato de isooctilo; bis-(6-metilheptil) éster de ácido ftálico }\end{array}$ & $27554-26-3$ & \\
\hline ESTER DIISOTRIDECILICO DE ACIDO FTALICO & $\begin{array}{l}\text { Ester diisotridecílico del ácido 1,2-bencenodicarboxílico; ftalato de } \\
\text { dilisotridecilo }\end{array}$ & $27253-26-5$ & \\
\hline ESTER DIMETILICO DE ACIDO TEREFTALICO & $\begin{array}{l}\text { Dimetil-1-1-4-bencenodicarboxilato del ácido 1,4-bencenodicarboxílico; } \\
\text { dimetil-p-ftalato; dimetil-tereftalato; DMT; metil-4-carbometoxibenzoato; } \\
\text { éster metílico de ácido tereftálico }\end{array}$ & $120-61-6$ & \\
\hline
\end{tabular}




\begin{tabular}{|c|c|c|c|c|c|c|}
\hline \multirow[b]{2}{*}{$\begin{array}{l}\text { Denominación } \\
\text { química } \\
\mathrm{N} \text { úmero CAS }\end{array}$} & \multicolumn{4}{|c|}{ Tarjetas Internacionales sobre la Seguridad de los Productos Q uímicos } & \multicolumn{2}{|c|}{ N IO SH (EE.UU.) } \\
\hline & $\begin{array}{l}\text { Período } \\
\text { corto de } \\
\text { exposición }\end{array}$ & $\begin{array}{l}\text { Período } \\
\text { largo de } \\
\text { exposición }\end{array}$ & $\begin{array}{l}\text { Vías de } \\
\text { exposición }\end{array}$ & Síntomas & $\begin{array}{l}\text { O rganos } \\
\text { afectados } \\
\text { Vías de } \\
\text { entrada }\end{array}$ & Síntomas \\
\hline $\begin{array}{c}\text { DIALLLFTALATO } \\
131-17-9 \\
\end{array}$ & ojos; piel; pulmone & hígado & Ingestión & Diarrea, dificultad respiratoria & & \\
\hline $\begin{array}{l}\text { DIBUTILFTALATO } \\
84-74-2\end{array}$ & & & & & $\begin{array}{l}\text { Ojos; sist resp; tract } \\
\text { Gl } \\
\text { Inh; ing; con }\end{array}$ & $\begin{array}{l}\text { Irrit ojos, sis resp superior, } \\
\text { estómago }\end{array}$ \\
\hline $\begin{array}{l}\text { DICICLOHEXXLFTALATO } \\
84.61 .7\end{array}$ & ojos; piel; tract res & & & & & \\
\hline $\begin{array}{l}\text { DIETILFTALATO } \\
84.66-2\end{array}$ & ojos; piel; SNC & & $\begin{array}{r}\text { Inhalación } \\
\text { Piel } \\
\text { Ojos }\end{array}$ & $\begin{array}{l}\text { Mareo, embotamiento } \\
\text { Enrojecimiento } \\
\text { Enrojecimiento, dolor }\end{array}$ & $\begin{array}{l}\text { Ojos; piel; sis resp; } \\
\text { SNC; SNP; sis repro } \\
\text { Inh; ing; con }\end{array}$ & $\begin{array}{l}\text { Irrit ojos, piel, nariz, garganta } \\
\text { cef, mar, náu; lag; posible } \\
\text { polineur, disfunc vestibular; } \\
\text { dolor, ent, deb, espasmos en } \\
\text { brazos y piernas; en animales } \\
\text { efectos repro }\end{array}$ \\
\hline $\begin{array}{l}\text { DIISODECILOFTALATO } \\
\text { 26761-40.0 }\end{array}$ & ojo; piel & hígado & $\begin{array}{r}\text { Piel } \\
\text { Ojos } \\
\text { Ingestión }\end{array}$ & $\begin{array}{l}\text { Enrojecimiento } \\
\text { Enrojecimiento } \\
\text { Mareo, náuseas, vómitos }\end{array}$ & & \\
\hline $\begin{array}{l}\text { DIMETILFTALATO } \\
131-11-3\end{array}$ & $\begin{array}{l}\text { ojos; nariz; } \\
\text { garganta }\end{array}$ & defectos congénitos & & & $\begin{array}{l}\text { Ojos; sis resp; tract } \\
\text { Gl } \\
\text { Inh; ing; con }\end{array}$ & $\begin{array}{l}\text { Irrit ojos, sis resp superior; } \\
\text { dolor estomacal }\end{array}$ \\
\hline $\begin{array}{l}\text { DIMETILTEREFTALATO } \\
120-61-6\end{array}$ & ojos & & & & & \\
\hline $\begin{array}{l}\text { DI-SeC-OCTILFTALATO } \\
117-81-7\end{array}$ & $\begin{array}{l}\text { ojos; piel; tract } \\
\text { resp; pulmones; } \\
\text { tract GI }\end{array}$ & piel & Inhalación & Tos, dolor de garganta & $\begin{array}{l}\text { ojos; tract Gl; sis } \\
\text { resp; SNC; hígado; } \\
\text { sis repro [en } \\
\text { animales: tumores } \\
\text { hepáticos] } \\
\text { Inh; ing; con }\end{array}$ & $\begin{array}{l}\text { Irrit ojos, muc; en animales: } \\
\text { lesiones hepáticas; efectos } \\
\text { terato; [carc.] }\end{array}$ \\
\hline
\end{tabular}

\begin{tabular}{|c|c|c|c|}
\hline $\begin{array}{l}\text { Denominación química } \\
\mathrm{N} \text { úmero CAS }\end{array}$ & Físicos & Q uímicos & $\begin{array}{l}\text { Clase o división } \\
\text { UN / Riesgos } \\
\text { subsidiarios }\end{array}$ \\
\hline $\begin{array}{l}\text { DIALLIFTALATO } \\
131-17-9\end{array}$ & & $\begin{array}{l}\text { Si no se inhibe, se polimeriza por calentamiento o en presencia de un catalizador En su } \\
\text { combustión forma óxidos de carbono tóxicos Reacciona con oxidantes fuertes, bases y ácidos }\end{array}$ & \\
\hline $\begin{array}{l}\text { DIBUTILFTALATO } \\
84-74.2\end{array}$ & $\begin{array}{l}\text { Pueden generarse cargas } \\
\text { electrostáticas por flujo, } \\
\text { agitación, etc. }\end{array}$ & Se descompone al arder, liberando vapores tóxicos e irritantes (anhídrido ftálico) & \\
\hline $\begin{array}{l}\text { DICICLOHEXILFTALATO } \\
84.61 .7\end{array}$ & & Reacciona con ácidos y bases & \\
\hline $\begin{array}{l}\text { DIETILFTALATO } \\
84-66-2\end{array}$ & & $\begin{array}{l}\text { Se descompone al calentarse } 0 \text { al arder liberando gases y vapores tóxicos (anhídrido ftálico) } \\
\text { Ataca algunos plásticos }\end{array}$ & \\
\hline
\end{tabular}




\begin{tabular}{|c|c|c|c|}
\hline $\begin{array}{l}\text { Denominación química } \\
\mathrm{N} \text { úmero CAS }\end{array}$ & Físicos & Q uímicos & $\begin{array}{l}\text { Clase o división } \\
\text { UN / Riesgos } \\
\text { subsidiarios }\end{array}$ \\
\hline $\begin{array}{l}\text { DIISODECILFTALATO } \\
\text { 26761-40-0 }\end{array}$ & & Ataca algunos tipos de plásticos & \\
\hline $\begin{array}{l}\text { DIIS00CTILFTALATO } \\
\text { 27554-26-3 }\end{array}$ & & Reacciona con oxidantes fuertes & \\
\hline $\begin{array}{l}\text { DI-SeC-OCTLLFTALATO } \\
117-81-7\end{array}$ & & Reacciona con oxidantes fuertes, ácidos, álcalis y nitratos & \\
\hline
\end{tabular}

\begin{tabular}{|c|c|c|c|c|c|c|c|c|c|c|c|}
\hline $\begin{array}{l}\text { Denominación química } \\
\mathrm{N} \text { úmero CAS }\end{array}$ & Color/ Forma & $\begin{array}{l}\text { p.e. } \\
\left({ }^{\circ} C\right)\end{array}$ & $\begin{array}{l}\text { p.f. } \\
\left({ }^{\circ} C\right)\end{array}$ & $\begin{array}{l}\mathrm{p} . \mathrm{m} . / \\
\text { (g/ } \\
\mathrm{mol})\end{array}$ & $\begin{array}{l}\text { Solubilidad } \\
\text { en agua }\end{array}$ & $\begin{array}{l}\text { Densidad } \\
\text { relativa } \\
\text { (agua }=1 \text { ) }\end{array}$ & $\begin{array}{l}\text { Densidad } \\
\text { relativa } \\
\text { de vapor } \\
\text { (aire=1) }\end{array}$ & $\begin{array}{l}\mathrm{Pvap} / \\
(\mathrm{kPa})\end{array}$ & $\begin{array}{l}\text { Límit. } \\
\text { inflam. }\end{array}$ & $\begin{array}{l}\text { p.ig. } \\
(\underline{O C})\end{array}$ & $\begin{array}{l}\text { p.aut } \\
\text { ig. } \\
(\mathrm{O} C)\end{array}$ \\
\hline $\begin{array}{l}\text { DIALLLFTALATO } \\
131-17-9 \\
\end{array}$ & $\begin{array}{l}\text { líquido oleaginoso } \\
\text { casi incoloro }\end{array}$ & $160-163$ & .70 & 246,26 & $\begin{array}{l}182 \mathrm{mg} / \mathrm{l} \\
\text { @ } 25^{\circ} \mathrm{C}\end{array}$ & 1,120 & 8,3 & $\begin{array}{l}310 \mathrm{~Pa} \\
@ 150^{\circ} \mathrm{C}\end{array}$ & & 166 & \\
\hline $\begin{array}{l}\text { DIBUTILFTALATO } \\
84-74.2\end{array}$ & $\begin{array}{l}\text { líquido viscoso entre } \\
\text { incoloro y amarillo } \\
\text { pálido; líquido } \\
\text { oleaginoso }\end{array}$ & 340 & .35 & 278,34 & insol & 1,0459 & 9,58 & $<0,01$ & $\begin{array}{l}0,5 \mathrm{li} \\
25,0 \mathrm{ls}\end{array}$ & $157 c c$ & 402 \\
\hline $\begin{array}{l}\text { DICICLOHEXILFTALATO } \\
84-61-7\end{array}$ & $\begin{array}{l}\text { sólido granulado } \\
\text { blanco }\end{array}$ & $\begin{array}{l}222-228 \\
\text { @ } 4 \mathrm{~mm} \mathrm{Hg}\end{array}$ & 66 & 330,4 & insol & 1,383 & & $\begin{array}{l}13,3 \mathrm{~Pa} \\
@ 150^{\circ} \mathrm{C}\end{array}$ & & 207 & \\
\hline $\begin{array}{l}\text { DIETILFTALATO } \\
84-66-2\end{array}$ & $\begin{array}{l}\text { líquido oleaginoso } \\
\text { incoloro }\end{array}$ & 295 & $-40,5$ & 222,3 & insol & 1,1175 & 7,7 & $\begin{array}{l}1,4 \\
@ 75^{\circ} \mathrm{C}\end{array}$ & 0,7 & $161 \mathrm{ca}$ & 457 \\
\hline $\begin{array}{l}\text { DIISODECILFTALATO } \\
\text { 26761-40-0 }\end{array}$ & & $\begin{array}{l}250-257 \\
@ 4 \mathrm{~mm} \mathrm{Hg} \\
\end{array}$ & -50 & 446,7 & insol & 0,966 & & $\begin{array}{l}147 \mathrm{~Pa} \\
@ 200^{\circ} \mathrm{C}\end{array}$ & $\begin{array}{l}0,3 \mathrm{li} \\
? \text { ls } \\
\end{array}$ & 232 oc & 402 \\
\hline $\begin{array}{l}\text { DIISOOCTILFTALATO } \\
\text { 27554-26-3 }\end{array}$ & $\begin{array}{l}\text { líquido viscoso casi } \\
\text { incoloro }\end{array}$ & 370 & -4 & 390,54 & insol & 0,986 & 13,5 & $<10 \mathrm{~Pa}$ & & 227 & 393 \\
\hline $\begin{array}{l}\text { DIMETILFTALATO } \\
131-11-3\end{array}$ & $\begin{array}{l}\text { líquido oleaginoso; } \\
\text { líquido viscoso } \\
\text { incoloro; cristales de } \\
\text { color amarillo pálido }\end{array}$ & 283,7 & 5,5 & 194,2 & insol & 1,1905 & 6,69 & $\begin{array}{l}<0,01 \\
\mathrm{~mm} \mathrm{Hg}\end{array}$ & $\begin{array}{l}0,9 \mathrm{li} \\
? \text { Is }\end{array}$ & 132 & 490 \\
\hline $\begin{array}{l}\text { DIMETILTEREFTALATO } \\
120-61-6\end{array}$ & $\begin{array}{l}\text { cristales incoloros; } \\
\text { agujas en éter }\end{array}$ & 288 & 140 & 194,2 & lig sol & $1,08 @ 25^{\circ} \mathrm{C}$ & 5,5 & $\begin{array}{l}1,7 \\
@ 150^{\circ} \mathrm{C}\end{array}$ & $\begin{array}{l}0,8 \mathrm{li} \\
11,8 \mathrm{ls} \\
\end{array}$ & $146 \mathrm{ca}$ & 500 \\
\hline $\begin{array}{l}\text { DI-sec-OCTILFTALATO } \\
117-81-7\end{array}$ & $\begin{array}{l}\text { líquido de color claro; } \\
\text { líquido oleaginoso } \\
\text { incoloro }\end{array}$ & 384 & -50 & 390,54 & $\begin{array}{l}0,01 \% \\
@ 25^{\circ} \mathrm{C}\end{array}$ & 0,9861 & 16,0 & 0,001 & $\begin{array}{l}0,3 \mathrm{li} \\
? \text { ls }\end{array}$ & $215 \mathrm{ca}$ & 390 \\
\hline $\begin{array}{l}\text { ESTER DIHEPTILICO DE ACIDO } \\
\text { FTALICO } \\
3648-21-3\end{array}$ & líquido incoloro & 360 & & 362,45 & $0,01 \%$ & & & & & & \\
\hline $\begin{array}{l}\text { ESTER DIISOBUTILICO DE ACIDO } \\
\text { FTALLO } \\
84-69-5\end{array}$ & líquido & 296,5 & .64 & 278,33 & insol & $\begin{array}{l}1,0490 \\
@ 15^{\circ} \mathrm{C}\end{array}$ & & & & $185 \mathrm{ca}$ & 432 \\
\hline
\end{tabular}




\section{PROPIEDADES DEL SIUCIO Y LOS COMPUESTOS ORGANOSIUCEOS}

\section{SILICE Y COMPUESTOS ORGANOSILICEOS}

D espués del oxígeno, el silicio es el elemento que más abunda en la T ierra. No aparece libre en la naturaleza, sino en forma de óxido (ślice) o silicato (feldespato, caolinita, etc.) en arena, rocas y arcilla. El silicio se obtiene calentando cuarzo $\left(\mathrm{SiO}_{2}\right)$ con carbono, un proceso en el que se libera monóxido de carbono y se obtiene silicio en bruto (98\% de pureza). Este grado de pureza es suficiente para su incorporación a aleaciones - por ejemplo, de aluminio y hierro- con el fin de hacerlas más duras y menos frágiles. El silicio puro se obtiene calentando silicio en bruto con cloro. Durante este proceso se produce el compuesto volátil $\mathrm{SiCl}_{4}$, que se separa por destilación. Si este líquido se calienta conjuntamente con hidrógeno, se libera silicio puro, que se configura en forma de varilla y las últimas impurezas se separan por flotación de la varilla calentando sucesivamente pequeñas partes de la misma hasta el punto de fusión, en una atmósfera de gas inerte, como argón, conjuntamente con algunos vestigios de elementos que se deseen añadir y que se disuelven en el silicio líquido.

L os siloxanos son compuestos que contienen oxígeno además de hidrógeno, silicio $\mathrm{y}$, normalmente, carbono (aunque existen algunos siloxanos inorgánicos). Partiendo de moléculas pequeñas, pueden formarse unidades más grandes (polímeros) con distintas propiedades (fluidez, elasticidad, estabilidad, etc.). Los siloxanos existen en forma de resinas, elastómeros (compuestos cauchutosos) 0 aceites.

\section{Usos}

El silicio se utiliza para obtener aleaciones de acero, aluminio, cobre, bronce y hierro. Se utiliza también ampliamente en la fabricación de semiconductores y en la producción de silanos y compuestos organosilíceos.

L os compuestos organosilíceos se utilizan en forma de resinas, elastómeros (compuestos cauchutosos) o aceites. Las resinas son compuestos organosilíceos que, cuando se mezclan con otras sustancias empleadas en la industria de las pinturas (endurecedores, aceleradores, etc.), forman capas muy estables que pueden aplicarse fácilmente incluso sobre bases a las que otras pinturas no suelen adherirse bien (como superficies metálicas). Además, son bastante resistentes al calentamiento momentáneo 0 al ataque por oxígeno y no se decoloran con la luz solar. Entre otras cosas, estas resinas se utilizan también como compuestos de moldeo (plásticos) y en la fabricación de espumas resistentes a altas temperaturas y útiles como termoaislantes. 0 tras resinas se utilizan en forma de las denominadas "pistas" (capas delgadas aplicadas en la industria electrónica) gracias a su baja combustibilidad y a sus excelentes propiedades como aislantes de la electricidad, incluso en presencia de humedad. Las resinas de silicio tienen numerosas aplicaciones por ser estables a altas temperaturas y repeler el agua, así como por su resistencia a los disolventes, las altas temperaturas y la luz solar. $L$ as resinas de silicio se utilizan en pinturas, barnices, compuestos de moldeo (plásticos), aislantes eléctricos, revestimientos sensibles a la presión y de desconexión, y laminados.

El silicato de metilo es un líquido bastante volátil utilizado en la fabricación de pantallas de televisión. Al descomponerse en agua, se forma una capa transparente de ácido silícico que fija la pantalla a la pared de cristal. El silicato de etilo se utiliza como ligante en la fabricación de moldes para procesos especiales de fundición de metales o como material de partida en síntesis químicas.

\section{Riesgos y su prevención}

En este artículo se hace referencia a los riesgos de los compuestos organosilíceos. El lector puede remitirse a otros artículos de esta E nciclopedia para una descripción de los importantes efectos en la salud de los silicatos, especialmente de los silicatos cristalinos. También se describen en otros artículos los efectos de los carburos de silicio.

Se desconocen los riesgos toxicológicos del silicio metálico. Para la mayoría de los proyectos reguladores, se considera simplemente un polvo molesto. Cuando el silicio se prepara y purifica en ausencia de aire, el proceso tiene lugar en un recipiente sellado y hermético para los gases que suele limitar la exposición. Los compuestos químicos que se utilizan conjuntamente con el silicio en diversos procesos de fabricación pueden entrañar también peligro. Aquí se consideran tres tipos de siliconas: silanos, siloxanos y heterosiloxanos.

Silanos. Los silanos contienen hidrógeno y silicio. La mayoría de ellos son sustancias aceitosas muy estables en sí mismas y de poca utilidad. No obstante, cuando se les añade cloro, nitrógeno u otros compuestos, pueden utilizarse para síntesis químicas. Tanto el tetraclorosilano como el triclorosilano son altamente reactivos y emiten vapores irritantes y asfixiantes. En contacto con el agua se descomponen (hidrólisis) liberando ácido clorhídrico. El agua presente en la atmósfera puede iniciar esta hidrólisis. Los productos de la hidrólisis irritan los ojos y el tracto respiratorio. Además, el triclorosilano arde fácilmente. Estos líquidos son tratados como sustancias corrosivas y se transportan en ampollas de cuarzo o cajas de acero inoxidable. L os derrames accidentales pueden hacerse inocuos con la adición de sosa caústica anhidra.

Los vapores aceitosos de siloxano irritan los ojos y a concentraciones muy altas afectan gravemente al sistema respiratorio. Por el contrario, los compuestos de resina de silicio se han considerado inocuos en el pasado y se han utilizado ampliamente para implantes corporales.

E lastómeros (compuestos de caucho). E stas sustancias se caracterizan por su gran estabilidad a temperaturas altas $\left(250^{\circ} \mathrm{C}\right)$ y bajas $\left(-75^{\circ} \mathrm{C}\right)$ y su resistencia al ataque de los productos químicos. Su inercia química es tal que se utilizan con frecuencia como material para implantes en vasos sanguíneos y otras partes del organismo. Además, son insolubles en muchos disolventes orgánicos, como tricloroetileno 0 acetona. L as membranas de caucho de silicona son fácilmente permeables a gases como el oxígeno, aunque estén disueltos en agua.

Debe recordarse la controversia y los conflictos legales suscitados por los efectos de los implantes de mama de silicona, estando dividida la opinión de los autores con respecto a los posibles riesgos para la salud a largo plazo.

Aceites. Estos compuestos conservan también su estabilidad cuando se exponen a cambios extremos en la temperatura. Por esta razón, se utilizan con frecuencia como lubricantes, ya que su viscosidad se mantiene más o menos constante a diferentes temperaturas. Se utilizan también como repelentes del agua, aplicándose por ejemplo a muros, tejidos o cuero. Sirven para facilitar el desmoldeado a presión y como agentes antiespumantes (esta última propiedad es útil, entre otras cosas, para los que sufren bronquitis crónica, puesto que la inhalación de los vapores de estos aceites les ayuda a expectorar). En animales de experimentación se ha observado que estas sustancias se eliminan muy 
lentamente de los pulmones, pero que su presencia no causa reacciones adversas. L as pomadas preparadas con siliconas se toleran también muy bien y, gracias a sus propiedades como repelentes del agua, contribuyen a prevenir o curar eczemas de contacto, puesto que evitan el contacto con las sustancias que causan reacciones de hipersensibilidad.

Los experimentos animales han demostrado que la inhalación de vapores muy concentrados puede producir una narcosis fatal; pero si los animales expuestos sobreviven a la narcosis, se recuperan totalmente. Los aceites de silicona irritan ligeramente la mucosa ocular, causando irritación indolora y lagrimeo. Sólo los compuestos de bajo peso molecular producen síntomas más graves.

H eterosiloxanos. Además de silicio, hidrógeno y oxígeno, los heterosiloxanos contienen algunos otros elementos como metales (aluminio, estaño, plomo, etc.), boro o arsénico, etc. Se hidrolizan fácilmente y, por tanto, son peligrosos para el cuerpo humano, la mayor parte del cual está formado por agua. Los heterosiloxanos suelen formarse como productos intermedios en síntesis químicas. El silicato de metilo y el silicato de etilo ocupan un lugar especial dentro de este grupo. El silicato de metilo, un líquido bastante volátil, se utiliza en la fabricación de pantallas de televisión. Al descomponerse en agua, se forma una película transparente de ácido silícico que fija la pantalla a la pared de cristal. Cuando el silicato de metilo, ya sea en forma líquida o vapor, contacta con los ojos, no produce un efecto inmediato, sino que éste aparece al cabo de 10 ó 12 horas, con dolor ocular violento acompañado de irritación y lagrimeo. La cornea se vuelve opaca y pueden aparecer úlceras que ocasionen ceguera. La inhalación de sus vapores puede causar daños irreparables en los pulmones y los riñones. Como quiera que el contacto con el vapor o con el líquido no produce un dolor inmediato que sirva de advertencia, esta sustancia exije la adopción de precauciones especiales. Debe evitarse la rotura de frascos, proteger los ojos con gafas herméticas a los gases y prevenir el riesgo de inhalación de vapores en caso de derrames, etc. mediante la instalación de un sistema de ventilación aspirante local.

EI silicato de etilo, que se utiliza como ligante en la fabricación de moldes para procesos especiales de fundición de metales 0 como material de partida en síntesis químicas, presenta una baja presión de vapor y esta propiedad física ayuda a reducir la exposición. A concentraciones altas, irrita las mucosas y a concentraciones muy altas se ha demostrado que es fatal para los animales.

La reactividad de los silicatos disminuye al aumentar su peso molecular. 
TABLAS DE SIUCIO Y COMPUESTOS ORGANOSIUCEOS

\begin{tabular}{|c|c|c|c|}
\hline Producto químico & Sinónimos/ Código UN & $\mathrm{N}$ úmero CAS & Fórmula estructural \\
\hline ACIDO SILICICO, SAL DISODICA & $\begin{array}{l}\text { B-W; Crystamet; metasilicato disódico; monosilicato disódico; Metso 20; } \\
\text { Metso beads, drymet; Sal disódica del ácido silíicico; silicato sódico; cristal } \\
\text { de agua }\end{array}$ & $6834-92-0$ & \\
\hline CARBURO DE SILICONA & $\begin{array}{l}\text { Annanox CK; Betarundum; Ultrafine; Carbofrax M; Carbolon; siliciuro de } \\
\text { carbono; Crystar; Crystolon 37; Crystolon 39; Densic c } 500\end{array}$ & $409-21-2$ & $\mathrm{SiC}$ \\
\hline DICLOROSILANO & & $4109-96-0$ & \\
\hline METIL DICLOROSILANO & $\begin{array}{l}\text { Diclorometilsilano } \\
\text { UN1242 }\end{array}$ & $75-54-7$ & \\
\hline METIL TRICLOROSILANO & $\begin{array}{l}\text { Metilsilicocloroformo; metilsilil tricloruro; triclorometilsilano } \\
\text { UN1250 }\end{array}$ & $75-79-6$ & \\
\hline MONOXIDO DE SILICONA & & $10477-28-6$ & $\mathrm{SiO}$ \\
\hline POLIDIMETILSILOXANO & $\begin{array}{l}\text { AF 72; AF 75; Dimethicone 350; Dow Corning 346; Geon; Good-rite; } \\
\text { Gum; Hycar; Latex; metil silicona; polimetilsiloxano }\end{array}$ & $9016-00-6$ & \\
\hline SILICATO CALCICO & $\begin{array}{l}\text { Hidrosilicato cálcico; monosilicato cálcico; polisilicato cálcico; } \\
\text { silicato cálcico; Calflo E; Calsil; CS lafarge; Florite R; Marimet 45; } \\
\text { Microcal 160; Promaxon P60; Silene WF; Silmos T; Solex; } \\
\text { Stabinex NW 7PS; Starlex I; SW 400; Toyofine A }\end{array}$ & $1344-95-2$ & \\
\hline SILICATO DE ETILO & $\begin{array}{l}\text { Etil ortosilicato; etil silicato; Extrema; silano, tetraetoxi-; TEOS; } \\
\text { tetraetoxisilano; tetraetil ortosilicato; tetraetil silicato } \\
\text { UN1292 }\end{array}$ & $78-10-4$ & \\
\hline SILICATO DE METILO & $\begin{array}{l}\text { Metil ortosilicato; metil silicato; éster metílico del ácido ortosilícico; } \\
\text { éster tetrametílico del ácido silícico; tetrametoxisilano; tetrametil silicato } \\
\text { UN2606 }\end{array}$ & $681-84-5$ & \\
\hline SILICONA & & $7440-21-3$ & Si \\
\hline TETRACLOROSILANO & $\begin{array}{l}\text { Extrema; cloruro de silicona; tetracloruro disilícico; tetracloruro de } \\
\text { silicona } \\
\text { UN1818 }\end{array}$ & $10026-04-7$ & \\
\hline TETRAFLUORURO DE SILICONA & $\begin{array}{l}\text { Perfluorosilano; silano, tetrafluoro-; Tetrafluorosilano } \\
\text { UN1859 }\end{array}$ & $7783-61-1$ & \\
\hline TETRAHIDRURO DE SILICONA & $\begin{array}{l}\text { Flots 100SC0; monosilano; silano; silicano } \\
\text { UN2203 }\end{array}$ & $7803-62-5$ & \\
\hline
\end{tabular}




\begin{tabular}{lll}
\hline Tabla 104.149 & $\bullet$ Identificación química. & \\
Producto químico & Sinónimos/ Código UN & úmero CAS Fórmula estructural \\
TRICLOROSILANO & Silicocloroformo; tricloromonosilano & $10025-78-2$ \\
\hline UN1295 & & \\
\hline TRIMETIL CLOROSILANO & $\begin{array}{l}\text { Clorotrimetilsilano; silano, trimetilcloro; clorotrimetilsilicano; } \\
\text { Tl 1163; trimetilisilil cloruro } \\
\text { UN1298 }\end{array}$ & \\
\hline
\end{tabular}

Tabla 104.150 • Riesgos para la salud.

\begin{tabular}{|c|c|c|c|c|c|c|}
\hline \multirow[b]{2}{*}{$\begin{array}{l}\text { Denominación } \\
\text { química } \\
\text { N úmero CAS }\end{array}$} & \multicolumn{4}{|c|}{ Tarjetas Internacionales sobre la Seguridad de los Productos Q uímicos } & \multicolumn{2}{|c|}{ N IO SH (EE.UU.) } \\
\hline & $\begin{array}{l}\text { Período } \\
\text { corto de } \\
\text { exposición }\end{array}$ & $\begin{array}{l}\text { Período } \\
\text { largo de } \\
\text { exposición }\end{array}$ & $\begin{array}{l}\text { Vías de } \\
\text { exposición }\end{array}$ & Síntomas & $\begin{array}{l}\text { O rganos } \\
\text { afectados } \\
\text { Vias de } \\
\text { entrada }\end{array}$ & Síntomas \\
\hline $\begin{array}{l}\text { ACIDO SILICICO, SAL DISODICA } \\
6834-92-0\end{array}$ & $\begin{array}{l}\text { ojos; piel; } \\
\text { tract resp; } \\
\text { pulmones }\end{array}$ & piel & $\begin{array}{r}\text { Inhalación } \\
\text { Piel } \\
\text { Ojos } \\
\text { Ingestión }\end{array}$ & $\begin{array}{l}\text { Sensación de quemazón, tos, disnea } \\
\text { Enrojecimiento, quemaduras graves en la piel, } \\
\text { dolor, ampollas } \\
\text { Enrojecimiento, dolor, visión borrosa, } \\
\text { quemaduras profundas graves } \\
\text { Sensación de quemazón, diarrea, shock o } \\
\text { colapso, vómitos, colapso }\end{array}$ & & \\
\hline $\begin{array}{c}\text { DICLOROSILANO } \\
4109.96 .0\end{array}$ & $\begin{array}{l}\text { ojos; piel; } \\
\text { tract resp; } \\
\text { pulmones }\end{array}$ & pulmones & $\begin{array}{r}\text { Inhalación } \\
\text { Piel } \\
\text { Ojos }\end{array}$ & $\begin{array}{l}\text { Sensación de quemazón, tos, dificultad } \\
\text { respiratoria, disnea, dolor de garganta } \\
\text { Enrojecimiento, quemaduras en la piel, } \\
\text { sensación de quemazón, dolor, ampollas } \\
\text { Enrojecimiento, dolor, pérdida de visión }\end{array}$ & & \\
\hline $\begin{array}{l}\text { METIL DICLOROSILANO } \\
75-54-7\end{array}$ & $\begin{array}{l}\text { ojos; piel; trac resp; } \\
\text { pulmones }\end{array}$ & & & & & \\
\hline $\begin{array}{l}\text { METIL TRICLOROSILANO } \\
75-79-6\end{array}$ & $\begin{array}{l}\text { ojos; piel; } \\
\text { tract resp; } \\
\text { pulmones }\end{array}$ & & $\begin{array}{r}\text { Inhalación } \\
\text { Piel } \\
\text { Ojos }\end{array}$ & $\begin{array}{l}\text { Corrosiva, sensación de quemazón, tos, } \\
\text { disnea, inconsciencia, los síntomas pueden } \\
\text { tardar en aparecer } \\
\text { Corrosiva, enrojecimiento, quemaduras en la } \\
\text { piel, dolor, ampollas } \\
\text { Corrosiva, enrojecimiento, dolor, pérdida de } \\
\text { visión, quemaduras profundas graves }\end{array}$ & & \\
\hline $\begin{array}{l}\text { POLIDIMETILSILOXANO } \\
9016-00-6\end{array}$ & ojos & & Ojos & Enrojecimiento, dolor & & \\
\hline $\begin{array}{l}\text { SILICATO DE ETILO } \\
78-10-4\end{array}$ & & & & & $\begin{array}{l}\text { Sis resp; hígado; } \\
\text { riñones; sangre; } \\
\text { piel; ojos } \\
\text { Inh; ing; con }\end{array}$ & $\begin{array}{l}\text { Irrit ojos, nariz; en animales: } \\
\text { lag, dis, edema pulm; } \\
\text { temblores, narco; lesiones } \\
\text { hepáticas y renales; anemia }\end{array}$ \\
\hline $\begin{array}{l}\text { SILICATO DE METILO } \\
681-84-5\end{array}$ & $\begin{array}{l}\text { tract resp; ojos; } \\
\text { pulmones }\end{array}$ & riñones; hígado & $\begin{array}{l}\text { Inhalación } \\
\text { Ojos }\end{array}$ & $\begin{array}{l}\text { Sensación de quemazón, tos, disnea, dolor de } \\
\text { garganta, los síntomas pueden tardar en } \\
\text { aparecer } \\
\text { Enrojecimiento, dolor, pérdida de visión }\end{array}$ & $\begin{array}{l}\text { Ojos; sis resp; } \\
\text { riñones } \\
\text { Inh; ing; con } \\
\text { (vap/ liq) }\end{array}$ & $\begin{array}{l}\text { Irrit ojos, lesiones córn } \\
\text { (incluso después de una corta } \\
\text { exposición a vapor); les } \\
\text { pulmonares y renales; edema } \\
\text { pulm }\end{array}$ \\
\hline
\end{tabular}




\begin{tabular}{|c|c|c|c|c|c|c|}
\hline \multirow[b]{2}{*}{$\begin{array}{l}\text { Denominación } \\
\text { química } \\
\mathrm{N} \text { úmero CAS }\end{array}$} & \multicolumn{4}{|c|}{ Tarjetas Internacionales sobre la Seguridad de los Productos Q uímicos } & \multicolumn{2}{|c|}{ N IO SH (EE.UU.) } \\
\hline & $\begin{array}{l}\text { Período } \\
\text { corto de } \\
\text { exposición }\end{array}$ & $\begin{array}{l}\text { Período } \\
\text { largo de } \\
\text { exposición }\end{array}$ & $\begin{array}{l}\text { Vías de } \\
\text { exposición }\end{array}$ & Síntomas & $\begin{array}{l}\text { O rganos } \\
\text { afectados } \\
\text { Vias de } \\
\text { entrada }\end{array}$ & Síntomas \\
\hline $\begin{array}{l}\text { TETRACLOROSILANO } \\
10026-04-7\end{array}$ & ojos; pulmones & & $\begin{array}{r}\text { Inhalación } \\
\text { Piel } \\
\text { 0jos }\end{array}$ & $\begin{array}{l}\text { Sensación de quemazón, tos, dificultad } \\
\text { respiratoria, disnea, dolor de garganta } \\
\text { Enrojecimiento, quemaduras en la piel, dolor, } \\
\text { ampollas } \\
\text { Enrojecimiento, dolor, pérdida de visión, } \\
\text { quemaduras profundas graves }\end{array}$ & & \\
\hline $\begin{array}{l}\text { TETRAFLUORURO DE SILICONA } \\
7783-61-1\end{array}$ & $\begin{array}{l}\text { ojos; piel; } \\
\text { tract resp; } \\
\text { pulmones }\end{array}$ & & $\begin{array}{r}\text { Inhalación } \\
\text { Piel } \\
\text { 0jos }\end{array}$ & $\begin{array}{l}\text { Sensación de quemazón, tos, dificultad } \\
\text { respiratoria, disnea, dolor de garganta } \\
\text { Enrojecimiento, quemaduras en la piel, dolor, } \\
\text { ampollas } \\
\text { Enrojecimiento, dolor, pérdida de visión, } \\
\text { quemaduras profundas graves }\end{array}$ & & \\
\hline $\begin{array}{l}\text { TETRAHIDRURO DE SILICONA } \\
\text { 7803-62-5 }\end{array}$ & $\begin{array}{l}\text { ojos; tract resp; } \\
\text { pulmones }\end{array}$ & pulmones & $\begin{array}{r}\text { Inhalación } \\
\text { Ojos } \\
\text { Ingestión }\end{array}$ & $\begin{array}{l}\text { Sensación de quemazón, tos, dificultad } \\
\text { respiratoria, disnea, dolor de garganta, los } \\
\text { síntomas pueden tardar en aparecer } \\
\text { Enrojecimiento, dolor } \\
\text { Debilidad }\end{array}$ & $\begin{array}{l}\text { Ojos; piel; sis resp; } \\
\text { SNC } \\
\text { Inh }\end{array}$ & Irrit ojos, piel, muc; náu, cef \\
\hline $\begin{array}{l}\text { TRICLOROSILANO } \\
10025-78-2\end{array}$ & $\begin{array}{l}\text { ojos; piel; } \\
\text { tract resp; } \\
\text { pulmones }\end{array}$ & pulmones & $\begin{array}{r}\text { Inhalación } \\
\text { Piel } \\
\text { 0jos }\end{array}$ & $\begin{array}{l}\text { Sensación de quemazón en el tórax, tos, } \\
\text { dificultad respiratoria, disnea, dolor de } \\
\text { garganta } \\
\text { Enrojecimiento, quemaduras en la piel, } \\
\text { sensación de quemazón, dolor, ampollas } \\
\text { Enrojecimiento, dolor, pérdida de visión }\end{array}$ & & \\
\hline $\begin{array}{l}\text { TRIMETILCLOROSILANO } \\
\text { 75-77-4 }\end{array}$ & $\begin{array}{l}\text { ojos; piel; } \\
\text { tract resp; } \\
\text { pulmones }\end{array}$ & piel & $\begin{array}{r}\text { Inhalación } \\
\text { Piel } \\
\text { 0jos } \\
\text { Ingestión }\end{array}$ & $\begin{array}{l}\text { Sensación de quemazón, tos, dificultad } \\
\text { respiratoria } \\
\text { Enrojecimiento, dolor, ampollas } \\
\text { Enrojecimiento, dolor, quemaduras profundas } \\
\text { graves } \\
\text { Dolor abdominal, sensación de quemazón, } \\
\text { debilidad }\end{array}$ & & \\
\hline
\end{tabular}

\begin{tabular}{|c|c|c|c|}
\hline $\begin{array}{l}\text { Denominación química } \\
\mathrm{N} \text { úmero CAS }\end{array}$ & Físicos & Q uímicos & $\begin{array}{l}\text { Clase o división } \\
\text { UN / Riesgos } \\
\text { subsidiarios }\end{array}$ \\
\hline $\begin{array}{l}\text { ACIDO SILICICO, SAL DISODICA } \\
6834.92 .0\end{array}$ & & $\begin{array}{l}\text { Es una base fuerte, reacciona violentamente con ácido y es corrosiva en presencia de aire } \\
\text { húmedo para metales como zinc, aluminio, estaño y plomo, formando un gas inflamable y } \\
\text { explosivo (hidrógeno) }\end{array}$ & \\
\hline $\begin{array}{l}\text { DICLOROSILANO } \\
4109-96.0\end{array}$ & $\begin{array}{l}\text { El gas es más pesado } \\
\text { que el aire }\end{array}$ & Reacciona violentamente con agua En contacto con el aire, emite cloruro de hidrógeno & \\
\hline $\begin{array}{l}\text { METIL DICLOROSILANO } \\
75-54-7\end{array}$ & & & $4.3 / 3 / 8$ \\
\hline $\begin{array}{l}\text { METIL TRICLOROSILANO } \\
75-79.6\end{array}$ & $\begin{array}{l}\text { El vapor es más pesado } \\
\text { que el aire y puede } \\
\text { desplazarse a ras del } \\
\text { suelo; posibilidad de } \\
\text { ignición a distancia }\end{array}$ & $\begin{array}{l}\text { Se descompone al calentarse, produciendo cloruro de hidrógeno Reacciona violentamente } \\
\text { con oxidantes fuertes Reacciona violentamente con agua y humedad, produciendo cloruro de } \\
\text { hidrógeno, con peligro de incendio y explosión Ataca metales como el aluminio y el magnesio }\end{array}$ & $3 / 8$ \\
\hline
\end{tabular}




\begin{tabular}{|c|c|c|c|}
\hline $\begin{array}{l}\text { Denominación química } \\
\mathrm{N} \text { úmero CAS }\end{array}$ & Físicos & Q uímicos & $\begin{array}{l}\text { Clase o división } \\
\text { UN / Riesgos } \\
\text { subsidiarios }\end{array}$ \\
\hline $\begin{array}{l}\text { POLIDIMETLSILOXANO } \\
9016-00-6\end{array}$ & & Se descompone al calentarse $(150 \stackrel{\circ}{ } \mathrm{C})$, produciendo formaldehído en pequeñas cantidades & \\
\hline $\begin{array}{l}\text { SILLCATO DE ETLLO } \\
78-10-4 \\
\end{array}$ & & & 3 \\
\hline $\begin{array}{l}\text { SILICONA } \\
7440-21-3 \\
\end{array}$ & & & 4.1 \\
\hline $\begin{array}{l}\text { TETRACLOROSILANO } \\
10026-04-7 \\
\end{array}$ & $\begin{array}{l}\text { El vapor es más pesado } \\
\text { que el aire }\end{array}$ & $\begin{array}{l}\text { Reacciona violentamente con agua En contacto con el aire, emite cloruro de hidrógeno y } \\
\text { ácido silícico }\end{array}$ & \\
\hline $\begin{array}{l}\text { TETRAFLUORURO DE SILICONA } \\
\text { 7783-61-1 }\end{array}$ & $\begin{array}{l}\text { El gas es más pesado } \\
\text { que el aire }\end{array}$ & Reacciona violentamente con agua En contacto con el aire, emite fluoruro de hidrógeno & 2.318 \\
\hline $\begin{array}{l}\text { TETRAHIDRURO DE SILICONA } \\
7803-62.5\end{array}$ & $\begin{array}{l}\text { El gas es más pesado } \\
\text { que el aire }\end{array}$ & Puede arder espontáneamente por contacto con aire a temperatura ambiente & \\
\hline $\begin{array}{l}\text { TRICLOROSILANO } \\
10025-78-2\end{array}$ & $\begin{array}{l}\text { El vapor es más pesado } \\
\text { que el aire y puede } \\
\text { desplazarse a ras del } \\
\text { suelo; posibilidad de } \\
\text { ignición a distancia }\end{array}$ & $\begin{array}{l}\text { Reacciona violentamente con agua En contacto con el aire, emite cloruro de hidrógeno } \\
\text { Ataca muchos metales en presencia de agua }\end{array}$ & $4.3 / 3 / 8$ \\
\hline $\begin{array}{l}\text { TRIMETILCLOROSILANO } \\
75-77-4\end{array}$ & $\begin{array}{l}\text { El vapor es más pesado } \\
\text { que el aire y puede } \\
\text { desplazarse a ras del } \\
\text { suelo; posibilidad de } \\
\text { ignición a distancia }\end{array}$ & $\begin{array}{l}\text { Se descompone al calentarse, liberando humos tóxicos y corrosivos (cloruro de hidrógeno, } \\
\text { fosgene) Reacciona violentamente con agua, cetonas, alcohol, aminas y muchas otras } \\
\text { sustancias, con peligro de explosión En contacto con el aire, emite humos corrosivos de } \\
\text { cloruro de hidrógeno }\end{array}$ & $3 / 8$ \\
\hline
\end{tabular}

\begin{tabular}{|c|c|c|c|c|c|c|c|c|c|c|c|}
\hline $\begin{array}{l}\text { Denominación química } \\
\mathrm{N} \text { úmero CAS }\end{array}$ & Color/ Forma & $\begin{array}{l}\text { p.e. } \\
(\because C)\end{array}$ & $\begin{array}{l}\text { p.f. } \\
(\stackrel{\circ}{ } \mathrm{C})\end{array}$ & $\begin{array}{l}\text { p.m.l } \\
\text { (g/ } \\
\text { mol) }\end{array}$ & $\begin{array}{l}\text { Solubilidad } \\
\text { en agua }\end{array}$ & $\begin{array}{l}\text { Densidad } \\
\text { relativa } \\
\text { (agua }=1 \text { ) }\end{array}$ & $\begin{array}{l}\text { Densidad } \\
\text { relativa } \\
\text { del vapor } \\
\text { (aire=1) }\end{array}$ & $\begin{array}{l}\text { Pvap/ } \\
(\mathrm{kPa})\end{array}$ & $\begin{array}{l}\text { Límit. } \\
\text { inflam. }\end{array}$ & $\begin{array}{l}\text { p.ig. } \\
(\because 0 C)\end{array}$ & $\begin{array}{l}\text { p.aut } \\
\text { ig. } \\
\left({ }^{\circ} \mathrm{C}\right)\end{array}$ \\
\hline $\begin{array}{l}\text { ACIDO SILICICO, SAL DISODICA } \\
6834.92 .0\end{array}$ & $\begin{array}{l}\text { cristales monoclínicos } \\
\text { incoloros; } \\
\text { normalmente } \\
\text { obtenido como vidrio; } \\
\text { también cristales } \\
\text { ortorrómbicos; } \\
\text { gránulos blancos sin } \\
\text { polvo }\end{array}$ & & 1089 & 122,07 & sol & 2,614 & & & & & \\
\hline $\begin{array}{l}\text { CARBURO DE SILICONA } \\
409-21-2\end{array}$ & $\begin{array}{l}\text { cristales afilados, } \\
\text { iridescentes, } \\
\text { extremadamente } \\
\text { duros, de color } \\
\text { verde o negro } \\
\text { azulado; } \\
\text { hexagonales o } \\
\text { cúbicos }\end{array}$ & & 2600 & 40,07 & insol & 3,23 & & & & & \\
\hline $\begin{array}{l}\text { DICLOROSILANO } \\
4109-96-0 \\
\end{array}$ & $\begin{array}{l}\text { gas licuado } \\
\text { comprimido }\end{array}$ & 8,2 & $-122,0$ & 101,01 & & 1,22 & 3,484 & & $\begin{array}{l}4,1 \mathrm{li} \\
99 \mathrm{ls}\end{array}$ & -307 & 100,58 \\
\hline $\begin{array}{l}\text { METIL DICLOROSILANO } \\
75-54-7\end{array}$ & líquido incoloro & 41 & .93 & 115,04 & lig sol & $1,10 @ 27^{\circ} \mathrm{C}$ & 3,97 & 46 & $\begin{array}{l}6,0 \mathrm{li} \\
55 \mathrm{ls}\end{array}$ & $-9 \mathrm{CC}$ & 316 \\
\hline
\end{tabular}


Tabla 104.152 • Propiedades físicas y químicas.

\begin{tabular}{|c|c|c|c|c|c|c|c|c|c|c|c|}
\hline $\begin{array}{l}\text { Denominación química } \\
\mathrm{N} \text { úmero CAS }\end{array}$ & Color/ Forma & $\begin{array}{l}\text { p.e. } \\
\left({ }^{\circ} \mathrm{C}\right)\end{array}$ & $\begin{array}{l}\text { p.f. } \\
(\stackrel{\circ}{ } C)\end{array}$ & $\begin{array}{l}\text { p.m.l } \\
\text { (g/ } \\
\text { mol) }\end{array}$ & $\begin{array}{l}\text { Solubilidad } \\
\text { en agua }\end{array}$ & $\begin{array}{l}\text { Densidad } \\
\text { relativa } \\
\text { (agua }=1 \text { ) }\end{array}$ & $\begin{array}{l}\text { Densidad } \\
\text { relativa } \\
\text { del vapor } \\
\text { (aire=1) }\end{array}$ & $\begin{array}{l}\text { Pvap/ } \\
(\mathrm{kPa})\end{array}$ & $\begin{array}{l}\text { Límit. } \\
\text { inflam. }\end{array}$ & $\begin{array}{l}\text { p.ig. } \\
(\underline{O C})\end{array}$ & $\begin{array}{l}\text { p.aut } \\
\text { ig. } \\
(\stackrel{\circ}{\circ})\end{array}$ \\
\hline $\begin{array}{l}\text { METIL TRICLOROSILANO } \\
75-79.6\end{array}$ & líquido incoloro & 66,4 & .90 & 149,48 & reacciona & $1,27 @ 25^{\circ} \mathrm{C}$ & 5,17 & 17,9 & $\begin{array}{l}5,1 \text { li } \\
? \text { ls }\end{array}$ & 8 & 404 \\
\hline $\begin{array}{l}\text { MONOXIDO DE SILICONA } \\
10097-28-6\end{array}$ & sólido negro amorfo & & & & & $2,15-2,18$ & & & & & \\
\hline $\begin{array}{l}\text { POLIDIMETILSILOXANO } \\
\text { 9016-00-6 }\end{array}$ & $\begin{array}{l}\text { líquido transparente } \\
\text { con distintos grados } \\
\text { de viscosidad }\end{array}$ & & & & insol & 0,97 & & & & $>200$ & \\
\hline $\begin{array}{l}\text { SILICATO CALCICO } \\
1344-95-2\end{array}$ & polvo blanco & & & & insol & 2,9 & & & & & \\
\hline $\begin{array}{l}\text { SILICATO DE ETILO } \\
\text { 78-10-4 }\end{array}$ & líquido incoloro & 168,8 & $-82,5$ & 208,30 & insol & 0,933 & 7,22 & $1,0 \mathrm{~mm} \mathrm{Hg}$ & $\begin{array}{l}1,3 \mathrm{li} \\
23 \mathrm{is}\end{array}$ & $52 \mathrm{ca}$ & \\
\hline $\begin{array}{l}\text { SILICATO DE METILO } \\
681-84-5\end{array}$ & líquido incoloro & $121-122$ & -2 & 152,25 & reacciona & 1,032 & 5,3 & 2,2 & & & \\
\hline $\begin{array}{l}\text { SILICATO SODICO } \\
1344-09-8\end{array}$ & $\begin{array}{l}\text { fragmentos o trozos } \\
\text { incoloros, blancos o } \\
\text { blancos grisáceos; } \\
\text { trozos de vidrio } \\
\text { verduzco; polvo } \\
\text { blanco; líquido turbio } \\
\text { o transparente }\end{array}$ & & & & lig sol & & & & & & \\
\hline $\begin{array}{l}\text { SILICONA } \\
\quad 7440-21-3\end{array}$ & $\begin{array}{l}\text { cristales negros o } \\
\text { grises, brillantes, con } \\
\text { forma de aguja o } \\
\text { placas octahédricas } \\
\text { (sistema cúbico); la } \\
\text { forma amorfa es } \\
\text { polvo marrón oscuro }\end{array}$ & 2355 & 1410 & 28,0855 & insol & & $\begin{array}{l}2,33 @ \\
25^{\circ} \mathrm{C} / 4^{\circ} \mathrm{C}\end{array}$ & & & & \\
\hline $\begin{array}{l}\text { TETRACLOROSILANO } \\
10026-04-7\end{array}$ & $\begin{array}{l}\text { líquido incoloro, } \\
\text { transparente, móvil }\end{array}$ & 59 & .70 & 169,89 & & $\begin{array}{l}1,52 \\
@ 00^{\circ} \mathrm{C} / 4^{\circ} \mathrm{C}\end{array}$ & 5,9 & $\begin{array}{l}0,14 \mathrm{~Pa} \\
@ 5.4^{\circ} \mathrm{C}\end{array}$ & & & \\
\hline $\begin{array}{l}\text { TETRAFLUORURO DE SILICONA } \\
7783-61-1\end{array}$ & gas incoloro & -86 & $-90,2$ & 104,06 & & $\begin{array}{l}1,590 \\
@-80^{\circ} \mathrm{C} \\
\text { (líquido) }\end{array}$ & 3,57 & & & & \\
\hline $\begin{array}{l}\text { TETRAHIDRURO DE SILICONA } \\
7803-62-5\end{array}$ & gas incoloro & -112 & -185 & 32,13 & $\begin{array}{l}\text { se descompone } \\
\text { lentamente }\end{array}$ & $16,32 @ 19{ }^{\circ} \mathrm{C}$ & 1,114 & & 1,37 & -22 & \\
\hline $\begin{array}{l}\text { TRICLOROSILANO } \\
10025-78-2\end{array}$ & líquido incoloro & 31,8 & $-126,5$ & 135,47 & & 1,3417 & 4,7 & $\begin{array}{l}13,3 @ \\
-16,4{ }^{\circ} \mathrm{C}\end{array}$ & $\begin{array}{l}1,2 \mathrm{li} \\
90,5 \mathrm{ls}\end{array}$ & $-14 \mathrm{ca}$ & $\begin{array}{l}93- \\
104\end{array}$ \\
\hline $\begin{array}{l}\text { TRIMETILCLOROSILANO } \\
75-77-4\end{array}$ & líquido incoloro & 57 & $-57,7$ & 108,66 & reacciona & $0,854 @ 25^{\circ} \mathrm{C}$ & 3,75 & 26,7 & $\begin{array}{l}1,8 \mathrm{li} \\
6 \mathrm{ls}\end{array}$ & -27 & \\
\hline
\end{tabular}




\section{COMPUEST OS ORGANICOS DE AZUFRE}

Los tioles (mercaptanos, tioalcoholes o sulfhidratos) son compuestos orgánicos sulfhidrilo monofuncionales, alifáticos 0 aromáticos, que se caracterizan por la presencia de grupos sulfhidrilo (-SH ). En general, los tioles poseen un olor intenso y desagradable, incluso a concentraciones muy bajas. A igual concentración, la intensidad del olor parece estar en relación inversa con el número de átomos de carbono de la molécula, de forma que el 1-dodecano-tiol y los tioles de cadena más larga son prácticamente inodoros. El principal método para la obtención de tioles consiste en la reacción de sulfuro de hidrógeno con olefinas o alcoholes a distintas temperaturas y presiones, en presencia de una serie de catalizadores y promotores, entre ellos ácidos, bases, peróxidos y sulfatos metálicos. EI hidrógeno del grupo -SH puede ser sustituido por mercurio (el término mercaptano se deriva del latín corpus mercurium captans, que significa cuerpos que captan mercurio) y otros metales pesados para formar mercapturos.

Los tioles se encuentran espontáneamente en todos los sistemas vivos. En las células vivas, la mayor parte de los tioles proceden del aminoácido cisteína y el tripéptido glutatión. Además, el metanotiol y el etanotiol se forman espontáneamente en el gas "agrio" a temperatura ambiente; los demás tioles son líquidos. Los alcanotioles $\mathrm{C}_{1}$ a $\mathrm{C}_{6}$ y el bencenotiol despiden un olor desagradable a concentraciones mucho menores que los otros tioles.

Los compuestos orgánicos de azufre se forman también por unión de una unidad sulfato $\left(\mathrm{SO}_{4}\right)$ a un grupo orgánico. Los sulfuros y las sales de sulfonio están constituidos por dos grupos orgánicos unidos a un átomo de azufre.

\section{Usos}

Los sulfuros y sulfatos orgánicos se utilizan en la industria como disolventes, productos químicos intermedios y aceleradores de la vulcanización del caucho, así como en baños galvanoplásticos para el recubrimiento de metales.

Los mercaptanos se utilizan principalmente como productos químicos intermedios en la fabricación de combustibles para aviones, insecticidas, fungicidas, fumigantes, colorantes, fármacos y otros compuestos químicos y para la detección de gases tóxicos inodoros. Elamil mercaptano (1-pentanotiol), el etil mercaptano y el terc-butil mercaptano (2-metil-2-propanotiol) se utilizan por su olor como aditivos para detectar fugas de gas, mientras que el propil mercaptano (propanotiol) y el metil mercaptano se emplean como aromatizantes para la odorización y aviso de otros gases tóxicos inodoros. El metil mercaptano se utiliza también para la síntesis de aromas sintéticos y como producto intermedio en la fabricación de pesticidas, combustibles para aviones, fungicidas y plásticos. El fenil mercaptano es un producto intermedio en la fabricación de insecticidas, fungicidas y fármacos. EI 1-dodecanetiol mercaptano (dodecil mercaptano) se utiliza en la fabricación de caucho sintético, plásticos, fármacos, insecticidas, fungicidas y detergentes no iónicos. Sirve también como agente complexante para la separación de los metales presentes en los residuos.

Elácido tioglicólico se utiliza para obtener tejidos plisados y como ingrediente de medios biológicos para el crecimiento de microorganismos. Es un componente de lacas para el pelo, plásticos y fármacos y un reactivo para la detección de hierro y otros iones metálicos.
El dimetil sulfato (eter dimetílico del ácido sulfúrico), un líquido aceitoso incoloro ligeramente soluble en agua, pero más soluble en disolventes orgánicos, se utiliza principalmente por sus propiedades metilantes para la obtención de esteres metílicos, éteres y aminas; en colorantes, fármacos y perfumes y en derivados fenólicos y otros compuestos químicos. Se emplea también como disolvente en la separación de aceites minerales.

El disulfuro de tetrametiltiuram (DTT, TMTD, Tiram, tirad, tiuram, Disulfuram), un cristal blanco o amarillo insoluble en agua, pero soluble en disolventes orgánicos, se utiliza como acelerador y vulcanizador del caucho, como fungicida para cosechas, frutas, nueces y setas, como bacteriostático en aceites y grasas comestibles y como ingrediente de cremas solares, aerosoles antisépticos, jabones y lociones. Se utiliza también como fungicida, repelente de roedores y conservante de la madera.

La etilen tiourea (2-imadazolidin etiona) y la tiourea se utilizan como componentes de baños galvanoplásticos. La etilen tiourea se utiliza también como colorante y en la industria farmacéutica, mientras que la tiourea tiene numerosas aplicaciones en las industrias fotográfica, textil, cosmética y papelera. La tiourea sirve para eliminar manchas en los negativos y como agente fijador en fotografía; como ingrediente de preparados capilares, productos químicos de limpieza y blanqueadores del papel; para el tratamiento del agua de las calderas y aguas residuales; para la fabricación de espejos antideslumbrantes; para evitar la aparición de manchas marrones en la madera de cicuta; como agente de pesado de la seda y como retardante de la llama en los tejidos.

EI dimetil sulfuro (metil sulfuro) se utiliza como gas oloroso y como aditivo alimentario. El alil propil disulfuro es otro aditivo alimentario y el dimetil sulfóxido (metil sulfóxido) (DM SO) es un disolvente que se encuentra en productos de limpieza industriales, pesticidas, decapantes para pinturas y barnices y anticongelantes 0 líquidos hidráulicos cuando se mezcla con agua. El 2,4-diaminoanisol sulfato (m-fenildiamino-4-metoxi-sulfato) se utiliza para el teñido de pieles y el lauril sulfato sódico (sal sódica de éster monododecílico de ácido sulfúrico) es un agente emulsionante utilizado en el procesamiento de metales, detergentes, champús, cremas, fármacos y alimentos.

\section{Riesgos}

\section{Tioles (mercaptanos)}

Los procesos industriales que utilizan tioles plantean una serie de problemas potenciales, entre ellos el peligro de incendio y explosión, así como efectos adversos en la salud de los trabajadores.

Incendio y explosión. La mayoría de los tioles son sustancias inflamables. Con los alcanotioles, la presión de vapor se reduce al aumentar el peso molecular. A temperaturas normales en el ambiente de trabajo, los tioles de bajo peso molecular $\left(C_{2}\right.$ a $\left.C_{6}\right)$ pueden evaporarse y formar mezclas explosivas con el aire. Los mercaptanos son líquidos típicamente inflamables, salvo el metil mercaptano, que es un gas. Su principal característica es un olor intenso y desagradable.

R iesgos para la salud. Los tioles tienen un olor intensamente desagradable y el contacto con el líquido o el vapor puede causar irritación de la piel, los ojos y las membranas mucosas del tracto respiratorio. L os tioles líquidos pueden también causar dermatitis por contacto. El bencenotiol parece tener propiedades más irritantes que los alcanotioles.

T odos los tioles se comportan como ácidos débiles y su efecto biólogo predominante se manifiesta en el sistema nervioso central. La inhalación es especialmente importante en el caso de 
los alcanotioles $C_{1}-C_{6}$, mientras que la exposición cutánea es el principal problema con los tioles de cadena más larga $\left(C_{7}\right.$ a $C_{12}$, $C_{16}, C_{18}$ ). El bencenotiol es el más tóxico de los tioles comunes en el lugar de trabajo y conlleva un riesgo importante de lesiones oculares.

La exposición accidental de los trabajadores a altas concentraciones de tioles (superiores a $50 \mathrm{ppm}$ ) produce debilidad muscular, náuseas, mareo y narcosis. Por vía sistémica, el metanotiol actúa como el sulfuro de hidrógeno y puede deprimir el sistema nervioso central, produciendo parálisis respiratoria y muerte. Puesto que el sulfuro de hidrógeno es una materia prima utilizada o generada en las plantas de producción de tioles, es necesario adoptar precauciones especiales para evitar su liberación en concentraciones peligrosas. Después de una exposición aguda, si no se produce la muerte inmediata, la irritación del tracto respiratorio inferior puede ocasionar edema pulmonar, a veces de aparición diferida, que de no recibir un tratamiento rápido puede tener consecuencias fatales. L as víctimas que sobreviven sufren lesiones hepáticas y renales, así como cefalea, mareo, marcha vacilante, náuseas y vómitos.

Acido tioglicólico. El ácido tioglicólico puro tiene un efecto irritante pronunciado en la piel y las mucosas. Cuando está diluido, su acción irritante es menos pronunciada. Se han dado casos de lesiones cutáneas producidas por sales (amónica, sódica) del ácido, como erupciones pruriginosas, papulopustulosas y vesiculares discretas en el cuello, las orejas y los hombros de personas que se habían hecho una permanente en el pelo. Algunos peluqueros han sufrido lesiones aisladas similares a quemaduras profundas y eczema de contacto en manos, antebrazos, rostro y cuello. Los tioglicolatos, que se usan mucho en la industria, exhiben una acción sensibilizante muy débil y causan dermatitis por irritación primaria. No obstante, se ha observado que la hidracida y los ésteres glicólicos del ácido tioglicólico poseen una acción sensibilizante pronunciada, habiéndose dado muchos casos de eczema de contacto entre los profesionales de la peluquería. Por este motivo, en Alemania se prohibió la venta de preparados que contuviesen hidracida. Los derivados del ácido tioglicólico también han producido algunos casos de perionixis y sequedad de la piel de las manos de los peluqueros. Sin embargo, cuando aparece una dermatitis en un profesional de la peluquería, hay que pensar que también puede estar producida por otros productos utilizados para realizar permanentes, por una excesiva alcalinidad y por las impurezas del hidrosulfuro sódico.

EI ácido tioglicólico exhibe un alto grado de toxicidad aguda.

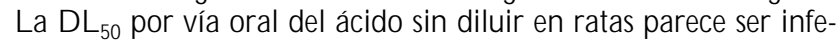
rior a $50 \mathrm{mg} / \mathrm{kg}$. Se absorbe rápidamente a través de la piel y, en el conejo, el $60 \%$ se excreta en la orina en un plazo de 24 horas en forma de sulfato inorgánico 0 azufre neutro.

Prevención. Los profesionales de la peluquería deben utilizar ácido tioglicólico o sus derivados sólo en soluciones diluidas con un pH casi neutro. En Suiza, por ejemplo, sólo está permitido utilizar soluciones al $7,5 \%$ con un $\mathrm{pH}$ máximo de 7,5 , o soluciones al $9 \%$ con un pH máximo de 8. Para aplicar esta solución, el peluquero debe protegerse las manos utilizando guantes de caucho o de plástico y evitar el contacto con los ojos. La solución debe neutralizarse lo más rápidamente posible y lavar la zona afectada al primer indicio de irritación.

Los profesionales de la peluquería que utilicen estos productos deben conocer todos los riesgos asociados a su uso y vigilar la aparición de cualquier signo precoz de exposición (es decir, sensación de quemazón, picores, etc.). Cuando padezcan alguna irritación cutánea, deben abstenerse de manipular estos productos. En los salones de peluquería, la ventilación debe ser suficiente para evitar que estos productos se acumulen en la atmósfera en forma de neblinas.

\section{Sulfatos y sulfuros}

EI dimetil sulfato es un tóxico extremadamente peligroso. La toxicidad se deriva de sus propiedades alquílicas y su hidrólisis a ácido sulfúrico y alcohol metilo. El líquido es muy irritante para la piel y las mucosas. En contacto con la piel produce ampollas que suelen curar lentamente, a veces con formación de costras. EI entumecimiento puede durar varios meses. La irritación de los ojos produce lagrimeo, sensibilidad a la luz (fotofobia), conjuntivitis y queratitis; en casos graves se han producido opacidades en la córnea y pérdida permanente de visión. A demás de la irritación aguda del tracto respiratorio, puede aparecer edema pulmonar diferido, bronquitis y neumonitis. El efecto del vapor en las terminaciones de los nervios trigémino, laríngeo y vago ocasiona a veces bradicardia o taquicardia y vasodilatación pulmonar.

Rara vez se han observado efectos a largo plazo y estos suelen limitarse a dificultades respiratorias y oculares.

Se ha demostrado que el dimetil sulfato es carcinógeno en la rata, tanto de forma directa como tras la exposición prenatal. La inhalación de 1 ppm origina la excreción urinaria de metilpurinas, lo que demuestra la existencia de un proceso de alquilación inespecífica del ADN. La Agencia Internacional para la Investigación sobre el Cáncer (IARC) ha clasificado al dimetilsulfato como un compuesto químico del Grupo 2A, probablemente cancerígeno para el ser humano.

Disulfuro de tetrametiltiuram (DTT). La exposición a DTT se produce por inhalación de polvo, aerosoles o nieblas. Los efectos locales son el resultado de la irritación de las mucosas: conjuntivitis, rinitis, estornudos y tos. EI DT T ocupa un lugar importante entre las sustancias que originan hipersensibilidad de contacto, posiblemente reflejando el uso frecuente de utensilios de goma en el hogar, en las fábricas y en medicina. Puede causar dermatitis de contacto, eritema y urticaria. La sensibilidad cutánea se confirma con la prueba de los parches.

Los trabajadores expuestos a DTT muestran intolerancia al alcohol, manifestada por congestión facial, palpitaciones, pulso rápido, hipotensión y mareo. Se cree que estos efectos se deben al bloqueo de la oxidación del acetaldehído. (El hómologo dietilo de DTT se comercializa con el nombre de Antabuse y se administra a los alcohólicos crónicos con la esperanza de que los síntomas tan desagradables que aparecen tras la ingestión de alcohol les ayude a superar el síndrome de abstinencia.)

La intoxicación por inhalación o ingestión de DT T produce náuseas, vómitos, diarrea, ataxia, hipotermia, hipotonía y, finalmente, parálisis ascendente con muerte por insuficiencia respiratoria. La toxicidad es mayor en presencia de grasas, aceites y disolventes lipídicos. EI DTT se metaboliza a disulfuro de carbono, atribuyéndose a este último efectos neurológicos y cardiovasculares.

\section{Medidas de salud y seguridad}

Las llamas abiertas y otras fuentes de ignición deben mantenerse alejadas de las zonas en donde se utilizan compuestos de azufre inflamables (p. ej., tioles), especialmente si son volátiles. Los procedimientos de emergencia y los métodos habituales de trabajo deben hacer hincapié en una manipulación adecuada, el control de los vertidos y el uso de equipos protectores adecuados, como respiradores y gafas de seguridad. Los tioles derramados deben neutralizarse con lejía de uso doméstico y regarse con agua abundante. La principal finalidad de las medidas de control es reducir la posibilidad de inhalación o contacto de la piel con los tioles, y especialmente de los ojos. En la medida de lo posible, el control debe centrarse en la fuente de exposición, ya sea realizando la operación en un recinto cerrado y/ o utilizando ventilación local por aspiración. Cuando estos controles técnicos no sean suficientes para reducir las concentraciones ambiente hasta 
niveles aceptables, se hará necesario el uso de respiradores para prevenir la irritación pulmonar y los efectos sistémicos. A bajas concentraciones (inferiores a $5 \mathrm{ppm}$ ), debe utilizarse un respirador de cartuchos con una semimascarilla y cartuchos para vapores orgánicos. A concentraciones altas se necesitan respiradores con máscara completa y suministro de aire.

En las zonas donde se utilicen cantidades apreciables de tioles, deben existir duchas, fuentes para lavarse los ojos y extintores de incendios. L os trabajadores expuestos deben disponer de lavabos, jabón y agua para limpiarse las manos.

Tratamiento. En situaciones de emergencia, los trabajadores afectados deben alejarse de la zona de exposición y en caso de haberse producido contaminación de los ojos o la piel, ser lavados con agua abundante, retirando rápidamente la ropa contaminada. En caso de inhalación de altas concentraciones, es aconsejable la hospitalización y observación durante al menos 72 horas, debido al riesgo de aparición tardía de edema pulmonar grave. Las medidas terapéuticas son similares a las recomendadas para las sustancias que irritan las vías respiratorias.

Las medidas de protección son las mismas que para el dióxido de azufre. Consisten en utilizar prendas impermeables, mandiles, guantes, gafas y botas cuando se trabaje con tioles líquidos que puedan salpicar o derramarse.

Todas las operaciones industriales relacionadas con el uso de dimetilsulfato deben realizarse en sistemas herméticamente cerrados y siguiendo los procedimientos recomendados para la manipulación de carcerígenos humanos. Se adoptarán las medidas necesarias para la correcta eliminación de cualquier derrame y estará absolutamente prohibido cualquier intento de limpiar los derrames masivos, como los que se producen en caso de rotura de un envase, hasta que toda la zona haya sido regada con agua abundante. $M$ uchos accidentes producidos por el dimetilsulfato han sido el resultado de intentos precipitados y sin protección de recoger la sustancia derramada. 


\section{TABLAS DE COMPUESTOS ORGANICOS DE AZUFRE}

\begin{tabular}{|c|c|c|c|}
\hline Producto químico & Sinónimos/ Código UN & $\mathrm{N}$ úmero CAS & Fórmula estructural \\
\hline ACIDO TIOACETICO & $\begin{array}{l}\text { Acetil mercaptano; ácido etanotióico; ácido etanotiólico; ácido } \\
\text { metanocarbotiólico; ácido tiacético; ácido tiolacético; ácido tionoacético } \\
\text { UN2436 }\end{array}$ & $507-09-5$ & \\
\hline ACIDO TIOGLICOLICO & $\begin{array}{l}\text { Acido 2-tioglicólico; mercaptoacetato; ácido mercaptoacético; ácido } \\
\text { 2-mercaptoacético; ácido 2-tioglicólico; ácido tiovánico } \\
\text { UN1940 }\end{array}$ & $68-11-1$ & 0 \\
\hline ANTU & $\begin{array}{l}\alpha \text {-Naftil tiourea; 1-naftaleniltiourea; 1-naftil tiourea; N-(1-naftil)-2-tiourea; } \\
\text { 1-(1-naftil)-2-tiourea } \\
\text { UN1651 }\end{array}$ & $86-88-4$ & \\
\hline BENCENOSULFONIL CLORURO & $\begin{array}{l}\text { Clorurobencenosulfónico } \\
\text { UN2225 }\end{array}$ & $98-09-9$ & \\
\hline terC-BUTIL MERCAPTANO & terc-Butanotiol; 2-metil-2-propanotiol & $75-66-1$ & \\
\hline n-BUTIL MERCAPTANO & $\begin{array}{l}\text { n-Butanotiol; butil mercaptano } \\
\text { UN2347 }\end{array}$ & $109-79-5$ & \\
\hline CICLOHEXIL-1-MERCAPTANO & $\begin{array}{l}\text { Ciclohexanotiol } \\
\text { UN3054 }\end{array}$ & $1569-69-3$ & \\
\hline DECIL MERCAPTANO & 1-Decanótido; decilmercaptano; n-decilmercaptano; 1-mercaptodecano & $143-10-2$ & \\
\hline DIETIL SULFATO & $\begin{array}{l}\text { Sulfato de dietilo; DS; etil sulfato; éster dietilico del ácido sulfúrico } \\
\text { UN1594 }\end{array}$ & $64-67-5$ & \\
\hline DIMETLL SULFATO & $\begin{array}{l}\text { Dimetil monosulfato } \\
\text { UN1595 }\end{array}$ & $77-78-1$ & \\
\hline DODECIL MERCAPTANO & $\begin{array}{l}\text { 1-Dodecanotiol; 1-dodecil mercaptano; lauril mercaptano; Pennfloat M; } \\
\text { Pennfloat S }\end{array}$ & $112-55-0$ & \\
\hline
\end{tabular}




\begin{tabular}{|c|c|c|c|}
\hline Producto químico & Sinónimos/ Código UN & $\mathrm{N}$ úmero CAS & Fórmula estructural \\
\hline FENIL MERCAPTANO & $\begin{array}{l}\text { Bencenotiol; tiofenol } \\
\text { UN2337 }\end{array}$ & $108-98-5$ & \\
\hline n-HEPTIL MERCAPTANO & 1-Heptanotiol & $1639-09-4$ & \\
\hline HEXANOTIOL & $\begin{array}{l}\text { Cetilmercaptano; hexadecanotiol-1; n-hexadecanotiol; } \\
\text { hexadecilmercaptano }\end{array}$ & $2917-26-2$ & \\
\hline n-HEXIL MERCAPTANO & 1-Hexanotiol & $111-31-9$ & \\
\hline ISOTIOCIANATO SODICO & $\begin{array}{l}\text { Rodanato sódico; rodanuro sódico; sulfocianato sódico; sulfocianuro } \\
\text { sódico; tiocianato sódico; tiocianuro sódico; sodio tiocianato }\end{array}$ & 540.72 .7 & $\mathrm{Na}^{+}$ \\
\hline
\end{tabular}

\begin{tabular}{ll}
\hline LAURIL SULFATO SODICO & $\begin{array}{l}\text { Monododecil sulfato sódico; dodecil sulfato sódico; } n \text {-dodecil sulfato } \\
\text { sódico; dodecil sulfato sódico; monolauril sulfato sódico }\end{array} \quad$ 151-21-3
\end{tabular}
sódico; dodecil sulfato sódico; monolauril sulfato sódico

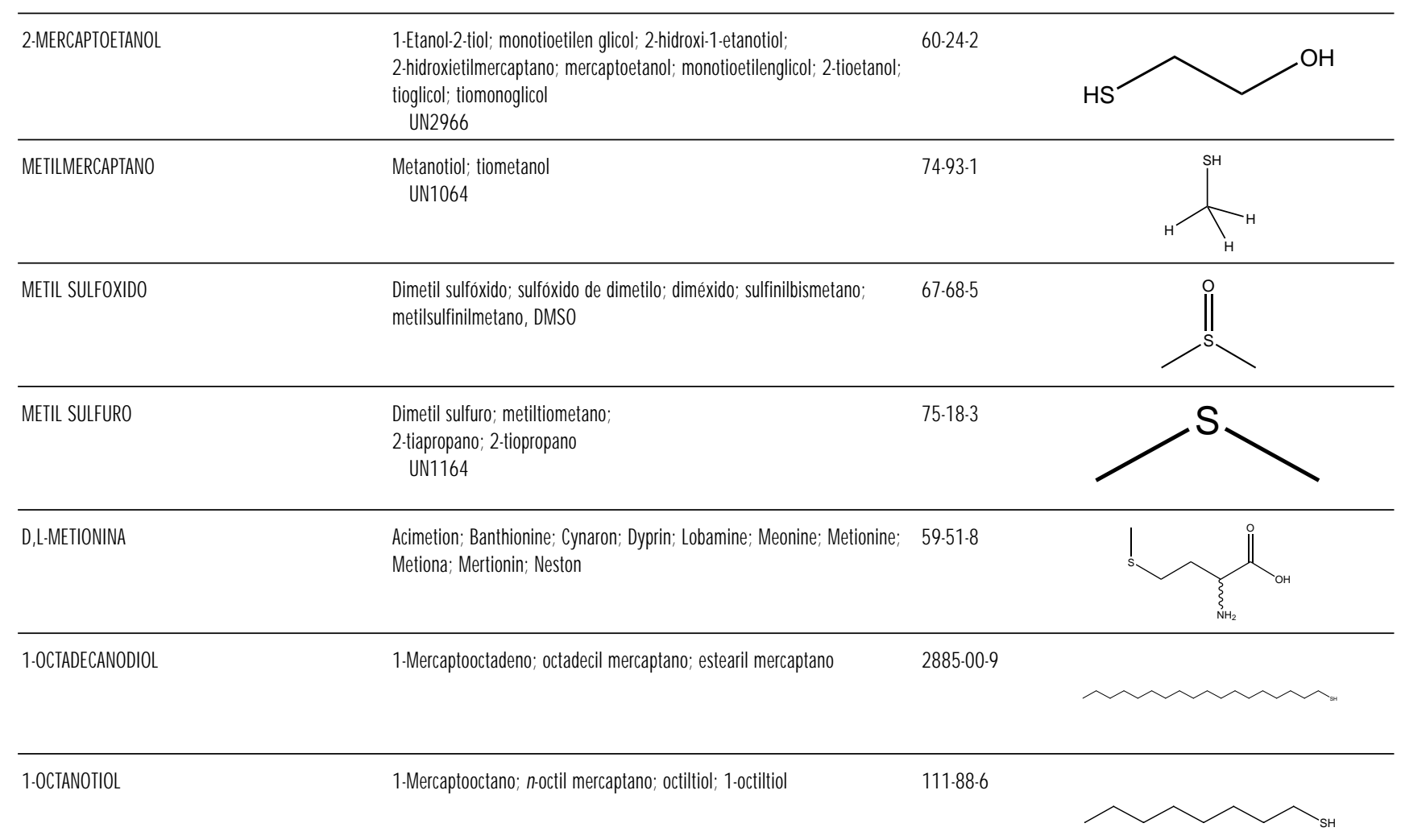




\begin{tabular}{|c|c|c|}
\hline Producto químico & Sinónimos/ Código UN & N úmero CAS Fórmula estructural \\
\hline 1-PENTANOTIOL & $\begin{array}{l}\text { Amil hidrosulfuro; amil mercaptano; n-amil mercaptano; amil sulfhidrato; } \\
\text { tioalcohol amílico; pentil mercaptano }\end{array}$ & $110-66-7$ \\
\hline PERCLOROMETLL MERCAPTANO & $\begin{array}{l}\text { PCM; sulfenil cloruro de triclorometano; triclorometanosulfenil cloruro; } \\
\text { triclorometilsulfenil cloruro } \\
\text { UN1670 }\end{array}$ & $594-42-3$ \\
\hline
\end{tabular}

PROPANOTIOL

107.03-9

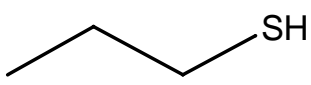

SULFATO DE BENCIDINA

(1,1'-Bifenil)-4,4'-diamina, sulfato (1:1)

$531-86-2$

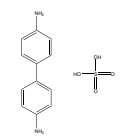

SULFURO DE CARBONILO

463-58-1

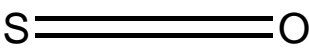

TIOACETAMIDA Acetotioamida; etanotioamida; ácido tioacetimídico

2,2'-TIODIETANOL $\quad$ Bis( $\beta$-hidroxietil) sulfuro; bis(2-hidroxietil) sulfuro; sulfuro $\quad 111-48-8$

de bis(2-hidroxietilo); tiodietilen glicol; tiodiglicol; $\beta$-tiodiglicol

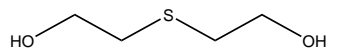

\begin{tabular}{ll}
\hline TIOUREA & Isotiourea; pseudotiourea; tiocarbamida; diamida del ácido tiocarbónico; \\
& beta-tiopseudourea; 2-tiopseudourea; 2-tiourea; THU \\
\hline TIRAM & Disulfuro de bis( (dimetilamino) carbonotioilo); sulfito de \\
& tetrametildiurano; disulfuro de tetrametilentiuram; diamida \\
& tetrametiltioperoxidicarbónica; tetrametiltiuram; bisulfuro de \\
& tetrametilitiuram; disulfuro de tetrametiltiuram
\end{tabular}

Tabla 104.154 - Riesgos para la salud.

\begin{tabular}{|c|c|c|c|c|c|c|}
\hline \multirow[b]{2}{*}{$\begin{array}{l}\text { Denominación } \\
\text { química } \\
\text { N úmero CAS }\end{array}$} & \multicolumn{4}{|c|}{ Tarjetas Internacionales sobre la Seguridad de los Productos Q uímicos } & \multicolumn{2}{|c|}{ N IOSH (EE.UU.) } \\
\hline & $\begin{array}{l}\text { Período } \\
\text { corto de exposición }\end{array}$ & $\begin{array}{l}\text { Período } \\
\text { largo de } \\
\text { exposición }\end{array}$ & $\begin{array}{l}\text { Vías de } \\
\text { exposición }\end{array}$ & Síntomas & $\begin{array}{l}\text { O rganos } \\
\text { afectados } \\
\text { Vías de } \\
\text { entrada }\end{array}$ & Síntomas \\
\hline $\begin{array}{l}\text { ACIDO TIOACETICO } \\
507-09 \cdot 5\end{array}$ & ojos; piel; tract resp; pulmones & riñones & $\begin{array}{r}\text { Inhalación } \\
\text { Piel } \\
\text { Ojos } \\
\text { Ingestión }\end{array}$ & $\begin{array}{l}\text { Tos, dificultad respiratoria, náuseas, dolor } \\
\text { de garganta, los síntomas pueden tardar } \\
\text { en aparecer } \\
\text { Sensación de quemazón, dolor } \\
\text { Enrojecimiento, dolor, quemaduras } \\
\text { profundas graves } \\
\text { Espasmos abdominales, sensación de } \\
\text { quemazón }\end{array}$ & & \\
\hline
\end{tabular}




\begin{tabular}{|c|c|c|c|c|c|c|}
\hline \multirow[b]{2}{*}{$\begin{array}{l}\text { Denominación } \\
\text { química } \\
\mathrm{N} \text { úmero CAS }\end{array}$} & \multicolumn{4}{|c|}{ Tarjetas Internacionales sobre la Seguridad de los Productos Q uímicos } & \multicolumn{2}{|c|}{ N IO SH (EE.UU.) } \\
\hline & $\begin{array}{l}\text { Período } \\
\text { corto de exposición }\end{array}$ & $\begin{array}{l}\text { Período } \\
\text { largo de } \\
\text { exposición }\end{array}$ & $\begin{array}{l}\text { Vías de } \\
\text { exposición }\end{array}$ & Síntomas & $\begin{array}{l}\text { Organos } \\
\text { afectados } \\
\text { Vías de } \\
\text { entrada }\end{array}$ & Síntomas \\
\hline $\begin{array}{l}\text { n-BUTIL MERCAPTANO } \\
\text { 109-79-5 }\end{array}$ & ojos; piel; tract resp; SNC; tiroides & & $\begin{array}{r}\text { Inhalación } \\
\text { Piel } \\
\text { Ojos } \\
\text { Ingestión } \\
\end{array}$ & $\begin{array}{l}\text { Debilidad, confusión, tos, mareo, cefalea, } \\
\text { náuseas, vómitos, disnea } \\
\text { Enrojecimiento, dolor } \\
\text { Enrojecimiento, dolor } \\
\text { Véase inhalación }\end{array}$ & $\begin{array}{l}\text { Sis resp; SNC; } \\
\text { hígado; riñones; } \\
\text { ojos; piel } \\
\text { Inh; ing; con }\end{array}$ & $\begin{array}{l}\text { Irrit ojos, piel; deb musc, } \\
\text { mal, sudor, náu, vómit, cef, } \\
\text { conf; en animales: narco, } \\
\text { desco, deb; cian, irrit pulm; } \\
\text { lesiones hepáticas y renales }\end{array}$ \\
\hline $\begin{array}{l}\text { terc-BUTIL MERCAPTANO } \\
75-66-1\end{array}$ & ojos; piel; tract resp; SNC & piel & $\begin{array}{r}\text { Inhalación } \\
\text { Piel } \\
\text { Ojos }\end{array}$ & $\begin{array}{l}\text { Tos, mareo, cefalea, náuseas, vómitos } \\
\text { Enrojecimiento } \\
\text { Enrojecimiento }\end{array}$ & & \\
\hline $\begin{array}{l}\text { CICLOHEXIL MERCAPTANO } \\
\text { 1569-69-3 }\end{array}$ & ojos; piel; tract resp; SNC & piel & $\begin{array}{r}\text { Inhalación } \\
\text { Piel } \\
\text { 0jos }\end{array}$ & $\begin{array}{l}\text { Tos, mareo, cefalea, náuseas, } \\
\text { inconsciencia, vómitos, debilidad } \\
\text { Enrojecimiento } \\
\text { Enrojecimiento }\end{array}$ & $\begin{array}{l}\text { Ojos; piel; sis } \\
\text { resp; SNC } \\
\text { Inh; abs; ing; con }\end{array}$ & $\begin{array}{l}\text { Irrit ojos, piel, sis resp; cef, } \\
\text { mar, deb, náu, vómit, } \\
\text { convuls; tos, estor, } \\
\text { laringitis, dis }\end{array}$ \\
\hline $\begin{array}{l}\text { DECIL MERCAPTANO } \\
143-10-2\end{array}$ & ojos; piel; tract resp; SNC & piel & $\begin{array}{r}\text { Inhalación } \\
\text { Piel } \\
\text { 0jos } \\
\end{array}$ & $\begin{array}{l}\text { Confusión, mareo, cefalea, náuseas, } \\
\text { inconsciencia, debilidad } \\
\text { Enrojecimiento } \\
\text { Enrojecimiento }\end{array}$ & $\begin{array}{l}\text { Ojos; piel; sis } \\
\text { resp } \\
\text { Inh; abs; ing; con }\end{array}$ & $\begin{array}{l}\text { Irrit ojos, piel, sis resp; } \\
\text { conf, mar, cef, sop, náu, } \\
\text { vómit, deb, convuls }\end{array}$ \\
\hline $\begin{array}{l}\text { DODECIL MERCAPTANO } \\
112-55-0\end{array}$ & ojos; piel; tract resp; SNC & piel & $\begin{array}{r}\text { Inhalación } \\
\\
\text { Piel } \\
\text { 0jos } \\
\text { Ingestión }\end{array}$ & $\begin{array}{l}\text { Confusión, tos, mareo, cefalea, náuseas, } \\
\text { disnea, dolor de garganta, inconsciencia, } \\
\text { debilidad } \\
\text { Enrojecimiento } \\
\text { Enrojecimiento, dolor } \\
\text { Dolor abdominal, embotamiento, cefalea, } \\
\text { náuseas, inconsciencia }\end{array}$ & $\begin{array}{l}\text { Ojos; piel; sis } \\
\text { resp; SNC; } \\
\text { sangre; } \\
\text { Inh; con }\end{array}$ & $\begin{array}{l}\text { Irrit ojos, piel, sis resp; tos; } \\
\text { dis, deb, conf, cian; dolor } \\
\text { abdom, náu; sens piel }\end{array}$ \\
\hline $\begin{array}{l}\text { DODECILBENCENOSULFONAT } \\
\text { O SODICO } \\
25155-30-0\end{array}$ & ojos; piel; tract resp & piel & $\begin{array}{r}\text { Inhalación } \\
\text { Piel } \\
\text { Ojos } \\
\text { Ingestión }\end{array}$ & $\begin{array}{l}\text { Tos, dificultad respiratoria } \\
\text { Enrojecimiento } \\
\text { Enrojecimiento, dolor } \\
\text { Diarrea, vómitos }\end{array}$ & & \\
\hline $\begin{array}{l}\text { ETIL MERCAPTANO } \\
75-08-1\end{array}$ & & & $\begin{array}{r}\text { Inhalación } \\
\text { Piel } \\
\text { 0jos }\end{array}$ & $\begin{array}{l}\text { Sopor, náuseas, inconsciencia, debilidad, } \\
\text { temblores } \\
\text { Enrojecimiento } \\
\text { Enrojecimiento, dolor }\end{array}$ & $\begin{array}{l}\text { Sis resp; hígado; } \\
\text { riñones; ojos; } \\
\text { sangre } \\
\text { Inh; con } \\
\end{array}$ & $\begin{array}{l}\text { Irrit muc; cef, náu; en } \\
\text { animals: desco, deb; } \\
\text { lesiones hepáticas y } \\
\text { renales; cian; narco }\end{array}$ \\
\hline $\begin{array}{l}\text { FENIL MERCAPTANO } \\
\text { 108-98.5 }\end{array}$ & ojos; piel; tract resp; SNC & piel & $\begin{array}{r}\text { Inhalación } \\
\text { Piel } \\
\text { Ojos } \\
\text { Ingestión }\end{array}$ & $\begin{array}{l}\text { Tos, cefalea, dificultad respiratoria } \\
\text { Enrojecimiento, dolor } \\
\text { Enrojecimiento, dolor } \\
\text { Náuseas, dolor de garganta }\end{array}$ & $\begin{array}{l}\text { Ojos; piel; sis } \\
\text { resp; SNC; } \\
\text { riñones; hígado; } \\
\text { bazo } \\
\text { Inh; abs; ing; con }\end{array}$ & $\begin{array}{l}\text { Irrit ojos, piel, sis resp; } \\
\text { derm; cian; tos, resp sib, } \\
\text { dis, edema pulm, neuitis; } \\
\text { cef, mar, SNC depres; náu, } \\
\text { vómit; lesiones en riñones, } \\
\text { hígado y bazo }\end{array}$ \\
\hline $\begin{array}{l}\text { HEXANOTIOL } \\
2917-26-2\end{array}$ & ojos; piel; tract resp; SNC & piel & $\begin{array}{r}\text { Inhalación } \\
\\
\text { Piel } \\
\text { 0jos }\end{array}$ & $\begin{array}{l}\text { Mareo, cefalea, náuseas, dolor de } \\
\text { garganta, inconsciencia, debilidad } \\
\text { Enrojecimiento } \\
\text { Enrojecimiento }\end{array}$ & $\begin{array}{l}\text { Ojos; piel; sis } \\
\text { resp; SNC; sangre } \\
\text { Inh; abs; ing; con }\end{array}$ & $\begin{array}{l}\text { Irrit ojos, piel, sis resp; cef, } \\
\text { mar, deb, cian, náu, } \\
\text { convuls }\end{array}$ \\
\hline $\begin{array}{l}\text { METIL MERCAPTANO } \\
74-93-1\end{array}$ & $\begin{array}{l}\text { ojos; piel; tract resp; pulmones; SNC; } \\
\text { sangre; piel }\end{array}$ & & $\begin{array}{r}\text { Inhalación } \\
\text { Piel } \\
\text { 0jos }\end{array}$ & $\begin{array}{l}\text { Tos, irritante, cefalea, náuseas, disnea, } \\
\text { dolor de garganta, inconsciencia } \\
\text { Enrojecimiento, irritante, dolor, en } \\
\text { contacto con el líquido: congelación } \\
\text { Enrojecimiento, irritante, dolor }\end{array}$ & $\begin{array}{l}\text { Sis resp; SNC; } \\
\text { ojos; piel; sangre } \\
\text { Inh; con (liq) }\end{array}$ & $\begin{array}{l}\text { Irrit ojos, piel, sis resp; } \\
\text { narco; cian; convuls; liq: } \\
\text { congelación }\end{array}$ \\
\hline $\begin{array}{l}\text { 1.OCTADECANOTIOL } \\
\text { 2885-00.9 }\end{array}$ & & & & & $\begin{array}{l}\text { Ojos; piel; sis } \\
\text { resp; SNC; sangre } \\
\text { Inh; abs; ing; con }\end{array}$ & $\begin{array}{l}\text { Irrit ojos, piel, sis resp; cef; } \\
\text { mar; deb; cian; náu; } \\
\text { convuls }\end{array}$ \\
\hline
\end{tabular}




\begin{tabular}{|c|c|c|c|c|c|c|}
\hline \multirow[b]{2}{*}{$\begin{array}{l}\text { Denominación } \\
\text { química } \\
\mathrm{N} \text { úmero CAS }\end{array}$} & \multicolumn{4}{|c|}{ Tarjetas Internacionales sobre la Seguridad de los Productos Q uímicos } & \multicolumn{2}{|c|}{ N IOSH (EE.UU.) } \\
\hline & $\begin{array}{l}\text { Período } \\
\text { corto de exposición }\end{array}$ & $\begin{array}{l}\text { Período } \\
\text { largo de } \\
\text { exposición }\end{array}$ & $\begin{array}{l}\text { Vías de } \\
\text { exposición }\end{array}$ & Síntomas & $\begin{array}{l}\text { O rganos } \\
\text { afectados } \\
\text { Vías de } \\
\text { entrada }\end{array}$ & Síntomas \\
\hline $\begin{array}{l}\text { 1-OCTANOTIOL } \\
111-88-6\end{array}$ & & & & & $\begin{array}{l}\text { Ojos; piel; sis } \\
\text { resp; sangre; SNC } \\
\text { Inh; ing; con }\end{array}$ & $\begin{array}{l}\text { Irrit ojos, piel, nariz, } \\
\text { garganta; deb; cian; incr } \\
\text { respiración; náu; sop; cef; } \\
\text { vómit }\end{array}$ \\
\hline $\begin{array}{l}\text { PERCLOROMETIL- } \\
\text { MERCAPTANO } \\
594-42-3\end{array}$ & ojos; piel; tract resp; pulmones & piel; pulmones & & & $\begin{array}{l}\text { Ojos; sis resp; } \\
\text { hígado; riñones; } \\
\text { piel } \\
\text { Inh; abs; ing; con }\end{array}$ & $\begin{array}{l}\text { Irrit ojos, piel, nariz, } \\
\text { garganta; lag; tos, dis, } \\
\text { dolor con resp profunda, } \\
\text { estertores; vómit; pal, } \\
\text { tacar; acidosis; anuria; } \\
\text { lesiones hepáticas y renale }\end{array}$ \\
\hline $\begin{array}{l}\text { PROPANOTIOL } \\
107-03-9\end{array}$ & & & & & $\begin{array}{l}\text { Ojos; piel; sis } \\
\text { resp; SNC; } \\
\text { sangre; hígado; } \\
\text { riñones } \\
\text { Inh; ing; con }\end{array}$ & $\begin{array}{l}\text { Irrit ojos, piel, nariz, } \\
\text { garganta, sis resp; cef, } \\
\text { náu, mar, cian; en } \\
\text { animales: lesiones } \\
\text { hepáticas y renales }\end{array}$ \\
\hline $\begin{array}{l}\text { TIOACETAMIDA } \\
62.55-5\end{array}$ & ojos; piel; tract resp & & $\begin{array}{l}\text { Inhalación } \\
\text { Piel } \\
\text { Ojos } \\
\text { Ingestión }\end{array}$ & $\begin{array}{l}\text { Tos, dificultad respiratoria, dolor de } \\
\text { garganta } \\
\text { Enrojecimiento } \\
\text { Enrojecimiento, dolor, visión borrosa } \\
\text { Sensación de quemazón, dolor de } \\
\text { garganta }\end{array}$ & & \\
\hline
\end{tabular}

\begin{tabular}{|c|c|c|c|}
\hline $\begin{array}{l}\text { Denominación química } \\
\text { N úmero CAS }\end{array}$ & Físicos & Q uímicos & $\begin{array}{l}\text { Clase o división } \\
\text { UN / Riesgos } \\
\text { subsidiarios }\end{array}$ \\
\hline $\begin{array}{l}\text { ACIDO MERCAPTOACETICO } \\
68-11-1\end{array}$ & & & 8 \\
\hline $\begin{array}{l}\text { ACIDO TIOACETICO } \\
507-09-5\end{array}$ & $\begin{array}{l}\text { El vapor es más pesado } \\
\text { que el aire y puede } \\
\text { desplazarse a ras del } \\
\text { suelo; posibilidad de } \\
\text { ignición a distancia }\end{array}$ & $\begin{array}{l}\text { Se descompone al arder, produciendo humos tóxicos y corrosivos (óxidos de azufre) Es } \\
\text { un ácido de fuerza intermedia y corrosiva Reacciona violentamente con oxidantes fuertes, } \\
\text { con peligro de incendio y explosión Reacciona lentamente con agua, formando ácido } \\
\text { acético y sulfuro de hidrógeno }\end{array}$ & \\
\hline $\begin{array}{l}\text { ANTU } \\
86-88-4\end{array}$ & & $\begin{array}{l}\text { Se descompone al calentarse produciendo humos tóxicos, entre ellos óxidos de nitrógeno y } \\
\text { óxidos de azufre Reacciona con oxidantes fuertes, con peligro de incendio y explosión }\end{array}$ & 6.1 \\
\hline $\begin{array}{l}\text { BENCENOSULFONIL CLORURO } \\
98-09-9\end{array}$ & & & 8 \\
\hline $\begin{array}{l}\text { n-BUTIL MERCAPTANO } \\
\text { 109-79-5 }\end{array}$ & $\begin{array}{l}\text { El vapor es más pesado } \\
\text { que el aire y puede } \\
\text { desplazarse a ras del } \\
\text { suelo; posibilidad de } \\
\text { ignición a distancia }\end{array}$ & $\begin{array}{l}\text { Se descompone al arder o calentarse, produciendo humos altamente tóxicos (dióxido de } \\
\text { azufre) Reacciona con ácidos, bases, metales alcalinos, y oxidantes fuertes }\end{array}$ & 3 \\
\hline $\begin{array}{l}\text { terc-BUTIL MERCAPTANO } \\
75-66-1\end{array}$ & $\begin{array}{l}\text { El vapor es más pesado } \\
\text { que el aire y puede } \\
\text { desplazarse a ras del } \\
\text { suelo; posibilidad de } \\
\text { ignición a distancia }\end{array}$ & $\begin{array}{l}\text { Se descompone al arder produciendo gases altamente tóxicos, entre ellos óxidos de azufre } \\
\text { Reacciona con ácidos fuertes, bases fuertes, metales alcalinos, agentes reductores fuertes y } \\
\text { oxidantes fuertes }\end{array}$ & \\
\hline
\end{tabular}




\begin{tabular}{|c|c|c|c|}
\hline $\begin{array}{l}\text { Denominación química } \\
\text { N úmero CAS }\end{array}$ & Físicos & Q uímicos & $\begin{array}{l}\text { Clase o división } \\
\text { UN / Riesgos } \\
\text { subsidiarios }\end{array}$ \\
\hline $\begin{array}{l}\text { CETIL MERCAPTANO } \\
2917-26-2\end{array}$ & & $\begin{array}{l}\text { Se descompone al arder, produciendo gases altamente tóxicos, entre ellos óxidos de azufre } \\
\text { Reacciona violentamente con oxidantes fuertes, ácidos, agentes reductores, metales alcalinos }\end{array}$ & \\
\hline $\begin{array}{l}\text { CICLOHEXIL MERCAPTANO } \\
\text { 1569-69-3 }\end{array}$ & & $\begin{array}{l}\text { Se descompone al arder, produciendo gases altamente tóxicos, entre ellos dióxido de azufre } \\
\text { Reacciona con oxidantes fuertes, agentes reductores y metales alcalinos }\end{array}$ & 3 \\
\hline $\begin{array}{l}\text { DECIL MERCAPTANO } \\
143-10-2\end{array}$ & & $\begin{array}{l}\text { Se descompone al arder, produciendo gases altamente tóxicos, entre ellos dióxido de azufre } \\
\text { Reacciona con oxidantes fuertes y bases fuertes }\end{array}$ & \\
\hline $\begin{array}{l}\text { DIETLL SULFATO } \\
64-67.5\end{array}$ & & $\begin{array}{l}\text { Se descompone al calentarse, produciendo humos inflamables y tóxicos Es un oxidante } \\
\text { fuerte y reacciona con materiales combustibles y reductores Es un agente reductor fuerte y } \\
\text { reacciona con oxidantes La solución en agua es un ácido fuerte, reacciona violentamente con } \\
\text { bases y es corrosiva }\end{array}$ & 6.1 \\
\hline $\begin{array}{l}\text { DIETIL SULFURO } \\
352-93-2\end{array}$ & & & 3 \\
\hline $\begin{array}{l}\text { DIMETIL SULFATO } \\
77-78-1\end{array}$ & & & $6.1 / 8$ \\
\hline $\begin{array}{l}\text { DIMETIL SULFOXIDO } \\
67-68-5\end{array}$ & $\begin{array}{l}\text { El vapor es más pesado } \\
\text { que el aire y puede } \\
\text { desplazarse a ras del } \\
\text { suelo; posibilidad de } \\
\text { ignición a distancia }\end{array}$ & $\begin{array}{l}\text { Se descompone al calentarse por encima de } 150^{\circ} \mathrm{Co} \text { al arder, produciendo humos tóxicos } \\
\text { Reacciona violentamente con oxidantes fuertes como percloratos }\end{array}$ & \\
\hline $\begin{array}{l}\text { DIMETIL SULFURO } \\
75-18-3\end{array}$ & $\begin{array}{l}\text { El vapor es más pesado } \\
\text { que el aire y puede } \\
\text { desplazarse a ras del } \\
\text { suelo; posibilidad de } \\
\text { ignición a distancia }\end{array}$ & $\begin{array}{l}\text { Se descompone al calentarse y al arder, produciendo humos tóxicos y corrosivos (sulfuro de } \\
\text { hidrógeno y óxidos de azufre) Reacciona violentamente con oxidantes fuertes, con peligro de } \\
\text { incendio y explosión }\end{array}$ & 3 \\
\hline $\begin{array}{l}\text { DODECIL MERCAPTANO } \\
112-55-0\end{array}$ & & $\begin{array}{l}\text { Se descompone al arder produciendo gases altamente tóxicos, entre ellos dióxido de azufre } \\
\text { Reacciona violentamente con oxidantes fuertes y metales alcalinos }\end{array}$ & \\
\hline $\begin{array}{l}\text { DODECILBENCENOSULFONATO SODICO } \\
25155-30-0\end{array}$ & & $\begin{array}{l}\text { Se descompone al calentarse y al arder, produciendo humos tóxicos e irritantes (óxidos de } \\
\text { azufre) Reacciona con ácidos o humos ácidos, produciendo humos tóxicos e irritantes (óxidos } \\
\text { de azufre) }\end{array}$ & \\
\hline $\begin{array}{l}\text { ETLL MERCAPTANO } \\
75-08-1\end{array}$ & $\begin{array}{l}\text { El vapor es más pesado } \\
\text { que el aire y puede } \\
\text { desplazarse a ras del } \\
\text { suelo; posibilidad de } \\
\text { ignición a distancia }\end{array}$ & $\begin{array}{l}\text { En su combustión forma monóxido de carbono, óxidos de azufre y sulfuro de hidrógeno ES } \\
\text { un ácido débil Reacciona con oxidantes, con peligro de incendio y explosión Reacciona } \\
\text { violentamente con ácidos fuertes y bases, con peligro de intoxicación }\end{array}$ & 3 \\
\hline $\begin{array}{l}\text { FENIL MERCAPTANO } \\
108-98-5\end{array}$ & & $\begin{array}{l}\text { Se descompone al calentarse, produciendo humos tóxicos (óxidos de azufre y monóxido de } \\
\text { carbono) Reacciona con ácidos liberando humos tóxicos (óxidos de azufre) }\end{array}$ & $6.1 / 3$ \\
\hline $\begin{array}{l}\text { LAURIL SULFATO SODICO } \\
151-21-3\end{array}$ & & En su combustión se forman gases tóxicos Libera humos tóxicos en un incendio & \\
\hline $\begin{array}{l}\text { 2-MERCAPTOETANOL } \\
60-24-2\end{array}$ & & & 8 \\
\hline $\begin{array}{l}\text { METANOSULFONIL CLORURO } \\
124-63.0\end{array}$ & & & $6.1 / 8$ \\
\hline $\begin{array}{l}\text { METILMERCAPTANO } \\
74-93-1\end{array}$ & $\begin{array}{l}\text { El gas es más pesado } \\
\text { que el aire y puede } \\
\text { desplazarse a ras del } \\
\text { suelo; posibilidad de } \\
\text { ignición a distancia }\end{array}$ & $\begin{array}{l}\text { Se descompone al calentarse y al arder, produciendo óxidos de azufre tóxicos Reacciona } \\
\text { violentamente con oxidantes fuertes Reacciona con ácidos para formar gases inflamables y } \\
\text { tóxicos (sulfuro de hidrógeno) }\end{array}$ & $2.3 / 2.1$ \\
\hline
\end{tabular}

\begin{tabular}{ll}
\hline D,L-METIONINA & Se descompone al calentarse, produciendo óxidos de azufre y óxidos nitrosos Reacciona con \\
$59-51-8$ & oxidantes fuertes
\end{tabular}


Tabla 104.155 • Riesgos físicos y químicos.

\begin{tabular}{|c|c|c|c|}
\hline $\begin{array}{l}\text { Denominación química } \\
\mathrm{N} \text { úmero CAS }\end{array}$ & Físicos & Q uímicos & $\begin{array}{l}\text { Clase o división } \\
\text { UN / Riesgos } \\
\text { subsidiarios }\end{array}$ \\
\hline $\begin{array}{l}\text { 1.PENTANOTIOL } \\
110-66-7 \\
\end{array}$ & & & 3 \\
\hline $\begin{array}{l}\text { PERCLOROMETIL MERCAPTANO } \\
594-42-3\end{array}$ & & & 6.1 \\
\hline $\begin{array}{l}\text { PROPANOTIOL } \\
107-03-9 \\
\end{array}$ & & & 3 \\
\hline $\begin{array}{l}\text { TIOACETAMIDA } \\
62-55-5 \\
\end{array}$ & & Se descompone al arder, produciendo humos tóxicos & \\
\hline $\begin{array}{l}\text { TIOCIANATO SODICO } \\
540-72.7\end{array}$ & & $\begin{array}{l}\text { Se descompone al calentarse y por influencia de la luz, produciendo humos tóxicos de óxidos } \\
\text { de azufre, óxidos de nitrógeno y cianuros Reacciona violentamente con ácidos, bases fuertes y } \\
\text { oxidantes fuertes }\end{array}$ & \\
\hline $\begin{array}{l}\text { TIOUREA } \\
62-56.6\end{array}$ & & $\begin{array}{l}\text { Se descompone al calentarse, produciendo humos tóxicos de óxidos de nitrógeno y óxidos de } \\
\text { azufre Reacciona con agentes oxidantes del sulfhidrilo, formando complejos y aductos con } \\
\text { sales metálicas y numerosos compuestos orgánicos, entre ellos proteínas y algunos hidratos de } \\
\text { carbono Reacciona violentamente con acroleína, ácidos fuertes y oxidantes fuertes }\end{array}$ & \\
\hline $\begin{array}{l}\text { TIRAM } \\
\quad 137-26-8\end{array}$ & $\begin{array}{l}\text { Posibilidad de explosión } \\
\text { de polvo cuando se } \\
\text { encuentra en forma de } \\
\text { polvo } 0 \text { granular y se } \\
\text { mezcla con el aire }\end{array}$ & $\begin{array}{l}\text { Se descompone al calentarse y al arder, produciendo humos tóxicos (óxidos de azufre, } \\
\text { nitrógeno) Reacciona con oxidantes fuertes, ácidos y materiales oxidables }\end{array}$ & 6.1 \\
\hline
\end{tabular}

\begin{tabular}{|c|c|c|c|c|c|c|c|c|c|c|c|}
\hline $\begin{array}{l}\text { Denominación química } \\
\mathrm{N} \text { úmero CAS }\end{array}$ & Color/ Forma & $\begin{array}{l}\mathrm{pe} \\
\left({ }^{\circ} \mathrm{C}\right)\end{array}$ & $\begin{array}{l}\mathrm{pf} \\
\left({ }^{\circ} \mathrm{C}\right)\end{array}$ & $\begin{array}{l}\text { p.m.l } \\
\text { (g/ } \\
\text { mol) }\end{array}$ & $\begin{array}{l}\text { Solubilidad } \\
\text { en agua }\end{array}$ & $\begin{array}{l}\text { Densidad } \\
\text { relativa } \\
\text { (agua }=1 \text { ) }\end{array}$ & $\begin{array}{l}\text { Densidad } \\
\text { relativa } \\
\text { del vapor } \\
\text { (aire=1) }\end{array}$ & $\begin{array}{l}\text { Pvap/ } \\
(\mathrm{kPa})\end{array}$ & $\begin{array}{l}\text { Límit. } \\
\text { inflam. }\end{array}$ & $\begin{array}{l}\text { p.ig. } \\
(\underline{O C})\end{array}$ & $\begin{array}{l}\text { p.aut } \\
\text { ig. } \\
\left({ }^{\circ} \mathrm{C}\right)\end{array}$ \\
\hline $\begin{array}{l}\text { ACIDO TIOACETICO } \\
507-09.5\end{array}$ & líquido amarillo & 93 & $<-17$ & 76,1 & lig sol & 1.064 & 2,62 & & & $18-21$ & \\
\hline $\begin{array}{l}\text { ACIDO TIOGLICOLICO } \\
68-11-1\end{array}$ & líquido incoloro & $\begin{array}{l}120 \\
@ 20 \mathrm{~mm} \mathrm{Hg}\end{array}$ & $-16,5$ & 92,1 & misc & 1,3253 & & $\begin{array}{l}10 \text { torr } \\
@ 18^{\circ} \mathrm{C}\end{array}$ & & & \\
\hline $\begin{array}{l}\text { n-BUTIL MERCAPTANO } \\
\text { 109-79-5 }\end{array}$ & líquido incoloro & 98,4 & -115.7 & 90,2 & lig sol & 0,8337 & 3,1 & 4,0 & & $2 c c$ & $<225$ \\
\hline $\begin{array}{l}\text { terc-BUTIL MERCAPTANO } \\
75-66-1\end{array}$ & $\begin{array}{l}\text { líquido móvi; líquido } \\
\text { incoloro }\end{array}$ & 64 & -0.5 & 90,2 & insol & 0,8002 & 3,1 & 19,0 & & $-26 c c$ & \\
\hline $\begin{array}{l}\text { CETIL MERCAPTANO } \\
2917-26-2 \\
\end{array}$ & líquido o sólido & 184 & 18 & & insol & 0,84 & 8,9 & $10 \mathrm{~Pa}$ & & 135 & \\
\hline $\begin{array}{l}\text { CICLOHEXIL MERCAPTANO } \\
1569-69-3\end{array}$ & líquido & 158 & -118 & 116,2 & insol & 0,9782 & 4,00 & 1,3 & & $43 \mathrm{cc}$ & \\
\hline $\begin{array}{l}\text { DECIL MERCAPTANO } \\
143-10-2\end{array}$ & líquido incoloro & 241 & .26 & 174,3 & insol & 0,84 & 6,0 & $<10 \mathrm{~Pa}$ & & & \\
\hline $\begin{array}{l}\text { DODECIL MERCAPTANO } \\
112 \cdot 55-0\end{array}$ & $\begin{array}{l}\text { líquido color agua o } \\
\text { amarillo claro; líquido } \\
\text { aceitoso incoloro }\end{array}$ & $\begin{array}{l}142-145 \\
@ 15 \mathrm{~mm} \mathrm{Hg}\end{array}$ & .7 & 202,4 & insol & 0,8450 & 7,0 & $\begin{array}{l}0,33 \\
@ 25^{\circ} \mathrm{C}\end{array}$ & & $\begin{array}{l}1278 \\
o c\end{array}$ & \\
\hline $\begin{array}{l}\text { DODECILBENCENOSULFONATO } \\
\text { SODICO } \\
25155-30-0\end{array}$ & $\begin{array}{l}\text { copos, gránulos o } \\
\text { polvo de color blanco } \\
\text { o amarillo claro }\end{array}$ & & 300 & & sol & $\begin{array}{l}\text { 1,0 para } \\
\text { suspensión al } \\
60 \%\end{array}$ & & & & & \\
\hline
\end{tabular}




\begin{tabular}{|c|c|c|c|c|c|c|c|c|c|c|c|}
\hline $\begin{array}{l}\text { Denominación química } \\
\mathrm{N} \text { úmero CAS }\end{array}$ & Color/ Forma & $\begin{array}{l}\text { pe } \\
(\underline{O C})\end{array}$ & $\begin{array}{l}\mathrm{pf} \\
(\mathrm{O} C)\end{array}$ & $\begin{array}{l}\text { p.m./ } \\
\text { (g/ } \\
\mathrm{mol})\end{array}$ & $\begin{array}{l}\text { Solubilidad } \\
\text { en agua }\end{array}$ & $\begin{array}{l}\text { Densidad } \\
\text { relativa } \\
\text { (agua }=1 \text { ) }\end{array}$ & $\begin{array}{l}\text { Densidad } \\
\text { relativa } \\
\text { del vapor } \\
\text { (aire=1) }\end{array}$ & $\begin{array}{l}\text { Pvap/ } \\
(\mathrm{kPa})\end{array}$ & $\begin{array}{l}\text { Límit. } \\
\text { inflam. }\end{array}$ & $\begin{array}{l}\text { p.ig. } \\
(\underline{O C})\end{array}$ & $\begin{array}{l}\text { p.aut } \\
\text { ig. } \\
(\stackrel{\circ}{ } \mathrm{C})\end{array}$ \\
\hline $\begin{array}{l}\text { ETIL MERCAPTANO } \\
75-08-1\end{array}$ & líquido incoloro & 35 & -144.4 & 62,13 & lig sol & 0,83907 & 2,14 & 589 & $\begin{array}{l}2,8 \| \\
18,0 \mathrm{sl}\end{array}$ & -483 & 299 \\
\hline $\begin{array}{l}\text { FENIL MERCAPTANO } \\
108-98.5\end{array}$ & $\begin{array}{l}\text { líquido color agua; } \\
\text { cristales tipo prisma } \\
\text { en éter de petróleo }\end{array}$ & 168 & $-14,8$ & 110,17 & insol & 1,0766 & 3,8 & $\begin{array}{l}0,13 \\
@ 18^{\circ} \mathrm{C}\end{array}$ & & $<55$ & \\
\hline $\begin{array}{l}\text { n-HEPTIL MERCAPTANO } \\
1639-09-4\end{array}$ & & 177 & -43 & 132,26 & insol & 0,8427 & & & & & \\
\hline $\begin{array}{l}\text { n-HEXIL MERCAPTANO } \\
111-31-9\end{array}$ & & 151 & -81 & 118,23 & insol & 0,8424 & & & & & \\
\hline $\begin{array}{l}\text { 2-MERCAPTOETANOL } \\
60-24-2\end{array}$ & $\begin{array}{l}\text { líquido móvil color } \\
\text { agua }\end{array}$ & $\begin{array}{l}157-158 @ \\
742 \mathrm{~mm} \mathrm{Hg} \\
\end{array}$ & & 78,13 & sol & 1,1143 & 2,7 & $\begin{array}{l}1,00 \\
\mathrm{~mm} \mathrm{Hg}\end{array}$ & & & \\
\hline $\begin{array}{l}\text { METANOSULFONIL CLORURO } \\
124.63-0\end{array}$ & líquido amarillo claro & $\begin{array}{l}62 \\
@ 18 \mathrm{~mm} \mathrm{Hg}\end{array}$ & -32 & 114,55 & insol & 1,4573 & & & & & \\
\hline $\begin{array}{l}\text { METIL MERCAPTANO } \\
74-93-1\end{array}$ & $\begin{array}{l}\text { líquido color agua por } \\
\text { debajo del punto de } \\
\text { ebullición o gas } \\
\text { incoloro }\end{array}$ & 5,9 & -123 & 48,1 & lig sol & 0,8665 & 1,66 & $\begin{array}{l}1520 \\
\mathrm{~mm} \mathrm{Hg} \\
\text { @ } 26,1{ }^{\circ} \mathrm{C}\end{array}$ & $\begin{array}{l}3,9 \| \\
21,8 \text { ul }\end{array}$ & -18 & \\
\hline $\begin{array}{l}\text { OCTADECANOTIOL } \\
2885.00 .9\end{array}$ & sólido & 205-209 & 25 & & & 0,8420 & & & & & \\
\hline $\begin{array}{l}\text { n-OCTANOTIOL } \\
111-88-6\end{array}$ & líquido color agua & 199,1 & $-49,2$ & 146,30 & & 0,8433 & & & & 46 & \\
\hline $\begin{array}{l}\text { 1-PENTANOTIOL } \\
110-66-7\end{array}$ & líquido & $\begin{array}{l}126,6 @ \\
460 \mathrm{~mm} \mathrm{Hg}\end{array}$ & $.75,7$ & 104,21 & insol & 0,8421 & 3,59 & $\begin{array}{l}13,8 \\
\mathrm{~mm} \mathrm{Hg} @ \\
25^{\circ} \mathrm{C}\end{array}$ & & $18 \mathrm{ca}$ & \\
\hline $\begin{array}{l}\text { PERCLOROMETIL MERCAPTANO } \\
594-42-3\end{array}$ & $\begin{array}{l}\text { líquido aceitoso } \\
\text { amarillo; amarillo o } \\
\text { rojo anaranjado }\end{array}$ & 147,5 & & 185,88 & insol & 1,6947 & 6,414 & $3 \mathrm{~mm} \mathrm{Hg}$ & & & \\
\hline $\begin{array}{l}\text { PROPANOTIOL } \\
107-03-9\end{array}$ & líquido móvil incoloro & $67-68$ & $-113,3$ & 76,17 & lig sol & $0,8411 \mathrm{~g} / \mathrm{ml}$ & & $\begin{array}{l}154.2 \\
\mathrm{~mm} \mathrm{Hg} \\
@ 25^{\circ} \mathrm{C}\end{array}$ & & -20 & \\
\hline $\begin{array}{l}\text { TIOACETAMIDA } \\
62.55-5\end{array}$ & $\begin{array}{l}\text { cristales en benceno; } \\
\text { laminillas incoloras; } \\
\text { cristales en alc, } \\
\text { placas en éter }\end{array}$ & & 116 & 75,1 & muy sol & & & & & & \\
\hline $\begin{array}{l}2,2^{\prime} \cdot \text { TIODIETANOL } \\
111-48-8\end{array}$ & & $164-166$ & -10 & 122,2 & & 1,1819 & & & & & \\
\hline
\end{tabular}




\section{COMPUESTOS INORGANICOS DE AZUFRE}

El azufre se encuentra en estado nativo en algunas regiones volcánicas, o en estado combinado formando sulfuros metálicos (piritas, galena, blenda, cinabrio), sulfatos (anglesita, yeso) o sulfuro de hidrógeno en algunas manantiales de agua o gas natural. En otros tiempos, las rocas extraídas de las minas de azufre se calentaban hasta el punto de fusión en hornos primitivos excavados en el suelo o hechos de hormigón de mampostería y abiertos en su parte superior (llamados en Sicilia calcaroni); el material que contenía azufre se cubría con una capa de escoria para evitar su contacto con el aire. En ambos casos, una parte del azufre natural se consumía como combustible.

El azufre elemental se extrae en su mayor parte del refinado del petróleo. En algunos países, el azufre se recupera como un subproducto de los minerales azufrados utilizados en la producción de cobre, plomo y zinc; también se obtiene por calcinación de las piritas de hierro para la producción de ácido sulfúrico.

\section{Usos}

El azufre se utiliza para la producción de ácido sulfúrico, sulfatos, hiposulfitos, disulfuro de carbono, y también en la fabricación de cerillas, la vulcanización del caucho, la fusión de electrones y la fabricación de bombas incendiarias; en agricultura se emplea para combatir los parásitos de las plantas y para el tratamiento de los vinos. Es también útil para blanquear pasta de madera y papel, tejidos y frutos secos. El azufre es un componente de los champús anticaspa, un agente ligante y extendedor de asfalto para la pavimentación de carreteras, un aislante eléctrico y un agente nucleante en las películas fotográficas.

EI dióxido de azufre sirve principalmente como producto químico intermedio en la producción de ácido sulfúrico, aunque también se utiliza en la producción de pasta de papel, almidón, sulfitos y tiosulfatos. Se utiliza para blanquear azúcar, fibras, cuero, colas y licor de azúcar; como material de partida para la síntesis orgánica de numerosas sustancias, entre ellas disulfuro de carbono, tiofeno, sulfonas y sulfonatos, y como conservante en las industrias vinícola y alimentaria. En combinación con amoníaco y la humedad ambiental, forma neblinas artificiales de sulfito amónico que protegen a los cultivos de las heladas nocturnas. EI dióxido de azufre se utiliza como desinfectante en las fábricas de cerveza, como agente en el proceso de flotación por espuma de minerales azufrados, como disolvente de extracción en el refinado del petróleo, como agente limpiador en el drenado con tubos de barro cocido y como agente de curtido en la industria del cuero.

El trióxido de azufre se utiliza como producto químico intermedio en la fabricación de ácido sulfúrico y ácido sulfúrico fumante para la sulfonación, en particular, de tintes y colorantes, y para la producción de ácido nítrico anhidro y explosivos. El trióxido de azufre sólido se comercializa con nombres como Sulphan y Triosul, y se utiliza principalmente para la sulfonación de ácidos orgánicos. EI tetrafluoruro de azufre es un agente de fluoración. EI hexafluoruro de azufre sirve como aislante gaseoso en instalaciones eléctricas de alto voltaje. EI sulfiril fluoruro se emplea como insecticida y fumigante.

EI hexafluoruro de azufre y el trioxiclorofluoruro de azufre se utilizan como materiales aislantes en sistemas de alto voltaje.

$M$ uchos de estos compuestos se emplean en industrias de colorantes, química, cuero, fotografía y siderurgia. 0 tros compuestos como metabisulfito sódico, trisulfito sódico, hidrosulfito sódico, sulfato amónico, tiosulfato sódico, sulfato cálcico, dióxido de azufre, sulfito sódico y metabisulfito potásico, sirven como aditivos, conservantes y decolorantes en la industria de los alimentos. En la industria textil, el trisulfito sódico y el sulfito sódico son decolorantes, el sulfato amónico y el sulfamato amónico se utilizan como materiales ignífugos y el sulfito sódico sirve para la impresión del algodón. El sulfato amónico y el disulfuro de carbono se utilizan en la fabricación de seda viscosa, y el tiosulfato sódico y el hidrosulfito sódico blanquean la pasta papelera y el papel. Además, el sulfato amónico y el tiosulfato sódico son agentes de curtido en la industria del cuero y el sulfamato amónico se utiliza en la producción de madera ignífuga y el tratamiento del papel de los cigarrillos.

El disulfuro de carbono es un disolvente de ceras, lacas, aceites y resinas, así como un lubricante de sopletes para cortar vidrio. Se utiliza para la vulcanización en frío del caucho y para producir catalizadores de petróleo. El sulfuro de hidrógeno, un subproducto del refinado del petróleo, sirve como aditivo de lubricantes sometidos a presiones extremas y lubricantes para cuchillas. Se utiliza en la producción de minerales y en la purificación de ácido clorhídrico y ácido sulfúrico.

\section{Riesgos}

\section{Sulfuro de hidrógeno}

El sulfuro de hidrógeno es un gas inflamable que arde con una llama azul, liberando dióxido de azufre, un gas muy irritante que posee un olor característico. L as mezclas de sulfuro de hidrógeno y aire en proporciones explosivas pueden detonar violentamente. Dado que los vapores son más pesados que el aire, tienden a acumularse en las zonas bajas y a diseminarse por la zona pegada al suelo hasta que entran en contacto con una fuente de ignición y se incendian. Cuando se expone al calor, el sulfuro de hidrógeno se descompone, dando hidrógeno y azufre, y cuando entra en contacto con agentes oxidantes como ácido nítrico, trifluoruro de cloro, etc., reaccionan violentamente y arden espontáneamente. Los agentes extintores recomendados para apagar incendios producidos por sulfuro de hidrógeno son dióxido de carbono, polvo seco químico y rociadores de agua.

Riesgos para la salud. Incluso a bajas concentraciones, el sulfuro de hidrógeno irrita los ojos y el tracto respiratorio. La intoxicación puede ser hiperaguda, aguda, subaguda o crónica. Las bajas concentraciones se detectan fácilmente por su olor característico a huevos podridos. Sin embargo, las exposiciones prolongadas adormecen el sentido del olfato y hacen del olor un medio muy poco fiable de advertencia. Las altas concentraciones pueden anular rápidamente el sentido del olfato. El sulfuro de hidrógeno penetra en el organismo a través del aparato respiratorio y se oxida rápidamente para formar compuestos de escasa toxicidad. $\mathrm{N}$ o existen fenómenos acumulativos y la eliminación tiene lugar a través del intestino, la orina y el aire espirado.

En los casos de intoxicación leve, por ejemplo, tras la exposición a una concentración de entre 10 y 500 ppm, la víctima puede sufrir cefalea durante varias horas, dolor en las piernas y rara vez pérdida de consciencia. En los casos de intoxicación moderada (entre 500 y 700 ppm), se produce pérdida de consciencia durante unos minutos, pero sin dificultad respiratoria. En los casos de intoxicación grave, la víctima entra en coma profundo con disnea, taquipnea y cianosis violeta-azulada en las pausas de apnea, taquicardia y convulsiones tónico-clónicas.

La inhalación de cantidades masivas de sulfuro de hidrógeno produce en poco tiempo anoxia, con el resultado de muerte por 
asfixia. La víctima puede sufrir convulsiones epileptiformes y quedarse aparentemente inconsciente, en ocasiones falleciendo sin volver a moverse. Este es un síndrome característico de la intoxicación por sulfuro de hidrógeno en los trabajadores de las cloacas. No obstante, en estos casos la intoxicación suele deberse a una mezcla de gases formada por metano, nitrógeno, dióxido de carbono y amoníaco.

En la intoxicación subaguda, los síntomas consisten en náuseas, malestar de estómago, eruptos fétidos, aliento con un olor característico a "huevos podridos" y diarrea. Estos trastornos del sistema digestivo pueden ir acompañados de trastornos del equilibrio, vértigo, sequedad e irritación de la nariz y la garganta con expectoración viscosa y mucopurulenta y estertores y roncus difusos.

Se han descrito casos de dolor retrosternal similar al observado en la angina pectoris, y el electrocardiograma puede mostrar una imagen característica de infarto de miocardio que, sin embargo, desaparece con bastante rapidez. Los ojos se ven afectados por edema palpebral, conjuntivitis bulbar y secreción mucopurulenta con, posiblemente, reducción de la agudeza visual, siendo todas estas lesiones normalmente bilaterales. Los trabajadores de las plantas azucareras y las cloacas conocen este síndrome como "ojos de gas". Se han descrito diversos efectos sistémicos, como cefalea, astenia, trastornos oculares, bronquitis crónica y presencia de una línea gris verdosa en las encías. Como ocurre con la intoxicación aguda, las lesiones oculares parecen predominar, con parálisis, meningitis, polineuritis e incluso alteración de la conducta.

En ratas, la exposición a sulfuro de hidrógeno tiene efectos teratogénicos.

M etabolismo y patología. El sulfuro de hidrógeno ejerce una acción tóxica general. Inhibe la enzima respiratoria de W arburg (citocromo oxidasa) por unión al hierro, bloqueando también los procesos de oxido-reducción. Esta inhibición de enzimas esenciales para la respiración celular puede tener consecuencias mortales. La sustancia ejerce una acción irritante local en las mucosas puesto que, al contacto con la humedad, forma sulfuros caústicos. Lo mismo puede ocurrir en el parénquima pulmonar como resultado de su combinación con las sustancias alcalinas de los tejidos. La investigación experimental ha demostrado que los sulfuros pasan a la circulación produciendo efectos respiratorios como polipnea, bradicardia e hipertensión por su acción en las zonas vasosensibles y reflexógenas de los nervios carótidos y el nervio de $\mathrm{H}$ ering.

El examen necrológico de las víctimas de intoxicación hiperaguda ha revelado la presencia de edema pulmonar y congestión de varios órganos. U n rasgo característico de la autopsia es el olor a sulfuro de hidrógeno que emana del cadáver diseccionado. O tras observaciones de interés son la presencia de hemorragias en la mucosa gástrica y la coloración verdosa de las partes más altas del intestino e incluso del cerebro.

\section{Disulfuro de carbono}

Los primeros casos de intoxicación por disulfuro de carbono se detectaron en el siglo XIX en Francia y Alemania, todos ellos relacionados con la vulcanización del caucho. Después de la primera Guerra Mundial aumentó la producción de rayón viscosa y, con ella, la incidencia de intoxicación aguda y crónica por disulfuro de carbono, que sigue siendo hoy día un problema grave en algunos países. T odavía se producen casos de intoxicación aguda y, sobre todo, crónica, si bien es verdad que los adelantos tecnológicos y la mejora de las condiciones de higiene de la fábricas han eliminado casi por completo estos problemas en otros países.

El disulfuro de carbono es principalmente una sustancia neurotóxica; por consiguiente, los síntomas más importantes son los que afectan a los sistemas nerviosos central y periférico. Las concentraciones de entre 0,5 y 0,7 mg/ I (entre 160 y 230 ppm) no causan síntomas agudos en el ser humano; las concentraciones de entre 1 y $1,2 \mathrm{mg} / \mathrm{l}$ (entre 320 y $390 \mathrm{ppm}$ ) pueden ser soportadas durante varias horas, con la aparición de cefalea y sensación de malestar después de 8 horas de exposición; a partir de una concentración de 3,6 mg/ I (1.150ppm) aparecen vértigos; las concentraciones de entre 6,4 y $10 \mathrm{mg} /$ I (entre 2.000 y $3.000 \mathrm{ppm}$ ) producen una intoxicación leve, con parestesia y respiración irregular al cabo de media hora o una hora. Con concentraciones de $15 \mathrm{mg} /$ I (4.800 ppm), la dosis es letal al cabo de 30 minutos; y con concentraciones superiores se produce pérdida de consciencia después de varias inhalaciones.

La intoxicación aguda ocurre sobre todo después de la exposición accidental a concentraciones muy altas. En poco tiempo se produce pérdida de consciencia, generalmente bastante profunda, con extinción de los reflejos de la córnea y de los tendones. La muerte sobreviene por bloqueo del centro respiratorio. Cuando el paciente recobra la consciencia, se observa agitación motora y desorientación. Si llega a recuperarse, suelen quedar secuelas, como trastornos psíquicos y lesiones permanentes en los sistemas nerviosos central y periférico. Los casos de intoxicación subaguda suelen producirse por exposición a concentraciones superiores a $2 \mathrm{mg} / \mathrm{l}$. Se manifiestan principalmente como trastornos mentales de tipo maníaco-depresivo; no obstante, a concentraciones menores los casos de polineuritis son los más frecuentes.

La intoxicación crónica empieza con debilidad, fatiga, cefalea, alteración del sueño, a menudo con pesadillas, parestesia y debilidad de las extremidades inferiores, pérdida de apetito y gastralgia. Aparecen también síntomas neurológicos y, con frecuencia, impotencia. La exposición continuada puede causar polineuritis, que supuestamente aparece después de trabajar a concentraciones de entre 0,3 y $0,5 \mathrm{mg} / \mathrm{I}$ durante varios años, siendo un síntoma precoz la disociación de los reflejos tendinosos en las extremidades inferiores. Las lesiones en los nervios cerebrales son menos frecuentes, pero se han observado casos de neuritis del nervio óptico y vestibular, así como alteración del olfato.

L os trabajadores varones expuestos pueden sufrir trastornos de tipo sexual (hipo y astenospermia), así como una disminución de la excreción de 17-cetoesteroides, 17-hidroxicorticosteroides y androsterona. En la mujer se han descrito trastornos de la menstruación, metrorragia y una mayor frecuencia de abortos. El disulfuro de carbono atraviesa la placenta. En animales se ha demostrado que produce efectos fetotóxicos y teratogénicos a concentraciones iguales 0 superiores a $32 \mathrm{ppm}$.

La relación entre el disulfuro de carbono y la aterosclerosis es un problema de especial interés. Antes de la segunda Guerra M undial no se prestó mucha atención a este hecho, pero a partir de entonces, cuando las intoxicaciones clásicas por disulfuro de carbono comenzaron a desaparecer en muchos países, varios autores observaron el desarrollo de aterosclerosis de los vasos cerebrales en trabajadores jóvenes de fábricas de rayón viscosa.

Los estudios olfalmodinamográficos en trabajadores jóvenes expuestos a concentraciones de disulfuro de carbono de entre 0,2 y $0,5 \mathrm{mg} / \mathrm{I}$ durante varios años demostraron que las presiones sanguíneas sistólica y diastólica en la retina eran superiores a las de la arteria braquial. Este incremento se debía a la hipertensión arterial en el cerebro y se vio que aparecían espasmos arteriales antes de la enfermedad subjetiva. En estos trabajadores se recomienda realizar una reoencefalografía para evaluar la función vascular cerebral, con la que se puede medir la resistencia eléctrica de la región craneal. La pulsación craneal provoca cambios en la resistencia, especialmente en los vasos intracraneales, pudiéndose, de este modo, detectar un posible aumento de la rigidez o espasmo de los vasos craneales. En los trabajadores 
japoneses se ha observado una mayor incidencia de microaneurismas y pequeñas hemorragias en la retina.

En los hombres que han sufrido una exposición crónica se ha comprobado la existencia de una hialinosis arteriocapilar, que constituye un tipo especial de arteriosclerosis por disulfuro de carbono. Por todo ello, el disulfuro de carbono debe ser considerado como un factor que contribuye al origen de este tipo de esclerosis, pero no como una causa directa. Esta hipótesis, así como los resultados de los análisis bioquímicos, han sido corroborados por otros informes que demuestran un aumento significativo de la arteriosclerosis en personas jóvenes expuestas a disulfuro de carbono. Con respecto a los riñones, parece ser que la glomeruloesclerosis de tipo Kimmelstiel-Wilson es más frecuente en las personas expuestas a disulfuro de carbono que en la población general. Investigadores británicos, finlandeses y de otros países han demostrado que la mortalidad por cardiopatías coronarias es mayor en los trabajadores varones expuestos durante muchos años a concentraciones relativamente bajas de disulfuro de carbono.

La absorción de disulfuro de carbono por vía respiratoria es bastante alta y, cuando se alcanza el estado de equilibrio de la inhalación, se retiene casi un $30 \%$ de la cantidad inhalada. EI tiempo necesario para alcanzar este estado varía desde un período muy corto hasta varias horas cuando se realiza un trabajo físico ligero. Una vez finalizada la exposición, una parte del disulfuro de carbono se excreta rápidamente a través del tracto respiratorio. La duración del período de desaturación depende del grado de exposición. A proximadamente entre el 80 y el $90 \%$ del disulfuro de carbono absorbido se metaboliza en el organismo con la formación de ditiocarbamatos y posible ciclización a tiazolidano. Debido al carácter nucleofílico del disulfuro de carbono, que reacciona especialmente con grupos $-\mathrm{SH}$, $-\mathrm{CH}, y-\mathrm{NH}_{2}$, es posible que se formen también otros metabolitos

El disulfuro de carbono se absorbe a través de la piel en cantidades considerables, pero menos que a través del tracto respiratorio. Los ditiocarbamatos quelan fácilmente metales como cobre, zinc, manganeso, cobalto y hierro. Se ha demostrado un mayor contenido de zinc en la orina de animales y seres humanos expuestos a disulfuro de carbono. Se cree asimismo que se produce una reacción directa con algunos de los metales contenidos en las metaloenzimas.

Las pruebas con microsomas hepáticos han demostrado la formación de oxisulfuro de carbono (OSC) y azufre atómico, que establece uniones covalentes con las membranas microsomales. 0 tros autores han observado en ratas que el disulfuro de carbono, tras sufrir una descomposición oxidativa, se une principalmente a la proteína P-450. En la orina se excreta una fracción del $1 \%$ como disulfuro de carbono, y de la fracción restante, se excreta casi un $30 \%$ como sulfatos inorgánicos y el resto como sulfatos orgánicos y algunos metabolitos desconocidos, uno de los cuales sería la tiourea.

Se piensa que la reacción del disulfuro de carbono con la vitamina $B_{6}$ es muy importante, ya que altera su metabolismo, lo que se manifiesta por una mayor excreción de ácido xanturénico y una menor excreción de ácido 4-piridoxínico, así como una menor concentración plasmática de piridoxina. Parece ser también que la utilización del cobre se ve alterada, según reflejan los niveles reducidos de ceruloplasmina en los animales y seres humanos expuestos. El disulfuro de carbono interfiere con el metabolismo cerebral de la serotonina por inhibición de ciertas enzimas. A demás, se ha demostrado que inhibe el factor de aclaramiento (lipasa activada por la heparina en presencia de lipoproteínas), interfiriendo así con el aclaramiento de las grasas del plasma sanguíneo. Esto puede provocar la acumulación de colesterol y sustancias lipídicas en las paredes de los vasos y acelerar el proceso aterosclerótico. Sin embargo, no todos los informes publicados sobre la inhibición del factor de aclaramiento resultan convincentes. Son muchos, aunque a menudo contradictorios, los estudios que hablan del comportamiento de las lipoproteínas y el colesterol en la sangre y los órganos de animales y seres humanos expuestos a disulfuro de carbono durante largos períodos de tiempo, o intoxicados por esta sustancia.

Se ha observado también una menor tolerancia a la glucosa del tipo de la diabetes química. Este fenómeno parece guardar relación con los altos niveles séricos de ácido xanturénico, que, como se ha demostrado en algunos experimentos, forma complejos con la insulina y reduce su actividad biológica. LoS estudios neuroquímicos han demostrado una alteración de los niveles de catecolaminas en el cerebro, así como en otros tejidos nerviosos. Estos hallazgos indican que el disulfuro de carbono altera la biosíntesis de las catecolaminas, probablemente inhibiendo la dopamina hidroxilasa por quelación del cobre enzimático.

El examen de animales intoxicados con disulfuro de carbono demuestra la aparición de una serie de cambios neurológicos. En el ser humano, los cambios consisten en una grave degeneración de la sustancia gris del cerebro y el cerebelo, alteraciones del sistema piramidal a nivel de la protuberancia y la médula, cambios degenerativos de los nervios periféricos y desintegración de sus vainas. También se han descrito casos de atrofia, hipertrofia y degeneración hialínica de las fibras musculares.

\section{Azufre y dióxido de azufre}

La extracción de minerales que contienen azufre puede ocasionar la inhalación de altas concentraciones de polvo de azufre en las minas y causar efectos nocivos en el sistema respiratorio. En las minas de azufre y al inicio de la exposición, el trabajador sufre catarro del tracto respiratorio superior, con tos y expectoración mucoide que puede contener granos de azufre. El asma es una complicación frecuente.

Los efectos agudos de la inhalación de azufre y sus compuestos inorgánicos afectan al sistema respiratorio superior (inflamación catarral de la mucosa nasal, que puede desarrollar una hipertrofia con abundante secreción nasal). Con frecuencia se produce traqueobronquitis, con falta de aliento (disnea), tos persistente y expectoración que, en ocasiones, puede ser sanguinolenta. También es posible que se produzca irritación de los ojos, con lagrimeo, fotofobia, conjuntivitis y blefaroconjuntivitis, y se han dado algunos casos de lesiones en el cristalino, con formación de opacidades e incluso cataratas y coriorretinitis focal.

En la piel pueden aparecer lesiones eritematosas y eczemas, así como signos de ulceración, especialmente cuando se trata de trabajadores cuyas manos sufren contactos prolongados y repetidos con azufre en polvo o compuestos sulfurosos, como por ejemplo durante los procesos de blanqueo y decoloración en la industria textil.

EI dióxido de azufre es uno de los contaminantes más comunes de los ambientes de trabajo. Se libera en grandes cantidades durante la fabricación de ácido sulfúrico, dióxido de azufre líquido y hierro colado, en el refinado de minerales ricos en azufre (cobre, plomo, zinc, etc.) y en la combustión de carbón rico en azufre. Se encuentra también como contaminante en la producción de celulosa, azúcar y superfosfatos, en la conservación de alimentos, en el refinado de petróleo, en procesos de decoloración y desinfección, etc.

El dióxido de azufre es un gas irritante y sus efectos se deben a la formación de ácido sulfuroso y sulfúrico en contacto con las mucosas húmedas. Puede penetrar en el organismo a través del tracto respiratorio, o también puede mezclarse con la saliva y al deglutir ésta, pasar al aparato digestivo en forma de ácido sulfuroso. Algunos autores creen que se absorbe a través de la piel. 
Debido a su gran solubilidad, el dióxido de azufre se distribuye rápidamente por todo el organismo, produciendo acidosis metabólica, con reducción de las reservas alcalinas de la sangre y eliminación compensatoria de amoníaco en la orina y alcalinización de la saliva. La acción tóxica general se manifiesta con trastornos del metabolismo de las proteínas y los hidratos de carbono, deficiencia de vitaminas B y C e inhibición de la oxidasa. En la sangre, el ácido sulfúrico se metaboliza a sulfatos que se excretan en la orina. Es probable que la absorción de grandes cantidades de dióxido de azufre tenga un efecto patológico en el sistema hematopoyético y pueda ocasionar metahemoglobina.

La intoxicación aguda se produce por inhalación de concentraciones muy altas de dióxido de azufre y se caracteriza por una irritación intensa de la conjuntiva y la mucosa del tracto respiratorio superior, con disnea y cianosis, seguidos en poco tiempo por alteración de la consciencia. La muerte puede sobrevenir por asfixia como consecuencia de un espasmo reflejo de la laringe, parada circulatoria súbita a nivel pulmonar o shock.

En la industria, la intoxicación por dióxido de azufre suele ser de naturaleza crónica. La acción irritante local de esta sustancia en las mucosas produce sensación de quemazón, sequedad y dolor en la nariz y la garganta, altera el sentido del olfato y causa secreción (que puede ser sanguinolenta), hemorragias nasales y tos seca o productiva, en ocasiones con esputos hemoptoicos. Se han descrito también problemas gástricos. Los síntomas objetivos consisten en hiperanemia pronunciada acompañada de edema de las mucosas de la nariz, la pared faríngea, las amigdalas y, en algunos casos, también la laringe. Se ha observado conjuntivitis crónica. En los estados más avanzados, el proceso se hace atrófico, con dilatación de los vasos sanguíneos en algunas regiones. Puede producirse ulceración del tabique nasal, que sangra fácilmente. Las personas con una larga historia de exposición a altas concentraciones de dióxido de azufre pueden sufrir bronquitis crónica acompañada de enfisema. Los síntomas iniciales consisten en una reducción de la capacidad vital en detrimento del volumen residual, hiperventilación compensatoria y reducción del consumo de oxígeno.

Estas manifestaciones suelen preceder al estadio radiológico, en el cual se aprecian sombras hiliares alargadas y densas, reticulación intensa producida por peribronquitis y, en algunos casos, bronquiectasia e incluso imágenes nodulares. Estas alteraciones radiológicas son bilaterales y más evidentes en las regiones medias y basales.

Pueden aparecer trastornos de la conducta y del sistema nervioso, probablemente debidos al efecto tóxico general del dióxido de azufre en el organismo.

La boca puede verse también afectada, con caries dentales y afección peridontal y gingival. Algunos pacientes se quejan de una destrucción dental rápida e indolora, caída de empastes y mayor sensibilidad de los dientes a los cambios de temperatura. Los síntomas objetivos consisten en pérdida de brillo y estriamiento y coloración amarillenta del esmalte.

El dióxido de azufre causa irritación de la piel que se agrava con la sudoración, un hecho que puede atribuirse a la conversión del dióxido de azufre en ácido sulfuroso en contacto con el sudor. Los síntomas iniciales del tracto respiratorio superior e inferior remiten con un tratamiento adecuado y el cese de la exposición a todas las fuentes de inflamación; no obstante, el pronóstico es sombrío en los casos más avanzados, sobre todo cuando se acompañan de bronquiectasias e insuficiencia cardíaca derecha.

Los efectos crónicos consisten principalmente en enfermedad broncopulmonar que, al cabo de varios años, puede complicarse con enfisema y bronquiectasia. Los senos maxilares y frontales se ven también afectados, generalmente de forma bilateral, y en algunos casos se observa pansinusitis. El examen radiológico del sistema respiratorio revela opacidades irregulares, especialmente en la región media-basal, mientras que las regiones apicales no suelen verse afectadas. En algunos casos se observa nodulación. La estratigrafía indica que el refuerzo de la trama pulmonar se debe a repleción vascular.

El examen de la función pulmonar puede indicar cambios en la ventilación pulmonar, aumento del consumo de oxígeno, reducción del volumen espiratorio por segundo y aumento del volumen residual. La capacidad de difusión del dióxido de carbono pulmonar se ve también afectada. Los trastornos suelen ser de naturaleza espasmódica. Los niveles de azufre en sangre pueden ser más elevados de lo normal, observándose un aumento de la excreción urinaria de sulfatos y de la proporción entre el azufre total y el orgánico.

El polvo de azufre y el dióxido de azufre están claramente relacionados con el origen de la bronquitis crónica. Irritan las mucosas y producen signos de obstrucción. La posibilidad de una esclerosis pulmonar inducida por el azufre ha sido objeto de numerosos debates, y la neumoconiosis por el azufre ("tioneumoconiosis") se describió por primera vez hace un siglo. Sin embargo, las investigaciones experimentales y las autopsias han demostrado que el azufre produce lesiones broncopulmonares crónicas pero no la formación de nódulos fibrosos que pudieran tener algún parecido con la silicosis.

\section{Otros compuestos de azufre}

Trióxido de azufre. La presión de vapor del trióxido de azufre aumenta rápidamente con la temperatura y, cuando la forma se funde, la presión alcanzada es explosiva. Por ello, los envases utilizados para su transporte y almacenamiento deben soportar presiones de entre 10 y 15 atm. El trióxido de azufre reacciona violentamente y de forma muy exotérmica con el agua para producir ácido sulfhídrico. Cuando se expone a la humedad del ambiente, desprende vapores y forma una neblina de ácido sulfúrico que puede llegar a ocupar todo el espacio útil y corroe los metales. Es un potente agente oxidante y, en estado líquido, carboniza la materia orgánica.

C uando se utiliza en estado sólido, líquido o gaseoso, o cuando se emplea ácido sulfúrico fumante o caliente, el trióxido de azufre contaminará el ambiente de trabajo. El dióxido de azufre presente en al aire se oxida por acción del oxígeno atmosférico para producir trióxido de azufre.

Esta sustancia se introduce en el organismo a través del tracto respiratorio y actúa como irritante local y como tóxico general, de forma análoga a la del dióxido de azufre, aunque su acción irritante es más pronunciada. Produce lesiones crónicas en el tracto respiratorio y puede disminuir las reservas alcalinas y alterar el metabolismo de las proteínas y los hidratos de carbono; se metaboliza a sulfato en la sangre y se elimina en la orina de la misma forma que el dióxido de azufre.

La acción tóxica del ácido sulfúrico fumante en el organismo es similar a la del ácido sulfúrico, si bien los síntomas objetivos son más pronunciados. Las medidas de salud y seguridad para el trióxido de azufre son similares a las recomendadas para el dióxido de azufre.

Sulfuro carbonilo (COS). El sulfuro carbonilo se encuentra en estado natural en los gases volcánicos y en las aguas sulfurosas. Se produce por reacción del ácido sulfúrico líquido con tiocianato amónico. El sulfuro carbonilo es bien conocido por su alto grado de toxicidad. Se ha observado que produce graves lesiones en el sistema nervioso, con efectos narcóticos a altas concentraciones y una acción irritante.

Es una potente sustancia oxidante y debe manipularse con las debidas precauciones. 
EI tetrafluoruro de azufre, el pentafluoruro de azufre $\left(\mathrm{S}_{2} \mathrm{~F}_{10}\right)$, el decafluoruro disulfúrico, el fluoruro sulfurilo $\left(\mathrm{SO}_{2} \mathrm{~F}_{2}\right)$, el oxifluoruro sulfúrico y el fluoruro de tionilo $\left(\mathrm{SO}_{2}\right)$ son todas ellas sustancias irritantes capaces de causar edema pulmonar en concentraciones superiores a los límites de exposición, debido a su insolubilidad en agua. El más peligroso es el pentafluoruro de azufre, que en presencia de humedad se hidroliza para formar fluoruro de hidrógeno y dióxido de azufre. Su acción irritante se considera más grave que la del fosgeno, no sólo en lo que se refiere a las dosis, sino también porque el edema pulmonar puede asociarse a hemorragias pulmonares. El fluoruro sulfurilo parece actuar principalmente como agente convulsivo en los animales de laboratorio.

L as medidas de salud y seguridad que deben adoptarse en caso de exposición a pentafluoruro de azufre son las mismas que las recomendadas para la mayoría de los compuestos que producen una intensa irritación. L os otros compuestos sulfofluorados deben de tratarse igual que el dióxido de azufre.

El cloruro de azufre es un líquido inflamable que conlleva un riesgo moderado de incendio asociado a la aparición de productos peligrosos con su descomposición: dióxido de azufre y cloruro de hidrógeno. Es un líquido humeante y corrosivo peligroso para los ojos; los vapores irritan los pulmones y las mucosas. En contacto con la piel, puede causar quemaduras químicas. Debe manipularse en recientos lo más cerrados posibles y los trabajadores deben utilizar equipos de protección personal, entre ellos equipos de protección ocular y respiratoria.

EI cloruro sulfurilo se forma por reacción directa del dióxido de azufre y el cloro en presencia de un catalizador que puede ser carbón vegetal, alcanfor o anhídrido acético. Se obtiene también calentando ácido clorosulfónico con sulfato de mercurio, antimonio o estaño como catalizador. Se utiliza en la fabricación de fármacos y colorantes y generalmente en síntesis orgánicas como agente de cloración, deshidratación o acilación.

El cloruro sulfurilo es un líquido corrosivo que, al contactar con el organismo, produce quemaduras. Sus vapores irritan el tracto respiratorio. Las precauciones que deben adoptarse son similares a las recomendadas para el cloruro de azufre.

\section{Medidas de salud y seguridad}

El polvo de azufre en suspensión conlleva peligro de incendio y explosión. Existe también el riesgo de una liberación insidiosa de dióxido de azufre que ocasione la inhalación de vapores irritantes. Los vapores liberados durante la fusión del azufre pueden contener suficiente cantidad de sulfuro de hidrógeno y disulfuro de carbono para permitir la ignición de la mezcla de aire y vapor al contactar con una superficie caliente. Este tipo de ignición puede originar la transmisión de las llamas al azufre fundido.

Los principales peligros durante la manipulación, el transporte y el almacenamiento del azufre fundido se deben a la inflamabilidad de la sustancia y a la posible liberación, durante su enfriamiento, de sulfuro de hidrógeno, que se inflama más fácilmente y es explosivo en el aire a concentraciones de entre 4,3 y $45 \%$. LoS trabajadores empleados en la extracción de azufre deben disponer de equipos autónomos de protección respiratoria, sobre todo para las operaciones de rescate. Estará prohibido fumar durante el transporte y la manipulación del azufre y en las zonas donde éste se almacena. Se evitará el contacto del azufre líquido o sublimado con una fuente de ignición y los almacenes de azufre no deben estar situados cerca de agentes oxidantes. La carga y descarga de azufre líquido requiere la adopción de medidas especiales de protección y prevención de incendios. El transporte y almacenamiento de azufre exige unos procedimientos adecuados de ventilación y evacuación del sulfuro de hidrógeno, así como un control periódico de su concentración, y protección de los tanques contra su corrosión por el sulfuro de hidrógeno.

El azufre es un mal conductor de la electricidad y tiende a acumular electricidad estática durante su transporte o procesado. L as descargas de electricidad estática pueden incendiar el polvo de azufre. Los depósitos pirofóricos de azufre ferroso que se forman en las paredes de los tanques constituyen también un peligro. En los montones de azufre son frecuentes los incendios y pueden comenzar de nuevo cuando, aparentemente, el incendio inicial haya quedado extinguido.

El disulfuro de carbono es también muy inflamable y explosivo.

El control del dióxido de azufre debe orientarse principalmente a reducir las emisiones de gas y a asegurar una ventilación adecuada para mantener las concentraciones de dióxido de azufre en el lugar de trabajo por debajo de los niveles máximos permisibles. Lo más aconsejable es realizar todos los procesos en cerrado. Los trabajadores deben disponer de equipos de protección respiratoria siempre que puedan verse expuestos, en circunstancias excepcionales, a concentraciones peligrosas.

Deben tomarse precauciones para evitar la emisión de polvo de azufre a la atmósfera y se recomienda el uso de respiradores cuando la concentración atmósferica de polvo sobrepase los límites máximos permisibles.

Los reconocimientos médicos previos al empleo deben servir para asegurar que personas con bronquitis o asma no se vean expuestas al azufre. Estas contraindicaciones deben también considerarse en los reconocimientos periódicos, en los que la exploración clínica se suplementará con una radiografía de tórax. 
TABLAS DE COMPUESTOS INORGANICOS DE AZUFRE

\begin{tabular}{|c|c|c|c|}
\hline Producto químico & Sinónimos/ Código UN & $\mathrm{N}$ úmero CAS & Fórmula estructural \\
\hline AZUFRE & $\begin{array}{l}\text { Azufre en polvo; azufre sublimado; azufre vocle** terrestre; Hexasul; } \\
\text { Kocide; Tesuloid; Thiolux; Thiovit } \\
\text { UN2448 } \\
\text { UN1350 }\end{array}$ & $7704-34-9$ & \\
\hline BISULFITO SODICO & $\begin{array}{l}\text { Sulfito sódico hidrógeno; sulfito monosódico; hidrógeno sulfito sódico; } \\
\text { sulfito sódico; sulfhidrato sódico; sal monosódica del ácido sulfuroso }\end{array}$ & $7631-90-5$ & N \\
\hline CLORURO SULFURILO & $\begin{array}{l}\text { Sulfonil cloruro; oxicloruro sulfúrico; cloruro de sulfurilo } \\
\text { UN1834 }\end{array}$ & $7791-25-5$ & \\
\hline CLORURO TIONILO & $\begin{array}{l}\text { Sulfinil cloruro; óxido de cloruro sulfúrico; dicloruro sulfuroso; } \\
\text { oxicloruro sulfuroso; tionil dicloruro } \\
\text { UN1836 }\end{array}$ & $7719-09-7$ & \\
\hline DIOXIDO DE AZUFRE & $\begin{array}{l}\text { Dióxido de azufre, ácido sulfuroso anhidro; anhídrido sulfuroso; } \\
\text { óxido sulfuroso; óxido de azufre; superóxido de azufre } \\
\text { UN1079 }\end{array}$ & $7446-09-5$ & \\
\hline DISULFURO DE CARBONO & $\begin{array}{l}\text { Bisulfuro de carbono; sulfuro de carbono; anhídrido ditiocarbónico; } \\
\text { anhídrido sulfocarbónico } \\
\text { UN1131 }\end{array}$ & $75-15-0$ & \\
\hline HIDROSULFITO SODICO & $\begin{array}{l}\text { Sal disódica del ácido ditionoso; D-ox; Hydrolin; K-brite; Reductone; } \\
\text { ditionita sódica; sodio ditionita; sulfoxilato sódico } \\
\text { UN1384 }\end{array}$ & $7775-14-6$ & \\
\hline METABISULFITO SODICO & $\begin{array}{l}\text { Disulfito disódico; metabisulfito disódico; pirosulfito disódico; sal disódica } \\
\text { del ácido disulfuroso; sal disódica del ácido pirosulfuroso; disulfito sódico; } \\
\text { pirosulfito sódico }\end{array}$ & $7681-57-4$ & \\
\hline PERSULFATO AMONICO & $\begin{array}{l}\text { Peroxidisulfato amónico; peroxidisulfato diamónico; } \\
\text { peroxidisulfato amónico; sal diamónica del ácido peroxidisulfúrico } \\
\text { UN1444 }\end{array}$ & $7727-54-0$ & \\
\hline PERSULFATO POTASICO & $\begin{array}{l}\text { Anthion; persulfato dipotásico; sal dipotásica del ácido peroxidisulfúrico; } \\
\text { peroxidisulfato potásico } \\
\text { UN1492 }\end{array}$ & $7727-21-1$ & $\mathrm{k}^{+}$ \\
\hline PERSULFATO SODICO & $\begin{array}{l}\text { Peroxidisulfato sódico; sal disódica del ácido peroxisulfúrico } \\
\text { UN1505 }\end{array}$ & $7775-27-1$ & $\mathrm{Na}^{+} \mathrm{O}-$ \\
\hline PIROSULFURO POTASICO & $\begin{array}{l}\text { Disulfuro dipotásico; sal dipotásica del ácido disulfuroso; disulfuro potásico; } \\
\text { sal dipotásica del ácido pirosulfuroso }\end{array}$ & $16731-55-8$ & $\|_{-s-1}^{0}$ \\
\hline SULFAMATO AMONICO & $\begin{array}{l}\text { Amcide; amidosulfonato amónico; amidosulfato amónico; } \\
\text { sulfamato amónico; sulfamato; sulfamato amonio }\end{array}$ & $7773-06-0$ & $\prod_{S-\mathrm{NH}_{2}}^{0}$ \\
\hline
\end{tabular}




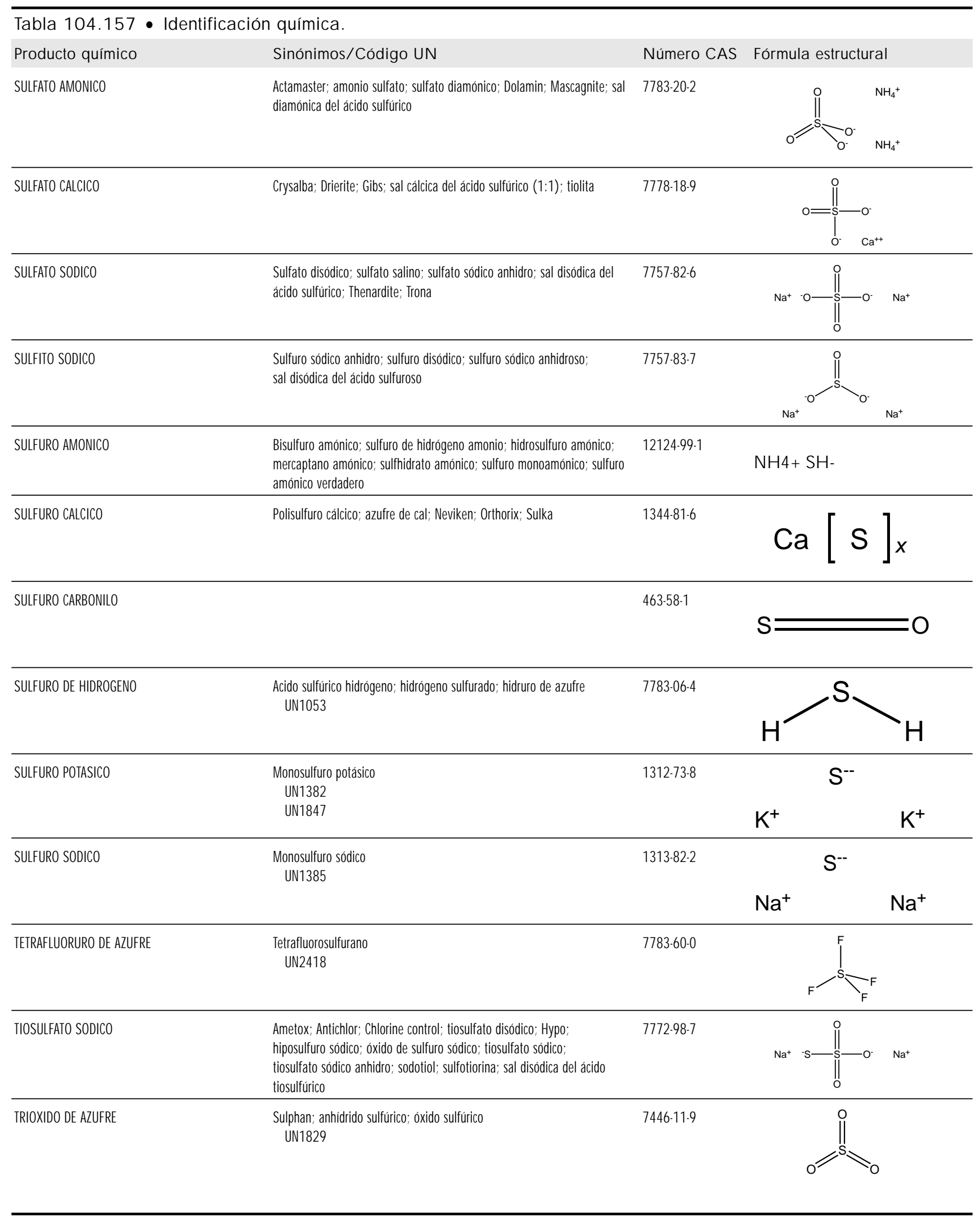




\begin{tabular}{|c|c|c|c|c|c|c|}
\hline \multirow[b]{2}{*}{$\begin{array}{l}\text { Denominación } \\
\text { química } \\
\text { N úmero CAS }\end{array}$} & \multicolumn{4}{|c|}{ Tarjetas Internacionales sobre la Seguridad de los Productos Q uímicos } & \multicolumn{2}{|c|}{ N IO SH (EE.UU.) } \\
\hline & $\begin{array}{l}\text { Período } \\
\text { corto de } \\
\text { exposición }\end{array}$ & $\begin{array}{l}\text { Período } \\
\text { largo de } \\
\text { exposición }\end{array}$ & $\begin{array}{l}\text { Vías de } \\
\text { exposición }\end{array}$ & Síntomas & $\begin{array}{l}\text { O rganos } \\
\text { afectados } \\
\text { Vías de } \\
\text { entrada }\end{array}$ & Síntomas \\
\hline $\begin{array}{l}\text { AZUFRE } \\
\quad 7704-34-9\end{array}$ & $\begin{array}{l}\text { ojos; piel; } \\
\text { tract resp; } \\
\text { pulmones }\end{array}$ & piel; tract resp & $\begin{array}{r}\text { Inhalación } \\
\text { Piel } \\
\text { 0jos } \\
\text { Ingestión }\end{array}$ & $\begin{array}{l}\text { Sensación de quemazón, tos, dolor de } \\
\text { garganta } \\
\text { Enrojecimiento } \\
\text { Enrojecimiento, dolor, visión borrosa } \\
\text { Sensación de quemazón, diarrea }\end{array}$ & & \\
\hline $\begin{array}{l}\text { DIOXIDO DE AZUFRE } \\
7446-09.5\end{array}$ & $\begin{array}{l}\text { ojos; tract resp; } \\
\text { pulmones; piel }\end{array}$ & pulmones & $\begin{array}{r}\text { Inhalación } \\
\text { Piel } \\
\text { 0jos } \\
\end{array}$ & $\begin{array}{l}\text { Irritación del tracto respiratorio, tos, ahogo, } \\
\text { estornudos } \\
\text { En contacto con el líquido: congelación } \\
\text { Irritación, quemaduras }\end{array}$ & $\begin{array}{l}\text { Sis resp; piel; ojos } \\
\text { Inh; con }\end{array}$ & $\begin{array}{l}\text { Irrit ojos, nariz, garganta; rin; } \\
\text { ahogo, tos; broncoconstricción } \\
\text { por reflejo; liq: congelación }\end{array}$ \\
\hline $\begin{array}{l}\text { DISULFURO DE CARBONO } \\
75-15-0\end{array}$ & $\begin{array}{l}\text { ojos; piel; } \\
\text { tract resp; } \\
\text { pulmones; SNC }\end{array}$ & & $\begin{array}{l}\text { Inhalación } \\
\text { Piel } \\
\text { 0jos }\end{array}$ & $\begin{array}{l}\text { Confusión, mareo, sopor, cefalea, náuseas, } \\
\text { disnea, vómitos, debilidad, irritabilidad, } \\
\text { alucinaciones } \\
\text { Puede absorberse, sequedad de piel, } \\
\text { enrojecimiento } \\
\text { Enrojecimiento, dolor }\end{array}$ & $\begin{array}{l}\text { SNC; SNP; SCV; } \\
\text { ojos; riñones; } \\
\text { hígado; piel; sis } \\
\text { repro } \\
\text { Inh; abs; ing; con }\end{array}$ & $\begin{array}{l}\text { Mar, cef, insomnio, ftg, ner, } \\
\text { anor, bajo-p; psicosis; polineur; } \\
\text { síndrome de tipo Parkinson; } \\
\text { cambios oculares; cardiopatía } \\
\text { coronaria; gastritis; lesiones } \\
\text { renales y hepáticas; } \\
\text { quemaduras en ojos y piel; } \\
\text { derm; efectos repro }\end{array}$ \\
\hline $\begin{array}{l}\text { SULFAMATO AM ONICO } \\
7773-06.0\end{array}$ & & & & & $\begin{array}{l}\text { Sis resp; ojos } \\
\text { Inh; con }\end{array}$ & $\begin{array}{l}\text { Irrit ojos, nariz, garganta; tos, } \\
\text { dis }\end{array}$ \\
\hline $\begin{array}{l}\text { SULFURO DE HIDROGENO } \\
7783-06-4\end{array}$ & & & & & $\begin{array}{l}\text { Sis resp; ojos; SNC } \\
\text { Inh; con }\end{array}$ & $\begin{array}{l}\text { Irrit ojos, sis resp; apnea, } \\
\text { coma, convuls; conj, dolor de } \\
\text { ojos, lag, foto, vesic córn; } \\
\text { mar, cef, ftg, irrit, insom; trast } \\
\text { Gl }\end{array}$ \\
\hline $\begin{array}{l}\text { SULFURO POTASICO } \\
1312-73-8\end{array}$ & $\begin{array}{l}\text { ojos; piel; } \\
\text { tract resp; } \\
\text { pulmones }\end{array}$ & & $\begin{array}{l}\text { Piel } \\
\text { 0jos }\end{array}$ & $\begin{array}{l}\text { Tos, mareo, sopor, cefalea, náuseas, disnea, } \\
\text { dolor de garganta, debilidad, los síntomas } \\
\text { pueden tener efectos diferidos } \\
\text { Enrojecimiento, quemaduras en la piel, dolor } \\
\text { Enrojecimiento, dolor, quemaduras profundas } \\
\text { graves }\end{array}$ & & \\
\hline
\end{tabular}

\begin{tabular}{|c|c|c|c|}
\hline $\begin{array}{l}\text { Denominación química } \\
\mathrm{N} \text { úmero CAS }\end{array}$ & Físicos & Q uímicos & $\begin{array}{l}\text { Clase o división } \\
\text { UN / Riesgos } \\
\text { subsidiarios }\end{array}$ \\
\hline $\begin{array}{l}\text { AZUFRE } \\
77704-34-9\end{array}$ & $\begin{array}{l}\text { Posibilidad de explosión } \\
\text { pulverulenta cuando se } \\
\text { encuentra en forma de } \\
\text { polvo o gránulos y se } \\
\text { mezcla con el aire En } \\
\text { seco puede cargarse } \\
\text { electrostáticamente como } \\
\text { resultado de turbulencias, } \\
\text { transporte neumático, } \\
\text { vertido, etc. }\end{array}$ & $\begin{array}{l}\text { En su combustión forma óxidos de azufre, entre ellos dióxido de azufre Reacciona } \\
\text { violentamente con oxidantes fuertes, con peligro de incendio y explosión }\end{array}$ & 4.1 \\
\hline
\end{tabular}


Tabla 104.159 • Riesgos físicos y químicos.

\begin{tabular}{|c|c|c|c|}
\hline $\begin{array}{l}\text { Denominación química } \\
\mathrm{N} \text { úmero CAS }\end{array}$ & Físicos & Q uímicos & $\begin{array}{l}\text { Clase o división } \\
\text { UN / Riesgos } \\
\text { subsidiarios }\end{array}$ \\
\hline $\begin{array}{l}\text { CLORURO TIONILO } \\
7719-09-7\end{array}$ & & & 8 \\
\hline $\begin{array}{l}\text { DIOXIDO DE AZUFRE } \\
7446-09.5\end{array}$ & & & 2.318 \\
\hline $\begin{array}{l}\text { DISULFURO DE CARBONO } \\
75-15-0\end{array}$ & $\begin{array}{l}\text { El vapor es más pesado } \\
\text { que el aire y puede } \\
\text { desplazarse a ras del } \\
\text { suelo; posibilidad de } \\
\text { ignición a distancia } \\
\text { Pueden generarse } \\
\text { cargas electrostáticas } \\
\text { omo resultado de flujo, } \\
\text { agitación, etc. }\end{array}$ & $\begin{array}{l}\text { Puede descomponerse explosivamente por impacto, fricción o sacudida Puede explotar al } \\
\text { calentarse Puede arder espontáneamente en contacto con el aire o superficies calientes, } \\
\text { liberando humos tóxicos de dióxido de azufre Reacciona violentamente con oxidantes, con } \\
\text { peligro de incendio y explosión Ataca algunos tipos de plásticos, caucho y revestimientos }\end{array}$ & $3 / 6.1$ \\
\hline $\begin{array}{l}\text { HIDROSULFITO SODICO } \\
7775-14-6\end{array}$ & & & 4.2 \\
\hline $\begin{array}{l}\text { PERSULFATO AMONICO } \\
7727-54-0\end{array}$ & & & 5.1 \\
\hline $\begin{array}{l}\text { PERSULFATO POTASICO } \\
7727-21-1 \\
\end{array}$ & & & 5.1 \\
\hline $\begin{array}{l}\text { PERSULFATO SODICO } \\
7775-27-1 \\
\end{array}$ & & & 5.1 \\
\hline $\begin{array}{l}\text { SULFATO AM ONICO } \\
7783-20-2\end{array}$ & & & 8 \\
\hline $\begin{array}{l}\text { SULFURO CARBONILO } \\
463-58-1 \\
\end{array}$ & & & $2.3 / 2.1$ \\
\hline $\begin{array}{l}\text { SULFURO DE HIDROGENO } \\
7783-06-4\end{array}$ & & & $2.3 / 2.1$ \\
\hline $\begin{array}{l}\text { SULFURO POTASICO } \\
1312-73-8\end{array}$ & $\begin{array}{l}\text { Posibilidad de explosión } \\
\text { pulverulenta cuando se } \\
\text { encuentra en forma de } \\
\text { polvo o granular y se } \\
\text { mezcla con el aire }\end{array}$ & $\begin{array}{l}\text { Al calentarse puede arder o explotar violentamente Puede descomponerse explosivamente } \\
\text { por impacto, fricción o sacudida Puede arder espontáneamente en contacto con el aire, } \\
\text { formando sulfuro de hidrógeno La solución en agua es una base fuerte, reacciona } \\
\text { violentamente con ácido y es corrosiva, formando dióxido de azufre }\end{array}$ & 4.2 \\
\hline $\begin{array}{l}\text { SULFURO SODICO } \\
1313-82-2 \\
\end{array}$ & & & 4.2 \\
\hline $\begin{array}{l}\text { TETRAFLUORURO DE AZUFRE } \\
7783-60-0\end{array}$ & & & 2.318 \\
\hline $\begin{array}{l}\text { TRIOXIDO DE AZUFRE } \\
7446-11-9\end{array}$ & & & 8 \\
\hline
\end{tabular}




\begin{tabular}{|c|c|c|c|c|c|c|c|c|c|c|c|}
\hline $\begin{array}{l}\text { Denominación química } \\
\mathrm{N} \text { úmero CAS }\end{array}$ & Color/ Forma & $\begin{array}{l}\text { p.e. } \\
\left({ }^{\circ} \mathrm{C}\right)\end{array}$ & $\begin{array}{l}\text { p.f. } \\
(\stackrel{\circ}{ }=)\end{array}$ & $\begin{array}{l}\text { p.m.l } \\
\text { (g/ } \\
\text { mol) }\end{array}$ & $\begin{array}{l}\text { Solubilidad } \\
\text { en agua }\end{array}$ & $\begin{array}{l}\text { Densidad } \\
\text { relativa } \\
\text { (agua }=1 \text { ) }\end{array}$ & $\begin{array}{l}\text { Densidad } \\
\text { relativa } \\
\text { de vapor } \\
\text { (aire=1) }\end{array}$ & $\begin{array}{l}\text { Pvap/ } \\
(\mathrm{kPa})\end{array}$ & $\begin{array}{l}\text { Límit. } \\
\text { inflam. }\end{array}$ & $\begin{array}{l}\text { p.ig. } \\
(\because C)\end{array}$ & $\begin{array}{l}\text { p.aut } \\
\text { ig. } \\
\left({ }^{\circ} \mathrm{C}\right)\end{array}$ \\
\hline $\begin{array}{l}\text { AZUFRE } \\
\text { 7704-34-9 }\end{array}$ & $\begin{array}{l}\text { cristales de color } \\
\text { ámbar ortorrómbicos, } \\
\text { cicloocta o } \\
\text { alfa-azufre; cristales } \\
\text { con forma de aguja, } \\
\text { monoclínicos, } \\
\text { cicloocta o } \\
\text { beta-azufre, } \\
\text { brillantes, opacos, de } \\
\text { color amarillo claro; } \\
\text { el azufre sublimado y } \\
\text { lavado tiene forma } \\
\text { de polvo cristalino } \\
\text { fino amarillo }\end{array}$ & 444,6 & $112-120$ & 32,06 & insol & 2,1 & $\begin{array}{l}0,00005 \\
\text { libras/ pies } \\
\text { @ } 32^{\circ} \mathrm{C}\end{array}$ & $\begin{array}{l}3,96 \times 10^{-6} \\
\mathrm{~mm} \mathrm{Hg} \\
\text { @ } 30,4^{\circ} \mathrm{C}\end{array}$ & $\begin{array}{l}35 \mathrm{mg} / \mathrm{l} \mathrm{li} \\
1400 \mathrm{ls}\end{array}$ & 207 & 232 \\
\hline $\begin{array}{l}\text { BISULFITO SODICO } \\
\text { 7631-90-5 }\end{array}$ & $\begin{array}{l}\text { cristal blanco o polvo } \\
\text { cristalino; polvo } \\
\text { granular; blanco, } \\
\text { monoclínico }\end{array}$ & & & 104,07 & $\begin{array}{l}3,5 \text { partes en } \\
\text { frío, } 2 \text { partes en } \\
\text { ebullición }\end{array}$ & 1,48 & & & & & \\
\hline $\begin{array}{l}\text { BROMURO DE AZUFRE } \\
13172-31-1\end{array}$ & líquido amarillo & 54 & -40 & 223,93 & se descompone & 2,63 & & & & & \\
\hline $\begin{array}{l}\text { CLORURO SULFURILO } \\
7791-25-5\end{array}$ & $\begin{array}{l}\text { líquido móvil, } \\
\text { incoloro }\end{array}$ & 69,3 & $-54,1$ & 134,98 & & 1,6674 & 4,7 & $\begin{array}{l}100 \mathrm{~mm} \mathrm{Hg} \\
@ 17,8^{\circ} \mathrm{C}\end{array}$ & & & \\
\hline $\begin{array}{l}\text { CLORURO TIONILO } \\
7719-09-7\end{array}$ & $\begin{array}{l}\text { líquido incoloro, } \\
\text { amarillo claro o } \\
\text { rojizo; líquido } \\
\text { refractario, } \\
\text { humeante, incoloro o } \\
\text { amarillo claro }\end{array}$ & 76 & $-104,5$ & 118,98 & & 1,638 & 4,1 & $\begin{array}{l}110 \mathrm{~mm} \mathrm{Hg} \\
\text { @ } 26^{\circ} \mathrm{C}\end{array}$ & & & \\
\hline $\begin{array}{l}\text { DIOXIDO DE AZUFRE } \\
7446-09-5\end{array}$ & líquido incoloro o gas & -10 & $.72,7$ & 64,07 & $8,5 \% @ 25^{\circ} \mathrm{C}$ & $\begin{array}{l}2,927 \mathrm{~g} / \mathrm{I} \\
\text { (gas); } 1,434 \\
\text { (líquido) }\end{array}$ & 2,2 & 330 & & & \\
\hline $\begin{array}{l}\text { DISULFURO DE CARBONO } \\
75-15-0\end{array}$ & $\begin{array}{l}\text { líquido móvil; líquido } \\
\text { transparente, } \\
\text { incoloro } 0 \\
\text { ligeramente amarillo }\end{array}$ & 46,5 & $-111,5$ & 76,14 & $0,2 \mathrm{~g} / 100 \mathrm{ml}$ & 1,2632 & 2,67 & $\begin{array}{l}48 \\
@ 25^{\circ} \mathrm{C}\end{array}$ & $\begin{array}{l}1,3 \mathrm{li} \\
50 \mathrm{ls}\end{array}$ & $-30 c c$ & 90 \\
\hline $\begin{array}{l}\text { HIDROSULFITO SODICO } \\
7775-14-6\end{array}$ & $\begin{array}{l}\text { polvo cristalino } \\
\text { blanco o blanco } \\
\text { grisáceo }\end{array}$ & & & 176,10 & & & & & & & \\
\hline $\begin{array}{l}\text { METABISULFITO SODICO } \\
7681-57-4\end{array}$ & $\begin{array}{l}\text { cristales blancos } 0 \\
\text { polvo cristalino } \\
\text { blanco } 0 \text { amarillento }\end{array}$ & & $\begin{array}{l}150 \text { se } \\
\text { des- } \\
\text { compone }\end{array}$ & 190,13 & $\begin{array}{l}54 \mathrm{~g} / 100 \mathrm{cc} ; \\
81,7 \mathrm{~g} / 100 \mathrm{cc} \\
@ 100{ }^{\circ} \mathrm{C}\end{array}$ & 1,4 & & & & & \\
\hline $\begin{array}{l}\text { PERSULFATO AMONICO } \\
7727-54.0\end{array}$ & cristales blancos & & $\begin{array}{l}120 \text { se } \\
\text { des- } \\
\text { compone }\end{array}$ & 228,19 & muy sol & 1,98 & & & & & \\
\hline $\begin{array}{l}\text { PERSULFATO POTASICO } \\
7727-21-1\end{array}$ & $\begin{array}{l}\text { cristal triclínico } \\
\text { incoloro; cristal } \\
\text { blanco }\end{array}$ & & & 270,3 & $\begin{array}{l}1,75 \mathrm{~g} / 100 \mathrm{cc} \\
@ 0^{\circ} \mathrm{C} ; \\
5,2 \mathrm{~g} / 100 \mathrm{cc} \\
@ 20^{\circ} \mathrm{C}\end{array}$ & 2,47 & & & & & \\
\hline $\begin{array}{l}\text { PIROSULFITO POTASICO } \\
\text { 16731-55-8 }\end{array}$ & $\begin{array}{l}\text { cristales blanco o } \\
\text { polvo cristalino; } \\
\text { placas monoclínicas } \\
\text { incoloras }\end{array}$ & & $\begin{array}{l}190 \text { se } \\
\text { des- } \\
\text { compone }\end{array}$ & 222,32 & muy sol & 2,34 & & & & & \\
\hline
\end{tabular}




\begin{tabular}{|c|c|c|c|c|c|c|c|c|c|c|}
\hline $\begin{array}{l}\text { Denominación química } \\
\mathrm{N} \text { úmero CAS }\end{array}$ & Color/ Forma & $\begin{array}{l}\text { p.e. } \\
\left({ }^{\circ} \mathrm{C}\right)\end{array}$ & $\begin{array}{l}\text { p.f. } \\
(\stackrel{0}{ } C)\end{array}$ & $\begin{array}{l}\text { p.m.l } \\
\text { (g/ } \\
\text { mol) }\end{array}$ & $\begin{array}{l}\text { Solubilidad } \\
\text { en agua }\end{array}$ & $\begin{array}{l}\text { Densidad } \\
\text { relativa } \\
\text { (agua }=1 \text { ) }\end{array}$ & $\begin{array}{l}\text { Densidad } \\
\text { relativa } \\
\text { de vapor } \\
\text { (aire=1) }\end{array}$ & $\begin{array}{l}\text { Pvap/ } \\
(\mathrm{kPa})\end{array}$ & $\begin{array}{l}\text { Límit. } \\
\text { inflam. }\end{array}$ & $\begin{array}{ll}\text { p.ig. p.aut } & \text { put } \\
(\stackrel{\circ}{ } \mathrm{C}) & \text { ig. } \\
& \left({ }^{\circ} \mathrm{C}\right)\end{array}$ \\
\hline $\begin{array}{l}\text { SULFAMATO AM ONICO } \\
7773-06-0\end{array}$ & $\begin{array}{l}\text { cristales ( placas } \\
\text { grandes); sustancia } \\
\text { cristalina incolora } 0 \\
\text { blanca; marrón } \\
\text { grisácea; sólido } \\
\text { cristalino brillante de } \\
\text { color amarillo-naranja }\end{array}$ & & 131 & 114,13 & $\begin{array}{l}166,6 \mathrm{~g} / 100 \mathrm{ml} \\
@ 10^{\circ} \mathrm{C} ; \\
2,16 \mathrm{~kg} / \mathrm{kg} \\
@ 25^{\circ} \mathrm{C}\end{array}$ & 1 (sólido) & & & & \\
\hline $\begin{array}{l}\text { SULFATO AMONICO } \\
7783-20-2\end{array}$ & $\begin{array}{l}\text { cristales rómbicos } \\
\text { incoloros; cristales } \\
\text { ortorrómbicos o } \\
\text { gránulos blancos; } \\
\text { cristales blancos o } \\
\text { marrón grisáceos } \\
\text { según su grado de } \\
\text { pureza }\end{array}$ & & & 132,14 & sol & $1,769 @ 50^{\circ} \mathrm{C}$ & & & & \\
\hline $\begin{array}{l}\text { SULFATO CALCICO } \\
7778-18.9\end{array}$ & $\begin{array}{l}\text { los cristales naturales } \\
\text { de anhidrito son } \\
\text { incoloros, rómbicos o } \\
\text { monoclínicos; los } \\
\text { cristales naturales de } \\
\text { anhidrito son } \\
\text { ortorrómbicos, el } \\
\text { color varía (blanco } \\
\text { con vetas azules, } \\
\text { grises o rojizas, } 0 \\
\text { rojo ladrillo); el } \\
\text { anhidrito insoluble } \\
\text { presenta la misma } \\
\text { estructura cristalina } \\
\text { que el anhidrito } \\
\text { mineral }\end{array}$ & 1193 & 1450 & 136,14 & lig sol & 2,960 & & & & \\
\hline $\begin{array}{l}\text { SULFATO SODICO } \\
7757-82.6\end{array}$ & $\begin{array}{l}\text { polvo blanco } 0 \\
\text { cristales } \\
\text { bipiramidales } \\
\text { ortorrómbicos; } \\
\text { cristales monoclínicos } \\
\text { a la temperatura de } \\
160-185^{\circ} \mathrm{C}\end{array}$ & & 888 & 142,06 & $\begin{array}{l}\text { sol en unas } 3,6 \\
\text { partes }\end{array}$ & 2,671 & & & & \\
\hline $\begin{array}{l}\text { SULFITO SODICO } \\
1313-82-2\end{array}$ & $\begin{array}{l}\text { cristales } \\
\text { transparentes; } \\
\text { grumos o escamas de } \\
\text { color amarillo o rojo } \\
\text { ladrillo; cristales } \\
\text { cúbicos o gránulos; } \\
\text { cristales amorfos, de } \\
\text { color blanco o } \\
\text { amarillo-rosáceo }\end{array}$ & & 1180 & 78,05 & $18,6 \mathrm{~g} / 100 \mathrm{~g}$ & $\begin{array}{l}1,856 \\
@ 14^{\circ} \mathrm{C} / 4^{\circ} \mathrm{C}\end{array}$ & & & & \\
\hline $\begin{array}{l}\text { SULFITO SODICO } \\
7757-83-7\end{array}$ & $\begin{array}{l}\text { cristales pequeños } 0 \\
\text { polvo; polvo blanco } 0 \\
\text { prismas hexagonales }\end{array}$ & & & 128,06 & $\begin{array}{l}\text { sol en } 3,2 \\
\text { partes }\end{array}$ & $\begin{array}{l}2,633 \\
@ 15,4^{\circ} \mathrm{C}\end{array}$ & & & & \\
\hline $\begin{array}{l}\text { SULFURO AMONICO } \\
12124-99-1\end{array}$ & cristales amarillos & & $\begin{array}{l}\text { se des- } \\
\text { compone }\end{array}$ & 68,14 & muy sol & & & & & \\
\hline $\begin{array}{l}\text { SULFURO CALCICO } \\
1344-81 \cdot 6\end{array}$ & $\begin{array}{l}\text { líquido maloliente de } \\
\text { color naranja intenso }\end{array}$ & & & & & $\begin{array}{l}1,28 \\
\text { @ } 15,6^{\circ} \mathrm{C}\end{array}$ & & & & \\
\hline
\end{tabular}




\begin{tabular}{|c|c|c|c|c|c|c|c|c|c|c|}
\hline $\begin{array}{l}\text { Denominación química } \\
\mathrm{N} \text { úmero CAS }\end{array}$ & Color/ Forma & $\begin{array}{l}\text { p.e. } \\
\left({ }^{\circ} \mathrm{C}\right)\end{array}$ & $\begin{array}{l}\text { p.f. } \\
(\stackrel{\circ}{ } C)\end{array}$ & $\begin{array}{l}\text { p.m.l } \\
\text { (g/ } \\
\text { mol) }\end{array}$ & $\begin{array}{l}\text { Solubilidad } \\
\text { en agua }\end{array}$ & $\begin{array}{l}\text { Densidad } \\
\text { relativa } \\
\text { (agua }=1 \text { ) }\end{array}$ & $\begin{array}{l}\text { Densidad } \\
\text { relativa } \\
\text { de vapor } \\
\text { (aire=1) }\end{array}$ & $\begin{array}{l}\text { Pvap/ } \\
(\mathrm{kPa})\end{array}$ & $\begin{array}{l}\text { Límit. } \\
\text { inflam. }\end{array}$ & $\begin{array}{ll}\text { p.ig. } & \text { p.aut } \\
\left({ }^{\circ} \mathrm{C}\right) & \text { ig. } \\
& (\stackrel{\circ}{ } \mathrm{C})\end{array}$ \\
\hline $\begin{array}{l}\text { SULFURO CARBONILO } \\
463-58-1\end{array}$ & gas & -30 & -138 & 60,08 & $\begin{array}{l}1220 \mathrm{mg} / \mathrm{la} \\
25^{\circ} \mathrm{C}\end{array}$ & $\begin{array}{l}1,028 @ \\
17^{\circ} \mathrm{C} / 4^{\circ} \mathrm{C}\end{array}$ & 2,1 & $\begin{array}{l}9412 \mathrm{~mm} \\
\mathrm{Hg} \text { a } 25^{\circ} \mathrm{C}\end{array}$ & $\begin{array}{l}12 \% \text { li } \\
29 \% \text { is }\end{array}$ & \\
\hline $\begin{array}{l}\text { SULFURO DE HIDROGENO } \\
7783-06-4\end{array}$ & gas incoloro & $-60,33$ & $-85,49$ & 34,08 & $1 \mathrm{~g} / 242 \mathrm{ml}$ & $\begin{array}{l}1,5392 \mathrm{~g} / \mathrm{l} \\
@ 0{ }^{\circ} \mathrm{C} ; 1,19 \\
\text { (gas) }\end{array}$ & 1,189 & $\begin{array}{l}1 \mathrm{~atm} \\
@-60,4^{\circ} \mathrm{C}\end{array}$ & $4,3 \mathrm{li}$ & 260 \\
\hline $\begin{array}{l}\text { SULFURO POTASICO } \\
1312-73.8\end{array}$ & $\begin{array}{l}\text { cristales cúbicos } \\
\text { blancos o placas } \\
\text { fundidas; masa } \\
\text { cristalina roja o } \\
\text { amarilla rojiza o } \\
\text { sólido fundido }\end{array}$ & & 912 & 110,26 & muy sol & $1,805 @ 14^{\circ} \mathrm{C}$ & & & & \\
\hline $\begin{array}{l}\text { TETRAFLUORURO DE AZUFRE } \\
7783-60-0\end{array}$ & gas & -40 & -124 & 108,05 & se descompone & & & & & \\
\hline $\begin{array}{l}\text { TIOSULFATO SODICO } \\
7772-98-7\end{array}$ & $\begin{array}{l}\text { polvo; cristales } \\
\text { monoclínicos } \\
\text { incoloros }\end{array}$ & & & 158,13 & $50 \mathrm{~g} / 100 \mathrm{ml}$ & 1,667 & & & & \\
\hline $\begin{array}{l}\text { TRIOXIDO DE AZUFRE } \\
7446-11-9\end{array}$ & $\begin{array}{l}\text { forma alfa, agujas } \\
\text { similares a las del } \\
\text { amianto; forma beta, } \\
\text { agujas similares a las } \\
\text { del amianto; forma } \\
\text { gamma, masa similar } \\
\text { al hielo o líquido }\end{array}$ & & & 80,07 & $\begin{array}{l}\text { sol en } 100 \\
\text { partes }\end{array}$ & & & $\begin{array}{l}73 \mathrm{~mm} \mathrm{Hg} \\
\text { @ } 25^{\circ} \mathrm{C}\end{array}$ & & \\
\hline
\end{tabular}




\section{MONOXIDO DE CARBONO}

Kari Kurppa

El monóxido de carbono ( $\mathrm{C} O$ ) es un gas inodoro e incoloro que reduce la capacidad de la hemoglobina para transportar y suministrar oxígeno.

Formación. El monóxido de carbono se produce cuando se queman materias orgánicas, como carbón, madera, papel, aceite, gasolina, explosivos o cualquier otra sustancia que contenga carbono, en una atmósfera con suministro limitado de aire u oxígeno. Si el proceso de combustión tiene lugar con un suministro abundante de aire, sin que la llama contacte con ninguna superficie, es poco probable que se genere monóxido de carbono. El CO se produce cuando la llama entra en contacto con una superficie que se encuentra a una temperatura inferior a la temperatura de ignición de la porción gaseosa de la llama. Las fuentes naturales producen un $90 \%$ del C 0 atmosférico y la actividad humana, cerca de un $10 \%$. Los vehículos motorizados generan entre el 55 y el $60 \%$ de esta última. L os gases de escape de los motores de combustión que utilizan gasolina como carburante (ignición por chispa) constituyen la principal fuente de $\mathrm{CO}$ ambiental. Los gases de escape de los motores diesel (ignición por compresión) contienen en torno al $0,1 \%$ de CO cuando el motor está bien reglado, pero cuando el reglaje es deficiente, o cuando el motor se fuerza o no se somete al debido mantenimiento, puede emitir cantidades considerables de CO. La instalación de dispositivos catalíticos o térmicos de inyección de combustible en los tubos de escape reduce considerablemente la cantidad de CO emitido. O tras importantes fuentes de CO son los hornos de ladrillo en las fundiciones, las unidades de destilación catalítica en las refinerías de petróleo, la destilación de hulla y madera, los hornos de cal, los hornos de recuperación de celulosa en las fábricas de papel kraft, la producción de metanol sintético y otros compuestos orgánicos derivados del monóxido de carbono, la sinterización del mineral en bruto para altos hornos, la producción de carburo, formaldehído y negro de humo, las coquerías, las fábricas de gas y las plantas de tratamiento de residuos.

Cualquier proceso en el que se realice una combustión incompleta de materia orgánica puede constituir una fuente de emisión de monóxido de carbono.

El monóxido de carbono se produce a escala industrial mediante oxidación parcial de hidrocarburos gaseosos obtenidos del gas natural o mediante gasificación de la hulla o el coque. Se utiliza como agente reductor en metalurgia, síntesis orgánicas y producción de carbonilos metálicos. Algunos gases industriales que se utilizan para calentar calderas y hornos, y para mover motores de gas, contienen monóxido de carbono.

Se cree que el monóxido de carbono es, con diferencia, la causa más común de intoxicación en la industria y en los hogares. $M$ iles de personas sucumben todos los años como consecuencia de intoxicaciones por $\mathrm{CO}$. El número de víctimas de intoxicaciones no mortales que quedan con lesiones permanentes del sistema nervioso central es todavía mayor. La magnitud del riesgo para la salud del monóxido de carbono, tanto si es mortal como si no lo es, es enorme y las intoxicaciones son incluso más frecuentes de lo que suele reconocerse.

Un porcentaje considerable de la población activa de cualquier país está sometida a una importante exposición a CO en su trabajo. EI CO es un riesgo siempre presente en la industria automovilística, los garajes y las estaciones de servicio. Los conductores de camiones pueden verse en peligro si los gases de escape del motor penetran en el interior de la cabina. Las profesiones con exposición potencial a CO son numerosas, por ejemplo: mecánicos de garajes, carboneros de carbón vegetal, trabajadores de altos hornos, herreros, mineros, trabajadores que construyen túneles, operarios del proceso $\mathrm{M}$ ond, trabajadores del gas, caldereros, horneros de cerámica, destiladores de madera, cocineros, panaderos, bomberos, personas que trabajan con formaldehído y muchos más. Durante los trabajos de soldadura en cubas de reacción, depósitos y otros recintos cerrados, se pueden acumular cantidades peligrosas de $C O$ si la ventilación no es suficiente. Las explosiones de metano y polvo de carbón en las minas de carbón producen "mofeta", que contienen cantidades considerables de CO y dióxido de carbono. Si la ventilación disminuye o se incrementan las emisiones de $\mathrm{CO}$ debido a fugas o problemas en los procesos, pueden producirse intoxicaciones accidentales de $\mathrm{CO}$ en actividades industriales que habitualmente no plantean problemas relacionados con este gas.

\section{Acción tóxica}

El cuerpo humano produce pequeñas cantidades de $\mathrm{CO}$ como consecuencia del catabolismo de la hemoglobina y otros pigmentos que contienen hemo, originando una saturación endógena de carboxihemoglobina ( $\mathrm{COHb}$ ) de entre 0,3 y $0,8 \%$ en sangre. La concentración endógena de $\mathrm{COHb}$ aumenta en las anemias hemolíticas y después de sufrir contusiones o hematomas importantes, que incrementan el catabolismo de la hemoglobina.

EI CO se absorbe fácilmente a través de los pulmones y pasa a la sangre. El efecto biológico mejor conocido del CO es su combinación con la hemoglobina para formar carboxihemoglobina. El monóxido de carbono compite con el oxígeno por los puntos de unión de las moléculas de hemoglobina. La afinidad de la hemoglobina humana por el $\mathrm{CO}$ es unas 240 veces mayor que su afinidad por el oxígeno. La formación de $\mathrm{COHb}$ tiene dos efectos negativos: bloquea el transporte de oxígeno inactivando la hemoglobina y su presencia en la sangre desplaza la curva de disociación de la oxihemoglobina hacia la izquierda, de manera que se impide el paso del oxígeno que queda a los tejidos. Este último efecto explica por qué la presencia de $\mathrm{COHb}$ en la sangre interfiere con la oxigenación de los tejidos bastante más que una reducción equivalente de la concentración de hemoglobina, por ejemplo, en caso de hemorragia. El monóxido de carbono se une también a la mioglobina para formar carboximioglobina, que puede alterar el metabolismo muscular, especialmente en el miocardio.

La relación aproximada entre carboxihemoglobina ( $\mathrm{COH}$ b) y oxihemoglobina $\left(\mathrm{O}_{2} \mathrm{H}\right.$ b) en la sangre puede calcularse a partir de la ecuación de $\mathrm{H}$ aldane. La relación entre $\mathrm{COHb}$ y $\mathrm{O}_{2} \mathrm{Hb}$ es proporcional a la relación entre las presiones parciales de $\mathrm{CO}$ y oxígeno en el aire alveolar:

$$
\frac{\mathrm{COH} \mathrm{b}}{\mathrm{O}_{2} \mathrm{Hb}}=240 \frac{\mathrm{pCO}}{\mathrm{pO}_{2}}
$$

Esta ecuación puede aplicarse en la mayoría de los casos para conocer la verdadera relación en estado de equilibrio. Para una cierta concentración de $\mathrm{CO}$ en el aire ambiente, la concentración de $\mathrm{COHb}$ aumenta o disminuye hacia el estado de equilibrio de acuerdo con esta ecuación. La dirección del cambio en la $\mathrm{CO} \mathrm{H} \mathrm{b}$ depende de su nivel de partida. Por ejemplo, la exposición continua a una atmósfera que contenga $35 \mathrm{ppm}$ de $\mathrm{CO}$ determinará un estado de equilibrio de aproximadamente un $5 \%$ de 
$\mathrm{COH}$ b en sangre. Si la concentración en el aire permanece invariable, tampoco variará el nivel de $\mathrm{COHb}$ en sangre. $\mathrm{Si}$ la concentración ambiental aumenta o disminuye, la de $\mathrm{COHb}$ tenderá a equilibrarse de nuevo. Un fumador empedernido puede presentar una concentración de $\mathrm{COHb}$ en sangre del $8 \%$ al comenzar la jornada laboral. Si se ve continuamente expuesto a una concentración de $35 \mathrm{ppm}$ de $\mathrm{CO}$ durante el trabajo, pero no fuma durante ese período, su nivel de $\mathrm{COHb}$ disminuirá gradualmente hasta alcanzar la concentración de equilibrio de un $5 \%$ de $\mathrm{COHb}$. Al mismo tiempo, el nivel de $\mathrm{COHb}$ en los trabajadores no fumadores aumentará gradualmente desde el nivel de partida de unos $0,8 \%$ de $\mathrm{COH}$ b endógeno hasta un nivel del $5 \%$. Por tanto, la absorción de $\mathrm{CO}$ y la acumulación de $\mathrm{COHb}$ se rigen por las leyes de los gases y la solución de la ecuación de Haldane dará el valor máximo aproximado de $\mathrm{COHb}$ para cualquier concentración de $\mathrm{CO}$ en el aire ambiental. No obstante, debe recordarse que el tiempo que transcurre hasta alcanzarse el equilibrio es de varias horas en el caso del hombre con las concentraciones ambientales de $\mathrm{CO}$ habitualmente encontradas en los lugares de trabajo. Por tanto, cuando se trata de evaluar el riesgo potencial para la salud de la exposición a CO, es importante tener en cuenta el tiempo de exposición además de la concentración de $\mathrm{CO}$ en el aire. La ventilación alveolar es otra variable importante que afecta a la velocidad de absorción de CO. Cuando la ventilación alveolar aumenta-por ejemplo, cuando se realiza un esfuerzo físico intenso- , el estado de equilibrio se alcanza antes que en una situación de ventilación normal.

La vida media biológica de la concentración de $\mathrm{COHb}$ en la sangre de personas adultas sedentarias es de 3 a 4 horas. La eliminación de $\mathrm{CO}$ se hace más lenta con la edad y cuanto menor sea el nivel inicial de $\mathrm{COHb}$, menor será la velocidad de eliminación.

\section{Intoxicación aguda}

La aparición de síntomas depende de la concentración de CO en el aire, el tiempo de exposición, el grado de esfuerzo y la susceptibilidad individual. Si la exposición es masiva, la víctima puede quedar inconsciente casi en el acto con pocos o ningún síntoma de advertencia. La exposición a concentraciones de entre 10.000 y 40.000 ppm produce la muerte en cuestión de minutos. Las concentraciones de entre 1.000 y 10.000 ppm causan síntomas de cefalea, mareo y náuseas a los 13 ó 15 minutos, que pueden ir seguidos de inconsciencia y muerte si la exposición se mantiene entre 10 y 45 minutos, dependiendo la rapidez de su aparición de la concentración. Por debajo de estos niveles, el tiempo transcurrido hasta la aparición de los síntomas es mayor: concentraciones de 500 ppm producen cefalea al cabo de 20 minutos y concentraciones de $200 \mathrm{ppm}$ hacen lo propio en un plazo de 50 minutos. En la Tabla 104.161 se indica la relación entre las concentraciones de carboxihemoglobina y los principales signos y síntomas.

La víctima de intoxicación por $\mathrm{CO}$ presenta un color rojo cereza característico. En los primeros momentos de la intoxicación, el paciente puede aparecer pálido. Más tarde, la piel, los lechos ungueales y las mucosas adquieren un color rojo cereza debido a la elevada concentración de carboxihemoglobina y a la baja concentración de hemoglobina reducida en la sangre. Este síntoma puede encontrarse con una concentración de $\mathrm{COHb}$ superior al $30 \%$, pero no es un signo fiable de la intoxicación por CO. El pulso del paciente es rápido e irregular. No se produce hipernea o ésta es muy leve hasta que se alcanzan concentraciones de $\mathrm{CO} \mathrm{H} \mathrm{b}$ muy altas.

Cuando estos síntomas aparecen en una persona que puede estar expuesta a monóxido de carbono en su trabajo, debe
Tabla 104.161 Principales signos y síntomas correspondientes a distintas concentraciones de carboxihemoglobina. ${ }^{1}$

\begin{tabular}{|c|c|}
\hline $\begin{array}{l}\text { Concentración } \\
\text { de carboxi- } \\
\text { hemoglobina }(\%)\end{array}$ & Principales signos y síntomas \\
\hline $0,3-0,7$ & Ausencia de síntomas. Nivel endógeno normal. \\
\hline $2,5-5$ & $\begin{array}{l}\text { Ausencia de síntomas. Aumento compensatorio del aporte } \\
\text { sanguíneo a ciertos órganos vitales. Los pacientes con } \\
\text { cardiovasculopatías graves pueden perder la reserva } \\
\text { compensatoria. En pacientes con angina de pecho aparece dolor } \\
\text { torácico al menor esfuerzo. }\end{array}$ \\
\hline $5-10$ & Ligero aumento del umbral de visión luminosa. \\
\hline $10-20$ & $\begin{array}{l}\text { Sensación de opresión en las sienes. Ligera cefalea. Respuestas } \\
\text { visuales provocadas anormales. Es posible que exista ligera fatiga } \\
\text { al realizar ejercicio. Puede producir la muerte del feto. Puede ser } \\
\text { mortal para pacientes con cardiopatías avanzadas. }\end{array}$ \\
\hline $20-30$ & $\begin{array}{l}\text { Cefalea ligera o moderada y palpitación de las sienes. Sonrojo. } \\
\text { Náuseas. Deterioro de la destreza manual fina. }\end{array}$ \\
\hline $30-40$ & $\begin{array}{l}\text { Cefalea intensa, vértigo, náuseas y vómitos. Debilidad. Irritabilidad } \\
\text { y dificultad para pensar. Síncope al realizar ejercicio. }\end{array}$ \\
\hline $40-50$ & $\begin{array}{l}\text { Los mismos síntomas que en el punto anterior, pero más acusados } \\
\text { y con mayor probabilidad de sufrir colapso y síncope. }\end{array}$ \\
\hline $50-60$ & $\begin{array}{l}\text { Posible coma con convulsiones intermitentes y respiración de } \\
\text { Cheyne-Stokes. }\end{array}$ \\
\hline $60-70$ & $\begin{array}{l}\text { Coma con convulsiones intermitentes. Depresión de las funciones } \\
\text { respiratorias y cardíacas. Posiblemente muerte. }\end{array}$ \\
\hline $70-80$ & $\begin{array}{l}\text { Pulso débil y respiración lenta. Depresión del centro respiratorio } \\
\text { que conduce a la muerte. }\end{array}$ \\
\hline
\end{tabular}

1 Existe una considerable variación en la aparición de los síntomas según los diferentes individuos.

sospecharse en el acto una intoxicación por este gas. El diagnóstico diferencial frente a intoxicación medicamentosa, intoxicación etílica aguda, accidente cerebrovascular, ataque cardíaco o coma diabético o urémico puede ser difícil y es bastante frecuente que se desestime o simplemente se olvide la posibilidad de que se trate de una intoxicación por monóxido de carbono. El diagnóstico de intoxicación por monóxido de carbono no debe considerarse definitivamente establecido en tanto no se tenga la certeza de que el organismo contiene cantidades anormales de CO. EI monóxido de carbono se detecta fácilmente en las muestras de sangre 0 , si la persona tiene los pulmones sanos, puede estimarse la concentración hemática de $\mathrm{COHb}$ en las muestras del aire alveolar exhalado al final de la espiración, que está en equilibrio con la concentración de $\mathrm{CO} \mathrm{H} \mathrm{b} \mathrm{en} \mathrm{sangre.}$

Los órganos críticos con respecto a la acción del $\mathrm{CO}$ son el cerebro y el corazón, por cuanto que ambos dependen del suministro ininterrumpido de oxígeno. El monóxido de carbono produce una sobrecarga del corazón merced a dos mecanismos: porque su trabajo aumenta para atender la demanda periférica de oxígeno y porque su propio suministro de oxígeno se ve reducido por el C O. Todo ello aumenta el riesgo de sufrir un infarto de miocardio.

La intoxicación aguda puede provocar complicaciones neurológicas o cardiovasculares que se manifiestan tan pronto como el 
paciente se recupera del coma inicial. En los casos de intoxicación grave puede producirse edema pulmonar (exceso de líquido en los tejidos pulmonares). T ambién puede aparecer neumonía, algunas veces por aspiración, horas o días después de la exposición, así como glucosuria o albuminuria transitorias. Algunos pacientes desarrollan insuficiencia renal aguda que complica la recuperación y otros presentan diferentes manifestaciones cutáneas.

Tras una intoxicación grave por $\mathrm{CO}$, el paciente puede sufrir edema cerebral con lesiones cerebrales irreversibles de distinto grado. La recuperación inicial puede ir seguida por una recaída neuropsiquiátrica días o semanas después de la intoxicación. Los estudios anatomopatológicos de casos mortales han demostrado que las lesiones afectan preferentemente a la sustancia blanca y no a las neuronas, en aquellas víctimas que sobreviven algunos días desde el momento de la intoxicación. El grado de afectación cerebral tras la intoxicación por $\mathrm{CO}$ depende de la intensidad y la duración de la exposición. Al recuperar la consciencia después de una intoxicación grave por $\mathrm{CO}$, el $50 \%$ de las víctimas presentaban un estado mental anormal manifestado en forma de irritabilidad, inquietud, delirio prolongado, depresión y ansiedad. El seguimiento durante tres años de estos pacientes reveló que un $33 \%$ presentaba deterioro de la personalidad y un $43 \%$, pérdida de memoria persistente.

Exposiciones repetidas. EI monóxido de carbono no se acumula en el organismo. Se elimina completamente después de cada exposición si la persona puede respirar aire fresco durante un período de tiempo suficiente. No obstante, es posible que intoxicaciones leves 0 moderadas repetidas que no producen inconsciencia, vayan destruyendo las células cerebrales y causen con el tiempo lesiones permanentes del sistema nervioso central, con multitud de posibles síntomas, como cefalea, mareo, irritabilidad, pérdida de memoria, cambios de personalidad y debilidad de las extremidades.

Las personas expuestas en repetidas ocasiones a concentraciones moderadas de $\mathrm{C} O$ están posiblemente adaptadas en cierta medida a la acción del $\mathrm{CO}$. Se cree que los mecanismos de adaptación son similares a la tolerancia que se desarrolla a la hipoxia en las grandes altitudes. Se ha observado un aumento de la concentración de hemoglobina y del hematocrito en los animales expuestos, pero no se ha podido cuantificar con exactitud la evolución con el tiempo ni el umbral de cambios similares en las personas expuestas.

Altitud. En las grandes alturas aumenta la posibilidad de que se produzcan combustiones incompletas y se incremente la producción de $\mathrm{CO}$, puesto que existe menos cantidad de oxígeno por unidad de aire que a nivel del mar. Las respuestas adversas del organismo también aumentan como consecuencia de las menores presiones parciales de oxígeno en el aire respirado. El déficit de oxígeno que se da en altitudes elevadas y los efectos del $\mathrm{CO}$ son aparentemente aditivos.

$\mathrm{H}$ idrocarburos halogenados derivados del metano. El diclorometano (cloruro de metileno), que es el principal componente de muchos decapantes para pintura y otros disolventes de este grupo, se metaboliza en el hígado produciendo CO. Este mecanismo puede hacer que la concentración de carboxihemoglobina aumente en los casos de intoxicación moderada.

Efectos de la exposición a pequeñas concentraciones de monóxido de carbono. En los últimos años se han realizado numerosas investigaciones sobre los efectos biológicos de concentraciones de $\mathrm{CO} \mathrm{H} \mathrm{b}$ inferiores al $10 \%$ en personas sanas y en pacientes con enfermedades cardiovasculares. L os pacientes con enfermedades cardiovasculares graves pueden perder la reserva compensatoria a concentraciones de $\mathrm{COHb}$ del $3 \%$, de forma que al menor esfuerzo físico provocará dolor torácico en pacientes con angina de pecho. El monóxido de carbono atraviesa fácilmente la barrera placentaria y alcanza al feto, que es más sensible a una carga hipóxica adicional, pudiendo verse amenazado su desarrollo normal.

Grupos susceptibles. Las personas cuya capacidad de transporte de oxígeno está reducida debido a anemia o hemoglobinopatías son más sensibles a la acción del CO. Lo mismo ocurre con la personas que tienen una mayor necesidad de oxígeno a causa de fiebre, hipertiroidismo o embarazo, los pacientes con hipoxia sistémica debido a insuficiencia respiratoria y los pacientes con cardiopatía isquémica y arteriosclerosis cerebral o generalizada. Los niños y jóvenes, cuya ventilación es más rápida que la de los adultos, alcanzan el nivel de intoxicación de $\mathrm{COH} \mathrm{b}$ antes que los adultos sanos. Asimismo, los fumadores, que parten de un nivel inicial de $\mathrm{COH}$ b más alto que los no fumadores, alcanzan más rápidamente concentraciones peligrosas de $\mathrm{COHb}$ cuando las exposiciones son altas. 


\section{Sumario}

Sistema internacional de unidades . . . . . . . . . . . . . . . . . . . . . . . . . . . 105.2

Acrónimos y abreviaturas . . . . . . . . . . . . . . . 105.4 


\section{SISTEMA INTERNACIONAL DE UNIDADES}

EI Sistema Internacional de U nidades es un sistema decimal de pesas y medidas que amplía el sistema métrico, en el que está basado. Su abreviatura en todos los idiomas es la sigla SI.

EI SI consta de siete unidades básicas (véase la Tabla 105.1). EI metro, igual a 1.650.763,73 longitudes de onda de la línea rojoanaranjada del espectro del kriptón-86 en el vacío, es la unidad SI de longitud. El kilogramo, aproximadamente igual a 2,2 libras avoirdupois e igual a 1.000 gramos (según la definición basada en el prototipo de platino e iridio que se conserva en la 0 ficina Internacional de Pesas y Medidas de Sèvres, Francia), es la unidad SI de masa. Es la única unidad base que sigue estando definida por un artefacto. Es también la única unidad SI con un prefijo como parte del nombre y de su símbolo. El segundo, igual a la duración de 9.192.631,770 ciclos de la radiación correspondiente a una transición determinada del átomo de cesio-133, es la unidad SI de tiempo. EI amperio es la unidad SI de corriente eléctrica y es igual a la corriente constante producida por un voltio que, cuando se mantiene en dos conductores paralelos separados por una distancia de un metro en el vacío, genera un fuerza electromagnética de $2 \times 10^{-7} \mathrm{~N} \mathrm{~m}^{-1}$. El kelvin, igual a 1/273,16 de la temperatura termodinámica en el punto triple del agua, es la unidad SI de temperatura termodinámica. Por su magnitud, el kelvin es igual al grado Celsius; sin embargo, una temperatura expresada en grados Celsius es igual al equivalente numérico de la temperatura en kelvins menos 273,15 . El mol es la unidad SI de cantidad de sustancia; contiene tantas unidades elementales de sustancia como átomos hay en $0,012 \mathrm{~kg}$ de carbono-12. Las unidades elementales deben especificarse, pues pueden ser átomos, electrones, iones, moléculas, radicales, etc. La candela es la unidad SI de intensidad luminosa. Es igual a la intensidad luminosa de la radiación de un cuerpo negro en dirección perpendicular procedente de una superficie de 1/ 600.000 metros

Tabla 105.1 Unidades de base del SI.

\begin{tabular}{lll} 
Magnitud & Nombre de la unidad SI & Símbolo \\
Longitud & Metro & $\mathrm{m}$ \\
Masa & Kilogramo & $\mathrm{kg}$ \\
Tiempo & Segundo & $\mathrm{S}$ \\
Corriente eléctrica & Amperio & $\mathrm{A}$ \\
Temperatura termodinámica & Kelvin² & $\mathrm{K}$ \\
Cantidad de sustancia & Mol & $\mathrm{mol}$ \\
Intensidad luminosa & Candela & $\mathrm{Cd}$ \\
& \\
1 Frecuentemente se utiliza el término "peso" cuando se quiere denotar "masa". \\
${ }^{2}$ La denominación "grado kelvin" y el símbolo "OK" se declararon obsoletos en una conferencia inter- \\
nacional celebrada en 1967. \\
\hline
\end{tabular}

Table 105.2 Unidades suplementarias del SI.

\begin{tabular}{llll}
\hline Magnitud & $\begin{array}{l}\text { Nombre de } \\
\text { la unidad SI }\end{array}$ & Símbolo & $\begin{array}{l}\text { Expresión en términos } \\
\text { de unidades Sl base }\end{array}$ \\
\hline Angulo plano & $\begin{array}{l}\text { Radián } \\
\text { Angulo sólido }\end{array}$ & $\begin{array}{l}\text { Esd } \\
\mathrm{m} \cdot \mathrm{m}^{-1}=1\end{array}$ & \begin{tabular}{l}
$\mathrm{m}^{2} \cdot \mathrm{m}^{-2}=1$ \\
\hline
\end{tabular} \\
\hline
\end{tabular}

Tabla 105.3 Unidades derivadas seleccionadas del SI expresadas en términos de unidades de base.

\begin{tabular}{lll} 
Magnitud & Nombre de la unidad SI & Símbolo \\
Area & Metro cuadrado & $\mathrm{m}^{2}$ \\
Volumen & Metro cúbico & $\mathrm{m}^{3}$ \\
Velocidad & Metro por segundo & $\mathrm{m} / \mathrm{s}$ \\
Aceleración & Metro por segundo al cuadrado & $\mathrm{m} / \mathrm{s}^{2}$ \\
Número de onda & Metro recíproco & $\mathrm{m}^{-1}$ \\
Densidad & Kilogramo por metro cúbico & $\mathrm{kg} / \mathrm{m}^{3}$ \\
Volumen espećfico & Metro cúbico por kilogramo & $\mathrm{m}^{3} / \mathrm{kg}^{2}$ \\
Densidad de corriente & Amperio por metro cuadrado & $\mathrm{A} / \mathrm{m}^{2}$ \\
Intensidad del campo magnético & Amperio por metro & $\mathrm{A} / \mathrm{m}$ \\
Concentración (de cantidad de & Mol por metro cúbico & $\mathrm{mol} / \mathrm{m}^{3}$ \\
sustancia) & & \\
Luminancia & Candela por metro cuadrado & $\mathrm{cd} / \mathrm{m}^{2}$ \\
\hline
\end{tabular}

Tabla 105.4 Unidades derivadas del SI con nombres especiales.

\begin{tabular}{|c|c|c|c|}
\hline Magnitud & $\begin{array}{l}\text { Nombre de } \\
\text { la unidad SI }\end{array}$ & Símbolo & $\begin{array}{l}\text { Expresión en } \\
\text { términos de } \\
\text { otras unidades }\end{array}$ \\
\hline Frecuencia & hercio & $\mathrm{Hz}$ & $s^{-1}$ \\
\hline Fuerza & newton & $\mathrm{N}$ & $\mathrm{m} \cdot \mathrm{kg} / \mathrm{s}^{2}$ \\
\hline Presión, tensión & pascal & $\mathrm{Pa}$ & $\mathrm{N} / \mathrm{m}^{2}$ \\
\hline $\begin{array}{l}\text { Energía, trabajo, } \\
\text { cantidad de calor }\end{array}$ & julio & J & $N \cdot m$ \\
\hline Potencia, flujo radiante & vatio & W & $\mathrm{J} / \mathrm{s}$ \\
\hline $\begin{array}{l}\text { Carga eléctrica, cantidad de electri- } \\
\text { cidad }\end{array}$ & - culombio & C & $S \cdot A$ \\
\hline $\begin{array}{l}\text { Potencial eléctrico, diferencia de } \\
\text { potencial, fuerza electromotriz }\end{array}$ & voltio & V & W/ A \\
\hline Capacitancia & faradio & $\mathrm{F}$ & $\mathrm{C} / \mathrm{V}$ \\
\hline Resistencia eléctrica & ohmio & Omega & $\mathrm{V} / \mathrm{A}$ \\
\hline Conductancia eléctrica & siémens & $S$ & A/ V \\
\hline Flujo magnético & wéber & Wb & $V \cdot S$ \\
\hline Densidad del flujo magnético & tesla & $T$ & $\mathrm{~Wb} / \mathrm{m}^{2}$ \\
\hline Inductancia & henrio & $H$ & Wb/A \\
\hline Temperatura Celsius ${ }^{1}$ & grado Celsius & ${ }^{\circ} \mathrm{C}$ & K \\
\hline Flujo luminoso & lumen & Im & $c d \cdot s r$ \\
\hline Actividad (de un radionúclido) & becquerel & $\mathrm{Bq}$ & $s^{-1}$ \\
\hline $\begin{array}{l}\text { Dosis absorbida, energía específica } \\
\text { impartida, kerma, índice de dosis } \\
\text { absorbida }\end{array}$ & gray & Gy & $J / \mathrm{kg}$ \\
\hline $\begin{array}{l}\text { Dosis equivalente, índice de dosis } \\
\text { equivalente }\end{array}$ & siévert & Sv & J/ kg \\
\hline
\end{tabular}

${ }^{1}$ Además de la temperatura termodinámica ( $T$ ) expresada en kelvins (véase la Tabla 105.1), se usa también la temperatura Celsius $(t)$, definida por la ecuación $t=T-T_{0}$ en la que $T_{0}=273,15 \mathrm{~K}$ por definición. La unidad "grado Celsius", que es igual a la unidad "kelvin", se usa para expresar temperaturas Celsius. En este caso, la expresión "grados Celsius" es un nombre especial que sustituye a "kelvin". Sin embargo, una diferencia o intervalo de temperaturas Celsius puede expresarse tanto en kelvins como en grados Celsius. 
Table 105.5 Ejemplos de unidades derivadas del SI expresadas con nombres especiales.

\begin{tabular}{lll} 
Magnitud & Nombre de la unidad SI & Símbolo \\
Viscosidad dinámica & pascal segundo & Pa·s \\
Momento de fuerza & newton metro & $\mathrm{N} \cdot \mathrm{m}$ \\
Tensión superficial & newton por metro & $\mathrm{N} / \mathrm{m}$ \\
$\begin{array}{l}\text { Densidad de flujo de calor, irra- } \\
\text { diancia }\end{array}$ & vatio por metro cuadrado & $\mathrm{W} / \mathrm{m}^{2}$ \\
Capacidad de calor, entropía & julio por kelvin & $\mathrm{J} / \mathrm{K}$ \\
Capacidad de calor específica, & julio por kilogramo kelvin & $\mathrm{J} /(\mathrm{kg} \cdot \mathrm{K})$ \\
entropía específica & & \\
Energía espećífica & julio por kilogramo & $\mathrm{J} / \mathrm{kg}$ \\
Conductividad térmica & vatio por metro kelvin & $\mathrm{W} /(\mathrm{m} \cdot \mathrm{K})$ \\
Densidad de energía & julio por metro cúbico & $\mathrm{J} / \mathrm{m}^{3}$ \\
Intensidad del campo eléctrico & voltio por metro & $\mathrm{V} / \mathrm{m}$ \\
Densidad de la carga eléctrica & culombio por metro cúbico & $\mathrm{C} / \mathrm{m}^{3}$ \\
Densidad del flujo eléctrico & culombio por metro cuadrado & $\mathrm{C} / \mathrm{m}^{2}$ \\
Permitividad & faradio por metro & $\mathrm{F} / \mathrm{m}$ \\
Permeabilidad & henry por metro & $\mathrm{H} / \mathrm{m}$ \\
Energía molar & julio por metro & $\mathrm{J} / \mathrm{mol}$ \\
Entropía molar, capacidad de calor & julio por mol kelvin & $\mathrm{J} /(\mathrm{mol} \cdot \mathrm{K})$ \\
molar & & \\
Exposición (rayos X y gamma) & culombio por kilogramo & $\mathrm{C} / \mathrm{kg}$ \\
Indice de dosis absorbida & gray por segundo & $\mathrm{Gy} / \mathrm{s}$ \\
& & \\
\hline
\end{tabular}

cuadrados a la temperatura de congelación del platino (2.042 kelvins) bajo una presión de 101,325 pascales; equivale aproximadamente a la intensidad luminosa de una sola vela de parafina.

EI SI incluye también dos unidades suplementarias (véase la Tabla 105.2): radián y estereorradián, que son unidades dimensionales de magnitud de ángulos planos y sólidos, respectivamente. Las unidades de otras magnitudes derivan de las siete básicas y las dos suplementarias.

La T abla 105.3 recoge un conjunto seleccionado de unidades SI derivadas, expresadas en términos de unidades base. Las unidades derivadas con nombres y símbolos especiales figuran en la Tabla 105.4. Estas pueden emplearse para expresar otras unidades derivadas (véase la T abla 105.5). Las dos unidades suplementarias pueden también usarse para expresar unidades derivadas (véase la T abla 105.6).

Los 16 prefijos usados para crear múltiplos y submúltiplos de las unidades SI se recogen en la Tabla 105.7. Como los prefijos

Table 105.6 Ejemplos de unidades derivadas del SI formadas con unidades suplementarias.

\begin{tabular}{lll} 
Magnitud & Nombre de la unidad SI & Símbolo \\
Velocidad angular & radián por segundo & $\mathrm{rad} / \mathrm{s}$ \\
Aceleración angular & radián por segundo cuadrado & $\mathrm{rad} / \mathrm{s}^{2}$ \\
Intensidad radiante & vatio por estereorradián & $\mathrm{W} / \mathrm{sr}$ \\
Radiancia & $\begin{array}{l}\text { vatio por metro cuadrado } \\
\text { estereorradián }\end{array}$ & $\mathrm{W} /\left(\mathrm{m}^{2} \cdot \mathrm{sr}\right)$ \\
\hline
\end{tabular}

Table 105.7 Prefijos del SI.

\begin{tabular}{lll} 
Factor & Prefijo & Símbolo \\
$10^{18}$ & exa & E \\
$10^{15}$ & peta & P \\
$10^{12}$ & tera & T \\
$10^{9}$ & giga & $\mathrm{G}$ \\
$10^{6}$ & mega & $\mathrm{M}$ \\
$10^{3}$ & kilo & $\mathrm{k}$ \\
$10^{2}$ & hecto & $\mathrm{h}$ \\
$10^{1}$ & deca & da \\
$10^{-1}$ & deci & $\mathrm{d}$ \\
$10^{-2}$ & centi & $\mathrm{C}$ \\
$10^{-3}$ & mili & $\mathrm{m}$ \\
$10^{-6}$ & micro & $\mathrm{m}$ \\
$10^{-9}$ & nano & $\mathrm{n}$ \\
$10^{-12}$ & pico & $\mathrm{p}$ \\
$10^{-15}$ & femto & $\mathrm{f}$ \\
$10^{-18}$ & atto & $\mathrm{a}$ \\
\hline
\end{tabular}

no se pueden acumular, se usan con el gramo (g), pero no con el kilogramo (kg).

$\mathrm{H}$ ay varias unidades de uso generalizado, sobre todo en Estados U nidos, pero no forman parte del SI. Las que se consideran aceptables para emplear con el SI en Estados U nidos se recogen en la Tabla 105.8. La Tabla 105.9 es una tabla de conversión de unidades del SI .

\section{Table 105.8 Unidades usadas junto con el SI.}

$\begin{array}{lll}\text { Nombre } & \text { Símbolo } & \text { Valor en unidades Sl } \\ \text { Minuto (tiempo) } & \min & 1 \mathrm{~min}=60 \mathrm{~s} \\ \text { Hora } & \mathrm{h} & 1 \mathrm{~h}=60 \mathrm{~min}=3.600 \mathrm{~s} \\ \text { Día } & d & 1 \mathrm{~d}=24 \mathrm{~h}=86.400 \mathrm{~s} \\ \text { Grado (ángulo) } & 0 & 1^{\circ}=(\mathrm{pi} / 180) \mathrm{rad} \\ \text { Minuto (ángulo) } & \mathrm{d} & 1 \mathrm{c}=(1 / 60)^{\circ}=(\mathrm{pi} / 10.800) \mathrm{rad} \\ \text { Segundo (ángulo) } & 2 & 1^{2}=(1 / 60) \mathrm{c}=(\mathrm{pi} / 648.000) \mathrm{rad} \\ \text { Litro } & \mathrm{I}^{1} & 1 \mathrm{l}=1 \mathrm{dm}^{3}=10^{-3} \mathrm{~m}^{3} \\ \text { Tonelada } & \mathrm{t} & 1 \mathrm{t}=10^{3} \mathrm{~kg} \\ \text { Hectárea (superficie de suelo) } & \text { ha } & 1 \mathrm{ha}=1 \mathrm{hm}^{2}=10^{4} \mathrm{~m}^{2} \\ \text { Electronvoltio }^{3} & \mathrm{eV} & 1 \mathrm{eV}=1,60218 \times 10^{-19} \mathrm{~J} \\ \text { Unidad unificada de masa }^{2} & \mathrm{u} & 1 \mathrm{u}=1,66054 \times 10^{-27} \mathrm{~kg} \\ \text { atómica }^{3} & & \end{array}$

1 Tanto "I" como "L" son símbolos aceptados del litro.

2 En algunos países, como Estados Unidos, se usa "tonelada métrica" en lugar de "tonelada".

${ }^{3}$ Los valores de estas unidades expresados en unidades SI no se conocen con exactitud, pues deben obtenerse mediante experimentación. El electronvoltio es la energía cinética adquirida por un electrón que atraviesa una diferencia de potencial de 1 voltio en el vacío. La unidad unificada de masa atómica es igual a $1 / 12$ de la masa del atómo del núclido ${ }^{22} \mathrm{C}$.

Agradecimientos: Los datos de las tablas proceden en su mayor parte del Instituto Nacional de N ormas y T ecnología de Estados Unidos (NIST). 
Tabla 105.9 Conversión a unidades SI de unidades que no forman parte del SI.

\begin{tabular}{|c|c|c|c|c|c|}
\hline De/ a & $\mathrm{A} / \mathrm{de}$ & Multiplicar por/ dividir por & De/ a & $\mathrm{A} / \mathrm{de}$ & Multiplicar por/ dividir por \\
\hline Pulgada (in) & m & $2,54 \times 10^{-2}$ & Libra/ in ${ }^{3}$ & $\mathrm{~kg} \mathrm{~m}^{-3}$ & $2,76799 \times 10^{4}$ \\
\hline Pie $(f t)$ & m & 0,3048 & $\mathrm{mmHg}$ & $\mathrm{Pa}$ & 133,322 \\
\hline Pulgada cuadrada (in²) & $m^{2}$ & $6,4516 \times 10^{-4}$ & Atmósfera (atm) & $\mathrm{Pa}$ & $1,01325 \times 10^{5}$ \\
\hline Pie cuadrado $\left(\mathrm{ft}^{2}\right)$ & $\mathrm{m}^{2}$ & $9,2903 \times 10^{-2}$ & Caballo de vapor (hp) & W & 745,7 \\
\hline Pulgada cúbica (in³) & $\mathrm{m}^{3}$ & $1,63871 \times 10^{-5}$ & ergio & । & $10^{-7}$ \\
\hline Pie cúbico $\left(\mathrm{ft}^{3}\right)$ & $\mathrm{m}^{3}$ & $2,83168 \times 10^{-2}$ & Electronvoltio (eV) & J & $1,60210 \times 10^{-19}$ \\
\hline Litro (I) & $\mathrm{m}^{3}$ & $10^{-3}$ & Kilovatio-hora (kW hr) & J & $3,6 \times 10^{6}$ \\
\hline Galón (gal) & $\mathrm{m}^{3}$ & $4,54609 \times 10^{-3}$ & Caloría (cal) & J & 4,1868 \\
\hline Milla/ hora $\left(\mathrm{mi} \mathrm{hr}^{-1}\right)$ & $\mathrm{m} \mathrm{s}^{-1}$ & 0,47704 & Dina & N & $10^{-5}$ \\
\hline Kilómetro/ hora $\left(\mathrm{km} \mathrm{hr}^{-1}\right)$ & $\mathrm{m} \mathrm{s}^{-1}$ & 0,27778 & kgf & N & 9,80665 \\
\hline Libra (lb) & $\mathrm{kg}$ & 0,453592 & Poundal & N & 0,138255 \\
\hline Gramo/ $\mathrm{cm}^{3}\left(\mathrm{~g} \mathrm{~cm}^{-3}\right)$ & $\mathrm{kg} \mathrm{m}^{-3}$ & $10^{3}$ & lbf & N & 4,44822 \\
\hline
\end{tabular}

\section{ACRONIMOS Y ABREVIAT URAS}

En esta E nciclopedia se utilizan los siguientes acrónimos y abreviaturas, sin embargo, la lista no es exhaustiva. No se incluyen, por ejemplo, las abreviaturas de sustancias químicas, tampoco aparecen las abreviaturas habituales de nombres de publicaciones periódicas. Del sistema internacional de unidades de medida y de sus abreviaturas se ocupa otra sección de este capítulo.
$A$

$A A$

.Alcohólicos A nónimos

AAA …..........Acción de Investigadores y

T rabajadores en Dinamarca

AAAS .........American Association for the

Advancement of Science

AAE …........Alveolitis alérgica extrínseca

AAO ….............A merican Academy of $O$ tolaryngology

AAR P ...............American Association of Retired Persons

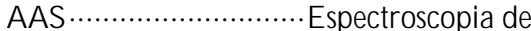
absorción atómica

AAT …......Asma agravada por el trabajo ABC …..................... A rea bajo la curva ABR IE ….............. nvestigación General Empresarial e Inventario y Evaluación de R iesgos

ABS …....Acrilonitrilo-butadieno-estireno a. de $C$. ...........................antes de C risto ACB …..............A nálisis coste-beneficio ACFTU …... onfederación de Sindicatos de China

ACGIH …....... Confederación Americana de $\mathrm{H}$ igienistas I ndustriales del Gobierno

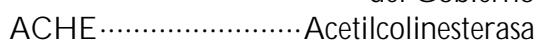
ACOG …..............American College of $O$ bstetricians and $G$ ynecologists ACS …..........A merican Cancer Society ACT …A seguramiento de la calidad total

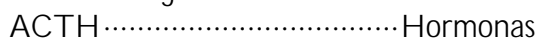
adrenocorticotrópicas ACT U …..............Australian Council of Trade Unions
ACU ….............Análisis de coste-utilidad

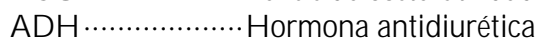

AD N …...........Acido desoxirribonucléico

AD N r...................AD N recombinable

ADR …..........Acuerdo europeo sobre el transporte internacional por carretera de sustancias peligrosas

AE …................... A bortos espontáneos

AEL ….......... ímites de emisión accesible AELC ….............A sociación E uropea de Libre Comercio

AFA …...Association of Flight Attendants AFFF .................. Espuma formadora de película acuosa

AFL-CIO …..........American Federation of $L$ abor and $C$ ongress of Industrial $O$ rganizations

AFN O R .................Association française de normalisation

AFSCM E ….......American Federation of State, County and M unicipal Employees

AG I $\ldots \ldots \ldots \ldots \ldots \ldots \ldots . \ldots \ldots$ mpactores de vidrio

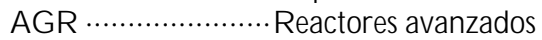
refrigerados con gas

AH A ….....American H ospital Association Al …........................Alveolo-intersticial AIChE ….............A merican Institute of Chemical Engineers

AIDS …...................SIDA Síndrome de inmunodeficiencia adquirida

AIEA …........A sociación Internacional de la Energía A tómica

AINES …......M ediación antiinflamatoria no esteroide
AIPR …….....A sociación I nternacional de Profesionales de la R ecolocación

AISI .....A merican I ron and Steel Institute AISS ……....A sociación I nternacional de la Seguridad Social

ALA …................A cido aminolevulínico

ALA-D …............. D ehidratasa del ácido aminolevulínico

ALARA …................ T an bajas como sea razonablemente posible

ALASEH T ........................... A sociación L atinoamericana de Seguridad y Salud Laboral

ALA-U …......A cido delta-aminolevulínico en orina

AM ….....................A islante mineral

AM C …...........A nálisis de minimización de costes

AM D …............... Servicio de M edicina del Trabajo

AM S ........A samblea M undial de la Salud AM S ….................Enfermedad aguda de la montaña

AN A …...........Anticuerpos antinucleares ANFO ….......... Fueloil de nitrato amónico ANSI …...................American $\mathrm{N}$ ational Standards Institute

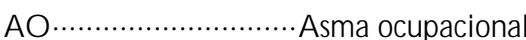

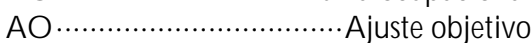
AOEC ….....Association of $O$ ccupational and Environmental Clinics

APE ……...Antígeno prostático específico APEC …........... Cooperación E conómica del Asia y el Pacífico

APELL ….... Sensibilización y preparación ante emergencias a nivel local 
APF …............A Association des paralysés de France

APF ….......Factor de protección asignado APH A .........................American Public $\mathrm{H}$ ealth Association APHIS ….........Animal and Plant $\mathrm{H}$ ealth Inspection Service API ….........A merican Petroleum Institute APPR ….....Army package power reactor ARET …..............R educción acelerada/ Eliminación de sustancias tóxicas

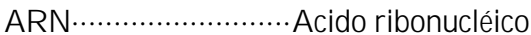

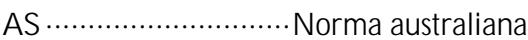
AS …............................ Ajuste subjetivo ASA …...American Society of Anesthetists ASEAN …..........Asociación de $\mathrm{N}$ aciones de Asia Sudoriental

ASH …............Angiosarcoma del hígado

ASH R AE …...A sociación norteamericana de técnicos en calefacción, refrigeración y acondicionamiento del aire

ASP $\ldots \ldots \ldots \ldots \ldots \ldots \ldots \ldots \ldots . . . \ldots \ldots$ ntoxicación con moluscos amnésica

ASSE ....................American Society of Safety Engineers

ASST ..................A sociación de Salud y Seguridad en el Trabajo de Japón

ASST AS ...........Association pour la santé et la sécurité du travail, secteur affaires sociales

AST M …..............American Society for T esting and $M$ aterials

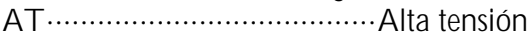
AT A …….....Alaska T rappers Association AT BC …......A Ifa-T ocoferol, beta caroteno AT S ……......American Thoracic Society AT SD R ......A gency for T oxic Substances and Disease R egistry

AUDIT ...............Alcohol U se Disorders Identification T est

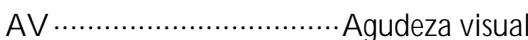

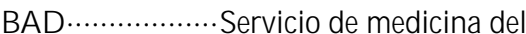
trabajo de las

Berufsgenossenschaften

BAE P........ Brainstem auditory potentials BAL …........................ Dimercaprol o antilewisita británica BAL …............... avado broncoalveolar BAU …....... nstituto de seguridad alemán BCF ..............Bulked continuous filament BC G .......Bacilo de Calmette and Guérin BE $\mid \cdots \cdots \cdots \cdot \ldots \cdot$ ndices de exposición biológica BEIR …................. Biological Effects of I onizing $R$ adiation

BG …............ as Berufgenossenschaften alemanas
BG M G …........... Sistema de medición de sustancias peligrosas

BG W ................Berufsgenossenschaft für G esundheitsdienst und Wohlfahrtspflege

BIA …..........................A sociación de Berufsgenossenschaften y su Instituto para la Seguridad en el trabajo

BID …..................Banco Interamericano de D esarrollo

BL …….....Niveles de seguridad biológica BLDSC ........... British Library D ocument Supply Centre

BLEVE …............ Explosión por vapor en expansión de un líquido hirviendo

BLP .........Buenas prácticas de laboratorio BLS …..................... Bureau of $L$ abor Statistics (EE UU)

BM D …............................. D osis fija

BM P …........Prácticas óptimas de gestión

BM R C …..................... British M edical R esearch C ouncil

BN A ….................. Bureau of $\mathrm{N}$ ational Affairs (EE UU)

BO D ....D emanda bioquímica de oxígeno BO F ….............. H orno de oxígeno básico

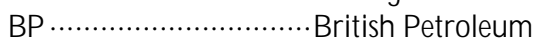
BPF ……... Buenas prácticas de fabricación BPN …..............Bajo peso al nacimiento BR S …................ Bortner R ating Scale BS …...................... N orma Británica BSI …............ British Standards I nstitute BT PS …............ T emperatura corporal y presión ambiente

BT V …........ Valor biológico de tolerancia BU PA …........................ British U nited Provident Association BW R ……R eactor de agua en ebullición

\section{C}

CA ……................ ajeros automáticos

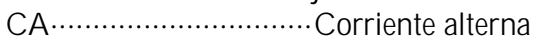

CAC …............. onocimientos, aptitudes y capacidades

CAD …..... D iseño asistido por ordenador

CAI …......... Calidad del aire en interiores

CAM …...........M embrana coricalantoica

CAM AC ……....A sociación de Control y

M edida de Actividades

Asistidas por O rdenador

CAM P ........A denosinmonofosfato cíclico

CAT …...................... T omografía axial computadorizada

CAT I ............Encuesta telefónica asistida por ordenador

CBI ….C omisión Ballenera Internacional C C …..................... C apacidad de cierre

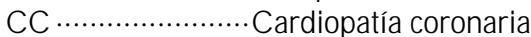

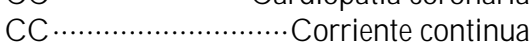

CCE Comisión de las Comunidades Europeas $\mathrm{CCH}$ F …........ Fiebre hemorrágica viral de C rimea-C ongo

CCITT …................. Comité consultatif international des organisations téléphoniques et télégraphiques

CCL …....... raqueo catalítico de líquidos $\mathrm{CCOHS}$................ anadian Centre for $\mathrm{O}$ ccupational $\mathrm{H}$ ealth and Safety

CCPS …................ Center for Chemical Process Safety

CCR …....... arcinoma de células renales CCT …................. Carcinoma de células de transición

CCT …........... Control de la calidad total

CCT …......... Craqueo catalítico termofor

CD …....... Consejeros en materia dietética CD …..................Borrador del Comité CDC …......... entros para el Control y la Prevención de Enfermedades CDS ….......... Cuestionario de diagnóstico de seguridad

CDT …...... Cumulative trauma disorders CE ……............... Comunidad Europea CECA ……........ omunidad E uropea del Carbón y del Acero

CEE ….C omunidad E conómica Europea CEEA ……........ Comunidad Europea de la Energía A tómica

CEFIC …............ Consejo de la Industria Q uímica Europea

CEI ….............. omisión Electrotécnica Internacional

CEIC …............... anada Employment and Immigration Commission CEM …............ Campo electromagnético CEM …......................C ompatibilidad E lectromagnética

CEN .Comité Europeo de N ormalización

CENELEC ……..... Comité européen de normalisation électrotechnique

CEN/T C ……....... Comisión Europea de N ormalización/ C omité T écnico

CEP ............... ertificado de Enfermedad Profesional

CEPA …..... ey canadiense de protección del medio ambiente

CEPAL ……... Comisión Económica para América L atina y el Caribe

CEPE ….......... omisión Económica para Europa (de las $\mathrm{N}$ aciones U nidas) CES …............... Confederación Europea de Sindicatos

CESPAP …..........C omisión E conómica y Social para A sia y el Pacífico

CET G …......... Comité de Expertos de las Naciones U nidas sobre transporte de mercancías peligrosas

CFST ..Comisión federal de coordinación 
CG ………….... romatografía de gases $\mathrm{CHC}$................ arcinoma hepatocelular

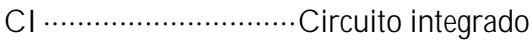
$\mathrm{Cl} \cdots \ldots \ldots \ldots \ldots . . . \cdots$ Coeficiente de inteligencia CIBC …........... Consejo Internacional de Investigación de Edificios

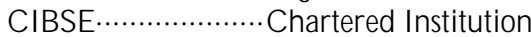
of Building Services Engineers

CID …............ oagulación intravascular diseminada

CIE …........... Commission internationale de l'éclairage

CIIU …...............Clasificación Industrial Internacional U niforme

CIM ….................Fabricación integrada por ordenador

CIM AS ...... Conferencia Internacional de Fondos del Seguro de Enfermedad y Sociedades M utualistas

CIM T ….........Comisión Internacional de M edicina del T rabajo

CIOM S …......... Council for International O rganizations of $M$ edical Sciences

CIOSL ........C onfederación I nternacional de 0 rganizaciones Sindicales Libres

CIR A ……. Comité Internacional para la reglamentación de ascensores

CIS ................... entro Internacional de Información sobre Seguridad y Salud en el T rabajo

CISM ID ….... Centro Peruano-Japonés de Investigaciones Sísmicas y

M itigación de Desastres

CIT …............C onferencia Internacional del Trabajo

CIT …....C uotas individuales negociables CIU C ................ Consejo Internacional de U niones Científicas

CLV …............... Cargar, levantar, volcar CM A ................ Chemical M anufacturers Association

CM L ….......... Coriomeningitis linfocítica

CM T …............. Confederación M undial del Trabajo

CNA …................ Caisse nationale suisse d'assurance en cas d'accidents

CNAM …........... Conservatoire national des arts et métiers

CN C …............ ontrol numérico asistido por ordenador

CNDEP …............... omité Nacional de Diagnóstico de Enfermedades Profesionales

CN G …............. as natural comprimido CNIST ….... Centro Nacional de Informes de Salud en el T rabajo

CNPTET ........... Centro Nacional para la Prevención y T ratamiento de las Enfermedades del Trabajo
CNUMAD …............. Conferencia de las $\mathrm{N}$ aciones $\mathrm{U}$ nidas sobre el $\mathrm{M}$ edio Ambiente y el D esarrollo

CO A …........ Canada-O ntario Agreement CO AP .................. ompuestos orgánicos asociados a partículas

COHSE ........... Confederation of $\mathrm{H}$ ealth Service E mployees

COLREG …............... Convenio sobre la regulación internacional de la prevención de colisiones en el mar

COMECON …….C onsejo de Asistencia E conómica M utua

COPD ….............Enfermedad pulmonar obstructiva crónica

C O PR 0 ….................... Coproporfirina

COPR O -U …..... Coproporfirina en orina

CORD …........... enter for $O$ ccupational R esearch and Development

$\mathrm{COSH}$....... Comités de Salud y Seguridad en el Trabajo

C O SV …............. ompuestos orgánicos semivolátiles

COTOREP …..... Commission technique d'orientation et de réinsertion professionnelle

CO V .......C ompuestos orgánicos volátiles COVT ……........ ompuestos orgánicos volátiles totales

CPCNP …... áncer de pulmón de células no pequeñas

CPCP........Carcinoma de células grandes y carcinoma de células pequeñas

CPDB ...... Base de datos sobre la potencia de los carcinógenos

CPIAS …............... Comité Internacional Permanente de la Seguridad Social

CPNM …Cáncer de piel no melanocítico

CPS …............. Estudio de la Prevención del Cáncer

CPSC …................... Consumer Product Safety Commission

CPTED ….............Prevención de delitos mediante el diseño medioambiental

CRU $\ldots . . . . . . . . . . . . U$ nidades sustituibles por el cliente

CSCL …................ ey de control de las sustancias químicas

CSHES ……....... Centros de Supervisión $\mathrm{H}$ igiénica y Epidemiológica E statal

C SM ............... Consejeros en materia de salud mental

CSO $\cdots \cdots \cdots \cdots \cdots \cdots \cdots \cdots \cdot \ldots$ anadian Standards O rganization

CST …....... Centros de salud en el trabajo

CST .......... Consejero en materia de salud en el trabajo

CTM Confederación de Trabajadores $\mathrm{M}$ ejicanos

CT N N H ..... Comité T écnico Nacional de N ormas H igiénicas CV D …........... D epósito en fase de vapor
CV D …....Enfermedades cardiovasculares CVI ….... nfiltración de vapores químicos CV L ...............C alidad de la vida laboral CV M ........ Capacidad voluntaria máxima

D

DALY ……........ Año de vida ajustado en función de la discapacidad

DAST ........... D rug A buse Screening T est

DBM S …........ Sistema de gestión de bases de datos

DBT ……........ D irectiva de baja tensión

DD 0 …............. Días desde la ovulación

DEM …............. Dosis eritémica mínima

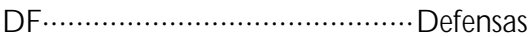

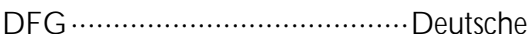

Forschungsgemeinschaft

DG …....................Dirección General

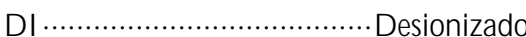

DIESAT ……R ed de Centros Científicos de los Países Bajos

DIN …....................... nstituto A lemán de N ormalización

DIP ...................M ontura doble en línea

DIS …...Borrador de norma internacional

DIST AT ................... D isability Statistics

Compendium de las $\mathrm{N}$ aciones $\mathrm{U}$ nidas

DIU …............... D ispositivo intrauterino

DKFZ ….... entro de Investigación sobre el Cáncer de Alemania

DLCO ……D isminución de la capacidad de difusión del monóxido de carbono

DLPW …..... Departamento de Protección y Bienestar de los T rabajadores

DM ….............. D irectiva de maquinaria

DM T …...............D osis máxima tolerada

DNU …................ D ispepsia no ulcerosa

DO E ….............. Department of Energy

(EE UU)

DOK -M EG A ….D ocumentación relativa a los $\mathrm{D}$ atos de $\mathrm{M}$ edición sobre Sustancias Peligrosas en el lugar de trabajo

DQ 0 ……D emanda química de oxígeno DS …................................ Ficha técnica DSI ……Difusión selectiva de información DSM …................M anual de diagnóstico estadístico de la A merican Psychiatric A ssociation

DSP …......................... Intoxicación con moluscos diarréica

DT L .......D osímetros termoluminiscentes

E

EA $\cdots \cdots \cdots \ldots \ldots \ldots \ldots \ldots$ Evaluación ambiental EAC ….............Enzima de conversión de la angiotensina 
EAF $\cdots \cdots \cdots \cdots \cdots \cdot \ldots+\cdots$ orno eléctrico de arco EBC …....................E quipo bajo control EBR …............ Eficacia biológica relativa ECA …...................A rea de captación epidemiológica

ECET O C ................European C hemical Industry E cology-T oxicology R esearch Centre

ECG ….................... Electrocardiografía EC J ..........Enferdad de C reutzfeldt-Jakob ECM …..............Enfermedad crónica de la montaña

ECO …..... entro Panamericano para la Ecología y la Salud H umanas

EC O SO C ............... Consejo Económico y Social

ECR ….............Estimación cuantificada de riesgos

ECVAM ….............. Centro Europeo de $\checkmark$ alidación de M étodos A Iternativos ED L ............................ Exposiciones de duración limitada

EDX A …..............Análisis radiológico de liberación de energía

E-E …......................Estímulo-estímulo

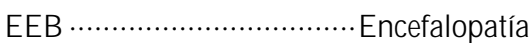
espongiforme bovina

EEG …................. Electroencefalograma EEO …......... gualdad de oportunidades de empleo

EEO C ….................Equal Employment O pportunity Commission de los EEUU EER $\ldots \ldots \ldots \ldots \ldots \ldots \ldots$.......... Equivalentes de radón en equilibrio

EFQM ….......Fundación E uropea para la Gestión de la Calidad

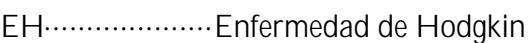
EH C …........ Criterios de salud ambiental EIA …...Evaluación de impacto ambiental EL ….................... Límites de exposición EL F …... Frecuencia extremadamente baja ELISA …..............Enzimoinmunoensayo EM $\cdots \cdots \ldots \ldots \ldots \ldots \ldots \ldots \ldots \ldots$. EM G …......................E lectromiografía EM I ….........Energía mínima de ignición EM I …...... nterferencia electromagnética

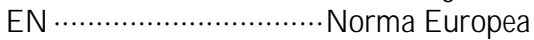
EN G ….................... E lectroneurografía EO G …................... E lectro oculográfico EPA ……........ Environmental Protection A gency de los Estados U nidos EPCI …...............Enfermedad pulmonar crónica inespecífica

EPE …............................. Estaciones de Prevención Epidémica

EPI …....Equipos de protección individual EPU …................ Espumas de poliuretano EPV $\cdots \cdots \cdots \cdots \cdots . . . . . .$. Estructuras de protección contra vuelcos E-R …....................E stímulo-respuesta
ER C …......E ducational R esource $C$ entres ERE $\ldots . . . . . . . . . . . .$. Enfermedad relacionada con el edificio

EREM P.............Programa de vigilancia radiológica medioambiental para casos de emergencia

ER G ….............Eastern R esearch G roup

ER IC ..................Educational R esources Information Center

ER S ..............E valuación de riesgos para la salud

ESA-IR S...... Sistema de R ecuperación de Información de la European Space Agency

ESD ….V álvulas de cierre de emergencia

ESP …E scleroderma sistémico progresivo

ET ….............Environmental technology

ET S ................ Efecto del trabajador sano

ET S …........................Enfermedades de transmisión sexual

ET SI …...... nstituto E uropeo de N ormas en T elecomunicaciones

EV O L ............E quipamiento de vigilancia óptima de locales

$F$

FA O ……... O rganización de las $\mathrm{N}$ aciones U nidas para la Agricultura y la Alimentación

FAS $\cdots \cdots \cdots \cdots \ldots . . . . .$. Formadores en materia de atención sanitaria

FBR $\cdots \cdots \cdots \cdots \cdot \ldots$ eactores reproductores de neutrones rápidos

FC ……...........Fijación del complemento

FCAW ............... Soldadura por arco con núcleo de material fundente

FCE ….... Factor de crecimiento epidémico

FDIS …...............Borrador definitivo de norma internacional

FEP ........Protoporfirina eritrocitaria libre

FEV $1 \cdots \cdots . . . . . V$ olumen espiratorio forzado en 1 segundo

FFP ……................ Firmes con precio fijo

FFPAF …..................... Firmes más tanto de adjudicación

FFR …........T asa de formación de humos

FG R …...........T asa de emisión de humos

FH SR …….........Fiebre hemorrágica con síndrome renal

FI $\cdots \ldots \ldots \ldots \ldots \ldots \ldots \ldots$............. Fumogos e ignífugos

FID ….... etector de ionización a la llama

FIDP ................Fibrosis intersticial difusa y progresiva

FIET …............Federación Internacional de Empleados, T écnicos y Similares

FIFR A ….... ey federal sobre insecticidas, fungicidas y rodenticidas
FIN N IDA …….....Agencia Internacional de D esarrollo de Finlandia

FM …................... Frecuencia modulada

FM A ……...... Fibras minerales artificiales

FM EA ……...Análisis de formas y efectos de averías

FM P …............. Fibrosis masiva progresiva

FNUAP …....... Fondo de Población de las Naciones U nidas

FOPS …......M edios de protección contra caída de objetos

FPA …........... Fire Protection Association

FR ….......................Factor reumatoide

FRC $\cdots \cdots \cdot \cdots \cdot . \cdot$ apacidad funcional residual

FREM …....... Fire risk evaluation method

FR PP ................. Polipropileno resistente a la llama

FSH $\cdots \cdots \cdots \cdots \cdots \cdots \cdots \cdot \ldots$ ormona estimuladora de folículos

FSM ….........Federación Sindical M undial

FSP ….............. Flujo sanguíneo periférico

FT P .............. Protocolos de transferencia de archivos

FV A …............... Fibras vítreas artificiales

FV C …............... apacidad vital forzada

FV P ….......Fiebre de los vapores de metal

GAG …................ lucosaminoglucano

GAT T ................A cuerdo G eneral sobre A ranceles A duaneros y Comercio $G C R \cdots \cdot \cdots \cdot$ eactores refrigerados con gas GEENET …...................R ed G lobal de Epidemiología A mbiental GEH …............... G rupos de exposición homogénea

GEM S .................. Sistemas genéricos de creación de modelos de errores

GISBAU G efahrstoff-Informa-tionssystem der Berufsgenossenschaften der Bauwirtschaft

G LSP ................ O peraciones de buenas prácticas a gran escala

GLW Q A .........Acuerdo sobre Calidad de las A guas de los $G$ randes $L$ agos G -M …....................... G eiger-M ueller GM ……....... Gestión del mantenimiento G M AW ….... Soldadura por arco metálico en atmósfera gaseosa

G NL …................... G as natural licuado

G OST …...... N ormas estatales de salud y seguridad en el trabajo de la Federación R usa

GRH $\cdots \cdots \cdots \cdot$..... estión de recursos humanos G R P ...........Plásticos reforzados con fibra de vidrio

GTAW …............. Soldadura de arco de tungsteno y protección gaseosa 
H

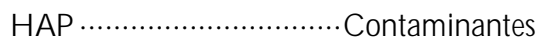
atmosféricos peligrosos

H ASS ........................... ome Accident Surveillance System

H AV ....................V ibración de la mano y el brazo

H AVS ……...... Síndrome de vibración de la mano y el brazo

H AZOP .................. Estudios de riesgos y capacidad operativa

H BIG …................ nmunoglobulina de la hepatitis $B$

H BsA g.................Antígeno de superficie de la hepatitis $B$

H C ...................... umo de flujo central

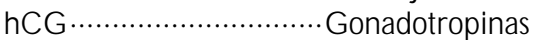
coriónicas humanas

H CIM …..........Fabricación integrada por ordenador y personas

H CS …............N orma de comunicación de riesgos

H DL …...... Lipoproteinas de alta densidad HEPA …......................A tenuadores de partículas de alta eficiencia H EPA …............Filtros de aire particulado de alta eficacia

H IP ...........Prensado isostático en caliente H iPox................ o xidación a alta presión

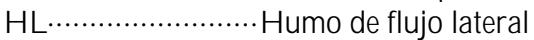
H M O …..................... O rganización de mantenimiento de la salud

H M T R I ................. H azardous M aterials T raining and R esearch Institute H PLC ……...... romatografía líquida de alta resolución

H R …......................H umedad relativa

H R ….................... Frecuencia cardíaca

H RB ….......................H iperactividad bronquial inespecífica

HRD I ....................... uman R esources Development Institute

H R G C …............ C olumnas capilares de alta resolución

H SE $\cdots . . . . . H$ ealth and Safety Executive del R eino U nido

H SE E S ................ H azardous Substances Emergency Events Surveillance H T A ….......... H umo de tabaco ambiental H V AC ................ Sistema de calefacción, ventilación y aire acondicionado H VBG ................. Federación Central de Berufsgenossenschaften

H V L …............C apa de hemirreducción H VLP...........Alto volumen, baja presión H VT …..........E spesor de hemirreducción

IAAM R H ….....A sociación Internacional de M edicina A grícola y Salud R ural
IACR S ……..... Comité I nter-agencias de Seguridad de la R adiación

IALA …........A sociación Internacional de Inspección de Trabajo

IAM nternational Association of $M$ achinists

IAM AW ….... International Association of $M$ achinists and Aerospace W orkers

IAR C .......Agencia Internacional para la Investigación sobre el Cáncer

IAS …........... nstituto de M edicina Social y del T rabajo

IASC ….............C onsejo Interamericano de Seguridad

IAT A ...............Asociación de T ransporte Aéreo Internacional

IBC ….. Institutional Biosafety C ommittee IBM ….... International Business $M$ achines IC ….................. Intervalo de confianza ICCV AM …..... Interagency C oordinating Committee for the $V$ alidation of Alternative $M$ ethods

ICD …...........Clasificación Internacional de Enfermedades

ICE …...................Enzima convertidora de interleucinas

ICEF …........Federación Internacional de T rabajadores de la Q uímica, Energía e Industrias Diversas

ICEM ….......Federación Internacional de Sindicatos $G$ enerales de los Sectores Q uímico, Energético y $\mathrm{M}$ inero

ICI $\cdots$. . ndustrial, comercial e institucional ICIDH ….... International C lassification of Impairments, Disabilities and $\mathrm{H}$ andicaps ICN .....................C onsejo Internacional de Enfermeras

ICNIR P .........Comisión Internacional de Protección contra la R adiación No lonizante

ICR P .............Comisión Internacional de Protección contra las $\mathrm{R}$ adiaciones

ICTU ..... rish Congress of T rade U nions

ID …....................... Diámetro interior

ID L H …......... nnmediatamente peligrosas para la vida y la salud

ID ND R ……Década Internacional de las $\mathrm{N}$ aciones U nidas para la R educción de las Catástrofes N aturales

IDPIS …............ Servicio de Información Integral sobre Fármacos y Tóxicos (T ailandia)

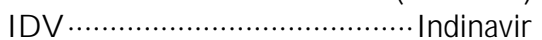

IEA …..............................A sociación Ergonómica Internacional

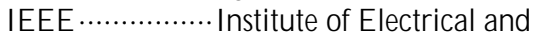
Electronic Engineers

IE L …............. nstituto Internacional de Estudios Laborales

IES …............. Sociedad de Ingeniería de la lluminación IFB …................. nvitación para licitar
IFIESR …..........Fundación Internacional para la E rgonomía Industrial y la Investigación sobre Seguridad

IFR CR C S …….Federación Internacional de las Sociedades de la C ruz R oja y de la M edialuna Roja

IFT ................ nterruptor de falla a tierra

IHEA ……A sociación Internacional para la Educación de los Cazadores

IISI …... Instituto Internacional del H ierro y el Acero

IJC ……....Comisión M ixta Internacional

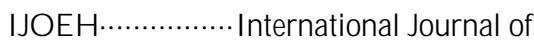
O ccupational and Environmental $\mathrm{H}$ ealth

IL ….................. Indice de levantamiento

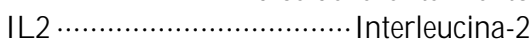

IL GWU …International Ladies G arment W orkers U nion

IM C ….............. Indice de masa corporal

IM D G C ódigo M arítimo Internacional de M ercancías Peligrosas

IM IS ….............. Sistema de Información Integrada de G estión

INES............... E scala internacional de accidentes nucleares

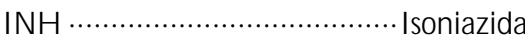

IN IR C/ IR PA ….... Comité Internacional de R adiación no Ionizante de la

A sociación Internacional de Protección contra la $\mathrm{R}$ adiación

IO CU …... O rganización Internacional de A sociaciones de Consumidores

IO H A …....Asociación Internacional para la Salud Laboral

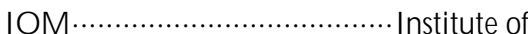
O ccupational M edicine

IO M / CAPM …...... nstituto de M edicina del Trabajo de la Academia C hina de M edicina Preventiva

IO M C ..........Programa Interorganizativo para una Correcta G estión de las Sustancias Q uímicas

IPC C …........ G rupo Intergubernamental sobre $\mathrm{C}$ ambios C limáticos

IPC S.............Programa Internacional de Seguridad de los Productos Q uímicos IPEC ...........Programa Internacional para la Erradicación del Trabajo Infantil

IPEET …....... Inter-American Partnership for Environmental Education and Training

IR …...................R adiación infrarroja

IREQ …................ V alor calculado del aislamiento requerido

IR PA …........A sociación Internacional de Protección contra la R adiación

IR PT C .............. R egistro internacional de productos químicos potencialmente tóxicos

IR SST .......... nstituto para la Seguridad y la Salud en el T rabajo (Q uebec, Canadá) 


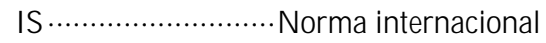
ISA …..............A sociación I nternacional de N ormalización

ISA …....... Instrument Society of America ISBN ……........... úmero internacional normalizado de los libros

ISCO …..........Clasificación normalizada internacional de ocupaciones

ISO …........... O rganización I nternacional de N ormalización

ISSA ….............. International Safety and Security Association

IST ….............. nstituciones de salud en el trabajo

ITPU …........ nstalaciones de tratamiento de propiedad pública

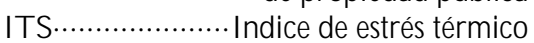

IU CN …............. nternational U nion for Conservation of $\mathrm{N}$ ature and $\mathrm{N}$ atural R esources-W orld C onservation U nion

$\int$

IUPAC …............ U nión Internacional de Q uímica Pura y A plicada

JAS ............E ncuesta de actividad Jenkins JECFA …... omité M ixto FAO / O M S de Expertos en Aditivos Alimentarios

JIT .................Producción garantizada en todo momento

JM A …........A sociación M édica Japonesa

JM PR .....R eunión Conjunta FA O / O M S sobre $R$ esiduos de Pesticidas

JPC G .............G rupo Coordinador M ixto de Presidentes

JPG ............G rupo M ixto de Presidentes JSO H ........... Sociedad Japonesa de Salud en el Trabajo

L

LADAPT …........ L igue pour l'adaptation des diminués physiques au travail

LAI …... ímites anuales de incorporación

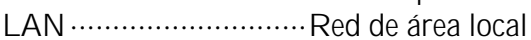

LCD …........ Indicadores de cristal líquido

LCFA …. imitación crónica al flujo aéreo

LCM …........ Leucemia mielocítica crónica

LCO …......... ectora de caracteres ópticos

LCT …......... iderazgo de la calidad total

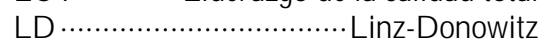

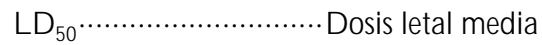

LDH $\cdots . . . . . . . . . . . . .$. Lactata deshidrogenasa

LDL …..... Lipoproteínas de baja densidad

LEC …...Encapsulado líquido C zochralski

LED ….................. Diodos luminiscentes

LEL ….......... ímites inferiores explosivos

LER …...... esión por esfuerzos repetitivos

LFCC …....................... Lesiones por frío con congelación
LFEC …….............. ímite fisiológico de exposición al calor

LFL …......... ímites inferiores inflamables

LFSC $\cdots$... esiones por frío sin congelación

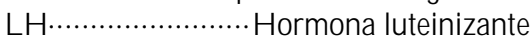

LISR EL ......M étodo de análisis estadístico

de los mínimos cuadrados ponderados

LIU NA ….... Laborers International U nion of $\mathrm{N}$ orth A merica

LLA …............ e eucemia linfocítica aguda

LLC ….......... L eucemia linfocítica crónica

LM A ….......... eucemia mielocítica aguda

LM C …..........L andell M ills Commodities

LM FBR ……......R eactores de neutrones rápidos refrigerados con metal líquido L NH .................... infoma no H odgkins

LN LA ….... e eucemia no linfocítica aguda

LO AEL ...............Nivel mínimo de efecto adverso observable

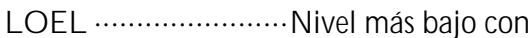
efecto observado

LO SC ............. Convenio de M ontego Bay sobre el $\mathrm{D}$ erecho del $\mathrm{M}$ ar

LPE …............... E pitaxia en fase líquida

LPG …............ G ases de petróleo licuado

LSF …............. Fundentes bajos en sólidos

LSZP ….................. Límite superior de la zona prescriptiva

LW GR ….......R eactores refrigerados con agua ligera y moderados con grafito

M

M A …...............M inisterio de Agricultura MAC …..................... Concentraciones máximas permisibles

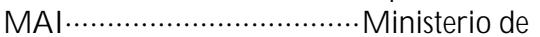
Administración I ndustrial

M AIM ...........M odelo de información de accidentes de $M$ erseyside

MAK …...... Concentración máxima en el lugar de trabajo

M AR PO L ............. C onvenio de $L$ ondres sobre prevención de la contaminación marina por el vertido de residuos y otras materias

MAST …................... M ichigan Alcohol Screening T est

M BA ….................. M aster of Business Administration

M BE ….........E pitaxia con haz molecular

M C ......M odificación del comportamiento M CA ….......M onitores continuos de aire

M CC ….....M ejora continua de la calidad M DS.............................M elanomas de diseminación superficial M DT …...........Equipos multidisciplinares MERCOSU R ..............M ercado Común del Sur

$\mathrm{M} \mathrm{eV}$..............M illones de electronvoltios
M H W ……...........M inisterio de Sanidad y Bienestar

M I G …......................... M etal gas inerte

MITI ................M inisterio de Comercio Internacional e Industria

M LA …......M elanomas lentiginosas acros M LSS ….............. Sólidos suspendidos en solución mixta

M M ….......................M ieloma múltiple

M M C ….C ompuestos metal-aglomerante

M M C ….........M illones de metros cúbicos

M M L …................ M elanomas malignos lentiginosos

M M PI ................... |ndice multifásico de personalidad de M innesota

M N ….....................M elanoma nodular

M N ….............................M icronúcleos

M O C V D ….....D eposición de vapores de sustancias químicas organometálicas M O RT ……Supervisión de la dirección y árbol de riesgos

M PD …......... Conjunto de datos mínimo previo a la comercialización

M PI …...........M asa particulada inhalable

M PI …..........M asa particulada inspirable

M PPD ……D año máximo probable para la propiedad

M PR ….........M asa particulada respirable M PST ….........M édicos promotores de la salud en el trabajo

M PT …............M asa particulada torácica

M R ........................M uy recomendado

M R C …............ Cartuchos de sustitución de metales

M R C …..........M edical R esearch C ouncil M R F …........... Instalaciones de reciclado de materiales

M SD …..........V alor de la dosis de mareo MSDS .............Ficha técnica de seguridad M SF ......M anufacturing-Science-Finance M SH A …...........M ine Safety and $\mathrm{H}$ ealth Administration

M ST ..........M édico de salud en el trabajo MT BF ............T iempo medio entre fallos MTF ….......Función de transferencia de la modulación

MU B …...........B Bloque de urea de melaza MUTR …..........M odelo de utilidad de la tecnología de rehabilitación

M V K …....M oolgavkar-Venzon-K nudson M V L C …….......... Capacidad máxima de carga voluntaria

M W e ...............M egavatios de eletricidad M WL …............ Carga de trabajo mental M WR ….......M egavatios de refrigeración MYR …..................M illones de ringgits

N

NADH $\cdots \cdots \ldots \ldots \ldots \ldots . . . N$ icotinamida-adenin dinucleótido 
N AEP $\ldots \ldots \ldots \ldots \ldots \ldots \ldots . . . \cdots$ National Asthma Education Program

NAET ……......N itrosaminas específicas del tabaco

NAS $\cdots . . . . . . . N$ ational A cademy of Science (Estados U nidos)

NASA …..........Administración $\mathrm{N}$ acional Aeronáutica y del Espacio (Estados U nidos)

NASA-T LX …....NASA T ask L oad Index NBC $\cdots \cdot . \cdot$ N ucleares, biológicas y químicas

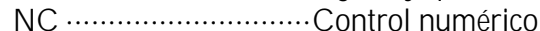
N C H S …....... N ational C enter for $\mathrm{H}$ ealth Statistics (Estados U nidos) $\mathrm{NCl}$................. National Cancer Institute (Estados U nidos)

NCR P ......National C ouncil on Radiation Protection and $M$ easurements

NCT B …............ N eurobehavioral Core Test Battery

NEET C ….........N ational Environmental E ducation and T raining Center, Inc. NES …..................... N eurobehavioral Evaluation System NESC ….N ational Electrical Safety Code NESH AP ….............. N orma A erospacial $\mathrm{N}$ acional sobre Emisiones para Contaminantes A tmosféricos Peligrosos

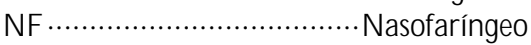

NFPA $\cdots \cdots \cdots \cdots \cdots . \cdots$ national Fire Protection Association (Estados U nidos)

$\mathrm{NH} \cdots \cdot \cdot \cdot$... eumonitis por hipersensibilidad N H ANES …...........Encuesta Nacional de Exploración Dietética y $M$ édica

NHIS ..................Encuesta N acional de Entrevistas sobre la Salud

NHS $\cdots \cdots \cdots \cdots \cdots \cdots \cdot \cdots$ ational H ealth Service NIC ….......................Países de reciente industrialización

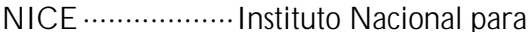
la M ejora de las Condiciones y el M edio A mbiente de T rabajo

NIEH S .................. N ational Institute for Environmental H ealth Sciences

$\mathrm{NIH} \cdots \cdots \cdots \cdots \cdot$ National Institutes of $\mathrm{H}$ ealth (Estados U nidos)

N IH G .......... N ational Institutes of $\mathrm{H}$ ealth Guidelines (Estados U nidos)

N I M H …............. N ational Institute for $M$ ental $\mathrm{H}$ ealth

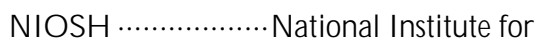
$\mathrm{O}$ ccupational Safety and $\mathrm{H}$ ealth (Estados U nidos)

NiPER A ….................. Nickel Producers Evironmental R esearch A ssociation NIPT S .......... D esviación permanente del umbral inducida por ruido

NIS ....N ivel de integridad de la seguridad NK …............. Células litolíticas naturales N M C ......... N eumoconiosis de los mineros del carbón
N M W C C …............. Comité N acional de Concentraciones M áximas en el Lugar de Trabajo

NOAEL ….................... Nivel sin efecto adverso observable

NOES …..............Encuesta N acional de Exposiciones Profesionales NO O .............................. Neumonía de origen ocupacional

NPA …........... N ormativa de prevención de accidentes

N PD …......... D etector de compuestos de nitrógeno y fósforo

NPR I …............ |nventario $\mathrm{N}$ acional de $\checkmark$ ertidos Contaminantes

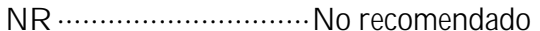

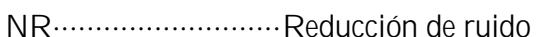
NRC ….........N ational R esearch C ouncil (Estados U nidos)

NR PB …...........N ational R adiological Protection Board

N R R …............ N oise R eduction R ating NSC …............ N ational Safety C ouncil (Estados U nidos)

N SF $\cdots \cdots \cdots \cdots . . . N$ ational Science Foundation

NTIS $\cdots \cdot . \cdot N$ ational T echnical Information Service (E stados U nidos)

NTO F …............... N ational Traumatic O ccupational Fatalities

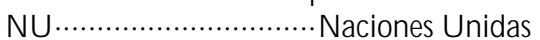
N V O C ………..... Compuestos orgánicos no volátiles

NYC/ T LC …....New Y ork C ity/ T axi and Limousine Commission

0

O AAAS …......A sma profesional asociado a la fundición de aluminio $\mathrm{OACl} \cdots \cdots . . . . . .0$ rganización Internacional de Aviación Civil O BM …............................. G estión del comportamiento organizativo

O C …........... nsecticidas organoclorados OCDE ….............. O rganización para la Cooperación y el D esarrollo Económico

O D …........................ D ensidades ópticas O DIN …........................... Servicio de R econocimientos Periódicos O DM ................... O mni Diurnal M odel OEA …...................... O rganización de Estados Americanos

OECD …....... O rganization for Economic and Cultural Development

OEL …... ímites de exposición profesional OES ….................. Límites de Exposición Profesional de la Dirección de Salud y Seguridad

O HAS ......................... Sistema híbrido automatizado abierto
O IE ……….... O rganización Internacional de Empleadores

OIG .......................... O rganizaciones intergubernamentales

OILPO L …............... Convention for the Prevention of Pollution of the Sea by 0 il

O IT ….................. O ficina Internacional del Trabajo

O IT ….......... O rganización Internacional del Trabajo

O M B ….............. O ffice of M anagement and Budget

O M C ….......... O rganización M undial del Comercio

O M G …............. O rganismo manipulado genéticamente

O MI …............. O rganización M arítima Internacional

O M N I …... Información sobre M edicina y Enfermería del T rabajo

O M S …........... O rganización M undial de la Salud

O M V PE ….........E pitaxia organometálica en fase de vapor

O N AC ...... ffice des anciens combattants O NG .... O rganización no gubernamental O NUDI …............... O rganización de las $\mathrm{N}$ aciones U nidas para el D esarrollo Industrial

O SH A ….......... O ccupational Safety and $\mathrm{H}$ ealth Administration

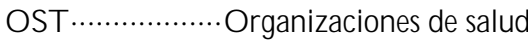
en el trabajo

O ST P .................. O ffice of Science and Technology Policy

O T A …............... O ffice of T echnology A ssessment

O TAN …......... O rganización del T ratado del A tlántico $\mathrm{N}$ orte

O UA ........................ O rganización de la U nidad Africana

$P$

P\&G .....................Proctor \& Gamble PAD ….............Presión arterial diastólica

PAE ….............Programa de asistencia a los empleados

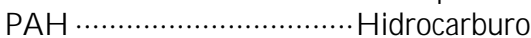
aromático policíclico

PAH O …........................Pan-American $\mathrm{H}$ ealth $\mathrm{O}$ rganization

PAM …............ Programas de A sistencia a los M iembros

PAPR $\cdots \cdots \cdots \cdots \cdot \ldots$ espirador motorizado de aire depurado

PAQ …............ Cuestionario del Análisis de Posición

PAR …............. ámparas parabólicas de reflector aluminizado 
PAS .........Personal de asistencia sanitaria PAS ...................Presión arterial sistólica PASP …................Personal de asistencia sanitaria primaria

PAW ......... Soldadura por arco de plasma PB ….................... Presión barométrica PC ….............. ontrolador programable

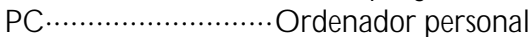
PCB …................. Bifenilos policlorados PCB …..........T arjeta de circuito impreso PCCA ….......Programas de conservación de la capacidad auditiva

PCH E …........... Colinesterasa plasmática PCR ….............R eacción en cadena de la polimerasa

PCT .........Prueba cutánea de tuberculina PD F ............Productos de degradación de la fibrina

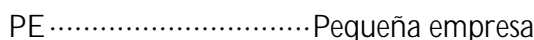
PE …..................Parada de emergencia

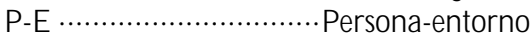
PE …....................Potenciales evocados $P E F$................M áximo flujo respiratorio PEG ....Pequeño para su edad gestacional PEL ….... ímites de exposición permisibles PES ………......Partículas en suspensión PES ....Programmable E lectronic Systems PETE .......Partnership for Environmental T echnology Education PFA .......Proteína fijadora de andrógenos PFD …....... Sistema de flotación personal PFDM ..Panel de fibra de densidad media PGM ..........Planta de gas manufacturado PH C ......................... entros sanitarios municipales (Finlandia)

PH S …................. Public H ealth Service (Estados U nidos)

PH WR …........R eactores de agua pesada a presión

PIB …...............Producto Interior Bruto PIC …….... nyección de carbón triturado PID …........... D etector de fotoionización PIR S ............Sensor pasivo por infrarrojos PIV .................... Pielografía intravenosa

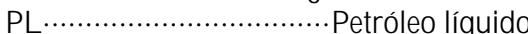
PLC …... ontrolador lógico programable PLS …....... Solución de lixiviación fecunda o impregnada

PM ….................. M etabolizador escaso

PM N ……........... N otificación previa a la fabricación

PN B ................Producto nacional bruto por habitante

PNO C ................Partícula no clasificada según otro criterio

PNU D............Programa de las $\mathrm{N}$ aciones U nidas para el D esarrollo

PNU M A ......... Programa de las $\mathrm{N}$ aciones U nidas para el M edio Ambiente

PO C ............................ Característica del rendimiento operativo
PO M S …........Perfil de estados de ánimo PPD …......... erivado proteico purificado PPE …............. Profilaxis post-exposición PPO .......Preferred provider organization PPQ …................ Protección frente a los productos químicos

PPQ PT …........ R egistro Internacional de Productos $\mathrm{Q}$ uímicos

Potencialmente T óxicos

PPS …........Prevención y promoción de la salud en el lugar de trabajo

PR A ….........Pre-R etirement Association

PR D …............ D ocumento de requisitos del producto

PR O BAS …....... Base de datos danesa de registro de productos

PSC $\cdots \cdots \cdots \cdots \cdots \cdots \cdots \cdot \ldots$ riterios probabilísticos de seguridad

PSL …........ Lista de sustancias prioritarias

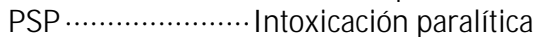
con moluscos

PT S ............Promoción T otal de la Salud PV …............................. Presión y vacío PV D ……....D eposición física de vapores PV D ...............Pantallas de visualización de datos

PW B $\cdots \cdots \cdot$ T arjeta de conexionado impreso PWI …................ Projects with Industry PWR ……......R eactor de agua a presión

\section{Q}

QALY …...........Año de vida ajustado en función de la calidad

QFD …….........D esarrollo de la función de calidad

\section{R}

RA …...................... Colofonia activa

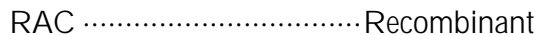
Advisory Committee

RACB ….......... Evaluación Reproductiva mediante Cría C ontinua

RADS …........... Síndrome de disfunción reactiva de las vías aéreas

RAP ............Plan de acciones correctoras

RA P......R iesgo atribuible en la población

RBM ...............................Perforadora

RBM K …........... T ubos de presión de los reactores de agua en ebullición

RCP …......R eanimación cardiopulmonar R C V …................... R etirada mediante cráteres verticales

RDF ….......... ombustibles derivados de los residuos

RE $\cdots \cdots \cdots \cdots \cdots \cdots \cdots \cdot \ldots$ etículo endoplásmico RF …........................R adiofrecuenia $\mathrm{R} f \mathrm{D} \ldots \ldots \ldots \ldots \ldots \ldots \ldots$ D osis de referencia
RFP …..................... Solicitud de oferta R H R …V elocidad de liberación de calor RID …....R eglamento sobre el transporte internacional ferroviario de sustancias peligrosas

RIE …........ G rabado con iones reactivos R M …................R esonancia magnética

R M A …. Colofonia de actividad atenuada R M N …....R esonancia magnética nuclear R NI …..............R adiación no ionizante R NUR ……......... O rganización R enault ROM …...... M olienda directa en la mina R PG …........ R eingeniería de los procesos de gestión

R R …...................... R espuesta rápida

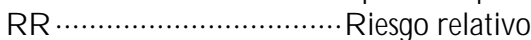
$R-R \cdots \cdots \cdots \cdots \cdots \cdots \cdots \cdot \cdots \cdot \cdots$ espuesta-respuesta R SU …............R esiduos sólidos urbanos RT B ….........Proteína de unión al retinol RTECS ….....R egistry of T oxic Effects of Chemical Substances RUV …................ Radiación ultravioleta R V ........................... V olumen residual R VH ….... espuesta ventilatoria hipóxica

$S$

SAE $\cdots \cdots \cdots \cdots \cdots . . . . .50 c i e d a d$ de Ingenieros de Automóviles

SAG …........ ompañía Soviética W ismut SA P.... Sistema de auditoría de Pellenberg SAR …....R elaciones estructura-actividad SAR …........T asa de absorción específica SAR A …. Superfund Act R eauthorization Amendment (E stados U nidos) SAT …........... Síndrome del aceite tóxico SAT …...........T ratamiento suelo-acuífero SAW …..... Soldadura por arco sumergido SBN $\ldots . . . . . . . . . .$. ndice de nitrógeno de una sola respiración

SBR …...... Caucho de estireno-butadieno SCAT …................. Equipos especiales de intervención en accidentes

SCE ….......................... ntercambio de cromátidas hermanas

SCI ….......... Síndrome del colon irritable SCU BA ….........................A paratos de respiración submarina SDAG ..................................C ompañía Soviético-Alemana W ismut

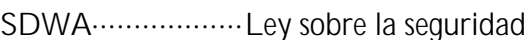
del agua potable

SE/ E/ P ................ Sistemas de seguridad eléctricos, electrónicos y programables SEAT ….... T ransmisibilidad de amplitud efectiva del asiento

SED ….... D iseño ergonómico del sistema SEE …....... Síndrome del edificio enfermo SEIU ….......... Sindicato Internacional de Empleados de Servicios 
SELF ….... Sociedad de Ergonomía de los Países Francófonos

SEM I …............ N ormas internacionales relativas a equipos y materiales semiconductores

SER ....... Sistema de energía de referencia SER …................ Supervisión electrónica del rendimiento

SIA ….......................... Semiconductor Industry Association

SIC ….......................... Clasificación Industrial N ormalizada

SICL …............. Sistema Internacional de Codificación de Lámparas

SIES …............ Sistema internacional de evaluación de la seguridad

SIL …................N iveles de interferencia del habla

SIM U VIM A / A limentos ...........Programa mixto PNUMA/FAO/OMS sobre vigilancia de la contaminación de los alimentos

SLM ….... Sistema de medición del sonido SM AW …........... Soldadura metálica por arco protegido

SM C …............ Componentes montados en superficie

SM H …. Síndrome del martillo hipotenar

SM ORT …............ T écnica de gestión de seguridad y revisión organizativa

SM R ..................... T asa de mortalidad relativa estandarizada

SM SL …....... Síndrome de muerte súbita del lactante

SM T …........T ecnología de montaje total en superficie

SNC …............. Sistema nervioso central SN O M ED …... om omenclatura Sistemática de M edicina

SN P .............. Sistema nervioso periférico SO GS ….... South 0 aks $G$ ambling Screen SO LAS …............... Conferencia sobre la seguridad de la vida en el mar SPES ........... Sistema sueco de evaluación del rendimiento

SPF $\cdots \cdots \cdots \cdots \cdots \cdots \cdots \cdots \cdots \cdots$ actor de protección SPH …................. Síndrome pulmonar por Hantavirus

SPL …............N Nivel de presión acústica

SPM ….............Partículas en suspensión

SPM ….............. Síndrome premenstrual

SPR IA ….......... Society for Participatory Research in Asia

SQ M ....Sensibilidades químicas múltiples SRE $\cdots \cdots \cdots \cdots . . \cdots$. Sistema reticuloendotelial SS ........................ Sólidos en suspensión SSA …..........Salud y seguridad ambiental ST C …........ Síndrome del túnel carpiano STEL ….............. Límite de exposición a corto plazo

ST EP ........Procedimiento de detección de sucesos en secuencias temporales
ST PO ……............ Síndrome tóxico por polvo orgánico

ST S …............ Sólidos totales suspendidos SU V A …… O rganización Nacional Suiza de A seguradoras de Accidentes

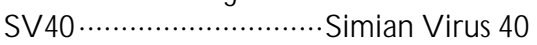

SV V …..............Síndrome vasoespástico relacionado con la vibración

SW O R D …. Surveillance of W ork-related R espiratory Disease

SX EW ……....Extracción por disolvente/ extracción electrolítica

$T$

T/ | …............T uberías e instrumentación TAD ……. Servicio de Inspección Técnica TAM …........... T orres de acceso móviles

TAR …............T ensión aeróbica relativa T B …....................... T raqueobronquial TBS-GA ….... Sondeo para el diagnóstico de tareas: trabajo mental

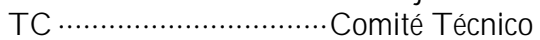

T C …........ T omografía computadorizada

T CAR …...T omografía computadorizada de alta resolución

TCEFU …...T omografía computarizada por emisión de fotón único

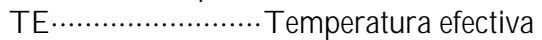

TEC …...T emperatura efectiva corregida

TEE …....T emperatura Efectiva Estándar

TEP $\ldots . . . . . . . . . . . . . . T$ T omografía por emisión de positrones

TEPT ……............ T rastorno por estrés postraumático

TER …......T eoría de la elección racional

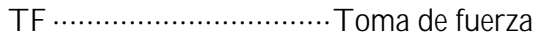

TFG ….................T ipos de fallo general

T GI ….............. T racto gastrointestinal

TH R -T eoría de la homeostasis del riesgo

TI …........................ T exas I nstruments

TIG …................. Gas inerte y tungsteno

T LAM …........... T ejido linfático asociado a mucosa

T LC …........... Capacidad pulmonar total

T LC ........T ratado de Libre Comercio de América del Norte

T LE ......... T ransferencia lineal de energía

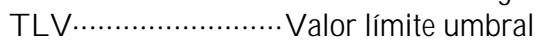

T LV -ST E L …V alor límite umbral-límite de exposición a corto plazo

T LV -T W A ....V alor límite umbral-media ponderada en el tiempo

TM C …..... T asa de mortalidad por casos

T M G …......T iempo medio invertido en el tratamiento de cada llamada

TM R P ..................... T asa de mortalidad relativa proporcional

T M R PC …... T asa de mortalidad relativa proporcional por cáncer

T N F ...............F actor de necrosis tumoral
T N O …....................... Dutch National Technical Institute

T O C ……......... Carbónico orgánico total

TO P ...............T ecnologías, organización y personal

T PC …............. T rastornos profesionales cervicobraquiales

T PDA …..............A cido graso de telurio radioyodinado

T Q M G …….... Gestión de la calidad total

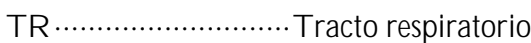
TR C …............... T ubo de rayos catódicos

TR GS …............. N ormas técnicas sobre Sustancias Peligrosas

$T R \mid \cdots \cdots \cdot \ldots \cdot$ nventario de $V$ ertidos T óxicos TS ….................... T anques subterráneos

TSC A …....... ey de Control de Sustancias T óxicas de los Estados U nidos

T SD ….T eoría de la detección de señales

TSH ........................... T ratamiento de sustitución hormonal

T SP ……....... antidad total de partículas sólidas en suspensión

T SS …................ T anques sobre el suelo

T T A …............... T rastornos traumáticos acumulados

TTFC …................. T anques con techos flotantes convertidos

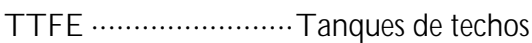
flotantes externos

TT L …T est de transformación linfocítica

T T S .......D esviación temporal del umbral

T U C ................T rades U nion Congress (R eino U nido)

TUR ….................R educción del uso de sustancias tóxicas

T UT B ……...... O ficina T écnica Sindical Europea para la Salud y la Seguridad en el Trabajo

TV L ............... Capa del valor un décimo

TW A …....M edia ponderada en el tiempo

TW AL …....... ímite medio ponderado en el tiempo

\section{U}

UAW …............... U nited A uto W orkers UE ….......................... U nión Europea

UFC ...... U nidades formadoras de colonias UIAT …......... U nidad de I nvestigación de Accidentes de Trabajo

UNCET G .....U nited Nations C ommittee of Experts on T ransport of $D$ angerous $G$ oods

U NCL O S ....C onferencia de las $\mathrm{N}$ aciones U nidas sobre el Derecho del $\mathrm{M}$ ar

U NCT AD …C onferencia de las $\mathrm{N}$ aciones U nidas sobre Comercioy D esarrollo

UNCT C .............. entro de las N aciones U nidas sobre las Empresas T ransnacionales 


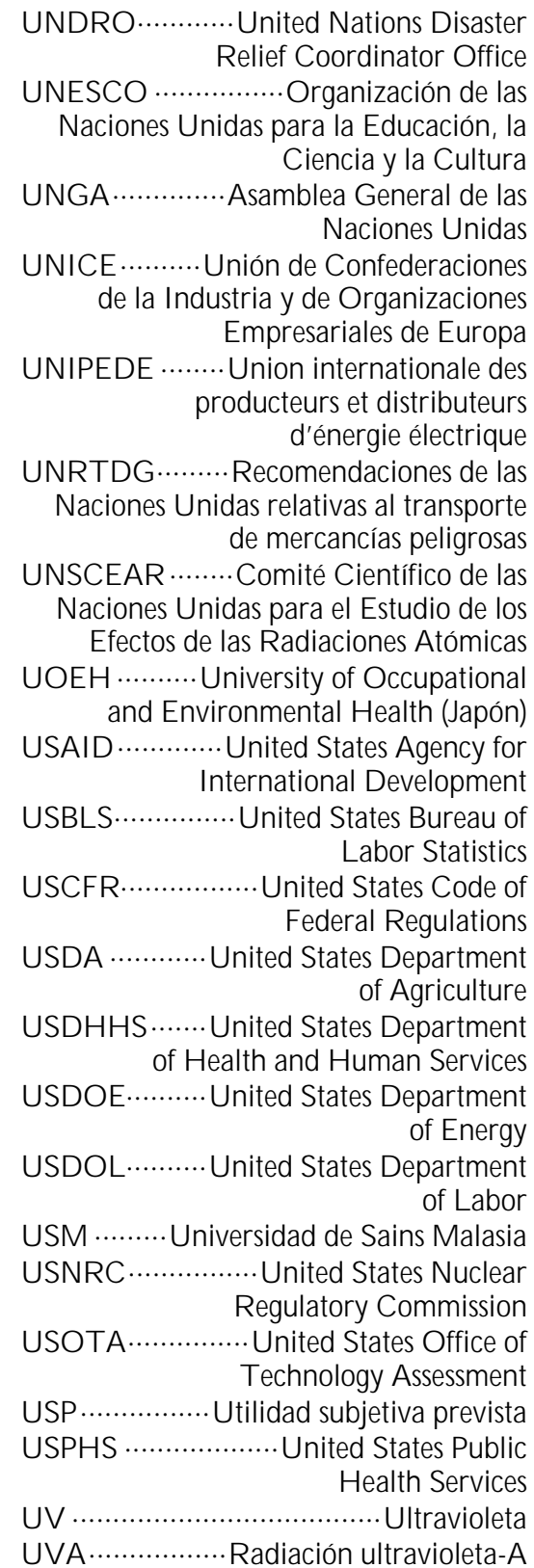

UV B …............R adiación ultravioleta-B

UV C …............. R adiación ultravioleta-C

UV G $\mid \cdots \ldots . . . . . . .$. Lámparas de ultravioleta

\section{V}

VAL …............ V entilación aspirante local VAV ...................... V olumen variable VC ….............................Capacidad vital VCM ...........V olumen corpuscular medio VEP $\cdots . . . V$ aloración del esfuerzo percibido VH A ……. V irus de la hepatitis de tipo A VH B …......V irus de la hepatitis de tipo $B$ VH C …..... V irus de la hepatitis de tipo $C$ VH D ….....V irus de la hepatitis de tipo D VIH …........... Virus de inmunodeficiencia humana

VIIF ….........V asodilatación intermitente inducida por el frío

VLF ….................M uy baja frecuencia VL P..........V álvula limitadora de presión VM T ……....M illa recorrida por vehículo VPE …............E pitaxia en fase de vapor VPP.....................Programa voluntario de protección

VPPB $\cdots \cdots \cdots \cdots \cdots \cdots \cdots \cdots \cdot \ldots$ értigo posicional paroxístico benigno VPU …............... V ariación permanente del umbral

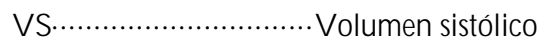
VSC ….........V olumen sanguíneo central VU B ...................... V olumen ultrabajo VWF …................D edo blanco inducido por vibración

W

WAN O …….......A sociación M undial de O peradores Nucleares WBGT …........T emperatura de globo de bulbo húmedo
WCGS $\cdots \cdots \ldots \ldots . . . . .$. W estern Collaborative Group Study

$W \mathrm{Cl} \cdots \ldots \ldots \ldots . . .$. ndice de Enfriamiento por el Viento

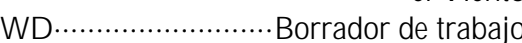
WE F ..............Fondo Sueco para el M edio A mbiente del Trabajo

WERC W aste-management Education and R esearch Consortium

WG …..................... G rupo de trabajo

WGT $\ldots . . . \cdots \cdots \ldots . . . .1$ ndice de temperatura de globo húmedo

WHIM S …........... Separador húmedo de alta intensidad

WH M IS …......... Sistema de información sobre materiales peligrosos en el lugar de trabajo (C anadá)

WHPA ….....Area de protección de pozos

WLM .................M eses Nivel de T rabajo WM A …......Asociación M édica M undial WR AP ......W aste R eduction Always Pays WR M D …T rastornos músculosqueléticos relacionados con el trabajo

Y

Y M CA ……........ Y oung M en's C hristian Association

Z

ZCT U …...............Zambia C ongress of

Trade U nions

ZDV ................................Zidovudina

ZeBW is $\cdots . . .0$ ficina $C$ entral de Asistencia de Wismut

ZEE $\cdot \cdots \cdot . . . . .$. Zonas económicas especiales ZIGUV ….......... Sistema de Información Central de las BG ZPP ….....................Zinc-protoporfirina ZR N …...............Zona de riesgo nominal 

$f=$ Figura
$t=$ Tabla

A

Abejas

abeja africana 70.6

de la miel 70.39

importación de 70.6

riesgo de picadura en trabajadores

forestales 68.28

Abiético

ácido 83.30

Aborto

aborto espontáneo 9.3

entre usuarias de PVD 52.18, 52.22

factores de riesgo 9.13

principales factores físicos $9.13 \mathrm{t}$

éteres de glicol, y $83.18,83.36$

fluoruros, y 83.18

riesgo de

en empleadas de la limpieza $\quad 100.5$

entre las cosmetólogas 100.10

riesgo en la fabricación de

semiconductores 83.18, 83.36

Véase también Pérdida fetal

Abrillantadores 72.9

Absentismo laboral

del profesorado 94.14

y estrés $5.16,34.64$

y mala calidad del aire interior 44.2

y salud mental 5.4

y violencia en el trabajo 51.6

Absorción

en tratamiento de aguas residuales 101.20

Acabado (industria textil)

mecánico, tipos

riesgos 89.21

químico

formaldehído 89.21

Academia Nacional de Ciencias de los Estados

U nidos

terminología sobre evaluación del

riesgo 33.78

Acanthamoeba 44.24

Acanthaster planci 38.5

Acaros

de almacén 70.22

productos de excreción de

y contaminación del aire interior 44.23 suspensión en el aire 67.21

Accesibilidad

y discapacidad 17.15

Accidentes

de automatización

en la corrección de una perturbación 58.11

problemas técnicos relacionados con $58.1058 .11 f$

protección del trabajador en 58.12

de caza 69.3

de circulación

del personal auxiliar y de

ambulancia 95.21

en el procesado del fieltro 89.18

en el sector de la confección 87.5

medidas de protección 87.5

en la industria

y proceso de comunicación de riesgos 54.25

y procesos de evaluación de riesgos 54.24

en los procesos de tinción 89.20

en pruebas de prototipos

en la industria del automóvil 91.9

"in itinere" 25.7, 26.7

marítimos

exposición al agua fría $\quad 42.48,42.52$

Véase también Frío

mayor

definición 39.9

mortales 68.5

en el mar 66.16

en el trabajo forestal 68.5

nucleares

convenios internacionales sobre 54.12

por radiación 48.34

Véase C atástrofes

de Three M ile Island $48.40,76.15$

del acelerador de $\mathrm{G}$ ulf $\mathrm{O}$ il

Company 48.35

en el reactor $n=1$ de Windscale 48.35

en el reactor SL-1 de Idaho 48.36

en la central de Chernóbil $48.43,76.15$

en la clínica de G oiânia 48.41

en la planta de Los Alamos 48.34

en radiografía industrial 48.36

Véase también Seguridad radiológica

químicos mayores

Véase $C$ atástrofes

y desarrollo tecnológico 29.3

y riesgos de los profesores 94.4
Accidentes de aviación

causas mecánicas 102.17

y fallo humano 102.17

y supervivencia a las aceleraciones 102.20

y transporte de materiales

peligrosos 102.18

Accidentes de trabajo

análisis de los 56.5 - 56.6

fases 56.5

modelo UIAT 56.22

Véase también Investigación de accidentes asistencia sanitaria 26.14

bases de datos 26.7

Código de práctica sobre la prevención de accidentes de trabajo graves 23.60

comunicación de casos 26.8

costes de los 56.43

a escala empresarial 56.43

en los trabajadores 56.43

para la economía nacional en conjunto 56.43

daños a los bienes 25.16

definición 26.7

definición en el sistema israelí 26.23

en instalaciones automatizadas 58.9

Véase también Accidentes de automatización

estadísticas en Alemania 32.22

codificación 32.25

colaboración del comité de empresa 32.25

objetivo de las estadísticas 32.22

obligación de notificación 32.22

por sectores industriales 32.25

usos de las estadísticas 32.25

factores nocivos 56.4

medidas de control 56.4

fuentes de exposición causantes 56.4

medidas de control 56.4

Véase también C ausas de accidentes

información sobre 56.25

modelo M AIM 56.25

método de análisis de Faverge 26.16

modelos de secuencia del

Véase I nvestigación de accidentes

niveles de análisis $56.6 f$

notificación y prevención en

Alemania 32.25

objetos que intervienen en los 56.27

y diccionario del software del

MAIM 56.27

partes de 32.14 
percepción del riesgo 26.11

por partes móviles de máquinas 58.9

por software y ordenadores 58.34

prevención de 23.28

reconocimiento del riesgo 56.3

registro y comunicación de accidentes de trabajo y enfermedades profesionales 23.60

rehabilitación 25.19

responsabilidad civil y penal $23.16-23.23$

responsabilidad de las empresas 29.100

responsabilidad por el accidente 26.12

y cuasiaccidentes 56.36

y estrés 26.11

y estrés postraumático 5.16

y factores humanos 56.4

Véase también Indemnización por accidentes de trabajo

Véase también Lesiones profesionales

Véase también Prevención de accidentes

Véase también R iesgos profesionales

Véase también Salud y seguridad en el trabajo

Accidentes eléctricos

causas de muerte 40.3

complicaciones cardiovasculares 40.5

cuadro clínico 40.5

en mujeres embarazadas 40.5

forma de onda de la señal eléctrica $\quad 40.4$

frecuencia de la señal eléctrica 40.4

influencia de los diversos parámetros eléctricos 40.3

límite de tensión convencional 40.4

quemaduras electrotérmicas 40.3

rayo 40.5

resistencia 40.4

tensión de contacto 40.3

tensión de seguridad 40.4

umbrales de corriente

intensidad 40.3

y corriente alterna y continua $\quad 40.4$

Véase también Electricidad

Véase también Electrización

Véase también Electrocución

Aceite de colza 39.5

Véase también Síndrome del aceite tóxico

Aceite mineral

vertido de 68.44

Aceite de resina producción de 72.12

A ceite lubricante en el medio ambiente 68.44

Aceites industriales

aditivos 82.39

aditivos antidesgaste 82.39

aditivos contra presiones extremas 82.39

aditivos para crear adherencia 82.39

aditivos para lubricidad 82.39

anticorrosivos 82.39 antiespumantes 82.39

antioxidantes 82.39

bactericidas 82.39

colorantes 82.39

correctores del índice de

viscosidad 82.39

desemulsionantes 82.39

detergentes 82.39

emulsionantes 82.39

de mecanizado y de proceso 82.38

disolventes 82.38

fabricación 82.39

calidad de los productos 82.40

procesos de mezcla y composición 82.39

productos acabados 82.40

fluidos de corte 82.38

grasas 82.38

para motores de automóviles 82.38

salud y seguridad 82.40

dermatitis de contacto 82.41

protección contra incendios 82.40

riesgo de cáncer 82.41

A ceites y grasas

elaboración 67.33

Aceleración

efectos fisiológicos de la 102.18

en el transporte aéreo 102.19

efectos sobre el sistema

cardiovascular 102.19

tolerancia humana a la 102.19

A celeradores de partículas

dispositivos de aviso y alarma en 48.31

radionucleidos producidos por 48.17

Aceptación de riesgos

aceptación de los riesgos óptimos $59.37 f$

consciencia de la 59.30, 59.32

contextos emocionales en 59.36

factores culturales en la 59.28

factores individuales en la 59.34

factores influyentes $59.33,59.34 f$

y comunicación de riesgos 59.38

y fenómeno del riesgo deseado 59.34

Véase también Evaluación del riesgo

Acerías

programas de salud y seguridad 73.6

Acero

aceros especiales 73.5

fabricación de acero 73.5

colada continua 73.5

lingoteras 73.6

fundición 82.19

riesgos en la fabricación del 73.6

explosiones 73.6

lesiones 73.6

quemaduras 73.6

transporte mecánico 73.6

tipos 92.6

acero de alta resistencia 92.6 acero dulce 92.6

aleaciones de acero 92.6

utilización en la industria naval 92.6

Acero inoxidable

compuestos de cromo hexavalente y de

níquel generados por la soldadura

del 72.16

humos de la soldadura del 72.16

Acero plomado

y humos de plomo 63.23

Acetaldehído 41.13

como carcinógeno del grupo 2B por la IARC 104.46

Acetales

Véase C etales

A cetato de vinilo

como carcinógeno del grupo 2B por la IARC 104.163

Acetatos 104.162

como disolventes 104.162

exposición a

pintores y 103.47

Acetazolamida 37.8 - 37.9, 37.14

A cético

ácido $64.41,72.20,85.10,85.15$

anuria y 104.13

empleo en la industria de la seda 89.15

uremia y 104.13

N-A cetilcisteina 63.8

Acetilcolina 42.4

A cetilcolinesterasa 27.20

Acetileno

inflamabilidad del 61.17

y riesgo de incendio $36.9,41.18$

Acetona $30.26,67.10,86.2$

Acido

abiético 83.30

acético 64.41, 72.20, 85.10, 85.15, 89.15, 104.13

ascórbico 65.13

cacodílico 27.10

cítrico 67.32

clorhídrico 41.15, 63.2, 104.6

clórico 39.4

peróxido de benzoilo y 104.363

8-aminolevulínico 27.12

8-aminolevulínico dehidratasa 27.12

8-glucárico 27.3

2, 4-diclorofenoxiacético 27.25

domoico 66.20

fluorhídrico 31.17, 39.33

fosfórico 70.21

hipúrico 27.14

inorgánico 104.5

almacenamiento 104.5

efectos en la salud 104.5

manipulación 104.6 
láctico 67.32

meso-2,3-dimercaptosuccínico 63.8

metilfenoxiacético 27.25

metilhipúrico 27.5

monometilarsónico 27.10

nítrico 41.13, 104.7

nitrilotriacético 104.338

orgánicos 104.12

riesgos 104.13

usos 104.12

oxálico 71.10, 104.15

perclórico 41.13

y riesgo de explosiones 61.13

plicático 71.10

salicílico 104.12

sulfhídrico $70.13,70.15$

exposición al 70.15

sulfúrico $41.13,104.7$

sulfuroso 72.8

tartárico 65.13

2-tiotiazolidina-4-carboxílico 27.23

tricloroacético 33.21

2, 4, 5-triclorofeno-oxiacético 27.25

Acidos minerales

$V$ éase A cido inorgánico

Aclimatación ventilatoria

respuesta ventilatoria hipóxica 37.6

variabilidad en función de las

personas 37.4

y sueño 37.5

Acné

Acoso sexual

a personal de hoteles 98.8

código de conducta de la Comisión

Europea 34.33

como agresión en el trabajo 51.5

como forma de discriminación sexual 51.5

datos sobre el 34.32

en el lugar de trabajo 24.4

en el sector de la confección 87.7

prevención 34.33

problemas derivados 34.33

rasgos comunes 34.32

Acrilamida

como carcinógeno del grupo 2A por la

IARC 104.74

efectos neurológicos 104.73

neuropatía periférica 104.74

Acrilatos

de etilo

como carcinógeno del grupo 2B por la IARC 104.172

de metilo

inclasificable como carcinógeno por la

IARC 104.172

efectos sobre la piel y el aparato

respiratorio 85.4
Acrilonitrilo

como carcinógeno del grupo 2A por la

IARC 104.138

precauciones 104.139

riesgos 104.138

tratamiento 104.139

Acroleína 44.7, 67.33

contaminante atmosférico 104.46

Acrosteolisis

y cloruro de vinilo 104.254

Acta U nica Europea

medidas de seguridad y salud en el trabajo 16.4

Véase también U nión Europea

Activación de lodos en tratamiento de aguas residuales 101.19

Actividad

Véase Análisis del trabajo

definición 29.9

Actividad física

lista de comprobación 29.18

Actividades docentes 94.2

Actividades educativas

riesgos y su prevención 94.2

Actores

alergias cutáneas 96.30

por el maquillaje 96.30

estrés en

causas 96.30

infantiles 96.31

protección de los 96.31

mortalidad por suicidios 96.6

riesgos en rodajes 96.30

tasas de mortalidad por cáncer 96.6

Actualización profesional, cursos 94.2

Acuarios

riesgos del trabajo en

y medidas de precaución 96.44

Acuáticas, especies

fenoles y 104.370

Acuerdo de Viena 68.36

A cuerdo $G$ eneral sobre A ranceles A duaneros y

Comercio

acuerdos de libre comercio 20.15

R onda de U ruguay 20.15

Véase también O rganización M undial de Comercio

Acuerdos comerciales 24.17

Véase también O rganización M undial de Comercio

Acufenos 47.4

Acuicultura

impactos ambientales 70.38

peligros para la salud 70.38

peligros y controles 70.37
Adaptación

de tipo aislante 42.51

de tipo hipotérmico 42.51

de tipo metabólico 42.51

fenotípica 42.51

genética 42.51

local de las extremidades 42.52

Adenocarcinoma

por inhalación de polvo de maderas 96.20 sinonasal 71.11

Adenopatía hiliar 10.33

Véase Enfermedad por berilio

Adhesivo termoimpregnado 67.25

Adhesivos

riesgos en carpintería 86.6

Aditivos químicos 65.17

Administración del trabajo

definición 23.3

Véase también Inspección de trabajo

Administración escolar

y políticas de salud y seguridad 94.13

y responsabilidad en materia de formación 94.13

Administración Federal de Aviación de Estados Unidos

y regulación del ruido en la industria aeroespacial 90.16

Administración para la Salud y la Seguridad en el T rabajo de Estados U nidos (O SH A) límite tolerable de ruido por jornada laboral 97.31

límites de exposición profesional 30.18 norma de exposición a microondas 97.33 norma sobre el control de la exposición laboral al plomo 63.43

norma sobre laboratorios 61.20

normas de seguridad en centrales eléctricas 76.15

normas para el trabajo con sustancias químicas 5.7

normas relativas a los géneros textiles no tejidos 89.21

normas sobre energía eléctrica 76.16

normas sobre la transmisión profesional de agentes patógenos en sangre 97.46

tablas de descompresión 36.4

y regulación de la exposición al polvo en la industria textil 89.11

Administradores

riesgos potenciales 94.3

ADN

agentes que dañan el 33.28

defectos heredados en su reparación y cáncer 33.39

Efectos de la radiación 48.5

gen antígeno $T$ del Simian V irus 40

(SV 40) 33.53 
gen inmortalizador 33.53

modificación química 33.38

mutaciones 33.49

cambios cromosómicos 33.49

cambios génicos 33.49

cambios genómicos 33.49

transfección de células primarias con 33.53

Adrenalina 34.11, 34.60

Aductos

determinación de los 33.45

Advertencias

activas 29.81

directrices 29.81

pasivas 29.81

Advertencias de seguridad

en prevención de riesgos

eficacia de las 59.32

interpretación de las 59.32

Aedes

aegypti $4.7,53.31$

spp 70.39

Aerobacter cloacae 89.31

$\checkmark$ éase Fiebre del colchonero

Aerococcus 44.23

Aeroespacial, industria

consideraciones medioambientales 90.13

controles 90.11

biológicos 90.11

de emisiones $90.15 t$

de los productos químicos 90.11

estudios de higiene industrial 90.11

identificación de situaciones de riesgo potencial 90.11

información sobre los riesgos 90.11

organización de los entornos de

trabajo 90.12

ventilación 90.12

instalaciones y procesos 90.3

materiales 90.2

consideraciones toxicológicas $90.12 \mathrm{t}$

materiales compuestos 90.12

riesgos derivados de la utilización de productos químicos $90.13 \mathrm{t}$

riesgos para la seguridad

caídas $90.4,90.6$

contacto con dispositivos eléctricos 90.4

cortes 90.4

exposición a sustancias químicas 90.4

factores ergonómicos 90.4

físicos 90.4

riesgos para la seguridad $90.5 \mathrm{t}$

riesgos químicos $90.14 \mathrm{t}$

visión general 90.2

Aeronaves

de alto rendimiento 102.19

efectos adversos de la aceleración $\quad 102.19$

mantenimiento de base de 102.13

riesgos físicos 102.13 riesgos químicos 102.13

mantenimiento en ruta de 102.12

y exposición a sustancias químicas 102.13

y niveles de ruido nocivos 102.12

y riesgo de los equipos móviles 102.12

militares

riesgos en el mantenimiento de $\mathbf{1 0 2 . 1 3}$

para usos agrícolas

riesgos en el mantenimiento de 102.13

peligrosidad del repostaje de 102.11

tripulación de

Véase T ripulación aérea

A eropuertos

construcción de 93.24

mantenimiento 93.24

riesgos del personal de tierra 102.11

riesgos ergonómicos 102.11

en agentes del servicio de pasajeros 102.11

y exposición a rayos $X$

en inspección de equipaje 102.12

A erosoles

detectores 30.24

efectos en la industria del calzado 88.8

heterodispersos 10.6

medios de muestreo 30.22

monodispersos 10.6

propiedades de las partículas 10.6

purificadores de aire 31.23

tipos de aerosoles 10.6

Afaquia

riesgo asociado a los procesos de reproducción y duplicación 85.12

Afasia 42.10

A fecciones musculosqueléticas 66.18

Véase Sistema musculosquelético

Africa

decenio de 198024.6

A frontamiento

definición 34.54

estilos de 34.54

activo-cognitivo 34.54

activo-de comportamiento 34.54

adaptativo 34.54

centrado en la valoración 34.54

centrado en las emociones 34.54

centrado en los problemas 34.54

de evitación 34.54

preventivo 34.54

social 34.54

evaluación del 34.55

y apoyo social 34.57

Afta epizoótica

riesgo en la industria de la piel y el calzado 88.9

A garicus bisporus 64.60

Agavillador 70.11
A gencia de L ucha contra Incendios de Japón 41.16

A gencia de Protección del M edio Ambiente de Estados U nidos (EPA)

regulación de emisiones contaminantes en la industria aeroespacial 90.15

y normativas sobre desmotado de algodón 89.9

y vertido de productos tóxicos 55.33

Agencia de Seguridad e H igiene en el T rabajo y normativas sobre desmotado de algodón 89.9

Agencia Internacional de la Energía

Atómica 39.30

reglamento para el transporte seguro de materiales radiactivos 39.30

Agencia Internacional para la Investigación sobre el Cáncer (IAR C)

aluminio 63.3

arsénico inorgánico, compuestos de 63.7 como cancerígenos según la IARC 63.7

base de datos sobre cancerígenos 27.19

cadmio 63.12

carcinogenicidad según la IARC 63.12

cáncer de pulmón en fumadores pasivos 44.15

clasificación de agentes cancerígenos $10.51,10.67,10.88,10.90$

componentes cancerígenos del humo de tabaco 44.12

criterios de carcinogénesis 2.5

datos sobre la incidencia del cáncer 2.17

efectos cancerígenos del

formaldehído 100.16

fundición del hierro y el acero 63.22 como proceso cancerígeno 63.22

identificación de los riesgos de carcinogenicidad 33.65 importancia de los datos mecanicistas 33.68

M onographs on the Evaluation of Carcinogenic $\mathrm{R}$ isks

to Humans 33.65

investigación en salud y seguridad en el trabajo 23.2

misión 23.52

níquel, compuestos de 63.36 cancerígenos del G rupo 1 según la IARC 63.36

plomo inorgánico 63.42 cancerígeno del Grupo 2B según la IARC 63.42

programa de monografías 2.15

R egistro Internacional de Personas Expuestas a Fenoxiherbicidas y

Contaminantes 32.3

valor de las pruebas de toxicidad genética 27.17

y clasificación del formaldehído 89.20 
cancerígeno del Grupo 1 según la

IARC 63.3

y diclorvos 62.16

y herbicida fenoxi derivado $2,4,5-\mathrm{T} \quad 62.14$

y los productos químicos 104.7, 104.46,

$104.73,104.80,104.97,104.121$,

$104.138,104.152,104.163,104.172$,

104.184, 104.192, 104.250, 104.275,

$104.364,104.395,104.407$

y pentaclorofenol 62.11

y percloroetileno (PERC) como cancerígeno

del grupo 2A 100.12

$y$ toxafeno 62.11

Agente blanqueante 72.8

Agente naranja 68.44

Agentes ambientales

influencia en el sistema

linfohematopoyético 1.2

Agentes blanqueantes 72.14

Agentes de limpieza 65.16

A gentes patógenos en sangre transmisión profesional de normas de la OSHA 97.46

Agentes quelantes 72.9

Agentes químicos exposición a los 72.14

Agorafobia 5.12

Agotamiento

Véase Estrés

del plantador 68.17

por calor 42.8

Agricultura

almacenamiento 64.24

alteraciones pulmonares asociadas a la agricultura 64.25

arroz 64.37

aventado 64.32

caña de azúcar 64.40

cereales $64.3,64.38$

cosechadoras 64.30

cultivos 64.26

cultivos amiláceos 64.3

de zonas con escasos recursos 64.26

descascarillado 64.32

efectos del cambio climático en la 53.30

escarda y labores de entretenimiento 64.29

fenoles en 104.368

flores cortadas 64.14

herramientas y maquinaria

manuales 64.27

importancia económica 64.2

invernaderos 64.11

jardinería 64.9

jardinería paisajística 64.9

leguminosas 64.3

mano de obra 64.5

máquinas 64.11 mecanización $\quad 64.22,64.33$

oleaginosas 64.39

operaciones manuales $64.26-64.32$

paisajismo 64.9

plaguicidas $64.7,64.13$

plantas 64.13

protección de las plantas 64.28

recolección 64.20 - 64.21, 64.30

repercusiones ambientales de la

y efectos en la población 53.7

revolución neolítica 64.2

revolución verde 64.26

riego 64.29

Sección Internacional de la AISS 23.66

siembra 64.28

sistemas agrícolas 64.5

tareas manuales de manipulación de materiales 64.32

trabajadores agrícolas 64.8

tractores agrícolas 64.33

transporte 64.25

trillado 64.31

viveros 64.11

Agricultura de plantación

productos de plantación 64.5

trabajo de plantación 64.6

accidentes relacionados con las

herramientas y equipos 64.6

accidentes relacionados con

vehículos 64.7

electricidad 64.7

enfermedades infecciosas 64.8

espacios confinados 64.8

fatiga y riesgos asociados al clima 64.6

incendios 64.7

lesiones y enfermedades causadas por animales 64.8

mano de obra infantil 64.6

plaguicidas 64.7

riesgos y su prevención 64.6

Agricultura urbana

paisajismo 64.9

sistemas agrícolas 64.9

Agrobacterium tumefaciens 77.32

Agua

calidad del 68.43

áreas forestales 68.43

reutilización 67.15

A guas residuales

constituyentes de las 55.33

control de las

neutralización del pH 83.38

precipitación química 83.37

materia orgánica en las

pruebas de laboratorio 55.29

procedentes de las industrias 55.33

características negativas de los

residuos 55.33 métodos avanzados de

tratamiento 55.35

técnicas de recirculación 55.34

tratamiento anaeróbico 67.14

tratamiento de 55.32

parámetros de eficiencia 55.33

por activación de lodos 55.33

Proyecto de R egeneración de la R egión de $D$ an 55.38, 55.41

sistema de tercer nivel 55.33

sistema de tratamiento primario 55.33

sistema de tratamiento secundario 55.33

sistemas de contacto biológico 55.33

tratamiento de las $55.32 \mathrm{t}$

procesos biológicos 101.19

procesos de tratamiento físico 101.18

procesos terciarios 101.20

tratamiento de los lodos 101.20

Véase también Plantas de tratamiento

vertidos de 55.30

selección del lugar 55.30

zonas de mezclado de

contaminantes 55.30

Agudeza visual 46.17

V éase también ojo

Air T raffic C ontroller $\mathrm{H}$ ealth $\mathrm{C}$ hange Study 34.61

Aire acondicionado

Véase Sistemas de aire acondicionado

Aire interior

composición química del 44.2

contaminantes 44.2 - 44.5

límites máximos específicos

para 44.28

químicos 44.6

determinación de contaminantes

químicos 44.18

microorganismos en el $\quad 44.3,44.5$

olor del 44.3

sistemas de filtración de $\mathbf{4 5 . 9}$

Véase también Calidad del aire interior

Aislamiento

en eliminación de residuos riesgos asociados al 101.25

proporcionado por la grasa

subcutánea 42.49

Aislamiento térmico de la ropa

aislamiento intrínseco $\quad 42.29$

aislamiento resultante 42.29

capas múltiples de tejido $\quad 42.28$

definición 42.29

ecuación 42.16

estimación 42.30

efecto de la actividad física y el viento 42.31

estimación de la resistencia al vapor 42.31

estimación física 42.30 
estimaciones con modelos

articulados 42.31

estimaciones obtenidas de tablas 42.30

factor de la superficie cubierta por la

ropa 42.30

resistencia relativa al vapor 42.31

factores influyentes 42.53

fórmulas y definiciones 42.27

grosor y cobertura típica de la ropa $\quad 42.30$

naturaleza del 42.26

para el trabajo en cámaras

frigoríficas 42.47

unidades clo 42.27

valores $42.56 \mathrm{t}$

ventilación en el interior de las

prendas 42.30

Véase también Calor

Véase también Control de la humedad

Véase también Prendas protectoras

Alarmas

en zonas de alta radiación 48.31

Alarmas acústicas

en hospitales

como inductores de error 97.21

Albuminuria

por ingestión accidental de arsenicales 63.6

por intoxicación de mercurio 63.30

Alcances de rayos

definición 40.2

Alcanoatos 104.177

Alcohol isopropilo 70.40

Alcoholes

diterpénicos 72.20

Alcoholismo

abuso y costes para la sociedad $\quad 15.83$

consumo en el lugar de trabajo 15.82

consumo y bajo peso al nacer 9.16

costes para la sociedad 15.83

dilemas éticos

Véase también Etica

efectos del uso en el lugar de trabajo 15.82

en actores 96.30

en conductores de camión 103.6

en el sector de la construcción 93.3

influencia en los indicadores

biológicos 27.4

intoxicación 104.32

relación con la psicosis 5.7

y agentes cancerígenos 2.12

y ceguera 104.33

y enfermedades cardiovasculares 3.8

y estrés 34.73

y metabolismo de los disolventes 27.5

y profesores 94.14

y susceptibilidad a los tóxicos 33.20

y tetracloruro de carbono 104.251

Aldehído cinámico 67.9
Aldehídos 68.26

irritación de piel, ojos y sistema

respiratorio 104.46

Aldosterona 42.7

Aldrín 27.24, 62.10, 71.8

Aleaciones

fundición 82.19

de aluminio y magnesio 82.19

de latón y bronce 82.19

Alemania

Administración de la O rganización

Sectorial 95.14

Berufsgenossenschaften 16.32

Servicio de M edicina del T rabajo 16.33

servicios externos $16.32 f$

Colegio Federal de M édicos 16.32

Ley de M edicina del Trabajo 16.31 obligaciones de los médicos $16.31 \mathrm{f}$

Ley de Seguridad en el T rabajo 16.31, 16.34

O rganización Sectorial para la Seguridad e Higiene 95.14

seguro de accidentes 16.32

servicios de vigilancia y seguridad 95.14

obligaciones generales del trabajador 95.15

R eglamento de prevención de accidentes de los servicios de vigilancia y seguridad 95.14, 95.16

responsabilidades generales del empresario 95.14

tareas de los servicios de seguridad 95.14

transporte de dinero y valores 95.15

uso de armas de fuego 95.15

uso de perros 95.15

sistema de gestión de calidad sector de la construcción 93.18 procedimientos formales de seguridad 93.18

sistema de seguro de accidentes 26.17

sistema dual de salud y seguridad en el trabajo 16.31

chequeo preventivo 16.31

médico de empresa 16.31

y sistema de información química GESTIS 61.27

Alergenos

de contacto

en productos de limpieza $\quad 100.3$

en vaquerías 70.22

y dermatitis 12.11

Alergia

a especies vegetales

en trabajadores de parques y

jardines 96.46

a los animales 70.17

a los colorantes en la industria textil 89.33 al látex

en trabajadores sanitarios 97.63

al paladio 63.37

al polen

procedente de aire interior 44.22

asociada a los procesos fotográficos 85.15

cutánea 33.42

de contacto 67.11

definición 33.41

del tracto respiratorio 33.42

e indemnización 25.9

en el sector de la construcción 93.3, 93.43 93.44

en la industria de la seda 89.15

en los procesos de tinción 89.20

pseudoalergia 33.41

riesgo en la industria de la piel y el

cuero 88.7

riesgos asociados en carpintería 86.13

tipos principales 33.42

Aleurita 67.33

Alexander

enfoque psicoanalítico de las úlceras (1950) 34.68

Alexitimia 34.11

Alfarería

materias primas 84.13

métodos de fabricación 84.12

colado 84.12

fabricación manual 84.12

torno de alfarero 84.12

y exposición al ślice 32.10

Alfombras tejidas 0 anudadas a mano

medidas preventivas 89.29

factores ergonómicos 89.29

ventilación 89.29

operaciones 89.28

diseño y tejeduría 89.28

preparación del hilo 89.28

riesgos propios 89.29

deformaciones óseas 89.29

estrés 89.29

riesgos biológicos 89.29

riesgos mecánicos 89.29

riesgos químicos 89.29

trastornos de la visión 89.29

Alfombras y moquetas

acabado 89.27

confección 89.25

alfombras de nudos 89.25

alfombras tejidas 89.26

prácticas de trabajo seguras 89.27

formación de los trabajadores 89.27

medidas de protección mecánica 89.27

producción de fibra e hilo 89.26

técnicas de coloración 89.27

Algodón, hilatura

apertura, mezcla y limpieza 89.10 
bobinado y encarretado 89.11

cardado y peinado 89.10

estirado y mechado 89.10

inhalación de polvo de algodón

(bisinosis) 89.11

Véase también Bisinosis

riesgos mecánicos 89.11

ruido 89.11

Algodón, producción y desmotado

almacenamiento 89.6

desmotado 89.7

lesiones 89.9

recolección 89.6

utilización de EPP 89.9

Alicates 29.41, 29.74

Alimentación, sector de la

acetatos en 104.162

ácido cítrico en 104.12

ácidos dicarboxílicos en 104.12

condiciones ambientales de frío 42.33

métodos de

en máquinas 58.22

Véase también C ámaras frigoríficas

Alimentos

almacenamiento de materias primas 67.2

conservación 67.4

del mar

contaminados 66.20

enfermedades transmitidas por 53.7

agentes biológicos 53.7

agentes biológicos transmisores $53.6 \mathrm{t}$

sustancias químicas 53.8 - 53.9

y contaminación ambiental 53.8

envasado 67.4

fabricación 67.3

manipulación de las materias primas 67.2

preparados 67.25

producción mundial de 67.2

Almacenamiento

de cereales o semillas oleaginosas 64.40

de materias primas 67.2

de productos agrícolas 64.23

de productos químicos 61.11

legislación sobre 61.13

y sistemas de gestión de almacén 102.72

Almacenes

normas del trabajo planificado 102.72

principios de prevención

de riesgos 102.75

riesgos de los operarios de

carretillas 102.76

riesgos para la salud 102.73

riesgos para la seguridad $\quad 102.74$

seguridad de los selectores de pedidos 102.76

Alopecia

en la fabricación de

semiconductores 83.18
Alquil plomo

indicador 27.12

Alquilación

refino de petróleo

Véase Craqueo

Alquitrán

exposición a sustancias volátiles

cancerígeneas en la industria del

automóvil 91.8

cáncer de pulmón 91.8

Alquitrán de hulla 31.17

Alteraciones asociadas a la agricultura $\quad 64.25$

Alteraciones cutáneas

en los trabajadores de las fábricas de pasta y papel 72.16

Altitud

Véase Presión barométrica

Véase T rabajo a grandes altitudes

equivalente 37.13

Altura, trabajo en

riesgos asociados en el sector de la construcción 93.31

Aluminio

absorción de 27,8 63.3

concentración 27.8

excreción 27.8

toxicidad 27.8

y daños cerebrales 63.3

y daños en el tejido nervioso 63.3

y enfermedad de Alzheimer 63.3

cloruro de 63.2

en el cracking del petróleo 63.2

en la industria del caucho 63.2

compuestos alquilados de 63.2

riesgo de incendios 63.3

riesgos de quemaduras 63.3

riesgos de toxicidad 63.3

exposición al óxido de 63.3

efectos toxicológicos 63.3

en la industria de la alfarería 63.3

y alteraciones pulmonares 63.3

fundición del 63.3

y enfermedad de Shaver 63.3

y exposición al dióxido de azufre 63.3

fundición y afino

asma profesional asociada 82.10

campos electromagnéticos 82.11

fabricación de electrodos de carbón 82.8

materiales y residuos $82.10 \mathrm{t}$

niveles de ruido 82.11

proceso Bayer 82.9

proceso electrolítico 82.8

reducción electrolítica 82.9

riesgo de cáncer 82.10

riesgos para la salud 82.10

operaciones de recuperación

controles técnicos $82.50 \mathrm{t}$

producción de 63.3 y asma de los alfareros 63.3

y cáncer 63.3

producción de aleaciones 63.3

y emisión de gases 63.3

utilización en la industria naval 92.6

Alumnos

y vacunaciones 94.4

Alveolitis alérgica

extrínseca $65.15,71.10$

y tratamiento de residuos 101.12

Alzheimer, enfermedad de

en trabajadores del aluminio $\quad 63.3$

interpretación de los efectos neurotóxicos 7.26

relación con la psicosis 5.6

riesgo asociado a los procesos de confección 87.4, 87.7

y relación con el aluminio 63.3

y trastornos cognitivos $5.2,5.19$

Amalberti

metaconocimientos 29.10

Ambulancia, conductores de

estrés en 103.5

exposición a gases anestésicos 103.5 exposición a isótopos radiactivos 103.5 exposición al ruido 103.5

Amenorrea

Véase Salud de la mujer

American Ceramic Society 84.20

A merican C onference of G overnment Industrial $\mathrm{H}$ ygienists (ACGIH)

Véase Conferencia Americana de H igienistas Industriales del Gobierno

American Friends Service Committee 64.16

American M edical Association

lista de incapacidades 25.14

American N ational Standards Institute (ANSI)

Consejo para el Interés de los Consumidores del 56.38

directrices sobre uso del láser 97.33

especificaciones de sonómetros 47.6

mediciones de ruido en la industria alimentaria 67.12

National Electrical Safety Code 40.15

N orma ANSI S1.4-1983

especificaciones de sonómetros 47.6

N orma ANSI S12.16

especificación del ruido en maquinaria nueva 47.9

N orma ANSI S3.19

protección auditiva real de los protectores de los oídos y atenuación física de las orejeras 31.12

N orma ANSI Z535.3 56.38

sobre símbolos de seguridad 56.38

N orma ANSI Z535.3

sobre símbolos de seguridad 56.38 
normas de protección ocular contra láseres 49.20

normas para los vehículos de transporte agrario 64.26

normas sobre señales y etiquetas de seguridad 56.38

nuevas normas sobre información en materia de seguridad 56.38

y la elaboración de un código de seguridad para ascensores 93.47

y la regulación de las sustancias químicas en la industria aeroespacial 90.10

American Petroleum Institute (API) 102.30

R ecomendación práctica $1637 \quad 102.30$ símbolos y códigos de color en estaciones de servicio 102.30

American Psychiatric Association 5.14

A merican Society for $T$ esting and $M$ aterials (AST M )

normas sobre disyuntores 40.15

ropa de protección 31.21

A merican Society of Addiction M edicine definición de alcoholismo 15.83

American Society of A gricultural Engineers (ASAE) 64.26

A merican Society of $\mathrm{H}$ eating, R efrigeration and Air Conditioning Engineers, ASH RAE 44.3 calidad del aire interior, normas 44.3

A merican Society of Safety Engineers (ASSE) guía de consultores de la 60.8

American T extile $M$ anufacturers Institute y programas de salud y seguridad en la industria textil 89.12

American Thoracic Society normas para la obtención del espirograma 10.8

American W elding Society guía publicada por la sobre prácticas de soldadura y corte 41.19

Ames, prueba de mutagenicidad

Véase Cáncer, prevención del cáncer profesional

Amianto

V éase Enfermedades pulmonares

A sbestos V ictims of America 23.36

como contaminante del aire interior 44.5

control de la exposición 32.10

en buques 102.50

en el sector de la construcción 93.43 asociado a distintos tipos de cáncer 93.3 en trabajos de rehabilitación 93.30

en entornos escolares 94.14

en la producción de hierro y acero 73.14

en veterinaria 28.6

enfermedad pleural 10.65 exposición al polvo de

en estaciones de servicio 102.36

exposición en la industria naval 92.13 exposición ocupacional 10.59

fibras de

cancerígenas 55.16

y contaminación atmosférica 55.16

fuentes de exposición 10.60

fuentes, productosy usos $10.58 \mathrm{t}$

perspectiva histórica $28.40-28.45$

procesos relacionados $10.58 \mathrm{t}$

producción comercial 10.57

riesgo asociado en carpintería 86.14

riesgo asociado en la industria del

automóvil 91.8

usos principales 10.58

Amiantosis 28.41

Amidas

como carcinógeno del grupo 2A o 2B por la IARC 104.73

Aminas

alifáticas 104.80

aromáticas

como carcinógenos del grupo 2B por la IARC 104.97

efectos cancerígenos en la construcción de motores de aviación 90.10

en estudios de cáncer de vejiga 28.23

fabricación de tintes y pigmentos 104.95

y cáncer de vejiga 104.97

y metahemoglobinemia 104.96

exposición a vapores en la industria del

automóvil

trastornos oculares 91.4

Amnesia

disociativa 5.19

Amoníaco

anhidro 65.16

en el procesado de alimentos 62.8

en la ganadería 62.8

en la industria alimentaria $\quad 67.10$

exposición en industrias gráficas 85.9

intoxicación 104.58

riesgos asociados en el estampado 89.20

toxicidad del 62.8

Anacardiaceae 12.5

Anafilaxia

por alergia al látex 97.63 - 97.64

A nálisis de desfases

para evaluación de programas de seguridad 59.3

A nálisis de riesgos

Cuestionario de diagnóstico de seguridad (CDS) 59.27

e indicadores de riesgo $\quad 59.27$

en una planta industrial 57.17

caso de transporte de gas desde un buque a un tanque 57.17 fuentes de información 57.17

método FMEA 57.17

caso del transporte de gas desde un

buque a un tanque 57.17

para componentes normalizados 57.18

método HAZOP 57.17

método MORT para 57.19

principales dificultades en los 57.16

A nálisis de sistemas

análisis a posteriori 58.2

análisis a priori 58.2

árbol de fallos en 58.3

operaciones lógicas $58.4 \mathrm{f}$

posible cadena de sucesos $58.4 \mathrm{f}$

creación de modelos 58.4

de máquinas modernas 58.4

de organizaciones humanas 58.5

en empresas 58.4

niveles de sistemas 58.4

método directo 58.2

método inverso 58.2 - 58.3

niveles de análisis múltiples 58.5

problemas asociados 58.5

y formas de acción preventiva 58.5

para equipos industriales 58.4

uso de simuladores en 58.3

y definición del sistema 58.3

Análisis del ciclo vital

Véase Evaluación del ciclo vital

A nálisis del trabajo

actividad 29.9

adquisición de información 29.9

gestos y posturas 29.9

procesos de pensamiento 29.10

pruebas 29.10

regulación 29.10

contexto 29.6

factores relevantes en función de la actividad 29.6

marco semántico 29.6

enfoques 29.16

rendimiento 29.11

tarea 29.7

cuantificación del tiempo 29.8

encomendada 29.8

presión de tiempos 29.8

Véase también Ergonomía

Véase también Fatiga

Véase también Listas de comprobación

Véase también O rganización del trabajo

Véase también Postura de trabajo

Véase también Vigilancia

Analizador de vapores orgánicos 30.24

Ancylostomae 64.38

Andamios

en la construcción 93.27, 93.39

características 93.27

en las tareas de demolición 93.32 
inspección y formación 93.28

instalación 93.27, 93.39

precauciones 93.39

riesgos 93.27

tipos 93.27, 93.39

Anemia

aplásica 1.2

inducida por el benceno 1.2

benceno y 104.283

cloropicrina y 104.339

dinitrobenceno y 104.347

éteres glicólicos y 104.201

falciforme 63.43

fenilhidracina y 104.122

ferropénica 63.43

fósforo y 104.383

hemolítica 63.43

e intoxicación por plomo 63.41

hipocrómica $62.11,63.11$

immunohemolítica 63.8

nitrocompuestos aromáticos y 104.346

por intoxicación de arsénico 63.6

Anemómetros

de aspas giratorias 42.17

de hilo caliente 42.17

Anestesistas

factores inductores de error en 97.21

tareas de los 29.7

Aneuploidía 33.49

Aneurisma

aórtico

riesgo asociado a la extinción de incendios 95.8

Angioedema

por alergia al látex 97.63

Angiografía control de la radiación ionizante en 97.33

Angiosarcoma

hepático 28.31, 63.7

registro internacional de casos 32.3

y arsénico 4.7

y cloruro de vinilo 4.7

Angiotensina 42.7

Anguila 70.6

Angustia

crisis de angustia 5.12

Véase T rastornos por ansiedad

Anhídrido

amónico 64.40

trimelítico 33.42

riesgos 104.15

orgánico 104.12

Anhidrosis 42.9

Anilina, intoxicación por 104.96

Animales

acuáticos 70.36

Véase R iesgos biológicos de compañía 70.36

de laboratorio 70.36

de peletería 70.36

manipulación de

alergias 103.30

formaldehídos 103.30

riesgos en la 103.29

síndrome de las vacas locas 103.31

reacciones alérgicas a los 70.36

zoonosis 70.36

Véase también A nimales domésticos

A nimales de tiro

cría y selección 70.32

en Asia 70.31

gestión, nutrición, producción 70.32

en Australia 70.33

en Bangladesh 70.33

en China 70.33

en la India 70.34

en $\mathrm{N}$ epal 70.34

en Sri Lanka 70.34

peligros potenciales y su control 70.34

Animales domésticos

cría de 70.15

herrería de 70.17

riesgos biológicos 70.36

Anopheles darlingi 53.34

Anorexia

en bailarines 96.26

en cantantes 96.29

Anosmia 63.11

Anoxia 33.31

nitrocompuestos aromáticos y 104.346

Ansiedad

Véase T rastornos por ansiedad

fobia a los ordenadores 5.13

relacionada con el trabajo 5.12

y satisfacción en el trabajo 34.65

Anti-12-hidroxi-endrín 27.24

Antígenos 67.9

de la hepatitis B 4.7

Antilewisita británica (BAL, dimercaprol) 63.8

Antimonio

absorción de 27.8

cutánea 63.4

compuestos de 63.4

toxicidad $63.4-63.5$

concentraciones de 27.8

dosis letal media 63.4

excreción de 27.8

exposición al 63.4

e infecciones cutáneas pustulares 63.4

e inflamación de las vías

respiratorias 63.4

y alteraciones cardíacas 63.4

y cambios pulmonares obstructivos 63.4 y conjuntivitis 63.4

y dermatitis 63.4

y efectos respiratorios crónicos 63.4

y gastritis 63.4

y neumoconiosis 63.4

y neumonía endógena de tipo

lipoide 63.4

y neumonitis 63.4

y perforaciones septales 63.4

y rinitis 63.4

inhalación de 63.4

intoxicación aguda por 63.4

síntomas 63.4

intoxicación crónica por 63.4

síntomas 63.4

intoxicación por ingestión 63.4

prevención de intoxicaciones por 63.5

en la minería 63.5

trióxido de 63.4

potencial cancerígeno 63.5

Antioxidantes

y nutrición 15.39

Antonovsky 34.54

estilo de afrontamiento 34.54

sentido de la coherencia 34.54

Antrax

en artesanos textiles 96.16

riesgo en el procesado del fieltro 89.18

riesgo en la caza 69.5

riesgo en la confección de alfombras 89.29

riesgo en la industria alimentaria 67.34

riesgo en la industria de la lana 89.13

riesgo en la industria de la piel y el cuero $88.4,88.7$

Antropometría

adaptación y regulación 29.34

dinámica 29.34

errores 29.33

instrumentos 29.32

antropómetro 29.32

calibradores 29.32

cefalómetros 29.32

estadiómetro 29.32

pelvímetros 29.32

muestreo y análisis 29.33

poblacional 29.34

precisión 29.33

procedimientos estadísticos 29.33

sistemas de variables 29.32

variables antropométricas 29.32

Antropómetro 29.32

Anuria

por efecto eléctrico 40.3

por gas arsina 63.8

por gas estibina 63.4

Año europeo de la protección de la seguridad, la higiene y la salud en el trabajo 23.45 
A parato digestivo

absorción de tóxicos 33.6, 33.11

velocidad de absorción 33.11

estrés profesional y 4.3

trabajo por turnos 4.3

glándulas salivales 4.5

hepatitis 4.2

hígado 4.5

Véase C áncer de hígado

enfermedades profesionales 4.6

esquistosomiasis 4.6

fiebre amarilla 4.7

hepatitis 4.6

hepatocarcinoma 4.8

hidatidosis hepática 4.6

incidencia 4.10

leptospira icterohaemorrhagiae 4.6

lesión hepatocelular 4.6

medidas preventivas 4.8

procesos tóxicos 4.7

pruebas de función hepática 4.6

trasplante hepático 4.10

infecciones profesionales 4.2

lesiones estomatológicas 4.4

clasificación 4.4

erosión dental 4.4

trastornos profesionales de los labios 4.4

páncreas

Véase Cáncer de páncreas

respiración bucal 4.3

sustancias químicas 4.2

ingestión de cáusticos 4.2

lesión hepática 4.2

mecanismos 4.2

sustancias tóxicas 4.2 - 4.3, 4.5

trastornos

en la conducción de camiones 103.8

A parato reproductor

evaluación de la reproducción mediante cría

continua en EE.UU. 33.64

Véase también Sistema reproductor femenino

Véase también Sistema reproductor masculino

Véase también T oxicidad en la reproducción

A parato respiratorio

asma ocupacional

Véase Asma

boranosy 104.130

capacidad ventilatoria 10.8

capacidad vital espiratoria 10.8

depósito de partículas $10.3 \mathrm{f}$

dióxido de azufre y 104.420

enfermedades 10.18

bronquitis crónica 10.69

fiebre por vapores de metal 10.19

fiebre por vapores de polímeros 10.20

fiebres por inhalación 10.18

relacionadas con el amianto 10.69

síndrome de disfunción reactiva de las vías aéreas 10.14 síndrome del polvo orgánico

tóxico 10.18

estructura y función

función pulmonar 10.8

del tracto respiratorio 10.4

transferencia de masa 10.2

complianza 10.11

efectos agudos y crónicos de la exposición ocupacional 10.11

efectos reversibles transitorios 10.13

efectos temporales agudos 10.13

exposición a gases de escape diesel 10.13

mediciones $10.8,10.12$

función y estructura $10.2 \mathrm{f}$

hiperactividad bronquial inespecífica 10.21

pruebas cuantitativas de H R B $\quad 10.24$

inhalación 10.5

irritación del

hidracinase 104.122

irritantes respiratorios 10.13

exposición aguda 10.14

exposición al irritante 10.14

exposiciones crónicas 10.17

oxidantes 10.14

resumen $10.14 \mathrm{t}$

polvo orgánico 10.27

agentes específicos 10.28

endotoxinas y 10.28

enfermedades causadas por $10.28 \mathrm{t}$

exposición y fuentes de riesgo $10.28 \mathrm{t}$

reacciones alérgicas respiratorias 10.7

alveolitis alérgica extrínseca 10.7

asma bronquial 10.7

shock anafiláctico 10.7

respuesta a los agentes irritantes 10.7

respuesta a los contaminantes atmosféricos

factores ambientales 10.7

factores del huésped 10.7

sustancias químicas tóxicas

asfixiantes 10.17

mecanismos de lesión pulmonar $10.14 \mathrm{t}$

toxicidad de los compuestos $10.17 \mathrm{t}$

tratamiento médico 10.18

tracto respiratorio

regiones del tracto respiratorio $10.4 \mathrm{t}$

vías aéreas extratorácicas 10.4

vías aéreas torácicas 10.4

A paratos eléctricos

acumuladores de níquel-cadmio 81.6

efectos sobre la salud 81.7

método de fabricación 81.6

reacción química 81.7

acumuladores de plomo 81.2

ácido sulfúrico 81.4

cuestiones ambientales 81.4

exposición a gases tóxicos 81.4

exposición al plomo 81.3

fibras minerales artificiales 81.4

polvo de talco 81.4 proceso de fabricación 81.2

riesgos para la salud 81.3

baterías y pilas 81.4

composición 81.5t

riesgos de la fabricación 81.5

cables eléctricos 81.8

aislamiento $81.8,81.10$

conductores 81.8

en los incendios 81.8

fabricación 81.9

operaciones auxiliares 81.9

riesgos ambientales 81.11

características de los trabajadores del sector 81.2

exposición a la radiación 103.48

importancia económica del sector 81.2

intoxicación 103.49

lámparas eléctricas 81.11

Véase Lámparas

materiales 81.11

riesgos de la fabricación 81.11

problemas ambientales asociados a la

fabricación 81.16

empleo de pilas y baterías 81.16

fabricación de cables eléctricos 81.16

reciclaje de las lámparas de

mercurio 81.16

reciclaje de los acumuladores de

plomo 81.16

reciclaje de los aparatos eléctricos 81.17

recuperación del cadmio 81.16

riesgos de la fabricación de cables 81.9

emisiones de partículas 81.11

máquinas 81.9

protectores oculares 81.9

ruido 81.9

riesgos laborales 103.48

Véase también Electrodomésticos

A paratos respiradores

autónomos (ARA) 67.11

A patita

riesgos para la salud de la 62.2

Apeadores 68.23

Apeo $68.5,68.7-68.8$

con motosierra 68.8

peligros 68.9

A picultores 70.39

A picultura $70.6,70.39$

A plasia medular por radiación 39.42

Apnea 37.5

Apoptosis 33.34

A poyo social

asesoramiento 34.55

ayuda tangible 34.55

compañía 34.55

de la estima 34.55

efectos sobre la salud 34.56 
emocional 34.55

estímulo 34.55

evaluativo 34.56

informativo 34.56

instrumental 34.56

lazos de interdependencia 34.57

y estrés 34.55

Apoyo socioemocional 34.9

Aprendiz

mano de obra barata 94.10

y contrato por escrito entre su empleador y él 94.10

A prendizaje

activo $34.8,34.11$

negativo 34.8

A prendizaje de adultos

Véase Formación

diseño de programas educativos 18.9

enfoque participativo 18.9

A provechamiento forestal

$V$ éase A provechamiento maderero

A provechamiento maderero 68.7

métodos, equipos y riesgos comunes 68.8

progreso tecnológico en el 68.7

Aqua regia 61.13

Aquiles, tendón de 6.30

Arañas 68.28

Arbitraje

e inspección de trabajo 23.11

en conflictos laborales 21.36

Arboles

plantación de 68.15

Arcilla 72.11

de polímeros

sustancias nocivas en las 96.23

silice libre en

y silicosis 62.2

Arco eléctrico 40.2

Arenisca

riesgos por exposición al sílice en la 62.2

Argiria

por exposición a la plata 63.38

prevención de la 63.38

Argirosis 4.4

Véase A parato digestivo

Armas 69.3

en las aulas 94.14

en las producciones de cine peligrosidad de las 96.36

riesgos asociados en las fuerzas armadas 95.18

Arousal 29.54

Arrancadora de mazorcas 64.22

Arrastradores

con cabrestantes 68.10

de garabato 68.10
Arrastre

de madera 68.10

Arrastrero 66.6

arrastreros-congeladores 66.8

Arroz

proceso de cultivo 64.37

almacenamiento 64.38

arado 64.37

escarda 64.37

recolección 64.37

secado 64.37

trasplante 64.37

trilla 64.37

Arsenamina 30.26

Arsénico

asociado a angiosarcoma 4.8

compuestos inorgánicos de 63.7

y cáncer 63.7

y malformaciones 63.7

compuestos orgánicos de 63.7

e intoxicación por arsina 63.7

en alimentos de origen marino 63.7

síntomas 63.8

tratamiento 63.8

en el agua de bebida 63.7

y cáncer de piel 63.7

exposición a dosis subletales 63.6

síntomas 63.6

exposición profesional al 63.8

medidas de salud y seguridad 63.8

intoxicación aguda

síntomas 63.6

y alteraciones neurológicas 63.6

y anemia 63.6

y hepatomegalia reversible 63.6

y leucopenia 63.6

intoxicación crónica 63.6

en los trabajadores de viñedos 63.6

y anemia 63.6

y leucopenia 63.6

y neuropatía periférica 63.7

y perforación del tabique nasal 63.7

y queratoconjuntivitis 63.7

y trastornos dermatológicos 63.7

y trastornos vasculares periféricos 63.6

toxicidad por ingestión 63.6 dosis letal 63.6

Arsénico inorgánico

concentraciones 27.10

determinación de la concentración 27.10

efectos tóxicos 27.10

excreción 27.10

Arseniuro de galio 27.10, 83.22

Arsina 83.25

intoxicación por 63.7

arsinobetaina 63.7

arsinocolina 63.7

Arteriosclerosis 3.5 disulfuro de carbono y 104.419

periférica precoz y frío 42.41

Artes gráficas

acabado 85.5

riesgos mecánicos 85.5

riesgos por manipulación de materiales 85.6

tensiones ergonómicas 85.6

confección de planchas 85.3

exposición al plomo 85.3

riesgos mecánicos 85.3

fabricación de tintas 85.4

control de la electricidad estática 85.4

protección contra incendios 85.4

riesgos mecánicos 85.4

impresión 85.5

exposición a disolventes 85.5

radiaciones UV 85.5

seguridad mecánica 85.5

uso de ventilación y equipos de protección personal 85.5

riesgos para la salud 85.3

V éase 0 rdenadores, Fotografía

exposiciones potenciales $85.10 \mathrm{t}$

por utilización de láser 85.4

técnicas de impresión 85.2

huecograbado 85.2

impresión planográfica 0

litográfica 85.3

serigrafía y permeografía 85.3

tipografía 85.2

Artesanía de la madera

efectos cancerígenos 96.20

de conservantes de la madera 96.20

maderas peligrosas 96.20

y cáncer nasal 96.20

y fenómeno de R aynaud 96.21

Artesanía textil

efectos de las fibras de origen

animal 96.16

lesiones musculares 96.17

modalidades de $96.16 \mathrm{t}$

precauciones generales 96.17

problemas pulmonares 96.16

por polvos de origen vegetal 96.16

respuestas alérgicas 96.17

a fibras sintéticas 96.17

riesgos químicos 96.16

Artesanos

enfermedades profesionales en 96.2

Articulaciones

$y$ huesos

Véase H ueso

Articulares, dolores

en conductores de camiones 103.8

en chóferes 103.14

Artistas

enfermedades profesionales en 96.2 
Artritis

artritis gotosa

Véase G ota

artritis reactiva

agentes desencadenantes $6.34 \mathrm{t}$

artritis reumatoide

directrices de tratamiento $6.33 \mathrm{t}$

asociada a la confección de

alfombras 89.29

de las manos

y frío 42.42

sistema musculosquelético, enfermedades

Véase también 0 steoartritis

Artrosis

carga mecánica 6.28

de cadera

Véase Cadera

de muñeca y mano

Véase M uñeca

de rodilla

Véase R odilla

del codo

Véase Codo

en el hombro

$\checkmark$ éase Hombro

generalizada 6.28

por vibraciones mano-brazo $\quad 50.10$

A samblea M undial de la Salud

Estrategia M undial para la Salud en el

Trabajo para Todos 16.3

Asbesto

asbestosis por 98.7

anatomía patológica 10.62

características clínicas 10.63

diagnóstico clínico 10.65

e inhalación de polvos de

asbestos 62.3

e inhalación de vermiculita 62.5

en el sector de la construcción 93.3

epidemiología 10.64

pruebas de función pulmonar 10.64

pruebas de laboratorio 10.64

radiografía de tórax $10.63,10.65$

y trabajo infantil 24.17

Véase también N eumoconiosis

peligrosidad del

en hoteles 98.7

y riesgos para la salud 62.3

Ascensores

controles 93.47

inspecciones y pruebas 93.48

mantenimiento 93.48

medidas de precaución 93.47

normalización 93.46

riesgos asociados 93.47

aplastamiento 93.47

caídas 93.47

cizallamiento 93.47

impacto 93.47 incendio 93.50

sobrecarga 93.47

uso de disolventes 93.50

tipos 93.46

visión general 93.46

y salud 93.50

Ascórbico

ácido 65.13

Aserrado

proceso de 71.4

A sesoramiento

sobre las condiciones de trabajo 23.33

A sfalto

composición química 93.57

medidas de salud y seguridad 93.58

equipos de protección personal 93.58

ventilación 93.58

procesado de asfalto 78.20

riesgos asociados 93.57

cáncer 93.58

exposición a hidrocarburos aromáticos polinucleares 93.57

incendio 93.58

irritación de la piel y de los ojos 93.57

quemaduras 93.57

trastornos respiratorios 93.58

visión general 93.57

Véase también R efino de petróleo

Asfixia

por electrocución 40.3

nitrilosy 104.138

A sfixiantes

químicos 33.31

simples 33.31

Asia

animales de tiro en 70.31

A sistencia sanitaria

causas de tensión cognitiva en 97.20

profesionales y funciones que

desempeñan $97.2 \mathrm{t}$

riesgos más comunes en el sector de la 97.3 según la NIOSH 97.3

Véase también T rabajadores sanitarios

A sistencia social 34.45

Asma

anhídrido ftálico y 104.14

azufre y 104.419

cloropicrina y 104.339

de origen agrícola 70.9

debida a hongos 44.25

diazometano y 104.121

en jardineros 103.28

en manipuladores de animales 103.30

en regiones frías 42.41

isocianatos y 104.320

mortalidad por 100.18

por exposición a productos de soldadura 83.15 por exposición al formaldehído 100.16

profesional 66.17

Véase A sma ocupacional

riesgo asociado a la industria del

papel 72.12

y platino 63.39

y proceso del aluminio 63.3

y tratamiento de residuos 101.12

Asma ocupacional

agentes causantes 10.21

agentes sensibilizantes $10.23 \mathrm{t}$

asma agravada por el trabajo 10.20, 10.23

asociada a la fundición de aluminio 82.10

de los alfareros 63.3

de los molineros 65.14

definiciones 10.22

definición de caso médico $10.22 \mathrm{t}$

del empaquetador de carne 99.15

entre los trabajadores de la industria pesquera 66.17

del panadero 67.32

diagnóstico 10.21 - 10.23

espirometría 10.24

exploración física 10.24

exposición ocupacional 10.23

historia clínica 10.24

historia profesional 10.23

pasos en la evaluación diagnóstica $10.22 \mathrm{t}$

pruebas cuantitativas de HRB 10.24

pruebas inmunológicas 10.24

en cosmetólogos y peluqueros 100.10

evaluación clínica 10.22

exposiciones en el lugar de trabajo 10.21

incapacidad debida a asma 10.26

notificación de casos 32.12

período de latencia 10.21

por irritantes respiratorios 10.21

por menoscabo médico 10.26

prevalencia 10.20

reacciones asmáticas 10.21

riesgo asociado a los servicios de policía 95.12

riesgo asociado en la industria del automóvil 91.9

riesgo en los procesos de confección 87.7

riesgos asociados en carpintería 86.13

síndrome de disfunción reactiva de las vías aéreas $10.21,10.23$

síntomas 10.21

tratamiento y prevención 10.25

Asociación

derechos de 21.10

libertad de asociación 21.10 derecho de afiliación 21.11 derecho de huelga 21.12

funcionarios públicos 21.11

jurisprudencia 21.12

negociación colectiva 21.12 
pluralismo sindical 21.11

principios 21.10

restricciones temporales 21.12

tradiciones colectivistas 21.11

A sociación de A sistencia Sanitaria de la U nión de Trabajadores de Berlín 23.32

A sociación de $\mathrm{N}$ aciones de A sia Sudoriental acuerdos de libre comercio 20.15

A sociación del Sudeste A siático

Véase A sociación de $\mathrm{N}$ aciones de A sia Sudoriental

Asociación francesa de normalización y regulación técnica de los ascensores 93.46

Asociación Internacional de Ensayos y

$M$ ateriales 40.15

Asociación Internacional de Epidemiología 19.19

Asociación internacional de equipo y materiales de semiconductores (SEM I) 83.19 directrices de seguridad para equipo de fabricación de semiconductores 83.19 guía del usuario sobre criterios de éxito ergonómico de proveedores 83.19

Asociación Internacional de Ergonomía (AIE) y diseño de información sobre seguridad 56.39

A sociación Internacional de Inspectores de

Trabajo (IALI) 23.69

actividades 23.69

estructura y miembros 23.69

objetivos 23.69

perspectiva histórica 23.69

publicaciones 23.69

A sociación Internacional de la Seguridad Social

(AISS) 23.45, $23.63-23.66$

actividades 23.64

investigación y documentación 23.64

regionales 23.64

técnicas 23.64

Comité permanente de prevención de riesgos profesionales 23.64

concepto de prevención de la AISS de seguridad mundial 23.67

congresos mundiales 23.65

estimación de las tasas de

electrocución 40.2

estructura y miembros 23.64

objetivo 23.63

perspectiva histórica 23.63

publicaciones 23.67

secciones internacionales de prevención de riesgos profesionales 23.66

A sociación Internacional de

N ormalización 40.15

A sociación Internacional de Protección

Radiológica (IR PA) 23.45
Comisión Internacional de

Protección de la R adiación no I onizante

(ICNIRP) 23.45

y exposición a campos eléctricos 49.3

A sociación Internacional para la Educación de los Cazadores (IHEA) 69.3

A sociación Internacional para la H igiene Industrial (AIHI) 30.3

A sociación Japonesa de Salud Industrial 5.20

A sociación M undial de $M$ édicos

Códigos profesionales 19.16

Código internacional de ética médica 19.16

Declaración de Ginebra 19.16

Declaración de H elsinki 19.16

A sociación $\mathrm{M}$ undial de $\mathrm{O}$ peradores $\mathrm{N}$ ucleares intercambio de información sobre accidentes nucleares 76.13

A sociación N orteamericana de T écnicos en

Calefacción, R efrigeración y

A condicionamiento del Aire

(ASHRAE) 85.8

Aspergillus 44.23, 44.25, 62.15, 67.10

clavatus 65.14

flavus 67.34

fumigatus $38.3,44.24$

niger 64.4

y riesgo de infección en la industria de la piel y el cuero 88.9

Aspergilosis 70.29

A ssociation of A merican $R$ ailroads (Estados Unidos)

y seguridad de camiones y vagones cisterna 102.58

Astenopía

en operadores de PVD 52.11, 52.14

Astilladoras 72.6

Astillas tipos de 72.6

Asstrand carga de trabajo relativa 29.36

Astronautas efectos de la microgravedad en $\quad 102.20$ trajes 42.15

A taxia 7.21

cerebelosa 42.10

cerebral

tolueno y 104.283

y mercurio 63.31

Atención

teorías de la atención y vigilancia 29.53

Atención domiciliaria servicios de experiencia de Nueva Y ork 97.11

Atletas profesionales patologías cardíacas en 96.55
A tmósferas

contaminada 94.14

explosivas

equipo a prueba de explosión 40.13

lugares peligrosos 40.12

peligros eléctricos en 40.12

protección contra descargas

electrostáticas 40.11

pulverulentas

peligros eléctricos en 40.12

Atornillar 29.42

Atrazina 27.24, 62.13

Atropellos

por un tractor 64.36

Aturdimiento 67.16

Audición

Véase 0 ído

desplazamientos permanentes del umbral (PTS) 50.5

por vibraciones de cuerpo

completo 50.5

fatiga auditiva 11.4

pérdida de $11.5,26.8$

en conductores de camión 103.7

umbral de audición 11.4

cálculo de la pérdida funcional $11.7 \mathrm{t}$

en la forja 96.13

en músicos 96.7, 96.27

y uso de herramientas vibrantes 50.11

Audífono

y alarmas acústicas 17.33

Véase también Pérdida auditiva, sordera

Audiometría

ejemplos de audiogramas $11.6 f$

Auditiva, fatiga 11.4

Véase 0 ído

Auditivo, trastorno

Véase T rastornos auditivos

Auditoría ambiental

ámbito de aplicación $54.28 \mathrm{t}$

definición de la $\mathrm{CCl} 54.27$

etapas fundamentales $54.29 \mathrm{t}$

medidas previas 54.28

monográfica 54.30

objetivos principales 54.27

previa a una absorción 54.30

previa a una venta 54.30

procedimientos 54.28

Auditorías de seguridad

análisis SM O RT en 57.21

sistema de auditoría de Pellenberg

(SAP) 57.6

elementos $57.6 \mathrm{t}$

opciones para la sinergia 57.7

sistemas integrados en el 57.6

y modificación del comportamiento

estrategias normativas-reeducativas $\mathbf{5 7 . 5}$ 
mediante sanciones 57.5

niveles de respuesta probable 57.5

por elecciones racionales 57.5

y tasa de accidentes 59.3

Aulas 94.4

Australia

animales de tiro en 70.33

Autobuses, conducción Véase C onducción de autobuses

Autocalentamiento 41.4, 41.7

Autoeducación

asistida 94.2

privada 94.2

Autoenseñanza

colectiva 94.2

individual 94.2

Autoestima

definición de la 34.52

medición de la 34.52

métodos para fomentar la 34.52

pérdida de la 34.15

y estrés 34.52

Autoevaluación de la competencia 34.52

Autoformación permanente 94.2

Autoinmunidad

definición 33.42

inmunógenos 33.42

patogénesis 33.42

Automatización

de máquinas herramienta 58.52

Véase también M áquinas herramienta C NC

Automatización de instalaciones

riesgos asociados a la 58.19

Véase también Accidentes de automatización

Automóvil, industria del

automatización

y medidas de protección 91.6

y riesgo de lesiones graves 91.6

clasificación del trabajo 91.7

distribución del empleo 91.2

exposición a sustancias químicas 91.4, 91.6

ácido crómico 91.4, 91.9

ácido sulfúrico 91.4, 91.9

aminas 91.4

cloruro de metileno 91.6

cobalto 91.5

dióxido de azufre 91.4

estireno 91.6

formaldehído 91.4

humos metálicos 91.4

monómero de diisocianato 91.6

monóxido de carbono 91.4

polvo con sílice 91.3

procesos de producción $91.2 \mathrm{t}$

riesgos mecánicos

y medidas de protección 91.5 riesgos para la salud y la seguridad 91.7

lesiones musculosqueléticas 91.8

lesiones traumáticas 91.8

medidas preventivas 91.8

riesgos químicos 91.8

sectores y procesos 91.2

depósitos de piezas 91.7

estampación 91.5

fabricación de locomotoras y vagones 91.7

forja y tratamiento térmico 91.5

fundición de aluminio 91.4

fundición de metales férreos 91.2

fundiciones no férreas 91.4

mecanizado 91.5

montaje 91.6

montaje de camiones pesados y de

maquinaria agrícola y de

construcción 91.7

paneles de carrocería y componentes

embellecedores de plástico 91.6

prueba de prototipos 91.7

y monóxido de carbono 104.430

visión general 91.2

Véase también M ecánicos de automóviles

Autonomía 34.26

en el trabajo

lista de comprobación 29.29

Autónomo

Véase Sistema nervioso

Véase Sistema nervioso autónomo

Autorregulación

y códigos deontológicos 19.4

Auxiliares de vuelo

responsabilidades de los 102.14

Véase también T ripulación aérea

Auxiliares docentes

riesgos potenciales de los 94.3

A valanchas

de nieve húmeda 39.26

de nieve seca 39.26

métodos de protección 39.27

avalanchas artificiales 39.28

barreras de apoyo 39.27

barreras de arrastre 39.27

barreras de bloqueo 39.27

barreras de desviación o frenado 39.27

zonas de alto riesgo 39.27

Aventado 64.32

A ves de corral

corrales de confinamiento para 70.27

producción 70.26

medidas de seguridad 70.30

riesgos para la seguridad 70.30

A viación, accidentes de

exterminadores de plagas y $\quad 103.18$

A vícola, industria 67.20
A vicultores 70.29

Véase A ves de corral

salud y seguridad de los 70.29

Avispas 68.28

Axón

estructura de los receptores cutáneos 11.33

Véase también N eurona

Azaconazol 71.6

Azada 64.28

Azidas 104.121

Azúcar

caña de 64.40

de remolacha 67.32

industria del 64.41

moreno 64.41

subproductos 64.41

Azufre

compuestos de azufre reducido 72.16

compuestos inorgánicos de 104.417

compuestos orgánicos de 104.406

Azul vitriolo 63.14

\section{B}

Babassu 67.33

Babesiosis 97.49

Bacillus anthracis 10.85

Bacillus cereus 67.27

Bacterias

contaminantes del aire interior 44.23

Bagazo 72.16

Bagazosis 64.41

Balas 70.12

Balcanes

nefropatía de los 8.12

Baldosas cerámicas

clasificación 84.14

fabricación 84.15

Ballena

caza comercial de la 66.20

Comisión Ballenera Internacional 66.20

Bálsamo de Judea 72.9

Banbury

malaxador 80.4

Véase N eumáticos, fabricación de

Banco M undial

clasificación de países por PN B 20.5

estudios sobre las causas de accidentes de tráfico 53.27

y generación de residuos sólidos

urbanos 101.23

y proyectos de desarrollo humano 24.2

Bandura

control personal (1986) 34.56 
métodos de autoeficacia (1977) 34.13

teoría de la autoeficacia/ motivación

(1977) 34.10

Bangkok 39.30

Bangladesh

animales de tiro en 70.33

Barban 62.14

Barcazas

para transporte de crudo y derivados del petróleo 102.56

Bares, empleados de

estrés cervical y dorsal 98.5

lesiones auditivas 98.5

y humo de tabaco ambiental 98.5

Bario

inhalación de 63.9

y baritosis 63.9

y neumoconiosis 63.9

intoxicación en la industria del

efectos 63.9

prevención 63.9

riesgo de explosión del 63.9

toxicidad por vía oral 63.9

dosis letal 63.9

Baritosis

en la fabricación del litopán 63.9

en la minería 63.9

asociada con silicosis 63.9

Barnices

plomo en

para cerámica 96.18

Barotrauma 36.5, 36.10

por compresión 36.10

por descompresión 36.11

Barreras

de luz 58.44, 58.48, 58.53, 58.59

y norma EN $50100 \quad 58.49$

de sensibilización

y protección de las máquinas 58.24

hematoencefálica 33.6, 33.13, 33.60

hematoplacentaria $33.6,33.13$

hematotesticular 33.6

histohematológica 33.13

Barriles 65.14

Bartenwerfer

procedimiento de escalas de la

activación central general 29.50

Bartlem y Locke

crítica al estudio de Coch y French 29.61

Batería

eléctrica 81.4

$V$ éase A paratos eléctricos

Baterías de acumuladores

prácticas de seguridad en la manipulación

de $102.32,102.36$

riesgos de las 102.32
Bauxita

y enfermedad de Shaver 62.3

y extracción de aluminio 82.8

Baygón 62.12

Bebidas

industria de las 65.2

bebidas alcohólicas 65.2

bebidas sin alcohol 65.2

para deportistas 42.13

Bedford

Temperatura Efectiva C orregida 42.20

Bélgica

inspección de trabajo en 23.12

Bence-J ones, prueba de para la proteinuria 1.5

Benceno

aberraciones cromosómicas 104.283

efecto en la médula ósea 1.2

en la gasolina

riesgos de los vapores de 102.35

exposiciones al

en los procesos de confección 87.4, 87.7

encoladores y 103.16

pintoresy 103.46

prohibición 103.16

riesgos asociados en la industria del

calzado 88.10

sustitución del 104.286

uso en una fábrica de tintes 23.23

y anemia aplásica 1.2

y leucemia en la industria del calzado 88.10

y sistema inmunitario $1.3,33.41$

Bencenotiol

lesiones oculares 104.407

Bencidina 28.6, 72.16

como carcinógeno del grupo 1 por la

IARC 104.98

Benzodiacepinas

y tratamiento de la ansiedad 5.8

Berilio

concentración 27.10

eliminación 27.10

enfermedad por $10.31-10.32$

adenopatía 10.33

enfermedad crónica 10.33

función pulmonar 10.34

exposición 27.10

extracción del mineral 10.31

formación de granulomas 10.32

lesiones cutáneas 10.33

medidas de seguridad y salud $\quad 10.35$

niveles normales 27.10

principales usos 10.32

proceso de fluoruro $10.31 \mathrm{f}$

propiedades $10.31 \mathrm{t}$

tratamiento con esteroides 10.36

y berilo 10.31 y cáncer de pulmón 10.35

Berilo

Véase Berilio

como fuente comercial de berilio 10.31

Bert, Paul, efecto de 36.2

Véase T oxicidad por oxígeno

Bertrand R ussell 19.11, 19.17

Betanal 62.12

Bhopal 23.34, 39.4, 39.19, 41.18

Véase T raslado de riesgos industriales

accidente de 1984 en U nion

Carbide 29.93

metilisocianato 104.320

Bidones 67.34

Bienestar

Véase Protección y promoción de la salud

afectivo 34.65

concepto amplio 34.66

concepto de 34.64

empleo del término 23.25

en el trabajo 34.65

medición del 34.65

programas de protección y promoción de la salud 15.3

térmico 42.34

y personalidad 34.65

Bifenilos policlorados (PCB) 53.15

efectos sobre la salud 53.9

Bilirrubina excreción por el hígado $\quad 4.5 f$

Bioacumulación 53.15

Bioaerosoles 30.22, 30.28

Biocontrol citogenético

estudios 27.18

lesiones cromosómicas identificables 27.18

pruebas 27.18

Biocontrol genético

biomarcadores $27.17 \mathrm{t}$

estudios 27.19

predicción del peligro cancerígeno 27.19

problemas éticos 27.20

tipos de lesión del ADN

identificables 27.17

Biodegradación 41.30

Biodiscos

para el tratamiento de vertidos 101.19

Biodiversidad

industria forestal y 68.44

industria pesquera y 66.19

Bioefluentes 45.15

Bioensayo

y evaluación del material radiactivo en el cuerpo 48.28

Bioestadística

en modelos de salud pública 
de investigación de accidentes

laborales 60.5

Biomarcadores

Véase $\mathrm{M}$ arcadores biológicos

aplicaciones en el ámbito de la salud en el trabajo 33.47

aspectos éticos de los estudios con $\quad 33.49$

control biológico 28.9

de la exposición

a sustancias químicas mutágenas 33.45

de la susceptibilidad 33.46

hipersusceptibilidad 33.47

susceptibilidad genética 33.47

del efecto

específicos 33.46

no específicos 33.46

generalidades 33.44

validez del diagnóstico 33.47

Biomecánica

aplicaciones 29.41

cálculo de la compresión discal 29.44

límites de peso recomendados 29.44

manipulación manual 29.43

objetivos y principios 29.40

posturas y movimientos 29.43

Biopersistencia 53.15

Biotecnología

Véase Industria de la biotecnología

Biotoxinas marinas

intoxicación por 53.9

Biotransformación 33.7, 33.13 - 33.14

Bióxido de azufre 66.17

Bipiridil

y lesiones en la piel 28.34

Bipolar

trastorno bipolar 5.1

Véase T rastorno maníaco-depresivo

Bis(clorometil) éter

carcinogenidad del 61.23

Bisditiocarbamatos 62.12

Bisinosis

asma profesional 10.29

bronquitis crónica 10.29

diagnóstico 10.30

en artesanos textiles 96.16

en la industria textil 89.30

exposición a polvo $89.11,89.24$

progresión de la enfermedad 89.31

situación actual 89.33

endotoxinas bacterianas 10.30

estudios realizados en Estados

Unidos 10.29

exposición al polvo de algodón 10.29

exposición en el trabajo 23.35

grados de la enfermedad $89.30 \mathrm{t}$

inflamación de las vías aéreas 10.29

neumonitis tóxica 10.29 opresión torácica 10.29

Véase también A parato respiratorio

Bismuto

exposición profesional al 63.10

y efectos neuropsíquicos 63.10

y encefalopatía 63.10

y nefrosis 63.10

Bisulfito de magnesio 72.8

Bisulfito sódico 72.8

Bisulfuro de carbono

riesgos asociados en la industria textil 89.33

Bitartrato potásico 65.13

Bitis arietans 38.12

Bitis atropos 38.9

Bittel

adaptación al frío 42.51

Blanqueo

etapas del procedimiento CEDED 72.8

secuencias de 72.9

sin cloro 72.8

Blastomyces dermatitidis 69.5

Blefaritis

diepoxibutano y 104.152

Bligh y Johnson

adaptación al 42.51

Blindajes radiológicos

Véase Seguridad radiológica

Bodegas 65.13

Bolsa de Gamow 37.12

Bolsas 65.8

Bolsas de muestreo 30.22

Bombas de muestreo 37.14

Bomberos

en incendios forestales 39.26

manipulación de materiales

peligrosos 41.28

relaciones de la empresa con el cuerpo de 41.28

trajes de 42.14

víctimas del cuerpo de 41.8

Boquilla

Véase Protectores respiratorios

Boranos

lesiones neurológicas 104.131

Boratos

efectos 104.130

Bórax 71.6

Borboteador 30.22

por inercia 30.23

Borreliosis 69.5

Bortner Rating Scale 34.50

Véase Escala de Clasificación de Bortner

Bosques 68.2
Botas

Véase Protectores de pies y piernas

Botellas de gas 61.15

con gases combustibles 61.17

precauciones 61.17

peligro de incendio y explosión de

las 61.17

precauciones para un uso seguro de 61.18

riesgo asociado al oxígeno 61.16

seguridad en las tareas de llenado 61.17

y quemaduras frías 61.16

y riesgos por la alta presión 61.16

Bothrops 38.8

Botones de parada de emergencia (PE) 58.43

Botsball 42.25

Botulismo 28.34

Boutonierre, deformación de 96.53

Boveri, Theodor mutagénesis y carcinogénesis 33.77

Bowman, cápsula de Véase $N$ efrona

Brady 34.69 trabajos con monos "ejecutivos" (1958) 34.69

Bragadores 68.4

Brasil

incendio de bloques de oficinas de São

Paulo 41.8

incidencia de la malaria 53.34

Brehmer, taxonomía de

características temporales del contexto 29.7

Bremsstrahlung (radiación de frenado) 48.22

Brillo fotométrico

Véase Luminancia

British Ceramic Society 84.20

British Standards Institute

Code of Practice 41.19

Guía de diseño de protecciones antirrayos 41.19

Brodifacoum 27.24

Bromo 41.13

Bromodesoxiuridina 27.18

Bromuro de vinilo

Véase $V$ inilo, bromuro de

Bronconeumonía

alérgica

por toxafeno 62.10

por humos de cloruro de zinc 63.52

Bronquitis

Véase Enfermedades pulmonares

catarral descamativa

por tetracloruro de germanio 63.21 crónica

en la industria textil 89.31 
en los trabajadores del titanio 63.49 en los trabajadores del vanadio 63.50 riesgo en la industria de la piel y el cuero 88.4

y consumo de tabaco 44.12 y extracción de pizarra 62.6 dióxido de azufre y 104.420 en el sector de la construcción 93.3 en la fabricación de cemento 93.52 en la industria de las bebidas 65.8 en los trabajadores del osmio 63.37 en los trabajadores del platino 63.39 en los trabajadores del titanio 63.48 en minería de la fluorita 62.4 por aerosoles de ferrovanadio 63.23 por exposición al frío 42.41

Brown y $\mathrm{H}$ olmes, modelo de para medición del clima de seguridad 59.10

Brucella 67.27

abortus $10.93 \mathrm{t}$

canis $10.93 \mathrm{t}$

melitensis $10.93 \mathrm{t}$

neotomae $10.93 \mathrm{t}$

ovis $10.93 \mathrm{t}$

suis $10.93 \mathrm{t}$

Brucelosis

exposición a

en la industria alimentaria 67.34

en la producción cárnica 67.19

transmisión por la sangre 97.49

riesgo de contagio de

en conductores 102.25

riesgo en la industria de la piel y el calzado 88.9

Buceo 36.2

barotrauma 36.10

calentamiento auxiliar 42.49

compresión de todo el organismo 36.8

e hipoxia 36.2

e intoxicación por monóxido de carbono 36.2

hipotermia por inmersión 42.48

lesiones físicas 36.8

pérdida de calor de convección 42.48

reanimación 36.13

recompresión 36.13

salvamento 36.13

tablas DCIEM 36.4

trajes de inmersión 42.49

y descompresión 36.3

y dióxido de carbono 36.3

y narcosis por nitrógeno 36.3

Bueyes 70.31

Búfalos

búfalo de Shanghai 70.34

Bulimia

en bailarines 96.26 en cantantes 96.29

Buques

Guía M édica Internacional 23.44

principales riesgos físicos y

químicos $102.49 \mathrm{t}$

principios de control y reducción de riesgos $102.49 \mathrm{t}$

Buques de pesca

Véase Pesca, trabajo a bordo de

alojamiento y equipamiento para la tripulación 66.9

Convenio internacional para la seguridad de los buques de pesca 66.10

definición 66.9

estabilidad y navegabilidad 66.10

seguridad 66.9

accidentes 66.16

accidentes mortales 66.16

Conferencia sobre buques de pesca de 197766.10

Convenio internacional para la seguridad de los buques de pesca 66.10

estanqueidad 66.10

incendios 66.17

lesiones no mortales 66.16

mortalidad por causas

desconocidas 66.18

Protocolo de Torremolinos 66.10 tipología

Véase Pesca, métodos

arrastrero 66.6

arrastreros de fondo a la pareja 66.6

buques con red de cerco de jareta 66.6

palangreros 66.7

trabajo a bordo de 66.6

Buques mercantes

control de plagas en 102.50

dedicados al transporte de GPL y

GNL 102.56

estructura social a bordo de los 102.46

factor humano en los accidentes en 102.51

para transporte de crudo y derivador del

petróleo 102.56

y riesgos profesionales 102.57

riesgos para la salud en $102.47,102.48 \mathrm{t}$

tipos de $102.46 \mathrm{t}$

transmisión de enfermedades infecciosas

en 102.50

Véase también Industria marítima

Buques-factoría 66.8

Bureau of L abor Statistics (BLS) 88.9 encuesta anual de lesiones y enfermedades profesionales $32.4,83.34$

Bureau of $M$ ines (Estados $U$ nidos) límites de exposición 30.31

Bureau of R adiological $\mathrm{H}$ ealth (Estados U nidos) categorías de los rayos láser 97.33
Burkitt, linfoma de 1.5

Burnout

Véase Síndrome de burnout

criterios diagnósticos 34.75

definición 34.74

estudios 34.75

intervenciones 34.75

Burros 70.30

Bursitis

en cosmetólogos y peluqueros 100.8

Burton, línea de 4.4

Butadieno 41.14

como cancerígeno del grupo 2A por la

IARC $\quad 104.275$

en la fabricación del caucho 80.9

mortalidad por leucemia y 80.16

Buzo, enfermedad del

trabajos en túneles

en el sector de la construcción 93.34

trabajos submarinos

en el sector de la

construcción 93.34

Buzos indígenas 66.2

C

Caballos

carreras de 70.30

cría de 70.30

peligros y precauciones 70.31

zoonosis 70.31

Cabeza

lesiones en la 31.9

Véase también C ascos de seguridad

Cabina Pendo 68.22

Cabinas aislantes

utilización en la

industria naval 92.14

Cable transportador de dinamita 39.28

Cables de fibra óptica 40.12

Cabras 70.22

Cacao 67.27

Cacodílico

ácido 27.10

Cadena verde 71.5

Cadera 6.27

artrosis de 6.28

estudios epidemiológicos 6.28

factores de riesgo individuales 6.28

Cadmio

absorción 27.10

absorción en el organismo 63.10

y producción de metalotioneina 63.10 como cancerígeno según la IARC 63.12 concentración 27.10 
exposición 27.10

exposición profesional

controles sanitarios 63.12

medidas de seguridad 63.12

tratamiento 63.12

inhalación de 63.11

y edema pulmonar 63.11

y neumonitis 63.11

intoxicación alimentaria por 63.11

intoxicación crónica por 63.11

síntomas 63.11

y enfisema pulmonar 63.11

y lesiones renales 63.11

y osteomalacias 63.11

y proteinuria tubular 63.11

y uremia 63.11

intoxicación por

como enfermedad laboral $\quad 53.3$

órgano diana 33.16

procesos de recuperación

controles técnicos $82.59 \mathrm{t}$

y tabaquismo 33.47

Café

industria del 65.7

fabricación 65.7

instantáneo 65.8

Cafeína 42.52

consumo de 34.63

y tabaquismo 34.63

Caídas

de objetos en la industria naval 92.15

en la fabricación de vidrio, cerámica y materiales afines $84.26,84.29$

en la industria aeroespacial 90.6

clasificación 90.6

controles de procedimiento 90.8

controles técnicos 90.7

equipos de protección personal 90.7

evaluación 90.6

plan de protección 90.6

en la industria alimentaria 67.6

en la industria cárnica 67.18

en la industria de la piel y el cuero 88.6

en operaciones de almacenamiento $y$ transporte 64.24

en operaciones de envasado 65.10

lesiones relacionadas con 32.17

riesgo en el sector de la construcción

acabados exteriores 93.31

andamios 93.27

demolición 93.31

en ascensores 93.47

en trabajos junto al agua o dentro del agua 93.33

en zanjas 93.37

instalación de servicios de

suministro 93.30

mantenimiento y limpieza 93.29

trabajos en cubiertas 93.28 riesgo en la industria naval 92.14

riesgos en la tejeduría 89.24

Caídas desde alturas

causas de 58.75

diferencias entre prevención y detención de $58.77 \mathrm{t}$

e inestabilidad postural 58.75

fuentes de información relacionadas con 58.75

estrategia de prevención de $58.76 f$

mortales 58.75

en el sector de la construcción 58.75

protección obligatoria contra 58.75

y límite legal de $3 \mathrm{~m} 58.75$

sistemas de detención de 58.77

sistemas de prevención de 58.77

Cajeros

en el comercio minorista

y lesiones por movimientos

repetitivos 99.15

Véase también Personal de caja

Cajones de aire comprimido 36.5

incendios 36.9

ruido 36.9

Cal viva 72.8

Caladeros 66.9

Véase Pesquerías

Calambres del cortador de cañas 42.8

del fogonero 42.6

del minero $42.6,42.8$

por calor 42.8

Calandria 72.10

Calcio 41.14

Caldera lejiadora 72.2

operador de

asfixia 103.39

exposición al ruido 103.39

irritación de las vías respiratorias 103.40

irritaciones oculares 103.40

riesgos laborales 103.39

Calefacción

Véase Sistemas de calefacción

Calidad

mejora continua de la 24.18

y ergonomía 29.5

Véase también C ontrol de calidad

Calidad de la atmósfera 55.12

Véase V igilancia de la calidad atmosférica

Calidad del agua 55.29

criterios de control 55.29

normas de la EPA 55.30

Véase también C ontaminación del agua

Calidad del aire 30.17

Calidad del aire interior

control analítico de la 44.18

métodos para toma de muestras 44.19 , 44.26 para captura de partículas y fibras 44.22

para compuestos orgánicos

volátiles 44.22

para detección de

microorganismos 44.26

para detectar plaguicidas 44.22

para el análisis de gases 44.21

planificación de la toma de

muestras 44.18

selección del método de análisis 44.19

control de la humedad 45.4

control de las fuentes de

contaminación 44.28

mantenimiento del edificio 44.29

normas para Europa (COST 6131989 y

1991) 44.29

ventilación 44.29

defectos más frecuentes 44.4

directrices de la 0 rganización M undial de

la Salud 44.3

e integridad del edificio $\quad 45.3$

e ionizadores 45.6

en ambientes industriales 44.29

y valores límite de exposición 44.29

en centros sanitarios 97.5

en museos 96.41

en oficinas 99.7

enfermedades relacionadas con $44.2 f$

factores asociados a la 45.7

medidas exploratorias de la 44.18

metodología para estimar la 44.17

percepción de la 45.15

reglamentación sobre 44.28

y absentismo laboral 44.2

y acondicionamiento del aire 44.6

y ahorro de energía $44.3,44.5$

y estrés 44.2

y fuentes de contaminación $\quad 45.8$

externas 45.8

internas 45.8

y medio ambiente externo 45.5

y métodos de control del aire 45.8

y métodos de depuración del aire 45.9

y microorganismos $44.3,44.5$

y olor 44.3

y ozonadores 45.6

y productividad 44.2

y síndrome del edificio enfermo 44.3

causas más frecuentes 44.3

síntomas 44.3

y sistema de calefacción 44.6

y sistema de ventilación 45.4

por desplazamiento 45.13

por dilución 45.11

y unidades olf 45.15

y ventilación 44.5

Véase también Contaminación del aire interior

Calidad total 34.37

Véase G estión de la calidad total 
Callosidad 12.19

Véase Estigmas profesionales

Calor

adaptación al 42.11

efectos en la industria de la piel y el cuero 88.7

en la elaboración de aceite 67.34

estrés por

en la extinción de incendios 95.6

exposición en la industria del

automóvil 91.4

intercambio de calor a través de la

ropa 42.26

aislamiento de los tejidos 42.28

aislamiento proporcionado por la

ropa 42.26

capas de aire y movimiento del

aire 42.26

conducción de calor del aire inmóvil y en movimiento 42.27

resistencia al vapor del aire y los tejidos 42.28

transferencia de calor por radiación 42.27

ola de 42.14

pérdida de calor por evaporación 42.4

respuestas fisiológicas al 42.2

capacidad aeróbica 42.7

diferencias individuales y étnicas 42.7

trabajo en condiciones de

en la industria alimentaria $\quad 67.8$

en la industria de la cerveza 65.15

en la industria del papel 72.14

Véase también Estrés por calor

Véase también Tolerancia al calor

Calor de gasificación 41.3

Calor metabólico 42.2

Calzado, industria del

accidentes 88.8

medidas de prevención 88.8

exposición a disolventes tóxicos 88.10

medio ambiente y 88.8

procesos 88.7

riesgo de incendio 88.8

trabajo a domicilio 88.9

trabajo infantil 88.7

visión general 88.7

Cama de siembra

preparación de la 64.27

Cámara de $\mathrm{C}$ omercio Internacional (CCI) definición de auditoría ambiental 54.27

Cámara, operadores de situaciones peligrosas 96.35

Cámaras de $\mathrm{K}$ anne (cámaras de ionización por flujo)

y detección de gases radiactivos 48.26

Cámaras frigoríficas

medidas de precaución con 98.3 trabajo en 42.47

y riesgos para la salud $67.13,67.25$

Cámaras hiperbáricas

incendios 36.9

silenciadores 36.9

trabajadores de las 36.8

Cambio

Véase R esistencia al cambio

Cambio climático

componentes básicos del 53.27

Convenio $\mathrm{M}$ arco de las $\mathrm{N}$ aciones $\mathrm{U}$ nidas sobre el 54.13

medidas preventivas 53.32

programas de vigilancia 53.32

y aumento de fitoplancton 53.30

y enfermedades infecciosas 53.29

y mortalidad relacionada con el calor 53.28

Cambio tecnológico

estudios de casos 20.7

y cultura 29.91

Camiones cisterna 102.31

limpieza de los 102.61

normativas de seguridad para 102.58

para productos del petróleo y otras

sustancias químicas 102.58

precauciones contra incendios 102.60

riesgo de cargas electrostáticas 102.60

seguridad en la carga y descarga $\quad 102.59$

Camiones, conducción

Véase Conducción de camiones

Campamentos forestales 68.40 condiciones de vida en los 68.40

Campañas

de promoción de la seguridad 60.27 eficacia en entornos industriales 60.27 estudio del caso del día nacional de la seguridad en la India 60.28

Campos de ELF y VLF

cambios metabólicos por 49.26

efectos sobre el sistema nervioso central 49.26

fuentes de exposición laboral a 49.24, $49.25 \mathrm{t}$

límites de exposición laboral a $49.27 \mathrm{t}$

mediciones de 49.25

y paso de corrientes por el cuerpo 49.26

Campos eléctricos

de muy baja frecuencia

Véase Campos de ELF y VLF estáticos

Véase $C$ ampos electrostáticos

fuentes de exposición a 49.2

niveles de exposición 49.2

directrices de la IR PA $\quad 49.3$

medidas para reducir los 49.4

sistemas de protección 49.3

Véase también C ampos magnéticos
Campos electromagnéticos (CEM)

e instalaciones eléctricas al

descubierto 94.14

en entornos escolares 94.14

y cáncer de mama 94.14

y leucemia 94.14

y líneas eléctricas de alta tensión 94.14

y pantallas de vídeo 94.14

y tumores cerebrales 94.14

Campos electrostáticos

descarga disruptiva por 49.28

efecto adverso de los 49.28

niveles de exposición profesional 49.29

según la ACGIH 49.29

según la NRPB 49.29

Campos magnéticos

de muy baja frecuencia

$V$ éase $C$ ampos de ELF y VLF

depresión de la melatonina por 49.3

y cáncer 49.3

derivados de las PVD

y efectos sobre el embarazo $52.7,52.15$, $52.18,52.23$

estáticos 49.30

efectos sobre la salud 49.31

límites de exposición a $49.32 \mathrm{t}$

medidas de protección en el

trabajo 49.31

medidores de 49.31

niveles de exposición $49.30 \mathrm{t}$

riesgo de cáncer 49.31

tecnologías usuarias de 49.31

exposición laboral a 49.2

y leucemia 49.2

niveles de exposición a 49.3

directrices de la IRPA 49.3

y adopción de medidas 49.4

sistemas de protección a 49.3

Véase también Campos eléctricos

Campylobacter 70.16

Canadá

A gencia de Salud y Seguridad en el Lugar de Trabajo 21.22

Canada Employment and Immigration

Commission (CEIC)

Programa de trabajo compartido 34.45

Canadian Standards O rganization

ropa de protección 31.21

Canadian WHMIS 65.12

Comisión de Accidentes de Trabajo 21.22

Comisión de Salud y Seguridad en el

Trabajo 21.22

Instituto de Investigación en M ateria de

Salud y Seguridad en el Trabajo 21.22

Planning of R equired N ursing 29.8

sindicatos y trabajadores

discapacitados 17.43

sistemas de clasificación de productos químicos 61.10 
sustancias tóxicas permanentes en los Grandes Lagos 55.47 - 55.50

y sistema de información (WH M IS)

sobre materiales peligrosos en el trabajo 61.10

Canales de control

categorías 58.47

entropía en los 58.46

fiabilidad de los 58.44

redundancia en los 58.46

requisitos de diseño de $58.44,58.47$

Véase también Sistemas de control de seguridad

Canales y muelles

en el sector de la construcción 93.24

$\checkmark$ éase 0 bras civiles

y medio ambiente 93.24

Cáncer

Véase Cáncer de cada órgano

Agencia Internacional para la Investigación

sobre el Cáncer 2.15, 66.18, 104.7

aminas aromáticas y 104.97

análisis del marco temporal 30.30

factores clave 2.2, 2.2t

porcentajes calculados $2.3 \mathrm{t}$

porcentajes por profesión 2.2

cánceres gastrointestinales 72.18

cánceres hematológicos 72.18

cancerígenos

agentes ambientales $2.7,2.10 \mathrm{t}$

fármacos 2.7, 2.9t

interacciones entre 2.12

pesticidas 2.6, 2.8t

cancerígenos profesionales

asociación con profesiones e

industrias 2.8

cancerígenos establecidos 2.5

cancerígenos industriales $2.4,2.8$

establecidos $2.5 \mathrm{t}$

exposición a 2.2

mutágenos 2.3

posibles $2.5,26 \mathrm{t}$

probables 2.5, 2.6t

Centro de Investigación sobre el Cáncer de Alemania (DK FZ) 32.30

clasificación de los riesgos por sectores profesionales $2.11 \mathrm{t}$

cribado del cáncer

cervical $15.53,15.57$

colorrectal 15.53

de mama 15.57

puntos a favor y en contra 15.53

recomendaciones sobre el

cribado $15.52 \mathrm{t}$

de origen profesional

en Suecia 49.2

de tiroides 48.9

por radiación 48.9

de vesícula 72.18 de vías urinarias 72.18

en catástrofes 39.21

en el sector de la construcción

en la fabricación de pasta y de papel 72.16

en la ganadería 70.9

en la industria pesquera 66.8

en pintores, dibujantes y grabadores

carcinógenos principales 96.8

entre los pescadores 66.18

enzima CY P2D 6 y riesgo de 33.27

epidemiología y registros del

cáncer 28.18

estudios epidemiológicos 2.2

causas profesionales de cáncer 2.2

éteres y 104.184

exposición profesional 2.2

identificación del riesgo de 33.49

incidencia por poblaciones $2.15 \mathrm{t}$

lengua

en fontaneros 103.23

leucemia 39.40

mecanismos 33.33

metastásis 33.77

mortalidad por

en actores 96.6

en artistas 96.6

objetivos y futuro de la evaluación del riesgo 33.80

origen ambiental $2.8,2.12$

combinado con factores genéticos 2.9

estudios epidemiológicos 2.9

incidencia por regiones $2.9 \mathrm{t}$

industrializados 2.12

pruebas de carcinogenicidad 2.12

según el nivel de desarrollo 2.12

según la región geográfica 2.9

tendencias a lo largo del tiempo 2.9

países en vías de desarrollo 2.3

períodos de latencia 32.32

personalidad y sensibilidad al 34.67

perspectiva histórica 33.76

por colas y disolventes

en encoladores 103.16

por irradiación 39.38

por radiación natural 48.9

prevención del cáncer profesional

eliminación de los cancerígenos 2.4, 2.18

en países industrializados 2.3

enfoques experimentales 2.18

epidemiología molecular 2.18

equipos de protección personal 2.18

estudios epidemiológicos 2.16

exploración selectiva $2.16-2.17$

historia del cáncer profesional 2.15

nuevos factores preventivos 2.19

países en vías de desarrollo 2.8

prueba de mutagenicidad 2.16

reducción de las exposiciones $2.4,2.18$ registros del cáncer 2.17

vigilancia de factores de riesgo 2.17

vigilancia y estadísticas 2.17

vigilancia y registros de

población 2.16

prevención general $2.15-2.18$

prevención y control en el lugar de

trabajo 15.48

consumo de tabaco 15.49

factores dietéticos 15.50

factores genéticos 15.50

factores hormonales 15.50

factores humorales 15.50

prevención primaria 15.49

proyecto "trabajar bien" 15.51

riesgo en la industria de la piel y el

cuero 88.5

riesgo para las mujeres 28.24

riesgos de 48.9

por radiación de bajo nivel 48.9

tasas de mortalidad relativas proporcionales por cáncer 28.16

y acontecimientos estresores 34.71

y defectos heredados en la reparación del ADN 33.39

y deterioro medioambiental 53.35

y estado de ánimo depresivo 34.70

y estrés 34.70

estudios de cohortes 34.70

experimentos con animales 34.71

incidencia de 34.70

pronóstico de 34.71

y exposición a compuestos electrófilos 33.39

y exposición al percloroetileno en lavanderías y tintorerías 100.12

y fibras de amianto 55.16

y hollín 55.16

y metales pesados

en las partículas en suspensión 55.16

y modificación del ADN 33.38

y radiación de

radiofrecuencia (RF) 49.21

y radiación electromagnética 32.7

y viudedad 34.70

Véase también Agencia internacional

para la investigación sobre el cáncer

Véase también Carcinogenicidad

Véase también Carcinógenos

Cáncer cerebral

y uso de teléfonos móviles 49.22

Cáncer colorrectal

en la industria de la piel y el cuero 88.10

en la industria textil 89.33

Cáncer de bronquios

y exposición a residuos peligrosos 53.26

Cáncer de cerebro

riesgo asociado a la extinción de incendios 95.8 
Cáncer de colon

en trabajadores de diseño en la industria del automóvil 91.9

en trabajadores de la industria del papel 72.18

Cáncer de escroto 28.2

Cáncer de esófago 4.2

Cáncer de estómago

e ingestión de vermiculita 62.5

relación entre el cáncer de estómago y el

trabajo en las fábricas de pasta y de

papel 72.18

por exposición al arsénico 63.7

riesgo en la industria del automóvil

en operaciones de estampación 91.9

Cáncer de hígado

angiosarcoma hepático 4.10

colangiocarcinoma 4.9

en la industria de la piel y el cuero 88.10

en portadores del VHB 97.46

exposición al cloruro de vinilo 4.10

factores de riesgo 4.10

hepatocarcinoma 4.9

incidencia media anual 4.10

medidas preventivas 4.10

trasplante hepático 4.10

y 2-nitropropano 104.340

Cáncer de la conjuntiva y radiación ultravioleta 49.9

Cáncer de la córnea y radiación ultravioleta 49.9

Cáncer de labios 66.18

Cáncer de laringe 10.89

riesgo en fumadores pasivos 96.57

Cáncer de mama

en entornos escolares 94.14

informe Forrest 15.61

mamografía 15.60

criterios de calidad 15.58

prevención en el lugar de trabajo 15.52

y campos electromagnéticos (CEM) 94.14

y plaguicidas 94.14

Cáncer de páncreas

causas 4.11

debido a exposición profesional 4.11

en la industria de la piel y el cuero 88.9

exposición a sustancias de riesgo 4.11

factores de riesgo 4.11

incidencia 4.11

pancreatitis 4.11

Cáncer de piel

de escroto 12.8

en los deshollinadores 12.8

hidrocarburos aromáticos

policíclicos 12.8

exterminadores de plagas y $\quad 103.19$

incidencia de 63.6 en soldadura 96.14

por intoxicación de arsénico 63.6

por radiación 48.8

melanoma maligno 12.9

de diseminación superficial 12.9

estudios epidemiológicos 12.10

incidencia 12.9

irradiación U V-B solar 12.9

lentiginosos 12.9

manchas melanóticas de

Hutchinson 12.9

melanomas nodulares 12.9

no melanoma y radiación UVB

ambiental 53.30

no melanocítico 12.7

grado de pigmentación 12.7

incidencia 12.7

ocupaciones de riesgo $12.8 \mathrm{t}$

radiación ionizante 12.9

radiación solar 12.8

prevención 12.9

riesgo de

en la agricultura 70.9

por radiación ultravioleta 97.33

y exposición a radiación ultravioleta 49.8

y fabricación de paraquat 28.34

y radiación UVB ambiental 53.28

Cáncer de próstata

en fontaneros 103.23

Cáncer de pulmón

anatomía patológica 10.66

asociado al amianto 10.66

causabilidad 10.67

e indemnización 25.9

e inhalación de vermiculita 62.5

en carpintería 86.14

en fontaneros 103.23

en la fabricación de vidrio, cerámica y materiales afines 84.31

en la industria de la piel y el cuero 88.9 88.10

en los mineros de Schneeberg 28.3

en los trabajadores del acero 63.22

en los trabajadores del antimonio 63.4

en los trabajadores del ferrocromo 63.22

en los trabajadores expuestos al

cadmio 63.11

en mineros de la hematita 63.22

en mineros de niobio 63.34

en pintores 103.46

en trabajadores de refinerías de níquel 63.35

en trabajadores expuestos a gases 28.3

epidemiología 10.67

inductibilidad de la CYP1A 1 y

tabaquismo 33.26

perspectiva histórica 10.66

por exposición a compuestos de cromo 63.17 por humo de tabaco ambiental

en no fumadores 44.15

por inhalación de fibras de asbesto

en escultores 96.9

por inhalación de polvo de amianto 93.3

por radón 48.9

relacionado con el berilio 10.35

relacionado con la asbestosis 10.67

riesgo asociado en la extinción de

incendios 95.7

riesgo en fumadores pasivos 96.57

riesgo en industrias gráficas 85.10

riesgo en la confección 87.7

riesgo en la industria del automóvil 91.8 -

91.9

exposición a polvo con sílice 91.8

exposiciones a hidrocarburos

polinucleares aromáticos 91.8

tipos histológicos 10.88

adenocarcinoma 10.88

carcinoma de células grandes 10.88

carcinoma de células pequeñas 10.88

carcinoma escamocelular 10.88

y alteración del gen CY P1A 133.27

y amianto 28.41

y exposición al polvo de asbestos 62.3

y formaldehído en la industria del automóvil 91.4

y partículas de óxido de hierro 63.21

y polvo de asbesto 98.7

y radón en el ambiente 44.11

y sílice cristalina

en tierra de diatomeas 62.7

Cáncer de riñón

carcinoma de células renales 8.11

diagnóstico 8.12

estudios epidemiológicos 8.11

factores ambientales 8.12

factores de riesgo 8.11

tabaquismo 8.11

factores etiológicos 8.11

incidencia 8.12

nefropatía de los Balcanes 8.12

patrón de síntomas 8.12

Cáncer de vejiga

aplicaciones de la citología urinaria 8.13

diagnóstico 8.13

en camioneros y taxistas 28.31

en la industria de la piel y el cuero

exposición a bencidina 88.9

en trabajadores expuestos a colorantes 28.3

estadiaje 8.14

exploración selectiva 8.13

exposiciones laborales 8.12

factor etiológico 8.12

incidencia 8.12

información a los trabajadores 23.36

marcadores biológicos 8.13

primer caso identificado 8.13 
riesgo asociado a la confección 87.7

tabaquismo 8.12

y exposición a colorantes azoicos en la industria textil 89.33

Cáncer del aparato genitourinario riesgo asociado a la extinción de incendios 95.8

Cáncer del aparato respiratorio cancerígenos respiratorios demostrados $10.90 \mathrm{t}$

cancerígenos respiratorios probables $10.90 \mathrm{t}$ de laringe 10.89

de pulmón 10.88

e insecticidas con arsénico 63.7

En la industria del papel 72.18

en los trabajadores del arsénico 63.7

epiclorhidrina 104.153

estudios epidemiológicos 10.90

factores de riesgo 10.90

mesotelioma 10.89

nasofaríngeo 10.89

nasosinusal 10.89

y consumo de tabaco

en minería del uranio 44.12

Cáncer del sistema nervioso central riesgo asociado a la extinción de incendios 95.8

Cáncer del tracto digestivo riesgo de 63.17 por exposición a cromatos 63.17

Cáncer hematopoyético riesgo asociado a la extinción de incendios 95.8

Cáncer infantil relación con exposición parental 9.24

Cáncer linfático riesgo asociado a la extinción de incendios 95.8

Cáncer nasofaríngeo

riesgo en la confección 87.7

riesgo en la industria maderera 71.11

Cáncer óseo 6.35

Cáncer rectal

en encoladores 103.17

en trabajadores de diseño de la industria del automóvil 91.9

Cáncer sinonasal

en encoladores 103.17

en la industria de la piel y el cuero 88.9

en la industria de la madera 71.11

en carpintería 86.14

en la industria del calzado 88.10

por inhalación de polvo de maderas 96.20

riesgo de

por exposición a cromatos 63.17

Cáncer testicular

en la industria de la piel y el cuero 88.9 riesgo asociado a la confección 87.7

riesgo en los servicios de policía

exposición a microondas emitidas por radares 95.12

Cancerígenos

base de datos de la A gencia Internacional para la Investigación sobre el

Cáncer 27.19

en la industria de la piel y el cuero 88.5

exposición a 30.27

identificación 27.16

límites de exposición profesional 30.35

$\beta$-naftilamina 23.36

notificación 32.10

registro de cancerígenos de

Finlandia 32.10

riesgo teórico de cáncer 30.34

Candida albicans 10.102

Candidiasis 70.29

Cansancio vital 34.13

Cantantes

anorexia y bulimia en 96.29

lesiones vocales en 96.28

causas 96.29

tratamiento 96.30

Caña de azúcar 64.40

machete 64.40

Caotín 72.11

Capacidad aeróbica 42.12

Capacidad de aclimatación 42.12

Capacidad visual 46.12

y edad 46.12

Capacitación 94.10

Capas de aire 42.27

Caprino

Véase R umiantes

Capucha

Véase también Protectores de ojos y cara

Caracteres alfanuméricos 29.84

Carbamatos

efectos tóxicos de los 62.12

Carbaril 62.12

Carbón

exposición al polvo de riesgos para los mineros 10.52 para la generación de energía 76.5 vegetal

uso para muestreo ambiental 30.21

Véase también Enfermedades pulmonares

Véase también N eumoconiosis

Carbonatación 65.4

Carbonato

cálcico 72.8

sódico $72.8,72.20$
Carbonilos metálicos

$\checkmark$ éase M etalcarbonilos

\section{Carbono 14}

Efectos biológicos de la radiación 48.8

Carbono, monóxido de

intoxicación por

y conductores de camiones 103.8

y encoladores 103.16

y mecánicos de coches 103.32

y operadores de caldera 103.39

y soldadores 103.51

Véase también M onóxido de carbono

Carboxihemoglobina 30.23, 39.26

Carbunco

Véase Ántrax

Véase Enfermedades respiratorias

Carburo cálcico queilitis y 104.58

Carcinogénesis

como proceso multifásico 33.77

mutagénesis 33.77

progresión 33.77

promoción 33.77

evaluación del riesgo 33.78

caracterización del riesgo 33.79

evaluación de la exposición 33.78

identificación de los peligros 33.78

objetivos y futuro 33.80

evaluación del riesgo de cáncer 27.18

extrapolaciones a dosis bajas 33.79

factores etiológicos 2.8

formación de aductos 27.3

grupos de clasificación 2.5

inestabilidad cromosómica 27.17

modelos matemáticos 2.3

pruebas de carcinogenicidad 2.12

relación con la genotoxicidad 27.16

sistema de evaluación 2.5

teoría multifásica de la 2.19

y evaluación de la causalidad en epidemiología 28.31

y marcadores biológicos 8.3

Carcinogenicidad

clasificación por categorías $2.5 t$

enfoque de la IARC de identificación

de los peligros 33.65

estudios sobre animales 33.67

evidencia inadecuada de carcinogenicidad 33.67

evidencia limitada de carcinogenicidad 33.67

evidencia que sugiere ausencia de carcinogenicidad 33.67

evidencia suficiente de carcinogenicidad 33.67

estudios sobre el cáncer en los humanos 33.66 
evidencia inadecuada de

carcinogenicidad 33.66

evidencia limitada de

carcinogenicidad 33.66

evidencia que sugiere ausencia de

carcinogenicidad 33.66

evidencia suficiente de

carcinogenicidad 33.66

evaluación de pruebas $2.4 \mathrm{t}$

evaluación global 33.67

Grupo 133.67

Grupo 2A 33.68

Grupo 2B 33.68

Grupo 333.68

Grupo 433.68

importancia de los datos

mecanicistas 33.68

otros datos de interés para la evaluación de

la 33.67

evidencia de efectos pertinentes sobre el comportamiento celular 33.67

evidencia de efectos sobre la expresión de genes pertinentes 33.67

evidencia de genotoxicidad 33.67

evidencia obtenida de relaciones

dosis-tiempo 33.67

otros enfoques 33.76

carcinogénesis como proceso

multifásico 33.77

evaluación del riesgo 33.77

hipótesis de "agentes sin umbral" 33.77

Carcinógenos

agentes "sin umbral" 33.78

clasificación 33.78

definición 33.76

en la industria de la piel y el cuero 88.9 -

88.10

ensayos sobre 33.49

específicos de especies 33.78

genotóxicos 33.78

grupo 133.67

grupo $2 \mathrm{~A} 33.68$

grupo 2B 33.68

grupo 333.68

grupo 433.68

no genotóxicos 33.78

perspectiva histórica 33.76

principios rectores de la evaluación de los 33.66

umbral de regulación 33.79

Carcinoma

Véase Cáncer de piel

bronquial

el caso de la Compañía Wismut 32.28

colorectal 33.27

de células basales $12.7,70.9$

de células de transición 8.12

de células renales

Véase C áncer de riñón en marineros 102.47

epidermoide 70.9

Cardiopatía aterosclerótica

aterosclerótica

riesgo asociado a los servicios de policía 95.11

coronaria 5.20

y karoshi 5.20

isquémica 34.49

por vibraciones 50.6

y radiación 39.43

Cardiovasculares 3.2

$V$ éase $\mathrm{C}$ ardiovasculares, trastornos

Véase Enfermedades cardiovasculares

Cardiovasculares, trastornos

asociados a la extinción de incendios 95.8 aneurisma aórtico 95.8

asociados a los servicios de policía cardiopatía aterosclerótica 95.11 infarto de miocardio agudo 95.11 prevención 95.12

en la industria de la piel y el cuero 88.10

CARE

Nicaragua 64.16

Carga de trabajo

función cerebral y 34.20

relativa

definición 29.36

sobrecarga cuantitativa 34.20

subcarga cualitativa 34.20

total 34.21

C arga mental de trabajo

definición 29.48

enfoque de exigencias de la tarea 29.50

enfoque exigencias-recursos 29.49

fatiga mental 29.55

valoración 29.49

valoración de la capacidad mental 29.49

valoración del esfuerzo 29.49

valoración en las listas de

comprobación 29.17

y ergonomía 29.15

Carga musculosquelética

y postura de trabajo 29.38

$V$ éase también T rastornos musculosqueléticos

Carga térmica $42.18 f, 42.20 \mathrm{t}$

Cargaderos 68.12

Caries

de origen profesional 4.4

dióxido de azufre y 104.420

Carne

elaboración de la 67.17

riesgos y su prevención 67.17

Carpintería

acabado 86.2

compuestos orgánicos volátiles

(COV) 86.6 riesgos 86.6

cáncer de pulmón, riesgo de 86.14

cáncer nasal, riesgo de 86.14

fabricación de muebles de madera $86.3 \mathrm{f}$

lesiones 86.13

máquinas copiadoras-fresadoras

estacionarias 86.7

causas de accidentes 86.8

diseño y construcción 86.10

medidas de prevención 86.10

riesgos 86.8

máquinas de cepillado de madera 86.10

cepilladoras mecánicas de espesor

unilateral 86.12

combinadas

cepilladora-regruesadora 86.13

extracción del serrín 86.10

máquinas de cepillado superficial 86.10

riesgos $86.11-86.12$

ruido 86.10

sistemas de protección 86.11

mecanizado 86.2

seguridad y máquinas aserradoras 86.2 seguridad y máquinas cortadoras 86.4 seguridad y máquinas lijadoras 86.5

medidas de protección 86.14

montaje 86.2

riesgos asociados a los adhesivos 86.6

preacabado 86.2

riesgos del serrín

carcinogenicidad 86.6

sistemas de extracción de polvo 86.6

secado 86.2

utilización de listas de control 86.8

Carrera profesional

etapas de la 34.47

medidas prácticas de ayuda 34.48

modelo de Levinson 34.47

modelo de Super 34.47

y estrés 34.48

Carreteras

mantenimiento 93.22

pavimentación 93.22

planificación de la construcción 93.22

Carretillas elevadoras

accidentes con 102.74

C arta Africana de Derechos $\mathrm{H}$ umanos y de los Pueblos 23.27

Carta Social Europea

Véase U nión Europea, Carta Social

Cartílago 6.6

Cartón

proceso de fabricación de 72.11

Véase Industria del papel y de la pasta de papel

Cascos de seguridad

accesorios 31.11

comodidad 31.11 
elección 31.10

elementos esenciales $31.8 f$

en el sector forestal 68.35

higiene y mantenimiento 31.11

lesiones en la cabeza 31.9

norma de seguridad ISO 23.61

norma ISO 3873-1997 31.9t

objetivo 31.9

para usos especiales 31.10

pruebas de rendimiento 31.10

requisitos 31.9

Véase también Protectores de ojos y cara

Cassel

resistencia del huésped (1976) 34.16

Cataratas

por descarga eléctrica 40.5

por radiación infrarroja 49.14

por radiación ionizante 48.8

por radiación ultravioleta 49.8

Cataratas corticales

por radiación ultravioleta $\mathbf{5 3 . 3 0}$

Catarro común 42.41

Catástrofes

accidentes naturales 39.15

avalanchas y corrimientos de

tierras 39.26

epidemiología 39.19

huracanes, ciclones y tormentas

tropicales 39.25

inundaciones y maremotos 39.23

mapas de riesgo 39.17

rayos e incendios forestales 39.26

tornados 39.25

zonas con alto riesgo 39.17

accidentes por radiación 39.32

centrales de reprocesamiento 39.33

centrales nucleares 39.32

Chernóbil 39.38

contacto directo 39.32

efectos en la agricultura 39.42

efectos psicosociales 39.40

efectos sobre la salud 39.36

efectos teratogénicos 39.38

en medicina 39.34

escala internacional de incidentes

nucleares $39.41 \mathrm{t}$

Goiânia 39.35

incendio de materiales radiactivos 41.13

instalaciones de producción de

combustible 39.33

irradiación externa 39.32

irradiación interna 39.32

poblaciones expuestas 39.35

prevención y directrices 39.41

protección de la población 39.42

radiación gamma de alta energía 39.42

radionúclidos 39.32

y sanidad pública 39.35

accidentes químicos mayores $39.3,39.19$ accidentes manifiestos 39.4

catástrofes lentas 39.4

control de los riesgos 39.11

cuasiaccidente 39.9

definición 39.9

derechos y obligaciones de los

trabajadores $39.10,39.12$

disposiciones de la OIT 39.7, 39.9

envenenamientos masivos 39.5

estimación cuantificada de riesgos 39.18

evaluación de riesgos 39.11, 39.13

información a la población 39.13

informe de seguridad sobre 39.9

instalaciones de alto riesgo 39.7, 39.9, 39.13

líneas directrices para el establecimiento de industrias químicas 39.51

modelos informáticos de dispersión de gases 39.16

normas de seguridad 39.11

planes de emergencia $39.10,39.13$

prevención de 39.7, 39.12, 39.14, 41.18

propios del desarrollo 39.6

responsabilidad de los países exportadores 39.14

riesgo de accidente mayor $39.8,39.12$

sistemas de seguridad 39.12

sustancias peligrosas 39.9

sustancias químicas $39.15 \mathrm{t}$

transnacionales 39.5

afectados por $39.2,39.21$

detección selectiva 39.22

muestras biológicas 39.23

cuantificación de sus efectos 39.20

cuasicatástrofes 39.16

definiciones $39.2,39.16$

distribución 39.3

efectos sociales y económicos de las 39.49

en A mérica Latina y el Caribe 39.49

epidemiólogos 39.22

estructuras de edificios 39.18

estudios epidemiológicos 39.22

evacuación 39.20

evaluación de las consecuencias 39.21

evaluación de los riesgos 39.18

evaluación del peligro 39.17

infraestructuras 39.18

mortalidad 39.21

planificación de emergencias 39.19

preparación para las $39.15,39.18$

equipos de emergencia 39.19

formación 39.20

información 39.19

plan de respuesta a emergencias 39.19

planes hospitalarios 39.19

recuperación posterior 39.20

reducción de riesgos 39.18

registros de afectados 39.21

resistencia de los hospitales 39.50 riesgo de accidentes tecnológicos 39.51

riesgos profesionales $39.23 \mathrm{t}$

servicios médicos de emergencia 39.49

tecnológicas 39.16 - 39.17

tipos de $39.3 \mathrm{t}$

vulnerabilidad 39.18

y lesiones por frío 42.39

zonas peligrosas 39.18

Catecol

tensión arterial y 104.369

Catecolaminas

alteración por vibraciones de las 50.4

Caucho

ácido nitrilotriacético en 104.338

consumo mundial $80.3 \mathrm{t}$

de látex 31.18

dermatitis por contacto con el 80.16

alergia al látex 80.16

fenoles en 104.368

fosfatos en 104.382

hidrocarburos alifáticos insaturados

en la 104.275

hidrocarburos aromáticos en $\quad 104.282$

industria del 80.2

obtención del látex 80.3

peligro de incendios 41.14

peróxidos orgánicos en la 104.363

polímeros del caucho $80.2 \mathrm{t}$

productos industriales 80.8

variedades del 80.3 - 80.4

caucho de especificación técnica 80.4

caucho natural epoxidizado 80.4

caucho natural termoplástico 80.4

crepés 80.4

látex 80.4

Causas de accidentes

acontecimientos sucesivos en las 56.25

software del MAIM 56.28

y modelo M AIM $56.25,56.27$

causas concurrentes $56.7 f, 56.8$

causas latentes 56.11

factores de motivación 56.12

factores humanos $56.8,56.10,57.7$

causas del error 57.7

modelo de Reason y Embrey 57.8

modelos del error 56.9

y clima de la organización 56.10

factores organizativos 56.10

información sobre 56.5

inmediatas $56.7 f, 56.8$

modelo de causalidad $56.9 f$

modelo de $\mathrm{H}$ ale y $\mathrm{G}$ lendon $\quad 56.16,56.18$

modelo de Surry 56.19

modelo general 56.22

modelo homeostático $56.13 f$

modelo WEF 56.20

modelo WEF perfeccionado 56.20

modelos de desviación 56.22

clasificación de las desviaciones 56.23 
pirámide de los accidentes 56.36

recogida de estadísticas 57.29

teoría de la casualidad pura 56.7

teoría de la causalidad múltiple 56.6

teoría de la homeostasis del riesgo

(THR) 56.11

y estilo de vida 56.12

y nivel de riesgo asumido 56.11

teoría de la probabilidad sesgada 56.7

teoría de la propensión al

accidente 56.7

teoría de la transferencia de energía 56.7

teoría del "efecto dominó" 56.6 secuencia de los factores 56.6

teoría del dominó de Bird 60.13

tipos de fallo general $57.10,57.13$

y aceptación de riesgos 59.30

y automatización de los procesos productivos 56.36

y factores de determinación del riesgo 56.31

Véase también Análisis de riesgos

Caza

características de los trabajadores de la 69.2

caza con cepo 69.2

enfermedades asociadas a la $\quad 69.4$ - 69.6

panorámica del sector 69.2

problemas ambientales y de salud pública 69.3

riesgos asociados 69.4

técnicas 69.3

armas de fuego 69.3

otras técnicas de caza 69.3

técnicas de caza con cepo 69.3

tratamiento de las pieles 69.3

Cazadores 69.2

Cebada

picor de la 65.14

Cebra 70.30

Cedro

blanco oriental 71.10

rojo occidental 71.10

Cefalea

asociada a neurotoxicidad 7.21

y síndrome del edificio enfermo $\quad 13.4$

Ceguera

de los eclipses

Véase R etinitis solar

del soldador

$\checkmark$ éase Fotoqueratitis

total 25.13

Celda de Lucas 48.26

Célula

bicapa lipídica 33.9

cocultivo de células de distintos órganos 33.53 función celular

y enzimas metabolizantes de

fármacos 33.28

líneas celulares continuas 33.53

medios de cultivo 33.53

Véase también Lesión celular

Véase también M uerte celular

Celular, lesión

Véase 0 ído

Células de Langerhans 33.40

Células de R eed-Sternberg 1.4

Células gliales 7.3

Células óseas 6.6

Celulosa 72.5

al sulfato 72.6

Cemento

composición 93.51

enfermedades asociadas 93.52

de la piel 93.52

del aparato digestivo 93.52

del aparato respiratorio 93.52

trastornos del oído y de la vista 93.52

trastornos reumáticos y nerviosos 93.52

medidas de salud y seguridad 93.53

filtros 93.53

ventilación 93.53

proceso de fabricación $93.51 \mathrm{f}$

producción 93.51

riesgos asociados 93.52

altas temperaturas ambiente 93.52

polvo 93.52

ruido 93.52

visión general 93.51

Cenizas 72.21

Censo de códigos profesionales de Estados U nidos 34.9

C enters for D isease $C$ ontrol and Prevention 70.6

Central

hidroeléctrica

Véase Energía hidráulica

termoeléctrica

Véase Combustibles fósiles

Central nuclear

combustible nuclear $39.36 \mathrm{f}$

estructura de contención 39.41

informe de P.L. K apitza 29.113

lecciones aprendidas en

Chernóbil 29.113

salas de control 29.82

seguridad en 39.41

situación actual en la U nión

Soviética 29.114

Véase también Accidente nuclear

Véase también T hree M ile I sland

Véase también Energía nuclear

Centralización 34.40
Centre d'études et de recherches de médecine aérospatiale (CER M A)

planificación del piloto de combate 29.11

Centro docente 94.2

Centro Europeo de $V$ alidación de $M$ étodos Alternativos (ECVAM) 33.55

Centro Internacional de Información sobre Seguridad y Salud en el Trabajo 103.2

Centro Panamericano para la Ecología y la Salud H umanas 23.44

Centro para la Investigación de la Epidemiología de Catástrofes de Lovaina 39.2

Centros de Control y Prevención de Enfermedades (CDC) de Estados U nidos estudios del tifus 97.44

Centros de enseñanza primaria y medidas de precaución 94.13 y riesgos 94.13

secundaria y medidas de precaución 94.13 y riesgos 94.13

Centros de mecanizado disposiciones de seguridad en la Directiva sobre máquinas (89/392/ECC) 58.56

Centros politécnicos 94.10

Centros sanitarios control de las condiciones microclimáticas 97.68 criterios de diseño de los 97.66 criterios de elección de materiales en 97.67 y Directiva del Consejo no 89/106/CE 97.68 necesidades de ventilación 97.69t productos químicos tóxicos $97.57 \mathrm{t}$ reducción del ruido en 97.6 opciones ergonómicas $97.6 \mathrm{t}$ sustancias químicas peligrosas en 97.4 Véase también H ospitales

Cepilladoras 71.6

Cera

del petróleo

Véase también R efino de petróleo

Cerámicas industriales 84.15

boranos en la 104.130

materias primas 84.17

principales aplicaciones 84.16

procesos de fabricación 84.16

Cercocebus 53.34

Cerdos 70.25

Cereales

cultivo de 64.38

elaboración de 67.28

incendio y explosión 67.29

seguridad mecánica 67.29 


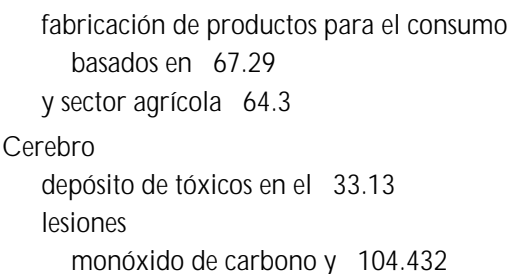
técnicas de imagen cerebral 7.24 visión inferior $7.7 f$

Cerramientos acústicos directrices para el diseño de 47.11

Cerveza 65.14

Cervical cribado del cáncer 15.57

Cetales

disolventes 104.45

irritación de piel, ojos y sistema respiratorio 104.46

Cetonas

disolventes 104.326

Ciano

cianosis 4.4

Véase A parato digestivo

acrilonitrilo y 104.138

aminas aromáticas y 104.97

fenilhidracina y 104.122

formiato de metilo y 104.177

nitrocompuestos aromáticos y 104.346

nitroglicerina y 104.339

compuestos de 104.137

Cianato potásico 62.14

Cianuro

de hidrógeno 41.13

cámaras de gas y 104.137

intoxicación 104.137

sales de

en galvanoplastia 96.13

y asfixia 33.32

Ciática

síndrome del piramidal 6.15

Ciclo de plantación

silvícola 68.16

Ciclo hidrológico 55.27

Cicloato 62.14

Ciclón 39.17

Véase $\mathrm{H}$ uracanes, ciclones y tormentas tropicales

Ciclotrimetilentrinitramina y explosiones 41.6

Cigarrillos Véase T abaco, tabaquismo

Cigoto

fases evolutivas 9.12

Véase también Sistema reproductor femenino

Ciguatera 53.9, 66.20

Ciguatoxina 66.20
Ciliar, lesión

Véase 0 ído

Cine, industria del

efectos especiales 96.35

con armas de fuego 96.36

de fuego 96.36

de niebla y humo 96.36

pirotécnicos 96.35

precauciones generales 96.35

equipos médicos y de emergencia 96.38

escenas peligrosas 96.36

con aeronaves 96.36

con animales 96.37

con fuegos y explosiones 96.37

con vehículos 96.36

en el agua 96.38

normas en materia de salud y seguridad 96.38

planes de salud y seguridad 96.38

riesgos en el área de la electricidad 96.34

riesgos en el rodaje $96.6,96.34$

accidentes mortales 96.6

en exteriores 96.34

medidas esenciales de seguridad 96.34

seguridad de estructuras y decorados 96.34

Cinetosis 50.14

Cintas transportadoras 65.5

Cinturones de seguridad porcentajes de uso de 59.31

Cipermetrina 27.23

Circonio 41.14, 41.31

exposición al 63.13

y granulomas peribronquiales 63.13

y neumoconiosis 63.13

y neumonía lobular 63.13

y neumonitis intersticial crónica 63.13

polvo de

y riesgo de explosión 63.13

y riesgo de incendio 63.13

y dermatitis de R hus (hiedra) 63.13

Circuitos de control 58.45

Véase también C anales de control

Circuitos integrados específicos de aplicación (ASIC) 58.64

Cirrosis

en portadores del VHB 97.46

$y$ alcohol 4.8

y piridina 104.228

y riesgos químicos 4.2

Citochalasina-B 27.18

Citrobacter 38.3

Citocromo $1.2,33.25,33.46$

Citopenia 1.2

Citoquinas 33.40

Cítrico

ácido 67.32
Ciudad de M éxico

exposición al ozono 53.14

terremoto de 39.19

Cladosporium 44.5, 44.23, 44.25

Clamidia 96.55

Clasificación de lesiones y enfermedades profesionales

sistema del D epartamento de T rabajo de

EE.UU. 32.13

características de los casos 32.14

ejemplos 32.17

episodio o exposición 32.15

fuente de la lesión o enfermedad 32.16

fuente secundaria de la lesión 0

enfermedad 32.16

naturaleza de la lesión 0 enfermedad 32.14

parte del cuerpo afectada 32.15

partes de accidente 32.14

requisitos para la aplicación 32.16

versión definitiva de la 32.14

sistemas obligatorios de

CIE-9 (Clasificación Internacional de Enfermedades) 32.32

SN O M ED (N omenclatura Sistemática de M edicina) 32.32

Clasificación industrial internacional uniforme de todas las actividades económicas 88.9

clasificación de la industria química 77.2

Clasificación Industrial N ormalizada

(SIC) 88.9

Clasificación Internacional de D eficiencias, Discapacidades y M inusvalías 17.5

Clasificación Internacional de Enfermedades enfermedades cardiovasculares 3.2 enfermedades pulmonares 10.28 porcentajes de cáncer $2.2 \mathrm{t}$ trastornos relacionados con las drogas y el alcohol 15.83

Clasificación Internacional de R adiografías de la $\mathrm{N}$ eumoconiosis opacidades de las radiografías 10.50

Clasificación normalizada internacional de ocupaciones (ISC O -88) 99.4

Clasificadoras automáticas 101.8

Clima de seguridad

estudios dedicados al 59.8

mediciones del 59.10

para la elaboración de una política de seguridad $59.8,59.11$

mediciones del $59.10 \mathrm{t}$

y prevención de lesiones 59.8

Clima organizativo

comunicación 34.41

conflicto 34.41

definiciones del concepto 59.8 
diferencia con clima psicológico 59.9

liderazgo 34.41

recompensas 34.41

Clima psicológico distinción con clima organizativo 59.9

Cloracné dioxina y 104.299

Cloramina 67.10

Cloranfenicol 1.2

Cloranil 62.16

Cloratos 41.13 sódico 72.15

Clorhídrico, ácido ácido 41.15, 63.2

edema de glotis y 104.6 necrosis dental 104.6

Cloro

en la industria del papel 72.12

en métodos de muestreo 30.21

escapes 39.16

liberación accidental de 65.6

producción comercial 77.20

proceso en celda de diafragma 77.20 proceso en celda de membrana 77.21 proceso en celda de mercurio 77.21 riesgos para la seguridad y la salud 77.21

Véase también Industria química quemaduras por 98.8

riesgos asociados en la tinción 89.19 riesgos en la producción de bebidas 65.16 toxicidad del en caso de incendio 41.13 y salud pública 33.51 tratamiento de aguas y 104.216

Cloro gaseoso

y síndrome de sufrimiento respiratorio del adulto 101.13

Clorofenato 71.5

Clorofenoles 71.8

Cloroformo como carcinógeno del grupo 2B por la IARC 104.251

Clorofluorocarbonos (CFC)

efectos sobre la capa de ozono 53.31 prohibición del uso de los CFC 53.11 sustancias químicas alternativas 53.31

Cloronaftalenos 71.8 hígado y piel, efectos en 104.297

Clorprofarm 62.14

Cloruro

cálcico

irritación de piel y mucosas 104.58 de alilo

inclasificable respecto a la carcinogenicidad por la IARC 104.254 de amonio

didecildimetílico 71.6

de benzoilo

inclasificable como carcinógeno por la IARC 104.364

de metileno 30.23

de metilo 66.17

de polivinilo 41.14, 67.10, 96.23

Véase también PVC

de vinilo 28.31, 32.3, 41.13

sódico 42.6

Clostridium botulinum 67.27

Coagulación

en tratamiento de residuos 101.18

Cobalto

absorción y eliminación 27.11

cobalto 6039.34

concentración 27.11

exposición 27.11

operaciones de recuperación controles técnicos 82.60 t

Cobre

exposición profesional al 63.15 medidas de protección 63.15

fundición y afino 82.4

cobre blister 82.5

conversión a partir del mineral $\quad 82.4$

electroafinado 82.5

exposición a polvos de mineral 82.5

lixiviación 82.5

mata de cobre 82.5

materiales y residuos $82.5 \mathrm{t}$

precauciones 82.5

intoxicación crónica

y enfermedad de Wilson 63.14

operaciones de recuperación

controles técnicos $82.52 \mathrm{t}$

riesgo de toxicidad por 63.14

toxicidad aguda

por ingestión 63.14

por inhalación 63.14

por tratamiento de quemaduras 63.14

Coccidiodes immitis

Véase Coccidioidomicosis

Coccidioidomicosis

riesgo en la caza 69.5

riesgo en la industria de la lana 89.13

Coces 70.15

Coch y French

estudio sobre la participación 29.61

Véase también Bartlem y Locke

Coches

luces de frenado 29.84

Cocina, personal de

y estrés por calor 98.3

y quemaduras de la piel 98.3

y riesgos de los aparatos 98.2
Código CIBSE de lluminación de Interiores (CIBSE Code for Interior Lighting, 1994) 46.21

Código deontológico ámbito de aplicación 19.3

código de conducta 19.3

código deontológico internacional para los profesionales de la salud en el trabajo 19.20

códigos internacionales 19.4

conductas poco éticas 19.3

contenido y estructura del 19.2

estudios de casos 19.2

finalidad de los códigos 19.2

historia reciente de la 19.3

para los profesionales de la salud en el trabajo 19.29

disposiciones legales 19.30

enfoque interdisciplinario 19.30

prácticas normativas 19.4

proceso de desarrollo 19.4

relación entre médico y paciente $19.2,19.5$

requisitos 19.7

compromisos percibidos 19.7

credibilidad 19.7

método científico 19.7

revisión mutua 19.7

Véase también Ética

Código modelo de prácticas de aprovechamiento forestal de la FAO 68.33

Codo

artrosis del 6.23

incidencia de la vibración 6.24

prevención y tratamiento 6.24

bursitis del olécranon 6.23

epicondilitis 6.23

incidencia en grupos de población $6.23 \mathrm{t}$

Cognitivos, trastornos

Véase T rastornos

Colada continua 73.5

Véase Fabricación del acero

Colágeno 6.8

Colangiocarcinoma

Véase Cáncer de hígado

Colapso por calor 42.8

Colas

en la elaboración de chapas 71.8

para encolado de madera

sustancias tóxicas en $96.21,103.17$

Colegios 94.15

universitarios 94.2

Cólera

cifra anual de casos de 53.21

epidemia de

en América Latina $\quad 53.2,53.21$

en Londres 53.18

y desastres climáticos 53.30 
Colesterol 3.6

Véase $\mathrm{H}$ iperlidemia

Colesterol sérico 34.15, 34.49

Colgadores 67.21

Cólico de Poitou 28.2

Cólico del pintor 96.2

Colinesterasa 28.10 plasmática 27.20

Colmenas 70.39

Colon irritable y estrés 34.69

Colores

identificación por 46.16

de equipos de incendios y de seguridad 46.16

de maquinaria 46.16

de un riesgo 46.16

en escaleras 46.16

en tuberías y canalizaciones 46.16

Colorimétrica

Véase T emperatura colorimétrica

Columna vertebral

cálculo de la compresión discal 29.44

discos intervertebrales 6.7

enfermedades de la

y vibraciones del cuerpo completo 50.5

región dorsal 6.15

mal de Sheuermann 6.15

trastornos degenerativos de la 50.5

como enfermedad de origen

profesional 50.5

y exposición a las vibraciones 50.5

Coma

coma de G lasgow 14.9

escala $14.9 t$

y lesión cerebral difusa 14.9

Combinaciones

de trabajo manual y

mecanizado 68.24

Combustibles

derivados del petróleo

toxicidad de los 102.35

Combustibles fósiles

combustión de

y contaminación del aire 53.9, 53.11, $53.13,53.23$

y efecto invernadero 53.31 - 53.32

generación de energía a partir de 76.5

funcionamiento de una

turbina-caldera 76.7

manipulación de las cenizas 76.7

manipulación del carbón 76.5

mantenimiento 76.7

operaciones 76.3

Combustión

calentamiento al rojo 41.9

con llama 41.9 de difusión 41.2

de premezclado 41.2

definiciones 41.8

generación de vapores 41.2

mezcla de tipo estequiométrico 41.2

sin llama $41.4,41.9$

velocidad de 41.3

Comercio minorista

estadísticas laborales $99.14 \mathrm{t}$

riesgos ambientales del 99.3

riesgos ergonómicos en el 99.2

Comisión Ballenera Internacional (CBI) 66.20

Comisión de Energía A tómica de Estados Unidos

criterios de salud profesional 10.35

Comisión del Codex Alimentarius y seguridad de los productos alimentarios 53.8

Comisión de las Comunidades Europeas 103.2

Comisión Económica para América Latina y el Caribe

estudios sobre las catástrofes 39.49

Comisión Económica para Europa de las $\mathrm{N}$ aciones U nidas (CEPE) y sustancias tóxicas permanentes 55.52

Comisión Ejecutiva de Salud y Seguridad del R eino U nido 23.12

Comisión Electrotécnica Internacional (CEI) actividades de prevención en cuatro tipos de ambiente 40.4

codificación de lámparas 46.5

curvas de probabilidad de fibrilación 40.3

especificaciones de sonómetros 47.6

estimación de las tasas de

electrocución 40.2

International Electrotechnical

Vocabulary 40.2

norma sobre sistemas de seguridad

eléctricos/ electrónicos/ programables

(CEI 1508) 58.63

ciclo de vida de la seguridad 58.66

fallos de hardware y software 58.69

niveles de integridad de la

seguridad 58.65

niveles de tolerancia a fallos 58.70

objetivos fundamentales 58.68

normas de seguridad sobre láseres 49.19

normas para instalaciones eléctricas 40.14

Comisión Europea

Véase también U nión Europea

Comisión Forestal de Zimbabwe 68.40

Comisión Interamericana de $D$ erechos

H umanos 23.27

Comisión Internacional de

Iluminación (CIE)

subdivisión de la banda de radiación infrarroja 49.10
Comisión Internacional de M edicina del

Trabajo (CIM T)

actividades 23.69

código deontológico internacional para los profesionales de salud en el

trabajo 19.31

deberes y obligaciones 19.31

principios éticos 19.31

requisitos para el ejercicio de las

funciones 19.32

código internacional de ética para los profesionales de la salud en el

trabajo 19.19, 27.6

estructura y miembros 23.68

objetivos 23.67

perspectiva histórica 23.67

prevención de riesgos en los hospitales 97.8

publicaciones 23.69

Comisión Internacional de Protección contra la R adiación no Ionizante (ICNIR P) límites de exposición a láseres 49.19 y exposición a campos eléctricos 49.3

Comisión Internacional de Protección

Radiológica (CIPR) 23.45

funciones del aparato respiratorio 10.2

límites de exposición a radiación

cósmica 102.15

durante el embarazo $\quad 102.15$

normas de seguridad radiológica 48.26 normas sobre cantidades y unidades en seguridad radiológica 48.3

Comisión Internacional de U nidades y M edidas de Radiación (ICRU)

definiciones de cantidades y unidades de radiación y radiactividad 48.3

Comité Científico de las $\mathrm{N}$ aciones $\mathrm{U}$ nidas para el Estudio de los Efectos de las

$R$ adiaciones $A$ tómicas

(UNSCEAR) 23.46 accidente de Chernóbil 48.44

Comité Conjunto OIT / O M S definición de la salud en el trabajo 16.21 Véase también Comité M ixto O IT / O M S

Comité Conjunto O IT / O M S sobre Salud y Seguridad en el Trabajo

Comisión Internacional del R in contra las enfermedades de transmisión sexual 23.30

Comité de empresa

relaciones con la inspección de trabajo 23.7

Comité de Expertos en la A plicación de Convenios y $R$ ecomendaciones (CEARC) 23.58

Comité de N ormas T écnicas de Sistemas de Transporte de DIN

y dispositivos de detección de obstáculos norma 7503158.29 
Comité de salud y seguridad

e inspección de trabajo 23.6

y derecho a conocer 23.35

Comité Europeo de Normalización

(CEN) 23.45, 64.26, 68.36

comités de ergonomía 29.14

elaboración de normas ergonómicas 29.14

EN 397

métodos de ensayo de cascos de seguridad 31.10

EN 45001

acreditación de los laboratorios 30.11

EN 689

evaluación de la exposición 30.4

normas CEN 29.13

normas de seguridad eléctrica $\quad 40.15$

y la regulación técnica de los ascensores 93.47

Comité Europeo de N ormalización

Electrotécnica 40.14

operación de instalaciones eléctricas 40.15

Comité Interagencias de Seguridad de la

Radiación 23.46

Comité Internacional para la

Reglamentación de Ascensores (CIRA)

normas de seguridad relativas a ascensores 93.46

Comité M ixto OIT / O M S sobre M edicina del

Trabajo

objetivos de salud en el trabajo 16.5

Comités

de salud y seguridad de la empresa

funciones 16.13

Véase también Servicios de salud en el trabajo

de salud y seguridad en el trabajo 21.23 , 67.8

Compañías de seguros

e indemnización por accidentes de trabajo 25.4

Complejo metalotioneina-cadmio 63.11

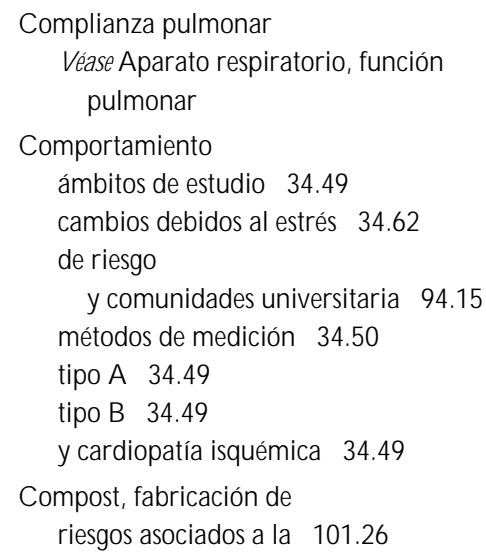

Complianza pulmonar

Véase A parato respiratorio, función pulmonar

Comportamiento

ámbitos de estudio 34.49

cambios debidos al estrés 34.62

de riesgo

y comunidades universitaria 94.15

métodos de medición 34.50

tipo A 34.49

tipo B 34.49

y cardiopatía isquémica 34.49

Compost, fabricación de

riesgos asociados a la 101.26

Compresores

seguridad de los 23.63

Compromiso

con la organización

lista de comprobación 29.31

patrones de comportamiento 34.50

Compuestos

de arsénico inorgánico 63.7

de azufre 73.14

de cromo hexavalente 72.16

de níquel 72.16

de selenio 63.45

de vanadio 63.50

organometálicos tóxicos 27.8

"sin umbral" 33.78

Compuestos de arsénico orgánico

toxicidad de los 66.3

Véase Arsénico

Compuestos de boros 104.130 lesiones neurológicas 104.131

Compuestos de cromo

exposición profesional a 63.16

fuentes de exposición 63.16

medidas de seguridad 63.17

medidas preventivas 63.17

vigilancia médica 63.17

y cáncer de pulmón 63.17

$y$ dermatitis 63.16

y trastornos respiratorios 63.16

y ulceraciones del tabique nasal 63.17

y úlceras 63.16

Compuestos fenilmercúricos

exposición profesional a los 63.30

Compuestos orgánicos

contaminación atmosférica por 55.17 métodos cromatográficos de detección 55.18

contaminación del aire por 44.6

Compuestos orgánicos volátiles

como fuentes de contaminación 44.5

contaminación del aire interior por 45.4 , 45.8

en edificios de nueva construcción 44.8

en interiores 44.10

concentraciones típicas 44.10

microbianos contaminantes del aire interior $\quad 44.24$

Computer Industry A Imanac

y estadísticas sobre uso de ordenadores 52.2

y relación entre ordenadores y población 52.2

Comunicación de riesgos diseño de procedimientos 54.26 elementos de la evaluación de $59.38 f$ filosofía subyacente 23.34

funciones 54.25 - 54.26

principales agentes 54.26 tareas centrales 54.25

Comunidad Económica Europea

Véase U nión Europea

Comunidades bentónicas 70.6

Concentraciones máximas admisibles Véase Límites de exposición profesional

Concentrado

de bebidas refrescantes 65.2 envases 65.2

Conciliación e inspección de trabajo 23.11

Condiciones climáticas 68.21

Condiciones medioambientales

en el sector de la construcción 93.3 controles medioambientales 93.6

Conducción de autobuses 102.24 diseño ergonómico del puesto de conducción 102.27

factores de estrés psicológico en 102.26 peligro de robos y agresiones 102.25 pérdidas auditivas por 102.25 riesgo de accidente de los vehículos 102.25 riesgos ergonómicos 102.25 y enfermedades infecciosas 102.25

Conducción de calor definición $41.3,42.15$ ecuación 41.2

Conducción de camiones exposición a radiación ionizante 103.7 solar 103.7

exposición al ruido 103.7

infarto de miocardio y obesidad 103.8

intoxicación y 103.7

períodos de conducción y de descanso 102.25

riesgos químicos en la 102.25

y accidentes de los vehículos 102.25

y enfermedades infecciosas 102.25

y lesiones de espalda 102.25

y pérdidas auditivas 102.25

y riesgo de asaltos y robos 102.25

Conducta indebida

de la empresa

e indemnización por lesiones 25.11

del trabajador

e indemnización por lesiones 25.10

Conductancia 40.6

Confección acabado y planchado 87.4

riesgos ergonómicos 87.4

cauchutado/ impermeabilización 87.4

diseño del producto y confección de

muestras 87.2

distribución 87.4

manipulación de materiales 87.4

enfermedades laborales $87.6 f$ 
ergonomía 87.2

fabricación de accesorios

de plástico y productos de plástico cosido 87.5

fabricación de botones, hebillas y otros ornamento 87.5

exposición a productos químicos 0 metales tóxicos 87.5

informatización 87.4

manejo de la máquina de coser 87.3

patronaje y corte 87.2

medidas de protección 87.2

plisado 87.4

exposición a sustancias químicas 87.4

visión general 87.2

Confederación Europea de Sindicatos negociación colectiva 21.18

principios éticos del uso de biomarcadores 28.4

Conferencia Americana de $\mathrm{H}$ igienistas Industriales del G obierno (ACGIH) 103.16, 104.153, 104.192, 104.209, 104.311 concentraciones máximas admisibles 30.33 D ocumentation of the Threshold Limit Values 30.34

índices biológicos de exposición 27.6

límites de exposición a campos electrostáticos 49.29

límites de exposición a la radiación infrarroja 49.13

recomendaciones sobre las condiciones climáticas 42.44

valores límite de exposición a contaminantes del aire 44.3

valores límite umbral 30.18

y la regulación de las sustancias químicas en la industria aeroespacial 90.10

y nivel de exposición al polvo en la industria textil 89.31

y potencial cancerígeno del trióxido de antimonio 63.5

y regulación de la exposición al polvo en la industria textil 89.11

y valor límite de exposición a vibraciones mano-brazo 50.12

Conferencia de las $\mathrm{N}$ aciones $\mathrm{U}$ nidas para el

$M$ edio Ambiente y el D esarrollo

(CNUMAD) 54.10, 54.31

Agenda XXI 54.2, 54.6

convenios concertados en $54.13-54.14$

Programa $21 \quad 53.4$

y daños transnacionales 54.12

Conferencia de Río

Véase $C$ onferencia de las $N$ aciones $U$ nidas para el M edio A mbiente y el D esarrollo (CNUMAD)

Conferencia Internacional de Seguridad de las Sustancias Q uímicas 23.47
Conferencia Internacional del Trabajo (CIT)

Convenio sobre el derecho de asociación (agricultura), 1921 (no 11) 21.10

Convenio sobre la protección del derecho de sindicación y los procedimientos para determinar las condiciones de empleo en la Administración pública (no 151) 21.7

R ecomendación no $112 \quad 16.5$

Recomendación sobre los procedimientos para determinar las condiciones de empleo en la Administración pública (no 159) 21.7

y requisitos de etiquetado de sustancias químicas 61.11

Conferenciantes 94.2

Confidencialidad

archivos personales informatizados 19.19

aspectos éticos 19.14

conciliación de intereses 19.16

sectores implicados 19.14

de la información 19.18

garantías administrativas 19.19

garantías técnicas 19.19

garantías implícitas 21.31

Véase también Ética

Confinamiento

confinamiento para aves de corral 70.27

de ganado 70.12

gases tóxicos y asfixiantes 70.13

riesgos respiratorios 70.14

transmisión de zoonosis del ganado al hombre 70.14

Conflicto de leyes 23.22

Conflictos laborales arbitraje 21.36

Congelación

Véase Frío, lesiones por congelación

inmediata $42.52,42.59$

líneas de 66.8

métodos 67.5

congelación al aire 67.5

congelación en lecho fluidificado 67.5

congelación por chorro 67.5

congelación por gas licuado 67.5

prevención farmacológica de la 42.52

profunda 42.39

superficial 42.39

tratamiento de la 42.39

Congestión

por descarga eléctrica 40.4

Congreso de Sindicatos de Zimbabwe 21.18

Congreso M undial de Salud y Seguridad en el Trabajo 23.60

Conjuntivitis

en los operadores de PVD 52.12

por sensibilidad al níquel 63.35

y exposición a platino 63.39
Conjuntivitis alérgica

por alergia al látex 97.63

Consejo de Estados Nórdicos

y salud y seguridad en el trabajo 23.45

Consejo de Europa

Carta Social Europea 23.45

Convenio Europeo para la Protección de los D erechos $\mathrm{H}$ umanos y de las $\mathrm{L}$ ibertades Fundamentales 19.16

R ecomendación (núm. R 81-1) sobre las bases de datos médicas 19.19

R esoluciones sobre la salud y seguridad en el trabajo 23.45

Consejo de la Industria Q uímica

Europea 20.20

directrices sobre transferencia de tecnología 20.20

Consejo N acional de M etrología y Pruebas de Suecia (M PR)

y evaluación de radiaciones de PVD 52.7

Conservación

de colecciones museísticas y exposición a sustancias químicas 96.44 y lesiones de tipo ergonómico 96.44 de los alimentos 67.4 métodos 67.4

Conservación de la energía 67.16

Constante psicrométrica 42.31

Construcción

alcoholismo 93.3

andamios 93.39

asbestosis 93.3

ascensores 93.46

inspecciones y pruebas 93.48

mantenimiento 93.48

medidas de precaución 93.47

normalización 93.46

riesgos asociados 93.47

tipos 93.46

visión general 93.46

asfalto 93.57

composición química 93.57

medidas de salud y seguridad 93.58

riesgos asociados 93.57

bronquitis 93.3

cáncer 93.3

cemento 93.51

enfermedades asociadas a la industria del 93.52

medidas de salud y seguridad 93.53

producción 93.51

riesgos asociados 93.52

tipos 93.51

de edificios comerciales 93.21

regulación 93.21

de viviendas 93.21

dermatitis 93.3

distribución del empleo 93.2 
especialización del trabajo 93.14 trabajadores inmigrantes 93.13 drogas 93.11 electrocución 93.9

elevadores de obra 93.50 características generales 93.50 normas de seguridad 93.50

escaleras mecánicas 93.48 condiciones generales de seguridad 93.48 mantenimiento e inspección 93.49 estrés 93.3

exposición al amianto 93.30

fatiga térmica 93.5

formación 93.17

sobre salud y seguridad en el trabajo 93.17

grava 93.58

riesgos de salud y seguridad 93.58

grúas 93.44

legislación 93.45

medidas de control 93.45

riesgos 93.44

tipos 93.44

herramientas 93.37

riesgos asociados a cada tipo 93.37

tipología 93.37

hipotermia 93.5

histoplasmosis 93.5

hormigón 93.53

encofrados 93.53

prevención de accidentes 93.55

tipos 93.53

industrial 93.21

seguridad en el montaje 93.22

intoxicación 93.3

labor de prevención de la ISO 23.61

máquinas y equipos 93.39

de movimiento de tierras 93.40

visión general 93.39

materiales 93.39

acero, aluminio y cobre 93.43

amianto 93.43

colas y pegamentos 93.43

ladrillos, hormigón y piedra 93.43

lana mineral 93.43

madera 93.44

pavimentos 93.43

pinturas e imprimaciones 93.43

plástico y caucho 93.43

yeso 93.44

neumoconiosis 93.10

neurológicos, trastornos 93.3

obras civiles 93.22

aeropuertos 93.24

canales y muelles 93.24

carreteras 93.22

ferrocarriles 93.24

presas 93.23 puentes 93.23

túneles 93.23

planificación y normas de

edificación 93.21

promotor 93.20

proyectistas 93.19

proyectos llave en mano 93.22

proyectos, tipología 93.19, 93.25

trabajos junto al agua o dentro del agua 93.33

demolición 93.31

desmontaje 93.33

nuevos locales 93.25

renovación 93.29

radiaciones 93.5

relaciones cliente-contratista 93.14

en materia de seguridad 93.15

relaciones contratista-contratista 93.15 en materia de salud 93.15

relaciones empresa-trabajador 93.16 formas de contratación 93.16

relaciones intersindicales 93.16 y seguridad 93.16

riesgos primarios $93.4 \mathrm{t}$

salud y seguridad en el trabajo, mejoras 93.17

Sección Internacional de la AISS 23.66 sectores principales 93.18 - 93.24

contratistas y autónomos 93.19

seguridad 93.19

diversificación de proyectos 93.18

público y privado 93.19

relación cliente-contratista 93.18

silicosis 93.3

símbolos gráficos utilizables en el equipo 23.63

trabajos submarinos 93.33

cajones 93.34

inmersiones 93.33

riesgos 93.33

túneles subacuáticos 93.34

transportadores de personas 93.49

vibraciones 93.10

zanjas 93.34

Consultores de seguridad

categorías 60.7

de la Administración pública $60.7,60.9$ puntos débiles 60.9

de las compañías de seguros 60.7 - 60.8 funciones específicas 60.8

evaluación de la actuación de los 60.10 privados $60.8-60.9$

funciones específicas 60.9

Consultores en materia de educación 94.2

Consumidores

salud de los 67.16

Consumo de alcohol

Véase A Icoholismo
Consumo de cigarrillos

Véase T abaquismo

Consumo de fármacos

y susceptibilidad individual a los tóxicos 33.20

Consumo de oxígeno

estimación 29.35

sistema de energía 29.102

y frecuencia cardíaca 29.35

V éase también $\mathrm{G}$ asto energético

Consumo de tabaco

Véase T abaquismo

Contadores

de centelleo de líquido 48.29

de centelleo de plástico $\quad 48.24$

de centelleo de sulfuro de zinc 48.24, 48.29

de cristales de yoduro de sodio ( $\mathrm{N}$ al) 48.24

de germanio (Ge) 48.29

G eiger-M ueller (G-M) 48.24, 48.29

proporcionales de gas 48.24

Contagiosas, enfermedades en conductores de ambulancia 103.5

Contaminación

actividades causantes de la 54.33

condiciones IDLH 31.28

control de la 55.53

principales métodos 55.53

del aire 72.19

excrementos del ganado 70.5

por hidrocarburos

convenios internacionales sobre 54.11

por los procesos productivos 54.3

prevención de la 54.34

características de los programas 54.35

caso de los G randes Lagos 55.51

ejemplos de 54.36

en Estados U nidos 54.35

estrategias básicas 55.53

estudio de la Business R oundtable 54.35

evaluación de peligros 55.57

impacto sobre el empleo 55.57

legislación 55.56

métodos principales 55.55

planes obligatorios 55.56

planes voluntarios 55.56

Programa "Pollution Prevention Pays"

(3P) 54.35

tecnologías aplicadas 54.36

vertido cero de contaminantes 55.54

y análisis del ciclo vital 54.36

y participación de los trabajadores 54.35

y reciclado 55.55

y salud de los trabajadores 55.56

prevención en la industria de la piel y el

calzado 88.12

reparación de la 55.53

y fugas de productos químicos 55.54

tipos de reparación 55.53 
y limpieza de lugares contaminados 55.54

y tratamiento de residuos peligrosos 55.54

y lluvia ácida 54.3

Véase también Protección personal

Contaminación atmosférica

asociada a la industria naval $\quad 92.17$

contaminantes más habituales 53.11

control de las fuentes industriales

de origen industrial

en los países desarrollo 53.9

evacuación de los residuos 55.6, 55.23

medidas de limpieza y

almacenamiento 55.6, 55.24

modificación de los procesos de

producción 55.6

principales medidas 55.6

sistemas de depuración de gases 55.23

sistemas de extracción localizada 55.24

sustitución de materiales 55.6, 55.23

vigilancia en tiempo real 55.24

y dispersión 55.23

y formación del personal 55.24

dispersión de los contaminantes

V éase M odelos de dispersión de contaminantes

efectos en la salud pública 55.7 estimación del coste de los 55.7

efectos sobre la salud de la

Véase también Contaminación del aire

en el interior 94.13

en interiores 54.6

en zonas urbanas 53.11

efectos nocivos de la 53.11

equipos para el control de la 55.6

de los olores 55.6

para contaminantes gaseosos 55.6

para partículas 55.6

fuentes de 30.17

fuentes emisoras 55.4

de origen industrial 55.5

estáticas 55.4

móviles 55.4

naturales 55.4

generada por la industria

alimentaria 67.14

medición de los contaminantes

Véase V igilancia de la calidad atmosférica

muestreo de emisiones 55.25

planes de control de la 55.5

aspectos fundamentales 55.5

e inventario de concentraciones de contaminantes 55.5

e inventario de efectos en la salud 55.6

e inventario de emisiones 55.5

modelos de dispersión 55.6

por contaminantes gaseosos 55.4

por dióxido de azufre 53.13 por las emisiones de los vehículos 55.7

por monóxido de carbono 53.14

por óxidos de nitrógeno 53.13

por ozono ambiental 53.13

por partículas inhalables (PM 10) 53.13

medidas de control 55.7

por partículas en suspensión 55.4

referencia basal 30.23

relacionada con los procesos de fabricación de pasta y de papel 72.19

sistemas de control de la 55.20

por límites de emisión de la fuente 55.22

selección de los controles 55.21

y eliminación de residuos peligrosos 55.23

y técnica BACT 55.22

sistemas de muestreo 55.25

muestreo extractivo 55.26

muestreo isocinético 55.26

para emisiones visibles 55.25

vigilancia in situ 55.26

transnacional

tratados internacionales sobre 54.12

y enfermedades dermatológicas 94.13

y enfermedades graves entre los

profesores 94.13

y enfermedades respiratorias 94.13

y normas sobre la calidad atmosférica 55.5

y percloroetileno (PERC) 100.12

y planificación del transporte 55.7

y planificación del uso del suelo 55.7

Contaminación de las aguas subterráneas contaminantes específicos 55.37

contaminantes no reactivos 55.37

contaminantes reactivos 55.37

dispersión de los contaminantes 55.37

fuentes de $55.36 \mathrm{f}$

prevención de la 55.37

y protección de acuíferos 55.38

y protección de los manantiales 55.38

y vertido de residuos peligrosos 53.16

Contaminación de las aguas superficiales y vertido de residuos peligrosos 53.16

Contaminación de los alimentos 53.7

por agentes biológicos 53.7

por emisiones de radionucleidos 53.9

por sustancias químicas 53.8 - 53.9

y metales pesados 53.9

Contaminación del agua

agentes contaminantes 53.19

asociada a la industria naval 92.17

prácticas óptimas de gestión 92.17

sistema de presa y compuerta 92.17

costes económicos de la 53.21

de las fábricas de pasta y de papel 72.20

de origen industrial

eliminación completa de la 72.20

en China 53.10

en los países en desarrollo 53.10, 53.18 en estuarios 55.31

en los lagos y pantanos 55.31

en mares y océanos

fuentes de contaminación 55.32

límites al vertido de residuos 55.28

y designaciones de uso de las aguas 55.28

métodos de valoración de riesgos 55.31

mortalidad por 53.21

por sustancias químicas 53.21

repercusión sobre la salud 53.21

principales enfermedades por 53.21

tipos de problemas de 53.18

y cambios de temperatura del agua

Véase C ontaminación térmica

Véase también A guas residuales

Contaminación del aire interior

contaminantes habituales 44.4

contaminantes químicos 44.6

control de las fuentes de

contaminación 44.28

normas para Europa (C O ST 6131989 y 1991) 44.29

y control del humo del tabaco 44.29

y mantenimiento del edificio 44.29

y ventilación 44.29

detritus en la 44.23

e integridad del edificio 45.3

en ambientes industriales 44.29

valores límite umbral de

exposición 44.29

métodos de control 45.8

mediante ventilación general 45.8

por control de la fuente 45.8

por ventilación de dilución 45.8

métodos de medición de la 44.6

natural 44.5

por ácaros 44.23

por aparatos de combustión 44.7

por bacterias 44.23

por compuestos orgánicos volátiles 44.8,

45.4

concentracionestípicas 44.10

en los edificios 44.11

en los materiales del edificio 45.4

en productos de consumo 44.8

métodos de detección 44.22

por contaminantes biológicos 44.22

por el humo de tabaco 44.7

Véase también $\mathrm{H}$ umo de tabaco ambiental (H T A)

por formaldehído ureico (FU) 44.7

por hongos 44.23

por insectos 44.23

por plaguicidas $44.5,44.11$

métodos de detección 44.22

por polen 44.22

por protozoos 44.24

por virus 44.23 
procedente del exterior $44.4,44.8,45.3$

fuentes principales 44.4

reglamentación 44.28

y control de la humedad 45.4

y ventilación 45.4

Véase también C alidad del aire interior

Contaminación del suelo

daños a los ecosistemas 53.16

de origen industrial

en los países en desarrollo 53.10

por vertido de residuos peligrosos 53.16

Contaminación industrial

en los países en desarrollo 53.9 - 53.11

industrias emisoras 53.9

niveles de exposición 53.9

y transporte de desechos tóxicos 53.10

y vertido incontrolado de residuos 53.10

Contaminación radiactiva

inspección de 48.29

instrumentos detectores de 48.24

lesiones cutáneas por 48.42

en el accidente de Chernóbil 48.44

en el accidente de G oiânia 48.42

medición de la 48.26

programas de vigilancia 48.23 - 48.24

equipo de vigilancia medioambiental típico 48.39

y Programa ER EM P 48.39

Véase también Seguridad radiológica

Contaminación térmica

control de la 55.36

límites en la liberación de calor 55.36

y vertido de aguas residuales 55.35

Contaminantes

de interiores $45.2 \mathrm{t}$

de masas de agua 55.28

degradables 55.28

no degradables 55.28

radionucléicos 55.28

del aire interior 45.3

en oficinas $99.8 \mathrm{t}$

en hogares 99.11

del aire exterior $53.12 \mathrm{t}$

gaseosos 55.4

como productores de ozono (0 3) 55.4

que emite una persona 45.15

Véase también Límites de exposición profesional

Contaminantes atmosféricos

efecto nocivo 44.3

efecto tolerable 44.3

efectos de la exposición a $\quad 44.3$

en el lugar de trabajo 61.24

prácticas de control de los 61.24

exposición a 30.4, 30.16

inventario de concentraciones de 55.5

NSE, nivel sin efecto 44.3

orgánicos 55.17
Véase también M odelos de dispersión

Contaminantes biológicos

y enfermedades transmitidas por alimentos 53.7

Contaminantes más comunes $55.4 \mathrm{t}$ efectos sobre la salud $53.13-53.14$

en el medio urbano 53.11

Contenedores criogénicos 102.61

Contrachapado $71.2,71.13$

procesos de elaboración 71.8

riesgos derivados de la elaboración de 71.8

Contratación

en el sector de la construcción 93.19

fuera de las fronteras nacionales 93.19

mediante licitaciones competitivas 93.19

precio y liquidación 93.20

tipos 93.20

Contratistas

en el sector de la construcción

contratos 93.19

dentro del sector privado 93.19

dentro del sector público 93.19

tipos 93.18

Control

concepto de $34.27,34.50$

escala de control del NIOSH 34.27

falta de 34.13

objetivo y subjetivo 34.27

personal 34.20

seminario del NIOSH 34.27

Control ambiental $27.2,30.28$

Control biológico

aplicación práctica 27.4

biomarcadores 28.9

conceptos básicos y definiciones 27.2

consideraciones éticas 27.6

control periódico 27.6

disponibilidad de datos de referencia 27.6

estudios epidemiológicos 27.6

evaluación de la exposición 30.27

exposición combinada a varias sustancias

tóxicas 27.5

factores de interferencia 27.4

frecuencia de la exposición 30.26

garantía de calidad 27.6

control de calidad interno 27.7

control de calidad postanalítico 27.8

control de calidad preanalítico 27.8

evaluación de calidad externa 27.7

expresión de los resultados por gramo de creatinina 27.8

selección del método 27.7

grupo de referencia 27.5

indicadores 27.4

indicadores biológicos 27.5

índices biológicos de exposición 27.4

información necesaria 27.4

marcadores biológicos 28.4 limitaciones 28.4

posibles usos 28.4

medios biológicos 30.23

metabolismo de disolventes 27.5

métodos de control 27.3

momento del muestreo 27.4

nivel aceptable de exposición 30.26

objetivos 27.2, 30.19

problemas de los estudios de

biocontrol 27.18

relación dosis-efecto 27.4

relación dosis-respuesta 27.4

uso de biomarcadores 33.47

valor de referencia 27.5

ventajas y limitaciones 27.3

Véase también Biocontrol citogenético

Véase también Biocontrol genético

Véase también $\mathrm{H}$ igiene industrial

Véase también M uestreo ambiental y biológico

Véase también Pesticidas

Control de calidad

en Japón 29.92

Control de la humedad

capacidad de absorción de un tejido 42.32 condensación del sudor evaporado 42.32 efectos de la absorción de humedad 42.32 retención de agua en los tejidos 42.32

Control de riesgos

en programas de seguridad 60.16

y ejecución de la tarea 59.28

Control del producto

gestión de la calidad total (GCT) 57.3

liderazgo de la calidad total 57.3 de la EFQM 57.3

Control del ruido 47.13

Controladores del tráfico aéreo estudio de los factores de estrés en 102.9 en Italia y EEUU 102.9

estudio de Sperandio 29.10

y episodios acústicos 102.10

y estrés 102.10

y trastornos visuales 102.8

Controladores lógicos programables (PLC) 58.64

Controladores programables (PC) 58.64

Controles

dispositivos de entrada de datos 29.78 otros métodos 29.79

teclados 29.78

dispositivos de presentación de datos $29.79,29.82$

indicadores visuales 29.79

estudios sobre coordinación motora 29.87

lista de comprobación 29.26

modelos mentales y compatibilidad 29.86

normas para la disposición de los 29.74

paneles de controles 29.80 
para un operador de pie 29.77

para un operador que trabaja

sentado 29.77

prevención del funcionamiento accidental 29.78

rótulos y advertencias 29.81

selección entre distintos tipos de 29.77

Véase también Indicadores

Véase también Paneles

Véase también T ratamiento de la información

Controles de acceso

a zonas de radiación 48.31

Controles de seguridad

de máquinas 58.43

Véase también Canales de control

Contusión

y traumatismo craneal 14.9

Convección

definición $41.3,42.15$

ecuación 41.2, 42.15

Convención americana sobre Derechos

H umanos 23.27

Convención de las $\mathrm{N}$ aciones U nidas sobre la eliminación de todas las formas de discriminación contra la mujer 23.24, 23.26, 23.29, 24.4

Convención internacional sobre líneas de carga 66.10

Convenio de Basilea movimientos transfronterizos de residuos peligrosos $53.14,101.28$

Convenio de Berna 104.382

Convenio de H elsinki (1992) sobre efectos transnacionales de los accidentes industriales 54.14 y ríos y lagos internacionales 54.14

Convenio de L ondres de 1972 y vertidos marinos 54.11

Convenio de Torremolinos sobre la seguridad de los buques de pesca 66.10

Convenio de V iena de 1985 sobre protección de la capa de ozono 54.13

Convenio Internacional para la Prevención de la Contaminación de las Embarcaciones 39.30, 102.58

Convenio Internacional para la Seguridad de la V ida H umana en el M ar 66.9 transporte de materiales peligrosos 39.30 y trajes antiinmersión 42.53

Convenio M AR PO L 1973/ 1978 contaminación producida por embarcaciones 54.11

Convenio sobre los servicios de salud en el trabajo 14.2

Convenios colectivos y trabajadores discapacitados 17.41
Convenios de la OIT

Véase 0 rganización internacional del trabajo

Convenios internacionales ambientales anteriores a la conferencia de Estocolmo de 197254.10

para la protección del medio ambiente marino $54.11-54.12$

sobre conservación de la naturaleza 54.11 sobre conservación de los hábitats 54.11 sobre contaminación atmosférica transnacional 54.12

sobre contaminación por hidrocarburos 54.11

sobre daños transnacionales de los accidentes nucleares 54.12

sobre protección de la capa de ozono $\quad 54.13$ sobre transporte internacional de residuos peligrosos 54.13

Convenios y R ecomendaciones de la O rganización Internacional del Trabajo (OIT)

Véase 0 rganización Internacional del Trabajo (OIT)

Cook

estudios sobre los límites de exposición 30.31

Cooperación Económica del A sia y el Pacífico acuerdos de libre comercio 20.15

Cooperación internacional 23.46 Véase también 0 rganizaciones internacionales

Coproporfiria 63.42

Coproporfirina 27.12

Coque

Véase Producción de coque

Coquización

Véase $\mathrm{C}$ raqueo

Véase Producción de coque

Cor pulmonale por radiación 48.8

Corindón 62.3

Córnea, edema de anhídrido acético y 104.14

Corrales de confinamiento 70.28

Correos, trabajadores de riesgos de los 101.6

Corrientes parásitas 41.10

Corta

a hecho 68.7

tipos de 68.36

Cortadoras-atadoras en la tala forestal 68.9

Cortes

en la fabricación de vidrio, cerámica y materiales afines 84.28

en los procesos de confección $\quad 87.2,87.5$ riesgo en carpintería 86.2

riesgo en industrias gráficas 85.5

riesgo en la industria del calzado 88.8

Corteza del arce, enfermedad de 86.14

Corteza suprarrenal 34.20

Cortisol 34.11, 34.20, 34.60

Cortocircuitos 41.10

Cosechadora

cosechadora combinada

autopropulsada 64.22

en operaciones forestales 68.9

Cosméticos

acetatos en 104.162

Directiva 76/ 768/ CEE 33.51

propilenglicol en 104.209

Cosmetólogos

enfermedades de la piel 100.9

enfermedades infecciosas 100.9

exposición a productos químicos 100.6

riesgo de cáncer en 100.10

rinitis alérgica en 100.10

trastornos musculosqueléticos en 100.8

soluciones ergonómicas 100.8

Costureras

Véase $\mathrm{D}$ edo de costurera

Cote

estudio sobre las fuentes de ignición 41.4

Fire Protection $\mathrm{H}$ andbook 41.8

Cowper, glándula de 9.5

Coxiella burnetii 44.5

Craneal

Véase L esiones craneales, traumatismo

Craneoencefálicas, lesiones 7.2 de origen traumático 7.2

Craqueo

Véase R efino de petróleo, procesos

alquilación 78.16

coquización 78.12

coquización continua 78.13

coquización retardada 78.12

craqueo catalítico 78.13

de lecho móvil 78.14

esquema del proceso $78.13 f$

termofor 78.14

craqueo térmico 78.12

en fase de vapor 78.12

hidrocraqueo 78.15

isomerización 78.18

medidas de seguridad 78.13 - 78.14

polimerización 78.16

reforma catalítica 78.17

reforma de hidrógeno al vapor 78.19

riesgos del proceso 78.14

Creatinina $8.3,27.5$

Véase Riñón

Creosota 71.11 
Creutzfeldt-Jakob, enfermedad de 70.6

Cribado

de lesiones cancerosas

Véase Cáncer, cribado

en tratamiento de residuos $\mathbf{1 0 1 . 1 8}$

Criptococosis 70.29

Criptosporidiosis 70.16

Crisálidas 70.39

Cristal, industria del

intoxicación en 103.11

riesgos en la 103.10

rotura de 65.16

Cristalero 103.10

estrés en 103.11

intoxicación 103.11

lesiones musculares y óseas 103.11

lesiones oculares 103.10

reuma 103.10

síndrome del tunel carpiano 103.11

Crocidolita 23.31

Cromatografía

de gases 30.24

de gases (GC) 55.18

Cromatografía líquida de alta resolución

(H PLC) 55.18

detectores de 55.18

Cromatógrafo de gases 30.24

Cromo

absorción 27.11

concentración 27.11

contaminación en la industria de la piel y el cuero 88.12

eliminación 27.11

en la industria láctea $\quad 67.27$

exposición profesional al

efectos nocivos 63.16

medidas de prevención 63.17

y cáncer de pulmón 63.17

Véase también Compuestos de cromo

riesgos asociados en la industria de la piel y

el cuero $88.4,88.9$

toxicidad 27.11

Cromosomas

efectos de la radiación $\quad 48.5$

Crotalus

adamanteus 38.9

atrox 38.9

durissus terrificus 38.9

scutulatus 38.9

Crudos

de petróleo

características y propiedades $75.3 \mathrm{t}$

Cryptococcus neoformans 69.5

C sikszentmihalyi

experiencia activa (1975) 34.11

Cuasiaccidente 39.9
Cubicación 68.7

Cubicaje 72.6

Cucharas de arrastre riesgo de vuelco en 58.71 y uso de EPV 58.74

Cuchillos 29.75, 67.6, 67.17

Cuello

anatomía y biomecánica 6.16

trastornos del cuello 6.16

factores psicológicos y sociales 6.18

grupos profesionales 6.17

hernia de disco 6.19

movimientos repetitivos 6.18

tensión cervical 6.19

tortícolis aguda 6.19

trastornos crónicos 6.19

vibración 6.18

Cuencas hidrográficas

fuentes de contaminación en las 55.28

Cuero, industria del

ácido clorhídrico en 104.5

ácido fómico en la 104.12

Cuerpos de H einz 1.6

hemólisis 1.7

Cuestionario de diagnóstico de seguridad (CDS) para análisis de riesgos 59.27

Cuestionario Statshalsan 34.14

Cuestionarios

archivo 28.40

aspectos éticos

confidencialidad 28.36

participación voluntaria 28.36

contenido 28.37

formato 28.38

lenguaje 28.37

longitud 28.37

preguntas manipuladoras 28.37

redacción 28.37

secuencia y estructura de las

preguntas 28.37

tipos de preguntas 28.37

diseño 28.34

diseño híbrido del estudio 28.36

planificación 28.39

empresas especializadas 28.39

formación de los encuestadores 28.39

funciones 28.34

índices y escalas 28.37

procesamiento 28.39

tipos 28.35

cuestionario enviado por correo 28.35

cuestionarios por teléfono 28.35

encuestas personales 28.35

validez y fiabilidad 28.36, 28.39

manual de codificación 28.38

pruebas piloto 28.39

sesgo de información 28.38

sesgo de memoria 28.38 sesgo de respuesta 28.38

sesgo por conveniencia social 28.38

validez de la expresión 28.37

validez del contenido 28.37

validez del criterio 28.37

Véase también Epidemiología del trabajo

Cuestiones ambientales y de salud pública 65.15

Cuidado de las personas de edad avanzada 34.45

Cuidado de los niños 34.45

Cultivo de la tierra 64.19

Cultivos

amiláceos 64.3

cultivos de plantación o perennes 64.27

de campo 64.26

de tierras altas y semialtas 64.27

en tierras húmedas 64.27

forrajeros 70.11

horticultura 64.27

pastizales 64.27

Cultura

aspectos microergonómicos relacionados con 29.93

definición 29.90

y diseño 29.93

y tecnología 29.90

aplicación de las características culturales para un diseño óptimo 29.92

compatibilidad y preferencias 29.91

Cultura de asociación 29.92

Cultura de seguridad

función de los mandos intermedios y

supervisores 59.5

e índices de siniestralidad 59.6

intervención jerárquica 59.5

intervención participativa 59.5

función de los trabajadores 59.6

y retroinformación positiva de los directivos 59.6

liderazgo de los altos directivos en 59.5

y baja siniestralidad 59.6

programa Tuttava 59.18

y aplicación de los programas 59.5

y desarrollo de una cultura de seguridad

integral 59.7

y eficacia de la política de seguridad 59.4

y noción de clima de seguridad 59.4

y reducción de accidentes 59.6

y uso de equipo de protección

individual 59.31

Cultura organizativa

componentes básicos 34.42

y trabajadores de edad avanzada 29.92

Cultura profesional 29.92

Cultura social 29.91 
Cumbre de Río

$V$ éase $\mathrm{N}$ aciones $\mathrm{U}$ nidas

Currículum vitae y recolocación 15.97

Cursos

de actualización profesional 94.2 de orientación para discapacitados 17.22 de prejubilación 15.93

Curtido

acabado 88.4

contaminación del aire 88.4

curado y expedición 88.3

tratamiento de los efluentes del curtido 88.11t

instalación de curtición 88.3

preparación 88.3

equipo de protección personal 88.3 ventilación 88.3

procesos típicos de curtido y acabado del cuero $88.4 f$

recurtido, coloreado y engrase en baño 88.3

tratamiento de las pieles $88.5 f$

Cutánea, enfermedad

Véase Piel, enfermedades de la

Cutáneo, cáncer

Véase Cáncer de piel

Cutáneo, receptor

Véase R eceptores cutáneos

Cytophaga 44.5

$\mathrm{CH}$

Chalcosis 63.14

Chalecos salvavidas 42.48

Chamuscadora 67.21

Chapas 71.8

Véase también Contrachapado

Chequeo

Véase R econocimiento médico

Chernóbil

accidente nuclear de

consecuencias sanitarias $39.5,39.20$, 48.43

contaminación de alimentos 53.9

medidas protectoras de la población 48.44

países afectados 48.43

causas del accidente 29.111

cambios en el programa de prueba 29.112

diseño inadecuado del reactor y de las barras de control 29.112

planificación defectuosa de las pruebas 29.111

política de secretismo 29.111

consideraciones ergonómicas 29.113 curso del accidente 29.112

fallos de diseño, deficiencias de manejo y

errores humanos 29.106

informe soviético a la AIEA 29.113

lecciones aprendidas 29.113

y seguridad de la energía 76.15

exposición a radiación 39.37

fusión del núcleo del reactor 39.32

medidas de seguridad 39.42

Chichoneras 31.11

China

animales de tiro en 70.33

Comité Nacional de Diagnóstico de

Enfermedades Profesionales 16.59

Comité T écnico N acional de $\mathrm{N}$ ormas Higiénicas 16.56

encuestas de higiene industrial $\quad 32.34$

Federación de Sindicatos de C hina 23.40

industrialización rural 20.26

enfermedades profesionales 20.27

migración rural generalizada 20.28

tasas de enfermedades

profesionales $20.27 \mathrm{t}$

Ley de T rabajo de $1994 \quad 23.40$

M inisterio de Salud Pública 23.40

M inisterio de Trabajo 23.40

normas y legislación de salud en el trabajo 16.56

prevención de enfermedades profesionales control de los peligros profesionales 16.60 t

protección de los derechos de los trabajadores 23.40

reforma de la estructura económica 16.53

R eglamento de Prevención y Control de Neumoconiosis 16.56

servicio de salud en el trabajo 16.54

en las pequeñas empresas 16.60

estructura organizativa 16.54

exploraciones sanitarias 16.58

gestión de las enfermedades profesionales 16.59

gestión de normas 16.56

instalaciones sanitarias $16.55 \mathrm{t}$

instituciones de salud en el trabajo 16.56

prevención de enfermedades

profesionales 16.57

programas de salud en el trabajo 16.60

red nacional de servicios $16.56 f$

revisión histórica 16.54

sistema de inspección sanitaria 16.56

supervisión medioambiental 16.57

Chispas

eléctricas 41.10

por fricción 41.11

Chocolate

industria del 67.27

Chófer 103.12

estrés en 103.14
Choque eléctrico

definición 40.2

D

Daboia ruselii 38.8

Dalapon-Na 62.14

Danza

lesiones relacionadas con la 96.25

Daños y perjuicios 25.25

e indemnizaciones a los trabajadores 25.25

Dasler

límite fisiológico de exposición al calor 42.25

Dazomet 62.16

D-dehidratasa del ácido aminolevulínico (ALA-D) 27.3

DDT

concentraciones en organoclorados 27.24

control de parásitos y 104.296

riesgo medioambiental del 53.9

sensibilización de la opinión pública ante el uso de 68.45

De L ange, curva de Véase V isión

Decapantes disolventes tóxicos en 96.21

Deceleración tolerancia humana a la $\quad 102.19$

Declaración de H elsinki 42.25

D eclaración U niversal de D erechos Humanos 19.16, 23.24, 23.30

Dedo blanco

Véase $R$ aynaud, fenómeno de enfermedad del 68.6 inducido por vibración (VWF) uso de herramientas mecánicas

en el sector de la construcción 93.38

Dedo de costurera 29.40

Dedo muerto

Véase $R$ aynaud, fenómeno de

Defensas de máquinas

defensa fija 58.16

en una prensa mecánica $58.15 f$

en una sierra de cinta $58.17 f$

defensas ajustables 58.16

en una sierra de cinta $58.17 f$

defensas autoajustables 58.16

en una sierra de brazo radial 58.17

defensas con enclavamiento 58.16

en una máquina plegadora $58.17 \mathrm{f}$

formación del trabajador sobre 58.15

requisitos generales 58.14

tipos $58.16 t$

Deficiencia

Véase D iscapacidad 
relación con la discapacidad 17.5

Deforestación 68.2

Deformación de Boutonierre 96.53

D elegado de personal

funciones 23.7

Delirio

$V$ éase T rastornos cognitivos

Demanda biológica de oxígeno (D BO ) 67.14, 72.20

Demanda química de oxígeno (D Q 0 ) 67.14

Demandas de indemnización por estrés 5.16

Demencia

exposición a sustancias tóxicas y 5.19

factores profesionales 5.19

profesión como factor de riesgo 5.19

Véase también trastornos mentales

Demolición

en el sector de la construcción 93.31

empleo de explosivos 93.32

métodos principales 93.32

planificación 93.32

riesgos asociados 93.32

polvo 93.33

ruido 93.32

Dengue

transmitido por mosquitos 53.31

Deontológico, código

Véase C ódigo deontológico

Departamento de A gricultura de Estados

Unidos (USDA) 67.12

D epartamento de T rabajo de Estados U nidos cálculo de niveles de exposición al ruido 47.2

índice de lesiones en la industria manufacturera 84.26

normas de seguridad en la industria manufacturera 84.21

0 ficina de Estadísticas $L$ aborales clasificación de lesiones y enfermedades profesionales 32.13

Dependencia de un solo empleador en la industria pesquera 66.14

Dependientes de comercio minorista 99.15 lesiones de los 99.15

Depleción

hídrica 42.9

salina 42.9

Deporte

en el lugar de trabajo 15.36

Depósitos de productos de petróleo líquido 102.62

D epósitos de combustible de los buques mercantes 102.57 en estaciones de servicio medidas de precaución en $\quad 102.30$

Depresión

Véase Salud mental

en médicos 97.27

síntomas 5.10

y cáncer 34.70

y estrés $5.18,34.73$

y satisfacción en el trabajo 34.65

Depresión táctil

inducida por vibraciones 50.10

Depresión tropical

Véase $\mathrm{H}$ uracanes, ciclones y tormentas tropicales

Depresión ventilatoria hipóxica 37.3

Depresores del sistema nervioso central 33.32

Depuración de gases 55.23 métodos de $55.22 \mathrm{t}, 55.23 \mathrm{t}$

Depuración del aire 45.9 por absorción de gases 45.10 por adsorción de gases 45.10 por generación de iones negativos 45.10 por ionización 45.24 por ozonadores 45.10 por precipitación electrostática 45.9 sistemas de filtración de partículas 45.9

Derecho de huelga

y relaciones laborales 21.12 Véase también Libertad de asociación

Derecho internacional problemas de aplicación y observancia 23.31

sanciones y castigos 23.31

D erechos de los trabajadores a la salud y seguridad en el trabajo problemas de aplicación y observancia 23.31

derecho a apartarse de un peligro 23.57 derecho a la negociación colectiva 23.58 derecho a saber 23.34

comités de salud y seguridad en el trabajo 23.35

Véase también Comunicación de los riesgos

derecho a una exploración médica 23.57 en China 23.40

en el Pacto Internacional de $D$ erechos

Económicos, Sociales y Culturales 23.26 en la $\mathrm{C}$ arta Social Europea 23.28

en la Declaración U niversal de D erechos H umanos 23.25

libertad de asociación 23.58

pertenecientes a minorías étnicas 23.33

y convenios de la OIT 23.56

Véase también Indemnizaciones

D erechos humanos

a la protección de la salud en el lugar de trabajo 23.30
Declaración U niversal de D erechos

Humanos 19.16

derechos humanos fundamentales 19.10

legislación sobre 23.25

participación de los trabajadores 19.12

principios éticos 19.17

respeto a la intimidad 19.17

y salud y seguridad en el trabajo 23.24

Véase también Ética

Dermatitis

Véase Enfermedades profesionales de la piel

ácidos inorgánicos y 104.5

aminas aromáticas y 104.97

anhídrido acético y 104.14

catecol y 104.369

compuestos epoxídicos y 104.152

contacto con destilados del petróleo en industrias gráficas 85.9

contacto con disolventes en industrias gráficas 85.4

de contacto 70.9, 12.4

alergenos cutáneos $12.11 \mathrm{t}$

alérgica 12.11

autoeccematización 12.12

características $12.10 \mathrm{t}$

de las amas de casa 12.12

diagnóstico 12.12

factores predisponentes $12.12 \mathrm{t}$

irritantes $12.10,12.11 \mathrm{t}$

morfología 12.11

sustancias irritantes y sensibilizantes $12.13 \mathrm{t}$

tipos 70.9

de fotocontacto 12.13

de R hus (hiedra) 63.13

dermatosis profesionales 12.14

dinitroclorobencenos y 104.346

en carpintería 86.13

en el sector de la construcción 93.3

asociada a la inhalación de fibras 93.43 prevención 93.12

en conductores de ambulancia 103.5

en chóferes 103.14

en empleados de estaciones de servicio 102.35

en empleados de limpieza 100.5

en empleados del hogar 100.17

en fontaneros 103.21

en fotografía $85.12,85.15$

por líquidos reveladores 96.11

en higienistas 103.24

en jardineros 103.28

en la confección de alfombras 89.29

en la construcción de motores de aviación 90.10

en la industria alimentaria 67.6

en la industria de la seda

mal de los baldes 89.15

en pintores 103.44 
eritematoide

por compuestos de estaño 63.19

esquistosomática 64.38

éteres y 104.184

fenilhidracina y 104.122

nitrilos y 104.138

nitrobenceno y 104.347

por antimonio 63.4

por compuestos de cromo 63.16

por exposición al arsénico 63.6 - 63.7

prueba epicutánea 12.13

alergenos cutáneos 12.13

biopsia cutánea 12.13

prueba del parche 12.13

riesgo asociado a los procesos de confección 87.7

riesgo en la industria del automóvil 91.5

riesgo en los procesos de tinción 89.20

tetrilo y 104.347

tioles y 104.406

tratamiento local 12.14

y óxido de selenio 63.45

Dermatitis alérgica

atópica por microorganismos

en el aire interior 44.24

debida a hongos 44.25

en peluqueros y cosmetólogos 100.9

en trabajadores del platino 63.39

por contacto 33.42

por níquel 63.35

Dermatofitosis

en la producción avícola 70.29

en la industria cárnica 67.19

y radiación ultravioleta 53.30

D ermatophagoides pteronyssinus 44.23

Dermatosis

ácido pícrico y 104.347

en el sector de la construcción exposición al polvo de cemento 93.10, 93.52, 93.54

en la industria de la piel y el cuero 88.4

influencia del cromo 88.4, 88.9

en operadores de calderas 103.40

encolador y 103.16

exterminadores de plagas y 103.19

riesgo en la industria del calzado 88.8 tetraclorofenol y 104.369

Dermatosis profesionales

factores de riesgo 12.15

alteraciones cutáneas 12.16

clasificación y efectos $12.15 \mathrm{t}$

infecciones bacterianas, víricas y

fúngicas 12.15

prevención en el lugar de trabajo 12.16

agentes limpiadores 12.17

cremas protectoras 12.17

equipos de protección 12.17

jabones industriales 12.17

medidas colectivas $12.16 \mathrm{t}$
Dermis

Véase Piel

Derrames

de materiales peligrosos 41.18

Derrien, método de dinitrofenol y 104.347

Desalinización refino de petróleo 78.7

Desarrollo anomalías del 9.2 Véase T eratogénesis

D esarrollo personal y ergonomía 29.6

Desarrollo sostenible $54.2,54.6,54.14,54.34$

Descanso

y fatiga 29.44

Véase también R ecuperación

Descarga disruptiva 40.9

D escargas eléctricas

Véase Accidentes eléctricos y electrización

D escargas electrostáticas protección contra las 40.11

Descascarillado 64.32

Descompresión

cámaras de burbuja 36.6

captación y liberación de gases 36.10

en el personal de las cámaras

hiperbáricas 36.4

enfermedad por $36.3,36.12$

habituación o aclimatación $\quad 36.3,37.2$

instrucciones $36.7 \mathrm{t}$

tablas Blackpool 36.4

tablas DCIEM 36.4

tablas de descompresión para cajones 36.4

tablas de Faesecke 36.4

tablas O SH A 36.4

trasiego 36.6

trastornos por 36.10

barotrauma 36.10

burbujas intravasculares 36.11

burbujas tisulares 36.11

embolia cerebral 36.12

fármacos 36.13

primeros auxilios 36.13

reanimación 36.13

recompresión 36.13

reincorporación al trabajo 36.14

síndrome de descompresión 36.12

síntomas 36.12

traslado 36.13

y buceo 36.4

y perforación de túneles 36.4

y trabajo en cajones de aire

comprimido 36.4

Desconexión eléctrica 65.6

Descongelación 42.39

Descortezadoras $68.7,64.32,72.6$
D esechos

de pescado y marisco 66.20

gestión de 70.18

D esempleo

causas 34.36

definición 34.35

desempleo estructural 24.13

desempleo friccional 24.13

problemas derivados 34.36

soluciones a sus efectos sociales negativos 34.36

tasa de 34.35

trabajadores "desalentados" 34.35

y evolución del mundo del trabajo 24.18

Desfiguración

indemnización por 25.16

Desherbadoras 64.29

Deshidratación

agotamiento por calor 42.6

colapso circulatorio 42.6

golpe de calor 42.6

variación del peso corporal 42.7

voluntaria 42.9

Véase también R ehidratación

D eshidratadores y secadores y peligro de incendio 41.17

Deshollinadores descripción del cáncer profesional 28.2 y cáncer de piel 2.2, 21.15

D eslumbramiento V éase lluminación

Desmochado 68.7, 68.9

Desorción 30.22

Despidos

Véase R ecolocación

Despigmentación

Véase L eucodermia

Desplumadoras 67.21

D esramaje peligros del 68.9

Destilación

en procesos químicos 65.11

Véase Industria química

Destilería 65.11

Destornilladores 29.76

Destreza manual

efectos del frío sobre la 42.35, 42.59

en función de las temperaturas tisulares locales 42.36

protección de las manos 42.44

y empleo de guantes 42.35

D etectores

aerosoles por luz dispersa 30.24

de aerosoles fibrosos 30.24

de conductividad térmica 44.21

de contaminación radiactiva 48.24 
en vigilancia radiológica

medioambiental 48.39

de contaminación radiactiva $48.25 t$

de humo para el hogar 41.8

de ionización de llama 44.21

pasivos o por difusión 30.22

Detectores de presencia

alfombrillas de contacto 58.26

para sistemas de robots múltiples 58.26

barras y cortinas de luz 58.26

campos de aplicación de los 58.25

de radar 58.28

de ultrasonidos 58.28

electromecánicos

en máquinas 58.17

en grandes vehículos $58.25,58.28$

informeISO TR $12155 \quad 58.29$

norma DIN 7503158.29

escáneres de láser como 58.28

fotoeléctricos

en máquinas 58.17

pasivos por infrarrojos 58.26

ventajas e inconvenientes 58.27

por impulsos luminosos 58.28

por radiofrecuencia

en máquinas 58.17

y sensores de movimiento 58.26

D etergentes

dermatitis 12.12

y lesiones oculares 33.32

y vertidos fosforados 55.47

Detritus

como fuente de alergenos 44.23

contaminación del aire interior por 44.23

fuentes de 44.23

Dexametasona $37.9,37.14$

Diabetes

insípida renal $8.3,8.5$

inducida por litio 8.5

síntomas 8.5

mellitus

y frío 42.41

Diagrama de I shikawa

Véase G estión de la calidad total

Diagrama psicrométrico 45.20

Diálogo social

pactos nacionales 21.5

Véase también R elaciones laborales

Diamantes

diseño de sistemas de fabricación 29.103

posibilidades de mejora del puesto de

trabajo 29.105

proceso de tallado 29.104

unidad de pulido de Gilad y M esser 29.106

Diarrea

diarrea del viajero 15.78

Véase $V$ iajes y protección de la salud prospecto informativo

dela OMS $15.79 f$

mortalidad infantil por 53.7

por contaminación alimentaria 53.7

D iátesis hemorrágica

por plaguicidas organoclorados 62.10

Diatomeas

Véase tierra de diatomeas

Diazometano

inclasificable como carcinógeno por la IARC 104.122

Dibenzo-p-dioxinas 72.20

policloradas 71.6

Dibromuro de etileno $\quad 102.49$

como carcinógeno del grupo $2 \mathrm{~A}$ por la IARC $\quad 104.255$

Dibujantes

exposición a materiales nocivos 96.8

problemas de salud entre 96.8

Diclofluanid 62.16

Diclona 62.16

Dicloro(2-clorovinil-)arsina (lewisita) 63.8

Diclorometano

riesgos 104.251

Dicloruro de etileno

como carcinógeno del grupo 2B por la

IARC 104.252

Diclorvos

cancerígeno del grupo 2B por la

IARC 62.16

Dieldrín $27.24,62.10$

Dieta

baja en grasas 15.41

intolerancia a la lactosa 15.41

para el embarazo y la lactancia 15.41

para trabajadores diabéticos 15.41

Difenacoum 27.24

Difenilmetano diisocianato (M DI) 102.13

Digestión continua 72.7

Digestivo

Véase A parato digestivo

Digestor $72.2,72.7$

Diisocianato de tolueno (T DI) y edema pulmonar 33.32 y mantenimiento de aeronaves 102.13

Dimercaprol (BAL) e intoxicación por arsina 63.8

Dimercaptopropanosulfonato sódico (D M PS 0 unitiol) 63.8

Dimetilformamida (DM F) como carcinógeno del grupo 2B por la IARC 104.74

efectos hepatotóxicos 104.74

exposición en los procesos de confección 87.4 hepatitis laboral 87.7

$\mathrm{N}, \mathrm{N}$-dimetilformamida 27.13

y cáncer de testículos en la

industria de la piel y el cuero $\quad 88.9$

cáncer testicular 87.7

Dimetilselenuro 27.13

Dimetilsulfato

como carcinógeno del grupo 2A por la

IARC la 104.407

Dinamarca

Ley de 23 de diciembre de 1975 sobre el medio ambiente de trabajo 23.7

Acción de Investigadores y

Trabajadores 23.32

inspección de trabajo en 23.13

relaciones laborales en 21.26

Dinamita 41.14

Dinitrobenceno

metahemoglobinemia 104.347

Dinitrofenol

hipertemia 104.347

intoxicación por 1.8

Dinobuton 62.16

Dinocap 62.16

Dinoseb 62.14

Dióxido de azufre

bagazosis 72.16

contaminación del aire por 44.9

detección de 44.21

exposición al 72.16

gaseoso 72.8

intoxicación 104.420

población mundial expuesta al 53.2

por combustión de combustibles

fósiles

mortalidad y morbilidad respiratorias 53.13

Dióxido de carbono

contaminante del aire interior 45.8

detección de 44.21

en la industria cárnica 67.19

en la industria de la cerveza 70.13

exposición a

en la ganadería 65.15

para extintores de incendios 41.6

para la extinción de incendios 41.24

y presión barométrica 36.3

Dióxido de cloro

exposición a altos niveles de 72.16

Dióxido de nitrógeno

concentraciones de

en el interior 44.10

detección de 44.21

Dioxinas cloradas 28.9

Diplopia

ojo, agudeza visual 11.11

Véase también V isión 
Diquat 27.25

Dirección

directivos "abrasivos" 34.39

estilo de 34.39

y liderazgo 34.39

Directivas de la U nión Europea

Directiva 67/ 548

requisitos de etiquetado de productos químicos 61.11

y clasificación de productos químicos 61.9

Directiva 76/207/ CEE sobre igualdad de trato 24.7

Directiva 76/ 768/ CEE (cosméticos) 33.51

Directiva 88/379/ CEE sobre preparados químicos 61.9

Directiva 89/ 106/ CE sobre elección de materiales en centros sanitarios 97.68

Directiva 89/391/ CEE sobre vacunación a trabajadores 97.46

Directiva 89/392/ CEE sobre máquinas diseño de sistemas de control 58.44 para centros de mecanizado 58.56 para fresadoras 58.55 para máquinas herramienta C NC 58.54 $-58.55$ para rectificadoras 58.58 para tornos 58.54

Directiva 89/686/ CEE 31.10, 31.21

Directiva $90 / 219 /$ CEE relativa a la utilización confinada de microorganismos modificados 23.40

Directiva 90/270/ CEE sobre trabajo con pantallas de visualización de datos $52.14,52.35$

Directiva 90/ 679/ CEE sobre protección de los trabajadores contra los riesgos relacionados con la exposición a agentes biológicos durante el trabajo 23.47

Directiva 92/ 29/ CEE relativa a las disposiciones mínimas de seguridad y de salud para promover una mejor asistencia médica a bordo de los buques 23.40

Directiva 92/ 57/ CEE relativa a las disposiciones mínimas de seguridad y de salud que deben aplicarse en las obras de construcción temporales o móviles 23.40

Directiva 92/ 58/ CEE relativa a las disposiciones mínimas en materia de señalización de seguridad y de la salud en el trabajo 23.40

Directiva 92/85/ CEE relativa a la aplicación de medidas para promover la mejora de la salud y la seguridad en el trabajo de la trabajadora embarazada, que haya dado a luz 0 en período de lactancia $23.39,24.8$
Directiva 92/ 91/ CEE relativa a las disposiciones mínimas destinadas a mejorar la protección en materia de seguridad y de salud de los trabajadores de las industrias extractivas por sondeos 23.39

Directiva 92/ 104/ CEE relativa a las disposiciones mínimas destinadas a mejorar la protección en materia de seguridad y de salud de los trabajadores de las industrias extractivas a cielo abierto o subterráneas 23.39

Directiva 93/ 88/ CEE por la que se modifica la Directiva 90/679/ CEE sobre la protección de los trabajadores contra los riesgos relacionados con la exposición a agentes biológicos durante el trabajo 23.39

Directiva 93/ 103/ CEE relativa a las disposiciones mínimas de seguridad y salud en el trabajo a bordo de los buques de pesca 23.39

Directiva marco 89/391/ CEE sobre la introducción de medidas de mejora de la salud y la seguridad en el trabajo 23.39

Directiva M arco de 1980 sobre los riesgos derivados del uso de agentes químicos, físicos y biológicos en el trabajo 23.39

Directiva M arco no 89/391/ CEE 16.3

Directiva relativa a los riesgos de accidentes graves en determinadas actividades industriales 39.14

Directiva Seveso

y comunicación de situaciones de riesgo 54.25

Directiva sobre mejora de la seguridad y de la salud de los trabajadores en el lugar de trabajo 16.4

Directivas relativas a los requisitos mínimos de salud y seguridad en el lugar de trabajo 16.4

Véase también U nión Europea

Directivos

enfermedades cardiovasculares 99.5

estrés técnico en 99.5

riesgos relacionados con los viajes 99.6

violencia y agresiones sobre 99.5

Directrices sobre salud y seguridad 94.11

Discapacidad 17.2

accesibilidad 17.15

acomodación del lugar de trabajo $\mathbf{1 7 . 1 5}$

eliminación de las barreras 17.15

actitudes sociales 17.13

caracterización negativa 17.3

causas de la 17.8

Clasificación Internacional de D eficiencias, Discapacidades y M inusvalías 17.5 criterios de clasificación 17.2 debate social 17.2

definición de discapacidad 17.4

definiciones extraídas de la práctica

legislativa 17.6

definiciones internacionales de

discapacidad 17.5

definiciones utilizadas en distintos países 17.6

O rganización Internacional del Trabajo 17.5

O rganización M undial de la Salud 17.5 derecho a la libre elección de profesión 17.14

derechos y obligaciones de la empresa 17.36 - 17.39 códigos de conducta 17.40 empresa como cliente 17.39 derechos y obligaciones del trabajador $17.40-17.49$ acción sindical 17.42 rehabilitación $17.46 f$ dimensión del entorno 17.2 discriminación indirecta 17.15 discriminación positiva 17.4 estudio de caso

Véase Francia

exclusión social 17.13

gestión de la discapacidad 17.25

acomodación razonable de los lugares de trabajo 17.27

actuación precoz 17.26

en el lugar de trabajo 17.25

equipo interno 17.28

ergonomía en el trabajo $\quad 17.27$

evaluadores médicos

independientes 17.28

objetivos realistas 17.25

participación de trabajadores y empresas 17.26

principios y procedimientos 17.28

problemas psicosociales 17.27

igualdad de oportunidades 17.7

integración profesional y social 17.7 medidas de rehabilitación profesional 17.7 organizaciones de discapacitados 17.16 política social y discapacidad $\mathbf{1 7 . 1 6}$

Convenio relativo a la discriminación en materia de empleo y ocupación 17.16

Convenio sobre la orientación profesional y la formación profesional en el desarrollo de los recursos humanos 17.16

Convenio sobre la readaptación profesional y el empleo de personas inválidas 17.16

leyes de cupos 17.20

objetivo de la indemnización 17.16

objetivo de la protección social 17.16 
Programa mundial de acción de las Naciones U nidas sobre personas discapacitadas 17.16

R ecomendación sobre la discriminación en materia de empleo y ocupación 17.16

R ecomendación sobre la orientación profesional y la formación profesional en el desarrollo de los recursos humanos 17.16

R ecomendación sobre la readaptación profesional y el empleo de personas inválidas 17.16

reglas uniformes de las $\mathrm{N}$ aciones $\mathrm{U}$ nidas sobre la igualdad de oportunidades para las personas con discapacidades 17.16

programas de integración laboral 17.38 reconocimiento jurídico 17.4

registro estadístico 17.4

servicios de apoyo a la rehabilitación $\quad 17.21$ asistencia técnica 17.22

cursos de orientación 17.22

rehabilitación médica 17.21

servicios de apoyo al empleo 17.21 empleo asistido 17.23 métodos de colocación 17.23 oportunidades de integración 17.24 política general de empleo 17.22 significado y repercusiones 17.2

Véase también $\mathrm{N}$ ormas laborales en materia de discapacidad

Discapacidades

Véase T rabajadores con discapacidades

clasificación internacional de limitaciones funcionales 29.83

costes "sociales" 29.100

definición de la OIT 29.83

derechos y obligaciones del trabajador salud y seguridad $17.44 f$

expectativa de vida sin discapacidades 29.97

limitación de la capacidad funcional física 29.101

sistema de energía 29.102

sistema locomotor 29.101

sistema neurológico 29.101

necesidad de tratamiento 29.103

Discapacitados

legislación sobre integración profesional de los $17.18 f$

Discos intervertebrales 6.7

anatomía 6.7

componentes principales 6.9

deformación del disco 6.8

enfermedades 6.10

disco roto o prolapsado 6.10

escoliosis 6.10

espondilolistesis 6.10 estenosis espinal 6.11

factores de riesgo 6.11

estructura del disco $6.7 f$

función del disco 6.8

metabolismo 6.10

respuesta a las cargas mecánicas. 6.9

Discriminación

por razón de sexo 24.7

Véase también Convención internacional

sobre la eliminación de todas las

formas de discriminación contra la mujer

y contragolpe 24.4

y discapacidad 17.12

convenios colectivos 17.42

formas de discriminación 17.14

Discriminación laboral

Véase también Prevención de la

discriminación

Discriminación positiva

y discapacidad 17.4

Diseño

de controles de seguridad 58.68

Véase también Sistemas de control de seguridad

de interfaces 52.32

desarrollo de prototipos 52.35

métodos de evaluación 52.36

normas de los fabricantes de

software 52.32

y análisis de necesidades 52.34

y características del trabajo 52.33

y características del usuario 52.33

de puestos de trabajo con PVD 52.4

factores psicosociales $52.28-52.31$

principios generales $52.4-52.6$

Diseño creativo 29.88

Diseño de productos y sistemas

color 29.93

consideración del envejecimiento 29.99

consideraciones culturales 29.93

compatibilidad entre el control y la representación visual 29.93

diferencias culturales 29.94

diseño de equipos de protección 29.93

diseño de interfaces 29.93

diseño del lugar de trabajo 29.93

costes, beneficios y utilidad del

diseño 29.99

diseño centrado en el usuario 29.95

diseño específico 29.102

diseño para todos los usuarios 29.99

el caso de Chernóbil 29.112

para la fabricación de diamantes 29.103

utilidad del producto y modelo mental del usuario 29.93

Diseño de sistemas para discapacitados análisis de coste-beneficio 29.100 análisis de tareas 29.89

diseño ergonómico de sistemas

(DES) 29.88, 29.103

documento de requisitos del producto

(PR D) y discapacidad 29.89

evaluación 29.90

investigación del usuario 29.89

modelo de utilidad de la tecnología de

rehabilitación 29.90

pruebas de los prototipos 29.90

Véase también Discapacidades

Diseño del lugar de trabajo

aspectos culturales 29.93

en ambientes fríos 42.45

lista de comprobación 29.19

Véase también Puesto de trabajo

Dismenorrea 15.56

Disolventes

con cloro

emanaciones peligrosas de los 96.35

riesgos para la piel 67.11

de pinturas

trastornos del sistema nervioso central por 96.9

de punto de ignición bajo 102.32

y riesgo de incendio 102.32

efectos en la industria del calzado 88.8

sobre el sistema nervioso central 88.8

efectos tóxicos de los 98.7

en artes gráficas

riesgos relacionados con 96.24

en la industria de la piel y el cuero 88.7

en la industria textil 89.3

en maquillaje de efectos

especiales 96.30

y lesiones por abrasión 96.32

en productos decapantes

toxicidad de los 96.21

evaluación de la exposición a 33.45

exposición en la industria naval 92.14 ,

92.16

orgánicos

lesiones hepáticas por 96.8

para la limpieza de equipos de radio 96.39

riesgo asociado en industrias gráficas 85.4 , $85.7,85.10$

riesgo de incendio en la tinción 89.19

riesgos asociados en la industria del

automóvil 91.6, 91.8

riesgos asociados en los procesos de confección 87.7

riesgos asociados en los procesos de estampado 89.20

emisiones a la atmósfera 89.20

fangos 89.20

incendio 89.20

riesgos en la construcción de motores de aviación 90.10 
técnicas de control en industrias

gráficas 85.13

uso en la construcción

riesgos asociados 93.30, 93.43

utilización en la industria aeroespacial

daños al medio ambiente 90.3

utilizados en la industria farmacéutica 79.5

y medio ambiente en la industria de la carpintería 86.7

y medio ambiente en la industria de la piel y el cuero 88.11

y riesgo de intoxicación y explosión en la fabricación de fibras sintéticas 89.17

Disolventes orgánicos

control biológico

indicadores de exposición 27.14

índice biológico de exposición 27.14

materiales biológicos 27.14

métodos analíticos 27.14

momento del muestreo 27.14

valor biológico de tolerancia 27.15

exposición combinada a varios 33.21

generalidades 27.13

toxicocinética 27.13

absorción 27.13

exposición 27.13

Dispepsia

dispepsia gástrica nerviosa 4.3

no ulcerosa

y estrés 34.69

Dispersión

en la eliminación de residuos 101.25

Displasia de la glándula tiroides y radiación 39.43

Disposiciones

en materia de salud pública 94.14

en materia de seguridad

en la industria forestal 68.31

Disposiciones legislativas en materia de salud pública 94.14

Dispositivos de aviso

en la zona posterior al vehículo 58.29

informeISO TR $12155 \quad 58.29$

norma DIN 7503158.29

en zonas de alta radiación 48.31

Dispositivos de conmutación de seguridad

de aislamiento 58.29

dispositivo de desconexión de seguridad 58.30

equipos de control para subsistemas 58.30 requisitos de los 58.30

función de seguridad de los 58.32

y circuitos de control de seguridad 58.32

interruptor maestro 58.30

interruptores de emergencia 58.31

interruptores de funciones

paneles de control de los 58.31

interruptores de supervisión 58.31
Dispositivos de seguridad para máquinas $58.16,58.19 t$

Dispositivos de visualización lista de comprobación 29.24

Distonía neurocirculatoria y radiación 39.43

Distracción por frío 42.35

Distribución del trabajo estructura 29.11

labilidad estructural 29.12

naturaleza de los intercambios 29.11

Distritos escolares 94.15

Disulfuro de carbono $27.13,27.23$ arteriosclerosis y 104.419

Disyuntores de corriente de defecto 40.13 magnéticos 40.14 magnetotérmicos 40.14 térmicos 40.14

Ditiocarbamatos $62.12,68.27$

Diuresis por frío $42.36,42.41,42.44$

Diversidad 70.5

Diversificación de proyectos en el sector de la construcción y aspectos de seguridad 93.14 y relaciones cliente-contratista 93.14 y relaciones contratista-contratista 93.15 y relaciones intersindicales 93.16

Docencia 94.2

Dolor crónico 26.15

Dolor lumbar clasificación de los pacientes 6.14 espondilólisis y espondilolistesis 6.14 factores de riesgo en el trabajo 6.13 factores de riesgo individuales 6.13 incidencia 6.12

prevención ergonómica 6.13

reducción de riesgos en el lugar de trabajo $6.13 \mathrm{t}$ síndrome del piramidal 6.15 tasas de prevalencia en la población finlandesa $6.12 \mathrm{t}$

y cambio de trabajo 26.10 y la talla de diamantes 29.104 y postura de trabajo 29.39

Dolor y padecimientos indemnización por 25.16

Domesticación $70.7,70.30$

Domoico ácido 66.20

Dosímetros $47.7,48.27$ de radiación ultravioleta 49.10 en emergencias radiológicas 48.40 tipos principales de 48.27

Dosis absorbida 33.45 absorbida o retenida 33.4

de exposición 33.4

de referencia 33.63

definición 33.2, 33.4

diana 33.4

efectiva 33.45

efectiva media 33.22

estimación de la 30.28

fija 33.79

interna 27.2

relación dosis-efecto 27.4

relación dosis-respuesta 27.4

letal 33.4

máxima 28.10

máxima tolerada 33.79

media 28.10, 33.22

media ponderada en el tiempo 28.10

teórica 33.4

Ley de $\mathrm{H}$ aber $\quad 33.4$

tisular 33.4

tolerable media 33.22

Véase también Exposición

Véase también Límites de exposición profesional

Dow

índice de riesgos

Véase también Industria química

Drepanocitosis 1.8

D rogadicción

Véase D rogas

Drogas

abuso y costes para la sociedad $\quad 15.83$

dependencia 15.83

abuso de sustancias entre las mujeres 15.87

sustancias que producen dependencia $15.83 \mathrm{t}$

dilemas éticos 19.25

Véase Ética

drogas psicoactivas 15.82

en el sector de la construcción 93.11

Drogodependencia

Véase D rogas

Droz

variabilidad biológica y control

biológico 30.29

Dupuytren, contractura de Véase M uñeca

E

Eagan

adaptación al frío 42.51

Eccema

Véase D ermatitis

Véase Eczema

Echinococcus granulosus 4.6 
Ecogenética 33.22

Economías de alcance 24.18

Ectasia capilar

en cantantes 96.29

Ectima contagiosa 70.11

Eczema

boratosy 104.130

del cemento 93.52

edema epidérmico intercelular 12.13

en empleados de limpieza $\quad 100.5$

en la industria de la piel y el cuero 88.9

riesgo asociado a la fabricación de

cemento 93.52

cromo 93.52

xileno y 104.284

Edad

gestacional

Véase G estación

y susceptibilidad a sustancias tóxicas 33.19

Edema

Véase Pulmón

pulmonar

riesgo en los procesos de tinción 89.19

Edema cerebral

de las grandes alturas $37.9,37.14$

por tri y tetraalquilos de estaño 63.19

retardado

por descarga eléctrica $\quad 40.5$

Edema perineural

por vibraciones mano-brazo $\quad 50.10$

Edema por calor 42.8

Edema pulmonar

de las grandes alturas $37.9,37.14$

por arsina 63.8

por compuestos orgánicos de estaño 63.19

por humos de cloruro de zinc 63.52

por inhalación de compuestos de

cadmio 63.11

por mercurio 63.29

por metalcarbonilos 63.32

por selenio 63.45

Edificaciones

en el sector de la construcción

definición 93.19

procesos 93.19

Edificio enfermo, síndrome del 13.2

climatización profesional 13.5

contaminantes $13.5 f$

enfermedad relacionada con el edificio 13.3

estudios epidemiológicos 13.3

estudios de exposición 13.4

estudios de población 13.4

estudios transversales 13.4

factores 13.3

contaminantes $13.3,13.5$

limpieza y el mantenimiento 13.3 ventilación mecánica 13.3

factores de riesgo individuales 13.5

estrés laboral 13.5

hipersensibilidad química 13.2

patología 13.2

síntomas $13.3 \mathrm{f}$

nasales 13.4

oculares 13.4

y trastornos neurológicos 7.21

sistema nervioso central 13.4

Edificios

enfermedades relacionadas con los 44.3

planificación contra incendios 41.19

requisitos de seguridad 41.20

Educación

Véase también Educación ambiental, aprendizaje

Educación ambiental

formación sobre medio ambiente en

Australia 18.18

programas de formación en Estados

Unidos 18.15

beneficiarios 18.16

community colleges 18.16

relación con la salud y seguridad en el

trabajo 18.15

en Estados U nidos 18.19

en Zambia 18.19

Véase también Formación ambiental

Educación permanente 94.2

Educador 94.2

Edulcorantes 65.17

Efecto corona 40.8

E fecto crítico

con umbral 33.17

definición 33.2, 33.16

definición de la OMS 33.16

definición del IPCS 33.16

efectos subcríticos 33.16

generalidades 33.16

sin umbral 33.18

Efecto del trabajador sano 28.13

Efecto D oppler

sensores de movimiento basados en el 58.26

Efecto invernadero

gases de 53.27

Véase también C ambio climático

Efectos adversos de agentes tóxicos definición 27.2, 33.17

Efectos especiales

en la industria del cine

peligro de los 96.35

Efedrina 42.52

Eficacia

y ergonomía 29.5
Efluentes

con una elevada demanda biológica de oxígeno 67.14

Ejecutivos 34.9

Véase también Profesionales

Ejercicio físico

programas en el lugar de trabajo 15.32

criterios de admisión 15.35

definición de objetivos 15.35

para poblaciones especiales 15.34

programas deportivos 15.36

seguridad y supervisión $\quad 15.35$

servicios básicos 15.33

Electricidad

afinidad electrónica 40.6

chispas 40.9

conductores de tierra 40.13

contactos eléctricos directos 40.2

contactos eléctricos indirectos 40.2

corrientes parásitas 41.10

cortocircuito 41.10

descargas eléctricas atmosféricas 40.5

disyuntores 40.13

fisiopatología 40.2

fusibles 40.14

sustitución de 40.17

hipersensibilidad a la 49.2

Ley de Joule para corriente continua 40.2

materiales aislantes 40.6

materiales conductores 40.6

peligros eléctricos 40.12

producción de

Véase Energía eléctrica

puesta a tierra 40.13

resistencia de alto contacto 41.10

riesgos en la elaboración de cerveza 65.15

riesgos en la fabricación de

semiconductores 83.19

Sección Internacional de la AISS 23.66 seguridad eléctrica

en la industria manufacturera 83.19

sistemas de unión equipotencial 40.13

sobrecarga 41.10

sobrevoltajes

inducidos por rayos 41.19

trabajos con 40.2

Véase también Accidentes eléctricos

Véase también Alcances de rayos

Véase también Choque eléctrico

Véase también Electrización

Véase también Electrocución

Véase también Electrostática

Véase también Instalaciones eléctricas

Electricidad estática

campo eléctrico 40.9

cargas por inducción 40.8

C ode of Practice for $\mathrm{C}$ ontrol of $\mathrm{U}$ ndesirable Static Electricity 40.10 
conductores 40.11

descargas disruptivas 40.8

descargas electrostáticas 40.9 protección contra las 40.11 y radio del electrodo 40.9

efecto corona 40.8

efectos nocivos 40.8

ejemplos de la industria 40.10

por fricción 40.6

principios de prevención 40.10

protección contra la 40.11, 41.11

reducción de la generación

de cargas 40.10

sensibilidad de los hidrocarburos

líquidos 40.10

toma de tierra 40.10

Véase también Electrostática

Eléctricos

Véase A paratos eléctricos

aparatos y equipos 81.2

Electrización

contracciones musculares 40.3

definición 40.2

incidentes de alta tensión $\quad 40.4$

incidentes de baja tensión $\quad 40.4$

lesiones 40.4

pronóstico 40.4

por anguilas eléctricas y rayas 40.2

quemaduras electrotérmicas 40.3 - 40.4

umbrales de corriente 40.3

yatrogénica 40.5

Véase también Accidentes eléctricos

Electrización estática 40.6

Electrocución

definición 40.2

diagnóstico médico-legal 40.5

en el sector de la construcción 93.9 riesgo asociado al uso de

herramientas 93.38

encoladores y 103.15

estimación de las tasas de 40.2

exterminadores de plagas 103.19

fallo de un Tribunal suizo en un caso de 23.24

jardinerosy 103.27

mecánicos de automóviles y 103.32

riesgo de 67.18

soldadores y 103.50, 103.52

Electrodomésticos

materiales de fabricación 81.14

procesos de fabricación 81.14

materiales utilizados $81.14 \mathrm{t}$

orden de procesos y riesgos $81.14 \mathrm{f}$

riesgo de incendio 81.15

riesgos de accidente 81.15

pruebas de control de

calidad 81.15

riesgos para la salud 81.15
Electroencefalograma (EEG)

alteraciones del

por exposición a campos eléctricos 49.2

Electroforesis

en gel 33.51

Electrolitos

en el plasma sanguíneo $42.6 \mathrm{t}$

Electroluminiscencia 46.2

Electromagnéticos, campos exposición en los procesos de confección 87.4, 87.7

riesgos para el embarazo 87.7

Véase también R adiación no ionizante

Electromedicina aparatos de 40.3

Electromiografía 29.41

Electromiograma (EM G) 50.4

Electrónica

boranos en la 104.130

en investigación sobre seguridad

laboral 60.4

y medio ambiente $83.37,83.40$

Electronics Industry Association 83.2

Electroplastia sales de cianuro en 96.13

Electrostática

carga 40.8

de paso 41.10

de recepción 41.10

separadas 41.10

chispa 41.11

riesgo de incendio o de explosión 41.11 corriente de gasto 40.7

distancia de amortiguación 40.9

ecuaciones básicas $40.7 \mathrm{t}$

fricción

contacto aislante-aislante 40.6

contacto metal y aislante 40.6

contacto metal-metal 40.6

interfaz sólido-líquido 40.6

polaridad 40.6

punto de descarga 40.9

rigidez dieléctrica del ambiente 40.8

Véase también Electricidad estática

Elevadoras de horquilla $\quad 65.6,65.10,65.12$

Eliminación de residuos

exposición a compuestos orgánicos volátiles (COV) 101.24

mediante vertido con incineración

abierta 101.25

riesgos de la 101.25

por aislamiento 101.25

por dispersión 101.25

por oxidación 101.25

por reducción/ hidrogenación 101.27

prioridades en el control de los riesgos 101.27 procesos de 101.23

y fabricación de "compost" 101.26

y riesgos profesionales

en la manipulación 101.24

Embaladoras 70.12

Embalsamadores

tuberculosis en 100.15

Véase también Servicios funerarios

Embarazo

Véase G estación

barrera hematoplacentaria 33.13

consecuencias fisiológicas 9.16

cambios del estado de ánimo 9.16

gasto cardíaco 9.16

modificaciones anatómicas 9.16

volumen respiratorio 9.16

discapacidad derivada del 9.30

estudios epidemiológicos $9.6 \mathrm{t}$

exposición profesional

consecuencias para la

descendencia 9.11f

mecanismos de la toxicidad

reproductiva 33.33

parto pretérmino 9.16

condiciones de trabajo 9.17

condiciones legales en Francia 9.18

fatiga laboral 9.17

medidas preventivas 9.18

modificación de las condiciones de

trabajo 9.19t

riesgos de fatiga laboral $9.17 \mathrm{t}$

trabajo físico 9.18

protección legal 9.25

estabilidad del empleo 9.28

límites de la protección 9.25

permiso por maternidad 9.25

permisos de paternidad 9.29

preaviso a la empresa 9.26

prestaciones en metálico 9.26

prohibición de la discriminación por

razón de embarazo 9.27

protección de la salud 9.27

requisitos 9.26

recomendaciones en EEUU 9.29 - 9.33

actividades extralaborales 9.30

categorías 9.29

detalles sobre la actividad 9.29

programa de atención de la salud 9.29

tolerancia al calor 42.12

y despido 23.26

y distribución de las sustancias químicas por el cuerpo 33.46

y excreción de sustancias tóxicas 33.7

y exposición al frío 42.42

Embolia

por barotrauma 36.12

Embotellado

de bebidas refrescantes 65.4

envasado 65.4 
llenado 65.4

del vino 65.14

Embriogénesis

y muerte celular 33.33

Emergencias

actuación en caso de 41.27

evacuación 41.27

plan de emergencia 41.27

plan de respuesta ante 94.12

planificación de 39.19, 41.26

servicios médicos 39.49, 41.27

Emetrópico, ojo 11.12

Emisiones atmosféricas

en el sector de la electrónica

absorción 83.39

adsorción 83.40

Emisividad 41.3

Empacadoras

deheno 64.23

Empleados del hogar

enfermedades de la piel en 100.18

muertes por cirrosis hepática en 100.18

prevención de los abusos contra los 100.18

principales riesgos y precauciones de

los 100.17

tareas generales de los 100.17

Empleo

e informatización 24.22

efectos de la reestructuración del trabajo 24.21

y discapacidad 17.13

normas laborales 17.16

Empleo doméstico

Véase Empleados del hogar

Empleo estacional 65.17

Empleo precario

generalidades 24.10

y evolución del mundo del trabajo 24.18

y trabajo infantil 24.16

Véase también Esclavitud

Véase también Trabajadores a destajo

Véase también $T$ rabajadores con contrato atípico

Véase también T rabajadores del sector informal

Véase también T rabajadores migrantes

Véase también Trabajo a domicilio

Véase también Trabajo infantil

Empresarios

y programas reglados de formación profesional 94.10

Empresas

empresas públicas 21.7

multinacionales 20.16

y traslado de riesgos

industriales 20.16

organizaciones de empresarios 21.6 estructura 21.6

responsabilidad en materia de salud y

seguridad en el trabajo 23.20

sector privado y relaciones laborales

Véase también R elaciones laborales

Encefalitis

de San Luis (SLE) 53.31

transmitida por mosquitos 53.31

Encefalopatía

Véase N eurotoxicidad

por bismuto 63.10

por tri y tetraalquilos de estaño 63.19

tóxica crónica profesional 7.11

Encefalopatía espongiforme bovina 67.34 , 70.6

Encefalopolineuritis 62.11

Encephalitozoon cuniculi 10.102

Encolador 103.15

bursitis 103.16

dedos pegados 103.16

"esnifado de cola" 103.16

exposición al ruido 103.16

incendio y exploxión 103.16

intoxicación 103.16

quemaduras y daños oculares 103.15

riesgos laborales 103.15

Encuestas

de actividades de J enkins 34.50

de percepción

para programas de seguridad $\quad 59.4,59.8$

descriptivas transversales 28.21

Véase también Cuestionarios

Endobronquitis

por exposición al titanio 63.49

Endocitosis 33.10

Endocrino, sistema

Véase Sistema neuroendocrino

Endotoxinas

en el proceso de eliminación de residuos 101.24

y zoonosis 70.9

liberación por golpe de calor 42.6

Endrín 27.24, 62.10

Energía

mínima de ignición 40.9

problemas relacionados con la según la Comisión de Salud y M edio Ambiente de la OMS 53.22

sistema de energía de referencia

(SER) 53.23

tecnologías de generación de

clasificación por riesgos 53.23

comparaciones con respecto a los riesgos 53.24

Energía eléctrica

líneas de alta tensión 76.15

riesgos de las centrales 76.15 choque eléctrico 76.17

reducción de accidentes 76.16

riesgos para el medio ambiente 76.17

cambio climático 76.18

campos electromagnéticos 76.18

contaminantes atmosféricos 76.18

niveles de ozono 76.18

protección del emplazamiento 76.18

riesgos para la seguridad 76.15

formación necesaria 76.16

normas OSHA 76.16

subestación de transmisión 76.15

Energía hidroeléctrica 76.2

central hidroeléctrica 76.2

control de las exposiciones $76.3 \mathrm{t}$

efectos medioambientales 76.3

estructura organizativa 76.3

inundación de agua ácida 76.3

mantenimiento de los equipos

generadores 76.3

operaciones de la central 76.3

riesgos de la generación de energía $76.3 t$ turbogeneradores 76.2

Energía nuclear

ciclo de combustible nuclear 76.11

combustible utilizado 76.8

combustibles 76.11

materiales absorbentes de neutrones 76.8

normas de seguridad 76.12

personal de operación 76.12

productos de fisión 76.8

reactor CANDU 76.11

reactor PWR 76.11

reactores M agnox 76.11

reactores térmicos 76.8

avanzados refrigerados con gas 76.10

blindajes 76.9

de agua en ebullición 76.10

de agua pesada a presión 76.9

moderador 76.9

principales características $76.9 \mathrm{t}$

reactor de agua a presión 76.9

refrigerados con agua ligera y moderados con grafito 76.10

refrigerados con gas 76.10

refrigerante 76.9

reproductores de neutrones

rápidos 76.10

turbogenerador 76.9

seguridad

características inherentes 76.13

características pasivas 76.14

principios de seguridad de diseño 76.14

producción de calor 76.13

productos de fisión altamente

radiactivos 76.13

radiación ionizante 76.13

sistemas de seguridad activos 76.14

sistema refrigerante 76.8 
Véase también C entral nuclear

$V$ éase también accidentes nucleares

Energía solar

unidades manufactureras de 53.31 seguridad en el trabajo 53.31

Energías renovables construcción de las instalaciones 53.23

Enfermedad

abono del salario en caso de 25.24

definición de la OIT 29.83

Enfermedad coronaria 34.11

Enfermedad de "I tai-itai" y exposición al cadmio $\quad 53.3,63.11$

Enfermedad de Chagas 53.29

Enfermedad de $\mathrm{H}$ odgkin etiología 1.5

mononucleosis infecciosa 1.5

incidencia 1.5

sistema de clasificación de R ye 1.5

V éase también L infoma no $\mathrm{H}$ odgkin

Enfermedad de Lyme

asociada a la cacería 69.5

riesgo de contagio de la

en trabajadores de parques $y$

jardines 96.46

Enfermedad de 0 nsan y contaminación industrial $\quad 53.10$

Enfermedad de Parkinson

y CYP2D 633.27

Enfermedad de Shaver en los trabajadores del aluminio 63.3 y bauxita 62.3

Enfermedad de Wilson 63.15 detección de la 63.15

Enfermedad del legionario $10.7,44.4,99.2$

Enfermedad del movimiento en el espacio (EM E) 102.21

Enfermedad del pie negro $V$ éase $\mathrm{G}$ angrena periférica

Enfermedad falciforme 37.10

Enfermedad ulcerosa péptica y estrés 34.68

Enfermedades

asociadas con la caza 69.4 - 69.6

autoinmunitarias 33.39

bucodentales 4.5

medidas preventivas 4.5

cutáneas

entre agricultores 70.9

de la piel 66.17

de transmisión sexual (ETS)

en la industria del sexo 96.55

riesgo de contagio en conductores de camión 102.25

riesgo de contagio en marineros 102.50 enfermedad de $\mathrm{N}$ ew Castle 70.14

enfermedad de Weil 70.38

enfermedad del descargador de silos 70.12

hepáticas 4.5

infecciosas 67.19

infecciosas y parasitarias de origen animal 67.11

no malignas

en la industria del papel 72.15

por traumas acumulados 67.7

profesionales

entre los trabajadores forestales 68.6

pulmón de granjero 70.12

relacionadas con el trabajo

definición 26.2

respiratorias

de origen agrícola 70.8

transmitidas por los animales 68.28

víricas

y destrucción del hábitat 53.34

Enfermedades cardiovasculares

aislamiento social 34.17

alteraciones ateroscleróticas $\quad 3.3$

enfermedad cerebrovascular 3.3

cardiopatía coronaria 34.67

como enfermedad profesional 3.2

consumo de alcohol 3.8

coronariopatías 3.2

dinitrobenceno y 104.347

ejercicio físico 3.8

en el lugar de trabajo 3.2

enfermedad cerebrovascular 34.67

enfermedades inflamatorias 3.2

estudios sobre $34.17,34.68$

factores biológicos

Véase Enfermedades infecciosas

factores de riesgo 3.5

alcohol 3.8

consumo de cigarrillos 3.6

consumo de sal 3.7

estrés profesional 3.8

factores socioeconómicos 3.8

falta de ejercicio 3.7

sobrepeso 3.7

trabajo por turnos 3.9

factores de riesgo 34.15

factores físicos 3.11 - 3.15

actividad física 3.12

exposición al calor 0 al frío 3.13

radiación ionizante 3.15

ruido 3.11

vibraciones 3.14

factores psicosociales 34.17

factores químicos 3.16

mecanismos patogénicos 3.16

monóxido de carbono 3.17

nitratos orgánicos 3.17

relación con el plomo 3.17

fluoroacetatos y 104.14 hipertensión 3.3

y sobrepeso $3.7 f$

hipertensión 34.67

incapacidad laboral en Alemania $3.5 t$

incidencia 3.3

miocardiopatías 3.2

dilatada 3.3

hipertrófica 3.3

restrictiva 3.3

monóxido de carbono y 104.431

morbilidad 3.4

mortalidad 3.4

mortalidad por grupos de edad $3.2,3.4 \mathrm{t}$

nutrición 3.7

prevalencia 3.2

rehabilitación y prevención 3.9 - 3.10

riesgo cardiovascular

en fumadores $3.6 f$

por enfermedades infecciosas $3.20 \mathrm{t}$

por sectores industriales $3.16 \mathrm{t}$

sobrepeso 3.7

tasas de mortalidad 3.4

trastornos circulatorios funcionales de las extremidades 3.3

trastornos del ritmo cardíaco 3.2

varicosidades venosas de las piernas 3.3

y estrés profesional 34.67

y recompensa social 34.68

y tabaquismo 3.6

Enfermedades infecciosas

en la industria del reciclado 101.22

en tripulaciones aéreas 102.18

enfermedad de Lyme 15.70

entre los trabajadores sanitarios 97.42

prevención 97.44

tratamientos profilácticos 97.45

riesgo de contagio de

en conductores de camiones y

autobuses 102.25

en marineros 102.50

riesgos de transmisión de

en peluqueros y cosmetólogos 100.9

vacunación preventiva en Alemania 32.27

VIH/SIDA 15.70

Enfermedades profesionales

admisibilidad de los casos 26.8

"barreras artificiales" al pago de la

indemnización 26.9

caso índice 32.2

catálogos de 25.8

cobertura del régimen de prestaciones 25.7

criterios de identificación 26.2, 28.31

definición 26.2

definición en el sistema israelí $26.23,26.25$

definición en el sistema japonés 26.28

definición en el sistema sueco 26.30

distinción entre lesión y enfermedad 25.8

encuestas oficiales 32.3

enfoque multifactorial 26.14 
estadísticas en A lemania 32.26

definición y notificación 32.26

elaboración 32.26

fuentes de información 32.27

tendencias 32.27

exposición al riesgo 26.9

lista de enfermedades profesionales de la

OIT 26.2, 26.4t

no mortales

análisis del riesgo 32.20

países en desarrollo 26.5

períodos de latencia 32.32

plazo de presentación de la

reclamación 23.21

por emisión de gases 63.3

en la producción de aleaciones de aluminio 63.3

problemas metodológicos en la vigilancia de las 28.33

existencia de una base de datos 28.34

registros internacionales 32.3

relación causal con la actividad

laboral 26.9

relacionadas con el amianto $10.57-10.70$

responsabilidad civil y penal $23.16-23.23$

trabajadores agrarios 26.6

trabajadores del sector sanitario 26.6

trastornos en la reproducción 26.6

traumatismos repetidos 32.4

y estrés 26.11

y tabaco 26.6

Véase también Clasificación de lesiones y enfermedades profesionales

Véase también Control biológico

Véase también Epidemiología del trabajo

Véase también Indemnizaciones

Véase también L esiones profesionales

Véase también M ortalidad de origen profesional

Véase también 0 rganizaciones voluntarias

Véase también $R$ iesgos profesionales

Véase también Salud y seguridad en el trabajo

Véase también V igilancia y notificación de enfermedades profesionales

Enfermedades pulmonares

asociadas a la extinción de incendios 95.8

enfermedad pulmonar obstructiva

crónica 95.8

inhalación de humos 95.8

asociadas a los servicios de policía 95.12

cáncer del aparato respiratorio 95.12

crónicas 10.37

de los mineros del carbón 10.52

bronquitis crónica 10.56

cáncer de pulmón 10.57

enfermedad pulmonar obstructiva 10.55

enfisema 10.56

fibrosis masiva progresiva 10.53 neumoconiosis de los mineros del

carbón 10.53

neumoconiosis reumatoide 10.56

silicosis 10.56

por metales pesados $10.71-10.74$

relacionadas con el amianto 10.57

asbestosis 10.62

destino de las fibras inhaladas 10.61

efectos celulares de las fibras

inhaladas 10.62

exposición en edificios 10.71

niveles de exposición 10.70

perspectiva histórica 10.57

radiografía de tórax 10.70

relación dosis-respuesta 10.62

suministros de agua 10.71

tipos de fibras 10.57

Enfermeras

factores de estrés en 97.23

lesiones musculosqueléticas 97.6

lesiones producidas por las agujas 97.4

Planning of R equired N ursing

(C anadá) 29.8

síndrome de burnout en 97.23

técnicas de apoyo contra el 97.24

tareas 29.8

tasa de partos prematuros en 97.16

tasa de suicidios entre las 97.23

tensión cognitiva en 97.20

e información deficiente 97.21

e interrupciones del trabajo 97.20

y diversidad de las tareas 97.20

y falsas alarmas 97.21

trabajo por turnos

y alteraciones del sueño 97.26

y aumento de la fatiga 97.26

trastornos lumbares en $97.17,97.38$

causas 97.39

métodos ergonómicos de

prevención 97.40

sistemas de tratamiento 97.40

y estrés psicosocial 97.40

Véase también T rabajadores sanitarios

Enfermería, personal de

riesgos potenciales 94.3

Véase también T rabajadores sanitarios

Enfisema

crónico

y extracción de pizarra 62.6

pulmonar

por exposición al cadmio 63.11

riesgo en el sector de la construcción

en la fabricación de cemento 93.52

Enflurano 97.60

Enfriamiento

Véase Estrés por frío

Enlatado 67.4

Enhydrina schitosa 38.6
Ensayos

con células germinales 33.50

con dioctilftalato (D O P) para clasificación de filtros 45.9

de D raize sobre irritación ocular 33.54 de FEP (ZPP)

Véase Protoporfirina eritrocítica (FEP)

de incubación en líquido 33.50

de mutagenicidad con salmonella 33.50

de mutagenicidad en células de

mamíferos 33.50

de sustancias químicas según la ley japonesa 33.58

generalidades 33.52

medida de la actividad de la lactico deshidrogenasa 33.52

prueba M T T 33.52

sondas fluorescentes 33.53

predicción de la toxicidad in vivo 33.52

técnicas de toxicología genética 33.50

Ensayos in vitro

de citotoxicidad 33.52

ensayo rojo neutro 33.52

para estudios de hepatotoxicidad 33.54

sobre irritación ocular 33.54

sobre toxicidad en órganos diana 33.53

Enseñanza

académica 94.2

de los oficios 94.10

elemental 94.3

institucional 94.2

preescolar 94.3

primaria 94.10

y formación profesional 94.10

reglada 94.2

secundaria $94.3,94.10$

riesgos del profesorado 94.4

Enterramiento

de residuos radiactivos 48.33

Entorno de trabajo

control ambiental $\quad 42.14$

parámetros básicos 42.16

presión parcial del vapor de agua 42.16

temperatura del aire 42.16

temperatura radiante media 42.17

velocidad del aire 42.17

percepciones comunes del

$V$ éase Clima de seguridad

refrigeración local 42.14

trabajo en ambientes fríos 42.33

y cultura organizativa 34.42

y prevención del estrés 34.76

Véase también A nálisis del trabajo

Véase también T rabajo en ambientes calurosos

Entropía

de los sistemas de control 58.46

Envasado de alimentos 67.4 métodos 67.4 
Envejecimiento

V éase T rabajadores de edad avanzada

Environmental Protection Agency (EPA) de

Estados U nidos

calidad del aire y salud pública 99.7

definición de plaguicidas 62.7

humo de tabaco ambiental

como cancerígeno del grupo A 44.15

y prevención de la contaminación 54.34

Enzimas

$$
\begin{aligned}
& \alpha \text {-Amilasa } 30.28 \\
& \text { Citocromo P450 } 33.25 \\
& \text { CYP1A } 33.26 \\
& \text { CYP2D } 6 \quad 33.26 \\
& \text { CYP2C } 19 \quad 33.26 \\
& \text { CYP2E } 133.27 \\
& \text { CYP3A } 33.27
\end{aligned}
$$

cultivo celular de enzimas humanas 33.24

hepáticas 8.5

metabolizantes de fármacos $33.21,33.23$

aldehído deshidrogenasas 33.25

epoxihidrolasas 33.25

sulfotransferasas 33.25

y función celular 33.28

metabolizantes de xenobióticos 33.21, 33.23

funcionamiento ambivalente 33.24

polimorfismos humanos de las 33.24

polimorfismo del gen GSTM 133.27

polimorfismos de otras enzimas (no

P450) 33.27

proteolíticas 65.13

renales

metabolizadoras de fármacos $8.4 \mathrm{t}$

urinarias 8.8

Eosinopenia 62.11

Epiclorhidrina 72.16

como carcinógeno del grupo $2 \mathrm{~A}$ por la

IARC 104.152

TLV para 104.153

Epicondilitis 26.8, 87.6

en usuarios de PVD 52.24

riesgo en los procesos de confección 87.6

Véase también Codo

Epidemias

rubéola 15.72

tuberculosis 15.72

Epidemiología

aplicada a la investigación de accidentes $60.2,60.5$

confusión sobre la $32.33,33.66$

curva de dosis-respuesta 33.4

definición 28.2

efecto del trabajador sano 32.33

en la sanidad pública 56.29

epidemiología molecular 2.16

evaluación de la exposición influencia de los polimorfismos

genéticos 33.28

evaluación de la exposición

profesional 32.31

calidad de los datos 32.32

consideración de los sesgos 32.33

estrategia de medición 32.31

mediciones 32.31

requisitos epidemiológicos 32.32

tratamiento de exposiciones

combinadas 32.33

validez de la medición 32.32

humo de tabaco ambiental

riesgo relativo 32.20

sesgo 33.66

tipos de estudios sobre el cáncer en los humanos 33.66

Véase también M ortalidad de origen profesional

Véase también V igilancia y notificación de enfermedades profesionales

Epidemiología del trabajo

aplicación 28.2

aspectos éticos 28.5

comunicación de los resultados 28.32

confidencialidad 28.32, 28.36

participación de los trabajadores 28.32

transparencia 28.32

confusión sobre la $28.5,28.23,28.25$

cuestionarios 28.34

definición 28.2

diseño de los estudios

diseño clásico de casos y controles 28.19

diseño transversal 28.21

encuestas transversales 28.21

estudio de casos y controles "anidados"

en una cohorte 28.21

estudio de cohortes 28.17

información 28.24

selección 28.24

efecto del trabajador sano 28.13

el caso del amianto 28.40

error de medida aleatorio 28.25

errores sistemáticos 28.22

confusión

interacción 28.23

sesgo de información $28.23,28.38$

sesgo de memoria 28.23

sesgo de selección 28.22, 28.32

sesgo por conveniencia social 28.38

sesgo por sospecha de exposición 28.23

evaluación de la causalidad 28.31

directrices propuestas por Sir Bradford Hill 28.31

inducción eliminatoria 28.32

inducción enumerativa 28.32

evaluación de la exposición $\quad 28.3,28.7$

biomarcadores 28.9 concentración media ponderada en el

tiempo 28.7

concentración pico 28.7

dosis 28.7

dosis máxima 28.10

dosis media 28.10

dosis media ponderada en el

tiempo 28.10

exposición 28.7

exposición a lo largo de toda la vida profesional 28.10

exposición acumulada 28.7

fuentes de información 28.8

índice de exposición acumulada 28.10

limitaciones de los procedimientos

analíticos 28.9

matrices de empleo-exposición 28.8, 28.10

mejoras 28.7

registros de higiene industrial 28.9

tiempo total de exposición 28.11

uso del control biológico 28.9

marcadores biológicos

limitaciones metodológicas 28.4

principios éticos 28.4

uso 28.4

medidas de la aparición de

enfermedades 28.11

frecuencias 28.11

incidencia 28.11

mortalidad 28.11

prevalencia durante un período 28.11

prevalencia instantánea 28.11

tasa bruta 28.12

tasa de incidencia 28.11

tasa de mortalidad de los casos 28.11

tasa de muerte 28.11

tasa de supervivencia 28.11

tasas 28.11

tasas ajustadas por edades 28.12

tasas específicas por edades 28.12

medidas de la asociación 28.12

cociente de tasas 28.12

diferencias de riesgos 28.12

diferencias de tasas 28.12

estandarización 28.13

índice de probabilidades 28.12

riesgo relativo 28.18

tasa de mortalidad relativa

estandarizada 28.13

tasa relativa estandarizada 28.13

métodos estadísticos 28.5, 28.26

Véase también Estadística

mortalidad proporcional 28.16

índices de probabilidad de la mortalidad 28.16

tasa de mortalidad relativa proporcional 28.16

objetivo 28.2 
participación de los trabajadores 28.6

pruebas de significación estadística 28.12

intervalos de confianza 28.12

relación entre exposición y

respuesta 28.13

valores $p 28.12$

riesgo atribuible 28.16

porcentaje de riesgo atribuible en la población 28.16

porcentaje de riesgo atribuible en los expuestos 28.16

riesgo atribuible en la población 28.16

riesgo atribuible en los expuestos 28.16

validez de los estudios 28.5

definición de validez 28.22

validez externa 28.23

validez interna 28.22

y enseñanza 28.5

Véase también Control biológico

Epidemiología psiquiátrica 34.73

Epidemiología veterinaria 28.6

Epidermis

Véase Piel

Epidídimo 9.5

Epinefrina 42.4

Episodio centinela 32.9

Epistaxis 42.10

Epitaxia

condensación de vapores de sustancias químicas organometálicas 83.26

epitaxia con haz molecular 83.25

epitaxia en fase de vapor 83.25

epitaxia en fase líquida 83.25

limpieza del reactor 83.26

Epoxídicos, compuestos 104.152 medidas de seguridad 104.154

Epstein-Barr, virus de 1.5

Equidos 70.30

Equilibrio

aferencias 11.9

disfunción 11.10

cinetosis 11.10

vestibular 11.10

eferencias 11.10

principales elementos $11.9 f$

vértigo 11.10

causas centrales 11.10

en el lugar del trabajo 11.11

Equilibrio hídrico y electrolítico 42.7

Equilibrio redox 33.19

Equilibrio térmico del ser humano

centros supra y preópticos del hipotálamo

anterior 42.2

ecuación del 42.22

sudoración necesaria 42.19

Equimosis 42.10
Equipamiento

en la industria naval 92.11

a bordo 92.11

de bloques 92.11

de unidades 92.11

Equipos de protección 29.93

Véase Prendas de protección

Equipos de protección individual (EPI) 63.3 en condiciones experimentales 94.12 en el sector de la construcción 59.31 en la industria 59.31

índice de utilización 59.31

en la instalación de embotellado 65.6

en la producción de galio 63.20

en procesos de la industria alimentaria 67.10

trabajo forestal 68.33

calzado protector 68.33

casco protector 68.35

protección facial y ocular 68.35

protectores auditivos 68.35

ropa protectora 68.33

uso en el sector de la construcción 93.29

uso en la industria naval 92.14

en las operaciones de pintura 92.15

en relación con los ojos 92.15

en trabajos de aislamiento 92.15

utilización en el desmotado de algodón 89.9

utilización en la extinción de incendios 95.10

utilización en la hilatura de algodón 89.11

y exposición al cromo 63.17

y prácticas de submarinismo 63.3

Equipos de protección personal (EPP)

Véase Equipos de protección individual (EPI)

Equipos industriales

riesgos asociados a los

$V$ éase también $R$ iesgos de los equipos

Equipos informáticos

sobrevoltajes inducidos por rayos 41.19

Ergociclómetro 29.36

Ergofisiólogo

en el lugar de trabajo 15.33

Ergonomía

activa 29.13

aplicada a la investigación de accidentes 60.2

aspectos tecnológicos 34.26

capacidad de adaptación 29.34

correctiva 29.2

definición 29.2

del trabajo hospitalario 97.15

disciplinas afines 29.4

diseño del puesto de trabajo 29.66

diseño para grupos específicos 29.88

diseños para la mayoría de las personas 29.99 e industria automovilística 29.3

e industria de fabricación 29.3

en el lugar de trabajo 15.13

en la extinción de incendios 95.9

uso del equipo de protección

individual 95.9

en la fabricación de semiconductores 83.36

en las fuerzas armadas 95.17

en sistemas con PV D

norma ISO $924152.36-52.38$

entorno físico 34.26

evaluación ergonómica de los puestos de

trabajo 29.68

modelo del cubo 29.68

factores organizativos 34.26

falta de adecuación ergonómica y

Chernóbil 29.111

historia de la 29.3

intervalo de tolerancia 29.3, 29.34

lista de comprobación ergonómica 29.18

macroergonomía 29.94

microergonomía 29.93

objetivos 29.4

fiabilidad y calidad 29.5

productividad y eficacia 29.5

salud y seguridad 29.4

satisfacción en el trabajo y desarrollo personal 29.5

prospectiva 29.2

protectora 29.13

tareas 34.26

y discapacidad en el lugar de trabajo 17.27

y normalización 29.12

campos de la normalización ergonómica 29.15

comités de normalización 29.13

cooperación ISO CEN 29.14

elaboración de normas

ergonómicas 29.14

orígenes 29.12

perspectivas 29.12

tipos de normas ergonómicas 29.13

y organización 35.7

Véase también A nálisis del trabajo

Véase también Antropometría

Véase también Biomecánica

Véase también D iseño

Véase también Fatiga

Véase también H erramientas

Véase también Listas de comprobación

Véase también Postura de trabajo

Véase también Trabajo muscular

Véase también Tratamiento de la información

Ergonómicos, factores

en la confección 87.2 - 87.4, 87.6

en la industria aeroespacial 90.5

ergonomía participativa 90.5

líneas alares 90.6

materiales compuestos 90.6 
remachado 90.6

talleres de cableado 90.5

en la industria de la piel y el cuero 88.4

levantamiento de materiales $88.4,88.7$

en la industria del automóvil 91.5 - 91.6

en la industria naval 92.13

y riesgos en fotografía 85.12

Erionita

y riesgo de cáncer 62.3

Erisipela 67.19

Erisipeloide 70.29

Eritema

ácido acético y 104.13

boratosy 104.130

dosis eritémica mínima (DEM) 49.7

por exposición a luz ultravioleta 97.33

por radiación ultravioleta 49.7

Eritrocitos 1.2, 1.6

Erosión

del suelo 68.43

Erotomanía

Véase T rastornos delirantes

Error humano

e inadecuación del diseño en

Chernóbil 29.106

y ergonomía 29.114

y fatiga 29.47

y fiabilidad 29.5

Erupción por calor Véase M iliaria

Escala de clasificación de Bortner 34.50

Escala del tipo A de Framingham 34.50

Escala Likert 28.37

Escaldaderas 67.21

Escaleras mecánicas

condiciones generales de seguridad 93.48 mantenimiento e inspección 93.49 riesgos asociados 93.48

Escalofríos $42.5,42.52$

Escáneres de láser detección de presencia con 58.28

Escarda

métodos de 64.29

y labores de entretenimiento 64.29

Escarificación prueba de 65.8

Escherichia coli $67.16,67.27,102.50$

Esclavitud 24.13

Esclerosis

de los ganglios linfáticos

y trabajo con piedra pómez 62.5 múltiple

en encoladores 103.17

Escolarización

y trabajo infantil 24.14
Escoliosis 6.10

V éase D iscos intervertebrales

Escorpiones 68.28

Escorrentías 71.12

Escroto

Véase Cáncer de escroto

Escudos

en el trabajo de metales 58.24

Escuelas 94.2, 94.10

Escuelas universitarias

y medidas de precaución 94.13

y riesgos 94.11

Escultura

herramientas neumáticas y eléctricas en 96.9

y fenómeno de R aynaud 96.9

precauciones generales en 96.9

riesgos de los materiales

actividades de $96.10 \mathrm{t}$

en actividades de modelado 96.10

y cáncer

por inhalación de fibras de asbesto 96.9 y riesgo de silicosis 96.9

Esmaltado

técnicas de 96.22

vapores tóxicos en el proceso de 96.22

y radiación infrarroja 96.22

Esmaltes

en la fabricación de metales 82.43

Esófago, cáncer de Véase C áncer de esófago

Espaciado 64.13

Espacios cerrados trabajo en 67.30

Espacios confinados $58.77,65.12,65.16$ accidentes mortales 58.78

por condiciones atmosféricas peligrosas 58.78

definición 58.77

en estaciones de servicio control del acceso a 102.33

en las instalaciones de la industria de bebidas 65.16

en plantas de tratamiento de residuos riesgo de los 101.11

identificación de los 58.78

métodos de control de acceso a 58.82

valoración de riesgos 58.81

ejemplo de formulario $58.78 \mathrm{t}$

Espacios restringidos 67.19

Espalda

lesiones de espalda 84.29

del personal auxiliar y de ambulancias 95.21

trastornos en la fabricación de vidrio, cerámica y materiales afines 84.29 y manipulación de materiales en industrias gráficas 85.4

Espalda del tejedor 96.2

España

Tribunal Supremo 23.23

Esparcedoras de estiércol 70.20

Especialistas

de cine y televisión riesgos y precauciones de los 96.37

Especialización

lista de comprobación 29.18

Espectro electromagnético 49.4, 49.5

Espectrofotometría de masas 30.25

Espectrómetro para infrarrojos 30.24

Espectrorradiómetro 49.10, 49.16

Espectroscopia

con excitación por plasma (ICP-OES) y determinación de metales en la SPM 55.16

de absorción atómica 30.25 y determinación de metales en la SPM 55.16

por absorción UV 30.25

Espermatogénesis

y sustancias tóxicas 9.5 exposición profesional a 9.6

Espermatozoides 9.5

y lesión genética 9.6

Véase también Espermatogénesis

Espermicida nonoxinol-9 y prevención de las ETS 96.56

Espermiogénesis 9.5

Espinal, médula 7.7

Espondilitis

anquilopoyética

Véase Sistema musculoesquelético criterios diagnósticos 6.34

Espondilólisis 6.14

V éase D olor lumbar

Espondilolistesis 6.14

V éase D olor lumbar

Espongiosis 12.13

Esquí

y avalanchas 39.27

Esquilado 70.23

Esquiladores 70.24

Esquistosomiasis 4.6, 4.8, 53.2

V éase A parato digestivo

Esquizoafectivo Véase T rastorno esquizoafectivo

Esquizofrenia

Véase Psicosis

y estrés 34.73

Esquizofreniforme

V éase T rastorno esquizofreniforme 
Establecimientos docentes 94.2

Estabulaciones 70.5

Estaciones de medición de la contaminación atmosférica 55.19

Estaciones de servicio causas de incendio en las 102.33 y sistemas de protección 102.33 condiciones de seguridad 102.30 en el abastecimiento a vehículos 102.30

en el suministro en recipientes portátiles 102.30

programas de prevención de accidentes 102.34

riesgo de atracos en 102.35

riesgos para la salud de los empleados 102.35 y equipos de protección individual 102.36 y medidas preventivas 102.36 salud y seguridad $102.34 \mathrm{f}$ seguridad de los surtidores 102.29 seguridad eléctrica en 102.31 suministro de combustible a medidas de seguridad durante el 102.30 tratamiento y eliminación de los residuos de las 102.37

Estadiómetro 29.32

Estadística

constante 28.27

definición 28.26

distribución binomial 28.28

escalas de medición 28.27

estimadores 28.27

hipótesis alternativas direccionales (asimétricas) 28.29

hipótesis alternativas no direccionales (simétricas) 28.29

hipótesis nula 28.29

métodos avanzados 28.30 métodos bayesianos 28.31 modelos aditivos generalizados 28.30 modelos de regresión 28.30 modelos lineales generalizados 28.30 modelos para medidas categóricas repetidas 28.30

sistemas de muestreo de Gibbs 28.31 muestra 28.27

muestreo aleatorio 28.27 parámetros 28.27 - 28.28 potencia del estudio 28.30 ruido 28.28

señal 28.28

unidad estadística 28.26

valor medio esperado 28.28

valor $p 28.30$

variable 28.27

variable aleatoria 28.28 varianza 28.28

Véase también E pidemiología del trabajo

Estadísticas

de accidentes de trabajo 57.29

fines de la recogida de 57.29

principios de aplicación 57.31

de enfermedades profesionales en

Alemania 32.26

potencia estadística 32.32

sobre accidentes de trabajo en Alemania 32.22

Estado

papel en las relaciones laborales 21.4

Estados U nidos

accidentes por partes móviles de máquinas en 58.9

actividades sindicales sobre salud en 16.43

actividades de investigación en 16.45

actividades reglamentarias públicas en 16.44

asistencia técnica a los trabajadores en 16.44

convenios colectivos en 16.45

formación y educación en 16.45

investigación de las reclamaciones en 16.44

afiliación sindical en distribución por sectores $16.43 \mathrm{t}$

Agencia de sustancias tóxicas y registro de enfermedades (ATSDR) 95.23

Sistema de vigilancia de situaciones de emergencia debidas a sustancias peligrosas (H SEES) 95.23

American College of $\mathrm{O}$ ccupational and Environmental M edicine 16.40

American Federation of $L$ abour and Congress of Industrial Organizations 16.43

American Public Health Association 16.47

American Society of Addiction Medicine 15.83 y alcoholismo 15.83

A sbestos V ictims of America 23.36

Association of $O$ ccupational and Environmental Clinics 16.47

Center for Art $\mathrm{H}$ azards de N ueva York 23.33

Comités de Salud y Seguridad en el Trabajo 23.35

Consejo $\mathrm{N}$ acional de R elaciones Laborales 21.18

Convenios colectivos 21.18

Environmental Protection Agency (EPA) 54.34 y prevención de la contaminación 54.34 grupos de alto riesgo por lesiones según la N IO SH 56.30 homicidio en

como causa de muerte en el trabajo 56.29

industrias de fabricación más ruidosas 47.3

Injured Workers 23.36

jurisprudencia en materia de embarazo y despido 23.27

Ley de contratos públicos de

Walsh-H ealey 30.34

Ley de control de las sustancias tóxicas 33.56

Ley de Control de Sustancias T óxicas (T SCA) 90.11

Ley de indemnización por accidente de trabajo de 1982, Virginia 23.29

Ley de informática de alto rendimiento 24.20

Ley de limpieza de las aguas 90.13

Ley de limpieza del aire 90.13

Ley de reacción, indemnización y responsabilidad medioambiental 16.46

Ley de salud y seguridad en el trabajo (1970) 16.35, 19.10, 21.17 - 21.18, 30.34 y valores éticos 19.10

Ley de salud y seguridad en el trabajo 197023.18

Ley federal de salud y seguridad en la minería del carbón 16.35

Ley nacional de política ambiental 54.15

Ley sobre ciudadanos con discapacidad 15.66, 17.20, 17.41

Ley sobre la igualdad en el trabajo 24.8

$M$ ine Safety and $H$ ealth

Administration 16.36

cumplimiento de las disposiciones de la

Ley de minas 16.37

muerte por lesiones profesionales en 56.28 , $56.30 \mathrm{f}$

$\mathrm{N}$ ational Advisory Committee on $\mathrm{O}$ ccupational Safety and $\mathrm{H}$ ealth 21.20

$N$ ational Center for

Environmental $\mathrm{H}$ ealth Strategies 23.36

National C ouncil on A lcoholism and D rug Dependence 15.83

$\mathrm{N}$ ational Institute for Environmental $\mathrm{H}$ ealth Sciences 16.46

$\mathrm{N}$ ational Institute for $\mathrm{O}$ ccupational Safety and $H$ ealth $16.35,16.37,93.37$ investigaciones de campo 16.37 investigaciones de laboratorio 16.37 investigaciones sobre lesiones $y$ enfermedades 16.37

programas de formación 16.37

R egistry of T oxic Effects of $C$ hemical Substances 16.37

y límites de exposición a sustancias tóxicas en zanjas 93.37 
norma sobre comunicación de riesgos de la Administración de Salud y Seguridad en el Trabajo 23.34

normativas de información sobre seguridad 56.38

$\mathrm{O}$ ccupational Safety and $\mathrm{H}$ ealth Administration 16.35

inspección 16.36 programa de aplicación 16.35 programa voluntario de protección 16.36 programas gestionados por los estados 16.36

Programa Nacional de T oxicología (NTP) 33.64

programas de detección de drogas 15.84 programas de medicina del trabajo 16.38 programas de prevención de la contaminación 54.35

programas de reducción del uso de sustancias tóxicas (T U R) 55.53

programas de salud en el trabajo 16.38 detección de abuso de sustancias 16.40 registros médicos 16.40

seguro de indemnización a los trabajadores 16.41

servicios de salud en el trabajo 16.34 centros de asistencia inmediata 16.42 en la época moderna 16.35 exploraciones médicas de vigilancia 16.39 gestión de casos 16.42 historia de los 16.34 instalaciones de los 16.38 modelo de pago por servicio 16.41 programas hospitalarios 16.42 servicios académicos 16.45 - 16.47 sindicatos y trabajadores discapacitados 17.42

Véase también Instituto $\mathrm{N}$ acional para la Salud y la Seguridad en el T rabajo

Estafilococosis 70.29

Estampado

Véase T inción, riesgos asociados

riesgos asociados al uso de

formaldehído 89.20

riesgos por el uso de disolventes 89.20

Estannosis por óxido de estaño 63.19

Estanques de estabilización de aguas residuales industriales 55.34 en tratamiento de aguas residuales 101.19 para el ganado 70.20

Estaño

exposición profesional al

riesgos 63.18

y dermatitis eritematoide 63.19

y edema cerebral 63.19

y edema pulmonar 63.19 y encefalopatía 63.19

y estannosis 63.19

y medidas preventivas 63.19

y medidas sanitarias 63.19

minería del 63.18

y exposición al radón 63.18

operaciones de recuperación

controles técnicos $82.61 \mathrm{t}$

toxicidad por ingestión 63.19

Esteres 104.162, 104.172, 104.177

Esterilidad

por radiación 48.8

Esterilización

por microondas 67.4

por radiación ionizante 67.4

Estibadores

límites de peso 29.44

Estibina

y anemia hemolítica aguda 63.8

intoxicación por 63.4

síntomas 63.4

Estiércol

almacenamiento 70.19

gases 70.20

gestión del 70.18

líquido 70.19

peligros de la aplicación 70.20

producción de 70.18

Estigmas

Véase Piel, enfermedades de la

Estigmas profesionales

callosidades 12.19

manchas de pigmentos 12.20

Estireno $30.23,30.29,72.16$

como carcinógeno del grupo 2A por la

IARC $\quad 104.285$

Estomatitis 4.4

por mercurio 4.5

Estrategias de prevención de $\mathrm{H}$ addon $56.33 \mathrm{t}$

Estreptomicina 67.32

Estrés

acceso limitado a unos servicios sanitarios adecuados 66.15

ajustes fisiológicos 34.60

métodos de medición 34.61

análisis ergonómico del 29.47

asesoramiento del 34.77

auditoría del 34.75

cambios del ritmo biológico 34.6

catecolaminas y 5.18

clase social y 34.14

combinación de dos factores de 29.48

como enfermedad profesional 26.5

control del 34.27

control personal 34.20

controladores del tráfico aéreo 26.11

de Selye $34.11,34.16$ debido al calor en las operaciones de

hilatura 89.12

en conductores de ambulancia 103.5

en conductores de camiones 103.8

en cristaleros 103.10

en chóferes 103.14

en exterminadores de plagas 103.19

en fontaneros 103.22

en higienistas 103.24

en mecánicos de automóviles 103.34

en modelistas 103.38

en operadores de calderas 103.40

en personal del servicio de comidas 98.4

factores estresantes 98.4

en reparadores de aparatos eléctricos 103.49

en soldadores 103.53

del profesorado 94.4

diseño de un programa de gestión del estrés 15.80

causas y programas de ayuda $15.81 \mathrm{f}$

factores laborales 15.80

problemas interpersonales 15.80

problemas somáticos 15.80

e indemnización 25.8

e índice de siniestralidad 26.11

efectos sobre el comportamiento 34.62

absentismo 34.64

alcoholismo 34.63

consumo de cafeína 34.63

drogadicción 34.63

tabaquismo 34.62

trastornos del sueño 34.63

en actores 96.30

en catástrofes 39.20

en controladores de vuelo $\quad 102.10$

en el sector de la construcción 93.3

en el trabajo 3.8

incidencia de enfermedad

cardiovascular 3.9

en el sector del transporte y el almacenamiento 102.4

en el trabajo 34.2 - 34.4, 34.25

en enfermeras

y carga de trabajo 97.23

en inspectores 101.4

en inundaciones 39.24

en la confección 87.3

en la confección de alfombras 89.29

en la fabricación de

semiconductores $83.18,83.34$

en la industria de la lana

y trabajo por turnos 89.14

en la industria del automóvil 91.7

trabajo por turnos 91.8

en la industria forestal 68.25

en la producción de hierro y acero 73.15

en los servicios de seguridad y de emergencia 95.2 
en la extinción de incendios 95.7

en las fuerzas armadas 95.16

en los servicios de policía $95.11,95.13$

por calor 95.6, 95.10, 95.18, 95.21,

95.23

en médicos 97.24

en servicio de pasajeros de

aeropuertos 102.12

en trabajadores de la hostelería 98.9

en trabajadores de oficinas 99.7

factores que provocan el 99.7

en profesionales y directivos 99.5

en trabajadores sociales 97.10

enfoque cognitivo 34.10

enfoque de afrontamiento 34.10

entre usuarios de PVD

factores relacionados con el $\quad 52.27$

soluciones para reducir el 52.30

técnicas de equilibrio

compensatorio 52.31

y problemas dérmicos 52.27

ergonómico 67.21

factores bioquímicos 5.18

factores de 29.47

factores hereditarios 34.4

factores situacionales

conflictos de roles 34.5

estresores físicos 34.5

falta de apoyo social 34.5

falta de control sobre la situación

personal 34.5

insuficiente carga cualitativa 34.5

sobrecarga cuantitativa 34.5

fisiológico

en la extinción de incendios 95.10

función digestiva y 4.3

generalidades 29.46

gestión del 34.76

hiperactivación inducida por el estrés 5.7

hormonas del 34.20

incertidumbre laboral y desempleo 66.15

indicador de estrés ocupacional 34.76

inseguridad laboral 5.12

instrumentos de evaluación

psicológica 5.18

mental progresivo 34.2

modelo cognitivo 34.13

modelo de ajuste persona-entorno 34.3 , 34.18

modelo de control de exigencias de

K arasek 99.2

modelo de demandas-control $34.3,34.6$,

$34.9,34.11,34.67$

modelo de K agan y Levi 34.16

modelo del NIOSH 34.3

modelo psicológico cognitivo 34.10

moderadores del estrés 34.2

musculosquelético

en comercio minorista 99.2 negativo $34.7,34.58$

papeles de la mujer en el mundo

laboral 5.18

patrones de comportamiento

tipo A 34.49

tipo B 34.49

por exposición al ruido $47.5,47.8,47.13$,

47.19

por vibración 3.14

positivo 34.7

Postraumático

En accidentes de radiación 39.40

prevención del 34.75

primaria 34.75

secundaria 34.76

terciaria 34.76

prolongado 34.66

psicológico $34.2,34.26$

teoría del estrés psicológico de

Lazarus 34.34

redes sociales 34.17

relación con el sistema nervioso

autónomo 7.8

relación con la psicosis 5.10

relacionado con el trabajo 5.17

respuesta fisiológica 34.13

sistema dinámico del estrés

fisiológico 34.13

sistema familia-trabajo $5.18-5.19$

técnico 99.5

teoría del estrés basada en la persona 34.11

térmico en marineros 102.48

trabajo por turnos y 4.3

úlcera péptica 4.9

vital 34.66

y acoso sexual 34.32

y afrontamiento 34.54

y apoyo social $34.16,34.55$

y autoestima 34.52

y cáncer 34.70

y clima organizativo 34.42

y contaminación del aire interior 44.2

y cuidado de personas de edad avanzada 34.46

y cultura organizativa 34.42

y desempleo 24.13

y enfermedades cardiovasculares 3.8

y enfermedades cardiovasculares 34.67

y estilo de dirección 34.39

y exposición al ruido

estudios experimentales 3.11

y formalización 34.41

y género 34.57

y grandes organizaciones 34.40

y jornadas prolongadas 43.7

y locus de control 34.53

y medición del rendimiento 34.43

y minorías étnicas 34.59

y organización del trabajo 24.19 y organización matricial 34.41

y problemas gastrointestinales $34.61,34.68$

y programas de promoción de la salud 15.8

y reacciones inmunitarias 34.66

y resistencia $34.16,34.51$

y roles asignados 34.31

y sobrecarga de trabajo 59.3

y socialización organizativa 34.46

y supervisión electrónica 34.30

y teletrabajo 99.12

y trabajo a tiempo parcial 99.2

y trabajo eventual 34.44

y trastornos mentales 34.73

y trastornos musculosqueléticos 34.72

y violencia en el lugar de trabajo 34.33

y violencia en el trabajo 51.5

demanda psicológica 34.7

estresores 34.2, 34.5

estructura organizativa 34.40

exigencias del trabajo $34.2,34.8$

factores psicosociales 34.3 - 34.5

factores sociales 34.15

modelo de French, Rogers y

Cobb 34.18

relaciones sociales en el lugar de trabajo 34.9

Véase $\mathrm{C}$ arga de trabajo

Véase también Ergonomía

Véase también Fatiga

Véase también Liderazgo

Véase también R ecuperación

Véase también Salud mental

Véase también Trabajo

Véase tambiénT rastorno por estrés postraumático

Estrés por calor

Véase Indices de estrés por calor

aclimatación artificial de los

trabajadores 42.8

aumento de la frecuencia cardíaca 42.8

definición 42.18

en hospitales 97.35

en lavanderías y tintorerías 100.13

en personal de cocina 98.3

límite fisiológico de exposición al calor 42.25

prevención del 42.11

aumento de la tolerancia al calor 42.11

control climático 42.14

modificación de las prácticas de

trabajo 42.14

prendas protectoras $42.14,42.16$

reposición oral de agua y

electrolitos 42.13

ritmo de trabajo 42.14

simulaciones dinámicas de la transferencia de calor a través de la ropa y el estrés

térmico del portador 42.32

temperatura interna 42.8 
trabajadores expuestos 42.6

y ropa de protección 31.21

Véase también Aislamiento térmico de la ropa

Véase también Calor

Véase también R egulación térmica

Véase también T emperatura corporal

Véase también T rastornos producidos por el calor

Estrés por frío

asimetrías térmicas 42.35

consumo de alcohol 42.51

coste de la protección 42.33

definición 42.54

efectos agudos del enfriamiento 42.34

efectos sobre el rendimiento 42.35

en la industria láctea 67.27

evaluación del 42.55

indice de enfriamiento por el

viento 42.59

índice IREQ $\quad 42.35,42.55$

exposición intermitente al frío 42.58

fenómeno de pendulación 42.37

mecanismos naturales de respuesta 42.33

niveles de tasa metabólica $42.55 t$

prendas de abrigo 42.33

prevención del $42.43,42.50$ - 42.53

aclimatación $\quad 42.43,42.51$

acondicionamiento de los

trabajadores 42.44

adaptación al frío 42.51

administración de fármacos 42.52

conducta $42.43,42.52$

dieta y equilibrio hídrico $42.43,42.51$

diseño del lugar de trabajo 42.45

habituación 42.51

medios técnicos $42.44,42.52$

prácticas de trabajo $42.45,42.52$

protección de las manos 42.44

protección de los trabajadores $42.46 \mathrm{t}$

reacciones en función de la

duración $42.33 t$

tipos de 42.54

enfriamiento convectivo de la piel $\quad 42.59$

enfriamiento de las extremidades 42.58

enfriamiento de los ojos 42.62

enfriamiento de todo el cuerpo 42.55

enfriamiento del tracto

respiratorio 42.62

frío por contacto 42.59

trabajo en ambientes fríos $42.45 \mathrm{t}$

tratamiento 42.39

Véase también Frío

Véase también H ipotermia

Véase también T rabajo en ambientes fríos

Estresores

análisis ergonómico del trabajo 29.16

específicos de la industria 34.6

trabajo automatizado 34.6

trabajo en serie 34.6 trabajo por turnos 34.6

influencia del género 34.57

inseguridad en el empleo 34.34

psicosociales 34.5

reacción en función del género 34.58

supervisión electrónica 34.30

Estroncio 90 39.32, 39.43

Estructura burocrática 34.40

Estructura matricial 34.41

Estructuras de protección contra vuelcos (EPV) en maquinaría móvil directivas de la CEE relativas a 58.73

en operaciones de transporte 64.36

en tractores 58.72

normas de la OCDE sobre 58.73

normas de la OIT 58.73

y disminución de accidentes 58.72

Estudiantes 94.2

Estudios de arte y control de la ventilación general 94.12

Estudios de casos y controles anidados en una cohorte 28.21

grupos emparejados 28.20

series independientes 28.20

Estudios de cohortes 28.17

Estudios epidemiológicos estudio de población en EEUU 2.2

sobre trabajadores de semiconductores 83.36

y control biológico 27.6

Estudios transversales 28.21

Etanol

asociado al retraso de crecimiento fetal 9.15

como disolvente orgánico 27.15

riesgos 104.33

y susceptibilidad a los tóxicos 33.20

Eter bis-(clorometílico)

como carcinógeno del grupo 1 por la IARC 104.184

Eteres 104.184

efecto narcótico 104.184

punto de ignición 104.184

Eteres de etilenglicol

exposición a

pintores y 103.47

Eteres de glicol 30.27

como disolventes 104.201

Etica

aspectos éticos de la investigación 19.8

caso de estudio 19.8

complejidad de los 19.9

obligación moral de participación 19.9

prima por riesgo 19.9

protocolos formales de

investigación 19.8

axiomas morales 19.11 sistemas de leyes y contratos 19.12

ciencia y ética 19.7

conductas poco éticas 19.3

confidencialidad de la información 19.5

conflicto de intereses 19.7

dilemas éticos relacionados con drogas y

alcohol 19.25

derecho a la intimidad 19.25

disciplina y tratamiento 19.27

drogasilegales 19.28

en el lugar de trabajo 19.25

servicios de asesoramiento 19.27

en el lugar de trabajo $19.10,19.20$

asunción del riesgo 19.11

confidencialidad de la

información 19.23

conflicto de intereses 19.24

consumo de drogas 19.24

derechos individuales y colectivos 19.20

determinación de prestaciones 19.25

profesionales de la salud pública 19.20

promoción de la salud y

motivaciones 19.21

reducción de gastos 19.21

voluntariedad o coacción 19.22

escala de justicia social $\quad 19.10$

ética y moral 19.6

integridad científica 19.5

paradigmas éticos 19.16

relación entre médico y paciente 19.5

Véase también Código deontológico

Véase también Confidencialidad

Etil alcohol 70.40

Etilbenceno 30.23

Etilen tiourea 27.23

Etilén-diamino tetracético ácido 72.9

Etilenclorhidrina, formación de y óxido de etileno 104.154

Etilenglicol

dinitrato

dinamita y 104.339

medidas de seguridad 104.340

y muerte 104.339

intoxicación metabólica 33.33

Etileno 41.2

incendio y explosión 104.275

óxido de

cataratas y 104.154

como carcinógeno del grupo 1 por la

IARC 104.153

efectos neurológicos y

neuropsiquiátricos 104.154

sistema reproductor y 104.154

Etino 41.2

Etiquetado

de advertencia 56.39

de sustancias químicas 56.39 
normas de diseño 56.39

de contenedores de material radiactivo 48.31

de embalajes con material radiactivo 48.32

disposiciones del OIEA 48.32

de productos químicos $61.10,61.15$

Directiva (CE) del Consejo

67/548 61.11

directrices ISO/CEI 61.10

Recomendación de la CIT 61.11

en prevención de riesgos 59.31

normativa sobre 56.38

Eufrates 70.5

Euler, modelo de dispersión de 55.9

Europa del Este

empleo de las mujeres 24.6

European Space Agency

Sistema de R ecuperación de Información 22.11

Eurotium 44.23

Eutrofización

en lagos y pantanos 55.31

y contaminación del agua 53.20

Evaluación ambiental

Véase Evaluación de impacto ambiental

Evaluación de impacto ambiental (EIA) aspectos económicos de la 54.17 $\mathrm{y}$ beneficios 54.17

definición 54.16

del medio ambiente interior 54.17

y mejora del trabajo 54.18

elementos considerados en la 54.16

Evaluación de peligros

Véase Evaluación de riesgos

en la prevención de la

contaminación 55.57

y plan de calidad atmosférica 55.8

Evaluación de riesgos

basada en juicios subjetivos 59.30

automatismos 59.30

contextos emocionales en 59.36

criterios de riesgo 54.25

cuantificación del riesgo 54.24

de máquinas herramienta C NC 58.52

de robots industriales 58.60

definiciones del riesgo 59.28

el temor como factor en 59.30

en los puestos de trabajo con ordenadores 59.28

identificación de los peligros 54.24

objetivos de la 54.24

parámetros para la 54.24

técnicas de 54.25

métodos 33.63

métodos formales de análisis 59.29

sesgos individuales en la 59.34

tecnológicos 59.29 terminología de la A cademia $\mathrm{N}$ acional de

Ciencias de EE.UU. 33.63

Véase también A nálisis de riesgos

Véase también Comunicación de riesgos

Evaluación de riesgos para la salud

cálculo cuantitativo del riesgo 15.28

cuestionario 15.28

gestión del programa 15.29

información 15.28

a las empresas 15.30

a los participantes 15.30

lista de control $15.31 \mathrm{f}$

seguimiento y evaluación 15.30

validez y utilidad 15.30

Evaluación del ciclo vital

análisis de inventario 54.21

definición de 54.20

definición y alcance de los objetivos 54.20

evaluación de los impactos 54.21

interpretación de los resultados 54.23

objetivos de la $54.20 f$

y desarrollo de productos ambientalmente inocuos 54.20, 54.23, 54.36

Evaporación

definición 42.16

ecuación 42.16

Evolución de la industria 65.2

Ewing, sarcoma de 6.35

Excavación

riesgos asociados 93.35

$$
\text { Véase Zanjas }
$$

Excavadoras

riesgo de vuelco en 58.71

y uso de EPV 58.74

Exclusión social

y discapacidad 17.13

Excrementos del ganado contribución al calentamiento global 70.5

Exigencias del puesto de trabajo exigencias de tiempo 29.67

Véase también T rabajo, demandas

Exophiala jeanselmei 44.24

Experimentos con animales

diferencias de susceptibilidad 33.18

Directiva 76/768/ CEE 33.51

efectos neurotóxicos 33.62

ensayo de $D$ raize sobre irritación

ocular 33.54

ensayos de toxicidad genética 33.49

métodos alternativos 33.51

oposición 33.51

ratones transgénicos 33.50

regla de la triple $R \quad 33.51$

sobre enfermedades

autoinmunitarias 33.39

sobre identificación de

inmunotóxicos 33.43 sobre sensibilización cutánea 33.39

sobre toxicidad 33.31

Exploraciones médicas

obligatoriedad de las 23.57

Explosión

alta explosión 41.6

control de la situación 41.27

de polvo

probabilidad de 40.9

del polvo de cereales 65.11

equivalente TNT 41.7

explosión por presión 41.6

BLEVE (Boiling Liquid Expanding

V apour Explosion) 41.7

ignición de suspensiones de polvo 41.7,

41.15

límites de explosividad 41.7

onda de detonación 41.7

pulverización de agua a alta presión 41.7

riesgo en la fabricación de fibras

sintéticas 89.17

riesgo en la fabricación de semiconductores

III-V 83.23

venteos 0 alivios de explosión 41.7

y evacuación de éter explosivo y ácido

pícrico acumulado en los laboratorios escolares 94.16

Explosivos

fabricación de

nitrocompuestos alifáticos en 104.338

nitrocompuestos aromáticos en

la 104.346

industria de

ácido perclórico en 104.5

ácido sulfúrico en 104.5

fenoles en 104.368

utilización en el sector de la construcción

en tareas de demolición 93.32

y peligro de incendio 41.14

Explotaciones agrícolas

y radiactividad 39.43

Exposición a agentes químicos y

biológicos 31.27

aguda 33.5

control de la exposición y predicción de la dosis 30.28

crónica 33.5

definición 33.2

determinación con biomarcadores 33.47

encuesta nacional de exposiciones

profesionales 32.10

escalas de exposición 32.32

exposición dérmica 30.29

exposición pico 30.29

factores que influyen en la 30.20

frecuencia de la exposición 30.26

índices de exposición biológica 30.18,

33.48

mediciones 32.31 
influencia de los polimorfismos

genéticos 33.28

modelos farmacocinéticos 30.29

múltiple 33.16

efectos aditivos 33.18

efectos antagónicos 33.18

efectos combinados 33.16

efectos sinérgicos 33.18

interacción de diversas sustancias

químicas 33.21

nivel aceptable de exposición 30.26

nivel de exposición 32.3

notificación 32.10

pautas de 30.14

tratamiento de exposiciones

combinadas 32.33

vías de exposición 30.16

y carcinogénesis 33.79

y sistema inmunitario 33.39

Véase también D osis

Véase también Límites de exposición profesional

Véase también T oxicología

Exposición a alergenos potenciales 33.43

Exposición a sustancias químicas

en la fabricación de indicadores de cristal líquido 83.22

en la fabricación de obleas de GaAs 83.23

en la fabricación de semiconductores III-V 83.26

Exposición al ruido

de carácter no laboral 47.3

y pérdida auditiva 47.3

elaboración de normas 47.3

industrias de fabricación más ruidosas de

Estados U nidos 47.3

límites de exposición permisibles

(PEL) $47.17 t$

y metabolismo del magnesio 47.5

Expulsión, métodos de en máquinas 58.22

Exterminadores de plagas 103.18

intoxicación 103.19

pesticidas y 103.19

riesgos laborales 103.18

Extinción de especies

consecuencias para la ciencia

biomédica 53.33

consecuencias para la salud de la 53.33

y pérdida de nuevos medicamentos 53.34

Extinción de incendios

apagar la llama 41.5

aptitud física 95.10

con trifluoruro de boro 41.14

control del flujo de vapores

combustibles 41.5

cortar el suministro de aire 41.6

desde aeronaves 68.21 desde tierra 68.19

equipos de protección

personal $95.5,95.10$

protección respiratoria 95.10

ergonomía 95.9

espumas de proteínas 41.5

espumas sintéticas 41.5

extintores portátiles 41.23

formación 95.5

formación y organización 68.21

indemnización por accidentes de

trabajo $95.9 \mathrm{t}$

insuflar aire 41.6

organización del trabajo 95.5

polvos secos 41.6

prioridades tácticas $95.4 \uparrow$

riesgo de daño por agua 41.24

riesgos físicos 95.5

esfuerzo físico 95.9

riesgos generales 95.4 - 95.5

deflagración 95.4 - 95.5

retroceso de llama 95.4

riesgos para la salud 95.7

cáncer de cerebro y del sistema nervioso 95.8

cáncer de pulmón 95.7

cáncer del aparato genitourinario 95.8

cáncer linfático y hematopoyético 95.8

enfermedades cardíacas 95.8

enfermedades pulmonares 95.8

lesiones 95.8

morbilidad y mortalidad laboral 95.7

riesgos psicológicos

estrés 95.7

riesgos químicos

asociados a la combustión de plásticos poliméricos 95.6

exposición a sustancias químicas 95.6

exposición al humo 95.6

riesgos térmicos 95.6

estrés por calor 95.6

quemaduras 95.6

rociadores de agua 41.23

sistemas de dióxido de carbono 41.24

sistemas de espuma 41.24

sistemas de gas inerte $41.6,41.25$

sistemas de halones 41.6, 41.25

sistemas de hidrocarburos

halogenados 41.25

sistemas de pulverización de agua 41.6, 41.24

visión general 95.3

Extintores 41.23

Extracción

por cable 68.11

Extractivos 71.10

Extractores de quillas 67.24

Extrapolaciones a dosis bajas 33.79
Extrasistolia

por descarga eléctrica $\quad 40.5$

Eyaculación

y espermatogénesis 9.5

F

Fábrica cerrada 72.20

Fabricación de baterías 32.9

Fabricación de dispositivos

aleación 83.27

decapado trasero 83.27

depósito de nitruro 83.27

difusión 83.27

grabado húmedo 83.27

metalización 83.27

proceso fotolitográfico 83.27

prueba final 83.27

Fabricación de obleas

crecimiento del lingote monocristalino 83.24

difracción de rayos $X \quad 83.24$

lavado de obleas 83.25

perfilado de bordes 83.25

pulimentado y bruñido 83.25

recorte, rectificado y troceado del lingote 83.24

síntesis de lingotes policristalinos 83.23 carga y sellado de la ampolla 83.23 chorreado/ limpieza del

lingote 83.24

crecimiento en horno 83.23

rotura de la ampolla 83.24

Fabricación de pigmentos 32.9

Fabricación integrada por ordenador estrategia de seguridad ISO para 58.42 medidas de protección 58.42

fuente principal de peligros en $58.41 \mathrm{f}$ perturbaciones en 58.42

y seguridad de los trabajadores 58.42

Fábricas

de pasta de papel $72.6,72.11$

riesgos 72.12

Factory $\mathrm{M}$ utual Engineering

Corporation

fichas de previsión de pérdidas 41.18

Faenia rectivirgula 44.23

Falucheras 66.10

Faludi

contragolpe 24.4

Fanger

ecuación del bienestar de 42.34

FAO

Código modelo de prácticas de aprovechamiento forestal 68.33

Faringitis de K ussmaul 63.29 
Faringitis inespecífica por mercurio 63.29

Farmacéutica, industria Véase Industria farmacéutica

Farmacocinética $y$ toxicidad 33.30

Farmacogenética 33.22

Farmacología en modelos de salud pública para investigación de accidentes laborales 60.5

Fármacos principales clases $79.3 \mathrm{t}$ Véase también Industria farmacéutica Fatiga

fatiga clínica 29.45

fatiga crónica 29.45

generalidades $29.44,29.46$

inhibición y activación 29.45 interpretación neurofisiológica 29.45 medidas preventivas $29.46,29.56$ mental y física

en conductores de camión 103.6

modelos de fatiga 29.47

pronóstico 29.47

síndrome de fatiga crónica 13.2

sistema de energía 29.102

y sobrecarga muscular 29.38

Véase también Estrés

Véase también R ecuperación

Véase también Sueño, privación del

Fatiga mental

definición 29.55

grados de 29.56

prevención 29.56

cambios en la estructura de las

tareas 29.56

descanso y sueño 29.56

pausas breves en el trabajo 29.56

recuperación 29.55

Véase también C arga mental de trabajo

Federación Internacional de las

Sociedades de la Cruz R oja y la

M edialuna R oja 39.2

y catástrofes 39.2

Federación Rusa

Inspección Federal de Trabajo 16.51

legislación de trabajo 16.50

normas estatales 16.50

oficina de salud y seguridad 16.50

R eglamentaciones

intersectoriales 16.50

reglamentaciones sectoriales 16.50

legislación sanitaria 16.51

supervisión higiénica del Estado 16.51

Ley Básica de Protección de la Salud 16.52

Ley Básica de Protección de los

Trabajadores 16.50
Ley de Bienestar H igiénico y

Epidemiológico de la Población 16.51

Ley de Seguro Sanitario 16.52

normas de exposición a sustancias químicas 23.40

protección de la salud de los trabajadores 16.52

salud y seguridad en el trabajo 16.50

Servicio H igiénico y Epidemiológico

Federal 16.51

Centro de Información y A nálisis de la Federación Rusa 16.51

Centros de Supervisión H igiénica y Epidemiológica Estatal 16.51

Comité Federal de la Federación rusa para la Supervisión H igiénica y Epidemiológica 16.51

servicios de salud en el trabajo 16.52

Federal Bureau of Investigations (FBI)

estadísticas sobre SID A en los servicios de policía 95.13

Feldespato

y silicosis 62.3

Fenilhidracina

lesiones cutáneas 104.122

Fenilsalicilato 27.5

Fenobarbital 36.2

Fenol

en desinfectantes

como agente cancerígeno 98.7

riesgos 104.368

Fenómeno de R aynaud

$V$ éase $R$ aynaud, fenómeno de

Fermentación 67.3

Fermi

potencial de 40.6

Ferroaleaciones

precauciones con las 63.23

situaciones de exposición peligrosa a 63.22

Ferroboro 63.22

Ferrocarriles

en el sector de la construcción 93.24

Ferrocromo 63.22

Ferromanganeso 63.23

Ferropenia 1.6

Ferrovanadio 63.23

Fertilizantes principales fertilizantes 62.8

Fiabilidad y ergonomía 29.5

Fibra para la fabricación de pasta y de papel 72.5

Fibras artificiales

efectos sobre la salud 10.84

factores de toxicidad 10.84

fibras sintéticas $10.84 \mathrm{t}$
Fibras de vidrio

procesos de fabricación 84.7

fabricación de lana aislante 84.10

fibras cerámicas refractarias 84.10

filamentos de vidrio continuos 84.7

Fibras minerales exposición en la industria naval 92.13

Fibrasópticas 84.11

Fibras sintéticas

clases 89.16

operaciones especiales 89.17

corte de fibras 89.17

rizado 89.17

prevención de accidentes en la fabricación de 89.17

producción 89.16

riesgo de incendio y explosión 89.17

disolventes 89.17

riesgo de intoxicación 89.17

y elaboración de prendas protectoras 89.17

Fibrilación atrial por descarga eléctrica 40.5

Fibrilación ventricular

por electrocución 40.3

y enfermedades cardiovasculares 34.67

Véase también Accidentes eléctricos y electricidad

Fibrinolisis por monóxido de carbono 53.14

Fibrogénicas, reacciones

asociadas al polvo de nuevos materiales textiles en la industria aeroespacial 90.13

Fibromialgia $6.4,6.32,13.2$

Véase T rastornos musculares

Fibrosis

hepática no cirrótica 4.7

intersticial progresiva, no nodular 63.3 en la industria de abrasivos de aluminio 63.3

perisinusoidal no cirrótica 4.8 por vibraciones mano-brazo 50.10 pulmonar focal 63.4

por exposición al antimonio 63.4 pulmonar idiopática 10.33 pulmonar intersticial 10.43 y polvo de titanio 63.49

Fibrosis pulmonar

en trabajadores del grafito $\quad 62.4$ por radiación 48.8

Fichas técnicas de seguridad de los materiales (FT SM ) 65.12

utilización en la industria aeroespacial 90.11

Fichas toxicológicas 30.14

Fick, ley de 33.9 
Fiebre

amarilla 53.27

de ciervos volantes 69.5

de los conejos 69.5

de malta 65.14

de Pontiac 44.3

del colchonero 89.31

del dengue 70.39

del heno 44.22

del humidificador $44.3,44.25$

hemorrágica

hemorrágica argentina 53.34

hemorrágica de Asia central 70.24

hemorrágica de Crimea-C ongo 70.24

ratas de laboratorio y 103.30

textil 89.31

Fiebre Q

en el sector agrícola 70.14

en la industria cárnica 67.20

en la industria de la piel y el calzado 88.9

Fiedler

teoría de la contingencia (1967) 34.39

Fieltro, procesado

accidentes 89.18

ántrax 89.18

incendio 89.18

polvo 89.18

productosquímicos 89.18

ruido 89.18

Fiji

escuela de aprovechamiento forestal 68.39

Filtros

atenuadores de la radiación óptica 49.17

de aire particulado de alta eficacia 45.9

de alta eficacia 45.9

de percolación

en tratamiento de aguas

residuales 101.19

de soldadura autooscurecible 49.17

eficacia de los 45.9

norma ASH RAE 52-76 45.9

Filtros HEPA 83.20

Finlandia

Ley sobre el permiso especial de maternidad 24.9

Fire Protection Association (R eino U nido) diploma "Fire Prevention" 41.16

Fire Service (R eino U nido) 41.8

First Chicago Corporation

programa de bienestar 15.25

programa de salud para la mujer 15.25

programas de salud 15.24

base de datos O M NI 15.25

Fischer-T ropsch, reacción de 104.32

Fisión

productos de la 76.8

Véase Energía nuclear
Fitoalexinas 33.25

Fitt, ley de 29.87

Flanagan

técnica del incidente crítico 29.7

Flexibilidad del horario de trabajo y cultura 29.94

y prevención de la sobrecarga muscular 29.38

Flixborough ( $R$ eino U nido) explosión de 104.239

Flores cortadas 64.14

Floricultura

factores de riesgo para la salud 64.15 producción 64.14

Flotación

en tratamiento de residuos $\quad 101.18$

Flujo sanguíneo periférico $\quad 42.3$

Fluometurón 62.14

Flúor 41.13

Fluorcarbonos 83.31

Fluorescencia 46.2

Fluorhídrico

ácido 31.17, 39.33

Fluorita

riesgos de la 62.3

Fluorocarburos

cáncer de piel y 104.191

capa de ozono y 104.191

toxicidad hepática y 104.193

Fluoruro

humos de 63.3

Fluter

por descarga eléctrica $\quad 40.5$

Fobia

a los ordenadores 5.13

agorafobia 5.12

Folículo

Véase 0 vario

Fondo Sueco para el M edio Ambiente de Trabajo

modelo WEF de accidentes laborales 56.19

Food and D rug Administration (FDA) regulación productos cosméticos 100.6 y enfermedades transmitidas por alimentos 53.8

Fontanero 103.21

aguas residuales 103.21

riesgos laborales 103.21

"rodilla de fontanero" 103.23

Fordismo

Véase R ecursos humanos

Forest Engineering R esearch Institute of Canada 68.18

Forja

Véase M etales, forja y estampación en caliente 96.13

pérdida de audición 96.13

riesgo de quemaduras 96.13

Formación

aprendizaje de adultos 18.7

diseño de programas educativos 18.9

artística 94.2, 94.13

derivados de materiales y

procesos 94.13

medidas de precaución 94.13

riesgos 94.13

autodidacta 94.2

básica 94.2

cambio tecnológico 18.4

científica 94.2

comunitaria 94.2

continua 94.2

de los directivos 18.19

contenido de los programas $18.25 f$

desarrollo curricular 18.20

en función del tamaño de la empresa 18.25

estructura organizativa 18.22

intermedios y altos directivos 18.2

prevención de accidentes 18.23

principios de dirección 18.22

proyecto M inerva 18.21

vías de acceso 18.21

de los equipos de extinción de incendios 95.5

de personal 40.17

en materia de riesgos eléctricos 40.17

sobre los problemas específicos del frío 42.44

de trabajadores de edad avanzada 29.97

del personal auxiliar y de

ambulancias 95.22

e introducción de nueva tecnología 29.57

en el puesto de trabajo 18.4, 94.10

en el sector de la construcción

cualificación de especialistas 93.16

prevención de riesgos laborales 93.8

sobre salud y seguridad en el trabajo 93.17

en los servicios de vigilancia y seguridad uso de armas de fuego 95.15

en materia de medio ambiente V éase E ducación ambiental

en materia de riesgos

objetivos pedagógicos 18.3

especialización 18.2

evaluación de la formación 18.7

factores psicosociales 18.4

formación de los trabajadores

educación obrera 18.8

educación popular 18.9

teoría del aprendizaje adulto 18.8

lista de comprobación 29.30

métodos didácticos 18.6 
para la prevención en procesos

fotográficos 85.17

preescolar 94.13

prioridades y objetivos 18.6

problemas que puede resolver la

formación 18.6

profesionales de la salud

atención médica primaria 18.28

certificación 18.30

contenido curricular 18.27

educación continua 18.29

enfermería de empresa 18.27

equipos interdisciplinarios $18.25,18.28$

especialización técnica $18.28 f$

médicos y enfermeros $18.28 f$

programas de licenciatura 18.5

programas educativos 18.27

programas internacionales 18.26

programas profesionales 18.26

técnicos en seguridad 18.28

proyecto africano de la OIT -FIN NIDA

Véase OIT -FIN NIDA

Sección Internacional de la AISS para la

Educación y la formación 23.67

sobre protección respiratoria 31.24

sobre salud y seguridad 94.10

técnica 94.2

y equipos de protección individual 31.2, 31.21

Formación profesional

acceso 94.10

prácticas en entornos de trabajo

reales 94.10

programas 94.10

y riesgos 94.10

derivados de contacto con agentes

físicos 94.10

derivados de contacto con sustancias químicas 94.10

derivados de la falta de equipos de prevención 94.10

derivados de la falta de formación 94.10

derivados de la falta de

información 94.10

derivados de la utilización de

maquinaria 94.10

Formaldehído

como cancerígeno del grupo 1B por la

IARC 104.47

contaminante del aire interior $44.5,44.22$

métodos de detección 44.22

en la industria textil 89.3

en maderas

en materiales de construcción $44.3,44.28$

en tableros de aglomerado 96.20

como contaminante del aire interior 44.8

exposición a

en la industria maderera 71.11 en la fabricación de pasta de

papel 72.16

exposición en fotografía 85.11

exposición en la industria del

automóvil 91.4, 91.7

exposición en los procesos de confección 87.4,87.6

medidas de protección en la confección 87.4

riesgo asociado en carpintería 86.14

riesgo para el medio ambiente 87.7

riesgos asociados en el estampado 89.20

trastornos oculares, dérmicos y

respiratorios efectos

cancerígenos 89.20

riesgos asociados en la producción de géneros textiles no tejidos 89.23

riesgos asociados en los procesos de acabado (textil) 89.21

y cáncer 100.7, 100.16

y cáncer de pulmón y nasofaríngeo en la confección 87.7

y dermatitis 87.7

y riesgo de abortos 100.10

Formalización 34.40

Formas galénicas

fabricación farmacéutica 79.12

compresión directa 79.12

golpeo 79.12

granulación húmeda 79.12

riesgos para la salud y seguridad 79.12

Forraje 70.11

Fosfamina $67.28,67.30$

Fosfatos 104.382

fertilizantes y pesticidas 104.385

proliferación de algas y 104.385

Fosfina 83.26

intoxicación 104.383

Fosforescencia 46.2

Fosfórico

ácido 70.21

Fósforo 104.382

"fosfonecrosis" de mandíbula 104.383

Fosfuro de hidrógeno

e ignición espontánea 41.9

Fosgeno 41.15

intoxicación por

en encoladores 103.15

en fontaneros 103.21

en pintores 103.45

en soldadores $103.50,103.52$

Fotoconjuntivitis por radiación ultravioleta 49.8

Fotografía

aspectos ergonómicos 85.12

dermatitis 85.12

e higiene personal 85.17 exposición a formaldehído 85.11

fenoles en 104.368

operaciones de procesamiento $85.11 \mathrm{f}$

peligros propios del cuarto oscuro 85.15

prevención 85.12

estrategias de control de riesgos profesionales 85.17

revelado en blanco y negro 85.14

control de riesgos en el 96.11

e inhalación de gases y vapores 96.11

y dermatitis de contacto 96.11

revelado en color 85.14

tiourea en 104.406

ventilación 85.15

y diseño de las instalaciones 85.16

y enfermedades pulmonares 85.11

y equipos de protección 85.15

Fotoluminiscencia 46.2

Fotón

tipos de ionización 48.2

interacciones con la materia $\quad 48.2 f$

Fotoqueratitis

en soldadores 49.17

por radiación ultravioleta $49.8,49.17$, 53.30

Fotoquerato-conjuntivitis por radiación ultravioleta 53.30

Fotorretinitis

por "luz azul" 49.15

producida por RUV 49.9

Fotosensibilidad

y dermatitis 12.3

Fotosensibilización cutánea

por radiación ultravioleta 49.8

Fractura de M aisonneuve 96.53

Fracturas

Véase T raumatismos craneales

Framingham

estudio de ictus y coronariopatías 3.5

Framingham Type A Scale

Véase Escala del Tipo A de Framingham

Francia

Código de T rabajo 23.17, 23.24

D epartamento de Inspección M édica del

Trabajo 16.26

organización general 16.26

Institut $\mathrm{N}$ ational de $\mathrm{R}$ echerche et de

Sècurité pour la Prevention des Accidents

du T ravail et des $M$ aladies

Professionnels 22.7, 26.7

legislación sobre discapacidad 17.9

clasificación de las discapacidades 17.9

criterios para la declaración de la discapacidad 17.11

escala de defectos y

discapacidades 17.12

inválidos de guerra 17.10 
medidas políticas discriminatorias 17.9

O ffice des anciens combattants 17.10

pensiones por invalidez de guerra 17.11 régimen de derecho común 17.11

sistemas de apoyo a los

discapacitados 17.10

sistemas de clasificación 17.11

subsidios por discapacidad 17.10

legislación sobre discapacidad

desarrollo histórico 17.9

Ley sobre medicina del trabajo 16.25

Frankenhaeuser

respuesta fisiológica al estrés (1986) 34.11

Frecuencia cardíaca

como índice de estrés por calor 42.21

durante el trabajo 34.61

y manipulación manual de materiales 29.37

y trabajo muscular dinámico 29.35

French y Bell

O rganization Development (1990) 34.31

Fresadoras

directrices de seguridad

de la Directiva sobre máquinas

(89/392/EEC) 58.55

Fricción

chispas 41.11

Frío

adaptación general al frío 42.51

adaptación local de las extremidades 42.52

efectos de la exposición al

distracción 42.35

diuresis por frío 42.44

enfriamiento 42.34

hipotermia $42.37,42.40$

sobre el corazón y la circulación $\quad 42.37$

sobre el rendimiento

neuromuscular 42.36

sobre la capacidad física para el

trabajo 42.36

sobre la destreza manual $\quad 42.35$

sobre la temperatura cutánea 42.36

sobre los pulmones y las vías

aéreas 42.37

exposición al 67.8

exposición intermitente al 42.58

grupos más expuestos 42.43

lesiones por frío con congelación 42.38

cuadro clínico 42.39

factores que predisponen 42.39

fisiopatología 42.38

influencia del viento 42.38

tratamiento 42.39

lesiones por frío sin congelación $\quad 42.39$

cuadro clínico 42.39

fisiopatología 42.39

prevención de las 42.40

tratamiento 42.40 métodos farmacológicos para prevenir las

lesiones por frío 42.52

percepción del frío 42.34

pérdida de calor en agua fría 42.48

tiempos de supervivencia 42.49

repercusiones sobre la salud

acrocianosis 42.42

criopatías 42.42

enfermedades infecciosas 42.41

estrés psicológico 42.42

influencia del tabaco y el alcohol 42.42

problemas musculosqueléticos 42.42

trastornos cardiovasculares 42.41

trastornos metabólicos 42.41

urticaria por frío 42.42

respuesta fisiológica a la inmersión en agua fría 42.48

respuestas del ser humano al enfriamiento 42.38

y farmacología 42.42

Véase también Estrés por frío

Véase también H ipotermia

Véase también T rabajo en ambientes fríos

Ftalatos

riesgos 104.394

Fuego

química y física del 41.2

Fuentes selladas

de material radiactivo

ensayo de fugas de 48.29

inventario físico de 48.30

Fuerzas armadas

asistencia sanitaria 95.19

formación 95.19

exposición a radiaciones 95.16

exposición a sustancias tóxicas 95.16, 95.19

exposición de trabajadores civiles 95.16

fuerzas de tierra 95.18

riesgos comunes 95.18

minas, riesgo asociado a su

utilización 95.19

riesgo de contraer enfermedades infecciosas 95.16

riesgo de estrés 95.16

riesgos asociados a las aeronaves

militares 95.17

fuerzas de aceleración excesivas 95.17

helicópteros 95.17

intoxicación 95.17

utilización de armas de fuego 95.18

visión general 95.16

Fuller y Brouha

predicción de la frecuencia

cardíaca 42.21

Fumigadores 64.41

Función ovárica

Véase Sistema reproductor femenino
Función pulmonar

estudios sobre los efectos en la función pulmonar 10.13

Fundación Europea para la G estión de la Calidad (EFQ M)

liderazgo de la calidad total (LCT) 57.3

Fundación Europea para la M ejora de las Condiciones de $\mathrm{V}$ ida y de $T$ rabajo estudio sobre las condiciones de trabajo (1991/ 92) 34.5

Fundación Internacional para la Investigación sobre la Ergonomía Industrial y la Seguridad (IFIESR)

y diseño de información sobre seguridad 56.39

Fundentes basados en colofonia riesgos para la seguridad 83.30

Fundición

de acero 82.19

de hierro 82.14

metales de fundición 82.13

moldeo permanente 82.19

procesos 82.13

riesgos

de la exposición al polvo 82.20

de la exposición ocular 82.22

de la rotura de muelas 82.20

de la soldadura 82.21

de sustancias cancerígenas 82.21

ruido y vibración 82.21

vibración de la mano y el

brazo 82.22

riesgos para la salud 82.20

tipos 82.19

fundición de precisión 82.20

fundición inyectada 82.19

tipos de hornos $82.13 \mathrm{t}$

Fundición artística

vaciado a la cera perdida

etapas 96.12

riesgos y precauciones 96.12

Fundición de cobre/ bronce 32.9

Fundición primaria y secundaria 32.9

Fundidores 28.3

Funerarias

V éase Servicios funerarios

Fungicidas

para la conservación de la madera 71.12 toxicidad de los 62.15

Fusarium 62.15

G

Gafas

Véase también Protectores de ojos y cara

Galding 70.29 
Galio

exposición profesional al 63.20

medidas de protección individual $\quad 63.20$

recomendaciones del Instituto $\mathrm{N}$ acional

para la Salud y la Seguridad en el

Trabajo (NIOSH) de EE.UU 63.20

reconocimientos médicos 63.20

toxicidad del 63.20

Galio 67G a

como agente detector de tumores 63.19

Galvanoplastia

en joyería

e inhalación de humos de metales 96.22

sales de cianuro en 96.13

Gammagrafía 39.34

Gamow

Véase Bolsa de $\mathrm{G}$ amow

Ganadería

características regionales 70.4

contaminación del agua y del aire 70.5

evolución y estructura del sector 70.2

importación de animales y de productos

animales 70.6

importancia económica 70.3

lesiones específicamente derivadas de

la 70.8

problemas de salud 70.7

enfermedades respiratorias 70.8

riesgos laborales 70.5

lesiones 70.15

riesgos ergonómicos 70.15

zoonosis 70.16

trabajadores 70.3

Ganado

en confinamiento 70.12

Gangrena periférica 63.6

Garrapata

y enfermedad de Lyme 15.70

Gas

de hidrocarburos 75.6

punto de inflamabilidad 75.6

de petróleo licuado 75.4

de pirólisis 75.6

de procesado de petróleo

composición $75.6 \mathrm{t}$

de procesado del petróleo 75.6

de síntesis 75.6

detección de gases

Véase M inería

intoxicación por 65.15

natural comprimido 75.6

natural licuado 75.6

Gas arsina

dosis letal 63.7

intoxicación por 63.7

Gas cianhídrico

en galvanoplastia y electroplastia 96.13
Gas mostaza

Exposición a

y cáncer respiratorio 10.91

en las fuerzas armadas 95.16

Gas natural

como combustible 75.6

pozos de gas húmedo 75.11

preparación de los campos de producción 75.12

procesos de absorción 75.11

fraccionamiento 75.12

reciclado del gas 75.12

recuperación de azufre 75.12

recuperación, extracción y

separación 75.11

producción y procesado 75.4

transporte y almacenamiento $\quad 104.239$

Véase también Petróleo

Gas natural licuado (GNL)

almacenamiento y transporte de 102.51

buques mercantes para transporte

de 102.56

camiones y vagones cisterna para 102.58 depósitos de almacenamiento de 102.68 riesgo de incendio de 102.70

riesgo de los recipientes de 102.69

Gases

combustibles 41.13

precauciones con los 61.17

de escape 68.26

de las motosierras 68.26

de soldeo 67.27

depósitos de almacenamiento 41.13

efectos neurotóxicos 7.11

efluentes 83.26

exposición en la fabricación de semiconductores III-V 83.26

exposición en la industria naval 92.13

inertes 41.13

y peligro de asfixia 61.17

medios de muestreo 30.21

no combustibles 41.13

refrigerantes $65.13,65.15$

riesgos de exposición 30.14

sulfurosos 72.19

tóxicos 66.17

tóxicos y asfixiantes 70.13

confinamiento del ganado 70.13

G ases anestésicos

concentración en

quirófanos de 97.61

exposición profesional a 97.62

medidas preventivas básicas 97.62

toxicidad de los 97.61

límites de exposición 97.61

y malformaciones congénitas 97.61

$G$ ases combustibles

precauciones con los 61.17
Gases comprimidos

clasificación $61.14 t$

marcado y rotulación de los recipientes $61.15,61.18$

normasISO sobre 61.18

medidas de seguridad 61.14

en operaciones de llenado $61.14,61.17$

precauciones del usuario de 61.18

precauciones en el transporte de 61.14 ,

61.18

riesgos principales en el uso de los 61.15

Véase también Botellas de gas

Gases inorgánicos

procedimientos de medición automáticos 55.14, 55.15t

manuales $55.13,55.14 \mathrm{t}$

Gasoductos

y transporte de gas natural 75.4

y transporte de materiales

peligrosos 39.29

Gasolina 68.26

Gasolina enfriada 42.39

Gasolineras

violencia en las 102.35

Véase también Estaciones de servicio

Gasto cardíaco

sistema de reflejos de los

barorreceptores 42.6

Gasto energético 29.35

Gastroduodenitis

y trabajo nocturno $\quad 43.4$

Gastrointestinales, trastornos Véase T rastornos gastrointestinales

Gatos

condiciones de seguridad en el uso de 58.8

Gel de sílice

uso para muestreo ambiental 30.21

Género

efectos principales 34.58

relación con otras variables 34.58

y estrés 34.57

y minorías profesionales 34.58

Géneros textiles no tejidos

acabado 89.23

colchado al aire 89.23

exposición a fibras en suspensión 89.23

colchado en mojado 89.23

colchado en seco 89.22

emanaciones tóxicas 89.23

emisiones de formaldehído 89.23

inhalación de fibras en suspensión 89.22

riesgos mecánicos 89.22

utilización de equipos de protección ocular 89.23

cosido-tricotado 89.23

ligamento hilado y fusión-soplado 89.22

medidas de protección 89.22 
riesgo de incendio 89.22

materias primas 89.21

consideraciones

medioambientales 89.21

fibras celulósicas 89.21

fibras sintéticas 89.22

procesos 89.22

visión general 89.21

G enes "antimuerte"

bcl-2 33.35

ced-9 33.35

Genes "promuerte"

apopaína o prICE 33.35

gen ced-3 33.35

p53 33.35

proteína de la membrana Fas 33.35

Genética

breves nociones 33.24

polimorfismo 33.24

determinantes genéticos de la respuesta

tóxica

citocromo P450 33.25

efecto sinérgico de dos o más

polimorfismos 33.27

enzimas metabolizantes 33.23

influencia en la evaluación de la

exposición 33.28

polimorfismo del gen GSTM 133.27

polimorfismos de otras enzimas (no

P450) 33.27

polimorfismos farmacogenéticos 33.24

principios generales $33.21-33.28$

susceptibilidad genética 33.47

uniones 33.28

Véase también M etabolismo

entrecruzamientos 33.38

información hereditaria 33.37

mutación 33.37

Véase también T oxicología genética

Genoma H umano

proyecto de la

industria de la biotecnología 77.37

G enotoxicidad 27.15, 33.67

Véase T oxicidad genética

Véase también Sustancias químicas genotóxicas

Genu valgum

en la confección de alfombras 89.29

Germanio

fabricación y uso del 63.21

medidas de seguridad 63.21

medidas sanitarias 63.21

toxicidad del 63.20

efecto fibrogénico 63.21

efectos nefrotóxicos 63.21

efectos neurotóxicos 63.21

fuentes de riesgo 63.20

intoxicación aguda 63.21
Gestación

anomalía congénita 9.14

contaminación por mercurio 9.14

sustancias tóxicas 9.14

teratógenos 9.14

edad gestacional 9.14

bajo peso al nacimiento $9.14,9.16$

consumo de tabaco 9.15

crecimiento fetal 9.15

estudios de exposiciones

ambientales 9.15

factores de riesgo 9.15t

exposición a sustancias tóxicas durante la 9.11

fase de desarrollo 9.11

embriogénesis 9.12

período fetal 9.12

pérdida fetal 9.12

Gestión ambiental

en la empresa 54.32

actividades evaluables 54.32

beneficios de la 54.32

limpieza de los lugares

contaminados 54.33

objetivos ambientales factibles 54.32

y relaciones laborales 54.33

programas y políticas vinculadas a la 54.32

y aplicación de normas

internacionales 54.31

y marco normativo local y nacional 54.32

Gestión de la calidad total

elementos fundamentales 34.37

mejora continua de la calidad 34.38

planificación estratégica 34.37

recopilación de datos estadísticos 34.38

transformación 34.37

valores compartidos 34.38

Gestión de la empresa

modelo orgánico de orientación

humana 57.3

teorías organizativas 57.2

y estructura de los "7 factores" de

M cK insey 57.2

y taylorismo 57.3

Gestión de la seguridad

ciclo de resolución de

problemas en 59.20

descentralización de la 59.8

e inspección en el lugar de trabajo 57.21

en la industria aeroespacial 90.4

evolución 90.4

programas 90.4

evaluación de la

y uso de encuestas de percepción 59.8

modelo T uttava en 59.18

modificación del comportamiento $59.13 f$

niveles de decisión en la 59.19

Programa de Disposición O perativa 57.21

tareas centrales de la 59.12 técnicas de modificación del

comportamiento 59.12

condiciones de éxito 59.15

especificación de conductas seguras 59.14

sistema T uttava 59.14

toma de decisiones en la

$V$ éase T oma de decisiones

y control de pérdidas 57.3

y cultura de seguridad 59.2

y espíritu asociativo 59.11

y evaluación de riesgos diagrama M ORT 57.19

y modificación de los

comportamientos 57.8

y tipos de fallo general 57.13

Véase también Programas de seguridad

Gestión de las instituciones educativas

de tipo jerárquico 94.11

falta de continuidad 94.11

formación insuficiente 94.11

riesgos no detectados 94.11

Gestión de residuos

fases 55.45

y condiciones de trabajo 55.46

y reciclado $55.45-55.46$

Véase también R esiduos

GESTIS

sistema normalizado de codificación $61.29 f$

Giardia 101.24

Gilsonita

y neumoconiosis 10.76

Gimnasios 94.4

Gingivitis

por intoxicación de mercurio $\quad 63.29$

Givoni

Indice de Estrés T érmico $\quad 42.19$

variación de la frecuencia cardíaca 42.21

Glándula tiroides y radiactividad 39.42

Glándulas salivales

Véase A parato digestivo

Glándulas sudoríparas

apocrinas 42.4

ecrinas 42.4

Glasgow, coma de

Véase L esiones craneales

Gliales, células 7.3

Gliceroles 104.209

Glicidaldehído

clasificado como cancerígeno del grupo 2B porlaIARC 104.47

Glicol

en anticongelantes 102.36

riesgos del $102.31,102.36$

lubricación 104.209

punto de congelación 104.209 
solubilización 104.209

Globos 68.11

Glomérulo

Véase $\mathrm{N}$ efrona

Glomerulonefritis

e importancia de los xenobióticos 8.5

inmunitaria compleja

y mercurio 33.42

Gloydius blomhoffii 38.9

Glucógeno 42.7

G lutamato sódico 67.32

Glutatión 33.8, 33.19

Goiânia accidente radiactivo en 39.35

Goldman

índices de estrés por calor 42.18

variación de la frecuencia cardíaca 42.21

Goleman

aptitudes de inteligencia emocional (1995) 34.9

Golpe de arco 49.8

$\checkmark$ éase Fotoqueratitis

Golpe de calor

alteraciones del sistema nervioso

central 42.10

características clínicas 42.9

clásico 42.9

inducido por el esfuerzo 42.9

prevención 42.10

tratamiento 42.10

Gonadotropina

V éase H ipotálamo, sistema reproductor femenino

Gonorrea 96.55

en marineros 102.50

Goodpasture, enfermedad de

V éase G lomerulonefritis

tolueno y 104.284

Gorgojo del cereal 65.14

Gorgojos 70.23

Gota 6.34

por hiperuricemia inducida por el

plomo 63.41

Véase también Sistema musculosquelético, enfermedades

Gouy

capa de 40.6

Gowler y L egge estilo de gestión participativo (1975) 34.39

Grabadores

exposición a materiales nocivos 96.8

problemas de salud entre 96.8

Grafito

riesgos físicos y químicos del 62.4

Grandes mamíferos 68.28
Granito

y riesgo de silicosis 62.4

Granulocitopenia por radiación 48.7

Granulocitos 1.3

Granulomatosis pulmonar 27.10

Gratificaciones

como incentivos a la seguridad 60.19

esquemas mixtos de 60.19

por sorteo 60.19

Gratton

artículo sobre la formación en materia de seguridad contra incendios 41.16

Grava

riesgos de salud y seguridad 93.58

ruido 93.60

sílice 93.58

trastornos musculosqueléticos 93.60

visión general 93.58

Gremios

y programas reglados de formación profesional 94.10

Gripe porcina 70.14

Grisú

acumulación en minas subterráneas 74.9 Véase M inería

explosión en Francia en 197423.23

Grúas

medidas de control 93.45

normas y legislación 93.45

riesgos

caída de materiales 93.44

eléctricos 93.44

fallos de la estructura y

sobrecargas 93.44

falta de estabilidad 93.44

fatiga 93.45

físicos 93.45

mantenimiento y procedimientos de montaje y desmontaje inadecuados 93.44

químicos 93.45

ruido 93.45

tipos 93.44

visión general 93.44

Grupo de Expertos Nórdicos efecto crítico 30.36

Grupo de T rabajo sobre T oxicidad de los

$M$ etales

definiciones toxicológicas 33.16

G rupo Intergubernamental de Expertos sobre

Cambios Climáticos (IPCC)

y emisión de gases de efecto invernadero 53.27

Guantes

y prevención de la dermatosis 12.17 y uso de herramientas 29.73

Guantes de protección 31.20

Véase también Prendas de protección

Guayule

Véase C aucho, industria del caucho

Gusano tornillo 70.39

Gusanos de seda

cría de 70.40

criadores de 70.40

Gusto

anatomía y fisiología 11.24

pruebas sobre el gusto 11.27

trastornos 11.24t, 11.25

H

H aber, ley de 30.28, 33.4

$\mathrm{H}$ abilidades

lista de comprobación 29.18

$\mathrm{H}$ abilidades humanas 29.3

$\mathrm{H}$ ábitos alimentarios

y susceptibilidad individual a los tóxicos 33.19

Habituación 42.51

$\mathrm{H}$ ackman

roles del trabajador (1992) 34.31

$\mathrm{H}$ afnio

peligro de incendio del 41.14

toxicidad del 63.13

Véase también Circonio

$\mathrm{H}$ aldane, J.S.

modelo de descompresión (1908) 36.4

$\mathrm{H}$ ale y $\mathrm{G}$ lendon

modelo para investigación de accidentes 56.16

$\mathrm{H}$ all-H eroult

células electrolíticas 82.9

Véase Alumino, fundición y afino

$\mathrm{H}$ allux valgus

en bailarines 96.26

$\mathrm{H}$ alógenos

daño ambiental 104.217

$\mathrm{H}$ alones 41.25

$\mathrm{H}$ alotano

en anestesia 97.60

toxicidad del 97.61

$\mathrm{H}$ antavirus

asociado a la caza 69.5

cuadro clínico 10.94

en agricultores 10.92

en entornos urbanos 10.94

estudios seroepidemiológicos 10.94

pruebas diagnósticas 10.94

relacionado con las condiciones climáticas 53.29 
$\mathrm{H}$ araway, Donna nueva cibernética del trabajo 24.21

$\mathrm{H}$ ardware componentes 29.93

$H$ arina

en la elaboración de cereales 67.31

$\mathrm{H}$ ealth and Safety Executive (R eino U nido) definición de violencia en el trabajo 51.2 difusión de la legislación 23.10 normas de contaminación atmosférica 83.31 servicio de datos del $M$ ajor Incident $D$ ata Service 39.31

$\mathrm{H}$ ealth and Safety Executive, R eino Unido 23.10

$\mathrm{H}$ ealth Education Authority encuesta general sobre la promoción de la salud 15.13

Heberden, nódulos de 6.7

$\mathrm{H}$ einz, cuerpos de

fenilhidracida y 104.122

nitrocompuestos aromáticos y 104.346

$\mathrm{H}$ elicobacter

$\checkmark$ éase A parato digestivo

infección por 4.2

y úlcera péptica 4.9

H elicópteros

aplicaciones civiles y militares de los 102.23

dispositivos de prevención 95.18

en la industria forestal 68.11

para desencadenar avalanchas 39.29

riesgos asociados en las fuerzas

armadas 95.17

fatiga 95.17

ruido 95.18

vibraciones 95.17

vuelos nocturnos 95.18

riesgos de salud y seguridad 102.22

y políticas operativas 102.23

para la prevención de

accidentes 102.23

H elmholtz

capa de 40.6

Hematemesis 42.10

H ematoma

y traumatismo craneal 14.9

H ematuria

causas frecuentes $8.6 \mathrm{t}$

diagnóstico diferencial 8.6

exposición tóxica 8.6

lesión glomerular 8.6

producida por el calor 42.10

seudohematuria 8.6

sistema nefrourinario 8.6

valoración clínica 8.6

Hemicelulosa 72.7
H emiplejía

producida por el calor $\quad 42.10$

Hemodiálisis 4.7

Hemoglobina 1.7

$\mathrm{H}$ emoglobinuria

ácido acético y 104.13

por gas estibina 63.4

por inhalación de gas arsina

H emólisis

con cuerpos de $\mathrm{H}$ einz $\quad 1.7$

e intoxicación por arsina 63.7

fósforo y 104.383

pruebas de función hepática 4.6

Hemoptisis 42.10

H emorragia conjuntival $\quad 42.10$

$\mathrm{H}$ emorragias retinianas 37.9

H emorroides

por vibraciones 50.6

H emostasia 1.2

Heno 70.11

$\mathrm{H}$ eno y forraje equipo de recolección de 64.23

HEPA

filtros

en el montaje de tarjetas de circuito impreso 83.33

H epático, cáncer

Véase Cáncer de hígado

$\mathrm{H}$ epatitis

asociada a procesos de confección 87.7

en una imprenta cromotipográfica 28.33

hepatitis B 4.6

medidas de control 4.8

profilaxis frente a la

en empleados de zoológicos 96.45

relación con el cáncer de hígado 4.10

riesgo del personal auxiliar y de

ambulancias 95.21

riesgo en los servicios de policía 95.14

H epatitis A

en trabajadores sanitarios 97.43

$\mathrm{H}$ epatitis B

en cirujanos y anatomopatólogos 97.4

en empleados de servicios

funerarios 100.15

entre los trabajadores sanitarios 97.42 , 97.46

H epatitis C

en trabajadores sanitarios $97.4,97.43$, 97.47

H epatitis D

en personal sanitario 97.47

H epatitis G 97.44

$\mathrm{H}$ epatitis tóxica

y plaguicidas 62.10
H epatoblastoma

Véase C áncer de hígado

$\mathrm{H}$ epatocarcinoma y cáncer de hígado 4.6

H epatocitos 4.2, 4.5, 4.9

H epatotoxicidad 33.54

hidrocarburos aromáticos y $\quad 104.283$

H eptacloro 71.8

$\mathrm{H}$ erbicida fenoxi derivado $2,4,5-\mathrm{T}$ cancerígeno del grupo 2B por la IARC 62.14

$\mathrm{H}$ erbicidas

efectos agudos y crónicos de 62.13

industria forestal 68.44

tipos de selectividad de los 62.13

H ernia

en conductores de camiones 103.7

H erpes 96.55

$\mathrm{H}$ erramientas

accionadas por combustible 58.7 peligros en el uso de 58.7

accionadas por gas 93.38 riesgos asociados 93.38

accionadas por pólvora 58.8 diseño seguro de las 58.8 precauciones en el uso de 58.8 y uso de protecciones 58.8

activadas por pólvora 93.38 riesgos asociados 93.38

alicates 29.74

cuchillos 29.75

de sujeción

en trabajo con máquinas 58.24

destornilladores y rascadores 29.76

diámetros recomendados 29.41, 29.71

eléctricas 93.38

riesgos asociados 93.38

en el sector de la construcción 93.37 tipología 93.37

fuerza del agarre y dimensiones de la mano 29.71

hidráulicas 93.38

importancia del sexo 29.74

lista de comprobación

ergonómica 29.28

mangos 29.71

forma 29.71

longitud 29.72

orientación 29.74

superficie y textura 29.72

manuales 93.37

riesgos asociados 93.37

martillos 29.75

mecánicas 93.38

protecciones 93.38

riesgos asociados 93.38

naturaleza del agarre 29.70

neumáticas 93.38 
protecciones 93.38

riesgos asociados 93.38

peso y equilibrio 29.72

riesgos asociados 93.38

fatiga 93.38

trastornos traumáticos

cumulativos 93.39

vibración 93.38

sierras y herramientas eléctricas 29.76

uso de guantes 29.73

usuarios diestros y zurdos 29.73

H erramientas de mano

peligro por uso incorrecto de 58.5

reglas básicas de seguridad 58.8

H erramientas eléctricas

lesiones por descargas de 58.6

prácticas de seguridad con 58.7

H erramientas hidráulicas

condiciones de seguridad de las 58.8

$H$ erramientas motorizadas

defensas en las 58.6

interruptores de seguridad 58.6

precauciones generales de seguridad 58.5

protección de partes móviles peligrosas de las 58.6

reglas básicas de seguridad 58.8

tipos de 58.5

según su fuente de energía 58.5

H erramientas neumáticas

y uso de protecciones 58.7

Herrborn

$\checkmark$ éase $T$ ransporte de materiales peligrosos

accidente en Alemania 39.30

Herrería 70.17

$\mathrm{H}$ eterocíclicos

compuestos heterocíclicos 104.227

H exaclorobenzeno 62.16

como carcinógeno del grupo 2B por la IARC 104.297

H exaclorobutadieno

inclasificable en términos de

carcinogenicidad por la IARC $\quad 104.252$

H exafluoruro de uranio 39.33

Hexano

adhesivos con

y neuropatía periférica 96.3

efectos 104.240

industria del tejido, calzado y

mueble 104.239

$\mathrm{N}$-hexano

riesgos asociados en la industria del calzado 88.10

Hidatidosis

hidatidosis hepática 4.6

Hidracina

como carcinógeno del grupo 2B por la IARC 104.122 e ignición espontánea 41.10

efectos hematológicos 104.122

exposición a

en operadores de calderas 103.40

toxicidad 104.122

un tratamiento de aguas 72.15

y sistema nervioso central 104.122

$\mathrm{H}$ idrocarburos

Véase Petróleo, gas natural

alicíclicos saturados 104.239

alifáticos 104.239

alifáticos halogenados

como irritantes locales 104.250

y cáncer 104.250

y depresión del sistema nevioso

central 104.250

y efectos neurológicos 104.250

y efectos sitémicos 104.250

aromáticos 68.26

inflamabilidad 104.283

desmercaptanización 78.21, 78.23

en la conducción de camiones 103.8

insaturados 75.6

poliaromáticos

alquitrán de hulla y 104.311

cáncer de piel y 104.311

cáncer de pulmón y 104.311

TLV spara 104.311

saturados 104.239

tratamiento 78.21

desasfaltado de disolventes 78.22

desparafinado de disolventes 78.21

extracción de disolventes 78.21

hidrotratamiento 78.22

medidas de seguridad 78.22

$\mathrm{H}$ idrocarburos gaseosos licuados (H GL) almacenamiento y transporte de 102.51

gasoductos de 102.51

métodos de almacenamiento a granel

de 102.68

riesgo de incendio de 102.70

riesgos de lesión profesional por 102.70

riesgos para la seguridad 102.69

transporte en buques mercantes de 102.56

Hidrogenación 67.33

Hidrógeno

peligro de incendio en la fabricación de semiconductores $83.20,83.25$

y combustión 41.2

y elaboración de aceites 67.33

Hidromeiosis 42.4

$\mathrm{H}$ idrometalurgia

Véase $M$ etalurgia, metales

H idrosulfito 72.9

Hidroxiapatita 33.14

Hidróxido

amónico 72.8

de magnesio 72.8 de sodio $67.34,70.21,72.8$

H idróxidos 41.13

Hidruros

hidruro de boro

anhídridos 41.13

e ignición espontánea 41.9

fósforo 41.13

hidruro de silicio

e ignición espontánea 41.9

H ielo azul

riesgos para el medio ambiente de las

actividades aeroespaciales 90.16

H ielo seco 67.25

$\mathrm{H}$ ierro

Véase Producción de hierro y acero

fundición de hierro 82.14

descarga y transporte 82.15

desmoldeo y vaciado 82.17

efectos para la salud 82.18

endurecimiento en frío 82.17

fabricación de machos 82.16

fabricación de modelos 82.15

fusión y colada 82.14

limpieza y desbarbado 82.18

medidas de protección personal 82.15

medidas de seguridad 82.14

polvo de sílice 82.16

proceso de moldeo 82.16

proceso Isocure 82.17

industria del hierro 73.2

prevención de riesgos en la 63.22

riesgos en la minería del 63.21

Hígado

Véase A parato digestivo

circulación enterohepática 4.5

dinitrobenceno e 104.347

intoxicación hepática en la industria textil 89.33

lesiones de

encoladores y 103.16

lesiones en el

compuestos orgánicos de azufre

y 104.407

nitroparafinas y 104.338

necrosis de

cresol y 104.370

y cloroformo 104.251

y cloruro de vinilo 104.255

y tetracloruro de carbono 104.251

Véase también Cáncer de hígado

$H$ igiene

en la industria alimentaria $\quad 67.6$

$\mathrm{H}$ igiene industrial

aplicada a la investigación de

accidentes 60.2

definición y objetivos $29.4,30.2$

en los países en desarrollo 32.11

encuestas en China 32.34 - 32.35 
estrategias de muestreo y medición 30.17 30.18

contenido de las muestras 30.19

control biológico y biomarcadores de la exposición 30.29

duración del muestreo 30.20

grupos de exposición homogénea 30.20

lugar de las muestras 30.19

muestras y frecuencia 30.21

objetivo 30.18

origen de las muestras 30.19

técnicas analíticas 30.24

técnicas de medición 30.21

estudios de la calidad del aire en el

interior 30.17

evaluación de la exposición 30.4, 30.16,

30.27

análisis del riesgo para la salud 30.28

control de la exposición y predicción de la dosis 30.28

influencia de los polimorfismos genéticos 33.28

intervalo de tiempo relevante 30.27 , 30.30

pauta de exposición 30.27

evaluación de riesgos 30.7, 30.14

evaluación del medio ambiente de

trabajo 30.15

evaluaciones 30.4

exposición simultánea a distintos

agentes 30.5

gestión de riesgos 30.7

identificación de riesgos 30.4, 30.11

inspección sobre el terreno 30.16

interacción con otros profesionales de la

salud en el trabajo 30.10

interpretación de los resultados 30.5

mediciones de control 30.5

pautas de exposición 30.14

práctica de la 30.4

prevención y control de riesgos $30.6,30.25$

controles administrativos 30.25

controles técnicos 30.25

coste de los controles 30.26

eficacia de los controles 30.26

facilidad de uso de los controles 30.26

frecuencia de la exposición 30.26

límites de exposición profesional 30.31

protección personal 30.25

programas y servicios 30.8

evaluación 30.11

garantía de calidad 30.10

gestión 30.10

información 30.9

instalaciones 30.9

laboratorios y equipos 30.9

planificación 30.9

principios generales 30.8

recursos humanos 30.8 vigilancia ambiental y biológica 30.15

Véase también Prevención de riesgos

Véase también $V$ igilancia de los riesgos profesionales

$\mathrm{H}$ igienista industrial

ámbitos de actuación 30.2

capacidades 30.8

certificación 30.3

definición 30.3

salud y seguridad personal 30.9

$\mathrm{H}$ igienistas

Véase $V$ igilancia del medio ambiente de trabajo

cánones de conducta ética 19.15

riesgos laborales 103.24

sustancias a las que se exponen $\quad 103.25$

H igrómetro 42.17

$\mathrm{H}$ ilanderías de algodón

y endotoxinas bacterianas 10.30

$\mathrm{Hill}$, Sir Bradford

directrices para las enfermedades crónicas 28.31

$\mathrm{H}$ ipercolesterolemia

consumo de antioxidantes 3.6

y dieta 3.6

Véase también H iperlipidemia

$H$ iperlipidemia 3.6

H ipernatremia 42.9

$\mathrm{H}$ iperqueratosis por arsénico 63.7

$\mathrm{H}$ ipersensibilidad por contacto agentes 33.42

$\mathrm{H}$ ipersensibilidad respiratoria sustancias químicas que la producen 33.42

H ipertensión

factores de riesgo 3.5

por exposición a la dimetilformamida

en encoladores 103.16

por vibraciones 50.6

prevención 3.6

tratamiento 3.5

umbral o límite 3.5

y función renal 8.5

H ipertermia 42.3, 42.9

$\mathrm{H}$ ipertonía neuromuscular por descarga eléctrica 40.4

H iperventilación reflectiva por descarga eléctrica 40.4

Hipoacusia por exposición al arsénico 63.7

H ipoclorito sódico 72.11

$\mathrm{H}$ ipófisis

y sistema reproductor femenino 9.9

H ipoosmótico 42.6

H ipotálamo

en el sistema nervioso 7.8 y sistema reproductor femenino 9.9

H ipotensión

y azidas 104.123

y etilenglicol dinitrato 104.339

H ipotermia

actuación en caso de 42.39

asociada a la caza 69.4

clasificación 42.40

hipotermia aguda por agotamiento 42.40

hipotermia aguda por inmersión 42.40

hipotermia con traumatismo importante 42.40

hipotermia crónica subclínica $\quad 42.40$

efectos fisiológicos 42.40

apatía 42.40

asístole 42.40

conducta extraña y ataxia 42.40

disartria, torpeza y dificultad del

habla 42.40

escalofríos 42.40

extrasístoles ventriculares 42.40

fibrilación ventricular 42.40

irritabilidad auricular $\quad 42.40$

letargo y coma 42.40

rigidez muscular 42.40

tiritona 42.40

generalidades 42.40

reacciones en función de la gravedad $42.37 \mathrm{t}$

tratamiento prehospitalario $\quad 42.40$

H ipotiroidismo

y depresión 5.11

H ipoxemia 37.2

H ipoxia 36.2, 37.8

H ipúlico

ácido 27.14

$\mathrm{H}$ istoplasma capsulatum

contaminante del aire interior 44.5 enfermedad de los cazadores 69.5

$\mathrm{H}$ istoplasmosis

en el sector de la construcción 93.5 exposición a agentes infecciosos 10.7

$\mathrm{H}$ istorias laborales

informatización para la evaluación de la exposición 28.8

H odgkin, enfermedad de 1.4, 71.11, 72.18

Véase E nfermedad de $\mathrm{H}$ odgkin

Hollín

emitido por los motores diesel 55.16 como cancerígeno 55.16

primer estudio de carcinogénesis 2.2

$\mathrm{H}$ olmes y $\mathrm{R}$ ahe acontecimientos vitales (1967) 34.16

Hombro

anatomía y biomecánica 6.20

artrosis 6.22 
incidencia de la vibración 6.23

patogenia de la artrosis primaria 6.22 osteoartritis 6.21

prevención de los trastornos 6.23

ergonomía participativa 6.23

tendinitis 6.21

tenosinovitis 6.21

H ome 0 ffice (R eino U nido) 41.8

Homeostasia 7.7

$\mathrm{H}$ omeostasis

factores internos y externos 5.7

Homicidios

en el lugar de trabajo 51.2 - 51.3

factores de riesgo 51.4

lugares de trabajo con las mayores

tasas de $51.3 \mathrm{t}$

por actividades delictivas 51.5

profesiones con las mayores tasas

de $51.4 \mathrm{t}$

sobre mujeres 51.2

en el lugar de trabajo 99.6

en Estados U nidos 99.6

trabajos con un mayor riesgo de 99.6

$\mathrm{H}$ ongos

contaminantes del aire interior 44.23

de transmisión aérea

como causas de enfermedad alérgica 44.24

propiedades alérgicas de los 44.24

H orarios de trabajo

diseño de los

en el sistema de turnos 43.8

horario de trabajo no tradicional 30.36

H ormigón

armaduras de refuerzo 93.55

elementos prefabricados 93.55

medidas de precaución 93.56

encofrados 93.53

riesgos asociados 93.55

tipos 93.53

prevención de accidentes 93.55

en la manipulación y

colocación 93.55

en las operaciones de mezcla 93.55

visión general 93.53

H ormonal, tratamiento de sustitución

Véase Salud de la mujer

hormonas antidiuréticas $\quad 42.7$

$\mathrm{H}$ ormonas adrenocorticotrópicas

(ACTH)

alteración por vibraciones de las 50.4

$H$ ormonas de la reproducción

Véase Sistema reproductivo

H ormonas del estrés

$\checkmark$ éase A drenalina, noradrenalina y cortisol

H ormonas tiroideas 42.4
H ornby y Clegg

participación en el diseño de sistemas 29.61

Hornos

alto horno 73.3

convertidor 73.5

fabricación de acero 73.5

horno de hogar abierto 73.5

hornos de coque 73.4

hornos eléctricos de arco $73.3,73.5$

para cerámica

riesgo de los combustibles en 96.19

riesgos 73.6

Véase también Producción de hierro y acero

$H$ ornos de madera

y peligro de incendio 41.17

$\mathrm{H}$ ornos de microondas

efectos de la radiación de

en personal de cocinas 98.3

$\mathrm{H}$ ornos y estufas

y peligro de incendio 41.17

H ospitales

brotes de tuberculosis en 97.51

control de la iluminación 97.36

control de los riesgos de origen químico

en 97.58

diseño ergonómico de las áreas de trabajo

de los 97.37

Proyecto H ospitales Europeos

Saludables 97.37

y mejora del rendimiento 97.37

efectos del calor sobre los

trabajadores 97.31

y estrés por calor 97.35

exposición a las microondas 97.33

exposición a ruidos en $97.31,97.33$

y pérdida auditiva $97.31,97.33$

y reducción de la productividad 97.31

exposiciones a sustancias químicas

en 97.57

gestión de los residuos peligrosos en 97.72

problemas de ventilación 97.31

programas de reducción del ruido en

los 97.31

respuesta ante las catástrofes 39.49

seguridad de las instalaciones eléctricas

en 97.30

y catástrofes 39.50

Véase también $C$ entros sanitarios

H ostelería

estrés en trabajadores de 98.9

incidencia de delitos y factores de riesgo de homicidio 98.9

lesiones musculosqueléticas 98.9

productos químicos tóxicos en 98.9

$\mathrm{H}$ oteles

acoso sexual a empleados de 98.8

planes de emergencia en 98.8 prevención de incendios 98.8

$\mathrm{H}$ oughton y $\mathrm{Y}$ aglou

Indice de T emperatura Efectiva 42.20

$\mathrm{Hoz} \quad 64.30$

H uelga

Véase R elaciones laborales

Hueso

actividad metabólica 33.14

adsorción de coloides 33.14

articulaciones 6.6

componentes articulares $6.6 \mathrm{t}$

del cráneo 6.6

elementos osteotrópicos 33.13

incorporación de tóxicos 33.14

osteoartritis 6.7

osteopenia 6.7

osteoporosis 6.6

partes interna y externa 6.6

reacciones de intercambio de

iones 33.14

Véase también Sistema musculosquelético

Huevos

producción 70.27

H umedad

Véase C ontrol de la humedad

H umedad relativa 42.16

H umo

agentes cancerígenos en el 44.12

agentes tóxicos y tumorígenos $44.14 \mathrm{t}$

benceno en 44.10

captación de 44.13

en trabajadores no

fumadores 44.13

como cancerígeno del grupo A 44.15

según la Environmental Protection

Agency 44.15

compuestos químicos

asociados al 44.7

de cromo y níquel 72.15

de tabaco ambiental (HTA) 44.7

medidas de protección 44.15

riesgos de exposición 30.15

y enfermedades respiratorias 44.14

y riesgo de cáncer 44.15

$\mathrm{H}$ untington, enfermedad de 5.6

H uracanes

ciclón tropical 39.25

ciclones y tormentas tropicales 39.17 , 39.25

depresión tropical 39.25

huracán 39.25

morbilidad y mortalidad 39.25

potencia destructiva 39.25

prevención y control 39.25

tifón 39.25

tormenta tropical 39.25

zonas geográficas 39.25 
$H$ utchinson, manchas de

Véase C áncer de piel, melanoma

$\mathrm{H}$ ydrus platurus 38.6

1

latrogénesis social 52.23

I conos 29.86

Ictericia

hepatocelular 4.5

Ictus 70.24

Identificación de los peligros enfoque de la IARC 33.65

enfoque japonés 33.57

sistema de ensayos 33.58

Identificación por colores

para destacar situaciones $u$ objetos 46.16

Ignición

autoignición 41.9

dirigida $41.4,41.9$

espontánea $41.4,41.9$

fuentes de $41.4,41.9$

chispas 41.11

ignición eléctrica 41.10

ignición espontánea 41.9

llama abierta 41.9

rayo 41.11

superficies calientes 41.11

influencia del espesor del material 41.4

proceso de 41.4

punto de 41.3

temperatura de 41.9

Igualdad de trato

y discapacidad 17.15

Véase T rato equitativo

I gualdad en el lugar de trabajo

barreras clásicas 24.7

principios generales 24.7

y protección de la salud de la mujer 24.7

y salud y seguridad 24.6

Véase también Discriminación

Iluminación

de las tareas visuales 46.18

deslumbramiento

directo $46.11,46.20$

factores que afectan al 46.11

incapacitante 46.20

índice de deslumbramiento límite

(Limiting G lare Index, LGI) 46.21

índice de deslumbramiento

sin corrección (U ncorrected

Glare Index, UGI) 46.21

maneras de evitar el 46.11

molesto 46.20

reflejado 46.11 distribución del flujo luminoso

distribución de "ala de

murciélago" 46.20

métodos 46.19

elección de los colores

colores brillantes 46.15

colores cálidos 46.14

colores fríos 46.15

colores oscuros 46.15

e identificación de objetos 46.16

normas prácticas básicas 46.15

en el diseño del entorno 34.23

en hospitales

control de la 97.36

en minas subterráneas 74.41

en puestos de trabajo con PVD 52.10,

52.13

en televisión y cine 96.35

estudios de

técnica de puntos de medición 46.20

lista de comprobación 29.22

magnitudes de 46.10

natural 46.12

y luz artificial 46.17

niveles mínimos de $46.8 f$

normas europeas CENTC 16946.10

objetivos 46.16

sistemas de $46.11 \mathrm{f}, 46.12$

basados en el método luménico de diseño 46.17

en interiores comerciales 46.17

general $46.12,46.17-46.18$

local 46.17

localizada $46.12,46.17$

unidades de 46.10

y confort visual $46.5,46.9,46.14,46.18$,

46.20

condiciones 46.20

diagrama de $K$ ruithof 46.14

requisitos 46.9

y factor de reflexión de las superficies 46.14

y fatiga ocular 46.11

y señalización 64.25

y visibilidad de un objeto 46.10

factores 46.10

Véase también Iluminancia

Iluminancia

instrumentos para medir la 46.21

con corrección cosenoidal 46.21

con corrección de color 46.21

diversidad de la 46.21

efectos

sobre el rendimiento visual 46.18

media 46.17

nivel de 46.8

para tareas visuales 46.17

uniformidad de la 46.21

valor medio de 46.20

y agudeza visual 46.18 y luminancia 46.18

y sistemas de iluminación 46.17

Ilustradores

exposición a materiales tóxicos 96.24

Impactor de vidrio 30.23

Impactos ambientales

de la industria pesquera marina mundial 66.19

de toda actividad humana 54.19

Véase también Evaluación de impacto ambiental

Véase también Evaluación del ciclo vital

Implosión, riesgo de

en la fabricación de

semiconductores III-V 83.23

Importancia económica 65.2

Imprenta

cromotipográfica

casos de hepatitis 28.33

síntomas neurológicos 28.33

intoxicación por xileno 104.284

Impresión

exposición al ruido 85.5

In vitro

ensayos de irritación ocular 33.54

ensayos de toxicidad 33.52

Incapacidad adquirida 24.2

Incapacidad crónica

definición 26.15

Incapacidad laboral

incapacidades múltiples 25.10

indemnización 25.13

Incapacidad parcial permanente

cálculo de las prestaciones 25.14 método de la pérdida prevista de ganancias 25.15

método del deterioro físico 25.14

variantes e híbridos 25.15

cantidad a tanto alzado 25.14

pensión fija 25.14

Incapacidad parcial transitoria nivel de prestaciones 25.13

Incapacidad total permanente pensión 25.14

Incapacidad total transitoria descalificación 25.13

recurrencia 25.16

reducción de las prestaciones 25.13

Incendio

Véase Combustión

Véase Extinción de incendios

Véase I gnición

Véase $M$ ateriales combustibles

Véase 0 rganización de la lucha contra incendios

Véase Prevención de incendios

Véase Protección contra incendios 
Véase $R$ iesgo de incendio

a bordo de buques 66.17

bases de datos sobre 41.8

comportamiento humano 41.22

de bloques de oficinas de São Paulo,

Brasil 41.8

de elementos y compuestos

radiactivos 41.13

de gas de petróleo licuado 41.7

de Londres de $1666 \quad 41.8$

de materiales líquidos 41.5

de metales 41.14

de productos de plástico y caucho 41.14

de un camión con tolueno 39.30

en ascensores $41.20,41.22$

en entornos de aire comprimido 36.9

en la central eléctrica de N ewark,

N ew Jersey 39.48

en la condensación de vapores de sustancias químicas organometálicas 83.27

en la fábrica de K uiyong, China 39.48

en la fábrica $\mathrm{H}$ amlet de $\mathrm{C}$ arolina del

Norte 39.48

en la fábrica $K$ ader de T ailandia 39.45

en la fábrica T riangle Shirtwaist de N ueva

York 39.47

en pozos de petróleo 41.6

ensayo del índice de oxígeno 41.6

espumas contra 41.5

evacuación $41.21,41.27$

forestales 39.26

morbilidad y mortalidad 39.26

prevención y control 39.26

y tormentas 39.26

fuentes de ignición 41.4

inercia térmica del material 41.4

información con fines de protección 41.7

formulario 41.8

informes sobre 41.8

investigación 41.8

límites de inflamabilidad 41.7

nebulizadores 41.6

peligro de

en la industria química 41.18

en vertederos 41.30

por descargas electrostáticas 40.9

por explosión de gases 41.13

por explosión de polvo 41.15

por explosivos 41.14

por ignición de fibras y textiles 41.12

por ignición de madera y sus

derivados 41.11

por ignición de plásticos 41.15

por inflamación de líquidos

combustibles 41.12

por polvo 41.15

por productos químicos 41.13

por soldadura y corte de

materiales 41.18 que presentan los equipos de

calefacción 41.17

plan de evacuación 39.48

por autocalentamiento $41.4,41.7$

por baños de grabado 83.20

prevención en carpintería 86.6

prevención en la fabricación de vidrio,

cerámica y materiales afines 84.26

proceso de transferencia del calor 41.2

ecuaciones básicas 41.2

producidos por electricidad estática 40.10

propagación de la llama 41.5

protección automática contra 39.48

protección en industrias gráficas 85.4

provocados 41.8

punto de ignición 41.3

resistencia estándar contra incendios 41.20

riesgo asociado a los procesos de

confección 87.5

medidas de protección 87.5

riesgo asociado al serrín 86.6

riesgo asociado en la industria de la

construcción 93.31

en acabados interiores 93.31

en ascensores 93.50

medidas de prevención 93.31

riesgo en el almacenamiento y manipulación de arsénico 83.23

riesgo en el procesado del fieltro 89.18

riesgo en industrias gráficas 85.5

riesgo en la fabricación de fibras

sintéticas 89.17

riesgo en la industria de la lana 89.13

riesgo en la industria del calzado 88.8

riesgo en la producción de géneros textiles

no tejidos 89.22

riesgo en la tejeduría 89.24

riesgo en los procesos de estampado 89.20

riesgo en los procesos de tinción 89.19

disolventesy colorantes

inflamables 89.19

simulacros 41.22

sistema de purga con hidrógeno 83.23

sistemas de rociado de agua 39.48

supresores químicos 41.5

tasas de mortalidad por incendio 41.8

velocidad de combustión 41.3

velocidad de liberación de calor 41.3

y riesgos de los profesores 94.4

Véase también Llama

Véase también $M$ ateriales ignífugos

Véase también $\mathrm{N}$ ational Fire Protection

Association

Véase también $R$ ayos

Incendios forestales

Véase Extinción de incendios

factores de riesgo 68.19

Incendios y explosiones

en minas subterráneas
Véase también M inería

Incentivos

Véase R emuneración

Incentivos a la seguridad

Véase Planes de incentivos

Incentivos salariales

y productividad 60.24

Incertidumbre

frente a un cambio organizativo 35.8

Incidencia acumulada 28.11

Incineración

de residuos radiactivos 48.33

Incineradoras

de residuos sólidos urbanos

riesgos en las 101.25

Incremento salarial

como incentivo a la seguridad 60.19

Incumplimiento grave 23.19

Indemnización por accidentes de trabajo

ajustes por inflación 25.18

asistencia médica 25.11

cálculo de las prestaciones

método de la pérdida efectiva de ganancias 25.15

método del deterioro físico 25.14

variantes e híbridos 25.15

casos de muerte 25.17

causas múltiples de incapacidad 25.9

clases de 23.22

clasificación abstracta de las lesiones 26.21

cobertura 25.2

ampliaciones 25.3

autónomos 25.2

personas cubiertas 25.2

regímenes especiales 25.3

sectores cubiertos 25.2

compensación 25.16, 25.19

conducta indebida de la empresa 25.11

convenios de la OIT sobre 23.29

daños a los bienes 25.16

datos de Estados U nidos 26.13

derecho a las prestaciones 25.6

accidentes 25.6

casos de enfermedad 25.7

causalidad en casos de lesiones 25.6

comienzo y terminación de la

cobertura 25.7

culpabilidad 25.7

desplazamientos 25.7

distinción entre lesión y

enfermedad 25.8

dolencias de espalda 25.9

fenómenos naturales 25.7

lugar de producción de la lesión 25.6

muerte 25.9

trastornos mentales - estrés 25.8

derecho de subrogación 25.23

desfiguración 25.16 
desigualdad frente al riesgo 26.9

dolor y padecimientos 25.16

en Alemania 26.17 - 26.21

en Israel $26.22-26.25$

en Japón 26.26 - 26.29

en Suecia 26.30

estudios 26.7

financiación 25.20

capitalización 25.22

clasificación de actividades y

primas 25.21

distribución de costes 25.20

equilibrio de las cuentas 25.21

impago de las primas 25.22

puntuación según la experiencia 25.21

incapacidades indemnizables 25.13

parcial permanente 25.14

parcial transitoria 25.13

total permanente 25.13

total transitoria 25.13

incapacidades múltiples 25.10

incapacidades sobrevenidas 25.9

incidencia de las lesiones y nivel de indemnización 26.8

neurosis de indemnización 25.16

objeciones a las reclamaciones 25.10

autolesiones 25.10

conducta indebida del reclamante 25.10

obligación de mantener el empleo 25.20

organización, administración y

adjudicación 25.3

acceso a la documentación 25.5

audiencia 25.4

cuestiones médicas 25.5

decisiones iniciales 25.3

defensa 25.5

investigaciones 25.4

manuales sobre normativa 25.6

pruebas 25.4

recursos 25.6

terminación 25.5

pagos en dinero 25.12

fijación del nivel salarial 25.12

nivel de indemnización 25.12

pagos indebidos 25.18

salario de referencia 25.12

tope máximo 25.13

partidas para rehabilitación 25.19

pérdidas indemnizables 25.10

personas a cargo 25.16

perspectiva histórica 26.6

primas o cotizaciones 25.22

falta de pago de 25.22

reducción por prevención 26.12

valoración de riesgos 25.23

protección de las prestaciones 25.18

reclamaciones basadas en el estrés 26.11

reclamaciones contra terceros 25.23

recogida de datos 26.13 recurrencia de la incapacidad 25.16

reforma de los sistemas de

indemnización 26.12

atención médica de los casos

indemnizables 26.13

comparabilidad internacional de las estadísticas 26.12

enfoque multifactorial de la

relación entre la enfermedad y el riesgo 26.14

enfoques ergonómicos 26.16

equiparación de la protección social 26.16

promoción de la rehabilitación 26.15

separar la indemnización de la prevención 26.13

régimen administrado por el gobierno 25.24

responsabilidad de la empresa $\quad 25.25$

daños y perjuicios 25.25

sistema israelí 26.22

situación en Suecia 26.13

subsidios 25.16

suspensión de las prestaciones 25.18

tributación 25.18

y sistemas de prevención de

las lesiones 26.7

y vigilancia de la salud en el trabajo 32.5

Véase también Indemnizaciones

India

animales de tiro 70.34

Asociación de Salud en el T rabajo de la India 16.64

campaña del día nacional de la seguridad 60.28

Indian Council of Agricultural R esearch (ICAR) 70.34

$M$ inisterio de T ransporte y $M$ arina

M ercante 70.34

normativa 16.65

Ley de fábricas 16.65

Ley de minas 16.65

Ley de seguridad, salud y bienestar de los trabajadores portuarios 16.65

servicios de salud en el trabajo 16.65

centro hospitalario 16.65

medicina del trabajo 16.65

mejora de la asistencia sanitaria 16.65

Indian C ouncil of Agricultural R esearch

(ICAR) 70.34

Indicadores

auditivos

sonar 29.87

visuales 29.79

características $29.75 f$

de riesgo industrial 59.30

escalas 29.80

paneles 29.80

pantallas electrónicas 29.80 uso de los colores 29.80

Indicadores de cristal líquido (LCD)

aplicación y frotación de la película de

orientación 83.21

deposición de ITO 83.21

fijación del polarizador 83.22

formación de filtros de color 83.21

formación de transistores en película

delgada 83.21

deposición de película delgada 83.21

modelado del dispositivo 83.21

inspección y prueba 83.22

inyección de cristal líquido 83.22

montaje 83.22

preparación del sustrato de vidrio 83.20

cortado, biselado y pulido 83.21

fabricación del vidrio 83.20

limpieza 83.21

Indices de estrés por calor

de exposición acumulada 28.10

de exposición biológica 30.18

de mortalidad proporcional (IM P) 94.14

entre el profesorado 94.14

por cáncer de mama 94.14

de probabilidades 28.19

directos 42.25

índice de 0 xford 42.25

temperatura de globo de bulbo húmedo $42.22,42.25$

empíricos 42.20

predicción de la frecuencia cardíaca $42.21-42.22$

tasa de sudoración prevista durante cuatro horas 42.21 - 42.22

temperatura efectiva corregida $\quad 42.20$

racionales 42.19

Indice de Estrés T érmico $42.19,42.22$

tasa de sudoración requerida 42.19 , 42.22

Temperatura Efectiva Estándar 42.20

Indio

riesgos del $\quad 63.23$

Industria

automovilística y ergonomía 29.3

cambios en la posguerra 29.3

de manufactura de tableros 71.9

electrónica

exposición al arsénico en la $\quad 63.20$

láctea

buenas prácticas de fabricación

(BPF) 67.26

riesgos y su prevención $\quad 67.27$

maderera 71.2

enfermedades no malignas 71.10

riesgo de lesiones 71.10

Véase también Industria del papel

pesquera

Véase Pesca 
dependencia de un solo

empleador 66.14

estrés del desempleo 66.15

Industria de la biotecnología

aplicaciones más recientes 77.37

biotecnología de plantas 77.35

consideraciones sociales y éticas $\quad 77.37$

control de riesgos 77.33

el caso de la Comunidad

Europea 77.36

el caso de los Estados U nidos $\quad 77.35$

debate sobre la seguridad 77.37

exposición a endotoxinas $\quad 77.34$

N ational Institutes of $\mathrm{H}$ ealth

Guidelines 77.33

productos de biotecnología 77.36

prohibición de experimentos 77.33

protección del trabajador $\quad 77.34$

Proyecto G enoma H umano $\quad 77.37$

regulación y legislación 77.33

riesgos biológicos 77.33

riesgos para la salud 77.36

sectores principales 77.33

trabajadores de los laboratorios 77.34

Industria de la piel y el cuero

accidentes 88.4

ahogamiento 88.4

caídas 88.6, 88.9

debidos al estado del suelo $\quad 88.4$

lesiones por escaldadura $\quad 88.4$

medidas de protección 88.6

por utilización de herramientas

manuales 88.6

riesgos mecánicos 88.4

agentes cancerígenos 88.5

alergia 88.7

efectos del calor 88.7

equipos de protección 88.7

exposición a polvo irritante 88.7

producción 88.2

ruido 88.7

visión general $\quad 88.2,88.5,88.9$

fabricación de prendas de peletería 88.6

tintura 88.6

tratamiento de las pieles 88.5

Industria de las bebidas

bebidas alcohólicas 65.2

cerveza 65.14

licores destilados 65.10

vino 65.13

bebidas sin alcohol 65.2

café 65.7

concentradas refrescantes 65.2

té 65.8

control del inventario $\quad 65.17$

Industria del caucho

controles de ingeniería $\quad 80.10$

campanas de aspiración 80.11

control de ruidos 80.12 disolventes 80.12

equipos de protección 80.12

estaciones de moldeo 80.12

exposición al polvo 80.10

materiales nocivos 80.10

placas de caucho 80.11

ergonomía 80.17

trastornos en el sistema óseo y

muscular 80.17

estudios epidemiológicos 80.15

cáncer 80.15 - 80.16

enfermedades pulmonares 80.15

exposición al benceno 80.15

exposición al butadieno 80.16

leucemia 80.15

mortalidad en la industria del

caucho 80.15

fabricación de neumáticos

Véase $N$ eumáticos

esquema del proceso $80.4 \mathrm{f}$

medidas de seguridad $\quad 80.13-80.14$

en las calandrias 80.13

en los laminadores 80.13

interrupción del funcionamiento de las máquinas 80.14

$\mathrm{N}$ ational Joint Industrial Council for the Rubber $M$ anufacturing Industry 80.13

plantaciones

riesgos para los trabajadores 80.3

problemas ambientales y de

seguridad 80.17

caucho residual 80.18

contaminación atmosférica $\quad 80.18$

contaminación del suelo y del agua 80.18

control de ingeniería 80.18

incineración de los residuos 80.18

residuos peligrosos 80.17

procesos de producción 80.4

productos industriales 80.8

adhesivos 80.8

látex 80.8

mangueras de caucho 80.8

productos no reforzados 80.8

productos reforzados 80.8

riesgos del procesamiento del caucho 80.9

y butadieno 80.9

efectos sobre la salud 80.9

estudios epidemiológicos 80.10

Industria del hierro y el acero

Véase Producción de hierro y acero

Industria del papel y de la pasta de papel

ácido nitrilotriacético 104.338

aspectos ambientales 72.19

contaminación 72.19

del agua 72.20

del aire 72.19

enfermedades no malignas estudios epidemiológicos específicos sobre

la 72.16

fosfatos en 104.382

importancia económica $\quad 72.4$

lesiones 72.15

mayores productores de pasta y papel $\quad 72.4$

población empleada 72.4

productos finales 72.9

riesgos 72.12

tratamiento de las aguas 72.11

tratamiento de sólidos 72.21

Industria del plástico

acetatos 104.162

fabricación de compuestos a partir de polímeros 77.25

riesgos para la salud 77.29

fosfatos en 104.382

ftalatos en 104.394

hidrocarburos alifáticos

insaturados 104.275

materiales dieléctricos 77.30

calentadores y selladores de radiofrecuencia 77.30

materias primas 77.25

peróxidos orgánicos en la 104.363

poliésteres aromáticos en la 104.177

procesado de plásticos 77.29

diagrama de producción $77.25 f$

riesgos de incendio y explosión 77.31

riesgos de lesiones 77.29

riesgos para la salud 77.32

secuencia de producción $77.25 f$

procesos de acabado 77.29

procesos de conversión $\quad 77.27$

calandrado 77.28

colada de películas 77.28

conformado por vacío $\quad 77.29$

extrusión 77.28

laminado 77.29

moldeo a presión 77.27

moldeo por compresión $\quad 77.27$

moldeo por insuflación de aire comprimido 77.28

moldeo por inyección 77.27

moldeo por rotación 77.28

tecnología de resinas 77.29

termoformado 77.28

productos volátiles de la

descomposición $77.25 \mathrm{t}$

Industria del reciclado

componentes de la plantilla en la 101.21

consideraciones de seguridad 101.23

de servicios completos 101.22

secuencia de operaciones

característica 101.22

lesiones más comunes $\quad 101.22 \mathrm{t}$

maquinaria y equipos utilizados en

una 101.22

riesgos ambientales y laborales $\quad 101.22$ 
secuencia de un sistema de procesado 101.22

Industria farmacéutica

ácido cloroacético en la 104.12 agentes biológicos y químicos 79.3 aspectos medioambientales 79.18 de los procesos de fabricación 79.18 modificaciones de los procesos 79.19 prevención de la contaminación 79.19 recuperación de recursos 79.19 reutilización de disolventes 79.19 disolventes utilizados $79.5 \mathrm{t}$ excipientes farmacéuticos 79.4 fármacos sintéticos 79.3 fenoles en 104.368 formas galénicas sólidas 79.15 laboratorios 79.17 operacionesfarmacéuticas 79.13 acondicionamiento 79.17 carga y descarga de sólidos y líquidos 79.13 composición 79.14 compresión 79.15 fabricación estéril 79.16 filtración 79.14 granulación 79.14 limpieza y mantenimiento 79.16 mezclado 79.15 molturación 79.14 pesada y la dispensación de sólidos y líquidos 79.13

riesgos para la seguridad $\quad 79.16$

secado 79.14

separaciones de líquidos 79.13

transferencia de líquidos 79.13

operarios químicos 79.13

proceso de fabricación 79.4 aspectos medioambientales 79.18

diseño técnico 79.12

equipos de procesado 79.12

esquema del proceso $79.4 f$

extracción biológica y natural 79.11

fermentación 79.5

medidas de control 79.12 - 79.13

riesgos biológicos 79.5

síntesis química 79.5

productos farmacéuticos 79.4

formas galénicas $79.4,79.12,79.15$

principios activos 79.4

productos naturales 79.3

productos químicos industriales 79.3

límites de exposición profesional $\quad 79.3$

programas de seguridad de los

procesos 79.18

propilenglicol en la 104.209

riesgos y prevención 79.17

control de la energía peligrosa $\quad 79.17$

diseño ergonómico 79.17

exposiciones a vapores 79.18 exposiciones al ruido 79.17

manipulación del material 79.17

protección de las máquinas 79.17

síntesis química de los productos 79.5

aguas madre 79.8

análisis de riesgos 79.11

intercambiadores de calor 79.8

reactores 79.7

Industria forestal

apeo 68.8

aprovechamiento maderero $\quad 68.7$

métodos, equipos y riesgos

comunes 68.8

progreso tecnológico en el $\quad 68.7$

condiciones de trabajo 68.36

cualificación 68.39

definición 68.2

disposiciones en materia de

seguridad 68.28

empleo 68.3

evolución de los recursos forestales y del sector 68.2

extracción 68.10

sistemas de 68.10

importancia económica $\quad 68.2$

medio ambiente 68.42

normas y disposiciones 68.11

percepción negativa 68.44

plantación de árboles 68.15

preparación y carga de las trozas 68.11

productos forestales no madereros 68.14

control y prevención de riesgos 68.15

riesgos 68.25

biológicos 68.28

químicos 68.26

transporte de la madera $\quad 68.12$

Véase también T rabajadores forestales

Industria láctea

buenas prácticas de fabricación

(BPF) 67.26

riesgos y su prevención $\quad 67.27$

Industria naval

automatización $\quad 92.2$ - 92.3

construcción de embarcaciones

pequeñas 92.15

Véase Construcción en acero

exposición a disolventes y polvos de epoxi 92.16

materiales utilizados 92.15

métodos de fabricación 92.16

plásticos reforzados con fibra de vidrio, uso de 92.15

riesgos para la salud y la

seguridad 92.16

construcción en acero $\quad 92.5$

corte 92.5

equipamiento 92.11

pintura y acabado 92.8

pruebas 92.11 soldadura 92.6

exposición al plomo $\quad 92.15$

organización del trabajo $\quad 92.2$

rotación del personal 92.14

proceso de construcción $\quad 92.3$

diseño 92.3

fabricación de subconjuntos 92.3

fabricación de unidades 92.3

instalación de equipamientos 92.5

montaje final $\quad 92.4$

pintura 92.4

realización de pruebas $92.4-92.5$

reparación 92.11

riesgos para la salud $\quad 92.13$

físicos 92.13

químicos 92.13

sensibilización de los trabajadores 92.2

trabajo al aire libre $92.2,92.13$

utilización de equipos de protección

individual 92.14

visión general $\quad 92.2$

y medio ambiente 92.16

Industria pirotécnica

materias primas 77.38

precauciones de la fabricación $\quad 77.39$

edificios 77.39

equipos 77.40

residuos 77.40

riesgos 77.39

Industria química

control de derrames 41.18

destilación 77.15

riesgos para la salud $\quad 77.15$

gestión de seguridad de procesos 77.3

análisis de los riesgos de los procesos 77.5

auditorías de autoevaluación 77.8

control del diseño 77.7

información sobre seguridad de los procesos 77.4

instrucciones de trabajo $\quad 77.6$

integridad mecánica 77.7

investigación de accidentes 0 incidentes 77.8

normas generales 77.8

organizaciones 77.4

preparación para emergencias 77.7

programas de cambio 77.5

requisitos básicos 77.3

revisiones 77.6

secretos comerciales 77.8

tecnología de la seguridad $\quad 77.4$

tipos de trabajo 77.6

intercambiadores de calor 77.16

fugas y exposición $\quad 77.16$

modelos $77.16 f$

localización de las plantas 41.18

medidas de seguridad en los reactores químicos 41.18 
parámetros de riesgo de los productos químicos 41.13

peligros 41.18

plantas químicas 77.6

almacenes 77.11

disposición de la planta $\quad 77.9$

sala de control 77.11

tanques de almacenamiento 77.11

torre de destilación $\quad 77.15$

unidades de proceso $\quad 77.10$

prevención de accidentes 41.18

principales sectores 77.2

productos intermedios 77.2

productos químicos básicos 77.2

productos químicos terminados 77.2

programas de seguridad $\quad 77.3$

reactores 77.13

catalizadores de lecho fijo $\quad 77.14$

catalizadores de lecho fluido $\quad 77.14$

proceso de reacción continua $\quad 77.13$

proceso de reacción discontinua 77.13

reactores de lecho fijo $\quad 77.13$

válvula de seguridad $\quad 77.14$

riesgo de incendio o de explosión 41.11

Sección Internacional de la AISS 23.66

sensibilidad de chispa de los materiales

peligrosos 41.11

tanques de almacenamiento

$V$ éase $T$ anques

Véase también Accidentes químicos en Catástrofes

Véase también $M$ ateriales peligrosos

Industria textil

consideraciones medioambientales 89.3

trastornos no respiratorios

infertilidad 89.33

intoxicación hepática 89.33

isquemia cardíaca 89.33

oncogénesis 89.33

reacciones alérgicas 89.33

trauma por movimientos

repetitivos 89.33

trastornos respiratorios en la $\quad 89.30$

bisinosis 89.30

bronquitis crónica 89.31

fiebre del colchonero 89.31

fiebres textiles 89.31

tos del tejedor 89.31

visión general 89.2

Industrialización

cambios en el tejido social $\quad 20.3$

países de reciente industrialización 20.3

Industrias alimentarias

almacenamiento de materias primas $\quad 67.2$

congelación

métodos 67.5

conservación 67.4

contaminación 67.14

atmosférica $\quad 67.14$ del agua $\quad 67.14$

residuos sólidos 67.14

efectos sobre la salud $\quad 67.8$

enfermedades infecciosas y parasitarias de

origen animal 67.11

problemas dermatológicos 67.11

trastornos musculosqueléticos 67.12

trastornos respiratorios 67.9

envasado 67.4

enlatado 67.4

envasado aséptico $\quad 67.5$

por congelación $\quad 67.5$

extracción 67.2

fabricación 67.3

cocción 67.4

destilación $\quad 67.4$

fermentación 67.3

secado 67.4

higiene 67.7

lesiones 67.6

accidentes por caída $\quad 67.6$

cuchillos 67.6

debidas al empleo de 67.6

estado del suelo 67.6

iluminación insuficiente o irregular 67.6

maquinaria 67.6

pozos o canales de drenaje al

descubierto 67.6

quemaduras y escaldaduras $\quad 67.6$

riesgos debidos a la $\quad 67.6$

trabajo en altura 67.6

vapor o polvo 67.6

manipulación de las materias

primas 67.2

producción mundial de alimentos 67.2

riesgos para la salud $\quad 67.7$

enfermedades infecciosas 0

parasitarias 67.7

salud de los consumidores $\quad 67.16$

sectores 67.16

carne 67.16

industria avícola $\quad 67.20$

Industrias marítimas

datos sobre morbilidad y

mortalidad 102.46

en Estados U nidos 102.46

riesgos para la salud 102.47

de carácter físico y químico $\quad 102.48$

de origen medioambiental $\quad 102.47$

Infección conjuntival de N ewcastle 70.29

Infección, riesgo de

en la industria de la piel y el cuero 88.4

afta epizoótica 88.9

ántrax 88.4

brucelosis 88.9

fiebre Q 88.9

leptospirosis 88.9

tétanos 88.9

zoonosis 88.4
Infecciones pulmonares

bacterianas 10.97

brucelosis 10.95

carbunco por inhalación 10.96

clamidiasis respiratoria 10.95

coriomeningitis linfocítica 10.94

de origen ocupacional $\quad 10.92$

en los agricultores 10.92

infección por hantavirus 10.92

infecciones zoonóticas 10.92

patógenos micóticos 10.92

en profesionales sanitarios 10.92

aspergilosis pulmonar invasiva $\quad 10.102$

infecciones bacterianas 10.102

sarampión 10.99

tosferina 10.100

trabajadores inmunodeprimidos 10.102

tuberculosis 10.100

enfermedades de origen

ocupacional $10.92 \mathrm{t}$

fiebre Q $\quad 10.96$

hantavirus 10.92

histoplasmosis 10.97

neumonías micóticas diversas 10.98

peste neumónica 10.96

Infecciosas, enfermedades

asociadas a los servicios de seguridad y de emergencia 95.3

hepatitis B y C $95.3,95.21$

SIDA e infección por VIH 95.3

tuberculosis 95.3

en chóferes 103.14

en el sector de la confección $\quad 87.7$

riesgo en las fuerzas armadas 95.16

Infertilidad

de causa tóxica 9.2

Inflamabilidad

límites inferiores típicos $40.9 \mathrm{t}$

peligro de 41.28 y explosiones 41.7

Información

búsqueda de información 22.11

avance de la tecnología $\quad 22.12$

técnicas de búsqueda 22.12

ciclo de información $22.3 f$

comunicaciones informáticas 22.16

en el proceso de producción 22.2

en formato electrónico 22.9

bases de datos 22.9

discos compactos 22.11

disquete 22.11

guías de búsqueda en línea 22.10

servicios en línea 22.10

sistemas abiertos 22.10

tipos de bases de datos 22.10

especialistas de salud y seguridad en el

trabajo 22.11

fuentes tradicionales en papel 22.8

boletín oficial 22.9 
compendios 22.9

enciclopedias 22.9

guías bibliográficas 22.8

índices de referencias

bibliográficas 22.8

libros de texto 22.9

literatura gris 22.9

microfichas 22.8

informatización y aplicaciones $22.5 f$

localización

itinerario $22.12 f$

ordenadores personales $\quad 22.16$

bases de datos 22.16

operador booleano 22.16

sistemas multimedia 22.16

seguridad en la empresa y ciclo de

información 22.3

servicio de información $\quad 22.13$

funciones 22.13

y bibliotecas 22.15

sistemas de información

sobre pesticidas $22.18 \mathrm{f}$

sobre sustancias tóxicas $22.20 f$

sobre la seguridad 22.2

a escala nacional y mundial $\quad 22.3$

acceso a la información $\quad 22.11$

aplicaciones 22.5

base de conocimientos 22.3

bases de datos 22.4

calidad de la información $\quad 22.7$

coste de la información 22.7

datos cuantitativos sobre riesgos 22.2

en el ámbito de la empresa 22.13

ergonomía 22.7

estadísticas 22.7

fuentes tradicionales en papel

información cualitativa $\quad 22.3$

inteligibilidad 22.3

investigación $\quad 22.7$

medidas cuantitativas 22.2

métodos de comunicación 22.2

objetivos 22.5

películas y vídeos 22.7

publicaciones básicas 22.8

revistas fundamentales 22.8

sensibilización de la sociedad 22.6

sistemas informatizados 22.5

usuarios 22.6, 22.8

Véase también Tratamiento de la información

Información sobre accidentes

componentes informativos 57.31

datos básicos 57.30

formulario tipo $57.32 f$

obligatoriedad de la 57.30

Información sobre seguridad

adaptada a la secuencia de un

accidente 56.37

objetivos y ejemplos de fuentes $56.37 \mathrm{t}$ directrices de la AIE $\quad 56.39$

directrices de la IFIESR $\quad 56.39$

elaboración de la 56.41

especificaciones de diseño $\quad 56.38$

de etiquetas y los manuales de instrucciones 56.38

de las fichas técnicas de seguridad (FTS) 56.38

de las señales y las etiquetas de advertencia 56.39

de símbolos de seguridad 56.38

fuentes de datos sobre 56.37

normas obligatorias 56.38

en los países industrializados 56.38

recomendaciones voluntarias 56.38

nuevas normas ANSI 56.38

sistema de $57.9 f$

sobre un producto 56.41

niveles en el diseño de 56.41 - 56.42

Informatización

aplicaciones de la información $\quad 22.5 f$

problemas psicosociales derivados de

la 52.28

soluciones 52.30

y carga de trabajo 52.30

y técnicas de equilibrio

compensatorio 52.31

Véase también Pantallas de visualización de datos (PVD)

y rendimiento 52.29

Infraestructuras urbanas

deficiencia de las

y riesgos para la salud 53.26

y salud $53.26 t$

Ingeniería

aplicada a la investigación de accidentes $60.2-60.3,60.5$

Inglaterra

promoción de la salud en el lugar de

trabajo $15.13-15.15$

actividades incluidas en la encuesta $15.14 \mathrm{t}$

encuesta sobre la 15.13

sindicatos y trabajadores

discapacitados 17.42

Véase también R eino U nido

Inhalación

criterios para la masa particulada $\quad 10.5 \mathrm{t}$

de partículas 10.5

masa particulada inhalable 10.5

masa particulada respirable $\quad 10.5$

masa particulada torácica $\quad 10.5$

Inhibición

de la acetilcolinesterasa y plaguicidas organofosforados 33.32

de la colinesterasa 33.46

Inmersión en agua fría

respuesta fisiológica $\quad 42.48$ tiempo de supervivencia $\quad 42.53$

uso de trajes impermeables 42.53

Inmisiones olfatométricas

Investigación y medición

enfoques metodológicos 55.19

Inmunodeficiencias congénitas 33.41

Inmunoglobulinas $33.41,34.66$

Inmunosupresión

mayor incidencia de infecciones 33.41

Inmunotoxicología

enfermedades autoinmunitarias $\quad 33.39$

evaluación del riesgo 33.42

enfoque de paralelogramo $\quad 33.43$

inmunotóxicos potenciales 33.43

mecanismos de inmunotoxicidad 33.41

alergia 33.41

autoinmunidad 33.42

funciones críticas 33.41

inmunosupresión 33.41

principios generales 33.39

Véase también Sistema inmunitario

Inmunotóxicos 33.39

Inorgánico

ácido 104.5

Insecticidas

contaminación interior por $\quad 44.8$

en la industria forestal 68.45

Insectos

cría de 70.38

gérmenes patógenos transmitidos

por 101.24

productos excretores de

y contaminación del aire interior $\quad 44.23$

Inseguridad en el empleo

estudios sobre la 34.35

soluciones a 34.35

Insomnio

Véase T rastornos del sueño

como síntoma de depresión $\quad 5.10$

crónico

en cantantes 96.29

y violencia en el trabajo 51.6

Inspección

consistencia de los servicios de $\quad 57.22$

contacto con los trabajadores en la $\quad 57.23$

de contaminación radiactiva $\quad 48.29$

de gestión 57.22

de las pequeñas empresas $57.22-57.23$

en el lugar de trabajo 57.21

en las grandes empresas 57.23

grupos de inspección radiológica 48.39

interna 57.24

intervalos entre inspecciones $\quad 57.23$

por órganos de inspección públicos 57.22 sobre salud y seguridad 57.22

servicios de

riesgos de 101.4 
Inspección de trabajo

autoinspección 23.7

autoridad central 23.3

colaboración con expertos y organismos de investigación 23.5

colaboración con la administración de la seguridad social $\quad 23.4$

competencias de los inspectores $\quad 23.12$

consultas preceptivas con los sindicatos 23.7

desafíos 23.70

en las minas 23.13

función de los trabajadores $\quad 23.7$

funciones 23.9

actuación en las reducciones de plantilla 23.11

conciliación y arbitraje 23.11

garantizar el cumplimiento de la legislación 23.9

información a la autoridad competente 23.10

información de naturaleza económica 23.11

información y asesoramiento de empresas $y$ trabajadores 23.10

prevención de la discriminación $\quad 23.11$

objetivos 23.8

participación de los agentes sociales en la inspección 23.7

primas 23.4

procedimiento de urgencia 23.14

relación con los trabajadores 23.6

relaciones con el comité de empresa 23.7

relaciones con el comité de salud y seguridad 23.6

relaciones con las organizaciones de empresarios y de trabajadores 23.6

relaciones con los delegados de personal 23.7

repercusiones de los cambios en el mundo laboral 23.69

sanciones $23.4,23.9$

servicios de campo 23.3

sistemas de inspección 23.11

por sectores de actividad $\quad 23.12$

según el objeto de la inspección 23.12

y administraciones locales 23.13

y autoridades judiciales 23.5

y autoridades regionales 23.5

y cooperación entre directivos y

trabajadores 23.8

y despido de delegados sindicales 23.11

y prevención 23.15

Véase también Convenio de la

OIT sobre la inspección del

trabajo, 1947 (no 81)

Véase también Inspectores de trabajo

Inspección industrial

y vigilancia 29.52
Inspecciones

de la producción 55.57

de los ambientes de trabajo $\quad 55.57$

y prevención de la contaminación $\quad 55.57$

del lugar de trabajo 55.57

Inspectores

de aviación

riesgos de los 102.10

Inspectores de trabajo

especialización de los 23.12

informes a la fiscalía 23.5

informes de los 23.3

normas de conducta 23.57

obligaciones 23.15

imparcialidad 23.15

independencia 23.15

reserva respecto al origen de las quejas 23.15

secreto profesional 23.15

poderes 23.13

adopción de medidas en caso de infracción 23.14

de jurisdicción 23.14

derecho de apelación $\quad 23.14$

libertad de entrada e inspección 23.13

Véase también A sociación internacional de inspectores de trabajo

Instalaciones de alto riesgo

Véase C atástrofes

emplazamiento 39.10

sustancias químicas utilizadas $39.15 t$

Instalaciones eléctricas

definición $\quad 40.15$

en ambientes húmedos o mojados 40.12

en la industria alimentaria $\quad 67.6$

equipo de protección $\quad 40.12$

fallos de fase-neutro $\quad 40.12$

fallos de fase-tierra $\quad 40.12$

fusibles 40.14

inducción 40.16

medidas preventivas en $\quad 40.11$

norma europea $\quad 40.15$

normas y reglamentos

internacionales 40.14

peligros eléctricos 40.12

procedimientos de trabajo $\quad 40.16$

con tensión $\quad 40.16$

en la proximidad de partes con

tensión 40.17

mantenimiento 40.17

sin tensión $\quad 40.16$

procedimientos operativos estándar 40.16

pruebas funcionales 40.16

y atmósferas pulverulentas 40.12

Véase también Disyuntores

Véase también Puesta a tierra

Véase también T rabajo en instalaciones eléctricas
Institución docente 94.3

Instituciones culturales 94.2

Instituciones educativas 94.2, 94.14 - 94.15

Institut national de la santé et de la recherche médicale

fallecimientos por electrocución 40.2

Institute of M edicine of the U S A cademy of Sciences 66.20

Instituto de D iseño de Sistemas de Seguridad de Emergencia (DIERS) 62.9

Instituto de Protección contra la R adiación (Suecia)

y reducción del campo magnético $\quad 49.4$

Instituto de salud en el trabajo de K iev 39.43

Instituto de toxicología química industrial 104.218

Instituto Europeo de Seguridad Conjunta 23.2

Instituto $\mathrm{N}$ acional de $\mathrm{N}$ ormas y T ecnología de Estados U nidos (NIST) 105.3

Instituto Nacional para la Salud y la Seguridad en el trabajo (NIOSH) de EE.UU 103.2

estudio sobre la seguridad de los plantadores silvícolas 68.17

información a los trabajadores 23.36

límites de exposición recomendados 30.18

manejo de reses 70.34

medidas de prevención de enfermedades mentales 5.7

programas de lucha contra la silicosis 10.37

y límites de exposición al arseniuro de galio 63.20

Institutos 94.10

Instrucción en las aulas 94.10

Instructores 94.2

Instrumentistas

problemas neuromusculosqueléticos

en 96.27

Insuficiencia renal

causas profesionales 8.10 t

por cadmio

y nivel máximo de creatinina según la OMS 63.12

síntomas 8.10

Inteligencia emocional $\quad 34.9$

Interagency Coordination Committee for the $V$ alidation of $A$ Iternative $M$ ethods (ICCVAM) 33.55

Intercambio iónico en tratamiento de aguas residuales $\quad 101.20$

Interfaces

en diseño de sistemas híbridos automatizados 58.39

Interfaz

definición de 52.31 
diseño de la 52.32 - 52.34

y desarrollo de prototipos 52.35 evaluación de la 52.36

Interferón 1.4

Internet

correo electrónico 22.17

mensajería electrónica 22.17

solicitud de fax 22.17

transferencia de archivos $\quad 22.17$

Interruptor maestro

para desconexión de sistemas $\quad 58.30$

Interruptores de emergencia

requisitos 58.31

Interruptores de funciones dispositivos de control de los 58.31

Interruptores de seguridad

en herramientas motorizadas de mano 58.6

Interruptores de supervisión requisitos de los 58.32

Intersticial

Véase $\mathrm{N}$ efritis

Intoxicación

en el sector de la construcción $\quad 93.3$

por cadmio 53.3

por plaguicidas 53.4

por plomo

en artistas y artesanos 96.2

por productos alimentarios

Véase A limentos, enfermedades

transmitidas por

y drogodependencia 15.83

Intoxicación

aguda

con moluscos 66.20

crónica 7.16

cuestionario de control $7.17 \mathrm{t}$

exposición a productos químicos $7.18 \mathrm{t}$

por estireno 104.285

por etilbenceno $\quad 104.285$

síntomas precoces 7.17

trastornos neuropsiquiátricos 7.18

por monóxido de carbono 36.2

síntomas 36.2

por pesticidas 7.15

por plaguicidas 64.14

por sustancias neurotóxicas 7.15

Véase también T oxicidad, mecanismos de la

Inundaciones y maremotos

inundaciones costeras 39.24

tsunami 39.24

inundaciones fluviales 39.24

inundaciones repentinas 39.24

morbilidad y mortalidad 39.24

prevención y control 39.24

Invernaderos

operaciones en los invernaderos 64.13 uso de plaguicidas en los $\quad 64.13$

Investigación

en universidades

y riesgos 94.11

sobre salud y seguridad 23.33

Investigación de accidentes

árbol de causas en $57.26,56.27 f$

conceptos principales del fenómeno del accidente $57.25 \mathrm{t}$

condiciones de eficacia de la $\quad 57.29$

detección de factores de accidente $\quad 57.28$

determinación de riesgos en

procedimiento cualitativo $58.36 f$

en los programas de seguridad $\quad 60.16$

entrevistas a los pacientes 56.27

y modelo M AIM 56.27

entrevistas en 57.26

error humano en 57.9

estadísticas de accidentes en la $\quad 57.29$

limitaciones de la $\quad 57.29$

método MORT en la 57.20

método ST EP 57.26

modelo de $\mathrm{H}$ ale y $\mathrm{G}$ lendon $\quad 56.16,56.18$

modelo de Surry $56.19 f$

modelo WEF $\quad 56.19$

ampliación del $\quad 56.20$

ventajas 56.19

perspectiva epidemiológica en $\quad 60.2$

recopilación de información $\quad 57.25$

tipos de fallo general en $\quad 57.10$

Investigación de la seguridad en el trabajo

función de la Administración pública en 60.6

modelo de análisis de seguridad para $\quad 60.2$

modelo de la salud pública aplicado a

la 60.2

comunicación de información de

seguridad 60.4

estrategias de prevención $\quad 60.3$

información sobre el riesgo $\quad 60.3$

métodos de recogida de

información 60.3

y vigilancia epidemiológica $\quad 60.2$

nuevos métodos científicos en $\quad 60.5$

objetivo de la 60.3

estrategias generales según

$\mathrm{H}$ addon $\quad 60.3$

principales tecnologías de $\quad 60.4$

Véase también Programas de seguridad

Iodo $131 \quad 39.32,39.40,39.42$

Ion bisulfito 72.8

Ionización

artificial $\quad 45.24$

eliminación de partículas por $\quad 45.10,45.24$

natural $\quad 45.24$

Ionizadores 45.6

Ionóforas 33.9
Iridio

compuestos solubles de $\quad 63.24$

lesiones por radiación de 63.24

toxicidad del 63.24

Irritación ocular

en los centros de producción

avícola 67.23

ensayo de Draize 33.54

ensayo ocular de poco volumen 33.54

ensayos in vitro sobre 33.54

I rritación respiratoria

hidrocarburos aromáticos y $\quad 104.283$

por exposición a productos de

soldadura $83.15,83.31-83.32$

I rritantes

como causantes de dermatitis 12.12

$\checkmark$ éase $D$ ermatitis

acumulativos 12.10

inmediatos 12.10

límites de exposición profesional 30.35

respiratorios

Véase A parato respiratorio

resumen $10.14 \mathrm{t}$

ISO

Véase O rganización internacional de normalización

Isocianatos

de metilo $\quad 39.4$

revestimientos 104.320

I soflurano 97.60

Isoplan 62.12

I sopreno

como cancerígeno del grupo 2B por la

IARC $\quad 104.275$

Isopropanol

y cáncer de laringe 104.33

y cáncer de senos nasales 104.33

Isquemia cardíaca

riesgo asociado al bisulfuro de carbono en la industria textil 89.33

Israel

Instituto N acional de Seguros 26.25

Ley del seguro nacional 26.25

M inisterio de sanidad 103.2

sistema de indemnización por accidentes de trabajo $26.22-26.25$

actualización de las prestaciones 26.26

asegurados 26.22

atención médica 26.23

cotizaciones 26.26

historia 26.25

Technion I srael Institute of

Technology

estudio sobre la industria del tallado de diamantes 29.104

Italia

estudio de los factores de estrés en $\quad 102.9$ 
Ley de 23 de diciembre de 1978 de reforma del sistema sanitario $\quad 23.13$

J

Jabones

y prevención de la dermatosis 12.17

y producción de aceite de resina $\quad 72.12$ Japón

A sociación de Salud y Seguridad en el

Trabajo 15.27

encuestas sobre la salud 5.21

Fundación para la Promoción de la Salud en el Trabajo 16.48

horas de trabajo en 5.21

Inventario de sustancias químicas existentes 33.58

karoshi 5.20

Ley de control de sustancias químicas en $33.44,33.58,61.10$

Ley de indemnización por accidentes de trabajo de $1947 \quad 26.26$

Ley de salud y seguridad industrial 5.21 , 16.48

Ley del seguro de enfermedad de $1922 \quad 26.27$

Plan de Promoción T otal de la Salud 5.21, 20.8

promoción de la salud en el lugar de trabajo 15.27

apoyo financiero del ministerio $\quad 15.28$ médicos promotores de la salud en el trabajo 15.27

plan de "promoción total de la salud" 15.27, 16.49

seguro de accidentes de trabajo $\quad 26.26$ accidentes in itinere 26.27

asistencia médica 26.26

cobertura 26.27

criterios de indemnización 26.28

enfermedades profesionales 26.28

historia 26.27

método de actualización $\quad 26.29$

pensión de enfermedad 26.27

pensión por minusvalía física $\quad 26.27$

prevención 26.29

primas $26.28-26.29$

riesgos asegurados 26.26

servicios asistenciales 26.27

subsidio de asistencia de

enfermería 26.27

subsidio de incapacidad temporal $\quad 26.27$

subsidio familiar 26.27

subsidio por gastos de entierro $\quad 26.27$

trabajadores amparados 26.26

servicios de salud en el trabajo 20.8

servicios de salud y seguridad en

el trabajo

asociación de seguros médicos 16.48 médico de salud en el trabajo 16.48

sistemas de financiación $\quad 16.49$

sindicatos y trabajadores

discapacitados 17.43

Sociedad Japonesa de Salud en el

Trabajo 16.49

Jardineros

ántrax 103.28

asma $\quad 103.28$

enfermedades micóticas 103.28

enfermedades parasitarias $\quad 103.28$

exposición al ruido $\quad 103.27$

fiebre del heno 103.28

mordeduras y picaduras 103.27

riesgos laborales 103.27

tétanos 103.28

Jardines de infancia 94.2

Jelinek

lesiones de $\quad 40.5$

Jenkins

encuesta de actividad $\quad 5.20$

Jenkins A ctivity Survey

Véase Encuesta de actividades de Jenkins

Jerarquía

y organización $\quad 35.3$

Johns H opkins Centre for Alternatives to

Animal T esting (CAAT) 33.55

Johnson

apoyo social (1986) $\quad 34.9$

Jornada de trabajo

anormal 34.21

trastornos biológicos 34.21

trastornos sociales 34.22

Jornada laboral

duración de la

$y$ trabajo por turnos 43.7

Joule

Ley de $\quad 40.2$

Joyería

corte y pulido de piedras en

riesgos y medidas preventivas 96.22

inhalación de humos y polvo de

metales 96.22

en procesos de soldado $\quad 96.23$

en pulido y corte de metales 96.23

procesos de galvanoplastia en 96.22

riesgos más frecuentes 96.22

pulido y corte de metales en $\quad 96.23$

K

$\mathrm{K}$ ader Industrial incendio 39.45

$\mathrm{K}$ agan y Levi modelo de estrés-enfermedad (1971) 34.16

K apitza, P.L.

informe sobre centrales nucleares 29.113
K arasek

cuestionario sobre el contenido de los puestos de trabajo (1985) 34.14

estilo de gestión participativo (1979) 34.39 modelo de

Véase Salud mental

relación con el karoshi $\quad 5.20$

modelo de la latitud de toma de

decisiones 34.27

$K$ arasek y $T$ heorell

censo de códigos profesionales de Estados

Unidos (1990) 34.9

$\mathrm{K}$ aroshi

comportamiento laboral 5.20

estudio en Japón 5.20

importante problema social

en Japón 5.20

incidencia de cardiopatía coronaria $\quad 5.20$

modelo de $\mathrm{K}$ arasek 5.20

reclamaciones 25.9

K hyshtym 39.33

K ieselguhr 62.7

K lebsiella 38.3

Kogi

tiempo de trabajo (1991) 34.21

K rebs, ciclo de 104.14

$\mathrm{K}$ rewski y cols.

umbral de regulación 33.79

K ruithof

diagrama de bienestar para diferentes niveles de iluminación y temperaturas colorimétricas 46.14

K upffer, células de 4.2

$K$ veim, prueba cutánea de Véase Enfermedad por berilio

L

Laborales, relaciones

Véase R elaciones laborales

Laboratorios

clasificación de sustancias de riesgo

en 61.19

de manipulación de materiales radiactivos 48.19

incendios y explosiones en $\quad 61.20$

lesiones por sustancias químicas $\quad 61.20$

norma sobre laboratorios de la

OSHA $\quad 61.20$

apéndice $A$, ventilación general de

laboratorios 61.21

peligro de los materiales incompatibles 61.23

prevención de incendios y

explosiones 61.22

prevención de intoxicaciones y quemaduras químicas 61.21 
protección contra quemaduras e

intoxicaciones 61.21

y control de la ventilación general $\quad 94.12$

Laboratorios de análisis

y vigilancia y notificación de enfermedades profesionales 32.5

Laboratorios de control biológico 27.6

Laboratory Center for Disease Control regulación de la exposición del personal auxiliar y de ambulancia a agentes infecciosos 95.22

Láctico

ácido 67.32

Lactosa

intolerancia a la 15.41

Ladrillos y baldosas

procedimientos de fabricación 84.18 materiales y procesamiento 84.18

Lagrange, modelo de dispersión de 55.10

Laminación

Véase T renes de laminación

Lámparas

categorías 46.12

según la coloración de la luz que emiten 46.12

según sus temperaturas colorimétricas 46.14

criterios de rendimiento 46.2

de arco $\quad 49.15$

de descarga $\quad 46.2,46.5-46.7$

atenuación de las 46.8

de filamentos 46.2

sensibilidad a la tensión $\quad 46.5$

de haluro metálico 46.7

de inducción 46.7

de mercurio 46.7

de alta presión 46.7

de cátodo caliente 46.6

de cátodo frío 46.6

multifosfóricas 46.6

y materiales fosfóricos 46.6

de radiación ultravioleta

riesgos 49.7

tipos de 49.7

de radiación ultravioleta

en centros sanitarios 97.33

de sodio 46.2

a baja presión 46.8

de alta presión $\quad 46.8$

fluorescentes 46.2

atenuación de altas frecuencias en las 46.17

de tamaño reducido $\quad 46.6$

halógenas de tungsteno $\quad 46.5$

de baja tensión $\quad 46.5$

incandescentes 46.5

en la iluminación comercial e industrial 46.5 en la iluminación de expositores 46.5

lámpara típica de iluminación

general (G eneral Lighting Service,

GLS) $\quad 46.5$

incandescentes

riesgos para la retina $\quad 49.15$

tipos de $46.4 \mathrm{t}$

infrarrojas 49.15

lámparas de descarga

de haluros metálicos 81.13

de mercurio de alta presión $\quad 81.13$

de sodio 81.13

fluorescentes 81.12

fluorescentes compactas 81.13

lámparas de filamento

de tungsteno 81.11

halógenas de tungsteno 81.11

reciclaje de lámparas de mercurio $\quad 81.14$

rendimiento lumínico $\quad 46.8$

riesgos de la fabricación $\quad 81.11$

de lámparas de mercurio $\quad 81.13$

de lámparas de sodio 81.14

de lámparas de tungsteno $\quad 81.12$

de lámparas fluorescentes 81.13

y control del flujo luminoso $\quad 46.19$

por difusión 46.19

por obstrucción 46.19

por reflexión 46.19

por refracción 46.19

Lámparas de radiaciones UV A y UV B 33.68

Lana de vidrio

e ignición espontánea $\quad 41.9$

Lana mineral

e ignición espontánea $\quad 41.9$

Lana, industria de la

ántrax 89.13

ergonómicas, consideraciones 89.13

manipulación de materiales 89.13

producción 89.12

cardado 89.12

peinado 89.12

riesgo de incendio 89.13

riesgos mecánicos 89.12

medidas de protección 89.12

ruido 89.12

Landell M ills Commodities Studies 88.2

Landolt, anillos de

Véase $\mathrm{O}$ jo, agudeza visual

Langerhans, células de

Véase D ermatitis alérgica

Lapsus

y privación del sueño 29.63

Véase también V igilancia

Laringe

Véase Cáncer de laringe

Laringitis alérgica

por alergia al látex 97.63
Laringitis crónica

en cantantes 96.29

Larra migrans 103.27

Láser

cirugía por exposición a vapores tóxicos $\quad 97.32$

riesgos para la retina 97.33

clasificación por clases de riesgo $\quad 49.18$

en comercio minorista

riesgos de los 99.15

límites de exposición humana a $\quad 49.19 t$

medios de protección ocular contra $\quad 49.20$

normas de seguridad sobre $\quad 49.19$

mediciones 49.20

riesgos asociados a su utilización en industrias gráficas $85.4,85.7$

riesgos de los

en servicios de control de vuelo $\quad 102.10$

vigilancia médica de los trabajadores con 49.20

Véase también $R$ ayos láser

Látex

alergia al $\quad 100.9$

reacciones alérgicas al

en trabajadores sanitarios 97.63

Véase también C aucho, industria del caucho

Latrodectus ctenus 38.7

L atrodectus mactans 38.7

Lavanderías

daños por descargas eléctricas $\quad 100.13$

estrés por calor en 98.7, 100.13

factores de riesgo ergonómicos en $\quad 100.13$

productos químicos nocivos en 100.12

quemaduras en 100.13

riesgos biológicos en 100.14

riesgos mecánicos 100.13

Lazarus y Folkman

enfoque de afrontamiento (1986) $\quad 34.10$

Lead Industries A ssociation, Inc. 83.31

Lechat

gestión de catástrofes 39.16

Leche

en polvo 67.26

excreción de tóxicos 33.15

Lechones 70.25

Leclanché

pila eléctrica

$\checkmark$ éase A paratos eléctricos

Lectora de caracteres ópticos (LCO) en servicios postales 101.8

Lectura labial

V éase Sordera, pérdida auditiva

Legibilidad 29.85

Véase también R ótulos

Legionario, enfermedad del

en fontaneros 103.21 
en la industria del automóvil

exposición a refrigerantes 91.9

y medio ambiente interior $\quad 44.4$

Legionella pneumophila $44.5,44.23,44.25$

Legionelosis 44.3

Legislación

sobre almacenamiento de productos químicos 61.13

sobre integración profesional de discapacitados $17.18 \mathrm{f}$

sobre productos químicos 61.13

sobre salud y seguridad de los

estudiantes 94.11

sobre salud y seguridad en el trabajo 94.14

sobre el consumo de tabaco $\quad 15.44$

sobre discapacidad $\quad 17.9$

sobre derechos humanos

fundamentales 23.25

Legislación ambiental

e incentivos y desincentivos

económicos 54.9

normas ambientales 54.8

referidas a las causas 54.8

referidas a los efectos 54.8

responsabilidad por daños 54.9

sanciones penales 54.9

sistemas de autorización previa 54.8

y control del uso del suelo 54.8

y legitimación activa

de las ONG 54.10

Leguminosas 64.3

Leishmaniasis

y radiación ultravioleta $\quad 53.30$

Leithead y Lind

encuesta sobre los trastornos por calor 42.18

Lentes

filtrantes de radiación $\quad 49.16$

Leptospira icterohaemorrhagiae 4.6

Véase A parato digestivo, hígado

Leptospirosis

en fontaneros 103.23

en jardineros 103.28

riesgo en la acuicultura $\quad 70.38$

riesgo en la industria cárnica

asociada al confinamiento del ganado 70.14

riesgo en la industria de la piel y el calzado 88.9

Lesión celular

apoptosis 33.34

definición $\quad 33.3,33.33$

estímulo inicial 33.35

lesiones letales 33.33

lesiones subletales o crónicas 33.33

macrolesiones 33.38

necrosis 33.34 oncosis 33.34

replicación errónea de

"microlesiones" 33.38

rutas de señalización $\quad 33.35$

Lesión craneal

$\checkmark$ éase T raumatismos, coma

Lesión cutánea 63.7

Lesión del nervio ulnar

en trabajadores de oficina

Lesión hepática 4.7

Véase A parato digestivo

acción del alcohol $\quad 4.8$

acción del paracetamol $\quad 4.8$

agentes 4.8

Lesión ocular

por toxicidad aguda $\quad 33.32$

Lesión periférica vascular por electrización $\quad 40.5$

Lesión por esfuerzo repetitivo (LER) con pantallas de visualización de datos (PVD) 98.6

de muñeca y mano 6.24

en cajeros de comercio $\quad 99.15$

en cajeros de hostelería 98.5

en empleados de hotel 98.6

en la industria textil 89.33

en personal de limpieza $\quad 98.6$

en personal de servicio de comidas 98.4

en trabajadores de oficinas 99.7

tendinitis 67.13

tenosinovitis 67.13

Véase también T rabajo muscular

y relación con la fatiga y el estrés 29.41

$y$ trastornos del cuello 6.18

Lesiones

en el desmotado de algodón $\quad 89.9$

costes asociados 89.9

en el sector de la construcción

coste 93.7

prevención 93.8

tipos 93.7

en la fabricación de

semiconductores 83.34

distribución de las tasas de

incidencia $83.34 \mathrm{f}$

incidencia comparada 83.35 - 83.36f

en la industria alimentaria $\quad 67.6$

en las industrias de la madera y la

carpintería 86.13

por cuerpos extraños, en la industria del automóvil 91.5 - 91.6

relacionadas con la agricultura $\quad 70.8$ contacto directo con el ganado 70.8

riesgo en los procesos de confección 87.3, 87.6

traumáticas en la industria de automóvil 91.8
Lesiones profesionales

autolesiones 25.10

causas en la fabricación de vidrio,

cerámica y materiales afines 84.28

conducta indebida 25.10

datos demográficos en la fabricación de

vidrio, cerámica y materiales

afines 84.27

definición en el sistema israelí $\quad 26.23$

definición en el sistema sueco $\quad 26.30$

distinción entre lesión y enfermedad $\quad 25.8$

no mortales

análisis del riesgo 32.20

rehabilitación 25.19

sesgo en las estadísticas 26.10

tasas de incidencia en la fabricación de

vidrio, cerámica y materiales

afines 84.26

pérdida de días de trabajo 84.27

y organización 35.9

Véase también Accidentes de trabajo

Véase también Clasificación de lesiones y enfermedades profesionales

Véase también Enfermedades profesionales

Véase también V igilancia y notificación de enfermedades profesionales

Leucemia

asociada al uso de benceno en la industria del calzado 88.10

benceno y 104.283

cuadro clínico 1.4

en entornos escolares 94.14

en profesiones "eléctricas" $\quad 49.2$

en trabajadores del aluminio $\quad 49.31$

factores de riesgo 1.4

incidencia 1.4

leucemia no linfocítica aguda $\quad 1.3$

linfática crónica $\quad 49.2$

linfocítica aguda 1.3

linfocítica crónica 1.3

mielocítica aguda 1.3

mielocítica crónica 1.3

mielógena aguda 1.3

mieloide aguda $\quad 49.2$

por irradiación 39.40

por radiación $\quad 48.8$ - 48.10

riesgo de 49.2

riesgo en pintura, dibujo

y grabado 96.8

tratamiento y prevención 1.4

y campos electromagnéticos (CEM) 94.14

Leucocitos 1.2

Leucodermia

por arsénico $\quad 63.7$

Leucopenia $1.2-1.3,39.22$

Leucoplaquia

en cantantes 96.29

Levinson 34.47 
modelo de las etapas de desarrollo de la vida humana (1986) 34.47

Lewin

efectos de la participación sobre la resistencia al cambio 29.61

Ley de Fick 33.9

Ley de Fitt 29.87

Ley de $\mathrm{H}$ aber $\quad 30.28,33.4$

Ley de Planck 46.2

para el comportamiento de un radiador de cuerpo negro 46.2

Ley de Poiseuille 33.9

Ley de R ecuperación y Conservación de los Recursos 90.13

Ley sobre Capacidad y R uido en los A eropuertos $\mathrm{N}$ orteamericanos regulación del ruido en la industria aeroespacial 90.16

Ley sobre la seguridad del agua potable (SDW A) protección de manantiales 55.38

Leydig, células de 9.7 V éase E spermatogénesis

Liberación de la tensión 34.7

Libertad académica 94.11

Libertad de asociación

Véase A sociación

OIT y tutela de la 23.58

Libertad de enseñanza y responsabilidad profesional 94.15

Libre comercio acuerdo de libre comercio $\quad 20.14$ - 20.15 normas sobre salud y seguridad en el trabajo 20.15 organizaciones y asociaciones 20.15 prácticas preventivas 20.16 recogida de información 20.16 recursos humanos 20.16

O rganización mundial del comercio 20.15

Licor blanco 72.8

Licor verde 72.8

Licores destilados 65.10

Liderazgo 34.39, 34.42

Lignina 72.7

Lignocaína 36.13

Lijado 71.8

Lijadoras 71.9

Likert, escala 28.37

Likert, R ensis modelo de vínculos 35.2

Límbico, sistema 7.7

Limitación definición de la OIT 29.83

Límites de acción biológica 33.48
Límites de exposición profesional aplicación en distintos países 30.32t concentraciones máximas admisibles 30.31 concepto del efecto umbral 30.34 datos necesarios para su establecimiento 30.35 experimentos animales 30.35 historia 30.31

horarios de trabajo no tradicionales $\mathbf{3 0 . 3 5}$

internacionales 30.36

niveles seguros de exposición $\quad 30.34$ para las exposiciones al polvo 30.31 principios y enfoques 30.34 protección ofrecida $\quad 30.35$ susceptibilidad individual $\quad 30.33$ uso previsto 30.33

valores límite umbral $\quad 30.31$ V éase también D osis

Limoneno 71.10

Limpieza en seco Véase T intorerías

Limpieza viaria protección contra los riesgos 101.17 riesgos para el trabajador 101.17

Limpieza, personal de carga cardiovascular $\quad 100.3$ exposición a productos químicos peligrosos 100.3 y tasas de cáncer $\quad 100.5$ problemas cutáneos 100.5 problemas musculosqueléticos en 100.3, 100.5

riesgo de abortos 100.5 y cardiopatías 100.5 Véase también Servicios de limpieza Lind

Indice de 0 xford $\quad 42.25$

Lindano 27.24, 71.8 y exposición neonatal 9.22

Líneas de $M$ ees 63.7

Linfocitopenia 33.41

Linfoma no Hodgkin

por radiación $\quad 48.10$

relación con ciertas profesiones 32.7

Véase también Enfermedad de H odgkin

Linfomas

entre los trabajadores de las fábricas de pasta y de papel 72.18

linfoma de Burkit $\quad 1.5$

linfoma no Hodgkin 1.5

factores 1.5

incidencia y la mortalidad $\quad 1.5$

linfomas malignos 1.4

exposición profesional 1.4

mortalidad 1.4

mieloma múltiple 1.4

riesgo en la industria maderera 71.11
Linfosarcoma 72.18

Linurón 62.14

Líquidos

riesgos de exposición $\quad 30.15$

ultrafríos 42.39

Listas de comprobación análisis ergonómico del trabajo 29.16

Cuestionario del Análisis de Posición PAQ 29.16

cuestionario nórdico 29.16

inventario de los componentes del trabajo

M ark II 29.16

"L es profils des postes" 29.16

lista de comprobación ergonómica

29.17

Listeria monocytogenes 67.27

Listeriosi 70.29

Litio 41.14, 41.31

Lixiviación $\quad 67.33,71.12$

Llama

abierta 41.9

de difusión 41.2

de premezclado $\quad 41.2$

propagación de la 41.5

Lluvia ácida 54.3

Lluvia radiactiva 39.32

V éase también R adiación ionizante, fuentes de

Lluvias intensas 39.17

Locus de control

comportamientos reactivos 34.53

definición 34.52

escalas 34.53

externo 34.52

interno 34.52

y apoyo social 34.53

Lodo

de perforación 75.9

Véase Petróleo

Lodos 72.21

Lorrain-Smith

Véase T oxicidad por oxígeno

Loss Prevention Council

Fire Prevention on Construction Sites 41.19

Lotens y $\mathrm{H}$ avenith aislamiento y resistencia al vapor de la ropa 42.31

L ove Canal $39.5,39.20$

Lubricantes

V éase A ceites industriales

Lubricantes industriales riesgos de los trenes de laminación

73.12

L ugar de trabajo

características ambientales 34.23

características físicas 34.22

condiciones ambientales exteriores 34.23 condiciones ergonómicas 34.25 
definición de factor de riesgo en el sistema sueco 26.30

diseño del $34.22,34.25 t$

y prevención de la enfermedad y promoción de la salud 34.24

e identificación de peligros 30.11

edificios e instalaciones

organización general de los 34.23

entrada de los inspectores de trabajo $\quad 23.13$

recursos de diseño en $34.25 \mathrm{t}$

saludable 24.2

zona de trabajo inmediata 34.22

Véase también Diseño del lugar de trabajo

Lumbares, molestias

en chóferes 103.14

en conductores de anbulancia $\quad 103.5$

en conductores de camiones $\quad 103.8$

en fontaneros 103.22

Luminancia

contraste de $46.9-46.10,46.19$

definición de 46.10

distribución de la $46.11,46.18,46.20$

valores máximos recomendados 46.11

e iluminancia 46.18

instrumentos para medir la $\quad 46.21$

tolerable por observación directa 46.11

y deslumbramiento $46.11,46.20$

Véase también Iluminación

Luminiscencia

tipos de 46.2

Lúpulo 65.14

L upus eritematoso sistémico

e hidrazina 33.42

Luz

distribución de la $\quad 46.19$

en el lugar de trabajo $\quad 46.9$

color adecuado $\quad 46.12$

criterios 46.9

exposición en industrias gráficas 85.7

natural $46.8,46.17$

distribución espectral de la $\quad 46.17$

para iluminar tareas 46.17

por descarga eléctrica 46.2

por incandescencia 46.2

Véase también Iluminación

Lyme, enfermedad de

Véase Enfermedades infecciosas

\section{M}

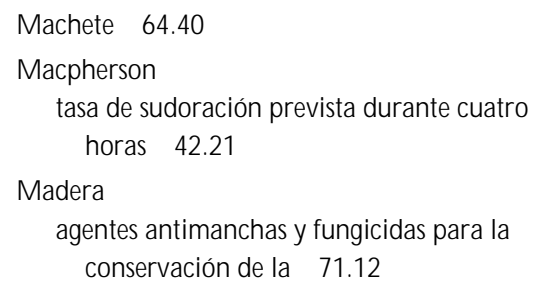

aprovechamiento y eliminación de residuos 71.11

cepillado 71.6

cortada 71.3

de construcción 71.5

principales productores mundiales

71.3

secado 71.6

serrado 71.6

transformación 71.2

transporte 68.12

manipulación y carga $\quad 68.12$

por carretera 68.13

variedades tóxicas, alérgicas y

biológicamente activas $86.14 \mathrm{t}$

verde 71.5

$M$ agnesio

efectos biológicos del 63.25

operaciones de recuperación controles técnicos $82.56 \mathrm{t}$

peligro en la manipulación de 63.25

propiedades toxicológicas del $\quad 63.25$

y riesgo de incendio $\quad 41.14$

$M$ agnetita

en las células humanas $\quad 49.3$

Maisonneuve, fractura de 96.53

M aíz

como ensilaje 70.12

mecanización del arranque del $\quad 64.22$

$\mathrm{M}$ al comportamiento

de los alumnos 94.14

$M$ al de altura

Véase Presión barométrica

$M$ al de descompresión

en el sector de la construcción $\quad 93.10$

$M$ al de los baldes

en la industria de la seda $\quad 89.15$

$M$ al de montaña

agudo $37.8,37.14$

montaña crónico 37.10

$M$ al del alfarero $\quad 96.2$

$M$ alaisia

servicio de información sobre

pesticidas 22.18

bases de datos 22.18

sistema informático de red 22.19

sistema Pestinfo 22.18

sistema videotex $\quad 22.18$

M alaria

en Brasil 53.34

muertes anuales por 53.29

urbana 53.27

y cambio climático $\quad 53.29$

$M$ alformaciones

en catástrofes 39.21

$M$ alformaciones congénitas

Véase Anomalía genética, gestación

por exposición a las PVD $\quad 52.19$
M allas equipotenciales $\quad 40.13$

Malta 65.15

M ama, cáncer de

Véase Cáncer de mama

M amografía

cáncer de mama

Véase también Salud de la mujer

estudio de caso 15.60

informe 15.61

programa de mamografías de $M$ arks and Spencer 15.60

M ancozeb 27.23

$M$ andamus 23.18

$M$ ando

y estructura organizativa $\quad 35.3$

$M$ andos bimanuales (M BM)

para protección de sistemas 58.43

$M$ anganeso

absorción 27.12

concentraciones 27.12

eliminación 27.12

intoxicación 27.12

intoxicación crónica por 63.26

fases 63.26

intoxicaciones por 63.26

en la minería $\quad 63.26$

prevención de la intoxicación por $\quad 63.27$

$M$ anganismo

fases del $\quad 63.26$

M aníaco-depresivo

Véase T rastorno maníaco-depresivo

$M$ aniobra de $V$ alsalva 36.11

$M$ anipulación de materiales

accidentes más frecuentes por 58.83

en industrias gráficas 85.4 - 85.6

vertidos accidentales e incidentes de tipo químico 85.4

en la industria de la lana $\quad 89.13$

en la tejeduría 89.24

principios de prevención de

accidentes $58.84-58.86$

proporción de accidentes por 58.82

M anipulación manual de cargas

lista de comprobación 29.19

y biomecánica 29.43

$M$ ano

sistema musculoesquéletico

Véase también M uñeca

$M$ antas 71.9

$M$ antenimiento

y cultura 29.94

$M$ antenimiento, personal de riesgos potenciales 94.3

M antequilla 67.26

$M$ anual Diagnóstico Estadístico

trastornos mentales $\quad 5.5,5.12,5.14$ 


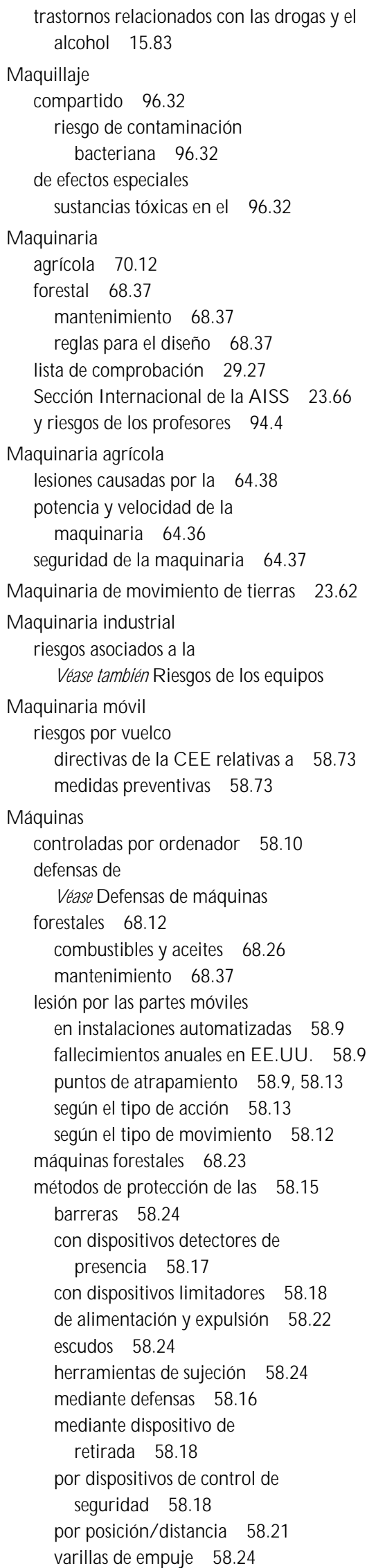

M áquinas automatizadas

Véase R obots

$\mathrm{M}$ áquinas herramienta $\mathrm{CNC}$

Directiva 89/392/ EEC sobre máquinas para 58.54

requisitos de seguridad

en modalidad de funcionamiento normal 58.53

sistemas de seguridad

en modo de funcionamiento especial 58.59

$M$ áquinas portátiles de rectificado accidentes con 32.25

Máquinas y equipos de movimiento de tierras 93.40 cabina 93.40 componentes eléctricos 93.41 condiciones de funcionamiento 93.42 equipación 93.41

estabilidad 93.41

inspección 93.42

mandose indicadores 93.41

mantenimiento 93.42

medidas de precaución $\quad 93.42$

protecciones y cubiertas 93.41

riesgosasociados 93.40

rotulado 93.42

sistemas de dirección y frenado 93.41

tipos 93.40

vibraciones 93.41

en el sector de la construcción

93.40

$M$ aquinistas ferroviarios

fatiga y calidad del sueño en y trabajo por turnos 43.3

M arca CE 68.36,83.18-83.19

Marcadores 67.24

$M$ arcadores biológicos asociados a daños celulares $8.8 \mathrm{t}$ categorías $8.7 f$ criterios de selección $8.7 \mathrm{t}$

de efecto 8.8

de enfermedades malignas 8.9

de nefrotoxicidad 8.8

identificación de los perfiles 8.9

relación con el cáncer de vejiga 8.9

respuesta al tratamiento $8.9 f$

$M$ areas rojas

e intoxicación por marisco $\quad 53.30$

M areo

crónico 50.16

en Cinerama 50.14

en IM AX 50.14

en simulador 50.14

espacial 50.14

inducido por el movimiento $50.2,50.14$

estímulos causantes 50.14

factores de incidencia $\quad 50.15$

medidas de prevención 50.16 movimientos causantes del 50.14

síntomas 50.14

M aricultura 70.37

$M$ arina mercante

control y reducción de riesgos en 102.51

Véase también Buques mercantes

M ármol

riesgos en explotaciones de 62.4

M artillos 29.75

M áscara completa

V éase Protectores respiratorios

M ascarilla

V éase Protectores respiratorios

M ástiles de amarre 68.11

$M$ ataderos 67.20

$M$ atarifes 67.34

$M$ ateriales

en el sector de la construcción

alergias 93.43

consideraciones sobre su elección 93.25

empleados en cubiertas 93.29

riesgos asociados a las pinturas 93.43

visión general 93.43

$M$ ateriales biológicos

medios de muestreo $\quad 30.22$

$M$ ateriales cancerígenos

amianto 94.14

en entornos escolares 94.14

$M$ ateriales combustibles

explosivos 41.14

fibras y textiles 41.12

tratamiento ignífugo $\quad 41.12$

gases 41.13

líquidos combustibles

tanques de almacenamiento $\quad 41.12$

líquidos combustibles e inflamables 41.12 punto de inflamación 41.13

madera y derivados 41.11

descomposición térmica 41.11

metales 41.14

plásticosy cauchos 41.14

polvo 41.15

productosquímicos 41.13

$\mathrm{M}$ ateriales de construcción contaminantes del aire en $\quad 45.4$ - 45.5

$M$ ateriales explosivos almacenamiento 40.12

$M$ ateriales fluorescentes 64.26

$M$ ateriales fosfóricos e iluminación 46.6

$M$ ateriales ignífugos 41.5

$M$ ateriales incompatibles e ignición espontánea 41.10

$M$ ateriales peligrosos

clases específicas de $\quad 41.31$

control de residuos 41.29 
gestión de 41.28

identificación de 41.28

etiqueta de material peligroso $\quad 41.28$

peligro de inflamabilidad $\quad 41.28$

peligros de reactividad

(inestabilidad) 41.28

peligros para la salud $\quad 41.28$

programas de gestión 94.12

$M$ ateriales radiactivos

transporte de 48.32

$M$ ateriales refractarios

diagrama de flujo general de la fabricación de refractarios $84.22 \mathrm{f}$

$M$ ateriales retrorreflectivos 64.26

$M$ ateriales trifosfóricos

e iluminación $\quad 46.6$

$M$ aterias primas

riesgos asociados 84.2

exposición a ruidos 84.2

partículas en suspensión en el aire 84.2

riesgos ergonómicos 84.2

riesgos físicos 84.2

tratamiento 84.2

$M$ aternidad

no discriminación por razón de 9.27

permiso de 9.25

duración normal 9.26

preaviso a la empresa 9.26

prestaciones en metálico 9.26

requisitos 9.26

protección de la $23.27,24.8$

acciones de carácter restrictivo 24.8

políticas de "protección fetal" 24.9

prohibición del trabajo en lugares

peligrosos 24.9

prohibición del trabajo nocturno 24.8

protección en la legislación

Véase también Embarazo

$M$ atriz de $\mathrm{H}$ addon 56.32

M auricio 64.40

M cArdle y cols

tasa de sudoración prevista durante cuatro horas 42.21

M ecánicos de automóviles

cambios hematológicos 103.33

exposición al ruido 103.33

irritaciones oculares 103.33

riesgo de cáncer 103.33

riesgos laborales 103.32

sustancias a las que se exponen $\quad 103.34$

trastornos de la piel 103.33

M ecánicos, riesgos

en la construcción de motores de aviación 90.10

en la industria de la piel y el cuero $\quad 88.4$

en la industria del automóvil

medidas de protección $\quad 91.5$ en la tejeduría 89.24

M ecanización en la agricultura $\quad 64.22$

$M$ edical R esearch C ouncil

y yodo radiactivo en alimentos $\mathbf{4 8 . 3 5}$

M edicina del trabajo

Association of $O$ ccupational and

Environmental Clinics 32.6

centros especializados 32.6

Comisión Internacional de M edicina del Trabajo

programas de formación 18.26

modelos médicos tradicionales 32.2

objetivo 29.2

proveedor centinela 32.6

Recomendación no 112 de la O IT 16.5

reconocimientos preventivos en

Alemania 32.22

vigilancia médica 32.2

M ediciones en epidemiología $\quad 32.31$

M édico del trabajo

ámbitos de actuación $\quad 30.2$

vigilancia médica 30.15

$M$ édicos

estrés en 97.24

índice de suicidios en $\quad 97.24$

trastornos afectivos

por trabajo nocturno $\quad 97.27$

$M$ edidas para la seguridad

y campus 94.15

M edio ambiente

compuestos corrosivos y metales pesados en industrias gráficas 85.4

de trabajo 54.3

convenios y recomendaciones de la

$$
\text { OIT } 54.4
$$

e industria aeroespacial $\quad 90.13$

caída de objetos 90.16

control de emisiones 90.15 - $90.16 \mathrm{t}$

disolventes 90.3

normativas 90.13

reducción de emisiones 90.16

e industria de la piel y el cuero $\quad 88.10$

aguas residuales 88.10

control de la contaminación del agua 88.11

control de la contaminación del

$$
\text { aire } 88.11
$$

impacto ambiental relacionado con las operaciones de curtido $88.11 f$

prevención de la contaminación 88.12

tratamiento de los residuos 88.12

uso de productos químicos

sintéticos 88.10

e industria del automóvil

disolventes 91.7

legislación 91.9

e industria del calzado 88.8

e industria naval $\quad 92.16$ contaminación atmosférica 92.17

contaminación del agua 92.17

gestión de residuos 92.17

tratamiento de aguas residuales 92.10 ,

92.17

e industria textil 89.3

aguas residuales 89.3

emisión de sustancias tóxicas 89.3

residuos de formaldehído 89.3

tratamiento de los residuos 89.11

e industrias gráficas $85.5,85.12$

equipos 85.13

residuos sólidos 85.13 - 85.14

efluentes fotográficos 85.13

técnicas de control 85.14

emisiones a la atmósfera

en los procesos de estampado 89.20

enfermedades de origen ambiental 53.2

escapes de material radiactivo al $\quad 48.29$

y programa de vigilancia

radiológica medioambiental

para casos de emergencia

(EREMP) 48.38

y técnicas de vigilancia $\quad 48.29$

estrategias de gestión del

en la empresa 54.32

factores internacionales 54.31

factores nacionales y locales 54.32

V éase también G estión ambiental

generación de fangos en el

estampado 89.20

legislación sobre

V éase L egislación ambiental

partículas en suspensión en el aire en la

fabricación de vidrio, cerámica y

materiales afines 84.31

política sobre

Véase Política ambiental

protección del 54.19

auditoría ambiental 54.27 - 54.28,

$54.30,54.32$

evaluación del ciclo vital $54.19-54.20$

54.22 - 54.23

inspecciones 54.5

programas de prevención de la

contaminación 54.35 - 54.36

reciclaje en la fabricación de vidrio, cerámica y materiales afines 84.31

relación con la salud humana 54.7 - 54.8

tratados internacionales sobre el

$V$ éase C onvenios internacionales ambientales

y carpintería 86.7

emisiones atmosféricas $\quad 86.7$

y confección 87.7

emanación de formaldehído 87.7

y el sector de la construcción

paisajismo 93.31

productos contaminados 93.24 
y la fabricación de fibras de vidrio $\quad 84.7$ y la fabricación de vidrio 84.5

M edio ambiente de trabajo

evaluación del 30.15

gestión de riesgos en el $\quad 30.7$

lista de comprobación $\quad 29.21$

y cultura de seguridad 59.7

Véase también H igiene industrial

M edios de comunicación de masas 94.2

M edroxiprogresterona $\quad 37.10$

M édula espinal 7.7

M édula ósea

éteres glicólicos y 104.201

y efecto del benceno 1.2

$M$ édula suprarrenal

y respuesta de "fight-flight" 34.11

M ees, líneas de

e intoxicación por arsénico

M eiosis 9.5

M eissner, corpúsculo de $\checkmark$ éase R eceptores cutáneos

M ejora continua de la calidad 34.37

M elanocitos

Véase Piel

M elanoma

Véase Cáncer de piel

por radiación ultravioleta $\quad 53.30$

M elanoma maligno

en marineros 102.47

M elanorragia 42.10

M elanosis

por arsénico 63.7

M elaza 67.32

M embranas celulares estructura y propiedades 33.9

M emoria

alteraciones en traumatismos craneales 14.10

$M$ enière, enfermedad de Véase Equilibrio, disfunción

M enopausia salud de la mujer $\quad 15.57$

M enorragia Véase Salud de la mujer

M ercado común del sur acuerdos de libre comercio $\quad 20.15$

M ercancías peligrosas en la conducción de camiones 103.7

M ercaprol 63.19

M ercosur acuerdos laborales V éase también R elaciones laborales

M ercurio

absorción 27.13

compuestos orgánicos de absorción de 63.30

envenenamiento con compuestos de 39.5

frecuencia de radiación característica 46.6

intoxicación 27.13

intoxicación aguda por 63.29

síntomas de una 63.29

intoxicación crónica por $\quad 61.22,63.30$

en los laboratorios 61.22

metálico 27.12

absorción 27.12

concentración 27.12

excreción 27.12

exposición 27.12

muestreo de enfermedades por $\quad 30.21$

operaciones de recuperación

controles técnicos $82.57 \mathrm{t}$

orgánico 63.30

riesgos del 63.30

reciclaje de lámparas de 81.14

y medidas de seguridad 63.31

Véase también Lámparas de

M erkel, célula de

$\checkmark$ éase R eceptores cutáneos

M ero 70.6

M erseyside

modelo de información de accidentes de 56.25

y reducción de la tasa de accidentes 56.26

M erulius lacrymans 64.39

M esotelioma

e inhalación de erionita 62.3

e inhalación de vermiculita 62.5

en el sector de la construcción 93.11

importancia del intervalo de tiempo $\quad 30.30$

por asbesto 98.7

M esotelioma maligno 62.3

anatomía patológica 10.67

características clínicas 10.67

epidemiología 10.68

etiología profesional 32.3

factores medioambientales 10.69

mesotelioma pleural $10.89,72.18$

mortalidad 32.6

papel de la tremolita 10.69

pleural y peritoneal 28.42

y exposición al polvo de asbestos 62.3

$M$ etabisulfito 65.13

M etabolismo

activación metabólica 33.7, 33.32

desactivación metabólica 33.8

enzimas metabolizantes de fármacos 33.21

huella dactilar metabólica 33.24

inducción 33.8

inhibición 33.8

Véase también Enzimas

Véase también G enética

M etabolismo de xenobióticos enzimas citocromo P450 33.8, 33.25
CYP2C 1933.26

CYP2D 633.26

CYP2E $1 \quad 33.27$

familias 33.25

historia y nomenclatura 33.25

subfamilia CY P1A 33.26

subfamilia CY P3A 33.27

enzimas metabolizantes de

xenobióticos 33.21

polimorfismos de otras enzimas (no P450) 33.27

reacciones de la fase $1 \quad 33.8,33.23$

reacciones de la fase $2 \quad 33.8,33.23$

M etabolito ácido mandélico 30.23

M etahemoglobina

cianosis 1.6

metahemoglobina reductasa 1.6

trastornos 1.6

$M$ etahemoglobinemia

agentes relacionados $1.2 \mathrm{t}$

aminas aromáticas y 104.97

por consumo de agua con nitratos 55.37

relacionada con la vivienda $\quad 53.26$

$M$ etalcarbonilos

propiedades físicas de algunos $63.32 \mathrm{t}$

toxicidad de los 63.32

M etaldehído

riesgos del 104.47

$M$ etales

compuestos organometálicos tóxicos 27.8

efectos neurotóxicos 7.11

forja y estampación 82.23

laceraciones $82.23-82.24$

lesiones 82.23

medidas de salud y seguridad $\quad 82.24$

riesgos 82.23

riesgos ambientales 82.25

riesgos químicos 82.23

fundición y afino $\quad 82.2$

de aluminio $82.8-82.10$

de cobre 82.4

de oro 82.11

de plomo 82.6

de zinc 82.7

estrés térmico 82.3

hidrometalurgia 82.2

lesiones 82.3

pirometalurgia 82.2

prevención de los riesgos 82.3

protección del medio ambiente 82.4 riesgos químicos 82.3

industria de los

ácidos inorgánicos en la 104.5

rectificado y pulido 82.35

muelas de rectificado 82.35

riesgo de incendio 82.36

riesgo de lesiones 82.35

riesgos para la salud 82.37 
recuperación 82.48

control de las emisiones 82.48

de cadmio 82.58

de cobalto 82.59

de cobre 82.50

de estaño 82.60

de magnesio 82.55

de mercurio 82.56

de metales preciosos 82.57

de níquel 82.57

de plomo 82.52

de selenio $\quad 82.59$

de titanio 82.61

de zinc 82.54

del aluminio $\quad 82.50$

programa de métodos de trabajo 82.49

riesgos físicos y químicos $63.52 \mathrm{t}$

riesgos para la salud 63.63t

soldadura y corte térmico $\quad 82.25$ - 82.30

al arco bajo gas protector 82.25

al arco con electrodo $\quad 82.25$

botellas de gas a presión 82.28

corte con gas 82.25

espacios confinados 82.31

fiebre por vapores de metal 82.31

generadores de acetileno $\quad 82.28$

por resistencia 82.27

prevención de incendios y

explosiones 82.28

radiación ionizante 82.31

radiación ultravioleta 82.30

riesgos de quemaduras 82.29

riesgos inherentes 82.27

riesgos químicos 82.30

ruido 82.31

seguridad eléctrica $\quad 82.29$

superficies metálicas 82.62

eficacia de lavado 82.64

métodos de limpieza 82.62

procesos de recubrimiento 82.64

recubrimientos 82.64

residuos específicos 82.63

seguridad, salud y medio

ambiente 82.62

tornos 82.31

accidentes 82.32

arrastre 82.34

de control numérico 82.32

elementos móviles de transmisión $\quad 82.33$

ergonomía 82.34

estructura 82.32

formación teórica y práctica $\quad 82.34$

mantenimiento 82.35

prevención de accidentes 82.33

tipos de torno 82.32

virutas 82.34

zonas de trabajo 82.34

tratamiento de superficie

anodizado 82.42 cianuración 82.47

diseño del lugar de trabajo 82.46

disoluciones ácidas y alcalinas 82.47

disolventes 82.47

electroconformación 82.42

endurecimiento 82.45

equipos de protección personal 82.46

esmalte vítreo 82.43

evaluación de la toxicidad 82.46

formación de los trabajadores 82.47

fosfatado 82.45

galvanizado 82.44

homogenización 82.45

hornos y estufas 82.48

impacto ambiental 82.61

imprimación 82.46

materiales para la fabricación de

esmaltes 82.43

metalización 82.45

mordentado 82.44

normalizado 82.45

polvo metálico 82.47

pulido electrolítico 82.42

recocido 82.44

recubrimiento con plásticos 82.46

recubrimiento electrolítico 82.42

resumen de los riesgos $82.42 \mathrm{t}$

riesgo de incendio 41.14

riesgos para la seguridad y la

salud 82.46

temple isotérmico $\quad 82.45$

termotratamiento 82.44

ventilación 82.46

valores de referencia y límites

biológicos $27.9 \mathrm{t}$

y metaloides esenciales y/ o tóxicos

interacciones 33.21

$M$ etales pesados

contaminantes del agua $\quad 53.20$

en las partículas en suspensión

efectos cancerígenos de los 55.16

procedimientos de medición 55.16

$M$ etales preciosos

proceso de recuperación

controles técnicos $82.58 \mathrm{t}$

M etalistería

V éase M etal, industria del

M etalotioneína $\quad 33.14,33.46,63.11$

M etaltioleína $\quad 27.11$

$M$ etalurgia

boranos en la industria 104.130

Fundición de hierro 82.13

procesado de metales

Véase M etales

sección Internacional de la AISS 23.66

$M$ etano

acumulación en minas

subterráneas 74.9 en plantas de tratamiento de residuos 101.13

en recintos de ganado confinado 70.13

incendio y explosión 104.239

M etanol

interacción con el etanol $\quad 27.15$

riesgos asociados a su utilización en industrias gráficas 85.9

M etil-butil-cetona

riesgo de neuropatías periféricas en los procesos de tinción 89.20

M etilfenoxiacético ácido 27.25

M etilhipídico ácido 27.5

M etilisobutilcarbinol preparación del carbón 74.30

M etilmetacrilato

en productos cosmetológicos sensibilidad al $\quad 100.7$

$M$ étodo Bergerhoff de medición del polvo sedimentable 55.16

$M$ étodo de Fanger para el confort térmico $\quad 45.20$

M étodo del árbol de causas $y$ antecedentes de un accidente $\quad 57.26$

M étodo M ORT

control de los riesgos de accidente $\quad 57.19$

en Estados U nidos 57.20

en la industria de Finlandia $\quad 57.20$

supervisión de la gestión y árbol de riesgos 57.19

M étodo ST EP $57.28 f$

y detección de sucesos en secuencias temporales 57.26

$M$ étodos educativos

formales 94.2

informales 94.2

$M$ etros

factores de riesgo específicos del personal de los 102.38

M éxico

exposición al ozono en Ciudad de

M éxico 53.14

programa Bracero (1942-1964) 24.11

terremoto de Ciudad de M éxico 39.19

$M$ eyer- $O$ verton hipótesis de 36.3

$\mathrm{M}$ ica

riesgos en minería de la $\quad 62.5$

M icosis $10.33,64.38$

M icotoxinas intoxicación alimentaria por $\quad 53.9$

M icrobiología

en modelos de salud pública $\quad 67.10$ 
para investigación de accidentes laborales 60.5

M icrocefalia

$$
\text { por irradiación } 39.38
$$

Micrococcus 44.23

M icrocontaminantes orgánicos 53.20

Microestación 68.16

M icrofisiómetro de sílice 33.55

M icrogravedad

anomalías cardiovasculares por la $\quad \mathbf{1 0 2 . 2 0}$

anomalías fisiológicas 102.22

riesgos hematológicos de la 102.21

y desgaste muscular 102.20

y enfermedad del movimiento en el espacio (EME) $\quad 102.21$

y pérdida de tejido óseo $\quad 102.21$

M icronúcleos 33.50

Microondas

norma O SH A de exposición a 97.33

$M$ icroordenadores multicanal para control de guillotinas 58.33

Microorganismos

en el aire interior $\quad 44.22,44.24$

efectos sobre la salud $\quad 44.24$

medidas de control 44.27

en el medio ambiente de trabajo $\quad 38.2$

en oficinas 99.2

zoonóticos 38.2

M icropolyspora faeni 44.23

Microsporum canis 69.5

M icrurus 38.8

Midriasis

por descarga eléctrica $\quad 40.4$ - 40.5

M iel 70.39

M ielina

características 7.3

y sustancias neurotóxicas 7.4

M ieloma

mieloma múltiple 1.4

factores profesionales de riesgo $\quad 1.6$ incidencia 1.5

M igrantes

trabajadores

Véase T rabajadores migrantes

M igrañas

y síndrome del edificio enfermo $\quad 13.4$

conductores de camión y $\quad 103.7$

M iliaria

cristalina $\quad 42.11$

profunda 42.11

rubra 42.11

Milkfish 70.6

M ilneb $\quad 62.16$

Milwaukee, hombro de

Véase $\mathrm{H}$ ueso
M inamata

enfermedad de 39.5

$M$ inas

Véase M inería, minas a cielo abierto inspección de trabajo en las 23.13 utilización en las fuerzas armadas riesgos asociados 95.19

$M$ inas subterráneas

iluminación 74.41

comparación de fuentes $74.41 \mathrm{t}$

fuente de iluminación 74.41

influencia en accidentes 74.42

normas de seguridad 74.41

refrigeración 74.36

equipos generadores 74.40

plantas de refrigeración 74.40

refrigeradores locales 74.40

ventilación 74.35

controles 74.39

de diferentes métodos de minería 74.36

de equipos con motor diesel 74.36

emergencias relacionadas 74.40

red de ventilación $\quad 74.37$

ventiladores $74.38-74.39$

vías de aire 74.38

M inerales 74.2

M inería

detección de gases 74.47

análisis de gases 74.51

células electroquímicas 74.48

combustión espontánea 74.51

cromatógrafo de gases 74.50

detectores de radiación infrarroja no dispersiva 74.49

detectores portátiles 74.47

elección del sistema 74.50

equipo de detección 74.47

explosiones 74.52

limitaciones de los instrumentos portátiles 74.49

metano 74.48

metanómetro catalítico 74.48

monóxido de carbono 74.47, 74.52

resultados en aire libre 74.51

sistema telemétrico automático 74.49

sistemas centralizados de control 74.49

sistemas de grupos de tubos 74.49

ubicación de los puntos de

muestreo 74.50

emergencias 74.52

acciones de respuesta 74.54

compromiso por parte de la organización 74.53

equipos y materiales $74.54 \mathrm{t}$

factores críticos $74.54 \mathrm{t}$

formación para la preparación $\quad 74.57 t$

gestión del riesgo 74.53

infraestructura de

comunicaciones 74.55 organización de emergencias 74.54

refugios 74.54

simulacros 74.57

sistemas de prevención y gestión 74.52

supervisión atmosférica 74.55

equipos de minería subterránea 74.17

camión de carga 74.17

perforadora de profundidad para pozos 74.17

tren perforador de frentes 74.17

vehículo de

carga-levantamiento-volcado 74.17

equipos de protección personal 74.42

careta 74.43

casco tradicional 74.42

escafandra 74.43

gafas de seguridad 74.43

lámpara de casco 74.42

protección contra el polvo 74.43

ropa 74.44

sistemas de comunicación 74.43

sombreros de seguridad 74.42

extracción del carbón 74.8

acarreo sobre raíles 74.17

manejo del mineral 74.17

impacto de la minería sobre el medio ambiente 74.2

incendios y explosiones 74.44 almacenamiento de combustibles 74.45 , 74.47

áreas de servicio permanente 74.44

contención de incendios 74.46

detección de gases o humos 74.46

equipos de extinción 74.46

equipos móviles 74.44

prevención de incendios 74.45

soldadura y corte 74.44

minas a cielo abierto $\quad 74.9$

acarreo 74.22

aspectos ambientales 74.23

capa de cobertura 74.20

características geológicas 74.24

ciclo de la mina 74.25

equipo de carga 74.21

extracción a cielo abierto 74.21

perforación y voladura 74.21

planificación 74.24

producción 74.24

riesgos 74.23

selección del equipo 74.20

sistema basado en cintas

transportadoras 74.25

sistema de camiones y palas 74.25

sistema de dragalinas 74.25

sistema por disolución 74.22

topografía 74.21

trituración 74.22

vertederos de lixiviación $\quad 74.23$

minas subterráneas 74.9 
acumulación de metano $\quad 74.9$

control de tierras 74.11

control del terreno 74.32

excavación de pozos $74.10-74.11$

excavación de una galería 74.10

explotación en retirada 74.19

explotación por

franjas-almacenes 74.13

extracción en escalón 74.13

hundimiento de subniveles 74.15

hundimiento en bloque 74.16

niveles inflamables de polvo 74.9

perforación con trépano de

diamantes 74.10

perforadora 74.11

por tajos largos $74.16,74.19$

rampas 74.18

relleno de los tajos 74.16

retirada mediante cráteres

verticales 74.15

sistema de cámaras y pilares 74.18

sistema de corte y relleno $\quad 74.13$

sistema de pilares 74.12

sistemas de extracción $\quad 74.10$

trazado de una mina $74.10,74.18$

vagonetas de transporte de

carbón 74.19

vehículo de cremallera 74.11

voladura 74.15

yacimiento inclinado 74.13

minería hidráulica 74.23

riesgos físicos 74.24

peligros para la salud 74.58

escasez de oxígeno $\quad 74.60$

exposición al amianto 74.59

exposición al polvo 74.59

exposición al ruido 74.60

exposición al sílice 74.59

gases nocivos $74.60 \mathrm{t}$

gases y vapores 74.60

partículas diesel 74.59

partículas transmitidas por el aire

presión térmica 74.61

radiación ionizante 74.60

precauciones de seguridad 74.19

preparación del carbón 74.28

almacenamiento 74.29

briquetación del carbón

bituminoso 74.31

briquetado 74.30

clasificación por tamaños 74.29

eliminación de residuos 74.31

flotación por espuma 74.30

lavado 74.29

mecanismos de fracturación 74.29

relaves 74.31

separación por densidad $\quad 74.30$

trituración 74.29

usos finales 74.28 primas del seguro de accidentes en

Alemania 26.22

procesamiento del mineral $\quad 74.25$

clasificadores 74.26

cribado 74.26

deshidratación 74.28

flotación 74.27

lixiviación 74.28

molienda 74.26

separadores magnéticos 74.27

trituración 74.26

prospección 74.4

condiciones físicas 74.5

desplazamientos 74.7

equipos pesados 74.7

eslingaje 74.8

excavaciones 74.7

formación 74.5

seguridad al aire libre 74.5

seguridad en el campamento 74.5

seguridad en la prospección 74.5

trabajos de prospección 74.5

sección Internacional de la AISS 23.66

y empleo 74.2

M inería del carbón

riesgo de muerte a largo plazo $\quad 53.25$

$M$ ineros 28.3

M inorías étnicas

estresores 34.59

problemas sanitarios de los

trabajadores 23.33

trabajadores afroamericanos 34.60

y apoyo social 34.59

y estrés

métodos de evaluación del 34.59

$y$ trabajos peligrosos 34.60

M inusvalía

Véase D iscapacidad

definición de la OIT 29.83

relación con la discapacidad $\quad 17.6$

$74.58 \quad$ M ioglobina 40.3

M iopía

en operadores de PVD 52.12

M ississauga, Canadá 39.30

M obiliario

de sistemas 52.6

M odelista 103.36

riesgos laborales 103.37

M odelo de ajuste persona-entorno afrontamiento 34.19

ajuste exigencias-capacidades 34.18

ajuste necesidades-ofertas 34.18

modelos estadísticos 34.19

propiedades dinámicas 34.19

M odelo de demandas-control

implicaciones macrosociales 34.13

respuesta fisiológica 34.11
M odelo de desviación de accidentes clasificación de las desviaciones $\quad 56.23$

Modelo de gestión de la calidad (modelo TQ M)

métodos de refuerzo $\quad 60.23$

objetivos de actuación del 60.23

ventajas e inconvenientes del $\quad 60.24$

y mejora de los niveles de seguridad $\quad 60.23$

M odelo de gestión del comportamiento

organizativo (modelo O BM )

capacidad a largo plazo del $\quad 60.22$

objetivos de seguridad del 60.21

reducción de la siniestralidad $\quad 60.22$

en Estados U nidos 60.22

en Finlandia 60.22

refuerzo del comportamiento seguro $\quad 60.22$

y medidas correctivas 60.22

y recompensas 60.22

y retroinformación 60.22

ventajas y desventajas del $\quad 60.23$

M odelo de $\mathrm{H}$ ale y $\mathrm{G}$ lendon

niveles de control del peligro 56.18

y comportamiento ante el peligro 56.17

y factor humano en los accidentes 56.16

$M$ odelo de $\mathrm{H}$ einrich

para causalidad de accidentes

Véase T eoría del efecto dominó

M odelo de Información de Accidentes de

M erseyside

diccionario del software del $\quad 56.27$

estructura de acontecimientos del 56.27

y reducción de la tasa de accidentes 56.26

M odelo de R eason y Embrey

y creación de modelos de error $\quad 57.8$

M odelo de Surry

para investigación de accidentes 56.19

M odelo de tres factores de Brown y $\mathrm{H}$ olmes para medición del clima de seguridad 59.10

M odelo de Zohar para mediciones del clima de seguridad 59.10

M odelo M AIM

Véase M odelo de información de accidentes de $M$ erseyside

M odelo WEF

de investigación de accidentes 56.19 perfeccionado 56.20

M odelos de dispersión de contaminantes en un terreno estructurado $\quad 55.10$

modelo de dispersión de Euler 55.9 modelo de flujo de diagnóstico 55.10 modelo de Lagrange 55.10 modelo gaussiano de penacho 55.9 modelo gaussiano de ráfaga 55.10 modelos de diagnóstico de masa constante 55.12 
modelos de flujo no hidrostático 55.12 modelos de pronóstico 55.11 para emisiones accidentales 55.10 parámetros de la fuente 55.8 parámetros meteorológicos 55.8 - 55.9 por fuentes de poca altura 55.11

M odelos O BM y TQM comparación $60.21 \mathrm{t}$

M ohos 71.10

M oldeo y fundición de metales 82.19

M olecular, epidemiología 2.16

M olibdeno riesgos de exposición al 63.33

M olienda proceso de fabricación de pinturas $\quad 67.29$ $\checkmark$ éase Pinturas y revestimientos

Molinate 62.14

M olusquicidas 104.369

$M$ onge enfermedad de 37.10

MONICA

estudio de la OMS 3.5

y tabaquismo 3.7

M onilia 64.38

$M$ onitores

para detección de contaminantes 44.6 , $44.19,44.21-44.22$

M onitores continuos de aire (M CA) $\quad 48.26$

M onómeros 67.24

efectos neurotóxicos 7.12

en envoltorios de plástico

transparente 67.24

M onometilarsónico ácido 27.10

M onoterpenos 71.10

M onotonía 34.6

M onóxido de carbono concentraciones de 44.10

en interiores 44.10

contaminación del aire interior por 45.8

detección de 44.21

efectos nocivos del 53.14

en gases de escape de los motores de combustión interna 102.35

exposición del personal auxiliar y de ambulancias 95.21

exposición en fábricas de ahumados 67.10

exposición en la extinción de

incendios 95.6, 95.8

exposición en la industria del

automóvil 91.4

exposición en las fuerzas armadas 95.18

intoxicación 104.430

aguda 33.31

límites de exposición profesional 30.31 muestreo para el control biológico 30.21

y presión barométrica 36.2

Véase también Intoxicación por monóxido de carbono

M ontaje de tarjetas de circuito impreso adición de fundente 83.30

fundentes bajos en sólidos 83.31

fundentes basados en colofonia 83.30

fundentes orgánicos 83.31

fundentes sintéticos activados 83.31

aplicación de pasta de soldar y

adhesivo e inserción de

componentes 83.29

endurecimiento de adhesivo y fluidificación de soldadura 83.30

inspección, retoque y prueba 83.32

limpieza previa y posterior 83.29

operaciones de apoyo- limpieza de plantillas 83.33

reproceso y reparación 83.33

soldadura por ola 83.31

precalentamiento 83.32

soldadura 83.32

M ontreal 104.191

Protocolo de

reducciones en la producción de CFC 53.31

reducciones en la producción de halones 41.25

M onurón 62.14

M oolgavkar

modelo matemático de 2.3

M oolgavkar-V enzon-K nudson modelos de base biológica 33.79

M orabia

grupos homogéneos 26.9

M orbilivirus equino 97.44

M orbilli 53.35

M ortalidad

de origen profesional coeficientes proporcionales de mortalidad 32.7

estudios 32.7

en la industria del automóvil

fundiciones 91.8

operaciones de mecanizado 91.9

entre los pescadores 66.18

medición de la 28.11

por causas desconocidas $\quad 66.18$

M orton, neuroma de 6.31

M osquitos 70.39

M otivación

de los trabajadores

modelo O BM 60.21

modelo T Q M $60.21-60.23$

para la seguridad $\quad 60.20$

M otivación personal 24.2
M otoniveladoras

riesgo de vuelco en 58.71

y uso de EPV 58.74

M otores de aviación, construcción actividades

fabricación de materiales plásticos compuestos 90.9

fresados químico y electroquímico $\quad 90.9$

mecanizado por descargas

eléctricas 90.9

soldadura por haz de electrones 90.9

taladrado mediante láser $\quad 90.9$

inspección y pruebas 90.9

materiales 90.9

metálicos 90.9

plásticos 90.9

riesgos para la salud $\quad 90.9$

dermatitis 90.10

exposición al plomo $\quad 90.11$

inhalación de emanaciones $\quad 90.10$

lesiones físicas 90.10

radiación 90.10

ruido 90.10

M otosierra

exámenes estándar para operarios

de 68.40

gases de escape 68.27

seguridad 68.12

Mowrah 67.33

M ucosas

irritación de las

y formiato de etilo $\quad 104.177$

y formiato de metilo 104.177

y nitrocompuestos 104.338

y peróxidos 104.363

irritación de las

y ácido acético $\quad 104.13$

y ácido fórmico 104.13

y ácido nítrico 104.6

quemadura en

ácido sulfúrico y $\quad 104.7$

M uelas abrasivas

precauciones de seguridad con $\quad 58.7$

M uerte aparente

por descarga eléctrica

40.4

M uerte celular

accidental 33.33

definición 33.3

generalidades 33.33

genes "antimuerte" 33.35

genes "promuerte" 33.35

necrosis 33.34

programada 33.33

Véase también Lesión celular

M uerte por causa del empleo

gastos de entierro 25.17

indemnización $\quad 25.9,25.17$

karoshi 25.9 
muerte no indemnizable 25.17

pensiones de viudedad 25.17

suicidio 25.9

supervivientes a cargo $\quad 25.17$

cohabitación 25.18

dependencia 25.17

M uestreador de rendija 30.23

M uestreadores de aire $\quad 44.27$

de filtro 44.26

muestreador centrífugo R euter 44.27

por impacto 44.26

volumétricos microbiológicos 44.24

M uestreadores por difusión $\quad 37.14$

M uestreo ambiental integrado $\quad 30.20$

bombas 30.21

M uestreo ambiental y biológico cuántas muestras deben tomarse y con qué frecuencia 30.21

de qué deben tomarse muestras 30.19

de quién deben tomarse muestras 30.19

detectores en tiempo real 30.23

dónde deben tomarse las muestras 30.19

duración 30.20

estrategias 30.18

grupos de exposición homogénea $\quad 30.20$

medios biológicos 30.23

objetivo 30.18

técnicas analíticas 30.24

técnicas de medición 30.21

gases y vapores 30.21

materiales biológicos 30.22

materias particuladas 30.22

muestreo activo y pasivo 30.21

toma de muestras en la piel y en las superficies 30.23

M uestreo del peor caso $\quad 30.20$

M uestreo en tiempo real 30.20

M uestreo selectivo granulométrico $\quad 30.22$

M ujeres

abuso de drogas entre las mujeres $\quad 15.87$

acoso sexual como forma de discriminación sexual 51.5

centros de salud para mujeres 15.55

Convención de las $\mathrm{N}$ aciones $\mathrm{U}$ nidas sobre la eliminación de todas las formas de discriminación contra la mujer 23.24, 23.29, 24.4

discriminación por razón de sexo $\quad 24.7$ prevención de la discriminación 23.11 e industrialización en China 20.25 embarazo y accidentes eléctricos 40.5 empleo en Europa del Este 24.6 en el comercio minorista 99.14 en el procesamiento del pescado 66.13 en la industria forestal 68.4

riesgos para la seguridad $\quad 68.6$

en puestos de gestión $\quad 99.4$

en trabajos administrativos 99.3 estrés 34.57

igualdad en el lugar de trabajo

igualdad de remuneración $\quad 24.7$

y protección de la salud 24.7

menopausia y salud de la mujer 15.57

no discriminación por motivos de

maternidad 9.27

osteoporosis $6.7,15.58$

papel en el mundo laboral 5.18

pescadoras 66.13

prestaciones de asistencia sanitaria $\quad 15.62 \mathrm{t}$

prestaciones ofrecidas por la empresa $15.63 \mathrm{t}$

programa de salud para la mujer en First Chicago Corporation 15.25

problemas de desempleo 34.31

programas de gestión de la

maternidad 15.63

problemas reproductivos de las trabajadoras migrantes 64.65

prohibición de la discriminación por razón de embarazo 9.27

reajuste estructural y 24.5

riesgo de cáncer en 28.24

salud materno-infantil 15.62

segregación de la población activa en

función del sexo 24.3

sindicatos y $\quad 21.7-21.9$

tabaco y 15.49

tópicos infundados 24.3

trabajadoras de la industria textil $\quad 3.12$

trabajo por turnos 43.5

trastornos musculosqueléticos en 6.17

varices 3.3

violencia contra las mujeres 24.5

y homicidios 51.2

y acoso sexual 51.5

y sexismo 24.3

y cáncer de mama 15.60

y dieta 15.59

Véase también Salud de la mujer

Mulo 70.30

M ultinacionales

traslado de riesgos industriales $\quad 20.16$

M ultisensibilidad química

Véase Sensibilidades químicas múltiples

$M$ uñeca y mano

artrosis 6.25

asociada a la vibración $\quad 6.26$

interfalángica distal 6.25

nódulos de $\mathrm{H}$ eberden $\quad 6.25$

síntomas 6.26

calambre del escritor 6.27

contractura de Dupuytren $\quad 6.26$

esfuerzos repetitivos 6.24

peritendinitis 6.24

quistes sinoviales 6.26

síndrome compartimental 6.26

tenosinovitis 6.24 de De Quervain 6.25

estenosante 6.25

incidencia en grupos de

población $6.24 \mathrm{t}$

M uscular

$V$ éase Enfermedades musculares

clasificación $6.4 \mathrm{f}$

M úsculos

músculos lisos 7.8

M usculosqueléticos, trastornos

en el baile profesional $\quad 96.6,96.26$

en el sector de la construcción 93.11

causas 93.12

prevención 93.12

en la confección $\quad 87.3$ - 87.4, 87.6

pinzamientos de nervios 87.6

síndrome del túnel carpiano 87.6

tendinitis 87.6

en la confección de alfombras 89.29

en la fabricación de alfombras 89.28

en la industria del automóvil 91.7 - 91.9

en la industria del calzado $\quad 88.8,88.10$

riesgos afrontados por el personal

auxiliar y de ambulancias 95.21

riesgos asociados en los servicios de policía

dolor de espalda 95.13

M useo de electropatología de V iena $\quad 40.5$

M useos

calidad del aire interior en los 96.41

gestión de las colecciones en los 96.44

riesgos y precauciones de las actividades $96.42 \mathrm{t}$

instalación de exposiciones en 96.43

riesgos y precauciones 96.43

servicios generales en 96.41

y riesgos más comunes 96.41

trabajos de renovación

exposición a materiales peligrosos 96.41 precauciones 96.41

M úsicos

problemas neuromusculosqueléticos

en $96.26-96.27$

protectores de oídos 96.27

riesgos de pérdida auditiva $\quad 96.27$

Mutación

cromosómica 33.50

definición 33.37

por irradiación 39.38

M utagénesis 9.2

M utagenicidad

carcinógenos 33.50

ensayos de 33.50

prueba de Ames 2.16

sistemas transgénicos 33.50

y Ley japonesa de control de las sustancias químicas 33.44

M utágenos

cancerígenos profesionales 2.3 
M ycobacterium avium $\quad 44.5,70.29$

M ycobacterium tuberculosis $44.25,97.43$, 97.50

N

\section{$\mathrm{N}$ aciones $\mathrm{U}$ nidas \\ agencias especializadas $\quad 23.44$ \\ A samblea General}

comités de la 23.49

$\mathrm{C}$ arta de las $\mathrm{N}$ aciones $\mathrm{U}$ nidas 23.24 23.25, 23.43

Centro de la Industria y el M edio Ambiente 73.19

Comité Científico de las $\mathrm{N}$ aciones $\mathrm{U}$ nidas para el Estudio de los E fectos de las $R$ adiaciones A tómicas 39.35

Comité de Expertos en el T ransporte de M ercancías Peligrosas del Consejo Económico y Social 23.44

compendio DISTAT 17.13

Conferencia de las $\mathrm{N}$ aciones $\mathrm{U}$ nidas sobre Comercio y Desarrollo (UNCTAD) 23.53

Conferencia sobre el M edio Ambiente y el Desarrollo 23.47

Consejo de administración fiduciaria 23.52

Consejo de Seguridad 23.51

Consejo Económico y Social 23.49 organos subsidiarios 23.51 relaciones con las organizaciones no gubernamentales 23.51

Convenio Internacional sobre la Protección de los $D$ erechos de los $T$ rabajadores M igrantes y los M iembros de sus Familias 24.11

Corte Internacional de Justicia 23.49

Cumbre sobre M edio A mbiente y Desarrollo 16.3

Agenda $21 \quad 16.3$

Declaración de Río 16.3

Década Internacional de las $\mathrm{N}$ aciones U nidas para la reducción de las catástrofes naturales $39.15,39.51$

estructura 23.49, 23.50f

Fondo de Población de las $\mathrm{N}$ aciones $\mathrm{U}$ nidas (FNUAP) 24.6

generalidades 23.48

idiomas oficiales 23.49

miembros 23.49

normas de las $\mathrm{N}$ aciones $\mathrm{U}$ nidas sobre la igualdad de oportunidades para las personas con discapacidades 17.3

$\mathrm{O}$ ficina de Coordinación de las $\mathrm{N}$ aciones U nidas para el Socorro en Catástrofes 39.2

Programa de las $\mathrm{N}$ aciones $\mathrm{U}$ nidas para el Desarrollo 23.44
Programa de las $\mathrm{N}$ aciones $\mathrm{U}$ nidas para el

M edio Ambiente (PNU M A) 23.44,

23.47, 23.52, 39.17, 73.19

funciones específicas 23.52

objetivo 23.52

recomendaciones sobre el transporte de sustancias peligrosas 39.31

Resolución 1990/ 31 de la Comisión de Derechos Humanos 23.24

secretaría 23.51

sensibilización y preparación ante emergencias a nivel local 39.17

y catástrofes 39.2

y salud y seguridad en el trabajo $\quad 23.52$

$N$ aegleri 44.24

$\mathrm{N}$ aftilaminas

y metahemoglobinemia $\quad 104.98$

$N$ aja haje 38.8

$\mathrm{N}$ aja kaouthia 38.8

Naja mossambica 38.8

Naja naja 38.8

$\mathrm{N}$ aja nigricollis 38.8

$N$ aja nivea 38.8

Naja sumatrana 38.8

$\mathrm{N}$ arcosis

por nitrógeno 36.3

tetrahidrofurano y 104.154

Nariz

irritación de la

acrilato de etilo $\quad 104.172$

hidracinase 104.122

Narrias 68.11

Nasofaríngeo, cáncer 10.89 Véase Cáncer

N asosinusal, cáncer 10.89 Véase Cáncer

National C ancer Institute (Estados

U nidos) 32.7

relación entre ciertas profesiones y el linfoma no H odgkin 32.7

$\mathrm{N}$ ational $\mathrm{C}$ enter for $\mathrm{H}$ ealth Statistics (Estados Unidos) encuestas nacionales de salud $\quad 32.8$

$N$ ational Council on Compensation Insurance 34.2

National C rime V ictimization Survey (Estados Unidos) agresiones en el lugar de trabajo $\quad 51.3$

$N$ ational Electrical Code $\quad 40.15$

$N$ ational Fire Protection Association (NFPA) 41.8, 100.13

Basic Incident R eport Form $\quad 41.8$

Fire $\mathrm{H}$ azards $\mathrm{H}$ andbook $\quad 41.16$

Fire Protection $\mathrm{H}$ andbook $\quad 41.16,41.19$

Fire Safety Concepts T ree 41.15

Firesafety Educator's H andbook 41.16
NFPA 1

Fire Prevention Code 41.16

NFPA 13

Installation of Sprinkler Systems 39.48 NFPA 25

Inspection, T esting, and $M$ aintenance of W ater-Based Fire Protection Systems 39.48

NFPA 70

National Electrical Code $\quad 40.15$

NFPA 72

Código nacional de alarma de incendio 39.48

NFPA 101

Código de salvamento $\quad 39.47$

NFPA 495

Código de materiales explosivos $\quad 41.14$ NFPA 704

Standard System for the Identification of the Fire $\mathrm{H}$ azards of $\mathrm{M}$ aterials $\quad 41.28$ normativa para las plantas de limpieza en seco 100.13

Public Fire Education M anual $\quad 41.16$ ropa de protección 31.21

Standard for the Installation of L ightning

Protection Systems 41.19

y seguridad de vagones y camiones cisterna 102.58

National $H$ ealth Service (R eino U nido) agresiones en el trabajo 51.3 programas de cribado 15.60

$N$ ational Institute for $\mathrm{O}$ ccupational Safety and $\mathrm{H}$ ealth (NIOSH)

Compendium of $\mathrm{H}$ earing Protective D evices 31.15

directrices para utilizar técnicas de vídeo en el análisis de riesgos 29.39

encuesta nacional de exposiciones profesionales $32.2,32.10$

estadísticas sobre pinturas 77.22

estudios sobre la producción avícola $\quad 67.23$ grupos de alto riesgo de lesión 56.30

límites de peso 29.44

métodos de control del estrés ambiental $\quad 42.26$

prácticas de trabajo en ambientes calurosos 42.25

productos cosméticos tóxicos 100.6

Programa de R ecursos Educativos 20.7

Programa de V igilancia y

Epidemiología del Plomo en la

Sangre de Adultos 32.5

protectores auditivos 31.14

Respirator Decision Logic 31.2

revisión de la ecuación del NIOSH para el diseño y evaluación de las tareas de levantamiento manual 29.68 salud y seguridad en el trabajo $\quad 16.35$ seminario sobre el control 34.27 
Sistema de N otificación de E pisodios Centinela para R iesgos Profesionales (SENSOR) 32.6

tablas de descompresión para cajones 36.4

$y$ alcanos 104.240

y butadieno 80.10

y concentración letal del sulfuro de hidrógeno 101.13

y límites de exposición a sustancias tóxicas en zanjas 93.37

y modelos de estrés 34.2

Véase también 0 ccupational Safety and $\mathrm{H}$ ealth Administration

$N$ ational Institute of Environmental $\mathrm{H}$ ealth

Services (Estados U nidos)

efectos del ruido intenso en el trabajo 97.31

National Institutes of $\mathrm{H}$ ealth G uidelines Véase Industria de la biotecnología

National Radiological Protection Board (NRPB)

y exposición a campos electrostáticos $\quad 49.29$

National R esearch Council (Estados U nidos) estudio sobre toxicidad de sustancias químicas $32.3,94.16$

N ational Safety Council (N SC) $\quad 64.25,70.8$

$\mathrm{N}$ ational T raumatic $\mathrm{O}$ ccupational Fatalities

(NT O F) Surveillance System 70.34

fallecimientos asociados a la industria agrícola y ganadera 70.34

homicidios en el lugar de trabajo $\quad 51.2$

$N$ aufragios

$V$ éase Accidentes marítimos

Nebulizadores 67.15

Necrosis

apoptótica 33.34

aséptica ósea 36.5

de la piel

por contaminación radiactiva $\quad 48.42$

estireno y 104.285

etilbenceno y 104.285

fósforo y 104.382

hepática

por indio 63.24

oncótica 33.34

ósea 23.17

renal

por compuestos de cromo $\quad 63.17$

quinona y 104.369

tubular

Véase Insuficiencia renal

$N$ efritis

intersticial $\quad 8.5$

$N$ efrona

Véase R iñón

función renal 8.3 intersticio renal 8.3

N efropatía

de los Balcanes 8.12

ehipertensión 8.5

etiología 8.5

factores de sensibilidad 8.10

por exposición al plomo 63.41

sustancias nefrotóxicas $8.10 t$

tóxica

por plaguicidas 62.10

$\mathrm{N}$ efrosis

por bismuto 63.10

N efrotoxicidad

Véase R iñón

diagnóstico y pruebas 8.3

marcadores biológicos 8.7

y xenobióticos 8.4

Negligencia

inexcusable 23.19

temeraria 23.19

Negociación colectiva

acción sindical en materia de salud y

seguridad 21.15

campañas sindicales 21.16

industrial textil en Estados

Unidos 21.15

organizaciones de trabajadores 21.16

sindicatos del siglo XIX 21.15

base jurídica 21.17

cobertura 21.17

conciliación o mediación 21.36

convenios sectoriales 21.17

futuro de la 21.19

mecanismo de aplicación 21.17

sistema de arbitraje 21.17

organizaciones de trabajadores 21.17

países de la antigua U nión Soviética 21.18

procedimiento de reclamación 21.35

proceso formal 21.16

negociaciones sobre salud y

seguridad 21.16

sistema japonés 21.18

Nelder y Wedderburn

M odelos Lineales G eneralizados 28.30

N eón

con fines artísticos

lesiones por radiación ultravioleta 96.15

riesgos de electrocución 96.14

Neonatal

exposición a sustancias tóxicas 9.19

bifenilos policlorados 9.22

disolventes 9.23

exposición a polvos y fibras

minerales 9.23

exposición al amianto 9.23

exposición al plomo 9.20

exposición ambiental al mercurio 9.20

fuentes de exposición 9.19 humo de tabaco ambiental 9.24

plaguicidas 9.21

radiacionesionizantes 9.24

Neoplasia

y dinitrofenol 1.8

V éase también Cáncer

Neopreno

traje húmedo de espuma de $\quad 42.49$

Nepal

animales de tiro 70.34

Nerviosa, célula

Véase $N$ eurona

Nervioso

V éase Sistema nervioso

N erviosos, trastornos

Véase T rastornos nerviosos

Neumáticos

fabricación de 80.4

calandrias 80.5

esquema del proceso de

fabricación $80.4 f$

extrusores 80.6

laminado 80.5

malaxador Banbury 80.4

masticación 80.5

mezclado de compuestos 80.4

inspección y acabado $\quad 80.7$

montaje de 80.6

problemas de salud y seguridad $\quad 80.7$

vulcanización 80.7

en baño de sales 80.9

nitrosaminas 80.9

Neumoconiosis

clasificación de las radiografías

clasificación de 1980 de la O IT $\quad$ 10.37t

Clasificación Internacional de $\mathrm{R}$ adiografías de Neumoconiosis $\quad 23.60$

colagenosa 10.36

Conferencia Internacional sobre las Enfermedades Profesionales de las V ías Respiratorias 23.60

Conferencia Internacional sobre Neumoconiosis 10.36

de los mineros del carbón 10.53

anatomía patológica 10.53

epidemiología 10.54

factores de riesgo 10.54

lesión asociada 10.53

mecanismos de la enfermedad

10.53

prevención 10.54

radiografía de tórax 10.53

tratamiento 10.54

definición 10.36

descripción de las radiografías

estándar $10.37 \mathrm{t}$

en el sector de la contrucción 93.10

en la fabricación de cemento 93.52

en los mineros de yeso $\quad 62.7$ 
en operadores de calderas $\quad 103.40$

en pintores 103.46

en soldadores 103.51

en trabajadores de la pizarra $\quad 62.6$

en trabajadores del grafito $\quad 62.4$

enfermedades pulmonares

profesionales 10.36

etiopatogenia 10.40

cascada de acontecimientos 10.46 , 10.48

exposición-dosis-respuesta 10.43

interacción

macrófagos-fibroblastos 10.46

lesiones fundamentales 10.45

partículas de polvo $\quad 10.44$

factores de riesgo $\quad 10.47$

fibrosis masiva progresiva 10.55

anatomía patológica 10.55

aspectos clínicos 10.55

epidemiología 10.55

mecanismos de la enfermedad $\quad 10.55$

prevención 10.55

radiografía 10.55

tratamiento 10.55

fibrótica nodular

y exposición a polvo de mica $\quad 62.5$

infradiagnóstico 32.7

marcadores biológicos 10.47

mortalidad 32.6

no colagenosa 10.36

nodular benigna 63.19

por óxido de estaño 63.19

partículas de polvo 10.43

por antimonio 63.4

por carburo de tungsteno $\quad 63.49$

por circonio 63.13

por manganeso 63.27

por molibdeno puro 63.33

por nitruro de niobio 63.34

por óxido de hierro 63.21

por óxido de molibdeno (M 00 3) 63.33

por sulfato de bario 63.9

por talco 62.7

signos clínicos de la 62.7

prevención $10.47,10.70$

y exposición al polvo $\quad 10.36$

Véase también Baritosis

Véase también Estannosis

Véase también Sílico-antimoniosis

Neumonía

de origen ocupacional 10.92

endógena de tipo lipoide

por aerosoles de antimonio 63.4

inhalación de partículas infecciosas 10.92

intersticial

por tetracloruro de germanio $\quad 63.21$ lobular

por lactato sódico de circonio 63.13

por compuestos de vanadio 63.50 por manganeso o mangánica 63.27

por radiación 48.8

química

por mercurio 63.29

Neumonitis

crónica

por carburo de titanio 63.49

eosinófila 63.35

y sensibilización al níquel 63.35

intersticial 63.32

y exposición al níquel carbonilo 63.32

intersticial aguda 63.32

por metalcarbonilos 63.32

intersticial crónica 63.13

por lactato de circonio 63.13

por zirconato de bario 63.13

intersticial descamativa 63.23

por inhalación de indio 63.23

por hipersensibilidad 44.3, 70.21, 71.11,

72.16

por microorganismos en el aire

interior 44.24

química 63.11

por inhalación de compuestos de cadmio 63.11

tóxica 10.29

Véase Bisinosis

N euritis periférica con parálisis 28.22

Neurobiología

de los procesos neurotóxicos 7.4

N euroendocrino

Véase Sistema neuroendocrino

Neuroendocrinología 7.9

N euroepidemiología

estudios de casos-controles 7.26

exposiciones profesionales 7.26

interpretación de los efectos

neurotóxicos 7.26

para la enfermedad de Alzheimer $\quad 7.27$

N eurolépticos

y tratamiento de la ansiedad $\quad 5.8$

N eurológicos, trastornos

en el sector de la construcción 93.3

exposición a humos de soldadura 93.44

Neurona

degeneración walleriana $\quad 7.4$

funciones tróficas 7.4

núcleo de la célula nerviosa 7.3

Neuropatía

cubital

en instrumentistas de cuerda 96.27

e intoxicación por arsénico 63.7

neuropatía periférica

Véase N eurotoxicidad

axonopatías 7.21

diagnóstico diferencial 7.22

por adhesivos con hexano 96.3 técnicas electrofisiológicas $\quad 7.22$

por plomo 63.41

traumática

en boxeadores profesionales 96.54

Neurosis

compensatoria 52.23

neurosis gástrica

V éase D ispepsia

Neurotoxicidad

autoridades reguladoras de los Estados

Unidos 33.60

barrera hematoencefálica $\quad 33.60$

caracterización del riesgo 33.63

determinación de la neurotoxicidad

intrínseca 33.60

diagnóstico 7.25

diagnóstico diferencial 7.25

disolventes orgánicos 7.13

asociados a efectos neurotóxicos $7.13 \mathrm{t}$

durante el desarrollo 33.60

efectos neurotóxicos por niveles $7.9 \mathrm{t}$

encefalopatía 7.11

evaluación de la exposición 33.63

evaluación de la relación

dosis-respuesta 33.62

evaluación del riesgo de 33.60

exposición y síntomas 7.25

gases 7.11

asociados a efectos neurotóxicos $7.11 \mathrm{t}$

generalidades 33.60

metales

asociados a efectos neurotóxicos $7.11 \mathrm{t}$

monómeros

asociados a efectos neurotóxicos $7.12 \mathrm{t}$ pesticidas

asociados a efectos neurotóxicos $7.14 \mathrm{t}$

polineuropatía 7.11

prevención de la neurotoxicidad

laboral $7.16 \mathrm{f}$

productos químicos 7.14

asociados a efectos neurotóxicos 7.14

pruebas esenciales de neurocomportamiento

delaOMS 33.62

pruebas neurológicas 7.22

baterías de detección 7.22

baterías nucleares $7.23 \mathrm{t}$

de los estados de ánimo $\quad 7.24$

mediciones electrofisiológicas 7.24

síndrome neurotóxico $\quad 7.20$

alteraciones del comportamiento $\quad 7.20$

deterioro de la función intelectual $\quad 7.20$

neuropatía 7.21

sensibilidad química múltiple 7.21

trastornos del movimiento 7.21

síntomas de la exposición a

neurotóxicos $7.11 f$

y plaguicidas 33.44

Neurotóxico

V éase Sistema nervioso 


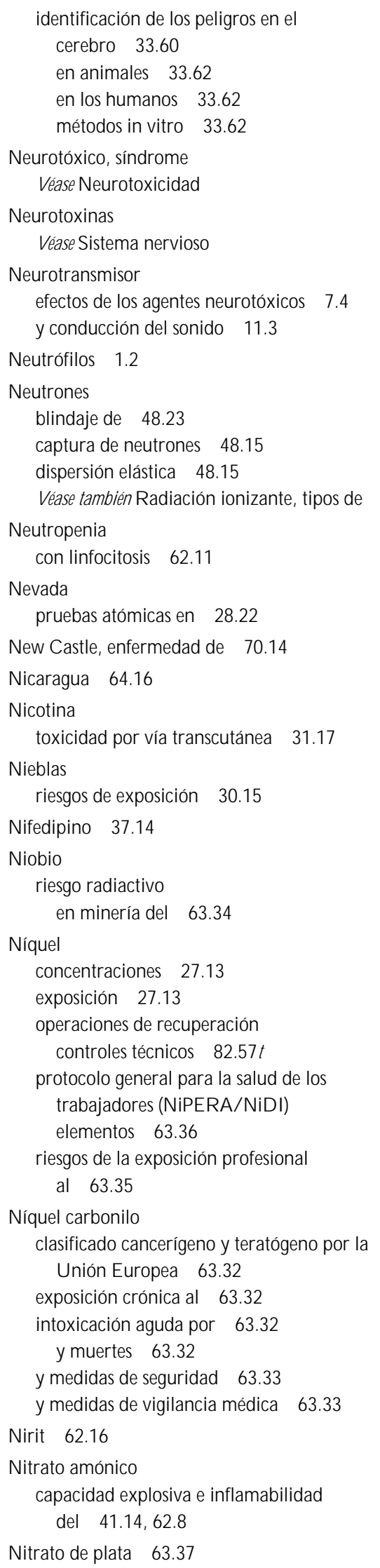

Nítrico, ácido

ácido 41.13

intoxicación 104.7

riesgos 104.7

Nitrilo

manipulación 104.138

Nitrilotriacético, ácido tratamiento de aguas y 104.338

Nitrobenceno metahemoglobinemia y $\quad 104.347$

Nitrocompuestos alifáticos 104.338 como disolventes 104.338

N itrocompuestos aromáticos 104.346 como disolventes 104.346 incendio y explosión 104.348 medidas de protección 104.348

Nitrofen $\quad 62.14$

Nitrógeno en el aire y en el agua $\quad 70.5$ en fertilizantes y daños medioambientales 62.8 óxido de

en la conducción de camiones 103.8 y presión barométrica 36.3

Nitroglicerina 104.339 como vasodilatador 104.338 dinamita y 104.338 manipulación 104.341 muerte súbita y 104.339 tensión arterial y 104.339

Nitroolefinas toxicidad 104.338

Nitropropano $\quad 102.49$ como cancerígeno del grupo A3 104.340

$N$ itrosamina como agente cancerígeno $\quad 80.9$

Nitrosodietilamina como cancerígeno del grupo $2 \mathrm{~A}$ por la IARC $\quad 104.80$

$\mathrm{N}$ itrosodimetilamina como cancerígeno del grupo 2A por la IARC $\quad 104.80$

Nitrosomorfolina como cancerígeno del grupo 2B por la IARC $\quad 104.80$

$\mathrm{N}$ itrosopiperidina como cancerígeno del grupo 2B por la IARC $\quad 104.80$

$\mathrm{N}$ itrosopirrolidina como cancerígeno del grupo 2B por la IARC $\quad 104.80$

Nódulos de los ordeñadores 70.11

N oradrenalina $34.20,34.60$

N orepinefrina 42.4
N orma Aeroespacial Nacional sobre

Emisiones para Contaminantes

Atmosféricos Peligrosos (NESH AP)

A gencia N orteamericana de Protección del M edio A mbiente 90.15

N ormas ANSI

Véase A merican N ational Standards Institute

N orma Británica 6472 (1992)

y evaluación de las vibraciones en edificios 50.3

N orma Británica 6841 (BSI 1987b)

y valor de la dosis de vibración $\quad 50.6$

N ormalización

acuerdo de $V$ iena $\quad 29.14$

comités 29.14

especificaciones técnicas $\quad 29.15$

y ergonomía 29.12

Véase también Comité Europeo de N ormalización

Véase también O rganización Internacional de N ormalización

N ormas europeas CENTC 169

y niveles mínimos de iluminación según las tareas realizadas $\quad 46.10$

Normas ISO

Véase 0 rganización internacional de normalización

Normas laborales

en materia de discapacidad $\quad 17.16$ disposiciones específicas sobre rehabilitación profesional y empleo 17.18

en la legislación laboral general $\quad 17.18$ en los distintos Estados miembros 17.18 igualdad de oportunidades 17.17 incluidas en leyes especiales $\quad 17.19$ medidas positivas específicas $\quad 17.17$ prohibición de la discriminación en el empleo $\quad 17.20$

sistema de tasas y subsidios $\quad 17.20$ sistemas de cupos 17.20

Véase también Convenios y recomendaciones de la OIT

Normas NE $\quad 68.36$

N ormas sobre la calidad atmosférica 55.7 $55.9,55.21$

Véase también Contaminación atmosférica

N orthwestern N ational Life Insurance

Company

casos de estrés en el trabajo 34.2

estudio sobre el estrés 5.18

Noruega

Comité nacional de formación $\quad 23.10$

Ley de 4 de febrero de 1977 , de protección de los trabajadores y del medio ambiente de trabajo $\quad 23.7$

Nubes radiactivas 39.32 
Nuclear, energía

Véase Energía nuclear

Véase también Central nuclear

Véase también Accidentes nucleares

Nuclear R egulatory Commission y programa de vigilancia EREM P 48.38

Nuevas tecnologías

agilidad 24.21

fabricación integrada por ordenador 24.21

fabricación "just in time" 24.21

comunicación 24.20

respuesta rápida 24.20

superautopista de la información $\quad 24.20$

y desempleo 24.21

y estrés 24.23

y organización del trabajo $\quad 24.19$

y polarización de la

población activa 24.22

$y$ teletrabajo 24.23

Nutrición

en el caso de los trabajadores

forestales 68.41

programas en el lugar de trabajo $\quad 15.37$

de reducción de peso $15.40 f$

dietas especiales 15.41

enfoques culturales 15.39

orientación general sobre

nutrición 15.38

servicios internos de suministro de comidas 15.37

sobrepeso 15.39

trastornos en el sector de la

construcción 93.11

y enfermedades cardiovasculares 3.7

0

0 'D onnell y Eggemeier

técnicas de la doble tarea $\quad 29.49$

O bras civiles

en el sector de la construcción

definición 93.19

procesos 93.19

O bras subterráneas

descripción 93.9

prevención de riesgos 93.10

riesgos asociados a cada tipo 93.9

O breros de la construcción

carga de trabajo relativa $\quad 29.36$

o bsesivo-compulsivo

Véase T rastorno obsesivo-compulsivo

$O$ ccupational Safety and $\mathrm{H}$ ealth

Administration (O SH A) $\quad 56.38,84.21$

actuaciones inspectoras 32.10

límites de exposición profesional $\quad 10.70$

norma de comunicación

de riesgos 56.38 programas en materia de

descompresión 36.4

registro escrito de lesiones y enfermedades profesionales 32.4

salud y seguridad en el trabajo $\quad 16.35$

valor límite umbral de exposición 10.19

y efectos del trabajo no estable 99.2

y límite tolerable de ruido 97.31

Véase también $\mathrm{N}$ ational Institut for

$\mathrm{O}$ ccupational Safety and $\mathrm{H}$ ealth

0 culares

lesiones

cristalerosy 103.10

encoladoresy 103.17

jardinerosy 103.27

pintoresy 103.44

riesgos

de lesión corneal en fotografía 85.12

en industrias gráficas 85.7

en procesos fotográficos 85.15

trastornos

asociados a la confección de alfombras 89.29

exposición a vapores de aminas en la industria del automóvil 91.4

O ffice des anciens combattants

Véase Francia, discapacidad

O ficina de Estadísticas Laborales (BLS) 84.21

O ficina de $T$ ransporte Ferroviario

Internacional

reglamento sobre el transporte

internacional ferroviario de sustancias

peligrosas 39.31

O ficina del R uido de la Agencia de Protección

Ambiental de Estados U nidos 47.3

O ficina Internacional de Pesas y M edidas de

Sèvres, Francia 105.2

O ficina Internacional del T rabajo accidentes laborales en el mundo 56.2

Centro Internacional de Información sobre Seguridad y Salud en el trabajo 22.7

estimación de las tasas de

electrocución 40.2

prevención de la neumoconiosis 10.37

$O$ ficina de Estadísticas Laborales de EE.UU .

(BLS)

consideración de la reparación de buques 92.2

0 ficinas

calidad del aire en $\quad 99.2$

contaminantes del aire 99.8

lesiones por uso de PVD 99.3

riesgos ambientales de 99.3

seguridad de las 99.7

riesgos eléctricos 99.7

riesgos potenciales 94.3

trabajadores de

e infecciones respiratorias 99.2 estrés 99.7

exposición al ruido y riesgo de

enfermedades coronarias 99.3

trastornos visuales por uso de

ordenadores 99.7

O hio 64.25

o ído

anatomía 11.2

órganos de la audición 11.2

órganos del equilibrio 11.3

equilibrio 11.9

fatiga auditiva 11.4

fisiología de la audición 11.3

conducción aérea del sonido 11.3

conducción ósea del sonido 11.3

límites de sensibilidad 11.4

fisiopatología 11.4

lesión celular 11.4

lesión ciliar 11.4

pérdida de audición 11.5

audiometría 11.6

exploración clínica 11.5

trastornos auditivos 11.8

OIT-FINNIDA

Proyecto Africano de Salud y

Seguridad 18.31

aprendizaje de alta calidad 18.31

formación de los formadores 18.31

inspectores de fábricas $18.32 f$

métodos de formación 18.32

métodos didácticos 18.34

planificación del currículo 18.33

selección de los formadores 18.33

O jo

agudeza visual

anillos de Landolt $\quad 11.13$

diplopia 11.18

efectos de la edad $\quad 11.21$

gráficos de Snellen 11.12f - 11.13

sensibilidad visual $\quad 11.15$

anatomía 11.11

ceguera

ácido clorhídrico y 104.6

peróxidosy 104.364

superfosfatos y 104.385

córnea, lesiones de

quinona y 104.369

dinitrobenceno y 104.347

errores de refracción

astigmatismo 11.20

representación esquemática $\quad 11.20 f$

gafas protectoras 11.23

irritación

ácidos monocarboxílcos

insaturados 104.13

acrilato de etilo 104.172

boranose 104.130

hidracinase 104.122

y ácido fórmico 104.13 
y ácido silícico 104.400

y fontaneros 103.21

y fósforo 104.383

y peróxidos 104.363

lesiones por descarga eléctrica $\quad 40.5$

mecanismo de acomodación 11.12

pruebas visuales 11.13

nivel de agudeza visual $\quad 11.13$

quemadura de

ácido glicólico y 104.14

azida sódica y 104.122

epiclorhidrina y 104.153

riesgos oculares en el trabajo $\quad 11.22$

ulceración de los

ácido sulfúrico y $\quad 104.7$

O leaginosas 64.39

O leoducto 39.29

Olf

percepción de 45.15

O Ifato

anatomía y fisiología 11.28

pérdida del olfato $11.28,11.32$

sentido químico común 11.28

tolerancia y adaptación $\quad 11.28$

trastornos olfatorios 11.29

procesos asociados $11.29 \mathrm{t}$

O Ifatorio, sistema

Véase 0 Ifato

O ligoanuria por electrización $\quad 40.5$

Oligosacáridos 72.20

O ligospermia

por radiación $\quad 48.8$

Oliguria

por gas arsina $\quad 63.8$

por ingestión accidental de arsenicales inorgánicos 63.6

Olor

de los concentrados de excrementos 70.5

del café 65.8

Oncocercosis

y radiación ultravioleta $\quad 53.30$

Oncogénesis

en la industria textil 89.33

Oncosis 33.34

0 ndas electromagnéticas

49.5

O pera

Véase T eatro y ópera

O peradores de cámara situaciones de peligro de los $\quad 96.35$

O peradores de PVD

riesgos en los servicios postales 101.6

y astenopía $52.11,52.14$

y conjuntivitis 52.12
Véase también Pantallas de visualización de datos

O peradores de radar 29.51

O pisthorcis felineus 33.69

O pisthorcis viverrini 33.69

O psoclonus 7.21

O rdenadores

accidentes debidos a $\quad 58.34$

por fallo en las especificaciones 58.34

por fallo operativo 58.34

por fallos aleatorios del hardware $\quad 58.34$

por interferencias

electromagnéticas 58.35

actividades creativas con $\quad 96.15$

prevención de la vista cansada 96.15

problemas de ergonomía $\quad 96.15$

aplicados a la seguridad 58.33

distribución en el mundo de $52.3 \mathrm{t}$

efectos de la radiación $\quad 96.15$

estadísticas sobre uso de 52.2

gestión de errores en usuarios de 52.34

interacciones ordenador/ hombre 52.31

desarrollo de las interfaces 52.32

norma ergonómica 9241 (ISO

1992) $52.36-52.37$

Véase también D iseño de interfaces

para control de equipos 58.9 accidente por fallo en los 58.10

y relación entre ordenadores y población 52.2

Véase también Fabricación integrada por ordenador

Véase también Pantallas de visualización de datos (PVD)

Véase también Sistema híbrido automatizado

O rejeras

Véase Protectores para los oídos

Orgánico

ácido 104.12

O rganismo Internacional de Energía

Atómica 23.44, 76.13

generalidades 23.52

protección contra la radiación ionizante y de seguridad de las fuentes de radiación 23.46

sistema de notificación de incidentes 76.13

transporte de material radiactivo, reglamentos 48.32

O rganización

ámbito de aplicación $\quad 35.3$

autoridad funcional $\quad 35.4$

cambio organizativo 35.5

aspectos psicosociales 35.8

y salud en el trabajo $35.6,35.10$

científica del trabajo

concepto de tarea encomendada 29.8

concepto de $35.2,35.7$ concepto de estructura $\quad 35.2$

de la lucha contra incendios 41.26

actuación en caso de emergencia $\quad 41.27$

evacuación 41.27

necesidades de las personas

discapacitadas 41.27

materiales peligrosos 41.28

planificación de emergencias 41.26

recuperación de las instalaciones 41.28

servicios médicos de emergencia 41.27

dimensiones estructurales básicas 35.3

estructuras paralelas 35.4

funcional 35.4

horizontal 35.3

investigación sobre los tipos de 35.4

matricial 34.41

métodos de medición 35.9

modelo de Likert 35.2

perspectiva de proceso 35.7

psicología organizacional 35.8 - 35.9

vertical 35.3

y ergonomía 35.7

y relaciones sociales 35.2

$y$ trabajo en red 35.4

O rganización Arabe del T rabajo

y salud y seguridad en el trabajo 23.45

O rganización de A viación Civil Internacional

(OACl)

instrucciones técnicas para la seguridad del transporte aéreo de sustancias peligrosas 39.31

manual de medicina de la aviación civil 23.44

normas ergonómicas para controladores de tráfico aéreo $\quad 102.8$

normas relativas a las emisiones de motores de aviación 90.13

y la regulación del ruido en la industria aeroespacial $\quad 90.16$

O rganización de Cooperación y D esarrollo

Económico

diseño del puesto de trabajo $\quad 34.4$

información estadística sobre desempleo 34.35

O rganización de Estados A mericanos y relaciones laborales 21.37

0 rganización de las $\mathrm{N}$ aciones $\mathrm{U}$ nidas

$\checkmark$ éase $\mathrm{N}$ aciones $\mathrm{U}$ nidas

Declaración U niversal de D erechos H umanos 19.16

Pacto Internacional de Derechos Civiles y Políticos 19.16

$R$ ecomendaciones relativas al transporte de mercancías peligrosas (UNRTDG) 61.8

O rganización de las $\mathrm{N}$ aciones $\mathrm{U}$ nidas para el D esarrollo Industrial (ONUDI) 23.44, 23.53 
O rganización de las $\mathrm{N}$ aciones U nidas para la Agricultura y la Alimentación (FAO)

Código internacional de conducta de la FAO sobre la distribución y el uso de plaguicidas 61.9

estudio sobre consumo mundial de fibra 89.4

Programa mixto PNU M A/FAO / O M S sobre vigilancia de la contaminación de los alimentos

(SIM U VIM A/ Alimentos) 53.8

R eunión Conjunta FAO / O M S sobre

R esiduos de Plaguicidas ( M PR ) $\quad 53.8$

y enfermedades del ganado 23.53

y pesticidas 23.53

y salud y seguridad en el trabajo 23.53

O rganización de las $\mathrm{N}$ aciones U nidas para la

Educación, la Ciencia y la Cultura

(UNESCO)

y contragolpe 24.4

O rganización del trabajo

concepto de tarea completa 29.58

en el sector de la construcción 93.2

en la confección $\quad 87.3,87.5$ - 87.6

trabajo a domicilio 87.5

trabajo infantil 87.5

en los servicios de extinción de incendios 95.5

jerarquía y cultura 29.94

lista de comprobación 29.24

nuevos métodos de 24.19

participación de los trabajadores 29.59

efectos de la participación 29.60

ergonomía abierta a la

participación 29.94

investigación sobre la

participación 29.60

participación en el diseño de

sistemas 29.61

procesos participativos 29.60

primacía de la tarea 29.57

roles asignados 34.31

uso ineficaz de la tecnología $\quad 29.57$

y cultura organizativa 29.92

y familia 29.94

y nuevas tecnologías 24.19

O rganización Internacional

de A sociaciones de Consumidores (IOCU) 23.45

O rganización Internacional de Empleadores 21.5

O rganización Internacional de N ormalización (ISO)

adopción de una norma

internacional 23.61

características 23.61

Comité técnico 94 para el equipo y la ropa de protección personal 31.21 comités de ergonomía $\quad 29.14$

comités técnicos 23.61, 23.62t

elaboración de normas ergonómicas 29.14

especificaciones de sonómetros 47.6

fracciones de masa particulada $\quad 30.22$

gestión del medio ambiente 20.14

ISO 263

evaluación de la exposición humana a la

vibración de la totalidad del cuerpo 23.61

ISO 532 (1975)

método de cálculo del nivel de sonoridad 47.8

ISO 608

maquinaria agrícola y forestal $\quad 68.12$

ISO 1999 (1990)

y pérdida auditiva por ruido 47.7

ISO 2204 (1979)

y métodos de medida de ruido $\quad 47.7$

y nivel de interferencia conversacional $\quad 47.8$

ISO 2631

y límites de exposición a vibraciones 50.6

ISO 3873-1977

cascos industriales de seguridad $31.9 t$, 31.10

ISO 4869-1

pruebas de atenuación 31.12

ISO 5349 (1986)

y exposición a vibraciones

mano-brazo 50.12

ISO 6385

principios ergonómicos en el diseño de los sistemas de trabajo 29.13

ISO 7000

símbolos gráficos utilizables en el equipo 23.63

ISO 7243

temperatura de globo de bulbo húmedo 42.18, 42.25

ISO 7726

sensores para medir los parámetros físicos del entorno 42.16

ISO 7730

bienestar térmico $\quad 42.34$

ISO 7933

datos básicos para la evaluación analítica $42.25 \mathrm{t}$

evaluación analítica $\quad 42.26 t$

tasa de sudoración requerida $\quad 42.19$

términos utilizados $\quad 42.24 \mathrm{t}$

ISO 8996

producción de calor metabólico 42.26, 42.55

ISO 9000

normas de la serie $\quad 16.18$

ISO 9241

cooperación ISO CEN 29.14 desarrollo de las interfaces de ordenador 52.36

directrices ISO/CEI 61.10 normas gases comprimidos $\quad 61.18$

requisitos ergonómicos para las PVD 52.36, 29.15, 52.33, 52.37

y diseño del puesto de trabajo con PVD 52.4

ISO 9886

frecuencia cardíaca como índice de estrés por calor 42.23

medición del estrés fisiológico $\quad 42.26$, 42.55

ISO 9920

aislamiento térmico $\quad 42.16,42.26$

características térmicas de las prendas de vestir 42.55

valores de aislamiento básico $\quad 42.57$

ISO 11064

diseño de salas de control $\quad 29.15$

ISO 11079

evaluación del enfriamiento de la piel 42.59

métodos de evaluación del estrés por frío 42.55

temperaturas críticas en las manos 42.59

ISO TR 12155

fabricación de sensores $\quad 58.29$

ISO CD 12894

prácticas de trabajo en ambientes calurosos 42.25

ISO 14000

gestión del medio ambiente 20.14

norma sobre tractores y maquinaria agrícola forestal 58.73

normas de seguridad en la industria

forestal 68.31

normas para instalaciones eléctricas $\quad 40.14$ normas sobre búsqueda de

información 22.16

normas sobre construcción 23.61

normas sobre luces de vehículos 64.26

normas sobre protección

antivuelco 68.11

objeto

origen y miembros 23.60

miembros corresponsales 23.60

miembros subscriptores 23.61

organismo miembro 23.60

publicaciones 23.61

ISO Catalogue 23.61

ISO M embership 23.61

ISO/IEC Directives 23.61

requisitos ergonómicos 52.36

trabajo técnico 23.61

y normas de etiquetado de productos

químicos 61.10

y seguridad en el trabajo 23.61 
O rganización Internacional del Trabajo (O IT) aplicación de los convenios 23.58

Centro Internacional de Formación 23.44, 23.59

clasificación del sector de la construcción 93.2

clasificación internacional de limitaciones funcionales de las personas 29.83

Código de práctica relativo a la prevención de accidentes en el mar 102.51

Código de práctica sobre la prevención de accidentes de trabajo graves 23.60

Códigos de conducta 23.28

coincidencias de estrategia con la OMS 23.48

Conferencia Internacional del T rabajo Protocolo de aplicación del Convenio no 8123.14

Resolución relativa a la mejora de las condiciones y del medio ambiente de trabajo 23.48

Constitución 23.28, 23.43, 23.54

Convenio no 10 sobre la edad mínima (agricultura) (1921) 64.38

Convenio $\mathrm{n}$ - 12 sobre la indemnización a trabajadores (agricultura), $1921 \quad 23.29$

Convenio no 17 sobre la indemnización por accidentes del trabajo, $1925 \quad 23.29$

Convenio $\mathrm{n} 018$ sobre las enfermedades profesionales, $1925 \quad 23.29,26.2$

Convenio no 24 sobre el seguro de enfermedad (industria), $1927 \quad 23.29$

Convenio no 25 sobre el seguro de enfermedad (agricultura), $1927 \quad 23.29$

Convenio no 32 sobre la protección de los cargadores de muelle contra los accidentes (revisado), $1932 \quad 23.28$

Convenio no 62 sobre las prescripciones de seguridad (edificación), $1937 \quad 23.28$

Convenio $\mathrm{n}$ - 77 sobre el examen médico de los menores (industria), $1946 \quad 23.28$

Convenio $\mathrm{n}$ - 78 sobre el examen médico de los menores (trabajos no industriales), $1946 \quad 23.28$

Convenio no 81 sobre la inspección del trabajo en la industria y el comercio, $1947 \quad 23.3,23.5,23.57$

Convenio $\mathrm{n}-84$ relativo al derecho de asociación y a la solución de los conflictos de trabajo en los territorios no metropolitanos, $1947 \quad 21.10$

Convenio no 87 sobre la libertad de asociación y protección del derecho de sindicación, $1948 \quad 21.10,21.36,23.29$

Convenio $\mathrm{n}-97$ sobre los trabajadores migrantes, 194924.11
Convenio no 98 relativo a la aplicación de los principios del derecho de sindicación y de negociación colectiva, $1949 \quad 21.10$, 23.29

Convenio $\mathrm{n}^{0} 100$ sobre igualdad de remuneración entre la mano de obra masculina y la mano de obra femenina por un mismo trabajo, 195124.7

Convenio no 103 relativo a la protección de la maternidad (revisado), 1952 9.26, 24.8

Convenio № 110 (1958) 64.38

Convenio $n=111$ relativo a la discriminación en materia de empleo y ocupación, 1958 9.28, 17.14, 24.2, 24.7,

Convenio no 115 sobre la protección contra las radiaciones 23.46

Convenio no 119 sobre la protección de la maquinaria, 196323.28

Convenio no 120 sobre la higiene (comercio y oficinas), 196423.28

Convenio no 121 sobre las prestaciones en caso de accidentes del trabajo y enfermedades profesionales $16.6,26.2$ lista de enfermedades profesionales 16.6

Convenio no 127 (1967) 64.38

Convenio no $129 \quad 23.4-23.5$

Convenio no 130 sobre asistencia médica y prestaciones económicas por enfermedad, 196923.29

Convenio no 135 relativo a la protección y facilidades que deben otorgarse a los representantes de los trabajadores en la empresa, $197121.10,21.23,23.11$

Convenio no 139 sobre el cáncer profesional, $1974 \quad 23.17$

Convenio $\mathrm{n}-140$ relativo a la licencia pagada de estudios, $1974 \quad 21.32$ aspectos destacados 21.32

Convenio $\mathrm{n}-141$ sobre las organizaciones de trabajadores rurales y su función en el desarrollo económico y social, $1975 \quad 21.10$

Convenio $\mathrm{n}-142$ sobre el desarrollo de los recursos humanos, 1975 (OIT 1975) 17.13

Convenio $\mathrm{n} 0143$ sobre los trabajadores migrantes (disposiciones complementarias), $1975 \quad 24.11$

Convenio $\mathrm{n} 0150$ sobre la Administración del Trabajo, $1978 \quad 23.3$

Convenio no 151 sobre la protección del derecho de sindicación y los procedimientos para determinar las condiciones de empleo en la Administración Pública, 1978 y Recomendación, 1978 ( $n$ - 158) 21.10

Convenio $\mathrm{n}=152$ sobre la seguridad y salud (trabajos portuarios), $1979 \quad 23.28$
Convenio $n=153$ sobre horarios de trabajo en transportes por carretera $\quad 102.25$

Convenio $\mathrm{n} 0154$ sobre el fomento de la negociación colectiva, $1981 \quad 21.10$, 21.15

Convenio no 155 sobre seguridad y salud de los trabajadores y medio ambiente de trabajo, 1981 16.2, 21.10, 21.38, 23.28, 23.48, 54.4

antecedentes 23.28

Convenio no 156 sobre los trabajadores con responsabilidades familiares, $1981 \quad 24.2$, 24.10

Convenio no 158 sobre la terminación de la relación de trabajo por iniciativa del empleador, $1982 \quad 9.28,21.38$

Convenio no 159 sobre la readaptación profesional y el empleo de personas inválidas, $1983 \quad 17.3,17.5,17.16,17.42$

Convenio $\mathrm{n}-161$ sobre los servicios de salud en el trabajo, $1985 \quad 16.2,23.48$

Convenio no 162 sobre la utilización del asbesto en condiciones de seguridad, $198621.10,23.31$

Convenio $n-169$ relativo a la inspección del trabajo en la agricultura, $1969 \quad 23.3$

Convenio № $170 \quad 23.17$

Convenio no 171 sobre el trabajo nocturno, 1989 23.59, 24.9

Convenio no 174 sobre la prevención de accidentes industriales graves, 1993 21.10, 21.29, 23.17, 23.56, 39.7, 39.9

Convenio $\mathrm{n} 0176$ sobre salud y seguridad en la minería de la OIT, $1955 \quad 74.58$

Convenios y recomendaciones sobre el trabajo en embarcaciones 102.51

Convenios y recomendaciones sobre salud y seguridad 23.48

Declaración de Filadelfia $\quad 23.43,23.54$

Declaración de 0 bjetivos 23.43

Declaración Tripartita de la OIT sobre Empresas M ultinacionales 21.19

Departamento de Condiciones de

Trabajo y M edio Ambiente 23.59

División de Condiciones de T rabajo y Servicios de Bienestar 23.59

División de Salud y Seguridad en el Trabajo 23.59

Programa Internacional para la Erradicación del T rabajo Infantil 23.59

estructura 23.54

Conferencia Internacional del Trabajo 23.54

Consejo de Administración 23.54

O ficina Internacional del Trabajo 23.54 
frecuencia de las inspecciones 57.23

funciones 23.59

fundación 23.53

generalidades 23.44

incumplimiento de los convenios 23.58

Informes de los estados miembros 23.4

Instituto Internacional de Estudios

Laborales 23.59

investigación en salud y seguridad en el

trabajo 23.2

lista de enfermedades profesionales de la OIT 26.2, 26.4t

$\mathrm{M}$ anual práctico de control de altos riesgos 39.7

mecanismos de investigación y comunicación 23.29

modelo de los convenios 23.55

normas en materia de salud y seguridad 23.28

Pacto Internacional de D erechos

Económicos, Sociales y

Culturales 21.10

papel en las relaciones laborales 21.5

Programa Internacional para la M ejora de las $\mathrm{C}$ ondiciones y el M edio Ambiente de Trabajo 23.44

Programa M undial de la Salud, la Seguridad y el M edio A mbiente 23.48

Programas internacionales de formación 18.26

Protocolo de 1995 al Convenio no 8123.6

publicaciones 23.59

ratificación de los convenios $23.55,23.58$

Recomendación no 14 (1921) 64.38

R ecomendación no 81 sobre la inspección de trabajo, 1947 21.37, 23.10-23.11, 23.15

Recomendación no 83 sobre la organización del servicio de empleo, $1948 \quad 17.16$

Recomendación no $86 \quad 24.11$

R ecomendación $n$ ㅇ 90 sobre la igualdad de remuneración entre la mano de obra masculina y la mano de obra femenina por un mismo trabajo, $1951 \quad 24.7$

R ecomendación no 92 sobre la conciliación y el arbitraje voluntarios, $1951 \quad 21.36$

R ecomendación no 95 sobre la protección de la salud de la maternidad, $1952 \quad 9.26$

Recomendación no 99 sobre la adaptación y readaptación profesionales de los inválidos, $1955 \quad 17.11$

Recomendación no 111 sobre la discriminación en materia de empleo y ocupación (no 111) 24.7

R ecomendación no $114 \quad 23.46$

R ecomendación no 121 sobre las prestaciones en caso de accidentes del trabajo y enfermedades profesionales, $196426.2,26.3 f$
R ecomendación no 133 sobre la inspección de trabajo (agricultura), 1969 ( $\mathrm{n}$ 133) $23.11,23.15$

Recomendación $n$ o 14323.11

R ecomendación $n$ ํ151 24.11

R ecomendación no $158 \quad 23.3$

Recomendación no 164 sobre seguridad y salud de los trabajadores y medio ambiente de trabajo, $198121.10,23.8,23.48$

R ecomendación № 168 sobre la readaptación profesional y el empleo de personas inválidas, 1983 ( $n$ ㅇ 168) 17.16

Recomendación № 17123.48

Recomendación sobre las cargas máximas 29.40

Resolución PIACT $\quad 23.59$

Resolución relativa a la seguridad y la exposición a los agentes biológicos en el trabajo 23.47

seguridad y salud en el trabajo forestal 68.32

Simposio internacional sobre enfermedades relacionadas con el trabajo, Linz, $1992 \quad 26.2$

tablas internacionales de datos antropométricos 29.33

toma de decisiones tripartita $\quad 23.54$

y ergonomía 29.3

y la minería 74.2

y programas de asistencia a los empleados 15.90

y protección contra vuelco en tractores 58.73

y reconocimientos médicos a operadores de PVD 52.14

y seguridad en la utilización de productos químicos en el trabajo 61.2 repertorio de recomendaciones prácticas $61.2,61.6,61.18,68.32$

y trabajadores migrantes 24.11

O rganización M arítima Internacional (O M I)

Código marítimo internacional de mercancías peligrosas (IM D G) 39.31, 61.8

Comité de seguridad marítima 66.10 subcomité sobre seguridad de los buques de pesca 66.10

Convenio Internacional para la Seguridad de la Vida H umana en el M ar 23.44 normas para seguridad de petroleros 102.56

prevención de la contaminación 23.53 seguridad de los trabajadores 23.53 y protección del medioambiente marino 54.11

O rganización M undial de la Salud (O M S) Air Q uality G uidelines for Europe 33.18
Centros colaboradores 16.19

Clasificación Internacional de Enfermedades 2.2

coincidencias de estrategia con la OIT 23.48

Comisión de Expertos sobre Promoción de la Salud en el Lugar de Trabajo $\quad 15.2$

Comisión de Salud y M edio

Ambiente 16.23

Constitución $\quad 23.24,23.43,23.52$

Cuadragésima Asamblea M undial de la Salud 23.48

Cumbre M undial para el Desarrollo Social 16.23

Declaración de Alma A ta sobre Asistencia Primaria 23.29

Declaración de Pekín sobre Salud Laboral para Todos 23.30

definición de afecciones de carácter multifactorial 66.18

definición de efecto crítico 33.16

definiciones de muerte fetal y

neonatal 9.12

Directrices para la calidad del aire interior 45.8

Directrices para la clasificación de los plaguicidas según el riesgo $\quad 62.18$

Directrices sobre la calidad atmosférica 55.5

estrategia global sobre salud en el trabajo para todos 20.2

incidencia mundial del SIDA 97.47

investigación en salud y seguridad en el trabajo 23.2

límites de exposición ocupacional $\quad 10.70$ en el lugar de trabajo $\quad 10.70$

límites reguladores de la exposición al polvo 10.57

normas de calidad del aire interior 44.3

O ficina R egional para Europa 16.5

planes de evaluación de calidad externa 27.8

prevención de la neumoconiosis 10.37

Programa de Acción para la Salud de los

Trabajadores 16.3

Programa Internacional de

Seguridad de las Sustancias Q uímicas (IPCS) 23.47

programas internacionales de formación 18.26

protección de la salud de los trabajadores 23.48

pruebas esenciales de

neurocomportamiento 33.62

recomendaciones sobre el SIDA en el trabajo 97.46

R ed G lobal de Epidemiología

Ambiental 23.52

trabajo con ordenadores 99.5 
y medición del comportamiento 34.50

O rganización M undial del Comercio 20.15

O rganización $\mathrm{N}$ acional Suiza de A seguradoras de Accidentes (SUVA) 86.7

O rganización Panamericana de la Salud (OPS) 23.30

Programa R egional de Salud

Laboral 23.44

promoción de la salud $\quad 16.29$

O rganización para la Cooperación y el

Desarrollo Económico (O CDE)

informe sobre el empleo de $1994 \quad 24.21$

normas de tractores

y estructuras de protección contra vuelco 58.73

prohibición de movimientos transfonterizos de residuos peligrosos 101.28

y armonización de los métodos de evaluación del riesgo 33.57

y políticas de salud y seguridad 23.2

y salud ambiental 23.45

O rganización para la U nidad de los Sindicatos

Africanos

C arta de Salud y Seguridad en el

$$
\text { Trabajo } 23.34
$$

O rganizaciones internacionales

criterios de legitimidad 23.2

funciones de las 23.43

intergubernamentales 23.42

no gubernamentales 23.45

Véase también Cooperación internacional

O rganizaciones voluntarias

actividades 23.33

investigación 23.33

para la salud y la seguridad en el

trabajo 23.32

Asbestos V ictims of America $\quad 23.36$

Injured W orkers 23.36

National C enter for Environmental

$\mathrm{H}$ ealth Strategies 23.36

publicaciones 23.33

redes internacionales 23.34

reivindicaciones 23.34

servicios de salud laboral $\quad 23.33$

O rgano crítico 27.2

Organo diana

definición $\quad 33.2,33.5$

generalidades 33.16

toxicidad en órganos diana $33.44,33.53$

métodos de los estudios 33.44

$V$ éase también T oxicocinética

Organoclorados 72.20

Organofosfatos 67.30

O rganofosforados 70.38

O rganoslinfoides 33.40

O rganosilíceos, compuestos 104.399

Ornitosis $10.95,70.14$
Véase Enfermedades pulmonares

Oro

fundición y afino 82.11

método de extracción 82.11

amalgamación $82.11-82.12$

cianuración 82.11

efectos ambientales 82.12

riesgos 82.12

Orsat

aparato de 37.14

O seo, cáncer

Véase Cáncer óseo

OSHA

Véase Administración para la Salud y la Seguridad en el T rabajo de Estados U nidos

O smio

riesgos y precauciones

en trabajadores del $\quad 63.37$

O smosis inversa

en tratamiento de aguas

residuales 101.20

0 steoartritis

en función de la edad 6.6

en personal de limpieza $\quad 100.5$

0 steoartrosis

por vibraciones mano-brazo $\quad 50.10$

0 steoblasto 6.6

0 steoclasto 6.6

0 steofitosis

por vibraciones mano-brazo $\quad 50.10$

0 steomalacias

por cadmio 63.11

Véase también Enfermedad de itai-itai

O steomielitis 6.35

O steonecrosis disbárica $\quad 36.4$

0 steopenia 6.7

0 steoporosis

Véase Salud de la mujer

en bailarines 96.26

en función de la edad 6.6

y dieta 15.59

y tabaquismo 15.59

y tratamiento de sustitución

hormonal 15.57

O steosarcoma 6.35

Véase Cáncer óseo

O tolitos 50.14

0 vario

folículo 9.10

Véase también Función ovárica, sistema reproductor femenino

O vejas 70.22

O vino 70.22

Véase R umiantes
O xálico, ácido riesgos 104.15

O xidación química en tratamiento de aguas residuales 101.20

0 xido de aluminio 63.3

O xido de arsénico

en la fabricación de semiconductores III-V 83.23

0 xido de azufre y contaminación del aire interior $\quad 44.4$ y salud ambiental 72.19

O xido de cobalto 27.11

O xido de estaño 63.19

O xido de etileno 41.13 y carcinogenicidad 33.69 y transporte de sustancias químicas 102.49

Oxido de hierro 63.21

Oxido de molibdeno 63.33

Oxido de plata 63.38

0 xido de selenio y conjuntivitis 63.45

O xido de tributilzina $\quad 71.8$

O xido de uranio 39.32

Oxido nítrico 78.5

0 xido nitroso

en anestesia toxicidad del 97.61

0 xidos de nitrógeno combustión a altas temperaturas $\quad 72.19$ contaminación del aire por $\quad 44.9$ trastornos respiratorios por 53.13

Oxígeno

concentrador de 37.13

demanda biológica de 72.20

enriquecido 37.13

puro $37.13,41.2$

toxicidad por oxígeno 36.2

O zonadores 45.6, 45.10

O zono

adelgazamiento de la capa de 53.28

e inmunosupresión 53.28

medidas preventivas 53.32

y cáncer de piel $53.28,53.30$

y enfermedades cutáneas 53.30

y enfermedades oculares 53.28

y melanoma 53.30

en el aire interior $\quad 44.9$

métodos de detección $\quad 44.21$

exposición al

en Ciudad de M éxico 53.14

y trastornos respiratorios $\quad 53.13$

fluorocarburos y 104.191

modelos de predicción de la dosis de 30.29

para eliminación de gases nocivos 45.10 protección de la capa de 54.13

Convenio de V iena de $1985 \quad 54.13$ 
Evaluación Científica de la D estrucción de la Capa de 0 zono 54.13

Protocolo de M ontreal de $1987 \quad 54.13$ riesgos en industrias gráficas $85.7,85.9$ riesgos en procesos de reproducción y duplicación 85.12

Véase también C ambio climático

P

Pacini, corpúsculo de $\checkmark$ éase R eceptores cutáneos

Pacto Internacional de Derechos E conómicos, Sociales y Culturales $23.25-23.26$

Paecilomyces 64.44

Paga por enfermedad 25.25

Paget, enfermedad de Véase Cáncer óseo

Pagos en dinero trabajadores por cuenta propia $\quad 25.12$

Paisajismo 64.9

Países Bajos

A sociación de lanas minerales, del Benelux 93.14

Comisión de Inspección de T rabajo y Política de Aplicación 21.20

Comisión para la Prevención de D esastres Provocados por Sustancias Peligrosas 21.20

Consejo Económico y Social 21.23

Fundación para el M edio Ambiente de Trabajo en el Sector de la Construcción 21.20

Fundación para el Trabajo 21.23

Fundación para la Asistencia Sanitaria en la Agricultura 21.20

Inspección de Trabajo 23.13

Investigación G eneral Empresarial e Inventario y Evaluación de Riesgos 93.13

Ley de Salud y Seguridad 93.13

Ley del consejo de medio ambiente de trabajo 21.20

Sindicato de la industria $\quad 93.14$

Sindicato de trabajadores de la construcción y de la madera 93.14

Países en vías de desarrollo

contaminación del agua $\quad 53.10,53.18$

contaminación del aire $\quad 53.9$

contaminación del suelo $\quad 53.10$

enfermedades profesionales 26.5

higiene industrial 32.11

incidencia del cáncer 2.3

países de reciente industrialización 20.3

prevención del cáncer profesional 2.8

transferencia de industrias peligrosas 28.6

transferencia de tecnología 32.11 vigilancia de la salud y seguridad

en el trabajo 32.11

vigilancia de los riesgos

profesionales 32.11

Países industrializados

salud y seguridad en el trabajo $\quad 20.5$

ventajas competitivas 20.12

Pala 64.28

Paladio

riesgos del 63.37

Palangreros 66.7

Paludismo 4.7

Pan

fabricación de 67.30

Panaderías 67.30

Pan-American $\mathrm{H}$ ealth $\mathrm{O}$ rganization (PAH O) y muertes violentas 24.5

Pancitopenia 1.3

Páncreas

Véase Cáncer de páncreas

cáncer en la industria de la piel y el cuero 88.9

Paneles 29.80

Pantallas de visualización de datos (PVD) campos magnéticos en las $49.24,52.18$ y efectos adversos en el embarazo 52.18, 52.21t, 52.22

control de reflejos en $52.10,52.11 \mathrm{f}$

diseño del puesto de trabajo con 52.4 52.5

e iluminación ambiental $\quad 52.10$

y condiciones de trabajo 52.28

y mejoras ergonómicas $52.14-52.15$

y norma ISO $9241 \quad 52.4$

distorsión visual 29.83

en hoteles

y lesiones por esfuerzo repetitivo 98.6

en oficinas

lesiones por uso de 99.3

en operaciones postales 101.8

en servicios de telecomunicaciones $\quad 101.10$

en servicios de telégrafos $\quad 101.10$

endiseñadores gráficos 96.23

legibilidad 29.85

molestias visuales por uso de 52.11 -

52.13, 96.23

factores de riesgo $52.12,52.13 f$

medidas de prevención 52.14

sensibilidad al parpadeo $\quad 52.13$

y trabajo nocturno 52.13

y uso de lentes correctoras 52.12

radiación emitida por 52.7

recomendaciones del M PR 52.7

reflejos cegadores 46.20

requisitos ergonómicos para 52.33

y norma ISO $9241 \quad 52.33,52.36-52.38$

Véase también Diseño de interfaces uso del color 29.80

y distancia visual adecuada $\quad 52.6$

y enfermedades dérmicas 52.27

y ergonomía 29.15

y estrés $52.28-52.29$

soluciones 52.30

técnicas de equilibrio

compensatorio 52.31

y línea de visión óptima $\quad 52.6$

y problemas musculosqueléticos 52.23

factores causantes $52.24,52.25 t, 52.26$

prevención 52.26

Pantallas faciales

Véase también Protectores de ojos y cara

Papel

fabricación de 72.2

papel kraft 72.6

papel pardo 72.8

reciclado 72.9

Véase también Industria del papel

Véase también Pasta de papel

Papeleras

Véase Industria del papel y de la pasta de papel

Paperas

Véase Parotiditis

Paquete refrigerado $\quad 67.23$

Parálisis del calzado 88.8

Parálisis respiratoria 28.33

Paraplejía 25.13

Paraquat 27.25

trabajadores de las fábricas de $\quad 28.34$

Paratión 27.22

intoxicación por 62.11

medición del 27.22

Parche, prueba del

$V$ éase $D$ ermatitis, prueba epicutánea

Paresia bilateral aguda 28.33

Parkinson, enfermedad de 5.6 parkinsonismo por mercurio $\quad 63.29$ parkinsonismo secundario $\quad 7.21$

Paroniquia

Véase U ña

Parotiditis

en personal sanitario $\quad 97.43$

Parques y jardines riesgos para empleados en 96.46 violencia sobre 96.47

Parques zoológicos peligros para el trabajador en y medidas de seguridad 96.44 y normativa de seguridad y salud 96.46

Partes de accidente 32.14

Partes móviles de las máquinas accidentes graves por 58.9 en instalaciones automatizadas 58.9 
amputaciones por 58.9

en EE.UU $\quad 58.9$

fallecimientos por 58.9

en EE.UU 58.9

peligro de los ejes rotativos 58.9

y puntos de atrapamiento $\quad 58.9,58.13$

peligro de los movimientos

alternativos 58.13

peligro por el movimiento

transversal 58.13

peligro por movimiento rotativo 58.12

riesgo de accidente 58.13

en acciones de cizallamiento $\quad 58.14$

en la acción de corte 58.13

en la acción de doblado 58.14

en la acción de perforación 58.14

Véase también $D$ efensas de máquinas

Participación de los trabajadores

en el diseño de productos y sistemas 29.95

en la organización del trabajo 29.59

Partículas

contaminación por 44.4

de origen biológico (biopartículas) en el aire interior $\quad 44.22$

Partículas alfa

blindaje de 48.23

Véase también $R$ adiación ionizante, tipos de

Partículas beta

blindajes de 48.22

Véase también $R$ adiación ionizante, tipos de

Partículas en suspensión

compuestos metálicos en 55.16

métodos para la determinación $\quad 55.16$

procedimientos de medición $55.15 \mathrm{t}$

determinación del polvo total $\quad 55.15$

determinaciones fraccionadas 55.15

y contaminación atmosférica $\quad 55.4$

Partículas inhalables (PM 10)

mortalidad y morbilidad respiratorias por 53.13

Parto

parto pretérmino

Véase Embarazo

Paschen

curva de 40.8

Pasta de papel

industria de la

Véase Industria del papel

pasta al sulfito de magnesio $\quad 72.8$

pasta kraft 72.8

pasta mecánico-química $\quad 72.7$

pasta química 72.7

pastas de "madera quimiomolida" 72.7

pastas mecánicas 72.6

procesos de elaboración 72.6

procedimiento al sulfato 72.7

procedimiento al sulfito $\quad 72.8$ refinadora de 72.7

Pasteurización 67.26

Pasto 70.11

Paustenbach

modelo "Brief y Scala" (1985) 37.15

Pavos 70.26

PBBS

como carcinógenos del grupo 2B por la IARC $\quad 104.297$

PCBS

como carcinógenos del grupo 2A por la IARC $\quad 104.297$

feto y 104.300

piel, efectos en 104.297

Pedales 29.77

Véase Controles

Pedernal 62.5

Pelaniis platurus 38.6

Peletera, industria

acetatos en la 104.162

m-nitrofenol en 104.346

Peligros

biológicos $30.12 \mathrm{t}$

evaluación cualitativa $\quad 30.14$

físicos $30.13 t$

generalidades 30.11

identificación de los 30.11

caracterización del lugar de trabajo 30.11

pautas de exposición $\quad 30.14$

químicos $30.12 \mathrm{t}$

Véase también R iesgos

Peluquerías

prevención de incendios en $\quad 100.9$

riesgos eléctricos en $\quad 100.9$

Peluqueros

enfermedades de la piel $\quad 100.9$

enfermedades infecciosas $\quad 100.9$

exposición a productos químicos

tóxicos 100.6

exposición a sustancias químicas $\quad 98.8$

rinitis alérgica en $\quad 100.10$

trastornos musculosqueléticos en $\quad 100.8$

soluciones ergonómicas $\quad 100.8$

Penicillium 44.5, 44.23, 62.15, 67.10

Penicillium camemberti 38.3

Penicillus glaucum

y riesgo de infección en la industria de la piel y el cuero 88.9

Pensiones de viudedad 25.17

Pentaclorofenol

biocida de amplio espectro 27.25

cancerígeno del grupo 2B según la

IARC 62.11

como carcinógeno del grupo 2B por la

IARC $\quad 104.369$ en conservantes de la madera

efectos cancerígenos del $\quad 96.20$

sal sódica de 71.5

en serrerías 71.11

Pepsinógeno 34.69

Péptidos 67.11

Pequeñas empresas

características $20.8 \mathrm{t}$

y programas de promoción de la salud 15.18

y salud y seguridad en el trabajo

20.8

Perácidos 72.9

Percepción

comportamiento motor perceptual 29.93

Véase también T ratamiento de la información

Percepción del riesgo

factores culturales en la 59.36

factores determinantes de la $\quad 59.29$

procesos psicológicos en 59.25

requisitos de los procesos cognitivos de 59.27

Véase también Aceptación del riesgo

Perclórico

ácido 41.13

Percloroetileno (PERC)

como cancerígeno del grupo $2 \mathrm{~A}$ por la IARC $\quad 100.12$

Percutánea, absorción

Véase Piel, absorción percutánea

Pérdida auditiva alarmas acústicas $\quad 17.32$

audífono 17.33

de carácter laboral $\quad 47.4$

y ruido de impulso $\quad 47.4$

y ruido intermitente 47.4

en el sector de la construcción $\quad 93.12$

asociada al ruido 93.12

prevención 93.12

en empleados de salas y bares 98.5

estigmatización de la sordera $\quad 17.31$

fuentes extralaborales

y socioacusia 47.4

inducida por ruido $47.2,47.4$ - 47.5, 47.18

y depresión 47.2

obstáculos a la promoción

profesional 17.33

problemas de comunicación $\quad 17.33$

en el lugar de trabajo 17.33

vida familiar 17.34

vida social 17.34

problemas producidos por la 17.34

prótesis auditivas 17.32

síntomas 47.3

y desviación temporal del umbral

(T emporary Threshold Shift, T TS) 47.4

y fármacos 47.4

y productos químicos 47.4

Véase también R ehabilitación 
Pérdida de conciencia por descarga eléctrica $\quad 40.4$

Pérdida fetal

definición $9.12 t$

Véase también A borto, gestación

Perforación

de pozos de petróleo 75.9 Véase Petróleo

Perforación de túneles

cámara de empuje 36.6

esclusas 36.6

incendios 36.9

lesiones de los trabajadores $\quad 36.9$

pantalla de seguridad 36.6

presurización 36.6

ruido 36.9

trabajo en la perforación de túneles 36.5

y descompresión 36.4

Peribronquitis

por exposición al titanio $\quad 63.49$

Periférico

Véase Sistema nervioso

Periodismo

peligrosidad del 96.39

grupo más vulnerable 96.40

medidas para reducir riesgos 96.40

Periplaneta americana $\quad 44.23$

Peritendinitis

Véase M uñeca

Permanganatos 41.13

Permeación 31.18

Peróxidos

de benzoilo

inclasificable como carcinógeno por la IARC $\quad 104.364$

de hidrógeno $67.27,72.9$

explosión 104.364

inclasificable como carcinógeno por la

IARC $\quad 104.364$

intoxicación 104.364

inorgánicos 41.13

manipulación 104.365

orgánicos 41.13

riesgos 104.363

Personal

de cocina 98.3

de correos 101.6

de enfermería 94.3

de limpieza 98.6

de mantenimiento 94.3

de oficinas 99.2

de recepción 98.6

de restauración 94.3, 98.5

de servicio de comidas 98.4

Personal auxiliar y de ambulancias

características generales de su

actividad 95.21 estrés laboral 95.22

exposición a agentes infecciosos $\quad 95.21$

formación 95.22

inhalación de humos y gases tóxicos 95.21

riesgos físicos 95.21

accidentes de circulación $\quad 95.21$

lesiones musculosqueléticas 95.21

lesiones térmicas 95.21

violencia 95.21

tuberculosis 95.22

vacunación 95.22

Personal de caja

en restaurantes

y lesiones por esfuerzo repetitivo $\quad 98.5$

Personal de control de sustancias peligrosas

actuación de policía y bomberos 95.22

Véase Servicios de policía y de extinción de incendios

características generales de su

actividad 95.22

contención y control de los vertidos 95.22

organización del sector 95.22

prevención 95.23

adopción y aplicación de normas de seguridad 95.23

descontaminación 95.23

formación 95.23

gestión y supervisión de los accidentes 95.23

información y sensibilización $\quad 95.24$

primeros auxilios 95.23

programas de vigilancia médica 95.24

retirada de residuos peligrosos 95.23

formación 95.23

riesgos asociados 95.23

contacto con la sangre y otros fluidos corporales de las víctimas $\quad 95.23$

estrés por calor 95.23

lesiones físicas 95.23

toxicidad 95.23

Personal de vuelo

Véase T ripulación aérea

Personal docente

enfermedades infecciosas $94.5 \mathrm{t}$

riesgos potenciales $94.3,94.6 \mathrm{t}$

Personal jerárquico

y evolución del mundo del trabajo $\quad 24.18$

Personal sanitario

Véase T rabajadores sanitarios

Personalidad

relación con la tensión del entorno y el aprendizaje 34.12

y sensibilidad al cáncer 34.67

Personas con discapacidades

Véase D iscapacidad

Pesca

captura accesoria $\quad 66.19$

capturas mundiales 66.2
Código de seguridad para los pescadores y

buques 66.9

eléctrica 70.37

impactos medioambientales 66.19

industria pesquera 66.2

a bordo 66.7

evolución y estructura 66.2

importancia económica $\quad 66.5$

procesamiento del pescado $\quad 66.7$

lugares de pesca 66.9

métodos 66.6

arrastre de fondo 66.6

arte de cerco 66.6

pesca a la línea en buques

pequeños 66.7

pesca de palangre 66.6

redes de deriva 66.7

repercusiones ambientales de la

y efectos en la población 53.7

trabajo a bordo de buques de pesca 66.6

buques pequeños de pesca 66.11

condiciones psicosociales 66.11

grandes buques 66.11

zonas de pesca 66.9

Peso

índice de levantamiento 29.44

límites de 29.44

Pesquerías

artesanales 66.2

de altura 66.9

de bajura 66.9

gestión de las 66.5

cuotas 66.5

industriales 66.2

Peste bubónica 69.5

Pesticidas

carbamatos 27.22

indicadores biológicos de efecto $\quad 27.22$

indicadores biológicos de

exposición 27.22

compuestos de amonio cuaternario $\quad 27.25$ indicadores biológicos de exposición 27.25

derivados cumarínicos 27.24

indicadores biológicos de efecto $\quad 27.24$

indicadores biológicos de exposición 27.25

4, 6-dinitro-o-cresol (D NOC) 27.25

ditiocarbamatos 27.23

indicadores biológicos de

exposición 27.23

efectos neurotóxicos 7.13

en cocinas y restaurantes $\quad 98.4$

envenenamientos 39.6

exposición $\quad 27.20$

exterminadores de plagas y 103.18

generalidades 27.20

herbicidas fenóxicos 27.25 


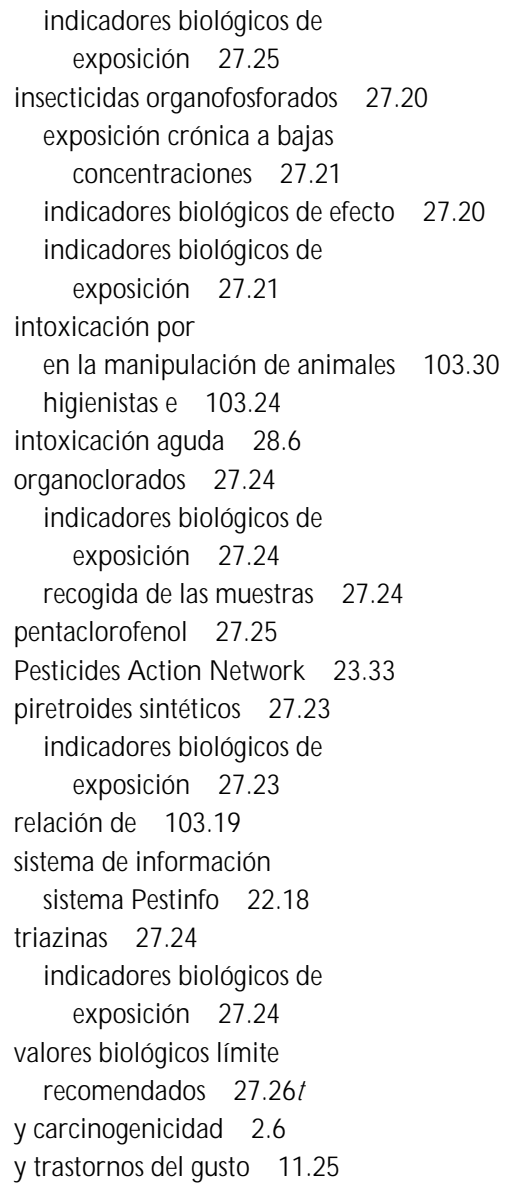

Peterborough, R eino U nido $\quad 39.30$

Petróleo

ceras derivadas 78.20

conservación de yacimientos 75.10 control de la contaminación $\quad 75.16$

crudos de petróleo 75.3

características y propiedades $75.3 \mathrm{t}$

de pizarras bituminosas 75.2

extracción 75.10

gases licuados del

usos 104.239

industria del

fenoles en 104.368

perforación 75.7

Véase Pozos

direccional 75.9

electroperforación 75.9

lodo de perforación 75.9

plataformas marinas 75.7

por percusión o con cable 75.8

revestimento 75.9

rotativa 75.9

rotopercutante 75.9

técnicas de perforación 75.9

terminación 75.10

tipos de plataforma submarina $75.8 \mathrm{t}$

tipos de pozos

turboperforación 75.9 pozos 75.8

de desarrollo $\quad 75.8$

de exploración 75.8

de geopresión y geotérmicos 75.8

de inyección 75.8

de múltiples zonas 75.8

de servicio $\quad 75.8$

mermados 75.8

preparación de los campos de

producción 75.12

condiciones de trabajo, salud y

seguridad 75.12

contratistas 75.12

equipo mínimo 75.12

riesgos profesionales 75.13

seguridad 75.13

servicios 75.12

proceso de refinado

Véase R efino del petróleo

prospecciones 75.6

estratigráficas 75.7

fotogramétricas aéreas 75.7

gravimétricas 75.7

magnetométricas 75.6

radiográficas 75.7

sísmicas 75.7

recuperación de yacimientos 75.10

acidificación 75.10

desplazamiento natural 75.11

fracturación 75.10

inyección de agua 75.11

inyección de fuego 75.11

inyección de líquido miscible 75.11

inyección de vapor 75.11

mantenimiento de la presión 75.11

por presión artificial 75.11

Véase también $\mathrm{G}$ as natural

Petróleo crudo

almacenamiento en depósitos al descubierto

de 102.62

almacenamiento y transporte de 102.51

conductos de transporte de 102.51

petroleros y barcazas para el transporte

de 102.56

tipos de canalización del $\quad 102.52$

Petroleros

normas de la O M I para seguridad

de 102.56

PFC

y el calentamiento global $\quad 83.8$

Picaduras 64.38

Pick, enfermedad de 5.6

Picor de la cebada $\quad 65.14$

Picrato de plata 63.38

Picture M ix Exposure (PIM EX) 30.6

Pie

fascitis plantar 6.32

hallux valgus 6.32 síndrome compartimental 6.31

síndrome del túnel del tarso $\quad 6.31$

tenosinovitis 6.31

Pie de inmersión 67.20

Pie de trinchera $\quad 67.20$

Piedra caliza

riesgos para la salud de la $\quad 62.5$

Piedra pómez

riesgos para la salud de la $\quad 62.5$

Piedras preciosas sintéticas 84.27

Piel

absorción percutánea $\quad 12.2-12.3$

absorción percutánea de tóxicos 33.6,

33.11

mecanismos 33.11

velocidad 33.11

afectos adversos de una toxicidad aguda 33.32

cambios de pigmentación $\quad 12.4$

dermatitis 12.10

en la fabricación de semiconductores 83.18

dermatitis profesional 12.2

diagnóstico de las enfermedades

profesionales 12.7

enfermedades de la $\quad 66.17$

en la conducción de camiones 103.8

enfermedades no profesionales 12.6

acné 12.6

dermatomicosis 12.6

eccemas crónicos 12.6

hiperhidrosis 12.6

enfermedades profesionales de la $\quad 12.2$

alteraciones ulcerosas 12.4

causas de las enfermedades $\quad 12.5$

cloracné 12.4

dermatitis de contacto aguda $\quad 12.3$

dermatitis de contacto eccematosa

crónica 12.3

dermatitis de contacto subaguda $\quad 12.3$

dermatitis por fotosensibilidad 12.3

dermatosis acneiformes $\quad 12.4$

estigmas profesionales 12.19

fisiopatología 12.4

foliculitis 12.4

granulomas 12.4

neoplasias 12.4

exposición al formaldehído en la

confección 87.4

exposición al sol y carcinogenicidad $\quad 33.68$

funciones fisiológicas 12.2

irritación de la

ácidos monocarboxílicos

insaturados 104.13

asociada a la industria de la piel y el cuero $88.4,88.7$

boranose 104.130

éteres glicólicos y $\quad 104.201$ 


\section{y ácido fórmico 104.13}

y cloropicrina 104.339

y compuestos orgánicos de azufre 104.407

y dióxido de azufre 104.420

y nitrocompuestos 104.338

y peróxidos 104.363

lesiones de la

encoladores y 103.16

exterminadores de plagas y $\quad 103.19$

necrosis

carbonatos alcalinos 104.57

quemadura de

ácido clorhídrico y 104.6

ácido glicólico y 104.14

ácido nítrico y 104.6

ácidos inorgánicos y 104.5

azida sódica y 104.122

fósforo y 104.383

hidracinasy 104.122

reacciones inducidas por el sudor $\quad 12.4$

representación esquemática $\quad 12.2 f$

riesgo de melanoma en industrias gráficas 85.10

riesgos asociados a los procesos

fotográficos 85.15

alergia 85.15

reacciones liquenoides 85.15

riesgos en industrias gráficas

asociados a la utilización de tintas 85.9

utilización de papel 85.7

sensibilización química 33.32

sistemas de defensa cutánea $\quad 12.3$

tipo de piel y pigmentación $\quad 12.6$

trastornos dérmicos

asociados al contacto con asfalto 93.57 -

93.58

en el montaje de tarjetas de circuito impreso 83.31

en la industria de la piel y el cuero $\quad 88.9$

Véase también Cáncer de piel

Pienso

almacenamiento del $\quad 70.12$

riesgos sanitarios 70.12

Pigmentos, manchas de

Véase Estigmas profesionales

Pila

eléctrica

Véase A paratos eléctricos

pila Leclanché

diagrama de producción $\quad 81.5 f$

riesgos de la fabricación 81.6

Píldora anticonceptiva

Véase Salud de la mujer

Pimárico

ácido 83.30

Pinguécula

y radiación ultravioleta $\quad 53.30$
Pintores

caída de muñeca 28.22

de carpintería metálica 32.9

riesgos laborales 103.43

sustancias a las que se expone $\quad 103.47$

Pintores artísticos

exposición a materiales nocivos 96.8

problemas de salud entre 96.8

riesgo de cáncer de riñón en 96.6

Pintura

en la industria naval $\quad 92.9$

composición 92.15

de cascos 92.10

de depósitos y de

compartimientos 92.10

de las superestructuras $\quad 92.10$

en bloques 92.10

equipos de aplicación $\quad 92.9$

prácticas y métodos 92.9

preparación de la superficie $\quad 92.10$

pulverización térmica 92.9

revestimiento de imprimación 92.9

sistemas de aplicación $\quad 92.9$

tipos 92.9

utilización de equipos de protección personal 92.15

fenoles en 104.368

resinas en 104.399

Pinturas y revestimientos

barnices 77.22

lacas 77.22

manipulación de materiales 77.23

pinturas 77.22

procesos de fabricación $\quad 77.22$

molienda 77.22

revestimientos en polvo $\quad 77.23$

riesgos asociados 77.23

Piretrinas 67.30

Pirimidina-5 27.12

Pirimor 62.12

Piroforicidad 41.10

Pirólisis 41.30

Pirometalurgia

Véase M etalurgia, metales

Pirotecnia

boranos en 104.130

en actividades recreativas $\quad 96.49$

fosfatos en 104.382

para efectos especiales 96.35

problemas asociados con la 96.35

Pirotécnica

Véase Industria pirotécnica

Piscifactorías 70.6, 70.38

Véase Acuicultura

Pistolas

de aire comprimido

precauciones en el uso de de pulverización

dispositivos de seguridad en

58.7

Piuria

sistema nefrourinario

8.6

Pizarra

bituminosa 75.2

Véase Petróleo de pizarras bituminosas

Plaguicidas

almacenamiento de los $\quad 62.16$

carbamatos y tiocarbamatos 62.11

intoxicación por 62.12

Clase IA: "extremadamente peligrosos" $62.20 \mathrm{t}$

Clase IB: "altamente peligrosos" $62.22 \mathrm{t}$

Clase II: "moderadamente

peligrosos" $62.24 \mathrm{t}$

Clase III: "ligeramente peligrosos" $62.29 \mathrm{t}$

Clasificación de la OMS 62.10

en función del riesgo 62.18

en función del riesgo agudo para la salud humana 62.10

clasificación en función del riesgo de 61.9

clordano 9.21

ecológicos 62.8

educación sobre los $\quad 64.16-64.18$

eliminación de 62.17

en bosques y viveros silvícolas 68.27

evaluación de los residuos de 53.8

improbabilidad de riesgo agudo $62.34 \mathrm{t}$

intoxicaciones por 64.14

lindano 9.22

métodos de aplicación de $\quad 64.14$

aerosoles 64.14

nebulizadores 64.14

plaguicidas en grano 64.14

pulverizadores 64.14

vaporizadores 64.14

mezcla y aplicación de 62.16

métodos de protección 62.17

mezclados con las colas 71.9

microcontaminantes orgánicos 53.20

no incluidos en la C lasificación

recomendada $62.42 \mathrm{t}$

obsoletos o no utilizados $62.42 \mathrm{t}$

organoclorados 62.10

intoxicaciones agudas por $\quad 62.10$

intoxicaciones crónicas 62.10

organofosforados 33.32

inhibición de la

acetilcolinesterasa $\quad 33.32$

organofosforados 62.11

acción tóxica de los 62.11

para el control de roedores

Véase también R odenticidas

para hongos

Véase también Fungicidas

para las malezas y las hierbas

Véase también $\mathrm{H}$ erbicidas

plaguicidas organofosforados 64.15 
requisitos de etiquetado de los 62.16

y contaminación del agua 53.20

y contaminación del suelo y de las aguas 53.15

y exposición neonatal 9.21

efectos tóxicos 9.21

Planck, Ley de 46.2

para el comportamiento de un radiador de cuerpo negro 46.2

Planes de emergencia

en instalaciones radiológicas $\quad 48.37$ vigilancia medioambiental $\quad 48.38$

y plan típico de una central nuclear 48.38

Planes de estudios

e información pertinente sobre salud y seguridad 94.12

Planes de incentivos

a la productividad $\quad 60.24$

efectos en la seguridad 60.24

a la seguridad $60.15,60.17$

ahorro neto 60.20

eficacia de los 60.25

esquemas mixtos de gratificación $\quad 60.19$

modos de recompensa 60.18

ocultación de accidentes en los 60.19

relación coste-beneficio $\quad 60.20$

rentabilidad de los 60.18

y reducción de la siniestralidad

Planificación del transporte

y control de la contaminación $\quad 55.7$

Planificación del uso del suelo

y control de la contaminación $\quad 55.7$

Plantación

deárboles 68.15

ciclo de plantación 68.16

equipamiento 68.16

estrategia de plantación $\quad 68.16$

peligros, efectos y medidas

preventivas 68.17

transporte de plantones 68.16

ventajas 68.42

Plantadoras 64.28

Plantadores

silvícolas 68.17

seguridad y la salud de los 68.17

Plantas de blanqueo 72.14

Plantas de producción $\quad 64.13$

Plantas de semillero 64.13

Plantas de tratamiento

de aguas residuales $\quad 101.10$

cloro gaseoso en 101.13

efectos de la exposición a productos

químicos en 101.12

gas metano en 101.13

riesgos físicos en las 101.11

riesgos microbiológicos 101.12

sulfuro de hidrógeno en $\quad 101.12$
Plaquetas 1.2

Plástico

Véase Industria del plástico

riesgo asociado en los procesos de confección 87.5

Plásticos y cauchos 41.14

Plata

riesgos de la 63.38

técnicas de recuperación en industrias gráficas 85.13

electrolisis 85.13

intercambio iónico 85.13

precipitación 85.13

sustitución de metales 85.13

y argiria 63.38

y medio ambiente en industrias gráficas 85.13

Platino

efectos alérgicos del $\quad 63.39$

efectos tóxicos del en trabajadores 63.39

Platinosis 63.39

Pleural, enfermedad relacionada con el amianto $\quad 10.65$ derrames pleurales 10.66 perspectiva histórica 10.65 placas pleurales 10.65 reacción visceroparietal 10.66

Plicático

ácido 71.10

Plomo

absorción del 63.40

en minería 63.40

concentración tolerable máxima $\quad 27.12$

control de la exposición laboral al 63.43 norma OSHA 63.43

efectos sobre el aparato reproductor masculino 63.42

efectos sobre el feto 63.42

excreción 27.12

exposición 27.11

exposición a humos en la industria del automóvil 91.4

exposición al 32.9

fundición de cobre/ bronce 32.9

fabricación de baterías 32.9

fabricación de pigmentos 32.9

fundición primaria y secundaria 32.9

exposición ambiental al $\quad 53.14$

exposición en el montaje de tarjetas de circuito impreso $\quad 83.29,83.32$

exposición en industrias gráficas 85.3

exposición en la industria naval 92.15 , 92.17

exposición en los procesos de confección 87.7

fundición y afino exposición a polvos de mineral $\quad 82.7$ materiales y residuos $82.7 \mathrm{t}$

precauciones 82.7

proceso de producción 82.6

sinterización 82.6

inorgánico 30.23, 31.17

intoxicación por 63.40

efectos endocrinos 63.41

efectos renales 63.41

pruebas de laboratorio para evaluar la 63.42

riesgos hematológicos 63.41

y deficiencias neurológicas 63.41

y disminución en la agudeza auditiva 63.41

y neuropatía periférica 63.41

medidas de salud y seguridad 63.44

niveles 27.11

operaciones de recuperación

controles técnicos $82.54 \mathrm{t}$

orgánico, compuestos de

medidas de seguridad con $\quad 63.44$

órganos diana 33.16

riesgo de intoxicación en la industria del automóvil 91.6

riesgos asociados en el sector de la

construcción

pinturas 93.43

riesgos asociados en la construcción de motores de aviación 90.11

toxicidad grave por 63.42

signos y síntomas de 63.42

toxicidad leve por exposición al $\quad 63.42$ síntomas 63.42

toxicidad moderada por 63.42

síntomas de 63.42

vías de entrada en el organismo $\quad 63.40$

y medio ambiente en la confección 87.7

Pluma de apeo $\quad 68.9$

Plutonio 23939.43

Poda 64.13

Podadores 64.13

Poiseuille, ley de 33.9

Poisson

coeficientes de regresión $\quad 28.30$

Polaridad 40.6

Polarización en la población activa $\quad 24.22$

Polen

en aire interior $\quad 44.22$

Polialquilos 41.14

Poliamidas 41.14

Policarbonatos 41.14

Policía

Véase Servicios de policía

Policitemia 37.12

Poliésteres 41.14

Poliestireno $41.14,67.25$ 
Polietileno

ropa de protección de 31.22

Polimerización

refino de petróleo

Véase $\mathrm{Craqueo}$

Polimetil-metacrilato $\quad 41.14$

Polimorfismo

de la debrisoquina 33.26

del gen GST M 133.27

de otras enzimas (no P450) 33.27

farmacogenético 33.24

humano de las enzimas metabolizantes de xenobióticos 33.24

Polineuritis 62.11

por plaguicidas organoclorados

62.10

Poliposis

trastornos olfatorios 11.29

Polisulfuros 41.14

Política ambiental

y emisiones locales de contaminación 54.3

y tecnologías productivas limpias 54.4 54.31

Política de seguridad

compromiso de la dirección $\quad 59.11$

y efecto sobre los trabajadores 59.11

concepto de responsabilidad en 59.3

concepto de seguridad integrada 57.4

conceptos ISO $9000 \quad 57.4$

criterios de autovaloración de la 59.3

y análisis de desfases 59.3

y auditorías 59.3

y cuantificación de los

siniestros 59.3

cultura de seguridad positiva en 59.2

criterios 59.2

evaluación de los resultados 59.3

con encuestas de percepción $\quad 59.4$

mediante entrevistas con los

trabajadores 59.4

por muestreo de comportamientos 59.4

implicación del clima de seguridad

en 59.12

métodos tradicionales 59.11

papel de los supervisores 59.2

planteamiento basado en el sistema

social 57.4

y control total de pérdidas $\quad 57.3$

$y$ liderazgo

como factor de éxito 59.3

Véase también C ultura de seguridad

Véase también Prevención de accidentes

Política laboral

definición 23.3

Poliuretanos 41.14

Véase I socianatos

Polivinilpirrolidona

y trastornos respiratorios $\quad 100.7$
Pollos

elaboración $\quad 67.20$

colgado en vivo 67.21

deshuesado 67.23

deshuesado de muslos y pollo

triturado 67.25

elaboración de platos preparados $\quad 67.25$

empaquetado y refrigeración $\quad 67.24$

extracción de vísceras 67.22

preparación 67.21

refrigeración $\quad 67.23$

trinchado 67.23

Polvo

$\checkmark$ éase $\mathrm{N}$ eumoconiosis

de algodón, cáñamo y lino 91.4 exposición en la industria del automóvil 91.4

de café 65.8

de canela 67.9

de carbón en minas subterráneas

Véase M inería

de cereales $65.11,67.30$

de harina 67.31

de madera $71.7,71.11,72.16$

de nuevos materiales textiles

en la industria aeroespacial $\quad 90.13$

de papel 72.16

de sílice, exposición en la industria del

automóvil 91.3

medidas de control 91.3

riesgo de cáncer de pulmón 91.8

de té 65.9

depositado

Véase Polvo sedimentable

en el sector de la construcción

en la fabricación del cemento 93.52

en las tareas de acabado $\quad 93.30$

en los trabajos con grava 93.58

en relación con encofrados 93.56

prevención 93.10

sílice cristalina $\quad 93.9,93.43$

yeso 93.44

en la recolección de cereales $\quad 64.20$

en suspensión

Véase Partículas en suspensión

explosiones 41.15, 65.9

explosivos 41.7

exposición en explotaciones

ganaderas 70.9

exposición en la industria de la piel y el

cuero $88.4,88.7$

esmerilado 88.4

exposición en la industria del calzado 88.8

exposición en la industria naval $\quad 92.13$

exposición en vaquerías 70.21

fibrogénicos 10.36

límites admisibles 30.31

medios de muestreo 30.22

metálicos e ignición espontánea $\quad 41.10$

mortalidad por exposición al polvo de algodón 89.32

negro 41.14

no fibrogénicos 10.36

orgánicos

enfermedad por exposición a $\quad 10.27$

partículas 70.14

riesgo asociado en la industria de la

lana 89.14

riesgos asociados en el procesado del

fieltro 89.18

riesgos de exposición $\quad 30.15$

sedimentable

medición del 55.16

Pontiac 44.3

Véase Fiebre de Pontiac

Porcino

peligros 70.25

medidas de prevención $\quad 70.26$

procesos de producción 70.25

Porfiria

cutánea tardía

dioxina y 104.299

intermitente aguda 63.42

Porphyria cutanea tarda $\quad 12.3$

Portugal 65.15

Posgrado, instituciones de 94.2

Postura de trabajo

aspectos culturales 29.93

ayudas y soportes 29.40

carga musculosquelética 29.38

factores influyentes 29.39

lista de comprobación 29.21

normativa 29.40

postura de la cabeza 29.77

postura sentada 29.41

registro y medición 29.39

análisis postural asistido por ordenador 29.39

cuestionarios de autoevaluación y diarios 29.39

método del diagrama de la postura de Corlett y Bishop 29.39

método O WAS 29.39

observación 29.39

regulación postural y

envejecimiento 29.96

y biomecánica 29.43

y diseño del puesto de trabajo 29.67

y dolor lumbar 29.39

y salud y seguridad 29.38

Potasio $39.7,41.14,41.31$

Pott, Percival

Estudios sobre el cáncer de escroto 28.2

Pozos

excavación de

Véase M inería, minas subterráneas 
perforación

Véase Petróleo

Prader-Willi, síndrome de

y exposición a los hidrocarburos 9.2

Precipitación

en tratamiento de aguas residuales 101.20

Precipitadores electrostáticos aplicaciones 45.10

Prejubilación

Véase Programas de

curso de prejubilación 15.93 contenido y duración 15.94

Prendas de abrigo

Véase Prendas de protección

Prendas de protección

bunkers 42.14

delantales reflectores $\quad 42.14$

educación y formación 31.21

homologación, certificación y

normas 31.20

mantenimiento 31.21

necesidades individuales 31.21 comodidad del trabajo, eficacia y protección 31.21

prendas de abrigo $42.30,42.38,42.45$

ajuste en función del frío $\quad 42.47$

coste de la protección 42.33

Prendas NBC 42.26

requisitos $31.19 t$

resistencia a la degradación y la penetración 31.18

resistencia a la permeación 31.18

riesgos para el cuerpo 31.17

biológicos 31.19

físicos 31.18

químicos 31.17

tipos de protección 31.19

traje "húmedo" 42.53

traje "seco" 42.53

traje de hielo 42.14

trajes de inmersión $\quad 42.49$

trajes impermeables 42.53

trajes refrigerados con aire $\quad 42.15$

trajes refrigerados con líquidos $\quad 42.15$

uso y mal uso 31.22

Véase también Aislamiento térmico de la ropa

Véase también C ontrol de la humedad

Véase también Equipos de protección

Prendas de vestir

tipos de 42.28

ventilación en el interior de las 42.30

Prensas 72.10

Presas

en el sector de la construcción $\quad 93.23$

Presbiacusia 11.7

Véase Pérdida auditiva

Presbicia 11.21
Presbiopía 11.21

Presión arterial

a grandes altitudes 37.3

y estrés 34.61

Presión barométrica

e intoxicación por monóxido de carbono 36.2

reducción de la 37.2

aclimatación 37.2, 37.5

cambios de la función cerebral 37.7

edema cerebral $\quad 37.9,37.14$

edema pulmonar $37.9,37.14$

efectos fisiológicos 37.5

exposición intermitente 37.5

hemorragias retinianas 37.9

hiperventilación 37.6

hipoxia 37.8

mal de montaña agudo $\quad 37.8,37.14$

mal de montaña crónico $\quad 37.10$

tolerancia 37.11

trastornos del sueño $\quad 37.5,37.7$

y gestación 37.10

y dióxido de carbono 36.3

y narcosis por nitrógeno 36.3

$y$ toxicidad por oxígeno 36.2

Véase también D escompresión

Véase también Trabajo a grandes altitudes

Presión parcial de vapor de agua diagrama psicrométrico $\quad 42.17$

Prestaciones por accidentes de trabajo y responsabilidad civil 23.19

y responsabilidad de la empresa 23.18

Prestaciones por enfermedad profesiona cobertura 23.19

Prevalencia

durante un período 28.11

instantánea 28.11

Prevención

de la discriminación

actuación de la inspección de trabajo 23.11

del personal de control de sustancias peligrosas 95.23

pautas $95.24 f$

dirigida al personal auxiliar y de ambulancias 95.22

vacunación 95.22

en la asistencia sanitaria de las fuerzas armadas 95.19

en la industria naval $\quad 92.14$

aislamiento de procesos 92.14

cerramiento 92.14

controles administrativos 92.14

controles de protección

individuales 92.14

controles técnicos 92.14

sustitución o eliminación de procesos 92.14 ventilación 92.14

en las operaciones de rescate

marítimo 95.21

medidas en los servicios de seguridad y de emergencia 95.3

adopción de precauciones generales 95.3

aplicadas al SIDA en los servicios de policía 95.13

investigación de incidentes graves 95.3 procesos de selección $\quad 95.3$

Prevención de accidentes

taxonomía del modelo de desviaciones en la 56.23

aplicaciones 56.24

análisis comparativo del riesgo 32.26

aplicación de la matriz de Haddon a $\quad 56.32$

clasificaciones del error $\quad 56.9$

errores basados en el

conocimiento 56.10

errores basados en la destreza 56.9

errores basados en las reglas 56.10

control consciente del peligro 56.18

en el modelo de $\mathrm{H}$ ale y $\mathrm{G}$ lendon 56.18

control de la transferencia de energía

en 56.7

control de riesgos en 59.28

control sobre el error humano para la 57.8

mediante instrucción 57.8

por mejora de la motivación 57.9

por premio y sanción $\quad 57.8$

y cambio del ambiente de trabajo 57.9

y selección del personal $\quad 57.9$

detectores de presencia en $\quad 58.25$

diez estrategias de prevención de

$\mathrm{H}$ addon 56.33

durante la manipulación de materiales

veintidós principios para la 58.84

e incentivos a la seguridad $\quad 60.18$

e información sobre accidentes $\quad 57.30$

equipo de protección individual 59.31

en la industria 59.31

estadísticas de accidentes en la $\quad 57.29$, 57.33

fases de intervención 56.32

y matriz de $\mathrm{H}$ addon 56.32

fuentes de información para la

Véase Información sobre seguridad

gasto de las Administraciones para 56.43

gastos de la empresa para 56.44

incentivos 56.44

mapas de datos de accidentes en la 57.31

medidas preventivas individuales 59.30

pirámide de los accidentes 56.36

programas de seguridad y

Véase también Programas de seguridad

retroinformación en la

y modelos de desviación $\quad 56.22,56.24$

y conocimiento del error 56.8 
y control de las desviaciones 56.24

y detección del peligro $\quad 59.27$

y entorno de trabajo 56.34

y evaluación de riesgos 59.26

y motivación del trabajador 56.14

mediante sanciones 56.14

programas de incentivos 56.14

y nivel de riesgo asumido 56.13

y percepción de los peligros 59.26

y planificación de la producción 56.34

y proceso homeostático 56.12

carácter autocorrector del 56.12

y reducción de las primas 26.12

y Sección Internacional

de la AISS 23.67

Véase también Investigación de accidentes

Prevención de incendios

detectores de humo $41.8,41.16$

en la fabricación de

semiconductores 83.20

formación en seguridad $39.48,41.16$

mantenimiento industrial $\quad 41.16$

requisitos de seguridad de los

edificios 39.45

Prevención de la contaminación $\quad 55.3,55.53$ $55.57,55.59$

Prevención de riesgos laborales

actitudes de los directivos y las empresas 26.12

advertencias de seguridad en 59.31

colaboración entre los interlocutores sociales 26.12

costes de la no prevención $\quad 23.16$

cultura de la prevención 23.16

definición 23.15

en Alemania $26.17-26.21$

en el embotellado y envasado de bebidas

refrescantes 65.4

en el sector de la construcción

asociada a la calidad 93.17

en relación con el hormigón 93.55

gestión 93.8

normativa de salud y seguridad 93.17

en Israel 26.26

en Japón 26.29

en Suecia 26.31

en Suiza 26.14

labor de la inspección de trabajo $\quad 23.15$

lesiones de la función reproductora 24.9

Véase también Control biológico

Véase también $R$ iesgos profesionales

Prevención del riesgo de lesiones

programas para la

Véase Programas de seguridad

Prevención sanitaria

en la construcción 93.11

beneficios económicos 93.13

contenido de los servicios

preventivos 93.11 servicios de salud laboral y

tipología 93.11

Prima de riesgo 23.21

Primas

de productividad

y efectos sobre la seguridad $\quad 60.24$

Primeros auxilios

criterios de planificación 14.3

configuración de la empresa $\quad 14.4$

disponibilidad de otros servicios de salud 14.4

equipo de salvamento especializado $\quad 14.7$

importancia de los primeros auxilios 14.2

casos de parada cardíaca 14.2

hemorragias 14.2

lesiones de la médula espinal 14.2

lesiones químicas oculares 14.2

modelos de clasificación 14.3

organización y planificación 14.3

peligros potenciales 14.3

personal de primeros auxilios 14.5

relación con otros servicios 14.2

requisitos básicos 14.4

centros de formación 14.6

contenido de los maletines 14.6

equipo, material e instalaciones 14.4

formación avanzada 14.6

formación básica 14.6

materias 14.6

recursos humanos 14.4

sala de primeros auxilios 14.7

riesgos específicos 14.2

asociados con un tipo de trabajo 14.3

sistemas de comunicación 14.7

plan de remisión 14.8

Procesadores de texto

compatibilidad estímulo-respuesta 29.86

Procesamiento

del pescado $66.7,66.13$

en tierra 66.13

Proceso de montaje de ordenadores 83.33

Producción

diseño de sistemas de 29.57

y principio de la tarea completa 29.58

participación en el diseño de sistemas 29.61

Producción cinematográfica Véase C ine, industria del

Producción de coque

coquización 73.9

subproductos recuperables $73.9 \mathrm{t}$

medidas de salud y seguridad 73.10

equipos móviles 73.10

mantenimiento y limpieza 73.10

procedimiento de carga 73.10

sistema de aspiración 73.10

ventilación por extracción 73.10

vigilancia médica 73.10 preparación del carbón 73.9

riesgos físicos 73.9

calor ambiental 73.9

riesgos mecánicos 73.9

equiposmóviles 73.9

riesgos químicos 73.9

emisiones de las retortas 73.9

Producción de hierro y acero

fabricación de acero 73.5

fabricación de hierro 73.3

intoxicación por monóxido de carbono 73.6

medidas de salud y seguridad 73.7

cursos de formación 73.7

equipos de protección personal 73.8

ergonomía 73.8

higiene industrial 73.8

inspección de la maquinaria 73.7

programas de seguridad 73.7

vigilancia médica 73.8

polvo y vapores 73.7

problemas de salud y seguridad 73.13

amianto 73.14

compuestos de azufre 73.14

contaminantes atmosféricos 73.14

estrés 73.15

exposición 73.13

hidrocarburos aromáticos

policíclicos 73.14

metales pesados 73.14

nieblas de aceite 73.14

nieblas de ácido 73.14

nucleidos radiactivos 73.14

polvo y vapores 73.14

problemas ergonómicos 73.13

productosquímicos 73.14

programas preventivos 73.15

rayosláser 73.13

ruido 73.13

ślice 73.14

vibración 73.13

repercusiones para el medio

ambiente 73.15

aceites y grasas 73.18

conservación de la energía 73.18

contaminantes atmosféricos 73.15

contaminantes de las aguas

residuales 73.17

contaminantes y desechos

generados $73.15 f$

dióxido de azufre 73.17

dióxido de carbono 73.17

emisiones orgánicas 73.17

metales pesados $73.17-73.18$

óxidos de nitrógeno 73.17

ozono 73.17

partículas 73.17

radiactividad 73.17

residuos sólidos 73.18 
sólidos en suspensión 73.18 riesgos diversos 73.7

Productividad

e incentivos salariales 66.24

en hospitales 97.31

planes de incentivos $\quad 60.24$

primas 60.24

y calidad del laire 44.2

y ergonomía 29.5

Productos agrícolas

almacenamiento 64.23

conservación en frío 64.24

gases y venenos 64.24

repercusiones sobre la salud $\quad 64.25$

riesgos derivados de la

maquinaria 64.24

De plantación 64.5

e ignición espontánea $\quad 41.10$

transporte 64.25

animales de carga $\quad 64.25$

principios generales de seguridad $\quad 64.25$

repercusiones sobre la salud $\quad 64.26$

viajes por carretera $\quad 64.25$

Productos de limpieza

potencialmente peligrosos 100.3

registro de productos PR O BAS y 100.3

y lesiones oculares 98.4

y quemaduras 98.4

Productos fitosanitarios 64.40

Productos lácteos 67.26

Productos químicos

Véase Sustancias químicas

clasificación de la peligrosidad de los

Véase Sistemas de clasificación de productos químicos

en lavanderías y tintorerías

riesgos por exposición a $\quad 100.12$

en peluquería y cosmetología

riesgos de los 100.6

para la agricultura $62.7,62.9$

seguridad en la fabricación de $\quad 62.9$

productos químicos peligrosos $100.4 \mathrm{t}$

en cosmética 98.8

en mantenimiento de piscinas y gimnasios 98.8

en productos de limpieza $\quad 98.7,100.4 \mathrm{t}$

requisitos de etiquetado de 61.10

seguridad en el uso en el trabajo de 61.2

repertorio de recomendaciones prácticas de la OIT $61.2,61.6,61.18$

tóxicos 67.19

y requisitos de etiquetado $\quad 61.12$

y seguridad en el almacenamiento 61.11

de sustancias corrosivas 61.13

de sustancias explosivas $\quad 61.12$

de sustancias inflamables 61.12

de sustancias oxidantes 61.12

de sustancias químicas tóxicas 61.13 legislación sobre 61.13

y sistema de información química

GESTIS 61.27

Profam 62.15

Profesionales

enfermedades cardiovasculares $\quad 99.5$

estrés técnico en 99.5

relación de $99.4 \mathrm{t}$

riesgos relacionados con los viajes 99.6

violencia y agresiones sobre 99.5

Profesiones

de mucha tensión 34.9

de poca tensión 34.9

riesgo relativo de incidentes no mortales 32.21

Profesorado

cualificaciones 94.2

modelos familiares 94.2

problemas 94.4

absentismo 94.4

agotamiento 94.4

estrés 94.4

violencia 94.4

proceso de aprendizaje 94.3

riesgos potenciales 94.3

accidentes 94.10

exposición a sustancias químicas 94.4

incendios 94.10

niveles de ruido excesivos 94.10

peligros relacionados con la

maquinaria 94.4

radiaciones 94.10

riesgos de carácter eléctrico $\quad 94.10$

tareas académicas 94.4

tareas especiales 94.4

y consumo de alcohol 94.14

y contaminación atmosférica 94.13

y responsabilidad 94.13

y su relación con los alumnos 94.2

y sus relaciones con las familias de los estudiantes 94.2

y tabaquismo 94.14

y vacunaciones 94.4

Programa de las $\mathrm{N}$ aciones $\mathrm{U}$ nidas para el D esarrollo

y salud y seguridad en el trabajo 23.53

Programa de las $\mathrm{N}$ aciones $\mathrm{U}$ nidas

para el M edio A mbiente (PNU M A) 54.11,

103.2

Programa de M ares R egionales del $\quad 54.12$

Programa Internacional de Seguridad

de las Sustancias Q uímicas (IPCS) 103.2

documentos sobre criterios de la toxicología de órganos diana 33.44

Environmental $\mathrm{H}$ ealth Criteria Documents 33.16

y armonización de los métodos de evaluación del riesgo 33.57
Programa Interorganizaciones para la G estión Segura de las Sustancias Q uímicas 23.47

Programa mixto PNU M A/ FAO / O M S sobre vigilancia de la contaminación de los alimentos

(SIM U VIM A/ A limentos) 53.8

Programa Nacional de T oxicología de EE.UU. 33.49

Programa T uttava

de modificación de comportamiento pro seguridad 59.16

beneficios efectivos 59.18

etapas y pasos $\quad$ 59.16f, $59.17-59.18$

Programas académicos 94.11

Programas

de asistencia a los empleados (PAE) y violencia laboral 51.8

de conservación de la audición (PCA) 47.14f de información y educación sobre riesgos y seguridad personal $\quad 94.15$

Programas de investigación y riesgos 94.11

Programas de salud y seguridad cuestiones de carácter ético $\quad 15.5$ acceso a la asistencia sanitaria $\quad 15.8$ confidencialidad e intimidad 15.7 conflictos de intereses $\quad 15.8$ costes 15.7 discriminación 15.6 elitismo frente a igualitarismo $\quad 15.5$ estrés 15.8 participación voluntaria 15.7 de asistencia a los empleados 15.88 cambio organizativo 15.91 cuestiones laborales y familiares 15.90 de detección de drogas en el lugar de trabajo 15.85 métodos de detección $\quad 15.85$

de ejercicio y capacidad física $\quad 15.32$ objetivos $15.35 f$ servicios básicos 15.33

de jubilación y prejubilación 15.92 curso de prejubilación 15.93 papel de la empresa 15.92 de mejora de la salud estudio de M aclaren Industries 15.22 de nutrición 15.37

de posjubilación 15.95

de promoción de la salud 16.12

de protección y promoción de la salud 15.2 aplicación del programa $\quad 15.5$ componentes del programa 15.3 estructura de un programa global $\quad 15.3$ evaluación del programa 15.5 objetivos básicos 15.3

de vigilancia de la salud $15.21 \mathrm{f}$

Véase también Servicios de salud 
Programas de seguridad

basados en modificación del

comportamiento 59.14

condiciones de éxito de las 59.15

eficacia de los 60.13

e incentivos al comportamiento seguro 60.15

y compromiso de la dirección $\quad 60.14$

y cuantificación de las pérdidas 60.15

y cultura de seguridad 59.2

y formación 60.14

y participación de la plantilla 59.6, 60.15

y recogida de datos 60.15

fases del éxito $59.16 f$

implantación de 60.11

actividad de los supervisores $\quad 60.12$

aprobación de la alta dirección $\quad 60.11$

equipo de trabajo 60.11

función de los directivos $\quad 60.12$

participación de los trabajadores $\quad 60.12$ proceso progresivo de 60.12

información sobre el terreno en 60.16

investigación de los accidentes en los 60.16

medidas de control de riesgos en 60.16

medios de prestación de primeros

auxilios 60.17

prevención de causas de catástrofes

en 60.17

Programa Tuttava $\quad 59.16$

etapas 59.17

valor de la retroinformación para $\quad 60.16$

Véase también Promoción de la seguridad

Programas educativos

contenido específico 18.11

derechos legales 18.11

disposiciones sindicales 18.11

identificación de los peligros 18.11

peligros para la salud 18.11

tecnologías de control 18.11

del Sindicato internacional de trabajadores químicos 18.13

evaluación de las necesidades 18.9

evaluación y seguimiento $\quad 18.11$

gráfico de métodos de enseñanza 18.11 t

objetivos educativos 18.10

obtención de apoyos 18.9

realización de una sesión educativa 18.11

selección de los métodos educativos 18.11

Véase también Formación

Programas informales de aprendizaje 94.10

Programas reglados

de formación profesional 94.10

y normativas relativas a las

cualificaciones 94.10

Prolactina

Véase H ipófisis, sistema reproductor femenino

Prometrina 62.14
Promoción

lista de comprobación $\quad 29.30$

Promoción de la salud

actividades según el tamaño de la plantilla $15.14 \mathrm{t}$

asistencia sanitaria $\quad 15.2$

categorías de resultados $\quad 15.6 \mathrm{f}$

elementos de un programa $15.10 \mathrm{f}$

en el lugar de trabajo 15.2

diseño ergonómico 15.13

estructura del programa $\quad 15.10$

evaluación de necesidades $\quad 15.9$

patrocinio de las empresas $\quad 15.9$

por las organizaciones sindicales 15.9

servicios de prevención $\quad 15.19$

tecnologías aplicables 15.12

trabajadores con necesidades especiales 15.11

temas de información $\quad$ 15.10f

Promoción de la seguridad

campañas de 60.27

Campaña del Día Nacional de la Seguridad en la India $\quad 60.28$

efecto perseguido en las 60.27

mediante incentivos $60.25-60.26$

criterios de concesión de los incentivos 60.25

Véase también Planes de incentivos

por mejora de la calidad

Véase también M odelo de gestión de la calidad (modelo T Q M)

por modificación del comportamiento

Véase también M odelo de gestión del comportamiento organizativo (modelo OBM )

teoría de los salarios compensatorios $\quad 60.25$ deficiencias de la $\quad 60.25$

y motivación de los trabajadores 60.20

y programas de comunicación 60.26

comunicaciones personales 60.27

mensajes basados en el temor 60.27

mensajes unidireccionales $\quad 60.27$

Promotor

en el sector de la construcción

definición 93.20

influencia en la salud y seguridad $\quad 93.21$

Propano

ecuación de combustión $\quad 41.2$

Propano líquido 42.39

Propazina 27.24

Propileno 39.30

Prostitución

Véase Sexo, industria del

Protección

dispositivos en carpintería $\quad$ 86.3-86.5

en el sector de la construcción

equipos de protección individual 93.6 ropa de protección personal

en la fabricación de

semiconductores 83.33

Protección contra incendios

acabado interior de los edificios $\quad 41.20$

características de los edificios 41.19

compartimentación de los edificios 39.47,

41.19 - 41.20

control del humo 41.20, 41.23

diseño de los sistemas de transporte de los

edificios 41.22

extintores portátiles y mangueras 41.23

integridad estructural de los

edificios 39.48, 41.20

medidas de protección activa $\quad 41.23$

medidas de protección pasiva 41.19

principios de 39.48

simulacros $41.22,41.27$

sistema de alarma $39.48,41.23$

sistema de detección de incendios 41.23

sistemas de espuma 41.24

sistemas de pulverización de

agua 41.24

sistemas de rociadores de agua $41.8,41.23$

vías de escape 41.21

recorridos de evacuación $\quad 41.22$

salidas 39.47

V éase también Extinción de incendios

Protección de la salud en los viajes

Véase V iajes

Protección de los trabajadores

Véase Inspección de trabajo

con prendas especializadas 42.14

contra cargas estáticas 40.11

contra la deshidratación $\quad 42.13$

contra trastornos provocados por el calor 42.11

Protección personal

aspectos generales 31.2

elementos de un programa de 31.2

ajuste 31.2

evaluación del peligro 31.2

formación y educación 31.2

mantenimiento y reparación 31.3

selección 31.2

equipo 30.25

protectores de la cabeza $\quad 31.9$

protectores de los oídos 31.11 - 31.16

protectores de ojos y cara 31.3

protectores de pies y piernas 31.7 - 31.8

protectores respiratorios $31.22-31.32$

ropa protectora 31.17

Véase también Equipos de protección individual (EPI)

V éase también Prendas de protección

Véase también $\mathrm{R}$ iesgos, prevención

Protección respiratoria

en instalaciones radiológicas $\quad 48.28$ 
Protección y promoción de la salud

enfermedades infecciosas 15.69

difusión de la información $\quad 15.70$

epidemias 15.72

intervenciones individuales 15.73

transmitidas por los alimentos 15.72

vacunaciones en el lugar de

trabajo 15.71

pequeñas empresas 15.16

posibles barreras a los programas 15.16

seguro de enfermedad $\quad 15.17$

sugerencias 15.18

ventajas del lugar de trabajo $\quad 15.17$

programas de 15.2

servicio de salud 15.19

acondicionamiento físico $\quad 15.22$

detección precoz de problemas de

salud 15.21

educación y formación $\quad 15.20$

estudio de caso 15.24

evaluación de los programas 15.22

reconocimientos médicos

periódicos 15.20

Protectores de la cabeza

Véase C ascos de seguridad

Protectores de ojos y cara

comodidad 31.7

limitaciones a la visión $\quad 31.2$ - 31.3

protección frente a

peligros concretos 31.4

lesiones traumáticas y químicas 31.4

radiación térmica 31.4

soldadura 31.5

tipos básicos 31.3

Protectores de pies y piernas

contra el peligro de descargas

eléctricas 31.8

contra lesiones de origen químico 31.8

frente al riesgo de quemaduras 31.8

puntera de seguridad 31.8

suelas 31.8

tipos 31.7

uso y mantenimiento $\quad 31.8$

Protectores oculares

contra el láser $\quad 49.20$

para fuentes de radiación óptica $\quad 49.16$

Protectores para los oídos

comodidad 31.15

efecto de oclusión 31.15

efecto sobre la comunicación $\quad 31.15$

elección 31.15

reducción activa del ruido $\quad 31.17$

sistemas de valoración 31.12

fiabilidad de los datos 31.14

método de la banda de octava 31.13

N oise R eduction Rating (NRR) 31.12

Single N umber R ating (SNR) 31.12

variabilidad 31.14 tipos 31.11

dispositivos activos sensibles a la

amplitud 31.17

dispositivos de respuesta plana 31.16

dispositivos pasivos sensibles a la

amplitud 31.16

orejeras $31.11,31.15$

protección acústica doble 31.16

tapones $31.11,31.16$

tapones para los oídos 31.11

Véase también R uido

Protectores respiratorios

dificultades 31.25

gafas y otros equipos

protectores 31.25

pelo facial 31.25

factor de protección asignado $\quad 31.28$

mantenimiento 31.24

para aerosoles, gases y vapores 31.28

para atmósferas pobres en oxígeno $\quad 31.30$

para situaciones de emergencia e

IDLH 31.28

procedimiento de elección 31.26

determinación de riesgos 31.27

estimación de la exposición $\quad 31.27$

etapas 31.28

índice de peligro 31.28

programas de protección

respiratoria 31.23

administración 31.24

evaluaciones médicas 31.25

formación 31.24

homologación 31.25

procedimientos operativos

escritos 31.24

prueba del ajuste 31.31

riesgos para el aparato

respiratorio 31.22

contaminantes 31.22

falta de oxígeno 31.22

tipos 31.23

aparato respirador autónomo $\quad 31.23$

cobertura de entradas 31.23

equipo semiautónomo 31.23

equipos mixtos 31.23

purificadores del aire 31.23

suministradores de aire 31.23

Proteínas

de estrés 33.46

interacción tóxica 33.38

Proteinuria

diagnóstico diferencial 8.6

y prueba de Bence-J ones 1.5

Proteoglucano 6.7, 6.9

Protocolo de M ontreal

reducciones en la producción

deCFC 53.31

de halones 41.25
Protoporfiria

eritropoyética 63.43

eritrocitaria $\quad 27.4,27.12$

Protoporfirina eritrocítica (FEP) 63.43

determinación de la 63.43

para medir la intoxicación por plomo 63.43

Protozoos

contaminantes del aire interior $\quad 44.24$

Protrombina 27.24

Proyectistas

en el sector de la construcción definición 93.19

Proyectos de construcción

apuntalamiento 93.26

e un solo costado 93.26

formación y supervisión 93.26

otros sistemas 93.26

concepción 93.25

medidas de prevención adoptadas por los proyectistas 93.25

riesgos asociados 93.25

utilización de materiales apropiados 93.25

demolición 93.31

desmontaje 93.33

excavación 93.25

riesgos asociados 93.26

Véase también Zanjas

superestructura 93.26

andamios 93.27

equipos de acceso motorizados 93.28

montaje de estructuras

metálicas 93.28

trabajos con escaleras 93.26

trabajos en cubiertas 93.28

Proyectos docentes 94.2

Prueba de Bence-J ones para la proteinuria $\quad 1.5$

Prueba del ajuste

método del acetato de isoamilo $31.29 f$

método del aerosol de sacarina $31.30 \mathrm{f}$

Prueba del parche con dicromato al 0 ,

$5 \% \quad 63.16$

Pseudocolinesterasa $\quad 27.3$

Pseudomonas 44.23-44.24

Pshychological Corporation

formulario C 34.50

Psicoactivas, sustancias

Véase D rogas psicoactivas

Psicoinmunología 34.66

Psicología cognitiva 34.10

Psicología del comportamiento

aplicada a la investigación de accidentes 60.2

Psicología organizacional $\quad 35.9$ 
Psicosis

antecedentes 5.7

del sombrerero loco 5.6

enfoques terapéuticos 5.8

esquizofrenia 5.6

rendimiento laboral 5.8

factores estresantes 5.8

estudio de M untaner 5.8

factores químicos 5.6

psicosis del sombrerero loco 5.6

gestión en el lugar de trabajo 5.9

psicosis posparto 5.7

reacciones psicóticas de base cultural $\quad 5.7$

trastornos neurológicos 5.6

Psicoterapia

enfoques psicoterapéuticos 5.11

psicofarmacología 5.11

Psicrómetro 42.17

Psitacosis 70.29

riesgo de contagio de

en trabajadores de parques y jardines 96.46

Psoriasis

y dermatitis de contacto $\quad 12.12$

Pterigión

y radiación ultravioleta $\quad 53.30$

Puesta a tierra

tierras de protección $\quad 40.13$

tierras funcionales $\quad 40.13$

Puesto de trabajo

análisis ergonómico del 26.16

diseño de 29.66

aspectos culturales 29.93

datos básicos 29.69

diseño ergonómico 29.66, 29.99

ejemplo 29.69

modelo del cubo 29.68

participación 29.66

peticiones de los usuarios 29.67

prioridades 29.67

proceso 29.66

variables adicionales 29.68

variables de la carga

musculosquelética 29.67

Véase también Trabajadores con discapacidades

diseño de

informe del T avistock Institute de

Londres 34.4

opinión de la O CDE 34.4

para el tallado de diamantes 29.104

presión barométrica del 37.14

valores límite umbral (TLV) 37.14

satisfacción en el

$\checkmark$ éase Bienestar

Véase también Diseño del lugar de trabajo

Pulga

picaduras de 69.5
Pulgar del alfarero 96.18

Pulimentado 83.25

Pulmón

Véase A parato respiratorio

absorción de tóxicos 33.5

bronquitis

compuestos orgánicos de azufre

$$
\text { y } 104.407
$$

de fumigador de viñedos 63.14

de granjero 70.21

de granjero agudo $\quad 70.9$

del esquimal $\quad 42.41$

del granjero $\quad 65.15$

edema de

ácido clorhídrico y 104.6

ácido nítrico y 104.7

acrilato de etilo y 104.172

anhídrido acético y 104.14

azidasy 104.121

boranosy 104.131

cloropicrina y 104.339

en encoladores 103.16

éter clorometilmetílico y 104.184

eliminación de tóxicos (desorción) 33.15

enfermedad crónica en la industria

textil 89.32

y relación con el tabaquismo 89.32

enfermedad pulmonar intersticial

riesgo en la industria del automóvil 91.5

enfermedades pulmonares en

fotografía 85.11

pulmón de agricultor 64.25

pulmón marrón 64.25

riesgo de cáncer en carpintería 86.14

riesgo de cáncer en la fabricación

de vidrio, cerámica y materiales

afines 84.31

riesgo de cáncer en la industria de la piel y el cuero $\quad 88.9$

riesgo de cáncer en la industria del automóvil 91.8

riesgo de cáncer en los procesos de confección 87.7

riesgo de edema en los procesos de tinción 89.19

sensibilización inmunitaria 33.32

Véase también Cáncer de pulmón

Véase también Enfermedades pulmonares

Véase también Función pulmonar

Pulmonares, enfermedades

Véase Enfermedades pulmonares

Pulpitis

caries y erosión dental $\quad 4.4$

Pulverizadores

pulverizador basculante 64.29

pulverizador de cubo manual $\quad 64.29$

pulverizador de mochila a motor 64.29

pulverizador de mochila de

compresión 64.28 pulverizador de mochila de palanca $\quad 64.28$

Puntero

Véase Indicadores

Purkinje, células de 104.219

Púrpura 42.10

Púrpura trombocitopénica

y diisocianato de tolueno 33.42

PVC 67.10

PVD

Véase Pantallas de visualización de datos

Véase también O peradores de PVD

Q

Q uemaduras

criogénicas 67.27

deRF 83.19

electrotérmicas

clásicas 40.4

de arco 40.4

mixtas 40.4

múltiples, extensas y profundas 40.4

en la fabricación de vidrio, cerámica y

materiales afines 84.28

en la industria alimentaria 67.6

etileno y 104.275

químicas

en la fabricación de

semiconductores $83.19,83.36$

riesgo del personal de control de sustancias peligrosas 95.23

riesgo en la industria del calzado 88.8 riesgo en los procesos de confección 87.4 riesgo en los procesos de tinción 89.19 riesgos en el sector de la construcción

en los trabajos con asfalto 93.57

en los trabajos en cubiertas 93.28

riesgos en la extinción de incendios 95.6, 95.8

riesgos en los procesos de confección $\quad 87.5$ térmicas 67.27

por contacto con productos de soldadura 83.32

Q ueratina

Véase Piel

Queratinización 33.33

Q ueratinocitos

Véase también Piel

Q ueratitis actínica 70.9

Q ueratoconjuntivitis

por exposición a arsénico $\quad 63.7$

por radiación ultravioleta $\quad 49.8$

riesgo en la fabricación de rayón 89.16

Q ueratopatía climática de gotitas y radiación ultravioleta 53.30

Q uerógeno

Véase Petróleo de pizarras bituminosas 
Q ueroseno

explosiones durante el llenado de depósitos 40.10

Q uímica

Véase Industria química

ácido cloroacético en la 104.12

nitroparafinas en la 104.338

peróxidos orgánicos en la 104.363

Q uimioprofilaxis

a trabajadores expuestos al VIH $\quad 97.49$

tras exposición profesional al VIH $\quad 97.49 \mathrm{t}$

Q uimiosensibles, sistemas $\quad 11.27$

Q uinometionato 62.16

Quinona

riesgos asociados en el procesado del fieltro trastornos oculares, dérmicos y respiratorios 89.18

Q uistes óseos

por vibraciones mano-brazo $\quad 50.10$

\section{R}

Rabia 69.4

riesgo de contagio de

en trabajadores de parques y

jardines 96.46

Racismo 101.29

Radiación

definición $\quad 41.3,42.15$

ecuación $\quad 41.2,42.15$

emitida por las PVD 52.7

en el sector de la construcción 93.5

exposición en la industria del automóvil 91.6

ionizante 67.4

lista de comprobación

29.23

natural

por radón 44.11

riesgo en la construcción de motores de

aviación 90.10

exposición a disolventes $\quad 90.10$

láser 90.10

rayos gamma 90.10

rayos $X \quad 90.10$

riesgos de los trenes de laminación 73.13

transferencia de calor por $\quad 42.27$

Radiación cósmica

sobre tripulaciones aéreas $\quad \mathbf{1 0 2 . 1 5}$

Véase también R adiación ionizante, fuentes de

Radiación de Cerenkov 48.41

$R$ adiación de microondas Véase también M icroondas

R adiación de radiofrecuencia ( $\mathrm{R} F$ ) efectos biológicos nocivos $\quad 49.21$ y riesgo de cáncer 49.21

en teléfonos móviles 49.22

y riesgo de cáncer cerebral $\quad 49.22$ fuentes de exposición laboral a $\quad 49.21$

límites de exposición $\quad 49.22$

norma C 95.1 de la IEEE $\quad 49.22$

según la IRPA $\quad 49.22$

Radiación electromagnética

características de las fuentes de riesgo 57.14

y cáncer 32.7

Radiación infrarroja (IR)

desequilibrio del sistema de termorregulación por 49.12

evaluación del riesgo de la $\quad 49.13$ técnicas de medición 49.13

fuentes de exposición $\quad 49.11$

lesiones de la retina por $\quad 49.14$

lesiones del cristalino por $\quad 49.12,49.14$

límites de exposición 49.13

de la ACGIH 49.13

longitudes de onda de la 49.10

medidas de protección 49.14

protección ocular 49.17

población expuesta

niveles de exposición aproximados $49.11 \mathrm{t}$

protección de la

en fraguas 96.13

quemaduras por 49.12

en la córnea $\quad 49.12,49.15$

en la piel $\quad 49.12,49.15$

y lesiones oculares

en soldadores 96.14

y opacidades lenticulares 49.15

en trabajadores del vidrio y el acero $\quad 49.15$

Radiación ionizante

anomalías del desarrollo por irradiación prenatal $\quad 48.11 \mathrm{t}$

definición $\quad 48.2$

e inhibición de la división celular $\quad 48.6$

efectos cancerígenos de la 48.8

estimación de riesgos de por vida 48.8

relación dosis-incidencia $\quad 48.8$

efectos hereditarios de la $\quad 48.10$

por irradiación de fondo natural $\quad 48.10$

por irradiación profesional $\quad 48.10$

efectos sobre el feto $\quad 48.10$

$y$ retraso mental grave 48.10

el caso de la Compañía Wismut 32.28

en la tripulación aérea

y riesgos para el feto $\quad 102.15$

fuentes de $48.15,48.17$

límites CIPR de exposición profesional a 102.15

personal sanitario expuesto a $\quad 97.5,97.32$

medidas preventivas de la 97.32

reacciones agudas de los tejidos a la 48.7 48.8

tipos de $48.11-48.15$

y aberraciones cromosómicas 48.5 y alteración del ADN $\quad 48.5$

y atrofia de los tejidos 48.6

y cáncer de pulmón 32.29

exposición al benceno 1.4

y mutaciones 48.5

y síndrome de radiación agudo $\quad 48.8$

Véase también Seguridad radiológica

Radiación láser

Véase Láseres

Radiación no ionizante (R NI)

cuantificación de la 49.4

espectro de 49.4

luz visible 64.15

radiación infrarroja 64.15

radiación ultravioleta (UV) 64.15

Radiación nuclear

riesgos asociados a la 57.14

Véase también $R$ adiación ionizante

Radiación óptica

filtros atenuadores de la 49.17

fuentes artificiales de $\quad 49.15$

límites de exposición laboral (LE) 49.16

medidas protectoras frente a la $\quad 49.16$

protectores oculares 49.16

medidores de riesgo de 49.16

por la luz solar 49.15

Véase también R adiación ultravioleta, radiación infrarroja

Radiación térmica

Véase R adiación infrarroja

Radiación ultravioleta (RUV)

componentes 49.6

en tratamiento médico

riesgos de la 97.33

eritema por 49.7

exposición en industrias gráficas 85.5

exposición en procesos de reproducción y duplicación 85.12

lámparas de 49.7

lentes filtrantes de la $\quad 49.16$

lesiones oculares por $49.8,53.30$

límites de exposición profesional $\quad 49.9$

medidas protectoras para 49.10

por equipos de soldadura al arco $\quad 49.7$

lesiones cutáneas 49.7

lesiones oculares 49.7

reacciones de fotosensibilidad a $\quad 49.8$

y agotamiento del ozono $\quad 53.28,53.30$

y cáncer 49.9

y cáncer de piel

en soldadura 96.14

y cáncer de piel no melanoma 53.30

y cataratas corticales 53.30

y enfermedades cutáneas infecciosas 53.30

y equipos de iluminación

para televisión y cine 96.35

y lesiones oculares

en soldadura 96.14 
Radiación $X$

terapéutica

dosis umbral $48.6 t$

Véase también $R$ ayos $X$

R adiaciones

N ormas básicas de seguridad para la

protección contra la radiación de OIEA/OIT/OMS/AEN-OCDE 23.46

y programas de formación profesional 94.10

y riesgos de los profesores 94.4

$R$ adiactividad

accidente de G oiânia 39.35

análisis médicos 39.44

dosis $39.37,39.43$

dosis absorbida 39.37

dosis colectiva $\quad 39.37$

dosis efectiva $\quad 39.37$

dosis en órgano 39.37

dosis equivalente 39.37

dosisfarmacológica 39.37

efectos sobre la salud 39.36

efectos deterministas 39.37

efectos estocásticos 39.38

en la generación de energía nuclear 76.13

en la producción de hierro y acero 73.17

ingestión de materias radiactivas 39.32

inhalación de partículas radiactivas 39.32

Iluvia radiactiva $39.32,39.44$

nubes radiactivas 39.32

partículas calientes 39.43

prevención en agricultura 39.44

protección de la población 39.42

radioterapia 39.32

Véase también C atástrofes

Radiation Accident R egistry de EE.UU. 39.35

Radiobioensayo $V$ éase Bioensayo

Radiofrecuencia Véase $R$ adiación de radiofrecuencia (RF)

$R$ adiografía industrial causa de accidentes en $\quad 48.36-48.37$

Radiografías y neumoconiosis 10.37

$R$ adionucleidos clasificación por grupos de toxicidad $48.18 \mathrm{t}$

R adionucleidos cosmógenos

Véase también $R$ adiación ionizante, fuentes de

$R$ adionucleidos naturales acumulación en el organismo de $\quad 48.17$

$R$ adionucleidos primordiales

Véase también R adiación ionizante, fuentes de

Radionúclidos 39.32t, 39.42

Radioscopia

control de la radiación ionizante en $\quad 97.33$
Radioterapia

y cáncer de tiroides 39.40

Radón

cáncer de pulmón por $\quad 28.23,44.11$

efectos sobre la población $\quad 44.12$

en el agua $\quad 44.12$

en el gas natural 44.12

en los edificios $\quad 44.5,44.11$

fuentes principales 44.11

en materiales de construcción $\quad 44.12$

exposición al 63.18

en las minas de estaño $\quad 63.18$

en operadores de caldera $\quad 103.41$

y cáncer de pulmón 30.30

el caso de la Compañía W ismut 32.27

R amazzini, Bernardino 28.2

Ranvier, nódulos de $7.3,11.33$

R appaport

efecto amortiguador en el receptor 30.28

Rascadores 29.76, 70.23

Rasmussen

naturaleza de las tareas $\quad 29.7$

Rasmussen, Pejtersen y Schmidts taxonomía de sistemas complejos 29.6

$R$ atas

diferencias de susceptibilidad con los humanos 33.18

Rátidas 70.26

$R$ aynaud, fenómeno de

asociado a dermatitis 12.4

como enfermedad de origen

profesional 50.11

en artesanos de la madera $\quad 96.21$

en escultores 96.9

en la industria del calzado $\quad 88.8$

por vibración de cuerpo completo 50.6

por vibraciones mano-brazo 50.11

relación dosis-efecto $\quad 50.12$

por vibraciones de cuerpo completo 50.6

y casos relacionados con la exposición a

cloruro de vinilo 4.7

y cloruro de vinilo 104.254

y enfermedad del dedo blanco 68.6

y evitación del frío intenso $\quad 42.52$

y exposición al arsénico $\quad 63.6,63.8$

y precauciones en ambientes fríos 42.52

y síndrome vasoespástico $\quad 3.14$

Rayón, fabricación de

medidas de protección 89.16

métodos de producción 89.15

proceso de cupramonio 89.16

proceso de la viscosa 89.15

riesgo de incendio y explosión 89.16

riesgos por exposición a sustancias químicas 89.16

Rayos

como fuente de ignición $\quad 41.11$ diagnóstico de descarga atmosférica $\quad 40.5$ e incendios forestales 39.26

efectos de 40.5

generalidades 41.19

pararrayos 41.19

protección contra $\quad 41.19$

$R$ ayos gamma

blindajes contra radiación por $\quad 48.20$

y espesor del blindaje 48.21

y tasa de dosis absorbida $\quad 48.20-48.21$

Véase también R adiación ionizante, tipos de

$R$ ayos infrarrojos 30.25

R ayos láser

con fines artísticos 96.14

dispositivos de seguridad $\quad 96.14$

de color 96.14

sustancias tóxicas en 96.14

en medicina

regulación del uso de 97.33

exhibiciones de 96.14

distancias normales de seguridad $\quad 96.14$

protección del público $\quad 96.14$

protectores de ojos y cara 31.6

Véase también Láser

$R$ ayos $X$

blindaje de aparatos de $48.21-48.22$

control de la exposición a

en centros sanitarios 97.32

exposiciones accidentales a $\quad 48.36$

fugas en la fabricación de semiconductores

III-V 83.24

procedentes de PVD 52.7

radiación por 48.17

Véase también R adiación ionizante, tipos de

Reacciones de hipersensibilidad

en los países industrializados $\quad 33.39$

R eacciones inmunitarias

al estrés 34.66

riesgos para la salud $\quad 34.67$

Reactor nuclear

Véase C entral nuclear

accidente de Chernóbil $\quad 48.7$

accidentes asociados a $\quad 48.37$

accidentes entre 1945 y $1987 \quad 48.7$

tipos de reactores térmicos $76.9 f$

Reactores

de las plantas químicas

Véase Industria química

Reactores químicos 41.18

R eason y Embrey, modelo de y modelos de error humano $\quad 57.8$

Recepción, personal de en hoteles

principales peligros 98.6

R eceptores cutáneos

estructura 11.33

función sensorial cutánea $\quad 11.34$ 
lesiones de los nervios periféricos 11.36

receptores capilares 11.35

receptores en la piel lampiña 11.35

reinervación 11.37

Reciclado

de residuos sólidos 55.45

clasificación centralizada $\quad 55.46$

motivos 55.46

separación en origen 55.46

y exposición a organismos

peligrosos 55.46

en el proceso de producción $\quad 55.55$

en la industria manufacturera $\quad 83.40$

industria del

Véase Industria del reciclado

y control de residuos 94.15

Recogedores

accidentes con 68.11

R ecogida de basuras domésticas

accidentes de trabajo más

comunes $101.16 \mathrm{t}$

carga de trabajo en la 101.14

factores para la disminución de riesgos 101.16

objetos peligrosos $101.14 \mathrm{t}$

riesgos por la manipulación de

objetos 101.14

tasa media anual de accidentes de trabajo en 101.16

R ecolección

formación de polvo durante la $\quad 64.20$

recolección manual 64.30

hoz 64.30

riesgos asociados con la $\quad 64.23$

Recolocación

individualización del proceso $\quad 15.96$

pérdida del empleo $\quad 15.96$

reducción de plantilla 15.96

sector de consultorías 15.97

Recompensas

como incentivo a la seguridad $\quad 60.19$

de control 60.26

informativas 60.26

Recompresión 36.13

Reconocimiento médico

en el lugar de trabajo $\quad 15.20$

Recortadores 67.24

Rectificadoras

directrices de seguridad

en Directiva sobre máquinas

(89/392/ ECC) 58.58

R ecuperación

de la privación de sueño 29.64

plan de respuesta 94.12

tiempo necesario para la 29.47

y fatiga mental 29.55

Véase también Descanso
R ecursos humanos

gestión de 21.3

contratación 21.3

evaluación del rendimiento $\quad 21.3$

formación 21.3

organización del trabajo $\quad 21.3$

valor añadido $21.3 f$

negociación colectiva 21.3

R ed europea sobre los riesgos en el trabajo 23.33

Redimensionamiento 24.13

R ediseño del trabajo procesos participativos 34.9

Reducción para la eliminación de residuos $\quad 101.27$

Reducción de plantilla

factores 34.34

intervención de la inspección de trabajo 23.11

y desempleo 24.13

Redundancia

en sistemas de control

Véase también Sistemas de control de seguridad

Reed

síndrome polar de la triyodotironina 42.51

R eed-Sternberg, células de y enfermedad de H odking $\quad 1.4$

R eestructuración

y principio de la tarea completa 29.58

R efinadora de pasta $\quad 72.7$

$R$ efinerías

Véase R efino de petróleo; craqueo

aguas residuales 78.25

generación de vapor 78.26

proceso de refino del petróleo $\quad 78.19$

torres de refrigeración $\quad 78.26$

Refino del petróleo

cargas petroquímicas 78.6

aceites de proceso 78.7

disolventes 78.6

lubricantes 78.7

catalizadores sólidos $\quad 78.5$

combustibles 78.5

de destilación 78.6

gas de petróleo licuado $\quad 78.5$

gasolina $78.5-78.6$

queroseno 78.5

residuales 78.6

cronología del proceso $78.3 \mathrm{t}$

historia de las refinerías 78.2

operaciones auxiliares 78.25

plantas de gas 78.24

insaturado 78.24

saturado 78.24

principales productos $78.4 \mathrm{t}$

procesos 78.7 craqueo $78.10,78.12$

desalinización 78.7

destilación al vacío 78.9

destilación atmosférica $\quad 78.8$

fraccionamiento del crudo 78.8

organigrama simplificado $\quad 78.3 \mathrm{f}$

procesos de mezcla 78.25

productos especiales 78.7

productos químicos 78.4

ácido sulfhídrico 78.5

ácido sulfúrico 78.5

agua amarga 78.5

cáusticos 78.5

dióxido de azufre 78.5

óxido nítrico 78.5

resumen de los procesos de refino $78.10 \mathrm{t}$

R eflectores 58.26

Reflexión $\quad 64.26$

$R$ efractarios

materiales $84.19-84.20$

y aplicaciones 84.20

R efrigerantes 67.7

R efrigerantes, nieblas de

exposición en la industria del

automóvil 91.5

asma de origen profesional $\quad 91.9$

disminución de la función pulmonar 91.9

enfermedad del legionario 91.9

medidas de control 91.5

síntomas respiratorios 91.9

R egents Advisory Committee on

Environmental Q uality in Schools

199494.14

R egistro internacional de productos químicos potencialmente tóxicos 23.52

R eglamento de Prevención de Accidentes de los Servicios de V igilancia y Seguridad

regulación de los servicios de seguridad y vigilancia en Alemania 95.14

Regulación

de la construcción

de edificios comerciales 93.21

instalación de servicios de

suministro 93.30

mantenimiento de carreteras $\quad 93.22$

R egulación térmica

en ambientes calurosos $\quad 42.3$

sudoración $\quad 42.3-42.5$

vasodilatación periférica $\quad 42.3$

en ambientes fríos 42.4

escalofríos 42.5

vasoconstricción periférica 42.4

vasodilatación inducida por frío $\quad 42.4$

R ehabilitación

asistencia permanente a la 25.19

en Alemania $26.17-26.21$ 
en el marco de la indemnización 25.19

incapacidad crónica 26.15

objetivos de la 25.19

prótesis para la 25.19

y discapacidad 17.7

rehabilitación profesional 17.21

y pérdida auditiva de origen

profesional 17.30

estigmatización de la sordera $\quad 17.31$

R ehabilitación laboral

en Alemania 26.21

en Israel 26.24 - 26.25

en Suecia 26.31

preventiva 25.20

social 25.19

R ehidratación

control hídrico y electrolítico $\quad 42.7$

líquido de 42.7

reposición oral de agua y electrolitos 42.13

R eino Unido

Comisión Ejecutiva de Salud y

Seguridad 23.12

competencias de los inspectores de

trabajo 23.12

Fire protection association

y diploma "fire prevention" 41.16

fire service 41.8

H ealth and Safety Commission 21.21

$\mathrm{H}$ ealth and Safety Executive 21.21

Home Office 41.8

instituciones de salud y seguridad $21.21 \mathrm{f}$

M inisterio del M edio A mbiente 23.12

$\mathrm{N}$ ational $\mathrm{H}$ ealth Service

y agresiones en el trabajo 51.3

centros de salud para mujeres 15.55

salud y seguridad en el trabajo 20.24t

Safety and $\mathrm{H}$ ealth Executive Information

Service 22.7

Servicio de A sesoramiento de M edicina del Trabajo 23.12

Tribunal Superior de Justicia 23.17

R elaciones estructura-actividad (SAR )

parámetros estimables 33.56

predecibilidad 33.57

principios generales 33.55

proceso del análisis 33.56

R elaciones industriales

Véase R elaciones laborales

$R$ elaciones laborales

actos de injerencia 21.12

comités conjuntos de salud y seguridad 21.17

conflicto individual 21.38

conflictos de derechos 21.37

tribunales de trabajo $\quad 21.37$

cooperación tripartita 21.19

asesoramiento 21.19

comités asesores 21.20 dependencia económica del

trabajador 21.3

derecho de huelga 21.12

desafíos 21.2

formación 21.31

aprendizaje activo 21.32

de salud y seguridad en el trabajo 21.32

ideología neoliberal 21.2

inspección de trabajo 21.32

aplicación de la legislación 21.33

enfoque especializado 21.34

enfoque generalista 21.34

función actual 21.34

órgano de control independiente 21.33

integrantes 21.4

empresas 21.6

estado 21.4

sindicatos 21.7

modelos 21.2

organizaciones consultivas 21.19

pactos nacionales 21.5

participación de los trabajadores 21.23 ,

21.28

círculos de calidad $\quad 21.24$

comités de empresa 21.24

comités de salud y seguridad 21.26

derechos de información y

consulta 21.29

propiedad de acciones 21.25

participación del Estado 21.2

prevención de los conflictos 21.34

conflictos de derechos 21.35

conflictos de intereses 21.35

individuales y colectivos 21.35

protección de la actividad sindical 21.12

resolución de conflictos 21.39

tribunales de trabajo 21.39

suspensión del trabajo 21.37

Remolacha

azucarera 67.32

industria de la 67.32

Remuneración

incentivos 34.43

financieros directos 34.43

financieros indirectos $\quad 34.44$

intangibles 34.44

sistema de participación en las ganancias 34.44

R enal, sistema

Véase R iñón

Renault

les profils des postes 29.16

Rendimiento

Véase A nálisis del trabajo

lumínico 46.2, 46.4 - 46.7

medición del 34.43

remuneración del 34.43

y privación del sueño 29.62
R endimiento físico

y temperatura del organismo $\quad 42.35$

Rendimiento lumínico 46.8

R endimiento visual $46.17,46.20$

R enio

manifestaciones tóxicas del 63.44

R enovación, trabajos de en el sector de la construcción

acabados exteriores 93.31

riesgo de caídas 93.31

acabados interiores 93.30

enyesado 93.30

exposición a disolventes 93.31

exposición al polvo 93.30

instalación térmica o acústica 93.31

riesgos asociados 93.30

riesgos de incendio 93.31

mantenimiento y limpieza 93.29

limpieza de ventanas 93.29

medidas preventivas 93.29

paisajismo 93.31

rehabilitación 93.29

caídas de personas y materiales 93.30

exposición al amianto 93.30

otros riesgos 93.30

suministros 93.30

regulación 93.30

riesgos 93.30

Reparación de buques

Véase Industria naval, proceso de construcción

grandes proyectos de reparación y conversión 92.12

planificación 92.12

procesos y prácticas 92.11

contratación 92.12

tipos habituales de trabajos 92.12

R eparador de aparatos eléctricos

V éase A paratos eléctricos

R epertorios de recomendaciones prácticas 68.32

R epliegue pasivo 34.10

R epresentaciones integradas o diagnósticas distorsiones de un polígono regular 29.83 gráficos de barras 29.83 métodos tridimensionales 29.83

R epresentantes de los trabajadores e inspección de trabajo 23.11

R eproductor, aparato V éase A parato reproductor

Reproducción y duplicación

copiadoras al alcohol 85.9

materiales 85.9

procesado 85.9

duplicadores digitales y multicopistas 85.9 materiales 85.9

procesamiento 85.9 
fotocopiadoras e impresoras láser 85.6

materiales 85.6

olores 85.8

procesamiento 85.6

riesgos 85.7

riesgos asociados al ozono $\quad 85.7,85.12$

ventilación y refrigeración 85.8

heliografía (diazo) 85.8

exposición a amoníaco $\quad 85.9$

materiales 85.9

máquinas de fax 85.8

materiales 85.8

procesamiento 85.8

República $\mathrm{Checa}$

minería del carbón 16.61

sistema de salud en el trabajo 16.61

estado actual 16.63

estructura económica 16.61

privatización 16.64

reforma en el sector 16.64

revisión histórica 16.61

transición a la economía de mercado 16.63

Rescate marítimo, servicios de

planificación y prevención $\quad 95.21$

capacidad de supervivencia $\quad 95.21$

riesgos específicos 95.20

ahogamiento 95.20

condiciones meteorológicas

extremas 95.20

exposición al agua salada $\quad 95.20$

hipotermia 95.20

inestabilidad 95.21

mareos 95.21

riesgos y características generales 95.19

Residuos

clasificación legal $\quad 55.44$

empaquetado "de laboratorio" 94.15

exposición a residuos de soldadura 83.32

fuentes de $55.45 t$

gestión en la industria naval $\quad 92.17$

neutralización de ácidos y álcalis 94.15

programas de gestión $\quad 94.12,94.16$

centralización 94.16

programas de reciclado 94.15

recuperación de disolventes 94.15

según su origen 55.43

sólidos 67.13

tratamiento de 55.46

Véase también $\mathrm{G}$ estión de residuos

tratamiento en la industria de la piel y el cuero 88.12

Residuos hospitalarios

eliminación de instrumentos

cortantes 97.74

enfermedades infecciosas $\quad 97.73 t$

líquidos 97.74

recogida y evacuación de 97.74

normas de transporte interno 97.74 requisitos para el almacenamiento 97.74

sistema de normas ISO 14000 para la gestión de 97.75

sistemas de clasificación de los 97.72

R esiduos industriales

contaminación térmica de las aguas 55.35 eliminación de 41.29

a través de contratistas 41.30

acolchado 41.30

biodegradación 41.30

combustión al aire libre $\quad 41.30$

enterramiento 41.30

incineración 41.30

pirólisis 41.30

vertido controlado 41.30

estanques de estabilización de 55.34

tratamiento de 55.34

R esiduos peligrosos

control del transporte de 101.28

efectos tóxicos 53.16

eliminación de 53.16

enfermedades por 53.26

plantas de tratamiento de 55.54

prohibición de movimientos transfronterizos de 101.28

transporte internacional de 54.13

tratamiento de 55.54

vertederos de 53.17

vías de exposición 53.16

$R$ esiduos radiactivos

métodos de eliminación de 48.32 - 48.33

R esiduos sólidos

en el sector de la electrónica 83.38 incineración 83.38

en la industria alimentaria gestión 67.14

R esiduos, operaciones de eliminación de Véase Eliminación de residuos

Resina

ácidos de 72.20

aislantes eléctricos 104.399

de urea 71.8

epoxi 41.14

fabricación de

ésteres acrílicos en la 104.172

fenólica 71.8

melamínica 71.8

utilización en la industria aeroespacial

consideraciones toxicológicas $\quad 90.12$

efectos sobre la piel $\quad 90.12$

exposición a componentes volátiles 90.12

R esistencia

al cambio 29.61

de alto contacto 41.10

del huésped 34.17

encuesta de puntos de vista

personales 34.51 estudios sobre 34.51

pruebas de personalidad 34.51

R esistividad 40.6

R esonancia magnética

y evaluación del traumatismo

craneoencefálico $\quad 14.9$

R esonancia magnética nuclear (R M N) 49.31

Respiradores

Véase también Protectores respiratorios

Respiratoria

salud 70.29

medidas de protección de la $\quad 70.29$

R espiratorio

$\checkmark$ éase A parato respiratorio

Véase Cáncer, cáncer respiratorio

Respiratorios, trastornos

asociados a la industria de la piel y el cuero 88.4

asociados a la inhalación de humos de asfalto 93.58

asociados al serrín en carpintería 86.13

asociados al trabajo con grava 93.59

en industrias gráficas riesgo de inhalación 85.7

en la industria de la seda $\quad 89.15$ tonsilitis 89.15

en la industria del automóvil 91.6, 91.8

influencia del formaldehído 91.4 neumoconiosis, bronquitis crónica y enfisema 91.4

en la industria textil 89.30 visión general histórica $89.30,89.32$

en procesos de reproducción y duplicación 85.12

en procesos fotográficos riesgo de inhalación 85.15

R esponsabilidad civil

carga de la prueba 23.20

clases de indemnización 23.22

conflicto de leyes 23.22

demandado 23.20

demandante 23.20

efecto disuasorio 23.24

en Alemania 26.18

en materia de salud y seguridad en el trabajo $23.16-23.23$

medios de defensa 23.21

plazos para reclamar 23.21

relación causal 23.21

R esponsabilidad de la empresa

daños y perjuicios 25.25

en el sistema alemán de seguro de accidentes 32.22

en Suiza 26.12

enervación de la responsabilidad de las empresas 26.18

R esponsabilidad en caso de desastre 29.114 
R esponsabilidad penal

efecto disuasorio 23.24

elementos del tipo delictivo $\quad 23.23$

en materia de salud y seguridad en el trabajo $23.16-23.23$

medios de defensa 23.23

personas responsables 23.23

procedimiento penal 23.23

sanciones 23.24

R esponsabilidad subsidiaria $\quad 23.20,25.22$

R estauración, personal de riesgos potenciales 94.3

Restaurantes prevención de incendios en 98.5

R etención de residuos radiactivos 48.33

Retina

riesgos de la cirugía por láser $\quad 97.33$ riesgos de la radiación infrarroja (IR) 49.14

riesgos de las lámparas incandescentes 49.15

R etinitis solar 49.15

R etroceso, riesgo

en cepilladoras mecánicas de espesor unilateral 86.12

en máquinas de cepillado superficial 86.11

R etroinformación en el trabajo lista de comprobación 29.29

R eumáticos, trastornos en la conducción de camiones 103.8

Reveladores para fotografía en blanco y negro y dermatitis de contacto 96.11

Revolución verde 64.26

R hizopus parasiticus 64.38

R hodococcus equi 10.102

de hidrocarburos gaseosos licuados 102.70

del circonio 63.13

del cloro 41.13

del gas natural licuado $\quad 102.70$

del magnesio 41.14

en ascensores 93.50

en cajones de aire comprimido $\quad 36.5$

en camiones cisterna 102.60

en el procesado del fieltro 89.18

en el sector de la construcción 93.31

en estaciones de servicio $\quad 102.38$

en hornos de madera 41.17

en hoteles 98.8

en la agricultura de plantación $\quad 64.7$

en la fabricación de rayón 89.16

en la fabricación de

semiconductores $83.30,83.25$

en la industria textil 89.22

en la industria de la lana 89.13

en la industria del calzado 88.8 en la industria del plástico $\quad 77.31$

en la industria química 41.11

en la minería 74.44

en la perforación de túneles $\quad 36.9$

en la tejeduría 89.24

en la tinción $\quad 89.19$

en la tinción 89.19

en laboratorios $\quad 61.20,61.22$

en las artes gráficas 85.4

en metales 82.36

en peluquerías 100.9

en restaurantes 98.5

en salas de teatro y ópera 96.31

en tanques 41.17

en tintorerías 100.13

en trenes de laminación $\quad 73.12$

forestales 39.26

R hodotorula 44.23

Rhus, dermatitis de 63.13

Rickettsia typhi $\quad 101.24$

Riego

bombas de vaivén 64.29

cesto oscilante 64.29

elevador hidráulico compensado

64.29

Riesgos

consideraciones éticas 19.11

definición 33.77

delimitación del término 59.33

evaluación de 30.7

elementos $30.8 f$

evaluación de la exposición $\quad 30.27$

gestión de 30.7

identificación de 30.4

prevención y control $30.6,30.25$ - 30.26

controles administrativos $\quad 30.25$

controles técnicos $30.6,30.25$

coste de los controles 30.26

eficacia de los controles 30.26

enfoque ideal 30.4

facilidad de uso de los controles 30.26

formación e información 30.27

intervención 30.26

protección personal 30.25

relativos 32.20

riesgo aceptable 30.8

vigilancia del riesgo y métodos de

estudio 30.15

vigilancia ambiental y biológica $\quad 30.15$

vigilancia médica 30.15

Véase también Evaluación del riesgo

V éase también H igiene industrial

Riesgos biológicos 38.2, 84.31

animales acuáticos $\quad 38.5$

celentéreos 38.5

equinodermos 38.5

esponja común 38.5

hidrofidios 38.6

moluscos 38.5 osteictios 38.6

polizoos 38.6

prevención de los riesgos 38.6

seláceos 38.6

animales terrestres $\quad 38.7$

arácnidos 38.7

arañas 38.7

chinches 38.7

escorpiones 38.7

garrapatas 38.7

insectos 38.7

quilópodos 38.7

en el lugar de trabajo $\quad 38.2$

entornos laborales $38.2 \mathrm{t}$

sector agrícola 38.3

servicios sanitarios 38.3

taxonomía de animales $38.2 \mathrm{t}$

taxonomía de microorganismos y plantas $38.2 \mathrm{t}$

transmisión de enfermedades

infecciosas 38.2

en la fabricación de vidrio, cerámica y materiales afines 84.31

entre trabajadores forestales $\quad 68.28$

microorganismos 38.2

enfermedades profesionales específicas 38.3

normas internacionales 38.5

Directiva europea $n=90 / 679 \quad 38.5$

vertebrados 38.4

lagartos venenosos $\quad 38.4$

mordeduras de serpiente $\quad 38.4$

prevención de los riesgos 38.4

$R$ iesgos de incendio

y aceites industriales 82.40

y aluminio 63.3

y aneurisma $\quad 95.8$

y aparatos eléctricos 81.8

y asfalto 93.58

y bario 63.9

y botellas de gas 61.17

y carga electrostática 41.11

y disolventes 102.32

y electrodomésticos 81.15

y explosivos 41.14

y fibras sintéticas 89.17

y profesorado 94.10

y quemaduras $95.6,95.8$

y rayos 39.26

y soldaduras $82.28,96.14$

$R$ iesgos de los equipos

análisis del accidente de

Flixborough 57.16

caso de un tanque de gas presurizado 57.15

circunstancias de riesgo $\quad 57.15$

factores de carga $\quad 57.14$

por liberación de productos químicos 57.14 
por mal funcionamiento $\quad 57.14$

y emisión de energía incontrolada 57.14

por radiación electromagnética $\quad 57.14$

por radiación nuclear $\quad 57.14$

y análisis de riesgos $\quad 57.13,57.16$

fuentes de información $\quad 57.17$

método FM EA 57.17

método HAZOP 57.17

$R$ iesgos eléctricos

de las instalaciones eléctricas $\quad 40.12$

en atmósferas explosivas 40.12

en atmósferas pulverulentas $\quad 40.12$

en oficinas 99.7

en peluquerías 100.9

en tintorerías 100.13

y formación 40.17

y manejo de grúas 93.44

y profesorado 94.10

R iesgos físicos

de las materias primas 84.2

de las prendas de protección $\quad 31.18$

de los metales $63.52 \mathrm{t}$

del grafito 62.4

del personal auxiliar 95.21

en aeronaves 102.13

en buques $102.49 \mathrm{t}$

en grúas 93.45

en la extinción de incendios 95.5

en la formación profesional $\quad 94.10$

en la industria aerospacial $\quad 90.4$

en la industria naval 92.13

en la minería 74.24

en la producción de coque 73.9

en las plantas de tratamiento 101.11

y aborto $9.13 \mathrm{t}$

y enfermedades cardiovasculares 3.11

Riesgos industriales

traslado de 20.20

avances en materia de salud pública 20.21

funciones de la Administración $\quad 20.21$

industrias peligrosas 20.4

información solicitada a los

inversores 20.23t

responsabilidad sobre los productos 20.20

R iesgos mecánicos

en el montaje de tarjetas de circuito

impreso 83.30, 83.32

en el proceso de montaje de ordenadores 83.33

R iesgos profesionales 103.2

definición de riesgo 28.11

desigualdad frente al riesgo 26.9

experiencia laboral $\quad 26.10$

nivel de cualificación 26.9

tipo de sistema salarial 26.10

en el sector de la construcción 93.2

biológicos 93.5 físicos 93.3

medición evaluación y control 93.6

químicos 93.3

sociales 93.6

en escuelas universitarias 94.11

en la fabricación de indicadores de cristal

líquido 83.21

en universidades 94.11

enfoque de la IARC de identificación de los peligros 33.65

enfoque japonés de identificación de los peligros 33.57

estimación con biomarcadores 33.48

evaluación del riesgo 33.57

evaluación del riesgo de

neurotoxicidad 33.60

experiencia de los trabajadores 26.16

exposición a lo largo de toda la vida

profesional 28.10

percepción del riesgo 26.11

propiedades de advertencia 30.26

riesgo de accidentes en determinados

sectores industriales 32.26

riesgo de incidentes no mortales 32.20

riesgo relativo 32.20

tasa de lesiones 32.20

y detección y control $\quad 94.15$

y dimensión de la empresa 26.11

Véase también Enfermedades profesionales

Véase también E pidemiología del trabajo

Véase también Prevención de riesgos del trabajo

Véase también V igilancia de los riesgos profesionales

R iesgos químicos

de las grúas 93.45

del grafito 62.4

en buques $102.49 \mathrm{t}$

en centros sanitarios 97.57

en el aire interior 44.6

en el almacenamiento de productos 61.11

en el procesado del fieltro 89.18

en el tejido de alfombras 89.29

en hospitales 97.58

en la artesanía textil 96.16

en la conducción de camiones $\quad 103.25$

en la extinción de incendios 95.6

en la hostelería $\quad 98.9$

en la industria aerospacial $\quad 102.13$

en la industria de la confección 87.5

en la industria de la cosmética $\quad 100.6$

en la industria del automóvil 91.18

en la industria forestal $\quad 68.2$

en la industria marítima $\quad 102.48$

en la industria química $\quad 41.13$

en la manipulación de materiales 85.4

en la manipulación de metales 82.13 ,

$82.23,82.30$

en la producción de coque 73.9 en lavanderías $\quad 100.2$

en los procesos de soldadura 82.30

en peluquería 100.6

y prendas de protección 31.17

y psicosis 5.6

Rinitis

debida a hongos 44.25

por antimonio 63.4

por detritus 44.23

Véase tambiénT rastornos olfatorios

Rinitis alérgica

en cosmetólogos y peluqueros $\quad 100.10$

Rinné, prueba de

Véase 0 ído, pérdida de audición

Riñón

anatomía y fisiopatología $\quad 8.2$

cáncer 8.11

función renal 8.2

insuficiencia renal 8.8

marcadores biológicos 8.8

lesiones

compuestos orgánicos de azufre

y $\quad 104.407$

nitroparafinas y $\quad 104.338$

necrosis de

cresol y 104.370

nefrona 8.2

nefropatía 8.9

nefrotoxicidad 8.3

trastornos renales 8.4

glomerulonefritis 8.4

insuficiencia renal aguda $\quad 8.10$

nefritis intersticial y tubular 8.5

nefropatía crónica 8.10

relacionados con el trabajo 8.9

y excreción de tóxicos 33.15

y tetracloruro de carbono $\quad 104.251$

Véase también Cáncer de riñón

Ritmo de trabajo $34.28 f$

autorregulación 34.29

efectos sobre el bienestar $\quad 34.29$

R itmos circadianos 34.21

alteración de los

en la tripulación aérea $\quad 102.17$

y estrés 43.2

y trabajo nocturno 43.6

$y$ trabajo por turnos 43.2

e inclinación matutina $\quad 43.2$

e inclinación vespertina $\quad 43.2$

Roach

concentración de un agente 30.28

R obots

accidentes relacionados con $\quad 58.40$

en Suecia 58.40

de alimentación y expulsión $\quad 58.23$

industriales 58.59

accidentes mortales 58.60

condiciones de seguridad $58.61-58.62$ 
peligros asociados a los 58.59

móviles 58.25

escáneres de láser en $\quad 58.25,58.28$

R ociadores automáticos $\quad 41.8,41.23$

Rodenticidas

categorías de los 62.12

peligrosidad de los 62.13

R odilla

artrosis 6.28

bursitis del pes anserinus 6.30

bursitis rotuliana 6.30

bursitis trocantérea 6.30

condromalacia rotuliana 6.30

estudios epidemiológicos 6.28

meralgia parestésica $\quad 6.30$

Rodio 63.44

R ohmert

concepto de estrés-tensión

expandido 29.35

$\mathrm{Rol}$

ambigüedad de $34.31,34.52$

sobrecarga de $34.31,34.52$

Rollizos

producción mundial anual $\quad 68.2$

Ropa

a prueba de cortes 68.33

$R$ opa de protección

Véase Equipos de protección individual

Véase Prendas de protección

Ropa de trabajo

y antropometría 29.32

Roth y Woods

análisis de la tarea cognitiva $\quad 29.7$

R otómetros 37.14

Rotter

teoría del aprendizaje social (1966) 34.53

Rótulos

directrices 29.81

legibilidad 29.82

Rubéola

efectos en el feto $\quad 97.44$

en trabajadores de la sanidad 97.44

R uedas de saca 68.11

$R$ uffini, receptor de

Véase R eceptores cutáneos

Ruido

asociado a las operaciones de hilatura de algodón 89.11

asociado a máquinas de cepillado en

carpintería 86.10

aversión al $\quad 47.5$

como factor de estrés 47.5

contaminación por

y tráfico urbano 53.27

continuo $47.3,47.5$

de impulso 47.3 efectos cardiovasculares $\quad 47.5$

en centros sanitarios $\quad 97.6$

y pérdida auditiva $97.31,97.33$

en el embotellado de bebidas 65.6

en el procesado del fieltro 89.18

en el sector de la construcción 93.3

en grúas 93.45

en la fabricación de cemento 93.52

en los trabajos con grava 93.60

exposición en las tareas de

demolición 93.32

pérdida de audición 93.12

producido por maquinaria de movimiento de tierras 93.40

en industrias gráficas 85.5

en instalaciones de confinamiento de animales 70.14

en la construcción de motores de aviación 90.10

en la elaboración de cereales $\quad 67.30$

en la fabricación de alfombras 89.28

en la fabricación de vidrio, cerámica y

materiales afines $84.26,84.30$

en la industria de la cerveza $\quad 65.15$

en la industria de la lana $89.14-89.15$

en la industria de la piel y el cuero 88.4 , 88.7

en la industria de pasta y papel 72.16

en la industria del automóvil 91.4 - 91.5

en la industria del calzado 88.8

en la industria del té 65.9

en la industria naval 92.15

en la pesca 66.17

en la producción de hierro y acero 73.13

en la tejeduría 89.24

en las aulas 94.4

en las industrias de fabricación $\quad 47.2$

en las operaciones de recolección $\quad 64.23$

en los procesos de envasado $\quad 67.12$

en un entorno de aire comprimido 36.9

exposición al ruido y rehabilitación 17.29

exposición de los conductores de

ambulancia 95.21

máxima permisible 47.8

riesgo en la industria alimentaria $\quad 67.8$

fuentes extralaborales 47.4

y socioacusia 47.4

instrumentos de medida del $\quad 47.6$

intermitente $47.3,47.5$

límite tolerable por jornada laboral 97.31 según la OSHA 97.31

lista de comprobación 29.21

medidas de control $\quad 47.2,47.8,47.11$

Directivas de la U nión Europea 47.8

e identificación del origen del ruido $47.9-47.10$

en bienes de equipo o maquinaria 47.8

Norma ANSI S12.16 47.9

y barreras acústicas 47.12 y cabinas insonorizadas $\quad 47.12$

y cerramientos acústicos 47.11 - 47.12

y tratamiento de la fuente de

ruido 47.11

métodos de medición del 47.6 - 47.7

niveles aconsejables en una clase 94.14

niveles peligrosos de 47.2

N oise R eduction R ating (NRR) 31.12

pérdida de audición inducida por el 11.4

programas de reducción del

en hospitales 97.31

regulación en la industria

aeroespacial 90.16

serrerías 71.6, 71.11

Single N umber R ating (SNR) 31.12

variable 47.3

y acufenos 47.4

y comportamientos antisociales 47.5

y fármacos ototóxicos 47.3

efectos combinados 47.3

y maquinaria de producción cárnica $\quad 67.19$

y mecanización de las vaquerías 70.21

y problemas de comunicación 47.5

y problemas de seguridad $\quad 47.5$

dispositivos visuales de aviso $\quad 47.5$

protectores auditivos 47.5

y productos químicos industriales 47.3

efectos combinados 47.3

y rendimiento laboral $\quad 47.5$

y riesgos de los profesores 94.4

Véase también Protectores para los oídos

Rumiantes

peligros 70.23

acción preventiva 70.24

procesos de cría 70.22

R usia

Véase Federación R usa

R ussell y Burch

regla de la triple $R \quad 33.51$

Rutenio 63.45

$R$ ye, sistema de clasificación

1.5

S

Saca 68.7

Sacrificio $\quad 67.16$

Saint Paul Fire and $M$ arine

Insurance 34.2

Sala limpia 83.33

Salario a destajo 34.6

Salarios compensatorios

en trabajos de alto riesgo $\quad 60.25$

Salas

de teatro y ópera

riesgos de incendio en 96.31

Salicílico, ácido

aspirina y 104.12 
Salidas de urgencia adecuación de los planos 29.86

Salinización del agua y pérdida de tierra fértil $\quad 53.19$

Saliva excreción de tóxicos 33.15

Salmonella

en la industria cárnica $\quad 67.16$

en la industria láctea 67.27

en la industria marítima 102.50

ensayos de mutagenicidad 33.50

infección por 4.2

Véase A parato digestivo

Salmonella typhi $\quad 97.42$

Salmonelosis

en la avicultura 70.29

en la cría de animales 70.16

fuentes principales de 53.8

Salud

definición 23.28

definición de salud laboral $\quad 23.25$

evaluación de riesgos para la 15.28

salud para todos $2000 \quad 23.29$

servicios de salud laboral 23.33

vigilancia de la salud 27.2

Véase también 0 rganización M undial de la Salud

Véase también Salud y Seguridad en el Trabajo

Salud ambiental vínculos con la salud en el trabajo $\quad 53.4$

Salud de la mujer

cáncer de mama 15.58

mamografía 15.58

Centros de Salud para M ujeres 15.55

en el Reino U nido $\quad 15.55$

en los Estados U nidos 15.55

en el lugar de trabajo 15.55

osteoporosis 15.58

dieta 15.59

factores de riesgo 15.59

postmenopáusica 15.58

programa de prevención $\quad 15.59$

senil 15.59

salud maternal e infantil 15.62

estrategia para la 15.65

políticas de las empresas 15.64

prestaciones de asistencia

sanitaria 15.62

prestaciones del seguro de

enfermedad 15.62t

prestaciones ofrecidas por la

empresa $15.63 \mathrm{t}$

primera infancia 15.64

programas de gestión de la

maternidad 15.63

programas de lactancia $\quad 15.64$ promoción de la salud prenatal $\quad 15.63$

trastornos menstruales 15.56

amenorrea 15.56

dismenorrea 15.56

en bailarinas 96.26

menopausia 15.57

menorragia 15.56

síndrome premenstrual $\quad 15.56$

tratamiento de sustitución

hormonal 15.57

Salud en el trabajo

apoyo social 34.56

cambio organizativo 35.6

edad 34.49

estructura organizativa $34.40,35.5$

etapas de la carrera 34.47

gestión de la calidad total 34.38

locus de control 34.53

prevención del estrés 34.75

programas de vigilancia y promoción

de la salud 34.76

Salud maternal e infantil 15.62

Salud mental

absentismo 5.4

ansiedad 5.12

factores de riesgo individuales 5.13

factores de riesgo profesionales 5.13

relacionada con el trabajo $\quad 5.12-5.13$

depresión 5.10

depresión mayor 5.10

desamparo aprendido 5.11

diagnóstico diferencial 5.11

enfoques psicoterapéuticos 5.11

etiología 5.11

prevención 5.11

relación con el estrés 5.11

diagnóstico 5.5

ejes de bienestar $5.3 f$

estrategias de gestión $5.5 t$

factores de riesgo $\quad 5.3-5.4$

distribución de los grupos

profesionales 5.4

factores estresantes $\quad 5.2,5.7$

factores psicosociales 5.2

marco legal en la U nión Europea 5.4

modelo conceptual $5.2 f$

modelo de Warr 5.3

prevención 5.5

programas de asistencia $\quad 5.10$

riesgo de estrés $5.3 f$

y relación con el trabajo $\quad 5.3$

Salud pública

vigilancia de la 32.2

y formación del alumnado 94.15

y programas de inspección, evaluación y control 94.15

Salud reproductora

Véase Salud maternal e infantil
Salud y seguridad en el trabajo aplicaciones de los biomarcadores 33.47 armonización de la normativa comunitaria 23.38

centros de asesoramiento 23.33

centros de investigación 23.33

códigos de conducta 23.28

códigos de práctica de la O IT $\quad 23.60$

colaboración internacional 23.47

como derecho humano 23.24

condiciones del trabajo infantil 24.15

Congreso M undial de Salud y

Seguridad en el Trabajo 23.60

consenso internacional 16.3

costes económicos 20.23

análisis de costes 20.24

en el R eino U nido $20.24 \mathrm{t}$

definición 23.30

derecho a conocer 23.34

derecho internacional 23.25

problemas de aplicación y

observancia 23.31

directiva de la UE $\quad 5.4$

efecto del trabajador sano $\quad 26.10$

en China 23.40

evaluación económica $\quad 20.25$

función de la O NU en la materia 23.52

incumplimiento de la normativa 25.23

Ley de salud y seguridad en el trabajo de

EE.UU. 30.34

marco legislativo 5.4

medios institucionales, estructurales y

jurídicos 23.2

normas de la OIT 23.28

obligaciones de fabricantes $y$

proveedores 23.17

sanciones a los infractores 23.18

obligaciones de los organismos

públicos 23.17

exigencia coercitiva de las 23.17

obligaciones de los trabajadores 23.18

regímenes disciplinarios 23.18

organizaciones de ámbito

comunitario 23.32

papel de la compañía aseguradora $\quad 25.22$

práctica de la salud en el trabajo 16.20

colaboración intersectorial $\quad 16.22$

cooperación interdisciplinaria 16.21

principios $16.22 \mathrm{t}$

responsabilidad civil y penal 23.16

sistema alemán de protección de la 32.22

tutela de los derechos a la 23.30

vigilancia en los países en desarrollo 32.11

y problemas de seguridad personal y

colectiva 94.11

Véase también Comité de salud y seguridad

Véase también Empleo precario

Véase también Ergonomía

Véase también $\mathrm{H}$ igiene industrial 
Véase también Salud laboral

Véase también T oxicología reguladora

Véase también $V$ igilancia y notificación de enfermedades profesionales

Sandoz, almacén de

incendio en Schweizerhalle $\quad 39.5,39.20$

Sangrado 67.16

Sangre

Véase Sistema linfohematopoyético

coagulación de la

trimetilbencenos y 104.285

dinitrobenceno y 104.347

Sanidad

Sección Internacional de la AISS para los

Servicios de Salud 23.67

Sanidad pública

control de las lesiones profesionales

en 56.28

investigación etiológica $\quad 56.30$

niveles de evaluación 56.33

principios de prevención 56.31

y determinación de grupos de

riesgo 56.30

modelos de práctica de la 56.28

Sanitarios

Véase T rabajadores sanitarios

Sarampión

en centros escolares 94.4

$\mathrm{y}$ vacunaciones 94.4

Sarcoidosis $10.33-10.34$

Véase también Enfermedad por berilio

Sarcoma

en la industria de la piel y el cuero $\quad 88.9$

Sarcoma reticular 72.18

Sarna 64.38

Satisfacción en el trabajo

y ergonomía $\quad 29.5,29.100$

Saturnismo

asociado a la utilización de pinturas en el sector de la construcción 93.43

Saxitoxina 66.20

Scarbrough y Corbett

participación en el diseño de sistemas 29.61

Schistosoma

haematobium 33.70

mansoni 33.75

School of Public $\mathrm{H}$ ealth de la U niversidad de

$M$ assachusetts

estudios epidemiológicos en el sector de los semiconductores 83.36

Schwann, células de 7.3, 11.33

Scrapie 67.34

Secaderos 71.5

Secoyosis 86.14
Secreción de adrenalina

y respuesta de "fight-flight" 34.11

Sector agrícola

características 64.5

evolución y estructura $\quad 64.2$

importancia económica $\quad 64.2$

mano de obra 64.5

Sector privado

empresas y relaciones laborales 21.6

Sector sanitario

y discriminación $\quad 24.4$

Sector voluntario

Véase O rganizaciones voluntarias

Sectores y procesos

estampación 91.9

fundición 91.8

mecanizado 91.9

montaje 91.9

Secuencias de blanqueo $\quad 72.9$

Seda, industria de la

afecciones de las vías respiratorias 89.15

dermatitis 89.15

exposición al ruido 89.15

monóxido de carbono, riesgos asociados

al 89.15

visión general de los procesos 89.14

Sedimentación

en tratamiento de residuos 101.18

Segadoras 64.11

Segunda R eunión de la R ed de C entros

Colaboradores en Salud Laboral 23.48

Estrategia G lobal sobre Salud Laboral para

Todos 23.48

Seguridad

del entorno de trabajo 15.2

medioambiental 94.14

personal 94.14

profesional 94.14

pública 94.14

y alumnos 94.14

Seguridad de los alimentos

del mar 66.20

e infecciones de origen animal $\quad 70.6$

Seguridad de los trabajadores

y estilo de dirección 34.39

y gestión de la calidad total 34.38

Seguridad de sistemas

Véase A nálisis de sistemas

Seguridad en el empleo

necesidad de 34.34

y estrés 34.2

Seguridad en el trabajo lista de comprobación 29.28

Seguridad radiológica blindajes 48.20

contra la radiación gamma de aparatos de rayos $X \quad 48.21-48.22$

de neutrones 48.23

de partículas alfa 48.23

de partículas beta 48.22

e inspecciones de contaminación $\quad 48.29$

instalaciones 48.18

acceso $\quad 48.19$

criterios de emplazamiento $\quad 48.19$

fontanería 48.20

revestimientos 48.20

tipos de laboratorios 48.19

ventilación $\quad 48.19-48.20$

límites de dosis según la CIPR $\quad 48.27$

normas de seguridad de la CIPR 48.26 48.27

programas de vigilancia $\quad 48.23-48.24$

equipo de vigilancia medioambiental

típico 48.39

vigilancia radiológica

medioambiental 48.38

y bioensayo 48.28

$y$ controles de acceso $\quad 48.30$

y dosímetros personales 48.27

y ensayo de fuga de fuentes selladas $\quad 48.29$

y etiquetado de contenedores 48.31

y formación del trabajador 48.33

y grupos de inspección $\quad 48.39$

en accidentes $\quad 48.39$

y planes de emergencia 48.34

y protección respiratoria 48.28

y ropa protectora 48.28

y señalización de zonas 48.30

Véase también Contaminación radiactiva

Seguridad social

generalidades 25.23

Véase también A sociación Internacional de la Seguridad Social

Véase también Seguros sociales

Véase también Sistemas de seguridad social

Seguridad y normativa legal

en el sector de la construcción

Alemania 93.18

asociada a políticas de licitación competitiva 93.21

en los Países Bajos 93.13

exigencias de prevención 93.18

manual de gestión de la calidad 93.17

modelos de gestión de

calidad/ prevención 93.17

modelos de gestión de seguridad; responsabilidad 93.17

Seguro de accidentes alemán

Berufgenossensahften 26.19

características fundamentales 26.18

cobertura 26.20

costes 26.18

culpa del asegurado $\quad 26.20$

enfermedades profesionales 26.20

estadística 26.20 
financiación 26.22

formación 26.19

funciones 26.17

historia 26.17

índices de siniestralidad 26.18

organización 26.17

pensiones 26.21

pensiones a supervivientes 26.21

prestaciones en metálico 26.21

prevención 26.19

primas $26.18,26.22$

protección de los trabajadores

estudio de caso 32.22

rehabilitación médica 26.20

rehabilitación profesional 26.21

rehabilitación social 26.21

servicios de inspección técnica $\quad 26.19$

supuestos asegurados 26.20

Seguro de enfermedad

enfermedades profesionales y accidentes de

trabajo 23.19

financiación del 23.19

y promoción de la salud $\quad 15.17$

Seguro de invalidez 25.25

Seguros sociales

administración 25.24

asistencia de rehabilitación $\quad 25.24$

cobertura 25.24

diferencias con la indemnización por accidentes de trabajo 25.24

financiación 25.24

generalidades 25.23

pensiones 25.24

prestación por enfermedad $\quad 25.24$

prestaciones 25.24

prestaciones de fallecimiento $\quad 25.24$

recursos 25.24

Selectores de pedidos

riesgos para la seguridad de los $102.75 \mathrm{t}$, 102.76

Selenio

absorción 27.13

concentraciones 27.13

excreción 27.13

operaciones de recuperación

controles técnicos $82.59 t$

riesgos de los compuestos de 63.45

Seligman

depresión e indefensión aprendida

(1976) 34.11

indefensión aprendida (1975) 34.8

Selikoff

estudio sobre enfermedades relacionadas

con el amianto 32.5

infradiagnóstico de neumoconiosis 32.7

Selye, $\mathrm{H}$ ans

definición de estrés 34.16

estrés de 34.16 estudios sobre el estrés $\quad 34.11$

Sematech 83.19

Sembradoras 64.28

Semen

Véase Líquido seminal

Semiconductor Industry Association (SIA)

estudios epidemiológicos en el sector de los semiconductores 83.36

Semiconductores de silicio

análisis de fallos y garantía de calidad 83.17

depósito de vapores de sustancias químicas (CVD) 83.12

depósito epitaxial de vapores de sustancias químicas 83.12

depósito no epitaxial de vapores de sustancias químicas 83.12

exposición a cloruro de

hidrógeno 83.12

expedición 83.18

generación y controles de residuos en la fabricación de semiconductores $83.39 t$

grabado 83.6

fuga de energía de R F 83.9

grabado químico húmedo 83.7

grabado químico seco 83.7

productos de reacción 83.9

impurificación 83.9

difusión 83.9

exposición a campos

electromagnéticos 83.11

exposición a rayos $X \quad 83.11$

exposiciones a arsénico 83.11

implantación iónica 83.11

implantadores de iones 83.11

liberación de gases tóxicos 83.9

quemaduras con ácido 83.11

litografía 83.4

alineación de máscara y exposición 83.5

aplicación de protector 83.4

arranque de la fotoprotección 83.6

cocido 83.6

exposición a radiación UV $\quad 83.5$

limpieza 83.4

peligros para la reproducción 83.4

rayos $\mathrm{X} \quad 83.6$

revelado 83.6

secado y precocido 83.5

uso de láseres 83.6

marcado y empaquetado 83.17

exposición al láser, contaminación

química 83.17

exposición al láser, zonas de control

provisionales 83.17

exposiciones a disolventes 83.17

metalización 83.13

aleación y cementación $\quad 83.15$

exposición a residuos metálicos 83.14

exposición al disolvente 83.14 fuga de RF 83.14

película delgada 83.14

película gruesa 83.14

plaqueado 83.14

recubrimiento trasero 83.15

montaje y prueba 83.15

clasificación y prueba de obleas 83.15

encapsulado 83.16

exposiciones al plomo 83.15

prueba de fugas y envejecimiento 83.16

prueba eléctrica final 83.17

separación de pastillas 83.15

sujetar y conectar pastillas 83.16

necesidades prioritarias $83.40 \mathrm{t}$

oxidación 83.3

oxidación húmeda 83.4

oxidación seca 83.4

quemaduras por ácido 83.7

sistemas de fotoprotección $83.5 \mathrm{t}$

Semidesintegración del iodo 39.42

Semimáscara

Véase Protectores respiratorios

Seminal, líquido

análisis bioquímico $\quad 9.5$

espermatogénesis 9.5

Sensibilidades químicas múltiples

diagnóstico 13.7

epidemiología 13.8

mecanismos psicológicos 13.8

neurotoxicidad 13.8

patogenia 13.7

agentes ambientales $\quad 13.8$

etiología psicosomática $\quad 13.8$

prevención 13.9

respuesta límbica amplificada 13.8

síndrome del edificio enfermo $\quad \mathbf{1 3 . 8}$

síntomas 13.7

en el sistema nervioso central $\quad 13.7$

síntomas crónicos 13.7

tratamiento clínico 13.9

principios terapéuticos 13.9

Sensores

de movimiento

de ultrasonidos 58.26

en grandes vehículos y equipos 58.28

pasivos por infrarrojos 58.26

Véase también D etectores de presencia

Sentido de la coherencia $\quad 34.54$

Sentimientos de dominio 34.12

Señales de advertencia

interpretación de las 59.32

normas sobre diseño de 56.39

para prevención de riesgos 59.31

Señales de tráfico

legibilidad 29.86

Señalización

de vehículos con material radiactivo $\quad 48.32$

de zonas de radiación 48.30 
Septicemia por mordeduras de animales 96.45

Septo nasal, erosión del riesgo en el sector de la construcción $\quad 93.44$

Sericultores 70.40

Sericultura 70.40

Serpiente, mordedura de

administración de un antídoto $\quad 38.10$ contraindicaciones 38.11 países desarrollados 38.10 reacciones al antídoto $38.10-38.11$ alteraciones de la presión arterial 38.9 atractaspididae 38.8

colúbridos 38.8

elápidos 38.8

insuficiencia renal $\quad 38.9$

muertes por 38.4

oftalmia venenosa 38.8

primeros auxilios 38.9

pruebas de laboratorio $\quad 38.9$

síntomas neurotóxicos $\quad 38.8$

tratamiento de apoyo 38.11

tratamiento hospitalario 38.10

vipéridos 38.8

y trabajadores forestales 68.28

Véase también $\mathrm{R}$ iesgos biológicos

Serrerías

Véase Industria maderera

modernas 71.6

riesgos para la seguridad y la salud $\quad 71.6$

y cáncer 71.11

Serrín

carcinogenicidad 86.6

exposición laboral al 71.10

irritación de ojos, nariz y

garganta 86.6

riesgos en carpintería $\quad 86.6,86.13$

sistemas de extracción local 86.6

trastornos respiratorios 86.13

Sertoli, células de 9.5 - 9.7

Servicio de comidas, personal de

lesiones por caídas 98.4

lesiones por esfuerzos repetitivos

(LER) $\quad$ 98.4, 98.8

quemaduras en la piel $\quad 98.4$

Servicio de telégrafos

y trastornos musculosqueléticos $\quad 101.10$

Servicios de apoyo al empleo e integración de los discapacitados $\quad 17.23$

Servicios de inspección

funciones 101.4

riesgos de los 101.4, 101.5t

Servicios de limpieza

de hoteles

estrés por calor 98.7

exposición a productos químicos 98.7

y lesiones por esfuerzo repetitivo 98.6
Servicios de policía

dolor de espalda 95.13

medidas de prevención 95.13

enfermedades pulmonares 95.12

asma 95.12

tabaquismo 95.12

estrés emocional y psicológico 95.11

exposición a la violencia 95.11

formación 95.11

riesgo de cáncer 95.12

cáncer testicular 95.12

riesgos biológicos 95.13

hepatitis 95.14

SIDA 95.13

trastornos cardiovasculares 95.11 prevención 95.12

visión general 95.10

riesgos 95.11

Servicios de salud ambiental prestación deficiente de 53.26

Servicios de salud en el trabajo

asesoramiento 16.10

cobertura de los trabajadores 20.8

cobertura en los distintos países 16.2

coordinación y comunicaciones 16.12

colaboración externa $\quad 16.13$

colaboración interna 16.13

comité de salud y seguridad de la empresa 16.13

de la pequeña empresa $\quad 16.27$

barreras estructurales 16.28

evaluación de las necesidades de la empresa 16.30

modelo de seguridad social $\quad 16.29$

modelo de servicios colectivos 16.29

organización 16.29

dotación de personal 16.17

en los países industrializados 16.19

evaluación de riesgos para la salud 16.7

financiación 16.18

funciones $y$ actividades $\quad 16.5,16.24$

información sobre peligros sanitarios 16.7

infraestructuras 16.14

para servicios de apoyo $\quad 16.17$

instrumentos de la O IT $\quad 16.2$

Ley ARBO holandesa 16.3

Ley finlandesa sobre servicios de salud en el trabajo 16.3

modelos 16.14

asistencia sanitaria primaria $\quad 16.16$

centros sanitarios privados 16.16

modelo colectivo o interempresas 16.15

por ramas de actividad $\quad 16.15$

seguridad social 16.16

servicio interno integrado 16.15

normas reguladoras 16.3

límites de exposición permisible 16.7

objetivos y valores comunes 16.25

orientación preliminar a la empresa $\quad 16.6$ primeros auxilios 16.10

promoción de la salud 16.12

rehabilitación de los trabajadores 16.11

servicios de seguridad 16.16

sistemas de evaluación 16.18

tipos de legislación 20.6

vigilancia en el lugar de trabajo 16.6

de la salud de los trabajadores 16.7

medidas preventivas y de control $\quad 16.9$

reconocimiento médico $\quad 16.8$

Véase también Convenio de la OIT

Véase también Estados U nidos, servicios de salud

Véase también Práctica de la salud en el

trabajo, en salud y seguridad en el trabajo

Servicios de seguridad pública

e instituciones educativas $\quad 94.15$

Servicios de seguridad y de emergencia

características generales 95.2

estrés 95.2

prevención 95.3

riesgo de padecer enfermedades

infecciosas 95.3

riesgo de sufrir lesiones 95.3

Servicios de vigilancia y seguridad

Véase A lemania, servicios de vigilancia y seguridad

Servicios educativos permanentes 94.2

Servicios funerarios

productos químicos nocivos 100.16

riesgos psicológicos 100.15

y trastorno por estrés postraumático (TEPT) $\quad 100.15$

y contagio de enfermedades $\quad 100.14$

y exposición al formaldehído $\quad 100.16$

y lesiones lumbares 100.16

Servicios médicos

de urgencia 94.15

y actividades efectuadas fuera del campus 94.15

y comunidades universitarias 94.15

Servicios postales

riesgos y prevención 101.6

con clasificadoras automáticas 101.8

en la fase de clasificación $\quad 101.7$

en servicios de mostrador 101.6

en servicios de reparto 101.8

en tareas de manipulación de

materiales 101.7

para operadores de PVD $\quad 101.8$

Servicios psicológicos

y comunidades universitarias $\quad 94.15$

Servicios públicos

problemas de salud en 101.2

asociados con el trabajo en interiores 101.2

relacionados con el trabajo al aire libre 101.2 
Sesgos

en los estudios epidemiológicos 32.33

Seveso 39.4, 39.16, 39.20

Sexismo 24.3

Sexo, industria del

medidas de precaución en la 96.56

propensión al alcoholismo y la drogadicción 96.56

y enfermedades de transmisión sexual 96.55

en la conducción de camiones $\quad 103.9$

y susceptibilidad a sustancias

tóxicas 33.19

y violencia 96.56

Sexual, acoso

$V$ éase A coso sexual

Shaver, enfermedad de en los trabajadores del aluminio 63.3

Shell Chemical Company 104.153

Shewhart

diagrama de control de 27.7

Shigella

infección por

Véase A parato digestivo

Shock

anafiláctico $\quad 70.11,70.39$

e hipotermia 42.40

por golpe de calor $\quad 42.10$

Sibiliancias 70.14

SIDA

Véase VIH / SID A

Siembra

plantación 64.28

siembra a golpes 64.28

siembra a voleo 64.28

siembra detrás de un arado $\quad 64.28$

siembra en líneas 64.28

trasplante 64.28

y cuidado de los cultivos $\quad 64.19$

Sierra de cadena

Véase M otosierra

Sierras 29.76

accidentes con $\quad 32.26$

Sífilis

en la industria del sexo $\quad 96.55$

en marineros 102.50

transmisión por la sangre $\quad 97.49$

Silano 83.19

Sílice 104.399

exposición al polvo de sílice

en la industria del

automóvil $\quad 91.3$ - 91.4

medidas de control 91.3

exposición en la fabricación de vidrio,

cerámica y materiales afines 84.30

y salud en la minería $\quad 74.58$ y silicosis 74.58

Sílice libre

y enfermedad de Shaver 63.3

y neumoconiosis 63.4

Silicio

utilización en la industria naval $\quad 92.15$

Sílico-antimoniosis 63.4

entre los mineros de antimonio $\quad 63.4$

Silicona 104.399

Silicosis

asociación a la tuberculosis $\quad 10.49$

complicaciones infecciosas $\quad 10.51$

cuadro clínico 10.50

definición 10.49

diagnóstico 10.51

e inhalación de polvo de sílice 62.6

el caso de la Compañía Wismut 32.28

en el sector de la

construcción 93.3, 93.43

en la fabricación de cemento 93.52

en los trabajos con grava 93.59

en escultores 96.9

en la producción de ferrosilicio $\quad 63.23$

en minería de la fluorita $\quad 62.4$

en trabajadores del granito

riesgo de 62.4

formas de silicosis 10.49

fibrosis masiva progresiva $\quad 10.49$

silicosis acelerada $\quad 10.49$

silicosis aguda 10.49

silicosis crónica 10.49

medidas terapéuticas 10.52

patogenia 10.49

por polvo de piedras

en joyería 96.22

por talco 62.7

prevención 10.51

exploración selectiva 10.52

vigilancia 10.52

pruebas de función pulmonar 10.51

riesgo de

por inhalación crónica de feldespato 62.3

tratamiento médico 10.52

y arcillas 62.2

y cáncer de pulmón 10.51

y trabajo con piedra pómez 62.5

Véase también $\mathrm{N}$ eumoconiosis

Silvicultura 68.4

Silos

Enfermedad del descargador de 70.12

Simazina 27.24

Simazine 62.15

Símbolo estándar internacional de radiación 48.30

Símbolos de seguridad

normas sobre diseño de 56.38
Simulaciones

de la transferencia de calor a través

de la ropa 42.32

en investigación sobre seguridad $\quad 60.4$

Síncope por calor 42.8

Sindicato Internacional de Empleados de

Servicios

programas sobre el VIH/SIDA 15.68

Sindicato Internacional de $M$ arinos programas sobre el VIH / SIDA 15.68

Sindicato Internacional de T rabajadores

Q uímicos

programa de formación de los trabajadores 18.13

metodología de la evaluación $\quad 18.14$

resultados y consecuencias 18.14

Sindicatos

acciones en favor de los

discapacitados 17.41

acuerdos laborales 21.14

acuerdo de Belén 21.14

afiliación 21.7

de la enseñanza 94.2

derechos sindicales 21.7

ejercicio de acciones civiles $\quad 23.20$

estructura sindical 21.9

federaciones internacionales $\quad 21.8$

federaciones sindicales 21.9

gestor sindical 21.9

libertad sindical 21.13

O rganización para la U nidad de los

Sindicatos A fricanos 23.34

otras formas de participación $\quad 21.9$

prestaciones 21.9

protección de la actividad sindical $\quad 21.12$

relaciones con la inspección de

trabajo 23.6

situación jurídica 21.8

y acoso sexual 24.4

y programas de prevención de lesiones y enfermedades 26.12

y programas reglados de formación profesional 94.10

Síndrome

del túnel carpiano $\quad 65.12$

Síndrome de astillamiento mediotibial en deportistas profesionales 96.54

Síndrome de burnout

en enfermeras 97.23

en trabajadores sanitarios $\quad 97.3$

Síndrome de colon irritable Véase Colon irritable

Síndrome de dependencia abuso de alcohol y otras drogas 15.82

Síndrome de estrés postraumático $\quad 34.14$ Véase T rastorno por estrés postraumático 
Síndrome de fatiga crónica $\quad 44.24$

Síndrome de inmunodeficiencia adquirida (SIDA)

Véase también V irus del SIDA

Síndrome de la salida torácica en trabajadores de oficina $\quad 99.7$

Síndrome de mareo $\quad 50.15$

Síndrome de radiación agudo características principales del $\quad 48.7 \mathrm{t}$ efectos deterministas 39.37 fases del 48.8 por el accidente de Chernóbil 48.44 por el accidente de Goiânia $\quad 48.42$ por el accidente de Los Alamos $\quad 48.34$

Síndrome de R aynaud Véase $R$ aynaud, fenómeno de

Síndrome de sobrecarga física en bailarines profesionales 96.6 entre los músicos 96.7

Síndrome de uso excesivo $\checkmark$ éase L esión por esfuerzo repetitivo

Síndrome de vibraciones mano-brazo (H AV) fases neurosensoriales del 50.11

Síndrome del aceite tóxico $\quad 39.20$ - 39.21

Síndrome del codo dolorido en instrumentistas de cuerda $\quad 96.27$

Síndrome del edificio enfermo $34.23,44.3$, $44.24,45.3$

en hospitales $97.5,97.31$

Síndrome del edificio hermético e infecciones respiratorias en oficinas 99.2

Síndrome del polvo orgánico tóxico (SPOT) de origen agrícola 70.9 en la industria textil 89.31 en serrerías 71.11 y eliminación de residuos 101.23 en explotaciones porcinas $70.7,70.14$ Véase también A parato respiratorio

Síndrome del túnel carpiano (ST C) 64.12 67.13

en cajeros de comercio $\quad 99.3$

en camareros 98.9

en cosmetólogos y peluqueros 100.8

en el sector de la construcción $\quad 93.39$

en empleados de hoteles 98.6

en empleados de servicios de comida 96.49 en instrumentistas de percusión $\quad 96.27$ en la confección 87.6

en la fabricación de semiconductores 83.36 en la industria del calzado $\quad 88.10$ en trabajadores de oficina $\quad 99.7$ en trabajadores postales 101.7 en usuarios de PVD $\quad 52.24$ influencia del sexo 32.21 por el trabajo con el torno 96.18

prevalencia 32.8

y uso de herramientas vibrantes 50.11

y uso de ordenadores 96.15

y utilización de PVD 99.3

Síndrome general de adaptación de Selye 34.8

Síndrome premenstrual Véase Salud de la mujer

Síndromes profesionales incapacidad total 13.2

y niveles de contaminantes específicos 13.2

Síntomas musculosqueléticos en la fabricación de semiconductores $83.18-83.19$

Sinusitis

riesgo en el sector de la construcción 93.44 Véase también T rastornos olfatorios

Sistema de auditoría de Pellenberg (SAP) 57.6

Sistema de cable 68.11

Sistema de clasificación de R ye 1.5

Sistema de creación de modelos de error genérico (SCM EG) $\quad 57.8$

Sistema de energía de referencia (SER) $\quad 53.23$

Sistema de manipulación de materiales $58.83 \mathrm{f}$

Sistema de turnos

de rotación rápida $\quad 43.7$

ventajas del 43.7

diseño de la jornada en el $\quad 43.7$

efectos sobre la salud del $\quad 43.4$

esquema básico de turnos de trabajo $\quad 43.9$ recomendaciones para el diseño de $43.6 \mathrm{f}$ y descanso entre turnos 43.8

y sentido de la rotación $\quad 43.8$

Véase también T rabajo por turnos

Sistema de vigilancia

de situaciones de emergencia debidas a sustancias peligrosas (H SEES)

seguimiento de incidentes que afectan a la salud pública 95.23

Sistema dinámico del estrés fisiológico 34.13

Sistema hematológico

Véase también Sistema linfohematopoyético

Sistema híbrido automatizado (H AS) actividades del trabajador $\quad 58.40$ grupos básicos de tareas 58.40 y estrés 58.40

asignación de tareas 58.38

control de lesiones y seguridad 58.40 normativa ISO 58.40

criterios de diseño y funcionamiento 58.38 basados en la persona 58.38 como sistemas abiertos 58.43 factores cognoscitivos humanos $\quad 58.39$ requisitos mínimos 58.43 desarrollo del software 58.39

en fabricación integrada por ordenador estrategia de seguridad ISO $\quad 58.42$ evaluación de riesgos 58.41 planificación de la seguridad $\quad 58.42$ prevención de las perturbaciones 58.42 identificación de peligros 58.40 papel del operador humano 58.37 clasificación del 58.39

problemas de funcionamiento 58.38 debidos a la automatización $\quad 58.38$ riesgos de accidente 58.40 sistemas genéricos de creación de modelos de errores (GEM S) 58.41 tipos básicos de errores humanos 58.41 variables de diseño del 58.37

Sistema inmunitario agresiones químicas 33.39 citoquinas 33.40 defensa no específica 33.40 evaluación del estado inmunitario 33.42 exposición al benceno 1.3 funciones 33.39 generalidades 33.40 inmunidad específica 33.40 celular 33.41

humoral 33.41

inmunosupresión 33.39

Véase también Inmunotoxicología

Sistema Internacional de Codificación de Lámparas (SICL) 46.5

Sistema Internacional de Evaluación de la Seguridad (SIES) $\quad 57.6$

Sistema Internacional de U nidades (SI) 105.2 amperio 105.2

candela 105.2

estereorradián 105.3

kelvin 105.2

kilogramo 105.2

metro 105.2

radián 105.3

segundo 105.2

Sistema límbico 7.7, 34.14

Sistema linfohematopoyético agentes ambientales $\quad 1.2$ agentes hemolíticos 1.7 drepanocitosis 1.8 eritrocitos circulantes 1.6

Sistema M undial de 0 bservación de los 0 céanos 53.32

Sistema M undial de 0 bservación del Clima 53.32

Sistema M undial de 0 bservación Terrestre 53.32

Sistema M undial de Vigilancia A mbiental control de la contaminación atmosférica $55.10 f$ 
Sistema musculosquelético

antebrazo, muñeca y mano $6.24-6.26$

cadera 6.27

codo 6.23

cuello 6.16

discos intervertebrales 6.7

dolor muscular 6.2

ejercicio 6.3

relacionado con el trabajo $\quad 6.4$

enfermedades $6.32-6.39$

artritis infecciosa 6.35

artritis reumatoide 6.32

cáncer óseo 6.35

espondilitis anquilopoyética 6.33

espondiloartropatía 6.33

fibromialgia 6.32

gota 6.34

osteomielitis 6.35

osteoporosis 6.35

hombro 6.19

lesión muscular 6.3

músculos 6.2

región lumbar 6.11

representación de una célula muscular 6.3

rodilla 6.27

tendones 6.4

Sistema nervioso

cerebro

hidrocarburos aromáticos y $\quad 104.283$

efectos de los disolventes en la industria del calzado 88.8

sistema nervioso autónomo $\quad 7.7-7.8$

control autónomo de los músculos

lisos 7.8

parasimpático 7.7

simpático 7.7

sistema nervioso central 7.5

sistema nervioso periférico 7.7

descripción de los pares craneales $7.7 \mathrm{t}$

nervios raquídeos 7.7

Sistema nervioso central

ácido sulfúrico y 104.7

alteraciones del

por vibraciones de cuerpo completo 50.5

depresión del

encoladores y 103.16

metacrilato de metilo y 104.172

nitroparafinas y 104.338

pirocatecol y 104.369

toxicidad aguda 33.32

dinitrobenceno y 104.347

disulfuro de carbono y 104.418

éteres glicólicos y 104.201

fluoroacetatos y 104.14

sensibilidad a los tóxicos en función de la edad 33.19

y neurotoxicidad durante el

desarrollo 33.60 y reacciones inmunitarias 34.66

Sistema nervioso periférico

disulfuro de carbono y $\quad 104.418$

Sistema neuroendocrino $\quad 7.8$

Sistema organizativo Véase O rganización

Sistema reproductor femenino ciclo menstrual 9.10

fertilización 9.11

hipotálamo e hipófisis 9.9

implantación 9.11

Sistema reproductor masculino

eje hipofisario-testicular 9.7

eje hipotálamo-hipofisario 9.6

éteres glicólicos y 104.201

exposición tóxica 9.8

función sexual 9.9

drogas 9.9

efectos de la exposición profesional

9.9

Sistema sanguíneo monóxido de carbono y 104.431

Sistema vestibular

alteraciones del

$y$ vibraciones 50.5

Sistemas aéreos de extracción $\quad 68.11$

Sistemas de advertencia recomendaciones sobre el diseño de $56.40 \mathrm{t}$

Sistemas de aire acondicionado

clasificaciones de los 45.22

elementos básicos de 45.24

en función de su cobertura $\quad 45.23$

en función del flujo de aire $\quad 45.23$

esquema simplificado $\quad 45.23 \mathrm{f}$

método de Fanger 45.20

propiedades termodinámicas del aire húmedo 45.19

y confort térmico $\quad 45.19$

condiciones generales 45.19

índices de 45.20

Sistemas de calefacción

características de los $\quad 45.22 f$

criterios de diseño de 45.21

objetivo de 45.18

y confort térmico $\quad 45.19$

condiciones generales $\quad 45.19$

índices de 45.20

método de Fanger 45.20

Sistemas de clasificación de productos químicos clasificaciones basadas en el

transporte 61.8

y Código marítimo internacional de mercancías peligrosas (IM D G) $\quad 61.8$

y Convenio de Basilea 61.9

y R ecomendaciones de las $\mathrm{N}$ aciones U nidas relativas al transporte de mercancías peligrosas

(UNRTDG) 61.8 en Australia 61.10

en Canadá 61.10

en Japón 61.10

para evaluar los riesgos de los

plaguicidas 61.9

y clasificación en función del riesgo de la OMS 61.9

Sistema del Antiguo Consejo de Ayuda

Económica M utua (CAEM) 61.9

y Directiva del Consejo (CE)

67/548/CEE 61.9

y Ley de control de sustancias tóxicas

(TSCA) 61.10

en EEUU $\quad 61.10$

Sistemas de control de seguridad

categorías 58.47

con detección automática de fallos 58.48

consideraciones para el diseño $\quad 58.47$

eléctricos, electrónicos y programables

(SE/E/P) 58.63

clases principales de dispositivos 58.64

fallos aleatorios del hardware 58.65 , 58.70

fallos sistemáticos $\quad 58.65,58.71$

fines 58.64

norma CEI $1508 \quad 58.63,58.65,58.67$ -

$58.68,58.70-58.71$

requisitos técnicos de diseño 58.68

electrónicos programables $\quad 58.49,58.62$

directrices sobre 58.63

ventajas de los 58.63

en herramientas CNC $\quad 58.59$

entropía en los 58.46

fiabilidad de los componentes 58.44

para robots industriales 58.61

redundancia en los 58.46

seguridad contra fallos 58.45

Sistemas de control $58.43 \mathrm{f}$

diseño general de $58.43 \mathrm{f}$

Sistemas de filtración para contaminantes del aire interior $\quad 45.4$

Sistemas de remuneración

basados en la producción 68.38

Sistemas de seguridad social

y protección de la salud y la seguridad en el trabajo 23.19

Sistemas de ventilación

en edificios no industriales $\quad 45.14$

directrices de la Comisión

Europea 45.14

flujo mínimo de aire exterior $\quad 45.14$

y carga de contaminación del aire $\quad 45.16$

y percepción de la calidad del

aire 45.15

y unidad decipol $\quad 45.15$

y unidad olf 45.15

general 45.11

objetivos básicos 45.11 
para controlar contaminantes químicos 45.11

para controlar el ambiente térmico 45.11

para la calidad del aire interior $\quad 45.5$

requisitos de diseño 45.5

por desplazamiento $45.11,45.13$

por dilución 45.11

velocidad de ventilación necesaria 45.11

Sistemas electrónicos programables

(SEP) 58.62

directrices sobre 58.63

para fines de seguridad $58.50,58.62$

ventajas de los 58.63

Sistemas hombre/ máquina (híbridos)

ingeniería cognoscitiva de los

Véase también Sistema híbrido automatizado

Sistemas informáticos

aplicados a la seguridad 58.33 accidentes relacionados con $\quad 58.33$ y sistemas tolerantes a fallos 58.37 precauciones para controlar y evitar errores en $58.37 f$

Sistemas, análisis de

Véase A nálisis de sistemas

Sitophilus granarius 65.14

Smith y Sainfort 34.25

teoría del equilibrio entre el estrés y el diseño del trabajo 34.25

Smog

$\checkmark$ éase A erosoles

Snellen, gráficos de ojo, agudeza visual 11.12

Sobrecarga 41.10

Sobrecarga física, síndrome de Véase Síndrome de sobrecarga física

Sobrecarga mental lista de comprobación

29.29

Sobrecarga muscular consecuencias 29.35

Sobreocupación en las aulas 94.4

Sobrepeso y enfermedades cardiovasculares $\quad 3.7$

Sobrepresión 41.7

Socialización apoyo de los supervisores 34.46 efectos sobre la salud 34.47 evaluación de la 34.46 información 34.46 programas de 34.47

Sociedad A mericana de Ingenieros de Calefacción, R efrigeración y

Acondicionamiento del Aire (ASHRAE) calidad del aire interior, normas 44.3

flujo de ventilación mínimo en edificios 45.14

Sociedad Americana del Cáncer 86.14

Sociedad para la Investigación Participativa en Asia 23.32

Socioacusia 47.4

Sociología de la salud mental 34.73

Soderberg

célula electrolítica

$\checkmark$ éase Aluminio, fundición y afino

Sodio 41.14, 41.31

Software

aplicado a la seguridad 58.51

aplicado a la seguridad de máquinas 58.33

componentes 29.93

para gestión de los hospitales 97.21

y cultura 29.94

Soldador 103.52

riesgos laborales $103.50,103.52$

Soldadura

en la construcción naval 92.6

soldadura con bronce y estaño 92.7

soldadura con gas 92.7

soldadura con láser 92.8

soldadura con roblonado 92.8

soldadura de arco de tungsteno y

protección gaseosa (GTAW) 92.7

soldadura eléctrica con escorias 92.8

soldadura eléctrica por gas 92.8

soldadura metálica por arco protegido

(SM AW) 92.6

soldadura por aluminotermia $\quad 92.8$

soldadura por arco con núcleo de material fundente (FCAW) 92.7

soldadura por arco de plasma

(PAW) 92.7

soldadura por arco metálico en atmósfera

gaseosa (G M AW ). 92.7

soldadura por arco sumergido

(SAW) 92.6

soldadura por haz de electrones

92.8

gases tóxicos en 96.14

lesiones dérmicas y oculares 96.14

por exposición a radiación 96.14

procesos de soldadura

descripción y riesgos $82.25 \mathrm{t}$

espacios confinados 82.31

fiebre por vapores de metal 82.31

prevención de incendiosy

explosiones 82.28

quemaduras 82.29

radiación ionizante 82.31

radiación ultravioleta 82.30

riesgos 82.27

riesgos químicos 82.30

ruido 82.31

protectores de ojos y cara 31.5 riesgo de incendio $\quad 96.14$

Soldadura manual diseño del puesto de trabajo 29.69

Soldadura y corte de materiales con gas combustible-oxígeno 41.18 medidas de protección $\quad 41.19$ peligros 41.18 por arco eléctrico 41.18

Somatotropina bovina (BST) 62.8

Somatotropina porcina (PST) 62.8

Sombrerero loco, síndrome del 7.18 Véase también Psicosis

Sonido

Véase también 0 ído

conducción aérea del 11.3

Sonómetro 47.6 - 47.7, 47.13, 67.12

Sopa fecal 67.23

Sordera

V éase Pérdida auditiva

estigma producido por la $17.30,17.35$

marco conceptual 17.30

problemas de comunicación 17.33

Sorgo

para ensilaje 70.12

Sosa cáustica

empleo en la extracción de aluminio $\quad 82.9$

manipulación de los bidones de refino 67.34

procedimiento de producción 72.12

Sperandio

regulación de la actividad 29.10

Sporobolomyces 44.23

Sri Lanka 67.9

animales de tiro 70.34

Stachybotrys atra $44.24,44.27$

Staphylococcus

aureus 38.3

epidermidis 44.23

Standard Industrial Classification 86.2

Standards for G eneral Industry, Part 1910

y regulación del desmotado de algodón 89.9

Staphylococcus aureus 67.27

Staphylococcus epidermidis 44.23

ST PO 70.14, 70.21

Streptococcus 44.23, 102.50

pneumoniae 10.102

suis 70.14

Subcarga mental

lista de comprobación $\quad 29.29$

Suberosis 86.14

Submarinos 36.3

Submarinos, trabajos

en el sector de la construcción

cajones 93.34 
enfermedad del buzo 93.34

exámenes y pruebas 93.33

inmersiones 93.33

riesgo de ahogamiento $\quad 93.34$

túneles subacuáticos 93.34

Sudáfrica

Ley de promoción del autogobierno 24.11 Sudor

excreción de tóxicos 33.15

Sudoración

efectos de la $\quad 42.5$

pérdida de electrolitos 42.6

principal factor de estrés para el organismo 42.18

Suecia

abuso de los sistemas de

indemnización 26.13

accidentes relacionados con robots 58.40

casos de cáncer profesional $\quad 49.2$

Consejo nacional de metrología y pruebas de Suecia (M PR)

y evaluación de radiaciones de PVD 52.7

Consejo de protección de los trabajadores 23.13

exposición a campos magnéticos y eléctricos medidas gubernamentales 49.4

Federación de agricultores 38.4

indemnización por accidentes de

trabajo 26.30

asegurados 26.30

causalidad 26.31

enfermedades profesionales 26.30

factores de riesgo en el lugar de trabajo 26.30

lesiones profesionales 26.30

objetivos 26.30

prevención 26.31

rehabilitación profesional 26.31

situación actual 26.31

vulnerabilidad personal 26.31

Ley de medio ambiente de trabajo 21.17

Ley de medio ambiente de trabajo de 19 de diciembre de $1977 \quad 23.7,23.13$

Ley del seguro de lesiones profesionales de 199326.30

Ley sobre el entorno de trabajo 34.27

O ficina central de estadística de Suecia 34.5

recomendaciones sobre el cribado del cáncer 49.2

Seguro Laboral de R esponsabilidad O bjetiva 26.30

Suelo

calidad del $\quad 68.42$

erosión 68.43

Sueño

déficit o falta de 29.62

efectos 29.64 privación del 29.62

efectos 29.62

jet lag 29.62

recuperación 29.64

sensación de somnolencia 29.63

y ritmos fisiológicos circadianos 29.62

sueño de mantenimiento 29.64

siesta nocturna 29.65

y envejecimiento 29.96

Suicidio

en actores 96.30

en empleados de servicios

funerarios 100.16

en profesionales de la sanidad 97.24

entre los pescadores $\quad 66.17$

inclinación al

en médicos 97.27

posible indemnización en caso de 25.9

Suiza

Comisión Federal de Coordinación (CFST) 26.14

enfermedades profesionales y dimensión de la empresa 26.11

Ley del seguro de accidentes 26.7

O rganización $N$ acional Suiza de

A seguradoras de Accidentes

(SUVA) 86.7

prevención de accidentes de

trabajo 26.14

prevención de riesgos laborales

normativa de salud y

seguridad 26.14

responsabilidad de la empresa 26.12

Sulfahemoglobina 1.7

Sulfato sódico 72.19

Sulfhídrico

ácido 70.15

Sulfito

procedimiento al $\quad 72.8$

Sulfúrico, ácido

lesiones dentales y $\quad 104.7$

riesgos 104.7

uñas y 104.7

volcanes y $\quad 104.7$

Sulfuro de hidrógeno

efecto de las altas concentraciones

de 101.13

intoxicación 104.417

patología 104.418

riesgos 104.417

y muestreo en tiempo real 30.21

y riesgo de asfixia 101.12

Sulfuro de sodio ( $\mathrm{N}$ a2S) $\quad 72.8$

Sulfuroso

ácido 72.8

Sullivan

desarrollo de la función de calidad 29.67
Super

modelo de desarrollo de la carrera profesional (1957) 34.47

Superpetroleros 102.56

Supervisión electrónica del rendimiento efectos estresores 34.30 intimidad del trabajador 34.30

Surfactantes de carga positiva efectos oculares 33.32

Surry, modelo de para investigación de accidentes 56.19

Susceptibilidad individual a los tóxicos 33.18 - 33.20

Sustancias corrosivas requisitos de almacenamiento de 61.13

Sustancias explosivas normas de almacenamiento de $\quad 61.12$

Sustancias inflamables requisitos de almacenaje de 61.12

Sustancias neurotóxicas deterioro asociado a la exposición $7.16 \mathrm{f}$ en el sistema nervioso 7.2 exposición a 7.15

Sustancias organocloradas 72.14

Sustancias oxidantes almacenamiento y manipulación de 61.12

Sustancias peligrosas cantidad umbral 39.9

clasificación de $\mathrm{N}$ aciones U nidas de 103.59

cooperación internacional $\quad 23.47$

definición 39.9

en el lugar de trabajo

y Sistema de información química GESTIS 61.27

exposición y cobertura del régimen de indemnización 25.7

información a los trabajadores 23.34

metales y compuestos organometálicos tóxicos 27.8

obligaciones de los fabricantes y proveedores 23.17

registro internacional de productos químicos potencialmente tóxicos 23.44

transferencia de industrias peligrosas 28.6 y enseñanza 94.13

y protección de la maternidad

24.9

y sindicatos 23.8

Véase también Cancerígenos

Véase también C ontrol biológico

Véase también D osis

Véase también $\mathrm{H}$ igiene industrial

Véase también Peligros

Véase también Pesticidas

Véase también Sustancias químicas

Véase también T oxicología 
Sustancias químicas

absorción a través de la piel $\quad 30.16,30.23$

almacenamiento en procesos

fotográficos 85.17

compuestos "sin umbral" 33.78

concentraciones máximas

admisibles 23.40

elementos osteotrópicos 33.13

en la asistencia sanitaria $\quad 97.56 \mathrm{t}$

evaluación de la exposición 30.27

exposición cruzada en la fabricación aeroespacial $\quad 90.3$

exposición en carpintería 86.14

exposición en industrias gráficas 85.3

contacto con metales pesados 85.4

uso de equipos de primeros

auxilios 85.4

exposición en la construcción de motores de aviación 90.10

aminas aromáticas 90.10

exposición en la extinción de

incendios 95.6

cianuro 95.7

hidrocarburos 95.6

monóxido de carbono 95.6

óxidos de nitrógeno 95.6

exposición en la industria

aeroespacial 90.11

riesgos asociados 90.13

exposición en la industria de la piel y el

cuero $88.3-88.4$

bronquitis crónica 88.4

irritación de la piel 88.7

exposición en la industria del

automóvil $91.5,91.8$

agentes cancerígenos 91.9

humos de soldadura 91.6

medidas de protección 91.4

productos de pirólisis 91.6

riesgo de cáncer 91.4

exposición en la industria naval 92.13 , 92.15

exposición en las fuerzas armadas 95.16, 95.19

exposición en los procesos de confección 87.4

exposición en los servicios de policía cianocrilato 95.12

exposición y salud humana 33.21

factores de clasificación $\quad 30.19$

genotóxicas 27.15

carcinogenicidad 27.16

definición de genotoxicidad 27.15

en toxicología genética 33.35

mutagenicidad 27.16

valor de las pruebas de toxicidad genética 27.17

Véase también Biocontrol citogenético

Véase también Biocontrol genético genotóxicas 33.35

inventario de sustancias químicas existentes deJapón 33.58

Ley de control de las sustancias químicas de Japón 33.58

monografías de la IARC $\quad 33.65$

peligrosas $65.6,65.9-67.10$

permeación 31.18

prevención de los riesgos asociados en la industria de la lana 89.14

Programa Internacional de Seguridad de las Sustancias Q uímicas 23.44

riesgo inmunotóxico 33.43

riesgos

prendas de protección 31.17

riesgos asociados en el procesado del

fieltro 89.18

riesgos asociados en la industria de la lana 89.13

afecciones dermatológicas 89.14

inhalación de gases 89.14

intoxicación 89.14

irritación 89.14

riesgos asociados en la tinción $\quad 89.19$ cloro y trastornos oculares, dérmicos y respiratorios 89.19

colorantes y dermatitis 89.20

productos cancerígenos 89.20

sensibilización inmunitaria 33.32

sistema de ensayos según la ley japonesa 33.58

tóxicas 53.15

accidentes con $\quad 53.15$

almacenamiento de 61.13

en buques 102.49

filtración y contaminación de aguas subterráneas 53.16

toxicidad relativa 33.53

V alores Límite U mbral $\quad 23.40$

y enfermedades profesionales 26.6

y experimentos 94.12

y personal docente 94.14

y riesgos de los profesores 94.4

Véase también Ensayos de toxicidad in vitro

Véase también Límites de exposición profesional

Véase también Pesticidas

Véase también R elaciones estructura-actividad

Véase también Sustancias peligrosas

Véase también T oxicología

Sustancias tóxicas

Véase Sustancias peligrosas y sustancias químicas

división 33.13

excreción 33.30

fichas toxicológicas 30.14

interacción de diversas sustancias químicas 33.21
Ley de control de las sustancias tóxicas de

EE.UU. 33.56

sistema de información 22.20

susceptibilidad individual $33.18-33.20$

y exposición neonatal 9.19

Véase también Control biológico

Véase también T oxicocinética

Véase también T oxicología

Sustancias tóxicas o peligrosas

exposición en la fabricación de vidrio, cerámica y materiales afines 84.26 aglomerantes y disolventes 84.31 corrosivos 84.31

fluoruros y boro 84.31

formaldehído, epóxidos y silanos 84.30

metales pesados 84.30

Sustancias tóxicas permanentes acciones internacionales contra $\quad 55.52$ eliminación de las

$$
\begin{gathered}
\text { caso de los } G \text { randes Lagos de } \\
\text { Canadá } 55.47 \text { - } 55.50
\end{gathered}
$$

Swedish Fire Protection Association $\quad 41.16$

Swiss Federal Institute of T echnology Zurich y trastornos en operadores de PVD $\quad 52.14$

\section{T}

T abaco

conductores de camiones y $\quad 103.9$ consumo en el lugar de trabajo $\quad 15.42$ consumo en todo el mundo 15.46 consumo y bajo peso al nacer 9.15 control en el lugar de trabajo 15.42 15.46 estudio de M erill Lynch $\quad 15.47$ razones a favor y en contra $\quad 15.49 f$ costes para las empresas $\quad 15.43$ enfermedades asociadas $\quad 44.12$ interacción entre trabajo y consumo de cigarrillos $15.42 f$

legislación sobre el consumo $\quad 15.44$ en España 15.44

medidas reguladoras 44.16

programas de abandono $\quad 15.45$

en M errill Lynch 15.48

evaluación de la eficacia $\quad 15.46$

prohibición en el lugar de trabajo

enfoques alternativos 15.45

y cáncer 44.12

y enfermedades profesionales 26.6

Véase también $\mathrm{H}$ umo de tabaco ambiental (HTA)

T abaquismo

Día mundial sin tabaco $\quad 15.46,15.47 t$

efectos del tabaquismo pasivo $\quad 44.14$

efectos sobre la salud 15.43

en el sector de la construcción 93.11

en los servicios de policía 95.12 
factor de confusión en epidemiología del trabajo 28.5

inhalación pasiva de humo 3.6

pasivo e indirecto 15.43

políticas antitabaco 15.48 disposiciones restrictivas $\quad 15.49 \mathrm{f}$

tasas de consumo de cigarrillos 3.7

y agentes cancerígenos 2.12

y cáncer de páncreas 4.11

y cáncer de riñón 8.11

y cáncer de vejiga 8.12

y consumo de cafeína 34.63

y distorsión de los indicadores de toxicidad 27.4

y enfermedades cardiovasculares 3.6

y exposición al radón 28.23

y nivel de inductibilidad de la

CYP1A1 33.26

y profesores 94.14

y riesgo de cáncer 15.49

y susceptibilidad individual a los tóxicos 33.19

T ableros manufacturados

categorías 71.2

de fibra 71.9

proceso húmedo 71.9

proceso seco 71.9

de madera maciza 71.2

de partículas $71.9,71.13$

industrias de 71.9

producción mundial 71.2

Tailandia

Centro N acional de Información sobre Salud y Seguridad en el

Trabajo 22.21

iniciativa de desarrollo rural 24.6

Instituto $\mathrm{N}$ acional para la $\mathrm{M}$ ejora de las Condiciones y el M edio A mbiente de

Trabajo 22.20

sistema de información para la

gestión 22.20

biblioteca 22.21

servicio de consultas 22.21

unidad de documentación 22.21

unidad informática 22.21

Taiwan

flota de 66.13

vigilancia de las enfermedades profesionales 28.33

T akata-Ara y W eltmann,

pruebas de 104.297

Talco

en la fabricación de papel 72.11

riesgos para la salud por 62.7

Talio

intoxicación profesional por 63.46

Taller de Estocolmo (Stockholm

W orkshop) $86 \quad 50.10$ y componente neurológico del síndrome de HAV $\quad 50.10$

y fases del fenómeno de $R$ aynaud 50.11

Talleres

y control de la ventilación general $\quad 94.12$

Talleres de arte 94.4

T alleres de pintura $\quad 32.9$

Taninos 65.13

Tanque

de siembra

Véase Industria farmacéutica, proceso de fabricación

Tanques

de almacenamiento en plantas químicas

Véase Industria química

control de emisiones 77.13

disposición del tanque 77.12

drenaje 77.12

exceso de llenado 77.12

fugas de los tanques 77.12

inspección y limpieza 77.12

riesgos para la seguridad 77.13

de enfriamiento

y peligro de incendio 41.17

Tántalo

riesgos del 63.47

Taquicardia 34.67

T aquicardia sinusal

por descarga eléctrica

Tarea

Véase Análisis del trabajo

análisis cognitivo de la $29.8 f$

análisis de tareas 29.89

características indispensables 29.51

características y privación del sueño 29.62

concepto de tarea completa 29.58

definición de tareas

lista de comprobación 29.29

y cultura 29.92

enfoque de exigencias de la tarea $\quad 29.50$

identificación con la tarea

lista de comprobación $\quad 29.29$

primacía de la tarea 29.57

T arjetas de cableado impreso

proceso de PW B: aspectos ambientales, de higiene y de seguridad $83.28 \mathrm{t}$

PW B, generación y controles de residuos $83.38 \mathrm{t}$

Tartárico

ácido 65.13

Tasa

bruta 28.12

de ataque 28.11

de dosis absorbida

para radiación gamma $\quad 48.20-48.21$

de incidencia 28.11

de mortalidad 28.11 relativa estandarizada $\quad 28.13$

relativa proporcional 28.16

de supervivencia 28.11

específica por edades 28.12

Taylor, Frederick

principios de la dirección científica $\quad 34.13$

T aylorismo $\quad 57.3$

Té

Véase Industria del té

bolsas de té 65.8

T eatro y ópera

ayudantes de vestuario en

medidas preventivas para 96.32

riesgos para la salud 96.32

procedimientos de control de

incendios 96.31

riesgos del maquillaje 96.32

seguridad de escenarios y decorados

y Directiva sobre máquinas

(89/392/CEE) 96.34

tipos de peligros de incendio 96.31

Teatros 94.4

T echnion Israel Institute of T echnology estudio sobre la industria del tallado de diamantes 29.104

T eclados

teclado de cuerda 29.87

y ergonomía $\quad 29.78,29.87$

Técnicas artísticas riesgos $96.4 \mathrm{t}$

Técnicas de imagen cerebral resonancia magnética 7.24 tomografía computarizada 7.24 tomografía por emisión de positrones 7.24

Técnicas de la doble tarea $\quad 29.50$

Técnico de laboratorio 103.56 riesgos laborales 103.57

T ecnología

causas del uso ineficaz de la 29.57

en el sector de la construccion aplicada a la reducción de riesgos laborales 93.6

riesgos de la mecanización 93.9

relación entre cultura y 29.90

aplicación de las características

culturales para un diseño óptimo 29.92

compatibilidad y preferencias 29.91

influencias restrictivas de la cultura 29.91

transferencia de tecnología $\quad 20.10$

T ecnologías productivas limpias

beneficios laborales 54.32

en un concepto de desarrollo sostenible 54.3

programas de tecnologías limpias en Europa 53.53 
T ejeduría

clasificación de trabajadores del

sector 89.23

riesgos para la salud 89.24

polvo de fibra 89.24

ruido 89.24

riesgos para la seguridad $\quad 89.24$

caídas 89.24

incendio 89.24

manipulación de materiales 89.24

maquinaria 89.24

visión general $\quad 89.23$

T ejidos

capacidad de absorción de vapor $\quad 42.32$

retención de agua 42.32

Telecomunicaciones

panorama del sector 101.9

riesgos para la seguridad y la salud en el sector 101.9

trabajo con PVD $\quad 101.10$

y trastornos musculosqueléticos acumulativos 101.10

T eléfonos móviles y riesgo de cáncer cerebral $\quad 49.22$

Telégrafos, servicio de riesgos ergonómicos en $\quad 101.10$

T eletrabajo 34.44

Véase T rabajo a domicilio

factores del crecimiento del 99.11

formas de contratación de 99.11

riesgos de salud y seguridad del 99.11

y estrés profesional 99.12

y responsabilidad de la empresa $\quad 99.12$

T elevisión, producciones para

riesgos y precauciones

Véase también Cine

Telurio

riesgos y precauciones con el $\quad 63.47$

Temperatura

ambiente 42.5

cambios de temperatura

conductores de camión y $\quad 103.7$

colorimétrica 46.14

corporal

calor metabólico $\quad 42.2$

control de la 42.2

de la periferia $\quad 42.2$

de referencia $\quad 42.3$

del núcleo $\quad 42.2$

frío 42.51

límites máximos de tolerancia $\quad 42.2$

media 42.2

Véase también Calor

Véase también R egulación térmica

Véase también T ermogénesis

Véase también T ermolisis

cutánea media $\quad 42.2$

de bulbo húmedo 42.16 de globo $\quad 42.2$

del aire $\quad 42.2,42.16$

del punto de rocío $\quad 42.16$

elevada

exposición a $\quad 65.10$

lista de comprobación 29.22

radiante media $\quad 42.17$

superficial de la persona $\quad 42.5$

termoneutra $\quad 42.34,42.48$

Temporeros 64.8

Tenax

uso para muestreo ambiental $\quad 30.21$

Tendinitis

bursitis calcánea 6.31

crónica

y uso de ordenadores 96.15

del tendón de Aquiles 6.31

en cajeros de comercio $\quad 99.3$

en cosmetólogos y peluqueros 100.8

en empleados de servicios de

comida 96.49

en trabajadores de oficina $\quad 99.7$

en trabajadores postales 101.7

y utilización de PVD 99.3

Tendones

deformación "elástica" 6.4

deformación "viscosa" 6.4

fuerzas musculares 6.4

mecanismos fisiológicos 6.5

trastornos de los tendones 6.5

Tenias 101.24

T enosinovitis

Véase M uñeca

e indemnización por accidentes de trabajo 26.8

en cajeros de comercio $\quad 99.3$

y utilización de PVD 99.3

Tensión del entorno relación con la personalidad $\quad 34.12$

Tensión en el trabajo 34.7 y trastornos musculosqueléticos 34.15 y trastornos psicológicos 34.15

Tensión mental componentes y consecuencias 29.55 Véase también Estrés

Tensión muscular y estrés 34.72

T ensión psicológica $\quad 34.7,34.10,34.19$

Teofilina 42.52

T eoría de la contingencia de Fiedler 34.39

T eoría de la elección racional (TER) en la toma de decisiones $\quad 59.20$

Teoría de la homeostasis del riesgo ( $\mathrm{THR}$ ) aplicada al tráfico rodado $\quad 56.12$ y causalidad de accidentes 56.11

Teoría de la utilidad subjetiva prevista (USP) en la toma de decisiones $\quad 59.20$
T eoría del "efecto dominó"

y causas de accidentes $56.6,56.25$

T eoría del aprendizaje social 34.53

T eoría del estrés psicológico de Lazarus 34.34

Terapia génica

Proyecto Genoma H umano

Véase también Industria de la biotecnología

T eratogénesis anomalías del desarrollo $9.2 f$

espectro de resultados 9.2

mecanismos teratogénicos 9.3

relación efecto-dosis 9.3

Véase también T eratología

Teratogénicos, mecanismos Véase T eratogénesis

T eratógenos, agentes y gestación 9.14

Teratología principios generales 9.2

Terbutilazina 27.24

T ercera edad cuidado de personas de edad 15.95 jubilación 15.92

Termogénesis 42.2

Termolisis 42.2, 42.32

Termómetro de esfera negra $\quad 42.17$

Terremoto

en A rmenia, diciembre de 198839.50

en Irán, junio de $1990 \quad 39.50$

factores de riesgo en hospitales 39.50 preparación de los hospitales 39.51

Tesaurosis 100.7

T etania por magnesio 63.25

T etanización del diafragma por electrización 40.3

T étanos por herida de asta de toro 96.51 profilaxis frente al

en empleados de zoológicos 96.45

riesgo asociado a la caza $\quad 69.5$

riesgo en la industria de la piel y el

cuero 88.9

y manipulación de residuos 101.24

T etracarbonilo de níquel toxicidad del 61.19

T etracloroetileno 33.58, 100.10

Tetraclorofenol 71.11

T etracloruro de carbono como carcinógeno del grupo 2B por la IARC $\quad 104.250$ y hepatitis 28.33

T etrilo

intoxicación 104.348 
T extil, industria

acetatos en la 104.162

ácido fórmico en la 104.12

ácido nitrilotriacético en $\quad 104.338$

Thermoactinomyces vulgaris 44.23

Thermomonospora

alba 64.61

curvata 64.61

fusca 64.61

Three M ile Island $\quad 29.82,29.111,39.33,39.40$

Threshold Limit V alues, TLV $\quad 70.13$

Tiabendazol 62.16

Tiempo de trabajo 35.7

y organización 35.7

Tiempo total de exposición $\quad 28.11$

Tierra de diatomeas en la elaboración del vino $\quad 65.13$ riesgos para la salud de la 62.7

Tifón

$V$ éase $\mathrm{H}$ uracanes, ciclones y tormentas tropicales

Tigris 70.5

Tinajas 65.13

Tinción 89.18

accidentes 89.20

clases de tintes 89.19

preparación de tejidos para la

tinción 89.19

proceso 89.19

riesgos asociados

incendio y explosión 89.19

medidas de protección 89.20

productos químicos 89.19

Tintes

efectos mutagénicos de los

en cosmetología $\quad 100.6$

Tintorerías

incendios en 100.13

quemaduras en 100.13

riesgos asociados al percloroetileno

(PERC) $\quad 100.12$

riesgos eléctricos 100.13

seguridad de las máquinas en $\quad 100.13$

y estrés por calor 100.13

Tiña

asociada a la caza $\quad 69.5$

de los animales 70.14

Tioles 104.406 incendio y explosión 104.406

T iozalsulfona 33.28

Tipos de fallo general en las causas de accidentes 57.10 y perfil de seguridad del sistema 57.11

Tiritona $\quad 42.40$

$\mathrm{T}$ isis del minero en trabajadores de la pizarra $\quad 62.6$
Titanio

operaciones de recuperación

controles técnicos $82.61 \mathrm{t}$

riesgos en la producción de 63.48

y combustión 41.14

Tobillo

Véase Pie

Tolerancia al calor

características del ser humano que

influyen 42.12

aclimatación al calor 42.12

capacidad física 42.12

dimensiones corporales $\quad 42.12$

edad 42.12

etnicidad $\quad 42.12$

obesidad 42.13

sexo $\quad 42.12$

trastornos de la salud y otros factores de estrés 42.13

prehidratación 42.13

programa para el mantenimiento de la

hidratación $\quad 42.13$

$y$ consumo de alcohol $\quad 42.13$

Tolueno 27.13, 31.28, 39.30, 68.26

clorados

como carcinógeno del grupo 2A por la

IARC $\quad 104.296$

efectos del

en encoladores $\quad 103.16$

$T$ oma de decisiones

autoridad sobre las tareas $\quad 34.7$

discrecionalidad de las capacidades 34.7

en gestión de la seguridad $\quad 59.19$

según el ciclo vital de la empresa 59.19

tipos de problemas básicos 59.20

y consecuencias por alternativa $\quad 59.20$

y resolución de problemas 59.20

y teoría de la elección racional 59.19 59.20

y teoría de la utilidad subjetiva $\quad 59.20$

en la empresa 59.22

como fuente de poder 59.23

control de la 59.23

y alternativas óptimas 59.22

y alternativas satisfactorias $\quad 59.23$

en situaciones de riesgo $\quad 59.29$

procesos mentales (heurística) de

las 59.29

y teoría de la utilidad subjetiva prevista (USP) 59.29

latitud de $34.3,34.6,34.14$

Tonsilitis

en la industria de la seda $\quad 89.15$

Tormenta

Véase $\mathrm{H}$ uracanes, ciclones y tormentas tropicales

Tornados

alarma de 39.26 aviso de 39.26

formación 39.25

morbilidad y mortalidad $\quad 39.25$

prevención y control 39.26

Tornos

del metal 82.31

directrices de seguridad

de la Directiva sobre máquinas (89/392/ ECC) 58.54

Toros

directrices para el manejo $\quad 70.35$

instalaciones 70.35

Torre de absorción 72.8

Torremolinos

Conferencia de 66.10

Convenio de T orremolinos sobre la seguridad de los buques de pesca 66.10

Tos del tejedor 89.31

Tostado

del café $\quad 65.8$

Toxafeno $\quad 62.10$

cancerígeno del grupo 2B según la IARC $\quad 62.11$

Toxicidad

de los alimentos 66.21

del mar 66.21

ensayos in vitro 33.51

mecanismos de la

efectos adversos 33.31

ejemplos 33.31

exposición 33.30

farmacocinética 33.30

generalidades $33.29-33.32$

técnicas para estudiar los 33.30

toxicidad aguda 33.31

toxicidad reproductiva 33.33

toxicidad subcrónica y crónica 33.32

mecanismos organoespecíficos de la 33.53

por oxígeno

convulsiones $\mathrm{G}$ ran $\mathrm{M}$ ar $\quad 36.2$

efecto de Paul Bert 36.2

efecto Lorrain-Smith 36.2

síntomas 36.2

relativa 33.53

sobre el desarrollo 9.2

Véase también T eratogénesis

T oxicidad en la reproducción caracterización del riesgo $\quad 33.65$

causas ambientales 9.4

ejemplos de exposiciones $9.3 \mathrm{t}$

evaluación de la exposición $\quad 33.65$

evaluación de la relación

dosis-respuesta 33.65

generalidades 33.60

identificación de los peligros 33.63

datos sobre humanos 33.63

ensayo con animales de experimentación 33.63 
ensayos in vitro 33.64 métodos de evaluación del riesgo 33.63 parámetros empleados 33.64 sustancias tóxicas $9.9 \mathrm{t}$ transmitida por el varón $\quad 9.4$

Toxicidad en órganos diana ensayos in vitro 33.53

Centro Europeo de Validación de $M$ étodos A lternativos (ECVAM) 33.55

cultivo de órganos completos 33.53

Interagency Coordination Committee for the $V$ alidation of A Iternative $M$ ethods (ICCVAM) 33.55

Johns $\mathrm{H}$ opkins $\mathrm{C}$ entre for Alternatives to A nimal T esting (CAAT) 33.55

líneas celulares continuas 33.53 órganos aislados perfundidos 33.54 rodajas tisulares 33.54 validación 33.55

Véase también Ensayos in vitro sobre irritación ocular

T oxicidad genética

evaluación de la 33.49 - 33.50

generalidades $33.49-33.50$

principales mutaciones del ADN $\quad 33.49$

Véase también T oxicología genética

T oxicocinética $27.4,27.13,33.8$

absorción de tóxicos 33.10

por el tracto gastrointestinal $\quad 33.11$

por el tracto respiratorio $\quad 33.10$ por la piel (dérmica o percutánea) 33.11

biotransformación y eliminación de los

tóxicos 33.14

eliminación por el pulmón

(desorción) 33.15

excreción renal 33.15

leche 33.15

métodos para incrementar la

$$
\text { eliminación } \quad 33.15
$$

saliva 33.15

sudor 33.15

velocidad de eliminación $\quad 33.14$

determinaciones de la exposición $\quad 33.15$

distribución de los tóxicos en el

organismo 33.12

acumulación en el pelo y las uñas 33.14

acumulación en los huesos 33.13

acumulación en tejidos ricos en

lípidos 33.13

barrera hematoencefálica 33.13

barrera histohematológica 33.13

barrera placentaria 33.13

distribución del tóxico en el interior de la célula 33.14

reacciones de intercambio de iones 33.14 retención en el sistema

reticuloendotelial 33.13

en disolventes orgánicos $\quad 27.13$

en la programación del control

biológico 27.4

estructura y propiedades de las

membranas 33.9

difusión 33.9

difusión facilitada o catalizada $\quad 33.10$

endocitosis 33.10

Ley de Fick 33.9

pinocitosis 33.10

transporte activo $\quad 33.10$

exposición múltiple 33.16

generalidades 33.8

propiedades fisicoquímicas de los

tóxicos 33.8

coeficiente de partición de N ernst 33.9

constante de disociación $\quad 33.9$

transporte de los tóxicos 33.12

Toxicodinámica

en la programación del control biológico 27.4

Toxicología 33.2

definiciones y conceptos 33.3

absorción gastrointestinal $\quad 33.6,33.11$

absorción percutánea $\quad 33.6,33.11$

absorción pulmonar $\quad 33.5,33.10$

aclaramiento 33.6

activación del oxígeno $\quad 33.8$

activación metabólica 33.7, 33.32

acumulación 33.6

antagonismo 33.4

área bajo la curva 33.6

barreras 33.6

biodisponibilidad 33.6

biotransformación 33.7

categorías de toxicidad $\quad 33.4$

concentración celular crítica 33.16

concentración crítica en un

órgano 33.16

curva de concentración-tiempo 33.6

desactivación metabólica 33.8

desorción 33.15

difusión 33.5, 33.9

difusión facilitada o catalizada $\quad 33.10$

distribución 33.6, 33.12

dosis 33.4

efecto adverso $\quad 33.17$

efecto crítico 33.16

efectos aditivos $33.4,33.18$

efectos agudos 33.5

efectos antagónicos 33.18

efectos crónicos 33.5

efectos sinérgicos 33.18

efectos sistémicos 33.5

eliminación $\quad 33.6,33.14$

endocitosis 33.10

enzimas citocromo P450 33.8 excreción 33.7, 33.30

exposición aguda 33.5

exposición crónica 33.5

extrapolaciones 33.5

factor de seguridad $\quad 33.5$

fagocitosis 33.5

filtración 33.5

inducción 33.8

inhibición 33.8

LOEL $\quad 33.4$

metabolismo 33.7

metabolismo de xenobióticos 33.7

modelos toxicocinéticos 33.7

NOEL (NOAEL) 33.4

órgano diana $33.5,33.16$

peligro 33.3

reacciones de la fase $1 \quad 33.8$

reacciones de la fase $2 \quad 33.8$

relación dosis-efecto 33.4

relación dosis-respuesta 33.4

riesgo 33.3

sinergismo $\quad 33.4$

tiempo de latencia 33.4

tolerancia 33.5

toxicidad 33.3

transferasas 33.8

transporte activo $\quad 33.5,33.10$

transporte en los flujos corporales 33.5

umbral de dosis 33.4

unión a la sangre 33.6

variabilidad genética 33.8

vida media biológica 33.6

volumen de distribución 33.6

xenobióticos 33.3

generalidades 33.2

hipótesis de "agentes sin umbral" 33.77

Ley de control de las sustancias químicas de Japón 33.58

Ley de control de las sustancias tóxicas de EE.UU. 33.56

métodos de ensayo 33.44

biomarcadores 33.44

ensayos de toxicidad in vitro $\quad 33.51$

Programa Nacional de Toxicología de EE.UU. 33.64

susceptibilidad individual 33.18 - 33.20, 33.22

determinantes genéticos 33.21 - 33.28

exposición concomitante a otras

sustancias químicas 33.21

influencia de la edad $\quad 33.19$

influencia de los fármacos 33.20

influencia de los hábitos

alimentarios $\quad 33.19$

influencia del alcohol 33.20

influencia del hábito de fumar 33.19

influencia del sexo 33.19

marginal resistente 33.23

marginal sensible 33.23 
principios generales 33.18

variaciones de la respuesta tóxica en la

población humana 33.22

Véase también Efecto crítico

Véase también E pidemiología

Véase también Inmunotoxicología

Véase también Ó rgano diana

Véase también R elaciones estructura-actividad (SAR)

Véase también Toxicidad

Véase también T oxicocinética

Véase también T oxicología genética

Toxicología genética

ensayos y técnicas 33.50

justificación y fundamento

teórico 33.49

entrecruzamientos 33.38

mutación 33.37

principios generales 33.35

replicación errónea de

"microlesiones" 33.38

situación actual y perspectivas 33.50

sustancias químicas genotóxicas 33.39

Véase también T oxicidad genética

Toxicología industrial 44.3

Toxicología preventiva $\quad 33.21$

Toxicología reguladora

evaluación del riesgo 33.57

armonización internacional de los

métodos de 33.57

caracterización del riesgo $\quad 33.57$

de neurotoxicidad 33.60

enfoque de EE.UU. 33.60

evaluación de la exposición $\quad 33.57$

evaluación de la relación

dosis-respuesta 33.57

identificación de los peligros según el

enfoque japonés $33.57-33.59$

identificación del peligro 33.57

principios generales 33.57

T oxicosis por cobre crónica heredada Véase Enfermedad de Wilson

Toxorhynchites spp 70.39

Trabajadoras

contragolpe 24.4

maternidad 24.3

segregación de la población activa en

función del sexo 24.3

techo de cristal 24.4

trabajo a domicilio 24.19

Véase también A coso sexual

Véase también Embarazo

Trabajadores

dedicados a la ganadería $\quad 70.3$

del mar 102.45

forestales 68.3

accidentes mortales 68.5

características 68.4 carga de trabajo 68.22

condiciones de trabajo 68.36

condiciones de vida 68.40

disposiciones en materia de

seguridad 68.28

división del trabajo 68.38

enfermedades profesionales $\quad 68.6$

factores sociales y psicológicos 68.24

formación 68.39

jornada laboral 68.39

nutrición $\quad 68.41$

problemas de salud y seguridad

riesgos 68.21

sistemas de remuneración $\quad 68.38$

supervisión 68.38

trabajo forestal manual 68.22

trabajo forestal

manual-motorizado 68.23

trabajo mecanizado 68.23

Véase también Participación de los trabajadores

Trabajadores "desalentados" 34.35

T rabajadores a "destajo"

efectos perjudiciales 24.12

generalidades 24.12

T rabajadores afroamericanos 34.60

Trabajadores agrícolas 64.8

accidentes de tráfico $\quad 64.9$

caídas 64.24

dislocaciones, distensiones y lesiones

traumáticas 64.9

educación sobre los plaguicidas 64.16 -

64.18

evaluación de necesidades $\quad 64.17$

evaluación y formación de los educadores 64.18

métodos y objetivos de la educación 64.17

enfermedades 64.9

dermatológicas 64.9

respiratorias 64.9

intoxicación por plaguicidas 64.9

migrantes $y$ temporeros 64.8

riesgo de intoxicación por plaguicidas 64.9

situación sanitaria $\quad 64.8$

Trabajadores autónomos

e indemnización por accidentes de trabajo 25.2

T rabajadores con contrato atípico $\quad 24.12$

trabajadores cedidos 24.12

trabajadores de subcontratas $\quad 24.12$

trabajadores temporales 24.12

y evolución del mundo del trabajo $\quad 24.18$

T rabajadores con discapacidades

diseño específico para $\quad 29.89,29.99$ -

29.100, 29.102

análisis de tareas 29.89

evaluación 29.90 prototipos 29.90

documento de requisitos de un producto

(PR D) y discapacidad $29.89,29.100$

modelo de utilidad de la tecnología de

rehabilitación 29.90, 29.99

Véase también Discapacidades

Trabajadorescualificados 94.10

Trabajadores de edad avanzada

capacidad de trabajo 29.96

datos sobre el envejecimiento de la

población activa 29.97

decadencia y progreso 29.96

diferencias entre hombres y mujeres 29.97

envejecimiento cognitivo 29.97

formas de acción 29.98

procesos de envejecimiento

orgánico 29.96

y formación 29.97

Trabajadores del sector informal 24.13

T rabajadores desfavorecidos

Véase también Empleo precario

Trabajadores discapacitados $\quad 24.7,24.10$

Trabajadores migrantes

documentos 24.11

ilegales 24.11

perspectiva histórica 24.11

prestaciones de indemnización 25.2

Trabajadores por cuenta propia

Véase T rabajadores autónomos

Trabajadores postales

Véase Servicios postales

Trabajadores sanitarios

alergia al látex en 97.63

medidas preventivas 97.64

contagio de hepatitis A $\quad 97.43$

contagio de la rubéola 97.44

efectos de la tensión física en $\quad 97.16$

enfermedades infecciosas entre los 97.42

indicaciones para la vacunación $97.45 \mathrm{t}$

medidas de prevención $\quad 97.44$

tratamientos profilácticos 97.45

estrés en 97.7

exposición a humos de láser 97.32

exposición a la radiación

ultravioleta 97.33

exposición a las microondas 97.33

y daños al aparato reproductor 97.33

exposición a radiación ionizante 97.5 ,

$97.13,97.32$

medidas preventivas 97.32

exposición a sustancias químicas peligrosas en 97.55

infección de la hepatitis B $\quad 97.42,97.46$

contagios anuales en Europa

O ccidental 97.42

vectores del contagio 97.43

infección de la hepatitis C 97.43, 97.47

fuentes de contagio 97.43 
infección de la hepatitis D $\quad 97.47$ infección por varicela entre los 97.43 infecciones nosocomiales en $\quad 97.38$ inhalación de gases anestésicos residuales 97.63

lesiones de columna vertebral $\quad 97.6$ lesiones producidas por agujas en 97.4 problemas lumbares $97.17,97.19$ problemas psicosociales en los 97.8 riesgo de parotiditis 97.43 sensibilidad a agentes irritantes 97.32 y mala calidad del aire 97.32 síndrome de burnout en $\quad 97.3,97.23$ tasa de partos prematuros 97.16 transmisión del virus del SIDA a 97.45 recomendaciones de los CDC 97.46 vías de transmisión $\quad 97.47$

tuberculosis en $97.43,97.50$ medidas de control de la infección 97.51

T rabajadores sociales atención domiciliaria experiencia de Nueva Y ork 97.11 en centros sanitarios 97.11 y exposición a infecciones 97.11 estrés en 97.10 exposición a la violencia de los 97.11

T rabajadores subempleados $\quad 24.14$

Trabajadores temporales y riesgos profesionales 26.10

Trabajo

a destajo $\quad 34.45$

a distancia 34.44

a domicilio $\quad 34.45$

a grandes altitudes $\quad 37.10$

edema cerebral 37.14

edema pulmonar $\quad 37.14$

elevación de la concentración de oxígeno 37.12

hipoxia 37.11

intolerancia 37.12

mal de montaña agudo $\quad 37.14$

muestreo del aire 37.15

peligros físicos 37.15

policitemia 37.12

reconocimiento previo $\quad 37.11$

selección de trabajadores 37.11

tolerancia $37.10-37.11$

tratamiento de urgencia 37.13

turnos de trabajo $37.12,37.15$

velocidad de desaclimatación $\quad 37.12$

Véase también Presión barométrica

a turnos 34.6

cambios del ritmo biológico 34.6

activo $\quad 34.8-34.9$

aspectos tecnológicos 34.26

automatizado 34.6

cambio de paradigmas y políticas 24.2 , 24.20 cambios en curso 29.6

características psicosociales $\quad 34.9$

compartido 34.44 - 34.45

con electricidad $\quad 40.2$

condiciones ergonómicas 34.25

demandas del

métodos de evaluación 34.14

y síntomas psicosomáticos 34.48

efectos sobre la salud física $\quad 34.57$

en casa 34.44

en entornos de aire comprimido $36.7 \mathrm{t}$

en red $35.4-35.5$

en serie 34.6

entorno físico 34.26

estructura del 29.11

eventual 34.44

evolución del mundo del $\quad 24.5,24.17$

y desempleo 24.18

y tecnología microelectrónica 24.18

factores organizativos $34.26,34.40$

mediciones psicosociales 34.14

pasivo $34.8-34.9$

ritmo de $34.28 \mathrm{f}$

roles asignados 34.31

satisfacción en el

Véase Bienestar

supervisión electrónica del $\quad 34.29$ - 34.30

tareas 34.26

teletrabajo 34.44

y bienestar 34.64

y violencia 24.5

Véase también Administración del trabajo

Véase también A nálisis del trabajo

Véase también Empleo

Véase también Empleo precario

Véase también Entorno de trabajo

Véase también Inspección de trabajo

Véase también Lugar de trabajo

Véase también M edio ambiente de trabajo

Véase también 0 rganización del tiempo de trabajo

Véase también O rganización del trabajo

Véase también Postura de trabajo

Trabajo a destajo

y riesgos profesionales 26.10

Trabajo a domicilio

e informatización 24.23

riesgos para la salud $24.19,24.23$

y evolución del mundo laboral $\quad 24.19$

Trabajo al aire libre 68.18

Trabajo de plantación $\quad 64.6$

Trabajo doméstico

Véase Empleados del hogar

T rabajo en ambientes calurosos control ambiental $\quad 42.14$

evaluación según las normas ISO $\quad 42.26$ exposiciones de duración limitada $\quad 42.20$ fundamentos físicos $\quad 42.15$ prácticas de trabajo $42.23 \mathrm{t}, 42.25$

procesos con calor húmedo 42.14

procesos con calor seco $\quad 42.14$

Véase también Aislamiento térmico de la ropa

Véase también Control de la humedad

Véase también Estrés por calor

Véase también Prendas protectoras

Trabajo en ambientes fríos $\quad 42.32$

características generales $\quad 42.54$

definición $\quad 42.32$

diseño del lugar de trabajo $\quad 42.45$

educación, formación y práctica 42.44

efectos sobre la capacidad física para el

trabajo 42.36, 42.38

exposición al agua fría 42.48

límites de tiempo $42.58-42.59$

modificación de las tareas $\quad 42.52$

organización del trabajo $\quad 42.38$

períodos de descanso 42.47

prácticas de trabajo $42.45,42.52$

problemas del trabajo en cámaras

frigoríficas 42.47

problemas específicos del trabajo en

exteriores fríos 42.47

programas de control de la salud $\quad 42.43$

protección contra el frío $\quad 42.38$

Véase también Prendas protectoras

protección personal $\quad 42.49$

rendimiento $42.35,42.53$

uso de carretillas con cabinas climatizadas 42.47

Véase también Estrés por frío, prevención

Véase también Trabajo en regiones árticas y subárticas

Trabajo en cajones de aire comprimido 36.5

T rabajo en instalaciones eléctricas 40.16

a distancia $\quad 40.17$

a potencial 40.17

con tensión $\quad 40.16$

en contacto 40.17

en la proximidad de partes con

tensión 40.17

formación del personal sobre riesgos 40.17

mantenimiento 40.17

sin tensión $\quad 40.16$

Trabajo en recintos cerrados en la industria naval $\quad 92.14$

Trabajo en regiones árticas y subárticas aislamiento geográfico $\quad 42.50$ empleo de trineos motorizados $\quad 42.50$ enfermedades endémicas $\quad 42.50$ estrés por frío 42.49 medidas específicas 42.50 riesgos para la salud $\quad 42.49$

Trabajo estático método O WAS 29.37

Trabajo forestal

Véase T rabajadores forestales 
Trabajo infantil

agentes peligrosos 24.17

causas 24.14

condiciones de trabajo $\quad 24.15$

consecuencias sociales y económicas 24.17

demanda 24.15

en el sector de la confección $\quad 87.7$

en la industria del calzado 88.7

esclavitud infantil 24.14

estadísticas 24.14

exposición a riesgos laborales $24.16 \mathrm{t}$

informe de un Comité de expertos de la OIT 24.14

prevención de lesiones 24.15

Programa internacional para la erradicación del trabajo infantil 23.59

sectores de actividad $24.16 \mathrm{t}$

y educación 24.14

Trabajo muscular

manipulación manual de materiales 29.34

carga de trabajo aceptable 29.37

carga de trabajo relativa 29.37

electromiografía 29.37

frecuencia cardíaca 29.37

sobrecarga muscular 29.35

fatiga 29.38

prevención 29.38

trabajo estático 29.34

carga de trabajo aceptable 29.37

trabajo muscular dinámico pesado 29.34

carga de trabajo aceptable 29.35

carga de trabajo relativa 29.36

valoración del esfuerzo percibido $\quad 29.37$

trabajo repetitivo 29.34

carga de trabajo aceptable 29.37

Véase también Lesión por esfuerzo repetitivo

y diseño del puesto de trabajo 29.67

Véase también Biomecánica

Trabajo nocturno

en panaderías 67.31

enfermedades contraindicadas para

el 43.12

permanente

ventajas del $\quad 43.6$

y perturbación de los ritmos

biológicos 43.6

y vida familiar 43.6

prohibición y protección de la

maternidad 24.8

y enfermedades gastrointestinales 43.4

Véase también T rabajo por turnos

Trabajo por turnos

como factor de estrés

en conductores de autobuses 102.26

distribución del tiempo libre en el $\quad 43.8$ efectos del

en trabajadores postales 101.6 eficacia de las pausas en el

reglas para mejorar la 43.11

y mejora del rendimiento $\quad 43.10$

y prevención de la fatiga 43.10

en empleados de hoteles

efectos del 98.6

en enfermeras $43.3,43.6$

en maquinistas ferroviarios $\quad 43.3$

factores de riesgo en 43.2

medidas de mejora del 43.13

recomendaciones de diseño del 43.6

para turno de noche permanente 43.6

para turnos de rotación rápida y

lenta 43.7

rendimiento en el trabajo y $\quad 43.5$

repercusión en la vida familiar del 43.5

en trabajadoras 43.5

tasas de mortalidad y 43.5

variables de tolerancia al $\quad 43.2$ - 43.3

y calidad del sueño $\quad 43.3$

en mujeres 43.5

trabajadoras 43.5

y cultura 29.94

y diseño de los horarios 43.8

y duración de la jornada 43.7

y enfermedades cardiovasculares 3.9

y enfermedades gastrointestinales 43.4

y estrés

por alteración del ritmo

circadiano 43.2

y límites de exposición profesional $\quad 30.35$

y medidas de salud en el trabajo $\quad 43.12$

y perturbación del sueño

en trabajadores sanitarios 97.26

y privación del sueño 29.62

y trastornos cardiovasculares 43.5

y trastornos digestivos 4.3

y trastornos menstruales 43.3

y trastornos neurológicos $\quad 43.5$

Trabajo repetitivo

afecciones por 32.21

y postura de trabajo 29.34

Trabajo, M edicina del

Véase M edicina del T rabajo

T rabajos junto al agua o dentro del agua

en el sector de la construcción

mal de Weil 93.33

precauciones 93.33

riesgos especiales 93.33

T ractores

accidentes por vuelco 58.72

con consecuencias mortales $\quad 58.72$

medidas preventivas 58.73

atropellos 64.36

cabinas 64.21

estabilidad 64.33

factores 64.34 estructuras de protección contra vuelcos

(EPV) 58.72

directivas de la CEE $\quad 58.73$

normas de la OCDE $\quad 58.73$

normas de la OIT 58.73

tipos de 58.72

y disminución de accidentes 58.72

lesiones asociadas 64.23

mejora de las condiciones de trabajo

de sus operadores 64.20

normas de seguridad 64.36

riesgos de los 64.33

vuelcos

estructura de protección contra vuelcos (EPV) 64.36

Tractores agrícolas

anclaje de los cinturones de

seguridad 23.63

Tráfico

accidentes de 53.27

como riesgo profesional $\quad 53.27$

conductores de ambulancia y 103.5

conductores de camiones y $\quad 103.6$

chóferes y 103.13

exterminadores de plagas y $\quad 103.18$

mecánicos de coches y 103.32

y contaminación del aire 53.27

y contaminación por ruido $\quad 53.27$

Tráfico aéreo

controladores de

Véase C ontroladores de tráfico aéreo

Trajes anticongelación $\quad 67.25$

Trajes de buceo 42.49

Tramperos 69.3

Transferasas 33.8

Transferencia de tecnología organizaciones internacionales 20.13

Transportadoras $\quad 65.5,65.15$

T ransportadores de personas Véase Escaleras mecánicas

Transporte

acuático $\quad 68.13$

de madera 68.13

de madera

ferroviario 68.14

de materiales peligrosos $39.29-39.31$

acuerdos internacionales 39.30

bibliografía 39.31

controles 39.31

definición 39.29

información 39.31

plan de empresa 39.30

planes locales y nacionales 39.30

población de riesgo 39.29

tipo de incidentes 39.29

zonas de riesgo 39.29 


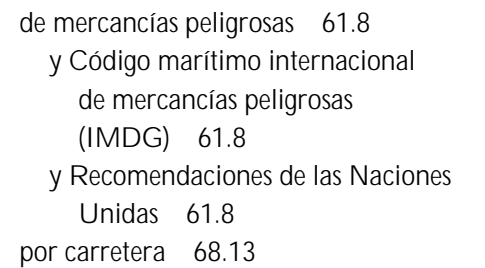

Transporte de cargas 64.32

Transporte de productos agrícolas 64.25

Transporte ferroviario

factores de riesgo $\quad 102.37$

asociadas a la administración y las operaciones ferroviarias 102.37, $102.39 t$

asociados al mantenimiento de las vías y los pasos a nivel 102.41 , 102.42t

asociados al mantenimiento y los accidentes de transporte 102.39, $102.40 \mathrm{t}$

medidas de control de los factores de riesgo $102.43 \mathrm{t}$

Traslado

de riesgos industriales

Véase R iesgos industriales

Trasplante 64.28

Trasquiladores 70.24

T rastorno por estrés postraumático (T EPT)

antecedentes psiquiátricos 5.14

diagnóstico 5.14

en el lugar de trabajo $5.14-5.15$

incidencia 5.15

prevención 5.15

reincorporación al trabajo $\quad 5.17$

seguimiento 5.17

vulnerabilidad $\quad 5.15$

y agresiones en el trabajo 51.6

Véase también T rastornos musculosqueléticos

Trastornos auditivos

inducidos por agentes físicos $\quad 11.8$

oído del soldador 11.9

presión barométrica 11.9

vibración 11.9

inducidos por productos químicos 11.8

asociados al sistema nervioso 11.8

exposición mixta al tolueno y al ruido 11.8

Trastornos del gusto

exposición a la radiación $\quad 11.27$

fármacos y medicamentos 11.26

traumatismo craneal $\quad 11.27$

uso de pesticidas 11.25

y exposición a metales 11.25

fiebre por humos metálicos 11.25

galvanismo oral 11.26

intervenciones dentales 11.26

soldadura en inmersión $\quad 11.26$
Trastornos del sueño

insomnio 34.63

T rastornos gastrointestinales

en los servicios de rescate marítimo 95.20

por exposición al antimonio $\quad 63.4$

y estrés $34.61,34.68$

dispepsia no ulcerosa 34.69

ulcera gástrica y duodenal 34.68

y riesgo de cáncer 72.18

y trabajo nocturno $\quad 43.4$

y trabajo por turnos 43.4

Trastornos mentales

burnout 34.74

relacionados con el uso de drogas y de alcohol 15.86

desintoxicación 15.86

tratamiento 15.86

trastorno esquizoafectivo $\quad 5.6$

Véase Esquizofrenia

trastorno esquizofreniforme $\quad 5.6$

Véase Esquizofrenia

trastorno maníaco-depresivo $\checkmark$ éase T rastorno bipolar

trastorno obsesivo-compulsivo 5.12

trastorno por ansiedad generalizada 5.12

trastornos delirantes Véase Psicosis

trastornos por ansiedad $5.11-5.12$

factores de riesgo 5.12

trastornos psicóticos 5.6

Véase Psicosis

y estrés 25.8, 34.73

alcoholismo 34.73

Areas de R eferencia

Epidemiológica 34.73

depresión 34.73

drogadicción 34.73

enfoques teóricos 34.73

esquizofrenia 34.73

T rastornos musculosqueléticos

clasificación y diagnóstico 6.4

de los talladores de diamantes 29.103

elaboración de alimentos 67.12

en la fabricación de vidrio, cerámica y materiales afines 84.28

factores de riesgo 6.3

intervenciones psicosociales 34.72

sobrecarga mecánica 6.2

y agresiones en el trabajo 51.6

y diseño del puesto de trabajo 29.67

y estrés 34.72

mecanismos conductuales 34.72

mecanismos físicos 34.72

mecanismos perceptivos 34.72

mecanismos psicofisiológicos 34.72

Trastornos nerviosos

asociados a la exposición a

disolventes 96.9 asociados a la fabricación de

cemento 93.52

asociados a los procesos de

confección 87.7

en el síndrome del edificio enfermo $\quad 13.4$

en industrias gráficas 85.4

por golpe de calor 42.10

Trastornos oculares

lesiones por aire comprimido $\quad 11.22$

por cuerpos extraños 11.22

provocados por la radiación $\quad 11.22$

radiación de las pantallas

catódicas 11.23

radiación infrarroja 11.23

radiación ultravioleta 11.22

quemaduras oculares 11.22

sustancias nocivas 11.23

T rastornos olfatorios

agentes ambientales 11.29

efectos sobre el sistema nervioso $\quad 11.32$

pruebas de quimiosensación 11.32

relacionados con el trabajo $\quad 11.29$

tabaquismo 11.32

traumatismos craneales 11.29

Trastornos provocados por el calor 42.8

alteraciones cutáneas $\quad 42.11$

astenia anhidrótica tropical $\quad 42.11$

miliaria 42.11

tratamiento 42.11

poblaciones de riesgo $\quad 42.8$

trastornos sistémicos 42.8

agotamiento por calor 42.8

calambres por calor 42.8

edema por calor $\quad 42.8$

golpe de calor 42.9

síncope por calor $\quad 42.8$

y personas de edad avanzada $\quad 42.9$

Véase también Estrés por calor

Trastornos respiratorios

en el montaje de tarjetas de circuito impreso 83.31

en la fabricación de fibras de vidrio 84.8, 84.10

en la fabricación de

semiconductores $83.18,83.36$

T ratado de libre comercio de América del norte acuerdo laboral incluido en el 21.6

Tratamiento de la información

capacidades y límites de decisión del ser

humano 29.86

compatibilidad estímulo-estímulo (E-E) y respuesta-respuesta (R-R) 29.87

compatibilidad

estímulo-respuesta 29.86

modelos mentales y

compatibilidad 29.86

capacidades y límites perceptivos del ser humano 29.82 
características de los símbolos alfanuméricos 29.84

condiciones distorsionadas 29.83

dimensiones integrales y

separables 29.82

distinción de características 29.82

iconos frente a palabras 29.86

identificación 29.84

juicios absolutos 29.84

lectura de palabras 29.85

límites sensoriales 29.82

envejecimiento cognitivo 29.97

límites de la programación y la ejecución motora 29.87

Tratamiento de los lodos

en tratamiento de aguas residuales 101.20

T ratamiento de sólidos 72.21

T ratamiento de vertidos en la industria del papel 72.11

Trato equitativo y discapacidad $\quad 17.15$

T rauma por movimientos repetitivos en la industria textil 89.33 síndrome del túnel carpiano 89.33

Traumatismos craneales 14.8

datos epidemiológicos 14.8

diagnóstico diferencial $\quad 14.9$

evaluación neuroquirúrgica $\quad 14.10$

lesiones difusas del tejido cerebral 14.9

conmoción 14.9

lesión axonal difusa $\quad 14.9$

lesiones focales del tejido cerebral $\quad 14.9$

contusión 14.9

hematoma 14.9

neurofisiopatología $\quad 14.8$

por descarga eléctrica 40.5

profesiones de riesgo 14.8

síntomas 14.8

T rementina $\quad 72.12$

Tremolita

influencia en el mesotelioma $\quad 10.69$

Trenes de laminación

cadena de procesos $73.1 \mathrm{f0}$

laminación continua en caliente 73.10

laminación en frío 73.10

riesgos 73.11

ácidos 73.12

calor radiante 73.12

equipos de protección personal $\quad 73.12$

gases y vapores 73.12

heridas 73.11

herramientas manuales 73.12

lesiones oculares 73.12

lesiones y quemaduras 73.11

lubricantes industriales 73.12

peligro de incendio 73.12

radiación ionizante 73.13 resbalones y caídas 73.12

ruido 73.12

transporte mecánico 73.12

vibración 73.12

T riangle Shirtwaist, N ueva Y ork incendio 39.45

Triángulo de fuego 68.19

Triboelectrización $\quad 40.6$

T ribunal Popular Permanente para los Peligros de 0 rigen Industrial y los D erechos

H umanos 23.34

T ributil fosfato 102.13

Trichoderma viride 44.24

Trichophyton verrucosum $\quad 69.5,70.14$

T ricloroacético

ácido 33.21

Tricloroetano

riesgos asociados en la industria aeroespacial $\quad 90.15$

Tricloroetileno 33.58 como carcinógeno del grupo 2A por la IARC $\quad 104.253$

Triclorofenol 39.4

Tricloruro fosfórico riesgos 104.384

Tricoderma $\quad 67.10$

Tricomoniasis 96.55

Tricotado mecánico

Véase T ejeduría

riesgos para la seguridad $\quad 89.24$

Trietilaluminio $\quad 61.19$

Trifluralin $\quad 62.15$

Triglicéridos 67.33

Trilladoras

trilladora a pedales 64.31

trilladoras a motor 64.31

Trineos motorizados 42.50

Trinitrotolueno

cataratas y $\quad 104.348$

ciclo menstrual y 104.348

metahemoglobina y 104.348

tracto urinario y 104.348

y anemia aplásica 1.3

y explosiones 41.6

Trióxido de cromo 27.11

Tripanosomiasis americana $\quad 53.29$

Tripulación

formada únicamente por hombres 66.11

Tripulación aérea

alteración de los ritmos circadianos $\quad 102.17$

carga de trabajo de la 102.16

factores 102.16

composición del personal técnico $\quad 102.14$

contaminación por ozono $\quad 102.15$

estrés físico en la 102.14 y calidad del aire $\quad 102.14$

y falta de oxígeno $\quad 102.14$

y trastornos debidos al

movimiento 102.15

exposición a radiaciones $\quad 102.15$

y riesgo de cáncer 102.15

y riesgos en el embarazo $\quad 102.15$

factores de estrés psicológico en la $\quad \mathbf{1 0 2 . 1 7}$

personal de cabina 102.14

tareas 102.14

problemas ergonómicos $\quad 102.16$

de la tripulación técnica $\quad 102.16$

para los auxiliares 102.16

riesgo de accidentes $\quad 102.17$

riesgo de enfermedades infecciosas $\quad 102.18$

Triquinosis 70.16

Triyodotironina 42.51

síndrome polar de la 42.51

Trombocitopenia

en la industria del calzado $\quad 88.10$

por efecto del benceno 1.2

por radiación 48.7

y diagnóstico de fibrosis hepática 4.7

Troncos 71.4

Tronzado 68.5

Trozas

preparación de las 68.11

T sunami 39.24

Tuberculosis

asociación a la silicosis $\quad 10.49$

asociado a los cazadores $\quad 69.5$

en centros escolares 94.4

en la industria marítima $\quad 102.50$

en profesionales sanitarios $\quad 10.100$

en servicios funerarios $\quad 100.15$

entre los trabajadores

sanitarios $97.43,97.50$

medidas específicas de reducción del riesgo $\quad 97.52-97.55$

programas de control de la infección 97.51

vías de transmisión 97.51

exposición del personal auxiliar y de

ambulancias 95.22

riesgo en el sector de la

confección 87.7

$\mathrm{y}$ vacunaciones 94.4

T ubos adsorbentes 30.21

T ubos colorimétricos

calibrados 37.14

en control de calidad del aire $\quad 44.19$

para detección de contaminantes

atmosféricos 30.24

para detección de ozono en

interiores 44.21

Túbulo contorneado

Véase N efrona 


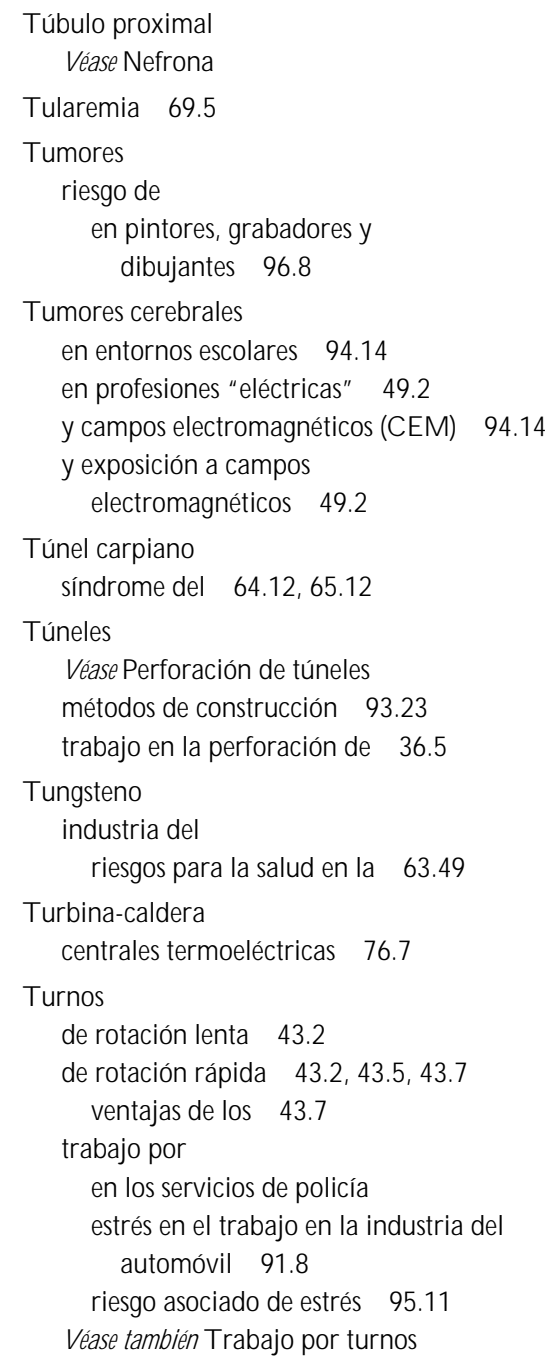

U

U crania 64.12
U ganda
inspección de trabajo 23.13
U Icera por cromo 63.16
U Icera genital 96.55
U Icera péptica
diagnóstico 4.9
duodenal 4.8
factores de riesgo 4.9
gástrica 4.8
incidencia 4.9
prevención 4.9
y trabajo por turnos 43.4
U mbral auditivo
variación permanente del
variación temporal del
Véase también O ído
U mbral de regulación 33.79

Ungueal, distrofia

$\checkmark$ éase Uña

U nidad decipol 45.15

U nidad olf 45.15

U nidades clo 42.27

U nión equipotencial $\quad 40.13$

Unión Europea (UE)

Acta U nica Europea y normalización ergonómica $\quad 29.13$

Acuerdo Europeo sobre el transporte internacional por carretera de sustancias peligrosas 39.31

Agencia Europea para la Salud y la Seguridad en el Lugar de Trabajo 23.37

armonización de la normativa de salud y seguridad 23.38

Carta Social 23.38

Carta Social Europea 21.36 procedimiento de arbitraje 21.36

Comisión Europea 23.37

Comité Consultivo de Seguridad, $\mathrm{H}$ igiene y Protección de la Salud en el

Trabajo 23.37

Comité económico y social 23.38

Directiva 76/ 207/ CEE del Consejo europeo sobre igualdad de trato 9.27 , 24.7

Directiva 76/ 768/ CEE sobre cosméticos 33.51

Directiva 89/ 106/ CEE sobre normas sobre ruido en equipos y maquinaria $\quad 47.8$

Directiva 89/391/ CEE relativa a la aplicación de medidas para promover la mejora de la seguridad y de la salud de los trabajadores 5.4, 16.3, 21.28, 21.37

Directiva 89/392/ CEE sobre normas sobre ruido en equipos y maquinaria 47.8

Directiva 89/655/ CEE sobre las condiciones mínimas de salud y seguridad en el trabajo para el uso de maquinaria por los trabajadores 93.39

Directiva 89/686/ CEE sobre normas sobre ruido en equipos y maquinaria 31.10 , $31.21,47.8$

Directiva 90/270/ CEE sobre PVD 29.15

Directiva 92/ 57/ CEE sobre las condiciones mínimas de salud y seguridad en obras de construcción móviles y provisionales 93.13, 93.39

Directiva 92/ 85/ CEE relativa a la aplicación de medidas para promover la mejora de la salud y la seguridad en el trabajo de la trabajadora embarazada, que haya dado a luz o en período de lactancia 24.8
Directiva 95/ 46/ CE sobre la protección de los individuos contra el procesamiento de datos personales y la libre circulación de dichos datos 19.19

Directiva de baja tensión $\quad 83.18$

Directiva de compatibilidad electromagnética 83.18

Directiva de maquinaria $\quad 83.18,93.39$

Directiva de productos de construcción 93.39

D irectiva relativa a los riesgos de accidentes graves en determinadas actividades industriales 39.14

Directivas sobre estructuras de protección contra vuelco 58.73

Directivas sobre medio ambiente 90.13

Directiva sobre seguridad de las máquinas 50.7

y reducción de las vibraciones $\quad 50.7$

estimación de las tasas de electrocución 40.2

Fundación Europea para la M ejora de las Condiciones de Vida y de

Trabajo 21.23, 23.37

mejora ambiental $\quad 18.20$

generalidades 23.37

instrumentos jurídicos 23.38

decisiones 23.38

dictámenes 23.38

directivas $23.38,23.45$

recomendaciones 23.38

reglamentos 23.38

marco legal en materia de salud mental 5.4

N orma EN -342 - proyecto de norma europea sobre aislamiento térmico de la ropa 42.57

N orma EN 511 - guantes de protección contra el frío 42.47, 42.59

N orma EN 474-1 de la Comunidad Europea 93.40

N orma EN 29241 ergonomía de sistemas con PVD $\quad 52.37$

Parlamento europeo 23.37

procedimiento del humo negro 55.16

para mediciones de la SPM $\quad 55.16$

procedimiento PM -10 para la medición de partículas en suspensión 55.15

propuesta de $D$ irectiva sobre agentes físicos 50.12

y niveles de exposición para vibración mano-brazo 50.12

Tratados 23.37

y acoso sexual 34.32

Véase también Directivas de la UE

U nión Internacional de Q uímica Pura y

Aplicada 104.310 
Union internationale des producteurs et distributeurs d'énergie électrique estimación de las tasas de electrocución 40.2

U nión M undial para la $\mathrm{N}$ aturaleza (UICN) 23.45

U nited States N ational C ancer Institute tasas de mortalidad por cáncer en artistas 96.6

U nited States $\mathrm{N}$ ational Institute for $O$ ccupational Safety and $\mathrm{H}$ ealth efectos de la niebla artificial en espectáculos 96.6

U niversidad de Concepción de Chile L aboratorio de ergonomía 68.24

U niversidad de J ohn $\mathrm{H}$ opkins (JHU) estudios epidemiológicos en el sector de los semiconductores 83.37

U niversidades y medidas de precaución 94.13 y riesgos $94.12 \mathrm{t}$

Uña

distrofia ungueal 12.18

dermatitis de contacto alérgica 12.19

medidas protectoras 12.19

paroniquia 12.18

U ranio

como combustible nuclear 76.8

consecuencias de la exposición al 32.27

Compañía soviética W ismut

(SAG) 32.27

minería del

y riesgo de muerte a largo plazo $\quad 53.25$

U rbanización

repercusiones para la salud $\quad 53.25$

y condiciones de vivienda 53.25

y crecimiento urbano 53.27

y servicios de salud ambiental $\quad 53.26$

y tráfico urbano 53.27

U remia

por cadmio 63.11

U rinario, sistema

Véase $V$ ejiga

U robilinógeno $4.5-4.6$

U rticaria

por alergia al látex 97.63

U ruguay, R onda de

Véase A cuerdo general sobre aranceles aduaneros y comercio

US Bureau of L abor Statistics estadísticas de siniestralidad laboral en la industria del automóvil 91.7

US Bureau of M ines 70.30

U S C otton D ust Standard 10.29

Véase Bisinosis

US Environmental Protection Agency criterio de concentración de

partículas 10.5

US Framingham H eart Study

sobre situación laboral y enfermedades coronarias 99.2

US State of California O ccupational Injury and I llness Prevention Program

y gestión de la salud y la seguridad en la industria textil 89.12

U suario

modelo mental 29.93

participación en el diseño 29.95

U veítis 63.14

V

V acas

V éase $V$ aquerías

deshi 70.33

$\mathrm{V}$ acas locas

enfermedad de las 67.34

$\checkmark$ aciado a la cera perdida etapas del proceso de y riesgos asociados 96.12

Vacuna

contra el sarampión $\quad 15.71$

contra la rubéola 15.71

de difteria-tétanos 15.71

de la gripe 15.71

hepatitis A 15.72

hepatitis B 15.71

inoculación accidental $\quad 70.14$

Vacunación 67.12

Véase Protección y promoción de la salud

de alumnos 94.4

de profesores 94.4

Vacuno 70.22

Véase R umiantes

Vacuolas

por vibraciones mano-brazo $\quad 50.10$

V agones cisterna

normativas sobre 102.58

para GNL y GPL $\quad 102.58$

para transporte de sustancias químicas $102.51,102.58$

seguridad de la carga y descarga

en 102.59

V alidez de los estudios 28.22 - 28.24

V alores límite umbral $\quad 30.18$

Véase también Límites de exposición profesional

$\checkmark$ anadio

absorción 27.13

concentraciones 27.13

excreción 27.13

toxicidad de los compuestos de 63.50
Vapores

medios de muestreo $\quad 30.21$

riesgos de exposición 30.14

y destilación de licores 65.12

Vaquerías

peligros y precauciones 70.21

riesgos ergonómicos 70.21

sustancias químicas 70.21

V aricela

en centros escolares 94.4

en personal sanitario 97.43

y vacunaciones 94.4

$\mathrm{V}$ arices

por vibraciones 50.6

$\mathrm{V}$ aricocele

por vibraciones 50.6

V arilla

de empuje

en trabajo con máquinas

58.24

V arsol 65.12

V asoconstricción periférica $\quad 42.4$

V asodilatación intermitente inducida por el frío $\quad 42.38$

V asodilatación periférica $\quad 42.3$

V ector de Poynting 49.5

$\checkmark$ ectores

enfermedades transmitidas por

y crecimiento urbano 53.27

y dengue 53.27

y fiebre amarilla $\quad 53.27$

y malaria urbana 53.27

principales enfermedades transmitidas por 53.29t

V ehículos agrícolas

accidentes 64.25

materiales fluorescentes 64.26

V ejiga

anatomía y fisiopatología 8.3

cálculos 8.4

función vesical 8.4

sistema neurológico 8.4

infecciones 8.4

lesión vesical 8.4

V éase también Cáncer de vejiga

V elocidad del aire

ecuación 42.17

instrumentos de medida 42.17

Ventilación

aplicación en la tejeduría $\quad 89.24$

aplicada en la extinción de incendios 95.4

de extracción localizada

en el montaje de tarjetas de circuito impreso 83.32

en edificios no industriales 45.14

en el sector de la construcción

en la industria del cemento 93.53 
en instalaciones sanitarias 97.5

en la industria aeroespacial

por dilución 90.12

ventilación aspirante localizada $\quad 90.12$

en la industria del automóvil 91.4

en la industria del calzado 88.8

en la industria naval 92.14

sistemas de circulación y

aspiración 92.10

en minas subterráneas 74.35

en procesos fotográficos 85.15

extracción localizada (VEL) 61.24

tipos de sistemas de 61.24

y control de contaminantes $\quad 61.24$

fugas de gases y disolventes

en la fabricación de

semiconductores 83.33

general 45.11

lista de comprobación 29.23

para control de la calidad del aire $\quad 44.29$

por desplazamiento $45.11,45.13$

por dilución 45.11

por extracción localizada 96.12

en artesanía de la madera $\quad 96.20$

en fundiciones comerciales 96.12

en joyería 96.23

en labores de soldadura $\quad 96.14$

en trabajos de cerámica 96.19

museos y galerías de arte 96.41

reducción de contaminantes en espacios interiores 44.29

sistemas de extracción localizada en la industria de la piel y el cuero $\quad 88.7$

y gasto energético 29.102

y "síndrome del edificio enfermo" $\quad 34.23$

Véase también Sistemas de ventilación

Ventiloconvectores de inducción $\quad 45.7$

V erbalizaciones 29.11

Vermiculita

riesgos para la salud $\quad 62.5$

Vermicultura 70.40

V erruca vulgaris $67.20,70.38$

Vertebral, columna

alteraciones en la

conducción de camiones y $\quad 103.9$

V ertederos

de residuos peligrosos $\quad 53.15,53.17,55.44$

efectos sobre la salud 53.16

y contaminación de las aguas

subterráneas $\quad 53.16-53.17$

Vertido

de aguas industriales 55.33

de aguas residuales 55.30

de residuos peligrosos 41.30

de residuos radiactivos 48.33

Vesical

Véase V ejiga
Viajes

y protección de la salud $\quad 15.74$

botiquín con medicamentos 15.75

consulta médica previa 15.75

contaminación del agua $\quad 15.78$

diarrea del viajero 15.78

en viajes aéreos prolongados $15.77 f$

enfermedades específicas $\quad 15.75$

jet-lag 15.76

mal de altura 15.78

malaria 15.77

picaduras de insectos 15.77

planificación del itinerario $\quad 15.74$

política establecida por escrito 15.74

prevención de los peligros 15.76

seguro de enfermedad 15.76

vacunaciones 15.75

Vías respiratorias

inflamación de las

por antimonio $\quad 63.4$

Vibración

del cuerpo completo 50.2

alteraciones fisiológicas 50.4

efectos adversos sobre el embarazo $\quad 50.6$

efectos cognitivos 50.4

efectos sobre el control manual 50.3

efectos sobre la visión 50.3

exposiciones profesionales a $\quad 50.3$

medición de las 50.7

medidas preventivas $50.8 \mathrm{t}$

reacciones psicológicas 50.4

y alteraciones circulatorias 50.6

y enfermedad de las vibraciones 50.5

y enfermedades de la columna $\quad 50.5$

y movimiento artificial pasivo del cuerpo 50.4

efectos en los tripulantes de aeronaves

militares 95.17

en edificios 50.3

directrices para la evaluación de las 50.3

en el sector de la construcción

en la maquinaria de movimiento de tierras 93.41

por el uso de herramientas mecánicas 93.38

y sus efectos perniciosos 93.10

en la producción de hierro y acero 73.13

en los conductores de camión 103.7

evaluación de la exposición humana a la

vibración de la totalidad del cuerpo

(ISO 263) 23.61

exposición en la industria del

automóvil 91.4

inducida con las motosierras 68.21

lista de comprobación $\quad 29.23$

mano-brazo 50.2

protección contra 31.18

riesgos de los trenes de laminación transmitida a las manos $\quad 50.2$

directrices sobre exposición a $\quad 50.12$

exposición de origen profesional 50.8

factores asociados a lesiones por $50.9 \mathrm{t}$

medición de las 50.13

prevención de lesiones 50.13

trastornos por $50.10-50.11$

valores límite umbral $\quad 50.12 \mathrm{t}$

$y$ "enfermedad de las

vibraciones" 50.11

y fenómeno de R aynaud 50.11

y herramientas a motor 50.8

y síndrome de vibraciones mano-brazo (HAV) 50.9

Vida laboral

condiciones psicosociales $\quad 34.4$

Vidrio

métodos de fabricación 84.5

fabricación de filamento continuo de vidrio $84.9 f$

procesos y materiales $84.6 \mathrm{ff}$

V idrio, cerámica y materiales afines

corte y soldadura 84.26

equipo protector individual 84.22

espacios restringidos 84.22

fuentes de energía peligrosas, control de 84.22

manejo del material $\quad 84.2,84.26$

levantamiento manual $\quad 84.2,84.28$

uso de automatismos 84.3

máquinas, equipo y herramientas de protección 84.22

operaciones de cocción o de fusión 84.2 exposición a energía radiante y

temperaturas muy elevadas 84.2

exposición a radiación infrarroja $\quad 84.2$

exposición a ruidos 84.2

exposiciones a productos de la

combustión 84.2

fuego 0 explosión 84.2

humos y partículas en suspensión en el aire 84.2

riesgos de la energía eléctrica 84.2

protección respiratoria 84.26

reacondicionamientos y actividades de

reconstrucción 84.3

riesgos para la salud y la seguridad $84.23 \mathrm{t}$

biológicos 84.31

caídas 84.26

cáncer de pulmón 84.31

contaminación 84.31

cortes 84.28

exposición a sustancias tóxicas 84.26

exposición al ruido 84.30

exposición al sílice 84.30

incendios 84.26

lesiones de espalda 84.29

quemaduras 49.15

trastornos musculosqueléticos 84.28 
seguridad eléctrica 84.22

superficies de circulación y de

trabajo 84.26

tasas de incidencia de las lesiones y

enfermedades ocupacionales no

mortales $84.29 \mathrm{t}$

vehículos industriales motorizados 84.26

y comunicación de riesgos 84.22

Vigilancia

bloqueos 29.53

clínica 39.21

del medio ambiente

cánones de conducta ética 19.15

del medio ambiente de trabajo 19.13

Código deontológico 19.14

comité TLV 19.13

higienistas del trabajo 19.14

límites de exposición profesional 19.13

normas internacionales de

exposición 19.14

disminución de la 29.52

estímulos "blanco" 29.51

estímulos de fondo 29.51

factores de situación y orgánicos 29.54

lapsus de atención 29.55

medida de rendimiento 29.52

medios para mejorar el rendimiento 29.54

procesos estratégicos 29.52

procesos no estratégicos 29.52

tareas 29.51

teoría de la detección de señales 29.52

teoría de la expectación 29.53

teorías de la atención 29.53

V igilancia de la calidad atmosférica

estaciones de medición 55.19

medidas de control de calidad 55.13

de los equipos 55.13

del procedimiento 55.13

planificación de las mediciones 55.12

en la medición de un área $\quad 55.12$

en la medición de una instalación 55.13

parámetros $55.12 \mathrm{t}$

selección de los puntos de

medición 55.13

procedimientos de medición 55.13

de "contaminantes atmosféricos

orgánicos" 55.17

de fibras contaminantes 55.16

de fibras de amianto $\quad 55.16$

de gases inorgánicos 55.13

de las precipitaciones húmedas 55.16

de partículas en suspensión $\quad 55.14$

de polvo sedimentable 55.16

del hollín 55.16

ópticos de larga distancia $\quad 55.17$

para la vigilancia rutinaria $\quad 55.19$

$\checkmark$ igilancia de los riesgos profesionales

datos 32.9

ejemplos 32.10 en los países en vías de desarrollo 32.11

naturaleza de los efectos sobre la

salud 32.11

generalidades 32.8

objetivos 32.10

uso de los episodios centinela $\quad 32.9$

Véase también $\mathrm{H}$ igiene industrial

Vigilancia electrónica

Véase Supervisión electrónica

Vigilancia médica

programas aplicados al personal de control de sustancias peligrosas 95.24

Vigilancia y notificación de enfermedades profesionales

en China 32.34

en los países en desarrollo $\quad 32.11$

ayuda de los organismos

internacionales 32.13

cruce de datos 32.13

en Singapur 32.12

obligatoriedad de la notificación 32.12

otras fuentes de información 32.12

problemas 32.11

registro de fábricas y procesos de

trabajo 32.12

utilización de los recursos

existentes 32.12

estadísticas de accidentes en

Alemania 32.22

fuentes de datos específicas $\quad 32.3$

altas hospitalarias 32.7

centros de medicina del trabajo 32.6

certificados de defunción 32.6

encuestas nacionales 32.8

encuestas oficiales 32.3

informes de los laboratorios 32.5

informes de los médicos 32.6

informes sobre la indemnización de los

trabajadores 32.5

registros internacionales 32.3

vigilancia a escala de empresa $\quad 32.4$

funciones 32.2

obstáculos 32.2

para la evaluación del medio ambiente de trabajo 30.15

vigilancia de los trabajadores del sector público 32.5

Véase también Clasificación de lesiones y enfermedades profesionales

Véase también Epidemiología

Vigilantes

de museos y galerías de arte riesgos para la salud de los 96.41

VIH/SIDA

en empleados de servicios

funerarios 100.15

en marineros 102.50

en trabajadores de la industria del sexo $\quad 96.55$ política sólida en el lugar de trabajo $\quad \mathbf{1 5 . 6 7}$

probabilidad de transmisión

profesional 97.47

programas educativos en el propio lugar de trabajo 15.68

relación entre el SIDA y el

desarrollo 15.69

respuestas sindicales sobre el 15.68

Sindicato Internacional de Empleados de Servicios 15.68

Sindicato Internacional de $M$ arinos 15.68

riesgo en los servicios de policía $\quad 95.13$

prevención 95.13

procedimiento de actuación de los funcionarios de policía 95.13

transmitido a los trabajadores

sanitarios 97.45

prácticas preventivas según los

CDC 97.46

profilaxis post-exposición $\quad 97.48$

vías de transmisión profesional del 97.47

$\checkmark$ inilo, bromuro de

como carcinógeno del grupo 2A por la

IARC $\quad 104.255$

Vinilo, cloruro de

alteraciones hepáticas 104.255

angiosarcoma 104.254

como carcinógeno del grupo 1 por la

IARC $\quad 104.254$

Vino

conservación 65.13

embotellado 65.14

industria del

azufre en 104.417

Violencia

contra el personal de seguridad $\quad 94.11$

contra las mujeres 24.5

contra los administradores

financieros 94.11

contra los profesores 94.4

definiciones de 51.2

ejercida contra el personal auxiliar y de ambulancias 95.21

en el lugar de trabajo 51.2

acoso sexual y 51.5

actividades delictivas y 51.5

alcance de la 51.3

consecuencias 34.34

consecuencias físicas de la $\quad 51.6$

definición 34.33

efectos psicológicos de la 51.6

en servicios de cara al público 51.5

estilo directivo y 51.5

estrategias de prevención de la 51.7

factores predictivos 34.33

factores psicosociales 34.33

medidas de intervención en casos

de 51.6 
medidas de protección $\quad 96.47$

prevalencia 34.33

programas de asistencia a los empleados

(PAE) 51.8

y abuso de alcohol 51.4

y actuación ante amenazas $\quad 51.7$

$y$ drogas 51.4

y enfermedad mental $\quad 51.4$

y estrés laboral 51.5

y modelo de prevención de delitos

mediante el diseño medioambiental

(CPTED) 51.7

y sistemas de seguridad $\quad 51.8$

en el trabajo sanitario $\quad 97.12$

en inspecciones sanitarias $\quad 103.24$

en la conducción de camiones $\quad 103.9$

en las gasolineras

factores de riesgo de 102.35

en locales nocturnos 96.56

exposición en los servicios

de policía 95.11

psíquica 96.47

sobre directivos y profesionales 99.5

sobre empleados del hogar $\quad 100.18$

sobre empleados en parques y

jardines 96.47

sobre prostitutas 96.56

sobre trabajadores de la hostelería 98.9

sobre trabajadores de oficinas 99.7

sobre trabajadores postales 101.6

sobre trabajadores sanitarios 51.6

sobre trabajadores sociales 97.10

teorías de la causalidad de la 51.4

y "envenenamiento" del lugar de

trabajo 24.5

Viperidae $38.3,38.8$

Virus

y contaminación del aire interior $\quad 44.23$

Virus de Ebola $97.4,97.44,102.50$

Virus de Epstein-Barr

y mononucleosis 1.5

Virus de la hepatitis B (VHB)

en los países africanos y asiáticos 97.4

riesgo de infección por 97.4

para los trabajadores sanitarios 97.4

V irus de la inmunodeficiencia

humana (VIH)

Véase VIH / SIDA

V irus de la pseudoviruela $\quad 70.11$

Vísceras 67.22

$V$ iscosa

Véase R ayón, fabricación de

Visión

Véase 0 jo

campo de fijación 11.12

campo visual 11.12

contraste de brillo 11.17

deslumbramiento $\quad 11.16$ dificultad de

en chóferes 103.14

en conductores de camiones $\quad 103.9$

diplopia 11.18

imágenes residuales 11.16

movimientos oculares 11.19

ilusiones de movimiento $\quad 11.19$

nivel de iluminación $11.17 \mathrm{t}$

requisitos visuales $11.13 \mathrm{t}$

tiempo de presentación del objeto $\quad 11.18$

visión binocular 11.18

visión en color 11.20

anomalías 11.20

visión estereoscópica 11.18

y conducción de vehículos 11.18

$\checkmark$ isitas de estudios 94.4

Vitamina C $\quad 33.19$

Viveros e invernaderos

actividades en los 64.12

poda 64.13

riesgos ergonómicos 64.12

Vivienda

problemas relacionados con la 53.26

y salud $53.25 t$

Voladuras

de avalanchas artificiales $\quad 39.28$

Volquetes

riesgo de vuelco en 58.71

V olumen espiratorio forzado

Véase Bisinosis

Votador 67.33

Vuelco

riesgos de

en maquinaria móvil 58.72

en tractores 64.33

Véase también Estructuras de protección contra vuelcos (EPV)

Vulcanización

Véase N eumáticos

Vulnerabilidad

a catástrofes 39.18

W

Walleriana degeneración walleriana Véase N eurona

Warfarina 27.24

Warr, modelo de Véase Salud mental

Warrick, regla de $29.81,29.86$

W eber, prueba de

Véase 0 ído, pérdida de audición

W egman

evaluación de la exposición $\quad 30.29$
W eil, enfermedad de

agente causante 4.6

en trabajos junto al agua o dentro del agua 70.38

en el sector de la construcción 93.33

Véase también L eptospirosis

Whisky 65.11

White

concepto de competencia (1959) 34.8

W ickens y $Y$ eh

teoría de la disociación

29.50

Williams

personalidad agresiva (1987) 34.12

Wilms, tumor de

Véase Cáncer de riñón

Wilson, enfermedad de 63.15

principios de

Véase T eratología

W ismut

consecuencias de la exposición al

uranio 32.27

datos obtenidos del sistema de salud de

Wismut 32.30

desarrollo histórico 32.27

localización de los antiguos

trabajadores 32.30

servicios de medicina del trabajo $\quad 32.30$

situación actual 32.29

Wittenoom (Australia) 39.20

Wollastonita

riesgos para la salud de la 62.7

W omack, Jones y R oos

producción ajustada 29.59

Woodcock

índice de permeabilidad al vapor de agua de la ropa 42.31

World Wide W eb 22.17

$X$

X enobióticos

exposiciones profesionales a 8.3

marcadores biológicos 8.8

nefrotoxicidad 8.4

resistencia a la exposición 8.10

y glomerulonefritis 8.5

Xileno 70.40

efectos del

en encoladores 103.16

Y

Y acimientos

de petróleo y gas natural 75.2

Y eso

riesgos de los trabajadores del $\quad 62.7$ 
Yodo

glándula tiroides 104.220

cáncer de tiroides 104.220

radiactividad $41.13,104.220$

contaminación de leche por $\quad 48.35$

Yusho (Japón)

desastre ecológico en $\quad 104.297$

\section{Z}

\section{Zanjas}

definición 93.34

medidas de protección $\quad 93.35,93.37$

ataluzado 93.35

determinación de la calidad del

aire 93.37

entibación 93.36

escudos 93.36

frente a caídas de materiales 0

herramientas 93.37

intentos de rescate mal

concebidos 93.37

plan de seguridad y salud $\quad 93.35,93.37$

tipos de terreno y entorno 93.35 unidades mixtas de

entibación-escudo 93.36

riesgos asociados al trabajo en 93.35

anegamientos 93.37

caídas 93.37

derrumbamiento 93.35

falta de oxígeno 93.37

gases $y$ humos letales 93.37

Zebroides 70.30

Zidovudina (ZDV) 97.48

Zinc

fundición y afino

exposición a polvos de mineral $\quad 82.8$

extracción electrolítica 82.7

lixiviación 82.7

materiales y residuos $82.8 \mathrm{t}$

precauciones 82.8

procesado electrolítico 82.7

proceso de concentrado $\quad 82.7$

tostación 82.7

operaciones de recuperación controles técnicos $82.55 \mathrm{t}$

riesgos en metalurgia y producción de 63.51
Zinc- protoporfirina (ZPP)

$\checkmark$ éase Protoporfirina eritrocítica (FEP)

Zohar, modelo de para medición del clima de seguridad 59.10

Zoológicos Véase Parques zoológicos

Zoonosis

asociadas a la caza $\quad 69.4$

asociadas con los caballos 70.31

prevención de las 70.8

riesgo en la industria de la piel y el cuero 88.4

riesgos de

en zoológicos y acuarios 96.45

riesgos en el lugar de trabajo en procesos alimentarios 67.7 vías generales de transmisión $\quad 70.8$

Zurdos

diseño de herramientas 29.67

y herramientas de recolección 64.30 

$f=$ Figura

$\mathrm{t}=\mathrm{T}$ abla

\section{A}

A ceite de esquisto $\quad 33.70$ Aceites minerales 33.70, 33.76

Acetal 104.48t, 104.53t, 104.54t

Acetaldehído oxima $104.82 t$, 104.89t, 104.91t

Acetaldehído $\quad 2.5,33.20,33.70$, $41.13,102.8,104.48 \mathrm{t}, 104.50 \mathrm{t}$, 104.53t, $104.54 \mathrm{t}$

Acetamida 33.70, 104.75t, 104.76t, 104.77t, 104.78t

Acetaminofeno $\quad 33.75$

Acetanilida 33.28

Acetato butílico 81.12

A cetato de amilo 91.6, 104.164t, 104.166t, 104.168t, 104.170t

A cetato de sec-amilo 104.164t, 104.166t, 104.168t, 104.170t

Acetato de bencilo 33.72 , 104.164t, 104.170t

A cetato de butilo 104.164t, 104.166t, 104.168t, 104.170t

A cetato de sec-butilo 104.164t, 104.166t 104.168t, 104.170t

Acetato de butilo 91.6

A cetato de terc-butilo 104.164t, 104.166t, 104.168t, 104.170t

Acetato de calcio $104.164 t$

Acetato de ciclohexilo 104.164t, 104.166t, 104.168t, 104.170t

A cetato de éter etílico de etilenglicol 104.203t, 104.204t, 104.206t, 104.207t

Acetato de éter monobutiletílico de etilenglicol 104.203t

Acetato de éter monobutílico de dietilenglicol 104.203t, 104.207t

Acetato de éter monobutílico de etilenglicol 104.204t, 104.206t, 104.207t
A cetato de éter monoetílico de etilenglicol 104.203t

A cetato de éter monometílico de etilenglicol 104.203t, 104.205t, 104.206t, 104.207t

Acetato de etilo $79.19,80.8$, 104.164t, 104.166t, 104.168t, 104.170t

A cetato de fenilo 104.164t, 104.166t, 104.168t, 104.170t

A cetato de sec-hexilo 104.164t, 104.167t, 104.168t, 104.170t

A cetato de isoamilo $31.29 \mathrm{f}$, 104.164t, 104.167t, 104.168t, 104.170t

A cetato de isobutilo 104.164t, 104.167t, 104.168t, 104.170t

A cetato de isopropilo 104.165t, 104.167t, 104.169t, 104.170t

A cetato de medroxiprogesterona 33.70

A cetato de metilazoximetanol 33.70

A cetato de metilo 104.165t, 104.167t, 104.169t, 104.170t

A cetato de 1-metoxi-2-propilo $104.165 \mathrm{t}$

A cetato de 2-metoxi-1-propilo 104.165t, 104.167t, 104.169t, 104.170t

A cetato de plomo 88.6

A cetato de polivinilo 33.72 , 96.21

Acetato de propilo 104.165t, 104.167t, 104.169t, 104.170t

A cetato de trifeniltina $\quad 8.10$

A cetato de vinilo $33.70,33.72$, 104.165t, 104.169t, 104.170t

A cetato de yodo $\quad 33.35$

Acetato etílico $\quad 44.10$

Acetato potásico 104.165t, 104.167t, 104.169t, 104.170t

Acetato sódico $104.165 t$, 104.167t, 104.169t, 104.170t

Acetazolamida 37.8 - 37.10, 37.14

2-Acetilaminofluoreno $104.75 t$, 104.76t, 104.78t
Acetilaminofluoreno 33.32

n-A cetil-beta- $d$-glucosaminidasa 8.3

Acetilbromuro 104.328t, 104.331t, 104.333t, 104.335t

n-A cetilcaprolactama $104.229 t$

n-A cetilcisteína 10.83

Acetilcloruro 104.328t, 104.333t

Acetilcolina 33.32

Acetileno 36.9, 41.18, 49.11, 57.15-57.16, 75.6, 78.10, 81.6, 82.28, 82.45, 92.7, 96.14, 102.69

A cetoacetato de etilo 104.165t, 104.167t, 104.169t, 104.170t

A cetoacetato de metilo 104.165t, 104.170t

Acetofenona 104.328t, 104.335t

o-A cetoluidina $104.114 \mathrm{t}$

Acetona 9.6f, 11.32, 27.13,

$30.26,31.18,33.7,33.15$,

44.10f, 67.10, 79.19, 86.2,

$89.17,92.9$ - 96.10, 96.24,

$96.39,100.7,104.328 \mathrm{t}$,

104.331t, 104.333t, 104.335t

Acetonitrilo 23.35f, 95.7, 104.141t, 104.144t, 104.146t, $104.148 \mathrm{t}$

o-A cetotoluidina $104.101 \mathrm{t}$

6-A cetoxy-2,4,-dimetil-M -dioxano $49.8 f$

Acido abiético $83.6 f$

Acido acético 48.42, 64.41, $72.20,75.10,80.8,85.10$ $85.11,85.15,89.15,96.11$, 101.19, 104.20t, 104.24t, $104.26 \mathrm{t}$

A cido acetilsalicílico 104.20t, 104.24t, 104.27t

A cido acrílico $3.72,104.16 t$, 104.20t, 104.24t, 104.27t

A cido adenosintrifosfórico $\quad 62.16$

A cido adipico $20.23,89.16$, 104.16t, 104.20t, 104.24t, $104.27 \mathrm{t}$

Acido alquilcarbámico $\quad 62.12$ p-Acido aminobenzoico 33.72
Acido 11-aminoundecanoico 33.72

Acido antranílico $\quad 33.72$

Acido araquidónico 33.25, 33.55

Acido arilcarbámico $\quad 62.12$ Acido arsénico $\quad 96.13$

A cido l-ascórbico 104.16t, 104.20t, 104.24t, 104.27t

A cido ascórbico 1.6, 15.51, 65.13

Acido benzoico 104.16t, 104.20t, 104.24t, 104.27t

Acido bórico, sal disódica 104.132t, 104.135t

Acido bórico $100.7,104.8 t$, 104.10t

Acido bromhídrico $\quad 96.14$

A cido p-terc-butilbenzoico 104.16t, 104.27t

A cido butírico 104.16t, 104.24t, 104.27t

Acido cacodílico $\quad 27.10$

A cido cafeico 33.70

A cido n-caproico 104.16t, 104.20t, 104.24t, 104.27t

Acido carbámico $\quad 62.12$

Acido carbólico 97.63

A cido carbónico $\quad 82.12,104.10 t$

A cido carbónico, sal cálcica 104.61t, 104.63t, 104.66t, 104.68t

A cido cianhídrico $\quad 4.4,7.21$, $31.17,82.3,82.12$ - 82.13, $82.47,96.12$ - $96.13,96.22$

Acido cítrico hidrato 104.21t, 104.24t, 104.27t

Acido cítrico $33.12,33.19$, 54.36, 64.41, 67.32, 104.16t, 104.21t, 104.24t, 104.27t

Acido cloréndico 33.70, 104.16t, 104.27t

Acido clorhídrico 4.9, 30.31, $33.72,41.15,55.4,64.41$, $72.11,73.10,73.14,75.10$, $75.13,78.10,78.19,78.22$, $78.25,81.6,81.12,81.16,82.9$, $82.44,82.61$ - 82.62, 88.5, 
$89.19,95.7,96.19,100.13$, 104.8t, 104.9t, 104.10t

A cido clórico, sal cálcica 104.63t, 104.66t

A cido cloroacético 104.16t, 104.21t, 104.24t, 104.28t

Acido m-clorobenzoico 104.16t, $104.28 \mathrm{t}$

Acido 0-clorobenzoico $\quad 104.16 \mathrm{t}$, $104.28 \mathrm{t}$

Acido p-clorobenzoico 104.16t, $104.28 \mathrm{t}$

Acido 2-cloropropiónico 104.16t, 104.28t

Acido clorosulfúrico 104.8t, 104.9t, 104.10t

Acido 4-cloro-o-toloxiacético $104.16 \mathrm{t}$

Acido crómico $\quad 12.4,81.6$, $82.19,82.44,82.46,82.62$ $88.9,91.4,91.9$

Acido crotónico 104.16t, 104.21t, 104.24t, 104.28t

Acido delta-aminolevulínico 27.12, $33.16-33.17$

A cido 2, 4-diclorfenoxiacético $104.16 \mathrm{t}$

Acido dicloroacético 33.72, 104.17t, 104.21t, 104.24t, $104.28 \mathrm{t}$

Acido 2, 4-diclorofenoxi propiónico $104.28 \mathrm{t}$

Acido 2, 4-diclorofenoxiacético 25.27, 104.21t, 104.25t, 104.28t

Acido 3, 6-dicloropicolinico 104.229t, 104.232t, 104.234t, $104.235 \mathrm{t}$

Acido 3-(2, 2'-dicloro-vinil)-2, 2'-dimetil-ciclopropano carboxílico 27.23

Acido 2, 3-difosfoglicérico $\quad 1.7$

Acido ditiocarbámico $\quad 62.12$

Acido domoico $\quad 7.9,66.20$

Acido edético 104.124t, 104.126t, 104.127t, 104.128t

A cido cis-9, 10-epoxiesteárico 33.72

Acido estérico $104.17 t, 104.21 \mathrm{t}$, $104.25 \mathrm{t}, 104.28 \mathrm{t}$

Acido etanodioico, dihidrato 104.21t, 104.25t, 104.28t

Acido etilén-diamino tetracético 72.9

Acido 2-etilhexanoico $\quad 104.21 \mathrm{t}$

Acido 2-etilhexoico $104.17 \mathrm{t}$ 104.25t, 104.28t

Acido fenoxiacético $\quad 1.5,62.19$

Acido fluorhídrico $\quad 20.23,31.17$, $39.33,62.4,75.10,75.14,78.16$
- 78.17, 78.30 - 78.32, 81.12, $82.44,82.47,82.61,96.13$, $100.13,102.13,102.58$

Acido fluoroacético 104.17t, 104.21t, 104.25t, 104.28t

Acido fluorosulfúrico $\quad 104.8 \mathrm{t}$, 104.9t, 104.10t

Acido fórmico $\quad 64.41,64.53$, $75.10,88.5,104.17 \mathrm{t}, 104.22 \mathrm{t}$, $104.25 \mathrm{t}, 104.28 \mathrm{t}$

A cido fosfórico $\quad 20.23,54.36$, $62.2,62.9,62.11,64.41,64.62$, $67.10,67.27,70.21,78.16$, $82.18,82.44,82.62,104.8 \mathrm{t}$, 104.9t, 104.10t

A cido ftálico $104.17 t, 104.22 \mathrm{t}$, $104.25 \mathrm{t}, 104.28 \mathrm{t}$

A cido fumárico $\quad 104.17 t, 104.29 t$

A cido gálico $104.17 t, 104.29 t$

A cido glicólico 33.33, 104.17t, $104.29 \mathrm{t}$

Acido d-glucárico $\quad 27.3$

Acido glucurónico 4.2, 33.8, 33.19

A cido glutámico $\quad 33.12,64.41$

A cido glutamínico 33.12

Acido heptanoico $104.17 \mathrm{t}$, $104.29 \mathrm{t}$

Acido hialurónico $\quad 6.7,6.8 f$

Acido hidrazoico 104.124t, 104.128t

Acido hidrofluobórico $\quad 104.9 t$, 104.8t, 104.10t

Acido hidroluórico $73.16 f$

Acido 4-hidroxi fenoxi benzoico 27.23

Acido hipúrico $\quad 27.14$

Acido isobutírico 104.17t, 104.25t, 104.29t

Acido isocianico, nitroiminodietilendi- $104.322 \mathrm{t}$

Acido isocianurico 104.141t, 104.147t, 104.148t

Acido isoftálico 92.16, 104.17t, $104.29 \mathrm{t}$

A cido láctico $\quad 33.12,67.32,88.5$, 104.22t, 104.25t, 104.29t

Acido laurico $\quad 104.18 \mathrm{t}, 104.29 \mathrm{t}$

Acido maleico 104.18t, 104.22t, 104.25t, 104.29t

Acido malónico $\quad 104.18 \mathrm{t}$ $104.29 \mathrm{t}$

Acido mandélico $\quad 7.24,30.23$, $104.18 \mathrm{t}$

Acido mercaptoacético $\quad 104.413 t$

Acido mercaptúrico $\quad 27.24$

Acido metacrílico 104.18t, 104.22t, 104.25t, 104.29t
Acido metacrílico, 2-dimetilaminoetilo $104.29 \mathrm{t}$

A cido 2-metil-4-clorofenoacético 104.22t, 104.29t

Acido 2-metil-4-clorofenoxiacético $104.25 \mathrm{t}$

Acido metilfenoxiacético $\quad 27.25$

Acido metilhipúrico $\quad 27.5$

Acido monometilarsónico $\quad 27.10$

Acido nafténico $\quad 78.8$

Acido nítrico $39.30,41.13$ 55.14, 62.9 - 67.10, 73.17, 78.5, $81.12,82.44,82.56,82.58$, $82.62,89.15,96.13,96.22$, 104.8t, 104.9t, 104.10t

Acido nitrilotriacético 33,70 , 104.342t, 104.344t

Acido nitroso 78.5

$\mathrm{N}$-Acido nitrosofólico 33.72

Acido nonanoico 104.18t, 104.29t

Acido 9-octadecenoico $\quad 104.18 \mathrm{t}$

Acido oleico $104.30 \mathrm{t}$

Acido oxálico 33.33, 64.41, 88.6, 96.21, 104.18t, 104.22t, 104.25t, 104.30t

Acido palmítico 104.18t, 104.22t, 104.25t, 104.30t

Acido paraaminobenzoico $\quad 49.8 f$

Acido paraaminosalicílico $\quad 4.8$

Acido parasórbico 33.72

Acido penićlico 33.72

Acido perclórico $41.13,104.8 t$, 104.10t, 104.11t

A cido perclórico, sal potasica 104.61t, 104.63t, 104.66t, $104.69 \mathrm{t}$

Acido perclórico, sal sódica 104.61t

Acido pícrico 4.4, 41.14 - 94.15, 104.349t, 104.353t, 104.356t, $104.358 \mathrm{t}$

Acido pirogálico 96.14, 104.374t, 104.377t, 104.378t

Acido piválico $104.18 \mathrm{t}, 104.30 \mathrm{t}$

Acido plicático 64.44

Acido poliacrílico $\quad 33.72,89.19$

Acido propiónico 104.18t, 104.22t, 104.25t, 104.30t

Acido prúsico 82.47

Acido quillaico $\quad 64.44$

Acido sacárico 64.41

Acido salicílico $104.18 \mathrm{t}, 104.22 \mathrm{t}$ 104.26t, 104.30t

Acido selénico $\quad 4.2$

Acido shikímico 33.72

Acido silícico $\quad 64.54,104.8 \mathrm{t}$, 104.11t
Acido silícico, sal disódica 104.401t, 104.402t, 104.403t, $104.404 \mathrm{t}$

Acido succínico 104.19t, 104.30t

A cido sulfámico 104.8t, 104.9t, 104.10t, 104.11t

Acido sulfanílico 104.19t, 104.23t, 104.26t, 104.30t

Acido sulfhídrico 4.4, 7.11, $64.62,70.9,70.13-70.15$, $70.18,70.26,70.29,75.3,75.12$ - $75.14,75.16,78.5$ - 78.8, $78.10,78.13-78.16,78.18$, 78.20 - 78.24, $78.26-78.27$, 78.32 - $78.33,82.4,89.3,96.13$, $102.55,102.57,102.64,102.67$, 102.70

A cido sulfúrico $\quad 2.8,4.2,4.11$ $10.31,10.92,11.32,20.23$, $41.10,41.13,45.9,54.34$, $54.36,55.4,55.14,55.23$, $55.53,62.9,64.62,67.10$, $67.14,72.12,73.10,73.14$, $73.17,74.23,78.5,78.16$ $78.17,78.24$ - 78.25, 78.30, $78.32,81.2$ - 81.4, 81.8 - 81.9, $81.12,82.2$ - 82.5, 82.7 - 82.8, $82.43-82.44,82.52,82.60$, $82.62,88.3,88.5,89.16,89.18$ $89.19,91.4,91.9,96.14,96.22$, $96.46,102.36,104.8 \mathrm{t}, 104.9 \mathrm{t}$, 104.10t, 104.11t

Acido sulfuroso $\quad 72.8$

Acido tánico $\quad 33.72,88.2,89.19$, 96.8

Acido tartárico $\quad 65.13,104.19 t$, 104.30t

Acido tereftálico $\quad 89.16,104.19 t$, 104.23t, 104.26t, 104.30t

A cido tetracético $\quad 85.13$

Acido tioacético 104.409t, 104.411t, 104.413t, 104.415t

Acido tioglicólico 104.409t, $104.415 \mathrm{t}$

Acido 2-tiotiazolidina-4-carboxílico 27.23

Acido p-toluensulfónico 104.19t, 104.23t, 104.25t, 104.30t

Acido tricloroacético 33.21, 33.72, 104.19t, 104.30t

A cido triclorofenoxiacético $104.19 \mathrm{t}$

Acido 2, 4, 5-triclorofenoxiacético $27.25,62.14-62.15,104.23 \mathrm{t}$ $104.26 \mathrm{t}, 104.30 \mathrm{t}$

Acido tricloroisocianúrico 104.124t, 104.127t, 104.128t

A cido trifluoroacético 104.19t, 104.26t, 104.30t 
Acido úrico 6.35

Acido valérico 104.19t, 104.23t, $104.31 \mathrm{t}$

Acridina 49.8f, 104.229t $104.235 \mathrm{t}$

Acrilamida 7.4, 7.12 - 7.13, 20.23, 33.70, 104.75t, 104.77t, $104.78 \mathrm{t}$

Acrilato de butilo 104.173t, 104.174t, 104.175t

Acrilato de n-butilo 33.72

Acrilato de decilo 104.173t, 104.175t

Acrilato de 2-etilhexilo 33.72

Acrilato de etilo 33.70, 104.173t, 104.174t, 104.175t

Acrilato de metilo 33.72, 104.173t, 104.174t, 104.175t

Acrilonitrilo 33.70, 10.92, $39.15,44.31,91.6$ - 95.7, 102.49, 104.141t, 104.144t, 104.147t, 104.148t

Acroleína $33.72,10.12,33.19$, $44.7,67.33,82.16,82.20$, $96.12,101.26,102.8104 .48 \mathrm{t}$, 104.50t, 104.53t, 104.54t

\section{Actina $6.3 \mathrm{f}$}

Actinomicina D 33.72

Adenina $33.37 f$

Adenosin difosfato $\quad 33.10$

Adenosin trifosfatasa $\quad 33.10$

Adenosin trifosfato 33.10

Adipato de di(2-etilhexilo) $\quad 33.72$

Adiponitrilo 104.141t, 104.147t, 104.148t

Adriamicina $\quad 33.70$

Afolato 33.72

Albúmina 64.41

Alcohol alílico $\quad 62.15,104.35 t$, 104.38t, 104.40t, 104.42t

Alcohol bencílico 85.15 , 104.35t, 104.38t, 104.40t, $104.42 \mathrm{t}$

Alcohol terc-butílico 104.35t, 104.38t, 104.41t, 104.42t

Alcohol butílico 104.35t, 104.38t, 104.42t

Alcohol n-butílico 86.14

Alcohol sec-butílico 104.35t, 104.38t, 104.41t, 104.42t

Alcohol 2-etilbutílico 104.35t, $104.42 \mathrm{t}$

Alcohol etílico 33.15, 64.41, $67.4,70.40,85.9$

Alcohol furfurílico 82.17 $82.18,82.21,104.156 \mathrm{t}$ 104.158t, 104.159t, 104.160t

Alcohol isoamílico 104.35t, 104.38t, 104.41t, 104.42t
Alcohol sec-isoamílico $\quad 104.38 \mathrm{t}$

Alcohol isobutílico 104.35t, 104.38t, 104.41t, 104.43t

Alcohol isodecílico 104.35t, 104.38t, 104.41t, 104.43t

Alcohol isooctílico 104.35 t 104.38t, 104.41t, 104.43t

Alcohol isopropílico 70.40 , $82.16,85.5,85.13,100.16$, 104.35t, 104.38t, 104.41t, $104.43 \mathrm{t}$

Alcohol metílico $\quad 7.20,91.6$

Alcohol olélico 104.35t, 104.43t

Alcohol terc-pentílico 104.35t, 104.43t

Alcohol polivinílico 33.73, $89.19,92.16$

Alcohol propargílico 104.36t, 104.39t, 104.41t, 104.43t

Alcohol sec-isoamílico $\quad 104.43 t$

Alcohol tetrahidrofurfurílico 104.36t, 104.39t, 104.41t, $104.43 \mathrm{t}$

Aldehído acético $\quad 23.41$

Aldehído cinámico 67.9, 104.48t, 104.54t

Aldicarb $33.41,33.73$

Aldrina $\quad 27.24,33.59 f, 33.73$, $44.8,55.48$ - 55.49, 62.10, 71.8

Alfacloralosa 62.12

Alfa-tocoferol $\quad 15.51$

Alginato de amonio $\quad 82.43$

Alilamina 104.82t, 104.86t, 104.89t, 104.91t

Alizarina $\quad 89.28$

Alopurinol $\quad 10.83$

Alquil mercurio $\quad 27.13$

Alquil plomo $\quad 27.8,27.12$

Alquitrán de hulla $33.70,10.91$, 92.9

Alúmina $\quad 10.76,45.10,62.3$, $82.8-82.9$

Aluminato sódico $\quad 82.43,82.60$

Aluminio $4.11,5.19,7.26,8.13$, $10.19,10.32,10.46,10.52$, $10.55,10.76-10.77,10.91$, $12.8,12.13,12.16,12.19$, $15.59,27.5,27.8,32.10,33.13$, $33.21,33.70,40.13$ - 41.14, $41.29,44.12,44.26,48.14 f$, $49.15,49.31,55.41,62.3$, $64.12,65.3,65.14,65.16,67.5$, $67.23,73.18,81.8,81.10$ $81.12,82.2,82.4,82.6,82.8$ $82.13,82.16,82.19,82.23$, $82.29,82.36,82.38$ - 82.39, $82.42,82.44$ - 82.45, 82.47 $82.48,82.50,82.54,82.57$, 82.60 - 82.62, 85.4, 89.2, 90.9,
91.4, 92.2, 92.6 - 92.9, 96.12, $96.18,101.21,102.2,102.41$, 102.58 - $102.59,102.63$

Amaranto 33.73

Americio $241 \quad 48.15$

Amianto 1.4, 2.2, 2.4, 2.16,

8.11, 10.36, 10.82, 10.91,

15.42f, 16.4, 16.40, 16.43,

16.47 - 16.48, 18.18, 20.21,

$20.29,23.45,30.18,31.27$ -

$32.28,32.28 f, 32.30,33.69$,

$33.78,44.5,44.28$ - 44.29,

44.31, 53.3 - 55.4, 55.48, 72.16,

75.13, 78.32, 80.10, 82.21,

94.4, 94.14, 97.56, 102.7,

$102.13,102.32,102.36$ -

$102.37,102.50,102.67-102.68$

Amida sódica $\quad 104.75 t, 104.78 t$

Amileno $\quad 78.16$

A milmetiléter terciario $\quad 78.5$

5-Aminoacenafteno $\quad 33.73$

2-Aminoantraquinona 33.73, $104.114 \mathrm{t}$

p-Aminoazobenceno $\quad 33.70$

Aminoazotolueno 104.124t, $104.128 \mathrm{t}$

o-A minoazotolueno $\quad 33.70$

4-A minobifenilo $\quad 8.13,44.12$, 44.14

$\gamma$-Aminobutirolactam $\quad 7.12$

4-Aminodifenilo 33.69, 104.101t, 104.107t, 104.111t, 104.115t

2-A mino-3, 4-dimetilimidazo[4,5-f]quinolina 33.71

2-Amino-3, 8-dimetilimidazo[4,5-f]quinoxalina 33.71

3-A mino-1, 4-dimetil-5H -pirido[4,3-b]indol 33.72

2-Aminodipirido[1, 2-a:3',2'-d]imidazol 33.71 Aminoetanolamina $\quad 12.16$

3-Amino-9-etilcarbazol 104.124t, 104.128t

A minoetiletanolamina $\quad 12.19$

$\mathrm{N}$-A minoetilpiperazina 104.229t, 104.234t, 104.235t

Aminofenol terciario 12.4

o-Aminofenol 104.101t, 104.107t, 104.111t, 104.115t p-Aminofenol 8.5, 104.101t, 104.111t, 104.115t

1-Amino-2-metilantraquinona 33.73, 104.101t, 104.114t

2-Amino-6-metildipirido[1,2-a:3',2'-d]imidazol 33.71

2-Amino-1-metil-6-fenilimidazo[4,5-b]piridina 33.72
2-Amino-3-metilimidazo[4,5-f]quinolina $\quad 33.70$

1-A mino-2-metil-5-nitrobenceno 104.349t, 104.356t, 104.358t

2-Amino-3-metil-9H -pirido[2,3-b]indol $\quad 33.71$

3-A mino-1-metil-5H -pirido[4,3-b]indol 33.72

4-Amino-2-nitrofenol 33.73, 104.349t, 104.358t

2-Amino-4-nitrofenol 33.73

2-Amino-5-nitrofenol 33.73

2-Amino-5-(5-nitro-2-furil)-1, 3, 4-tiadiazol $\quad 33.70$

2-Amino-5-nitrotiazol 33.73

2-Aminopiridina 104.229t, 104.232t, 104.234t, 104.236t

2-A mino-9H -pirido[2,3-b]indol 33.70

1-Amino-2-propanol 104.86t

3-Amino-1,2,4-triazol 104.124t

Amitrol 33.71

Amoníaco 10.14, 10.19 - 10.20, $10,82,11.27,11.32,30.31$, $39.4,39.15,44.8,44.13,53.4$, $53.19,55.4,55.14,55.33$, $55.35,55.42,57.15$ - 57.16, $57.18,62.8$ - 62.9, 64.61 64-62, 65.4, 65.6, 65.11, 65.13, 65.15 - 65.17, 66.17, 67.7, $67.10,67.14,67.19,67.27$, $70.5,70.9,70.13-70.14,70.18$, $70.20,70.26,70.29,70.31$, $70.38,72.8$ - 73.9, 73.15, $73.16 f, 73.17$ - 73.18, 78.5 $78.6,78.8,78.10,78.13$ - 78.15, $78.17,78.22,78.24-78.26$, $78.33,80.3,81.12$ - 81.13, $82.17,82.44-82.45,82.55$, 85.9 - 85.10, 85.15, 86.2, 88.11, $89.16,89.19,89.20,89.29$, $95.23,96.11,98.4,98.7,99.16$, $100.7,101.20,104.61 \mathrm{t}, 104.63 \mathrm{t}$, 104.66t, 104.69t

A monio didecildimetílico $\quad 71.6$ Amonio 41.10, 55.37, 78.24,

$79.16,82.51,88.6$

Ampicilina 33.73

A naranjado de acridina $\quad 33.73$

Anfetamina 29.54

Angelicina 33.73

Anhidrido acético 104.19t, 104.23t, 104.26t, 104.31t

Anhídrido amónico 64.40, 64.73

Anhídrido carbónico $\quad 7.11,7.20$ - 7.21, 37.3

Anhidrido del ácido trimelítico 104.19t 
Anhídrido ftálico 92.16, 104.19t, 104.23t, 104.26t, $104.31 \mathrm{t}$

Anhídrido maleico 104.19t, 104.23t, 104.26t, 104.31t

Anhídrido propiónico 104.20t, 104.23t, 104.26t, 104.31t Anhídrido succínico $\quad 33.73$ Anhídrido sulfúrico $\quad 64.41$ Anhídrido trimelítico 33.42, 104.23t, 104.26t, 104.31t

Anilina 1.6, 1.8, 12.21, 16.63, $33.28,33.73,53.20,88.5,88.7$, $89.14,89.19,89.28,104.101 t$, 104.107t, 104.111t, 104.115t

o-A nisidina 104.101t, 104.107t, 104.112t, 104.115t

p-Anisidina 33.73, 104.101t, 104.108t, 104.112t, 104.115t Anisol 104.184t, 104.186t, $104.187 \mathrm{t}$

Antantreno 33.73

Anti-12-hidroxi-endrín $\quad 27.24$

Antimoniato sódico $\quad 82.43$

Antimonio cálcico 81.4

Antimonio $3.16,4.4,4.7,11.25$, 27.8, 33.12, 53.31, 81.4, 82.6 $82.7,82.19,82.43,82.52$ $82.54,82.61,91.6,96.22$

Antraceno 12.3, 12.8, 33.73, 49.8f, 104.311t, 104.312t, 104.313t, 104.314t, 104.315t, 104.316t, 104.317t

Antralinato de cinamilo $\quad 33.73$

Antraquinona $\quad 49.8 f, 101.20$

Antu 104.409t, 104.413t

Aramita 33.71

Argón $41 \quad 48.38$

Argón $\quad 41.25,46.6,49.18$, 55.17, $74.36,75.3,81.11,81.13$, $82.25,82.30,92.7,100.12$

Arsenamina $1.7,30.26,82.3$, $82.12,82.52$

Arseniato de cobre $\quad 96.20$

Arsénico $74 \quad 48.13$

Arsénico 1.3, 1.7, 2.2 - 2.4, 2.19, 3.16 - 3.17, 4.2, $4.4-4.5$, 4.7, 5.6, 7.20, 8.11, 10.7, 10.19, $10.91,11.8,12.8$ - 12.9, 12.18, 15.42f, 16.33f, 27.4, 27.8, 27.10, 32.5, 32.28, 32.30, 33.6, $33.12,33.15,33.19,33.69$, 33.78, 44.12, 44.31, 48.13f, 53.3, 53.16, 53.21, 53.31, 55.5, 55.16, 55.36, 55.41, 74.60, $76.7,81.4,81.9,82.3$ - 82.7, $82.12,82.52,88.9,92.15,96.8$, $96.13,96.43,100.16$

Arsenito sódico $\quad 64.53$
Arseniuro cálcico $\quad 81.4$

Arseniuro de galio 27.10

Arsina $\quad 4.7,81.4,96.13$

Aspartamo $\quad 65.4$

Aspirina $\quad 33.23$

Ata 33.15

Atrazina 2.7, 27.24, 27,24f, $33.71,62.13$

Auramina $8.13,33.70-33.71$, 104.101t, 104.115t

Aurotioglucosa 33.73

Azacitidina $\quad 33.70$

Azaconazol 71.6

Azaserina 33.71, 104.124t, $104.128 \mathrm{t}$

Azatioprina $\quad 10.91,12.14,33.69$

Azida sódica 104.124t, 104.126t, 104.127t, 104.128t

Aziridil benzoquinona 33.73

Aziridina $\quad 33.73$

2-(1-Aziridinil)etanol 33.73

Azobenceno 33.73, 104.124t, $104.128 \mathrm{t}$

1,1'-Azobis(formamida) 104.124t, 104.126t, 104.127t, $104.128 \mathrm{t}$

Azufre $23.41,41.10,44.9$, 54.12, 55.6 - 55.7, 62.15, 64.46, $64.66,70.19,72.8,72.14$, $72.16,72.19$ - 72.20, 73.4, 73.9, $73.14,73.17,74.28,74.45$, $74.47,74.49,74.52,74.59,75.2$ - 75.3, 75.12, 78.3 - 78.7, 78.9 $78.10,78.15-78.17,78.21$ $78.25,81.4,82.2,82.5-82.6$, $82.19,82.38$ - 82.39, 82.61, $88.4,89.19,91.4,102.42$, 102.65, 104.422t, 104.424t, $104.426 \mathrm{t}$

Azul de metileno $1.6-1.7,12.4$, $49.8 \mathrm{f}$

Azul evans $\quad 33.73$

\section{B}

Bal $\quad 33.14-33.15$

Barban 62.14

Bario 33.6, 33.13, 53.31, 55.41, 81.13, 82.46, 96.18

Base de michler 104.101t, 104.115t

Benceno 1.2 - 1.4, 1.6, 1.9, 2.2 $2.5,2.8,2.16-3.17,4.2,4.4$, $8.11,9.27,11.32,16.33 f, 16.39$, $16.63,16.65,20.9,20.29$, $20.31,23.24,23.55,27.5$, 27.18, 30.24, 30.31, 31.17, 32.34, 33.10, 33.19, 33.41, $33.69,44.7,44.10,44.10 f$,
$44.12,44.28,44.31,53.16$, $53.20,55.5,55.13,55.19$ $55.21,67.10,67.34,73.15$, 73.17, 75.13, 78.4, 78.6, 78.10, 78.12 - $78.15,78.17$ - 78.20 , $78.22,78.25,78.32,79.18$ $79.19,80.10,80.15$ - 81.16, 87.4, 87.7 - 88.10, 89.17, 89.19, $95.6,96.8,97.32,100.10$ $100.12,102.35,102.49,102.55$, 102.57, 102.67, 104.287t, 104.289t, 104.291t, 104.293t

Bencenosulfonil cloruro 104.409t, 104.413t

Bencidina 2.4, 4.10, 8.5, 8.13, $30.16,33.33,33.69$ - 33.70, 72.16, 88.6, 88.9, 104.101t, 104.108t, 104.112t, 104.115t

Benomil 64.44

Benzo[a]acridina 33.73

Benzo[c]acridina 33.73

Benzo[a]antraceno $33.70,55.5$, 104.314t, 104.315t, 104.317t

Benzalcloruro 104.302t, 104.304t, 104.306t, 104.307t

Benzaldehído 44.10f, 104.48t, 104.50t, 104.54t

Benzo[c]fenantreno $\quad 33.73$

Benzofenona 104.328t, 104.331t, 104.333t, 104.335t

Benzo[b]fluoranteno 33.71, 104.314t, 104.315t, 104.316t, $104.317 \mathrm{t}$

Benzo[k]fluoranteno 33.71, 104.314t, 104.315t, 104.316t, $104.317 \mathrm{t}$

Benzo[j]fluoranteno 33.71

Benzo[ghi]fluoranteno 33.73, 104.314t, 104.315t, 104.316t, $104.317 \mathrm{t}$

Benzo[a]fluoreno $\quad 33.73$

Benzo[b]fluoreno 33.73

Benzo[c]fluoreno 33.73

Benzo[ghi]perileno 33.73, 55.5, 104.314t, 104.315t, 104.316t, $104.317 \mathrm{t}$

Benzo[a]pireno 33.70, 44.7, 53.16, 55.5, 55.50, 85.9, 104.314t, 104.315t, 104.316t

Benzo[e]pireno 33.73

Benzoato de bencilo dietilénico 104.181t

Benzoato de bencilo 104.177t, 104.181t

Benzoato de butilo $\quad 104.177 \mathrm{t}$ Benzoato de etilo 104.177t Benzoato de metilo $104.177 \mathrm{t}$, 104.181t
Benzofenona 49.8f, 104.325t, 104.328t, 104.330t, 104.332t

Benzoguanamina 104.229t, 104.234t, 104.236t

Benzonitrilo 95.7, 104.141t, 104.144t, 104.147t, 104.149t

Benzopireno $10.57,12.8$

p-Benzoquinona dioxima 33.73

p-Benzoquinona 104.328t, 104.331t, 104.333t, 104.335t

Benzotiacil-2-ciclohexilsulfenamida $104.75 \mathrm{t}, 104.78 \mathrm{t}$

1,2, 3-Benzotriazol 104.229t, 104.236t

Benzotricloruro 33.72, 104.307t Benzotrifluoruro 104.196t, 104.198t

Berilato sódico $\quad 10.31$

Berilio $7 \quad 48.17$

Berilio 3.16, 10.31, - 10.35, 10.32f, 10.91, 12.4, 27.8, 27.10, 33.12 - 33.13, 33.42, 33.69, $48.15,55.5,55.16,81.8,81.10$ $81.11,81.13,82.13,82.30$, $82.47,102.13$

Beta-caroteno $15.39,15.50$ 15.51

Betanal $\quad 62.12$

Bicarbonato amónico 104.61t, $104.69 \mathrm{t}$

Bicarbonato sódico 78.23, 102.33, 104.61t, 104.69t

Bicicloheptadieno $104.280 \mathrm{t}$

Bicloruro de mercurio 97.63

Bicromato sódico 89.29

Bifenilo policlorado (aroclor 1242) 104.302t, 104.308t

Bifenilo policlorado (aroclor 1254) 104.302t, 104.304t, 104.306t, $104.308 \mathrm{t}$

Bifenilos polibromados 4.10 , $9.8,9.14,9.21$ - 30, 23, 33.41, $33.70,33.72,39.5,44.22,53.9$, $53.15,66.20,81.16$, $96.8,104.302 \mathrm{t}$

Biglucano $\quad 6.7$

Biscloroetil nitrosourea 33.70

Bis(2-cloroetil)éter $\quad 33.73$

Bis(2-cloroetil)-2-naftilamina 33.69

Bis(b-cloroetil)sulfuro $\quad 10.92$

Bis(4-clorofenil)-1,1,1-tricloroetano 9.21

Bis(clorometil)éter 33.69, 104.188t, 104.189t

Bis(2-cloro-1-metiletil)éter 33.73 1,2-Bis(clorometoxi)etano 33.73

1,4-Bis(clorometoximetil)benceno 33.73 
Bis(2-dimetilaminoetil)éter $104.83 \mathrm{t}$

Bis(2, 3-epoxiciclopentil)éter 33.73

Bisfenol A diglicidil éter 33.73

Bis(2-hidroxietil)ditiocarbamato de potasio 33.73

1,3-Bis(hidroximetil)urea $104.84 \mathrm{t}$

Bismuto 4.4, 33.14, 48.16, $48.16 f$, , 53.31, 82.7, 96.22

Bisulfato sódico $44.22,72.7$, 96.22

Bisulfito de magnesio $\quad 72.8$

Bisulfito sódico 72.8, 89.19, 104.422t, 104.426t

Bisulfuro amónico 78.14 $78.15,78.22$

Bisulfuro de carbono 55.4 $55.5,89.15$ - 89.16, 89.19, 89.33

Bitartrato potásico $\quad 65.13-65.14$

Bleomicinas 33.71

Borato de zinc 12.16

Borato sódico 82.43

Bórax 71.6

Boro 64.66, 76.8, 89.2, 104.132t, 104.135t

Borohidruro de sodio $\quad 104.134 t$

Brodifacoum 27.24

Bromato cálcico 104.61t, 104.69t

Bromato de potasio 33.71, 104.61t, 104.66t, 104.69t Bromato sódico 104.61t, 104.66t, 104.69t

Bromhidrato de hioscina $\quad 50.16$

Bromo 4.4, 30.31, 33.13, 41.13, $46.5,53.17,64.64,78.12$, 96.14, 104.220t, 104.221t, 104.223t, 104.225t

m-Bromoanilina $104.101 \mathrm{t}$

Bromobenceno 104.302t, 104.306t, 104.308t

1-Bromobutano $104.257 \mathrm{t}$, 104.266t

Bromocloroacetonitrilo 33.73

1-Bromo-2-cloroetano 104.257t, 104.266t

Bromodiclorometano 33.71

Bromoetano $33.73,65.15$

Bromoformo 33.73, 104.257t, 104.260t, 104.264t, 104.266t

Bromometano 7.21, 12.4

1-Bromo-2-propanona 104.328t, 104.335t

Bromotrifluorometano 104.193t, 104.195t, 104.196t, $104.198 \mathrm{t}$
Bromuro cianogeno 104.141t, 104.144t, 104.147t, 104.149t

Bromuro de alilo 104.269t, 104.272t, 104.273t

Bromuro de etilo 104.257t, 104.260t, 104.266t

Bromuro de azufre $104.426 \mathrm{t}$

Bromuro de bencilo 104.302t, 104.306t, 104.308t

Bromuro de hidrógeno 81.11 $81.12,104.220 t, 104.223 \mathrm{t}$

Bromuro de metilo 33.73, $53.28,54.13,62.15,67.10$, 104.257t, 104.260t, 104.264t, $104.266 \mathrm{t}$

Bromuro de

propargilo 104.269t, 104.272t, 104.273t

Bromuro de vinilo 33.70 , 104.269t, 104.272t, 104.273t

Bromuro metílico 81.11

Bromuro potásico 104.61t, 104.69t

Butadieno $1.4,4.10,78.6,80.9$ $80.10,80.16,85.6,91.6,102.49$

1,2-Butadieno $\quad 78.10$

1,3-Butadieno $\quad 2.5,33.70,78.10$ 80.9 - 80.10, 80.16, 104.277t, 104.278t, 104.279t, 104.280t

Butano $41.24,57.15,67.8,75.3$ - 75.4, 75.6, 78.5, 78.18, 78.25, 102.68 - 102.69, 102.71, 104.243t, 104.244t, 104.246t, $104.247 \mathrm{t}$

n-Butano 78.18

1,3-Butanodiamina 104.82t, 104.91t

1,2-Butanodiol 104.211t

1,3-Butanodiol 104.211t, 104.212t, 104.213t

1,4-Butanodiol 89.16, 104.211t, 104.212t, 104.213t

Butanol 44.8

2-Buteno 104.277t, 104.278t, 104.279t

cis-2-Buteno 104.278t, 104.279t, 104.280t

n-Buteno $\quad 104.279 t$

trans-2-Buteno 104.278t, 104.279t, 104.280t

Butil alcohol 104.41t

N-Butil mercaptano 104.409t, 104.412t, 104.413t, 104.415t

$\mathrm{N}$-Butilacetato 44.8

Butilaldehído $\quad 102.8,104.48 t$ 104.51t, 104.53t, 104.54t

Butilamina 104.82t, 104.86t, 104.89t, 104.91t

$\mathrm{N}$-Butilamina 85.11
sec-Butilamina 104.82t, 104.86t, 104.89t, 104.91t

Butileno 78.16

p-terc-Butilfenol 104.371t, 104.378t

Butilhidroxitolueno $\quad 33.73$

Butilomercaptano 11.32

4-terc-Butilpirocatecol 104.371t, 104.378t

p-terc-Butiltolueno 104.287t, 104.289t, 104.291t, 104.293t

Butinol de polivinilo 82.46

Butirato de butilo $104.177 \mathrm{t}$, 104.182t

$\beta$-Butirolactona $\quad 104.177 \mathrm{t}$ $\gamma$-Butirolactona 33.73

Butironitrilo 104.141t, 104.147t, 104.149t

2-Butoxietanol $44.10 f$

Butoxipiperonilo 33.73

C

Cadmio $\quad 2.2,3.16$ - 3.17, 4.2, 4.4 - 8.5, 8.11, 9.11, 10.7, $10.14,10.19,10.82,10.91$, 11.25, 11.31 - 11.32, 16,33f, $16.63,20.4,20.23,27.3-27.6$, 27.8, $27.10-27.11,30.11,32.5$, $32.33,33.12$ - 33.14, 33.16, 33.18 - $33.21,33.28,33.46$ $33.47,33.69,53.3,53.9,53.16$, $53.20,55.5,55.16,55.20$, $55.41,55.51 f, 73.7,73.17$ $73.18,74.41,74.43,76.2,76.8$ $81.4,81.6$ - 81.8, 81.10 - 81.12, 81.16, 82.3 - 82.4, 82.7, 82.13, $82.19,82.30,82.43,82.46$, $82.48,82.54,82.58$ - 82.60, $82.62,82.64,86.6,91.4,96.8$, 96.13 - $96.15,96.18$ - 96.19 , $96.22,96.24,96.58,102.41$

Ca-EDTA $\quad 33.14-33.15$

Cafeína 29.54, 33.73, 34.63, $42.13,42.51-42.52,65.8$

Calcio 5.19, 6.3, 6.7, 6.9, 6.21, 6.35, 15.38 - 15.39, 15.59, $15.78,33.6,33.11,33.13$ $33.14,33.35,33.53,39.43$, 41.14, 53.31, 53.33, 55.37, $55.41-64.42,64.66,72.19$. 72.20, 74.31, 78.27, 81.4, 82.7, $82.39,82.46,82.63,102.21$ 102.22, 104.61t, 104.66t, $104.69 \mathrm{t}$

Canfeno clorado 104.302t, 104.305t, 104.306t, 104.308t

Cantaridina 33.73

Caprolactam 7.12
Caprolactama 33.76

Captafol 2.6, 33.70, 64.44

Captán $\quad 33.73,64.44$

Carbamato de metilo $\quad 33.73$

Carbamato de propilo $\quad 33.73$

Carbaril 62.12

Carbarilo 33.73

Carbatión 62.12

Carbazol $\quad 33.73$

3-C arbetoxipsoraleno $\quad 33.73$

Carbine 64.44

Carbofurano $104.177 \mathrm{t}, 104.181 \mathrm{t}$

Carbonato cálcico 62.4 - 62.6, $64.61,72.8,80.18,85.8$, 104.61t, 104.69t

Carbonato de amonio $\quad 82.51$

Carbonato de bario 82.43, 82.45

Carbonato de cadmio $\quad 100.17$

Carbonato de dietilo 104.177t, 104.181t

Carbonato de dimetilo 20.23, 104.177t, 104.181t

Carbonato de litio $\quad 8.5,104.61 \mathrm{t}$, 104.63t, 104.66t, 104.69t

Carbonato de magnesio 62.5, 82.43

Carbonato de plomo $\quad 82.46$

Carbonato potásico 104.61 t, $104.69 \mathrm{t}$

Carbonato sódico $72.8,72.20$, $78.23,82.17,82.24,82.43$ $82.45,82.55,88.6,89.19$, $104.61 \mathrm{t}, 104.66 \mathrm{t}, 104.69 \mathrm{t}$

Carbonilo de níquel 81.7

Carbono $14 \quad 48.8,48.17,48.29$

Carbono 81.2, 81.6, 81.11, $81.17,82.6,82.38,82.45$, $82.50,89.2,101.20,102.58$ 102.59

Carboxilato de 3,4-epoxi-6-metilciclohexilmetil-3,4-epoxi-6-metilciclohexano 33.73

Carburo cálcico 10.91, 12.4, 82.28, 104.61t, 104.63t, 104.66t, $104.70 \mathrm{t}$

Carburo de hierro 82.45

Carburo de silicio 10.87, 82.35

Carburo de silicona $104.401 \mathrm{t}$ $104.404 t$

Carburo de tantalio $\quad 10.74$

Carburo de titanio 10.74

Carburo de tungsteno 10.73, 90.3

Carmoisina $\quad 33.73$

Carragenina $33.72-33.73$

Catecol 33.73, 104.371t, 104.374t, 104.377t, 104.379t

Catecolbutilo terciario $\quad 12.4$ 
Cerio $10.78,82.13,91.3$

C esio $134 \quad 39.43$

C esio 137 39.32, 39.33, 39.34f 39,36f, 39.43, 48.7 - 48.8, $48.17,48.35,48.37,48.42$

Cesio $\quad 33.12-33.13$

Cetena 104.328t, 104.331t, 104.334t, 104.336t

Cetil mercaptano 104.414t, 104.415t

Cetona de michler 104.101t, $104.115 t$

Cfc $53.11,53.27-53.28,53.31$

Cianamida cálcica 104.141t, 104.147t, 104.149t

Cianamida 104.141t, 104.144t, 104.147t, 104.149t

Cianato potásico $\quad 62.14$ 104.141t, 104.149t

Cianogeno 104.141t, 104.147t, $104.149 t$

Cianuro 11.25, 53.10, 82.4, $96.22,97.57,104.141 \mathrm{t}$

Cianuro cálcico 82.63, 104.141t, 104.145t, 104.147t, $104.149 t$

Cianuro de bario 82.63

Cianuro de hidrógeno 10.14, $10.17,30.24,30.31,41.13$, $41.15,44.7,44.13,73.9,95.6$, $97.32,100.13,104.142 \mathrm{t}$, 104.145t, 104.147t, 104.149t

Cianuro de oro $\quad 82.12$

Cianuro de potasio 33.33 , 33.35, 82.11 - 82.12, 104.142t, 104.145t, 104.147t, 104.149t

Cianuro de yodo 104.142t, 104.145t, 104.147t, 104.150t

Cianuro sódico $74.23,82.12$, $82.45,104.142 t, 104.145 \mathrm{t}$, 104.147t, 104.150t

Cicasina 33.71

Ciclamato de sodio $\quad 33.73$

Cicloato 62.14

Cicloclorotina 33.73

Ciclofosfamida 2.10, 33.41, $33.69,104.75 \mathrm{t}, 104.77 \mathrm{t}, 104.78 \mathrm{t}$

1,3-Ciclohexadieno 104.279t

Ciclohexadienor $104.278 \mathrm{t}$

Ciclohexano 44.10f, 80.8, $80.12,104.243 t, 104.244 t$, 104.246t, 104.247t

Ciclohexanol 104.36t, 104.39t, 104.43t

Ciclohexanona 33.73, 104.328t, 104.331t, 104.334t, 104.336t

Ciclohexeno 104.277t, 104.278t, 104.279t, 104.280t
Ciclohexil isocianato 104.322t, 104.323t, 104.324t, 104.325t

Ciclohexilamina 104.82t, 104.86t, 104.92t

Ciclohexil mercaptano 104.412t, 104.414t, 104.415t

Ciclohexil-1-mercaptano 104.409t

Cicloheximida $\quad 104.75 t, 104.78 t$

Ciclopentadieno 104.277t, 104.278t, 104.279t, 104.280t

Ciclopentano 104.243t, 104.245t, 104.246t, 104.247t

Ciclopenta de pireno 33.73

Ciclopentanona 104.328t, 104.331t, 104.334t, 104.336t

Ciclopropano 97.60, 104.243t, $104.246 \mathrm{t}, 104.247 \mathrm{t}$

Ciclosporina 33.69

Ciclotrimetilentrinitramina $\quad 41.6$

Cilohexilamina $104.89 \mathrm{t}$

p-Cimeno 104.287t, 104.289t, 104.291t, 104.293t

Cimetidina 33.73

Cinaricina $\quad 50.16$

Cipermetrina 27.23

Circonio 12.4, 41.14, 41.30, $62.4,76.8,76.11$ - 81.12, 81.14, $82.43,82.61$

Cisplatino $\quad 2.7,8.5,33.70$

Citrato de clomifeno $\quad 33.73$

Citrinina $\quad 33.73$

Clofibrato 33.73

Cloral 33.73, 104.53t, 104.54t

Clorambucil 33.69

Cloranfenicol $1.2-1.3,2.7$, 33.70, 70.6

Cloranil 62.16

Cloranilo $\quad 62.15$

Clorato cálcico 104.61t, 104.66t, 104.70t

Clorato potásico $\quad 89.14,96.58$, 104.61t, 104.64t, 104.67t, $104.70 \mathrm{t}$

Clorato sódico $72.11,72.15$, 104.61t, 104.70t

Clordano 9.21 - 9.22, 9.24, $33.59 f, 33.71,44.8,55.48$ 55.50

Clordecona $\quad 9.8,9.21$

Clordecone 33.71

Clordimeformo $\quad 33.73$

Clorhidrato de anilina 104.102t, 104.108t, 104.112t, 104.115t

o-Clorhidrato de anisidina 104.102t

Clorhidrato de 0-anisidina 104.112t
Clorhidrato de dimetilamina 104.82t, 104.92t

Clorhidrato de $\mathrm{p}$-fenilendiamina 104.102t, 104.108t

Clorhidrato de fenilhidracina 104.124t, 104.127t, 104.128t

Clorhidrato de hidracina 104.124t, 104.129t

Clorhidrato de hidroxilamina 104.116t

Clorhidrato de meclocina $\quad 50.16$

Clorhidrato de metilhidracina 104.124t, 104.127t

Clorhidrato de procarbazina 33.70

Clorhidrato de prometacina 50.16

Clorito de sodio $\quad 33.73,104.61 t$, 104.67t, 104.70t

Clornafacina 33.69

Cloro 9.20, 10.7, 10.14, 10.82 $10.83,12.10,15.23,14.42 f$, $20.21,20.23,30.21,30.24$, $30.31,33.13,33.51,39.4,39.15$ - 39.16, 39.30, 41.13, 42.6, 49.31, 53.15, 53.17, 54.13, 55.41 - 55.42, 55.50, 55.52, 57.15 - 57.16, 64.48, 65.6, $65.16-65.17,67.10,67.19$, $67.23,67.27,72.8,72.11$ $72.12,72.15,72.18,72.20$, $78.7,78.12,78.17$ - 78.18, $78.32,80.9,80.18,81.4,81.8$, 81.10 - 81.11, 82.19, 82.38, $82.50,82.59-82.60,82.63$, $88.3,89.14,89.19,95.7$ - 96.8, $96.19,96.35,100.13,101.12$ $101.13,102.50,104.220 t$, 104.222t, 104.223t, 104.225t

Cloroacetaldehído 104.48t, 104.53t, 104.54t

2-Cloroacetamida 104.75t, 104.77t, 104.78t

Cloroacetato de etilo 104.165t, 104.169t, 104.171t

Cloroacetilcloruro $104.336 \mathrm{t}$

2-Cloroacetofenona 104.328t, 104.331t, 104.334t, 104.336t

Cloroacetonitrilo 33.73, 104.142t, 104.145t, 104.147t, 104.150t

m-Cloroanilina 104.102t, 104.108t, 104.112t, 104.116t o-Cloroanilina 104.102t, 104.108t, 104.112t, 104.116t p-Cloroanilina $33.71,104.102 t$, 104.108t, 104.112t, 104.116t p-Clorobenceno $\quad 7.12$
Clorobencilato $33.73,104.302 t$, 104.306t, 104.308t

0-Clorobenciliden malononitrilo 104.142t, 104.145t, 104.150t

o-Clorobenzaldehído 104.48t, 104.51t, 104.53t, 104.54t

Clorobromometano 104.257t, 104.260t, 104.264t, 104.266t

1-Cloro-3-bromopropano $104.257 \mathrm{t}, 104.264 \mathrm{t}$, 104.266t

1-Clorobutano $104.257 \mathrm{t}$, 104.264t, 104.266t

2-Cloro-1,3-butadieno 104.269t, 104.272t, 104.273t

p-Cloro-m-cresol 104.371t, 104.377t, 104.379t

Clorocromato potásico $\quad 96.12$

Clorodibromometano 33.73

Clorodifenilos 12.4

1-Cloro-1,1-difluoretano 104.193t

1,1,1-C lorodifluoretano 104.196t, 104.198t

Clorodifluorobromometano 104.193t, 104.195t, 104.197t, 104.198t

Clorodifluorometano 33.73, 104.193t, 104.195t, 104.197t, $104.198 \mathrm{t}$

1-Cloro-2,4-dinitrobenceno 104.349t, 104.353t, 104.356t, $104.358 \mathrm{t}$

0-Cloroestireno 104.293t

Cloroetano 33.73

2-Cloroetanol 104.36t, 104.39t, 104.41t, 104.43t

1-(2-Cloroetil)-3-ciclohexil-1-nitrosourea $\quad 33.70$

1-(2-Cloroetil)-3-(4-metilciclohexil)-1-nitrosourea 33.69

Clorofenato $71.5,71.11$

4-Cloro-o-fenilendiamina 33.71 , 104.102t, 104.116t

4-Cloro-m-fenilendiamina 33.73

Clorofenol 2.7, 4.10, 71.8,

71.11 - 71.12, 88.3, 88.5

2-Clorofenol 104.377t, 104.379t

3-Clorofenol 104.377t, 104.379t

4-Clorofenol 104.377t, 104.379t

m-Clorofenol 104.371t

o-Clorofenol 104.371t

p-Clorofenol 104.371t, 104.374t

Clorofenoles 33.71

Clorofluorofosfato de calcio 81.12

C lorofluorofosfato de estroncio 81.12 
Clorofluorometano 33.73, 104.193t, 104.199t

Cloroformiato de bencilo 104.302t, 104.306t, 104.308t

Cloroformiato de decilo $104.177 \mathrm{t}$

Cloroformiato de etilo 104.177t, 104.180t, 104.181t, 104.182t

Cloroformiato de fenilo 104.177t

Cloroformiato de isopropilo $104.257 \mathrm{t}, 104.260 \mathrm{t}$, 104.264t, 104.266t

Cloroformiato de metilo 104.178t, 104.180t, 104.181t, 104.182

Cloroformiato estearílico $104.177 \mathrm{t}$

Cloroformiato laurílico $\quad$ 104.178t

Cloroformiato miristílico 104.178t

Cloroformo de metilo 54.13, 54.36

Cloroformo 3.17, 4.7 - 4.8 $4.10,8.5,33.27,33.32,33.71$, 44.10f, 53.16, 72.19, 79.8, $79.19,96.18,97.60,102.49$, $104.257 \mathrm{t}, 104.260 \mathrm{t}, 104.264 \mathrm{t}$, 104.266

2-Cloro-n-hidroximetilacetamida $104.75 \mathrm{t}$

Clorometano $\quad 65.15$

4-Clorometilbifenilo 104.302t, 104.308

Clorometilmetileter $\quad 33.69$, 104.189t

2-Cloro-2-metilpropano $104.257 \mathrm{t}, 104.260 \mathrm{t}$, $104.266 \mathrm{t}$

1-Cloro-2-metilpropeno 33.71

1-Cloro-2-metil-1-propeno 104.269t, 104.273t

3-Cloro-2-metilpropeno 33.73, 104.269t, 104.272t, 104.273t

Cloronaftaleno 71.8

1-Cloronaftaleno 104.302t, $104.308 \mathrm{t}$

Cloronaftalenos 12.4

Cloroneb $\quad 62.15$

1-Cloro-2-nitrobenceno 104.349t, 104.353t, 104.356t

1-Cloro-3-nitrobenceno 104.349t, 104.356t, 104.358t

1-Cloro-4-nitrobenceno 104.349t, 104.353t, 104.356t 104.358

2-Cloro-3-nitrobenceno 104.358t
2-Cloro-4-nitroanilina 104.102t, 104.112t, 104.116t

Cloronitrobencenos 33.73

1-Cloro-1-nitroetano 104.342t, 104.344t

Cloronitrofenol $\quad 62.18$

1-Cloro-1-nitropropano 104.342t, 104.344t

2-Cloro-2-nitropropano 104.340t, 104.343t

Cloropentafluoretano 104.193t, 104.195t, 104.197t, 104.199t

Cloropicrina 62.15, 104.342t, 104.344t

Cloropreno $\quad 33.73,80.18$

2-Cloropropano 104.257t, 104.264t, 104.266t

3-Cloro-1,2-propanodiol $104.211 t$

1-Cloro-2-propanona 104.328t, 104.331t, 104.334t, 104.336t

Cloropropham 33.73

Cloroquina $\quad 15.73,15.77,33.73$

Clorotalonilo $33.73,64.44$ o-Clorotolueno 104.302t, 104.306t, 104.308t

4-Cloro-o-toluidina $\quad 104.102 \mathrm{t}$

5-Cloro-o-toluidina 104.102t, 104.112t, 104.116t, 104.306t

p-Cloro-o-toluidina 33.70

Clorotrifenilos 12.4

Clorotrifluoretano 104.199t

Clorotrifluoretileno 104.193t, 104.199t

2-C loro-1,1,1-trifluoroetano 33.73

Clorotrifluorometano 104.193t, 104.195t, 104.197t, 104.199t

Cloroxurón $\quad 62.14$

Clorozotocina 33.70

Clorprofarm $\quad 62.14$

Clorpromazina $\quad 4.8$

Clortolurón 62.14

Cloruro amónico de zinc $\quad 82.44$

Cloruro amónico 78.18, 88.3, 88.6, 104.61t, 104.64t, 104.67t, $104.70 \mathrm{t}$

Cloruro cálcico $\quad 12.5,67.26$ $82.56,104.61 \mathrm{t}, 104.70 \mathrm{t}$

Cloruro cianógeno $104.142 \mathrm{t}$, 104.146t, 104.150t

Cloruro cianúrico $104.125 \mathrm{t}$ 104.127t, 104.129t

Cloruro cloroacético 104.328t

Cloruro de acriflavina $\quad 33.73$

Cloruro de alilo 33.73, 104.269t, 104.271t, 104.272t, $104.273 \mathrm{t}$
Cloruro de aluminio $\quad 20.23$, $78.16,78.18$

Cloruro de amonio didecildimetílico 71.6

Cloruro de amonio $\quad 78.8,78.10$ $81.6,82.55,96.36$

Cloruro de azufre 104.220t, 104.222t, 104.223t, 104.225t

Cloruro de bario $\quad 82.19$

Cloruro de benceno 104.302t 104.305t, 104.306t, 104.308t

Cloruro de bencilo 33.72, 104.302t, 104.305t, 104.306t, $104.308 \mathrm{t}$

Cloruro de benzal $\quad 33.72$

Cloruro de benzatonio 104.303t, 104.305t, 104.306t, $104.308 \mathrm{t}$

Cloruro de benzoilo 33.73 , 104.303t, 104.307t, 104.308t

Cloruro de berilio $\quad 10.31$

Cloruro de butirilo $104.31 \mathrm{t}$

Cloruro de cesio $137 \quad 48.41$

Cloruro de cianógeno 104.148t

Cloruro de dietilcarbamoilo 104.75t, 104.78t

Cloruro de dimetilcarbamoilo 33.70, 104.75t, 104.77t, 104.78

3,5-C loruro de dinitrobenzoilo 104.349t, 104.358t

Cloruro de (2,3-epoxipropil)trimetilamonio $104.156 \mathrm{t}$

Cloruro de estaño 96.18

Cloruro de etilo $104.257 \mathrm{t}$, 104.260t, 104.264t, 104.266t

Cloruro de fósforo $104.386 t$

Cloruro de hidrógeno 30.31 $78.8,78.10,78.18$ - 78.19 81.10 - 81.11, 82.4, 82.44 $82.55,82.59,95.6,96.23$, 101.26

Cloruro de hierro 96.22

Cloruro de isobutilo $104.257 \mathrm{t}$, 104.260t, 104.266t

Cloruro de litio 104.61t 104.64t, 104.67t, 104.70t

Cloruro de mercurio $\quad 4.4,7.12$, $11.32,33.35,88.3,96.44$

Cloruro de metileno $4.10,7.13$, $30.19 f, 30.23,33.71,65.7$ $79.8,79.19,82.64,91.6,96.2$ $96.8,96.21,96.39,102.13$, 104.258t, 104.261t, 104.264t, $104.267 \mathrm{t}$

Cloruro de metilo $\quad 4.7,16.33 f$, $33.73,54.13,66.17,67.7$, 92.17, 104.258t, 104.261t, 104.264t, 104.267t
Cloruro de nitrógeno $104.220 \mathrm{t}$, $104.225 \mathrm{t}$

Cloruro de plata 85.13

Cloruro de polivinilo $\quad 4.7,10.44$ $12.4,12.18,16.68,30.22,31.19$ - 31.20, 32.3, 33.73, 41.14, $64.12,67.10,81.4,82.30$ $82.46,95.7,96.10,96.23$, $97.67,101.24,101.26$

Cloruro de pralidoxima 33.32

Cloruro de propargilo 104.269t, $104.273 t$

Cloruro de tereftaloilo 104.303t, 104.305t, 104.308t

Cloruro de tetrametilamonio 104.61t, 104.70t

Cloruro de tionilo $\quad 81.5,81.16$

Cloruro de vinilideno 33.73 , 104.269t, 104.271t, 104.272t, $104.273 t$

Cloruro de vinilo $\quad 1.6,2.2,2.8$, $2.16,2.18,3.3,4.7$ - 4.8, 4.10, 16.4, 16.33f, 20.21, 27.18, 32.3, $33.27,33.42,33.69,33.78$, $41.13,53.16,53.20,55.48$, $102.50,104.269 t, 104.271 \mathrm{t}$, $104.272 \mathrm{t}, 104.273 \mathrm{t}$

Cloruro de zinc 4.4, 10.7, $10.19,11.26,81.6,81.8,82.55$, $82.59,88.3,96.36$

Cloruro férrico $\quad 101.18$

Cloruro potásico 82.56

Cloruro sódico 42.5 - 42.7, $42.13,67.26,82.56,82.58$, $88.3,104.61 \mathrm{t}, 104.70 \mathrm{t}$

Cloruro sulfurilo 104.422t, 104.424t, 104.426t

Cloruro tionilo 104.422t, 104.425t, 104.426t

Cloruro vinílico 10.92

Cobalto $3.16-3.17,4.2,10.19$, 10.73 - 10.76, 10.92, 11.26 27.8, 27.11, 33.11, 33.14, $33,71,39.35,55.16,55.41$, $71.8,78.5,81.8,81.12,82.2$ $82.3,82.43,82.48,82.59$ $82.60,82.64,90.3,90.9$ - 90.10 , $91.5,96.22,96.24,100.3$

Cobalto $58 \quad 48.37$

Cobalto 60 39.34, 48.13, 48.13f, 48.37

Cobre 1.7, 4.4, 4.11, 10.20

$10.32,11.25,11.32,33.12$ 33.14 - $33.15,33.20$ - 33.21 , $41.11,53.20,54.36,55.4-55.5$, $55.36,55.41,62.15,64.64$, $64.66,65.14,70.17,71.6$, $73.18,74.16,74.21,74.23$, $74.28,79.5,81.8-81.11,81.17$ 
$82.2,82.4$ - 82.7, 82.11 - 82.12, $82.19,82.30$ - 82.31, 82.38 -

$82.39,82.45,82.48,82.50$ -

$82.52,82.54,82.57$ - 82.58, 82.60, 82.62, 85.4, 88.7, 91.4,

$92.6,92.13,96.12,96.14$,

$96.22,101.20,102.2,102.69$

Cocaína 5.7, 9.9, 15.82, 53.33,

64.76

Codeína 64.76

Colchicina $\quad 8.5,104.75 t, 104.79 t$

Colesterol 33.73

Colina 33.9

Compuestos orgánicos de

mercurio 27.13

Compuestos orgánicos nitroge-

nados 4.4

Congestina 38.5

Copolímeros de acrilonitrilo-butadieno-estireno 33.73

Copolímeros de cloruro de vinilideno-cloruro de vinilo $\quad 33.73$

Copolímeros de cloruro de viniloacetato de vinilo 33.73

Copolímeros de estireno-acrilonitrilo 33.73

Copolímeros de estireno-butadieno 33.73

Coroneno $33.73,55.5$

Creosota $12.8,64.44$

$\mathrm{m}$-C residina $\quad 33.73$

p-Cresidina 33.71, 104.102t,

104.112t, 104.116t

0-C resol-4, 6-dinitroacetato $104.165 \mathrm{t}$

m-Cresol 104.371t, 104.374t, $104.377 \mathrm{t}, 104.379 \mathrm{t}$

0-C resol 104.371t, 104.374t, 104.377t, 104.379t

p-Cresol 104.371t, 104.374t, 104.377t, 104.379t

C resol, todos los isómeros 104.371t, 104.374t, 104.377t, $104.379 t$

Criptón $85 \quad 48.38,81.13$

Criptón $\quad 46.6,48.26$

Crisacina 33.71

Criseno 33.73, 104.314t, $104.317 \mathrm{t}$

Crisoidina 33.73

Cromato de plomo 85.4, 96.21, 102.36

Cromato 91.7

Cromo 2.2, 2.12, 4.4, 8.3, 8.5, $8.11,10.19,10.91,11.25$ $11.26,12.2,12.7,12.16,12.20$, $16.65,20.29,27.8,27.11$, $32.10,33.6,33.12,33.42$, $33.69,33.73,44.31,53.10$,
53.16, 53.20, 55.16, 55.34, 55.36 - $55.37,55.41,67.27$, $71.8,72.15$ - 72.16, 73.5, 73.7, $73.12,73.14,73.17$ - 73.18, 81.9, 81.12, 82.10, 82.13, $82.21,82.30,82.42,82.46$ $82.47,82.54,82.61$ - 82.64, $85.4,88.3$ - 88.5, 88.7, 88.9 $88.10,88.12,89.19,90.3,90.9$ $90.10,91.4,91.6,92.6,92.17$, $96.2,96.9,96.13$ - 96.14, 96.22, $100.3,101.20$ - 101.21, 102.41

Crotonaldehído $33.73,102.8$, 104.48t, 104.53t, 104.54t

Cumarina $33.73,104.229 t$, 104.236t, 104.303t, 104.305t Cumeno 44.10f, 104.287t, 104.289t, 104.291t, 104.293t

D

Dacarbazina 33.71

Dalapon-Na 62.14

Dantrona 33.71

Dapsona 33.73

Daunomicina 33.71

Dazomet $\quad 62.15-62.16,64.56$

D de 27.24

DDT $\quad 2.7$ - 4.8, 9.8, 9.11, 9.21 -

$9.22,9.24,20.14,27.3,27.24$,

$33.13,33.15,33.59 f, 33.71$,

38.7, 53.9, 53.35, 55.48 - 55.50,

$62.10,88.3,96.44,104.303 \mathrm{t}$, 104.305t, 104.308t

DDVP 64.44

Decaborano 104.132t, 104.133t, 104.134t, 104.135t

Decahidronaftaleno 104.287t, 104.291t, 104.293t

Decano 104.243t, 104.245t, $104.246 \mathrm{t}, 104.247 \mathrm{t}$

Decil mercaptano 104.409t, 104.412t, 104.414t, 104.415t

D eltametrina $\quad 27.23$

D eltametrina 33.73

Demeclociclina 8.5

Desmetrina $\quad 62.14$

Deuterio $\quad 48.15,76.8$ - 76.9

Diacetato de 1, 2-propanodiol $104.165 t$

Diacetato de a-propilenglicol 104.182t

Diacetilaminoazotolueno $\quad 33.73$

$\mathrm{N}, \mathrm{N}^{\prime}$-diacetilbencidina $\quad 33.71$

4,4'-D iacetilbencidina 104.75t, $104.79 t$

Diacetona 104.328t, 104.332t, 104.334t, 104.336t
Diacrilato de 1,3-butanodiol 104.173t, 104.175t

Dialato $\quad 33.73,62.14$

Dialilamina 104.82t, 104.86t, 104.89t, 104.92t

Dialilcianurato 104.142t, 104.148t

Dialilftalato 104.396t, 104.397t, 104.398t

Diamina de hexametileno $\quad 89.16$

2,4-Diaminoanisol 33.71, 104.102t, 104.116t

3,3'-Diaminobencidina 104.103t, 104.116t

4,4'-Diaminodifenil éter 33.71

4,4'-Diaminodifenilmetano 4.8, $104.116 \mathrm{t}$

3,3'-Diaminodipropilamina 104.82t, 104.90t, 104.92t

1,2-Diamino-4-nitrobenceno 33.74

1,4-Diamino-2-nitrobenceno 33.74

2,4-Diaminotolueno $\quad 33.71$ 104.103t, 104.108t, 104.112t, $104.116 \mathrm{t}$

2,5-Diaminotolueno 33.74

2,6-Diaminotolueno 104.103t, 104.109t, 104.112t, 104.116t

Diamox 37.14

Dianisidina $\quad 89.20$

o-Dianisidina 33.71

Dianisidina diisocianato 104.322t, 104.325t

Diazepam 33.74

Diazinon $\quad 44.8,64.44$

Diazometano 33.74, 104.125t, 104.126t, 104.129t

Dibenzo[a,h]acridina 33.71, 104.314t, 104.317t

Dibenzo[a,j]acridina 33.71, 104.314t, 104.318t

Dibenzoantraceno $\quad 12.8$

Dibenzo[a,c]antraceno $\quad 33.74$

Dibenzo[a,h]antraceno 33.70, 55.5, 104.314t, 104.316t, $104.318 \mathrm{t}$

Dibenzo[a,j]antraceno $\quad 33.74$

Dibenzoato de dietilenglicol 104.178t

3,4,5,6-D ibenzocarbazol 104.229t, 104.236t

7h-D ibenzo[c,g]carbazol 33.71

Dibenzo-p-dioxina 33.74, 104.156t, 104.160t

Dibenzodioxinas cloradas 33.74

Dibenzo-p-dioxinas policloradas 33.74

Dibenzo[a,e]fluoranteno $\quad 33.74$
Dibenzofurano 104.314t, $104.318 \mathrm{t}$

Dibenzofuranos policlorados 33.74

Dibenzo[h,rst]pentafeno 33.74

Dibenzo[a,e]pireno 33.71, 104.314t, 104.318t

Dibenzo[a,h]pireno 33.71, 104.315t, 104.318t

Dibenzo[a,i]pireno 33.71, 104.315t, 104.318t

Diborano 104.132t, 104.133t, 104.134t, 104.135t

Dibromoacetonitrilo 33.74

Dibromocloropropano 9.8, $20.14,64.13$

1,2-Dibromocloropropano 9.6

1,2-3-Dibromocloropropano $104.264 t$

1,2-Dibromo-3-cloropropano 33.71, 104.258t, 104.261t, $104.267 \mathrm{t}$

Dibromoetano 104.261t, 104.264t, 104.267t

1,2-Dibromoetano 104.261t

Dibromometano 62.15, 104.258t

1,2-Dibromoetano 4.10

Dibromuro de etileno 2.7, 9.6, 9.6f, 33.70, 102.50, 104.258t, $104.261 \mathrm{t}, 104.265 \mathrm{t}, 104.267 \mathrm{t}$

Dibutil fenil fosfato 104.386t, 104.392t

Dibutil fosfato 104.386t, 104.388t, 104.392t

Dibutilamina 104.82t, 104.89t, $104.92 \mathrm{t}$

2-Dibutilaminoetanol 104.82t, $104.92 \mathrm{t}$

$\mathrm{N}, \mathrm{N}$-D ibutilanilina $\quad 104.103 \mathrm{t}$

2,6-D i-terc-butil-p-cresol 104.371t, 104.374t, 104.377t, 104.378t

2,6-D i-terc-butilfenol 104.371t, 104.378t

Dibutilftalato 104.396t, 104.397t, 104.398t

Dicetena 104.329t, 104.332t, 104.334t, 104.336t

Dicianodiamida 104.142t, 104.146t, 104.148t, 104.150t

Diciclohexilamina 104.82t, 104.89t, 104.92t

Diciclohexilaminonitrito 104.103t, 104.112t

Diciclohexilftalato 104.396t, 104.397t, 104.398t

Diclofluanid $\quad 62.16$

Diclona $\quad 62.15-62.16$ 
Dicloracetilcloruro $\quad 104.334 t$

Diclorhidrato de 1, 4-bencendiamina $104.112 t, 104.116 t$

Diclorhidrato de 2, 4-diaminofenol 104.103t, 104.116t

Diclorhidrato de 3, 3'-diclorobencidina $104.103 t$

Diclorhidrato de 3, 3'-dimetoxibencidina $104.103 t$

3,3'-D icloro-4, 4'-diaminodifenil éter 33.71

Dicloroacetilcloruro 104.329t, 104.332t, 104.336t

Dicloroacetileno 33.74 104.269t, 104.273t

Dicloroacetonitrilo 33.74

Dicloroanilina 104.103t, 104.109t, 104.112t, 104.116t

2,4-Dicloroanilina 104.103t, 104.109t, 104.112t, 104.117t

2,5-Dicloroanilina 104.103t, 104.109t, 104.112t, 104.117t

2,6-Dicloroanilina 104.103t, 104.109t, 104.113t, 104.117t

3,4-Dicloroanilina 104.103t, 104.109t, 104.113t, 104.117t

Diclorobenceno $\quad 44.10 f, 89.19$

1,3-diclorobenceno $44.10 f$

1,4-diclorobenceno $44.10 f$

m-Diclorobenceno 104.303t, 104.308t

0-Diclorobenceno 33.74, 104.303t, 104.309t

p-Diclorobenceno 33.71, 104.303t, 104.305t, 104.307t, 104.309t

3,3'-Diclorobencidina 8.13, 33.71, 104.104t, 104.109t, 104.113t, $104.117 \mathrm{t}$

1,4-Dicloro-2-buteno 104.269t, 104.273t

Diclorocianurato sódico 104.125t, 104.126t, 104.127t 104.129t

Diclorodifluorometano 104.193t, 104.195t, 104.197t 104.199t

Dicloroetano $\quad 62.11$

1,1-Dicloroetano 104.258t, 104.261t, 104.265t, 104.267t

1,2-Dicloroetano 4.10, 20.31, 33.71

1,1-Dicloroeteno $104.272 \mathrm{t}$

1,2-Dicloroetileno 104.270t, 104.272t, 104.273t

cis-1,2-Dicloroetileno 104.269t, 104.272t, 104.274t

trans-1,2-Dicloroeti-

leno $104.270 t, 104.272 \mathrm{tt}$
Dicloroetil formal 104.48t, $104.55 t$

2,4-Diclorofenol 104.372t, 104.375t, 104.377t, 104.379t

2,5-Diclorofenol 104.372t 104.375t, 104.377t, 104.379t

3,5-Diclorofenol 104.372t, 104.375t, 104.377t, 104.379t

Diclorofluorometano 104.193t, 104.195t, 104.197t, 104.199t

Diclorometano 2.5, 33.71, $55.17,86.14$

1,2-Dicloro-3-nitrobenceno 104.349t, 104.353t

1,2-Dicloro-4-nitrobenceno 104.349t, 104.353t, 104.358t

2,4-Dicloro-1-nitrobenceno 104.349t, 104.353t, 104.358t

1,1-D icloro-1-nitroetano 104.342t, 104.344t

2,2'-Dicloro-n-metildietilamina 104.83t, 104.92t

2,6-Dicloro-para-fenilendiamina 33.74

1,1-Dicloropropano 104.258t, 104.262t, 104.265t, 104.267t

1,2-Dicloropropano 33.74, 104.258t, 104.262t, 104.265t, $104.267 \mathrm{t}$

1,3-Dicloropropano 104.258t, 104.262t, 104.265t, 104.267t

1,1,2-Dicloropropano 64.44

1,3-Dicloro-2-propanol 104.36t, $104.43 \mathrm{t}$

1,2-Dicloro-2-propeno 104.270t, 104.272t, 104.274t

1,3-Dicloropropeno 33.71, 64.44, 104.270t, 104.272t, 104.274t

cis-1,3-Dicloropropeno 104.270t, 104.272t, 104.274t

trans-1,3-D icloropropeno $104.270 t, 104.272 t$, 104.274t

Diclorosilano 104.401t, 104.402t, 104.403t, 104.404t

Diclorotetrafluoretano $104.197 \mathrm{t}$, 104.199t

1,2-D icloro-1,1,2,2-tetrafluoretano 104.193t

Dicloruro de azufre 104.220t, 104.223t, 104.225t

Dicloruro de s-2-(dimetilamino)-etil-isotiouronio 85.15

Dicloruro de etileno 104.258t, 104.262t, 104.265t, 104.267t

Diclorvos 33.71, 62.16, 96.44

Dicofol 33.74
Dicromato potásico $\quad 12.4,89.29$, 96.12

Dicromato sódico $\quad 82.62$

Dieldrín 33.74

Dieldrín $\quad 9.11,9.21$ - 9.22, $27.24,62.10$

Diepoxibutano 33.71

1,2,3,4-D iepoxibutano 104.156t, 104.160t

Diepóxido de 4-vinilciclohexeno 33.71

Dietanolamina $78.21,78.23$ 78.24, 82.42, 104.83t, 104.86t, 104.89t, 104.92t

Dietil sulfato $\quad 104.409 t, 104.414 t$

Dietil sulfuro $104.414 t$

Dietil tiofosforil cloruro 104.385t

Dietilamina 104.83t, 104.87t, 104.89t, 104.92t

2-Dietilaminoetanol 104.83t, 104.87t, 104.89t, 104.92t

m-Dietilaminofenol 104.104t, 104.117t

$\mathrm{N}, \mathrm{N}$-D ietilanilina 104.104t, 104.113t, 104.117t

Dietilbenceno $104.287 \mathrm{t}$ 104.289t, 104.292t, 104.293t

2-6-Dietilbutil terciario $\quad 82.39$

Dietilcetona 104.329t, 104.332t, 104.334t, 104.336t

Dietilditiocarbamato sódico 104.178t

Dietilditiocarbamato $\quad 33.74$

Dietilen glicol dinitrato 104.342t, 104.344t

Dietilenglicol 104.211t, 104.212t, 104.213t

Dietilentriamina 104.83t, 104.87t, 104.89t, 104.92t

Dietilestilbestrol 2.10

Dietiléter $\quad 11.32$

Dietilexilftalato 96.23

Dietilftalato $104.396 t, 104.397 t$ 104.398t

Dietilhexil ftalato $\quad 4.10$

Di-2-etilhexilftalato $\quad 53.16$

1,2-Dietilhidracina 104.125 , 104.129t, 33.71

$\mathrm{N}, \mathrm{N}$,-D ietil-meta-toluamida $15.77,74.5$

Dietilsilbestrol 33.69

Dietiltiofosforil cloruro 104.388t, 104.390t, 104.392t

Difenacoum 27.24

Difenilamina 104.104t, 104.109t, 104.113t, 104.117t

2.4'-D ifenildiamina $\quad 33.74$
$\mathrm{N}, \mathrm{N}^{\prime}$-difenil-p-fenilendiamina 104.104t, 104.117t

1,3-D ifenilguanidina 104.104t, 104.117t

2,4-D ifenilhidrazina $\quad 44.22$

4,4-D ifenilmetano diisocianato 102.13

Difenilo 104.287t, 104.290t, 104.292t, 104.294t

Difenilos clorados 12.6

Difluoretano 104.193t

1,1-Difluoretano 104.197t, 104.199t

Difluorodibromometano 104.193t, 104.195t, 104.197t, $104.199 \mathrm{t}$

Difluoruro de oxigeno 104.220t, 104.222t, 104.224t, 104.225t

Diglicidil resorcinol éter 33.71

Diheptilftalato $104.396 \mathrm{t}$

Dihidrocloruro de manomustina 33.74

Dihidrocloruro de piperazina 104.229t, 104.236t

Dihidrosafrol 33.71

1,8-Dihidroxiantraquinona 33.71

Dihidroximetilfuratricina $\quad 33.72$, 33.74

4,4'-Diisocianato de 3,3'-dimetoxibencidina 33.74

Diisocianato de hexametileno 89.16

Diisocianato de 4,4'-metilendifenilo 33.74

Diisocianato de metilo $\quad 82.21$

Diisocianato de 1,5-naftaleno 33.74

Diisocianato de polimetilenpolifenilo $\quad 33.74$

Diisocianato de tolueno 1.8 , $10.13,33.32,33.42,33.71$, $81.10,81.16,91.6,102.13$

Diisodecilftalato 104.396t, $104.397 \mathrm{t}, 104.398 \mathrm{t}$

Diisooctilftalato $104.398 \mathrm{t}$

Diisopropanolamina 104.83t, 104.87t, 104.90t, 104.92t

Diisopropilamina 104.83t, 104.87t, 104.89t, 104.92t

Dilaurato dibutílico 82.46

Dimenhidrinato $\quad 50.16$

Dimercapto-1-propanol $\quad 7.12$

Dimetanosulfonato de butanediol 33.69

Dimetil acetamida $\quad 104.79 t$

Dimetil -p-aminoazobenceno $104.126 \mathrm{t}$

1,2-D imetilbenceno $\quad 44.10 f$ 
1,4-D imetilbenceno $44.10 f$

2,2-Dimetilbutano 104.243t, $104.247 \mathrm{t}$

2,3-Dimetilbutano 104.243t, 104.246t, 104.247t

2,2-dimetilpropano 104.243t, $104.247 \mathrm{t}$

Dimetil disulfuro $\quad 72.16,72.19$

Dimetil hidrógeno fosfito 104.386t, 104.392t

Dimetil sulfato 104.409t, $104.414 t$

Dimetil sulfoxido $\quad 104.414 \mathrm{t}$

Dimetil sulfuro $72.19,104.414 t$

Dimetilacetal 104.48t, 104.55t

Dimetilacetamida 104.76t, 104.77t, 104.78t

Dimetilamina 11.32, 104.83t, 104.87t, 104.89t, 104.92t

Dimetilaminoazobenceno 104.104t, 104.109t, 104.117t

p-Dimetilaminoazobenceno 33.71

2-D imetilaminoetanol 104.83t $104.87 \mathrm{t}$

3-Dimetilaminopropilamina 104.83t, 104.92t

4,4'-D imetilangelicina $\quad 33.74$

4,5'-D imetilangelicina $\quad 33.74$

2,6-Dimetilanilina (2,6-xilidina) 33.71

Dimetilanilina 104.104t, 104.110t, 104.113t, 104.117t

$\mathrm{N}, \mathrm{N}$-dimetilanilina 33.74

3,3'-D imetilbencidina (0-tolidina) 33.71

7,12-D imetilbenz(a)antraceno 33.41

2,2-D imetil-1-butanol $\quad 104.36 \mathrm{t}$ $104.43 \mathrm{t}$

1,10-D imetil-trans-9-decalol 44.24

Dimetildihidroxietilén urea 89.21

5,6-D imetil-2-dimetilamino-4-pirimidinil metilcarbamato 62.12

2,2-Dimetil-1,3-dioxolan-4-metanol 104.48t, 104.51t, 104.53t, 104.55t

Dimetilditiocarbamato sódico 80.3

Dimetilenglicol 104.211t, 104.213t

Dimetiletanolamina $104.90 \mathrm{t}$, $104.92 \mathrm{t}$

Dimetiletilamina $\quad 82.17,82.22$

1,4-D imetilfenantreno 33.74

2,4-Dimetilfenol 104.372t, 104.377t, 104.379t
Dimetilformamida 104.76t, 104.77t, 104.78t, 104.79t

$\mathrm{N}, \mathrm{N}$-dimetilformamida 27.13

Dimetilformamida $33.71,87.4$, 87.6 - 87.7, 88.9

Dimetilftalato 104.396t, 104.397t, 104.398t

2,6-D imetil-4-heptanol 104.36t, $104.43 \mathrm{t}$

2,6-D imetil-4-heptanona 104.329t, 104.332t, 104.334t, $104.336 \mathrm{t}$

1,1-D imetilhidracina 33.71 , 104.125t, 104.127t, 104.129t

1,2-D imetilhidracina 33.71, 104.125t, 104.127t, 104.129t

2,4-D imetil-3-pentanol $104.43 \mathrm{t}$

Dimetiltereftalato 104.397t, 104.398t

Dimetil-p-toluidina $\quad 100.7$

$\mathrm{N}, \mathrm{N}$-dimetil-p-toluidina 104.104t, 104.109t, 104.113t, $104.117 \mathrm{t}$

3,5-D imetil-1,2,4-tritiolona 44.24

Dimetoxano 33.74

3,3'-Dimetoxibencidina 33.71

1,2-Dimetoxietano 104.203t

$\mathrm{N}, \mathrm{N}$ '-di-2-naftil-p-fenilendiamina 104.106t, 104.119t

2,4-Dinitroanilina 104.104t, 104.110t, 104.113t, 104.117t

Dinitrobenceno 104.349t, 104.353t, 104.356t, 104.358t

m-Dinitrobenceno 104.349t

o-Dinitrobenceno 104.350t, 104.354t, 104.356t, 104.359t p-Dinitrobenceno 104.350t, 104.354t, 104.356t, 104.359t

1,3-D initrobenceno 104.354t, 104.356t, 104.358t

2,4-D initroclorobenceno 33.32, 33.42

Dinitrocresol $\quad 4.4-4.5,33.12$

o-Dinitrocresol 104.377t

Dinitro-o-cresol 62.16, 104.372t, 104.375t, 104.379t

4,6-D initro-o-cresol 27.25

2,4-D initrofenilhidrazina 55.18

Dinitrofenol $1.8,4.7,33.32$

2,3-D initrofenol 104.350t, 104.359t

2,4-D initrofenol 104.350t, 104.354t, 104.356t, 104.359t

3,7-D initrofluoranteno 33.71

3,9-D initrofluoranteno 33.71

Dinitronaftaleno $104.350 t$

1,5-D initronaftaleno 104.350t, 104.359t
1,6-Dinitropireno 33.71, 104.350t

1,8-Dinitropireno 33.71, 104.350t

1,3-Dinitropireno 33.74, 104.350t

Dinitrosopentametilentetramina 33.74

Dinitrotolueno 104.350t, 104.354t, 104.356t, 104.359t

2,3-D initrotolueno 104.350t, 104.354t, 104.357t, 104.359t

2,4-Dinitrotolueno 33.71, 104.350t, 104.354t, 104.357t, $104.359 \mathrm{t}$

2,5-D initrotolueno 104.350t, 104.359t

2,6-Dinitrotolueno 33.71, 104.350t, 104.354t, 104.357t, $104.359 \mathrm{t}$

3,4-Dinitrotolueno 104.351t, $104.354 t, 104.357 t, 104.359 t$

3,5-D initro-o-toluidina 104.351t

3,5-D initro-p-toluidina 104.351t, 104.359t

Dinobuton 62.16

Dinocap 62.16

Dinoseb 62.14

Di-sec-octilftalato 104.396t, 104.397t, 104.398t

p-Dioxano 104.49t, 104.51t, $104.53 \mathrm{t}, 104.55 \mathrm{t}$

1,4-Dioxano 33.71, 44.10f

Dióxido de azufre $10.7,10.12$, $10.76,10.82,15.23,15.42 f$, $30.24,31.28,33.74,39.15$, 44.6, 44.8 - 44.9, 44.12, 44.21, 44.31, 45.10, 45.21, 53.2, 53.9, 53.11 - 53.12, 54.34, 55.4 $55.5,55.14,55.19,55.21,55.23$ - 55.24, 55.26, 55.53, 62.9, $64.41,65.13,65.15,66.17$, $67.9,72.8,72.15$ - 72.16, 72.19, 73.12, 73.15, 73.16f, 73.17, $74.23,74.47,74.49,74.59$, $78.5,78.20,78.22$ - 78.24, $78.26,78.33,81.5,81.11$ 81.12, 81.16, 82.3 - 82.8, 82.10, $82.19,82.51,82.59,85.11$, 85.15, 89.14, 89.19, 91.4, 91.9, 95.6, 96.11, 102.39, 104.422t, 104.424t, 104.425t, 104.426t

Dióxido de carbono $\quad 10.2,10.17$, 20.5, 20.23, 33.5, 36.3, 36.10, $37.3,37.5$ - 37.6, 37.11, 41.2, 41.6, $41.13-41.14,41.17$, 41.24 - 41.25, 44.4f, 44.5 - 44.6, $44.8,44.19,44.21,44.29,45.8$, $45.10,45.14,45.16,49.31$,
$53.3,53.27,53.30,53.34$ $54.36,55.16,55.29,55.53$, $55.55,62.9,64.24,64.40$ $64.41,64.62,65.4,65.11$ $66.17,67.5$ - 67.6, 67.8, 67.10, $67.19,67.30-67.32,70.5$, $70.13,70.18,73.17-73.18$ $74.33,74.36,74.46-74.49$, $74.52,75.3,75.11,75.14$ $75.16,76.8,76.10$ - 76.11 , 76.17 - 76.18, $78.14-78.15$, $78.19,78.23$ - 78.27, 78.32, $79.18,82.17$ - 82.18, 82.25, $82.28,82.30,82.48,89.18$, $91.5,96.36$ - $96.37,96.46$, $96.49,96.57,98.3,101.19$ $101.20,102.57,102.66$

Dióxido de cloro 15.23, 55.33, 72.7 - 72.8, 72.11, $72.15-72.16$

Dióxido de manganeso 81.4, $81.6-81.7$

Dióxido de nitrógeno 10.8 , $10.19,30.24,33.41,44.5,44.7$, 44.9 - 44.10, 44.21, 44.31, 55.4, $55.19,64.73,70.12,73.15$, 73.16f, 73.17, 74.47, 74.49, $74.59,78.5,82.27,82.30,95.6$, $96.13,102.39$

Dióxido de selenio $\quad 12.19$

Dióxido de silicio $10.49,10.76$, $10.87,62.6,81.8$

Dióxido de titanio $10.36,10.44$, $33.74,48.42,85.8$ - 92.9

Dióxido de torio 4.7

Dióxido de uranio $\quad 76.8,76.11$

Dióxido de vinilciclohexeno 104.156t, 104.159t, 104.160t

Dioxina $33.23,33.26,33.28$, $33.57,39.16,62.15,71.12$

Dipentilamina $104.83 t, 104.87 t$, 104.90t, 104.92t

Dipropilcetona 104.329t, 104.334t, 104.336t

Dipropilenglicol 104.211t, 104.212t, 104.213t

Diquat $7.15,12.19,27.25$, 62.14

Disprosio $\quad 10.78,46.7$

Disulfiram $12.4,33.74$

m-D isulfito $\quad 101.20$

Disulfuro de carbono $3.16,4.2$, 5.6, 7.13, 7.21, 7.24, 7.26, 9.23, $11.8,16.33 f, 27.13,27.23$, $30.22,30.31,33.15,44.22$, $47.4,62.12,80.15,104.422 \mathrm{t}$, 104.424t, 104.425t, 104.426t Disulfuro de 2-mercaptobenzotiazol 104.229t, 104.232t, 104.234t, 104.236t 
Disulfuro de plata 85.13

Disulfuro de tetrametiltiuram 80.3

Ditiocarbamato 62.15

Ditiofosfato de zinc 82.39

Ditranol 33.74

Diurón 62.14

Divinilbenceno $104.287 t$

104.290t, 104.292t, 104.294t

D ma $\quad 27.10$

Dmsa 33.15

Dodecil mercaptano 104.409t, 104.412t, 104.414t, 104.415t

Dodecilbenceno $104.287 \mathrm{t}$,

104.290t, 104.292t, 104.294t

D odecilbencenosulfonato sódico

104.409t, 104.412t, 104.414t, $104.415 \mathrm{t}$

Dodina 62.14

Doxefazepam 33.74

Doxiciclina 15.77

Droloxifeno 33.74

Dulcina 33.74

\section{E}

Efedrina $\quad 42.52$

Endosulfán 8.10

Endrín $\quad 27.24,33.59 f, 33.74$

Enflurano 97.60, 104.194t,

104.195t, 104.197t, 104.199t

Eosina $33.74,49.8 f$

Epiclorhidrina 104.156t,

104.158t, 104.159t, 104.160t

Epiclorhidrina $33.70,72.16$

Epn 64.44

1,2-Epoxibutano 33.74,

104.156t, 104.158t, 104.159t, 104.160t

1,2-Epoxietilbenceno $104.156 \mathrm{t}$, 104.160t

1,2-Epoxipropano 104.156t, 104.158t, 104.160t

2,3-Epoxipropanol 104.156t, 104.158t, 104.160t

Eptam 62.12

Erbio 10.78

Erionita 33.69

Escandio 46.7, 81.13

Esfingosina 33.9

Espato flúor 82.43

Espironolactona 33.74

Espumas de poliuretano $\quad 33.74$

Estannato sódico 82.60

Estaño tributilo 1.7

Estaño 4.10 - 4.11, 10.19,

$30.30,46.7,67.5,67.8,74.23$,

$74.60,81.8,82.7,82.35,82.43$, $82.48,82.60$ - 82.62, 91.6 -
$92.7,92.13$ - 96.14, 96.22, 101.21

Estazolam 33.74

Estearato de glicidilo 33.74

Estearato de magnesio $\quad 79.12$

Ester dietílico de ácido tereftálico 104.396t

Ester diheptílico de ácido ftálico 104.398t

Ester diisobutílico de ácido ftálico 104.396t, 104.398t

Ester diisooctílico de ácido ftálico 104.396t

Ester diisotridecílico de ácido ftálico 104.396t

Ester dimetílico de ácido tereftálico 104.396t

Ester etilénico ciclico de ácido carbónico $104.178 \mathrm{t}$

Ester etílico de ácido carbámico 104.178t, 104.181t

Ester ((3,5,6-tricloro-2-piridinil)oxi)-,2-butoxietílico del ácido acético $104.165 \mathrm{t}$

Esterigmatocistina 33.71

Estibina $1.7,81.4,82.52$

Estireno 1.4, 1.6, 7.12 - 7.13,

7.24, 9.6f, 11.8, 11.32, 16.63,

27.5, 30.23, 30.29, 31.28,

33.71, 44.10f, 72.16, 85.6, 91.6, 104.287t, 104.290t, 104.292t, $104.294 \mathrm{t}$

Estireno-butadieno $\quad 80.9,80.16$

Estreptomicina 64.44

Estreptozotocina 33.71

Estresores $34.2,34.4,34.10$

Estricnina $7.14,96.44$

Estroncio $89 \quad 48.35$

Estroncio $90 \quad 39.32,39.43,48.8$, $48.17,48.29,48.35$

Estroncio 33.6, 33.13, 53.31, 55.41

Etano 33.46, 53.20, 67.8, 75.3 $75.4,75.11,78.24,104.243 t$, 104.245t, 104.246t, 104.247t

1,2-Etanodiamina $104.87 \mathrm{t}$

Etanol $9.9,9.15,27.5,27.15$, $33.5,33.20,78.25,96.44$, 104.36t, 104.39t, 104.41t, $104.43 \mathrm{t}$

Etanolamina $33.9,104.83 \mathrm{t}$, 104.87t, 104.90t, 104.92t

Eter alilfenílico 104.184t, $104.187 \mathrm{t}$

Eter alilglicidílico 104.156t, 104.158t, 104.160t

Eter alílico $104.187 \mathrm{t}$

Eter bencílico 104.184t, $104.187 t$
Eter bis-(4-amino-3-clorofenílico) 104.188t

Eter bis(clorometílico) 10.92, 55.4, 104.188t

Eter butilglicidílico 104.156t, 104.158t, 104.160t

Eter n-butílico de trietilenglicol 104.184t, 104.185t, 104.187t

Eter clorometilmetílico $104.188 \mathrm{t}$

Eter cresilglicidílico 104.156t, 104.161t

Eter de etilenglicol $1.3,9.6 f$

Eter de monobencilo de hidroquinona 12.5

Eter dialílico $\quad 104.184 t$

Eter dibutílico 104.184t, 104.185t

Eter di-n-butílico 104.186t, 104.187t

Eter dicloroetílico 104.188t, 104.189t

Eter diclorofenílico $\quad 104.188 \mathrm{t}$

Eter dicloroisopropílico 104.188t, 104.189t

Eter dietílico de dietilenglicol 104.203t, 104.205t, 104.206t, $104.207 \mathrm{t}$

Eter dietílico de etilenglicol 104.203t, 104.206t

Eter dietílico $97.60,104.184 t$, 104.185t, 104.186t, 104.187t

Eter diglicidílico de 1,4-butanodiol 104.203t, 104.205t, 104.207t

Eter diglicidílico de dietilenglicol 104.203t, 104.205t

Eter diglicidílico de hidroquinona 104.157t

Eter diglicidílico de resorcinol 104.157t, 104.161t

Eter diglicidílico 104.157t, 104.158t, 104.161t

1,1-Eter dimetiletilglicidílico 104.157t, 104.161t

Eter dimetílico $\quad 104.187 \mathrm{t}$

Eter dipropílico 104.184t, 104.186t, 104.187t

Eter etilbutílico 104.184t, 104.186t, 104.187t

2-Eter etilhexilglicidílico 104.157t

Eter etilmetílico $104.184 t$ 104.186t, 104.187t

Eter fenilglicidílico 104.157t, 104.158t, 104.161t

Eter fenílico de etilenglicol 104.203t, 104.205t, 104.206t, $104.207 \mathrm{t}$

Eter fenílico $104.186 \mathrm{t}, 104.187 \mathrm{t}$ Eter glicólico $\quad 82.64,85.9,96.8$
Eter isopropilglicidílico 104.157t, 104.159t, 104.161t

Eter isopropílico 104.184t, 104.185t, 104.186t, 104.187t

Eter metil-terc-butílico 104.185t, 104.186t, 104.187t

Eter metílico de dietilenglicol 104.206t

Eter metílico de dipropilenglicol 104.203t, 104.205t, 104.206t, $104.207 \mathrm{t}$

Eter metílico de etilenglicol 104.204t, 104.205t, 104.206t, $104.207 \mathrm{t}$

Eter metílico 104.184t

Eter metilpropílico 104.185t, 104.186t, 104.187t

Eter metilvinílico 104.185t, 104.186t, 104.187t

Eter 2-metoxietílico de 2-etoxietilo 104.204t

Eter monobutílico de dietilenglicol 104.204t, 104.205t, 104.206t, $104.207 \mathrm{t}$

Eter monobutílico de etilenglicol 104.204t, 104.205t, 104.206t, $104.208 \mathrm{t}$

Eter monoetílico de dietilenglicol 104.204t, 104.205t, 104.208t

Eter monometílico de dietilenglicol 104.204t, 104.205t, 104.208t

Eter monometílico de propilenglicol 104.204t, 104.205t, 104.206t, 104.208t

Eter monopropílico de etilenglicol 104.204t, 104.206t, 104.207t, $104.208 \mathrm{t}$

Eter pentaclorofenílico $\quad 104.188 \mathrm{t}$

Eter pentílico 104.185t

Eter tetraclorofenílico $104.188 \mathrm{t}$

Eter vinílico de 2,2,2-trifluoretilo 104.194t

Eterato de trifluoruro de boro 104.132t, 104.134t, 104.135t

Eteres de clorometilo $\quad 44.12$

Eteres de glicol $\quad 20.23,100.7$

Etil acrilato 11.32

Etil-2-cianurato $104.142 t$

Etil hexaldehído $104.51 \mathrm{t}$

2-Etil hexaldehído $104.53 t$

Etil isocianato 104.322t, 104.324t, 104.325t

Etil mercaptano 104.412t, 104.414t, 104.416t

Etil metil cetona oxima $104.92 \mathrm{t}$

Etilacetato $\quad 100.7$

Etilamilcetona 104.329t, 104.334t, 104.336t 
Etilamina 104.84t, 104.87t, 104.90t, 104.93t

N-Etilanilina 104.104t 104.113t, 104.118t

Etilato sódico 104.61t, 104.70t

Etilbenceno 27.5, 30.23, 44.10f, 55.5, 78.9, 104.287t, 104.290t, 104.292t, 104.294t

Etilbutilcetona 104.329t, 104.332t, 104.336t

Etilbutiléter terciario $\quad 78.5$

$\mathrm{N}, \mathrm{N}$ '-etilen bis(estearamida) 104.76t, 104.78t, 104.79t

Etilén diamina férrica del ácido tetracético 85.13

Etilen glicol dinitrato mezclado con nitroglicerina (1:1) 104.342t, 104.344t

Etilen glicol dinitrato $104.342 \mathrm{t}$, 104.343t, 104.344t

Etilen tiourea $\quad 27.23$

Etilen-bis-ditiocarbamato 27.23

Etilendiamina $104.84 t, 104.90 t$, 104.93t

Etilenglicol 33.33, 89.16, 102.13, 104.211t, 104.212t, 104.213t

Etilenimina $104.84 t$, 104.88t, 104.90t, 104.93t

Etileno $33.74,41.2,45.10$, $53.20,67.8,74.50,75.6,78.6$, $78.10,78.16,80.9,104.277 \mathrm{t}$, 104.278t, 104.279t, 104.281t

Etilenoglicol 4.10

Etilhexaldehído $104.55 \mathrm{t}$

2-Etilhexanal $104.49 \mathrm{t}$

2-Etil-1,3-hexanodiol 104.211t $104.213 t$

Etilhexanol 44.11

2-Etil-1-hexanol 104.36t, 104.39t, 104.41t, 104.43t

Etilhexil 2-acrilato $104.174 t$

2-Etilhexil acrilato 104.173t, $104.175 t$

2-Etilhexilamina 104.84t, $104.93 \mathrm{t}$

Etiliden norborneno $104.277 \mathrm{t}$, 104.278t

Etilideno norborneno $\quad 104.279 t$ 104.281t

Etilmercaptano $\quad 104.409 t$

Etilmetacrilato $\quad 100.7$

Etilmetilcetona oxima $\quad 104.84 \mathrm{t}$

$\mathrm{N}$-Etilmorfolina 104.229t, $104.236 \mathrm{t}$

1-Etilnaftaleno 104.287t, $104.294 \mathrm{t}$

2-Etilnaftaleno $104.287 \mathrm{t}$ 104.294t
$\mathrm{N}$-Etil-N-nitrosourea 33.7

Etilparatión 27.22

2-Etiltolueno $\quad 55.5$

3-Etiltolueno 55.5

4-Etiltolueno 55.5

Etino 41.2

Etionamida 33.74

2-Etoxietanol 9.8, 104.206t,

$104.207 \mathrm{t}, 104.208 \mathrm{t}$

Etoxietilacetato 44.8

Eugenol 33.74

Eurex 62.12

Europio 10.78

\section{F}

Fansidar $\quad 15.77$

Fenacetina $\quad 2.7,8.12,33.70$

Fenantreno $33.74,49.8 f$, 104.315t, 104.318t

Fenazopiridina 104.229t, 104.236t

Fenicarbazida $\quad 33.74$

Fenil cloroformato $\quad 104.53 \mathrm{t}$

Fenil isocianato 104.322t, 104.324t, 104.325t

Fenil mercaptano 104.410t, 104.412t, 104.414t, 104.416t

Fenilacetonitrilo 104.142t, 104.148t, 104.150t

Fenilbutazona $\quad 33.74$

4-Fenilciclohexeno $\quad 13.6$

m-Fenilenbis(metilamina) 104.105t, 104.118t

m-Fenilendiamina 33.74, 104.105t, 104.113t, 104.118t

o-Fenilendiamina 104.105t, 104.113t, 104.118t

p-Fenilendiamina $\quad 33.74,85.15$, $88.6,100.9$, 104.105t, 104.110t, 104.113t, 104.118t

Fenilenpireno 104.230t, 104.232t, 104.234t, 104.236t

Feniletanol $104.36 \mathrm{t}$

1-Feniletanol $104.43 \mathrm{t}$

2-Feniletanol 104.39t, 104.41t, 104.43t

$\mathrm{N}$-Feniletanolamina $104.105 \mathrm{t}$, 104.118t

o-Fenilfenato de sodio $\quad 33.71$

0-Fenilfenol $33.74,104.288 \mathrm{t}$

Fenilfosfina $\quad 104.386 t, 104.392 t$

Fenilglicidil éter 33.71

Fenilhidrazina 4.7, 104.125t, 104.126t, 104.127t, 104.129t

$\mathrm{N}$-Fenil-p-naftilamina $\quad 104.104 \mathrm{t}$

$\mathrm{N}$-Fenil-1-naftilamina 104.104t, 104.110t, 104.113t, 104.118t

$\mathrm{N}$-Fenil-2-naftilamina $\quad 33.74$
N-Fenil-naftilamina $\quad 104.118 t$

Fenilnaftilamina $\quad 82.39$

Fenilsalicilato $\quad 27.5$

Fenitoína 33.71

Fenobarbital $\quad 33.21,33.71$

Fenol butilo terciario 12.4

Fenol 4.2, 4.4, 4.11, 31.10, $33.74,53.20,55.36,71.9$ $71.10,78.5,78.8,78.10,78.13$ $78.14,78.20$ - 78.22, 78.25 $78.26,78.32$ - 78.33, 79.18, 80.16 - 82.18, 82.39, 82.64, 91.3 - 91.4, 96.8, 96.11, 98.7, $100.16,104.372 \mathrm{t}, 104.375 \mathrm{t}$, 104.377t, 104.380t

Fenol-formaldehído $\quad 91.4,96.20$

Fenotiazina $4.8,104.230$, 104.232t, 104.234t, 104.236t

Fenvalerato 33.74

Ferbam 33.74, 62.12

Ferrocianuro potásico 96.13

Ferrocromo 82.2

Fibrillas de p-aramida 33.74

Fluometurona $33.74,62.14$

Flúor $4.4,10.7,10.76,16.33 f$, 33.6, 41.13, 53.21, 62.2 - 62.3, $82.9,82.50,96.19,104.220 \mathrm{t}$, 104.222t, 104.224t, 104.225t

Fluoracetamida $\quad 62.12$

Fluoranteno 33.74, 104.315t, 104.318t

Fluoreno $\quad 33.74$

Fluorita 62.4

Fluoroacetato sódico $104.166 \mathrm{t}_{\text {, }}$ 104.167t, 104.169t, 104.171t

1-Fluoro-2,4-dinitrobenceno 104.351t, 104.359t

Fluoroxeno 97.60

5-Fluoruracilo 33.74

Fluoruro amónico 104.62t, 104.67t, 104.70t

Fluoruro cálcico $\quad 62.3$ - 62.4, 104.220t

Fluoruro de aluminio $\quad 82.50$

Fluoruro de berilio 10.31

Fluoruro de calcio $\quad 48.27$

Fluoruro de carbonilo 104.220t, 104.222t, 104.224t, 104.225t

Fluoruro de hidrógeno 4.11, 78.17, 78.32, 104.220t, 104.222t, 104.224t, 104.225t

Fluoruro de hierro $\quad 78.17$

Fluoruro de litio $\quad 48.27,97.32$

Fluoruro de perclorilo 104.220t, 104.222t, 104.224t, 104.225t

Fluoruro de polivinilo 30.22

Fluoruro de sulfurilo 104.220t, 104.224t, 104.226t
Fluoruro de vinilideno 33.74, 104.194t, 104.195t, 104.197t, 104.199t, 104.274t

Fluoruro de vinilo 33.70, 104.194t, 104.196t, 104.197t, 104.199t, 104.274t

Fluoruro potásico 104.62t, 104.67t, 104.70t

Fluoruro sódico $\quad 88.3$

Fluoruros 10.76, 10.78, 33.74, 82.27

Fluvoxamina $\quad 13.9$

Formaldehído 2.5, 4.11, 7.11, $10.20,10.87,10.92,10.97$ -

$10.98,11.23,11.32,12.19$, $13.5,23.41,32.10,33.70,44.3$, $44.4 f, 44.5$ - 44.9, 44.10f, 44.11, $44.22,44.28$ - 44.29, 45.3, 45.8, 45.10, 53.31, 55.4, 62.15, $64.44,64.48,67.10,70.38,71.8$ - $71.11,71.13,72.16,72.18$, $74.60,75.9,75.13,79.16,81.12$ - 81.13, 85.10 - 85.12, 85.15, $86.6,86.14,87.4,87.6$ - 87.7, $87.6 f, 88.5$ - 88.6, 88.9 - 88.10, $89.3,89.14,89.20$ - 89.21 , 89.23, 91.3 - $91.4,91.7,91.9$, $94.14,95.6$ - $96.8,96.16,96.20$ - $96.21,96.29,96.43-96.44$, $97.5,97.14,97.32,97.56$, $99.16,100.7,100.10,100.16$, $102.8,102.50,104.49 \mathrm{t}, 104.51 \mathrm{t}$, 104.53t, $104.55 \mathrm{t}$

Formalina $\quad 67.10$

Formamida 104.76t, 104.77t, 104.78t, 104.79t

Formiato de bencilo 104.178t, $104.182 \mathrm{t}$

Formiato de butilo $104.178 \mathrm{t}$, 104.180t, 104.181t, 104.182t

Formiato de etilo 104.178t, 104.180t, 104.181t, 104.182t

Formiato de isoamilo 104.178t, 104.182t

Formiato de metilo 104.178t, 104.180t, 104.182t, 104.181t

Formiato sódico 104.178t, 104.180t, 104.181t, 104.182t

2-(2-Formilhidrazino)-4-(5-nitro2-furil)tiazol 33.71

Formol 82.17, 82.21 - 82.22, $82.24,82.37$

Fosfamina $\quad 67.28,67.30,81.12$

Fosfato amónico 62.7 -62.9, $82.45-82.46$

Fosfato cálcico 62.2

Fosfato de aluminio $\quad 67.28$

Fosfato de calcio 33.35

Fosfato de hierro $82.45,82.64$ 
Fosfato de manganeso $\quad 82.45$, 82.64

Fosfato de titanio 82.46

Fosfato de zinc $82.45,82.64$

Fosfato diamónico 104.71t

Fosfato sódico dibásico 104.62t, $104.71 \mathrm{t}$

Fosfato sódico 82.45 - 82.46, 104.62t, 104.71t

Fosfato trisódico $\quad 82.44$

Fosfato vanadato de itrio 81.13

Fosfato 6.7, 33.9

Fosfina $67.10,82.18,104.386 \mathrm{t}$, 104.388t, 104.390t, 104.392t

Fosforil oxicloruro 104.392t

Fósforo (rojo) 104.386t

Fósforo $32 \quad 48.12$

Fósforo 4.2, 4.4 - 4.5, 4.7, $15.59,16.33 f, 23.54,23.56$, 41.13, 53.19 - 53.20, 55.18, $55.31,55.33,62.2,62.7,62.11$, $64.48,64.64,64.75,73.4$, $82.38,96.43,101.19,102.30$, 104.388t, 104.390t, 104.392t

Fosfuro cálcico 104.386t, 104.390t, 104.392t

Fosfuro de hidrógeno $\quad 41.9$

Fosfuro de zinc 7.14, 7.24, 62.12

Fosgeno 7.11, 10.7, 10.12, $20.21,20.23-30.24,41.15$, $82.30,82.47,96.14,100.13$, $101.26,104.220 \mathrm{t}, 104.222 \mathrm{t}$, 104.224t, 104.226t

Freón $\quad 7.13,96.8,96.39$

Fructosa 65.4

Ftalato de di(2-etilhexilo) 33.71

Ftalato 33.74

Ftalodinitrilo $104.142 t, 104.150 t$

Ftalonitrilo 104.142t, 104.150t

Furano 71.12

Furazolidona 33.74

Furfural $33.74,78.20-78.22$, 104.157t, 104.159t, 104.160t, 104.161t

2-(2-Furil)-3-(5-nitro-2-furil)acrilamida 33.70

Furosemida $\quad 33.74,37.9-37.10$

\section{G}

Gadolinio $10.78,76.8$

Galio $67 \quad 10.47-10.48,10.65$, 10.66

Galio 53.31

Gas carbónico 53.20

Gasolina 1.4, 1.6, 16.63, 20.14, $20.23,53.10$ - 53.11, 53.20, 53.31
Gemfibrozilo $\quad 33.74$

Geosmina 44.24

Germanio $\quad 48.29$

Giromitrina $\quad 33.74$

Glicerilfosforilcolina $\quad 9.5$

Glicerina $\quad 12.17$

Glicerol 33.9, 104.211t, 104.213t

Glicerol-tributirato $104.182 \mathrm{t}$

Glicidaldehído 33.71, 104.49t, 104.53t, 104.55t

Glicidol $\quad 96.8$

Glicol 75.11, 78.6, 78.22, 78.27, $96.6,102.31,102.36-102.37$

Glucosa $\quad 6.9-6.11,64.41$

Glutamato monosódico 11.27

Glutamato sódico 67.32

Glutaraldehído $\quad 67.10,79.16$, 100.16, 104.49t, 104.51t, 104.53t, 104.55t

Glutatión $\quad 10.83,33.8,33.19$, $33.24,33.27$

Grafito $\quad 76.8$

Gramoxone 62.14

Griseofulvina 33.71

Guanina $33.37 \mathrm{f}$

Guayacol 104.157t, 104.161t

H

$H$ afnio $\quad 33.13-41.14,76.8$

H alón $1301 \quad 41.25$

Halón $75.16,102.57$

H alotano $3.17,4.8,9.23,97.60$ - 97.61, 104.194t, 104.196t, $104.199 \mathrm{t}$

H aluro de plata 96.11

Helio $4 \quad 48.11$

H elio $10.11,36.2-36.3,36.14$, $44.22,75.3,82.25,82.30,92.7$

H eptacloro 33.71, 71.8, 104.258t, 104.265t, 104.267t

H eptano 3.17, 67.34, 78.6, $80.8,80.10,88.8,104.243 \mathrm{t}$, $104.245 \mathrm{t}, 104.246 \mathrm{t}, 104.247 \mathrm{t}$

n-H eptano $44.8,55.5$

H eptanol 104.36t, 104.39t, $104.43 \mathrm{t}$

2-H eptanol $104.36 \mathrm{t}$

$\mathrm{n}$-H eptil mercaptano 104.410t, $104.416 \mathrm{t}$

Heroína 9.9, 64.76

$\mathrm{H}$ exaclorobenceno 9.11, 33.41, $33.59 f, 33.71,55.50,62.15$ $62.16,104.303 \mathrm{t}, 104.305 \mathrm{t}$ 104.307t, 104.309t

H exaclorobutadieno 33.74, 62.11, 104.270t, 104.271t, 104.272t, 104.274t
H exaclorociclohexano 9.22, 33.71, 104.258t, 104.262t,

104.265t, 104.267t

$\alpha-H$ exaclorociclohexano 104.258t, 104.262t,

104.265t, 104.267t

$\beta$-H exaclorociclohexano 104.258t, 104.262t, 104.265t, 104.267t

$\delta$-H exaclorociclohexano $104.259 \mathrm{t}, 104.267 \mathrm{t}$

$\mathrm{H}$ exaclorociclopentadieno $104.270 t$

H exacloro-1,3-ciclopentadieno $104.274 t$

H exaclorodibenzo-p-dioxina 12.4

H exacloroetano 33.74, 104.259t, 104.262t, 104.265t, $104.267 \mathrm{t}$

H exaclorofeno $33.74,62.15$, 97.14, 104.303t, 104.307t, $104.309 \mathrm{t}$

H exacloronaftaleno 104.303t, 104.309t

H exacloropropeno 104.270t, 104.274t

H exacloruro de benceno 9.22

H exafluoracetona 104.194t, 104.198t, 104.199t

H exafluoropropileno $\quad 104.199 t$

$\mathrm{H}$ exafluorosilicato sódico 104.220t, 104.226t

H exafluoruro de azufre $\quad 76.2$, 104.221t, 104.222t, 104.224t, $104.226 \mathrm{t}$

H exafluoruro de uranio $\quad 39.33$, 76.11

H exametil fosforamida 104.386t, 104.392t

H exametilendiamina 104.84t, 104.88t, 104.90t, 104.93t

$\mathrm{H}$ exametileno-diisocianato 104.322t, 104.323t, 104.324t, $104.325 t$

H exametilentetramina 81.13 , 104.84t, 104.93t

H exametilfosforamida 33.71

$\mathrm{H}$ examina de pentaetileno 82.46

n-H exano $\quad 7.22,7.24,11.8,44.8$ $55.5,78.18$ - 78.19, 88.8, 88.10, $96.8,96.24,102.13$

$\mathrm{H}$ exano 9.23, 27.5, 31.18, $67.10,67.33$ - 67.34, 78.6, $78.10,78.22,80.7-80.8,80.10$, $88.8,96.3,96.24,104.243 \mathrm{t}$, 104.245t, 104.246t, 104.248t
1,6-H exanodiol 104.211t, 104.212t, 104.213t

2,5-H exanodiol 104.211t, $104.212 \mathrm{t}, 104.214 \mathrm{t}$

2,5-H exanodiona 104.329t, $104.336 \mathrm{t}$

H exanol 104.36t, 104.39t, 104.41t, 104.43t

2-H exanol $104.44 t$

H exanotiol 104.410t, 104.412t

1-H exeno 104.277t,104.278t, 104.279t, 104.281t

$\mathrm{n}$-H exil mercaptano $\quad 104.410 \mathrm{t}$, 104.416t

H exilenglicol 104.211t, 104.212t, 104.213t, 104.214t

Hexógeno 41.14

Hidracida sódica 75.9

2-H idracinoetanol 104.125t, $104.129 \mathrm{t}$

Hidracrilonitrilo 104.142t, $104.150 \mathrm{t}$

H idralazina $\quad 33.74$

H idrato de ácido cítrico $104.20 t$

H idrato de cloral 33.74 , 104.51t, 104.55t

H idrato de hidrazina $\quad 104.125 t$

H idrazida de ácido isónicotínico 33.74

H idrazida maleica $\quad 33.74$

H idrazina 4.10, 30.24, 33.42, $33.71,72.11,72.15$ - 72.16, 104.125t, 104.126t, 104.127t, $104.129 \mathrm{t}$

Hidrazobenceno 104.125t, $104.129 \mathrm{t}$

2,4-H idrazona 55.18

H idrocarburos aromáticos policíclicos 53.20

Hidroclorotiacida $\quad 8.5,33.74$

$\mathrm{H}$ idrocloruro de fenazopiridina 33.71

$\mathrm{H}$ idrocloruro de fenoxibenzamina 33.71

$\mathrm{H}$ idrocloruro de pronetalol 33.74

H idrocloruro de semicarbazida 33.74

$\mathrm{H}$ idrocloruro de trimustina 33.72

Hidrógeno 381.13

H idrógeno de arsénico $\quad 20.23$

Hidrógeno 4.7, 40.12 - 40.13, 41.2, 48.26, 57.16, 62.3, 62.9, $67.33,72.12,73.9,74.47$ $74.51,75.2-75.3,75.6,76.8-$ $76.9,78.3$ - 78.4, 78.12, 78.14 $78.20,78.22,78.29,81.4-81.5$, $81.14,81.16,82.28,82.42$, 
$82.44,82.48,82.51$ - 82.52, $101.19,102.33,102.36$

H idrógenofosfito de dimetilo 33.74

H idroperóxido de terc-butilo 104.365t, 104.366t, 104.367t

$H$ idroperóxido de cumeno 104.365t, 104.366t, 104.367t

Hidroquinona 12.4, 33.74, $85.10,85.15,96.11,104.372 t$, 104.375t, 104.377t, 104.380t

H idrosilicato de aluminio $\quad 78.13$ Hidrosulfito de zinc 72.9 H idrosulfito sódico $\quad 72.9,89.19$, 104.422t, 104.425t, 104.426t

H idroxiacetonitrilo $\quad 104.143 \mathrm{t}$ 104.150t

H idroxianisol butilado 33.71

Hidroxiapatita 33.14

4-H idroxiazobenceno 33.74

2-H idroxibifenilo 104.372t, 104.375t, 104.377t, 104.380t

H idroxibutilfluorocarbono 54.13

3-H idroxibutiraldehído 104.49t, 104.53t, $104.55 t$

8-H idroxi-2'-desoxiguanosina 33.45

H idróxido cálcico 72.16, 82.63, 104.62t, 104.64t, 104.67t, $104.71 \mathrm{t}$

H idróxido de aluminio $\quad 41.29$

Hidróxido de amonio 10.31, $64.53,72.8,100.6,104.62 \mathrm{t}$, 104.67t, 104.71t

H idróxido de bario 82.63 H idróxido de berilio $\quad 10.31$, $10.32 f$

H idróxido de cadmio $\quad 81.7$

$\mathrm{H}$ idróxido de litio monohidrato 104.62t, 104.64t, 104.67t, $104.71 \mathrm{t}$

H idróxido de litio 81.7 - 81.8, 104.62t, 104.64t, 104.67t, $104.71 \mathrm{t}$

H idróxido de magnesio $\quad 72.8$

Hidróxido de níquel 81.7

H idróxido de potasio 12.14 ,

41.29, 81.5, 81.7 - 81.8, 82.44, 104.62t, 104.64t, 104.67t, $104.71 \mathrm{t}$

Hidróxido de sodio 10.31 , $12.17,41.29,62.3-62.4,67.34$, $70.21,72.7-72.8,72.11,75.13$, $78.16,78.23-78.24,81.7$. $81.8,82.44,82.60,89.15$, $89.19,96.21,100.7,104.62 \mathrm{t}$, 104.65t, 104.67t, 104.71t
H idroxietiletilendiamina 104.84t, 104.93t

$\mathrm{N}$-7-(2-hidroxietil)guanina

Hidroxilamina $104.118 \mathrm{t}$

2-H idroxi-2-metilpropionitrilo 104.143t, 104.146t, 104.148t, $104.150 \mathrm{t}$

Hidroxiprolina $\quad 44.13$

2-H idroxipropil acrilato 104.173t, 104.174t, 104.175t

8-H idroxiquinolina de cobre 33.74

8-Hidroxiquinolina $\quad 33.74$

Hidroxisenkirkina 33.74

5-H idroxitriptamina 38.5 - 38.6

H idruro cálcico 104.62t, 104.67t, 104.71t

H idruro de antimonio $\quad 1.7$

$\mathrm{H}$ idruro de boro $\quad 41.9$

H idruro de litio 104.62t, 104.65t, 104.67t, 104.71t

H idruro de silicio 41.9

$\mathrm{H}$ ierro $59 \quad 48.37$

H ierro 4.4 - 4.5, 4.7, 7.26,

$10.76,10.81-10.82,11.22$,

$15.38,33.11$ - 33.12, 33.20 -

$33.21,41.10,41.14,44.12$,

$48.23,53.9,55.4$ - 55.5, 55.36 -

$55.37,55.41,55.48,62.3,73.2$ -

73.4, 73.6 - 73.8, 73.12 - 73.13,

$73.15,73.17-73.18,74.16$,

74.27 - 74.28, 74.34, 78.18,

$81.11,82.2,82.5$ - 82.7, 82.13 -

$82.16,82.18$ - 82.22, 82.31,

$82.35-82.36,82.43-82.45$,

$82.48,82.50,82.53-82.54$,

$82.60,82.63,85.13,89.19$,

$90.9,91.2$ - $91.5,96.12,96.18$

H ioscina $\quad 50.16$

H ipoclorito cálcico 64.56, 101.20

H ipoclorito sódico 44.28, 72.11, 101.20, 104.62t, 104.67t, $104.71 \mathrm{t}$

Holmio $\quad 10.78$

I

Indeno[1,2,3-cd]pireno 33.71

Indeno $104.288 t, 104.294 t$

Indio 46.7, 53.31

Indometacina 8.5

Ionomicina 33.35

Iridio $192 \quad 48.29$

Isatidina $\quad 33.74$

I sobutano 78.9, 78.15 - 78.17, 104.243t, 104.246t, 104.248t

I sobutanolamina 104.84t,

104.88t, 104.93t
I sobuteno $104.277 \mathrm{t}, 104.280 \mathrm{t}$

I sobutilaldehído 102.8, 104.49t, $104.55 \mathrm{t}$

I sobutilamina $104.84 t, 104.90 \mathrm{t}$, $104.93 \mathrm{t}$

I sobutiraldehído $\quad 104.53 \mathrm{t}$

Isobutironitrilo 104.143t,

104.148t, 104.150t

I socianato de difenilmetileno 82.17

I socianato de metilo $\quad 39.4,39.19$

I soflurano $\quad 97.60-97.61$

I soforona diamina 104.88t, 104.90t, 104.93t

I soforona diisocianato 104.322t, 104.323t, 104.324t, 104.325t

I soforona 104.329t, 104.332t, $104.336 \mathrm{t}$

I sofosfamida $\quad 33.74$

Isohexano 104.243t, 104.248t

I soniazida $\quad 4.8,33.74$

Isopentano 78.19

Isoplan 62.12

I sopreno 33.71, 41.14, 104.277t, 104.278t, 104.280t, 104.281t

Isopropanol 10.92, 33.70, $33.74,96.44$

Isopropanolamina $104.84 \mathrm{t}$, 104.90t, 104.93t

I sopropilamina $85.11,104.84 \mathrm{t}$, 104.88t, 104.90t, 104.93t

$\mathrm{N}$-I sopropilanilina $104.105 \mathrm{t}$, 104.110t, 104.118t

I sopropilbenceno $\quad 55.5$

$\mathrm{N}$-I sopropil-n'-fenil-p-fenilendiamina 104.105t, 104.110t, 104.113t, 104.118t

I sopropoxifenil-n-metilcarbamato 62.12

Isosafrol $\quad 33.74$

I sotiocianato de alilo 33.74,

104.146t, 104.148t, 104.150t

I sotiocianato sódico 104.410 t

Isotiocianato $104.143 \mathrm{t}$

I sovalerato de alilo $\quad 33.74$

Iterbio 10.78

Itrio $\quad 53.31,81.12-81.13$

Jacobine $\quad 33.74$

K

K aempferol $\quad 33.74$

Kepone $\quad 9.6 f, 9.8,9.21,33.71$

K evlar $10.86,12.18,89.2$
Lactato 90de butilo $104.178 t$

Láctico deshidrogenasa 33.52

Lactona de ácido butírico 104.179t

Lactonitrilo $\quad$ 104.143t, 104.150t

Lanolina $12.17,100.7$

Lantano $\quad 10.78,33.13,81.12$

Lasiocarpina 33.71

Lauril sulfato sódico 12.16, 104.410t, 104.414t

Lecitina $\quad 12.17$

Levulosa 64.41

Lignosulforato amónico $\quad 74.31$

Limoneno 44.10, 71.10, 104.288t, 104.294t

D-Limoneno 33.74, 104.288t, 104.290t, 104.292t, 104.294t

I-Limoneno 104.288t, 104.292t, $104.294 \mathrm{t}$

Lindano 1.3, $9.21-9.22,27.24$, $44.8,71.8$

Linurón $\quad 62.14$

Litio 8.3, 8.5, 11.27, 33.13 $41.14,41.30,46.7,55.41,62.5$, 81.4 - 81.5, 81.8, 81.16, 82.39, $96.18,104.62 \mathrm{t}, 104.65 \mathrm{t}, 104.67 \mathrm{t}$, $104.71 \mathrm{t}$

Lutecio 10.78

Luteoskyrina $\quad 33.74$

M

M agenta $\quad 33.70-33.71,89.20$

M agnesio 4.9, 10.31 - 10.32, 40.13 - 41.14, 41.30, 42.6, $42.13,47.5,55.41,64.66$, $70.17,72.19,76.10$ - 76.11, $81.11,82.2,82.7,82.13$ - 82.14, $82.19,82.29,82.36,82.47$ $82.48,82.50,82.55-82.56$, $82.63,91.3,92.6$

Magnesita $\quad 82.35$

Malatión 9.11, 22.17, 33.74, $44.8,64.44$

M alonaldehído $\quad 33.74$

M alonato de dietilo $\quad 104.179 t$

$M$ alononitrilo 104.143t, 104.148t, 104.150t

M aloprim $\quad 15.77$

M ancozeb $\quad 27.23$

M andelonitrilo 104.143t, 104.150t

M aneb 7.15, 27.23, 33.74, $62.12,64.44$

$M$ anganeso $58 \quad 48.37$

$M$ anganeso $\quad 4.2,4.4-7.6$, $7.9,7.11,7.15,7.18,7.21,7.23$ 
- 7.24, 7.26, 10.19, 16.63, 23.41, 27.12, 27.23, 30.11, 33.11, 55.36, 55.41, 73.7, $73.14,73.17$ - 73.18, 74.23, $81.13,82.31,82.43,82.54$, $82.57,82.63,86.6,92.6,96.8$, $96.22,102.41$

$M$ anzeb $\quad 64.44$

M arihuana $\quad 5.7,64.76$

M arrón sudan R R 33.74

M edfalán 33.74

M efloquina $\quad 15.77$

M elamina $33.74,71.9,89.20$, 104.105t, 104.118t

M elfalán 33.69

Meperidina 7.21

M ercaptano $\quad 55.5,78.10,78.14$, 78.23

2-M ercaptobenzotiazol 104.230t, 104.232t, 104.234t, $104.236 \mathrm{t}$

2-M ercaptoetanol $\quad 104.410 t$, 104.414t, 104.416t

6-M ercaptopurina $\quad 33.74$ M ercurio inorgánico 27.12 . 27.13, 33.6, 33.12

M ercurio orgánico 33.6, 33.12 M ercurio $4.2,4.5$ - 5.6, 7.9, $7.11,7.18,7.21,7.24,7.26,8.8$, $8.11,9.11,9.13-9.14,9.20$ $9.21,10.14,10.19,11.8,11.25$ $11.26,11.32,12.3,12.18$, $16.33 f, 16.63,20.4,27.3$ - 27.6, $27.8,27.12$ - 27.13, 30.11, $30.18,30.21,30.24-30.25$, $31.22,32.5,32.34,33.2,33.7$, 33.13 - 33.16, 33.19 - 33.20, $33.42,33.60,33.74,39.5,42.16$ - $42.17,45.5,45.10,46.2,46.6$ $46.8,49.7,53.3,53.9$ - 53.10, $53.16,53.20,53.35-55.36$, $55.41,55.48,55.50$ - 55.51, $62.15,66.20,67.10,72.12$, 73.17, 74.4, 74.41, 74.60, 76.3, $76.18,81.4$ - $81.5,81.7,81.12$ $81.14,81.16$ - 81.17, 82.4, $82.11-82.12,82.48,82.56-$ $82.57,82.60,85.9,92.15,96.8$, 96.13 - $96.15,96.22,96.24$, $96.35,96.41,97.56,97.71$, $100.16,101.20$

M erfalán 33.71

M esilato de hicantona $\quad 33.74$

M etabisulfito sódico 96.11, 104.422t, 104.426t

$M$ etabisulfitos $\quad 33.74$

M etacrilato de butilo 104.173t, 104.175t
M etacrilato de etilo 104.173t, 104.174t, 104.175t

M etacrilato de metilo $\quad 33.74$, 104.173t, 104.174t, 104.175t

M etacrilato de polimetilo $\quad 33.74$

M etacroleína $\quad 102.8$

M etafenilenodiamina $\quad 12.4$

M etaldehído $\quad 104.49 t, 104.55 t$

M etalotioneína $\quad 33.14,33.21$

M etaltioneína 27.10

M etano 7.21, 10.17, 36.5 - 36.6, $40.13,44.8,53.20,53.27$, $55.17,55.19,57.16,59.25$, $62.9,67.14,70.5,70.13,70.18$, $70.20,70.26,72.20,73.9,74.9$, 74.18 - $74.19,74.33,74.36$, $74.41,74.45,74.47-74.52$, $74.60,75.2-75.3,75.6,75.11$ 78.19 - 78.20, 82.45, 101.11 $101.13,101.19,101.27,102.69$

M etanol 16.33f, 27.13, 27.15, 53.31, 72.11, 78.25, 85.9, 86.14, 89.3, 96.39, 100.16, 102.70, 104.37t, 104.39t, 104.41t, 104.44t

M etanosulfonato de etilo 33.71

$M$ etanosulfonato de metilo 33.71

M etanosulfonil cloruro 104.414t, 104.416t

M etil bromuro 64.56

M etil n-butilcetona $\quad 96.8$

M etil 2-cianoacrilato $104.150 \mathrm{t}$

Metilciclohexano 104.244t, 104.245t, 104.246t, 104.248t

M etil diclorosilano 104.401t, 104.402t, 104.403t, 104.404t

M etil etil cetona $\quad 27.5,44.10 f$, 104.329t

M etil isocianato $104.322 t$, 104.323t, 104.324t, 104.325t

M etil mercaptano 72.19 , 104.412t, 104.416t

M etil mercurio $7.4,9.14,27.13$

M etil sulfoxido 104.410 t

$M$ etil sulfuro $104.410 \mathrm{t}$

M etil triclorosilano 104.401t, 104.402t, 104.403t, 104.405t

2-M etil-1-butanol 104.37t, 104.39t, 104.44t

2-M etil-1-nitroantraquinona 33.71, 104.351t, 104.359t

2-M etil-4-pentanol 104.37t, 104.40t, 104.42t, 104.44t

M etilacrilonitrilo 104.143t, 104.148t, 104.150t

M etilal 104.49t, 104.51t, 104.54t, $104.55 \mathrm{t}$
M etilamilcetona $104.329 \mathrm{t}$, 104.332t, 104.334t, 104.336t

M etilamina $104.85 \mathrm{t}, 104.88 \mathrm{t}$, 104.90t, 104.93t

2-M etilaminoetanol $\quad 104.85 \mathrm{t}$, 104.93t

p-metilaminofenol 104.105t, 104.113t, 104.118t

p-metil-aminofenolsulfato 85.15 , 96.11

5-M etilangelicina $\quad 33.74$

M etilanilina $104.105 t, 104.110 t$, 104.113t, 104.118t

M etilato sódico $104.62 \mathrm{t}$, 104.65t, 104.68t, 104.71t

2-M etilaziridina 33.71

2-M etilbutano 104.244t, 104.245t, 104.246t, 104.248t

M etil-n-butil cetona 7.24

M etil-tert-butil éter $\quad 102.67$

M etilbutilcetona $\quad 7.22,88.8$, 89.20, 104.329t, 104.332t, 104.334t, 104.337t

M etilbutiléter terciario $\quad 78.5$, 78.25

M etil-2-cianoacrilato $\quad 104.143 t$

$\mathrm{N}$-metilciclohexanol $\quad 104.37 \mathrm{t}$

M etilciclohexanol 104.37t, 104.39t, 104.41t, 104.44t

m-metilciclohexanol 104.39t, 104.41t, 104.44t

o-metilciclohexanol 104.37t, 104.40t, 104.41t, 104.44t

2-M etilciclohexanona 104.329t, 104.332t, 104.337t

M etilcloroformo 27.5

3-M etilcolantreno 33.41

5-M etilcriseno 33.71

1-M etilcriseno 33.74

2-M etilcriseno 33.74

3-M etilcriseno 33.74

4-M etilcriseno $\quad 33.74$

6-M etilcriseno $\quad 33.74$

M etildietanolamina $\quad 78.23$

4-M etil-2,6-dinitroanilina 104.351t

M etilditiocarbamato sódico 62.12

M etilen bis(fenilisocianato) 104.322t, 104.323t, 104.324t, $104.325 \mathrm{t}$

4,4'-M etilen-bis-2-cloroanilina $8.13,33.68,104.119 t$

4,4'-M etilen-bis (cloroanilina) 104.105t

4,4'-M etilenbis(n,n-dimetil)bencenamina 33.75

4,4'-M etilenbis(2-metilanilina) $104.105 t$
2,4'-M etilendianilina $\quad$ 104.105t

4,4-M etilendianilina $\quad 104.106 \mathrm{t}$

4,4'-M etilendianilina 8.13 , 33.71

4,4'-M etileno bis(2-cloroanilina) 33.70

4,4'-M etileno bis(2-metilanilina) 33.71

4,4-M etileno-bis-2-cloroanilina 2.4

M etilestireno $104.288 \mathrm{t}$, 104.290t, 104.292t, 104.294t $\alpha$-metilestireno 104.288t, 104.290t, 104.292t, 104.294t m-metilestireno 104.288t, 104.290t, 104.292t, 104.294t o-metilestireno 104.288t, 104.290t, 104.292t, 104.294t p-metilestireno 104.288t, 104.290t, 104.292t, 104.294t

M etiletilcetona $7.24,78.20$, 86.14, 88.8, 92.9, 96.39, 100.7, 104.332t, 104.334t, 104.337t

1-M etilfenantreno $\quad 33.75$

$\mathrm{N}$-metil-4-fenil-1,2,3,6-tetrahidropiridina 7.26

1-M etil-4-fenil-1,2,3,6-tetrahidropiridina $7.11,7.21$

2-M etilfluoranteno $\quad 33.75$

3-M etilfluoranteno $\quad 33.75$

M etilformamida 104.76t, $104.79 t$

M etilglioxal $\quad 33.75$

2-M etilheptano 104.244t, 104.245t, 104.246t, 104.248t

5-M etil-3-heptanona 104.329t, $104.332 \mathrm{t}, 104.337 \mathrm{t}$

3-M etilhexano $\quad 55.5$

5-M etil-2-hexanona 104.330t, 104.333t, 104.334t, 104.337t

M etilhidrazina $104.125 t$, 104.127t, 104.128t, 104.129t

M etilisobutilcetona 78.20 , 100.13, 104.330t, 104.333t, $104.335 \mathrm{t}, 104.337 \mathrm{t}$

M etilisocianato $\quad 7.15$

M etilisopropilcetona 104.330t, 104.333t, 104.335t, 104.337t

M etilmercaptano 104.410t, 104.414t

M etil-mercurio $\quad 11.8$

M etilmercurio 33.71, 7.15, 7.23, 9.21, 33.19

M etilmetacrilato $\quad 100.7$

$\mathrm{N}$-metilmorfolina $104.230 \mathrm{t}$, $104.236 \mathrm{t}$

$\mathrm{N}$-metil-N , 4-dinitrosoanilina 33.75 
$\mathrm{N}$-metil-N '-nitro-N -nitrosoguanidina 33.70

M etilnaftaleno 104.288 ,

104.290t, 104.292t, 104.294t

4-(M etilnitrosamina)-1-(3-piri-

dilo)-1-butanona $\quad 44.14$

4-(M etilnitrosamino)-1-(3-piridil)-1-butanona 33.26

$\mathrm{N}$-metil-N -nitrosoanilina 104.351t, 104.359t

$\mathrm{N}$-metil-N -nitrosourea $\quad 33.70$

$\mathrm{N}$-metil-N -nitrosouretano 33.71

$\mathrm{N}$-metilolacrilamida $\quad 33.75$

M etilparatión $\quad 27.22,33.75$

3-M etilpentano 104.244t, 104.246t, 104.248t

2-M etilpiridina 104.230t, 104.232t, 104.234t, 104.236t

3-M etilpiridina 104.230 , 104.232t, 104.234t, 104.237t

4-M etilpiridina $104.230 \mathrm{t}$, 104.232t, 104.234t, 104.237t

7-M etilpirido[3, 4-c]psoraleno 33.75

1-M etil-2-pirrolidinona 104.230t

1-M etil-2-pirrolidona 104.233t, 104.234t, 104.237t

M etilpropilcetona 104.330 , 104.333t, 104.335t, 104.337t

M etiltestosterona 4.8

M etiltiouracilo 33.71

M etilvinilcetona $104.330 \mathrm{t}$, 104.337t

M etimazol $\quad 11.27$

D,L-M etionina $104.410 t$, 104.414t

M etotrexato $\quad 33.75$

2-M etoxiacetato de etilo 104.168t, 104.169t

3-M etoxi-1-butanol 104.40t, 104.42t, 104.44t

3-(M etoxicarbonil) aminofenil-N -(3-metilfenil) carbamato 62.12

M etoxicloro $\quad 33.75$

2-M etoxietanol 9.5

4-M etoxifenol 104.372t, $104.380 \mathrm{t}$

M etoxiflurano $\quad 8.5,97.60$

4-M etoxi-4-metil-2-pentanona 104.330t, 104.335t, 104.337t

2-M etoxipropan-1-ol $\quad 104.44 \mathrm{t}$

8-M etoxipsoraleno 33.69

5-M etoxipsoraleno $\quad 33.70$

M etronidazol 33.71

M ezcla de éter fenílico y bifenilo $104.187 \mathrm{t}$

Milneb $\quad 62.16$
M irex $33.71,53.35,55.48$, 55.50

M itomicina c 33.71

M olibdeno $99 \quad 48.13,48.13 f$

M olibdeno $55.41,74.16,78.5$,

$78.7,78.17,81.12,82.39,82.61$

Molinate $\quad 62.14$

M onocrotalina 33.71

M onoetanolamina 78.23

M onolinurón 62.14

M onotioglicolato de glicerol 100.7

M onóxido de carbono 1.6, 3.6, 3.16 - 3.17, 4.4, 7.11, 7.15 -

$7.16,7.20$ - $7.21,8.5,9.15$, 10.10 - 10.11, 10.14, 10.18, $10.34,10.50,10.76,11.8,13.3$, $13.5,15.23,16.33 f, 16.63,27.4$, $30.6,30.19 f, 30.20$ - 30.21, 30.23 - 30.24, 30.30f, 30.31,

$30.33,33.6,33.12,33.19$, $33.25,33.31,33.35,36.2$ - 36.3 , 39.26, 41.15, 44.4 - 44.7, 44.4f, 44.9 - 44.10, 44.19, 44.21, $44.29,44.31,45.8,45.10$, 45.16, 45.21, 47.4, 53.11, 53.14, 55.4 - 55.6, 55.14, 55.19, $58.7,59.25,62.3,64.24,64.41$, $64.73,65.6,65.15$ - 65.17, $66.17,67.10,67.27,67.31$, $70.13,70.26,70.29,70.40$, 71.8, 72.19, 73.4, 73.6, 73.8, $73.10,73.12,73.15,73.16 f$, $74.36,74.44,74.47$ - 74.49, 74.51 - 74.52, 74.59 - 74.60, $78.5,78.13-78.14,78.16$, 78.18 - 78.19, 78.27, 78.33, $81.7,82.3,82.5,82.7-82.8$ $82.15,82.18$ - 82.20, 82.27, $82.30,82.45,82.48,82.51$, 82.53, 89.15, 91.4 - 91.5, 91.7 $91.8,92.17,95.6,96.12$ - 96.14 , $96.19,96.46,96.57,98.6$, $99.11,99.16,100.13,101.17$, 102.29, 102.35, 102.39, 102.70, 102.76

M onóxido de nitrógeno $\quad 55.19$, 74.59

M onóxido de plomo 82.43

M onóxido de silicona 104.401t, $104.405 t$

M onurón $\quad 33.75,62.14$

M orfina $\quad 37.9,53.33,64.76$

M orfolina $33.75,72.11$, 104.230t, 104.233t, 104.234t, $104.237 \mathrm{t}$

4-M orfolinacetonitrilo $\quad$ 104.143t

4-M orfolincarboxaldehído $104.49 \mathrm{t}$
4-M orfolincarboxialdehído $104.55 t$

5-(M orfolinometilo)-3-(5-nitrofurfurilideno)amino-2-oxazolidinona 33.71

M ostaza de uracilo 33.72

M ostaza nitrogenada $\quad 12.4,12.8$, 33.70

M yleran $\quad 33.69$

N

N $104.116 t$

$\mathrm{N}$ afenopino $\quad 33.72$

$N$ afta $78.10,78.17,78.19$ -

78.20, 80.8, 81.12, 89.19, 91.6, $92.17,100.13$

N aftaceno 104.315t, 104.318t

1,5-N aftalendiamina 33.75 , 104.106t, 104.110t, 104.113t, $104.119 \mathrm{t}$

$N$ aftaleno $\quad 1.7,44.7-44.8$, $44.11,53.20,88.3,104.288 \mathrm{t}$, 104.291t, 104.294t

1,5- $\mathrm{N}$ aftaleno-diisocianato $104.322 \mathrm{t}$

N aftalina $\quad 96.44$

$N$ aftenato de cobre $\quad 12.6$

$\mathrm{N}$ aftenato de plomo 82.39

$\alpha$-naftilamina $104.106 \mathrm{t}$, 104.110t, 104.113t, 104.119t

$\beta$-naftilamina $44.12,81.10$, 104.106t, 104.110t, 104.113t, $104.119 \mathrm{t}$

1-N aftilamina $\quad 33.75$

2-N aftilamina $\quad 2.4-2.5,8.13$, 33.69

1,5-N aftileno-diisocianato 104.323t, 104.324t, 104.325t

1-N aftiltiourea $\quad 33.75$

$\mathrm{N}$ aftol $\quad 89.19$

Naftóxido sódico $\quad 89.19$

Naled 64.44

Neodimio 10.78

N eón $\quad 46.7,96.14$ - 96.15

$\mathrm{N}$ eopentilglicol 104.212t,

104.214t

N eopreno 41.14

Neptunio (isótopos) 48.16f,

Neptunio $237 \quad 48.15$

N icotina $\quad 3.6,9.15,9.24,13.5$ $15.42,15.45-15.48,29.54$ $31.17,33.19,34.63,42.42$, $42.52,44.7,44.13$ - 44.14 , 44.16 - $44.17,53.33,64.55$ $64.59,64.73,104.230 t$, 104.233t, 104.234t, 104.237t Nifedipino $\quad 37.9,37.14$ Niobio $\quad 82.57,82.61$
Níquel $60 \quad 48.13,48.13 f$ Níquel carbonilo $\quad 78.14,82.4$

Níquel 2.2, 2.4, 2.12, 4.4, 4.11, $10.7,10.31$ - 10.32, 10.91, $11.26,11.32,12.7,12.16$, $16.33 f, 27.8,27.13,32.10$, $32.33,33.41$ - $33.42,41.11$ $44.12,44.31,53.3,55.5,55.16$, 55.41, 55.51f, 67.27, 67.33, $70.17,72.15-72.16,73.5$, $73.12,73.14,73.17,74.41$, $74.43,74.60,76.2,78.5,78.14$, 78.19, 81.4 - 81.8, 81.11, 81.16, 82.2 - $82.3,82.10,82.13,82.21$, $82.23,82.30,82.42$ - 82.43, 82.46 - 82.48, 82.57, 82.59 $82.60,82.62-82.63,90.3,90.9$ - $90.10,91.4,92.6,96.8$ - 96.9, $96.13-96.14,96.22,100.3$, $101.20-101.21$

Níquel $\quad 33.69,33.72$

Niridazol 33.72

Nirit 62.16

Nitiacida $\quad 33.75$

Nitrato cálcico $12.4,104.62 \mathrm{t}$, 104.68t, 104.72t

Nitrato de amonio $\quad 41.14,62.7$ $62.8,64.48,73.17,74.10$, 74.21, 104.62t, 104.68t, 104.72t Nitrato de cadmio $\quad 81.7$ Nitrato de etilo $104.342 \mathrm{t}$, 104.345t

Nitrato de níquel $\quad 81.7$ Nitrato de peroxiacetilo $\quad 55.4$ Nitrato de plata $\quad 48.26,85.13$ Nitrato de plomo 88.6 Nitrato de n-propilo 104.180 t

Nitrato de propilo 104.342t, $104.345 \mathrm{t}$

Nitrato potásico 104.62t, 104.68t, 104.72t

Nitrato sódico $\quad 82.24,82.43$, $82.60,104.62 \mathrm{t}, 104.68 \mathrm{t}, 104.72 \mathrm{t}$ Nitratos 1.6, 53.11, 53.18 $53.19,53.21$

Nitrito cálcico $\quad 104.62 t, 104.72 t$ Nitrito de amilo 82.47, 104.342t, 104.345t

$\mathrm{N}$ itrito de diciclohexilamina 104.119t

Nitrito de etilo 104.342t, $104.345 \mathrm{t}$

Nitrito de sodio $\quad 33.32,82.24$, 82.42 - 82.43, 82.60, 104.62t, 104.65t, 104.68t, 104.72t N itrito potásico $104.62 \mathrm{t}$, 104.65t, 104.68t, 104.72t Nitritos $\quad 1.6$ 
5-N itroacenafteno $\quad 33.72$, 104.351t, 104.359t

m-Nitroanilina 104.106t, 104.110t, 104.114t, 104.119t 0-N itroanilina 104.106t, 104.111t, 104.114t, 104.119t p-Nitroanilina 55.18, 104.106t, 104.111t, 104.114t, 104.119t

5-Nitro-0-anisidina 33.75, 104.351t, 104.357t, 104.359t

2-N itroanisol 33.72

9-N itroantraceno 33.75

Nitrobenceno $16.63,33.72$, 104.351t, 104.355t, 104.357t, 104.360 t

Nitrobencenos $\quad 1.6$

7-N itrobenz[a]antraceno $\quad 33.75$

6-N itrobenzo[a]pireno $\quad 33.75$

4-N itrobifenilo $\quad 8.13,33.75$

Nitrocelulosa 96.39

6-N itrocriseno $\quad 33.72$

4-Nitrodifenilamina 104.351t, 104.355t, 104.357t

4-Nitrodifenilo 104.351t, 104.360t

Nitroetano 11.32, 104.343t, 104.344t, 104.345t

Nitrofen $62.14,64.44,104.351 t$, 104.355t, 104.360t

4-N itrofenilbenzanamina 104.360t

2-Nitro-p-fenilendiamina 104.351t, 104.360t

Nitrofeno 33.72

m-nitrofenol 104.352t, 104.357t, 104.360t

o-nitrofenol 104.352t, 104.357t, $104.360 \mathrm{t}$

p-nitrofenol 27.22, 62.11, 104.352t, 104.355t, 104.357t, $104.360 \mathrm{t}$

3-N itrofluoranteno $\quad 33.75$

2-Nitrofluoreno 33.72

Nitrofural 33.75

Nitrofurantoína 33.75

Nitrofurazona 33.75

1-(5-N itrofurfurilideno)amino-2-imidazolidinona 33.72

N-4-(5-N itro-2-furil)-2-tiazolil acetamida 33.72

Nitrógeno 9.8 - 10.9, 10.10f, $10.11,10.17,33.30$ - 33.31, 33.38, 36.2 - 36.6, 36.8 - 36.9, $36.11,37.11,37.13,41.2,41.6$ 41.13 - 41.14, 41.25, 41.29, $44.22,46.7,53.19$ - 53.20, $53.33,55.18,55.31,55.33$, $55.37,55.53,57.15$ - 57.16, 62.7 - 62.9, 64.48, 64.54 -
$64.55,64.57,64.64,64.66$, $64.73,67.5,67.25,67.30,70.5$, $70.20,72.8$ - 73.9, 74.36, 74.46, $74.51,74.59$ - $74.60,75.2$ $75.4,75.10$ - 75.11, 75.14, 78.4, $78.7,78.10,78.14$ - 78.17, $78.21-78.22,78.28-78.29$, $79.18,81.14,82.17,82.25$, $82.45,82.48,85.15,92.6,95.6$, $96.36,100.12$ - 100.13, 101.18 $101.19,101.26,102.56,102.60$, $102.62,102.66$

Nitroglicerina $3.16,16.33 \mathrm{f}$, 41.14, 104.343t, 104.345t

Nitroglicol $16.33 \mathrm{f}$

Nitrometano 104.343t, 104.344t, 104.345t

1-Nitronaftaleno 33.75 , 104.352t, 104.357t, 104.360t

2-N itronaftaleno 33.75, 104.352t, 104.360t

3-Nitroperileno 33.75

1-Nitropireno 33.72, 104.352t

2-Nitropireno 33.75

4-Nitropireno 33.72

Nitropropano $\quad 102.50$

1-Nitropropano 104.343t, 104.345t

2-N itropropano 33.72, 104.343t, 104.345t

Nitrosamina $\quad 80.8,80.10$

$\mathrm{N}$-nitrosamina $\quad 80.7$

Nitrosaminas 44.7

$\mathrm{N}$-nitrosoaminas 4.10

N'-nitrosoanabasina 33.75

$\mathrm{N}$ '-nitrosoanatabina 33.75

$\mathrm{N}$-nitrosodietanolamina 33.72 , 82.42

$\mathrm{N}$-nitrosodietilamina $\quad 33.70$

$\mathrm{N}$-nitrosodifenilamina $\quad 33.75$

p-nitrosodifenilamina 33.75 , 104.352t, 104.360t

$\mathrm{N}$-nitrosodimetilamina $\quad 33.70$, $33.38 f$

$\mathrm{N}$-nitrosodi-n-butilamina $\quad 33.72$

$\mathrm{N}$-nitrosodi-n-propilamina 33.72

$\mathrm{N}$-nitrosoguvacina 33.75

$\mathrm{N}$-nitrosoguvacolina $\quad 33.75$

$\mathrm{N}$-nitrosohidroxiprolina 33.75

4-(N -N itrosometilamino)-4-(3-piridil)-1-butanal 33.75

4-(N -N itrosometilamino)-1-(3-piridil)-1-butanona 33.72

3-(N-N itrosometilaminopropionaIdehído 33.75

3-(N-N itrosometilamino)propionitrilo 33.72

$\mathrm{N}$-nitrosometiletilamina $\quad 33.72$ $\mathrm{N}$-nitrosometilvinilamina $\quad 33.72$
$\mathrm{N}$-nitrosomorfolina 33.72

$\mathrm{N}$-nitrosonornicotina 33.72 , 104.230t, 104.237t

$\mathrm{N}$-nitrosopiperidina $\quad 33.72$

$\mathrm{N}$-nitrosopirrolidina 33.72

$\mathrm{N}$-nitrosoprolina $33.75,44.13$

n-Nitrososarcosina 33.72

m-N itrotolueno 104.352t, 104.357t, 104.360t

0-N itrotolueno 104.352t,

104.355t, 104.357t, 104.360t

p-Nitrotolueno 104.352t,

104.355t, 104.357t, 104.361t

5-N itro-o-toluidina 33.75

Nitrovina 33.75

Nitruro de fósforo $\quad 81.12$

Nitruro de titanio $\quad 10.74$

Nnk 33.26

Nobam 62.12

Nonano 44.10f, 104.244t,

104.246t, 104.248t

n-N onano $\quad 55.5$

Nonanol 104.37t, 104.44t

$\mathrm{N}$ onilfenol, todos los isómeros

104.372t, 104.375t, 104.380t

Norbormida 62.12

Nylon $6 \quad 33.75$

0

O cratoxina A 33.72

O ctabromobifenilo $\quad 104.303 t$

O ctacloroestireno $\quad 55.50$

O ctacloronaftaleno 104.303t, 104.307t, 104.309t

1-0 ctadecanodiol 104.410t

O ctadecanotiol 104.412t

1-O ctadecanotiol 104.411t

1,7-0 ctadieno 104.277t, 104.278t, 104.280t

O ctafluorisobutileno 104.194t, 104.196t

O ctano 44.10f, 55.5, 104.244t, 104.245t, 104.247t, 104.248t

O ctanol 104.37t, 104.44t

2-0 ctanol 104.37t, 104.44t

n-O ctanotiol $104.416 \mathrm{t}$

1-0 ctanotiol 104.410t, 104.413t

1-O cteno 104.277t, 104.278t,

104.280t, 104.281t

1-0 cten-3-ol 44.24

O leato de glicidilo 33.75

O pio 64.76

O ro $4.5,10.82,30.31,33.14$,

$42.12,74.2-74.3,74.16,74.21$

- 74.23, 74.60, 82.2, 82.4 - 82.5,

$82.7,82.11$ - 82.12, 82.42,

82.57 - 82.58, 82.62, 96.2,

$96.12,96.22$
O xalato de amonio $\quad 104.179 t$

0 xalato de etilo 104.179t,

$104.182 \mathrm{t}$

Oxazepam 33.72

O xibenzona $49.8 f$

O xicloruro de fósforo $104.386 \mathrm{t}$ 104.390t

4,4'-0 xidianilina 104.106t, $104.119 \mathrm{t}$

Oxido bórico 104.132t, 104.133t, 104.134t, 104.136t

0 xido de aluminio $\quad 82.9,82.35$, $10.74,10.76$ - 10.77, 10.85f, $10.86,11.25,62.3,62.5,82.35$, $92.9,96.13$

0 xido de antimonio $\quad 11.25$, 82.43

0 xido de azufre $\quad 55.14,73.16 f$, $82.6,82.54,92.17,96.19,96.43$

O xido de bario 10.87

O xido de berilio $10.31-10.32$

0 xido de cadmio $11.25,81.5$, $81.7,81.10$

0 xido de calcio $\quad 10.87,12.4$ $12.5,62.3,104.62 \mathrm{t}, 104.65 \mathrm{t}$, 104.68t, 104.72t

Oxido de cloro 104.221t, 104.223t, 104.224t, 104.226t

O xido de cobalto 27.11

Oxido de cobre $10.19,11.25$, $74.23,82.7,82.51$

0 xido de decabromodifenilo 33.75

Oxido de deuterio $\quad 76.8$

O xido de dietileno 89.13

O xido de difenilo clorado $104.188 \mathrm{t}$

0 xido de estaño $\quad 10.36,11.25$, 82.60

0 xido de 7,8-estireno $\quad 33.70$

0 xido de etileno $1.4-1.5$, $27.18,33.45,33.69,41.13$, 79.16, 97.5, 97.14, 97.56, 102.50, 104.157t, 104.159t, 104.160t, 104.161t

O xido de fósforo $104.386 \mathrm{t}$

Oxido de hidrógeno 76.8

0 xido de hierro 10.7, 10.19, $10.36,10.77,11.25,33.75$, 49.17, 55.4, 62.2, 62.6, 73.12, $73.17,81.7,82.5,82.15,82.19$, $82.29,82.35,82.52,85.7,92.9$, $96.13,102.41$

O xido de litio 10.87

Oxido de magnesio 10.77 , $10.87,11.25,72.8,81.8,82.19$

0 xido de manganeso 11.25 , 55.4

O xido de mercurio $\quad 81.5,81.16$ 
Oxido de mesitilo 104.330t, 104.335t, 104.337t

0 xido de níquel $\quad 11.25$

0 xido de nitrógeno 4.11, 10.7, 10.82 - 10.83, 44.4f, 81.17, $82.19,82.21,82.51,96.14$ $102.8,102.76$

O xido de paladio 74.48

O xido de plata $11.25,81.4$, 81.16

0 xido de plomo 11.25, 81.2 $81.3,82.6,96.18$

0 xido de potasio $10.87,62.3$, $62.7,104.62 \mathrm{t}, 104.66 \mathrm{t}, 104.68 \mathrm{t}$ $104.72 \mathrm{t}$

Oxido de propileno 33.72

0 xido de selenio $\quad 11.25$

Oxido de sodio $10.87,62.3$

Oxido de titanio $10.87,12.17$

Oxido de tribultitina 33.41

Oxido de tributilzina 71.8

O xido de tris(1-aziridinil)fosfina 33.75

0 xido de tris(2-metil-1-aziridinil)fosfina $\quad 33.75$

Oxido de tritio 48.26

Oxido de uranio $39.32,76.10$ 76.11

O xido de vanadio $\quad 82.10$

Oxido de zinc $10.19,10.87$, $11.25,73.16 f, 78.24,80.3,82.7$, $82.43,82.55,92.9$

O xido nítrico $44.5,44.9,55.4$, $74.49,78.5,102.39$

O xido nitroso 7.11, 20.23, $53.27,96.46,97.60$ - 97.61

$\mathrm{N}-0$ xido polivinil piridina 10.52

0 xidos de azufre $44.4,49.31$, $53.12,67.10,67.14,72.19$, $73.15,73.17,82.55$

O xidos de carbono $\quad 44.6,73.9$

Oxidos de hierro $\quad 73.15,73.18$

Oxidos de nitrógeno 15.23 , 36.2, 44.4, 44.6, 44.9 - 45.10, $45.21,53.11$ - 53.13, 54.12, 55.4 - 55.5, 55.14, 64.24, 66.17, $72.19,73.12,73.15,73.17$, $74.36,74.59$ - 74.60, 76.8, $76.17,78.10,78.33,91.5$

O xidos nitrosos 45.25

Oxifenbutazona 33.75

Oxígeno 3.17, $6.9-6.11,7.2$, $7.11,7.13,7.21,9.15$ - 9.16, $10.10-10.11,10.18,10.76$, $11.32,30.6,30.24,31.22$ $31.24,31.27$ - 31.28, 31.30 $31.31,33.3,33.5,33.8,33.12$, 33.31 - $33.32,33.37,33.54$, 36.2 - $36.5,36.8$ - 36.14, 37.2 -
$37.15,37.2 f, 37.3 f, 37.4 f, 37.6 f$, $37.8 f, 41.2$ - 41.3, 41.5 - 41.6, 41.8 - 41.9, 41.12 - 41.15, 41.18 - 41.19, 41.24 - 41.25, 44.8, $44.19,45.10,53.13,53.18$ 53.21, 53.30, 53.34, 55.16, 55.29 - 55.31, 55.33, 55.35, $55.42,57.14$ - 57.16, 59.25, $62.9,64.8,64.24,64.32,64.40$, $64.62,64.73,66.17,66.20$, $67.2,67.14,67.19,67.27,67.29$ - $67.30,70.5,70.13,70.18$, $70.29,70.38,72.8,72.11,72.19$ - 72.20, 73.2 - 73.5, 73.7 - 73.8, $73.15,73.16 f, 73.17-73.18$, 74.28 - 74.29, 74.36, 74.44, 74.47 - $74.50,74.59$ - 74.60 , 75.2 - 75.3, 75.6, 75.11, 78.4 $78.7,78.13,78.21,78.23,78.26$ - 78.27, 78.32, 81.2, 81.4, 81.12, 81.14, 82.3, 82.5, 82.11, $82.17,82.20,82.25,82.28$ $82.29,82.31,82.42-82.43$, $82.45,82.48,92.6$ - $92.7,92.9$, $92.14,96.14,96.36$ - 96.37 , $96.57,97.60,97.62,99.16$, 100.12, 101.4, 101.11 - 101.12, $101.19-101.20,101.26,102.14$ - 102.15, 102.18 - 102.19, 102.21, 102.48, 102.55, 102.57, 102.60, 102.64 - 102.66, $102.68,102.70,102.76$

Oximociclohexanona 104.330t, $104.337 \mathrm{t}$

O zono $10.82-10.83,11.32$, $12.10,13.6,20.23,30.14$, $30.29,33.23,33.30,33.41$, $41.25,44.5$ - 44.6, 44.8 - 44.9, $44.21,44.31,45.10,45.25$, $49.7,49.15,53.3$ - 53.4, 53.11 $53.14,53.13 f, 53.28,53.30$ $53.32,53.34$ - 53.35, 54.12 54.13, 54.30, 54.36, 55.3 - 55.5, $55.12,55.14,55.19,55.33$, $67.27,72.9,73.12,73.17,76.2$, $76.8,76.18,80.18,81.10$, $82.21,82.27,82.30,82.62,85.7$ - 85.9, 85.12 - 96.14, 96.57, $100.12,101.12$ - 101.13, 102.15

\section{P}

Paladio $\quad 82.57,82.61,96.46$ Paraarámido 10.86 Parabenzoquinona 96.14 Paracetamol 33.75 Paracresol 82.39 Paradiclorobenceno $\quad 44.8,96.44$ Parafina $\quad 81.6-81.7$
Paraformaldehído 81.12, 104.49t, 104.51t, 104.54t, $104.55 \mathrm{t}$

Paraldehído 104.49t, 104.54t, $104.55 \mathrm{t}$

Paraquat $7.15,7.26,12.19$, $22.17,27.25,33.32,62.13$ 62.14

Pararosanilina 44.21

Parationa 9.11, 27.22, 33.75, $62.11,64.44$

Patulina 33.75

Pcb 9.21 - 9.22, 27.3, 33.12, $33.41,33.57$ - 33.58, 33.60, $53.9,53.16,53.35,55.48,55.50$ - 55.51, 73.18, 81.14, 81.17, 102.7

Pcp $\quad 5.7$

Pectina 64.41

Penicilamina $11.27,33.14$

Pentaborano 104.132t, 104.133t, 104.134t, 104.136t

Pentabromuro de fósforo 104.221t, 104.224t, 104.226t

Pentacetato de dietilentriamina de tecnecio $\quad 10.47$

Pentaclorobenceno 62.15, 104.303t, 104.305t, 104.307t, 104.309t

Pentacloroetano 33.75, 104.259t, 104.265t, 104.267t

Pentaclorofenato sódico $\quad 80.3$

Pentaclorofenol 27.25, 33.72, $44.8,45.5,55.54,62.11,71.5$ $71.6,71.11,88.9,96.20$, 104.372t, 104.376t, 104.378t, $104.380 \mathrm{t}$

Pentaclorofenol, sal sódica 104.372t, 104.376t, 104.378t, $104.380 \mathrm{t}$

Pentacloronaftaleno 104.304t, 104.305t, 104.307t, 104.309t

Pentacloronitrobenceno 33.75 , 62.15

Pentacloruro de fósforo 104.386t, 104.388t, 104.390t, $104.392 \mathrm{t}$

Pentadecano 44.10f,

Pentaeritritol tetranitrato 104.343t, 104.344t, 104.345t Pentaeritritol 104.212t, 104.214t

Pentafluoruro de azufre 104.221t, 104.223t

Pentafluoruro de bromo 104.221t, 104.223t, 104.224t, 104.226t

Pentamina de tetraetileno $\quad 82.46$ n-Pentano 78.18 - 78.19
Pentano 75.3, 104.244t, 104.245t, 104.247t, 104.248t

1,5-Pentanodiamina 104.85t, $104.93 \mathrm{t}$

2,4-Pentanodiona 104.330t, 104.333t, 104.335t, 104.337t

1-Pentanol 104.37t, 104.40t, 104.42t, 104.44t

3-Pentanol 104.37t, 104.40t, 104.42t, 104.44t

1-Pentanotiol 104.411t, 104.415t, 104.416t

Pentaóxido de vanadio $\quad 10.7$

Pentasulfuro de fósforo 104.386t, 104.389t, 104.390t, $104.392 \mathrm{t}$

6-Pentil--pirona 44.24

Pentoxido de fósforo 104.389t, 104.391t, 104.391t

Pentóxido de vanadio 81.13, 82.19

Perborato sódico 88.6, 104.132t, 104.136t

Percloretileno 87.7

Percloroetileno 4.10, 9.6f, $33.42,82.59,100.10$

Perclorometil mercaptano 104.411t, 104.413t, 104.415t, $104.416 \mathrm{t}$

Perfluorisobutileno 104.194t, 104.196t, 104.199t

Perileno 33.75, 104.315t

Permetrina $15.77,27.23,33.75$, 74.5

Peroxidicarbonato de diisopropilo 104.365t, 104.366t, 104.367t

Peróxido de benzoilo 33.75 , 104.365t, 104.366t, 104.367t

Peróxido de dicumilo 104.365t, 104.366t, 104.367t

Peróxido de dodecanoilo 104.365t, 104.366t, 104.367t

Peróxido de hidrógeno 33.8, $33.75,67.27,72.9,86.2,88.6$, $89.14,89.18$ - 89.19, 96.21 , 101.20, 104.365t, 104.366t, $104.367 \mathrm{t}$

Peróxido de lauroilo 33.75

Peróxido de plomo 81.2

Peróxido de sodio 89.14, 100.6, 104.62t, 104.68t, $104.72 \mathrm{t}$

Persulfato amónico 54.36, 104.422t, 104.425t, 104.426t

Persulfato de amonio 100.6, 100.9

Persulfato potásico 100.6, 104.422t, 104.425t, 104.426t

Persulfato sódico 104.422t, $104.425 \mathrm{t}$ 
Peryodato potásico 104.63t, $104.73 \mathrm{t}$

Petasitenina 33.75

Picloram 33.75

o-Pineno $44.10 \mathrm{f}$

Piperazina 104.230t, 104.234t, $104.237 \mathrm{t}$

Piperidina 104.230t, 104.233t, 104.234t, 104.237t

Pireno 33.75, 104.315t, $104.319 t$

Piretrina $\quad 64.44$

Piridina 73.9, 82.17, 95.7, 104.230t, 104.233t, 104.234t, $104.237 \mathrm{t}$

Pirido[3,4-c]psoraleno 33.75

Pirimetamina 33.75

Pirimidina $104.231 \mathrm{t}, 104.237 \mathrm{t}$

Pirimor 62.12

Pirita 82.6

Pirofosfato tetrapotásico 104.387t, 104.389t, 104.391t, 104.392t

Pirofosfato tetrasódico 104.387t, 104.389t, 104.391t, 104.393t

Pirogalol 104.372t

Pirosulfito potásico $\quad 104.426 \mathrm{t}$

Pirosulfuro potásico $\quad 104.422 \mathrm{t}$

Pirrolidina 104.231t, 104.235t, $104.237 \mathrm{t}$

2-Pirrolidinona 104.231t, 104.233t, 104.235t, 104.237t

Pirrolidona de polivinilo $\quad 33.75$

Plata $4.4,10.19,11.26,55.41$, 74.21 - $74.23,81.8,81.16,82.2$, $82.5,82.7,82.42,82.57$ - 82.58, $82.60,82.62,85.13$ - 85.14, $96.2,96.11-96.12,96.22$

Platino 11.29, 33.42, 78.5, $78.17,82.57$ - 82.58, 82.62, $96.12,96.22$

Plomo 1.2, 1.7, 2.5, 3.16 - 3.17, 4.3 - $4.4,4.11,5.6,6.35,7.4$ $7.5,7.9,7.11,7.20-7.21,7.24$, $7.26-7.27,8.5,8.11,9.66,9.8$, $9.11,9.13,9.15-9.16,9.20$, $9.27,10.14,10.92,11.8,11.22$, $11.26,12.5,12.21,15.82,16.4$, $16.33 f, 16.37,16.40,16.43$, 16.47 - 16.48, 16.63, 16.65, 18.4, 18.15, 18.18, 20.2, 20.4, $20.14,20.23,20.29,23.41$, $23.45,23.56,27.3-27.8,27.11$ - 27.12, 30.11, 30.16, 30.18, $30.19 f, 30.21-30.23,30.31$, 31.17 - 31.18, 31.22, 31.27, 32.5 - 32.6, 32.8 - 32.10, 32.34, $33.2,33.6,33.11-33.17,33.19$ - 33.21, 33.30, 33.41, 33.48,
$33.60,33.72,33.75,40.13$, 44.4f, 44.29, 44.31, 47.4, 48.11, 48.14f, 48.16 - 48.17, 48.16f, 48.20 - 48.21, 48.28, 53.3 53.4, 53.9 - 53.11, 53.14, $53.14 f, 53.16,53.20,53.35$, 55.4 - 55.5, 55.7, 55.16, 55.24, $55.36,55.41,55.48,55.50$, $66.20,67.5,67.8,71.8,73.7$ $73.12,73.14,73.17$ - 73.18, $74.41,74.43,74.60,76.2$, $76.17,78.6,80.8$ - 80.10, 81.2 81.5, 81.7, 81.9 - 81.13, 81.16, 82.2 - 82.8, 82.12, 82.19, 82.30, $82.39,82.41,82.44$ - 82.48, 82.51 - 82.54, 82.58, 82.60, $82.62,82.64,85.2$ - $85.3,86.6$, 87.5 - 87.7, 87.6f, 88.7, 89.29, $90.3,90.10$ - $90.11,91.4,91.6$ 91.7, 92.9, 92.13, 92.15, 92.17, $94.4,94.14,96.2,96.8$ - 96.9, 96.12 - $96.14,96.18,96.21$ $96.24,96.34,96.41,96.58$, $97.32,100.6,100.15$ - 100.16, 101.2, 101.10, 101.17, 101.21, $101.25,101.28,102.30,102.36$ - 102.37, $102.64-102.65$

Plomo (isótopos) $\quad 48.16 f$

Plutonio 239 39.43, 48.15, 76.10

Plutonio $39.32-39.33,41.14$, 48.34 - 48.35, 82.30

Plutonio (isótopos) $\quad 48.16 \mathrm{f}$

Poliacetato de vinilo $\quad 89.18$

Poliacrilonitrilo $\quad 10.86,89.16$

Polibutadieno 80.9

Policarbonatos 64.12

Policloropineno 62.11

Policloropreno $\quad 33.75,88.8$

Polidimetilsiloxano 85.7, 104.401t, 104.402t, 104.404t, $104.405 t$

Poliéster 31.10, 64.12, 97.35, 97.57, 102.36

Poliestireno 33.75, 41.14, 91.4, 91.6, 91.9

Polietileno de cloro $\quad 31.19$

Polietileno 12.18, 31.10 - 31.11, $31.20,31.22,33.75,41.12$, $45.8,55.17,64.12,67.5,74.49$, $81.4,81.8,82.46,89.21$ - 89.22, $89.33,92.16,95.7,97.72$ 97.73

Polimetil-metacrilato $\quad 41.14$ Polipropileno 31.10, 33.75, $41.12,89.21-89.22$

Politetrafluoretileno $\quad 81.8,81.10$ Politetrafluoroetano $\quad 10.20$
Politetrafluoroetileno $\quad 30.22$, $33.75,40.10$

Poliuretano $31.20,74.60,81.9$, 82.15, 91.4, 91.6 - 91.7, 95.7, $101.10,101.26,102.13$

Polivinil alcohol 31.18

Polivinilpiridina-N-óxido $\quad 10.46$

Polivinilpirrolidona $\quad 10.79,100.7$

Polonio $210 \quad 44.12,48.15$

Polonio 32.27, 33.12, 48.16 48.17

Potasio 33.13, 33.35, 39.43, $41.14,41.30,42.6,42.13$, 48.17, 55.36, 55.41, 62.7, $64.48,64.66,102.22,104.63 \mathrm{t}$, 104.68t, 104.73t

Praseodimio 10.78

Prazepam 33.75

Prednimustina $\quad 33.75$

Prednisona 33.75

Profam 62.15

Proguanil $\quad 15.77$

Promecio $147 \quad 81.13$

Prometacina 50.16

Prometeo 10.78

Prometrina 62.14

Propaclor 62.14

Propanal 104.52t, 104.54t, $104.56 \mathrm{t}$

Propanil 62.15

Propano 12.10, 41.2, 41.7, $42.39,57.16,67.8,67.27,75.3$ 75.4, 75.6, 75.11, 78.5, 78.9, $78.16,78.20,78.22,78.24$, $82.5,82.28,82.45,89.28$, 96.36, 102.68 - 102.69, 102.71, 104.244t, 104.245t, 104.247t, $104.248 \mathrm{t}$

1,3-Propanodiamina $104.85 \mathrm{t}$, $104.93 \mathrm{t}$

Propanol 104.37t, 104.40t, 104.42t, 104.44t

1,3-Propanosultona 33.72

Propanotiol 104.411t, 104.413t, 104.415t, 104.416t

Propazina $27.24,62.14$

Propenilbenceno 104.288t, 104.291t, 104.292t, 104.295t

Propham 33.75

Propilamina 104.85t, 104.88t, 104.91t, 104.93t

n-propilbenceno $104.288 \mathrm{t}$ 104.295t

Propilbenceno 55.5

1,2-Propilen glicol dinitrato 104.343t, 104.345t

Propilendiamina $104.93 \mathrm{t}$

Propilendiamina-1,2-propanodiamina $104.85 \mathrm{t}$
Propilenglicol 85.9, 92.16, 102.13, 104.212t, 104.213t, $104.214 \mathrm{t}$

Propilenimina 33.71, 104.231t, 104.233t, 104.235t, 104.237t

Propileno $33.75,39.30,75.6$, $78.6,78.16,78.24,89.17$

Propiltiouracilo 33.72

Propiltiourea 1.7

Propiolactona $104.179 t$

$\beta$-Propiolactona 33.72

Propionaldehído $102.8,104.49 t$

Propionato de butilo 104.179t, 104.180t, 104.181t, 104.182t

Propionato de etilo 104.179t, 104.182t

Propionato de metilo 104.179t, 104.182t

Propionitrilo 104.143t, 104.146t, 104.148t, 104.151t

Ptaquilosida 33.75

0

Q uercetina 33.75

Q uinina 49.8f,

Q uinoleina 104.231t, 104.233t, $104.235 \mathrm{t}, 104.237 \mathrm{t}$

Q uinometionato $\quad 62.16$

Q uinona 89.18

p-Quinona 33.75

Q uintoceno 33.75

R

Radio $226 \quad 44.11$

Radio 2.16, 32.27, 33.6, 33.15, $44.11,48.8,48.30$

Radio (isótopos) $48.16 f$

Radón $220 \quad 44.11$

Radón $222 \quad 44.11$

Radón $\quad 2.7,2.12,9.24,10.92$, 13.5f, 15.42f, 30.30, 32.27 $32.28,32.28 f, 32.30,32.33$, 33.12 - $33.13,33.15,33.33$, 33.70 - $34.71,44.3,44.4 f, 44.5$ 44.6, 44.11 - 44.12, 44.11f, $44.29,44.31,45.3,45.8,48.2$ $48.9,48.15$ - 48.17, 44.16f, $48.26,48.30,74.36,74.60$, 94.14

R adón (isótopos) 48.16f

Randox 64.44

Renio 78.17

Reserpina 33.75

R esinas de fenol-formaldehído 81.13 
R esinas de fenol-formol $\quad 82.17$ 82.18

Resinas epoxídicas 81.16, 102.36

R esinas fenólicas $\quad 82.35,82.46$

R esorcinol 33.75, 104.373t, 104.378t, 104.380t

Retrorsina 33.75

R hodamina 33.75

Riddelliína 33.75

R ifampicina 33.75

Ripazepam 33.75

R ojo sudan $7 b \quad 33.75$

Rubidio 33.13, 62.5

Rugulosina $\quad 33.75$

\section{S}

Sacarina $31.30 f, 33.72$

Sacarosa 65.4

Safrol 104.49t, 104.56t

Sal sódica del ácido propiónico 104.179t, 104.180t, 104.182t

Sales de tetrakis(hidroximetil)fosfonio $\quad 33.75$

Samario 10.78

Selenac de etilo $\quad 33.75$

Selenac de metilo $\quad 33.75$

Selenio 10.19, 11.25, 15.39,

15.50 - 15.51, 27.8, 33.12,

$33.19,33.75,53.21,55.41$

$82.43,82.48,82.59,96.12$

Senecifilina 33.75

Senkirkina 33.75

Sepiolita 33.75

Silano 81.8, 81.12

Silicato de aluminio $\quad 10.76$

Silicato de bario 62.3

Silicato de berilio $\quad 81.12$

Silicato de calcio $10.77,62.3$, 62.7, 104.401t, 104.405t

Silicato de etilo 82.46, 104.401t, 104.402t, 104.404t, 104.405t

Silicato de hierro $82.5,82.52$

Silicato de magnesio $\quad 10.79,62.6$

Silicato de metilo 104.401t,

104.402t, 104.405t

Silicato de plomo 81.12

Silicato de potasio $\quad 62.3$

Silicato de sodio $\quad 62.3,82.17$ -

$82.18,82.24,101.21,104.405 t$

Silicatos de aluminio $62.2-62.3$

Sílice $10.36,10.49,10.76,12.4$,

$15.42 f, 16.40,20.29,32.10$,

$33.70,33.75,53.31,62.3$,

$64.54,76.7,80.10,81.10,82.4$ -

82.6, 82.9, 82.18, 82.21, 82.57, 96.13

Silicio $\quad 74.49,89.2,92.6,92.15$
Silicofluoruro sódico 10.31

Silicona $85.6-85.7,104.401$, 104.404t, 104.405t

Simazina $\quad 27.24,33.75,62.15$

Sinfitina 33.75

Sodio $22 \quad 48.17$

Sodio $\quad 6.9,33.12$ - 33.13, 33.34 $33.35,41.14,41.30,42.6,46.2$,

46.7 - 46.8, 55.36 - 55.37,

$55.41,62.3,64.66,72.8,72.12$, $72.20,74.41$ - 74.42, 81.4,

81.13 - 81.14, 82.39, 104.63t, $104.68 \mathrm{t}, 104.73 \mathrm{t}$

Succinato de dietilo $\quad 104.179 t$

Succinonitrilo 104.143t, 104.151t

Sudan I 33.75

Sudan II 33.75

Sudan III 33.75

Sulfafurazol $\quad 33.75$

Sulfalato 33.72

Sulfamato amónico 104.422t, 104.424t, 104.427t

Sulfametazina $\quad 70.6$

Sulfametoxazol $\quad 33.75$

Sulfato amónico 62.7 - 62.8, $64.48,88.3,104.423 t, 104.425 t$, $104.427 \mathrm{t}$

Sulfato de aluminio $\quad 101.18$

Sulfato de amonio $\quad 73.17$

Sulfato de bario 10.36

Sulfato de bencidina $104.411 \mathrm{t}$

Sulfato de calcio $10.77,55.16$, $62.7,82.63,96.9,104.423 \mathrm{t}$, $104.427 \mathrm{t}$

Sulfato de cobre $\quad 82.5,82.52$, 82.58

Sulfato de cromo $\quad 88.2$ - 88.3

Sulfato de dietilo 33.70

Sulfato de diisopropilo 33.72

Sulfato de dimetilo 33.70

Sulfato de efedrina $\quad 50.16$

Sulfato de fenelcina 33.75

Sulfato de hidrazina $104.125 \mathrm{t}$, 104.129t

Sulfato de hidroxilamina 85.15 , 104.119t

Sulfato de hierro $74.23,82.58$, $82.63,88.6,101.18$

Sulfato de magnesio $\quad 82.43$

Sulfato de níquel $\quad 100.9$

Sulfato de plomo 81.2

Sulfato de vinblastina $\quad 33.75$

Sulfato de vincristina $\quad 33.75$

Sulfato de zinc 82.7

Sulfato ferroso $12.16,101.20$

Sulfato sódico $\quad 45.21,72.14$,

$72.19,104.423 \mathrm{t}, 104.427 \mathrm{t}$

Sulfisoxazol $\quad 15.77,33.75$
Sulfito amónico $\quad 72.8$

Sulfito de magnesio $\quad 72.8$

Sulfito sódico $72.8,82.59$

$89.19,104.423 \mathrm{t}, 104.427 \mathrm{t}$

Sulfolano 104.231t, 104.237t

Sulfona de 1, 3-propano 104.231t

Sulfona $104.237 \mathrm{t}$

Sulfonato sódico $\quad 82.39$

Sulfuro cálcico 104.423t, $104.427 \mathrm{t}$

Sulfuro de amonio 78.8, 104.423t, 104.427t

Sulfuro de bis(1-aziridinil)morfolinofosfina 33.75

Sulfuro de carbonilo 104.411t, 104.423t, 104.425t, 104.428t

Sulfuro de cobre $74.23,82.4$ $82.6,82.52$

Sulfuro de etileno 33.75

Sulfuro de hidrógeno 1.7, 10.7, $10.18,11.8,11.32,15.23$, 16.33f, 30.6, 30.21, 30.24, $39.20,44.19,45.10,53.20$, $55.4,66.17,72.8,72.14$ - 72.16 72.19, 73.9, 73.14, 73.17, 74.47, 74.49, 74.60, 76.16f, $85.13,88.5,88.12,89.16$ 101.11 - 101.13, 101.26 101.27, 104.423t, 104.424t, 104.425t, $104.428 \mathrm{t}$

Sulfuro de hierro $62.4,78.14$, $78.16,78.22,81.4,82.4$ - 82.5, $82.38,102.65$

Sulfuro de plata $\quad 85.13,96.12$

Sulfuro de plomo 4.4, 82.6

Sulfuro de sodio $72.8,88.3$, $101.13,104.423 \mathrm{t}, 104.425 \mathrm{t}$

Sulfuro de zinc 48.29

Sulfuro potásico 104.423t, 104.424t, 104.425t, 104.428t

sym-etilciclohexiletil tiocarbamato 62.12

sym-etil-N, N-dipropil tiocarbamato 62.12

sym-propil-N -etil-N -butiltiocarbamato 62.12

\section{T}

T alasio $\quad 38.5$

Talidomida 33.33

Talio 7.14, 33.11, 46.7, 53.31

T amoxifeno $\quad 33.70$

T antalio $183 \quad 48.37$

Tántalo 96.13

T artrato nicotinico $\quad 104.231 \mathrm{t}$ 104.233t, 104.235t, 104.237t

T ecnecio $99 \quad 48.13,48.13 f$
Teflon 104.194t, 104.199t

T elurac de etilo 33.75

Telurio $132 \quad 39.39$

Telurio $\quad 11.25,23.41,33.12$

Telurio (isótopos) 48.16f

T emazepam $\quad 33.75$

Teobromina $\quad 33.75$

Teofilina $33.75,42.52$

Terbio 10.78

Terbutilazina $\quad 27.24$

terc-butil mercaptano 104.409t, 104.412t, 104.413t, 104.415t

terc-butilamina $\quad 104.82 t, 104.91 \mathrm{t}$

terc-butil-4-hidroxianisol

104.184t

Terpeno $\quad 44.8$

Terpenos policlorados 33.76

T etraborato sódico decahidrato 104.132t, 104.133t, 104.134t, 104.136t

T etrabromuro de acetileno 104.259t

Tetrabromuro de carbono 104.259t, 104.262t, 104.265t, 104.268t

T etracloroazoxibenceno $\quad 12.4$

1,2,4,5-T etraclorobenceno 104.304t, 104.305t, 104.307t, $104.309 \mathrm{t}$

2,2',5,5'-T etraclorobencidina 33.75

T etraclorodibenzodioxina $\quad 12.4$

2,3,7,8-T etra-clorodibenzo-p-dioxina 1.5 - 1.6, 9.21, 62.14, 71.11, 33.41, $33.74,39.4,104.304 t, 104.309 t$

1,1,2,2-T etracloro-1, 2-difluoretano 104.198t, 104.194t, 104.196t, 104.199t

1,1,1,2-T etracloro-2, 2-difluoretano 104.194t, 104.196t, 104.198t, 104.200t

1,1,1,2-T etracloroetano 33.76,104.259t, 104.265t, $104.268 \mathrm{t}$

1,1,2,2-T etracloroetano 33.76, 44.10f, 104.259t, 104.263t, $104.265 \mathrm{t}, 104.268 \mathrm{t}$

Tetracloroetano 4.7, 16.33f, 104.259t, 104.268t

T etracloroeteno $\quad 55.5$

T etracloroetileno $9.23,16.33 f$, $16.63,27.5,33.58,33.59 f$, $33.70,44.10 f, 53.16,89.18$, $100.10,104.270 t, 104.271 \mathrm{t}$, $104.273 \mathrm{t}, 104.274 \mathrm{t}$

T etraclorofenato 71.5

2,3,4,6-T etraclorofenol 104.378t, 104.380t 
2,3,5,6-T etraclorofenol

104.373t, 104.376t, 104.378t, $104.380 \mathrm{t}$

2,4,5,6-T etraclorofenol $104.373 \mathrm{t}$

Tetraclorofenol $\quad 71.11$

Tetraclorometano 55.5. 16.33f

Tetracloronaftaleno 104.304t, 104.309t

T etraclorosilano 104.401t, 104.403t, 104.404t, 104.405t

T etracloruro de carbono 3.17, $4.2,4.7,4.10,30.28,30.31$, $33.21,33.27,33.32,33.59 f$, 33.72, 44.10f, 53.20, 54.13, 80.15 - 81.16, 85.11, 89.14, $89.17,96.8,96.10,100.10$, $102.49,104.259 \mathrm{t}, 104.263 \mathrm{t}$, $104.265 \mathrm{t}, 104.268 \mathrm{t}$

Tetracloruro de silicio $\quad 81.8$

Tetraclorvinfós 33.76

Tetradecano $44.10 \mathrm{f}$

Tetraetil plomo $7.12,9.20,12.3$, $27.12,33.13,53.20,78.5$, $82.52,102.67$

Tetraetilenpentamina $104.85 \mathrm{t}$, 104.91t, 104.93t

T etrafluoretileno 104.194t, $104.200 t$

T etrafluoroetileno $\quad 33.76$

Tetrafluorometano 104.194t, 104.196t, 104.198t, 104.200t

T etrafluoruro de azufre 104.423t, 104.425t, 104.428t

Tetrafluoruro de silicona 104.401t, 104.403t, 104.404t, $104.405 t$

T etrahidroborato sódico 104.132t, 104.136t

T etrahidrodimetilfurano 104.157t

Tetrahidrofurano $104.157 \mathrm{t}$, 104.159t, 104.160t, 104.161t

1,2,3,4-T etrahidronaftaleno 104.289t, 104.295t

Tetrahidrotiofeno 104.231t, 104.233t, 104.235t, 104.238t

T etrahidruro de silicona 104.401t, 104.403t, 104.404t, $104.405 t$

T etrametil plomo $\quad 27.12,78.5$

Tetrametilsuccinonitrilo 104.143t, 104.146t, 104.148t, 104.151t

Tetramina $\quad 38.5$

Tetranitrometano 33.72, 104.343t, 104.345t

T etraóxido de plomo 82.43
Tetrilo 104.352t, 104.355t, 104.358t, 104.361t

Tetrodotoxina $\quad 7.9$

Thiram 33.76

Tiabendazol $\quad 62.16$

Tillam 62.12

Timina 33.37f,

T ioacetamida 33.72, 104.411t, 104.413t, 104.415t, 104.416t

Tiobisbutilcresol 104.372t, $104.380 \mathrm{t}$

4,4'-T io-bis-(6-terc-butil-m-cresol) 104.373t, 104.381t

Ticcianato de amonio 104.144t, 104.151t

T iocianato potásico 104.144t, 104.151t

T iocianato sódico $\quad 104.415 t$

2-(T iocianometiltio)benzotiazol 71.6

T iodianilina $\quad 33.72$

2,2'-T iodietanol 104.411t, $104.416 \mathrm{t}$

Tiofeno 78.23, 104.231t, 104.233t, 104.235t, 104.238t

Tiofosforil cloruro 104.387t, 104.389t, 104.391t, 104.393t

T ioglicolato de amonio 100.7 , 100.9

T ioglicolato de glicerol 100.7, 100.9

Tiosulfato de plata 85.13

Tiosulfato de sodio 96.11, 104.423t, 104.428t

Tiotepa $\quad 33.70$

Tiouracilo 33.76

T iourea de etileno 33.72

Tiourea 33.72, 104.411t, $104.415 \mathrm{t}$

Tiram 62.12, 64.44, 104.411t, 104.415t

L-T iroxina $\quad 15.59$

Titanio 41.14, 41.30, 74.23, $82.5,82.13,82.23,82.42$ $82.43,82.48,82.57,82.61$, $88.12,90.9,96.13$ - 96.14 , 96.18

0-Tolidina 104.106t, 104.111t, 104.114t, 104.119t

Tolueno de vinilo 33.76

Tolueno-diisocianato 104.322t, 104.324t, 104.325t

Tolueno-2,4-diisocianato 104.322t, 104.323t, 104.324t, $104.325 \mathrm{t}$

Tolueno-2,6-diisocianato 104.323t, 104.324t, 104.325t

Tolueno 4.2, 4.7, 5.6, 7.11, 7.20 - 7.21, 11.8, 11.32, 16.33f,
$16.63,20.31,27.5,27.13$ $27.15,31.18,31.28,33.76$, 44.8, 44.10f, 47.4, 53.16, 55.5, 55.19, 73.15, 73.17, 78.6, $78.17,78.20,78.22,80.8,85.3$ $85.4,85.10,86.14,88.8,89.19$, 91.6, 92.17, 96.8, 96.24, 100.7, 104.289t, 104.291t, 104.293t, $104.295 \mathrm{t}$

m-T oluidina $\quad 104.106 t, 104.114 t$, $104.119 t$

0-T oluidina $33.72,104.106 \mathrm{t}$, 104.111t, 104.114t, 104.119t

p-T oluidina $104.106 t, 104.114 t$, $104.120 \mathrm{t}$

0-T oluidino $\quad 102.50$

T oremifeno 33.76

T orio $232 \quad 48.15$

Torio $234 \quad 48.11$

T orio $33.12,44.11,48.15$ $48.16,81.11,81.13,82.13$

T orio (isótopos) $\quad 48.16 f$

Toxafeno 4.10, 33.72, 55.48, $55.50,62.11$

Trans-1,4-diclorobuteno $\quad 33.74$

T rans-2-(dimetilamino)metilimino-5-2-(5-nitro-2-

furil)-vinil-1,3,4-oxadiazol 33.71

T reosulfán $\quad 33.70$

Triacetina $\quad 104.166 \mathrm{t}, 104.171 \mathrm{t}$

Trialilamina 104.85t, 104.91t, 104.93t

T riazicuona 33.76

1,2,4-T riazol 104.125t, 104.127t, 104.128t, 104.129t

T ribromuro de boro 104.132t, 104.133t, 104.134t, 104.136t

T ribromuro de fósforo 104.221t, 104.224t, 104.226t

Tributil fosfato 102.13 , 104.387t, 104.389t, 104.391t, 104.393t

Tributilamina 104.85t, 104.91t, $104.94 \mathrm{t}$

Tributirina $\quad 104.179 \mathrm{t}$

Tricloretileno 87.7, 89.13, 89.17, 104.270t, 104.271t, 104.273t, 104.274t

Triclorfón 33.76

Triclormetina 33.72

2,3,4-T ricloro $104.378 \mathrm{t}$

2,3,5-T ricloro 104.378t

T ricloroacetato sódico ácido tricloroacético, sal sódica 104.166t

T ricloroacetonitrilo 33.76

1,1,1-T ricloroetano 33.76, 55.5, 7.13, 44.10, 54.13, 80.8, 82.62,
$86.14,87.7,96.8,104.259 t$, 104.263t, 104.265t, 104.268t

1,1,2-T ricloroetano 33.76, 104.259t, 104.263t, 104.268t

Triclorobenceno 44.10f,

1,2,3-T riclorobenceno 104.304t, 104.307t, 104.309t

1,2,4-T riclorobenceno 7.12, 104.304t, 104.305t, 104.307t, $104.309 \mathrm{t}$

1,3,5-T riclorobenceno 104.304t, 104.306t, 104.307t, 104.309t

2,3,4-T ricloro-1-buteno $104.270 \mathrm{t}, 104.274 \mathrm{t}$

Tricloroetano 33.76, 55.5, 7.13, $44.10,44.10 f, 54.13,80.8$, $82.62,86.14,87.7,92.17,96.8$

Tricloroetileno 3.17, 4.8, 7.13, 7.24, 7.26, 11.8, 12.4, 12.10, $16.63,27.5,33.42,33.58$, $33.59 f, 33.70,53.16,65.15$, $67.10,79.19-82.20,82.57$ 82.61, 92.17, 96.8, 97.60, $100.10,100.13$

Triclorofenol 104.372t, 104.375t, 104.377t, 104.380t 2, 3, 6-T riclorofenol

2,3,4-T riclorofenol 104.373t, $104.381 \mathrm{t}$

2,3,5-T riclorofenol 104.373t, 104.376t, 104.381t

2,3,6-T riclorofenol 104.373t, 104.376t, 104.378t, 104.381t

2,4,5-T riclorofenol 104.373t, 104.376t, 104.378t, 104.381t

2,4,6-T riclorofenol 104.372t, 104.376t, 104.378t, 104.381t

Triclorofenol 39.4

Triclorofluorometano 104.195t, 104.196t, 104.198t, 104.200t

Triclorometano 55.5

Triclorometilbenceno 104.304t, 104.306t, 104.307t

Tricloronaftaleno 104.304t, 104.306t, 104.307t, 104.309t

1,2,3-T ricloropropano 104.259t, 104.263t, 104.266t, 104.268t

Triclorosilano 104.402t, 104.403t, 104.404t, 104.405t

1,1,2-T ricloro-1,2,2-trifluoretano 104.194t, 104.196t, 104.200t, $104.198 \mathrm{t}$

T ricloruro de boro 104.132t, 104.134t, 104.135t, 104.136t

Tricloruro de etileno $16.33 \mathrm{f}$

T ricloruro de fósforo 104.389t, 104.391t, 104.393t

Tri-o-cresil fosfato $104.387 \mathrm{t}$, 104.389t, 104.391t, 104.393t 
T ricresil fosfato 104.387t, 104.391t, 104.393t

Tridecanol 44.10f, 104.37t, 104.44t

T rietanolamina $\quad 12.16,82.42$, $85.15,104.85 \mathrm{t}, 104.94 \mathrm{t}$

T rietil fosfato $104.387 \mathrm{t}$, 104.393t

T rietil fosfito $104.387 \mathrm{t}$ 104.390t, 104.391t, 104.393t

Trietilamina 82.17, 82.22, 104.85t, 104.88t, 104.91t, $104.94 \mathrm{t}$

Trietilborano 104.132t, 104.136t

Trietilenglicol diglidicil éter 33.76

Trietilentetramina $104.85 \mathrm{t}$, 104.88t, 104.91t, 104.94t

Trietiltina 11.8

T rifenil fosfato $104.387 \mathrm{t}$, 104.390t, 104.393t

T rifenil fosfina $104.387 \mathrm{t}$, $104.393 \mathrm{t}$

Trifenil fosfito $104.387 \mathrm{t}$, 104.390t, 104.391t, 104.393t

Trifenilamina $104.107 \mathrm{t}$, 104.120t

Trifenileno $\quad 33.76$

Trifenilfosfina 104.390t, 104.391t

Trifeniltina 33.59f,

Trifluoro tolueno $\quad 104.195 t$

Trifluorometano 104.195t, 104.198t, 104.200t

Trifluoruro de boro 41.14, 104.133t, 104.134t, 104.135t, $104.136 \mathrm{t}$

T rifluoruro de cloro 104.221t, 104.223t, 104.225t, 104.226t

T rifluoruro de nitrógeno 104.221t, 104.225t, 104.226t

T rifluralina $\quad 33.76,62.15$

Triisopropanolamina 104.85t, 104.88t, 104.91t, 104.94t

T rimer- captotriazina trisódica 85.13

T rimetil borato 104.133t, 104.134t

Trimetil clorosilano $\quad 104.402 \mathrm{t}$

T rimetil fosfato $104.387 \mathrm{t}$, 104.390t, 104.391t, 104.393t

Trimetil fosfito 104.387 , 104.391t, 104.393t

Trimetilamina $66.17,104.86 \mathrm{t}$, 104.88t, 104.91t, 104.94t

4, 4', 6-T rimetilangelicina 33.76
2,4,5-T rimetilanilina 33.76, 104.107t, 104.120t

2,4,6-T rimetilanilina 33.76

1,2,4-T rimetilbenceno 55.5 , 44.10f

1,3,5-T rimetilbenceno 44.10f, 55.5, 104.289t, 104.293t, $104.295 \mathrm{t}$

Trimetilborato 104.135t, 104.136t

Trimetilclorosilano 104.403t, 104.404t, 104.405t

3,5,5-T rimetilhexanal $\quad 104.50 \mathrm{t}$

3,5,5-T rimetil-1-hexanol 104.40t, 104.42t, 104.44t

2,2,4-T rimetilpentano 104.244t, 104.245t, 104.247t, 104.248t

2,2,4-T rimetil-1-penteno $104.278 \mathrm{t}$

2,2,4-T rimetil-2-penteno 104.278t

2,4,4-T rimetil-1-penteno 104.277t, 104.280t, 104.281t

2,4,4-T rimetil-2-penteno 104.277t, 104.280t, 104.281t

4,5',8-T rimetilpsoraleno 33.76

Trimetiltina $11.8,47.4$

2,4,7-T rinitrofluoren-9-ona 104.352t, 104.361t

1,3,6-T rinitropireno $\quad 104.352 \mathrm{t}$

Trinitrotolueno $1.3,4.7,12.4$, $32.34,41.6,72.9$

2,4,6-T rinitrotolueno 33.76, 104.352t, 104.355t, 104.358t, 104.361t

Trioxano 104.50t, 104.56t

Trióxido de antimonio $\quad 33.72$

Trióxido de arsénico 96.44

Trióxido de arsenio $\quad 12.4-12.5$

T rioxido de azufre $55.4,62.9$, 104.423t, 104.425t, 104.428t

Trióxido de cromo 27.11

Tripolifosfato sódico 104.63t, $104.73 \mathrm{t}$

Tripropilamina 104.86t, 104.91t, 104.94t

Tris(aziridinil)-p-benzoquinona 33.76

2,4,6-T ris(1-aziridinil)-s-triazina 33.76

T ris(2-cloroetil) fosfato 33.76

1,2,3-T ris(clorometoxi)propano 33.76

T ris-2,3-dibromopropil fosfato $33.70,104.388 \mathrm{t}, 104.393 \mathrm{t}$
T ris(2-etilhexil) fosfato $104.388 t$, 104.390t, 104.391t, 104.393t

T risulfuro de antimonio 33.76

T risulfuro de tetrafósforo 104.388t, 104.391t, 104.393t

Tritio 48.2, 48.8, 48.12, 48.17, $48.24,48.26,48.28$ - 48.29 , 48.37

Tulio 10.78

T ungsteno $10.74,46.2,46.5$ $46.7,49.7,49.15,73.5,74.23$, 74.41 - $74.42,81.11$ - 81.12, $82.27,92.7$

U

U ranio $235 \quad 48.15,76.8-76.10$

U ranio 238 44.11, 48.11, 48.15, 76.8

U ranio $2.7,2.12,10.92,15.42 f$, 32.27 - 32.31, 33.12, 39.33, $39.36 f, 41.14,44.11,48.2$, $48.15-48.16,48.35,74.23$, $74.36,74.43,74.60-74.61$ $76.8,76.10$ - 76.11, 82.43, 96.22

U ranio (isótopos) 48.16f,

U retano 33.72

Undecano $44.10 f$

V

Valeraldehído 104.50t, 104.54t, $104.56 \mathrm{t}$

$\checkmark$ anadato de itrio 81.13

V anadio 4.4, 11.25, 27.8, 27.13, $73.15,82.43,82.61,96.18$

Vapam 62.15

4-V inilciclohexeno 33.72

2-V inilpiridina 104.231t, 104.235t, 104.238t

$\mathrm{N}$-vinil-2-pirrolidona $\quad 33.76$

Viniltolueno 7.12

V ioleta de bencilo 4B 33.72

Vitamina A 15.38 - 15.39,

$15.50,33.19,33.33$

Vitamina C $10.83,15.38$ -

15.39, 15.50 - 15.51, 33.19, 64.42

Vitamina D $\quad 6.7,15.59$

Vitamina E $\quad 10.83,15.39,15.50$ $-15.51,33.19$

Vitamina K 27.24, 27.25f,

Vitamina B $\quad 15.38$

\section{W}

Warfarina $\quad 27.24$

Wollastonita 33.76

$X$

X enón $133 \quad 48.38$

X enón $135 \quad 48.38$

$X$ enón $\quad 29.112,31.10,48.26$, $49.14,96.8,96.57$

m-Xileno 44.8, 104.289t, 104.291t, 104.293t, 104.295t

o-X ileno 44.8, 104.289t,

104.291t, 104.293t, 104.295t

p-Xileno 44.8, 104.289t, 104.291t, 104.293t, 104.295t

Xileno 11.8, 11.32, 16.33f,

16.63, 20.31, 27.5, 47.4 - 55.5, $55.19,70.40,73.15,73.17$ $78.6,78.9,78.17,80.15,81.12$, $86.14,88.8,89.19,91.6,92.9$, $92.17,96.24,100.7$

Xileno 33.76

Xilidina 104.107t, 104.111t, 104.114t, 104.120t

2,3-X ilidina $104.107 t, 104.114 t$, $104.120 \mathrm{t}$

2,4-Xilidina $33.76,104.107 t$, 104.114t, 104.120t

2,5-Xilidina 33.76

3,4-X ilidina 104.107t, 104.114t, $104.120 \mathrm{t}$

X ylenol 104.373t

Y

Y odato potásico 104.63t, $104.73 \mathrm{t}$

Yodo $125 \quad 48.29$

Yodo $131 \quad 39.32,39.40,39.42$ $39.43,48.28,48.35,48.37$

Yodo $133 \quad 39.39$

Yodo 4.4, 29.112, 39.39, 39.42, $41.13,46.5,48.8,48.26,48.35$, $53.21,64.64,104.221 \mathrm{t}, 104.226 \mathrm{t}$ Yodoformo 104.259t, 104.268t

3-Y odo-2-propinil-butil-carbamato 71.6

Yoduro de etilo 104.259t, 104.263t, 104.266t, 104.268t

Yoduro de metilo 33.76 , 104.259t, 104.263t, 104.266t, $104.268 \mathrm{t}$

Y oduro de potasio $44.21,45.10$, $48.44,104.63 \mathrm{t}, 104.73 \mathrm{t}$

Yoduro de sodio $\quad 48.29,104.63 t$, $104.73 \mathrm{t}$ 


\section{Z}

Zectran $\quad 33.76$

Zeolita de plata 48.26

Zidovudina 97.46
Zinc $4.11,7.20-7.21,9.5$, $10.19,10.32,11.25,12.17$, $15.38,15.51,30.31,33.12$, $33.14,33.20,33.53,41.14$, 42.13, 53.20, 55.4, 55.41, $64.66,73.14,73.16 f, 73.17$,
$79.5,80.18,81.4,81.6,81.8$ $81.16,82.2,82.6$ - 82.8, 82.12, 82.19, 82.30- 82.31, 82.39, $82.44,82.46,82.48,82.50$, 82.54 - 82.55, 82.59 - 82.60, $82.62,82.64,85.4,91.4,91.9$,
$92.6,92.9,92.15,96.12,96.14$, $96.22,101.28,102.2$

Zinc-protoporfirina 33.17

Zineb 27.23, 33.76, 62.12, 64.44

Ziram $33.76,62.12,64.44$

\section{- INDICE POR NUMERO CAS}

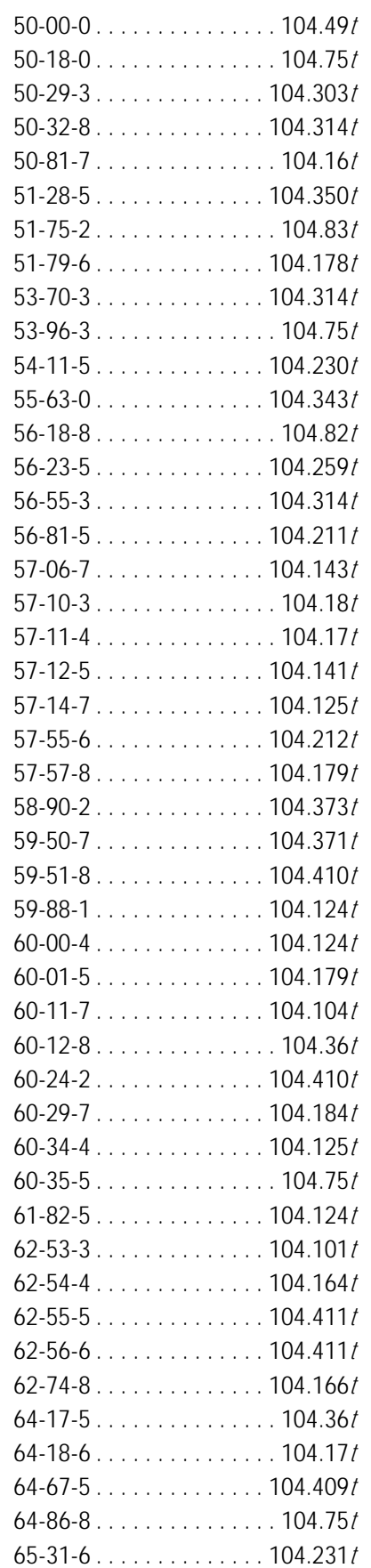

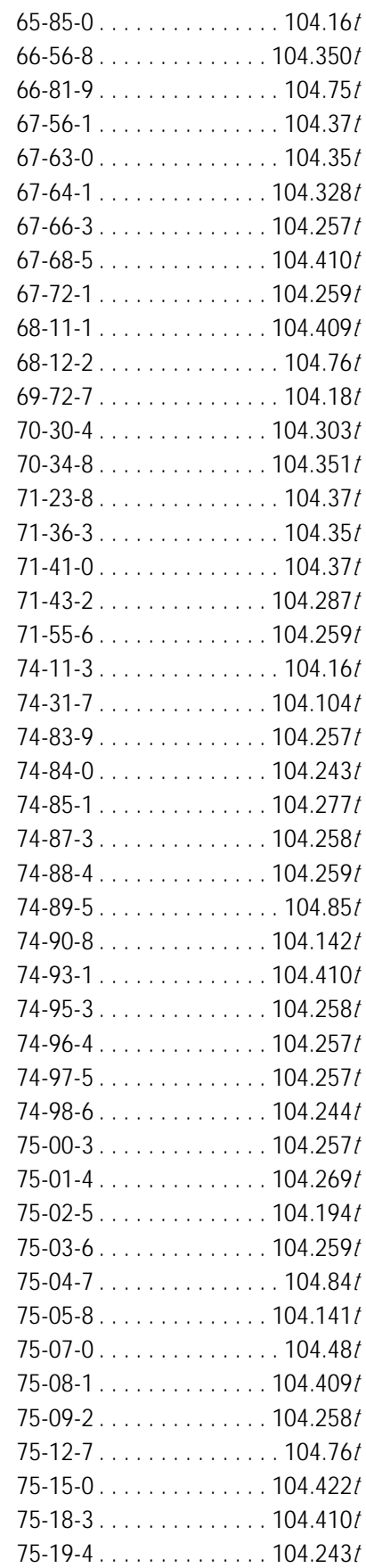

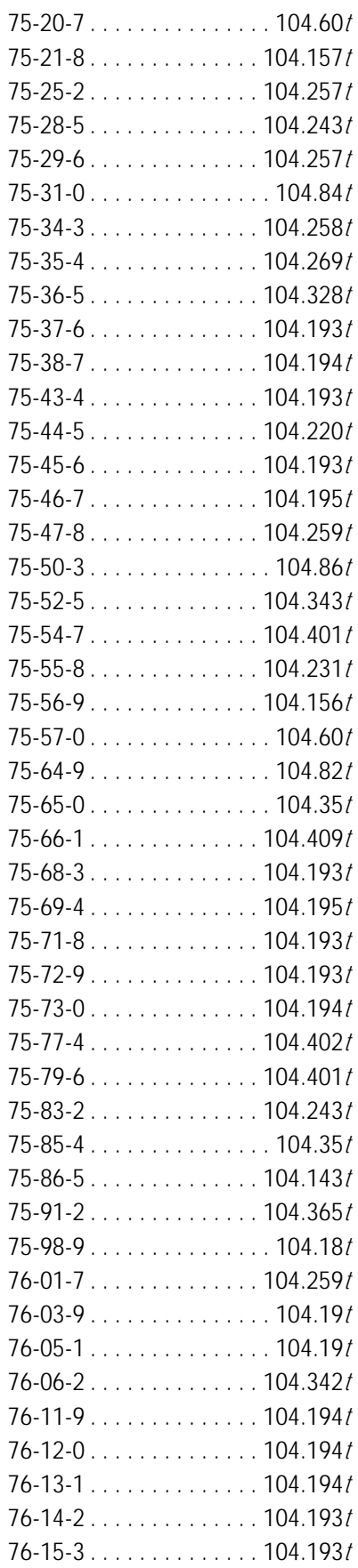

\begin{tabular}{|c|c|}
\hline & \\
\hline$-47-4$ & \\
\hline$-78-1$ & \\
\hline$-92-9$ & \\
\hline$-10-4$ & $104.401 \mathrm{t}$ \\
\hline$-11-5$ & $104.343 \mathrm{t}$ \\
\hline$-30-8$ & $387 t$ \\
\hline $3-40-0$ & $104.387 \mathrm{t}$ \\
\hline $3-42-2$ & $104.388 \mathrm{t}$ \\
\hline $3-59-1$ & $104.329 t$ \\
\hline B-78-4 & . 104.244t \\
\hline 8-79-5 & . $104.277 \mathrm{t}$ \\
\hline $3-81-9$ & . . 104.84t \\
\hline 78-82-0 & $.104 .143 t$ \\
\hline 3-83-1 & $4.35 t$ \\
\hline 78-84-2 & $\ldots 10$ \\
\hline $78-87-5$ & 104 \\
\hline 78-88-6 & . 104.270t \\
\hline $8-90-0$ & $\ldots 10$ \\
\hline $78-92-2$ & $\ldots 10$ \\
\hline 78-93-3 & 104 \\
\hline 78-94-4 & 104 \\
\hline $8-95-5$ & .104 \\
\hline $78-96-6$ & $\ldots 10$ \\
\hline 78-97-7 & 10 \\
\hline 78-99-9 & $104.258 \mathrm{t}$ \\
\hline 79-00-5 & 104.259 \\
\hline 79-01-6 & 104.270 \\
\hline $79-04-9$ & .104 \\
\hline 79-06-1 & $\ldots 10$ \\
\hline 79-07-2 & . . 104.75 \\
\hline 79-09-4 & . . 10 \\
\hline $79-10-7$ & . . 104.16t \\
\hline $79-11-8$ & $\ldots 10$ \\
\hline $79-14-1$ & . . 10 \\
\hline $79-20-9$ & . 104.165 \\
\hline $79-22-1$ & $.104 .178 \mathrm{t}$ \\
\hline $79-24-3$ & . $104.343 \mathrm{t}$ \\
\hline $79-27-6$ & $104.259 t$ \\
\hline $79-29-8$ & . $104.243 \mathrm{t}$ \\
\hline $79-31-2$ & $\ldots 104.17 \mathrm{t}$ \\
\hline $79-34-5$ & $.104 .259 \mathrm{t}$ \\
\hline $79-36-7$ & $104.329 t$ \\
\hline $79-38-9$ & $.104 .193 \mathrm{t}$ \\
\hline$-41-4$ & . . 104.18 \\
\hline 12 & .10 \\
\hline
\end{tabular}




\begin{tabular}{|c|c|c|}
\hline $9-44-7 \ldots$ & . . 104.19t & $98-73-7$. \\
\hline $.104 .343 t$ & $.104 .177 \mathrm{t}$ & $98-82-8 \ldots$ \\
\hline $.104 .365 t$ & $.104 .365 t$ & 98-83-9. . \\
\hline$\ldots \ldots \ldots 104.365 t$ & $\ldots 104.49 t$ & $.104 .328 \mathrm{t}$ \\
\hline$\ldots \ldots \ldots 104.173 t$ & $\ldots 104.16 \mathrm{t}$ & $.104 .302 \mathrm{t}$ \\
\hline . 104.101t & . . 104.16t & . . 104.303t \\
\hline$\ldots 104.315 t$ & . . 104.229t & . . 104.351t \\
\hline . . . . . . 104.396t & $\ldots \ldots \ldots 104.211 \mathrm{t}$ & $\ldots \ldots \ldots 104.352 \mathrm{t}$ \\
\hline$\ldots \ldots \ldots 104.396 t$ & $\ldots \ldots \ldots \ldots 104.288 \mathrm{t}$ & $\ldots 104.106 t$ \\
\hline . . 104.396t & $104.229 \mathrm{t}$ & $\ldots 104.349 t$ \\
\hline $4-74-2 \ldots \ldots \ldots \ldots \ldots 104.396 t$ & $\ldots \ldots \ldots 104.75 t$ & $\ldots \ldots \ldots 104.349 t$ \\
\hline$\ldots \ldots \ldots 104.315 t$ & $\ldots \ldots \ldots \ldots 104.289 t$ & $99-55-8 \ldots \ldots \ldots \ldots .104 .349 t$ \\
\hline$\ldots \ldots \ldots \ldots 104.19 t$ & $\ldots \ldots \ldots \ldots 104.371 t$ & $99-59-2 \ldots \ldots \ldots \ldots \ldots 104.351 \mathrm{t}$ \\
\hline $104.352 \mathrm{t}$ & . . 104.302t & $\ldots 104.349 t$ \\
\hline $5-88-4 \ldots \ldots \ldots \ldots \ldots 104.409 t$ & . . 104.303t & $\ldots \ldots \ldots 104.287 t$ \\
\hline$\ldots \ldots \ldots 104.107 t$ & $\ldots \ldots \ldots \ldots 104.102 t$ & $99-97-8 \ldots \ldots \ldots \ldots \ldots 104.104 t$ \\
\hline $87-61-6 \ldots \ldots \ldots \ldots . \ldots 104.304 t$ & $\ldots \ldots \ldots \ldots 104.106 t$ & $99-99-0 \ldots \ldots \ldots \ldots 104.352 \mathrm{t}$ \\
\hline$-66-1 \ldots \ldots \ldots \ldots \ldots 104.372 t$ & $\ldots \ldots \ldots \ldots 104.105 t$ & $100-00-5 \ldots \ldots \ldots \ldots 104.349 t$ \\
\hline $7-68-3 \ldots \ldots \ldots \ldots . \ldots 104.270 t$ & $\ldots \ldots \ldots \ldots 104.101 t$ & $100-01-6 \ldots \ldots \ldots \ldots 104.106 t$ \\
\hline . . . . . . 104.19t & $\ldots \ldots \ldots$ & $100-02-7 \ldots \ldots \ldots \ldots 104.352 \mathrm{t}$ \\
\hline $87-86-5 \ldots \ldots \ldots \ldots \ldots$ 104.372t & $\ldots \ldots \ldots \ldots 104.107 t$ & $100-20-9 \ldots \ldots \ldots \ldots 104.303 t$ \\
\hline $87-90-1 \ldots \ldots \ldots \ldots \ldots 104.124 t$ & $95-68-1$. & $100-21-0 \ldots \ldots \ldots$ \\
\hline $88-06-2 \ldots \ldots \ldots \ldots \ldots 104.373 t$ & $\ldots \ldots \ldots \ldots 104.102 t$ & $100-25-4 \ldots \ldots \ldots \ldots 104.350 \mathrm{t}$ \\
\hline $88-10-8 \ldots \ldots \ldots \ldots \ldots 104.75 t$ & $\ldots \ldots \ldots \ldots 104.103 t$ & $100-37-8 \ldots \ldots \ldots \ldots \ldots 104.83 t$ \\
\hline $88-72-2 \ldots \ldots \ldots \ldots \ldots 104.352 \mathrm{t}$ & $\ldots \ldots \ldots \ldots 104.102 \mathrm{t}$ & $100-39-0 \ldots \ldots \ldots \ldots 104.302 \mathrm{t}$ \\
\hline $88-73-3 \ldots \ldots \ldots \ldots \ldots 104.349 t$ & $\ldots \ldots \ldots \ldots 104.103 t$ & $100-41-4 \ldots \ldots \ldots \ldots 104.287 \mathrm{t}$ \\
\hline $88-74-4 \ldots \ldots \ldots \ldots \ldots 104.106 t$ & $\ldots \ldots \ldots 104.103 t$ & $\ldots \ldots \ldots \ldots 104.287 t$ \\
\hline $88-75-5 \ldots \ldots \ldots \ldots \ldots$ 104.352t & $\ldots \ldots \ldots 104.102 t$ & $\ldots \ldots \ldots 104.302 t$ \\
\hline $88-89-1 \ldots \ldots \ldots \ldots . . \ldots 104.349 t$ & $\ldots \ldots \ldots \ldots 104.179 t$ & $100-47-0 \ldots \ldots \ldots \ldots 104.141 \mathrm{t}$ \\
\hline $88-99-3 \ldots \ldots \ldots \ldots \ldots 104.17 t$ & $95-94-3$. & $100-51-6 \ldots \ldots \ldots \ldots 104.35 t$ \\
\hline$\ldots \ldots \ldots \ldots 104.48 \mathrm{t}$ & . . 104.373t & $100-52-7 \ldots$ \\
\hline $90-04-0 \ldots \ldots \ldots \ldots . \ldots 104.101 t$ & $\ldots \ldots \ldots \ldots 104.156 t$ & $100-61-8 \ldots \ldots \ldots \ldots 104.105 t$ \\
\hline $90-05-1 \ldots \ldots \ldots \ldots . \ldots 104.157 t$ & $\ldots \ldots \ldots \ldots 104.258 \mathrm{t}$ & $100-63-0 \ldots \ldots \ldots \ldots 104.125 t$ \\
\hline $90-13-1 \ldots \ldots \ldots \ldots \ldots 104.302 t$ & $96-14-0 \ldots$ & $100-64-1 \ldots \ldots \ldots \ldots .104 .330 t$ \\
\hline $90-30-2 \ldots \ldots \ldots \ldots \ldots 104.104 t$ & . . 104.259t & $100-66-3 \ldots \ldots \ldots \ldots 104.184 t$ \\
\hline$\ldots \ldots \ldots 104.372 t$ & . . 104.329t & $100-69-6 \ldots$ \\
\hline$\ldots \ldots \ldots \ldots 104.18 \mathrm{t}$ & $\ldots \ldots \ldots \ldots 104.36 t$ & $100-74-3 \ldots \ldots \ldots \ldots .104 .229 t$ \\
\hline $90-94-8 \ldots \ldots \ldots \ldots \ldots 104.101 t$ & $\ldots \ldots \ldots \ldots 104.211 t$ & $100-79-8 \ldots \ldots \ldots \ldots \ldots 104.48 \mathrm{t}$ \\
\hline $91-08-7 \ldots \ldots \ldots \ldots . \ldots 104.323 t$ & $6-29-7 \ldots$ & $100-80-1 \ldots \ldots \ldots \ldots 104.288 \mathrm{t}$ \\
\hline $91-15-6 \ldots \ldots \ldots \ldots \ldots 104.142 \mathrm{t}$ & $\ldots \ldots \ldots \ldots 104.173 t$ & $\ldots \ldots \ldots 104.84 t$ \\
\hline $91-17-8 \ldots \ldots \ldots \ldots \ldots 104.287 t$ & $96-48-0 \ldots \ldots \ldots \ldots 104.179 t$ & $101-02-0 \ldots \ldots \ldots \ldots 104.387 t$ \\
\hline $91-20-3 \ldots \ldots \ldots \ldots \ldots 104.288 t$ & $96-49-1 \ldots \ldots \ldots \ldots .104 .178 t$ & $101-14-4 \ldots \ldots \ldots \ldots 104.105 t$ \\
\hline $91-22-5 \ldots \ldots \ldots \ldots \ldots 104.231 t$ & $\ldots \ldots \ldots \ldots 104.373 t$ & $101-61-1$. \\
\hline $91-59-8 \ldots \ldots \ldots \ldots \ldots 104.106 t$ & . . 104.349t & $.104 .322 t$ \\
\hline$\ldots \ldots \ldots .104 .229 t$ & . . 104.104t & $101-72-4$ \\
\hline $91-64-5 \ldots \ldots \ldots \ldots \ldots 104.303 t$ & . . 104.124t & $101-77-9 \ldots$ \\
\hline $91-66-7 \ldots \ldots \ldots \ldots \ldots 104.104 t$ & . . 104.173t & $101-80-4 \ldots$ \\
\hline $91-68-9 \ldots \ldots \ldots \ldots \ldots 104.104 t$ & . . 104.173t & $101-83-7 \ldots$ \\
\hline $91-76-9 \ldots \ldots \ldots \ldots 104.229 t$ & $7-94-9 \ldots \ldots \ldots \ldots \ldots 104.132 t$ & $101-90-6 \ldots \ldots \ldots \ldots 104.157 t$ \\
\hline $91-93-0 \ldots \ldots \ldots \ldots 104.322 t$ & $7-95-0 \ldots \ldots \ldots \ldots \ldots 104.35 t$ & $102-06-7 \ldots \ldots \ldots \ldots \ldots 104.104 t$ \\
\hline $91-94-1 \ldots \ldots \ldots \ldots \ldots 104.104 t$ & $\ldots 104.36 \mathrm{t}$ & $102-69-2 \ldots \ldots \ldots \ldots$ \\
\hline $91-95-2 \ldots \ldots \ldots \ldots \ldots 104.103 t$ & . . 104.156t & $102-70-5 \ldots \ldots \ldots$ \\
\hline $92-52-4 \ldots$ & . . 104.157t & $102-71-6$ \\
\hline $92-67-1 \ldots \ldots \ldots \ldots \ldots 104.101 t$ & $98-07-7 \ldots \ldots \ldots \ldots \ldots 104.304 t$ & $102-76-1 \ldots \ldots \ldots \ldots 104.166 t$ \\
\hline $92-84-2 \ldots \ldots \ldots \ldots \ldots 104.230 t$ & $98-08-8 \ldots \ldots \ldots \ldots \ldots 104.195 t$ & $102-81-8 \ldots \ldots \ldots \ldots \ldots 104.82 t$ \\
\hline $92-87-5 \ldots \ldots \ldots \ldots \ldots 104.101 t$ & $98-09-9 \ldots \ldots \ldots \ldots \ldots 104.409 t$ & $102-82-9 \ldots \ldots \ldots \ldots \ldots 104.85 t$ \\
\hline ... 104.351t & . . 104.371t & $103-11-7 \ldots \ldots \ldots \ldots 104.173 t$ \\
\hline $93-46-9 \ldots$ & . . 104.287t & 103-33-3. \\
\hline $93-58-3 \ldots \ldots \ldots \ldots \ldots 104.177 t$ & 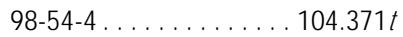 & $103-50-4 \ldots \ldots \ldots \ldots$ \\
\hline
\end{tabular}

103-65-1 . . . . . . . . 104.288t

103-69-5 . . . . . . . 104.104t 103-71-9 . . . . . . . . 104.322t

104-15-4 . . . . . . . . . . 104.19t

$104-57-4 \ldots \ldots \ldots \ldots$. . . . . . .

104-75-6 . . . . . . . . . . 104.84t

104-76-7 . . . . . . . . . . 104.36t

104-94-9 . . . . . . . . 104.101t

105-37-3 . . . . . . . . . 104.179t

105-39-5 . . . . . . . . 104.165t

105-45-3 . . . . . . . . 104.165t

105-46-4 . . . . . . . . . 104.164t

105-53-3 . . . . . . . . 104.179t

105-57-7 . . . . . . . . 104.48t

105-58-8 . . . . . . . . 104.177t

105-64-6 . . . . . . . . . 104.365t

$105-67-9 \ldots \ldots \ldots \ldots$. . . 104.372t

105-74-8 . . . . . . . . 104.365t

106-35-4 . . . . . . . . . 104.329t

106-42-3 . . . . . . . . . 104.289t

106-44-5 . . . . . . . . . . 104.371t

106-46-7 . . . . . . . . . 104.303t

$106-47-8 \ldots \ldots \ldots \ldots . .104 .102 t$

106-48-9 . . . . . . . . . 104.371t

106-49-0 . . . . . . . . . 104.106t

106-50-3 . . . . . . . 104.105t

106-51-4 . . . . . . . . . . 104.328t

106-68-3 . . . . . . . . . . 104.329t

106-87-6 . . . . . . . 104.156t

106-88-7 . . . . . . . . . . 104.156t

106-89-8 . . . . . . . . . . . 104.156t

$106-92-3 \ldots \ldots \ldots \ldots$. . . . . . .

106-93-4 . . . . . . . . . . 104.258t

106-95-6 . . . . . . . . . . . 104.269t

106-96-7 . . . . . . . . 104.269t

106-97-8 . . . . . . . . . 104.243t

106-99-0 . . . . . . . . 104.277t

107-01-7 . . . . . . . . 104.277t

107-02-8 . . . . . . . . . . 104.48t

$107-03-9 \ldots \ldots \ldots \ldots .104 .411 \mathrm{t}$

107-04-0 . . . . . . . 104.257t

107-05-1 . . . . . . . . . 104.269t

$107-06-2 \ldots \ldots \ldots . . .104 .258 \mathrm{t}$

107-07-3 . . . . . . . 104.36t

$107-10-8 \ldots \ldots \ldots \ldots . . .104 .85 t$

$107-11-9 \ldots \ldots \ldots \ldots . . .104 .82 \mathrm{t}$

107-12-0 . . . . . . . . 104.143t

107-13-1 . . . . . . . . . . 104.141t

$107-14-2 \ldots \ldots \ldots \ldots .104 .142 \mathrm{t}$

107-15-3 . . . . . . . . . 104.84t

107-16-4 . . . . . . . . . . 104.143t

107-18-6 . . . . . . . . . . . 104.35t

107-19-7 . . . . . . . . . 104.36t

107-20-0 . . . . . . . . 104.48t

107-21-1 . . . . . . . . . . 104.211t

107-25-5 . . . . . . . . 104.185t

$107-29-9 \ldots \ldots \ldots \ldots . .104 .82 \mathrm{t}$

$107-30-2 \ldots \ldots \ldots \ldots .104 .188 \mathrm{t}$

107-31-3 . . . . . . 104.178t 


\begin{tabular}{|c|c|}
\hline & \\
\hline & 04.277 \\
\hline & \\
\hline 1-66-4. & $104.386 \mathrm{t}$ \\
\hline 7-70-0. & \\
\hline 7-83-5. & \\
\hline-9. & \\
\hline 7-88-0. & 10 \\
\hline 7-89-1. & \\
\hline 7-92-6. & . . 104 \\
\hline 7-98-2. & 10 \\
\hline 8-01-0. & $\ldots 10$ \\
\hline 8-03-2. & .104 \\
\hline 8-05-4 . & .10 \\
\hline $8-10-1$. & .10 \\
\hline 8-11-2. & $\ldots 10$ \\
\hline 81-69-2 & . 104.142 \\
\hline 8-18-9. & . . 104.83t \\
\hline $08-20-3$. & .10 \\
\hline 88-21-4. & 10 \\
\hline 8-23-6. & 10 \\
\hline 8-24-7. & $\ldots 1$ \\
\hline $108-31-6$. & $\ldots 1$ \\
\hline 8-38-3. & 10 \\
\hline 8-39-4. & 10 \\
\hline 8-42-9. & .10 \\
\hline 88-43-0. & .10 \\
\hline 8-44-1. & .10 \\
\hline $8-45-2$ & 10 \\
\hline 8-46-3. & 10 \\
\hline 8-60-1. & 1.188 \\
\hline 108-62-3. & $\ldots 10$ \\
\hline $8-65-6$ & .10 \\
\hline 8-67-8. & . 104.289 \\
\hline 8-70-3. & .10 \\
\hline 88-77-0. & .10 \\
\hline 8-78-1. & .10 \\
\hline $8-80-5$ & 10 \\
\hline 8-82-7. & $\ldots 1$ \\
\hline )8-83-8. & .1 \\
\hline 8-84-9. & .10 \\
\hline 8-86-1. & 104 \\
\hline 08-87-2. & .104 \\
\hline 08-88-3. & 1.28 \\
\hline 108-89-4 . & $.10<$ \\
\hline 108-90-7. & . . 104.302 \\
\hline 108-91-8 . & . . 104.82 \\
\hline 108-93-0 . & . . 104.3 \\
\hline 108-94-1. & .10 \\
\hline 08-95-2. & . . 104.372 \\
\hline 108-98-5. & 104.410 \\
\hline 8-99-6. & .10 \\
\hline 99-02-4. & 104.230 \\
\hline 109-06-8 & . . 104.230 \\
\hline $99-21-7$ & . . 104.177 \\
\hline $9-52-4$. & . . 104.1 \\
\hline 9-55-7. & . . 104.8 \\
\hline & 104 \\
\hline & \\
\hline
\end{tabular}

109-65-9 . . . . . . . . 104.257t $109-66-0 \ldots . . . \ldots . .104 .244 t$ 109-69-3 . . . . . . . . . 104.257t 109-70-6 . . . . . . . . . . 104.257t $109-73-9 \ldots \ldots \ldots \ldots . . .104 .82 \mathrm{t}$ $109-74-0$. . . . . . . . . . 104.141t 109-76-2 . . . . . . . . . . 104.85t $109-77-3 \ldots \ldots \ldots \ldots .104 .143 t$ $109-78-4 \ldots \ldots \ldots . . .104 .142 \mathrm{t}$ 109-79-5 . . . . . . . . . . 104.409t $109-83-1 \ldots \ldots \ldots \ldots . .104 .85 t$ $109-84-2 \ldots \ldots \ldots \ldots . .104 .125 t$ 109-86-4 . . . . . . . . . . . 104.204t $109-87-5 \ldots \ldots \ldots \ldots . .104 .49 \mathrm{t}$ 109-89-7 . . . . . . . . . . 104.83t 109-90-0 . . . . . . . . 104.322t $109-94-4 \ldots \ldots \ldots . . .104 .178 t$ $109-95-5 \ldots \ldots \ldots \ldots . . .204 .342 t$ $109-99-9 \ldots \ldots \ldots . .104 .157 t$ $110-01-0 \ldots \ldots \ldots . . .104 .231 t$ 110-02-1 . . . . . . . . . . 104.231t 110-12-3 . . . . . . . . 104.330t $110-13-4 \ldots \ldots \ldots . . .104 .329 t$ $110-15-6 \ldots . . . . . \ldots . .104 .19 t$ 110-16-7 . . . . . . . . . . 104.18t $110-17-8 \ldots \ldots \ldots \ldots .104 .17 t$ 110-19-0 . . . . . . . . . 104.164t 110-30-5 . . . . . . . . . 104.76t 110-43-0 . . . . . . . . 104.329t $110-45-2 \ldots . . . . . . .104 .178 \mathrm{t}$ 110-46-3 . . . . . . . . . 104.342t $110-49-6 \ldots \ldots \ldots . . .104 .203 t$ 110-54-3 . . . . . . . . . 104.243t $110-61-2 \ldots . . . \ldots . .104 .143 t$ $110-62-3 \ldots \ldots \ldots \ldots . . .104 .50 t$ $110-63-4$. . . . . . . . . . 104.211t 110-66-7 . . . . . . . . . 104.411t 110-71-4 . . . . . . . . . 104.203t 110-80-5 . . . . . . . . . 104.203t $110-82-7 \ldots \ldots \ldots . .104 .243 \mathrm{t}$ $110-83-8 \ldots . . . \ldots . . .104 .277 \mathrm{t}$ $110-85-0 \ldots \ldots \ldots . . .104 .230 \mathrm{t}$ 110-86-1 . . . . . . . . . 104.230t $110-88-3 \ldots \ldots \ldots . . .104 .50 t$ $110-89-4 \ldots \ldots \ldots . . .104 .230 \mathrm{t}$ 110-91-8 . . . . . . . . . 104.230t

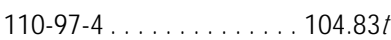
$110-98-5 \ldots \ldots \ldots \ldots$. . . . . . . . $111 t$ 111-14-8 . . . . . . . . . . 104.17t $111-15-9 \ldots \ldots \ldots . .104 .203 \mathrm{t}$ $111-27-3 \ldots \ldots \ldots \ldots . . .64 .36 \mathrm{t}$ 111-30-8 . . . . . . . . . . 104.49t $111-31-9 \ldots \ldots \ldots . . .104 .410 \mathrm{t}$ 111-40-0 . . . . . . . . . 104.83t 111-41-1 . . . . . . . . . . 104.84t $111-42-2 \ldots \ldots \ldots . . .6104 .83 \mathrm{t}$ $111-43-3 \ldots \ldots \ldots \ldots . .104 .184 t$ $111-44-4$. . . . . . . . . . . 104.188t $111-46-6 \ldots \ldots . . .2104 .211 \mathrm{t}$
111-48-8 . . . . . . . . . . 104.411t $111-65-9 \ldots \ldots \ldots \ldots 104.244 t$ $111-66-0 \ldots \ldots \ldots \ldots .104 .277 \mathrm{t}$ 111-69-3 . . . . . . . . . . 104.141t $111-70-6 \ldots \ldots \ldots \ldots .104 .36 \mathrm{t}$ 111-76-2 . . . . . . . . . 104.204t $111-77-3 \ldots \ldots \ldots . . .104 .204 t$ $111-84-2 \ldots \ldots \ldots \ldots .104 .244 t$ $111-87-5 \ldots \ldots \ldots \ldots .104 .37 \mathrm{t}$

$111-88-6$. . . . . . . . . . 104.410t

$111-90-0 \ldots \ldots \ldots . .104 .204 t$

111-91-1 . . . . . . . . . . . 104.48t

$111-92-2 \ldots . . . \ldots . . .104 .82 \mathrm{t}$

$112-05-0 \ldots \ldots \ldots \ldots .104 .18 \mathrm{t}$

1120-71-4 . . . . . . . . 104.231t

$112-07-2$. . . . . . . . . . 104.203t

$112-24-3 \ldots \ldots \ldots \ldots . .104 .85 t$

$112-34-5 \ldots \ldots \ldots \ldots$. . . . . . . $204 t$

$112-36-7$. . . . . . . . . . . 104.203t

$112-55-0 \ldots \ldots \ldots \ldots . . .104 .409 t$

$112-57-2 \ldots \ldots \ldots \ldots . . .104 .85 t$

$112-70-9 \ldots \ldots \ldots \ldots .104 .37 \mathrm{t}$

$112-80-1 \ldots \ldots \ldots \ldots . .104 .18 \mathrm{t}$

$115-02-6 \ldots . . . \ldots . . .104 .124 t$

115-10-6 . . . . . . . . . 104.184t

$115-11-7 \ldots \ldots \ldots \ldots .104 .277 \mathrm{t}$

115-28-6 . . . . . . . . . . 104.16t

$115-77-5 \ldots \ldots \ldots \ldots .104 .212 \mathrm{t}$

$115-86-6 \ldots \ldots \ldots \ldots .104 .387 \mathrm{t}$

$116-14-3 \ldots \ldots \ldots \ldots . . .104 .194 t$

117-81-7 . . . . . . . . . 104.396t

$118-74-1 \ldots \ldots \ldots \ldots .104 .303 t$

118-91-2 . . . . . . . . . 104.16t

118-96-7 . . . . . . . . . . 104.352t

$119-34-6 \ldots . . \ldots . . .104 .349 t$

$119-61-9 \ldots \ldots . . . \ldots .104 .328 t$

$119-64-2$. . . . . . . . . . 104.289t

119-93-7 . . . . . . . . . . 104.106t

120-12-7 . . . . . . . . . . 104.314t

120-51-4 . . . . . . . . . 104.177t

120-55-8 . . . . . . . . . 104.178t

$120-61-6 \ldots . . . \ldots . .104 .396 t$

120-66-1 . . . . . . . . . . . 104.101t

$120-71-8 \ldots \ldots \ldots \ldots . .104 .102 t$

$120-78-5 \ldots \ldots \ldots . . .104 .229 t$

120-80-9 . . . . . . . . . . 104.371t

$120-82-1 \ldots \ldots \ldots \ldots . . .104 .304 t$

120-83-2 . . . . . . . . . . 104.372t

$120-92-3 \ldots \ldots \ldots . . .104 .328 t$

$121-14-2 \ldots \ldots \ldots . . .104 .350 t$

121-43-7 . . . . . . . . 104.133t

$121-44-8 \ldots \ldots \ldots \ldots . .104 .85 t$

$121-45-9 \ldots \ldots \ldots \ldots \ldots . .104 .387 t$

$121-54-0 \ldots \ldots \ldots \ldots .104 .303 t$

$121-57-3 \ldots \ldots \ldots \ldots .104 .19 t$

$121-69-7 \ldots \ldots \ldots \ldots . . .104 .104 t$

$121-73-3 \ldots \ldots \ldots \ldots .104 .349 t$

$121-87-9 \ldots \ldots \ldots . .104 .102 t$

$121-91-5 \ldots \ldots \ldots \ldots \ldots 104.17 t$
122-20-3 . . . . . . . . . 104.85t

$122-39-4 \ldots \ldots \ldots \ldots .104 .104 t$

$122-52-1 \ldots \ldots \ldots \ldots . . .64 .387 t$

122-60-1 . . . . . . . . . 104.157t

$122-66-7 \ldots \ldots \ldots \ldots 104.125 t$

122-79-2 . . . . . . . . . 104.164t

$122-98-5 \ldots \ldots \ldots \ldots . . \ldots 104.105 t$

$122-99-6 \ldots \ldots \ldots \ldots$. . . . . . . $203 t$

123-01-3 . . . . . . . . . 104.287t

123-05-7 . . . . . . . . . . . 104.49t

$123-19-3 \ldots \ldots \ldots \ldots 104.329 t$

123-25-1 . . . . . . . . . 104.179t

123-30-8 . . . . . . . . . . 104.101t

$123-31-9 \ldots \ldots \ldots \ldots 104.372 \mathrm{t}$

123-38-6 . . . . . . . . . . . 104.49t

$123-39-7 \ldots \ldots \ldots \ldots . \ldots 104.76 \mathrm{t}$

$123-42-2 \ldots \ldots \ldots \ldots .104 .328 \mathrm{t}$

123-51-3 . . . . . . . . . . 104.35t

123-54-6 . . . . . . . . . 104.330t

$123-62-6 \ldots \ldots \ldots \ldots 104.20 \mathrm{t}$

123-63-7 . . . . . . . . . . . 104.49t

$123-72-8 \ldots \ldots \ldots \ldots . . \ldots 104.48 \mathrm{t}$

$123-75-1 \ldots \ldots \ldots \ldots$. . . . . . 231t

123-77-3 . . . . . . . . . 104.124t

$123-86-4 \ldots \ldots \ldots \ldots .104 .164 t$

123-91-1 . . . . . . . . . 104.49t

$123-92-2 \ldots \ldots \ldots \ldots . .104 .164 t$

123-96-6 . . . . . . . . . . 104.37t

124-02-7 . . . . . . . . . 104.82t

124-04-9 . . . . . . . . . . 104.16t

$124-09-4 \ldots \ldots \ldots \ldots . . .104 .84 \mathrm{t}$

124-17-4 . . . . . . . . 104.203t

124-18-5 . . . . . . . . . . 104.243t

124-40-3 . . . . . . . . . . 104.83t

124-41-4 . . . . . . . . . 104.61t

124-68-5 . . . . . . . . . . . 104.84t

126-30-7 . . . . . . . . 104.212t

126-33-0 . . . . . . . . 104.231t

126-72-7 . . . . . . . . . . 104.388t

$126-73-8 \ldots \ldots \ldots \ldots . . \ldots 4.387 t$

126-98-7 . . . . . . . . . 104.143t

126-99-8 . . . . . . . . . . 104.269t

127-08-2 . . . . . . . . . . 104.165t

127-09-3 . . . . . . . 104.165t

$127-18-4 \ldots \ldots \ldots \ldots . . .2704 .270 t$

127-19-5 . . . . . . . . . 104.76t

128-37-0 . . . . . . . . 104.371t

128-39-2 . . . . . . . . . . 104.371t

129-00-0 . . . . . . . . . 104.315t

129-15-7 . . . . . . . . . 104.351t

129-79-3 . . . . . . . 104.352t

131-11-3 . . . . . . . . . . 104.396t

131-17-9 . . . . . . . . 104.396t

$1312-73-8 \ldots \ldots \ldots \ldots .104 .423 t$

131-52-2 . . . . . . . . . 104.372t

132-27-4 . . . . . . . . . 104.288t

$132-32-1 \ldots \ldots \ldots \ldots . .104 .124 t$

132-64-9 . . . . . . . . . . 104.314t

$134-29-2 \ldots \ldots \ldots \ldots .104 .102 \mathrm{t}$ 


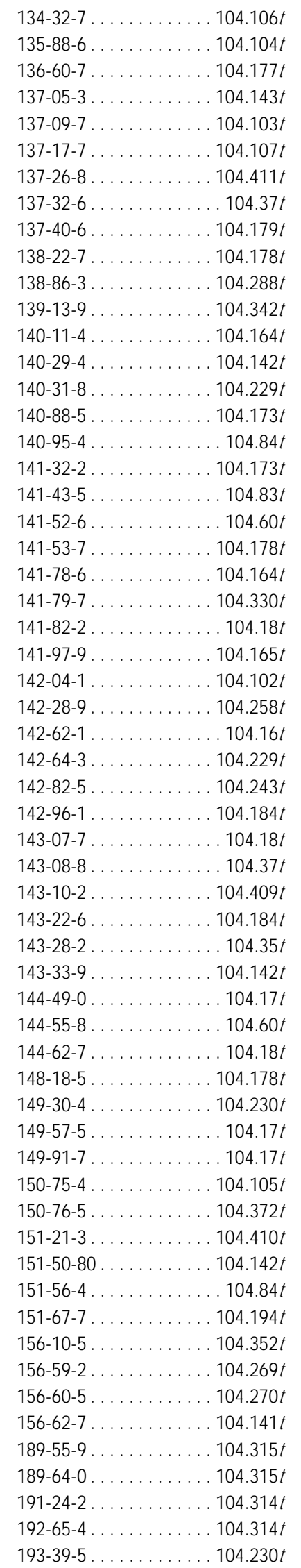

\begin{tabular}{|c|c|}
\hline $194-59-2 \ldots$ & $540-59-0$. \\
\hline $198-55-0 \ldots$ & $540-67-0 \ldots$ \\
\hline . 104.314t & $540-72-7 \ldots$ \\
\hline $205-99-2 \ldots \ldots \ldots \ldots 104.314 t$ & $\ldots \ldots \ldots 104.125 t$ \\
\hline $206-44-0 \ldots \ldots \ldots \ldots 104.315 t$ & $540-84-1 \ldots$ \\
\hline . . 104.314t & $540-88-5 \ldots$ \\
\hline . 104.314t & $541-41-3 \ldots$ \\
\hline $24-42-0 \ldots \ldots \ldots \ldots . . \ldots 104.314 t$ & $\ldots \ldots \ldots 104.303 t$ \\
\hline $226-36-8 \ldots \ldots \ldots \ldots \ldots 104.314 t$ & $541-85-5$ \\
\hline . . 104.229t & $542-75-6$ \\
\hline$\ldots \ldots \ldots 104.156 t$ & $542-88-1 \ldots$ \\
\hline $87-92-3 \ldots \ldots \ldots \ldots \ldots 104.243 t$ & $\ldots \ldots \ldots 104.277 t$ \\
\hline $288-88-0 \ldots \ldots \ldots \ldots 104.125 t$ & $\ldots \ldots \ldots \ldots 104.36 t$ \\
\hline $289-95-2 \ldots \ldots \ldots \ldots .104 .231 t$ & $\ldots \ldots \ldots 104.19 t$ \\
\hline$\ldots \ldots \ldots \ldots 104.125 t$ & $554-00-7 \ldots$ \\
\hline $319-84-6 \ldots \ldots \ldots \ldots 104.258 t$ & $\ldots \ldots \ldots 104.179 t$ \\
\hline $319-85-7 \ldots \ldots \ldots \ldots 104.258 \mathrm{t}$ & $554-13-2 \ldots \ldots \ldots \ldots \ldots 104.60 \mathrm{t}$ \\
\hline $319-86-8 \ldots \ldots \ldots \ldots \ldots$ 104.259t & $\ldots \ldots \ldots 104.352 t$ \\
\hline $333-20-0 \ldots \ldots \ldots \ldots$ 104.144t & $556-52-5 \ldots \ldots \ldots \ldots 104.156 t$ \\
\hline $334-88-3 \ldots \ldots \ldots \ldots 104.125 t$ & $557-17-5 \ldots \ldots \ldots \ldots 104.185 t$ \\
\hline$\ldots \ldots \ldots 104.220 t$ & $\ldots \ldots \ldots .104 .184 t$ \\
\hline$\ldots \ldots \ldots$ 104.193t & $\ldots \ldots \ldots 104.259 t$ \\
\hline . . . . . . . . 104.194t & $\ldots \ldots \ldots .104 .269 t$ \\
\hline$\ldots \ldots \ldots \ldots 104.194 t$ & $\ldots \ldots \ldots 104.330 t$ \\
\hline$\ldots \ldots \ldots \ldots 104.401 t$ & $\ldots \ldots \ldots 104.352 t$ \\
\hline $420-04-2 \ldots \ldots \ldots \ldots$. $104.141 t$ & $583-59-5 \ldots \ldots \ldots \ldots 104.37 t$ \\
\hline $460-19-5 \ldots \ldots \ldots \ldots . .104 .141 t$ & $\ldots \ldots \ldots 104.329 t$ \\
\hline $461-58-5 \ldots \ldots \ldots \ldots 104.142 t$ & $583-78-8 \ldots \ldots \ldots \ldots 104.372 t$ \\
\hline $462-94-2 \ldots \ldots \ldots \ldots \ldots 104.85 t$ & $\ldots \ldots \ldots \ldots 104.37 t$ \\
\hline $463-51-4 \ldots \ldots \ldots \ldots 104.328 t$ & $\ldots \ldots \ldots \ldots 104.211 t$ \\
\hline 463-58-1 . . . . . . . 104.411t, & $\ldots \ldots \ldots \ldots 104.60 t$ \\
\hline $463-59-1 \ldots \ldots \ldots \ldots 104.423 t$ & $584-84-9 \ldots \ldots \ldots \ldots 104.322 t$ \\
\hline$\ldots \ldots \ldots 104.243 t$ & $\ldots \ldots \ldots \ldots 104.179 t$ \\
\hline $471-34-1 \ldots \ldots \ldots \ldots . . .6104 .60 t$ & $590-28-3 \ldots \ldots \ldots \ldots . . \ldots 104.141 \mathrm{t}$ \\
\hline $479-45-8 \ldots \ldots \ldots \ldots .104 .352 t$ & $590-88-5 \ldots \ldots \ldots \ldots \ldots$ 104.82t \\
\hline $492-80-8 \ldots \ldots \ldots \ldots . . \ldots 104.101 t$ & $591-19-5 \ldots$ \\
\hline $497-19-8 \ldots \ldots \ldots \ldots \ldots 104.60 t$ & $591-23-1 \ldots \ldots \ldots \ldots 104.37 t$ \\
\hline $501-53-1 \ldots \ldots \ldots \ldots 104.302 t$ & $591-35-5 \ldots \ldots \ldots \ldots 104.372 t$ \\
\hline $504-29-0 \ldots \ldots \ldots \ldots 104.229 t$ & $591-78-6 \ldots \ldots \ldots \ldots 104.329 t$ \\
\hline $506-59-2 \ldots \ldots \ldots \ldots \ldots 104.82 t$ & $592-01-8 \ldots$ \\
\hline $506-68-3 \ldots \ldots \ldots \ldots$. . . . . . & $592-27-8 \ldots \ldots \ldots \ldots$ \\
\hline $506-77-4 \ldots \ldots \ldots \ldots 104.142 t$ & $592-41-6 \ldots \ldots \ldots \ldots$ \\
\hline $506-78-5 \ldots \ldots \ldots \ldots 104.142 \mathrm{t}$ & $592-84-7 \ldots \ldots \ldots \ldots .104 .178 \mathrm{t}$ \\
\hline $506-96-7 \ldots \ldots \ldots \ldots 104.328 t$ & $593-60-2 \ldots$ \\
\hline $507-09-5 \ldots \ldots \ldots \ldots 104.409 t$ & $593-70-4 \ldots \ldots \ldots \ldots .104 .193 t$ \\
\hline $507-20-0 \ldots \ldots \ldots \ldots 104.257 t$ & $594-42-3 \ldots \ldots \ldots \ldots 104.411 t$ \\
\hline 509-14-8 . . . . . . . 104.343t & 594-71-8 . . . . . . . 104.342t \\
\hline $510-15-6 \ldots \ldots \ldots \ldots 104.302 t$ & $\ldots \ldots \ldots 104.342 t$ \\
\hline $512-56-1 \ldots \ldots \ldots \ldots . \ldots 104.387 t$ & $\ldots \ldots \ldots .104 .328 t$ \\
\hline $513-36-0 \ldots \ldots \ldots \ldots 104.257 t$ & $598-78-7 \ldots \ldots \ldots \ldots 104.16 t$ \\
\hline $513-37-1 \ldots \ldots \ldots \ldots 104.269 t$ & $598-92-5 \ldots \ldots \ldots \ldots 104.342 \mathrm{t}$ \\
\hline $513-85-9 \ldots \ldots \ldots \ldots$ 104.211t & $600-25-9 \ldots \ldots \ldots \ldots .104 .342 \mathrm{t}$ \\
\hline $528-29-0 \ldots \ldots \ldots \ldots 104.350 t$ & $602-01-7 \ldots \ldots \ldots \ldots 104.350 \mathrm{t}$ \\
\hline $531-86-2 \ldots \ldots \ldots \ldots \ldots 104.411 t$ & $602-87-9 \ldots \ldots \ldots \ldots 104.351 t$ \\
\hline $532-27-4 \ldots \ldots \ldots \ldots \ldots 104.328 t$ & $603-34-9 \ldots \ldots \ldots \ldots 104.107 t$ \\
\hline $532-28-5 \ldots \ldots \ldots \ldots$. . . . . . & $603-35-0 \ldots \ldots \ldots \ldots .104 .387 t$ \\
\hline $534-15-6 \ldots \ldots \ldots \ldots \ldots 104.48 t$ & $605-71-0 \ldots \ldots \ldots \ldots 104.350 \mathrm{t}$ \\
\hline $534-52-1 \ldots \ldots \ldots \ldots$ 104.372t & $606-20-2 \ldots \ldots \ldots \ldots 104.350 \mathrm{t}$ \\
\hline $535-80-8 \ldots \ldots \ldots \ldots \ldots 104.16 t$ & $608-27-5 \ldots \ldots \ldots \ldots 104.103 t$ \\
\hline
\end{tabular}

608-31-1 .......... 104.103t $608-73-1 \ldots . . \ldots \ldots . .104 .258 \mathrm{t}$ 608-93-5 . . . . . . . . 104.303t 610-39-9 . . . . . . . . . 104.351t 611-06-3 . . . . . . . 104.349t 611-15-4 . . . . . . . . . . . 104.288t $612-83-9 \ldots \ldots . . \ldots . .104 .103 t$ $613-29-6 \ldots . . . \ldots \ldots .104 .103 \mathrm{t}$ 613-35-4 . . . . . . . . . . . 104.75t 614-00-6 . . . . . . . . . 104.351t $615-05-4 \ldots \ldots \ldots \ldots .104 .102 t$ 616-38-6 . . . . . . . . . . 104.177t 616-45-5 . . . . . . . . . 104.231t 619-15-8 .......... 104.350t $622-45-7 \ldots \ldots \ldots \ldots .104 .164 t$ $622-97-9 \ldots \ldots \ldots \ldots . .104 .288 \mathrm{t}$ $623-84-7 \ldots \ldots \ldots \ldots .104 .165 t$ 624-18-0 . . . . . . . . 104.102t 624-65-7 . . . . . . . . . 104.269t 624-83-9 . . . . . . . . 104.322t 625-58-1 . . . . . . . . . . 104.342t 626-17-5 . . . . . . . . 104.142t 626-38-0 . . . . . . . . 104.164t 627-13-4 . . . . . . . . . . 104.342t 628-63-7 . . . . . . . . . . 104.164t 628-81-9 . . . . . . . . 104.184t 628-96-6 . . . . . . . . . 104.342t 629-11-8 . . . . . . . . . 104.211t $629-14-1 \ldots \ldots \ldots \ldots . . .204 .203 t$ 630-20-6 . . . . . . . . . . . 104.259t 636-09-9 . . . . . . . . . 104.396t 638-21-1 . . . . . . . . 104.386t 650-51-1 . . . . . . . . . . 104.166t 674-82-8 . . . . . . . . . . 104.329t $680-31-9 \ldots \ldots \ldots \ldots$. . . . . . . . . . . . 1046 t 681-84-5 . . . . . . . . . 104.401t 684-16-2 . . . . . . . . . . 104.194t 693-21-0 . . . . . . . . 104.342t 693-65-2 . . . . . . . . . 104.185t 764-41-0 . . . . . . . . . . 104.269t 765-34-4 . . . . . . . . . 104.49t 768-52-5 . . . . . . . . 104.105t 822-06-0 . . . . . . . . 104.322t 823-40-5 . . . . . . . 104.103t 836-30-6 . . . . . . . . 104.351t 838-88-0 . . . . . . . . . 104.105t 868-85-9 . . . . . . . . 104.386t 872-50-4 . . . . . . . . 104.230t 873-66-5 . . . . . . . . . . 104.288t 933-75-5 . . . . . . . . 104.373t 933-78-8 . . . . . . . . . 104.373t 935-95-5 . . . . . . . . 104.373t 939-27-5 . . . . . . . 104.287t 999-61-1 . . . . . . . . . . 104.173t 1002-67-1 . . . . . . . . . 104.204t 1066-33-7 . . . . . . . . . . 104.60t $1113-38-8 \ldots . . \ldots \ldots . .104 .179 t$ $1127-76-0 \ldots \ldots \ldots .104 .287 t$ $1185-33-7 \ldots \ldots \ldots \ldots .104 .36 t$ 


\begin{tabular}{|c|c|c|}
\hline $1208-52-2 \ldots \ldots \ldots$ & $2551-62-4 \ldots$ & 7601-54-9. . \\
\hline $1300-71-6 \ldots \ldots \ldots \ldots 104.373 t$ & $2644-70-4 \ldots$ & 7601-89-0. . \\
\hline . . 104.107t & $2698-41-1 \ldots$ & 7601-90-3. . \\
\hline $.104 .132 \mathrm{t}$ & $\ldots 104.220 \mathrm{t}$ & $7616-94-6 \ldots$ \\
\hline $03-96-4 \ldots \ldots \ldots \ldots .104 .132 t$ & $2807-30-9 \ldots$ & $7631-90-5 \ldots$ \\
\hline $05-62-0 \ldots \ldots \ldots \ldots$ 104.61t & 2832-19-1 . . & 7631-99-4 . \\
\hline $05-78-8 \ldots \ldots \ldots$ & $2885-00-9 \ldots$ & $7632-00-0 \ldots$ \\
\hline $05-99-3 \ldots \ldots \ldots \ldots 104.386 t$ & $2893-78-9 \ldots \ldots \ldots \ldots 104.125 t$ & . . . 104.132t \\
\hline $10-58-3 \ldots \ldots \ldots \ldots . .104 .61 t$ & $2917-26-2 \ldots \ldots \ldots \ldots 104.410 \mathrm{t}$ & $7637-07-2 \ldots$ \\
\hline $10-65-2 \ldots \ldots \ldots \ldots \ldots 104.61 \mathrm{t}$ & $2935-44-6 \ldots$ & 7647-01-0 . \\
\hline $10-66-3 \ldots \ldots \ldots$ & $3033-62-3 \ldots$ & $7647-14-5 \ldots$ \\
\hline $10-73-2 \ldots \ldots \ldots \ldots .104 .61 t$ & $3033-77-0 \ldots \ldots \ldots \ldots 104.156 t$ & $7664-38-2 \ldots$ \\
\hline $13-60-6 \ldots \ldots \ldots \ldots 104.61 t$ & $3068-88-0 \ldots \ldots \ldots \ldots 104.177 t$ & $\ldots \ldots \ldots 104.220 \mathrm{t}$ \\
\hline $13-82-2 \ldots \ldots \ldots \ldots 104.423 t$ & $3129-91-7 \ldots \ldots \ldots \ldots .104 .103 t$ & 7664-41-7 . . \\
\hline $.104 .386 \mathrm{t}$ & 3173-53-3. . & 7664-93-9. \\
\hline . . 104.386t & $\ldots \ldots \ldots 104.322 t$ & $7665-72-7 \ldots$ \\
\hline $14-85-8 \ldots \ldots \ldots \ldots 104.388 \mathrm{t}$ & $3209-22-1 \ldots \ldots \ldots \ldots$ 104.349t & $\ldots \ldots \ldots 104.62 t$ \\
\hline $1317-65-3 \ldots \ldots \ldots \ldots$ 104.60t & $3333-52-6 \ldots \ldots \ldots \ldots 104.143 t$ & 7681-52-9.. \\
\hline $19-77-3 \ldots \ldots \ldots \ldots 104.371 t$ & $3648-21-3 \ldots \ldots \ldots \ldots 104.396 t$ & $7681-57-4 \ldots$ \\
\hline $20-94-1 \ldots \ldots \ldots \ldots 104.157 t$ & $3710-30-3 \ldots \ldots \ldots \ldots 104.277 t$ & $7681-82-5 \ldots \ldots \ldots \ldots .104 .62 t$ \\
\hline $21-64-8 \ldots \ldots \ldots \ldots 104.304 t$ & $3724-65-0 \ldots \ldots \ldots \ldots 104.16 t$ & $7697-37-2 \ldots \ldots \ldots \ldots .104 .8 \mathrm{t}$ \\
\hline $1321-65-9 \ldots \ldots \ldots \ldots 104.304 t$ & $3811-04-9 \ldots \ldots \ldots \ldots 104.60 \mathrm{t}$ & $\ldots \ldots \ldots \ldots 104.8 \mathrm{t}$ \\
\hline $321-74-0 \ldots \ldots \ldots \ldots 104.287 t$ & $3982-91-0 \ldots \ldots \ldots \ldots 104.387 t$ & 7704-34-9 . . \\
\hline $321-94-4 \ldots \ldots \ldots \ldots 104.288 t$ & $4016-14-2 \ldots \ldots \ldots \ldots 104.157 t$ & 7719-09-7 . . \\
\hline $330-43-4 \ldots \ldots \ldots \ldots$ 104.132t & $4098-71-9 \ldots \ldots \ldots \ldots 104.322 t$ & $\ldots \ldots \ldots 104.386 t$ \\
\hline $330-78-5 \ldots \ldots \ldots \ldots 104.387 t$ & $4109-96-0 \ldots \ldots \ldots \ldots 104.401 t$ & $\ldots \ldots \ldots 104.365 t$ \\
\hline $1335-87-1 \ldots \ldots \ldots \ldots$ 104.303t & $4170-30-3 \ldots \ldots \ldots \ldots .104 .48 t$ & $7722-88-5 \ldots$ \\
\hline $35-88-2 \ldots \ldots \ldots \ldots 104.304 t$ & $\ldots \ldots \ldots 104.203 t$ & $7723-14-0 \ldots \ldots \ldots \ldots 104.386 t$ \\
\hline $336-21-6 \ldots \ldots \ldots \ldots .104 .61 t$ & $\ldots \ldots \ldots 104.49 t$ & $7726-95-6 \ldots \ldots \ldots \ldots$ 104.220t \\
\hline $344-81-6 \ldots \ldots \ldots \ldots$. . . . . . .423t & $\ldots \ldots \ldots 104.351 \mathrm{t}$ & $\ldots \ldots \ldots 104.422 \mathrm{t}$ \\
\hline $1344-95-2 \ldots \ldots \ldots \ldots .104 .401 t$ & $5329-14-6 \ldots$ & 7727-54-0 . . \\
\hline $464-53-5 \ldots \ldots \ldots \ldots 104.156 t$ & $5435-64-3 \ldots$ & $7757-79-1 \ldots$ \\
\hline $1477-55-0 \ldots \ldots \ldots \ldots 104.105 t$ & $5522-43-0 \ldots \ldots \ldots \ldots .104 .352 t$ & $7757-82-6 \ldots \ldots \ldots \ldots 104.423 t$ \\
\hline $1563-66-2 \ldots \ldots \ldots \ldots 104.177 t$ & $5714-22-7 \ldots \ldots \ldots \ldots 104.221 \mathrm{t}$ & $7757-83-7 \ldots \ldots \ldots \ldots 104.423 t$ \\
\hline $1569-69-3 \ldots \ldots \ldots \ldots$ 104.409t & $5807-02-3 \ldots \ldots \ldots \ldots .104 .143 t$ & 7758-01-2 . . \\
\hline $1615-80-1 \ldots \ldots \ldots \ldots 104.125 t$ & $5949-29-1 \ldots \ldots \ldots \ldots$ 104.20t & $7758-02-3 \ldots$ \\
\hline $1634-04-4 \ldots \ldots \ldots \ldots 104.185 t$ & $5989-27-5 \ldots \ldots \ldots \ldots 104.288 t$ & $7758-05-6 \ldots \ldots \ldots$ \\
\hline $1639-09-4 \ldots \ldots \ldots \ldots 104.410 t$ & $5989-54-8 \ldots \ldots \ldots \ldots 104.288 t$ & $7758-09-0 \ldots \ldots \ldots \ldots 104.61 \mathrm{t}$ \\
\hline $1667-11-4 \ldots \ldots \ldots \ldots .104 .302 t$ & $6393-42-6 \ldots \ldots \ldots \ldots$ 104.351t & $7758-19-2 \ldots \ldots \ldots \ldots 104.60 \mathrm{t}$ \\
\hline $1702-17-6 \ldots \ldots \ldots \ldots$. . . . . & $6423-43-4 \ldots \ldots \ldots \ldots .104 .343 t$ & $7758-29-4 \ldots$ \\
\hline $1746-01-6 \ldots \ldots \ldots \ldots$. . . . . & $6484-52-2 \ldots$ & $7772-98-7 \ldots \ldots \ldots$ \\
\hline $1746-13-0 \ldots \ldots \ldots \ldots .104 .184 t$ & $6834-92-0 \ldots \ldots \ldots \ldots 104.401 \mathrm{t}$ & $7773-06-0 \ldots \ldots \ldots \ldots 104.422 \mathrm{t}$ \\
\hline $1762-95-4 \ldots \ldots \ldots \ldots 104.144 t$ & $7046-61-9 \ldots \ldots \ldots \ldots 104.322 t$ & $7775-09-9 \ldots \ldots \ldots \ldots 104.60 \mathrm{t}$ \\
\hline $1836-75-5 \ldots \ldots \ldots \ldots 104.351 t$ & $7085-85-0 \ldots$ & $7775-14-6 \ldots$ \\
\hline $1885-14-9 \ldots \ldots \ldots \ldots 104.177 t$ & $7320-34-5 \ldots \ldots \ldots$ & $7775-27-1 \ldots \ldots \ldots$ \\
\hline $1888-71-7 \ldots \ldots \ldots \ldots 104.270 t$ & $7339-53-9 \ldots \ldots \ldots \ldots 104.124 t$ & 7778-18-9. . \\
\hline $1888-91-1 \ldots \ldots \ldots \ldots$ 104.229t & $7439-93-2 \ldots \ldots \ldots \ldots .104 .61 t$ & $\ldots \ldots \ldots 104.60 t$ \\
\hline $2050-92-2 \ldots \ldots \ldots \ldots \ldots$ 104.83t & 7440-09-7 . .......... 104.62t & $7782-41-4 \ldots \ldots \ldots \ldots 104.220 \mathrm{t}$ \\
\hline $2156-96-9 \ldots \ldots \ldots \ldots 104.173 t$ & $7440-21-3 \ldots \ldots \ldots \ldots 104.401 \mathrm{t}$ & $7782-50-5 \ldots \ldots \ldots \ldots 104.220 \mathrm{t}$ \\
\hline 2234-13-1 . . . . . . . 104.303t & $7440-23-5 \ldots \ldots \ldots \ldots .104 .62 t$ & $7782-79-8 \ldots \ldots \ldots \ldots 104.124 t$ \\
\hline $2238-07-5 \ldots \ldots \ldots \ldots 104.157 t$ & $7440-42-8 \ldots \ldots \ldots \ldots 104.132 t$ & $7782-92-5 \ldots \ldots \ldots \ldots 104.75 t$ \\
\hline $2243-62-1 \ldots \ldots \ldots \ldots 104.106 t$ & $7440-70-2 \ldots \ldots \ldots \ldots 104.60 t$ & $7783-06-4 \ldots \ldots \ldots \ldots 104.423 t$ \\
\hline $2425-01-6 \ldots \ldots \ldots \ldots 104.157 t$ & $7446-09-5 \ldots \ldots \ldots \ldots$ 104.422t & $7783-20-2 \ldots \ldots \ldots \ldots 104.423 t$ \\
\hline $2425-79-8 \ldots \ldots \ldots \ldots .104 .203 t$ & 7446-11-9......... 104.423t & 7783-41-7 . . . . . . . 104.220t \\
\hline $2426-08-6 \ldots \ldots \ldots \ldots$. . . . . & $7447-41-8 \ldots \ldots \ldots \ldots .104 .60 t$ & $7783-54-2 \ldots \ldots \ldots \ldots 104.221 t$ \\
\hline 2431-50-7 .......... 104.270t & $7553-56-2 \ldots \ldots \ldots \ldots .104 .221 \mathrm{t}$ & 7783-60-0 . . . . . . . 104.423t \\
\hline $2461-15-6 \ldots \ldots \ldots \ldots . .104 .157 t$ & $7558-79-4 \ldots \ldots \ldots \ldots .104 .61 t$ & $7783-61-1 \ldots \ldots \ldots \ldots 104.401 \mathrm{t}$ \\
\hline 2524-04-1 . . . . . . . 104.386t & $7572-29-4 \ldots \ldots \ldots \ldots$ 104.269t & $7789-21-1 \ldots \ldots \ldots \ldots \ldots 104.8 \mathrm{t}$ \\
\hline $2528-36-1 \ldots \ldots \ldots \ldots 104.386 t$ & $7580-67-8 \ldots \ldots \ldots \ldots 104.61 \mathrm{t}$ & $7789-23-3 \ldots \ldots \ldots \ldots 104.61 \mathrm{t}$ \\
\hline
\end{tabular}

7789-30-2 . . . . . . . 104.221t 7789-38-0 . . . . . . . 104.60t 7789-60-8 . . . . . . . . . 104.221t 7789-69-7 . . . . . . . 104.221t 7789-75-5 ......... 104.220t 7789-78-8 . . . . . . . . . 104.61t 7790-21-8 . . . . . . . . 104.62t 7790-91-2 . . . . . . . . 104.221t 7790-94-5 . . . . . . . . . . . 104.8t 7791-25-5 . . . . . . 104.422t 7803-51-2 . . . . . . 104.386t 7803-57-8 . . . . . . . 104.125t 7803-62-5 ......... 104.401t 8001-35-2 . . . . . . . . 104.302t 9002-84-0 . . . . . . . . 104.194t 9016-00-6 .......... 104.401t 10025-67-9 ......... 104.220t 10025-78-2 . . . . . . . . 104.402t 10025-85-1 ......... 104.220t 10025-87-3 ......... 104.386t 10026-04-7 . . . . . . . . 104.401t 10026-13-8 . . . . . . . 104.386t 10034-93-2 . . . . . . 104.125t 10035-10-6 ......... 104.220t 10043-35-3 .......... 104.8t 10043-52-4 . . . . . . . . 104.60t 10049-04-4 . . . . . . . . 104.221t 10061-01-5......... 104.270t 10061-02-6 . . . . . . . 104.270t 10102-75-7 . . . . . . . 104.60t 10124-37-5 .......... 104.61t 10137-74-3 .......... 104.60t 10294-33-4 . . . . . . . . 104.132t 10294-34-5 . . . . . . . . 104.132t 10477-28-6......... 104.401t 10545-99-0 . . . . . . 104.220t 11097-69-1 . . . . . . . . 104.302t 12124-99-1 . . . . . . . 104.423t 12125-01-8 .......... 104.61t 12125-02-9 . . . . . . . 104.60t 12136-45-7 . . . . . . . 104.61t 13780-06-8 . . . . . . . . 104.61t 13838-16-9 . . . . . . . . 104.194t 13952-84-6 . . . . . . . . 104.82t 14371-10-9 . . . . . . . . . 104.48t 15950-66-0 . . . . . . . 104.373t 16219-75-3 ........ 104.277t 16543-55-8 . . . . . . . . 104.230t 16731-55-8 . . . . . . 104.422t 16872-11-0 . . . . . . . 104.8t 16893-85-9 . . . . . . . 104.220t 16940-66-2 . . . . . . . . 104.132t 17702-41-9 . . . . . . . 104.132t 18461-55-7 . . . . . . . 104.165t 19287-45-7 . . . . . . 104.132t 19406-51-0 . . . . . . 104.351t 19485-03-1 . . . . . . . 104.173t 19624-22-7 . . . . . . . 104.132t 20325-40-0....... 104.103t 


\begin{tabular}{|c|c|}
\hline $24460-74-0$ & . $104.178 \mathrm{t}$ \\
\hline $25013-15-4$ & . $104.288 \mathrm{t}$ \\
\hline $25013-16-5$ & $.104 .184 t$ \\
\hline $25154-52-3$ & $.104 .372 \mathrm{t}$ \\
\hline $25154-54-5$ & . 104.349t \\
\hline $25155-30-0$ & $.104 .409 t$ \\
\hline $25321-14-6$ & $.104 .350 \mathrm{t}$ \\
\hline $25322-20-7$ & $.104 .259 t$ \\
\hline $25339-17-7$ & . . 104.35t \\
\hline $5340-17-4$ & $104.287 \mathrm{t}$ \\
\hline
\end{tabular}

$25639-42-3 \ldots \ldots \ldots .104 .37 t$ 26447-14-3 . . . . . . . 104.156t 26471-62-5 . . . . . . . . 104.322t 26628-22-8 . . . . . . . . 104.124t 26761-40-0 . . . . . . . 104.396t 26952-21-6 . . . . . . . . . 104.35t 27253-26-5 . . . . . . . 104.396t $27478-34-8 \ldots \ldots \ldots .104 .350 t$ 27554-26-3 . . . . . . . . 104.396t 27858-07-7 ........ 104.303t
28434-86-8 . . . . . . . 104.188t

28675-08-3 . . . . . . . . 104.188t

30525-89-4 . . . . . . . . . 104.49t

31242-93-0 . . . . . . . . 104.188t

$31242-94-1 \ldots \ldots \ldots \ldots$. . . . . . . $188 \mathrm{t}$

34590-94-8 . . . . . . . . 104.203t

35572-78-2 . . . . . . . . . 104.351t

$42279-29-8 \ldots \ldots \ldots . . \ldots 104.188 \mathrm{t}$

42397-64-8 . . . . . . . . 104.350t

$42397-65-9 \ldots \ldots \ldots .104 .350 t$
51637-93-5 . $104.177 \mathrm{t}$

$53469-21-9 \ldots \ldots \ldots . . \ldots 404.302 \mathrm{t}$

53569-64-5 . . . . . . . . 104.342t

55488-51-2 . . . . . . . 104.177t

56677-60-2 . . . . . . . 104.178t

59536-65-1 . . . . . . . . 104.302t

64700-56-7 . . . . . . . . 104.165t

70657-70-4 . . . . . . . 104.165t

75321-19-6 . . . . . . . . 104.352t

75321-20-9 . . . . . . 104.350t 
A

Aaniratti, S. . . . . . . . . . . . . 97

Aanonsen, A ............. 43

AAOHN Executive

Committee. ............. 19

Aarli, JA................ 7

Aarons, JH ............... 33

Aasland, OG . . . . ......... 15

A barbanel, JM .............. 7

Abbey, A . . . . ........... 59

Abbey, $\mathrm{H} \ldots \ldots \ldots \ldots \ldots$. . 49, 53

Abdelghany, $H \ldots \ldots \ldots \ldots . . .80$

Abdo, R . ............. 94, 97

Abdollahzadeh, S.......... 83

A becassis ............... 54

Abel, A ................ 101

Abeles, $M \ldots \ldots \ldots \ldots \ldots \ldots$

A beliovich, D . . . . . . . . . . 9

Abella, RS ............... 17

Abelson, M A . .............. 59

Abener, W ...............6 63

Abenhaim, L . ........... 26

A berg, E............... 52

A beysekera, JD A . . . . . . . . 29

A beytunga, PK ........... 22

Abildgaard, A . . . . . . . . 13

Abiteboul, D . . . . . . . . . . . 97

Abraham, G.............. 9

Abraham, J ............... 10

Abraham, JL ........... 10,63

Abraham, M H . . . . . . . . . . . 30

Abraham, P ............. 39

Abraham, S ............. 15

Abramowicz, D ............. 3

Abrams, $H \ldots \ldots \ldots \ldots \ldots 88$

Abrams, RH ............. 54

Abramson, M J ........ 10, 13

Abriou, P . . . . . . . . . . . . . 97

Abrons, $\mathrm{HL} \ldots \ldots \ldots \ldots \ldots$

Absher, A ................ 10

Absher, M P .............. . 10

Acha, $P \ldots \ldots \ldots \ldots \ldots \ldots . . \ldots$

Acha, PN ..............69 69

Achauer, BM ............. 98

Acheson, E . . . . . . . . . . . 88

Acheson, ED ............. 30

Ackerson, M A . ............ 74

Acquavella, J ............ 91

Acton, $W \ldots \ldots \ldots . . . . . .99$

Acton, WI .............. 47

Adami, HG . ............ 15

Adami, $\mathrm{H}-\mathrm{O} \ldots \ldots \ldots \ldots \ldots . . \ldots$

Adams, AF............... 3

Adams, IM . . . . . . . . . . 6

Adams, JC . . . .......... 6

Adams, JE ............... 34
Adams, JGU ............. 56

Adams, LL ............... 34

Adams, PH. . ...........6 64

Adams, R.............. 21

Adams, RM . . . . . . . . . . . 12

Adams, W . . . .......... 48

Adams, WV . ............ 77

Adamson, IY R . . . . . . . . . . . 10

Adegboye, AA . . . . . . . . . 97

Ader, $R \ldots \ldots \ldots \ldots . . . \ldots 34$

Ades, $A \ldots \ldots \ldots \ldots \ldots . . \ldots 73$

Adesnik, M.............. 33

Adgey, AA ............. 3

Adkins, BJ ............... 10

Adkins, LE . . . . . . . . . . 30

Adler, $\mathrm{FH} \ldots \ldots \ldots \ldots \ldots \ldots 11$

Adlkofer, F . . . . . . . . . . . . . . 44

Adriaanse, $\mathrm{H}$............. 34

Adrian, WK .............. 11

Agaath, PK ............ 73

Agaba, DF ..............6 65

Agaba, EF .............664

Agabiti, $N \ldots \ldots \ldots \ldots .63$

Agardy, M T . . . . . . . . . . 66

Agee, JM .............. 7

Agencia Internacional para la

Investigación sobre el

Cáncer (IARC) ..... 1, 2, 4, 8,

$9,10,12,27,32,33,44,48,53$,

$63,71,72,73,74,80,81,82$,

$85,88,91,93,100,103$

A gency for $\mathrm{H}$ ealth Care Policy

and R esearch (AH CPR). .... 6

Agency for Toxic Substances

and Disease R egistry

(ATSDR ). ....... 9, 63, 100

Agius, $R \ldots \ldots \ldots \ldots 10,79$

Aglietta, M . . . . . . . . . . . 97

Agner, $T \ldots \ldots \ldots \ldots$ 12, 93

Agnew, $J \ldots \ldots \ldots \ldots \ldots .7,11$

Agostini, R . . . . . . . . . . . . . 88

Agren, G . .............. 34

Agricola, G. . ......... 32, 74

Aguilera, $X \ldots \ldots \ldots \ldots . . . . . . . . .6$

Agüir, $V \ldots \ldots \ldots \ldots . . . . .97$

A hearn, DG . . . . . . . . . . . 13

A hearn, FL. . . . . . . . . . . . 34

Ahern, SK . . . . . . . . . . . 97

A hibom, A . . . . . . . . . . . 88

A hlberg-H ulten, G . . . . . . . . . 3

Ahlbom, A ........ 7, 28, 52

Ahlborg, JR .............9

Ahlgren, GH . . ......... 70

Ahlin, J............... 97

Ahlman, K ............... 3

Ahlström, R ............ 11
Ahman, $M \ldots . . . \ldots . . . . .86$

Ahn, BH............... 29

Ahn, DK .............. 9

Ahonen, M . . . . . . . . . . . . 29

Ahrens, U. . . . . . . . . . . . . . 58

Ahrens, W .............. 32

Ahroon, WA .............47 47

Aiello, JR ............... 34

Ainsworth, TH............ 3

Aisner, J . . . . . . . . . . . . . . . . . 10

Aitio, A . . . . . . . . 2, 27, 89

Ajello, L............... 64

Ajodhia, JM .............. 11

Ajwani, M K ................ 39

A kabas, SH ............15, 17

A kabri, M................5 52

Akande, A . . ............ 34

A kehurst, BC . ............ 64

Akerblom, M . . ........... 27

Akerele, $0 \ldots \ldots \ldots \ldots . \ldots 53$

Akerkar, S .............. 44

Åkerstedt, A . . . . . . . . . . . . . . . 43

Akerstedt, $T$. . . . . . . . . . . . 29

Åkerstedt, $T$. . . . . . . . . . . . . . 3

Åkesson, B . . . . . . . . . . 12, 66

Akin, FW . . . . . . . . . . . . . . 38

Akin, RE ............... 70

Akinfieva, TA ............6 63

Akinori, $\mathrm{H}$. . . . . . . . . . . . 97

A kleyev, AV . . . . . . . . . . . . . . 39

Akmakjian, J . ............6 6

Aks, SE. .................63 63

A kselrod, S. . . . . . . . . . . . . . 34

Aksoy, $M \ldots \ldots \ldots \ldots .2,20$

Ala-K etola, L . . . . . . . . . . . . . . 6

Alam, M............... 97

Alarie, Y . . . . . . . . . . . . . . . 30

Alavanja, M CR ........... . 44

Alazraki, ND .............6 63

Alban, DH . . . . . . . . . . . . . . 68

Albers, WA , Jr............. 59

Albert, DM .............. 12

Albert, $K \ldots \ldots \ldots \ldots 60$

Albert, RE ........ . 33, 48, 100

Alberti, PW ............. 73

Albertini, RJ. . . . . . . . . . . . . 33

Alberts, B . . . . . . . . . . . . . . 33

Alberts, WM ............. 10

Albrecht, S. . . . . . . . . . . . . 34

Albrecht, WN ............ 10

Albrechtsen, $0 \ldots \ldots \ldots \ldots 13$

Albrektsen, G . . . . . . . . . . . 7

Albright, B ............. 3

Albuisson, E . . . . . . . . . . . . 63

Alcini, D . . . . . . . . . . . . 27

Alderfer, RJ . .............. 64
Alderman, L. . . . . . . . . . . . . . . 39

Alderman, M .............. 34

Alderson, $M \ldots \ldots \ldots$. 2, 9, 87

Aldhous, $P \ldots \ldots \ldots \ldots \ldots .70$

Aldi, RG ...............6 65

Aldrich, FD ........... 9

al-Eissa, Y A ............... 3

Aleksandrovskii, VG . . . . . . . 38

Alessio, L . . . . . . . . . . . . . 27

Alexander, $F$. . . . . . . . . . . . . 34

Alexander, J0 ............ 70

Alexander, P . . . . . . . . . . . . 96

Alexander, SJ . . . . . . . . . . 50

Alexander, WJ . . . . . . . . . . . 97

Alexandersen, $0 \ldots \ldots \ldots \ldots$

Alexandratos, N . . . . . . . . . . . 64

Alfred, HJ. . . . . . . . . . . . . . . . 97

Alfredsson, L . . . . . 3, 6, 43, 100

Algera, JA .............. 29

Algeri, S . . . . . . . . . . . . 43

Alho, J................... 32

Alho, $M \ldots \ldots \ldots \ldots \ldots . \ldots 2$

Ali, A ................. 53

Alimova, ST ............. 3

al-jiffry, M S . . . . . . . . . . . 97

Al-Juburi, AZ . . . . . . . . . . 9

All, $A \ldots \ldots \ldots \ldots \ldots . \ldots 33$

Allan, EA ................ 34

Allan, JS . . . . . . . . . . . . . 53

Allan, R . . . . . . . . . . . . . . . . 33

Allan, TM ................ 3

Allander, E...............6 6

Allegrante, JP . . . . . . . . . . . 15

Allen, EA . . . . . . . . . . . . . . . 97

Allen, $G \ldots \ldots \ldots \ldots \ldots \ldots$

Allen, $L \ldots \ldots \ldots \ldots \ldots . \ldots 34$

Allen, SG . . ............. 49

Allen, $T \ldots \ldots \ldots \ldots \ldots \ldots . \ldots 34$

Allmeers, $\mathrm{H}$. . . . . . . . . . . . 97

Allread, WG . . . . . . . . . . . . . 80

Allred, E............... 9

Allum, JHJ . . . . . . . . . . . . . 11

Allyn, B . . . . . . . . . . . . 38

Allyn, PA . . . . . . . . . . . . 98

Alm, NO .............. 42

Almeder, RF . ........... 19

Almers, $S \ldots \ldots \ldots \ldots \ldots \ldots 6$

Alpen, M A . . . . . . . . . . 97

Al-R awi, NY ........... 9

Alston, P.............. 23

Alter, MJ . . ............ 97

Althouse, RB . . . . . . . . . . 10

Altman, DG ............. 28

Altman, I . . . . . . . . . . . . . . . 34

Altman, $\mathrm{N} \ldots \ldots \ldots \ldots \ldots \ldots 14$

Altman, RD . . . . . . . . . . . 6 
Altmura, BM ..........9

Altura, BM . . . . . . . . . . . . . 3

Altura, BT ............ 3

Alty, J . . . . . . . . . . . . . . . . . 29

Alvares, C . . . . . . . . . . . . 29

Alvarez-D ardet, C . . . . . . . . 87

Alverson, DL . . . . . . . . . . . 66

Alvesson, M . . . . . . . . . . 35

Alwan, WH . . . . . . . . . . . 77

Amador, $R \ldots \ldots \ldots \ldots \ldots \ldots 7$

Amaducci, $L \ldots \ldots \ldots \ldots \ldots \ldots 7$

A malberti, R . . . . . . . . . . 29

Amandus, HE . . . . . . . . 56, 60

Amdur, M O . . . . . . . . 7, 33, 101

Amdur, MOR . . . . . . . . . . 30

American Academy of

O rthopedic Surgeons . . . 6, 6, 96

A merican C ollege of

$O$ bstetricians and

Gynecologists (ACO G ) . . . . 15

American College of

O ccupational and

Environmental M edicine . . . 19

A merican C ollege of Sports

M edicine.

A merican C onference of

G overnmental Industrial

$\mathrm{H}$ ygienists (AC GIH ) . . . . . 10

$27,28,30,42,44,45,49,50$,

$61,70,79,80,82,83,97,101$ 103

A merican D ietetic Association (ADA) .............. 15

A merican Federation of $\mathrm{L}$ abor and $C$ ongress of Industrial O rganizations (AFL -CIO ) . . 99

American Geological Institute ............... 74

A merican $\mathrm{H}$ eart Association NYCA . . . . . . . . . . . 15

American $\mathrm{H}$ ospital Association (AHA) . . . . . . . . . . . 97

A merican Industrial $\mathrm{H}$ ygiene Association (AIH A) . . . 3, 31, 61

A merican Institute of Architects. . . 97

A merican Institute of A rchitects Committee on Architecture for $\mathrm{H}$ ealth . . . . . . . . . . . . 97

A merican Institute of $C$ hemical Engineers (AIChE) . . . . . 4 41

A merican Iron and Stee Institute (AISI) . . . . . . 21, 73

American L ung Association. . . . 15 American $\mathrm{N}$ ational Standards Institute (AN SI ) . . . . 31, 32, $40,47,48,49,56,61,82,83$, $84,93,96,102,103$

A merican N uclear Society. . . . . 48

A merican 0 ccupational $M$ edical Association (AOM A)

American Petroleum Institute (API) . . . . 75, 77, 78, 82, 102
American Psychiatric Association (APA) . . . . 5, 39, 51

A merican Public $\mathrm{H}$ ealth

Association (APHA)

A merican Society for T esting

and $M$ aterials (AST M ) . . . 13, 134

A merican Society of $\mathrm{H}$ eating,

R efrigerating and

Air-conditioning Engineers

(ASHRAE) . . . . 44, 13, 97, 45

A merican Society of $M$ echanical

Engineers (ASM E) . . . . . . . . 93

American Society of Safety

Engineers (ASSE ) . . . . . 19, 60

A merican T extile R eporter . . . . 89

American Thoracic Society

(ATS) . . . . . . . . . . . . . . 10

A merican $\mathrm{V}$ eterinary $\mathrm{M}$ edical Association (AVM A) . . . . . 69

A merican W elding Society (AWS) .............41

Amery, A . . . . . . . . . . . 63

Ames, CM ............ 34

A mick, $B C \ldots \ldots \ldots \ldots \ldots \ldots 52$

Amick, BC, III . . . . . . . . . 34

Amin-Zaki, L . . . . . . . . . 9

Ammau, Z . ..............

Amoore, JE ............ 11

Amor, $B \ldots \ldots \ldots \ldots \ldots \ldots \ldots 6$

Amoruso, $\mathrm{MA} \ldots \ldots \ldots \ldots \ldots 1$

Amott, $T \ldots \ldots \ldots \ldots \ldots \ldots 9$

Amphoux, L. . . . . . . . . . . . . 29

Amsel, J . . . . . . . . . . . . 93

Amsler, RW . . . . . . . . . . . . . 7

Amundsen, A . . . . . . . . . 15

$A n, K \ldots \ldots \ldots \ldots \ldots \ldots \ldots$

Analytische $C$ hemie [Q uímica analítica] . . . . . . . . . . 55

Anastas, MY . . . . . . . . . 79

Anda, RF . . . . . . . . . . . 15

Andersen, A ......... 9, 10,63

Andersen, D . . . . . . . . . . . . . . 19

Andersen, HC . . . . . . . . . 11, 86

Andersen, I . . . . . . . . 11, 86

Andersen, JB . . . . . . . . . . . . . 49

Andersen, KE ........... 33

Andersen, $0 \ldots \ldots \ldots \ldots \ldots \ldots . . .43$

Andersen, R . . . . . . . . . . . 66

Anderson, A . . . . . . . . . . 44, 80

Anderson, B . . . . . . . . . . 24, 100

Anderson, DF . . . . . . . . 95

Anderson, DM . . . . . . . . . . . 66

Anderson, DR . . . . . . . . 15

Anderson, EA ........... 34

Anderson, G BJ . . . . . . . . . . . 97

Anderson, $H \ldots \ldots \ldots \ldots \ldots . . . . .$.

Anderson, H A . . . . . . . . 9, 64, 94

Anderson, H B . . . . . . . . 56, 58

Anderson, JAD ...........6

Anderson, JC . . . . . . . . . . 34

Anderson, JH . . . . . . . . . . . 87

Anderson, J J . . . . . . . . . . 6

Anderson, JJB . . . . . . . . . 15

Anderson, JR . . . . . . . . . 52
Anderson, M C . . . . . . . . . . 49

Anderson, M S . . . . . . . . . . . . 19

Anderson, RL . . . . . . . . . . 64

Anderson, R R . . . . . . . . . . . 49

Anderson, TW . . . . . . . . . . . 48

Andersson, G . . . . . . . . . . 6, 29

Andersson, G BJ . . . . . . . . 6, 100

Andersson, GBS. . . . . . . . . . . 97

Andersson, K ............ 3, 13

Andersson, $\mathrm{N} \ldots \ldots \ldots \ldots \ldots \ldots . . . .39$

Andersson, $\mathrm{R} \ldots \ldots \ldots \ldots \ldots 56$

Andersson, $\mathrm{S} \ldots \ldots \ldots \ldots \ldots \ldots 6$

Andersson, $T \ldots \ldots \ldots \ldots \ldots 13$

Andjelkovich, DA . . 3, 80, 91, 100

Andlauer, P . . . . . . . . . 43, 29

Andley, U P . . . . . . . . . . . . 49

Ando, $K \ldots \ldots \ldots \ldots \ldots . \ldots 96$

Andre, FE . . . . . . . . . . 97

Andre, $M \ldots \ldots \ldots \ldots . \ldots 34,52$

André, $P \ldots \ldots \ldots \ldots \ldots \ldots$

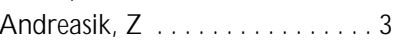

Andreeff, $M \ldots \ldots \ldots \ldots \ldots 1$

Andreoni, D . . . . . . . . . . . . . 40

Andres, V . . . . . . . . . . . . . . 27

Andrews, JL . . . . . . . . . . . . 10

Andrews, JSJ . ........... 53

Andrews, K W ............ 100

Andriessen, JHTH . . . . . . . . 59

Andringa, $A \ldots \ldots \ldots \ldots \ldots \ldots 11$

A neshensel, CS . . . . . . . . . . 34

Anfuso, D . . . . . . . . . . . . . . 34

Angelides, AC . . . . . . . . . 6

Angelillo, IF . . . . . . . . . . 38

Anger, $G \ldots \ldots \ldots \ldots \ldots \ldots 3$

Anger, $\mathrm{KW} \ldots \ldots \ldots \ldots \ldots 7$

Anger, WK ........ 7, 60, 33

A ngerer, J.............. 101

Angersbach, D . . . . . . . 3, 29, 43

Angier, N . . . . . . . . . . . . 53

Angiuli, $G \ldots \ldots \ldots \ldots \ldots .27$

Aniolczyk, R ...........4 49

Anjou, C-G ........... 3

Anker, R .............. 24

Ankrah, M ............ 96

Anliker, M .............. 6

Annanmäki, M............ 3

Annau, Z . ............... 19

Annegers, JF . . ......... 72

Anniko, M .............. 11

Anshlem-O Ison, B . . . . . . . . 7

Anson, $E \ldots \ldots \ldots \ldots \ldots . . . . .83$

Anthony, H M . . . . . . . . . 89

Anthony, JC . . . . . . . . . . 5, 34

Anthony, PP............4

Antic, R . . . . . . . . . . . . 10

Antilla, A .............. 9

Antman, K . . . . . . . . . . . 9, 10

Anton, DJ . . . . . . . . . . . . . 102

A ntoni, H . . . . . . . . . . . 40, 82

Antonovsky, A . . . . . . . . . . 34

Antonucci, T C . . . . . . . . . . . 34

Anttila, A .............. 9

Aoki, K.............. 53

Aoli, K ................ 88
Aoyama, $\mathrm{H} \ldots \ldots \ldots \ldots 34,97$

A pley, $A G \ldots \ldots \ldots \ldots \ldots \ldots 6$

A postoli, L . . . . . . . . . . . . . . 27

A postoli, P . . . . . . . . 9, 27, 43

Appelman, LM ....... 30, 100

Appels, A . . . . . . . . . . . . . 34

A pple Computer C $0 \ldots \ldots . . .52$

Apple, J ............... 56

A ppleton, D . . . . . . . . . . . . . 29

Appley, M H . . . . . . . . . . . . 34

Aprili, F . ............9

Apt, W .............. 3

Apter, A . . . . . . . . . . . . . . 13

Apud, $E \ldots \ldots \ldots \ldots \ldots \ldots 6$

Arai, $M \ldots \ldots \ldots \ldots \ldots 5$

Araki, S . . . . . . . . . . . 34, 5

A rbetarskyddsstyrelsen (J unta

$\mathrm{N}$ acional de $\mathrm{H}$ igiene $\mathrm{y}$

Seguridad en el T rabajo

de Suecia). . . . . . . . . . . . . 93

Arbosti, G . . . . . . . . . . . . . 79

Arbouw Foundation . . ......993

Arceivala, S] . ........... 53

Archea, J . . . . . . . . . . . . . . 34

Archer, DL.... . . . . . . . . . . 53

Ardsmiti, N . . . . . . . . . . 38

Arenas, JP . . . . . . . . . . . . . . 47

Arendt, J . . . . . . . . . . . . 43

ARET Secretariat . . . . . . . . . 55

Arfaioli, $C \ldots \ldots \ldots \ldots \ldots \ldots .7$

Arger, $\mathrm{PH} \ldots \ldots \ldots \ldots \ldots \ldots 64$

Arheim, DD . . . . . . . . . . . 96

A riens, EJ . . . . . . . . . . . 33

A riffin, $R \ldots \ldots \ldots \ldots . \ldots 22$

Arizio, A. . . . . . . . . . . . . . 101

Arlidge, JT . . . . . . . . . . . . . 89

Arlien-Søborg P . . . . . . . . . 7

Armbrustmacher, VW . . . . . . 72

Armenakis, AA . . . . . . . . . . 34

Armistead, G . . . . . . . . . 78, 102

Armitage, $P$. . . . . . . . . . 2, 28

Armon, C . . . . . . . . . . . . 7

Armstrong, A . . . . . . . . . . . . 34

Armstrong, B . . 9, 10, 52, 87, 100

Armstrong, $B G \ldots \ldots \ldots \ldots \ldots 3$

Armstrong, BK ..... 3, 28, 12

Armstrong, $E G \ldots \ldots \ldots \ldots . .9$

Armstrong, $\mathrm{H} \ldots \ldots \ldots \ldots \ldots$. . . . 100

Armstrong, JG . . . . . . . . . . 10

Armstrong, LD . . . . . . . . . . 62

Armstrong, P . . . . . . . . . . 100

Armstrong, RA . . . . . . . . . 96

Armstrong, $T J \ldots \ldots \ldots \ldots \ldots 6$

Armstrong, WT . . . . . . . . . 15

Arndt, DM . . . . . . . . . . 9

Arnett, FC . . . . . . . . . . 6

Arnetz, BB . . . . . . . . . 52, 99

Arnhold, T . . . . . . . . . . . . 59

Arnmow, P. . . . . . . . . . . . 97

Arnold, HJ . . ........... 56

Arnold, JL . . . . . . . . . . . . . 100

Arnold, T . . . . . . . . . . . . . 19

Arntz, H-R . . . . . . . . . . 3

Aro, $S \ldots \ldots \ldots \ldots \ldots \ldots \ldots \ldots . . \ldots$ 
Aromaa, A . . . . . . . . . . 6 Aronoff, GM . . . . . . . . . 26

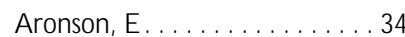
Aronsson, G . . . . . . . . 6, 34, 52 Arossa, W . . . . . . . . . . . . . . 101 Arp, EW . . . . . . . . . 3, 80 Arribada, A . . . . . . . . . 3 Arroyo, JF . . . . ......... 52 Arroyo, M G . . . . . . . . . . 23 Arsenault, A . . . . . 26, 34, 52, 68 Arslan, A . . . . . . . . . . . . 53 Arstila, AU . . . . . . . . . . . 33 A rteau, J. . . . . . . . . . 58, 68 Arthur, RD ............ 9 Arvey, RD . . . . . . . . . . 29 Asal, NR . . . . . . . . 8, 100 Asamblea General de las

$\mathrm{N}$ aciones $\mathrm{U}$ nidas . . . . . . . . . . 23

A sante-D uah DK . . . . . . . . . . 101

A sbestos Institute . . . . . . . . . . . 10

Asbury, AK ............. 14

Aschoff, J . . . . . . . . 34, 102

Asghar, A . . . . . . . . . . 68

Ashby, J . . . . . . . . . . . . 33

Ashford, NA . . . 13, 19, 23, 28, 33

Ashikaga, T . . . . . . . . . . 86

Ashraf, S . . . . . . . . . . . . . . 24

A shtekar, SP. . . . . . . . . . . . 64

Ashton, D . . . . . . . . . . . . . 15

Ashworth, J . . . . . . . . . . . . 64

Asikainen, A . . . . . . . . . . 13

Askenasy, AR . . . . . . . . . . 34

Askerooth, G . . . . . . . . . 97

ASKMAR ............. 83

Askoy, M ............ 88

Asnaes, S . . . . . . . . . . . . . . 100

Asociación de Industrias

A erospaciales (AIA) . . . . . . 90

Asociación de la Salud

Profesional N eerlandesa . . . 101

A sociación de $\mathrm{N}$ aciones del

Sudeste A siático (ASEAN). . . 54

Asociación de Salud y

Seguridad en el T rabajo

(ASST) de Japón . . . . . . . . . 93

Asociación de T ramperos de

Alaska (ATA).

Asociación Internacional de

Equipo y $M$ ateriales de

Semiconductores (SEM I) . . . 83

Asociación Internacional de

la Seguridad Social

(AISS) . . . . . . . 16, 29, 50

Asociación Internacional de

Protección contra la R adición

(International R adiation

Protection Association

IRPA) . . . . . . . . . 3, 49

Asociación Internacional para la

Educación de los $C$ azadores

(IHEA).

A sociación M édica M undial . . . 19

Asom, M T . . . . . . . . . . 83

Assennato, $G \ldots \ldots \ldots \ldots \ldots . . .9$
Association française de

normalisation. .......

Association of American

R ailroads.

Association of $C$ onsulting

$M$ anagement Engineers . . . 60

Association of $O$ ccupational and Environmental $\mathrm{Clinics}$ (AOEC).

Association of Systematics Collections.

Association of the Electronics T elecommunications and Business Equipment Industries (EEA) . .

Association pour la santé et la sécurité au travail secteur affaires sociales (ASST SAS).

Association Suisse des Electriciens .

$\ldots \ldots \ldots 40$

Astakhova, LN . . . . . . . . . . . . 48

Astier, A . . . . . . . . . . . . . . 97

Aston, DA . . . . . . . . . . . 9

Astrand, I . . . . . . . . . . . . . 29

Åstrand, PO . . . . . . . . . . . . 43

Atherley, $G \ldots \ldots \ldots \ldots \ldots .22$

Atherly, GA . . . . . . . . . . 30

Atherton, $P \ldots \ldots \ldots \ldots \ldots .22$

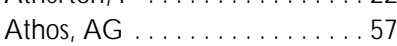

Atkin, $M \ldots \ldots \ldots \ldots \ldots \ldots 64$

Atkins, DHF. . . . . . . . . . . 55

Atkins, E. . . . . . . . . . 73, 82

Atkins, $E H \ldots \ldots \ldots \ldots \ldots \ldots$

Atkinson, $E \ldots \ldots \ldots \ldots \ldots .64$

Atkinson, W . . . . . . . . . . . . 10

Atta, M V . . . . . . . . . . . . 64

Attardi, B . . . . . . . . . . . . . . 9

Attfield, M D . . . . . . . . . . . . 10

Attrup, L . . . . . . . . . . . . . 19

Aubele, $M \ldots \ldots \ldots \ldots \ldots \ldots 63$

Auburtin, G . . . . . . . . . 10

A uchter, JF. . . . . . . . . . . . . 80

Auer, A .............. 11

Auerbach, $0 \ldots \ldots \ldots \ldots \ldots .44$

Auerbach, PS . . . . . . . . . . 37

A ugenstein, DG . . . . . . . . 47

Auger, JE . . . . . . . . . . . . . 77

Auger, PL . . . . . . . . . . . 44

Augustinsson, K B . . . . . . . . 27

Ault, B . . . . . . . . . . . 10, 70

Aune, IA ............... 29

Auray, JP . . . . . . . . . . . 9

Ausiello, DA............. 8

A ussel, L. . . . . . . . . . . . . . 100

Austic, RE . . . . . . . . . . . . 70

Austin, E . . . . . . . . . . . 91

Austin, $\mathrm{H} \ldots \ldots \ldots \ldots \ldots \ldots 91$

Australian Canegrowers . . . . . . 64

Australian College of

O ccupational M edicine. . . . . 19

Auty, JH . . . . . . . . . . . 70

Avants, SK . . . . . . . . . . . . . 15

Avdeev, PS. . . . . . . . . . . 49
A vers, PE

Avery, $B$

.

A vila, $R \ldots \ldots \ldots \ldots \ldots \ldots 65$

Avioli, LV . . . . . . . . . . 6

Aw, TC ............ 18

Awa, A . . . . . . . . . . . . 48

Awang, $R \ldots \ldots \ldots \ldots \ldots \ldots 22$

A wumbila, $B \ldots \ldots \ldots \ldots \ldots 9$

Axéll, $T \ldots \ldots \ldots \ldots \ldots \ldots 11$

Axelrod, J . . . . . . . . . . . . . 34

Axelsen, N . . . . . . . . . . . . . . 19

Axelson, 0 . 3, 7, 10, 28, 52, 72, 88

Axelsson, A . . . . . . . 11, 31, 96

Axelsson, G . . . . . . . . . . 97

Axelsson, S- $\AA$. . . . . . . . . . . . . 68

Axmacher, B . . . . . . . . . 6, 10

A yestaran, S. . . . . . . . . . . . 34

Ayoub, M M . . . . . . . . . . . 29

Ayres, JA . . . . . . . . . . . . 11

A yrton-Paris, JA . . . . . . . . . 28

Azar, A.............. 3

Azchgo, W . . . . . . . . . 63

Azofra, J.............. 3

Azoulay, S . . . ........ 97

Azov, $Y \ldots \ldots \ldots \ldots \ldots \ldots \ldots 5$

Azrin, $\mathrm{NH} \ldots \ldots \ldots \ldots . \ldots 34$

\section{B}

Baatrup, E . . . . . . . . . . 11

Baba, $T \ldots \ldots \ldots \ldots \ldots \ldots . . . \ldots$

Baba, VV . . . . . . . . . . . . 34

Babazona, A . . . . . . . . . . 34

Babbie, E ... . . . . . . . . . 28

Babbitt, PA .......... 100

Babin, A . . . . . . . . . . . . . 96

Babisch, W. . . . . . . . . . 3

Babish, JG . . . . . . . . . 38

Babrauskas, V . . .........41

Bach, B. . . . . . . . . . . . . 101

Bach, E. . . . . . . . . . . 9

Bach, MJ . . . . . . . . . . 97

Bach, $R \ldots \ldots \ldots \ldots \ldots \ldots 13$

Bachman, R . . . . . . . . . 51, 99

Bachmann, S . . . . . . . . . . . . 70

Bacin, F . . . . . . . . . . 63

Back, K . . . . . . . . . . . 34

Bäck, J . . . . . . . . . . . . 29

Backström, T . . . . . . . . 58

Bacon, P. . . . . . . . . . . . . 41

Badet, E . . . . . . . . . . . . . . 97

Baer, R . . . . . . . . . . . . . . 42

Baerheim, A . . . . . . . . . . 10

Baert, JH . . . . . . . . . . . . 10

Baetjer, AM . . . . . . . . . . . . 30

Baeza-Squiban, A . . . . . . . . 10

Bahari, M B . . . . . . . . . . . 22

Baharom, AR . . . . . . . . . 38

Bahner, M ............ 77

Bahr, H . . . . . . . . . . 38

Bahy, M . . . . . . . . . . . . 101

Baile, WF . . . . . . . . . . . . 15

Bailer, JC . . . . . . . . . . . 30

Bailey, C . ...........44,59
Baily, CW . . . . . . . . . . 59

Bainbridge, L . . . . . . . 29, 56, 58

Bainton, D . . . . . . . . . . 3

Bair, FE . . . . . . . . . . . . 99

Baird, DD ............ 9

Baitsch, C............. 29

Bajdik, CD . . . . . . . . . . . 9

Bakar, A . . . . . . . . . . . . . 103

Bake, B. . . . . . . . . . . . . 10

Baker, D . . . . . . 3, 34, 52, 70, 88

Baker, EL . . 3, 7, 32, 38, 39, 81, 96

Baker, F . . . . . . . . . . 34

Baker, HWG . . . . . . . . . 9

Baker, JA . . . . . . . . . . 3, 69

Baker, K . . . . . . . . . . . 20

Baker, R ............ 56

Baker, SP . . . . . . . . . . . 56, 60

Bakir, F . . .......... 9

Balabuha, NS. . . . . . . . . . . 33

Balafrej, A . . . . . .........96

Balbus, JM . . . . . . . . . . 53

Balcarová, $0 \ldots \ldots \ldots \ldots \ldots$

Balch, CM ............. 12

Balcry, CN . . . . . . . . . . . 34

Baldes, JJ . . . . . . . . . . . . 60

Baldesseroni, A . . . . . . . . 88

Baldwin, D . . . . . . . . . . . . 83

Bales, R . . . . . . . . . . . . 100

Balestra, V . . . . . . . . . . 4

Balick, MJ .............. 53

Balkwill, A . . . . . . . . . . . 48

Ball, ED . . . . . . . . . . . . 1

Ballantyne, JC . . . . . . . . . . 11

Ballenger, $J \ldots \ldots \ldots \ldots \ldots \ldots . . \ldots$

Ballesteros, M .......... 96

Ballieux, RE . . . . . . . . . . . . 34

Balls, M . . . . . . . . . . . 33

Balmes, J . . . . . . . . . . 10, 71

Balmes, JR . . . . . . . . 10, 72, 73

Balogh, I . . ...........66 66

Balogh, SA . . . . . . . . . 3, 9

Baloh, RW . . . . . . . . . . 11

Balzer, K . . . . . . . . . . . . . 77

Bamber, G . . . . . . . . . . . 21

Bamber, L . . . . . . . . . . . 56

Bammer, G . . . . . . . . . . 52

Bampton, M............. 52

Banco M undial . 15, 20, 23, 53, 54

Band, PR . . . . . . . . . . 32, 100

Bandea, CL . . . . . . . . . . . 97

Bandura, A. . . . . . . . . . . 34

Bane, B. . . . . . . . . . . . . . . 8

Banes, A . . . . . . . . . . . . . 6

Bangay, M J . . . . . . . . . 49, 102

Bangdiwala, S . . . . . . . . . 53

Banister, E . . . . . . . . . . . . 68

Banister, EW . . . . . . . . 42, 68

Banja, JD . . . . . . . . . . . . . . . 17

Banks, DE . . . . . . . . . . 10, 74

Banks, M .............. 34

Banks, M H . . . . . . . . . . . . . . . 29

Banks, $0 \ldots \ldots \ldots \ldots \ldots \ldots .43$

Banwart, WC . . . . . . . . . . . 70

Baptiste, M S . . . . . . . . . . 72 
Baquet, CR ............. 10 Bar-Sela, S............. 11 Bar, N ................ 31 Barakat, A ............. 9 Baram, M S . . . . . . . ...... 19 Baranson, J. . . . . . . . . . . . 29 Barbe, $G \ldots \ldots \ldots \ldots \ldots 42$ Barber, DE............. 45 Barber, EM ............ 70 Barber, $\mathrm{HO} \ldots \ldots \ldots \ldots \ldots \ldots 11$ Barberger-G ateau, P . . . . . . . . 5 Barbero, A . . . . . . . . . . . . 89 Barbieri, F ...............27 27 Barbos, R P............. 101 Barceloux, DG . ............ 10 Barchas, JD .............. 5 Barchielli, A . . . . . . . . . . . 89 Barclay, D ................ 32 Bard, JM ................. Bárdarson, HR ..........66 66 Bardin, CW . . . . . . . . . . . . 9 Bardos, P . .............. 101 Bargal, D . ................ 15 Barge, S ............... 24 Bargeron, CB............ 49 Baril, M ................. 9 Barker, TA .............. 15 Barlett, NR ............. 11 Barletta, T . . . . . . . . . . . . 77 Barlow, DH .............. 15 Barlow, S ............... 33 Barltrop, D.............. 7 Barna, SC . ............. 84 Barnard, M A . . . . . . . . . . . . 96 Barnard, PJ . ............. 52 Barnavol, B ..............4 42 Barnes, JA . . . . . . . . . . . . 81 Barnes, R ................ 34 Barnes, RE . . . . . . . . . . . . 91 Barnet, RJ .............. 20 Barnett, BC ............. 34 Barnett, R ............. 56 Barnett, RC . . . . . . . . . . . 34 Barnhart, S ............. 16 Barnum, DT . .............21 Barnwell, TO ............. 55 Baron, JA .............. 3, 15 Baron, S............... 32 Barone, JG . ............... 8 Barquet, A . . . . . . . . . . 27, 9 Barr, JK ................ 15 Barr, RG ...............40 40 Barregård, L . . . . . . . . . . . 11 Barrell, J................ 19 Barrentine, BF . . . . . . . . . . . 9 Barrera, C .............. 53 Barrett, JC ............... 33 Barrow, CS ..............11 Barry, PL . . . . . . . . . . . . 27 Barry, $T J \ldots \ldots \ldots \ldots \ldots 41$ Barss, PG ............. 56 Bartal, E.............. 6 Bartels, U . ............... 55 Bartenwerfer, H . . . . . . . . . . . 29
Barth, $F \ldots \ldots \ldots \ldots \ldots 66$ Barth, $R \ldots \ldots \ldots \ldots \ldots . . .9$ Bartknecht, W . ........... 77 Bartko, JJ ................ 5 Bartlem, CS . ............29 Bartlett, RH . ............ 98 Bartman, F. . . . . . . . . . . . . 101 Barton, E . . . . . . . . . . . 6 Barton, J................ 43 Bartoshuk, LM . ............ 11 Bartrop, RW ............... 34 Bartsch, H . . . . . . . . 27, 28 Bartter, $T$. . . . . . . . . . . . . 63 Baruch, GK . . . . . . . . . . . . . 34 Barwick, K D . . . . . . . . . . . 59 Barwick, K W . . . . . . . . . . 87, 89 Bascom, R . . . . . . . . 13, 53, 72 Baser, M . . . . . . . . . . . . . . . 10 Baser, M E ........... 32, 9 Bass, BM ...............34 Bass, C . ............... 34 Bass, JH ............. 13, 34 Bassett, CAL . . . . . . . . . . . 49 Basta, N . . . . . . . . . . . . . . 77 Basten, A . . . . . . . . . . . . . . 49 Bastian, R . . . . . . . . . . . . . 96 Bastian, RW . . . . . . . . . . . . 96 Bastien, JM C . . . . . . . . . . . . 52 Bastion, C . . ..............29 29 Bataille, M ..............29 29 Bates, DV . . . . . . . . . . . . . . 53 Bates, BA . . . . . . . . . . . . . . 44 Batstone, $R \ldots \ldots \ldots \ldots 53$ Battista, G . . . . . . . . . . 86, 88 Battle, W ............... 43 Baturin, VV . . . . . . . . . . . . 45 Baudet, M . .............997 Bauer, M A . . . . . . . . . . 10, 70 Bauer, M S . . . . . . . . . . . . . . . 97 Bauer, R . . . . . . . . . . . . . . 13 Bauer, S . .............. 83 Baughman, K ............ 3 Baum, A .............. 34, 39 Baum, GL .............. 10 Baum, $T \ldots \ldots \ldots \ldots \ldots 5$ Baum, T M . ............. 97

Bauman, S.............. 11 Baumgartner, E . . . . . . . . 43 Baur, $X \ldots \ldots \ldots \ldots . . . . .97$ Bavdekar, A .............. 3 Baverstock, KF . . . . . . . . 39 Bawden, WF . .............74 Baxter, DE . . . . . . . . . . . 6 Baxter, PJ . . . . . 4, 39, 64, 70, 100 Baxtiola, RJ . ............. 97 Bay-N ielsen, H . . . . . . . . . . 42 Bayer, R . . . . . . . . . . . 19, 23 Bayle, R ............... 77 Baylink, DJ..............6 6 Beaglehole, R......... 7, 28 Bean, G . . . . . . . . . . . . . . . 5 Bean, R . . . . . . . . . . . . . 21 Bean, $T \ldots \ldots \ldots \ldots . . . .70$ Bean, TL . . . . . . . . . . . . . . . 64
Bearden, A . . . . . . . . . . 73 Beasalel, V B . . . . . . . . . . . . . 34 Beasley, R .............. 10 Beaton, AE . . . . . . . . . . . . . 59 Beaton, R . . . . . . . . . . . . . 5 Beatrice, ES . . . . . . . . . . . 49 Beatty, J . ................. 97

Beauchamp, T . . . . . . . 19, 28 Beauchesne, M -N . . . . . . . . 29 Beaulieu, J-F . ........... 10 Beaumanoire, A . . . . . . . . . 11 Beaumont, G P . . . . . . . . . 10 Beaumont, $J \ldots \ldots \ldots$ 73, 83, 88 Beaumont, PB . . . . . . . . . 21 Beauvais, F. . . . . . . . . . . 34 Becher, $H \ldots \ldots \ldots \ldots \ldots \ldots . . . .32$ Bechtold, WE............ 1 Beck-Friis B . . . . . . . . . . . 97 Beck, AT ............... 34 Beck, G] . . . . . . . . . . . 89 Beck, M H. . . . . . . . . . . . . . 100 Beck, RW . . . . . . . . . . . . . 10 Becker, AG . . . . . . . . . . . 34 Becker, CA . ............. 15 Becker, CE............. 3 Becker, D . ............... 101 Becker, E . ...............1] Becker, FD . . . . . . . . . . . 34 Becker, G . . . . . . . . . . . . . 58 Becker, GT . . . . . . . . . . . 79 Becker, M . . . . . . . . . . . . . 30 Becker, PE . . . . . . . . . . . . 10

Beckett, W . . . . . . . . . . . . . 10

Beckett, WS . . . . . . . . . 87, 89

Becking, $G \ldots \ldots \ldots \ldots \ldots 27$

Becklake, M .............. 10

Becque, G . . . . . . . . . . . . . . 97

Bédard, M C . . . . . . . . . . . . . 17

Bedeian, AG . . ............ 34

Bedford, $T \ldots \ldots \ldots \ldots$. 42, 45

Bedwal, RS . ............. 11

Beede, DE . . . . . . . . . . . . 101 Beehr, TA ................ 34 Beermann, B . . . . . . . . . 43 Beers, KN ............. 102 Beery, $W \ldots \ldots \ldots \ldots \ldots 15$ Beery, WL . . . . . . . . . . . . 15 Begin, D . . . . . . . . . . 1, 4, 12 Bégin, $R \ldots \ldots \ldots \ldots \ldots 10$ Bégin, $T \ldots \ldots \ldots \ldots \ldots . \ldots 10$ Begley, S . .............. 19 Behrens, M . . ........... 58 Behrens, V . . . . . . . . . . . 32 Behrens, VJ ............. 32 Behrman, K H . . . . . . . . . . 97 Behymer, D ............... 3 Beier, R ................55 55

Beiler, $H \ldots \ldots \ldots \ldots \ldots . \ldots 2$ Beiser, M ............... 5 Bel Castro, AN . . . . . . . . . 42 Belaich, S.............. 3 Béland, $F$. . . . . . . . . . . . . . 59 Belanger, $A \ldots \ldots \ldots \ldots . . .3$ Bélanger, $\mathrm{R} \ldots \ldots \ldots \ldots \ldots . \ldots 68$
Bélanger, S. . . . . . . . . . . . 7 Belden, ST . . . . . . . . . . . . . 15 Belding, HS . . . . . . . . . . . 42 Belin, L . . . . . . . . . . . 10, 101 Belizan, JM ..............99 Bell, B ............... 28

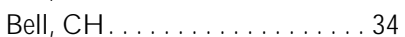
Bell, D ................ 97 Bell, G ..............6 6 Bell, I .................13 Bell, IR ............... 11 Bell, PA .............4 46 Bell, R ............... 58 Bell, R G . . . . . . . . . . . . 70 Bell, S............... 88 Bellace, J .............. 21 Bellakhdar, J ............. 96 Bellamy, RF . . . . . . . . . . . 95 Belleville, R . ............ 98 Belli, S ............... 86 Bellinger, D . . . . . . . . 7, 9 Bellotti, G................ 3 Bellville, JW . . . . . . . . . . . . . 97 Beltran, J ............... 6 Ben-Aryeh, $H \ldots \ldots \ldots \ldots \ldots 4$ Ben-David, M ........... 9 Ben-Israel, R . . . . . . . . . . . 21 Benarey, H A . . . . . . . . . . . 80 Benchop, RJ.............. 34 Bencko, V . . . . . . . . . . 11, 16 Bender, JR . . . . . . . . . . . . 10 Bender, M A . . . . . . . . . . . . . . 33 Bender, TR .......... 56, 60 Bender, TR . . ............ 56 Bene detto, A . . . . . . . . . 97 Benenson, AS . . . 70, 97, 102, 103 Benezra, C . .......... 33, 100 Benhamou, E ............ 28 Benne, K D . . . . . . . . . . . . 57 Benner, A . . . . . . . . . . . . . 21 Benner, L . . . . . . . . . . . . . 18, 57 Benner, $L$. . . . . . . . . . . 56 Bennett, AM ............. 77 Bennett, B . . .............. 32 Bennett, D . . . . . . . . . . 54, 55 Bennett, JV . . . ........... 97 Bennett, $P$. . . . . . . . . . . . . 36 Bennett, PB . . . . . . . . . . 42, 66 Bennett, R M ............6 6 Bennis, WG . . . . . . . . . . . 34, 57 Beno, J.................. 70 Benoit, $0 \ldots \ldots \ldots \ldots \ldots .43$ Benowitz, NL . . . . . . . . . . . 34 Benschop, RJ . . . . . . . . . . . 34 Bensimon, G . . . . . . . . . . . 43 Benson, AJ . ............... 50 Benson, J M . . . . . . . . . . . . .6 64 Bentall, RP.............. 5 Benwell-M orison, DA . . . . . . 49 Benyon, D . . . . . . . . . . . . 52 Bequele, A . . . . . . . . . 88, 99 Beraha, R..............43 Beral, V ....... 2, 10, 12, 52, 53 Berardi, BM . . . . . . . . . . 38 
Berardi, V P . ............ 3

Berardinelli, SP . . . . . . . . . . 12

Berblund, U ............. 11

Berdell, M S .............. 26

Beredford, SA ............ 9

Berek, J................ 97

Berenguer, $\mathrm{MJ} \ldots \ldots \ldots \ldots \ldots 44$

Berezesky, IK ............ 33

Berezin, Y D . . . . . . . . . . . . 49

Berg, M .............. 52

Berg, $S \ldots \ldots \ldots \ldots \ldots \ldots . \ldots 9$

Berg, WE .............. 34

Bergenudd, $H \ldots \ldots \ldots \ldots .6$

Berger, D . . . . . . . . . . . . 49

Berger, EH . . . . . . . . . 31, 47

Berger, SA . ............. 38

Bergholtz, L............. 11

Bergkvist, $U \ldots \ldots \ldots \ldots \ldots \ldots 6$

Berglund, B ......... 3, 11, 47

Berglund, J.............. 3

Berglund, $L G \ldots \ldots \ldots \ldots \ldots 42$

Berglund, $U \ldots \ldots \ldots \ldots \ldots . . . . .3$

Bergman-Losman, B . . . . . . . 34

Bergman, BR .............. 34

Bergman, M ............. 11

Bergmann, EM . . . . . . . . 63

Bergqvist, $\mathrm{U} \ldots \ldots \ldots \ldots \ldots . \ldots 52$

Bergström, R . . . . . . . . . . 10

Berkanovic, E. ............ 18

Berkeley, L . . . . . . . . . . . . . . . 91

Berkman, L . ............. 5

Berkowitz, GS ............ 9

Berkowitz, M ............ 17

Berland, T . . ........... 97

Berland, $Y \ldots \ldots \ldots \ldots \ldots . . . . . .3$

Berlin, A . . . . . . 4, 10, 27, 33, 38

Berlin, JA . . . . . . . . . . . . . 3

Berlin, M ..............6 63

Berlinguet, L . . . . . . . . 11, 52

Berman, DS ............... 34

Berman, NE.............. 11

Bernard, A . . . . . . . . . 27, 63

Bernard, B ............... 34

Bernard, BP . . . . . . . . . . . 34

Bernard, E ............... 3

Bernardinelli, L . . . . . . . . . . . 80

Bernaudin, JF. . . . . . . . . . 10

Berndt, ER . .............. 5

Berner, B . .............. 43

Bernett, $P \ldots \ldots \ldots \ldots \ldots 6$

Bernhardt, JH .......... 3, 49

Bernhardt, U ............. 59

Bernhart, S.............. 72

Bernier, R .............. 19

Bernstein, A . . . . . . . . . . . . 34

Bernstein, D . . . . . . . . . . . 10

Bernstein, IL . . . . . . . . . . . 10

Bernstein, L . . . . . . . . . . 3, 15

Bernstein, M E . . . . . . . . . . . 33

Bernstein, M S . . . . . . . . 10, 11

Berntson, GG . . . . . . . . . . . 34

Berova, N............... 12

Berquist, KR ............ 4

Berra, A . .............. 10
Berreman, C . . ............ 34

Berridge, J .............. 34

Berrino, F.......... 32, 88

Berry, DA ............. 7

Berry, ER ............. 49

Berry, G.............. 10

Bersani, M ............. 27

Bersch, B . ............. 37

Berta, I............. 41

Bertazzi, PA . . . . 1, 10, 32, 39, 85

Bertera, RL . . . . . . . . . . . . 15

Berthelette, D . . . . . . . 26, 52, 11

Berthiaume, $Y \ldots \ldots \ldots \ldots 10$

Berthier, C . ............ 97

Berthold, $H \ldots \ldots \ldots \ldots$. 94,97

Berthold, $\mathrm{K} \ldots \ldots \ldots \ldots . . .97$

Bertold, $H \ldots \ldots \ldots \ldots \ldots 97$

Bertollini, R ............. 39

Berton, $K \ldots \ldots \ldots \ldots \ldots . \ldots 34$

Bertram, DA ............ 97

Bertrand, A . . . . . . . . . . . . 3

Bertucat, I .............. 9

Bertucci, R . ............ 97

Berufsgenossenschaft für

Gesundheitsdienst und Wohl-

fahrtspflege (BG W) . . . 61, 97

Berufsgenossenschaftliches

Institut für A rbeitssicherheit

(BIA) ................ 77

Besch, EL ............... 13

Beschorner, WE........... 3

Besse, $T \ldots \ldots \ldots \ldots . . . . .97$

Besser, GM .............9

Besser, R .............. 11

Bestratén, $M \ldots \ldots \ldots \ldots 46$

Betcherman, $G \ldots \ldots \ldots \ldots 24$

Bethe, H A . . . . . . . . . . . . . 48

Bethe, RM . . ............ 45

Beutler, E............ 1, 33

Bevan, C . ............... 10

Bevan, M M ............. 10

Beveridge, M CM . . . . . . . . . 70

Beverstock, GC ........... 1

Bewanger, PC . . . . . . . . 77

Beyts, JP .............. 11

Bhagat, RS. . . . . . . . . . . 29

Bhartia, PK ............. 53

Bhartiya, VR ............ 100

Bhattacharya, D........... 70

Bhave, S................ 3

Bhowmick, AK .......... 80

Biagi, M ................21

Bianchi, C .............9 9

Bicakova-R ocher, A . . . . . . . 43

Bickel, H . . . . . . . . . . . . . . 5

Bickel, K L . ............. 74

Bielec, M ............. 49

Bielichowska-Cybula, G . . . . 38

Biener, L . . . . . . . . . . . . 34, 99

Bienfait, HG . ...........6 63

Bieniawski, YT . . . . . . . . . 74

Bientz, M . . . . . . . . . . . . 10

Biering-Sørensen, $F \ldots \ldots \ldots 6$

Bierman, EL . . . . . . . . . . . 6
Biersner, RJ . . . . . . . . . . 29

Biersteker, $\mathrm{K} \ldots \ldots \ldots \ldots \ldots 70$

Bietendorf, J. . . . . . . . . . . 34

Bigbee, D . . . . . . . . . . . . . 95

Bigbee, WL . . . . . . . . . . . 48

Bigger, T J . . . . . . . . . . . 97

Bignon, J . .............. 10

Bijan, S............... 12

Bikson, TK .............. 52

Bilderling, P . . . . . . . . . 3

Billings, A . . . . . . . . . . . . 34

Billings, $C E \ldots \ldots \ldots \ldots .45$

Billings, JH . . . . . . . . . . . . 15

Billon-G alland, M A . . . . . . . . . 10

Bilodeau, G ............... 10

Biman, D . . . . . . . . . . . . . . . 59

Binder, S .............. 95

Binford, $\mathrm{CH} \ldots \ldots \ldots \ldots \ldots 10$

Bing, J ..................... 17

Bingham, E . . . . . . . 19, 23, 24

Bini, M . . . . . . . . . . . . . 49

Binks, K . . . . . . . . . . . . . 48

Biocca, M . ............ 28

Birchall, JP.............. 11

Bird, FE . . . . . . . . . . . 16, 60

Birioukov, A . ............. 39

Birk, T .................. 80

Birngruber, R. . . . . . . . . . 49

Birnie, P................. 54

Birrell, F . . . . . . . . . . . . . . 97

Birren, JE . . . . . . . . . . . . . 29

Bis, W............................ 38

Bisesi, M . . . . . . . . . . . . . 101

Bisgard, E. . . . . . . . . . . . . 37

Bishop, C . ............. 70

Bishop, L . ................ 53

Bishop, PL . . . . . . . . . . . . 55

Bishop, RP . . . . . . . . . . . . . 29

Bishri, D . . . . . . . . . . . . . . 48

Bissel, L . . . . . . . . . . . . . . . 97

Bisson, G . . . . . . . . . . . . . . 10

Bitker, TE .............997

Bitot, T . . . . . . . . . . . . . 97

Bittel, J . . . . . . . . . . . . . . 42

Bittel, JH M . . . . . . . . . . . 42

Bitterman, $\mathrm{H}$. . . . . . . . . . . . . . 66

Bjerkedal, T . . . . . . . . . . . 52

Bjerselius, R . . . . . . . . . . . . 11

Bjlard, J-L . . . . . . . . . . . . 93

Black, B . . . . . . . . . . . . . 28

Black, DW .............. 13

Black, K G ............. 9

Black, RA............... 3

Blacker, JH. ............663

Blackwell, R . . . . . . . . . . . . 52

Blade, L . . . . . . . . . . . . . . . 100

Blainey, AD . . . . . . . . . . . . 100

Blair, A.... 4, 12, 32, 71, 96, 100

Blair, J . . . . . . . . . . . . . . 28

Blair, SJ ..............6

Blair, SN ................. 3

Blaire, S . . . . . . . . . . . 97

Blake, RL .............. 6

Blakeney, R N . . . . . . . . . . 34
Blakeslee, S . ............ 53

Blanc, P . . . . . . . . . . . . . 3, 10

Blanc, PD . . . . . . . . . . . 10, 11

Blanchard, EB . . . . . . . . . . 34

Blanchard, JW . . . . . . . . . . 63

Blanchard, M . . . . . . . . . . . . 97

Blanco, C . . . . . . . . . . . . . . 97

Bland, JH . .............. 6

Blandford, T B . . . . . . . . . . . . 10

Blane, $\mathrm{H} \ldots \ldots \ldots \ldots \ldots \ldots . \ldots 34$

Blanks, R . . . . . . . . . . . . 34

Blanpain, C . . . . . . . . . . . 97

Blanpain, R . . . . . . . . . 21, 54

Blaschke, E. . . . . . . . . . . . . 10

Blascovich, J. . . . . . . . . . . 99

Blass, JP ................6 6

Blaszkowicz, M .........4 43

Blau, GE ................ 33

Blau, TH ...............95 95

Blau, W ................ 97

Blaustein, AR . . . . . . . . . . 53

Blaycock, B . . . . . ........ 97

Blazer, M J . . . . . . . . . . . . 97

Bleecker, M ........ 7, 11, 13

Bleeker, $T$. . . . . . . . . . . 52

Bless, D .............. 96

Blettner, M . . . . . . . . . . . 28

Blevins, D . . . . . . . . . . . 28

Blide, $G \ldots \ldots \ldots \ldots \ldots 66$

Bligh, $J \ldots \ldots \ldots \ldots \ldots \ldots \ldots . .42$

Blignault, I . ............ 52

Blinder, AS ............... 34

Bliss Industries........... 83

Bloch, DA .............. 6

Block, J................ 55

Blodgett, JT . . . . . . . . . . . 39

Bloksma, N. . . . . . . . . . . . 33

Blom, DHJ............. 43

Blomquist, $G \ldots \ldots \ldots \ldots \ldots . . . \ldots 38$

Blondin, $0 \ldots \ldots \ldots \ldots \ldots 28$

Bloom, AD . . . . . . . . . . . . 33

Bloom, BR .............. 10

Bloom, DE . . . . . . . . . . . . 101

Bloom, FE .............. 7

Bloom, JC ............. 33

Bloom, $T \ldots \ldots \ldots \ldots . . . \ldots, 73,88$

Bloom, TF .............. 3

Bloomfield, CD ............

Bloomfield, JJ............ . 89

Blot, W . . . . . . . . . . . . . 88

Blot, WJ ........ 1, 44, 63, 72

Blount, BW ........... 10, 11

Blow, RJ . . . . . . . . . . . . . . 97

Bluen, SD . . . . . . . . . . . . . 59

Blum, A . . . . . . . . . . . 15

Blum, $\mathrm{S} \ldots \ldots \ldots \ldots \ldots . \ldots 80$

Blum, TC .............. 19

Blumberg, M ........... 29

Blume, $J \ldots \ldots \ldots \ldots \ldots \ldots . .7$

Blume, SB ............. 15

Blunden, PB............ 3

Blüthner, R . . . . . . . . . . 50

Blye, $P \ldots \ldots \ldots \ldots \ldots \ldots 41$

Boal, WL . . . . . . . . . . . 28 
Bobadilla, JL . . . . ......... 15 Bobak, DA .............. 15

Bober, TW . . . . . . . . . . . 85

Bobick, $T \ldots \ldots \ldots \ldots .64,86$

Bochner, S . ............. 34

Bock, K W ............... 33

Bock, $N \ldots \ldots \ldots . . . . .99$

Bockerstette, JA . . . . . . . . . 34

Böckle, B .............. 26

Boctor, M ............... 10

Boddington, $T$. . . . . . . . . 41

Bode, F................6 63

Boden, LI . . . . . . . . . . . . . 23

Bodie, M . ............... 38

Bodin, L............. 7, 9

Bodner, K M ............. 11

Boe, $J \ldots \ldots \ldots \ldots \ldots \ldots 10$

Boehm, G............... 97

Boeniger, $M \ldots \ldots \ldots \ldots \ldots$

Boeryd, B .............. 72

Boettcher, FA . . . . . . . . . . . 47

Bofetta, P . . . . . . . . . . 71

Boff, K ............... 29

Boffetta, P ... 2, 10, 28, 86, 88

Bogatov, KM ............ 3

Bogers, M .............. 30

Bogett, $B \ldots \ldots \ldots \ldots \ldots 4$

Bogoroch, R............ 10

Bohl, J .................11

Bohle, $P \ldots \ldots \ldots \ldots \ldots . \ldots 4$

Bohlin, G . ............. 34

Bohlman, M ............. 7

Boice, JDJ . ............. 48

Boicourt, GW ............ 77

Boies, SJ . . . . . . . . . . . 29

Boileau, R ............... 10

Boise, JD ............... 32

Boissin, JP ............ 52

Boisvieux-U Irich, E . . . . . . . . 10

Bojanic, I . .............. 15

Bojkov, R ............... 53

Bokat, SA ..............21

Bokina, AI . . ............. 11

Bokuma, E .............. 9

Boleij, J............. 70,86

Boleij, JSM . . . . . . . . . . 13, 30

Bolis, V . . . . . . . . . . . . . . . 10

Bolla, KI ................ 11

Bolle-Wilson, $K \ldots \ldots \ldots \ldots 13$

Bolliger, B . ............. 83

Bollinger, E ............ 97

Bolm-A udorf, U . . . . . . . . . 32, 86

Bolm, AU . . . . . . . . . . . . . 63

Bolmen, JD ............. 83

Bolsaitis, P . . . . . . . . . . . . 10

Bolt, HM .............. 43

Böltz, K ............68 68

Bolumar, F......... 87, 97

Bombardier, C ............6 6

Bomford, RR ............ 11

Bonassi, S. . . . . . . . . . . . 88

Bond, JT ............... 34

Bonde, JPE.............. 9

Bone, CM . . . . . . . . . . 3, 26
Bongers, P . . . . . . . . . 97

Bongers, PM ......... 34, 50

Bonhomme, M G . .......... 9

Boni, M ................27

Bonin, RL . . ............ 15

Bonita, R ............ . 7, 28

Bonjer, FH . . . . . . . . . . . . . 43

Bonneau, J.............. 95

Bonneau, R H . . . . . . . . . . . . 34

Bonnefoi, M . ............. 11

Bonner, $R$...............8

Bonnet, M H . . . . . . . . . 43, 102

Bonnet, N . . . . . . . . . . . . . 97

Bonsall, JL . . . . . . . . . . . . 64

Bonyhady, $T$. . . . . . . . . 54

Bonzanino, A . . . . . . . . . 80

Bookspan, J ..............66 66

Boone, $L \ldots \ldots \ldots \ldots \ldots \ldots 11$

Boone, WP.............. 70

Boore, J................ 34

Booth-K ewley S. . . . . . . . . . 34

Booth, DM . . . . . . . . . . . . . 65

Booth, M . . . . . . . . . . . . 10

Booth, R.............. 56

Bootzin, R R . . . . . . . . 43, 102

Borcham, J............. 44

Borcherding, $\mathrm{K} \ldots \ldots \ldots \ldots . \ldots 59$

Borchgrevink, $H \ldots \ldots \ldots . . .31$

Borgelsen, A . . . . . . . . . 68, 78

Borget, M . . . . . . . . . . . 64

Borghoff, S............. 33

Borglum, B............. 100

Borja-Arburto, VH ......... 53

Borm, PJA ............. 10

Börner, F . .............. 58

Bornschein, RL . . . . . . . . . . 9

Borowiak, A . . . . . . . . . . . . 55

Borsky, I . . . . . . . . . . . . . 97

Bos, W ................ 89

Boshuizen, HC . . . . . . . . . . 50

Bosnjakovic, BFM ..........49 49

Bostrand, L . . . . . . . . . . . 68

Boswell, RT . . . . . . . . . . . 13

Both, R............... . 55

Botros, BA ............. 101

Botsford, JH . . . . . . . . . . . . . 42

Botta, GC . . . . . . . . . . . . . 10

Bottcher, R W. . . . . . . . . . . . . 70

Bottura, G . . . . . . . . . . . . . 88

Bouchard, C..............

Bouchard, P............ 58

Bouchayer, M ............96 96

Boucher, RC . ............ 10

Bouhnik, C . ............97

Bouhuys, A . . . . . . . . 10, 89

Bouige, D . . . . . . . . . . . . 10

Boulard, R . . . . . . . . . . . . 97

Boundy, M G . ............ 10

Bourcier, DR . . . . . . . . . . . 90

Bourdelean, $P \ldots \ldots \ldots \ldots 43$

Bourdon, F.............29

Bourdouxhe, M ............... 101

Bourgeois, P............ 97

Bourlière, $F \ldots \ldots \ldots \ldots \ldots .29$
Boushey, H A . . . . . . . 10, 11 Bousiges, A . . . . . . . . . . 21 Bousquet, A . . . . . 11, 26, 52, 97 Bouteiller, D. . . . . . . . . . . 21

Boutelier, C . . . . . . . . . . 42

Bouwhuis, DG . . . . . . . . . . 52

Bouyer, J ............ . 28, 30

Bovbjerg, D . . . . . . . . . . . 34

Bovenzi, M . . . . . . . . . . . . . 3

Bowden, DH ............ 10

Bowden, K M . .............. 15

Bowditch, J............ 5

Bowditch, M ............. 30

Bowen, BC . . . . . . . . . . . . 14

Bowen, ID . . . . . . . . . . . . 33

Bowen, JD . . . . . . . . . . . . . 7

Bowers, DG . . . . . . . . . . 102

Bowes, PC . . . . . . . . . . . 41

Bowler, $R \ldots \ldots \ldots \ldots \ldots \ldots 7$

Bowling, A . ............. 96

Bowman, JD . . .......... 87

Boxer, PA.............. 64

Boyd, GN . . . . . . . . . . . . . . 10

Boyer, DW . . ............... 39

Boyer, SJ . ............... 37

Boyes, RJ .............. 9

Boyhous, A............. 33

Boying, JD . . . . . . . . . . . 6

Boylan, J. . . . . . . . . . . . . . 79

Boyle, A . . . . . . . . . . . . . . 54

Boyle, AE . .............. 54

Boyle, AR . . . . . . . . . . . . . 41

Boysen, $M \ldots \ldots \ldots \ldots \ldots 11$

Bozzo, TS ...............77

Brachman, PS . ........... 97

Brackbill, RM .......... 7, 32

Bracken, M B . . . . . . . . . . . 9

Bracker, A . . . . . . . . . . . . . 13

Bradford, WJ . . . . . . . . . . . 41

Bradley, G . .......... 29, 52

Bradley, WG .............. 7

Bradway, DE . . . . . . . . . . 27

Brady, BH G. . . . . . . . . . . . . 74

Brady, JV . ............... 34

Bragt, PC . . . . . . . . . . . . 27

Brahser, GW . . . . . . . . . . . . 100

Braid, P . . . . . . . . . . . . . 69

Braithwaite, M . . . . . . . . . . 88

Bramwell, RS........ . 34, 52

Brand-Elnagger, J . . . . . . . . 97

Brand, A . ............... 1

Brand, JJ .................. 50

Brand, RJ . . . . . . . . . . . 15, 34

Brandau, R .............. 33

Brandfonbrener, AG . . . . . . . 96

Brands, R . . . . . . . . . . . . . . . 95

Brandt, AD . . . . . . . . . . . 103

Brandt, I. . . . . . . . . . . . . 11

Brandt, LPA . . . . . . . . . . . 34, 52

Brandt, T . .............. 11

Brandt-R auf, P. . . . . . . . 79, 101

Branz, H ............. 68

Braun-Falco, 0 ........... 39

Braunwald, E............ 53
Braverman, M ............ 5

Bray, D.................. 33

Bray, G ............ 5, 15

Brazier, AM ............... 100

Breakwell, GM . . . . . . . . . . 97

Bréart, $G \ldots \ldots \ldots \ldots \ldots . \ldots 28$

Breaugh, J A . . . . . . . . . . . . . 34

Breault, J ............... 10

Brecht, J................ 3

Bredow, HD ............ 58

Breeze, R G . . . . . . . . . . . . . 10

Bregman, DJ .............. 39

Brehmer, B. .......... 29, 59

Breidenbach, WC .........6 6

Breithaupt, $\mathrm{H} \ldots \ldots \ldots \ldots \ldots 43$

Breithaupt, M K . ........... 38

Breman, JV . .............. 70

Bremner, WJ . ............. 9

Brenin, GM . . ............ 11

Brennan, M F . . . . . . . . . . . . 4 4

Brennan, R . . . . . . . . . . . 34

Brenner, D . . . . . . . . . . . . . . . 34

Brenner, DJ . . . . . . . . . . . . . . 97

Brenner, JM . . ............. 70

Brenner, M . .............. 34

Brenner, $W \ldots \ldots \ldots \ldots .43$

Breslow, L ............... 52

Breslow, NE . . . . . . . . . 10, 28

Bresnitz, EA . . . . . . . . . . . . 101

Bretherick, L . . . . . . . . . . . . 22

Bretin, $\mathrm{H} \ldots \ldots \ldots \ldots . \ldots 100$

Brett, A ................ 30

Bretthauer, C . ........... 44

Breum, NO .............. 45

Brewer, L . . . . . . . . . . . 63

Brewster, C . ............. 21

Breznitz, S . . . . . . . . . 5, 34

Briazgounov, IP . . . . . . . . 3

Brice, D . . . . . . . . . . . . . 42

Brickman, D ............. 56

Bridges, BA ............. 30

Bridges, J ............... 33

Bridigare, RR ........... 53

Brief, AP .............. 34

Brief, RS ...........44, 63

Brieger, GH . . . . . . . . . . . 19

Brien, WW . . . . . . . . . . . . 7

Briggs, $\mathrm{AH} \ldots \ldots \ldots \ldots \ldots . . . . .33$

Brigham, J .............. 15

Brigham, K L . . . . . . . . . . . . 10

Bright, $P \ldots \ldots \ldots \ldots \ldots 18$

Brill, $A B \ldots \ldots \ldots \ldots \ldots \ldots, 48$

Brill, M............... 34

Brinckmann, $P \ldots \ldots \ldots \ldots \ldots 6$

Bringhurst, LS . . . . . . . . . . 64

Brinkman-K aplan, VL . . . . . . 15

Brinton, LA . . . . . . . . . . . . 86, 100

Briones, J . . . . . . . . . . . . 15

Brisson, C . . . . . . . . . 34, 87

British Columbia and Yukon

Chamber of M ines Safety

Committee. ............ . 74

British $\mathrm{R}$ ubber $\mathrm{M}$ anufacturers'

Association (BR M A) . . . . . 80 
British Standards Institute (BSI ) . . . . . . . . 31, 41, 50 British Standards 0 rganisation (BSO)................49

Brittain, J . . . . . . . . . . . . 64

Brittebo, EB ............. 11

Britten, RH . ............ 89

Broad, W ................ 19

Broadbeck, FC . . . . . . . . . 52

Broadhead, WF . ........... 34

Broberg, AG .............. 34

Broberg, E . . ............ 97

Brochard, P .......... 10, 32

Brock, TD . . . . . . . . . . . . 38

Brockner, J.............. 34

Brodbeck, B . . . . . . . . . . . 58

Broddee, RW . ............64 64

Broderick, TR . . . . . . . . . . . 77

Brodeur, J . .............. 27

Brodsky, CM ........... 5, 13

Brodsky, L .............. 91

Brody, AR ............... 10

Brody, B.............. 26

Brody, D . ............. 21

Brody, DJ ................ 9

Brody, JE ............... 53

Brollo, A................. 9

Broman, CL............. 34

Bromet, EJ ............ 34, 39

Bronson, RC . ............ 9

Bronstein, A . . . . . . . . . . 21

Bronwyn, L . . . . . . . . . . . 10

Brookes, KJA . ............. 10

Brooks-Gunn, J . .......... 96

Brooks, AL ............... 10

Brooks, BR............... 7

Brooks, GM ............. 10

Brooks, RR ............ 96

Brooks, SD . . . . . . . . . . . 100

Brooks, SM ......... 9, 10, 11

Brophy, M .............. 101

Brosschot, JF ............ 34

Brostoff, J . . . . . . . . . . . . . . 33

Brouer, EJ .............. 27

Brough, HB ............... 70

Broughton, RJ . ........ 29, 43

Brouha, L.............. 42

Brouqui, P.............. 3

Brouwer, DH . ............ 27

Brouwer, R ............. 70

Brouwers, A . ........... 52

Browden, FJ . ............. 97

Brown, BW, Jr...........997

Brown, CM L . . . . . . . . . . . 52

Brown, CW ............6 6

Brown, DA..........29, 101

Brown, DF ............. 89

Brown, DP ......... 71, 100

Brown, DT . .............. 31

Brown, EG ............. 9

Brown, EN .............. 43

Brown, ET ............ 74

Brown, FK ............. 70

Brown, FM. . . . . . . . . . . . 43
Brown, GW . . . . . . . . . . 68

Brown, J............... 95

Brown, JE............. 101

Brown, JL.............. 11

Brown, LC . . . . . . . . . . . . . . 55

Brown, LR . . . . . . . . . 64, 70

Brown, M H . . . . . . . . . . . . 91

Brown, $P \ldots \ldots \ldots \ldots \ldots 48$

Brown, PDN ............9 9

Brown, RFR ............ 10

Brown, RH ..........55, 61

Brown, RL ...................... 59

Brown, SE .............. 15

Brown, SK ..........................

Browne, A ............... 34

Browne, CD ............. 52

Browne, K ........... 9, 10

Browne, RC .............4 43

Browning, CA .......... 71

Brownson, RC . . . . . . . . . . 44

Brownstone, DM . . ........64 64

Bruaux, P.............66 63

Brubaker, RE . . . . . . . 10,63

Brubaker, TH ...........64 64

Bruce, DL ............. 97

Brucker, G . ......... 97, 100

Bruckmann, P . . . . . . . . . . 55

Bruder .................29 29

Bruening, JC .............60 60

Bruevich, TS .............6 63

Brugman, JL . . . . . . . . . . 6

Brugnone, F . . . . . . . . . . 29

Bruk, GY . ............... 39

Brun, $R \ldots \ldots \ldots . . . \ldots 66$

Brune, DK ............. 97

Brunekreef, B............ 13

Brunet, R . . . . . . . . . . . . . 45

Brunnemann, K D . . . . . . . . . 44

Bruno, K ...............20 20

Bruno, PJ ............... 96

Brunsveld, VM .......... 100

Brunton, JL . . . . . . . . . . . 38

Brusick, DJ . . . . . . . . . . . . 33

Brusis, O A ............... 3

Brüske-H ohlfeld, I . . . . . . . 32

Bruyere, S . . . . . . . . . . . . 17

Bruyn, GW ............. 7

Bruyntjes, JP . . . . . . . . . . 100

Bruyzeel, D P . . . . . . . . . . . 27

Bruzzi, P. . ............... 39

Bryan, JL . . ............ 41

Bryant, CJ ................ 10

Bryant, HE. . . . . . . . . . . . . 52

Bryant, PM . ............48

Bryant, WS . . . . . . . . . . . . 39

Buccino, KR ............997

Buchan, R M . . . . . . . . . . . 97

Bucher, AM ............. 80

Bücherl, W . . . . . . . . . . . . . 38

Buchet, JP . . . . . . . . . . . . 63

Bucholz, RW . ............96 96

Buchwald, D . . . . . . . . . . . 13

Buck, C . ..............28

Buck, LB ...............11
Buck, $M \ldots \ldots \ldots \ldots \ldots . \ldots 55$

Buck, $V \ldots \ldots \ldots \ldots . . . \ldots 34$

Buckle, P ...........6, 52

Buckle, PW ............. 97

Buckley, EE . . . . . . . . . . . 38

Buckwalter, $G$. . . . . . . . . . 87

Buckwalter, JA . . . . . . . . . . . . 6

Bucsela, HA . . . . . . . . . . . 53

Budianto, E ..............83

Budzynska, A . . . . . . . . . . 79

Buell, P.................. 52

Buffler, PA . . . . . . . . . . . 72

Bugard, P..............29 29

Bugbee, $P \ldots \ldots \ldots \ldots \ldots .41$

Buhr, E.............. 49

Buiatti, E . . . . . . . . . 8 88, 89

Bull, D ...............664

Bullard, H .............. 51

Bullard, RD .............. 34

Bullock, DG .............27

Bundesverband der Landwirtschaftlichen Berufs- genossen-

chaften (BVLB) . . . . . . . . 68

Bungay, GT . . . . . . . . . 15

Bunge, $J \ldots \ldots \ldots \ldots \ldots \ldots 18$

Bunge, $M \ldots \ldots \ldots \ldots 28$

Bunin, GR ..............72

Bunn, WB ...........10, 16

Bunnage, $D \ldots \ldots \ldots \ldots \ldots 43$

Bünte, $H \ldots \ldots \ldots \ldots . \ldots 68$

Buonicore, AJ . .......... 82

Buono, A ............... 5

Burch, RL ............... 33

Burchell, B . .............. 33

Burdoff, A .......... 30, 32

Bureau of $L$ abor Statistics

(BLS)........ 31, 32, 34, 36,

$67,83,88,93,98,102$

Bureau of $M$ ines ...........

Bureau of National Affairs

(BNA) . ......15, 16, 34, 58

Bureau of R adiological $H$ ealth . 49

Bureau of the Census. . . . . 32, 71

Burford, JG ..............64 64

Burge, $\mathrm{H} \ldots \ldots \ldots \ldots$. . . . 13, 101

Burge, PS . . . . . . . . . . . . 13

Burge, $S \ldots \ldots \ldots \ldots \ldots . \ldots 34$

Burger, EJ . ..............26

Burger, $G \ldots \ldots \ldots \ldots \ldots 63$

Burger, $\mathrm{HG} \ldots \ldots \ldots \ldots \ldots . .9$

Burgers, SL GE . . . . . . . . . 64 Burgess, WA ....661, 77, 80, 82

Burgheer, R . . . . . . . . . . . . . 70

Burhenne, W . ............. 54

Burhill, D . . . . . . . . . . . . . 97

Buring, JE ......... 15, 28, 97

Buringh, E ............. 30

Burke, DS ............... 53

Burke, FJ . ............. 97

Burke, JE .............. 10

Burke, JF .............. 40

Burke, M J ............... 34

Burke, TA .............. 53

Burke, $W \ldots \ldots \ldots \ldots \ldots . . .34$
Burkhard, J . ............63 63

Burkhart, G . . . . . . . . . 3, 89, 93

Burleson, G . ............... 33

Burman, KD ............42 42

Burmeister, LF . . . . . . . . . 70

Burmeister, LJ . ............ 10

Burnett, C . . . . . . 32, 64, 89, 94

Burney, M B . . . . . . . . . . . 10

Burns, F . . . . . . . . . . . . . 74

Burns, FJ . ............ 48

Burns, J M............. 34

Burr, G............. 81

Burr, GA .............96 96

Burrell, R . . . . . . . . 10, 33, 38

Burring, JE............. 3

Burrows, GD ............ 26

Bursey, RG ............ 70

Burstein, JM . . . . . . . . . . . . . 32

Burtner, AP ............. 11

Burton, $A C \ldots \ldots \ldots \ldots \ldots 42$

Burton, DJ . . . . . . . . . . . . . 79

Burton, FL . ............ 103

Burton, R . . . . . . . . . . . . . . . 97

Burton, RC . ............. 12

Burton, WN .............. 15

Bury, AH ...............6 63

Bus, JS .............. 30, 33

Busch, K A .............. 30

Buselmaier, W . ............ 9

Bush, D . . . . . . . . . . . . . . 13

Bush, RK . ............. 77

Büssing, A . . . . . . . . . . . . . . 97

Bustelo, C.............. 34

Buswell, S. . . . . . . . . . . . 64

Butterworth, BE ............ 30

Butz, M ..............93

Buxton, V M . . . . . . . . . . . 59

Buzanov, VA . . . . . . . . . . . 48

Buzzoni, A . . . . . . . . . . . . . 27

Bye, E............... 10

Byerley, WF . . . . . . . . . . . 34

Byers, $T \ldots \ldots \ldots \ldots \ldots 15$

Byers, VS . . . . . . . . . . 13

Bygren, LO .............6 65

Byosiere, $\mathrm{P} \ldots \ldots \ldots \ldots \ldots . \ldots 34$

Byrne, CD .............47 4

Byrne, $G \ldots \ldots \ldots \ldots . . . \ldots 34$

Byrne, R N . . . . . . . . . . 64

C

Cabal, C............... 97

Cabal, F . . . . . . . . . . . . 97

Cabe, PA ................ 33

Cabenago, A ............. 10

Cabral-Anderson, LJ . . . . . . . 10

Cacciabue, PC . . . . . . . . . . 29

Cacioppo, JT . . . . . . . . . . 34

Cadarette, BS. . . . . . . . . . . 42

Cadet, G . . . . . . . . . . . . 83

Cafferty, $M \ldots \ldots \ldots \ldots \ldots 6$

Caffier, $G \ldots \ldots \ldots \ldots \ldots \ldots . . \ldots$

Caffrey, RE ........... 83

Cagle, $P \ldots \ldots \ldots \ldots \ldots . . .10$ 
Cahill, J............. 3, 34

Caille, EJ ............... 29

Cailliet, R............. 6

Cain, JD ................9

Cain, PS................ 34

Cain, WS .......... 11, 13, 45

Caiozzo, VJ ............... 3

Cairncross, $\mathrm{S} \ldots \ldots \ldots \ldots \ldots 53$

Caisse nationale d'assurance maladie des travailleurs salariés. . ...

Çakir, A . . . . . . . . . . . . . . 34, 52

Cakir, G................ 34

Calabrese, EJ . . . . . 19, 30, 55, 83

Calabrese, LH ............ 96

Calandruccio, RA ......... 70

Caldart, CC ........23, 28, 33

Calder, IM ............... 70

Calderon, C ............. 101

Caldwell, DF .............. 34

Caldwell, S. . . . . . . . . . . . 64

Calhoun, LL . ............. 11

Caliber Associates . . . . . . . . . . 15

California D epartment of $\mathrm{H}$ ealth

Services.

California State Fire M arshall

Film Advisory Committee . . 96

Calin, A . . ..............6 6

Callahan, C ............... 34

Callan, JR ..............997

Callan, V ................. 34

Callender, TJ ............. 11

Calnan, CD .............. 71

Calvert, $G \ldots \ldots \ldots \ldots . . . .68$

Calvert, GM ...........664

Camann, DE ..............9

Cámara de Comercio

Internacional. . . . . . . . . . . 54

Cambar, J................4 43

Cambieri, A .............. 97

Cameron, D ............... 70

Caminita, BH ............89 89

Cammock, R ..............97 97

Campanella, G............ 7

Campanini, DS ............. 6

Campbell, AM G ........... 7

Campbell, CC ............. 9

Campbell, EJ . . . . . . . . . . . . . 37

Campbell, JM .............10

Campbell, PA .............10

Campbell, S............. 28

Campbell, SM ............6 6

Campbell, WP ...........664

Campell, S.............. 72

Campiglio, L . . . . . . . . . . . . 54

Campion, EW ............. 5

Campion, M A . . . . . . ....... 29

Canada R oyal Commission on

Equality in Employment. . . . 17

Canadian Centre for

$\mathrm{O}$ ccupational $\mathrm{H}$ ealth and

Safety (CCO HS) . . . . . 22, 96

Canadian Labour

Congress
Canadian M edical Association. 19

Canadian Pulp and Paper

Association ............. 72

Canadian Standards Association (CSA) . ............ 54, 93

Canadian U rban Transit Association ............ 102

Cancro, R ............... 5

Candas, $V \ldots \ldots \ldots \ldots . .42$

Candela, RG ............. 9

Candelaria, A..............969

Canfield, RE .............. 9

Cannon, CG .............997

Cannon, WB . . . . . . . . . . . . 34

Canossa, E . . . . . . . . . . . . . 27

Cantel, M M . . . . . . . . . . . . .997

Canter, D . . . . . . . . . . . 34, 41

Cantin, A ................ 10

Cantinieaux, B ........... 10

Cantor, K................28

Capecchi, M .............. 33

Capellaro, E..............65

Capelli, G................ 97

Capelli-Schellpfeffer, M . ..... 40

Caplan, RD . . .............. 34

Caplin, G ................ 34

Capocaccia, R .............. 10

Caporaso, N . . . . . . . . . . . . 28

Capron, AM ..............19

Caras, RA ............... 70

Caravel, JP............. 42

Carayon, D . .............. 5

Carayon, P......... 6, 34, 52

Carayon-Sainfort, P........ 52

Card, LE ............... 70

Card, SK ................ 52

Cardenas, O A ............96 96

Cardis, E ................. 39

Cardo, D ................997

Cardoso, JLC . . . . . . . . . . . 38

Cardullo, AC .............96 96

Carel, TJH ............... 73

Carey, JC .................99

Carey, $T \ldots \ldots \ldots \ldots \ldots . \ldots 5$

Carillo, T ...............997

Carjaval, S. . . . . . . . . . . . . 96

Carlen, PL . . . . . . . . . . . . . 11

Carlisle, L. . . . . . . . . . . . . . . . 11

Carlsen, E . . . . . . . . . . . . . 53

Carlson, $T$. .............96

Carlson, V . . .............83

Carlsson, GE ............. 11

Carmella, SG . ............ 44

Carmichael, AJ ............5 52

Carmines, EG . . . . . . . . . . . . 28

Carney, EW . . . . . . . . . . . . 33

Carniglia ................. 84

Caro, DHJ .............. 29

Caro, J..................89 89

Caron, C ...............24

Carpenter, A .............. 97

Carpenter, J . . . . . . . . . . . . . 13

Carpenter, L . . . . . . . . 10, 39

Carpenter, T G . . . . . . . . . . . 64
Carpentier, J . . . . . . . 23, 43

Carr, A.................99 97

Carr, BI ................ 4

Carr, J................ 10

Carra, J................. 9

Carreras, $\mathrm{N} \ldots \ldots . . . . . . . .99$

Carroll, JM ............... 52

Carroll, LA ............... 77

Carson, R............... 17

Carstensen, $0 \ldots \ldots \ldots \ldots 70$

Cartensen, JM ..............665 65

Carter, FA ............ 29, 43

Carter, NL . . . . . . . . . . . . . . . 3

Carter, R C . . . . . . . . . . . . . . 29

Carthey, J............ 56, 59

Cartier, A . . . . . . . . . . . . . . 10

Carton, B . ..............61 61

Carton, K................ 72

Cartwright, D ............ 15

Cartwright, S.............. 34

Carvalheiro Beijer, M ....... 10

Carvalheiro, M F . . . . . . 10, 65

Cary, AE .................. 64

Casaletti, G .............. 43

Casarett, GW . . . . . . . . . . . 48

Casarett, LJ ............... 30

Case, B.................. 10

Case, RAM ............ 28

Casey, HW ............. 28

Casey, PB................ 9

Cashman, JR ............. 33

Casini, VJ...............40 40

Casper, ES ............. 4

Casper, J ................ 96

Caspersen, CJ ............. 3

Cass, JR ...............6 6

Cassel, J . . . . . . . . . . . . . . . 34

Cassel, JP . . . . . . . . . . . . . 34

Cassidy, M JD . .............. 11

Cassitto, M G . . . . . . . . . . . . . 7

Castagna, R ............. 40

Castell, JV ............... 33

Castellan, R M . . . . . . . . 10, 10, 89

Castelli, WA .............. 6

Castells, M . . . . . . . . . . . . . . 24

Casti, L.................. 57

Castillejos, M . ............. 53

Castillo, DN . . . . . . . . . . . 51, 56

Castillo, JG............... 100

Castillo, NT . . .............. 55

Castillo, R ............. 97

Castle, M ................ 39

Castleman, B . . . . . . . . . . . . 20

Castleman, BI ....... 19, 30, 20

Castleman, WL . . . . . . . . . . . . 10

Casto, KM ................ 20

Castorino, J.............. 32

Castranova, V ............. 10

Catalano, R . ........... 34, 51

Cataldo, M F ............ 59

Catalona, W............. 8

Catananti, C . . . . . . . . . . . 97

Cateleyn, $L \ldots \ldots \ldots \ldots \ldots . \ldots 28$

Catenacci, G . . . . . . . . . . . 27
Catlett, LR .............. 82

Cats, A ................ 6

Cats-Baril, WL . . . . . . . . . . 97

Cattledge, GTH ..........56

Caunce, $M \ldots . . . \ldots \ldots \ldots . . . .3$

Cavagna, C . ............. 10

Cavanagh, J............ 7, 20

Cavanaugh, HA.......... 18

Cavaré, J...............997 97

Caverni, JP.............. 29

Cayless, M A .............. 46

Cayten, CG . . . . . . . . . . . 14

Cazamian, $\mathrm{P} \ldots \ldots \ldots \ldots$. . 23, 43

Cecchi, F . . . . . . . . . . . 88

Cekan, E . .............. 52

Cember, $\mathrm{H} \ldots \ldots \ldots \ldots \ldots \ldots 48$

Cena, K .............. 42

Center for Chemical Process

Safety (C CPS) . . . . . 54, 59, 77

Center for Corporate Public

Involvement............ 15

Centers for Disease Control

(CDC) . . 15, 39, 53, 95, 97, 103

Centers for Disease Control

and Prevention (CDC) . . 3, 10,

$24,56,60,69,70$

Centre nationale de l'équipment

hospitalier ............ 97

Centre of International

Projects ................ 30

Centro de la $\mathrm{N}$ aciones

U nidas sobre Empresas

Transnacionales

(UNCTC). . .

Centro Internacional de Información sobre

Seguridad y Salud en el

Trabajo (CIS)...........

Investigaciones Sísmicas y

M itigación de Desastres . . . . 39

Certad-Fombona, G . . . . . . 63

Cerutti, S . . . . . . . . . . . . . . 34

Cervinka, R . . . . . . . . . . 43

Cesana, G . . . . . . 29 29, 43, 77, 97

Ceulemans, E........... 81

Chadwick, K H . . . . . . . . . . 39

Chafer, SB . . . . . . . . . . . . . 19

Chaffin, D ..............6 6

Chaffin, DB ...........6, 29

Chagnon, SAJR . ............ 39

Chalermchaikit, $T$. . . . . . . . 27

Chalk, R............... 19

Chamak, B............... 10

Chamberlain, DL ......... 41

Chamberlain, EAC ......... 74

Chamberland, M E. . . . . . . . . 97

Chamberlin, RI . . . . . . 10, 63

Chambless, L . . . . . . . . . . . . . 80

Champion, GD . . . . . . . . 52

Champlin, R ............. 1

Chan, F . . . . . . . . . . . . . 17

Chan, KE. . . . . . . . . . . 38

Chan, OY ..............64 


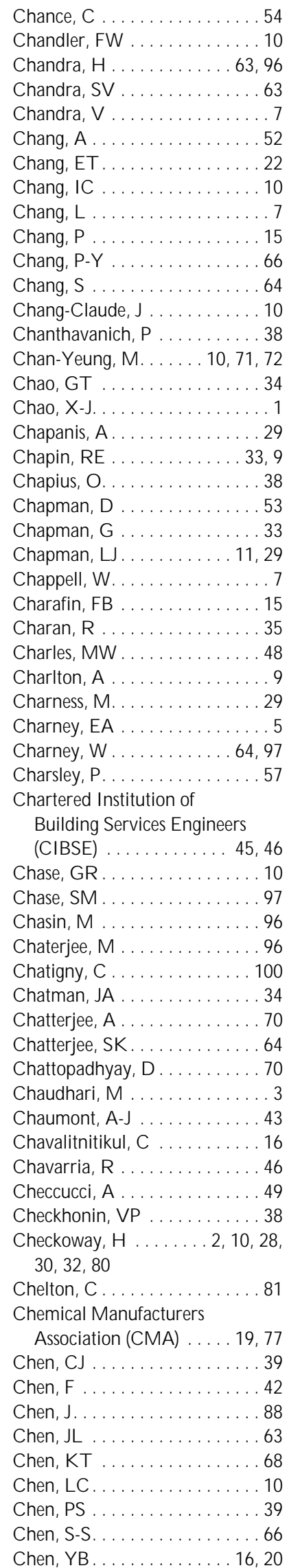

Chen, $\mathrm{Z}$

Cheng, $F$

.....73, 82

Cheng, YS .............. 10

Chensue, SW . . . . . . . . . . . 10

Cherniack, M G . . . . . . . . . 82

Cherniack, NS . . . . . . . . . . . 37

Cherniss, C ............. 34

Chernofsky, M A .......... 7

Chernyuk, VI............. 39

Cherrie, $A H \ldots \ldots \ldots \ldots . \ldots 77$

Cherrie, JW ............... 10

Cherry, JA ............... 55

Cherry, JP .............. 70

Cherry, N.......... 52, 100

Cherry, NM ........... 7, 9

Chesney, M ............ 99

Chesney, M A . . . . . . . . . . . . 34

Chestnut, DE ............. 34

Cheung, $C \ldots \ldots \ldots \ldots . \ldots 38$

Cheung, $Y \ldots \ldots \ldots \ldots \ldots 6$

Chevron Corporation ....... 102

Chew, DCE .............. 59

Cheynier, A . . .......... 53

Chia, KS ............ 16, 20

Chia, SE............ 9, 11

Chiang, $\mathrm{H}-\mathrm{C} \ldots \ldots \ldots \ldots \ldots 66$

Chiazze, L . .......... 10, 93

Chicken, JC . . . . . . . . . . . 59

Chignell, M H . ........ 29, 52

Children of Alcoholics

Foundation .............. 15

Chillag, N................ 3

Chilmonczyk, BA..........9

Chilton, $\mathrm{CH} \ldots \ldots \ldots \ldots \ldots 41$

Chin, E.............. 97

Chin, $R \ldots \ldots \ldots \ldots$

Chinitz, $L \ldots \ldots \ldots \ldots \ldots \ldots 6$

Chinn, S. . . . . . . . . . . . 10

Chio, $A \ldots \ldots \ldots \ldots \ldots \ldots$

Chisholm, JJ, Jr ........... 9

Chiu, S...............64 64

Chládek, V.............. 11

Cho, K................ 101

Cho, YJ ................ 101

Choi, BCK ........... 26, 80

Chong, JP. . . . . . . . . . . . . 96

Chopard, JL . . . . . . . . . . . . 43

Choquet, R ..............4 40

Chorba, TL . . . . . . . . . . . . . 32

Chou, BR.............. 49

Chou, FS .............. 86

Chou, LM ............... 38

Chou, T.............. 97

Choudhuri, S............ 11

Chow, JC............... 7

Chow, W-H .............. 1

Chowdhury, AK .......... 9

Chowdhury, JR ........... 33

Chowdhury, M A ...........53

Chowdhury, $\mathrm{NH} \ldots \ldots \ldots \ldots 32$

Chrenko, FA ............. 45

Chriske, H .......... 94, 97

Chrislip, DW ............. 7

Christ, E. . . . . . . . . . . 3
Christ, W....

Christensen, CC

Christensen, $\mathrm{K}$

Christiani, D

Christiani, DC

Christiansen, $\mathrm{C}$

Christiansen, JU................ 87

Christiansson, C..........64 64

Christie, B .............. 52

$\mathrm{Chu}, \mathrm{JCH} \ldots \ldots \ldots \ldots \ldots . .97$

Chudnovetes, AY . . . . . . . . . . 38

Chung, J................ 13

Churchill, R.............54

Churchman, A . . . . . . . . . . . 34

Churg, A ........... 10, 28

Churg, J ...............28

Churg, J.............. 10

Chwat, M . ...............89

Chylack, LT . ............ . 49

Ciacco, C . ..............65 65

Cianfrocco, R ............ 56

Ciaranello, RD ............5 5

Ciesielski, C . . . . . . . . . . . . 97

Ciesielski, S ..............11

CIGNA Corporation ........ 15

Citron, KM .............. 10

Cizinsky, G ............. 73

Cizkova, $M \ldots \ldots \ldots \ldots 63$

Claeys, F ..............663

Clain, M R . . . . . . . . . . . . 6

Clapp, DE ............... 9

Clare, PR . . . . . . . . . . . . . . 96

Clark, CS............... 101

Clark, D ................. 56

Clark, DC ............. 97

Clark, ID ................. 34

Clark, JA ................ 42

Clark, JM ..............28

Clark, L . . . . . . . . . . . . . . 34

Clark, M ...............43

Clark, N . . . . . . . . . . . . . . . 96

Clark, P ...............6 6

Clark, RH ...............8 83

Clark, RP............ 3, 42

Clark, SP . ............... 70

Clarke, D . . . . . . . . . . . . 73, 82

Clarke, EA . . . . . . . . . . . . . 48

Clarke, IR ............... 70

Clarke, K ................ 48

Clarkson, P ..............96 96

Clarkson, $T$. . ........... 27

Clarkson, TW ........ 7, 9, 39

Clausen, G . . . . . . . . . . . 13, 45

Clavel, J . . . . . . . . . . . . . . . 28

Clayson, D B . . . . . . . . . . . 28

Clayton, D . . . . . . . . . . . . 28

Clayton, FE . . . . . . . . . 30, 64

Clayton, GD .......... 30, 64

Clayton, PJ . . . . . . . . . . . . . . 97

Clayton, Y M .............. 10

Cleek, M A . . . . . . . . . . . . . . . 19

Clegg, C . . . . . . . . . . . . . . 29

Clegg, ED ............. 9

Clemens, R . . . . . . . 94, 97
Clement International

Corporation. ............9 9

Clement, RE . . . . . . . . . . . 55

Clemmer, D ............. 56

Clerc, J................... 21

Clerc, J-M ...........64, 99

Clerisi, WJ ............... 11

Cleuet, A ................ 49

Cleveland, RJ . . . . . . . . . . . . 59

Clevenstine, E . . . . . . . . . 22

Clifford, C ................ 15

Cline, R G . . . . . . . . . . 68

Cloutier, E . . . . . . . . . . 68, 101

Cloutier, L-G . . . . . . . . . . . 10

Clumeck, N . ............. 97

Coalición-AgSafe para la

Salud y Seguridad en la

Agricultura

Coalition on Smoking and H ealth ................. 15

Coates, G . . . . . . . . . . 10, 37

Coats, TJ ............... 59

Cobb, JB .............. 20

Cobb, K............... 101

Cobb, S............ 4, 34

Cober, R .......... 43, 97

Coblentz, WR ............ 49

Coburn, A ............... 39

Coch, L ................ 29

Cochrane, AL .............. 10

Cocirla, A. ............... 79

Cockcroft, A. . . . . . . . . . . . 97

Cockcroft, DW . . . . . . . 10, 64

Código Internacional de Ética

M édica. ................ 19

Coelho, GV ............... 34

Coenen, W . . . . . . . . . 32, 93

Coffe, RD .............4 41

Coffey, DS ............. 8

Coffman, GA ............ 15

Coggon, D ......... 6, 30, 32

Coghlan, JD . . . . . . . . . . . . 70

Coghlin, J. . . . . . . . . . . . . . 44

Cohen, A . . . . . . . . . . 34, 59

Cohen, AJ . ..............97

Cohen, B . . . . . . . . . 34, 52

Cohen, BJ .............. 70

Cohen, EN . . . . . . . . . . . . . 97

Cohen, $\mathrm{HH} \ldots \ldots \ldots \ldots . \ldots 59$

Cohen, K S. . . . . . . . . . . . . 19

Cohen, L . . . . . . . . . . . . 39

Cohen, M . . . . . . . . . . . . . . 101

Cohen, M L . . . . . . . . . . 52, 53

Cohen, $N \ldots \ldots$. . . . . . . . . . 34

Cohen, R . . . . . . . . . . . . . . 83

Cohen, RJ ............... 34

Cohen, RL . . . . . . . . . . . . . . 34

Cohen, S .......... 34, 52

Cohen-R osenthal, E . . . . . . . . 18

Cointreau-Levine, S. . . . . . . 101

Colby, TV .............. 10

Cold, E................ 64

Colditz, GA . . . . . . . . . . . 3

Cole, BD ............... 10 
Cole, CA .............49

Cole, E . . . . . . . . . . . . . . . 13

Cole, G. . . . . . . . . . . . . . 79

Cole, $P \ldots \ldots \ldots \ldots \ldots \ldots . . . .40$

Cole, RJ . . . . . . . . . . . . . . 34

Cole, WC . . . . . . . . . . . . . . 70

Coleman, C . . . . . . . . . . . . 96

Coleman, CN . . . . . . . . . . . . 1

Coleman, JW . . . . . . . . . . . . . 11

Coleman, M P . . . . . . . . . . 53

Coleman, P . . . . . . . . . . . . 18

Coleman, R . . . . . . . . . . . 100

Coleman, RM ............ 43

Coleshaw, SR W . . . . . . . . . . . 3

Colihan, JP. . . . . . . . . . 34

Colin, D . . . . . . . . 71, 86, 88

Collart, AM ............. 10

Collett, C . . . . . . . . . . . . . 38

Colley, J . . . . . . . . . . . . . 22

Collier, PF . . . . . . . . . . . 80

Colligan, M J . 3, 18, 29, 34, 43, 97

Collins, JW ............ 56

Collins, P . . . . . . . . . . . 97

Collins, WK . . . . . . . . . . 64

Collinson, IL . . ......... 56

Collis, EL . . . . . . . . . . . . 89

Collis, M D . . . . . . . . . . . 45

Collis, M L . . . . . . . . . . . . 69

Colombi, A . . . . . . 27, 44, 101

Colombo, F . . .......... 10

Colosio, C . . ........... 27

Colquhoun, WP. . . . 3, 29, 34, 43

Colton, R . . . . . . . . . . . 96

Colton, T . . . . . . . . . . . . 97

Colwell, RR . . . . . . . . . . . 53

Comba, P. . . . . . . . . 28, 88

Combs, JW ........... 10

Comer, NL ............ 5

Cometto-M uñiz, JE . . . . . . 11, 13

Comisión de las $C$ omunidades

Europeas (CCE) . . . . . 23, 27,

42, 46, 61, 93, 97, 103

Comisión Económica para

Europa de la $\mathrm{N}$ aciones U nidas

(CEPE) . ............ 77

Comisión Electroténica

Internacional (CEI) . . . 40 40, 46,

$47,49,58,59$

Comisión Europea (CE). 16, 41, 54

Comisión Internacional de

M edicina del T rabajo

(CIM T) . . . . . . . 16, 18, 30

Comisión Internacional de

Protección contra la R adiación

no Ionizante (I nternational

Commission on Non-lonizing

$\mathrm{R}$ adiation Protection

ICNIRP).

Comisión Internacional de Protección R adiológica

(CIPR ) . . . . . . 10, 33, 39, 48

Comisión Internacional de

U nidades y $M$ adidas

R adiológicas (ICRU M ) . . . . 48
Comisión M ixta Internacional (International Joint

Commission, IJC) . . . . . . . 55

Comisión $M$ undial sobre $M$ edio Ambiente y D esarrollo

(WCED ) . . . . . . . 20, 30, 54

Comité A sesor sobre R iesgos

M ayores. . . . . . . . . . . . . 57

Comité Científico de las

$\mathrm{N}$ aciones U nidas para el

Estudio de los E fectos de las

$R$ adiaciones $A$ tómicas

(UNSCEAR). . . . . . . 39, 38

Comité Conjunto O IT / O M S

sobre M edicina del

Trabajo . . . . . . . . . 16, 18, 26

Comité de Expertos de las

$\mathrm{N}$ aciones $\mathrm{U}$ nidas sobre el

T ransporte de $\mathrm{M}$ ateriales

Peligrosos.

Comité Especial sobre Etica

M édica. . . . . . . . . . . . . . 19

Comité Europeo de

Normalización (CEN) . . 10, 29

30, 31, 42, 45, 68, 93

Comité M ixto FAO / O M S de Expertos en A ditivos

Alimentarios (JECFA) . . . . . 63

Commenges, $D \ldots \ldots \ldots \ldots \ldots 5$

Commings, $K$ B . . . . . . . . 8

Commission de la santé et de la sécurité du travail . . . . . . . . . 12

Commission internationale de I'éclairage (C IE ) . . . . . . . 46, 49

Commission on the Future of W orker-M anagement

R elations. . . 93

Committee on G overnment O perations. ............ 19

Commoner, B ........ . 54, 55

Commonwealth M edical

Association ............ 24

Community $\mathrm{H}$ ealth $\mathrm{N}$ etwork. . . 43

Comunidad Económica

Europea (CEE) . . 19, 31, 40, 58

Concina, E . . . . . . . . . . . 101

Condek, PC . . . ........... 39

Cone, J . . . . . . . . . . 7, 13, 45

Coney, N . . . . . . . . . . . . . 34

Confederación Internacional de O rganizaciones Sindicales Libres (CIOSL). . . . . . . . . . 99

Confer, DL ............. 1

Conferencia de las $\mathrm{N}$ aciones U nidas sobre el M edio Ambiente y el Desarrollo (CNUMAD) . . . . . . . 16, 53

Connally, LB . . . . . . . . 28, 64 Conne, E . . . . . . . . . . . . . 97

Connell, BR . . . . . . . . . . . 34

Connelly, A . . . . . . . . . 15

Conner, DH . . . . . . . . . . . 10

Connolly, C . . . . . . . . . . . 58

Connolly, JS..............49
Conolly, JH ............ 3

Conolly, R B . . . . . . . . . . . . . 11

Conover, DL . . . . . . . . . . 52

Conrad, DG . . . . . . . . . . . . . 34

Conrad, P............... 19

Conseil national de l'O rdre des

M édecins . . . . . . . . . . . . . . 19

Consejo A sesor para

Discapacitados. . . . . . . . . . 7

Consejo de la Indusria Q uímica

Europea (CEFIC) . . . . . . . . 20

Consejo de la Salud de los

Países Bajos, Comité para

la Evaluación de la

Carcinogenicidad de las

Sustancias Q uimicas . . . . . . 33

Consejo de las $C$ omunidades

Europeas (CCE) . . . . . 16, 39,

$45,47,50,77,93,97$

Consejo de $\mathrm{M}$ ateriales $\mathrm{D}$ entales, Instrumentos y Equipos . . . . 11

Consejo de $\mathrm{M}$ inistros de los Estados Nórdicos. . . . . . . . . . . 7

Consejo de U nión Europea . . . . 50

Consejo Internacional del

$M$ etal y el M edio A mbiente (ICME).

Consejo $\mathrm{N}$ acional de $\mathrm{D}$ efensa de Víctimas del $\mathrm{K}$ aroshi. . . . . . . . 5

Consonni, D. . . . . . . . . . 1, 39

Constabile, DW . . . . . . . . . . 65

Constance, JD . . . . . . . . . . . 45

Constantino, JP . . . . . . . . . 73

Construction Safety Association of C anada . . . . . . . . . . . . 93

Construction Safety Association of 0 ntario . . . . . . . . . 93

Consult A merica . . . . . . . . . . 15

Content, R M . . . . . . . . . . 83

Conti, DJ . . . . . . . . . . 15

Contrada, RJ . . . . . . . . . . . 34

Converse, JM . . . . . . . . . . . 28

Conway, TL.............. 34

Cook, C . . . . . . . . . . . . 10

Cook, EF ............. 5

Cook, GC............ 53

Cook, R R. . . . . . . . . 19, 28

Cook, S .............. 52

Cook, WA .............. 30

Coombs, CF............ 83

Coon, MJ .............. 33

Cooper, B. . . . . . . . . . . . . 5

Cooper, C .......... 5, 6, 34

Cooper, CL . . . . 5, 15, 34, 52, 78

Cooper, CS . . . . . . . . . . 44

Cooper, DA . . . . . . . . . . . . . 97

Cooper, J . . . . . . . . . . . . . 97

Cooper, JB . . . . . . . . . . . . 97

Cooper, JE . . . . . . . . . . . . . 97

Cooper, JR . . . . . . . . . . . . 7

Cooper, M D ............. 59

Cooper, NS . . .......... 6

Cooper, PP. . . . . . . . . . . . 15

Cooper, PR ............ 14
Cooper, R . . . . . . . . . 33

Cooper, WC ........ 10, 30, 44

Copass, M K . . . . . . . . . . 40

Copenhaever, E . . . . . . . . . . 13

Copenhaver,. ED . . . . . . . . . 44

Coppee, GH ............64 64

Coppolo, DP . . . . . . . . . 70

Coray, KE . . . . . . . . . . 52

Corbeil, J-F . . . . . . . . . . 58

Corbella, J . . . . ........ 9

Corbett, JM . . . . . . . 29, 56, 58

Corbett, TH . . . . . . . . . . . 19

Corbitt, RA . . . . . . . . . . 83

Corbo, GM ............63

Cordes, DH . . . . . . . . 18, 64

Cordier, S . . . . . . . . . . . 28

Cordingley, ES. . . . . . . . . . 52

Corey, P.............. 52

Coriel, P.............. . 19

Cork, JS, III . . . . . . . . . . . 29

Corlett, EN ......... 29, 43

Corlett, N . . . . . . . . . . 29, 100

Cormier, Y . . . . . . . . . . 10

Corn, J................ 21

Corn, JK . . . . . . . . . 23, 89

Corn, M . . . . . . 23, 30, 83, 94

Cornelison, JD . . . . . . . . . . . . 57

Cornell, C . . . . ......... 96

Cornfield, J . . . . . . . . . . 28

Cornut, G . . . . . . . . . . . 96

Corporación de Seguro

Laboral de R esponsabilidad

O bjetiva. ............. 26

Corporate $\mathrm{H}$ ealth Policies

Group ............... 15

Correa, A . ............. 83

Corson, J . . . . . . . . . . . . 10

Cortés, M . . . . . . . . . . . 53

Corveil, J-F . . . . . . . . . . 58

Corwin, J . . . . . . . . . . 11

Cossermelli, W . . . . . . . . . . 6

Costa, G . . . . . 29, 34, 43, 97, 102

Costantini, A . . . . . . . . . . . . . 88

Costanzo, R M . . . . . . . . . . 11

Costello, JT . . . . . . . . . . . 38

Cote, AE .............4 41

Cotes, JE . . . . . . . . 10, 64, 70

Cotran, RS. . . . . . . . . . . . 10

Cottica, D . . . . . . . . . . 27

Cotton, JL . . . . . . . . . . . . 29

Cotzin, M . . . . . . . . . . . . 50

Coughlin, S . . . . . . . . . 19, 101

Coulston, F . . . . . . . . . 39

Coultras, DB ........... 9

Coumbis, JJ . . . . . . . . . . . 64

Council for International

$O$ rganizations of $M$ edical

Sciences (CIO M S). . 19, 28, 101

Council of State Science

Supervisors . . . . . . . . . . . 94

C ouncil on Scientific Affairs of

the American M edical

Association . . . . . . . . 11, 96

Counts, $W \ldots \ldots \ldots \ldots \ldots \ldots 13$ 
Courcel, $M \ldots \ldots \ldots \ldots \ldots 87$

Courtice, FC . . . . . . . . . . . 33

Courtney, KD ............ 27

Courtney, M ............ 101

Courville, J............. 100

Couser, JI............... 101

Cousineau, JM . ............ 26

Covello, V ............... 54

Cowdonan, J .............. 23

Cowell, JWF........ 15, 16, 19

Cowie, R ................ 10

Cowles, SR . . . . . . . . 19, 28

Cox, A ...............664

Cox, C............. 34, 52

Cox, LM ..............64 64

Cox, RD .............. 95

Cox, RS ............... 1

Cox, S................. 34

Cox, T ................ 34

Coye, MJ ............. 19, 64

Coyle, PV............... 3

Craciunescu, DG ..........6 63

Craddock, G ............ 97

Craft, B ................. 32

Craft, BF .......... 10, 78

Craig, A .............. 43

Craig, DK ............. 10

Craig, R............... 3

Craighead, JE ........... 10

Cralley, LJ . . . . . . 30 30, 33, 37, 44

Cralley, LV ...... 30, 33, 37, 44

Cramer, SH ................ 5

Crampton, GH ............ 11

Crane, E................. 70

Cranmer, ME ............ 27

Cravalho, EG............40 40

Craven, R B . . . . . . . . . . . . 39

Crawford, $T J \ldots \ldots \ldots \ldots . . .63$

Crawford, WW ........... 83

Crawford-Brown, DJ . . . 2, 28, 32

Cray, C ............... 101

Creedon, M A . . . . . . . 15, 34

Creighton, WB. . . . . . . . . . . 21

Cremer, P ............... 34

Crenshaw, AH ............ 6

Crepet, $M$. ............ 8

Crespi, $C L \ldots \ldots \ldots \ldots \ldots . . . \ldots 33$

Cresteil, $T$............. 33

Cristofari, M-F........... 97

Critchley, M............ 96

Crivellaro, W . . . . . . . . . . . 34

Croce, EJ ................. 39

Crocq, L............... 29

Croft, $P \ldots \ldots \ldots \ldots \ldots 6$

Croft, SL .............6 63

Cromwell, $0 \ldots \ldots \ldots .63,70$

Cron, WL............... 34

Cronin, E.............. 12

Crook, B............. 38, 101

Croon, JJAB............ 100

Cross, J................. 97

Cross, RE.............. 39

Cross, $T \ldots \ldots \ldots \ldots \ldots 66$

Crouch, $C \ldots \ldots \ldots \ldots \ldots .21$
Crouch, EA ............. 30

Crouch, J............... 13

Croughan, J.............. 5

Crow, SA ............... 13

Crowell, M D . . . . . . . . . . . 34

Crowl, D ...............79

Crowley, M ............. 70

Crowther, A .............. 34

Cru, D ................ 59

Cruddas, M ............6

Cruess, RL ..............6 6

Crum, R M . . . . . . . . . . . . 34

Crump, KS ............94

Cryer, C . .............68 68

Crystal, RG ............. 10

C sikszentmihalyi, M ........ 34

Cubit, D ................ 100

Cueto, C . ..............27

Cuevas, M .............. 97

Cullen, AP . . . . . . . . . . . . . 49

Cullen, JH . . . . . . . . . . . . . . 43

Cullen, JW . . . . . . . . . . . . . 2

Cullen, $M \ldots \ldots \ldots \ldots \ldots 64$

Cullen, M R .... . 6, 7, 9, 10, 11,

$13,72,73,87,89$

Culler, M D ............. 9

Culver, C .............. 58

Culver, D . . . . . . . . . . . . . 97

Culver, DH .............97

Cumbre M undial sobre

Desarrollo Social . . . . . . . . . 16

Cumming, $\mathrm{CW} \ldots \ldots . . .96$

Cumming, $\mathrm{HJ} \ldots \ldots \ldots \ldots 41$

Cummings, LL . . . . . . . . . . . 34

Cummins, R . . . . . . . . . . . 34

Cundell, D .............. 100

Cunningham, HW . . . . . . . . . 85

Cuny, $X \ldots \ldots \ldots \ldots . \ldots 59$

Cupples, LA ............. 15

Cura, NM .............66

Curley, A ..............27

Curran, JW ..............97 97

Currie, AR ............... 33

Curry, FN ....................... 64

Curti, R ...............43

Curtis, EC . . . . . . . . . . . . . 34

Curtis, LR ...............4

Curtis, RA . . . . . . . . .......... 3

Curtiss, D . .............. 96

Curwen, $\mathrm{M}$.............. 3

Cushman, WH . . . . . . . . . . 29

Cutlip, PM ..............56

Cvetanovski, J . ............ 34

Cvetkovich, G . ............ 59

CW, Gurney .............. 1

C witco, G.......... 34, 52

Cymerman, A . . . . . . . . . . 37

Cynkier, I. . ............ 86

Cyranek, G . ..............229

Czaja, R . . . . . . . . . . . . 28

Czajkowski, S............ 34

Czarnecki, DJ . ............. 36

Czeiler, CA ..............997

Czeisler, CA .............43 43
Czeisler, M P . . . . . . . . . . . 43 Czekaj, AM .............43

Czerki, PA .............. 49

Czernielewski, A ........... 12

\section{D}

Daanen, HAM . . . . . . . . . . 42

Dabeka, RW ............. . 9

Dabis, F . . . . . . . . . . . 28

Dachler, H P. . . . . . . . . . . . . 29

Daftuar, CN . . . . . . . . . . . 29

Dagon, $T J \ldots \ldots \ldots \ldots . . .65$

D'Agostino, R ............ 3

Dahl, J R ............... 70

Dahl, OF ............... 13

Dahl, S................ 38

Dahlén, $\mathrm{G} \ldots \ldots \ldots \ldots \ldots . . \ldots 11$

Dahlgren, K . . . . . . . . . . . . 43

Dahlman, S . . . . . . . . . . . . 29

Dahlqvist, M ............. 10

Dai, T-R .............. 1

Daigle, $R \ldots \ldots \ldots \ldots 68$

Dainoff, $M \ldots \ldots \ldots \ldots . . \ldots 34,52$

Dake, K .................5 59

Dal Conte, G . . . . . . . . . . 52

Dalal, N . . . . . . . . . . . . . . . 10

Dale, ML ................ 19

Dale, WE ............... 27

Dalens, $\mathrm{H} \ldots \ldots \ldots \ldots \ldots \ldots . . . . . .63$

D'Alesandro, M M . . . . . . . . 42

Dalgaard, JB ............66 66

Daling, JR ............. 100

Dalinka, M K .............6 6

Dalioma, $U$. . . . . . . . . . . 89

Dalle, D .................. 10

DalleV alle, JM . . . . . . . . . . . . 30

Dalley, A ............... 10

Dally, M B ................6 63

d'Alonzo, CA ............. 34

Dalton, A . . . . . . . . . . . . . . 21

Daltveit, AK ............ 9

Daly, HE ............... 20

Damasio, A ............... 34

Damiani, G ............. 97

Damiecki, P . . . . . . . . . . . . . . 53

Damluji, SF . . . . . . . . . . . 9

Damme, B .............. 83

Damokosh, A . . . . . . . . . . . 53

D'Amorim, M ............ 34

Dancer, E............... 11

d'Andrea, F . . . . . . . . . . . 43

Danese, $P$. . . . . . . . . . . . . . . 89

Danev, S . . . . . . . . . . . . . . 43

Daniel, RK . . . . . . . . . . . 6, 11

Daniel, W............... 13

Daniel, WW . . . . . . . . . . . . . 15

Daniele, R P . . . . . . . . . . . . . 10

Daniell, W ............... 16

Daniell, WE . . . . . . . . . . . . 9

Daniellou, F . . . . . . . . . . . 52

Daniels, E. . . . . . . . . . . . . . . . 53

Daniels, SM ............... 17

Danielson, RW . . . . . . . . . . 47
Danielsson, $L \ldots \ldots \ldots \ldots \ldots 6$

Danish Indoor Study G roup . . . 13

D ankelman, I . . . . . . . . . . . 64

Danko, S ................. 34

Dannenberg, AL ........... 3

Danner, DL ............... 34

Darby, SC . . . . . . . . . . . . 48

Darden, EB, Jr . . . . . . . . . 102

Darian-Smith, I . . . . . . . . . 11

Daroff, RB ............... 7

Darrow, D .............. 10

D artigues, JF . . . . . . . . . . . 5

Darwish, M ............. 101

Das, B . . . . . . . . . . . . . 29

Das, JJ .................. 39

Das, PK .............. 96

Das, $R \ldots \ldots \ldots \ldots \ldots \ldots$

Dascal, A . . . . . . . . . . . . 63

D'Ascanio, I . . . . . . . . . . . 97

Dasgupta, AK ........... 73

Dasler, AR . . . . . . . . . . . 42

Date, CJ............... 22

Dato, VM ................ 10

Dattola, R .............. 7

Daube, JR .............. 7

Dauber, JH ............ 10

Dauge, RR . . . . . . . . . . . . 70

Daull, $F \ldots \ldots \ldots \ldots \ldots 42$

Daum, SM . ........ 9, 23, 103

D'Auria, D . . . . . . . . . . . . . 18

Davanger, M ............ 49

Davanipour, Z . . . . . . . 7, 87

David, M ............... 52

Davidow, W.............. 24

Davidson, B . . . . . . . . . . . 15

Davidson, CA . . . . . . . . . . 10

Davidson, DM ............. 3

Davidson, J ..............64

Davidson, M J . . . . . . . . . . 52

Davidson, N . . . . . . . . . . . 38

Davidson, RD . . . . . . . . . . 31

Davies, BT . . . . . . . . . . 29

Davies, DR ............. 64

Davies, J............... 56

Davies, JC .............. 56

Davies, JE . . . . . ...... 9, 64

Davies, NV ............. 20

Davies, PC . . . . . . . . . . . . . 39

Davies, PD . . . . . . . . . . . 49

Davies, RE .............. 49

Davies, RJ .......... 11, 100

Davies, SF . . . . . . . . . . . 10

Davis-K ing, KE . . . . . . . . . 64

Davis, DL . . . . . . . . . . . 53, 66

Davis, G . . . . . . . . . . . . 10

Davis, J............... 48

Davis, JD ................ 7

Davis, JM G . .............. 10

Davis, JR . .............. 9

Davis, $\mathrm{NH} \ldots \ldots \ldots \ldots \ldots 41$

Davis, $P \ldots \ldots \ldots \ldots \ldots 6$

Davis, RG ............. 102

Davis, RL . . . . . . . . . . . . 95

Davis, RM . . . . . . . . . . . 15 
Davis, RR ............ 47

Davis, S . . . . . . . . . . . 100

Davis, WT . . . . . . . . . 82

Davis, YM . . . . . . . . . 97

Dawis, RV . . . . . . . . . . . 34

Dawkins, RL . . . . . . . . . . 97

Dawson, A . . . . . . . . . . . 9

Dawson, DA ............. 34

Dawson, DM ............ 7

Dawson, JA . ............ 27

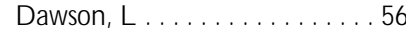

Dawson, M W . . . . . . . . . . . 64

Dawson, NJ . . . . . . . . . . . 19

Dawson, S . . . .......... 21

Dax, EM ............. 97

Day, K ............. 91

Day, NE ............ 28

Day, R . . . . . . . . . . 42

Day, RA............. 3

Dayan, AD . . . . . . . . . . 33

Dayton, 0 W ............ 6

Dayton, P.............6 6

Dayton, PK . . . . . . . . . 66

Daywalt, J . . . . . . . . . . 97

de-K lerk, NH . . . . . . . . . . . 9

De, $A \ldots \ldots \ldots \ldots \ldots \ldots 97$

de Ancelar, KZ .......... 43

De Andrés, R . . . . . . . . . . 97

de Backer, G . . . . . . . . 3, 34

de Bacquer, $D \ldots \ldots \ldots \ldots \ldots$.

De Boer, JB . . . . . . . . . . . 46

de Bruyn, $A$. . . . . . . . . 28, 100

De Camp Wilson, T D . . . . . . . 29

de $C$ apus, $B \ldots \ldots \ldots \ldots \ldots . . . .88$

De Carlos, A . . . . . . . . . 39

de C asadevante R omani, CF. . . 54

de Chambost, $M$. . . . . . . . . . 97

De Fremont, J . . . . . . . . . 97

de $G$ audemaris, R . . . . . . . . 97

de Gier, E. . . . . . . . . . . . . 5

de Givry, J . . . . . . . . . . . 21

de Graaff, J . . . . . . . . . . . 38

De Grip, A . . . . . . . . . . . . 99

De Groot, $A C \ldots \ldots \ldots \ldots \ldots 12$

de Jonge, $H C \ldots \ldots \ldots \ldots \ldots .22$

De K eyser, $V \ldots \ldots \ldots \ldots . \ldots . . .29$

de $K$ eyser, $V \ldots \ldots \ldots \ldots \ldots 97$

DeK ock, A . . . . . . . . . . 38

de $K$ retzer, DM . . . . . . . . . . 9

de la Cuesta, CG . . . . . . . . . 100

De Lisi, PS . . . . . . . . . . . . 29

DeLuca, J . . . . . . . . . . . 13

de $M$ esquita, $H$ B . . . . . . . . 32

de $M$ ontmollin, M . . . . . . . . 29

de $M$ orais, SM F . . . . . . . . . 33

de 0 nis, $M \ldots \ldots \ldots \ldots \ldots . . \ldots$

De R onde, M M . . . . . . . . . 97

de $R 00, A \ldots \ldots \ldots \ldots \ldots . .21$

De Sanjose, S. . . . . . . . . . . . 28

De Smedt, M . . . . . . . . . 43

De Terssac, G . . . . . . . . . . 29

de Viottis, JM . . . . . . . . . . . 10

de $V$ ries, FF . . . ......... 3

de $V$ ries, J . . . . . . . . . . 29
De Winter, CR . . . . . . . 97 de Winter, CR . . . . . . . . . . . 34

De Witte, L . . . . . . . . . . 97

Dean, J . . . . . . . . . . . . . 33

D ean, JA ............4 41

Dean, JH . . . .......... 33

deAndrale, $A E \ldots \ldots \ldots \ldots \ldots .3$

Dearman, RJ . . .......... 11

DeBacker, G ............ 3

DeBernardis, MJ . . . . . . . . 27

Deblon, G . . . . . . . . . . . . 29

Debry, G . . . . . . . . . 34, 43

Debus, $G \ldots \ldots \ldots \ldots \ldots \ldots$

DeC arli, G . . . . . . . . . 80, 97

Decheng, C . . . . . . . . . . 63

Deci, EL . . . . . . . . . . . . . . 29

D ecker, JA . . . . . . . . . . . . . 102

Declaration of $\mathrm{H}$ elsinki . . . . . . 19

Decortis, F . . . . . . . . . . 29

DeC otiis, TA . . . . . . . . . . . 59

D ecouflé, P. . . . . . . 2, 87, 88, 91

DeC resce, $R$. . . . . . . . . . . . 15

Decreto del Presidente del

Consejo de M inistros. . . . . . 97

Dedhia, HV . . . . . . . . . . . . 9

Dedobbeleer, N . . . . . . . . . . 59

Deems, D A . . . . . . . . . . 11

Deere $\&$ C $0 \ldots \ldots \ldots \ldots 64,70$

D eery, S . . . . . . . . . . . . . 21

D eeter, DP . . . . . . . . . . . . 95

deFaire, $U \ldots \ldots \ldots \ldots \ldots \ldots$

Defares, PB . . . . . . . . . . 34

Deffer, PAJ . . . . . . . . . . 6

DeFoliart, GR . . . . . . . . . 70

DeFriese, GH . . . . . . . . . . . 15

Degener, T . . . . . . . . . 17

D egerth, R . . . . . . . . . . . 4

DeG reve, TB . . . . . . . . . . . 29

DeH aan, N . . ..........41

DeH art, R . . . . . . 7, 95, 102

Dehlin, $0 \ldots \ldots \ldots \ldots \ldots \ldots 97$

Deisseroth, $A B \ldots \ldots \ldots \ldots \ldots 1$

D eitmer, $P \ldots \ldots \ldots \ldots \ldots \ldots .43$

D eitz, D . . . . . . . . . . . 34

Dejima, M . . . . . . . . . . 97

Dejours, $C \ldots \ldots \ldots \ldots 26,59$

Dejoy, DM ........ 3, 15, 59

D el uanes Paardo, JR . . . . . . . . 96

Delacoste, $F \ldots \ldots \ldots \ldots \ldots . .96$

Delaney, T . . . . . . . . . . . . 10

Delaporte, M F . . . . . . . 97, 100

Delbart, H . . . . . . . . . . . 97

DeLeo, VA. . . . . . . . . . . 96

Dellenbaugh, CA . . . . . . . . 32

Dellon, AL . . . . . . . . . . . 11

Delord, Y . . . . . . . . . . . 65

Delorme, C . . . . . . . . . . 100

Deluca, F . . . . . . . . . . 4

Delzell, E . . . . . . . . . . . 80, 91

Dement, W . . . . . . . . . . . 34

Demers, L M . . . . . . . . . . . . . 10

Demers, P . . 3, 10, 71, 72, 86, 88, 100

Demidchik, EP. . . . . . . . . 48
Deming, WE . . . . . . . . 34

DeM orais, $C F \ldots \ldots \ldots \ldots \ldots$

Dempsey, AN ........... 10

D empsey, JA . . . . . . . . . 37

Dencker, $F \ldots \ldots \ldots \ldots \ldots \ldots 66$

Denes, AE .............4

Deng, JF . . . . . . . . . . . . 10

Denisco, RA . . . . . . . . . . . 97

Denison, DR . . . . . . . . . 59

Denisov, El. . . . . . . . . . 47

D enmark, FL . . . . . . . . . . 34

Denning, J . . . . . . . . . . 15

Dennis, M ............ 70

DeNo, DW . . . . . . . . . . . . 49

Denton, JA . . . . . . . . . . . . 6

D epartamento de Derechos

Civiles de AFL-CIO ..... 17

DePlaen, $P \ldots \ldots \ldots \ldots \ldots \ldots . .63$

DePlanque, M M ........... 1

Depue, $\mathrm{RH} \ldots \ldots \ldots \ldots \ldots . . .96$

Dequae, $L \ldots \ldots \ldots \ldots \ldots \ldots . \ldots$

Derby, S. . . . . . . . . . . . . 59

D'Ercole, JA . . . . . . . . . . . . 9

Derenne, JP . . . . . . . . . . . 37

Derickson, A . . . . . . . . . . 21

Derickson, AD . . . . . . . . . 24

D'Erico, M M . . . . . . . . . . . 38

DeR osa, E . . . . . . . . . . 27

Derriennic, F . . . . . . . . . . . 28

D esbaumes, P . . . . . . . . . . 101

D escotes, J . . . . . . . . . . . 33

D esiraju, T . . . . . . . . . . . 11

Desmarais, M C . . . . . . . . . 52

Despouy, L . . . . . . . . . . . . . . 17

Désy, M . . . . . . . . . 28, 72

Detels, $R \ldots \ldots \ldots \ldots \ldots \ldots 48$

D eters, Of . . . . . . . . . . . . 49

deT reville, $0 \ldots \ldots \ldots \ldots . \ldots . \ldots 102$

Deulofue, $V \ldots \ldots \ldots \ldots \ldots \ldots . .38$

Deutsche Electrotechnische

Kommission

D eutsche Forschungsgemeinschaft (DFG) . . . . . . . . . . . 27

Deutschmann, C ......... 5

D evalia, JL . . . . . . . . . . . . 11

D evary, Y . . . . . . . . . . . . 33

Devereux, R B . . . . . . . . . 34

Devesa, SS . . . . . . . . . . . . 1, 28

D evienne, A . . . . . . . . . . . . 97

D evis, $T \ldots \ldots \ldots \ldots \ldots \ldots 3$

DeV ita, VTJ $1,4,8,10,12,15,28$

Devlin, RB . . . . . . . . . . . 13

D eV ries, I. . . . . . . . . . . . . 34

Devroede, $G \ldots \ldots \ldots \ldots . . .89$

Dew, EJ . . . . . . . . . . . 70

Dew, M A . . . . . . . . . . 34, 39

Dewar, R . . . . 1, 4, 12, 28, 72, 89

Dewe, PJ . . . . . . . . . . 34

DeW olf, CJ . . ......... 5

Deyo, RA .............. 97

Dhahir, HT ............. 9

Dhara, VD . . . . . . . . . . . 95

Dharmarajan, V .......... 10

Dhondt, $S \ldots \ldots \ldots \ldots \ldots \ldots \ldots 5$ di Domenico, A . . . . . . . . . 39

Di Luzio, NR . . . . . . . . . . . . . 10

Diaper, D . . . . . . . . . . . 52

Diaz-Perez, R ..........6

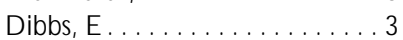

DiBerardinis, L . . . . . . . 13, 80

Dick, JA . . . . . . . . . . . 10

Dicke, $W \ldots \ldots \ldots \ldots \ldots . \ldots 58$

Dickerson, O B . . . . . 16, 77, 102

Dickie, DE . . . . . . . . . . . 93

Dickinson, DE . . . . . . . . . . 17

Dickinson, $\mathrm{H} \ldots \ldots \ldots \ldots \ldots . .48$

Dickinson, J . . . . . . . . . . 11

Dickson, JW . . . . . . . . . . . . 59

DiD onato, JA . . . . . . . . . 33

Dieges, $\mathrm{PH} \ldots \ldots \ldots \ldots \ldots \ldots 64$

Diehl, W. . . . . . . . . . . 55

Diekershoff, $K \ldots \ldots \ldots \ldots \ldots 56$

Diekmann, A . . . . . . . . . . . 43

Diem, JE . . . . . . . . . . . . 10

Dierks, F. . . . . . . . . . . 58

Dieterly, D . . . . . . . . . . . . 59

Dietz, MS . . . . . . . . . . . . 44

Diffey, B . . . . . . . . . . . . 49

Diggory, HJP . . . . . . . . . . . 96

Digiacinto, $G V \ldots \ldots \ldots \ldots 6$

Dijkmans, B . . . . . . . . . 6

Dilley, KJ . . . . . . . . . . . . 49

Dillon, A . . . . . . . . . . . . . 29

Dillon, HK . . . . . . . . . . . . . 27

Dillon, PJ . ............ 55

Dimich-W ard, H . . . . . . . 71

Dinardi, SR . . . . . . . . . . 30

Dincol, $G \ldots \ldots \ldots \ldots \ldots \ldots . \ldots 20$

DinCol, $G \ldots \ldots \ldots \ldots \ldots . . . .$.

DiNenno, PJ ............41

Dinerman, M . . . . . . . . . 97

Ding, $C-Y \ldots \ldots \ldots \ldots \ldots \ldots 1$

Ding, CK . . . . . . . . . . . 33

Dinges, DF . . . . . . . . . . 29

Dingman, RR . . . . . . . . . 77

Dingwall-Fordyce J . . . . . 10, 89

Dinse, GE .............. 53

Dipple, A . . . . . . . . . . . 27

Direktoratet fur

A rbejdstilsynet. . . . . . . . . . 98

Dirkx, J. . . . . . . . . . 43, 97

D isabled Forestry W orkers

Foundation of Canada . . . . 17

Dische, M R . . . . . . . . . . . . 101

Discher, D . . . . . . . . . . . . 20

Dishman, RH . . . . . . . . 15

Ditecco, D . . . . . . . . . . . 34

DiT ecco, D . . . . . . . . . . 52

Ditman, D . . . . . . . . . . . . 34

Dix, MR . . . . . . . . . . 11

Dixon, JJ ............. 5

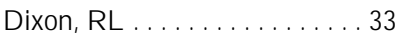

Dixon, SW .............. 31

Djordjevic, DDP . . . . . . . 26

Djuric, D . . . . . . . . . 33

D mitrukha, NW . . . . . . . . 38

Do Pico, GA ............ 10

Doadrio-V illarejo JC . . . . . . 63 
Dobbin, RD . . . . . ........ 39

Dobie, RA ............... 11

Dobry, CA .............. 10

Docherty, D . ............ 69

Dockery, D.............. 53

Dockery, DW.......... 10, 53

Dodgson, J . . . . . . . . . . . 10

Dodier, N . . ............... 59

Dodson, JD ............... 34

Dodson, NV . . ............. 52

Dodson, R .............. 10

Dodson, RF . . . . . . . . 73, 82

Doekes, G .............. 30

Doell, D . . . . . . . . . . . . . . 10

Doherty, RA ............. 9

Dohr, D ................43

Dohrenwend, B ......... 5, 34

Doig, AT . . . . . . . . . . . 89

Doignon, J . . . . . . . . . . . 4

Dökert, B ............... 3

Dolara, P . . . . . . . . . . . . 44

Dold, C ............... 53

Doll, R . .... 2, 10, 19, 28, 39, 48

Dolovich, J.............. 10

Dolphin, CT ............. 33

Domagk, A .............. 6

Domanska, A . . . . . . . . . . 38

Domanski, LM . . . . . . . . . . 28

Domingo, $M \ldots \ldots \ldots \ldots 53$

Dominguez, $R \ldots \ldots \ldots \ldots 96$

Dômont, A .............. 97

Domschke, W ...........68 68

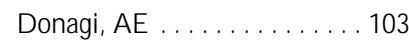

Donald, C ............... 59

Donaldson, DH . . . . . . . . . 6

Donaldson, GC . ........... 3

Donaldson, K . . . . . . . . . . . 10

Donbk, L ................ 101

Donchin, E............. 29

Donelly, SC ............ 10

Dönges, $G \ldots \ldots \ldots \ldots \ldots . \ldots$

Donham, KJ ........ 10, 64, 70

Doniol-Shaw, G . . . . . . . . . 100

Donnachie, PE........... 40

Donnarieix, D .............63 63

Donofrio, DJ .............. 100

Donoghue, EA ........... 41

Donoghue, JA ........... 90

Donovan, R . . . . . . . . . 97

Dooley, D............ 34, 51

D ooms-G oossens, A . . . . . . 100

Döös, M .............. 58

Dorard, G ............. 52

Dornan, J............... 100

Doroklin, ER .............. 3

Dorset, HG ............ 41

Dosemeci, M ........... 1, 32

Dosman, JA ....... 10, 38, 64, 70

Doto, IL . . . . . . . . . . . . . . 4

Doty, RE ............... 34

Doty, RL .............. 11

Dougados, M ............ 6

Dougherty, RC ........... 9

Douglas, AS . . . . . . . . . . . . . 3
D ouglas, JDM ............ 70

Douglas, $R \ldots \ldots \ldots \ldots \ldots 10$

Douglas, R B............ 34

Doull, J............ 7, 30, 33

D oumenge, JP . . . . . . . . . 38

Dourson, M J ............. 30

Dovalova, S ............4 43

Doving, K B ............. 11

D ow Chemical Company . . . . . 77

Dowler, JK ............... 9

Downes, $S \ldots \ldots \ldots \ldots \ldots .48$

Downie, JH ............ 43

Doyle, B ............... 17

Doyle, CA .............. 89

Draaisma, D ............. 5

Drache, D ............ 20, 24

Drachmann, JG . . . . . . . . . 32

Dramaix, M ............ . 3, 34

Drancourt, M............ 3

Drapeau, G . ............. 10

Draper, $\mathrm{M} \mathrm{H} \ldots \ldots \ldots \ldots \ldots . \ldots 33$

Draper, SW . . . . . . . . . . . 52

Draper, WM .............27

Dratochvilova, J...........99

Drenth, PJD . . . . . . . . . 4 43, 59

Drever, F . . . . . . . . . 2, 51

Drews, CD .............87

Dreyfus, $] \ldots \ldots \ldots \ldots \ldots . . \ldots$

Dreyfus, M G . ............ 9

Driedger, D . . . . . . . . . . . . . 17

Drinker, DK ............. 30

Drinker, P . ............. 30

D rinkwater , J . . . . . . . . . . 5

Driscoll, RJ .............96

Driscoll, T R . . . . . . . 10, 40, 70

Dröge, C .............. 43

Drouin, $P \ldots \ldots \ldots \ldots \ldots . .68$

Droz, PO ........... 28, 30

Drucker, J . . . . . . . . . . . . 28

Drummond, JN . . . . . . . . . 97

Drummond, $M \ldots \ldots \ldots .20$

Drury, CG . . . . . . . . .......... 29

Drysdale, DD ............ 41

Du M azaubrum, C . ....... 97

Duarte, $G \ldots \ldots \ldots \ldots \ldots 65$

Dubielzig, R R . . . . . . . . . . 28

Dubin, N . . . . . . . . . . . . . . 94

Dubois, D. . . . . . . . . . . . . 42

Dubois, EF . . . . . . . . . . 42

Dubois, F . . . . . . . . . . . . . 10

Dubrow, R . . . . . . . 32, 85, 89

Ducatman, A ........ 13, 77, 81

Ducatman, BS . . . . . . . . . . 81

Ducel, G............... 101

Ducharme, J. . . . . . . . . . . . 52

Duchateau, J .............. 10

Duchene, A ............. 49

Ducic, $G \ldots \ldots \ldots \ldots \ldots 7$

Duck, BW ............. 75

Duckert, L . . . . . . . . . . . 11

Ducoffre, $G \ldots \ldots \ldots \ldots 66$

Ducombs, G........................ 58

Duda, L ............... 58

Dudney, CS . . . . . . . . . . . . 44
Dudney, PJ.............. 13

Dufaut, $A \ldots \ldots \ldots \ldots \ldots 64$

Duffus, JH ............. 33

Duffy, JF ............. 43

Duffy, R M .............. 95

Dufresne, $A \ldots \ldots \ldots \ldots 10$

Duguay, $P$. . . . . . . . . . . . 17

Duh, RW .............. 100

Duhon, D . . . . . . . . . . . 11, 21

Duhra, $P \ldots \ldots \ldots \ldots$....... 89

Dukes-D obos, FN .......... 3

Dumas, EP . . . . . . . . . . . 27

Dumitru, D . .............26

Dummel, K . . . . . . . . . . . . . 68

Dumon, W . . . . . . . . . . . . . . 24

Duncan-jones, $\mathrm{P} \ldots \ldots \ldots \ldots 34$

Duncan, $\mathrm{K} \ldots \ldots \ldots \ldots \ldots 6$

Duncan, M M . . . . . . . . . . . . . 15

Dunette, M D . . . . . . . . . . . 59

Dungworth, DL . . . . . . . . . 10

Dunham, RB . . . . . . . . . . . 34

Dunham, W . . . . . . . . . . . . 42

Dunlop Co . . . . . . . . . . . . 80

Dunlop, J . ............... 21

Dunn, AJ ................ 10

Dunn, CW ............... 79

Dunn, DE ...........11, 47

Dunn, LO ........... 34, 39

Dunnette, D . . . . . . . . . . . . . 35

Dunnette, M D . . . . . . . . . . . 5, 34

Dunnicliff, J . . . . . . . . . . . . 74

Dunning, $\mathrm{H} \ldots \ldots \ldots \ldots . \ldots 21$

Dunphy, BE ............ 90

Dupont, HT . . . . . . . . . . . 3

Dupuis, $\mathrm{H} \ldots \ldots \ldots \ldots, 6,50$

Dupuis, M .............6 6

Dupuy, R . ............. 4

Durafourg, J............. 29

Durao, A ............. 7, 33

Duray, $\mathrm{PH} \ldots \ldots \ldots \ldots \ldots . . \ldots$

Durham, TW............ 5

Durkin, $M \ldots \ldots \ldots \ldots . \ldots 39$

Durnin, JVGA . . . . . . . . . . 68

Durning, AT . . ............ 70

Durocher, LP. . . . . . . . . . . 12

Durrafourg, J . . . . . . . . . . . . . 26

Duru, $G \ldots \ldots \ldots \ldots \ldots . . . \ldots$

Dusseault, M B . . . . . . . . . . . . 74

Dutch $\mathrm{H}$ ealth Council . . . . . . . 49

Duthie, JJR ..............6 6

Duthie, R B............ 6

Dutka, AJ . . . . . . . . . . . . 36

Dutkiewicz, B. . . . . . . . . . . 63

Dutkiewicz, J . . . . . . . . . 38

Dutkiewicz, T . . . . . . . . 63

Dutt, $P \ldots \ldots \ldots \ldots \ldots . . \ldots 6$

Dutta, Ak ................ 70

Dutton, $C B \ldots \ldots \ldots \ldots$

Dutton, JE . . . . . . . . . . . . . . 34

Dutton, RE . . . . . . . . . . . . . 10

Dutton, SL . . . . . . . . . . . . . 9

Duverneuil, G . . . . .........4 43

Duyn, JV . . . . . . . . . . . . 89

Dvorak, J . . . . . . . . . . . . 6
D wyer, JH ............ 51

Dwyer, $T$. . . . . . . . . . . . . 59

Dybdahl, $T$............... 15

Dybuncio, A............. 73

Dybunico, A............. 82

Dycka, J . ............... 9

Dyer, CL . . . . . . . . . . . . . 66

Dyer, L............... 21

Dykes, $\mathrm{M} \mathrm{H} \ldots \ldots \ldots \ldots . . \ldots 9$

Dykes, RW . . . . . . . . . . 11

Dykewicz, CA ........... 10

\section{E}

Eadsforth, CV . . .......... 27

Eagan, CJ.............. 42

Eakin-H offman, J. . . . . . . . . 59

Eakin, JM . . . . . . . . . . . . . 59

Earl, JD ................ 12

Earnest, GS . . . . . . . . . . 100

Eastes, W . . . . . . . . . . . . . . 10

Eastman, Cl . . . . . . . . 43, 102

Eastman K odak Company . . . . 85

Eaton, DL . . . ............ 33

Eaton, JC . . . . . . . . . . . . . . 3

Eaton, WW ........... 5, 34

Ebadat, V . . . . . . . . . . . . . . . 77

Ebbing, $U \ldots \ldots \ldots \ldots \ldots \ldots 43$

Ebert, $K \ldots \ldots \ldots \ldots \ldots \ldots$

Eberts, CG . . . . . . . . . . . . 59

Eberts, R . .......... 34, 52

Eberts, RB . . . . . . . . . . . 59

Ebramzadeh, E . . . . . . . . . 7

Eccles, JL . . . . . . . . . . . . . . . 9

Echt, A . . . . . . . . . . . . . 67

Eckenfelder, WW . . . . . . . . . . 55

Eckenhoff, JE . . . . . . . . . . . . . 97

Eckenrode, J.............. 15

Eckerson, J . . . . . . . . . . . . . . 69

Eckroth, D . . . . . . . . . . . . 22

Eckroth, ET . . . . . . . . . . . . 83

Ecobichon, DJ . ........... 7

Economopoulos, AP . . . . . . . 55

Eddy, I ............... 55

Edel, $P O \ldots \ldots \ldots \ldots \ldots 36$

Edholm, O G . . . . . . . 3, 29, 42

Edington, DW . . .......... 15

Edland, A . .............. 11

Edling, C . . . . . 3, 11, 32, 48, 97

Edmonds, C . . . . . . . . . . . . 36

Edwards, BB ........... 9

Edwards, C . . . . . . . . . . . 89

Edwards, CRW .......... 9

Edwards, FC . . . . . . . . . . 3, 97

Edwards, JR . . . . . . . . . . . . 34

Edwards, JSA . . . . . . . . . . 42

Edwards, ME . . . . . . . . . . . 34

Edwards, P. . . . . . . . . . . 19

Edwards, RHT . . . . . . . . 6

Edwards, RS . . . . . . . . . . 97

Edwards, RW . . . . . . . . . . 34

Edwards, W . . . . . . . . . . . 59

Edworthy, SM ........... 6

Efendiev, FB . .............. 3 
Egalite, ME ............. 38 Egan-Baum, E . . . . . . . . . . . 91 Egan, DE ............. 52 Egbert, DS ............. 28 Egeland, GM .......... 3, 52 Egen, NB . . . . . . . . . . . . 70 Egenaes, J.............. 52 Eggemeier, FT . . . . . . . . . . 29 Eggleston, LA . . . . . . . . . . . 41 Ehlers, $P \ldots \ldots \ldots \ldots \ldots \ldots 4$ Ehling, UH .............. 9 Ehrenberg, R............ 7 Ehrengut, $W \ldots \ldots \ldots \ldots . .97$ Ehrlich, PR ............. 53 Eichenhorn, MS ........... 9 Eicher, LC . . . . . . . . . . . 64 Eicher, RW .............. 57 Eide, $K$ A .............. 97 Eiff, AW................ 3 Eiken, $0 \ldots \ldots \ldots \ldots \ldots \ldots 42$ Eikmann, $T \ldots \ldots \ldots \ldots . \ldots 38$ Eilers, K ............... 29 Einbrodt, HJ ............. 38 Einstein, A . . . . . . . . . . . . 19 Eisen, $E \ldots \ldots \ldots \ldots \ldots . \ldots 32$ Eisen, EA . . . . . . . 10, 30, 91 Eisenbud, $M$. . . . . . . . . . . . . 48 Eisenbud, ME ............ 10 Eisenhardt, D . . . . . . . . . . . 102 Ekberg, PHS .............. 59 Ekblom, B ............. 100 Ekbom, A .............. 4 Ekholm, J..............6 6 Eklund, A . ................ 10

Eklund, JAE............. 17

Ekner, D ............... 87

Eksler, ND ............... 11

El-Ayouby, N . . . . . . . . . . 10

El-Etri, M M . ............11

El Batawi, M A . . . . . . . 64, 93

El H aitem, M . . . . . . . . . . . 96

El Nabout, R . . . . . . . . . . 10 el Said, S ................ 101

Elander, J............... 34

Elbers, $G \ldots \ldots \ldots \ldots \ldots . \ldots 5$

Elder, JA ............... 49

Electronic Industries

Association (EIA) . . . . . . . . 83

Eleftherakis, A . .......... 45

Elfarra, AA . . . . . . . . . . . . 33

Elfstrom, A . . . . . . . . . . 52

Elgstrand, K . . . . . . . . . . . 6

Elias, J ............... 97

Elias, R................. 29

Elinder, C-G ...........6 63

Eliopulos, E ............. 3

Elixhauser, A ............ 15

Elkin, EP . . . . . . . . . . 87

Elkner, K P.............. 9

Ellenbecker, $M \ldots \ldots \ldots$. . . 54, 55, 61

Ellenhorn, MJ ............. 10

Ellermann, K . . . . . . . . . . . . 55

Ellersten, B............... 34

Ellicott, CW . . . . . . . . . . . . . 74
Elling, $\mathrm{RH} \ldots \ldots \ldots \ldots \ldots 23$

Ellinger, $\mathrm{S} \ldots \ldots \ldots \ldots \ldots . \ldots 52$

Ellington, $\mathrm{H} \ldots \ldots \ldots \ldots \ldots . \ldots 18$

Elliot, D . ................. 36

Elliot, $\mathrm{DH} \ldots \ldots \ldots \ldots \ldots 42$

Elliot, $\mathrm{L} \ldots \ldots \ldots \ldots \ldots \ldots$

Elliot, $P \ldots \ldots \ldots \ldots . . \ldots 34$

Elliott, DH .............66 66

Elliott, L . . . . . . . . . . . . . . . 100

Ellis, JL................ 70

Ellis, $L \ldots \ldots \ldots \ldots \ldots \ldots . \ldots 95$

Ellison, EP . . . . . . . . . . . 20

Ellman, $\mathrm{GL} \ldots \ldots \ldots \ldots \ldots 27$

Ellwood, JM . . . . . . . . . . . . . 12

Elofsson, $5 \ldots \ldots \ldots \ldots \ldots$ 7, 34

Elsenhans, B............. 33

Elswood, J ..............6 6

Elvey, R ................5 52

Elwood, PC ........... 3, 89

Ely, B .................29

Elzinga, A ................ 29

Embleton, TFW . . . . . . . . . . . 47

Embrey, DE.............. 59

Emde, $E \ldots \ldots \ldots \ldots \ldots 43$

Emery, FE . . . . . . . . 29, 58

Emery, R ............... 101

Emes, J] .................. 3

Emmanuel, DA ........... 10

Emmett, EA . . . . . . . 34, 49, 53

Emmett, FA . . . . . . . . . . . 27

Empson, J................29 29

Emslie-Smith, D . ........ 42

Enander, A . ............ 42

Enarson, D . . . . . . . . . . 73, 82

Enarson, DA ........... 97

Enderlein, $\mathrm{G} \ldots \ldots \ldots \ldots \ldots 3$

Endresen, C . . . . . . . . . . . . 34

Endresen, IM . . . . . . . . . . . . . 34

Energy Information

Administration ...........75

Eneroth, $P \ldots \ldots \ldots \ldots . \ldots 52$

Eng, E .............. 56

Eng, $P \ldots \ldots \ldots . . . . . . .93$

Engel, A . . . . . . . . . . . . . 6

Engelberg, AL . . . . . . . . 10, 19

Engelen, JJM . . ........... 10

Engelhard, $\mathrm{H} \ldots \ldots \ldots \ldots \ldots 61$

Engels, C . .............21

Engels, $] \ldots \ldots \ldots \ldots \ldots \ldots 97$

Engels, LH . . . . . . . . . . . . . . . 32

Engeström, $Y \ldots \ldots \ldots \ldots 18$

Engholm, G . . . . . . . . . . . . . 93

Englade, J. . . . . . . . . . . . . . 97

England, MJ............. 15

Englander, $V$. . . . . . . . . . . . 85

Englen, M D . . . . . . . . . . . . . 10

Englund, A. . . . . . . . . . . . 93

Englund, $C \ldots \ldots \ldots \ldots \ldots 43$

Engrav, LH ............. 40

Ennever, FK ............ 2

Ennis, JR ..............997

Ennis, M ............ 11

Enos, HR . . . . . . . . . . . . . 27

Ensminger, $\mathrm{ME} \ldots \ldots \ldots \ldots \ldots 70$
Enterline, PE . . . . . . . 10, 89 Entin, AD ............... 5

Entwisle, B . ............. 59

Environment $C$ anada ..... . 54, 55

Environmental Protection

Agency (A ustralia) ......... 74

Environmental, Protection

Agency (EPA).... 10, 33, 48,

$55,77,79,82,83,86,97,100$

Enzmann, D . . . . ......... 34

Epler, GR ............. 10

Epstein, E. . . . . . . . . . . . 101

Epstein, J . . . . . . . . . . . . . . 49

Epstein, PE ............. 10

Epstein, PR . . . . . . . . . . 53

Epstein, R ............ 1, 3

Equal Employment O pportunity Commission (EEOC)...... 16

Erdem, S . . . . . . . . 20, 88

Erdling, $C \ldots \ldots \ldots \ldots \ldots 88$

Erdmann, U . . . . . . . . . . . . . . 3

Erekson, $T \ldots \ldots \ldots \ldots \ldots 17$

Erickson, D . . . . . . . . . . . 5, 15

Erickson, DE . . .......... 67

Erickson, WA . ............ 52

Ericson, A ............. 52

Ericson, K A . . . . . . . . . . . . 29

Ericsson, JLE . . . . . . . . . . . 72

Eriksen, $P \ldots \ldots \ldots \ldots \ldots \ldots .49$

Eriksson, A . . . . . . . . . . . 49

Eriksson, $H \ldots \ldots \ldots \ldots 66$

Eriksson, $M \ldots \ldots \ldots \ldots \ldots 9$

Erkhardt, K ............ 52

Erkinjuntti, T . . . . . . . . 7, 87

Erlich, SM ............. 70

Ermida U riarte, 0 . . . . . . . . . 21

Ernst, E . . . . . . . . . . . . . 97

Ernst, $G \ldots \ldots \ldots \ldots \ldots . \ldots 43$

Ernst, $\mathrm{H} \ldots \ldots \ldots \ldots \ldots \ldots$

Ernst, P . . . . . . . . . . . 10

Ernsting, J ....... 50, 95, 102

Escher, G . .............. 83

Escribà Agüir, V ......... 97

Eshelman, P............. 34

Eskelinen, $\mathrm{K} \ldots \ldots \ldots \ldots \ldots$. . 7

Eskenazi, B. . . . . . . . . . . . 83, 87

Esler, M ................. 34

Esposito, AL. . . . . . . . . . . . . . 10

Essle, $N \ldots \ldots \ldots \ldots \ldots . \ldots 70$

Estabrook, RW ............ 33

Estébanez, P........... 96

Esterman, A . . . . . . . . . . . . 10

Esteve, J . . . . . . . . . 10, 28, 53

Estey, E . . . . . . . . . . . . . . 1

Estil, CF . . . . . . . . . . . . . 100

Estlander, T . . . . . 64, 85, 89

Estlund, B ............ 97

Estryn-Béhar, M ... . 43, 97, 100 Etherton, JR . . . . . . . . . . . 58, 64

Etienne, J............... 3

Etienne, JL . . . . . . . . . . . . 42

Eto, R............... 48

Ettala, M .............. 101

Ettinger, WH . . . . . . . . . 6
Etzel, $R \ldots \ldots \ldots \ldots \ldots . \ldots 53$

Eudy, LW ............. 44

Eure, JA ............... 32

Euro-FIET Commerce Trade

Section............... 99

Eursin, $H \ldots \ldots \ldots \ldots \ldots . \ldots 34$

Euzéby, A. . . . . . . . . . . . . . 26

Evaldre, $M \ldots \ldots \ldots \ldots \ldots 5$

Evang, GW . . . . . . . . . . . . 34

Evang, $K \ldots \ldots \ldots \ldots \ldots 29$

Evans, $G \ldots \ldots \ldots \ldots 6,55$

Evans, $H \ldots \ldots \ldots \ldots \ldots 12$

Evans, J .............. 11

Evans, MJ . . . . . . . . . . . 10

Evans, NJ . . . . . . . . . . . 48

Evans, $0 \ldots \ldots \ldots \ldots . \ldots 34$

Evans, $P \ldots \ldots \ldots \ldots \ldots \ldots 6$

Evans, RI . . . . . . . . . . . . 96

Evans, RW . . . . . . . . . . 96

Eveloff, SE . . . . . . . . . . . 97

Evenson, DP ........... 9

Everett, M A . . . . . . . . . . 49

Everett, $P \ldots \ldots \ldots \ldots$. . . . . . . 34

Everly, GS, Jr. . . . . . . . . . 34

Evers, $G \ldots \ldots \ldots \ldots \ldots . \ldots 34$

Ewing, $A D \ldots \ldots \ldots \ldots \ldots 21$

Ewing, JA .............. 15

Exxon Company . . . . . 78, 82, 102

Eyeland, GM . ........... 89

Eysenck, HJ . . . . . . . . . . . . . . 5

Eyssen, G . . . . . . . . . . . . 59

Ezell, S................. 51

Ezraty, A ............ 97

\section{F}

Fabiano, VL............. 3

Fabro, S............. 9

Factory M utual Engineering

Corporation (FM) . .......41

Faden, $\mathrm{R} \ldots \ldots \ldots \ldots . \ldots 23$

Fadier, E . . . . . . . . . . . . 29

Fagan, J . . . . . . . . . . . . 51

Fagergberg, $G \ldots \ldots \ldots \ldots 15$

Fahs, $M \ldots \ldots \ldots \ldots . \ldots 93$

Fahs, M D . . . . . . . . . . . . 32

Fair, W............... 8

Fait, $A \ldots \ldots \ldots \ldots \ldots 27$

Faivre, M . . . . . . . . ..... 97

Fajen, JM . . . . . . . . 3, 80, 88, 89

Fakhouri, AJ ........... 6

Falagiani, $P$. . . . . . . . . . . 65

Falk, H . . . . . . . . . 39, 56

Falk, SA ............... 97

Falleiros, J . ............ 3

Fallentin, B............66 66

Fallentin, N . . . . . . . . . . . 100

Fallon, F............... 79

Faludi, S. . . . . . . . . . . . . 24

Falzon, P . . ........... 29

Fam, AG .............6 6

Fan, HW . . . . . . . . . . . 38

Fanger, PO .... 42, 44, 45, 97

Fankhauser, $F$. . . . . . . . . . 49 
Fantel, AG . ............ 9 FAO/ECE/ILO Joint

Committee. . .

Faragher, EB ................. 89

Farant, JP. . . . . . . . . . . . . 13

Faravelli, $P \ldots \ldots \ldots \ldots \ldots . . .88$

Farber, BA .............. 34

Farber, SJ ............. 6

Farbtukh, TA . . . . . . . . 38

Farfel, M R ............. 9

Farine, $\mathrm{G} \ldots \ldots \ldots \ldots \ldots \ldots . \ldots 79$

Färkkilä, M .............. 3

Farman, JC ............. 53

Farmer, JJ .............. 97

Farmer, ME .............. 5

Farnsworth, NR .......... 53

Farrell, RA............. 49

Farrington, $P \ldots \ldots \ldots \ldots . .97$

Farris, M T . ............. 102

Farzadegan, $\mathrm{H}$............ 100

Fashoyin, $T$. . . .......... 21

Fathallah, $F \ldots \ldots \ldots \ldots \ldots 80$

Faucett, J . . . . . . . . . . 34

Faucon, D . . . .......... 97

Faught, J .............. 100

Faulkner, DN . . . . . . . . . . 102

Faure, J ................ 97

Faure, $\mathrm{MH} \ldots \ldots \ldots \ldots \ldots . \ldots 10$

Fauske, $\mathrm{S} \ldots \ldots \ldots \ldots \ldots \ldots \ldots$

Faverge, JM ......... 26, 29

Favero, M S ............. 97

Favrot-Laurens, LL . . . . . . . 97

Favus, MJ............... 6

Fawcett, E ............. 19

Fawcett, J .............. 97

Fayerweather, WE .... 19, 28, 63

Fearirheller, SH . . . . . . . . 70

Fears, TR .............. 49

Featherstone, R M . . . . . . . . 27

Fechter, LD . . . . . . . . . 11, 47

Feddes, JJR ............ 70

Feder, RJ ............. 96

Federación Internacional de Empleados, Técnicos y Profesionales (FIET) . . . . . . 99

Federación Internacional de las Sociedades de la Cruz R oja y la M edialuna $R$ oja

(IFRCRCS)....

Federación Internacional de Trabajadores de la Q uímica, Energía e Industrias Diversas (ICEF).

Federal Department of Civil A viation................ 39

Federal Emergency $M$ anagement Agency (FEM A). . . . . . . . . 39

Federal M inistry for Public Economy and Transport . . . 39

Fedotov, I. . . . . . . . . . . 22

Feeley, JC.............. 44

Feeney, A . . . . . . . . . . . . 34

Feffer, $\mathrm{HL} \ldots \ldots \ldots \ldots \ldots . . \ldots 7$

Feigenbaum, AV . ......... 34
Fein, $G \ldots \ldots \ldots \ldots \ldots \ldots$. 9

Fein, $M \ldots \ldots \ldots \ldots . . . .34$

Feinman, SE ............ 80

Feinstein, AR . . . . . . . . . 9, 19

Feitshans, IL . ............23

Felch, LJ................ 15

Feldman, AS . ...........47 47

Feldman, DC . . . . . . . . . . 34

Feldman, $F \ldots \ldots \ldots \ldots \ldots \ldots$

Feldman, HA . . . . . . . . . . . . 10

Feldman, $R \ldots \ldots \ldots . . . .96$

Feldman, RG . . . . . . . . . . 7

Feldman, RH . . . . . . . . . . . 34

Felice, LJ . . . . . . . . . . . . . 27

Fellenius, E. . . . . . . . . . 6

Fellin, $P \ldots \ldots \ldots \ldots \ldots 44$

Fellingham, SA .......... 3

Fellner, D . . . . . . . . . . . . . . 59

Felson, DT . . . . . . . . . . 6

Felton, JS ............... 16

Fengolio-Preiser, C . . ....... 10

Fenichel, GM . . . . . . . . . . . 7

Fenley, M A . . . . . . . . . . . . . 51

Fenoglio, S ............. 80

Fenske, R . . . . . . . . . . . . . 64

Fenske, RA.......... . 9, 32

Fenster, L . . . . . . . . . . . . . 34, 52

Feo, $0 \ldots \ldots \ldots \ldots \ldots 7$

Fera, MA ............. 11

Ferber, M A . . . . . . . . . . . . . 34

Fergusen, $T \ldots \ldots \ldots \ldots \ldots 5$

Ferguson, $A B J \ldots \ldots \ldots \ldots 6$

Ferguson, $H \ldots \ldots \ldots \ldots \ldots 6$

Ferguson, IR ............. 70

Ferguson, SA . ........... 80

Ferguson, $T \ldots \ldots \ldots \ldots \ldots .70$

Ferguson, TS . . . . . . . . . . . . 64

Fergusson, JE . . . . . . . . . 33

Ferioli, A . ............ 9, 27

Ferlay, J ............ 1, 4, 10

Fermand, S . ............. 97

Fernández Guerrero, M L . . . . . . 3

Fernández, E . . . . . . . . . . . . 4

Fernández, JP . . . . . . . . . 34

Fernández-C aldas, E . . . . . . . 70

Fernando, DN . . . . . . . . . . . . 97

Feron, VJ ......... 30, 90, 100

Ferrari, $S \ldots \ldots \ldots \ldots \ldots . . . . . . . .43$

Ferrario, M ............4 43

Ferrario, $P \ldots \ldots \ldots \ldots \ldots 52$

Ferraris, F . . . . . . . . 88

Ferrel, J ................. 33

Ferrer, L. . . . . . . . . . . . . . 53

Ferris, GR ............21

Ferris, JR . . . . . . . . . . . . 72

Ferro, $G \ldots \ldots \ldots \ldots \ldots 10,82$

Ferro, R .............. 63

Ferry, $T \ldots \ldots \ldots \ldots \ldots . \ldots 18$

Ferry, TS .............. 56

Ferstandig . . . .......... 97

Feucht, $\mathrm{H} \ldots \ldots \ldots \ldots \ldots . . .97$

Feuerstein, C . . . . . . . . . . . 42

Feustel, PJ . ............. 10

Feyer, A-M . . . . . . . . . . . 56
Feyereisen, R . . . . . . . . . 33

Fialka, V. . . . . . . . . . . . . . 97

Fidler, AT . .............6 64

Fiechtner, JJ ............. 6

Fiedler, FE . . . . . . . . . . . . . . 34

Fiedler, $\mathrm{N} \ldots \ldots \ldots \ldots \ldots \ldots . .13$

Fiedler, NL . . . . . . . . . . . . . . . . . . 13

Fiedler, RC . .......... 3, 95

Fiedles, BN . . . . . . . . . . . . 97

Field, $P \ldots \ldots \ldots \ldots \ldots \ldots 6$

Field, RHG . . . . . . . . . . 59

Field, WE . . . . . . . . . . . . 64

Fielder, RC . ...........91

Fielding, JE . . . . . . . . 3, 15, 34

Fieldman, $G \ldots \ldots \ldots \ldots \ldots 34$

Fieldner, AC . ........... 30

Fields, H A . . . . . . . . . . . 97

Fields, LL . . . . . . . . . . . . . . 66

Fies.................. 11

Fievet, C............... 3

Fife, D . . . . . . . . . . . . . 14

Figgs, LW . . . . . . . . . . . . . 32

Figley, CR .............. 34

Figueroa, JP . . . . . . . . . . 8 81

Filion, $R \ldots \ldots \ldots \ldots \ldots 10$

Fillenbaum, $G \ldots \ldots \ldots \ldots .5$

Findlay, PC ............. 3

Fine, $A \ldots \ldots \ldots \ldots \ldots . . \ldots 10$

Fine, IJ ............... 72

Fine, JM . . . . . . . . . . . . . . 11

Fine, JT ............. 10

Fine, $L \ldots \ldots \ldots 6,10,34,38,52$

Fine, LJ . ... 6, 28, 29, 32, 34, 80

Finestone, AJ . . . . . . . . . . 5, 34

Fingerhut, $M \ldots \ldots \ldots \ldots 88$

Fingscheidt, $E \ldots \ldots \ldots . .97$

Fink, JN .......... 10, 80, 101

Fink, R . . . . . . . . . . . . . . 77

Finkel, AJ . . . . . . . . . . . . . 4

Finkelman, J. . . . . . . . . 53

Finkelstein, M N . . . . . . . . . 73

Finkelstein, SN . . . . . . . . . . 5

Finklea, JA . . . . . . . . . . . . . . 30

Finley, B............... 30

Finley, GA . . . . . . . . . . . . 97

Finnegan, M . . . . . . . . . . . 13

Finnic, J . . . . . . . . . . . . . . 49

Finnigan, JP . . . . . . . . . . . . . 34

Finulli, $M \ldots \ldots \ldots \ldots \ldots 10$

Fiorino, F . . . . . . . . . . . 15

Fiorio, A . . . . . . . . . . . 88

Firenze, RJ . . . . . . . . . . . 30

Firth, R .............. 102

Firth-C ozens, J. . . . . . . 34, 97

Fischbach, $T \ldots \ldots \ldots \ldots \ldots \ldots 7$

Fischbein, A . . . . . . . . . . 9

Fischbein, AS . . . . . . . . . . . 9

Fischer, D. . . . . . . . . 23, 46

Fischer, E . . . . . . . . . . . . . 32

Fischer, JJ.............. 10

FIscher-H och, SP ......... 10

Fischhoff, B . . . . . . . . . . . . 59

Fischman, M L . . . . . . . . . . . 83

Fiserova-Berferova, $\vee \ldots \ldots .27,30$
Fiset, J-Y . . . . . . . . . 52

Fishbeck, W . . . . . . . . . . . . 15

Fishbein, M ............ 96

Fisher, AA . . . . . . . . 80, 96

Fisher, C . . ............. 34

Fisher, LD . . . . . . . . . . . . . 3

Fisher, R . . . . . . . . . . . 21

Fisher, S......... 29, 34, 93

Fisher, $\mathrm{T}$. . . . . . . . . . . . . . . 97

Fisher, $Y \mathrm{~L} \ldots \ldots \ldots \ldots \ldots 49$

Fishman, AP . . . . . . . . . . . . 37

Fishman, D . . . . . . . . . . . 34

Fishoff, DA . . . . . . . . . . . . . 77

Fishwick, D . . . . . . . . . . . . 89

Fisk, GH . . . . . . . . . . . . 79

Fitch, K .......... 96, 97

Fitsimmons, J . . . . . . . . . 9

Fitzgerald, LF . . . . . . . . 34

Fitzgerald, $M X \ldots \ldots \ldots \ldots 10$

Fitzgerald, RO ........... 68

Fitzpatrick, TB . . . . . . . . . 49

Fitzsimons, M P . . . . . . . . 79

Fjeldstad, $P \ldots \ldots \ldots \ldots \ldots .61$

Flamm, K.............. 20

Flamm, WG ............. 2

Flanagan, JL . . . . . . . . . . 29

Flanagan, 0 . . . . . . . . . . . 59

Flannery, JT . . . . . . . . . . . . 100

Flannigan, B. . . . . . . . 13, 44

Flatt, M ............. 83

Flavin, DK .............. 15

Flawans, HL . . . . . . . . . . 7

Flay, BR . . . . . . . . . . . . 34

Flechter, B . . . . . . . . . . . . . 34

Fleeger, A . . . . . . . . . . . 64

Flegal, K M .............. 9

Fleishman, EA . . . . . . . . . . 29

Flemming, D $0 \ldots \ldots \ldots \ldots 77$

Flemming, LE ............. 1

Flemming, NC . . . . . . . . 66

Flesch, JP . . . . . . . . . . . . . 81

Fletcher, AC ....... 10, 30, 73

Fletcher, AM . . . . . . . . . . . . 89

Fletcher, B . . . . . . . . . . 100

Fletcher, GF . . . . . . . . . . . 17

Flickinger, JC . . . . . . . . . . . 4

Fliedner, TM . . . . . . . . . . 43

Flipp, N . . . . . . . . . . . 83

Flodin, $U \ldots \ldots \ldots \ldots \ldots$ 7, 88

Flomenbaum, NE . . . . . . . . 10

Florentine, MJ . . . . . . . . . . 9

Florian, $\mathrm{HJ} \ldots \ldots \ldots \ldots \ldots 68$

Floyd, H H . . . . . . . . . . . 97

Floyd, M ...............96 96

Floyd, T . . . . . . . . . . . 53

Flügel, B............... 29

Flügge, $R \ldots \ldots \ldots \ldots \ldots 43$

Flury, $F \ldots \ldots \ldots \ldots . \ldots 30$

Flyvholm, M -A ......... 100

Foa, EB .............. 51

Foá, PP...............6 6

Foà, $V \ldots \ldots \ldots \ldots \ldots \ldots \ldots, 27$

Foarde, $K \ldots \ldots \ldots \ldots \ldots \ldots$

Fobelets, AP . . . . . . . . 42 
Focks, DA $\ldots \ldots \ldots \ldots \ldots 53$ Fodor, I ..............41 Fog, $P \ldots \ldots \ldots \ldots \ldots \ldots 11$ Fogel, $C \ldots \ldots \ldots \ldots \ldots 101$ Fogelman, I ............6 6 Fogelmark, B . . . . . . . . . 10 Fogg, LF............... 34 Foglis, TA ............. 70 Folb, PI ...............11 Folgering, HTM .........6 64 Foliart, D ................. 10 Folkard, S. . . . . . . 29, 34, 43 Folke, C ...............6 64 Folkman, S. . . . . . . . . . . . 34 Follen, M A . ............. 70 Folliot, D ............... 40 Folse, JR ............... 97 Fomon, JS .............. 9 Fonchain, F . ........... 97 Fondo de Población de las

$N$ aciones U nidas (U NFPA) . 24

Fondo Sueco para el M edio A mbiente de T rabajo

[A rbetarskyddsfonden] .... . 56 Fondo sueco para el M edio

A mbiente de T rabajo . . . . . . 44 Fone, C . . . . . . . . . . . . . . 77

Foner, PS ..............21

Foo, SC ................. 11

Food and Drug Administration

(FDA) .............. 15

Food and Nutrition Board. . . . 66

Foran, J ............ 54, 55

Forastiere, F............6 63

Forastieri, V . . . . . . . . . 24

Forberg, $0 \ldots \ldots \ldots \ldots \ldots 11$

Forbes, DF . . . . . . . . . . 49

Forbes, PD . . . . . . . . . . 49

Forcier, $L \ldots \ldots \ldots \ldots \ldots \ldots .6$

Forconi, G ............ 101

Ford, C.............. 96

Ford, CV ..............97 97

Ford, DL ................ 34

Ford, DP .............. 11

Ford-Jones, L . . . . . . . . . . . 38

Forest Engineering W orking

Group of South Africa (FESA)

68

Foret, $\mathrm{J} \ldots \ldots \ldots \ldots \ldots \ldots 43$

Forget, $G \ldots \ldots \ldots \ldots . .38,64$

Forgotson, EH . . . . . . . . 48

Forman, SA ............... 3

Fornazzari, $L \ldots \ldots \ldots \ldots \ldots \ldots 11$

Forrest, $P \ldots \ldots \ldots \ldots \ldots . . \ldots 15$

Forsman, L. . . . . . . . . . . . . . 34

Forsman, S. . . . . . . . . . . 64

Forst, L. . . . . . . . . . . . . . . 89

Forster, $\mathrm{H} \ldots \ldots \ldots \ldots \ldots$. . . . . 38

Forth, W ................ 33

Fortmann, RC . . . . . . . . . 9

Fosbroke, D ..............56 56

Fosbroke, DE . . . . . . . . . . 93

Foudin, AS. ............. 77

Fouillot, JP . . . . . . . . . . . . 97
Foulds, IS ............ 89

Fouriaud, C . .............. 3

Fournier, $C \ldots \ldots \ldots \ldots 34$

Fournier-Betz, M . . . . . . . 3, 63

Fourré, $L \ldots \ldots \ldots \ldots \ldots .43$

Foussereau, J ............ 100

Fowinkle, FJ . . . . . . . . . . 15

Fowler, BA.............. 1

Fowler, $C \ldots \ldots \ldots \ldots \ldots 32$

Fowler, D . . . . . . . . 71, 72

Fowler, HE . .............8 85

Fowler, JF, Jr . . . . . . . . . 12

Fowler, SR . . . . . . . . ..... 42

Fox, AJ ....... 7, 34, 80, 89

Fox, BH ............... 34

Fox, DK ...............6 60

Fox, DL .............. 55

Fox, JG........ 38, 42, 43, 70

Fox, M B..............21

Fox, SL ...............11

Frada, G................ 4

Fradkin, GE . . . . . . . . . . . . 33

Franc, M .............. 97

Franca, FOS ............. 38

Franceschetti, G . . . . . . 49

Francesconi, R P . . . . . . . . 42

Franchini, M ............ 89

Francioli, D . . . . . . . . . . . 52

Francioli, P. . . . . . . . . . . . 97

Francis, TJR ......... 36, 42

Franck, C............... 13

Franck, IM . . . . . . . . . . . 64

François, M .............26

Francois, $P$. . . . . . . . . . . . . 34

Frandenhaeuser, M . ........ 5

Frank, AL. . . . . . . . . . . . . . 52

Frank, ME .............. 11

Frank, R . . . . . . . . . . . . . . . 19

Frank, R G . . . . . . . . . . . 34

Franke, A . . . . . . . . . . . . . 56

Franke, D . .............. 13

Franke, WD . . . . . . . . . . . . 95

Frankel, M S. . . . . . . . . . . . . 19

Frankenhaeuser, M . . . . . 34, 99

Franklin, CM . ..............6

Franklin, J . . . . . . . . . . . . . . 74

Frankos, V ............... 33

Frankowski, RF . . . . . . . . . . 72

Franks, JR .......... 31, 47

Franssen, AC . . . . . . . . . . . 63

Fransway, AF . . . . . . . . . 97

Frantz, JP . . . . . . . . . . . 56, 59

Fraser, D . . . . . . . . . . . . . . 40

Fraser, J ................ 32

Fraser, JG . . . . . . . . . . . . . 9

Fraser, $P \ldots \ldots \ldots \ldots . . . \ldots 10$

Fraser, RG . . . . . . . . . . . . . 10

Fraser, RS ............... 10

Fraser, TM . . . . . . . . . . . . . 29

Fraser, WJ .............. 79

Fratiglioni, L . . . . . . . . . . . 7

Frauendorf, $\mathrm{H} \ldots \ldots \ldots \ldots \ldots .3$

Fraumeni, J . . . . 2, 4, 12, 28, 100

Fraust, $C L \ldots \ldots \ldots \ldots \ldots . .83$
Frazier, CA ............ 70

Frazier, JM .............. 33

Frazier, K.............. 39

Frazier, T . . . . . ........ 32

Frederiksen, M . . . . . . . . . . 59

Fredlund, $P \ldots \ldots \ldots \ldots \ldots . . .34$

Fredriksson, $M \ldots \ldots \ldots .7,34,72$

Freeberg, M H ...........66 66

Freed, $V \ldots \ldots \ldots \ldots \ldots \ldots 64$

Freedman, B . . . .......... 103

Freedman, SM . . . . . . . . . . . . 35

Freeman, CS . . . . . . . . . . 81

Freeman, G . . . . . . . . . . . . . 10

Freeman, K . . . . . . . . . . . . 97

Freeman, RS . . . . . . . . . . . . 49

Freemann, K . . . . . . . . . . . . 97

Freemantle, N ............. 20

Freestone, D. . . . . . . . . . . . . 54

Freeze, RA . ............. 55

Fregert, S . . . . . . . . . . . . 93

Freidrich Naumann

Foundation ............. 39

Freifelder, D . . . . . . . . . . . . . 77

Freimark, S . . . . . . . . . . . 52

Freire, $P \ldots \ldots \ldots \ldots \ldots . .59$

Freis, JF . ........... 6, 15

Freivalds, A . . . . . . . . 29, 64

Freixa, A ............. 44

French, D . . . . . . . . . . . . . 34

French, J ................. 39

French, JG .............. 7

French, JR P . . . . . . . . . 29, 29, 34

French, KA ............82

French, M A . . . . . . . . . . . . 97

French, WL . . . . . . . . . . . 34

Frenkel, S. . . . . . . . . . . . . . . 21

Frentzel-Beyme, R . . . . . . . . . 10

Frese, $M$. . . . . . . . . . 34, 43, 52

Fresenius, J . . . . . . . . . . . . . . 55

Fresenius, Z . . . . . . . . . . 55

Fretz, P. . . . . . . . . . . 70

Freudenberger, HJ . ........ 5

Freund, E. . . . . . . . . . 32, 58

Frey, C..............6 6

Friber, $L \ldots \ldots \ldots \ldots \ldots \ldots . \ldots 53$

Friberg, L. . . . . . . . . . . . 27, 63

Fried, C . . . . . . . . . . . . . 19

Fried, $Y \ldots \ldots \ldots \ldots \ldots \ldots \ldots 34$

Friedberg, W . . . . . . . . . 102

Friedenwald, JS . . . . . . . . . . 48

Friedland, JM . . . . . . . . . 28

Friedlander, BR . . . . . . . . 85

Friedman, DE . . . . . . . . . . . 34

Friedman, HS . . . . . . . . . . . 34

Friedman, J . . . . . . . . . . . . . . 34

Friedman, M . . . . . . . . . . 5, 34

Friedman, R.............. 34

Friedman, RC . . . . . . . . . 97

Friedman, W . . . . . . . . . . . 23

Friedman-J imenez, G . . . . . . 87

Friedrichsen, $\mathrm{G} \ldots \ldots \ldots \ldots .43$

Friele, RD ............. 97

Frielingsdorf, $R \ldots \ldots \ldots \ldots 43$

Fries, JF . . . . . . . . . . . 6
Frigul, $N \ldots \ldots \ldots \ldots \ldots 100$

Frimat, $P \ldots \ldots \ldots \ldots \ldots 12$

Frimodt-M uller, $B$. . . . . . . . . 42

Frings-D resen, $\mathrm{M} \mathrm{H} \mathrm{W} \ldots \ldots \ldots 29$

Frischer, $T \ldots \ldots \ldots \ldots \ldots . . . .9$

Friscoll, R..............96

Fritze, $E \ldots \ldots \ldots \ldots \ldots \ldots \ldots$

Fröberg, J............. 29, 43

Frocki, IJ . ............... 97

Frödin, $T \ldots \ldots \ldots \ldots \ldots \ldots$

Froeb, HF . . . . . . . . . . . 44

Froehlich, PA . . . . . . . . . . . 70

Froggatt, KL . . . . . . . . . . 29

Froines, JR . . . . . . . . . . . . 32

Frölén, $H \ldots \ldots \ldots \ldots \ldots . . . \ldots 2$

Frommer, MS . . . . . . . . . 40, 70

Fromzel, VA . . .......... 49

Frondel, $C \ldots \ldots \ldots \ldots \ldots 10$

Froom, P .............. 102

Froomberg, $\mathrm{H} \ldots \ldots \ldots \ldots .9$

Frosch, PJ.......... 33, 64

Fruchart, JC ............. 3

Frumin, E. . . . . . . . . . . . . 88

Frumkin, $\mathrm{H} \ldots \ldots \ldots \ldots 2,53$

Fruscella, J . . . . . . . . . . 102

Fry, HJH $\ldots \ldots \ldots \ldots \ldots . \ldots 52$

Fry, SA . . . . . . . . . . . . 48

Fryar, C . .............. 10

Frye, $\mathrm{HJH} \ldots \ldots \ldots \ldots \ldots 96$

Fryer, D . . . . . . . . . . . . . 34

Frymoyer, JF . . . . . . . . . 6

Frymoyer, JW . . ............ 97

$\mathrm{Fu}, \mathrm{H} \ldots \ldots \ldots \ldots \ldots . \ldots 8$

$\mathrm{Fu}, \mathrm{KH} \ldots \ldots \ldots \ldots \ldots 28$

Fubini, $B \ldots \ldots \ldots \ldots \ldots$

Fuchs, $S \ldots \ldots \ldots \ldots \ldots \ldots$

Fuchs, V . . . . . . . . . . . 20

Fueredi, GA . . . . . . . . . . . 36

Fuerst, $R \ldots \ldots \ldots \ldots \ldots . \ldots 38$

Fuglesang, A . ........... 29

Fuji-K uriyama, $Y \ldots \ldots \ldots . . .33$

Fujinami, $T \ldots \ldots \ldots \ldots \ldots 5$

Fujinawa, A ............. 5

Fujita, $0 \ldots \ldots \ldots \ldots \ldots \ldots$

Fujita, $\mathrm{S} \ldots \ldots \ldots \ldots \ldots \ldots 10$

Fuks, $Z \ldots \ldots \ldots \ldots \ldots \ldots$

Fukuzaki, $\mathrm{H} \ldots \ldots \ldots \ldots \ldots . . \ldots$

Fuller, FH . . . . . . . . . . 42

Fuller, M ............... 39

Fullerton, CS ......... 39, 100

Fulton, JA ............. 83

Fulwood, R ............ 15

Fund, DA . ............ 6

Fundación Alemana para el

D esarrollo Internacional . . . . 74

Fundación Europea para la

M ejora de las $C$ ondiciones

de Vida y Trabajo . . . 15, 18, 34

Fundación para la Salud en el

T rabajo de AFL-CIO . . . . . 17

Fung, DYC .............4

Fung, $K \ldots \ldots \ldots \ldots \ldots 28$

Fung, $Y B \ldots \ldots \ldots \ldots \ldots 6$

Fung, $Y C \ldots \ldots \ldots \ldots \ldots \ldots \ldots 6$ 
Funk, SC .............. 34 Funkemeyer, M . . . . . . . . . . . 74 Fuortes, L.............. 32 Furby, $L \ldots \ldots \ldots \ldots \ldots \ldots$ Furey, JG ............. 6 Furlan, R ............... 34 Furner, S . ............. 97 Furon, D ............... 3 Fusi, S . ............... 11 Fusilier, M R . . . . . . . . . . . 34 Fyfe, $A \ldots \ldots \ldots \ldots \ldots .68$

\section{G}

Gaardboe, $0 \ldots \ldots \ldots \ldots 87$

Gabel, VP ............... 49

Gabel-H ughes, K S. . . . . . . . . 51

Gablenz-K olakovic, S . . . . . . . 34

G äbler, H . . . . . . . . . . . . . 68

Gaborieau, D . . . ......... 97

Gaborieau, J. . . . . . . . . . . 97

Gacharna, M G ............ 53

Gad, SC ............... 33

Gadaskina, ID . . . . . . . . . 33

Gadbois, C . . . . . . . . 29, 43, 97

Gaensler, EA . . . . . . . . . . . 10

Gaffey, W.............. 100

Gaffney, K .............. 97

Gaffuri, E.............. 43

Gaffuri, FE............ 27

Gage, JC .............. 27

Gagge, AP . . . . . . . . . . . 42

Gaglione, P ............. 10

Gagnon, M .............. 5

Gagnon, P ............. 11

Gaines, BR . . . . . . . . . . . . 52

Gais, $P \ldots \ldots \ldots \ldots \ldots . \ldots 6$

Galal-G orchev, $H \ldots \ldots \ldots . \ldots 53$

Gale, AG ................ 11

Gales, R.............66 66

Galinsky, E.............. 34

Galinsky, T ............ 34

Galitis, M M .............. 73

Gallacher, JEJ ............ 3

Gallagher, RF ............ 32

Gallagher, R P . . . . . . . . . 100

Gallant, M ............. 33

Gallant, S............... 34

Galloway, M T ............ 6

Gallwey, T ............. 43

Galsbeek, H . . . . . . . . . 20, 24

Galvin, DE............. 17

Gamberale, F.......... 3, 7

Gambini, G ............. 79

Gamble, G0 ............ 34

Gamble, J.............. 28

Gamble, JF............... 80

Gamboa, PM ............. 100

Games, WP .............. 97

Gammage, R B ........... . 45

Gammaige, R B ........... 44

Gamsky, T . ............. 70

Ganau, A ............... 34

Gandevia, B............. 89
Gandhi, OP ............ 49

Gandolfi, A ..............4 4

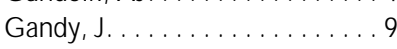

Gange, RW ............. 49

Gann, PH. . . . . . . . . . . . . 44

Gans, C ............... 38

Gans, K A . . . . . . . . . . . 38

Ganster, D . . . . . . . . . . . . 19

Ganster, DC .............. 34

Gao, F ............... 53

Garabrant, D . . . . . . . . . . 88

Garabrant, DH ............ 3

Garasto, G . ............. 27

Garber, N .............. 38

Garcia Padros, M ......... 96

Garcia, BE ............. 100

Garcia, JE ............... 34

Garcia, JGN . . . . . . . . . . . 73, 82

Garcia, M M ............. . 74

Garcia, R...............9 9

Gardell, B......... 5, 34, 52

Gardenghi, B ........... 100

Gardiner, $H \ldots \ldots \ldots \ldots . \ldots 53$

Gardiner, K ............ 46

Gardiner, M M . ........... 52

Gardner, DG . . . . . . . . . . . . 34

Gardner, ER . . ..........97 97

Gardner, M J . . . . . . 3, 10, 28, 48

Gärdsell, $P \ldots \ldots \ldots \ldots \ldots 6$

Gareau, $Y$................ 33

Garfinkel, L . . . . . . . . . . 15, 28

Garg, A ............6, 29

Garg, N ............63,64

Garner, JS .............. 97

Garrick, JM .............. 96

Garrison, R ............ . 5, 34

Garrity, D ................ 13

Garside, R .............. 40

Gartside, P............... 10

Gary, C .............. 40

Gary, $\mathrm{H}, \mathrm{J}$. .............. 10

Garzia, HW . ............ 77

Gaskin, JE . . . . . . . . . . . . . 68

Gaston, SR . . . . . . . . . . . . . . 49

Gates, LB . . . . . . . . . . . . . . . 17

Gatter, RA . . . . . . . . . . . . . 6

Gaube, J.............. 97

Gaudichet, A . ........... 10

Gaultier, M ..............4

Gaultney, LD . . . . . . . . . . . . . 64

Gauthier, J-M .......... 68

Gauthier, R . . . . . . . . . . . . 52

Gautrat, J . . . . . . . . . . . . . 29

Gauvain-Piquard, A . . . . . . . . 97

Gawkrodger, DJ........... 100

Gay, C ............... 77

Gaydos, JC.............. 95

Gaylor, D . . . . . . . . . . . 33

Gaylor, DH ............. 18

Gaylor, DW .............. 33

Gazenko, O G ............. 37

Gebrewold, A.............. 3

Gebski, V . ............. 49

Geddes, M . . . . . . . . . . . . . 89
Gee, BL ............... 10

Gee, D .................. 21

G eeraets, WJ . . . . . . . . . . . . 49

Geertz, C . ...............29

Gehring, PJ . ......... 30, 33

Geiger, SK .............. 19

Geiser, K ........... 54, 55

Gelberman, $R \ldots \ldots \ldots \ldots 6$

Gelboin, HV ............. 33

Gelbrich, W.............. 3

Geller, AC ................12

Geller, ES. ............... 60

Gellermann, W ........... 19

G ellerstedt, S . . . . . . . . . . . . . 68

Gellin, GA . . . . . . . . 12, 96, 101

Gemne, $G \ldots \ldots \ldots \ldots . \ldots 3,6$

Gendrop, SC ............. 34

Gennarelli, TA. . . . . . . . . . . . 14

Gennaro, A .............. 79

Gentile, IW ............... 9

Gentner, NE . . . . . . . . . . . . 53

Gentry, JJ ............... 102

Gentry, WD ............... 34

Geoghegan, GR ............ 5

George, JM .............. 34

George, RB .............. 64

George, WS . . . . . . . . . . . . 90

Georgii, HW .............. 55

Georgotas, A . ............. 5

Gerain, J ................. 10

Gerardi, M A .............. 34

Gerasimova, IL . ............6 63

Gerber, M A . . . . . . . . . . . . . 97

Gerber, WS ............. . 80

Gerberding, JL............ 97

Gerencser, VF . . . . . . . . . . . 38

Gerger, AJ . . . . . . . . . . . . . 28

Gérin, $M \ldots \ldots \ldots 1,4,12,28,30$,

$72,89,100$

Germain, GL . . . . . . . . . . . . . 16

German, $P$.............. 59

Germer, J . . . . . . . . . . . . . . 58

Germer, WD .............. 3

Germino, VH ........ 10, 89

Gerrard, $S \ldots \ldots \ldots \ldots \ldots 66$

Gerrits, JPG . . . . . . . . . . . 64

Gershman, J.............. 20

Gershon, RRM ............ 100

Gershon-C ohen, J . . . . . . . . 64

Gerson, R................ 5

Gerstle, FF . . . . . . . . . . . 97

Gert, B............... 19

Gerusky, $T \ldots \ldots \ldots \ldots \ldots 48$

Gervais, M ............. 100

Gestal, JJ .................997

Getchell, TV . . . . . . . . . . . . . 11

Getty, L . . . . . . . . . . . . . . . 17

Gewirth, A ............. 19

Gezonheidsraad (Consejo de

Salud de los Países Bajos) . . . 49

Ghane, $\mathrm{V}$

G hata, JN . . . . . . . . . . . . . . . 43

Ghezzo, H ............. 10

Ghosh, PK . . . . . . . . . . . 75
Ghosh, SK ............. 64

Ghyselen, JP. . . . . . . . . . . . . 81

Giamello, E .............. 10

Gianelli, M . .............. 11

Giannini, CA . . . . . . . . . . . . . 5

Gibbs, $A \ldots \ldots \ldots \ldots \ldots . \ldots 9$

Gibbs, $A E \ldots \ldots \ldots \ldots 10$

Gibbs, $G \ldots \ldots \ldots \ldots \ldots 10$

Gibbs, T . . . . . . . . . . . . . 10

Gibbs, WE .............. 10

Gibson, GG . . . . . . . . . . . . . 33

Gibson, JE . . . . . . . . . . . . 30

Gibson, JJ................ 60

Gibson, SJ .............. 52

Gibson, T.............. 6

Gideon, JA . . . . . . . . . . . . . . 30

Gielen, AC . . . . . . . . . . . . 56

Giere, R N . . . . . . . . . . . . 28

Gierke, HE............. 3

Gies, H P............... 49

G iesser-W eigt, M . . . . . . . . . 102

Giguère, $D \ldots \ldots \ldots \ldots \ldots 68$

Gilad, I................ 29

Gilbert, AN ............... 11

Gilbert, ES............. 9, 39

Gilbertini, M . ........... 15

Gilbertson, TA . . . . . . . . . . 11

Gilby, PG .............. 63

Gilchrist, JD . . . . . . . . . . . . . . 74

Gilet, JC . . . . . . . . . . . . 40, 45

Gilioli, R .............. 7

Gill, C ................21

Gill, JJ ................. 34

Gill, N ................ 97

Gill, 0 N . ................ 70

Gill, WL . . . . . . . . . . . . . . 99

Gillberg, M .........29, 43

Gillenwater, JY . . . . . . . . . 8

Gilleo, K ............... 83

Gilles, HM ............... 53

Gillespie, I . . . . . . . . . . . . . 97

Gillespie, JR . . . . . . . . . . . . 70

Gillin, JC . . . . . . . . . . . . . . 34

Gillis, CR ............... 3

Gilman, E . . . . . . . . . . . . . 77

Gilman, JA . . . . . . . . . . . . . 79

Gilsanz, V . . . . . . . . . . . . . 39

Gilson, JC . . . . . . . . . . 10, 89

Giltvedt, J.............. 80

Gima, AS ................. 3

Gimmercman, A .......... 53

Ginanni, R . . . . . . . . . . . . . . 10

Ginesta, J . . . . . . . . . . . . . . . 97

Gingras, S . . . . . . . . . . 87, 97

Ginsberg, G . . . . . . . . . . 83

Ginsberg, $H \ldots \ldots \ldots \ldots . . . .97$

Ginsburg, CM .......... 9, 10

Ginsburg, KS ........... 3

Ginsburg, MJ ............ 56

Giogino, R ............. 9

Giorgi, M . ............. 97

Gir, E................. 101

Girard, AM ............. 26

Girard, DM . ............. 9 
Girault, $P \ldots \ldots \ldots \ldots \ldots \ldots 43$

Girgis, K .............. 63

Giri, K ............... 24

Girier-D esportes, C . . . . ... 97

Girlanda, P ............. 7

Giroire, JM .............. 5

Girot, J............... 97

Giroux, D..............9 9

Giroux, L ............... 52

Gisolfi, CV ............. 42

Gite, LP ............... 64

Gitterman, A . . . . . . . . . . . . 15

Giullemin, M P . . . . . . . . . . 65

Giusti, CW . . . . . . . . . . . . . 97

Givon, R .............. 3

Givoni, B .............. 42

Gladen, BC .............. 9

Gladstone, A . . . . . . . . . . . . 21

Gladstone, L . . . . . . . . . . 15

Glaister, DH ............. 102

Glantz, SA . . . . . . . . . . . 3, 15

Glanz, K ............... 15

Glascock, LA . . . . . . . . . . . 64

Glaser, R ................ 34

Glasgow, GP ............63 63

Glasgow, RE ............. 3

Glass, DC ............... 30

Glass, RI ............... 39

Glass, $S \ldots \ldots \ldots \ldots \ldots 68$

Glass, WI . .............. 20

G latstein, EJ . . . . . . . . . . 10

Glazer, E . . . . . . . . . . . . . . 85

Glazer, M............... 19

Gleanson, R . . . . . . . . . . . . 93

Gleason, JF . . . . . . . . . . . 53

Gleeson, K . ................ 37

G leick, J . . . . . . . . . . . . . . . 57

Glendon, Al . . . . . . . 56, 59, 66

Glenn, B............ 54, 55

Glenn, CG . . . . . . . . . . . 29

Glenn, ES ............. 29

Glew, RH .............. 97

Glick, JL................. 19

Glick, WH .............. 59

Glickman, LT ............ 28

Glied, S ................ 15

G lindmeyer, H W . . . . . . 10, 89

Global Environmental

M onitoring System

(GEM S/ Air) (Sistema

$M$ undial de $V$ igilancia

Ambiental/ Aire) . . . . . . . . . . 55

Gloyne, SR ............. 28

Glynn, RJ ............... 5

Goble, W ................ 58

Gochfeld, M ............ . 9

Godaert, GLR ............. 34

Godbold, JG ............. 98

Goddard, J . . . . . . . . . . . . . 70

Goddard, JC .............89

Godfrey, J .............. 15

Godish, T . . . ............. 44

Goeh-A kue-Gad, M M . . . . . . . 97

Goelzer, B . . . . . . . . . . . . . . 16
Goetzel, RZ . . . . . . . . . . . . 15

Goguelin, P .............59

Goh, CL............ 52, 83

Goh, LG ..............88

Gold, D ............ 53, 103

Gold, DR . . . . . . . . . . . . . . 97

Gold, E............... 83

Gold, EB ............ 9, 83

Goldberg, AM ............. 33

Goldberg, DL ........... 6

Goldberg, E ............... 34

Goldberg, LA . . . . . . . . . . . 19

Goldberg, M ....... 10, 28, 72

Goldberg, M S . . . . . . . . . . . . . 89

Goldberg, P . ............ 10

Goldberg, RJ ........... 3, 97

Goldberg, V .............6

Goldberg, VM .............6 6

Goldberger, L . . . . . . . . 5, 34

Goldbud................ 48

Goldenberg, DL.......... 6

Goldenhar, LM ........ 56, 64

Goldenstein-Schainberg, C . . . . 6

Goldfarb, W. . . . . . . . . . . . . 54

Goldfrank, LR ............ 10

Goldhaber, M K .......... 52

Goldie, I............. 6, 100

Goldman, A . . . . . . . . . . . . 21

Goldman, FD .............6

Goldman, J . . . . . . . . . . . . . 33

Goldman, LI . . . . . . . . . . . . 97

Goldman, LR . . . . . . . . . . . . . 9

Goldman, RF ............ 42

Goldsmith, $A H \ldots \ldots \ldots . .82$

Goldsmith, D . . . . . . . . . . 80

Goldsmith, DF . . . . . . . . 64, 61

Goldsmith, JR ............ 7

Goldstein, B . . . . . . . . . . . . . 10

Goldstein, BD ............. 1

Goldstein, F . . . . . . . . . . . 3

Goldstein, I . ............ 34

Goldstein, JA . . . . . . . . . . . 33

Goldstein, R B ............. 13

Goldstein, RH . . . . . . . . . . 10

Goldstein, RS. . . . . . . . . . . 8

Goldstein, SA . . . . . . . . . . . . . . 6

Goldzieher, JW ............ 79

Goldzieher, M A . . . . . . . . . . 79

Goleman, D ............... 34

Golemblewski, RT . . . . . . . . . 34

Goljanitzki, JA . ........... 6

Golsse, JM ...............68 68

Gomel, M ............. 3, 44

Gomes, MJM .............6 65

Gómez Garcés, JL . . . . . . . . . . . 3

Gomez-Dantes, H . . . . . . . . . 53

Gómez-Lechón, M J . . . . . . . . 33

Gonella, $G \ldots \ldots \ldots \ldots \ldots 43$

Gong, Z . . . . . . . . . . . . . 89

Gonik, V . .........26, 97

Gonzales, C . . . . . . . . . . . 28

Gonzales, M . . . . . . . . . . . . 64

Gonzales, PL . . . . . . . . . . . 55

Gonzales, R R. . . . . . . . . . . . 42
Gonzalez, FJ . ........... 33

Gonzalez, R M . ........... 10

Gonzalez, V . ............ 97

Gooch, C . . ............. 97

Goodall, DG .............4 41

Goodhead, DJ .............48

Gooding, RZ . . . . . . . . . . . 29

Goodings, $A C \ldots \ldots \ldots \ldots 42$

Goodman, KW ............ 19

Goodman, LA ............. 34

Goodman, N . . . . . . . . . . . . 89

Goodrich, R............. 34

Goodrow, M H . . . . . . . . . . . 27

Goodstein, LP . . . . . . . . . 56, 58

Googins, B .............. 15

Gopalakrichnakone, P...... 38

Gopher, D . . . . . . . . . . . . . 29

Goran, M H . . . . . . . . . . . . 97

Gorden, K . . . . . . . . . . . 14

Gordon, BF .............41 4

Gordon, BR ............. 21

Gordon, C . ............. 17

Gordon, D . . . . . . . . . . . . . . 34

Gordon, DJ ................ 3

Gordon, GC ............. 52

Gordon, JE.............. 60

Gordon, JG .............. 70

Gordon, JS .............. 70

Gordon, PR . . . . . . . . . . . 70

Gordon, RE . . . . . . . . . . . 10

Gordon, SL . . . . . . . . . . 6

Gordon, T . . . . . . . . . 10, 11

Gore, S................ 15

Gorecki, $T$. . . . . . . . . . . . . 44

Górgolas, M . . . . . . . . . . . 3

Gorhe, DS . . . . . . . . . . . . . 70

Gori, GB ........... . 2, 49

Gorman, DF . ........... 36

Gorman, D M . . . . . . . . . . . . 34

Gormsen, C .............. 11

Gorstein, J ............... 3

Goss, D ................ 21

Gosselin, RE . . . . . . . . . 11, 85

Gosset, P . . . . . . . . . . . . 10

Gostomzyk, J-G . . . . . . . . . . 44

Goswami, A . . . . . . . . . . . . . 64

Gotlieb, C . . . . . . . . . . . . . 19

Goto, $\mathrm{H} \ldots \ldots \ldots \ldots \ldots \ldots$

Goto, S................. 3

Gotoh, $0 \ldots \ldots \ldots \ldots . . . . . .33$

Gotthard, R . . . . . . . . . . 10

Gottlieb, BH ............. 34

Gottlieb, CA ........... 9

Gottlieb, M ............ 72

Gottlieb, M S . . . . . . . . . . . 52

Gottlieb, O R .............. 53

Goudswaard, A . . . . . . . . . 5

Gough, H............. 34

Gould, GM ............. 15

Gould, JD . . . . . . . . . . 29, 52

Gould, KL . ............. 15

Goulet, MJ . . . . . . . . . . . . 6

Gourbiere, E ............. 40

Gourmelon, P . . . . . . . . . 39
Governa, M ............. 97

Gower, W .............6 6

Gowler, D ............ 29, 34

Gozlan, C............... 97

Graber, DJ . . . . . . . . . . . . 37

Graber, DR .............. 64

Grabler, P . . . . . . . . . . . . . . 97

Graceffa, $P \ldots \ldots \ldots \ldots \ldots 10$

Gracely, E . . . . . . . . . . . . 101

Grad, FP .............23

Grady, JK ..............29 29

Grady, RM .............29 29

Graeber, RC . ............ 102

Graebner, W . . . . . . . . . . . . 19

Graef, JW.............. 9

Graf, $0 \ldots \ldots \ldots \ldots 29,43$

Graham, A . . . . . . . . . . . . 34

Graham, BL . . . . . . . . . . . . . 70

Graham, C............. 97

Graham, $\mathrm{CH}$............. 11

Graham, D............... 10

Graham, DE ............ 13

Graham, JI. . . . . . . . . . . . . . . 74

Graham, JM ............ 70

Graham, RM . ............ 15

Graham, TB ............ 42

Grajewski, BA ........... 52

Gralla, EJ ............... 100

Graman, PS . . . . . . . . . . . . 10

Gramlich, EM ........... 34

Grams, $T \ldots \ldots \ldots \ldots \ldots 58$

Gran, JT ............. 6

Granata, KP ........... 80

Granberg, PO ...........4 42

Grandjean, E . . . . . 6, 11, 29,

$34,46,52,59,89$

Grandjean, P . . . . . . 9, 19, 33

Grandolfo, M . . . . . . . . . . . . 49

Graneek, BJ . ............. 71

Grannes, SG . ...........74

Granqvist, M .............. 34

Grant, A.............. 11

Grant, BF . . . . . . . . . . . . . . 34

Grant, CC . . . . . . . . . . . . 39

Grant, DM . . . . . . . . . . . . 33

Grant, LD ............ 9, 30

Grant, M ............... 15

Grant, S . . . . . . . . . . . . 29

Grant, WB ................ 55

Gratton, J . . . . . . . . . . . . . 41

Gratton, M A ............. 47

Grauman, D . . . . . . . . . . 100

Gravenstein, JS ........... 97

Graves, AB. . . . . . . . . . . . . . 7

Gravesen, S ....... 10, 13, 44

Grawford, $V \ldots \ldots \ldots \ldots \ldots . . \ldots$

Gray, CN ............... 13

Gray, LE ................ 33

Gray, RH ................ 83

Grayson, $M \ldots \ldots \ldots \ldots . \ldots 22$

Grayson, RC . . . . . . . . . . . 10

Grayson, SJ . . . . . . . . . . . . 41

Graziano, J. . . . . . . . . . . . 101

Grazier, K . ........... 97 
Great Lakes Scientific Advisory Board. .............. 54, 55

G reaves, IA ............. 10

Greaves, RF . . . . . . . . . . . . 15

Greek, BF . . . . . . . . . . . . . 80

Green, $A \ldots \ldots \ldots \ldots \ldots 97$

Green, B................ 34

Green, BL ............... 34

Green, CR . . . . . . . . . . . . . 44

Green, D . .............. 83

Green, DP .............6, 6, 96

Green, DW ............. 77

Green, $\mathrm{FH} \ldots \ldots \ldots \ldots \ldots 10$

Green, GE . . . . . . . . . . . . . . 74

Green, $\mathrm{GM} \ldots \ldots \ldots \ldots \ldots 34$

Green, $\mathrm{GR} \ldots \ldots \ldots \ldots \ldots .74$

Green, JM .............. 10

Green, $L \ldots \ldots \ldots \ldots \ldots \ldots \ldots . . . \ldots 2$

Green, LW . . . . . . . . . . . . . 56

Green, M S . . . . . . . . . . . . . 31

Green, $N \ldots \ldots \ldots \ldots \ldots . \ldots 34$

Green, RS .............. 9

Greenbaum, J . . . . . . 29, 99

Greenberg, ER .......... 97

Greenberg, M R . ........... 19

G reenberg, PE ............ 5

G reenblatt, GA . . . . . . . . . . 89

Greene, JC . ..............4

Greene, M W . . . . . . . . . . . . . 49

Greene, RE . . . . . . . . . . . . . 10

Greene, R M . . . . . . . . . . . 63

Greene, $S \ldots \ldots \ldots \ldots \ldots . \ldots 59$

Greene, TC . . . . . . . . . . . 46

Greene, WAJ . . . . . . . . . . . . . 39

Greenglass, ER .......... 34

G reenhalgh, $L \ldots \ldots \ldots \ldots \ldots . \ldots 34$

Greenhalgh, $P \ldots \ldots \ldots \ldots .64$

Greenhow, EH $\ldots \ldots \ldots \ldots 89$

Greenlagh, L . . . . . . . . . . 34

G reenland, S . . . . . . . . . . 28

G reenpeace .............. 101

G reenwald, P.... 10, 15, 39, 72

Greenwood, BM ............ 38

Grefen, K . . . . . . . . . . . . 55

Gregg, M B............ 53

Gregory, R . . . . . . . . . . . . . 59

Greif, S............... 29

Greil, H . . . . . . . . . . . . . . 29

Grenner, $Y \ldots \ldots \ldots \ldots \ldots 97$

Gresham, LS . . . . . . . . . . . . 11

G ressel, M G . . . . . . . . . . . . 30

Gressot, M ............... 26

Greuer, RE . . . . . . . . . . . . 74

Greuter, M A .............. 29

G reutmann, $T$. . . . . . . . 29, 43

Greve, $K \ldots \ldots \ldots \ldots \ldots 13$

Grey, SM . .............. 29

Gridley, $G \ldots \ldots \ldots \ldots \ldots 4$

Grieco, A . . . . . . . . . . . 29, 43

Griffin, GA............6 64

Griffin, $M \ldots \ldots \ldots \ldots \ldots . . . . .93$

Griffin, M J . . . . . . . . . . . 3, 50

Griffin, PR .............. 33

Griffin, $R \ldots \ldots \ldots \ldots \ldots . . . \ldots 6$
Griffin, RE ............ 74

Griffin, WV ............ 97

Griffith, DE ........... 82

Griffith, DM ............. 10

Griffith, JF ............. 41

Griffiths, JF ........... 41

Griffiths, K . . . . . . . . . . . . 34

Griffiths, $M \ldots \ldots \ldots \ldots . . . .9$

Griffiths, WD . . . . . . . . . . . 101

Grifith, DE.............73

Grimalt, $F \ldots \ldots \ldots \ldots . . \ldots 100$

Grimby, G . . . . . . . . . . . 97

Grimes, CT ..............47 47

Grisham, JW ............. 39

Grob, PJ ............... 97

Groenendal, $H \ldots \ldots \ldots \ldots . \ldots 12$

Groenewald, JH . . . . . . . . . 38

Groeneweg, J . . . . . . . . 57, 59, 78

Groesneken, D . . . . . . . . . . . 9

Groleau, S ............... 10

Gronley, JK ............. 6

Grönning, M ............ 7

Grönquist, R . . . . . . . . . . . 68

Groper, $H \ldots \ldots \ldots \ldots . \ldots 39$

Gros, J...............60 60

Grosdemange, JP . . . . . . . . 31

Gross, C . ................ 17

Gross, D ................ 3

Gross, J............... 15

Gross, P............... 33

Gross, R................. 3

Grossgarten, K . . . . . . . . . . . . 32

Grossklaus, D . . . . . . . . . . 53

Grossman, EA . . . . . . . . . . . 81

Grossweiner, LI . . . . . . . . . . 49

Grote, $G \ldots . . . \ldots \ldots \ldots . . .29$

Grote, J . . . . . . . . . . . . . . 9

Groth, T . . . . . . . . . . . . . . 27

Grover, PL . . . . . . . . . . . . . 44

Gruaeu, GE . . . . . . . . . . . . . 10

Grube, BJ . . . . . . . . . . . . . 40

Gruber, JE ............... 34

Gruman, JC .............. 15

Grunberg, M M ........... 34

Grunberg, NE . . . . . . . . . . 34

Grund, N . . . . . . . . . . . . . 89

Gründemann, RWM . . . . . . . . . 5

Grunwald, J . ............. 20

Grupo Intergubernamental de Expertos sobre $C$ ambios

Climáticos (IPCC) . . . . . 53

Grushka, M .............11

Gruvberger, B . ........... 93

Gryfe, $\mathrm{Cl} \ldots \ldots \ldots \ldots \ldots . \ldots 58$

Grzech-Sukalo, H .......... 43

Grzybowski, S . . . . . . . . . . . 97

Guardino, X .......... 44, 97

Guastello, SJ ............. 56

Guay, J . ................ 97

Gubler, H............... 39

Gudakovskii, Y P . . . . . . . . . 49

Gueguen, A . . . . . . . . . . . . . 97

Guelaud, F . . . . . . . . . . . . 29

Guendelman, S . ........ 34, 87
G uénel, P . .............. . 30 Guengant, A . ............ 29

Guengerich, FP . . . . . . . . . . 33

Guennou, C ............... 10

Guercilena, S . . . . . . . . . . . 39

Guerin, M ............. 86

Guerin, M R . . . . . . . . . . . . 44

Guerrant, RL ............ 15

Guerrero-Betancourt, D . . . . . . 9

Guerry, D, III ............49

Guerry, RK ...............49

Guertin, S . ............. 101

Guidera, JA . . ............ 100

Guidotti, TL . . . . . . 3, 11, 15, 16,

$19,34,95$

Guignard, J . ............ 10

Guilianelli, C . . . . . . . . . . . 10

Guillaume, J. . . . . . . . . . . . 97

Guillerm, R ............ 29

Guin, JD ................12

Guinchat, $C \ldots \ldots \ldots \ldots 22$

Guiot, A . ............... . 43

Guk Cho, N . . . . . . . . . . . . . 34

Gulati, L. . . . . . . . . . . 24, 100

Gulf Publishing Company. 82, 102

Gullett, AD . . . . . . . . . . . . . 89

Gun, RT .............. 10

Gunderson, PD ..........64 64

Gunn, P................47 47

Gunnarsdóttir, H . . . . . . . . . 66

Gunnarsson, L-G . . . . . . . . . . 7

Gunsalas, IC .............. 33

Gunter, EW .............. 9

Gunther, $T \ldots \ldots \ldots \ldots \ldots . . . . .3$

Guo, J................68 68

Gupta, BN .........63, 64, 96

Guralnick, L. . . . . . . . . . . . . 32

Gurney, M .............. 3

Gussum, LV . . . . . . . . . . . . . 25

Gustafon, K . . . . . . . . . . . . 70

Gustafsson, $H \ldots \ldots \ldots \ldots \ldots 13$

Gustavsson, P........ 80, 101

Gustin, J.................. 3

Gute, DM ............ 89

Gutek, B................ 34

Guthrie, HA............ 15

Gutierres, SE . . . . . . . . . . . . . 34

Gutman, D................ 4

Gutmann, L............. 11

Guttmann, HE. . . . . . . . . . . . 59

Guzzanti, E . . . . . . . . . . . 97

G wynne, JW ............ 97

Gylseth, B . . . . . . . . . . . . 63

Gyntelberg, F........ 3, 11, 13

\section{$\mathrm{H}$}

$H$ aas, $J \ldots \ldots \ldots \ldots \ldots$ 59, 102 Habeck, R ........... 17, 59

$\mathrm{H}$ aber, RA . . . . . . . . . . . 8 84

H acker, PD ............. 49

H acker, W . . . . . . . . . . . . 29, 59

H ackett, PH . . . . . . . . . . . . 37

H ackman, JR . . . . . . . 29, 34, 52
$H$ adden, SG . . . . . . . . . . 23

H addon, W . . . . . . 56, 57, 60, 103

H addow, JE .......... 9, 44

$\mathrm{H}$ adjimichael, $\mathrm{O}$ C . . . . . . . . . 63

$\mathrm{H}$ adler, N M . . . . . . . . . . . . . . 6

H adler, SC . . . . . ......... 97

$H$ aëntjens, $C$. . . . . . . . . . . . 100

$H$ aerting, $F H \ldots \ldots \ldots \ldots . . . .32$

H agberg, $M$. . . . 6, 7, 52, 97, 100

$H$ agberg, $S \ldots \ldots \ldots \ldots \ldots . \ldots 72$

$H$ agen, $T \ldots \ldots \ldots \ldots \ldots . \ldots 77$

Hägg, GM ............ 6

$\mathrm{H}$ aggard, $\mathrm{H} H \ldots \ldots \ldots \ldots . . . . .30$

$H$ agland, $K \ldots \ldots \ldots \ldots \ldots 66$

$\mathrm{H}$ aglind, $M \ldots \ldots \ldots . . . . .70$

$H$ aglind, $P \ldots \ldots \ldots . . . .10$

$H$ agman, $M \ldots \ldots \ldots \ldots . . .73$

Hagman, N . . . . . . . . . . . . . 34

H agmar, L . . . . . . . . . 12, 66, 88

H agner, I-M . . . . . . . . . . . . 100

$H$ ahn, $H \ldots \ldots \ldots \ldots \ldots \ldots . \ldots 17$

Hahn, ME ............. 34

$\mathrm{H}$ aider, $M$. . . . . . . . . . . . 43

$H$ aigh, $R \ldots \ldots \ldots \ldots . . . . .97$

$H$ aight, FA . ............ 59

$H$ ail, $D H \ldots \ldots \ldots \ldots . . . \ldots 10$

$H$ aile, DG .............. 53

$H$ aile, $F \ldots \ldots \ldots \ldots \ldots 68$

$H$ aines, J . . . . . . . . . . . 101

$H$ aines, $T \ldots \ldots \ldots . .26,59$

$\mathrm{H}$ ak, $\mathrm{A} \ldots . . . \ldots \ldots \ldots . . .43$

H akama, M . . . . . . . . 2, 10, 80

Hake, C ............... 96

H akim-Serfaty, C . . . . . . . . 97

$H$ akim, R .............. 83

H äkkinen, K ............ 56

H akkola, M ............. 102

H akola, T . . . . . . . . . . . . . . 29

H akulinen, $T$. . . . . . . . . 10, 72

$H$ alasz, F . . . . . . . . . . . . 52

$\mathrm{H}$ ale, AR ............ 59, 66

$\mathrm{H}$ ale, $A R \ldots \ldots \ldots \ldots \ldots . \ldots 56$

$\mathrm{H}$ ale, $M \ldots \ldots \ldots \ldots . \ldots 56$

$\mathrm{H}$ ales, $\mathrm{CA} \ldots \ldots \ldots \ldots .63$

$\mathrm{H}$ ales, JRS . ............ 42

$\mathrm{H}$ ales, RE. . . . . . . . . . . . . 5

$\mathrm{H}$ ales, $\mathrm{T} \ldots \ldots \ldots \ldots \ldots . . . .434,98$

$\mathrm{H}$ ales, T R . . . . . . . . . . . 34

$H$ aley, NJ .............. 9

Halhuber, C.............. 3

Halik, J............... 3

$\mathrm{H}$ all, $\mathrm{A}, \ldots \ldots \ldots \ldots \ldots \ldots, \ldots 8$

$\mathrm{H}$ all, AJ ................ 9

$\mathrm{H}$ all, CB................ 10

$\mathrm{H}$ all, $\mathrm{D} \ldots \ldots \ldots \ldots \ldots \ldots \ldots ., 70$

Hall, DT ............... 34

$\mathrm{H}$ all, E .................. 34

$\mathrm{H}$ all, EJ .............. 48

$\mathrm{H}$ all, EM ............... 34

$\mathrm{H}$ all, $\mathrm{HI} \ldots \ldots \ldots \ldots \ldots \ldots 9$

$\mathrm{H}$ all, JH ............... 15

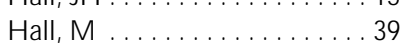

$\mathrm{H}$ all, M G . . . . . . . . . . . . . . . 49

$\mathrm{H}$ all, M M ............. 80 
$H$ all, $N \ldots \ldots \ldots \ldots \ldots \ldots 96$

Hall, R B. . . . . . . . . . . . . . 34

$\mathrm{H}$ all, RC ............ 97

$\mathrm{H}$ all, S . . . . . . . . . . . 97

Hall, WD .............. 19

$\mathrm{H}$ allen, M . . . . . . . . . . . 19

$\mathrm{H}$ alling, $\mathrm{HE} \ldots \ldots \ldots \ldots \ldots . . .42$

H allman, K . . . . . . . . . 13

H allock, M . . . . . . . . . . . 20

H allock, MF . . . . . . . . . . 83

H alm, M A . . . . . . . . . . 97

H alperin, W . . . 3 3, 32, 52, 73, 88,

94, 100

H alpern, $M \ldots \ldots \ldots \ldots \ldots 6$

H alpin, DM G . . . . . . . . . 71

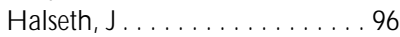

Ham, WT ............ 49

H amacher, W ........... 56

H amaty, D . . . . . . . . . . 6

H amberg, DA . . . . . . . . 5

H ambraeus, L ........... 3

H amburg, DA . . . . . . . . . 34

$\mathrm{H}$ amelin, P. . . . . . . . . . 29, 43

$\mathrm{H}$ amerman, D . . . . . . . . . . 6

H amernik, R P . . . . . . . . 31, 47

$\mathrm{H}$ amilton, A . . . . . . . . . 30, 50

H amilton, GC . . . . . . . . . . 14

$\mathrm{H}$ amilton, JD . . . . . . . . . 10, 89

$\mathrm{H}$ amilton, $\mathrm{L} \ldots \ldots \ldots \ldots \ldots \ldots . . . .96$

$\mathrm{H}$ amilton, LV ........... 34

$\mathrm{H}$ amilton, $\mathrm{M} \ldots \ldots \ldots \ldots \ldots 45$

$\mathrm{H}$ amilton, SK .......... 15

$\mathrm{H}$ amilton, W G . . . . . . . . . . 96

H amlet, M P . . . . . . . . . . . 42

H ammad, $Y Y \ldots \ldots \ldots \ldots \ldots 10$

H ammar, SP . ............ 10

H ammel, HT . . . . . . . . . . 42

H ammer, JC ........... 5

H ammer, L . . . . . . . . . . . 15

H ammon, SK ........... 9

$\mathrm{H}$ ammond, E . . . . . . . . . . . 19

$\mathrm{H}$ ammond, EC . . . . . . . 28, 32

$H$ ammond, $K \ldots \ldots \ldots \ldots . . .83$

H ammond, PB . . . . . . . . . . 59

H ammond, SK . . . . . . . . 44, 83

H amsová, L . . . . . . . . . . . . . 16

H amza, A. . . . ......... 53

$\mathrm{H}$ an, JR ........... 6

H ancock, PA . . . . . . . . . . 29

$\mathrm{H}$ andcock, PA . . . . . . . . . 52

$\mathrm{H}$ andjiev, $\mathrm{S} \ldots \ldots \ldots \ldots \ldots . . . . . . . .43$

$H$ ane, $M \ldots . \ldots \ldots \ldots \ldots \ldots .7$

H änicke, K . . . . . . . . . . . . . 29

H anke, BK . . . . . . . . . . . . 14

H anke, J . . . . . . . . . . . . 33

$\mathrm{H}$ anker, JP . . . . . . . . . . . 9

H ankinson, JL . . . . . . . . 10, 89

$\mathrm{H}$ anley, J . . . . . . . . . . 13

H anley, PR .............83

H ann, D . . . . . . . . . . . . 15

H anna, A . . . . . . . . . . . . . 29

$\mathrm{H}$ annaford, $\mathrm{PC} \ldots \ldots \ldots \ldots \ldots 12$

H annan, M T . .......... 6

$\mathrm{H}$ änninen, $\mathrm{H} \ldots \ldots \ldots \ldots \ldots .7$
$H$ änninen, $K \ldots \ldots \ldots \ldots \ldots 6$

H änninen, $0 \ldots \ldots$. . . 43, 100

$H$ änninen, $V \ldots \ldots \ldots \ldots \ldots . . . . . . . .44$

$H$ anniquet, $A M \ldots . \ldots \ldots . .42$

$\mathrm{H}$ annons, S . . . . . . . . . . 10

H annum, H . . . ......... 23

$\mathrm{H}$ anoa, R . . . . . . . . . . . . 10

H anrahan, LP . . . . . . . . . 64, 94

$\mathrm{H}$ ansch, $\mathrm{C} \ldots \ldots \ldots \ldots \ldots . \ldots 33$

$\mathrm{H}$ ansem, GK ........... 13

$H$ ansen, $A M \ldots \ldots \ldots \ldots 100$

$H$ ansen, $B \ldots \ldots \ldots \ldots \ldots 66$

$H$ ansen, $C \ldots \ldots \ldots \ldots \ldots 6 . \ldots 6$

$H$ ansen, DJ . .......... 6, 32

$H$ ansen, ES ............. 3

$H$ ansen, $H \ldots \ldots \ldots \ldots . . .3,39$

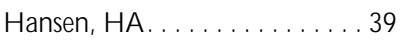

$H$ ansen, I . . . . . . . . . . . . . 70

$H$ ansen, $J \ldots \ldots \ldots \ldots \ldots .6,9$

$H$ ansen, JA . . . . . . . . . . . . 26

$H$ ansen, $K \ldots \ldots \ldots \ldots \ldots \ldots$

$\mathrm{H}$ ansen, $\mathrm{K} \mathrm{S}$. . . . . . . . . . . . . 100

H ansen, $L \ldots \ldots \ldots \ldots$. . . . . 13, 59

$H$ ansen, LF . . . . . . . . . . . 13

$\mathrm{H}$ ansen, SM . . . . . . . . . . 6

$\mathrm{H}$ anson, CE . . . . . . . . . . . 17

$\mathrm{H}$ anson, $\mathrm{M} \ldots \ldots \ldots \ldots \ldots \ldots . \ldots 15$

$\mathrm{H}$ anson, RJ . . . ......... 41

$H$ ansson, $G \AA \ldots \ldots \ldots \ldots \ldots 66$

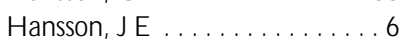

$H$ ansson, JE . . . . . . . . . . 68

$\mathrm{H}$ ansson $\mathrm{M}$ ild, $K \ldots \ldots \ldots$. . . . . 49

$H$ ansson, $T \ldots \ldots \ldots \ldots \ldots . . . . . . . .64$

H anstad, T . . . . . . . . . . . . 64

H app, A . . . . . . . . . 34, 52

H arada, M . . . . . . . . . . . . 29

Harano, RM ...........6 60

$\mathrm{H}$ aratani, $\mathrm{T} \ldots \ldots \ldots \ldots \ldots$. . . . 34

H araway, DJ . . . . . . . . . . . 24

H arber, LC . . . . . . . . . . . . 49

$\mathrm{H}$ arber, $\mathrm{P} \ldots \ldots . .10,71,72,73,97$

$\mathrm{H}$ ard, DL . . . . . . . . . . . 64

H ardaker, WT J . . . . . . . . . . 96

$\mathrm{H}$ arding, $\mathrm{J} \ldots \ldots \ldots \ldots . \ldots . . .49$

H ardman, . . . . . . . . . . . . 79

$\mathrm{H}$ ardoy, JE . . . . . . . . . . . 53

H ardy, HL . . . . . . . . . . . . 10

$\mathrm{H}$ ardy, JL . . . . . . . . . . . 53

$H$ ardy, $P \ldots \ldots \ldots \ldots \ldots . . . . . . . . . .$.

$H$ are, V C . . . . . . . . . . . 56

Härenstam, A .......... 3

H arford, TC . . . . . . . . . 34, 100

$H$ argens, AR ...........6

H argrove, $J L \ldots \ldots \ldots \ldots \ldots .23$

$H$ aring, $M \ldots \ldots \ldots \ldots \ldots \ldots . . . \ldots$

$\mathrm{H}$ arju, V . . . . ........ 6

H arkonen, R . . . . . . . . . 29

H arkowitz, H . . . . . . . . . 6

H arley, CS............. 41

$\mathrm{H}$ arley, R ............. 10

H ärmä, M . . . . . . . . 29, 43

$\mathrm{H}$ arms-R ingdahl, K . . . . . . . 6

$\mathrm{H}$ arm,s-R ingdahl L . . . . . . 56, 58

$\mathrm{H}$ arpham, T . . . . . . . . 53
$H$ arries, M G

$\mathrm{H}$ arrington, $\mathrm{AM}$

H arrington, JM . . . . . 34, 43, 46

$\mathrm{H}$ arrington, JS . . . . . . . . . . . 10

$\mathrm{H}$ arrington, $\mathrm{M} \ldots \ldots \ldots \ldots \ldots \ldots .79$

$\mathrm{H}$ arrington, RM .........96

H arris-Bass, J . . . . . . . . . . . 13

Harris, AW ............ 49

$\mathrm{H}$ arris, CM . . . . . . . 31, 47

Harris, CS . . . .......... 3

H arris, DR . . . . . . . . . . . 83

H arris, G . . . ......... 100

H arris, J . . . . . . . . . . . . . 15

H arris, JS . . . . . . . . . . 3, 15, 34

H arris, $L \ldots \ldots \ldots \ldots \ldots \ldots 15$

Harris, MJ . . . . . . . . . . . 34

$H$ arris, RL . . . . . . . . . 30, 80

$\mathrm{H}$ arris, TC . . . . . . . . . . . . 59

H arris, TR . . . . . . . . . . . . . 89

$\mathrm{H}$ arris, W . . . . .........4 43

$\mathrm{H}$ arrison, BA ........... 53

H arrison, DI . . .......... 38

Harrison, DW ........... 3

H arrison, EF . . . ........ 59

H arrison, GA . . . . . . . . . . . 34

$H$ arrison, JC . . . ........ 10

H arrison, JE . . . . . . . . . . 40, 70

$\mathrm{H}$ arrison, LB . . . . . . . . . . 10

H arrison, M D . . . . . . . . . . 29

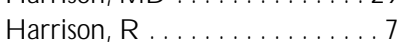

H arrison, RJ . . . . . . . . . 83

H arrison, RV . . . . . . . . . . 34

H arrod, J . . . . . . . . . . . . . 21

H arstela, P . . . . . . . . . . . . . 68

$H$ art, D ............ 52

$H$ art, DE ............ 7

$\mathrm{H}$ art, $\mathrm{S} \ldots \ldots \ldots \ldots \ldots \ldots . \ldots 29$

$\mathrm{H}$ art, WM ............ 11

$H$ arten, GA . . . . . . . . . . . . 82

$H$ artge, $P \ldots \ldots \ldots \ldots \ldots$. . . 89

$\mathrm{H}$ arting, $\mathrm{FH} \ldots \ldots \ldots \ldots \ldots . . . .28$

$\mathrm{H}$ artman, $\mathrm{HL} \ldots \ldots . \ldots \ldots . . .74$

H artmann, H T . . . . . . . . . 34

H artsky, M A . . . . . . . . . 10

H artson, HR . . ......... 52

$\mathrm{H}$ arvey, $\mathrm{AL} \ldots \ldots \ldots \ldots \ldots . . . . .38$

H arvey, D . . ............96

H asan, J . . . . . . . . . . . . . 3, 50

H asegawa, A . . . . . . . . . . 10

H asegawa, K . . . . . . . . . . 41

H asegawa, Y . . . . . . . 4, 10

H aselhurst, J . . . . . . . . . . . 15

H ashimoto, A. . . . . . . . . . 3

$\mathrm{H}$ askell, WL . . . . . . . . . . . 3

H askins, LK . . . . . . . . . . . 64

$H$ asle, $P \ldots \ldots \ldots \ldots \ldots \ldots$

H assall, A . . . . . . . . . . . . . . 47

H asselhorn, H M . . . . . . . . 97

H assi, J . . . . . . . . . . . . . . . . 42

H astings, L. . . . . . . . . . . . 11

$\mathrm{H}$ atch, $\mathrm{T} \ldots \ldots \ldots \ldots \ldots . \ldots 33$

$\mathrm{H}$ atch, $\mathrm{TF} \ldots \ldots \ldots \ldots \ldots \ldots 42$

$\mathrm{H}$ athaway, GL . . . . . . . . 83

$\mathrm{H}$ atschek, $\mathrm{T} \ldots \ldots \ldots \ldots \ldots .65$
$H$ attis, DB . . . . . . . . 28, 33

H aughey, M A . . . . . . . . . 15

H auke, $P \ldots \ldots \ldots \ldots \ldots . .43$

$\mathrm{H}$ auptverband der $\mathrm{G}$ ewerblichen

Berufsgenossenschaften . . . 40

$H$ ausen, $B$. . . . . . . . . . . . 71

$H$ ausen, BM . . . . . . . . . 64, 83

H auss, F . . . . . . . . . . . 16

H ausser, K W . . . . . . . . . . . 49

$H$ aussler, BJ . . . . . . . . . . . 85

$H$ austein, UF . . . . . . . . . . 9

$H$ avenith, G . . . . . . . . . . 42

H avlik, R ............ 5

H awke, N . . . . . . . . . . . 54

H awkes, $\mathrm{CH} \ldots \ldots \ldots \ldots \ldots .7$

H awkes, R W . . . ........ 59

H awkins, C . . . . . . . . . 97

H awkins, L . . . . . . . . . . . . . 18

H awkins, LH . . . . . . . . . 45

H awkins, NC . . . . . . . . . 33

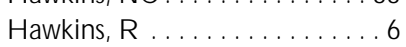

H awkinson, TE . . . . . . . . 45

H awks, SN , Jr . . . . . . . . 64

H ay, A ............. 64

H ay, M . . . . . . . . . . . . 97

H ayano, $\mathrm{J} . \ldots \ldots \ldots \ldots \ldots \ldots 5$

H ayashi, SI . . . ......... 33

H ayes, AW . . . . . . . . . . 9, 33

Hayes, $C \ldots \ldots \ldots \ldots \ldots \ldots 5$

H ayes, $H$ M . . . . . . . . . . 28

H ayes, R B . . . . . . . . 1, 28, 100

$\mathrm{H}$ ayes, WJ ........... . 9, 27

H ayes, WJJ. . . . . . . . . . . 64

H aynes, M R ............ 59

$H$ aynie, JS . . . . . . . . . . . . 48

H ayward, J . . . . . . . . . . . 69

H azebroucq, G . . . . . . . . . 97

H azzard, WR . . . . . . . . . . 6

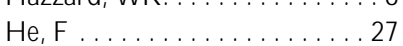

He, JS. .............. 16

Head, PW ............. 11

H eading, R C . . . . . . . . . . 97

H eady, JA . . . . ......... 3

$\mathrm{H}$ eal, A. . . . . . . . . . . . 47

H ealey, LA . . . . . . . . . . . . . 6

H ealing, T D . . . . . . . . . . . 100

$\mathrm{H}$ ealth and Safety

Commission. . . . . 21, 39, 83, 96

$\mathrm{H}$ ealth and Safety Executive

(H SE ) . . . . . . 27, 40, 45, 56,

$58,81,85,89,103$

$\mathrm{H}$ ealth and W elfare C anada . . . 24

$\mathrm{H}$ ealth Project $\mathrm{C}$ onsortium . . . . 15

$\mathrm{H}$ ealth Standards $O$ ffice . . . . . . 16

H eaply, LJ . . . . . . . . . . . . . . 89

H earle, JWS. . . . . . . . . . . . 42

H earne, FT . . . . . . . . . . 85

H eatfield, B . . . . . . . . . . 8

H eath, CW J . . . . . . . . . . 39

H eath, DF . . . . . . . . . 27

H eath, E. . . . . . . . . . . . . 18

$H$ eath, ED . . . . . . . . . . . 18

H eaton, A . . . . . . . . . . . 15

H eavner, DK . . . . . . . . . . . 44 
Heberer, $H \ldots \ldots \ldots \ldots \ldots \ldots 61$

$H$ echt, NB . . . . . . . . . . . . 9

Hecht, SS............. 44

H ecker, S . . . . . . . . . . 20, 21

Hed, J.................... 10

H edblad, M A . . . . . . . . . . . . . 52

Hedden, $1 \ldots \ldots \ldots \ldots \ldots .43$

H edegård, $B \ldots \ldots \ldots \ldots \ldots 11$

Hedge, A . ...... 13, 34, 45, 52

H edgecock, C . ............ 10

H edges, $P \ldots \ldots \ldots \ldots \ldots . . .63$

H edley, D G F . . . . . . . . . . . . 74

H edlund, J . . ............. 34

H edman, M . . . . . . . . . . . . . 34

H eederik, D . . . . . . . . . 30, 70

$H$ eeren, $T \ldots \ldots \ldots \ldots \ldots 15$

H effner, JE.............. 10

$H$ eflich, $\mathrm{RH} \ldots \ldots \ldots \ldots \ldots . . .33$

Hegyi, E.............. 12

$H$ eiberg, D . . . . . . . . . . . . 95

H eida, $H \ldots \ldots \ldots \ldots 101$

Heide, R . . . . . . . . . . . . . 50

Heijnen, CJ .............. 34

H eijungs, R ............. 54

$H$ eikkila, $P \ldots \ldots \ldots \ldots \ldots . . . . .9$

H eikkilä, T . . . . . . . . . . . 68

Heikkonen, J ............. 16

H eilbrun, A . . . . . . . . . . . . . 34

H eilmeyer, $L \ldots \ldots \ldots \ldots \ldots 68$

H eilpern, J . . . . . . . . . . . . . 34

H eimbach, DM ........... 40

$H$ eimlich, RE .............6 64

$\mathrm{H}$ ein, $\mathrm{HO} \ldots \ldots \ldots \ldots \ldots, \ldots, 11$

$H$ eindell, JJ.............. 33

$H$ eineman, EF . . . . . . . . . . 4

H einemann, L . . . . . . . . . . . . 3

Heinerman, EF . . . . . . . . . . 12

$H$ einiger, $H J \ldots \ldots \ldots \ldots 33$

H einkel, $K \ldots \ldots \ldots \ldots \ldots . . . . . .4$

$H$ einonen, $E \ldots \ldots \ldots \ldots \ldots . \ldots$

$H$ einonen, $O P \ldots \ldots \ldots \ldots 52$

Heinrich, $H \ldots \ldots \ldots \ldots \ldots 59$

H einrich, HW . . . . . . . . . 56, 58

H einsohn, RJ . . . . . . . . . . 45

Heinzow, B . ............ 101

H eitbrink, WA . . . . . . . . . . . . 80

H elander, IM . . . . . . . . . . . . . 10

H elander, M . ........ 29, 52

H elb, GK .............. 83

Helcamp, JC .............. 3

H elfet, AJ . . . . . . . . . . . 6

H elin, P . . . . . . . . . . . . . 100

H elios, II ............. 17

Heliövaara, M ...........6 6

H ellenbrand, K G . . . . . . . . . . 9

Heller, BR ............... 34

Heller, F. . . . . . . . . . . . . . 34

H eller, FA ............. 59

H eller, W-D . . . . . . . . . . . . 44

H ellman, S. . 1, 4, 8, 10, 12, 15, 28

H ellstrom, L.............. 31

H ellström, M . . ......... 97

H ellstrom, S............ 97

Helme, RD ............ 52
Helmer, R ............. 53

H elmert, $U \ldots \ldots \ldots \ldots \ldots \ldots . .3$

H elmkamp, JC . . . . . . . . 3, 26

H elmke, $G$. . . . . . . . . . . . . 20

H elmore, $K \ldots \ldots \ldots \ldots .64$

H elmstrom, B ........... 13

H elpio, E . . . . . . . . . . . 89

H eltzer, JE .............. 5

H emenway, D . . . . . . . . . . . 10

H eming, B . ............. 56

$\mathrm{H}$ emmi, $\mathrm{T} \ldots \ldots \ldots \ldots \ldots . . . .34$

H emminki, K . . . . . . 9, 27, 52, 80

H emning, B . . . . . . . . . . . . 59

Hémon, D . . . . . . . . . . . 28, 30

H emstreet, G . . . . . . . . . . . 8

H enao, $\mathrm{S} \ldots \ldots \ldots \ldots \ldots . . . .66$

H enderson, BE . . . . . . . 15, 85

H enderson, D . . . . . . . . . 31, 47

H enderson, S . . . . . . . . . . 34

$\mathrm{H}$ enderson, $\mathrm{V} \ldots \ldots \ldots \ldots . . .89$

$H$ enderson, VL . . . . . . . . . . 10

H enderson, VW . . . . . . . . 7, 87

H enderson, $Y \ldots \ldots \ldots \ldots . \ldots 30$

$H$ endrick, $H \ldots \ldots \ldots \ldots \ldots 6$

H endrick, HW . . . . . . . . . . 29

$H$ endrick, K . ............ 57

H endriek, CB............ 73

H enifin, M S. . . . . . . . . . 34, 99

H eniig, JH .............. 13

H enkin, L. . . . . . . . . . . . . . . . 23

H enman, BA . . . . . . . . . . 27

H enneberger, PK . . . . . . . 72

H ennekens, CH . . . . 3, 15, 28, 97

H ennon, CB. . . . . . . . . . . . 64

H enrichs, K . ............ 32

H enriksen, L . . . . . . . . . . . . 85

H enriques, J . . . . . . . . . . . . . 65

H enry, JP . . . . . . . . . . . . . . 34

H enry, M . . . . . . . . . . . . . 29

H enschler, D . ............. 33

H ensley, M J . ............ 10

$\mathrm{H}$ enson, PM . . . . . . . . . . . . 10

H enson, RA . ............. 96

H ensten-Petterson, A . . . . . . . 63

H eppleston, AG . . . . . . . . . . 10

H eptonstall, J . . . . . . . . . . . . . . 97

H erber, RFM . . . . . . . . . . . . 43

Herbert, A . . . . . . . . . . . . . 10

H erbert, FA ............ 86

H erbert, $P \ldots \ldots \ldots \ldots . .3,39$

Herberts, $P \ldots \ldots \ldots \ldots \ldots .6$

Herbst, M C .............. 3

Herbst, PN . . . . . . . . . . . . 34

H erd, JA . .............. 19

H erishanu, Y . . . . . . . . . . . . . 7

H erloff, B . . . . . . . . . . . . . .99

H erlot, P . . . . . . . . . . . . . 29

Herman, DR ............. 80

H erman, JR . . . . . . . . . . . . . 53

Hermann-K unz, E. . . . . . . . . . 9

H ermans, G . . . ........... 11

Hermon, C.............. 52

H ernándes-A vila, M . ........ 53

H ernández, A . . . . . . 6, 44, 46
H ernández, AF . . . . . . . . . 64 $H$ ernandez, CA . ........... 34 H ernandez, $M$. . . . . . . . . . . 53 H ernandez, PA . . . . . . . . . . . 6 H ernandez, WA . . . . . . . . 6 H ernberg, S . . . 1 1, 3, 4, 52, 89, 91 H ernberg, $S \ldots \ldots \ldots \ldots 28$ H errick, RF . . . . . . . . 64, 100 $H$ erring, $P \ldots \ldots \ldots \ldots . .83$ H errmann, H . . . . . . . . . . . 43 H erschler, R. . . . . . . . . . . . 71 H erscovici, A . . . . . . . . . . . . 69 H ersey, JC ............. 97 Hershman, EB . . . . . . . . . . . 96 Herskowitz, A . ............. 3 Hertel, RF . . . . . . . . . . . . . 33 $\mathrm{H}$ ertog, $\mathrm{K} \ldots \ldots \ldots \ldots \ldots . . . .97$ H ertstein, J. . . . . . . . . . . . . . . . 9 H ertz, R P.............. 102 $H$ ertzberg, $M \ldots \ldots \ldots \ldots \ldots .74$ H ertzman, C . . . . . . . . . . . 71 H erwig, B............... 29 H erwig, $T \ldots \ldots \ldots \ldots \ldots 58$ $H$ erzberg, $F \ldots \ldots \ldots . .34,52$ Herzschuh, R. . . . . . . . . . . 83 H eselmans, $M \ldots \ldots \ldots \ldots 57$ H eseltine, E . . . . . . . . . . 28, 33 H esse, A . . . . . . . . . . . . . . 97 H esse, W . . . . . . . . . . . 28, 32 H essel, PA . . . . . . . . . . 10, 86 H essel, $T \ldots \ldots \ldots \ldots \ldots . .6$ H esser, J . . . . . . . . . . . . . . . . . . 72

H essol, NA . ............... 9 H esterberg, TW . . . . . . . . . . . 10

H estrin, L................ 34 H etes, R . . . . . . . . . . . . . . . 99

$H$ etrick, RL . . . . . . . . . 67

$H$ ettinger, $T \ldots \ldots \ldots \ldots .43$

$H$ ettinger, TP. . . . . . . . . . . 11

Hétu, R . . . . . . . . . . 17, 97

H euchert, G............. 3

H eus, $R \ldots \ldots \ldots \ldots \ldots 42$

H ewitt Associates. . . . . . . . . . . . 34

H ewitt, JB ............... 38

H ewitt, W ..............8

$\mathrm{H}$ ey, E . . . . . . . . . . . . . . 54

H eyden, $\mathrm{S} \ldots \ldots \ldots \ldots \ldots . . .69$

H eyer, $\mathrm{N} \ldots \ldots \ldots \ldots . . . . .3$

$\mathrm{H}$ eyer, NJ .............. 10

H eyman, A . . . . . . . . . . . . . . . 7

H eymann, DL . . . . . . . . . . . . 38

H eywood, PG . . . . . . .......11

Heyworth, F. . . . . . . . . . . . . 3

$\mathrm{H}$ iatt, R A . . . . . . . . . . . 34, 52

Hickey, 」 . . . . . . . . . . . . 43, 70

H ickey, JLS ............... 30

H ickman, FJ. ............ 97

Hicks, A . . . . . . . . . . . . . 13

Hicks, AM ..............9

Hickson, M A . . . . . . . . . . . . 15

H idley, JH ............... 59

$H$ ietanen, $M$. . . . . . . . . . . . 52

Higashi, $T \ldots \ldots \ldots \ldots \ldots . . .16$

$H$ iggins, D N . . . . . . . . . . . . . . 94
$H$ iggins, JT . . . . . . . . . . . 41

H igginson, J . . 1, 2, 4, 8, 10, 12, 19

$\mathrm{H}$ igh, D . . . . . . . . . . . . . . 39

Highley, C . .............. 34

Higuchi, M de L ............ 3

Hilado, CJ ................41

$H$ ildebrand, I . . . . . . . . . . 3

$H$ ildebrandt, E........... 54

Hildebrandt, $G \ldots \ldots \ldots .43$

Hildebrandt, $V \ldots \ldots \ldots \ldots$

H ildebrandt, VH . . . . . . . . . 34

H ildebrandt, VV . . . . . . . . . 97

$H$ ill, $A B \ldots \ldots \ldots .26,28,89$

$\mathrm{Hill}, \mathrm{C} \ldots \ldots \ldots \ldots \ldots \ldots . .48$

Hill, LH ............... 10

Hill, NS ................ 97

Hill, RB, Jr. ............... 33

Hill, S.................. 34

Hilles, SB . . . . . . . . . . . . 15

Hills, B . . . . . . . . . . . 88

Hills, BW ............. . 88

Hills, $M \ldots \ldots \ldots \ldots \ldots 28$

Hilpmann, C . . . . . . . . . . . 43

Hilt, B ............... 44

$\mathrm{H}$ ilton-C halfen, S. . . . . . . . 34

H immelstein, JS . . . . . . . 5, 10, 63

$\mathrm{H}$ inderliter, $\mathrm{AL} \ldots \ldots \ldots \ldots .3,34$

$H$ inds, WC . . . . . . . . . . . 10

$H$ ines, CJ . . . . . . . . . . . . . . 83

$H$ ines, $L L \ldots \ldots \ldots \ldots \ldots \ldots \ldots$

$H$ ines, R N .............. 33

Hingson, RW . . . . . . . . . . . 15

$H$ innis, $H A \ldots \ldots \ldots . \ldots 69$

Hinrichs, $K \ldots \ldots \ldots \ldots . . . \ldots$

$H$ inze, $J \ldots \ldots \ldots \ldots \ldots \ldots 93$

$\mathrm{H}$ iro, $\mathrm{H} \ldots \ldots \ldots \ldots \ldots . . . . .5$

H iroshi, $0 \ldots \ldots \ldots . . \ldots . . .97$

Hirouchi, J ................ 3

$H$ irsch-K reinsen, $H \ldots \ldots \ldots \ldots . . . . .29$

$H$ irsch, $G \ldots \ldots \ldots \ldots \ldots . \ldots 59$

$\mathrm{H}$ irsch, PM ............. 34

$\mathrm{H}$ irsch, VM ............ 53

$\mathrm{H}$ irschel, BJ . . . . . . . . . . . . . . 97

H irschheim, R . . . . . . . . . 29

H irschhorn, L . ........... 34

H irschler, M M . . . . . . . . . . . 41

$H$ irsh, BJ ............... 34

Hirsh, RB............ 30

H irshhorn, L . . . . . . . . . . . 34

H jelmen, AM . . . . . . . . . . . . 34

H jort, C . . . . . . . . . . . 70

H jorth, N . . . . . . . . . . . . . 100

$H$ nizdo, E................................

$\mathrm{Ho}, \mathrm{DD} \ldots \ldots \ldots \ldots \ldots . . . . . .97$

HO, M-W .............. 77

$\mathrm{Ho}, \mathrm{MH} \ldots \ldots \ldots \ldots \ldots . . . .27$

$H$ oaglund, $F T$. .......... 6

H oar Zahm, S ........ 4, 12

H obbs, MS.............. 9

Hobfoll, WE............. 5

HoC, JM .............. 29

H ock, ET ............. 44

H ocking, B. . . . . . . . . . . . . 52

H odge, $B \ldots \ldots \ldots \ldots \ldots \ldots 9$ 
H odge, $H C \ldots \ldots \ldots \ldots \ldots 11$ H odge, H D . . . . . . . . . . . . . 85 H odges-A eberhard, J . . . . . . . 21 H odges, W . . . . . . . . . . . . . 34 H odgson, E . . . . . . . . . 33, 8 H odgson, JT ............. 30 H odgson, M . . . . . . . . . . . 13 H odgson, M J . . . . . . . 13, 45, 85 Hodous, TK . ............. 10 H odson, SJ . . . . . . . . . . . . 59 Hodson, WK .............. 34 Hoek, E . . . . . . . . . . . . . . . 74 Hoel, D ................. 53 Hoel, D G . . . . . . . . . . . 2, 53 Hoen, B . . . . . . . . . . . . . 97 H oet, $P \ldots \ldots \ldots \ldots \ldots . \ldots 27$ H oevenberg, J . . .......... 99 $\mathrm{H}$ off, A . . . . . . . . . . . . . . . 43 $\mathrm{H}$ off, JC ............... 38 H offman, B ............. 3, 93 H offman, $L \ldots \ldots \ldots \ldots \ldots \ldots .4$ H offman, $\mathrm{P} \ldots \ldots \ldots \ldots . . .3,83$ H offman, PN . ............ 100 $\mathrm{H}$ offman, R ............. 13 H offman, RE ......... 10, 32 H offman, SS . ............ 5 H offman, WS . . . . . . . . . . . 34 H offmann, D . . . . . . . . . . . 44 H offmeister, $H \ldots \ldots \ldots \ldots \ldots . . .3$ $H$ ofman, RF . . . . . . . . . . 66 H ofmann, F . . . . . . . 3, 94, 97 H ofmann, $\mathrm{H} \ldots \ldots \ldots \ldots, 39$ H ofmann, K . . . . . . . . . . . 34 H ofstede, G . . . . . . . . . . . . 29 H ogan, DJ . . . ............ 70 Hogan, M D . . . . . . . . . . . . . 2 Högfors, C . . . . . . . . . . . . 6 Hogg, JC .............. 10 H ogland, S. . . . . . . . . . . . . 70 H oglund, S. . . . . . . . . . 38 H ogman, PG . . . . . ....... 11 H ogstedt, C . . . 3, 6, 7, 9, 80, 100 H ogue, JM . .............. 49 H ogya, PT . ............. 95 H ohenstein Institute . . . . . . . 100 H ohmann, B . . ........... 11 H ohmann, H . . . . . . . . . . . . 54 H oidal, JR . . . . . . . . . . . . . . 10 H oladay, D . ............. 20 Holbrook, TL ...........997 H olden, C ............... 39 H oldren, M . . . . . . . . . . . . . 55 Hole, DJ................. 3 Holff, AH ...............4 H olgate, ST . . . . . . . . . . . . . 10 $\mathrm{H}$ oll, P ................. 21 Holladay, L . . . . . . . . . . . . . 49 H olland, J. . . . . . . . . . . . 48 Holland, JL . . . . . . . . . . . . . . 5 H olland, S . . . . . . . . . . . 52 H olland, WC . . . . . . . . . . . . 33 Holliday, M R . . . . . . . . . . . . 11 Holling, $H \ldots \ldots \ldots \ldots \ldots 29$ H ollinger, FB . . . . . . . . . 95, 97
H ollins, R............ 85 Hollis, JF ................ 3 H ollnagel, E . . . . . . . 56, 58, 29 Holly, EA ................9 $\mathrm{Holm}, \mathrm{A} \ldots \ldots \ldots \ldots \ldots . . . \ldots 3$ $\mathrm{H}$ olm, JO .............. 97 $\mathrm{Holm}, \mathrm{S} \ldots \ldots \ldots \ldots \ldots \ldots 6$ H olmberg, B ............ 80 H olmberg, K . . . . . . . . . . 38 H olmberg, PC . . . . . . . . . 52 Holmér, I . . . . . . . . . . . . . 42 H olmér, RI . . . . . . . . . . . . 42 H olmes, $H \ldots \ldots \ldots \ldots . \ldots 59$ Holmes, LB . . . . . . . . . . . . . . . . . . 9 H olmes, R G . . . . . . . . . . . . 64 H olmes, TH . . . . . . . . . . . . . . . 34 H olmström, M . . . . . . . 11, 86 H olness, D L . . . . . . . . . . . . . . 70 Hölscher, H . . . . . . . . . . 58 Holt, HFT . ..............96 Holt, K . . . . . . . . . . . . . . 39 $\mathrm{H}$ olt, $\mathrm{PG} \ldots \ldots \ldots \ldots \ldots \ldots 10$ H olt, R R ................ 34 H olter, JB.............. 6 H oltmann, G . . . . . . . . . . . . 34 Holtz, J............... 11 $\mathrm{H}$ oltz, JL ...............96 96 Holtzman, EJ . . . . . . . . . . . . 8 Holtzman, MJ . ........... 10 H olub, $\mathrm{H} \ldots \ldots$. . . . . . . . . . . 63 Holzer, M ............... 10 H olzner, CL . . . . . . . . . . . . . . 30 H omberger, E . . . . . . . . . . 39 Homer, CJ . . . . . . . . . . . . . 9 H ommel, G . ......... 22, 41 Homonnai, ZT ........... 9 Homsi, C ..............6 H onchar, PA ............. 32 H onda, $Y \ldots \ldots \ldots . . . . . . .91$ H ondras, M A . . . . . . . . . . . . 6 $\mathrm{H}$ ong, $\mathrm{CY} \ldots \ldots \ldots \ldots . \ldots 87$ $\mathrm{H}$ ong, VT ............. 10 Hong, WK ............... 10 Honma, $H \ldots \ldots \ldots \ldots . . . . .3$ H onrubia, $V$............. 11 H ood, JD ................. 11 H oogenboom-V ergedaal,

AM M . . . . . . . . . . . . . . 53 H oogendijk, EM G ......... 11 H ooisma, J . . . . . . . . . . . . . 7 H ook, J............... 8 H oolwerf, G . . . . . . . . . . . 43 Hooper, WK ............. 33 H oosima, J.............. 11 H ootsmans, H . . . . . . . . . . . . 34 H oover, HC . . . . . . . . . . 32, 74 H oover, LH . . . . . . . . . . . 32, 74 Hoover, M C .............34 Hoover, M D ............. 10 Hoover, RH . . . . . . . . . . . . 79 Hoover, R N . . . . . . . . 28, 71, 89 Hopewell, PC . . . . . . . . . . . . 10 H opf, HC . . . . . . . . . . . . . 11 H opkins, BL . . . . . . . . . . . . 60
H opkins, C . ............. 10 Hopp, JW . ............... 34 H opps, J ............... 97 Hopwood, BEC . . . . . . . . . . 89 89 H orisberger, $B \ldots \ldots \ldots \ldots 65$ $\mathrm{H}$ orm, JW ............. 10 Horn, D .............. 28 H ornbein, TF . . ........... 37 H ornberger, S . . . . . . . . . 43 H ornby, P . . . . . . . . . . . 29 H orne, EO . . . . . . . . . . . . 39 H orne, JA . . . . . . . . . . . . 43 H orner, WE . . . . . . . . . . . . 64 H ornsby, $A \ldots \ldots \ldots . . .66$ H ornung, FW ........... 89 H ornung, RW ... 3, 9, 32, 52, 82 Horowitz, M M . . . . . . . . . . 97 H orowitz, M R . . . . . . . . . . . 83 H orte, LG ............. 100 Hörte, S-尺̊ . . . . . . . . . . . . 58 H örtnagel, J . ............ 7 H orvath, E............. 16 H osker, M E ............. 28 H osker, R P .............. 55 H osmer, DW, Jr. . . . . . . . . 83 H osni, DE .............. 29

H ospital Provincial de

Guangdong para la

Prevención y el Tratamiento de las Enfermedades

Profesionales ........ 16, 20

H ossmann, K -A . . . . . . . . . . 49

$H ø s t, L \ldots \ldots \ldots \ldots \ldots 66$ H otimsky, A . . . . . . . . . . . . 10

$\mathrm{H}$ otz, $\mathrm{P} \ldots \ldots \ldots \ldots \ldots \ldots 11$ Hou, W............... 83

H ouba, R ................ 30 H oucine, $0 \ldots \ldots$.......... 10 H ough, L . . . . . . . . . . . . . 34 H ough, LM ........... 34, 35 H ough, R ........... 34, 51 H oughton, AN ............. 12 H oughton, DL . . . . . . . . . . . . 79 H oughton, FC . . . . . . . . . 42 H oughton, PW . ........... 11 H ouse, DE . . . . . . . . . . . . . . 13 H ouse, J . . . . . . . . 15, 34, 52 H ouse, JS . ............... 34 H ousiaux, A ............. 29 H ousset, $P \ldots \ldots \ldots \ldots \ldots .4$ H ouston, B. . . . . . . . . . . . 34 H ouston, CS . . . . . . . . . . . 37 Houston, SC ............ 6 H outman, I . . . . . . . . . . . 5, 34 H outman, ILD . . . . . . . . . . . . . 5 H ovarth, EP......... 77, 102 H ovden, J. . . . . . . . . . . 56, 59 H ovinga, $M \ldots . . . \ldots \ldots . .80$ H owald, H . . . . . . . . . . . . . 6 H oward, B . . ............ 71 H oward, IP . . . . . . . . . . . . . 11 H oward, JK .......... . 7, 32 H oward, R . . . . . . . . . . . . . . 34

$\mathrm{H}$ owarth, $\mathrm{Cl} \ldots \ldots \ldots \ldots 59$
H owarth, M V ............ 10 H owd, RA .............. 11 H owe-G rant, M . . . . . . . . . . 84 Howe, GR ............. 32 H owell, DS ............6 6 Howes, MJ . . . . . . . . . . . . 83 H owland, M A . . . . . . . . . . . . 10 Hox, J .................. 59 Hoy, DA ............... 15 Hoyos, CG............. 59 Hoyos, CT ............ 59 H rbacek, EM . . . . . . . . . . 41 H rubec, $Z \ldots \ldots \ldots \ldots \ldots .48$ H ryhorczuk, D . . . . . . . . . . . . 89 H ryhorczuk, DO . . . . . . 63, 97 H sia, Y . .............. 11 H su, $\mathrm{P} \ldots \ldots \ldots \ldots \ldots . . . .97$ H su, S-H ............ 29 H sueh, K D.............. 47 $H u, D J \ldots \ldots \ldots \ldots \ldots . \ldots 38$ $\mathrm{Hu}, \mathrm{FC} \ldots \ldots \ldots \ldots \ldots 28$ $\mathrm{Hu}, \mathrm{PY} \ldots \ldots \ldots \ldots \ldots \ldots 9$ $\mathrm{Hu}, \mathrm{X} \ldots \ldots \ldots \ldots . \ldots . \ldots . \ldots$ Huang, CC .............. 10 H uang, J. . . . . . . . . . . . . . . 89 Hubacova, L . . ............ 97 H ubbard, AE . . . . . . . . . . . 34 H ubbard, R .............. 33 H uber, $\mathrm{H} \ldots \ldots \ldots \ldots . . . . .97$ Huber, $0 \ldots \ldots \ldots \ldots . \ldots 59$ H ubert, DE . . . . . . . . . . 60 H uck, PEJ ............. 42 H udiberg, JJ . . . . . . . . . . . 34 H udnell, HK . . . . . . . . . . . 13 H udock, S ............... 18 H udson, $\mathrm{HT} \ldots \ldots \ldots \ldots .49$ H udson Institute ........... 15 H udson, PM . . . . . . . . . . . 97 Hudson, PT ............ 56 H udson, PT W . . . . . . 57, 59, 78 H udspeth, AJ . ............ 11 Huerta, J ................ 53 H uet, $T \ldots \ldots \ldots \ldots \ldots$ Huey, BM .............. 29 H uff, JE .............. 33 H ugentobler, M K . . . . . 3, 34, 56 Hughes, AJ . . . . . . . . . . . . 74 Hughes, EG . . . . . . . . . . 63 Hughes, $J \ldots \ldots \ldots \ldots \ldots . \ldots 34$ H ughes, JE . . . . . . . . . . . . . 6 Hughes, JL............ 96 Hughes, JM ............. 10 H ughes, JP . . . . . . . . . . . . 83 Hughes, JPW . . . . . . . . . . 10 Hughes, M . . . . . . . . . . . . . . 34 Hughes, R ............. 10 Hughes, RT . . . . . . . . . . . 38 Hui, YH .............67 67 H uici, $A \ldots \ldots \ldots \ldots . . . . .28$ Huie, $G \ldots \ldots \ldots \ldots . \ldots 96$ H uiskamp, R . . . . . . . . . 21 H uitfeldt, B . . . . . . . . . . 6 Hulbert, WC . . . . . . . . . . . 10 Hull, BP . . . . . . . . . . . 10 
Hull, HF............. 32

Hull, JG ................ 34

Hultman, G ............ 100

H uman Capital Initiative

$(\mathrm{HCl}) \ldots \ldots \ldots \ldots \ldots \ldots$

H uman R esources D evelopment

Canada .................. 24

Humber, JM ............. 19

Hume, $D \ldots \ldots \ldots \ldots \ldots 28$

H uminer, D . . . . . . . . . . . 38

H umphrey, FE........... 100

H umphreys, $P$. . . . . . . . . . . . 59

$H$ under, $G G \ldots \ldots \ldots \ldots .6$

H ungerford, LL . . . . . . . . . . 28

H unninghake, GW ........ 10

H unsaker, $\mathrm{H} \ldots \ldots \ldots \ldots . . . . .63$

$H$ unt, EH ............. 97

H unt, GM ............. 97

Hunt, $H \ldots \ldots \ldots \ldots \ldots 17$

H unt, HA.......... 17, 59

Hunt, LW ............. 97

Hunt, M R ............. 27

Hunt, RD . ............. 33

H unter, D ......... 11, 22, 39

H unter, JAA. . . . . . . . . . . 100

H unter, K ............. 41

H unter, WJ ......... 20, 38, 43

Huntoon, $\mathrm{CL} \ldots \ldots \ldots \ldots . \ldots 2$

Huq, A ................ 53

Hurd, $S \ldots \ldots \ldots \ldots \ldots \ldots . .97$

Hurley, JF .............. 10

H urrell, J . . . . . . . . 5, 34, 52, 99

$\mathrm{H}$ ursch, $\mathrm{Cl} \ldots \ldots \ldots \ldots \ldots 43$

Hurst, M W . . . . . . . . 26, 102

H urst, R . . . . . . . . . . . . 8

H usain, T . . . . . . . . 63, 64, 96

Husby, $G \ldots \ldots \ldots \ldots \ldots \ldots$

Husman, K ........... 7, 16

Husmo, M . .............66

H ussain, $\mathrm{M} \mathrm{H} \ldots \ldots \ldots \ldots \ldots 10$

H ussain, SH . . ........... 22

$H$ ussin, $A H \ldots \ldots \ldots \ldots . .22$

H ussman, $T \ldots \ldots \ldots \ldots \ldots . . .89$

Hutchings, $S \ldots \ldots \ldots \ldots 85$

H utchins, $C L \ldots \ldots \ldots \ldots . . .63$

H utchins, EL . . . . . . . . . . 52

Hutchins, GM ............ 3

H utchinson, JD . .......... 66

Hutchinson, LJ . . . . . . . . . T

H utchinson, TA . .......... 9

H utchison, J . . . . . . . . . . . 15

$H$ uth, $F \ldots \ldots \ldots \ldots \ldots 10$

Huth, GC ............. 44

$H$ üttner, $H \ldots \ldots \ldots \ldots \ldots . . . \ldots$

H uuskonen, $H$. . . . . . . . . . . . . 52

Huuskonen, M . . . . . . . . 6, 16

Huws, U . . . . . . . . . . . . . 99

Huxsoll, DL ........... 28

$H$ wang, CP ............. 34

H wang, JS .............. 83

Hyde, $J \ldots \ldots \ldots \ldots \ldots \ldots . . . \ldots$

Hyde, M L . . . . . . . . . . . . 73

Hyner, GC . . . . . . . . . . . . 26

$H$ yttinen, $M$. . . . . . . . . . . 59 lacopelli, D ............ 102

Ibanez, M D . . . . . . . . . . . . 64

Ibrahim, P . . . . . . . . . . . . 22

Iden, CR .............. 83

Idzoir-Walus, B . .......... 3

IEA W orkshop on Ethics $\mathrm{H}$ ealth

Policy and Epidemiology . . . 19

Iggo, A . . . . . . . . . . . . . . 11

Ignesti, A . . . . . . . . . . . . . 49

Ihde, DC .............. 10

Ihman, A . . .............. 34

Ihrig, AM . . . . . . . . . . . 4 4

lida, M . ...............96 96

Ikeda, Y . . . . . . . . . . . . . . . 100

Ikuta, F. . . . . . . . . . . . . . 11

Ilabaca, C. . . . . . . . . . . . . 68

Ilgen, DR ........... 34, 59

Illman, DL ................ 20

Illuminating Engineering

Society of $\mathrm{N}$ orth America

(IESNA) . ......... 11, 46

IImarinen, J . . . . . . . . 3, 29, 43

Ilstrup, D . . . . . . . . . . . . . 6

Ilyna, OV . ..............64 64

Imada, AS . . . ............. 29

Imai, M ................ 34

Imbus, $H \ldots \ldots \ldots \ldots . . . .86$

Imbus, HR . . . . . . . . . . . . 89

Immel, HR . ............. 100

Industrial Accident Prevention

Association (IAPA) . ...... 88

Industrial Biotechnology

Association ............ 77

Industrial Risk Insurers (IRI) . . 77

Industry Wide Labor-

$M$ anagement Safety

Committee for the M otion

Picture and T elevision

Industry ............. 96

Infante, $P \ldots \ldots \ldots \ldots \ldots .1$

Infante-R ivard, C . . . . 10, 52, 87

Ing, $R \ldots \ldots \ldots \ldots \ldots . \ldots 39$

Ingall, $T$ J ..............42 42

Ingebrethsen, BJ .........44

Ingelman-Sundberg, $\mathrm{H}$. . . . . . 86

Ingle, $R \ldots \ldots \ldots \ldots . \ldots 4$

Innocenti, A . . . . . . . . . . . . 11

Inohara, $\mathrm{H} \ldots \ldots \ldots \ldots \ldots \ldots . \ldots 21$

Inoue, $\mathrm{S} \ldots \ldots \ldots \ldots \ldots . . . . .34$

Institut de recherche en santé

et en sécurité du travail

(IRSST) .............. 52

Institute for $\mathrm{H}$ ealth Policy . . . . . 15

Institute of Electrical and

Electronic Engineers (IEEE). 49

Institute of $M$ edicine

$($ IO M ) ......... 16, 32, 53

Institute of $\mathrm{O}$ ccupational

$\mathrm{H}$ ealth $(\mathrm{IOH}) \ldots \ldots \ldots 16,22$

Institute of Shortening and

Edible 0 ils. ..............

Instituto de Prevención y

Tratamiento de las
Enfermedades Profesionales

de Dalian .............. 20

Instituto finlandés de Salud

en el Trabajo. . . . . . . . 27, 93

Instituto Internacional de

Estadística . . . . . . . . . . . . 19

Instituto Internacional del

$\mathrm{H}$ ierro y el A cero (IISI

International Iron and Steel

Institute). .

Instrument Society of America (ISA) ................ 59

International Business $\mathrm{M}$ achines

Corp ................ 52

International Chamber of

Shipping ............. 102

International Fabricare

Institute.............. 100

International Institute of

Synthetic R ubber

Producers. .

International Labor Rights

Education and Research

Fund (ILREF) . . . . . . . . . 20

International U nion of Pure

and Applied Chemistry

(IUPAC) ............61

International U nion. . . . . . . . 24

Inzitari, D ................ 7

I owa D epartment of Public

H ealth . . . . . . . . . . . . . . 70

Ippolito, G . ..............997

Iregren, A............ 7, 73

Irgens, LM . . . . . . . . . . . . . . 9

Irion, $H \ldots \ldots \ldots \ldots \ldots . \ldots 4$

Irr, W................. 10

Irunk, IG ..............997

Irwin, RS ............... 63

I saacson, RL . . . . . . . . . . . 13

Isager, $H \ldots \ldots \ldots \ldots \ldots$. . . . 11

I saksson, A ................... 7

Iscono, WG .............. 5

Isenman, AW . . . . . . . . . . . . .9

Ishii, EK ................. 3

Ishikawa, K .............. 34

Ising, $\mathrm{H} \ldots \ldots \ldots \ldots . . . . . .4,47$

Iskander, A. .............. 43

Iskra-G olec, I . . . . . . . . . . . 43

Ison, JR .............. 11

Ison, TG .............25

Israel, BA . . . . . . . . 3, 34, 56

Israel, I. . . . . . . . . . . . . . . . 3

Israeli, E. . . . . . . . . . . . . . 77

Isselbacher, KJ . . . . . . . . . . 53

Isseroff, JE . . . . . . . . . . . . . . 13

Itani, T............... 52

ITM, Inc ................ 83

I vancevich, JM . . . . . . . . 34, 35

Ivankovic, D. . . . . . . . . . . . 89

Iverson, $M \ldots \ldots \ldots \ldots . .70$

I wano, K ................9797

I watsubo, Y ......... 32, 100

Iyanagi, $T \ldots \ldots \ldots \ldots . \ldots 33$

Izraeli, D N . . . . . . . . . . . . 34
Jaakola, J................ 13

Jablon, S. . . . . . . . . . . . . . . 48

Jablonski, L . . . . . . . . . . . . 38

Jacjels, R ................ 38

Jack, TA.............. 93

Jackaman, P. . . . . . . . . . . . 22

Jackson, DN . . . . . . . . . . . . . 34

Jackson, GW .............. 15

Jackson, P. . . . . . . . . . . . . . 34

Jackson, RJ............... 9

Jackson, SE ............... 34

Jaco, EG ............... 19

Jacob, I...............42

Jacob, M P . . . . . . . . . . . . . 10

Jacobi, W............... 32

Jacobs, F............... 3

Jacobs, HE............. 5

Jacobs, R .............. 70

Jacobs, RJ ............... 30

Jacobs, R R . . . . . . . . . . 10, 89

Jacobsen, M . ............. 10

Jacobsen, P. . . . . . . . . . . . . 11

Jacobson, G . . . . . . . . . . . . 10

Jacobson, $\mathrm{HI} \ldots \ldots \ldots \ldots . . . .39$

Jacobson, JL . . . . . . . . . . . . . . 9

Jacobson, M ............. 41

Jacobson, SF . . . . . . . . . . . 97

Jacobson, SL . . . . ......... 9

Jacobson, SW . ............ 9

Jacoby, SM ............. 21

Jacqmin, H.............. 5

Jacquenot, P. . . . . . . . . . . . . . 97

Jacques, CH M . . . . . . . . . . . 97

Jacques, $P \ldots \ldots \ldots \ldots \ldots . .97$

Jacquinet-Salord, M D . . . . . . . 3

Jadassohn, W . . . . . . . . . . . . 49

Jaenicke, K F . . . . . . . . . . 49

Jaeschke, W ............... 55

Jaffe, ES . . . . . . . . . . . . . 1

Jaffe, RB.............. 9

Jagels, $R \ldots \ldots \ldots \ldots \ldots . .71$

Jäger, M . . . . . . . . . . . . 97

Jagger, J . . . . . . . . . . . . . . 97

Jagielo, P . . . . . . . . . . . 70

Jagtenberg, R . . . . . . . . . . . 21

Jahn, D . . . . . . . . . . . . . 3

Jahr, J................... 30

Jahss, M H ............. 6, 96

Jakubowski, A ........... 43

Jamal, M ..............4 43

Jamal, SM ............ 43

James, CR . . . . . . . . . . . . . 34

James, E . . . . . . . . . . . . 10

James, ER . . . . . . . . . . . . 64

James, K ................. 34

James, LR ............. 59

James, PA . . . . . . . . . . . . . . 64

James, SA . . . . . . . . . . . . . 9

Jamieson, E . . . . . . . . . . . . . 10

Jamieson, G G . . . . . . . . 15, 19

Jamison, A . . . . . . . . . . . . . . 29

Jamison, DT .............. 15

Jamleson, GG ............ 16 
Jamner, LD . . . . . . . . . . . 34 Janbell, H . . . . . . . . . . . . . . . . 98 Janckewicz . . . . . . . . . . . . 10 Janecki, CJ . . . . . . . . . . . . 6 Janerich, DT . . . . . . . . . . 39 Janis, IL . . . . . . . . . . . . . . 59 Jankanish, M . . . . . . . . . 88 Jann, BB . . . . . . . . . . . . . 17 Janni, K . . . . . . . . . . . . . . . 70 Jansen, EJH M . . . . . . . . . . 33 Jansen, PLM . ............ 33

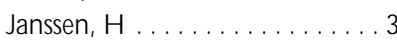
Janssen, W . . . . . . . . . . . . 56 Janssen, Y M W . . . . . . . . . . . 10 Janssens, M . . . . . . . . . . . 41 Janszen, D B . . . . . . . . . . . . 91 Jantunen, M . . . . . . . . . . . 13 Jany, SE . . . . . . . . . . . . . 49

Japan Industrial D esign Promotion 0 rganization (IIDPO) ............ 29

Jäppinen, P . . . . . . . . 71, 72

Jarashow . . . . . . . . . . 54

Jarosz, D . . . . . . . . . . 3

Jarrett, M . . . . . . . . . . . . . 5

Jarrett, QT . . . . . . . . . . . 83

Järup, $L \ldots \ldots \ldots \ldots \ldots \ldots \ldots . . \ldots 3$

Järvenpää, AE . . . . . . . . . . 22

Järvholm, B . . . . . . . . 72, 94

Järvholm, U . . . . . . . . . . . . 6

Järvinen, E . . . . . . . . . . 3, 91

Jarvis, BB . . . . . . . . . . . . 13, 44

Jasis, M . . . . . . . . . . . . . . . 87

Jastrzebowski, W . . . . . . . . . . . 29

Jaurand, M C . . . . . . . . . . . 10

Javeland, B. . . . . . . . . . . . . 82

Jaycock, M A . . . . . . . . . . . 20

Jayson, M IV . . . . . . . . . . 6, 6, 97

Jeanneret, PR . . . . . . . . . . . . . 29

Jederlinic, PJ . . . . . . . . 10, 63

Jefferson, LS. . . . . . . . . . . . . 9

Jeffreys, J . . . . . . . . . . 5

legaden, $D \ldots \ldots \ldots \ldots \ldots \ldots \ldots$

Jenkins, BD . . . . . . . . . . . 40

Jenkins, CD . . . . . 5, 26, 34, 102

Jenkins, EL . . . . . . . . . 51, 56, 99

Jenkins, PA . . . . . . . . . . . . 10

Jenkins, R . . . . . . . . . . . 34

Jenkins, R A . . . . . . . . . . . 44

Jenks, CW .............. 21

Jennett, B . . . . . . . . . . . . . 14

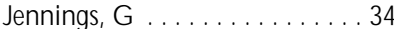

Jennings, JC . . . . . . . . . . . 6

Jennings, K R . . . . . . . . . . . 29

Jennings, NS . . . . . . . . . . . 74

Jennings, R . . . . . . . . . . . . . 34

Jensen, KIF . . . . . . . . . . . 13

Jensen, NE . . . . . . . . . . . 9

Jensen, $0 \ldots \ldots \ldots \ldots \ldots \ldots$

Jensen, $\mathrm{OM} \ldots \ldots \ldots \ldots \ldots \ldots 9$

Jensen, PL . . . . . . . . . . . 6

Jensen, R . . . . . . . . . . . . 100

Jensen, R C . . . . . . . . . . . 64

Jensen, RH.
Jensen, $R L \ldots \ldots \ldots \ldots \ldots \ldots 9$

Jernberg, LE ...........41

Jetten, TH . . . . . . . . . 53

Jewett, 」 . . . . . . . . . . . . . . 72

Jex, SM .............. 34

Jeyaratnam, J . . . . 2, 16, 20, 22,

$28,39,52,64,93$

Jhangri, GS . . . . . . . . . . 28

Jiang, Z-L. . . . . . . . . . . . 1

Jiménez Casado, M . . . . . . . . 3

Jin, $A \ldots \ldots \ldots \ldots \ldots \ldots . \ldots . \ldots . \ldots$

Jirasek, L . . . . . . . . . . . 12

Jöckel, K H . . . . . . . . . . . . . 32

Johanning, E . . . . . . 44, 93, 101

Johannson, G . . . . . . . . . 3, 35

Johannsson, S-E . . . . . . . . . 100

Johansen, C . . . . . . . . . . 6

Johanson, G . . . . . . . . . . . . . 33

Johansson, A . . . . . . . . 17, 29

Johansson, B . . . . . . . . 11, 56

Johansson, G . . . . . . . . 34, 52

Johansson, L . . . . . . . . . 73

Johansson, S. . . . . . . . . . . 70

John, EM . . . . . . . . . . . 100

John, RS . . . . . . . . . . . 59

Johnsen, CR . . . . . . . . . . 13

Johnsen, $\mathrm{H} \ldots \ldots \ldots \ldots \ldots \ldots \ldots 7$

Johnson, A . . . . . . . . . 73, 82

Johnson, A-C . . . . . . . . . . . 11

Johnson, B . . . . . . . . . . 58, 59

Johnson, BL . . . . . . 7, 33, 34, 53

Johnson, CA .......... 43

Johnson, C C .......... 72

Johnson, D . . . . . . . . . . . . . 7

Johnson, E . . . . . . . . 15, 32

Johnson, EF . . . . . . . . . . . 33

Johnson, EJ . . . .......... 59

Johnson, G . . . . . . . . . . . 91

Johnson, GI . . . . . . . . . . . 52

Johnson, H . . . . . . . . . . 52

Johnson, JA . . . . . . . . . . 64, 97

Johnson, JL . . . . . . . . . . 12

Johnson, JV . . . . . . . . . . 34, 35

Johnson, KA ...........6 6

Johnson, K G . .............42

Johnson, KW . . . . . . . . . . 15

Johnson, L . . . . . . . . . . . . 64

Johnson, LC . . . . . . . . . 3, 29, 43

Johnson, $M \ldots \ldots \ldots \ldots \ldots 34$

Johnson, $\mathrm{M} \mathrm{H} \ldots \ldots \ldots \ldots \ldots . . . . .14$

Johnson, M R . . . . . . . . . . 26

Johnson, NF . . . . . . . . . . . . 10

Johnson, OA ........... 19

Johnson, $P \ldots \ldots \ldots \ldots \ldots \ldots . \ldots 52$

Johnson, SA . . . . . . . . . . 70

Johnson, TV ............ 3

Johnson, WG . . . . . . . . . 57

Johnston, A . . . . . . . . . . . 23

Johnston, JJ . . . . . . . . . . . . 56

Johnston, OE . . . . . . . . . . . 100

Johnston, RC . . . . . . . . . . . 6

Joint Industrial Safety Council

of Sweden . . . . . . . . . . . 21

Joki, $S \ldots \ldots \ldots \ldots \ldots \ldots . \ldots 6$
Jokinen, $M \ldots \ldots \ldots \ldots \ldots . .97$

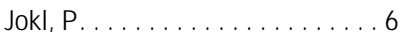

Jokulioma, H . . . . . . . . . 68

Jolanki, R . . . . . . . . . . . . . . . . 85

Jonasson, G . . . . . . . . . . . 97

Jones, AD . . . . . . . . . . . . 10, 27

Jones, AP . . . . . . . . . . . . . 59

Jones, BR . . . . . . . . . . . . 97

Jones, BW ..............42 42

Jones, D . . . . . . . . . . . . . . 21

Jones, DA.............. 6

Jones, $D L \ldots \ldots \ldots \ldots \ldots \ldots . .64$

Jones, FS . . . . . . . . . . . . 80

Jones, HD .............. 10

Jones, JC . . . . . . . . . . . 33

Jones, JE . . . . . . . . . . . . . . . 74

Jones, JH . . . . . . . . 63, 83

Jones, K C. . . . . . . . . . . . . . 52

Jones, L . . . . . . . . . . . . 17

Jones, ME . . . . . . . . . . . 12

Jones, M R . . . . . . . . . . . 38

Jones, PG . . . . . . . . . . . 59

Jones, R . . . . . . . . . . . . 10, 97

Jones, RD . . . . . . . . . . . . 30

Jones, R N . . . . . . . . . . . . 10, 89

Jones, RT . . . . . . . . . . . . 97

Jones, T . . . . . . . . . . . . . 8, 29

Jones, TH . . . . . . . . . . . . . 64

Jones, TR . . . . . . . . . . . . . . 10

Jones, W . . . . . . . . . . . . . . 70

Jones, WG . . . . . . . . . . . 101

Jones, WJ . . . . . . . . . . . . . . 64

Jonssen, CR . . . . . . . . . . 13

Jonsson, B . . . . . . . . 6, 100

Jonsson, BG . . . . . . . . . 3, 43

Jönsson, $E \ldots \ldots . \ldots . \ldots . .49$

Jonsson, P. . . . . . . . . . 64, 101

Jordan, J. . . . . . . . . . . . . 10

Jordan, PT . . . . . . . . . . . . . 82

Jørgensen, $K \ldots \ldots \ldots \ldots \ldots 6$

Jörgensen, $N \ldots \ldots \ldots \ldots \ldots 6$

Jorgensen, $\mathrm{P} \ldots \ldots \ldots \ldots \ldots \ldots 5$

Joris, I. . . . . . . . . . . . . . . . 33

Jorm, AF . . . . . . . . . 7

Josch, $R \ldots \ldots \ldots \ldots \ldots \ldots 43$

Joshi, DD . . . . . . . . . . . . . 70

Joshi, V R . . . . . . . . . . . . . . 39

Jost, J . . . . . . . . . . . . . . 97

Joubert, JR . . . . . . . . . . . 38

Journet, W . . . . . . . . . . . . . 64

Jovel, JR . . . . . . . . . . . . . 39

Jowell, R . . . . . . . . . . . . 19

Jowett, D . . . . . . . . . . . . 100

Joy, DS. . . . . . . . . . . . . 34

Joy, RM ............ 7

Joyce, WF ............. 59

Joyner, K H ........49, 102

Jozuka, S . . . . . . . . . . . . . 5

Jubb, KVF . . . . . . . . . . . . 10

Jucker, $A \ldots \ldots \ldots \ldots \ldots \ldots 6$

Judd, FK ............. 26

Judson, FN . . . . . . . . . . . . 97

Juhlin, R. . . . . . . . . . . 6

Julian, J . . . . . . . . . . . . . 80
Julian, JA . . . . . . . . . . . 10

Juliussen, $E \ldots \ldots \ldots \ldots \ldots$. . . . 52

Juminer, B . . . . . . . . . . 38

Junge, $A \ldots \ldots \ldots \ldots \ldots \ldots . \ldots 34$

Jungermann, $H \ldots \ldots \ldots \ldots . \ldots 59$

Junghanss, $T \ldots \ldots \ldots \ldots \ldots . \ldots 38$

Junker, BH . . . . . . . . . . . . 59

Juntunen, $M L \ldots \ldots$. . . . . . . 68

Jupiter, JB . . . . . . . . . . . 6

Juran, JM . . . . . . . . . . . . . 34

Jürgens, $\mathrm{HW} \ldots \ldots \ldots \ldots \ldots . \ldots 29$

Jurinski, N B . . . . . . . . . . . . . 82

Jurvélius, $M \ldots \ldots \ldots \ldots \ldots 68$

Jusoh, M . . . . . . . . . . . . . 22

Justice, A . . . . . . . . . . 34

Jusuino, JC . . . . . . . . . . . . 34

Juto, JE . . . . . . . . . . . 13

Juul, $S \ldots \ldots \ldots \ldots \ldots \ldots$

Juutilainen, J . . . . . . . . . . 52

\section{$K$}

K abat, GC . . . . . . . . . . . 44

K achru, DM ........... 11

K aczmarek, R G . . . . . . . . . . 97

K aczmarek, T . . . . . . . . . 80

$K$ adefors, $R \ldots \ldots \ldots 6,29,66$

K ader, $H \ldots \ldots \ldots \ldots \ldots \ldots 89$

K adlecek, J. . . . . . . . . . . . 55

K adlubar, EE . . . . . . . . . . 27

K adlubar, FF . . . . . . . . . . 28

K aduka, N G . . . . . . . . . . . 39

$K$ adushin, $A \ldots \ldots \ldots \ldots \ldots . \ldots 34$

K aempe, $B$. . . . . . . . . . . . 66

K aempffer, AM ......... . 44

K agan, A . . . . . . . . . . 3, 34

K agann, RH ........... 55

K agey, BT . . . . . . . . . 96

Kahn, A ............. 15

Kahn, JP . . . . . . . . . . 5

Kahn, RL . . . . . . . . . . . . 34

K ahn, S . . . . . . . . . . . . 5, 34

K ahneman, D . . . . . . . . 29, 59

K ahnemann, D . . . . . . . . . 59

K aihilahti, J . . . . . . . . . . . 34

$K$ ainberger, $F \ldots \ldots \ldots \ldots \ldots 6$

$K$ aiser, $P \ldots \ldots \ldots \ldots 42,74$

K aji, H............. 3

K alat, J. . . . . . . . . . . . 64

Kaldor, J . . . . . . . . . 80, 88

$K$ ales, A . . . . . . . . . . . . 34

K alica, AR . . . . . . . . . . . . 10

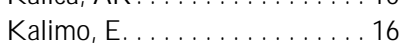

Kalimo, R . . . . . . . 3, 16, 52

K aliterna, L . . . . . . . . . . . 29, 43

K alkstein, LS . . . . . . . . . . 53

K allberg, VP . . . . . . . . 56

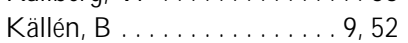

K allenberger, $W \ldots \ldots \ldots \ldots 88$

K allikowski, $P \ldots \ldots \ldots \ldots \ldots 13$

K allner, A . . . . . . . . . . 52

Kalow, W. . . . . . . . . . . 33

K amata, E . . . . . . . . . . 100

K amataki, $T \ldots \ldots \ldots \ldots \ldots \ldots . . . \ldots 33$ 
K aminski, $M \ldots \ldots \ldots \ldots 9,97$

K ammenmeyer, J .......... 70

K ammerman, S.......... 15

K ammüller, ME ........... 33

Kamon, E ............... 3

Kamp, DW ............. 10

Kamp, J............... 15

K ampmann, $R \ldots \ldots \ldots \ldots 43$

$\mathrm{K}$ an, $X \mathrm{G} \ldots \ldots \ldots \ldots 16,20$

K anarek, A .............. 55

K anarek, DJ............. 10

K anatani, K . . . . . . . . . . . 64

$K$ anawaty, $G \ldots \ldots \ldots \ldots . \ldots 52$

K anceljak, B ............ 65

$\mathrm{K}$ anda, $\mathrm{S} \ldots \ldots \ldots \ldots \ldots . . . . . . .$.

$K$ andel, ER ........... 7, 11

$\mathrm{K}$ andolin, I .........44, 97

$\mathrm{K}$ andolin $\mathrm{O}$ Isson, I . .......43

$\mathrm{K}$ ane, $\mathrm{H} \ldots \ldots \ldots \ldots .664,70$

$\mathrm{K}$ ane, JW ................ 40

$K$ ane, LE . . . . . . . . . . . . . . . . 30

$\mathrm{K}$ ane, $\mathrm{MA} \ldots \ldots \ldots \ldots$. . . . . . 38

K aneko, M ............. 29

$\mathrm{K}$ aneko, $\mathrm{T} \ldots \ldots \ldots \ldots \ldots 100$

$K$ anerva, $L \ldots \ldots \ldots \ldots \ldots$. . 64, 85

$K$ angas, $J \ldots \ldots \ldots \ldots \ldots 68$

K annel, WB . ............ 3, 6

$K$ anninen, $K \ldots \ldots \ldots \ldots 68$

$\mathrm{K}$ ano, $\mathrm{N} \ldots \ldots \ldots \ldots \ldots . \ldots 29$

K ansi, P . . . . . . . . . . . . . 29

$\mathrm{K}$ antarjian, $\mathrm{H} \ldots \ldots \ldots \ldots \ldots$

$\mathrm{K}$ antola, $\mathrm{M} \ldots \ldots \ldots \ldots \ldots 68$

$\mathrm{K}$ ao, TC.............. 100

K apitaniak, B............. 97

Kapitonova, M E .......... 38

K aplan, GA .............. 34

K aplan, GD . . ............. 15

K aplan, HI. . . . . . . . . . . . . . 5

Kaplan, IM .............66

Kaplan, PE .............. 17

Kaplan, R ............... 34

Kaplan, RF ............... 3

K aplan, R M . ............. 97

Kaplan, S............ 34, 100

K aplan, SA ............. 100

K aplan, SR ............. 6

Kaplan, YS .............. 10

K app, M C ............. 89

Kapre, SS.............. 101

$\mathrm{K}$ apur, BM .............11

Karacan, I ............. 43

$\mathrm{K}$ araoglou, A ............. 39

K arasek, R . . . 3, 5, 24, 34, 35, 43

K arasek, RA . . . 3, 20, 34, 52, 99

Karat, J............... 52

$K$ arava, $R \ldots \ldots \ldots \ldots . .91$

$\mathrm{K}$ arberger, $T \ldots \ldots \ldots \ldots \ldots 64$

$K$ arhausen, $L R \ldots \ldots \ldots 28$

K arhonen, PJ . ............. 10

K arhu, $0 \ldots \ldots \ldots \ldots \ldots 29$

$\mathrm{K}$ arim, Z ............... 22

$K$ arin, $M \ldots \ldots \ldots \ldots \ldots . \ldots . \ldots$

$K$ aristo, $A \ldots \ldots \ldots \ldots \ldots 16$

$K$ arjalainen, $A \ldots \ldots \ldots \ldots 10$
K arkashion, C .......... 100

K ärkkäinen, $A \ldots \ldots \ldots \ldots .6$

K arlan, H B ............. 34

K arlsson, B-M ...........4 4

$\mathrm{K}$ arlsson, J . . . . . . . . . . . . . . 3

$\mathrm{K}$ arlsson, $\mathrm{K} \ldots \ldots \ldots \ldots \ldots . \ldots$

K arlsson, M ............. 7

$K$ arlsson, $R \ldots \ldots \ldots \ldots 66$

$K$ armaus, $W \ldots \ldots \ldots .99,52$

K arnaukh, NG ............. 3

$\mathrm{K}$ arns, ME .............6 63

K arpachevska, SI . . . . . . . . 38

K arpakka, J ..............6

K arpilow, C ............. 15

Karpinski, K F ........... 9

Karr, C ..............664

$\mathrm{K}$ arr, $\mathrm{S} \ldots \ldots \ldots \ldots \ldots \ldots 10$

K arrasch, K ............43 43

K arter, M JJ ............. 41

Karvonen, $J \ldots \ldots \ldots \ldots \ldots . . . . .3$

$K$ arvonen, $M$. . . . . . . . . . . 28

Karvonen, M J ......... 34, 43

K arwowski, W ...... 17, 22, 29,

$34,56,58,59$

K asakov, VS ............ 48

K asdan, M L............. . 40

K ashparov, VA ........... 39

$\mathrm{K}$ asl, SV ............. 34, 52

$K$ asperson, RE . .......... 59

$\mathrm{K}$ ass, I ................ 10

$\mathrm{K}$ astenholz, E.......... 68

K asumovic, J . . . . . . . . . . 97

K aswandik, NT ........... 9

K atiyar, PS .............74

K atkin, E ............. 99

$K$ ato, $H \ldots \ldots \ldots \ldots 10,48$

K ato, $M \ldots \ldots \ldots \ldots \ldots$

$K$ aton, $W \ldots \ldots \ldots \ldots \ldots$

$\mathrm{K}$ atsnelson, BA ........... 10

$\mathrm{K}$ atz, DF .............. 9

$\mathrm{K}$ atz, $\mathrm{HC} \ldots \ldots \ldots \ldots \ldots 21$

$\mathrm{K}$ atz, JN ................ 3

Katz, R ..............99 97

$\mathrm{K}$ atz, RM ............. 100

$\mathrm{K}$ atz, SH ............... 30

$\mathrm{K}$ atzenellenbogen, I . . . . . . . . 79

$K$ atzman, $R \ldots \ldots \ldots \ldots \ldots$

K aufman, BE.............21

K aufman, L . . . . . . . . . 29, 64

K aufmann, AF ............. 3

K aufmann, PG ........... 34

K augmann, $0 \ldots \ldots \ldots \ldots 43$

$\mathrm{K}$ aul, G ................ 3

$\mathrm{K}$ aupen- $\mathrm{H}$ aas, $\mathrm{H} \ldots \ldots \ldots \ldots 52$

K auppi, $A \ldots \ldots \ldots \ldots \ldots 18$

$K$ auppinen- $T$ oropainen, $K$. 34, 43

$K$ auppinen, $T \ldots 2,4,24,30,32$

$K$ avanagh, MF..........42 42

$\mathrm{K}$ avanaugh- $\mathrm{M} \mathrm{CH}$ ugh, $\mathrm{AL}$. . . . . . 3

K avaressi, N . . . . . . . . . . . . . . 89

K awachi, I . ............68

Kawagoe, $K \ldots \ldots \ldots \ldots \ldots 41$

K awahara, J............. 3

$\mathrm{K}$ awajiri, $\mathrm{K} \ldots \ldots \ldots \ldots . \ldots 33$
K awakami, N............ 34

$\mathrm{K}$ ay, CR.............. 12

$K$ ay, JP.............. 89

$K$ aye, WE ........... 9, 95

$K$ azantis, $G \ldots \ldots \ldots \ldots . \ldots 33$

K azantsis, $G \ldots \ldots \ldots \ldots \ldots 63$

K azemi, H . . . . . . . . . . 10, 63

K aznowski, A ............. 38

$K$ eane, MJ ............... 10

$\mathrm{K}$ ear, FW............. 83

K eating, $M J \ldots \ldots \ldots \ldots \ldots 1$

$K$ eatinge, WR ............ 3

K ecklund, $G \ldots \ldots \ldots \ldots 43$

K edia, BL ............... 29

K ee, WC ............... 52

K eele, CA .............. 11

$K$ eenan, K P . . . . . . . . . . . 10

$K$ eenan, M A . . . . . . . . . . . . . 6

K eeney, RL . . . . . . . . . . . . 59

K eenlyside, R......... 13, 100

$K$ eenlyside, $R H$. . . . . . . . . . 81

K eeping, HS ............. 9

K eesing, R M . . . . . . . . . . . . 29

K eesling, JE .............. 53

K ehrer, JP ........... 10, 33

$K$ eidar, $A \ldots \ldots \ldots \ldots \ldots 96$

$K$ eifer, $M \ldots \ldots \ldots \ldots \ldots .7$

$K$ eil, $U \ldots \ldots \ldots \ldots \ldots . . \ldots 80$

K eimig, D G . ........ 10, 32

K eita, GP. . . . . . . . . . 15, 34

$K$ eith, $L \ldots \ldots \ldots \ldots . . . . . .9$

K eith, PR . . . . . . . . . . . . . 9

$K$ eith, $R \ldots \ldots \ldots \ldots \ldots, 41$

K eith, RW ............. 11

K elfa, C . . . . . . . . . . 97

$K$ elin, $R \ldots \ldots \ldots \ldots \ldots \ldots 9 . \ldots 9$

K ellar, K A . . . . . . . . . . . . . . 10

K elleher, SE. . . . . . . . . . . . . 34

K ellerman, $G \ldots \ldots \ldots \ldots \ldots . .33$

K elley, J ............... 10

K elley, K A . . . . . . . . . . . . 64

K elley, WD .............64 64

K ello, D ................. 27

$\mathrm{K}$ elly-M CN eil, $K \ldots \ldots \ldots . .13$

$K$ elly-M cN eil, $N$. . . . . . . . . . . 13

K elly, CA . . . . . . . . . . . . . 15

$K$ elly, DP ................ 10

K elly, EG . . . . . . . . . . . . 74

K elly, KM ............. 40

$K$ elly, M ................. 34

K elly, PL ................ 3

K elly, RJ ..............43

K elly, RT . . . . . . . . . . . . . 97

K elly, TL ..............43

K elman, $\mathrm{S} \ldots \ldots \ldots \ldots \ldots \ldots . . . . .34$

K elsey, J............ 6, 34

K elsey, J L. . . . . . . . . . . . . . . . 97

K elsey, TW . . ........... 64

K elsh, M ............... 7

K empe, $P \ldots \ldots \ldots \ldots . \ldots 97$

K emper, B ................ 33

K endrick, JS. ............. 3

$K$ endrick, $M$............. 20

K ennedy, GL . . . . . . . . . . . 10
K ennedy, JC ............ 6

K ennedy, K . .............. 10

K ennedy, K W . . . . . . . . . . . 6

K ennedy, $P$. . ............. 20

K ennedy, PC . . . . . . . . . . . . 10

K ennedy, RD ............. 10

K ennedy, S . .......... 34, 53

K ennedy, TP . . ............ 10

K ennelley, K . . . . . . . . . . . . . 77

$K$ enneth, $W \ldots \ldots \ldots \ldots .42$

K enney, SP . . . . . . . . . . . . . 30

K enney, WL . . . . . . . . . . . 42

K enny, $P \ldots \ldots \ldots \ldots . . . .18$

$K$ enyon, EM . . . . . . . . . . . . 55

K eoleian, GA . . . . . . . . . . . . 54

K epenne, $P$. . . . . . . . . . . . 29

$K e r, A \ldots \ldots \ldots \ldots \ldots . \ldots 70$

$K$ erber, RA ............ 48

K erckhoff, A . . . . . . . . . . 34

K erguelen, A . ............. 29

K erivan, JE . . . . . . . . . . . . 31

K erkhof, A .............43

K erley, LM ............ . 97

K ern, $\mathrm{U} \ldots \ldots \ldots \ldots \ldots \ldots . \ldots 73$

K erns, WD............. 100

K eromes, A . . ........... 37

K err, JB .............. 53

K err, JFR ............... 33

K err, JH . . . . . . . . . . . 97

K err M uir, M ............. 39

$K$ err, $R \ldots \ldots \ldots \ldots \ldots 6$

K erstens, J . . . . . . . . . 43, 97

K ersteter, SL . ............. 3

K ersting, $H \ldots \ldots \ldots \ldots .61$

K erva, A ............... 2

$K$ essel, TM ............ 7

K essler-H arris, A . . . . . . . . . . . 24

K essler, II. . . . . . . . . . . . . . 100

K essler, R C . . . . . . . . . . . . . 34

K estin, IG . . . . ......... 97

K estler, E.............. 9

K etchum, L . . . . . . . . . . . 29

K ey, M M .............. 96

K eye, WRJ.............. 9

K eyes, DG ............. 11

K eyserling, WM ....... 29, 87

K eystone, JS. . . . . . . . . . . . . 74

K ezíc, $\mathrm{S} \ldots \ldots \ldots \ldots \ldots \ldots . \ldots . \ldots 33$

K hadri, $\mathrm{H} \ldots \ldots \ldots \ldots . . . .96$

K halidi, A .............. 9

$\mathrm{K}$ han, $\mathrm{M} \mathrm{H} \ldots \ldots \ldots \ldots . . .70$

K haw, KT .............. 3

K hera, K S............. 33

$K$ hintsenberg, IA . . . . . . . . . 38

$K$ hogali, $M \ldots \ldots \ldots \ldots \ldots \ldots 42$

K hokhar, J.............. 97

K houri, IF ............... 1

K ialseth, TO . .......... 100

K idd, P.......... 56, 58, 64

K iecolt-G laser, JK . . . . . . . . . 34

$K$ iefer, $M$. . . . . . . . . . . . . . . 70

K iemeney, LA . . . . . . . . . . 12

$K$ iese, $M \ldots \ldots \ldots \ldots \ldots \ldots .1$

K iesswetter, E . . . . . . . . 34, 43 
K ihlman, $T \ldots \ldots \ldots \ldots \ldots 47$ Kilbom, Å . . . . . . 6, 29, 52, 97 Kilbourne, EM ........39, 53 Kilburn, KH ......... 10,89 Kiloh, LG ............. 34 K ilpikari, I ............. 80 K imber, I .............. 33 Kimmel, CA ............. 33 K immel, GL ............ 33 Kimmins, $H \ldots \ldots \ldots \ldots 68$ Kimotsuki, K ............. 29 K imura, $H$. . . . . . . . . . . . . 37 Kimura, $T \ldots \ldots \ldots \ldots . \ldots 33$ $K$ ind, $A \ldots \ldots \ldots \ldots \ldots 15$ $K$ indwall, EP ............. 36 K ing, BW ............. 83 $\mathrm{K}$ ing, $\mathrm{CH} \ldots \ldots \ldots \ldots \ldots . . \ldots 97$ King, JB .............. 38 King, $M \ldots \ldots \ldots \ldots . \ldots 70$ King, $P \ldots \ldots \ldots \ldots 50,95,101$ King, PK . . . . . . . . . . . . 102 King, SW . . . . . . . . . . . . . . 34 King, $T \ldots \ldots \ldots \ldots \ldots$ K ingman, S ........... 53 K ingsley, K B ........... 89 K ingsley, PR ........... 29 K inlen, LJ .............. 48 K inlen, LJ .............. 28 K inloch-de-los, S . . . . . . . . 97 Kinloch, CD ............. 40 Kinnamon, SC ............ 11 K inney, JS ............. 29 K insella, TJ ............... 4 Kinsley, K B . . . . . . . . . . . . 10 Kipen, $H \ldots \ldots \ldots \ldots \ldots$ 13, 85 Kipen, $H$ M .......... 13, 96 K irchner, B . . . . . . . . . . . . 97 Kirk, GD .............. 79 Kirk, IW............. . 89

Kirk, RE .................... 103

K irkeeide, RL ........... 15

K irkendal, DT . ...........96 96 K irwan, B ................ 59

Kirwan, B .............. 56

Kishi, R ................ 11

K isner, SM . . . . . . . . . . . . . . . 93

Kisner, SM ............. 56

$K$ iss, $A \ldots \ldots \ldots \ldots \ldots 54$

Kissel, $F N \ldots \ldots \ldots \ldots .74$

Kitada, $Y \ldots \ldots \ldots \ldots \ldots 11$

K ittel, $F \ldots \ldots \ldots \ldots \ldots, 34$

Kittler, $H \ldots \ldots \ldots \ldots \ldots .43$

Kittner, SJ ................ 5

Kitz, RJ ............. 97

Kivi, $P \ldots \ldots \ldots \ldots \ldots, 6,29$

K ivimäki, J.............. 6

K ivimäki, M . . . . . . . . . . . 97

K ivinen, J . . . . . . . . . . . . 29

K ivisto, H . . . . . . . . . . . . . . 89

K jaergard, S............ 13

K jaerulff, J . .............. 9

K jellberg, A . . . . . . . . . . . 3, 7

K jellén, $U \ldots \ldots \ldots 22,56,57$

K jellström, T . . . 7, 28, 38, 53, 63
K laassen, CD . . . . . . 30, 33, 101 K laber M offet, J A . . . . . . . 20, 97 K larnet, R ............. 96 K lassen, CD .............. 7 $\mathrm{K}$ latt, M L . . . . . . . . . . . . . . . 70 Klaue, $K \ldots \ldots \ldots \ldots . . . .6$ K laukkla, T . . . . . . . . . . . 16 K launig, JE .............. 4 K lavis, G .............. 79

K lebanoff, M A............9 9 K leczkowski, BM ........... 97 K lee, JB ................. 50 K leiber, D ............... 34

K lein, BR . . . . . . . . . . . . . 97

K lein, D . . . . . . . . . . 60, 103

K lein, H K . . . . . . . . . . . . . 29

K lein, RL . .............. 33

K lein, R S . . . . . . . . . . . . . 97

K lein, T ools............ 93

K lein, $\mathrm{V} \ldots \ldots \ldots \ldots \ldots . . . . .55$

K leinbaum, D . . . . . . . . 11, 28

K leinbeck, U . . . . . . . . . . . . 29

K leindorer, PR . . . . . . . . . . 39

K leiner, M M .............. 21

$K$ leinerman, J . ........... 10

K leinert, $\mathrm{HE} \ldots \ldots \ldots \ldots, 6,40$

K leinhesselink, R R . . . . . . . . 59

K leinman, A ............. 5

K leinman, M T . ............ 3

$\mathrm{K}$ leinsasser, $0 \ldots \ldots \ldots . . . .96$

K leinschmidt, V . . . . . . . . . . 55

K lem, TJ . . . . . . . . . . . . . . 39

$\mathrm{K}$ len, $\mathrm{K} \ldots \ldots \ldots \ldots \ldots \ldots . . . .28$

$\mathrm{K}$ len, $\mathrm{T} \ldots \ldots \ldots \ldots \ldots .68$

$\mathrm{K}$ lett, $\mathrm{T} \ldots \ldots \ldots \ldots \ldots 9 . \ldots 9$

K letz, $T \ldots \ldots \ldots \ldots \ldots \ldots 5$

K liemt, $\mathrm{G} \ldots \ldots \ldots \ldots \ldots 56$

K ligman, A . . . . . . . . . . . . . 49

$\mathrm{K}$ lima, $\ldots \ldots \ldots \ldots \ldots \ldots \ldots . . .67$

K limmer, $F \ldots \ldots \ldots .29,43$

$K$ lincewicz, $S \ldots \ldots \ldots \ldots 64$

$K$ line, $J \ldots \ldots \ldots \ldots \ldots . . . \ldots$

$\mathrm{K}$ ling, $\mathrm{H} \ldots \ldots \ldots \ldots . ., 3,72,88$

K litzman, $S \ldots \ldots \ldots \ldots 34,52$

$\mathrm{K}$ lix, $\mathrm{F} \ldots \ldots \ldots \ldots \ldots \ldots, 52$

K lockow, D . . . . . . . . . . . . 55

K loetzel, K . . . . . . . . . . . . . . . 3

K lote, JH . . . . . . . . . . . . . . . 41

Kluckhohn, C ............ 29

K luin-N elemans, HC . . . . . . . . 1

K luin, M P .............. 1

K lünder, K B . . . . . . . . . 6

K napikowa, D ............. 3

K napp, JW.............. 55

K napp, LW .............. 70

$K$ nauth, $E \ldots \ldots \ldots \ldots .43$

K nauth, $P \ldots \ldots \ldots . .3,29,34,43$

K nave, $B \ldots \ldots \ldots \ldots, 7,52$

$K$ neeland, JB . . . . . . . . . . . . 6

K neip, $T$. . ............. 53

K nekt, P. . . . . . . . . . . . . 6

K nibbe, JJ . . ............. 97

K night, $C \ldots \ldots \ldots \ldots \ldots 66$

K night, G . . . . . . . . . 9
K night, J . . . . . . . . . . 44

K night, JL . ............ 34

$K$ night, $K \ldots \ldots \ldots \ldots \ldots 10$

Knight, K K ............. 15

Knip, M ..............42 42

Knipe, DM ............ 97

K nishkowy, B. . . . . . . . . . . 96

$K$ nobil, $E \ldots \ldots \ldots \ldots \ldots . \ldots$

Knoblauch, A ........... 70

$\mathrm{K}$ nobloch, $M \ldots \ldots \ldots \ldots \ldots 6$

K noeppel, $H \ldots \ldots \ldots \ldots \ldots 13$

Knolle, WR ............. . 83

Knop, W ................ 101

K nopp, D . . . . . . . . . . . . . . 68

K noppel, H ......... 44, 97

K norz, W.............. 101

K nowlton, RE ........... 58

$K$ nox, JM ............... 49

Knox, NW .............. 57

K nutsson, A . ....... 3, 43, 97

$\mathrm{K} 0, Y-C \ldots \ldots \ldots \ldots 10,66$

K obasa, S........ . 5, 34, 99

K obert, R ................. 30

K obryn, $U \ldots \ldots \ldots \ldots \ldots . . . \ldots$

Koch, $G \ldots \ldots \ldots \ldots \ldots$

Koch, $\mathrm{HU} \ldots \ldots \ldots \ldots . . .97$

Koch, $P \ldots \ldots \ldots \ldots \ldots . . .71$

Kochan, F ............. 26

K ochan, TA .............. 21

K ochanova, EM ............ 3

Kocher, W . .............. 6

K ochuyt, AM . . . . . . . . . . . . 70

Kociba, RJ............. 11

K ock, FJ . . . . . . . . . . . . . . 74

Koda, S ............... 97

K oella, WP ............... 43

$K$ oelsch, K A ............ 4

K oenig, $K L \ldots \ldots \ldots \ldots . . . .100$

K oester, CJ . . . . . . . . . . . . . 55

K offel, WE . . . . . . . . . . . . 4 41

$K$ ofman, $S \ldots \ldots \ldots \ldots \ldots . \ldots 15$

K ofoed, L.............. 34

K ogevinas, $M \ldots$. . 2, 32, 71, 86, 88

Kogevinas, M .......... 28

Kogi, $H \ldots \ldots \ldots \ldots \ldots 18$

K ogi, K ..... 16, 29, 34, 43, 97

K ogler, GF............. 6

Koh, D ............... 18, 52

Koh, HK .............. 12

$\mathrm{K}$ oh, KT ............ 87

K ohatsu, ND . . . . . . . . . 6

K öhler, C . .............. 29

K ohler, S ................ 15

Kohn, M ................ 34

K ohout, J . . . . . . . . . . . . . 63

Kohr, RL .............. 98

K ohyama, $A \ldots \ldots \ldots \ldots 11$

K oivusalo, $M \ldots \ldots \ldots \ldots \ldots 2$

$K$ ok, R ............... 70

K okkarinen, J. . . . . . . . . . . 10

Kolare, S . ...............66 66

Koller, M . ........... 29, 43

K olmodin-H edman, B . . . 27, 38, 49,86
K omaki, J. . . . . . . . . 59, 60 Komanowski, M .......... 70 K omitzer, $M \ldots \ldots \ldots \ldots . . . .34$

K omodon-H edman . . . . . . . . 43

Kompier, M . . . . . . . . . . 5, 34, 97

K omulainen, $\mathrm{H} \ldots \ldots \ldots \ldots . .52$

$\mathrm{K}$ onar, $\mathrm{E} \ldots \ldots \ldots \ldots \ldots \ldots \ldots . \ldots 34$

Kongerud, J............ 10

Konietzko, $\mathrm{H} \ldots \ldots \ldots \ldots \ldots . . . . .3$

Konig, $A \ldots \ldots \ldots \ldots \ldots 17$

Konno, A ............... 3

Kono, K............... 18

K onradt, U .............. 59

K onyscheva, LK . . . . . . . . . . . 10

Konz, S ............ 29, 52

K onzen, J L............... 10

K oontz, M D ............44 44

K oop, CE.............. 15

K oopman, JS ............ 53

K oopman, P............. 59

Koopman, PL . . . . . . . . 34, 59

K opecky, KJ ............. 10

K oplan, JP . . . . . . . . . . . . . . 96

Koponen, $M \ldots \ldots \ldots \ldots . .3$

Korallus, $U \ldots \ldots \ldots \ldots . \ldots 33$

Koren, $G \ldots \ldots \ldots \ldots \ldots 19$

Koren, $\mathrm{H} \ldots \ldots \ldots \ldots \ldots \ldots$

$K$ orn, RJ .............. 10

K ornfeld, DS . . . . . . . . . . 97

Kornhauser, A . . . . . . . . . . 34

K ornhuber, $\mathrm{HH} \ldots \ldots \ldots \ldots ., 11$

Kornitzer, M .............. 3

K orostoff, J............. 21

K orte, $R \ldots \ldots \ldots \ldots . \ldots 38$

$K$ orzis, $J \ldots \ldots \ldots \ldots \ldots 24$

K osdron-Zabiegala B. . . . . . . . 44

K oskela, R-S . . . . . . . . . 3, 91

K oskinen, $H \ldots \ldots \ldots \ldots \ldots 4$

K oslowski, M . . . . . . . . . . . . 59

Koss, M P.............. 34

Kossover, EM ............. 33

K osten, TR . . . . . . . . . . 15

K öster, D . . . . . . . . . . . . . . . . . 97

K öster, $M \ldots \ldots \ldots \ldots \ldots \ldots 6$

K oster-D reese $Y \ldots \ldots \ldots \ldots 17$

K otapa, M J . . . . . . . . . . . . 14

K öth-Jahr I ............. 55

K otsugi, $F \ldots \ldots \ldots \ldots \ldots 9$

K ou, Q $-R \ldots \ldots \ldots \ldots \ldots 1$

K oulack, D............... 34

Kowalczuk, $\mathrm{Cl} \ldots \ldots \ldots \ldots . \ldots 9$

Koys, DJ ................ 59

K ozin, $F \ldots \ldots \ldots \ldots \ldots \ldots 6$

K ozlowski, SWJ . ........... 34

K raemer, B . . . . . . . . . . 80

K raenzlin, M E . . . . . . . . . . 6

K rakoff, LR . . . . . . . . . . . 101

K rämer, G .............. 11

K ramer, HJ . . . . . . . . . . . . . . 33

K ramer, K K ............ 11

K ramer, M D . . . . . . . . . . . . . 3

K ramer, M N . . . . . . . . . . . . . 101

Kramer, MS ............. 9

K ramer, RA . . . . . . . . . 9 
K ramer, $S \ldots \ldots \ldots \ldots \ldots 23$

$\mathrm{K}$ rane, RJ................ 7

K rane, SM . . . . . . . . . . . 6

K rantz, DS. .............. 34

K rashnyuh, EP . . . . . . . . 64

K rasnoff, $L \ldots \ldots \ldots \ldots \ldots \ldots . \ldots 34$

K rasnyuk, EP ............ 39

Kraus, $H \ldots \ldots \ldots \ldots . . . . .97$

Kraus, JF . .............. 14

K rause, $N \ldots \ldots \ldots \ldots \ldots 49$

K rause, $\mathrm{TH} \ldots \ldots \ldots \ldots \ldots 59$

K rauss, RM .............. 9

K raut, RE ............. 52

K rawczynski, K . . ........ 97

K rebsbach, $R \ldots \ldots \ldots \ldots \ldots . . . \ldots$

K recter, RA ............. 77

K reft, IGG ............. 59

K reibel, $R \ldots \ldots \ldots \ldots . . . . .34$

K reiss, $K \ldots \ldots \ldots \ldots 7,10,13$

K ress, $S \ldots \ldots \ldots \ldots \ldots . \ldots 33$

K retschmer, LW . . . . . . . 11, 47

$\mathrm{K}$ reuter, $\mathrm{M} \mathrm{W} \ldots \ldots \ldots \ldots 56$

K reutz, R . . . . . . . . . . . 3

K reutzkampf, $F \ldots \ldots \ldots \ldots 58$

K rewski, D ............ 2, 33

K ricker, $A \ldots \ldots \ldots \ldots \ldots 12$

K riebel, D . . . . . . . . 10, 88, 89

K rieger, GR . . . . . . . . . 7, 64

$K$ rieger, $H \ldots \ldots \ldots \ldots \ldots 21$

K riegseis, W . . . . . . . . . . . . 10

K rieiss, JK ............. 97

K ripke, DF.............. 34

K ripke, $L \ldots \ldots \ldots \ldots \ldots . \ldots 49$

K ripke, $M L \ldots \ldots \ldots \ldots . \ldots 53$

K ris-Etherton, PM . . . . . . . 15

K ris, M G . ............. 10

K rishanan, K . . . . . . . . . . . . 27

K rishna $M$ urti, $C R \ldots \ldots . . . .39$

K rissoff, WB. . . . . . . . . . . 6

$K$ ristein, M ............. 15

K ristensen, $P \ldots \ldots \ldots \ldots . . . .9$

$K$ ristensen, $S \ldots \ldots \ldots \ldots \ldots . . \ldots$

K ristensen, TS . . . . . . . . 3, 34, 43

K ristiansen, JJ ............. 9

$K$ roeber, $A L \ldots \ldots \ldots \ldots . \ldots 29$

K roeling, $P \ldots \ldots \ldots \ldots \ldots . .13$

K roemer-Elbert, K E . . . . . . . 29

K roemer, H B. . . . . . . . . . . . 29

K roemer, KHE ........... 29

Kroes, W ............ . 5, 34

K roese, ED .............. 33

Krogoll, $T \ldots \ldots \ldots \ldots \ldots 34$

K rohn, K .............. 83

K romhout, D . ............ 30

K romhout, $H \ldots \ldots \ldots$. 28, 30, 86

Kron, $T \ldots \ldots \ldots \ldots \ldots 63$

K ronauer, RE ........... 43

K ronenberg, RS . . . . . . 73, 82

K roon, PJ............... 16

K roschwitz, J . . . . . . . . 79, 84

K ross, B . . . . . . . . . . . . 64

K rueger, A . . . . . . . . . . . . . 49

Krueger, GP . . . . . . . . . . . 34

K rueger, $\mathrm{H} \ldots \ldots \ldots \ldots \ldots 11,52$
Krug, $E \ldots \ldots \ldots \ldots \ldots 27$

Krug, JH, Jr............ 5

Krugman, PR .......... 20

K rumboltz, JD . . . . . . . . . . . 5

Kruppa, B ........... 3, 47

K ruysse, $\mathrm{HW} \ldots \ldots \ldots \ldots \ldots 57$

K ruyt-G aspersz, JA . . . . . . . . 100

K ryger, $M \ldots \ldots \ldots \ldots . .96$

K siazek, T G . . . . . . . . . . . 101

K uark, JK .............29

K ubaschewski, $0 \ldots \ldots \ldots \ldots 63$

Kublosch, J . . ........... 97

K ucera, J ..............9

K uchuk, AA . . . . . . . . . . . . . . 38

K udlinski, D .............. 101

K uehr, J ............... 9

K uettner, $K \ldots \ldots \ldots \ldots \ldots 6$

K ufakwandi, F . . . . . . . . . . 68

K uhlmann, W . .......... 43

K uhn, DC .............. 10

K uhn, K . . . . . . . . . . . . 58

K uhnert, $K \ldots \ldots \ldots \ldots \ldots$

K uhnert, KW ............ 34

Kuhrer, I . . . . . . . . . . . . I 1

K uijten, $R \ldots \ldots \ldots \ldots \ldots 72$

K uikka, $P \ldots \ldots \ldots \ldots \ldots . . \ldots$

K uivanen, R . . . . . . . . 56, 58

K ujala, VM ............ 97

K ukita, A .............. 49

K ukull, WA .............. 7

K uller, LH ............ 3, 34

K ullman, $G \ldots \ldots \ldots \ldots . \ldots 101$

Kullman, GJ . ............ 10

K umar, D ............... 34

K umar, S ............ 41

Kumar, V.............. 10

Kumlin, A . . . . . . . . . . . . 13

K ummer, K ............. 54

K undi, $M \ldots \ldots \ldots \ldots \ldots .43$

K undiev, YI .......... 33, 64

K undisin, R B . . . . . . . . . . . 44

K unesh, RF . ........... . 83

K unkel, SL . . . . . . . . . . . . . . 10

K unreuther, $\mathrm{H} \ldots \ldots \ldots \ldots . \ldots 59$

K unreuther, HC . ........... 39

$K$ unst, $A E \ldots \ldots \ldots . . . . . .3$

Kuntz, WD ............. 10

Kunz, C . . . . . . . . . . . 97

K unz, E .............. 32

Kuo, C ............... 70

Kuorinka, I ..........6, 29

K uorinka, IAA . . . . . . . . . . 6

K uorinka, T . . . . . . . . . . . . . 29

K uosma, E . . . . . . . . . . 6

K upper, LL . . . . . . . 6, 28, 30, 80

K üpper, R . . . . . . . . . . . . 43

K urabayashi, L . ........... 5

Kural, $0 \ldots \ldots \ldots \ldots \ldots 74$

K urata, FK ............. 11

K uratorium für W aldarbeit und

Forsttechnik (K WF). . . . . . 68

K urfürst, $W \ldots \ldots \ldots \ldots \ldots . \ldots 58$

K urihara, $M$............ 53

K urland, LT . . . . . . . . . . . 7
K urppa, K ....... 6, 52, 72

Kurttio, P..............27

K urumatani, $N \ldots \ldots \ldots . .99$

K urup, VP............. 101

K urzman, PA . . . . . . . . . 15, 97

K uschner, K ............ 100

K uschner, SH ............. 7

Kusiak, R ..............73 73

K usiak, RA . . . . . . . . . 32, 82

Kustov, VV .............. 33

K utler, AA ............... 78

K utschera, H P . . . . . . . . . 6

K uzmits, FE .............51

K uzniewski, P . . . . . . . . . . 38

K våle, G................. 7

$K$ venberg, JE . . . . . . . . . . . . 53

K vitzau, B . . . . . . . . . . . 68

$\mathrm{K}$ wa, SL ............... 72

K wiatkowski, $S \ldots \ldots \ldots \ldots 3$

K won, K S ...............29

$K y, H \ldots \ldots \ldots \ldots \ldots 10$

K ygornen, $P \ldots \ldots \ldots \ldots 10,52$

K ylian, H . . . . . . . . . . . . . . . 29

Kyng, M..............29 29

$K$ yyronen, $P \ldots \ldots \ldots \ldots . .9$

\section{L}

La, Caille J............... 89

La Terra, G . . . . . . . . . . . . . . . 97

Laaser, U . . . . . . . . . . . . . . . . 3

LaBar, G ............... 17

Labelle, M ............... 33

Labig, CE................. 5

Labonville, B . ........... 83

$L$ aborers International $U$ nion of

N orth America (LIUNA) . . 18

Labrèche, FP .............. 7

Labrecque, G . ............. . 43

Lac Lanoux Arbitration. . . . . . . . 54

Lacerte, M . . . . . . . . . . . . . . 17

Lacey, J .............. 38, 101

Lachapelle, JM . ............ 12

Lachenbruch, PA . . . . . . . . . . 34

Lacher, A . . . . . . . . . . . . . . . . 97

Lack, A. . .................. 70

Lackman, DB............ 97

Lacoste, M . . . . . . . . . . . . . . 29

Lacroix, R ............... 26

Ladell, WSS.............. 42

Ladenson, R F . ........... 19

LaD ou, J . . 19, 28, 29, 34, 43, 83

Laegreid, WW . . . . . . . . . . . . 10

Laeser, R P . . . . . . . . . . . . . . 58

Laflamme, $L \ldots \ldots \ldots \ldots . .26,68$

Laforest, JC ............. 45

Lafuma, C . . . . . . . . . . . . . 10

Lagerlöf, E . . . . . . . . . . 56, 97

Lagier, F. . . . . . . . . . . . . . . 10

Lahaye, D . . . . . . . . . . . . . 97

Lahey, M A . . . . . . . . . . . . . . 34

Lahiri, S. . . . . . . . . . . . . . . 37

Lahl, U................. 9

Lahmann, E................ 55
Laippala, P.............99 93

Laird, I . . . . . . . . . . . . . . . . 68

Lakey, J ............... . 49

Lakha, AS ............... 89

Lakhani, R . . . . . . . . . 1, 4, 12

Lakshmana, M K ............ 11

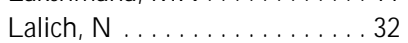

Lalich, NR ............... 32

Lalonde, M .......... 15, 17

Lalu, K................. 10

Lamalle, $Y \ldots \ldots \ldots \ldots \ldots . . .99$

Lamarche, MJ . . . . . . . . . . 97

Lamarre, $L \ldots \ldots \ldots \ldots \ldots . . . .76$

Lamb, D................ 10

Lamb, JC, IV ..............9

Lamb, ME ................. 34

Lambert, G .............. 34

Lambrozo, J.............. 40

Lammert, KH ...........4

Lamoureaux, $\mathrm{RH} \ldots \ldots \ldots 63$

Lamoureux, G . . . . . . . . . . . . 10

Lampher, BP . . . . . . . . . . 97

Lan, A . . . . . . . . . . . . . . . . 58

Lan, $Y \ldots \ldots \ldots \ldots . \ldots 6$

Lancet, D . . . . . . . . . . . . . 33

Landau, C . . . . .......... 97

Landau, K . . . . . . . . . 3, 29, 43, 97

Landen, D D . . . . . . . . . . 56, 60

Landen, RO .............. 43

Landewe, M BM . . . . . . . . . . . 97

Landi, M T . . . . . . . . . 1, 28, 39

Lando, $\mathrm{H} \ldots \ldots \ldots \ldots \ldots \ldots . . . .15$

Landrigan, PJ ..... . 9, 10, 23, 32, $82,88,93,96,98$

Landrock, AH ............ 95

Landsbergis, PA . . . . . . . 3, 34, 102

$L$ andström, $U \ldots \ldots \ldots \ldots . . . . .3$

Landtblom, A-M ........... 7

Landy, FJ . . . . . . . . . . . . . . 34

Lane, NE ................ 6

Lane, $P . . . . . . . . . . . . . . .70$

Lane, RE .............. 89

Lang, JT . . . . . . . . . . . . . . . 34

Lang, $P \ldots \ldots \ldots \ldots \ldots . \ldots 4$

Lang, $R \ldots \ldots \ldots \ldots \ldots$

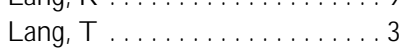

Langan, JP . . . . . . . . . . . . . . 19

L angård, S . . . . . . . . . . . 44, 63

Lange-Anderson, K . . . . . . . 29

Lange-A sschenfeld, $\mathrm{H}$. . . . . . . . 3

Lange, $M \ldots \ldots \ldots . . . . .97$

Lange, $W \ldots \ldots \ldots . . . . . . . .97$

Langenskiöld, A . . . . . . . . . . 6

Langer, AM . . . . . . . . . . . . . 10

Langer, HJ . . . . . . . . . . . . . . . 58

Langer, R . . . . . . . . . . . . . . . 53

Langley, RL . . . . . . . . . . . . . 70

Langlois, R G . . . . . . . . . . . 48

Langner, RR . . . . . . . . . . . 30

Lanier, EB . . . . . . . . . . . . 59

LaNier, ME ............. 30

Lanphear, BP............. 38

Lansbury, R . . . . . . . . . . . . 21

Lansman, SL . . . . . . . . . . . . 101 
Lantin, G . . . . . . . . . . . . 43 Lao, Y J................. 101 Laouri, M.............. 15 Lapare, S ............... 11 Lapham, LW . . . . . . . . . . . . 11 Lapin, CA .............. 10 Laplanche, A . . . . . . . . . . . . 48 Lapointe, $G \ldots \ldots \ldots \ldots \ldots 9$ Laporte, A . . . . . . . . . . . . . . 43 LaPorte, RE............. 34 Lapp, NL ................ 10 Lappe, K ...............6 64 Laquer, W ................ 10 L'Archeveque, J . . . . . . . . . . . 10 Laria, R . . . . . . . . . . . . . . 88 Laring, J............... 29 Lark, J .................. 59 LaR occo, JM .............. 34 Laroche, C .............. 17 Larochelle, $\mathrm{L} \ldots \ldots \ldots \ldots \ldots . \ldots 52$ Larprie, JC ............... 59 Larribe, $F \ldots \ldots \ldots \ldots \ldots . .7$ Larsby, B ............... 11 Larsen, CK .............. 13 Larsen, M. . .............66 66 Larsen, $T \ldots \ldots \ldots \ldots \ldots .42$ Larsh, SE ................ 1 Larson, A . . . . . . . . . . . . . . 25 Larson, EB . . . . . . . . . . . . . . 7 Larson, JRJ . .............. 34 Larson, M G . ............... 3 Larson, $R \ldots \ldots \ldots \ldots \ldots . \ldots 8$ Larsson, K . ............... 10 Larsson, L . . . . . . . . . . . . . . 101

Larsson, TJ ............... 59 Larsson, TJ ............... 56 Larue, C................ 68 Larwood, L . . . . . . . . . . . . . . . . . 34 Laskey, J . . . . . . . . . . . . . . . . 33 Laskin, S ............. 1, 100 Laskowski, JS . . . . . . . . . . . . . 74

Lasley, B................ 83 Lasley, BL . . . . . . . . . . . . . 83 Lassiter, D . . . . . . . . . . . . 83 Last, JA ................. 10 Last, JM . ....... . . 23, 56, 95, 103 Last, LR . . . . . . . . . . . . . . . . . 34 Last, M L . ................ 102 Laster, R ............... 11 Lata, $A \ldots \ldots \ldots \ldots \ldots .63$ Lataille, JJ .............. 41 Latham, GP . . . . . . . . . . . . 60 Latiff, AA . . .............. 22 Latinga, $H \ldots \ldots \ldots \ldots . . . .100$ Lau, SL ............... 97 Läubli, $T$............... 52 Laufer, N . ................ 9 Laufs, R . ............... 97 Laughlin, ME.............. 3 Laumon, B.............. 9 Launer, LJ . ................ 9 Launis, M . . . . . . . . . . . . . . 29 Laurell, AC . . . . . . . . . . . 28 Laurig, W. . . . . . . . . . 29, 43, 97
Lauritsen, J. . . . . . . . . . . 70 Lauweryns, JM ........... 10 Lauwerys, R . . . . . . 10, 27, 33, 63 Lauwerys, R R ........... 81 LaV ecchia, C . . . . . . . . . . 4, 80 Lavender, SA . . . . . . . . . . . . . 80 LaVia, M F . . . . . . . . . . . . . 33

Laviana, JE ............... 34 Lavie, P .............. 3, 43

Laville, A ................ 29

Laviolette, M .............. 10

Lawler, EE . . . . . . . . . . . 34, 59

Lawless, P. . . . . . . . . . . . . . 51

Lawrence, JS . . ............6 6

Lawrence, TS ............64 64

Laws, ER .......... 9, 27, 64

Lawther, A . . . . . . . . . . . . . . 50

Lawton, M P . . . . . . . . . . . . . 33

Layard, M .............. 10

Layde, PM ............... 70

Layne, LA . . . . . . . . . . . . . 56

Lazar, PH ................99

Lazar, V . . . . . . . . . . . . . . . . 79

Lazarini, HJ . ............. 4

Lazarus, $\mathrm{H} \ldots \ldots \ldots \ldots \ldots . .43$

Lazarus, L . . . . . . . . . . . . . 34

Lazarus, RS . . . . . . . . . . . . 5, 34

Lazebnik, YA . ............. 33

Lazzara, CP . ............. 74

Lazzarin, A . . . . . . . . . . . . 97

Le Clerc, JL ................ 3

Le Gall, V .............. 97

LeV ot, A .............. 97

Leach-M arshall, JM . . . . . . . . . 83

Leach, ER . . . . . . . . . . . . 29

Leach, J . . . . . . . . . . 10, 89

Leach, RE ............. 6

L ead Industries A ssociation . . . . 83

L eadbetter, WB . . . . . . . . . . . . . 6

Leaderer, BS .............. 13

Leahy, M . . . . . . . . . . . . . . 17

Leakey, RE . . . . . . . . . . . 22

Leana, CR . . . . . . . . . . . . . 29

Leather, $P$. . . . . . . . . . . . . 34

Leavey, J ............... 83

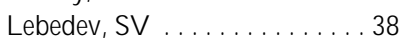

Lebedeva, NV . . . . . . . . . . . . 3

LeBlanc, FE . . . . . . . . . . . . . 6

LeBlanc, J . .............42

LeBlansch, K . . . . . . . . . . . . 54

LeBon, B ............... 10

Lebowitz, M D . . . . . . . . . . 39

Lechat, M F . . . . . . . . . . . . 39

Lechner, M C . . . . . . . . . . . . 33

Lechner, V M . . . . . . . . . . . . . 15

Leck, I ................ 88

Leckie, N . . . . . . . . . . . . . . . . 24

Leclerc, A . . . . . . . . . . . . . . 86

Lecours, R ................ 10

Lecuyer, DW . . . . . . . . . . . 49

Leddo, JS . . . . . . . . . . . . . . 94

Lederman, RJ . . . . . . . . . . . . 96

Ledin, $T \ldots \ldots \ldots \ldots \ldots . . . .11$

Ledingham, JG G . .......... 38
Lednar, WM ............ 80 Lee, A. . . . . . . . . . . . . . . . 53 Lee, $C \ldots \ldots \ldots \ldots \ldots . . . . .6$ Lee, $\mathrm{CH} \ldots \ldots \ldots \ldots \ldots \ldots 10$

Lee, CS ...............64 64

Lee, $C Y \ldots \ldots \ldots \ldots \ldots . \ldots 38$

Lee, DHK ................ 10

Lee, DHK ............... 28

Lee, EU ................. 34

Lee, EW ................ 94

Lee, HP ................. 11

Lee, HS ................. 32

Lee, JS ............. 10, 19, 78

Lee, JW .................. 34

Lee, K A ............... 97

Lee, K P ................. 10

Lee, $N \ldots \ldots \ldots \ldots \ldots \ldots . \ldots 55$

Lee, $P \ldots \ldots \ldots \ldots \ldots \ldots . . . . . .34$

Lee, PJ ................ 87

Lee, $R \ldots \ldots \ldots \ldots \ldots . . .70$

Lee, RC ............... 40

Lee, RG . ............... 7

Lee, RJ . . . . . . . . . . . . . . . . . 94

Lee, $S A \ldots \ldots \ldots \ldots \ldots . \ldots 22$

Lee, SB................. 77

Lee, SD ................. 30

Lee, SH ................ 14

Lee, ST ........... 3, 9, 89

Lee, $S Y \ldots \ldots \ldots \ldots \ldots . . .29$

Lee, WR . . . . . . . . . . . . . . . . 64

L eegard, J. . . . . . . . . . . . . . . 97

Leenaerts, L . . . . . . . . . . . . 10

Leeper, E . . . . . . . . . . . . . 76

Lees, FP . . . . . . . . . . . . . . 41

Lees, REM . . . . . . . . . . . . 20

Leet, $T \ldots \ldots \ldots \ldots \ldots . \ldots 91$

L efante, JJ . . . . . . . . . . . . . . 89

L effingwell, SS ............. 3

Lefort, $\rfloor \ldots . . . . \ldots \ldots \ldots \ldots . .43$

LeFuart, C . ............... 3

Legaspi, JA ............... 77

L éger, D . . . . . . . . . . . 97

Léger, JP . . . . . . . . . . . . . . 26

Legge, $K \ldots \ldots \ldots \ldots . .29,34$

LeG rande, D . . . . . . . . 5, 34, 52

Legters, LJ . . . . . . . . . . . . . . . . 95

Lehman, $P$. . . . . . . . . . . . . . 21

Lehmann, $G$. . . . . . . . . . . . . 43

Lehmann, K B . . . . . . . . . . . 30

Lehnert, G . . . . . . . . . . . . . . 101

Lehrer, SB . . . . . . . . . . . . 64

Lehtinen, S. . . . . . . . . . . 16, 18

Lehto, M R . . . . . . . . 56, 59

Lehtonen, M ............. 80

Lehtonen, R . . . . . . . . . . . . . . 16

Leibenguth, RE . . . . . . . . . 83

Leibson, B ............... 34

Leichnitz, K . . . . . . . . . . . 37

Leid, RW . . . . . . . . . . . . . . 10

Leidel, NA ............... 30

Leigh-D oyle, S . . . . . . . . . . . 24

Leigh, J . . . . . . . . . . . . . . 10, 34

Leight, J . . . . . . . . . . . . . 70

Leino, PI ................ 34
Leirisalo-R epo, M ......... 6 Leistikow, B . . . . . . . . . . . . 70

Leithead, CA . . . . . . . . . . . 42

Lejhancova, M . . . . . . . . . . 68

Lemasters, G . . . . . . 9, 10, 11, 47

Lemasters, JJ ............... 4

Lemen, R . . . . . . . . . . . . . . . . 5

Lemen, RA .......... 19, 71

Lempereur, JJ . . . . . . . . . . . 97

LeN et, M .............. 56

Leng, RA ................ 70

Lenga, RE ............... 103

Lengnick-H all, M L . . . . . . . . . . 29

Lenhart, SW ............... 70

Lenihan, $K L$. . . . . . . . . . . 83

Lenkner, LA............... 3

Lennep, HJV . . . . . . . . . . . 8 89

Lennernäs, $M \ldots \ldots \ldots \ldots \ldots . . . . .3$

Lenssen, $\mathrm{N} \ldots \ldots \ldots \ldots$. . . 64, 70

Lenzi, $\mathrm{S} \ldots \ldots \ldots \ldots \ldots \ldots . \ldots 88$

Leo, A ............... 33

Leon, DA . . . . . . . . . . . . . . 85

Léonard, A . . . . . . . . . . . . . . 10, 27

Leonard, JF . . . . . . . . . . . 63

Leonard, L . . . . . . . . . . . . . . . 34

Leonard, RC . . . . . . . . . . 33

Leonard, RJ . . . . . . . . . . . . . 97

Leonard, S............... 70

Leoni, E . . . . . . . . . . . . . . . 38

Leopold, DA . . . . . . . . . . . . 11

Leow, YH ..............83

Lepage, RP . . . . . . . . . . 97

L'Epée, $P \ldots \ldots \ldots \ldots \ldots .4$

Leplat, J . . . . . . . . . 29, 56, 59

Lepofsky, M D . . . ........... 17

Leport, C ................. 3

LePorte, RE . . . . . . . . . . . . . . 33

Leppäluoto, J . . . . . . . . . . 42

Leppanen, A . . . . . . . . . . . . . . 52

Leppanen, R A . . . . . . . . . . . 97

Leppilahti, J . . . . . . . . . . . . 6

Lerman, Y . . . . . . . . 85, 96

Leroy, TR . . . . . . . . . . . . . 64

Lert, $F \ldots \ldots \ldots \ldots \ldots . . . . .67$

Lesieur, HR ............. 15

Leslie, K $0 \ldots \ldots \ldots \ldots \ldots$

Leslie, PJ . ............... 97

Lesmes, G . . . . . . . . . . . . . . 15

Lessard, J ...............6 6

Lesur, $0 \ldots \ldots \ldots \ldots \ldots$. . . . . . 10

Letenneur, $L \ldots \ldots \ldots \ldots \ldots$

Letourneau, Y ............. 26

Lettau, LA . . . . . . . . . . . . . 97

Letz, R . . . . . . . . . . . . 7, 97

Leuliet, S . . . . . . . . . . . 43

Leung, $H M \ldots \ldots \ldots \ldots . \ldots 28$

Leung, $\mathrm{HW} \ldots \ldots \ldots \ldots . \ldots 30$

Leung, $K \ldots \ldots \ldots \ldots \ldots . \ldots 34$

Leung, W-Y . . . . . . . . . . . 13

Leurgans, $S \ldots \ldots \ldots \ldots . \ldots 80$

LeV asseur, SA . . . . . . . . . . . . 52

Levenson, NG . ........... 58

Levenson, SM ........... 15

Levenstein, C . . . . . . . . . . 23 


\begin{tabular}{|c|c|}
\hline & \\
\hline eventhal, JM & \\
\hline everett, SD . & .102 \\
\hline Evesque, C. & \\
\hline & \\
\hline evi, F . . . & $\ldots \ldots \ldots 4,4$ \\
\hline evi, L . & $\ldots 3,5,15,34,5$ \\
\hline evi, PE . & \\
\hline & \\
\hline evin, H . . & $\ldots 13,9$ \\
\hline evin, J. . . & \\
\hline evin, JC & $\ldots \ldots \ldots 73,8$ \\
\hline evin, JS & \\
\hline evin, L. & $\ldots \ldots 10,2$ \\
\hline evin, LI . . & \\
\hline evin, M A . . & 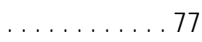 \\
\hline evin, PF . . . & \\
\hline evin, S . . & .8 \\
\hline evin, W .. & \\
\hline vine, CA. . & \\
\hline evine, EL .. & $\ldots \ldots \ldots$ \\
\hline evine, ML . . & $\ldots \ldots \ldots \ldots 7$ \\
\hline evine, RJ ... & $\ldots .3,9,91,10$ \\
\hline evine, RL . . . & $\ldots \ldots \ldots \ldots 1$ \\
\hline$S \ldots$ & \\
\hline vinson, DJ & $\ldots \ldots$ \\
\hline vinson, $\mathrm{H}$. & $\ldots \ldots \ldots$ \\
\hline evison, D . . . & $\ldots \ldots \ldots$ \\
\hline h, A ... & $\ldots \ldots \ldots$ \\
\hline RE. & $\ldots \ldots \ldots$ \\
\hline Levy-Leboyer, & $\ldots \ldots \ldots$ \\
\hline & $\ldots \ldots \ldots \ldots$ \\
\hline & $\ldots \ldots \ldots$ \\
\hline Levy, BA ... & $\ldots \ldots \ldots \ldots$ \\
\hline Levy, BS .... & . . 2, 7, 19, 20, 2 \\
\hline
\end{tabular}

Levy, M ........... 11, 17

Levy, S............. 29, 59

Lew, EA ................ 15

Lew, RA............... 12

Lewalter, J ............... 33

Lewchuk, W............... 59

Lewin, D ............... 21

Lewin, K ....... 15, 29, 34, 59

Lewin, $N \ldots \ldots \ldots \ldots \ldots$

Lewin, $R \ldots \ldots \ldots \ldots \ldots 22$

Lewis, BM .............. 13

Lewis, C . . . . . . . . . . . 29, 52

Lewis, EK ............. 43

Lewis, FA . .............. 82

Lewis, GL ............. 55

Lewis, J............... 33

Lewis, M ................ 3

Lewis, R . . . . . . . . . . . . . . 25

Lewis, RG . . . . . . . . . . 9, 44

Lewis, RJ . . . . . . . . 22, 63, 103

Lewis, RRJ . . . . . . . . . . . . 41

Lewis, S . . . . . . . . . . . . . 34

Lewittes, LR . . . . . . . . . . . . . . 97

Lewy, R . . . . . . . . . . . 97

Ley, J-J................. 3

Ley, R ............... 34

$L i, A P \ldots \ldots \ldots \ldots \ldots \ldots 33$

$L \mathrm{~L}, \mathrm{C}-\mathrm{Y} \ldots \ldots \ldots \ldots \ldots \ldots$
Li, D-G ............... 1

$L i, F P \ldots \ldots \ldots \ldots . . . .9,10$

$L i, G-L \ldots \ldots \ldots \ldots \ldots \ldots$

$L i, G \ldots \ldots \ldots \ldots \ldots \ldots 6$

$L i, J Y \ldots \ldots \ldots \ldots \ldots \ldots 63$

Li, L-A ................ 3

Li, WM ............... 28

$L i, W X \ldots \ldots \ldots \ldots \ldots 80$

Liang, M H . . . . . . . . . . . . . 3, 6

Liang, $Y \ldots \ldots \ldots \ldots \ldots \ldots$

Liberati, D . . . . . . . . . . . . . 34

Liberatos, P . . . . . . . . . . . . 34

Liberman, DF . . . . . . . . . 70, 77

Liberman, R P . . . . . . . . . . . . . 5

Libert, JP ..............4 42

Libretti, A ............. 43

Lichtbroun, AS . . ..........6

Lichtenstein, N . . . . . . . . . . . . 77

Lichtenstein, S . . . . . . . . . . 59

Liddell, D . . . . . . . . . . . . . 10

Liddle, J . . . . . . . . . . . . . . . 96

Lidell, FDK .............. 10

Lidén, C . . . . . . . . . . . . . . . 52

Lidén, E . . . . . . . . . . . . 68

Lidén, $S \ldots \ldots \ldots \ldots \ldots . \ldots 52$

Liem, JH ............... 34

Liem, R ................. 34

Liengswangwong, $\vee \ldots \ldots \ldots 64$

Lierl, M B . ................ 97

Liesivuori, J . . . . . . . . . . . 68

Liévin, D . ............... 26

Lievore, F. . . . . . . . . . . . . . 43

Lifshitz, M .............. 15

Lifshitz, YR . . . . . . . . . . . . 29

Liggit, HD . .............. 10

Light, E ................. 13

Light, K C.............. 34

Lighting Industry Federation. . . 46

Lijnen, P. . . . . . . . . . . . . . . . . 63

Liker, JK ................ 29

Likert, R ............. 35, 59

Lilienfeld, AM . . . . . . . . . . . 28

Lilienfeld, D . . . . . . . . . . . . 28

Lilis, R ................. 9

Lilley, BM ............... 32

Lillrank, B . . . . . . . . . . . . . . . 29

Lilpper, RW . . . . . . . . . . . . . 10

Lim, LL . . . . . . . . . . . . . . . 24

Lim, S ................ 5

Lim, SY ............. 34, 52

Lim, TK . . . . . . . . . . . 34

Lima, C ................ 11

Limbird, L . . . . . . . . . . . . . . . 79

Lin, RS................ 100

Lin, $X-F \ldots \ldots \ldots \ldots \ldots . .1$

Lincoln, JM .............. 70

Lind, $A R \ldots \ldots \ldots \ldots . .42$

Lindahl, BIB . . . . . . . . . . 28

Lindahl, R . . . . . . . . . . . . 68

Lindars, DC . . . . . . . . . . 80

Lindberg, $H \ldots \ldots \ldots \ldots \ldots 6$

Lindberg, $P \ldots \ldots \ldots . . . .58$

Lindbohm, M L . . . . . . . . 9, 52

Linde, $\mathrm{HW}$. . . . . . . . . . . . . . 97
Lindell, B

Lindell, SE

Lindeman, $E$

indén, $K \ldots \ldots \ldots 12,56,66$

Lindenberg, CS . . . . . . . . . . . 34

Lindenboom, $\mathrm{RH} \ldots \ldots \ldots . . .37$

Linder, $M \ldots \ldots \ldots \ldots \ldots \ldots 67$

Linder, $R \ldots \ldots \ldots \ldots \ldots . . . . .33$

Lindgärde, $F \ldots \ldots \ldots \ldots, 34$

Lindgren, $F \ldots \ldots \ldots \ldots 31,96$

Lindner, I . . . . . . . . . . . . . 97

Lindsay, $V \ldots \ldots \ldots \ldots \ldots 68$

Lindström, A . . . . . . . . . . . . 97

Lindstrom, $K \ldots \ldots \ldots \ldots \ldots . .7$

Lindström, K . . . . . . . 34, 52, 97

Lindvall, $T \ldots \ldots \ldots . . .3,13,47$

Linehan, $W \ldots \ldots \ldots \ldots . . .8$

Linet, $M \ldots \ldots \ldots \ldots \ldots \ldots$. . . . 32

Ling, $H \ldots \ldots \ldots \ldots \ldots . \ldots 63$

Ling, SL . . . . . . . . . . . 87

Link, B ............. . 5, 34

Linneman, CC . . . . . . . . . . . 97

Linnman, I . . . . . . . . . . . . . . 44

Linville, J..............41

Linz, DH ............... 13

Lipman, NS ........... . 38, 70

Lipoff, E................. 17

Lippit, $G \ldots \ldots \ldots \ldots \ldots 60$

Lippitt, R ................. 34

Lippmann, M . . . . . . . . . . . 7, 10

Lippold, BH ................ 33

Lipscomb, DM . . . . . . . . . . . . . 31

Lipski, S...............49

Lipsky, D B . . . . . . . . . . . . . . 21

Lipton, S ................ 77

Lischeron, JA . . . . . . . . . . . . 29

Lisk, DJ . . . . . . . . . . . . . . . 38

Liss, GM .............6, 6, 73

Lisson, $G \ldots \ldots \ldots \ldots \ldots \ldots \ldots . \ldots$

Lisson, J . . . . . . . . . . . . . . . 10

Lister, C . . . . . . . . . . . . . . . 26

Listrom, M . . . . . . . . . . . . . 10

Litchfield, P . . . . . . . . . . . . 42

Little, M P.............. 48

Litton, CD . . . . . . . . . . . . . 74

Littorin, M . . . . . . . . . . . . . . 32

Liu, E................... 1

Liu, M ................ . 89

Liu, RT ............... 45

Liu, $\mathrm{S} \ldots \ldots . . . . . . . . . . . .65$

Liu, $X \mathrm{~L} \ldots \ldots \ldots \ldots \ldots \ldots$

Liukkonen, $P \ldots \ldots \ldots \ldots \ldots . .34$

Livecchi-G onnot, GH . . . . . . . 42

Ljungberg, AS . . . ......... . 97

Ljunggren, G . . . . . . . . . . . . . 100

Llewellyn, $\mathrm{CH}$. . . . . . . . . . . . . 95

Llewellyn, FJ .............. 41

Llewellyn, GC . . . . . . . . . . . . 44

Llewelyn-D avies, R . . . . . . . . 97

Llhado-Arkhipoff, J . . . . . . . . . 97

Lloyd, DC . . . . . . . . . . . . . . 48

Lloyd, EL . . . . . . . . . . . . 3, 42

Lloyd, GER .............. 54

Lloyd, M H . . . . . . . . . . 100
Lloyd, RD . . . . . . . ........ 48

Lo Presti, E . . . . . . . . . . . . . . 97

Lobban, M C . . . . . . . . . 29, 43

Lobreau, JP ................ 3

Locke, D . . . . . . . . . . . . . . . . 64

Locke, E... . . . . . . . . . . . . 29

Locke, EA ......... . . . . 29, 34

Locke, J ................ 10

Locke, R. . . . . . . . . . . . . . . 21

Lockey, J . ............... 10

Lockey, JE . . . . . . . . . . . 9, 10, 39

Lockey, RF. . . . . . . . . . . . . 70

Lockhart, CJ . . . .......... 97

Lockshin, RA . . . . . . . . . . . . . 33

Lockwood, AH . . . . . . . . . . . 96

Lode, $H$. .................. 3

Lodge, JPJ ................ 55

Loeb, R G . . . . . . . . . . . . . . 97

Loevinsohn, M ............ 53

Loew, FM ............... 70

Loewenson, R . . . . . . . . 21, 28

Loewey, AG . . ............ 33

Lofquist, LH ............ 34

Loftas, T........... 64, 70

Loftus, JNS. ............68 68

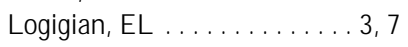

Logue, JN . . . . . . . . . . . . . . . 39

Lohrer, $\mathrm{H} \ldots \ldots \ldots \ldots \ldots \ldots 6$

L oikkanen, I . . . . . . . . . . . . . 101

Loiseau, PM . . . . . . . . . . . . . . . 63

Lomaliza, K . . . . . . . . . . . . . . 70

London, M . . . . . . . . . . . . . 34

London, S ............. 9

Long, L ................. 96

Long, Y M ............. 80

Longini, IM , Jr. . . . . . . . . . 53

Longo, DL ............... 1

Longo, WE .............. 9

Longstreth, J . . . . . . . . . . . 53

Looman, CWN .............. 3

Loomis, DP . . . . . . . . . . 11, 53

Loomis, TA .............. 33

Loper, JC ................. 33

Lopes, LL.............. . 59

Lopez Alverez, J. . . . . . . . . . 39

Lopez, H . . . . . . . . . . . . . . . 3

Lopez, M . . . . . . . . . . . . . 64

Lopez, R . . . . . . . . . . . . . . . 64

Lord, M W . . . . . . . . . . . . . . 19

Lorenz, D . . . . . . . . . . . . 6

Lorintz, Z . . . . . . . . . . . . 79

Lorke, D................. 9

Lorsch, JW . . . . . . . . . . . . . . 34

Loschiavo, JL . . . . . . . . . . . . 31

Loshchilov, NA . . . . . . . . . . . 39

Loskant, H . . . . . . . . . . . . . . 43

Losonczy, K . . . . . . . . . . . . 5

Loss Prevention Council . . . . . 41

Lot, F . . . . . . . . . . . . . . . . 97

Lotas, M . . . . . . . . . . . . . 97

Lotens, WA . . . . . . . . . . . . . 42

Lotze, M T . . . . . . . . . . . . 4

Loubiere, R . . . . . . . . . . . . 3

Louhevaara, $V \ldots \ldots \ldots \ldots \ldots . . . \ldots 29$ 
Louie, R . . . . . . . . . . . 4 L ouis-G uerin, C . . . . . . . . . . . 34 Louis, DS . . . . . . . . . . . . 6 Louis, M R . . . . . . . . . . . . . 34 Loury, M ............... 11 Louvar, J . . . . . .......... 79 Love, EJ . . . . . . . . . . 7, 52 Loving, RT . . . . . . . . . . . 34 Lövsund, $P \ldots \ldots \ldots \ldots \ldots \ldots 49$

Low, PA . . . . . . . . . . . 42 Lowe, BF . . . . . . . . . . . . . 34

Lowe, GS . . . . . . . . . . . . . 34

Löwel, $H \ldots \ldots \ldots \ldots \ldots \ldots \ldots 3$

Lowenstein, K L . . . . . . . . . . . . 84

Lowenthal, GL . . . . . . . . . . . 10

Löwenthal, I. . . . . . . . . . . 43

Lower, K S . . . . . . . . . . . . . . 28

Lowis, A . . . . . . . . . . . . . 18

Lowman, RL . . . . . . . . . . . 5

Lowrance, WW . . . . . . . . . . . 19

Lowry, C . . . . . . . . . . . . 36

Lowy, FH . . . . . . . . . . 19

Loy, TS . . . . . . . . . . . 44

$L u, J \ldots \ldots \ldots \ldots \ldots \ldots \ldots . \ldots 10$

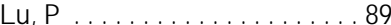

$\mathrm{Lu}, \mathrm{W} \ldots \ldots \ldots \ldots \ldots \ldots \ldots \ldots 1$

Lubenau, J0 .............48

Lubin, JH . . . . . . . . . . 32, 48, 63

Lucas, AD ............... 27

Lucas, S . . . . . . . . . . . . . . . . 17

Lucchini, F. . . . . . . . . . . . . 4

Luce, $D \ldots \ldots \ldots \ldots \ldots$. . . . . . 86

Luceri, G . . . . . . . . . . . . 44

Lucewicz, M ............ 70

Luchetti, R . . . . . . . . . . . . . . . 34

Luchtel, DR . . . . . . . . . . . . . . 10

Luckhurst, E . . . . . . . . . . . . 34

Luckiesh, M L . . . . . . . . . . . 49

Luczak, A . . . . . . . . . . . . . . . 34

Luczak, F . . . . . . . . . . . . . 102

Luczak, H . . . . . . . . . . 29, 43

Ludwig, $H \ldots \ldots \ldots \ldots \ldots \ldots 1$

Luebeck, EG .............. 2

Lukasiak, J . . . . . . . . . . . . 44

Lukawski, S . . . . . . . . . . . . . . 6

Luke, B. . . . . . . . . . . . . 9

Lumsden, JC . . . . . . . . . . . 10

Lumsdun, JC . . . . . . . . . . . . . 89

Lun, K C . . . . . . . . . . . . . 18

Luna, $P \ldots \ldots \ldots \ldots \ldots \ldots$. . . 46, 97

Lund, DJ . . . . ..........49

Lund, E . . . . . . . . . . . . . 38

Lund, J . . . . . . . . . . . . . . . 102

Lund, M W . . . . . . . . . . . . . . . 29

Lund, SP . . . . . . . . . . . 7

L und U niversity. . . . . . . . . . . 96

Lundberg, $C \ldots \ldots \ldots \ldots \ldots . . . .34$

Lundberg, $0 \ldots \ldots \ldots \ldots \ldots . \ldots 34$

Lundberg, P . . . . . . . . . . . . . 30

Lundberg, $U \ldots \ldots \ldots \ldots$. . . . . 99

Lundborg, $G \ldots \ldots \ldots \ldots \ldots \ldots 6$

Lunde-J ensen, P. . . . . . . . . . . 34

Lundgren, $N \ldots \ldots \ldots \ldots \ldots \ldots$

Lundholm, M . . . . . . . . 10, 101
Lundy, A . . . . . . . . . . . . . . 100

Lunsford, R A . . . . . . . . . . . . . . 80

Lunt, $N \ldots \ldots \ldots \ldots \ldots$. . . . . 17

Luo, AS . . . . . ...........6 63

Luo, ML. . . . . . . . . . . . . . . 39

Lurie, HE . . . . . . . . . . . . . . 97

Lusby, LG . . . . . . . . . . . . . . 64

Lushbaugh, C C . . . . . . . . . . 48

Lushniak, B . . . . . . . . . . . . . 85

Luster, M I . . . . . . . . . . . . . 33

Lusty, $T \ldots \ldots \ldots \ldots \ldots \ldots \ldots$

Luthman, G . . . . . . . . . . . 6

Luthra, HS. . . . . . . . . . . . . . 6

Luttman, A . . . . . . . . . . . 97

Luttringer, J-M .......... 21

Lutz, B . . . . . . . . . . . . . 29

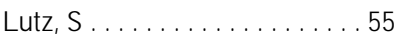

Luxon, LM . . . . . . . . . . . . . . 11

Luyten-K ellerman, $M$. . . . . . . 33

Luz, GA . . . . . . . . . . . . . . . 95

$\lfloor u z,\rfloor \ldots \ldots \ldots \ldots \ldots \ldots \ldots 31$

Lybarger, JA . . . . . . . . . . 7

Lydahl, E . . . . . . . . . . . . 73

Lyle, M J . . . . . . . . . . . . 6

Lyle, WH . . . . . . . . . . . . . 10

Lyles, WB. . . . . . . . . . . . 13

Lynch, JP . . . . . . . . . . . . . . . 10

Lynch, JR . . . . . . . . . . . 30, 77

Lynch, K M . . . . . . . . . 28

Lynch, M . . . . . . . . . . . . 97

Lynch, M S . . . . . . . . . . . . . . 97

Lynden, M . . . . . . . . . . . . . 96

Lynge, E. . . . . . . . . . . . . . . 32

Lynge, $E \ldots \ldots . \ldots . \ldots . \ldots 28$

Lynn, I . . . . . . . . . . . . . . . 34

Lyon, JL . . . . . . . . . . . . . . . 48

Lyon, $L \ldots \ldots \ldots \ldots \ldots \ldots \ldots .48$

Lyons, M . . . . . . . . . . . . 64

Lyster, S . . . . . . . . . . . . . . . . . 54

Lyubchansky, ER . . . . . . . . . . 39

\section{$M$}

M a, W-S ............86

$M$ aasen, $A \ldots \ldots \ldots \ldots \ldots \ldots 43$

M aatela,.$\ldots \ldots \ldots \ldots \ldots \ldots \ldots 6$

M abuchi, K . . . . . . . . . . . 48

M acaion, DP . . . . . . . . . 41

M acaluso, $M \ldots \ldots \ldots \ldots 80,91$

M acartney, 」 . . . . . . . . . . . . 8 89

M acC ollum, DV .......... 93

M acC ubbin, PA . ........... 72

$M$ acD iarmid, SC . . . . . . . . 70

M acfarlane, DK............ 19

M acG rath, HK . . . . . . . . . . 97

M acG regor, D . . . . . . . . . . . 59

$\mathrm{M}$ acH attie, LE . . . . . . . . . . . . 42

M achemer, $L \ldots \ldots \ldots \ldots \ldots \ldots 9$

M achlis, GE . . . . . . . . . . . . . 59

M aciejewska, A . . . . . . . 38

M ack, J. . . . . . . . . . . . . . 2

M ack, RL . . . . . . . . . . 52

M ack, TM . . . . . . . . . 4

M ack ay, $C \ldots \ldots \ldots \ldots \ldots \ldots 34$
M ackenbach, JP.......... 3

M ack enzie, EJ . . . . . . . . . . . 56

M ackenzie, PI . . . . . . . . . 33

M ackenzie-W ood, P . . . . . . . . 74

M ackie, R R . . . . . . . 43, 50, 97

M ack innon, CA . . . . . . . . . . 34

M ack innon, DP . . . . . . . . 51

M ack innon, SE . . . . . . . . . 11

M acko, M B . . . . . . . . . . . . . 97

M aclaren, WM . . ......... 10

$M$ acL ean, $A \ldots \ldots \ldots \ldots$. . . . 5, 52

M aclean, $D \ldots \ldots \ldots \ldots \ldots .42$

M acL ean, L . . . . . . . . . . . 73, 82

M aclure, $M \ldots \ldots \ldots \ldots \ldots$, 28

$M$ acM ahon, $B \ldots \ldots \ldots .3,10,28$

M acpherson, RK . . . . . . . . . 42

M acskásy, $H \ldots \ldots \ldots \ldots \ldots .41$

M acsween, R N M . . . . . . . . . . 4

M acun, I . . . . .......... 26

$M$ addi, $S \ldots \ldots \ldots \ldots$ 5, 34, 99

M adelien, $M \ldots \ldots \ldots \ldots \ldots 18$

$M$ adigan, $M$ T . . . . . . . . . 38

M adow, $L \ldots \ldots \ldots \ldots \ldots \ldots . \ldots$

M adsen, $T L \ldots . . \ldots \ldots \ldots . . .42$

M adwed, JB . . . . . . . . . . . . . 34

M aerker, G . . . . . . . . . . 70

$M$ aes, $S \ldots \ldots \ldots \ldots \ldots \ldots . \ldots 34$

M age, D . . . . . . . . . . . 55

$M$ agee, $P C \ldots \ldots \ldots \ldots \ldots \ldots 3$

$M$ agee, $P N \ldots \ldots \ldots \ldots$. . . . . 33

$M$ agee, $T \ldots \ldots \ldots \ldots \ldots \ldots 6$

M agnier, M . . . . . . . . . . 102

$M$ agnus, $P$. . . . . . . . . . . 10

M agnuson, $\mathrm{HI} \ldots \ldots \ldots \ldots \ldots . . . .30$

M agnusson, $M \ldots \ldots \ldots \ldots \ldots . . .34$

M aguire, $N \ldots \ldots \ldots$. . . . . . . . 97

M aguire, T G . . . . . . . . . 28

M ahaffey, KR . . . . . . . . . 9

$M$ ahan, RP . . . . . . . . 43

M ahar, H . . . . . . . . . . . . . 100

M ahashabde, S . . . . . . . . . 39

M ahendra, PN . . . . . . . . . . . 96

Maher, EL . . . . . . . . . . . . . 34

Mahn, JW ............. 103

M aibach, HI . . 9, 33, 63, 70, 100

$M$ aier, A. . . . . . . . . . 88

$M$ aier, $K \ldots \ldots \ldots \ldots \ldots \ldots 4$

$M$ ainville, $C \ldots \ldots \ldots \ldots \ldots \ldots .44$

M aizlish, $D \ldots \ldots \ldots \ldots \ldots \ldots 7$

$M$ aizlish, $N \ldots \ldots \ldots \ldots \ldots$ 7, 91

M ajchrzak, A . . . . . . . . . . 29

$M$ ajeed, $A B A \ldots \ldots \ldots \ldots \ldots 22$

$M$ ajid, MIA . . . . . . . . . 22

M ajno, G . . . . . . . . . . 33

M äkelä, $M \ldots \ldots \ldots \ldots \ldots \ldots 6$

M aki, DG . . . . . . . . . . . . . . 97

M akin, PJ . . . . . . . . . . . . 59

$M$ akinen-K iljunen, S . . . . . . . 64

M akino, S . . . . . . . . . . . . . 97

M akoilkina, EP . . . . . . . 63

M akower, J . . .............999

M alamood, HS . . . . . . . . . 34

M alarkey, W .............. 34

$M$ alasit, $P \ldots \ldots \ldots \ldots \ldots \ldots . \ldots 38$
M alaveille, $C \ldots \ldots \ldots \ldots \ldots 28$

M alawski, SK . . . . . . . . . . 6

M alcan, JW ............. 51

M alchaire, JB . . . . . . . . . . . 97

M alcolm, Al . . . . . . . . . . 15

Male, D . . . . . . . . . . . . . . . 33

M alek, A . ..............9

$M$ aletskos, $C J \ldots \ldots \ldots \ldots . . .83$

M alhotra, $\mathrm{HL} \ldots \ldots \ldots \ldots . . .96$

M alker, B . . . . . . . . . . . 88

M alker, BK ............. 72

M alker, $H \ldots \ldots \ldots \ldots$ 32, 88

M alker, H SR . . . . . . . . . . . . 72

M alkin, R . . . . . . . . . . . . 101

M allal, SA . . . . . . . . . . . . . 97

M alliani, A . . . . . . . . . . . 34

M allin, K . . . . . . . . . . . 91

M allino, $\mathrm{DL} \ldots \ldots \ldots \ldots \ldots \ldots 26$

M allion, J M . . . . . . . . . . . 97

M alloch, B . . . . . . . . . . . 69

Mallon, DF . . . . . . . . . . 97

M almberg, $P$. . . . . . . . . 10, 38

M almros, P . . . . . . . . . 64, 101

Malo, 」 . . . . . . . . . . . . . . 72

Malo, JL . . . . . . . . . . . . 10, 71

M alone, M . . . . . . . . . . . . 24

M aloney, DM ............. 19

M aloney, J0 ............ 77

Maloney, TM ............ 71

M alot, G . . . . . . . . . . 97

Maloy, $E \ldots \ldots \ldots \ldots . \ldots 96$

M amelle, $N \ldots \ldots \ldots \ldots \ldots \ldots 9$

M an, SFP . . . . . . . . . . . 10, 42

M anahan, SE . . . . . . . . . . . 83

M anara, G . . . . . . . . . . . . . 97

$M$ ancinella, $A \ldots \ldots \ldots \ldots .63$

M ancini, G. . . . . . . . . . . . 29

M ancuso, TF . . . . . . . . . . . . 10

$M$ andaras, RA . . . . . . . . . . . 1

$M$ andel, GS . . . . . . . . . . . . 10

$M$ andel, JS . . . . . . . . . . . . . 44

$M$ andel, NS . . . . . . . . . . . . . 10

M andel, W . . . . . . . . . . . . . 5, 34

$M$ andelker, J . . . . . . . . . . 15

$M$ andell, $W \ldots \ldots \ldots \ldots . \ldots 34$

$M$ andelo, $P \ldots \ldots \ldots \ldots \ldots \ldots 46$

$M$ andlebaum, I . . . . . . . . . 39

M andler, $G \ldots \ldots \ldots \ldots \ldots \ldots 5$

M anencia, I . . . . . . . . . . . 100

$M$ angelsen, M A . . . . . . . . . . . 14

M angiapane, $R \ldots \ldots \ldots \ldots .7$

$M$ angione, $C M \ldots \ldots \ldots \ldots$

$M$ angione, $\mathrm{TW}$. . . . . . . . . . 34

Mankin, $\mathrm{H} J \ldots \ldots \ldots \ldots \ldots . \ldots$

Mann, FC ............43

Mann, L................ 59

Mann, N . . . . . . . . . . . 34

Mann, RA . . . . . . . . . . . 6

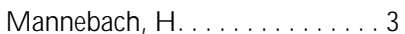

M anninen, A . . . . . . . . . . 68

$M$ anning, DP . . . . . . . . . 56

$M$ anning, $M G \ldots \ldots \ldots \ldots . . . .34$

$M$ anoli, A . . . . . . . . . . . . . 6

M anson, JE . . . . . . . . . . 3 


\begin{tabular}{|c|c|}
\hline M anson, WM . . . & \\
\hline M antei, M M . . & 52 \\
\hline M antell, M .... & \\
\hline M antout, B.... & \\
\hline M anuaba, $A \ldots \ldots$ & \\
\hline M anyachin, VD ... & \\
\hline$M$ anz, $A \ldots \ldots$. & \\
\hline M anzin, A ... & \\
\hline M anzione, LT . & 83 \\
\hline$M$ ao, $Y \ldots \ldots \ldots \ldots \ldots$ & \\
\hline M ara, DD ............ & \\
\hline M ara, G ....... & \\
\hline$M$ araNo $0, F \ldots \ldots \ldots$ & \\
\hline M arans, $\mathrm{RW} \ldots \ldots \ldots$ & \\
\hline M arazza, $R \ldots \ldots \ldots \ldots 6$ & \\
\hline $\begin{array}{l}\text { M arbury, } M C \ldots \ldots \ldots \ldots \ldots \\
\text { March of Dimes Birth Defects }\end{array}$ & \\
\hline
\end{tabular}

Foundation ...........15

$M$ arch, J.............. 59

March, JG .............. 59

Marchak, P .......... 20, 24

$M$ archand, A ............ 59

$M$ archat, $B \ldots \ldots \ldots \ldots \ldots 10$

$M$ archetta, A . . . . . . . . . 34

$M$ archi, $M \ldots \ldots \ldots \ldots \ldots 7$

$M$ arco, RD ............. 80

$M \operatorname{arcos}, H M \ldots \ldots \ldots . . .83$

$M$ arcus, $A C \ldots \ldots \ldots \ldots . .18$

$M$ arcus, $R \ldots \ldots \ldots \ldots . . . .97$

Marek, J-J ............. 11

Marek, $M \ldots \ldots \ldots \ldots \ldots 11$

M arek, $T$. ............. 34

$M$ ares, $A \ldots \ldots \ldots \ldots . \ldots 97$

$M$ aret, $K$ H . . . . . . . . . . . 37

$M$ argolin, A . . . . . . . . . 15

$M$ argolis, B.............. 34

$M$ argolis, BK .............. 5

M argolis, HS . . . . . . . . . . . 97

M argolis, $\mathrm{KL} \ldots \ldots \ldots \ldots \ldots 15$

$M$ argolskee, RF . . ......... 11

$M$ argulis, S............. 34

$M$ arie, $Y \ldots \ldots \ldots \ldots \ldots \ldots 3$

$M$ arine Safety Agency . . . . . . 102

Marino, KE ............... 34

$M$ ario, AA ..............49

$M$ arion, D . . . . . . . . . . . . 32

$M$ arion, SA .......... 32, 71

Marions, $0 \ldots \ldots \ldots \ldots .6$

Mark, AL ............... 34

Marka, C ............. 97

M arkham, SE ............ 34

M arkopoulos, $P \ldots \ldots \ldots \ldots 52$

M arkowitz, S . . . . . . 10, 32, 93

M arkowitz, SB . ........... 32

M arks, B. . . ........... 51

$M$ arks, R .......... 9, 89

M arlankar, M G . .......... 64

M armor, $M$............... 91

$M$ armot, $M \ldots \ldots \ldots \ldots . . .3,34$

M arne, $M$ J . ............ 97

Maroni, $M \ldots \ldots \ldots \ldots .7,27$

M arotz-Baden, R . . . . . . . . . 64

$M$ aroudas, $A \ldots \ldots \ldots \ldots \ldots 6$

$M$ arques, $A$. . . . . . . . . . 65
$M$ arques, JM ............ 9

M arras, WS . . . . . . . 29, 58, 80

Marrero, J . ........................... 95

$M$ arrs, TC ............. 95

$M$ arsden, AM ........... 46

$M$ arsden, $C D \ldots \ldots \ldots \ldots 6,7$

$M$ arsella, AJ . . . . . . . . . . . 99

Marsh, B .............. 93

Marsh, GM ............. 10

$M$ arsh, JL............... 31

$M$ arsh, JP ............... 10

$M$ arshal, S . . . . . . . . . . . 68

$M$ arshall, $C \ldots \ldots \ldots \ldots 52$

M arshall, J . . . . . . . . 34, 52, 95

$M$ arshall, $M \ldots \ldots \ldots \ldots . . . . . . . .$.

M arshall, NL . . . . . . . . . . 34

$\mathrm{M}$ arshall, VW ........... 97

Martel, M . . . . . . . . . . . . . . 10

Martell, J . .............. 19

Martelli, C . . . . . . . . . . . 88 88

$M$ artens, $\mathrm{M} \mathrm{H} \ldots \ldots \ldots \ldots . \ldots 21$

$M$ artens, WM ........... 53

$M$ arti, $B \ldots \ldots \ldots \ldots \ldots 6$

$M$ arti, GE ............. 1

M artí, M C ............ 44

M artignone, $G \ldots \ldots \ldots \ldots . . .88$

$M$ artikainen, $M$. . . . . . . . . 13

$M$ artin, $B \ldots \ldots \ldots \ldots \ldots 52$

$M$ artin, D D ................ 34

$M$ artin, E . . . . . . . . . . . . . 4

$M$ artin, EV ............. 34

$M$ artin, J ...............50

$M$ artin, JB .............. 53

$M$ artin, JH . ............. 11

$M$ artin, JK . . . . . . . . . . . 34

$M$ artin, JT ............41

$M$ artin, LS . . . . . . . . . . . 97

$M$ artin, NB .............64 64

M artin, PL . . . . . . . . . . . . 64

$M$ artin, RH ............. 9

$M$ artin, RL............ 102

$M$ artin, SE .............. 51

$M$ artin, SF . . . . . . . . . . . . 51

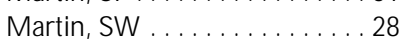

$M$ artin, $T \ldots \ldots \ldots \ldots \ldots 29$

$M$ artin, TR ............ 10

$M$ artin, $\mathrm{VH} \ldots \ldots \ldots \ldots . \ldots 30$

$M$ artineau, $L \ldots \ldots \ldots \ldots . .42$

$M$ artinez, GA . . . . . . . . . 15

$M$ artinez, $S \ldots \ldots \ldots \ldots .28$

$M$ artin-M arcos, M . . . . . . . . 39

$M$ artone, $T$. . . . . . . . . . . 28

M artonik, J............. 81

Maruna, $H \ldots \ldots \ldots \ldots . . .97$

M arx, $\mathrm{HH} \ldots \ldots \ldots \ldots \ldots 68$

$M$ arx, J.............. 70

$M \operatorname{arx}, J] \ldots \ldots \ldots \ldots \ldots 10$

M arx, M............... 102

$M$ arxer, F.............. 52

M asali, M . ............. 29

M aschewsky-Schneider, U .... 3

M asek, LC . . . . . . . . . . . . . . . 10

Masi, AT .............. 6

M asi, M A . . . . . . . . . . . . 44
Masihi, K N ............97 97

Masironi, $R \ldots \ldots \ldots \ldots . . . . .3$

M askin, A . . . . . . . . . . . . . . 15

M askuko, K ............ 97

M aslach, C . .............. 34

M aslansky, CJ ............ 30

M aslansky, SP . . . . . . . . . . 30

Maslow, AH .............. 34

Mason, J............... 20

M ason, JO .............. 19

M ason, JW . . . . . . . . . . . . . . 34

Mason, TJ ................ 1

M asood, D ............. 101

M assachusetts Biotechnology

Council Community

R elations Committee . . . . . . 77

M assachusetts I nstitute of

T echnology (M IT ) . . . . . . . . . 96

$M$ asschelein, R . . . . . . . . . . . . 9

M assé, $S \ldots \ldots \ldots \ldots \ldots \ldots 10$

M assel, H K . . . . . . . . . . . . . 5

M assip, P ............... 3

$M$ asson, $A \ldots \ldots \ldots \ldots . . . .67$

Masson, $H \ldots \ldots \ldots \ldots \ldots 7$

M astin, S . . ............. 97

M asuda, Y ............... 39

M asuyama, $S \ldots \ldots \ldots \ldots . . . .37$

M aswuelet, AC ..........6

M atarazzo, JD . . . . . . . . . . . 19

$M$ athew, RM . . . . . . . . . . . 8 80

M athias, CGT . . . . . . . . . . 70

$M$ athias, $T$............. 12

M athiesen, E . . . . . . . . . 97

Mathur, A . ............. 34

Mathur, $N \ldots \ldots \ldots 63,64,96$

$M$ atikainen, $E$............. 7

M atlai, $P \ldots \ldots \ldots \ldots . \ldots 53$

$M$ atos, E.......... 2, 28, 71

Matre, R .............. 34

M atsuda, A ............ 97

M atsumoto, AM ...........9

M atsumoto, $K \ldots \ldots \ldots 29,43$

$M$ atte, TD ....... . 9, 32, 38, 81

M attera, VD . . ........... 83

M atteson, M T . . . . . . . . . 34, 35

M atteucci, MJ ............ 11

$M$ atthes, $R$. . . . . . . . . . . . . . 49

M atthew, RM . . . . . . . . . . . 91

$M$ atthews, $C G \ldots \ldots \ldots \ldots 11$

$M$ atthews, $K$ A . . . . . . . . . 3, 34

$M$ atthews, LS. . . . . . . . . . . . 6

$M$ atthews, $R \ldots \ldots \ldots \ldots 29$

M attiason, I . . . . . . . . . . . . . . 34

M attila, M ........22, 29, 59

M attis, M C . . . . . . . . . . . 34

M attison, DR ......... 9, 33

$M$ attlis, M ............... 17

Mattock, $M$.............. 3

$M$ attson, $M$.............. 43

$M$ attsson, $T$. . . . . . . . . 6

$M$ auch, $P \ldots \ldots \ldots \ldots \ldots 1$

$M$ auff, $A \ldots \ldots \ldots \ldots \ldots \ldots . . . \ldots$

$M$ aughan, RJ ........... 42

M aunder, $L$. . . . . . . . . . . . . . . 89
M aunder, $L R \ldots \ldots \ldots \ldots \ldots 89$

$M$ aung- $M$ aung-Lay . . . . . . . . 38

M ausner, B . . . . . . . . . . . . 34

M ausner, JS . . . . . . . . . 23, 97

M auzini, BM . . . . . . . . . . . 89

Max, M D .............66 66

$M$ axey, KF............. 95

Maxey, M N . . . . ............. 101

$M$ axfield, ME............. 3

$M$ ay, J ........... 10, 70, 77

May, $M \ldots \ldots \ldots \ldots \ldots 10$

Mayer, A ........ 29, 31, 49

$M$ ayer, RE .............. 52

$M$ ayer, TA . . . . . . . . . . . . . 14

$M$ ayerick, $B$. . . . . . . . . . . 10

$M$ ayes, B . . . . . . . . . . . . . 19

$M$ ayes, BT . . . . . . . . . . . . 34

$M$ ayes, $T$. .............. 29

$M$ ayhew, $D J \ldots \ldots \ldots \ldots \ldots 52$

$M$ aynard, $A$.............. 20

M aynard, JE ..........4, 97

$M$ aynard, $R L$............. 95

Mayo, RS............... 36

$M$ ayrent, SL ............. 97

$M$ ays, BT . . . . . . . . . . . . . . 34

$M$ azai, CG ............. 3

M azaux, J M .............. 5

M azumdar, S............. 3

M azura, A . ............... 15

M azzuckelli, LF ........... 28

M c Innes, G . . . . . . . . . . . . 55

M cAfee, R B . . . . . . 22, 56, 59, 60

M cArdle, $B \ldots \ldots \ldots \ldots .42$

$M$ cArdle, WD ............ 42

M cArthur, C . . . ......... 97

McCabe, D . ............. 21

M cCain, GA ........... 6

McCall, T . . ........... 97

M cCalla, M ............. 6

McCallum, RI .......... 3, 10

McCallum, RL .......... 97

M CCally, RL ............ . 49

M CCammon, CS ........... 3

M cCammon, JB.......... . 100

M CC andless, JB ........... 10

M cCann, K B . . . . . . . . . . . 59

M cCann, M.......... 94, 96

M cCarroll, HJ ............. 7

M cCarroll, JE ........... 100

M CC arthy, CM ...........83

M CC arthy, H . . . . . . . . . . 17

M CC arthy, SM ........... 44

M cC aughey, BG .......... 39

M cC aughey, WTE . . . . . . . 10

M cCauley, ME ........... 50

McClenny, W ............. 55

M cClenny, WA . . . . . . . . . . . 55

McCloy, E .............. 97

McClusky, P. . . . . . . . . . . 19

M CC onnell, $R \ldots \ldots \ldots \ldots 9$

M CCord, CP ............. 10

M cCord, JF . . . . . . . . . . . 97

M cCormick, EJ . ........ 29, 34

M cCormick, RD . ......... 97 
M CC ormick, WC .......... 7 $M$ CC reath, DR . . . . . . . . . 74 M cC ue, JD .............. 97 M cCulloch, J .............6 M cC ullough, EA ......... 42 M cC ullough, RE ........... 37 M cC unney, RJ........... 16 M cC urdy, A . ............83 83 M cC urdy, S . . . . . . . . . . 83 M cC urdy, SA . . . . . . . 64, 83 M cC usker, J . . . . . . . . . . . . . 39 M cC utchen, CW . . . . . . . . . 19 $M C D$ ermott, $M$. ........... 10 M CD iarmid, M A . . . . 15, 81, 100 M CD onald, AD ... . 9, 10, 52, 100 $M$ CD onald, $D \ldots \ldots \ldots \ldots . .48$ M CD onald, JC . 6, 7, 9, 10, 52, 100 M CD onald, WJ ............ 14 M CD onnell, R ............20 M CD onnell, WF............ 53 M CD onough, $\mathrm{MT}$. . ........ 97 M CD ougal, $L \ldots \ldots \ldots \ldots \ldots . .100$ $M C D$ ougall, WD, III .........9 M CD owell, EM ...........10 M CD owell, ME ........... 32 M CD uffie, H H . . . . . . . 38, 64, 70 M cElroy, CT . ............ 53 M cElroy, JC . . . . . . . . . . 34 M CElvenny, DM . . . . . . . . . 48 M cEvoy, RD . . . . . . . . . . 10 M cEwan, YW . . . . . . . . 29, 43 M cEwen, J . . . . . . . . . . . . . . 48 M CG arity, T $0 \ldots \ldots \ldots \ldots 23$ M CGee, K P .............. 52 MCGill, M ..............97 M cG ivern, RF . . . . . . . . . . . 52 M CG rath, A . . . . . . . . . . . . 34 M cG rath, J............ 5, 34 M cG regor, DB. . . . . . . . . 27, 33 M cG regor, $M \ldots \ldots \ldots \ldots .6$ M cGuinn, Y . . . . . . . . . . . 79 M CG uire, T G . . . . . . . . . . 15 M CH enry, CR .............83 M clntosh, DJ . . . . . . . . . . 29 M clntosh, $\mathrm{N} \ldots \ldots \ldots \ldots \ldots \ldots$ M clntyre, AJ . . . . . . . . . . 8 83 M clntyre, DA . . . . . . . . . . . . 42 $M$ clntyre, JM . . . . . . . . . . . 9 M clntyre, JWR . . . . . . . . . 97 M clntyre, OR ............. I M cjilton, C . . . . . . . . . . . . 70 M cK ay, R ............... 10 M cK ee, GH .............. 34 M cK enna, C . . ........... 97 M cK enna, MJ ............. 30 $M$ CK enzie, AD . . . . . . . . . . . . 9 M CK errow, CB . . . . . . . . 10, 89 M ck ersie, RB . ........... 21 M ckhann, G M . . . . . . . . . . . . 14 M cK ibben, $P$. . . . . . . . . . . 97 M cK inlay, A .............. 49 M cK innery, WN , Jr. . . . . . . . . 80 M cK inney, JD . ............. 9 M cK inney, PW . . . . . . . . . . . . 97
M cK innon, RA ............ 33 M CK night, JT . ...........664 M cK oan, JW . ............. 39 M CLachlan, $\mathrm{RL} \ldots \ldots \ldots \ldots . . .9$ M CLanahan, SM ...........15 M cLaney, M A . ............ 34 M CLary, PW ............. 26 M CL aughin, $J \ldots \ldots \ldots \ldots . . .88$ M CL aughlin, JK . . . . 4, 32, 44, 72 M CL aughlin, JR . . . . . . . . . 48 M CLaughlin, WI . ........... 58 M cLean, A . . . . . . . . . . . . . . 5 M CLean, AA .............. 15 M CLean, LA .............. 34 M CL oughlin, Q ...........43 M cLymore, $R \ldots \ldots \ldots \ldots 70$ M CM ahon, RJ ............ 51 $M \mathrm{CM}$ anus, T N . . . . . . . . . . . 58 M cM ichael, AJ . . . . 27, 33, 53, 80 M cM ichael, J . . . . . . . . . . . . 28 M cM ichel, AJ . ........... .6 M CM illan, D . . . . . . . . . . . . . 70 M CM illan, D D . . . . . . . . . . . . 10 M cM ullen, $K \ldots \ldots \ldots \ldots . .24$ M CNab, I.................. M cN ally, M S .............. 3 M cNiven, R . . . . . . . . . . . . . 89 M cPeters, R . . . . . . . . . . . . 53 M CPherson, A . . . . . . . . . . . . 15 M CPherson, CK . . . . . . . . . . 15 M CQ ueen, DS . . . . . . . . . . . . 37 M cQ uiston, TH . . . . . . . . . . 18 M CShane, DJ . . . . . . . . . . . 6 M cShane, DP . . . . . . . . . . . . 73 M cSween, TE . . ........... 59 M cVittie, DJ . .............993 M cW hinney. . . . . . . . . . . . . 29 $M$ eade, TW ............... 3 M eadows, MJ. ............99 M eadows, $R$. . . . . . . . . . . . 70 M earelli, I ..............4 M easham, AR ............ 15 M ecklenburgh, IC . ......... 77 M edical Economics C o . . . . . . 79 M edical R esearch Council . . . . 10 M edina, E . . . . . . . . . . . . . . 44 M edina, R . . ............. 44 M edrow, $W \ldots \ldots \ldots \ldots . . .55$ $M$ edsger, TAJ ...........6 6 M eek, AH ...............28 M eek, DC . . . . . . . . . . . 15 M eeks, A . . . . . . . . . . . . . 9 M eenan, RF . . . . . . . . . . . . 6 $M$ ees, WC . . . . . . . . . . . . 34 $M$ effert, $K \ldots \ldots \ldots \ldots . . .58$ M egathlin, KN ............9 M eggs, WJ ................. 13, 70 M ehendale, $\mathrm{HM} \ldots \ldots \ldots \ldots 4$ $M$ ehevs, A . . . . . . . . . . . . . 97 $M$ ehl, ES . . . . . . . . . . . . 44 44 M ehIman, M A . . . . . . . . . . . . 53 M ehta, PJ . . . . . . . . . . . . . . 39 M eier, $\mathrm{H} \ldots \ldots \ldots \ldots \ldots . . .33$ M eier, $\rfloor \ldots \ldots \ldots \ldots \ldots \ldots \ldots . .38$
M eier-Sydow, J . ..........66 63 M eifort, J . . . . . . . . . . . . 102 M eiklejohn, A . . . . . . . . 6 $M$ einert, $R \ldots \ldots \ldots \ldots \ldots .9$ M einhardt, TJ . . . . . . . . . 38 M eisner, M . . . . . . . . . . . . 34 M ekjavic, I . . . . . . . . . . . . 42

M ekjavic, IB............ 42 M ekky, S ................ 10

M el'nikova, EA . . . . . . . . . 38 M elamed, S . . . . . . . . . . . . . 31 M elamed, Y . . . . . . . . . . . . 66

M elden, A . . . . . . . . . . . . . . 19

M elenka, LS. . . . . . . . . . . . . . 86

M elia, JL . ...............59

M elick, ME .............. 39

M elick, M F . . ............ 39

M elin, B . ................ 34

M elius, J........... 13, 95

M elius, J M . ............ 32, 39

M elleby, A .............997

M ellin, $M \ldots . \ldots \ldots \ldots \ldots . .22$

M ellion, M B. . . . . . . . . . . . . 96

M ellman, M A . . . . . . . . . . . . 28

M elloni, B ............. 10

M ellstrom, G . . . . . . . . . . . 38

M elton, $\mathrm{HE} \ldots \ldots \ldots \ldots \ldots . . . .66$

M elton, J . ..............6 6

$M$ endell, $M \ldots \ldots \ldots \ldots 13$

M endell, MJ .............. 13

M endelsohn, $M L$. . . . . . . . . . . 33

$M$ endelson, $P$. . . . . . . . . . . . . 29

$M$ endes, B . ..............6 65

M enerey, D . . . . . . . . . . . . . 54

$M$ eneses, $F \ldots \ldots \ldots \ldots \ldots 5$

$M$ eng, J-F............. 1

M enke, R . . . . . . . . . . . . . 81 81

M enn, JT . . . . . . . . . . . . . 93

M enn, T . . . . . . . . . . . . . 63

M enné, $T \ldots \ldots \ldots \ldots . . .33,64$

Menou, $M$..............22

$M$ ense, $S \ldots \ldots \ldots \ldots \ldots 66$

M enu, JP ................ . 29

M enzel, D B . . . . . . . . . . . . 30

M enzel, G . . . . . . . . . . . . . 50

M enzies, $\mathrm{H} \ldots \ldots \ldots \ldots \ldots . .24$

M enzies, RI . . . . . . . . . . . . . 13

$M$ eo, G . . . . . . . . . . . . . . 80

M erchant, JA . . . 3, 10, 32, 70, 89 M erchant, JP . . . . . . . . . . . . . 64 M erchant, JR ............664 M ercier, P . . . . . . . . . . . . 65 $M$ erck and $C_{0} \ldots \ldots \ldots \ldots 63$ M ercy, JA . . . . . . . . . . . . . . 51

M éreau, $P \ldots \ldots \ldots \ldots \ldots 45$

M ereau, $P \ldots \ldots \ldots \ldots . . .97$

$M$ eredith, S . . . . . . . . . . . . . 10

Merewether, ERA $\ldots \ldots \ldots 28$

M erget, R. . . . . . . . . . . . . 63

M ergler, D ........... 7, 11

M erian, E. . ...............63 63

M eridian R esearch, Inc . . . 64, 93

M eridith, S. . . . . . . . . . . . . 83

Merler, E . . . . . . . . . . . . 88
M erletti, $F \ldots \ldots \ldots \ldots \ldots 28$

M erlo, CA ..............67 67

M erlo, $F \ldots \ldots \ldots \ldots \ldots 88$

M ermelstein, R . . . . . . . . . . 10

M ero, R P ............... 34

M errigan, DM . . . . . . . . . . 15

M erriman, EA . . . . . . . . . . . . . 10

M erry, CJ.............. 47

M erry, W . . . . . . . . . . . . . 74

M eshkati, N . . . . . . . . . . . . 29

M eslin, EM ............... 19

M esser, E . . . . . . . . . . . . 29

$M$ essina, $C \ldots \ldots \ldots \ldots \ldots .7$

M essing, EM ............. 8

M essing, K . . . . . . . . . . . 100

M essite, $\rfloor \ldots . . . \ldots$. . . . . . . 98

M ester, U . . . . . . . . . . . . . . 58

M etenier, I . . . . . . . . . . . . 100

M ethner, M M ............9 9

$M$ ettler, FA . . .............48 48

$M$ ettzler, DE . . . . . . . . . 33

$M$ etz, $B \ldots \ldots \ldots \ldots \ldots .42$

M etz, SG ............... 77

M etzger, BB . . . . . . . . . . . 72

M euch, M G . . . . . . . . . . . . 97

M eulenbelt, $\rfloor \ldots \ldots \ldots \ldots . \ldots 39$

M eurman, LO . ............. 10

$M$ exican Secretariat of $L$ abor and Social W elfare . . . . . . . 21

M eybeck, M . . . . . . . . . . . . . 53

M eyer, BD . . . . . . . . . . . . . 34

M eyer, CR . . . . . . . . . . . . . . . 79

M eyer, J-J............ 11, 52

M eyer, J . ................. 26

Meyer, M R .............. 33

M eyer, $R$................ 97

M eyer, SW . . ............ 10

M eyer, $T\rfloor \ldots \ldots \ldots . . . . .99$

M eyer, UA . . . . . . . . . . . . . 33

M eyer-Bisch, C . . . . . . . . . 4 47

M eyers, J R . . . . . . . . . . . . 64, 640

M eyerson, $D \ldots \ldots \ldots \ldots \ldots . .34$

M ezey, G . . . . . . . . . . . . . . . . 51

M ichael, $0 \ldots \ldots \ldots \ldots \ldots 10$

M ichaelchuk, D . . . . . . . . . . 86 86

M ichaelis, M . . . . . ........ 97

M ichaels, D . . . . . . 34, 53, 85, 100

M ichaels, D M . . . . . . . . . . 72

M ichaels, JF . ............. 3

M ichaelson, SM . . . . . . . . . . . 49

Michalak, R ............... 3

M ichel, $0 \ldots . . \ldots \ldots \ldots . . .10$

M ichel-Briand, C . . . . . . . . . 43

M ichelson, JE. . . . . . . . . . . . 6

M ichelson, W . . . . . . . . . . . . . 34

M ichelsson, J-E . . . . . . . . . . . 6

M ichet, CJ . . . . . . . . . . . . 6

M ickelsen, RL . . . . . . . . . . 100

M icoud, M . ................ 3

$M$ icroelectronics and Computer

T echnology Corporation

(MCC) .............. 83

M icrosoft Corp ............ 52

M icrosonic $\mathrm{G} \mathrm{mbH} \ldots \ldots \ldots . \ldots 58$ 
Middaugh, DA........... 13 M iddaugh, $J \ldots \ldots \ldots \ldots \ldots 42$ M iddleton, WG . . . . . . . . . 10 M idtgård, U . . . . . . . . . . . . 7 Mielck, A . ............... 3 $M$ iettinen, OS . . . . . . . . . . 28 M iezio, K . . . . . . . . . . . . 34, 52 M ikaelsson, $B \ldots \ldots \ldots \ldots \ldots 26$ M ikheev, M . ........ 16, 28, 64 Mikoczy, Z . . . . . . . 66, 88 M ilanini, G . . . . . . . . . . . . 97 Milby, TH ...............99

Mild, KH ..............49 49

M iles, J . . . . . . . . . . . . . . . . 64

M iles, JW ................ 39

Milham, $S \ldots \ldots \ldots \ldots \ldots . \ldots 32$

M ilham, SJ . . . . . . . . . . . . 72

M ilic-E mili, J . . . . . . . . . . . 37

Miligi, I . . . . . . . . . . . . 88

M ilkowska, G . ...........6 63

Milky, M M . . . . . . . . . . . 53

Milla, $M H \ldots \ldots \ldots \ldots . . .69$

M illanta, L . . . . . . . . . . . . . . . . 49

Millar, JD ............ 23, 32

Millar, K ................ 3

Milledge, JS . ............. 37

M illender, LH . ............6

Miller, $A B \ldots \ldots \ldots \ldots . .96$

M iller, B. . . . . . . . . . . 41, 71

Miller, BA . . . . . . . . . . . . . 91

Miller, BG ............... 10

Miller, CS . . . ........ 11, 13

Miller, D . ............. 12, 35

M iller, DK ................. 33

Miller, DR . . . . . . . . . . . 12

Miller, E. . . . . . . . . . . 10, 97

Miller, FJ . . . . . . . . . . . 30, 91

Miller, $\mathrm{H} \ldots \ldots \ldots \ldots$. . . . . 87, 89

Miller, HI. . . . . . . . . . . . . . 77

Miller, JD ............. 13, 44

Miller, JK . .............. 97

Miller, JM ......... 55, 56, 97

Miller, JW ................ 3

Miller, $K \ldots \ldots \ldots \ldots$. . . . 33

Miller, KE ............. 96

Miller, KI . . . . . . . . . . . . . 34

M iller, L . . . . . . . . . . . . . . . . . 70

Miller, LK . . . . . . . . . . . . . . 97

Miller, LS . . . . . . . . . . . . . . . 34

M iller, M L . . . . . . . . . . . . . . . 11

Miller, NE .............. 19

Miller, PL . . . . . . . . . . . . . . 96

Miller, RA ............. 64

M iller, RB . . . . ........... 97

Miller, RE . . . . . . . . . . . . 68

Miller, RL . .............. 29

Miller, R R . . . . . . . . . . 11

Miller, S . . . . . . . . . . . 34, 39

M iller, TQ . ............... 34

Millers, $K \ldots \ldots \ldots \ldots \ldots 10$

Millman, PR ............ 97

Millner, PD . . . . . . . . . . . . 101

Mills, GR .............. 58

Mills, JL . . . . . . . . . . . 33
Mills, WJ . ............. 42

$M$ ilne, $A H \ldots \ldots$. .......... 70

M ilne, J . . . . . . . . . . . . . 89

Mils, C .................43

M ilton, $G \ldots \ldots \ldots \ldots \ldots 12$

M ims, SR . . . . . . . . . . . . . 11

$M$ inard, $D \ldots \ldots \ldots \ldots \ldots .42$

$M$ incheva, L............ 43

$M$ ines Accident Prevention

Association 0 ntario. . . . . . 74

$M$ ines, $R \ldots \ldots \ldots \ldots .664$

Ming, $J \ldots \ldots \ldots \ldots \ldots 63$

$M$ inisterio de A suntos Sociales y Empleo ............... 16

M inisterio de Bosques de Fiji . . 68

$M$ inisterio de Comercio

Internacional e Industria

(MITI). .

M inisterio de Desarrollo de Cualificaciones ...........68 68

M inisterio de Salud Pública (M inistry of Public $\mathrm{H}$ ealth, $\mathrm{MOPH})$... 16,20

M inisterio de Sanidad de la R epública Checa M inisterio de Trabajo........... 16, 34

$M$ inisterium für $U$ mwelt . . . . . 55 $M$ inistro de Trabajo y Asuntos Sociales (Alemania) . . . . . . 17

$M$ inkler, M . . . . . . . . . . . . . . . 59

M ino, $Y \ldots \ldots \ldots \ldots . \ldots 34$

M inoia, $L \ldots \ldots \ldots \ldots \ldots . \ldots 27$

M inor, AF . .............. 15

M inors, D. . . . . . . . . . . . . 29

M inors, DS ..........29, 43

M inors, $S \ldots \ldots \ldots \ldots \ldots . . . .43$

M inter, SG . . . . . . . . . . . . . 59

$M$ intz, $F \ldots \ldots \ldots \ldots \ldots . . \ldots 31$

Mintz, J ............... 5

M intzberg, $H \ldots \ldots \ldots \ldots . \ldots 35$

$M$ irer, $F \ldots \ldots \ldots \ldots . . .91$

Miriam, A ............ 100

Mishima, $N \ldots \ldots \ldots . . . .55$

M ishiros, S . . . . . . . . . . . 97

M isner, ST . . . . . . . . . . . . 38

M isra, UK . . . . . . . . . . . . . 11

M isumi, $J \ldots \ldots \ldots \ldots \ldots . . . \ldots 34$

M ital, A . . . . . . . . . . . 29, 56

M itbriet, I I . . . . . . . . . . . . 49

M itchell, CA . . . . . . . . . . . 89

$M$ itchell, D . . . . . . . . 21, 74

$M$ itchell, DM . . . . . . . . . . . 6

Mitchell, J . ............. 5

$M$ itchell, $0 \ldots \ldots \ldots \ldots \ldots 21$

M itchell, R . . . . . . . . . . . 21, 29

M itchell, SN . ............ 49

$M$ itchell, $T$. . . . . . . . . . . . 9, 9, 83

$M$ itsui, $T$. . ............ 97

Mitter, S................ 21

Mittleman, M A . . . . . . . . . . . 3

M iura, $T \ldots \ldots \ldots \ldots \ldots . \ldots 31$

M iyamoto, $Y \ldots \ldots \ldots \ldots 102$

$M$ izoue, $T$. . .............. 16

Mizuno, T . . . . . . . . . 41
M obbs, I. ............68 68

M obed, K .............664 64

M obil 0 il Corporation 78, 82, 102

Modig, B ............... 97

M oen, B . ............... 7

M oens, $G \ldots \ldots \ldots \ldots . . .997$

M oghadam, V M . . . . . . . . . . 24

Mogil, M ................ 39

M ohan, D . ............ 58,64

M ohnen, V ............. 55

Mohner, M ............... 32

Mohnhan, J . ............... 5

Mohr, DL ...............56

Mohr, U . . . . . . . . . . . 10, 33

M oinov, S .............. 73

M oira, CY .......... 73, 82

M oleski, WH .............. 34

M olgaard, CA ............. 11

M ølhave, L.............. 13

Molin, I . ................997

Molin, L................ 10

M olina, MJ ............... 53

M olinini, R . . . . . . . . . . . . . . 9

Molitor, M R ............. 54

M oll van Charante, AW . . . . . . 47

Moll, T . . . . . . . . . . 29, 43

Möller, C ................11

Moller, $\mathrm{H} \ldots \ldots \ldots \ldots \ldots \ldots 33$

M öller, T . . . . . . . . . . 12, 66

Molocznik, A . . . . . . . . . . 38

M olska, J ............... 38

M olyneux, M K B . . . . . . . 10,89

Momm, W ............. 17

M omtahan, K . . .......... 97

M omtahan, K L . . . . . . . . . 97

M onaco, F . . . . . . . . . . . . . 97

M onaghan, $S \ldots \ldots \ldots \ldots . . .88$

M oneta, $G$. . . . . . . . . . . . . . . 4

M oneti, G . .............. . 44

M onge, $C \ldots \ldots \ldots \ldots \ldots . \ldots 37$

M onge, PR . . . . . . . . . . . . 34

M ongkolsapaya, J . . . . . . . 38

M onk, AF. . . . . . . . . . . . . 29

M onk, $T \ldots \ldots \ldots$. . . . 43, 43, 102

M onk, TH .... 29, 34, 43, 52, 96

M onoson, R . . . . . . . . . . . . . 70

Monou, $\mathrm{H} \ldots \ldots \ldots \ldots . . . . .5$

M onoz, N . . . . . . . . . . . . . . 8

Monro, J ................. 39

Monson, RR . . . . . . . . . . 28

M onson, RR ..... 3, 72, 80, 91

M onster, AC . . . . . . . . . . 4 43

M ontagna, W . . . . . . . . . . . 33

M onteagudo, FSE .......... 11

M ontgomery, $F \ldots \ldots \ldots \ldots 6$

M ontgomery, $\mathrm{H} \ldots \ldots \ldots \ldots 59$

M ontgomery, S . . . . . . . . . . 53

M onticello, T M ........... 11

M ontillier, J . . . . . . . . . . . . . 75

M ontoliu, M A . . .......... 97

M ontoya-Aguilar, C . ....... 97

M oog, R............... 43

M oolenaar, RJ . ............ 33

M oolgavkar, SH ............ 2
M oon, $P \ldots \ldots \ldots \ldots \ldots .46$

M oon, RE ............... 36

Moon, S................ 34

Moore, JG ............... 34

M oore, JS. . . . . . . . . . . . 6

Moore, LG . . . . . . . . . . . . 37

M oore, M . . . . . . . . . . . . . 99

M oore, RA............. 97

M oore, R M . . . . . . . . . . . 97

M oore, SR W ............66 66

Moore-E de, M C ..........43 43

Moors, SH .............. 43

M oos, $H \ldots \ldots \ldots \ldots . \ldots 68$

M oos, R . . . . . . . . . . . 34

M oo-Young, M ..........6 65

M orabia, A .............26

M oran, FX .............. 100

M oran, LA . . . . . . . . . . . . . 59

M oran, $T$ J . .............. 89

M oran, TP............. 52

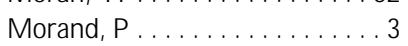

M orata, TC . . . . . . . . . 11, 47

M oravec, M . . . . . . . . . . . . . 59

M orawetz, JS ............. 18

M oray, N . . . . . . . . . . . . 29

Morch, $H \ldots \ldots \ldots \ldots \ldots . \ldots 34$

M ordish, R . . . . . . . . . . . . 89

M oreau, WM . . . . . . . . . . . 83

Morel, $0 \ldots \ldots \ldots \ldots . . . .97$

M oreland, JB . . . . . . . . . . . . . 47

M oreland, R ............ 7

Morell, M . . . . . . . . . . . . . . . 34

Moren, $A \ldots \ldots \ldots \ldots 28$

M oretti, EC . . . . . . . . . . . 77

Morey, $P \ldots \ldots \ldots \ldots \ldots 10$

M orey, PR . . ........... 44

M orgade, C . . . . . . . . . 9, 27

M organ, CT . . ........... 29

M organ, DV ............ 83

M organ, E ............... 10

M organ, G . . . . . . . . . 35, 59

M organ, K T . ............ 11

M organ, LG . . . . . . . . . . . . . 63

M organ, PGM . . . . . . . . . . 89

M organ, $U \ldots \ldots \ldots \ldots \ldots .72$

M organ, WK . . . . . . . . . . . 70

$M$ organ, WK C . . .......... 10

M orgenstem, $\mathrm{H} \ldots \ldots \ldots \ldots \ldots .7$

M orgenstern, $F \ldots \ldots \ldots \ldots 23$

M orgenstern, $H$. . . . . . . . 28

M orgenstern, $0 \ldots \ldots \ldots \ldots . . .59$

M ori, S............... 80

Morill, JC ............... . 47

M orison, WL . . . . . . . . . 49, 53

M orissette, R . . . . . . . . . . 24

M orita, M .............41

M orita, Y . . . . . . . . . . . . . . 43

M oriya, T M . . . . . . . . . . . 101

M oriyama, $T$. . . . . . . . . . . . 97

Mörl, $H \ldots \ldots \ldots \ldots \ldots . \ldots$

M orrill, JC . . . . . . . . . . . . . 101

M orring, K . . . . . . . . 10, 70

M orris, HF . . . . . . . . . . . . 11

Morris, JN . . . . . . . . . . . 3 
M orris, PD . . . . ......... 70

M orris, RM .............74

M orrison, A . . . . . . . . . . 88

M orrison, AS . . . . . . . . . . . 39

M orrison, D . . . . . . . . . . . 64

M orrison, EW ............ 34

M orrison, HI . . . . . . . . 1, 32, 64

M orrison, JB . ........... 42

M orrison, M ........... 96

M orrow, GS............ 74

M orrow, L............. 11

M orrow, PC ............ 34

M orrow, PE ............ 10

M ors, WB .............. 53

Morse, RM ............ 15

M ortazavi, S . ............. 34

M ortensen, JT . . . . . . . . . . 38

M orton, M . . . . . . . . . . . . . 80

Morton, WE ........ 42, 94

M osely, WH............. 15

Moser, R . . ............. 16

M oser, V C . . . . . . . . . . . . 33

Moses, $T \ldots \ldots \ldots \ldots . .63$

M oshowitz, A........... 52

M osier, SL ............. 52

M oskowitz, RW . . . . . . . . . . 6

M osovsky, J .............88 83

M osovsky, JA . . . . . . . . . . 83

M oss, CE ............. 52

M oss, GB ............. 97

M ossholder, K W . . ..... 29, 34

M ossini, E .............. 43

M ossman, BT ............ 10

M ossop, R . . . . . . . . . . . . 96

M ostofi, FK ............. 95

Moter, SE ................ 3

M othershead, JL, Jr . . . . . . . . 19

M otohaschi, $Y \ldots \ldots \ldots \ldots .43$

Mott, AE ............... 11

Mott, KE .............. 38

Mott, PE ..............43

M ouchet, M . . . . . . . . . . . . 97

M oudgil, T . . . . . . . . . . . . 97

M ouilleseux, A . . . . . . . . . 44

M oulin, F-X ............. 3

Moulin, JJ .......... 3, 63, 82

M ounce, LM ............. 9

M ountcastle, VB . ......... 11

M owrer, DS............. 77

M ozzon, D . . . . . . . . . . . 101

M rowietz, U . . . . . . . . . . . 3

M roz, M M ............... 10

M ubarak, SJ . . . . . . . . . . . . 6

M uchnick-Baku, S . ........ 15

M uckler, FA . . . . . . . . . . . . . . . 97

M ueller, CG............. 11

M ueller, GJ . . . . . . . . . . . . 49

M ueller, HA............ . 49

M ueller, M R ............. 83

M uhle, $H \ldots \ldots \ldots \ldots \ldots 10$

M uijser, $H \ldots \ldots \ldots \ldots \ldots 11$

M uilenberg, M . . . . . . . . . . 101

M uir, AR .............. 11

Muir, $C \ldots \ldots \ldots \ldots \ldots \ldots$
M uir, CS ....... 1, 2, 4, 10, 12

M uir, DC .............. 26

M uir, DCF .......... 10,80

M ukhopadhyay, N . . . . . . . . . 77

M ukhtar, H . . . . . . . . . . . . . . 33

Mul, CAM .............97

Mulach, R . . . . . . . . . . . . 80

Mulcahy, F........... 97

M ulder, GJ.............. 33

M ulder, PGH . . . . . . . . . 47

M uldoon, JT . ............. 32

Muldoon, SR . . . . . . . . . . . . 73

M uldoon, TL . . . . . . . . . . . . 74

M ullan, RJ . . . . . . . . . . . . . . . . 70

Muller, D . . . . . . . . . . . . . . . 9

M üller, EA . ................. 43

M üller, HE. . . . . . . . . . . . . 97

M uller, J . . . . . . . . . . . . . . 82

Muller, JE .............. 3

M üller, K M ................

M ullerworth, JH . .......... 52

M ulligan, WJ . . . . . . . . . . . . 96

M ullin, LS . . . . . . . . . . . . . . 3

M ullins, JR . ............41

M ullis, RN . . . . . . . . . . . . . 15

M ullye, $E \ldots \ldots \ldots \ldots \ldots 5$

M umford, E . . . . . . . . . . . . 29

M unch, B . . . . . . . . . . . 45

M unday, NA ............. 33

M undel, M E . . . . . . . . . . . . 34

$M$ undt, $K A \ldots \ldots . . . . .880$

$M$ undus, $P \ldots \ldots \ldots \ldots \ldots . .7$

M unene, J . .............. 34

M unipov, $V \ldots \ldots \ldots \ldots .29$

M unk-M adsen, E . . . . . . . . . 66

M unoz, B.......... 1, 49,53

$M$ unoz, $F \ldots \ldots \ldots \ldots . . . .9$

M unoz, $M \ldots \ldots \ldots \ldots 12$

M unson, A . . . . . . . . . . . 33

M untaner, C . . . . . . . . . . . 5, 34

M uñoz, N . ........... 4, 10

Mur, D .............. 87

Mur, J............... 52

Mur, JM ............. 3, 63

Muratov, VR ............49 49

M urawski, SA ...........66

M urminen, $M$........... 91

M urphy, $B J \ldots \ldots \ldots \ldots \ldots 6$

M urphy, CC . . . . . . . . . 88

M urphy, D . . . . . . . . . . . . . 70

M urphy, DJ . ............ 64

M urphy, JD . . . . .......... 97

M urphy, JE .............23

M urphy, L . . . . . . . . . . . . . . 99

M urphy, LI . . . . . . . . . . . . . . 88 88

M urphy, LR ........ 5, 34, 52

M urphy, M ............97

M urphy, MJ ............ 27

M urphy, M R . . . . . . . . . . . . 77

M urphy, RC . ........... 10

M urphy, RXJ ............ 7

M urphy, $S \ldots \ldots \ldots \ldots \ldots \ldots . \ldots$

M urphy, SE . . . . . . . . . . . 44

M urray, FJ . . . . . . . . . . . . . . 30
M urray, JF . . . . . . . . . 10, 37

M urray, R ........... 10, 89

Murray, TH . ............. 19

Murray, V . ............. 39

Murray, WE ........... 52

M urrell, KFH ............ 34

M urtadha, M . ............. 9

M urthy, $L I \ldots \ldots \ldots \ldots \ldots 70$

M urza, G . .............. 3

M urza, VI . . . .......... 38

M urzin, AG . . . . . . . . . . . . 49

M ushak, $P \ldots \ldots \ldots \ldots \ldots 11$

Musk, AW ............... 9

M ustac, M . . . . . . . . . . . 3

M ustafa, KY . . . . . . . . . . 89

$M$ utanen, $P$. . . . . . . . . . . . . 3

M utaner, C . . . . . . . . . . . 34

M utel, CF ..............70

M uthuthamby, $P \ldots \ldots \ldots 96$

Muto, $T \ldots \ldots \ldots \ldots \ldots \ldots$

Mutschler, E . . ........... 33

M utter, SH .............42 42

M ycroft, FJ . . . . . . . . . . . . . 32

$M$ yers, $J \ldots \ldots \ldots \ldots \ldots \ldots 10$

M yers, JR . . . . . . . . . . . . . 64

$M$ yers, LA . . . . . . . . . . . 77

$M$ yers, M F . . . . . . . . . . . . . 95

$M$ yers, $M L \ldots \ldots \ldots \ldots \ldots$. . . 64

$M$ yers, WE . . . . . . . . . . . . 88

$M$ yint-L win . . . . . . . . . . . . 38

Myles, J . . . . . . . . . . . . . . . 24

Myles, SM . . . . . . . . . . . . . . 89

Myrsten, A-L . . . . . . . . . 34

N

$N$ aalsund, $A \ldots \ldots \ldots \ldots \ldots 10$

Nabieva, GV . . . . . . . . . 75, 78

Nachemson, $A \ldots \ldots \ldots \ldots \ldots 6$

Nachemson, AL . . . . . . . . . 97

Nachreiner, F . . . . . . . . . . 29, 43

$N$ aciones $U$ nidas. . . . . 17, 22, 23,

$44,53,54,72,76,103$

Nadel, JA ........... 10, 37

Nadel-K lein, J . . . . . . . . . . . 66

N adler, D . . . . . . . . . . . . . . . 59

Nadon, $L \ldots \ldots \ldots \ldots$. . . 4, 12, 89

N aess-A ndersen, CR . . . . 68, 78

$\mathrm{Nag}, \mathrm{D} \ldots \ldots \ldots \ldots \ldots \ldots \ldots 11$

$\mathrm{Nag}, \mathrm{PK} \ldots \ldots \ldots \ldots \ldots 64$

Nagamachi, M . . . . . . . . . 29

Nagata, S................. 5

N agataki, S. . . . . . . . . . . . . . . 48

Nageda, N L . . . . . . . . . . . . . 44

Nagel, DA . . . . . . . . . . . . . 6

Nagle, HT . .............. 11

Nagodawithana, T W . . . . . . . . 65

Nagy, J . . . . . . . . . . . . . 41

Nagy, M C . . . . . . ........6 64

Nahmias, M . . . . . . . . . . . 22

Nahrwold, D . . . . . . . . . . . 39

N aimark, A . . . . . . . . . . . 6

$N$ air, $N \ldots \ldots \ldots \ldots \ldots \ldots 11$

Naitoh, $\mathrm{P}, \ldots \ldots \ldots \ldots \ldots . .43$
Najenson, $T$. . . . . . . . . . 31

Nakagiri, S............... 97

Nakamura, K . ............ 3

Nakamuri, K . . . . . . . . . . . 13

Nakano, K K ............. 80

Nakaza, M .............. 86

Nakazawa, T . . . . . . . . . . . . 64

Namiesnik, J. . . . . . . . . . . 44

Nanci, D . . . . . . . . . . . . . 29

Nankin, $\mathrm{H} \ldots \ldots \ldots \ldots . . . .9$

Naoi, A. . . . . . . . . . . . . . . . 34

Narasimhan, GL . . . . . . . . . . 70

$\mathrm{N}$ asanen, M . . . . . . . . . . . 59, 93

$\mathrm{N}$ asca, $\mathrm{P} \ldots \ldots \ldots \ldots \ldots \ldots . . \ldots 72$

Nash, $G \ldots \ldots \ldots \ldots \ldots 63$

Naslund, $\mathrm{PH} \ldots \ldots \ldots \ldots . . . .33$

$\mathrm{Nass}, \mathrm{CC} \ldots \ldots \ldots \ldots \ldots . \ldots 72$

Nastasi, L . . . . . . . . . . . . . . . 88

Natasi, L. . . . . . . . . . . . . . . 89

Natelson, B. . . . . . . . . . . . 13

Nater, JP ............... 100

$N$ athan, $P E$. . . . . . . . . . . . 19

Nathanson, $T$. . . . . . . . . . . 44

$N$ ational A cademy of Sciences

(NAS). ..... 10, 30, 48, 63, 77

$N$ ational Advisory Council for

H uman $\mathrm{G}$ enome R esearch . 15

$N$ ational Asthma Education

Program (NAEP) . . . . . . . 10

$\mathrm{N}$ ational Board of Forestry . . . . 68

$N$ ational Board of Labour

Protection ....

National Centre of

$\mathrm{O}$ ccupational $\mathrm{H}$ ealth

Reporting ( $\mathrm{NCOHR}$ )...... 16

National Committee for

Childhood Agricultural

Injury Prevention ........ 64

$\mathrm{N}$ ational Committee for Injury

Prevention.............. 56

$N$ ational Committee on

Recombinant DNA

$M$ olecules, Assembly of Life

Sciences, R esearch Council,

$\mathrm{N}$ ational A cademy of

Sciences. ....

$N$ ational Coordinating

Committee on W orksite

$\mathrm{H}$ ealth Promotion......

National C ouncil on

Compensation Insurance

(NCCl)....

$\mathrm{N}$ ational Council on

$R$ adiation Protection

and $M$ easurements

(NCRP) ............

$N$ ational Electronic

$M$ anufacturers Association

(NEM A).

$N$ ational Fire Protection

Association (N FPA) . . . . 39, 41,58,

$67,74,75,77,80,96,100,102$

National $\mathrm{H}$ ealth Service

(NHS) 97 
$\mathrm{N}$ ational $\mathrm{H}$ eart, Lung and

Blood Institute.

$\mathrm{N}$ ational Injury C ontrol

Conference ...........

N ational Institute for

O ccupational Safety and

$\mathrm{H}$ ealth $(\mathrm{NIOSH}) \ldots . .2,8,10$,

$15,16,18,24,29,31,34,42$

$45,51,58,60,63,64,67,70$,

71, 77, 93, 94, 95, 96, 97, 99, $100,102,103$

$\mathrm{N}$ ational Institute for the

Conservation of Cultural

Property

N ational Institute for W orking

Life ................. 26

National Institute of

Environmental $\mathrm{H}$ ealth

Sciences (NIEHS) . . . . . . 10

$\mathrm{N}$ ational Institute of $\mathrm{H}$ ealth (Japan).................. 77

$\mathrm{N}$ ational Institutes of $\mathrm{H}$ ealth

(NIH )........ 15, 48, 70, 77

$\mathrm{N}$ ational Joint Industrial

Council for the R ubber

$M$ anufacturing Industry . . . 80

National L-P G as

Association ............ 102

$\mathrm{N}$ ational Proficiency $\mathrm{T}$ est

Council (N PT C) . . . . . . . 68

$N$ ational R adiological Protection

Board (N R PB) . . . . . . . . . . 49

$N$ ational R esearch Council

(NRC). . ....... 8, 9, 15, 30,

$32,33,44,48,49,53,59,60$,

$64,70,76,79,94,102$

National Safety Council

(NSC) . ...... 30, 31, 64, 70,

75, 77, 82, 102, 103

$N$ ational Shipbuilding R esearch

Program (N SR P) . . . . . . . . 92

$N$ ational Statistics Bureau . . 16, 20

$\mathrm{N}$ ational T echnical Information

Service (NTIS). . . . . . . . . 70

Naumann, B . . . . . . . . . . . . 79

Naus, A . ............... 11

Navarro, C . . . . . . . . . . . 29

Navarro, V . . . . . . . . . . . . . 20

Navino, C . ............. 97

Navratil, J. . . . . . . . . . . . . 95

Nawakami, N . ............. 5

Naylor, JD . .................. 59

$\mathrm{N}$ eal, AC ............... 16

$\mathrm{N}$ eal, PA . . . . . . . . . . . . . . 89 89

$\mathrm{N}$ eal, R A . . . . . . . . . . . . . . 63

Neale, AV . ............. 95

Neale, D . . . . . . . . . . . . . . . . 6

Nebert, DW . . . . . . . . . . . . 33

Neculcea, D . . . . . . . . . . . . . 44

Neculcea, J. . . . . . . . . . . . . 44

$\mathrm{N}$ edeltcheva, $\mathrm{K} \ldots \ldots \ldots \ldots .43$

N eedleman, C . . . . . . . . . . . 23

N eedleman, $\mathrm{H} \ldots \ldots \ldots \ldots . . .9$

N eedleman, $\mathrm{H} L$. . . . . . . . . 7 7, 9, 19
Néel, F . . . . . . . . . . . . 52

$\mathrm{N}$ eel, JV ............... 48

$\mathrm{N}$ eer, CS .............. 6

$\mathrm{N}$ eff, WS ............... 5

Negandhi, ART . . . . . . . . . . 29

N egri, E ............. 4, 80

Negro-V ilar, A . . . . . . . . . . . 9

Nehling, A . . . . . . . . . . . . 34

N eild, PJ . . . . . . . . . . . . . . . 3

$\mathrm{N}$ eill, JD ................ 9

Neill, P . . . . . . . . . . . . . . 96

$\mathrm{N}$ eilsen, B. . . . . . . . . . . . . I

N elemans, PJ . . . . . . . . . . . . 12

N elsing, S. . . . . . . . . . . . . . . . 97

Nelson, C . . . . . . . . . . . . 52

Nelson, DL............... 34

Nelson, DR ............... 33

Nelson, K . ................99

Nelson, N . . . . . . . . . . . . . 100

Nelson, PV . .............664 64

Nelson, RA . ............. 53

Nelson, SE . . . . . . . . . . . . . 9

Nelson, TJ . . . . . . . . . . . 31

Nemery, B . . . . . . . 10, 11, 63, 89

Nengtsson, G . . . . . . . . . . . . 29

Nénot, JC . . . . . . . . . . . . . 39

N ersting, L . . . . . . . . . . . . . . . 101

Nertney, RJ ............... 57

Nesca, M ................ 34

Nesheim, M C . . . . . . . . . . . . 70

Ness, SA . . . . . . . . . . . . . 30

Nestor, DE . . . . . . . . . . . . 86

N ethercott, J . . . . . . . . . . 70

N ethercott, JR . . . . . . . . . . . . 70

N etzel, JP . . . . . . . . . . . . . . 77

Neubauer, A ............... I

Neuman, $M$................ 33

N euman, WG . ............. 33

Neumann, PG . . . . . . . . . . 58

Neumann, PJ . ............. 59

N eumann-H aefelin, D . . . . . . 97

Neustadt, DH . . . ......... 6

N eutra, RR .............. 52

N evalainen, A . . . . . . . 13, 44

Neveux, LM . . . . . . . . . . . . . . . . 9

$\mathrm{N}$ evitt, A.............. 101

$\mathrm{N}$ ew Straits T imes.......... 22

$\mathrm{N}$ ew $\mathrm{Y}$ ork Academy of

$M$ edicine ................ 15

$\mathrm{N}$ ew $\mathrm{Y}$ ork Business G roup on

$\mathrm{H}$ ealth ............... 15

N ew Y ork City D epartment of $\mathrm{H}$ ealth ............... 4

N ew Y ork City/ T axi and Limousine Commission (TLC) .............. 51

N ew $Y$ ork State U nited

T eachers (NY SU T ) . . . . . . . 94 Newbower, RS. . . . . . . . . . . 97

Newburgh, LH .......... 42

Newcombe, DS . ............ 33

Newcomer, CE . . . . . . . . . 70

N ewell, A . . . . . . . . . . . . . . 52

N ewell, K W . . . . . . . . . . . . . . 28
N ewkirk, WL . . ............ 16

$\mathrm{N}$ ewland, HS . . . . . . . . . 4 49, 53

N ewman, B . . . . . . . . . . . . 41

N ewman, BJ. . . . . . . . . . . . . . 85

N ewman, JE. . . . . . . . . . . . . . 34

N ewman, LS ............... 10

N ewman, SC . . . . . . . . . 98, 100

Newman-T aylor, AJ . ......... 71

N eyman, J .................. I

$\mathrm{Ng}, \mathrm{D} \ldots \ldots \ldots \ldots \ldots \ldots . \ldots 74$

$\mathrm{Ng}, \mathrm{PW} \ldots \ldots \ldots \ldots \ldots 22$

$\mathrm{Ng}, \mathrm{SK} \ldots \ldots \ldots \ldots . \ldots 83$

$\mathrm{Ng}, \mathrm{TP} \ldots \ldots \ldots \ldots \ldots . . . .68$

$\mathrm{Ni}, J \mathrm{~A} \ldots \ldots \ldots \ldots \ldots . \ldots 80$

Niaura, R . . . . . . . . . . . . . 34

Nibel, $H \ldots \ldots \ldots \ldots \ldots \ldots$. . . . 52

Nichol, KL . ............. 15

Nichols, AW. . . . . . . . . . . . . . 6

Nichols, PJ . .............. 70

Nicholson, DW . . . . . . . . . . 33

Nicholson, N . . . . . . . . . . . 29

Nicholson, WJ . . . . . . . . . . 9, 10

Nick, L . . . . . . . . . . . . . . . . 63

N ickel D evelopment Institute . . 63

Nickell, WT . . . . . . . . . . . . . 11

Nicklin, S . . . . . . . . . . . . 33

Nicogossian, AE . . . . . . . . . 102

Nicolosi, C . . . . . . . . . . . . . 7

Nicolova, R . . . . . . . . . . . . 43

Niebel, BW ..............34

Nieboer, E . . . . . . . . . . . . . 63

$\mathrm{N}$ ielsen, B . . . . . . . . . . . . . . . 42

Nielsen, CV . . . . . . . . . 34, 52

Nielsen, G D . . . . . . . . . . . 13, 30

Nielsen, J . . . . . . . . . . 52, 100

Nielsen, $0 \ldots \ldots \ldots \ldots \ldots . .13$

$\mathrm{N}$ ielsen, PA .............. 13

Nielsen, $R \ldots \ldots \ldots \ldots \ldots .42$

Nielsen, TL . . . . . . . . . . . . . 97

Nielsn, J0 ............ 97

Nielson, $H \ldots \ldots \ldots . . . .65$

Niemcryk, SJ . . . . . . . . . . 26

Niemi, J . ................. 16

Niessen, LW . . . . . . . . . . . . . 53

Niessner, R . . . . . . . . . . . . . 55

Niewoehner, DE . . . . . . . . . . 10

Nightingale, $E \ldots \ldots \ldots \ldots . \ldots 23$

Nijboer, ID . . . . . . . . . . . . . . . 5

Nikolaeva, NI . . . . . . . . . . . . 63

Niland, J . . . . . . . . . . . . . . . 21

Niles, CA . . . . . . . . . . . 7

Nilner, K . ............... 11

Nilolova, $\mathrm{N} . \ldots \ldots \ldots \ldots . .443$

Nilsson, A . . . . . . . . . . . 12, 66

Nilsson, B . . . . . . . . . . . . 6, 11

Nilsson, C . . . . . . . . . . . . 52

Nilsson, C-A. . . . . . . . . . . 68

Nilsson, $H \ldots \ldots \ldots \ldots \ldots 42$

Nilsson, J A . . . . . . . . . . . . . . . 34

Nilsson, N 0 . . . . . . . . . . . . . . . 97

Nilsson, SEG . . . . . . . . . . . 49

Nimmannitya, S. . . . . . . . . . . 53

Ninteman, DJ . . . . . . . . . . . 74

$\mathrm{N}$ isalak, A . . . . . . . . . . . . . . 53
Nisbett, R . . . . . . . . . . . 59

Nisbett, RE . . . . . . . . . . . . 29

Nise, $G \ldots \ldots \ldots \ldots \ldots . . . . .85$

$\mathrm{N}$ ishi, $Y \ldots \ldots \ldots \ldots \ldots \ldots . \ldots 42$

$\mathrm{N}$ ishida, K . . . . . . . . . . . . . 18

Nishimoto, $T$. . . . . . . . . . . 41

Niskanen, $T$. . . . . . . . . . . . . 6

Nisula, BC ............. 9

Niu, M T . . . . . . . . . . . . . . 97

Nixon, CW ............... 31

Noah, $T \ldots \ldots \ldots \ldots \ldots \ldots$

Noble, W . . . . . . . . . . . . . . 17

Nobre, C ................ 53

Nogareda, C . . . . . . . . . 44, 46

N ogareda, S. . . . . . . . . . . 46

Nogueira, D P . . . . . . . . . . . 53, 64

Nolan, P................. 37

Nolan, RJ . . . . . . . . . . . . . . . 33

Nolan, RP . . . . . . . . . . . . 10

Nolin, AD ......... 9, 52, 100

Nollen, SD ............... 30

Nollkaemper, A . . . . . . . . . . 54

Nomura, S . . . . . . . . . . . . . . 64

N onotte-V arly, C . . . . . . . . . 42

Noonan, D . . . . . . . . . . . . . 49

N oonan, EA . . . . . . . . . . . 15

N oordergraaf, G . . . . . . . . . 39

N oorlind-Brage, $H \ldots \ldots \ldots, 7,10$

Norbäck, D . . . . ........... 11

Nordander, C . . .........66 66

Nordberg, G F . . . . 9, 27, 33, 63

N ordenfelt, L . . . . . . . . . . . . 28

Nordheim, EV . . . . ....... 41

Nordin, M . . . . . . . . . . . . 100

Nordlee, JA . . . . . . . . . . . 77

Nordman, $\mathrm{CH} \ldots \ldots \ldots \ldots . .3,89$

Nordman, H . . ...... 10, 16, 63

N ordmann, M . . . . . . . . . . . 28

Nordstrom, D L . . . . . . . . . . . 70

Nordvall, L............... 9

Norell, S . . . . . . . . . . . . . . 28

Norell, SE ............. 100

Norén, A . . . . . . . . . . . . . . 6

Noriega, M . ............. 28

N orma Europea (NE) . ....... 31

Norman, DA . . . . . . . . . . 29, 52

Noro, K ............29, 56

Norpoth, K . . . . . . . . . . 88

Norppa, $\mathrm{H} \ldots \ldots \ldots \ldots \ldots . . . . .6$

Norris, R N . . . . . . . . . . . . . 96

Norrving, B . . . . . . . 12, 66

Norse, EA .............. 64

Norseth, $T \ldots \ldots \ldots \ldots \ldots 80$

Norström, A . . . . . . . . . . . . . . 68

North, FM . . . . . . . . . . . 34

North, $G \ldots \ldots \ldots \ldots \ldots \ldots$

N orthcott, H C . . . . . . . . . . 34

Northheim, C . . .......... 99

$\mathrm{N}$ orthwestern $\mathrm{N}$ ational

Life ............. 4, 5, 34

N orton, S . . . . . . . . . . . . . 7

Norwalk, E . . . . . . . . . . . . 8

Noster, U . . . . . . . . . . . . . . . . 64

N otermans, S. . . . . . . . . . 53 
N otkola, $\mathrm{V} \ldots \ldots \ldots \ldots \ldots \ldots$ Noto, K ............... 58

Notten, WR F . . . . . . . . . 43 Novaco, R ............. 34, 51 Novak, M . . . . . . . . . . . . . 69 Novey, HS ............... 10 Novotny, TE ............. 9 Nowak, E . . . . . . . . . . . . 29 Noweir, M H ......... 53, 97 Noworal, C . ............ 43 N riagu, J0 . . .......... 33, 63 Nubé, J. . . . . . . . . . . . . . . 96 Nuber, C . . . . . . . . . . . . . 29 Nübling, M . . . . . . . . . . . . . . 97 Nuckolls, K B . . . . . ........ 34 N uclear Energy Agency. . . . . . 39 Nuclear R egulatory

Commission (NUREG) . . . . . 48

Nuki, $G \ldots \ldots \ldots \ldots \ldots$

Numerof, RE . . . . . . . . . . . . 34

Nunes, $F \ldots \ldots \ldots \ldots \ldots 13$

Nunn, AJ . ..............6 63

N unnally, JC . . . . . . . . . . . . 59

Nurminen, M . .......... 3, 20

N urminen, $T$. . . . . . . . . . . 52

Nurninen, $M \ldots \ldots \ldots \ldots .7$

Nussbaum, K . . . . . . . . . . . . 34

Nutt, A . . . . . . . . . . . . 80

Nuttens, M $-\mathrm{C} \ldots \ldots \ldots \ldots \ldots$

$\mathrm{N}$ wanyanwu, O C . . . . . . . . 100

Nye, D ................. 34

Nyland, $\mathrm{H} \ldots \ldots \ldots \ldots \ldots .7$

Nylén, PR ............. 11

Nyman, I . . . . . . . . . . . . . . . 97

Nyman, $K \ldots \ldots \ldots \ldots 16$

Nyman, $T$. . . . . . . . . . . . . 21

Nyrén, $0 \ldots \ldots \ldots \ldots \ldots$

Nyssen, AS . . . . . . . . . 29, 97

0

O'Berg, M .............. 100

0 'Berien, DM . . ............ 38

O 'Brian, JT . . . . . . . . . . . . . 42

O 'Brian, PC . . . . . . . . . . . . . 7

O'Brien, C . . . . . . . . . . . . . . . 19

0 'Brien, K .............. 97

O 'Brodovich, H . . . . . . . . . . . 10

O 'Campo, P.............. 34

O'C arroll, TM .............97 97

O 'C onnell, BJ. .............. 34

0 'Connor, GT . . . . . . . . . . . 3

O 'Connor, JF . . . . . . . . . . . . . . 9

0 'Connor, RW ............ 10

O 'D onnel, M P . . . . . . . . . . . . 3

O 'D onnell, M P . . . . . . . 15, 34

O 'D onnell, RD ............29 29

0 'D onoghue, DH ......... 96

0 'D onoghue, JL ......... 7, 85

O 'D owd, G ............. 8

O'Fallon, WM ......... 10,89

O'Farrell, B ............... 34

0 'G lenis, EL . . . . . . . . . . . . . 70

0 'H anlon, JF . ............. 50
O 'Leary, $L \ldots \ldots \ldots \ldots \ldots \ldots$

O'Leary, LM ............... 9

O 'M ara, WC .............83

O 'N eal, FO ............... 10

O 'Neil, B . . ............... 56

O 'N eill, D ...............17

$\mathrm{O}$ 'N eill, HJ................ 3

$\mathrm{O}$ 'N eill, IK ...............27

O 'N eill, L . . . . . . . . . . . . . . . 103

O 'N eill, R............... 23

$O$ 'R ear, CE .............. 44

O 'Regan, R G . ............. 37

0 'R eilly, CA ..............34

0 'R eilly, JP . . . . . . . . . . . . . 11

$\mathrm{O}$ 'R ourke, $S \ldots \ldots \ldots \ldots . \ldots 32$

O'T oole, C.......... 64, 70

0 akes, $D \ldots \ldots \ldots \ldots \ldots 10$

$\mathrm{O}$ akley, $\mathrm{K} \ldots \ldots \ldots \ldots . . . . .97$

O ayama, $Y \ldots \ldots \ldots \ldots . \ldots 24$

O badia, I . ...............22 22

O bata, K . . . . . . . . . . . . . 88

O bbard, ME ............69 69

0 berdoerster, G. . . . . . . . . . 63

Ö berg, B .............. 43

0 berg, PA .............49 49

O bolenskaja, AJ . . . . ......... 6

O borne, DJ . .............42 42

O bstfeld, M ............ 20

O ccupational H ealth Services

for Small-Scale Industries. . 20

0 ccupational Injury Prevention

Panel

.. 56

O ccupational Safety and

$\mathrm{H}$ ealth $\mathrm{Administration}$

(O SHA) ..... 32 43, 56, 58,

$61,67,76,77,78,82,89,93$, 97,100

0 chs, $T \ldots \ldots \ldots \ldots . . . . . . .34$

0 dero de $D i o s, A \ldots \ldots \ldots \ldots 21$

Ö dkvist, L . .............. 11

0 echslin, J . ...............21

0 ehling, A . . . . . . . . . . . . 100

O ëler, JM . . . . . . . . . . . . . . . 97

0 elz, $0 \ldots \ldots \ldots \ldots \ldots . . . \ldots 37$

0 emus, $B \ldots \ldots \ldots \ldots . . . .63$

O esterreich, R . . . . . . . . . . 34

0 etting, ER . .............. 34

O ffice of $D$ isease Prevention

and $\mathrm{H}$ ealth Promotion . . . . . 15

$O$ ffice of $M$ anagement and

Budget (O M B). . . . . . 32, 88

$O$ ffice of $O$ ccupational

$H$ ealth ................ 10

O ffice of Population Censuses and Surveys. . . . . . . . . . . 73

O ffice of Population Censuses. . . 2

O ffice of R esearch Integrity

(ORI)....

$\mathrm{O}$ ffice of Science and

T echnology Policy (O ST P) . . 77

$O$ ffice of T echnology

Assessment (OT A). . 19, 33, 52

0 ffice of the Assistant

Secretary for $\mathrm{H}$ ealth . . . . . . 19
O ficina del Coordinador de las $N$ aciones U nidas para el

Socorro en Casos de D esastre

(UNDRO) ............. 39

O ficina Federal de la Salud

(Suiza) ................ 53

0 garam, DA ............. 65

O gata, $N \ldots \ldots \ldots \ldots \ldots . \ldots 27$

O gawa, $\mathrm{H} \ldots \ldots \ldots \ldots \ldots 11$

0 gawa, $Y \ldots \ldots \ldots \ldots \ldots 100$

O gilivie, BD . . . . . . . . . . . 43

0 gilvie, GK ........... 28

0 gilvie, RD . . . . . . . . . . 29

0 ginski, A . . . . . . . . . . . 29, 43

O hama, E ............. 11

O hara, $\mathrm{H} \ldots . . . \ldots \ldots \ldots \ldots . .34$

O hlemiller, $T$ J ............ 41

Ö hling, P . . . . . . . . . . . . . . 97

O hlsson, K ............66 66

$\mathrm{O} h \mathrm{~h}, \mathrm{M} \ldots \ldots \ldots \ldots \ldots \ldots$

Ö hman, A . . . . . . . . . . . . . . 34

Ohno, $Y \ldots \ldots \ldots \ldots \ldots . . . . .88$

O htani, H . . . . . . . . . . . . 41

0 ishi, $N \ldots . . . \ldots . . . \ldots 24$

O jajärvi, $A \ldots \ldots \ldots \ldots \ldots 4$

O jesjo, L . . . . . . . . . . . . . . 34

O kada, A . . . . . . . . . . . . . 3

O kamoto, $H \ldots \ldots \ldots \ldots \ldots . .97$

O kot-M wang $M \ldots \ldots \ldots 64,65$

0 krojek, $M$.............. 3

O kubo, $T \ldots \ldots \ldots \ldots \ldots 16$

O kuda, K . . . . . . . . . . . . . . 33

O kun, A .............. 88

Ó lafsdóttir, H . . . . . . . . . . 66

O lafsson, $M H \ldots \ldots \ldots \ldots 6$

O lcerst, R B ................ 38

O Idenberg, B . . . . . . . . 3, 44

Oldham, GR . . . . . 29, 34, 52

Oldham, PD ............. 10

O lenchock, SA ........ 10, 38,

$64,70,89,101$

0 lesen, BW . . . . . . . . . . 42

O Iff, $M \ldots \ldots \ldots \ldots \ldots \ldots . . . . . .34$

O lishifski, JB ............. 30

O livato, D . . . . . . . . . . . . . 43

Oliver, A . . . . . . . . . . . . . . . 59

Oliver, $K \ldots \ldots \ldots \ldots \ldots$

Oliver, LC ................ 3

Olivieri, I . ............. 6

Olkinuora, M .............96 96

Olkinuora, M A ........... 97

O llagnier, E . . . . . . . . . . . . . 97

Ollier, S . . . . . . . . . . . . . 100

O llila, H . ............. . 29, 43

O Imedo, EL . . . . . . . . . . . . . 34

O Imi, R . . . . . . . . . . . . . 49

Olmsted, E. . . . . . . . . 101, 102

O Imsted, M . .............. 53

OIsen, EG . . . . . . . . . . . . . 49

O Isen, J . . . . . . . . 9, 28, 89

OIsen, JH . . . . . . . 9, 10, 85, 100

OIsen, K.............. 72

O Isen, N . . . . . . . . . . . . . . . . 3

Olsen, RL . . . . . . . . . . . . 49
O Isen, RT ............ 79

OIsen, SE ........... 56, 58

O Ishaw, AF ............ 9

OIsher, RH . . . . . . . . . . . 48

Olsheski, J . . . . . . . . . . . . . . 17

OIson, J ................... 64

OIson, K A . . . . . . . . . . . . . . 70

O Isson, $K \ldots \ldots \ldots \ldots \ldots 43$

O meish, TM .............40 40

O menn, GS . ........... 48

Oncins, $M \ldots \ldots \ldots . . .446$

Onder, $\mathrm{HH} \ldots \ldots \ldots \ldots . \ldots 29$

Ong, CN ...... 9, 11, 18, 43, 52

Ong, SG ............... 89

O nishi, $N \ldots \ldots \ldots \ldots \ldots .29$

O ntario Film and T elevision

Industry Section 11

A dvisory Committee . . . . . . . 96

O ntario M etal Finishing

Industry Pollution

Prevention Project ....... 82

O ntario M inistry of Labour. . . . 93

$O$ ntario $M$ inistry of the

Environment (O M E) . . . 54, 55

0 patowski, S . . ........... 100

0 patz, JP ............... 34

0 pen Software Foundation . . . . 52

0 penshaw, PJ . ............ 77

O rava, S. ............... 6

O rchard, TJ . . ............ 34

O rganisme professionel de prévention du bâtiment et des travaux publics (O PPBTP)

O rganismo Internacional de la Energía A tómica

(OIEA)........ 23, 39, 48, 53

O rganización de A viación

Civil Internacional

$(\mathrm{OACl}) \ldots \ldots \ldots \ldots . . . . .90$

0 rganización de las $\mathrm{N}$ aciones U nidas para la Agricultura y la Alimentación

(FAO) .............

$65,66,68,70,71,72$

$\mathrm{O}$ rganización de las $\mathrm{N}$ aciones U nidas para la Educación, la

Ciencia y la Cultura

(UNESC O )............29

O rganización del T ratado del Atlántico N orte (OTAN). . . . 10

O rganización Internacional

de N ormalización

(International 0 rganization

for Standardization, ISO ). . 10,

$22,29,31,42,47,50,52,56$, $58,59,64,68,93$

O rganización Internacional del Trabajo (OIT) . ... 1, 5, 6, $9,10,16,17,18,19,20,21,22$, $23,24,26,29,32,34,39,43$, $45,46,47,49,52,54,58,64$, $66,68,71,72,73,74,75,78$, $79,88,93,99,100,102,103$ 
O rganización M arítima Internacional (International $M$ aritime 0 rganization, IM 0)................66 66

O rganización M eteorológica M undial (O M M ). . ......... 53

O rganización M undial de la Salud (O M S) . . . . . 2, 3, 7, 9, $10,11,13,15,16,17,18,20$, $23,24,27,30,32,33,34,38$ $39,42,44,45,49,52,53,55$, $62,63,64,66,73,93,96,97$, 103

O rganización Panamericana de la Salud (O PS) . . . . 23, 24, $39,53,96$

O rganización para la Cooperación y el Desarrollo Económico (OCDE). ... 17, 24, $33,34,39,54,56,58,63,64$

Orgaram, DA ..........6 64

O rigasa, $H \ldots \ldots \ldots \ldots \ldots . . . . .9$

Orkin, $M \ldots \ldots \ldots \ldots \ldots . \ldots 70$

Orlic, $M \ldots \ldots \ldots \ldots \ldots .70$

Orloske, AJ .............994

Orlowski, E ............... 32

Orman, D ................ 5

Ormerod, AJ .............. 34

Ornish, D ................. 15

Ornstein, S. . . . . . . . . . . . . 34

Orr, E ................. 34

Orrick, S ............... 15

O rris, P ........... 95, 97

Orsak, CL ................ 34

Orsi, D . ................ 88

O rtega y G asset, I . . . . . . . . . . 69

O rtega, B ............... 5

O rtelius, S ............... 100

Ö rtendahl, T W ............ 11

O rth-Gomer K ,...... 3, 34, 43

O rtlieb, DW . ............ 18

Ortmeyer, C ............ 89

Ory, FG ............... 96

O saba, M JM ............ 9

0 safo, $S \ldots \ldots \ldots \ldots \ldots \ldots 54$

O sborne, DG . ............ 74

O sborne, DJ.............. 34

O sborne, M A . . . . . . . . . . . . 7

O shima, $\mathrm{H} \ldots \ldots \ldots \ldots \ldots . . . . .9$

O sipow, SH ............... 34

O sorio, AM ............. 89

0 sornio-V argas, $A \ldots \ldots \ldots . . .33$

Ö stberg, $0 \ldots \ldots \ldots \ldots .44,52$

0 stby, J .................. 33

0 ster, G . . . . . . . . . . . . . . . 10

O ster, H . . . . . . . . . . . . . . . . 10

O sterhoust, C............41

O sterwalder, J . ........... 70

0 stiguy, $\mathrm{G} \ldots \ldots \ldots \ldots \ldots . \ldots 10$

0 stroff, SM ............. 10

O strowska, $\mathrm{H} \ldots \ldots \ldots \ldots \ldots \ldots .4$

O strowski, R ........4 41, 78

0 stry, $A \ldots \ldots \ldots \ldots . . . . .71$

O take, M ............ 39, 48
O thmer, DF ........... 103

Otson, $R \ldots \ldots \ldots \ldots \ldots 44$

$0 \mathrm{tt}, \mathrm{C} \ldots \ldots \ldots \ldots \ldots \ldots 9 . \ldots 9$

$\mathrm{Ott}, \mathrm{G} \ldots \ldots \ldots \ldots \ldots \ldots, \ldots$

Otte, KE .............. 9

0 tten, J A . . . . . . . . . . . . . . . 44

O tterbeck, K .............. 55

Ottmann, W ........... 34, 43

Otto, D................. 11

0 tto, DA ................ 13

O tway, $\mathrm{HJ} \ldots \ldots \ldots \ldots \ldots . \ldots 59$

O uellette, SC . ............ 34

0 vereynder, M A . . . . . . . . . . 16

O verman, S . . . . . . . . . . 17, 34

$\mathrm{O}$ verton, $\mathrm{JH} \ldots \ldots \ldots \ldots \ldots . . . .30$

O verzier, $C \ldots \ldots \ldots \ldots . . . . .3$

O wen, $N \ldots \ldots \ldots \ldots . . . \ldots, 44$

0 wen, $R \ldots \ldots . . . . . .88$

0 wens, DW . . . . . . . . . . . 49

0 wen-Smith, $\vee \ldots \ldots \ldots \ldots 100$

O xenburg, $M \ldots \ldots \ldots . . .93$

Oxenburgh, $M \ldots \ldots \ldots \ldots 66$

$O$ yanagi, $K \ldots \ldots \ldots \ldots 11$

O zaki, M ...............21

Ozols, J................ 33

$P$

Pace, PE................. 13

Pacheco, H. . . . . . . . . . . . . 33

Pacheco, JC ............... 3

Pacholski, L . . . . . . . . . . . 29, 58

Paci, C ................. 9

Paci, E ................. 88

Paci, P ................ 21

Pacynski, A. . . . . . . . . . . . . . . 79

Paddle, GM . . . . . . . . . . . . . . 3

Padgett, SJ ............... 3

Padieu, R ............. 28

Padmos, P . . . . . . . . . . . 52

Paetz, H . . . . . . . . . . . . . 38

Paffenbarger, RS . ........... 3

Pagani, C . . . . . . . . . . . . . . 79

Pagani, M .............. 34

Paganini-H ill, A . . . . . . . . . . 85

Pagels, H R . . . . . . . . . . . . . . . 29

Pahwa, P . . . . . . . . . . . . 70

Pai, H . . . . . . . . . . . . . . . 89

Paillard, M . . . . . . . . . . . . . 97

Paine, SW ............... 34

Paine, WE .............. 34

Pál, K ..................41 4

Palagiani, L . . . . . . . . . . . . . . . 65

Palastanga, $N \ldots \ldots \ldots \ldots \ldots$

Palenciano, L . . . . . . . . . . . . . . . 97

Palermo, A . ............. 43

Pålhagen, $S \ldots \ldots \ldots \ldots \ldots .7$

Palheta, D . . . . . . . . . . . . 82

Pallak, M S . . . . . . . . . . . . . 34

Palm, U-B . . . . . . . . . . . . . . . 3

Palmer, K N . . . . . . . . . . . . 41

Palmer, N . . . . . . . . . . . . . . . 10

Palmerud, $G \ldots \ldots \ldots \ldots 6$

Palmes, ED . . . . . . . . . . . . 37
Palmgren, $U \ldots \ldots \ldots \ldots \ldots 13$

Palomaki, GE. ............ 9

Palosuo, $T \ldots \ldots \ldots \ldots 66$

Pålsson, $B \ldots \ldots \ldots \ldots \ldots .66$

Paludi, M A . . . . . . . . . . . . 34

Palver, A ................ 34

Pan, CS ................. 34

Pan, W-H ................. 3

Pandit, A ................ 3

Pandolf, K B ............ 42

Panett, B .................. 30

Pangtey, BS . . . . . . . . . . . 63

Panisset, JC . . . . . . . . . . . . . 7

Panlilio, AL . . . . . . . . . . . . . . . 97

Panov, GE . . . . . . . . . . . . . 75

Panti, NK . ............... 70

Panush, RS ...............6

Panuska, R . ............... 50

Panzani, RC . . . . . . . . . . . 65

Paoli, M C . . . . . . . . . . . . . . 97

Paoli, P.............. 16, 34

Papadakis, J . . . . . . . . . . . . . 44

Papastavrou, JD . . . . . . . . . . . 59

Papp, A ................ 79

Pappas, G P .............. 10

Paquay, $C \ldots \ldots \ldots \ldots \ldots 29$

Paquette, N ............... 12

Paramore, B............. 29

Parasuramen, S . . . . ......... 19

Paré, JAP . . . . . . . . . . . . . . . 10

Paré, PD . ................ 10

Parenti, C . . . . . . . . . . . . . . . 97

Parides, M . . . . . . . . . . . 101

Parikh, JR . . . . . . . . . . . . 89

Parish, WE.............6 63

Park, C ................. 30

Park, CN ................ 33

Park, R................ 91

Park, RM . . . . . . . . . . . 91

Parke, DV ................ 33

Parker, D . . . . . . . . . . . . . 70

Parker, DA . . . . . . . . . . . 34

Parker, J . . . . . . . . . . . . 10,70

Parker, JC ............... 77

Parker, JE. . . . . . . . . . . . . . 64

Parker, L . . . . . . . . . . . . . . . . 48

Parker, SP . . . . . . . . . . . . 83

Parkes, H G . . . . . . . . . . . 80

Parkes, K R . . . . . . . . . . . . 34, 78

Parkes, RW ............ 10

Parkes, WR ........... 10, 70

Parkhomenko, VI . . . . . . . 39

Parkhurst, B . . . . . . . . . . . . . . 55

Parkim, M ...............1

Parkin, DM ........ 1, 2, 4, 10

Parkington, JJ. . . . . . . . . . . . 59

Parkinson, DK . . . . . . 34, 39, 85

Parkinson, $W \ldots \ldots \ldots \ldots . . . .8$

Parlamento de las $C$ omunidades

Europeas. . . . . . . . . . . . . 77

Parmeggiani, L . . 7, 23, 26, 45, 89

Parmentier, C . . . . . . . . . . . 39

Parmley, WW ............. 3

Parr, WH . . . . . . . . . . . . 52
Parris, $H \ldots \ldots \ldots \ldots \ldots \ldots 34$

Parrish, JA . . . . . . . . . . . . 49

Parrish, RG . . . . . . . . . . . 39

Parron, DL............... 34

Parrón, T . .............. 64

Parrondo-I glesias, E. . . . . . . . 63

Parrot, AC ................ 34

Parrot, J................ 3

Parsaei, H R . . . . . . . . . . . . . . 29

Parsons, K C . . . . . . . . . . 42

Parsons, RA . . . . . . . . . . . . 103

Parsons, SD . . . . . . . . . . . 64

Partanen, $T$. . . . . . 2, 3, 4, 64, 89

Partinen, M ............... 34

Partridge, REH ............6 6

Parveen, $S \ldots \ldots \ldots \ldots \ldots . \ldots 5$

Parving, A . . . . . . . . . . . 11

Pasanen, A . . . . . . . . . . . . . . . 13

Pasanen, P . . . . . . . . . . . . 13

Pascale, RTA . . . . . . . . . . . . . 57

Paschal, DC . . . . . . . . . . . 9

Pascot, D . . . . . . . . . . . . . 29

Pasero, G . . . . . . . . . . . . . 6

Pashal, DC ............... 9

Pasini, F . ............... 9

Pasquier, B............. 21

Pass, HI . . . . . . . . . . . . . . . 10

Passchier, WF ........... 49

Passmore, R . . . . . . . . . . . 68

Pastides, H . . . . . . . . . . . . . . 83

Patchefsky, AS ............ 10

Pate, RR ............... 3

Patel, R ............ 58, 64

Path, LRC . . . . . . . . . . . . 70

Pathak, M A .............. 49

Pati, G .................. 17

Pátkei, P............. 43

Patkin, M . . . . . . . . . . . . . 97

Patnick, J . . . . . . . . . . . . . 15

Paton, E................. 15

Patosaari, $P \ldots \ldots \ldots \ldots 68$

Patterson, DJ . . . . . . . . . . . . 37

Patterson, JC . . . . . . . . . . . . . 34

Patterson, R . . . . . . . . . . . . 101

Pattison, DC ............. 3

Pattison, M.............. 10

Patton, HD ............... 11

Patty, FA . . . . . . . . . . 30, 103

Patz, JA ............... 53

Paul, M .............. 9, 44

Pauline, M B.............. 73

Paull, JM ................. 101

Paulmier, M . . . . . . . . . . . 43

Paulson, $G \ldots \ldots \ldots \ldots \ldots . . \ldots 18$

Paureau, J ................ 40

Paustenbach, DJ . . . . . . 30, 37

Pavia, M . . . . . . . . . . . . . . . 38

Pavkov, KL ............. 100

Pawluk, RJ . . . . . . . . . . . . . 49

Payer, L . . . . . . . . . . . . . 97

Payne, R . . . . . . 5, 15, 34, 52, 97

Paz, GF ............... 9

Peabody, TD . . . . . . . . . . 6

Pearce, $N \ldots \ldots \ldots \ldots .28,64,100$ 
Pearce, NE . . . . . . 2, 4, 12, 28, 32 Pearlin, LI . . . . . . . . . . . . . 19 Pearse, W............... 23 Pearson, D . . . . . . . . . . . . . 54 Pearson, RD ............. 97 Pease, $W \ldots \ldots \ldots \ldots . . . . .33$ Pechacek, TF . ........... 15 Pecina, M M . . ............. 15 Peck, P . . . . . . . . . . . . . . . 34

Pecor, $\mathrm{CH} \ldots \ldots \ldots \ldots \ldots . \ldots 55$ Pedersen, OF . . . . . . . . . . . . 10 Pederson, DH ............. 32

Pederson, OF . . . . . . . . . . . 13

Peebles, M . . . . . . . . . . . . . 96

Peeters, $H \ldots \ldots \ldots \ldots \ldots \ldots . . . .3$

Peh, J ..................9

Peigne, E . . . . . . . . . . . . 100

Peigné, $E \ldots \ldots \ldots \ldots$. . . . . . 97

Peimer, CA ............. 7

Peinecke, $W \ldots \ldots \ldots \ldots \ldots . .97$

Peiraccini, G . ........... 44

Peisert, M . . . . . . . . . . . . . . 39

Pejtersen, A . . . . . . . . . . . . 29

Pekkarinen, M ............ 52

Pelclová, D . .............. 16

Pélegrin, B . . . . . . . . . . . 26

Pelerin, $M \ldots \ldots \ldots \ldots \ldots . \ldots 52$

Pelikan, JM ..............97

Pell, S.................... 34

Pellegrino, ED ............. 19

Pellet ..................668

Pelletier, A . . . . . . . . . . . 97, 100

Pelletier, C . . . . . . . . . . . . 68

Pelletier, K ................. 5

Pelletier, KR ............ 15

Pelmear, PL ............... 3

Péloquin, S............ 10

Peltokallio, P .............6 6

Peltonen, $\mathrm{K} \ldots \ldots \ldots$. . . . 80, 89

Peltz, PA .............. 96

Pelzing, M .............83

Pena, L.................. 97

Pendy, L.................. 97

Peng, Y . . . . . . . . . . . . 29

Penn, PE .............43, 102

Pennebaker, JW . . . . . . . . . . . 34

Pennefather, J . ............. 36

Penner, M ............... 15

Penner, S . ................ 15

Pennington, RL . . . . . . . . . . 77

Penny, R ............... 34

Pentii, J ................... 34

Pentilla, A . .............. 10

Pentney, W . . ............. 17

Pepe, PE. . . . . . . . . . . . . . . 95

Pepys, J......... 10, 63, 64, 100

Perbellini, L . . . . . . . . . . . . 27

Perdrix, A. . . . . . . . . . . . . . 97

Pereau, P ............... 97

Pereira-Barretto, AC . . ....... 3

Perera, FP . . . . . . . . . . . . 8

Peres, $L \ldots \ldots \ldots \ldots \ldots \ldots$

Pérez, L . . . . . . . . . . . 97

Perez, $P$. . . . . . . . . . . . . 9
Pérez, S ..............997 Perez-O ronoz, GI . . . . . . . . . 10 Perkins, $\mathrm{H} \mathrm{H}, \mathrm{Jr} \ldots \ldots \ldots \ldots . .69$ Perlman, LG . .............. 17 Perloff, R ............... 34 Pernanen, $K \ldots \ldots \ldots \ldots \ldots . . .51$ Pernis, B. . . . . . . . . . . . . . . . 10 Peroni, E . . . . . . . . . . 9, 43 Perper, JB. . . . . . . . . . . . . . . 30 Perrault, G . . . . . . . . . . . 10 Perrin, B................. 10 Perrin, M F . . . . . . . . . . . . 38 Perrone, $\mathrm{N} \ldots \ldots \ldots \ldots \ldots \ldots 6$ Perrow, C............... 59 Perry, GF . . . . . . . . . . . . 99 Perry, J...............6 6 Perry, JH ..............4 41 Perry, L . . . . . . . . . . . . . 34 Perry, R ................ 79 Perry, RH ..............77 Perry, S ..............96 96

Pershagen, $G \ldots \ldots \ldots \ldots$. 9, 44 Perski, A.................. 3 Person, $M \ldots \ldots \ldots \ldots \ldots . . . . .60$ Persons, WS . . . . . . . . . . . . 64 Persson, B . . . . . . . . . 63, 72 Persson, $H \ldots \ldots \ldots \ldots \ldots .7$ Persson, HR . . . . . . . . . . . . 8 84 Persson, J . . . . . . . . . . . . . . . . . 29 Pertsemlidis, D . . . . . . . . . . 101 Perucci, CA ............. 63 Pervin, LA . . . . . . . . . . . . . . . 34 Pesatori, AC ............ 1, 39 Peslin, R . . . . . . . . . . . . . . . . 10 Pessuto, J . ................ 101 Peteet, D . . . . . . . . . . . . . . . . 79 Peter, $R \ldots \ldots \ldots \ldots \ldots . \ldots 34$ Peter, R U . . . . . . . . . . . . . . . . . 39 Peters, A . . . . . . . . . . . . . . . 80 Peters, $\mathrm{BH} \ldots \ldots \ldots \ldots . . . . .34$ Peters, BJ . . . . . . . . . . . . . . 102 Peters, $G \ldots \ldots \ldots \ldots \ldots 60$ Peters, $\mathrm{H} \ldots \ldots \ldots \ldots \ldots . . . .3$ Peters, HA . . . . . . . . . . . . . 11 Peters, JL . . . . . . . . . . . . . . 34 Peters, JM ........ 3, 9, 10, 80 Peters, K F . . . . . . . . . . . . . . 97 Peters, $L \ldots \ldots \ldots \ldots \ldots \ldots \ldots . \ldots 12$ Peters, MI . . . . . . . . . . . . 49 Peters, R D . . . . . . . . . . . . . . 51 Peters, R H . . . . . . . . . . . . 60 Peters, R M . . . . . . . . . . . . . 37 Peters, TJ . . . . . . . . . . . . . . 57 Peters, WC . . . . . . . . . . . . . 74 Petersen, C . . . . . . . . . . . . . 101 Petersen, D . . . . . . . . . . . 22, 59 Petersen, DC . . . . . . . . . . . . . 59 Petersen, DD . . . . . . . . . . . 33 Petersen, I . . . . . . . . . . . . . . 66 Petersen, $M \ldots \ldots \ldots \ldots$. . 32, 34 Petersen, PE . . . . . . . . . . . . . . 11 Petersen, RC . . . . . . . . . . . . 83 Peters-G olden, H . . . . . . . . . . . . 34 Peterson, D . . . . . . . . . . . 58
Peterson, EA . . . . . . . . . . 47 Peterson, K D . . . . . . . . . . . . 96 Peterson, K W ............. 15 Peterson, M F . . . . . . . . . . . . 34 Peterson, M R . . . . . . . . 10, 34 Peterson, RWE . ............ 34 Peterson, WA . . . . . . . . . . . . . 96 Peterson, $Y \ldots \ldots \ldots \ldots \ldots$. . . 70 Petesdorf, RG . ........... 53 Peticlerc, M .............. 10 Petiot, JC ................. 3 Peto, J.............. 10, 30 Peto, $R \ldots \ldots \ldots \ldots \ldots \ldots \ldots 2$ Petraitis, J . . . . . . . . . . . . . . 34 Petrescu, L . . . . . . . . . . . . . . 29 Petrioli, G. . . . . . . . . . . . . . . . 88 Petrone, RL . . . . . . . . . . . . 8 Petrosillo, N . . . . . . . . . . . . . 97 Petroski, H . . . . . . . . . . . . 57 Petrow, GA .............. 3 Petry, H . . . . . . . . . . . . . . . 102 Petska-J uliussen, K . . . . . . . . . . 52 Petsonk, E . . . . . . . . . . . . . 101 Petsonk, EL . . . . . . . . . . . . 10 Petterson, B . . . . . . . . . . . . . . 44 Petzold, A................ 55 Peyser, HS . . . . . . . . . . . . . . 34 Pézerat, $\mathrm{H} \ldots \ldots \ldots \ldots \ldots \ldots$ Pfaffenberger, CD . . . . . . . . 27 Pfanschmidt, ML . . . . . . . . . . 7 Pfeffer, $\mathrm{H}-\mathrm{U} \ldots \ldots \ldots \ldots \ldots$ Pfeiffer, P...............11

Pham, DT ..............29

Pheasant, S. . . . . . . . . . . . . . 29

Phelan, J. . . . . . . . . . . . . . . 34

Phenow, KJ . . . . . . . . . . . . 34

Pheterson, G . ........... 96

Philip, RN . . ............ 97

Philipp, R . . . . . . . . . . . . 22

Philipsen, H . . . . . . . . . . . . 97

Philipson, B . . . . . . . . . . . . 73

Philipsson, R ............ 100

Phillips, CB ............. 3

Phillips, IR ............. 33

Phillips, JI. ............66 63

Phillips, JS . . . . . . . . . . . . 34, 35

Phillips, RA ............. 59

Phillips, RE . . . . . . . . . . 38

Philpot, RM .............. 33

Phongpaichit, P . . . . . . . . . 96

Phoolchund, HN . . . . . . . . . 64 Phoon, WH .............. 32 Phoon, WO ........ 16, 18, 96 Phthisis Prevention Committee. 30 Piacitelli, L . . . . . . . . . . . . . . 70 Piazza, G] . . . . . . . . . . . . 70 Piboleau, R .............. 97

Picciano, M F . . . . . . . . . . . 15 Pichenot, JC . . . . . . . . . . . . . 97 Pickering, AC . . . . . . . . . 89 Pickering, CAC . . . . . . . 10, 13 Pickering, $T$. . . . . . . . . . . . . 34 Pickering, TG ............ 34 Pickett, CK ............... 37
Pickle, $L \ldots \ldots \ldots \ldots \ldots \ldots .72$

Picková, J.................. 3

Pickvance, S.............. 23

Picot, $G \ldots \ldots \ldots \ldots \ldots . . \ldots 24$

Pidgeon, NF . . . . . . . . . . . . . 59

Piekarski, C . . . . . . . . . . . . 3

Pieler, J. . . . . . . . . . . . . . . . . . 38

Pielke, RA . . ............. 55

Pieper, C . . . . . . . . . . . . . 34

Pieper, U ................ 29

Pierce, DA . . . . . . . . . . 10, 32

Pierce, J . . . . . . . . . . . . . 15

Pierce, J L . . . . . . . . . . . . . . . 34

Pierret-G olbreich, C . . . . . . . . 52

Pietra, R. . . . . . . . . . . . . 10

Pifer, JW . . . . . . . . . . . . . . . 85

Pigeon, M J . . . . . . . . . . . . . 10

Piguet, PF . . . . . . . . . . . . . 10

Pihrt, J ................. 11

Piirilä, P . ............. 64

Pike, K . . . . . . . . . . . . . 5

Pike, M C . ............ 15

Pileggi, $F \ldots \ldots \ldots \ldots \ldots$

Pilger, C . ............... 70

Pilla, AA............... 49

Pillsburg, $\mathrm{HC} \ldots \ldots \ldots \ldots \ldots . . \ldots$

Pimble, $] \ldots \ldots \ldots \ldots \ldots \ldots \ldots 2$

Pinals, RS. . . . . . . . . . 6

Pinchera, A . . . . . . . . . . . . 39

Pinchon, M C . . . . . . . . . . . . . . 10

Pineault, $M \ldots \ldots \ldots \ldots 40$

Pinent, A . . . . . . . . . . . . . . . 33

Pines, AM .............. 34

Pineschi, L . . . . . . . . . . . . . . 54

Ping, L . . . . . . . . . . . . . . . 64

Pinneau, R . . . . . . . . . . . . . . 34

Pinneau, SRJ . . . . . . . . . . . . . . 34

Pinney, J................ 15

Pinney, R . . . . . . . . . . . . . . 24

Pinney, SM ............... 13

Pinsker, $\mathrm{H}$............. 97

Pinstrup-Andersen, $P \ldots \ldots \ldots 64$

Piolatto, G . . . . . . . . . . 10, 65, 80

Piore, $M \ldots \ldots \ldots \ldots \ldots . .21$

Piotrkowski, CS . . . . . . . . 34, 52

Piotrowski, JK ........... 33

Piper, DW ............... 34

Pippard, E .............. . 88

Piquemal, $P \ldots \ldots \ldots \ldots \ldots . .3$

Pira, E ................ 80

Pirkle, JL .............. 9

Pisa, $R \ldots \ldots \ldots . . . . . .88$

Pisa, $Z \ldots \ldots \ldots \ldots \ldots . . \ldots$

Pisani, $P \ldots \ldots \ldots \ldots$. 1, 2, 4, 10

Piserchia, PV .......... 3, 15

Pistelli, R ..............6 63

Pitha, JV ................ 8

Pitlik, S................ 38

Pitt-C atsouphes, M . . . . . . . . 34

Pitteloud, JJ .............. 101

Pitts, D ................. 49

Pizatella, TJ . . . . . . . . . 86, 99

Pizzichini, M A . . . . . . . . . . 97

Pizzinelli, $P \ldots \ldots \ldots \ldots \ldots \ldots . .34$ 
Pizzo, CJ . .............. 37

Pjatak, OA ............. 48

Planck, M . . . . . . . . . . . . 19

Planguwes, $J \ldots \ldots \ldots \ldots \ldots .7$

Plant, TM . . . . . . . . . . . . . . 9

Plat, $G \ldots \ldots \ldots \ldots \ldots \ldots 10$

Plater, ZJB . . . . . . . . . . . . 54

Plato, $N \ldots \ldots \ldots \ldots \ldots$......... 100

Platt, $A E \ldots \ldots \ldots \ldots \ldots \ldots 70$

Platt, AJ .............. 97

Platts, BW ............... 38

Pleck, JH . .............. 34

Pleil, J................. 55

Plewes, LW .............6 6

Ploog, BA.............. 29

Plowchalk, DR ........... 9

Plummer, M............. 3

Pluto, $R \ldots \ldots \ldots \ldots \ldots \ldots 3$

Pocchiari, F ............. 39

Pocekay, C . .............. 83

Pochyly, DF . ............ 18

Pocock, SJ ............... 43

Poellmann, L . . . . . . . . . . . 43

Pohlabeln, $H \ldots \ldots \ldots \ldots . \ldots 32$

Pohorecky, LA ............. 34

Poinsignon, $\mathrm{H} \ldots \ldots \ldots \ldots . . .97$

Pointer, P.............. 21

Poirier, $A \ldots \ldots \ldots \ldots \ldots . \ldots 26$

Poirier, $P \ldots \ldots \ldots \ldots \ldots 97$

Pokorny, M LI . . . . . . . . . . 43

Pokorski, J . ........... 29, 43

Pokrovsky, VI ........... 16

Polasek, J . . . . . . . . . . . . 43

Polen, M R . . . . . . . . . . . . . . 52

Polis, M ................ 94

Politser, PE............... 59

Polk, C . . . . . . . . . . . . . . 49

Pollack, ES............ 32, 93

Pollack, SH ............. 98

Pollard, TM ............... 34

Pollet, B . . .............. 97

Pollier, L . . . . . . . . . . . . . 38

Polly, SJ ................43

Polywka, D............. 97

Polzleitner, D . ............ 6

Pompeiano, $0 \ldots \ldots \ldots \ldots \ldots 11$

Pomroy, WH ............. 74

Pontén, B . . . . . . . . . . 68

Ponti, A ................ 30

Pool, J................... 59

Pool, SL . . . . . . . . . . . . 102

Poole, C ................28

Poole, CJM ............ 29

Pooley, F ............... 9

Pooley, FD . . . . . . . . . . . . . 10

Pope, CA ............... 53

Pope, JG..............66 66

Pope, $\mathrm{MH} \ldots \ldots \ldots \ldots \ldots 6$

Popendorf, W............ 64

Popendorf, WJ . . . . . . . . . 10, 70

Porcher, JM ............. 10

Porcq, F . . . . . . . . . . . 73

Pordo, S............... 99

Porras, JI ............. 34, 35
Porta, M.............. 4

Portefaix, P . . . . . . . . . . . 63

Portek, I . . . . . . . . . . . . . 97

Porter, K . .............. 97

Porter, LW ............... 56

Porter, RW .............. 34

Ports, TA . . . . . . . . . . . . . . . . 15

Poschen, $P \ldots \ldots \ldots \ldots \ldots 68$

Post, WK ............... 30

Postow, E.............. 49

Pot, $F \ldots \ldots \ldots \ldots \ldots \ldots 52$

Pot, $P \ldots \ldots \ldots \ldots \ldots . . \ldots . \ldots$

Potashnik, G ............ 9

Pott, F .................... 10, 55

Pott, $P \ldots \ldots \ldots \ldots \ldots \ldots 28$

Pott, $P \ldots \ldots \ldots \ldots \ldots \ldots 2$

Potter, ME ................ 3

Pottier, A . . . . . . . . . . . . . . . 97

Pottier, M . . . . . . . . . . . . . 97

Poulsen, LL . . . . . . . . . . . . . . 33

Poulton, EC . . . . . . . . . . . . 97

Powell, CA . . . . . . . . . . . 48

Powell, $\mathrm{CH} \ldots \ldots \ldots \ldots 96$

Powell, J . ...............

Powell, KE.............. 3

Powell, LH . . . . . . . . . . . 34

Powell, LII . . . . . . . . . . . . . . 34

Powers, JH . . . . . . . . . . . . . . 70

Powers, M B . . . . . . . . . . . 93

Powers, RF. . . . . . . . . . . . 68

Powitz, RW . . . . . . . . . . . . 18

Pöyhönen, $T$........... 97

Pradhan, CK .............64 64

Praditsuwan, P . . . . . . . . . . 80

Pransky, GS .............. 5

Prasad, R . . . . . . . . . . . . . 83

Pratt, D ......... 10, 64, 70, 77

Pratt, M ................. 3

Pratt, P............ 10, 89

Pratt, PC ............................

Pratt, WB............... 33

Prausnitz, C . . . . . . . . . . . 10

Preece, J................. 52

Preiser, WFE . . . . . . . . . . . 34

Preller, $L \ldots \ldots \ldots \ldots \ldots \ldots 13$

Prerovská, I . .............. 3

Press Standards Board of

Finance .................. 85

Pressel, G . . . . . . . . . . . . . . . 63

Presser, S . . . . . . . . . . . . . 28

Preston, DC . . . . . . . . . . . . . . . . 7

Preston, DL ............... 10

Preston-M artin, S . . . . . . . 48

Preul, HC . . . . . . . . . . . . . 55

Preuss, $0 \ldots \ldots \ldots \ldots . .10$

Preventive Services T ask

Force................ 15

Prevots, DR . . . . . . . . . . . . 53

Prible, R................ 15

Price W aterhouse. . . . . . . . . . 99

Price, AR ............... 19

Price, CJ................ 3

Price, DL . . . . . . . . . . . . 13

Price, GJ. . .
Price, GR ............ 47

Price, $R H \ldots \ldots \ldots \ldots \ldots . . . \ldots 34$

Price-G reen, PA . . . . . . . . . . 95

Priest, JD . . . . . . . . . . . . . . .6

Priester, WA . . . . . . . . . . . . 1

Prince, VA .............. 34

Prinz, B . . . . . . . . . . . . 55

Prior, WA . ............... 10

Prisyazhiuk, A ........... 48

Pritchard, JA ............. 31

Pritchard, RD . ........... 59

Privalova, LI ............. 10

Prockup, $\mathrm{L} \ldots \ldots \ldots \ldots \ldots . . . .96$

Proctor, D . . . . . . . . . . . . . . 30

Proctor, M ................ 70

Proctor, $\mathrm{NH} \ldots \ldots \ldots \ldots . . .63$

Proctor, SP.............. 7

Programa de las $\mathrm{N}$ aciones

U nidas para el D esarrollo (PNUD) ......... 24, 64, 70

Programa de las $\mathrm{N}$ aciones U nidas para el M edio

Ambiente (PNU M A) . . . 3, 18,

$39,53,55,73,74,88$

Programa Internacional de

Seguridad de las Sustancias

Q uímicas (IPCS) . . . . . 27, 33,

61, 62, 103

Prokopets, GV . . . . . . . . . . . . 38

Proshchak, VP . . . . . . . . . . . . . 39

Prospero, E ............... 38

Prosterman, RL . . . . . . . . . . . . . 64

Proust, AA ............... 89

Prpic-M ajic, D . . . . . . . . . . 33

Prumper, J . . ............. 52

Pryor, AJ ...............41

Pryor, GT ............. 11

Pryor, W ............... 101

Przylecki, S. . . . . . . . . . . . . 79

Puci, N ................ 88

Puckett, C ............. 1

Puckett, J . . . . . . . . . ............ 101

Puga, A .................. 33

Pugh, DS ................ 34

Pugh, TF . . . . . . . . . . . 28

Pukkala, E ... . 4 4, 10, 71, 72, 80

Pulkkinen, AJ . . . . . . . . . . . 9

Pulp and Paper International

$$
\text { (PPI). }
$$

Pulver, AE ...............

Punnett, $L \ldots \ldots \ldots \ldots \ldots \ldots . .67$

Puntoni, R . . . . . . . . . . . . . 88 88

Pupo-N ogueira, D . . . . . . . . . 18

Pupp, N ...............6 63

Puranen, J ................6 6

Purkayastha, $P \ldots \ldots \ldots \ldots .20$

Puro, V ................997

Purrott, RJ . . . . . . . . . . . . . . 48

Pursel, V G . . . . . . . . . . . . . . 70

Purser, DA . . . . . . . . . . . . . . . 41

Puryear, K eita G . . . ......... 5

Putz-Anderson, V . . 6, 29, 32, 34

Pycock, J . ............. 52

Pyykkö, I . . . . . . . . . . . . . . . 3
$\mathrm{Qu}, \mathrm{YH} \ldots \ldots \ldots \ldots \ldots \ldots 80$

Q uaintance, M K . . . . . . . . 29

Q ualley, CA ...........99, 96

Q uanjer, PH ............. 10

Q ueinnec, $Y \ldots \ldots \ldots \ldots \ldots 52$

Q uellmalz, K . .............. 77

Q uencer, R M . . . . . . . . . . . . . 14

Q uénel, $P \ldots \ldots \ldots \ldots \ldots \ldots$

Q uenzer, LD . . . . . . . . . . . 7

Q uick, JC .......... 5, 34, 52

Q uick, JD . . . . . . . . . . . . . . 34

Q uick, RC . . . . . . . . . . . 34

Q uigley, K S............. 34

Q uinlan, PJ . . . . . . . . . . . . . 44

Q uinn, M L . . . . . . . . . 97

Q uinn, R ................. 34

Q uinn, RP ............. 34

Q uinn, WE ............83

Q uinsey, VI . . . . . . . . . . 51

Q uintana, JF . . . . . . . . . . . 97

Q uinter, J............... 52

Q uiralte, J . . . . . . . . . . 97

Q uirino, I. . . . . . . . . . . . 55

$R$

Raabe, GK .......... 19, 28

Raabe, $O G \ldots \ldots \ldots \ldots 10$

R aatgever, JW . . . . . . . 28, 100

Rabano, ES . . . . . . . . . . 55

Rabash, J ................. 59

Raber, R R . . . . . . . . . . . 45

Rabinowitz, M...........9 9

Rabinowitz, $S \ldots \ldots \ldots \ldots 34$

Rabkin, JG .............. 5

Rachman, SJ . . . . . . . . . . . . 59

Rachootin, $P \ldots \ldots \ldots . . .89$

Rader, J ................. 58

Radford, EP. . . . . . . . . 32, 73

R adford, J . . . . . . . . . . . 18

Radford, $M$. . . . . . . . . . . . . 34

Radice, $L$. . . . . . . . . . . . . . 39

Radin, EL . . ............ 6

Radosevic-V idacek, B . . . . 29, 43

$R$ adwin, $R G \ldots \ldots \ldots \ldots 6$

R adziszewski, E . . . . . . . . . 29

Rae, DS ................. 5

Rae, $S \ldots \ldots \ldots \ldots \ldots \ldots \ldots 10$

R afaeli, A . . . . . . . . . . . . . . . 34

R aff, M. . . . . . . . . . . . . . . 33

R afferty, E . . . . . . . . . . 13

Rafferty, PJ . . . . . . . . . . . 44

Raffle, PAB ........... 3, 64

R affray, $M \ldots \ldots \ldots \ldots \ldots 97$

R afnsdottir, GL . . . . . . . . 66

$R$ afnsson, $V \ldots \ldots \ldots \ldots \ldots 66$

Raford, $P \ldots \ldots \ldots \ldots \ldots . \ldots 72$

Rafusson, $V \ldots \ldots \ldots \ldots \ldots 6$

R agland, DR . . . . . . . . . . . . 34

Rahe, RH ................. 34

Rahimi, $M \ldots \ldots \ldots \ldots$. . . . . 56, 58

Rahkonen, P . ........... 101

Rahman, R . ............. 53 
R ainbird, G . . . . . . . . . . 17

Rainer, D . . . . . . . . . . . 83

R aitasalo, $R \ldots \ldots \ldots \ldots 16$

Rajan, $B \ldots \ldots \ldots \ldots \ldots 61$

Rajewsky, B . . . . . . . . . . . 32

Raju, SM ............... 33

Raju, TR ............. 11

Rajulu, $S \ldots \ldots \ldots \ldots \ldots 80$

Rallison, $M \mathrm{~L} \ldots \ldots \ldots \ldots \ldots . \ldots 48$

Ralph, D ............... 34

Ramaciotti, D ......... 26, 97

Ramakrishna, RS ..........96

R amanathan, CS ...........15

Ramaswami, NS . . . . . . . . . . 70

R amaswatny, A . .......... 74

Ramazinni, B............ 30

Ramazzini, B . 6, 10, 19, 28, 89, 96

R amette, JP . . . . . . . . . . . . 97

R amirez, S............ 15

R ammage, $\mathrm{L} \ldots \ldots \ldots \ldots \ldots . . .96$

Rampen, $\mathrm{FH} \ldots \ldots \ldots \ldots \ldots 12$

Ramsdell, HS ........... 28

Ramsey, F . . . . . . . . . . 83

Rando, RJ .............. 89

Rank, B ............... 97

Rannels, AM .............. 37

Ranney, D . . . . . . . . . ..... 96

Rantala, K ......... 9, 16, 52

Rantanan, J . . . . . . . . . . . . . 20

Rantanen, E. . . . . . . . . . . . 59

Rantanen, J . . . . . . . . 16, 18

Rao, J................. 8

Rao, NV ............... 10

Raoult, D ................ 10

R appaport, J ............. 34

R appaport, SM ...... 28, 30, 32

Rarey, KE ........................

Rasbash, DJ ............. 41

Rask-Andersen, A . . . . 10, 38

Raskowsky, M ........... 6

R asmussen, J 29, 52, 56, 57, 58, 59

Rasmussen, $\mathrm{K} \ldots \ldots \ldots . .38,70$

Rastogi, SK .........63, 64, 96

$R$ atcliffe, JM ............. 9

Ratta, A ................6 64

Rauch, $S \ldots \ldots \ldots \ldots \ldots$. . . .

Raudenbush, SW........... 34

Rausch, W............. 6

R auterberg, M ........ 29, 43

Ravden, SJ . . . . . . . . . . . . 52

Raw, GJ ................ 13

Rawles, JM ................ 3

Raybold, WE ............ 74

Rayman, R B ......... 95, 102

Raymond, $L \ldots \ldots \ldots \ldots \ldots 28$

Rayner, J ............... 100

Razak, DA .............. 22

Razak, DS ...............22 22

R azienne, M E . . . . . . . . . . . 53

Razor, M $0 \ldots \ldots \ldots \ldots . . . .63$

R azzaboni, L . . . . . . . . . . . . . 10

Rea, DF ............ 18, 64

Rea, K................ 59

Rea, MS............... 11
R ead-G uernsey, J . . . . . . . 38 Read, GF . . . . . . . . . . . . . . 34

Réal, J ................ 52

Reason, J . . . . . . . . 29, 34, 58

Reason, JT . . 50, 56, 57, 58, 59, 78

R eaud Thomas, G . . . . . . . . . 38

Rebentisch, E............. 3

Reber, R ..............21

Rebert, CS.............11

R ebiffé, $R \ldots \ldots \ldots \ldots \ldots 29$

Rebitzer, JB .............. 21

Rebuck, AS ............... 37

Recht, C..............664

Record, FM . . . . . . . . . . . . 77

Rector, HE .............44 44

Rector, NA ............. 5

Reding, D . .............64 64

Redlich, CA . . . . . . . 13, 87, 89

Redmond, CK .......... 3, 73

Reece, RD . ............... 19

Reed, AV . . . . . . . . . . . . . . . 52

R eed, CE ............ 10, 97

Reed, $G \ldots \ldots \ldots \ldots \ldots .65$

Reed, $\mathrm{HL} \ldots \ldots \ldots \ldots \ldots . .42$

Reed, LD . . . . . . . . . . . . . . 70

R eed, M................. 34

Reed, R R ................ 19

R eedman, JH . . . . . . . . . . . . 74

Rees, JV .................. 59

Rees, $T \ldots \ldots \ldots \ldots \ldots \ldots 11$

Reese, $C D \ldots \ldots \ldots \ldots . \ldots 58$

Reeve, $G \ldots \ldots \ldots \ldots \ldots . . \ldots$

R eeves, JT . ............. 37

Reeves, WC .............. 53

Refshauge, $C \ldots \ldots \ldots \ldots 23$

Refsum, $H \ldots \ldots \ldots \ldots \ldots 42$

R efsum, HE . . . . . . . . . 68, 78

Regalia, I . .............. 21

R egents Advisory Committee

on Environmental Q uality

in Schools

Reggiani, G ............. 39

R égie nationale des usines

R enault (R NUR) . . . . . . . 29

Regier, DA . . . . . . . . . . 5, 34

R egister, $0 \ldots \ldots \ldots \ldots \ldots 102$

Rehm, S............... 47

Rehmann, I ............... 4

Reich, RB ............... 34

Reich, WT ............... 19

Reichborn-K enneruud, S . . . . 63

Reichers, AE . . . . . . . . . . . 59

Reichrtova, E...........6 63

Reid, F . ...............96 96

Reid, $G \ldots \ldots \ldots \ldots \ldots . . .55$

Reid, HA . . . . . . . . . . . . . . 38

Reid, $N \ldots \ldots \ldots \ldots . . . . .34$

Reid, SJ .............. 27

Reif, JS. . . . . . . . . . 28, 64, 97

R eiffer, FJ............. 10

Reilley, MSJ. . ...........66 66

Reilly, $B \ldots \ldots \ldots \ldots \ldots \ldots .21$

Reilly, JP ............. 40

Reilly, N P. . . . . . . . . . . . . . . 34
Reilula, KE .............97 97

Reily, CA .............. 887

R eimann, DO ........... 101

R eimann, J . . . . . . . . . . . . . 102

R einberg, A . . . . . . . . 29, 43

R einberg, $N \ldots \ldots \ldots \ldots \ldots 43$

Reindell, $\mathrm{H} \ldots \ldots \ldots \ldots \ldots \ldots$

Reiners, $H$. . . . . . . . . . . . 102

Reinert, D . . . . . . . . . . . . 58

Reinhard, KRT . . . . . . . 97

R einhardt, CF . . . . . . . . . 3

R einig, WC . ........... 48

R einikainen, $L M \ldots \ldots \ldots \ldots 13$

Reisch, M S . . . . . . . . . . . 80

Reisen, WK . . . . . . . . . . . . 53

Reish, D . . . . . . . . . . . . . . 55

Reisine, JD . . . . . . . . . . . . . 34

R eiskin, HK . . . . . . . . . . . . . 34

R eiss, AJ .............. 51

R eist, $P \ldots \ldots \ldots \ldots \ldots \ldots . .43$

Reist, PC . . . . . . . . . . . 30

R eith, $A K \ldots \ldots \ldots \ldots 66$

R eitz, RH . . . . . . . . . . . 30, 33

R eker, GT . . . . . . . . . . . . 34

Remer, $P$. . . . . . . . . . . . . . . 34

Remer, R . . . . . . . . . . . . . 34

R emick, DG . . . . . . . . . . . . . 10

Rempel, D ............... 34

Renard, $H \ldots \ldots \ldots \ldots \ldots . \ldots 53$

Renaud, M..............21

Renaud, $R \ldots \ldots \ldots \ldots . . . .9$

Rendall, RE . . . . . . . . . . . . . 10

Rendall, REG ...........63

Renes, LE . . . . . . . . . . . . . 30

R engam, $S \ldots \ldots \ldots \ldots \ldots .22$

R enkopf, $P \ldots \ldots \ldots \ldots \ldots 10$

Renn, $0 \ldots \ldots \ldots \ldots \ldots \ldots 59$

Renner, RM ............. 28

Renton, K A . . . . . . . . . . . . 63

Rentos, PG . . . . . . . . . . . 43

Renzi, GD . . . . . . . . . . . . 10

Renzi, PM ............... 10

Repacholi, M . . . . . . . . . . . . 49

Repacholi, M.............49 49

R epetti, RL . ............. 34

Repine, JE . . . . . . . . . . . . . . . 10

Repo, $H \ldots \ldots \ldots \ldots \ldots \ldots 6$

Resch, M ................ 34

Reschauer, G . ........... 97

Reskin, BF . . . . . . . . . . . . . 34

Resnick, R ............. 16

Respicio, BL.............. 11

Resser, $K \ldots \ldots \ldots \ldots \ldots . . . . .34$

Ressler, KJ ............... 11

Rest, K M . . . . . . . . . . . . . . . 19

Resu, G . . . . . . . . . . . . . . . . 79

Retic, A ................ 8

Rettie, $A E \ldots \ldots \ldots \ldots . \ldots 33$

R euben, DB . . . . . . . . . . . 97

Reuchlin, M . . . . . . . . . . . 29

R eunala, $T \ldots \ldots \ldots \ldots 64,93$

Reuss, G. . . . . . . . . . . . 58

Reutsch, C-J. . . . . . . . . . . . 77

Reverente, BR . . . . . . . . . . . 16
R eview Panel on Coronary-

Prone Behavior and

Coronary H eart Disease . . . . 34

Rexroad, CE ............. 70

Rey, P ........ 11, 26, 52, 101

R eynolds, B . . . . . . . . . 15, 96

R eynolds, J. . . . . . . . . . . . . . . 79

Reynolds, PM ........... 28

R eynolds, SJ . . . . . . . . . . . . 70

R eynolds, WJ . ........... 6

Reznick, RK . . . . . . . . . . . 97

R heingold, HR .......... 52

$R$ hind, Brown W . . . . . . . . . 10

R hoades, B] . . . . . . . . . . . . 83

R hoades, HM ............ 34

Rhoades, T P . . . . . . . . . . . . . 59

R hoads, JM . . . . . . . . . . 97

R hodes, RS . . . . . . . . . . . 97

Riad-Fahmy, D . . . . . . . . 34

Rials, $R \ldots \ldots \ldots \ldots \ldots . \ldots 77$

Ribak, J . . . . . . . . . . . . . 102

Ribeiro, SA ............ 70

Rice, $A \ldots \ldots \ldots \ldots \ldots \ldots . .21$

Rice, B............... 100

Rice, $C \ldots \ldots \ldots \ldots \ldots \ldots . \ldots 10$

Rice, $\mathrm{CH} \ldots \ldots \ldots \ldots \ldots . \ldots 30$

Rice, DP ............. 56

Rich, E.............. 52

Richalet, J-P . . . . . . . . . . . 37

Richard, HR . . . . . . . . . . . . . 34

Richard, JL ............. 52

Richards, DAB . . . . . . . . . . 4 42

Richards, JT . . . ......... 29

Richards, RJ . . . . . . . . . . 10

Richards, T B . . . . . . . . 10, 32

Richardson, G .......... 15, 20

Richardson, HW . . . . . . . . 36

Richardson, J . . . . . . . . . 59

Richardson, JH . . . . . . . . . 38

Richardson, L . . . . 1, 4, 12, 28, 72

Richardson, R B . .......... 91

Richelson, G ............ 5

Richerson, H B . . . . . . . . . . . 10

Richmond, K ............ 15

Richoux, C.............. 100

Richter, E. . . . . . . . . . . . . 27

Richter, ED . . . . . . . . . . . . 11

Richter, J . . . . . . . . . . . . . . . 34

Richter, P.............. 29

Richter, SA . . . . . . . . . . . . . 30

Rickards, J . . . . . . . . . . 68

Ricks, RC . . . . . . . . . . . 48

Riddell, RW . . . . . . . . . . 10

Ridker, PM .............. 3

Riecker, G . . . . . . . . . . . . . . 3

Riedel, F. . . . . . . . . . . . . . 44

Rieger, CHL . . . . . . . . . . . . 44

Riel, KA............... 6

Riely, CA . . . . . . . . . . . . . . 89

Riemann, HP........... 3

R ietschel, RI . ........... 12

R iffiod, D . . . . . . . . . . . . . . . 100

Rigau-Perez, JG . . . . . . . . . . 39

Rigg, $S \ldots \ldots \ldots \ldots \ldots \ldots 6$ 


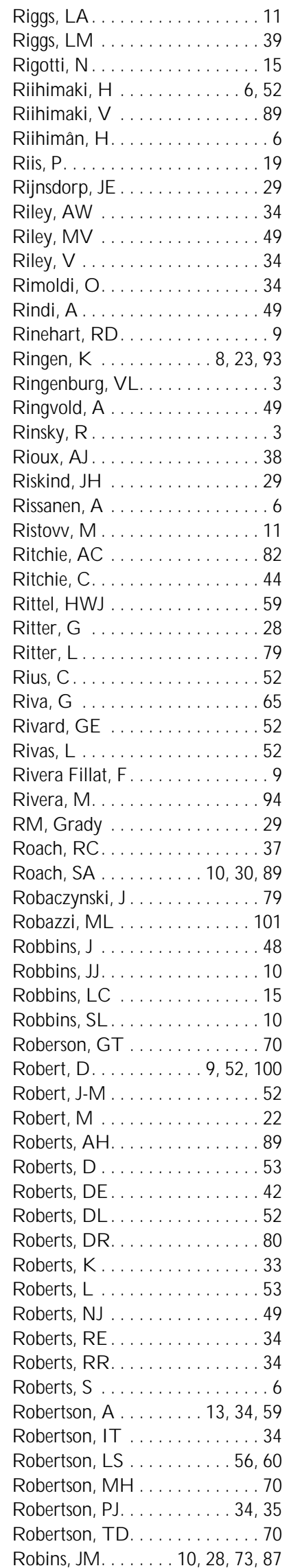

Robins, LN .......... 5, 34 Robins, T G ............. 30 R obinson, AT C . . . . . . . . 89 R obinson, BS............ 34 Robinson, C.... . 32, 71, 72, 93 Robinson, D............ 68 Robinson, G . . . . . . . . . . . . 11 Robinson, JC . . . . . . . . . . 34 R obinson, NA . . . . . . . . . 54 Robinson, PK ............ 29 R ochanachin, M ........... 38 R oche, LM . . . . . . . . . . . . . 32 Roche, W............... 5 Rocher, M .............. 97 R ochette, HE . . . . . . . . . . . 73 R ochowansky, S. . . . . . . . . 22 Röckert, HOE ............ 11 Rockwell, DM . . . . . . . . . . . 94 Rockwood, CA ..........96 96 Rodahl, K ............. 43 R odale, $R \ldots \ldots \ldots \ldots \ldots . . \ldots 15$ Rodamilans, $M \ldots \ldots \ldots . .99$ Rodary, C . . . . . . . . . . . . . 97 Rodd, M G . . . . . . . . . . . . 29 Rodella, S . . . . . . . . . . . . 88 88 Roder, D . ............... 10 Rodero, F...............68 68 R odgers, B . . . . . . . . . . . 34 R odgers, W ............. 34 Rodricks, JV . . . . . . . . . . . . . . 30 Rodrigue, DG ............ 53 R odrigues-Pereira, RM . .....6 6 R odrigues de 0 liveira, A . . . . . . 39 R odriguez-R igau, LJ . . . . . . . . . 9 R odriguez Artalejo, F . . . . . . . 96 Rodriguez, B . . . . . . . . . . . 97 R odriguez de Castro, F . . . . . . 97 Rodriguez, E . . . . . . . . . . . . 64 Roels, H . . . . . . . . . . . . . . 63 R oels, H A . . . . . . . . . . . . . 81 R oels, J ............... 57 Rogacz, S............ 97 Rogalski, J .............. 29 Rogan, JM ............... 10 Rogan, WJ .............. 9 Rogers, CR ......... . 34, 59 Rogers, FE . . . . . . . . . . . 41 Rogers, J . . . . . . . . . . . . . 21 Rogers, JW .......... . 83, 102 Rogers, $T \ldots \ldots \ldots \ldots \ldots 15$ Rogers, $Y \ldots \ldots \ldots \ldots \ldots . \ldots 5$ Roggeveen, $V$. . . . . . . . . . . . 57 Roggli, VL ................. 9 Rogot, E............... 3 Rohde, CA............. 9 Rohde, M . . . . . . . . . . . . . 64 R ohmert, W. . . . . . . . . . 29, 43 Rohrborn, $G \ldots \ldots \ldots \ldots \ldots 9$ Rohrer, K M . ............. 52 Rohrmann, B............ . 59 R oi, $R \ldots \ldots . . . . . . .27$ Roitt, I . ................ 33 R ola-Pleszczynski, M . . . . . . . 10 Roll, R . . . . . . . . . . . . . . . 9
Rolland, C . . . . . . . . . . . 29 Rollin, $\mathrm{H} \ldots \ldots \ldots \ldots \ldots . . .11$ Rollin, M ...............4 40 Rolloos, M ............. 45 Rom, WN .... 10, 19, 32, 37, 78 R omaguera, C . . . . . . . . 100 Romahn, R ............ 43 Roman, E............. 52 Roman, P.............. 19 Roman, PM .............. 19 Romana, M C . . . . . . . . . . . . 6 Romano, C .........10,65 Romano, F ............. 38 Romano, $T\} \ldots \ldots \ldots \ldots \ldots 6$ Rombach, $V \ldots \ldots \ldots \ldots 29$ Romelsjo, A . . . . . . . . . . . . . . 34 Romeo, $L \ldots \ldots \ldots \ldots \ldots . . . .9$ Romieu, I.............. 53 Romon, $M \ldots \ldots \ldots \ldots \ldots$ R onda, JM ..............4 43 R ondia, D .............6 63 Ronneberg, A . . . . . . . 68, 78 Ronson, RR . . . . . . . . . . . . 32 Rooke, G . . . . . . . . . . . . 89 Rooke, G B .......... 10, 89 Rooks, S.............. 83 Rooney, FP . . . . . . . . . . . 88 83 Roos, D ............... 29 Roos, $H \ldots \ldots \ldots \ldots \ldots .66$ Roos, M . . . . . . . . . . . . . . 10 Roos, N ............. 58, 59 Roper, WL . . . . . . . . . . . . . . 9 Ropo, A ............... 34 Roquelaure, $Y \ldots \ldots \ldots . . .97$ Rosa, EA ............... 59 Rosa, RR . . . . . . 29, 34, 43, 102 Rosario, M . . . . . . . . . . . . 34 Rosas, I ............... 101 Rosbrook, B............. 15 Rosch, P.............. 5 Roscoe, R.............. 71 Rose, $C L \ldots \ldots \ldots \ldots \ldots 96$ Rose, CS ............ 10, 11 Rose, $G \ldots \ldots \ldots \ldots \ldots . \ldots 3$ Rose, JA................ 27 Rose, NR ............... 33 Rose, RM . . . . . . . 4, 26, 34, 102 Rose, WW . .............. 67 R osekind, M R . . . . . . . . . . . . . 97 Rosell, M G . . . . . . . . . . . . . . 97 R oseman, J............. 101 R oseman, J M . . . . . . . . . . . . 70 R osemond, GP . . . . . . . . . 97 R osen, A . . . . . . . . . . . . 15 Rosen, G . . . . . . . . . . 5, 30, 98 Rosén, G . .............. 11 Rosen, N . . . . . . . . . . . . . . . 34 Rosen, SD . . . . . . . . . . . . . 21 Rosenau, MJ . ............. 95 R osenber, $T \ldots \ldots \ldots \ldots . . .97$ R osenberg, D . . . . . . . . . . . . 52 Rosenberg, DJ . . . . . . . . . . 29 Rosenberg, J . ............ . 44 Rosenberg, M . . . . . . . . . 34
R osenberg, MI.......... 51

R osenberg, MJ ........... 9

R osenberg, $S \ldots \ldots \ldots \ldots \ldots 8$

R osenberg, SA . 1, 4, 10, 12, 15, 28

R osenberg, ZS .......... 6

R osenblatt, Z . . . . . . . . . . . . 34

R osenfield, AL . . . . . . . . . . . . 6

R osenfield, J............. 101

R osengren, A . . . . . . . . . . . . 3, 34

R osenhead, J . . . . . . . . . . . 59

Rosenman, K .......... 10, 70

R osenman, K D . . . . . . . . 32, 94

R osenman, RH . . . . . . . . . 5, 34

R osenstock, $C \ldots \ldots \ldots \ldots 11$

R osenstock, L . . 3, 6, 9, 16, 32, 64, 72,99

R osenstock, LR ............ 31

Rosenthal, E . . . . . . . . . . 53 R osenthal, FS. . . . 49, 53, 83, 101 R osenthal, R A . . . . . . . . . . . . 34

Rosette, C . . . . . . . . . . . . 33

Roskamm, $\mathrm{H} \ldots \ldots \ldots \ldots \ldots . \ldots 3$

R oskies, E. . . . . . . . . . . . . . . . 34

Rosner, B .............. 97

Ross, $A D \ldots \ldots \ldots \ldots \ldots 28$

Ross, B.............. 11

Ross, CC ............. 70

Ross, DS ............... 5

Ross, L . . . . . . . . . . . . . . 59

R oss, M D .............. 9

Ross, R................ 15

Ross, RK . . . . . . . . . . . . 15, 85

R ossa, A .............. 97

R ossi, G . . . . . . . . . . . 34, 47

Rossi, M............ 54, 55

R ossignol, M ............. 40

R ossiter, CE . . . . . . . . 10, 101

R ossman, M D . . . . . . . . . . . . 10

R ossmanith, H P. . . . . . . . . . . 56

Roßmann, J.............. 58

Rossner, R . . . . . . . . . . . . . . 43

R ossol, M ............ 94, 96

Rosson, M B . . . . . . . . . . . . . . 52

Rostaing, M C . . . . . . . . . 97

R otatori, A . . . . . . . . . . . 17

R otchford, N L . . . . . . . . . . . . . 34

Roth, EM . . . . . . . . . . 29, 37

R oth, JA . . . . . . . . . . . . . 51

R oth, $P \ldots \ldots \ldots \ldots \ldots . \ldots 32$

Roth, RA .............. 4

Roth, $R T \ldots \ldots \ldots \ldots \ldots .7$

Roth, WC ............96

R othbaum, BO ........... 51

R othman, $K J \ldots \ldots \ldots \ldots$. . . . 32

R othman, KJ . . . . . . . . . . . 28

R othman, N . . . . . . . . . . . . 1, 83

Rothmann, RH . . . . . . . . 6, 97

R othstein, M ........... 23

Rothwell, K . . . . . . . . . . . . 3

Rotimi, $C \ldots \ldots \ldots \ldots . . . .91$

Rotman, $C \ldots \ldots \ldots \ldots \ldots . . .97$

R otmans, J . . . . . . . . . . . . . . 53

R oto, $P \ldots \ldots \ldots \ldots \ldots . \ldots 93$

Rotter, J B . . . . . . . . . . . . . . 34 
Round, JM ............. 6 Roundtree, G........... 90 R ouse, WB............. 29 Roush, GC .............. 100 R ousseau, D M . . . . . . . . . . . 34 R oustang, G . . . . . . . . . . . 29 R ovell, CR .............64 64 Rowe, SA ............... 3 R owell, LB . . . . . . . . . . . . 42 Rowens, $B \ldots \ldots \ldots \ldots \ldots 9$ Rowland, FS ..............53 R owland, IR ............. 33 R owntree, RA . . . . . . . . . . 64 Roy, CR .............. 49 Roy, DJ ................ 34 R oyak-Schaler, R.......... 34 R oyal College of N ursing ..... 19 R oyal College of Physicians. . . 19 Royal, H D . . . . . . . . . . . . 48 Royal, JW ............... 50 R oyal Society of Chemistry (RSC)............ 100, 103

R oyal Society of M edicine. . . . . 39 R oychowdhury, M . ........ 83 Roys, MS .............. 13 R oyster, JD . . . . . . . . . . . 47 R oyster, LH . . . . . . . . . . . . . 47 R ozan, $R \ldots \ldots \ldots \ldots \ldots 63$ R ozanski, A . . . . . . . . . . . . 34 R ozeman, A . . . . . . . . . . . . 17 R ozmiarek, $\mathrm{H} \ldots \ldots \ldots \ldots . \ldots 70$ Rubenowitz, E . . . . . . . . . . 10 R ubenstein, $\mathrm{H} \ldots \ldots \ldots \ldots \ldots . \ldots 18$ R ubenstein, $M$. . . . . . . . . . . 34 Rubin, $\mathrm{CH} \ldots \ldots \ldots \ldots \ldots . . .94$ Rubin, $G \ldots \ldots \ldots \ldots \ldots 52$ Rubin, JR . .............83 Rubin, $P \ldots \ldots \ldots \ldots \ldots . \ldots 48$ Rubin, R . .............997 Rubino, GF . . . . . . . . . 11, 52 Rubino, MJ ............. 70 Rubino, $N \ldots \ldots \ldots . . .49$ Ruch, TC .............. 11 Rud, $B \ldots \ldots \ldots \ldots \ldots \ldots 6$ Ruda, JM ................23 Rudacille, D . . . . . . . . . . . . . 33 Ruddick, AJ . .............. 52 Ruddy, EN . . . . . . . . . . . . . . 77 Ruder, AM ............. 100 Rudnick, SA............. 9 Rudolph, E ............29 R ufener-Press, C . . . . . . . . . 101 Ruffolo, JJ ................49 Ruge, I...............83 Ruhm, CJ............. 34 Ruiter, DJ .............. 12 Ruíz, $S \ldots \ldots \ldots \ldots \ldots \ldots 5$ Ruiz-Q uintinallia, A . . . . . . 18 R uiz-V elasco, S . . . . . . . . . . 53 Rumar, K............. 59 Rumeau, $C \ldots \ldots \ldots \ldots \ldots .9$ R umeau R ouquette, $C$. . . . . . 28 Rumel, D . ............... 38 R umelhart, $D E \ldots \ldots \ldots \ldots . \ldots 52$
Rumjancev, GI . ......... 50 R ummel-Bulska, I . . . . . . 54, 101 R ummel, RJ............. 59 Rummel, W . .............. 33 Rummer, R . . . . . . . . . . . . 68 Runge, $C F \ldots \ldots \ldots \ldots \ldots 64$ Ruppert, E ............. 59 Rus, V ...............59 Rush, RV .............. 5 R ussek-C ohen, E . . . . . . . . 53 Russel, E . . . . . . . . . . . . . . . . 19 R ussell, B . . . . . . . . . . . . . . 19 Russell, DS. . ............ 11 Russell, FE . . . . . . . . . . . . . . 38 Russell, IJ . . . . . . . . . . . .6 6 Russell, J C ..............64 64 Russell, WM S ............. 33 Russo, NF . . . . . . . . . . . 34 Ruster, B .............. 54 Ruszkowski, AM .........996 Rusznak, C ............11 Rutenfranz, J . . . . . 3, 29, 34, 43 Ruth, A ............... 13 Ruth, JH ..............11 Rutter, CM ..............34 Ruuhilehto, K ............ 57 Ruuskanen, J . . . . . . . . . . . . 13 Ryan, A ...............96 Ryan, AS ............... 15 Ryan, C . . . . . . . . . . . 21

Ryan, DE ..............96 Ryan, GA . . . . . . . . . . . . . 52

Ryan, GM ............. 43 Ryan, LP . . . . . . . . . . . . . . . 77 Ryan, PJ..............6 Ryback, LP . . . . . . . . . . . . 11 Rycroft, RJG . . . . . . . . 33, 64 Rydell, $N \ldots \ldots \ldots \ldots \ldots .6$ Rydevik, $\mathrm{BL} \ldots \ldots \ldots \ldots \ldots \ldots 6$ Rydholm, D .............6 6 Ryding, S-O . . . . . . . . . . 54 Rylander, E . . . . . . . . . . . 9 Rylander, $L \ldots \ldots \ldots \ldots \ldots 66$ Rylander, R ..... 10, 13, 30, 64, 70, 89, 97, 101

Ryssel, $H \ldots \ldots \ldots \ldots . . . . .83$

Ryu, JE ..............9 Ryvers, D . . . . . . . . . . . . 43, 97 Ryzan, CA .............. 53

\section{$S$}

Saal, RC . .............. 100

Saarela, I ...............6

Saarela, KL . . . . . . . . . . . . . 22

Saari, J ........... 56, 59, 93

Saarilahti, M ............6 68

Sabbioni, E .......... 10, 27

Saccomanno, FK .......... 101

Saccomanno, G . . . . . . . . . . 44

Sachare, A . . . . . . . . . . . . . . 96

Sack, DA ................. 53

Sadava, SW . . . . . . . . . . . . 34

Sadecky, E . . . . . . . . . . . . . 38
Sadhro, S . . . . . . . . . . . . 89

Sadock, BJ . ............... 5

Sadoul, P............... 10

Saenger, G . . . . . . . . . . . . 9

Saenz, D. . . . . . . . . . . . . . 34

Saez, R A . . . . . . . . . . . . . 1

Safary, A . . . . . . . . . . . 97

Safford, SK ............ 32

Safina, C . ............. 70

Sager, DB............. 9

Sager, $P \ldots \ldots \ldots \ldots \ldots \ldots 27$

Sager, PR ............. 9

Sahagian, CR ............. 5

Sahel, JA . . . . . . . . . . . . . . 12

Saiki, CL . ............. 83

Sainani, GS . . . . . . . . . . 39

Sainfort, PC . . . . . . . . 34, 52

Sainio, $H \ldots \ldots \ldots \ldots . . . . .93$

Saint R emy, A . . . . . . . . . 63

Saint-Arnaud, L . . . . . . . . . . . 97

Saito, $H$. ............. 3, 29

Saito, $K \ldots \ldots \ldots \ldots \ldots \ldots . \ldots$

Saito, M . . . . . . . . . . . 100

Saito, $Y \ldots \ldots \ldots 29,43,97$

Saiz, SG . . . . . . . . . . . 27

Sakai, K ............. 29, 97

Sakula, A . . . . . . . . . . . . . . 64

Sakurai, $H \ldots \ldots \ldots \ldots \ldots . \ldots$

Salamon, R .............. 5

Salamone, $L \ldots \ldots \ldots \ldots \ldots \ldots . .4$

Salazar-G ruesco, E . . . . . . . . 97

Salg, J................... 32

Salg, JA ............... 32

Salinas, E . . . . . . . . . . . . . 101

Salit, IE ............... 38

Salive, $M \ldots \ldots \ldots \ldots \ldots \ldots 5$

Sallmen, M .......... 9, 52

Sällsten, G . . . . . . . . . . . . . . 72

Salmon, A . . . . . . . . . . . . . . 39

Salmon, ER ............. 83

Salmun, LM . ............. 9

Salomon-N ekiriai, C . . . . . . . 10

Salpukas, A . . . . . . . . . 75, 78

Salsi, S ................. 31

Salter, R...............6

Saltin, B . . . . . . . . . . . . . . 3

Salvaggio, JE . . . . . . . 10, 64

Salvato, JA . . . . . . . . . . . . . 101

Salvendy, G . 29, 34, 52, 56, 58, 59 Salvi, RJ ................ 31

Salzinger, $\mathrm{K} \ldots \ldots \ldots \ldots \ldots 52$

Salzmann, JJ ................ 39

Samah, NA . . . . . . . . . . . . 22

Samaja, M ................ 37

Samathakorn, S . . . . . . . . . 16

Sambeth, J................ 39

Sambiase, $N V$. . . . . . . . . . . 3

Samelson, N M . . . . . . . . . 18, 93

Samet, JM ................. 32

Samkoff, JS ............. 97

Sammarco, GJ . ........... 96

Sampliner, RE . . . . . . . . . . . 97

Sampson, K .............21

Sampson, RJ . . . . . . . . . . 102
Samsom, KT . . . . . . . . . 23

Samuels, S ............. . 9, 83

Samuels, SW . . . . . . . . . 19, 23

Sanarico, M ................ 39

Sanchez, C.............. 34

Sánchez, S ............... 53

Sand, PH . . . . . . . . . . . . . . 54

Sandahl, E .............. 93

Sandberg, M . . . . . . . . . . . 45

Sandelands, LE . . . . . . . . . 34

Sanders, AB . . . . . . . . . . . . . 14

Sanders, GS . . . . . . . . . . . . . 34

Sanders, K . . . . . . . . . . . . . 5, 34

Sanders, K H . . . . . . . . . . . 52

Sanders, M . . . . . . . . . . . . 34

Sanderson, JW . . . . . . . . . . . 43

Sanderson, PM ........... 29

Sanderson, WT . . . . . 10, 64, 67

Sándi, G............... 22

Sandler, DP . . . . . . . . . . . 1

Sandoval, J............... 3

Sandover, DJ ............... 3

Sandret, N . . . . . . . . . . . . . 100

Sands, DG . . . . . . . . . . . . . 83

Sandstron, M . ............ 13

Sanfilippo, DJ, II ........... 9

Sanford, JP. . . . . . . . . . . . . . 53

Sano, $H \ldots \ldots \ldots \ldots \ldots . \ldots . \ldots$

Santee, WE . . . . . . . . . . . . . 42

Santen, RJ . . . . . . . . . . . . . 9

Santo, $0 \ldots \ldots \ldots \ldots \ldots \ldots 65$

Santos, U P . . . . . . . . . . . . . . 47

Santucci, M . . . . . . . . . . . 88

Sappino, AP . . . . . . . . . . . 10

Saracci, R . . 10, 28, 39,82, 88, 100 Sarason, IG . . . . . . . . . . . . 34

Saraste, $H \ldots \ldots \ldots \ldots \ldots 6$

Saraste, $M \ldots \ldots \ldots \ldots \ldots 6$

Sardinas, A . . . . . . . . . . . . . 3

Sargent, EV . . . . . . . . . . . 79

Sarkady, L . . . . . . . . . . . . 11

Sarkis, $H \ldots \ldots \ldots \ldots \ldots . \ldots 59$

Sarnquist, FH ............ 37

Sarow, PG . . . . . ........ 94

Sartor, F..............66 63

Sartori, M ................ 97

Sasakawa, N. . . . . . . . . . . . 43

Sass, R .................. 59

Sasseville, D . . . . . . . . . . 12

Sassi, C................ . 89

Sassine, M P ............ 7

Sass-K ortsak, A . . . . . . . . 18, 70

Sastre, J .................6 64

Sataloff, RT . . . . . . . . . . . 96

Sathasivam, P . . . . . . . . . 42

Sathiakumar, N . . . . . . . . . 80

Sato, A . . . . . . . . . . . . . 33

Sato, $F \ldots \ldots \ldots \ldots \ldots 42$

Sato, $H \ldots \ldots \ldots$. . . . . . . . . . 34

Sato, $K \ldots \ldots \ldots \ldots \ldots \ldots 42$

Sato, $R \ldots \ldots \ldots \ldots \ldots . \ldots 33$

Sattelle, D . . . . . . . . . . . 77

Satterfield, S. . . . . . . . . . . . 3

Satterthwaite, D . . . . . . . . . . 53 
Satterthwaite, F . . . . . . . 53 Satterwaite, D . ...........64 64 Saunder, RD ............ 49 Saunders, JB . ............ 15 Saunders, NA . . . . . . . . . . . 10 Saunders, WM . ............ 97 Saurel, D . . . . . . . . . . . . . . 97 Saurel-Cubizolles, MJ .... . 9, 97 Sauret, H . . . . ........... 97 Sauter, M .............. 97 Sauter, S. . . . . . . . . . . . . 5, 34 Sauter, SL . . . . . . 5, 15, 34, 52 Savage, CM .............. 29 Savage, G. . . . . . . . . . . . 34 Savage, LJ ............... 59 Savchenko, IL . ............ 38 Savchenko, NI . . . . . . . . . . 38 Savelkould, TJF . ........... 39 Savitz, D . .... 9, 28, 39, 94, 100 Savoie, FH .............. 96 Savolainen, K ........... 27

Savourey, G . . . . . . . . . . . . 42 Savourey, GLM .......... 42

Savov, A.............. 11

Savoyant, A ............. 29

Savy-M oore, RJ ........... 9

Sawka, M N ..............42 42

Sawyer, CN . .............. 55

Sax, NI . . . . . . . . 22, 63, 103

Saxén, L. . . . . . . . . . . . . . . . . . 52

Saxton, M J............... 34

Sayer, R M .............. 49

Sayers, RR . ............. 30

Scala, RA . ........... 43, 63

Scalet, EA ............. 52

Scallon, L . . . . . . . . . . . . . . . 70

Scalone, AA . . . . . . . . . . . 31

Scalt, JW ............... 42

Scansetti, G . ......... 10,63

Scapin, DL.............. 52

Scarbrough, H . .......... 29

Scardino, PT ............. 8

Scarff, RW ............... 79

Scarpace, $L \ldots \ldots \ldots \ldots \ldots . . .63$

Scarpace, LP . . . . . . . . . . 83

Scarpelli, A.............. . 88

Scarselli, G.............. 89

Scase, R .............. 21

Schable, CA............. 97

Schable, CN ............. 97

Schachter, EN ........... 89

Schaefer, C .............. 34

Schaefer, JA ............. 100

Schaefer, M .............. 9

Schaeffer, N M . . . . . . . . . . . . . 48

Schäfer, KH ............ 52

Schäfer, RE .............. 59

Schaffer, $P \ldots \ldots \ldots \ldots \ldots . . . \ldots$

Schaffner, K F ........... 28

Schaible, UE ............. 3

Schall, EL .............96

Schallenberg, G . . . . . . . . . 97

Schaller, JG .............. 6

Schalock, RL ............. 17
Schantz, SP . . . . . . . . . . 10 Scharf, $T$. . . . . . . . . . . . 34, 64 Scharff, L............... 34 Scharlach, AE ............. 34 Scharmann, A . ........... 10 Schaubroeck, J............. 34 Schaufeli, WB ............ 34 Schaumberg, HH ....... 7, 33 Schauss, AG .............6 63 Schecter, A . . . . . . . . . . 9, 39 Scheeper, B . . . . . . . . . . . . 86 Scheer, S . . . . . . . . . . . . . . 17 Scheff, PA .......... 44, 77 Schein, EH . . . . . . . . 34, 57, 59 Schellart, AJM ............. 5 Schelp, L . .............. 56 Schenker, M . . . . . . . 70, 71, 83 Schenker, M B . . . . . . . 9, 10, 64 $72,73,83$

Schepsis, AA .............6 6

Scher, $\mathrm{H} \ldots \ldots \ldots \ldots \ldots \ldots . . . \ldots$

Scherer, G . . . . . . . . . . . . . 44

Scherf, BD . . . . . . . . . . 64, 70

Scherff, J . .............. 102

Scherwitz, L. . . . . . . . . . . . . 34

Scherwitz, LW . . . . . . . . . . . 15

Scheuer, PJ . ............. 4

Scheufler, $H \ldots \ldots \ldots \ldots \ldots . .63$

Scheuplein, RJ . ............ 2

Schibye, B . . . . . . . . . . . . 87

Schicht, RJ .............. 39

Schienstock, G . . . . . . . . . . 52

Schiffer, D .............. 7

Schiffman, SS ............11

Schilling, A . . . . . . . . . . . . . 29

Schilling, CJ............ 101

Schilling, RS ............ 101

Schilling, R SF . . . . . 3, 10, 66, 89

Schira, JC.............. 11

Schirren, CG ............ 49

Schlatterer, JP . ........... 9

Schleifer, LM . . . . . . . . . . . . 34

Schleifer, LR . . . . . . . . . . . . . 34

Schlenker, B. . . . . . . . . . . . . 34

Schlesinger, R B . . . . . . . . . . 10

Schlesselman, JJ . . . . . . . . . . 28

Schlief, G . ................ 3

Schlitt, $H$. . ............... 27

Schlosser, M ............. 9

Schlussel, Y .............. 34

Schmauss, AK ............ 4

Schmidt, E . . . . . . . . . . . . . 54

Schmidt, G. . . . . . . . . . 102

Schmidt, J0 ............. 70

Schmidt, K-H ........... 43

Schmidt, M .............. 50

Schmidt, M J............. 70

Schmidt, R............ 83

Schmidt, WH . . . . . . . . . . . 34

Schmidtke, H . . . . . . . . . . . 29

Schmidt-K ehl, L . . . . . . . . . 30

Schmidts, K . . . . . . . . . . . . 29

Schmieden, BA .......... 26

Schmitz, B . . . . . . . . . . . 43
Schmuckli, $F \ldots \ldots \ldots \ldots \ldots 11$ Schnall, P................ 34 Schnall, PL............ 3, 34 Schnauber, $H \ldots \ldots \ldots \ldots \ldots .73$ Schneider de V illegas, G . . . . . . 24 Schneider, B. ........... 34, 59 Schneider, BE . . . . . . . . . . . 96 Schneider, EL . ............ 34 Schneider, K ............ 53 Schneider, M F . . . . . . . . . 43 Schneider, S............. 93 Schneider, $T$. ............ 30 Schneider, WJ ............. 15 Schneiter, R. . . . . . . . . . . . . 89 Schnitt, D..............96 Schnitt, J M . . . . . . . . . . . . . . . 96 Schnittmann, SM . . . . . . . . . 97 Schnoor, T . . . . . . . . . . . . 73 Schnorr, TM ........ 3, 52, 89 Schoen, FJ ............... 10 Schoenbach, V . . . . . . . . . . . 34 Schoenbach, VJ ........... 15 Schoenberg, J . . . . . . . . . . . . 89 Schoene, R B .............. 37 Schoenfeld, I . ...........997 Schoepfle, GK ............. 20 Schölmerich, P............. 3 Scholte, $R \ldots \ldots \ldots \ldots \ldots 12$ Scholz, H ................43 Schommer, R R . . . . . . . . . 100 Schonfeld, IS .............. 34 Schönfelder, E . . . . . . . 29, 43 Schooler, C ........... 19, 34 Schoonard, J.............29 29 Schor, J ..............20, 24 Schotherfeld, A . . . . . . . . . . 7 Schottenfeld, D . . . . . . . . . 2, 4 Schottenfeld, RS . . . . . . . . . . 13 Schottes, C . . . . . . . . . . . . . 11 Schrader, S .............. 38 Schrader, SM . ............ 9 Schrag, PE .............. 89 Schramke, CJ............. 13 Schrauzer, GN . . . . . . . . . . . 63 Schrecker, T . ......... 54, 55 Schregle, J ............... 21 Schreiber, IS .............. 9 Schreiber, P . . . . . . . . . . . . . 58 Schreibwer, P............ 58 Schrenk, H H . . . . . . . . . . . . 30 Schrock, JR ............. 96 Schröder, R ................ 3 Schroeder, DJ ............. 102 Schroeder, S. ............. 11 Schroepfer, GJ . . . . . . . . . . . . 55 Schröer, CAP............ 97 Schröer, HT . . . . . . . . . . . . 97 Schubert, $F \ldots \ldots \ldots \ldots . . . . .3$ Schubert, $H \ldots \ldots \ldots \ldots \ldots 12$ Schubert, J . . . . . . . . . . . 33 Schuckmann, $F \ldots \ldots \ldots \ldots . . .3$ Schuemann, K . . . . . . . . . . 33 Schuh, J................ 102 Schühlein, W . . . . . . . . . . . 102
Schulberg, HC . . . . . . . 34, 39 39 Schüldt, K . . . . . . . . . . 6 Schuler, RS ........... 29, 34 Schulgen, $G \ldots \ldots \ldots \ldots \ldots$. . . 9 Schull, W . . . . . . . . . . . . . . 48 Schull, WJ . . . . . . . 10, 39, 48 Schulte, PA . . . . . . 8, 10, 23, 28, $56,64,93$

Schultes, RE ............. 53

Schultz, D . ........... 96

Schultze-Werninghaus, G . . . . 63

Schultz-Wild, R . . . . . . . . . . 29

Schulz, FH ............... 3

Schulz, KH . . . . . . . . . 64

Schulze-Schencking, M ....... 9

Schuman, SH . . . . . . . . . . . 64

Schumann, AM ......... 30, 33

Schumann, J ............. 80

Schurig, U ............. 43

Schurman, D . ............ 6

Schurman, S] . ............. 56

Schurman, SJ . . . . . . . . . 3, 34

Schuster, M M ............. 34

Schutz, A . . . . . . . . . 12, 88

Schütz, A . . . . . . . . . . 66

Schuyler, M .............. 10

Schwab, C ............... 70

Schwabe, CW ............ 28

Schwanninger, U .......... 52

Schwartz, BS . . . . . . . . . . . . 11

Schwartz, CA ............ 49

Schwartz, D . . . . . . . . . . . 9

Schwartz, DA......... 10, 72

Schwartz, GE . . . . . . . . . . 17

Schwartz, GR ........... 14

Schwartz, HH . . . . . . . . . . 7

Schwartz, HJ . . . . . . . . 10, 100

Schwartz, J........... 11, 34

Schwartz, JE . . . . . . . . . . 34

Schwartz, LW ............. 10

Schwartz, M............. 15

Schwartz, NB........... 9

Schwartz, PM ............ 9

Schwartz, WA . . ......... 97

Schwarz, M ............. 33

Schwarz, SP . . . . . . . . . . 34

Schwarze, $5 \ldots \ldots \ldots \ldots \ldots . . \ldots$

Schwarzenau, P . . . . . . . . . 43

Schweiger, DM . . . . . . 29, 34

Schweisfurth, H . . . . . . . . . 11

Schweizer, J . . . . . . . . . . 33

Schweizerische U nfall-

versicherungsanstalt

(SUVA).

Schwela, DH . . . . . . . . . . . 55

Schwickerath, $H \ldots \ldots \ldots \ldots 11$

Schwing, RC . . . . . . . . . . . 59

Schwitteck, M ........... 43

Sclare, G . . . . . . . . . . . . . . . 10

Scofield, ME ............. 15

Scolari, FG . . . . . . . . . . . . . . 100

Scorcetti, G . ............. 65

Scott $V$ an Fossen, D . . . . . . . . 10

Scott, AJ . . . . . ..... 29, 34, 43 


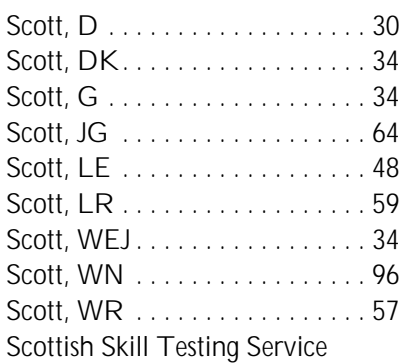

(SST S) . . . . . . . . . . . . . . 68

Scotto, J . . . . . . . . . . . . . . . 49

Scribner, RA . . . . . . . . . . . . 51

Scuderi, P.............. 10

Seacat, $\mathrm{H} \ldots \ldots \ldots \ldots \ldots . . .63$

Seals, J ............... 96

Seamon, PJ .............. 10

Seashore, LK . . . . . . . . . . . . . . 19

Seaton, A . . . . . . . . . . 10, 70

Seaton, J. . . . . . . . . . . . . . . . 10

Seay, $S \ldots \ldots \ldots \ldots \ldots \ldots$

Sebastian, M ............ 40

Sebastian, NC . . . . . . . . . . 64

Sébastien, P .............. 10

Sébillotte, $S \ldots \ldots \ldots \ldots \ldots 52$

Seddon, JM ............... 5

Sedman, T . . . . . . . . . . . . . . 96

Seeber, AE . . . . . . . . . . . . 43

Seegal, $\ldots \ldots \ldots \ldots \ldots \ldots . . . . .93$

Seegal, JL . . . . . . . . . . . . . . . 93

Seemayer, TA . . . . . . . . . . 10

Sega, R................4 43

Segal, $S \ldots \ldots \ldots \ldots \ldots . . . .6$

Segerback, D . . . . . . . . . . . . 27

Seibt, A ............... 43

Seidal, K ..............6 63

Seidel, D ................ 34

Seidel, $H \ldots \ldots \ldots \ldots \ldots . \ldots 50$

Seidel, $K \ldots \ldots \ldots \ldots . . .444$

Seidell, JC .............. 15

Seidenari, S . . . . . . . . . . . 89

Seidl, G . . . . . . . . . . . . 6

Seidler, E . ............... 97

Seidman, $H \ldots \ldots .10,28,30,32$

Seifert, B ................ 32

Seifert, $H \ldots \ldots \ldots \ldots \ldots .4$

Seifert, J . . . . . . . . . . . 44

Seigler, HF . . . . . . . . . . . . 12

Seiji, M................ 49

Seiler, JP . ............... 30

Seinen, $W \ldots \ldots \ldots \ldots . . . .33$

Seixas, NS ................ 30

Sejersted, O M ............6 6

Sekimpi, DK ..........64, 65

Selby, GB.............. 1

Selevan, SG ............ 9

Seligman, M EP . . . . . . . . . 34

Seligman, PJ..... . 32, 94, 98, 100

Selikoff, II .......... . 9, 10, 19,

$23,28,30,32$

Sellakumar, AR ........... 100

Sellers, P. . . . . . . . . . . . . . 53

Selner, JC . ............... 13

Seltzer, $F \ldots \ldots \ldots \ldots$. . . . . 97
Seltzer, J. . . . . . . . . . . . . 34

Selvin, $S \ldots \ldots \ldots \ldots \ldots$ 3, 83

Selye, $H \ldots \ldots \ldots \ldots \ldots . \ldots 34$

Selzer, M L . . . . . . . . . . . . . . . . 15

SEM ATECH . ........... 83

Semchuk, K M ....... 7, 64, 70

Semeijn, J. . . . . . . . . . . . . 102

Semenciw, R .............

Semenciw, RM . ...........64 64

Semenenko, AD . ...........11

Semmer, N. . . . . . . . . . . . . . 43

Semorin, RJ . .............. 39

Sen G upta, DN . . . . . . . . . . . 70

Sen, R N . . . . . . . . . . . 29, 64

Senden, TH . ............ 97

Senecal, JA . . . . . . . . . . . . . 77

Senevirane, SR . . . . . . . . 97

Senft, $V \ldots \ldots \ldots \ldots . . . . .63$

Senge, $P \ldots \ldots \ldots \ldots \ldots 18,34$

Seniori, C . ................ 88

Sennewald, E........... 44

Senthilselvan, A . . . . . . . 64, 70

Seppäläinen, AM H . . ......... 7

Seppanen, $0 \ldots \ldots \ldots \ldots \ldots 13$

Sepulveda-A mor, J.......... 53

Serafin, J ............... 10

Serdula, M K .............. 15

Sergean, R . . . . . . . . . 29, 43

Sergysels, $R \ldots \ldots \ldots \ldots \ldots 10$

Serig, DI ...............997

Serrano, P ..............53

Serrano, S ............... 39

Serrrano, CV . ............. 24

Service, WS . . . . . . . . . . . . . 70

Sessions, R B............. 10

Sessle, BJ . ................ 11

Sestito, J . . . . . . . . . . . . . 32

Sestito, JP . . . . . . . . . . . . 32

Seta, JA . . . . . . . . . . . . . . 32

Sethi, AA . . . . . . . . . . . . . 29

Setiadi, B . . . . . . . . . . . . . 34

Settle, R G ............. 11

Sever, JL . ............... 97

Sever, LE . . . . . . . . . . . . . . 9

Severson, $\mathrm{HH} \ldots \ldots \ldots \ldots . . .3$

Seyfried, E . . . . . . . . . . . . 17

Seyoum, G . . . . . . . . . . . . . 97

Shackel, B . . . . . . . . . . . . . 29

Shadick, NA . . . . . . . . . . . . . 3

Shafai-Sahrai, Y............59 59

Shafik, M T . ............ 27

Shah, F............... 83

Shahal, B ............... 3

Shahnavaz, H ........ 17, 29

Shaikh, R ...................... 30

Shakir, KM M ...........42 42

Shalat, SL ........... 87, 89

Shale, JH . . . ........... 97

Shamoo, A . . . . . . . . . . . . . 19

Shan, W...............6 63

Shanan, J . . . . . . . . . . . . . . 34

Shankar, BS ............. 56

Shanklin, JD . . . . . . . . . . . . 53

Shannon, BC . . . . . . . . . . . 34
Shannon, HS . . . . . . 10, 56, 59 Shannon, M W . . . . . . . . . . . . 9

Shao, $Y \ldots \ldots \ldots \ldots . . . . . .34$

Shapira, Z . ............. 59

Shapiro, CN . ............. 97

Shapiro, D . . . . . . . . . . . . 34

Shapiro, ET . . . . . . . . . . . . 97

Shapiro, IM ............. 19

Shapiro, J......... 32, 48, 93

Shapiro, RA ............. 97

Shapiro, S ............... 15

Sharapova, YEN ........... 10

Shariff, N . . ............... 22

Sharma, M P............. 11

Sharma, TP ............. 41

Sharp, D ................ 53

Sharp, DS ............... 3

Sharp, $H \ldots \ldots \ldots \ldots \ldots 2$

Sharp, JT ............... 6

Sharpe, JA .............. 11

Sharpe, RM .............. 9

Sharphorn, DH ............ 19

Shaver, FM .............96 96

Shaver, PR ............... 34

Shaw, CR............... 33

Shaw, EG.............. 6

Shaw, $H \ldots \ldots \ldots \ldots \ldots \ldots 12$

Shaw, JB ...............29 29

Shaw, LK ............. 100

Shaw, MLG ............. 52

Shawn, M B ............... 3

Shea, S.................. . 3

Shearwood, W . ........... 97

Sheedy, JE . . . . . . . . . . . . . . 11

Sheehy, JK .............. 83

Sheehy, JW . . . . . . . . . 63, 83

Sheehy, M P . . . . . . . . . . . 6

Shelby, M D .............. 33

Sheldon, TA . ............ 20

Shelef, G ................ 55

Shell, RL ............... 34

Shellenberger, S........... 5

Shelton, D . . . . . . . . . . . . . . 54

Shelton, GL . . . . . . . . . . . 96

Sheon, RP . . . . . . . . . . . . 6

Shepard, RD . . . . . . . . . . . . 43

Shepard, T............... 9

Shephard, RJ . . . . . . . . . . . 3

Shephare, EA. ............. 33

Shepherd, A . . . . . . . . . . . . 52

Shepherd, J . . . . . . . . . . . 51

Sheppard, AR . ...........4 49

Sheppard, D. . . . . . . . . . . . . . 10

Sheppard, RA ............. 32

Sheps, CG . . . . . . . . . . . . . 18

Sheps, DS. . . . . . . . . . . . . 3

Sheps, M D . . . . . . . . . . . . 9

Sherer, $P \ldots \ldots \ldots \ldots \ldots 21$

Sheridan, $T$. . . . . . . . . . . 58

Sherin, BJ.............. 83

Sherlock, SPV . . . . . . . . . 4

Sherman, A . . . . . . . . . . . . 83

Sherris, C . . . . . . . . . . . . 31

Sherris, JC . . . . . . . . . . 38
Sherson, D . . . . . . . . . . . 70

Sherwood, JB . . . . . . . . . . . . . . 3

Shi, $N \ldots \ldots \ldots \ldots$. . . . . . . 89

Shi, $X \ldots \ldots \ldots \ldots \ldots . \ldots 10$

Shiba, S . . . . . . . . . . . . 34

Shields, PG ........... 28

Shilling, S................. 32

Shilon, $M \ldots \ldots \ldots \ldots \ldots 9$

Shima, S................ 5

Shimizu, $Y \ldots \ldots \ldots \ldots \ldots 10$

Shimomitsu, T ........... 5

Shindo, E. . . . . . . . . . . . 97

Shindo, H ............29

Shinghthong, B . . . . . . . . 38

Shinn, M ............... 34

Shiono, PH ............. 9

Shipley, M . ............... 34

Shipley, M T . . . . . . . . . . . 11

Shipley, W . . ............ 8

Shitzer, A . . . . . . . . . . . 42

Shivhare, US . . . . . . . . . . 70

Shkarinov, LN . . . . . . . . . . . 47

Shneiderman, B . . . . . . . . . . . 52

Shope, RE ................ 53

Shore, DL ............... 1

Shore, RE . . . . . . . . . 39, 48

Short, B . ................ 33

Short, JF............... 59

Shorter, E. . . . . . . . . . . . . 13

Shortreed, JH . . . . . . . . . . . 101

Shostak, AB . . . . . . . . . . . . 102

Shotton, R . . . . . . . . . . . . . . 57

Showalter, PS. . . . . . . . . . 95

Shrey, D................ 17

Shrivastava, DK .......... 101

Shrock, DL . ............. 102

Shugaar, A . . . . . . . . . . . 29

Shukla, K P. . . . . . . . . . . . 96

Shulka, J. . . . . . . . . . . . . 53

Shulman, SA ............. 92

Shumacher, MJ . .......... 70

Shumaker, S. .............. 34

Shumnes, E . . . . . . . . . . . . . 79

Shupak, A ..............66 66

Shurg, A............... 10

Shusterman, D . . . . . . . . 10, 11

Shuter, D . . . . . . . . . . . . . 27

Shutske, JM . . . . . . . . . . . . . 64

Shy, C ............ 53, 100

Shy, CM ............80, 100

Siblerud, RL ............. 11

Sidell, FR . . . . . . . . . . . . . 95

Sidman, J . . . . . . . . . . . . 13

Sieber, U . . . .............43 43

Sieber, WK . . ............ 93

Siegel, A . .............. 97

Siegel, E . . . . . . . . . . . . . 9

Siegel, H A . . . . . . . . . . . . 19

Siegel, M . . . . . . . . . . . 11, 70

Siegell, JH ............. 77

Siegrist, J ............. 3, 34

Siekewitz, P . . . . . . . . . . 33

Siemiatycki, J ...... 1, 2, 4, 12,

$28,72,89$ 
Sienkiewicz, ZJ . .........49 Sienko, DG .............. 7 Sienra, J................ 53

Siest, G................. 33

Sievers, K . . . . . . . . . . . 6

Sigal, SL . . . . . . . . . . 87, 89

Sigala, F . . . . . . . . . . . . 3

Sigelmen, $5 \ldots \ldots \ldots \ldots \ldots 48$

Sigholm, G . . . . . . . . . . 6

Sigler, JA ............... 23

Sigman-G rant, M J . . . . . . . . 15

Sigmon, R . . . . . . . . . . . . 33

Sigsgaard, T . . . . . . 10, 70, 101

Sigsgaard, TI . . . . . . . . . . . 9

Sikstorm, E. . . . . . . . . . . 38

Silaev, AA .............6 63

Silano, V ................ 39

Silberg, MJ.............. 34

Silbergeld, EK . ........... 33

Silflow, RM .............. 10

Silva, FG ............. 8

Silvaggio, $T \ldots \ldots \ldots \ldots \ldots$.

Silverman, B . ........... 15

Silverman, C . ........... 49

Silverman, DJ . ........... 89

Silverman, DT . . ......... 96

Silverman, SB ............ 34

SilverPlatter ............. 22

Silverstein, B . . . . . . 6, 52, 91

Silverstein, M . . . . . . . . . . . 91

Silverstone, $D$. . . . . . . . . . . 94

Silvestri, G . ............ 99

Sim, M R .............. 13

Sim, TC . .............97 97

Simard, M . . . ........ 21, 59

Simcox, $N J \ldots \ldots \ldots \ldots \ldots .64$

Sime, W............... 19

Sime, WE.............. 34

Simeone, FA ...........6 6

Simma, B............... 54

Simmons, BP ..........6, 97

Simmons, DH ............ 10

Simmons, JM ............. 41

Simmons, M P .............66 66

Simmons, RB............ 13

Simon, B ............... 15

Simon, GE.............. 13

Simon, $H \ldots \ldots \ldots \ldots \ldots . \ldots 59$

Simon, HA........... 29, 59

Simon, J................. 39

Simon, M M .............. 3

Simon, SL .............. 48

Simonato, $L \ldots \ldots \ldots \ldots \ldots 28$

Simonato, L . . . . . . 2, 10, 82, 88

Simonds, RH . . . . . . . . . . 59

Simonis, AM ............ 33

Simons, DG . . . . . . . . . . . 6

Simonsen, $L \ldots \ldots \ldots \ldots \ldots \ldots$. . . . . . . . . . . .

Simor, AE ............... 38

Simpson, DM............. 3

Simpson, JM .............44

Simpson, WM , Jr. . . . . . . . . 64

Sims, RR .............. 34

Sin, $A \ldots \ldots \ldots \ldots \ldots \ldots$
Sinaiko, WH ............ 29

Sinclair, AI. .............11

Sinclair, TC . ............ 56

Sinclair, V ............. 24

Sindicato Internacional de

Empleados de Servicios

(SEIU) ................. 51

Singal, $M \ldots \ldots \ldots \ldots \ldots 10$

Singer, JE . . . . . . . . . . . . . 34

Singer, $K \ldots \ldots \ldots \ldots \ldots 96$

Singer, M V .............. 34

Singgih, SIR . . . . . . . . . 100

Singleton, WJ.............4 43

Singleton, WT . . . . . . . 29, 59

Singson, RD ............. 6

Sinha, TN .............. 34

Sininscalco, C . .......... 54

Sinks, $T \ldots \ldots \ldots \ldots 9,10,85$

Sinks, TH . . . . . . . . . . . 12

Siple, PA .............. 42

Siraj, M F .............. 22

Sirianni, $C \ldots \ldots \ldots \ldots \ldots . \ldots 5$

Siroky, M B............. 7

Sittig, $M \ldots \ldots \ldots \ldots \ldots 63$

Siwek, R................ 77

Siwinski, G............. 64

Sjårgaard, G . ........... 52

Sjöden, PO . .......... 52, 97

Sjøgaard, B ............. 6

Sjøgaard, G . . . . . . . . 6, 87

Sjögren, B ..............6 63

Skalpe, $10 \ldots \ldots \ldots \ldots . . .72$

Skaptadóttir, UD . . . . . . . . 66

Skau, K A ................ 11

Skeith, KJ ..............6

Skerfving, S .............66 66

Skevington, SM ..........6 6

Skillicorn, P . . . . . . . . . . . . 64

Skinar, M . . . . . . . . . . . . . 96

Skinner, H A . . . . . . . . . . . . 15

Skinner, HCW . . . . . . . . . . 10

Skipper, P. . . . . . . . . . . . 28

Skipper, PL . . . . . . . . . . . . 44

Skjei, EW . . . . . . . . . . . . . . 43

Sklar, EM ............... 14

Skocik, D . . . . . . . . . . . . . . . . . 102

Skodol, AE .............. 5

Skor, $T \ldots \ldots \ldots \ldots . \ldots 87$

Skornik, WA ............ 10

Skoupy, A ......... 68, 78

Skov, P............... 13

Skredtvedt, OT .......... 31

Skyberg, K . . . . . . . . . 11, 68, 78

Slaga, $T \ldots \ldots \ldots \ldots \ldots . \ldots 30$

Slanina, J ................ 55

Slappendel, C . . . . . . . . . 68

Slater, J . . . . . . . . . . . . . . 49

Slater, JE . . . . . . . . . . . . . 80

Slavicek, R .............. 63

Slease, R B . . . . . . . . . . . 1

Sleeman, PJ . . . . . . . . . . . 94 94

Slighter, R . . . . . . . . . . . . 32

Slikker, W .............. 7

Sliney, D . . . . . . . . . . . 96
Sliney, DH . . . ............ 49

Sliwinska, E . . . . . . . . . . . 42

Sloan, M F . . . . . . . . . . . . . 10

Sloan, R P................ 15

Slocombe, RF . . . . . . . . . . . 10

Slocum, JWJ .......... 34, 59

Slora, K B ................ 34

Slovic, P............... 59

Sluis-C remer, GK . . . . . . . . 10

Sly, K................ 100

Smagghe, $G \ldots \ldots \ldots \ldots \ldots \ldots 3$

Smaggle, $G \ldots \ldots \ldots \ldots \ldots 63$

Smedt, DE . . . . . . . . ...... 97

Smith, A . . . . . . . 3, 10, 43, 80

Smith, $A B \ldots \ldots \ldots \ldots 13,100$

Smith, $A C \ldots \ldots \ldots \ldots . \ldots 74$

Smith, AG .............. 9

Smith, AH ............. 3, 80

Smith, AP.............. 43

Smith, CP .............. 79

Smith, CS .............. 92

Smith, D ........... 10, 70

Smith, DJ . . ......................... 36

Smith, DV ............... 11

Smith, E................ 33

Smith, EC . ............. 52

Smith, EM ............ 33, 34

Smith, EM B............. 33

Smith, $G \ldots \ldots \ldots \ldots . . . . .97$

Smith, GD ................. 3

Smith, GJW .............. 10

Smith, GS .............. 56

Smith, $H \ldots \ldots \ldots \ldots \ldots 48$

Smith, J ................. 48

Smith, JB . .............. 53

Smith, JC ................9

Smith, JL . . . . . . . . . . 4, 29, 58

Smith, JW ............... 101

Smith, KC . . ............ . 49

Smith, KD .............. 9

Smith, KR .............. 34

Smith, L . . . . . . . . . 40, 43, 68

Smith, M ........ 5, 9, 34, 68

Smith, MJ . . 6, 29, 34, 52, 59, 97

Smith, M L . . . . . . . . . . . . . . 15

Smith, M T . . . . . . . . . . . . 1

Smith, NJ . . . . . . . . . . 27, 97

Smith, $P \ldots \ldots \ldots \ldots \ldots . . .43$

Smith, PA............. 84

Smith, PB................ 34

Smith, PE ........... 3, 42

Smith, PG .............. 10

Smith, RA . ............... 11

Smith, RB ............ 17, 59

Smith, RE ............ 100

Smith, RF . .............6 64

Smith, R G . ...........11, 30

Smith, RP . . . . . . . 11, 85, 101

Smith, S . . . . . . . . . . . . . 96

Smith, SL . . . . . . . . . 41, 52

Smith, TA .............. 59

Smith, TJ ............. 28

Smith, TJ ........ 10, 30, 68, 91

Smith, WA ............ 28
Smith-Coggins, $R \ldots \ldots \ldots .97$

Smith-Schneider, L M . . . . . . . 15

Smolander, J . .............6 6

Smolensky, M ............43

Smolik, HJ ................ 3

Smolik, R................. 3

Smook, GA ............. 72

Smorgawiewicz, W ........ 44

Smoyer, KE . . . . . . . . . . . . 53

Smulders, $P \ldots \ldots \ldots \ldots \ldots \ldots$

Smulders, PGW . . . . . . . . . . 97

Smulevich, V B . . . . . . . . . . 80

Smulson, ME . . . . . . . . . . . 33

Smyth, HF . . . . . . . . . . . 30

Smyth, JA................ 53

Smythe, HA............ 6

Snashall, D .............. 28

Sneddon, IB . . . . . . . . . . . . 9

Snee, M P . . . . . . . . . . . 9, 48

Snee, $R \ldots \ldots \ldots \ldots \ldots . \ldots 30$

Snella, M-C . . . . . . . . . . . 10

Snidman, NC . . . . . . . . . . 34

Snoek, JD . . . . . . . . . . . . . . 34

Snoke, W . . . ............ 97

Snook, S............... 52

Snook, SH ........... 6, 97

Snow, BR .............. 52

Snow, C ............... 97

Snow-Antle, S . ............ 15

Snyder, CA ............. 100

Snyder, HL . . . . . . . . . . . . 29

Snyder, JW............... 96

Snyder, K.............. 64

Snyder, L . . . . . . . . . . . . . . . 102

Snyder, R............ 1, 3

Snyderman, BB ........... 34

Sobczak, PM . ............ 64

Sobel, E ............ 7, 87

Sobels, FH . . . . . . . . . . . 30

Sober, DJ ............... 83

Sobolov, M .............6 65

Social Sciences and $H$ umanities

$R$ esearch Council of

Canada.............. 19

Societé française d'énergie

nucléaire ............. 53

Society for M ining,

$M$ etallurgy and Exploration

(SME) .

Society for N utrition

Education .............. 15

Society for Prospective

M edicine.............

Society of Automotive

Engineers (SAE) . . . 56, 58, 93

Society of Environmental

Toxicology and Chemistry

(SETAC)............ 54

Society of the Plastics Industry . 77

Society of T ribologists and

Lubrication Engineers

(ST LE) . ............. 77

Sockrider, M M .......... 9

Soda, M . . . . . . . . . . . . . 48 
Söderfeldt, B . . . . . . . . . . 7

Soderman, E . . . . . . . . . . . 86

Söderström, D . . . . . . . . . 11

Sofue, I. . . . . . . . . . . . . . 96

Sogaard, K ............. 100

Sohn, RS ...............6 6

Sohnle, PG . . ............ 10

Sokas, P ................ 13

Sökeland, J.............. 97

Sokol, RZ ............... 52

Sokolov, JJ ................ 15

Sokolska, G . ............. 49

Solano, D . . . . . . . . . . . . . . . 10

Solari, A .................. 3

Solberg, YJ........... 11, 64

Solé, M D . ................ 44

Solé, M G ................ 46

Solet, D ................. 72

Solgaard, J . . . . . . . . . 11, 86

Soliman, AK . . . . . . . . . . . 101

Solinger, J . ............ 887

Solionova, LG ............ 80

Solomon, CM ............29

Solomon, PA .............. 55

Solomon, SR ............. 34

Sommer, K ............. 29

Sommer, R .............. 34

Sommerich, $\mathrm{CM} \ldots \ldots \ldots \ldots 80$

Sommese, $T \ldots \ldots \ldots \ldots \ldots . . . .34$

Sonbolian, N . . . . . . . . . . . 10

Sonn, E ................ 52

Sonnenberg, ASM ..........64 64

Sonnenblick, BP. . . . . . . . . 48

Sonnerfeld, NL . . . . . . . . . . . . 9

Sorahan, R............. 80

Sorbowale, NC . . ...........997

Sorensen, G . . . . . . . . . 15, 34

Sorensen, W............. 101

Sorenson, R . . . . . . . . . . . 34

Sorenson, W G . . . . . . . . 38, 44

Sorsa, $M \ldots \ldots \ldots \ldots .9,28,80$

Sorvali, P ............... 29

Soskolne, CL . . . . . . . 19, 28, 101

Soto, $R \ldots \ldots \ldots \ldots \ldots \ldots$

Souchkevitch, G............ 39

Soudine, A . . . . . . . . . . . . 55

Souter, CA .............. 10

Souter, FCG ........... 95

Soutern, DJ ............... 3

South Australian $\mathrm{H}$ ealth

Commission Epidemiology

Branch ............... 52

South, M A . . . . . . . . . . . . 97

Southam N ews. . . . . . . . . . . 101

Southee, $J \ldots \ldots \ldots \ldots \ldots . \ldots 33$

Southwood, KE ............ 34

Southwood, R ............. 10

Sovet, U . . ............... 100

Søvik, G...............66 66

Soyinka, $F \ldots \ldots \ldots \ldots \ldots 97$

Soyseth, V ............... 10

Sozialversicherung der

Bauern...............6 68

Spaans, F . . . . . . . . . . . . . 7
Spacapan, S ............. 34 Spadafor, Cl ..............28

Spadafor, CJ ..............33

Spandorfer, M . ............96 96

Sparer, J............ . 87, 89

Sparke, P ............... 29

Sparrow, D ............ 3, 95

Spcikett, JT .............. 3

Spear, RC ................. 3

Spector, P............... 34

Spector, PE ................ 34

Speizer, FE. . . . . . . 10, 53, 97

Spelten, E. . . . . . . . . . . . . 43

Spence, AA ............. 97

Spence, IP . . . . . . . . . . . . 38

Spence, R................ 39

Spencer, AB . . . . . . . . . . . 100

Spencer, DJ . . . . . . . . . . . . 89

Spencer, PJ . . . . . . . . . . . 63

Spencer, PS . ........... . 7, 33

Spengler, R . . . . . . . . . . . . 59

Sperandio, JC ............29

Sperling, L . . . . . . . . . . . . . . 29

Spetz, C-L ............. 3, 43

Spice, B ................. 19

Spiegelman, D . . . . . . . . . . 30

Spielberger, CD . ............ 34

Spielman, AL ............11

Spilker, B . ................ 79

Spinaci, S. . . . . . . . . . . . . 101

Spinas, P . . . ............29 29

Spinelli, JJ ............. 32, 100

Spira, W...............664

Spirtas, R ............. 28

Spirtas, R . . . . . . . . 32, 6, 80

Spitzer, RE ............... 5

Spitzer, WO . ...........6

Spivey, GH . . . . . . . . . . 28

Spivey, GH ............ 19

Spokane, AR ............... 34

Spottiswood, DJ . ........... 74

Sprau, D ................ 101

Spreafico, F ............... 33

Sprince, NL . . . . . . . . . . 10,63

Springer, AM . ............ 72

Springer, J ............. 82

Springfeldt, B........... 58

Spritz, M R . . . . . . . . . . . . 72

Sprößig, M .............. 3

Spundin, D ............... 32

Spurgeon, A . . . . . . . . . . . 34

Spurzem, JR .............. 39

Srivastava, AK ............. 5

Srivastava, P. ............ 97

St. Paul Fire and $M$ arine. . . . . . 34

St.-Jacques, C .............21

Staal W ästerlund, D . . . . . . . . 68

Stachel, B................ 9

Stack, S ................. 34

Stadler, JC . .............. 10

Staessen, J ...............6 63

Stafford, FW ............. 11

Staines, G. . . . . . . . . . . . 34

Stair, R. . . . . . . . . . . . 49
Stallen, PJ............... 59

Stallones, $L \ldots \ldots \ldots \ldots \ldots$. . . . . 10

Stamm, R..............61 61

Stammerjohn, L. . . . . . . . 34, 52

Stamoy, J ................ . 8

Stanbury, M . . . . . . . . . . . . 32

Stanley, CF .............. 10

Stanley, JM ............... 3

Stannard, JN . . . . . . . . . . . . . 48

Stansfeld, SA . . . . . . . . . . 34

Stanton, J . . . . . . . . . . . . . . . 22

Stanton, M F. . . . . . . . . . . . 10

Stara, JF . . . . . . . . . . . . . . . 30

Staramler, JH . . . . . . . . . . . . 29

Stark, AD ................ 39

Starkman, BS . . . . . . . . . . . 79

Starr, C . ........... 59, 60

Starr, HG.............. 9

Starr, JC ............... 100

State of 0 hio . ............ 55

Statistical Abstract of the

U nited States. . . . . . . . . . . 16

Statistics Canada . . . . . . . . 71, 93

Statistisches Bundesamt. . . . . . . 53

Staudt, F . . . . . . . . . . . 68

Stauffer, R N . . . . . . . . . . . . 97

Stave, GM . . . . . . . . . . 15, 86

Staveland, LE . . . . . . . . . 29

Staw, BM . . . . . . . . . . . 29, 34

Stayner, $L \ldots \ldots \ldots \ldots \ldots \ldots$

Stayner, LT . . . . . . . . . . . . 100

Steadman, $\mathrm{HJ} \ldots \ldots \ldots \ldots \ldots$

Stechschulte, DJ . . . . . . . . . 10

Steckler, AB . . . . . . . . . . . 56

Steel, J . . . . . . . . . . . 64, 640

Steele, FI . . . . . . . . . . . . . . 34

Steels, MJ ................ 3

Steenland, K . . . . . . . 9, 73, 89

Steeno, $0 \ldots \ldots \ldots \ldots \ldots . . . . .9$

Steensberg, J ............66

Steere, AC ............... 3

Steers, RM . . . . . . . . . . . . 56

Steffensmeier, DJ . . . . . . . . . . . 34

Stein, A . . . . . . . . . . 10, 43

Stein, D . . . . . . . . . . . . . 102

Stein, DS . . . . . . . . . . . 97

Stein, Z .............. 9

Steinberg, L . . . . . . . . . . . . . . . . 34

Steinberger, $E \ldots \ldots \ldots \ldots . .9$

Steineck, G . . . . . . . . . . . . . 100

Steiner, B . . . . . . . . . . . . 70

Steinert, G . . . . . . . . . . 94, 97

Steinfeld, E............. 34

Steingrímsdóttir, O A . . . . . . 6

Steinke, WE . . . . . . . . . . . . . 64

Steinmetz, C . . . . . . ...... 97

Steinwachs, DM .......... 56

Stellman, JM ......... 23, 34,

$52,97,99,103$

Stellman, SD . . . .

$28,86,97$

Stelmach, GE.............. 59

Stem, C . . . . . . . . . . . . . 70

Stenberg, B ............ 13

Stengel, $B \ldots \ldots \ldots \ldots \ldots \ldots \ldots 28$
Stenlund, B . . . . . . . . . . 6

Stenman, E . . . . . . . . . . . . 11

Stenson, S . . . . . . . . . . . . 49

Stephens, D . . . . . . . . . . . . 11

Stephens, PM . . . . . . . . . . . . 34

Stephens, RE . . . . . . . . . . . 96

Stephens, RJ . . . . . . . . . . . . . 10

Stephens, $T$. . . . . . . . . . . 3

Steppacher, RC . . . . . . . . 97

Steptoe, A ............... 34

Sterenborg, HJCM ......... 49

Sterling, DA . . . . . . . . . . . . . 97

Sterling, TD . . . . . . . . . . . 38

Stern, AC . . . . . . . . . . . . . . 55

Stern, $F \ldots \ldots \ldots \ldots$ 32, 88

Stern, FB . . . . . . . . 3, 85, 88

Sternbach, D . . . . . . . . . . . 5

Sternberg, KJ . . . . . . . . . . . 34

Sternheim, M M . . ........ 40

Stevens, C . . . . . . . . . . 88, 97

Stevens, CE . . . . . . . . . . 97

Stevens, D . . . . . . . . . . . . . 21

Stevens, EAM ............. 70

Stevens, JC . . . . . . . . . . . . 11

Stevens, JF . . . . . . . . . . . . 63

Stevens, W . . . . . . . . . . . . . 48

Stevens, WC . . . . . . . . . . . 97

Stevens, WK ............ 53

Stevens, WS . . . . . . . . . . . . 48

Stevenson, K . . . . . . . . . . 55

Stewart, CJ..............64 64

Stewart, J.............. 83

Stewart, JH ............ 83

Stewart, P......... . 71, 100

Stewart, R ............ 96

Stewart, SC . . . . . . . . . . 15

Stewart, TFM ............ 52

Stewart, W . . . . . . . . . . . 11, 34

Stezhka, V A . . . . . . . . . . . . 39

Stickl, H................ 3

Stidham, KR ........... 12

Stieglitz, P . . . . . . . . . . 97

Stiglin, LE . . . . . . . . . . . . . . 5

Stijnen, J . . . . . . . . . . . . 57

Stiles, AR . . . . . . . . . . . 62

Stiles, D . . . . . . . . . . . . . . 5

Stille, WT . .............. 10

Stirling, $Y \ldots \ldots \ldots \ldots \ldots \ldots . . . . .3$

Stitzer, M L. . . . . . . . . . . . 15

Stjernberg, EI . . . . . . . . 68

Stobbe, $H \ldots \ldots \ldots \ldots \ldots . \ldots$

Stock, $5 \ldots \ldots \ldots \ldots \ldots \ldots 6$

Stockbridge, H . . . . . . . . 13

Stockholm MUSIC Study

Group $1 \ldots \ldots \ldots \ldots \ldots 6$

Stockholm W orkshop $86 \ldots . . .50$

Stoddart, GL . . . . . . . . . . 20

Stokinger, $\mathrm{HE} \ldots \ldots \ldots \ldots . \ldots 30$

Stoklov, M . . . . . . . . . . . . 97

Stokols, D............... 34

Stolarski, R ............. 53

Stolk, JM ............... 5

Stolk, $T \ldots \ldots \ldots \ldots \ldots \ldots 68$

Stollenz, E . . . . . . . . . . . 68 
Stoller, $N \ldots \ldots \ldots \ldots \ldots . . .96$

Stolwijk, JA . . . . . . . . . . . . . 13

Stolz, JL . ................64

Stolzenberg, $\mathrm{H} \ldots \ldots \ldots \ldots \ldots . . .3$

Stone, ER ............... 59

Stone, $N\} \ldots \ldots \ldots \ldots \ldots .72$

Stone, PJ ............... 34

Stone, R............... 33

Stone, RA ............. 10

Stone, RS.............. 48

Stonecipher, LJ . ........... 26

Stoney, CM ............... 34

Stoppleman, M RH ........ 79

Storch, G . . . . . . . . . . . . . 64

Storer, JS .............. 97

Storey, E .............. 10

Storm, P-C ............. 54

Stössel, U . . . . . . . . . . . . . 94, 97

Stott, $H \ldots \ldots \ldots \ldots \ldots 89$

Stott, WT ............ 30, 33

Stout, M A ............ 56

Stout, $N \ldots \ldots \ldots \ldots \ldots . . . . .99$

Stout, RW ............... 3

Stoynev, A .............. 43

Strader, C . ............. 100

Straif, K .............. 80

Strang, $J \ldots \ldots \ldots \ldots \ldots \ldots .74$

Strang, P . . . . . . . . . . . . . 97

Strange, GR .............. 14

Stransky, L. . . . . . . . . . . . 64

Strassman, PA ............ 52

Stratton, J.............6 60

Straughan, JK ........... 80

Straus, R ............... 34

Strauss, M ............. 93

Straw, BM .............. 34

Streeck, W . . . . . . . . . . . . . 21

Streekvervoer N ederland. . . . . 102

Strehlke, B . . . . . . . . . . . 68

Streitz, $N \ldots \ldots \ldots \ldots \ldots . \ldots 52$

Strelka, F .............97

Strich, G ............ 73

Strickland, D . ............. 38

Strickland, PT . ........... 33

Stricoff, RS ............. 103

Strieter, R M . . . . . . . . . . . 10

Strohal, R.............6 63

Strohl, K P ............. 100

Strohm, $0 \ldots \ldots \ldots \ldots$ 29, 43

Strom, E............... 10

Strom, G ............. 13

Ström, M .............. 10

Stromberg, AH .......... 34

Strömberg, $U \ldots \ldots \ldots \ldots 66,88$

Stroschein, A . . . . . . . . . 42

Stroud, $C \ldots \ldots \ldots \ldots \ldots 66$

Strube, MJ ............... 34

Strudenmayer, H . .......... 13

Struwe, $G \ldots \ldots \ldots \ldots \ldots \ldots 7$

Stsjazhko, VA . ........... 39

Stubbs, DA............. 97

Stubbs, HA ............ 9

Stuchly, K ............ 49

Stuchly, M ............. 52
Stuchly, M A. . . . . . . . . . . 49 49

Stuck, BE . ..............49

Stucker, I . . . . . . . . . . . . 28

Stückrath, $M \ldots \ldots \ldots \ldots 61$

Studer, G . . . . . . . . . . . . . . 43

Stueland, D .............. 70

Stueve, A .............. 5

Stumpf, SA............. 34

Sturm, A .............68 68

Styf, J ................ 6

Su, WPD ...............6 63

Suadicani, P........... 3, 11

Suares, LT . ............... 3

Suarez Imazor, M E . . . . . . . . 28

Subramanian, K .......... 11

Suchindran, CM .......... 9

Suchman, EA .........60, 103

Suchsland, $0 \ldots \ldots \ldots \ldots . .71$

Suciu, I. . . . . . . . . . . . 79

Suess, MJ . .............. 49

Sugarbaker, J . . . . . . . . . . 93

Sugawa, $0 \ldots \ldots \ldots \ldots \ldots .41$

Sugimoto, $K \ldots \ldots \ldots \ldots \ldots$

Sugimoto, $N \ldots \ldots \ldots \ldots . \ldots 6,58$

Sugita, $T \ldots \ldots \ldots \ldots . \ldots 37$

Suh, M W . . . . . . . . . . . . . 89

Suissa, S . . . . . . . . . . . . . . 26

Sulatto, $F \ldots \ldots \ldots \ldots \ldots 65$

Sulkava, R ........... 7, 87

Sullivan, C . ........... 72

Sullivan, $F \ldots \ldots \ldots \ldots \ldots . \ldots 33$

Sullivan, HC . . . . . . . . . . 27

Sullivan, JB ........... 7, 64

Sullivan, LP . . . . . . . . . . . . . 29

Sullivan, MJ . . . . . . . . . . . 11

Sullivan, SL . . . . . . . . . . . . 11

Sulotto, $F \ldots \ldots \ldots \ldots \ldots 10$

Sulowski, AC . . . . . . . . . . 58

Suls, J . . . . . . . . . . . . . . 34

Sulty, H A . ............. 91

Sulzer-Azaroff, B . . . . . . . . . 59

Sumari, $P \ldots \ldots \ldots \ldots \ldots . . \ldots$

Summers, C . . . . . . . . . 19, 23

Summers, LA ............. 27

Sumpson, JM .............. 3

Sumrell, BM ............. 9

Sun M icrosystems, Inc. . . . . . . 52

Sundaresan, $N \ldots \ldots \ldots \ldots .6$

Sundberg, J . ........... 96

Sundborm, L . . . . . . . . . . . . . 34

Sundell, $]$............... 13

Sundell, L............... 7

Sunderman, FW, Jr . . . . . . . 63

Sundermann, A . . .......... 3

Sundin, A . . . . . . . . . . . . . . . 29

Sundin, DS .............. 32

Sundquist, E.......... 2, 32

Sundstrom, E................ 34

Sundström-Frisk C . . . . . . 68, 68, 97

Suokas, J ...............6 60

Suomäki, HL . . . . . . . . . 68

Super, DE . . . . . . . . . . . . 34

Supich, $C \ldots \ldots \ldots \ldots \ldots . \ldots 38$

Supple, K M ............. 6
Suppliers of Advanced

Composite $M$ aterials

Association (SACM A) . . . . . 90

Suresch, DL .............. 3

Surry, J............... 56

Suruda, A............. 40

Susan, S . . ............. 49

Susi, $P \ldots \ldots \ldots \ldots . . . . .93$

Susser, M ............ 9, 19

Susser, MW ............. 9

Suter, AH . ........... 30, 47

Sutherland, SK . .......... 38

Sutherland, VF . . . . . . . . . 59

Sutherland, VJ . . . . . . . 5, 34, 78

Sutter, C................. 33

Sutter, E............... 49

Sutton, CD ............. 34

Sutton, IS. . . . . . . . . . . . . . . 77

Sutton, JR .............. 37

Sutton, $\mathrm{PL} \ldots \ldots \ldots \ldots \ldots . \ldots 40$

Sutton, RI ............... 34

Suurküla, J ..............6 6

Suurnäkki, T . ............. 3

Suvorov, GA ............47 47

Svane, $0 \ldots \ldots \ldots \ldots \ldots 6$

Svanström, L . . . . . . . . . . 56

Svedenstål, N-M . . . . . . . . 52

Sveinsdóttir, $T \ldots \ldots \ldots \ldots 6$

Svenson, B-G . . . . . . . 66, 85

Svenson, $0 \ldots \ldots \ldots \ldots \ldots \ldots . \ldots 59$

Swaim, M . . . . . . . . . . . . . 15

Swaim, R ............... 15

Swain, AD .............. 59

Swan, S . . . . . . . . . . . . 34, 83

Swan, SH . . . . . . . . . . 52, 83

Swanbeck, G . ............. 52

Swann-D'E milia, B . . . . . . . . 97

Swanson, FA ............. 85

Swanson, JA . . . . . . . . . . . . . 34

Swanson, M C . .......... 97

Swanson, $N \ldots \ldots \ldots \ldots .6,64$

Swanson, NG . . . . . . . . . . . 34

Swarbick, J. . . . . . . . . . . . . 79

Swazey, JP ................ 19

Swedish Theatre Federation . . . 96

Sweeney, AM . . . . . . . . . . . . 33

Sweeney, JJ . .............. 34

Sweeney, M . . . . . . . . . . . . 88

Sweet, AY .............. 9

Sweeten, JM . . . . . . . . . . . . . . 70

Sweetnam, PM ........ 3, 89

Swenberg, J.............. 33

Swenberg, JA . . . . . . . . . . . 100

Swensson, A . . . . . . . . . 27, 43

Swerdlow, AJ . . . . . . . . . 2, 49

Swinnerton, KA .......... 20

Swiss Interdisciplinary Committee

for Biosafety in R esearch and

Technology (SCBS) . . . . . . 77

Sydow, B . . ............. 97

Symanski, E . . . . . . . . . 28, 30

Syme, SL . . . . . . . . . . . . 34

Symon, $K \ldots \ldots \ldots \ldots \ldots 11$

Symons, MJ . . . . . . . . . . . 9, 80
Syndercombe-C ourt, P . . . . . 3

Syracuse R esearch

Corporation.

Sysilampi, ML ......

System Safety Society . . . . . . . . . 58

Szabo, R M . . . . . . . . . . . . 7

Szabo, S................ 34

Szczerba, K . ............. 3

Szeszenia-D aborowaska, N . . . . 80

Szmigielski, S . . . . . . . . . . 49

Szudy, E................. 23

Szyazkowicz, M . ........... 33

Szyfres, B . ............ 3, 69

Szymezak, W . . . . . . . . . . 80

\section{$T$}

T abar, L.................. 15

T abershaw, IR . . . . . . . . . . . 10

T achakra, SS . . . . . . . . . . . 39

T aghizadek, K . . . . . . . . . . . 44

T agliacozzo, R ............ 99

Taguchi, S............. 9

Tait, K ............... 30

Takac, L................. 63

T akahashi, K ............ 16

Takai, $H \ldots \ldots \ldots \ldots \ldots \ldots 6$

Takala, J............. 16, 22

T akala, T . ............... 6

Takam, J . . . . . . . . . . . . 89

T akayanagi, $\mathrm{T} \ldots \ldots \ldots \ldots . .69$

Takeda, J . . . . . . . . . . . . . . 69

T akeuchi, S . . . . . . . . . . . 5

T alaska, G . ............. 28

Talbot, WH .............. 11

Talbott, E............... 3

Talijancic, A ............ 3

Talpaz, M .............. 1

Tamblyn, R M ............. 13

Tamblyn, RT . . . . . . . . . . 13

T ammeling, G] . . . . . . . . . 10

Tams, IP ................. 101

T amura, $T \ldots \ldots \ldots \ldots \ldots . . .42$

Tan, KT ............... 64

Tan, $\mathrm{SH} \ldots \ldots \ldots \ldots \ldots \ldots 22$

Tan, TC . . . . . . . . . . . . . 96

T anaka, S...... . 3, 32, 79, 100

T anaka, T ............... 97

Tandon, R .............. 95

Tandon, SK . . . . . . . . . . . . 11

T anguy, J . . . . . . . . . . . . 52

T aniguchi, $\mathrm{H} \ldots \ldots \ldots \ldots . . . . .3$

T anis, D . . . . . . . . . . . . . . 47

Tannahill, R .......... 64, 70

T annant, D D . . . . . . . . . . . 74

Tannas, LE ............... . 29

T annenbaum, SR . . . . 28, 44

T annenbaum, $\mathrm{TN} \ldots \ldots \ldots \ldots 97$

Tanner, CM .............. 7

Tanner, JM .............. 34

Tanner, M S............... 9

Tannock, GW ............. 4

Tansley, B ............. 97

Tansley, BW .............. 97 
Tapola, $H \ldots \ldots \ldots \ldots \ldots 68$

Tara, HS ............... 22

T archer, AB ............. 7

T ardieu, H . . . . . . . . . . . . . . 29

T arlau, ES ............... 30

Tarloff, JB .............. 8

Tarlov, AR ............... 34

T arone, RE ............. 28

Tarrants, WE . . . . . . . . . . 22

T arrière, C . . . . . . . . . . . 29

Tart, M A .................. 77

T ask Force on Adult Immunization ............. 15

Taskinen, $H \ldots \ldots \ldots . .9,24,52$

T askinen, $\mathrm{HK}$ K . . . . . . . . . . . . 9

T assinary, LG ............ 34

Tassini, M ............... 11

T asto, D L............. 43, 97

Tate, $R \ldots \ldots \ldots \ldots \ldots . . . \ldots 97$

Tatken, $\mathrm{RL}$.............. 71

T atton-Braen, W . . . . . . . . . 97

Taube, A ................ 44

T audorff, E .............. 13

T aulbee, JD . ............. . 80

Tawn, EJ . ...............48 48

Taylor, A . . . . . . . . . . . 82

Taylor, AE ................ 34

Taylor, AH ............. 49

Taylor, BA ................ 33

Taylor, DH ............... 59

Taylor, FW ........... 34, 52

Taylor, G . ............ 10, 39

Taylor, H R ......... 49, 53

Taylor, J............... 5, 7

Taylor, JA ............. 1, 7

Taylor, JS................ 80

Taylor, M M ............. 52

Taylor, P ............. 97

Taylor, PE . . . . . . . . . . . . 97

T aylor, PJ.......... 3, 43, 97

Taylor, PW ............... 33

Taylor, S ...............6 6

Taylor, SE ................ 34

T aylor, SL . .............. 77

Taylor, SM ............... 10

T aylor, ST . ............... 55

Taylor, SW ................ 3

Taylor, SWS ............. 89

Taylor, TA .............. 21

Taylor, W .................. 3

T chobanoglous, G . . ........ 103

T chopp, P ...............26

T easdale, P. . . . . . . . . . . . 20

T echnica ................... 39

T eeters, WR . . . . . . . . . . . . 39

T egeris, A. .............. 10

Teich, AH ............... 19

T eichman, R . . . . . . . . . . . 79

Teiger, $C \ldots \ldots \ldots \ldots \ldots . .29$

Teijonsalo, J. . . . . . . . . . 13

T eisinger, J . . . . . . . . . . . . . . 33

T eitelman, AM ...........9 9

Teitz, C . . . . . . . . . . .... 96

Teleky, L . . . . . . . . . . . . . . . 21
T elesca, D R . . . . . . . . . . . 81 T elisman, S . . . . . . . . . . . . . 33

Tell, RA ............... 49

T ellegen, A . . . . . . . . . . . . . 34

T empleton, DM . . . . . . . . . . 63

Templeton, PA ...........6 63

Tennant, C . . . . . . . . . . . . . . 34

T ennant, RW . .............. 33

Tennstedt, D . . . . . . . . . . . . 12

T eorey, TJ . . . . . . . . . . . . . 52

Tepas, D . ................. 34

Tepas, DI . . . . . . 3, 29, 43, 52, 102

Tephly, TR ............... 33

Tepper, LB . . . . . . . . . . . . . 10

Teppo, L ................ 10

T eratogen, L . . . . . . . . . . . . . 97

Terayama, K . . . . . . . . . . . 11

T erborg, JR .................

Terborgh, J .............. 53

Terell, JD . . . . . . . . . . . . . . 48

Terho, EO .............. 10

Teri, L ................... 7

Terris, W . . . . . . . . . . . . 34

T erzis, JK . . . . . . . . . . . . . 11

Teschke, K . . . . . . . . . . 32, 71

T essari, JD . . . . . . . . . . . . 28

T estagrossa, PA . . . . . . . . . . . 83

Tetrick, LE. . . . . . . . . . . . . . 34

Tewarson, A ............4 41

Teyssier-Cotte, C . . . . . . . . . . 97

Thackrah, CT . . . . . . . . . . . 6

Thain, EM . . . . . . . . . . . . 27

Tham, K P . . . . . . . . . . . 22

Tham, R .............. 11

Thar, WE. . . . . . . . . 19, 28

Tharp, G ................ 19

Tharp, GD . . . . . . . . . . . . . 34

Tharr, D ............... 71

Thayer, PW . ............. 29

Theakston, RD G . . . . . . . . . . 38

Thean, PC . . . . . . . . . . . . 38

Thébaud-M ony, A . . . . . . . . 100

Thedell, T D . . . . . . . . . . . . . . 70

Theis, $H \ldots \ldots \ldots \ldots \ldots$. . . . . 43

Thelin, A . . . . . . . . . . . . . .6

Thely, D . . . . . . . . . . . . . . 97

Themann, CL . . . . . . . . . . . 31

Theodore, $L \ldots \ldots \ldots \ldots \ldots \ldots .79$

Theorell, R . ............. 52

Theorell, $T$.......... 3, 5, 20

$24,34,43,97$

Thereau, J

. . 29

Thériault, G . . . . . . . 3, 10, 15, 89

Thiébault, J .............43

Thierry, D . . . . . . . . . . . . . . . 39

Thierry, H .............43

Thiery, L . . . . . . . . . . . . . . . . 47

Thiis-Evensen, E . . . . . . . . . . 43

Thijs, L. . . . . . . . . . . . . . . 63

Thilly, F . . . . . . . . . . . . 19

Thimbleby, H . ........... 52

Thirkell, J.............. 21

Thirlaway, M . . . . . . . . . . . 34

Thirumoorthy, $T \ldots \ldots \ldots \ldots 64$
Thoits, PA . . . . . . . . . . 34

Thomas, A . . . . . . . . . . . . 41

Thomas, $C \ldots \ldots \ldots \ldots \ldots 52$

Thomas, DC .............48 48

Thomas, GM . . . . . . . . . . . 89

Thomas, HE . . . . . . . . . . 3, 95

Thomas, JA . . . . . . . . . . . . . . 77

Thomas, LA .............. 77

Thomas, M . . . . . . . . . . . 58

Thomas, $P \ldots \ldots \ldots \ldots$. . . . 85

Thomas, PR . . . . . . . . . 73, 82

Thomas, RE ........... 89

Thomas, RG . ............ 10

Thomas, $T \ldots \ldots \ldots \ldots . . .48$

Thomassen, D G . . . . . . . . . . . 10

Thome, FW . . . . . . . . . . . . . 44

Thomé-K ozmiensky, KJ . . . . . 97

Thomford, PJ . . . . . . . . . . 9, 9, 33

Thompson, AR ........... 6

Thompson, AS . . . . . . . . . . 34

Thompson, $\mathrm{CN} \ldots \ldots \ldots \ldots .74$

Thompson, HA . . . . . . . . . . 21

Thompson, JD . . . . . . . . . . . 59

Thompson, JF . . . . . . . . . 97

Thompson, JP . . . . . . . . . . 9

Thompson, PD ............ 3

Thompson, SI ............. 3

Thomson, HE . .......... 41

Thomson, M L . . . . . . . . . . . 42

Thorens, B . . . . . . . . . . . . . 11

Thoresen, CE . . . . . . . . . . . 34

Thornberry, NA . . . . . . . . . 33

Thorne, PF ............4 41

Thorne, PS. . . . . . . . . . . . . . 70

Thorner, M $0 \ldots \ldots \ldots \ldots . . .9$

Thornton, A . . . . . . . . . . . . 10

Thornton, P . . . . . . . . . . . . 17

Thorstensen, T C . . . . . . . . . . 88

Threlfall, WJ . . . . . . . . 32, 100

Thrupp, LA . . . . . . . . . . . . 64

Thrusfield, M V ........... 28

Thrush, SF . . . . . . . . . . . 66

Thu, KM ............... 70

Thullen, J............... 9

Thümler, R . . . . . . . . . . 11

Thun, $M$................ 3

Thun, MJ .......... 52, 63

Thune, PO . . . . . . . . . . . . . . 64

Thurber, CS ............. 11

Thurman, J . . . . . . . . . . . . 18

Thurman, JE . . . . . . . . 16, 29

Thys, JP ................ 3

Tiarks, AE . . . . . . . . . . 68

Tiberghien, $G \ldots \ldots \ldots \ldots 29$

Tichauer, ER . . . . . . . . . . . . . 29

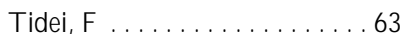

Tidswell, $M$. .............. 6

Tien, A. . . . . . . . . . . . . . 5, 34

Tietjen, $M \ldots \ldots \ldots \ldots \ldots 4$

Tiitola, K . . . . . . . . . . . . . . 3

Tikkanen, J . . . . . . . . . . . . . 52

Tikriti, S. . . . . . . . . . . . . 9

Till, JE ................ 48

Tiller, FW ........... 3,97
Tiller, JR ............... 3

Tilley, AJ ................43

Tilley, L . . . . . . . . . . . . . . 40

Tillman, B ................ 29

Tillman, P . . . . . . . . . . . . 29

Tilma, A................ 70

Tilson, H A . . . . . . . . . . . . . . . 33

Tilson, J ................ 15

T imber Industry Ergonomics

Group ............... 71

Timbrook, CL . ........ . 98, 100

Timmeny, W . . . . . . . . . . . . 1

Timmons, ED . . . . . . . . . . . . 74

T in-N u-Swe . . . . . . . . . . 38

Tindall, B.............. 97

T inelli, C . . . . . . . . . . . . . . . 80

T ingelstad, J............ . 9

T inmannsvik, RK .......... 57

Tintori, R . . . . . . . . . . . 97

Tipton, A . .............. 7

Tirmarche, $M$............ 32

Tironi, A . . . . . . . . . . . 1, 39

Tirpak, DA .............. 53

T itenko-H olland, $\mathrm{N} \ldots \ldots \ldots \ldots 1$

Titze, I . . . . . . . . . . . . . . . 96

Tiunov, LA .............. 33

To-Figueras, J . . . . . . . . . 9

To, $T \ldots \ldots \ldots \ldots \ldots \ldots$

Tobe, $M \ldots \ldots \ldots \ldots \ldots$

Todd, WF ............. 92

Tofler, GH . . . . . . . . . . . . . . . . 3

Toivanen, $\mathrm{H} \ldots \ldots \ldots \ldots$

Tokars, J . . . . . . . . . . . . 97

Tola, S............. 71, 72

Tolbert, PE ......... 91, 100

Tollerud, D . . . . . . . . . . . . 73

Tolley, E ................ 10

Tolliver, DL . . . . . . . . . . . . 83

Tollman, S................ 56

Tolonen, M ................ 3

Tomas, JM ............... 59

T ombleson, JBL . . . . . . . 10, 89

Tominaga, S . . . . . . . . . . . 53

Tomkins, BA ........... 44

Tomlin, $C \ldots \ldots \ldots \ldots \ldots 66$

Tomoda, S......... 65, 67

Toner, M ................ 64

Toner, M M . . . . . . . . . . 42

Toniolo, P ............... 53

Toniolo, PG . . . . . . . . . . . . . 94

Tonnel, AB ............. 10

Tooley, FV . . . . . . . . . . . . . 84

Toomingas, A . . . . . . . . 97

T oomingas, J . . . . . . . . . . . 6

T oorenenbergen, AW . . . . . . . 64

Topalova, M .............43 43

Topf, M . . . . . . . . . . . 97

Topping, M D ........... 38

Tordoir, WF . . . . . . . . . . 27

Toren, $\mathrm{K} \ldots \ldots \ldots \ldots . \ldots 100$

Torén, $K \ldots \ldots \ldots \ldots \ldots 72$

Tormanns, GA . . . . . . . . 97

Törner, M ..............66 66

Tornquist, A . . . . . . . . 97 
Torrance, GW . . . . . . . . . 20

Torre, KJ ............... 55

Torres, R .............. 3

Torstila, I . . . . . . . . . . . 34

Torsvall, L . . . . . . . . . . 29, 43

Tortosa, RD . . . . . . . . . . . . 7

Toscano, G ......... 51, 93

Tossaveinen, A . . . . . . . . 10, 91

Tosteson, $\mathrm{H} \ldots \ldots \ldots \ldots \ldots \ldots . . . . . .$.

Tosteson, T . ............ 53

Tosteson, TD . . . . . . . . . . . . 97

Totterdell, P. . . . . . . . . 29, 43

Tottrup, J............... 13

Tottszer, A . . . . . . . . . . . . . 95

Tougas, $Y \ldots \ldots \ldots \ldots \ldots 17$

Tousey, PM ............. 80

Toussaint, J .............. 4

Towne, W . . . . . .......... 88

Townes, BD . . . . . . . . . . . 37

Townsend, JA ........... 77

Townsend, M ............ 97

Trachsler, G............. 70

Trades U nion Congress. . . . . . . . 18

Traencker, K . ............... 3

Trah, G ................ 24

Trail Smelter Arbitration. . . . . . 54

Tramm, M L. . . . . . . . . . . . . . 15

Trammel, HL . . . . . . . . . . 28

Tran, N . ............... 97

Tran Quoc, H . . . . . . . . . . . . 17

Tränkle, U . . . . . . . . . . . . . . 102

Transkov, S . . ........... 64

T ransport and General

W orkers U nion . . . . . . . . 102

Transwell, AK ............. 10

Trapp, AL .............. 10

Trattnig, $S \ldots \ldots \ldots \ldots \ldots \ldots 6$

Travell, J ................ 6

Travers, PH . . . . . . . . . . . . 7

Travis, CC ............ 1, 30

Travis, LB ............... 1

Trebilcock, A . . ........... 21

Tredici, $T$. . . . . . . . . . . . . . 49

Treiman, DJ.............. 34

Treitman, RD . . . . . . . . . . . 61

Tremblay, CG . . . . . . . . . . . . . 3

Trent, LS ............... 10

Treu, $T$. .............. 21

Triano, Jj ................ 6

Tribolo, A .............. 7

Tribukait, B ............. 52

Trice, MF............... 10

Trichopoulos, D .......... 28

Trickett, JC ............. 74

Trimpop, R . . . . . . . . . . . 59

Trinco, $R \ldots \ldots \ldots \ldots . . . . .99$

Tripp, VW . . . . . . . . . . . 89

Trites, D. . . . . . . . . . . . 68

Trites, DG . . . . . . . . . . . 68

Troen, HN . . . . . . . . . . . . 9

Troen, $P \ldots \ldots \ldots \ldots \ldots 9$

Troisi, CL . . . . . . . . . . . . 95

Trokel, S . . . . . . . . . . . . 49

Trombley, L.............. 10
Tronko, N D . . . . . . . . . . . . 39

Trost, DC . . . . . . . . . . . . . 3

Trott, AT . .............. 14

Trottier, A . . . . . . . . . . . . . 95

Trouiller, P . . . . . . . . . . . 97

Troup, JDG ............ 56

Trout, DB ............. 96

Troxler, P. . . . . . . . . . . . 29

Trudeau, C .............. 10

Trumbull, R............ 34

Trump, B...............8

Trump, BF . . . . . . . . . . . 8, 33

Truong, T-D ........... 96

T sai, JT . . . ..................... 10

T sai, M -J ................ 3

T sakok, FH M ............ 9

T saneva, N. . . . . . . . . . . . . 43

T sang, HC . . . . . . . . . . . . . . 96

Tschopp, A . . . . . . . . 6, 11

T so, TC . ...............64 64

Tsubota, K . . . . . . . . . . . . . 13

T suda, $F \ldots \ldots \ldots \ldots \ldots \ldots 97$

T suda, $T$. . . . . . . . . . . . . . . . 34

T sunoda, $T \ldots \ldots \ldots \ldots . \ldots 5$

Tsyb, AF . ............... 39

Tu, AT ............. 38, 70

Tubasuri, TH ............ 100

Tubiana, R ............6 6

T uch, SA ................ 34

Tüchsen, $F \ldots \ldots \ldots \ldots \ldots$. . . . . . 3

T ucker, A . . . . . . . . . . . . 15

Tucker, DC . .............. 3

T ucker, JB . . . . . . . . . . . 53

Tucker, $M$...............99

T ucker, M A . . . . . . . . . . . . . . . 1

Tuden, A . . . . . . . . . . . . . . . 59

Tugwell, $P$. . . . . . . . . . . . . . 6

T uikainen, $\mathrm{H} \ldots \ldots \ldots \ldots \ldots$

Tully, $M \ldots \ldots \ldots \ldots \ldots \ldots 9$

Tun-Pe................. 38

Tung, WH . .............. 49

Tuohy, C ............. 59

T uominen, R . . . . . . . . . . . . 56

Tuomisto, M . . . . . . . . . . 34

Turcot, D . . . . . . . . . . . . . . 68

Turek, FW . . . . . . . . . . . . . . . 44 43

T uriel, I . . . . . . . . . . . . 44, 45

T urjanmaa, K . . . . . . . . . 12, 64

T urk, JL ................. 33

T urk, JW . ..............6 63

Turl, LH ............. 42

T urnbull, G] ..............64 64

T urnbull, N . ............. 100

T urner-W arwick, M ........ 71

T urner, A G . . . . . . . . . . . . . . 97

T urner, F . . . . . . . . . . . . . . . 70

T urner, JB . . . . . . . . . . . . . . 34

T urner, JR . . . . . . . . . . . . 34

T urner, RJ . . . . . . . . . . . . . . . 34

Turner, $T$. . . . . . . . . . . . . . . 9

Turner, TW . . . . . . . . . . . . . . 9

Turnicky, R P . . . . . . . . . . 3

Tusé, $B \ldots \ldots . . . \ldots . . . . .83$

Tushman, $\mathrm{ML}$. . . . . . . . . . . . 59
T uve, RL . . . . . . . . . . . . 95

T vedt, B . . . . . . . . . . . . . . . 11

T versky, A . . . . . . . . . . . . . . . 59

T wedt, S. . . . . . . . . . . . . . . 19

T weed, $V \ldots \ldots \ldots \ldots \ldots 16$

T wentyman, O P . . . . . . . . 10

T wiggs, J . . . . . . . . . . . . . . . 70

Tyler, JS............... 29

Tyler, NK .............. 10

Tyler, PD . .............. 97

Tyler, WS .............. 10

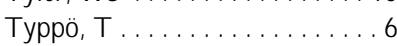

Tyroler, H A . . . . . . . . . . . 3, 80

Tyson, S . . . . . . . . . . . . . . . 21

T zischinsky, $0 \ldots \ldots \ldots \ldots . .3$

\section{U}

U chida, Y............. 100

Udo, ES ................ 68

U ehata, $T \ldots \ldots \ldots \ldots \ldots \ldots, 5,43$

U emura, $K \ldots \ldots \ldots \ldots . . . .3$

U jda, JR . . . . . . . . . . . 10, 89

UK H ealth and Safety

Commission (H SC) . . . . . . . 80

Ulfvarson, $U \ldots \ldots \ldots 10,98$

Ulich, E . . . . . . . . . . . . 29, 29, 43

U llmark, P . . . . . . . . . . . . . 97

Ullrich, D . . . . . . . . . . . . . . 32

Ullsperger, P . . . . . . . . . . . 50

Ulmer, D . . . . . . . . . . . . . . . 34

Ulrich, R . . . . . . . . . . 68, 78

Ulschak, F . . . . . . . . . . . 15

U megae, $Y \ldots \ldots \ldots \ldots \ldots .64$

Unden, $A-L \ldots \ldots \ldots \ldots . . . .3$

Undén, $A-L \ldots \ldots \ldots \ldots . . . .34$

Underwood, EJ . . . . . . . . . . 63

Undeutsch, $K \ldots \ldots \ldots \ldots .43$

Ungers, LJ . . . . . . . . . . . . . . . . 83

Ungpakorn, G . . . . . . . . . . 34

Ungváry, G ............. 16

Unison ................. 51

$U$ nited $N$ ations D epartment of

Technical Cooperation for

Development............ 74

Unrau, P . . . . . . . . . . . 53

Upton, A . . . . . . . . . . . . 28

U pton, AC ...........48, 53

U ragoda, CG . . . . . . . . . . . 89

U ranium Institute . . . . . . . . . 76

Urba, WJ . . . . . . . . . . . . . . . 1

Urbach, F..............49 49

U rbain, M A . . . . . . . . . . . . . . 97

Urban Edge............... 53

Urban, JPG ................ 6

Urban, P . .............. 16

Urbanek, R . .............. 9

Urie, RL. . . . . . . . . . . . . . . 7

U rsano, RJ . . . . . . . . . . 39, 100

Ursin, $H \ldots \ldots \ldots \ldots \ldots . . . \ldots 34$

Ury, W................21

US A gency for International

Development

(USAID) . .

..............
US A tomic Energy Commission

$(A E C) \ldots \ldots \ldots \ldots . . .48$

US C oast Guard . . . . . . . . . 102

US Congress .............. 33

US D epartment of A griculture

(USDA ) . ...... 15, 64, 67, 70

US Department of

Commerce. ....

$15,69,72$

US D epartment of Energy. . 48, 76

US D epartment of $\mathrm{H}$ ealth

and Human Services

(USD H H S). . . 3, 10, 15, 32, 34

US D epartment of $\mathrm{H}$ ealth,

Education and W elfare . . . . . 15

US D epartment of Labor . . 15, 16,

$21,30,32,34,64,76,89,103$

US D epartment of State . . . . . 64

US D epartment of the Interior.

Fish and Wildlife Service . . 69

US D epartment of

Transportation (D OT) . . . . 102

US Environmental Protection

A gency (EPA) ...... 9, 44, 76

U S G eneral Accounting 0 ffice

(GAO) ..........15, 34, 64

U S H ouse of R epresentatives . . 34

US M erit Systems Protection

Board. . . . .

34

US N uclear R egulatory

Commission....

48,5

and $\mathrm{H}$ ealth Promotion ..... 15

U S O ffice of Personnel

$M$ anagement.

U S O ffice of T echnology

A ssessment. . . . . . 27, 34, 54, 55

US Preventive Services

Task Force . ......... . 3, 97

U S Public H ealth Service. . 15, 32, 102

U S Senate . . . . . . . . . . . . . 102

US Small Business

Administration ............ 15

U S Surgeon G eneral . . . . . . . . . 44

U sher, V................63 63

USSR M inistry of $\mathrm{H}$ ealth . . . . 49

U sui, $M \ldots \ldots \ldots \ldots \ldots$

U utela, A . . . . . . . . . . . 34

Uyeno, ET . . . . . . . . . . 11

\section{V}

V aca-M arin, M A .......... 53

Vacek, P............. 10,86

Vacher, J ..............66 66

Vaeth, JM ............ 48

Vaga, A . . . . . . . . . . . . . 65

Vahter, M .............6 63

Vahtera, J............... 34

Vaichere, $\mathrm{E} \ldots \ldots \ldots \ldots \ldots 43$

Vaichère, $E$. . . . . . . . . . . . 97

Vaidya, SA . . . . . . . . . . 24

V aidyanathan, $K \ldots \ldots \ldots \ldots 39$

V aillancourt, JP . . . . . . . . . . 33 
Vaillant, GE............ 97 Vainio, E ............... 16 Vainio, H . . 2, 9, 27, 28, 33, 71, 80 Vaisman, Al. . . . . . . . . . . . 97 Valbjorn, $0 \ldots \ldots \ldots \ldots 13$ Valciukas, JA ............. 7 $V$ aldés, $S \ldots \ldots \ldots \ldots \ldots 68$ Vale, JA ............... 9 Valentino, M .............99 97 Valerio, M G ............. 10 Valiani, M ................11 Valiante, DJ .............. 10 Valic, F.................. 10 Valko, RJ ...............997 Vallejo, A ...............6 6 Vallentyne, $S \ldots \ldots \ldots \ldots . .97$ Vallerand, AL ............4 42

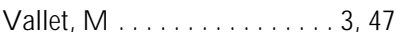
Vallin, $G \ldots \ldots \ldots \ldots \ldots .4$ Vallyathan, NV . ........... 10 Vallyathan, V......... 10, 28 V alot, JM ................ 29 Valsecchi, M ............88 $V$ alticos, $N \ldots \ldots \ldots \ldots \ldots 21$ Van, LSF ................ 32 V an-der-V enne, M T . . . . . . . 38 V an-H oeyveld, E . .......... 70 $V$ an Akkerveeken, PF . . . . . . . 17 van Amerongen, VR . . . . . . . 57 $V$ an Amerongen, WE . . . . . . . 38 $V$ an Cott, H P............ 29 Van Daele, A . . . . . . . . . . . . 29 $V$ an Daele, P .......... 43, 97 van Damme, K . . . . . . . . . 28

Van Damme, $P$. . . . . . . . . 97

$V$ an de $K$ erckhove, J . ........ 57

Van De Wal, BW............. 38

$V$ an den Bogart, $H$ G G . ......664 64

$V$ an den Ende, G . . . . . . . . . . 64

$V$ an der Beek, AJ . .......... 29

van der $\mathrm{G}$ rinten, $\mathrm{M} \ldots \ldots \ldots \ldots 5$

van der $\mathrm{K}$ reek, FW . ......... 30

van der Leun, JC . . . . . . . . . . 49

van der Linden, $S \ldots \ldots \ldots \ldots$

$V$ an der Schrier, JH . ......... 57

$\checkmark$ an der Star, A ............ 97

$\mathrm{V}$ an der $\mathrm{V}$ enne, $\mathrm{M} \mathrm{T} \ldots \ldots . . .33$

van der Walle, H B . . . . . . . . . 100

van der Werf, P . . . . . . . . 101

van der Zee, SC . . . . . . . . . . 101

$\checkmark$ an Deursen, CGL . . ....... 97

van Dijk, FJH . . . . . . . 3, 11, 47

van Dilla, M A ............ 42

van Duijn, CM ............ 7

Van Ert, MD . . . . . . . . . . . 80

Van Gaalen, LC . . . . . . . . . . 29

Van Gilder, TJ . ............ 96

Van Gils, E .............. 57

V an G riensven, LJ LD . . . . . . . 64

Van $\mathrm{H}$ aaren, JPM ..........664

van $\mathrm{H}$ age- $\mathrm{H}$ amsten, $\mathrm{M}$. . . . . . . 70

van $\mathrm{H}$ arrison, $\mathrm{R} \ldots \ldots \ldots \ldots . \ldots 34$

$\mathrm{V}$ an $\mathrm{H}$ ogdalem, $\mathrm{H} \ldots \ldots \ldots . .99$

van $\mathrm{H}$ oof, $J \ldots \ldots \ldots \ldots \ldots \ldots . . \ldots 21$
Van H outen, J . . . . . . . . . . 77 van $\mathrm{K}$ ranen, $\mathrm{H}$ J . . . . . . . . . . . 33 $\mathrm{V}$ an $\mathrm{K}$ rieken, $\mathrm{HJ}$. ........... 1 Van Lamsweerde, C . ........ 18 van $L$ arebeke, $N \ldots \ldots \ldots \ldots$ van L eeuwen, FE . . . . . . . . . . . 49 $V$ an Leeuwen, $P$. . . . . . . . . . . 43 van Liemt, G . . . . . . . . . . . 20 Van Lierde, $M \ldots \ldots \ldots \ldots . . .9$ $V$ an Loon, PCC ............64 64 $V$ an $M$ aanen, J ............. 34 van $\mathrm{N}$ etten, $\mathrm{C} \ldots \ldots \ldots \ldots$. . . . 32, 95 Van 0 rden, DR ............ 94 Van O sdell, D .............. 13 van Potolsky, G . ........... 21 van R ood, JJ.............. I van $R$ un, $P E M \ldots \ldots \ldots \ldots . \ldots 30$ van R uysseveldt, 」 . . . . . . . . . 21 van Ryn, M ............. 34 van Saase, JL . . . . . . . . . . . . 6 van Sittert, NJ . . . . . . . . . 27 $V$ an Son, $M$............... 17 Van Sprundel, M . . . . . . . . . . 10 Van Treuren, R R ........... 34 van $V$ alkenburg, $R A$. . . . . . 79 van $W$ aarden .............. 21 Van Zant, P . . . . . . . . . . . 83 Vance, $R \ldots \ldots \ldots \ldots \ldots . \ldots$ Vanchieri, C ..............15 Vandagriff, RB ............ 3 Vandenberg, J............. 33 $V$ anderG riend, RA ........ 96 Vanderkolk, BS ............ 34 Vandevyver, B . . . . . . . . . . . 45 Vanhala, E.............. 10 Vanhee, D ................ 10 Vanhoorne, M .............. 3 Vanini, GC .............97 Vanni, R ............... 49 vanR eek, J . ............... 34 Vanwesenbeeck, I ........96 96 Varaillac, P ............ 100 Varey, CA ...............997 Varghese, $A \ldots \ldots \ldots \ldots \ldots 1$ $V$ artiainen, $T \ldots \ldots \ldots \ldots . \ldots 27$ Vartianen, M . . . . . . . . . . . . 34 Vasiliou, V ................ 33 Vasiljev, JA ............... 33 V asquez-C astelanos, JC . . . . . . 64 Vasquez, C.............. 100 Vassalli, P............... 10 Vaugham, $P \ldots \ldots \ldots \ldots . . .53$ Vaughan, GL............ 10 Vaughan, TL ............ 100 Vaughn, S ............... 99 Vaughn, TL ..............9 Vaught, JB .............. . 100 Väyrynen, $S \ldots \ldots \ldots \ldots .68$ Veatch, R M . . . . . . . . . . . 19 $V$ eazie, M A . ....... 56, 60, 64 V eeradejkriengkrai, C . ...... 16 V ejlupková, J . . . . . . . . . . . 16 Vellar, OD ...............42 42 V ellend, $\mathrm{H} \ldots \ldots \ldots \ldots \ldots \ldots \ldots . \ldots 38$
V ellenga, D B . . . . . . . . . 102 Vena, JE........... 3, 91, 95 V enable, $H \ldots \ldots \ldots \ldots \ldots \ldots . \ldots 32$ Venables, K M ............63 63 Vener, KJ................ 34 Venkatram, A ............ 55 Venuto, $C$................ 7 Venzia, RA ...............55 Venzke, J ............... 70 $\checkmark$ epsalainen, $P \ldots \ldots \ldots \ldots 29$ Veral, $V \ldots . . . \ldots \ldots \ldots \ldots . .1$ Verband D eutscher

V erkehrsunternehmen .... 102

Verbeek, AL . . . . . . . . . . . . . . 12

Verbeek, JHA .............. 3

Verberk, M M ............. 27

Verdecchia, A ........... 10

Verdolini-M arston, $\mathrm{K} \ldots \ldots . .96$

Vereerstraeten, $P \ldots \ldots \ldots \ldots 3$

$\checkmark$ ereine D eutscher Ingenieure

(VDI)................55

Verevis, C . .............21

Verhaegen, P . . . . . . . 43, 97

Verhock, W .............. 88

Verhoeff, AP . . . . . . . . . . 44 44

Verma, A ...............21

Verma, D ............... 59

Verma, KK ............ 18

Vermel', $A E \ldots \ldots \ldots \ldots \ldots \ldots 3$

Vernault, J-C . . . . . . . . . . . . 10

Vernon, SW . .............. 34

Verrelle, $P$. . . . . . . . . . . . . 63

Verriest, G .............. 11

Verschaeve, $L \ldots \ldots \ldots \ldots . .49$

Versloot, JM .............. 17

V ertongen, $F \ldots \ldots \ldots \ldots \ldots$

Vervalin, $\mathrm{CH} \ldots \ldots \ldots \ldots \ldots 78$

Verzetti, G . . . . . . . . . . . . . . 97

Vesley, D . ................. 70

Vessey, M P .......... 12, 15

Vessio, G ...............11

V esterberg, $0 \ldots \ldots \ldots \ldots . \ldots 38$

V esterhauge, S. . . . . . . . . . . 11

V eulemans, $H \ldots \ldots \ldots \ldots . . .6$

Veyret, B . . . . . . . . . . . . 49

Veys, CA ............. 80

Veys, E...............6 6

Vezina, M . ............... 34

V ezina, $N \ldots \ldots \ldots \ldots . . . .887$

Viaene, B . . . . . . . . . . . . . . 97

Viau, C ............ 28, 63

V icerstaff, $S \ldots \ldots \ldots \ldots \ldots .21$

Vickers, RR . . . . . . . . . . . . 34

Vidacek, S . . . . . . . . . . . 29, 43

Videman, $T$. . . . . . . . . . . . . 6

Viedge, $C \ldots \ldots \ldots \ldots \ldots 34$

Viessman, $W \ldots \ldots \ldots \ldots . . .55$

Vieux, N.............29, 43

Vigliani, EC . . . . . . . . 10, 89

Vigon, BW . ............. 54

Vihina, $T \ldots \ldots \ldots \ldots \ldots .20$

Viikari-Juntura, E . . . . 6, 16, 52

Viitanen, $M$. . . . . . . . . . . . . 7

Viitasara, E . . . . . . . . . . 17
Vikström, AO .......... 43

Villanueva, E . . . . . . . . . . . . 64

Villanueva, PA ............. 14

Villaplana, J............... 100

Villar, J.................99

Villard M ackintosh, L . . . . . . . 12

Villarejo, D . ............... 64

Villegas, J ............. 28

Villemeur, A . . . . . . . . . . . 58

Villenave, D . . . . . . . . . . 38

Villeneuve, J. . . . . . . . . . . . . 97

Vincent, $F$. . . . . . . . . . . . 99

Vincent, JH ............. 10

Vincente, K . . . . . . . . . . . . . . 29

Vindieni, C . . . . . . . . . 88

Vineis, P. . . . . . . . . . . 2, 19, 28

Viner, D . . . . . . . . . . . . 18

V inet, $A$. . . . . . . . . . . . 34, 87

Vingård, E . . . . . . . . 6, 100

Vinken, $\mathrm{PJ} \ldots \ldots \ldots \ldots \ldots \ldots 7$

Vinokur, A . . . . . . . . . . . . . . 34

Vinson, R P . . . . . . . . . . . 74

Vinterberg, $H \ldots \ldots \ldots \ldots 6$

Vinti, $H \ldots \ldots \ldots \ldots \ldots \ldots . \ldots$

Vinzents, P. . . . . . . . . . . 61

Violanti, JM . . ............ 95

Violland, M . . . . . . . . . . . . 102

Vir, AK ............... 101

Viravan, C . . . . . . . . . . . . 38

Virchow, R ............. 7

Virnelli, S................ 34

Virokannas, H . . . . . . . . . . . . . 3

Virtamo, M ............ 91

Vischer, JC . . . . . . . . . . . . 34

Viscusi, WK . . . . . . . . . 22, 54

Visinescu, I. . . . . . . . . . . . . . 79

Visser, J . . . . . . . . . . . . . 21

Visser, $R \ldots \ldots \ldots \ldots \ldots 68$

Vital, JP . . . . . . . . . . . . . 11

Vitek, TJ, Jr . . . . . . . . . . 65

Viten, VPh . . . . . . . . . . . 64

Vivian, J . ................ 70

Vlahox, D ............... 100

V leeschdrager, E .......... 29

Vlek, C................. 59

Vobecky, J . . . . . . . . . . . . . 89

Vocaturo, K G ............ 10

Voelker, R . . . . . . . . . . . . 15

Vogel, $L \ldots \ldots \ldots \ldots \ldots \ldots . \ldots 21$

Vogelzang, $N$ J . . . . . . . . . . 8

Vogt, JJ ...............42 42

Voisin, C ............... 10

Vojtecky, M A . . . . . . . . . . . 18

Volante, M............... 10

Vollenweider, RA .......... 55

Vollrath, DA .............29

Volpe, M ................ 97

Volpert, W..........29, 34

V on Allman, S . . . . . . . . . . . 39

Von Allmen, $M \ldots \ldots \ldots .26$

von Behr, M .............. 29

Von Behren, J ............. 34

Von Essen, $\mathrm{S} \ldots \ldots \ldots \ldots \ldots 70$

von Gierke, HE ........... 47 
von $\mathrm{N}$ andelstadh, $\mathrm{P} \ldots \ldots \ldots . .52$ von N eumann, J. . . . . . . . . . . 59 V on Richthofen, W . . . . . . . . 23 von V olkmann, R . . . . . . . . . . 28 von W interfeldt, D . . . . . . . . . 59 Voogd, M.............. 97 Vorpahl, KW . . . . . . . . . 82 Vos, JG ............. 33 Vossenas, $\mathrm{P} \ldots \ldots \ldots \ldots \ldots . . .93$ Vouk, VB . . . . . . . . . . 63 Voulk, V ............. 27 V ranckx, R ........... 97 Vroon, PA . . . . . . . . . . . 59 Vurdien, J . . . . . . . . . . . . 97 Vuylsteek, K . . . . . . . . . . 28 Vyskocil, A...........6 63

\section{W}

W acholder, $S \ldots \ldots \ldots \ldots \ldots$ 1, 72

Wacholder, S ........... 28

Wadden, RA . . . . . . . 44 44, 77

Wade, JG . . . . . . . . . . . . 97

Wade, N . . . . . . . . . . . . 19

Wade, $R \ldots \ldots \ldots \ldots \ldots \ldots . .83$

Wadel, C . . . . . . . . . . 66

Waga, M A . . . . . . . . . . . . 24

Wägar, G . . . . . . . . . . . . 3

Wagenaar, W . . . . . 56, 59, 67, 78

Wagner, EH . . . . . . . . . . 15

Wagner, G . . . . . . . . . 2, 10

Wagner, GR . . . . . . . . . 10, 23

Wagner, JA . . . . . . . . . . 29

Wagner, JC . . . . . . . . . . 10

Wagner, PD . . . . . . . . . . 37

Wagner, R . . . . . . . . . . . . 29

Wagstaff, $H$. . . . . . . . . . . 70

Wahlberg, JE . . . . . . . . . 52

Wahlen, $L \ldots \ldots \ldots \ldots \ldots \ldots 97$

Waiter, A . . . . . . . . . . . . 89

Waitzman, $N$ J . . . . . . . . . 34

Wakeford, R . . . . . . . . . 48

W akelyn, PJ . . . . . . . . . . . . . 89

Wald, NJ . . . . . . . . . . 39, 44

Wald, PH . . . . . . . . . . 86

Waldeck, D . . . . . . . . . . 93

Walden, D . . . . . . . . . . . . 34

Waldon, H M . . . . . . . . . . 34

Waldron, $H$ A . . . . . . . . . . 2

Walker, AE ............9

Walker, AM . . . . . . . . 6, 28

Walker, E . . . . . . . . . . . . 40

Walker, J . . . . . . . . 43, 88, 101

Walker, JT . . . . . . . . . . . 28

Walker, P . . . . . . . . . . . 39

Walker, RF . . . . . . . . . . 34

Walker, S . . . . . . . . . . . . . 74

Walker Smith, GJ . . . . . . . . 73

Wall, RJ . . . . . . . . . . . 70

Wall, S . . . . . . . . . . . 13, 44

Wall, TD . . . . . . . . . . . 29

Wallace, H M . . . . . . . . . . . 24

W allace, J . . . . . . . . . . . 34

Wallace, $L \ldots \ldots \ldots \ldots \ldots \ldots \ldots 44$
Wallace, $M \ldots \ldots \ldots \ldots \ldots \ldots 43$

Wallace, $R \ldots \ldots \ldots \ldots \ldots \ldots 5$

W allace, R B . . . . . . . . 102, 103

Wallace, WE . . . . . . . . . . 10

W allaert, B . . . . . . . . . . . . 10

W allentowitz, H . . . . . . . . . . . 102

Waller, JA . . . . . . . . . 56, 70

Wallerstein, N . . . . . . 18, 56, 64

W allerstein, N B . . . . . . . . . . 18

Wallich, $R \ldots \ldots \ldots \ldots \ldots . . \ldots$

Wallin, $\rfloor \ldots \ldots \ldots \ldots \ldots \ldots . .21$

Wallin, $L \ldots \ldots \ldots \ldots \ldots \ldots . . \ldots 34$

W allingford, $K \ldots \ldots \ldots \ldots . \ldots 13$

Wallis, $G \ldots \ldots \ldots \ldots \ldots \ldots . .81$

Walrath, J. . . . . . . . . . 88, 100

Walsc, P . . . . . . . . . . 8

Walsh, CS . . . . . . . . . 13

Walsh, DC . . . . . . . . . . 15, 34

Walsh, JK . . . . . . . . . 43, 102

Walsh, JWT . . . . . . . . . . 46

Walsh, M P . . . . . . . . . . 55

Walsh, $N \ldots \ldots \ldots \ldots \ldots \ldots 26$

Walsh, PJ . . . . . . . . . . . 44

Walsh, WM . . . . . . . . . . 96

W alter, JW . . . . . . . . . . . . . 97

W alters, AD . . . . . . . . . . 74

W alters, D . . . . . . . . . . . . 21

W alters, D B . . . . . . . . . . . . 103

Walters, V . . . . . . . . . 26, 59

Walton, RE . . . . . . . . . . 59

Walton, WH ............ 10

Walz, T . . . . . . . . . . . 97

Wan, CK ............. 34

Wan, $H \ldots \ldots \ldots \ldots \ldots \ldots 64$

Wandke, $H \ldots \ldots \ldots \ldots \ldots \ldots 52$

W ands, SE . . . . . . . . . . . . 97

Wang, BG ............ 102

Wang, DA . . . . . . . . . . . 80

Wang, $\mathrm{H}$ W. . . . . . . . . . . 80

Wang, JD . . . . . . . . . . . . 28

Wang, JZ . . . . . . . . . . . . 63

Wang, $\mathrm{LCH} \ldots \ldots \ldots \ldots \ldots \ldots 42$

Wang, $\mathrm{M}-\mathrm{J} \ldots \ldots \ldots \ldots \ldots . . . .86$

Wang, ML . . . . . . . . . . . . 87

Wang, WF . ............. 80

W ang, WM $-Y \ldots \ldots \ldots \ldots . . .29$

W ang, $X Y \ldots \ldots \ldots \ldots \ldots \ldots 2$

Wang, $Y-Z \ldots \ldots \ldots \ldots \ldots \ldots 1$

Wannell, $T \ldots \ldots \ldots \ldots \ldots . .24$

Wanner, H-U . . . . . . . . . . . 44

Wanous, JP ............ . 34

Waples, M .............. 8

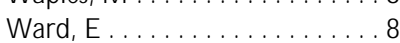

Ward, EM ............ 100

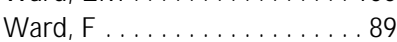

Ward, HW . . . . . . . . . . . 34

Ward, J. . . . . . . . . . . . 100

Ward, JB . . . . . . . . . . 27

Ward, JF . . . . . . . . . . 48

Ward, JM ............ 33

Ward, M P . . . . . . . . . . 37

Ward, WD ............ 47

Ward, WS ............ 8

Ware $A \ldots \ldots \ldots \ldots \ldots \ldots 9$
Ware, M R ............ 13

Ware, RL . . . . . . . . . . . 10

Wargin, WA. . . . . . . . . . 27

Warheit, DB. . . . . . . . . . . 10

W aridel, S . . . . . . . . . . 17

Waring, JM ............ 15

Waring, PM . . . . . . . . . 10

Waris, $P \ldots \ldots \ldots \ldots \ldots \ldots 6$

Wark, TEE ........... 15

Warner, E . . . . . . . . . 63

Warner, R ..............47

W arner Schaie, K . . . . . . . . 29

Warr, P . . . . . . . . . . 5, 88

Warr, PB ............. 34

W arrell, D A . . . . . . . . 38, 53

Warren, BL ............ 6

Warren, $K \ldots \ldots \ldots \ldots \ldots . . . .34$

Warren, $M \ldots \ldots \ldots \ldots \ldots$. . . . . 96

Warren, $Y \ldots \ldots \ldots \ldots \ldots \ldots 52$

W arshaw, LJ . . . . . 9 9, 15, 26, 98

Warshaw, RH ........... 10

W artman, SA . . . . . . . . . . . . 97

Warwick, DP . . . . . . . . . 43

W arwick, M . . . . . . . . . . 83

W asserman, DE . . . . . . . . . . 3

W asylenko, M J . . . . . . . . . . 6

W atanabe, A . . . . . . . . . . . . 29

W atanabe, J . . . . . . . . . . . 33

W atanabe, $P G$. . . . . . . . . 30, 33

W ater Environment Federation 55

W aterhouse, J . . . . . . . . . . 29

W aterhouse, JAH . . . . . . . . . 80

W aterhouse, JM . . . . . . . . 29, 43

Waterhouse, $T \ldots \ldots \ldots \ldots \ldots 2$

W aterman, M R . . . . . . . . 33

Waterman, $\mathrm{RH} \ldots \ldots \ldots \ldots . . .57$

Waternaux, $C \ldots \ldots \ldots \ldots .9$

W aters, TR . . . . . . . . . 6, 29

W aterworth, JA . . . . . . . . 52

W atkins, DK . . . . . . . 10, 93

Watling, RJ . . . . . . . . . . 10

Watrous, RM . . . . . . . . . . 79

W atrud, LS . . . . . . . . . . . 77

Watson, D . . . . . . . . . . 34

Watson, JD ............. 33

Watson, SD ............ 17

Watt, A .............889

Watt, F . . . . . . . . . . . 10

W atts-J ones, D . . . . . . . . . . . . 34

Watts, DM . . . . . . . . . . . 53

Watts, JC . . . . . . . . . . 10

Watts, KI . . . . . . . . . . . 41

Watts, RR ........... 27

Wawrzinoszek, $M \ldots \ldots \ldots \ldots . . .3$

Waxman, DJ . . . . . . . . . . 33

W axweiler, R . . . . . . . . . . . . 88

W axweiller, J . . . . . . . . . . . 72

Waxweiller, RJ . . . . . . . . . . 91

W earden, AQ ............ 10

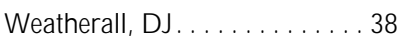

W eathers, $J \ldots$. . . . . . . . . . 83

W eaver, CN . . . . . . . . . . . . 34

W eaver, V . . . . . . . . . . . . 100

W ebb Associates . . . . . . . . . . 29
Webb, B . . . . . . . . . 21

Webb, CA ............. 34

Webb, S . . . . . . . . . . . 21

Webber, M M . . . . . . . . . . . 59

W eber-Falkensammer, $\mathrm{H} \ldots \ldots .3$

Weber, A . . . . . . . . . . . 10, 67

Weber, AJ . . ........... 10

Weber, $A L \ldots \ldots \ldots \ldots \ldots \ldots 63$

Weber, K . . . . . . . . . . 55

Weber, RP . . . . . . . . . . . 3

Weber, S . . . . . . . . . . . . . 101

Weber, TG ........... 6

Weber, WW . . . . . . . . . . . . 33

W ebster, J . . . . . . . . . . . . . 34

Wechsler, CJ ............ 13

Wecker, JR . . . . . . . . . . . 11

Wecks, J . . . . . . . . . . . . . . 97

Wedderburn, A . . . . . 29, 43, 97

Wedderburn, AAI . . . . . . . 43

Wedel, $\mathrm{H} \ldots \ldots \ldots \ldots \ldots \ldots . \ldots 34$

W edge, JH . . . . . . . . . . . 6

Weed, DL . . . . . . . . . . . 28

W eekes, D M ........... 45

W eeks, D M . . . . . . . . . . 44

W eeks, JL . . . . . . . . . . . 23, 56, 93

Wegman, DH . . 1, 6, 7, 10, 16, 19,

$23,30,32,34,64,87,88,91,93$

Wegman, IH ........... 7

Wehner, T . . . . . . . . . . . . 58

Wehrle, G . . . . . . . . . . . 97

W eidenmüller, $R$. . . . . . . . . . 72

Weido, AJ . . . . . . . . . . . . 97

Weihrauch, TR . . . . . . . . . 68

Weil, CS.............. 30

Weil, D . . . . . . . . . . . . . . 97

Weil, E ................. 33

Weil, $\mathrm{H} \ldots \ldots \ldots \ldots \ldots \ldots 10$

Weil, JV . . . . . . . . . . . . 37

Weiland, SK ........... 80

W eill Fassina, A . . . . . . . . . . 29

Weill, $H \ldots \ldots \ldots \ldots \ldots \ldots . .89$

Weinbaum, Z . . . . . . . . . 7

W einberg, $A M \ldots . \ldots \ldots \ldots \ldots . .24$

Weinberg, AN . . . . . . . . 10

Weinberg, CR . . . . . . . . . . 9

W einberg, J . . . . . . . . . . 100

Weinbery, W . . . . . . . . . . 55

Weiner, A . . . . . . . . . . . . 34

Weiner, $H \ldots \ldots \ldots \ldots \ldots . .34$

Weiner, JA . . . . . . . . . . . . . 72

Weiner, JS . . . . . . . . . . . . 42

Weinger, $\rfloor \ldots \ldots \ldots \ldots \ldots$. . . . . 64

W einger, $M \ldots \ldots \ldots \ldots$ 18, 64

Weinstein, $\mathrm{CH} \ldots \ldots \ldots \ldots \ldots 16$

W einstein, $J \ldots \ldots \ldots \ldots \ldots \ldots \ldots 6$

W einstein, $N \ldots \ldots \ldots \ldots$. . . . 52

W einstein, SL . . . . . . . . . 6

Weinstock, M A . . . . . . . . . 12

Weir, FW ............. 3

Weir, GS . . . . . . . . . . . 29

W eisburger, JH . . . . . . . . . 24

W eisenburger, DD . . . . . . . . 100

Weisman, CS . . . . . . . . . . . . 15

Weiss, B . . . . . . . . . . . . . 39 
Weiss, DB ............. 9

Weiss, JM . ............. 34

Weiss, M .............21

Weiss, M A .............. 10

Weiss, NS . . . . . . . . . . . . 3

Weiss, SM ............. 19

Weiss, ST . . . . . . . . . . 3, 95

Weiss, $T \ldots \ldots \ldots \ldots \ldots . \ldots 19$

Weissman, M W . . . . . . . . . . . 5

Weitzman, A . . . . . . . . . . 10

W eizenfeld, $H \ldots \ldots \ldots \ldots . \ldots 53$

W elborn, JW . . . . . . . . . . . . 89

Welch, AR .............. 11

Welch, BA ............. 97

Welch, E ............... 17

Welch, J . . . . . . . . . . . . 41

Welch, $L \ldots \ldots \ldots \ldots \ldots$ 32, 93

Welch, LS ............ 13, 9

Welford, AT . . . . . . . . . . 29

Welinsky, E . . . . . . . . . . . . 10

Well, R...............6

Wellburn, $\vee \ldots \ldots \ldots \ldots \ldots 68$

Wells, AV . ............. 96

Wells, CG ............68

Wells, EA .............. 5

Wells, GA.............. 95

Wells, $\ldots \ldots \ldots \ldots \ldots \ldots \ldots 3$

Wells, RE .............. 10

Wells, RP . . . . . . . . . . . 22

Welty, JR . . . . . . . . . . . . 41

Wenäll ................. 102

Wendt, GR ............ 50

Wenger, $C B \ldots \ldots \ldots \ldots 42$

Wennberg, A . . . . . . . . . . 7, 73

Wentz, DK .............97 97

Wentz, M . . . . . . . . . . . . . 100

Wenzel, R P . . . . . . . . . . . . 53

Wergeland, E............ 10

Werner, E . . . . . . . . . . . . . 43

Werner, $M \ldots \ldots \ldots \ldots .43$

Werner, $\mathrm{N} \ldots \ldots \ldots . . . . .83$

Wertheimer, $\mathrm{N}$. . . . . . . . . . . . 76

Wessen, B. . . . . . . . . . . . . . 13

West, JB ........... 10, 37

West, R ................. 34

West, SK ........... 49, 53

Westberg, $\mathrm{H} \ldots \ldots \ldots \ldots \ldots . \ldots 72$

Westerholm, P . . . . . . 7, 10,52

W estgaard, RH . . .......... 34

Westgaard, R .............6

W estgard, J0 . . . . . . . . . . 27

Westin, AF ............... 34

Westin, JB .............. 11

Westinghouse, Electric

Corporation. ............ 56

Westlander, G . .... 17, 35, 52, 97

Westman, DP............. 19

Westman, $M \ldots \ldots \ldots \ldots 34$

Westrin, C-G . . . . . . . . . . . . 19

Wetherell, $L \ldots \ldots \ldots \ldots \ldots$

W etterwald, M F. . . . . . . . . . 64

W ettman, $0 \ldots \ldots \ldots \ldots \ldots 68$

Wever, RA . .............. 43

Wexley, K N . . . . . . . . . . . . . 34
Weymouth, FW . . . . . . . . 11 Whaley, KE . . . . . . . . . . . . . 17 Wheat, JR .............64 64 Wheeler, L . . . . . . . . . . . . . 34 Whelan, CS . . . . . . . . . . . . 39 Whelan, ME . . . . . . . . . . . 42 Whelan, S . . . . . . . . . . . . . 2 Whelpton, CP ........... 43 Whetten, DA . . . . . . . . . . . 34 Whinnery, JE . . . . . . . . . 102 Whirmer, J...............64 64 Whitaker, A . . . . . . . . . . . . 34 White, DP . . . . . . . . . . . . . 37 White, DW. . . . . . . . . . . . 10 White, E. . . . . . . . . . . . . 28 White, ET . . . . . . . . . . . 34 White, GF . .............. 59 White, IR . . . . . . . . . . . . . 64 White, J ................ 38 White, JC . . . . . . . . . . . . . 53 White, JR . . . . . . . . . . . 44 White, $L \ldots \ldots \ldots \ldots \ldots$. . . . 5, 96 White, M . . . . . . . . . . . . . 53 White, PA ............. 29 White $R \ldots \ldots . \ldots . \ldots . .34$ White, RF ............. 7 White, $\mathrm{RH} \ldots \ldots \ldots \ldots \ldots \ldots 4$ White, RK ............. 34 White, SE . . . . . . . . . . . . 34 Whitefield, D . . . . . . . . . . . 43 Whitehead, C . . . . . . . . . . . 13 Whitehead, LW . . . . . . . . 32, 86 Whitehead, T P . . . . . . . . 27 Whitehead, WE . . . . . . . . . . 34 Whitelaw, WA . . . . . . . . . 37 Whiting, GS ............. 30 Whitlow, J ............... 39 Whitmire, RE ............5 53 Whitten, $P$. . . . . . . . . . . . . 70 Whittenberger, JL . . . . . . . . . . 3 Whorton, D . . . . . . . . . . . . 9 Whyte, WF . . . . . . . . . . . 34 Wichmann, HE . . . . . . . . . 32 Wickens, C . . . . . . . 29, 34, 52 Wickens, CD . . . . . . . . . . . 29 Wickham, C . . . . . . . . . . . 6 Wicks, CE ............. 41 Wickström, G . . . . . . . . . . . 6 Widdicomb, JG . . ............... 37 Widebäck, PG . ........... 52 Widfeldt, AK ............. 34 Widfeldt, JR . . . . . . . . . . . . 34 Widynski, M ............43 43 Wiebe, DJ ................ 34 Wiedemann, P . . . . . . . . . . 59 Wiegand, G . . . . . . . . . . . . 55 Wieland-Eckelmann, R . . . . . . 29 Wielgosz, AT . . . . . . . . . . . 3 Wiemann, $\mathrm{H} \ldots \ldots \ldots . . . .99$ Wiens, D . . . . . . . . . . . . 3 Wiese, NK . . . . . . . . . . . . . 10 Wiesel, SW . . . . . . . . . . . 6, 97 Wieslander, G . . . . . . . . . . 11 W iessberg, J $B$. . . . . . . . . . . . . . I
W iessner, JH ........... 10 Wigaeus $\mathrm{H}$ jelm, E . . . . . . . . 97 Wigand, R . . . . . . . . . . . . . 97 Wiggins, $P \ldots \ldots \ldots \ldots \ldots$ Wigglesworth, EC . . . . . . . . . 18 Wight, $G \ldots \ldots \ldots \ldots \ldots 55$ Wigle, $Y \ldots \ldots \ldots \ldots \ldots \ldots$. . . . . . Wijnans, MJ ............6 63 Wikström, B-0 .......... 3 Wikström, J . . . . . . . . 7,87 Wikström, L. . . . . . . . . . . . 29 Wilber, CS .............. 15 Wilborg, B ..............43 Wilbourn, 」............... 2 Wilcosky, $T \ldots \ldots \ldots \ldots . \ldots 80$ Wilcosky, TC . ............ 3 Wilcox, AJ ...............9 9 Wilcox, BL ............... 34 Wilcox, T G ............96 96 Wild, DK ............... 32 Wild, HW .............43 Wild, P........... 3, 63, 82 Wilde, GJS . . . . . . . . 56, 59, 60 Wilder, RL.............. 6 Wilderspin, M P . . . . . . . . . 10 Wildgruber, $C M \ldots \ldots \ldots 43$ Wiles, FJ . . . . . . . . . . . . . 10 Wiley, H.............. 96 Wiley, MJ. . . . . . . . . . . . . 52 Wilezynska, U . . ..........8 80 Wilhardt, P . . . . . . . . 13, 66 Wilhelm, M R . . . . . . . . . . 29 Wilhelmsen, $L \ldots \ldots \ldots \ldots$. . 34 Wilhelmsson, $B$. . . . . . . . . 11 Wilie, CD ............... 50 Wilk, N................ 73 Wilk, VA .............. 64 Wilke, HJ ............... 5 Wilkenfeld, C . . . . . . . . . . 101 Wilkie, AG . . . . . . . . . . . . 89 Wilkins, CK ............. 13 Wilkins, JR . ............ 9 Wilkins, K ............. 1 Wilkins, PA . . . . . . . . . 47 Wilkinson, B............ 101 Wilkinson, CF . . .......... 30 Wilkinson, DA ............ 11 Wilkinson, $R$. . . . . . . . . . . . 70 Wilkinson, RT . . . . . 29, 43, 97 Wilkons, CK ............ 13 Willeberg, P . . . . . . . . 28 Willems, E . . . . . . . . . . . . 99 Willemze, $R \ldots \ldots \ldots \ldots \ldots 1$ Willens, $\mathrm{H} \ldots \ldots \ldots \ldots \ldots . . . .3$ Willet, K M . . . . . . . . . . . . 997 Williams, A ............. 20 Williams, CC . . . . . . . . . . . 34 Williams, D .............. 39 Williams, DE . . . . . . . . . . 33 Williams, E . . . . . . . . . 29 Williams, ER ............ 7 Williams, JA . . . . . . . . . . . . 97 Williams, JBW . . . . . . . . . . 5 Williams, K . . . . . . . . . . . 17
Williams, M . . . . . . 83, 97

Williams, M E . . . . . . . . . . . 83

Williams, $N \ldots \ldots \ldots \ldots \ldots 10$

Williams, NR . . . . . . . . . . . 34

Williams, PG . . . . . . . . . . . 34

Williams, R ............ 29

Williams, R BJ . . . . . . . . . . 34

Williams, RC . ...........64 64

Williams, RL . . . . . . . . . 43

Williams, $T \ldots \ldots \ldots \ldots \ldots 70$

Williams, T M . . . . . . . . . . . 80

Williams, WW . . . . . . . 15, 97

Williamson, AM . . . . . . . . 43, 56

Williamson, DE . . . . . . . . . . 15

Williamson, M R .........48

Williamson, PAM ......... 101

Willich, SN ............... 3

Willie, D . . . . . . . . . . . . 97

Willis, I................ 49

Willis, R .............. 83

Williston, EM . . . . . . . . . 71

Wills, BA ............... 74

Wilpert, B. . . . . . . . . . . . 29

Wilson, DB . . . . . . . . . . . 70

Wilson, E . . . . . . . . . . . . . 30

Wilson, EO . . .......... 53

Wilson, FC . . . . . . . . . . 9

Wilson, G . . . . . . . . . 34, 51

Wilson, J. . . . . . . . . . 52, 55, 100

Wilson, JD ............... 53

Wilson, JG .............. 9

Wilson, JR . . . . . . . . . . . . . 29

Wilson, $K \ldots \ldots \ldots \ldots \ldots 64$

Wilson, $M \ldots \ldots \ldots \ldots \ldots 6$

Wilson, M A . . . . . . . . . . 97

Wilson, M D . .............. 52

Wilson, M G . . . . . . . . . . . . 15

Wilson, R . . . . . . . . . . . . 30

Wilson, RE. . . . . . . . . . . 41

Wilson, RJ . ............. 13

Wilson, S . . . . . . 13, 34, 52, 100

Wilson, TS............... 10

Winberg, S. . . . . . . . . . . . . 11

Winblad, B.............. 7

Winckler, R . . . . . . . . . . . . 40

Windau, J . . . . . . . . . . . . . 51, 93

Winder, C . . . . . . . . . . . 95

Windham, GC . . . . . . . . . . 52

Windle-T aylor, E.......... 38

Windmuller, JP . . . . . . . . . . 21

Wineman, J . . . . . . . . . . 34

Wing, S ................. 2

Wingate, $D L \ldots \ldots \ldots \ldots \ldots 34$

Wingren, $G \ldots \ldots \ldots \ldots \ldots .72$

Winkel, J . . . . . . . . . . . . 6, 100

Winkelmann, R . . . . . . . 82, 88

Winkler, $J \ldots \ldots \ldots \ldots \ldots . . . . .3$

Winkler, $P$. . . . . . . . . . . . . 55

Winkler, WG . . . . . . . . . . 69

Winn, AR . . . . . . 22, 59, 60

Winn, AR ............. 56

Winslow, R M . . . . . . . . . . . . 37

Wintemute, $G \ldots \ldots \ldots \ldots .64$

Winter, $P \ldots \ldots \ldots \ldots .10,71,88$ 
Winter, RD . . . . . . . . . . 97

Wintermeyer, LA . . . . . . . . 32

Wintermeyer, SF . . . . . . 10, 11

Winters, SJ . .............. . 9

Wipf, HK . . . . . . . . . . . . 39

Wiseman, J............. 53

Wisner, A . . . . . . . . . . . . 29

Wissler, EH .............42 42

Wiswesser, WJ . . . . . . . . . 62

Witek, TJ . . . . . . . . 11, 89

Witkower, A............ 26

Witschi, M . ............. 30

Witt, CE. . . . . . . . . . 102

Witt, LA . . . . . . . . . . . . . 102

Witting, $P \ldots \ldots \ldots \ldots \ldots \ldots 15$

Wittman, LB . . . . . . . . . 70

Witz, G .............. 1

Wlodarczak, K . . . . . . . . . . 38

Wlodarczyk, JH . ........... 10

Wobbe, $G \ldots \ldots \ldots \ldots \ldots 43$

Woellner, R . . . . . . . . . . . . 70

Woest, TE .............. 100

Wohleber, C . ........... 19

Wohlwill, J.............. 34

W ojtczak-Jaroszowa, J . . . . . . 3

W ojtczak, J. . . . . . . . . . . . 38

Wokutch, R .............21

Wolbarsht, M........... 96

Wolbarsht, M L ........... 49

Wold, TM .............. 66

Wolf, AH .............. 10

Wolf, $P \ldots \ldots \ldots \ldots \ldots . . . .60$

Wolf, PH ............ 80

Wolf, S ................. 34

Wolf, SG ............. 5

Wolf, SL . . . . . . . . . . . . 17

Wolfe, DM . . . . . . . . . . . . 34

Wolfe, $F \ldots \ldots \ldots \ldots \ldots .6$

Wolfe, $L \ldots \ldots \ldots \ldots \ldots \ldots \ldots . \ldots 77$

Wolff, DM .............. 58

Wolff, HL............ 100

Wolff, HP............. 97

Wolff, I.............. 83

Wolff, $L \ldots \ldots \ldots \ldots \ldots . . . .63$

Wolff, M S ............ 9, 94

Wölfle, J ............... 97

Wolfson, $C \ldots \ldots \ldots \ldots \ldots$.

Wolkoff, P . . . . . . . . 13, 97

Wolkoff, $P \ldots \ldots \ldots \ldots \ldots 44$

Wolson, AH .............. 7

Wolters, GJR . . . . . . . . . . . 30

Wolyniec, P . . . . . . . . . . 34

Womack, J . . . . . ........ 29

W omen's $O$ ccupational $H$ ealth

R esource Center . . ........ 94

Wong, CK ............... 39

Wong, GY ............... 59

Wong, $H \ldots \ldots \ldots \ldots 10,11$

Wong, J ................ 83

Wong, LL.............. 96

Wong, $0 \ldots \ldots \ldots \ldots$. . 30

Wong, PT P ............ 34

Wong, WL $\ldots \ldots \ldots \ldots \ldots 6$

Woo, SL.............. 6
Wood, $\mathrm{CH} \ldots \ldots \ldots \ldots \ldots . . . .69$

Wood, $N \ldots \ldots \ldots \ldots . \ldots 22$

Wood, PD .............. 6

Wood, R ..........34, 39, 55

Wood, RC . . . . . . . . . . . . 13

Wood, RK ..............64 64

Wood, WB.............. 28

Woodcock, AH ...........4 42

Woodger, JH ............. 19

Woodhead, AD ............ 33

Woodhouse, G . . . . . . . . . . . 59

Woodhouse, PR ............ 3

Woodrow, R .............15

Woodruff, TJ . ............. 15

Woods, B . . . . . . . . . . . . . 71

Woods, D . . . . . . . . . . . . . 58

Woods, D . . . . . . . . . . . . 56

Woods, D D . . . . . . . . . . . . 29

Woods, DR ............. 77

Woods, GM .............. 78

Woods, JE . . . . . . . . . . . . . 13

Woods, NF . . . . . . . . . . . . . 97

Woodside, M . . . . . . . . . . . . . 15

Woodson, GE ............ 71

Woodson, WE . . . . . . . . . . 29

Woodward, A ............ 32

Woolcock, A . . . . . . . . . . . . . 10

Wooley, T . ............. 97

Woolley, WD .............41

Woolson, RF . . . . . . . . . . . . 28

Worgul, TJ............ 9

Workers' Compensation Board

of British Columbia........ 72

Working, PK ............ 9

W orkplace $\mathrm{H}$ azard and T obacco

Education Project . . . . . . . . 93

W orksafe A ustralia. . . . . . . 19, 103

Woskie, SR .......... 30, 83

Woutersen, RA . . . . . . . . . 100

Woychik, JH ............ 70

Wrenn, G . ............. 30

Wright, $\mathrm{BH} \ldots \ldots \ldots \ldots . \ldots 34$

Wright, D . . . . . . . . . 15, 17

Wright, EA . ............ 3

Wright, FB . . . . . . . . . . 16

Wright, JL . . . . . . . . . . . 10

Wright, R .............. 34

Wright, $S \ldots \ldots \ldots \ldots 34,83$

Wright, $T \ldots \ldots \ldots \ldots \ldots 11$

Wright, WC . . . . . . . . . . 89

Wu, KK .............. 6

Wu, M-F .............11

Wu, M M ............. 28

Wu, T-N $\ldots \ldots \ldots \ldots \ldots 66$

Wu, YX ................ 102

Wugofski, L . . . . . . . . . . 97

Wuisman, O PJM . ..........6 64

Wulfsohn, M ............ 28

Wundt, $W \ldots \ldots \ldots . . . . . .34$

Wurm, M . ............ 34

Wusteman, M ............ 10

Wycoff, SJ ...............4

Wyers, GP . . . . . . . . . . 55

Wyers, $H \ldots \ldots \ldots \ldots \ldots 28$
Wyker, A . . . . . . . . . . . 8

Wylie, D ............... 97

Wyllie, AH .............. 33

Wyllie, $L \ldots \ldots \ldots \ldots \ldots . \ldots 39$

Wynder, EJ .............. 2

Wynder, EL .............44

Wyndham, $\mathrm{CH} \ldots \ldots \ldots \ldots . . .3$

Wyngaard, $J \ldots \ldots \ldots \ldots \ldots 55$

Wynne, GF . .............. 53

Wynne, RF .............43

Wyon, $D \ldots \ldots \ldots \ldots . . . . .13$

$X$

$X$ aiz, $D \ldots \ldots \ldots \ldots \ldots 27$

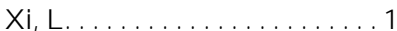

$X$ iang, TS ............... 32

Xinshui, Z ................63 63

Xintaras, C . ......... 33, 53

$X$ intaris, $C \ldots \ldots \ldots \ldots . . .7$

Xuan, $X \ldots \ldots \ldots \ldots . . .63$

\section{$Y$}

Yadav, BG . . ..............64 64

Yaffe, $H \ldots \ldots \ldots \ldots \ldots . . . . . .9$

Yager, JW ............... 30

Yaglou, CP............. 42

Yagoglou, CP.......... 42

Yajima, $\mathrm{H} \ldots \ldots \ldots \ldots \ldots 41$

Yakuboff, K P........... 40

Yakushiji, $T \ldots \ldots \ldots \ldots . . . .9$

Yamamoto, $\mathrm{H} \ldots \ldots . \ldots . .44$

Yamamoto, $N$............. 11

Yamamoto, RS . . . . .......... 24

Yamamura, $K \ldots \ldots \ldots \ldots 11$

Yamamura, $Y \ldots \ldots \ldots \ldots .96$

Yamartino, RJ .............55 55

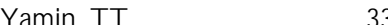

$Y$ an, $C Y \ldots \ldots \ldots \ldots \ldots 10$

$Y$ an, $X \ldots \ldots \ldots \ldots \ldots . \ldots 34$

$Y$ anagisawa, $Y \ldots \ldots \ldots \ldots . . .9$

Yanazaki, C ..............997

Y ancey, AH . . . . . . . . . . . . . 51

Yang, C ................ 101

Yang, C-L ............. 52

$Y$ ang, J................ 10

Yang, LF . . . . . . . . . . . . . . 63

Yang, $N \ldots \ldots \ldots \ldots \ldots . . . .70$

Y anuzzi, LA . ............ 49

Yarborough, CM ........... 34

Y ardley, L . . . . . . . . . . . . . . 11

Y assi, A . . . . . . . . . . . . 26, 26, 97

Yassin, M S. . . . . . . . . . . . . 97

Yasuno, $Y \ldots \ldots \ldots \ldots \ldots . \ldots 3$

Yates, JE ............... 5

$Y$ ates, JF. . . . . . . . . . . . . . 59

Yau, ACMC ...........6 6

Ydrevorg, B ............. 7

Ye, P-Z, ............... 1

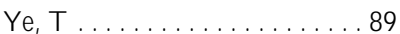

Y eargin-Allsopp, M . . . . . . . . 88 87

Y eggy, J . . . . . . . . . . . . 70

Yeh, YY ................. 29
Yen, LT . . . . . . . . . . . . 15

Yeni, SSC ............... 9

$Y$ eo, $P \ldots \ldots \ldots \ldots \ldots . \ldots 70$

Yeoh, HF .............. 22

Y erkes, R M .............. 34

Y immermann, L . ......... 21

Yin, S-N ................ 1

Ylikoski, M ............... 52

Yobs, AR ............. 27

Yocom, JE ............. 44

Y odaiken, RE . . . . . . . . . . 27

Y oder, JD . ............ 19, 34

Yodofsky, S ............... 5

Y oftrey, JM .............. 33

Yokum, L.............. 96

Yontchev, E ............. 11

Y oshida, K . . ............ 86

Yoshida, S . . . . . . . . . . . . 5

Yoshimaru, $\mathrm{H} \ldots \ldots \ldots \ldots .48$

Y oshimoto, $Y \ldots \ldots \ldots \ldots .48$

Yoshimura, $\mathrm{H} \ldots \ldots \ldots \ldots . . . . . . .6$

Y oshinobu, Sato. . . . . . . . . . . 58

You, XJ ............... 80

Younes, $M \ldots \ldots \ldots \ldots . \ldots 33$

Young, AJ ............. 42

Young, FE .............. 53

Young, JE .............. 52

Young, JS . . . . . . . . . . . 11

Young, JT ............. 11

Young, $L \ldots \ldots \ldots \ldots \ldots \ldots \ldots . \ldots 10$

Young, Q .............. 91

Young, RM ............. 52

Young, SEJ ............. 100

Ytting, UJ . . . . . . . . . . . . . 63

Yttrehus, $K \ldots \ldots \ldots \ldots . \ldots 42$

Yu, H-S ..............66 66

Yu, HHS .............. 45

$Y u, S Z \ldots \ldots \ldots \ldots \ldots . \ldots 80$

$Y u, V L \ldots \ldots \ldots \ldots \ldots \ldots . \ldots . \ldots . \ldots$

Yuasa, $K \ldots \ldots \ldots \ldots \ldots 10$

Yudin, $Y B$. . . . . . . . . . . . . 39

Yue, $L \ldots \ldots \ldots \ldots \ldots \ldots . \ldots 53$

Yuhua, $\mathrm{H} \ldots \ldots \ldots \ldots \ldots . \ldots 63$

Y unginger, J. . . . . . . . . . . 100

Y unginger, JW . . . . . . . . . . 97

Yunus, M B.............. 6

Y ushchenko, VI . . . . . . . . . . . 39

Yusof, M ............. 22

\section{Z}

Zabinska, $0 \ldots \ldots \ldots \ldots \ldots .4$

Zaccaro, S] .............. 34

Zachariae, C .............93 93

Zachary, G.............. 5

Zachrisson, M ...........99 97

Zack, M ................. 39

Zaebst, D . . . . . . . . . . . . . 79

Zaffanella, LE . . . . . . . . . . . 49

Zahm, SH ............. 100

Zajac, LP ............... 20

Zajda, EP . . . . . . . . . . . 10

Zajtchuk, R ............. 95

Zak, MJ ............... 93 


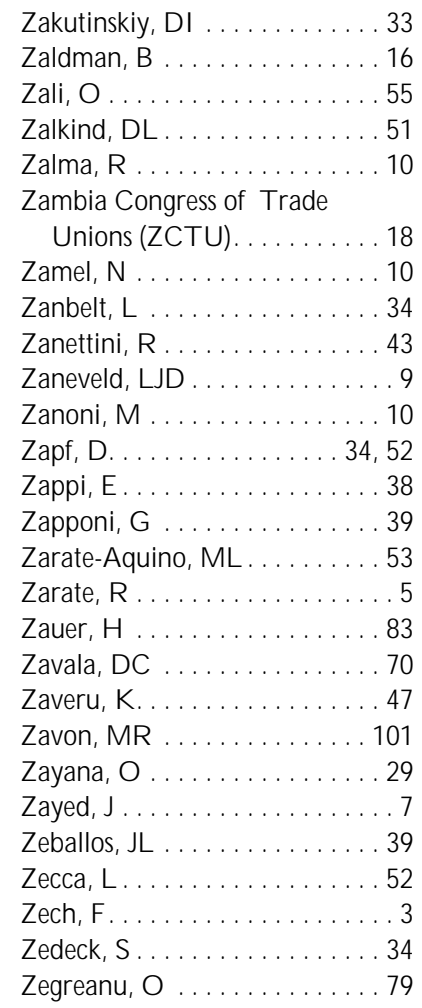

Zakutinskiy, DI ........................ 33

...... 16

Zalkind, DL ............. 51

Zalma, R ............... 10

Zambia C ongress of T rade

Zamel, N . . . . . . . . . . . . . . . 10

Zanbelt, L . . . . . . . . . . . . . 34

Zanettini, $R \ldots \ldots \ldots \ldots \ldots$. 43

Zaneveld, LJD ..............

Zapf, D.............. 34, 52

Zappi, E................ 38

Zapponi, G ...............39

Zarate-Aquino, ML . ......... 53

Zauer $\mathrm{H}$.............................85

Zavala, DC ..............70 70

Zaveru, K...............47

Zayed, I..................

Zeballos, JL ................ 39
Zeidler, $\mathrm{H}$

Zeiger, $\mathrm{E} \ldots \ldots \ldots \ldots \ldots \ldots . . \ldots \ldots$

Zeilmaker, MJ ............ 33

Zeitels, S................96 96

Zejda, JE ........... 10, 38

Zejda, WD ...............64

Zeldis, St . ................ 3

Zelkowitz, RS .............34

Zeller, RA ..............28

Zeman, GH ............. 83

Zembroski, EL . . . . . . . . . . . 59

Zenick, $\mathrm{H} \ldots \ldots \ldots \ldots \ldots . . .9$

Zenz, C . 3, 10, 16, 30, 36, 77, 102

Zerbib, JC ............... 39

Zerefos, C ...............53

Zerlett, G . .......... 3, 6, 50

Zernik, F .............. 30

Zeschmar, B..............99

Zev, M ................59

Zhan, $K \ldots \ldots \ldots \ldots \ldots . . . . . . .5$

Zhang, L ................. 33

Zhang, L-P............... I

Zhang, $S \ldots \ldots \ldots \ldots \ldots \ldots . . \ldots$

Zhang, SZ ............... 3

Zhang, W............... 89

Zhang, W-Y ............. 1

Zhang, $X-C \ldots \ldots \ldots \ldots \ldots$. . . . . .

Zhang, YK ............. 29
Zhang, Z-N

Zhang, ZF

Zhao, Y

Zhicheng, S

Zho, J-S

Zhou, C ...

Zhu, G

Zicheng, $S \ldots \ldots \ldots \ldots \ldots 63$

Ziegler, DM . .............. 33

Ziegler, EE ..............9

Zielhuis, RL . . . . . . . . . . 30, 43

Zielinski, JM . .............. 2

Ziem, GE . . . . . . . . . . . 19, 30

Ziem, $U$.................. 10

Zierrock, K -H ............. 55

Zikarge, A .............. 9

Zilko, JL................83 83

Zillstorff, $\mathrm{K} \ldots \ldots \ldots \ldots \ldots 11$

Zimmer, L ............... 34

Zimolong, B........... 58, 59

Zimring, $C \ldots \ldots \ldots \ldots \ldots 34$

Zinchenko, V . . . . . . . . . . . 29

Zinenko, GM . . . . . . . . . . . . 3

Zinn, S...............21

Zinsstag, ..................63

Zippel, $R \ldots \ldots \ldots \ldots \ldots \ldots$

Ziqing, $X \ldots \ldots \ldots \ldots \ldots 63$

Zirschky, J
Ziskind, $M \ldots \ldots \ldots \ldots \ldots 10$

Zitting, A ................ 6

Zober, A................ 3

Zocchetti, C ....... 1, 10, 39, 85

Zodrow, S .............. 70

Zoganas, L . . . . . . . . . . 11, 97

Zohar, D ............. 34, 59

Zoloth, R .............. 72

Zoloth, SR . . . . . . . . . . 34, 85

Zoppa, RM ............. 15

Zubko, MN ............... 3

Zuboff, $S \ldots \ldots \ldots \ldots \ldots . \ldots 52$

Zuch, C ................9

Zuckerman, M . . . . . . . . . . . 59

Zuclich, JA . ............. 49

Zuehlke, RL............ 70

Zugibe, FT ............. 38

Zukerman, Z ............ 9

Zulaika, J..............66

Zummermann, C . .........99

Zuniga, CM A ...........96

Zurlo, J................ 33

Zuskin, E . . . . . . . . . 65, 89

Zweers, T . ............. 13

Zwennis, WCM ...........63 63

Zwiener, RJ ............. 9

Zycherman, LA ........... 96

Zyzanski, SJ . . . . . . . . . . . 5 


\section{P.K. Abeytunga}

$\mathrm{C}$ anadian C entre for $\mathrm{O}$ ccupational $\mathrm{H}$ ealth and Safety

$250 \mathrm{M}$ ain Street East

H amilton, 0 ntario L $8 \mathrm{~N} 1 \mathrm{H} 6$, Canadá

Tel: 1 (416) 572-4537

Fax: 1 (416) 572-2206

E-mail: abey@ccohs.ca

Puesto(s) actual(es): V ice-President, Director General

Puesto(s) anterior(es): Safety Advisor, W est Sussex County C ouncil; Factory Inspecting Engineer, Sri Lanka D epartment of Labour

E studios: M Sc, 1974, U niversidad de A ston; PhD, 1978, U niversidad de Aston

A reas de interés: salud y seguridad profesional; programas y proyectos internacionales; desarrollo por medios electrónicos; conceptualización, desarrollo y puesta en marcha de servicios de información nacionales e internacionales

\section{Ursula Ackermann-Liebrich}

Instituto de M edicina Social y Preventiva

Steinengraben 49

4051 Basel, Suiza

T el: 41612676066

Fax: 41612676190

Puesto(s) actual(es): Profesora, Jefa de departamento

Puesto(s) anterior(es): Directora adjunta, Comisión $M$ édica C ristiana/ Consejo M undial de I glesias; Investigadora, Escuela de Salud Pública Santiago

E studios: M D, 1970, U niversidad de Basel; Dipl Trop M ed, 1970, Instituto Suizo de M edicina T ropical; M Sc, 1975, L ondon School of $\mathrm{H}$ ygiene and T ropical M edicine

A reas de interés: salud ambiental; epidemiología; contaminación atmosférica

\section{Michael Adess}

H uman Factors Division

U nited States C oast G uard

2100 Second St. SW

R oom 5308

Washington, DC 20593-0001, Estados U nidos

T el: 1 (202) 267-1388

Fax: 1 (202) 267-4355

Puesto(s) actual(es): Chief

Puesto(s) anterior(es): Chief, Environmental $\mathrm{H}$ ealth Branch, U nited States C oast G uard; Assistant Chief, Safety and

Environmental $\mathrm{H}$ ealth Division, US Coast Guard

E studios: BS, 1962, U niversity of $V$ ermont; M S, 1964, U niversity of V ermont; PhD, 1971 U niversity of M innesota School of Public $\mathrm{H}$ ealth
A reas de interés: salud ambiental; salud en el trabajo; gestión de la evaluación de riesgos

\section{Sheila H. Akabas}

W orkplace Center

Columbia U niversity School of Social W ork

622 W. 113th Street

8th Floor

N ueva Y ork, Nueva Y ork 10025, Estados

Unidos

T el: 1 (212) 854-5173

Fax: 1 (212) 854-2975

E-mail: sal2@ columbia.edu

Puesto(s) actual(es): Professor of Social W ork, Director

Puesto(s) anterior(es): Associate D irector, Just O ne Break; R esearch Director, Amalgamated Clothing W orkers of A merica M enta $\mathrm{H}$ ealth Project

E studios: PhD, 1970, N ew Y ork U niversity: M BA, 1956, N ew Y ork U niversity; BS, 1951, Cornell U niversity

A reas de interés: trabajo, discapacidad y pensiones de trabajo; programas de asistencia al empleado; asuntos relacionados con el mundo de la mujer; acoso sexual; gestión de recursos humanos; diversidad en e lugar de trabajo

\section{Munehira Akita}

Facultad de Ciencias Sociales y de la nformación

U niversidad Nihon Fukushi,

26 T akezono-cho Japón

K awashima- N ishikyo-ku

$K$ yoto 615 , Japón

Tel: 81753817578

Fax: 81753945335

E-mail: c51666@jpnkudpc.bitnet

Puesto(s) actual(es): Director, Profesor

Puesto(s) anterior(es): Profesor emérito, Instituto de T ecnología de $\mathrm{K}$ yoto

E studios: BA, 1953, U niv. de $K$ yoto; M A, 1955 , Univ. de K yoto; PhD, 1962, Columbia U niversity

A reas de interés: percepción humana del color y EEG

\section{Leen Akkers}

Stichting Arbouw

Postbox 0114

1005 AC Amsterdam, Países Bajos

Tel: 310205805580

Fax: 310205805555

Puesto(s) actual(es): Director ejecutivo

Puesto(s) anterior(es): Director ejecutivo de la Federación H olandesa de D eportes; profesor de niños con desequilibrios emocionales
Estudios: 1962-1967, U niversidad de G roningen 1972-1976, Cursos de Dirección en R eino U nido y Países Bajos

A reas de interés: salud y seguridad en la industria de la construcción

\section{Avraham Aladjem}

Instituto I sraelí de Seguridad e H igiene en el Trabajo

65213 T el A viv, I srael

Tel: 9723556258

Fax: 97235562584

Puesto(s) anterior(es): Investigador, Centro de Investigación Soreq

E studios: D Sc, 1972, Instituto I sraelí de T ecnología

A reas de interés: higiene en el trabajo; métodos avanzados de análisis

\section{R.G. Aldi}

$\mathrm{Q}$ uality and Environmental Affairs

$H$ iram Walker and Sons $L$ td.

Walkerville, O ntario N 8Y 4S5, Canadá

Puesto(s) actual(es): Director

\section{Lorenzo Alessio}

Instituto de M edicina del T rabajo, U niversidad de Brescia

P.le Spedali Civili 1

25123 Brescia, I talia

T el: 3930396496

Fax: 3930394902

E-mail: medlav@ master.cci.unibs.it

Puesto(s) actual(es): Profesor, Director

Estudios: M D, 1965

Areas de interés: toxicología industrial; vigilancia biológica de metales y disolventes; inmunotoxicología

\section{Priscilla Alexander}

N orth American T ask Force on Prostitution

785 Broadway

Apt 4L

Nueva Y ork, N ueva Y ork 10025-2834, Estados Unidos

Tel: 1 (212) 866-8854

Fax: 1 (212) 8668854

E-mail: pja14@columbia.edu

Puesto(s) actual(es): C o-coordinator: D ata $M$ anager, Foundation for R esearch on Sexually T ransmitted Diseases, Inc., Nueva Y ork

Puesto(s) anterior(es): A sessor, W orld $\mathrm{H}$ ealth O rganization, G lobal Programme on AIDS; Education Coordinator, California Prostitutes Education Project; Co-Director, COYOTE, San Francisco, CA, USA

E studios: BA, 1960, Bennington College; Candidate M PH , C olumbia University School of Public $\mathrm{H}$ ealth 
A reas de interés: salud y seguridad laboral relacionadas con el sexo en el trabajo; leyes y normativas públicas; ética e investigación; enfermedades infecciosas, estigma e ideología del contagio; enfoques de salud pública y normas sobre prevención y control de enfermedades de transmisión sexual, incluido el SIDA

\section{Sydney Allison}

Communications Division

M intek

$200 \mathrm{H}$ ans Strijdom D rive

R andburg 2125, Sudáfrica

T el: 011 709-4111

Fax: 011 793-2413

E studios: M Sc, 1962, U niversity of $\mathrm{N}$ atal; PhD, 1966, Imperial College

A reas de interés: tecnología del tratamiento de minerales

\section{Alfred A. Amendola}

Safety Engineering Program

T exas A\&M U niversity

131D Zachry Engineering Center

College Station, T exas 77843-3133, Estados Unidos

Tel: 1 (409) 845-4107

Fax: 1 (409) 845-6443

E-mail: amen@tamu.edu

Puesto(s) actual(es): R esearch Associate Professor, Associate Director

Puesto(s) anterior(es): Acting Director, DSR , N ational Institute for $O$ ccupational Safety and H ealth; D eputy D irector, DSR, $N$ ational Institute for $O$ ccupational Safety and H ealth; J efe, M PS, ECT B, DPSE, National Institute for $\mathrm{O}$ ccupational Safety and $\mathrm{H}$ ealth

E studios: PhD, 1989, T exas A\&M U niversity

A reas de interés: ingeniería de la seguridad; ergonomía

\section{Yngve Anderberg \\ Fire Safety D esign AB}

A partado de correos 2170

22202 L und, Suecia

T el: 4646140020

Fax: 4646140030

E-mail: yngve.anderberg@glunet.se

Puesto(s) actual(es): Director ejecutivo

Puesto(s) anterior(es): Profesor, D epartmento de M ecánica de Estructuras y Construcción en hormigón, Instituto L und de T ecnología

E studios: PhD, 1976, Ingeniería de seguridad contra incendios

A reas de interés: ingeniería de seguridad contra incendios

\section{Judith Anderson}

Department of Environmental and

$\mathrm{O}$ ccupational $\mathrm{H}$ ealth

George W ashington U niversity

2300 K Street NW \#201

W ashington, DC 20037, Estados U nidos

T el: 1 (202) 994-7467

Fax: 1 (202) 994-0011

E-mail: janderso@gwis2.circ.gwu.edu

Puesto(s) actual(es): R esearch Associate
Puesto(s) anterior(es): R esearch Assistant, Division of Epidemiology, British Columbia Cancer Agency, $\mathrm{V}$ ancouver

E studios: M Sc, 1995, U niversity of British Columbia

A reas de interés: evaluación de riesgo en la industria de la construcción y en la industria del papel y la pasta de papel

\section{Ragnar Andersson}

D epartamento de Salud Pública

División de M edicina Social

Instituto $\mathrm{K}$ arolinska

17283 Sundbyberg, Suecia

T el: 4686290500

Fax: 468986367

E-mail: ragnar.andersson@ phs.ki.se

Puesto(s) actual(es): Director del programa de lesiones

E studios: M Eng, 1976, U niversidad de L und, Facultad de T ecnología; PhD, 1991 , Instituto K arolinska, D epartmento de M edicina Social

A reas de interés: promoción de la seguridad colectiva; prevención de accidentes laborales

\section{Diego Andreoni}

Via Filippo Civinini 85

00197 R oma, I talia

T el: 3968078131

Puesto(s) anterior(es): Director G eneral, ENPI, R oma; A sesor en salud y seguridad de la 0 ficina Internacional del T rabajo y la A sociación Internacional de la Seguridad Social, Ginebra

E studios: D r Ing, 1929, Politécnico, M ilán, I talia

A reas de interés: salud y seguridad general y del trabajo

\section{W. Stanley Anthony}

U nited States D epartment of A griculture Agricultural R esearch Service

P.O. Box 256

Stoneville, M S 38776, Estados U nidos

T el: 1 (601) 686-3094

Fax: 1 (601) 686-5483

E-mail: anthonys@ars.usda.gov

Puesto(s) actual(es): Supervisory Agricultural Engineer, U S Cotton G inning Laboratory

Puesto(s) anterior(es): A gricultural Engineer, US Cotton Ginning Laboratory; M ilitary Engineer, US Army; R esearch Associate, M ississippi State U niversity; Field Entomologist, T hompson-H ayward Chemical Company

E studios: M Sc, 1970, M ississippi State U niversity

A reas de interés: control informático en desmotadoras de algodón; empaquetado de balas de algodón; conservación de la calidad del algodón; limpieza del algodón

\section{Elias Apud}

Departamento de Fisiopatología

U niversidad de Concepción

Casilla 4025

Concepción, Chile

Tel: 5641280336
Fax: 5641245975

E-mail: eapud@buo.dpi.udec.cl

Puesto(s) actual(es): D irector

Puesto(s) anterior(es): J efe, Sección de Ergonomía, U niversidad de Concepción

E studios: PhD, Loughborough U niversity; M Sc, U niversidad de Loughborough

A reas de interés: ergonomía; fisiología del trabajo

\section{M.P. Arias}

Departamento de Seguridad y Salud Ambiental, H ospital Clínico U niv.

08036 Barcelona, España

Tel: 3432275400

Fax: 3432275454

Puesto(s) actual(es): J efe

Puesto(s) anterior(es): A yudante técnico en el D epartamento de Seguridad y Salud; A yudante técnico en salud y seguridad ambientales y protección radiológica

E studios: Lic. Ciencias, 1988, U niversidad de Salamanca; Dipl. Ing. A mbiental, 1992, M inisterio de Industria y Energía; D octor Ciencias, 1993, U niversidad Politécnica de Cataluña

A reas de interés: gestión de residuos; manipulación y eliminación de cancerígenos: prevención de riesgos para la salud en el trabajo

\section{Peter Arlien-Soborg}

D epartamento de N eurología

$\mathrm{H}$ ospital $\mathrm{H}$ vidovre

U niversidad de Copenhage

K ettegárd Alle 30

2100 Copenhage, Dinamarca

T el: 4536322405

Fax: 4536323312

Puesto(s) actual(es): J efe

E studios: Física, 1968, U niversidad de Arhus, Dinamarca; D M , 1983, U niversidad de Copenhage

A reas de interés: neurotoxicología; desórdenes cerebro-vasculares; mielopatía; demencias

\section{Bruce K. Armstrong}

Cancer C ontrol Information Centre

$\mathrm{N}$ ew South Wales $\mathrm{C}$ ancer $\mathrm{C}$ ouncil

P.O. Box $572 \mathrm{~K}$ ings $\mathrm{C}$ ross

Sidney, N ueva G ales del Sur 2011, Australia

Tel: 61293341837

Fax: 61293680843

E-mail: brucea@nswcc.org.au

Puesto(s) actual(es): Director

Puesto(s) anterior(es): Director, Australian Institute of $\mathrm{H}$ ealth and W elfare; D eputy Director, A gencia Internacional para la Investigación sobre el Cáncer

E studios: BM edSc, 1967; M B, BS, 1969; D Phil, 1975, 0 xon

A reas de interés: epidemiología de exposición al sol y cáncer de piel

\section{James R. Armstrong}

O ntario N atural R esources Safety Association North Bay, O ntario P1B 8K 6, Canadá

Puesto(s) actual(es): T echnical Services Coordinator 
Puesto(s) anterior(es): Industrial $\mathrm{H}$ ygienist, $\mathrm{M}$ ines Accident Prevention Association; O ccupational $\mathrm{H}$ ealth Supervisor, C liffs of Canada Ltd.

E studios: CIH ; Bus Admin, 1972, N orthern College of A pplied Arts and T echnology

\section{Pat Armstrong}

School of C anadian Studies

Carleton University

O ttawa, O ntario K IS 5B6, Canadá

T el: 1 (613) 520-2366

Fax: 1 (613) 520-3903

E-mail: patarmstrong@carleton.ca

Puesto(s) actual(es): Professor, Director

Puesto(s) anterior(es): Chair, D epartment of Sociology, Y ork U niversity

E studios: BA, 1966, U niversity of T oronto; M A, 1975, C arleton U niversity; PhD , 1984 Carleton U niversity

A reas de interés: mujeres y trabajo; prestación y prestadores de asistencia sanitaria

\section{Thomas Armstrong}

School of Public H ealth

$U$ niversity of $\mathrm{M}$ ichigan

1205 Beal Avenue

Ann Arbor, M ichigan 48109-2117, Estados Unidos

T el: 1 (313) 763-3742

Fax: 1 (313) 764-3451

E-mail: tja@amich.edu

Puesto(s) actual(es): Professor of O ccupational $\mathrm{H}$ ealth, Industrial and $\mathrm{O}$ perations Engineering

E studios: BSE., 1971, U niversity of M ichigan; M PH , 1972, U niversity of M ichigan; PhD, 1976, U niversity of M ichigan

A reas de interés: salud laboral; biomecánica profesional; fisiología del trabajo; trastornos musculosqueléticos asociados al trabajo

\section{Ragnar Arnason}

Departmento de Economía

U niversidad de I slandia

O ddi v/ Sudurgotu

101 R eykjavik, Islandia

T el: 354 525-4539

Fax: 354 552-6806

E-mail: ragnara@rhi.hi.is

Puesto(s) actual(es): Profesor

E studios: M Sc, 1977, L ondon School of Economics; PhD, 1984, U niversity of British Columbia

A reas de interés: economía de pesquerías; economía de los recursos naturales

Ian M. F. Arnold

Noranda Inc.

181 Bay Street \#4100

P.O.Box 755

BCE Place

Toronto, O ntario M 5J 2T 3, Canadá

T el: 1 (416) 982-7200

Fax: 1 (416) 982-7471

Puesto(s) actual(es): M edical Director and Director of $\mathrm{O}$ ccupational $\mathrm{H}$ ealth

Puesto(s) anterior(es): M edical Director, D ow
E studios: M D, 1968, Q ueen's U niversity of K ingston; M Sc, 1971, M cG ill U niversity; D O HS, 1981, M cM aster U niversity

A reas de interés: programas de mejora de la salud en el trabajo en Canadá y a escala internacional

\section{Jean Arteau}

Seguridad y T écnica

Instituto para la Investigación de la Salud y la

Seguridad en el Trabajo

505 boulevard De $M$ aisonneuve $O$ uest

M ontreal, Q uébec $\mathrm{H}$ 3C 3A2, C anadá

Tel: 1 (514) 288-1551

Fax: 1 (514) 288-9399

E-mail: arteau.jean@irsst.qc.ca

Puesto(s) actual(es): Investigador

Puesto(s) anterior(es): Especialista en geomecánica para la Comisión de investigación de la tragedia de la mina de Belmoral, G obierno de Q uébec;

E studios: BASc, 1974, Ecole Polytechnique de M ontréal; M ASc, 1977, Ecole Polytechnique de M ontréal; PhD, 1984 E cole Polytechnique de M ontréal

A reas de interés: energía absorbida de los postes de anclaje para cuerdas de seguridad horizontales; sistemas de detección de caída para subida a postes de madera (instaladores de teléfono, telégrafo, etc); protección contra caídas

\section{Tony Ashdown}

\section{G rassy G arth}

Elkridge, M aryland 21075, Estados U nidos

Tel: 1 (410) 298-1000 ext. 675

Fax: 1 (410) 298-8187

E-mail: aka@sprintmail.com

Puesto(s) anterior(es): Corporate Safety Supervisor, O ttawa Silica C o.; Supervisor, Safety and Industrial H ygiene, Allied-Signal; Sr. Safety Engineer (T hiokol Corp); Safety and Security Supervisor, (Chevron Chemical); Supervisor - Safety and Ergonomics (Perdue Farms)

E studios: M S, 1975, Illinois State U niversity

A reas de interés: ergonomía; gestión del riesgo; salud en el trabajo; gestión ambiental; revisión de acuerdos

\section{George Astrakianakis}

Cancer Control R esearch

British Columbia Cancer Agency

600 West 10 th A venue

Vancouver, British Columbia V 57 4E6, Canadá

T el: 1 (604) 877-6005

Fax: 1 (604) 877-1868

E-mail: gastraki@bccancer.be.ca

Puesto(s) actual(es): R esearch Scientist

Estudios: B Eng, M Eng

\section{Gordon Atherley}

$O$ beron Composer Software

100 Lakeshore R oad East

Suite 303

O akville, O ntario L6J 6M 9, Canadá

Tel: 1 (905) 842-9425

Fax: 1 (905) 849-6365

E-mail: atherley@ pecs.gsalink.com

E studios: M BChB, 1957, M anchester; M D, 1967, $\mathrm{M}$ anchester
Michael D. Attfield

Division of R espiratory D isease Studies

National Institute for O ccupational Safety and

Health

1095 Willowdale R oad

M organtown, W est V irginia 26505, Estados Unidos

T el: 1 (304) 285-5737

Fax: 1 (304) 285-5861

E-mail: mda1@ niords1.em.cdc.gov

Puesto(s) actual(es): E pidemiologist

Puesto(s) anterior(es): Statistician, Institute of

$O$ ccupational M edicine, Edinburgh, Escocia

E studios: PhD, 1986, W est V irginia U niversity A reas de interés: carbón, gasóleo

\section{Jörg Augusta}

Arbeitsgruppe Ergonomie und W aldarbeit $L$ andesanstalt für W ald- und Forstwirtschaft ägerstrasse 1

D -99867 G otha, Alemania

Tel: 493621225112

Fax: 493621225114 od. 22522

A reas de interés: ergonomía

\section{William Avery}

Systems Safety M anagement U SA, Inc.

8394 Sandpoint Boulevard

O rlando, Florida 32819, Estados U nidos

Tel: 1 (407) 354-1186

Fax: 1 (407) 354-5295

Puesto(s) actual(es): President

Puesto(s) anterior(es): V ice-president, Safety and Security, Boardwalk and Baseball, Inc.

E studios: Associate of Science, 1976, $\mathrm{H}$ illsborough Community College

A reas de interés: seguridad de atracciones recreativas; gestión de acontecimientos multitudinarios; seguridad de parques acuáticos; centros de entretenimiento; seguridad en el deporte, ocio y entretenimiento

\section{Rahmat Awang}

U nidad de Información sobre D rogas y

Sustancias Tóxicas

Centro Nacional de T oxicología

U niversidad Sains de M alaisia

Penang 11800, M alaisia

Tel: 60416570099

Fax: 60416568417

Puesto(s) actual(es): Profesor asociado, Jefe

Puesto(s) anterior(es): Profesor, Jefe de la U nidad de Información sobre Fármacos, Escuela de Ciencias Farmacéuticas, U niv. Sains de M alaisia

E studios: BPharm, 1981, U niversidad Sains de M alaisia; PharmD , 1985, U niversity of M innesota

A reas de interés: vigilancia y control de sustancias tóxicas; información y evaluación de fármacos

Olav Axelson

División de M edicina del Trabajo y A mbiental Departmento de Salud y M edio ambiente U niversidad de Linköping

58185 Linköping, Suecia 
Tel: 4613221440

Fax: 4613145831

E-mail: olav.axelson@ymk.liu.se

Puesto(s) actual(es): Profesor

Puesto(s) anterior(es): M édico ayudante (medicina interna, medicina laboral); Profesor, J efe, D epartamento de M edicina del Trabajo y Ambiental

E studios: M D, 1964, U niversidad de Göteborg A reas de interés: epidemiología de la salud en el trabajo; epidemiología ambiental; métodos epidemiológicos; cáncer y neuroepidemiología; radiación (radón); disolventes; plaguicidas

\section{Page Ayres}

N ewport N ews Shipbuilding

D 027

B79-1

4104 W ashington A venue

Newport N ews, V irginia 23607, Estados U nidos

T el: 1 (757) 688-2755

Fax: 1 (757) 688-6007

E-mail: ayres rp@nns.com

Puesto(s) actual(es): Senior Environmental Engineer

Puesto(s) anterior(es): Consultant, R egional D evelopment Institute; $M$ anager, Environmental Affairs, N orth Carolina Phosphate Corporation; $\mathrm{M}$ arine Scientist, $V$ irginia Institute of $M$ arine Science, G loucester Pt., VA; T echnical Scientist, C ousteau Society

E studios: BS, 1971, V irginia Polytechnic Institute; M S, 1988, East Carolina U niversity

A reas de interés: construcción y reconstrucción de ecosistemas; zonas húmedas; biología/ bioquímica evolutiva

\section{Angela R. Babin}

Center for Safety in the Arts

336 W est End Avenue

Apt \#14C

N ueva Y ork, N ueva Y ork 10023, Estados

Unidos

T el: 1 (212) 873-6151

Puesto(s) actual(es): Associate Director

Puesto(s) anterior(es): C onsultant, N ew Y ork Committee for $O$ ccupational Safety and $\mathrm{H}$ ealth; Sound Level Study for L ocal 802 AF of M usicians Broadway Shows R esearch Assistant, C olumbia U niversity

E studios: BA, 1984, C olumbia U niversity; M S 1989, C ity U niversity of N ew Y ork;

A reas de interés: salud y seguridad para artistas escénicos, sobre todo músicos; gestión de residuos peligrosos, aspectos ambientales para artistas

\section{Tomas Backström}

Instituto Nacional de la V ida Laboral

17184 Solna, Suecia

Tel: 4687309100

Fax: 4687301967

E-mail: tbacks@niwl.se

Puesto(s) actual(es): Investigador
Puesto(s) anterior(es): Instituto R eal de T ecnología; Instituto N acional de Salud en el T rabajo

E studios: M Sc, 1982, Instituto R eal de T ecnología; PhD, 1996, Instituto L und de T ecnología

A reas de interés: accidentes de trabajo; producción automatizada; análisis de riesgos en la industria; gestión de la seguridad en el lugar de trabajo

\section{David E. Baker}

College of Agriculture

Food and $N$ atural R esources

U niversidad de $\mathrm{M}$ issouri-Columbia

R oom 2-70,

Agriculture Building

Columbia, M ontana 65211, Estados U nidos

T el: 1 (573) 882-6385

Fax: 1 (573) 884-7993

E-mail: David_E._Baker@mucc-

mail.missouri.edu

Puesto(s) actual(es): Assistant Program Director

Puesto(s) anterior(es): Extension Safety and O ccupational H ealth Specialist

E studios: BS, 1970, Illinois State U niversity; M S, 1975, Illinois State U niversity

A reas de interés: salud y seguridad en Agricultura

\section{Dean B. Baker}

Center for O ccupational and Environmental $\mathrm{H}$ ealth,

U niversity of California-I rvine

I rvine, California 92612, Estados U nidos

T el: 1 (714) 824-8641

Fax: 1 (714) 824-2345

E-mail: dbbaker@uci.edu

Puesto(s) actual(es): Professor of M edicine, Director

Puesto(s) anterior(es): Associate Professor, M ount Sinai School of M edicine; A ssistant Professor, School of Public H ealth, U niversidad de California-L os Angeles; $M$ edical $O$ fficer, $N$ ational Institute for O ccupational Safety and $\mathrm{H}$ ealth

E studios: BS, 1973, U niversidad de California-L os A ngeles; M PH , 1976, U niversity of C alifornia-Berkeley; M D, 1977, U niversity of C alifornia-San Diego

A reas de interés: epidemiología ambiental y laboral; asma de origen ambiental; residuos peligrosos; efectos inmunológicos de metales pesados y plaguicidas

\section{Robin Baker}

L abor O ccupational H ealth Program

U niversity of California-Berkeley

Berkeley, C alifornia 94720-5120, Estados

Unidos

T el: 1 (510) 642-5507

Fax: 1 (510) 643-5698

E-mail: R baker@aclink4.berkeley.edu

Puesto(s) actual(es): Director

E studios: M PH

\section{David G. Baldwin}

H ewlett Packard Company

1501 Page M ill R oad

$M$ ailstop: M S 5 U E
Palo Alto, California 94304, Estados U nidos Fax: 1 (415) 852-8692

E-mail: dbaldwin@hp.com

Puesto(s) actual(es): Corporate Industrial H ygiene $M$ anager

E studios: $\mathrm{CIH}$

\section{Isabelle Balty}

Instituto N acional de Investigación de la Seguridad y Prevención de R iesgos en el Trabajo

30 rue 0 livier $\mathrm{N}$ oyer

75680 París C edex 14, Francia

Tel: 33140443167

Fax: 33140443075

E studios: Eng., 1982, Institut $N$ ational A gronomique, París-G rignon

A reas de interés: equipos de protección individual

\section{Gabriele Bammer}

$N$ ational $C$ entre for E pidemiology and Population $\mathrm{H}$ ealth,

Australian National U niversity

Canberra, Australian C apital T erritory 0200 Australia

T el: 6162490716

Fax: 6162490740

E-mail: gabriele.bammer@nceph.anv.

Puesto(s) actual(es): Fellow

Puesto(s) anterior(es): R esearch Fellow, R esearch School of Social Sciences, Australian N ational U niversity

E studios: BA, 1973, Flinders U niversity of South A ustralia; BSC, 1974, Flinders U niversity of South Australia; PhD, 1980, U niversity of Sydney

Tamas Banky

Departamento Científico

Instituto de Control de Calidad e Innovación en la Construcción

Diószegi út 37

1113 Budapest, H ungría

Tel: 3611613672

Fax: 3611613672

Puesto(s) actual(es): Director de Protección contra el Fuego; Subsecretario general, GTE

E studios: M Sc, 1971, U niversidad T écnica de Budapest; Dr, 1989, U niversidad T écnica de Budapest

A reas de interés: Ingeniería contra incendios; modelos y pruebas contra el fuego; garantías de calidad; normalización: toxicología

\section{Gail Coningsby Barazani}

5340 N. M agnolia Avenue

Chicago, Illinois 60640, Estados U nidos Tel: 1 (312) 728-5795

Puesto(s) anterior(es): Art T eacher, T herapist R esearch A ssistant and A ssociate, U niversity of Illinois, C hicago, School of Public $\mathrm{H}$ ealth; R egulatory Affairs Specialist, Carnow, Conibear and Associates, Chicago

E studios: M PH , 1968, U niversity of Illinois

A reas de interés: Salud y seguridad en el trabajo en las artes 


\section{Hjalmar R. Bardarson}

H rauntunga v. Alftanesveg

$210 \mathrm{G}$ ardabaer, I slandia Tel: 354 555-0729

Puesto(s) actual(es): Director Estatal de Navegación

Puesto(s) anterior(es): D iseñador de embarcaciones en astilleros en Dinamarca, Inglaterra e Islandia; Director Estatal de N avegación, I slandia; Presidente, A samblea IM 0 Londres; Presidente del Comité de lá IM $O$ sobre seguridad en barcos de pesca; Primer V icepresidente, C onferencia Internacional IM 0 sobre seguridad en barcos de pesca, T orremolinos, España, 1977; Presidente, Comité M ixto de A sesores de la FAO, OIT, eIM O, Código de Seguridad para pescadores y barcos de pesca; Presidente, L ondon Dumping Convention; Presidente, Comité T ecnológico de la IM 0

E studios: M Sc, 1947, U niversidad de Dinamarca

A reas de interés: D iseño de embarcaciones; estabilidad y seguridad de buques de pesca; refrigeradores de barcos; investigación y desarrollo de salvavidas hinchables para embarcaciones; prevención de la contaminación del mar

\section{Julian Barling}

School of Business

Q ueens U niversity

K ingston, O ntario K 7L 3N 6, Canadá

Tel: 1 (613) 545-2477

Fax: 1 (613) 545-6589

E-mail: Barling]@qsilver.queensu.ca

Puesto(s) actual(es): Professor of O rganizational Behaviour and Psychology

E studios: PhD

A reas de interés: V iolencia en el lugar de trabajo; estrés laboral; W orkplace violence; work stress; sindicatos

\section{Donald Barnard}

U nited States D epartment of A griculture Agricultural R esearch Service

PO Box 14565

Gainseville, Florida 32604, Estados U nidos Tel: 1 (352) 374-5930

Fax: 1 (352) 374-5922

E-mail: dbarnard@gainsville.usda.ufl.edu

Puesto(s) actual(es): Supervisory R esearch Entomologist

Puesto(s) anterior(es): Post-D octoral Fellow, Colorado State U niversity; R esearch Entomologist, U nited States D epartment of A griculture, Agricultural R esearch Service

E studios: PhD, 1977, U niversity of C alifornia

A reas de interés: entomología médica y veterinaria; vectores ecológicos; gestión integrada de plagas

\section{Rosalind C. Barnett}

21 Partridge Hill Rd.

W eston, M assachusetts 02193, Estados U nidos

T el: 1 (617) 893-3646

Fax: 1 (617) 894-4635

E-mail: R_Barnett@harvard.edu
Puesto(s) actual(es): Senior Affiliated Scholar, R esearch $C$ enter, $R$ adcliffe College, Cambridge, M assachusetts; A djunct Professor, D epartment of W ork Environment, U niversity of $M$ assachusetts-L owell

Puesto(s) anterior(es): Senior R esearch Associate, Center for R esearch on Women, W ellesley College, $M$ A

E studios: BA, 1964, H arvard U niversity; PhD 1969, Q ueens College, N ueva Y ork

A reas de interés: estrés en el lugar de trabajo; sexo; familia y trabajo

\section{Subhash K. Batra}

N onwovens C ooperative R esearch C enter C ollege of T extiles

N orth C arolina State U niversity

Box 8301

R aleigh, Carolina del Norte 27695-8301,

Estados U nidos

T el: 1 (919) 515-6555

Fax: 1 (919) 515-4556

E-mail: subhash.batra@ncsu.edu

Puesto(s) actual(es): Director

Puesto(s) anterior(es): Professor; Associate Professor

E studios: BT ext, 1957, U niv. de D elhi; SM , 1961, M assachusetts Institute of T echnology; PhD, 1966, R PI; SM , 1977, $M$ assachusetts Institute of T echnology

A reas de interés: ciencia y tecnología de fibras sintéticas

\section{Giuseppe Battista}

Cattedra di M edicina Preventiva dei Lavoratori U niversidad de Siena

$\checkmark$ ia dei T ufi 1

53100 Siena, I talia

Tel: 39577586753

Fax: 39577586 706/ 586148

E-mail: ORSI@MAILSR V.UNISI.IT

Puesto(s) actual(es): Profesor de M edicina Preventiva para los T rabajadores

Puesto(s) anterior(es): Profesor asociado, M edicina del Trabajo, U niversidad de Pisa

E studios: M D , 1972, U niversidad de Siena

A reas de interés: Epidemiología laboral; medicina preventiva

\section{Peter J. Baxter}

D epartment of C ommunity $M$ edicine

Institute of Public $\mathrm{H}$ ealth

U niversity of Cambridge

R obinson Way

C ambridge CB2 2SR, R eino U nido

T el: 441223336590

Fax: 441223336584

Puesto(s) actual(es): C onsultant 0 ccupational Physician

E studios: M D; M Sc; FR CP; FFOM

A reas de interés: $C$ atástrofes naturales y tecnológicas; contaminación atmosférica; medicina del trabajo y ambiental

\section{Thomas L. Bean}

D epartment of Food, Agricultural and Biological Engineering

0 hio State U niversity

590 W oody $H$ ayes D rive \#218

Columbus, O hio 43210, Estados U nidos
Tel: 1 (614) 292-6519/9455

Fax: 1 (614) 292-9448

E-mail: bean.3@osu.edu

Puesto(s) actual(es): Safety L eader, Professor

Puesto(s) anterior(es): Safety Specialist,

Cooperative Extension Service, W est V irginia U niversity; Professor, C enter for Extension and Continuing Education, W est $V$ irginia U niversity

E studios: BS, 1969, U niversity of N evada; M S, 1976, W est V irginia U niversity; EdD, 1982, W est V irginia U niversity

A reas de interés: Seguridad y salud en la agricultura

\section{Randal D. Beaton}

Psychosocial and Community $\mathrm{H}$ ealth Department

U niversity of W ashington

Box 357263

Seattle, W ashington 98195, Estados U nidos

Tel: 1 (206) 543-8551

Fax: 1 (206) 685-9551

E-mail: randyb@u.washington.edu

Puesto(s) actual(es): R esearch A ssociate Professor; Clinical Psychologist

Puesto(s) anterior(es): A cting Instructor, Department of $R$ ehabilitation $M$ edicine U niversity of W ashington School of M edicine; Consultant to T M J R esearch, D ental Fears R esearch C linic, U niversity W ashington, School of Dentistry

E studios: BA, 1967, California State U niversity; PhD, 1972, U niversity of W ashington; Post D octorate, 1977, U niversity of W ashington

A reas de interés: Evaluación y tratamiento de trastornos por estrés postraumático; estrés en trabajadores de servicios de urgencia; normas de diagnóstico del estrés profesional

\section{Marcaret R. Becklake}

Departments of $M$ edicine and of E pidemiology and Biostatistics

Associate $\mathrm{M}$ ember

D epartment of O ccupational $\mathrm{H}$ ealth

R espiratory Epidemiology U nit

M cG ill U niversity

1110 Pine A venue W est

M ontreal, Q uébec $\mathrm{H} 3 \mathrm{~A}$ 1A3, Canadá

T el: 1 (514) 398-6973

Fax: 1 (514) 398-8981

E-mail: Beck-

lake@M eakins.L an.M cG ill.CA

Puesto(s) actual(es): Professor

Puesto(s) anterior(es): C areer Investigator, $\mathrm{M}$ edical R esearch $C$ ouncil of $C$ anada; $\mathrm{H}$ ead, Epidemiology U nit, $\mathrm{N}$ ational $\mathrm{C}$ enter for O ccupational $\mathrm{H}$ ealth, Johannesburg, South A frica; Professor, D epartment of Community $\mathrm{H}$ ealth, $\mathrm{U}$ niversity of the W itwatersrand, Johannesburgo, Sudáfrica

E studios: M B, BCh, 1944, U niversity of the W itwatersrand; M R CP, 1946, R oyal College of Physicians, Londres; M D, 1951, U niversity of the W itwatersrand

A reas de interés: enfermedades de transmisión aérea en el trabajo; enfermedades de 
pleura y pulmones por asbesto; epidemiología de la enfermedad de transmisión aérea en adultos; factores ambientales del asma infantil

\section{Bernardo Bedrikow}

Rua Padre Joao M anoel

1126-ap. 51

01411-000 São Paulo, Brasil

T el: 5511 853-8287

Fax: 5511 853-8287

Puesto(s) anterior(es): J efe de Seguridad y Salud en el Trabajo, Serviço Social da Industria, São Paulo: Director, M edicina Social, H ospital Servidor Publico Estadual, São Paulo; Profesor asociado; M edicina en el Trabajo, Faculdade de Ciências M édicas da Santa C asa de São Paulo; A sesor regional, Salud y Seguridad en el T rabajo, O ficina R egional para América y el $C$ aribe de la $O$ rganización Internacional del Trabajo; Sector médico, R ama de Seguridad y Salud en el T rabajo de la O rganización Internacional del Trabajo

E studios: M D, 1947, U niversidad de São Paulo; M PH , 1952, H arvard School of Public $\mathrm{H}$ ealth

A reas de interés: Cáncer profesional; agentes biológicos (lepra y tuberculosis en el trabajo); prevención de grandes accidentes

\section{Raymond Bégin}

Pneumologie CHU

U niversidad de Sherbrooke

$300112^{\mathrm{e}}$ avenue $\mathrm{N}$ ord

Sherbrooke, $Q$ uébec $11 \mathrm{H}$ 5N 4, Canadá

T el: 1 (819) 346-1110 ext. 4144

Fax: 1 (819) 820-6422

Puesto(s) actual(es): Profesor de medicina

E studios: M D , 1968, U niversidad de L aval

A reas de interés: Enfermedades pulmonares de origen profesional

\section{François Béland}

$G$ roupe de $R$ echerche Interdisciplinaire en Santé

U niversité de M ontréal-Faculté de M édecine

C.P. 6128 Succursale Centre-V ille

M ontreal, Q uébec $\mathrm{H} 3 \mathrm{C}$ 3) 7, C anadá

Tel: 1 (514) 343-6185

Fax: 1 (514) 343-2207

E-mail: belandf@ere.umontreal.ca

Puesto(s) actual(es): Professeur Agrégé

E studios: PhD, 1978, U niversité L aval

A reas de interés: atención a largo plazo; salud en e ámbito de la comunidad

\section{Louis S. Beliczky}

T echnical Advisors and Consultants to T rade Unionists

P.O. Box 312

Wickliffe, 0 hio 44092, Estados U nidos

T el: 1 (216) 585-2046

Fax: 1 (216) 944-8436

Puesto(s) actual (es): Industrial H ygiene

Consultant, Principal; C onsultant,

U nited Steel W orkers of A merica,

International A ssociation of M echanists,

International Federation of Chemical
Energy and $\mathrm{G}$ eneral Labor; Consultant USD OL, OSH A, and the Free Trade U nion Institute

Puesto(s) anterior(es): Director of Industrial $H$ ygiene, Safety, and Worker Compensation, U nited R ubber, Cork, L inoleum and Plastic W orkers (actualmente, U nited Steel W orkers)

E studios: BS, 1949, John C arrol U niversity; M S, 1953, K ent State U niversity; M PH, 1955, U niversity of Pittsburgh, School of Public H ealth

\section{David M. Bell}

HIV Infections Branch

$N$ ational C enter for Infectious Diseases

$M$ ail Code E-68

Atlanta, G eorgia 30333, Estados U nidos

T el: 1 (404) 639-6425

Fax: 1 (404) 639-6459

Puesto(s) actual(es): J efe

E studios: M D, 1977, H arvard M edical School

A reas de interés: T ransmisión del VIH en asistencia sanitaria

\section{Ron Bell}

Electrical and Control Systems U nit

$\mathrm{H}$ ealth and Safety Executive

M erseyside L20 3Q Z, R eino U nido

Tel: 441519514788

Fax: 441519514630

Puesto(s) actual(es): H ead; Director of Science and Technology

Puesto(s) anterior(es): Chair, IEC W orking G roup on Functional Safety

E studios: BSC

A reas de interés: Sistemas de control de seguridad

\section{Vladimir Bencko}

Facultad Principal de M edicina

Instituto de $\mathrm{H}$ igiene y Epidemiología

U niversidad C arlos de Praga

Studnickova 7

12800 Praga 2, R epública Checa

T el: 422292431

Fax: 422296792

Puesto(s) actual(es): Profesor, J efe

Puesto(s) anterior(es): J efe, D epartamento de $H$ igiene en el Instituto de Salud T ropical, posgraduado en el Instituto de M edicina y Farmacia de Praga (1985-1990)

E studios: M D, 1961, U niversidad Carlos de Praga; PhD, 1980, U niversidad C arlos de Praga

A reas de interés: V igilancia biológica y aspectos inmunológicos de la exposición ambiental y laboral, especialmente a fragmentos de metales tóxicos, emisiones de gases de motores de vehículos, hidrocarburos polihalogenados y residuos hospitalarios; epidemiología ambiental del cáncer; impacto del deterioro ambiental sobre la salud y problemas de evaluación de riesgo

\section{Joel Bender}

H ealth Sciences

$O$ wens- $C$ orning

$O$ ne $O$ wens-C orning Parkway

Toledo, O hio 43659, Estados U nidos
Tel: 1 (419) 248-7329

Fax: 1 (419) 325-3329

E-mail: joel.bender@ owenscorning.com

Puesto(s) actual(es): V ice-President, Chief M edical 0 fficer

Puesto(s) anterior(es): M edical Director, Conoco, Inc.

E studios: BS, 1969, N orth Dakota State University; M SPH , 1972, U niversity of N orth C arolina, School of Public H ealth; PhD, 1974, D rexel U niversity; M D. 1978, U niversity of Alabama; Board Certified, 1982, American Board of Preventive M edicine, Specialist in O ccupational M edicine

\section{David Bennett}

Workplace $\mathrm{H}$ ealth

Safety and Environment

Canadian Labour Congress

2841 Riverside D rive

O ttawa, O ntario K IV 8X 7, Canadá

Tel: 1 (613) 521-3400

Fax: 1 (613) 521-4655

Puesto(s) actual(es): N ational D irector

Puesto(s) anterior(es): N ational R epresentative, Environment: W orkplace, $\mathrm{H}$ ealth and Safety; $\mathrm{C}$ anadian Labour Congress; Fire Fighter, C ambridge Fire and R escue Service, R eino U nido

E studios: M A, 1968, Cambridge U niversity; PhD, 1973, M cGill U niversity, C anadá

A reas de interés: prevención de la contaminación: estado científico de las disciplinas de salud ambiental

\section{Alan J. Benson}

Royal Air Force School of A viation M edicine Farnborough $H$ ants GU 14-6SZ, R eino U nido T el: 441252394362

Fax: 441252393469

Puesto(s) actual(es): Consultant, A viation M edicine Puesto(s) anterior(es): Senior M edical O fficer (R esearch), H ead of Special Senses Division, R oyal Air Force, Institute of A viation M edicine. Farnborough, R eino U nido

E studios: BSc, 1951, U niversity of M anchester M Sc, 1952, U niversity of $M$ anchester: M B ChB, 1955, U niversity of $M$ anchester, $R$ eino $U$ nido

\section{María José Berenguer Subils}

Centro N acional de Condiciones de T rabajo Instituto $\mathrm{N}$ acional de Seguridad e H igiene en el Trabajo

Calle Dulcet 2-10

08034 Barcelona, España

E studios: Licenciada en Ciencias Q uímicas, 1966, U niversidad de Barcelona

A reas de interés: A nálisis ambiental; calidad del aire interior

\section{Irene K. Berezesky}

Department of Pathology

U niversity of M aryland School of M edicine 10 South Pine Street

Baltimore, M aryland 21201-1192, Estados Unidos 
Fax: 1 (410) 706-3743

E-mail: iberezes@umabnet.ab.umd.edu Puesto(s) actual(es): Instructor

Puesto(s) anterior(es): R esearch Associate, D epartment of Pathology, U niversity of $\mathrm{M}$ aryland; Biologist, N ational $\mathrm{C}$ ancer Institute, Bethesda, M aryland; Biological $R$ esearch A ssistant, $M$ assachusetts General H ospital, Boston, M A

E studios: BA, 1958, Boston U niversity

A reas de interés: papel de los desplazamientos de iones, específicamente el $\mathrm{C} \mathrm{a}^{2}+$, en las lesiones celulares y efectos de la desrregulación cada ión sobre la transducción de señales y la expresión genética

\section{Mats Berg}

Departmento de D ermatología

H ospital K arolinska

17176 Estocolmo, Suecia

Tel: 4686905402

Fax: 4686905975

Puesto(s) actual(es): $M$ édico

E studios: M D, 1981, Instituto K arolinska; Dr M ed Sci, 1989, Instituto K arolinska

A reas de interés: monitores y piel; acné rosacea; factores psicológicos y enfermedades de la piel

\section{Elliott H. Berger}

Auditory R esearch D epartment

E-A-R / A earo Company

7911 Zionsville R oad

Indianapolis, Indiana 46268-1657, Estados

Unidos

T el: 1 (317) 692-3031

Fax: 1 (317) 692-3116

E-mail: eberger@ compuserve.com

Puesto(s) actual(es): Senior Scientist

E studios: BS, 1974, R ensselaer Polytechnic Institute; M S, 1976, N orth Carolina State U niversity

Areas de interés: Diseño de protección auditiva,

desarrollo y rendimiento;

desarrollo de normas, reglas y programas en protección y conservación de la audición; efectos del ruido sobre la audición y la comunicación

\section{Kenneth I. Berger}

Department of Pulmonary and $\mathrm{C}$ ritical $\mathrm{C}$ are

$\mathrm{N}$ ew $\mathrm{Y}$ ork U niversity $\mathrm{M}$ edical C enter

550 First A venue

N ueva Y ork, N ueva Y ork 10016, Estados U nidos

T el: 1 (212) 263-6479

Fax: 1 (212) 263-8442

E-mail: kbea1092@aol.com

Puesto(s) actual(es): Instructor of M edicine

E studios: BA, 1989, Boston U niversity; M D, 1989, Boston U niversity School of M edicine

\section{Ulf Bergqvist}

Instituto Nacional para la V ida Laboral

17184 Solna, Suecia

T el: 4687309773

Fax: 468820556

E-mail: ulfbq@niwl.se
Puesto(s) actual(es): Investigador

E studios: M Sc T echn, 1973, Instituto R eal de T ecnología; Dr M ed Sc, 1994, Instituto $\mathrm{K}$ arolinska

A reas de interés: Problemas de salud relacionados con los campos eléctricos y magnéticos y tecnología de la información

\section{Deborah E. Berkowitz}

$O$ ffice of Safety and $\mathrm{H}$ ealth

U nited Food and Commercial W orkers

1775 K Street NW

W ashington DC 20006-1598, Estados U nidos

T el: 1 (202) 223-3111

Fax: 1 (202) 446-1562

Puesto(s) actual(es): Director

Puesto(s) anterior(es): Director, O ccupationa Safety and $\mathrm{H}$ ealth, Food and Allied Service T rade D epartment, AFL -CIO

E studios: BA, 1977, O berlin College

A reas de interés: trastornos traumáticos acumulados; riesgos en el lugar de trabajo y bajos ingresos en la industria alimentaria

\section{Pier Alberto Bertazzi}

Istituto di M edicina del Lavoro

U niversità di M ilano

$\checkmark$ ia San Barnaba 8

20122 M ilán, I talia

T el: 3925450812

Fax: 3925512344

E-mail: bertazzi@imiucca.csi.unimi.it

Puesto(s) actual(es): Profesor asociado

E studios: M D , 1971, U niversidad de M ilán M PH , 1974, U niversidad de M ilán

A reas de interés: M étodos epidemiológicos; etiología del cáncer; epidemiología ambiental

\section{Diane Berthelette}

M BA R esearch Program

D epartment of A dministrative Sciences

U niversidad de Q uébec

P.0. Box 6192

Downtown Station

M ontreal, Q uébec H 3C 4R 2, C anadá

T el: 1 (514) 987-3000 ext. 3955

Fax: 1 (514) 987-3343

E-mail: berthelette.diane@uqam.ca

Puesto(s) actual(es): Associate Professor, Director

Puesto(s) anterior(es): Programme $M$ anager, Institute for $\mathrm{O}$ ccupational $\mathrm{H}$ ealth and Safety R esearch

E studios: M Sc, 1980, D epartment of Anthropology, U niversity of M ontreal: PhD, 1991, Faculty of M edicine, U niversity of M ontreal

A reas de interés: evaluación de políticas y programas de salud y seguridad en el trabajo; metodología de la investigación; teorías organizativas

\section{Joan Bertin}

School of Public $\mathrm{H}$ ealth

Columbia U niversity

$60 \mathrm{H}$ aven Avenue B-3

N ueva Y ork, N ueva Y ork 10032, Estados Unidos

Tel: 1 (212) 304-5282
Fax: 1 (212) 305-7024

Puesto(s) anterior(es): J oanne W oodward Chair in Public Policy, Sarah Lawrence C ollege; A ssociate D irector, W omen's R ights Project, American Civil L iberties U nion

E studios: JD, 1973, N ew Y ork U niversity School of Law; BA, 1967, Smith College

\section{Marco Biagi}

Dipartimento di Economia Aziendale

U niversità di M odena

$\mathrm{V}$ ia $\mathrm{V}$ aldonica 14

M ódena, I talia

Tel: 3951261050

Fax: 3951236482

Puesto(s) actual(es): Profesor de Derecho Laboral

Puesto(s) anterior(es): Profesor adjunto, U niversidad de Bolonia

E studios: título M agna cum laude, Facultad de Derecho, U niversidad de Bolonia

A reas de interés: relaciones industriales comparadas y dirección de recursos humanos

\section{Annibale Biggeri}

Escuela de M edicina

U niversidad de Florencia

$\checkmark$ iale M orgagni 59

50134 Florencia, Italia

Tel: 39554237211

Fax: 39554223560

E-mail: abiggeri@stat.ds.unifi.it

Puesto(s) actual(es): Profesor de Estadística M édica

Puesto(s) anterior(es): Epidemiólogo, U nidad de Epidemiología C SPO ; Investigador, Instituto N acional del Cáncer, Génova, sección de Florencia

E studios: M D, 1978, U niversidad de Florencia; Postgrad. (PH ), 1982, U niversidad de Florencia; M ed Stat, 1987, U niversidad de M ilán

A reas de interés: bioestadística; análisis espacial; modelos lineales generalizados; epidemiología; análisis geográfico; epidemiología ambiental

\section{Donald J. Birmingham}

Department of D ermatology

W ayne State U niversity

Detroit, M ichigan 48202, Estados U nidos Tel: 1(313) 881-7918

Puesto(s) actual(es): Professor Emeritus

Puesto(s) anterior(es): U nited States Public H ealth Service; Chief, D ermatoses-O ccupationa $\mathrm{H}$ ealth Field Q uarters, Cincinnati, $\mathrm{OH}$; Professor, D ermatology, Wayne State U niversity, School of M edicine

E studios: BS, 1936, J ohn Carroll U niversity, Cleveland, O hio; M D, 1940, St. Louis U niversity, School of M edicine

A reas de interés: $D$ ermatitis de contacto: causas, tratamiento y prevención; dermatosis profesional

\section{Ronald Bisset}

Scott Wilson

7-9 M entone $G$ ardens

Edimburgo EH 9 2D J, Escocia, R eino U nido

Tel: 441316620308

Fax: 441316620311 
Puesto(s) actual(es): Senior A ssociate

Puesto(s) anterior(es): D eputy Executive Director, Centre for Environmental $M$ anagement and Planning, U niversity of A berdeen, Escocia

E studios: M A, 1972, Edinburgh U niversity; M Sc, 1974, Salford U niversity

A reas de interés: Evaluación del impacto ambiental y social

\section{Jacques H.M. Bittel}

Centre de R echerche du Service de Santé des Armées

24 avenue des $M$ aquis du G résivaudan

B.P. 87

38702 La T ronche Cedex, Francia

Tel: 3376636943

Fax: 3376636945

Puesto(s) actual(es): J efe, D epartamento de Factores $\mathrm{H}$ umanos

E studios: M D; Diplome d'Etudes et de R echerches en Biologie $H$ umaine (DERBH)

A reas de interés: $R$ egulación térmica; calor; frío; altitud; ropa de protección

\section{William Blackburn}

N orth Carolina State U niversity

College of T extiles

Box 8301

R aleigh, Carolina del N orte 27695-8301.

Estados U nidos

Tel: 1 (919) 515-6557

Fax: 1 (919) 515-4556

E-mail: wblackb@tx.ncsu.edu

Puesto(s) actual(es): Senior R esearch Associate

Puesto(s) anterior(es): T echnical Director, INDA, The Association of the N onwoven Fabrics Industry; T echnical Director, Abanda, Ltd.; M anager, T echnical Services, M onsanto N onwovens: President, Blackburn C onsulting, Inc.

E studios: BS, 1947, U niversity of M iami; M S, 1951, U niversity of M iami

A reas de interés: fibras sintéticas textiles

\section{Helmut Blome}

Berufsgenossenschaftliches Institut für Arbeitssicherheit

Alte $\mathrm{H}$ eerstrasse 111

53757 Sankt Augustin, Alemania

Tel: 492241231705

Fax: 492241231234

Puesto(s) actual(es): Subdirector

E studios: Dr rer nat

\section{Sheila B. Blume}

Alcoholism

Chemical D ependency and Compulsive

Gambling Programs

South $\mathrm{O}$ aks $\mathrm{H}$ ospital

400 Sunrise Highway

A mityville, N ueva Y ork 11701, Estados U nidos Tel: 1 (516) 264-4000 ext 5017

Fax: 1 (516) 264-4509

Puesto(s) actual(es): M edical Director

Puesto(s) anterior(es): Director, N ew Y ork State, Division of Alcoholism and Alcohol Abuse; $M$ edical Director, $N$ ational
Council on Alcoholism and Drug

Dependence

E studios: M D , 1958, $\mathrm{H}$ arvard M edical School

A reas de interés: alcoholismo; dependencia de los productos químicos; juego compulsivo

\section{Frank Bochmann}

Berufsgenossenschaftliches I nstitut für A rbeitssicherheit

$\mathrm{H}$ auptverband der gewerblichen

Berufsgenossenschaften

Alte H eerstrasse 111

53754 Sankt Augustin, Alemania

T el: 49224123102

Fax: 492241231234

Puesto(s) actual(es): Jefe de sección, Epidemiología E studios: Dr. phil.

\section{Paolo Boffetta}

U nidad de Epidemiología del C áncer ambiental Agencia Internacional para la Investigación

sobre el Cáncer

150 cours Albert-T homas

69372 Lyon Cedex 08, Francia

Tel: 33472738485

Fax: 33472738575

E-mail: boffetta@ iarc.fr

Puesto(s) actual(es): J efe

\section{Marcel-André Boillat}

Instituto de Ciencias de la Salud en el T rabajo U niversidad de Lausana

Rue du Bugnon 19

1005 Lausana, Suiza

T el: 41213147421

Fax: 41213147420

Puesto(s) actual(es): Profesor asociado

E studios: M D; M S

A reas de interés: epidemiología de los trastornos relacionados con el trabajo; formación en medicina laboral

\section{Madeleine Bourdouxhe}

W ork O rganization Program

Institute for $\mathrm{O}$ ccupational $\mathrm{H}$ ealth and Safety R esearch

505 boulevard De $\mathrm{M}$ aisonneuve 0 uest

M ontreal, Q uébec $\mathrm{H}$ 3C 3C 2, C anadá

T el: 1 (514) 288-1551 ex207

Fax: 1 (514) 822-6097

E-mail: bourdouxhe.madeleine@ irsst.qc.ca

Puesto(s) actual(es): R esearcher

E studios: G r. Physiotherapy, 1969, Beeckman Institute; BSc, U niversity of M ontreal; M Sc, 1985, U niversity of M ontreal $\mathrm{Q}$ uébec

A reas de interés: Seguridad y salud en el trabajo; trabajo por turnos y trabajo nocturno organización del trabajo

\section{Massimo Bovenzi}

Instituto de M edicina del T rabajo

U niversidad de T rieste

$\checkmark$ ia della Pietà 19

34129 T rieste, I talia

T el: 39403992313

Fax: 3940368199

E-mail: bovenzi@univ.trieste.it
Puesto(s) actual(es): M édico; Profesor contratado de higiene industrial

E studios: M D, 1975, U niversidad de T rieste; especialida (medicina del trabajo e higiene industrial), 1978, U niversidad de Padua; especialidad (cardiología), 1982, U niversidad de T rieste

A reas de interés: trastornos musculosqueléticos y vasculares por vibraciones mano-brazo; trastornos de columna por vibraciones de cuerpo completo; relación dosis-respuesta en exposición a vibraciones; epidemiología laboral del cáncer; trastornos del tejido conector y esclerosis múltiple; epidemiología del asma

\section{Carole Brabant}

$4248 \mathrm{H}$ ampton Avenue

$M$ ontreal, $\mathrm{Q}$ uébec $\mathrm{H}$ 4A 2K 9, C anadá E-mail: brabant@larc.info.uqam.ca

Puesto(s) actual(es): O ccupational and Environmental $\mathrm{H}$ ealth $\mathrm{R}$ esearch Consultant

Puesto(s) anterior(es): I nvited researcher, Q uébec Institute of R esearch in O ccupational $\mathrm{H}$ ealth and Safety (IR SST)

E studios: PhD, 1991, U niversity of Q uébec A reas de interés: salud en el trabajo de la mujer; exposiciones complejas; patrones de exposición laboral; aproximación interdisciplinar

\section{Mario Braga}

U nidad de Evaluación Epidemiológica Agencia de Servicios R egionales de Salud Piazzale M arconi 25

00122 R oma, I talia

Puesto(s) actual(es): Subdirector

\section{Paul Brandt-Rauf}

Columbia U niversity

$60 \mathrm{H}$ aven Avenue $\mathrm{B}-1$

Nueva Y ork, N ueva Y ork 10032, Estados Unidos

T el: 1 (212) 305-3464

Fax: 1 (212) 305-4012

E-mail: PWB 1@columbia.edu

Puesto(s) actual(es): Professor of Public H ealth; Director of $O$ ccupational and Environmental M edicine

E studios: ScD, 1974, C olumbia U niversity; M D, 1979, Columbia University; DrPH (Env Sci), 1987, Columbia U niversity

A reas de interés: carcinogénesis; bioética; epidemiología molecular; estructura molecular

\section{Sherry I. Brandt-Rauf}

Columbia U niversity

630 W est 168th Street

Nueva Y ork, Nueva Y ork 10032, Estados

Unidos

T el: 1 (212) 305-6914

Fax: 1 (212) 305-6416

Puesto(s) actual(es): A ssistant Professor of Social M edicine

E studios: M Phil, 1978, Columbia U niversity; JD, 1981, Columbia U niversity

A reas de interés: M edicina y D erecho; ética médica 


\section{Mark Braverman}

Crisis $M$ anagement Group Inc

381 Elliot Street

N ewton U pper Falls, M assachusetts 02164, Estados U nidos

T el: 1 (617) 969-7600

Fax: 1 (617) 969-7646

E-mail: cmg381@aol.com

Puesto(s) actual(es): Principal

E studios: BA, 1970, Columbia U niversity; M Ed, 1974, H arvard U niversity; PhD , 1986, Boston U niversity

A reas de interés: cambios organizativos y riesgos de trastornos para la salud en el trabajo; causas y prevención de la violencia en el trabajo

\section{John Brazendale}

$\mathrm{H}$ ealth and Safety Executive

Bootle M erseyside L 20 30 Z, R eino U nido

Tel: 441519513432

Fax: 441519513418

E-mail: john.brazendale@ hse.gov.uk

Puesto(s) actual(es): Principal Specialist Inspector

E studios: BSc, 1976; M Sc, 1989

A reas de interés: sistemas de control para la seguridad

\section{Dietmar Breuer}

Berufsgenossenschaftliches Institut für

Arbeitssicherheit

Alte H eerstrasse 111

D-53757 Sankt Augustin, Alemania

Tel: 49-2241-231-2533

Fax: 49-2241-231-234

E-mail: bia@hvbg.de

Puesto(s) actual(es): Jefe de sección

E studios: Dr, 1988, U niversidad Padebau

A reas de interés: lubricantes de enfriamiento; nitrosaminas; ácidos inorgánicos; garantía de calidad

\section{Douglas F. Briggs}

Boeing Commercial Airplane Group

The Boeing Company

P.O. Box 3707

M S 76-51

Seattle, W ashington 98124, Estados U nidos

Tel: 1 (206) 237-8600

Fax: 1 (206) 237-8593

Puesto(s) actual(es): G roup M anager of Safety and $\mathrm{H}$ ealth

Puesto(s) anterior(es): Director of Environmental/ O ccupational Safety and H ealth, T odd Shipyards Corporation

E studios: BS, 1974, C olorado State U niversity; M SPA, 1984, U niversity of W ashington

A reas de interés: cambios en la cultura de la seguridad

\section{Cecilia Brighi}

Departamento de Política Internaciona

CISL Confederación Internacional de

Sindicatos

Via Po 21

R oma, I talia

T el: 3968473357

Fax: 3968413782
A reas de interés: medio ambiente; salud y seguridad; cláusula social; relaciones industriales

\section{Robert Bringer}

Environmental T echnology and Services 3M

St. Paul, M innesota 55133-3331, Estados Unidos

Puesto(s) anterior(es): Staff V ice-President

E studios: Dr

\section{Jere A. Brittain}

226 Poole A gricultural Center

Clemson, Carolina del Sur 29634-0375, Estados Unidos

T el: 1 (803) 656-3410

Fax: 1 (803) 656-4960

E-mail: jbrttn@clustl.clemson.edu

E studios: PhD

\section{Mary O. Brophy}

5954 Smith R oad

N orth Syracuse, N ueva Y ork 13212, Estados

Unidos

T el: 1 (315) 479-3441

E-mail: mbrophy@sescra.esc.edu

Puesto(s) anterior(es): Environmental T oxicologist, Syracuse R esearch Corporation; R esearch A ssistant, Professor, SU N 4 $\mathrm{H}$ ealth Science $\mathrm{C}$ enter, $\mathrm{M}$ edical School

E studios: PhD, 1979, U niversity of M ichigan; $\mathrm{CIH} ; \mathrm{CPE}$

A reas de interés: Ergonomía; evaluación del riesgo

\section{Jeremy Brown}

R oyal Canadian M ounted Police

1200 V anier Parkway

O ttawa, O ntario K 1A OR 2, Canadá

T el: 1 (613) 723-2418

Fax: 1 (613) 998-4537

E-mail: jbrown1712@aol.com

Puesto(s) actual(es): H ead of O ccupational $\mathrm{H}$ ealth; Clinical Assistant Professor of M edicine, U niversity of $\mathrm{O}$ ttawa

Puesto(s) anterior(es): Lieutenant C ommander, Canadian Armed Forces (N avy); Assistant Professor M edicine, University of Saskatchewan

E studios: BSc, 1972, M CG ill U niversity; M DCM , 1977, M CG ill U niversity; FR CPC, R oyal College Physicians and Surgeons; FACP, 1987, American College of Physicians

A reas de interés: dolor de espalda en el trabajo policial; normas de visión para el trabajo policial; audición en trabajadores de comunicación de emergencias

\section{Mary E. Brown}

National Institute for $O$ ccupational Safety and $\mathrm{H}$ ealth,

U nited States C enters for D isease C ontrol and Prevention,

4676 C olumbia Parkway R -7

Cincinnati, O hio 45226-1998, Estados U nidos

T el: 1 (513) 841-4329

Fax: 1 (513) 841-4500

E-mail: mnb9@cdc.gov

Puesto(s) actual(es): M orehouse School of M edicine-Senior R esearch Fellow
Puesto(s) anterior(es): E pidemic Intelligence Service Fellow, C enters for D isease C ontrol and Prevention; $\mathrm{H}$ ead, Public $\mathrm{H}$ ealth, U nited States Air Force

E studios: BA, 1976, M ount Senario College; BS 1982, U niversity of M innesota; DVM , 1984, U niversity of M innesota; M PH , 1989, U niversity of M innesota

A reas de interés: patógenos/ enfermedades infecciosas emergentes; patógenos de transmisión sanguínea; salud en el trabajo y endotoxinas en fluidos metálicos: medicina internacional

\section{Peter Bruckmann}

$\mathrm{L}$ andesumweltamt des $\mathrm{L}$ andes

Nordrhein-W estfalen

W allmeyerstrasse 60

45133 Essen, Alemania

T el: 492017995258

Fax: 492017995575

Puesto(s) actual(es): J efe de división de control ambienta

E studios: Dr rer nat, 1974, U niversidad de $M$ ünster

A reas de interés: control ambiental; contaminación atmosférica; contaminación fotoquímica del aire

\section{Peter J. Bruno}

Insall Scott K elly

Institute for $\mathrm{O}$ rthopedics and Sports M edicine

535 Park Avenue

Nueva Y ork, N ueva Y ork 10021, Estados Unidos

T el: 1 (212) 838-3155

Fax: 1 (212) 838-8570

E-mail:wb2vvs@execnet.com

Puesto(s) actual(es): Internist; Sports M edicine Consultant to "The G olfer"; Board of T rustees, American C ollege of Sports $M$ edicine $\mathrm{N}$ ational

Puesto(s) anterior(es): Physician and Internist in various A merican hospitals and sport groups; Instructor in C linical M edicine, Sports M edicine

E studios: BS, 1971, U nion College; M D, 1975, $\mathrm{H}$ ahnemann U niversity

\section{Norman Brusk}

Borden Services Company,

180 East Broad Street

15th Floor

Columbus, O hio 43215, Estados U nidos

Tel: 1 (614) 225-2267

Fax: 1 (614) 225-7638

Puesto(s) actual(es): H ealth and Safety $M$ anager

E studios: BS, 1964, W ayne State U niversity; M S 1974, W ayne State U niversity School of M edicine; JD, 1992, C apital U niversity School of Law

A reas de interés: higiene industrial integra

\section{William B. Bunn}

N avistar Corporation

455 C ity Front Place D rive

Chicago, Illinois 60601, Estados U nidos

Tel: 1 (312) 836-2800

Fax: 1 (312) 836-3959 
Puesto(s) actual(es): Director, H ealth, W orkers Compensation, Safety

E studios: M D , 1979; JD , 1979; M PH , 1983

A reas de interés: dirección médica; toxicología; epidemiología (sobre todo cáncer y enfermedades de pulmón); cuestiones legales; medicina internacional

\section{Françoise Burhenne-Guilmin}

Centro de D erecho Ambiental

U nión Internacional para la Conservación de la Naturaleza

Adenauerallee 214

53113 Bonn, Alemania

Tel: 492282692231

Fax: 492282692250

E-mail: elcb2hg.iucn.ch

Puesto(s) actual(es): Directora

Puesto(s) anterior(es): Secretaria, Comisión sobre D erecho ambiental de la U nión Internacional para la Conservación de la Naturaleza, Administración Política; D irectora jurídica; U nión Internacional para la C onservación de la $\mathrm{N}$ aturaleza

E studios: D octora en D erecho, 1966, U niversidad de Bruselas

A reas de interés: diversidad biológica; legislación ambiental internacional; legislación para el desarrollo sostenible

\section{Ronald J. Burke}

School of Business

Y ork U niversity

SSB-325N

$4700 \mathrm{~K}$ eele Street

N orth Y ork, O ntario M 3] 1P3, Canadá

T el: 1 (416) 736-5096

Fax: 1 (416) 736-5687

E-mail: rburke@ bus.yorku.ca

Puesto(s) actual(es): Professor

Puesto(s) anterior(es): Professor, School of Business, U niversity of $M$ innesota

E studios: BA, U niversity of $M$ anitoba; $M A$, U niversity of M ichigan; PhD, U niversity of M ichigan

A reas de interés: estrés profesional; cambio organizativo

\section{Wayne N. Burton}

First N ational Bank of C hicago

$O$ ne First N ational Plaza

Suite 0006

Chicago, Illinois 60670-0006, Estados U nidos

Tel: 1 (312) 732-6437

Fax: 1 (312) 732-7995

E-mail:

wayne_n_burtonmd@em.fcnbd.com

Puesto(s) actual(es): First V ice-President, Corporate M edical Director; Associate Clinical Professor of $M$ edicine and Psychiatry, N orthwestern U niversity

M edical School, C hicago

Puesto(s) anterior(es): Chairman, Board of Directors, $M$ idwest Business G roup on $\mathrm{H}$ ealth; President, Central States O ccupational M edical Association; President, M edical Directors Club of Chicago

E studios: BA, 1969, U niversity of California-Santa Barbara; M D, 1974, U niversity of $O$ regon M edical School
A reas de interés: medicina del trabajo; promoción de la salud en el lugar de trabajo

\section{Butz}

$H$ auptverband der gewerblichen Berufsgenossenschaften

Alte $\mathrm{H}$ eerstrasse 111

53754 Sankt Augustin, Alemania

Tel: 49224123101

Fax: 492241231333

Puesto(s) actual(es): J efe de sección

E studios: PhD , 1978, U niversidad de Bonn

A reas de interés: Estadísticas sobre enfermedad en el trabajo

\section{LaMont Byrd}

International Brotherhood of T eamsters

AFL-CIO

25 L ouisiana A venue N W

W ashington, DC 20001, Estados U nidos

T el: 1 (202) 624-6960

Fax: 1 (202) 624-8740

Puesto(s) actual(es): Director of Safety and $\mathrm{H}$ ealth

E studios: M S, 1990, U niversity of C incinnati

A reas de interés: pruebas de alcohol y drogas; salud y seguridad para el trabajador; ergonomía

\section{Roxanne Cabral}

D epartment of R esearch

A merican Federation of State

County and M unicipal Employees

1625 L Street NW

W ashington, DC 20036, Estados U nidos T el: 1 (202) 429-1236

Fax: 1 (202) 223-3255

E studios: $\mathrm{M}$ PH

\section{Ahmet Çakir}

Instituto de Ergonomía para las C iencias

Sociales y del Trabajo

Compañía de Investigación $L$ td.

Soldauer Platz 3

14055 Berlín, Alemania

Tel: 49303021050

Fax: 49303019840

E-mail: a.cakir@bigmac.b.shuttle.de

Puesto(s) actual(es): Presidente científico

Puesto(s) anterior(es): Ayudante de investigación

E studios: D r Ing, 1975, U niversidad T écnica de Berlín

A reas de interés: Ergonomía; interfaz hombre-ordenador; seguridad en el trabajo

\section{Buck Cameron}

Carpenters H ealth and Safety Fund

7016 46th A venue SW

Seattle, W ashington 98136, Estados U nidos Tel: 1 (206) 935-7748

Fax: 1 (206) 935-7808

E-mail: buckcamron@aol.com

Puesto(s) actual(es): Director, $\mathrm{H}$ ealth Effects

Puesto(s) anterior(es): Industrial H ygienist, IAM District 751; Industrial $H$ ygienist/ Business R epresentative, T eamster Airline Division

E studios: BA, 1969, U niversity of San Francisco; BS, 1977, U niversity of C alifornia, Berkeley; M S, 1982, U niversity of California, Berkeley
A reas de interés: Salud y seguridad en el trabajo en la construcción y sector aeroespacial; estrés por calor

\section{Donald M. Campbell}

$\mathrm{H}$ ealth Protection

Auckland $\mathrm{H}$ ealth $\mathrm{C}$ are

20 wens $R$ oad

Epsom

Private Bag 92

605 Symonds Street

Auckland, Nueva Zelanda

Tel: 6492621855

Fax: 6496307431

E studios: M BC hB, 1971, U niversity of A berdeen

A reas de interés: reacción epidemiológica a incidentes de salud pública; agua potable; vigilancia de accidentes

\section{Giovanni Capeli}

Instituto di I giene

Universita C attolica D el sacro C uore

Largo A Gemelli 1

R oma 00168, I talia

T el: 3963058202

Fax: 3963058202

E-mail: ibiig@rm.unicatt.it

Puesto(s) actual(es): Profesor adjunto

E studios: 1990, U niversidad C atólica; M D, 1994, U niv. C atólica

A reas de interés: bioestadística, gestión de la asistencia sanitaria; calidad del aire interior

\section{Robert D. Caplan}

George W ashington U niversity

2125 G Street NW

Washington, DC 20052, Estados U nidos

Tel: 1 (202) 994-6322

Fax: 1 (202) 994-1602

E-mail: rcaplan@gwis2.circ.gwu.edu

Puesto(s) actual(es): Professor of Psychology

Puesto(s) anterior(es): Study Director, Institute for Social R esearch, U niversity of M ichigan

E studios: PhD , 1971, U niversity of M ichigan

A reas de interées: intervenciones en cambio de empleo; estrés y modo de afrontarlo evaluación y puesta en práctica de programas

\section{Pascale Carayon}

Department of I ndustrial Engineering

U niversity of W isconsin

1513 U niversity A venue

$M$ adison, W isconsin 53706, Estados U nidos

Tel: 1 (608) 262-9797

Fax: 1 (608) 262-8454

E-mail: pascale@engr.wisc.edu

Puesto(s) actual(es): profesor adjunto, profesor invitado, Ecole des $\mathrm{M}$ ines de $\mathrm{N}$ ancy, Francia

E studios: PhD, 1988, U niversity of W isconsin-M adison

A reas de interés: organización del trabajo y factores psicosociales en el trabajo; trastornos traumáticos acumulativos; gestión de calidad; estrés profesional

\section{Sue Cartwright}

$M$ anchester School of M anagment

U niversity of $\mathrm{M}$ anchester 
$M$ anchester M 60 16D, R eino U nido

Puesto(s) actual(es): Senior R esearch Fellow

E studios: PhD

\section{Emilio Castejón Vilella}

Centro N acional de Condiciones de Trabajo Instituto $\mathrm{N}$ acional de Seguridad e $\mathrm{H}$ igiene en el

Trabajo

Calle Dulcet 2-10

Barcelona 08034, España

T el: 3432800102

Fax: 3432803642

Puesto(s) actual(es): Director

E studios: Ing Ind (química y metalurgia), 1970,

Escuela T écnica Superior de Ingenieros Industriales de Barcelona; Ing G énie

Chim, 1972, Institut N ational Polytechnique de T oulouse; Lic. Farmacia, 1978, U niversidad de Barcelona

A reas de interés: $\mathrm{H}$ igiene industrial; ruido; gestión de la salud en el trabajo; temperatura ambiental

\section{Barry Castleman}

2412 Pickwick R oad

Baltimore, M aryland 21207, Estados U nidos

T el: 1 (410) 448-2648

Fax: 1 (410) 448-2368

Puesto(s) actual(es): Environmental Consultant

E studios: BES, 1968, J ohns H opkins U niversity; M SE, 1972, Johns H opkins U niversity; ScD, 1985, Johns H opkins School of $\mathrm{H}$ ygiene and Public $\mathrm{H}$ ealth

A reas de interés: asbesto; influencia de las empresas sobre los valores límite umbral exportación de riesgos industriales a los países en vías de desarrollo

Physician and Internist in various A merican hospitals and sport groups; Instructor in Clinical M edicine, Sports M edicine

\section{Catananti}

Policlinico "A. G emelli" - Instituto di I giene U niversità

Cattolica del Sacro Cuore

L argo A. G emelli 1

R oma 00168, Italia

Tel: 3963058202

Fax: 3963058202

E studios: M D

\section{Larry J. Chapman}

U niversity of W isconsin

College of A gricultural and Life Sciences 208 M erry Street

$M$ adison, W isconsin 53704, Estados U nidos T el: 1 (608) 262-3310

Fax: 1 (608) 262-1228

E-mail: ljchapma@ facstaff.wisc.edu

Puesto(s) actual(es): Associate Scientist; Associate Scientist, N eurology Department, U niversity of W isconsin School of M edicine

\section{Chaiyuth Chavalitnitikul}

Instituto Nacional para la M ejora de las Condiciones de Trabajo y el M edio Ambiente

22/ 3 Baromrachachonnanee $\mathrm{H}$ wy.

Thaling-C han, Bangkok 10170, T ailandia
Tel: 6624486498

Fax: 6624486509

E-mail: chaiyc@mozart.inet.co.th

Puesto(s) actual(es): Director

Puesto(s) anterior(es): Subdirector, División de Salud en el T rabajo, M inisterio de Salud Pública

E studios: BSc, 1971, U niversidad M ahidol de T ailandia; M PH , 1977, U niversity of Pittsburgh; PhD, 1981, D rexel U niversity

A reas de interés: $\mathrm{H}$ igiene industrial; gestión de la seguridad; ergonomía

\section{Haim Chayon}

D epartamento de Incapacidad L aboral Instituto N acional de Seguros

5 Givat C anada Street

PO Box 11072

Jerusalén, I srae

T el: 97226762923

Puesto(s) anterior(es): Director

E studios: M J, 1958, U niversidad H ebrea

\section{Wejping Chen}

Alberta $\mathrm{H}$ ealth

$\mathrm{H}$ ealth Surveillance

9th Floor

10025 Jasper A venue

T elus Plaza N orth T ower

Box 1360

Edmonton, Alberta T 5] 2N 3, Canadá

Tel: 1 (403) 4274518

Fax: 1 (403) 4226663

E-mail: chenwe@mail.health.gov.ab.ca

Puesto(s) actual(es): H ealth R isk A ssessment Specialist

Puesto(s) anterior(es): G astroenterologist, The Second Affiliated H ospital, U niversidad M édica Zhejiang, Y angzhou, C hina; R esearch Associate, ECO R esearch Chair, Environmental R isk $M$ anagement, $U$ niversity of Alberta

E studios: M D, 1983, U niversidad M édica Zhejiang, Y angzhou; M Sc, 1993, U niversity of Alberta

A reas de interés: evaluación del riesgo ambiental y gestión del riesgo; programas de formación en salud ambiental para médicos y graduados

\section{Tsun-Jen Cheng}

Instituto de M edicina del T rabajo e $\mathrm{H}$ igiene ndustria

Facultad de Salud Pública

U niversidad N acional de T aiwán

1-Jen-Ai R oad-1st Sec.

T aipei, T aiwán, C hina

T el: $88623123456 \times 8467$

Fax: 88623957845

E-mail: T cheng@ha.mc.ntu.edu.tw

Puesto(s) actual(es): Profesor adjunto

Puesto(s) anterior(es): Instructor, U niv. Nacional de T aiwán

E studios: BM , 1980, T aipei M edical C ollege; M PH , 1984, H arvard School of Public $H$ ealth; ScD, 1995, H arvard School of Public Health

A reas de interés: medicina del trabajo y ambiental; epidemiología molecular
Michael Chereisky

Instituto I sraelí para la Salud y la H igiene en el Trabajo

PO Box 1122

$22 \mathrm{M}$ aze Street

61010 T el A viv, Israel

T el: $972-3 / 6200-281$

Fax: 972-3/ 6299-331

\section{I. Chernyuk}

nstituto de Salud en el T rabajo

75 Saksagansky str.

$252033 \mathrm{~K}$ iev, U crania

Tel: 380442208030

Fax: 380442206677

Puesto(s) actual(es): Subdirector, $\mathrm{H}$ igiene laboral en campos de cultivo

Puesto(s) anterior(es): J efe de laboratorio

E studios: Cand M ed Sc, 1970; Dr M ed Sc, 1987

A reas de interés: higiene laboral y fisiología de agricultores; exposición conjunta al ruido y a la vibración; riesgos para la salud en el trabajo

Robert N. Cherry, Jr.

HQDA (DACS-SF)

200 Army Pentagon

W ashington, DC 20310, Estados U nidos

T el: 1 (703) 695-7291

Fax: 1 (703) 697-4055

E-mail: bobcherry@aol.com

Puesto(s) actual(es): Director of Army R adiation Safety

Puesto(s) anterior(es): Director of $\mathrm{R}$ adiation and Entomological Sciences, US Army $\mathrm{C}$ enter for $\mathrm{H}$ ealth Promotion and Preventive $M$ edicine, Aberdeen Proving Ground, $M$ aryland; A ssociate Professor of Physics, U nited States M ilitary A cademy, W est Point

E studios: BS, 1968, U niversity of M ichigan; M S 1972, U niversity of M ichigan; PhD, 1975, U niversity of M ichigan

A reas de interés: gestión de la seguridad de la radiación ionizante y no ionizante; física de la salud médica

\section{Kee-Seng Chia}

Departamento de M edicina del T rabajo y

Familiar en la Comunidad

U niversidad Nacional de Singapur

L ower K ent Ridge R oad

Singapur, Singapur

Tel: 657749311

Fax: 657791489

E-mail: cofcks@nus.sg

Puesto(s) actual(es): Profesor asociado

E studios: M BBS, 1981; M Sc, 1985; M D, 1995

A reas de interés: nefrotoxicidad de productos químicos industriales; bioindicadores de carcinogénesis

\section{Gerolamo Chiappino}

Instituto di M edicina del Lavoro

$\checkmark$ ia San Barnaba 8

20122 M ilán, I talia

Tel: 3925417324

Fax: 3925516539

Puesto(s) actual(es): Profesor, Director del Centro de M edicina del Trabajo 
E studios: M D, 1958, Universidad de Pavia; Prof patología, 1965; Prof. medicina de trabajo, 1975

A reas de interés: asbesto y sus efectos biológicos

\section{Eric Chivian}

$56 \mathrm{H}$ awes St

Brookline, M assachusetts 02146, Estados

Unidos

Tel: 1 (617) 738-9443

Fax: 1 (617) 734-8822

E-mail: chivian@M IT .edu

Puesto(s) actual(es): Assistant Clinical Professor of Psychiatry, $\mathrm{H}$ arvard M edical School Director, $\mathrm{C}$ enter for $\mathrm{H}$ ealth and the $\mathrm{G}$ lobal Environment, $\mathrm{H}$ arvard $\mathrm{M}$ edical School; Staff Psychiatrist, M assachusetts Institute of T echnology

Puesto(s) anterior(es): Director, Project on G lobal Environmental $\mathrm{C}$ hange and $\mathrm{H}$ ealth Physicians for Social R esponsibility

E studios: $A B, H$ arvard C ollege; $M D, H$ arvard $M$ edical School

A reas de interés: pérdida de biodiversidad, extinción de especies y consecuencias para la salud humana; participación de los médicos en la educación pública y la información sobre políticas activas acerca del cambio global del medio ambiente

\section{John P. Chong}

Center for $\mathrm{H}$ uman Performance and $\mathrm{H}$ ealth

Promotion

565 Sanatorium R oad

H amilton, O ntario L9C 7N 4, Canadá

T el: 1 (416) 574-5444

Fax: 1 (416) 574-1119

Puesto(s) actual(es): M edical Director

Puesto(s) anterior(es): A ssistant Professor, D epartment of C linical E pidemiology and Biostatistics, M cM aster U niversity

E studios: AR CT, 1971, R oyal C onservatory of M usic of T oronto; BASC, 1975 ,

U niversity of T oronto; M D, 1978,

M cM aster U niversity; M Sc, 1982 ,

M cM aster U niversity; FR C PC, 1984

$R$ oyal $C$ ollege of Physicians and

Surgeons of $\mathrm{C}$ anada

A reas de interés: medicina para artistas

\section{Eberhard Christ}

Vibración y R uido

Berufsgenossenschaftliches Institut für A rbeitssicherheit-BIA

Alte H eerstaße 111

53757 Sankt Augustin, Alemania

T el: 49-2241-231-2600

Fax: 49-2241-231-2234

Puesto(s) actual(es): J efe de departamento

Puesto(s) anterior(es): I efe de departamento, R uido y vibración; Coordinador de pruebas y certificación de EPI

E studios: PhD, 1973,

A reas de interés: exposición a ruido y vibraciones en varones; equipos de protección individual

\section{Nancy Clark}

M ount Sinai School of M edicine Box 1057
1 G ustave L evy Place

N ueva Y ork, N ueva Y ork 10029, Estados Unidos

T el: 1 (212) 241-0108

Fax: 1 (212) 996-0407

E-mail: NClark@smtplink.mssm.edu

Puesto(s) actual(es): Director, $\mathrm{H}$ ead of Construction Program

E studios: M A, 1978, N ew Y ork U niversity

A reas de interés: salud y seguridad en la construcción

\section{Emmert C. Clevenstine}

Centro Internacional de Información para la

Salud y la Seguridad en el T rabajo

0 ficina Internacional del T rabajo

4 route des $M$ orillons

1211 G inebra 22, Suiza

T el: 41227998317

Fax: 41227998516

E-mail: clevenstine@ilo.org

Puesto(s) actual(es): Director de sistemas

Puesto(s) anterior(es): Director adjunto, Departamento de Bioquímica, Servicio de Productos Q uímicos

E studios: BA, 1967, U niversity of Illinois Champaign-U rbana; M S, 1968, U niversity of Illinois

Champaign-U rbana; PhD, 1977, $\mathrm{V}$ anderbilt U niversity

\section{Esther Cloutier}

Institut de R echerche en Santé et en Sécurité du Travail

505 boulevard De M aisonneuve 0 uest

M ontreal, Q uébec H 3A 3C 2, C anadá

Tel: 1 (514) 288-1551

Fax: 1 (514) 288-6097

Puesto(s) actual(es): Investigadora

E studios: PhD, 1978, París V

A reas de interés: Accidentes; envejecimiento

\section{Wilfried Coenen}

Berufsgenossenschaftliches I nstitut für A rbeitssicherheit

$\mathrm{H}$ auptverband der gewerblichen

Berufsgenossenschaften

Alte $\mathrm{H}$ eerstraße 111

53757 Sankt Augustin, Alemania

T el: 492241231300

Fax: 492241231596

E-mail: 106003,1631@ compuserve.com

Puesto(s) actual(es): Director de prevención

Puesto(s) anterior(es): Subdirector, Instituto para la Seguridad en el Trabajo; Director, Instituto para la Seguridad en el Trabajo

E studios: Dipl Ing, 1961, Physikalisch T echnische Lehranstalt (FH), Lübeck

A reas de interés: salud y seguridad en el trabajo

\section{Edward Cohen-Rosenthal}

School of Industrial and L abor R elations

Cornell U niversity

I thaca, N ueva Y ork 14853, Estados U nidos

Tel: 1 (607) 255-8160

Fax: 1 (607) 254-0238

E-mail: ec23@cornell.edu

Puesto(s) actual(es): Director, W ork and Environment I nitiative
Puesto(s) anterior(es): A ssistant to the President, International U nion of Bricklayers and Allied Craftsmen

E studios: M ed, 1975, H arvard U niversity

A reas de interés: relación entre la mejora ambiental y los trabajadores y el lugar de trabajo; relaciones laborales creativas

\section{Lenora Sarah Colbert}

O ccupational Safety and H ealth D epartment $1199 \mathrm{~N}$ ational $\mathrm{H}$ ealth and $\mathrm{H}$ uman Services Employees U nion

310 W est 43rd Street

N ueva Y ork, N ueva Y ork 10036, Estados Unidos

Tel: 1 (212) 583-1890

Fax: 1 (212) 695-0538

Puesto(s) actual(es): V ice-President

A reas de interés: salud pública, radiología, salud y seguridad

\section{Paula Coleman}

$\mathrm{C}$ arpenters $\mathrm{H}$ ealth and Safety Fund

101 Constitution A venue

Washington, DC 20001, Estados U nidos

T el: 1 (202) 546-6206

Fax: 1 (202) 547-7244

Puesto(s) actual(es): C urriculum Specialist

Puesto(s) anterior(es): Education Director, Fund Center for Worker $\mathrm{H}$ ealth and Safety Education, Cincinnati, $\mathrm{OH}$; Program Coordinator, $\mathrm{H}$ ealth and Safety Dept. ILGWU, N ew Y ork; Program Coordinator, T exas C enter for Policy Studies, Austin

E studios: BS, 1978, H unter College, N ueva Y ork A reas de interés: educación de adultos, alfabetización; ergonomía, trastornos traumatológicos acumulativos en la construcción; espacios confinados; protección contra caídas

\section{James J. Collins}

General M ills

$1 \mathrm{G}$ eneral M ills Boulevard

$M$ inneapolis, M innesota 55426, Estados U nidos T el: 1 (612) 540-2355

Fax: 1 (612) 540-4878

E-mail: colli002@mail.genmills.com

E studios: M aster of Industrial Safety, 1980 U niversity of M innesota, D uluth; C SP $\mathrm{CIH}$

\section{Janet L. Collins}

Division of $O$ ccupational M edicine

Sherman $\mathrm{H}$ ealth Systems

Elgin, Illinois 60123, Estados U nidos

T el: 1 (708) 742-7084

Fax: 1 (708) 742-7181

Puesto(s) actual(es): M edical Director

E studios: M D

\section{Renzo Comini}

ENEL SpA

$\checkmark$ ia T agliamento 9

00198 R oma 1, Italia

T el: 39685092616

Fax: 39685095712

Puesto(s) actual(es): R esponsable DSG U nita' Centrale Sicurezza ed I giene del Lavoro

E studios: Dr Ing 


\section{James Cone}

U niversity of California

San Francisco

$1517 \mathrm{H}$ enry Street

Berkeley, California 94709, Estados U nidos

T el: 1 (510) 540-2194

Fax: 1 (510) 644-8234

E-mail: jcone@igc.org

Puesto(s) actual(es): Assistant Clinical Professor

Puesto(s) anterior(es): $\mathrm{H}$ ead, O ccupational $\mathrm{H}$ ealth Clinic, San Francisco G eneral H ospital

E studios: M D, 1978, U niversity of California; M PH, 1978, U niversity of California

A reas de interés: enfermedades infecciosas en el trabajo; enfermedades asociadas a la construcción; efectos sobre la salud de los vertidos químicos

\section{George A. Conway}

Alaska Field Station

Division of Safety R esearch

N ational Institute for O ccupational Safety and $\mathrm{H}$ ealth

4230 U niversity D rive

Suite 310

Anchorage, Alaska 99508, Estados U nidos

Tel: 1 (907) 271-2382

Fax: 1 (907) 271-2390

E-mail: gocl@cdc.gov

Puesto(s) actual(es): C hief

Puesto(s) anterior(es): M edical E pidemiologist, Division of HIV / AIDS, N ational Center for Infectious Diseases, US C enters for Disease Control and Prevention

E studios: M D , 1985, U niversidad de N uevo M éxico; M PH, 1987, U niversidad de Carolina del Sur

A reas de interés: epidemiología y prevención de lesiones traumáticas y enfermedades infecciosas

\section{Cary L. Cooper}

U niversity of $M$ anchester

Institute of Science and T echnology

PO Box 88

$M$ anchester M 60 IQ D, R eino U nido

T el: 441612003440

Fax: 441612003518

E-mail: cary.cooper@umist.ac.uk

Puesto(s) actual(es): Professor of O rganizational Psychology; Pro V ice Chancellor, $\mathrm{U}$ niversity of $\mathrm{M}$ anchester Institute of T echnology

E studios: BS, U niversity of C alifornia-L os Angeles; M BA, U niversity of California-L os Angeles; M Sc, U niversity of $M$ anchester; PhD, U niversity of L eeds, R eino U nido

A reas de interés: estrés laboral; mujeres trabajadoras; psicología industrial y organizativa

\section{Georges H. Coppée}

Sección M édica

R ama de Seguridad y Salud en el T rabajo

O ficina Internacional del Trabajo

4 route des $M$ orillons

1211 G inebra 22, Suiza

T el: 41227996710

Fax: 41227996878
Puesto(s) actual(es): J efe

Puesto(s) anterior(es): R esidente, Servicio de urgencias del H ospital des Anglais, Lieja, Bélgica; Inspector médico de trabajo, Lieja, Bélgica; J efe del servicio médico en las M inas Bou Azzer y Bou Skour, $M$ arruecos; Especialista regional de la O IT en $O$ riente $M$ edio, Beirut, Líbano

E studios: M D , 1964, U niversidad de Lieja, Bélgica; Dipl H ig, 1965, Univ.de Lieja, Bélgica

A reas de interés: protección frente a la radiación; servicios de salud profesional; ética en la salud en el trabajo

\section{Wayne D. Corneil}

$\mathrm{H}$ ealth $\mathrm{C}$ anada $\mathrm{R} \mathrm{m} .2227$

2nd FI. Finance Bldg. CP0202A2

T urney's Pasture

O ttawa, O ntario K 1A OL 3, Canadá

T el: 1 (613) 957-7678

Fax: 1 (613) 941-3940

E-mail: wcorneil@hpb.hwc.ca

Puesto(s) actual(es): Director, O perations Eastern R egion; T eaching and R esearch Fellow, $D$ epartment of E pidemiology and Community M edicine, U niversity of Ottawa, Canada

Puesto(s) anterior(es): N ational C onsultant (Employee Assistance Services); A cting Senior Consultant; PSH, $\mathrm{H}$ ealth and W elfare-C anada, $\mathrm{O}$ ttawa; Project Director, Alcohol in Employment Settings, proyecto conjunto de la O M S y la O IT, Ginebra, Suiza; C onsultant (H ealth Systems; O ccupational Programs) $\mathrm{H}$ ealth and W elfare-C anada, Ottawa

E studios: BA, 1977, St. Patrick's C ollege; M SW, 1986, Carleton U niversity; SCD, 1993 Johns $\mathrm{H}$ opkins U niversity

A reas de interés: Incidencia y prevalencia de trastornos por estrés postraumático entre empleados de servicios de urgencias; efectos psicológicos de las agresiones a enfermeras; uso de redes de apoyo para médicos de asistencia primaria; tasas de utilización del servicio social y la asistencia sanitaria como consecuencia de la reducción

\section{James Corry}

Corporate W ellness and Fitness Services $M$ etropolitan Life Insurance C ompany $1 \mathrm{M}$ adison Avenue

N ueva Y ork, N ueva Y ork 10010, Estados U nidos

T el: 1 (212) 578-5132

Fax: 1 (212) 578-7795

Puesto(s) actual(es): Director

Puesto(s) anterior(es): Director of $\mathrm{H}$ ealth Education, M ount Sinai M edical C enter; Assistant Professor of $\mathrm{H}$ ealth E ducation U niversity of N orth T exas; Assistant Director of $\mathrm{H}$ ealth $\mathrm{E}$ ducation, $\mathrm{O}$ regon Department of Education, Salem

E studios: BS, 1968, M anhattan College; M S, 1971, City U niversity of N ew Y ork; PhD 1975, U niversity of O regon

A reas de interés: programas corporativos de salud: efectividad/ calidad/mano de obra

\section{Maureen P. Corry}

$M$ aternity $C$ enter Association

281 Park Avenue South

5th Floor

N ueva Y ork, N ueva Y ork 10010, Estados

Unidos

Tel: 1 (212) 7775000

Fax: 1 (212) 7779320

Puesto(s) actual(es): Executive Director

Puesto(s) anterior(es): Director, Education and $\mathrm{H}$ ealth Promotion, M arch of Dimes Birth D efects Foundation; Director, Community Services, $M$ arch of Dimes Birth D efects Foundation

E studios: BS, 1981, T exas W omen's U niversity; M PH , 1991, Y ale School of M edicine

A reas de interés: salud maternal e infantil; promoción de la salud; atención a la maternidad en el entorno familiar

\section{John W.F. Cowel}

Workers' Compensation Board of Alberta 9925- 107 Street

P.0. Box 2415

Edmonton, Alberta T 5] 2S5, Canadá

T el: 1 (403) 498-4900

Fax: 1 (403) 422-0972

Puesto(s) actual(es): President, Chief Executive O fficer; A djunct Professor, U niversity of Alberta-Faculty of M edicine; President, Association of W orkers' Compensation Boards of $C$ anada

Puesto(s) anterior(es): V ice President, $\mathrm{H}$ ealth, Safety and Environment, NOVA Corporation; President, Association of W orkers' C ompensation Boards of Canada

E studios: BSc, 1966, U niversity of T oronto; M Sc 1967, U niversity of T oronto; M D , 1970, U niversity of $\mathrm{T}$ oronto

A reas de interés: indemnizaciones al trabajador: legislación, financiación, administración, políticas y prácticas; prevención y reducción de lesiones

\section{Robert Coyle}

European Bank for R econstruction and D evelopment

1 Exchange Square

Londres EC 2A-2EH, R eino U nido

Tel: 441713386000

Fax: 441713386100

Puesto(s) actual(es): Principal Environment Specialist

\section{Michael Crane}

Con Edison

$\mathrm{O}$ ccupational $\mathrm{H}$ ealth

30 Flatbush Avenue

Brooklyn, N ueva Y ork 11217, Estados U nidos

Tel: 1 (718) 802-5200

Fax: 1 (718) 802-5282

E-mail: cranem@coned.com

Puesto(s) actual(es): A ssistant V ice-President

E studios: M D, 1977, U niversity of R ochester; M PH, 1985, C olumbia U niversity

\section{Breen Creighton}

Corrs C hambers W estgarth

600 Bourke Street

M elbourne, V ictoria 3000, Australia 
T el: 61396723173

Fax: 613965544

Puesto(s) actual(es): Special Counsel, Industrial Relations

Puesto(s) anterior(es): Professor of L aw and Legal Studies, La T robe U niversity;

Consultant, A ustralian G overnment T ask Force on R atification of IL O Conventions; Principal Legal 0 fficer, Freedom of Association Branch International Labour O rganization; Legal O fficer, Australian C ouncil of $T$ rade $U$ nions

E studios: LLB, 1969, Q ueens U niversity; PhD, 1975, C ambridge U niversity

A reas de interés: protección internacional de la libre asociación; principios internacionales relativos al trabajo infantil; relaciones industriales y salud y seguridad en el trabajo; legislación y disciplina de trabajo

\section{Marie L. Cros-Courtial}

Département AES

U niversité Paul V aléry-M ontpellier III

R oute de $M$ ende BP 5043

$34032 \mathrm{M}$ ontpellier Cedex, France

T el: 33467142167

Fax: 33467142485

Puesto(s) actual(es): $M$ aître de Conférence en droit

Puesto(s) anterior(es): Profesora adjunta

E studios: M aitrise en D roit, U niversidad St. Etienne; Dr Law, U niversidad Lyon III

A reas de interés: Derecho médico y social

\section{Derrick Crump}

Indoor Environment G roup

Building R esearch Establishment

Garston W atford WD 2 7JR

T el: 441923664452

Fax: 441923664786

Puesto(s) actual(es): Project L eader;

E studios: BSc, 1977, U niversity of Southampton; PhD, 1980, U niversity of Aston

A reas de interés: calidad del aire interior; emisiones de productos químicos de edificios y productos de consumo

\section{Mark R. Cullen}

Y ale U niversity School of M edicine N ew H aven, Connecticut 06510, Estados

U nidos

Tel: 1 (203) 785-5885

Fax: 1 (203) 785-7391

E-mail: mrcullen@aol.com

Puesto(s) actual(es): Professor of M edicine and Public $\mathrm{H}$ ealth; Director, $Y$ ale O ccupational and Environmental $M$ edicine Program

E studios: M D, 1976, Y ale U niversity

A reas de interés: bioindicadores; asma profesional; isocianatos; prevención contra sustancias químicas; plomo

\section{Ellen Cutler}

$M$ arch of Dimes Birth D efects Foundation $1275 \mathrm{M}$ amaroneck A venue
White Plains, N ueva Y ork 10605, Estados

U nidosT el: 1 (914) 997-4441

Fax: 1 (914) 428-9366

Puesto(s) actual(es): N ational Director, Program Services

E studios: M PA, 1991, N ew Y ork U niversity

\section{Jorge da Rocha Gomes}

Universidad de São Paulo

Escuela de Salud Pública

Av Dr. Arnaldo 715

01246-904 São Paulo, Brasil

T el: 011 282-3842

Fax: 011 853-0681

E-mail: liro@usp.br

Puesto(s) actual(es): Profesor emérito

Puesto(s) anterior(es): J efe del Departamento de Salud A mbiental; Escuela de Salud Pública; J efe del servicio de salud en el trabajo de V olkswagen (Brasil); Presidente de la Asociación Nacional de M edicina en el Trabajo

E studios: M D , 1960, Escuela de M edicina de Porto Alegre R S

A reas de interés: enfermedades profesionales: accidentes; organización de servicios de medicina en el trabajo

\section{Monica Dahlquist}

D epartamento de T ecnología Ambiental y

Ciencias del Trabajo

Instituto R eal de T ecnología

Fiskartorpsv 15A

10044 Estocolmo, Suecia

T el: 4687906044

Fax: 468108377

E-mail: myran@aml.kth.se

Puesto(s) actual(es): Investigadora principal, Profesora adjunta

Puesto(s) anterior(es): T écnico en investigación

E studios: PhD, 1990, Instituto $R$ eal de T ecnología

A reas de interés: procedimientos para disminuir la emisión de partículas de los motores de gasoil

\section{Göran Dahlström}

Centro del Frío

Geologgatan 7A

98131 K iruna, Suecia

Tel: 4698082430

Fax: 4698082480

Puesto(s) actual(es): $M$ édico, $M$ édico jefe, Director

Puesto(s) anterior(es): D octor en M edicina, especialista en tratamiento ortopédico, H ospital Central de Boden; Director del H ospital K iruna (1985-1987), Centro de Atención Sanitaria en el Trabajo

E studios: M D, 1977, U niversidad de U meå

A reas de interés: efectos del frío en el hombre y el medio ambiente, trabajo al aire libre y ocio; motos de nieve; accidentes en el ártico y subártico

\section{Antonio J. Dajer}

8 rue $D$ evès

92200 N euilly-sur-Seine, Francia
Tel: 33147471228

Fax: 33147471228

E-mail: 101603-2270@ compuserve.com

Puesto(s) actual(es): Attendency Physician, N ew Y ork D owntown H ospital, Emergency Department

Puesto(s) anterior(es): A cting Director, Emergency Department, M DH

E studios: BA, 1978 H arvard College; M D, 1983, $\mathrm{N}$ ew $\mathrm{Y}$ ork U niversity

A reas de interés: medicina de urgencia

\section{Neil Dalhouse}

T ourism and H ospitality Industry

$\mathrm{H}$ ealth and Safety Education Program

$250 \mathrm{Y}$ onge Street

Suite 2800

Toronto, O ntario M 5B 2N 4, Canadá

Tel: 1 (416) 506-8888

Fax: 1 (416) 506-9305

Puesto(s) actual(es): G eneral M anager

\section{Gianfranco Damiani}

Instituto di I giene

U niversità C attolica del Sacro C uore

L argo A. Gemelli 1

R oma 00168 , Italia

Tel: 3963058202

Fax: 3963058202

Puesto(s) actual(es): Profesor adjunto

E studios: 1989, U niversidad Católica; M D , 1993, Univ. C atólica

A reas de interés: salud pública y aspectos económicos

\section{Louis Damphousse}

Noranda Forest Inc.

PO Box 2400

Buckingham, Q uébec J8L 2X 3, C anadá T el: 1 (819) 986-4330

Fax: 1 (819) 986-6522

Puesto(s) actual(es): M edical C onsultant, James M aclaren Industries, Inc.

E studios: M D, 1979; M Sc, 1995, M cGill University

A reas de interés: bienestar

\section{Frank Darby}

O ccupational Safety and H ealth Service,

Department of $L$ abour

Te T ari M ahi Aurora House,

The Terrace

PO Box 3705

Wellington, N ueva Zelanda

T el: 6444954452

Fax: 6444990891

Puesto(s) actual(es): Scientist

E studios: BSc, 1970, Canterbury; M Sc, 1987, L oughborough

A reas de interés: prevención del síndrome de exceso de trabajo

\section{Alois David}

Departamento de M edicina del T rabajo

Escuela de Estudios M édicos para

Postgraduados

R uská 85

10005 Praga 10, R epública C heca 
Tel: 42267311976

Fax: 422745575

Puesto(s) actual(es): J efe

Puesto(s) anterior(es): Profesor, D epartamento de Enfermedades Profesionales, Facultad de M edicina, U niv. Carlos, Praga; Subdirector, Instituto de Higiene Industrial y Enfermedades Profesionales, Praga; M édico jefe, O rganización M undial de la Salud, Ginebra; M édico jefe, Trabajo Internacional, Ginebra

E studios: M D, 1951, U niv. Carlos, Praga; PhD, 1959, Facultad de M edicina, U niv. Carlos, Praga

A reas de interés: Formación en salud laboral; organización y funciones de los servicios de salud en el trabajo

\section{Hugh W. Davies}

$\mathrm{O}$ ccupational $\mathrm{H}$ ygiene Program

U niversity of British Columbia

3rd Floor

Library Processing C entre

2206 East M all

V ancouver, British Columbia V 6T 1Z3,

Canadá

T el: 1 (604) 822-6777

Fax: 1 (604) 822-4994

E-mail: hdavies@unixg.ubc.ca

Puesto(s) actual(es): 0 ccupational $\mathrm{H}$ ygienist

Estudios: M Sc, 1995, U niversity of British Columbia

A reas de interés: morbilidad y mortalidad en trabajadores expuestos a polvo de madera

\section{John C. Davies}

Computing Services D epartment

niversity of Liverpool

P.O. Box 147

Liverpool L69 3BX, R eino U nido

Tel: 01517943723

Fax: 01517943759

E-mail: J.C.Davies@liverpool.ac.uk

Puesto(s) actual(es): Programmer, Analyst

E studios: BSc, 1970, H ull U niversity; M Sc, 1974, U niversity of L ondon; PhD, 1978,

U niversity of Liverpool

A reas de interés: Investigación de accidentes

\section{Véronique De Keyser}

Bat. B. 32

Université de Liège

4000 Lieja, Bélgica

T el: 3241662013

Fax: 3241662944

E-mail: dekeyser@vm1.ulg.ac.be

Puesto(s) actual(es): Profesora de psicología del trabajo, Decana de la Facultad

E studios: BS, 1968, U niversidad Libre de Bruselas; PhD, 1974, U niversidad Libre de Bruselas

A reas de interés: fiabilidad humana; ergonomía cognitiva

\section{Nicole Dedobbeleer}

Department of Social and Preventive M edicine U niversité de M ontréal GRIS-Faculté de $M$ édecine

C.P. 6128 Succursale
Centre-Ville

M ontreal, Q uébec $\mathrm{H} 3 \mathrm{C}$ 3J 7, C anadá

Tel: 1 (514) 343-6185

Fax: 1 (514) 343-2207

David M. DeMarini

U nited States Environmental Protection Agency

M D-68,

R esearch T riangle Park, C arolina del N orte

27711, Estados U nidos

T el: 1 (919) 541-1510

Fax: 1 (919) 541-0694

E-mail: demarini@ herl45.herl.epa.gov

Puesto(s) actual(es): G enetic T oxicologist

E studios: PhD, 1980, Illinois State U niversity

A reas de interés: espectros de mutaciones, mezclas complejas contról biológico humano

\section{Paul A. Demers}

O ccupational H ygiene Program

University of British Columbia

2206 East M all

3rd Floor

V ancouver, British Columbia V 6T 1Z3, Canadá

Tel: 1 (604) 822-0585

Fax: 1 (604) 822-9588

E-mail: pdemers@unixg.ubc.ca

Puesto(s) actual(es): Assistant Professor

Puesto(s) anterior(es): R esearch Associate, U niversity of W ashington; R esearch T raining Fellow, International Agency for R esearch on $C$ ancer

E studios: M Sc, 1987, U niversity of W ashington PhD, 1991, U niversity of W ashington

A reas de interés: efectos sobre la salud de la exposición a polvo de madera; riesgos para la salud y la seguridad en silvicultura

\section{Edouard I. Denisov}

Instituto de la Salud en el Trabajo R AM S

31 Prospekt Budennogo

105275 M oscú, Federación R usa Tel: 70953650209

Puesto(s) actual(es): Investigador

Puesto(s) anterior(es): Investigador

E studios: Físicó, 1960, U niv. Estatal de M oscú, D epartamento de Física; graduando en Ciencia T écnica, 1970

A reas de interés: ruido y vibraciones en el trabajo

\section{S.K. Dheri}

Servicio Central de Bomberos de N ueva Delhi Connaught Lane

Nueva D elhi 110001, India

Tel: 91113314000

Fax: 91113312593

Puesto(s) actual(es): J efe de bomberos

Puesto(s) anterior(es): J efe de bomberos, Shimla-1, $\mathrm{H}$ imachal Pradesh, India

Estudios: Adv Dipl , 1967, Colegio National de Bomberos, Nagpur, India; G raduado, 1968, Institución de T écnicos en Incendios, India

A reas de interés: prevención de incendios en edificios de gran altura

\section{Lou DiBerardinis}

Environmental M edical Services

M assachusetts Institute of T echnology
$77 \mathrm{M}$ assachusetts $A$ venue

Bldg. 20C-204

Cambridge, M assachusetts 02139, Estados

Unidos

T el: 1 (617) 253-9389

Fax: 1 (617) 253-4879

E-mail: loudib@mit.edu

Puesto(s) actual(es): Industrial H ygiene O fficer; $\checkmark$ isiting L ecturer on $O$ ccupational $\mathrm{H}$ ealth, $\mathrm{H}$ arvard $U$ niversity; President,

DiBerardinis A ssociates, Inc., C onsulting Engineers

Puesto(s) anterior(es): Industrial H ygiene Engineer, Polaroid Corporation; Industrial $\mathrm{H}$ ygienist, U niversity $\mathrm{H}$ ealth Services, $\mathrm{H}$ arvard U niversity

E studios: BS, 1970, N ortheastern U niversity; M S, 1975, $\mathrm{H}$ arvard U niversity

A reas de interés: diseño de sistemas de ventilación cursos de aprendizaje de higiene industrial; diseño y dirección de programas de higiene industrial

\section{Bertram D. Dinman}

G raduate School of Public $\mathrm{H}$ ealth

U niversity of Pittsburgh

Pittsburgh, Pensilvania 15261, Estados U nidos

Tel: 1 (412) 624-1306

Fax: 1 (412) 624-3040

E-mail: dinman@cis.pitt.edu

Puesto(s) actual(es): C linical Professor O ccupational M edicine

Puesto(s) anterior(es): V ice President, $\mathrm{H}$ ealth and Safety, Aluminium $\mathrm{C}$ o. of America; Professor, O ccupational M edicine, U niversity of M ichigan, School of Public $H$ ealth; Professor, Preventive M edicine, $O$ hio State U niversity, C ollege of M edicine

E studios: M D, 1951, T emple U niversity College of M edicine; SCD, 1957, U niversity of Cincinnati

A reas de interés: problemas de salud en la industria del aluminio; toxicología de fluoruros en la industria; evaluación de riesgos químicos en el trabajo

\section{Dusan Djuric}

Instituto de Salud en el T rabajo y R adiológica

D eligradska 29

11000 Belgrado, Y ugoslavia

Tel: 38111685485

Fax: 38111643675

Puesto(s) actual(es): A sesor científico en toxicología

Puesto(s) anterior(es): J efe del D epartamento de Toxicología

E studios: Ingeniería Q uímica, 1953, Facultad de T ecnología Q uímica, Zagreb; DSc, 1958, U niv. de Zagreb; Especialista en T oxicología del trabajo, 1965 Facultad de Farmacia de Belgrado

Areas de interés: toxicología en el trabajo y ambiental

\section{Leonard A. Dobrovolsky}

Departamento de Información M édica y

Científica

Instituto de Salud en el Trabajo

75 Saksagansky Street

$252033 \mathrm{~K}$ iev, U crania 
T el: 442206106

Fax: 442206677

Puesto(s) actual(es): J efe

Puesto(s) anterior(es): Alumno, Instituto M édico de $\mathrm{K}$ iev; subdirector del $\mathrm{H}$ ospital de Distrito, Chu K azakhstan; Postgraduado (1957-1960), Científico, Lab. de R adiología (1960-1968) del Instituto para la Salud en el Trabajo de K iev; Director regional para la Salud en el T rabajo O rganización M undial de la Salud, EURO, Copenhage

E studios: M D, 1955, Instituto M édico de K iev; PhD, 1963, Instituto para la Salud en el Trabajo, K iev; DSc, 1988, Instituto para la Salud en el Trabajo, K iev

A reas de interés: efectos conjuntos en el organismo de factores ionizantes y no ionizantes; uso seguro de plaguicidas; efectos de la alta temperatura; efectos de los metales pesados

\section{Basil Dolphin}

$\mathrm{H}$ ealthworks

M uhlenberg $\mathrm{H}$ ospital

2545 Schoenersville R oad

Behtlehem, Pensilvania, Estados U nidos

T el: 1 (610) 861-2249

Fax: 1 (610) 861-8034

Puesto(s) actual(es): M edical Director

E studios: M D; M PH

\section{Alexander E. Donagi}

Centro de Información

Instituto Israelí de Seguridad e H igiene en el

Trabajo

$49 \mathrm{H}$ avradim Str.

G anei-Y ehuda 56905, Israel

Tel: 97236351347

Fax: 97236299331

Puesto(s) actual(es): Director

Puesto(s) anterior(es): J efe de la Administración de Salud A mbiental, M inisterio de Salud de Israel; Director, Instituto de Investigación de Salud Ambiental, U niv. de Tel Aviv

E studios: DSc, 1962, U niversity of C incinnati, $\mathrm{O}$ hio; M PH , U niversity of Pittsburgh

A reas de interés: gestión de centros de información; salud en el trabajo y ambiental

\section{Kelley Donham}

Department of Preventative M edicine and Environmental $\mathrm{H}$ ealth

Institute for $\mathrm{R}$ ural and Environmental $\mathrm{H}$ ealth

College of $M$ edicine

U niversity of I owa

1000 akdale Campus-124 IR EH

I owa City, I owa 52242-5000, Estados U nidos T el: 1319 335-4190

Fax: 1319 335-4225

E-mail: kelley-donham@uiowa.edu

Estudios: DVM

\section{Marianne Döös}

División de Psicología Social y O rganizativa Instituto Nacional de la V ida Laboral Ekelundsvägen 16
17184 Solna, Suecia

T el: 4687309037

Fax: 4687301967

E-mail: mdoos@niwl.se

Puesto(s) anterior(es): Instituto Nacional de la Salud en el T rabajo; Instituto R eal de T ecnología, U nidad de Investigación de Accidentes en el Trabajo

E studios: BS, 1972, U niversidad de Estocolmo;

A reas de interés: aprendizaje por experiencia/ cotidiano; accidentes de trabajo; producción automatizada; análisis de riesgo participativo

\section{Mel Doyle}

W orkers' Educational Association

T emple H ouse

17 V ictoria Park Square

Londres E 2-9PB, R eino U nido

Tel: 441819831515

Fax: 441819834840

E-mail: mel.doyle@mcri.geonet.de

Puesto(s) actual(es): D eputy G eneral Secretary

Puesto(s) anterior(es): Director, Programas de enseñanza para trabajadores, Centro Internacional de Formación ILO , T urín, I talia; R esearch Fellow, Institute for I rish Studies, Q ueen's U niversity, Belfast

E studios: BA, 1967, U niversity of Southampton; M Phil, 1973, U niversity of Southampton

A reas de interés: relaciones laborales; metodologías de formación

\section{Dennis P. Driscoll}

Associates in A coustics, Inc

718 A spen Place

Evergreen, Colorado 80439, Estados U nidos T el: 1 (303) 670-9270

Fax: 1 (303) 670-9937

E-mail: 72614.763@ compuserve.com

E studios: PE

\section{Dougal D. Drysdale}

D epartment of $\mathrm{C}$ ivil and Environmental Engineering

U niversity of E dinburgh

$\mathrm{K}$ ings Building

Edimburgo EH 9 3J N, Escocia, R eino U nido

T el: 441316505724

Fax: 441316679238

E-mail: dougal@sryø.civ.ed.ac.uk

Puesto(s) actual(es): R eader in Fire Safety Engineering

E studios: BSc, 1962, U niversity of E dinburgh; PhD, 1966, U niversity of Cambridge

A reas de interés: ignición y crecimiento inicial del incendio; dinámica de incendios

\section{Walter Dümmer}

A sociación Chilena de Seguridad

Casilla 14565

Correo Central

Santiago, Chile

Tel: 5622225533

Fax: 5622223533

Puesto(s) actual(es): A sesor técnico, Asociación Chilena de Seguridad
Puesto(s) anterior(es): Director, División de Salud en el Trabajo, Asociación Chilena de Seguridad; Jefe, Servicio N acional de la Salud de Chile, sección de Salud en el Trabajo

E studios: Ingeniero químico, 1950, U niversidad de Concepción, Chile; M PH, 1953, Pittsburgh U niversity

\section{Louis-Philippe Durocher}

U niversity of M ontreal

5965 Sherbrooke-East

M ontreal, Q uébec H 1N-1B7, C anadá

Tel: 1 (514) 253-3930

Fax: 1 (514) 253-9373

Puesto(s) actual(es): D ermatology Professor; $\mathrm{H}$ ead, Dermatology T raining Program

Puesto(s) anterior(es): V ice President, Q uébec's $M$ edical Experts Society

E studios: M D, FR CPC (D erm), 1975, U niversity of $M$ ontreal

A reas de interés: enfermedad dérmica de origen laboral; dermatitis de contacto

\section{Robert W. Dykes}

Centre de recherche

Institut de réadaptation de $M$ ontréal

M ontreal, Q uébec H 3C - 3J 7, C anadá

T el: 1 (514) 340-2078

Fax: 1 (514) 340-2154

E-mail: dykes@ere.umontreal.ca

Puesto(s) actual(es): D irector

Puesto(s) anterior(es): Director, M icrosurgical R esearch Laboratories, R oyal V ictoria H ospital M CG ill U niversity, M ontreal

E studios: AA, 1967, U niversity of California-Berkeley; PhD, 1971, Johns $\mathrm{H}$ opkins U niversity

A reas de interés: sistema somatosensorial; plasticidad neuronal en las principales zonas sensoriales del córtex

\section{Dennis Dykstra}

Centro de Investigación Forestal Internacional PO Box 6596 JK PWB

Jakarta 10065, Indonesia

Tel: 62251622622

Fax: 62251622100

E-mail: d.dykstra@cgnet.com

Puesto(s) actual(es): Subdirector general de investigación

Puesto(s) anterior(es): Profesor adjunto de Ingeniería forestal, O regon State U niversity; Profesor adjunto de Silvicultura, Y ale U niversity; Profesor de Ingeniería forestal, U niv. Sokoine, M orogoro, (T anzania); Investigador, Instituto Internacional de Análisis de Sistemas A plicados, Laxenburg, Austria; Profesor de Silvicultura, N orthern A rizona U niversity; Director de Silvicultura, FAO, R oma

E studios: BS, 1966, O regon State U niversity; M BA, 1971, U niversity of O regon; PhD 1976, 0 regon State U niversity

A reas de interés: gestión sostenible de las selvas tropicales; sistemas de tala de impacto reducido 


\section{Gary S. Earnest}

$\mathrm{N}$ ational Institute for $\mathrm{O}$ ccupational Safety and $\mathrm{H}$ ealth

Engineering C ontrol T echnology Branch Division of Physical Sciences and Engineering 4676 C olumbia Parkway

Cincinnati, O hio 45226, Estados U nidos T el: 1 (513) 541-4221

Fax: 1 (513) 841-4506

E-mail: gse0@cdc.gov

Puesto(s) actual(es): Engineering $O$ fficer

E studios: M S; PE; CSP

\section{William Eaton}

Department of $\mathrm{M}$ ental $\mathrm{H}$ ygiene

School of $\mathrm{H}$ ygiene and Public $\mathrm{H}$ ealth

Johns H opkins U niversity,

624 N orth Broadway

R oom 880

Baltimore, M aryland 21205, Estados U nidos

Tel: 1 (410) 955-3923

Fax: 1 (410) 955-9088

Puesto(s) actual(es): Professor

Puesto(s) anterior(es): Staff Investigator, Community and Family Psychiatry, Jewish General H ospital, M ontreal; A ssistant Professor, D epartment of Sociology M cG ill U niversity, M ontreal; Assistant C hief, C enter for Epidemiologic Studies $\mathrm{N}$ ational Institute of $\mathrm{M}$ ental $\mathrm{H}$ ealth, R ockville, M D; A ssociate Professor a Professor, Johns H opkins U niversity D epartment of M ental $H$ ygiene, D epartment of $H$ ealth Policy and $M$ anagement; J oint A ppointments J ohns H opkins U niversity, D epartment of Sociology, D epartment of Psychology and Behavioral Sciences

E studios: BA, 1969, W esleyan U niversity, M iddletown, Connecticut; M S, 1971 , U niversity of W isconsin-M adison; PhD, 1973, U niversity of W isconsin-M adison, $M$ adison, Wisconsin

\section{Alan Echt}

$H$ azard Evaluations and T echnical Assistance Branch

$\mathrm{N}$ ational Institute for $\mathrm{O}$ ccupational Safety and $\mathrm{H}$ ealth

676 C olumbia Parkway

Cincinnati, O hio 45226, Estados U nidos

Tel: 1 (513) 841-4111

Fax: 1 (513) 458-7147

E-mail: ase0@ nioshel.em.cdc.gov

Puesto(s) actual(es): Industrial $\mathrm{H}$ ygienist

Puesto(s) anterior(es): Senior Industrial H ygiene Specialist, BP O il Company, M arcus $\mathrm{H}$ ook R efinery; Industrial $\mathrm{H}$ ygienist, Philadelphia Naval Shipyard; $\mathrm{H}$ ealth Compliance $\mathrm{O}$ fficer, N orth Carolina D epartment of $L$ abor

E studios: BS, 1981, U niversity of C alifornia at R iverside; M PH , 1985, U niversity of $\mathrm{M}$ ichigan

\section{Olli Eeronheimo}

Instituto Finlandés de Investigación Forestal Box 18

$01301 \mathrm{~V}$ antaa, Finlandia

T el: 358985705342
Fax: 358985705361

E-mail: olli.eeronheimo@metla.fi

Puesto(s) actual(es): Investigador; Profesor;

U niversidad de T ecnología de $\mathrm{H}$ elsinki

Puesto(s) anterior(es): Coordinador, Programa Científico, XX Congreso M undial de la U nión Internacional de 0 rganizaciones de Investigación Forestal, T ampere, Finlandia; Director forestal adjunto, O rganización para la Alimentación y la Agricultura (FAO) de las $\mathrm{N}$ aciones U nidas, R oma; Consultorías para FT P Finlandia y la O IT

E studios: M Sc, 1982, U niversidad de H elsinki

A reas de interés: repoblación forestal; plantilla en trabajo forestal; silvicultura internacional

\section{Lawrence D. Eicher}

O rganización Internacional de N ormalización

1 rue de $V$ arembé

Case Postale 56

1211 G inebra 20, Suiza

T el: 41227490111

Fax: 41227333430

E-mail: central@isocs.iso.ch

Puesto(s) actual(es): Secretario general

Puesto(s) anterior(es): Secretario general adjunto; Director, O rganización Internacional para la N ormalización; O ficina $\mathrm{N}$ acional de Normalización

E studios: BA, 1960, U niversity of N orthern Colorado; PhD, 1971, T exas A\&M University

A reas de interés: normalización internacional y libre comercio

\section{John Elias}

$\mathrm{H}$ ealth Sciences $\mathrm{C}$ entre

$O$ ccupational and Environmental M edicine

618-700 M cD ormat Ave

W innipeg, M anitoba R 3E OT 2, Canadá

Tel: 1 (204) 789-3293

Fax: 1 (204) 787-1172

E-mail: elias@b/dghsc.lan7.umanitoba.ca

Puesto(s) actual(es): Senior O ccupational H ygienist

Puesto(s) anterior(es): H ead, Industrial H ygiene,

Province of $\mathrm{M}$ anitoba; $\mathrm{H}$ ead, Air

Pollution, Province of $M$ anitoba

E studios: M PH , 1976, U niversity of M innesota

\section{Carl-G. Elinder}

Departmento de M edicina del R iñón

K 56

$\mathrm{H}$ ospital U niversitario $\mathrm{H}$ uddinge

S-14186 H uddinge, Suecia

T el: 4687462613

Fax: 4687114742

E-mail: carl.elinder@klinvct.ki.sc

Puesto(s) actual(es): Especialista en N efrología, Profesor asociado

E studios: M D, 1978, Instituto K arolinska; PhD

A reas de interés: toxicidad de metales; epidemiología; nefrología

\section{G. Enderlein}

Risk A ssessment

Instituto Federal de Seguridad y Salud

Nöldnerstrasse 40/ 42
10317 Berlín, Alemania

Tel: 493051548130

Fax: 493051548170

Puesto(s) actual(es): J efe de grupo

E studios: M D, 1957, U niversidad de Leipzig; D r rer nat, 1970

A reas de interés: métodos epidemiológicos; epidemiología laboral; bioestadística

\section{Daniel English}

Eastman K odak Company

1700 D ewey A venue

B-65/ R L

R ochester, N ueva Y ork 14650-1818, Estados

Unidos

T el: 1 (716) 4777186

Fax: 1 (716) 4774374

Puesto(s) actual(es): U nit Director

\section{Claes W. Englund}

A sociación de T eatros y O rquestas de Suecia

T eatrarnas R iksforbund

Birger Jarisgaten 39

Box 1778

11187 Estocolmo, Suecia

Tel: 4684117360

Fax: 468240939

Puesto(s) actual(es): Director, A sesor jurídico

Puesto(s) anterior(es): Secretario y Director adjunto de Empleados de Comercio y otras asociaciones, T eatrarnas R iksforbund; M inisterio de E conomía, Servicio Civil

E studios: BL L, 1966, U niversidad de Estocolmo A reas de interés: convenios colectivos en T eatro y M úsica; copyright y asesoría jurídica

\section{Madeleine R. Estryn-Béhar}

H ôpital Saint L ouis

1 Ave Claude $V$ ellefaux

París 75010, Francia

Tel: 33142555281

Fax: 33142554321

Puesto(s) actual(es): Profesional de la salud en el trabajo

Puesto(s) anterior(es): Profesional de la salud en el trabajo, $\mathrm{H}$ ôpital $\mathrm{H}$ enri M ondor, 94 C réteil

E studios: PhD

\section{Lynda Ewers}

Industrywide Studies Branch

Division of Surveillance

R obert A.T aft $L$ aboratories

Department of $\mathrm{H}$ ealth and $\mathrm{H}$ uman Services

N ational Institute for $O$ ccupational Safety and

$\mathrm{H}$ ealth

4676 Columbia Parkway

Cincinnati, O hio 45226, Estados U nidos

Puesto(s) anterior(es): A ssistant Professor, Eastern K entucky U niversity

E studios: PhD , 1992, U niversity of C incinatti

Michael J. Fagel

Aurora Packing $\mathrm{C} 0$. , Inc.

PO Box 209

N orth Aurora, Illinois 60542-0209, Estados

Unidos 
Tel: 1 (630) 897-0551

Fax: 1 (630) 897-0647

E-mail:mjfissaf@aol.com

Puesto(s) actual(es): Corporate Safety Director; Director, Emergency $\mathrm{M}$ anagement Agency; Federal Emergency $M$ anagement A gency Safety CAD RE reservist; $O$ ccupational $H$ ealth and Safety Association Special G overnment Employee; V PP Site Inspection T eam $M$ ember

E studios: BS, 1975, U niversity of N ebraska; M S, 1995, Columbia Southern U niversity; $\mathrm{PhD}, 1996$, Columbia Southern U niversity

A reas de interés: A sociación de Seguridad y Salud en el T rabajo; Programa de Protección V oluntaria; gestión de catástrofes; estrés por incidentes graves; seguridad pública

\section{John Fajen}

AIG Consultants

8070 Beechmont Avenue

Cincinnati, 0 hio 45255, Estados U nidos

Tel: 1 (513) 474-2232

Fax: 1 (513) 474-2655

Puesto(s) actual(es): Director, Industrial H ygiene and Ergonomics

E studios: BS, 1973, U tah State U niversity; M S, 1977, T emple U niversity

\section{Zuheir Ibrahim Fakhri}

Departamento de Salud en el T rabajo

$M$ inisterio de Salud

PO Box 58475

R iyadh 11594, Arabia Saudí

$$
\text { Tel: } 4791073
$$

Fax: 4731544

Puesto(s) actual(es): A sesor de Salud en el T rabajo

Puesto(s) anterior(es): Profesor adjunto, Salud en el Trabajo, U niv. de G ezira; M édico de Salud en el T rabajo, M inisterio de Salud; Examinador externo para postgraduados, U niv. de Jartúm, Sudán, y U niversidades Abd Al Aziz y R ey Faisal, Arabia Saudí

E studios: M BBS, 1968, U niv. de Jartúm; DIH, 1973, R oyal College of Physicians; M Sc, 1973, London U niversity; M D, 1982, U niv. de Jartúm, Sudán

A reas de interés: salud en el trabajo; alergias; plaguicidas; microbiología

\section{John W. Farquhar}

Stanford Center for R esearch in Disease Prevention

Stanford U niversity School of M edicine 1000 W elch R oad

Palo Alto, California 94304-1885, Estados U nidos

T el: 1 (415) 723-6051

Fax: 1 (415) 725-6906

E-mail: JFarquhar@scrdp.stanford.edu

Puesto(s) actual(es): Director

E studios: AB, 1949; M D, 1952, U niversity of California-Berkeley School of M edicine

A reas de interés: métodos de control en el ámbito comunitario de los factores de riesgo de enfermedades crónicas; política sanitaria internacional; prevención de trastornos cardiovasculares

\section{Joseph Fedoruk}

Center for $\mathrm{O}$ ccupational and Environmental $\mathrm{H}$ ealth

U niversity of California-I rvine

19722 M acArthur Boulevard

I rvine, California 92701, Estados U nidos

T el: 1 (714) 824-8641

Fax: 1 (714) 550-7211

E-mail:mjinc@aol.com

Puesto(s) actual(es): M edical Director

Puesto(s) anterior(es): V ice President, $\mathrm{H}$ ealth Services, M ed-T ox Associates, Inc

E studios: M D , 1978, U niversity of Alberta

A reas de interés: calidad del aire interior

\section{Igor A. Fedotov}

$R$ ama de Seguridad y Salud en el T rabajo

O ficina Internacional del T rabajo

4 route des $M$ orillons

1211 G inebra 22, Suiza

Tel: 41227997079

Fax: 41227996878

Puesto(s) actual(es): especialista en medicina del trabajo

Puesto(s) anterior(es): investigador en el Instituto de Investigación y Ciencia de Higiene Industrial y Enfermedades en el Trabajo, Academia R usa de Ciencias M édicas; Funcionario de la OIT en la R ama de Seguridad y Salud en el T rabajo, D epart. de M edio Ambiente y Condiciones de Trabajo

E studios: M D, 1977, A cademia M édica Setchenov de M oscú; M Sc, 1982 Instituto de Investigación y Ciencia de H igiene Industrial y Enfermedades Profesionales de la Academia R usa de Ciencias M édicas

A reas de interés: enfermedades respiratorias en el trabajo; fibras sintéticas y minerales; promoción de la salud en el trabajo servicios de salud en el trabajo

\section{John Feldman}

Raytheon Company

Executive 0 ffice

141 Spring Street

Lexington, M assachusetts 02173 , Estados U nidos

T el: 1 (617) 860-1640

Fax: 1 (617) 860-2210

E-mail:

john_b_feldman@ccmail.eo.ray.com

Puesto(s) actual(es): Corporate M anager, $\mathrm{O}$ ccupational Safety $\mathrm{H}$ ealth

Puesto(s) anterior(es): $M$ anager Safety and $H$ ealth, General Electric C O., Aircraft Engine Group

E studios: BS, 1967, Worcester Polytechnic Institute; M S, 1969, U niversity of Pennsylvania; M S, 1972, H arvard Schoo of Public H ealth

A reas de interés: seguridad y salud en el trabajo en ambientes industriales

\section{Robert G. Feldman}

Department of N eurology

Boston U niversity School of M edicine

80 East Concord Street

Boston, M assachusetts 02118-2394, Estados

Unidos

Tel: 1 (617) 638-5350

Fax: 1 (617) 638-5354

Puesto(s) actual(es): Professor, Chair; Professor of Public $\mathrm{H}$ ealth, Environmental $\mathrm{H}$ ealth- $\mathrm{N}$ eurology

E studios: BA, 1954, U niversity of Cincinnati, $M C M$ icken C ollege of Liberal Arts and Sciences; M D , 1958, U niversity of Cincinnati

A reas de interés: enfermedad de Parkinson; neurotoxicología; trastornos de movilidad

\section{Adalberto Ferioli}

Centro Internacional para la Seguridad de los Plaguicidas

$\mathrm{V}$ ia $\mathrm{M}$ agenta 25

20020 Busto G arolfo, I talia

Tel: 39331499371

Fax: 39331568023

Puesto(s) actual(es): científico en T oxicología del Trabajo

Puesto(s) anterior(es): Post D octoral Fellowship (Junior scientist), M edical R esearch Council, T oxicology U nit, Carshalton, UK ; M édico adjunto, U nidad H ospitalaria de M edicina del T rabajo, Brescia, Italia

E studios: M D , 1979, U niversidad de M ilán; especialización en M edicina del T rabajo, 1984, U niversidad de Milán; PhD, 1987, U niversidad de Bari

A reas de interés: efectos sobre la salud de la exposición a plaguicidas; contro biológico de los trabajadores de la industria y la agricultura

\section{Anne-Marie Feyer}

$\mathrm{N}$ ational Institute for $\mathrm{O}$ ccupational Safety and $\mathrm{H}$ ealth

GPO Box 58

Sydney, Nueva G ales del Sur 2001, Australia Tel: 6125659311

Fax: 6125659300

Puesto(s) actual(es): Senior R esearch Scientist

E studios: BA; PhD

\section{William Field}

Purdue U niversity

1146 Agricultural and Biological Engineering Building

W est L afayette, Indiana 47907-1146, Estados Unidos

Tel: 1 (765) 494-1191

Fax: 1 (317) 496-1115

E-mail: field@ecn.purdue.edu

Puesto(s) actual(es): Professor

Puesto(s) anterior(es): Assistant Professor, Purdue University; Associate Professor, Purdue U niversity

E studios: BS, 1971, State U niv. College at Buffalo; M S, 1975, U niv. of M innesota; EdD, 1977, U niv. of M innesota 
A reas de interés: prevención de daños en la agricultura; respuesta de emergencia en trabajo agrícola; tecnología rural de apoyo para personas con discapacidades

\section{Jonathan E. Fielding}

School of M edicine and Public $\mathrm{H}$ ealth

U niversity of C alifornia-L os Angeles

10833 Le C onte A venue

Los Angeles, California 90095-1772, Estados Unidos

T el: 1 (310) 206-1141

Fax: 1 (310) 825-3868

E-mail: jfieldin@ucla.edu

Puesto(s) actual(es): Professor of $\mathrm{H}$ ealth Services and Pediatrics, C 0-Director, Center for $\mathrm{H}$ ealthier $\mathrm{C}$ hildren, Families and Communities; U CLA Schools of Public $\mathrm{H}$ ealth and $\mathrm{M}$ edicine, President-Elect, A merican College of Preventive $M$ edicine

Puesto(s) anterior(es): V ice-President for $\mathrm{H}$ ealth Policy, Johnson and Johnson Corporation; V ice-President and $\mathrm{H}$ ealth Director, Johnson and Johnson $\mathrm{H}$ ealth $M$ anagement, Inc.; Founder, CEO, US Corporate $\mathrm{H}$ ealth $\mathrm{M}$ anagement, Inc.

E studios: BA, 1964, W illiams C ollege; M A, 1969 $\mathrm{H}$ arvard U niversity, $\mathrm{G}$ raduate School of Arts and Sciences; M D, 1969, $\mathrm{H}$ arvard U niversity, School of M edicine; M PH 1971, H arvard U niversity, School of Public H ealth; M BA, 1977, Wharton School of Business Administration Finance

A reas de interés: trabajos de alto riesgo; análisis coste-beneficio y coste-eficacia de medidas preventivas; ayudas del sector privado para la mejora de sistemas de prevención de la salud; competencia en asistencia sanitaria y efectos de la reglamentación

\section{John F. Finklea}

Center T o Protect W orkers' R ights

111 M assachusetts A venue N W

Suite 509

W ashington, DC 20001, Estados U nidos

T el: 1 (202) 962-8490

Fax: 1 (202) 962-8499

Puesto(s) actual(es): M edical 0 fficer

Puesto(s) anterior(es): Director, N ational Institute for $\mathrm{O}$ ccupational Safety and $\mathrm{H}$ ealth

E studios: M D, 1958, M edical C ollege of South Carolina; D rPH , 1966, U niversity of M ichigan

A reas de interés: seguridad y salud en el trabajo; control de lesiones; control de la contaminación del aire

\section{Manfred Fischer}

V erwaltungs-Berufgenossenschaft

Deelbögenkamp 4

D-22297 H amburgo, Alemania

Tel: 494051462550

Fax: 494051462013

Puesto(s) actual(es): Director de la Inspección Técnica

\section{Brian Flannigan}

Department of Biological Sciences

H eriot-W att U niversity

Riccarton

Edimburgo EH 14 4AS, Escocia, R eino U nido

Tel: 441314513457

Fax: 441314513009

E-mail: b.flannigan@hw.ac.uk

Puesto(s) actual(es): R eader in M icrobiology

Puesto(s) anterior(es): Lecturer, Senior Lecturer in D epartment of Biological Sciences

E studios: BSc, 1957, Edimburgo; PhD, 1969, H eriot-Watt

A reas de interés: crecimiento de moho sobre materiales de construcción; metodología para la gestión de la exposición a microorganismos de transmisión aérea; A spergiloma en Brasil y R eino U nido efectos de las micotoxinas en procesos de fabricación de cerveza y malta; micotoxinas en esporas de transmision aérea

\section{Vito Foà}

Instituto di M edicina del Lavoro

U niversidad de M ilán

Via San Barnaba 8

20122 M ilán, I talia

T el: 39255181723

Fax: 3925456025

Puesto(s) actual(es): profesor de higiente industrial

Puesto(s) anterior(es): profesor de higiene industrial, U niversidad de Bari, I talia

E studios: M D , 1960, U niversidad de M ilán

A reas de interés: toxicología industrial; higiene industrial

\section{Dominique Folliot}

Service $G$ énéral de $M$ édecine du T ravail

30 avenue de W agram

75382 París Cedex 08, France

T el: 33147647256

Fax: 33147647575

Puesto(s) actual(es): Subjefa de departamento

Puesto(s) anterior(es): J efa de división de toxicología industria

E studios: M D , 1975, París V I; Farmacología, T oxicología, Fernand W idal; CES, 1976

A reas de interés: exposición a campos electromagnéticos en el medio ambiente laboral; políticas en materia de salud y trabajo; control de productos químicos en grandes empresas

\section{Stewart Forbes}

Canadian C enter for Pollution Prevention,

100 Charlotte Street

Sarnia, O ntario N 7T 4R 2, Canadá

Tel: 1 (519) 337-3423

Fax: 1 (519) 337-3486

E-mail: c2p2@sarnia.com

Puesto(s) actual(es): Executive Director

Puesto(s) anterior(es): $\mathrm{M}$ anufacturing $\mathrm{M}$ anager, ICI Nitrogen Products

E studios: BSc, Cape T own

A reas de interés: estrategias, información y tecnologías de prevención de la contaminación

\section{Linda S. Forst}

$G$ reat $L$ akes $C$ enter for $O$ ccupational Safety and H ealth

UIC School of Public Health

2121 W. T aylor

$\mathrm{m} / \mathrm{c} 922$

Chicago, Illinois 60612, Estados U nidos

Tel: 1 (312) 996-7887

Fax: 1 (312) 413-7369

E-mail: forst-L @uic.edu

Puesto(s) actual(es): Assistant Professor

Puesto(s) anterior(es): C hief Physician, G reater Cincinnati $\mathrm{O}$ ccupational $\mathrm{H}$ ealth $\mathrm{C}$ enter

E studios: BSc, 1973, M ichigan State U niversity; M S, 1979, U niversity of A rizona; M D, 1983, M ichigan State U niversity; M PH , 1987, U niversity of Illinois, C hicago

Areas de interés: toxicidad del plomo; aprendizaje a distancia; sistemas de información geográfica

\section{Richard Forster}

Lighting Division N ewsletter

41 Duke's Wood

Crowthorne Berks R G 45 6N F, R eino U nido Tel: 441344775751

Fax: 441344775751

Puesto(s) actual(es): Lighting Consultant

\section{Bernard H. Fox}

Boston U niversity School of M edicine 85 East N ewton Street

Boston, M assachusetts 02118, Estados U nidos Tel: 1 (617) 638-7160

Fax: 1 (617) 638-7016

Puesto(s) actual(es): Professor of Psychiatry

Puesto(s) anterior(es): M anager of Social Science, Biometry Branch, National C ancer Institute; A ssociate C hief of R esearch, N eurological and Sensory D isease Control Program, National C enter for Chronic Diseases, US Public H ealth Service; R esearch Psychologist, N ational Institutes of $\mathrm{M}$ ental $\mathrm{H}$ ealth

E studios: BS, 1940, U niversity of M assachusetts; M S, 1947, T ufts U niversity; PhD, 1949, U niversity of R ochester

A reas de interés: factores psicológicos en epidemiología del cáncer; psiconeuroinmunología; psico-oncología

\section{Janet Fox}

Safety and Industrial H ygiene

Con Edison

4 Irving Place

N ueva Y ork, N ueva Y ork 10003, Estados

Unidos

Tel: 1 (212) 780-8601

Fax: 1 (212) 614-1516

Puesto(s) actual(es): Director

Puesto(s) anterior(es): Audiologist; Industrial $\mathrm{H}$ ygienist

E studios: M A, 1979, C ity U niversity of N ew Y ork; M A, 1986, N ew Y ork U niversity

\section{James Francis}

Naval Submarine M edical R esearch L aboratory $\mathrm{N}$ aval Submarine Base

New London 
G roton, Connecticut 06349-5900, Estados Unidos

T el: 1 (860) 449-4005

Fax: 1 (860) 449-2553

E-mail: francis@nsmrl.navy.mil

Puesto(s) actual(es): Senior Scientist

Puesto(s) anterior(es): Senior M edical O fficer, Diving $M$ edicine, $R$ oyal $N$ avy Exchange M edical O fficer N M R I, Bethesda; $\mathrm{H}$ ead of $U$ ndersea $\mathrm{M}$ edicine, Institute of $\mathrm{N}$ aval $M$ edicine, Alverstoke, G osport, R eino Unido

E studios: BSc, 1974, U niversity of L ondon; M B, BS, 1977, U niversity of L ondon; M Sc 1982, U niversity of L ondon; PhD, 1994 University of London; M FO M , 1994, R oyal C ollege of Physicians, L ondon

A reas de interés: medicina del buceo; medicina térmica; medicina del submarinismo

\section{Marianne Frankenhaeuser}

Departamento de Psicología

U niversidad de Estocolmo

10691 Estocolmo, Suecia

T el: 468163684

Fax: 468153587

E-mail: mf@ psychology.su.se

Puesto(s) actual(es): Profesora emérita de psicología

Puesto(s) anterior(es): Profesora de psicología, Instituto K arolinska; Directora de investigación, Instituto Sueco de Investigación de $\mathrm{N}$ egocios y $\mathrm{V}$ ida Laboral

E studios: Diplomatura en Psicología, 1947, U niversity of O xford; BA, 1950, U niversidad de $\mathrm{H}$ elsinki; M A, 1954, U niversidad de Estocolmo; PhD, 1959, U niversidad de U ppsala

A reas de interés: aplicación de la teoría y la investigación sobre el estrés a: a) estrategias de prevención y actuación en el trabajo; b) cuestiones de liderazgo; c) política social; $y$ d) cuestiones de desarme nuclear y paz; estrés en humanos y afrontamiento del mismo en relación con la salud, desde un punto de vista psicobiológico

\section{John R. Franks}

Bioacoustics and O ccupational V ibration Section,

$\mathrm{N}$ ational Institute for $\mathrm{O}$ ccupational Safety and $\mathrm{H}$ ealth,

Division of Biomedical and Behavioral Science,

R obert $A$. T aft L aboratories,

4676 C olumbia Parkway

$M$ ail Stop $\mathrm{C}-27$

Cincinnati, O hio 45226-1998, Estados U nidos

T el: 1 (513) 533-8151

Fax: 1 (513) 533-8139

E-mail: jrf3@cdc.gov

Puesto(s) actual(es): Section Chief

Puesto(s) anterior(es): A ssistant Professor, Audiology, A rizona State U niversity; Associate Professor, Audiology, Northern Illinois U niversity

E studios: M A, 1969, W ashington U niversity; PhD, 1975, Purdue U niversity
A reas de interés: prevención de la pérdida de audición, ruido, habla; acústica: ingeniería y arquitectura

\section{David J. Franson}

Safety M anagement Services C ompany

300 Security Building

PO Box 28

D ubuque, I owa 52004-0028, Estados U nidos

T el: 1 (319) 583-7344 ext. 276

Fax: 1 (319) 583-7339

E-mail: safetymgt@ch-sisco.com

Puesto(s) actual(es): O ccupational Safety and $\mathrm{H}$ ealth $\mathrm{C}$ onsultant

Puesto(s) anterior(es): Safety Director, IBP, Inc. Emporia, K ansas; O ccupational Safety and $\mathrm{H}$ ealth Consultant, Wyatt Company, Chicago, IL

E studios: BS, 1985, U niversity of W isconsin, Platteville; Certified Safety Professional, Associate $R$ isk $M$ anagement

A reas de interés: conformidad con la A sociación de Salud y Seguridad en el trabajo; protectores en las máquinas; formación en materia de seguridad; procesos cuantitativos de auditoría; seguridad de flotas; industria alimentaria y de bebidas

\section{T.M. Fraser}

\section{U niversity of W aterloo}

Box 1606

N iagara-on-the-Lake, O ntario L OS 1J0, Canadá T el: 1 (905) 468-5243

Puesto(s) actual(es): Professor Emeritus

Puesto(s) anterior(es): Professor and Chairman, D epartment of Systems D esign Engineering, U niversity of W aterloo, Canadá

E studios: M B, CLB, 1944, U niversity of Edinburgh; M D, 1948, U niversity of Edinburgh; M Sc, O hio State U niversity; PENG, 1961, Toronto

A reas de interés: condiciones de trabajo

\section{James S. Frederick}

H ealth, Safety and Environment D epartment

U nited Steelworkers of A merica

Five G ateway Center

Pittsburgh, Pennsylvania 15222, Estados U nidos

T el: 1 (412) 562-2400

Fax: 1 (412) 562-2484

E-mail: 71112,1352@ compuserve.com

Puesto(s) actual(es): Industrial $\mathrm{H}$ ygienist

\section{David Freestone}

Law School

U niversity of $\mathrm{H}$ ull

H ull, HU6 7RX, R eino U nido

Tel: 01482465705

Fax: 01482466388

E-mail: D.A.Freestone@law.hull.ac.uk

Puesto(s) actual(es): Professor of International Law

Puesto(s) anterior(es): Adviser, M inistry of Foreign Affairs, Antigua y Barbuda

E studios: LLB, 1969, U niversity of H ull; LLM , 1970, U niversity of L ondon

A reas de interés: legislación internacional en materia de gestión ambiental y de recursos; legislación del medio ambiente marino, incluidas las leyes costeras; legislación internacional de la industria pesquera; leyes de la C omunidad Europea, sobre todo en sus aspectos institucionales y medioambientales

\section{Jean G. French}

U niversity of N orth Carolina School of Public $\mathrm{H}$ ealth

323 Burris Place

Chapel H ill, Carolina del N orte 27516, Estados Unidos

T el: 1 (919) 933-8198

Puesto(s) actual(es): A djunct Professor of Epidemiology

Puesto(s) anterior(es): Senior Science Advisory Staff, National Institute for $O$ ccupational Safety and $\mathrm{H}$ ealth, $\mathrm{C}$ enters for D isease Control; H ealth Scientist, Assistant to the Director, C enter for Environmental $\mathrm{H}$ ealth, Centers for D isease C ontrol

E studios: Dr PH , 1966, U niversity of M ichigan; $\mathrm{MOH}$, Johns H opkins U niversity

A reas de interés: epidemiología de siniestros; neurotoxicidad

\section{Herbert J. Freudenberger}

18 East 87th Street

N ueva Y ork, N ueva Y ork 10128-0505, Estados Unidos

Tel: 1 (212) 427-8500

Puesto(s) actual(es): Psychologist/ Psychoanalyst

E studios: PhD, 1956, N ew Y ork U niversity

A reas de interés: estrés; abuso de sustancias

\section{Barry Friedlander}

Exxon Biomedical Sciences, Inc.

$M$ ettlers R oad

CN 2305

East M illstone, N ew Jersey 08875-2350, Estados Unidos

T el: 1 (908) 873-6702

Fax: 1 (908) 873-6009

Puesto(s) actual(es): Senior Environmental $\mathrm{H}$ ealth Advisor

Puesto(s) anterior(es): Director, M edical and $\mathrm{H}$ ealth Sciences, M onsanto Company; Director, O ccupational $\mathrm{H}$ ealth Services, Eastman K odak; C hief, O ccupational and $\mathrm{Employee} H$ ealth, $\mathrm{M}$ aryland $\mathrm{D}$ epartment of $\mathrm{H}$ ealth; $\mathrm{O}$ ccupational $\mathrm{H}$ ealth $\mathrm{O}$ fficer, U S A rmy

E studios: AB, 1964, U niversity of Pennsylvania; M D , 1968, W est V irginia U niversity M edical School; M PH, 1970, Johns $\mathrm{H}$ opkins School of $\mathrm{H}$ ygiene and Public $\mathrm{H}$ ealth

A reas de interés: aspectos sanitarios del cambio climático global; estudios internacionales sobre incidencia del cáncer en la industria; efectos del benceno sobre la salud

\section{George Friedman-Jiménez}

Bellevue/ N ew Y ork U niversity O ccupational and Environmental M edicine Clinic

Bellevue H ospital Center

426 First A venue

R oom CD 349

N ueva Y ork, Nueva Y ork 10016, Estados Unidos 
Tel: 1 (212) 562-4572

Fax: 1 (212) 562-4574

E-mail: frdmanj@is3.nyu.edu

Puesto(s) actual(es): Director; Attending Physician

E studios: M D, 1982, Albert Einstein College of M edicine

A reas de interés: epidemiología en el trabajo, epidemiología clínica, medicina del trabajo

\section{Howard Frumkin}

R ollins School of Public H ealth

Emory U niversity

Atlanta, G eorgia 30322, Estados U nidos

Tel: 1 (404) 727-3697

Fax: 1 (404) 727-8744

E-mail: frumkin@sph.emory.eom

Estudios: DrPH ;

A reas de interés: política en materia de salud ambiental y en el trabajo; toxicidad de plomo; lesiones de origen laboral

\section{Daniel Ganster}

Department of $\mathrm{M}$ anagement

U niversity of Arkansas

Fayetteville, A rkansas 72701, Estados U nidos

Tel: 1 (501) 575-6216

Fax: 1 (501) 575-7687

E-mail: dganster@ comp.uark.edu

Puesto(s) actual(es): Professor, D epartment Chair

E studios: PhD, 1978, Purdue U niversity

A reas de interés: estrés laboral crónico; medida de estrés; intervención del estrés empresarial

\section{Lawrence Garfinke}

American Cancer Society

1180 A venue of the Americas

Nueva Y ork, Nueva Y ork 10036, Estados Unidos

T el: 1 (212) 382-2169

Fax: 1 (212) 719-0193

E-mail: 103204.514@ compuserve.com

Puesto(s) actual(es): C onsultant

Puesto(s) anterior(es): V ice President for Epidemiology and Statistics, American Cancer Society

E studios: M A, 1949, Columbia U niversity

A reas de interés: consumo de tabaco y salud tendencias sobre incidencia del cáncer y mortalidad

\section{Joel C. Gaydos}

U nited States Army C enter for $\mathrm{H}$ ealth Promotion and Preventive $M$ edicine

Army Proving Ground, M aryland 21010 , Estados U nidos

T el: 1 (410) 671-4312

Puesto(s) actual(es): Director, Clinical Preventive $M$ edicine

Puesto(s) anterior(es): Director, U nited States Army $O$ ccupational $M$ edicine R esidency Program, A berdeen Proving Ground

E studios: M D, 1968, W est V irginia U niversity M PH , 1972, U niversity of Pittsburgh

A reas de interés: pérdida de audición por ruido

\section{Otto Geiecker}

Allgemeine U nfall V ersicherungsanstalt

Zuckerkandlgasse 7
1190 V iena, Austria

Tel: 4314794191

Puesto(s) actual(es): A sesor de rehabilitación Representante del Consejo de Europa-R.I.

Puesto(s) anterior(es): Subdirector general, AUV A; Presidente, R.I.

E studios: D kfm, 1952, U niversidad de Economía, $\checkmark$ iena

A reas de interés: política social y rehabilitación

\section{Afsaneh Gerami}

H ewlett-Packard Company

350-370 T rimble R oad

$M$ ailstop $90 \mathrm{~L} 0$

San José, California 95131-1008, Estados Unidos

Puesto(s) actual(es): Environmental $\mathrm{H}$ ealth and Safety Consultant

Puesto(s) anterior(es): $\mathrm{H}$ ealth and Safety Specialist

E studios: BS, 1997, San Jose State U niv.: Completed coursework for $M$ asters D egree, San J ose State U niversity

\section{Kenneth Gerecke}

$O$ ccupational Safety and $\mathrm{H}$ ealth Administration U nited States D epartment of $L$ abor

Gateway Building

Suite 2100

$3535 \mathrm{M}$ arket Street

Philadelphia, Pennsylvania 19104, Estados Unidos

T el: 1 (215) 596-1201

Fax: 1 (215) 596-4872

Puesto(s) actual(es): Assistant R egional Administration

E studios: CIH , M S, 1975, N ew Y ork U niversity

\section{Adrian V. Gheorghe}

Director de Investigación

ETH-Zentrum

Instituto Federal Suizo de T ecnología

8092 Zurich, Suiza

$$
\text { T el: } 4116325938
$$

Fax: 411632109

Puesto(s) anterior(es): Funcionario internacional; Director de gestión de proyectos

E studios: M Sc, 1968, U niversidad Politécnica de Bucarest; PhD, 1975, City U niversity, Londres

A reas de interés: gestión del riesgo; gestión de seguridad; análisis de decisiones

\section{Gary Gibson}

Durham Board of Education

400 T auton R oad East

Whitby, O ntario L IR 2K 6, Canadá

Tel: 1 (905) 666-6408

Fax: 1 (905) 666-6969

E-mail: gibsong@ durham.edu.on.ca

E studios: BSc

\section{Gary A. Gibson}

$M$ ines R escue Board

GPO Box 4853

Sydney, N ueva Gales del Sur 2001, Australia

T el: 61292248981

Fax: 61292248910

E-mail: garygib@minesrescue.org.au
Puesto(s) actual(es): Chief Executive 0 fficer

Puesto(s) anterior(es): $M$ anager $O$ perations, BH P Collieries Division, W ollongong

E studios: M BA, 1994, U niversity of W ollongong

A reas de interés: preparación de emergencias; rescate en minas; minería del carbón: productividad y mejora de la seguridad

\section{Denis Giguère}

Safety-Ergonomics R esearch Programme Institute for $\mathrm{O}$ ccupational $\mathrm{H}$ ealth and Safety R esearch

505 boulevard $\mathrm{De} M$ aisonneuve $O$ uest M ontreal, Q uébec $\mathrm{H} 3 \mathrm{~A}$ 3C 2 C anadá

Tel: 1 (514) 288-1551

Fax: 1 (514) 288-6097

E-mail: giguere@cam.org

Puesto(s) actual(es): Ergonomist

E studios: M Sc, 1981, U niversity of Q uébec; DESS, 1992, Ergonomie, Ecole Polytechnique de M ontréal

A reas de interés: ergonomía de vehículos (visibilidad, vehículos profesionales); servicios públicos (por ejemplo, policía bomberos)

\section{Issachar Gilad}

Facultad de Ingeniería Industrial y

Administración

Instituto de T ecnología de I srael

$\mathrm{H}$ aifa 32000 , Israel

T el: 97248294434

Fax: 97248235194

E-mail: igilad@ie.technion.ac.il

Puesto(s) actual(es): Profesor, Jefe, A rea de Ingeniería Industrial; J efe, Laboratorio de Ergonomía e Investigación del Trabajo

Puesto(s) anterior(es): Director, Sociedad de Ergonomía de Israel

E studios: BSc, 1972, T echnion IIT ; M Sc, 1976, T echnion IIT; PhD, 1978, N ew Y ork University

A reas de interés: métodos de medición y productividad en el trabajo; ergonomía industrial; biomecánica del trabajo; técnicas de rehabilitación

\section{William I. Glass}

$10 \mathrm{~K}$ am Park Place

Christchurch, Nueva Zelanda

Tel: 006433433737

Fax: 006433433737

Puesto(s) actual(es): 0 ccupational M edical Specialist; C onsultant to D epartment of Labour in $\mathrm{O}$ ccupational $\mathrm{M}$ edicine; Convenor $\mathrm{N}$ ational Asbestos M edical Panel

Puesto(s) anterior(es): H ead O ccupational $\mathrm{H}$ ealth U nit, $O$ tago $U$ niversity

Estudios: M B, ChB, 1956, Nueva Zelanda; D PH DIH, 1959; M FO M , 1978; FFOM 1988 FAFO M, 1985, Australasia

A reas de interés: servicios de salud en pequeños lugares de trabajo; neurotoxicidad de disolventes; trastornos respiratorios de origen laboral (asbesto) 


\section{Berenice I. Ferrari Goelzer}

O ficina de M edicina del T rabajo

O rganización M undial de la Salud

20 avenue Appia

1211 G inebra, Suiza

Tel: 41227913483

Estudios: $\mathrm{CIH}$; $\mathrm{M} \mathrm{PH}$

\section{David Gold}

Sección de Seguridad y Salud en el Trabajo

O ficina Internacional del T rabajo

4 route des $M$ orillons

1211 G inebra 22, Suiza

Tel: 41227996183

Fax: 41227996878

E-mail: gold@ilo.org

Puesto(s) actual(es): Director de salud y seguridad en el trabajo

Puesto(s) anterior(es): A sesor técnico jefe, Programa de Salud y Seguridad en el Trabajo en el Pacífico Asiático, O ficina Internacional del T rabajo; Director de estudios y formación, 0 ficina Internacional de Trabajo, G inebra; Presidente, Safety Education Associates, Goodwin M ills, $M$ aine, EE UU

E studios: BA, 1973, Suffolk U niv:; M O Ed, 1976 U niv. of $\mathrm{New} \mathrm{H}$ ampshire; estudios de doctorado, U niversidad T ecnológica T ampere, Finlandia

A reas de interés: formación para la seguridad y la salud; información sobre salud y seguridad; salud y seguridad en submarinismo; salud y seguridad en la construcción; salud y seguridad en el trabajo

\section{Kristan D. Goldfein}

$M$ anager of $C$ orporate W ellness

$M$ errill Lynch

World Financial C enter

N ueva Y ork, N ueva Y ork 10281-1303, Estados Unidos

Tel: 1 (212) 449-9212

Fax: 1 (212) 449-9220

Puesto(s) actual(es): M anager, C orporate W ellness, M erill Lynch

Puesto(s) anterior(es): Adjunct A ssistant Professor, T eachers C ollege, Columbia U niversity; Adjunct A ssistant Professor, Columbia U niversity School of Public H ealth

E studios: DEd, 1993, Columbia U niversity

A reas de interés: desarrollo de programas de calidad; extensión de los servicios de salud a empleados a nivel nacional

\section{Bernard D. Goldstein}

Environmental and $\mathrm{O}$ ccupational $\mathrm{H}$ ealth

Sciences Institute

681 Frelinghuysen $\mathrm{R}$ oad

PO Box 1179

Piscataway, N ew Jersey 08855-1179, Estados

Unidos

T el: 1 (908) 445-0205

Fax: 1 (908) 445-0131

E-mail: bgold@eohsi.rutgers.edu

Puesto(s) actual(es): Director; Professor and

Chairman, Department of

Environmental and Community
M edicine, U M DNJ-R obert W ood Johnson M edical School

E studios: M D, 1962, N ew Y ork U niversity School of M edicine

A reas de interés: benceno; ozono; gestión del riesgo; contaminación del aire; riesgos en el lugar de trabajo; leucemia

\section{David Gompertz}

Institute of $\mathrm{O}$ ccupational $\mathrm{H}$ ealth

U niversity of Birmingham

Birmingham B15 2T T, R eino U nido

Tel: 441214146030

Fax: 441214146217

Puesto(s) actual(es): Consultant

Puesto(s) anterior(es): Deputy M edical Director (R esearch and Pathology), UK H ealth and Safety Executive

E studios: M D , 1960, U niversity of Birmingham; PhD, 1965, U niversity of L ondon

A reas de interés: monitorización biológica

\section{D.F. Gorman}

\section{School of M edicine}

U niversity of Auckland

Private Bag 92-019

Auckland, N ueva Zelanda

T el: 6493737599 ext. 6587

Fax: 6493737006

E-mail: d.gorman@auckland.ac.nz

Puesto(s) actual(es): H ead, O ccupational M edicine

Puesto(s) anterior(es): Director of M edical Services, R oyal New Zealand Navy

E studios: M D, 1978, U niversity of Auckland; PhD, 1988, U niversity of Sydney

A reas de interés: enfermedad por descompresión; toxicidad del monóxido de carbono; control de incidentes; programas de rehabilitación

\section{Marilyn K. Gowing}

Personnel R esources and D evelopment Center $U$ nited States $O$ ffice of Personnel $M$ anagement 1900 E. Street NW

R oom 6355

W ashington, DC 20415, Estados U nidos

T el: 1 (202) 606-0820

Fax: 1 (202) 606-1399

E-mail: gowing@tmn.com.

Puesto(s) actual(es): Director

Puesto(s) anterior(es): M anager, O rganizationa Consulting, Laventhal and $\mathrm{H}$ orwath; Director, Assessment Services, International Personnel $\mathrm{M}$ anagement Association

E studios: PhD, 1981, G eorge W ashington U niversity

A reas de interés: evaluación de organizaciones; salud en el trabajo

Joke J.H. Grady-van den Nieuwboer Centro R oessingh de R ehabilitación

$\mathrm{H}$ aaksbergen, Países Bajos

Puesto(s) anterior(es): Profesor de ergonomía física y miembro del personal investigador, D epartamento de Ergonomía, U niv.T wente te Enschede, Países Bajos; Director interino del D epartamento OT del Centro de R ehabilitación “het
R oessingh", Enschede, Países Bajos

A sesor de diseño para discapacitados;

Director de proyecto de investigación,

IR O N Instituut voor R esearch,

$\mathrm{O}$ ntwikkeling en $\mathrm{N}$ ascholing

De R uyterlaan 25

E studios: BSc, 1972, Instituto H olandés de T erapia del Trabajo, Amsterdam; M Sc 1989, U niversidad de G roningen;

A reas de interés: diseño y asistencia técnica; rehabilitación

\section{Per-Ola Granberg}

Departamento del Instituto K arolinska

Engelbrektsgatan 21

11432 Estocolmo, Suecia

T el: 4686115456

Puesto(s) anterior(es): A ntiguo profesor de cirugía endocrina en el H ospital K arolinska, Estocolmo

E studios: M D, 1948, Instituto K arolinska; PhD, 1962, Instituto K arolinska

A reas de interés: enseñanza e investigación de medicina de la región Artica

\section{Philippe Grandjean}

Instituto de M edicina de la C omunidad

U niversidad de 0 dense

Winslowparken 17

50000 dense, Dinamarca

Tel: 4566158600

Fax: 4565911458

E-mail: p.grandjean@winsloew.ou.dk

Puesto(s) actual(es): Profesor de medicina ambiental

E studios: M D, 1974, U niversidad de Copenhague; M Sc, 1978, U niversidad de Copenhague

\section{Martino Grandolfo}

Departamento de Física

Instituto Superiore di Sanità

$\mathrm{V}$ iale R egina Elena 299

00161 R oma, I talia

Tel: 3964456266

Fax: 39649902227

E-mail: internet: martino@iss.it

Puesto(s) actual(es): Director

Puesto(s) anterior(es): I stituto Superiore di Sanita; V icepresidente, C omisión Internacional para la Protección a la R adiación No Ionizante

E studios: Licenciado en Física N uclear, 1964, Universidad de R oma

A reas de interés: efectos biológicos y dosimetría de la radiación electromagnética no ionizante

\section{Casey C. Grant}

C odes and Standards Administration

N ational Fire Protection Association

International

1 Batterymarch Park

PO Box 9101

Q uincy, M assachusetts 02269-9101, Estados

Unidos

Tel: 1 (617) 770-3000

Fax: 1 (617) 770-3500

E-mail: cgrant@nfpa.org 
Puesto(s) actual(es): A ssistant V ice-President

Puesto(s) anterior(es): Senior Engineer, Fire Protection Services, I mpell Corporation; T echnical Director, C odes and Standards

E studios: BS, 1981, U niversity of M aryland; M S 1988, W orcester Polytechnic Institute

\section{Gary N. Greenberg}

Department Community and Family M edicine

Duke U niversity M edical C enter

Durham, Carolina del N orte 27705, Estados Unidos

T el: 1 (919) 286-3232

Fax: 1 (919) 286-1021

E-mail: green@11mc.duke.edu

Department Community and Family M edicine

Puesto(s) actual(es): Division Chief, O ccupational and Environmental M edicine; Assistant Clinical Professor

E studios: BS, M D, 1978, N orthwestern U niversity M edical School; M PH, 1984, U niversity of N orth Carolina School of Public $\mathrm{H}$ ealth

\section{Peter Greenwald}

Division of $\mathrm{C}$ ancer Prevention and Control

National $C$ ancer Institute

Building 31

R oom 10A52,

9000 R ockville Pike

Bethesda, M aryland 20892-2580, Estados

Unidos

T el: 1 (301) 496-6616

Fax: 1 (301) 496-9931

Puesto(s) actual(es): Director

Puesto(s) anterior(es): Director of E pidemiology, $\mathrm{N}$ ew Y ork State D epartment of $\mathrm{H}$ ealth

E studios: M D, 1961, State U niversity of N ew Y ork, Syracuse; DrPH , 1974, H arvard School of Public H ealth

A reas de interés: investigación para la prevención del cáncer

\section{Dieter Greiner}

$\mathrm{H}$ auptverband der gewerblichen

Berufsgenossenschaften,

Alte $\mathrm{H}$ eerstrasse 111

53754 Sankt Augustin, Alemania

Tel: 492241231107

Fax: 492241231108

Puesto(s) actual(es): Subdirector general; Director gerente, $\mathrm{H}$ ospital de Accidentes de Berlín; Presidente, C omité Permanente de la A sociación Internacional de la Seguridad Social sobre Seguros contra A ccidentes de T rabajo y Enfermedades Profesionales

E studios: Dr jur, LLD, U niversidad de Colonia A reas de interés: legislación internacional sobre seguros por accidente, especialmente unidad de diseño de la prevención, rehabilitación y compensación en un servicio globa

\section{Leo J.L.D. Van Griensven}

Estación Experimental de $\mathrm{H}$ ongos PO Box 6042

5960 AA H orst, Países Bajos

Tel: 31774647575

Fax: 31774641567
E-mail: mushvg@via.n

Puesto(s) actual(es): Profesor de M icología aplicada, U niversidad Católica de Nijmegen, Países Bajos; Director, Estación Experimental de H ongos

Puesto(s) anterior(es): J efe de la U nidad de Patología Experimental, D epartamento de Patología, Facultad de M edicina de la U niv.E rasmus, R otterdam

E studios: PhD, 1970, U niv. de A gricultura W ageningen

A reas de interés: genética molecular de hongos

Michael J. Griffin

Institute of Sound and V ibration R esearch

U niversity of Southampton

Southampton S017 1BJ, R eino U nido

T el: 441703592277

Fax: 441703592927

E-mail: mjg@isur.salon.ac.uk

Puesto(s) actual(es): Professor of H uman Factors

E studios: BSc, 1968, U niversity of Southampton; PhD, 1972, U niversity of Southampton

\section{Carsten Groenberg}

Laboratorio N acional RISO

PO Box 49

4000 R oskilde, Dinamarca

Tel: 4546775134

Fax: 4546757101

E-mail: rag-cagr@ risoe.dk

Puesto(s) actual(es): Ingeniero investigador

E studios: M Sc, 1967, U niversidad T écnica de Dinamarca

A reas de interés: organización de emergencias; gestión del riesgo; comunicación del riesgo

\section{Jop Groeneweg}

Centro de Investigación de la Seguridad

U niversidad de L eiden

PO Box 9555

2300 R B Leiden, Países Bajos

T el: 31715273627

Fax: 31715273619

E-mail: groeneweg@ rulfsw.leidenuniv.nl

Puesto(s) actual(es): Investigador

E studios: M S, 1985; PhD, 1992

A reas de interés: error humano; gestión de respuesta ante emergencias; sistemas de gestión de la seguridad

\section{Gudela Grote}

Institut für Arbeitpsychologie

Eidgenössische T echnische H ochschule

Nelkenstrasse 11

8092 Zurich, Suiza
T el: 4116327086
Fax: 4116321186
E-mail: grote@ifap.bepr.ethz.ch

Puesto(s) actual(es): Profesora adjunta de Psicología del T rabajo y de 0 rganizaciones

E studios: BA, 1984, U niversidad T écnica de Berlín; PhD , 1987, G eorgia Institute of Technology, Atlanta

A reas de interés: desarrollo de la personalidad y trabajo; diseño de sistemas de trabajo de alto riesgo; conceptos psicológicos sobre el trabajo automatizado; cambio organizativo
Saul G. Gruner

S.G. Gruner A ssociates, Inc.

227 Lansdowne

W estport, C onnecticut 06880, Estados U nidos Tel: 1 (203) 255-5348

Puesto(s) actual(es): C onsultant in 0 utplacement

Puesto(s) anterior(es): Senior V ice-President, Thinc Consulting G roup; President, Executive Job Counselors

E studios: M S, 1939, U niversity of M assachusetts; BS, 1938, U niversity of M assachusetts

\section{Xavier Guardino Solá}

Centro N acional de Condiciones de T rabajo Instituto $\mathrm{N}$ acional de Seguridad e H igiene en el Trabajo

Calle Dulcet 2-10

08034 Barcelona, España

T el: 3432800102

Fax: 3432803642

Puesto(s) actual(es): J efe de D epartamento

E studios: PhD; M aster (Ingeniería ambiental)

A reas de interés: calidad del aire interior; toxicología; salud y seguridad en trabajadores de la asistencia sanitaria

\section{Juan Guasch Farrás}

Centro $\mathrm{N}$ acional de Condiciones de T rabajo Instituto $\mathrm{N}$ acional de Seguridad e $\mathrm{H}$ igiene en el Trabajo

C alle Dulcet 2-10

08034 Barcelona, España

T el: 3432800102

Fax: 3432803642

Puesto(s) actual(es): J efe de la Sección de Condiciones de Trabajo

E studios: Licenciado en Ciencias Q uímicas, 1972, Facultad de Ciencias de la U niversidad de Barcelona

A reas de interés: contaminantes químicos ambientales; contaminantes energéticos: ruido, calor, radiaciones no-ionizantes; gestión de la prevención; seguridad química

\section{Tee L. Guidotti}

U niversity of A lberta Faculty of M edicine

13-103 C linical Services Building

Edmonton, Alberta T 6G 2G 3, Canadá

Tel: 1 (403) 492-7849

Fax: 1 (403) 492-9677

E-mail: tee.guidotti@ualberta.ca

Puesto(s) actual(es): Professor of O ccupational and Environmental M edicine

Puesto(s) anterior(es): K illam A nnual Professor

E studios: M D , 1975, U niversity of California at San D iego; M PH, 1981, Johns H opkins School of $\mathrm{H}$ ygiene and Public $\mathrm{H}$ ealth

Areas de interés: calidad del aire; toxicología por inhalación

\section{Paul D. Gunderson}

\section{$M$ arshfield Clinic}

$\mathrm{N}$ ational Farm M edicine $\mathrm{C}$ enter

1000 North 0 ak A venue

M arshfield, W isconsin 54449, Estados U nidos

E studios: PhD 


\section{Krishan Chand Gupta}

$\mathrm{F}-4 / 2$

$\checkmark$ indhya Apts

Shopping Centre

Sector 6

ashi

Bombay 400 703, India

Tel: 912240912850

Fax: 912240930790

Puesto(s) actual(es): Director general, Consejo de Seguridad Nacional

Puesto(s) anterior(es): Director general, Servicio de A sesoría de Fábricas e Institutos de T rabajo, M inisterio de T rabajo, India

E studios: BE, 1961, Colegio de Ingeniería de Delhi

A reas de interés: campañas de salud y seguridad en el trabajo, legislación y cumplimiento; formación; seguridad química y prevención de emergencias; preparación y respuesta; control de riesgos de accidentes; auditorías de seguridad y asesoramiento técnico; programas de concienciación colectiva

\section{Per Gustavsson}

D epartamento de Salud en el T rabajo

$\mathrm{H}$ ospital K arolinska

17176 Estocolmo, Suecia

T el: 4687293056

Fax: 468334333

E-mail: pgu@ymed.ks.se

Puesto(s) actual(es): Profesor adjunto

Puesto(s) anterior(es): $M$ édico

E studios: M D , 1978, Instituto K arolinska; PhD, 1989, Instituto K arolinska

A reas de interés: epidemiología laboral; cáncer de origen laboral y enfermedades del corazón; efectos de productos combustibles

\section{Winfried Hacker}

T echnische U niversität D resden

Sektion A rbeitswissenschaften

M ommsenstrasse13

01062 D resde, Alemania

Tel: 00493514634695

Fax: 00493514633522

E-mail: wobst@psy1.psych.tu-dresden.de

Puesto(s) actual(es): C atedrático de Psicología General, U niversidad T ecnológica de Dresde

E studios: Dr rer nat, 1960, TH Dresde; Dr rer nat habil, 1964, TU D resde

A reas de interés: carga mental; síndrome de burn-out; análisis de tareas; asignación de funciones en sistemas hombre-máquina

\section{John G. Hadley}

O wens-C orning

$\mathrm{H}$ ealth Sciences

S\&T Center 21

2790 C olumbus R oad

Granville, O hio 43023-1200, Estados U nidos

Tel: 1 (614) 321-7228

Fax: 1 (614) 321-4228

E-mail: john.hadley@ owenscorning.com

Puesto(s) actual(es): Corporate T oxicologist

E studios: PhD, 1977, Duke U niversity
A reas de interés: toxicología de fibras

\section{Mats Hagberg}

D epartmento de M edicina del T rabajo

St. Sigfridsgatan 85

SE -412 66 G oteborg, Suecia

Tel: 46-31-335-4890

Fax: 46-31-409728

E-mail: mats.hagberg@ymk.gu.se

E studios: PhD; M D

\section{Niels Jorn Hahn}

Grupo de Trabajo sobre R eciclaje y R educción de $R$ esiduos

ISWA

R enholdningsselskabet $\mathrm{R} 98$

$\mathrm{K}$ raftværksvej 25

2300 C openhague S, Dinamarca T el: 4532661898

Puesto(s) actual(es): Director gerente

Estudios: M Sc

\section{Kari K. Häkkinen}

Industrial Insurance L td.

PO Box 12

$00211 \mathrm{H}$ elsinki, Finlandia

T el: 358969611

Fax: 358969612232

Puesto(s) actual(es): A sesor técnico, Director de prevención de pérdidas

Puesto(s) anterior(es): Director adjunto, Investigador, Instituto de Salud en el T rabajo, D epartamento de Seguridad en el T rabajo, Finlandia

E studios: PhD, 1985, U niv. de T ecnología de $\mathrm{H}$ elsinki

A reas de interés: gestión de la seguridad; seguros y gestión del riesgo; seguridad en la manipulación de materiales

\section{Andrew R. Hale}

U niversidad T ecnológica de D elft

Grupo de ciencia de la seguridad

$\mathrm{K}$ anaalweg $2 \mathrm{~B}$

2628 EB D elft, Países Bajos

Tel: 31152781706

Fax: 31152622235

E-mail: a.r.hale@wtm.tudelft.nl

Puesto(s) actual(es): Profesor de ciencia de la seguridad

Puesto(s) anterior(es): U niversity of Aston; N ational Institute of Industrial Psychology

E studios: M A, 1966, C ambridge U niversity; PhD, 1978, Aston U niversity

A reas de interés: gestión de la seguridad; regulación y certificación de la seguridad; factores humanos y formación

\section{David Hamerman}

R esnick Gerontology C enter

Albert Einstein College of $M$ edicine

$M$ ontefiore $M$ edical C enter

111 East 210th Street

Bronx, N ueva Y ork 10467, Estados U nidos Tel: 1 (718) 655-2542

Fax: 1 (718) 547-2626

Puesto(s) actual(es): Director

E studios: M D

\section{Leonard Derwent Hamilton}

O rganización M undial de la Salud

Collaborating $C$ enter

Brookhaven National Laboratory

Building 490D

U pton, N ueva Y ork 11973, Estados U nidos

Tel: 1 (516) 344-2004

Fax: 1 (516) 344-7867

Puesto(s) actual(es): Professor of $M$ edicine, $\mathrm{H}$ ealth Sciences $\mathrm{C}$ enter, State U niversity of $\mathrm{N} \mathrm{ew}$ Y ork at Stony Brook; A djunct Professor of Biometry and Epidemiology,

D epartment of Biometry and

Epidemiology, M edical U niversity of South Carolina, Charleston

Puesto(s) anterior(es): Sloan-K ettering Institute and M emorial H ospital, NY; Senior Scientist, Brookhaven N ational Laboratory, U pton NY

E studios: BA, 1943; BM , BCh, 1945; M A, 1946; DM , 1951, O xford U niversity; PhD 1952, Cambridge U niversity; Lic Physician (NY State), 1955; US Board of Pathology (H ermatology), 1961

A reas de interés: impacto ambiental y sobre la salud de las fuentes de energía desde la exploración hasta su utilización; gestión del riesgo de los peligros ambientales

\section{Hans Hamrin}

Atlas Copco R ock D rills AB

10523 Estocolmo, Suecia

T el: 468743 8000/ 8183

Fax: 4687438440

E-mail: hans.hamrin@ swipnet.se

Puesto(s) actual(es): A sesor principal, M inería

E studios: M Sc

\section{Jonathan T. Haney}

7705 Farley Lane

M anlius, N ueva Y ork 13104, Estados U nidos Tel: 1 (315) 682-3064

E-mail: arlsjth@aol.com

E studios: M S; $\mathrm{CIH}$

\section{Kjell Hansson Mild}

Instituto $\mathrm{N}$ acional del Trabajo

PO Box 7654

90713 U meå, Suecia

Tel: 4690165098

Fax: 4690166508

E-mail:mild@nioh.se

Puesto(s) actual(es): Investigador

E studios: PhD , 1974, U niv. de U meå

A reas de interés: bioelectromagnetismo

\section{Takashi Haratani}

Instituto $\mathrm{N}$ acional de H igiene Industria

21-1 Nagao 6-chome T ama-ku

K awasaki 214, Japón

Tel: 81448656111

Fax: 81448656116

E-mail: haratani@ niih.go.jp

Puesto(s) actual(es): Investigador

Estudios: BS, 1981, U niversidad de T okio: M S, 1983, U niv.de T okio; PhD, 1986, U niv. de Tokio

A reas de interés: estrés laboral; salud mental en el trabajo 


\section{David L. Hardy}

Division of Safety R esearch

N ational Institute for $O$ ccupational Safety and $\mathrm{H}$ ealth

1095 Willowdale R oad

M S-1133

M organtown, W est V irginia 26505, Estados Unidos

T el: 1 (304) 285-6068

Fax: 1 (304) 285-6047

E-mail: dlh6@cdc.gov

Puesto(s) actual(es): R esearch Safety Engineer

Puesto(s) anterior(es): O ccupational Safety and $H$ ealth Specialist

E studios: BSc, 1979, U niversity of M issouri; M Ed, 1981, U niversity of M issouri; PhD, 1989, O hio State U niversity

A reas de interés: intervención y prevención de lesiones en agricultura; lesiones en la infancia por la actividad agrícola

\section{Francis Hardy}

C onstruction Safety A ssociation of O ntario

21 V oyager $\mathrm{Ct}$. South

Etobicoke, O ntario M 9W 5M 7, Canadá

T el: 1 (416) 674-2726

Fax: 1 (416) 674-8866

Puesto(s) actual(es): Project Coordinator, Construction Safety A ssociation of O ntario

E studios: P Eng

\section{Susan E. Harman}

M edical and Chirurgical Faculty Library

1211 Cathedral Street

Baltimore, M aryland 21201, Estados U nidos

T el: 1 (410) 539-0872

Fax: 1 (410) 727-5967

E-mail: techserv@ access.digex.net

Puesto(s) actual(es): Associate Librarian, Clearinghouse $\mathrm{C}$ oordinator

Puesto(s) anterior(es): R eference and Circulation Librarian, M edical and Chirurgical Faculty of M aryland; A ssistant Librarian/ Cataloger, U niversity of $M$ aryland Eastern Shore; M usic T eacher, Campbell County Schools, R ustburg V A; M usic T eacher, $\mathrm{H}$ ampshire County Schools, R omney, WV

E studios: BA, 1972, Shenandoah Conservatory of M usic; M SLS, 1978, Shippensburg State College; M Ed, 1986, T owson State U niversity

A reas de interés: enfermedades profesionales de artistas escénicos

Robert L. Harris

U niversity of N orth Carolina-C hapel $\mathrm{H}$ ill

4620 Fernham Place

$\mathrm{R}$ aleigh, Carolina del N orte 27612, Estados Unidos

T el: 1 (919) 787-3956

Puesto(s) actual(es): Professor Emeritus

E studios: PhD; $\mathrm{ClH}$

\section{Jillian Haslehurst}

H ealth Services

$\mathrm{M}$ arks and Spencer PLC

47 Baker Street

Londres W 1A 1DN, R eino U nido

Tel: 441712686632

Fax: 441712683107

Puesto(s) actual(es): M edical Adviser, M arks and Spencer PLC

E studios: M B, ChB, 1975, U niversity of M anchester; AFO M , 1981, L ondon School of $\mathrm{H}$ ygiene and $\mathrm{T}$ ropical M edicine

A reas de interés: mamografías; salud en el trabajo

\section{Thomas E. Hawkinson}

General Mills

1 General M ills Boulevard 4N

M inneapolis, M innesota 55426, Estados U nidos

Tel: 1 (612) 540-3550

Fax: 1 (612) 541-5000

E-mail: hawki000@mail.genmills.com

Puesto(s) actual(es): Safety and Environmental Engineering $\mathrm{M}$ anage

E studios: M S; CIH ; C SP; ROH

\section{Fengsheng He}

Instituto de M edicina del Trabajo

A cademia C hina de M edicina Preventiva

$29 \mathrm{~N}$ an Wei Road

Pekín 100050, China

T el: 861063175465

Fax: 861063014323

E-mail: hefs@ccs.capm.ac.cn

Puesto(s) actual(es): Profesor, Director honorario

Puesto(s) anterior(es): M édico, O rganización $M$ undial de la Salud

E studios: M D, 1955, Escuela de M edicina Nanjing

A reas de interés: N eurotoxicología; neurología de trabajo

\section{Catherine A. Heaney}

$\mathrm{O}$ hio State U niversity School of Public $\mathrm{H}$ ealth

320 W. 10th Avenue

Columbus, O hio 43210, Estados U nidos

T el: 1 (614) 293-3908

Fax: 1 (614) 293-3937

E-mail: heaney.1@osu.edu

Puesto(s) actual(es): Associate Professor

E studios: BA, 1981, $\mathrm{H}$ arvard U niversity; M PH, 1985, U niversity of M ichigan; PhD 1988, U niversity of M ichigan

A reas de interés: reducción del estrés laboral; factores psicosociales en el trabajo; salud mental

\section{Steven Hecker}

$L$ abor Education and R esearch $C$ enter

1289 U niversity of $O$ regon

Eugene, O regon 97403-1289, Estados U nidos

T el: 1 (541) 346-2788

Fax: 1 (541) 346-2790

E-mail: shecker@oregon.uoregon.edu

Puesto(s) actual(es): Associate Professor
E studios: BA, 1972, Y ale C ollege; M SPH, 1981, $U$ niversity of $W$ ashington

A reas de interés: ergonomía en la asistencia sanitaria y construcción; desarrollo de programas y evaluación de la formación salud y seguridad en el trabajo; principios de trabajo internacionales

\section{Dick Heederik}

Departamento de Epidemiología y M edicina Pública

U niversidad de Agricultura W ageningen

PO Box 238

Dreijenlaan 1

6700 AE Wageningen, Países Bajos

Tel: 31837082012

Fax: 31837082782

E-mail: dick.heederik@medew.hegl.wau.ne

Puesto(s) actual(es): Profesor asociado de epidemiología del trabajo

E studios: M Sc, 1984; PhD, 1991

A reas de interés: exposición a bioaerosoles y evaluación del riesgo de alergias de origen laboral

\section{Kees A. van der Heijden}

Centro Europeo de Salud y M edio Ambiente de la O rganización M undial de la Salud

A. van Leewenhoeklaan 9

PO Box 10

3730 AA De Biltoven, Países Bajos

T el: $31-30 / 295-311$

Fax: 31-30/ 294-120

Puesto(s) actual(es): Director-División de Bilthoven

Puesto(s) anterior(es): Director de toxicología, Instituto N acional de Salud Pública y M edio A mbiente

A reas de interés: salud ambiental

\section{Lothar AJ. Heinemann}

Centro ZEG de Epidemiología e Investigaciones $M$ édicas

Schönerlinder Strasse 11-12

16341 Zepernick, Alemania

Tel: 49309492159

Fax: 49309497538

Puesto(s) actual(es): D irector; Profesor adjunto de Epidemiología y Bioestadística, M cG ill University

Puesto(s) anterior(es): J efe del D epartamento de Epidemiología, A cademia de las C iencias de Berlín

E studios: M D, 1968, U niv. H umboldt, Berlín; Dr Sc M ed, 1977, Univ. H umboldt, Berlín;

Areas de interés: E pidemiología y prevención de enfermedades crónicas (sobre todo enfermedades cardiovasculares); fármaco-epidemiología y evaluación tecnológica

\section{Rudolf Heinrich}

Sección de Explotación Forestal y T ransporte de la O rganización de las $\mathrm{N}$ aciones $\mathrm{U}$ nidas para la A gricultura y la Alimentación (FAO)

Viale delle T erme di Caracalla

00100 R oma, I talia 
Tel: 39652254727

Fax: 39652255618

E-mail: rudolf.heinrich at fao.org

Puesto(s) actual(es): J efe

Puesto(s) anterior(es): J Jefe, Sección de explotación maderera y transporte, O rganización para la Agricultura y la Alimentación (FAO)

E studios: Ingeniero agrónomo, 1965 , U niv.A grícola y Forestal, $V$ iena; PhD, 1983, U niv. Agrícola y Forestal, V iena

A reas de interés: A plicación de mejores prácticas forestales; introducción de prácticas forestales responsables y sostenibles desde un punto de vista ambiental; uso de productos forestales sin madera; formación del personal forestal; seguridad, salud y ergonomía en operaciones forestales; sistema de ingeniería forestal y tecnología; evaluación del impacto ambiental de las explotaciones forestales

\section{Rolf Helbig}

Institut für Arbeitswissenschaft

T echnische $\mathrm{H}$ ochschule D armstadt

Petersenstrasse 30

64287 D armstadt, Alemania

Tel: 496151163188

Fax: 496151163488

E-mail: helbig@ hrz1.hiz.thdarmstadt.de

Puesto(s) actual(es): Ingeniero jefe

E studios: Dr Ing

A reas de interés: análisis del trabajo; diseño del trabajo

\section{Jon P. Hellerstein}

O wens-Corning

$\mathrm{O}$ ccupational $\mathrm{H}$ ealth and Safety

0 ne $O$ wens-C orning Parkway

T oledo, 0 hio 43659, Estados U nidos

T el: 1 (419) 248-7338

Fax: 1 (419) 248-6260

E-mail: jon.hellerstein@ owens-cor-

ning.com

Puesto(s) actual(es): Leader, $\mathrm{O}$ ccupational $\mathrm{H}$ ealth and Safety

Puesto(s) anterior(es): $\mathrm{M}$ anager, $\mathrm{H}$ azard Communication/Industrial H ygiene, T remco, Inc.; $H$ ealth Scientist, Life Systems Inc

E studios: BA, 1977, M acalester College; M S 1980, U niversity of M innesota School of Public H ealth

A reas de interés: exposición y evaluación de riesgo; comunicación del riesgo; ergonomía y manipulación de materiales; gestión de procedimientos de seguridad/ evaluación de peligros; examen de diseños de seguridad

\section{Richard Helmer}

Salud Ambiental U rbana

O rganización M undial de la Salud

20 avenue Appia

1211 G inebra 27, Suiza

Tel: 41227913761

Fax: 41227914127

E-mail: helmerr@who.ch
Puesto(s) actual(es): J efe; profesor visitante, U niversidad de Surrey

Puesto(s) anterior(es): Científico, Estrategias globales de salud ambiental y gestión de calidad del agua, O rganización M undial de la Salud

E studios: PhD, 1971, U niv. de Stuttgart; M PH 1985, U niversity of N orth Carolina

A reas de interés: agua y salud; medio ambiente urbano

\section{George P. Hemstreet, II I}

D epartment of U rology

U niversity of O klahoma- School of M edicine

920 Stanton L. Y oung

Floor 5SP-330

O klahoma City, O klahoma 73190, Estados

Unidos

T el: 1 (405) 271-6902

Fax: 1 (405) 271-3118

E-mail: H emstreet@uokhsc.edu

Puesto(s) actual(es): Professor

Puesto(s) anterior(es): Associate Professor, Division of U rology, D ept. of Surgery, Asst. Prof. Dept. of M icrobiology and Immunology, U niversity of $M$ ississippi M edic C enter: Assistant Professor, Division of U rology, Dept. of Surgery, Asst. Prof., D ept of $M$ icrobiology and Immunology, U niversity of Alabama at Birmingham

E studios: M edical School, 1964-68, $\mathrm{H}$ ahnemann $M$ edical College and $\mathrm{H}$ ospital, Philadelphia; R esidency, 1968-70, U niversity of $\mathrm{O}$ klahoma $\mathrm{H}$ ealth Sciences Center; Postdoctoral and R esidency, 1970-76, Duke University M edical Center

A reas de interés: Bioindicadores para el cáncer de vejiga; cáncer de próstata; análisis cuantitativo de la fluorescencia (Q FIA)

\section{Robin Herbert}

The M ount Sinai M edical C enter

Box 1058

O ne G ustave L.L evy Place

N ueva Y ork, N ueva Y ork 10029, Estados U nidos

T el: 1 (212) 241-6173

Fax: 1 (212) 996-0407

Puesto(s) actual(es): M edical C o-Director, D epartment Community M edicine, M ount Sinai Center for Environmental and $O$ ccupational $M$ edicine

E studios: M D , 1982, SU NY at Stony Brook

A reas de interés: trastornos musculosqueléticos de origen laboral; indemnizaciones a los trabadores

\section{Fred W. Hermann}

$M$ inistry of Employment and Investment

1810 Blanshard Street

V ictoria, British Columbia U 8V 1X 4, Canadá

T el: 1 (604) 952-0494

Fax: 1 (604) 952-0491

E-mail: fhermann@galaxy.gov.bc.ca

Puesto(s) actual(es): C hief Inspector of $M$ ines

Puesto(s) anterior(es): $M$ ine Superintendent, Brunswick M ining and Smelting Corp., LTD; Chief Engineer, Brunswick $M$ ining and Smelting C orp., LT D; Senior Project
Engineer, Brunswick $M$ ining and Smelting Corp., LT D; Production Supervisor, Brunswick $M$ ining and Smelting Corp., LTD

E studios: BA, 1977, U niversity of C algary; BSC,

1980 , South Dakota School of M ines and

Technology; M Sc, 1981, South Dakota

School of $\mathrm{M}$ ines and $\mathrm{T}$ echnology

A reas de interés: salud y seguridad en las minas

\section{Ana Hernández Calleja}

Centro $\mathrm{N}$ acional de $\mathrm{C}$ ondiciones de T rabajo

Instituto $\mathrm{N}$ acional de Seguridad e $\mathrm{H}$ igiene en el

Trabajo

Calle Dulcet 2-10

08034 Barcelona, E spaña

T el: 3432800102

Fax: 3432803642

Puesto(s) actual(es): T écnico en salud y seguridad en el trabajo

E studios: Ciencias Biológicas, 1982

A reas de interés: higiene industrial; evaluación de contaminantes biológicos; síndrome del edificio cerrado

\section{Sven Hernberg}

K uusisaarennolku 4A

$00340 \mathrm{H}$ elsinki, Finlandia

T el: 3589482912

Fax: 3589482912

E-mail: sven.hernberg@ sgh.pp.fi

K uusisaarennolku 4A

Puesto(s) actual(es): Profesor emérito; Editor jefe del Boletín Escandinavo de M edio A mbiente de T rabajo y Salud

Puesto(s) anterior(es): Director de investigación, Director, D epart. de E pidemiología y Bioestadística, Instituto Finlandés de M edicina del Trabajo

E studios: M D , 1959, U niversidad de H elsinki; PhD, 1967, Univ. de H elsinki

A reas de interés: epidemiología del trabajo

\section{Robert Herrick}

Department of Environmental $\mathrm{H}$ ealth

$\mathrm{H}$ arvard School of Public $\mathrm{H}$ ealth

Building $1665 \mathrm{H}$ untingdon A venue

Boston, M assachusetts 02115, Estados U nidos

T el: 1 (617) 432-0674

Fax: 1 (617) 432-3349

E-mail: herrick@hohp.harvard.edu

Estudios: Dr

\section{I vanildo Hespanhol}

Departamento de Ingeniería H idráulica y Sanitaria

U niversidad de Sao Paulo

A.V. Prof. Almeida Prado 271

P.0. Box 61548

05508-900 Sao Paulo SP, Brasil

T el: $55-11 / 8185286$

Fax: 55-11/ 8185423

E-mail: ivanhes@usp.br

Puesto(s) actual(es): Profesor de ingeniería ambiental

Puesto(s) anterior(es): A sesor en T ecnología, O rganización M undial de la Salud

E studios: PhD, U niversidad de Sao Paulo; PhD, U niversity of California at Berkeley 
A reas de interés: ingeniería ambiental; medicina pública; reutilización de aguas residuales gestión de calidad del agua

\section{Thomas A. Hethmon}

Phelps D odge Corporation

$2600 \mathrm{~N}$ C entral A venue

Phoenix, A rizona 85004-3014, Estados U nidos

Tel: 1602 234-8111

Fax: 1602 234-4809

E-mail: tahethmon@phelpsd.com

Puesto(s) actual(es): Director, O ccupational $\mathrm{H}$ ealth and Safety

Puesto(s) anterior(es): Corporate Industrial $\mathrm{H}$ ygienist, Phelps D odge Corporation; Session Industrial $\mathrm{H}$ ygienist, Philip Edelman, M D and Associates; Assistant Industrial $\mathrm{H}$ ygienist, $\mathrm{M}$ obil $\mathrm{O}$ Corporation

E studios: BS, 1982, U niversity of C alifornia, Los Angeles; M S, 1989, California State U niversity, N orthridge

A reas de interés: gestión de la salud y la seguridad; medición de la higiene en el trabajo

\section{Gerd E. Heuchert}

Instituto Federal de Seguridad y Salud en el Trabajo

Nöldnerstrasse 40/ 42

D-10317 Berlín, Alemania

T el: 493051548100

Fax: 493051548170

Puesto(s) actual(es): J efe del D epartamento de epidemiología

E studios: M D, 1970, U niv. H umbolt, Berlín; DrScM ed, 1970, A kademie für Ärztliche Fortbildung, Berlín

A reas de interés: epidemiología y prevención de enfermedades de origen laboral; medicina del trabajo

\section{Herbert Heuer}

Institut für A rbeitsphysiologie

U niversität D ortmund

Ardeystrasse 67

44139 D ortmund, Alemania

T el: 492311084301

Fax: 492311084340

E-mail: heuer@arb.phys.uni.dortmund.de

Puesto(s) actual(es): Jefe de departamento

E studios: Dipl, 1973, Philipps U niversität M arburg; Dr rer nat, 1978, Philipps U niversität $\mathrm{M}$ arburg

A reas de interés: psicología del trabajo; actuación humana

\section{Penny D. Higgins}

Corporate H ealth Services

Northwest $\mathrm{C}$ ommunity $\mathrm{H}$ ealthcare

3060 Salt Creek Lane

Suite 110

A rlington H eights, Illinois 60005-8101, Estados

Unidos

T el: 1 (708) 577-4095

Fax: 1 (708) 590-6308

Puesto(s) actual(es): Director

Puesto(s) anterior(es): Director, $M$ anaged Care, M ount Sinai H ospital M edical C enter

E studios: AD N , 1983, T riton College; BSH A, 1990, C ollege of St. Francis
A reas de interés: medicina del trabajo; asistencia dirigida

\section{David L. Hinkamp}

U niversity of $\mathrm{M}$ ichigan School of Public $\mathrm{H}$ ealth $1420 \mathrm{~W}$ ashington $\mathrm{H}$ eights

Ann Arbor, M ichigan 48109-2029, Estados

Unidos

T el: 1 (708) 470-6181

Fax: 1 (708) 470-3630

E-mail: dhinkamp@sph.umich.edu

Puesto(s) actual(es): V isiting Assistant Professor

Puesto(s) anterior(es): Director,

O ccupational/ Environmental M edicine, St. $\mathrm{M}$ ary $\mathrm{H}$ ospital, $\mathrm{C}$ hicago $\mathrm{M}$ edical School

E studios: M D, 1978, U niversity of M ichigan M edical School; M PH, 1980, U niversity of $M$ ichigan School of Public $H$ ealth

A reas de interés: riesgos en el trabajo para músicos profesionales; riesgos de la exposición al ruido

\section{Jeffrey Hinksman}

15 G rosvenor R oad

Langley $\mathrm{V}$ ale

Epsom Surrey K T 18 6J G, R eino U nido

Tel: 441372275939

Fax: 441372275939

Puesto(s) actual(es): H ealth and Safety Consultant

Puesto(s) anterior(es): D eputy C hief Inspector, UK $\mathrm{H}$ ealth and Safety Executive

E studios: BA, 1957, C ambridge

A reas de interés: seguridad en la construcción

\section{Matthew Hirsheimer}

Pepsi Cola Company

1 Pepsi Way

Somers, N ueva Y ork 10589-2201, Estados U nidos

T el: 1 (914) 767-6591

Fax: 1 (914) 767-1748

Puesto(s) actual(es): M anager, Safety and Security

\section{Roberts Hites}

Delta Airlines

D epartment 025

PO Box 20706

Atlanta, G eorgia 30320-6001, Estados U nidos

T el: 1 (404) 714-3719

Fax: 1 (404) 714-3310

E-mail: robert.hites@delta-air.com

Puesto(s) actual(es): Corporate Safety A nalyst

Puesto(s) anterior(es): Aircraft $M$ aintenance, D elta Airlines; Aircraft $M$ aintenance and Air Crewman, U nited States A rmy N ational Guard

E studios: BS, 1989, Embry R iddle Aeronautical U niversity; AAS, 1992, Clayton College and State U niversity

A reas de interés: protección frente a caídas en mantenimiento de aeronaves

\section{Manh Trung Ho}

Institut N ational de R echerche et de Sécurité,

30 rue $O$ livier $N$ oyer

75680 París C edex 14, Francia

T el: 33140443132

Fax: 33140443099
Puesto(s) actual(es): Subdirector de A plicaciones de Prevención

Puesto(s) anterior(es): J efe del D epartamento de Estudios T écnicos y A plicaciones; J efe del D epart. de M edio A mbiente Físico y Seguridad

E studios: Ingénieur civil des M ines, 1959, Ecole $\mathrm{N}$ ationale Supérieure des $\mathrm{M}$ ines de Paris

A reas de interés: métodos y directrices para la evaluación de riesgos en el trabajo

\section{Michael J. Hodgson}

$U$ niversity of C onnecticut $\mathrm{H}$ ealth $\mathrm{C}$ enter M C 6300

263 Farmington A venue

Farmington, C onnecticut 06030-6105, Estados Unidos

Tel: 1 (203) 679-2337

Fax: 1 (203) 679-1349

E-mail: hodgson@nso.uchc.edu

Puesto(s) actual(es): A ssociate Professor of M edicine

Puesto(s) anterior(es): Associate Professor of $M$ edicine and Industrial and Environmental $\mathrm{H}$ ealth Sciences, U niversity of Pittsburg; Epidemic Intelligence Service O fficer DR DS, $\mathrm{N}$ ational Institute for $\mathrm{O}$ ccupational Safety and $\mathrm{H}$ ealth, Centers for D isease Control

E studios: M D, 1975, U niversidad de Frankfurt Alemania; M PH , 1985, U niversity of Pittsburg

A reas de interés: asma; medio ambiente en interiores; ergonomía; ILD

\section{P. Hoet}

U nidad de T oxicología Industrial y M edicina del Trabajo

Facultad de M edicina

U niversidad C atólica de L ovaina, 30

$54 \mathrm{Clos} C$ hapelle-aux-C hamps

1200 Bruselas, Bélgica

T el: 3227643220

Fax: 3227643228

E-mail: HOET @ toxi.ucl.ac.be

Puesto(s) actual(es): Investigador asociado; A sesor médico de la Junta de Compensación de Accidentes de T rabajo (Bélgica)

E studios: M D, 1984, U niversidad Católica de Lovaina; M IH, 1987, U niv. Católica de L ovaina; M Sc, 1989, U niv. Católica de Lovaina

A reas de interés: toxicología humana

\section{Burkhard Hoffmann}

$H$ auptverband der gewerblichen

Berufsgenossenschaften

Alte H eerstrassel11

53754 Sankt Augustin, Alemania

Tel: 492241231387

Fax: 492241231333

Puesto(s) actual(es): J efe de la sección de D ocumentación y Estadística

E studios: Dipl Phil, 1979, U niversity of O xford

\section{Dietrich Hoffmann}

American $\mathrm{H}$ ealth Foundation

1 Dana R oad

V alhalla, N ueva Y ork 10595, Estados U nidos 
T el: 1 (914) 789-7163

Fax: 1 (914) 592-6317

Puesto(s) actual(es): Associate Director

Puesto(s) anterior(es): Associate M ember, Sloan-K ettering Institute for C ancer R esearch

E studios: BS, 1957, U niv. de K iel; M S, 1955 , U niv. de K iel; PhD, 1957, Instituto $M$ ax-Planck de Bioquímica

A reas de interés: carcinogénesis del tabaco; metabolismo de bioindicadores; uniones de ADN ; bioensayos y contaminación atmosférica y de interiores; bioindicadores; genotoxicidad de plaguicidas

\section{Friedrich Hofmann}

U niversitätsklinikum

Arbeitsmedizin

Berliner Allee 6

D 79110 Friburgo, Alemania

T el: 497612702011

Fax: 497612702013

Puesto(s) actual(es): Profesor de medicina del trabajo

E studios: BSC, 1969, U niversidad de Braunschweig; M Sc, 1971, U niversidad de G öttingen; PhD, 1973, U niversidad de Göttingen; posdoctorado en Bioquímica y M edicina; M D, 1979 , U niversidad de Friburgo; especialización (med. del trabajo), 1986, U niversidad de Friburgo; idoneidad, 1989

A reas de interés: enfermedades infecciosas en el trabajo y trastornos musculosqueléticos

\section{Johan Högberg}

Departamento de Toxicología

Instituto Nacional del Trabajo

Ekelundsvägen 16

17184 Solna, Suecia

T el: 4687309316

Fax: 4687303312

E-mail: johan.hogberg@niwl.se

Puesto(s) actual(es): Profesor de toxicología

E studios: M D, 1973, Instituto K arolinska; PhD, 1975, Instituto K arolinska

A reas de interés: carcinogénesis de productos químicos; dosis-respuesta

\section{Charles M. Hohman}

East $\mathrm{O}$ hio $\mathrm{M}$ achinery Company

55 South Terrace A venue

N ewark, O hio 43055, Estados U nidos

T el: 1 (614) 522-2287

Fax: 1 (614) 522-4929

E-mail: chohman@eomnewark.eohiomach.com

Puesto(s) anterior(es): T echnical C onsultant

E studios: BM E, 1967, O hio State U niversity; M BA, O hio U niversity

A reas de interés: perfeccionamiento de los hornos de fundición; tecnología de compuestos

\section{Judith C. Holder}

Duke U niversity M edical C enter

Box 3834

Durham, NC 27710, Estados U nidos

T el: 1 (919) 861-0244

Fax: 1 (919) 286-1121
Puesto(s) actual(es): A ssistant Director of $\mathrm{O}$ ccupational $\mathrm{M}$ ental $\mathrm{H}$ ealth Programs

Puesto(s) anterior(es): Community $\mathrm{M}$ ental $\mathrm{H}$ ealth, $M$ anaged $C$ are; $M$ ental $H$ ealth C onsultant, $R$ esidential T reatment, C areer Services

E studios: PhD, 1995, Southern Illinois U niversity; M S, 1985, U niversity of $M$ aryland

A reas de interés: estrés laboral de minorías (actitudes, programas preventivos, evaluación de la asistencia y asesoramiento, acuerdo de organizaciones, elaboración de informes en incidentes graves, factores psicosociales de traumas acumulativos); violencia en el lugar de trabajo

\section{Bo Holmberg}

D epartamento de T oxicología

Instituto Nacional del Trabajo

Ekelundsvägen 16

17184 Solna, Suecia

T el: 4687309759

Fax: 4687303312

Puesto(s) actual(es): Profesor

E studios: PhD, 1969, U niv. de Estocolmo

A reas de interés: carcinogénesis en el trabajo; evaluación del riesgo

\section{Ingvar Holmér}

División de Fisiología del T rabajo y Ambiental Instituto $\mathrm{N}$ acional del Trabajo

Ekelundsvägen 16

17184 Solna, Suecia
T el: 4687309100
Fax: 4687301967
E-mail: iholmer@niwl.se

Puesto(s) actual(es): Profesor

E studios: PhD, 1974, U niversidad de Estocolmo; Docencia, 1976, U niversidad de Estocolmo

A reas de interés: psicología del trabajo; ergonomía; fisiología térmica

\section{Irene L.D. Houtman}

Prevención y Salud T NO

W assenaarseweg 56

P.O. Box 2215

2301 CE L eiden, Países Bajos

Tel: 31715181698

Fax: 31715181920

E-mail: houtman@pg.tno.nl

Puesto(s) actual(es): Investigadora, Sección de Salud y Trabajo

Puesto(s) anterior(es): Investigadora, U niv. Libre, Facultad de $\mathrm{Ciencias}$ del M ovimiento H umano

E studios: PhD, 1990, U niv. Libre

A reas de interés: tendencias (en el trabajo, el estrés y la salud); relaciones entre el coste y el beneficio en el trabajo y la salud

\section{Ninica L. Howard}

SHARP

Division of $L$ abor and Industries

PO Box 44330

O lympia, WA 98504-4330, Estados U nidos Tel: 1360 902-6557

Puesto(s) actual(es): Ergonomist
Puesto(s) anterior(es): R esearch A ssistant, Work Environment D epartment, U niversity of M assachusetts, L owell

E studios: M S

\section{M.J. Howes}

RHP C onsultants

Redbrooke H ouse

Trevu R oad

Camborne

Cornwall TR 12 7AQ, R eino U nido

T el: 441209717704

Fax: 441209718704

E-mail: mjhowes rhp@compuserve.com

Puesto(s) actual(es): Partner

Puesto(s) anterior(es): G roup V entilation Engineer U nion Corporation; Senior Lecturer, Camborne School of $M$ ines

Estudios: AC SM , 1966, Camborne School of M ines; PhD, 1992, U niversity of N ottingham

A reas de interés: ventilación y refrigeración en minas; radiaciones ionizantes en minas; estrés por calor y control del calor en minas; ventiladores y diseño de ventiladores helicoidales

\section{Ann F. Hubbs}

$\mathrm{N}$ ational Institute for $\mathrm{O}$ ccupational Safety and $\mathrm{H}$ ealth

NIOSH -ALOSH

M / S 211

1095 Willowdale $\mathrm{Rd}$

M organtown, WV 26505-2888, Estados U nidos Tel: 1 (304) 285-6128

Fax: 1 (304) 285-5861

E-mail: afho@ niords1.em.cdc.gov

Puesto(s) actual(es): R esearch T oxicologist

E studios: BS, 1978, T exas A\&M U niversity; BS 1980, T exas A\&M U niversity; DVM, 1981, T exas A\&M U niversity; M S, 1986 , Perdue U niversity; PhD, 1989, Colorado State U niversity

A reas de interés: mecanismos de las lesiones de pulmón por intoxicación; carcinogénesis pulmonar; enfermedades de origen animal; medicina de animales de laboratorio

\section{James Huff}

Environmental C arcinogenesis Program $\mathrm{N}$ ational Institute of Environmental $\mathrm{H}$ ealth Sciences- NIH

PO Box 12233

R esearch T riangle Park

NC 27709, Estados U nidos

Tel: 1 (919) 541-3780

Fax: 1 (919) 541-7666

E-mail: huff1@niehs.nih.gov

Puesto(s) actual(es): Scientist

Puesto(s) anterior(es): C ientífico, A gencia Internacional para la Investigación sobre el Cáncer, Lyon; Assistant Professor, U niversity of R ochester, M edical C enter

E studios: BS, 1963, Philadelphia College of Pharmacy and Science; M S, 1965 . Philadelphia C ollege of Pharmacy and Science; PhD, 1968, Perdue U niversity 
A reas de interés: mecanismos de carcinogénesis química; identificación de los riesgos de cáncer asociados con los productos químicos

\section{Gordon Huie}

Insall Scott K elly

170 East End A venue

N ueva Y ork, N ueva Y ork 10128, Estados

U nidos

Tel: 1 (212) 472-6606

Puesto(s) actual(es): Director, Insall Scott K elly Institute

\section{Vilma R. Hunt}

77 M agnolia Av

M agnolia, M A 01930, Estados U nidos

T el: 1 (508) 525-3354

Fax: 1 (508) 525-3188

E-mail: vrhunt@harvarda.harvard.edu

Puesto(s) actual(es): Adjunct Professor, D epartment of W ork Environment, U niversity of M assachusetts-L owell

Puesto(s) anterior(es): D eputy Assistant Administrator, $\mathrm{H}$ ealth R esearch, US Environmental Protection Agency: Professor of Environmental $\mathrm{H}$ ealth, Pennsylvania State U niversity

E studios: BDS, 1950, U niversity of Sydney; AM 1956, $\mathrm{H}$ arvard U niversity

A reas de interés: historia del uranio

\section{David Huntzinger}

America W est Airlines

4000 East Sky H arbor Blvd.

Phoenix, A rizona 85034, Estados U nidos

Tel: 1 (602) 693-5088

Fax: 1 (602) 693-2855

E-mail: dlhsafe@goodnet.com

Puesto(s) actual(es): V ice-President

Puesto(s) anterior(es): Senior Principal Scientist, Accident Investigator, Boeing Commercial Air Plane G roup; Accident Investigator, Bell H elicopter

E studios: BA,1975, U niversity of $\mathrm{H}$ awaii; M S, 1985, U niversity of Southern California; PhD, 1995, U nion Institute

A reas de interés: viajes, fotografía, vuelos

Joseph J. Hurrell, Jr.

N ational Institute for $O$ ccupational Safety $\&$ $\mathrm{H}$ ealth

4676 Columbia Pkwy

Cincinnati, O hio 45226-1998, Estados U nidos

T el: 1 (513) 841-4403

Fax: 1 (513) 458-7105

E-mail: jjh3@nioshel.em.cdc.gov

Puesto(s) actual(es): Supervisory R esearch Epidemiologist

Puesto(s) anterior(es): A djunct Professor of Psychology, $X$ avier U niversity

E studios: BA, M iami U niversity; M A, X avier U niversity; PhD, M iami U niversity

\section{Masayuki Ikeda}

$\mathrm{K}$ ioto Industrial H ealth Association 67

$\mathrm{N}$ ishinokyo-K itatsuboicho

Nakagyo-ku

K ioto 604, Japón

Tel: 81758230533

Fax: 81758238020038
E-mail: mbh02572@ niftyserve.or.jp

Puesto(s) actual(es): Director gerente

Puesto(s) anterior(es): Profesor, U niv.de K ioto, Facultad de M edicina

E studios: M D , 1957, U niv. de K ioto; PhD, 1963, Univ. de K ioto

A reas de interés: vigilancia biológica de productos químicos industriales y ambientales; evaluación del riesgo de productos químicos

\section{Claire Infante-Rivard}

D epartment of $\mathrm{O}$ ccupational $\mathrm{H}$ ealth

M cG ill U niversity Faculty of M edicine

$M$ ontreal, $Q$ uébec, $C$ anadá

T el: 1 (514) 398-4231

Fax: 1 (514) 398-7435

E-mail: mdci@musica.mcgill.ca

Puesto(s) actual(es): Professor

Puesto(s) anterior(es): Associate Professor

E studios: M D , 1971, U niversité de M ontréal; M PH , 1972, U niversity of California-L os Angeles; PhD, 1982, M cG ill U niversity

A reas de interés: exposición ambiental y laboral del progenitor (previos y en el transcurso del embarazo) y enfermedades de la infancia; trastornos respiratorios de origen laboral

\section{William I rwin}

$M$ assachusetts Institute of T echnology

$77 \mathrm{M}$ assachusetts A venue

R oom 20C - 207

Cambridge, M A 02139, Estados U nidos

T el: 1 (617) 253-2180

Fax: 1 (617) 253-4879

E-mail: w_irwin@mit.edu

Puesto(s) actual(es): H ealth Physics Consultant $\mathrm{H}$ ealth Physicist, A ssistant $\mathrm{R}$ adiation Protection 0 fficer

Puesto(s) anterior(es): N uclear Power T echnical instructor and Supervisor

E studios: BA, 1980, Christopher N ewport College of the College of W illiam and M ary; M BA, 1992, N ew H ampshire College; M S, 1994, U niv. of

$M$ assachusetts; D octoral C andidate U niv. of M assachusetts

A reas de interés: seguridad de láseres; riesgos y seguridad de los campos electromagnéticos de baja frecuencia y de la radiofrecuencia; radiactividad ambiental; exposición de la población a radiaciones ionizantes; análisis de accidentes causados por radiación; seguridad de las recombinaciones de AD N ; ingeniería del medio ambiente laboral; seguridad radiológica en biotecnología; garantía de calidad de laboratorios

\section{Terence G. Ison}

2265 North End

$\mathrm{G}$ anges

British Columbia, V8K 1A7, Canadá

Tel: 1 (250) 537-1988

Fax: 1 (250) 537-1988

E-mail: ison@ raven.bc.ca

Puesto(s) actual(es): Barrister, Solicitor

Puesto(s) anterior(es): Professor, Y ork U niversity; Professor, Q ueens U niversity; Chairman,
Workers' Compensation Board of British Columbia

E studios: LLB, 1957, U niversity of L ondon; LLM , 1959, H arvard U niversity; LLD, 1981, U niversity of L ondon

A reas de interés: sistemas de compensación para discapacidades y muerte prematura; salud y seguridad en el trabajo

\section{Masaaki Iuchi}

Sección de Seguridad del T rabajador $M$ inisterio de T rabajo

1-2-2 $\mathrm{K}$ asumigaseki

Chiyoda-ku, T okio, Japón

Tel: 810335026770

Fax: 810335022278

Puesto(s) actual(es): Sección de Política de Empleo

Puesto(s) anterior(es): D epartamento de Formación, sección de R ehabilitación Profesional, O ficina Internacional del Trabajo

E studios: Facultad de D erecho, 1986, U niv. de $\mathrm{K}$ ioto

A reas de interés: rehabilitación profesional de discapacitados; política de empleo

\section{John M. Ivancevich}

C ollege of Business A dministration

$U$ niversity of $\mathrm{H}$ ouston

4800 Calhoun

R oom $305 \mathrm{M}$ elcher $\mathrm{H}$ all

H ouston, TX 77204-4607, Estados U nidos

Tel: 1 (713) 743-4605

Fax: 1 (713) 743-4648

E-mail: Jivance@UH.EDU

Puesto(s) actual(es): H ugh R oy and Lillie C ranz Cullen Chair and Professor of $O$ rganizational Behavior and $M$ anagement

Puesto(s) anterior(es): Executive V ice President for Academic Affairs, Provost

E studios: DBA, U niversity of M aryland

A reas de interés: fijación de metas de la organización; sistemas de compensación medicina preventiva; control del estrés

A. Lee Ivester

Corporate Safety and W orkers' C ompensation Fieldcrest Cannon Inc.

O ne L ake Circle P.O. Box 107

$\mathrm{K}$ annapolis, Carolina del N orte 29081, Estados Unidos

Tel: 1 (704) 939-2055

Fax: 1 (704) 939-2064

E-mail: livester@sprymet.com

Puesto(s) actual(es): Director

Puesto(s) anterior(es): I ndustrial H ygienist, Liberty M utual Ins. Co.

E studios: BS, 1966, Clemson U niversity; M S, 1976, U niversity of N orth Carolina-C hapel Hill

Nikolai F. Izmerov

Academia R usa de Ciencias M édicas 31 Prospekt Fudennogo 105275 M oscú, Federación R usa

Tel: 70953660209

Fax: 70953660583 
Puesto(s) actual (es): Director, Instituto de M edicina del T rabajo de la Academia $R$ usa de $C$ iencias $M$ édicas

E studios: M S; PhD; Profesor de epidemiología, 1972, Instituto de M edicina del T rabajo de la Academia R usa de Ciencias M édicas

A reas de interés: epidemiología de medicina del trabajo

\section{Regina Jäckel}

Instituto Federal de Seguridad y Salud en el Trabajo

Nöldnerstrasse 40/ 42

D-10317 Berlín, Alemania

Tel: 4930151548311

Fax: 4930151548170

Puesto(s) actual(es): Científico en el Departamento de Efectos sobre la Salud de las Sustancias Peligrosas

E studios: M D 1976, U niversidad H umboldt de Berlín

A reas de interés: riesgos biológicos en el trabajo; neumología

\section{Anthony W. Jackson}

O ntario $\mathrm{H}$ ydro-Fossil

Fossil Business U nit

700 U niversity A venue $\mathrm{H}$ 15-B27

Toronto, 0 ntario M 5G 1X 6, Canadá

Tel: 1416 592-5171

Fax: 1416 592-5218

E-mail: tony.jackson@hydro.on.ca

Puesto(s) actual(es): Senior H ealth and Safety Advisor

E studios: PhD, 1971, M cM asters U niversity, $\mathrm{H}$ amilton, $\mathrm{O}$ ntario

A reas de interés: gestión convencional de la seguridad, motivación; gestión de materiales peligrosos

\section{Peter Jacobsen}

Centro C línico de M edicina del T rabajo

R igshospitalet

T agensvej 20

2200 C openhague, Dinamarca

T el: 4535457122

Fax: 4535457349

Puesto(s) actual(es): Director médico

E studios: especialidad médica (PH), 1989; especialización en medicina del trabajo, 1992

A reas de interés: toxicología clínica

\section{Marek Jakubowski}

Instituto N ofer de M edicina del T rabajo

8 Sw T eresy Street PO Box 199

90-950 Lódz, Polonia

Tel: 4842314801

Fax: 4842348331

Puesto(s) actual(es): Secretaría científica, J efe de división de medicina del trabajo y salud ambiental

Puesto(s) anterior(es): J efe de departamento de vigilancia biológica

E studios: M Sc, 1962, Farmacia, Escuela M édica de Lodz; PhD, 1968, Farmacia, Escuela de $M$ edicina de $G$ dansk

A reas de interés: control biológico de exposición a sustancias tóxicas; evaluación del riesgo
Lars Järup

D ept. de Salud A mbiental

Box 1186

S-17224 Sundbyberg, Suecia

T el: 4686292614

Fax: 468285902

E-mail: Lars.J arup@ mailbox.swipnet.se

Puesto(s) actual(es): M édico ambiental

Puesto(s) anterior(es): $M$ édico del trabajo

E studios: M Sc, 1966, U niv. Lund; M D, 1984, Instituto K arolinska; PhD, 1992, Instituto $\mathrm{K}$ arolinska

\section{Kunthala Jayaraman}

Centro de Biotecnología

U niversidad Anna

M adrás 600 025, India

T el: 91442350299

Fax: 91442350299

E-mail: bioinau@iitm.ernet.in

Puesto(s) actual(es): Director, Centro de Biotecnología, U niv. Anna

Puesto(s) anterior(es): M aître de recherche CNR S

E studios: PhD, 1964, U niversidad de M adrás

A reas de interés: control biológico de plagas; ingeniería genética; inmunología de la infección parasitaria

\section{David Jenkins}

U niversity of T exas M edical Branch,

$D$ epartment of Preventive M edicine

Galveston, TX 77555, Estados U nidos

Tel: 1 (409) 772-2551

Fax: 1 (409) 772-5272

Puesto(s) actual(es): Professor of Preventive $M$ edicine and $C$ ommunity $H$ ealth; Professor of Psychiatry and Behavioural Sciences

Puesto(s) anterior(es): Director, O rganización M undial de la Salud Collaborating Center for Psychosocial Factors and $\mathrm{H}$ ealth, Galveston, TX; Professor of Psychiatry and Behavioral Epidemiology, Boston U niversity School of M edicine; Professor of Epidemiology, U niversity of N orth Carolina, Chapel Hill

E studios: AB, 1950, U niversity of C hicago; $M$ A, 1953, U niversity of C hicago; PhD, 1960, U niversity of N orth Carolina

A reas de interés: evaluación cuantitativa del impacto de los factores psicosociales y del comportamiento sobre la salud y la calidad de vida

\section{E. Lynn Jenkins}

C enters for D isease C ontrol and Prevention

$\mathrm{N}$ ational Institute fo $\mathrm{O}$ ccupational Safety and

$\mathrm{H}$ ealth

Division of Safety R esearch

1095 Willowdale R oad

M organtown, WV 26505-2888, Estados U nidos T el: 1 (304) 285-6013

Fax: 1 (304) 285-6047

\section{Norman S. Jennings}

D epartamento de Actividades Sectoriales

$O$ ficina Internacional del T rabajo

4 route des $M$ orillons

1211 G inebra 22, Suiza

T el: 4122 799-7529

Fax: $4122799-7967$
E-mail: jennings@ilo.org

Puesto(s) actual(es): Especialista industrial

E studios: BSc; G rad. Dip. Ec.

A reas de interéé: M inería; industrias de metales básicos

\section{Steve M. Jex}

Department of Psychology

U niversity of W isconsin O shkosh

O shkosh, WI 54901, Estados U nidos

T el: 1 (414) 424-2300

Fax: 1 (414) 424-7313

Puesto(s) actual(es): Associate Professor

Puesto(s) anterior(es): A ssociate Professor of Psychology, C entral M ichigan U niversity

E studios: PhD, 1988, U niversity of South Florida

A reas de interés: estrés laboral; salud del trabajador; rendimiento en grupo

\section{Jerry Jeyaratnam}

U niversidad N acional de Singapur

Singapur 0511, Singapur

Tel: 657749400

Fax: 657791489

Puesto(s) actual(es): J efe, División de medicina de trabajo; Secretario general, Comisión Internacional de M edicina del T rabajo

E studios: M BBS, 1962, U niv. de Ceylon; M Sc, 1971, U niversity of L ondon; PhD, 1974, U niversity of L ondon; FFO M , 1987. R oyal C ollege of Physicians, L ondon

A reas de interés: plaguicidas; servicios de salud en el trabajo

\section{Gunnar Johanson}

Departamento de T oxicología

Instituto $\mathrm{N}$ acional de la V ida Laboral $(\mathrm{NIOH})$

17184 Solna, Suecia

T el: 4687309628

Fax: 4687301967

E-mail: gunnar.johanson@nioh.se

Puesto(s) actual(es): Investigador

Puesto(s) anterior(es): Profesor asociado, medicina del trabajo experimental y ambiental, Univ. de U ppsala

E studios: BSc, 1973, U niv. de U ppsala; M Sc, 1984, Instituto K arolinska, Estocolmo; Dr M ed Sc, 1988, Instituto K arolinska, Estocolmo

A reas de interés: butadieno; cadmio; trietilbutil éter; glicol-éteres; exposición por inhalación; mercurio; trimetilbutil éter; disolventes orgánicos; toxicocinéticos

\section{Barry L. Johnson}

Agency for T oxic Substances and D isease R egistry

1600 Clifton R oad

N.E (M S-E28)

Atlanta, GA 30333, Estados U nidos

Tel: 1 (404) 639-0700

Fax: 1 (404) 639-0744

E-mail: blj2@atsoaal.em.cdc.gov

Puesto(s) actual(es): Assistant Administrator, A ssistant Surgeon G eneral

Puesto(s) anterior(es): Director, Division of Biomedical and Behavioral Science, National Institute for O ccupational Safety and $\mathrm{H}$ ealth 
E studios: PhD, 1967, lowa State U niversity A reas de interés: epidemiología ambiental; neurotoxicología, comunicación del riesgo

\section{Jeffrey V. Johnson}

Johns H opkins School of Public Health 624 N. Broadway

7th Floor

Baltimore, M D 21205, Estados U nidos

T el: 1 (410) 955-2312

Fax: 1 (410) 955-7241

E-mail: jvjohnso@ phnet.sph.jhu.edu

Puesto(s) actual(es): Associate Professor of Social Sciences, M edicine, $O$ ccupational $\mathrm{H}$ ealth

Puesto(s) anterior(es): Investigador invitado, U niversidad de Estocolmo; Investigador invitado, Instituto $\mathrm{K}$ arolinska

E studios: BA, 1980, U niversity of M innesota; PhD, 1986, Johns H opkins School of Public $\mathrm{H}$ ealth

A reas de interés: riesgos psicosociales del entorno de trabajo; efectos de los procesos de control colectivo en el trabajo sobre el estrés; medición de la especificidad de género, clase y raza con respecto al riesgo de enfermedad crónica; determinantes psicosociales de las lesiones de espalda; trabajo afectivo en tareas de servicioa personas; impacto de la reorganización y la asistencia dirigida sobre el medio ambiente psicosocial de los empleados de asistencia sanitaria; extensión de la medición del medio ambiente laboral al trabajo no retribuido desarrollado en el hogar; efectos a largo plazo de la economía mundial sobre la reestructuración del mercado laboral y el medio ambiente de trabajo

\section{Peter F. Johnson}

Arup Fire Engineering

79-81 Franklin Street

M elbourne, VIC 3146, Australia

Tel: 61396636811

Fax: 61396631546

E-mail: peter.johnson@ arup.com

Puesto(s) actual(es): $M$ anager

Puesto(s) anterior(es): Principal Fire Protection Engineer, Scientific Services L aboratory, Port M elbourne, Australia; Services Laboratory, Port M elbourne, Australia; $G$ roup Leader, Arup Fire, Londres

E studios: BSc, 1968, M onash U niversity, Australia; Dipl Ed, 1969, M onash University, Australia; M Sc, 1986, W orcester Polytechnic Institute

A reas de interés: evaluación de riesgos de incendio; diseño técnico contra incendios basado en la actuación; detección y extinción de incendios

\section{Steven B. Johnson}

U niversity of $M$ aine

Cooperative Extension

$\mathrm{H}$ oulton $\mathrm{R}$ oad

PO Box 727

Presque I sle, M E 04769, Estados U nidos Tel: 1207 764-3361
Fax: 1207 764-3362

E-mail: sjohnson@umce.umext.maine.edu Puesto(s) actual(es): Specialist

E studios: BS, 1977, U niversity of

Wisconsin-M adison; M S, 1979,

$U$ niversity of $M$ aine at $\mathrm{O}$ rono; $\mathrm{PhD}$,

1982, U niversity of Florida

\section{Alan Jones}

Alberta Labour

5704-47 Avenue

Vermillion, AB T 9X 1K 4, Canadá

T el: 1 (403) 853-8147

Fax: 1 (403) 853-8289

E-mail: jonesad@lab.gov.ab.ca

Puesto(s) actual(es): Fire Services Advisor, Alberta L abour, Issues and R egional

$M$ anagement

Puesto(s) anterior(es): D eputy Fire Chief, O perations, Portagé la Prairie, $M$ anitoba; Fire Prevention O fficer, Saskatchewan Fire Commissioner's O ffice

\section{D. Joshi}

Centro Nacional de Investigación de Zoonosis e $\mathrm{H}$ igiene Alimentaria

Tahachal

PO Box 1885

K atmandú, Nepal

Tel: 977 1 2-70667

Fax: $97712-72694$

E-mail: dd joshi@npl.healthnet.org

Puesto(s) actual(es): Director

A reas de interés: salud de ecosistemas; enfermedades de origen animal

\section{T. K. Joshi}

c/ o The D eputy Director

Leyla T igmo-R eddy

OIT -D elhi

India

B-22 N ew K rishna Park

V ikas Puri, N ueva D elhi 110 018, India

T el: 00915510392

Fax: 00912929417

E-mail: joshitk@ giasdl01.vsnl.net.in

Puesto(s) actual(es): Consultor

Puesto(s) anterior(es): R esearch Fellow, M edicina del T rabajo, London U niversity

E studios: M BBS, 1968, U niv. Lucknow, India; M S, 1973, U niv. K anpur; M Sc, 1986, London U niversity

A reas de interés: evaluación de servicios salud en el trabajo; riesgos para la salud y la seguridad de materiales peligrosos; medicina del trabajo en la industria del hierro y del acero

\section{Marja-Liisa Juntunen}

Instituto Finlandés de Investigación Forestal

Estación de Investigación Suonenjoki

Juntintie 40

FIN -77600 Suonenjoki, Finlandia

T el: 35879513811

Fax: 35879513068

E-mail: M arja-Liisa.Juntunen@metla.fi

Puesto(s) actual(es): Investigadora
E studios: M Sc, 1978, U niversidad de K uopio, Finlandia

A reas de interés: Ergonomía, plaguicidas

\section{Mike Jurvélius}

Consultoría Suvex

Suvikkaankuja 12

13500, Finlandia

Tel: 358176380076

Fax: 358176381241

Puesto(s) actual(es): Consultor superior

Puesto(s) anterior(es): Director de proyectos

E studios: BSc, 1988, U niv. Forestal Ekenäs, Finlandia; diplomatura en Enseñanza, 1986, U niv. Forestal K uru, Finlandia

A reas de interés: salud y seguridad en el trabajo en desarrollo rural; formación de educadores y profesores forestales; control de incendios forestales

\section{Kirsten Jorgensen}

O ficina de Análisis y D ocumentación Arbejdstilsynet

L andskronagade 33

2100 Copenhague, Dinamarca

Tel: 4531180088

Fax: 4531182062

Puesto(s) actual(es): J efa de departamento

Puesto(s) anterior(es): J efa de departamento, $R$ egistro $D$ anés de Accidentes $y$ Enfermedades Laborales; Científica, U niversidad T écnica de Dinamarca

E studios: M Sc, 1974, U niversidad T écnica de Dinamarca; PhD , 1982, U niv. Técnica de Dinamarca

A reas de interés: sistemas de información para la mejora del medio ambiente de trabajo

\section{Roland Kadefors}

Departamento de Prevención de Lesiones, U niversidad Tecnológica Chalmers 40275 G öteborg, Suecia

Puesto(s) actual(es): Profesor

\section{Fritz Käferstein}

Unidad de Seguridad de los A limentos O rganización M undial de la Salud

20 avenue Appia

1211 Ginebra 27, Suiza

Tel: 41227913535

Fax: 41227910746

E-mail: käferstein@who.ch

Puesto(s) actual(es): J efe

Puesto(s) anterior(es): Director y profesor, 0 ficina

Federal de Salud

(Bundesgesundheitsamt), Berlín,

Alemania

E studios: Dr M ed V et, 1964, U niversidad de Giessen, Alemania

\section{Yu. S. Kagan}

Instituto Nacional de la Salud

M inisterio U craniano de la Salud

$6 \mathrm{G}$ eroyev 0 borony

$252127 \mathrm{~K}$ iev, U crania

Tel: 70442613278

Fax: 70442614773 
Puesto(s) actual(es): J efe de departamento de Toxicología G eneral

E studios: M D; PhD; Prof, 1968

A reas de interés: problemas teóricos y prácticos de toxicología general; toxicología y organofosfatos; problema de toxicidad selectiva; relación estructura-actividad mecanismos de acción combinada de plaguicidas

\section{Jeffrey P. Kahn}

W orkPsych Associates Inc.

300 C entral Park West

N ueva Y ork, N ueva Y ork 10024, Estados Unidos

\section{T el: 1 (212) 362-4099}

Puesto(s) actual(es): President; President, Academy of $O$ rganizational and $O$ ccupational Psychiatry Faculty, Cornell U niversity M edical C ollege;

E studios: BA, 1975, Swarthmore College; M D, 1979, C olumbia U niversity; R esidency, 1983, Columbia U niversity

A reas de interés: psiquiatría del trabajo y organizaciones

\section{Juhani Kangas}

Instituto R egional de K uopio de M edicina del Trabajo

Instituto Finlandés de M edicina del T rabajo

P.O. Box 93

$70701 \mathrm{~K}$ uopio, Finlandia

T el: 35871201211

Fax: 35871201265

Puesto(s) actual(es): Director del Instituto R egional de K uopio de M edicina del T rabajo

Puesto(s) anterior(es): T utor de química analítica, A bo A kademi; A nalista, M olinos de papel y pasta de papel K emi O y; H igienista industrial, Compañía del A cero $R$ autaruukki 0 y; J efe de L aboratorio, Instituto R egional de K uopio de M edicina del T rabajo; Subdirector, Inst. R eg. de K uopio de $M$ edicina del Trabajo

E studios: BSc, 1968, A cademia A bo; M Sc, 1971 Academia A bo; especialidad en $\mathrm{H}$ igiene Industrial, 1977, Instituto de M edicina del T rabajo; licenciatura en Filosofía, 1985, U niversidad de K uopio; PhD, 1988, U niversidad de K uoppio

A reas de interés: higiene industrial; plaguicidas, agricultura y silvicultura

\section{Valeriy A. Kaptsov}

Instituto R uso de Higiene en el T ransporte Ferroviario

1 Pakgauznoye Shosse

125438 M oscú, Federación R usa

Tel: 70951568457

Fax: 70959653842

Puesto(s) actual(es): Director, Instituto R uso de $\mathrm{H}$ igiene en el T ransporte Ferroviario

\section{Robert Karasek}

Department of Work Environment U niversity of M assachusetts-L owell

1 U niversity A venue

Lowell, M A 01854, Estados U nidos

T el: 1 (508) 934-3250

Fax: 1 (508) 452-5711
Puesto(s) actual(es): Professor

Puesto(s) anterior(es): Assistant Professor, D epartment of Industrial and $M$ anagement Engineering, Columbia U niversity; A ssociate Professor, Department of Industrial and Systems Engineering, U niversity of Southern California, Los Angeles

E studios: BA, 1966, Princton U niversity; $M$. Architecture, 1968, U niv. of Pennsylvania; M S, 1974, M assachusetts Institute of T echnology; PhD, 1976, $M$ assachusetts Institute of T echnology

A reas de interés: diseño de organización saludable del trabajo e implicaciones en política económica; coordinación internacional y normalización de la evaluación de las características psicosociales del trabajo; modelos dinámicos de estrés

\section{Craig Karpilow}

International Professional Associates Ltd.

539 Q ueen Anne Ave. N. \#158

Seattle, WA 98109, Estados U nidos

Tel: 1 (206) 781-3845

Fax: 1 (206) 938-1922

Puesto(s) actual(es): President, Federal Employee $\mathrm{O}$ ccupational $\mathrm{H}$ ealth $\mathrm{C}$ onsultant

Puesto(s) anterior(es): M edical Director, Q ueen Anne M edical C enter; M edical Director, $T$ ravel and Tropical Disease, $C$ linic of Seattle; M edical Director, N orthwest $\mathrm{O}$ ccupational $\mathrm{H}$ ealth $\mathrm{C}$ enter; $\mathrm{C}$ linical Professor, Family Practice, University of W ashington, Seattle

E studios: BSc, 1964, U niversity of Alberta; M A, 1970, U niversity Southern California; M D, 1974, UAG / D alhousie U niversity; CCFP, 1977, M emorial U niversity; ABFP, 1978, American Board of Familiy Practice; FACO EM , 1985, Fellowship O ccupational M edicine

A reas de interés: programas de salud en el trabajo para corporaciones multinacionales y otras entidades con empleados de riesgo; desarrollo de hospitales y clínicas en países de industrialización reciente, con atención especial en la medicina del trabajo, prevención y tratamiento; desarrollo de redes de atención primaria rurales para programas de vacunación; formación a empleados de asistencia sanitaria en áreas pobres; desarrollo y puesta en marcha de programas de asistencia sanitaria a trabajadores que viajan; alteraciones del sistema circadiano y enfermedades tropicales

\section{Thomas Karsky}

U niversity of I daho

Department of Biological and A gricultural

Engineering

Engineering/ Physics Building

M oscow, ID 83844-0904, Estados U nidos

T el: 1 (208) 885-7627

Fax: 1 (208) 885-7908

E-mail: tkarsky@uidaho.edu

Puesto(s) actual(es): Extension Safety Specialist, D epartment of Biological and Agricultural Engineering
E studios: M S, 1974, N orth Dakota State U niversity

A reas de interés: seguridad en granjas; asistencia a granjeros con discapacidades; tecnología de aplicación de productos químicos agrícolas

\section{Waldemar Karwowski}

Center for Industrial Ergonomics

University of L ouisville

L ouisville, K Y 402292, Estados U nidos

T el: 1 (502) 852-7173

Fax: 1 (502) 852-7397

E-mail:w0karw03@ulkyvm.louisville.edu

Puesto(s) actual(es): Professor of Industrial Engineering , Director

Puesto(s) anterior(es): Becado Fulbright, Profesor visitante, U niv. T ecnológica de T ampere, Finlandia

E studios: M S, 1978, U niversidad T écnica de W roclaw, Polonia; PhD, 1982, Industrial Engineering/ Ergonomics, T exas T ech U niversity, Lubbock

\section{Timo Kauppinen}

Departamento de Epidemiología y Bioestadística

Instituto Finlandés de $M$ edicina del T rabajo

T opeliuksenkatu 41A

FIN-00250 H elsinki, Finlandia

Tel: 358947471

Fax: 3589414634

E-mail:

kauppinen_timo/ eb@occuphealth.fi

Puesto(s) actual(es): J efe de la Sección de R egistro

E studios: PhD, 1986

A reas de interés: vigilancia; evaluación del riesgo; epidemiología; enfermedades de trabajo

\section{George Kazantzis}

Centre for Environmental T echnology

Imperial College

48 Princes $\mathrm{G}$ ardens

Londres SW 7 2PE, R eino U nido

Fax: 441712258544

\section{Homayoun Kazemi}

Pulmonary \& C ritical Care U nit

$M$ assachusetts $G$ eneral $H$ ospital

Fruit Street

Boston, M A 02114, Estados U nidos

Tel: 1 (617) 724-7821

Fax: 1 (617) 726-6878

E-mail: K azemi

H @@Al.M GH.H arvard.Edu

Puesto(s) actual(es): Professor of M edicine

Puesto(s) anterior(es): V isiting Fellow, $\mathrm{H}$ ammersmith $\mathrm{H}$ ospital, Londres; Professor of M edicine,

$\mathrm{H}$ arvard/ $\mathrm{M}$ assachusetts I nstitute of T echnology Division of $\mathrm{H}$ ealth, Science and T echnology; A sesor honorario, $\mathrm{H}$ ospital de Shanghai Primeros Ciudadanos, Shanghai, China; Profesor visitante, U niv. de G hent, Bélgica; Director, U S Beryllium Case R egistry; Consultant, Federal Aviation Agency; Profesor visitante de medicina, Peking U nion M edical College, Pekín 
E studios: BA, 1954, L afayette College, Easton; M D, 1958, Columbia U niversity, College of Physicians and Surgeons

A reas de interés: fisiología patológica pulmonar; enfermedades por berilio; enfermedades de pulmón en el trabajo

\section{Anya Keefe}

Policy and R egulation D evelopment Bureau W orkers' Compensation Board of British Columbia

PO Box 5350

Stn T erminal

Vancouver, BC V 6B 5L 5, Canadá

T el: 1 (604) 214-6708

Fax: 1 (604) 279-7604

E-mail: akeefe@wcb.bc.ca

Puesto(s) actual(es): Policy A nalyst

Puesto(s) anterior(es): R esearch Assistant, Division of E pidemiology and $C$ ancer Prevention, British Columbia Cancer Agency

E studios: M Sc, 1997, U niversity of British Columbia; BASc, 1988, U niversity of British Columbia

A reas de interés: desarrollo de reglamentos; evaluación de exposiciones; comunicación de riesgos

\section{Anat Keidar}

V ox H umana $\mathrm{V}$ oice Laboratory

$\mathrm{H}$ ead and N eck Surgical G roup

N ew Y ork C enter for $\mathrm{V}$ oice and Swallowing

Disorders

425 W est 59 th Street

Suite 4E

N ueva Y ork, N ueva Y ork 10019, Estados Unidos

Tel: $1212262-4444$

Fax: 1212 523-6364

E-mail: hnsg@aol.com

Puesto(s) actual(es): V oice L ab Director

Puesto(s) anterior(es): A ssistant Professor D epartment of $\mathrm{O}$ tolaryngology, $\mathrm{H}$ ead and N eck Surgery, W ashington U niversity $M$ edical C enter

E studios: M A, 1979, U niversity of I owa; M A, 1981, U niversity of I owa; PhD, 1986, U niversity of I owa

A reas de interés: trastornos de la voz; aspectos psicogénicos y neurogénicos de la producción de la voz; pedagogía vocal técnicas de canto

\section{Gwendolyn Puryear Keita}

Public Interest Directorate

American Psychological Association

750 First Street N W

W ashington, DC 20002-4242, Estados U nidos

T el: 1 (202) 336-6044

Fax: 1 (202) 336-6040

E-mail: gpk.apa@email.apa.org

Puesto(s) actual(es): Associate Executive Director

Puesto(s) anterior(es): Director of R esearch and T raining, $\mathrm{H}$ oward U niversity

E studios: BA, 1970, Bennet College; M S, 1971 H oward U niversity; PhD , 1977, H oward University

A reas de interés: estrés laboral y salud; salud en las mujeres; mujeres y trabajo; minorías étnicas y trabajo; mujeres y depresión; violencia del varón hacia la mujer

\section{Barry P. Kelley}

Chloride Industrial Batteries Ltd.

PO Box 5

Clifton Junction

Swinton

$M$ anchester M 27 8L R, R eino U nido

Tel: 441617944611

Fax: 441617936606

Puesto(s) actual(es): O ccupational $\mathrm{H}$ ygienist

Puesto(s) anterior(es): R esearch $C$ hemist

E studios: BSc, 1974, U niversity of Sheffield; PhD 1977, U niversity of Sheffield

A reas de interés: exposición laboral al plomo

\section{Susan M. Kennedy}

U niversity of British Columbia

Library Processing $C$ entre

V ancouver, BC V 6T -123, C anadá

T el: 1 (604) 822-9577

Fax: 1 (604) 822-9588

E-mail: kennedy@unixg.ubc.ca

Puesto(s) actual(es): A ssociate Professor and Director

\section{W. Larry Kenney}

N oll Physiological R esearch C enter

Pennsylvania State U niversity

U niversity Park, PA 16802-6900, Estados Unidos

T el: 1 (814) 863-1672

Fax: 1 (814) 865-4602

E-mail: W7K @PSUVM .PSU .EDU

Puesto(s) actual(es): Professor of Applied Physiology

E studios: PhD, 1983, Penn. State U niversity

\section{Johan Van de Kerckhove}

K. U. Leuven-HIVA-VORM ING

$K$ asteel de $M$ aurissens

W eligerveld 6

3212 Pellenberg, Bélgica

Tel: 3216463993

Fax: 3216463975

Puesto(s) actual(es): Profesor, Director

E studios: Dr Soc Sci

A reas de interés: gestión de la seguridad; cultura de la seguridad; auditoría de seguridad

\section{Assa Kilbom}

Instituto Nacional del Trabajo

17184 Solna, Suecia

T el: 4687309296

Fax: 4687309881

E-mail: asa.k.lbom@niwl.se

Puesto(s) actual(es): Director, D epartamento de Ergonomía

Puesto(s) anterior(es): M édico colegiado,1965: Profesor adjunto, Instituto K arolinska

E studios: M D, 1971, Instituto K arolinska

A reas de interés: trastornos musculosqueléticos de origen laboral; ergonomía de maquinaria y herramientas de mano; envejecimiento de la mano de obra; condiciones de trabajo de la mujer y trastornos de origen laboral

\section{Kikuzi Kimura}

Instituto de Ciencias del T rabajo

2-8-14 Sugao M iyamae-ku

K awasaki 216, Japón

T el: 81449772121

Fax: 81449777504

Puesto(s) actual(es): M iembro honorario, Instituto de Ciencias del Trabajo

Puesto(s) anterior(es): Subdirector, Instituto de Ciencias del Trabajo

E studios: Dr M ed Sc, 1974, U niv. M édica y Dental de T okio

A reas de interés: evaluación y control del medio ambiente de trabajo; medición del polvo ambiental; protección respiratoria

\section{Eric P. Kindwall}

$M$ edical C ollege of W isconsin

200 Wisconsin A venue

M ilwaukee, WI 53226, Estados U nidos

Tel: 1 (414) 454-5060

Fax: 1 (414) 259-0901

E-mail: erickind-

wall@qmail.surgery.mcw.edu

Puesto(s) actual(es): A ssociate Professor, Director of $\mathrm{H}$ yperbaric $\mathrm{M}$ edicine

Puesto(s) anterior(es): A ssistant Director, U S N avy Undersea M edical Institute

E studios: M D, 1960, Y ale U niversity School of M edicine

A reas de interés: medicina clínica hiperbárica; trabajo con aire comprimido; medicina de buceo

\section{Howard M. Kipen}

Environmental \& O ccupational H ealth Sciences Institute

681 Frelinghuysen $\mathrm{R}$ oad

PO Box 1179

Piscataway, NJ 08855-1179, Estados U nidos

Tel: 1 (908) 445-0182

Fax: 1 (908) 445-3644

E-mail: K ipen@EOHSI.RUTGERS.EDU

Puesto(s) actual(es): Associate Professor and Director, Division of O ccupational $\mathrm{H}$ ealth

\section{Urban Kjellén}

Norsk H ydro A.S.

Postboks 200

1321 Stabekk, N oruega

Tel: 4722739776

Fax: 4722737870

E-mail: NHTUKJ@NHT.HYDRO.COM

Puesto(s) actual(es): Ingeniero jefe; Profesor de gestión de la seguridad en la U niv. N oruega de C iencia y T ecnología, Trondheim

Puesto(s) anterior(es): Ingeniero investigador Instituto R eal de T ecnología, Estocolmo

E studios: M S, 1971, Instituto R eal de T ecnología, Estocolmo; PhD, 1983, Instituto R eal de T ecnología, Estocolmo

A reas de interés: gestión de la salud, la seguridad y el medio ambiente; sistemas de información para la seguridad; análisis de riesgos 


\section{Tord Kjellström}

O ficina de Salud A mbiental M undial e Integrada

O rganización M undial de la Salud

20 avenue Appia

1211 G inebra 27, Suiza

Tel: 41227913760

Fax: 41227914123

E-mail: kjellstromt@who.ch

Puesto(s) actual(es): Director

Puesto(s) anterior(es): Profesor, M edicina del T rabajo, U niversity of Sydney, Sydney, Australia

E studios: M Sc, 1967, Instituto R eal de T ecnología Estocolmo; Dr M ed Sc, 1977, Instituto K arolinska, Estocolmo

A reas de interés: epidemiología del trabajo y ambiental; análisis de riesgos para la salud

\section{Georg R. Kliesch}

Condiciones de Trabajo y M edio A mbiente

O ficina I nternacional del T rabajo

4 route des $M$ orillons

1211 G inebra 22, Suiza

Puesto(s) actual(es): Antiguo director

Puesto(s) anterior(es): J efe, Administración de Salud y Seguridad en el Trabajo de Alemania, M inisterio de Trabajo, Bonn; Director, D epartamento de Condiciones de T rabajo y M edio A mbiente, $O$ ficina Internacional del Trabajo

E studios: M in Eng, 1956, Bergakademie Clausthal; Bergassessor, 1961, $O$ berbergamt $\mathrm{D}$ ortmund

\section{Peter Knauth}

Institut für Industriebetriebslehre und

Industrielle Produktion (IIP)

U niversität $\mathrm{K}$ arlsruhe $(\mathrm{TH})$

H ertzstrasse 16

$76187 \mathrm{~K}$ arlsruhe, Alemania

Tel: 00497216084564

Fax: 0049721758909

E-mail: peter.knauth wiwi.U N I-

KARLSRUHE.DE

Puesto(s) actual(es): Profesor, J efe del D epartamento de Ergonomía en Instituto de Producción Industrial

E studios: estudios de ingeniería industrial U niversidad de D armstadt; PhD , 1975, U niversidad de D armstadt;

A reas de interés: horarios de trabajo/ trabajo por turnos; remodelación del trabajo; aplicación de nuevas tecnologías

\section{Bengt Knave}

Departamento de N eurología

Instituto N acional de la V ida L aboral

17184 Solna, Suecia

Tel: 468820556

Fax: 468820556

\section{Stephanie Knopp}

Tyler School of Arts

Beech and Penrose A venue

Philadelphia, PA 19027, Estados U nidos

T el: 1 (215) 242-2932

Fax: 1 (215) 242-9231

Puesto(s) actual(es): Associate Professor of G raphic Design
Puesto(s) anterior(es): Art Director, U niversity of Georgia

E studios: BA, 1972, T ulane U niversity; M FA, 1978, Pennsylvania State U niversity

A reas de interés: diseño asistido por ordenador y fotografía

\section{Manolis Kogevinas}

Institut M unicipal d'Investigació M èdica

(IM IM)

Dr. Aiguader R d. 80

08003 Barcelona, España

Tel: 3432211009

Fax: 3432213237

E-mail: kogevinas@imim.es

Puesto(s) actual(es): Profesor asociado, U nidad de Investigación de la Salud R espiratoria y Ambiental

Puesto(s) anterior(es): Epidemiólogo, U nidad de Epidemiología Analítica, Agencia Internacional para la Investigación sobre el Cáncer

E studios: licenciatura en M edicina, 1982, Facultad de M edicina de Atenas, G recia; M Sc, 1984, L ondon School of H ygiene and T ropical M edicine; PhD, 1989 $U$ niversity of L ondon

A reas de interés: cáncer de origen laboral; trastornos respiratorios en el trabajo; efectos sobre la salud de las dioxinas y otros compuestos organoclorados

\section{Kazutaka Kogi}

Instituto de Ciencias del T rabajo (ISL)

2-8-14 Sugao

M iyamae-ku

K awasaki 216, Japón

T el: 81449772121

Fax: 81449777504

Puesto(s) actual(es): Director

Puesto(s) anterior(es): Director, D epartamento de Condiciones de T rabajo y M edio A mbiente, 0 ficina Internacional del T rabajo; J efe de la Sección de Salud y Seguridad en el T rabajo, 0 ficina Internacional del Trabajo

E studios: M D , 1958, Facultad de M edicina, U niversidad de T okio; Dr M ed Sci, 1990, U niv. O kayama

A reas de interés: evaluación de la fatiga; trabajo por turnos; ergonomía participativa; mejoras de bajo costo

\section{David Koh}

D epartamento de M edicina C omunitaria, del Trabajo y de la Familia

U niversidad N acional de Singapur

L ower $K$ ent $R$ idge $R$ oad

0511 Singapur, Singapur

Tel: 657749300

Fax: 657791489

E-mail: cofkohd@nus.sg

Puesto(s) actual(es): Profesor asociado

Puesto(s) anterior(es): Subdirector, División de Salud y Seguridad en el T rabajo, Junta N acional de Productividad, Singapur

E studios: M B, BS, 1980, U niversidad de Singapur; M Sc, 1985, U niversidad N acional de Singapur; PhD, 1992, U niversity of Birmingham; FFO M , 1994,
Faculty of $O$ ccupational M edicine, R oyal College of Physicians, L ondon

A reas de interés: dermatología laboral; enseñanza y formación en medicina del trabajo; salud de trabajadores en electrónica y en transporte

\section{Larry R. Kohler}

Importancia del M edio A mbiente y el D esarrollo Sostenible

O ficina Internacional del T rabajo

4 route des $M$ orillons

1211 Ginebra 22, Suiza

Tel: 41227997456

Fax: 41227988685

E-mail: kohler@hql.ilo.ch

E studios: BA, 1968, M ichigan State U niversity; M A, 1970, Carleton U niversity; PhD 1985, J ohns H opkins U niversity School of Advanced International Studies

A reas de interés: vínculos entre medio ambiente laboral, medio ambiente general y desarrollo sostenible; papel de los tres aspectos en el medio ambiente y el mundo laboral

\section{Michiel A.J. Kompier}

U niversidad de Nijmegen

M ontessorilaan 3

6525 H R N ijmegen, Países Bajos

Tel: 31243612639

Fax: 31243615937

E-mail: kompier@psych.kun.nl

Puesto(s) actual(es): Profesor de Psicología del Trabajo y de las 0 rganizaciones

Puesto(s) anterior(es): J efe de departamento de organización del trabajo,

TN O -Prevención y Salud, L eiden

E studios: PhD, 1988;

A reas de interés: estrés laboral; trabajo en equipo; absentismo por enfermedad; flexibilidad laboral

\section{Eero Korhonen}

Instituto Finlandés de M edicina del T rabajo

Departamento de Fisiología

Laajaniityntie 1

FIN -01620 V antaa, Finlandia

Tel: 358-9/ 4747795

Fax: 358-9/ 890713

E-mail: eero.korhonen@ occuphealth.fi

Puesto(s) actual(es): J efe de la U nidad de Fisiología del T rabajo; Investigador

E studios: PhD, 1974, U niv.de H elsinki

A reas de interés: capacidad de trabajo de trabajadores de edad avanzada; trabajo de rescate

\section{Lawrence D. Kornreich}

Enviro- $\mathrm{H}$ ealth and Safety $M$ anagement

$111 \mathrm{H}$ oward Blvd. Suite 108

M ount Arlington, NJ 07856, Estados U nidos

T el: 1 (201) 398-8850

Fax: 1 (201) 398-8037

Puesto(s) actual(es): President

Puesto(s) anterior(es): Director, Environment and Safety, IT T Corporation

E studios: AB, 1960, Columbia C ollege; M S, 1963, U niversity of D elaware; M SPH 1967, U niversity of N orth Carolina at 
Chapel H ill; PhD, 1973, U niversity of $\mathrm{N}$ orth Carolina at Chapel $\mathrm{H}$ ill

A reas de interés: gestión de la salud y la seguridad ambiental; desarrollo profesional en un mundo cambiante; programas universitarios de higiene industrial

\section{Ludmila P. Korotich}

Departamento de Investigación en $\mathrm{H}$ igiene Instituto de Salud en el Trabajo de la Academia $R$ usa de $C$ iencias M édicas

31 Prospect Budennogo

105275 M oscú, Federación R usa

T el: 70953654482

Fax: 70959653842

A reas de interés: trabajo y salud de los trabajadores del sector médico; trabajo en higiene y enfermedades profesionales

\section{Andreas Kranig}

HVBG H auptverband der gewerblichen

Berufsgenossenschaften

Alte $H$ eerstrassel11

53754 Sankt Augustin, Alemania

Tel: 492241231144

Fax: 492241231333

Puesto(s) actual(es): J efe de departamento

Puesto(s) anterior(es): Profesor, D erecho Social y Laboral; Berufsgenossenschaftliche A kademie

E studios: Dr jur,1982, Fern-U niversität, $H$ agen

A reas de interés: Derecho social; legislación de seguros por accidente

\section{Richard S. Kraus}

Petroleum Safety Consultants

8712 C hippendale Court

Annandale, VA 22003-3807, Estados U nidos

T el: 1 (703) 978-0006

Fax: 1 (703) 978-2392

Puesto(s) actual(es): N ational Safety and Fire Protection Codes and Standards Consultant

Puesto(s) anterior(es): M obil O il Corporation, US $M$ arketing and R efining Safety Executive $M$ anagement

E studios: BS, 1956, Purdue U niversity, W est Lafayette; PE, Ingeniero de protección profesional contra incendios (W isconsin); Inspector forense (American Board of Forensic Examiners); Director de programas de emergencia (Federal Emergency $M$ anagement Agency)

\section{Leon Kreitzman}

$\mathrm{H}$ enley Centre

9 Bridewell Place

Blackfriars

Londres EC 4V 6AY, R eino U nido

Tel: 441816741902

Fax: 441811787911

E-mail: 100537,3456@ composurue.cgm

Puesto(s) actual(es): Director, Customer Foresight; Consultant

Puesto(s) anterior(es): Director, $\mathrm{H}$ ealth Environment Studio 3, $\mathrm{H}$ enley Centre

E studios: BSc, 1964, U niversity of Bristol; M Sc, 1968, London School of Economics
A reas de interés: atención a largo plazo a personas de edad avanzada; uso de técnicas no lineales en predicción social

\section{Penny M. Kris-Etherton}

N utrition Department

Pennsylvania State U niversity

College of $\mathrm{H}$ ealth and $\mathrm{H}$ uman D evelopment

S126 H enderson Building

U niversity Park, PA 16802-6504, Estados

Unidos

Tel: 1 (814) 863-2923

Fax: 1 (814) 863-6103

\section{Karl H.E. Kroemer}

Industrial Ergonomics L aboratory

$\mathrm{H}$ uman Factors Engineering C enter

D epartment of Industrial Systems Engineering

Blacksburg, V A 24061-0118, Estados U nidos

Tel: 1 (540) 231-5677

Fax: 1 (540) 231-3322

E-mail: karlk@vt.edu.

Puesto(s) actual(es): Professor, D irector

Puesto(s) anterior(es): Professor, Wayne State U niversity; V icepresidente, BAU, Alemania; Ingeniero de investigación, USAF; Ingeniero de investigación, M PI Arbeitsphysiologie, Alemania

E studios: Dipl Ing, 1960, T echnische U niversität $H$ annover; D I Ing, 1965, T echnische $\mathrm{U}$ niversität $\mathrm{H}$ annover

\section{Yuri Kundiev}

A cadémico de la Academia $\mathrm{N}$ acional de las

Ciencias de $U$ crania

Instituto de Salud en el T rabajo

75 Saksagansky str.

$252033 \mathrm{~K}$ iev, U crania

Tel: 70442208030

Fax: 70442206677

Puesto(s) actual(es): Director

Puesto(s) anterior(es): Subdirector del Instituto de $\mathrm{K}$ iev de Salud en el Trabajo; Profesor, Instituto de M edicina de $\mathrm{K}$ iev

E studios: M D, 1951; C and M ed Sc, 1955; DrSc med, 1967

A reas de interés: medicina del trabajo en agricultura; toxicología de plaguicidas

\section{Ilkka Kuorinka}

Institut de R echerche en Santé et en Sécurité du T ravail

505 boulevard De M aisonneuve 0 uest

11th Floor

M ontreal, $Q$ uébec $H 3$ A 3C2, Canadá

T el: 1 (514) 288-1551

Fax: 1 (514) 288-6097

E-mail: R33475@ er.uqam.ca

Puesto(s) actual(es): Director

A reas de interés: ergonomía participativa

\section{Joseph LaDou}

Division of O ccupational \& Environmental Medicine

U niversity of C alifornia-San Francisco

350 Parnassus A venue Suite 609

San Francisco, CA 94117, Estados U nidos

Tel: 1 (415) 476-4951

Fax: 1 (415) 476-6426
E-mail: jocladou@aol.com

Puesto(s) actual(es): D irector, International C enter for $O$ ccupational $M$ edicine

Puesto(s) anterior(es): Chief, Division of $O$ ccupational and Environmental $M$ edicine, D epartment of $M$ edicine, U niversity of California-San Francisco

Estudios: BS, 1960, U niversity of California-Berkeley; M S-U.C.S.F, 1962 Department of Pharmacology; Board Certification, 1975, American Board of Preventive M edicine

\section{Lucie Laflamme}

Instituto K arolinska

Departamento de M edicina Internacional de Salud y Social

Sturegatan 2

6a planta

S-17283 Sundbyberg, Suecia

T el: 4686290596

Fax: 468986367

Puesto(s) actual(es): Investigadora principal, Profesora universitaria

Puesto(s) anterior(es): Investigadora, Instituto para la Investigación de la Salud y la Seguridad en el T rabajo, M ontreal

E studios: PhD,1987, U niv. de Laval, Ste Foy, Q uébec, Canadá

A reas de interés: estudio de los accidentes; accidentes laborales y organización del trabajo; accidentes de trabajo y vejez; lesiones en la enseñanza

\section{Paul A. Landsbergis}

Cornell U niversity M edical College

Division of $\mathrm{H}$ ypertension

525 East 68 Street

Nueva Y ork, N ueva Y ork 10021, Estados

Unidos

Tel: 1212 799-4843

Fax: 1212 746-8451

E-mail: palands@med.cornell.edu

Puesto(s) actual(es): Assistant Professor of Epidemiology; Adjunct Assistant Professor, D epartment of C ommunity M edicine, M ount Sinai School of $M$ edicine

Puesto(s) anterior(es): Assistant Extension Specialist (Assistant Professor), Labor Education C enter, R utgers U niversity; A ssistant Professor, D epartment of Environmental and $\mathrm{C}$ ommunity $M$ edicine, $U$ niversity of $M$ edicine and D entistry of $\mathrm{N}$ ew Jersey; Post-D octoral Fellow in Epidemiology, $\mathrm{H}$ ypertension Center, Cornell U niversity $M$ edical College

E studios: M A, 1977, N ew Y ork U niversity; EdD, 1986, R utgers U niversity; M PH , 1993, Columbia U niversity; PhD, 1999 (expected), Columbia U niversity

A reas de interés: organización del trabajo; estrés laboral; intervenciones en salud laboral; hipertensión; trastornos musculosqueléticos; trastornos psiquiátricos 
Frank J. Landy

L andy, Jacobs and Associates

2737 M apleton Suite 301

Boulder, CO 80304, Estados U nidos Tel: 1 (303) 440-4755

Puesto(s) actual(es): Director, Center for Applied Behavioral Sciences

Puesto(s) anterior(es): Director, Applied Psychology Institute

E studios: BA, 1964, V illanova U niversity; M A 1966, Bowling G reen State U niversity; PhD, 1969, Bowling G reen State U niversity

\section{Sverre Langärd}

C entro de M edicina del T rabajo y A mbiental $\mathrm{H}$ ospital Nacional

00270 slo (R ikshospitalet), N oruega

T el: 4722111807

Fax: 4722867418

\section{Jay Lasser}

Center for W ork Stress R eduction

1031 Farmington Avenue

Farmington, CT 06032, Estados U nidos

T el: 1 (860) 677-2550

Fax: 1 (860) 677-4975

Puesto(s) actual(es): Director

E studios: BA, 1985, Colgate U niversity; M D 1990, U niversity of M edicine and Dentistry of N ew Jersey

A reas de interés: gestión y reducción del estrés en el lugar de trabajo

\section{Donald V. Lassiter}

$7127 \mathrm{~V}$ ia L omas

San J osé, CA 94304, Estados U nidos

T el: 1 (408) 225-9481

Fax: 1 (408) 226-7822

E-mail: lassiter@ix.netcom.com

Puesto(s) actual(es): Environmental and $\mathrm{O}$ ccupational $\mathrm{H}$ ealth Consultant

Puesto(s) anterior(es): Senior Scientist, N ational Institute for O ccupational Safety and $\mathrm{H}$ ealth; Special A ssistant for $\mathrm{O}$ ccupational $\mathrm{H}$ ealth, $\mathrm{O}$ ccupational Safety and H ealth Administration; Senior Scientist, SR I International; A ssistant Professor, G eorge W ashington M edical School

E studios: BS, U niversity of O klahoma; M S, U niversity of O klahoma School of Public $\mathrm{H}$ ealth; $\mathrm{PhD}$, U niversity of $\mathrm{O}$ klahoma School of Public H ealth

A reas de interés: vigilancia de lesiones y enfermedades de determinadas poblaciones laborales

\section{Patricia Alma Last}

$26 \mathrm{H}$ andside $\mathrm{L}$ ane

W elwyn Garden City

$\mathrm{H}$ erts $\mathrm{AL} 8$ 6SF, R eino U nido T el: 707371462

Puesto(s) actual(es): Consultant

Puesto(s) anterior(es): Director of W omen's Screening, BU PA H ealth Services, London
E studios: M B, BS, 1958, L ondon U niversity: FRCS, 1964, G lasgow C ollege of Surgeons; FR C O G, 1982, C ollege of $O$ bstetricians and $\mathrm{G}$ ynaecologists, London

A reas de interés: iniciativas de apoyo a la salud de la mujer

\section{Aishah A. Latiff}

Centro de Control del "Doping"

U niversidad de $M$ alaisia

M inden, Penang 11800, M alaisia

Tel: 6046569869

Fax: 6046569869

E-mail: alaishah@usm.my

Puesto(s) actual(es): Director

Puesto(s) anterior(es): Profesor

E studios: BSc, 1976, U niversity of M elbourne; PhD , 1981, U niversity of M elbourne

A reas de interés: abuso de drogas y tratamiento de la adicción; fármaco-epidemiología

\section{Wolfgang Laurig}

Departamento de Ergonomía

Institut für A rbeitsphysiologie (IfAD o)

U niversität D ortmund

Ardeystrasse 67

44139 D ortmund, Alemania

Tel: 492311084361

Fax: 492311084402

E-mail: laurig@arb-phys.uni-dortmund.de

Puesto(s) actual(es): Director

E studios: Dipl Ing, 1965, TH Darmstadt

A reas de interés: fisiología del trabajo; sistemas expertos sobre ergonomía; diseño del trabajo

\section{Robert R. Lauwerys}

U nidad de T oxicología Industrial y M edicina del Trabajo

Facultad de M edicina

U niversidad C atólica de L ovaina, 30

$54 \mathrm{Clos}$ Chapelle-aux-C hamps

1200 Bruselas, Bélgica

T el: 3227643220

Fax: 3227643228

E-mail: lauwerys@toxi.ucl.ac.be

Puesto(s) actual(es): Profesor en M edicina de Trabajo

E studios: M D, 1962, U niversidad C atólica de L ovaina, Bélgica; M IH, 1965 , U niversidad C atólica de L ovaina Bélgica; M Sc, 1966, H arvard U niversity; DSc, 1968, $H$ arvard U niversity

A reas de interés: toxicología industrial y ambiental

\section{Antoine Laville}

Laboratoire d'Ergonomie

Physiologique/ Cognitive

É cole Pratique des $\mathrm{H}$ autes Études

41 rue $\mathrm{G}$ ay-L ussac

75005 París, Francia

T el: 33140468444

Fax: 33144417169

Puesto(s) actual(es): Profesor, Director

Puesto(s) anterior(es): Sous Directeur de laboratoire, $\mathrm{C}$ onservatoire $\mathrm{N}$ ational des Arts et M étiers, París
E studios: M D

A reas de interés: Ergonomía; envejecimiento y trabajo

\section{Tom B. Leamon}

Liberty M utual R esearch C enter for Safety and $\mathrm{H}$ ealth

71 Frankland R oad

H opkinton M A 01748, Estados U nidos

T el: 1 (508) 435-9061 x235

Fax: 1 (508) 435-8136

E-mail: msmailz.leamont1@tsod.Imig.com

Puesto(s) actual(es): V ice-President, Director

Puesto(s) anterior(es): Professor, C hair, D epartment of Industrial Engineering, T exas T ech U niversity, Lubbock, TX; Acting D ean, College of Engineering and Engineering T echnology, N orthern Illinois U niversity, D ekalb; Professor, C hair, D epartment of Industrial Engineering, N orthern Illinois U niversity

E studios: BSc, U niversity of $M$ anchester, $M$ anchester; $M$ Sc, U niversity of Aston, Birmingham; M Sc, Institute of T echnology, Cranfield; PhD, Institute of Technology, Cranfield

A reas de interés: incapacidad por dolor lumbar; manipulación manual de materiales; resbalones y caídas

\section{Pam Tau Lee}

U niversity of California-Berkeley

Labor $\mathrm{O}$ ccupational $\mathrm{H}$ ealth Program

2515 Channing Way

Berkeley, CA 94720, Estados U nidos

Tel: $1510642-5507$

Fax: 1510 643-5698

E-mail: ptlee@uclink4.berkeley.edu

A reas de interés: medicina del trabajo y ambiental; justicia medioambiental; gestión del trabajo compartido; remodelación del empleo

\section{David LeGrande}

C ommunications W orkers of A merica

501 Third Street N W

W ashington, DC 20001-2797, Estados U nidos Tel: 1202 434-1160

Fax: 1202 434-1467

Puesto(s) actual(es): Director, 0 ccupational Safety and $\mathrm{H}$ ealth

E studios: BA, Sacramento State U niversity; M A, 1975, M ichigan State U niversity

A reas de interés: salud y seguridad en el trabajo; ergonomía; vigilancia médica del asbesto; calidad del aire en interiores

\section{Mark R. Lehto}

School of I ndustrial Engineering

Purdue U niversity

$1287 \mathrm{G}$ rissom $\mathrm{H}$ all

W est L afayette, IN 47907-1287, Estados U nidos

Tel: 1 (317) 494-5428

Fax: 1 (317) 494-1299

E-mail: lehto@ecu.perdue.edu

Puesto(s) actual(es): Associate Professor

Puesto(s) anterior(es): V isiting A ssociate Professor of Psychology, U niversity of W estern

A ustralia, Perth; V isiting A ssistant

Professor of Industrial Engineering,

University of M ichigan, Ann Arbor 
E studios: BSIE, 1978, O regon State U niversity; M SIE, 1981, Perdue U niversity; PhD, 1985 , U niversity of M ichigan

Areas de interés: información del producto; señales y etiquetas de aviso; fichas técnicas de seguridad (M SDS); toma de decisiones en mateia de seguridad

\section{Carol J. Lehtola}

U niversity of Florida

Department of Agricultural and Biological

Engineering

Gainesville, FL 32611, Estados U nidos

T el: 1352 392-8064

Fax: 1352 392-4092

E-mail: clehtola@ agen.ufl.edu

Puesto(s) actual(es): Assistant Professor

Puesto(s) anterior(es): Injury Prevention Specialist, The U niversity of I owa; $M$ anager, Agricultural Division, $N$ ational Safety Council

E studios: BSAE, 1973, South Dakota State U niversity; M S, 1988, lowa State U niversity; PhD, 1992, I owa State U niversity

A reas de interés: seguridad en agricultura; ergonomía; seguridad en tractores y maquinaria agrícola

\section{Marjatta Leirisalo-Repo}

D epartamento de M edicina

H ospital Central de la U niv. de H elsinki

$\mathrm{H}$ aartmaninkatu 4

$00290 \mathrm{H}$ elsinki, Finlandia

T el: 35894712528

Fax: 35894714048

E-mail: leirisal@ cc.helsinki.fi

Puesto(s) actual(es): A sesora de R eumatología

E studios: M D, 1969, U niversidad de H elsinki

A reas de interés: artritis reactiva; factores de pronóstico en artritis reumatoide; tratamiento de artritis reumatoide

\section{Grace Kawas Lemasters}

University of C incinnati M edical C enter 231 Bethesda Avenue

PO Box 670182

Cincinnati, $O$ hio 45267-0182, Estados U nidos

Tel: 1 (513) 558-0030

Fax: 1 (513) 558-6272

E-mail: grace.lemasters@uc.edu

Puesto(s) actual(es): Professor of Epidemiology and Environmental $\mathrm{H}$ ealth; Director, Division of Epidemiology and Biostatistics

E studios: BSN, 1970, Indiana U niversity; M S, 1973, U niversity of Cincinnati; PhD, 1983, U niversity of Cincinnati

A reas de interés: epidemiología reproductiva; bioindicadores de exposición a disolventes de combustibles; efectos reproductivos de la mujer en el cuerpo militar; métodos epidemiológicos

\section{Richard A. Lemen}

$3495 \mathrm{H}$ ighgate $\mathrm{H}$ ills D rive

Duluth, GA 30155, Estados U nidos

Tel: 1 (770) 813-3250

Fax: 1 (770) 813-3236

E-mail: rlemen@paradise.net
Puesto(s) actual(es): Assistant Surgeon G eneral and D eputy D irector, N ational Institute for $\mathrm{O}$ ccupational Safety and $\mathrm{H}$ ealth

Puesto(s) anterior(es): Assistant Director, National institute for O ccupational Safety and $\mathrm{H}$ ealth; Director, DSDT T, N ational Institute for O ccupational Safety and $\mathrm{H}$ ealth

E studios: BA, Central M ethodist College; M S, U niversity of $M$ issouri; PhD, U niversity of Cincinnati

A reas de interés: salud en el trabajo e internacional; política de salud pública; epidemiología

\section{Steven W. Lenhart}

$\mathrm{N}$ ational Institute for $\mathrm{O}$ ccupational Safety and $\mathrm{H}$ ealth

Div. Surveillance

$\mathrm{H}$ azard Evaluation and Field Studies

4676 Columbia Parkway

Cincinnati, O hio 45226-1998, Estados U nidos

T el: 1 (513) 841-4374

Fax: 1 (513) 458-7147

E-mail: swl1@ nioshe1.em.cdc.gov

Puesto(s) actual(es): Industrial $\mathrm{H}$ ygienist

\section{Michel Lesage}

1001 boulevard M ont-R oyal

Appt. 502

M ontreal, Q uébec $\mathrm{H} 2 \mathrm{~V} 2 \mathrm{H} 4$, C anadá

T el: 1 (514) 277-7714

Fax: 1 (514) 277-5221

Puesto(s) actual(es): A sesor médico

Puesto(s) anterior(es): Especialista en medicina de trabajo, 0 ficina Internacional del Trabajo, Ginebra

E studios: M D, 1962, U niv. Laval, Q uébec; M D, 1962, U niv. Laval, Q uébec; CSPQ 1981, Facultad de M edicina, Q uébec

\section{Charles Levenstein}

W ork Environment D epartment U niversity of $M$ assachusetts-L owell 1 U nivesity A venue L owell M assachusetts 01854, Estados U nidos

T el: 1 (978) 934-3268

Fax: 1(978) 452-5711

E-mail: C harles levenstein@uml.edu

Puesto(s) actual(es): Professor of W ork Environmental Policy

E studios: PhD, 1976, M .I.T .; M S, 1981, H arvard

A reas de interés: economía política de salud en el trabajo; impacto de la privatización sobre la salud, la seguridad y el medio ambiente

\section{Lennart Levi}

Departamento de Investigación del Estrés Instituto $\mathrm{K}$ arolinska

Box 220

17177 Estocolmo, Suecia

Tel: 4687286970

Fax: 468337575

E-mail: Lennart.Levi@ipm.ki.se

Puesto(s) actual(es): Profesor

Puesto(s) anterior(es): Director del Instituto N acional Sueco de Factores Psicosociales y Salud y del Departamento de Investigación del $\mathrm{E}$ strés del $\mathrm{C}$ entro Psicosocial de la O rganización M undial de la Salud
Estudios: M D, 1959, Instituto K arolinska, Estocolmo; PhD, 1972, Instituto $\mathrm{K}$ arolinska, Estocolmo; Profesor de medicina psicosocial, 1978, Consejo Sueco de Investigación M édica y 1986 Instituto $\mathrm{K}$ arolinska, Estocolmo;

Areas de interés: salud psicosocial en el trabajo; estrés y trabajo; medicina preventiva; promoción de la salud; métodos de reducción de la distancia entre la ciencia y la política

\section{Ilise Levy-Feitshans}

G lobal Alliance for Women's $\mathrm{H}$ ealth and Trustee Society of M edical J urisprudence $5355 \mathrm{H}$ enry H. Parkway

R iverdale, N ueva Y ork 10471, Estados U nidos

Tel: 1 (718) 549-6235

Fax: 1 (718) 549-6235

E-mail: sljc49a@ prodigy.com

Puesto(s) actual(es): Expert, International L aw and Women's $\mathrm{H}$ ealth $\mathrm{L}$ aw; Director $\mathrm{O}$ ccupational $\mathrm{H}$ ealth and $\mathrm{H}$ ealth $\mathrm{C}$ are L aw, Compliance Systems L egal G roup

Puesto(s) anterior(es): Acting Director, Legislative D rafting R esearch Fund; Columbia U niversity School of $L$ aw

E studios: BA, 1979, Barnard College, Columbia U niversity; JD, 1983, G eorgetown U niversity Law Center; M Sc, 1995, Johns H opkins U niversity School of $\mathrm{H}$ ygiene and Public $\mathrm{H}$ ealth

A reas de interés: derechos humanos para lugares de trabajo sanos; leyes y tratados de salud internacional; impacto de las pruebas genéticas sobre las políticas sanitarias (en el lugar de trabajo, a nivel nacional e internacional)

\section{Robert M. Lewy}

Presbyterian $\mathrm{H}$ ospital at Columbia Presbyterian $M$ edical $C$ enter

$H$ arkness 1-1120 Fort W ashington \& 168th Street

Nueva Y ork, Nueva Y ork 10032, Estados Unidos

Tel: 1 (212) 305-5050

Fax: 1 (212) 305-5905

Puesto(s) actual (es): Associate Professor of $M$ edicine and Public $\mathrm{H}$ ealth, Columbia Presbyterian M edical Center

\section{Norbert Lichtenstein}

Berufsgenossenschaftliches Institut fur

Arbeitssicherheit

$H$ auptverband der gewerblichen Berufsgenossenschaften-H V BG ,

Alte $\mathrm{H}$ eerstrasse 111

D-53757 Sankt Augustin, Alemania

Tel: 49-2241-231-2530

Fax: 49-2241-231-2234

E-mail: N.Lichtenstein@bvdg.de

Puesto(s) actual(es): J efe de departamento

\section{Sture Lidén}

Departamento de Dermatología

H ospital K arolinska

Box 120

17176 Estocolmo, Suecia

Tel: 4686905401

Fax: 4686905972 
Puesto(s) actual(es): Profesor, Presidente, Instituto del O ído, los O jos y la Piel, D epartamento de D ermatología, H ospital K arolinska

Puesto(s) anterior(es): Profesor adjunto de dermatología, U niv. de U ppsala Profesor, cátedra del Dep. de Dermatología, U niv. de U mea

E studios: M D, 1961, U niversidad de U ppsala PhD, 1967, U niversidad de U ppsala

A reas de interés: síndromes de somatización ambiental; inflamación neurogénica

\section{Elena Adán Liébana}

Centro N acional de C ondiciones de T rabajo

Instituto $\mathrm{N}$ acional de Seguridad e $\mathrm{H}$ igiene en el Trabajo

Calle Dulcet 2-10

08034 Barcelona, España

T el: 3432800102

Fax: 3432803642

Puesto(s) actual(es): T écnico en seguridad y salud en el trabajo

Puesto(s) anterior(es): T écnico en calidad y medio ambiente

E studios: Ingeniería química, 1993, Instituto Q uímico de Sarriá, Barcelona

\section{Linnéa Lillienberg}

Departamento de M edicina del T rabajo

H ospital Sahlgrenska

St. Sigfridsgatan 85

41266 G öteborg, Suecia

Tel: 4631354877

Fax: 4631409728

E-mail: linnea.lillienberg@ymk.gu.se

Puesto(s) actual(es): H igienista industrial

E studios: PhD , 1981, D epartamento de Q uímica Analítica y $M$ arina, U niv. de G öteborg

A reas de interés: métodos de muestreo y estrategias de medición; evaluación del riesgo en estudios epidemiológicos, sobre todo para trastornos respiratorios de origen laboral

\section{Soo-Yee Lim}

Applied Psychology and Ergonomics Branch $\mathrm{N}$ ational Institute for $\mathrm{O}$ ccupational Safety and $\mathrm{H}$ ealth

4676 C olumbia Parkway

Cincinnati, O hio 45226-1998, Estados U nidos

Tel: 1 (513) 533-8169

Fax: 1 (513) 533-8510

E-mail: sdl7@ niobbsl.em.cdc.gov

Puesto(s) actual(es): N ational R esearch C ouncil Associate

E studios: PhD, 1994, U niversity of W isconsin, M adison

A reas de interés: papel de los factores psicosociales del trabajo sobre la salud musculosquelética; ergonomía de oficinas; características de la organización y salud en el lugar de trabajo; estrés laboral

\section{Hans Göran Linder}

División de Construcción

Consejo $\mathrm{N}$ acional de Seguridad y Salud en el

Trabajo

Ekelundsvägen 16

17184 Solna, Suecia
Tel: 4687309000

Fax: 4687309842

\section{Kari Lindstrom}

Departamento de Psicología

Instituto Finlandés de M edicina del T rabajo

T opeliuksenkatu 4laA

$00250 \mathrm{H}$ elsinki, Finlandia

Tel: 35894747719

Fax: 3589890713

E-mail: kali@ occuphealth.fi

Puesto(s) actual(es): C atedrático de investigación

Puesto(s) anterior(es): Psicólogo clínico; Científico; Director de departamento

E studios: PhD, 1981, U niversidad de H elsinki

A reas de interés: cultura de la organización; desarrollo de la organización; trabajo y salud del personal de asistencia sanitaria

\section{Anthony Linehan}

2 Brookside $M$ anor Leigh R oad,

Wimborne, Dorset BH 21 2BZ, R eino U nido Tel: 441202848597

\section{Herbert I. Linn}

Division of Safety R esearch

$\mathrm{N}$ ational Institute of $\mathrm{O}$ ccupational Safety and

$\mathrm{H}$ ealth

1095 Willowdale R oad

M organtown, WV 26505-2888, Estados U nidos

T el: 1 (304) 284-5900

Fax: 1 (304) 284-6047

E-mail: hil1@ niosr1.em.cdc.gov

Puesto(s) actual(es): Chief, Information $M$ anagement and Dissemination Activity

E studios: BA, 1976, Fairmont State College; M S, 1986, M arshall U niversity

A reas de interés: difusión de la información; comunicaciones sobre salud y seguridad: tecnología de la información aplicada a la investigación y comunicación de lesiones en el trabajo

\section{Morton Lippmann}

N elson Institute of Environmental M edicine

N ew Y ork U niversity

$M$ edical Center

T uxedo, N ueva Y ork 10987, Estados U nidos

T el: 1 (914) 351-2396

Fax: 1 (914) 351-5472

Puesto(s) actual(es): Professor

Puesto(s) anterior(es): R esearch Engineer, D ell Electronics Corporation; Industrial $\mathrm{H}$ ygienist, US A tomic Energy Commission; Industrial H ygienist, US Public $\mathrm{H}$ ealth Service

E studios: BChE, 1954, T he Cooper U nion; SM 1955, H arvard U niversity; PhD, 1967, N ew Y ork U niversity

A reas de interés: evaluación de la exposición en humanos; efectos sobre la salud de sustancias tóxicas de transmisión aérea

\section{Sydney Lipton}

$1056 \mathrm{H}$ olcomb Street

Port T ownsend, W ashington 98368, Estados Unidos

T el: 1 (306) 385-9571

Puesto(s) actual(es): C onsultant
Puesto(s) anterior(es): jubilado de la Exxon $R$ esearch and Engineering

E studios: BS, Stevens I nstitute of T echnology; MS, Stevens Institute of T echnology

James E. Lockey

O ccupational and Environmental M edicine Division

U niversity of C incinnati

231 Bethesda Avenue P.O. Box 670182

Cincinnati, 0 hio 45267-0182, Estados U nidos

T el: 1 (513) 558-0030

Fax: 1 (513) 558-6272

E-mail: Lockey]E@Email.uc.EDU

Puesto(s) actual(es): Professor and Director

E studios: BA, 1968, K enyon College; M D, 1972, T emple U niversity School of M edicine;

M S, 1985, U niversity of C incinnati College of $M$ edicine

\section{Gordon M. Lodde}

742 Ferndale R oad

M t. Joy, PA 17552-9384, Estados U nidos Tel: 1 (717) 684-2057

Puesto(s) actual(es): H ealth Physics Consultant;

E studios: BS, 1958, Perdue U niversity; 1964, U niversity of R ochester

A reas de interés: física aplicada de la salud; dosimetría; radiobiología

\section{Wouter A. Lotens}

Instituto de Investigación de Factores H umanos TNO

PO.Box 23

3769 ZG Soesterberg, Países Bajos

Tel: 31346356211

Fax: 31346353977

E-mail: lotens@tm.tno.nl

Puesto(s) actual(es): J efe de departamento de M edio A mbiente de T rabajo

E studios: PhD, 1993, U niversidad de T ecnología Delft

A reas de interés: fisiología térmica; ropas de protección; ergonomía del lugar de trabajo; ambientes virtuales

\section{Veikko Louhevaara}

Departamento de Fisiología

Instituto Finlandés de M edicina del T rabajo

T opeliuksenkatu 41 aA

$00250 \mathrm{H}$ elsinki, Finlandia

T el: 358947471

Fax: 3589890713

E-mail: vlou@occuphealth.fi

Puesto(s) actual(es): Profesor de investigación: Profesor de Ergonomía, U niversidad de K uopio

Puesto(s) anterior(es): I nvestigador, Instituto Finlandés de M edicina del T rabajo; Investigador especial, Instituto Finlandés de M edicina del T rabajo; I nvestigador superior, Instituto Finlandés de M edicina del Trabajo

E studios: PhD, 1985, U niversidad de K uopio

A reas de interés: Ergonomía; envejecimiento; fisiología del trabajo; tareas especiales; mantenimiento de la capacidad de trabajo 


\section{Henk van Loveren}

Laboratorio de Patología

P.O.Box 13

3720 BA Bilthoven, Países Bajos

\section{John Lund}

School for W orkers

U niversity of W isconsin- Extension

$422 \mathrm{~L}$ owell $\mathrm{H}$ all

610 L angdon Street

$M$ adison, WI 53703, Estados U nidos

Tel: 1 (608) 262-9847

Fax: 1 (608) 265-2391

E-mail: jlund@ facslaff.wisc.edu

Puesto(s) actual(es): Professor

\section{Paul V. Lynch}

34 Butler R oad

H ingham M A 02043, Estados U nidos

Tel: 1 (617) 749-2440

Fax: 1 (617) 749-2440

E-mail: safety now@aol.com

Puesto(s) anterior(es): Chief, Safety Staff, US Department of the Interior, Bureau of $L$ and $M$ anagement, W ashington, DC

E studios: BA, 1954, St. Anselm's College; graduación, 1972, U niversity of N ew $\mathrm{H}$ ampshire

A reas de interés: tránsito urbano y suburbano

\section{Michelle Madelien}

Paulson and Cooper

421 W est M elrose Street

Suite 10-C

Chicago, Illinois 60657-3807, Estados U nidos

Tel: 1 (312) 659-7803

Fax: 1 (312) 880-0028

E-mail: 74403,3330

\section{Susan Magor}

Environmental $\mathrm{H}$ ealth and Safety,

Concordia U niversity

1455 boulevard $\mathrm{D}$ e $\mathrm{M}$ aisonneuve $\mathrm{O}$ uest

M ontreal, Q uébec H 3 G 1M 8, C anadá

Tel: 1 (514) 848-4876

Fax: 1 (514) 848-2807

E-mail: magor@vax2.concordia.ca

Puesto(s) actual(es): Director, Environmental $\mathrm{H}$ ealth and Safety

E studios: BA, 1977, Concordia U niversity; DO H 1984, M cG ill U niversity; M Sc, 1989 M cG ill U niversity

A reas de interés: gestión de la salud, la seguridad y el medio ambiente

\section{A. Mahr}

Berufsgenossenschaft der Strassen-

$\mathrm{U}$-Bahnen und Eisenbahnen

Fontenay la

D-20354 H amburgo, Alemania

Tel: $494044118-200$

Fax: 4940 44118-140

Puesto(s) actual(es): T echnischer Aufsichtsbeamter

Mohd Isa Abdul Majid

Centro Nacional de T oxicología

U niversidad Sains de $M$ alaisia

Penang 11800, M alaisia
Tel: 6046570099

Fax: 6046568417

E-mail: misa@usm.my

Puesto(s) actual(es): Profesor, Jefe de la U nidad del Laboratorio de T oxicología

Puesto(s) anterior(es): Profesor, Escuela de Ciencias Farmacéuticas, U niv. Sains de M alaisia

E studios: BPharm, 1984, U niv. Sains de M alaisia; PhD , 1988, U niversidad de Bath

A reas de interés: vigilancia toxicológica; toxicología analítica; tecnología de plaguicidas

\section{Kathryn A. Makos}

$O$ ffice of Environmental $M$ anagement and Safety

Smithsonian Institution

490 L'Enfant Plaza

Suite 4202

Washington, DC 20560, Estados U nidos

T el: 1 (202) 287-3615

Fax: 1 (202) 287-3243

E-mail: makoska@ic.si.edu

Puesto(s) actual(es): Senior Industrial H ygienist

Puesto(s) anterior(es): Industrial H ygiene Program $M$ anager, US D epartment of Energy, Chicago $O$ perations 0 ffice; Supervisor Illinois $O$ ccupational Safety and $\mathrm{H}$ ealth Administration $\mathrm{O}$ n-site Consultation Program

E studios: M PH , 1983, U niversity of Illinois; BSc, 1974, M undelein College

A reas de interés: gestión del riesgo ambiental y para la seguridad basada en la conservación y las colecciones; seguridad en laboratorios

\section{Jacques Malchaire}

U nité $\mathrm{H}$ ygiène et Physiologie du T ravail

U niversité C atholique de Lovaina

Clos Chapelle aux Champs 3038

1200 Bruselas, Bélgica

T el: 3227643229

Fax: 3227643954

E-mail: malchaire@hytr.ucl.ac.be

Puesto(s) actual(es): Profesor

E studios: Ingeniería, 1968, U niversidad C atólica de L ovaina, Bélgica; M Sc, 1972, PhD 1974, U niversity of Cincinnati

A reas de interés: trastornos musculosqueléticos y trabajo repetitivo; efectos neurológicos de las vibraciones; evaluación del estres por calor; gestión del riesgo de los agentes químicos

\section{Bohuslav Málek}

Departamento de M edicina del Trabajo

Instituto de $\mathrm{H}$ igiene de Praga

Pöslova 121

10600 Praga 10, R epública Checa

T el: 42224212460

Fax: 42224212335

Puesto(s) actual(es): J efe de departamento

E studios: M U Dr, 1955, Facultad de M edicina de la U niv. Carlos de Praga

A reas de interés: toxicología industria
David E. Malter

$M$ alter Associates, Inc.

8021 Washington

D owners G rove, Illinois 60516, Estados U nidos Tel: 1 (630) 910-4243

Fax: 1 (630) 910-4243

E-mail: maltrassoc@aol.com

Puesto(s) actual (es): President

Puesto(s) anterior(es): Director, $\mathrm{H}$ ealth and Safety, W aste $M$ anagement, Inc.

E studios: BS, 1976, U niversity of W ashington M S, 1980, U niversity of Illinois

A reas de interés: sistemas de gestión de la salud y la seguridad

\section{Nicole Mamelle}

INSER M Institut N ational de le Santé et de la Recherche M édicale

151 cours Albert Thomas

69424 Lyon Cedex 03, Francia

Tel: 3372681950

Fax: 3372681951

Puesto(s) actual(es): D irector, Investigador: Director de la U nidad 265, IN SER M

E studios: PhD, 1966, U niversidad de París

A reas de interés: E pidemiología; salud pública; etapa prenatal; trabajo durante el embarazo; crecimiento infantil; exploración del cáncer de mama

\section{Norman M. Mann}

Connecticut Chemosensory C linical R esearch Center

University of $\mathrm{C}$ onnecticut $\mathrm{H}$ ealth $\mathrm{C}$ enter

Department of M edicine

203 Farmington Ave

Farmington, CT 06030-3705, Estados U nidos

Tel: 1 (203) 679-2459

Fax: 1 (203) 679-2910

Puesto(s) actual(es): Internist, Assistant Professor in M edicine

Puesto(s) anterior(es): A ssociate in M edicine, St. Francis $\mathrm{H}$ ospital $\mathrm{M}$ edical $\mathrm{C}$ enter, $\mathrm{H}$ artford, CT

E studios: BA, 1942, Y ale U niversity; M D, 1945 , D ownstate $M$ edical $C$ enter

A reas de interés: investigación clínica de la quimiosensibilidad

\section{S.Z. Mansdorf}

Liberty International R isk Services

175 Berkeley Street

Boston, M A 02117, Estados U nidos

Tel: 1 (617) 574-5686

Fax: 1 (617) 574-6635

E-mail: msmail9.mansdorz@Imig.com

Puesto(s) actual(es): $M$ anaging Director

\section{Alfred C. Marcus}

C ancer R esearch Center

1600 Pierce Street

Denver, Colorado 80214, Estados U nidos

T el: 1 (303) 239-3397

Fax: 1 (303) 233-1863

Puesto(s) actual(es): Director, Division of Behavioral Science R esearch

Estudios: PhD 


\section{Kazimierz J. Marek}

Departamento Clínico

Instituto de M edicina del T rabajo y Salud

Ambiental

$13 \mathrm{~K}$ oscielna Street

41 Sosnowiec, Polonia

Tel: 4832661388

Fax: 4832661124

Puesto(s) actual(es): J efe

E studios: M D , 1952, A cademia M édica, K raków

A reas de interés: enfermedades laborales; enfermedades de pulmón de origen laboral

\section{Anthony A. Marfin}

Division of R espiratory Disease Studies

National Institute of $O$ ccupational Safety and

$\mathrm{H}$ ealth

1095 W illowdale R oad

M organtown, WV 26505-2845, Estados U nidos

Tel: 1 (503) 731-4024

Fax: 1 (503) 731-4798

E-mail: aam0@wonder.em.cdc.gov

Puesto(s) actual(es): M edical E pidemiologist, $O$ regon $\mathrm{H}$ ealth Division

Puesto(s) anterior(es): M edical E pidemiologist, C enters for Disease $C$ ontrol and Prevention

E studios: M D, 1983, U niversity of California at Davis; M PH , 1990, U niversity of California Berkeley

A reas de interés: patógenos respiratorios; salud del refugiado; epidemiología de enfermedades infecciosas

\section{Pia Markkanen}

c/ o ILO ROAP ILO/FINNIDA Programa R egional del PacíficoAsiático sobre Salud y Seguridad en el Trabajo

$\mathrm{R}$ ajadamnoen $\mathrm{N}$ ok A venue

P.0. Box 2-349

Bangkok 10200, T ailandia

T el: 6622882494

Fax: 6622678030

E-mail: markkanen@ilobkk.or.th

\section{Adrienne Markowitz}

R etail, W holesale and D epartment Store U nion, AFL-CIO

CLC

30 East 29th Street

N ueva Y ork, N ueva Y ork 10016, Estados Unidos

Tel: 1 (212) 684-5300

Fax: 1 (212) 779-2809

Puesto(s) actual(es): Director of $\mathrm{H}$ ealth and Safety

Puesto(s) anterior(es): R esearch Scientist, N ew Jersey Department of $\mathrm{H}$ ealth,

O ccupational H ealth Service; Industrial $\mathrm{H}$ ygienist, Bergen C ounty D epartment of $\mathrm{H}$ ealth Services, $\mathrm{O}$ ccupational and Environmental $\mathrm{H}$ ealth

E studios: M Sc, 1988, H unter College, City U niversity of $\mathrm{N}$ ew Y ork

A reas de interés: armonización de la clasificación de productos químicos; ergonomía

\section{Steven B. Markowitz}

Division of Environmental and 0 ccupational M edicine
M ount Sinai School of M edicine

N ueva Y ork, N ueva Y ork 10029-6574, Estados Unidos

T el: 1 (212) 241-7941

Fax: 1 (212) 996-0407

E-mail: kg@doc.mssm.edu

Puesto(s) actual(es): D eputy Director, Associate Professor

E studios: BA, 1975, Y ale U niversity; M D, 1981 C olumbia College of Physicians and Surgeons

A reas de interés: vigilancia de la enfermedad laboral; medicina clínica del trabajo

\section{Marco Maroni}

C entro Internacional para la Seguridad de los Plaguicidas (ICPS)

$\mathrm{V}$ ia M agenta 25

20020 Busto Garolfo, M ilán, Italia

T el: 39331568091

Fax: 39331568023

Puesto(s) actual(es): Director; Profesor de M edicina del Trabajo, U niversidad de Milán

E studios: M D , 1974, U niversidad de M ilán; Specialization (M edicina del T rabajo), 1976, U niversidad de M ilán Specialización (M ed T ox), 1980, U niversidad de Pavia

A reas de interés: toxicología en el trabajo y ambiental; calidad del aire interior y plaguicidas

\section{William S. Marras}

O hio State U niversity

D epartment of Industrial and System

Engineering

Biodynamics L aboratory

1971 N eil A venue

Columbus, $O$ hio 43210, Estados U nidos T el: 1 (614) 292-2016

Fax: 1 (614) 292-7852

Puesto(s) actual(es): Professor, Director

\section{Linda S. Martín}

CDC NIOSH

1600 Clifton R oad-F40

Atlanta, GA 30333, Estados U nidos

Tel: 1 (404) 639-1530

Fax: 1 (404) 639-3064

E-mail: Ism2@ niood1.em.cdc.gov

Puesto(s) actual(es): Director, H IV Activity, $\mathrm{N}$ ational Institute for $\mathrm{O}$ ccupational Safety and $\mathrm{H}$ ealth

Puesto(s) anterior(es): M anagement/ L eadership D evelopment Program, A ssistant to the D eputy Director, C enters for D isease Control

E studios: BS, 1968, U niversity of Alabama; M S, 1972, G eorgia State U niversity; PhD, 1982, Emory U niversity

A reas de interés: salud en el trabajo; prevención de enfermedades infecciosas transmitidas en el trabajo

\section{Albert Marty}

SU V A - O rganización Nacional Suiza de Seguros de Accidentes

P.O. Box 4358

6002 Lucerna, Suiza
Tel: 41414195111

Fax: 41414195870

Puesto(s) actual(es): Ingeniero de seguridad para certificación de productos

E studios: Ingeniería mecánica H T L, Instituto de Ingeniería mecánica de Lucerna, Suiza

A reas de interés: gestión del riesgo, análisis y evaluación; máquinas herramienta en el sector del metal; robots industriales; sistemas FM S

\section{John Masaitis}

4139 S. Atlantic Avenue \#B109

N ew Smyrna Beach, FL 32169, Estados U nidos Tel: 1904 427-0090

Puesto(s) actual(es): Consultant

Puesto(s) anterior(es): Director, Industrial H ygiene E studios: BS, 1962, K ing's C ollege, W ilkes-Barre, PA

A reas de interés: elaboración de normas; litigios; higiene industrial completa

\section{Christina Maslach}

U niversity of $C$ alifornia

Department of Psychology

BerkeleyT olman $\mathrm{H}$ all

Berkeley, CA 94720-1650, Estados U nidos

Tel: 1 (510) 642-7140

Fax: 1 (415) 673-2294

E-mail: maslach@cmsa.berkeley.edu

Puesto(s) actual(es): Professor

E studios: $A B, 1967, H$ arvard- $R$ adcliffe C ollege; PhD, 1971, Stanford U niversity

A reas de interés: estrés laboral y síndrome de burn-out; psicología de la salud

\section{Steve Mason}

Boeing C ommercial Airplane G roup

POBox 3707

M S 97-29

Seattle, WA 98124, Estados U nidos

T el: 1 (206) 235-2130

Puesto(s) actual(es): Senior $M$ anager, Chemica T echnology

E studios: BS, 1979, W ashington State U niversity A reas de interés: materiales y procesos aerospaciales

\section{Toshio Matsushita}

U niv.K agoshima

8-35-1 Sakuragaoka

K agoshima 890, Japón

T el: 81992755288

Fax: 81992658434

E-mail: matsush@med3.kufm.kagoshi-

ma-u.ac.jp

Puesto(s) actual(es): Profesor, Facultad de M edicina

Puesto(s) anterior(es): Investigador asociado; U niv. $\mathrm{N}$ agoya Profesor asistente, U niv. K umamoto; Profesor asociado, U niv. K umamoto

E studios: M D, 1958, U niv. N agoya, PhD, 1963 postgraduación, Escuela de M edicina, U niv. Nagoya

A reas de interés: alergia ambiental y laboral; envenenamiento por plaguicidas: medicina agrícola 


\section{R. Matthes}

Bundesamt für Strahlenschutz

Institut für Strahlenhygiene (IC N IR P)

Ingolstädter Landstrasse 1

85764 N euherberg/ 0 berschleissheim

T el: 418931603237

Fax: 418931603111

E-mail: matthes@bfs.de

Puesto(s) actual(es): J efe, D osimetría NIR

Puesto(s) anterior(es): Secretario científico ICN IR P

E studios: Dipl Ing, U niv. T écnica

\section{Chester Matthews}

Bath Iron Works

G eneral Dynamics Corp. 4 Q uarry R oad

Brunswick, M aine 04011, Estados U nidos

Tel: 1 (207) 442-1633

Fax: 1 (207) 442-3356

E-mail: cmatthews@biw.com

Puesto(s) actual(es): Director, Environment, $H$ ealth and Safety

Puesto(s) anterior(es): Director, Safety and $\mathrm{H}$ ealth, $M$ artin M arietta Corp.; Director, Safety and $\mathrm{H}$ ealth, $\mathrm{G}$ eneral Electric

\section{Donald Mattison}

G raduate School of Public H ealth

U niversity of Pittsburgh

111 Parran $\mathrm{H}$ all

130 D esoto Street

Pittsburgh, PA 15261, Estados U nidos

Tel: 1 (412) 624-3001

Fax: 1 (412) 624-3309

E-mail: mattison@ vms.cis.pitt.edu

Puesto(s) actual(es): D ean, Professor

Puesto(s) anterior(es): Professor of 0 bstretics,

Gynecology and Toxicology, U niversity of A rkansas

E studios: BA, Angsburg College; M S, $M$ assachusetts Institute of T echnology; M D, Columbia U niversity

A reas de interés: toxicología; biología evolutiva y reproductiva; evaluación del riesgo

\section{John May}

The $\mathrm{M}$ ary Imogene Bassett H ospital

O ne A twell R oad

Cooperstown, N ueva Y ork 13326, Estados

Unidos

Tel: 16075476023

Fax: 16075476087

Puesto(s) actual(es): Director, The N ew Y ork Center for Agricultural M edicine and $\mathrm{H}$ ealth

Puesto(s) anterior(es): Chief, Pulmonary Division, The $\mathrm{M}$ ary I mogene Bassett H ospital, Cooperstown, N ew Y ork

E studios: BS, 1969, The U niversity of N otre Dame; M D, 1973, Case W estern R eserve U niversity School of M edicine

A reas de interés: medicina agrícola y seguridad; pérdida de audición; artritis; lesiones; riesgos tóxicos; estrés emocional; lesiones en la infancia; riesgos durante el embarazo

\section{Alain Mayer}

Institut N ational de R echerche et de Sécurité

A venue de Bourgogne
$V$ andoeuvre Cedex 54501, Francia

T el: 33140443000

Fax: 33140443099

E-mail: mayer@inrs.fr

Puesto(s) actual(es): J efe de departamento

E studios: Ingeniería electromecánica, 1971

\section{Alan Maynard}

Department of E conomics,

U niversity of $Y$ ork

$\mathrm{H}$ eslington, Y ork Y $O 1$ 5DD, R eino U nido

Tel: 4401904433645

Fax: 4401904434517

E-mail: akm3@york.ac.uk

Puesto(s) actual(es): Professor

Puesto(s) anterior(es): Professor of $\mathrm{H}$ ealth Economics, Director of the Centre for $\mathrm{H}$ ealth Economics, U niversity of J ost

A reas de interés: reforma de la asistencia sanitaria; valoración económica; atención primaria

\section{Lucien Y. Maystre}

Institut de G énie de l'Environnement

Ecole Polytechnique Fédérale de

L ausanne-EPFL

1015 Lausana, Suiza

T el: 41216932711

Fax: 41216932859

Puesto(s) actual(es): Directora

Puesto(s) anterior(es): Ingeniera jefe, Ginebra Director de proyecto, Programa de D esarrollo de las $\mathrm{N}$ aciones U nidas

E studios: Dipl Ing, 1956, Eidgenössische T echnische H ochschule Zurich (EPFZ); M Sc, 1969, Johns H opkins U niversity

A reas de interés: evaluación ambiental estratégica y regional; formación de posgrados en gestión técnica y ambiental

\section{Daniel McBain}

75 Dundurn N.

Hamilton, O N L8R 3E4, Canadá

T el: 1 (905) 524-0939

Puesto(s) actual(es): M edical student

Puesto(s) anterior(es): W riter, Editor, T ranslator

E studios: D ipl Broadcasting, 1979, M ount R oyal C ollege, Calgary; BA, 1985, U niversity of Calgary; M A, 1987, Concordia University, $M$ ontrea

A reas de interés: medicina general

\section{Michael McCann}

77 Seventh Avenue \#PhG

N ueva Y ork, N ueva Y ork 10011-6645, Estados Unidos

T el: 1 (212) 255-0615

Fax: 1 (212) 691-5490

E-mail: michael.mccann@worldnet.alt.net

Puesto(s) actual(es): Senior Associate Editor, Encyclopaedia of $\mathrm{O}$ ccupational $\mathrm{H}$ ealth and Safety; Industrial H ygiene Consultant

Puesto(s) anterior(es): Executive Director, Center for Safety in the Arts

E studios: BSc, 1964, U niversity of Calgary, Canadá; PhD, 1972, Columbia U niversity
A reas de interés: artes y oficios: espectáculos: enseñanza; pequeño comercio; Internet; información para la salud y la seguridad

Robert J. McCunney

$M$ assachusetts I nstitute of T echnology

$77 \mathrm{M}$ assachusetts A venue 20B-238

Cambridge, M A 02139, Estados U nidos

Tel: 1 (617) 253-5360

Fax: 1 (617) 253-4879

E-mail: mccunney@mitvma.mit.edu

Puesto(s) actual(es): Director, Environmental M edical Service;

Puesto(s) anterior(es): C hief, O ccupational and Environmental M edicine, Boston U niversity $M$ edical C enter

E studios: BS, 1971, D rexel U niversity Philadelphia; M S, 1972, U niversity of M innesota; M D, 1976, Jefferson M edical College Philadelphia; M PH, 1981 $\mathrm{H}$ arvard School of Public $\mathrm{H}$ ealth

A reas de interés: vigilancia médica; enfermedades de pulmón de origen laboral

\section{George J. McDonald}

International T ransport W orkers U nion of America

80 W est End A venue

N ueva Y ork, N ueva Y ork 10023, Estados Unidos

Tel: 1212 873-6000

Fax: 1212 721-1431

E-mail: twusafe@tiac.com

Puesto(s) actual(es): Director, Safety and $\mathrm{H}$ ealth

Puesto(s) anterior(es): V ice President, TWU L ocal 100

\section{Bruce McKay}

SeaW eb

4058 R ue Dorion

M ontreal, Q uébec H 2K 4B9, C anadá

Tel: 1 (514) 598-8030

Fax: 1 (514) 598-8030

E-mail: bmckay@ seaweb.org

Puesto(s) actual(es): Senior R esearcher

Puesto(s) anterior(es): Investigador, Campaña de la Biodiversidad, G reenpeace Internacional; Coordinador de ecotoxicología, U nidad Científica de G reenpeace Internacional; Director, $\mathrm{G}$ reenpeace $\mathrm{Q}$ uébec

A reas de interés: cambio global del medio ambiente marino e industria pesquera; nutrientes y contaminación por productos químicos tóxicos; radiación UV-B; introducción de especies; desarrollo costero y efecto invernadero

\section{Ross A. McKinnon}

Environmental $\mathrm{H}$ ealth U nit

U niversity of $\mathrm{C}$ incinnati M edical $\mathrm{C}$ enter

3223 Eden Avenue

PO Box 670056

Cincinnati, O hio 45267-0056, Estados U nidos

Tel: 1 (513) 558-1719

Fax: 1 (513) 558-0925

Puesto(s) actual(es): Postdoctoral Fellow

E studios: PhD, 1993, Flinders U niversity of South Australia; BPharm, 1983, U niversity of South Australia 
S.D. McMahon

L ogging Industry R esearch O rganisation PO Box 147

R otorua, N ueva Zelanda

Tel: 6473487168

Fax: 6473462886

E-mail: shane@liro.fri.cri.nz

Puesto(s) actual(es): Senior Environmental R esearcher

Puesto(s) anterior(es): Soil Physicist, N ew Zealand Forest R esearch Institute

E studios: M Sc, 1990, U niversity of W aikato, $\mathrm{H}$ amilton, $\mathrm{NZ}$

A reas de interés: alteración del suelo causada por las las cosechas; incorporación de valores ambientales en los procesos de planificación de las cosechas

\section{Neil McManus}

N orth W est O ccupational H ealth and Safety

1174 C hamberlain D rive N orth

Vancouver, BC V 7K 1P3, Canadá

Tel: 1 (604) 980-8512

Fax: 1 (604) 980-8512

Puesto(s) actual(es): C onsulting Industrial $\mathrm{H}$ ygienist

Puesto(s) anterior(es): Industrial H ygienist, Imperial $\mathrm{O}$ il Limited; $\mathrm{H}$ ealth Physicist, A tomic Energy of $C$ anada Limited; Industrial $\mathrm{H}$ ygiene $\mathrm{C}$ onsultant, Industrial Accident Prevention A ssociation of O ntario $\mathrm{O}$ ccupational $\mathrm{H}$ ealth $\mathrm{O}$ fficer, $\mathrm{M}$ anitoba $\mathrm{H}$ ydro; Senior Industrial H ygienist, M onenco Consultants; Senior $\mathrm{O}$ ccupational $\mathrm{H}$ ygienist, L ockhart R isk $M$ anagement; Industrial $H$ ygiene Consultant, CP R ail System

E studios: BSc, 1969; M Sc, 1973; BEd, 1973; M Eng, 1984

\section{Nona McQuay}

N ew Y ork State Public Employees Federation 110 Pearl Street

7th Floor

Buffalo, N ueva Y ork 14202, Estados U nidos Tel: 1 (800) 462-1462

Fax: 1 (716) 853-3109

Puesto(s) actual(es): H ealth and Safety Specialist

Puesto(s) anterior(es): Extension Associate, Cornell U niversity, School of Industrial and L abor R elations

E studios: BS, 1984, State U niversity of N ew Y ork at Buffalo; M S, 1990, State U niversity of $\mathrm{N}$ ew $\mathrm{Y}$ ork at Buffalo

A reas de interés: enfermedades infecciosas; ergonomía; técnicas de formación

\section{Tom A. McQuiston}

U niversity of N orth Carolina

117 Balsam C ourt

Chapel H ill, N C 27514, Estados U nidos

T el: 1 (919) 932-6079

Fax: 1 (919) 932-6079

E-mail: 40tmcquiston@ sophia.sph.unc.edu

Puesto(s) actual(es): Doctoral Student, Graduate School

Puesto(s) anterior(es): Director of Industrial $\mathrm{H}$ ygiene, U nited $\mathrm{R}$ ubber W orkers;
Industrial H ygienist/ Project Director

International Chemical W orkers U nion

E studios: M S, 1983, U niversity of C incinnati

A reas de interés: salud en el trabajo del empleado y educación en materia de seguridad

\section{Douglas J. McVittie}

C onstruction Safety Association of O ntario

21 V oyager C ourt South

Etobicoke, O N M 9W 5M 7, Canadá

T el: 1 (416) 674-2726

Fax: 1 (416) 674-8866

Puesto(s) actual(es): M anager, T echnical Services

E studios: Diploma (O cc. H ealth and Safety), 1982, M cM aster U niversity; Diploma (Civil Engineering T echnology), 1975. Fanshawe College

A reas de interés: salud y seguridad en la construcción; tecnologías de la salud y la seguridad

\section{Dick J. Meertens}

A sociación Internacional de la Seguridad Social - ISSA

4 rte des $M$ orillons

1211 G inebra 22, Suiza

Tel: 41227996249

Fax: 41227998509

E-mail: meertens@issa.org

Puesto(s) actual(es): Director de programa, Prevención y Seguros de Accidentes

Puesto(s) anterior(es): Director, Bureau Bouw V eilig, Países Bajos

E studios: Ingeniero de seguridad, 1971, V eiligheidsinstituut, Países Bajos

A reas de interés: salud y seguridad laboral y general; cuestiones ambientales: campañas de seguridad y salud

\section{Karlheinz Meffert}

BIA-Berufsgenossenschaftliches Institut für A rbeitssicherheit

$H$ auptverband der gewerblichen

Berufsgenossenschaften

Alte $\mathrm{H}$ eerstrasse 111

D -53754 Sankt Augustin, Alemania

Tel: 49-2241-231-2700

Fax: 49-2241-231-2234

Puesto(s) actual(es): Director

\section{Ronald L. Melnick}

N ational Institute of Environmental Sciences PO Box 12233

R esearch T riangle Park, NC 27709, Estados Unidos

Tel: 1919 541-4142

Fax: 1919 541-3647

E-mail: melnick r@niehs.nih.gov

Puesto(s) actual(es): T oxicologist, $N$ ational Institute of Environmental $\mathrm{H}$ ealth Sciences, $\mathrm{N}$ ational Institutes of $\mathrm{H}$ ealth

Puesto(s) anterior(es): A gency R epresentative White $\mathrm{H}$ ouse $\mathrm{O}$ ffice of Science and T echnology Policy, W ashington, DC; $G$ roup L eader, Pharmacological and Biochemical M odeling $G$ roup, Laboratory of Computational Biology and Risk Analysis, NIESH

E studios: BS, 1965, R utgers U niversity; PhD, 1970, U niversity of M assachusetts
A reas de interés: creación de modelos toxicocinéticos y bioquímicos de sustancias químicas por epóxido; identificación y descripción de los efectos, incluido el cáncer, de la intoxicación química

\section{Claude Menguy}

L aboratoire C entral des Industries Electriques $(\mathrm{LCIE})$

B.P. 8

92266 Fontenay aux R oses, Francia

Tel: 33140956380

Fax: 33140956399

Puesto(s) actual(es): Director de departamento de $M$ ateriales y Estrés A mbiental

E studios: Ingenierái, IN PG , G renoble

A reas de interés: comportamiento del fuego; materiales aislantes; electricidad estática

\section{Heather Menzies}

School of C anadian Studies Carleton U niversity

1125 Colonel By Drive

Ottawa, O N K 1S 5B6, Canadá

Tel: 1 (613) 788-2366

Fax: 1 (613) 788-3903

E-mail: hmenzies@ccs.carleton.ca

Puesto(s) actual(es): W riter, A djunct Professor

E studios: BA, 1970, M cG ill U niversity

A reas de interés: redes digitales; ciberespacio; Internet; nuevas tecnologías de reproducción

\section{Donna Meroler}

U niversité du Q uébec à $M$ ontréal-CIN BIO SE

Case postale 8888 Succursale CV

$\mathrm{M}$ ontreal, $\mathrm{Q}$ uébec $\mathrm{H} 3 \mathrm{C}$ 3P8, C anadá

Tel: 1 (514) 982-3000 ×3355

Fax: 1 (514) 987-6183

E-mail: mergler.donna@uqam.ca

Puesto(s) actual(es): Profesor

E studios: PhD, 1973, M cG ill U niversity

A reas de interés: detección de los efectos neurotóxicos iniciales en la exposición a metales; disolventes orgánicos y plaguicidas, desde el punto de vista de la vigilancia preventiva de la población expuesta e intervención

\section{Franco Merletti}

U nidad de Epidemiología del Cáncer U niversità di T urín and U niversity H ospita $\checkmark$ ia Santena 7

10126 T urín, I talia

Tel: 39116706500

Fax: 39116706692

Puesto(s) actual(es): Profesor de estadística médica

E studios: M D, 1975, U niversidad de T urín; M S, 1978, H arvard School of Public H ealth

A reas de interés: epidemiología laboral; epidemiología molecular; investigación etiológica

\section{Karen Messing}

U niversité du $\mathrm{Q}$ uébec à $\mathrm{M}$ ontréal

Centre pour l'étude des interactions biologiques CP 8888 Succ-C entreville

M ontreal, Q uébec H 3C 3P8, Canadá

T el: 1 (514) 987-3334

Fax: 1 (514) 987-6183

E-mail: messing.karen@ugam.ca 
Puesto(s) actual(es): Professor of Biology

E studios: PhD, M cG ill U niversity

\section{Jacqueline Messite}

1216 Fifth A venue

N ueva Y ork, N ueva Y ork 10029, Estados Unidos

Tel: 1 (212) 876-8200 ext. 250

Fax: 1 (212) 348-2238

Puesto(s) actual(es): Executive Director Public $\mathrm{H}$ ealth

Puesto(s) anterior(es): 0 ccupational Safety and $\mathrm{H}$ ealth, $\mathrm{N}$ ational Institute for $\mathrm{O}$ ccupational Safety and $\mathrm{H}$ ealth; Director, Division of Administrative $\mathrm{H}$ ygiene and $\mathrm{O}$ ccupational $\mathrm{H}$ ealth, $\mathrm{N}$ ew Y ork State D epartment of $L$ abor

E studios: M D, 1949, State U niversity of $\mathrm{N}$ ew York, $\mathrm{H}$ ealth Services $\mathrm{C}$ enter

A reas de interés: medicina preventiva de salud pública; medicina del trabajo

\section{Mark Methner}

$\mathrm{N}$ ational Institute for $\mathrm{O}$ ccupational Safety and $\mathrm{H}$ ealth

Division of Surveillance

$H$ azard Evaluation and Field Studies

4676 Columbia Parkway (R -19)

Cincinatti, 0 hio 45226, Estados U nidos

T el: 1513 841-4325

Fax: 1513 841-4489

E-mail:mmm5@cdc.gov

Puesto(s) actual(es): Industrial H ygienist

E studios: AS, 1983, M iddlesex College; BS, 1985, Stockton State College; M S, 1988, R utgers U niversity; PhD , 1992, R utgers U niversity

A reas de interés: evaluación de la exposición a plaguicidas; vigilancia de riesgos; evaluación de peligros de la construcción de viviendas

\section{Jean-Jacques Meyer}

Instituto de Ciencias de la M edicina del T rabajo (IST)

Rue du Bugnon 19

1005 Lausana, Suiza

T el: 41213147421

Fax: 41213147420

E-mail: jean-

jacques.meyer@inst.hospvd.ch

Puesto(s) actual(es): J efe del Laboratorio de Ergonomía de la V isión; Profesor de ergonomía, Ecole Supérieure de D esign Industriel, Lausana

Puesto(s) anterior(es): Chargé de recherche à I'Institut de M édecine Sociale et Préventive de la Faculté de M édecine de I'U niversité de G enève (1976)

E studios: Lic (Bio H um), 1962; Thèse (Phys visuelle), 1972

A reas de interés: ergonomía de la visión ergo-oftalmología; ergonomía y diseño visión nocturna; iluminación; visión y envejecimiento

\section{John Meyer}

West V irginia U niversity School of M edicine Institute of $O$ ccupational and Environmental $\mathrm{H}$ ealth
P.O. Box 9190

M SS 3801

M organtown, WV 26506-9190, Estados U nidos

Tel: 1 (304) 293-3693

Fax: 1 (304) 293-2629

E-mail: jmeyer@wvuioeh1.hsc.wvv.edu

Puesto(s) actual(es): Associate R esidency Director

Puesto(s) anterior(es): 0 ccupational and Environmental M edicine, Boston U niversity M edical C enter H ospital

E studios: BA, 1981, H amilton College; M D 1985, Cornell U niversity; M PH , 1995, Boston U niversity

A reas de interés: educación en materia de medicina del trabajo; medicina clínica del trabajo; salud en el trabajo en los centros médicos

\section{Jarl-Erik Michelsson}

Suur-Sarvilahden kartano

07900 L oviisa, Finlandia

Tel: 35815531538

Fax: 35815531538

\section{Jack L. Mickle}

Jack L. M ickle and Associates

1903 Linn Street

Boone, lowa 50036-1316, Estados U nidos

Tel: 1 (515) 432-3743

Fax: 1 (515) 432-9229

Puesto(s) actual(es): Emeritus Professor; Consultant

Puesto(s) anterior(es): Professor of Civil Engineering, Civil and Construction Engineering D epartment, l owa State U niversity

E studios: BS, 1952, lowa State U niversity; M S, 1955, I owa State U niversity; PhD, 1960 I owa State U niversity

A reas de interés: seguridad en excavaciones

\section{John A. Miles}

Department of Agricultural Engineering U niversity of $\mathrm{C}$ alifornia-D avis

Davis, California 95616, Estados U nidos

Tel: 1 (916) 752-6210

Fax: 1 (916) 742-2640

E-mail: jamiles@ucdavis.edu

Puesto(s) actual(es): Professor

E studios: PhD ,1970, Cornell U niversity

A reas de interés: ergonomía y diseño en actividades agrícolas y forestales

\section{Frank Miller}

Environmental $\mathrm{H}$ ealth and Safety $\mathrm{O}$ ffice

Columbia U niversity $\mathrm{H}$ ealth Sciences

630 W est 168th Street

Box 8

N ueva Y ork, N ueva Y ork 10032, Estados

Unidos

T el: 1 (212) 795-3067

Fax: 1 (212) 795-5847

Puesto(s) actual (es): $\mathrm{H}$ azardous $\mathrm{M}$ aterials $\mathrm{O}$ fficer

Puesto(s) anterior(es): Associate Professor, U niversity of Wisconsin Center System; Senior R esearch Chemist, A merican $M$ achine and Foundry

E studios: BS, 1953, College of the City of $\mathrm{N}$ ew Y ork; M S, 1957, U niversity of K ansas; $\mathrm{PhD}, 1970$, U niversity of D elaware
A reas de interés: seguridad en laboratorios; higiene química

\section{Gordon Miller}

REXAM Inc.

PO Box 368

$M$ atthews, NC 28106-7003, Estados U nidos

Tel: 1 (704) 847-9171

Fax: 1 (704) 845-4335

E-mail:

gordon.c.miller@custom.rexam.com

Puesto(s) actual(es): M anager, Safety and Environmental Affairs

E studios: BA, 1970, W ashington and J efferson College; M SPH , 1975, U niversity of N orth Carolina, Chapel H ill

A reas de interés: gestión de la salud, programas en materia de seguridad y medio ambiente

\section{James Miller}

Industrial and $O$ perations Engineering

University of M ichigan

2392 Fuller R oad

Ann Arbor, MI 48105, Estados U nidos

\section{Bruce Arthur Millies}

International Brotherhood of T eamsters

P.O. Box 10862

Bainbridge Island, WA 98110, Estados U nidos

Tel: 1 (206) 842-7503

Fax: 1 (206) 842-7503

E-mail: bmillies@drizzle.com

Puesto(s) actual(es): Industrial H ygienist

Puesto(s) anterior(es): Assistant Professor, Industrial $\mathrm{H}$ ygiene and Safety, Empire State C ollege, State U niversity of N ew Y ork Instructor, Industrial $\mathrm{H}$ ygiene and Safety, U niversity of W ashington $G$ raduate D epartment of Environmental $\mathrm{H}$ ealth

E studios: JD, 1977, N ortheastern U niversity School of Law; M S, 1986, U niversity of Washington

A reas de interés: desarrollo de programas de formación de trabajadores; higiene industrial completa

Franklin E. Mirer

International U nion

U nited A uto W orkers (U AW

8000 East J efferson A venue

Detroit, M I 48214, Estados U nidos

Tel: 1 (313) 926-5563

Fax: 1 (313) 824-4473

Puesto(s) actual(es): Director, $\mathrm{H}$ ealth and Safety D epartment

\section{R. Rita Misra}

National C ancer Institute

Laboratory of $C$ omparative $C$ arcinogenesis

Frederick $C$ ancer R esearch \& D ev. C enter

Bldg 538

R oom 205E

Frederick, M D 21702-1201, Estados U nidos

T el: 1 (301) 846-5420

Fax: 1 (301) 846-5946

Puesto(s) actual(es): Postdoctoral Fellow

E studios: PhD, 1989, C ornell U niversity

A reas de interés: daños y reparación de ADN: carcinogénesis inorgánica; mutagénesis y carcinogénesis ambiental 


\section{Courtney S. Mitchel}

CSM Consulting

73 South Devinney Street

Golden, C O 80401, Estados U nidos

Tel: 1303 271-1593

Fax: 1303 215-0957

E-mail: mitchellcs@aol.com

Puesto(s) actual(es): C onsultant

Puesto(s) anterior(es): L ecturer, Dalhousie U niversity, $\mathrm{H}$ alifax, N ova Scotia; Lecturer, U niversity of British Columbia, $\mathrm{V}$ ancouver

E studios: BSc, 1966, U niversity of W ashington, Seattle; M A, 1970, Stanford U niversity, Palo Alto, CA; M Sc, 1970, Stanford U niversity, Palo Alto, CA

A reas de interés: investigación y elaboración de manuales de seguridad para departamentos de exploración de compañías mineras

\section{William Mitchel}

BH P M inerals International Exploration Inc. 1597 C ole Boulevard

Suite 250

Golden, C O 80401, Estados U nidos

T el: 1303 232-7779

Fax: 1303 235-0267

E-mail: mitchell.william.ws@bhp.com.au

Puesto(s) actual(es): $M$ anager, Exploration Administration

Puesto(s) anterior(es): Exploration $\mathrm{M}$ anager, Canada, BH P M inerals C anada Ltd.

E studios: BSc, 1969, A berdeen U niv., Scotland; M Sc, 1973, U niversity of British Columbia

A reas de interés: descubrimiento de minerales mediante exploración

\section{Toyohiko Miura}

Instituto de Ciencias del T rabajo

2-8-14 Sygao M iyamae-ku

K awasaki 216, Japón

T el: 81449772121

Fax: 81449777504

Puesto(s) actual(es): M iembro de honor

Puesto(s) anterior(es): V icepresidente del Instituto de $C$ iencias del Trabajo

E studios: M D

A reas de interés: historia de la medicina del trabajo

\section{Willi Momm}

R ama de R ehabilitación Profesional

O ficina Internacional del Trabajo, Bureau 9-82 4 route des $M$ orillons

1211 G inebra 22, Suiza

Tel: 41227996834

Fax: 41227988885

E-mail: frehab@hq1.ilo.ch

Puesto(s) actual(es): Jefe

E studios: M D, U niv. de H eidelberg, Alemania

A reas de interés: formación y políticas de empleo para discapacitados

\section{Timothy H. Monk}

Western Psychiatric Institute and C linic

3811 O 'H ara Street

R oom D-1123
Pittsburgh, PA 15238, Estados U nidos

T el: 1 (412) 624-2246

Fax: 1 (412) 624-2841

Puesto(s) actual(es): Professor of Psychiatry, U niversity of Pittsburgh

Puesto(s) anterior(es): Assistant Professor of Psychology and Psychiatry, Cornel U niversity M edical C ollege

E studios: PhD, 1974, U niversity of N ottingham

A reas de interés: ritmos circadianos y sueño y sus alteraciones en el trabajo por turnos, envejecimiento, depresión y viajes espaciales

\section{Monteau}

Institut $\mathrm{N}$ ational de R echerche et de Sécurité

A venue de Bourgogne

B.P. 27

54501 V andoeuvre Cedex, Francia

Tel: 3383502070

Fax: 3383502182

Puesto(s) actual(es): C hef du service accidentologie

E studios: D iplomé de I'Institut d'administration des entreprises, 1970; Diplomé d'études supérieures de psychologie industrielle 1971, París

A reas de interés: gestión de la seguridad; análisis de accidentes; diagnóstico de la seguridad; indicadores de seguridad

\section{J.S. Morawetz}

ICWU C enter for W orker H ealth \& Safety Education

329 R ace Street

Cincinnati, O hio 45202-3534, Estados U nidos

T el: 1 (513) 621-8882

Fax: 1 (513) 621-8247

E-mail: jsmora-

wetz@cwhse.cwhse-cn.ccmail.compuserve.com

Puesto(s) actual(es): Director, ICWU C enter for W orker $\mathrm{H}$ ealth and Safety Education

Puesto(s) anterior(es): Director, H ealth and Safety, International $\mathrm{M}$ olders and Allied W orkers U nion; E pidemic Intelligence Service 0 fficer, Industry W ide Structures Branch and $\mathrm{H}$ azard Evaluations Branch, $\mathrm{NIOSH}$

E studios: SCM , 1983, H arvard School of Public $\mathrm{H}$ ealth

\section{Vivian K. Morgan}

N ational Institute for O ccupational Safety and $\mathrm{H}$ ealth

4676 C olumbia Parkway

Cincinnati, O hio 45226-1998, Estados U nidos

T el: 1 (513) 533-8326

Fax: 1 (513) 533-8588

E-mail: ukm1@niosdj1.em.cdc.gou

Puesto(s) actual(es): C hief, T echnical Information Branch

E studios: BS, U niversity of C incinnati

A reas de interés: difución de la información

\section{W. G. Morison}

Morwil Inc

471 Bob-0-Link R oad

M ississauga, O N L5] 2P3, Canada

T el: 1 (905) 822-9183
Fax: 1 (905) 822-9183

Puesto(s) actual(es): President, M orwil Inc.

Puesto(s) anterior(es): V ice-President, D esign and Construction, $\mathrm{O}$ ntario $\mathrm{H}$ ydro; Director,

D esign and Development, O ntario $\mathrm{H}$ ydro

E studios: BSc, 1948, U niversity of Alberta; M Sc, 1948, Stanford U niversity

\section{Sharon L. Morris}

Continuing Education D epartment

University of W ashington

4225 R oosevelt Way NE

R oom 119

Seattle, WA 98105, Estados U nidos

Tel: 1 (202) 543-9540

Fax: 1 (202)685-3872

Puesto(s) actual(es): Senior Lecturer, A ssistant Chair for Community $\mathrm{O}$ utreach

Puesto(s) anterior(es): Special Assistant to Director, National Institute for $O$ ccupational Safety and H ealth; Lecturer, D epartment of Environmental H ealth, UW; L egislative Director, $\mathrm{N}$ ational Institute for $\mathrm{O}$ ccupational Safety and $\mathrm{H}$ ealth

E studios: BA, 1965, R eed College

\section{April E. Mott}

C onnecticut $C$ hemosensory $C$ linical $R$ esearch Center

University of $\mathrm{C}$ onnecticut $\mathrm{H}$ ealth $\mathrm{C}$ enter

263 Farmington A venue

Farmington, CT 06030-3705, Estados U nidos

Tel: 1 (860) 679-2459

Fax: 1 (860) 679-1383

E-mail: amott@neuron.uchc.edu

Puesto(s) actual(es): M edical Director; Assistant Professor

E studios: BA, 1975, Antioch College; M D, 1977, $M$ ichigan State U niversity

A reas de interés: trastornos de gusto y olfato síndrome de la boca quemada

\section{Sonia Muchnick-Baku}

W ashington Business $\mathrm{G}$ roup on $\mathrm{H}$ ealth

777 N Capitol Street NE Suite 800

W ashington, DC 20002, Estados U nidos

Tel: 1 (202) 408-9320

Fax: 1 (202) 408-9322

E-mail: muchnick@wbgh.com

Puesto(s) actual(es): D irector; A ssociate Faculty, Johns $\mathrm{H}$ opkins School of $\mathrm{H}$ ygiene and Public $\mathrm{H}$ ealth

Puesto(s) anterior(es): Senior $\mathrm{H}$ ealth Educator, $M$ aryland $D$ epartment of $\mathrm{H}$ ealth and $M$ ental $H$ ygiene; Director, Advocacy and Education, $\mathrm{M}$ ifflin Community $\mathrm{H}$ ealth Center, $\mathrm{M}$ adison, WI

E studios: BA, G rinnel C ollege; M A, U niversity of $W$ isconsin-M adison; $M S C$, Johns $\mathrm{H}$ opkins School of $\mathrm{H}$ ygiene and Public $\mathrm{H}$ ealth

A reas de interés: prestación de asistencia sanitaria en áreas rurales; mujeres y poblaciones culturalmente diferentes 


\section{Robert J. Mullan}

$\mathrm{N}$ ational Institute for $\mathrm{O}$ ccupational Safety and $\mathrm{H}$ ealth

1600 C lifton R oad

N.E. F-40

Atlanta, GA 30333, Estados U nidos

Tel: 1 (404) 639-1533

Fax: 1 (404) 639-3064

E-mail: rjml@nioodl.em.cdc.gov

Puesto(s) actual(es): M edical O fficer, H IV / AIDS Activity, $\mathrm{N}$ ational Institute for $O$ ccupational Safety and $\mathrm{H}$ ealth, C enters for D isease C ontrol and Intervention

Puesto(s) anterior(es): C hief, M edical Section, Surveillance Branch, Division of $\mathrm{H}$ azard Evaluations and Field Studies, $N$ ational Institute for O ccupational Safety and $\mathrm{H}$ ealth; Chief, Division of E pidemiology, $\mathrm{R}$ hode I sland D epartment of $\mathrm{H}$ ealth, E pidemic Intelligence Service 0 fficer, Centers for D isease Control

E studios: BS, 1973, U niversity of M innesota; M D, 1977, U niversity of M innesota

\section{Vladimir M. Munipov}

Departamento de Psicología

A cademia R usa de Enseñanza

8 Pogodinskaya UI.

H abitación 428

119905 M oscú, Federación R usa

T el: 70952468626

Fax: 70952468595

E-mail: acad@rae.msk.su

Puesto(s) actual(es): Profesor de ergonomía

Puesto(s) anterior(es): Subdirector, Instituto de Investigación de Diseño Industrial

E studios: M S, 1968, U niv. Estatal de M oscú

A reas de interés: ergonomía psicológica; diseño de máquinas orientado al hombre, entorno y software; modelos informatizados de entornos de trabajo

\section{Eva Munk-Madsen}

U niversidad de T romso

Facultad de Ciencias de la Pesca de N oruega

9037 T romso, N oruega

Tel: 4777646000

Fax: 4777646021

E-mail: evam@nfh.uit.no

Puesto(s) actual(es): Profesora

A reas de interés: mujeres en el sector pesquero; relación entre sexos; sector pesquero en países en vías de desarrollo; desarrollo sostenible en el sector pesquero

\section{Carles Muntaner}

Dept. of M ental $\mathrm{H}$ ygiene and Public $\mathrm{H}$ ealth Johns H opkins U niversity

624 Broadway

Baltimore, M D 21205, Estados U nidos Tel: 1 (301) 496-3383

Fax: 1 (301) 402-0601

E-mail: mutanec@irp.nimh.nih.gov

Puesto(s) actual(es): V isiting A ssociate, Instructor

E studios: M D, 1982, U niv. de Barcelona; PhD, 1985; M H S, 1992, Johns H opkins School of Public $\mathrm{H}$ ealth

A reas de interés: clases sociales; procesos de trabajo; salud mental; enfermedades cardiovasculares; epidemiología social

\section{Daniel Murphy}

$\mathrm{N}$ ational Authority for $\mathrm{O}$ ccupational Safety and $\mathrm{H}$ ealth

10 Hogan Place

Dublín 2, Irlanda

Tel: 35316620400

Fax: 35316620411

E-mail: dan@hsa.ie

Puesto(s) actual(es): Director, O ccupational M edical Services

Puesto(s) anterior(es): Industrial M edical O fficer, British Airways: Employment $M$ edical Adviser, British $\mathrm{H}$ ealth and Safety Executive; M edical O fficer, I rish Electricity Supply Board

E studios: M B, BCh, BAO ., 1965, U niversity College Dublin; D O bst. R COG, 1969 , R COG, Londres; DIH, 1971, Conjoint Board, Londres; FFO M , RCP, 1977, R oyal College Physicians I reland; FFO M, RCP, 1992, R oyal College Physicians, Londres

A reas de interés: trabajadoras embarazadas; recopilación de datos sobre enfermedades profesionales; procedimientos de vigilancia de la salud

\section{Dennis J. Murphy}

Pennsylvania State U niversity

221 A gricultural Engineering Building

U niversity Park, PA 16802, Estados U nidos

T el: 1 (814) 865-7157

Fax: 1 (814) 863-1031

E-mail: djm13@psu.edu

Puesto(s) actual(es): Professor, D epartment of Agricultural and Biological Engineering

\section{Lawrence R. Murphy}

Applied Psychology \& Ergon. Branch

$\mathrm{N}$ ational Institute of $\mathrm{O}$ ccupational Safety and

$\mathrm{H}$ ealth

R obert $T$ aft $L$ aboratories

4676 C olumbia Parkway M S-C 24

Cincinnati, O hio 45226-1998, Estados U nidos

T el: 1 (513) 533-8171

Fax: 1 (513) 533-8510

E-mail: Irm2@ niobbs1.em.cdc.gov

Puesto(s) actual(es): R esearch Psychologist

Puesto(s) anterior(es): R esearch Fellow,

Psychosomatic and Psychiatric Institute,

$M$ ichael R eese M edical C enter, Chicago, IL

E studios: M A, 1973, D ePaul U niversity; PhD 1975, D ePaul U niversity

A reas de interés: identificación de características de las organizaciones de trabajo sano; reducción de la exposición de los trabajadores al VIH y a otros patógenos de transmisión sanguínea

\section{Joshua Muscat}

American $\mathrm{H}$ ealth Foundation

320 East 43rd Street

N ueva Y ork, N ueva Y ork 10017, Estados Unidos

T el: 1 212-551-2530

Fax: 1212 687-2339

E-mail: jqm9937@is2.nyu.edu

Puesto(s) anterior(es): R esearch Analyst, $M$ emorial Sloan-K ettering $C$ ancer $C$ enter
E studios: M PH, 1985, Y ale U niversity

A reas de interés: emisiones de vehículos y cáncer del pulmón; campos electromagnéticos y cáncer cerebral

\section{Karl J. Musgrave}

W yoming State $\mathrm{H}$ ealth D epartment

$\mathrm{H}$ athaway Building

R oom 481

Cheyenne, WY 82002, Estados U nidos

Tel: 1 (307) 777-3657

Fax: 1 (307) 777-5402

E-mail: musgioiw@wonder.em.cdc.gov

Puesto(s) actual(es): State Chronic Disease Epidemiologist

Puesto(s) anterior(es): Epidemiologist, Division of R espiratory Disease Studies, N ational Institute for $O$ ccupational Safety and $\mathrm{H}$ ealth

E studios: BS, 1981, U niversity of C olorado; DV M , 1988, Colorado State U niversity; M PH , 1989, H arvard U niversity

A reas de interés: enfermedades transmitidas por animales en trabajadores agrícolas

\section{Melvin L. Myers}

National Institute for 0 ccupational Safety \& $\mathrm{H}$ ealth

CDC

O ffice of Extramural Coordination \& Special

Projects

1293 Berkeley R oad

A vondale Estates, G A 30002-1517, Estados

Unidos

Tel: 1 (404) 288-7085

Fax: 1 (404) 639-2196

E-mail: mlm2@cdc.gov

Puesto(s) actual(es): D eputy Director

Puesto(s) anterior(es): Special A ssistant to the Director, N ational I nstitute for $\mathrm{O}$ ccupational Safety and $\mathrm{H}$ ealth; Director, O ffice of Program Planning and Evaluation, $\mathrm{N}$ ational I nstitute for $O$ ccupational Safety and $\mathrm{H}$ ealth; T echnical Assistant to the D eputy A ssistant Director, O ffice of R esearch and Development, Environmental Protection Agency

E studios: BS, 1967, U niversity of I daho; M PA 1977, Indiana U niversity

A reas de interés: seguridad y salud en el sector agrícola; seguridad y salud en la construcción; política de salud ambiental y del trabajo; historia de la seguridad y la salud en el trabajo

\section{Friedhelm Nachreiner}

AE Arbeits- und O rganisationspsychologie U niversität O Idenburg FB 5-Psychologie Birkenweg 3

261110 ldenburg, Alemania

Tel: 494417988203

Fax: 494417988333

E-mail: nachreiner@psycho-

logie.uni.oldenburg.de

Puesto(s) actual(es): Profesor de psicología aplicada

E studios: Dr rer nat, 1974, U niversität K öln

A reas de interés: trabajo por turnos; carga de trabajo intelectual; supervisión 


\section{Pranab Kumar Nag}

Instituto Nacional de M edicina del T rabajo $M$ eghani $\mathrm{N}$ agar

A hmedabad 380-016, India

Tel: 91797867351

Fax: 91797866630

Puesto(s) actual(es): Científico, Subdirector

Puesto(s) anterior(es): Investigador jefe, D epartamento de ergonomía y fisiología ambiental

E studios: BSc, 1970, U niv. de Calcuta, India; M Sc, 1972, U niv. de Calcuta, India; PhD, 1977, U niv. de Calcuta, India; DSc, 1991, U niv. de Calcuta, India

A reas de interés: macroergonomía y diseño de organizaciones; antropometría; biomecánica y fisiología ambienta

\section{Daniel W. Nebert}

U niversity of C incinnati M edical C enter 3223 Eden Avenue

Cincinnati, O hio 45267-0056, Estados U nidos T el: 1 (513) 558-0155

Fax: 1 (513) 558-0925

E-mail: dan.nebert@uc.edu

Puesto(s) actual(es): Director, C enter for Environmental G enetics; Professor of Pediatrics, $\mathrm{H}$ ead

Puesto(s) anterior(es): Adjunct Professor, US Coordinator of US-C hina M edica G enetics Program, N ational Institute of $\mathrm{C}$ hild $\mathrm{H}$ ealth and $\mathrm{H}$ uman $\mathrm{D}$ evelopment, $\mathrm{NIH}$

E studios: BA, 1959, W esleyan U niversity, C onnecticut; M S, U niversity of 0 regon M edical School; M D, 1964, U niversity of $O$ regon Portland

A reas de interés: diferencias genéticas en la propensión a la intoxicación o el cáncer causados por sustancias químicas ambientales y drogas

\section{Carolyn E. Needleman}

Graduate School of Social W ork \& Social R esearch

Bryn M awr College

300 Airdale R oad

Bryn M awr, PA 19010-2899, Estados U nidos

Tel: 1 (610) 520-2633

Fax: 1 (610) 520-2655

E-mail: cneedle@brynmawr.edu

Puesto(s) actual(es): Professor, Director, O ccupational/ Environmental $\mathrm{H}$ ealth Program

Puesto(s) anterior(es): Director, D octoral Program in Social Work

E studios: PhD, 1978, W ashington U niversity in St. Louis

A reas de interés: aspectos sociales de la seguridad y la salud en el trabajo; políticas de salud pública; comunicación de riesgos; notificación de trabajadores de alto riesgo; envenenamiento por plomo en la infancia; investigación de la intervención

\section{Barbara Neis}

Department of Sociology

$M$ emorial U niversity

St. Johns, N ewfoundland A1C 557, Canadá
Tel: 1709 737-4592

Fax: 1709 737-2075

E-mail: bneis@morgan.ucs.mun.ca

Puesto(s) actual(es): Associate Professor and $\mathrm{H}$ ead, D epartment of Sociology

E studios: BA, 1976, Y ork U niversity, T oronto; M A, 1980, M emorial U niversity, St. Johns; PhD, 1988, U niversity of T oronto

A reas de interés: salud en el trabajo de la mujer en procesamiento de pescado; conocimiento ecológico y ciencia pesquera; factores de salud y sexo; política económica del sector pesquero

\section{Debra L. Nelson}

D epartment of $M$ anagement

College of Business A dministration

O klahoma State U niversity

Stillwater, OK 74078, Estados U nidos

Tel: 1 (405) 744-5106

Fax: 1 (405) 744-5180

E-mail: dln0802@okway.okstate.edu

Puesto(s) actual(es): Professor of $M$ anagement, CBA Associates Professor

E studios: BBA, 1978, T exas T ech U niversity; M BA, 1981, U niversity of T exas at A rlington; PhD, 1985, U niversity of T exas at A rlington

A reas de interés: gestión del estrés (laboral y organizativo); integración del recién llegado

\section{Thomas J. Nelson}

\section{NIHSInc.}

2401 East $M$ all

Ardentown, DE 19810, Estados U nidos

T el: 1 (302) 475-6244

Fax: 1 (302) 475-6245

E-mail: 73374,2144@ compuserve.lom

E studios: BS, 1967, U niversity of D elaware

A reas de interés: protección respiratoria; evaluación del riesgo

\section{Christian E. Newcomer}

U niversity of N orth Carolina

CB \#7115

B-12 Berryhill

Chapel H ill, NC 27599-7115, Estados U nidos

Tel: 1919 966-3113

Fax: 1919 966-0291

E-mail: cnewcome@med.unc.edu

Puesto(s) actual(es): Director and R esearch Associate Professor, Laboratory Animal $M$ edicine, School of M edicine

Puesto(s) anterior(es): Director, Division of L aboratory A nimal M edicine, T ufts-N ew England M edical Center, Boston, M A; Director and R esearch Scientist, Division of $C$ omparative $M$ edicine, $M$ assachusetts Institute of T echnology, Cambridge, M A

E studios: BS, 1973, U niversity of M ichigan; V M D, 1977, U niversity of Pennsylvania; M S, 1981, U niversity of M ichigan

A reas de interés: enfermedades infecciosas espontáneas e inducidas en animales de laboratorio; zoonosis; gnotobiótica; identificación del riesgo y control instalaciones con animales para la investigación

\section{Bodil Nielsen}

Instituto August K rogh

U niversidad de C openhague

13 U niversitetsparken

2100 C openhague $\varnothing$, D inamarca

Tel: 4535321620

Fax: 4535321567

E-mail: bnielsen@aki.ku.dk

Puesto(s) actual(es): Profesora asociada, Directora

E studios: Cand mag, 1959, U niv. de Copenhague; Dr Phil, 1969, Univ. de Copenhague

A reas de interés: regulación de la temperatura de las personas durante el trabajo; contro ambiental térmico de la circulación y la sudoración; agua y equilibrio electrolítico

\section{Gunnar Nordberg}

Departamento de M edicina A mbiental

U niversidad de U meå

S-901 87 U meå, Suecia

T el: 4690102727

Fax: 4690779630

E-mail: gunnar.nordberg@envmed.umu.se

Puesto(s) actual(es): Profesor y director

Puesto(s) anterior(es): Profesor y director,

D epartamento de M edicina A mbiental, U niv. de 0 dense

E studios: PhD , 1972, Instituto K arolinska; M D, 1977, Instituto K arolinska

A reas de interés: toxicología y epidemiología de metales

Jacqueline Nubé

Departamento de Psicología

Facultad de M etodología

R oeterstraat 15

1018 W B Amsterdam, Países Bajos

Tel: 205256870

Fax: 206390026

E-mail: ml.dorman@macmail.psy.uva.nl

Puesto(s) actual(es): Investigadora asociada en el D epartamento de Psicología, Facultad de M etodología, U niv. de A msterdam

Puesto(s) anterior(es): Profesor invitado en Japón, Lationamérica y países europeos en materia de inhibidores beta, pánico escénico en músicos; Coordinador/Delegado, Proyecto E uropeo de Investigación E ducativa, Univ. de Amsterdam; Consejero estudiantil/ Profesor de música

E studios: PhD, 1995, U niv.de A msterdam; Drs, 1987, U niversidad de Amsterdam; BSc, 1987, U niv.de A msterdam; M A, 1983, Conservatorio de Alkmaar, Países Bajos

A reas de interés: investigación multidisciplinar sobre los efectos de los inhibidores beta y otras drogas en artes escénicas, estrés, pánico escénico, etc.

\section{Helen Nugent}

Adobe $C$ reative Inc

133 Parkhurst Blvd.

Toronto, O N M 4G 2E8, Canadá

Tel: 1 (416) 696-1910

Fax: 1 (416) 896-2776

Puesto(s) actual(es): G eneral M anager 


\section{Sarah A. Nunneley}

Armstrong Laboratory

Brooks Air Force Base, TX 78235-5302, Estados

Unidos

Tel: 1 (210) 536-3814

Fax: 1 (210) 536-2761

E-mail:

nunneley.kirk.decnet@hsdd3.brooks.af.mil

Puesto(s) actual(es): R esearch Physician

Puesto(s) anterior(es): Assistant Professor of Physiology, State U niversity of N ew Y ork at Buffalo

E studios: BA, 1963, M ount H olyoke College; M D, 1967, U niversity of M innesota; M S, 1970, O hio State U niversity

A reas de interés: reacciones fisiológicas al calor, el frío, el ejercicio, la altitud y la aceleración

\section{David A. O'Malley}

Diamond Environmental Ltd.

Archway H ouse

Station R oad

Chester CH 1 3DW, R eino U nido

Tel: 44244311440

Fax: 44244315752

Puesto(s) actual(es): M anaging Director

E studios: BSc, 1974, U niversity of W arwick; M Sc, 1976, U niversity of M anchester

\section{Isaac Obadia}

O ficina Internacional del T rabajo

4 route des $M$ orillons

1211 Ginebra 22, Suiza

T el: 41227996746

Fax: 41227996878

E-mail: obadia@ilo.ch

Puesto(s) actual(es): Director de Salud y Seguridad

E studios: C iencas aplicadas, tecnología de polímeros, 1970, R yezson Polytechnical Institute, T oronto

A reas de interés: seguridad de sustancias químicas; ética relacionada con la difusión de la información sobre salud y seguridad en el trabajo

\section{Tokuo Ogawa}

D epartamento de Fisiología

U niv. de M edicina de Aich

Nagakute, Aichi 480-11, Japón

T el: 81561623311

Fax: 81561639809

Puesto(s) actual(es): Profesor emérito, profesor visitante

Puesto(s) anterior(es): Profesor, Director del Depart. de Fisiología de la U niv.de M edicina de Aichi

E studios: M D, 1953, Facultad de M edicina, U niv. de Nagoya; PhD, 1960, U niv. de Nagoya

A reas de interés: fisiología y patofisiología de la sudoración; regulación térmica en los ancianos durante el trabajo y el ejercicio

\section{Toshiteru Okubo}

D epartamento de E pidemiología A mbiental U niversidad de Salud A mbiental y del T rabajo Instituto de C iencias E cológicas I ndustriales 1-1 I seigaoka
Y ahatanishi-ku

K itakyushu City 807, Japón

Tel: 81936917401

Fax: 81936017324

E-mail: okubo001@med.uoeh-u.ac.jp

Puesto(s) actual(es): Profesor, Director, D epartamento de Epidemiología Ambiental

Puesto(s) anterior(es): Profesor asociado, Facultad de M edicina Jichi; Profesor, Facultad de M edicina, U niv. K eio

E studios: M D, 1967, U niv. K eio; Dr M ed Sc, 1978, U niv. K eio

A reas de interés: epidemiología del trabajo; desarrollo de indicadores de salud; educación y práctica de la salud laboral

\section{Hulda Ólafsdóttir}

Administración de Salud y Seguridad en el Trabajo

D epartamento de M edicina del T rabajo

PO Box 12220

132 R eikiavik, Islandia

Tel: 3545672500

Fax: 3545674086

E-mail: hulda@ver.is

Puesto(s) actual(es): Fisioterapeuta

E studios: Fisioterapia, 1980

A reas de interés: ergonomía; industria del procesado de pescado; movimientos repetitivos

\section{Gary W. Olmstead}

General Mills

$1 \mathrm{G}$ eneral M ills Boulevard

M inneapolis, M N 55426, Estados U nidos

T el: 1612 540-2400

Fax: 1612 540-4878

Puesto(s) actual(es): Director, Safety and Environmental $M$ anagement

\section{Edward A. Olmsted}

O Imsted Environmental Services

R R 1 Box 480

Garrison, N ueva Y ork 10524, Estados U nidos

T el: 1914 424-4077

Fax: 1914 424-3482

E-mail: oesenv@aol.com

Puesto(s) actual(es): President, 0 Imsted Environmental Services

Puesto(s) anterior(es): Associate Director, Environmental H ealth and Safety, Columbia U niversity

E studios: BA; M S

A reas de interés: calidad del aire en interiores, higiene industrial; seguridad

\section{Shauna Olney}

R ama de Libertad de A sociación

O ficina Internacional del Trabajo

4 route des $M$ orillons

1211 G inebra 22, Suiza

T el: 41227998083

Fax: 41227997670

Puesto(s) actual(es): Director jurídico

\section{E.N. Orlov}

Departamento de Seguro Social

$M$ inisterio de Trabajo

103706 M oscú, Federación R usa
Puesto(s) actual(es): I efe, D epartamento de Seguro Social, M inisterio de T rabajo, Federación R usa

Peter Orris

Division of $O$ ccupational M edicine

Cook County H ospital

720 S. W olcott

Chicago, Illinois 60612, Estados U nidos

Tel: 1 (312) 633-5310

Fax: 1 (312) 633-6442

E-mail:porris@uic.edu

Puesto(s) actual(es): A ssociate Professor of M edicine, U niversity of Illinois; Attending Physician

Puesto(s) anterior(es): R esearch Director, G reat $L$ akes $C$ enter for $O$ ccupational and Environmental Safety and $\mathrm{H}$ ealth, U niversity of Illinois School of Public $\mathrm{H}$ ealth; M edical D irector, Corporate $\mathrm{H}$ ealth Services, N orthwest Community H ospital

Estudios: AB, 1967, $\mathrm{H}$ arvard C ollege; $\mathrm{M} \mathrm{PH}$ 1970, Y ale School of Public H ealth; M D 1975, C hicago M edical School, U niversity of $\mathrm{H}$ ealth Sciences

A reas de interés: estrés; salud y seguridad en bomberos; asma ambiental y laboral

\section{Kristina Orth-Gomér}

Instituto N acional de Factores Psicosociales y Salud

Box 230

17177 Estocolmo, Suecia

T el: 4687286955

Fax: 468301123

Puesto(s) actual(es): Profesora

Puesto(s) anterior(es): Profesora ayudante, U nidad para la Investigación de Factores del M edio A mbiente Social y la Salud; Investigadora adjunta, Consejo Sueco de Investigación $\mathrm{M}$ édica

E studios: M D, 1972, Instituto K arolinska, Estocolmo; PhD, 1979, Instituto $\mathrm{K}$ arolinska, Estocolmo; especialista en M edicina interna, 1980, Instituto K arolinska

A reas de interés: estrés en el trabajo; apoyo social; salud de la mujer; enfermedades del corazón

\section{Dave W. Ortlieb}

U nited Paperworkers International U nion P.O. Box 1475

Nashville, TN 37202, Estados U nidos

Tel: 1 (615) 834-8590

Fax: 1 (615) 833-9332

Puesto(s) actual(es): D irector, Safety and $\mathrm{H}$ ealth D epartment

Puesto(s) anterior(es): D irector, $\mathrm{H}$ ealth and Safety D epartment, Allied Industrial W orkers of A merica, W isconsin; D irector, $\mathrm{H}$ ealth and Safety D epartment, International C hemical W orkers U nion, O hio; $\mathrm{O}$ ccupational Safety and $\mathrm{H}$ ealth R esearch Consultant, W isconsin D epartment of Industry Labor and $H$ uman R elations, M adison

E studios: BS, 1974, State U niversity C ollege at Buffalo, N ueva Y ork 
A reas de interés: salud y seguridad ambiental y del trabajo

\section{George R. Osborne}

Lucent T echnologies

2000 NE Expressway

Norcross, GA 30071, Estados U nidos

Tel: $1770798-3654$

Fax: 1770 798-3296

E-mail: georgeosborne@lucent.com

Puesto(s) actual(es): Industrial $\mathrm{H}$ ygiene $\mathrm{M}$ anager

Puesto(s) anterior(es): H ouston Lighting and

Power; C elanese $\mathrm{C}$ hemical; Babcock and Wilcox

E studios: BS, 1965; M S, 1976

A reas de interés: fibra óptica; toxicología; acústica

\section{Debra Osinsky}

332 Summit Place

$\mathrm{H}$ ighland Park, NJ 08904, Estados U nidos

Tel: 1908 247-6515

E-mail: bamoore@ rci.rutgers.edu

Puesto(s) actual(es): Editorial C onsultant, Encyclopaedia of $\mathrm{O}$ ccupational $\mathrm{H}$ ealth and Safety

Puesto(s) anterior(es): Director, R ight-to-K now T raining Program, D istrict Council 37, AFSCME, N ueva Y ork, NY

E studios: M PH , 1984, Columbia U niversity School of Public H ealth

A reas de interés: medicina del trabajo; salud en el ámbito comunitario

\section{Gerald Ott}

BASF Corporation

3000 C ontinental D rive N orth

M ount O live, NJ 07828-1234, Estados U nidos

T el: 1 (201) 426-6997

Fax: 1 (201) 426-6894

E-mail: ottm@basf.com

Puesto(s) actual(es): Director of E pidemiology

Puesto(s) anterior(es): Senior Consultant, Arthur D. Little, Inc.; Director of E pidemiology, U nion Carbide Corporation; R esearch L eader, The D ow Chemical Company

E studios: BSc, 1964, U niversity of W yoming: MS, 1965, U niversity of W yoming; PhD, 1982, U niversity of M ichigan

A reas de interés: epidemiología industrial; evaluación de la exposición, empleo de las pruebas humanas en la evaluación cuantitativa del riesgo

\section{Heinz Otten}

Abteilung A rbeitsmedizin $\mathrm{H}$ auptverband der gewerblichen Berufsgenossenschaften e. V

Alte $H$ eerstrassel11

53754 Sankt Augustin, Alemania

T el: 492241231370

Fax: 492241231333

Puesto(s) actual(es): Jefe

Puesto(s) anterior(es): Investigador ayudante, O ficina Federal de Salud, Berlín; Investigador ayudante, Departamento de M edicina de la U niv.de Bonn
E studios: Dr rer nat Psychologist, 1991, Universidad de T rier

A reas de interés: medicina del trabajo; prevención; detección temprana de la enfermedad; radiación ionizante; vibración por ruido; fibras

\section{Suzanne C. Ouellette}

The G raduate School U niversity Center

$\mathrm{T}$ he $\mathrm{C}$ ity $U$ niversity of N ew Y ork

33 W est 42nd Street

N ueva Y ork, N ueva Y ork 10036, Estados Unidos

T el: 1 (212) 642-2532

Fax: 1 (212) 642-1922

E-mail: sco@cunyvmsl.gc.cuny.edu

Puesto(s) actual(es): Professor

Puesto(s) anterior(es): Program H ead, Social/ Personality Psychology Faculty, $U$ niversity of $\mathrm{C}$ hicago

E studios: PhD, 1977, U niversity of C hicago

A reas de interés: personalidad y salud; psicología de la religión; desarrollo adulto; estrés laboral con relación al SIDA; voluntariado

\section{Muneto Ozaki}

O ficina Internacional del Trabajo (LEG/REL)

4 route des $M$ orillons

1211 G inebra 22, Suiza T el: 41227998655

\section{Freda L. Paltie}

20 D riveway \#204

Ottawa, O N K 2P 1C8, Canadá

Tel: 1 (613) 234-9167

Fax: 1 (613) 234-9167

Puesto(s) actual(es): C onsultant, $\mathrm{H}$ ealth and Social Policy;

Puesto(s) anterior(es): Senior Adviser, Status of Women, $\mathrm{H}$ ealth and W elfare, Canada; C oordinator, Status of W omen, Privy Council O ffice, Canada

E studios: BA, 1945, Q ueen's U niversity, K ingston; BSW, 1949, M cG ill U niversity; M PH, H adassah-H ebrew U niversity School of Public $\mathrm{H}$ ealth and Community M edicine

A reas de interés: salud y desarrollo de la mujer; reconversión y sus consecuencias en política social y salud; aspectos psicosociales de la salud

\section{Sheila Pantry}

Sheila Pantry Associates-Information Services Consultancy

$85 \mathrm{~T}$ he $\mathrm{M}$ eadows

Todwick

Sheffield S31 0J G, R eino U nido

T el: 441909771024

Fax: 441909772829

\section{Jon K. Parish}

The Lane Corporation

Box 151

E. Franklin A venue

Altavista, V A 24517-0151, Estados U nidos T el: 1 (804) 369-3675

Fax: 1 (804) 369-3644
Puesto(s) actual(es): Director, Loss Control and Environment

E studios: BBA

\section{John E. Parker}

N ational Institute for O ccupational Safety and $\mathrm{H}$ ealth

1095 Willowdale R oad

M organtown WV 26505-2888, Estados U nidos

Tel: 1 (304) 285-5724

Fax: 1 (304) 285-5861

E-mail: jep@ niords1.em.cdc.gov

Puesto(s) actual(es): C hief, Examination Processing Branch, DRDS, N ational Institute for $O$ ccupational Safety and $\mathrm{H}$ ealth; Adjunct A ssociate Professor, W est $V$ irginia U niversity School of M edicine

Puesto(s) anterior(es): D eputy $C$ hief, D ept. of M edicine, USPH S H ospital, San Francisco, CA; Clinical Director (Chief of Staff), U SPH S Indian H ospital, Whiteriver, $A Z$

E studios: M D, 1976, W ayne State U niversity

A reas de interés: radiografía de tórax para el reconocimiento de la neumoconiosis; estrategias de prevención de la neumoconiosis; exploración y vigilancia de trabajadores expuestos a polvo; enfermedades por polvos orgánicos

\section{Kenneth C. Parsons}

D epartment of H uman Sciences

L oughborough U niversity of T echnology

L oughborough L eicester LE 11 3T U, R eino Unido

Tel: 441309223023

E-mail: k.c.parsons@lboro.ac.uk

Puesto(s) actual(es): Senior Lecturer in Climatic Ergonomics

E studios: BSc, 1974, L oughborough U niversity; PGCE, 1975, C ambridge U niversity; PhD, 1980, Southampton U niversity

A reas de interés: estrés por calor; confort térmico; estrés por frío; función térmica de la ropa; modelos de regulación térmica en el hombre

\section{Timo Partanen}

Agencia Internacional para la Investigación sobre el Cáncer

150 cours Albert-T homas

69372 Lyon C edex 08, Francia

T el: 3372738485

Fax: 3372738575

E-mail: boffetta@ friarc51.bitnet

\section{Relford E. Patterson}

$O$ ffice of the A ssistant Secretary of Defense/ $\mathrm{H}$ ealth Affairs

R oom 3D 366

1200 D efense Pentagon

W ashington, DC 20301, Estados U nidos T el: 1 (703) 695-7116

Fax: 1 (703) 693-2548

E-mail: rpatters@ha.osd.mil

Puesto(s) actual(es): C olonel, USAF, M C ; D eputy Director, Scientific Activities, Clinical Services 
Puesto(s) anterior(es): O ccupational M edicine Consultant, $O$ ffice of the Surgeon G eneral, U nited States Air Force; Assistant Professor and Director, Environmental and $\mathrm{O}$ ccupational $\mathrm{H}$ ealth Division, D epartment of Preventive $M$ edicine and Biometrics, U niformed Services; Assistant Director, A eromedical Services, M alcolm G row USAF M edical Center, Andrews Air Force Base

E studios: M D, 1978, G eorgetown U niversity M edical School; M PH, 1986, Johns $\mathrm{H}$ opkins U niversity; R esidency in A erospace $M$ edicine, 1987, USAF School of Aerospace $M$ edicine, Brooks AFB, TX

A reas de interés: prevención y control de lesiones; vigilancia médica para operaciones militares

\section{Jonathan A. Patz}

Johns $\mathrm{H}$ opkins School of $\mathrm{H}$ ygiene and Public $\mathrm{H}$ ealth

$615 \mathrm{~N}$ Wolfe St.

R oom 7041

Baltimore, M D 21205-2179, Estados U nidos

Tel: 1 (410) 955-4130

Fax: 1 (410) 955-1811

E-mail: jpatz@phnet.sph.jhu.edu

Puesto(s) actual(es): R esearch Associate

E studios: M D, 1987, C ase W estern R eserve, School of M edicine; M PH , 1992, Johns $\mathrm{H}$ opkins $\mathrm{School}$ of $\mathrm{H}$ ygiene and Public $\mathrm{H}$ ealth

A reas de interés: cambio climático global y enfermedades infecciosas; evaluación integrada del riesgo

\section{Edna Paulson}

Library of the A merican Petroleum Institute 1220 L Street NW

W ashington, DC 20005, Estados U nidos T el: 1 (202) 682-8040

Fax: 1 (202) 682-8232

E-mail: aplib @ cais.com

\section{Glenn Paulson}

Paulson and Cooper, Inc. PO Box 1541

Jackson H ole, WY 83001-1541, Estados U nidos

Tel: 1 (307) 734-0350

Fax: 1 (307) 734-0248

E-mail: compu serve74403,3330

Puesto(s) actual(es): President

Puesto(s) anterior(es): R esearch Professor, Illinois Institute of T echnology; V ice-President, Clean Sites, Inc.; Senior V ice-President, $\mathrm{N}$ ational Audubon Society

E studios: BA, 1963, N orthwestern U niversity; PhD, 1970, R ockefeller U niversity

A reas de interés: materiales y residuos peligrosos y radiactivos (técnicas, reglamentos y políticas); riesgos laborales de las tecnologías ambientales

\section{Dennis J. Paustenbach}

Chem Risk ${ }^{\circledR}$

1135 Atlantic Avenue

Alameda CA 94501, Estados U nidos

Tel: 1 (510) 521-5200
Fax: 1 (510) 521-1547

Puesto(s) actual(es): V ice-President, Chief Technical 0 fficer

E studios: Chem Eng, 1974, R ose-H ulman; M S 1977, U niversity of M ichigan; M S, 1978, Indiana State U niversity; PhD, 1982. Purdue U niversity

\section{Neil Pearce}

W ellington School of M edicine

P.0. Box 7343

W ellington, Nueva Zelanda

Tel: $6443855999 \times 6845$

Fax: 6443895427

E-mail: neil@wnmeds.ac.n2

Puesto(s) actual(es): Associate Professor, W ellington Asthma R esearch G roup

Puesto(s) anterior(es): Biostatistician, D epartment of Community H ealth, WSM , N.Z Lecturer in Epidemiology, Department of Community H ealth, WSM, N.Z.

E studios: PhD

\section{Gerald F. Peedin}

N orth Carolina State U niversity

Crop Science D epartment

Box 7620

Raleigh, NC 27695, Estados U nidos

Tel: 1 (919) 515-4058

Fax: 1 (919) 515-7959

E-mail: gpeedin@wolf.ces.ncsu.edu

Puesto(s) actual(es): Philip M orris Professor

E studios: PhD

\section{Daniela Pelclová}

Clínica de Enfermedades Profesionales U niversidad $\mathrm{C}$ arlos de Praga Vysehradská 49

12821 Praga, R epública C heca

Tel: 422293868

Fax: 422293868

Puesto(s) actual(es): J efa de departamento

Puesto(s) anterior(es): I efa del Centro de Información Toxicológica

E studios: M D , 1978, Facultad de M edicina, U niv.Carlos de Praga; especialización en M edicina Interna, 1982, U niv.C arlos de Praga; PhD, 1990, U niv. Carlos de Praga; especialización en M edicina del Trabajo, 1991, U niv. Carlos de Praga

A reas de interés: toxicología del trabajo; genotoxicidad

\section{Peter L. Pelmear}

$\mathrm{O}$ ccupational and Environmental $\mathrm{H}$ ealth

St. M ichael's H ospital

30 Bond Street

Toronto, ON M 5B 1W8, Canadá

Tel: 1 (416) 867-7470

Fax: 1 (416) 864-5870

Puesto(s) actual(es): Active Staff Consultant; Associate Professor, U niversity of Toronto

Puesto(s) anterior(es): Senior M edical O fficer GK N, UK ; Director, Chief Physician, $\mathrm{O}$ ccupational $\mathrm{H}$ ealth Branch, $\mathrm{M}$ inistry of Labour, T oronto
E studios: M BBS, 1951, G uy's H ospital, U niversity of L ondon; M D, 1974, U niversity of L ondon; FFO M , 1982. Faculty of $O$ ccupational $M$ edicine, $R$ oyal College of Physicians, L ondon

A reas de interés: diagnóstico y tratamiento del síndrome de vibraciones mano-brazo

\section{Edith Perlebach}

$\mathrm{H}$ auptverband der gewerblichen Berufsgenossenschaften (H V BG

Alte $\mathrm{H}$ eerstrasse 111

53754 Sankt Augustin, Alemania

Tel: 492241231300

Fax: 492241231333

\section{Debra A. Perry}

Perry, W inans and Company

4801 Connecticut Av. \#906

Washington, DC 20008, Estados U nidos

Tel: 1 (202) 364-0623

Fax: 1 (202) 237-2065

E-mail: debwin@aol.com

Puesto(s) actual(es): President

Puesto(s) anterior(es): Experto en rehabilitación profesional, O ficina Internacional del Trabajo; National PWI Coordinator, Goodwill Industries, International; Independant Consultant

E studios: M Ed, A uburn U niversity

A reas de interés: rehabilitación internacional; colocación de personas con discapacidades; participación de empresarios y sindicatos en procesos de rehabilitación

\section{Dan Petersen}

1909 E. La V ieve Lane

Tempe, AZ 85284, Estados U nidos

T el: 1 (602) 838-8908

Fax: 1 (602) 831-8155

Puesto(s) actual(es): President, DPA Inc

Puesto(s) anterior(es): Professor, A rizona State U niversity; A ssistant V ice-President, Industrial Indemnity; Director, Loss Control, All State Insurance, N ationwide Insurance; Director of T raining, Employees Insurance

E studios: BS, 1952, I owa State U niversity; M S 1972, U niversity of N ebraska; EPD, 1980, C olorado U niversity

A reas de interés: gestión de la seguridad

\section{Edward L. Petsonk}

Division of R espiratory D isease Studies $\mathrm{N}$ ational Institute of $\mathrm{O}$ ccupational Safety and $\mathrm{H}$ ealth

1095 W illowdale R oad

M organtown, WV 26505-2888, Estados U nidos

Tel: 1 (304) 285-5714

Fax: 1 (304) 285-5861

E-mail: elp@niordsl.em.cdc.gov

Puesto(s) actual(es): C hief, Clinical Section

Puesto(s) anterior(es): A ssociate Professor of $M$ edicine, W est $V$ irginia U niversity School of M edicine

E studios: M D, CM 1973, M cG ill U niversity

A reas de interés: hipersensibilidad a corrientes de aire; asma de origen profesional 


\section{Hans-Ulrich Pfeffer}

$L$ andesumweltamt des $L$ andes

N ordrhein-W estfalen

Wallneyerstrasse 6

45133 Essen, Alemania

Tel: 492017995264

Fax: 492017995575

Puesto(s) actual(es): Jefe del Control de Contaminación A tmosférica

E studios: Dr, 1977 U niversidad de M ünster

A reas de interés: contaminantes del aire; contaminación atmosférica; educación en materia de salud ambiental; toxicología clínica; calidad del aire en interiores

\section{Wai-on Phoon}

U niversity of Sydney

PO Box 818

Pymble N SW 2073, Australia

Tel: 6123705152

Fax: 6124408961

Puesto(s) actual(es): Professor,H ead, D epartment of $\mathrm{O}$ ccupational $\mathrm{H}$ ealth

Puesto(s) anterior(es): Acting Director, $\mathrm{N}$ ational Institute of $\mathrm{O}$ ccupational $\mathrm{H}$ ealth and Safety, Australia; Director, Professional Education Program, W orksafe A ustralia Chair, ILO/ WHO Joint Expert Committee on $\mathrm{O}$ ccupational $\mathrm{H}$ ealth Senior M edical O fficer, Shell International Petroleum Ltd.

E studios: $M B, B S$, U niversity of $M$ alaya; $F R C P$, Londres, UK ; FFOM , DIH and DCH., UK; FFPH M, UK; FRACP, H on FAFOM and FAFRM, Australia

A reas de interés: educación en materia de salud en el trabajo; salud y seguridad en el trabajo en pequeñas industrias; toxicología clínica; calidad del aire en interiores

\section{Peter Pickeril}

M SA International

121 Gamma D rive

Pittsburgh, PA 15238, Estados U nidos

T el: 14129673345

Fax: 14129673476

E-mail: peterpickerill@ msanet.com

Puesto(s) actual(es): R egional Director, Asia and Australia

Puesto(s) anterior(es): President, M SA C anada, Inc.

Estudios: BSC, 1965, U niversity of M anchester. UK: M .Eng, 1974, Concordia University, M ontreal, C anada; M BA, 1984, U niversity of T oronto

\section{Simon Pickvance}

Sheffield O ccupational $\mathrm{H}$ ealth Project

M udford's Buildings

37 Exchange Street

Sheffield S2 5T R, R eino U nido

Tel: 441142755760

Fax: 441142767257

Puesto(s) actual(es): O ccupational $\mathrm{H}$ ealth Advisor

Puesto(s) anterior(es): Senior R esearch Fellow,

Centre for $O$ ccupational and

Environmental H ealth Policy R esearch,

De M ontfort U niversity, L eicester

E studios: BA
A reas de interés: servicios de salud en el trabajo comparados; salud en el trabajo en la asistencia primaria; salud y seguridad en trabajadores del acero

\section{Lou Piombino}

Lipton

800 Sylvan A venue

Englewood Cliffs, NJ 07632, Estados U nidos T el: 1201 894-7723

Puesto(s) actual(es): $\mathrm{M}$ anager, Safety, $\mathrm{H}$ ealth and Environmental

Estudios: BS

\section{Chaya S. Piotrkowski}

Graduate School of Social Service

Fordham U niversity

$113 \mathrm{~W}$. 60th Street

N ueva Y ork, Nueva Y ork 10023-7479, Estados Unidos

T el: 1 (212) 636-6652

Fax: 1 (212) 636-7876

E-mail: drcsp@aol.com

Puesto(s) actual(es): Professor; V isiting R esearch Scientist, $Y$ ale U niversity

Puesto(s) anterior(es): Director, NCJW Center for the Child, Nueva Y ork; A ssociate Professor, St. John's U niversity, Jamaica, NY; A ssistant Professor. Y ale U niversity, $\mathrm{N}$ ew $\mathrm{H}$ aven, CT ; Assistant Professor, Graduate Faculty of the $\mathrm{N}$ ew School for Social R esearch

E studios: BA, 1969, U niversity of California-Berkeley; PhD, 1977, U niversity of M ichigan

A reas de interés: trabajo y familia; salud en el trabajo en mujeres trabajadoras; trabajo de menores y empleo juvenil

\section{Thomas W. Planek}

$N$ ational Safety Council

1121 Spring Lake D rive

I tasca, Illinois 60143, Estados U nidos

T el: 1 (708) 775-2324

Fax: 1 (708) 285-0242

Puesto(s) actual(es): Director, R esearch and Statistical Services

Puesto(s) anterior(es): Director, Planning and O rganizational D evelopment

E studios: PhD, 1965, Loyola U niversity, Chicago

A reas de interés: evaluación de la efectividad aplicada; evaluación de necesidades en organizaciones de los sectores público y privado; diseño de la actitud del empleado; sondeos para determinar la eficacia de la seguridad en el trabajo; sistemas de gestión de la salud

\section{James W. Platner}

Cornell U niversity

Industrial and Labor R elations

90 State Street \#600

Albany, N ueva Y ork 12207, Estados U nidos T el: 1518 449-41461

Fax: 1518 426-0643

E-mail: jp42@ cornell.edu

E studios: PhD, U niversity of R ochester

A reas de interés: desarrollo global de la higiene en el trabajo; recursos humanos y sistemas de información para médicos; estructuras organizativas y políticas para la aplicación de sistemas de control y anticipación del riesgo

\section{Becky Plattus}

U nion of N eedletrades, Industrial and T extile Employees

218 W. 40 Street

Nueva Y ork, Nueva Y ork 10018, Estados

Unidos

Tel: $1212730-7500$

Fax: 1212 840-0475

E-mail: bplat@uniteunion.org

Puesto(s) actual(es): Political Education Director, Local 89-22-1

Puesto(s) anterior(es): Co-Director, $\mathrm{H}$ ealth and Safety Department, U nion of N eedletrades, Industrial and T extile Employees

\section{Gustav Poinsting}

V erkehrs-Arbeitsinspektorat

Bundesministerium für öffentliche W irtschaft und Verkehr

R adetzkystrasse 2

$1031 \mathrm{~V}$ iena, Austria

Tel: 431711624400

Fax: 431711624499

Puesto(s) actual(es): Leiter der G ruppe V erkehrs-Arbeitsinspektorat

Puesto(s) anterior(es): R eferatsleiter und Leiter der Sicherheitstechnik der österreichischen Post- und T elegraphenverwaltung

E studios: Ing, Nachrichtentechnik, $\mathrm{H}$ öhere T echnische Lehranstalt; Dipl Ing, T echnische Physik, T echnische U niversität W ien

A reas de interés: Arbeitnehmerschutz; G esundheitsprävention; V erkehrswesen

Tessa M. Pollard

Department of Anthropology

U niversity of D urham

143 O Id Elvet

Durham DH $13 \mathrm{H}$ N, R eino U nido

Tel: 441913742846

Fax: 441913742870

E-mail: t.m.pollard@durham.ac.uk

Puesto(s) actual(es): Lecturer

Puesto(s) anterior(es): R esearch Fellow, St. G eorge's H ospital M edical School, U niversity of L ondon

E studios: D Phil, 1993, U niversity of O xford A reas de interés: estrés laboral, salud cardiovascular e inseguridad; diferencias por sexo en los efectos del estrés laboral sobre la salud

\section{Bengt Pontén}

Departamento de Eficacia O peracional

U niv. Sueca de Ciencias A grícolas

$77698 \mathrm{G}$ arpenberg, Suecia

T el: 4622526074

Fax: 4622526100

E-mail: bengt.ponten@ state.slw.se

Puesto(s) actual(es): Profesor, Análisis del T rabajo

E studios: M Sc, 1981; PhD, 1989, D epartamento de Eficacia O peracional 
Intereses: aplicación de nuevas estrategias para el desarrollo de la vida laboral y la producción conjunta con empresas forestales; cultura de la organización

\section{Charles T. Pope}

N orfolk A rea O ffice

$\mathrm{O}$ ccupational Safety and $\mathrm{H}$ ealth Administration D epartment of $L$ abor

Federal O ffice Building R oom 835

$200 \mathrm{G}$ randby M all

Norfolk, V A 23510, Estados U nidos

T el: 1 (804) 441-3820

Fax: 1 (804) 441-3594

\section{William Popendorf}

Department of Biology

U tah State U niversity

Logan, UT 84322-5305, Estados U nidos

Tel: 14357972566

Fax: 14357971575

E-mail: wjp@cc.usu.edu

Puesto(s) actual(es): Professor

E studios: PhD, 1976, U niversity of California, Berkeley

\section{Stefano Porru}

stituto di M edicina del L avoro

U niversità di Brescia

P.le Spedali Civili 1

25123 Brescia, I talia

T el: 3930396496

Fax: 3930394902

E-mail: alessio@master.cci.unibs.it

\section{Sydney W. Porter, Jr.}

CH P Porter Consulants, Inc.

125 Argyle R oad

Ardmore, PA 19003, Estados U nidos

T el: 1 (610) 896-5353

Fax: 1 (610) 642-7804

Puesto(s) actual(es): President; Adjunct Professor D rexel U niversity, G raduate Institute of Environmental Studies

Puesto(s) anterior(es): V ice-President of $\mathrm{H}$ ealth Physics and co-founder of R adiation $M$ anagement $C$ orporation

E studios: BS, 1954, St. Johns C ollege; G raduate studies in Physical Chemistry, 1956, Johns H opkins U niversity; G raduate studies in R adiochemistry, $\mathrm{N}$ ew $\mathrm{Y}$ ork University

A reas de interés: física de la salud; dosimetría de la radiación (incluido el radón); vigilancia radiológica ambiental; planificación de emergencias

\section{Peter Poschen}

Sección de Actividades Industriales

O ficina Internacional del Trabajo

Bureau 3-85

4 route des $M$ orillons

1211 G inebra 22, Suiza

Tel: 41227996188

Fax: 41227997967

E-mail: poschen@ilo.org

Puesto(s) actual(es): Especialista en silvicultura e industrias madereras
E studios: M Sc, 1980, U niv, de Friburgo; PhD 1987, U niv. de Friburgo

A reas de interés: mano de obra, seguridad, formación y empleo en el sector foresta

\section{Herbert C. Preul}

Department of Civil and Environmental Engineering

U niversity of C incinnat

760 Ludlow A venue

Cincinnati, O hio 45220, Estados U nidos

T el: 1 (513) 221-5291

Fax: 1 (513) 221-5291

E-mail: hpreul@boss.cee.uc.edu

Puesto(s) actual(es): Professor Emeritus, Consultant on Civil and Environmental Engineering

Puesto(s) anterior(es): Professor of Civil and Environmental Engineering; Director of W ater R esources L aboratory, U niversity of Cincinnati

E studios: PhD, 1964, U niversity of M innesota

A reas de interés: gestión internacional de recursos acuáticos; control del alcantarillado urbano; control de la contaminación de agua; prevención de la contaminación

\section{Christine Proctor}

Proctor $\mathrm{O}$ ccupational Safety and $\mathrm{H}$ ealth

PO Box 22

Ansonia Station

Nueva Y ork, Nueva Y ork 10023, Estados

Unidos

T el: 1212 496-1169

Fax: 1212 496-1169

E-mail: 72714.2467@compuserve.com

\section{John Quackenbush}

International U nion of Elevator C onstructors 8105 Adair Lane

Springfield, VA 22151-1808, Estados U nidos

Tel: 1 (703) 321-9344

Fax: 1 (703) 321-7721

Puesto(s) actual(es): International R epresentative

A reas de interés: D epartamento de $G$ remios de la Construcción y la Edificación, AFL-CIO, Comité de Seguridad y Salud

\section{James Campbell Quick}

Journal of O ccupational H ealth Psychology

University of $T$ exas at A rlington

PO Box 19313

Arlington, TX 76019-0313, Estados U nidos

Tel: 1 (817) 272-3514

Fax: 1 (817) 272-3515

E-mail: jquick@uta.edu

Puesto(s) actual(es): Professor of O rganizational Behavior; Editor, "J ournal of O ccupational H ealth Psychology"

E studios: M BA, 1975, U niversity of H ouston; PhD, 1977, U niversity of H ouston; cursos de posgrado, 1985, H arvard M edical School; cursos de posgrado, 1989, U niversity of T exas H ealth Science Center at San Antonio

A reas de interés: gestión de la prevención del estrés; estrés en la mujer; estrés del ejecutivo; estrés en combate

\section{Irene Raehlmann}

M arkusplatz 3

96045 Bamberg, A lemania

Tel: 499518631803

Fax: 499518631804

Puesto(s) actual(es): Professorin für A rbeitswissenschaft

Puesto(s) anterior(es): W issenschaftliche Assistentin A kademische R ätin

E studios: M A, 1969, T echnische U niversität Berlin; Dr Phil., 1973, TUB $\mathrm{H}$ abilitation, 1986, TUB

\section{Vilhjálmur Rafnsson}

Administración de Seguridad y Salud en el Trabajo

PO Box 12220

132 R eikiavik, I slandia

T el: 3545674086

Fax: 3545674086

E-mail: vira@ver.is

Puesto(s) actual(es): Director J efe M édico, Departamento de M edicina del T rabajo: Profesor asociado de M edicina Preventiva, Facultad de M edicina, U niv. de Islandia

E studios: M D, 1973, U niv. de Islandia; PhD 1981, U niversidad de G öteborg, Suecia

A reas de interés: epidemiología; salud en el trabajo; etiología del cáncer; estudios sobre mortalidad

\section{Ray RaLonde}

School of Fisheries and 0 cean Sciences U niversity of Alaska

2221 East N orthern Lights Blvd. \#110

Anchorage, Alaska 99508, Estados U nidos T el: 1 (907) 274-9691

Fax: 1 (907) 277-5242

E studios: BS, 1969, O regon State U niversity M S, 1988, U niversity of I daho

\section{Fernando Ramos Pérez}

Cerámica G aya Fores

R omeu de Corbera núm.16-5a

46006 V alencia, E spaña

T el: 9623220095

Puesto(s) actual(es): J efe del departamento de calidad

Puesto(s) anterior(es): Instituto $\mathrm{N}$ acional de Seguridad y Salud, D epartamento de Seguridad y C ondiciones del M aterial, Barcelona

E studios: Ind Eng, 1994, U niversidad Politécnica de V alencia, Facultad de Ciencias A plicadas

A reas de interés: seguridad, prevención e higiene en la industria; desarrollo y puesta en marcha de sistemas de prevención y calidad total (certificaciones ISO 9000); sistemas hidráulicos y maquinaria; redes hidráulicas de distribución

\section{Robert Ransom}

Sección de R ehabilitación Profesional

O ficina Internacional del T rabajo

4 route des $M$ orillons

1211 Ginebra 22, Suiza 
Tel: 41227998335

Fax: 41227996310

E-mail: ransom@ilo.org

Puesto(s) actual(es): Especialista principal

Puesto(s) anterior(es): Director, D epartamento Internacional, G oodwill Industries of America

E studios: M A, School of International Service, American U niversity

\section{Jorma Rantanen}

Instituto Finlandés de $M$ edicina del T rabajo

T opeliuksenkatu 41 a A

$00250 \mathrm{H}$ elsinki, Finlandia

T el: 35804747340

Fax: 35804747548

E-mail: jran@ occuphealth.fi

Puesto(s) actual(es): Director general

Puesto(s) anterior(es): Director, D epartamento de $\mathrm{H}$ igiene Industrial y T oxicología, Instituto Finlandés de M edicina del Trabajo

E studios: M D , 1967, U niversidad de T urku; PhD, 1973, U niversidad de T urku

A reas de interés: evaluación del riesgo; servicios de medicina del trabajo; trabajo en entornos de tecnología punta; salud internacional

\section{A. Raouf}

G.I.K.I TOPI

N.W.F.P., Pakistán

Tel: 92537271897

Fax: 92537271862

E-mail: raouf.giki@sdnpk.undp.org

Puesto(s) actual(es): V icerrector

Puesto(s) anterior(es): Profesor

E studios: PhD, 1970, U niversity of W indsor

A reas de interés: enseñanza de técnicas de mantenimiento de la calidad

\section{Carl Raskin}

C anadian Labour Force D evelopment Board 66 Slater Street-23rd Floor

O ttawa, O N K 1P 5H 1, Canadá

Tel: 1 (613) 230-6557

Fax: 1 (613) 230-7681

E-mail: craskin@magi.com

E studios: BA, 1969, Concordia U niversity; Dip Ed, 1970, M cG ill U niversity

A reas de interés: derechos humanos; discapacidad

\section{Russell B. Rayman}

The Aerospace M edical Association

320 South $\mathrm{H}$ enry Street

Alexandria, V A 22314, Estados U nidos

T el: 1 (703) 739-2240 x103

Fax: 1 (703) 739-9652

E-mail: rrayman@asma.org

Puesto(s) actual(es): Executive Director

Puesto(s) anterior(es): C olonel, U nited States A ir Force

E studios: M D, 1961, U niversity of M ichigan; M PH , 1969, Johns H opkins U niversity

A reas de interés: medicina aerospacial

\section{Dzulkifli Abdul Razak}

Centro Nacional de T oxicología

U niversidad Sains de M alaisia
Penang 11800, M alaisia

Tel: 6046570099

Fax: 6046568417

E-mail: dir-npc@usm.my

Puesto(s) actual(es): Director, Profesor

Puesto(s) anterior(es): V icedecano, Facultad de Ciencias Farmacéuticas, U niv. Sains de $\mathrm{M}$ alaisia

E studios: BPharm, 1976, U niv. Sains de M alaisia; M Sc, 1976, U niv. de Strathclyde

A reas de interés: servicios de información sobre drogas y sustancias tóxicas; informática sanitaria

\section{John T. Reeves}

Pediatric Intensive C are B-131

U niversity of Colorado $\mathrm{H}$ ealth Sciences C enter 4200 East N inth Ave.

Denver, CO 80262, Estados U nidos

T el: 1 (303) 270-8298

Fax: 1 (303) 270-8353

E-mail: john.reeves@uchsc.edu

Puesto(s) actual(es): Professor Emeritus of $M$ edicine and Pediatrics

\section{Beth Donovan Reh}

NIOSH

4676 Columbia Parkway, R 11

Cincinnati, 0 hio 45226, Estados U nidos

Tel: 1 (513) 841-4374

Fax: 1 (513) 841-4488

E-mail: byd3@ nioshel.em.cdc.gov

Puesto(s) actual(es): Industrial H ygienist

E studios: M H S, 1993, J ohns H opkins School of $\mathrm{H}$ ygiene and Public $\mathrm{H}$ ealth

A reas de interés: riesgos del caucho/ nitrosamina; fluidos metálicos; vigilancia biológica

\section{Dietmar A.J. Reinert}

Berufsgenossenschaftliches I nstitut für Arbeitssicherheit

Alte $\mathrm{H}$ eerstrsse 111

53754 Sankt Augustin, Alemania

Tel: 492241231645

Fax: 492241231234

E-mail: 100565.2233@ compuserve.com

Puesto(s) actual(es): J efe de Subdivisión de Electrónica

E studios: BA, 1984, U niv, de Bonn; Dr rer nat, 1987, U niv. de Bonn

A reas de interés: sistemas electrónicos programables en cuestiones relacionadas con la seguridad; software de seguridad dispositivos de protección activados por sensores

\section{Michael Repacholi}

O rganización M undial de la Salud

20 avenue Appia

1211 G inebra 27, Suiza

Tel: 41227913427

Fax: 41227914123

E-mail: repacholim@who.ch

Puesto(s) actual(es): Especialista en radiación

Puesto(s) anterior(es): Científico jefe, R oyal Adelaide H ospital, Adelaida, Australia Sur

E studios: BSc, 1965, U niversity of W estern Australia; M Sc, 1969, London
U niversity; PhD, 1980, 0 ttawa

U niversity

A reas de interés: radiación no ionizante; investigación, evaluación del riesgo, protección y normas

\section{Toni Retsch}

SU V A-O rganización Suiza de Seguros de Accidente

R össlimattstrasse 39

Postfach 4358

6002 Lucerna, Suiza

$$
\text { Tel: } 41414195376
$$

Fax: 41414195870

Puesto(s) actual(es): Bereichsleiter ALM 2

E studios: Dipl Ing

\section{Paule Rey}

Facultad de M edicina

19 rue du Bourg-D essus

1248 H ermance, Suiza

Tel: 41227512887

Puesto(s) actual(es): Profesora emérita, U niv.de Ginebra

Puesto(s) anterior(es): Profesora, M edicina del Trabajo y Ergonomía, U niversidad de G inebra; Professor, K ansas State U niversity

E studios: M D H arvard School of Public H ealth; $\mathrm{MPH}$

A reas de interés: monitores; análisis de decisiones en medicina del trabajo; compensación a los trabajadores, análisis de datos

\section{Tom Rhodarmer}

DAYCO/MARK IV

2150 South M ain Street

W aynesville, NC 28786, Estados U nidos

Tel: 1 (704) 456-8276

Fax: 1 (704) 452-1126

Puesto(s) actual(es): Director, Environmental $H$ ealth and Safety for M ARK IV Industries, worldwide

Puesto(s) anterior(es): R esearch and D evelopment Chemist, R ubber Compounder,

DAY C O ; $M$ anager of Process

Engineering, DAY CO Products; Plant

Level $M$ anager of Environmental Affairs

E studios: BS, 1965, W estern Carolina U niversity

A reas de interés: reciclado

\section{Annie Rice}

$\mathrm{H}$ ealth Safety Environment C onsultants La Ville

74130 Petit Bornand, Francia

Tel: 3350250472

Fax: 3350250472

Puesto(s) actual(es): Directora

Puesto(s) anterior(es): Directora de seguridad y salud en el trabajo y medio ambiente, Federación Internacional de

T rabajadores de los Sectores Q uímico, de la Energía y G eneral

E studios: BSc, 1972, U niv. of East Anglia

A reas de interés: formación y estudios en seguridad y salud en el trabajo; medio ambiente y desarrollo sostenible; productos químicos, plaguicidas; educación del trabajador 


\section{David Richardson}

Eastman K odak,

K odak Park,

$\mathrm{H}$ ealth and Environment Laboratories

B-320

R ochester, N ueva Y ork 14652-6253, Estados

Unidos

Tel: 1 (716) 722-5200

Fax: 1 (716) 477-2863

E-mail: dprich@kodak.com

Puesto(s) actual(es): U nit Director, Applied \& R eg. T oxicology

E studios: BS, 1977, State U niv. of N ew Y ork at Cortland; M PH, 1979, U niv. of M ichigan;

A reas de interés: análisis y modelos de exposición; exposición a productos químicos por debajo de los valores umbral; efectos de la exposición a compuestos; calidad del aire interior; evalución y comunicación de riesgos; peligros potenciales de los productos químicos para fotografía

\section{Sandra Karen Richman}

$N$ at. Board of Directors

American Fed.of TV \& R adio Artists

67 W est Ferry Street

N ew H ope, PA 18938, Estados U nidos

T el: 1 (215) 862-0236

Fax: 1 (215) 862-5942

Puesto(s) actual(es): Safety C onsultant, Entertainment Industry; N ational Board of Directors, A merican Federation of T V and R adio Artists

Puesto(s) anterior(es): N ational Board of Directors, Screen Actors G uild; Safety C onsultant, Actors Equity; President, Professional Stuntmens Federation; President Stuntwomen International; Stunt Coordinator, TV production, motion pictures, commercials and music videos

E studios: License, British School of M otor R acing

A reas de interés: salud y seguridad en artes y espectáculos

\section{Peter Richter}

Institut für A rbeits-, 0 rganisations- und

Sozialpsychologie

T echnische U niversität D resden

1062 D resde, Alemania

T el: 493514633784

Fax: 493514633589

E-mail: richter@psych.tu.dresden.de

Puesto(s) actual(es): Profesor

E studios: Dr rer nat, 1981, T U D resden

A reas de interés: diseño del puesto de trabajo; monitorización; psicofisiología cardiovascular; rehabilitación profesional; carga de trabajo intelectual

\section{Ted J. Rickard}

O ntario College of Art

$100 \mathrm{M} \mathrm{cC}$ aul Street

Toronto, ON M 5T 1W 1, Canadá

T el: 1 (416) 977-6000

Fax: 1 (416) 977-0235

Puesto(s) actual(es): Director, H ealth, Safety and Security
E studios: BA, 1979, U niversity of T oronto; M LS 1981, U niversity of T oronto

A reas de interés: seguridad y salud en las artes

\section{Hilkka Riihimäki}

Instituto Finlandés de M edicina del T rabajo

T opeliuksenkatu 41 a A

$00250 \mathrm{H}$ elsinki, Finlandia

Tel: 358947471

Fax: 35892414634

E-mail: hrii@occuphealth.fi

Puesto(s) actual(es): Director, D epartamento de E pidemiología y Bioestadística

Puesto(s) anterior(es): Investigador científico, Instituto Finlandés de M edicina de T rabajo; J efe de la U nidad de Investigación M édica; LEL Fondo de Pensiones de T rabajo, $\mathrm{H}$ elsinki. Finlandia

E studios: M Sc, 1967, U niv. de H elsinki; Lic.med., 1975, U niv. de H elsinki; DrM edSc., 1990, U niv. de H elsinki

A reas de interés: epidemiología en medicina del trabajo; trastornos musculosqueléticos

\section{Knut Ringen}

$111 \mathrm{M}$ ass A ve N.W

The C enter to Protect W orkers' R ights

W ashington, DC 20001, Estados U nidos

T el: 1 (202) 962-8490

Fax: 1 (202) 962-8499

E-mail: kringen@cpwr.com

Puesto(s) actual(es): Director, T he C enter to Protect W orkers' R ights

Puesto(s) anterior(es): Executive D irector, Laborers $H$ ealth and Safety Fund; Special Expert, N ational Cancer Institute; Director W orkers Institute for Safety and H ealth; Study Director, N ational A cademy of Sciences

E studios: M H A, 1974, M edical C ollege of V irginia; M PH, 1975, Johns H opkins U niversity; DrPH, 1977, Johns H opkins U niversity

A reas de interés: salud y seguridad en la construcción; sistemas de asistencia sanitaria

\section{Jean Marc Robert}

Ecole Polytechnique

D épartement de $M$ athémathique et $G$ énie

Industriel

CP 6079

Succ. Centre Ville

M ontreal, Q uébec H 3C 3A 7, C anadá

T el: 1 (514) 340-4566

Fax: 1 (514) 340-4173

E-mail: jmrobert@indus.polymtl.ca

Puesto(s) actual(es): Professor

Puesto(s) anterior(es): N ational R esearch Associate, NASA-AM ES R esearch Center; Associate R esearcher, X ER OX -PAR C

E studios: M D , 1976, U niv. of M ontreal, Q uébec; DESS, 1978, U niv.de París V, La Sorbonne; PhD, 1982, U niv.de París V La Sorbonne

A reas de interés: interfaces hombre-ordenador; aprendizaje de sistemas informáticos; ergonomía cognitiva; gestión de errores análisis de tareas

\section{Sally Roberts}

Centre for Spinal Studies

R obert I ones and Agnes $\mathrm{H}$ unt $\mathrm{O}$ rthopaedic

District H ospital

O swestry, Shropshire SY 10 7AG, R eino U nido

Tel: $441691655311 \times 3707$

Fax: 441691657968

E-mail: s.roberts@ keele.ac.uk

Puesto(s) actual(es): C linical Scientist

Estudios: BSc, PhD

A reas de interés: disco intervertebral; inmuno-histoquímica de colágenos; inervación de proteoglicilos; dolor lumbar; escoliosis

\section{Dilys Robertson}

6 Norwood R oad

Toronto, O N M 4E 2R B, Canadá

Tel: 1 (416) 690-9449

Fax: 1 (416) 690-0344

E-mail: dilys@pecs.gsalink.com

Puesto(s) actual(es): O H S C onsultant

Puesto(s) anterior(es): L ecturer, U niversity of $M$ anitoba; R esearch Superviser, Industrial Accident Prevention Association, O ntario; Personnel $M$ anager, Londres

E studios: BA, 1964, R hodes U niversity

A reas de interés: diseño de la formación; comités mixtos de salud y seguridad investigación

Walter Rohmert

Institut für Arbeitswissenschaft

T echnische H ochschule D armstadt

Petersenstrasse 30

64287 D armstadt, Alemania

T el: 496151162987

Fax: 496151163488

Puesto(s) actual(es): Profesor emérito

Puesto(s) anterior(es): J efe de departamento

Areas de interés: análisis y diseño del trabajo

\section{William N. Rom}

Division of Pulmonary and $\mathrm{C}$ ritical $\mathrm{C}$ are M edicine

N ew Y ork U niversity School of M edicine

$D$ epts of $M$ edicine and Environmental $M$ ed 550 First A venue

Nueva Y ork, N ueva Y ork 10016, Estados Unidos

Tel: 1 (212) 263-6479

Fax: 1 (212) 263-8442

Puesto(s) actual(es): C hief

Puesto(s) anterior(es): Senior Investigator, Pulmonary Branch, $\mathrm{NHIBI}, \mathrm{N}$ ational Institutes of $\mathrm{H}$ ealth

E studios: M D, 1971, U niversity of M innesota; M PH, 1973, H arvard School of Public $\mathrm{H}$ ealth

A reas de interés: enfermedad pulmonar profesional; tuberculosis; cáncer de pulmón

\section{sabelle Romieu}

Centro Panamericano R egional de E cología y Salud H umanas

Ap/ do Postal 37-473

06696 Ciudad de M éxico, M éxico 
Tel: 5272711091 ext. 93

Fax: 5272711090

E-mail: romieu@ servidor.unam.mx

Puesto(s) actual(es): Epidemióloga médica

Puesto(s) anterior(es): A yudante en O ncología, Instituto del Cáncer, M ontpellier, Francia; R esearch Assistant, Channing Laboratory, $\mathrm{H}$ arvard School of $M$ edicine; R esearch Fellow, Cancer Biology, $\mathrm{H}$ arvard School of Public $\mathrm{H}$ ealth, Boston; Epidemióloga médica, O rganización Panamericana de la Salud

E studios: M D, 1979, Facultad de M edicina, M ontpellier, Francia; M PH, 1985, $\mathrm{H}$ arvard School of Public H ealth; DSc, 1988, $\mathrm{H}$ arvard School of Public H ealth

A reas de interés: medio ambiente (contaminación atmosférica, metales pesados) y epidemiología nutricional; salud materna e infantil

\section{Gracia Rosel}

T écnico de prevención del Instituto Nacional de Seguridad e H igiene en el Trabajo

Calle Dulcet 2-10

08034 Barcelona, España

Tel: 3432800102

Fax: 3432803642

Puesto(s) actual(es): Jefa del Laboratorio de Cromatografía de $\mathrm{G}$ ases

E studios: T écnico en farmacia, 1970, E scuela de Ingeniería T écnica Industrial de Barcelona

A reas de interés: cromatografía y técnicas relacionadas; calidad del aire interior

\section{Jonathan Rosen}

NYS Public Employees Federation

AFL-CIO

$\mathrm{O}$ ccupational $\mathrm{H}$ ealth and Safety D epartment

1168-70 Troy-Schenectady R oad

PO Box 12414

Albany, N ueva Y ork 12212-2414, Estados

Unidos

T el: $1518785-1900 \times 254$

Fax: 1 518-785-1814

E-mail: 104042.123@ compuserve.com

Puesto(s) actual(es): Director, O ccupational H ealth and Safety Department

Puesto(s) anterior(es): H ealth ansd Safety Coordinator, A. 0. Smith A utomotive Products Company and Smith Steelworkers U nion, D.A.L.U ., AFL-CIO

E studios: M A, 1995, U niv.of M ichigan

A reas de interés: calidad del aire interior; riesgos en oficinas y asistencia sanitaria; ergonomía; violencia en el lugar de trabajo; enfermedades infecciosas

\section{Beth J. Rosenberg}

T ufts School of M edicine

D epartment of Family M edicine and Community $\mathrm{H}$ ealth

$136 \mathrm{H}$ arrison A venue

Boston, M A 02111, Estados U nidos

Tel: 1617 636-6651

Fax: 1617 636-7417

E-mail: brosenb@opal.tufts.edu

Puesto(s) actual(es): Associate Professor
E studios: BA, 1975, W ellesley College; M PH 1983, Boston U niversity School of Public $\mathrm{H}$ ealth; ScD, 1995, U niversity of

$M$ assachusetts at $L$ owell

A reas de interés: determinantes sociales de la salud laboral y ambiental; agricultura sostenible

\section{Linda Rosenstock}

$\mathrm{N}$ ational Institute for $\mathrm{O}$ ccupational Safety and $\mathrm{H}$ ealth

$\mathrm{H}$ ubert $\mathrm{H}$.H umphrey Building R m.715H

200 Independence A venue SW

W ashington, DC 20201, Estados U nidos

T el: 1 (202) 401-6997

Fax: 1 (202) 205-2207

E-mail: Izr6@oddc1.em.cdc.gov

Puesto(s) actual(es): Director

Puesto(s) anterior(es): Professor, D epartment M edicine and Environmental $\mathrm{H}$ ealth U niversity of W ashington; Director O ccupational M edicine Program, U niversity of W ashington

E studios: M D, M PH, 1977, Johns H opkins

A reas de interés: medicina clínica del trabajo; políticas de salud en el trabajo

\section{Clara S. Ross}

U niversity of C incinnati

Environmental and $\mathrm{O}$ ccupational $\mathrm{H}$ ealth

Consultants, Inc.

801 Ludlow Avenue

Cincinnati, O hio 45220, Estados U nidos

$$
\text { Tel: } 1 \text { (513) 281-7761 }
$$

Fax: 1 (513) 281-7761

Puesto(s) actual(es): President

E studios: M D, 1985, U niv. of C incinnati College of M edicine; JD, 1988, U niv. of Cincinnati C ollege of Law

A reas de interés: legislación en materia de medicina laboral; salud y seguridad en el trabajo en asistencia sanitaria; salud ambiental

\section{Monona Rossol}

Arts, Crafts and Theater Safety

181 T hompson Street \#23

N ueva Y ork, N ueva Y ork 10012-2586, Estados Unidos

T el: 1 (212) 777-0062

Puesto(s) actual(es): Industrial $\mathrm{H}$ ygienist

E studios: M S; M FA

\section{Pekka Roto}

Instituto R egional de M edicina del T rabajo de T ampere

P.O.Box 486

33101 T ampere, Finlandia

T el: 358312608650

Fax: 358312608615

E-mail: prot@occuphealth.fi

Puesto(s) actual(es): J efe médico

Puesto(s) anterior(es): M édico del trabajo, $\mathrm{O}$ utokumpu Ltd K okkola

E studios: M D, 1971, U niv. de H elsinki, Finlandia; M Sc, 1976, $\mathrm{H}$ arvard U niversity, USA; PhD, 1980, U niv. O ulu, Finlandia
A reas de interés: medicina del trabajo en la construcción; enfermedades pulmonares de origen laboral

\section{Denise M. Rousseau}

Carnegie M ellon U niversity

Pittsburgh, PA 15213-3890, Estados U nidos

Tel: 1 (412) 268-8470

Fax: 1 (412) 268-7036

E-mail: denise rousseau@ andrew.cmu.edu

Puesto(s) actual(es): Professor of O rganizational Behavior

Puesto(s) anterior(es): Professor, N orthwestern U niversity; A ssistant Professor, U niversity of $\mathrm{M}$ ichigan

E studios: PhD, 1977, U niversity of California

A reas de interés: compromisos psicológicos; cambio de relaciones en el trabajo; cultura y rendimiento

Julia D. Royster

Environmental N oise C onsultants, Inc

P.O. Box 30698

R aleigh, C arolina del N orte 27622-0698,

Estados U nidos

T el: 1 (919) 782-1624

Fax: 1 (919) 781-2396

E-mail: effective hcps@compuserve.com

Puesto(s) actual(es): President

E studios: BA, 1972, U niversity of N orth Carolina at Chapel Hill; M S, 1975, U niversity of North Carolina at Chapel H ill; PhD, 1981, N orth Carolina State U niversity

A reas de interés: efectividad de programas de conservación de la audición; variabilidad de datos audiométricos; disminución de la protección auditiva del mundo real

\section{Larry H. Royster}

Department of M echanical and Aerospace Engineering

N orth Carolina State U niversity

P.O. Box 7910

R aleigh, N C 27695-7910, Estados U nidos Tel: 1 (919) 515-5675

Fax: 1 (919) 515-7968

E-mail: royster@cos.ncsu.edu

Puesto(s) actual(es): Professor

Puesto(s) anterior(es): Senior D esign Engineer, $\mathrm{N}$ orth American A viation

E studios: BS, 1959, N orth Carolina State U niversity; PhD, 1968, N orth Carolina State U niversity

A reas de interés: control del ruido y la vibración; efectos del ruido y la vibración en el hombre

James R. Rubin

H ewlett-Packard Company

3404 East $\mathrm{H}$ armony $\mathrm{R} \mathrm{d}$

$\mathrm{M}$ ailstop 85

Ft. Collins, CO 80525-9599, Estados U nidos

Tel: 1 (970) 229-4880

Fax: 1 (970) 229-6584

E-mail: jamie rubin@hp.com

Puesto(s) actual(es): Environmental $\mathrm{H}$ ealth and Safety Specialist

Puesto(s) anterior(es): H ewlett Packard; H oneywell; D epartment of $L$ abor, O ccupational Safety and $\mathrm{H}$ ealth Administration 
E studios: BS, 1976, Colorado State U niversity; M S, 1978, U niversity of C incinnat

\section{Avima M. Ruder}

R obert A. T aft Laboratories DH HS/ NIO SH Division-Surveillance

$H$ azard Evaluations \& Field Studies

4676 C olumbia Parkway

Cincinnati, 0 hio 45226, Estados U nidos

T el: 1 (513) 841-4440

Fax: 1 (513) 841-4486

E-mail: amr2@moshei.em.cdc.gov

Puesto(s) actual(es): C hief, E pidemiology 2 Section

A reas de interés: epidemiología del cáncer de origen profesiona

\section{John Rudge}

School of $\mathrm{M}$ anagement

U niversity of South Australia,

North T errace G PO Box 2471

A delaida 5000, Australia

Tel: 6183020351

Fax: 6183020411

E-mail: john.rudge@unisa.edu.au.

Puesto(s) actual(es): Senior Lecturer, O HS Programs C oordinato

E studios: BS, 1966, Sydney U niversity; M BA, 1986, A delaide U niversity

A reas de interés: enseñanza de la gestión de la salud y la seguridad; enseñanza de la inspección y formación para la salud y la seguridad en el trabajo

\section{Jon Rudnick}

Dow Corning Corporation

P.O. Box 994 M ail \#C 01120

M idland, M I 48686-0994, Estados U nidos

T el: 1 (517) 496-1521

Fax: 1 (517) 496-8065

Puesto(s) actual(es): C orporate M edical Director

Puesto(s) anterior(es): Corporate M edical Director, C onsolidated N atural G as C orp Pittsburgh, PA; C orporate Director of Safety and $\mathrm{H}$ ealth, Bath I ronworks Shipbuilding $\mathrm{C} 0$, Bath, $\mathrm{M} \mathrm{E}$ $\checkmark$ ice-President and Director for $\mathrm{O}$ ccupational $\mathrm{H}$ ealth, R esearch M edical Center, $\mathrm{K}$ ansas, $\mathrm{M} \mathrm{O}$

E studios: M Sc, 1968, Columbia U niv.; M D, 1975, U niv. of N ew M exico School of M edicine; M PH, 1993, U niv.of Pittsburgh G raduate School of Public $\mathrm{H}$ ealth

\section{John W. Ruser}

Compensation R esearch G roup

U nited States Bureau of Labor Statistics

Postal Square Building

R oom 41

$302 \mathrm{M}$ assachusetts A venue NE

Washington, DC 20212, Estados U nidos

T el: 1 (202) 606-7392

Fax: 1 (202) 606-6310

E-mail: R user J @bls.gov

Puesto(s) actual(es): Acting Chief

Puesto(s) anterior(es): Senior R esearch Economist, Bureau of $L$ abor Statistics

E studios: BA, 1977, Princeton U niv.; M A, 1980 U niv. of Chicago; PhD, 1983, U niv. of Chicago
A reas de interés: seguros de indemnización a trabajadores; regulación de la seguridad del lugar de trabajo

\section{Sven-Olof Ryding}

Consejo Sueco EM AS

$C$ entro de $C$ omercio $M$ undia

PO Box 70390

10724 Estocolmo, Suecia

Tel: 4687006254

Fax: 4687006201

Puesto(s) actual(es): Profesor ayudante, Director gerente

Puesto(s) anterior(es): J efe del D epartamento del A gua, Instituto Sueco de Investigación A mbiental; A sesor científico, Federación de Industrias de Suecia

E studios: PhD, 1978, Instituto de Limnología, U niv. de U ppsala

\section{Ragnar Rylander}

D epart. de M edicina A mbiental

U niv.de G öteborg

M edicinaregatan 16

41390 G öteborg, Suecia

T el: 46317733601

Fax: 4631825004

E-mail: ragnar.rylander@envmed.gu.se

Puesto(s) actual(es): Profesor

Estudios: M D; PhD

\section{David L.S. Ryon}

Division of Pulmonary and C ritical Care M edicine

N ew Y ork U niversity

Depts of $M$ edicine and Envir. M ed.

550 First Avenue

N ueva Y ork, N ueva Y ork 10016, Estados Unidos

T el: 1 (212) 263-6479

Fax: 1 (212) 263-8442

\section{Jorma Saari}

Faculty of A pplied $\mathrm{H}$ ealth Sciences

U niversity of W aterloo

Waterloo, O N N 2L 3G 1, Canadá

Tel: 1 (519) 885-1211 x5876

Fax: 1 (519) 746-6776

E-mail: jsari@ healthy.uwaterloo.ca

Puesto(s) actual(es): Professor

Puesto(s) anterior(es): Director, D epartamento de Seguridad, Instituto Finlandés de M edicina del Trabajo

E studios: Dr tech, 1977, U niv. de T ecnología de Helsinki

A reas de interés: gestión de la seguridad; intervención para la seguridad y la salud

\section{M. Sack}

$\mathrm{N}$ avy Environmental $\mathrm{H}$ ealth $\mathrm{C}$ enter

N orfolk, VA, Estados U nidos

Tel: 1757 363-5568

Fax: 1757 445-9481

E-mail: sackd@ehc50.med.navy.mil

Puesto(s) anterior(es): Force M edical O fficer, Submarine Force, U S A tlantic Fleet; $\mathrm{O}$ fficer in Charge, $\mathrm{N}$ aval U ndersea Medical Institute
E studios: BS, 1979, Pennsylvania State U niversity; M D , 1981, J efferson M edical C ollege; M S, 1988, U niversity of C incinnat

\section{Gavriel Salvendy}

Purdue U niversity

West L afayette

$1287 \mathrm{G}$ rissom $\mathrm{H}$ all W est

Lafayette, IN 47907-1287, Estados U nidos

Tel: 1 (317) 494-5426

Fax: 1 (317) 494-0874

Puesto(s) actual(es): Professor of Industrial Engineering

\section{Sheldon W. Samuels}

Ramazzini Institute for O cc. \& Env. H ealth R esearch

PO Box 1570

Solomons I sland, M D 20688, Estados U nidos Tel: 1 (410) 326-2543

Fax: 1 (410) 326-6808

Puesto(s) actual(es): V ice-President; C onsultant, Carpenter $\mathrm{H}$ ealth and Safety Fund

Puesto(s) anterior(es): Lecturer, M t. Sinai School of $M$ edicine and J ohns $\mathrm{H}$ opkins $\mathrm{U}$ niversity School of $\mathrm{H}$ ygiene and Public $\mathrm{H}$ ealth; Director, $\mathrm{H}$ ealth, Safety and Environment, IUD/AFL-CIO

E studios: BA, 1951, U niv. of Chicago; G raduate School (Filosofía y A ntropología) UIC

A reas de interés: cuestiones teóricas, morales y de difusión de genética de poblaciones; cultura; medio ambiente de trabajo y tecnologías emergentes

Andries F. Sanders

D epartamento de Psiconomía

$\checkmark$ rije U niversiteit

1111 de Boelelaan

1081 H V A msterdam, Países Bajos

Tel: 31204448786

Fax: 31204448832

E-mail: ineke@psy.vu.n

Puesto(s) actual(es): Profesor de Psicología Cognitiva

E studios: PhD, 1963, U trecht

A reas de interés: simulación; tiempo de reacción

Igor V. Sanotskij

Instituto de M edicina del T rabajo

Academia R usa de C iencias M édicas

31 Prospekt Budennogo

105275 M oscú, Federación R usa

Tel: 70953660592

Fax: 70953660583

Puesto(s) actual(es): A sesor científico; Presidente, Centro T oxicológico, Academia de M edicina de la M arina; Profesor de toxicología

E studios: M D, 1953, A cademia de M edicina de la M arina, Instituto de Patología y Terapia de Intoxicaciones; PhD , 1965 Instituto de $\mathrm{H}$ igiene Industrial y Enfermedades Profesionales

Areas de interés: toxicología preventiva: filosofía, metodología, aplicaciones, niveles de seguridad; protección ambiental contra sustancias químicas; efectos a largo plazo de la exposición química 


\section{Rodolfo Saracci}

Consejo Nacional de Investigación

Pisa, Italia

Puesto(s) actual(es): Director; Investigador, A sesor de la Agencia Internacional para la Investigación sobre el Cáncer

E studios: M D

\section{Annie J. Sasco}

IARC/INSERM/WHO

150 cours Albert Thomas

69372 Lyon C edex 08, Francia

Tel: 33472738412

Fax: 33472738342

E-mail: sasco@iarc.fr

Puesto(s) actual(es): J efe del Programa de Epidemiología para la Prevención del Cáncer; Jefa en funciones, Agencia Internacional para la Investigación sobre el Cáncer; Programa para el Control del Cáncer, O rganización M undial de la Salud

Puesto(s) anterior(es): Fellow, H arvard U niversity; R esearcher, I N SE R M ; Investigador, Agencia Internacional para la Investigación sobre el Cáncer

E studios: M D, 1978, U niv. de Burdeos; M PH 1979, H arvard U niversity; M S, 1980, $\mathrm{H}$ arvard U niversity; DrPH , 1986, $\mathrm{H}$ arvard U niversity

A reas de interés: papel de los agentes biológicos en el cáncer en trabajadores de la investigación; etiología y prevención de cáncer de mama; control del tabaco

\section{Denis Sasseville}

R oyal V ictoria H ospital

Division of Dermatology

Room M 9.30

687 Pine A venue W est

M ontreal, Q uébec H 3A 1A1, Canadá

Tel: 1 (514) 843-1550

Fax: 1 (514) 982-0686

Puesto(s) actual(es): Assistant Professor of M edicine, M cG ill U niversity

E studios: M D, 1972, Laval U niversity, Q uébec; FR CPC, 1980, M cG ill U niversity; DABD, 1980

A reas de interés: dermatitis de contacto

\section{Steven L. Sauter}

$\mathrm{N}$ ational Institute for $\mathrm{O}$ ccupational Safety and Health

4676 C olumbia Parkway M S C - 24

Cincinnati, O hio 45226-1998, Estados U nidos

Tel: 1 (513) 533-8383

Fax: 1 (513) 533-8596

E-mail: SLS4@niobbsl.em.cdc.gov

Puesto(s) actual(es): C hief

Puesto(s) anterior(es): U niv. of W isconsin, Department of Preventive M edicine

E studios: PhD, Industrial Psychology, U niv. of W isconsin

A reas de interés: estrés laboral; factores psicosociales y salud en el trabajo

\section{Marianne Saux}

$M$ inistère du T ravai
Inspection M édicale du T ravail

1 Place de Fontenoy

75007 París, Francia

Tel: 33140564068

Fax: 33140565052

Puesto(s) actual(es): Chef de Service de I'Inspection du Travail; $C$ hef du bureau de la M édecine du Travail

Puesto(s) anterior(es): M édecin Inspecteur R égional du T ravail et de la $M$ ain d'oeuvre; $M$ édecin $C$ onseil Compagnie de Saint Soboui

E studios: D octeur en M édecine; CES (O cc M ed); $C E S$ de $M$ édecine Aeronautique et Spatiale

A reas de interés: organización y regulación de la seguridad y la salud en el trabajo

\section{Heikki Savolainen}

Instituto Científico de M edicina del T rabajo

Rue du Bugnon 19

1005 L ausana, Suiza

T el: 41213147421

Fax: 41213147420

Puesto(s) actual(es): Profesor de medicina de trabajo

Puesto(s) anterior(es): Director de investigación (Neurotoxicología) del Instituto de M edicina del Trabajo, H elsinki

E studios: Dr M ed Sc, 1974, U niv. de H elsinki

A reas de interés: neurotoxicología clínica; nefrotoxicidad de sustancias químicas industriales; tratamiento de nuevos polímeros

\section{G. Savourey}

Centre de R echerche du Service de Santé des Armées

"Emile Pardé"

24 avenue des M aquis du G résivaudan

B.P. 87

$38702 \mathrm{~L}$ a T ronche C edex, Francia

Tel: 3376636944

Fax: 3376636945

Puesto(s) actual(es): Investigador especialista

Puesto(s) anterior(es): A ssistant de R echerches

E studios: M D , 1981; D octeur ès Sciences de la V ie, 1992, L yon, Francia; $\mathrm{H}$ abilitation à Diriger des R echerches, 1993, Lyon, Francia

A reas de interés: calor; frío; altitud

\section{Neil Schachter}

M ount Sinai M edical Center

Pulmonary Division

O ne G ustave L evy Place

Box 1232

N ueva Y ork, N ueva Y ork 10029, Estados Unidos

T el: 1212 241-6047

Fax: 1212 831-3560

E-mail: nschachter@stmplink.mssh.edu

Puesto(s) actual(es): M aurice $\mathrm{H}$ exter, Professor of M edicine

Puesto(s) anterior(es): Associate Professor, Y ale $U$ niv. School of M edicine; $M$ edical Director, R espiratory C are, Y ale-N ew $\mathrm{H}$ aven $\mathrm{H}$ ospital
E studios: Baccalaureat, 1960, Lycée Français, NY ; $A B, 1964$, Columbia U niv.; M D 1968, NYU School of M edicine; Fellow, 1972, Edward Livingstone T rudeau

A reas de interés: enfermedades pulmonares de origen profesional y ambiental; fisiología pulmonar; farmacología pulmonar

\section{Ted Scharf}

Division of Biomedical and Behavioral Science N ational Institute for $O$ ccupational Safety and $\mathrm{H}$ ealth

4676 Columbia Parkway C - 24

Cincinnati, O hio 45226-1998, Estados U nidos

Tel: 1 (513) 533-8170

Fax: 1 (513) 533-8596

E-mail: fes0@cdc.gov

Puesto(s) actual(es): R esearch Psychologist

E studios: PhD, 1995, U niv. of California

A reas de interés: entornos de trabajo peligrosos; carga de trabajo en granjas; estrés y riesgos de lesiones

John M. Schaubroeck

U niv. of N ebraska- Lincoln

P.0. Box 880491

Lincoln, NE 68588-0419, Estados U nidos

Tel: 1 (402) 472-3179

Fax: 1 (402) 472-5855

E-mail: jschaubr@unlinfo.unl.edu

Puesto(s) actual(es): Associate Professor

E studios: PhD, 1988, Purdue U niversity

A reas de interés: personalidad, actitudes ante el trabajo

\section{Marc B. Schenker}

University of C alifornia

Department of Epidemiology and Preventive

M edicine

TB-168

Davis, CA 95616-8638, Estados U nidos Tel: 1916 752-5676

Fax: 1916 752-3239

E-mail: mbschenker@ucdavis.edu

Puesto(s) actual(es): D irector, U niv. of California A gricultural $\mathrm{H}$ ealth and Safety $\mathrm{C}$ enter

Puesto(s) anterior(es): Division Chief, Division of O ccupational/ Environmental M edicine and Epidemiology, D epartment of Internal M edicine, U niv. of California-D avis; Associate Professor of M edicine, U niv. of CaliforniaDavis

E studios: BA, 1969, U niv. of C alifornia-Berkeley M D, 1973, U niv. of California-San Francisco School of M edicine; M PH 1980, H arvard School of Public H ealth

A reas de interés: factores de riesgo laborales y ambientales en enfermedades respiratorias y cáncer de pulmón; control biológico de exposiciones de riesgo en el trabajo; peligros para la salud de las exposiciones en la agricultura; riesgos profesionales para la reproducción; peligros para la salud en la industria de semiconductores; aspectos internacionales en salud profesional y ambiental 
Richard Schilling

11C Prior Bolton Street

Londres N $13 \mathrm{NX}$, R eino U nido

Tel: 441713591627

Puesto(s) actual(es): C onsultant 0 ccupational $\mathrm{H}$ ealth

Puesto(s) anterior(es): Professor U niv. of L ondon Director T U C C entenary Institute of $\mathrm{O}$ ccupational $\mathrm{H}$ ealth, L ondon School of $H$ ygiene and $T$ ropical M edicine

E studios: M BBS, 1937, St. T homas's H ospital M edical School; DPH, DIH, 1947 London School of $\mathrm{H}$ ygiene and T M ; M D L ondres; DSc, 1962, U niv. of L ondon

A reas de interés: epidemiología del trabajo; trastornos respiratorios en trabajadores del sector textil

\section{Lawrence M. Schleifer}

D epartment of $\mathrm{H}$ ealth $\mathrm{E}$ ducation

U niv. of $\mathrm{M}$ aryland

College Park

M D 20742, Estados U nidos

Tel: 1 (301) 231-8928

Fax: 1 (301) 231-8928

Puesto(s) actual(es): Adjunct Associate Professor

Puesto(s) anterior(es): R esearch Psychologist, $\mathrm{N}$ ational Institute for $\mathrm{O}$ ccupational Safety and $\mathrm{H}$ ealth

E studios: DEd, 1978, U niversity of Albany

A reas de interés: medicina del trabajo; estrés laboral; ergonomía; trastornos musculosqueléticos; psicofisiología respiratoria

\section{Guido Schmitter}

SUVA

O rganismo de Certificación

Postfach 4358

6002 Lucerna, Suiza

Tel: 41414195111

Fax: 41414195870

Puesto(s) actual(es): Ingeniero de seguridad, Certificación de Productos

E studios: Ingeniería mecánica H T L, Instituto de Ingeniería M ecánica, Lucerna; Ingeniería de T ecnología de la Información, Ingeniería de N egocios y Administración Instituto de T ecnología de la Información en Administración Económica y de Empresa de Lucerna; diseño de vehículos aerospaciales, Facultad de Aeronáutica, Inst. De T ecnología C ranfield

A reas de interés: gestión del riesgo; evaluación y análisis del riesgo; máquinas herramienta en trabajadores del metal; robots industriales; sistemas FM S

\section{Scott P. Schneider}

W orkers' Inst. for Safety \& H ealth

Div. O ccupational $\mathrm{H}$ ealth Foundation

1126 Sixteenth Street N W

Washington, DC 20036, Estados U nidos

Tel: 1 (202) 887-1980

Fax: 1 (202) 887-0191
William J. Schneider

M organ G uaranty T rust C 0 of NY

23 W all Street

N ueva Y ork, N ueva Y ork 10260-0023, Estados Unidos

T el: 1 (212) 235-1001

Fax: 1 (212) 235-4934

Puesto(s) actual(es): Director, $\mathrm{H}$ ealth Services; Associate Clinical Professor of M edicine and Epidemiology, Albert Einstein C ollege of $M$ edicine

Puesto(s) anterior(es): A ssistant Director of M edicine, M ontefiore H ospital; Director, Employees' $\mathrm{H}$ ealth Clinic, M ontefiore H ospital; A ssistant Professor of M edicine $\mathrm{N}$ ew Y ork U niv. School of M edicine

E studios: BS, 1959, T ufts U niv.; M D, 1963 Columbia U niv. College of Physicians and Surgeons; M PH , 1991, Columbia U niv. School of Public $\mathrm{H}$ ealth

A reas de interés: medicina del trabajo: enfermedades infecciosas; medicina interna; prestación de asistencia sanitaria

Wolfram D. Schneider

Instituto Federal de Seguridad y Salud en el Trabajo

N öldnerstrasse 40/ 42

D-10317 Berlín, Alemania

Tel: 493051548300

Fax: 493051548170

Puesto(s) actual(es): J efe de departamento, Efectos en la Salud de Sustancias Peligrosas

Puesto(s) anterior(es): M édico jefe de los laboratorios de diagnóstico, Clínica y consulta de pacientes externos del Instituto de M edicina del Trabajo, Berlín

E studios: M D, 1963, U niv. H umboldt, Berlín; Dr Sc M ed, 1981, A kademie für Arztliche Fortbildung, Berlín; H on Professor, 1989, A kademie für A rztliche Fortbildung, Berlín;

A reas de interés: sustancias peligrosas por inhalación; relaciones dosis-efecto; valores límite umbra

\section{Steven Schrader}

$\mathrm{N}$ ational Institute for $\mathrm{O}$ ccupational Safety and $\mathrm{H}$ ealth

4676 C olumbia Parkway C 23

Cincinnati, O hio 45226-1998, Estados U nidos

Tel: 1 (513) 533-8210

Fax: 1 (513) 533-8510

E-mail: sms4@cdc.gov

Puesto(s) actual(es): C hief, Functional T oxicology Section

E studios: PhD, U niversity of M issouri; Post D oc, U niversity of $\mathrm{M}$ iami

A reas de interés: toxicología reproductiva en la mujer

\section{Paul Schreiber}

Bundesanstalt für Arbeitsschutz

Postfach 170202

44061 D ortmund, Alemania

Tel: 492319071315

Fax: 492319071454
E studios: Diplom-Physiker, Dr rer nat, T echnische $\mathrm{H}$ ochschule Aachen

A reas de interés: seguridad de las nuevas tecnologías; nuevos sensores para la seguridad en el trabajo; seguridad de todo tipo de plantas de producción y procesado; seguridad funcional, seguridad informática, sistemas complejos

\section{Horst Schulz}

$\mathrm{H}$ auptverband der gewerblichen Berufsgenossenschaften e. V.

Alte H eerstrasse 111

53754 Sankt Augustin, Alemania

T el: 492241231272

Fax: 492241231334

\section{Stanley H. Schuman}

O ccupational and Environmental M edicine $O$ ffice and Agromedicine Program M edical Univ. of South C arolina and Clemson U niv. $305 \mathrm{H}$ arborview T ower

Charleston, SC 29425, Estados U nidos Tel: 1 (803) 792-2281

Fax: 1 (803) 792-4702

E-mail: caldwest@musc.edu (Internet)

Puesto(s) actual(es): M edical Director, Professor of Family M edicine; Editor-in-C hief, The J ournal of Agromedicine, $\mathrm{H}$ aworth Publishers

Puesto(s) anterior(es): Professor of E pidemiology, U niversity of $\mathrm{M}$ ichigan School of Public $\mathrm{H}$ ealth

E studios: M D, 1948, W ashington U niversity, St. L ouis; M PH, 1960, U niversity of M ichigan; Am Board of Pediatrics, 1960; DrPH , 1962, U niv. of M ichigan

\section{Charles V. Schwab}

I owa State U niversity

A gricultural and Biosystems Engineering

Ames, IA 50010-3080, Estados U nidos

Tel: 1515 294-6360

Fax: 1 515-294-9973

E-mail: cvschwab@iastate.edu

Puesto(s) actual(es): A ssociate Professor

E studios: M S, 1982, U niversity of K entucky; PhD, 1989, U niversity of K entucky

A reas de interés: seguridad en el sector agrícola

\section{Menachem Schwart}

Instituto de H igiene y Seguridad en el T rabajo

$22 \mathrm{M}$ azeh Street

P.O.Box 1122

Tel A viv 61010, Israel

Tel: 97236297314

Fax: 97235252448

E-mail: osh-il@metvision.met.il

Puesto(s) actual(es): Director general, Instituto de Seguridad e H igiene en el Trabajo de I srael; co-editor, I srael J ournal of 0 ccupational $\mathrm{H}$ ealth; Presidente del Comité de N ormalización de la Seguridad, Instituto de N ormalización de I srael

Puesto(s) anterior(es): Director, R evlon Cosmetics Factory, I srael; D irector, O SEM (Fabricantes alimentarios) Plant; D irector de Division en la I srael $M$ etal $C$ on Company 
E studios: BSc, 1965, T echnion, $\mathrm{H}$ aifa, Israel; M Sc, 1996, U niv. de T el-A viv

A reas de interés: formación y educación para la seguridad y la higiene en el trabajo; sistemas de gestión de higiene y seguridad

\section{Dietrich Schwela}

División de A poyo 0 peraciona

O rganización M undial de la Salud

20 avenue Appia

1211 G inebra 27, Suiza

Tel: 41227914261

Fax: 41227910816

E-mail: schwelad@who.ch

Puesto(s) actual(es): Salud ambiental urbana

Puesto(s) anterior(es): J efe de grupo, División de Efectos de los Contaminantes de la Atmósfera, Centro Estatal de Investigación de la C ontaminación Atmosférica, R hin Norte, W estphalia, Essen, Alemania

E studios: PhD, 1968, U niv.de Bonn

A reas de interés: contaminación del aire en interiores y gestión del ruido

\section{W. Norman Scott}

Insall Scott K elly

170 East End A venue

N ueva Y ork, N ueva Y ork 10128, Estados

Unidos

T el: 1 (212) 472-6606

\section{Susan Scott-Parker}

Employers' Forum on Disability

N utmeg $\mathrm{H}$ ouse

$60 \mathrm{G}$ ainsford Street

L ondres SE 1 2NY, R eino U nido

T el: 441714033020

Fax: 441714030404

Puesto(s) actual(es): Chief Executive

Puesto(s) anterior(es): M anaging Director of Scott-Parker Associates; Coverdale Associate

E studios: BA, Carlton U niversity

\section{Patrick Sébastien}

N orton M atériaux A vancé

$\mathrm{R}$ ue Jean $\mathrm{M}$ onet

ZAC-DUM IN

84306 C availlon Cedex, Francia

Tel: 33608176142

Fax: 33490763734

Puesto(s) actual(es): Director científico

E studios: PhD

A reas de interés: gestión de la investigación y el desarrollo en salud y seguridad en e trabajo

\section{Jane L. Seegal}

The C enter to Protect W orkers' R ights

$111 \mathrm{M}$ assachusetts $A$ ve NW

Washington, DC 20001, Estados U nidos

T el: 1 (202) 962-8490

Fax: 1 (202) 962-8499

E-mail: 71112,1454@ compuserve.com

Puesto(s) actual(es): Communication Director

E studios: M A, 1970, U niversity of W isconsin; M S, 1977, Columbia U niversity
A reas de interés: salud y seguridad en la construcción

\section{Rita Seguin}

$H$ iram W alker and Sons Ltd.

W alkerville, ON N 8Y 4S5, Canadá

Puesto(s) actual(es): Safety and Disability M anager

\section{Marie-Claire Séguret}

O rganización Internacional del Trabajo

4 route des $M$ orillons

1211 G inebra 22, Suiza

T el: 44227996732

Fax: 44227998451

Puesto(s) actual(es): Especialista asociada

A reas de interés: igualdad de oportunidades y de trato entre hombres y mujeres en el trabajo

\section{Helmut Seidel}

Bundesanstalt für A rbeitsmedizin

Postfach 5

10266 Berlín, Alemania

Tel: 493055138430

Fax: 493055138170

Puesto(s) actual(es): J efe de grupo de investigación

E studios: Dr M ed., 1968, U niv. H umboldt, Berlín; Dr Sc M ed, 1981, Academia para la Educación de M édicos Posgraduados, Berlín

A reas de interés: efectos de la vibración de cuerpo completo en la zona lumbar; biomecánica del trabajo; efectos combinados de la vibración de cuerpo completo y el ruido; electromiograma (EM G) de los músculos de la espalda

\section{Hansjörg Seiler}

Tribunal Federal Suizo (Bundesgericht)

T errassenweg 31

3110 M ünsingen, Suiza

Tel: 41317215041

Puesto(s) actual(es): Secretario del T ribunal Federal Suizo (Bundesgericht)

Puesto(s) anterior(es): Director, Proyecto de Seguridad y R iesgos de Sistemas T ecnológicos, Instituto Federal Suizo de T ecnología, Zurich

E studios: PhD, 1986, U niv. de Berna; Privatdocent, 1993, U niv. de Berna

A reas de interés: derecho constitucional y administrativo; derecho y tecnología; derecho y riesgo; regulación en función del riesgo; derecho ambiental; planificación regional de la seguridad

\section{Anna Maria Seppäläinen}

D epartamento de N eurología

U niv. de H elsinki

$\mathrm{H}$ aartmaninkatu 4

$00290 \mathrm{H}$ elsinki, Finlandia

T el: 35894712493

Fax: 35894714003

E-mail: anna-maria.seppa-

lainen@ hyks.mailnet.fi

Puesto(s) actual(es): J efa, División de N eurofisiología C línica

Puesto(s) anterior(es): J efa del Laboratorio de N eurofisiología Clínica, Instituto de Medicina del Trabajo, $\mathrm{H}$ elsink
E studios: M D , 1961, U niv, de H elsinki; PhD. 1973, U niv. de H elsinki

A reas de interés: problemas del sistemas nervioso periférico relacionados con el tipo de trabajo y el envejecimiento

\section{Lowell E. Sever}

Battelle Seattle R esearch C enter

4000 N.E. 41st St

Seattle, W A 98105-5428, Estados U nidos

T el: 1 (206) 528-3348

Fax: 1 (206) 528-3550

E-mail: sever@battelle.org

Puesto(s) actual(es): Program Director, Public $\mathrm{H}$ ealth Sciences; Affiliate Professor of Epidemiology and Environmental $\mathrm{H}$ ealth, $U$ niversity of W ashington

Puesto(s) anterior(es): T echnical G roup L eader, Epidemiology, $\mathrm{H}$ ealth $\mathrm{R}$ isk A ssessment D epartment, Battelle Pacific N orthwest L aboratories; A ssistant Director for Science, Division of Birth D efects and D evelopmental Disabilities, C enters for Disease Control

E studios: BA, 1966, U niv. of W ashington; M A 1968, U niv. of W isconsin; PhD, 1973, U niv. of W ashington

A reas de interés: epidemiología perinatal; riesgos para la reproducción de origen laboral y ambienta

\section{Erwin Seyfried}

FHVR-Berlín

Alt-Friedrichsfelde 60

10315 Berlín, Alemania

T el: 493051614304

Fax: 493051614300

E-mail: 03080152651@ btxgate.de

Puesto(s) actual(es): Profesor de psicología social; Director, U nidad de Investigación sobre Formación Profesional, M ercado de Trabajo y Evaluación

E studios: BA, 1980, FU Berlín; PhD, 1988, FU Berlín

A reas de interés: calidad de la formación profesional; evaluación de la formación profesional y los programas de empleo; integración de discapacitados en la vida laboral

\section{Behrouz Shahandeh}

Rama de R ehabilitación Profesional

O rganización Internacional del T rabajo

4 route des $M$ orillons

1211 Ginebra 22, Suiza

T el: 41227996833

Puesto(s) actual(es): asesor sobre drogas y alcohol

\section{Houshang Shahnavaz}

D epartamento de Ciencias del T rabajo

U niversity of L uleå

97187 L uleå, Suecia

T el: 4692091473

Fax: 4692091030

E-mail: houshang.shahnavaz@arb.luth.se

Puesto(s) actual(es): Profesor de ergonomía industrial; Director, C entro de Ergonomía de Países en D esarrollo

Puesto(s) anterior(es): Profesor suplente, Psicología T écnica, Departamento de Ciencias del Trabajo, Univ. L uleå 
E studios: Dipl Ing, 1960, U niv. T écnica de Darmstadt; M Sc, 1974, U niversity of Birmingham; PhD, 1976, U niversity of Birmingham

A reas de interés: ergonomía de los sistemas de trabajo, interacción entre personas y ordenadores; ergonomía de países en desarrollo y transferencia de tecnología

\section{Harry S. Shannon}

O ccupational $\mathrm{H}$ ealth Programme

M cM aster U niversity

$1200 \mathrm{M}$ ain Street W est

Hamilton, $\mathrm{ON}$ L 8N 375, Canadá

T el: 1 (905) 525-9140

Fax: 1 (905) 577-0017

E-mail: shannon@fhs,M cM aster.ca

Puesto(s) actual(es): Professor; Senior Scientist, Institute for Work and $\mathrm{H}$ ealth

E studios: BA, 1970, O xford U niversity; M Sc 1971, Birmingham U niversity; PhD, 1978, U niversity of L ondon

A reas de interés: accidentes de trabajo; factores organizativos en el trabajo; trastornos musculosqueléticos de origen laboral

\section{Victor Shantora}

T oxics Pollution Prevention Directorate

Environment

O ttawa, O N K 1A OH 3, Canadá

Tel: 1 (819) 953-1114

Fax: 1 (819) 953-5371

E-mail: shantorav@cpit91.am.doe.ca

Puesto(s) actual(es): Director G eneral

E studios: M Sc, 1971, U niversity of W aterloo

A reas de interés: gestión de sustancias tóxicas; prevención de la contaminación

\section{Richard L. Shell}

U niversity of Cincinnati

Department of M echanical, Industrial and

Nuclear Engineering

M ail Location 116

Cincinnati, 0 hio 45221, Estados U nidos

Tel: 1 (513) 556-2634

Fax: 1 (513) 566-4999

Puesto(s) actual(es): Professor of Industrial Engineering

\section{Logan C. Shelman}

N ewport N ews Shipbuilding

Environmental

H ealth and Safety D epartment

4101 Washington Avenue

Newport N ews, VA 23607, Estados U nidos

Tel: 1757 380-7128

Fax: 1757 688-6007

E-mail: shelman_Ic@nns.com

Puesto(s) actual(es): Senior Environmental Engineer

Puesto(s) anterior(es): Nuclear Auditor; $R$ adiological Controls Engineer

E studios: BS, 1983, U niv. of K entucky; M . Eng. Adm., 1990, G eorge W ashington U niversity

A reas de interés: gestión de residuos sólidos peligrosos

\section{Arie Shirom}

Facultad de G estión
Univ, de T el Aviv

P.O.Box 39040

69978 T el Aviv, I srael

T el: 97236408100

Fax: 97236409560

E-mail: ashirom@ccsg.tau.ac.il

Puesto(s) actual(es): Profesor

Puesto(s) anterior(es): A sesor editorial

\section{Niu Shiru}

Instituto de Salud y T écnica A mbientales Academia C hina de M edicina Preventiva

$29 \mathrm{~N}$ an W ei R oad

Pekín 100050, China

Tel: 86103014326

Fax: 86103014342

Puesto(s) actual(es): Profesor, Director honorario

Puesto(s) anterior(es): Profesor, Director del Instituto de Salud y T écnica

Ambientales, A cademia China de $M$ edicina Preventiva

E studios: PhD, 1959, Instituto de Leningrado de Ciencias de la Edificación, antigua U nión Soviética

A reas de interés: tecnologías adecuadas de eliminación de polvo y purificación del aire para pequeñas industrias

\section{Steven Short}

Division of R espiratory Disease Studies

$\mathrm{N}$ ational Institute for $\mathrm{O}$ ccupational Safety and

$\mathrm{H}$ ealth

1095 Willowdale R oad

M organtown, WV 26505-2845, Estados U nidos

T el: 1 (304) 285-5723

Fax: 1 (304) 285-5861

Puesto(s) actual(es): M edical 0 fficer

Puesto(s) anterior(es): Pulmonary R esearch Fellow, CDC/NIOSH/DRDS/ CIB M organtown, WV; M edical Director/ Staff Internist, WW H astings Indian H ospital T ahlequah, O klahoma

E studios: BS, 1978, Southwestern College, W infield; D O , 1983, K irksville College at $O$ steopathic M edicine

A reas de interés: medicina clínica pulmonar; salud respiratoria en trabajadores agrícolas

\section{Donald E. Shrey}

2959 Perthwood Dr.

Cincinnati, 0 hio 45244, Estados U nidos

T el: 1 (513) 232-2661

Fax: 1 (513) 232-2661

E-mail: shreyde@ucunix.san.uc.edu

Puesto(s) actual(es): Associate Professor, U niversity of Cincinnati M edical C enter; President, Advanced T ransitions Inc.

E studios: PhD, 1976, Syracuse U niversity

A reas de interés: gestión, investigación, formación y consultoría sobre la discapacidad causada en el lugar de trabajo; gestión de lesiones en trabajadores de la industria; rehabilitacion profesional e indemnizaciones al trabajador

\section{Joë Shufro}

NYCOSH 275-7th Avenue

8th floor

N ueva Y ork, N ueva Y ork 10001, Estados

Unidos
Tel: 1 (212) 627-3900

Fax: 1 (212) 627-9812

Puesto(s) actual(es): Executive Director

Estudios: PhD, 1976, U niv. of W isconsin

\section{Konstantin K. Sidorov}

R egistro R uso de Sustancias Biológicas y

Q uímicas Peligrosas

18-20 V adkovsky per.

101479 M oscú, Federación Rusa

T el: 70959733021

Fax: 70959732657

E-mail: root@ regdang.msk.ru

Puesto(s) actual(es): Subdirector

Puesto(s) anterior(es): J efe del Departamento de T oxicología, Instituto de Higiene Industrial y Enfermedades Profesionales A cademia R usa de Ciencias M édicas

E studios: Graduado, 1961, Facultad de M edicina K alinin; Dr M ed Sci, 1987, Instituto de $H$ igiene Industrial y Enfermedades Profesionales

A reas de interés: problemas generales de toxicología en el trabajo

\section{Itzhak Siev-Ner}

Centro M édico I sraelí de Artes Escénicas 109 R othschild Blvd

65271 T el Aviv, Israel

Tel: 97236854690

Fax: 97236858263

E-mail: zivner@ netvision.net.il

Puesto(s) actual(es): Cirujano O rtopédico, M edicina Física y R ehabilitación, Centro $M$ édico de Sheba, T el-H ashomer

Puesto(s) anterior(es): Cirujano O rtopédico, Centro $M$ édico de Sheba, $\mathrm{T}$ el-H ashomer Escuela de M edicina Sackler, U niv. de Tel Aviv

Estudios: M D

A reas de interés: medicina de artes escénicas: medicina de apoyo; rehabilitación

\section{Ellen K. Silbergeld}

D epartment of E pidemiology \& Preventive $M$ edicine

U niversity of $M$ aryland at Baltimore

665 W est R edwood Street

Baltimore, M D 21201-1596, Estados U nidos

Tel: 1 (410) 706-1736

Fax: 1 (410) 706-8013

E-mail: esilber@epin.ab.umd.edu

Puesto(s) actual(es): Professor

Puesto(s) anterior(es): Senior Scientist, Environmental D efense Fund W ashington, DC

E studios: AB, 1967, V assar College; PhD, 1972, Johns H opkins

A reas de interés: toxicología ambiental; epidemiología molecular

\section{Marcel Simard}

Ecole des R elations I ndustrielles

U niversité de M ontréal

C.P. 6128 Succursale

M ontreal, Q uébec $\mathrm{H} 3 \mathrm{C}$ 3) 7, C anadá

Tel: 1 (514) 343-6193

Fax: 1 (514) 343-5764 
Puesto(s) actual(es): Professor

E studios: PhD, 1981, U niversité de M ontréal

A reas de interés: cultura y organización de la seguridad; prevención y cambios de comportamiento; comités de higiene industrial; políticas públicas y salud y seguridad en el trabajo

\section{Leif Simonsen}

Departamento de T oxicología y Biología Instituto $\mathrm{N}$ acional de M edicina del T rabajo Lersø Parkallé 105

2100 Copenhage, Dinamarca

Tel: 4539299711

Fax: 4539270107

E-mail: Isi@ami.dk

Puesto(s) actual(es): Científico

E studios: PhD, 1982, U niv. de Copenhage

A reas de interés: función sensorial, envejecimiento y demencia en animales de laboratorio

\section{Ken Sims}

Thrigby $\mathrm{H}$ all Wildlife $\mathrm{G}$ ardens

Filby G reat $Y$ armouth

Norfolk NR 29 3DR, R eino U nido

Tel: 441493369477

Fax: 441493369256

Puesto(s) actual(es): Director

A reas de interés: diseño de zoológicos

\section{William T. Singleton}

Borough H ouse

R othbury-M orpeth

N orthumberland NE65 7U A, R eino U nido T el: 441669620041

Puesto(s) actual(es): Professor Emeritus

Puesto(s) anterior(es): H ead, A pplied Psychology Department, Aston U niversity, UK

E studios: M A, 1950, Cambridge U niversity; DSc, 1971, Aston U niversity

A reas de interés: jubilación

\section{Susan Sink}

5925 N. Paulina \#1W

Chicago, Illinois 60660, Estados U nidos

T el: 1 (312) 784-9406

E-mail: ssink@luc.edu

Puesto(s) actual(es): Freelance W riter/ Editor

E studios: M FA, 1991, Sarah Lawrence College, Nueva Y ork

A reas de interés: gestión de residuos peligrosos; tecnologías ambientales

\section{Gisela Sjøgaard}

D epartamento de Fisiología

Instituto N acional de M edicina del T rabajo

L ersø Parkallé 105

2100 C openhage, Dinamarca

Tel: 4539299711
Fax: 4539270107
E-mail: gs@ami.dk

Puesto(s) actual(es): Directora de departamento, Profesora, en la U niv. de Copenhage, Dinamarca

E studios: M aths, 1968, U niv. de Copenhage; Phys Ed, 1971, U niv. de Copenhage;
W ork Phys, 1975, U niv.de Copenhage; PhD, 1979; Dr M ed Sc, 1990

A reas de interés: trastornos musculosqueléticos de origen laboral; epidemiología; cuantificación de la exposición en el lugar de trabajo; modelos de biomecánica

\section{Reinald Skiba}

Bergische U niversitat- G esamthochschule W uppertal

G ausstrasse 20

Postfach 100127

42097 W uppertal, Alemania

T el: 492024392053

Fax: 492024392127

Puesto(s) actual(es): Profesor de seguridad técnica y producción

\section{David H. Sliney}

\section{USACHPPM}

Attn: M CHB-DC-O LO

A berdeen Proving Ground M D 21010-5422, Estados U nidos

Tel: 1 (410) 671-3002

Fax: 1 (410) 877-1646

Puesto(s) actual(es): Commander

\section{Robert G. Smerko}

The Chlorine Institute Inc.

2001 L. St. NW

Suite 506

Washington, DC 20036, Estados U nidos

$$
\text { T el: } 1 \text { (202) 872-4724 }
$$

Fax: 1 (202) 223-7225

E-mail: sbradley@clz.com

Puesto(s) actual(es): President

\section{Donald L. Smith}

Nabisco Inc. Environmental Affairs and Safety

200 D eForest A venue

East $\mathrm{H}$ anover, $\mathrm{N}$ ew Jersey 07936, Estados Unidos

T el: 1 (973) 503-2009

Fax: 1 (973) 503-2311

E-mail: smithdon@ nabisco.com

Puesto(s) actual(es): Environmental Affairs and Safety $M$ anager

Puesto(s) anterior(es): Staff A ssistant, Safety, $\mathrm{H}$ ealth and Environmental Affairs, E.I. DuPont Photosystems, R ochester, N ueva Y ork

E studios: BSIE, 1974, Western N ew England

A reas de interés: seguridad e higiene industrial

\section{Gordon S. Smith}

Johns H opkins U niversity School of Public $\mathrm{H}$ ealth

624 N Broadway

Baltimore, M D 21205, Estados U nidos

T el: 1 (410) 955-7980

Fax: 1 (410) 614-2797

E-mail: gsmith@phnet.sph.jhu.edu

Puesto(s) actual(es): Associate Professor

E studios: M B, ChB, 1975, 0 tago U niversity M edical School; M PH , 1981, H arvard School of Public $\mathrm{H}$ ealth

A reas de interés: lesiones laborales; prevención de lesiones; lesiones y alcohol

\section{Ian R. Smith}

Program D evelopment Branch

O ntario M inistry of Environment and Energy

40 St. Clair Avenue W (14th floor)

T oronto, O N M 4V 1M 2, Canadá

Tel: 1 (416) 314-7996

Fax: 1 (416) 314-4128

E-mail: smithi@gov.on.ca

Puesto(s) actual(es): LAM P Coordinator

Puesto(s) anterior(es): Biohazards Scientist

E studios: M Sc, 1983, U niv. of G uelph

A reas de interés: epidemiología del cáncer; políticas para las sustancias tóxicas persistentes

\section{Michael J. Smith}

Univ. of Wisconsin

Department of Industrial Engineering

1513 U niversity A venue

M adison, WI 53706, Estados U nidos

Tel: 1 (608) 263-6329

Fax: 1 (608) 262-8454

E-mail: mjsmith@ macc.wisc.edu

Puesto(s) actual(es): Professor, D epartment $C$ hair

E studios: $B A, U$ niv. of W isconsin; $M A$, U niv. of W isconsin; PhD, U niv. of W isconsin

A reas de interés: estrés laboral; diseño del puesto de trabajo; seguridad en el trabajo

\section{N. A. Smith}

20 Valiant $\mathrm{G}$ ardens

Sprotbrough, D oncaster D N 5 7RU, R eino U nido

T el: 441302782514

Fax: 441302782514

Puesto(s) actual(es): Lighting Consultant

Puesto(s) anterior(es): Senior Lecturer; Lighting Engineer

E studios: BA, 1983, O pen U niversity; PhD, 1996, Univ. of Sheffield

A reas de interés: la iluminación y la salud y la seguridad en el trabajo y ambientales

\section{Juhani Smolander}

Departamento de Fisiología

Instituto Finlandés de M edicina del T rabajo

Laajaniityntie 1

$01620 \mathrm{~V}$ antaa, Finlandia

T el: 3580890713

Fax: 3580890713

E-mail: jsmo@ occuphealth.fi

Puesto(s) actual(es): Investigador

Puesto(s) anterior(es): Investigador ayudante; Investigador especializado

E studios: PhD, 1987, U niv. de K uopio

A reas de interés: fisiología laboral, térmica y del envejecimiento

\section{Marianne Smukowski}

U niversity of Wisconsin

Center for Dairy R esearch

1605 Linden Drive

M adison, WI 53706, Estados U nidos

Tel: 1608 256-6346

Fax: 1608 262-1578

E-mail: msmuk@cdr.wisc.edu

Puesto(s) actual(es): D airy Safety A pplications Coordinator 
Puesto(s) anterior(es): Q uality Control Specialist, L and O ' Lakes; Supervisor, U nited States D epartment of A griculture, D airy Division

E studios: BS, 1980, U niv. of W isconsin

A reas de interés: seguridad en productos lácteos

\section{David Snowball}

$\mathrm{H}$ ealth \& Safety Executive

R ose C ourt

2 Southwark Bridge

L ondres SE 1 9H S, R eino U nido

T el: 441717176643

Fax: 441717176990

Puesto(s) actual(es): Deputy Director G eneral's O ffice

Puesto(s) anterior(es): Her M ajesty's Inspector of $\mathrm{H}$ ealth and Safety

E studios: BA, 1979, L eeds U niversity; PhD, 1984, L eeds U niversity

\section{Jack W. Snyder}

T homas J efferson U niversity

125 South 11th Street 401 Pavilion

Philadelphia, PA 19107-4998, Estados U nidos Tel: 1 (215) 955-4895

Fax: 1 (215) 923-6039

E-mail: snyderj@jeflin.tju.edu

Puesto(s) actual(es): Associate Professor, Emergency $M$ edicine and Laboratory M edicine, Thomas J efferson U niversity

E studios: BS, N orthwestern U niversity; M D, N orthwestern U niversity; M FS, G eorge W ashington U niversity; M PH, Johns $\mathrm{H}$ opkins U niversity; PhD, M edical College of V irginia; JD, G eorgetown U niversity

A reas de interés: toxicología clínica y de investigación; medicina del trabajo; medicina legal; medicina en las artes

\section{Jerzy A. Sokal}

Instituto de M edicina del T rabajo y Salud

Ambiental

$13 \mathrm{~K}$ oscielna Street

41-200 Sosnowiec, Polonia

T el: 4832660640

Fax: 4832661124

E-mail: jas@imp.sosnowiec.pl

Puesto(s) actual(es): Director

Puesto(s) anterior(es): J efe del D epartamento de Evaluación de la T oxicidad, Instituto N ofer de M edicina del T rabajo, L odz, Polonia; Presidente del Grupo Q uímico, Comité Polaco M AC

E studios: PhD, 1971, U niv. de Lodz; DSc, 1985, U niversidad M édica de L odz; Profesor de Ciencias M édicas, 1997, U niv. $M$ édica de Silesia

A reas de interés: medicina del trabajo; salud ambiental

\section{Marja Sorsa}

M inisterio de Educación

PB 293

$00171 \mathrm{H}$ elsinki, Finlandia

Tel: 358913417463

Fax: 3589656765

E-mail: marja.sorsa@minedu.ti
Puesto(s) actual(es): Directora

Puesto(s) anterior(es): Directora de departamento; profesora de investigación

E studios: PhD, 1969, U niv. de H elsinki

A reas de interés: ética de la investigación genética; políticas científicas

\section{Colin L. Soskolne}

Dept. of Public H ealth Sciences

U niversity of Alberta

13-103 Clinical Sciences Building

Edmonton, AB T 6G 2G 3, Canadá

Tel: 1 (403) 492-6013

Fax: 1 (403) 492-0364

E-mail: colin.soskolne@ualberta.ca

Puesto(s) actual(es): Professor, Director of $G$ raduate $T$ raining

Puesto(s) anterior(es): Professor, Director, Epidemiology Program

E studios: BSc, 1970, U niv. of the W itwatersrand, Johannesburg, South Africa; BSc, 1971, U niv. of the W itwatersrand,

Johannesburg, South Africa; PhD, 1982, U niv. of Pennsylvania

A reas de interés: epidemiología del trabajo y ambiental del cáncer; deontología profesional

\section{Jerry Spiegel}

70 Niagara St.

W innipeg, M anitoba R 3N OT 9, Canadá Tel: 1 (204) 945-7482

Fax: 1 (204) 945-1211

Puesto(s) actual(es): Director, M anitoba Environment, Pollution Prevention

\section{Bengt Springfeldt}

D epartamento de M edicina Social y Salud Internacional

Instituto $\mathrm{K}$ arolinska

17283 Sundbyberg, Suecia

Tel: 4686497454

Fax: 4686497454

Puesto(s) anterior(es): Instituto R eal de T ecnología, D epartamento de $\mathrm{C}$ iencias del T rabajo, Estocolmo; Consejo Nacional de M edicina del T rabajo, Solna

E studios: PhD, 1993, Instituto R eal de T ecnología, D epartamento de Ciencias del Trabajo, Estocolmo

A reas de interés: costes de los accidentes de trabajo lesiones con cuchillos en el corte de carne

\section{Lorann Stallones}

Colorade State U niversity

D epartment of Environmental $\mathrm{H}$ ealth

Fort Collins, CO 80523, Estados U nidos

Tel: 1 (970) 491-6156

Fax: 1 (970) 491-1815

E-mail: istallones@vines.colostate.edu

E studios: M PH ; PhD

\section{Roger Stamm}

Berufsgenosssenschaftliches I nstitut für

A rbeitssicherheit

Alte $\mathrm{H}$ eerstrasse 111

53754 Sankt Augustin, Alemania

Tel: 492241231761

Fax: 492241231234

E-mail: S00100@ibm.rhrz.uni-bonn.de
Puesto(s) actual(es): J efe del D epartamento C entral

Puesto(s) anterior(es): C ientífico, U niv. de Bonn, Instituto de G eología; Científico, Fundación Alfred-W egener, Bonn; Científico, U niv. de Saarland, Instituto de Biofísica

Estudios: Dipl G eol, 1977, U niv.de Bonn; Dr rer nat, 1981, U niversidad de Bonn

A reas de interés: sistemas de información: productos químicos; exposición en el lugar de trabajo; EDI; prevención; evaluación de riesgos; epidemiología

\section{Heide Stark}

Departamento de Epidemiología

Instituto Federal de Seguridad y Salud en e

Trabajo

Nöldnerstrasse 40/ 42

D-10317 Berlín, Alemania

Tel: 493051548131

Fax: 493051548170

Puesto(s) actual(es): E pidemióloga del trabajo

A reas de interés: E pidemiología y prevención de lesiones en el trabajo; medicina de trabajo

William E. Steinke

U niversity of California Biological and Agricultural Engineering

Department

$O$ ne Shields A venue

Davis, CA 95616, Estados U nidos

Tel: 1916 752-1613

Fax: 1916 752-2640

E-mail: westinke@ucdavis.edu

Puesto(s) actual(es): Extension Agricultural Engineer

E studios: BS, 1975, M ichigan State U niversity; M S, 1978, U niversity of H awaii; PhD 1989, U niv. of California

A reas de interés: seguridad agrícola, ergonomía y salud; modelos y medición de plaguicidas para huertos; medida y representación estadística del riego por goteo

\section{Jeanne Mager Stellman}

School of Public H ealth

Columbia U niversity

600 W est 168th Street

N ueva Y ork, N ueva Y ork 10032, Estados Unidos

Tel: 1 (212) 3051164

Fax: 1 (212) 3053405

E-mail: jms13@columbia.edu

\section{Steven D. Stellman}

American $\mathrm{H}$ ealth Foundation

320 East 43rd Street

N ueva Y ork, N ueva Y ork 10017, Estados Unidos

Tel: 1 (212) 551-2521

Fax: 1 (212) 687-2339

E-mail: 70116.1546@compuserve.com

Puesto(s) actual(es): C hief, Division of Epidemiology

Puesto(s) anterior(es): A ssistant Commissioner for Biostatistics and E pidemiologic R esearch, $\mathrm{N}$ ew Y ork C ity D epartment of $\mathrm{H}$ ealth; A ssistant $V$ ice President for E pidemiology, A merican C ancer Society 
E studios: BSc, 1966, O hio State U niversity, Columbus; PhD, 1971, N ew Y ork U niv.; M PH, 1992, Columbia U niv.

A reas de interés: epidemiología del cáncer; tabaquismo; cáncer de mama

\section{Terje Sten}

División de Seguridad y Fiabilidad

SINTEF-Fundación para la Investigación

Científica e Industrial

Strindv. 2

7034 T rondheim, N oruega

T el: 4773592466

Fax: 4773592896

E-mail: terje.sten@indman.sintef.no

Puesto(s) actual(es): Director de investigación

Puesto(s) anterior(es): Director de la División de asistencia de Seguridad y Fiabilidad

E studios: C and, 1967, U niv. de 0 slo

A reas de interés: toma de decisiones en materia de seguridad; análisis de accidentes; gestión de la seguridad

\section{Craig R. Stenberg}

Duke U niversity M edical School Box 2914

Durham, NC 27710, Estados U nidos

Puesto(s) actual(es): Director, O ccupational $\mathrm{M}$ ental $\mathrm{H}$ ealth Programs

E studios: PhD

\section{Andrew Steptoe}

D epartment of Psychology

St. G eorge's H ospital M edical School U niversity of $L$ ondon

Cranmer Terrace

L ondres SW 17 ORE, R eino U nido

Tel: 441817255603

Fax: 441817672741

E-mail: asteptoe@ sghms.ac.uk

Puesto(s) actual(es): Professor

E studios: BA, 1972, U niv. of C ambridge; M A 1976, U niv. of C ambridge; DPhil, 1976, U niv. of O xford; DSc, 1995, U niv. of London

A reas de interés: psicología de la salud; psicofisiología; salud y estilo de vida

\section{Frank Stern}

$\mathrm{CDC} / \mathrm{NIOSH}$

M S-R 13

4676 C olumbia Parkway

Cincinnati, O hio 45226, Estados U nidos

Tel: 1513 841-4519

Fax: 1513 841-4486

E-mail: fbs@nioshel.em.cdc.gov

Puesto(s) actual(es): Senior R esearch Epidemiologist

Puesto(s) anterior(es): Supervisory E pidemiologist

E studios: BBA, 1967, U niv. of C incinnati; M S, 1980, U niv. of C incinnati

A reas de interés: curtido de cuero; toxicidad del monóxido de carbono; trabajadores de la construcción

James H. Stewart

$\mathrm{H}$ arvard U niversity School of Public $\mathrm{H}$ ealth
$665 \mathrm{H}$ untington Ave

Boston, M A 02115, Estados U nidos

E-mail: jim@ harv-ehs.mh3,harvard.edu

\section{Tom F.M. Stewart}

System Concepts L td.

2 Savoy Court Strand

Londres W C 2R OEZ, R eino U nido

Tel: 441712403388

Fax: 441712405212

E-mail: tom@ system.concepts.com

Puesto(s) actual(es): M anaging Director

Puesto(s) anterior(es): L ecturer in Ergonomics,

U niversity of T echnology,

L oughborough; Senior Consultant,

Butlercoxt Partnery; Projects M anager W illis Faber

E studios: BSc, 1968, U niv. of G lasgow; BSc, 1970, U niversity of G lasgow

A reas de interés: Ergonomía

\section{B.J. Stiles}

$N$ ational AIDS Fund

ST E. \#1200

1400 Eye Street NW

W ashington, DC 20005, Estados U nidos T el: 1 (202) 408-1818

Fax: 1 (202) 408-1818

Puesto(s) actual(es): Executive V ice President

Puesto(s) anterior(es): President, $\mathrm{N}$ ational L eadership C oalition on AIDS

E studios: BA, 1954, T exas W esleyan College; BD, 1957, Perkins School of Theology, Southern M ethodist U niv.; G raduate study, $V$ anderbilt U niversity

A reas de interés: reacción del sector privado al VIH/ SIDA; liderazgo corporativo en el SIDA; tendencias sobre el SIDA en el lugar de trabajo; corporaciones multinacionales; respuestas en el trabajo al SIDA

\section{Laura Stock}

U niversity of C alifornia,

Berkeley School of Public Health,

2515 Channing Way

Berkeley, CA 94720-5120, Estados U nidos

T el: 1 (510) 642-5507

Fax: 1 (510) 643-5698

E-mail: Istock@uclink4.berkeley.edu

Puesto(s) actual(es): L abor O ccupational $\mathrm{H}$ ealth Program, School of Public H ealth

E studios: BA, 1977, Brown U niversity, Providence; M PH , 1983, U niversity of California-Berkeley

\section{Daniel Stokols}

School of Social E cology

U niversity of California

Irvine, CA 92717-5150, Estados U nidos

T el: 1 (714) 856-6094

Fax: 1 (714) 824-2056

E-mail: dstokols@uci.edu

Puesto(s) actual(es): Professor, D ean

Puesto(s) anterior(es): President, Division of Population and Environmental Psychology (Division 34), American Psychological Association
E studios: BA, 1969, U niv, of Chicago; M A, 1971, $\mathrm{U}$ niv. of N orth Carolina at $\mathrm{C}$ hapel $\mathrm{H}$ ill; PhD, 1973, U niv. of N orth Carolina

A reas de interés: diseño y evaluación de programas de promoción de la salud en la comunidad y en el lugar de trabajo; factores de estrés en el trabajo y bienestar del empleado; perspectivas teóricas sobre las interacciones hombre-ambiente

\section{Ulrich Stössel}

Departamento de Sociología de la M edicina

U niversidad de Friburgo

Stefan M eier Strasse 17

79104 Friburgo, Alemania

Tel: 497612035520

Fax: 497612035520

E-mail: stoessel@ sun1.ruf.uni-freiburg.de

Puesto(s) actual(es): Profesor académico

E studios: Dr. Phil., 1979, U niversidad de Dortmund

A reas de interés: medicina del trabajo; salud pública; promoción de la salud

\section{Phillip W. Strine}

National Institute for $O$ ccupational Safety and $\mathrm{H}$ ealth

Building 1

R oom 300

71600 C lifton R oad NE

Atlanta, GA 30333, Estados U nidos

Tel: 1 (404) 639-3773

Fax: 1 (404) 639-2196

E-mail: pstrine@bellsouth.net

Puesto(s) actual(es): Special A ssistant to the A ssistant Surgeon G eneral, D eputy Director

Puesto(s) anterior(es): Public H ealth Advisor, Division of Sexually T ransmitted D iseases, C enters for D isease C ontrol and Prevention

E studios: BA, Simpson College; G raduate Studies, N orthwestern U niv., U niv. of Wyoming

A reas de interés: enfermedades infecciosas y epidemiología del trabajo; servicios de salud preventiva

\section{J. M. Strother}

Feildcrest Cannon, Inc

$O$ ne $L$ ake $D$ rive

K annapolis, NC 28081, Estados U nidos

Tel: 1704 939-2491

Fax: 1704 939-2302

E studios: BS, 1964, U niv. of N orth Carolina, Chapel $\mathrm{H}$ ill

\section{Dean T. Stueland}

National Farm M edicine C enter

1000 North 0 ak A venue

$M$ arshfield, WI 54449, Estados U nidos

Tel: 1715 387-9298

Fax: 1715 389-3131

E-mail: stueland@mfldclin.edu

Puesto(s) actual(es): M edical Director

E studios: M SEE, 1973, U niv. of W isconsin; M D 1977, U niv. of W isconsin; M PH , 1997, $\mathrm{M}$ edical $\mathrm{C}$ ollege of $\mathrm{W}$ isconsin 
A reas de interés: medicina de urgencia; prevención y vigilancia de lesiones; exposición y lesiones en agricultura; prestación de asistencia sanitaria en el medio rural

\section{Zhi Su}

M inisterio de Sanidad

Departamento de Inspección y Supervisión

$44 \mathrm{H}$ ouhai Beiyan

Pekín 100725, China

T el: 861064001675

Fax: 861064015609

Puesto(s) actual(es): Director, División de Nutrición e Inspección de H igiene Alimentaria

Puesto(s) anterior(es): Subdirector, División de M edicina del Trabajo

E studios: M D , 1982, U niv. M édica de China O ccidental; M PH , 1989, U niv. de M edicina de Pekín

A reas de interés: medicina del trabajo; administración y política activa en sanidad; legislación sanitaria; seguridad e higiene de los alimentos

\section{Jerry Suls}

Department of Psychology U niversity of I owa

Spence Laboratories

I owa City, IA 52242, Estados U nidos

Tel: 1 (319) 335-0569

Fax: 1 (319) 335-0191

E-mail: jsuls@blue.weeg.uiowa.edu

Puesto(s) actual(es): Professor

Puesto(s) anterior(es): Professor, Psychology, State U niv. of N ew Y ork at Albany

E studios: PhD, 1973, T emple U niversity

A reas de interés: trastornos cardiovasculares; enfermedades $\mathrm{G}$ 7; estrés y enfermedad

\section{F. William Sunderman, Jr.}

U niv. of C onnecticut M edical School

263 Farmington A venue

Farmington, CT 06030-2225, Estados U nidos

Tel: 1 (203) 679-2328

Fax: 1 (203) 679-2154

E-mail: sunderman@nsol.uchc.edu

Puesto(s) actual(es): Professor of T oxicology

E studios: BS, 1952, Emory U niversity; M D, 1955, Jefferson U niversity

A reas de interés: toxicología de metales; carcinogénesis; teratogénesis

\section{Alice H. Suter}

Industrial Audiology and Community Noise

Alice Suter \& A ssociates

575 Dogwood Way

A shland, O R 97520, Estados U nidos

T el: 1 (503) 488-8077

Fax: 1 (503) 488-8077

E-mail: asuter@cdsnet.net

Puesto(s) actual(es): Principal Consultant

Puesto(s) anterior(es): Project $M$ anager, N oise Standard, US O ccupational Safety and $\mathrm{H}$ ealth Administration; Senior Bioacoustical Scientist, O ffice of N oise A batement and Control, US

Environmental Protection Administration
E studios: PhD, U niv. of M aryland

A reas de interés: incapacidad auditiva; efectos de la exposición a ruido ambiental

\section{German A. Suvorov}

Instituto de Salud en el T rabajo (A cademia

R usa de Ciencias M édicas)

31 Prospekt Budennogo

105275 M oscú, Federación R usa

T el: 70953654603

Fax: 70953660583

Puesto(s) actual(es): Subdirector

Puesto(s) anterior(es): J efe del Laboratorio de Factores Físicos

E studios: BS, 1960, Instituto de $\mathrm{H}$ igiene de L eningrado; Postgraduado, 1963; M D, $\mathrm{PhD}$, Instituto de $\mathrm{H}$ igiene de L eningrado

A reas de interés: desarrollo de patologías debidas a vibraciones de cuerpo completo y a vibraciones mano-brazo; ruido industrial

\section{Haruko Suzuki}

Instituto de la Ciencia del Trabajo (ISL)

2-8-14 Sugao M iyamae-ku

K awasaki 216, Japón

Tel: 81449772121

Fax: 81449777504

Puesto(s) actual(es): División de Información Científica

E studios: 1970, U niv. M etropolitana de T okyo

A reas de interés: la mujer en el trabajo; vida laboral de las mujeres

\section{John J. Svagr}

K raft Foods

Safety and $R$ isk $M$ anagement D epartment

800 W estchester A venue, R A-4S

R ye Brook, N ueva Y ork 10573-1301, Estados Unidos

T el: 1914 335-4743

Fax: 1914 335-4703

E-mail: jsvagr@kraft.com

Puesto(s) actual(es): $M$ anager, Industrial $H$ ygiene and Safety-N orth A merica

Puesto(s) anterior(es): $M$ anager, R egulatory Affairs-Eutectic C astolin Corporation Flushing, NY; Senior Industrial $\mathrm{H}$ ygienist, $\mathrm{N}$ ew $\mathrm{Y}$ ork $\mathrm{C}$ ity $\mathrm{T}$ ransit Authority, Brooklyn, NY; Industrial $\mathrm{H}$ ygienist, American $\mathrm{Cyanamid}$ R esearch Labs, Stamford, CT; Industrial $H$ ygienist, Insulating $M$ aterials-G eneral Electric, Schenectady, NY

E studios: BA, 1975, 0 akland U niversity, R ochester, M I; M PH , 1979, U niversity of Michigan, Ann Arbor

A reas de interés: salud y seguridad en la manipulación y distribución de alimentos; legislación en materia de prácticas de higiene industrial y aspectos gubernamentales

\section{Naomi Swanson}

NIOSH Robert A. T aft Laboratories

4676 C olumbia Parkway

Cincinnati, O hio 45226-1998, Estados U nidos

T el: 1 (513) 533-8165

Fax: 1 (513) 533-8510
E-mail:nws3@niobbsl.em.cdc.gov

Puesto(s) actual(es): C hief, M otivation and Stress Research Section

Puesto(s) anterior(es): R esearch Psychologist, $\mathrm{N}$ ational Institute for $\mathrm{O}$ ccupational Safety and $\mathrm{H}$ ealth

E studios: PhD, 1989, U niv. of W isconsin, M adison

A reas de interés: estrés laboral; ergonomía de pantallas de visualización

\section{William Symons}

Washington State U niversity

Biological Systems Engineering D epartment

Pullman, WA 99164-6120, Estados U nidos

Tel: 1 (509) 335-2902

Fax: 1 (509) 335-2722

E-mail: symons@mail.wsu.edu

Puesto(s) actual(es): Associate Professor, Safety Specialist

Puesto(s) anterior(es): Assistant Professor D epartment of Agricultural Engineering Southern Illinois U niversity; A ssistant Professor, Agricultural T echnical Institute, O hio State U niversity

E studios: BS, 1969, Chico State U niv. California; M S, 1973, California State U niv.-Fresno; PhD, 1975, O hio State Univ.

A reas de interés: seguridad en granjas; mecanización en la agricultura

\section{Keith D. Tait}

Pfizer Inc. 88460

Corporate H ealth and Safety

235 E 42nd Street

N ueva Y ork, N ueva Y ork 10017-5755, Estados

Unidos

Tel: 1 (212) 573-3640

Fax: 1 (212) 573-7442

E-mail: compuserve: 74764,1465

Puesto(s) actual(es): A ssistant Director, Corporate $\mathrm{H}$ ealth and Safety

Puesto(s) anterior(es): Safety M anager, Industrial $H$ ygienist, $A T \& T$ Bell Labs

E studios: M PH , 1981, Y ale U niversity; M FS 1981, Y ale U niversity; BA, 1978, State U niversity of $\mathrm{N}$ ew $\mathrm{Y}$ ork, Plattsburgh

\section{Ken Takahashi}

D epartamento de E pidemiología A mbienta

U niversidad de M edicina del T rabajo y A mbiental

O rio

Yahatanishi

K itakyushu 807, Japón

Tel: 81936917454

Fax: 8193601732

E-mail: kataka@rose.med.uoeh-u.ac.jp

Puesto(s) actual(es): Profesor asociado

E studios: M D, 1983, U niv. K eio, Japón; Dr M ed Sc, 1990, U niversidad de M edicina de T rabajo y A mbiental, Japón; M PH, 1991, U niv. of Pittsburgh, G raduate School of Public Health

A reas de interés: epidemiología del trabajo y ambiental; servicios de salud en el trabajo 


\section{Jukka Takala}

Sección de Seguridad y Salud en el T rabajo O rganización Internacional del Trabajo 4 route des $M$ orillons

1211 G inebra 22, Suiza

T el: 41227996740

Fax: 41227986253

E-mail: takala@ilo.ch or

100043.2440@ compuserve.com

Puesto(s) actual(es): Jefe de Sección

Puesto(s) anterior(es): J efe de la Sección Internacional de Salud y Seguridad en el T rabajo, O rganización Internacional del T rabajo; Asesor técnico jefe,

O rganización Internacional del T rabajo, K enia, T ailandia; Subdirector, Departamento de Seguridad de M áquinas, M inisterio de T rabajo, Finlandia

E studios: D rT ech., 1992, U niversidad de T ecnología de T ampere; M Sc, 1970, U niversidad de T ecnología de H elsinki

A reas de interés: información para la salud y la seguridad en el trabajo (impresa, en CD-R O M, en línea, por Internet); cooperación técnica en salud y seguridad en el trabajo

\section{Krishna K. Talluri}

Duke U niversity M edical C enter Box 3837

Durham, NC 27710, Estados U nidos

$$
\text { T el: } 1 \text { (919) 684-2258 }
$$

Puesto(s) actual(es): R esident, Psychiatry

Puesto(s) anterior(es): Private Practice; Emergency R oom M edical O fficer Castries, St. L ucia, W est Indies; R esearch A ssociate, Clinical Pharmacology, O hio State U niversity

E studios: M B, BS, 1975, Sri V enkatesloara $M$ edical C ollege, T irupati, India

A reas de interés: psiquiatría y abuso de sustancias

\section{Gary M. Taylor}

T aylor/ Wagner Inc.

19 Pleasant A venue

Willowdale, O N M 2M 1L8, Canadá

Tel: 1 (416) 222-9715

Fax: 1 (416) 250-0967

E-mail: Gary-T aylor@taylorwagner.com

\section{James S. Taylor}

Cleveland Clinic Foundation

9500 Euclid Avenue

Cleveland, O hio 44195-5032, Estados U nidos

Tel: 1216 444-5723

Fax: 1216 445-6365

E-mail: taylorj@ cesmtp.ccf.org

Puesto(s) actual(es): H ead, Industrial D ermatology

Puesto(s) anterior(es): M edical O fficer, National Institute for $O$ ccupational Safety and $\mathrm{H}$ ealth Education

E studios: M D, Indiana U niversity

A reas de interés: dermatología ambiental y laboral; dermatitis de contacto y pruebas con parche; alergia al látex, al caucho, a los guantes; acné por compuestos de cloro; publicaciones científicas
Rachael F. Taylor

262 R te. D'O rnex

Prevessin-M oëns

01280 Ferney-V oltaire, Francia

T el: 3350401979

Fax: 3350429082

E-mail: rachael@demon

Puesto(s) actual(es): C onsultora

Puesto(s) anterior(es): A yudante de edición, O rganización Internacional del Trabajo, Enciclopedia de Salud y Seguridad en el Trabajo; R esidente, O rganización Internacional del Trabajo

E studios: LLB, 1993, Q ueen M ary Westfield C ollege, U niv. of L ondon

\section{Spomenka Telišman}

Instituto de I nvestigaciones $M$ édicas y $M$ edicina del Trabajo

PO Box 291

K saverska cesta 2

10001 Zagreb, Croacia

T el: 3851221573

Fax: 3851274572

E-mail: telisman@mimi.imi.hr

Puesto(s) actual(es): C onsultor científico

Puesto(s) anterior(es): A yudante de investigación, Científico asociado, Científico asociado jefe, Instituto de Investigaciones M édicas y M edicina del T rabajo

E studios: BSc, 1971, Facultad de Ciencia y $M$ atemáticas en la U niv. de Zagreb; M Sc, 1974, U niversidad de Zagreb; DSc, 1983, U niversidad de Zagreb;

A reas de interés: efectos en la salud de la interacción entre metales esenciales y/ 0 tóxicos; metaloides en el hombre (en especial plomo, cadmio, cobre, zinc y selenio)

\section{Benedetto Terracini}

U niversità di T urín y H ospital U niversitario

Sez. di Anatomia e Istologia Patologica

$\checkmark$ ia Santena 7

10126 T urín, I talia

T el: 39116706526

Fax: 39116706692

Puesto(s) actual(es): J efe de la U nidad de Epidemiología del Cáncer

A reas de interés: epidemiología del cáncer, carcinogénesis, catástrofe ambiental

\section{Kay Teschke}

Univ. of British Columbia

D epartment of $\mathrm{H}$ ealth $\mathrm{C}$ are and Epidemiology

$M$ ather Building

V ancouver, BC V 6T 1Z3, Canadá

Tel: 1 (604) 822-2401

Fax: 1 (604) 822-4994

E-mail: teschke@unixg.ubc.ca

Puesto(s) actual(es): Associate Professor

E studios: M PH, 1982, U niv. of California-Berkeley; PhD, 1994, U niv. of W ashington

A reas de interés: industria forestal; factores de exposición; evaluación de la exposición para epidemiología

\section{Jamie Tessler}

69 R utland R oad

Brooklyn, N ueva Y ork 11225, Estados U nidos

Tel: 718-693-7870

E-mail: jtessler@igc.org

Puesto(s) actual(es): Public Employees Federation

Puesto(s) anterior(es): Coordinator: Ergonomics Training Program; $\mathrm{O}$ ccupational $\mathrm{H}$ ealth and Safety C onsultant; $\mathrm{H}$ ealth and Safety Specialist

E studios: M PH , 1993, H unter C ollege

A reas de interés: ergonomía en asistencia sanitaria; sensibilidad a productos químicos de baja intensidad; enfermedades infecciosas; creación de comités conjuntos dirección/ trabajadores; educación y formación

\section{Lois E. Tetrick}

U niversity of $\mathrm{H}$ ouston

Department of Psychology

H ouston, TX 77204-5341, Estados U nidos

Tel: 1 (713) 743-8516

Fax: 1 (713) 743-8588

E-mail: Itetrick@uh.edu

Puesto(s) actual(es): Professor

Puesto(s) anterior(es): D epartment of Psychology, Wayne State U niversity

E studios: PhD, 1983, G eorgia Institute of T echnology

A reas de interés: psicología de la salud en el trabajo; estrés laboral; dedicación profesional

\section{Töres Theorell}

Instituto N acional de Factores Psicosociales y Salud

Box 230

17177 Estocolmo, Suecia

Tel: 4687286400

Fax: 468344143

E-mail: tores.theorell@ipm.ki.se

Puesto(s) actual(es): Profesor, Director

Puesto(s) anterior(es): M édico, M edicina interna; $M$ édico ayudante jefe; Profesor; Instituto $\mathrm{N}$ acional de Factores Psicosociales y

Salud; Director, Profesor, Instituto $\mathrm{N}$ acional de Factores Psicosociales y Salud, Instituto K arolinska; Senior R esearcher, School of Public H ealth Johns H opkins U niversity; M édico jefe de Factores Psicosociales en el Dep. de $M$ edicina del Trabajo, $\mathrm{H}$ ospital $\mathrm{K}$ arolinska

E studios: M edicina, 1967, Instituto K arolinska, Estocolmo; M D, PhD, 1971, Instituto K arolinska, Estocolmo; Profesor asistente, 1973, Instituto K arolinska, Estocolmo;

A reas de interés: psicología del medio ambiente de trabajo; trastornos cardiovasculares; trastornos funcionales

\section{Richard J. Thomas}

$\mathrm{N}$ avy Environmental and Preventive M edicine Unit N umber T wo

U nited States N avy

312 N ottingham R oad

W illiamsburg, V irginia 23185-4913, Estados

Unidos 
T el: 1 (757) 220-3761

Fax: 1 (757) 444-1191

E-mail: thomasrj@pol.net

Puesto(s) actual(es): 0 fficer in Charge; O ccupational M edicine Physician

Puesto(s) anterior(es): Preventive M edicine 0 fficer, III $\mathrm{M}$ arine Expeditionary Force and $O$ ccupational M edicine Physician, $\mathrm{N}$ aval H ospital; D eputy Director for $\mathrm{O}$ ccupational $\mathrm{H}$ ealth, $\mathrm{O}$ ccupational $M$ edicine D epartment $\mathrm{H}$ ead, $\mathrm{N}$ avy Environmental $\mathrm{H}$ ealth $\mathrm{C}$ enter

E studios: BS, 1975, U nited States N aval Academy; M D, 1979, G eorgetown U niversity; M PH , 1984, Johns H opkins University

A reas de interés: medicina del trabajo, medicina preventiva y sanidad pública; epidemiología relacionada con militares

\section{Frank H. Thorn}

$N$ ewport N ews Shipbuilding

Environmental $\mathrm{H}$ ealth and Safety

Department

4101 Washington A venue

N ewport N ews, VA 23607, Estados U nidos Tel: 1757 688-9247

Fax: 1757 688-6007

E-mail: thorn_fh@nns.com

Puesto(s) actual(es): $M$ anager, Environmental Engineering

Puesto(s) anterior(es): N uclear W ater Chemist; Environmental $\mathrm{M}$ onitor and Coordinator; Environmental Engineer

E studios: AS, 1983, Thomas N elson Community College; BS, 1996, O Id Dominion U niversity

A reas de interés: Acta del Agua Limpia; vertidos de aguas residuales industriales/ de agua de

\section{James R. Thornton}

N ewport N ews Shipbuilding

Environmental $\mathrm{H}$ ealth and Safety Division

4101 Washington A venue

Dept. 027

N ewport N ews, VA 23607-2770, Estados

Unidos

Tel: 1757 380-4651

Fax: 1757 688-7673

E-mail: thornton_rj@nns.com

Puesto(s) actual(es): Director, Environmental, $\mathrm{H}$ ealth, and Safety Division

Puesto(s) anterior(es): $M$ anager, $\mathrm{H}$ ealth, Safety and Environmental D epartment, N ewport N ews Shipbuilding; Industrial H ygienist, $R$ esearch Triangle Institute, $R$ aleigh, $\mathrm{NC}$ : Industrial H ygienist, T ennessee Valley Authority, M uscle Shoals, AL

E studios: BS, 1969, Auburn U niversity; M S, 1972, T exas A\&M U niversity

\section{Kendall Thu}

U niverstiy of l owa

College of M edicine

Institute for R ural and Environmental $\mathrm{H}$ ealth

124 AM R F

1000 akdale $C$ ampus

I owa City, IA 52242, Estados U nidos

T el: 1319 335-4224
Fax: 1319 335-4225

E-mail: kendall-thu@uiowa.edu

E studios: PhD, 1992, U niversity of I owa

A reas de interés: factores de riesgo de lesiones en el sector agrícola; agricultura industrial y salud rural; política agrícola y Estado

\section{Ulrike Tittelbach}

Instituto Federal de Seguridad y Salud en el

Trabajo

Nöldnerstrasse $40 / 42$

D-10317 Berlín, Alemania

Tel: 493051548330

Fax: 493051548170

Puesto(s) actual(es): Científico, D epartamento de Efectos sobre la Salud de Sustancias Peligrosas

E studios: M D, 1966, M edizinische A kademie Erfurt

\section{Lori Todd}

U niversity of N orth Carolina

CB7 400

Chapel Hill, NC 27599-7100, Estados U nidos

T el: 1 (919) 966-7302

Fax: 1 (919) 966-4711

E-mail: todd@ hatteras.cs.unc.edu

Puesto(s) actual(es): Assistant Professor Industrial Hygiene

E studios: BS, 1975, Antioch College; M S, 1980 , Cornell U niv.; PhD, 1990, U niv. of $\mathrm{N}$ orth $\mathrm{C}$ arolina at $\mathrm{C}$ hapel $\mathrm{H}$ ill

\section{Dennis Tolsma}

$N$ ational Institute for $O$ ccupational Safety and $\mathrm{H}$ ealth

Centers for D isease Control and Prevention

1600 Clifton R oad NE

Atlanta, GA 30333, Estados U nidos

T el: 1 (404) 639-2376

Fax: 1 (404) 639-2196

\section{Kjell Torén}

H ospital U niversitario Sahlgrenska

Departamento de M edicina del T rabajo

St Sigfridsgatan 85B

41266 G öteborg, Suecia

T el: 4631354872

Fax: 4631409728

Puesto(s) actual(es): Profesor asociado de M edicina del Trabajo

A reas de interés: efectos en la salud por las operaciones con molinos de pulpa de papel y pape

\section{James R. Townhill}

2601 Cannon Blvd

K annapolis, NC 28083, Estados U nidos

T el: 704-938-1604

Fax: 704-938-4010

Puesto(s) anterior(es): Safety M anager and Safety Director, G eneral Tire, Inc

E studios: BS Biology, 1962, Dickenson College, Carlsle, PA

\section{Angela K. Traiforos}

Center for Admin. Rehabilitation \&

Employment Services

International Association of $M$ achinists

$9000 \mathrm{M}$ achinists Place

U pper M arlboro, M D 20772, Estados U nidos
Tel: 1 (301) 967-4717

Fax: 1 (301) 967-4585

Puesto(s) actual(es): Executive Director

Puesto(s) anterior(es): D eputy Executive Director,

IAM CARES; Employment Coordinator, Lt. J. K ennedy Institute

E studios: Diploma de enseñanza de francés, 1971, Academia Francesa, Atenas, G recia; BA, 1976, Purdue U niv.; M Ed, 1983, U niv. of M aryland

A reas de interés: rehabilitación profesional; ergonomía; salud y seguridad; economía de la discapacidad; iniciativas dirección-empleado; vuelta al trabajo; rehabilitación internacional

\section{Anne Trebilcock}

O ficina de A sesoramiento J urídico

O rganización Internacional del Trabajo

4 route des $M$ orillons

1211 G inebra 22, Suiza

Tel: 41227997182

Fax: 41227884736

Puesto(s) actual(es): D irectora jurídica

Puesto(s) anterior(es): Especialista en Derecho Laboral, O rganización Internacional del T rabajo; Investigadora, Instituto $M$ ax Planck, H eidelberg, Alemania; Assistant G eneral C ounsel, U nited Auto W orkers U nion, Detroit

E studios: BA, 1970, W ellesley College; JD, 1974 U niversity of California-Berkeley

A reas de interés: $\mathrm{D}$ erecho laboral; legislación pública internacional

\section{John Trent}

Alaska D epartment of Fish and Game

Division of Wildlife Conservation

333 R aspberry R oad

Anchorage, AK 99518, Estados U nidos

T el: 1907 267-2191

Fax: 1907 267-2433

E-mail: johnt@ fishgame.state.ak.us

Puesto(s) actual(es): Wildlife Biologist; R ural Issues Coordinator

Puesto(s) anterior(es): Barrow Area Biologist; $M$ anagement $C$ oordinator-South $C$ entral Alaska

E studios: BS, 1967, U niv. of A laska-Fairbanks; M S, 1982, U niv. of W isconsin-M adison; PhD, U niv. of Wisconsin-M adison

\section{Rüdiger M. Trimpop}

Univ. Friedrich Schille

07743 Jena, Alemania

$$
\text { Tel: } 49233681804
$$

Fax: 49233681804

Puesto(s) actual(es): Profesor ayudante

Puesto(s) anterior(es): Profesor, U niv.de Bochum

E studios: Dip, 1985, U niv. de Bochum, Alemania; PhD, 1990, Q ueens U niversity, K ingston, C anadá

A reas de interés: salud y seguridad; asunción del riesgo; motivación en el trabajo

\section{Don Trotter}

School of Engineering L aurentian U niversity

Ramsey Lake R oad

Sudbury, ON P3E 2C6, Canadá 
T el: 1 (705) 675-1151

Fax: 1 (705) 675-4862

Puesto(s) actual(es): Professor of $M$ ining Engineering

Puesto(s) anterior(es): Director, Centre for $M$ ining and $M$ ineral Exploration R esearch; $M$ anager, $M$ ines Accident Prevention Association of $O$ ntario

E studios: B Eng., 1957, Q ueen's U niversity, Canadá; M Eng, 1976, M cGill U niversity

A reas de interés: iluminación en minas; salud y seguridad en la minería

\section{RenéTroxler}

0 berseeburghalde 24

6006 L ucerna, Suiza

$$
\text { T el: } 41413702880
$$$$
\text { Fax: } 41413702880
$$

Puesto(s) actual(es): Ingeniero de seguridad E studios: Dipl. M aschineningenieur, HTL/ ST V A reas de interés: Sicherheitsschaltungen/ Sicherheitsschaltein-richtungen; Produktesicherheitsregelung in Europa und weltweit

\section{Benjamin F. Trump}

Univ. of $\mathrm{M}$ aryland School of M edicine 10 South Pine Street

Baltimore, M D 21201-1192, Estados U nidos

T el: 1 (410) 706-7070

Fax: 1 (410) 706-3743

E-mail: BT rump@umabnet.ab.umd.edu

Puesto(s) actual(es): Professor and Chairman, D epartment of Pathology

Puesto(s) anterior(es): R esearch Investigator, AFIP, W ashington, DC; Assistant Professor, Department of Pathology, U niv. of Washington School of M edicine, Seattle; A ssociate Professor, D epartment of Pathology, Duke Univ., Durham, NC; Professor, D epartment of Pathology, Duke U niv., Durham, NC

E studios: BA, 1953, U niv. of M issouri; M D, 1957, U niv. of $\mathrm{K}$ ansas

A reas de interés: mecanismos de reacción celulares y subcelulares a lesiones de la célula, incluida la carcinogénesis

\section{Tom Tseng}

4905 Dufferin Street

Downsview, ON M 3H 5T 4, Canadá

T el: 1 (416) 739-5853

Fax: 1 (416) 739-4159

E-mail: tsengt@aestor.am.doe.ca@gw

Puesto(s) actual(es): Senior Advisor, Environment Canadá, O ntario R egion

Puesto(s) anterior(es): $M$ anager, Pollution Prevention and Abatement

E studios: PhD, 1979, Cornell U niversity

A reas de interés: sustancias tóxicas

\section{Ulf Ulfvarson}

Instituto R eal de T ecnología

Departamento de T ecnología A mbiental y Ciencias del T rabajo

10044 Estocolmo, Suecia

T el: 4687906055
Fax: 468108377

E-mail: ulfu@aml.kth.se

Puesto(s) actual(es): Profesor de ergonomía industrial

Puesto(s) anterior(es): Profesor de higiene en el trabajo, Consejo N acional de Salud y Seguridad en el Trabajo, Solna, Suecia

E studios: PhD, 1970, Instituto R eal de T ecnología, Estocolmo

A reas de interés: ingeniería ambiental; ciencia de trabajo

\section{Eberhard Ulich}

Eidgenössische T echnische H ochschule ETH Institut für Arbeitspsychologie

N elkenstrasse 11

8092 Zurich, Suiza

Tel: 4116327072

Fax: 4116321186

E-mail: @ifap.bepr.ethz.ch

Puesto(s) actual(es): Director, Instituto de Psicología del Trabajo, Instituto Federal Suizo de T ecnología

\section{Timothy J. Ungs}

U S C oast G uard H eadquarters

2100 2nd Street SW

W ashington, DC 20593, Estados U nidos

T el: 1 (202) 267-0692

Fax: 1 (202) 267-4355

Puesto(s) actual(es): Commandant (G-WK S-3)

E studios: M D; M S

\section{Arthur C. Upton}

401 E 86th Street

Apt. 12B

N ueva Y ork, N ueva Y ork 10028, Estados Unidos

T el: 1 (212) 348-4361

Fax: 1 (212) 410-9847

E-mail: acupton@cohsi.rntgers.edu

Puesto(s) actual(es): C linical Professor of Environmental and Community M edicine, UM DNJ R obert Wood Johnson M edical School

Puesto(s) anterior(es): Professor, Environmental M edicine, N ew Y ork U niv. School of $M$ edicine; Director, $\mathrm{N}$ ational $\mathrm{C}$ ancer Institute

E studios: BA, 1944, U niv. of M ichigan; M D, 1946, U niv. of M ichigan

A reas de interés: lesiones por radiación; salud ambiental

\section{Jill P.G. Urban}

Laboratory of Physiology

U niversity of $\mathrm{O}$ xford

Parks R oad

O xford OX 1 3PT, R eino U nido

T el: 441865272509

Fax: 441865272469

E-mail: jpgu@physiol.ox.ac.uk

Puesto(s) actual(es): Senior R esearch Fellow

E studios: PhD, 1977, U niv. of L ondon

A reas de interés: fisiología del disco intervertebral
Holger Ursin

Universidad de Bergen

Årstadveien 21

5009 Bergen, N oruega

Tel: 4755206227

Fax: 4755296535

Puesto(s) actual(es): Profesor, D epartamento de Psicología Biológica y M édica

Puesto(s) anterior(es): Profesor visitante; Secretario general de la XIV Conferencia Nórdica de Fisiología y Farmacología, Bergen

E studios: M D, 1965, U niversidad de 0 slo

A reas de interés: patología, psicología del estrés

\section{Antero Vähäpassi}

O rganización Internacional del T rabajo 5-103

4 route des $M$ orillons

1211 Ginebra 22, Suiza

Tel: 41227997884

Fax: 41227880952

E-mail: vahapassi@hq1.ilo.ch

Puesto(s) actual(es): A sesor técnico jefe

Puesto(s) anterior(es): Profesor suplente; Inspector jefe; Ingeniero de seguridad

E studios: M Sc, 1972, U niv. T écnica de H elsinki; Lic T ech, 1978, U niversidad de T ecnología de T ampere

A reas de interés: administración e inspección de trabajo en economías de transición; salud y seguridad en el trabajo, sobre todo en economías en desarrollo; educación y práctica en adultos

\section{Harri Vainio}

Agencia Internacional para la Investigación sobre el Cáncer

150 cours Albert-T homas

F-69372 Lyon, Francia

Tel: 33472738418

Fax: 33472738319

E-mail: vainio@iarc.fr

Puesto(s) actual(es): J efe, U nidad de Q uimioprevención

Puesto(s) anterior(es): Director, D epart. de H igiene Industrial y T oxicología, Instituto Finlandés de M edicina del T rabajo

A reas de interés: cáncer; epidemiología molecular; quimioprevención

José A. Valciukas

Lincoln $\mathrm{M}$ edical and $\mathrm{M}$ ental $\mathrm{H}$ ealth $\mathrm{C}$ enter

234 E 149th Street

Bronx, N ueva Y ork 10451, Estados U nidos Tel: 1 (718) 579-5779

Fax: 1 (718) 579-5283

Puesto(s) actual(es): D irector, Psychology Internship T raining Program

Puesto(s) anterior(es): Senior Psychologist, Forensic Psychiatry Clinic, N ew Y ork State; Editor, Environmental R esearch: Associate Professor, M ount Sinai School of $M$ edicine

E studios: PhD, 1970, G raduate Center, City U niversity of N ew Y ork

A reas de interés: neuropsicología clínica y forense; neurotoxicología laboral y ambiental; neurociencias 


\section{Mark A. Veazie}

A rizona E mergency $M$ edicine R esearch $C$ enter $U$ niv. of A rizona

1501 N. Campbell Avenue

Tucson, AR 85724, Estados U nidos

T el: 1 (520) 626-2542

E-mail: mark@aemrc.arizona.edu

Puesto(s) actual(es): Assistant Director of R esearch

Puesto(s) anterior(es): E pidemiologist, N ational Institute for $O$ ccupational Safety and $\mathrm{H}$ ealth, M organtown, WV

\section{María Luz Vega Ruiz}

O rganización Internacional del Trabajo

4 route des $M$ orillons

1211 G inebra 22, Suiza

T el: 41227998084

Fax: 41227998749

Puesto(s) actual(es): Especialista en D erecho laboral y relaciones laborales

Puesto(s) anterior(es): Inspectora de trabajo y seguridad social, España

E studios: especialidad en D erecho y R elaciones L aborales e Inspección de T rabajo, 1986, M inisterio de Trabajo, España; licenciatura, Derecho L aboral, 1985 U niversidad Complutense, M adrid, España

A reas de interés: derecho y relaciones laborales

\section{Pierre Verger}

L ab. d'E pidémiologie et d'A nalyse du D étriment Sanitaire

Institut de Protection et de Sûreté Nucléaire BP 6

92265 Fontenay-aux-R oses CEDEX, Francia

Tel: 33146549619

Fax: 33146570386

E-mail: verger@mandrake.cea.fr

Puesto(s) actual(es): Director de proyecto

E studios: M M ed Sc 1992

A reas de interés: epidemiología en situaciones de catástrofe; epidemiología de la radiación ionizante

\section{Marc Vericel}

Faculté de D roit U niversité de Saint-E tienne

c/ o Cros-Courtiel

43 rue Clément Fouissier

42100 Saint-Etienne, Francia

T el: 3377387774

Puesto(s) actual(es): M aître de Conférence, Faculté de Droit

A reas de interés: Droit du travail

\section{Eira Viikari-Juntura}

Instituto Finlandés de M edicina del T rabajo

T opeliuksenkatu 4la A

$00250 \mathrm{H}$ elsinki, Finlandia

Fax: 35892414634

E-mail: evii occuphealth.fi

Puesto(s) actual(es): J efe del D epartamento de Fisiología

E studios: M D, 1975, Facultad de M edicina, U niversidad de T urku, Finlandia; especialidad en Fisiatría, 1982, Consejo N acional de Salud, H elsinki; D r M ed Sci, 1988, Facultad de M edicina, U niv. de
Helsinki; profesor, 1994, Facultad de M edicina, U niv. de H elsinki

A reas de interés: trastornos de origen laboral en cuello y miembros superiores; epidemiología; prevención; medición de la salud y capacidad funcional; evaluación de riesgos

Anaide Vilasboas de Andrade

Fundaçao J orge D uprat Figueiredo de

Segurança e M edicina do T rabalho

(FUNDACENTRO)

R ua Alceu Amoroso Lina 142

Canimho das Arvores

41820-770, Salvador-BA, Brasil

Tel: $5571341-1412$

Fax: 071 341-1466

Puesto(s) actual(es): J efe de servicios técnicos

Centro R egional da Bahia (CR BA)

Puesto(s) anterior(es): Coordinador técnico

E studios: Ingeniero Civil, 1979, Faculdade de Engenharia G eneral R oberto Lisboa, R io de Janeiro; Ingeniero de seguridad, 1980, Pontificia U niversidade C atólica do R io de Janeiro

\section{Paolo Vineis}

H ospital C entral y U niversidad de T urín

$\mathrm{V}$ ia M azzini 52

10126 T urín, I talia

T el: 39116706525

Fax: 39116706692

Puesto(s) actual(es): Subdirector, U nidad de Epidemiología del Cáncer

E studios: M D , 1976, U niversidad de T urín

A reas de interés: epidemiología molecular; ética

\section{Eva Vingård}

Instituto N acional del Trabajo

S-17176 Solna, Suecia

T el: 4687295460

Fax: 468334333

Puesto(s) actual(es): M édica investigadora

E studios: M D , 1973, U niversidad de Lund, Suecia; PhD, 1991, Instituto K arolinska, Estocolmo

A reas de interés: 0 steoartrosis, trastornos lumbares, de cuello y hombros y carga física derivada de actividades en el trabajo y en el tiempo libre; factores psicosociales y trabajo; desempleo y salud

\section{Amiran D. Vinokur}

Institute for Social R esearch

U niv. of M ichigan

426 Thompson Street

Ann Arbor, M I 48106, Estados U nidos

T el: 1 (313) 747-0858

Fax: 1 (313) 936-0548

E-mail: avinokur@umich.edu

Puesto(s) actual(es): R esearch Scientist

Puesto(s) anterior(es): L ecturer, Senior L ecturer; Associate R esearch Scientist

E studios: BA, 1966, H ebrew U niversity, Jerusalem; M A, 1969, U niv. of M ichigan; PhD, 1970, U niv. of M ichigan

A reas de interés: causas y consecuencias del estrés en las áreas de salud, trabajo y desempleo; papel del apoyo y del rechazo social en el proceso de superación del estrés

\section{Jean-Jacques Vogt}

14 rue Thiers

F-92100 Boulogne, Francia

Tel: 33 1/476-10561

Puesto(s) anterior(es): Subdirector general, INR S; Director de investigación del CNRS

E studios: M D, 1964

A reas de interés: fisiología térmica, fisiología laboral, ergonomía

\section{Serge Volkoff}

\section{CREAPT}

Centre de R echerche et d'Etudes sur l'A ge et les Populations au Travail

11 rue Gay-L ussac

75005 París, Francia

T el: 33140468442

Fax: 33143268816

Puesto(s) actual(es): D irector

Puesto(s) anterior(es): J efe del departamento de estudios y estadísticas sobre condiciones de trabajo, M inisterio de T rabajo, París

E studios: Ecole polytechnique, 1966; Ecole nationale de la statistique et des études économiques, 1969

A reas de interés: enfoques demográfico y ergonómico del envejecimiento en el trabajo

\section{W. von Richthofen}

Sección de Administración L aboral O rganización Internacional del T rabajo 1211 G inebra 22, Suiza

Puesto(s) actual(es): Especialista en inspección laboral, Sección de Administración Laboral, O rganización Internacional del Trabajo

E studios: Abogado

\section{Georg Vondracek}

SU V A-C aisse N ationale Suisse d'A ssurance Postfach 4358

Rösslimattstr. 39

6005 L ucerna, Suiza

T el: 41414195353

Fax: 41414195870

Puesto(s) actual(es): Experto en evaluación de riesgos en aparatos y sistemas eléctricos y electrónicos

E studios: Dipl.Ing., 1957, U niversidad de Praga

A reas de interés: seguridad, fiabilidad

\section{Joseph G. Vos}

Instituto N acional de Salud Pública y M edio Ambiente

PO Box 1

Antonie van Leeuwenhoeklaan 9

3720 BA Bilthoven, Países Bajos

Tel: 31302742075

Fax: 31302744437

E-mail: j.vos@rivm.n

Puesto(s) actual(es): J efe del Laboratorio de Patología e Inmunobiología; Profesor de Patología T oxicológica, U niv. de U trecht 
Estudios: DV M, 1967; PhD, 1972

A reas de interés: evaluación de la inmunotoxicidad; patologíla toxicológica

\section{Michael Waalkes}

National C ancer Institute-FCRDC

Frederick, M D 21702-1201, Estados U nidos

Tel: 1 (301) 846-8737

Fax: 1 (301) 846-8946

E-mail: waalkes@ ncifcrf.gov

Puesto(s) actual(es): C hief, Inorganic Carcinogenesis Section

E studios: PhD, 1981, W est V irginia U niversity

A reas de interés: carcinogénesis de metales; toxicología reproductiva

\section{Gregory R. Wagner}

Division of R espiratory Disease Studies N ational Institute of $O$ ccupational Safety and $\mathrm{H}$ ealth

1059 W illowdale R oad

M organtown, WV 26505-2845, Estados U nidos

Tel: 1 (304) 285-5749

Fax: 1 (304) 285-5861

E-mail: GRW3@niords1.em.cdc.gov

Puesto(s) actual(es): Director

Puesto(s) anterior(es): Director, Division of O ccupational and Environmental

M edicine; A ssociate Professor,

Department of Family and C ommunity

$\mathrm{H}$ ealth, $\mathrm{M}$ arshall U niversity School of

M edicine

E studios: BA, 1969, H arvard U niversity; M D 1974, Albert Einstein College of M edicine

A reas de interés: prevención de lesiones y enfermedades profesionales; supervisión médica y vigilancia de la salud epidemiología de trastornos pulmonares profesionales

\section{Phillip J. Wakelyn}

$\mathrm{N}$ ational $\mathrm{C}$ otton C ouncil of America

$1521 \mathrm{~N}$ ew $\mathrm{H}$ ampshire A venue

W ashington DC 20036, Estados U nidos

T el: 1202 745-7805

Fax: 1202 483-4040

E-mail: pwakelyn@ cotton.org

Puesto(s) actual(es): Senior Scientist, Environmental $\mathrm{H}$ ealth and Safety

Puesto(s) anterior(es): Lecturer, D epartment of T extile Engineering, T exas T ech. U niversity; H ead of Chemical R esearch, T extile R esearch C enter, T exas T ech. U niversity; R esearch $C$ hemist, Fibers Division, Dow-Badisch Company; R esearch Chemist, Fibers Division, D ow Chemical Company

E studios: BS, 1963, Emory U niversity; M S, 1968 G eorgia Institute of T echnology; PhD 1971, T he U niversity of Leeds, England

A reas de interés: salud, seguridad, cuestiones ambientales y de consumo; polvo de algodón; contaminación atmosférica

\section{Simon Walker}

I.E.T.S.

$16 \mathrm{G}$ athorne $\mathrm{R}$ oad

Oxford OX 3 8NF, R eino U nido

Tel: 441865761875
Fax: 441865761875

Puesto(s) actual(es): Principal

Puesto(s) anterior(es): Executive Editor, International $\mathrm{M}$ ining $\mathrm{M}$ agazine

E studios: BSc, 1972, U niv. of L eeds; M Sc, 1981, $C$ amborne School of $M$ ines

A reas de interés: minerales, industrias de perforación y construcción

\section{Nina Wallerstein}

U niversity of $\mathrm{N}$ ew $\mathrm{M}$ éjico

2400 T ucker A venue NE

Albuquerque, NM 87131-5241, Estados U nidos

Tel: 1 (505) 272-4173

Fax: 1 (505) 272-4494

E-mail: nwall@unm.edu

Puesto(s) actual(es): Associate Professor, D epartment of Family and C ommunity $M$ edicine; Director, $M$ asters in Public $\mathrm{H}$ ealth Program

Puesto(s) anterior(es): Assistant Professor, D epartment of Family and C ommunity M edicine, UNM

E studios: BA, 1976, U niv. of California-Berkeley; M PH, 1980, U niv. of California-Berkeley; DrPH, 1988, U niv. of California-Berkeley

A reas de interés: cultura de la capacitación; educación popular; metodología valoración y educación en la salud y la seguridad; evaluación de ámbito comunitario

\section{Anthony D. Walters}

K ilborn Engineering Pacific Ltd.

1380 Burrard Street

Vancouver, BC V 6Z 2B7, Canadá

Tel: 1 (604) 669-8811

Fax: 1 (604) 669-0847

E-mail: awalters@kilbom.com

Puesto(s) actual(es): M anager, C oal Preparation

Puesto(s) anterior(es): Divisional Coal Process Engineer, Anglo American Corporation, South Africa; Plant Superintendent, C oal Preparation/ Coke W orks, Anglo American Corporation (W ankie Colliert), Zimbabwe

E studios: BSc, 1961, Leeds U niversity; Postgrad Dipl, 1962, L eeds U niversity; M Eng 1976, Pennsylvania State U niversity

A reas de interés: diseño de plantas de procesamiento del carbón; avances internacionales en materia de procesamiento del carbón; purificación del carbón; secado térmico del carbón; combustión espontánea del carbón

\section{Jung-Der Wang}

Colegio U niversitario N acional de T aiwán de

Salud Pública

1 Jen-Ai R oad

1st Section

T aipei, T aiwán, China

T el: 88623562224

Fax: 88623224660

E-mail: jdwang@ntumcl.mc.ntu.edu.tw

Puesto(s) actual(es): Profesor y Director, Instituto de $\mathrm{M}$ edicina del T rabajo e $\mathrm{H}$ igiene Industrial
Puesto(s) anterior(es): Presidente, A sociación de M edicina del Trabajo y A mbiental

E studios: M B, 1975, Colegio de M edicina de la U niv. N ac. De T aiwán; M IH, 1979, $\mathrm{H}$ arvard U niversity School of Public $\mathrm{H}$ ealth; ScD , 1982, $\mathrm{H}$ arvard U niversity School of Public H ealth

A reas de interés: diagnóstico de trastornos profesionales y ambientales; prevención de la contaminación; valoración y decisión en servicios de salud; métodos epidemiológicos

\section{Lance A. Ward}

Pepsi C ola General Bottlers, Inc

III C rossroads of C ommerce

3501 Algonquin R oad

R olling M eadows, Illinois 60008, Estados

Unidos

T el: 1847 397-7701

Fax: 1847 818-6000

E-mail: laward@pcgb.com

Puesto(s) actual(es): C orporate Director of $\mathrm{H}$ ealth and Safety

Puesto(s) anterior(es): C orporate M anager, Safety and Security, K raft Foodservice, Inc.; Corporate $M$ anager, L oss Prevention, Wickes Cos. Inc.

E studios: BA, N ational L ouis U niversity, Evanston IL

\section{Peter Warr}

Institute of W ork Psychology

U niversity of Sheffield

Sheffield S10 2T N, R eino U nido

Tel: 441142756600

Fax: 441142727206

E-mail:p.warr@sheffield.ac.uk

Puesto(s) actual(es): R esearch Professor

Puesto(s) anterior(es): Director, M R C/ERR C, Social and Applied Psychology U nit U niversity of Sheffield

Estudios: BA, 1960, Cambridge: PhD, 1963, Sheffield

A reas de interés: bienestar y actuación del empleado; rendimiento, formación y desarrollo

\section{David A. Warrel}

Centre for T ropical M edicine

U niversity of $\mathrm{O}$ xford

John R adcliffe $\mathrm{H}$ ospital

H eadington O xford OX 39DV, R eino U nido

T el: 441865220968

Fax: 441865220984

Puesto(s) actual(es): Professor; Director

Puesto(s) anterior(es): Director, T ropical M edicine R esearch Programme, 0 xford U niversity

E studios: 1961, Christ C hurch O xford; 1966, St. Thomas H ospital M edical School

A reas de interés: malaria, rabia, mordeduras y picaduras de animales

\section{Leon J. Warshaw}

Institute of Environmental M edicine

180 W est End A venue \#6C

N ueva Y ork, N ueva Y ork 10023-4926, Estados

Unidos

Tel: 1 (212) 877-1060

E-mail: 76451.333@ compuserve.com 
Puesto(s) actual(es): C linical Professor

Puesto(s) anterior(es): Executive Director, $\mathrm{N} \mathrm{ew}$ Y ork Business G roup on H ealth; D eputy Director for $\mathrm{H}$ ealth Affairs, $\mathrm{N}$ ew $\mathrm{Y}$ ork City $M$ ayor's $O$ ffice of $O$ perations; $\mathrm{V}$ ice-President, Corporate $\mathrm{M}$ edical Director, Equitable Life Assurance Society of the US

E studios: BA, 1938, Columbia College; M D, 1942, C olumbia College of Physicians and Surgeons

A reas de interés: organización de servicios de salud laboral; promoción de la salud; estrés; violencia en el lugar de trabajo

\section{Philip G. Watanabe}

T oxicology C onsultant 5535 C anvasback $R \mathrm{~d}$.

Blaine, WA 98230-6303, Estados U nidos

Tel: 1 (360) 371-5048

Fax: 1 (360) 371-4005

E-mail: phlptox@aol.com

Puesto(s) actual(es): Independent T oxicology Consultant

Puesto(s) anterior(es): Directory of T oxicology R esearch Laboratory, D ow Chemical Company; Director, $\mathrm{H}$ ealth Sciences, D ow Chemical Company

E studios: BS, 1969, U niversity C alifornia, I rvine; PhD , 1974, U tah State U niversity

A reas de interés: evaluación y gestión del riesgo; mecanismos de toxicidad; carcinogénesis

\section{James L. Weeks}

G eorge W ashington U niversity M edical Center Division of $\mathrm{O}$ ccupational and Environmental Medicine

2300 K St. NW 201

Washington, DC 20037, Estados U nidos

T el: 1 (202) 994-1734

Fax: 1 (202) 994-0011

E-mail: weeks@gwis2.circ.gwu.edu

Puesto(s) actual(es): Associate R esearch Professor, Division of $O$ ccupational and Environmental M edicine, George W ashington U niversity M edical Center

Puesto(s) anterior(es): D eputy Director, Department of $\mathrm{H}$ ealth and Safety, U nited $\mathrm{M}$ ine W orkers of A merica

E studios: BS, 1965, U niversity of C alifornia; M A 1971, C ase W estern R eserve U niversity.; SCD, 1980, $\mathrm{H}$ arvard School of Public $\mathrm{H}$ ealth

A reas de interés: enfermedad pulmonar profesional en mineros del carbón; lesiones profesionales en trabajadores de la construcción; política activa para la prevención de enfermedades laborales y ambientales

\section{David H. Wegman}

U niversity of M assachusetts L owell

1 University A venue

L owell, M A 01854, Estados U nidos

Tel: 1 (508) 934-3265

Fax: 1 (508) 452-5711

E-mail: wegmand@woods.uml.edu

Puesto(s) actual(es): Professor and Chair, D epartment of W ork Environment;
A djunct Professor, $\mathrm{H}$ arvard School of Public Health

Puesto(s) anterior(es): Professor, Director, Division of Environmental and O ccupational $\mathrm{H}$ ealth Services, U niv. of C alifornia

E studios: BA, 1962, Swarthmore C ollege; M D, 1966, $\mathrm{H}$ arvard M edical School, Boston M S, 1972, H arvard School of Public $\mathrm{H}$ ealth

A reas de interés: estudios epidemiológicos de enfermedades respiratorias profesionales; trastornos musculosqueléticos y cáncer; metodología de la vigilancia de riesgos en el trabajo

\section{Beat Wegmüller}

Suva-C aidde N ationale Suisse d'A ssurance

Postfach 4358

CH -002 L ucerna, Suiza

Tel: $4141419-5373$

Fax: 4141 419-5757

Puesto(s) actual(es): Ingeniero de seguridad

A reas de interés: seguridad y salud en la industria maderera

\section{Elisabete Weiderpass}

D epartamento de E pidemiología del Cáncer

U niv. de U ppsala

75185 U ppsala, Suecia

T el: 4618665057

Fax: 4618503431

E-mail: elisabete.weiderpass@epic.uu.se

Puesto(s) actual(es): doctorando en epidemiología del cáncer

Puesto(s) anterior(es): A yudante de investigación, Universidad Federal de Pelotas, Brasil

E studios: M D , 1992, U niversidad Federal de Pelotas, Brasil; M Sc, 1994, U niversidad Federal de Pelotas, Brasil

A reas de interés: epidemiología del cáncer (cánceres ligados al sistema hormonal)

\section{John V. Weil}

Cardiovascular-Pulmonary R esearch Laboratory

$U$ niv. of Colorado $\mathrm{H}$ ealth Sciences $\mathrm{C}$ enter

4200 East Ninth A ve

Denver, CO 80262, Estados U nidos

T el: 1 (303) 270-4471

Fax: 1 (303) 270-4871

E-mail: john.weil@uchsc.edu

Puesto(s) actual(es): Director

\section{Merri Weinger}

O ficina de Sanidad A mbiental G lobal e Integrada

O rganización M undial de la Salud

20 avenue Appia

1211 Ginebra 27, Suiza

Tel: 41227914344

Fax: 41227914123

E-mail: weingerm@who.ch

Puesto(s) actual(es): Especialista en educación

Puesto(s) anterior(es): Especialista en comunicación, California D epartment of $H$ ealth Services, Emeryville; M anager, T oxics Education and Training Program, Department of Public H ealth, San Francisco, CA
E studios: M PH, 1980, School of Public H ealth, Univ. of C alifornia-Berkeley

A reas de interés: formación y planificación nacional en salud laboral y ambiental; formación del profesorado

\section{Edmundo Werna}

PC C - Poli U SP- U niversidade de Sao Paulo A ve Prof. Luciano G ualberto 3/ 380 Cidade Universitaria

Sao Paulo SP 05508-900, Brasil

Tel: 55118185449

Fax: 55118185715

E-mail: edwerna@usp.br

Puesto(s) actual(es): Investigador

Puesto(s) anterior(es): Investigador, Programa de Salud U rbana, L ondon School of $H$ ygiene and T ropical M edicine; U rbanista, M inisterio de la V ivienda y T rabajos Públicos, M ozambique: U rbanista, U niversidad Federal de $\mathrm{M}$ inas Gerais, Brasil

E studios: BSc, 1980, U niversidad de M inas Gerais; M Phil, 1988, U niv. of Sussex; PhD, 1992, Univ. College L ondon

A reas de interés: gestión urbana en países en desarrollo; salud urbana en países en desarrollo

John B. West

UCSD Department of M edicine

$9500 \mathrm{G}$ ilman D rive

La Jolla, CA 92093-0623, Estados U nidos

Tel: 1 (619) 534-4192

Fax: 1 (619) 534-4812

E-mail: jwest@ucsd.edu

Puesto(s) actual(es): Professor of M edicine and Physiology

Puesto(s) anterior(es): R eader in M edicine, R oyal Postgraduate M edical School, Londres

E studios: M BBS, 1951, Adelaide U niv.; M D, 1958, A delaide U niversity; PhD, 1960, L ondon U niversity; DSc, 1980, A delaide U niversity

A reas de interés: fisiología y medicina de grandes altitudes; fisiología y medicina espacial; fisiología respiratoria

\section{Paul Westcott}

$M$ ine Consult

Level 2

60 Archer Street

Chatswood NSW 1067, Australia

Tel: 612 9413-3200

Fax: 612 9413-2202

E-mail: minecons@ozemail.com.au

Puesto(s) actual(es): Director, Consulting $M$ ining Engineer

E studios: B Eng, 1973, U niversity of N SW

A reas de interés: minas de carbón a cielo abierto

Peter J.M. Westerholm

Instituto N acional del Trabajo

Ekelundsvagen 16

17184 Solna, Suecia

Tel: 4687309029

Fax: 4687309860

E-mail: pwesterholm@nioh.se 
Puesto(s) actual(es): Profesor de epidemiología del trabajo

Puesto(s) anterior(es): A sesor médico, Confederación Sueca de Sindicatos; Epidemiólogo asesor, Consejo $\mathrm{N}$ acional de Salud y Bienestar; Subdirector médico, Consejo Nacional de Salud y Bienestar

E studios: titulado en M edicina, 1960; especialista en cirujía general, 1972; M D, 1980 , U niv. de U meå; Profesor de medicina del trabajo, 1983, U niv. de U meå; Profesor, 1989, Instituto N acional del T rabajo

A reas de interés: epidemiología cardiovascular (laboral)

\section{Gunnela Westlander \\ U niversidad de Estocolmo \\ Departamento de Psicología \\ Frescati H agväg 8 \\ S-106 91 Estocolmo, Suecia \\ Tel: 468801827 \\ Fax: 468268663 \\ E-mail:}

gunnela.westlander@mailbox.swipnet.se

Puesto(s) actual(es): Profesora emérita; Profesora de Psicología, U niv. de Linköping

Puesto(s) anterior(es): Profesora, Jefa de la División de Psicología Social y de la

O rganización; investigadora, C onsejo Sueco de Administración de Personal

E studios: BA, 1953, U niv. de U ppsala; L ic, 1969, U niversidad de Estocolmo; PhD, 1977, U niversidad de Estocolmo

A reas de interés: calidad de la vida activa; relaciones industriales; cambio de la organización y tecnología; estrategias de intervención; desarrollo crítico de las ciencias de la organización

\section{Othmar Wettmann}

SU V A - O rganización N acional Suiza de

Seguros de Accidente

Sección Forestal

Box 4358

6002 L ucerna, Suiza

T el: 414195111

Fax: 414195204

Puesto(s) actual(es): Jefe de sección

E studios: Dipl. Silvicultura ETH

\section{Aidan White}

Federación Internacional de Periodistas

266 R ue R oyale

1210 Bruselas, Bélgica

Tel: 3222232265

Fax: 3222192976

E-mail: ifj@gn.apc.org

Puesto(s) actual(es): Secretaría general

Puesto(s) anterior(es): Periodista de T he Guardian

\section{Marion Wichmann-Fiebig}

D ez.233.3 A bteilung 2 U mweltqualität

L andesumweltamt N ordrhein-W estfalen

Wallneyerstrasse 6

D-45133 Essen, Alemania

T el: 492017995172

Fax: 492017995574

E-mail: 106475.3571@ compuserve.com
Puesto(s) actual(es): D ezernentin Schutz der Atmosphäre

\section{Julian Wilbourn}

Agencia Internacional para la Investigación sobre el Cáncer

150 cours A lbert-T homas

69372 Lyon Cedex 08, Francia

Tel: 3372738511

Fax: 3372738575

E studios: BSC

\section{Gerald J.S. Wilde}

Q ueen's U niversity

K ingston, O N K 7L 3N 6, Canadá

Tel: 1 (613) 545-2889

Fax: 1 (613) 545-4999

E-mail: wildeg@pavlov.psyc.queensu.ca

Puesto(s) actual(es): Professor of Psychology

E studios: PhD, 1962, U niversidad de Amsterdam, Países Bajos

A reas de interés: Ergonomía; conducta del tráfico y causas de accidentes

\section{Michael E. Williams}

Apple Computer, Inc.

20450 Stevens $C$ reek Boulevard

$M$ ailstop 76 EHS

Cupertino, CA 95014, Estados U nidos

Tel: 1 (408) 974-0370

Fax: 1 (408) 974-1950

E-mail: willi.me@apple.com

Puesto(s) actual(es): C orporate $M$ anager, Environmental $\mathrm{H}$ ealth and Safety

Puesto(s) anterior(es): Corporate H ealth, Safety and Industrial $H$ ygiene $M$ anager, Advanced M icro D evices; Corporate Evironmental $\mathrm{H}$ ealth and Safety $M$ anager, American M icrosystems, Inc.; Special A ssistant, D eputy C hief of $\mathrm{H}$ ealth, California O ccupational Safety and $\mathrm{H}$ ealth Administration

E studios: BA, 1972, Fresno State U niversity, Fresno, CA; M PH, 1973, U niversity of California-Berkeley; M S, 1975, U niv. of California-Berkeley

A reas de interés: aspectos de salud y seguridad de semiconductores; formación en la industria electrónica; ergonomías; campos electromagnéticos

\section{Ann M. Williamson}

$\mathrm{N}$ ational Institute for $\mathrm{O}$ ccupational Safety and $\mathrm{H}$ ealth

GPO Box 58

Sydney N SW 2001, Australia

$$
\text { Tel: } 6125659311
$$

Fax: 6125659300

Puesto(s) actual(es): Principal R esearch Scientist; $\mathrm{H}$ ead $\mathrm{H}$ uman Factors and Ergonomics U nit

E studios: BSc, 1976, La T robe U niversity; PhD, 1979, La T robe U niversity

A reas de interés: causalidad de accidentes; fatiga; efectos de la exposición ambiental sobre el funcionamiento neurocomportamental

\section{Denis Winter}

División de Estudios de Accidentes Instituto de Seguridad y Protección Nuclear
BP 6

60-68 avenue du G énéral Leclerc

92265 Fontenay-aux-R oses CEDEX , Francia

T el: 33146549619

Fax: 33146570386

E-mail: winter@basilic.cea.fr

\section{Linda Wolfe}

Environmental M edical Service

$M$ assachusetts I nstitute of T echnology

$77 \mathrm{M}$ assachusetts A venue 56-255

Cambridge, M assachusetts 02139-4307, Estados

Unidos

Tel: 1 (617) 258-5648

Fax: 1 (617) 258- 5856

E-mail: Iwolfe@ mit.edu

Puesto(s) actual(es): A ssociate Biosafety 0 fficer

Puesto(s) anterior(es): Safety O fficer, Biotechnica International

E studios: BS, 1974, G eorgetown U niversity

A reas de interés: controles administrativos; compromiso colectivo y aceptación de la biotecnología

\section{Mary S. Wolff}

M ount Sinai School of M edicine

1 G ustave L. Levy Place

Nueva Y ork, Nueva Y ork 10029, Estados

Unidos

Tel: 1 (212) 241-6173

Fax: 1 (212) 996-0407

E-mail: mwolff@smtplink.mssm.edu

Puesto(s) actual(es): Professor of Community $M$ edicine

E studios: PhD

\section{Malinee Wongphanich}

M inisterio de Sanidad

Departamento de Salud

Tiwanon Road

$M$ uang District

Provincia de N onhaburi 11000, T ailandia

Tel: 6625918380

Fax: 6625918172

Puesto(s) actual(es): A sesor de medicina del Trabajo

Puesto(s) anterior(es): J efe del D pto. De Salud en el Trabajo, Facultad de Salud Pública, U niversidad de $\mathrm{M}$ ahidol, T ailandia; Presidente de honor, Asociación Asiática de Salud en el Trabajo

E studios: M D, 1959, U niv. of M edical Sciences, Thailandia

A reas de interés: educación y práctica en medicina del trabajo

\section{Ray C. Woodcock}

NEO Corporation

PO Box 646

W aynesville, NC 28786, U nites States

T el: 1 (704) 456-4332

Fax: 1 (704) 456-4216

E-mail: rcwoodcock@aol.com

Puesto(s) actual(es): V ice-President

Puesto(s) anterior(es): $M$ anager, Environmental Services, D ayco Corporation; Industrial $\mathrm{H}$ ygiene $\mathrm{C}$ onsultant, $\mathrm{O}$ ccupational $\mathrm{H}$ ealth Branch, $\mathrm{N}$ orth $\mathrm{C}$ arolina Division of $\mathrm{H}$ ealth Services 
Estudios: AB, 1967, T aylor U niv., U pland, Indiana; M S, 1971, H arvard School of Public $\mathrm{H}$ ealth

A reas de interés: seguridad y salud en la construcción en relación con el asbesto el plomo y otros materiales peligrosos; acuerdos ambientales

\section{Patrisha Woolard}

The M ount Sinai School of M edicine Box 1057

10581 G ustave L. Levy Place

N ueva Y ork, N ueva Y ork 10029-6574, Estados Unidos

T el: 1 (212) 831-3872

Fax: 1 (212) 996-0407

E-mail: pw@doc.mssm.edu

Puesto(s) actual(es): Student (M D / PhD Program), $M$ ount Sinai School of M edicine

E studios: BA, 1993, V assar College

A reas de interés: neurotoxicología

\section{Frank B. Wright}

European $\mathrm{O}$ ccupational $\mathrm{H}$ ealth $\&$

Safety Law R esearch Centre

U niversity of Salford

Bridgewater Building

Salford

G reater $M$ anchester $M 5$ 4WT, R eino U nido

T el: $441617455000 \times 4472$

Fax: 441614407749

E-mail: f.b.wright@time.salford.ac.uk

Puesto(s) actual(es): Director, Professor of $O$ ccupational $\mathrm{H}$ ealth, Safety and Environmental Law

E studios: LLB, LLM, PhD

A reas de interés: legislación en materia de salud y seguridad en el trabajo; derecho ambienta

\section{H. Beric Wright}

Brudenell H ouse

Church St.

Q uainton A ylesbury

Bucks H P22 4AW, R eino U nido

T el: 441296655250

Puesto(s) anterior(es): M edical Director, Board M ember, British U nited Association; President, Pre-R etirement A ssociation

E studios: M BBS , 1942; FR C S (UK) ); M FO M (UK)

\section{Michael J. Wright}

$\mathrm{H}$ ealth

Safety \& Env. Dept. \& Education Dept.

U nited Steelworkers of A merica

Five $\mathrm{G}$ ateway C enter-R oom 902

Pittsburgh, PA 15222, Estados U nidos

Tel: 1 (412) 562-2581

Fax: 1 (412) 562-2584

E-mail: steelworker@IGC.APC.ORG .

Puesto(s) actual(es): Director

E studios: BS, 1969, Cornell; M S, 1977, H arvard

A reas de interés: trabajadores y medio ambiente; causas subyacentes de los accidentes industriales; programas de seguridad y salud integral del lugar de trabajo educación del trabajador; armonización internacional de la comunicación de riesgo químico

\section{Ernst Wynder}

A merican $\mathrm{H}$ ealth Foundation

320 E. 43rd Street

N ueva Y ork, N ueva Y ork 10017, Estados Unidos

T el: 1 (212) 551-2500

Fax: 1 (212) 687-2339

Puesto(s) actual(es): President; Adjunct $M$ ember, $M$ emorial Sloan-K ettering $C$ ancer Center

Puesto(s) anterior(es): Chief, D epartment of Epidemiology, M emoria Sloan-K ettering $C$ ancer $C$ enter

E studios: BA, 1943, N ew Y ork U niversity, NY; M D, 1950, Washington U niversity, St. Louis

A reas de interés: prevención del cáncer; epidemiología; tabaco; nutrición; enseñanza

\section{B. $\mathbf{H} . \mathbf{X u}$}

Facultad de M edicina

U niv. K agoshima

8-35-1 Sakuragaoka

K agoshima 890, Japón

T el: 8199 275-5291

Fax: 8199 265-8434

E-mail: xubaohui@med3.kufm.kagoshima-u.ac.jp

Puesto(s) actual(es): Profesor adjunto

Puesto(s) anterior(es): A yudante de investigación, Facultad de M edicina de la U niv. de K agoshima, Japón

E studios: 1985, U niv. de M ed. Shanxi, C hina; 1988, M áster, U niv. M édica $C$ hina M edical; 1994, PhD, U niv. K agoshima

A reas de interés: alergia ambiental y profesional; medicina del trabajo; predicción del potencial alérgico de sustancias químicas

\section{Lucy Yardley}

Department of Psychology

U niversity C ollege L ondon

G ower Street

Londres WC 1E 6BT, R eino U nido

Tel: $441713877050 \times 5308$

Fax: 441714364276

E-mail: I.yardley@ucl.ac.uk

Puesto(s) actual(es): Senior Lecturer

Puesto(s) anterior(es): Audiological Scientist

E studios: M Sc, Southampton U niversity; PhD, Southampton U niversity

A reas de interés: aspectos psicológicos de la desorientación; la orientación y e equilibrio

\section{Annalee Yassi}

O ccupational \& Environmental H ealth U nit U niversity of $\mathrm{M}$ anitoba

5112-750 Bannatyne A venue

Winnipeg, M B M anitoba R 3E OW 3, C anadá

Tel: 1 (204) 789-3289

Fax: 1 (204) 772-8748

E-mail: yassi@bldghsc.lan1.umanitoba.ca

Puesto(s) actual(es): Director

\section{Dennis Zaebst}

NIOSH R-44

4676 C olumbia Parkway

Cincinnati, O hio 45226, Estados U nidos
Tel: 1513 841-4459

Fax: 1513 841-4470

E-mail: ddz1@cdc.gov

Puesto(s) actual(es): Industrial H ygienist (R esearch) E studios: M S, 1974, O hio State U niverstiy A reas de interés: técnicas de investigación; riesgos históricos; uso de datos sobre la exposición en investigación epidemiológica; riesgo de los gases de combustión del gasóleo; salud en el sector agrícola; calidad del medio ambiente de interiores; ordenadores en la investigación de higiene industrial

\section{Sheila H. Zahm}

National Cancer Institute-EPN 4186130 Executive Blvd.

R ockville, M D 20892-7364, Estados U nidos

T el: 1 (301) 496-8157

Fax: 1 (301) 402-1819

E-mail: zahms@epndce.nci.nih.gov

Puesto(s) actual(es): E pidemiologist; D eputy Chief, O ccupational Epidemiology Branch

E studios: M Sc, 1977, H arvard U niversity School of Public H ealth; SCD , 1980, $\mathrm{H}$ arvard U niversity School of Public H ealth

A reas de interés: cáncer profesional; plaguicidas; sustancias químicas

\section{José Luis Zeballos}

Palmas № 530

CP 11000

Lomas de Chapultepec, $M$ éjico

Tel: 5252028200

Fax: 5255208868

E-mail: Internet:mex-pwr@paho org

Puesto(s) actual(es): R epresentante de la O rganización Panamericana de la Salud/ O M S

Puesto(s) anterior(es): A sesor sobre preparación ante emergencias y socorro ante el desastre

E studios: M D, 1969, U niversidad M ayor de San Andrés, La Paz, Bolivia; M PH, 1975, U niversidad de Puerto Rico, San Juan, Puerto R ico

A reas de interés: medicina de catástrofes; epidemiología; planificación de la salud; salud internacional

\section{Jan E. Zejda}

Departamento de Epidemiología

nstituto de M edicina del T rabajo y Sanidad

Ambiental

$13 \mathrm{~K}$ oscielna Street

41-200 Sosnowiec, Polonia

Tel: 4832663357

Fax: 4832660220

Puesto(s) actual(es): J efe

Puesto(s) anterior(es): J efe, C entro Colaborador de la $O$ rganización $M$ undial de la Salud

E studios: M D, 1978, A cademia M édica, T ódz, Polonia; Dipl (enfermedades internas) 1982, Sociedad M édica Polaca; Dipl (epidemiología, bioestadística), 1990, M cG ill U niversity, M ontreal, C anadá

A reas de interés: epidemiología ambiental; epidemiología profesional; trastornos respiratorios; enfermedades profesionales de pulmón 


\section{Albert M. Zielinski}

GE Lighting

Lighting Environmental $\mathrm{H}$ ealth and Safety

Department

Building 335

1975 N oble R oad

Cleveland, O hio 44112, Estados U nidos

T el: 1 (216) 266-3349

Fax: 1 (216) 226-6663

E-mail: albert.zielinski@lighting.ge.com

Puesto(s) actual(es): Senior T echnical Leader, Industrial $\mathrm{H}$ ealth

E studios: BS, 1976, Cleveland State U niversity

A reas de interés: higiene industrial global

\section{Bernhard M. Zimolong}

Univ. del Ruhr, Bochum

Departamento de Psicología Industrial y de la O rganización

44780 Bochum, Alemania

Tel: 492347004607

Fax: 492347094112

E-mail: ge@ auo.psy.ruhr-uni-bochum.de

Puesto(s) actual(es): Profesor de psicología industrial y organizativa; Portavoz del Centro Especial de Investigación 187

E studios: BA, 1970, U niversität M ünster; PhD (Dr rer nat), 1974, T echnische U niversität Braunschweig; habilitación, 1981, T echnische U niversität Braunschweig; catedrático, 1984, R uhr-U niversität Bochum

A reas de interés: gestión del riesgo, gestión de la seguridad total; diseño del trabajo; grupos de trabajo
Thomas Zosel

3M Company Building 41-01-05

P.O. Box 33331

St.Paul, M N 55133-3331, Estados U nidos

Tel: 1 (612) 778-4805

Fax: 1 (612) 778-7203

E-mail: twzosel@mmm.com

Puesto(s) actual(es): $M$ anager, Environmental Initiatives

E studios: BS, 1967, U niv. of W isconsin

A reas de interés: prevención de la contaminación; patrones de medición de residuos; desviación en el cumplimiento de las pautas ambientales

\section{Jozef Zurada}

College of Business and Public Administrration

U niversity of L ouisville

Louisville, K Y 40292, Estados U nidos

T el: 1 (502) 852-4681

Fax: 1 (502) 852-7557

E-mail: jmzura01@ulkyvm.louisville.edu

Puesto(s) actual(es): Assistant Professor

Puesto(s) anterior(es): Consultant

E studios: PhD, 1995, U niversity of L ouisville, USA

A reas de interés: seguridad en robots; interacción hombre-ordenador; aplicación de redes neurales; arquitectura informática y sistemas operativos; factores humanos en los procesos de fabricación

\section{Joanne Zurlo}

Center for Alternatives to Animal T esting
Johns H opkins School of H ygiene \& Public $\mathrm{H}$ ealth

$111 \mathrm{M}$ arket Place Suite 840

Baltimore, M D 21202-6709, Estados U nidos T el: 1 (410) 223-1615

Fax: 1 (410) 223-1603

E-mail: jzurlo@welchlink.welch.jhu.edu

Puesto(s) actual(es): Associate Director

Puesto(s) anterior(es): Assistant Professor, Dartmouth M edical School; Assistant Professor, Johns H opkins School of $\mathrm{H}$ ygiene and Public $\mathrm{H}$ ealth, Baltimore

E studios: PhD, 1979, N ew Y ork U niversity

Areas de interés: toxicología in vitro; hepatoxicología; reducción; cultura y reemplazo del uso de animales en biología

\section{Craig Zwerling}

Injury Prevention R esearch C enter

College of M edicine

U niversity of I owa

124 AM R F

1000 akdale Campus

lowa City, lowa 52242, Estados U nidos

T el: 1 (319) 335-4418

Fax: 1 (319) 335-4425

E-mail: craig-zwerling@uiowa.edu

Puesto(s) actual(es): Director

E studios: PhD , 1976, H arvard U niversity; M D, 1980, C ase W estern R eserve U niv.; M PH , 1980, H arvard School of Public $\mathrm{H}$ ealth

Areas de interés: epidemiología de lesiones

\section{- IndiCe Del DiReCTORIO}

\section{Por nombre}

A beytunga, P.K......... DIR.1 Ackermann-Liebrich,

U rsula .............. DIR .1

Adess, M ichael .......... DIR.1

A kabas, Sheila H. ........ DIR.1

A kita, M unehira .......... DIR .I

Akkers, Leen ............ DIR.1

Aladjem, Avraham ........ DIR .I

Aldi, R.G............ DIR.I

Alessio, Lorenzo ......... . DIR .1

Alexander, Priscilla ....... . DIR .1

Allison, Sydney .......... DIR .2

A mendola, Alfred A . ...... DIR .2

Anderberg, Yngve........ DIR .2

Anderson, Judith .......... DIR .2

Andersson, Ragnar . ...... DIR .2

Andreoni, Diego .......... DIR .2

Anthony, W. Stanley...... . DIR .2

A pud, Elias ............ DIR.2

A rias, M.P. ........... DIR .2

Arlien-Søborg, Peter ...... DIR .2

Armstrong, Bruce K ....... DIR .2

Armstrong, James R....... DIR .2

Armstrong, Pat ........... DIR .3

Armstrong, Thomas ...... . DIR.3

Arnason, R agnar . . . . . . . . DIR .3
Arnold, Ian M. F. ......... DIR.3 Arteau, Jean. ............. DIR.3

Ashdown, Tony......... DIR.3 Astrakianakis, George ..... . DIR .3 Atherley, Gordon ......... DIR.3 Attfield, M ichael D........ . DIR.3 Augusta, Jörg. ........... DIR.3 Avery, William .......... DIR.3 A wang, Rahmat ......... DIR.3 Axelson, O lav ............ DIR.3 Ayres, Page ............ DIR.4 Babin, Angela R......... DIR .4 Backström, Tomas. ........ DIR .4 Baker, David E.......... . DIR .4 Baker, D ean B. . . . . . . . . DIR .4 Baker, R obin ........... DIR .4 Baldwin, David G... . . . . . . DIR.4 Balty, I sabelle .......... . DIR .4 Bammer, Gabriele. . . . . . . . DIR .4 Banky, T amas ........... DIR .4 Barazani, G ail Coningsby. . DIR .4 Bardarson, H jalmar R . . . . . DIR.5 Barling, Julian ........... DIR .5 Barnard, Donald ......... DIR.5 Barnett, R osalind C....... DIR .5 Batra, Subhash K ......... DIR.5
Battista, Giuseppe . . . . . . . . D DIR .5 Baxter, Peter J. . . . . . . . . . DIR .5 Bean, Thomas L... . . . . . . . . DIR.5 Beaton, Randal D... . . . . . . DIR .5 Becklake, M argaret R .. . . . . DIR .5 Bedrikow, Bernardo ...... DIR.6 Bégin, R aymond ........ DIR. 6 Béland, François . ......... DIR.6 Beliczky, Louis S... . . . . . . . DIR .6 Bell, David M ........... DIR.6 Bell, Ron ............... DIR.6 Bencko, V ladimir . . . . . . . DIR.6 Bender, Joel............. DIR . 6 Bennett, David .......... DIR.6 Benson, Alan J. ........... DIR .6 Berenguer Subils, M aría

José ................ DIR.6 Berezesky, Irene K . . . . . . . DIR .6 Berg, $M$ ats. . . . . . . . . . . . DIR .7 Berger, Elliott H . . . . . . . . . . . DIR .7 Berger, K enneth I. . . . . . . DIR .7 Bergqvist, U If. . . . . . . . . . DIR .7 Berkowitz, Deborah E. .... DIR .7 Bertazzi, Pier Alberto ...... DIR .7 Berthelette, Diane . . . . . . . . DIR.7 Bertin, Joan . . . . . . . . . . . DIR .7
Biagi, M arco ............ DIR .7 Biggeri, Annibale. ........ . DIR .7 Birmingham, D onald J. . . . DIR .7 Bisset, R onald ........... DIR .7 Bittel, Jacques H. . . . . . . . . DIR .8 Blackburn, William . . . . . . DIR .8 Blome, $\mathrm{H}$ elmut . . . . . . . . DIR .8 Blume, Sheila B. . . . . . . . DIR .8 Bochmann, Frank ........ DIR .8 Boffetta, Paolo . . . . . . . . . DIR.8 Boillat, M arcel-André. . . . . DIR .8 Bourdouxhe, M adeleine . . . DIR .8 Bovenzi, M assimo . . . . . . . . DIR .8 Brabant, Carole. ........ . DIR .8 Braga, M ario . . . . . . . . . . DIR.8 Brandt-R auf, Paul . . . . . . . DIR .8 Brandt-R auf, Sherry I. . . . . DIR .8 Braverman, M ark ........ DIR .9 Brazendale, John ......... DIR.9 Breuer, Dietmar ......... DIR.9 Briggs, D ouglas F........ DIR.9 Brighi, Cecilia . . . . . . . . . DIR .9 Bringer, R obert......... DIR.9 Brittain, Jere A. . . . . . . . . DIR.9 Brophy, M ary $0 \ldots \ldots \ldots$ DIR. 9 Brown, Jeremy. . . . . . . . . . DIR.9 
Brown, M ary E.......... . DIR.9 Bruckmann, Peter . . . . . . . DIR.9 Bruno, Peter J... . . . . . . . . DIR.9 Brusk, N orman .......... DIR.9 Bunn, William B......... . DIR.9 Burhenne-Guilmin,

Françoise. ............ DIR .10 Burke, R onald J........ DIR .10 Burton, Wayne N . . . . . . . . DIR .10 Butz, M............. DIR.10 Byrd, LaM ont .......... DIR.10 Cabral, R oxanne........ . DIR .10 Çakir, Ahmet........... DIR.10 Cameron, Buck .......... DIR .10 Campbell, Donald M ..... DIR .10 Capelli, Giovanni ........ DIR.10 Caplan, R obert D........ DIR .10 Carayon, Pascale........ DIR.10 Cartwright, Sue......... DIR.10 Castejón Vilella, Emilio. . . DIR .11 Castleman, Barry. . . . . . . . DIR.11 Catananti, C........... DIR.11 Chapman, Larry J. ....... DIR .11 Chavalitnitikul, Chaiyuth . DIR .11 Chayon, H aim. . . . . . . . . DIR.11 Chen, Weiping ......... DIR.11 Cheng, T sun-Jen ........ DIR.11 Chereisky, M ichael . . . . . . DIR.11 Chernyuk, V. I......... DIR.11 Cherry, R obert N., J . . . . . DIR .11 Chia, K ee-Seng......... DIR.11 Chiappino, Gerolamo .... . DIR .11 Chivian, Eric.......... DIR.12 Chong, John P. ......... . DIR .12 Christ, Eberhard ........ DIR.12 Clark, Nancy........... . DIR .12 Clevenstine, Emmert C. . . DIR .12 Cloutier, Esther ......... DIR .12 Coenen, Wilfried........ DIR .12 Cohen-R osenthal,

Edward ............ DIR.12 Colbert, Lenora Sarah ... DIR.12 Coleman, Paula......... DIR.12 Collins, James ... . . . . . . . DIR .12 Collins, Janet L.......... DIR .12 Comini, Renzo . . . . . . . . DIR.12 Cone, James ........... DIR.13 Conway, George A....... . DIR.13 Cooper, Cary L. ........ DIR.13 Coppée, G eorges H. . . . . . DIR.13 Corneil, Wayne D. . . . . . . DIR.13 Corry, James........... DIR.13 Corry, M aureen P. . . . . . . DIR .13 Cowell, John W.F........ DIR.13 Coyle, R obert .......... DIR.13 Crane, M ichael ......... DIR .13 Creighton, Breen ........ . DIR.13 Cros-C ourtial, M arie L. . . DIR .14 Crump, Derrick......... DIR.14 Cullen, M ark R . ........ DIR .14 Cutler, Ellen ............ DIR.14 da R ocha G omes, Jorge . . DIR .14 Dahlqvist, M onica... . . . . . DIR .14 Dahlström, Göran ....... DIR .14
Dajer, Antonio J......... DIR.14 Dalhouse, N eil. ......... . DIR .14 Damiani, Gianfranco ... . DIR.14 Damphousse, Louis..... . . DIR.14 Darby, Frank. . . . . . . . . . DIR.14 David, Alois. . . . . . . . . . . DIR .14 Davies, H ugh W......... DIR.15 Davies, John C......... DIR.15 De K eyser, Véronique. . . . DIR .15 D edobbeleer, Nicole . . . . . DIR.15 D eM arini, David M . ..... . DIR .15 Demers, Paul A . ........ DIR.15 Denisov, Edouard I. ..... DIR.15 Dheri, S.K . . . . . . . . . . . DIR.15 DiBerardinis, Lou ....... . DIR.15 Dinman, Bertram D..... . DIR.15 Djuric, Dusan .......... DIR.15 Dobrovolsky,

Leonard A . .......... DIR.15

D olphin, Basil .......... DIR.16

Donagi, Alexander E. . . . . DIR.16

Donham, K elley ........ DIR.16 Döös, M arianne........ DIR.16

Doyle, M el............ DIR.16 Driscoll, Dennis P... . . . . . DIR.16 Drysdale, D ougal D..... . DIR.16 Dümmer, Walter ........ DIR .16 Durocher, Louis-Philippe . DIR.16 Dykes, R obert W. . ...... DIR.16 Dykstra, Dennis. ........ DIR.16 Earnest, Gary S. . . . . . . . DIR.17 Eaton, William ......... DIR.17 Echt, Alan ............ DIR .17 Eeronheimo, Olli........ DIR.17 Eicher, Lawrence D..... . DIR .17 Elias, John ............ DIR .17 Elinder, Carl-G . . . . . . . . . DIR.17 Enderlein, G... . . . . . . . . DIR.17 English, Daniel ......... DIR.17 Englund, Claes W. ...... DIR.17 Estryn-Béhar,

M adeleine R. ........ DIR.17 Ewers, Lynda. . . . . . . . . . . DIR.17 Fagel, M ichael J. . . . . . . . . DIR .17 Fajen, John ............ DIR.18 Fakhri, Zuheir Ibrahim . . . DIR .18 Farquhar, John W. ..... . DIR.18 Fedoruk, M. Joseph . . . . . . DIR.18 Fedotov, I gor A . ....... DIR.18 Feldman, John.......... DIR.18 Feldman, R obert G . . . . . . DIR.18 Ferioli, A dalberto ........ DIR.18 Feyer, Anne-M arie . . . . . . . DIR .18 Field, William ........ . . . DIR.18 Fielding, J onathan E... . . . DIR .19 Finklea, John F......... DIR.19 Fischer, M anfred . . . . . . . DIR.19 Flannigan, Brian ........ DIR.19 Foà, Vito ............ DIR.19 Folliot, D ominique ...... . DIR .19 Forbes, Stewart . . . . . . . . DIR .19 Forst, Linda S. . . . . . . . . . . DIR .19 Forster, Richard ........ DIR.19 Fox, Bernard H . . . . . . . . DIR.19
Fox, Janet ............ DIR.19 Francis, James.......... . DIR.19 Frankenhaeuser,

M arianne ........... DIR.20

Franks, John R . . . . . . . . DIR .20

Franson, David J. ....... DIR .20

Fraser, T.M . .......... DIR .20

Frederick, James S. . . . . . . DIR .20

Freestone, David . . . . . . . . DIR .20

French, Jean G......... DIR .20

Freudenberger, H erbert J.. DIR .20

Friedlander, Barry. . . . . . . DIR .20

Friedman-Jiménez,

George ............. DIR.20

Frumkin, H oward . . . . . . . DIR .21

Ganster, Daniel .......... DIR.21

Garfinkel, Lawrence ..... . DIR .21

Gaydos, Joel C.......... DIR .21

G eiecker, 0 tto.......... DIR .21

Gerami, Afsaneh ......... DIR .21

G erecke, K enneth . . . . . . . DIR .21

G heorghe, Adrian V . . . . . DIR .21

Gibson, Gary. . . . . . . . . . DIR .21

Gibson, Gary A. ........ DIR .21

Giquère, Denis. .......... DIR .21

Gilad, Issachar.......... DIR .21

Glass, William I......... DIR.21

Goelzer, Berenice I.

Ferrari............. DIR.22

Gold, David............ DIR.22

Goldfein, K ristan D. . . . . DIR .22

Goldstein, Bernard D . . . . . DIR .22

Gompertz, David. ....... DIR .22

Gorman, D.F. .......... DIR.22

Gowing, M arilyn K . .... . DIR.22

Grady-van den N ieuwboer,

JokeJ.H. ............ DIR.22

G ranberg, Per-0 la ...... DIR .22

Grandjean, Philippe ..... DIR .22

Grandolfo, M artino. ..... . DIR .22

Grant, Casey C.......... DIR.22

G reenberg, Gary N . . . . . DIR .23

G reenwald, Peter. ........ DIR .23

G reiner, Dieter ........ . . DIR .23

$\mathrm{V}$ an Griensven, Leo

J.L.D. .............. DIR.23

Griffin, M ichael J........ DIR.23

Groenberg, Carsten. . . . . . DIR .23

Groeneweg, Jop......... DIR .23

Grote, Gudela . . . . . . . . . . DIR .23

Gruner, Saul G... . . . . . . . DIR .23

Guardino Solá, X avier ... DIR.23

Guasch Farrás, Juan .... . . DIR .23

Guidotti, T ee L.......... . DIR.23

Gunderson, Paul D...... . . DIR.23

Gupta, K rishan Chand . . . DIR .24 Gustavsson, Per . . . . . . . . . DIR .24 H acker, W infried. ....... DIR .24 H adley, John G. ........ DIR .24 H agberg, M ats. ........ . DIR .24 H ahn, Niels Jørn . . . . . . . . DIR .24 H äkkinen, K ari K . . . . . . . DIR .24 H ale, Andrew R........ . DIR.24 H amerman, David ...... DIR.24
H amilton, Leonard

Derwent ............. DIR.24

H amrin, H ans......... DIR.24

H aney, Jonathan T ... . . . . DIR .24 $\mathrm{H}$ ansson M ild, K jell . . . . . DIR .24 H aratani, Takashi ....... . DIR .24 H ardy, D avid L. . . . . . . . DIR .25 H ardy, Francis.......... DIR.25 H arman, Susan E. . . . . . . . DIR .25 H arris, R obert L......... DIR.25 H aslehurst, Jillian ........ DIR .25 H awkinson, Thomas E... . DIR .25 $\mathrm{He}$, Fengsheng. ......... DIR.25 H eaney, C atherine A. . . . . DIR .25 H ecker, Steven ......... DIR.25 H eederik, Dick .......... DIR.25 V an der H eijden, K ees A. . DIR .25 H einemann, Lothar A.J. . . DIR .25 H einrich, R udolf . ....... DIR .25 H elbig, R olf. . . . . . . . . . . DIR .26 H ellerstein, J on P. . . . . . . . DIR .26 H elmer, R ichard . ........ DIR.26 H emstreet, G eorge P., III . DIR .26 H erbert, R obin ......... DIR .26 H ermann, Fred W. . . . . . . DIR.26 H ernández Calleja, Ana . . DIR .26 H ernberg, Sven . . . . . . . . . DIR .26 H errick, R obert......... DIR.26 H espanhol, I vanildo ..... . DIR .26 H ethmon, T homas A . . . . . DIR .27 H euchert, G erd E........ DIR .27 H euer, H erbert . . . . . . . . DIR .27 H iggins, Penny D........ DIR.27 H inkamp, D avid L....... . DIR .27 H inksman, Jeffrey . . . . . . . DIR . 27 H irsheimer, M atthew . . . . DIR .27 H ites, R oberts . . . . . . . . . DIR .27 H o, M anh T rung ........ DIR.27 H odgson, M ichael J . . . . . DIR .27 H oet, P.............. DIR.27 H offmann, Burkhard. . . . . DIR .27 H offmann, Dietrich. . . . . . DIR .27 H ofmann, Friedrich . . . . . DIR .28 Högberg, Johan ......... DIR .28 H ohman, Charles M . . . . DIR .28 H older, Judith C.......... DIR .28 H olmberg, Bo ......... DIR .28 H olmér, Ingvar ......... DIR .28 H outman, Irene L.D. . . . . DIR .28 H oward, Ninica L. . . . . . . DIR .28 Howes, M.J........... DIR.28 Hubbs, Ann F........... DIR .28 H uff, James . . . . . . . . . . DIR.28 H uie, G ordon . . . . . . . . . DIR .29 H unt, Vilma R.......... DIR.29 H untzinger, David ...... DIR.29 H urrell, J oseph J., J r. . . . . . DIR .29 Ikeda, M asayuki ........ DIR.29 Infante-R ivard, Claire. ... DIR .29 Irwin, William .......... DIR.29 I son, T erence G . . . . . . . . DIR .29 I uchi, M asaaki. . . . . . . . . . DIR .29 I vancevich, John M . . . . . DIR.29 I vester, A. Lee ..... . . . . . . DIR .29 
Izmerov, Nikolai F. . . . . . DIR.29 Jäckel, R egina . . . . . . . . . DIR .30 Jackson, Anthony W... . . . . DIR.30 Jacobsen, Peter ......... . DIR .30 Jakubowski, M arek . . . . . . DIR .30 Järup, Lars. . . . . . . . . . DIR .30 Jayaraman, K unthala . . . . DIR .30 Jenkins, C. David. . . . . . . . DIR .30 Jenkins, E. Lynn . . . . . . . . DIR.30 Jennings, N orman S. . . . . DIR .30 Jex, Steve M . . . . . . . . . . DIR.30 Jeyaratnam, Jerry ........ DIR .30 Johanson, Gunnar . . . . . . . DIR .30 Johnson, Barry L. . . . . . . DIR .30 Johnson, Jeffrey V. . . . . . DIR .31 Johnson, Peter F. . . . . . . . DIR .31 Johnson, Steven B. . . . . . . DIR.31 Jones, Alan. . . . . . . . . . . DIR.31 Joshi, D. D. . . . . . . . . DIR.31 Joshi, T. K . . . . . . . . . DIR .31 Jørgensen, K irsten . . . . . . . DIR .31 Juntunen, M arja-Liisa . . . . DIR .31 Jurvélius, M ike. . . . . . . . . . DIR .31 K adefors, R oland . . . . . . DIR .31 K äferstein, Fritz. . . . . . . . . DIR .31 K agan, Y u.S. . . . . . . . . DIR.31 K ahn, Jeffrey P......... DIR.32 K angas, Juhani . . . . . . . . . DIR .32 K aptsov, V aleriy A...... . . DIR .32 K arasek, R obert . . . . . . . DIR.32 K arpilow, Craig. ........ DIR 32 K arsky, Thomas ........ . DIR.32 K arwowski, W aldemar . . . DIR.32 K auppinen, Timo . . . . . . . DIR.32 K azantzis, G eorge. . . . . . . DIR .32 K azemi, H omayoun . . . . . DIR .32 K eefe, Anya. . . . . . . . . . . DIR.33 K eidar, Anat .......... DIR .33 K eita, G wendolyn

Puryear ............ DIR.33 K elley, Barry P.... . . . . . DIR.33 K ennedy, Susan M... . . . . DIR .33 K enney, W. Larry........ DIR.33 V an de K erckhove, Johan. DIR.33 K ilbom, Åsa. . . . . . . . . . . . DIR.33 K imura, K ikuzi . . . . . . . . DIR.33 K indwall, Eric P........ DIR.33 K ipen, H oward M . . . . . . DIR .33 K jellén, U rban. . . . . . . . . . DIR .33 K jellström, T ord . . . . . . . DIR .34 K liesch, G eorg R. . . . . . . DIR .34 K nauth, Peter . . . . . . . . . DIR .34 K nave, Bengt. . . . . . . . . . . DIR .34 K nopp, Stephanie. . . . . . . DIR .34 K ogevinas, M anolis. . . . . . DIR .34 K ogi, K azutaka . . . . . . . . DIR .34 K oh, David ............ DIR.34 K ohler, Larry R. . . . . . . . DIR .34 K ompier, M ichiel A.J... . . . DIR .34 Korhonen, Eero ......... DIR.34 K ornreich, Lawrence D. . . DIR .34 Korotich, Ludmila P. . . . . DIR .35 K ranig, Andreas . . . . . . . DIR. 35 K raus, Richard S. . . . . . . DIR .35
K reitzman, Leon . . . . . . . . DIR .35 K ris-Etherton, Penny M .. . DIR .35 K roemer, K arl H.E. . . . . . DIR .35 K undiev, Y uri . . . . . . . . . DIR .35 K uorinka, Ilkka . . . . . . . . DIR .35 LaD ou, J oseph. . . . . . . . . DIR .35 L aflamme, Lucie . . . . . . . DIR .35 Landsbergis, Paul A. . . . . . DIR .35 Landy, Frank J. . . . . . . . . DIR.36 L angärd, Sverre. . . . . . . . . DIR .36 Lasser, Jay . . . . . . . . . . . . . DIR .36 L assiter, D onald V . . . . . . . DIR .36 L ast, Patricia Alma . . . . . . DIR .36 L atiff, Aishah A. . . . . . . . DIR .36 L aurig, W olfgang. . . . . . . DIR .36 L auwerys, R obert R . . . . . . DIR .36 L aville, A ntoine. . . . . . . . DIR .36 Leamon, Tom B.......... DIR.36 Lee, Pam T au .......... DIR.36 LeG rande, David ....... DIR.36 Lehto, M ark R . . . . . . . . . DIR.36 Lehtola, Carol J . . . . . . . DIR .37 L eirisalo-R epo, M arjatta. . DIR .37 Lemasters, G race K awas. . DIR .37 Lemen, R ichard A. . . . . . DIR .37 Lenhart, Steven W. . . . . . DIR .37 L esage, M ichel. . . . . . . . . . DIR .37 Levenstein, Charles. . . . . . DIR .37 Levi, Lennart. . . . . . . . . . DIR.37 Levy-Feitshans, Ilise . . . . DIR .37 Lewy, R obert M . . . . . . . . DIR .37 Lichtenstein, N orbert . . . . DIR .37 Lidén, Sture. . . . . . . . . . . DIR .37 L iébana, Elena Adán. . . . . DIR .38 Lillienberg, Linnéa . . . . . . DIR .38 Lim, Soo-Y ee. . . . . . . . . . . DIR .38 Linder, $\mathrm{H}$ ans G öran . . . . . DIR .38 Lindstrom, K ari. . . . . . . . . DIR .38 Linehan, Anthony . . . . . . . DIR .38 Linn, H erbert I. . . . . . . . . DIR .38 Lippmann, M orton . . . . . . DIR .38 Lipton, Sydney . . . . . . . . . DIR .38 Lockey, James E. . . . . . . . . DIR .38 Lodde, Gordon M . . . . . . DIR .38 L otens, W outer A. . . . . . . . DIR .38 L ouhevaara, V eikko . . . . . DIR.38 van Loveren, H enk . . . . . . DIR .39 Lund, John ........... DIR .39 Lynch, Paul V .. . . . . . . . . . DIR .39 M adelien, M ichelle . . . . . . DIR .39 M agor, Susan . . . . . . . . DIR .39 M ahr, A............. DIR.39 M ajid, M ohd I sa Abdul. . . DIR .39 M akos, K athryn A. . . . . . DIR .39 M alchaire, Jacques . . . . . . DIR .39 M álek, Bohuslav .... . . . . DIR .39 M alter, D avid E. . . . . . . . DIR .39 M amelle, Nicole . . . . . . . DIR.39 M ann, N orman M . . . . . . DIR .39 M ansdorf, S.Z. . . . . . . . DIR.39 M arcus, Alfred C. . . . . . . DIR .39 M arek, K azimierz J . . . . . DIR .40 M arfin, Anthony A... . . . . DIR .40 M arkkanen, Pia . . . . . . . . DIR .40
M arkowitz, Adrienne . . . . DIR.40 M arkowitz, Steven B. . . . . DIR .40 M aroni, M arco . . . . . . . . DIR .40 M arras, William S. . . . . . DIR .40 M artin, Linda S. . . . . . . . DIR .40 M arty, Albert. . . . . . . . . . DIR .40 M asaitis, J ohn . . . . . . . . . DIR .40 M aslach, Christina ..... . DIR .40 M ason, Steve. . . . . . . . . . . DIR .40 M atsushita, T oshio . . . . . . DIR .40 $M$ atthes, R . . . . . . . . . . DIR .41 $M$ atthews, Chester. . . . . . . DIR .41 $M$ attison, D onald . . . . . . . DIR .41 M ay, John ............. DIR .41 M ayer, Alain ........... DIR .41 M aynard, Alan ......... . DIR .41 M aystre, Lucien Y . . . . . . DIR .41 M cBain, Daniel . . . . . . . . . DIR .41 M cCann, M ichael . . . . . . DIR .41 M cC unney, R obert J. . . . . DIR .41 M cD onald, G eorge J. . . . . DIR .41 M cK ay, Bruce. . . . . . . . . DIR .41 M cK innon, R oss A... . . . . DIR .41 M CM ahon, S.D. . . . . . . . DIR .41 M cM anus, Neil . . . . . . . . . DIR .42 M cQ uay, N ona . . . . . . . . . DIR.42 M cQ uiston, T om A. . . . . . DIR .42 M cV ittie, Douglas]. . . . . DIR.42 M eertens, Dick J... . . . . . . DIR .42 M effert, K arlheinz. . . . . . . DIR .42 M elnick, R onald L . . . . . . DIR .42 M enzies, H eather . . . . . . . DIR .42 M ergler, Donna. . . . . . . . DIR .42 M erletti, Franco .......... DIR .42 $M$ essing, $K$ aren . . . . . . . . . DIR.42 M essite, Jacqueline . . . . . . DIR.43 M ethner, M ark . . . . . . . . . DIR .43 M eyer, Jean-Jacques . . . . . DIR.43 M eyer, John. . . . . . . . . . . DIR.43 M ichelsson, Jarl-Erik. . . . . DIR.43 M ickle, Jack L... . . . . . . . . DIR.43 M iles, John A. . . . . . . . . DIR .43 M iller, Frank . . . . . . . . . . DIR.43 M iller, Gordon .......... DIR.43 M iller, James.... . . . . . . DIR.43 M illies, Bruce Arthur. . . . . DIR.43 M irer, Franklin E. . . . . . . DIR .43 M isra, R. Rita . . . . . . . . . . DIR .43 M itchell, C ourtney S. . . . . DIR .44 M itchell, William. . . . . . . . DIR .44 M iura, T oyohiko . . . . . . . DIR .44 M omm, Willi . . . . . . . . . . DIR.44 M onk, T imothy H . . . . . . . DIR .44 M onteau, M . . . . . . . . . . . DIR .44 M orawetz, J.S.. . . . . . . . . DIR .44 M organ, V ivian K . . . . . . DIR .44 M orison, W. G. . . . . . . . . DIR .44 M orris, Sharon L. . . . . . . DIR .44 M ott, A pril E. . . . . . . . . DIR .44 M uchnick-Baku, Sonia . . . DIR .44 M ullan, R obert J. . . . . . . . DIR .45 M unipov, V ladimir M . . . DIR.45 M unk-M adsen, Eva. . . . . . DIR .45 M untaner, Carles ....... . DIR .45
M urphy, Daniel. . . . . . . . DIR .45 M urphy, Dennis]... . . . . . DIR.45 M urphy, Lawrence R... . . . DIR.45 M uscat, Joshua . . . . . . . . . DIR .45 M usgrave, K arl J. . . . . . . DIR.45 $M$ yers, M elvin L......... . DIR .45 N achreiner, Friedhelm . . . DIR.45 $\mathrm{N}$ ag, Pranab K umar . . . . . DIR .46 N ebert, Daniel W....... . . DIR .46 N eedleman, Carolyn E... . DIR .46 N eis, Barbara. . . . . . . . . . DIR .46 N elson, Debra L. . . . . . . . . DIR .46 N elson, Thomas]... . . . . . DIR .46 N ewcomer, Christian E. . . DIR .46 Nielsen, Bodil . . . . . . . . DIR.46 N ordberg, Gunnar . . . . . DIR.46 Nubé, Jacqueline. . . . . . . . DIR .46 N ugent, H elen . . . . . . . . . DIR .46 N unneley, Sarah A... . . . . DIR .47 O 'M alley, D avid A..... . . DIR.47 O badia, I saac . . . . . . . . . DIR .47 O gawa, T okuo ......... DIR .47 O kubo, T oshiteru ..... . . DIR.47 Ó lafsdóttir, H ulda. . . . . . . DIR.47 O Imstead, G ary W... . . . . DIR .47 O Imsted, Edward A . . . . . . DIR .47 O Iney, Shauna. . . . . . . . . DIR .47 O rlov, E.N. . . . . . . . . . DIR.47 O rris, Peter . . . . . . . . . . . DIR .47 O rth-G omér, K ristina. . . . DIR .47 O rtlieb, Dave W......... . DIR.47 O sborne, G eorge R . . . . . . DIR.48 O sinsky, Debra . . . . . . . DIR .48 O tt, M. Gerald . . . . . . . . DIR .48 O tten, $\mathrm{H}$ einz . . . . . . . . . . DIR .48 O uellette, Suzanne C . . . . . DIR .48 O zaki, M uneto . . . . . . . . DIR .48 Paltiel, Freda L... . . . . . . . . DIR.48 Pantry, Sheila . . . . . . . . . . DIR .48 Parish, Jon K . . . . . . . . . DIR.48 Parker, J ohn E. . . . . . . . . DIR .48 Parsons, K enneth C. . . . . . DIR .48 Partanen, Timo . . . . . . . . . DIR .48 Patterson, R elford E. . . . . . DIR .48 Patz, Jonathan A. . . . . . DIR .49 Paulson, Edna .......... . DIR.49 Paulson, Glenn ......... . DIR.49 Paustenbach, Dennis]. . . . DIR.49 Pearce, N eil . . . . . . . . . . DIR .49 Peedin, Gerald F. . . . . . . . DIR .49 Pelclová, D aniela. . . . . . . . DIR .49 Pelmear, Peter L... . . . . . . . DIR .49 Perlebach, Edith . . . . . . . DIR .49 Perry, Debra A. . . . . . . . . . DIR.49 Petersen, Dan .......... DIR.49 Petsonk, Edward L. . . . . . . DIR.49 Pfeffer, $\mathrm{H}$ ans-U Irich . . . . . DIR .50 Phoon, Wai-on .......... DIR.50 Pickerill, Peter . . . . . . . . . DIR .50 Pickvance, Simon ....... . DIR.50 Piombino, Lou. . . . . . . . . . DIR.50 Piotrkowski, Chaya S. . . . . DIR.50 Planek, Thomas W ... . . . . DIR .50 Platner, James W. . . . . . . DIR .50 
Plattus, Becky ......... DIR.50 Poinstingl, Gustav . . . . . . . DIR .50 Pollard, Tessa M . . . . . . . DIR. 50 Pontén, Bengt .......... DIR.50 Pope, Charles T . . . . . . . . DIR.51 Popendorf, William ...... DIR.51 Porru, Stefano .......... . DIR .51 Porter, Sydney W., Jr. . . . . DIR .51 Poschen, Peter ........... DIR .51 Preul, Herbert C.. . . . . . . DIR .51 Proctor, Christine ........ DIR .51 Q uackenbush, John. ..... DIR .51 Q uick, James Campbell. . . DIR .51 R aehlmann, Irene....... DIR .51 R afnsson, V ilhjálmur .... DIR .51 RaLonde, Ray.......... DIR.51 R amos Pérez, Fernando .. DIR .51 R ansom, Robert ........ DIR .51 R antanen, Jorma........ DIR .52 Raouf, A............ DIR.52 Raskin, Carl........... DIR .52 R ayman, R ussell B...... . DIR .52 Razak, D zulkifli Abdul ... DIR .52 R eeves, John T......... DIR .52 Reh, Beth Donovan. ..... DIR.52 R einert, Dietmar A.J. . . . . DIR.52 R epacholi, M ichael . . . . . . DIR .52 Retsch, T oni .......... DIR.52 Rey, Paule............ DIR .52 R hodarmer, T om ....... DIR.52 Rice, Annie ........... DIR.52 Richardson, David ...... DIR.53 R ichman, Sandra K aren. . DIR .53 R ichter, Peter .......... DIR .53 Rickard, T ed J.......... DIR .53 R iihimäki, H ilkka . . . . . . . DIR .53 Ringen, $K$ nut. . . . . . . . . . DIR .53 R obert, Jean M arc. ...... DIR .53 R oberts, Sally ......... DIR.53 R obertson, Dilys ........ DIR .53 Rohmert, Walter ........ DIR .53 R om, W illiam N........ DIR.53 R omieu, I sabelle . . . . . . . . DIR .53 R osell, M . Gracia . . . . . . . DIR .54 R osen, Jonathan ........ DIR .54 R osenberg, Beth J . . . . . . . DIR .54 R osenstock, Linda....... . DIR.54 R oss, Clara S. .......... DIR .54 R ossol, M onona ........ DIR.54 Roto, Pekka............ DIR.54 R ousseau, D enise M ... . . . DIR .54 R oyster, Julia D . . . . . . . . DIR .54 R oyster, Larry H . . . . . . . . DIR .54 R ubin, James R . . . . . . . DIR . 54 Ruder, A vima M . ....... DIR .55 Rudge, John ........... DIR .55 Rudnick, Jon ........... DIR .55 R user, John W......... DIR .55 Ryding, Sven-O lof. . . . . . DIR .55 Rylander, Ragnar ....... DIR .55 Ryon, David L.S.. . . . . . . DIR .55 Saari, Jorma ........... DIR .55 Sack, D. M............ DIR.55 Salvendy, Gavriel ....... DIR .55
Samuels, Sheldon W. .... DIR .55 Sanders, Andries F. . . . . . . DIR .55 Sanotskij, I gor V . . . . . . . . DIR .55 Saracci, R odolfo ......... DIR .56 Sasco, Annie J.......... DIR.56 Sasseville, Denis. ........ DIR.56 Sauter, Steven L......... . DIR .56 Saux, M arianne. ........ DIR .56 Savolainen, H eikki . . . . . . DIR.56 Savourey, G. . ......... DIR.56 Schachter, N eil . . . . . . . . DIR .56 Scharf, Ted ............ DIR.56 Schaubroeck, John M ..... DIR.56 Schenker, M arc B....... DIR .56 Schilling, Richard ....... DIR.57 Schleifer, L awrence M . . . . DIR .57 Schmitter, G uido........ DIR .57 Schneider, Scott P. ...... DIR.57 Schneider, William J. .... DIR.57 Schneider, W olfram D... . DIR.57 Schrader, Steven ........ DIR.57 Schreiber, Paul ......... DIR .57 Schulz, Horst.......... DIR.57 Schuman, Stanley H . . . . . DIR .57 Schwab, Charles V....... . DIR .57 Schwartz, M enachem .... DIR.57 Schwela, Dietrich ........ DIR.58 Scott, W. N orman . . . . . . . DIR .58 Scott-Parker, Susan . . . . . . DIR .58 Sébastien, Patrick ....... DIR .58 Seegal, Jane L........... . DIR .58 Seguin, Rita. . . . . . . . . . DIR.58 Séguret, M arie-Claire ... . DIR .58 Seidel, H elmut. . . . . . . . . . DIR .58 Seiler, H ansjörg. . . . . . . . . DIR .58 Seppäläinen, Anna

M aria .............. DIR.58 Sever, Lowell E.. . . . . . . . . DIR.58 Seyfried, Erwin ......... DIR .58 Shahandeh, Behrouz..... DIR.58 Shahnavaz, H oushang . . . DIR .58 Shannon, H arry S. . . . . . . DIR .59 Shantora, Victor . . . . . . . . DIR .59 Shell, R ichard L.... . . . . . DIR .59 Shelman, Logan C . . . . . . DIR .59 Shirom, Arie .......... DIR.59 Shiru, Niu ............ DIR.59 Short, Steven ........... DIR .59 Shrey, Donald E........ DIR.59 Shufro, Joël ............ DIR.59 Sidorov, K onstantin K ... . DIR .59 Siev-N er, Itzhak . . . . . . . . DIR .59 Silbergeld, Ellen K . . . . . . . DIR .59 Simard, M arcel . . . . . . . . . DIR .59 Simonsen, Leif. . . . . . . . . . DIR .60 Sims, K en ............ DIR.60 Singleton, William T . . . . DIR .60 Sink, Susan ........... DIR.60 Sjøgaard, Gisela ........ . DIR.60 Skiba, R einald . . . . . . . . . DIR .60 Sliney, D avid H . . . . . . . . DIR .60 Smerko, R obert G . . . . . . . DIR .60 Smith, D onald L........ . DIR.60 Smith, Gordon S. . . . . . . DIR .60
Smith, Ian R.......... DIR .60 Smith, M ichael J......... . DIR .60 Smith, N. A. .......... DIR.60 Smolander, Juhani. ....... DIR .60 Smukowski, M arianne. ... DIR .60 Snowball, David ........ DIR.61 Snyder, Jack W.......... . DIR.61 Sokal, Jerzy A........... DIR.61 Sorsa, M arja . ........... DIR.61 Soskolne, Colin L. . . . . . . . . DIR .61 Spiegel, Jerry . . . . . . . . . . DIR .61 Springfeldt, Bengt . . . . . . . DIR .61 Stallones, Lorann . . . . . . . DIR .61 Stamm, Roger . . . . . . . . . DIR .61 Stark, H eide. . . . . . . . . . . DIR .61 Steinke, William E. . . . . . . DIR .61 Stellman, Jeanne M ager . . DIR .61 Stellman, Steven D . . . . . . . DIR .61 Sten, T erje............. DIR.62 Stenberg, Craig R. . ..... DIR .62 Steptoe, Andrew ......... DIR .62 Stern, Frank. ........... DIR.62 Stewart, James H . . . . . . . D DIR .62 Stewart, Tom F.M. ...... DIR.62 Stiles, B.J............. DIR.62 Stock, Laura ........... DIR.62 Stokols, Daniel. . . . . . . . . . DIR.62 Stössel, U Irich . . . . . . . . . . DIR .62 Strine, Phillip W......... DIR.62 Strother, J. M........... DIR.62 Stueland, Dean T ........ DIR .62 Su, Zhi . .............. . DIR.63 Suls, Jerry ............ DIR.63 Sunderman, F. William,

Jr. .............. DIR.63 Suter, Alice H ... . . . . . . . . . DIR .63 Suvorov, German A. . . . . . DIR.63 Suzuki, H aruko . . . . . . . . . DIR.63 Svagr, John J............ DIR .63 Swanson, N aomi . ....... . DIR .63 Symons, William . . . . . . . . DIR .63 Tait, K eith D.......... DIR.63 T akahashi, K en ......... . DIR .63 T akala, Jukka. .......... . DIR.64 T alluri, K rishna K . . . . . . . DIR .64 T aylor, G ary M . . . . . . . . . . DIR .64 T aylor, James S. ........ . DIR .64 T aylor, R achael F. ...... . DIR.64 T elišman, Spomenka. . . . . DIR .64 T erracini, Benedetto . . . . . DIR .64 T eschke, K ay. .......... . DIR.64 T essler, Jamie . . . . . . . . . . DIR .64 T etrick, Lois E. . . . . . . . . . DIR .64 Theorell, Töres ......... . DIR.64 Thomas, Richard J... . . . . . DIR .64 Thorn, Frank H . . . . . . . . . DIR .65 Thornton, James R ... . . . . . DIR .65 Thu, K endall ........... DIR. 65 T ittelbach, U Irike ........ DIR .65 Todd, Lori............. . DIR.65 Tolsma, Dennis. . . . . . . . DIR .65 T orén, $K$ jell. . . . . . . . . . . . DIR .65 T ownhill, James R. ...... DIR .65 Traiforos, Angela K . . . . . . DIR .65
Trebilcock, Anne........ DIR .65 Trent, John ............ DIR .65 T rimpop, R üdiger M . . . . . D IR . 65 Trotter, D on ............ . DIR.65 Troxler, R ené . . . . . . . . . . DIR.66 Trump, Benjamin F...... DIR .66 T seng, T om . ........... DIR .66 U Ifvarson, U If .......... DIR.66 U lich, Eberhard. . . . . . . . . DIR .66 Ungs, T imothy J......... . DIR .66 U pton, Arthur C . . . . . . DIR .66 U rban, Jill P.G . . . . . . . . . . DIR .66 U rsin, H olger. . . . . . . . . . DIR .66 V ähäpassi, Antero ........ DIR .66 Vainio, H arri ........... DIR .66 Valciukas, José A . . . . . . . DIR.66 V eazie, M ark A. ........ DIR .67 V ega R uiz, M aria Luz. ... DIR .67 V erger, Pierre .......... DIR.67 V ericel, $M$ arc. .......... . DIR .67 Viikari-J untura, Eira .... . DIR .67 Vilasboas de Andrade

A naide............. DIR.67 Vineis, Paolo ........... DIR .67 V ingård, Eva . .......... DIR.67 Vinokur, A miran D. . . . . DIR.67 V ogt, Jean-J acques ....... DIR .67 V olkoff, Serge .......... DIR.67 von R ichthofen, W....... DIR .67 V ondracek, G eorg. . . . . . . DIR .67 V os, Joseph G........... DIR .67 Waalkes, M ichael ........ DIR .68 Wagner, G regory R . . . . . . DIR .68 W akelyn, Phillip J......... DIR .68 Walker, Simon......... DIR.68 W allerstein, Nina. . . . . . . . DIR .68 Walters, Anthony D . . . . . . DIR .68 Wang, Jung-D er ......... DIR.68 W ard, L ance A ........... DIR.68 Warr, Peter ............ DIR.68 Warrell, David A. . . . . . . DIR.68 W arshaw, Leon J. . . . . . . DIR.68 W atanabe, Philip G . . . . . . DIR .69 W eeks, James L. . . . . . . . . DIR .69 W egman, David H . . . . . . . DIR .69 W egmüller, Beat . . . . . . . . DIR .69 W eiderpass, Elisabete .... . DIR .69 W eil, John V ... . . . . . . . . DIR .69 Weinger, M erri ......... DIR.69 Werna, Edmundo . ....... DIR .69 W est, John B........... . DIR.69 W estcott, Paul . . . . . . . . . DIR .69 W esterholm, Peter J.M ... . DIR .69 W estlander, G unnela. .... . DIR .70 Wettmann, 0 thmar ..... DIR.70 White, Aidan ........... . DIR .70 Wichmann-Fiebig,

M arion ............ DIR .70 Wilbourn, Julian ........ DIR .70 Wilde, G erald J.S. . . . . . DIR .70 Williams, M ichael E...... DIR .70 Williamson, Ann M . . . . . . DIR .70 Winter, Denis .......... DIR.70 Wolfe, Linda ........... DIR .70 
Wolff, M ary S.......... DIR .70 W ongphanich, M alinee. . . DIR .70 W oodcock, R ay C. ...... DIR.70 Woolard, Patrisha ....... DIR .71 Wright, Frank B........ DIR .71 Wright, H. Beric ........ DIR.71 Wright, M ichael J....... . DIR .71 Wynder, Ernst......... DIR.71 XU, B. H............ DIR.71 Yardley, Lucy .......... DIR.71 Y assi, Annalee. . . . . . . . . DIR . 71 Zaebst, D ennis. ......... DIR.71 Zahm, Sheila H . ........ DIR .71 Zeballos, José L uis. . . . . . . DIR .71 Zejda, Jan E........... DIR.71 Zielinski, Albert M ....... DIR.72 Zimolong, Bernhard M . . . DIR.72 Zosel, Thomas. ......... . DIR.72 Zurada, Jozef. .......... DIR.72 Zurlo, Joanne .......... DIR.72 Zwerling, Craig......... DIR.72

\section{Por países}

\section{Alemania}

Augusta, Jörg. . . . . . . . . DIR .3 Blome, Helmut . . . . . . . . . DIR.8 Bochmann, Frank . . . . . . . DIR .8 Breuer, Dietmar . . . . . . . DIR.9 Bruckmann, Peter ........ DIR.9 Burhenne-Guilmin,

Françoise. ........... DIR.10

Butz, M............. DIR.10

Çakir, A hmet. .......... DIR .10

Christ, Eberhard ......... DIR.12

Coenen, Wilfried........ DIR .12

Enderlein, G........... DIR .17

Fischer, M anfred . . . . . . . . DIR .19

G reiner, Dieter ......... DIR .23

H acker, W infried. . . . . . . DIR .24

H einemann, Lothar A.J. . . DIR .25

H elbig, R olf. .......... DIR.26

H euchert, G erd E........ DIR .27

H euer, H erbert . ........ DIR .27

H offmann, Burkhard. . . . . DIR .27

H ofmann, Friedrich . . . . . DIR .28

Jäckel, R egina . . . . . . . . . DIR .30

K nauth, Peter .......... . DIR .34

K ranig, Andreas ......... DIR .35

Laurig, Wolfgang. . ...... . DIR.36

Lichtenstein, N orbert .... . DIR .37

Mahr, A. ............ DIR.39

M atthes, R.......... DIR .41 M effert, $K$ arlheinz. . . . . . . DIR.42 Nachreiner, Friedhelm ... DIR .45 $\mathrm{O}$ tten, $\mathrm{H}$ einz . . . . . . . . . . DIR .48 Perlebach, Edith ........ DIR.49 Pfeffer, H ans-U Irich . ..... DIR .50 R aehlmann, Irene . . . . . . DIR .51 Reinert, Dietmar A.J. . . . . DIR .52 Richter, Peter .......... DIR.53 R ohmert, Walter ........ DIR .53 Schneider, W olfram D. . . . DIR .57 Schreiber, Paul ........ DIR .57
Schulz, H orst. ......... . DIR.57 Seidel, H elmut. . . . . . . . . DIR .58 Seyfried, Erwin ......... DIR.58 Skiba, Reinald .......... DIR .60 Stamm, R oger .......... DIR .61 Stark, H eide. . . . . . . . . . . DIR .61 Stössel, U Irich . ......... DIR .62 Tittelbach, U Irike ....... . DIR .65 T rimpop, R üdiger M . . . . . DIR .65 Wichmann-Fiebig,

M arion ............. DIR .70 Zimolong, Bernhard M . . . DIR.72

\section{Arabia Saudí}

Fakhri, Zuheir Ibrahim . . . DIR .18

\section{Australia}

Armstrong, Bruce K...... DIR.2

Bammer, Gabriele. ....... . DIR .4

Creighton, Breen........ DIR.13

Feyer, Anne-M arie . . . . . . DIR .18 Gibson, Gary A......... DIR .21 Johnson, Peter F......... DIR .31 Phoon, Wai-on ......... DIR .50 Rudge, John ........... DIR.55 Westcott, Paul .......... DIR .69 Williamson, Ann M . . . . . DIR .70

\section{Austria}

G eiecker, 0 tto.......... DIR.21 Poinstingl, G ustav . . . . . . . DIR .50

\section{Bélgica}

De K eyser, Véronique. . . . DIR.15 H oet, P............. DIR .27 V an de K erckhove, Johan. DIR.33 Lauwerys, R obert R..... . DIR.36 M alchaire, Jacques . . . . . . DIR .39 White, Aidan .......... DIR .70

\section{Brasil}

Bedrikow, Bernardo ...... DIR .6 da R ocha Gomes, Jorge . . DIR .14 H espanhol, I vanildo .... . DIR .26 Vilasboas de Andrade,

Anaide............. DIR.67 Werna, Edmundo . . . . . . . DIR .69

\section{Canadá}

A beytunga, P.K......... DIR .1 Aldi, R.G. ............. DIR.1 Armstrong, James R....... . DIR .2 Armstrong, Pat .......... DIR.3 Arnold, Ian M . F. ........ DIR.3 Arteau, Jean. ............ DIR.3 Astrakianakis, G eorge .... . . DIR.3 Atherley, Gordon ......... DIR.3 Barling, Julian .......... DIR.5 Becklake, M argaret R..... . DIR .5 Bégin, R aymond . . . . . . . . DIR .6 Béland, François . . . . . . . . DIR.6 Bennett, David ......... DIR.6 Berthelette, Diane . . . . . . . . DIR .7 Bourdouxhe, M adeleine ... DIR .8
Brabant, Carole.......... DIR.8 Brown, Jeremy. . . . . . . . . DIR.9 Burke, R onald J. . . . . . . . DIR .10 Chen, Weiping ......... DIR .11 Chong, John P. . . . . . . . . DIR.12 Cloutier, Esther .......... DIR .12 Corneil, Wayne D. . ..... DIR.13 Cowell, J ohn W.F....... DIR.13 Dalhouse, Neil......... . DIR .14 Damphousse, Louis. . . . . . DIR.14 Davies, H ugh W........ . DIR.15 D edobbeleer, Nicole .... . DIR.15 Demers, Paul A. ........ DIR .15 Durocher, Louis-Philippe . DIR .16 Dykes, R obert W....... DIR .16 Elias, John ............ DIR.17 Forbes, Stewart ......... DIR .19 Fraser, T.M . . . . . . . . . . DIR .20 Gibson, Gary.......... . DIR .21 Giguère, Denis. . . . . . . . . DIR .21 Guidotti, T ee L... . . . . . . . DIR.23 H ardy, Francis. ........ . DIR .25 H ermann, Fred W. . . . . . . DIR.26 Infante-R ivard, Claire. . . . DIR .29 I son, Terence G . . . . . . . . DIR.29 Jackson, Anthony W..... . . DIR.30 Jones, Alan. ............ . DIR.31 K eefe, Anya............ DIR.33 K ennedy, Susan M ....... DIR .33 K uorinka, Ilkka . . . . . . . . . DIR .35 Lesage, M ichel. ......... . DIR.37 M agor, Susan ......... DIR.39 M CBain, Daniel . . . . . . . . DIR .41 M cK ay, Bruce......... DIR.41 M CM anus, N eil ......... DIR.42 M cV ittie, D ouglas . . . . . . DIR .42 M enzies, $H$ eather . . . . . . . DIR .42 M ergler, D onna. ........ DIR.42 M essing, $K$ aren . . . . . . . . . DIR .42 M orison, W. G . . . . . . . . DIR .44 $\mathrm{N}$ eis, Barbara. . . . . . . . . . DIR .46 Nugent, H elen . . . . . . . . . DIR .46 Paltiel, Freda L... . . . . . . . . DIR .48 Pelmear, Peter L... . . . . . . . DIR .49 Raskin, Carl. . . . . . . . . . DIR.52 Rickard, Ted J. . . . . . . . . DIR.53 R obert, J ean M arc. ...... DIR .53 Robertson, Dilys ....... . . DIR .53 Saari, Jorma ........... DIR .55 Sasseville, Denis. . . . . . . . DIR.56 Seguin, Rita. . . . . . . . . . DIR.58 Shannon, H arry S. . . . . . . DIR .59 Shantora, Victor ........ . DIR .59 Simard, M arcel ......... DIR .59 Smith, Ian R... . . . . . . . . DIR .60 Soskolne, Colin L. . . . . . . . DIR .61 Spiegel, Jerry........... DIR .61 Taylor, Gary M . . . . . . . . DIR .64 Teschke, K ay. . . . . . . . . . . DIR .64 Trotter, D on ........... . DIR .65 T seng, T om . . . . . . . . . . . DIR .66 Walters, Anthony D . . . . . DIR .68 Wilde, G erald J.S. . . . . . . DIR.70 Yassi, Annalee. . . . . . . . . . DIR .71

\section{Chile}

A pud, Elias ............. DIR.2

Dümmer, Walter........ DIR .16

\section{China}

Cheng, T sun-Jen ........ DIR .11 $\mathrm{H} \mathrm{e}$, Fengsheng. . . . . . . . . DIR.25 Shiru, Niu ............ DIR.59 Su, Zhi. ............. . DIR.63 Wang, Jung-Der ........ DIR.68

\section{Croacia}

T elišman, Spomenka. . . . . DIR .64

\section{Dinamarca}

Arlien-Søborg, Peter ..... . . DIR.2 G randjean, Philippe ..... DIR .22 G roenberg, Carsten. . . . . . DIR . 23 H ahn, N iels Jørn . ....... . DIR .24 Jacobsen, Peter ........ . . DIR .30 Jørgensen, $\mathrm{K}$ irsten ........ DIR .31 Nielsen, Bodil .......... DIR.46 Simonsen, Leif.......... DIR.60 Sjøgaard, Gisela . . . . . . . . DIR .60

\section{E spaña}

Arias, M .P. ........... DIR.2

Berenguer Subils, M aría

José ................ . DIR.6

Castejón Vilella, Emilio. . . DIR.11 Guardino Solá, X avier ... DIR.23 Guasch Farrás, Juan ..... . DIR.23 H ernández Calleja, Ana . . DIR .26 K ogevinas, M anolis. .... . . DIR .34 L iébana, Elena Adán. . . . . DIR .38 Ramos Pérez, Fernando .. . DIR .51 R osell, M. Gracia ... . . . . . DIR .54

\section{E stados Unidos}

Adess, M ichael .......... . DIR .I A kabas, Sheila H. ........ DIR.1 Alexander, Priscilla . . . . . . . DIR .1 Amendola, Alfred A....... DIR .2 Anderson, Judith .......... DIR .2 Anthony, W. Stanley....... DIR.2 Armstrong, Thomas ....... DIR .3 Ashdown, T ony .......... DIR.3 Attfield, M ichael D........ DIR.3 Avery, William .......... DIR.3 Ayres, Page ............. DIR.4 Babin, Angela R . . . . . . . . . DIR .4 Baker, David E........... DIR .4 Baker, D ean B. . . . . . . . . DIR .4 Baker, R obin . . . . . . . . . . DIR.4 Baldwin, David G......... DIR.4 Barazani, G ail Coningsby. . DIR .4 Barnard, D onald ......... DIR .5 Barnett, R osalind C. . . . . . DIR .5 Batra, Subhash K ......... DIR.5 Bean, Thomas L.......... DIR .5 Beaton, $R$ andal D......... DIR.5 Beliczky, Louis S... . . . . . . . DIR .6 Bell, David M . . . . . . . . DIR.6 Bender, Joel............ DIR.6 
Berezesky, Irene K . . . . . . . DIR .6 Berger, Elliott H............ . DIR .7 Berger, K enneth I. ....... DIR .7 Berkowitz, Deborah E. .... DIR.7 Bertin, Joan ............. DIR.7 Birmingham, D onald J... . . DIR.7 Blackburn, William . . . . . . DIR .8 Blume, Sheila B. ........ DIR .8 Brandt-R auf, Paul . . . . . . . . DIR .8 Brandt-R auf, Sherry I. . . . . DIR .8 Braverman, M ark ........ DIR.9 Briggs, D ouglas F. . . . . . . . . DIR.9 Bringer, R obert. . . . . . . . DIR .9 Brittain, Jere A. . . . . . . . . DIR.9 Brophy, M ary $0 \ldots \ldots \ldots$..... DIR.9 Brown, M ary E.......... DIR.9 Bruno, Peter J............. DIR.9 Brusk, Norman ......... DIR.9 Bunn, William B........ DIR.9 Burton, Wayne N........ . DIR .10 Byrd, LaM ont ........... DIR.10 Cabral, R oxanne. ....... . DIR .10 Cameron, Buck.......... DIR.10 Caplan, R obert D........ . DIR .10 Carayon, Pascale........ DIR.10 Castleman, Barry. ........ DIR .11 Chapman, Larry J. ...... . DIR.11 Cherry, R obert N., J r. . . . . DIR .11 Chivian, Eric .......... DIR.12 Clark, Nancy........... DIR.12 Cohen-R osenthal, Edward DIR .12 Colbert, Lenora Sarah ... DIR.12 Coleman, Paula.......... DIR.12 Collins, James J... . . . . . . . DIR.12 Collins, Janet L............ DIR .12 Cone, James .......... DIR .13 Conway, George A....... DIR.13 Corry, James........... DIR.13 Corry, M aureen P. . . . . . . DIR.13 Crane, M ichael .......... DIR.13 Cullen, M ark R . . . . . . . . DIR .14 Cutler, Ellen ............ DIR.14 D eM arini, David M ...... DIR .15 DiBerardinis, Lou ....... . DIR.15 Dinman, Bertram D...... DIR.15 Dolphin, Basil .......... DIR.16 Donham, K elley ......... DIR.16 D riscoll, Dennis P........ DIR .16 Earnest, Gary S. . . . . . . . DIR .17 Eaton, William ......... DIR.17 Echt, Alan ........... DIR .17 English, Daniel ......... DIR .17 Ewers, Lynda. ......... . DIR .17 Fagel, M ichael J. ....... DIR .17 Fajen, John ........... DIR.18 Farquhar, John W. ...... DIR.18 Fedoruk, M. Joseph...... . DIR.18 Feldman, John.......... DIR.18 Feldman, R obert G . . . . . . DIR .18 Field, William .......... DIR.18 Fielding, Jonathan E... . . . DIR .19 Finklea, John F.......... . DIR.19 Forst, Linda S.......... . DIR .19 Fox, Bernard H . ....... DIR.19
Fox, Janet .......... DIR.19 Francis, James.......... . DIR .19 Franks, John R . . . . . . . . DIR .20 Franson, David J. ....... DIR .20 Frederick, James S. . . . . . . DIR .20 French, Jean G......... . DIR .20 Freudenberger, H erbert J.. DIR .20 Friedlander, Barry....... DIR .20 Friedman-Jiménez,

G eorge ............ DIR.20 Frumkin, H oward ....... . DIR.21 Ganster, Daniel......... DIR .21 Garfinkel, Lawrence ... . . . DIR.21 Gaydos, Joel C......... . DIR .21 Gerami, Afsaneh . . . . . . . . DIR .21 Gerecke, K enneth ..... . . . DIR.21 Goldfein, K ristan D. . . . . . DIR .22 Goldstein, Bernard D... . . DIR.22 Gowing, M arilyn K . . . . . DIR .22 Grant, Casey C......... . DIR.22 Greenberg, Gary N. . . . . . DIR.23 Greenwald, Peter...... . . DIR.23 Gruner, Saul G......... . DIR.23 Gunderson, Paul D...... . DIR.23 H adley, John G. . . . . . . . DIR .24 H amerman, D avid ...... DIR .24 $\mathrm{H}$ amilton, Leonard

$$
\text { Derwent ... }
$$

DIR.24

H aney, Jonathan T ....... . DIR .24 H ardy, D avid L. . . . . . . . . DIR. 25 H arman, Susan E....... . DIR .25 H arris, R obert L........ . DIR. 25 H awkinson, Thomas E... . DIR .25 H eaney, C atherine A. . . . . DIR .25 H ecker, Steven ......... DIR .25 H ellerstein, J on P. ....... DIR .26 H emstreet, G eorge P., III . DIR .26 H erbert, R obin ......... DIR .26 H errick, R obert. ........ . DIR .26 H ethmon, Thomas A . . . . . DIR .27 H iggins, Penny D . . . . . . . DIR .27 H inkamp, David L..... . . . DIR.27 H irsheimer, M atthew . . . . DIR .27 $H$ ites, R oberts ......... . DIR .27 H odgson, M ichael J. . . . . . DIR .27 H offmann, Dietrich. . . . . DIR .27 H ohman, Charles M . . . . D DIR .28 H older, Judith C......... DIR .28 H oward, N inica L. . . . . . . DIR .28 H ubbs, Ann F.......... DIR.28 H uff, James . . . . . . . . . . . DIR .28 H uie, Gordon .......... DIR .29 H unt, Vilma R......... . DIR.29 H untzinger, David ...... DIR.29 H urrell, J oseph J., Jr. . . . . . DIR .29 Irwin, William ......... . DIR.29 I vancevich, John M . . . . . DIR .29 Ivester, A. Lee. . . . . . . . . . DIR.29 Jenkins, C. D avid. . . . . . . . DIR.30 Jenkins, E. Lynn ........ DIR .30 Jex, Steve M.......... DIR.30 Johnson, Barry L. . . . . . . . DIR .30 Johnson, Jeffrey V . . . . . . DIR .31 Johnson, Steven B. . . . . . DIR .31
K ahn, Jeffrey P......... DIR .32 K arasek, R obert ........ DIR.32 K arpilow, Craig. ........ DIR .32 K arsky, Thomas ........ DIR.32 K arwowski, Waldemar ... DIR.32 K azemi, H omayoun ..... . DIR .32 K eidar, Anat.......... DIR.33 K eita, G wendolyn

Puryear. DIR.33 K enney, W. Larry . . . . . . . DIR.33 $K$ indwall, Eric P........ DIR.33 K ipen, H oward M . . . . . . . DIR.33 K nopp, Stephanie....... . DIR .34 K ornreich, Lawrence D. . . DIR .34 K raus, Richard S. ....... DIR .35 K ris-Etherton, Penny M ... DIR .35 K roemer, K arl H.E. ..... DIR. 35 LaD ou, Joseph.......... DIR.35 Landsbergis, Paul A. ..... . DIR.35 Landy, Frank J.......... DIR.36 Lasser, Jay . . . . . . . . . . . . DIR. 36 Lassiter, D onald V . . . . . . . DIR .36 Leamon, T om B......... DIR.36 Lee, Pam T au .......... DIR.36 LeG rande, David ....... DIR.36 Lehto, M ark R.......... DIR.36 Lehtola, Carol J. ......... DIR.37 Lemasters, G race K awas. . DIR .37 Lemen, Richard A . . . . . . DIR. 37 Lenhart, Steven W.... . . . DIR.37 Levenstein, Charles...... DIR.37 Levy-Feitshans, Ilise .... . DIR. 37 Lewy, R obert M ......... DIR.37 Lim, Soo-Y ee. . . . . . . . . . DIR. 38 Linn, H erbert I. . . . . . . . DIR.38 Lippmann, M orton . ..... . DIR .38 Lipton, Sydney ......... DIR.38 Lockey, James E. . . . . . . . . DIR .38 Lodde, Gordon M . . . . . . DIR. 38 Lund, John ............ DIR.39 Lynch, Paul V ........... DIR.39 M adelien, M ichelle ...... . DIR.39 M akos, K athryn A...... DIR .39 M alter, D avid E. . . . . . . . DIR.39 M ann, N orman M . . . . . . DIR. 39 M ansdorf, S.Z. . . . . . . . . . DIR.39 M arcus, Alfred C....... DIR.39 M arfin, Anthony A...... . DIR .40 M arkowitz, Adrienne ... . DIR .40 M arkowitz, Steven B. . . . . DIR .40 M arras, William S. . . . . . DIR .40 $M$ artin, Linda S. ........ DIR .40 M asaitis, John ......... . . DIR .40 M aslach, Christina ...... . DIR .40 M ason, Steve. ........ . . DIR .40 M atthews, Chester. ...... DIR .41 M attison, D onald ........ DIR .41 M ay, John ............ DIR .41 M cCann, M ichael . ... . . . DIR .41 M cC unney, R obert . . . . . DIR .41 M CD onald, G eorge J. .... DIR .41 M cK innon, R oss A... . . . . DIR .41 M CQ uay, N ona ........ . DIR .42 M cQ uiston, T om A . . . . . . DIR .42
M elnick, R onald L...... . DIR .42 M essite, J acqueline ...... . DIR .43 M ethner, M ark ......... DIR.43 M eyer, John........... DIR.43 M ickle, Jack L... . . . . . . . . DIR .43 M iles, John A.......... DIR.43 M iller, Frank . . . . . . . . . . . DIR .43 M iller, Gordon ......... DIR.43 M iller, James........... . DIR .43 M illies, Bruce Arthur. ... . DIR .43 M irer, Franklin E....... DIR.43 M isra, R. Rita .......... . DIR .43 M itchell, Courtney S. . . . . DIR .44 M itchell, William. . . . . . . . DIR .44 M onk, T imothy H . . . . . . DIR .44 M orawetz, J.S. . . . . . . . . . DIR .44 M organ, V ivian K . . . . . . DIR .44 M orris, Sharon L. . . . . . . DIR .44 M ott, A pril E. .......... DIR .44 M uchnick-Baku, Sonia . . . DIR .44 M ullan, R obert J. ........ DIR .45 M untaner, Carles ........ DIR .45 M urphy, Dennis]........ DIR.45 M urphy, Lawrence R... . . DIR .45 M uscat, J oshua ......... . DIR .45 M usgrave, K arl J. . . . . . . DIR.45 $M$ yers, $M$ elvin L.......... DIR .45 Nebert, D aniel W........ DIR.46 N eedleman, C arolyn E... . DIR .46 Nelson, Debra L.... . . . . . . DIR.46 $\mathrm{N}$ elson, Thomas J........ . DIR .46 Newcomer, Christian E. . . DIR .46 N unneley, Sarah A...... . DIR .47 O Imstead, Gary W........ DIR .47 O Imsted, Edward A. . . . . . DIR .47 O rris, Peter ............. DIR .47 O rtlieb, Dave W... . . . . . . DIR.47 O sborne, G eorge R. ..... . DIR .48 O sinsky, Debra ....... . . DIR.48 O tt, M. Gerald ......... DIR .48 O uellette, Suzanne C... . . DIR .48 Parish, Jon K ........... DIR .48 Parker, J ohn E. ......... DIR .48 Patterson, R elford E...... DIR .48 Patz, Jonathan A. . . . . . DIR .49 Paulson, Edna . . . . . . . . . . . DIR.49 Paulson, Glenn .......... DIR.49 Paustenbach, Dennis J. . . . DIR .49 Peedin, Gerald F. . . . . . . DIR .49 Perry, Debra A . . . . . . . . . DIR.49 Petersen, Dan .......... DIR.49 Petsonk, Edward L. . . . . . . DIR .49 Pickerill, Peter .......... . DIR .50 Piombino, Lou. ......... DIR.50 Piotrkowski, Chaya S. . . . . DIR .50 Planek, Thomas W....... . DIR .50 Platner, James W. . . . . . . . DIR .50 Plattus, Becky ......... DIR .50 Pope, Charles T . ......... DIR .51 Popendorf, William ...... DIR.51 Porter, Sydney W., Jr. . . . . DIR .51 Preul, H erbert C........ . DIR.51 Proctor, Christine ....... DIR .51 Q uackenbush, John...... DIR.51 
Q uick, James C ampbell. . . DIR .51 RaLonde, Ray......... DIR.51 R ayman, R ussell B. . . . . . . DIR .52 R eeves, John T ......... DIR .52 Reh, Beth D onovan. . . . . . DIR .52 R hodarmer, T om ....... DIR.52 Richardson, David ...... DIR.53 R ichman, Sandra K aren. . DIR .53 R ingen, K nut. .......... DIR .53 Rom, William N........ . DIR.53 R osen, Jonathan ........ DIR .54 R osenberg, Beth J.. . . . . . . DIR .54 R osenstock, Linda . . . . . . . DIR .54 R oss, Clara S. . . . . . . . . . DIR .54 R ossol, M onona ........ DIR.54 R ousseau, Denise M ... . . . . DIR .54 R oyster, Julia D. . . . . . . . DIR .54 R oyster, Larry H . . . . . . . . DIR .54 R ubin, James R . . . . . . . . DIR .54 Ruder, A vima M . . . . . . . DIR .55 Rudnick, J on .......... . . DIR.55 Ruser, John W......... DIR.55 Ryon, David L.S......... DIR.55 Sack, D. M............ DIR .55 Salvendy, Gavriel ........ DIR .55 Samuels, Sheldon W. . . . . DIR .55 Sauter, Steven L... . . . . . . . DIR .56 Schachter, N eil . . . . . . . . DIR .56 Scharf, Ted ............ DIR.56 Schaubroeck, John M ... . . DIR.56 Schenker, M arc B....... . DIR .56 Schleifer, Lawrence M . . . . DIR .57 Schneider, Scott P. . . . . . DIR .57 Schneider, William J. . . . . DIR.57 Schrader, Steven ........ DIR.57 Schuman, Stanley H . . . . . DIR .57 Schwab, Charles V....... . DIR .57 Scott, W. N orman . . . . . . . DIR .58 Seegal, Jane L... . . . . . . . . DIR .58 Sever, Lowell E... . . . . . . . . DIR .58 Shell, Richard L. . . . . . . . DIR .59 Shelman, Logan C . . . . . . DIR.59 Short, Steven ............ DIR .59 Shrey, Donald E......... DIR.59 Shufro, Joël ........... DIR.59 Silbergeld, Ellen K . . . . . . DIR.59 Sink, Susan ........... DIR .60 Sliney, D avid H . . . . . . . . DIR .60 Smerko, R obert G . . . . . . . DIR .60 Smith, D onald L... . . . . . . DIR .60 Smith, G ordon S. . . . . . . . DIR .60 Smith, M ichael J......... . DIR .60 Smukowski, M arianne. . . . DIR .60 Snyder, Jack W.......... . DIR.61 Stallones, Lorann ........ DIR .61 Steinke, William E. ...... DIR .61 Stellman, Jeanne M ager . . DIR .61 Stellman, Steven D ... . . . . DIR .61 Stenberg, Craig R . . . . . . . DIR .62 Stern, Frank. .......... DIR.62 Stewart, James H . . . . . . . DIR .62
Stiles, B.J.............. DIR .62 Stock, Laura ........... DIR.62 Stokols, Daniel. . . . . . . . . . DIR .62 Strine, Phillip W......... DIR .62 Strother, J. M . . . . . . . . . DIR .62 Stueland, D ean T . . . . . . . . DIR .62 Suls, Jerry ............. DIR .63 Sunderman, F. William, Jr. DIR .63 Suter, Alice H ... . . . . . . . . DIR .63 Svagr, John J............ DIR.63 Swanson, N aomi . . . . . . . . DIR .63 Symons, William . . . . . . . DIR .63 T ait, K eith D . ......... DIR .63 T alluri, K rishna K . ..... . DIR .64 Taylor, James S. . . . . . . . DIR .64 T essler, Jamie . . . . . . . . . . DIR .64 Tetrick, Lois E. . . . . . . . . DIR .64 Thomas, Richard J...... . . DIR .64 Thorn, Frank H . . . . . . . DIR .65 Thornton, James R ... . . . . DIR .65 Thu, K endall. . . . . . . . . . DIR.65 Todd, Lori ............ . DIR .65 Tolsma, Dennis......... DIR .65 Townhill, James R . . . . . . DIR .65 Traiforos, Angela K . . . . . . DIR .65 Trent, John ........... DIR .65 Trump, Benjamin F...... DIR .66 Ungs, T imothy J......... . DIR .66 Upton, Arthur C . ...... DIR .66 Valciukas, José A . . . . . . DIR .66 Veazie, M ark A. ....... DIR .67 Vinokur, Amiran D. . . . . . DIR .67 Waalkes, M ichael ....... DIR .68 Wagner, G regory R . . . . . . DIR .68 W akelyn, Phillip J... . . . . DIR .68 W allerstein, Nina. . . . . . . DIR .68 W ard, Lance A... . . . . . . . DIR .68 Warshaw, Leon J. ....... DIR.68 W atanabe, Philip G . . . . . . DIR.69 W eeks, James L. . . . . . . . . DIR .69 W egman, D avid H . . . . . . . DIR .69 Weil, John V........... DIR.69 West, John B........... DIR .69 Williams, M ichael E... . . . DIR .70 Wolfe, Linda ........... DIR .70 Wolff, M ary S.......... . DIR.70 Woodcock, Ray C....... DIR.70 W oolard, Patrisha ....... . DIR .71 Wright, M ichael J... . . . . DIR .71 Wynder, Ernst. . . . . . . . DIR .71 Zaebst, Dennis. ......... DIR .71 Zahm, Sheila H. ........ DIR .71 Zielinski, A lbert M . . . . . . . . DIR .72 Zosel, Thomas. ......... . DIR.72 Zurada, Jozef........... DIR .72 Zurlo, Joanne .......... DIR.72 Zwerling, Craig......... DIR.72

\section{Federación Rusa}

Denisov, Edouard I. . . . . DIR.15 Izmerov, Nikolai F. . . . . . DIR.29
K aptsov, V aleriy A....... DIR.32 K orotich, L udmila P. .... . DIR .35 M unipov, V ladimir M . . . . DIR .45 O rlov, E.N. ............ DIR.47 Sanotskij, I gor V ... . . . . . . DIR .55 Sidorov, K onstantin K ... . DIR .59 Suvorov, German A...... DIR .63

\section{Finlandia}

Eeronheimo, O lli........ DIR .17 H äkkinen, K ari K . . . . . . . DIR .24 H ernberg, Sven ......... DIR .26 J untunen, M arja-Liisa ... . DIR .31 Jurvélius, M ike. ....... . . . DIR .31 $\mathrm{K}$ angas, Juhani ......... DIR 32 $\mathrm{K}$ auppinen, $\mathrm{T}$ imo ....... DIR .32 K orhonen, Eero ........ DIR.34 Leirisalo-R epo, M arjatta. . DIR .37 Lindstrom, K ari........ . DIR.38 L ouhevaara, V eikko ..... . DIR.38 M ichelsson, Jarl-Erik. . . . DIR .43 R antanen, Jorma. . . . . . . DIR .52 Riihimäki, H ilkka ....... . DIR .53 R oto, Pekka............ DIR .54 Seppäläinen, Anna M aria . DIR .58 Smolander, Juhani. ...... . DIR .60 Sorsa, M arja ............ DIR .61 V iikari-Juntura, Eira ..... DIR .67

\section{Francia}

Balty, Isabelle ........... DIR .4 Bittel, Jacques H .M . . . . . . . DIR .8 Boffetta, Paolo ........... DIR .8 Cros-C ourtial, M arie L. .. DIR .14 Dajer, Antonio J......... DIR .14 Estryn-Béhar,

M adeleine R . . . . . . . DIR .17 Folliot, D ominique ....... DIR .19 Ho, M anh Trung ....... DIR.27 Laville, Antoine........ . . DIR .36 M amelle, Nicole ........ . DIR.39 M ayer, Alain ........... DIR.41 M enguy, Claude ........ . DIR .42 M onteau, M ........... . DIR .44 Partanen, Timo . . . . . . . . . DIR .48 Rice, Annie ........... DIR .52 Sasco, Annie ... . . . . . . . . DIR .56 Saux, M arianne. . . . . . . . DIR .56 Savourey, G........... DIR .56 Sébastien, Patrick ....... . DIR .58 T aylor, R achael F. ...... DIR .64 Vainio, $\mathrm{H}$ arri........... DIR .66 Verger, Pierre ......... DIR.67 Vericel, M arc. .......... . DIR .67 V ogt, J ean-Jacques ...... . DIR .67 V olkoff, Serge .......... DIR .67 Wilbourn, Julian .... . . . . DIR .70 Winter, Denis .......... DIR.70

\section{H ungría}

Banky, Tamas........... DIR.4

\section{India}

Dheri, S.K............. DIR.15 Gupta, K rishan Chand ... DIR .24 Jayaraman, K unthala .... . DIR .30 Joshi, T.K ............. DIR.31 Nag, Pranab K umar ..... . DIR .46

\section{Indonesia}

Dykstra, Dennis. . . . . . . . . DIR .16

\section{Irlanda}

M urphy, Daniel......... DIR .45

\section{Islandia}

Arnason, Ragnar.......... DIR.3 Bardarson, H jalmar R . . . . . DIR .5 Ó lafsdóttir, Hulda . ...... . DIR .47 R afnsson, Vilhjálmur .... DIR .51

\section{Israel}

Aladjem, Avraham ........ DIR .1 Chayon, Haim . . . . . . . . . DIR.11 Chereisky, M ichael ...... DIR.11 Donagi, A lexander E. .... . DIR .16 Gilad, Issachar. ......... DIR .21 Schwartz, M enachem . . . . DIR .57 Shirom, Arie ..... . . . . . DIR .59 Siev-Ner, Itzhak ........ DIR .59

\section{Italia}

Alessio, Lorenzo .......... DIR.1 Andreoni, Diego ......... DIR.2 Battista, G iuseppe ........ . . DIR .5 Bertazzi, Pier Alberto . .... DIR .7 Biagi, M arco ............ . DIR .7 Biggeri, Annibale. . . . . . . . DIR .7 Bovenzi, M assimo . . . . . . . DIR .8 Braga, M ario . . . . . . . . . DIR .8 Brighi, Cecilia .......... DIR .9 Capelli, Giovanni ....... DIR.10 Catananti, C........... DIR .11 Chiappino, Gerolamo .... . DIR .11 Comini, R enzo ......... DIR.12 Damiani, Gianfranco .... . DIR .14 Ferioli, A dalberto ........ . DIR .18 Foà, Vito ............. DIR.19 Grandolfo, M artino. ..... . DIR .22 H einrich, R udolf ........ DIR.25 $M$ aroni, M arco ......... DIR .40 M erletti, Franco ........ DIR.42 Porru, Stefano ........... . DIR .51 Saracci, R odolfo . ....... . DIR .56 Terracini, Benedetto ..... . DIR .64 V ineis, Paolo ........... DIR.67

\section{Japón}

A kita, M unehira .......... DIR .1 H aratani, T akashi . . . . . . . DIR .24 I keda, M asayuki ........ DIR.29 I uchi, M asaaki . . . . . . . . . DIR .29 K imura, K ikuzi ......... . DIR.33 
K ogi, K azutaka......... . DIR.34 M atsushita, Toshio .... . . . DIR .40 M iura, T oyohiko ........ DIR.44 O gawa, T okuo ......... DIR.47 O kubo, T oshiteru ....... . DIR.47 Suzuki, H aruko . . . . . . . . . DIR .63 Takahashi, K en ......... DIR.63 Xu, B.H............ DIR.71

\section{Malaisia}

A wang, R ahmat ......... DIR.3 Latiff, Aishah A........ DIR.36 M ajid, M ohd Isa Abdul. . . DIR.39 Razak, D zulkifli Abdul ... DIR .52

\section{M éxico}

R omieu, I sabelle ........ . DIR .53 Zeballos, J osé L uis. . . . . . . DIR .71

Nepal

Joshi, D. D. ............ DIR.31

\section{Noruega}

K jellén, U rban. .......... DIR .33 Langärd, Sverre. ........ DIR.36 M unk-M adsen, Eva...... . DIR .45 Sten, Terje. ........... DIR .62 U rsin, H olger. . . . . . . . . . . DIR .66

\section{Nueva Zelanda}

Campbell, D onald M ..... . DIR .10 Darby, Frank.......... DIR .14 Glass, William I. . . . . . . . DIR .21 Gorman, D.F.......... DIR.22 M CM ahon, S.D. . . . . . . . DIR .42 Pearce, N eil . . . . . . . . . . DIR .49

\section{Países Bajos}

Akkers, Leen ............ DIR.1 Van Griensven, Leo J.L.D. DIR.23 Groeneweg, Jop......... DIR.23 $\mathrm{H}$ ale, Andrew R......... DIR .24 H eederik, Dick ......... DIR .25 van der $\mathrm{H}$ eijden, $\mathrm{K}$ ees A. . DIR.25 H outman, Irene L.D. . . . . DIR .28 K ompier, M ichiel A.J.... . DIR .34 Lotens, W outer A . . . . . . . . DIR .38 van L overen, H enk . . . . . . DIR. 39 Nubé, Jacqueline. . . . . . . . DIR .46 Sanders, Andries F....... DIR .55 V os, J oseph G........... DIR .67 Grady-van den Nieuwboer,

JokeJ.H. ........... DIR.22

\section{Pakistán}

Raouf, A.

DIR.52

\section{Polonia}

Jakubowski, M arek ...... DIR.30 M arek, K azimierz . . . . . . DIR .40
Sokal, Jerzy A . . . . . . . . . . DIR .61 Zejda, Jan E. . . . . . . . . . DIR .71

\section{Reino Unido}

Baxter, Peter J. ........... DIR .5 Bell, R on ............... DIR.6 Benson, Alan J. . . . . . . . . . DIR .6 Bisset, R onald ........... DIR .7 Brazendale, John ......... DIR .9 Cartwright, Sue......... DIR .10 Cooper, Cary L. . . . . . . . . DIR.13 Coyle, R obert .......... DIR .13 Crump, Derrick......... . DIR .14 Davies, John C......... DIR .15 Doyle, M el............. DIR.16 D rysdale, D ougal D. . . . . DIR .16 Flannigan, Brian ........ DIR .19 Forster, Richard ........ DIR.19 Freestone, David ........ DIR .20 Gompertz, David........ DIR.22 G riffin, M ichael J........ DIR .23 H aslehurst, Jillian ....... . DIR .25 H inksman, Jeffrey . . . . . . . DIR .27 H owes, M.J.. . . . . . . . . . DIR .28 K azantzis, G eorge. . . . . . . DIR .32 K elley, Barry P......... DIR.33 K reitzman, Leon ........ . DIR.35 Last, Patricia A Ima . . . . . . DIR .36 Linehan, Anthony . . . . . . . DIR . 38 M aynard, Alan ......... DIR .41 0 'M alley, D avid A ....... . DIR .47 Pantry, Sheila ......... . DIR.48 Parsons, K enneth C . . . . . . DIR .48 Pickvance, Simon ........ DIR.50 Pollard, T essa M . ....... DIR.50 Roberts, Sally .......... DIR .53 Schilling, Richard ....... DIR .57 Scott-Parker, Susan . . . . . . DIR .58 Sims, K en ............ DIR .60 Singleton, William T . . . . DIR .60 Smith, N. A . . . . . . . . . . . DIR.60 Snowball, David ........ DIR .61 Steptoe, Andrew ..... . . . . DIR .62 Stewart, T om F.M . . . . . . DIR. 62 U rban, Jill P.G . . . . . . . . . DIR .66 Walker, Simon.......... DIR.68 Warr, Peter ............ DIR.68 Warrell, D avid A. . . . . . . DIR .68 Wright, Frank B. . . . . . . DIR .71 Wright, H. Beric ......... DIR .71 Y ardley, Lucy ......... . DIR.71

\section{República Checa}

Bencko, V ladimir ......... DIR.6

David, Alois............ DIR .14 Málek, Bohuslav ........ DIR.39 Pelclová, Daniela. . . . . . . DIR .49

\section{Singapur}

Chia, K ee-Seng......... DIR.11
Jeyaratnam, Jerry ....... DIR .30 Koh, David ............ DIR.34

\section{Suecia}

Anderberg, Yngve........ DIR .2

Andersson, Ragnar . . . . . . . DIR .2

Axelson, O lav ........... . DIR.3

Backström, Tomas. . . . . . . DIR .4

Berg, M ats. . . . . . . . . . . . DIR.7

Bergqvist, U If. .......... DIR .7

Dahlqvist, M onica. . . . . . . DIR.14

Dahlström, Göran . ...... . DIR .14

Döös, M arianne. . . . . . . . DIR .16

Elinder, Carl-G . ........ DIR.17

Englund, Claes W. . ...... DIR .17 Frankenhaeuser,

M arianne ........... DIR.20

G ranberg, Per-0 la ..... . DIR .22

Gustavsson, Per ......... DIR .24

$\mathrm{H}$ agberg, M ats. . . . . . . . . DIR .24

$\mathrm{H}$ amrin, $\mathrm{H}$ ans.......... DIR .24

$\mathrm{H}$ ansson M ild, K jell . . . . . DIR . 24

Högberg, Johan . . . . . . . D DIR .28

H olmberg, Bo . . . . . . . . . DIR .28

H olmér, Ingvar . . . . . . . . DIR .28

Järup, Lars. ........... DIR.30 Johanson, Gunnar . . . . . . . DIR .30

$K$ adefors, R oland ........ DIR.31 K ilbom, Åsa. ............ DIR 33

K nave, Bengt.......... DIR.34 L aflamme, Lucie......... . DIR.35

Levi, Lennart. . . . . . . . . . DIR.37 Lidén, Sture. . . . . . . . . . DIR .37 Lillienberg, Linnéa . . . . . . DIR .38 Linder, $\mathrm{H}$ ans $\mathrm{G}$ öran . . . . . . DIR.38 N ordberg, Gunnar ...... . DIR.46 O rth-G omér, $\mathrm{K}$ ristina. ... DIR .47 Pontén, Bengt .......... . DIR .50 Ryding, Sven-0 lof. . . . . . . DIR .55 Rylander, Ragnar . . . . . . . DIR .55 Shahnavaz, H oushang . . . DIR.58 Springfeldt, Bengt ....... DIR .61 Theorell, Töres ......... . DIR .64 Torén, K jell. . . . . . . . . . . DIR .65 U Ifvarson, U If . . . . . . . . . DIR .66 Vingård, Eva .......... DIR .67 W eiderpass, Elisabete .... . DIR .69 Westerholm, Peter J.M ... . DIR .69 Westlander, G unnela. .... DIR.70

\section{Suiza}

Ackermann-Liebrich,

$$
\text { U rsula ............. DIR.1 }
$$

Boillat, M arcel-André . . . . DIR .8 Clevenstine,

Emmert C . . . . . . . . . DIR.12 Coppée, Georges H. . . . . . DIR.13 Eicher, Lawrence D. . . . . . DIR.17 Fedotov, I gor A. . . . . . . . DIR.18 Gheorghe, Adrian V . ... . DIR .21
G oelzer, Berenice I.

Ferrari............. DIR.22

Gold, David............ DIR.22 G rote, Gudela . . . . . . . . . . DIR .23 H elmer, R ichard ......... DIR.26 Jennings, N orman S. . . . . . DIR.30 K äferstein, Fritz. . . . . . . . . DIR .31 K jellström, T ord ......... DIR.34 K liesch, G eorg R . ........ DIR.34 K ohler, Larry R......... DIR.34 M arty, A lbert. ........... DIR .40 M aystre, Lucien Y . . . . . . . DIR .41 M eertens, Dick J... . . . . . . DIR .42 M eyer, Jean-Jacques . . . . . DIR .43 M omm, Willi . . . . . . . . . . DIR .44 O badia, I saac . . . . . . . . . DIR .47 O Iney, Shauna. ......... DIR.47 O zaki, M uneto .......... DIR .48 Poschen, Peter......... DIR.51 R ansom, R obert ......... DIR.51 Repacholi, M ichael . . . . . . DIR.52 R etsch, T oni ........... DIR.52 Rey, Paule............ DIR.52 Savolainen, H eikki . . . . . . DIR.56 Schmitter, Guido. . . . . . . . DIR .57 Schwela, Dietrich ........ DIR .58 Séguret, M arie-C laire . . . . DIR .58 Seiler, H ansjörg. . . . . . . . DIR .58 Shahandeh, Behrouz. . . . . DIR .58 T akala, Jukka. .......... DIR .64 T rebilcock, Anne. ........ DIR.65 Troxler, R ené ........... . DIR.66 U lich, Eberhard. . . . . . . . DIR .66 V ähäpassi, Antero . . . . . . . DIR .66 V ega R uiz, M aria Luz. ... DIR.67 von R ichthofen, W . . . . . . . DIR .67 V ondracek, G eorg. . . . . . . DIR .67 W egmüller, Beat . . . . . . . . DIR .69 Weinger, M erri ......... DIR.69 W ettmann, 0 thmar ..... DIR .70

\section{Suráfrica}

Allison, Sydney .......... DIR .2

\section{Tailandia}

Chavalitnitikul, Chaiyuth . DIR .11 M arkkanen, Pia . ........ . DIR .40 W ongphanich, M alinee. . DIR .70

\section{U crania}

Chernyuk, V. I.......... DIR.11 Dobrovolsky, Leonard A. . DIR.15 Kagan, Yu.S........... DIR.31 K undiev, Y uri .......... DIR.35

\section{Yugoslavia}

Djuric, Dusan .......... DIR.15 
